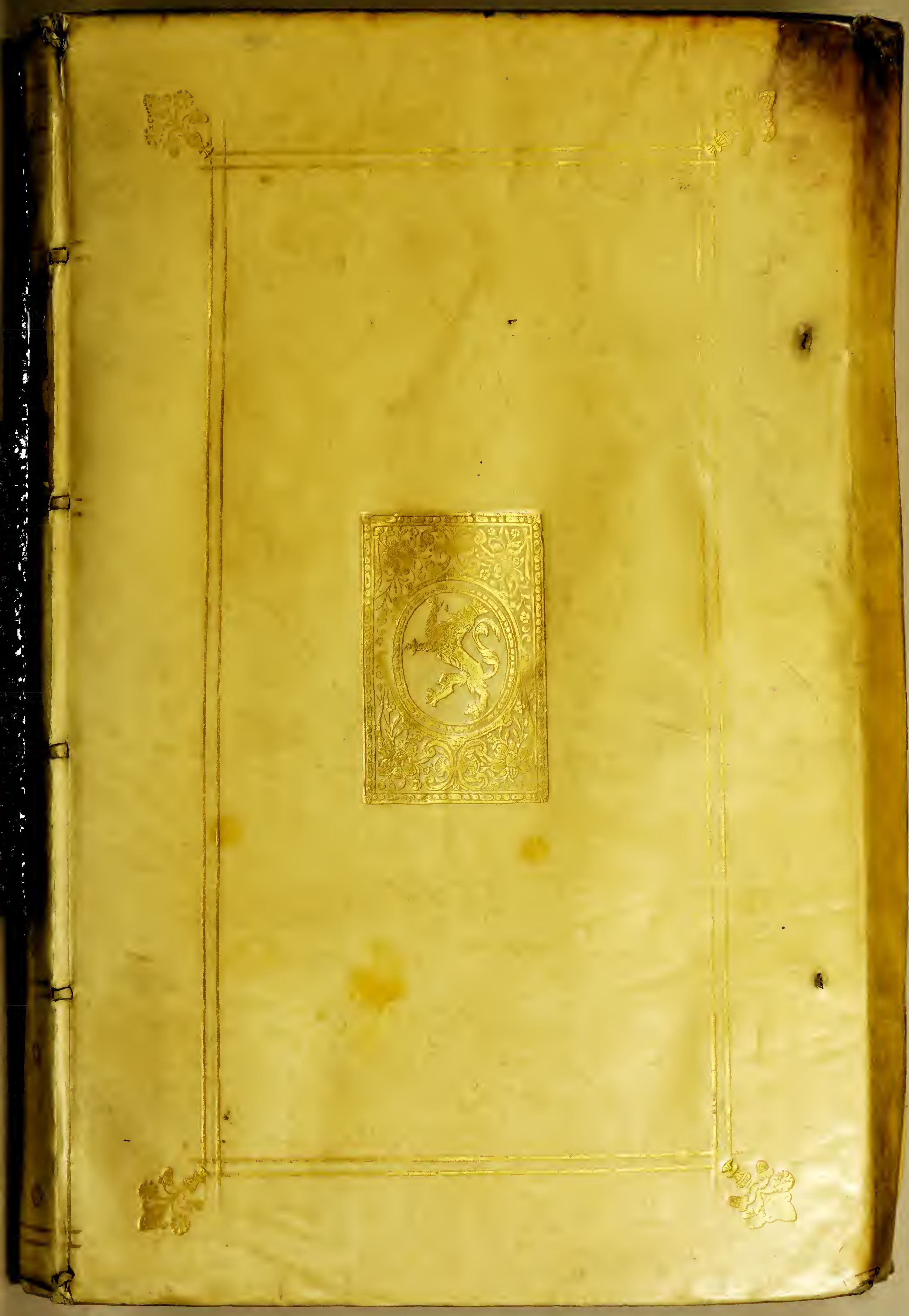




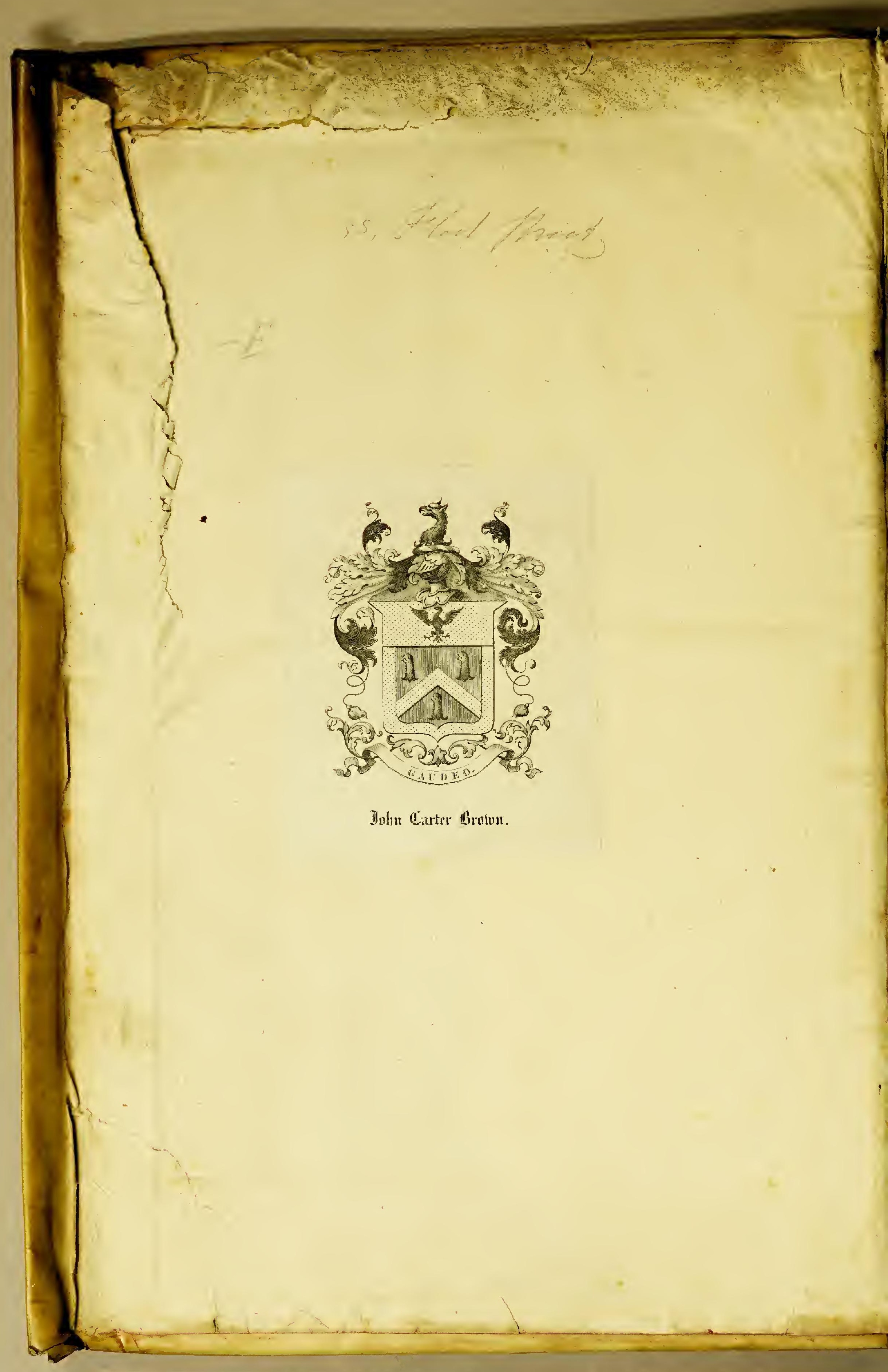








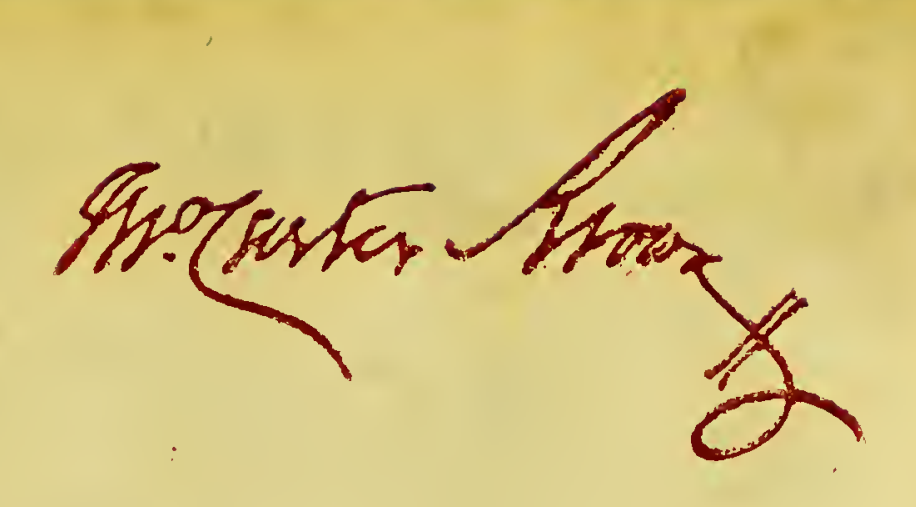

Nieuvve Wereldt

Dfte

Betrthetifuinghe

V A N

\section{VVEST-INDIEN. 9100?}

I O A N E S de LAET. 



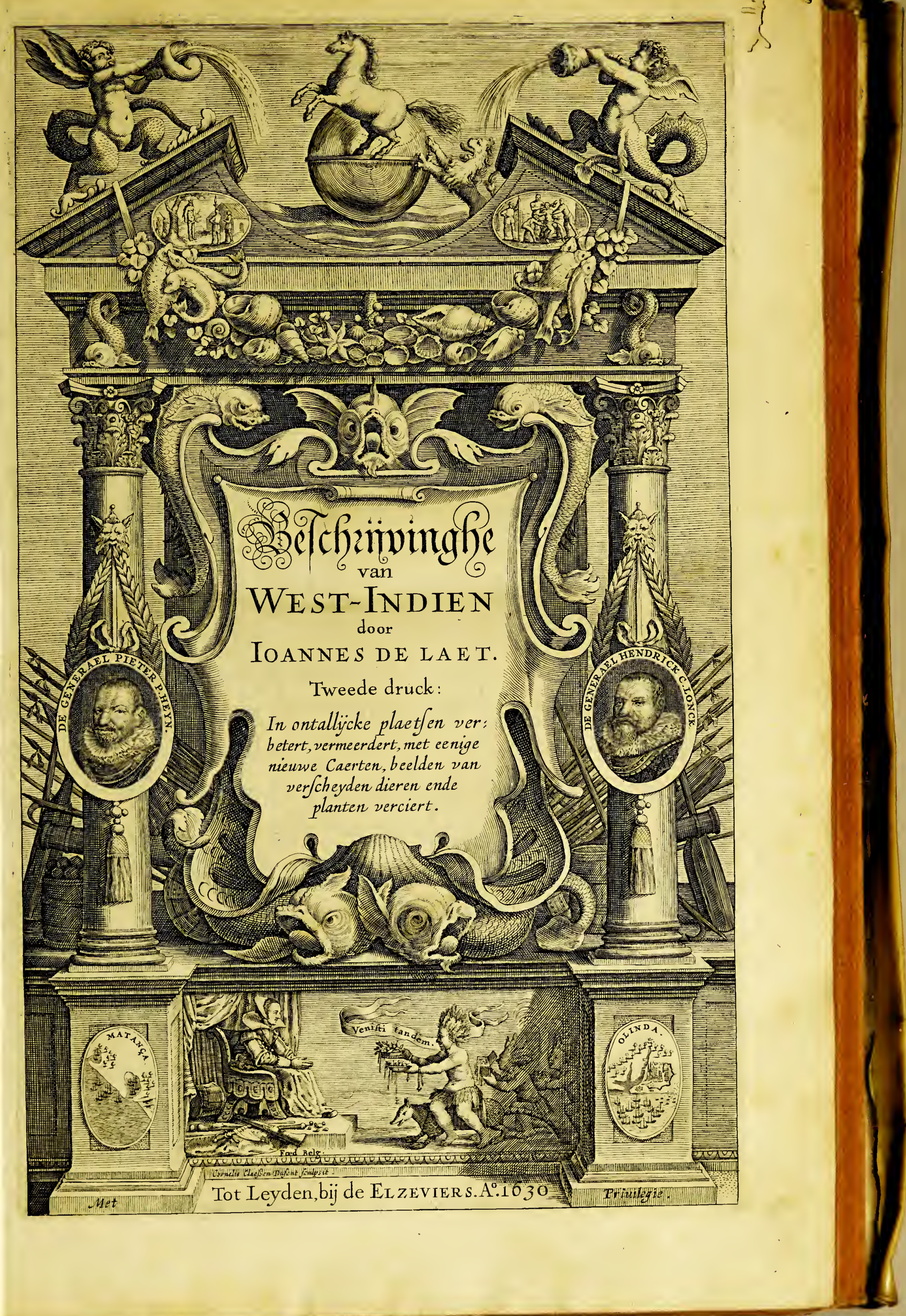




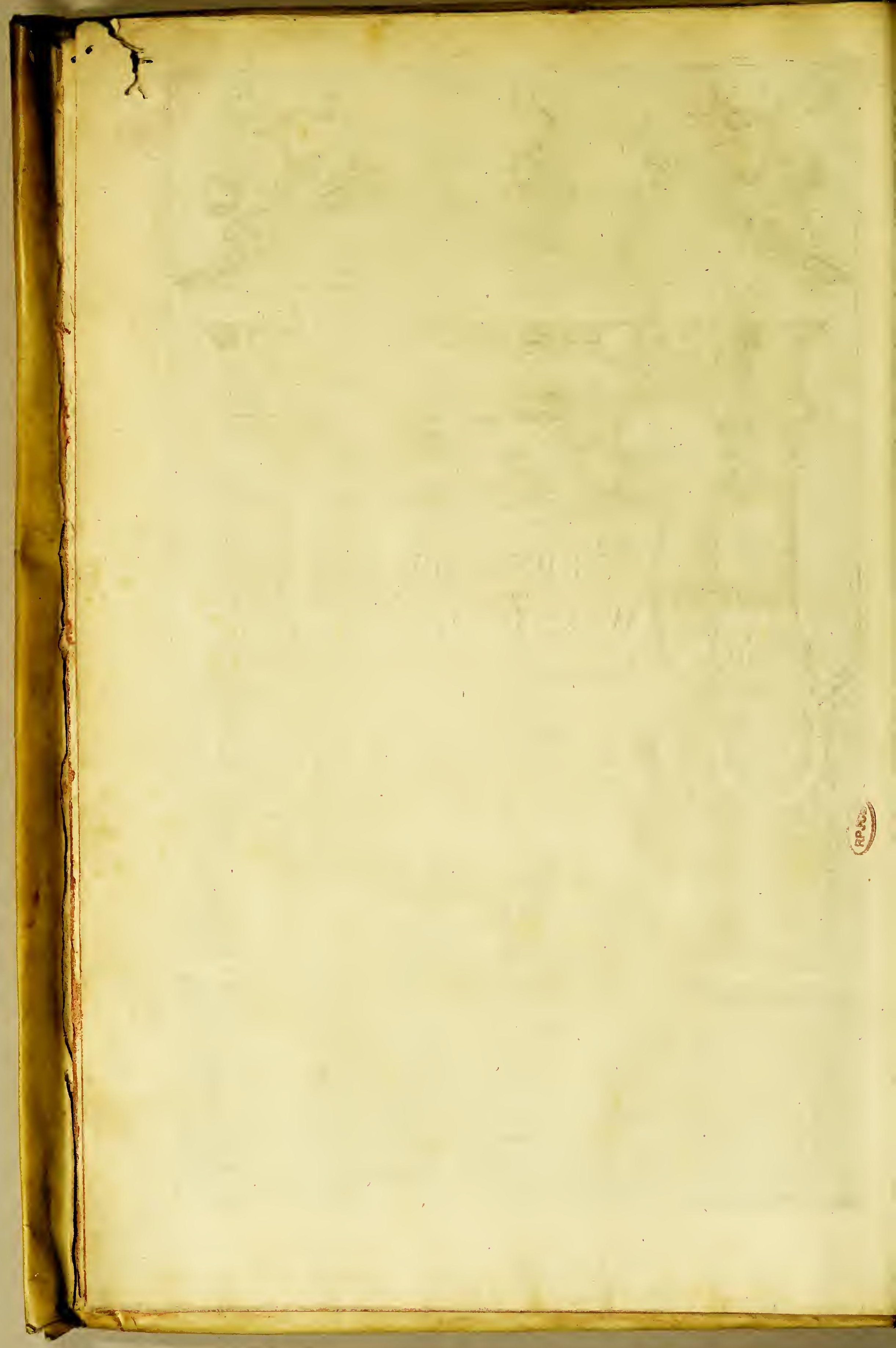


Aen de Doorlucbtighe ende Hoogh-mogbende Heeren, mijn Heeren

\section{$\begin{array}{lllll}S & T & A & T & E\end{array}$ \\ $G E N E R A E R$ \\ der vereenighde Nederlanden.}

Min HeEren,

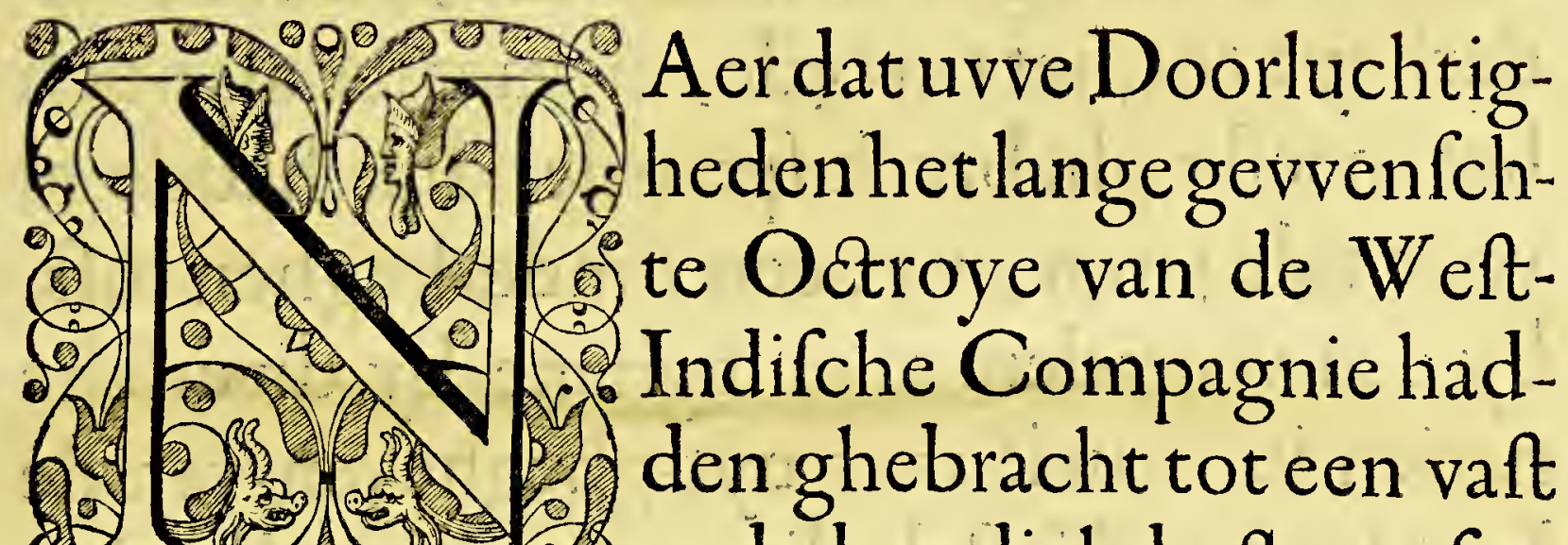
6 ende bondich befluyt, foo vvas het nu tijdt dat alle ghetrouvve Lief-hebbers des Vaderlandts, haer uyterfte befte fouden doen,om te vervorderen de middelen die noodigh zijn tot uyt-voeringe van fo grooten ende ghevvichtigen vverck; vvelcke middelen alfoofy beftaen in tvveedeelen, te vveten, in 't op-brengen van een groot Capitael, tot uytruftinghe van een aenfienlijck getal van Schepen, hoogh-noodigh tot het bevaren ende befoecken van foo vele ende vvijdt-verfpreyde Landen, als in den voorfchreven Octroye

$$
\text { 许 } 3 \text { begre- }
$$


begrepen zijn; eñ ten anderen, in goedekenniffe van de voorfchreven Landen ende Luyden, tot onderrechtinghe van de gene die de directie van defe Weft-Indifche Compagnie bevolen is, als mede die, de vvelcke de refolutien hier te Lande genomen, fullen gaen uytvoeren: Tot vervorderinghe van beyde defe middelen, hebbe ick naer mijn fchuldirhe plicht ende geringh vermoghen, getracht foo vele toe te brengen als ick konde, ende infonderheyt tot het tvveede, alvvaer ick als noch het meefte ghebreck fpeurde. Ick hadde al voor vele jaren, uyt een fonderlinghen luft, by een vergadert alles 't ghene by diverfche natien in druck vvas uyt-ghegheven van de Landen van Weft-Indien; oock eenighe ghefchreven Iournalen van eenighe Stier-lieden van onfe natie; ende daer uyt feeckere korte aen-teeckeninghen ghetrocken : Uyt de vvelcke ick, door aen-porringhe van verfcheyden Heeren ende vrienden, defe Befchrijvinghe van Weft-Indien hebbe by een ghefteldt, vvelck nu onder de befcherminghe van uvven Doorluchtigen naem voort-komt. Sy en konde noch en behoorde by my niemandt anders toe-gheeyghent te vvorden, als uvve Doorluchtigheden, als vvefende

Vaders 
Vaders van 't V aderlandt, ende Aenlegghers ende Voorftanders van het groote vverck,om vvelckes vville defe Befchrijvinghe is verveerdicht. Wat arbeydt ende moeyte by my in dit vverck te vervoorderen is genomen, fullen die lichtelijck oordeelen die de vvijdtlufticheyt van defe Landen, ende diverfiteyt van Autheuren, uyt de vvelcke dit vverck is ghenomen, fullen aen fien: Alle de vergeldinghe die ick daer voor vervvachte, is, dat uvveDoorluchtigheden gelieven defen mijnen arbeydt met een goede ooghe aen te fchouvven, ende te aenveerden als een ghetuygenis van mijnen vvillighen dienft ende fchuldige danckbaerheyt. Den Almogenden Godt ende ghenadigen befchermer van ons lieve Vaderlandt, geve uvve Doorluchtigheden een gheluckighe endelanghduerighe regeringe, overvvinninghe van fyne vyanden, tot voorftandt van $f y$ ne Kercke ende vvelftandt van alle trouvvhertighe ingefetene van defe Landen, gelijck 't felve gheduerlijck door vyerige ghebeden vvordt verfocht door my.

Vove Doorluchtigbeden ootmoedighen Dienaer

$$
\text { I OANNES de LAET. }
$$

vyt Leyden defen 15. Kovember Lnno 1624.

P R I- 


\section{PR I I L E G I E.}

国

Staten Generael der V.evenichde Nederlanden, bebben gheconfenteert ende gheoctroyeert, confenteeren ende octroyeerenmidis-defen lohan de Laet, vvoonende tot Leyden, dat by voor den tÿdt van tvvaelf Iaren naest-komende,. alleen in de vereenichdo Provincien fal moghen doen. Drucken, ende uyt-gheven, in diverfche talen, feecker Boeck, ghenaemt Nieuwe VVereldt, ofte Befchrijvinghe van. VVeft-Indien, verciert met diverfche Kaerten, tot onderrechtinghe van bet felve Boeck, ofte Hiftorie. Verbiedende allen, ende een jeghelycken Ingefetenen van defe Landen,'t voorf. Boeck binnen den voorf. ty dt van tvvaelf Iaren, directelïc, of indirectelyc, in't gebeel, ofte ten deele, in't groot, ofte in't kleyn, in eenigerley tale te doen na-drucken ende uyt-gheven, oft elders naer-ghedruct in de vereenichde Provincien te brenghen, om verkoft, of te uyt-ghegeven te vvorden; ofte ooc eenighe Kaerten in't gheheel ofte fuc-ghevoijs, uyt bet voorf. Boec te nemen, om by andere Boecken uyt-ghegeven te voorden, fonder confent van den voornoemden Iohan de Laet, by verbeurte van de felve na-ghedructe exemplaren of te Boecken, daer in fodanige Kaerten in't ghebeel, of te deel, gheronden mochtenvverden,ende daer-en-boven een fomme van fes hondert guldens; $t$ ' appliceeren een derdendeel daer van tot beboefvan den Officier die de calangie doen fal, het twreede derdendeel tot beboef van den armen;ende bet refterende derdendecl tot beboef van den voorfz. Iohan de Laet. Verbiedende voorts ghelücke materie voortaen te Drucken, of te uyt te gheven, fonder dat d'Originelen van dien eerft by ons gevifiteert, ende daer toe confent ghegheven zy, op pene by onfe voorgaende Placcaten op't futuck van de Druckeryen gheemaneert.

Gedaen ter vergaderinge van de Hoogh-gbemelte Heeren Staten Generael, in 's Graven-Haghe op den XVII. Fulii fefthien bondert vier-en-twpintich.

I. MagNVs $V^{\mathrm{t}}$.

Ter Ordonnantie van de felve

I. van Goch. 



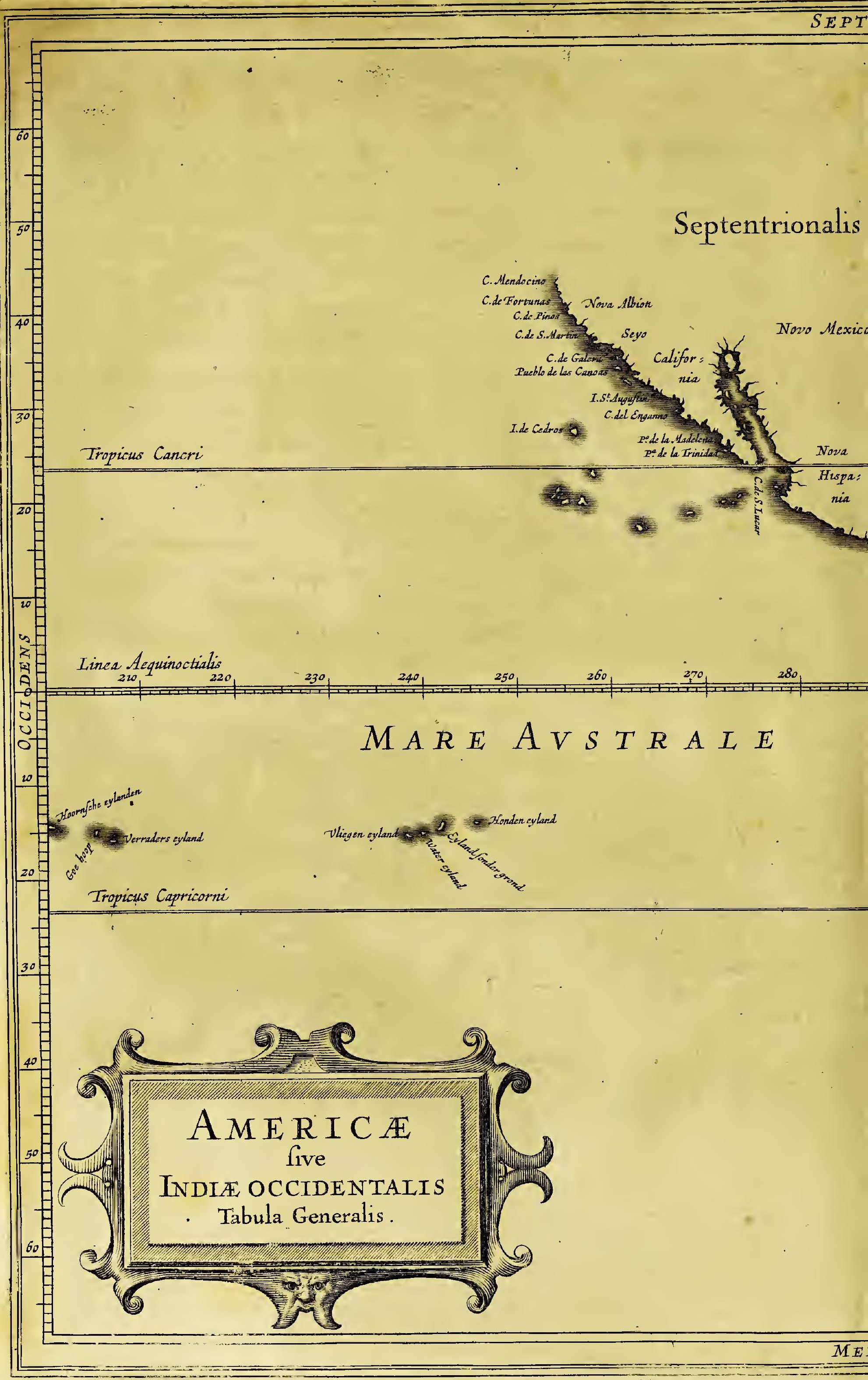





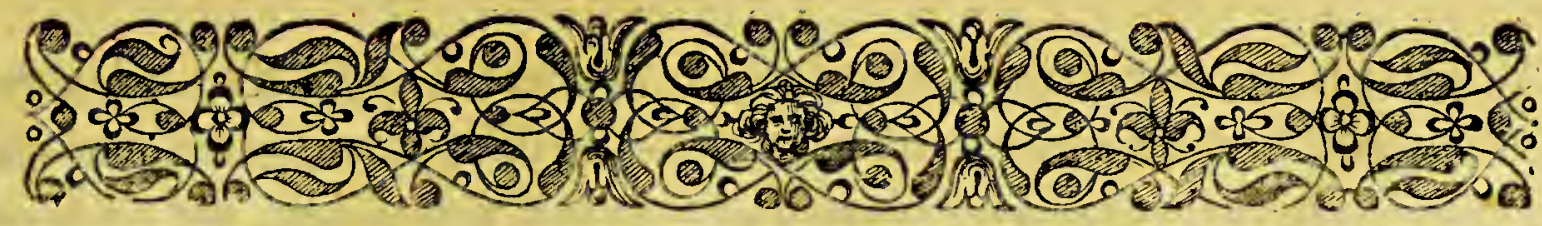

$$
\begin{aligned}
& \text { Voor-reden ende Inleydinghe tot de } \\
& \text { volghende Befchrijvinghe. }
\end{aligned}
$$

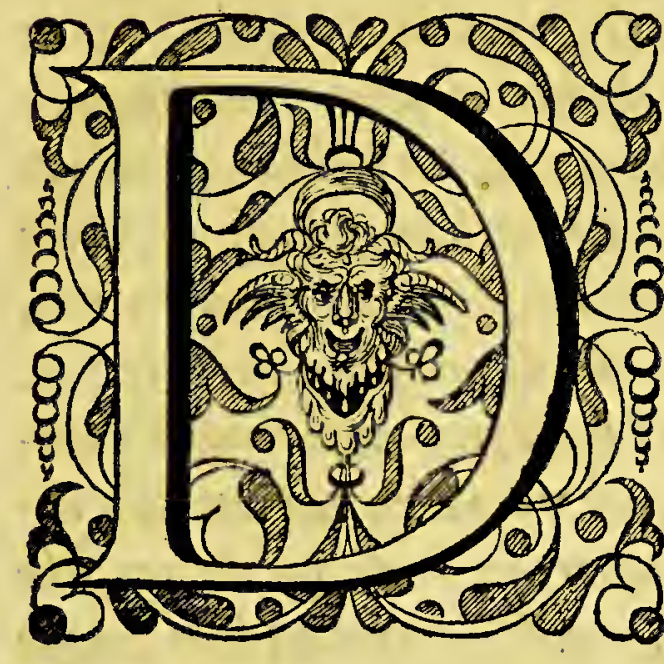

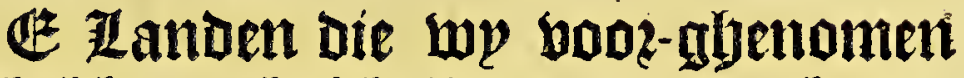
hebben te bertherijen / wozben by be $=$ le America, ente ban bele Welt-Indien, ende van andere oock anders ghe $=$ naemt:mijn mevninge en is niet vele wookden te maken over den naem/te weten/ oft die recht glbegewen is ofte niet; mo fal ghenoegh welen/ dat de Jefer vetifaet / dat nuin voozmemen is tefebzijuen van dat vietoe gedeelte bes weteldts / welek wo hier booz in thlepne hebben afgbes

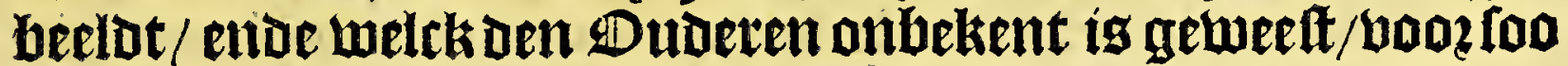
wele by haer felyziften is blijekenoe/ (boewel ick niet en ontken=

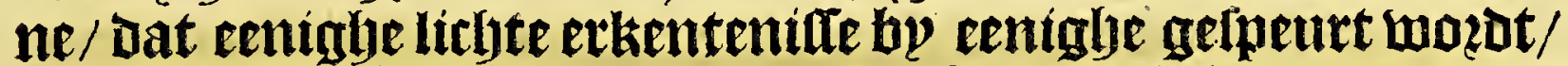
als't telue te fien is by lofephus de Acofta, die defe farcke verban= oelt in Ipn Hiftorie Naturael ende Morael van Weft-Indien :) endoe fints Den fate veerthien hondert twee-en-theglyenticly dooz Don Chriftopher Colon ofte Columbus eetft is begonnen te on= Decken:lyoewel Americus Vefpucius Die eenigen tijot daernaer is gekomen/ De eete heeft/ Dat defe Zanden bele nate ivnen naem wozben ghenoemt. Den lkoningly van Spaegnien / ofte om epglyentlifelier te fpzertken / van Caftilien ende Leon, will beb=

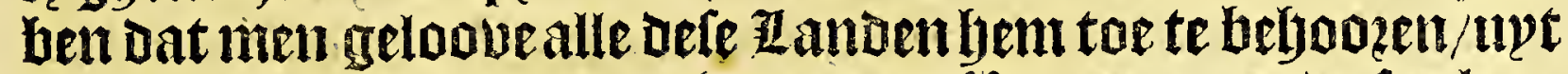
kracht van ern gifte des 1 aus van 1hoomen/ ende feeckete vetoetinghe enoe afpalingle daet op ghebolght tuffelyen lyem ende den lionumgh van Porrugal: Dooz midoel vall weleke bet= deelinghe ae litoone van Portugal aen fích trectit bet gantíclye

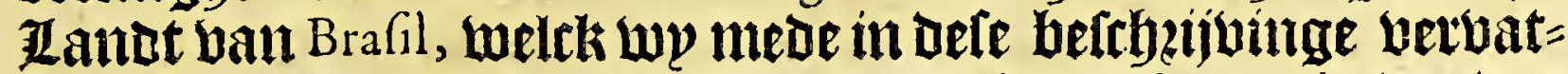

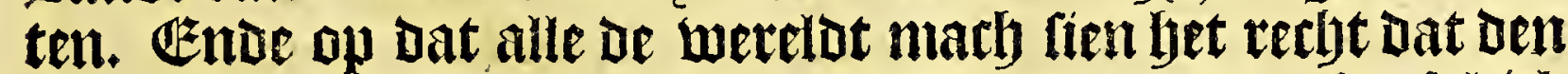
lkoningly van Spaegnien in Defen fich toe-eygent / foo fal iak bier vam woozde tot woozde in-voeglen de aetl-maeninge die be eerite ontoeckers yan dere zanoen / upt den name yan den Honingl aen be in-gljeboozne enibe befitters van die sanoen plachten te unen; aelijek den liftozie-frlyzijuer Anconio de Herrera Daet van een booz-felyzift fteldet in fin eerfte Decade in' $t \mathfrak{k}$ bende yoeck aen' t verethiende Capittel / lupdende aldus: 
Fck N.N. dienaer roan de alderhooghfte ende machtighfte Koninghen van Caftilla ende Leon, overvvinners van de Barbarifche nacien, baren Ambaffadeur ende Capiteyn, gheve us te kennen naer mïn beft vermoghen, dat Godt onfen Heere, een ende ceuvvigh, Schiep den Hemel ende Aerde, ende een Man ende een Vrouvve, van vvelcke gby ende voy, ende alle men fchen voort-ghebracht zïn, ende alle naer ons nocb roort-komen fullen: docb door de menighte van de generatien die vàn de Jelve gheproten zün, fints vüf duyfent ende meer jaren berpvaerts dat de vvereldt ghe fchapen is ghevoeeft, voas bet noodigh, dat de eene menfchen in d'een, ende d'ander in d'ander ghedeelte fouden vooonen, ende verdeeldt vvorden in vele R̈̈cken ende Provincien, om dat $f y$ baer alle in een ghervefte niet en konden onderbouden. Van alle defe rolckeren beeft de Heere onfe Godt de forghe ende last ghegheven aen eenen die ghenaemt voas Petrus, op dat by Heer ende Overfte foude vvefen van alle de menfchen des vverelts, dat fe alle bem fouden gheboorfamen, ende dat by't booft foude ziyn van't gantfche menfchelïck ghejlacht, voaer dat de felve oock vooonden ofte leefden, ende van Dvat Dvet, gheloof, of ie fecte fy oock vvaren: ende gaf de gant fche voereldt tot $\int y$ nen dienfte ende onder Jyn ghebiedt: ende boevvel by bem belafte fyn Stoel te fetten te Roomen, als vvefende de gheleghenfte plaet fe om de gantfche voereldt te regieren; joo liet by bem nuet te min rory in eenigh ander ghedeelte des pvereldts de felve te fetten ende te houden; om te oordeelen ende te bedoving hen alle volckeren, Chriftenen, Mooren, Ioden, Heydenen, endevan vvat fecte ofte gheloof $f y$ mocbien vvefen. Defe noemdemen Papa, vielckis te feg ghen vvonderbaerliycke Overfte, Vader ende befchermer, door dien by is een $V$ ader ende Gouverneur rvan alle menfchen. Defen beylighen Vader gheboorfaemden, ende namen voor haren Heere, Koringh ende Overfte van de gantfche vvijde vvereldt, alle de ghene die in dient tijdt leefáen; van ghelÿcke beefimen oock gbebouden alle de andere die vervolghens verkoren zijin tot de Paufelïcke vveerdigheyt; ende't felve is foo vervolght tot op beden, ende fal foo vervolght voorden tot het eynde des voereldts. Een van defe Hooge-priefters voorfeydt, als Heere van de vverelt, fchonck defe Eylanden ende vafte Landen in ende aen de Zee Oceanus gheleghen, aen de Catbolïcke Koninghen van Caltilla', vpelck doen vparen Don Ferdinando ende Donna Y Yabel, boogb-loffelücker ghedachtenis, ende aen bare erfghenamen onfe Heeren, met alles vvat daer in is; ghelijck't felve begrepen is in feeckere fchriften daer van gemaeckt, vvelck ghy meught fien foo ghy vvildt: Soo dat fyn $\mathrm{M}^{\mathrm{t}}$ is Koningh ende Heer van defe Eylanden ende riafte Landen uyt kracht van de voor/chreDen gifte; Ende eenighe Eylanden, ende by naer alle die dit is te kennen ghegheven, hebben reede fyn $\mathrm{M}^{\mathrm{c}}$ over fulcx voor Koningh ende Heere aen-ghenomen, bem gheboor faemt ende gedient, ende dienen bem noch als onderdanen fchuldigh zïn, ende dat met ghemoede, ende fonder eenighen teghenftandt; daer naer fonder uyt-ftel, mede onderricht zïnde als van't voorgaende, gheboorfaemden $f y$ mede de Religieufe mannen, die by baer toe-fondt, om ons beylighe Gbeloove door ben.

te per- 
ce verftaen, ende daer in ondervvefen te vvorden; ende alle die uyt baren vï̈en voille ende onbed voongen forder giften ofe ander be/preck doen Chrifenen vierden ende noch blÿpen, onefing b fyn Majeltey b blydelijck ende mildelïck, ende gheboodt dat menfe foude bandelen als fyn andere onder danen ende vafallen: ende ghy-lieden züt ghebouden mede alfoo te doen. Derbalven joo bidde ende perfoecke ick w 100 vecle my moghelijcken is, dai gby voilt aen-mercken't ghene ick ghefeyt bebbe, ende dat ghy, om 't felve beter te ruerfaen, enaie waer op te beraden, neemt feeckeren tïdt, als billyick is, ende dat gby erkent de beylighe Kercke voor Vrowove ende Overfte ruan de gantfche vpereldt, ende den opperften Priefter genaemt $\mathrm{Papa}$, in haren naem, ende fyn Majefteyt in fyn plaetfe als opperfte Heer ende Koning b van de Eylanden ende vafte landen, wyt kracht van de voorfz. gifte:ende dat ghy toe-laet daí de ee Religienfe Vaders bet boven-perbaelde u verkondighen. Soo ghy foo doct, fult ghy vvel doen, en't ghene ghy aen fyn Majeftey $\mathrm{t}$ Chuldigh zijt: ende ick in fynen name fal w aen-vaerden in aller liefde, ende fal u laten wove vrouvven ende kinderen ury fonder lavernije, op dat gby daer mede vryelïck doet voat u ghelieft ende goedt vindt, ghelïck ghedaen bobben de in-pvoonders van meeft alle d'ander Eylanden : ende boven defen foo fal fyn Majelteyt u gheven vele rorjheden ende groote belooninghen. Maer indien gby bet niet en doet, ende ter quader trow voen uyt-fel. foeckt, foo laet icku Dveten, dat ick door de bulpe Godts met macht teghen a fal in-trecken, ende uoorlogbe aen doen van allen kanten naer dat ick beft fal konnen, ende Jal u brenghern onder bet jock ende gheboorfaembeyt wan de Kercke ende fyn Majelteyt, ende fal uvve voüpen endé kinderen voegh nemen ende tot laven maecken, verkoopen, ende voorder daer mede baindelen als fyne Majefteyt fal ghebieden; Ick fal upve goederen benemen, ende alle quaedi ende fchade doen, die ick kan, als aen vajallen die niet en vvillen gheboorfaemen, of te aen-nemen baren Heere, maer bem voeder preken ende teghen-ftaen. Ende protefteere, dat de doodt-jlaghen ende fchade daer uyt te volghen, door wove eyghen fchuldt ontfaen, ende niet door fyn MajeAtey ofte my ende defe Cavalleros die mei my züngekomen. Ende ick begeere dat by den teghenvooordighen. Notaris deier van ghefeghelde ghetwyghenis my. Sal

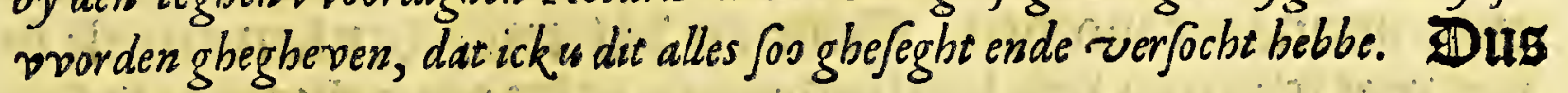
vetre Herrera.

adpt weleke infinuatie ende pzoteftatie nien kan fien yet on= ahetwifelt (foo fy het noemen) recht van oen koningh ban

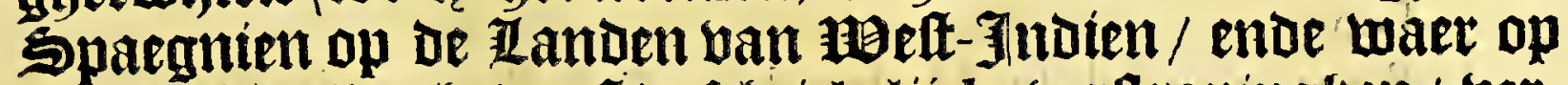

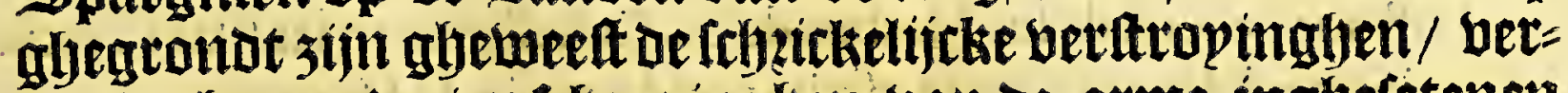
nelinghen ende bettlyeuringljen van be atme inghetetenen ban die lanoen / in-neminghe ban bare platen / beroobinglje ban alle bate goedecen/ende tor-epglyentnghe ban alles' tgene daerin die landen wozot gljebanden; Doch laet ons weder-kee= ten tot ons booziglje legglien. 
3ck hebbe bopz-ghenomen dac vietde ende nieum ontdeckte

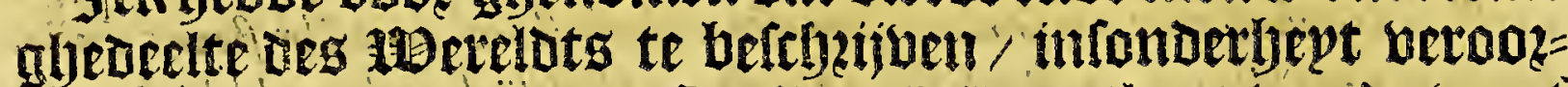
faeckt zintoe doo de aenftaende glyelegentlyept ban oe vaett

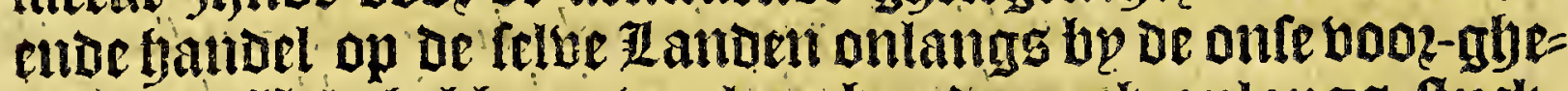
ioment acle beblen over langl enoe noty onlangs fturk= wijs lyaren arbevde ende wetenfryap daer in befterot; entigbe Doo glyefichte choe eyglen erwarenthepe daet vanonder-ticlyt; andere upt hooen fegahen ende aen-lepdinghe ban de geene tie dere zanden ghefien ende dooz-wandelt bebben: Dan ghes= lijek de ecrie neeritiger ende aendachter is ont aen te mercken

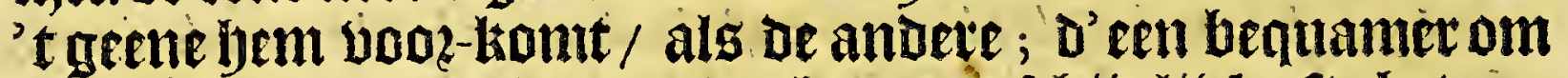

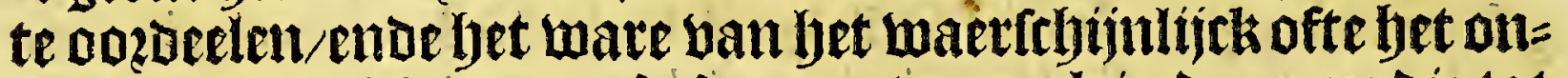
waer te onderfelyepden / fo fpenten we oock in de geene die tot noch toe de befryzijuinghe van defe landen baet bebben onder: wonoen / een geoote berfebeyoentlyept / ende in commighe oock groote nis-haghen : onte gloenegentbevt is om't ghe mepn ende de grene Die hiet aen-gheleghen is / wal te onder rithten / Doo? onderlinghe berghelijckinglye van alles't geene ban defe lanoen tot norb toe is berclyeden ende tot onfe lyan= den gljeksonen / Des weghen wy in deren tweeden Datuck reede ontallijcke fauten yebben verbetert; ende feer beel op nieums inglewoeght/entde op 't laette noth be ghevoeglyt 't geene ons

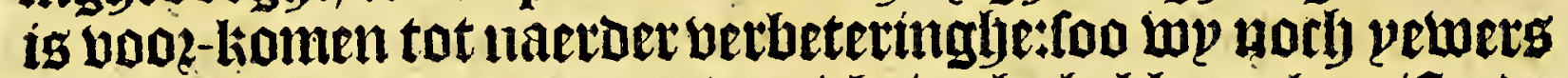
oooz glyebeck van goede ondertichtinghe hebben ghemift / de faute en belyoott niet ons / maer de Srljeijuers die wy gevolgt bebben \% toe-gertlyetuen te wozden: fo wo ons oork uergripen

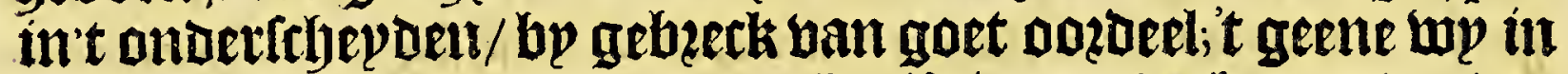
ander berozagen lonoer frljerpe berifpinge / bethopen wp dat in ous mede ten beften fal ghedupdt wozden: aan de geene oie bet berbeteren konnen/willen wy altijots gaetne glyeleert ende vermaent wozden. Eende op dat een peder kennelijtk fp upt wat rehziften Defe bercheijuinghe is by een gebzacht/ fo ful= leit wy lyer in voeghen een regifter van de 2 becken die wy vooznanentlijcken liebben glievolght.

Parte primera de la Chronica del Peru: Hecha por Pedro de Cieça de Leon.

Hiftoria general de los Hechos de los Caftellanos en las Inas i Tierra Firme del mar Oceano, efcrita por Antonio de Herrera.

Defcripcion de las Indias Occidentales de Antonic de Herrera.

Hiftoria del defcubriemento y conquilta de la Provincia del Peru \&x. Auguftin de Zarate.

Diego Fernandes Hiftoria del Peru.

Hifto- 
Hiftoria natural y moral de las Indias por el Padre Iofeph de Acofta.

Relacam Annal das coufas que fezeram os Padres da companhia de Iefus nas partes da India Oriental \& no Brafil, \& cc.

Conquefta de las Moluccas por Leonardo de Argenfola.

Argentina por Martin del Barco.

Araucana de Don Alonfo de Ercilla y Cuniga.

Delle navigationi \& viaggi racolte da $\mathrm{M}$. Gio Battifa Ramufio volume terzo, nel quale fi contiene le Navigationi al mundo nuovo, \&c.

Iarrici Thefaurus rerum Indicarum.

Defcriptionis Ptolomaicx augmentum Cornelii Wijtflict.

Decades Occanicx Petri Martyris.

La Hiftoria de las Indias, par Francifo Lopez de Gomara Clerigo.

Popilliniere de trois mondes.

Thever France Antarticque.

Hiftoire de Brafil par Iean Lery.

Les Voyages du Sieur Champlain.

Hiftoire de la Novelle France parMarc. Lefcarboe.

Hiftoire de la miffion de Peres Capuchins en l'the de Maragnan \& terres circonvoifines par le R. P. Claude d'Abbeville.

Traicté de la Navigation \& des Voyages de decouverte \& conquefte modernes, \& principalement des Francois. Paris. 1629 .

The Third volume of the voyages, Navigations and difcoveries of the Englifch Nation, \&cc collected by Richard Hackluydt.

Purchas pelgrimage or Relations of the World, by Samuel Purchas.

A map of Virginia with à defcription of the countrey by Capiteyn Smith.

A defcription of New Engeland by Cap. Iohn Smith.

A briefe Relation of the difcouerye and plantation of New England.

New Englandts trial by Cap. Iohn Smith.

A Relation or Iournall of the beginning and proceedings of the English plantation fetled at Plimouth in New England.

A difcours and difcouery of New-found-land, written by Captain Richard. Whitbourne of Exmouth, \&cc.

A Relation of à Voyagie to Guiana, performed by Robert Harcourt. A map of the Sommer Eylands, once kalled the Bermudas.

A Letter fent in to England from the Summer Ilands.

Ian Huyghen van Linfchoten Befchrijvinghe van America; \&cc.

Iournael van de voyagie naer Rio de la Plata, ghedaen met het Schip de Silveren VVerelt, onder ' $t$ Admiraelfchap van Laurens Bicker,\&c.

Hiftorifch verhael van de voyagie naer de Strate van Magallanes, onder den Admirael Mahu, \&c. door Barent Ianfz. Chirurgijn.

$$
\text { के } 3 \text { Voyagie }
$$


Voyagie van Olivier van Noordt.

Voyagie van Ioris van Spilberghen door de Strate.

Iournael van de wonderlijcke reyfe ghedaen door Willem Cornelifz.

Schouten van Hoorn, Anno i6rg.1616. \&c.

Toortfe der Zee-vaerdt door Dirck Ruyters.

Ende cyndelijck verfcheyden Iournalen ende aenteeckeninghen van de Schippers, Commifen, ende Stier-lieden die defe Landen onlangs hebben bevaren door lalt van dẹ Geoctroyeerde VVeftIndifche Compagnie.

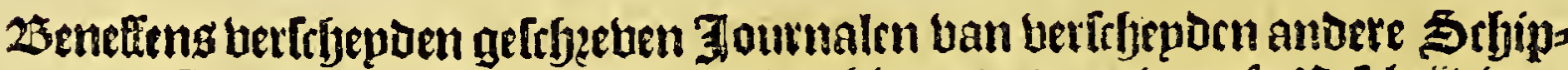
perg ende Stier-lieden/ welclier namen wo bier ende daet in onfe 25 stcbejuinge bebben upt-gbeozuclit.

Boots am met gaede azoze boozts te baren in't boo -ghenomen twetch / foo

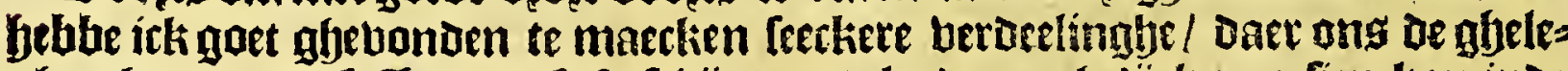
ghentbept van dele Zanoen [elfs fchönt toe te lepoen ; glyeligckmen fien kan inde

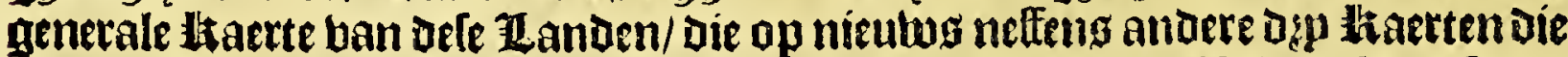

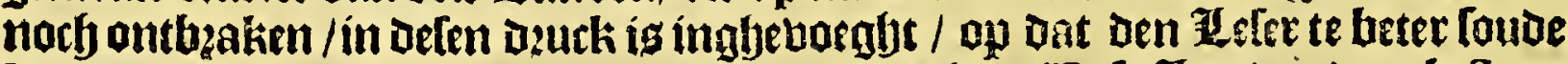

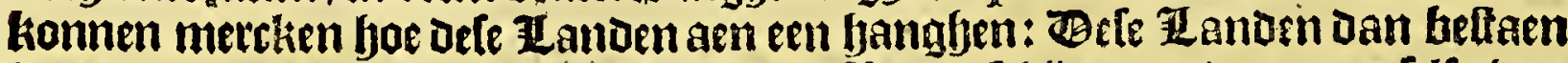

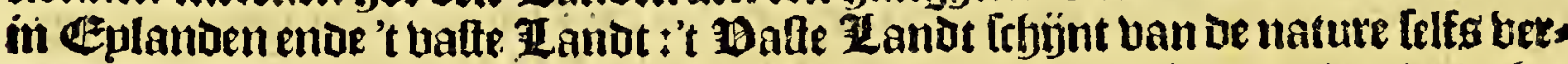
deelt te weren ín twee deelen/waer ban bet eene ftreckt naer bet noozwen/ende Jet

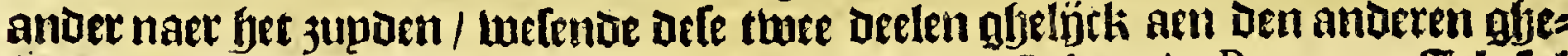

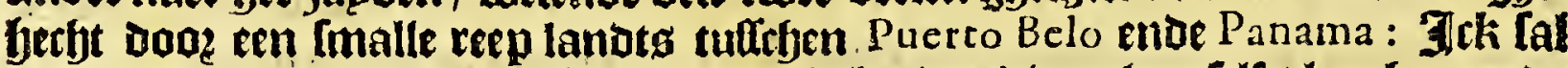

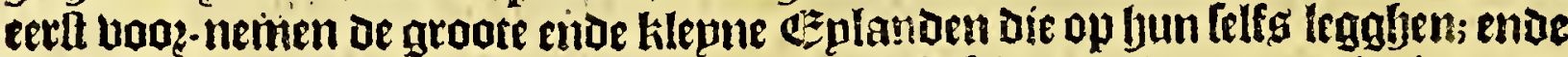

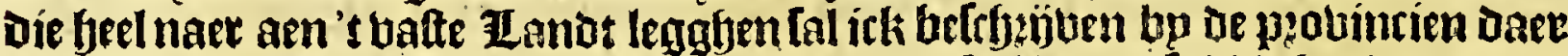

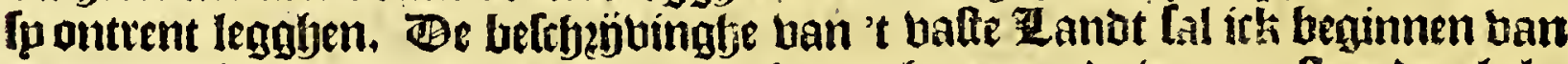

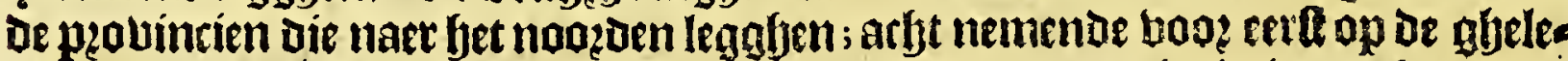
ghenthept ende gfeitalte ban elcke groote ofte kleptre piobincie in 't glemepn/ Daer naer op oe fteden ende twoon-plaetten die daet bejentoneglys in bebonden

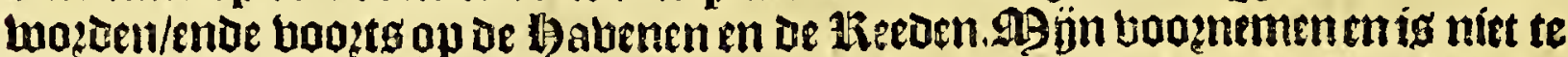

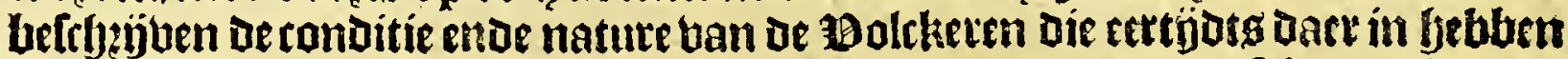

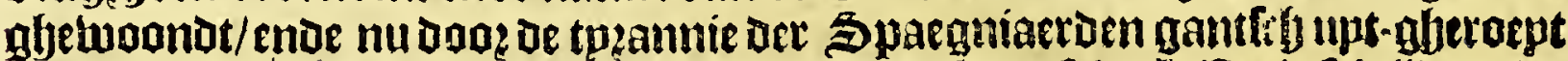

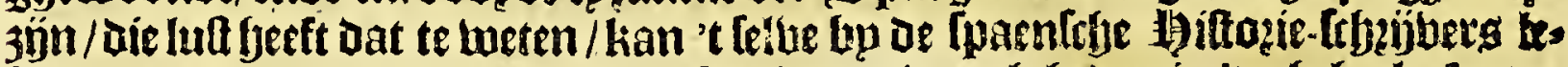

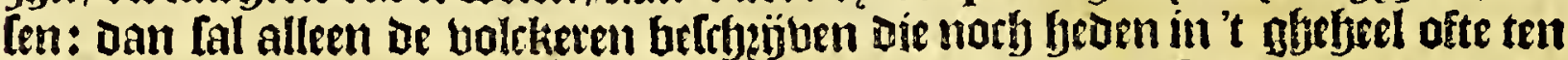
beele ouerigh 3ïn. Eenoe op dat een peoer in't hozt marb fien 't gbeene in oefe

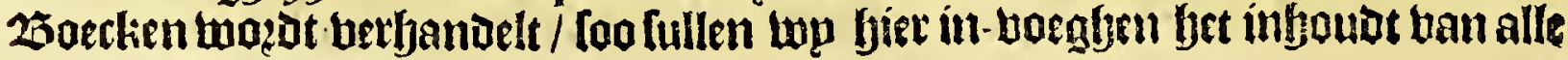
de 25aecken ende Capitte!en.

Het eerfe Boeck. Van de Weft-Indirche Eylanden.

Cap. I. WAn't eylandt S'Iuan de Puerto Rico in't ghemeyn.

2. Van de fteden ende woon-plaetien eertijdes ende nu by de Spaegniaerden in dit eylande be woondt.

3. Van de havenen ende andere ghelegentheden van dit eylandt; endevan Mona.

4. Van de ghelegentheyt van's eylandr Hifpaniola in 'r ghemeyn.

5. Van de provincien van dit eylandr.

6. Van de fteden der Spaegniaerden die eertijdts in dit eylandr waren.

7. Van de fteden der Spaegniaerden die nuzijn in't eylandt S' Domingo. 
8. Van de andere fteden defes eylandes.

9. Van de rievieren van dit eylandt.

10. Van de kufte, havenen, reeden endekapen van dit eylandt.

ir. Van de kleyne eylandekens die rondtom Hifpaniola legghen.

12. Van de ghelegentheye van't eylandt Cuba in't ghemeyn.

13. Van de verfcheyden provincien ende tievieren van Cuba.

14. Van de fteden van'teylandt Cuba'.

I5. Van de Havana.

16. Van de kufte, havenen ende punten van Cuba.

17. Naerder aen-teyckeninge van de noordt-kufte van Cuba ende de kleyne eylandekens legghende rondrom.

18. Befchrijvinghe van 't eylandt Iamaica.

19. Van de eylanden die men nu ghemeynlijck noemt Lucaios.

20. Van de eylanden die men noemt Canibales.

2I. Van de refteerende eylanden diefe noemen Canibales.

22. Vande Bermudez eylanden.

23. Van de colonien van de Engelfchen op de Bermudez, ende voordere byfondere ghelegentheden van de eylandekens ende kufte.

24. Voorder verhael van de ghelegentheye van de Bermudez.

\section{Het trveede Boeck. Van Nova Francia.}

Cap. I. $C$ Enerale befchrijvinghe van Terreneuf, de gheleghentheye van'e eylandr, geftalte van ' $t$ landt ende luchi, ende anders.

2. Van't volck woonende op' $t$ eylandr. Terreneuf, haer gheftalte ende manicren, haer wooninghen ende anders.

3. Van de havenen rievieren, punten ende reeden van dit eylandt.

4. Van de groote banck van Terreneuf, ende voorts van Inle de Sable.

5. Van de gelegentheden van de eylanden van cap Breton, fyn havenen ende reeden,ende manieren van 't volck dat daer op woont.

6. Van de kleyne eylanden by 't eylandt cap Breton gheleghen, ende infonderheye van't eylandt Ramea, ende de Wal-ruffen die men daer vanght.

7. Van't vafte landt by noorden Terreneuf, ftreckende naer de rieviere van Canada, ende weft-kufte van Terreneuf, ende de aen-legghende eylanden.

s. Voorder befchrijvinghe van de kufte aen de noordt-zijde van de Golfe St Laurens, ende de ghelegentheden daer ontrent.

9. Pertinente befchrijvinghe van de kufte rontom een geet deel van de Golfo Sant Laurens by Iean Alfonfe.

10. Van 'r eylande Natifcorec ofte Affumtion, ende de rievier Chichedec.

Ir. Befchrijvinghe van de haven van $T$ adouffac, ende de rievier Saguenay.

12. Particuliere belchrijvinghe van het ghedeelte van de rieviere van Canada tor het punt van Quebecq toe.

13. Voorder befchrijvinghe van de rievier Canada, ende van Hochelaga uye detweede voyagie van laques $Q$ uartier.

I4. Befchrijvinge van $Q u e b e c q, e n d e$ voorder ontdeckinghe van de groote rievier van Canada by $\mathrm{M}^{x}$ Champlain.

1j. Van de ghedaente ende manieren van leven van de Wilden in dit quartier.

16. Befchrijvinghe van de zuydr-kufte van Nova Franciä, ende eerft van Campreau, endeandere havenen tot cap de Sable toe.

17. Veorder befchrijvinghe van de kufte van Accadie tot Port Real toe.

$* 4 \quad$ I $8 . \mathrm{Be}$ -


18. Befchrijvinghe van de placten, havenen ende rievieren, gheleghen in de groote baye Françoyfe tot de rieviere Pem togouet toe.

19. Van de rieviere Pemtogouer, vvelck fchijnt te wefen Norumbega.

20. Vervolgh van de kufte van Norumbegue, ende befchrijvinghe van de rieviere Quinibeque, uyt $\mathrm{M}^{\mathrm{r}}$ Champlain.

21. Vervolgh van de kufte van Quinibeque weft-waerts, ende van de rieviere Chovacoet; de gheftalte van de Wilden die men'noeme Almouchiquois.

22. Vervolgh van dekufte naer'tzuyden toe; van de haven Beauport ende Cap Sant Louis ende andere plaetfen; uyt $\mathrm{M}^{\mathrm{r}}$ Champlain.

23. Een kort verhael van de procedueren der Françoyfen in dit quartier van den jare 1534 . tot 1544 .

24. Voordere procedueren van de Françoyfen in verfcheyden andere quartieren van Nova Francia, ende infonderheyt te Sante Croix en Pors Royal.

25. Procedueren van de Françoyfen op de rieviere Canada. Appendix. Van Nieuw Schotlandr.

\section{Het derdeBoeck. Van Virginia.}

Cap. r. D E voyagie van Iehan de Verazzano.

2. De gelegentheyt van het decl dat de Engelfche nu noemen Nieuw Engelandt, by Capiteyn Smith befchreven.

3. Particuliere befchrijvinghe van't felve quartier.

4. Verhael van'tghene eenighe jaren herwaerts by de Enghelfche is voorghenomen in 't felve quartier.

5. Geleghertheyt van Nieu w Engelandt, als het nu wordt ghenomen, uyt het rela es van die Compagnie.

6. Befchrijvinghe van Nieu w Pleytmouth in Nieuw Engelandt geleghen.

7. Eerfte ontdeckinghe ende generale befchrijvinghe van 't quartier, welck by de onfe Nieu Nederlandt wordt ghenaent.

8. Geleghentheydr van de Cufte yan Nieu Nederlande van de Pyebaye af tot aen de groote rieviere de Montaignes.

9. Van de groote Noordt rievier van Nieu Nederlandt.

10. Van de gheftalte van 't landt ende manieren van' $x$ volck aen de rievier.

1i. Voordere befchrijvinghe van de kufte tot de andere groote Rievier,ende van daer vorder tot op de acht-en. dertich graden; ende'tgene by de vrye Nederlanders daer is verricht.

12. De gheleghentheyt van Virginia daer de Engelfche nu woonen, befchreven door Capiteyn Iohn Smith.

13. Befchrijvinghe van de byfondere rievieren ende volckeren van't landt van Virginia daer de Engelfchen nu woonen.

14. Van de eyghen vruchten van Virginia die daer van felfs waffen.

I5. Befchrijvinghe van debyfondere vruchten die by de VVilden ghevvonnen vvorden; hoe fy die planten ende ghebruycken.

16. Befchrijvinge van de dieren die men in dit quarcier van Virginia vindt.

17. Van't volck van de lande, haer manieren, kleedinghe, vvooninge, \&c.

18. Van de procedueren van de Engelfche fints den jare 1606.

19. Byfondere ontdeckinghe van de baye Chefapeack by Capiteyn Smith.

20. Kort verhael van de voordere procedueren fines den jare 1608 .

23. Voorderverhael van de procedueren tot den jare I621.

22. Befchrijvinge van Virginia door Sir Walther Ralegh eerft ontdect inden iare 1584 . ende de vervolgende: vruchten ende dieren van't landt. 
23. Van de dinghen die daer te lande ghevonden worden, daer men eenighen handel kan mede drijven: ende de manieren van's volck.

24. Verhael van de procedueren in dit quartier tor den jare 1586.

25. Voorder procedueren van de Engelfche tot den jare 1590.

\section{Het vierde Boeck. Van Florida.}

Cap. 1. F Erfte ontdeckinghe van Florida.

2. ETweede ontdeckinghe van de landen van Florida by de Spaegniaerden.

3. Derde ontdeckinghe by de Spaegniaerden in den jare 1528 .

4. Vierde ontdeckinghe van't lande van Florida, onder't beleyt van Hernando de Soto in den jare i 539.

5. Vervolgh van de vierde ontdeckinghe.

6. Voorder verhael van de vierde ontdeckinghe by Soto.

7. Vervolgh van de felve reyle by Hernando de Soto.

8. Vervolgh van den felven tocht näer de doodt van Soto.

9. Deontdeckinghe van Florida by de Françoyfen voor-ghenomen, onder het beleyt van lean Ribault.

10. Detweede voyagie van de Françoyfen naer Florida, onder het beleyde van Capiteyn Laudoniere.

11. De derde voyagie van deFrançoyfen naer Florida, onder CapiteynRibauldt.

12. De vierde voyagie onder het beleyde van Dominico Gourgues.

33. Delimiten van Florida, als Herrera die befchrijft.

14. De natuere van 't landt; de geftalte ende manieren van ' $t$ volck ghelijck die by Laurdoniere befchreven worden.

15. De regieringh ende politie van defe Indianen van Florida.

16. Befchrijvinghe van de twee fterckten die de Spaegniaerden teghenwoor. digh hebben in Florida.

17. Befchrijvinghe van de kufte van Florida.

18. Andere befchrijvinghe van de felve kufte, uyt lan Huyghen van Linfchoten.

\section{Het:rijfde Boeck. Van Nova Hifpania.}

Cap.r. $\mathrm{B}^{\text {Efchrijvinghe van de provincie van Nova Hifpania in'rghemeyn; de }}$ gheleghentheyde van de'verfcheyden landen ende volckeren.

2. Befchrijvinghe van de boomen, kruyden ende ghewaffen van Nova Hifpania:

3. Van verfcheyden herfen ende gummen die in Nova Hifpania vallen, ende verdeclinghe van defe provincie.

4. Befchrijvinghe van de provincie van Mexico in't byfonder, de verfcheyden landen ende volckeren daer onder begrepen.

5. Van de groote ftadt Mexico, Hooft. ftadt van Nova Hifpania.

6. Van de andere plaetfen ontrent Mexico gheleghen.

7. Befchrijvinghe van Acapulco de haven van Mexico aen de zuydt.zee.

8. De ghelegentheden van de provincie van Panuco, ende de fteden in 't felve quartier gheleghen.

9. Van de manieren van de Mexicanen, hare taele ende regeringhe.

10. De ghelegentheyt vande provincie van Tlafcala in's ghemeyn.

11. Van ' $t$ Bifdom van Tlafcala, ende de ftadt daer in gheleghen, ghenaeme Puebla de los Angeles, ende de woon-ttede der Indianen.

22. Van de ftadt Segura, ende de gheleghentheden van de provincie Tepeaca.

13. Van 
13. Van de ftade Vera Cruz, ende de voornaemfte haven van Nova Hifpania, St luan de Vlua.

14. Befchrijvinghe van de kufte van' $t$ Bifdom van Tlafcala aẹn de noordt-zee, met de Eylanden daer onder gheleghen.

15. Particuliere befchrij vinghe'van ' $t$ Bifdom van Guaxaca.

16. Byfondere befchrijvinghe van de provincie van Mifteca ende andere provincien daer aen gheleghen, behoorende tor Guaxaca.

17. Defteden der Spaegniaerden in de provincie Guaxaca.

18. Befchrijvinghe van de kufte ende havenen van Guaxaca.

19. Befehrijvinghe van de provincie Mechoacan in't ghemeyn.

20. Van de particuliere provincien begrepen onder dit Bifdom van Mechoacan, ende van de Chichimecas.

21. Defteden by de Spaegniaerden bewoont in defe provincie.

22. De havenen ende kutte van defe provincie aen de zuydt-zee; ende noch eenighe fteden ende vlecken.

23. Van de provincie van Yucatan in' $t$ ghemeyn.

24. Van de particuliere provincien die onder Yucatan worden ghereeckent, ende by wie defe landen eerft zijn ontdeckt.

25. De Ateden by de Spaegniaerden be woont in Yucatan.

26. De kufte ende havenen van defe provincie.

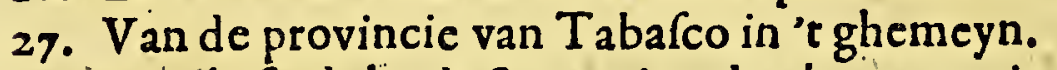

28. Van de ftadt by de Spaegniaerden be woont in defe provincie, rieviere ende zee-kulte van Tabafco.

\section{Het fefte Boeck. Van Nova Galicia ofte Guadalaiara.}

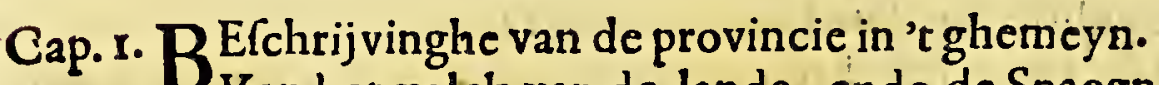

2. Dan het volck van de lande, ende de Spaegniaerden die daer woorien.

3. Van de provincie van Guadalaiara in 't particulier, ende de fteden die in dit deel by de Spaegniaerden worden bewoont.

4. Byfondere befchrijvinghe van de provincie van $X_{a l i f c o}$ ende deftade daer in gheleghen, als mede van de provincie van Chiametla.

5. Particuliere befchrijvinge van de provincie van Culuacan, ende haer eerfte ontdeckinghe by Nun no de Guzman.

6. Van de provincie van Cinaloa, ende haer eerfe ontdeckinghe.

7. Van de provincie Vxitipa, ende haer gheleghentheyt.

8. Particuliere befchrijvinghe van de provincie van de Zacatecas, ende verfcheyden filver-mijnen daer in gheleghen.

9. Particuliere befchrijvinghe van Nova Vizcaia, ende byfondere filver-mijnen daer in gheleghen.

10. Befchrijvinghe van de landen van California, ende haer eerfte onedeckinghe by de fchepen van Don Hernando Cortes, ende andere.

11. De voyagie van Francifco de Ulloa.

12. Vervolgh van de voyagie voornoemt.

13. De reyfe by lande van Fray Marcos de Niza.

14. Verhael van de reyfe by lande van Francifco Vafquez de Cornado, uyt bevel van 'den Vice-Roy Don Antonio de Mendoça.

15. Oprechte befchrijvinghe van Cibola, Tonteac, Marata, Acus, ghelijck de felve is vervoordert by Cornado voornoemt.

16. De voyagie van Hernando Alarcon by zee.

17. Een ànder voyagie roor den Vice-Roy op de kufte van Nova Galicia ende California.

18. Extract 
18. Extract uyt de voyagie van Francifco Gualle van Nova Hifpania naer de Philippinas, ende China, \&c.

19. Extract uyt de voyagie van Thomas Candish, voor foo veel fy de kufte van Nova Hifpania ende California is betreffende.

20. Befchrijvinghe van Nova Albion uyt de voyagie van Sir Francis Draeck door de ftrate van Magallanes.

21. De eerfte ontdeckinge van de landen van Novo Mexico, inden jare is 83. voor-ghenomen.

22. Vervolgh van de felve ontdeckinghe by Antonio de Efpeio:

23. Voorder verhael van de ghelegentheyt van defe Provincien van Neuvo Mexico, ende't ghene de SSpaegniacrden daer faghen.

24. Vervolgh van'telve verhael van Nieu Mexico.

25. Verhael van den toche van Don Iuan de Onate naer Novo Mexico inden jare 1599.

26. Befchrijvinghe van de kufte van Nova Galicia op de zuy dt.zee.

\section{Flet fevende Boeck. Uan Guatemala.}

Cap.r. $\mathrm{B}$ Efchrijvinghe van de audientie van Guatemala in 't ghemeyn.

2. Befchrijvinghe van de provincie van Chiapa in ' $t$ ghemeyn.

3. Voorderbefchrijvinge van Chiapa in't particulier, ende de ftadt Cuidad Real daer in gheleghen.

4. Van de provincie van Soconufco ende Súchitepec.

5. Particuliere befchrijvinghe van de provincie Verapaz, ende de woonplaeifen der Spaegniaerden daer in gheleghen.

6. Voorder belchrijvinghe van Verapaz ende van Golfo Dulce.

7. Byfondere befchrij vinghe van de provincie die eyghenclijck Guatemala wordt ghenaemt, ende hare eyghenfchappen.

8. Particuliere befchrijvinghe van de provincie van Yzalcos.

9. Van de provincien San Salvador, San Miguel ende Chuluteca, ende hare byfondere ghelegentheden.

10. Befchrijvinghe van de Atade S. Iago de Guatemala.

II. Vạn de anderc fteden van defe provincien, San Salvador, la Trinidad, San Miguel, ende Xerez de la Frontera.

13. Havenen ende kufte aen de zuydr-zeevan Guatemala.

13. Befchrijvinghe van de provincie de Honduras in ' $r$ ghemeyn.

14. Van de ftadt Valladolid in Honduras, Garcias a Dios en San Pedro.

15. Van puerto de Cavallos, Truxillo ende Sant lorge.

16. Kufte, havenen ende eylanden van Honduras.

17. Van de provincie Nicaragua in tighemeyn.

18. Van de fteden van dit gouvernement.

19. Kufte, ende havenen, van de provincie van Nicaragua.

20. Befchrijvinghe van de provincie van Cofta Rica.

21. Van Veragua, haer eertte ontdeckinghe ende ghelegentheyr.

22. Befchrijvinghe van defteden ende vlecken die by de Spaegniaerden nu bewoond worden in de provincie van Veragua.

\section{Het acbtste Boeck. Van:Terra Firma.}

Cap. 1. WAn de gheleghentheyt,palen ende geftaltenis van de provincie ofre 2. Van de ftadt Panama.

3. Pertinente befchrijvinge vande ftadt Pamama ende alle aenkomften, door 
Iuan Battifta Antonelli Ingenieur, ghefonden aen den Koningh van Spaegnien, ghelijck't felve by $\mathrm{M}^{\mathrm{r}}$ Hackluydt is uyt-ghegeven.

4. Van de Stadt Nombre de Dios.

5. Van de gheleghentheyt van Puerto Belo, uyt 't raport van Antonelli.

6. Van de Nieuwe ftadt by Puerto Belo gheleght, ende van de ftadt Nata.

7. Van de Rievieren van defe Provincie.

8. Van de Rieviere Darien, ende de Provincie.

9. Van de fteden die eertijdts zijn gheweeft in de Provincie Darien.

10. Van de kufte, havenen ende punten van de provincie Panama.

II. Van de Eylandekens ontrent defe kufte.

12. Van de voyagie van Ian Oxenham Engelfman.

13. Befchrijvinghe van de provincic van Cartagena in't ghemeyn.

14. Van de ftadt Cartagena.

15. Naerder befchrijvinghe van de ftadt met haer aen-komften, by Antonelli.

16. Van de andere fteden van defe Provincie.

17. Van de Rievieren, havenen ende Punten van defe provincie.

18. Van de gheleghentheyt van de provincie Santa Martha.

19. Van de ftadt Santa Martha.

20. Van deanderefteden ende plaetén van defe provincie.

2I. Van derievieren, kaben, havenen ende kuften van dit gouvernement.

22. Van de ftadt ende't gouvernement van Rio de la Hacha.

\section{Hetneghende Boeck. Uan Neuvo Reyno de Granada.}

Cap. 1. E eerfte ontdékinghe van Neuvo Reyno, onder het beleyt van den Licenciaet Gonzalo Ximenez de Quefada in ' $t$ jaer 1536.

2. Befchrijvinghe van de gheleghentheyt van defe Provincie in ' $t$ ghemeyn, ende de byfondere Provincien daer onder begrepen.

3. Befchrijvinghe van de hooft-ftadt Santa Fé de Bogota, de vlecke Sant Miguel, de ftadt Tocayma, ende gheleghentheyt van de landen daer on. trent.

4. Byfondere befchrijvinghe van de provincien die by de volckeren bewoont vverden die men noemt Mufos ende Colymas, de gheftalte van 't landt, \&c.

5. Gheleghentheyt van deftadt la Trinidad ende la Palma.

6. Befchrijvinge van de refteerende fteden ende plaetfen van Neuvo Reyno de Granada; te weten, Tunia, Pamplona, Sant Chriftoval, Merida, Belez, Marequita, Ybague, la Vittoria; Sant Iuan de los Llanos.

7. Befchrijvinghe van de ghelegentheyt ende gheftaltenis van de provincie van Popaian in't ghemeyn, ende de particuliere provincien daer onder begrepen.

8. Vande Hooft-ftade van defe provincie Popaian:

9. Particuliere befehrijvinghe van den oorfprongh van de groote rievier de Madalena, ende haren loop door verfcheyden landen.

10. Van deftadt Antiochia endeghelegentheden daer ontrent: de wegh van defe ftadt naer Anzerma, ende van de ftadt Caramanta.

11. Vervolgh van de wegh van Antiochia naer Anzerma toe, ende befchrijvinghe van de ftadt Sarita Ana de Anzerma.

12. De wegh van deftadt Antiochia naer Arma toe, de gelegentheyt van de provinicien tuffchen beyden gheleghen zijnde : ende oock van de ftadt Arma.

13. Van de Provincie van Carrapa ende die van Quymbaia, tot de Stadt van Cartago toe, ende van deftadt Cartago. 
14. Befchrijvinghe van de ftadt Cali ende de Landen daer ontrent gheleghen, als mede van de Haven Bonaventura.

19. De wegh van de ftadt Cali naer de ftadt Popaian.

16. De wegh van de ftadt Popaian naer de ftadt Pafto, ende de byfondere gheleghentheyt van dat quartier: ende van de ftadt Paftofelfs.

17. Van de andere fteden onder het Gouvernement van Popaian, ende cerft van de ftadt Timana ende Guadalaiara de Buga.

18. Van de refteerendefteden van defe provincie, Sane Scbaftian de la Plata, Almaguer, Trux́illo, Madrigal ende Agreda.

19. Van de havenen, reeden, punten, rievieren ende Eylanden op de kufe van defe provincie aen de zuydt-zee gheleghen.

\section{Het thrende Boeck. Van Peru.}

Cap. I. Enerale befchrijvinghe van't Koninghrijck van Peru, fyngheftalte ende eyghenfchappen in 't ghemeyn, ende verdeelinghe van dien: als mede de ghemeyne manieren van 't volck.

2. Van eenighe planten ende vruchten, als mede gedierten die defe landen van Peru door-gaens ghelijck eyghen zijn.

3. Verdeelinghe van 't lande van Peru in verfcheyden provincien : ende befchrijvinghe van Quito in het ghemeyn: de gheftalte van de landen, \&cc.

4. De wegh van de ftadt Pafto naer Sant Francifco del Quito toe, ende de ghelegentheyt van de landen tuffchen beyden ghelegen.

5. Befchrijvinghe van de hooft- Atade Sant Francilco del Quito.

6. De wegh van SantFrancifco del $Q$ uito naer Rhiobamba toe, ende de geftalte van de landen ende volckeren tuffchen beyden ghelegen.

7. Van't koftelijck Palleys van Thomebamba; van de Cannaris, de geftalte van haer provincie ende haer manieren.

8. Befchrijvinge vande wegh van de provincie van Quito naer de kufte van de zuydt-zee, ende de ghelegentheyt van de landen daer ontrent gheleghen.

9. Befchrijvinghe van de ftade Puerto Veio, ende de ftadt S. Iago de Guaiquil, ende Caftro, in de provincie van Bunigando.

10. Vervolgh van de Koninghlijcke wegh van Thomebamba af tot de ftadt Loxa toe, ende de gelegentheydt van de Landen daer ontrent, van Loxa ende Cuença.

11. Van de ftade Zamora ende Iaen, ende ghelegentheyt van de landen daer omher gheleghen; ende van Chuquimaio.

12. Befchrijvinghe van de playnen van Peru totde ftadt Sant Miguel toe; van de valleye van Tumbez; van de ftadt San Miguel, ende de haven Paita.

13. Van de binnenlandefche provincie de los Quixos ende la Canela, behoorende tot her ghedeelte van Quito.

14. Van de provincie van de Bracomoros, ende fteden daer in ghelegen;ende van Yguarfongo ofe Iuan de Salinas.

15. Aenreeckeninghe van de gheleghentheyt endeftreckinghe van de kufte van de provincie van $Q$ uito op de zuydt-zee, hare havenen, rievieren en punten.

16. Groote endeghelegentheyt van de audientie van Lima: de wegh van $S^{5}$ Miguel naer de ftadr. Truxillo toe.

17. Van de vlecke Miraflores, ende de ftadt Truxillo: ende vlecke Santa ofre Parilla : oock Arnedo.

$$
\text { *** } 18 \text {. Van }
$$


18. Van de valleyen die voorder zijn ghelegen van Truxillo af, tot de hoofeftadr Lima toe; ende haer byfondere ghelegentheden.

19. De geleghentheydt van de ftadt los Reyes ofte Lima.

20. Van de valleye Pachacama, ende vervolghende valleyen langhs de kufte van.de zuydt-zee, ende haer gheftalte tot Guarcotoe; van de vlecke Cannette.

2r. Vervolgh van de playnen van Peru langhs de kufte van Guarco af, tor Tarapaca toe, ende van de vlecke Valuerde ende ftadt A requipa.

22. Vervolgh van de binnenlandtfche provincien; langhs de koninghlijcke wegh over 't gheberghte van Guancabamba, van de Chachapoyas ende' Moyobamba.

23. Vervolgh van de binnenlandtfche provincien van Caxamalca tot Guanuco toe, ende van de ftadt Leon de Guanuco.

24. Van de binnenlantfche provincien van Guanuco af, tot die van Guamanga, daer de ftadt la Vittoria is gheleghen.

25. Vervolgh van de binnenlandefche provincien langhs de wegh van de Ingas, van Guamanga af, tot de ftadr Cufco toe.

26. Befchrijvinghe van de groote ftadt $\mathrm{Cu} f(c o$, ende de gelegentheydt van de Landen daer ontrent gheleghen: van San Francifco de la Vittoria, ende San Iuan del Oro, in de provincie van Carabaya.

27. Van de havenen,kaben, punten ende rievieren langhs de kufte van Peru, in't begrijp van de audientie van Lima, ende de ftreckinge van de kufte.

28. Befchrijvinge van de derde audientie van Peru, welck fy nocmen los Charcas, in't ghemeyn, te weten, hare palen ende anders.

29. De wegh ende de ghelegentheyt van de provincien gheleghen tuffchen beyden de ftade Cufco, ende de ftadt la Paz: van Collao.

30. Van't groote meyr Titicaca, in 't midden van Collao gheleghen.

3 I. Voorder befchrijvinghe van de landen ende volckeren ghelegen langhs den toe-wegh van Cufco,tot la Paz: van Chiquito ende de ftadr nueftra Sennora de la Paz, inde provincie Chuquiabo.

32. Vervolgh van de koninghlijcke wegh tot de ftadt la Plata.

33. Van de ftadt Potofi, ende rijcke filver-mijnen aldaer: van Porco.

34. Van de havenen, reeden, kaben ende rievieren op de zee-kutte van los Charcas, ende de ftreckinghe van de felve kufte.

35. Van de binnenlandefche provincie, ende de ftadt Santa Cruz de la Sierrâ.

\section{Het elfste Boeck. Van Chile.}

Cap.I. D generale befchrijvinghe van de provincie van Chile.

2. Dande Wóeftijne van Atacama ende de weghen over landt van't Koninghrijck van Peru naer de provincien van Chile toe.

3. Van de valleyen Copiapo, Guafco ende Chile.

4. Befchrijvinghe van de Steden la Serena ende Sant Iago.

5. Van de ftadt Concepcion, ende van 't eylandt Santa Maria.

6. Van de Provincien van Arauco, Tucapel ende Puren.

7. Van het eylandt la Mocha, ende die van Iuan Fernandez.

8. Van de ftade de los Confines ofteVilla Neuva de los Infantes, ende van de ftade Imperial.

9. Van deftadt Villa Rica; de ftadt Valdivia, ende de gheleghentheyt daer ontrent.

10. Van deftadt Oforno ende Chilue ofte Caftro, ende de provincie $\mathrm{Chu}$. cuito.

1 I. Befchrij- 
1!. Befchrijvinghe van de zee-kufte van Chile, havenen, reeden, caben, bayen ende rievieren van de 26 graden af, tot de 33 graden toe.

12. Vervolgh van dekufte van Chile van Valparayfo af, tot op de hooghte van wat meer als $t$ wee. en-veertich graden.

13. Befchrijvinghe van de binnenlandtfche provincie Tucuman, ende de principaelifte ftade St Iago del Eftero.

14. Van de fteden San Miguel, noftra Sennora de Talavera ende Cordua.

Ij. Van noch cenighe andere fteden ende gheleghentheden van Tucuman.

\section{Het trvaelffe Boeck. Van Magallanica.} Cap. r. $\mathrm{B}$
Efchrijvinghe van de provincien van de Strate van Magallanes in hee
ghemeyn.

2. Kort verhael van de voyagie van Pedro Sarmiento van de zaydt-zee door de Strate van Magallanes naer Hifpanien.

3. Befchrijvinghe van de kufte van Chile af tot aen de Strate.

4. Gheleghentheyt van de Strate Magallanes felfs by de Spaegniaerden.

5. Voorder befchrijvinghe van de Strate felfs by de Spaegniaerden.

6. Befchrijvinghe van de Strate als die by de Engelfche is bevonden.

7. Befchrijvinge van de Strate uyt de voyagie van Thomas Candish.

8. De voyagie van Sir Richard Ha wkins door de Strate.

9. Befchrijvinghe van de Strate ghelijck die by de Nederlanders is bevonden in den jaere $159 \mathrm{~S}$.

Io. Voorder befchrijvinghe naer de bevindinghe van de Nederlanders.

11. Befchrijvinghe van de nieuwe Strate van le Maire.

12. Voyagie van de Spaegniaerden door de Strate le Maire.

13. Voyagie van den Heer Admirael Iaques L'hermite door de Strate le Maire.

14. Verhael van de voyagie van Diego Flores, ende 't bou wen van eenighe fteden by de Spaegniaerden in de Strate van Magallanes.

\section{Het dertbiende Boeck. Van Rio de la Plata.}

Cap. I. $\mathrm{B}$ Echrijvinghe van de landen ende zee.kufte gheleghen tuffchen de Strate van Magallanes, ende Rio de la Plata, by de Spaegniaerden. 2. Befchrijvinghe van de felve landen naer bevindinghe der Engelfchen.

3. Befchrijvinghe van ' $t$ felve quartier naer de bevindinghe der Nederlanders.

4. Generale befchrijvinghe van de gheleghentheden van de provincien die on. der Rio de la Plata worden ghereeckent.

5. Befchrijuinghe van de rieviere in ' $r$ gros, met haer eerfte ontdeckinghe.

6. Befchrijuinghe van de rieviere by Martin del Barco in fyn Argentina.

7. Particuliere befchrijvinghe van de rieviere by andere Spaegniaerden.

8. Befchrijvinghe van de rievier naer bevindinghe der Nederlanders.

9. Van diverfehe natien van Wilden die ontrent defe rieviere woonen.

10. Van de fteden in defe provincie gheleghen, ende eertt van Buenos Ayrés.

I1. Van de ftadt Affumcion ende de gheleghentheyt daer ontrent.

12. Befchrijvinghe van de andere fteden ende plaetfen van defe provincie, te weten Santa Fé, San Salvador ende andere.

13. Van de havenen, Eylanden ende punten op de kufte van defe provincie.

14. Befchrijuinghe van de kufte ghelijck die by Figueredo in fyn Roteiro ende by Dirck Ruyters is uyt-ghegeven. 


\section{Het reertbiende Boeck. Van Brafil.}

Cap... C. Enerale befchrijvinghe van't landt van Brafil, zijn eerfte ontdeckinghe ende andere gheleghentheden.

2. Van de vier-voetighe ghedierten van defe provincie.

3. Van't glievogelte ende kruypende ghedierte van defe provincic.

4. Van de boomen, vruchien ende ghewaffen.

5. De kruyden, wortelen en ander ghewaffen.

6. Ghelegentheyt van de in-gheboorne van Brafil in' $t$ ghemeyn.

7. Van de Capitania $S^{t}$ Vincent ende fteden der Spaegniaerden.

8. Van Rio de İenero ende de gheleghentheden daer ontrent.

9. Van de Capitania by de Porcugeelen ghenaemt Spiritu Santo.

10. Van de Capitania Porto Seguro ende de woon-plaetfen der Portugeefen.

II. Van de Capitania van los lilos, ende de gheleghentheyt van dien.

12. Befchrijvinghe van de Bàhia de todos los Santos.

13. Van de Capitania van Pernambuco, ende de gheleghentheyde daer on. trent.

14. Van de Capitania Tamaraca, ende die van Paraiva.

15. Befchrijvitighe van de kufte van Sane Vincent af, tor de Bahia de todos los

16. Voorder befchrijvinghe van de kufte van de Bahia, tot Rio Grande ofte Poreingi.

17. Vervolgh van de kufte van R. Grande tot de Marannon.

18. Eenighe ghenerale aen-merckinghe op de provincien van Marannon ende de rechte ghelegentheyt der felver.

19. Befchrijvinghe van de Eylanden van Fernand de Norohna, ghelijck die by de Françoyfen worden befchreven.

20. Befchrijvinghevan 't Eylandt Maragnan by de Françoyfen.

21. Gheftalte van de luche ende vruchebaerheyt van't Eylandt Maragnan.

22. Befchrijvinghe van de fruyt-boomen die daer waffen.

23. Befchrijvinghe van eenighe fonderlinghe kruyden ende aerdt-vruchten die op dit Eylandr groeyen; ende van'r ghevogelte.

24. Befchrijvinghe van de viffchen die in de zee ende rievieren worden ghevonden by 't Eylandt Maragnan ende daer ontrent.

25. Befchrijvinghe van de vier-voetighe dieren die op het Eylande Maragnan ende't vafte landt worden ghevonden.

26. Befchrijvinghe van ' $t$ volck van de lande, haer af-komfte, gheftalte ende manieren, ende andere qualiteyten.

27. De gheleghentheyt van Topouy tapere ende Comma aen't vafte landt.

28. Kort verhael van't gheene eenighe jaren gheduerende by de Françoyfen is voor-ghenomen in dit quartier, ende van den bergh Ibouypap.

\section{Het pijfthiende Boeck. Van de Wilde Cufte ofte Guaiana.}

Cap. I. CHeleghentheyt van dekufte van Marannon af, tot aen de groote rievier de $S$ t luan de las Amazonas.

2. Befchrijvinghe van de rieviere, ende haer cerfte ontdeckinghe.

3. Detweede voyagie van Orellana, ende voorder gheleghentheyt van de ricvier.

4. Ontdeckinghe van de rieviere Tobo ofte de las Amazonas by onfe Nederlanders, ende eerlt de gheleghentheyt van de ooft-zijde. 
5. Voorder belchrijvinghe van de groote rieviere de las Amazonas, ende de gheleghentheyt van de felve.

6. Vervolgh van de rievieren ende landen van Rio de las Amazonas af, tor dea hoeck van de baye van Wiapoco.

7. Befchrijuinghe van de baye ende rieviere van Wiapoco, ende andere.

8. Voordere aen-merckinghe op de rieviere Wiapoco, uyt de onder-vindinghen van onfe Nederlanders.

9. Befchrijvinghe van de rievieren Apurwaca, Couwo ende Wia.

10. Befchrijvinghe van de rieviere Caiane, ende de ghelegentheden van delanden ende volckeren die daer ontrent woonen.

II. Van de gheftalte des luchts ende't weder, ende volck van de lande.

I2. Van de lijf-tocht van 't landt tot onderhoude van des menfchen leven.

13. Van de koopmanichappen die in' $t$ lande worden ghevonden.

I4. Vervolgh van de kufte ende verfcheyden rievieren.

15. Van de rieviere Orenoque in 't ghemeyn, volgens het ghené de Spaegniaerdendaer van hebben uyt-ghegheven.

16. Voorder ontdeckinghe van de rieviere ghenaeme Viapari by Geronymo de Ortal.

17. Vervolgh van de ontdeckinghe van dit ghewefte by Don Gonzalo Xime. nes de Quefada; ende Antonio de Berreo.

18. De eerfte voyagie van Sir Walter Ralegh op den Orenoque, 1595.

ig. Voorderverhael van den tochevan Sir Walther $R$ àlegh, ende de ghelegent. heden van de rieviere Orenoque.

20. Detweede voyagie van de Engelfchen naer Guiana, onder het beleyt van Laurens Keymis in den jare 1596 . Ende de derde befchreven by Thomas Masham; ende delefte van Sir Walther Ralegh felfs.

21. Gheleghentheden van de rieviere Orenoque, naer de bevindinghe van onfe Nederlanders.

22. Befchrijvinghe van't Eylandt la Trinidad, als mede' $r$ Eylandt $T$ abago.

\section{Het feftbiende Boeck. Van Nova Andaluzia.}

Cap. I. $B$ Efchrijvinghe van 't vermaerde Eylandt Margarita.

2. B. Van de Eylanden Cubagua ende Coche.

3. Van Punta de Araya daer de vermaerde zour-pannen zijn, ende de ghelegentheyt van 'tlandt daer ontrent.

4. Befchrijvinghe van de provincie van Cumana, ende de gheleghentheyt van de landen ende volckeren daer ontrent.

5. Kort verhael van't ghene by de Spaegniaerden in dit quartier van Cumana in voor-tijden is aen-gherecht.

6. Voorder verhael van'tghene by Ortal ende Sedenno is voor-ghenomen.

7. Vervolgh van den tocht van Sedenno in dit ghe wefte.

8. Befchrijvinghe van 't Gouvernement ende de provincie van Venezuela in het ghemeyn, ende de verdeelinghe van dien.

9. Van de eerfte ontdeckinghe van het lande van Venezuela by de Hoogh: duytfchen, ende het ghene eenighe jaeten gheduerende is voor-ghevallen.

10. Befchrijvinghé van de ftadt Coro, ende de gheleghentheyt daer ontrent; noftra Sennora de Carvalleda, Sant Iago de Leon, Nova Valencia, ende Nova Xerez.

II. Befchrijvinghe van de ftadt Nieu Segovia, ende de gheleghentheden daer om.her.

$$
* * *_{3} \quad \text { I2, Be. }
$$


12. Befchrijvinghe van de Stadt Tucuyo, Truxillo, Laguna, ende de gheleghentheyr daer ontrent.

- 13. Befchrijvinghe van 't groote lack Maracaybo : ende van Maracapana op de uyterfte limiten van dit Gouvernement naer't ooften.

I 4. Befchrijvinghe van de eylanden die voor defe kufte ligghen, te weten I. Blanca, Tortuga, Orchilla, Rocca, I. de Aves.

15. Befchrijvinghe van de Eylanden Bonayre, Curacao ende Aruba.

16. Befchrijvinghe van de havenen, kaben, rievieren van dit Gouvernement van Venezuela.

By-hanghfel om by te voeghen aen de voorgaende boecken.

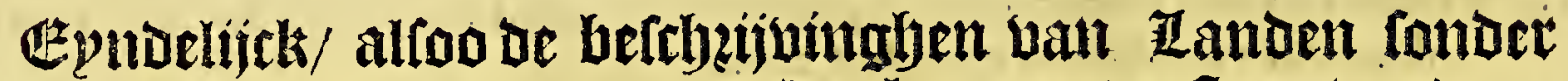
Grograplyiche liaetten niet wel en konnen verftaen wozoen/ foo hebben wo naet ons bermoghen ghetracht de felbe te doen maecken foo nact ae wacte gheleghentlyept ende gheftalte der lanben / als ons moglyelijeken is glyeweett / upt be waetfe ende beite befrlyeijuinghen/als oock mede upt de liaerten voo? Defen by anteren upt-ghegheben; ae weltke wp in beelen dee = Ien hetben ghefoeht te verbeteren / ghelijek wo verboopen be gleene dic berftanot hebben van defe materie / fullen bebin= Den: $\mathfrak{y} \mathfrak{e}$ - wel wo niet en twijffelen oft daer siin noch beel mirftellinglien ouer-ghebleben dooz ghebreck baul beter onderrichtinglye / die wy metter tijot van de onte hopen te bekonten; Daet-en-tuathen fullen befe ghenoegy zijn tot verffandt van oe bolghende befethzijoinglye / alloo tp daet naex gljeticht 3 ijn; waer toe ons fonderlingl behulplaem is ghe weeft de indultrie ende etwatentbeydt ban Heffel Gerritz die de liaetten meeft ontwozpen ende glyeltelt lyeft. 


\section{Regifter van de Kaerten, de welcke moeten in- ghevoeght worden als volght.}

Be Genaerele llaette boo dele Jinlepoingle.

Te flarte uan ae Weft-Indifche Eylanden tooz pag. I.

De Laerte ban Nova Francia boos pag. 45 .

De liaette van Nova Anglia, Novum Belgium \&c. vod pag. 89 .

De Lltaette uan Florida boo? pag. 137 .

Jee Haette ban Nova Hifpania, Nova Galicia ente Guatemala bode pag. I69.

Be liaette uan Terra Firma, Neuvo Reyno de Granada ende Popajan vope

pag. $30 \mathrm{I}$.

De Laerte ban Peru booz pag. 357

De Haerte bam Chile booz pag. 425 .

De Haette van de Strate van Magallanes voog pag. 449:

De ltaette van Rio de la Plata, Tucuman, ende Santa Cruz de la Sierra booz pag. 477 .

De Haerte van Brafil booz pag. $50 \mathrm{r}$.

De llaerte ban Guiana boo? pag. 552 .

De ltaette ban Venezuela bod pag. 597 . 


\section{E $\quad R \quad R \quad A \quad T \quad A$.}

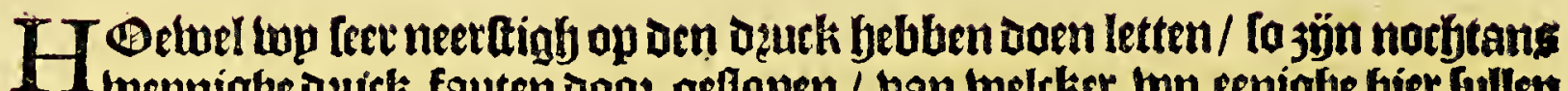

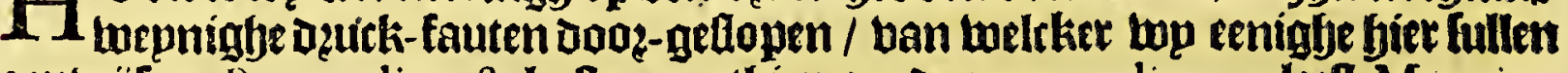
aemuniffn: Pag. 17. lin. 18. Ieeft negentlbien graden. pag.3r.lin.42. Leeft Martyres ende de Caios. pag. 35 .lin. 28. Ieelt van ontrent aclutbien graoen. pag.330. 1.32. Ieelt

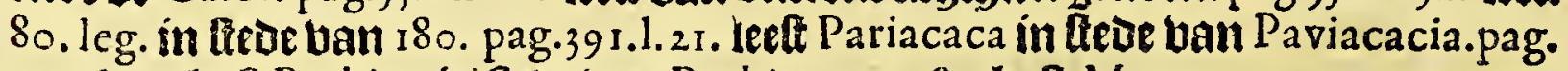
577.1. I . Itefl Berbice in fteue ban Berbin. pag. 5 3 . Itefl Macureguaray. pag. 599 . 1.27. leelt Galera in ttede van Calera. Soo der noth entighe toube moghen twe=

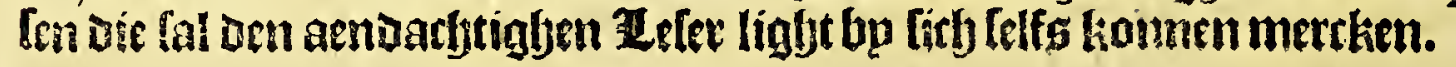





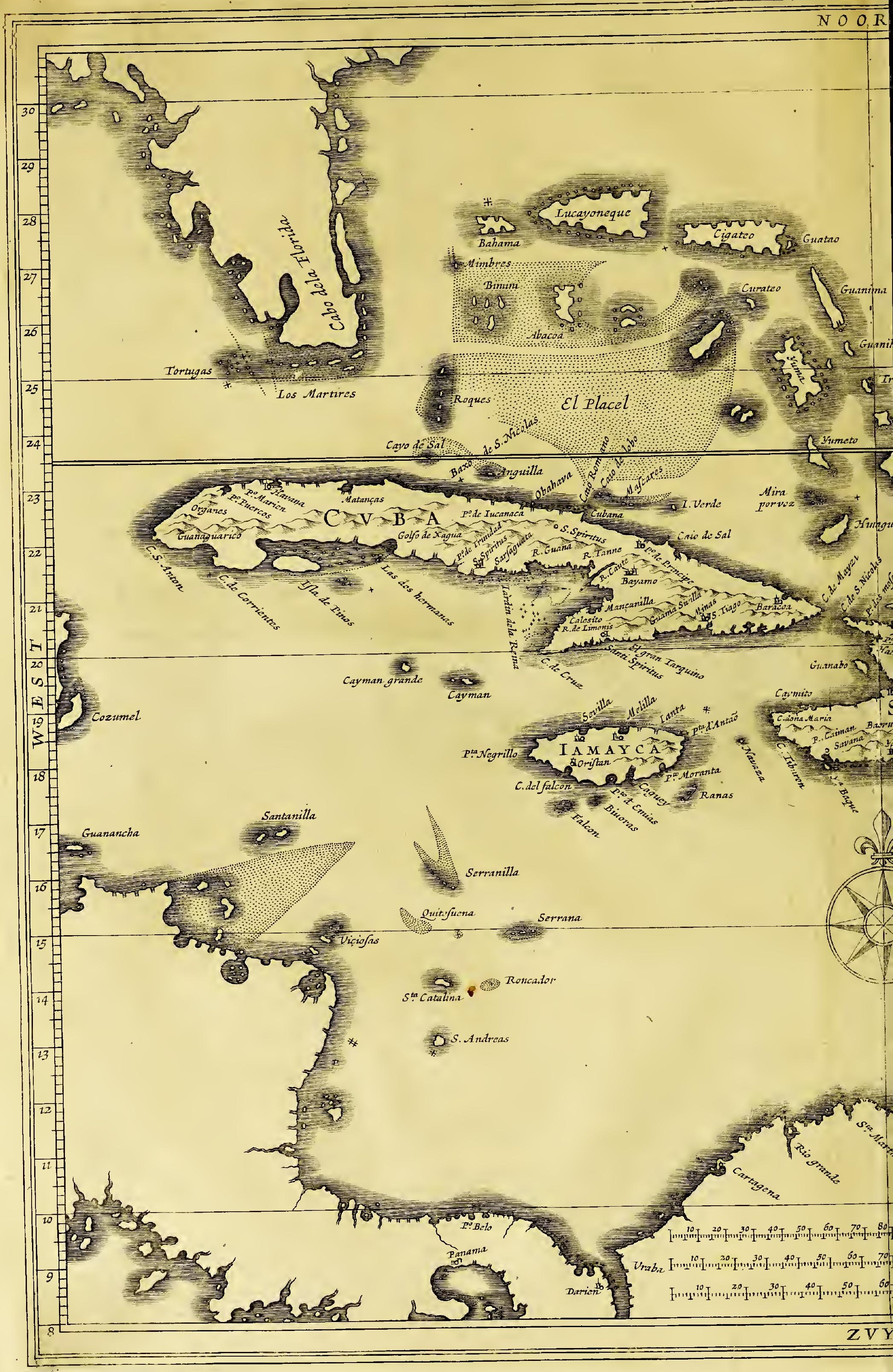




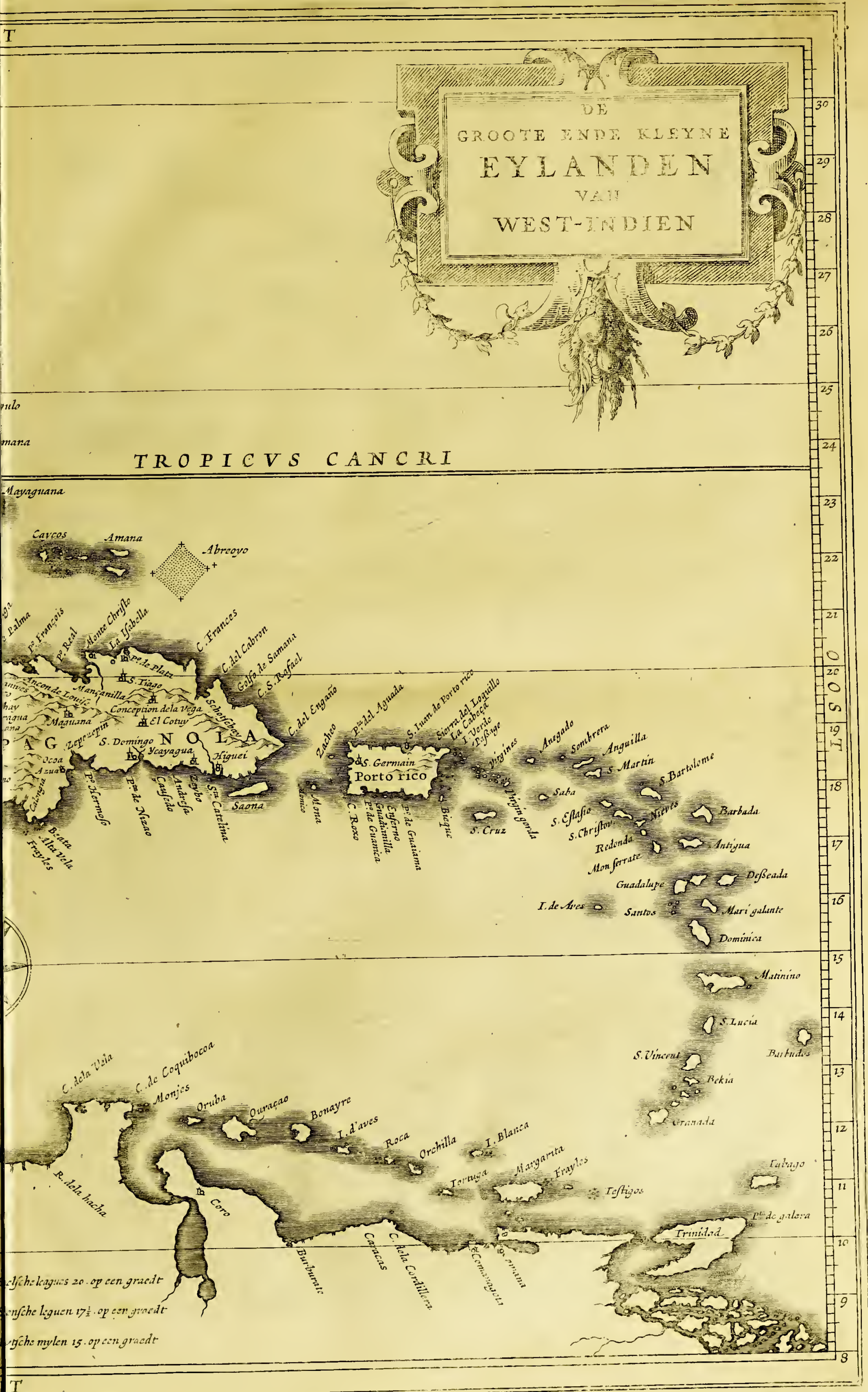



BE S C HR I I V I N G HE

atan

W E S T - I N D I E N.

Wet exte 25oech.

\section{Vande Weft-Indifche Eylanden.}

\section{Inlepoinglye.}

O Nder de VVest-Indifche Landen prefenteren fich voor eerft de Eylanden; ;oo groote; gelïck $S^{t}$ Iuan, Hifpaniola, Cuba, Iamaica; als kleene, de voelcke de Spaegniaerden gemeenlÿcken verdeelen in tovee banden, noemende de eene de Sotavento, vvelcke ligghen by-zuyden de groote Eylanden ende naer't of te aen't vaste landt van't zuydt-deel van America; de andere de Barlovento liggende noordtvvaerts naer't vafte lant van Florida toe, vvefende defe Eylanden de eerste die van Chriftophoro Columbo zün ont deckt. VVy fullen eerst befchrüpen de groote, gelïcfe op een rïje ligghen, beginnende van $\mathrm{St}^{\mathrm{t}}$ Iuan de Puerto Rico, alfoo bet't Oostelïckste is; ende daer naer de kleyne, volghens de voorgaende reparticie.

\section{VAN'T EYLANT S IUAN DE PUERTO RICO.}

\section{Set eerlte Capittel.}

Vande ghelegentheden van dit Eylandt in't ghemeyn.

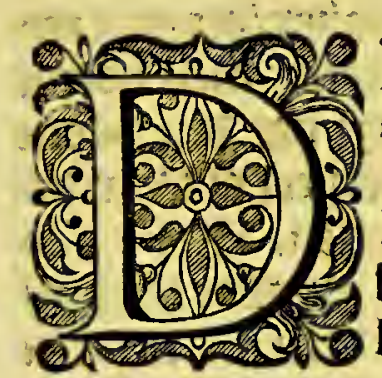

3t $\mathbb{E}$ plandt wierdt eettijots bp De inwoonderen ende geluueten in baie tale genoemt Borriquen; den Ammirand Columbus "tfelue ontideckende inden jate i493, noembe bet $S$. Iuan Baptifta: $\mathfrak{J}$ s gelegen twaelf ofte vífthien * leguen naer't

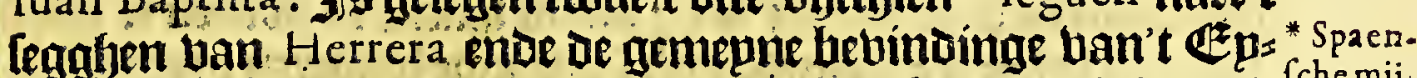
lant Hifpaniola naer bet ooften: eñ bonoert Tesendertigh banit len. punt ban Paria, j, eliue n. als Linfchoten libezft, Be beele Dec.r.1. 3upd-kufte lept op oe booglete van antrent lebenthien graden bp noozan den 7.c.4. Aquinoctiael, enoe ae noogot kufte lepot op de booghte van achthien graden/ min ofte mer: Figuere do in hn Roteiro ftelt be noozat-zjoe op achthien gladen

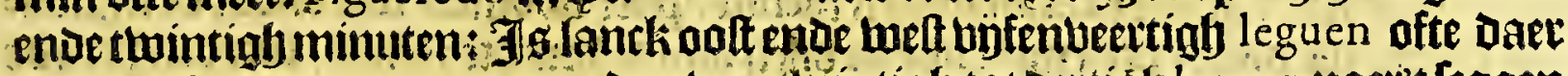

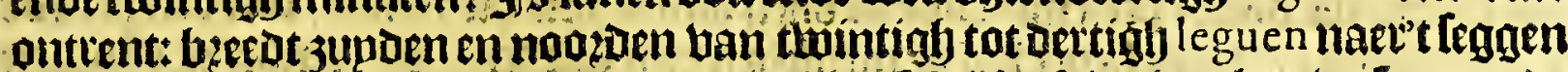

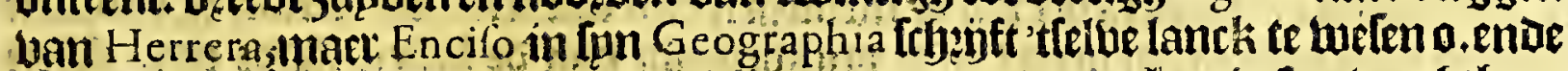

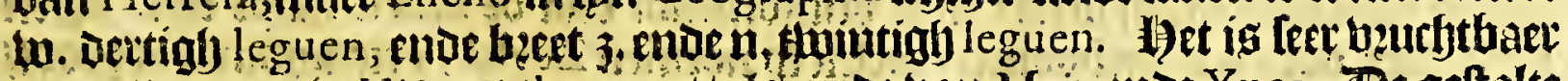
van alle tgene in Hispaniola groent/alg mede van Maz ende Yuca. Oe geftalte

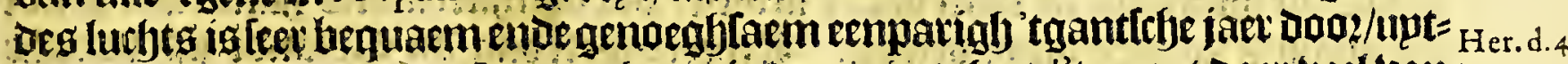
genamen in Dece mb. en Lanuar. Geten is Daer niet te ljet /'tregent daet beel ban 1.5. c.3. Maio tot September, joetuel niet alle jaren eben tieel in Augufto en Seprember pleqfender tomente vallen uiele noemen Huracanes, ontrent de conjunctie ban

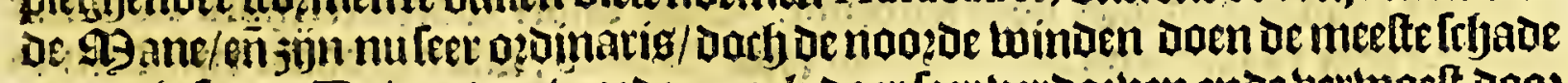

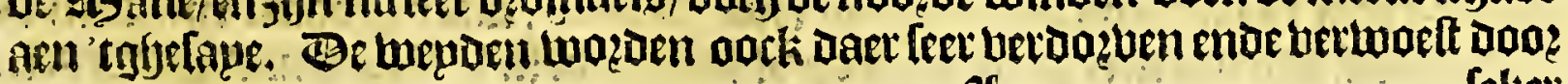
iो?

leket 


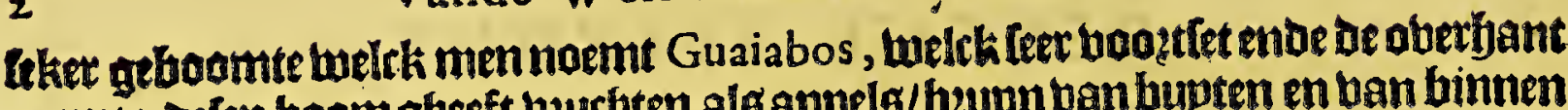
neemt: oten boom gheeft butgten alsappelg/bupn van bupten en ban binnen

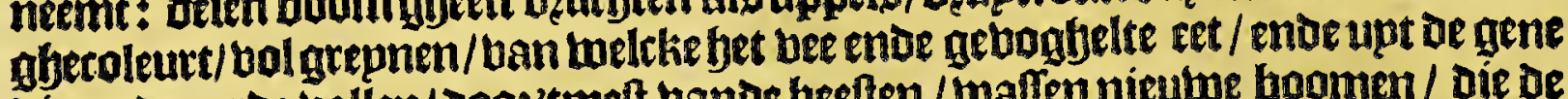
die op oe aetoe ballen/ Doo?'tmelt bande beelten/wallen nieube boomen / die de

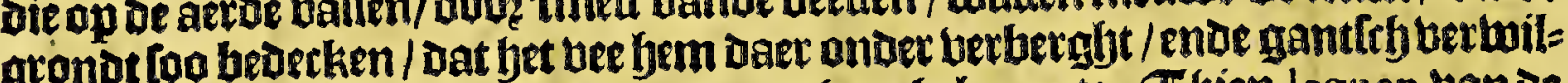
bert/oock en twatt daer gheen gras oniser bet gheboomte. (Thien leguen van De

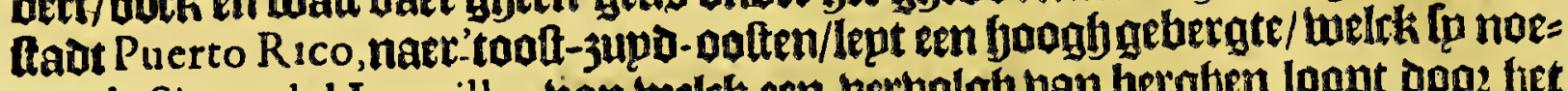
menla Sierra del Loquillo, vam welck een berbolgh van betofen loopt ooo tyet

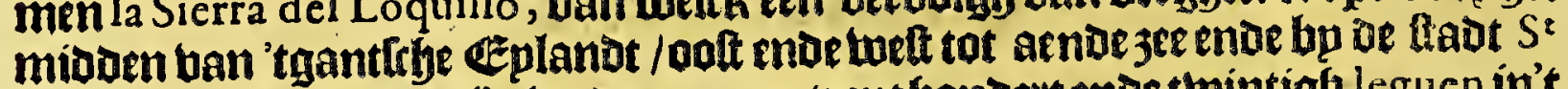
German. omgaen is / loo beeft bet nochtang wel oepenthintigh riebieren Die inde jee loas

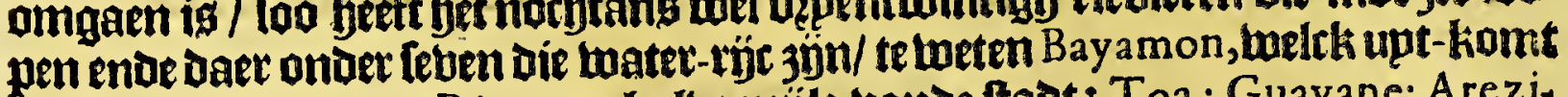
inoe bape van Puerto Rico, een halbe mijle tande ftadt: Toa: Guayane: Arezi.

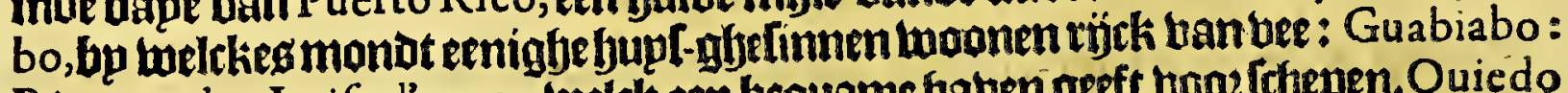
Rio grande: Luifa d'agua, weltk een bequame baten geeft boos fetrepen. Ouiedo

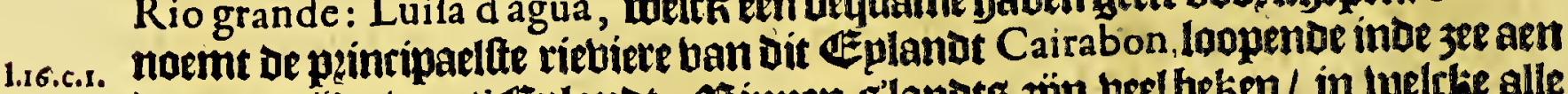

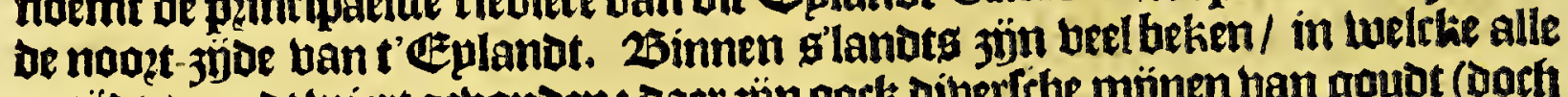

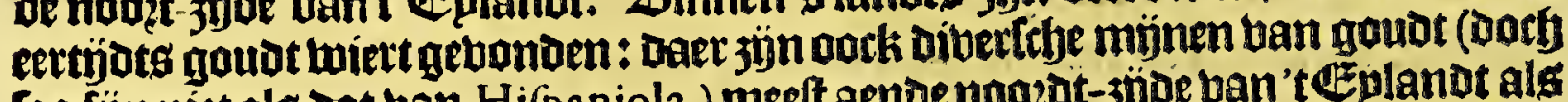

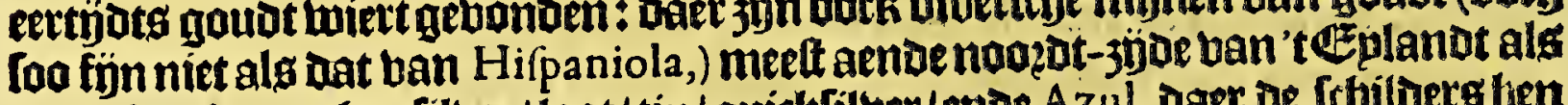
Ouiedo ghetumght : filber/ lont/tin/quickfilber/ende Azul, Daer oe frbiluers ben ban dienen. Baer jän thien Ingenios ofte fuptker-molens / welcke jaetlitx upt: bzenghen býfthien auplent A rroben, enve konden meeroer upt-bzenghen/indien

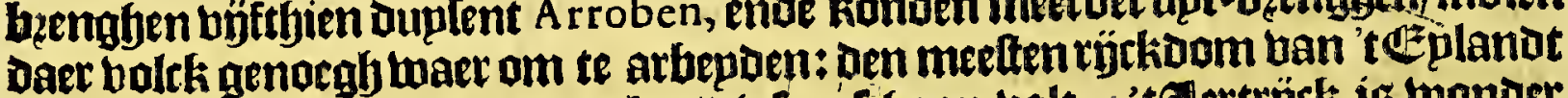

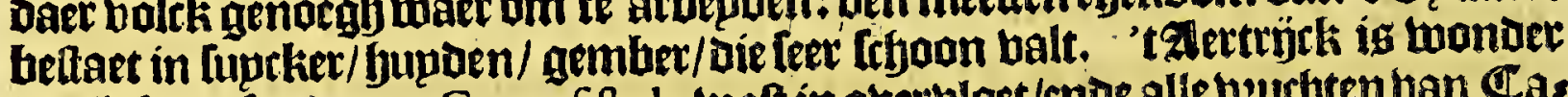
veuthtbaet/[oo datter Cannafift ol a waft ín ouetbloet/ende alle beuchten ban $\mathbb{C a s}$ Ailien (uptgelondett oljben/ welcker boomen baer toel wallen/ Dorb geben geen bueften) ende allerbande krupoen. 9 en binot daer den boom Tabernaculo, (Ouiedo noemt of gumme ofte bertt die daer uan komt Tabunuco) welck upt=

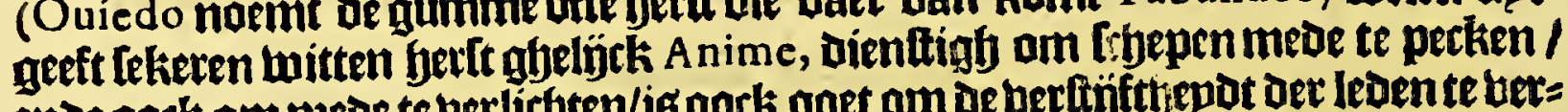

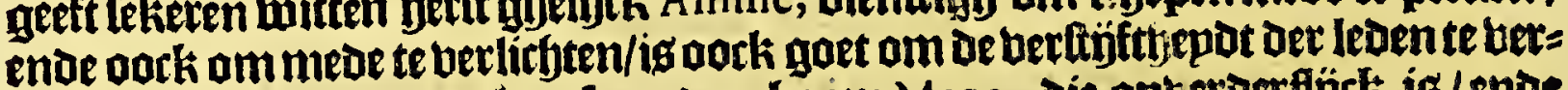

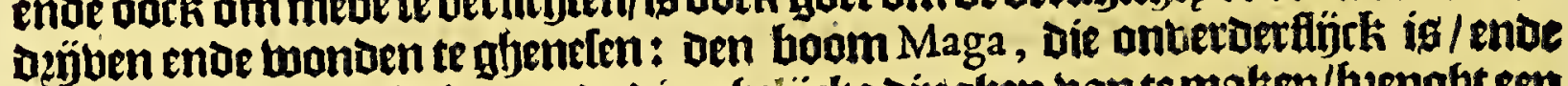
bequaem om inckt-kokerg ende dierghelÿcke dinghen vante maken/bzenght een bloem voottgalg een roole. Baet valt oock beel Palo fanto, belck men noemt Guaiacan, pock Dienende om mede te berwen / Dan Ouiedo legt Dat Den boom Diefe noemen Palo fanto, vertrbepden is uan Guaiacan; boetwel bet bout ban de: feri boom de felbe kracht beeft om de fpaentede packen te gbenefen. De Higillo

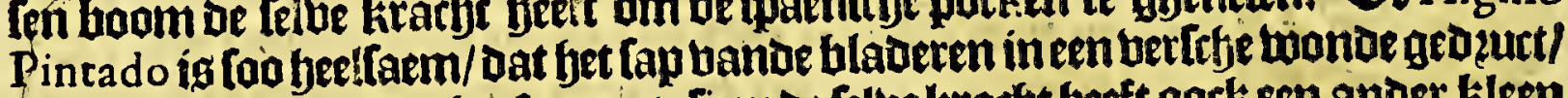
men baer niet meer en boeft naer te fien: de feltue krarft beeft oockeen ander kileen boomken/melek fp noemen ban Santa Maria ; ende een ander genaemt Balfamo. - Baer igeen fteerkentekrupt/beenigenoe boget een witte bloeme als een biolette/ porfjwat langer/ welcklp noemen Quibey, wat dieten baet taneten/oiefterten:

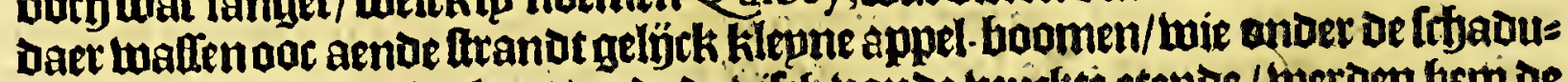

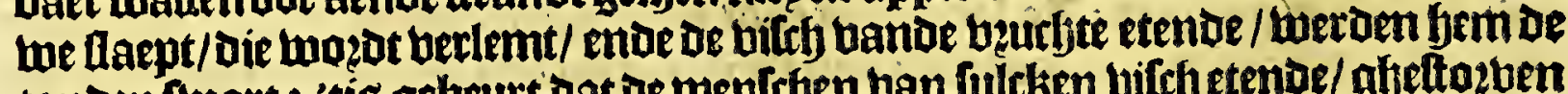

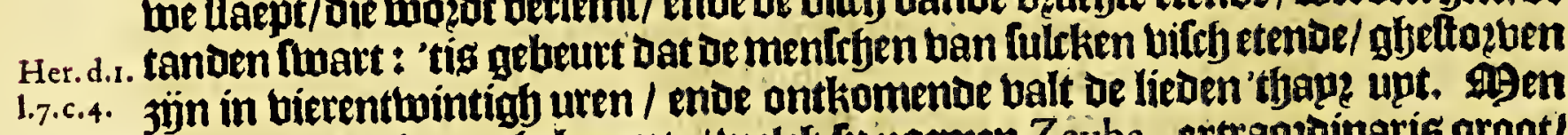
heeft daet oock een gheboomte / welck [s noemen Zeyba, erttaozioinaris groot) bebbenoe fomtijots de ftam onder co dick / dat büftyien mang batioc aen bande Die qualïrk konnen ombaurmen. 'Cmeerendeel ban dit Eplanot jön fooghe berghen/ waer van eenighe feer dirbt met hoomenjön betwallen/ende metrfyoon lirugut/ghelïek in Hifpaniola : beeft wepnigh blark lanat / trel ballepen / met

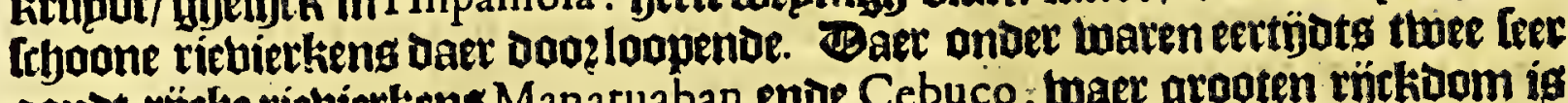

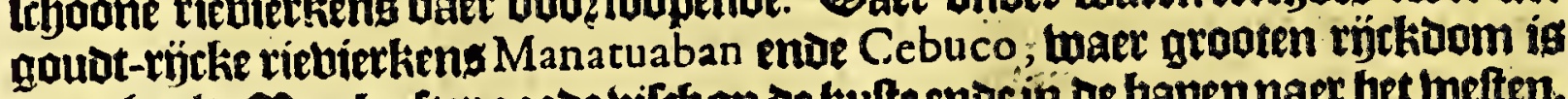
uptgebaelt. Agen befter goede biltg op of kulte ende in de bapennaer bet loftten. 
Her eerlte Boeck.

Mert theror Capittel.

Vande Steden ende woon-plaetfen in dir Eylandt eertijdts ende nu noch by de Spaegniaerden bevvoont.

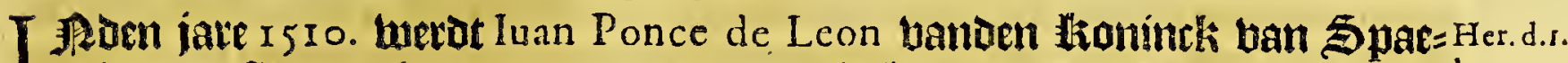

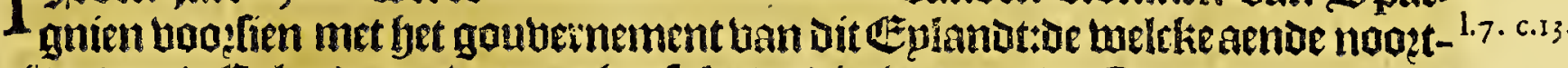

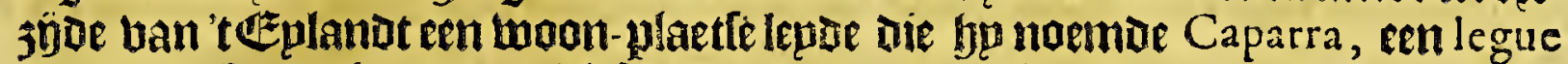

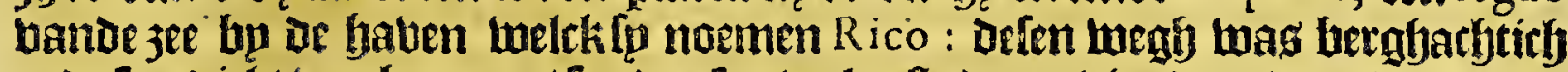
ende feet dicht ban boomen/ too dat foo beel cofte de plobiande ende andere noot=

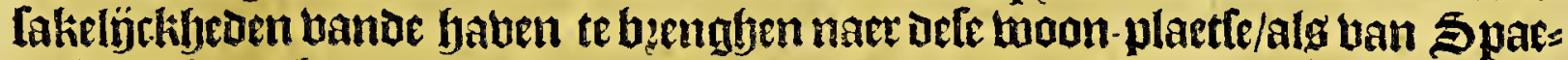
gnien te benghen tot De hateen / norljtans doo? ie begheerte ban 'tgoubt te bet: gaderen/bleef de plaetle bewoont voo? thien of thaelf jaren. Baer naet beran= Deroen fo bam plaetle / ende namen bare troon-plaets bp naet aen 'tjooft ban 't teplanot in een ballepe op de felve nooęt-Hufte ontrent Daet nu S' German legt (Daer lopfjer naet ban fulten fpelken) enoe noemden die Guanica, Dooe dien fa Daet entige goubt-rijetke viebieren bonben: ende weder eenigfien tijot daet naet

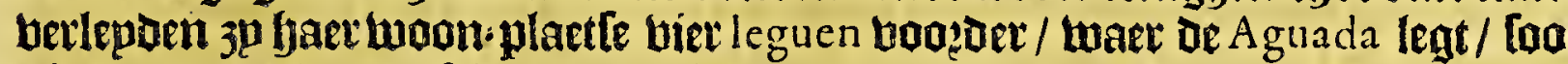
obenoemt om dat de froependaer liemen inater balem/enoe naemben die Soto maior; ende keetuenepnoclijck tot de boot-gaende ballepe/noemende de plactfe St German. Herrera feglyt in fun Deferip. de lás Indias, cap. 7. Dat Guanica toas geteghen op de jupit-kufte / ontuent aaer mu ig Puerto de Mofquitos, ent

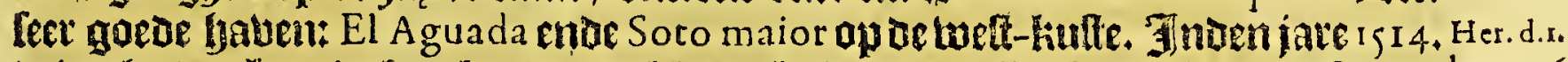

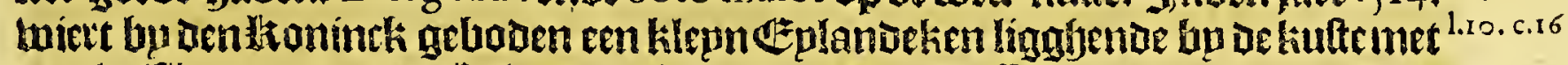

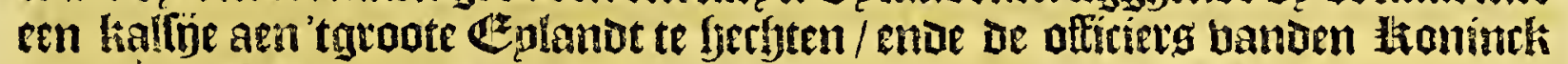

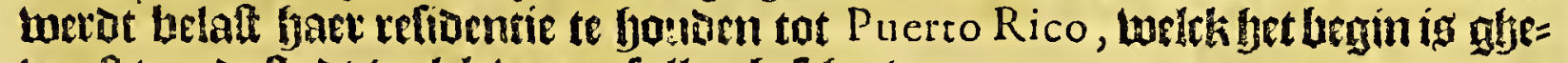

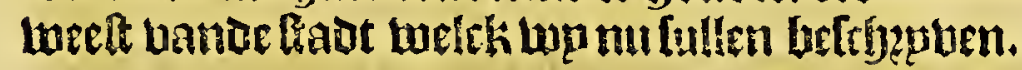

$$
\text { St I U.A N DE POR TO RICO. }
$$

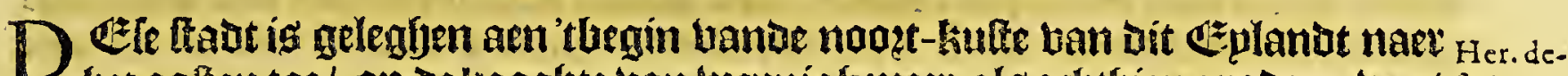

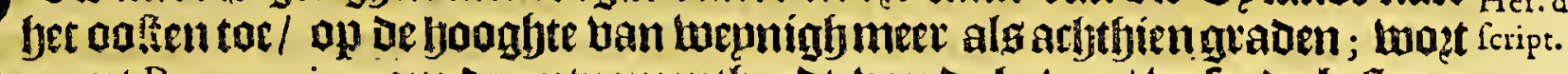
afjenoent Puerto rico om ae uptnementfiged ban ae gauen / wefende befloten ende bertekert boo de tempeelten: De ftaot is gelegfen op en lilepneplandeken/Her. d.4

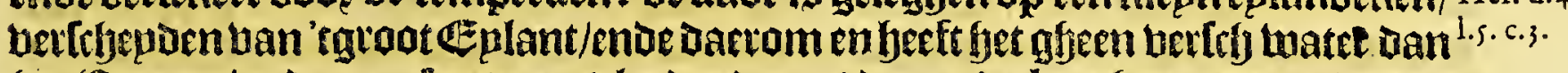

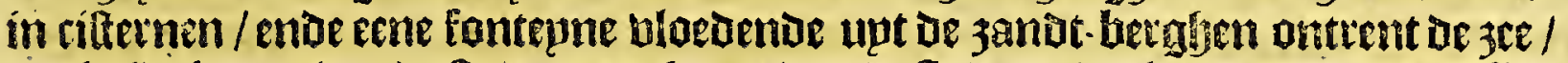

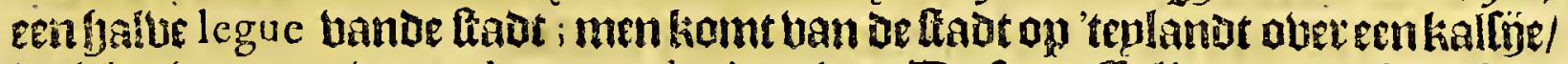
wefch gljenormt inert el puente de Aguilar. De foetrefte lígt op een hoogfte / tueles fp noentet el morro empinado, aen 'timiomen van de baten/als een engte/

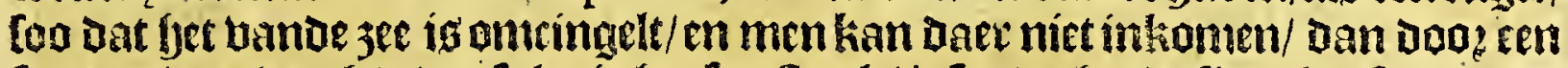

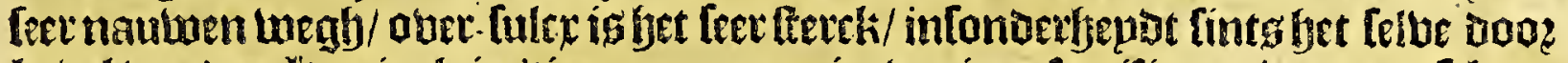

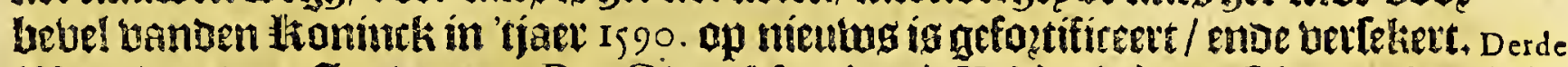

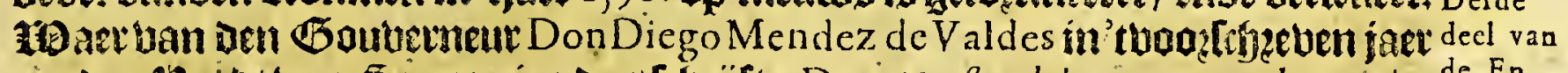

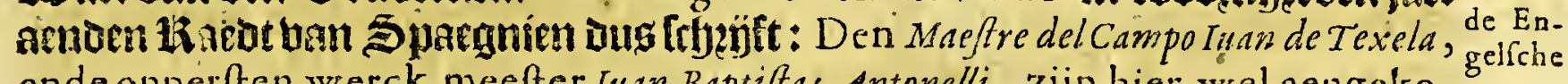
ende opperften werck-meefter Iuan Baptifta Antonelli, zijn hier wel aengeko- voyage. men, ende hebben de ftadt befichticht met alle de gelegentheden rondt-om, ende hebben uytgemercke een plaetfe toc opbouvvinghe van een fterck Kafteel, daer'tlande feer vvel mede te vreden is : het ftaet op een feer bequame placts, te vvecen, een hooghen bergh aen 'cinkomen vande haven, ende reycke overnacr her punt van 'elande, hebbende foo veel ruymte van binnen, datmen daer dry duyfent man foude konnen logieren. 'tSal gehout vvorden triangels vvijfe, reyckende tot aen de baye, ende wy fillender veertich goede ftucken ghefchuts moghen planten. Ick vervvachte vijf Canons aye Spaegnien, met feherp, pulver, ende andere vvapenen, door dien hier van alles groor gebreck is. Syn Majefteye heeft hier ghefonden trvee hondert foldaten onder tvvee Capiteynen : Ick monftere tvveemael ter maendt alle het volck van 'tEylandt, ende bevinde 
feer naer vijfthien hondert vveerbare mannen, ende tachtich te peerde. Als 'tfort fal vol trocken zijn, fal't het fterckfte zijn, dat fyn Majefteyt in gantfch Indien heefe. 'Tvolck flaepe nu gheruft, daer hier te voren de Engheliche ons quamen braveren tot inde mondt vande haven. Bug Letre Den Gouberneut. Raer 'tbethael vande bapagie banden Grabe ban Cumberland en bebindinge

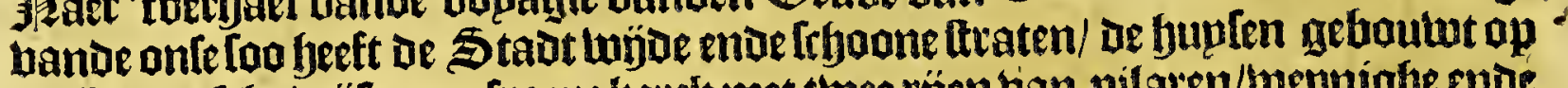

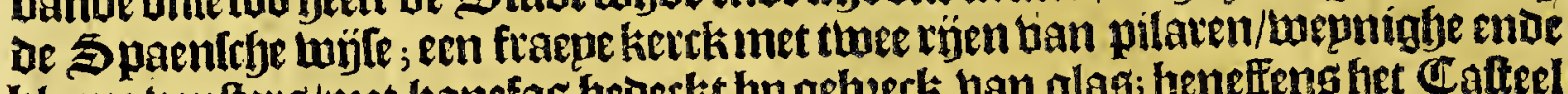
kleune benfters/met kanefas bedecht bo gebeck ban glag; beneffens bet Cafteel

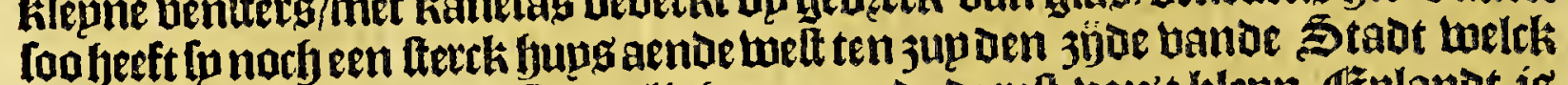
[pnoemen Fortaleza; de Stadt líght open ende de reft ban't klepn Eplanot is

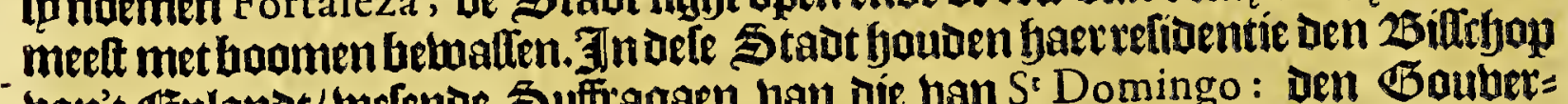

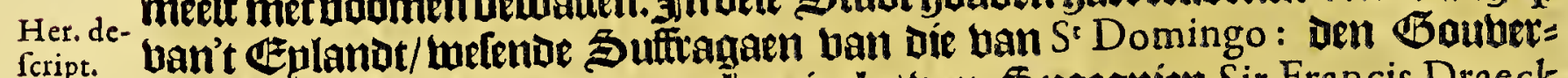

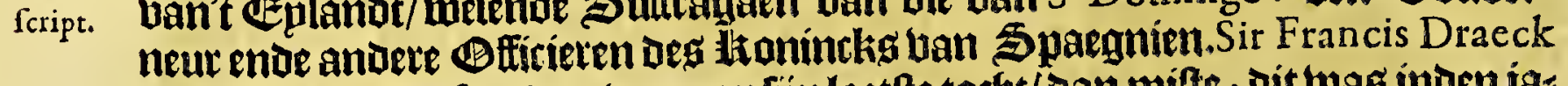

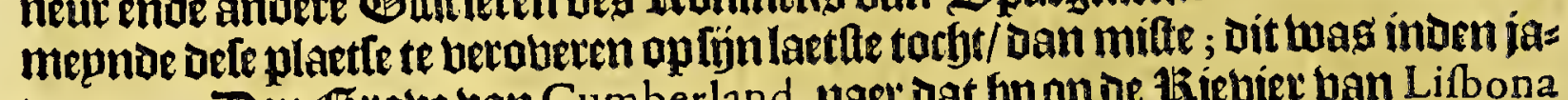
Purchas $\mathfrak{r e}$ I 595 . Den Graue ban Cumberland, naet dat Gp op De Krieviet van Lifbona pelgrim. ac Caraken hadoe in ghefoutuen / índen jate 1597 . vaet naet dele plaet / ende

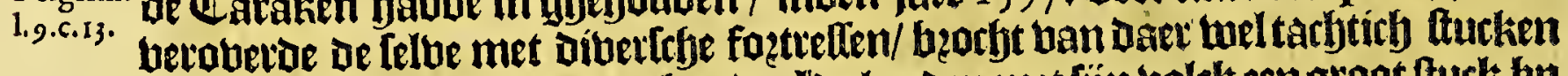

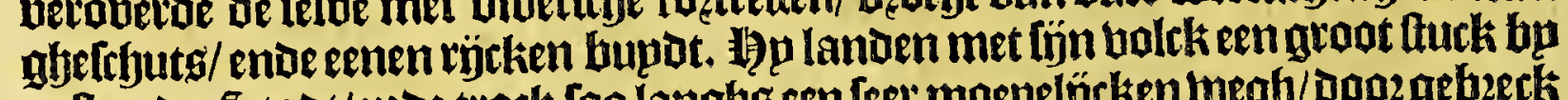

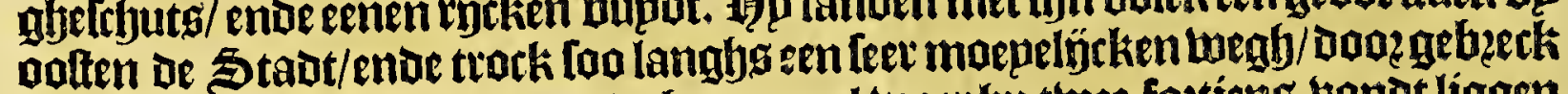

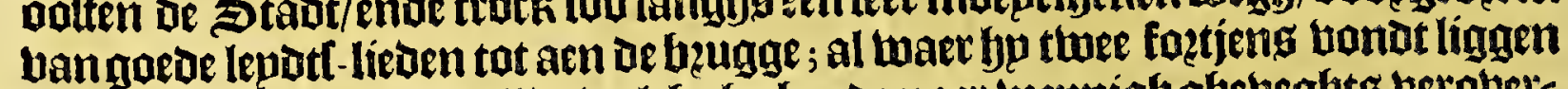

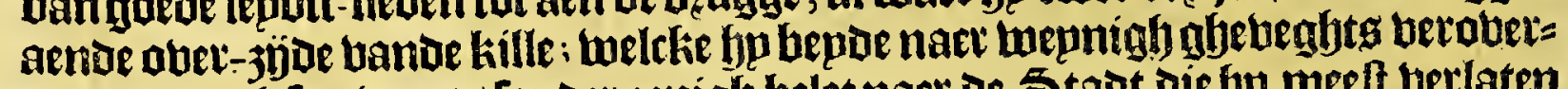
De/ende track foo voots fonder eenigh belet naet de Stadt die hp meeft verlaten

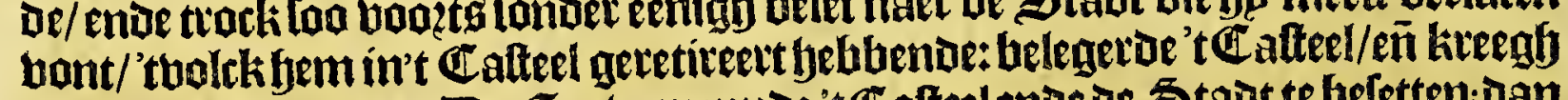

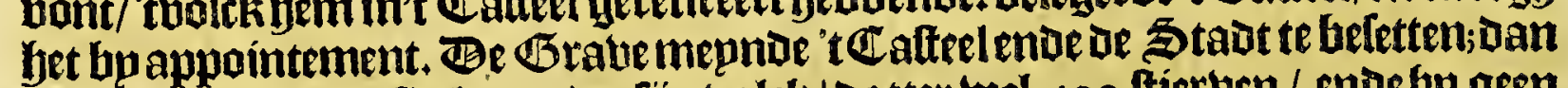

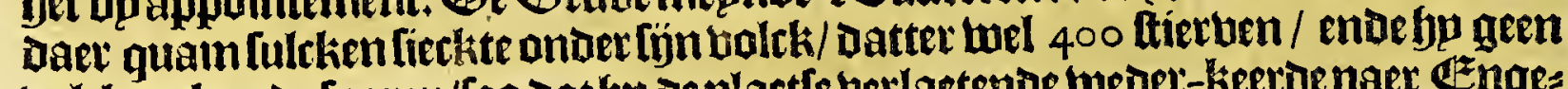

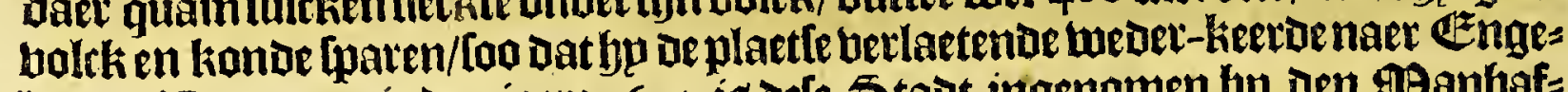
lanbt. Taer naer inden jaere 1625 . ig dele Stadt ingenomen bp den 99 anjaf= tígen Genetael ban Der Melt- Indiftye Compannieg Bloten Boudu wijn Hen-

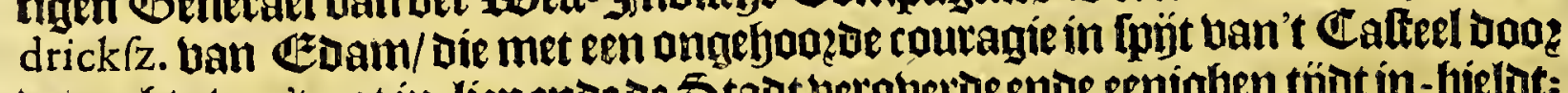
je englite van't gat in-liepende de 3 tadt verobet de ende eenighen tijot in-bielot: ban alloo hy te fmack ban bolck was om' $t$ Cafteel met maght aen te arípen/ foo

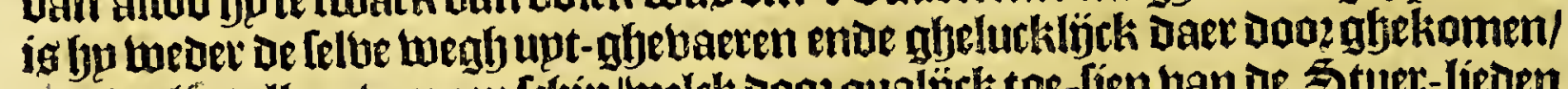

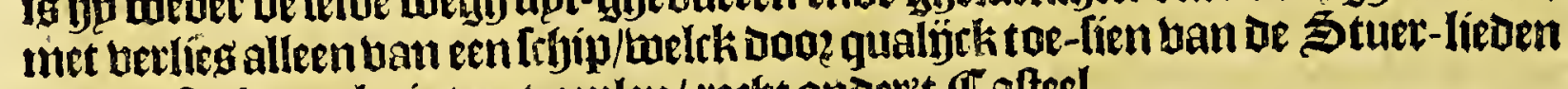
was ualt gferaecht int upt-jeplen/ rectyt onder't Calted.

St G E R M A N.

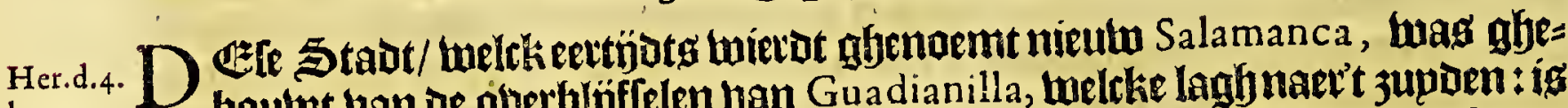
boulut ban de oberblýffelen ban Guadianilla, welcke laghnaet' 3 upoen: igs gelegen bier leguen bande $3 \mathfrak{e} /$ Dertigh ofte Dependertigh leguen van Por o Rico,

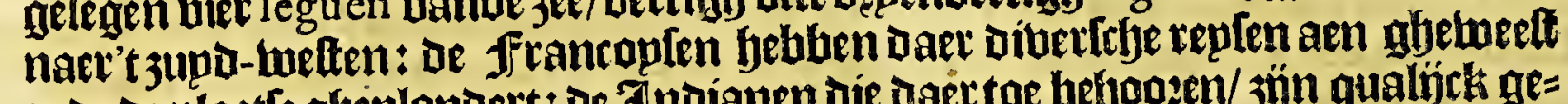

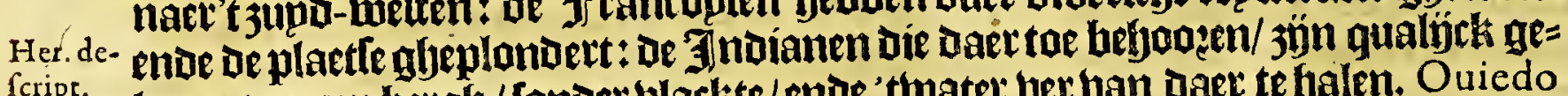
fcript. logeert op een betah / Ionder blacke/ende' thater ber ban daer te halen. Ouiedo

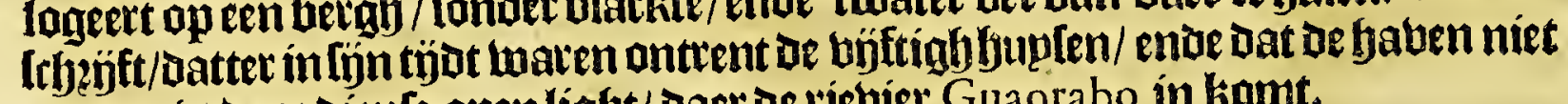
gaet en is Dooz Dienle apenlight/ Daer De rievier Gua orabo in kamt.

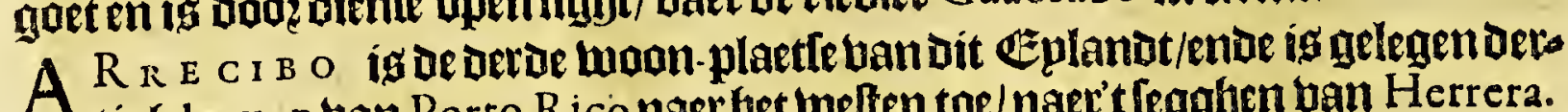
A tigh leguen ban Porto Rico naechet welten toe/naer't legghen ban Herrera.

1)et oetoe Capittel.

Vande Havenen ende andere gheleghentheden van dit Eylandr; ende van Mona.

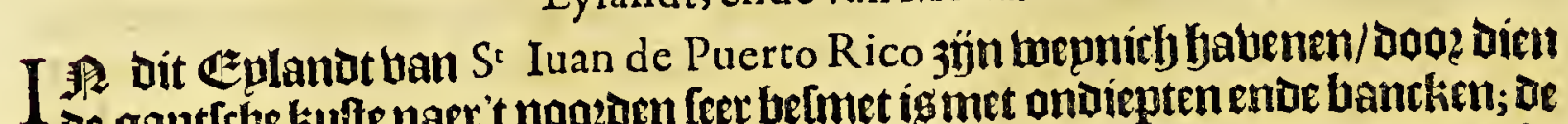
1 be gantfrbe kufte naer't noożden ferc belmet igmet ondiepten ende bancken; ae bauenen die daer 3 ÿn/ligghen naer't dolten ban Porto Rico, ende is eenrupglye 
Het eerfte Boeck.

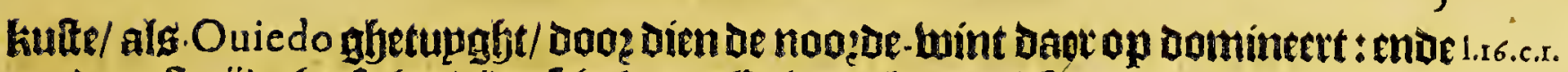

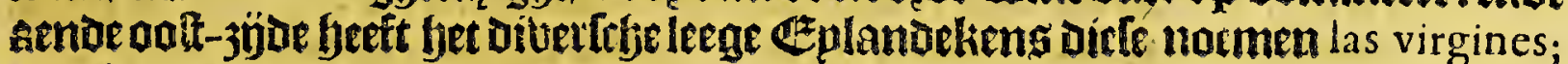

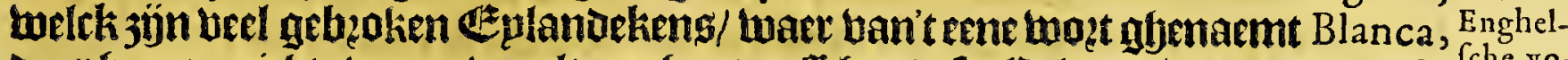

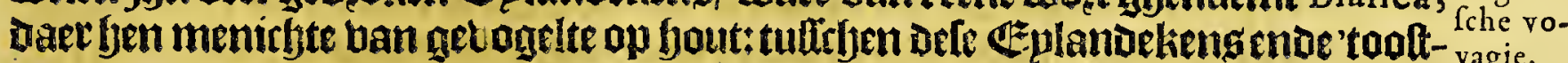
epnde banit $\mathbb{C}^{z}$ planat $S^{r}$ I uan lighteen Canael / weiclifp normen el pafaio, Daet=

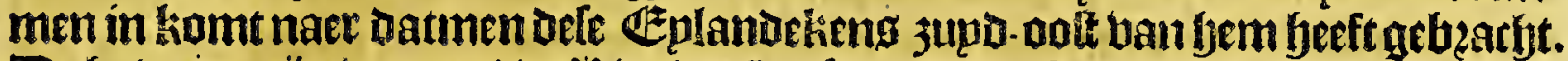

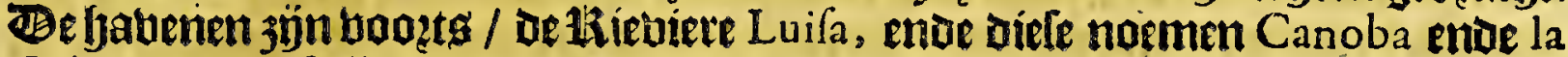
Cabeça, het ooftelijcklte punt bant bet Geplanot bp fjet obleberghte del Loquillo,

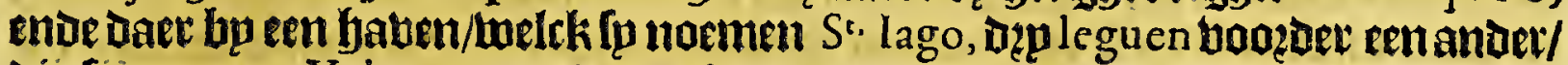
Die fi noemen Yabucoa, ente dep leguen bambe kufte een kiepn Eplandeken

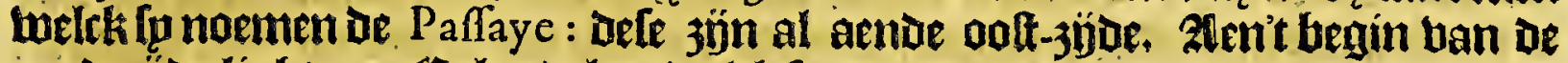

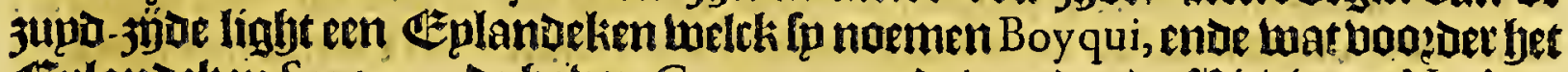
EEplandelien Santana, De baben Guayama, ente boozore de Híetuieten Neabon

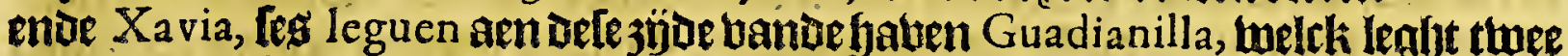

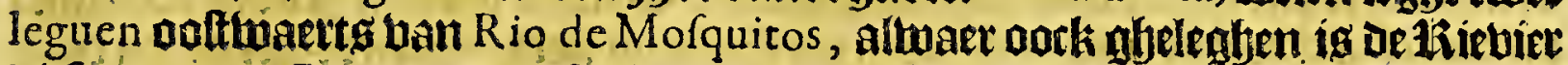
diefenoemen Guanica, ende fés leguen booger Cabo roxo, het weltelijekftepunt

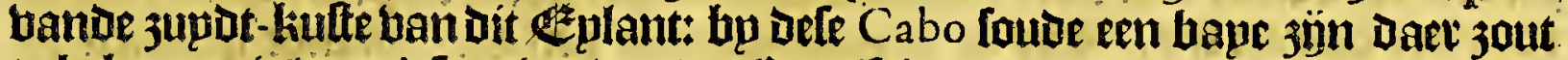

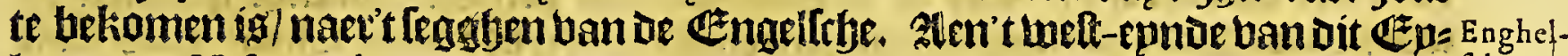
lant naer Hifpaniola toe leght bet Eplande Mona, (Daet wo terfont lullen ban fche vo-

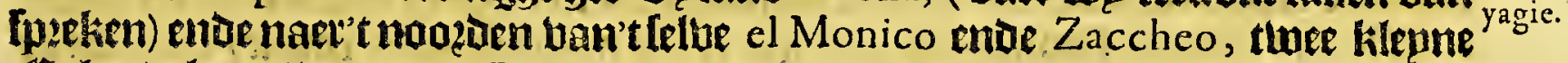

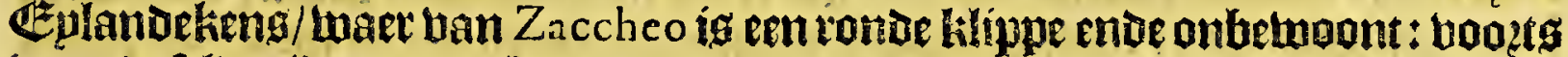

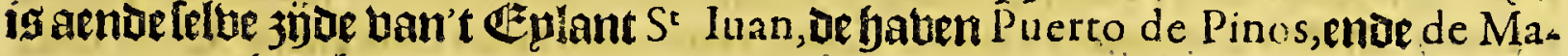

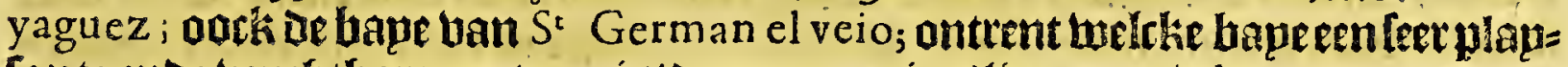
Tante ende butfitbate contrepe íg/ Daet ozaengien/limoenen/plantanos enoe an=

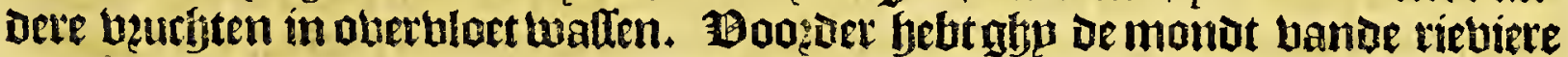
Guanabo ofte la Aguada, ende norb troo? Det Die han Guahataca. Alen ar feltue

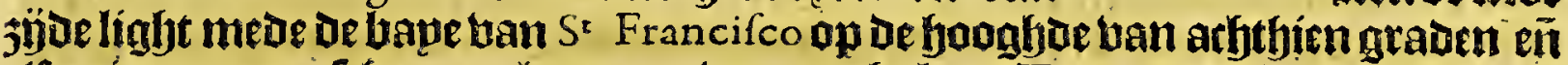
elf minuten; een feboone plaets om thater te balen. Baet naet op denoot-kufte ban dit Eplant de riebiere Camay enoe Cebuco,ende Toa, ontrent Puerco Rico: ende in t midoen vande jee nael't 3 upden toe bier ofte büf Ezplandefiens diefe noemen las Haberianas.

Mona iseen klepn ezplandeken; gelegen op be 18 guaden ende 8 ofte 10 mi=

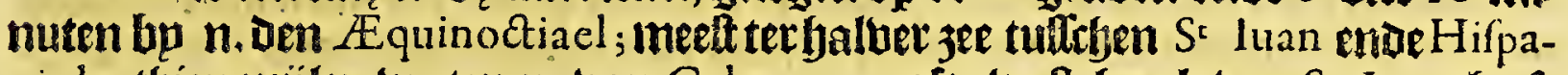

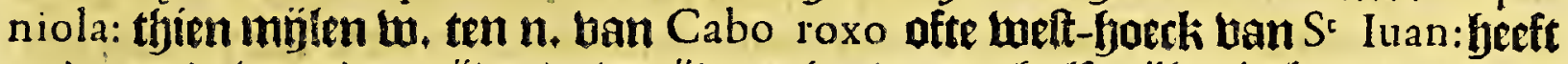

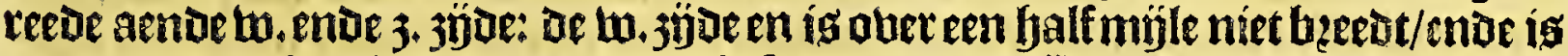

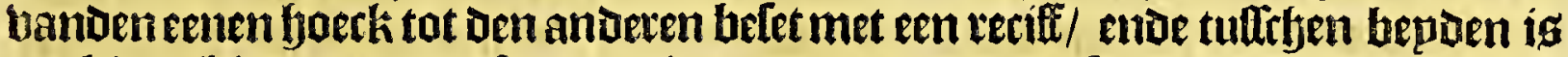
Een klepn binnen luater/ Loo Dat als De $3 e e$ een loepning frhiet / Daer niet is aen te komen: aen De 3. jöDe is ouer al jand-Itrand/en beter om aen te komen : Dorf de grond is rontomklippigl en bupl / [oo datmen wel moet toe-fien twaetmen fin antker laet ballen. Op Dit Ezplandt ig geen berfry-bater té behomen; Daet en uroont geen tolck / maer daer jünfoogn-beeften op/ uerekeng ende bocken/poth

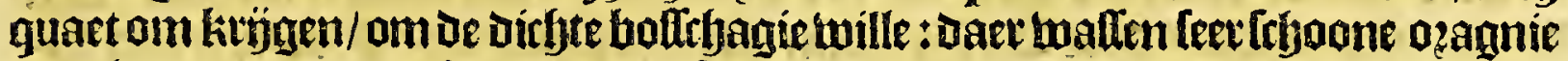

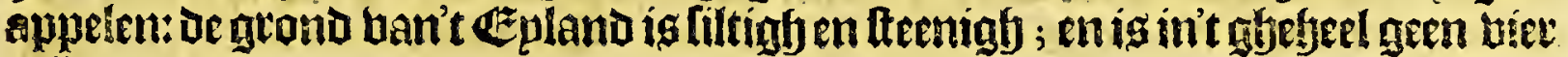
mijlen groot.

\section{VAN 'TEYLANDT HISPANIOLA. \\ Het vierode Capittel. \\ Vande ghelegentheyde van dit Eylandr in't ghemeyn.}

H Ët Eplanot'thelck De Sparaniaetoen de naem ban Hifpaniola bebben

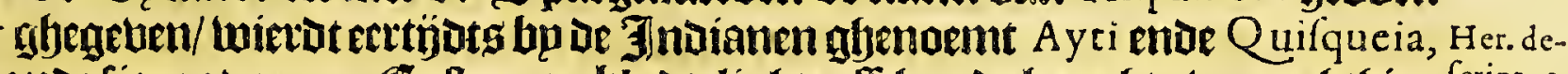

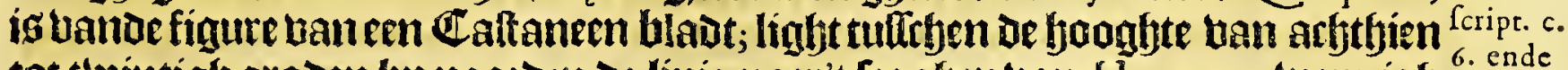
tot thintigg graden bp noozden de linie naev't legghen van Herrera, wepnigh dec.r.1.3. 
meet ofte min; hebbende in Ipn om-Loop bp oe bier yondert leguen; is lantk

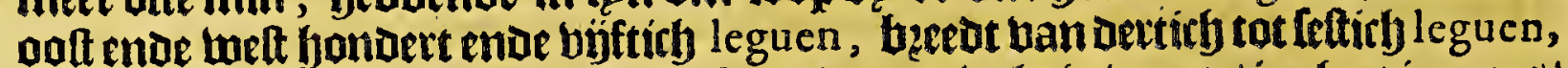

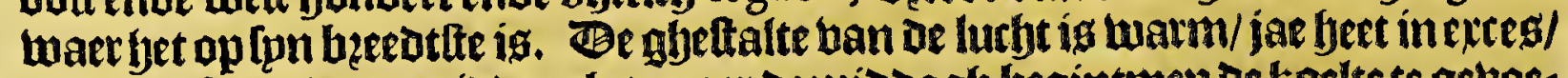
Acoft Dorf meef Deg book-midoarghg: naer demidoang begintmen de lioelte te getors

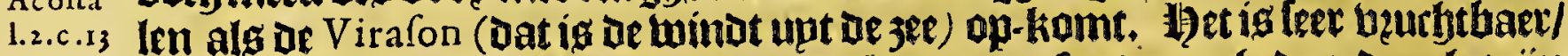
ende heeft feer [efjoone wepden boo? aloerfande vee/ foo datter fyeden- daeghys jün

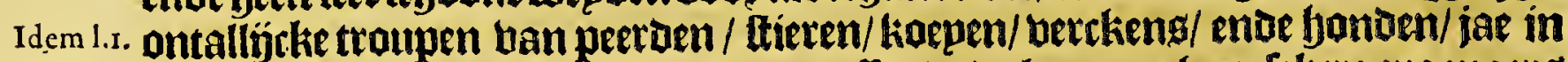

c.21. Lulcke menirgte dat bet bee ban ftieven/ affen/ende koepengheen fekere epgenaers en feeft/ maer diele eetf op't velt ofte gbebergbte han kriggen ende opoden die

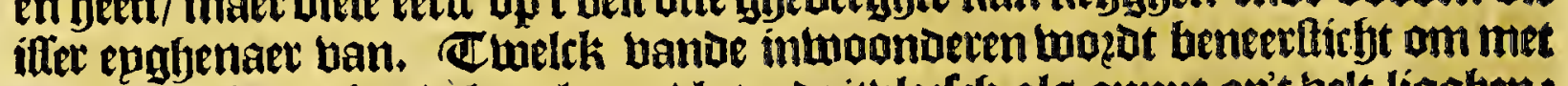

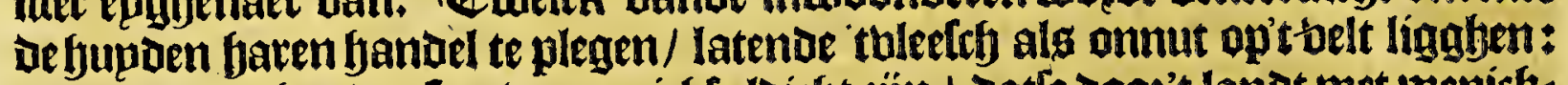

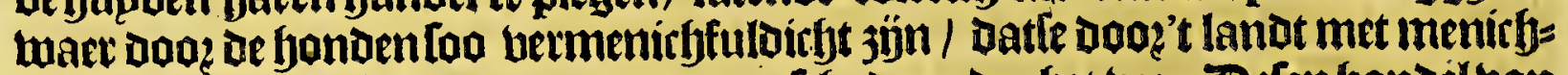
ten loopen als walben/ende doen aroote frhade onjer bet bee. Defen bandel ban De hupden is een bande befte ban dit quartiex. Be Telbe bonden beblen oock gbe:

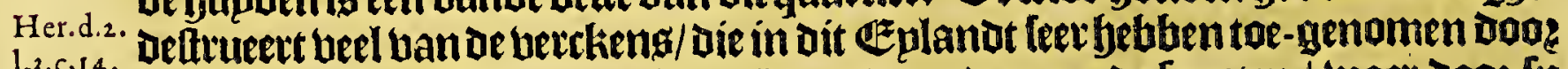

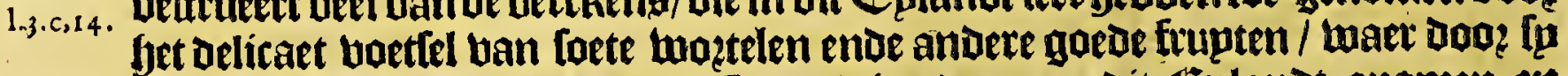

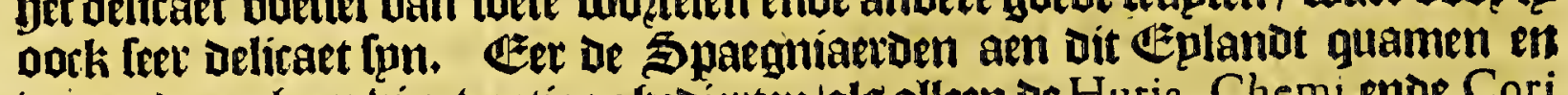
waren daer gbeen vier-boetige gfedierten/als alleen de Hutia, Chemi, ende Cori

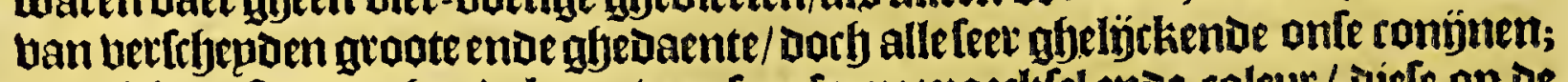
ende fekere ftomme honjekens ban feer frape maeckfel enoe coleur/ jiefe op de jagbt abebzupckten: norb gheenighe benijnighe dieten om de menleben frbade te doen/ hoetwel daex anders gheen Ganghen en adoersen onbeken. Ban daet

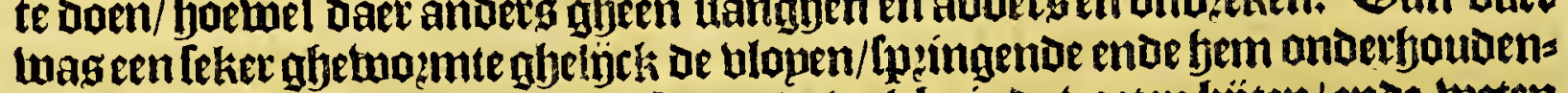

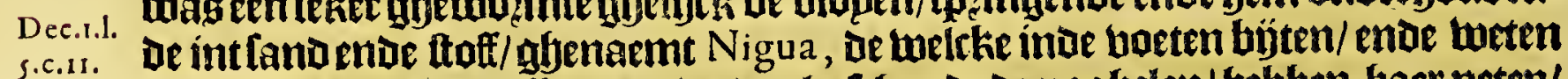

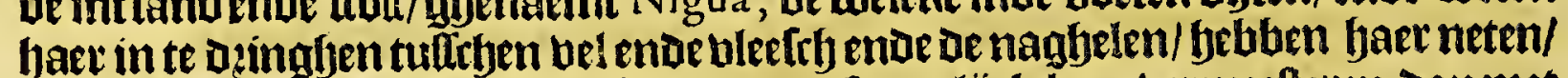

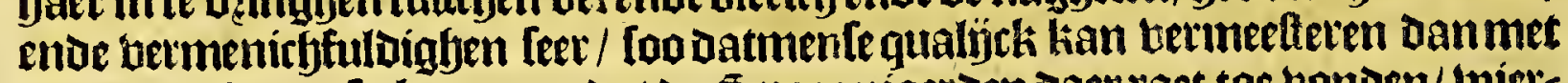
uperende heete pletkeng; eer dat oe Spaegmaerden Daer raet toe honden/ thiet= den [p daer van loo ghequelt/Dat eenighe de teenen/jae de boeten bet'looen. On= der de bilteren die daer werden ghe bonden / ig aenmerckeng weerdigh / diemen noemt Manati, welch feem bouat in ae zee ende de ríbieten/van maeckelel alseen

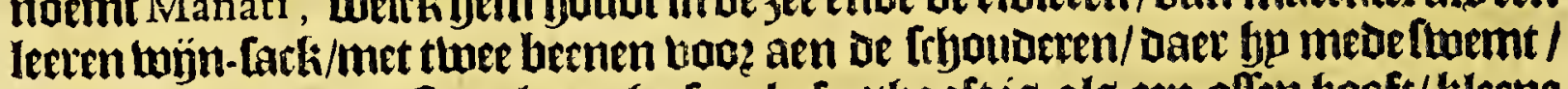
banmioden naet oe feert loopt lop [mal af ; 'thooft is als een offen fooft/kleene

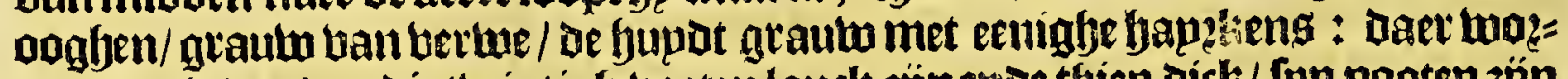

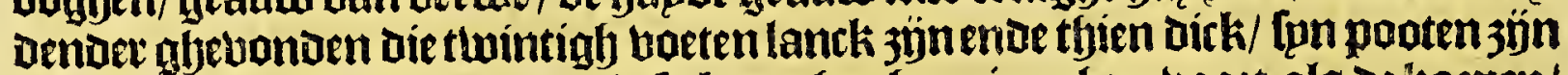
tonotmet wiet klaumen aen elck/ [p beenghen baet jonghen bodet als de koeuen/ ende bebben twee boeten daetfe die mede boeden; ae fmaert is meer dan ban

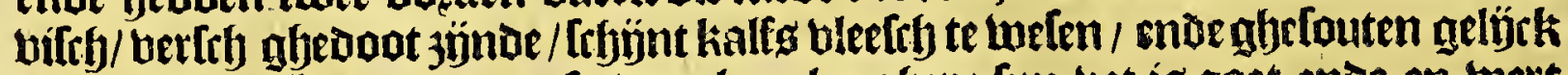
tonjn/ Dan is beter ende confervert hem langher : fpn yet is goet ende en wert niet gartt/men bet bet leder daet mede: beeft benighe fteenen in thooft groepende

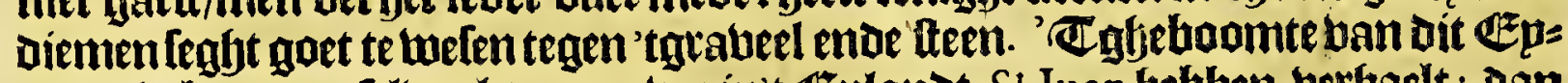

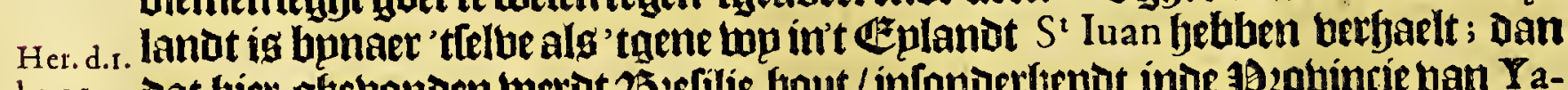

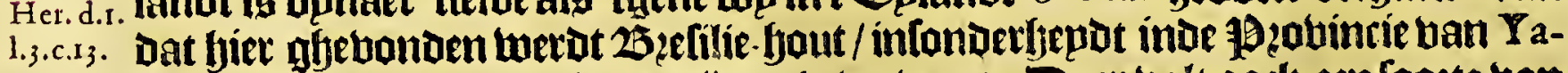
quimo, van twaer meniclyte ertijots is tertboet. Baer balt pock een fookte han

Acoft.l. peper diefe A xi noemen / van berthepden foozten / welck eettijots bp ae Indias

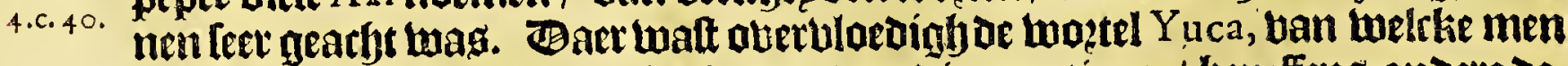
oe Cazabi maectit / welch is het bzoodt ban aie quartieren / beneffens andere de= licate burbten/alg en footte van Plaranen, tweltk [p Dominicos noemen/kleen

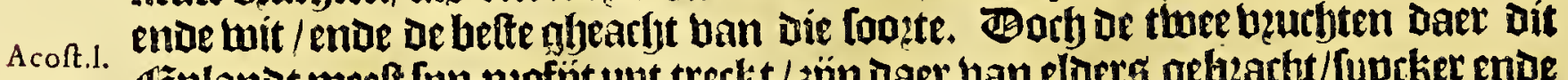

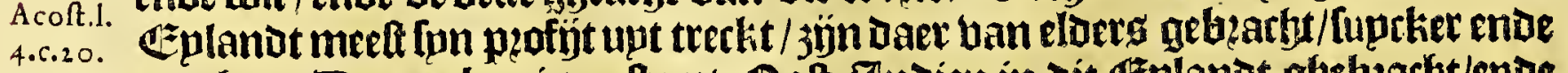

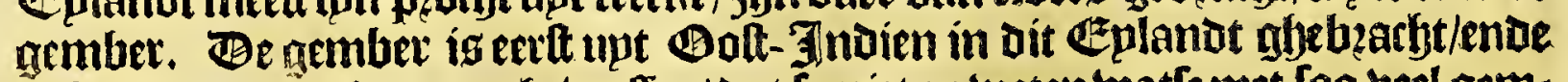
in futcken ouer-bloet aenghe balten/oat fo niet en weten watfe met foo beel gem=

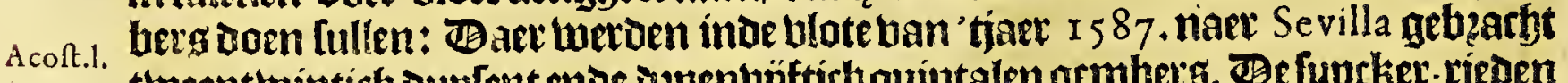

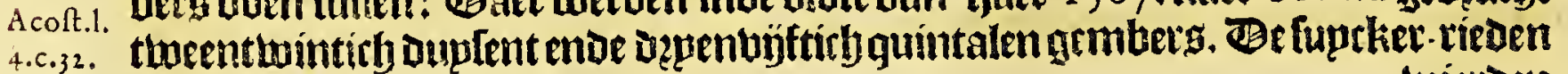
twietoen 
Het eerfte Boeck.

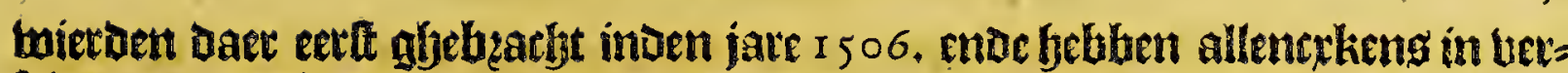

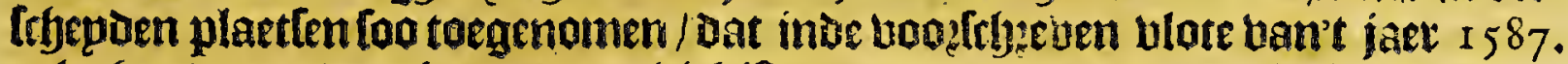

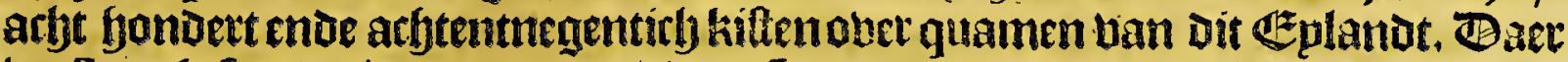

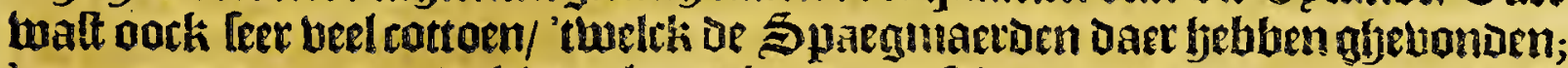
'tgroept aen grogte ende tileene boomkens/ meelt in oe ballepen. Baer en plagh

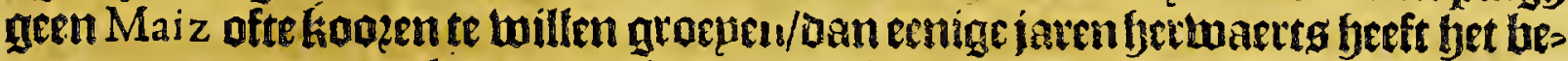

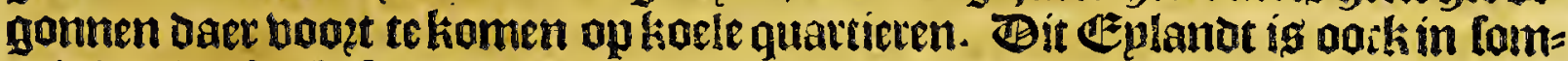
migfe plaeten befmet net be fnoode boomen Guaiabos, daet wa hien boen fols-

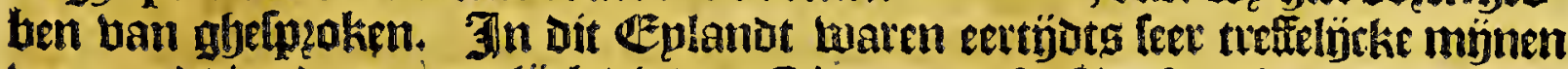
ban goude / ende namentlincli die van Cibao ende S' Chriftoval, enoe andere;

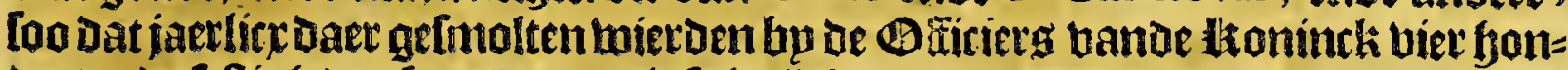

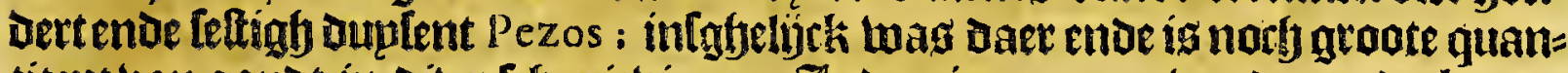

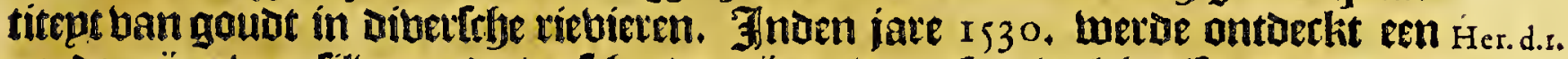

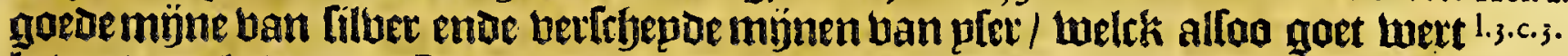

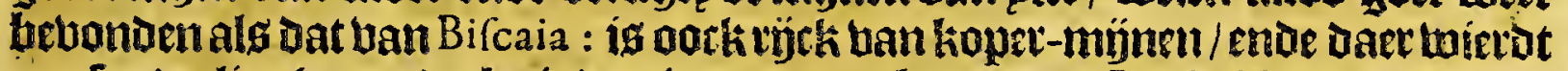

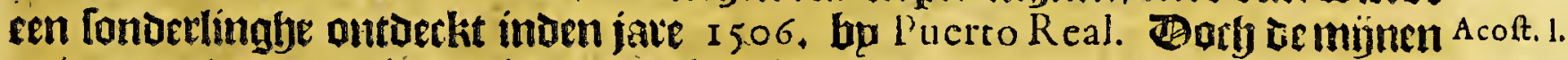

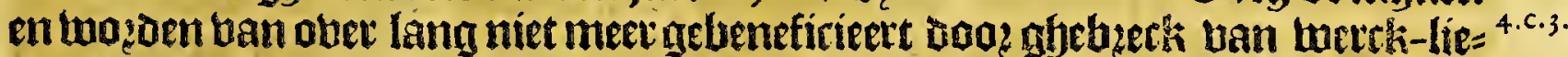

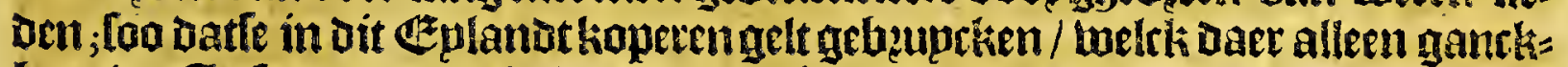

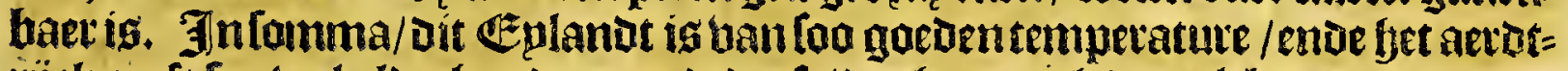

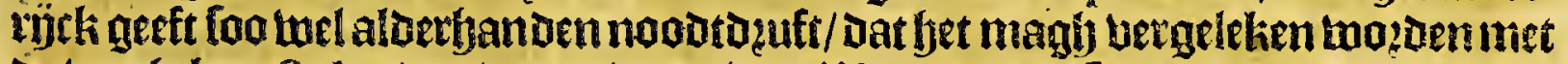

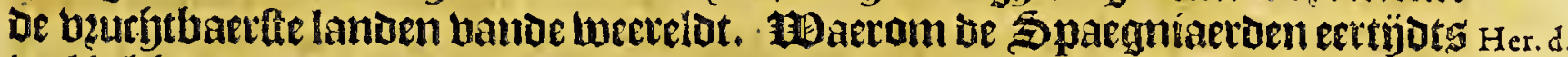

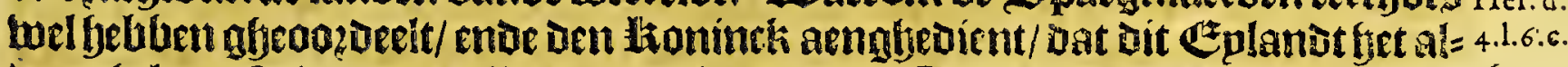

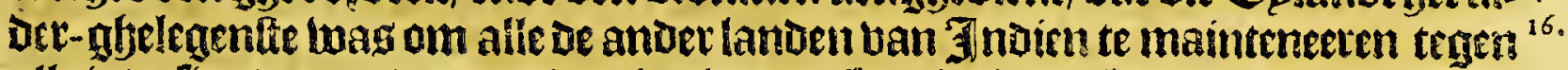

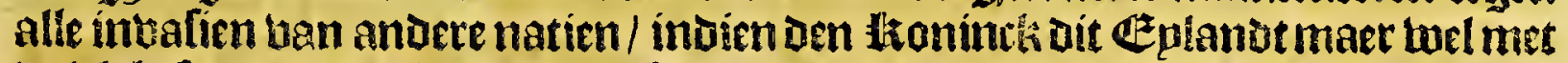
bolck belette / ende alle de bloten belaite in't gaenende keeren Daet aen te looyen: Doch dit aùnge en ig nict ghevolght ghelweelf / maer is ter contratie thamot eerit

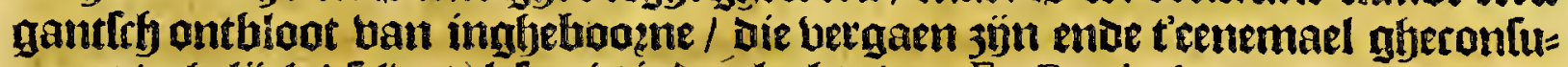
meett / ghelích tteltue te lefen ís inve tlarbte van Fr. Bartholomeo de las Cafas; Her. d.r.

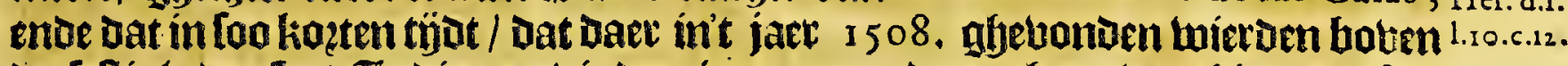

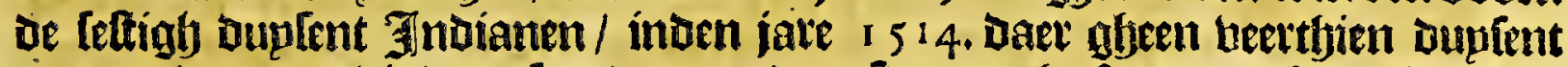
imeet en waren te binden; ;oo datmen daet fwarten feeft moeten benghen: ten

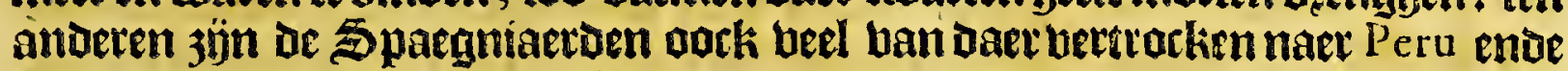
Nova Hifpania, ende andere lanoen/ daermen met de arme inabebozene te be=

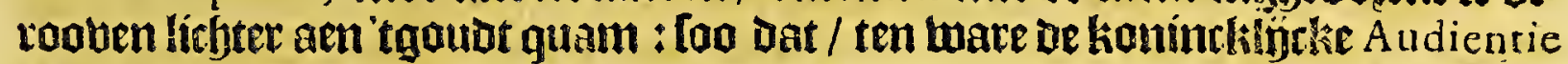

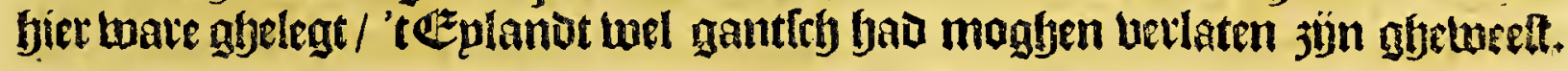

het büfoe Capittel.

Vande Provincien van dit Eylandt.

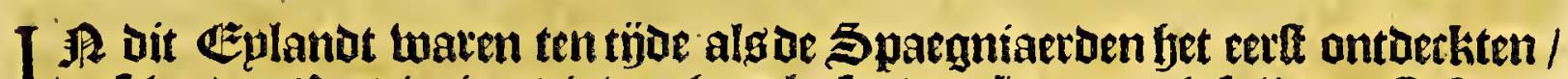

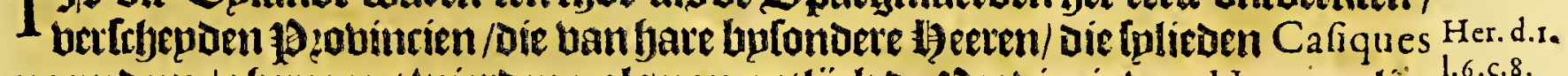

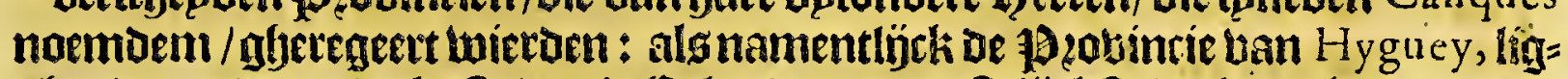

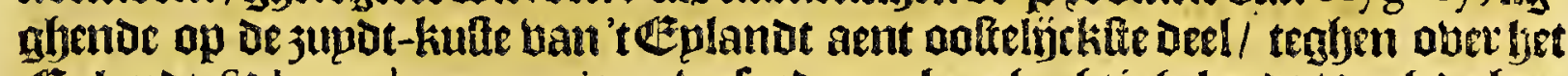
Eplandet $S^{t}$ luan de porto rico, wefende een bergharfitigh lanot / oorf oe ber=

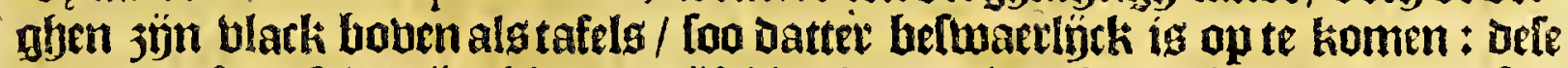
plepnen ofte tafelen 3̈̈ntbien tot büftyien leguen langh ende baeed / al met leet

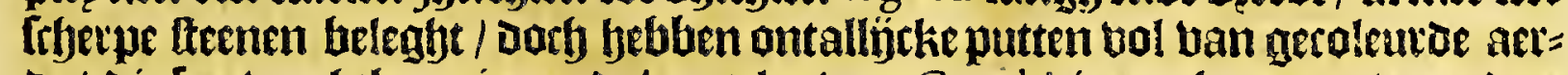
be / Die fect beuthtbaer is um be twotelen ban Cazabi in te planten enoe andere

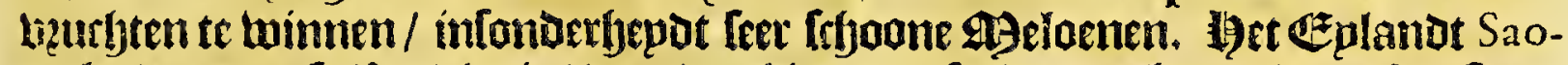

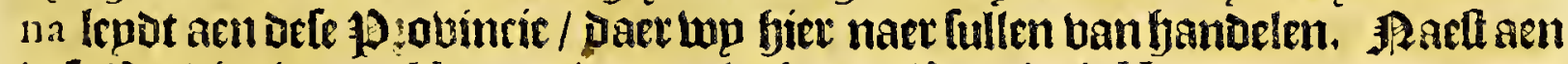

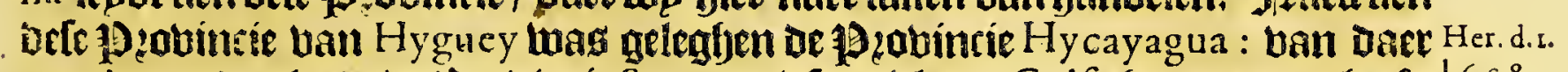

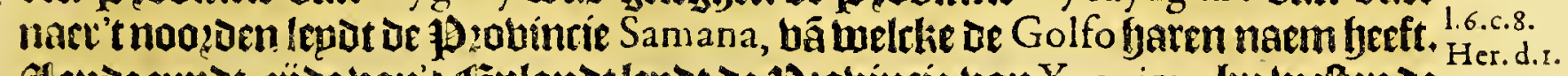

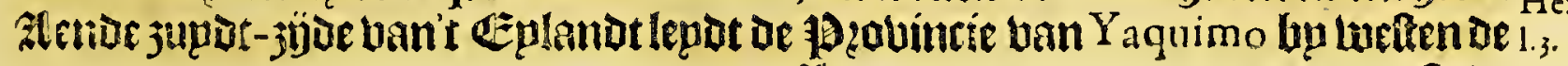




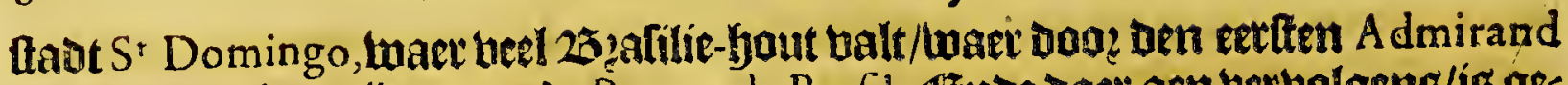
Her.d.2. Columbus Die eertijtsnoemae Puerto de Brafil. EEnoe Daet aen berbolgeng/íg ge=

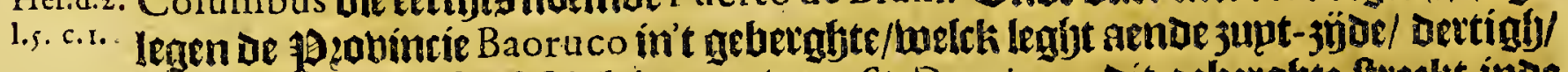
tuerting/ujftigh eñ 'ffettigh leguen van $S^{t}$ Domingo: dit geberghte aterkt inde

Dec.5. 1. Hengte(naer' tfeggen ban Herrera)'teltigh leguen, ende is thintigh eñ meer bzert/

2.c.6. Conver water eñ ander boet fel boo? de menfefen;ende de peerden en han men Daer

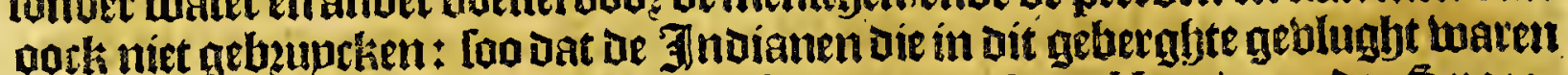
onder feet belepdet tan een 3 mbiaen diele noemben Don Henrique, ae spaeg=

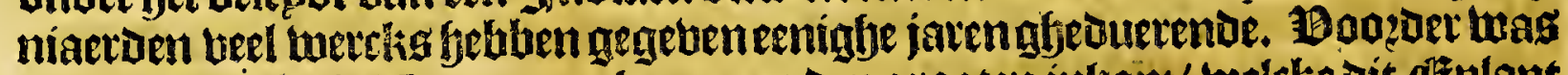

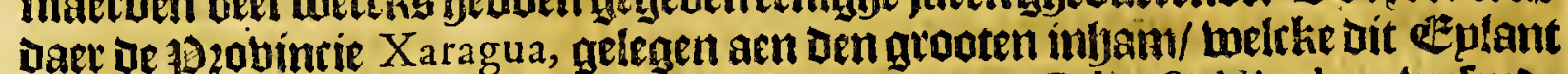

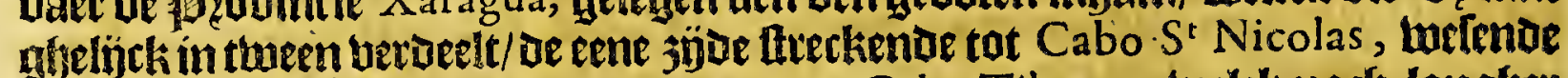

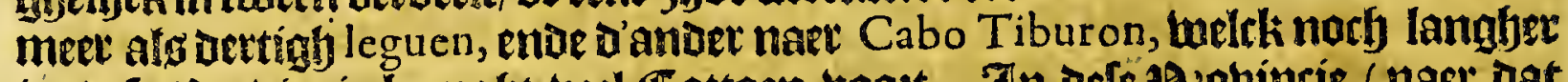

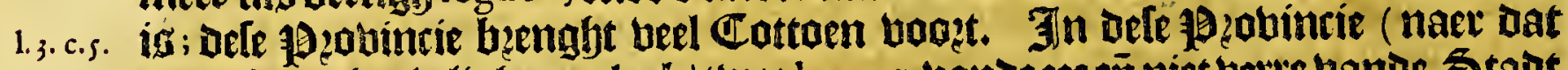

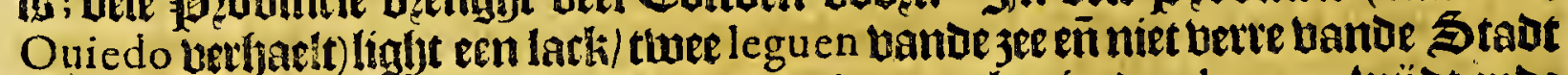
Yaguan, ftreckende naet fet oalten; ende is aen't begin Dep leguen wijet ende

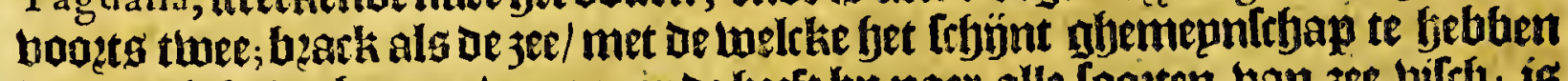

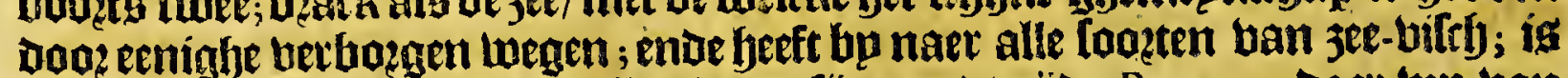
ontrent is i 8 leguen lamgh:

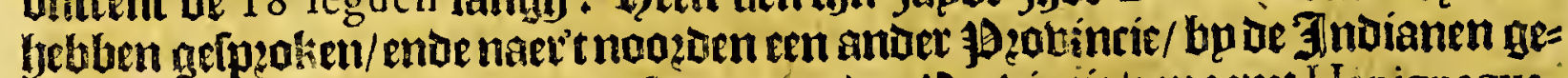
normt Guahaba; enoe naer't wetten cen ander 10robincie/genaemt Haniguagya,

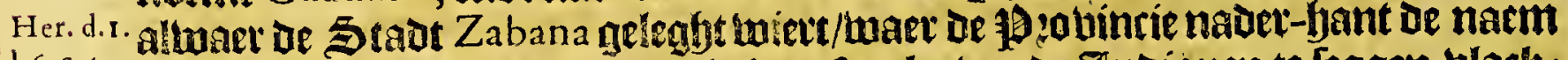

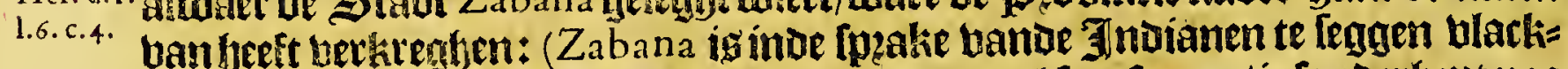

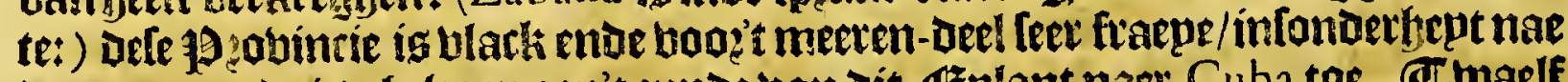

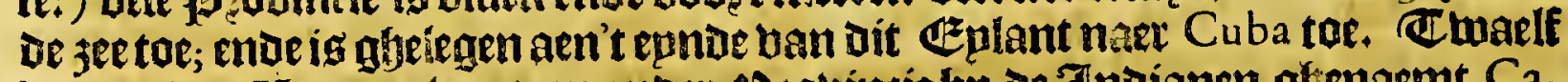

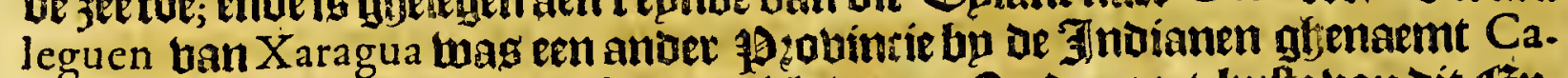

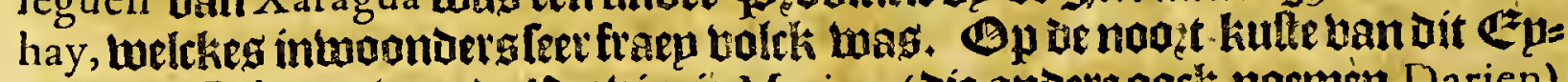
Her. d.r. lanot na Cuba toe toas de plobincie Marien (die andere oar: noemen Darien)

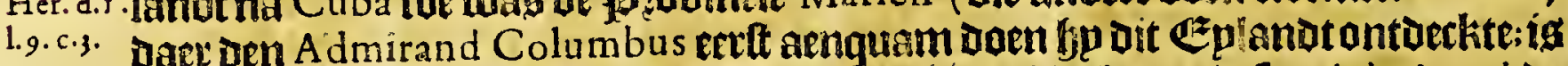

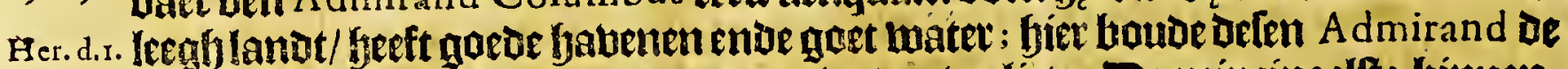
1.c.4. Stadt Navidad, welck fp Daet naer weoer tertiet. De peincipaelte binnen-

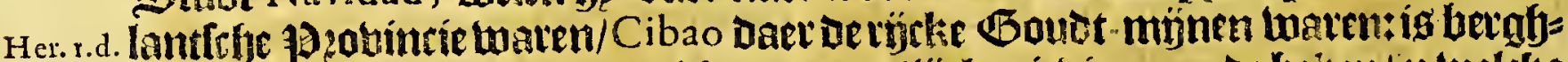
1.2. c.10. ashtigh ende alle mengoust uant; ba! ban teer hooghe Jajn-boemen; ghetonte lanot ende Her. d.r. goede luth / ende feer goet mater. 't Gount dat intue beken mozot gyebonoen

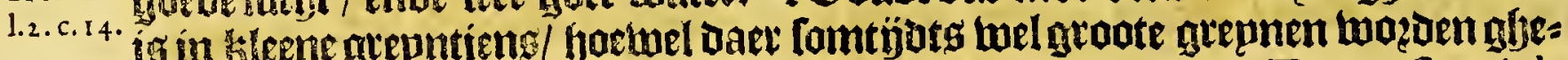
bonden. Ba ate jün oort Coper-mínen ende wepnigh Azul. Beneetlten Admirand bouve bier een fortrefie uie hp noembe $\mathrm{S}^{\mathrm{t}}$ Thomas. Baer naer bolght

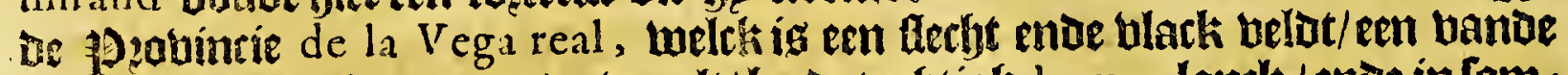

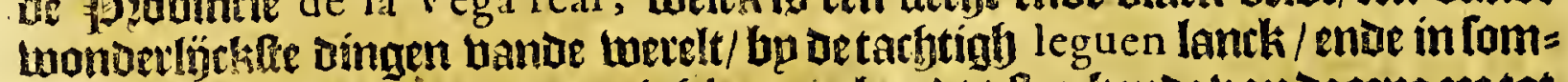

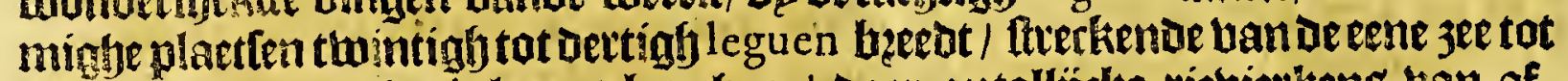
ie anoeve ; is omringhelt met berghen / Daet ontallijtte rievietkeng tan af-

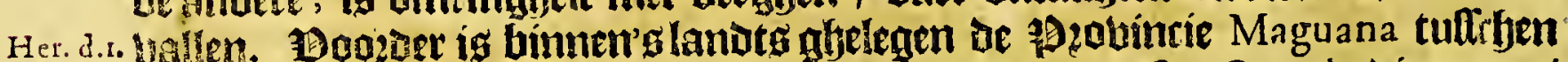

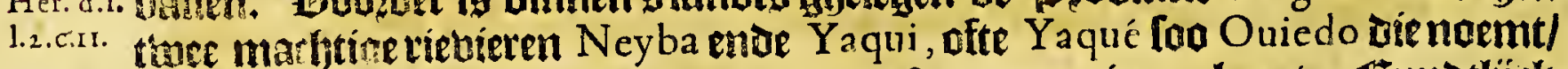

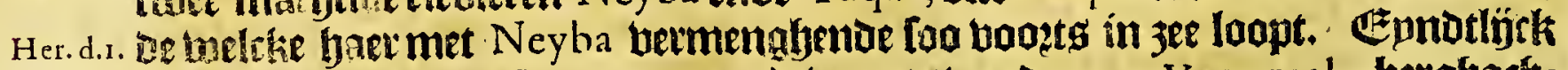

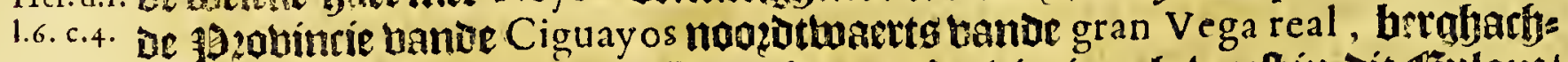

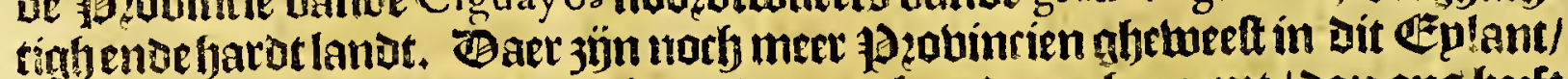

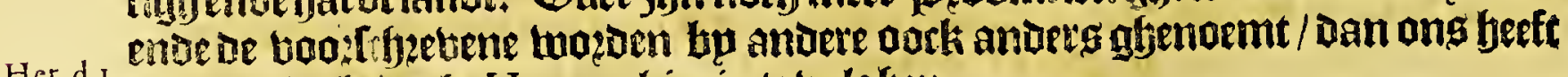

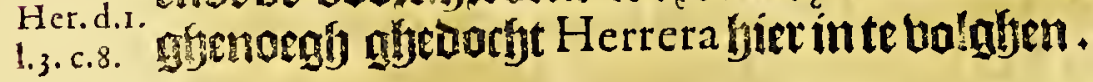

\section{bet lefte Capittel.}

Vande Steden der Spaegniaerden die eertijts in dit Eylande waren.

1

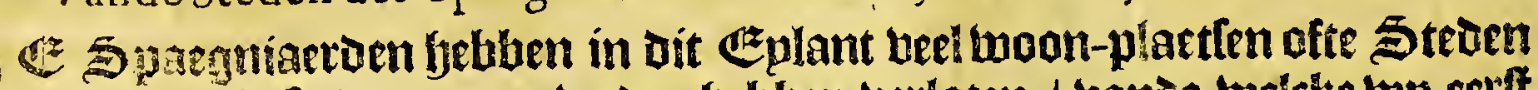

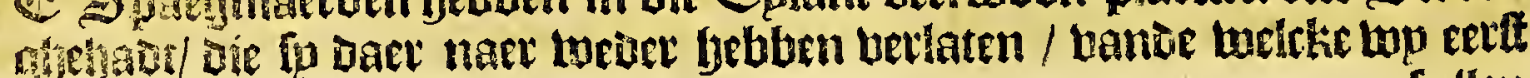
fullen 


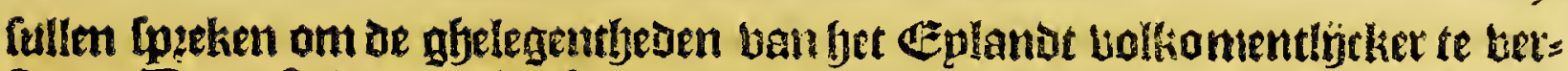
ftaen. Be eerlte woon-plaetfe vooz Chriftophorus Columbus in fun eetfe topa = Her.

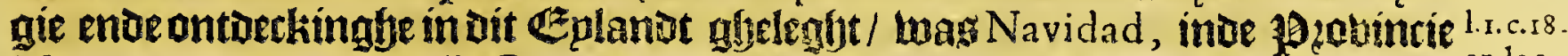
Marien daer Doen ter tỏt Guacanagari Cazique lwas; fogode en quede haten enderg.

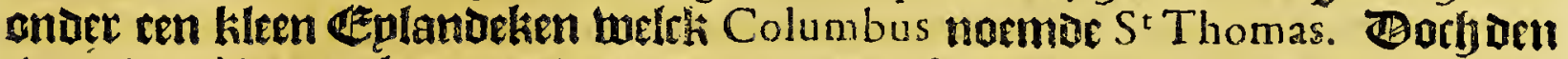

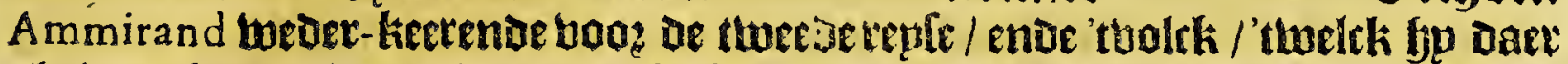

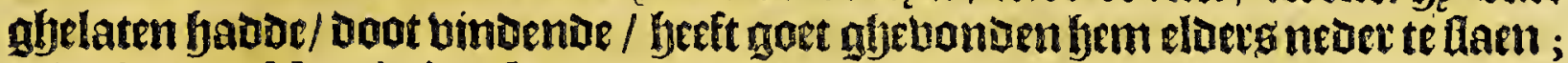

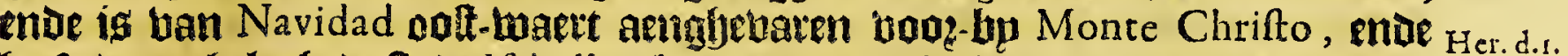
beeft daer ghelegft de ftadt l fabella, bp een gioute riebier / met een gaede haven/ 1.2. c. 1.

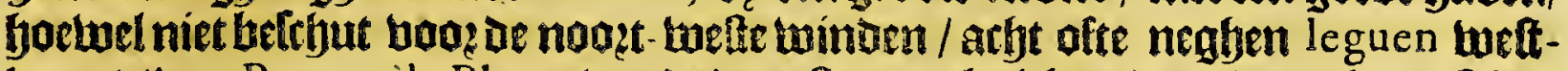
waets van Puerto de Plata : vondt Daev ftecn en halch/ende andere nhereetfrljap

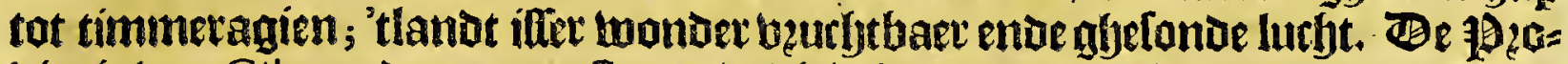
bincie ban Cibao, Daer 'tmeefte goudt biel / is maer thintigh leguen ban dace; enve twas naer gheleghen bp de gran Vega real, baer wp hier bozen ban fyeblen

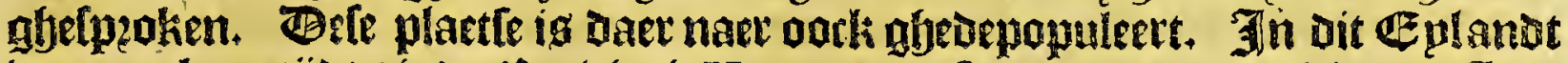

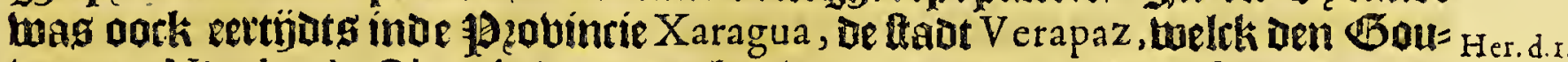

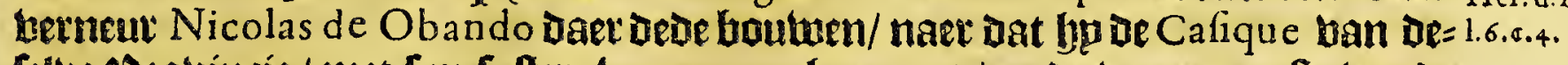

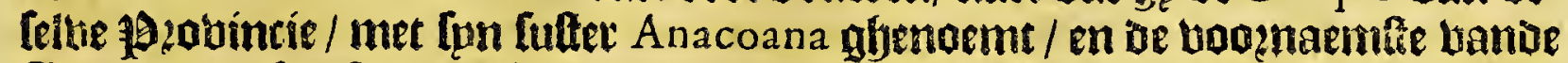

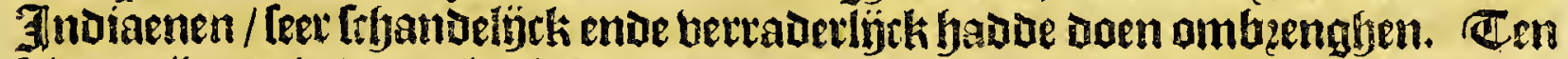
Iétuen tijoe wierat oack gheboumet Salva terta de la Zabana', imbe 1920uincie Her. d.

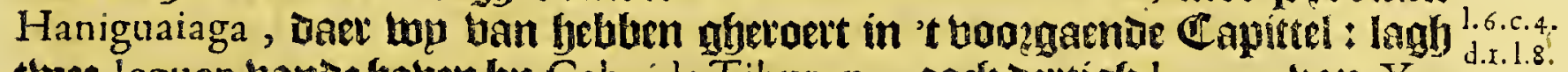
thee. leguen bande faben bp Cabo de Tiburon : oock dertigh leguen ban Xa- ${ }_{c} .3$.

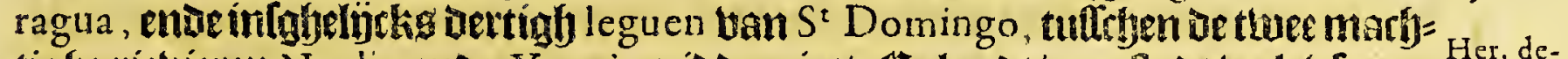

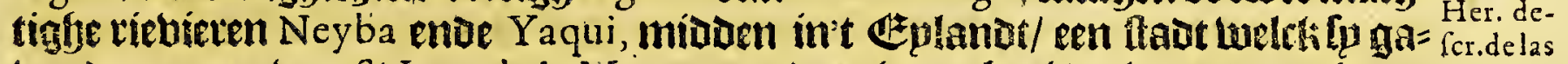
ben Den naem wan $S^{t}$ I uan de la Maguana : Dan ís ooch al berlaten/ uptgheno= Ind.

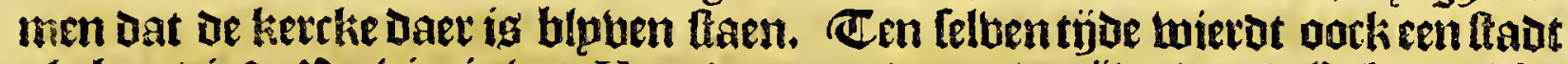

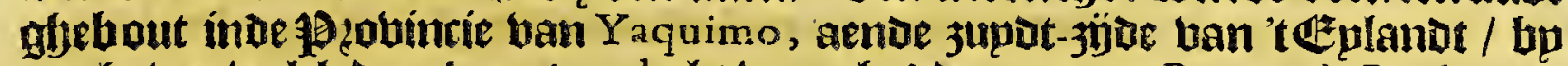
ten baben toelck ben Ammirand als bozen badae genoemt Puerto de Brafil, met ${ }_{\text {Her.de- }}$

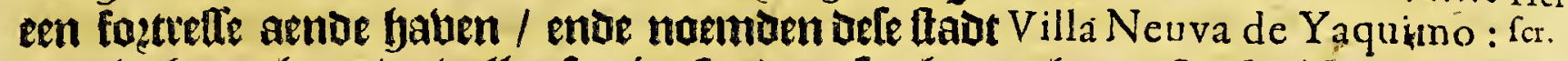
Daet leght mory een tertuallen foetjen [oo de onle aljetupghen. Opck el Bonao bu Cotuy, waet erelt hp Columbus ten foztreffe has ghelepor tot befryerminglise van oe mỉnen; lagh negenthien aft twintich leguen ban $S^{2}$ Domingo, aen een Ouied. betuftbaet ende luftich vlack telot / loo dat fet abondantie ban Maiz ende Car. ${ }^{1.4 . c .8}$. fabi enoe ander vittualie upt-bzatft. Baer was vockertijots arbt leguen noot-

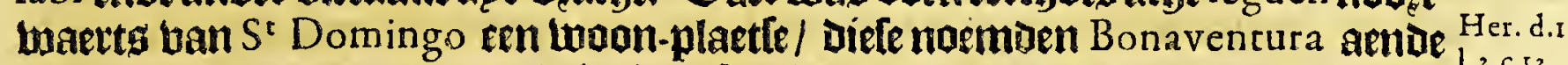

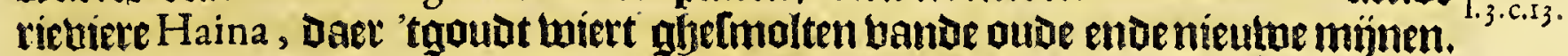

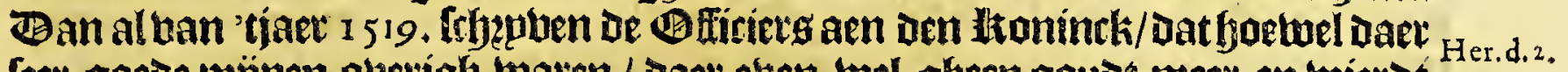

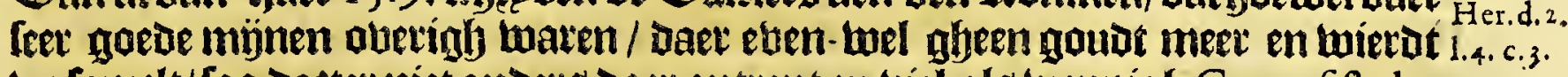
berfamelt/ foo datter niet anders daer ontrent en biel als wepnigh Cannafiftola :

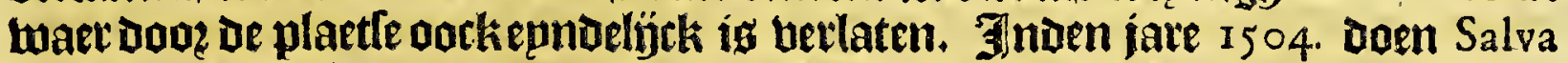
Leon twetot ghebout / mert mede te landt-iwaet in gheleght Santa crus de Ay-

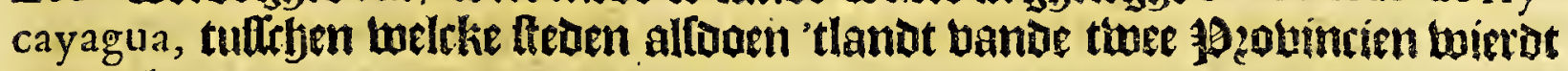
betoeplt.

\section{Dat fevende Capittel.}

Vande Steden der Spaegniaerden die nu zijn in dit Eylande, ende eerft van $S^{t}$ Domingo.

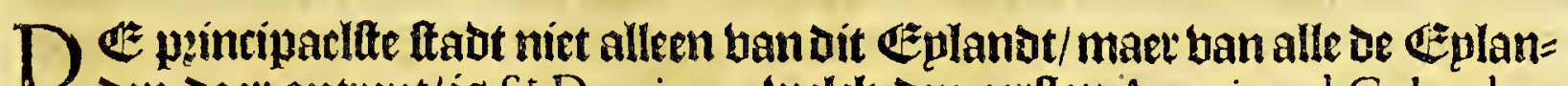
Den Daet ontrent/ig $S^{t}$ Domingo, welck den eetfen Ammirand Columbus normie de nienlue Ifabella, (Doch defe naem is niet gebleben.) Defe ftadt miert giebant bp den Adelantado Bartholomeus Columbus upt bevel enoe Dooz laft

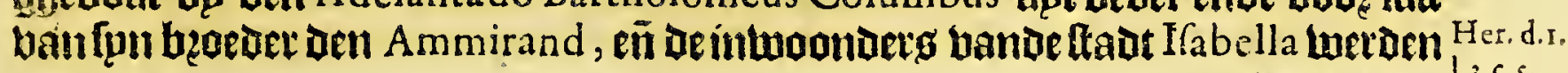
oetwaetts ${ }^{\text {l.3.c.5. }}$ 


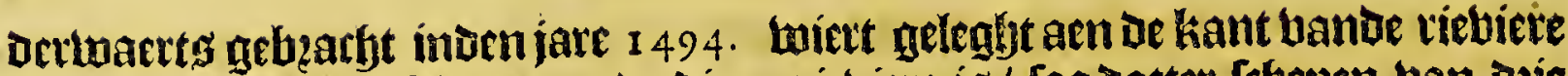
Ozama, melch een feljoone ende diepe riebiete is/ foa datter frbepen ban dzie

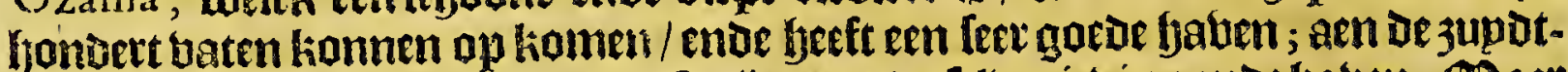

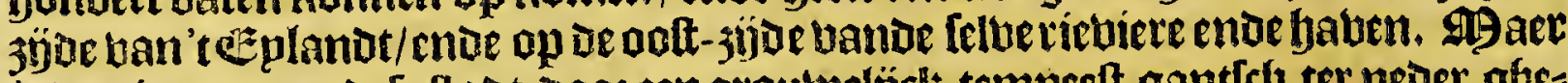

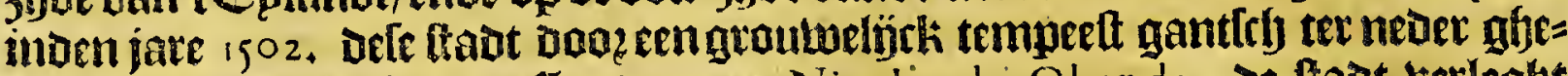

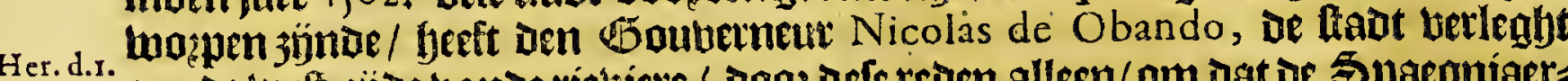

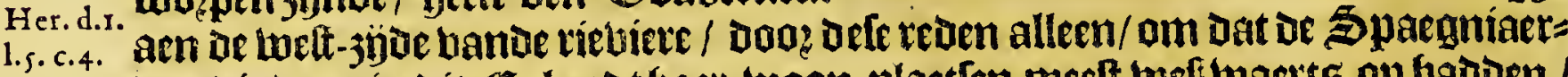

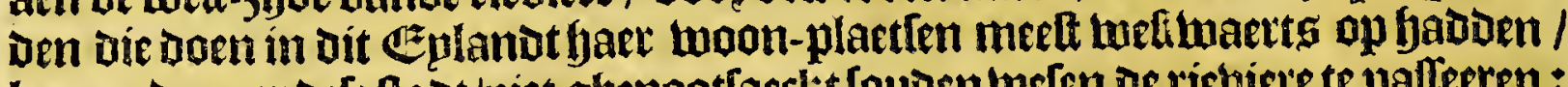

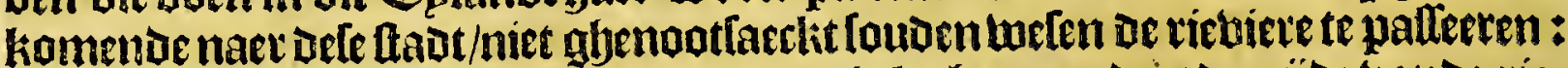
niet teabenitaende dat te logen beter was gheleghen aen d'ander jübe bande rie=

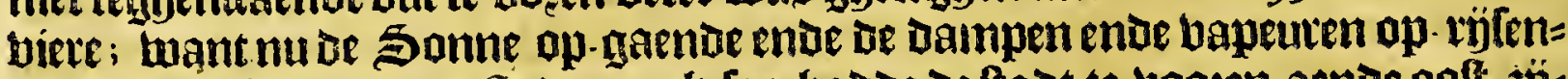

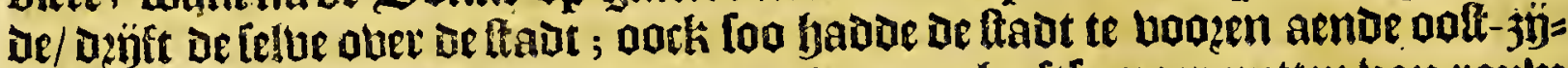

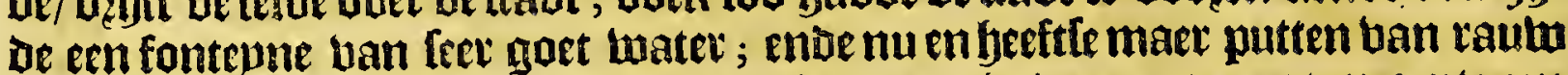
enoe grof water/ enoe de intwoonaets en konnen niet dan met groate moepte om water aende fontepne ouer-baren; moetenoe warhten naer de 25 arcke/ ofte felfs ecn bekaftighen; enoefret ober-varen en is niet bupten perïckel als de riebiere

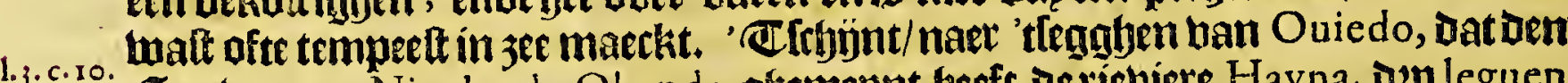
Gatuerneut Nicolas de Obando gbemepnt beeft De rieniere Hayna, Dep leguen

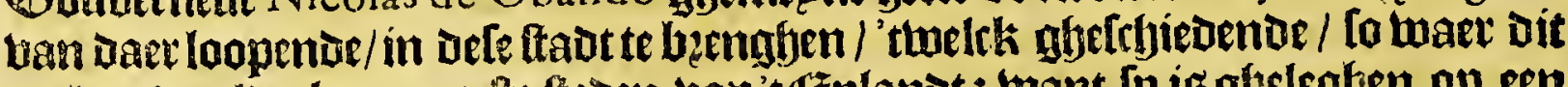

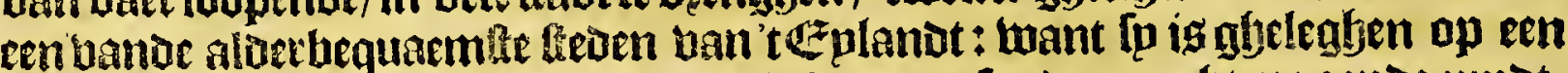
effen vlactien geonor ald eer tafe/ choe ig bemuert fonver giariten: aende 3 updt=

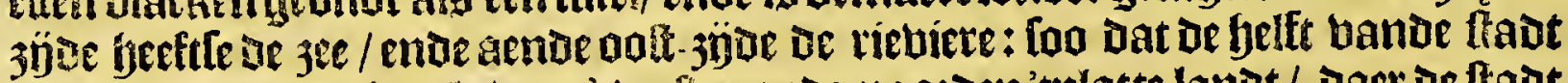

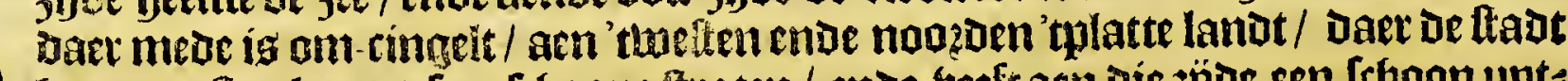

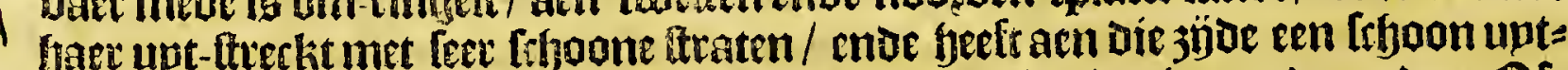

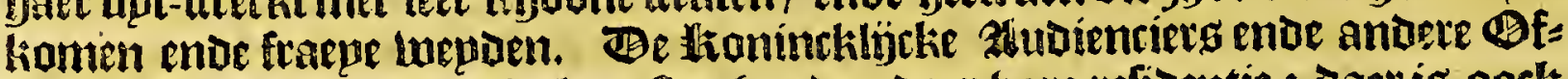

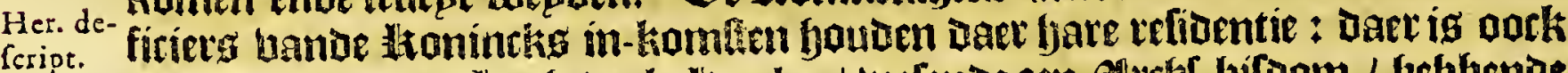

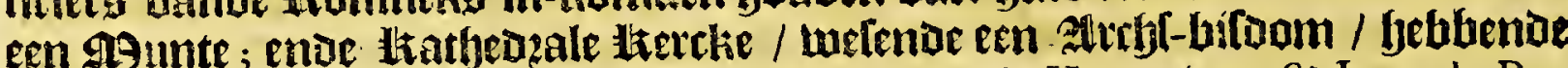
onder fich be 25 frommen uan Conception ende la Vega; van $S^{t}$ Itan de Puerro Rico, Cuba, Venezuela, ende de zlboije uan Iamaica : Daev jún inde ftadt Díuertrate filoolters uan Dominiranten/ f rantilcanenenoe de la mercede : pock twee Ponmen liloaftets: ecn Collegie iaetmen ae Grammatica leett / bebben=

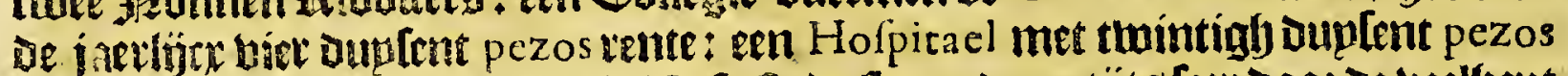

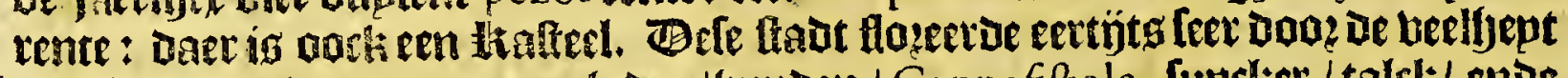
Her.d.2. van folgepen bie daer quamen laven/hupDen / Cannafiftola, fuptker / talck/ ende

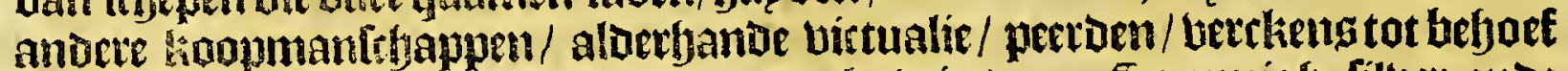

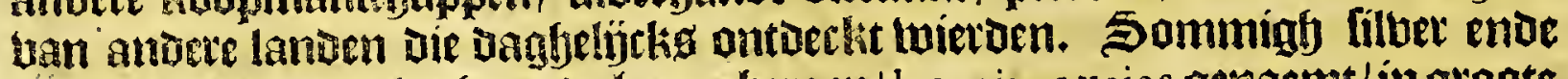

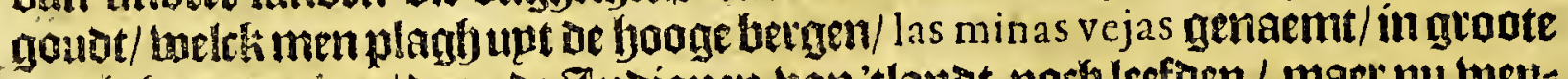

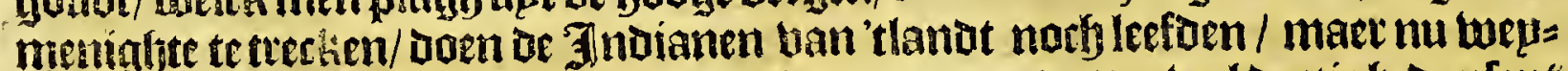

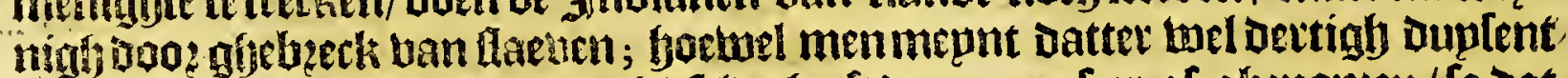

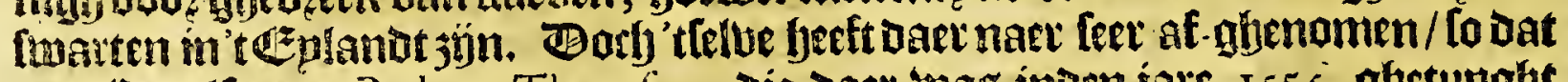
ent Ennelf-man Robert Thomion, die Daer was inden jare I 55 . ghetupght

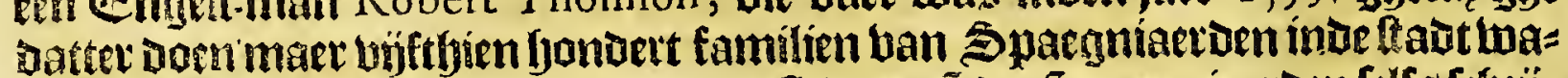

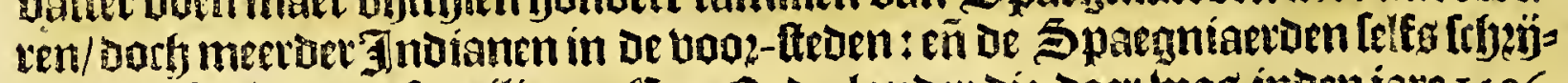

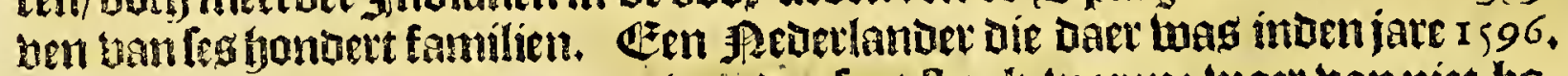

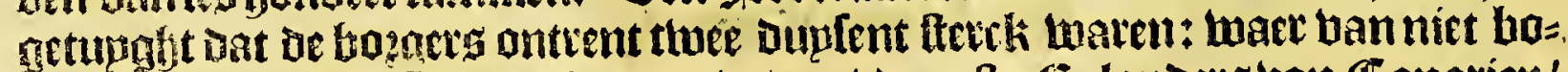

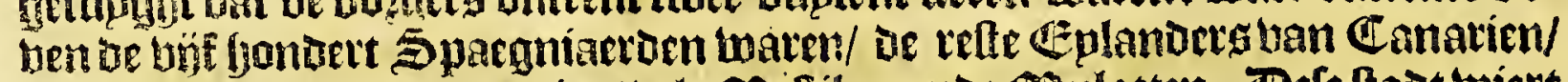

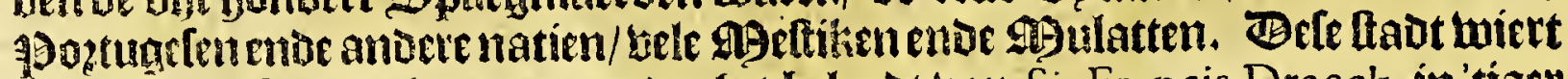

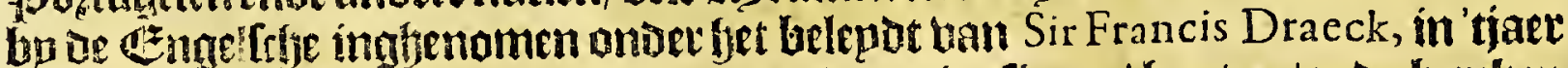

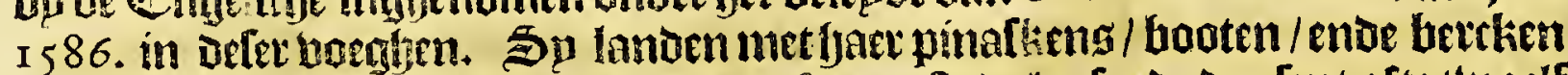

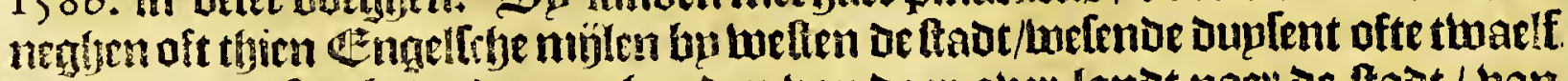

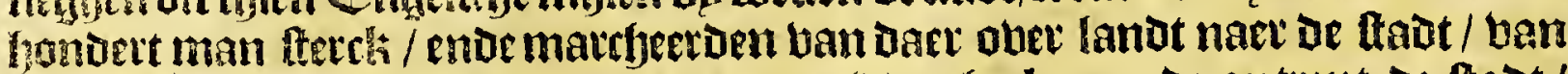

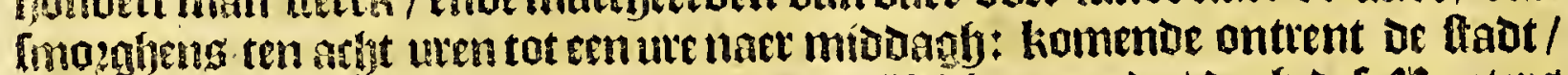

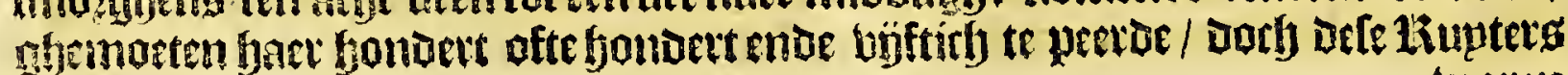
waten 
Het eerfte Bocck.

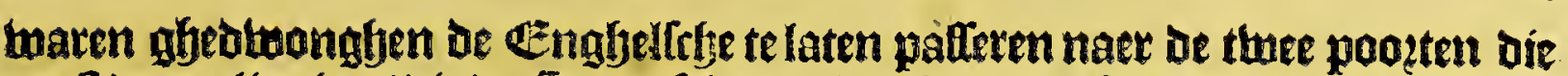
naeft de jee ligghen/ die de Spaenf(be met bolckende gefryut yadoen booz- Tien/

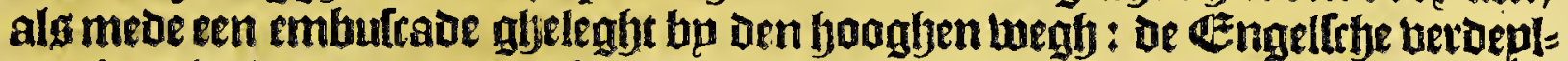
Den haer in twee troupen oun bepde de poosten teffeng te helpinghen; ende een de thatge van'tgroff geitbut upt-geftaen beblende/met bepnigh berlies ban bolck/

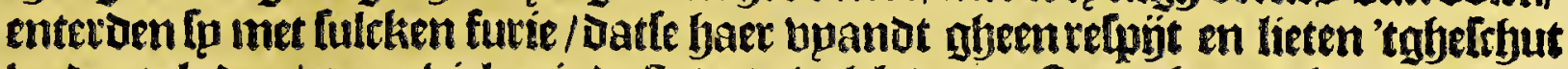

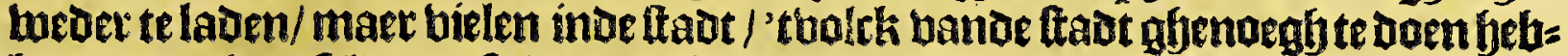
benoe met baer felbente falberen: fp trocken tot op de merckt/mefende een frfjoo= ne vier-kante plaetfe / alwaer bepte de troupen malkanderen ghemoeten / ende

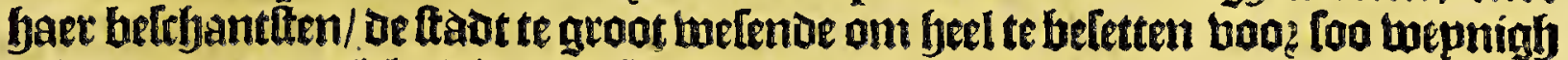

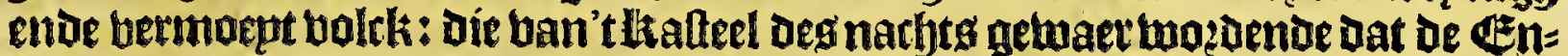
gellebe pooghoen de poote te bermeelteren/jÿn berloopenmet betcken/ober-lefjes pende naer đ'anier jübe ban de riebiere: De UEngellebe bebieloen de plaetfe een gantiche maenot / ende naec datte een goet deel daet han berbzandt badoen ende

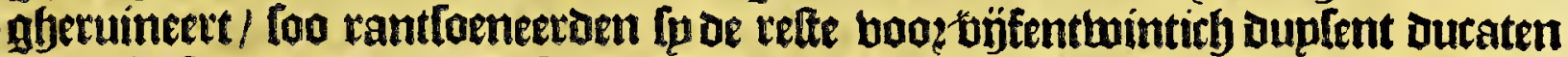
ban büf fryellingben ente feg penninghen fterlintr'tfuck : tonoen Daer gbeen

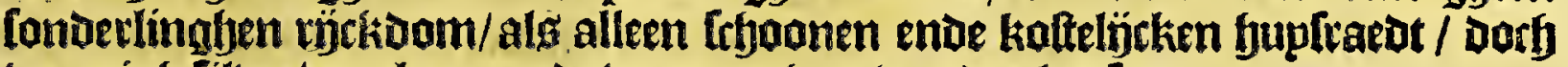
wepnigg filluertuerchs naer de betmaettbept ban de plaetle.

()et atbtfte Capittel.

Van de andere Steden van dit Eylandt.

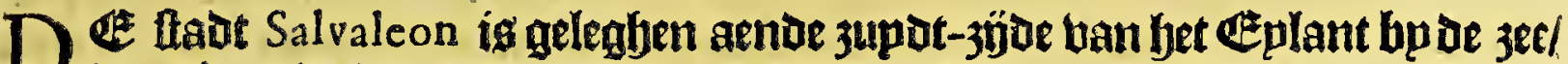
inde jayouintie ban Higuey, arftentwintify leguen poltwaerts ban S' Domingo : ae Officiets Irlyetten aen Den thaninck int jaex 1519 . Dat / boetwel dele Her.d.2.

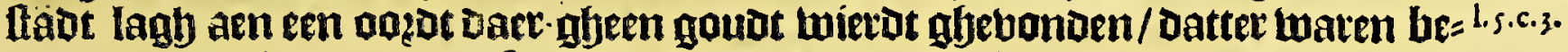
gonnen eenighe Ingenios ofte lupcket-meuleng te maken/ ende dat bet bee daet meer toe-nam als aen ecnigh anoer oozat ban bit \&plandr.

Be ftaot Zeybo is gfjeleglyen twintich leguen ban $S^{t}$ Domingo, ooftwaert Her. de. naex bet Eplandt Saona toe

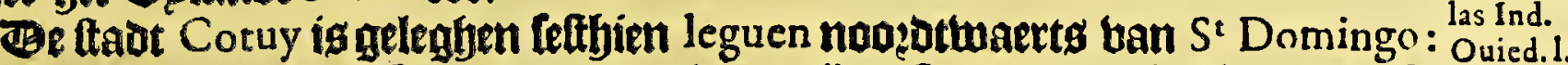

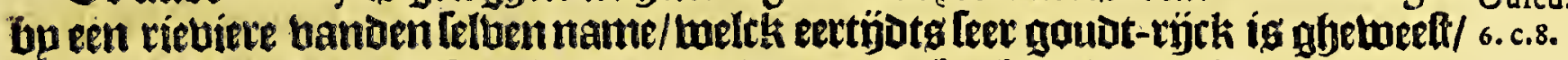

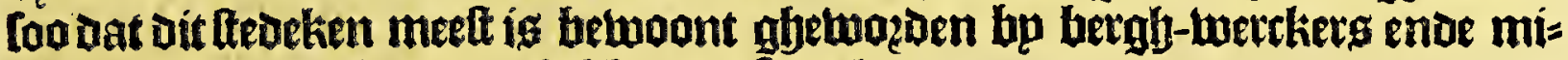
neurs die hiet beel goudts foblen bertamelt.

De fabt Azua íg ghelegen op de juptot-kutte ban dit Eplanot bierentmintith Her.deleguen van $S^{r}$ Domingo naer 'tweften : daetom-lyex 3 j̈n beel luptket-meuleng: fcrip. De ftad wordt oark abenoemt Comportela, ende de plaetfe daet De Indianen ende Stwarten woonen/Azua.

De thadt.Yaguana, welck oork wetot gyenaemt Santa Maria del Puerto, Dooz Her. de-

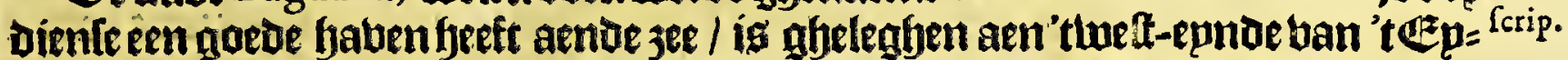

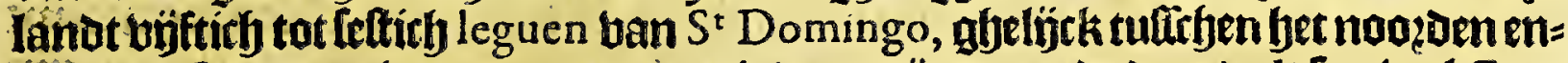
oe het beften; Daer is groote appaientie ban minnen; ente baer balt leer beel Can. Her.d.2. nafiftola : ende baer is goede nbeleghenthept ban lupcker Ingenios te maken: ${ }_{1.5 . c .3 .}$

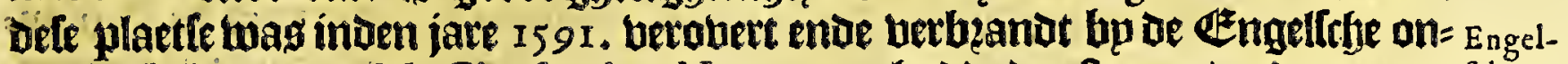

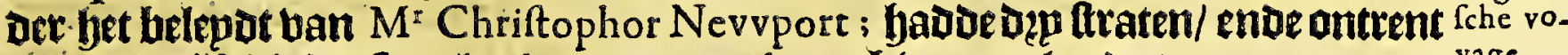

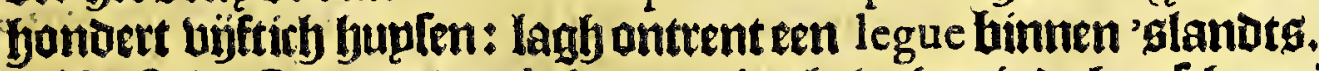

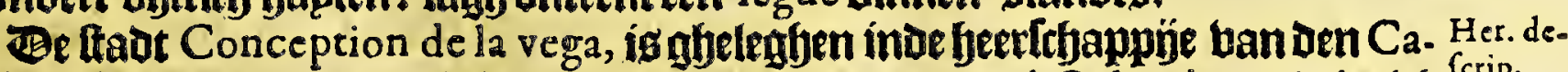
fique Guarinoex, toerdt ghebout up aeneerten Ammirand Columbus ; twintich frip. leguen van $S^{t}$ Domingo, naer' tmooet-ooften: Ouiedo fegft dertich leguen : Daet 1.3.c.10. is een Hatbedzale Hercke / Dotf gheunieert met die ban St Domingo; ende een . Hloolter nan Mimne-bzoeders.

De ttadt $S^{i}$ lago de los Caualeros, is ghelegfen thien leguen uan Conception Her.de-

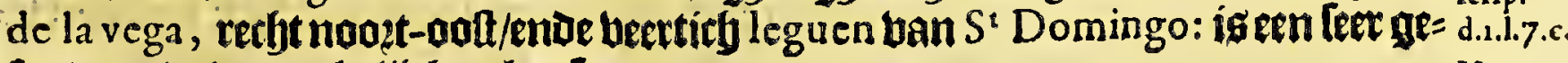
conoe ende uermakeligclie plaetle.

Be fladt Is. 
12

Vande Weft-Indifche Eylandets.

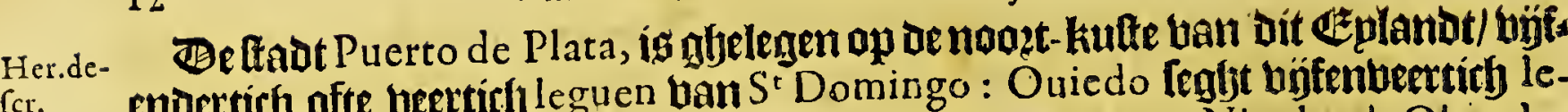

enoerticy ofte beettich leguen ban $S^{t}$ Domingo: Ouiedo [egljt binfenteertich le-

1.4.c.8. Guen: wett ahebout in ien jate 1502, bp Den Bouberneul Nicolas deObando, tot beter ghelegentbepdit bande commercien met de frbepen komende upt Spaes anien/mibtgdien maet thien leguen is ban de gran Vega (die norb tjien leguen

Ig ban $S^{t}$ Iago boomoemt) fetthien leguen ban Conception, ende thaelf leguen

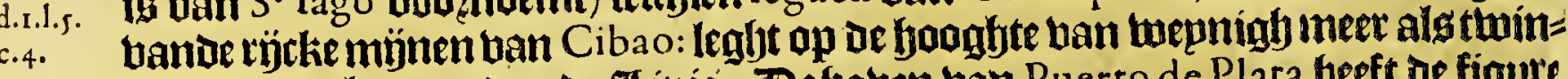
tígh graden bp noozenen de Zlinie. Be bahen bam Puerto de Plara beeft de figure

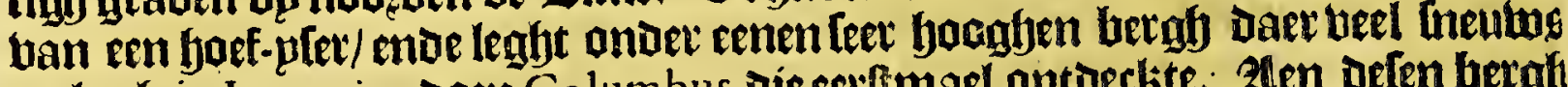
op lagh in lanuario, Doen Columbus die eerfmael ontuectite. Alen Defen bergh leght ie ttadt/ ende op oe haben aende Later-kant leght een kalteel.

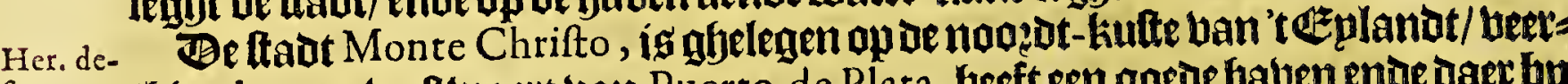

fcr. thien leguen luettwaett ban Puerto de Plata, heeft een gaede haven ende daer bp een zout-panne: heeft eenen ljooghen bethf bande glyedaente ban een tente / bol

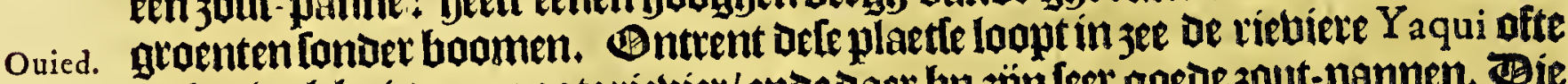

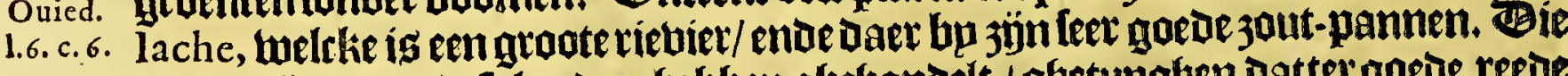

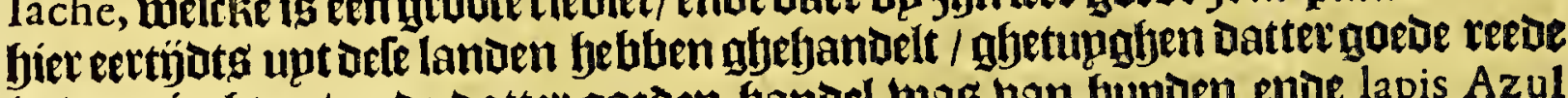
ig booz jarbten / ende datter goeden handel was ban bupden ende lapis Azul abetefineert.

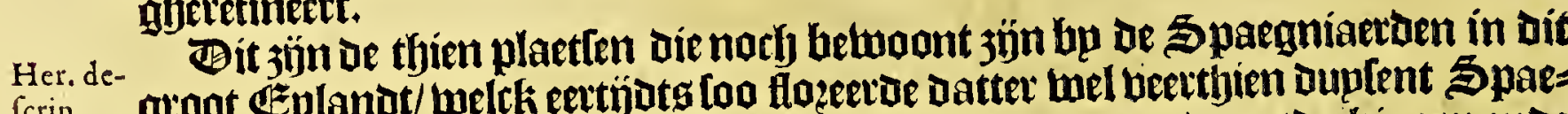

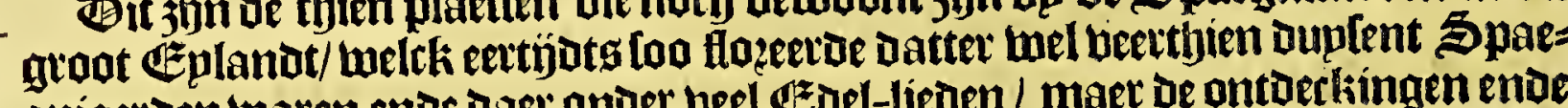
gniartoen waren ende Daer onder beel Ezol-lieden/ maer de ontoerlingen ende

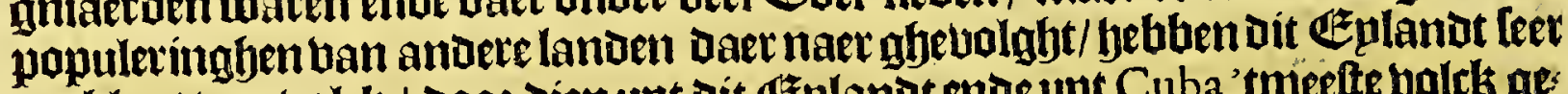

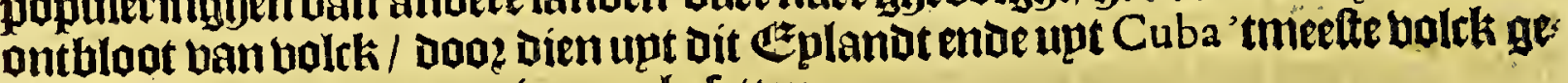
tracken ig am ander quattierente befetten.

\$et neghende Capíttel.

Vande Rievieren van dit Eylandt.

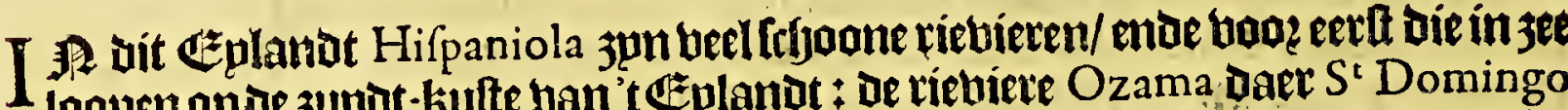

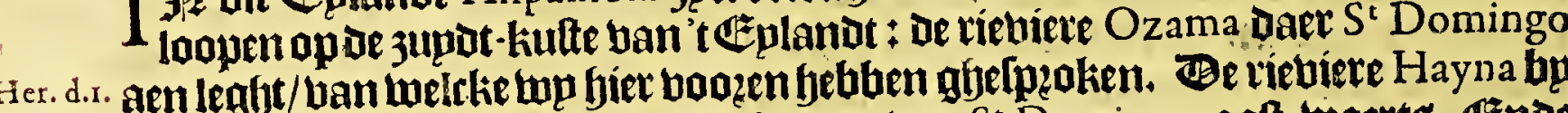

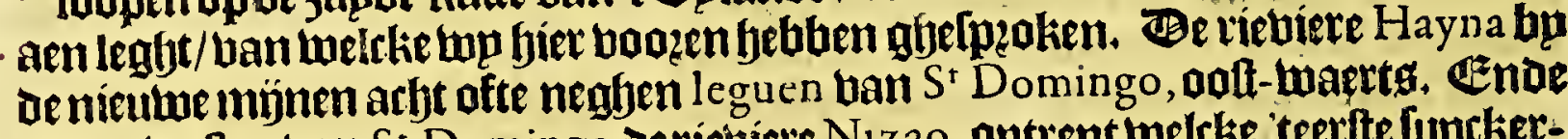
naer 'tweften ban $S^{t}$ Domingo De rieviete Nizao, ontrent welcke tertte fupckerHer. d.r. riedt gheplant wietor / ín een plaetfe glyenaemt Laguate. Daer naer de riebier

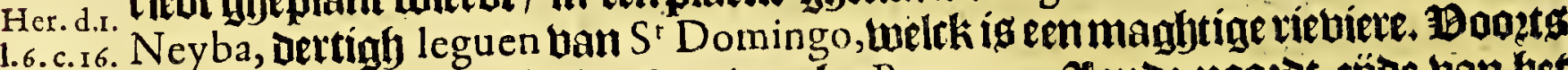

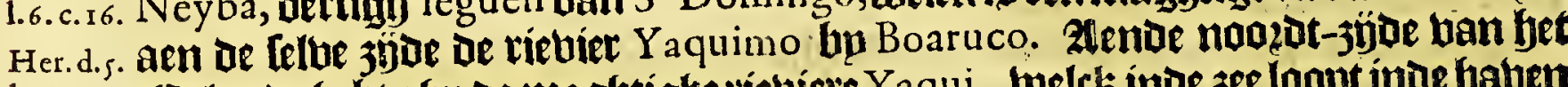

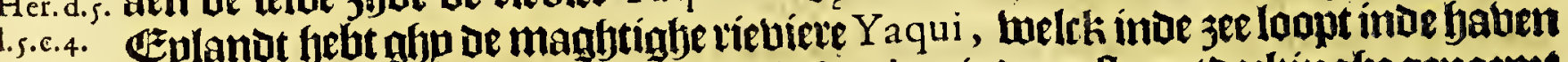
Her. d.r. ban Monte Chrifto, ende wierae bp Columbus inde eerlte ontoerkingbe genoeme

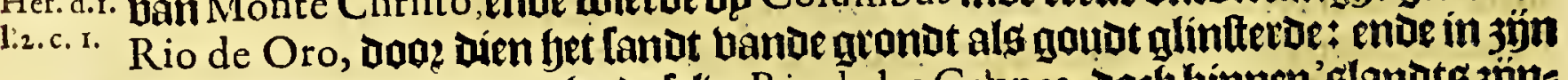

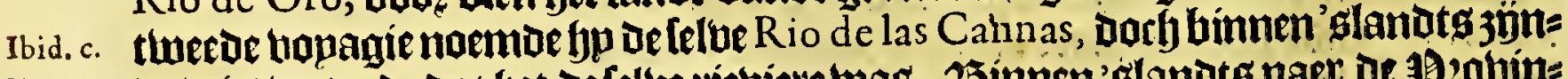

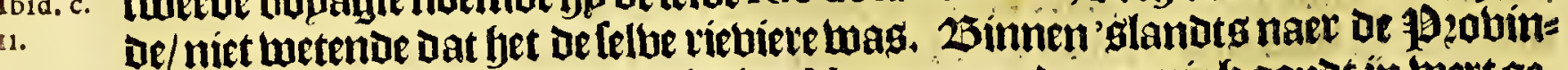
ríe ban Cibao toe heftmen de riebiere Nicayagua, Daer eenigh goust ím mert gebonden; in defe víebirte komen Dęu andete beken / Buenicum die de Sparani= aetaen noemen Rio Seco, ende Coatenicu, ende de derde Cibu ; melck feer rúté

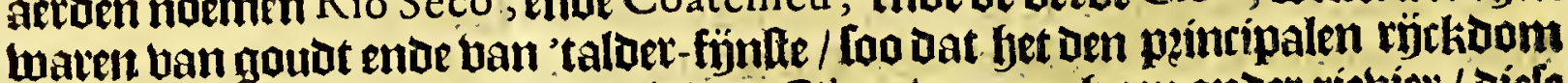

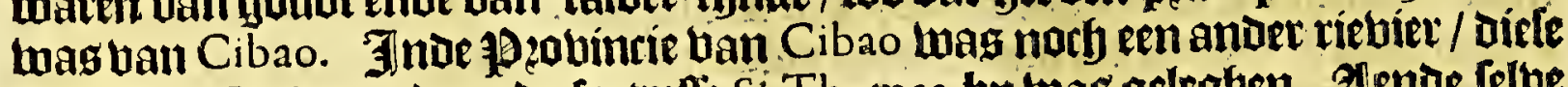
noemben Xanique, Daer ie foetrelle $S$. Thomas bu wag geleghen. Atende felbe noot-jübe heeftmen de viebier Lan Martin A lonfo, uñf ofte leg le guen ban Puer-

to de Plata, met een haluen/ die Columbus noemoe Puerto de Gracia : Dęp leguen

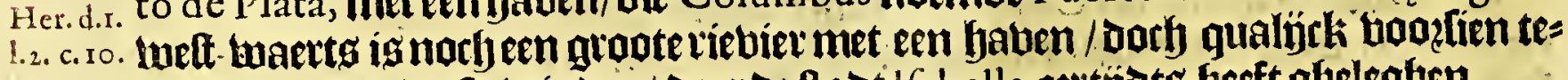

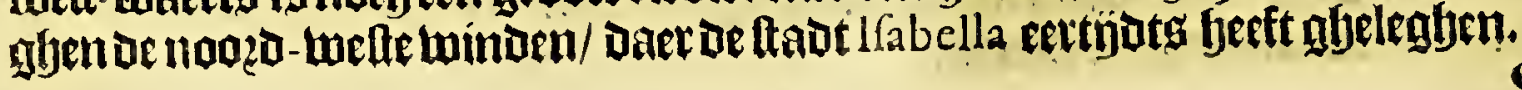

EE⿰H 


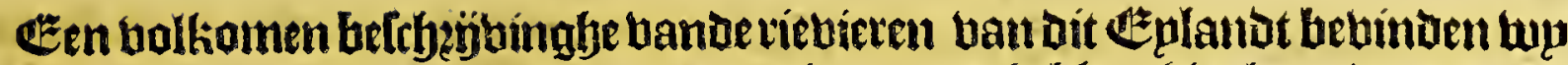

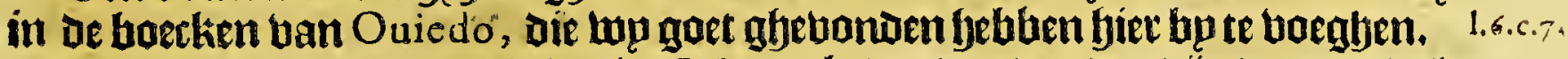

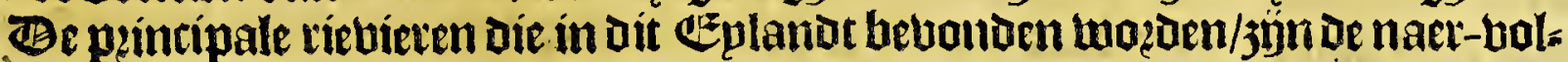

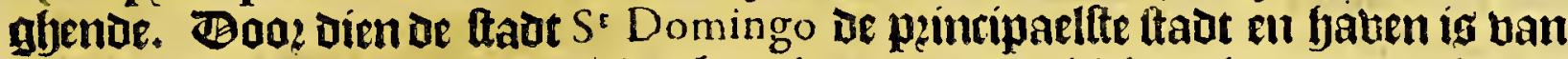

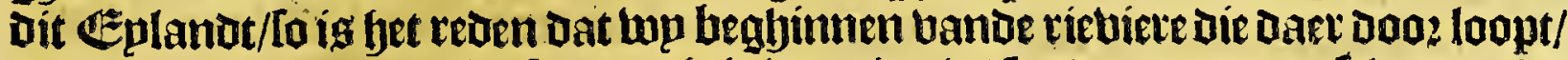
ghenaemt Ozama; welck Leet martytighen oiep is/ [oo dat oe groote lrbepen ghys= laden saer in komen/ende tot op acht oft thien paften ban tland abozeren / foo datte ober een plancke upt de frhepen op tlant gaen/ende de fifepen laden ende ontladen. Inoen jare 1533 . quambier in het frbip Imperiale, luetende een trbip

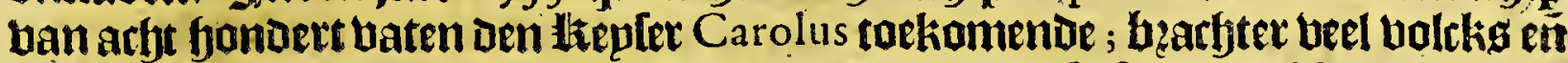

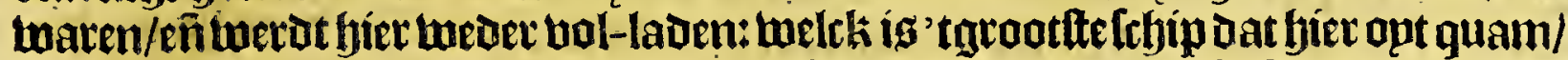
enve lagf eben-Lel maer I 8. oft 20, palten van tlanat. Befle frfepen kannen hier fonder Dangier oork bu natht upt loopen; Doos dien be diepte ban de viebier bu naer altijots ghelïtk blÿft. Soo dat Deferibieve enoe fon baben feet goet is / ende wo dot bevaten met ued batckenende ranoen/ Ton tot ghebsupck van de bit=

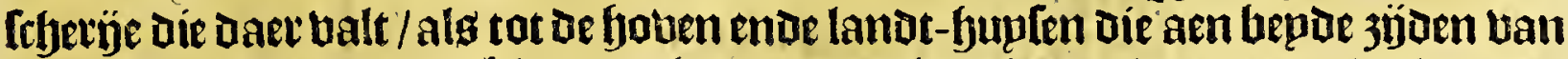

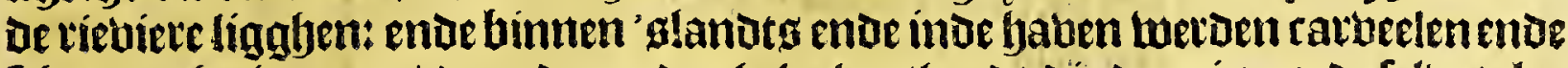

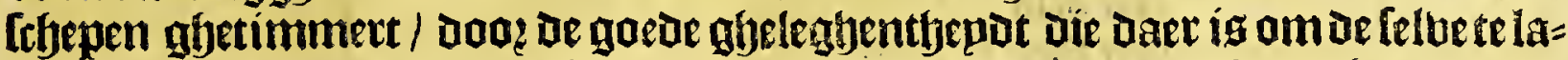
ten af-loopen. 'Chater en ig niet gaet om te deincken/ doo dien oe yaben ende

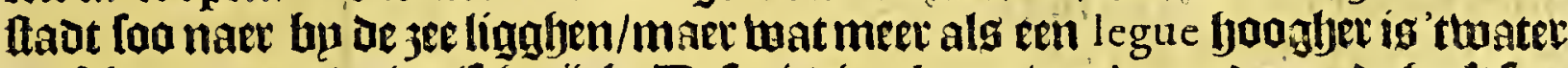

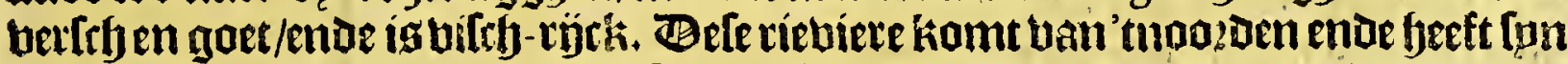
upt-Lateriughe in 't jupoen; beeft in'tinkomen bier badem aiepte ende meer/en= de ahelórke diepte oock aende hadt $S^{r}$ Domingo.

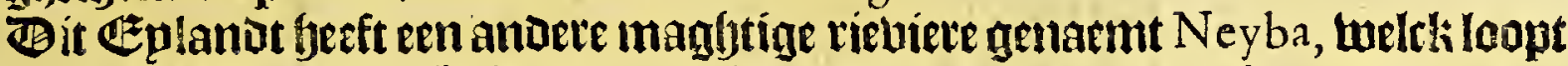

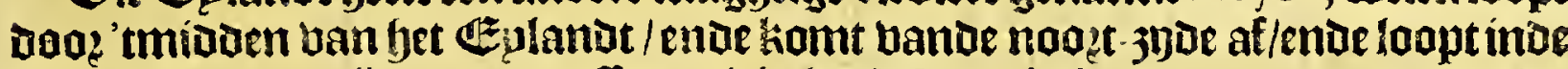

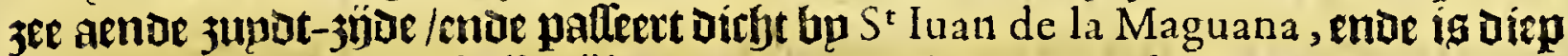
inde monat/maet een fjalf mujle opluaerta ondiep ende onbelwoont.

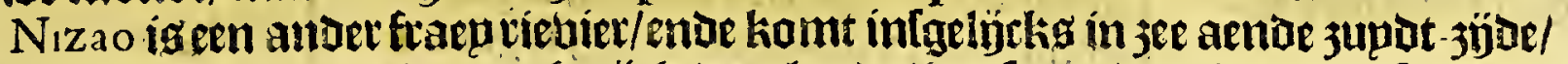

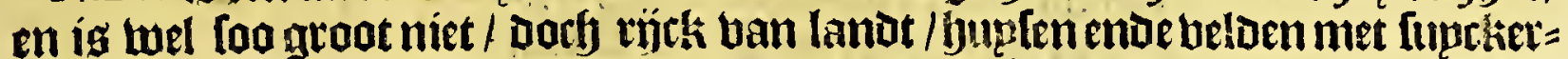

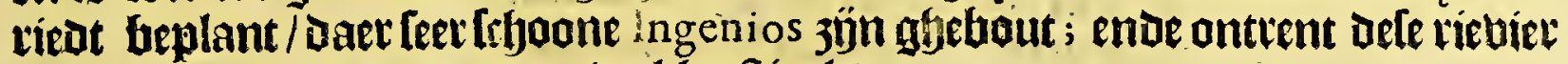

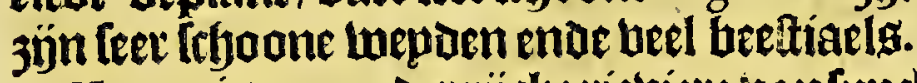

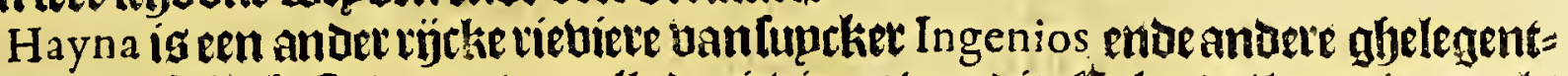

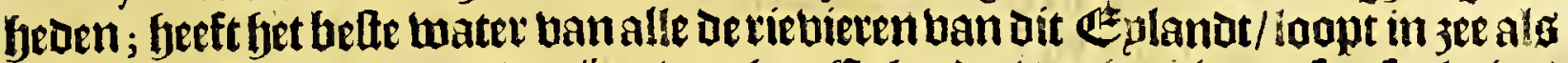

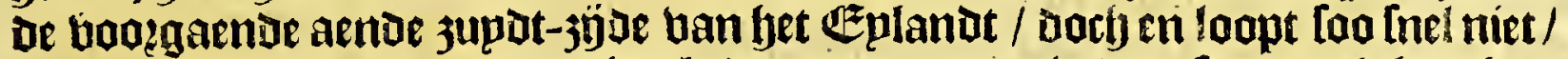

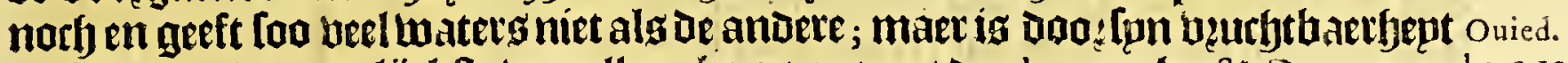

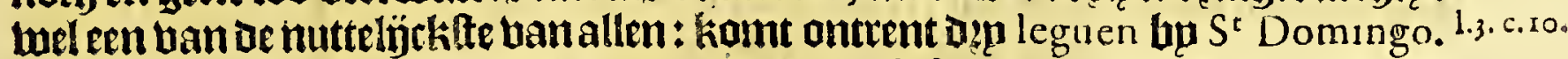

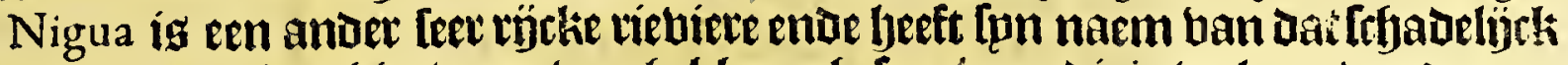

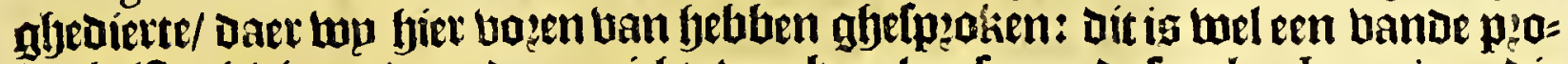

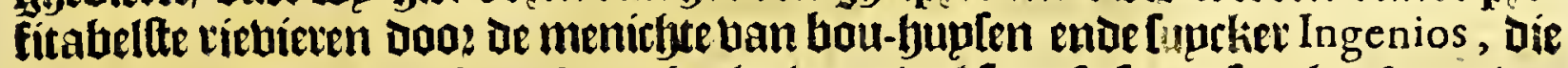

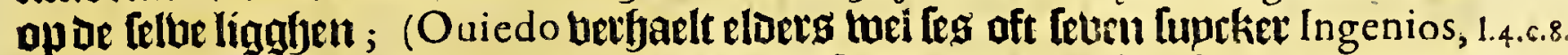

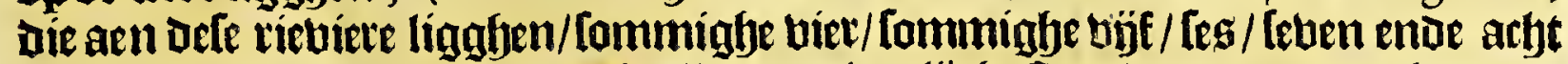
leguen ban $S^{t}$ Domingo:) wekk alleeneen beerlÿcke ltaet konnen ander fouden.

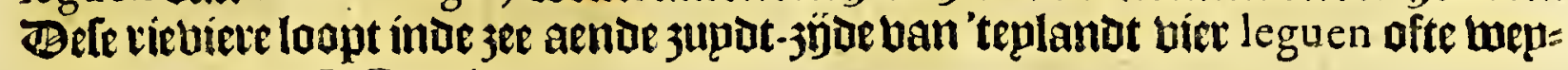
nirf meet ban $S^{t}$ Domingo.

Yuna is een bande fuelife rietuieten bandit Eplandt / loopt doo de 13:obintie

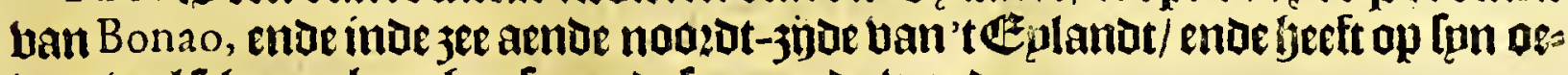
bets beel frhoone hou-fjuplen ende feer goede wepuen.

la che (ofte/als ander Die noemen/laquin) is oe naem ban theeriebierenín dít [eplandt / waer van De eene fyaer boeght bu Ney ba, ende met de Teloe ín jee loopt/ yaten naem berliefenoe. B'ander is ban meerder ímpaztantie/ ende loopt ii jee

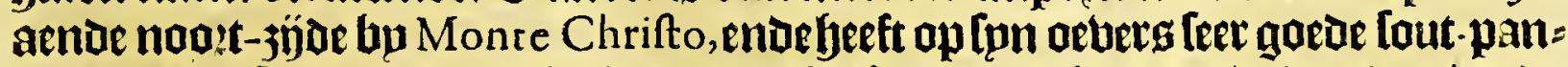
nen: is een fine/-loopenderiebiete / ende beeft ontent haet goede Loepoen/ ende Ifyoane bou-buplen. 
Hatibonico isten andet groote ende fnel loopende rietuiere / welck in 3 ee loopt

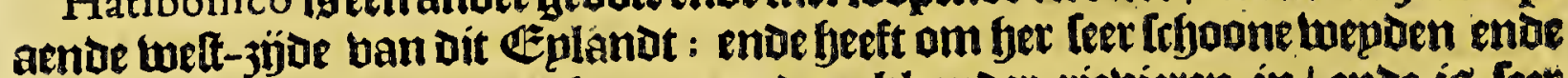
goet laep-lanot / ende daer komen andere kleender riebieren in/ ende ig leet bilry-rn̈tk.

Ouiedo maeckt elders noty mentie ban be riebieren: Cazui elf leguen ban St Domingo, daet een fraep Ingenio ban Luptker aen ig gheleghen.

Sanate bier-en-twintíth leguen vâ $S^{t}$ Domingo in de 13 zobintie van Hyguey.

Chiabon infagbeligck vier-en-tmintich leguen tan St Domingo.

Detujl wo nu dicklwils bebben guépzoken vande luptker Ingenios ban tit

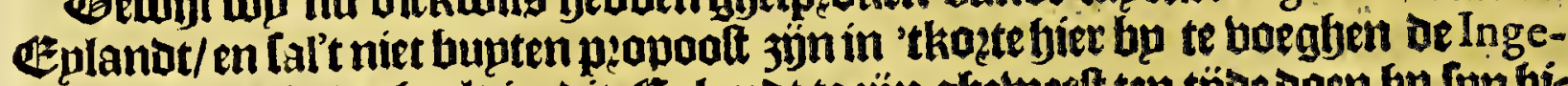

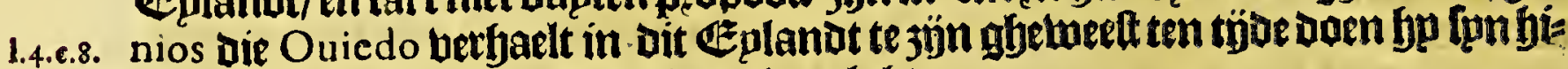

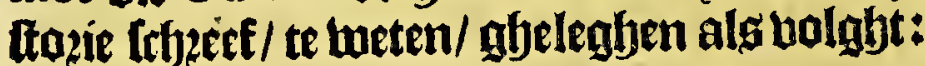

Op ae riebier Nigua een bǘ leguen

een feven leguen

$\mathfrak{e e n}$ legleguen

een biet en een fyalf leguen

een acht leguen

een biet leguen

Opde riébier Iuca en thee le guen

Op De rieluier Haina een Defp leguen

Op De rieuier Irabo een vier leguen

Opde riebier Nizao een atht leguen

een arljt leguen

ecn neglen leguen

(Dp de rievier Ocoa een Leftyien leguen

Op oe riebier Cepi ent bp Azua tmintith leguen

Op de rieviet $\mathrm{Bia}$

een bp A zua azp-en-thintich leguen

cen bp Azua bier-en-twintich leguen

ban S: Do-

mingo.

een in Azua met eentio[-meulen.

een in de Teloe plaets kio[-meulen.

een in St Juan de la Maguana beertity leg

en in de telve plaetle.

Op de riebier Cazui enn elf leguen

Op de riebier Sanate ên biet-en-thintity leguen

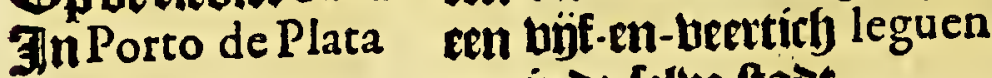

een inde telve ftadt.

en inde felve plartle thof-meulen:

een ander thof-meulen.

$\exists \mathfrak{I n}$ Bonao

een negbenttjien leguen

een thien leguen

Op deriev. Chiabon een viex-en twintity leguen

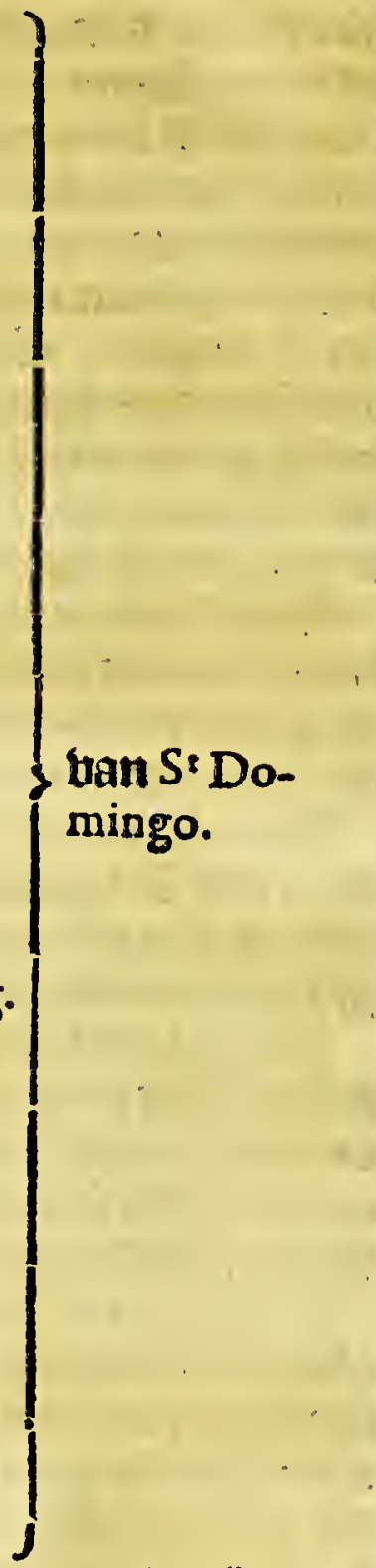

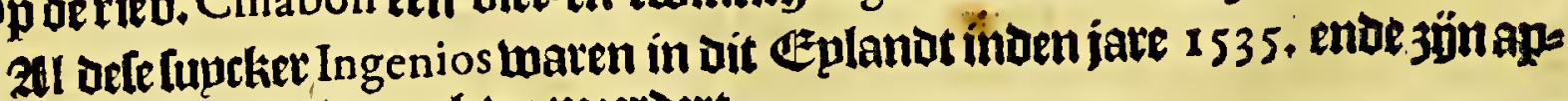
parentlïrk Daet naer noty bermeerdert.

\section{Met thiende Capittel.}

Vande kufte, havenen, reeden, kapen van dit Eylandt Hifpaniola.

$\mathrm{D}$

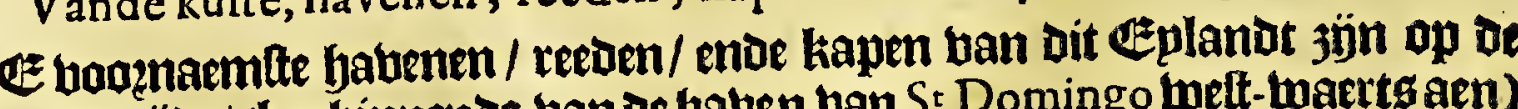

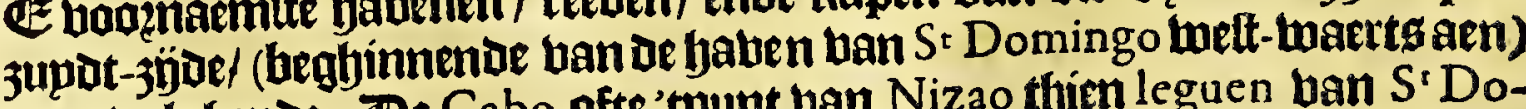

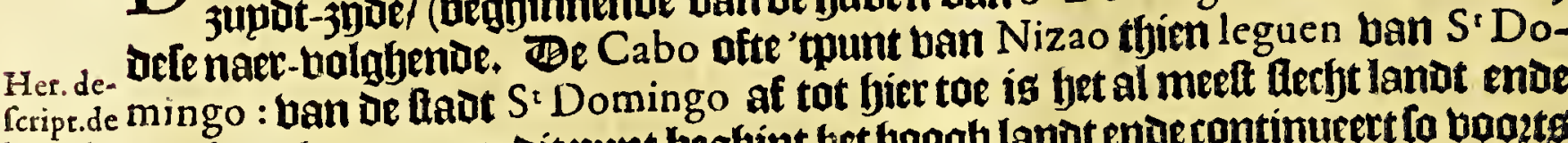

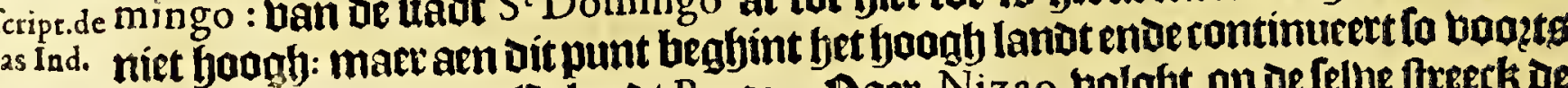

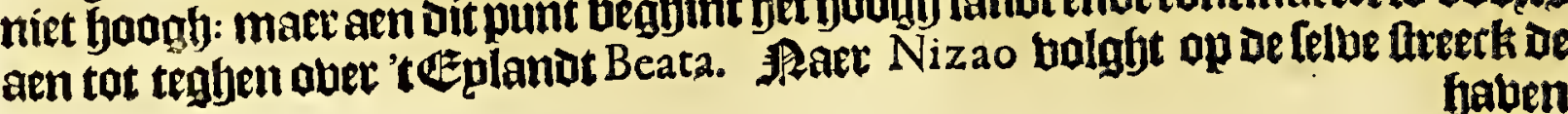

flaben 
Het cerfte Boeck.

faben bar $O$ coa atjetjien leguen ban $S^{t}$ Domingo, welch is een infmam oftebave daex de bloten tuillende naer Nova Hifpania antieten/enae haer bertuetrfyen/too

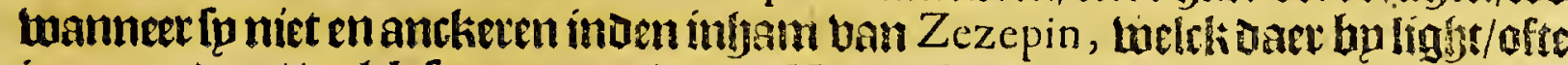
in een andere/ welek fo naenten Puerto Hermolo, twee leguen eet glan te Oco2 komt : want Puerto Hermofo light 16 , leguen ban $S^{2}$ Domingo luef - Want

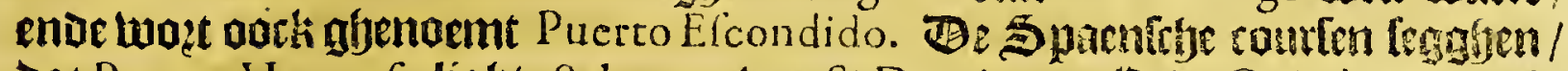
Dat Puerto Hermofo light I 8. leguen Ban S Domingo. Enar Ouiedo genmglat d.r. 1. s.

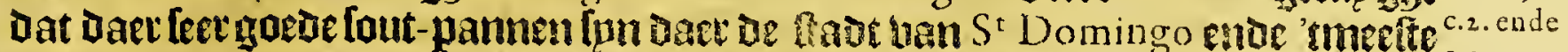

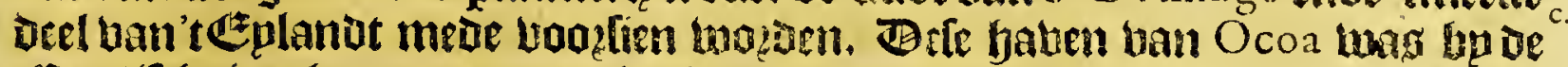

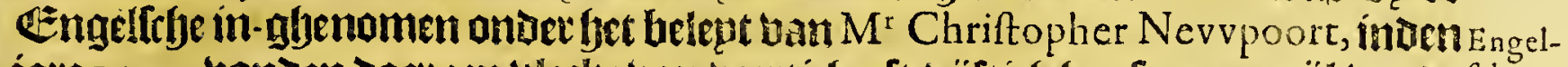

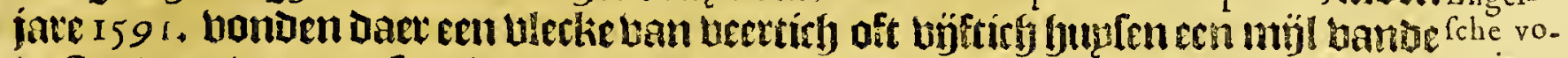

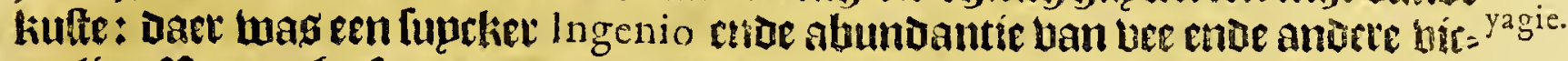

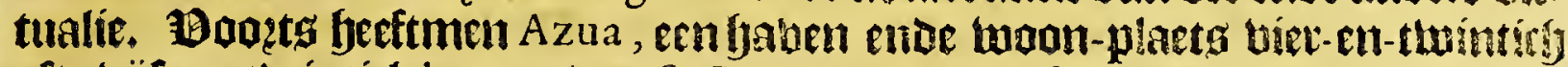

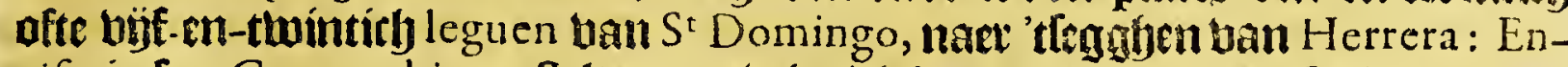

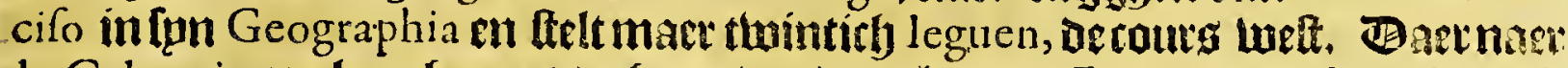

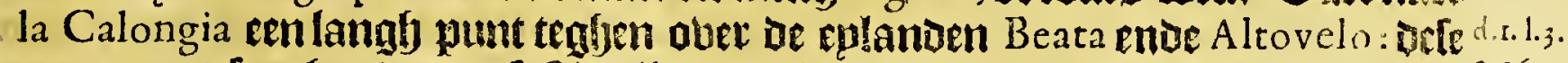

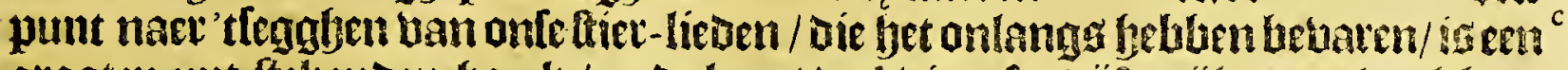

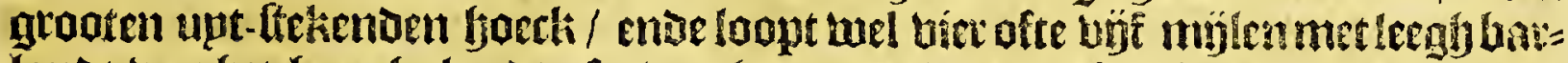

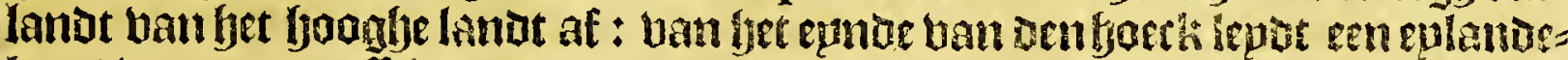

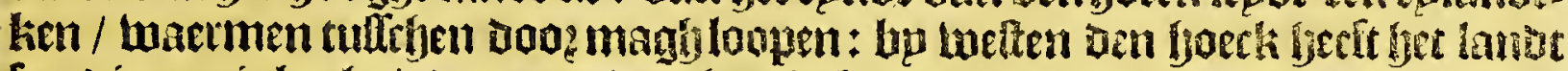
foo diepen inbuebt/ Datraen Den foech hohen komenoe geen lande en liet.

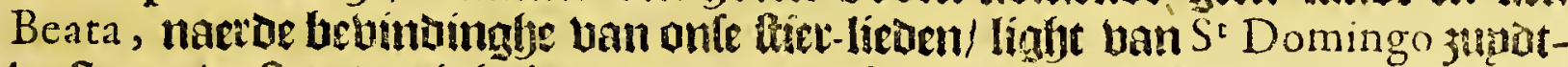
tueft tan twelien Dettigh leguen, ente Altovelo feg miglen ban Beata naev

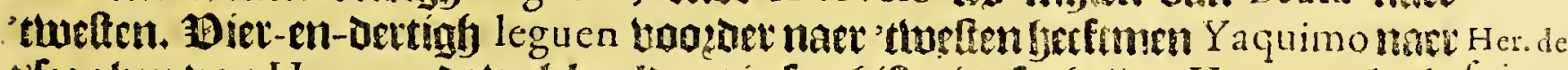

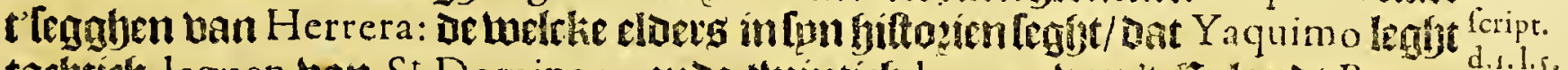

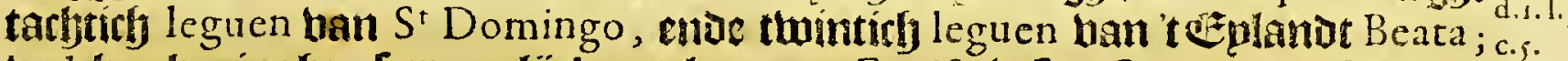

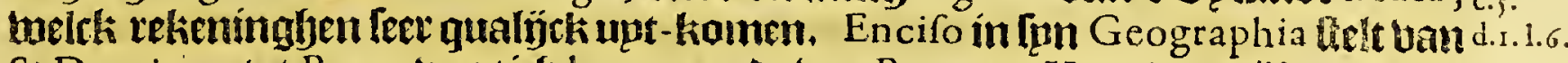

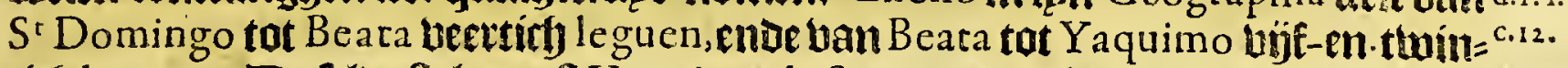
tith leguen. De felue feelt naelt Yaquimo, la Savana teetrith leguen boosort/tan welth een Cabo in jee ftreckt naet fet zupDen wel arfit leguen, thoe de hufte

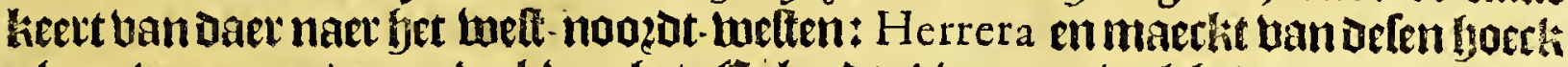
gheen bermaen / maer twel ban bet Gplanot Abaque, welck daer toog-leght:

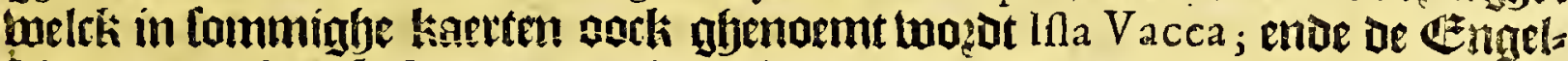
frlje noemen bet Ifla Baque, daet wp bier naer noef fullen ban hermaten. De Spaenfrje couten noemen dit punt Bacoa; enoe leggben / Datmen Beata pal= ferende bp de bupten-jyjde/ftracks komt te fien Alto velo, ende ban daer maetmen fteren beit ten jupden oum te blijuen bande pulandelteng los Frailes, ende allmen [oo verte isals oe Frailes, moetmen ftieren welt ten noozden/ [oogactmen Ledht

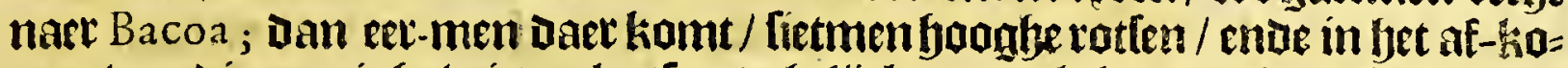

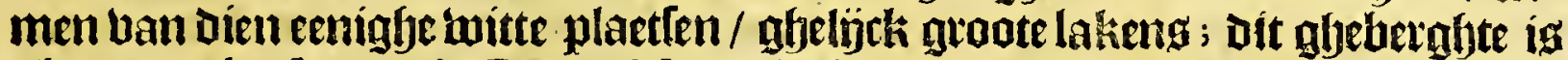
afenoemt las Sierras de Donna Maria. Bit punt light op de lyoogfte van feven=

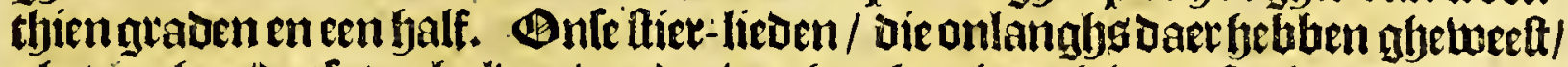
ghetupgyen/satte ten halben bande twee boecken ljoggh lanot fadgen/met eenen liennelyjeken betgly met eet haoel bu weften/welcken bergh het lanot wat leeghet

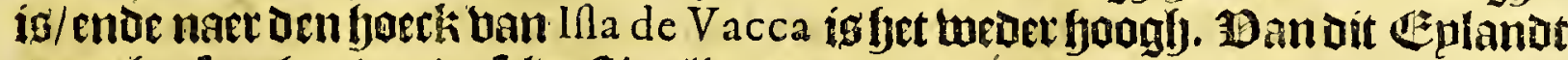
(naet fyet fegghen Lambe felve ftier-lieden) tot den unt-hoed ban $S^{t}$ Domingo,

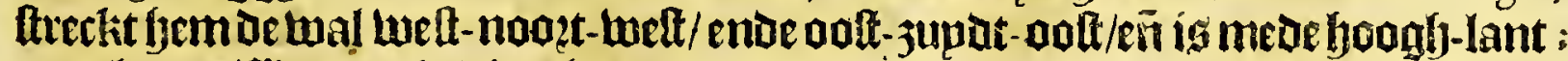
naer baet gitlingeen ig diteulandt tuan Cabo Tiburon maet vijfthien ofte felthien

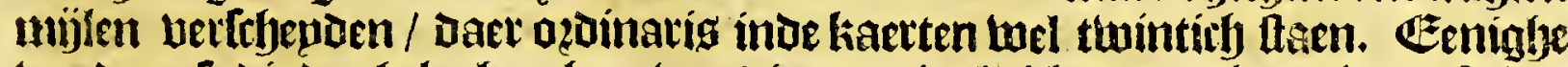
vande onfe die ae gheleghentfept ban Dit quartiet ljebben aengheteeckent / ftellen bier ontrent de reede van. Congon, daet goese berberfinglye entoe eenighen han=

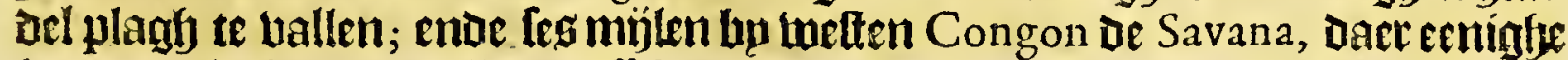

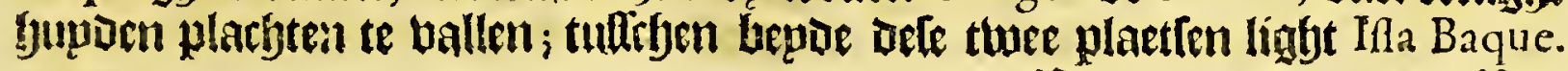

$$
252 \text { valt }
$$




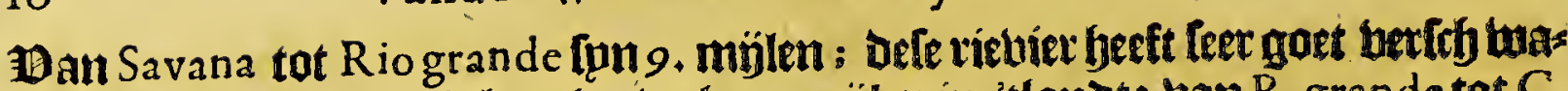
ter/ende kamt ban 'tghelaetghte wel I 4. mijlen in 'tlandt: van R. grande tat C.

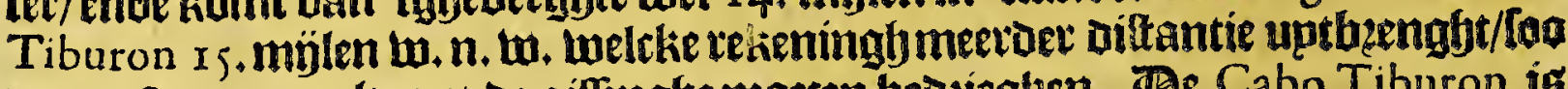
vat oe ftroomen altemet of giflinghe moeten bedyeglyen. De Cabo Tiburon is

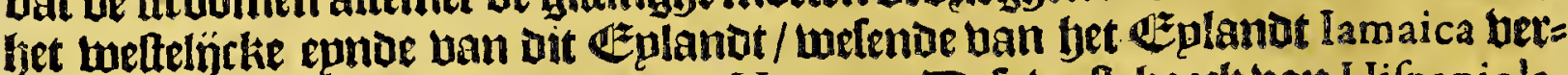
f́hepden 20 . leguen, na'tfegghen uan Herrera. Befe beft-fyoech ban Hifpaniola, ig ber-af black / wel een yalf mijl ban oe wal niet bouen unjfthien ofte fetthien ba:

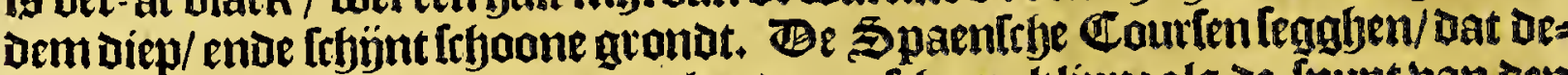
fe llaep leght Dalenae na de 3 ee/makende een fcherpe klippe als De inupt ban den biffy Tiburon, ende op den top lebinnen witte weghen met lekete gaten/ belck

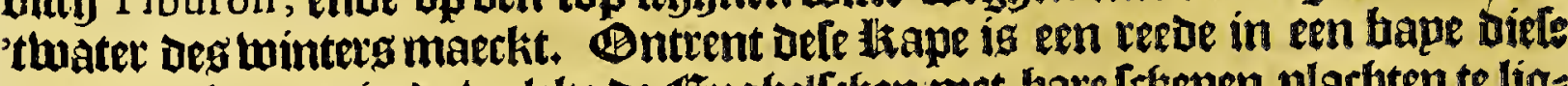

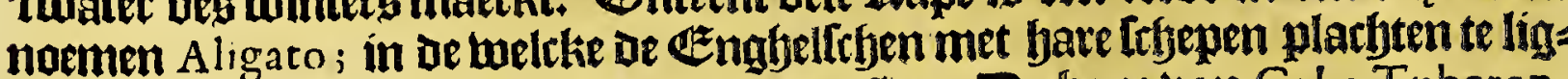
ahen om op de 3 lote wan $S^{t}$ Doningo te paften. Be bape ban Cabo Tuberon, light op I 8, gladen 25. minuten: Daer ig goede ancher gronot / enue aen landt is

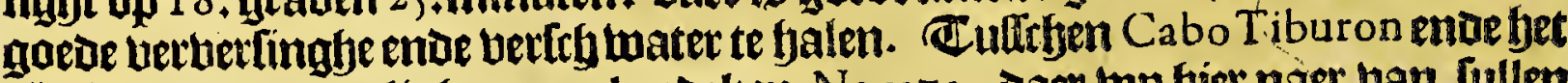
Etplandt Iamaica, light een eplandelien Navaza, Daer twy fiet naer ban fullen [pekken. Ban Cabo Tiburon jün 12, leguen tot Cabo Roio ofie Roxo naer 'tnoozen toe/als Herrera abetupgljt. Defle Cabo wazot oack alfenoemt bp ae

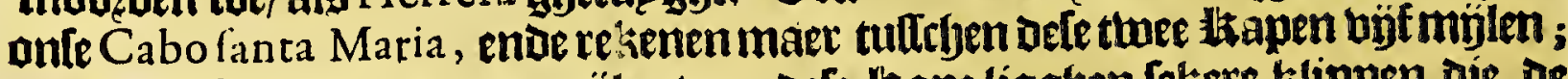
ende waet frhouken dat 7, mïlen ban defe thape ligghen fetere klippen die de Spaenniaerden noemen los Barraderos. Han baer keert de kulte naer bet oolten/

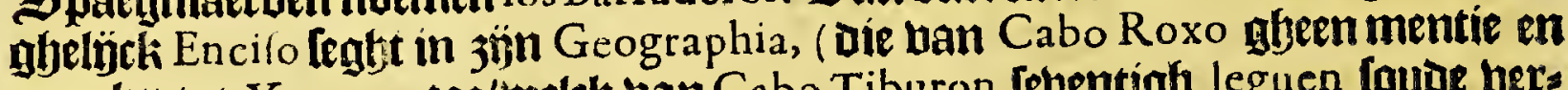
maectit) tot Xaragua tor/welck ban Cabo Tiburon [ebentigh leguen foude bers

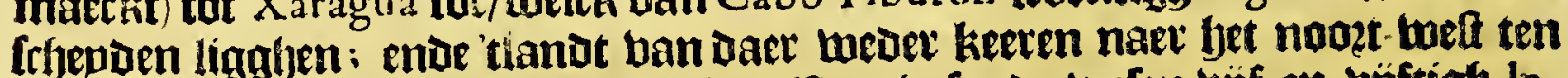

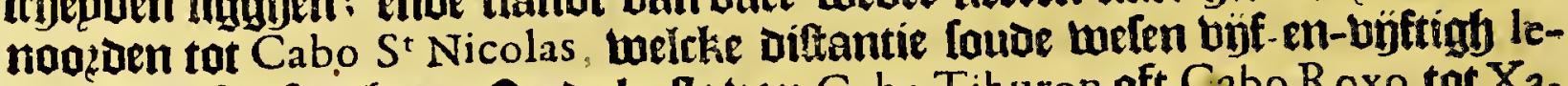
guen naer fijn lagghert. Op de kufte ban Cabo Tiburon oft Cabo Roxo, tot Xa. ragua toe lígaben los Roques afte Hermanos, Depp klepneplandeseng: endeCaymito een andertilepn eplandetien: ende't teplanot Guanabo affyt leguen langhy

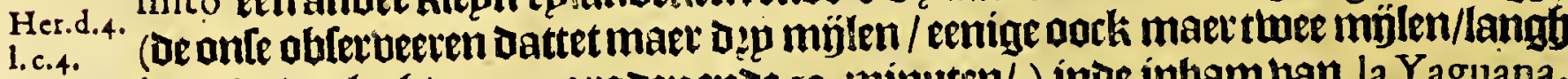
is/ ende datlegft op I 9. aladenende 30 . minuten/) inde inbam ban la Yaguana,

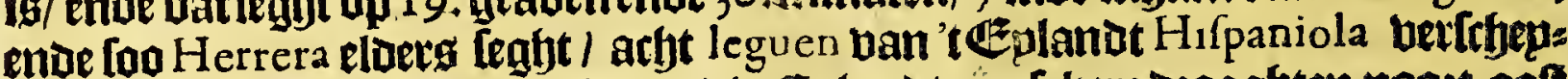

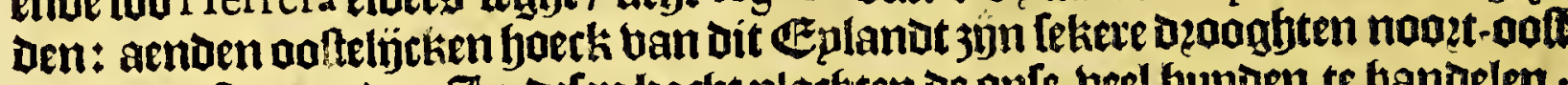
aen in Jee treetienoe. $31 n$ delen bacht plactyen oe onte beel bupden te handelen,

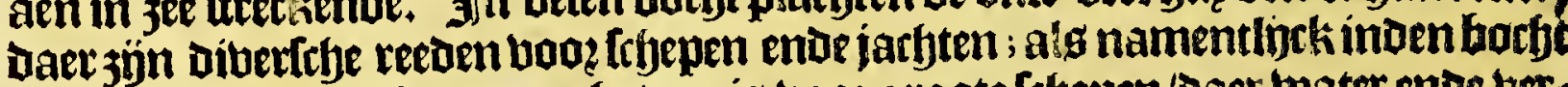
Goiave, welck een bequame hauen is tooe groote Ifbepen/oaer water ente ber: berlingbe te bekomen is / enae oack bupaen plactjten te ballen. Haat voozder de Gaeben van la Yaguana, aente jupot-jyoe ban often infjam; ende aen de noozot=

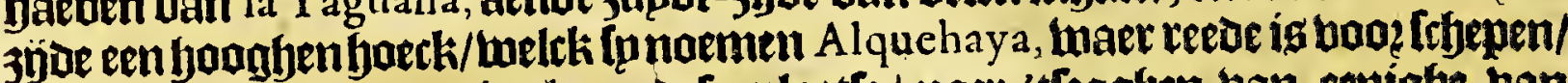
ende Cannafiftola is te haelen : Defe plaetfe / naet' 'tleggben ban eenigbe ban

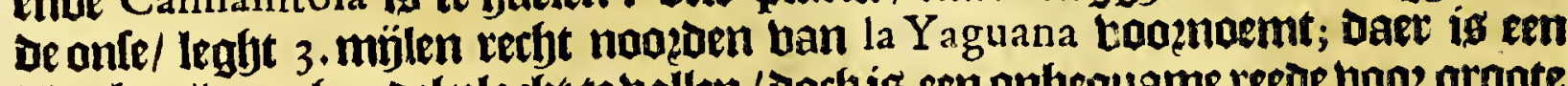
blectken/waer fandel plarbet te ballen/ Darb is een onbequame reede booz groote

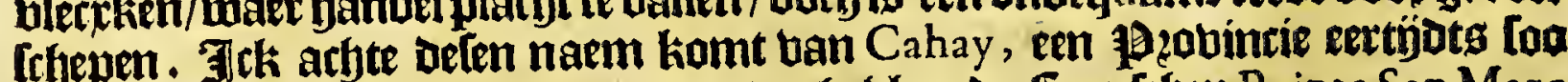

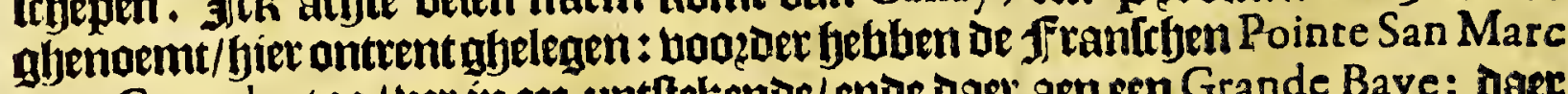
naer Guanabo toe / uer in jee upttetkende/ende daet aen een Grande Baye: Daer aen volgftetenrievier / die de anlenoemen Artibonice, ende wp upt Ouiedo fier boozen hebben abenoemt Hatibonico: hier is reede voo jachten/ende bier placlfe men beel hupden te halen: boozder ftellen de onle hier Guaniaves, welck een noes

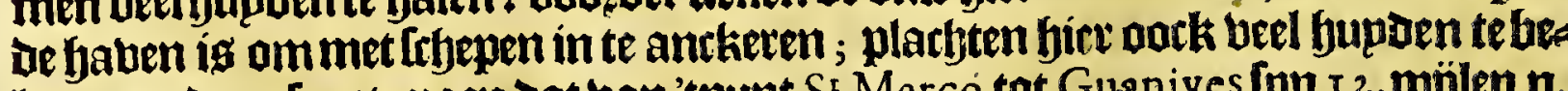
komen : De unle getupgen dat ban 'tpunt $S^{r}$ Marco tat Guanives fpn I 2, mỉlen n. ten a.ende 5. ten w. ende dat Guanives light 16. mülen 3, th. ten 3. ente n. a. ten

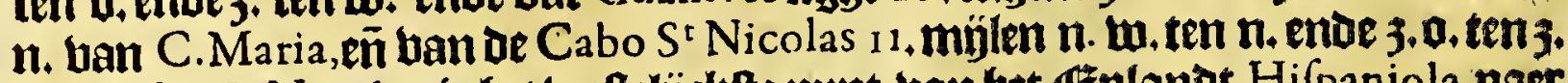

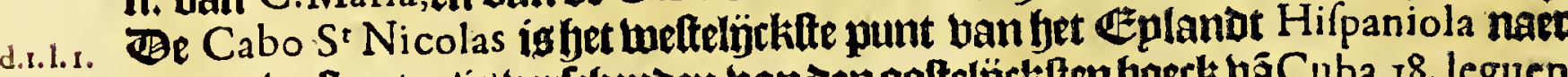

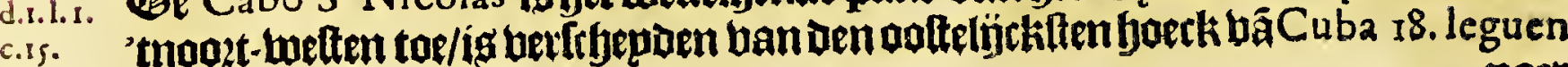


naet bet leggen wan Herrera; onle fliet-lieten die daev oulanglyg feblen getureft fegghen/ Datmen ín 'tmidoen bepde de foecken kan fien/ende rekenen maet 12 .

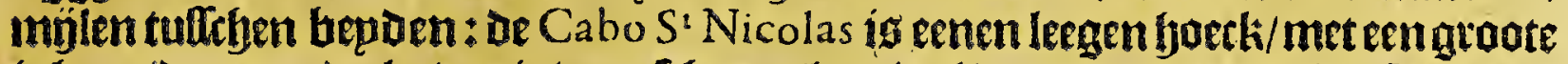

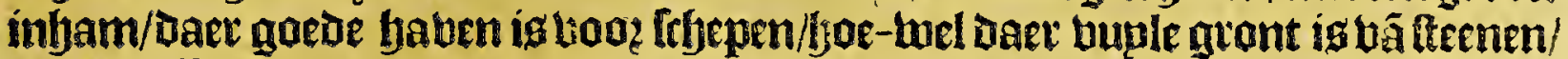

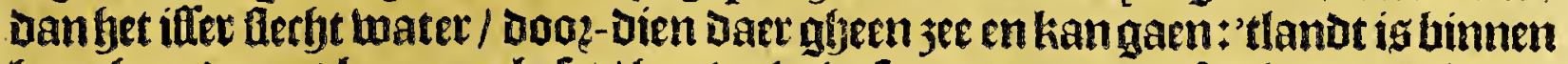

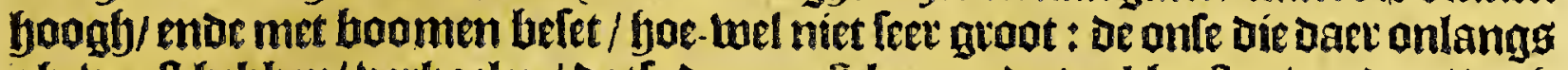

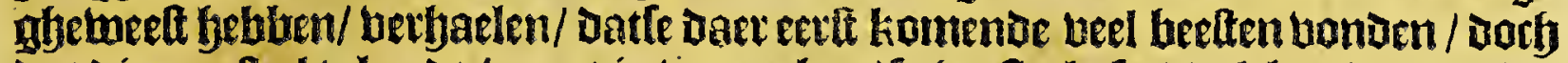

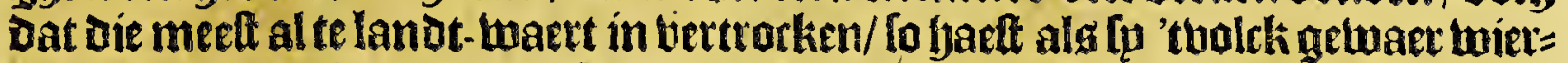

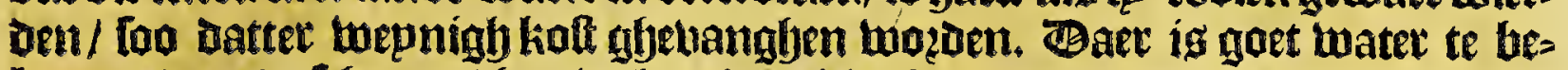

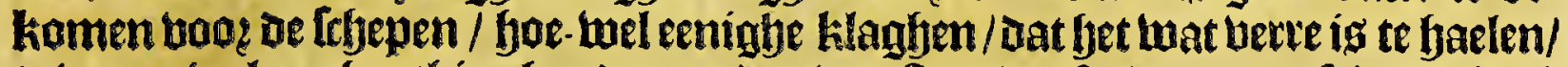
te tueten wel neghenthien yondert tweoen ban franot af / Daet een af-twateringh is ban een ballepe / Doth komt niet beneden/maer finckt ínoe aetae hegg. Onte ftier-lieden Die laett bier bebbengbetueelt/mepnen de diftantie tuftegen Cabo de

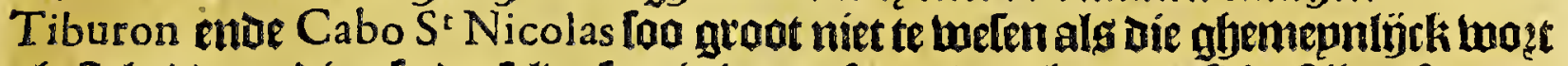

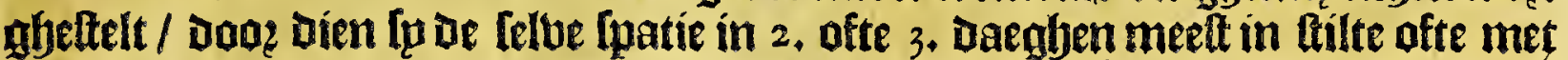

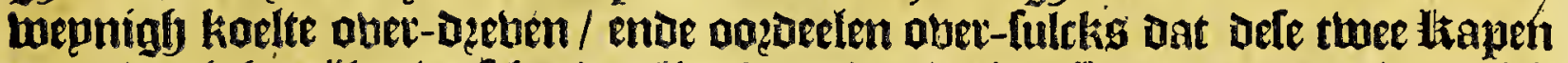

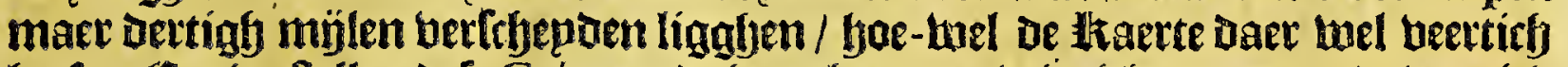
beeft. Eenige ftellen dele Cabo op de ljoaghte ban twintich graden ende bectich

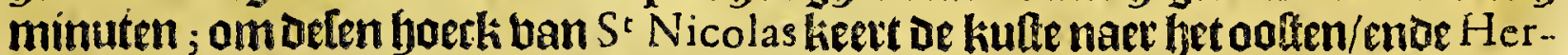
rera felt biet op defe nodet-kulte ban Hifpaniola, Puerto de Mofquitos; Die De onfe in faet op-Doeninghen hambe kufte oock etkennen. Baet aen felt Herrera

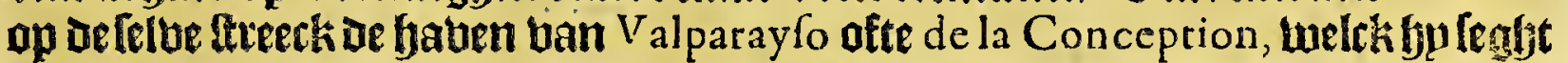
te ligghen twinticy leguen ban Cabo $S^{t}$ Nicolas: biet ofte naeft Puerto de Mofquitos ftellen de onfe in fare aen-tepelieninglyen Pore Parys ofte Pais : altwaer cen rievierken ban berfely water Toude ligaben. Bele haven/naer'tlegghen vaneeni=

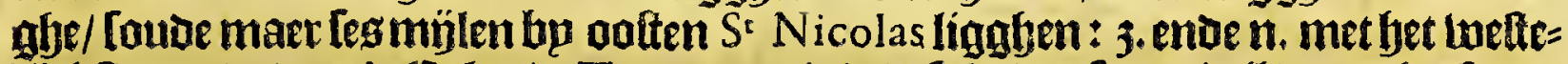
libcklte epnoe ban 't ezplanot Torruga ; die in Defe hauen [etten wil/moet fet fetten dicht onder de oolt-wal / Doos dien bet een feer afgaende grondt ís enoe wel 40 . bauemen diep/een gotelingh fryeut hanide twal; bier plaght goesen gandel ende

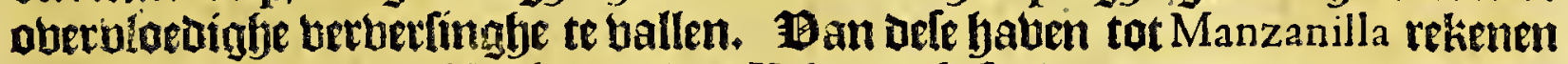
[p 23, mólen o.ten $n$. Be faben van Valparayfo loude noozd ende jupden líg= ghen met het Etalandt Tortuga, als Herrera betuphyt / welck met uele Port Paris abet een komt.

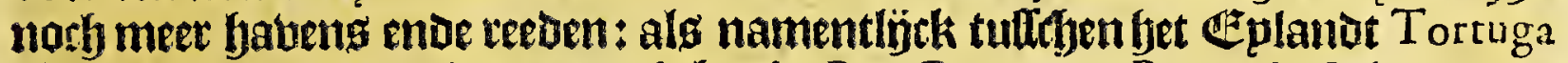
ende Hifpaniola bood-loppende / geht gljp Rio Caimanes, Porto de Palma, ende Puerto Santa Cruz, meltke hepae goede babenen zün boaz fibepen/ ende men haeloe hier in booz-tjoen beel fupDen : Daek naer Ancon de Luis, altwaet een rie= biertien is om twater te falen / ende een copet-bergf / loo eenige bande onfe fjeb= ben aen-remerckt : dele Ancon de Luis heeft entilepneplandelien int in-kamen.

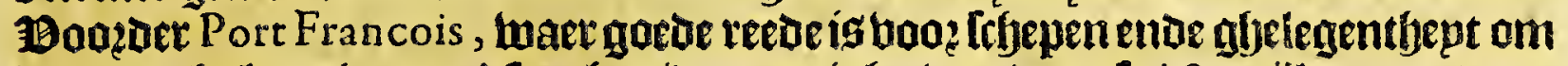
water te halen: is naet'tfegafien than eenighe ban de onle / 8. mijlen jo. teno. vande Tortuga, ende 4. mijlen bp imeften Manzanilla. Hicr aen ftellen andere port Real. Clwatif mijlen ban port Real naer'tooften ftelt Herrera Monte Chri-

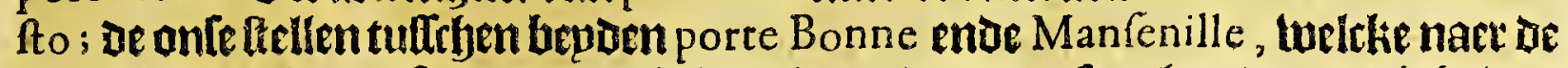

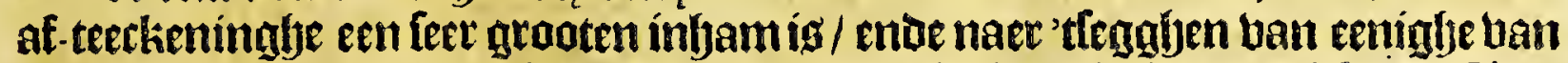

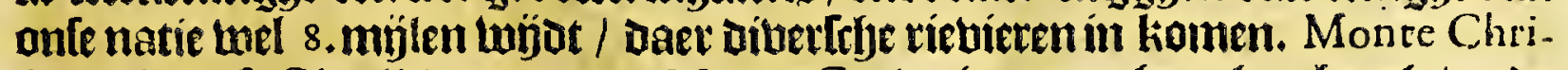
fto, die onfe ftier-lieden naemen Monte Cruis, ígenen ljooghen luetgly / ende

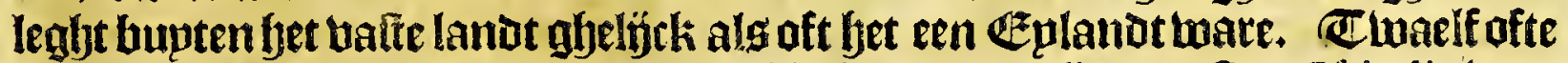
meet leguen boozver fte!t Herrera la Y fabela (Daet eertiots oe Itadt Ifabella was nitrbout / welcli ue onle in faer aen-teeckeningben oock kennen:) ende infghe= Ińcks thaelf leguen voozotr (eldets Leght gp negen) Puerto de Plara. Herrera

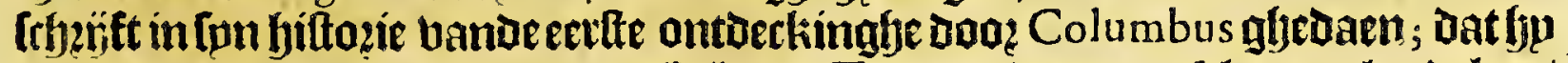

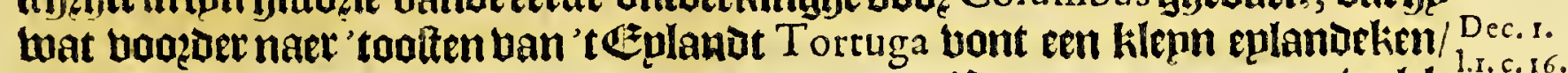




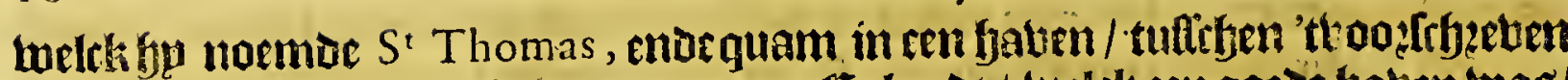

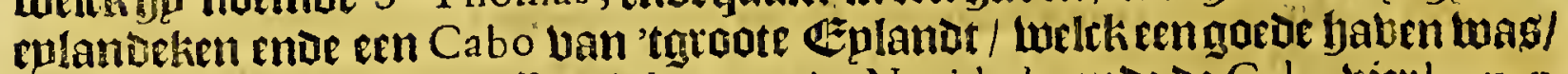

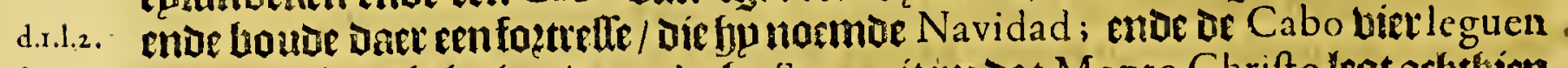
c.r. Lan Navidad ajeleghen/noemoe by Santo : itembat Monte Chrifto legt achthien leguen ban Santo, ende dat bu Monte Chrifto enn eplanot ligft dart goede fout= panmen jün: Dat uerticly leguen ban Monte Chrifto naex 'toalten is gheleghen Punta Roxa, ende een tuepnigb van oaer Rio de Gracia, twelthi dact naer bebou=

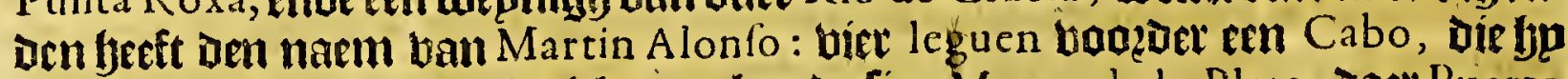
noemoen Belprado, ban tuelek imen honde fien Monte de la Plata, Daet Puerto de Plata lu light. Doots barenoe langs de luffe met fet current ende frape toes ber meet wan thien leguen tont fjp heel berl taben/Die fpp noemoedel angel, punta del Yerro, el redondo, el Frances, Cabo de bon tiempo, el Taiado, van melcke Cabo Frances funnaem noef heft behouoen/ende ig aen tom-kerten bande ku=

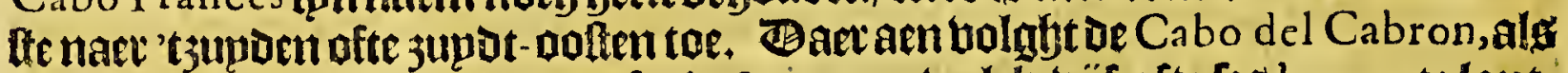
Her de Herrera lettl : ende toptoer Golfo de Samana, welck bijf ofte fes leguen te lant=

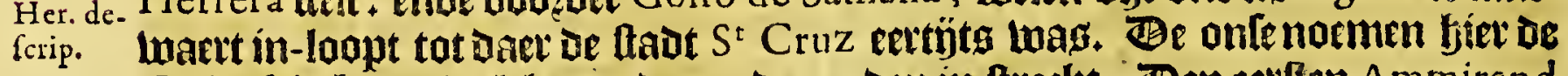

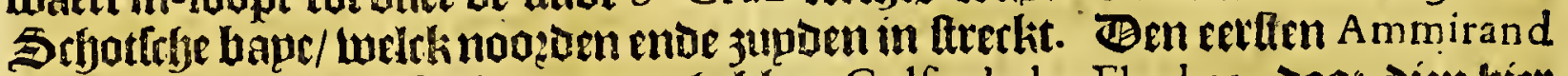

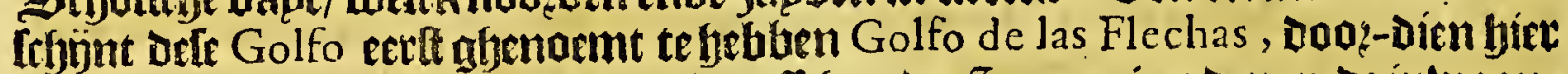

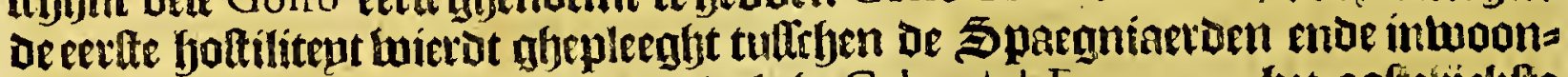
d.r.1.2. Deren ban yet Eplandt. Baer aen volght Cabo del Enganno, bet oofteiprkfte

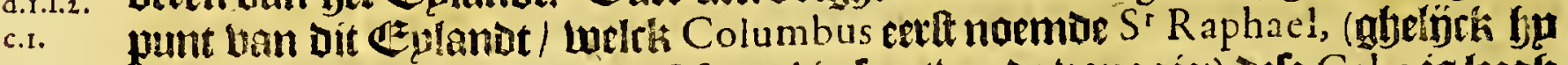
Cabo Tiburon oac noembe $S^{t}$ Miguel in (pn twecue vopagíe:) orle Cabo is leegh

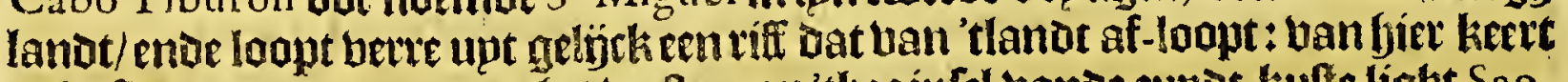

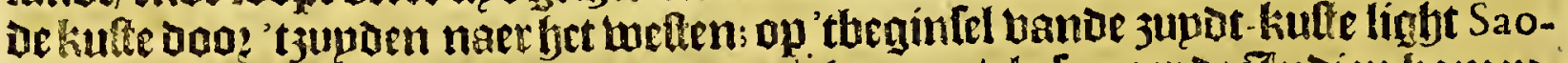

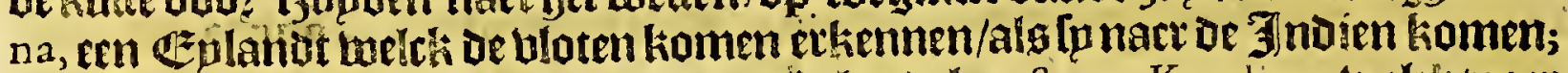

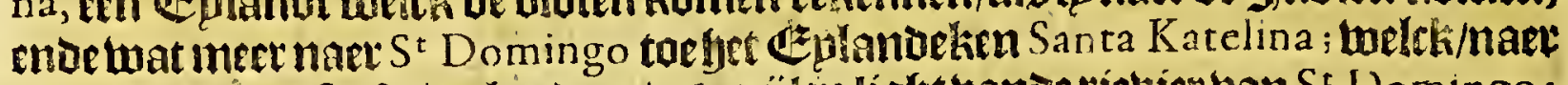

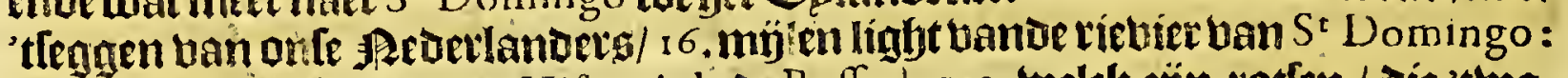
ende aen thare lanot ban Hifpaniola de Buffadores, welck jün totten / die 'twa:

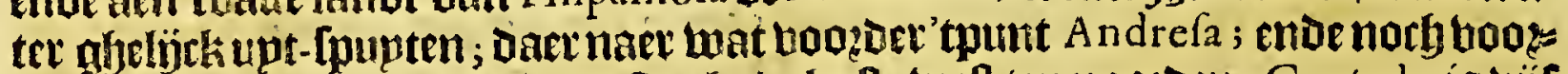

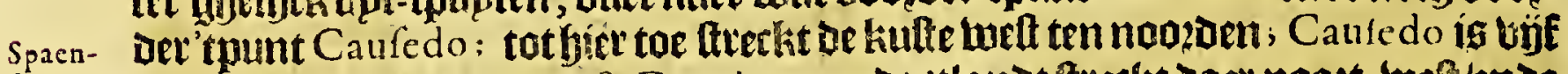

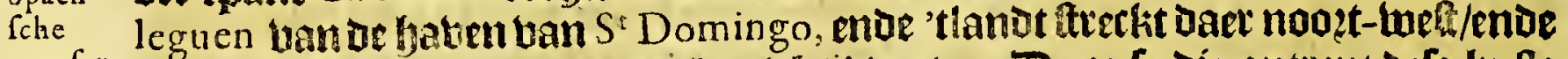
courfen. Fumvit- oolt : enbe Dit punt legfit leeglb bi thater. De onte die ontrent iefe kufte maren inoen jate I 619 . maechen mentie ban oe riebiele $S^{t}$ Pedro, dic aen thalte

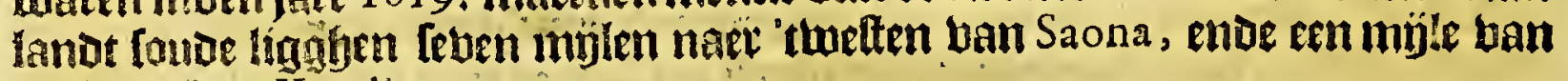
teplandesten Katalina.

\section{Wet elfoe Capittel:}

Vande kleyne Eylandekens die rondt-om H I S P A N I O I A ligghen.

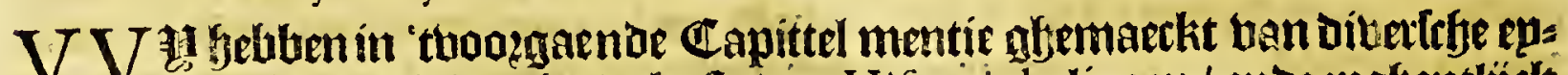

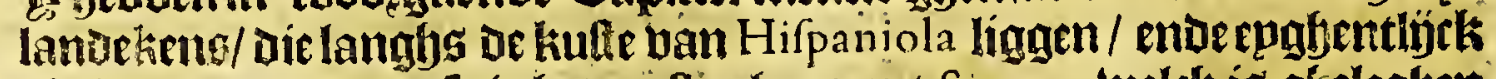

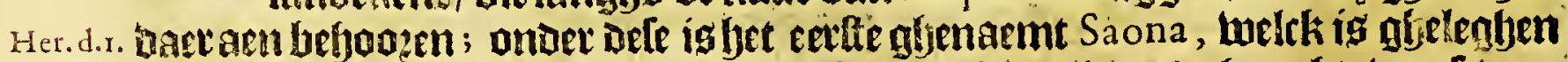

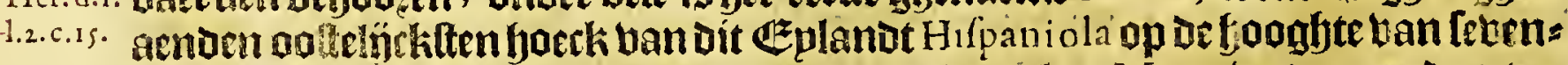

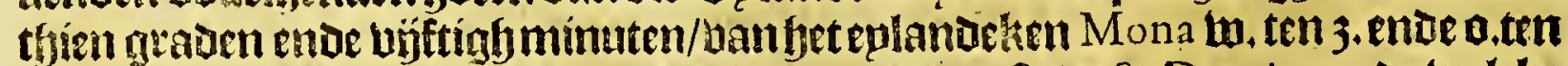

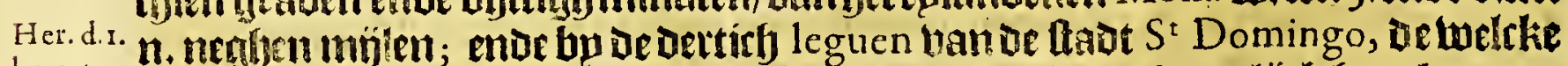

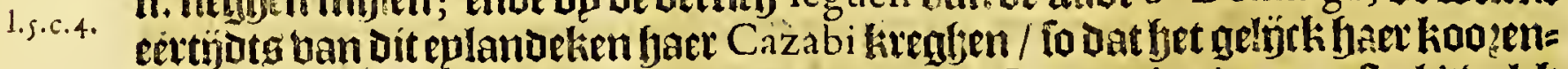

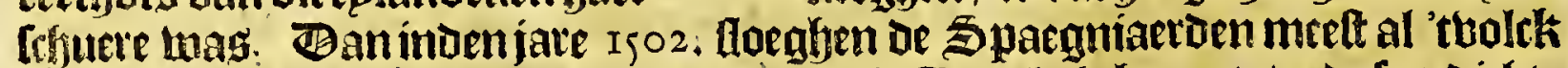
Her. d. . Doot/foo dat fyet eplandeken anbetwoont bleef. IIs bolgheboomte/ende feer Dichte

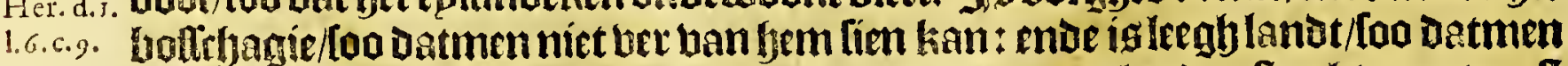

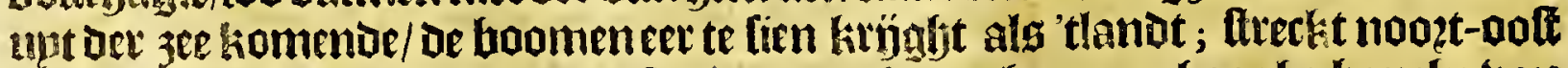

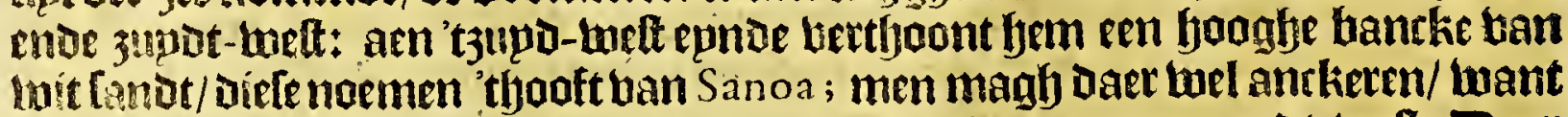

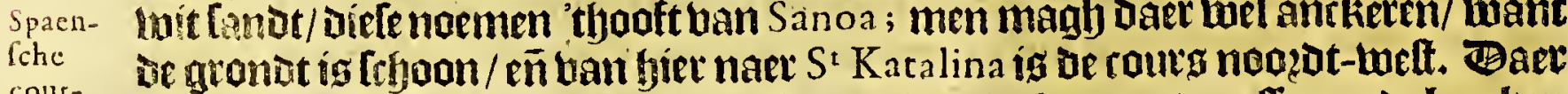

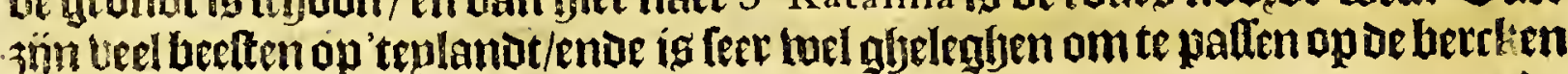
ende 
ende tarbeelen die azinatis tullefen $S^{r}$ Domingo enor Porto Rico vaeten.

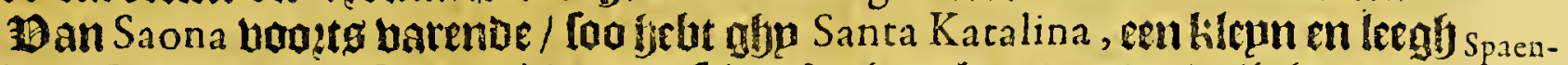

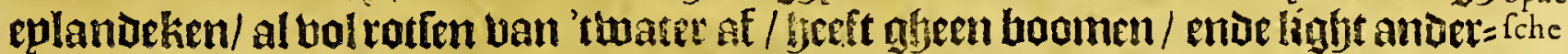

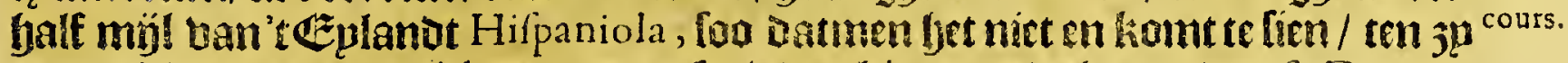
men dirht onjer de wall loopt: men feplt wan hier naet de faten ban S' Domin.

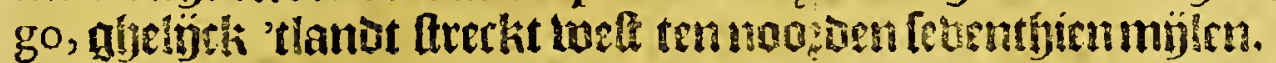

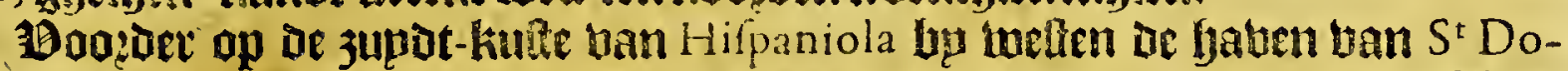

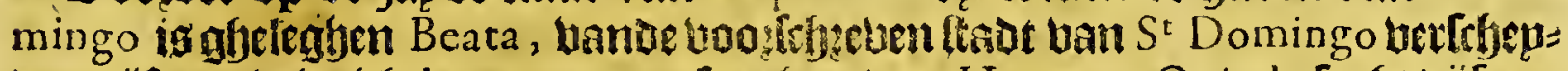

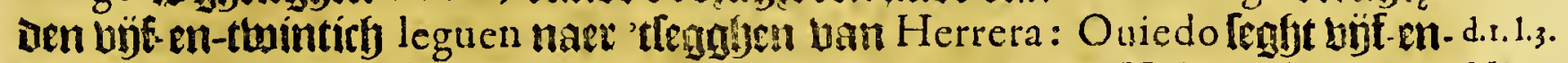

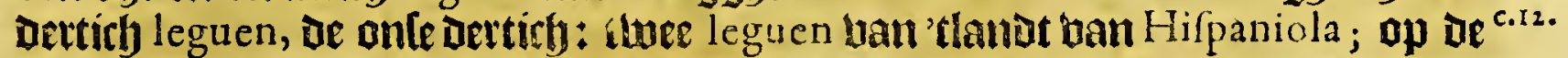

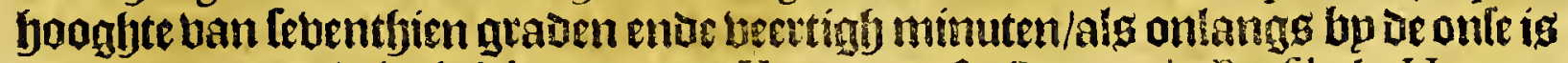
endetuonoen: thintigh leguen ban Yaquimo ofte Puerto de Brafil alg Herrera d.r.1. 6.

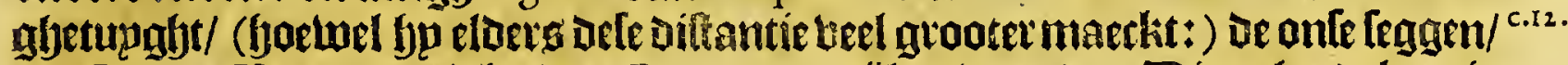

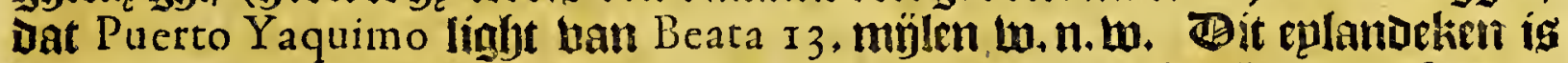

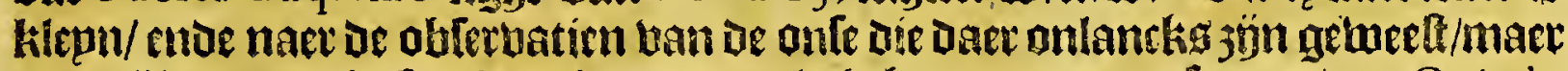

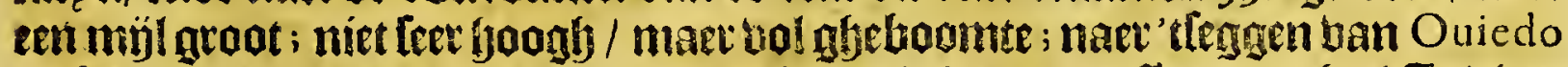

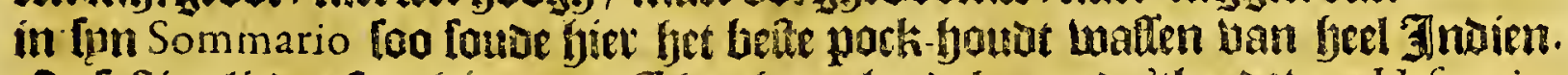

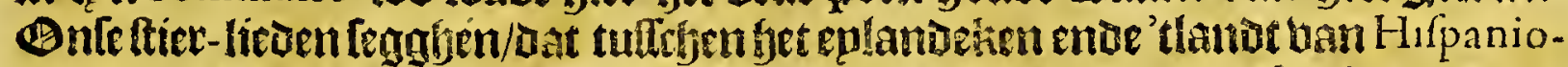

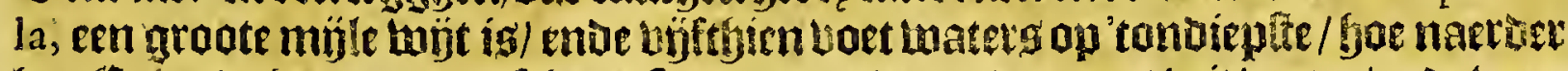

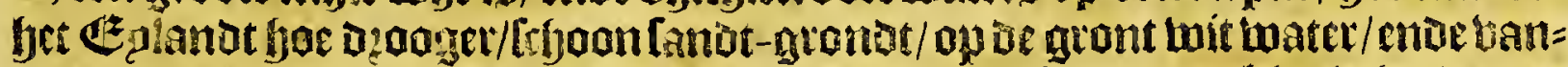

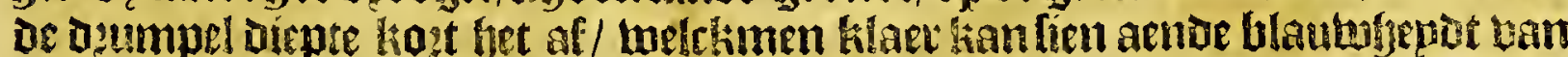

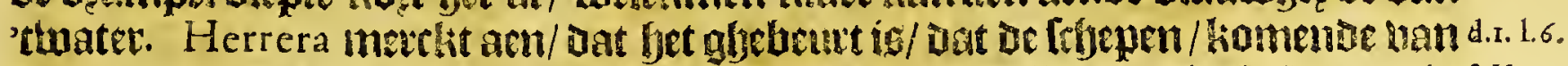

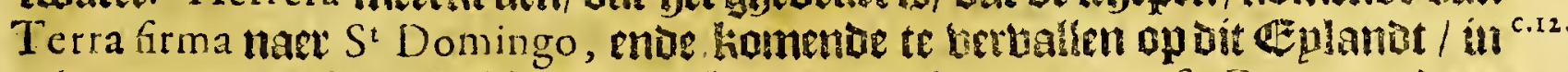

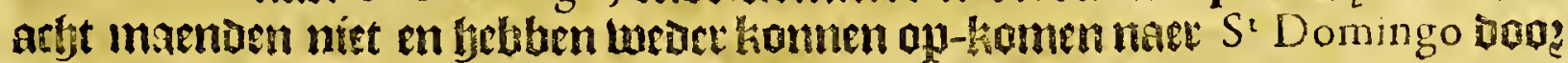
oe contratietedt bande brifen enoe froom.

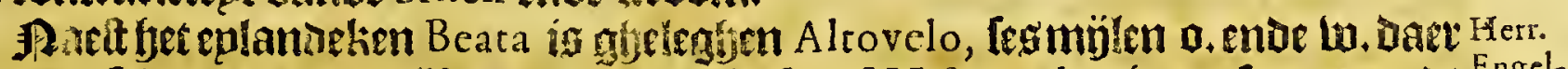

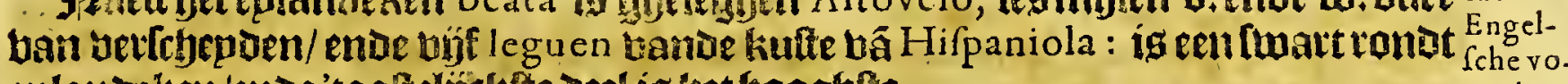

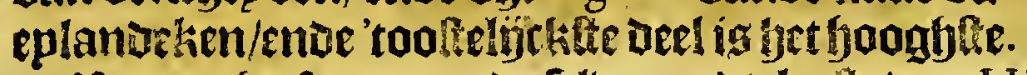

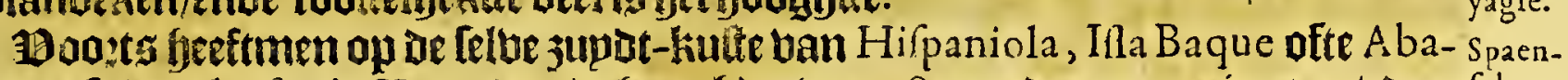

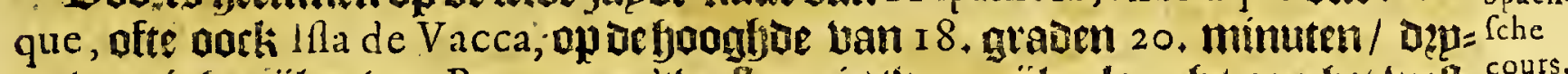

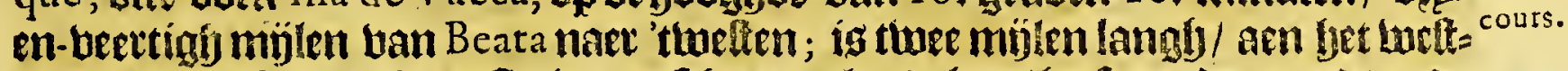

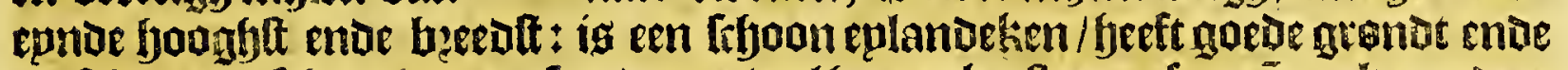

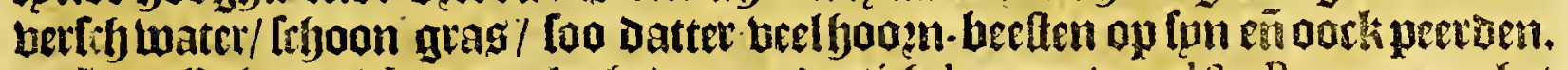

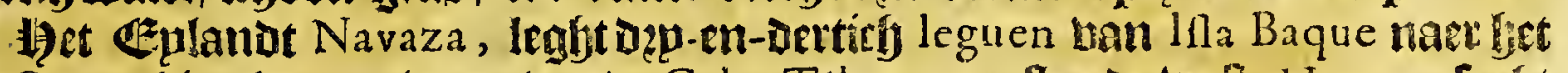
tweften: thien leguen in 3 ee bande Cabo Tiburon oof ende tuelt: Herrera tegint d.s. 1.6. eiders dat het maev arjt leguen is bande vooz-frijetern Cape, toen Columbus c.4.

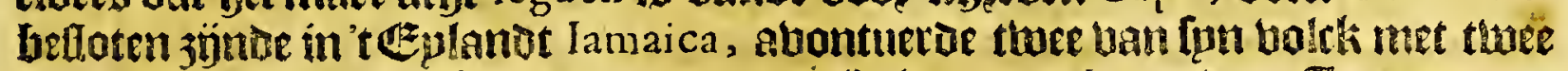

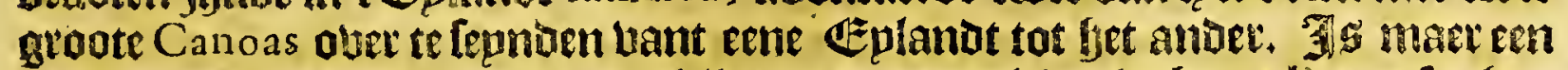

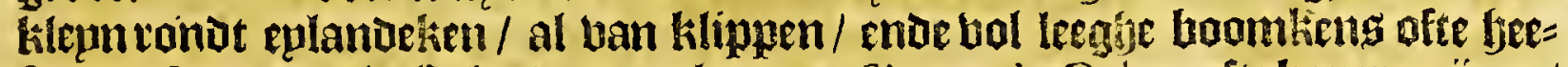
ftetg. Bin van dit Eplandt te zeplen naet Sierras de Cohre ofte Kopei-1mínen/Spaen.

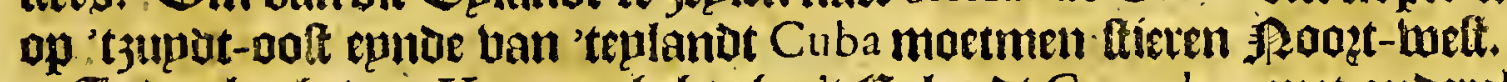

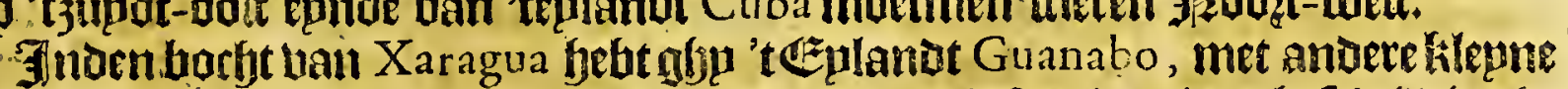

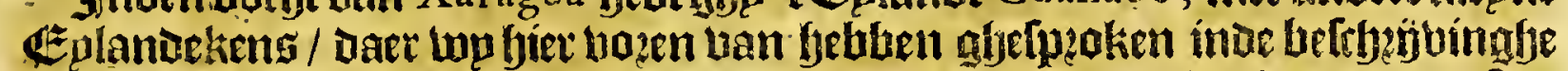

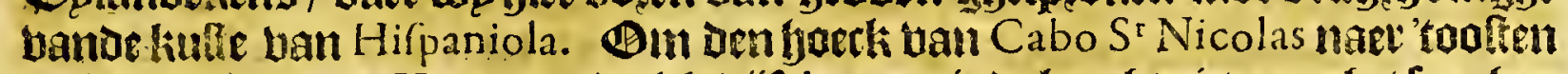
fegbt bet Eplandt Tortuga, Inelek bujf leguen inaelenglte is nast bet ferghen

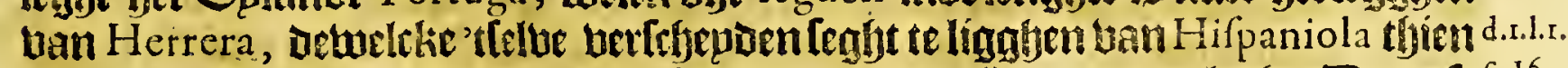

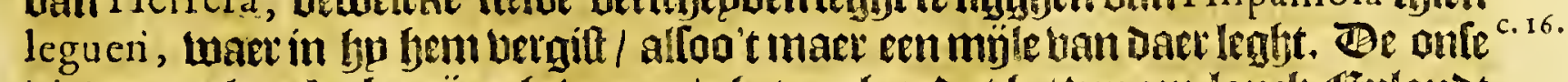

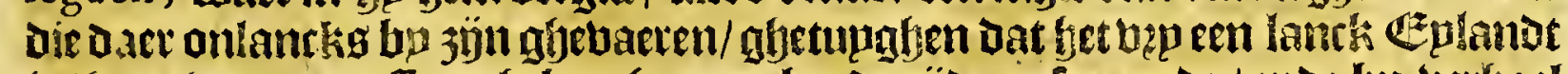

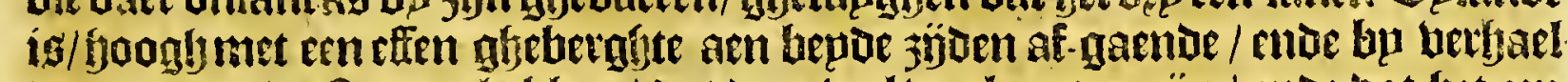
van andere berftaen te bebuen / Dat Daer beel berckens op jün/ ende bat fet een

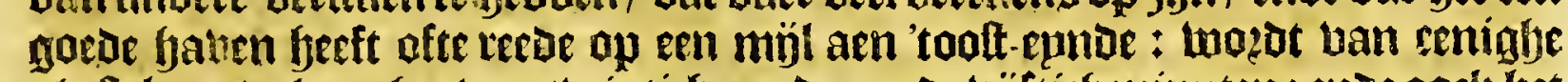
ghe?telt op ae booghte ban thintich graden ende büfticf mimuten: enoe ooch bet berchens epland ghenoent. 


\section{VAN 'T EYLANDT C UBA.}

Hot twaelfoe Capittel.

Vande gheleghentheden van 'tEylandt $\mathrm{C} u$ в $A$ in 'tghemeyn.

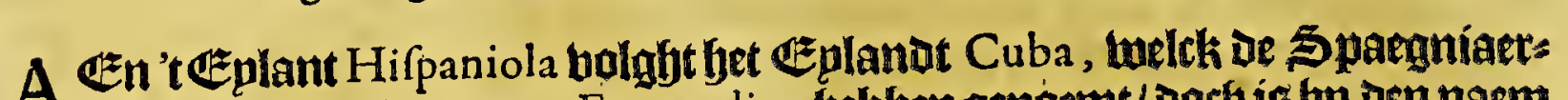

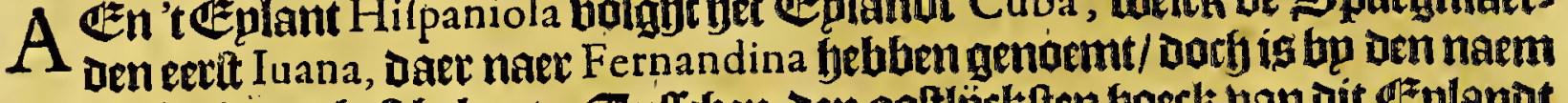

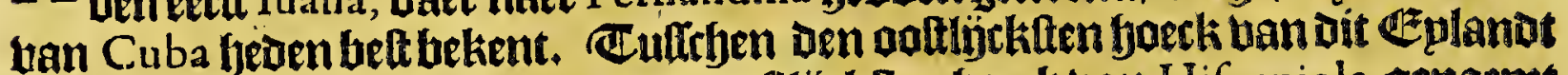
d.r.1. r. Ghenaemt Cabo de Maizi, enoe aen weltlibckitten boeck ban Hifpaniola, genaemt

c.rs. Cabo $S^{t}$ Nicolas, jün afythien leguen naet 'tfegghen ban Herrera: Maet nate 'tlegghen ban Ouiedo twintich; ende naer dat Encifo lrbyëft in fpn Geographia

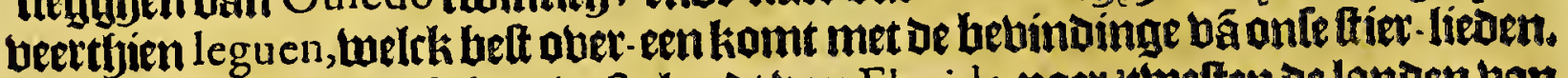

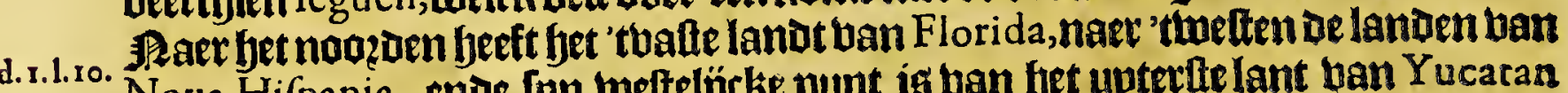
c.8. Nova Hifpania, ende fpn weltelícke punt ig ban bet upterfte lant ban Yucatan

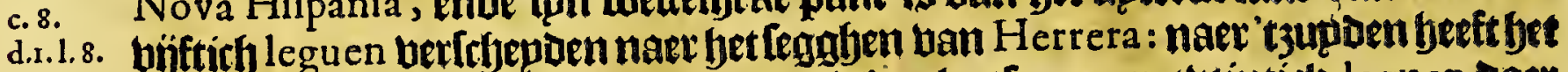
c. 5. 't Gzplanot ban la maica, welck op enniglje plaetten maer twintirb legu en toaer

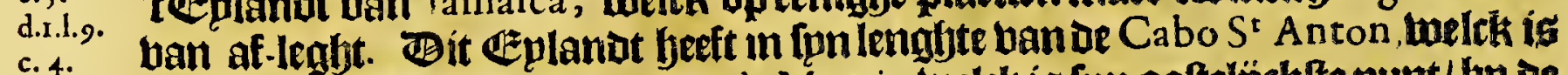

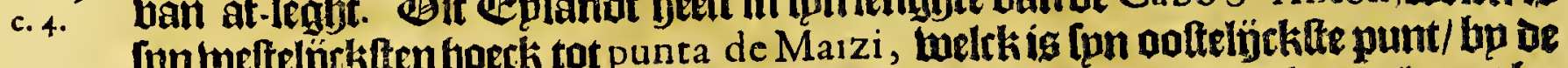

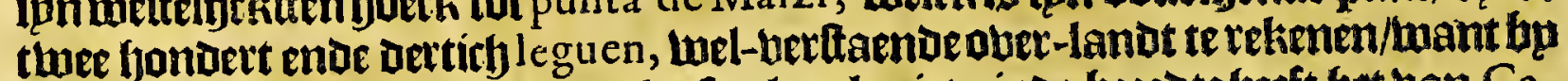
luchtende 'twater temeten en ig bet fon lantk niet : inoe beesote beeft bet ban $\mathrm{Ca}$

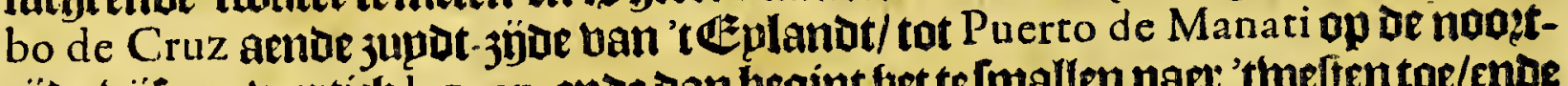

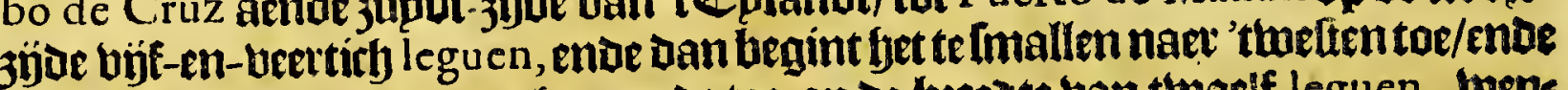
loopt ban daec boozer tot get epnde toe op de beedte van twaelf leguen, toeps

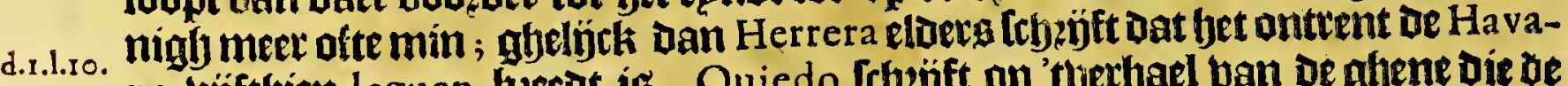
c.8. na byjfthien leguen beetat is. Ouiedo Itheijft op therthael van de ghene die de

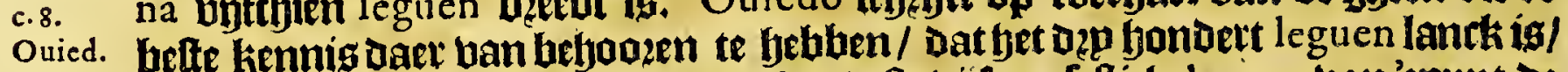

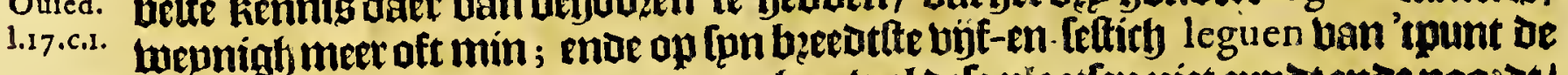
Iardines tot bet punt van Lu canaca: foe-wel of [e platten niet 3 upot enoe nodgot/

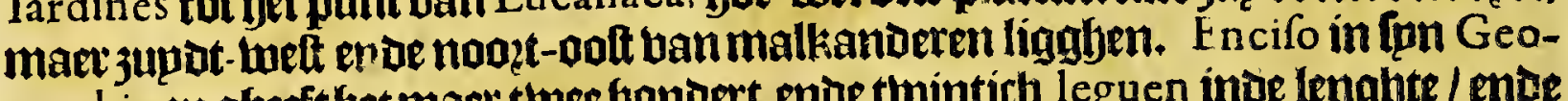
graphia engheft fyet maet twee honoert enoe tmintich leguen inoe lengbte / ente

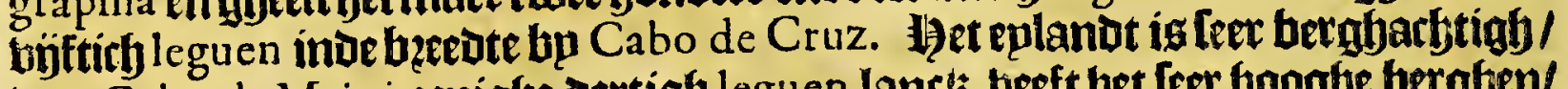
uan Cabo de Maizi eenighe Dertighy leguen lancli beeft bet teet fooghe bergfen/

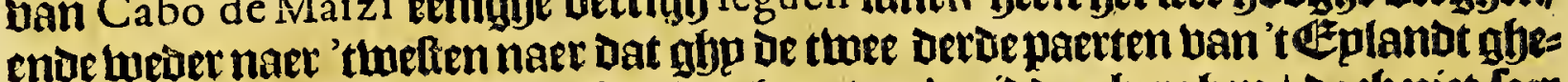

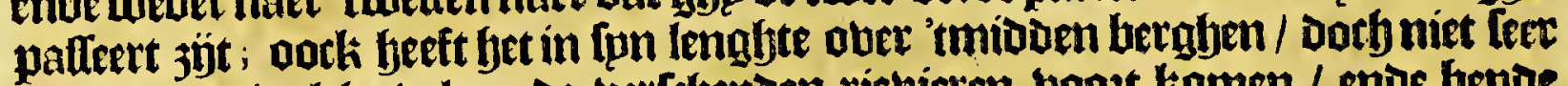
joogh / upt twelcke bele ende betfrbepon riebieren boot-komen / ende bepoe

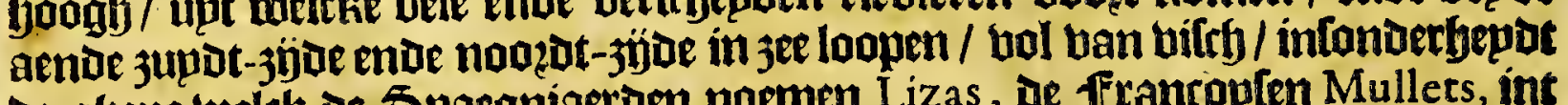
be aliene welck de Spaegniaerden noemen Lizas, of ffranropten Mullets, int ILatinn Capito ofte Cephalus; ente die de Spatgniaerden noemen Sabalos, ende ie francopfen Alozes, in 't I atÿn Alofa, ende in onte tale Eift / komende op

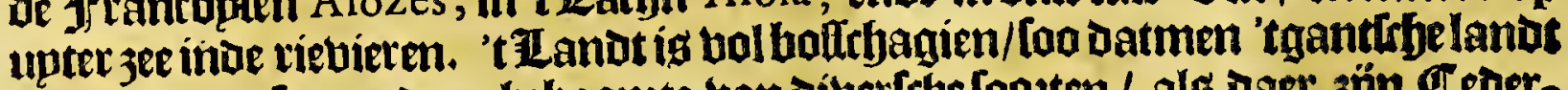

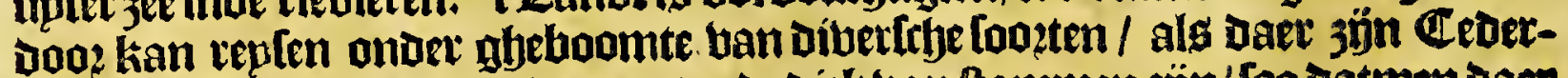

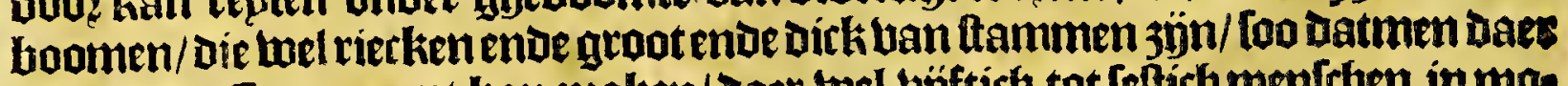
feer groote Canoen upt kan maken/Daer wel búfticfy tot leltich menteben in mo ghen / van weleke daet eertijotg feet beel waren in Dat Eplandt. Entue boopts andere boomen ban Storax, foo Datmen desmozabeng ttaende op exnighe boogten/alg de Conne op gaet/ende de bapeuren fich ber[plepden / vande bieren die de

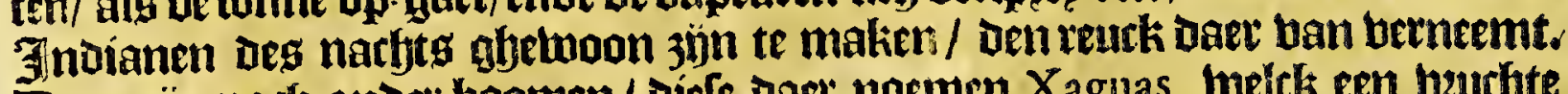

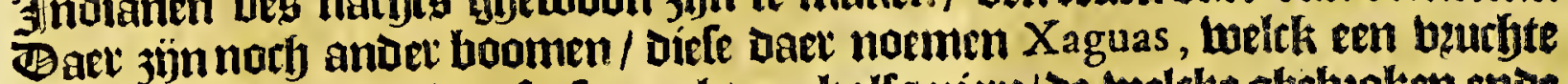
aeuen foo groot/enoe ban fatloen als een balfs niece/ oe welcke gbebzoken enoe

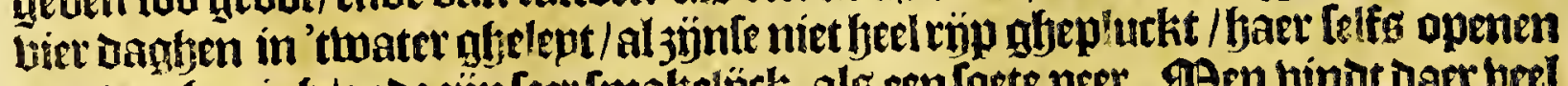

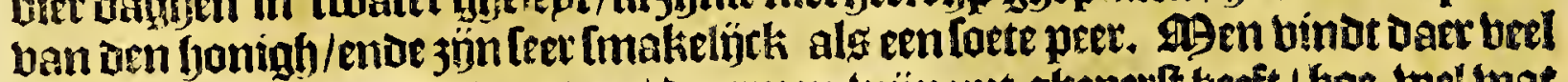

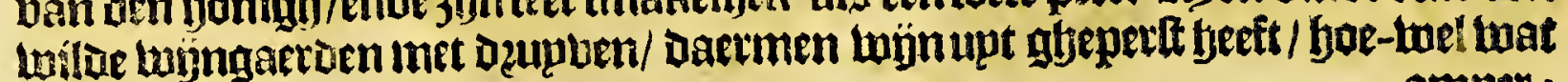
amper: 


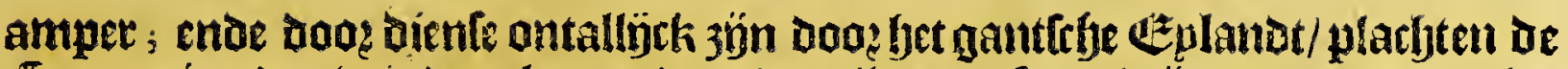

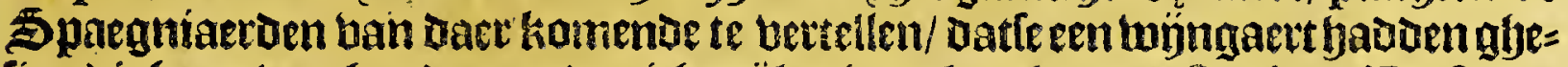

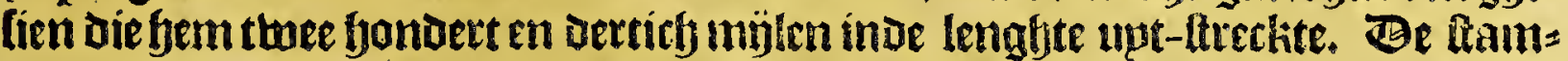
men jün ban fommighe loo dich alga cenman in lpn midoelt. Taer ig aengroate

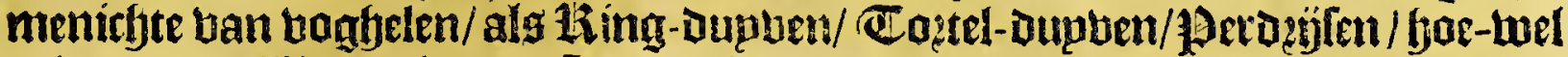

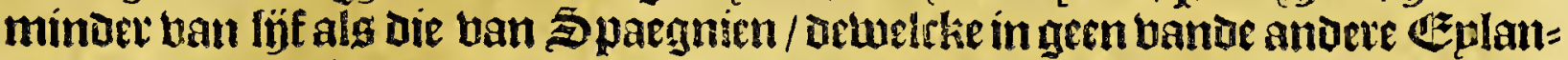
oen en wozoen ghebonden; Daer 3 pll ooch anoere boghels/ban fattaenals ltra=

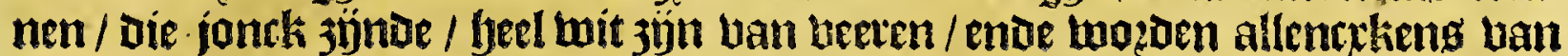
aldetfande coleuren; ie Spatgniactoen noemen die nu Flamencos, indien oe felbe ghebonden twietden in Nova Hifpania; fouden daet groot werck ban maken

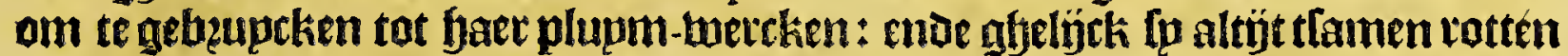
büf bondert / ja duptent in een troupe / fo fringnt get een kudoe frbaepen te tuelen met rodt gheteeckent/daetefitten; en blieghen Dod-gaeng niet / maet fitten aen De jee-kant met de beenen in 'twater/ende Deincken joubt watel/[a Dat de Jindia:

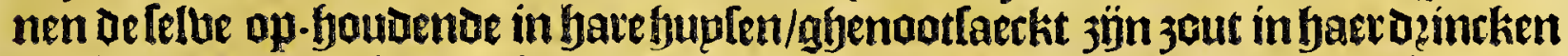

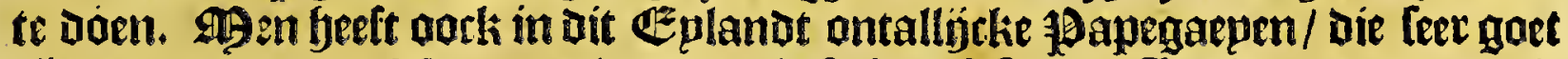

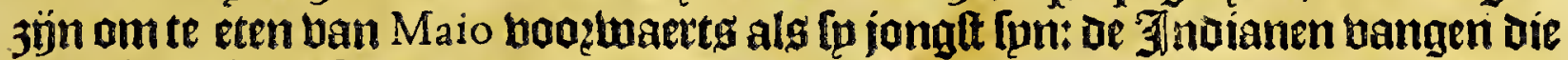
op defe wajle: [p [etten een jongben ban elf oft thaelf jaten in eenen boom/thjooft

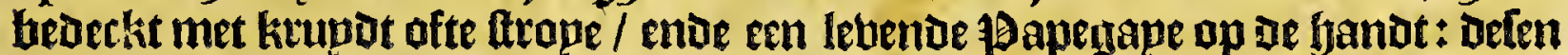

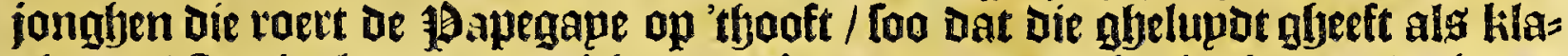
gljende / ftrachss komter menichte ban loapegapen toe-ghewloghen / ende inden

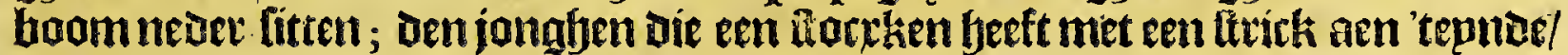
weet met beisensirfept d'en lBapenarpe boosende dander naer den ftrich am 'thooft te merpen/ ende foo naet hem te trecken/ weinghende die den bals af/enòe onder Den boom latende vallen/ Doos defemaniete tanghender fo foo vele als fp

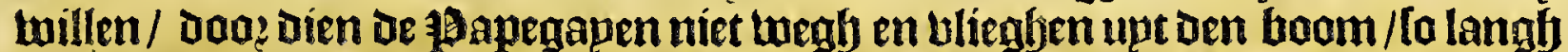
De 19apegaepe die oe jonghe op de handt beft klagende gelupt geeft: De Spae=

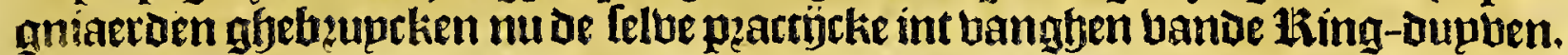

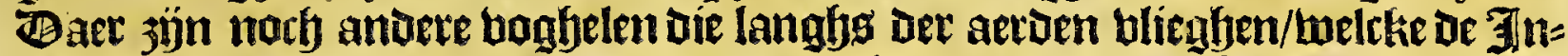
dianennoemen Bambiayas, ende banghen die int loopen; affeloden jünde / abe.

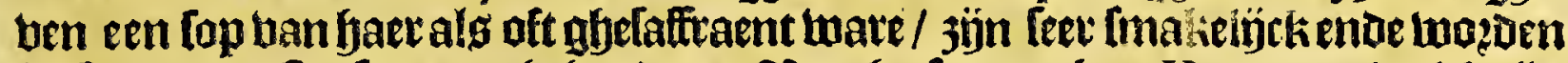

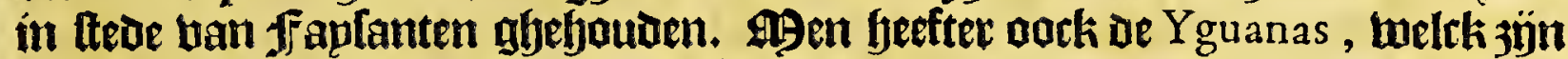

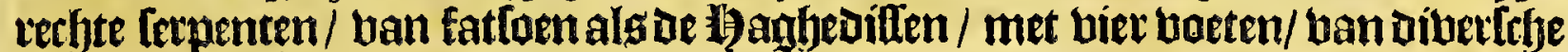
groote; of Spatgniaerden eten diemede / foo hier als in ander gletwelten yan

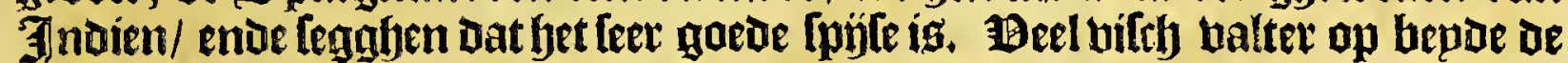
kulten: te toeten Beepen die de Spaegniaetts noemen Aguias, ende andere diefe noemen Moxavras, ende dietghelyette bekende ende onbekende meer: ende ghelijck aende zupdt-jübe ban dit Eulandt ligghen de ontallÿcke eplande= keng diefe noemen Iardin de la Reyna, jumtmen Daer ontelbare Srbilt padoen/ banfulcken groote/ Datter gbetuonden jün lwieng bet ende bleefebyondert ponden

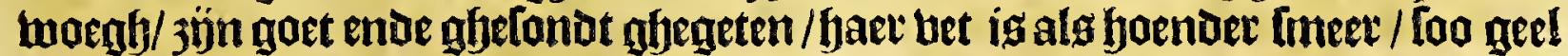

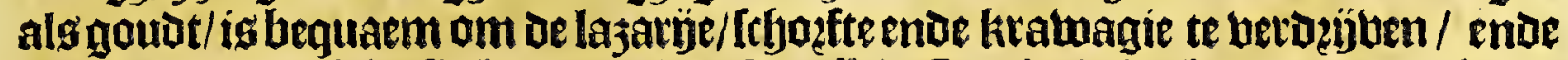

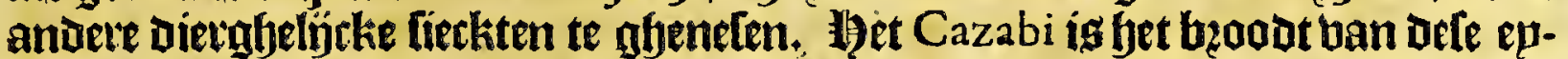
landen/ valt frier feec abondant/ende aheen ban d'ander eplanden is foo aber= blocdigf ban bictualie : Inant 'tuffene top ban Hifpaniola ghelept hebben / geeft hier oock plaet fe/Datter is ontallincke bee banftieren/koepen/enoe berckeng; [oo

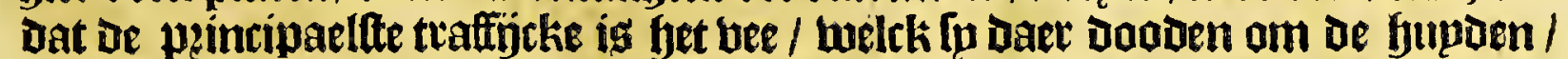
Iuaet toe de Sparmiaerden beel Smarten emplopeten; ie berckens mettenle)

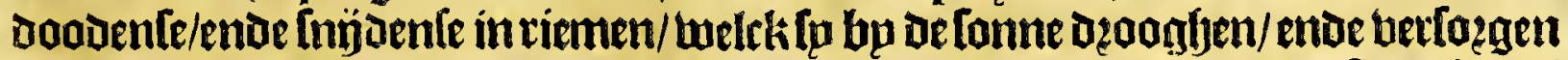
foo pravifie boos de frhepen die naer 5 paegnien keeten. Baet walt oock beel cattoen int wiltoe / welclie de Indianen pleghen te berendeneñ te Lpinmen. Baer Her,de-

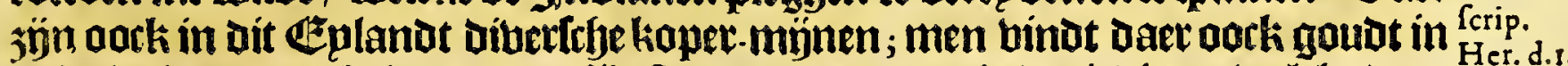

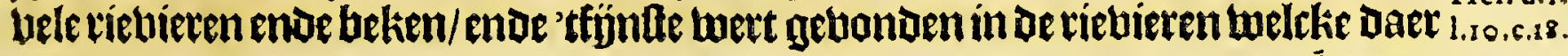




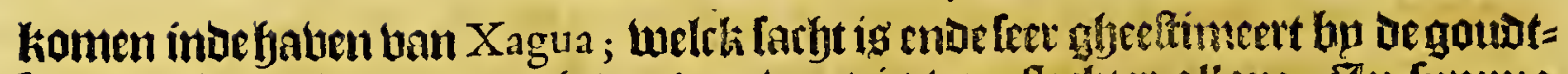

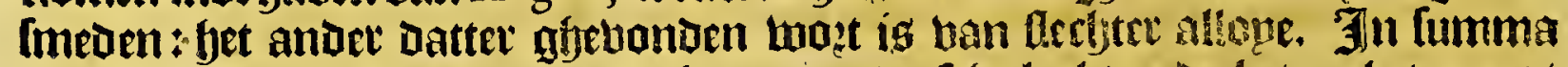

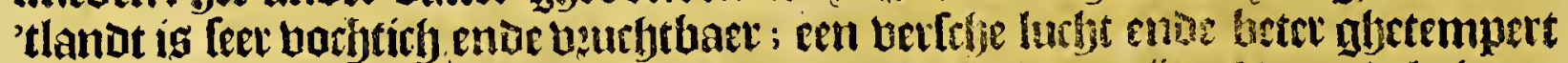
alg die ban Hifpaniola. De Raturelen tan Dit Epland sign al booz bele jaten

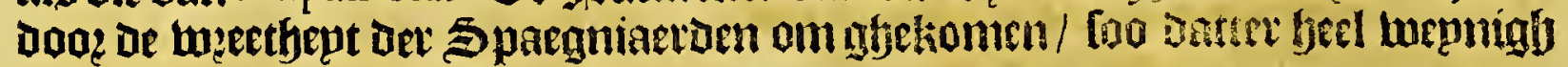
bolcks is in dit groot eplander.

1)et derthimbe Capittel.

Vande verfcheyden Provincien ende rievieren van' 'Eylandt $C$ и в A.

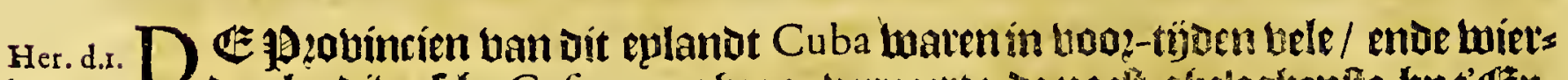

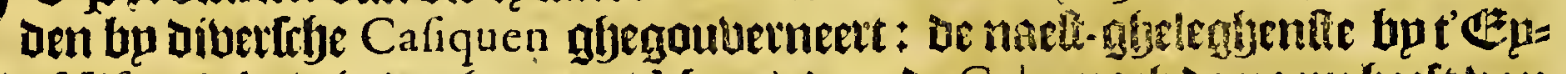
lanot Hifpaniola luírtot nujenaeme May ci, Daer de Cabo norly te naem beeft ban

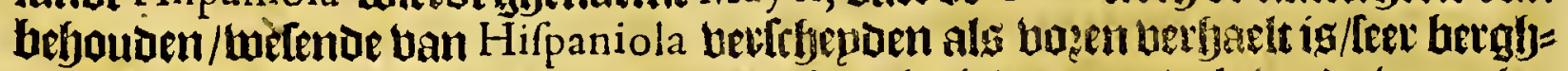

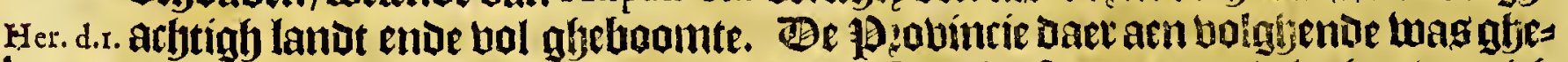

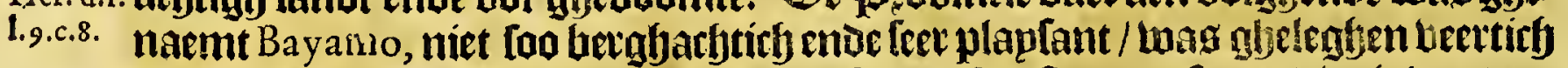
oft bijftich leguen van Baracoa naev' twelten. Paeft aen Defe vatincie twag ge=

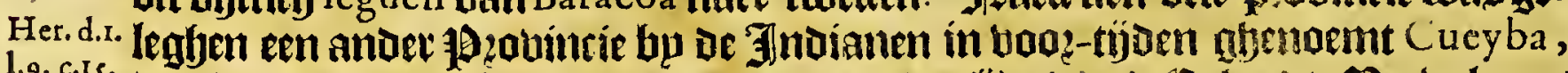

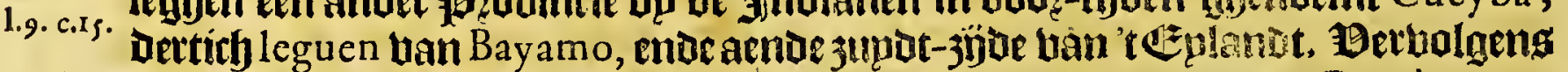

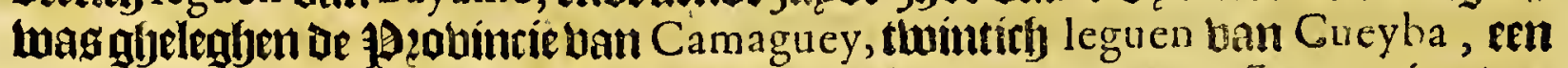

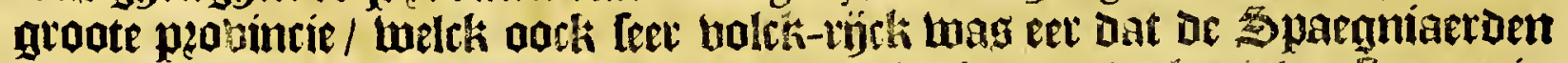

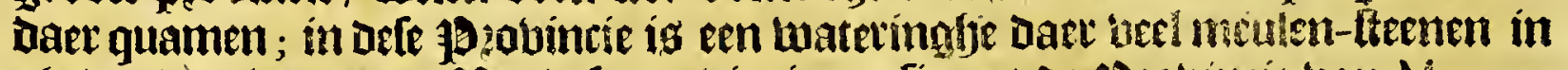

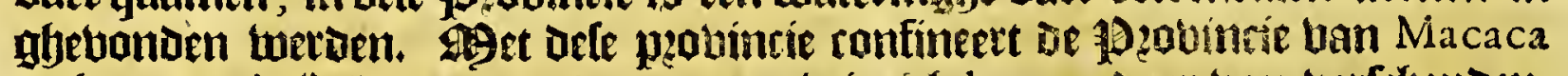

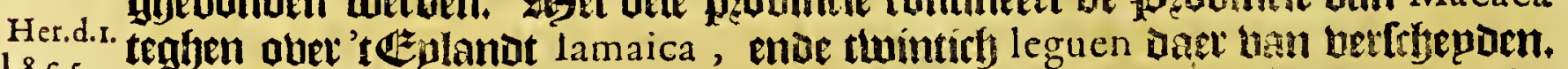

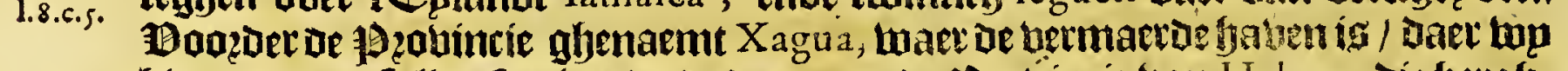

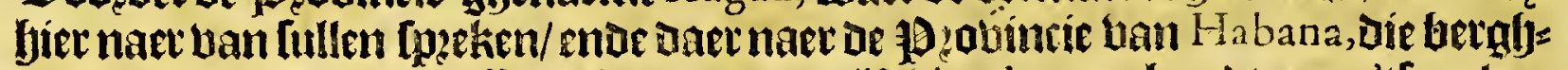

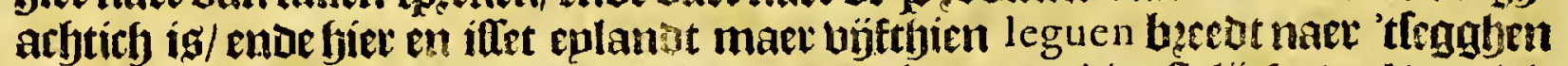

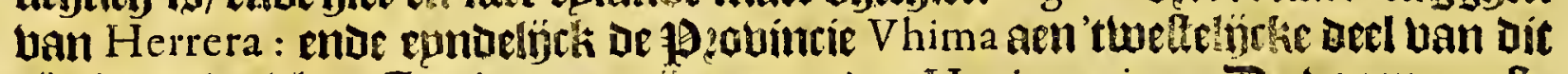

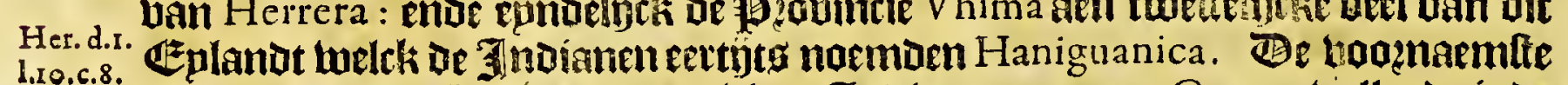

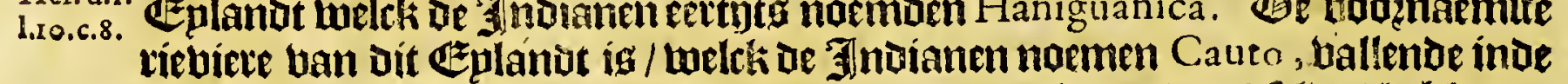

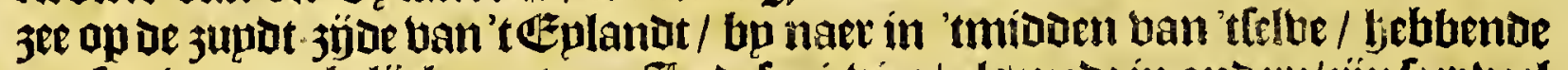

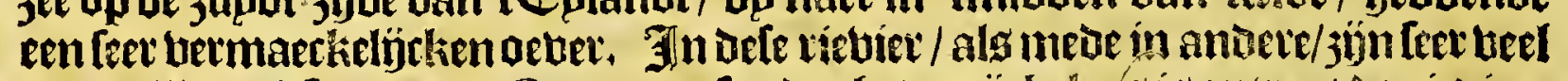
tracodillen/oiele noemen Caimanes, foo dat bet perijtielents is ontrent ue vieblete te bernathten / want fp komen op 'tlandt / ende woeten se mentefen laegh die fu

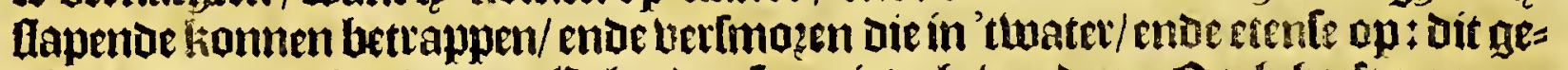

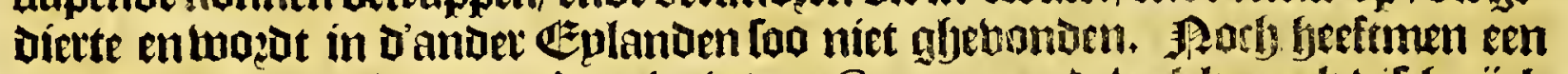

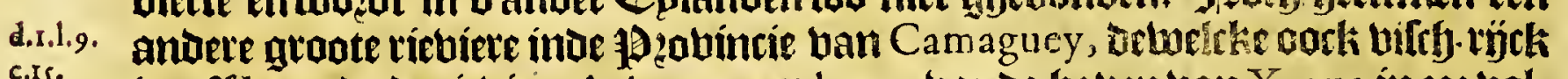
is. 2Al mede deriebiete A rimao, efn legue bande yaven van Xagua in $3 \mathfrak{e r}$ bal=

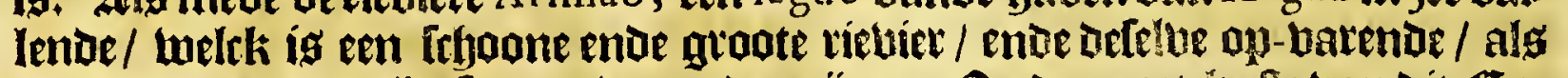

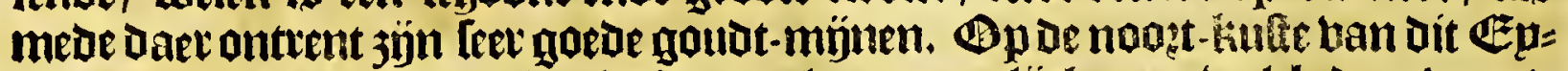
lanot felut gho oork eenighe tievieten/ als namentligth eene tuelck den Ammirand Columbus noemae de la Luna, ende een ander / bie by noemae de Mares, waet de ljaben ban Baracoa ig/ Daet tup bier naet banfullen fpedien.

Het beetthienae Capittal,

Van de fteden van't Eylandt C $\mathrm{C}$ B $\mathrm{A}$.

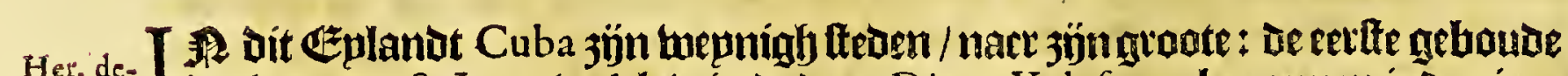
Her. de- I
is ghent. I I I. op de zupht-kulte van dit Eplandt/beettich leguen van Cabo de Tiburon in Hifpaniola : twee leguen bande jee / meftens een hauen die ear bande brefe is

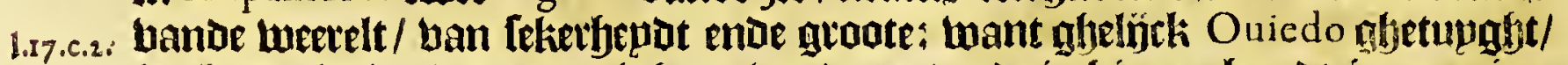
is gbeen riebiete/ maet een infjam bande $3 e$ / ende ig binnen beecot ín maniete 


$$
\text { Her ecrfte Boeck. }
$$

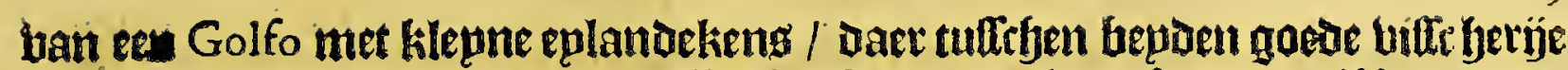
is / ende de trbepen kannen daer lígghen fonder ancker oft toulw. Mo aer Doo? uele ftadt eertiots leet toe-nam Date mel twee supfent burghers hadoe: Dan nu

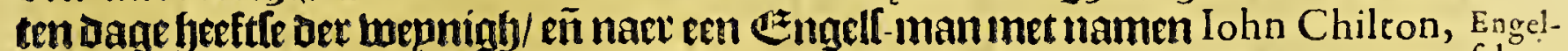

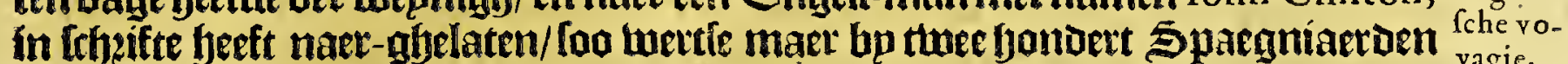
ofte daet ontrent bewoont / Geeft een Catbedzale ketche / fuffiagaen ban $S^{t}$ Do-

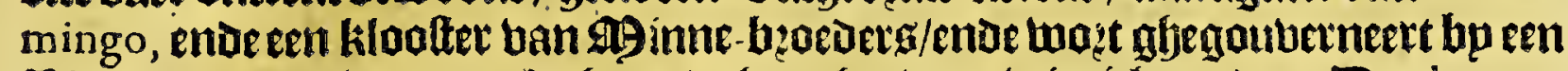

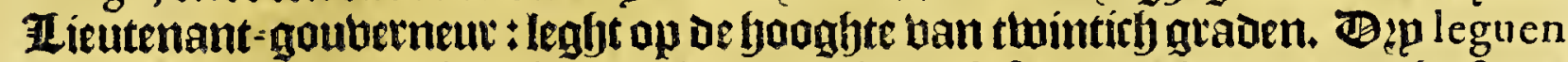
ban urfe ftadt aen enen herghigen lioper-mijne/ Die feer goet koper upt-abeeften= of in groote ahondantie / foo Dat Ouiedo bethaelt / dat uan bijf quintalenmi= netale aetoe / twee fupber kaper jün ghebleben. ßRaer Dat íck ban een ban oe

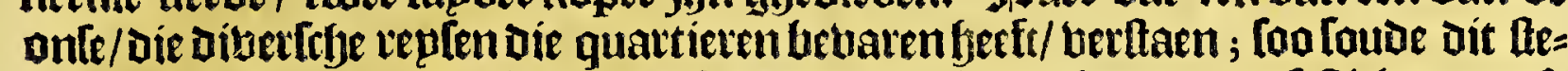
Deken inden jare I60I, bpeenen Capitepn Clife met bonoert en feltichman af=

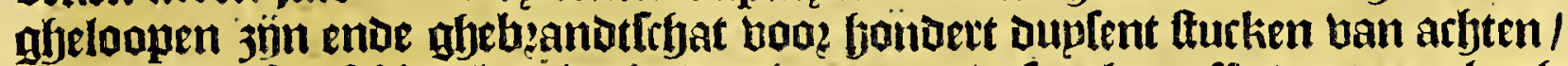

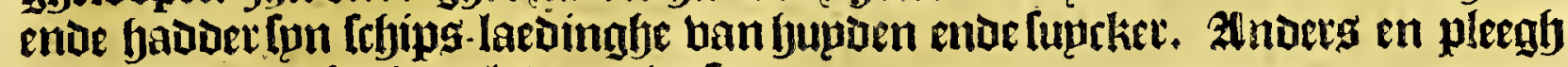
biet hoog de anle niet te laden te tweten.

De ftaot Baracoa is inlabelých in fet eerfte affechout bp Diego Velafques aen

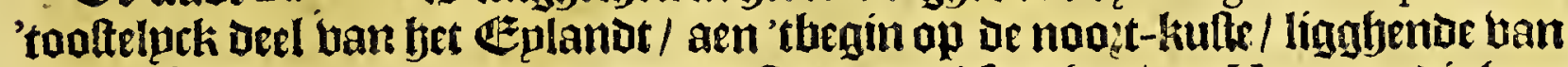
S! Iago feltich leguen naet' tmoosot ooften/ naer 'tfegghen ban Herrera, Die bem

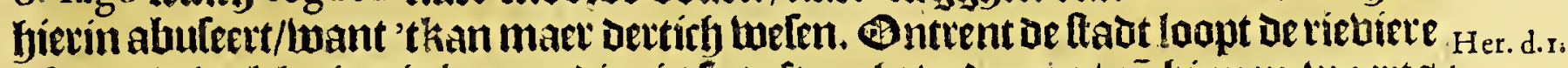

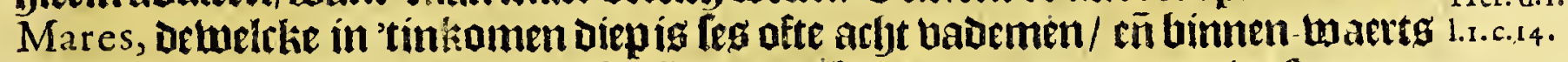

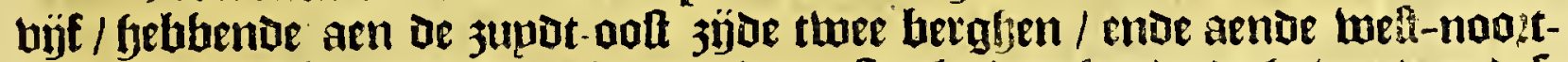

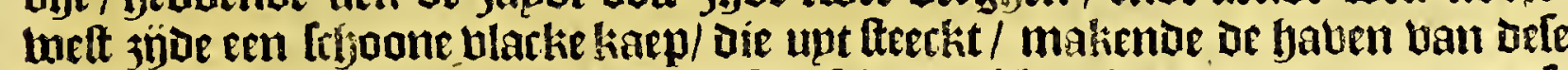
plact fe. Hiet antrent balt beel ende feer frboon ebben bout; ende naet de onle d.r.1.9.

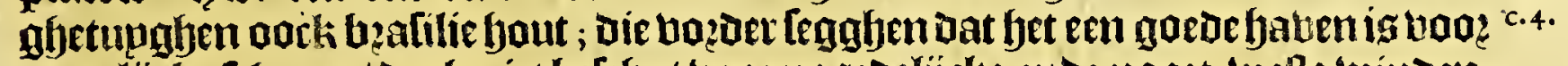

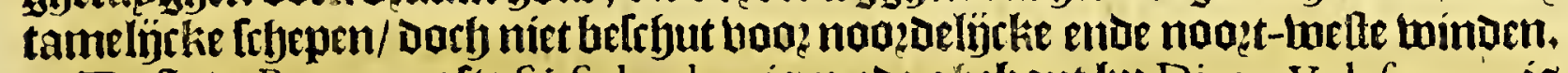

De ftadr Bayamo ofte S'Salvador, is mese gijehout bu Diego Velafques; is Her. de-

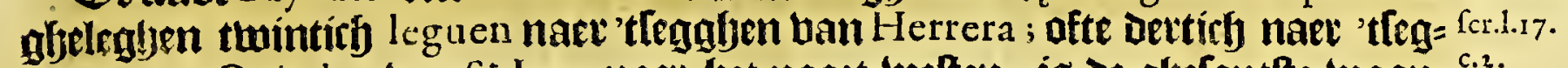

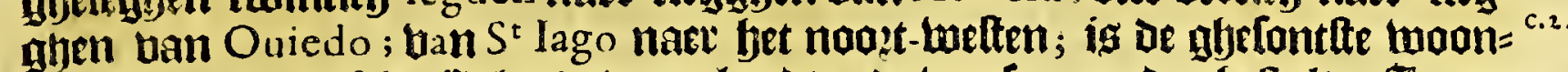
plaetle han'tgantlche Eplanot/ open lanot enae banfeet goede gheltalte. $\mathbf{Z}$ neen Her.d.4. rieviere uan den felben name antrent defe ftadt moeden ghetanden rande fteenen 1.5.c.2.

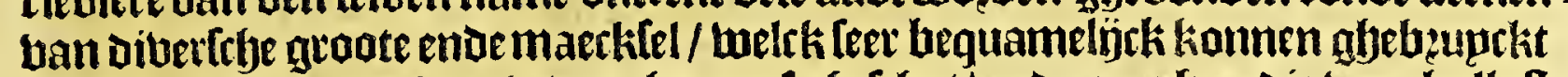

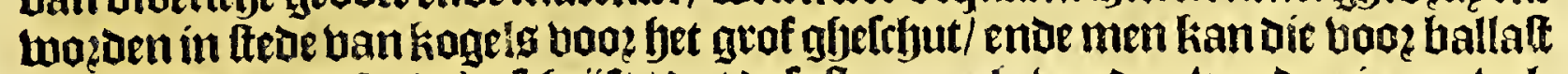
ober-bzenglyen. Ouiedo fofenft / Dat defe fteenen ghetuonoen two den meen bal= lepe twel deg leguen lanck/ ende Dat gheleghen if tulfrgen dele ftadt ende $S^{t}$ lago, byfthien leguen ban $S^{t}$ lago.

Deftadtende haben Puerto del Principe, ig gheleghen op de noott-kufte tan Her. de-

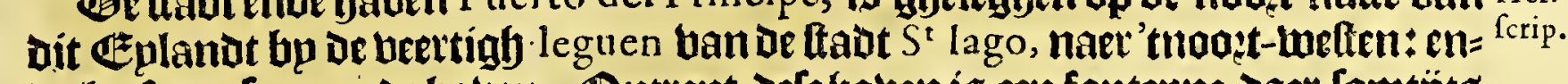

be heefteen Leer goede bauen. Ontrent Dele fyaben is een fontepne daer lomtÿts ${ }_{\text {Her. d.r: }}$

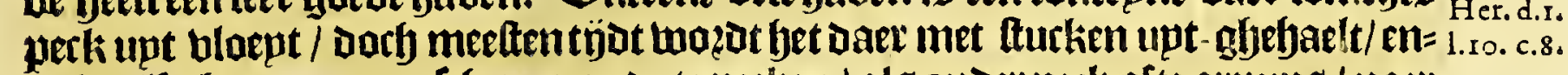

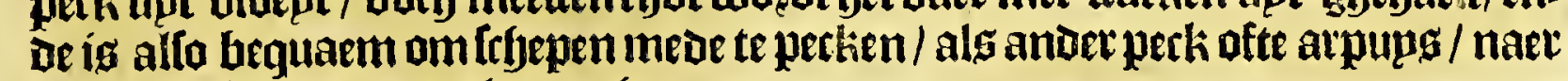
Dat Quic do daer uan gljetupght.

$1.17 \cdot c .8$.

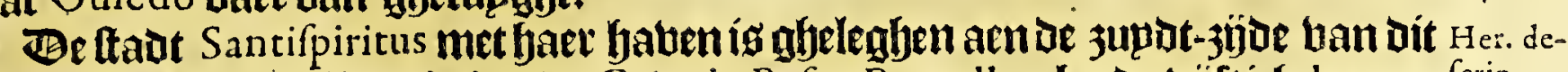

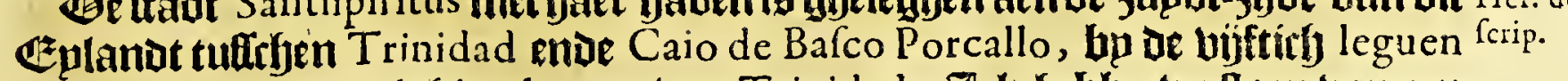

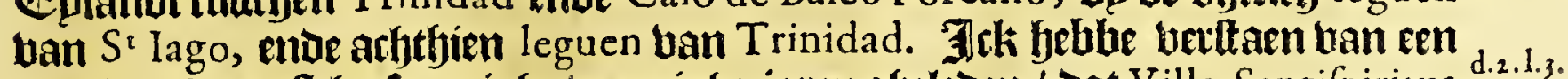

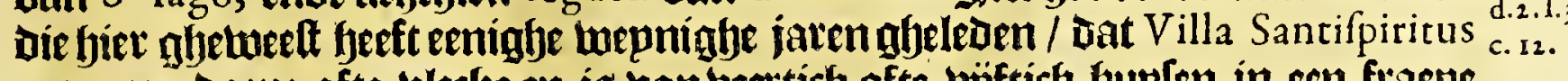
maer cen oozpe ofte blecke en is van beettich ofte vijftity huplen in een fraepe quartier ; bujf ofte les mijlen banoe 3 ee/ ap een rieuierlien/ welsk fp noemen Saaz, helckmen met doepen apmagh baren: daet ballen beelfupden/ende legt inde wegh ban $S^{t} I a g o$, Trinidad ende Bayamo naer de Havana toe.

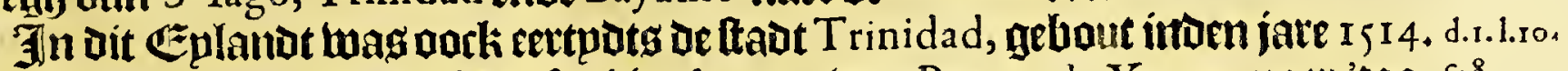
aoaz Diego Velafques neghen ofe thien leguen van Puerto de Xagua naev' toa = c.8.

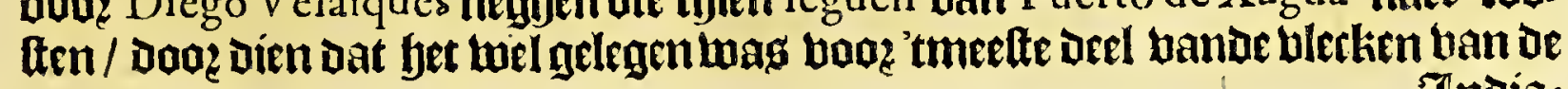
India: 


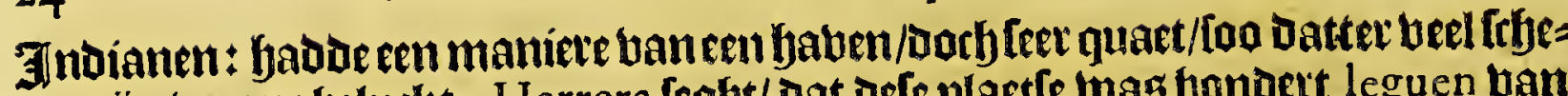

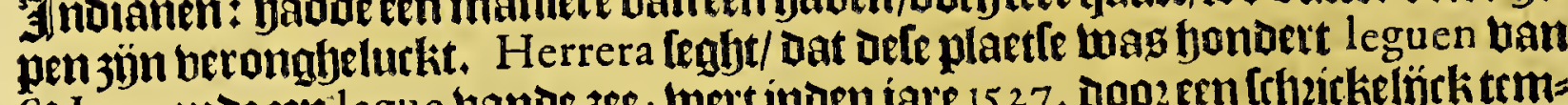

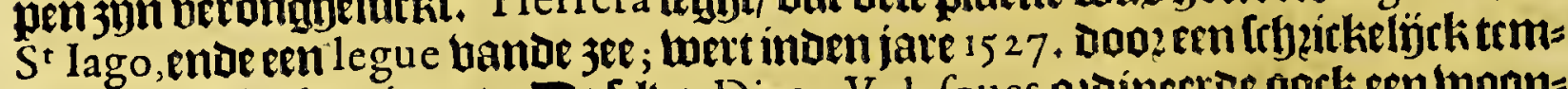

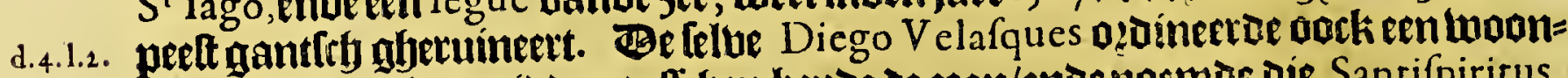

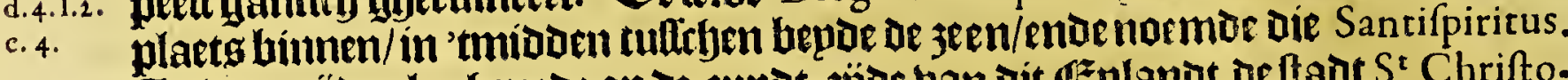

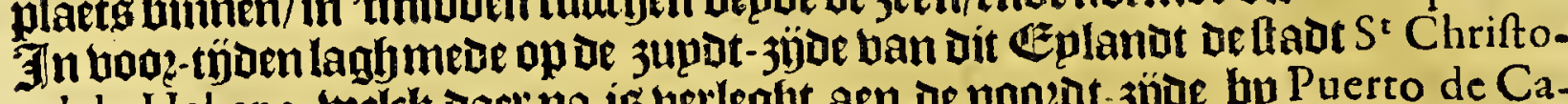

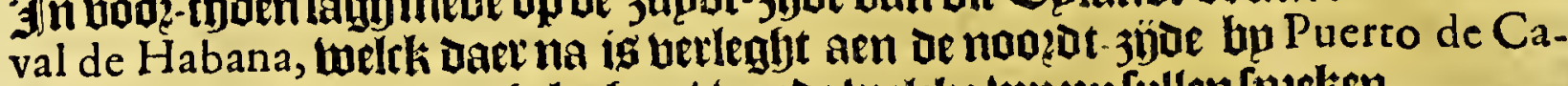

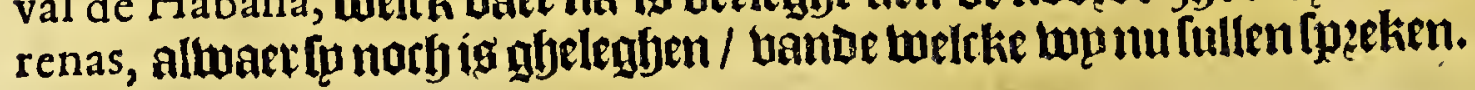

1)et vijfthiende Capittel.

$$
\text { Vănde } H A \text { V A N A. }
$$

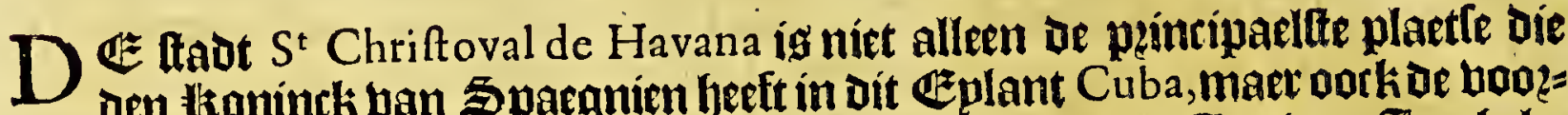

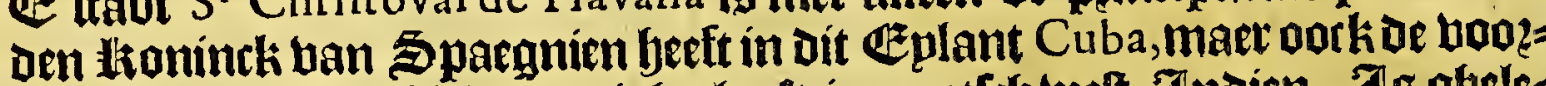

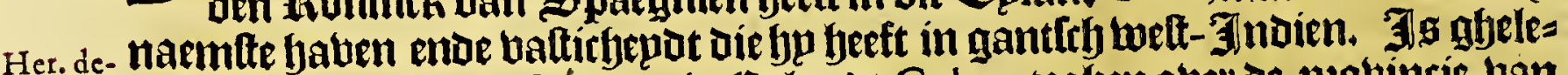

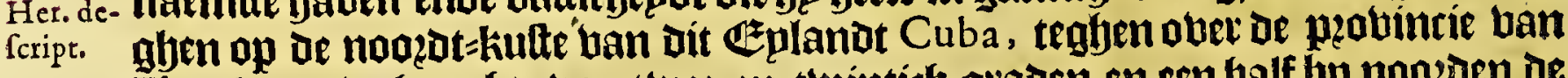
Florida, op be yoogbte ban twee-en-twintich graden en een balf bp noozecon ofe

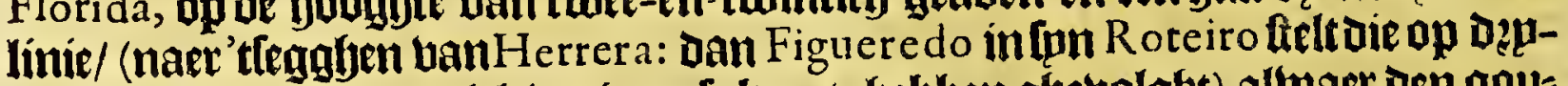

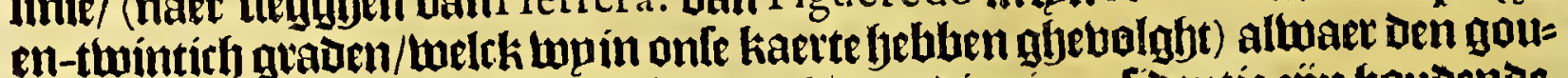

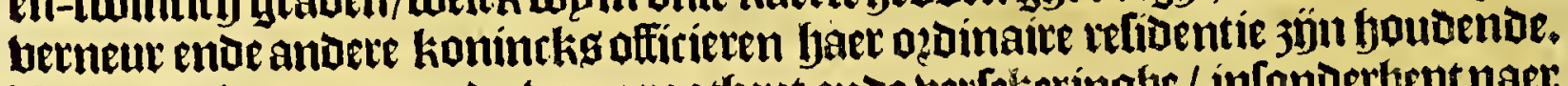

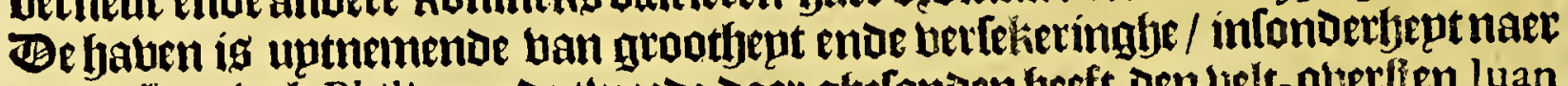

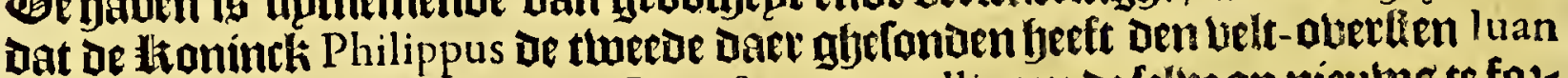

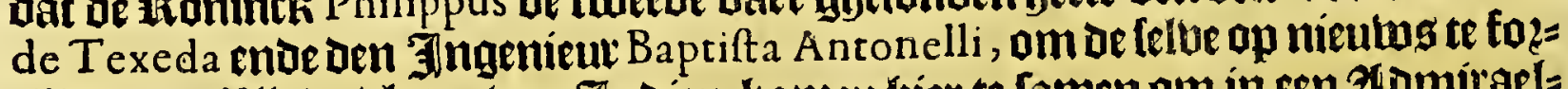

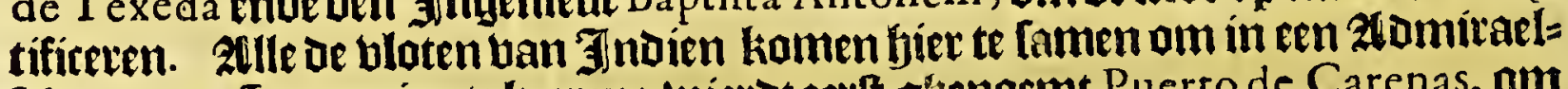
fthap naer $\$$ paegnien te ketren: wierot eetif ghenoemt Puerto de Carenas, om

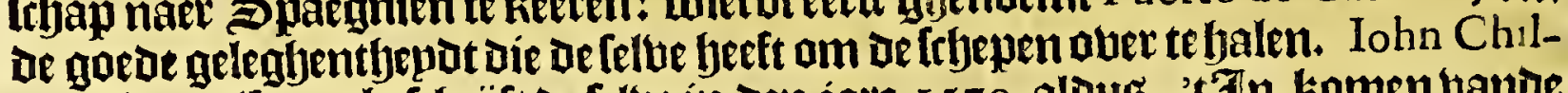

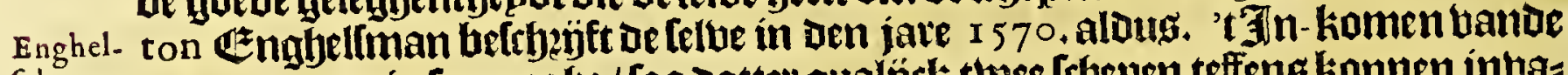

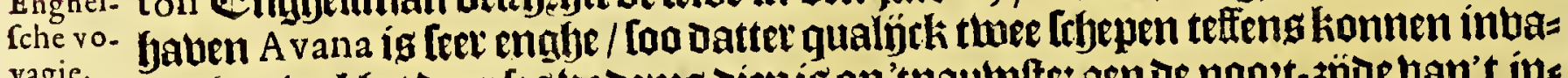

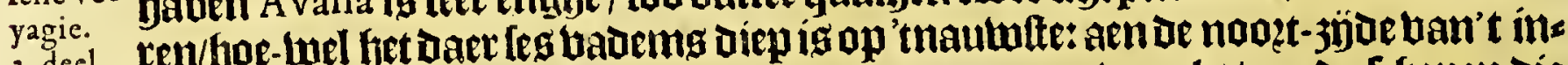

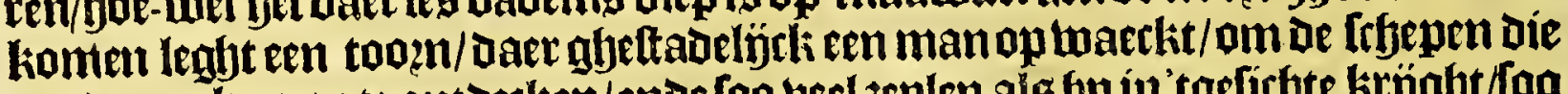

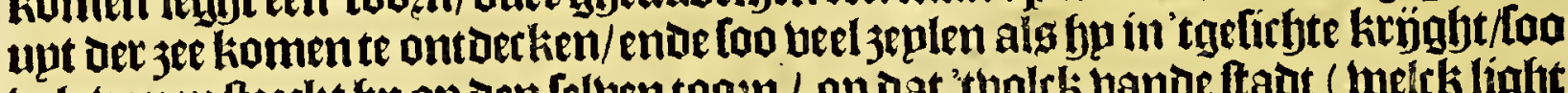

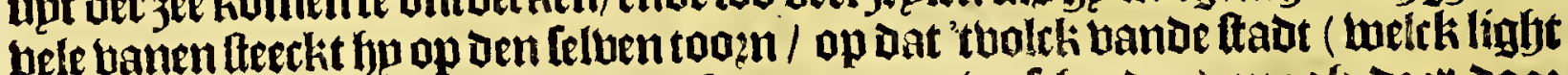

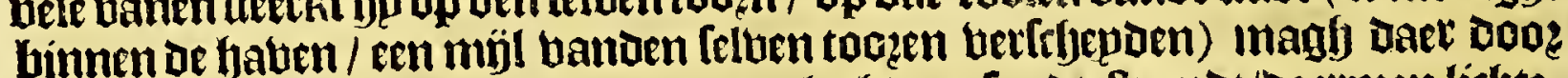

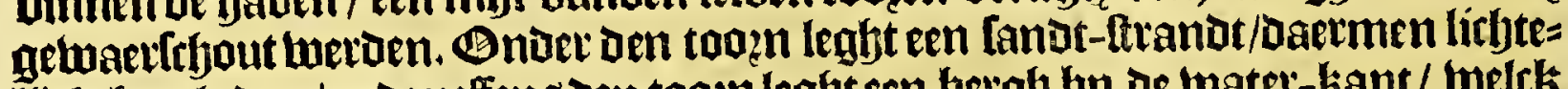

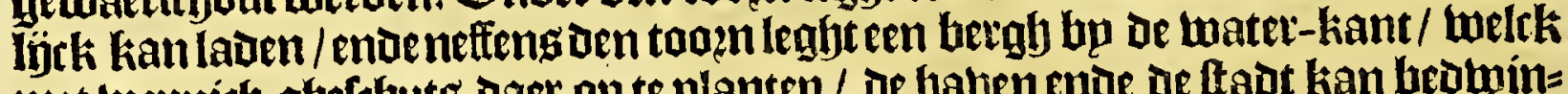
met twepnirf abefrbuts Daer op te planten / oe Gaten ende de ftaot kan beowin=

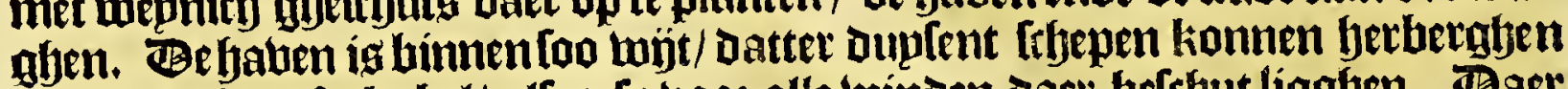

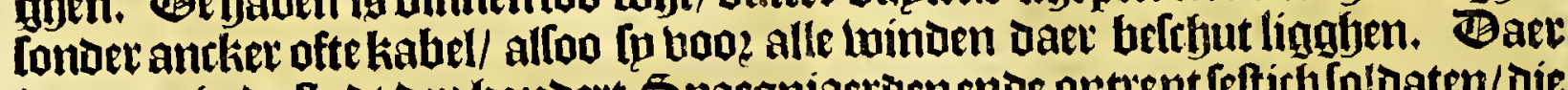

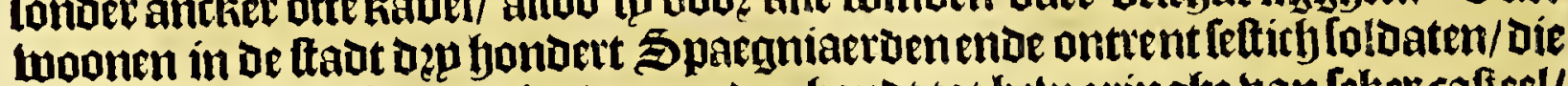

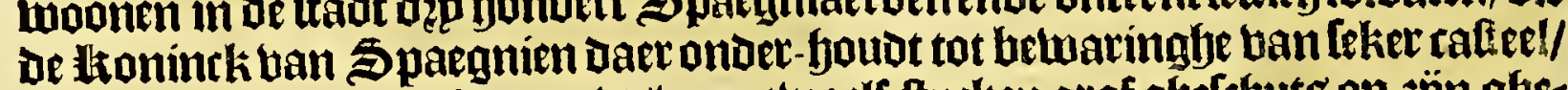

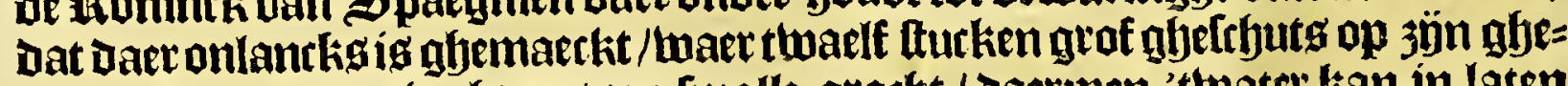
plant/ ende is om-ringht met een fmalle gracht / Dartimen 'twater kan in laten

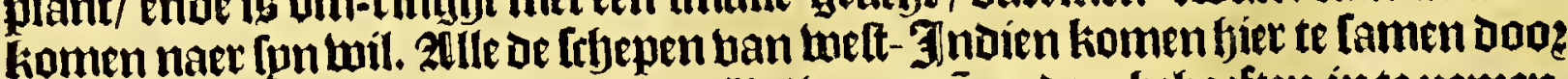

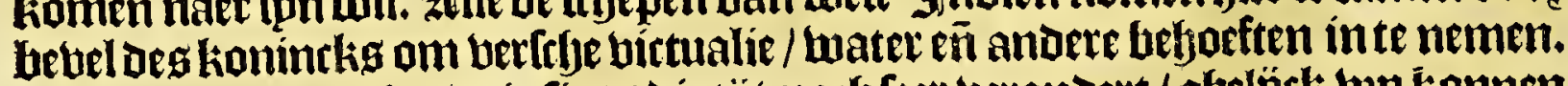

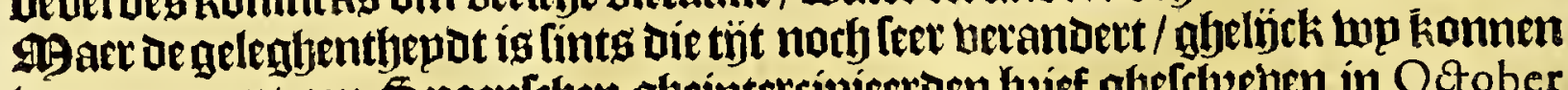

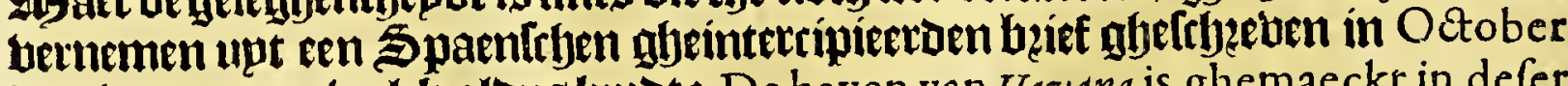
Des jaets 1590 . wuelck aldus lupot: De haven van Havana is ghemaeckr in defer voeghen. Het in-komen is by een feer enghe Canael, vvelck duert de lenghte van een Geurelingh-fcheur, ende van daer opent fy haer breeder ende breeder: aen'tinkomen zijn tvvee uyt.ftekende punten landts, vvaer nieuvvelijck zijn gheleght tvveeftercke fortreffen, daer veel ghefchuts op is gheplant; beneffens een feer fterck ende vermaert kafteel aende ftadr, dat on-vvinbaer is. In defe dry forten ligghen by de duyfent foldaten in garnifoen. Oock zijn bier tvvee galleyen 
Het eerfte Boeck.

galleyen om de kufte te bevrijden. Hier worden in aller yl getimimert achthien chepen die men noemt Fregatten; zijn feer hechte fchepen, ende fullen maer luttel diepte behoeven, foo datmenfe tuffchen de ondicpten vande Vlaemfche bancken fal konnen gebruycken; fy werden te hooger op-geboeyt, om dat hier over-vloet is van feer goet ende onverderfijck houdr. Bren anter birf op ac

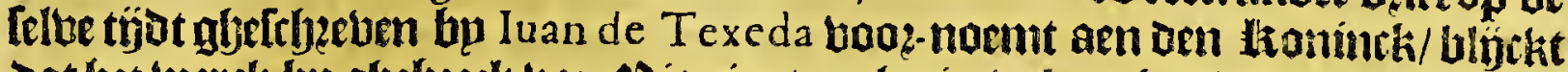
Dat bet loetck bu ghebzeck ban pioniers noch niet Lol-togben was / ende dat een

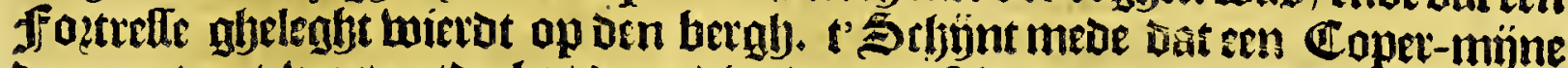

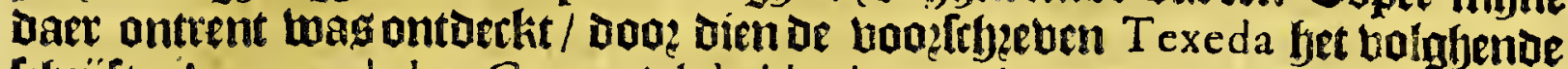
frljejft: Aengaende het Coper; ick hebbe het noch tweemael in't - werck gheleght, ende de proeve daer van ghenomen; waer in meer geles is ghefpendeert als ick-wel wenfchte, door dien daer gheen profijt van is ghekomen. Icken wete niet wat de oorfake is, als dat het nier ghedaen is naer behooren by degene die $t^{\prime}$ werck daer van in handen hebben, \&c. 't Thkomen ban Deljatien ig ontient

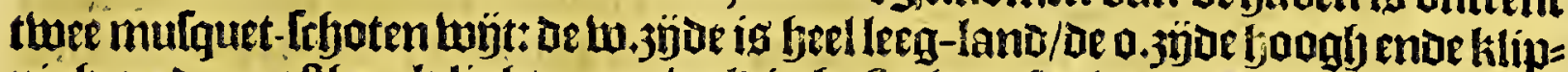

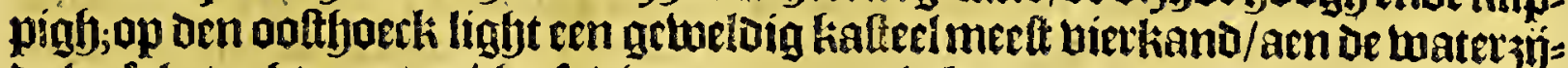

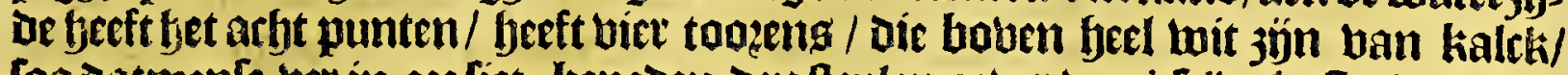

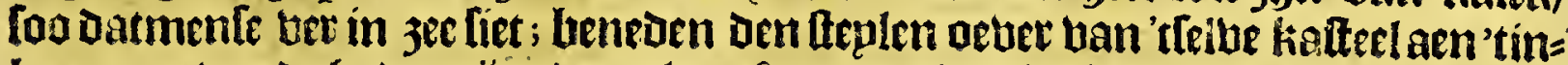
kommen bande baben jün tweeplattefozmen dic tol gefofuts ftaen/an tim tam:

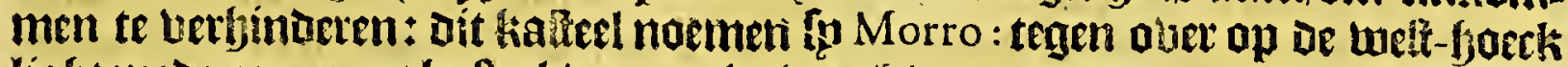
light mede cen groot kafted / maet niet googh taan nueten / meelt geipgr:

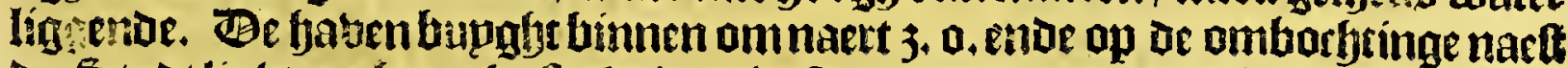

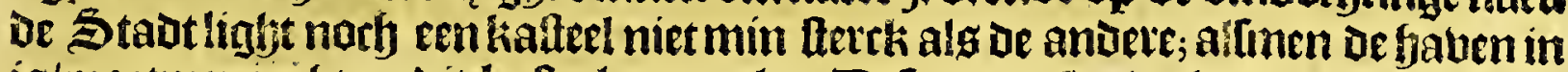

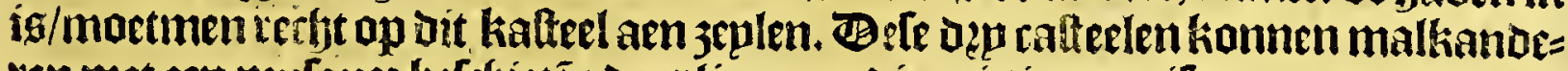

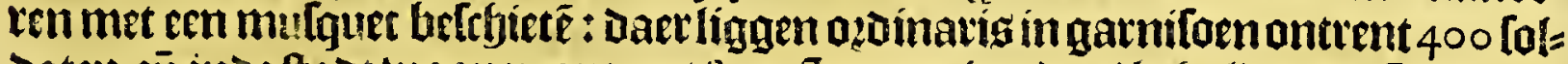

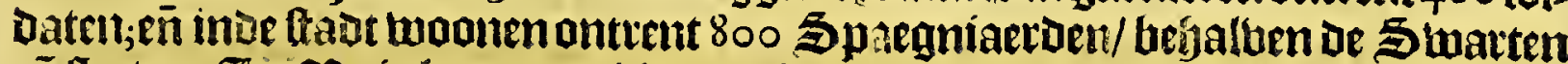

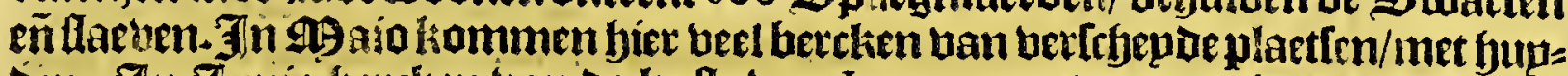

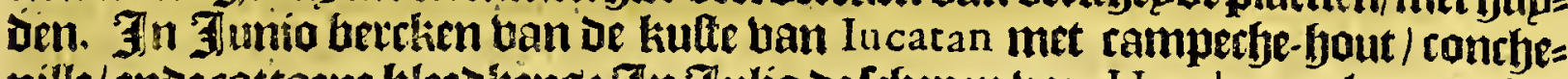

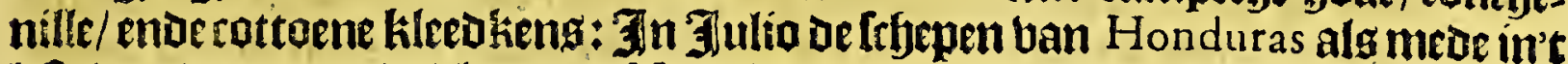
Iefte ban oe maent de blote tan Nova Hifpania; ende in't begin van zlugulfi ie blate ban Terra Firma. Tan booz berfchepden occalien beranderen fo bel baet tijoen/Dorb foo datle niet light biet kommen naer'tbegin ban September.

\section{Het Ieftbienoe Capittel. \\ Van de Kufte; Havenen ende Punten van C u B A.}

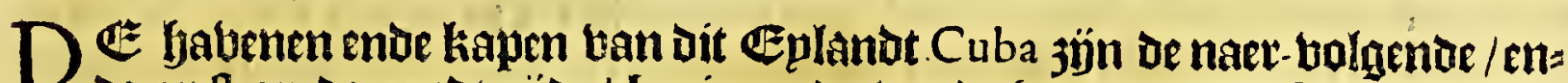

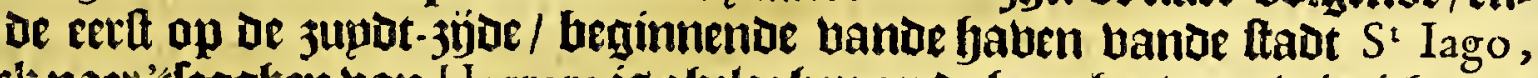

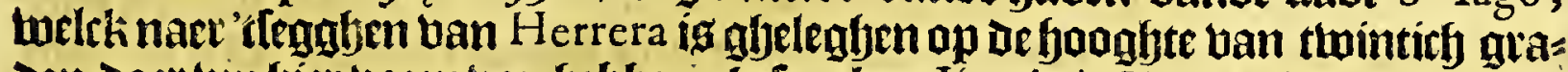

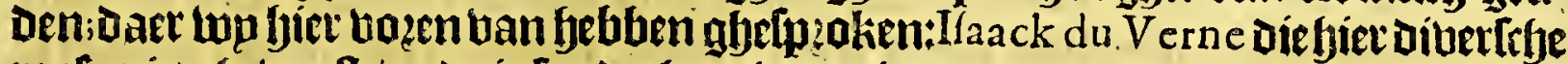

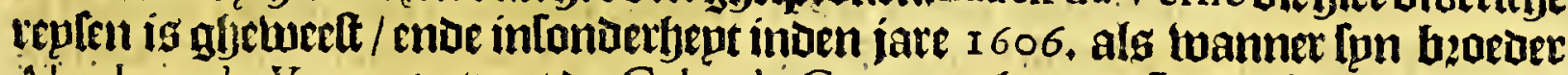
Abraham du Varne ontrent de Cabo de Cruz, teghen de Spaentre Galleonts veomelinck arijoende is gebleben; nbetupght ban oele hauen/ Datte igeen naum gat in't in-komen / eñ beft aenoe ooft-jyjoe een klepnrift in jee ltreckende/eñ aen=

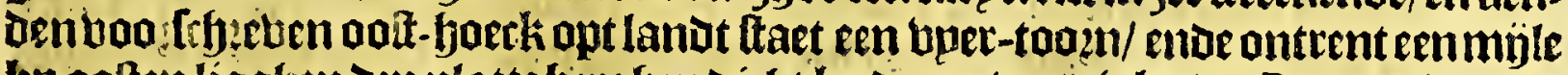

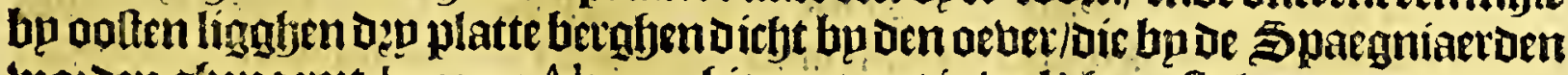
wozocn ghenaemt Les tres Altares; Gier ontrent is mel 'tyoogete lanot van'tgant=

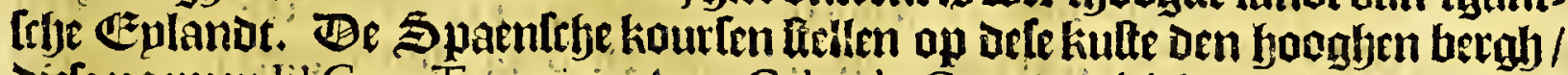
tiefe noemen El Gran Tarquino, wan Cabo de Cruz ortitify leguen nare 'tooften

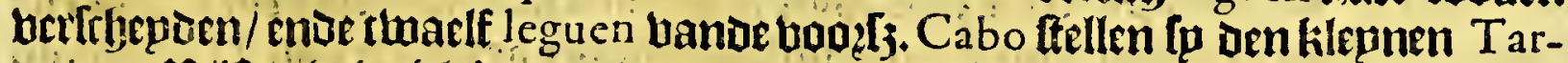

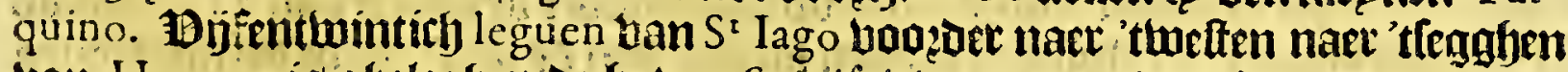
ban Herrera is ghelengen de lyauen Santifpiritus, ende tmadf leguen boozaer Cábo de Cruz. De onfe fellew tufiefon St Iago enae Cabo de Cruz, thee habe= 
nen / Guama Sevillie ende Porto Portillie : welct een leer brquame plaetle loude wefen om be frbepen te berghen boo alle twinden/fyebbende int in-komen Degp ba:

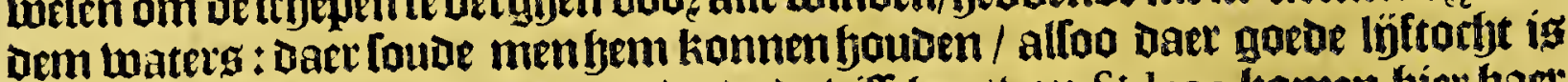

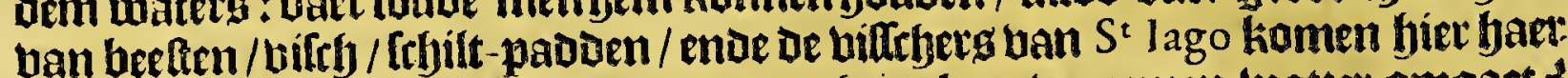
fryilt-padden Deogen / foo Datmen ban gaer han bernemen matter omgaet? De boogoe ban Cabo de Cruz moat leet berffyepoen ghelelt; Figueredo ftelt

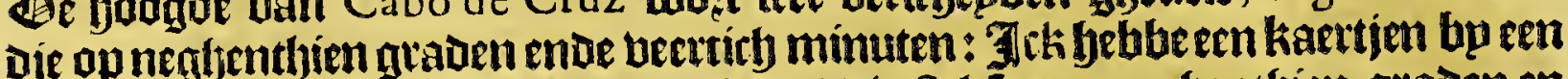
franlman fert curiculelöthen geteectient / Die fteltfe op neghentbien graden en oertich minuten: een aeninǵtinghe bauboogljoen bp $M$ Hackluyd op twintich araden/Dace Herrera lebjunt mede te arcozecen/twelck tup volaben: íf enlegge Lape bol ltupcken met een af-lopenuen boeck toaet ban een riff at. ftreckt / eñ is ghenoect te kennell. Ban defen boecl booets en fult gbog gheen lande lien/alloo De diltantie ende wajote ban de bape tulferyen dit punt ende los Iardines Ieet groos

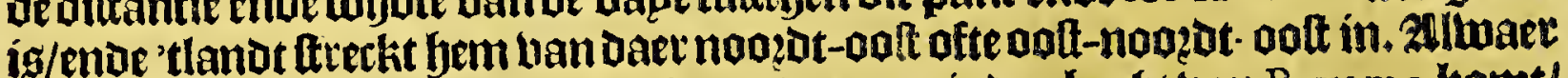
bele Eplandekens onder-wegen liganen/ ectmen inden bocbt ban Bayamo kamt/

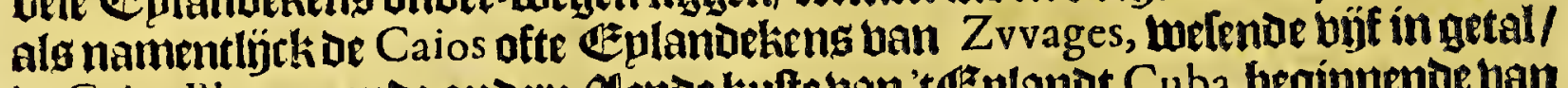

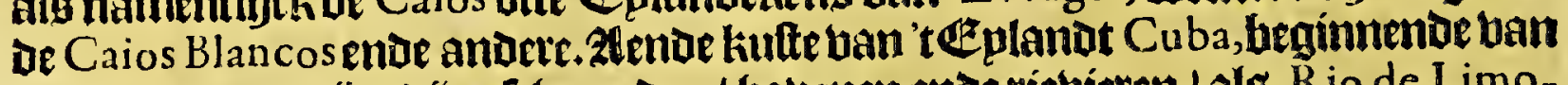
Cabo de Cruz jün aítuettetye reeden / havenen ende riebieren / alg Rio de Limones, ghelijtl de onle die noemen; be fi' tancoplennoemen die Rio à Citrons, daer

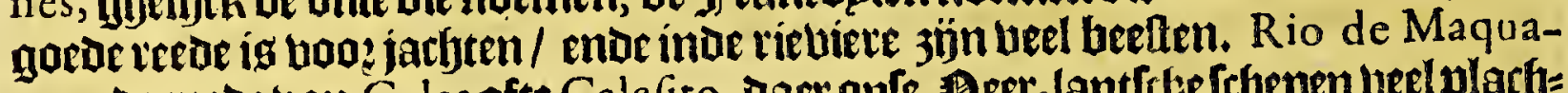
que : De veroe van Cales ofte Cale fito, vaer onfe \$Rer-lantflye fryepen ued placty=

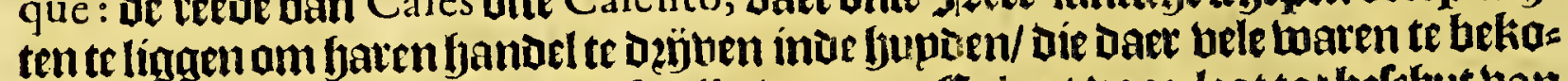

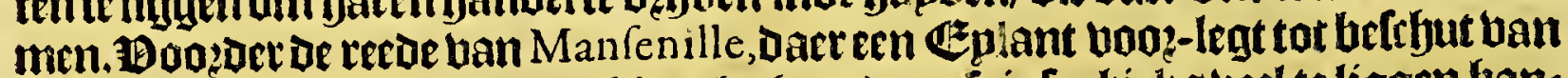

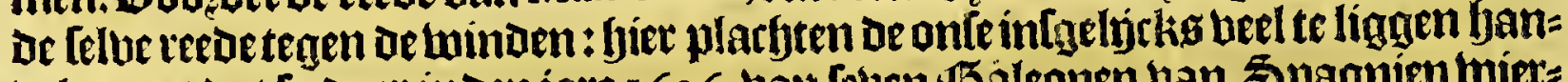

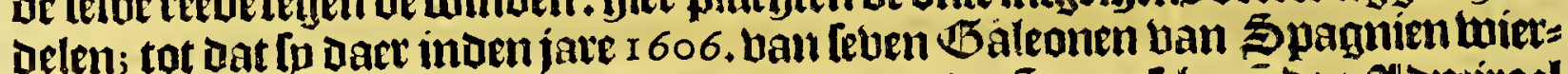

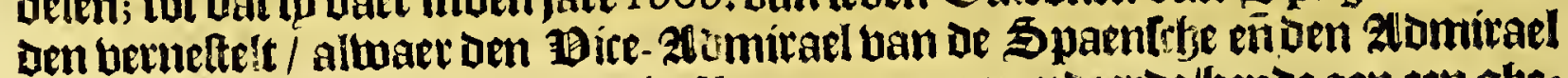

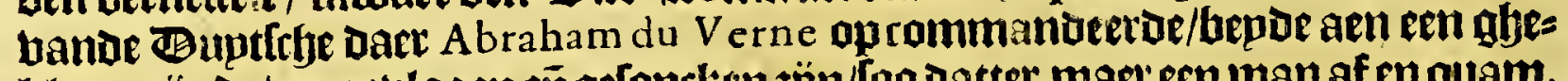

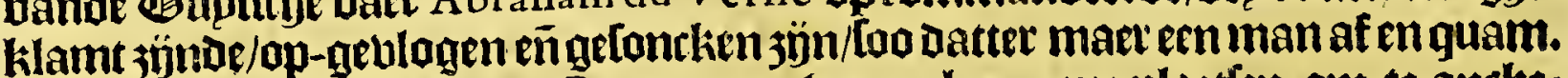
Boozoer jüninue borbt van Bayamo norb meer bequame plaetlen om te ancke= ren ; als Iqueteo een Kilepn riebietken / Daet recde ig bode jadften / ende daetples ghen beel bupden te ballen: Boye een hauentien daet een klepn kiteexken uptloopt/goede teecue vooz jachten, Dan daet leght een fant-plate. Rio de Caute, waet ebbe enoe bloet gaet/ eñ loopt tot ontrent thee mijlennaer aen be ftaot ban Bayamo; hiet ontrent ís het al leegh lanot meet Zabanes ofte beloen. Bopzoer tueft-

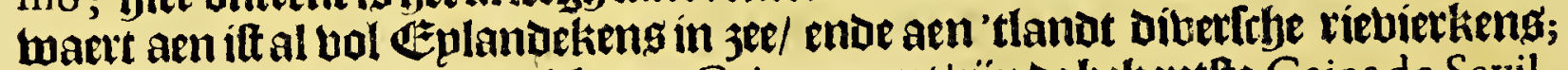
onder arfe eplandeltens/welckmen Caios noemt/3ün be bekentlte Caios de Sevil-

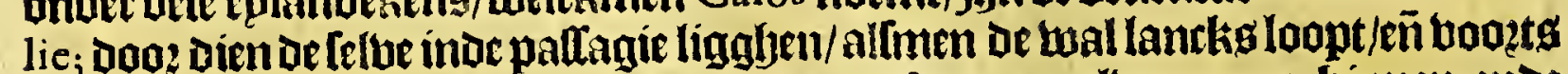
Caio Romano, Caio Galere ende las Angouftouras, almatmen binmen ende bupten dele Caios anckeren mady met aroote ende klepne febepen. Op De kulfe van Cuba is Rio Tanne daer goede reede is noos jarhten enoe plarbt banuel te ballen in buponen. Rio Sivillie: Rio Hernando : Rio Guana: Sarfaguata : Rio de San Pedro; darr is al reede boo jachten/ende pleeghlyantel te ballen in hupden. Santa Maria en bape met een Ëplandeken boog aende mondt / daer goede reede arfter íg / ende inen baet de bape toozts in met chaloepen / alloabet daet ondirp

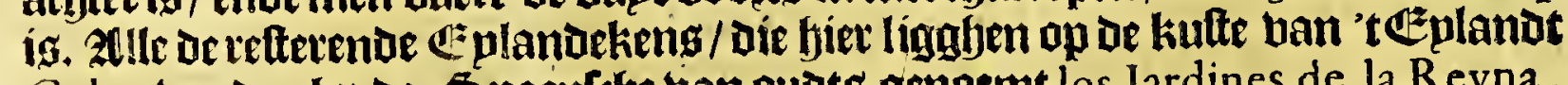
Cuba, tweruen bp de Spaentrye van oubte genoemt los Iardines de la Reyna, liggen meeft op de hoogte van 2 I graden: jón ontallï̆cke eplandekeng/ondiepten ende klippen / Daer oe 3 Re met enge canalen tulfthen loopt / loo dat bet feet danges

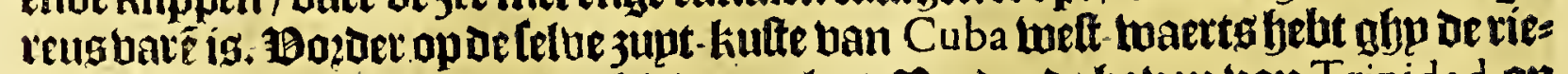
viere Saffe, Daer de blecke Santifiritus op legt. Bogater de bauen van T rinidad, op ae hoorhte ban een-en-twintich graden bp noogoen de linie/ bp De dertich leguen d. 4. L. 2. Lan Cabo de Cruz: (Herrera leglyt eloers inlpunfiftozie/oat Trinidad leght bans

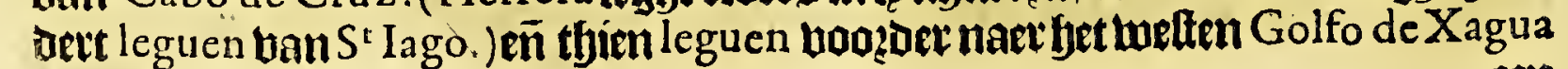


Het eerfte Boeck.

een grooten in-bürkmeteenighe Éplandekeng int mioden. De flaben ban Xagua ('eght Herrera) en feeft baets gelïrk niet inde gantfrye werelt/oe frbepen ba= d. r. . . .

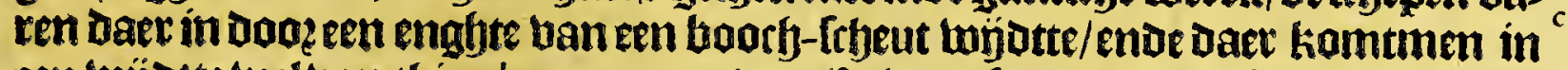
een wojotte wel ban thien leguen, met dep eplanoekeng/daer or fobepen konnen aen baft ghelegft woeden aen ftactien / fonder datle betroeren/ boo? dien alle de

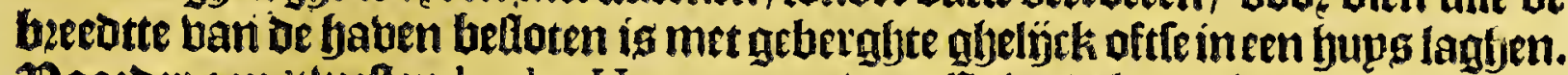
1Bopzder aen 'thelten las dos Hermanas, twee Éplandekeng/liggende aen' the ginfel ban een groote blackte ofte ondiep than eplanoe Spaegniaerden noemen Camarco, tuffityen de kulte ban bet Eplant Cuba enve Illa de Pinos; ban waer tot de Cabo de Corrientes, jön twaelf leguen. Be Cabo spaêfche de Corrientes ígen leegbe katep/fockel niet loo leegh als'tanoer lamot Datter kourfen. naelt aen gheleghen is; 'tpunt banoe Cabo is al but jandt / enoe welt-waett upt en fult ghjoghen lanot tien/ Doo dien'teplanot Cuba Dare een groote bape freft. De onfe tegghen de feltue te ligglen op een-en-twintiry graden enoe beetticb mis nuten; ende batter berf'y water is te bekonten: Dattet een leegf lant is met liwarte Iteenen: twaelf leguen van Cabo de Corrientes liggt De bermaetio Cabo $S^{\mathfrak{t}} \mathrm{An}$ - Her. de-

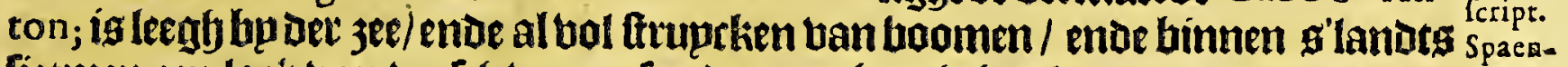
fietmen een lark ban bertef water; foo datmen bp gljebeeck Daer water math in- fche nemen. Op de noost-3yoe uan de kaep fult ggp onder-frbepoen en loalm-boom cours. hoogbet dan deveiterende hoomen/ende bettjoont fem ronot bouen inden top/

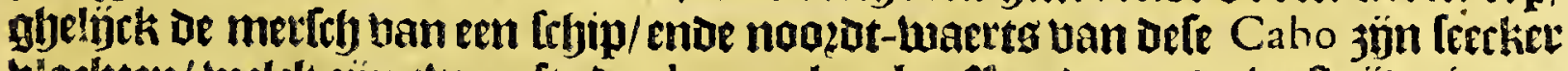
blackten/melck 3ijn twee ofte dep leguen lanck. Alen ae zupot-weft jijoe is een

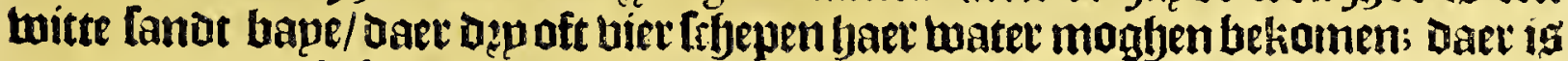

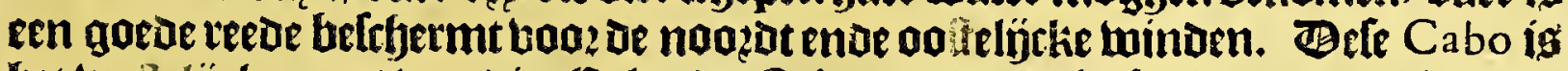

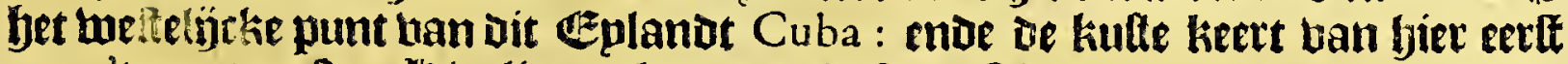

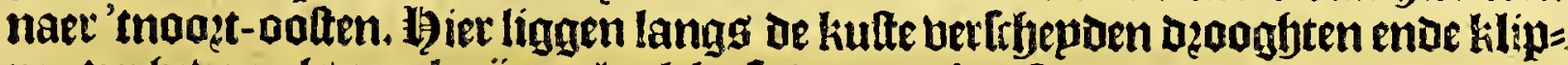
pen betbeben als ozgel-pijpen/helcke fp Daetom/os Organos noemen; aen 'tepn=

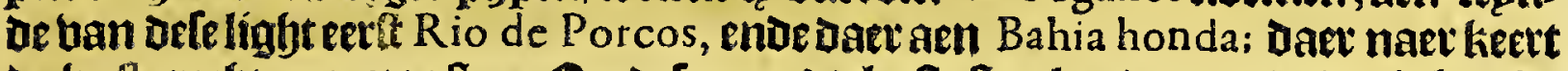

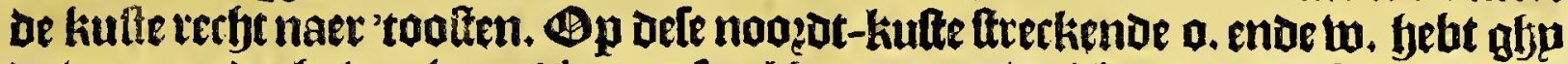

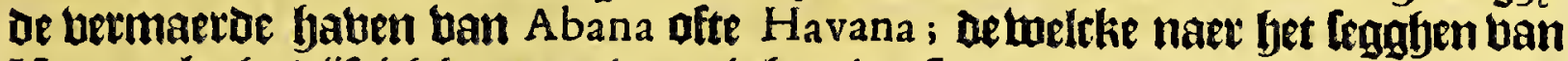
Herrera leght búftich leguen, weqnigf min ofte meet ban de Cabo $S^{\prime}$ Anton. d.r. 1.7. cufteffen dele haben uan Havana ende de $C_{2}$ bo $S^{t}$ Anton booz-Lrbeeten/ neghen mijlennaer 'tleggfen ban de onle welt-maettg ban de Havana leght een ander Enghelfraepe yaben/ diefe noemen de Cavannas, hebbende in'tgabt Dęp en ken balf ba= fche vo. Dem maters met de blaedt/ hinnen jünde hebt $\mathfrak{g l j p} 7.8$. 9.en 10 . vadem/min oft ${ }^{\text {yagie. }}$ meer/ende goede anckergronot: ende bequaem om bimen duplent frbepen te

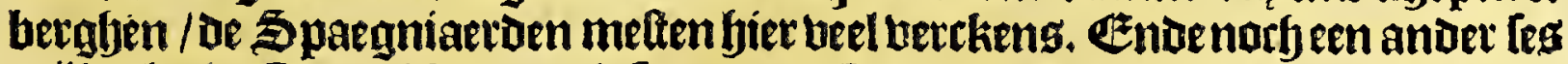
mülen bp terelten oe Havana die [p noemen Puerto de Marien naet een riebierken ende feet kennelÿcken bergh diele noemen Meza de Marien : is in fet in. kamen (belck leer enghig) diep 6 oft 7 badem; fieft ban binnen twee groote in-wijetaen) elek twel een falf mïle langh/met gaede diepte enoe bequaem om bele lihepen te

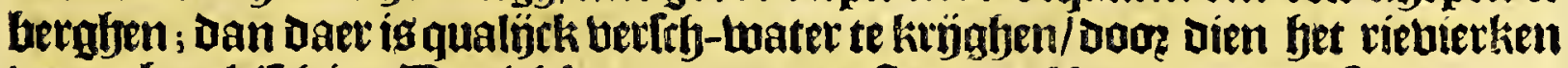

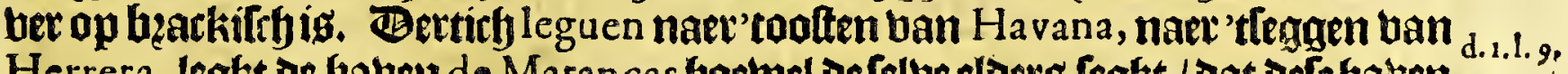

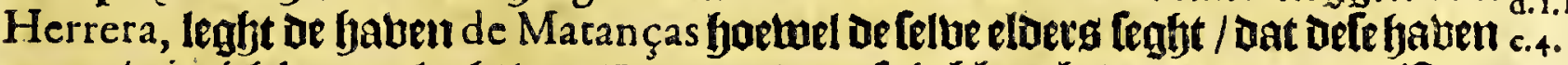
maer thintich leguen leght ban Ha vana, (De onlebehben bebonoen dat oe diftan=

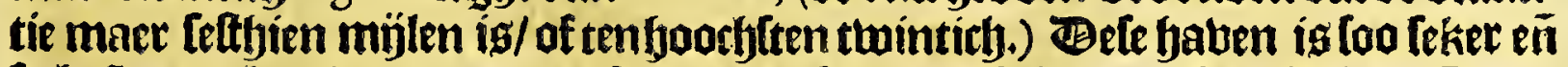
to hefloten niet als de Havana. Ontrent defe batuen light eenen betafj die de Spaes spa šche gniaeroennoemen el pan de Matan ças:fyet ís eenen rondenfjoop ftaende op leegh kours. lanot/ende als ghp Der noozot ende 3 upot af-Ieght/[oo bertjoont fjet bem als twee jadelg/ende aen de welt-jüoe maeckt het een groot gbebzaken lanot/gelijck line= kenoenaet de jee toe. Ban fier booztnaet 'toolten is de kufte feet periculeus/we= fende belmet met hancken ende klippen/ende te $3 e$ - waert if een groote blackte/ foo dat bet biet feer foggelj̈ck te baren ig booz groote lefepen: welck bp oe Spae=

$$
\mathbb{C}_{2} \text { gniaeraen }
$$


gniagtoen twot genoemt el Iardin del Rey, aen luelcket hooft leght het Epland Obahava. banP uerto de Matanças tot puerto de Yucanaca ttelt Herrera bïftich

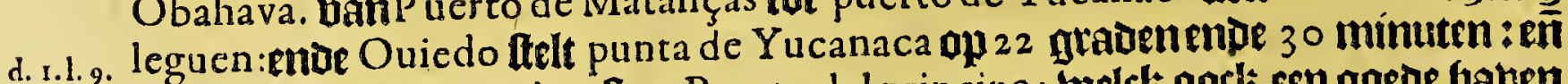
c.4. arbt leguen mieer naer 'taaften Puerto del principe : welsk oock een goede baten ig/enoe Ieglyt bp naer in 'tmidoen uan bet Ezplandt Cuba, naer 'ttegghen ban Herrera vier oft les leguen boazder bande bauen bau Hernando Alonfo, ende feg leguen betnaex 'toolten Cubana, weick een punt is. De haben van Baracoa is thintich leguen bp welten ban Cabo de Mayzi, welck is fjet ooltelijelte punt van 't Ifplant Cuba: (naet'tlegghen van Herrera, dan de Spaenlrye Kourten leggen

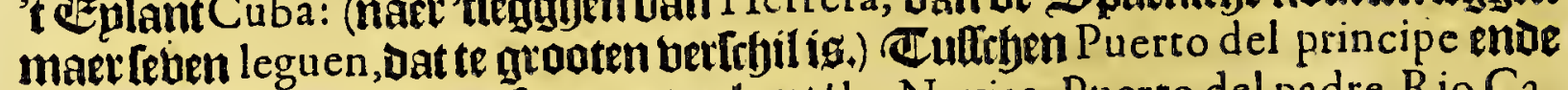
Baracoa mozoen bp oe onfe aengeteeckent/ las Novias, Puerto del padre, Rio Caia wan, Rio Kefive; ende van Baracoa tot het punt Mayzi, Bomes ende Mate. Een ban De onle die dele kulte beeft bebaren relient ban punta de Mayzi tot pun-

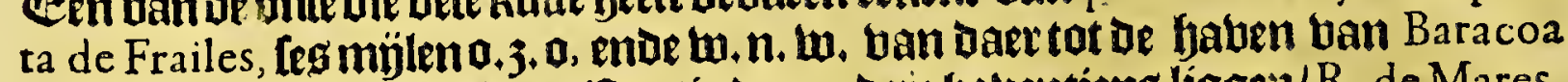
4. mülen o.eñ w. in weilcke diltantie dę andete babentjeng lígge: / R. de Mares, Bomo, ende Mata, dan en jún niet dan booz chaloupen ofte jachten / enmen kan= Der met een n. minotqualíck upt. Ban punta de Mayzi keert oe kulte naer bet

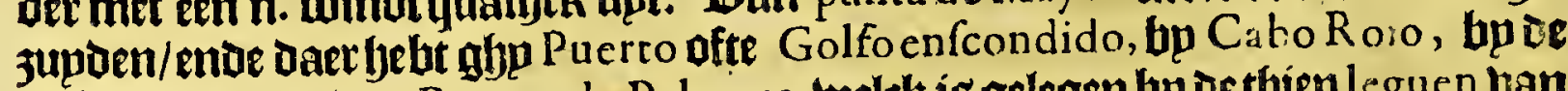
thinticly leguen van Puerto de Palomas, weltk ís gelegen bp ur thien leguen ban

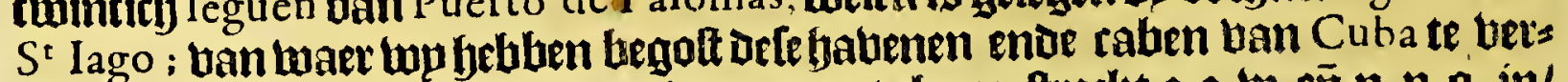
volgen. Bele Puerto de Palomas is een groote bape; (trerkt 3.3 . w. eñ n. n. a.in/

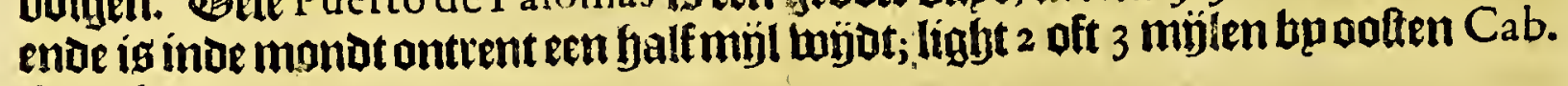
de Palma.

\section{1)et leventbiende Capittel.}

Naerder aenteeckeninghe vande Noord-kufte van C v B A ende de kleyne Eylanden ligghende rondtom.

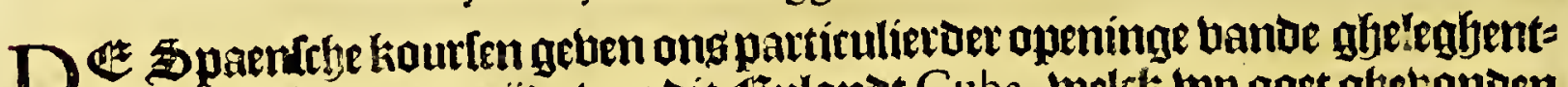

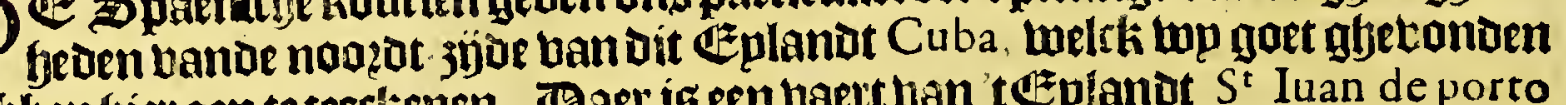
bebjenfier aen te teechenen. Thaer ig een vaert Lan t $t$ Eplanot $S^{t}$ Iuan de porto Rico naer de Havana toe/langs de noozot-kuike uan 't éplant Hifpaniola, welck

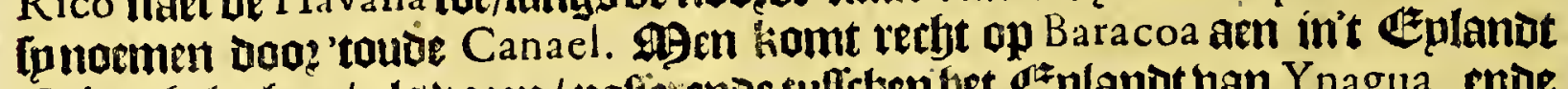

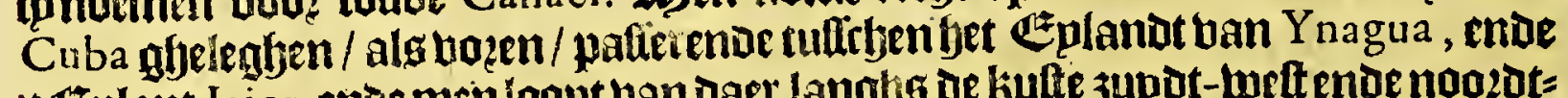
't Ezplant laico;ente men loopt van daer langhs de kufte zupot-kueftende noozot= noft: tot Datmentiomt aen las Sierras de Cubana, enoe biet begfint oe bape tan

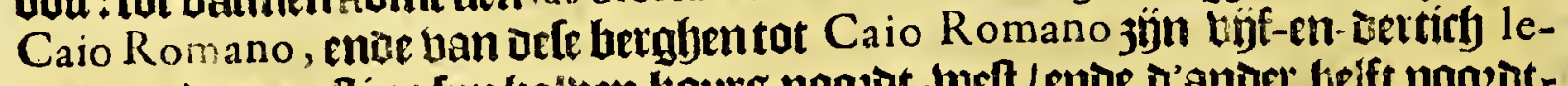

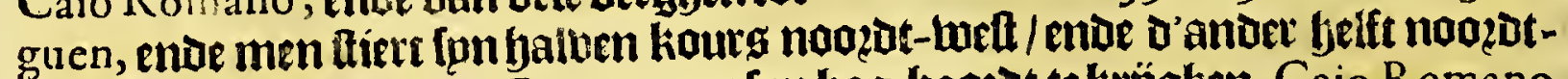
meft ten melten/ om Caio Romano oplpn bag boozot te krüghen. Caio Romano

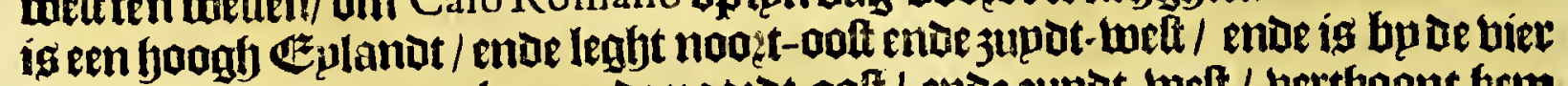
leguen lanck; Daer aen komende nodzd-oolt / enoe jupdt-wett / bertfyoont frem cen ronden hoop/ende in't midoen queligct thee 3 adelg/ D'een aen D'eene/ ende D'ander aen d'ander 3 joe; maer liggenoe met fet fetuenooet eñ 3 upden/bertoont bemeen zadel ín'tmidoen. Ban Caio Romano tot Caio de Cruz jyndęe leguen,

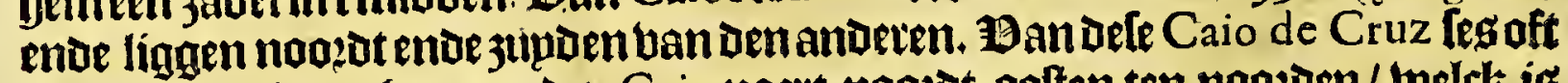
feven leguen ignorly een ander Caio maert noozot-oolten ten noogedn/ melck ig woot ende Luit ende aleffen: loopende langg De kufte (welck bier al ftreckt 3 upat: weft eñ noott-oolt) Dooz't ranael naer be Mantança toe / fietmen lekere betgten wel achthien ofte thinitity leguen langh / die alle als jabels thoonen/enoe als ghp 'tpımt han de lelve juput-welt van u bebt ghebzacht / foo 3 b́t ghp in't midoen ban'tranael ende eben berte van Caio Romano ende Matanças. Jn["

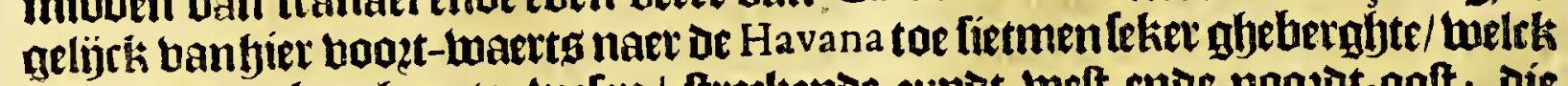

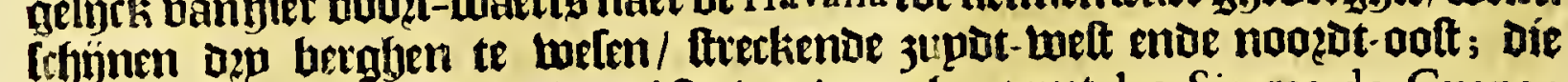

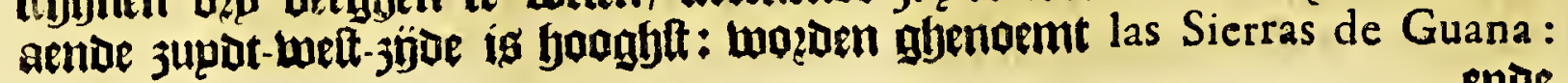
enue 
Het eerfte Boeck.

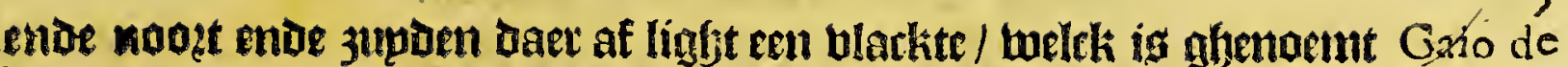

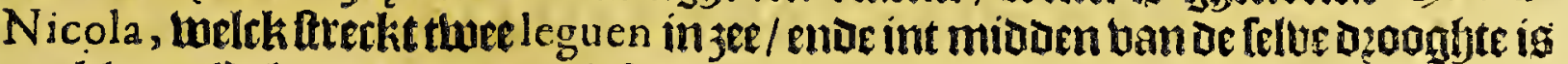

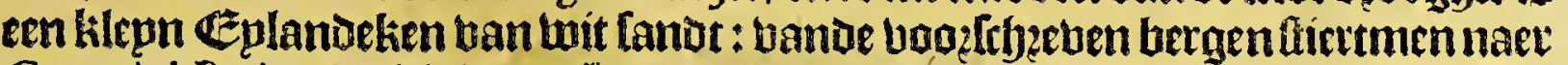

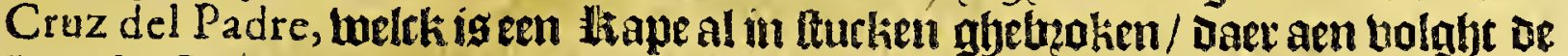

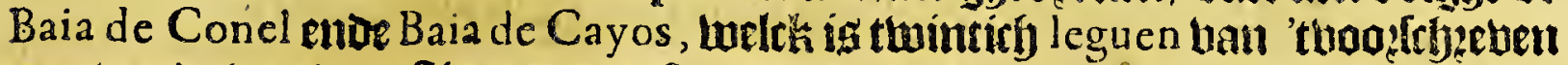
punt: enoe ban Daer ftietrmen weft-noot - welt om te gaen naet puerto de Man-

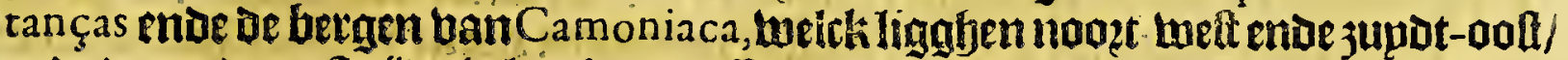

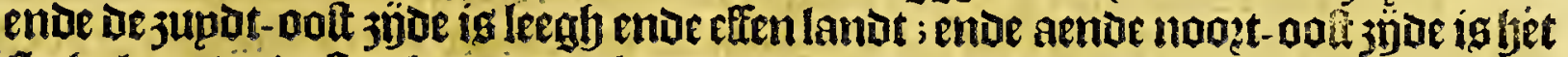
Aergt lant / ende ftrectit naer de bape ban Mantanças.

Bnber de Czulanden ligaende rondtom Cuba jün eenighe aen-mertkeng

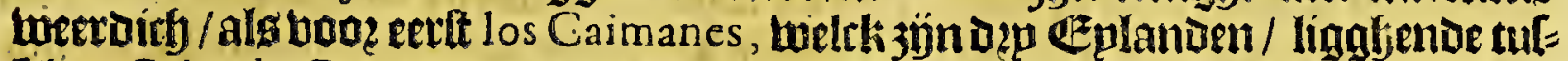
frthen Cabo de Cruz ende het Epplandt de Pinos. Het eerlte ofte hilepnile Cayman

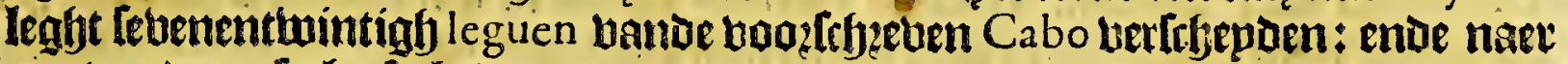
een banoe onle beeft betonden/ op de booglte ban negfentfyien graden enoe Teg en beertich minuten: welt-jupt-Luefter maen maeckt daer foogh water: Daer enig geen goet twater opt Culant / aan heel Srfilt-padoen/Conjnen/ Banfen

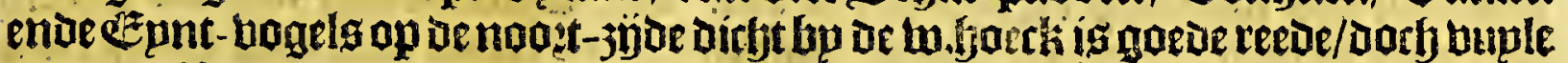

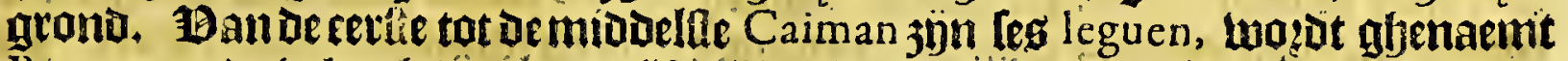
Braccas, ende ig leegh/ontient unf injlen int tonse / men binter obetblost ban

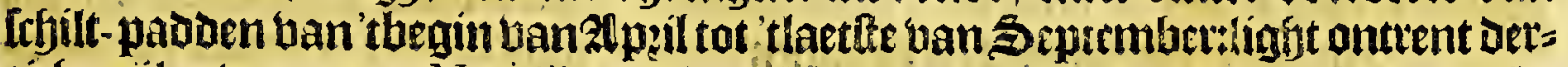
tich mij!en uan punta Negrillo aen la maica. Fandaet tot ùegroote Caiman jïn

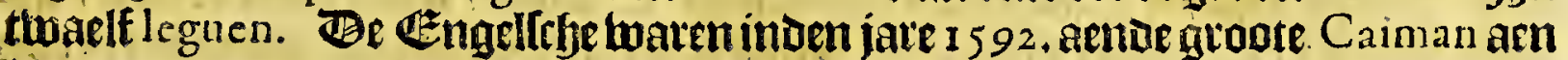

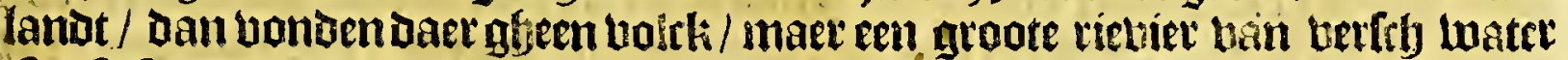

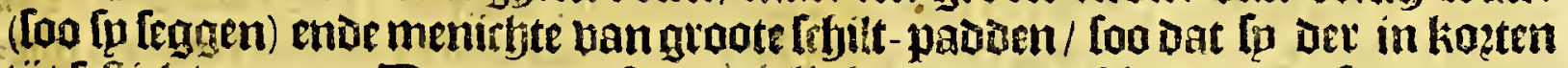

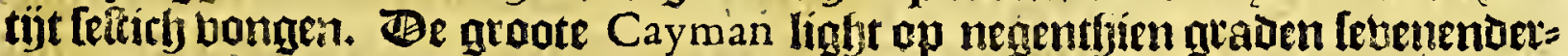

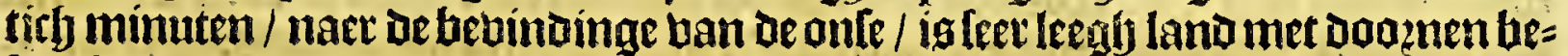

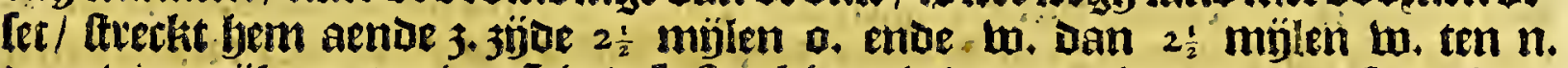
Dan the mülenn. ten to. eñ in dele freckinge ig de reede ineen urogte [and-bap/ ban biumen meeft moerais ban fout- water daet veel foutenelle twalt; daer is acen

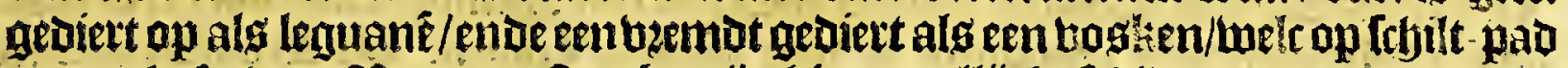

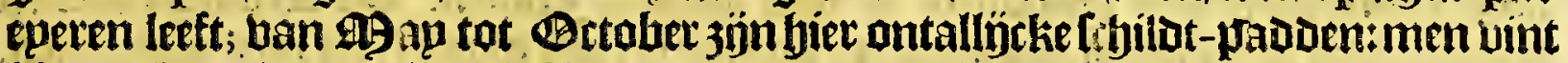

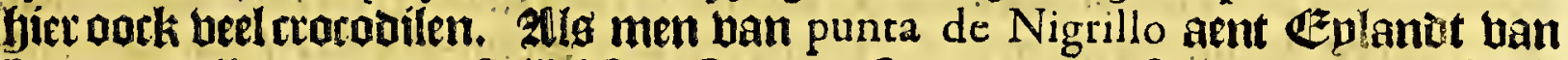
Iamaica wil naer den ooftelijckitten Caiman, [oo moetmen fteten nooft-bett een

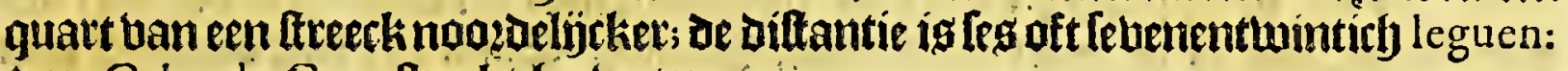
uan Cabo de Cruz ftrethit lip w. ten j.

Het Gelanot de Pinos leght ap oe jupot jüje ban 't Éplant Cuba, ap de boogfte ban eenentwintich graden bp nopzen de linie; is twel tbien leguen Her. de-

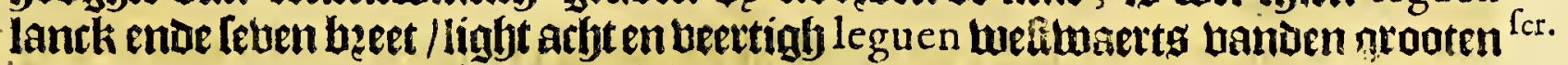

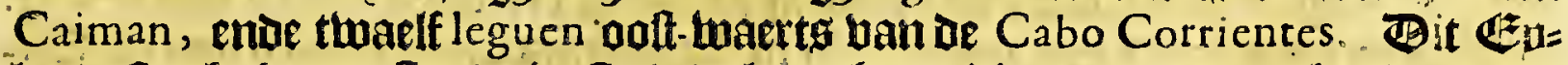
lanot ftreckt bem oolt ende welt, ig bolban beubeltiens / ende daer bp komende

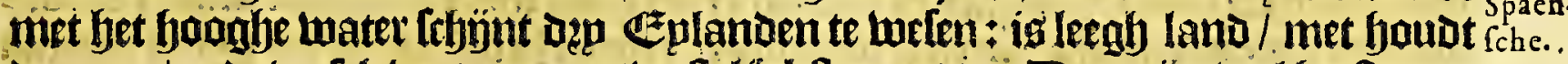
baer op / enoe berfél water naev 'tweltelincklte punt toe. Daer jojn beel beeftenop cousbanltieten ende kaepen; Daeren woonen gheen ofte tuequigh Spaegniaerden; moe die kamenoer maer fomtijots am de beeftente Dooden/ ende bupsen te ma= ken. Ileght inde werb boo? ue leyependienaer Nova Hifjania ende oock naet de Ha vana loopen/too datmen teer bequamelijek de feloe daet antrent kan onoetTribepen.

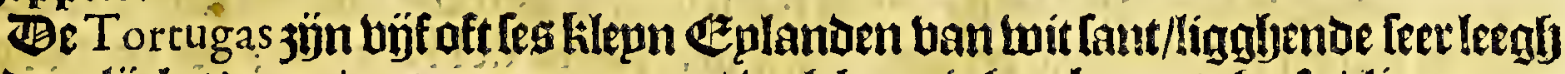

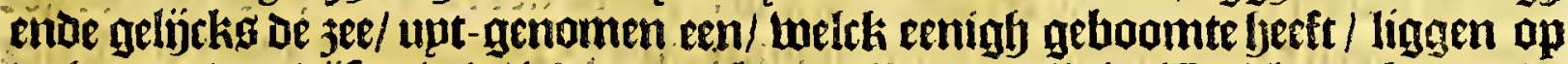
de boogte ban byjentwintich graden bp noogoen ae linie. Te bloten komente

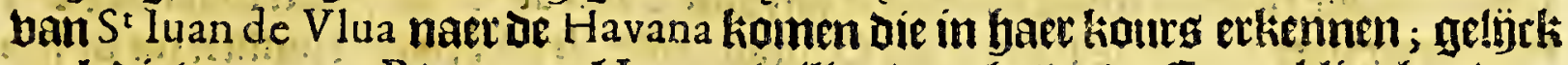
oock die ban porto Rico naek Havana taillen booz bet oud Canael: ligaben banDe Havana les en derticy leguen, dekulte ban Florida nael,

$$
\text { a } 3 \text { VAN }
$$


Vande Weft-Indifche Eylanden.

VAN'TEYIANDT IAMAICA.

Het arbthiende Capittel.

Befchrijvinge van't Eylandt ende fyne gheleghentheden.

D Oen Den ertten Ammirand Columbus Dit Eplanut eet ondertite/ gaf fp

"tfelue den naem uan S' Iago ; dorb is nu up uen naem lamaica beft befient:

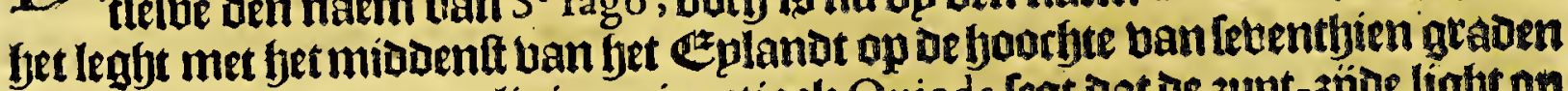
en een yalf bp nowzon de linie equinortiael: Ouieda legt Dat of 3 upt-3joe light op

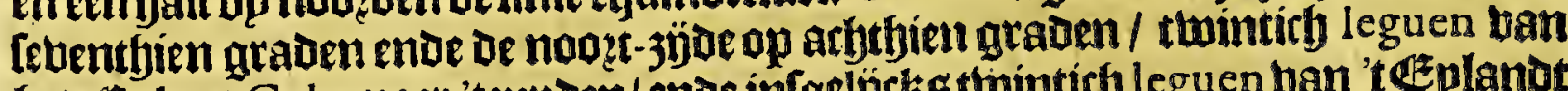

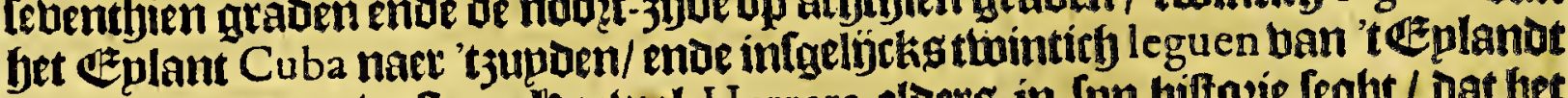

d. r.1.6. Hifpaniola naet 'twelten. Hatwel Herrera eloerg in lun biftaje legbt / Dat bet

c.3. ooftelịcke punt ban lamaica light büfen twintich leguen ban $H$ ifpaniola: twelcke Ipatie ban $3 e e$ de Spaegniaeroen ouer baeten in thare Canoas, Doen den Ammi. rand Columbus Ipn'rfepen aen't Eplant banIamaica am boogh bad glyeloopen/ nemenoe bart kours op't éplanot Navaza. Dit Eplanot ban lamaica is jon: Dert ende vïftich leguen int ronde; unftich leguen lanck oolt ende taett / ende

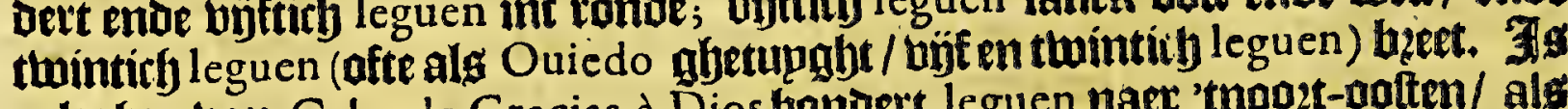
gelequen uan Cabo de Gracias à Dios bonoert leguen naer 'mooet-antten/ als'

1.9. c. 3 Ouiedo frbejfft / ende fjondert en twintich leguen ban Cartagena naet bet noo?s

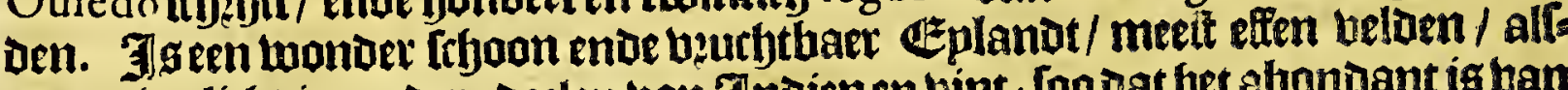
men niet licht in andere Deelen van Jnoienen vint; too dat bet abondant is ban bivess; men befter menichte ban peeruen / ftieren/ koepen ende bertheng; het

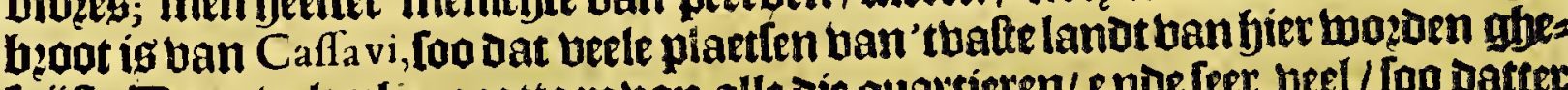

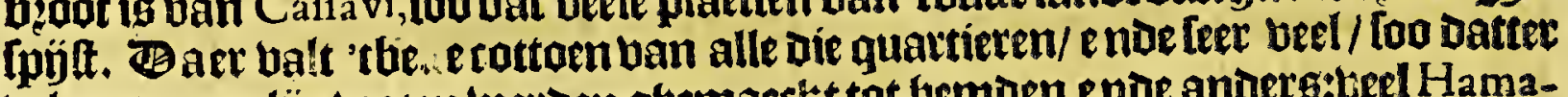
bele cottoene lïnwaten weroen ghemaectst tot hemoen ende anoers:teel Hamacas, welck jün de banglende bejoen / aiele in Jindien gbebeuptken: men feeftex oock eertijots een wepnigh goutots ghetuonoen: Daer wallen leer fraetie frupten: Tn fomma die daer abetweeft gebben geten bet Defr obetupgtyenis/Dat fet De plai=

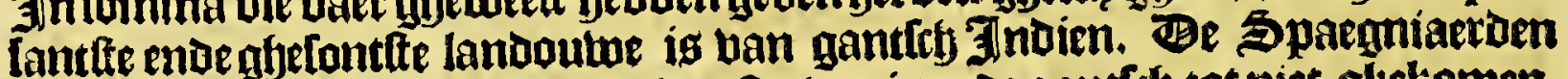
bonden daer beel boleks / welck al berltoetwen is enoe gantfy tot niet gljetsomen. Sp febben Dafr teabenlwoozoigh Dep fteden ofte moon-plaetfen/ als nament=

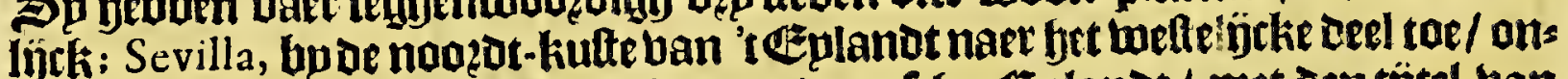

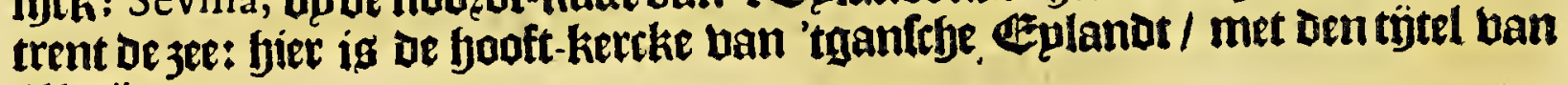
Zlbuje.

Melilla op de fellue naozot-kulte beettbien leguen banSevilla boozeftyetten naet bet oolten toe.

Oriftan op oe zupde-kufte op t'meltelincke epunde berthien leguen ban Sevilla.

Dan of ftadt de la Vega, ban welcke de zimmiranten als heren ban Dit Ep-

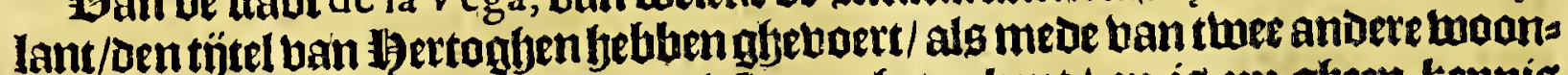
plaetlen / die in eenigbe kaerten noch ttaen gheteeckent / en is nu gheen kennis meer. De Uzngelfche onoer yet belepot van Sir Anthoni Sherly, inden jare 1596.

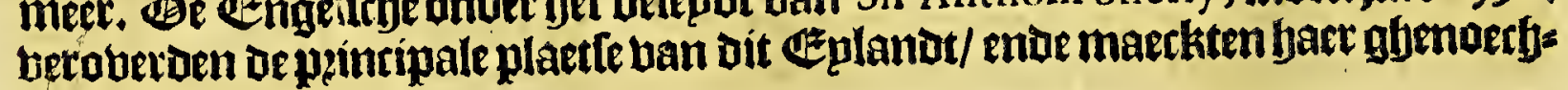
faem meetter daer van.

Het ooltelïktitte deel ban dit Ezplant is het punt Moranta, op de Eulte naet tnoozoen: thien leguen ban Daer naer fet betten legft oe baben lanta, endetbien leguen boozder die van Melila : noch thien leguen voozuer (andere fegghen twin= tifh) De flaben ban Sevilla, eet gfjp komt aen punta del Negrillo; op oe boogoes han achthien graden enoe veertbien minuten: (boe!ck punt naer of onle be gitlinge

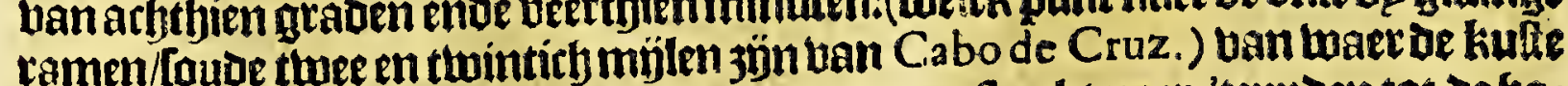
harrkeert naex Cabo de Falcon hp Oriftan, enoe Itreckt naer 't3upden tot oe gas

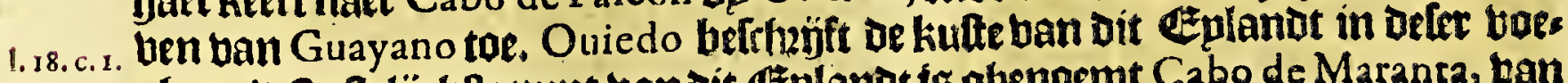

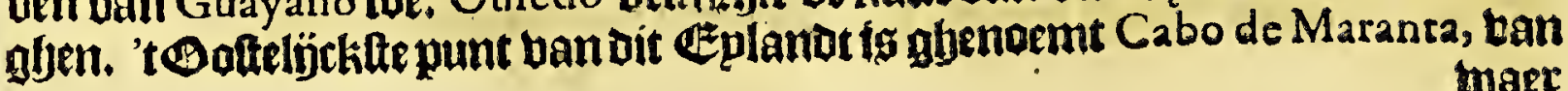
wart 


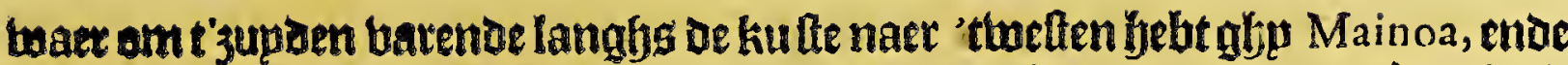

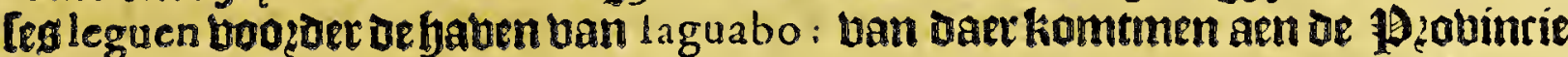
ban Aguaia, ende aen'tepnde í Punta de Negrillo; ban dart am 'tnoorden komt= men aen of ftadt Sevilla, ende vooteder en hlepn Eeplandeken Daet Melilla in Ieght: bookde naer 'tonften de flaben Guaigata; ende van daev komtmen boo:=

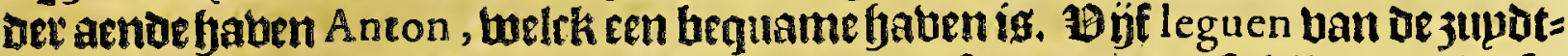

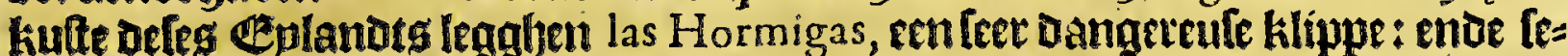

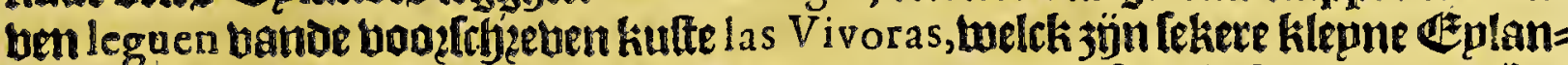
Dekensomui ngtban Klippen; ente naev' t jupDen ban de felbe la Serrana,een ezp= landeken omringht ban blackten ende Deorbten/met andete 4 ofte 5 Datr o m bet:

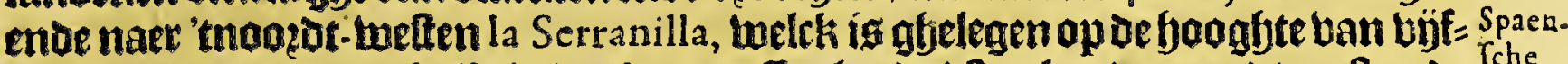
thiengradenende cen falf / ig leegh ende effen land / ftreckende noosot - oolt enve cours. juudet-welt / oe jee beerkt daec rontom op / upt-ghenomen dat bet aenoe jupot=

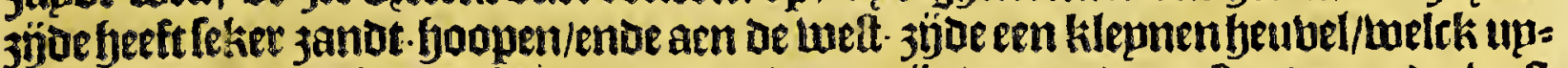

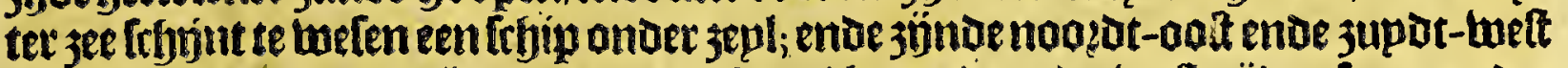

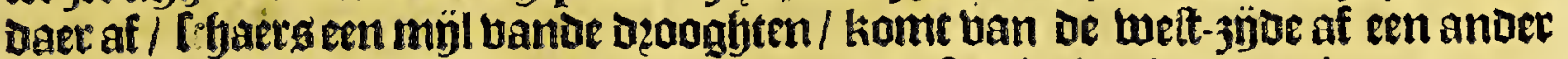

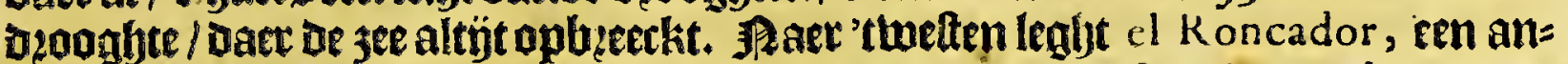

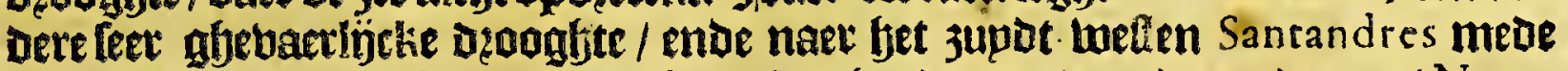
een Eplandt amringlt ban deooghten/ leqghende noojot ende jupden met Nombre de Dios, hp oe beettich leguen aaer van bertigepden/ende een ander Eplanot

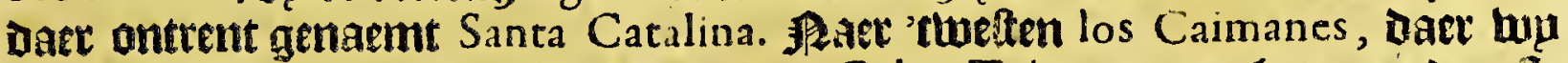
bier boten ban bebben gelpzoken: an Cabo Tyburon, tot het noazdoolt-

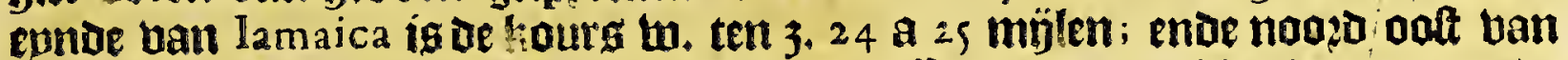

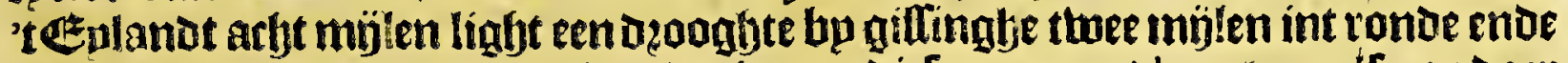
op de boogfoe van 8 grao.ende 3 minuten oirle noemen A breolos, allimen daer aen benint te kammen tanmen oe grond wel fen ende ifter 8 a 9 badem diepende eermen daec aen komt beftmen groote rabelingh ban twater. Dooz al defe Depoghten moetmen bel omfien alfmen naet dit Geplanot mil.

VAN DE KLEYNE EYLANDEN VAN WEST-INDIEN.

(hat neglenthienide Capittel.

Vande Eylanden die men nu ghemeenlijck noemt Lv c a y os.

H et ghetal ban de klepne Eplanoen ontrent defe groote gheleghen / is leer groot ende onfeker: fp twozoen abemepnelïrk berdeplt in twee deelen/ te weten/los Lucayos, ende los Canibales. Los L ucayos woęzen gubenoemt alle de

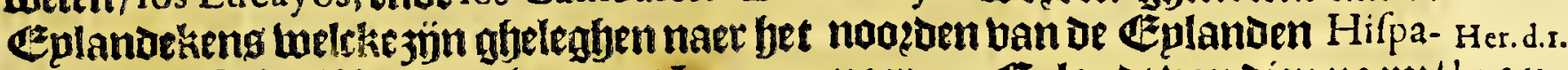
niola ende Cuba, noojoen gbenoemt Lucayos naer een Eplanot van dien narm/1.9.c.12. welek wel het noozelijeklte is ban hum allen: Defe Eplanoen Lucayos jün ane bets han dep footen: oe eerfte footte jün die van Bahama, welck de naem bebten gbegeven aen bet betnacmt Canatl ban Ba hama, melck fo furieufen cutrent beeft

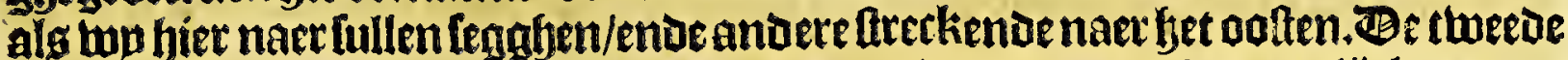

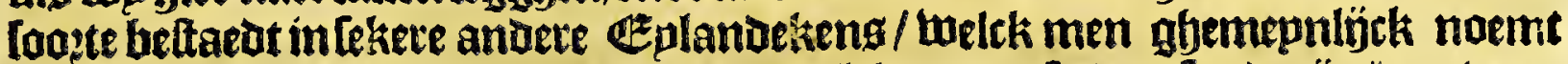

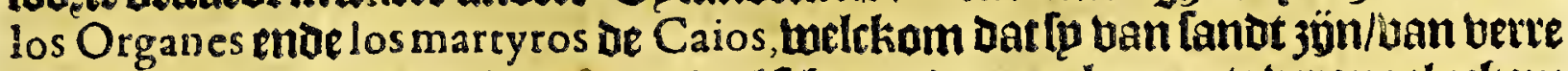

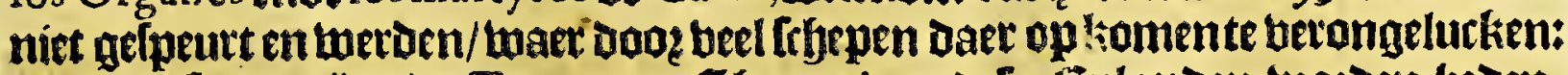

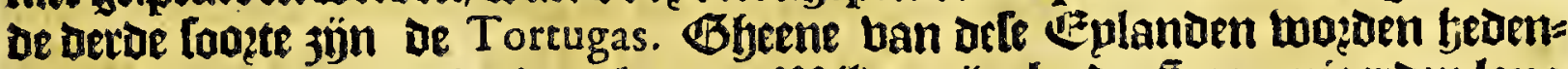

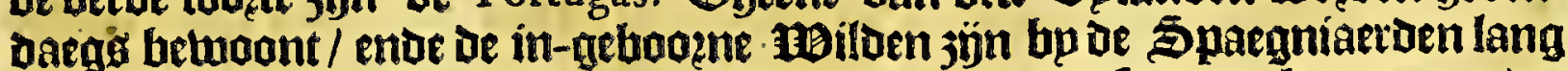

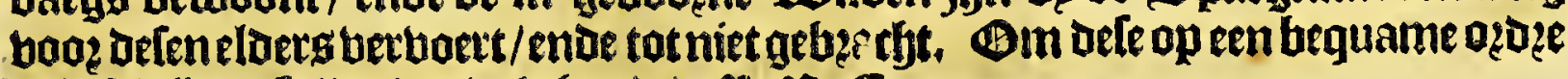
te belebejuen fullen wop bo!ghen den 2A. 25: $\mathbb{C}$.

A bacoa iscen Eplande ligghende int mioden ban be Dzooghten/ welck [u nae = Her. d.s. men ban Bimini, enbe ig thaelf leguen lanrk / $\mathrm{log}$ Herrera leght.

A checambey is een anoer Eeplandelien niet berteghelegyen ban Ab2coa, ende ontrent detelbe D googlten/De groote anbetient.

$$
\mathbb{C}_{4}
$$




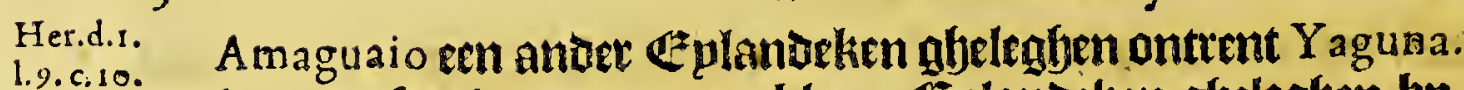

1.9.c.10. Amana ofte Amaguana een kilevn Geplandetien gheleghen bp wetten ban of

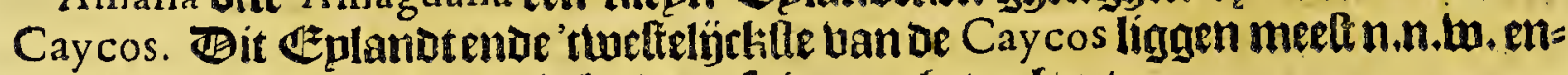
oe $3 . j$. a banoen anoeten als bp of anle is aengheteetkent.

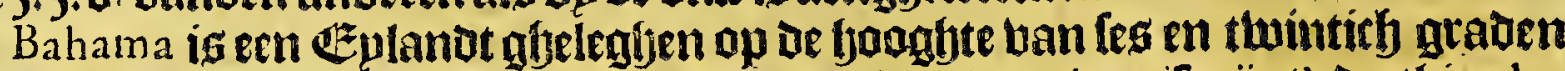
ende een yalf naev'tfegghen ban Herrera, (die hem Daer in milgrijpt) Derthien le-

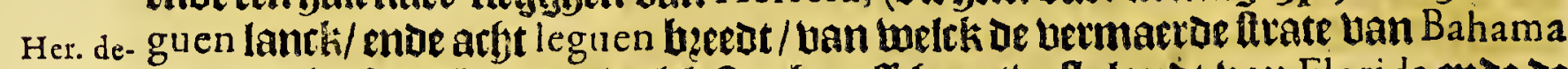

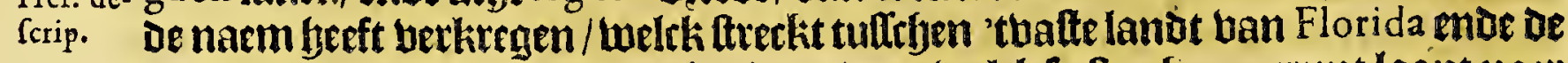
ondiepten / die fp noemen los Mimbres, Dao twelck fo fterctien rurtent loopt naet betnoo?den/Dat foetwel oe febepen boą De hint hebben 'tfelle jupot-waett aen qualjek kannen op-jeplen/ maer kannen 'trelue oack teglyen den wint / noozot:

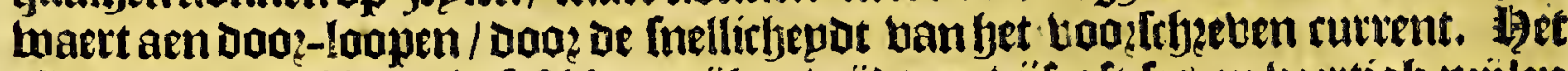

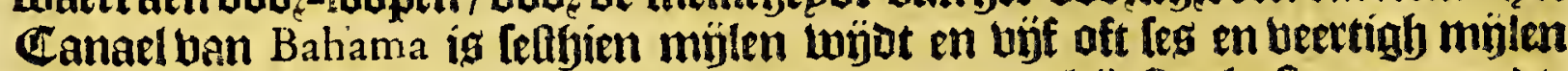

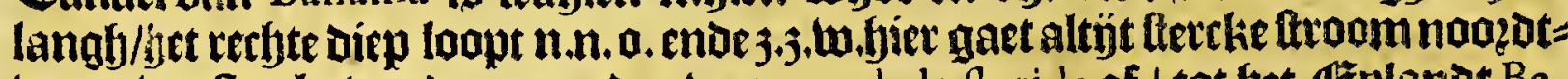
maettht: ftreckt bande 25 grauen uan cap. de la forida af / tat bet Eplanor Ba. hama op 28 graden van dit Eplanot 3upd-Laert benen 3 ijn al blacken en Dzooghtenende bp noozden baer ban is de groote $3 \mathrm{et}$.

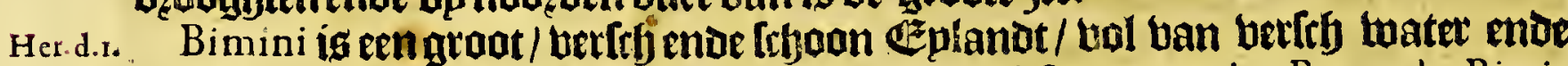
1.9. c.x. gebaante; Ieght intmidaen Џan de Dzaogften / diefenaemen los Baxos de Bimini, ende ig büf leguen landk.

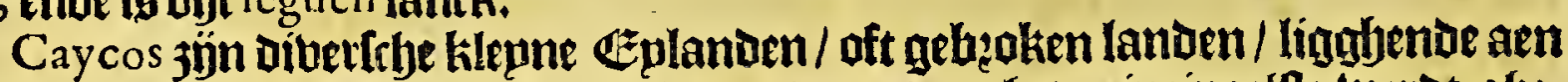
ende in een groote blackte ofte ondiepte; waer van yet pincipaelte werot abes naemt Cay cos, ende is gheleghen ap de boongte bam een en twintífy graden naer Get fegaben ban Herrera: (Dodj naet de bevinoinge van de onfe/ jet 3 up Delícklfte

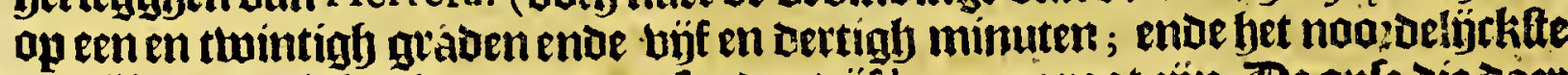

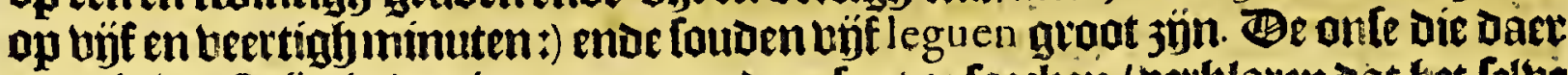
aen ghetweet jỷn in denjare 1623 . om daet fout te foecken/netklaten dat fet felbe Geplandtig gheleghen / van Porto Fran çois aen'tuatte landt ban Hifpaniola, on-

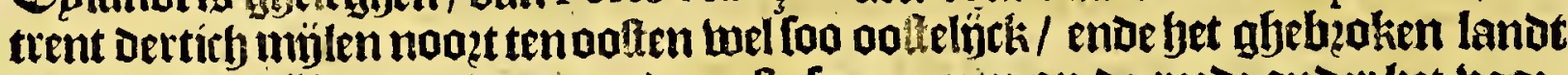
ontrent Dęe mijlen daer ban noogot-aoft: [u quamen op de reede ander bet baoz-

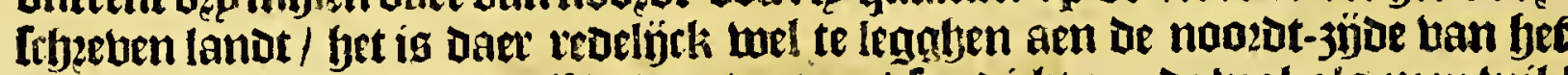
Éplandt op tyien ofte twaelf vaoem waters / foo Dicht aen or loal als men will

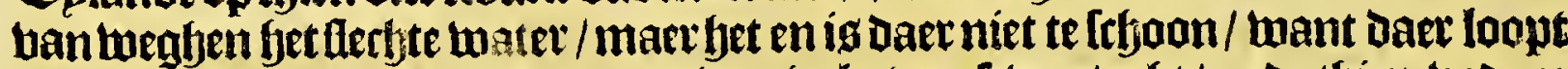

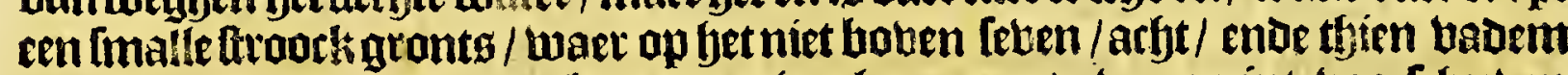
diep is / ende mepning daer bupten en is glieen gront: waren int hod frbeten Eplanot aen landt/als mede metlefupten aen't gebzaken lanot / both en bans Den daet abeen fout / ljoetuel daet feer bequame pannen traren om fout in te

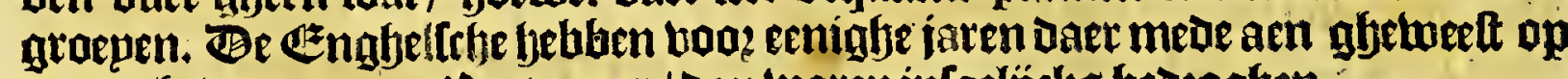

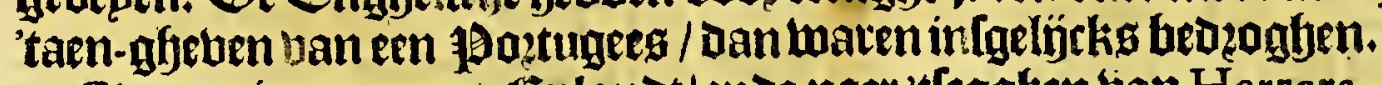

Ciga teo is enn groot $\mathbb{E}$ plandt/ende naer'tegahen than Herrera, ban bujf-enthintich leguen, de welcke fyet ltelt op fes tot feten en twintich graden bp nooz= oen of línie / ban Lucayoneque naer'tyupd-oofteri/ elloe ban Bahama naet bet oulten.

Conciva is mede een Ceplandeken/ abelegen naet'tnouzden ban te Caycos, endenaer'toolten uan't 1 ezplanot Amana.

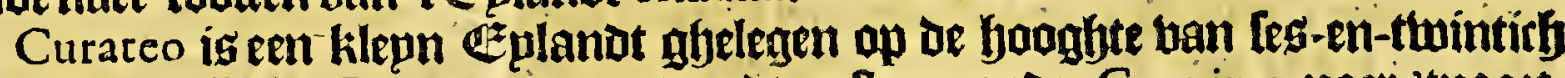
graden / neffeng Ciguateo naet 'tjupdot-oolten; ende Guanima naet 'tmopts welten.

Her.d.r. Guanahani 'teerfte Eplanot welck Dert A mmirand Columbus ontoeckte uan

1.r.c.12. alle de E'planden ende $\mathcal{L}$ Landen ban MOelt. Indien/ ende noemde 'tlelbe $S^{t}$ Sal. vador, is büfthien leguen lanck / enoe bol van baamen/ ende goet hater in't midesn: feeft op of kufte naer' tnaazd-lueften/eenfeer bequame haven/Daer men

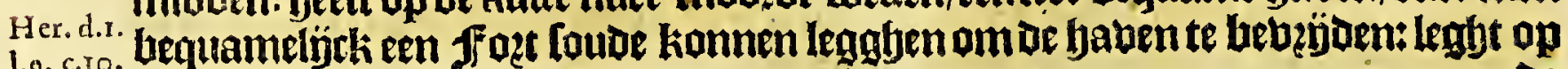

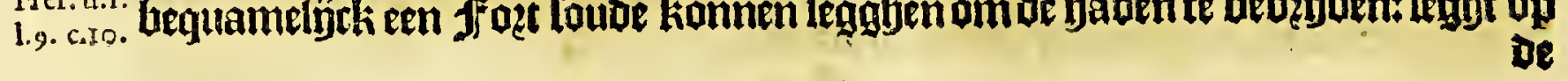


te booghte bar bỷf-en-twinticl graden ende twee detoe naer teggen ban Her. rera. Den Ammirand Columbus bont Daer beel cottoentwallende.

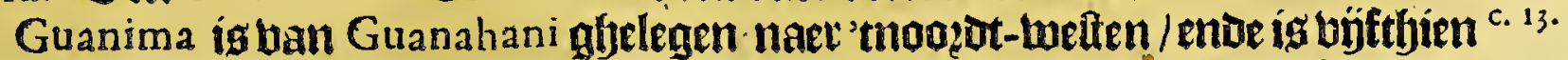
leguen lanck/ moethien beetot: Ithijnt fet eplandt te twelen Dat Columbus ont= Deckte/ [even leguen ban Guanahani, ende dat fy noemoe $S^{\text {ta }}$ Maria de la con.

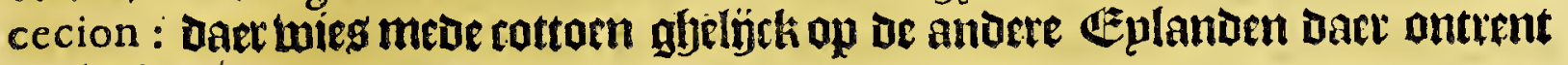
ableleghen.

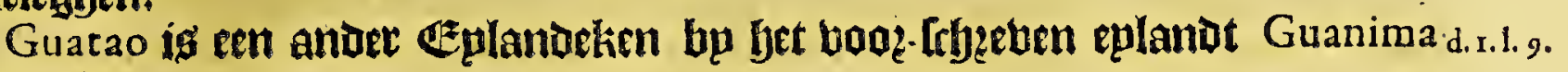
gheleghen.

Lucayoneque ofte aock Yucayoneque ig fyet uptertfe eplanot ban orfe equlan= Den naer' tmoogen op oe booghte han meer als leven-en-twintich graden; ban welck men foudot dat alle ofle eplandekeng den naem ban Lucayos bebben bet: kreghen.

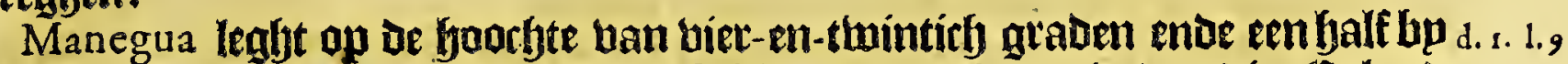

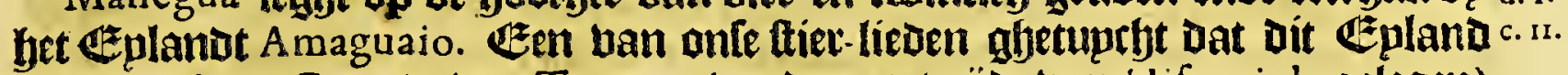

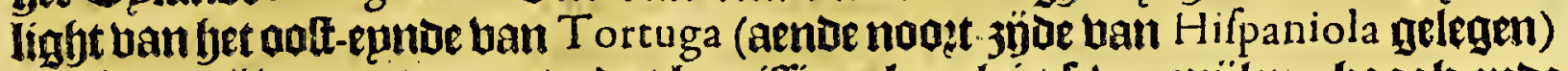
adbthien mỉlenj. ende n. ende dat bu nillingelangh is feben mülen; boogl ende met bergltents betet.

Macarey is gantleh om.ringt ban blackten ende ondiepten : fpnte taet fooghte

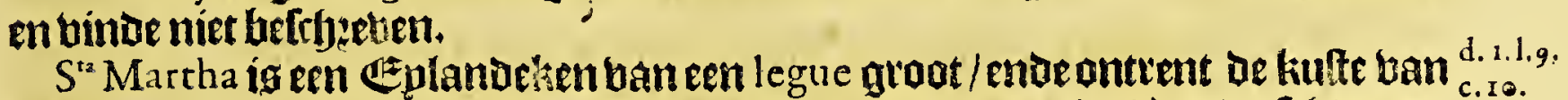
Florida, ap De fooghte ban Tewen-en-twintirh graden;men bint daer vertch thater.

Marcyres igeen verbolqh ban Eplanoeiteng enoe klippen op oe ljoogt:te ban

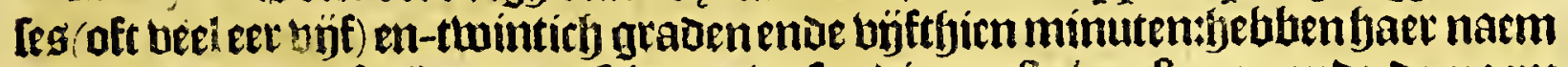

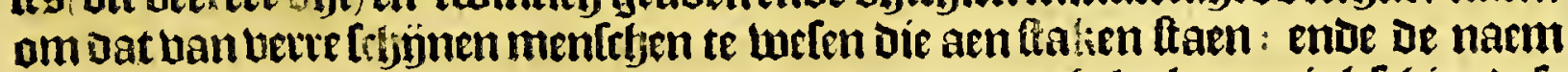

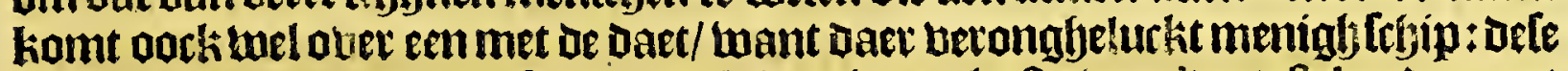

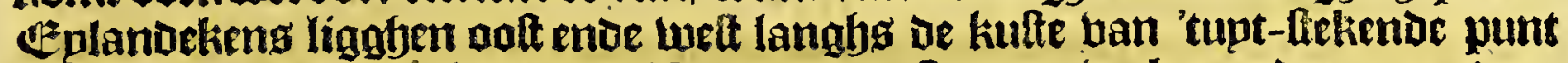
ban Florida : enve de bloten ban Havana nael Spaegnien keetende moeten daer

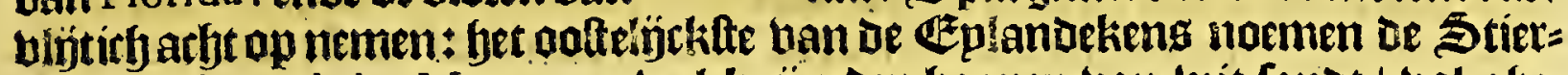

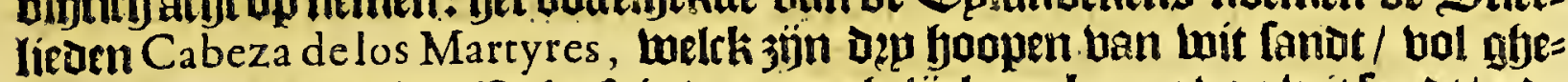

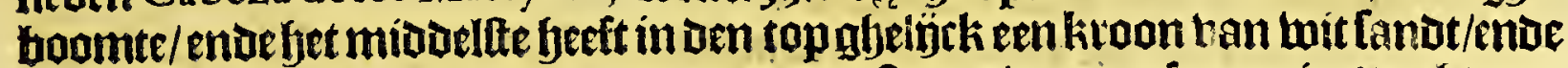
is hoogher ende grootec alg De ander twee: Om te Leten oftmen in 'trerfite tanael ig ofte niet/ moetmen wel arbt nemen/goe defe Cabeza de los Martyres ban cen liggt / want ligghenoe ban een ooft enoe loelt / foo en is men nody niet int ca= nael; maet als men baet met leght noozot-oolt ende juptr-weft / fo is men in't tanael.

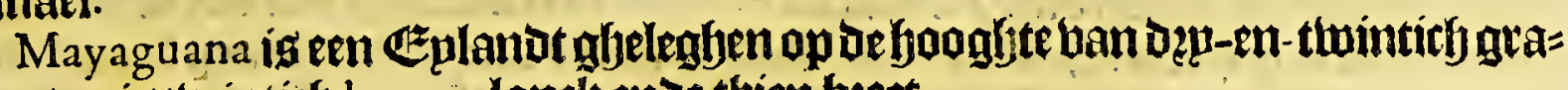
Den/en igtwintity leguen lantkende thien beet.

- Mimbres ígen eplanueken gelegen op Den boerk vande Doorhten ban Bimini.

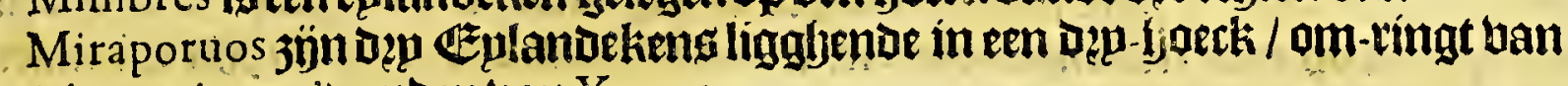
ondiepten/naer tzupoen ban Yumeto.

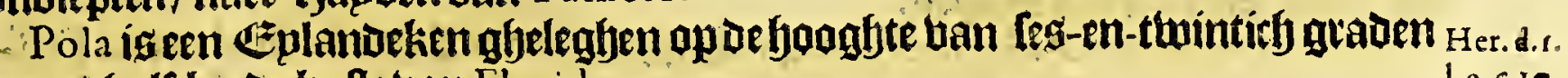
an een half bp de kulte ban Florida.

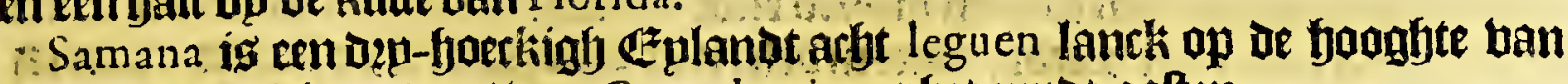

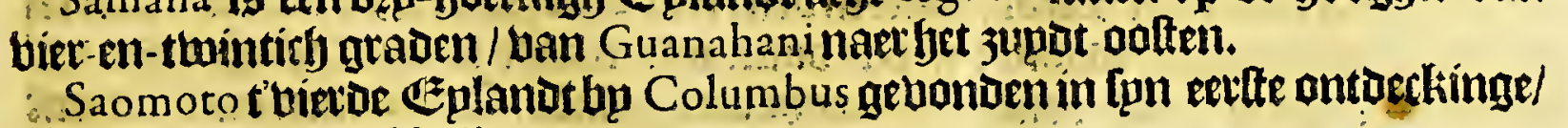
twelck by noemoe lfabella.

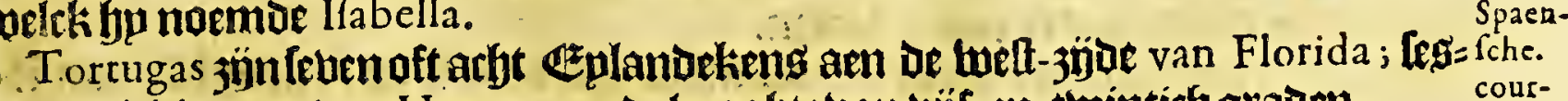

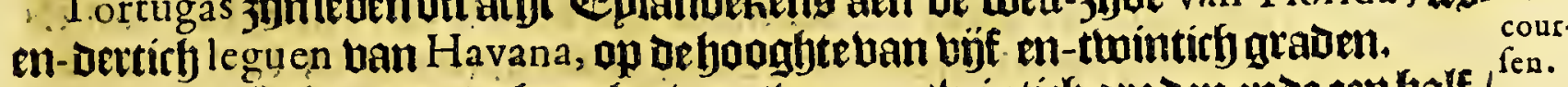

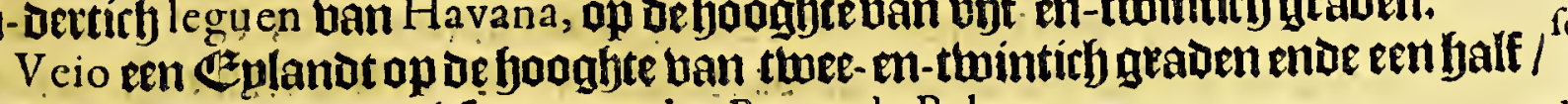
ontrent de ondiepten / Diele noemen los Baxos de Babueca.

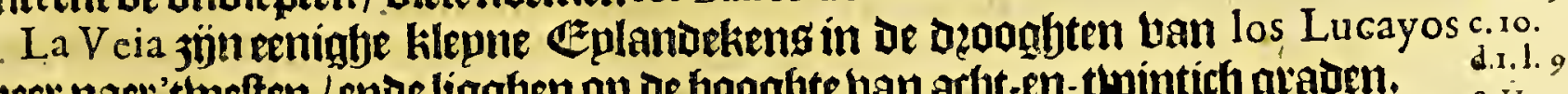
mere naer'tweften/enoe ligghen op de foogdte ban atyt-en-twintich giaden. 


\section{Vande Weft-Indifche Eylanden.}

Yabaque een Eplanot tfien leguen great/op De hooghte wan thee-en-twintich graden eneen half; noozot-welt ban Maguana.

d. r.t.g.

Yaguna een Ezplandeken ontrent De Caycos, ap de fooghte ban bier-en-twin= c.io. tichgraden.

Ynagua een Eplanot thien leguen groot / op De booghte bain twintich graden en een half; ofte beel eer twee-en-twintigh graden : ligghendenoazot-tweft ban De Tortuga, (onder't teplant Hifpaniola glyeleghen) ende inde twegh ban de ghene die Dode 'toude kanael loopen uan Puerto Rico naer de Havana. Paer oe bebin=

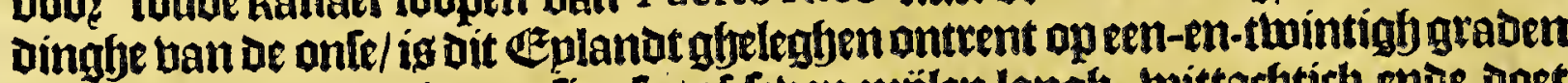
ende thien minuten; int aenlien les of [euen mijlen langh; bittatbtich ende toet ljemop als beel Eplandekens / bae-helmaet eenen is / int midoen ift redelijck boogh: bet ooft-epnoe light meeft noozaen ban bet weft-epnive van Tortuga booz-noemt / berlébepden ontrent thinticly mülen.

Yuma twintich leguen lanck enue arbt beet naec'tlogghen ban Herrera, op De booghte ban biet-en-thintich gradenende en balf: jupgt-weit ban Guanima. Yumeto viftthien leguen lantk / op de fooghte han ogp-en-twinticl graden en een balf naet bet noozedn ban Hifpaniola.

\section{Het thintichlte Capittel.}

Vande Eylanden die men noemt C A N I B A I ES.

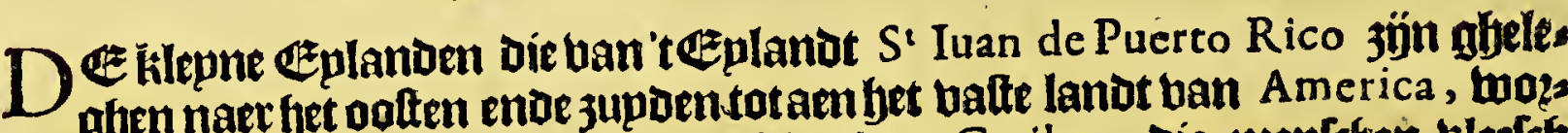
gyen naer bet ooften ende 3 upoen sotaen bet valte lanot ban America, two Den ghenaemt Canibales, am de menichte ban Caribes, Die mentefyen bleelth

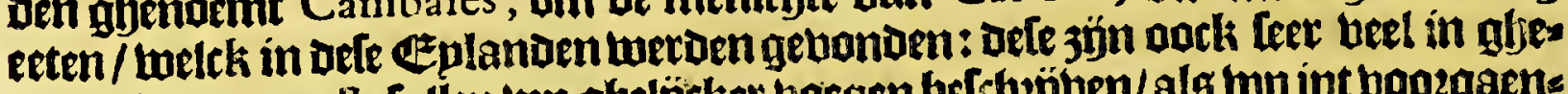

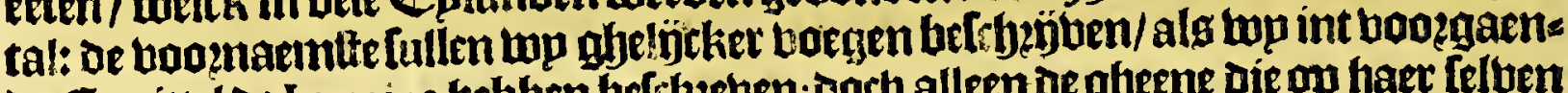
ot Capittel De Lucaios hebluen bef beeten; Dorb alleen de abeene die op haer feloen

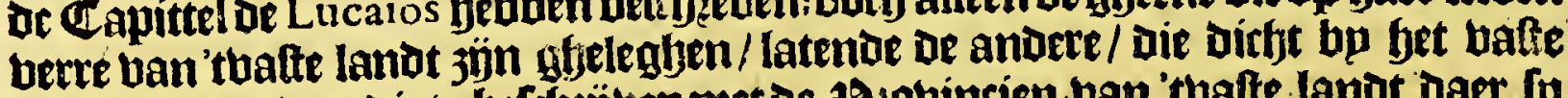

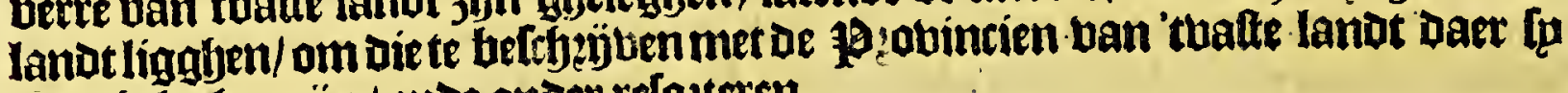
aen gheleghen zún / entac onder relozteren.

Anegada leght naet fiet oolten uan't eplanat $S^{t}$ Iuan de porto Rico, ontrent

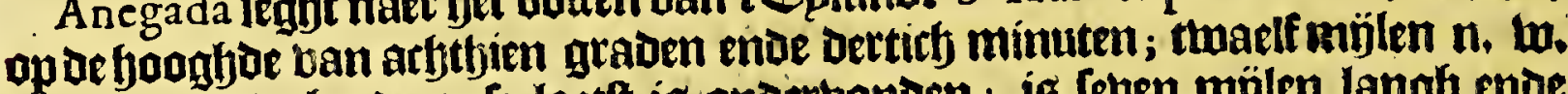
ban Saba als bu de onle laett is onderbonden; is leven mälen langf ende gantleb met ondiewten entoe blackten omeingelt.

Anguilla light op de fooghte ban arbthien graden eñ bier.en-twintigh minus

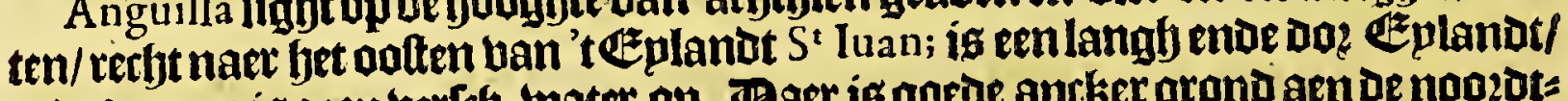
ende daer en is geen bertet-water op. Baer is goede ancker grono aen de noozot:

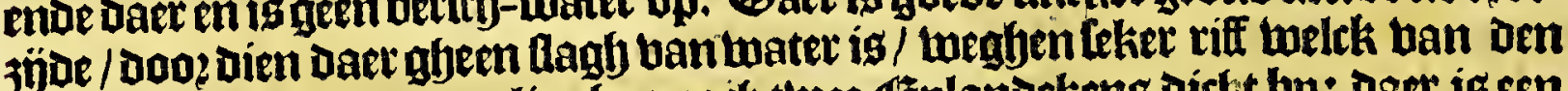
ooft-boeck af-ftreckt; Daer ligghen noth twee Geplandekenz Dicht bp: Daet is een Cout-panne op ende een frape hape om te laeden: Dan Daer en ig in jọn týt maet Tout boos thee oft Dep Ichepen.

Antigua ofte Santa Maria el Antigua ig gheleghen tuttritien Barbada entue Deffeada op de booghjoe ban lelthien graden ende býftigh minuten: is les oft feuen mülenlangljende thee bzetot; rontom belet met Dzoaghtenende [anden: Daet en is aheen tertelj water; woontot gften bolck op: 'tlanot is moeralligh enoe bol gebromte; is [eer black aenoe jupot ende twelt-kanot / foo datmen daet ontrent kommende' tioodt niet en mach [paren.

Barbada is afheleghen naet oe bethindinghe tan de onfe op de booghoe wan fes bentbien gradenende dertith minuten: twaelf of dertfien mijlen van Montferrate naett n, o. isfeel leegh ende do lanot / ende ontent vier mülen langb; aende zupot-jijoc ilt berte blarkende daerloopen eenighe reten af.

Barbados ofte Barbudos ig een ander \&plande /gheleghen ban Dominica naex fet 3 upat-ooften / op de booggoe ban dertbien greadenende twintigh ofte beeting minuten 
Het cerfte Boeck.

minuten (want be ob[erbatien die barieren in'tgftal dau be minuten:) is ban ghed aente obael ende ontrent oe bÿfthien oft [eltjien mujlen in' tomgaen; yoetuet

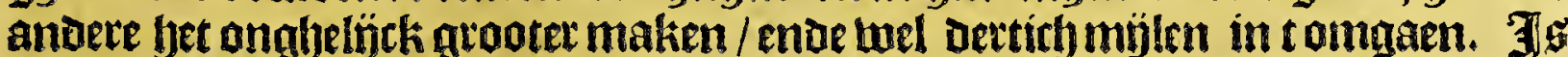
luftigh in't aenfien/groen ban geboonte/auer al oirgt fonoer open-Leloen: yoagh-

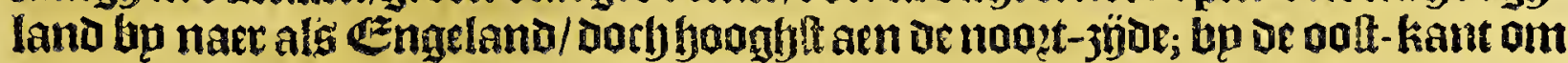
al meel in 'tronde met eenigge boerkieng/Daer al viffkeng ban af-Aeken/[ommi=

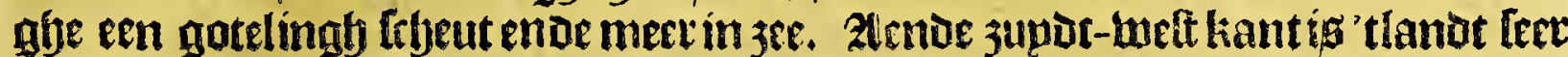
weeloerigh met boomen betwafen / ende saer is ren jandt-bape/ daetmen fetten han op is is 20 ende 30 bademen baters; jet dicpter bard aff / ente de grond

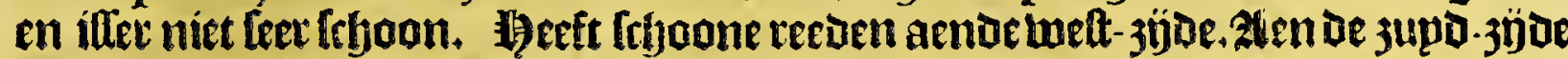
is een groote hape/ maer in beel frhepen koumen ligghen; ende daet loopt een rie=

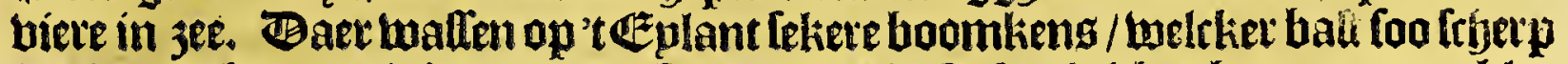
is als gember (entige bande onfe noemen die Cofte) gebben bzupn groene bla:

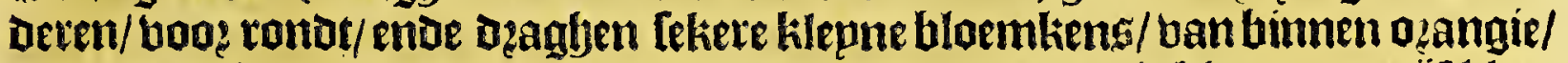
met zen geele grono/ ende ban buptenpurper bancoleur / bebbenmaer byjf klep= ne ende ronde bladerkeng; groepen in trollen te gader als de bliet; den balt uande

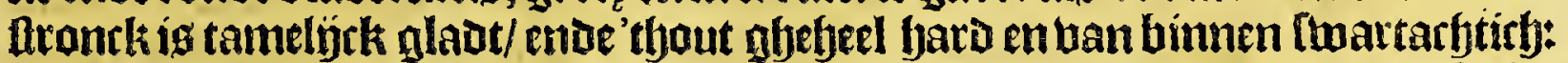

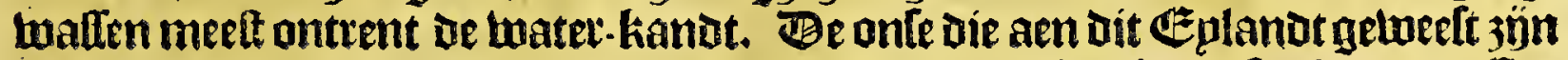

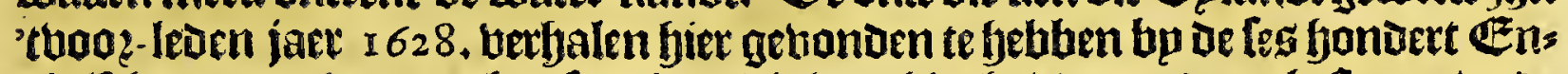

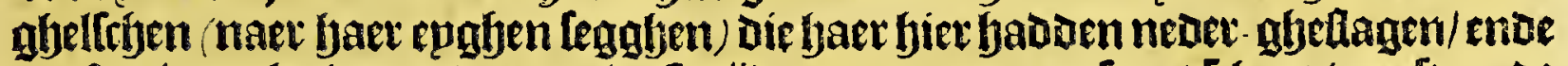

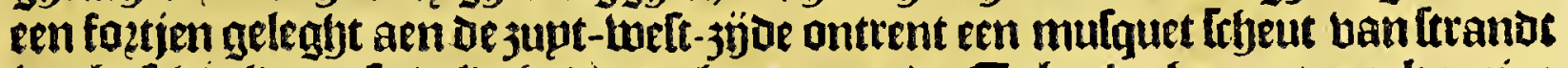

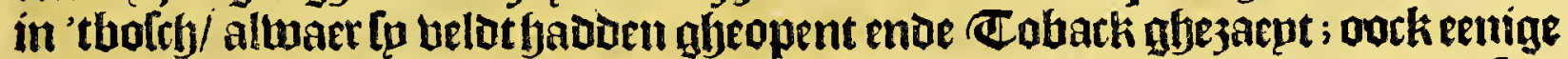
Dzangie ende limoen- boomen geplant/neffens andere bzurbten: Daer boos tfo:t is Aechte leede op 25 bademen gleen mulquet frbeut ban de twal / buple hlippige

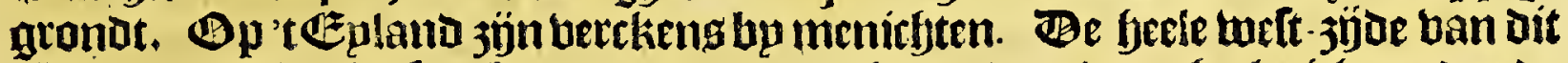
Eplande en is niet feer bequaem om te ancketen/ ten Laec beel aicht ander ae mal.

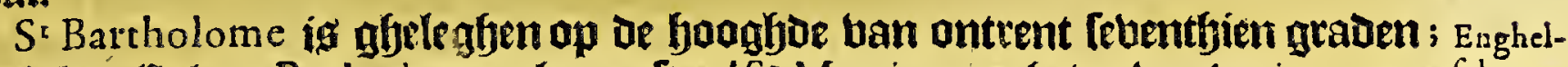

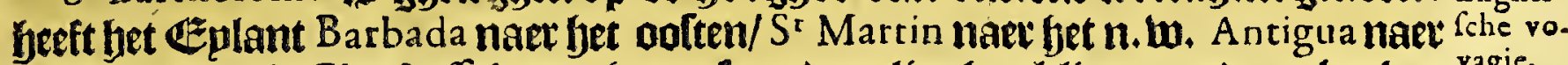
bet j. o. ende $S^{r}$ Chriftoffel naer bet welten: Daer ligghen klippen ende gebzaken ${ }^{\text {yagie. }}$

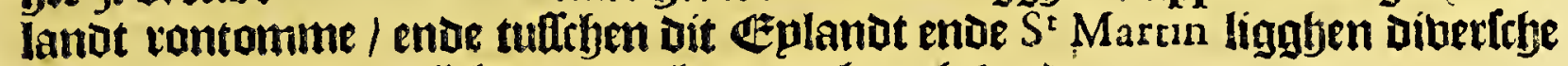
kilippen; ig eentameláck groot eplano/en foogh-lano.

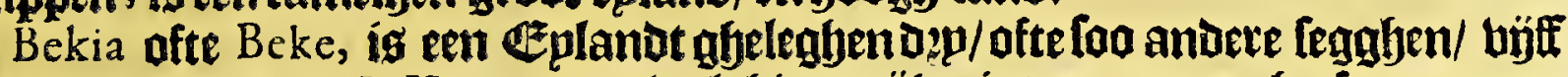
mülen 3. 3. w. van $S^{t}$ V incent, en wel thien mülenint om-gaen; Geeft maer cen baepe die in 'tinkomen twee mílen wijotig/ Daermen beel brtebut lian ligghen; allmen daet met frbepen wíl in komen / maetmen bp den ooft-haeck om loeten/ aen foecli en ofte twee kabel lenghte frlyoumenoe/want daer een blinde klip ligt: inde baep tomenoe moetmen reetht ooft aen loopennaer oe fand-ftranot/ig daet

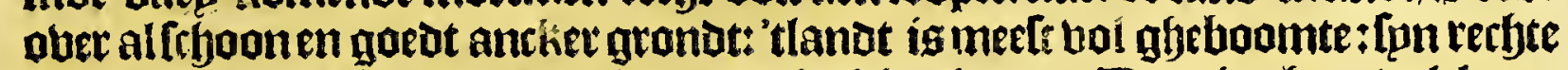

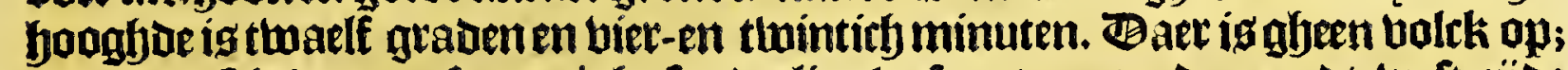
gheen bertey-matet ofte eenighe fonderlinghe frupten: op de noozat-ineft 3 joe ig een lout pan.

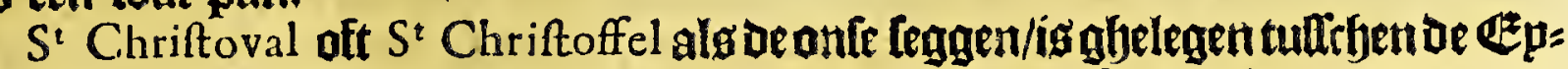
landen Nieves ende $S^{r}$ Euftafio, op de jooghoe van febenthien graden ende twintiry tot dertirly minuten: Itreclit bem inde lenghte tullerben yet 3 . o, ende bet

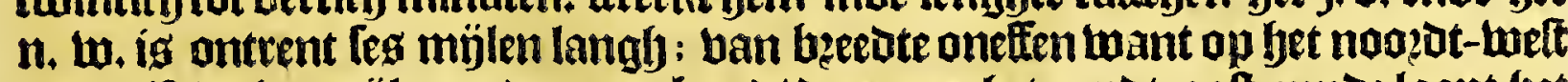
ephoe ift wel 2. mịlen ende meer beed/ Dan naet het jupdt-ooft epnoe loopt yet

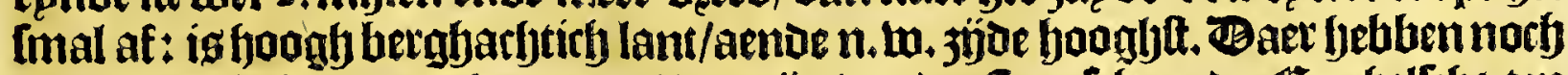

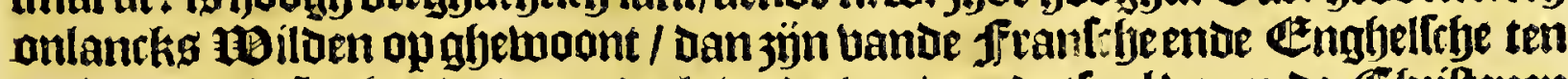

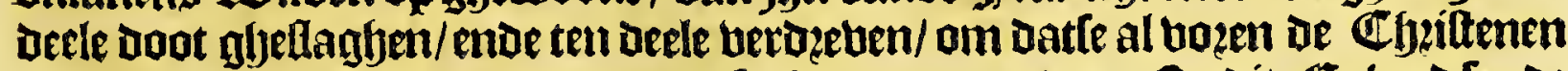
qualýck badoen ghefjandeit ende ghelorbt te bermoozoen. Op dit Eppland Toude pock-houbt te binaen we[en; aen'tzupat-ooft epnoe ż̈n eenighe (out-pannen)

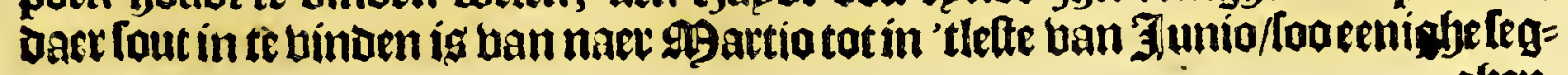
$\mathfrak{g} \mathfrak{b} \mathfrak{e n}$. 


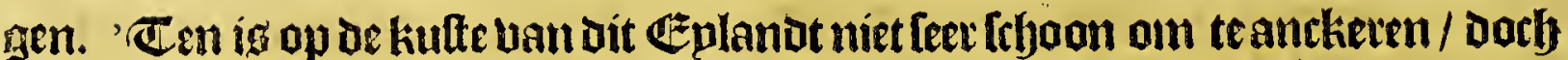

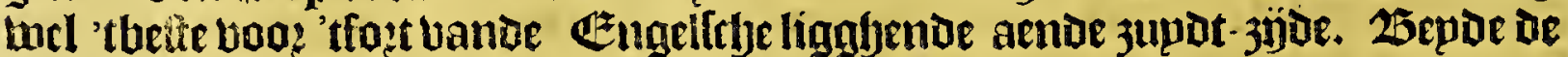

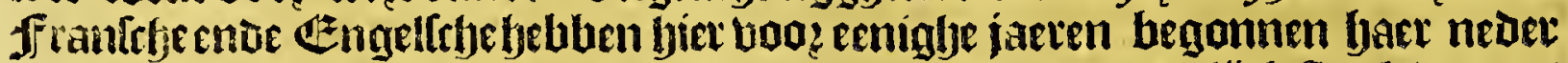

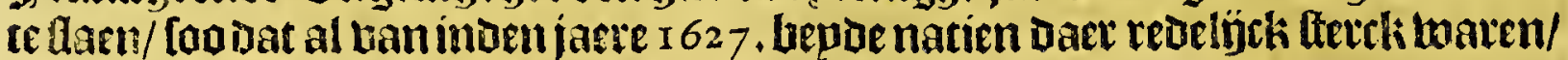

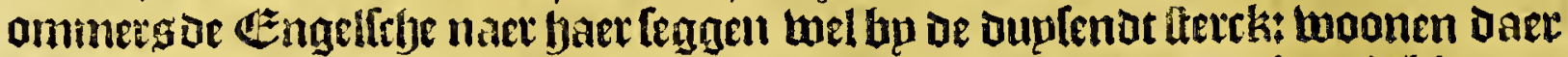
met den anderen in beede/ endefoo dat de franlefe faer ghelegentfept bebben op

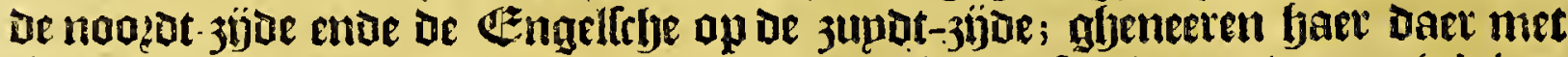
Cabark te planten / welck daer feer goet ualt. De onte die daer waten ín't jaet 1627.ende 1628 . Frgahen dat ban Pabember tot 'tepnoe ban J anuar, Daer meeit

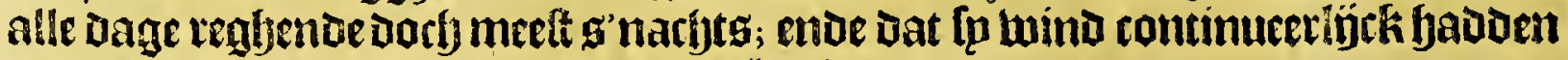
tot den a. ten 3. ende a. 3. o. met jaroe kaelte.

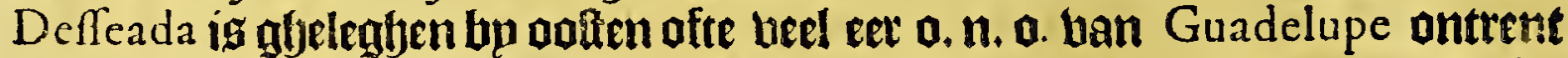

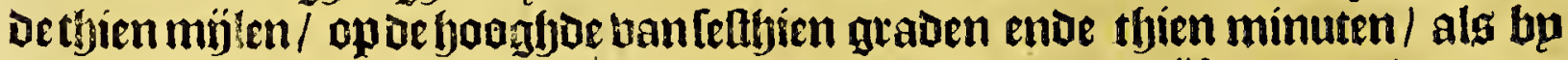

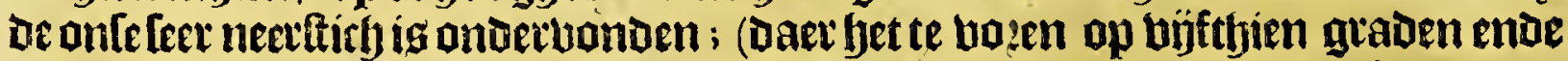

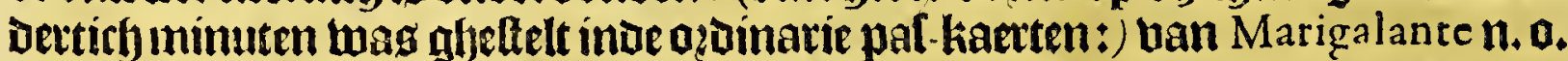

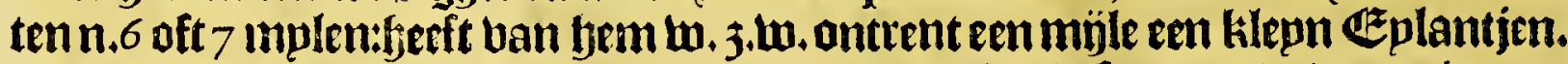

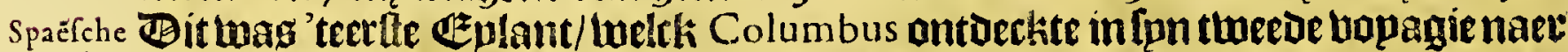

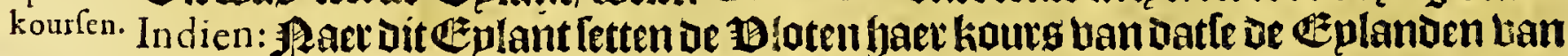

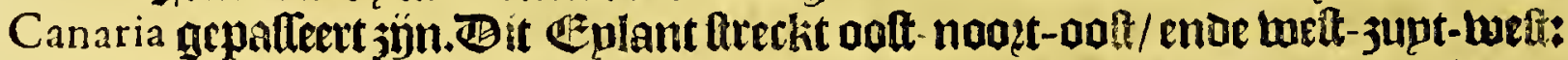

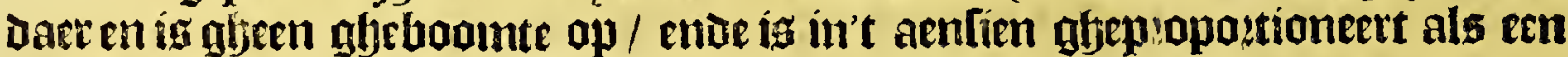

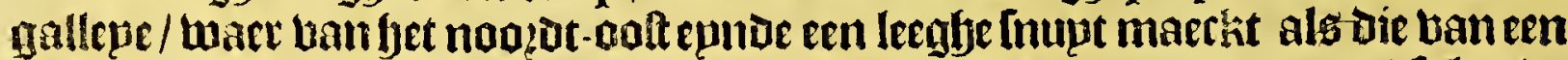

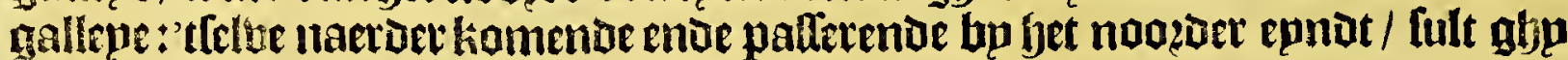
fien fwart lanot met twitte ghebzoken ftreken/als beubeltions han fanot met roo=

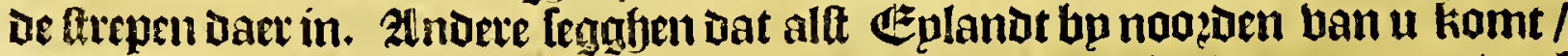
Dat bee fyem dan hettjounot als en ronot bzoot; enoe dat bet daet rontom bupl ende ruifich ig.

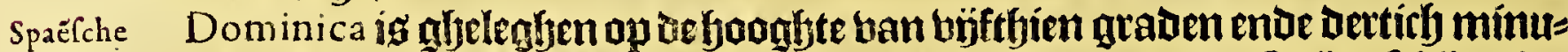

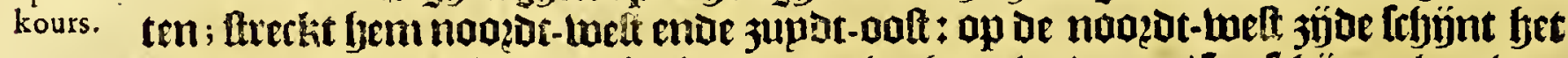

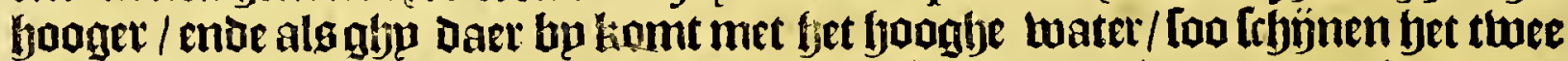
Eplanden te welen/maer naetder komenoe / lietmen dat bet maet een ig: aen te 3upot-aoft jó oe fulopfuen ren black ende lanck punt / ende daet ap een rotfe/ als

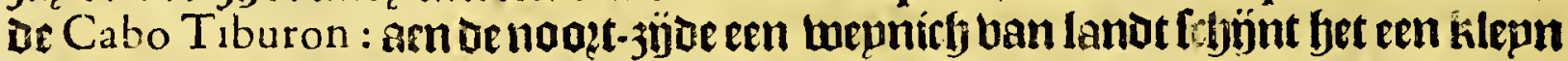

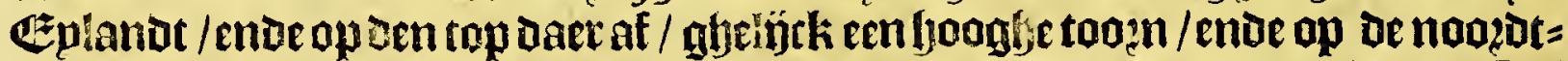

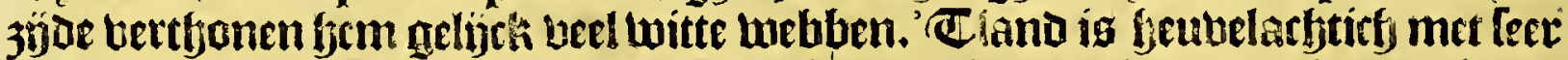

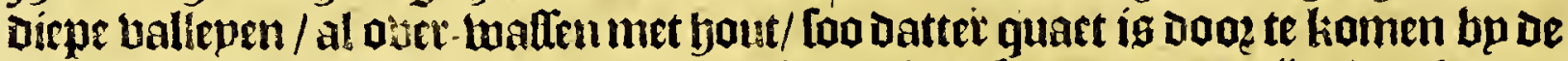

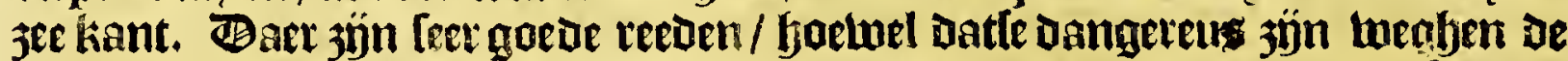

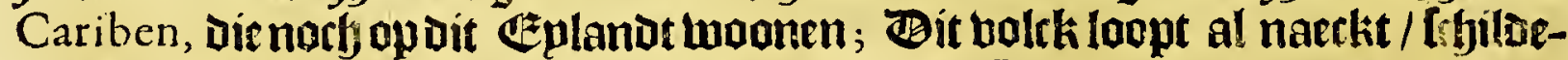

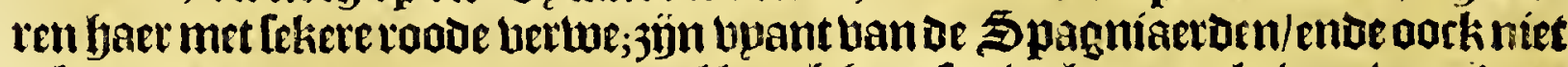
te betrouwen tooz andere: Dzagen al langh fyap? foo wel mang alg bzoutwent daet

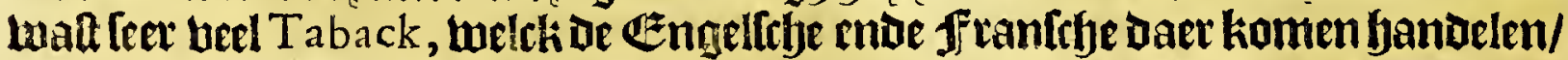

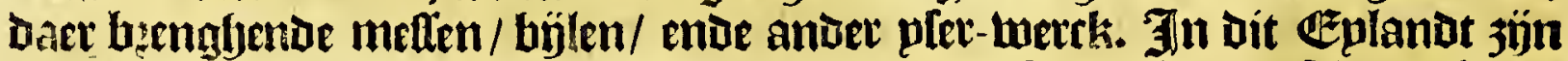

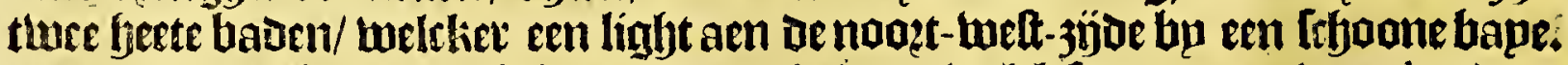

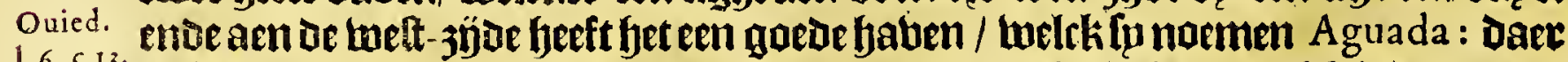

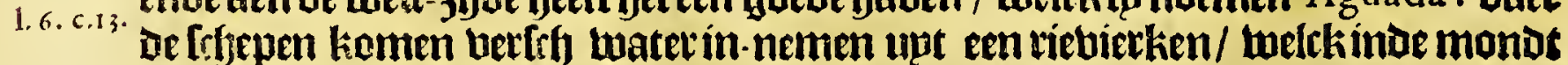
truinticy palten mijot is.

$S^{t}$ Euftafio is een klepn ezplandt / ende ig ghelenten bp bet Eplanot $S^{t}$ Chri-

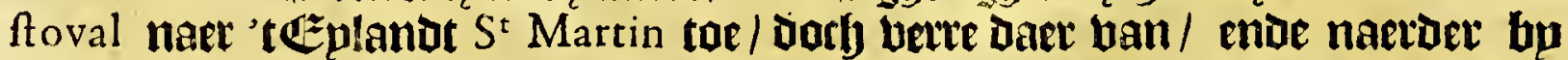
Saba, ende $S^{t}$ Chriftoval, alloa ban bit laetlte maet twee mijlen en een falf berfrbepden is: op oe fooghte ban feventbien graden ende bertich minuten/ aljelibe als laetle bp oe onle is aengheteechent: berthoont hem met een ronoen

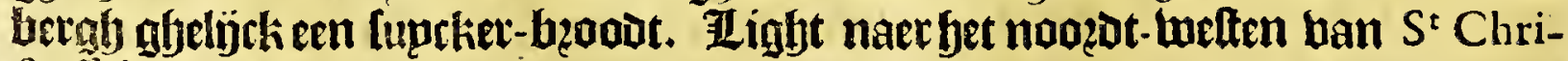
Itoffel,

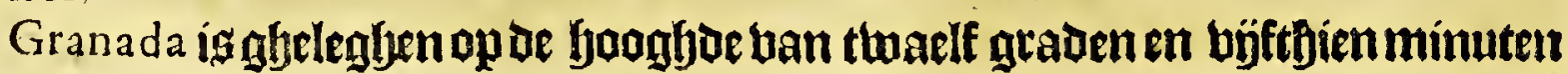
(wepnich 
(Lepnigh min ofte meet: Lant de ob[etbatien varieten inde ninuten; ) berfefep:

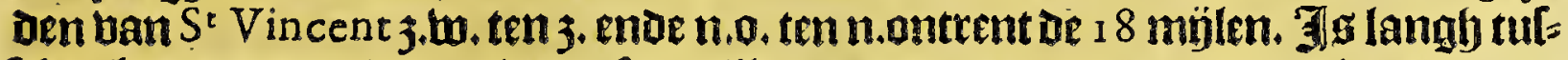

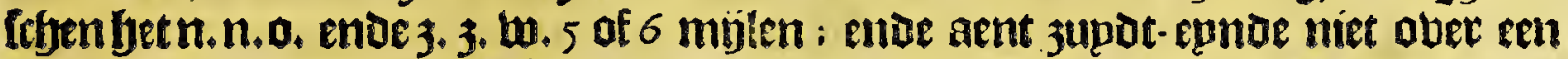
balf mijle beecot; light meelt in de gedaente ban een halue mane; feffteen boogen bergh bouen andere upt-ftekende: oe grond ig ftyoon eñ goedt: is feet bzurbtbaet

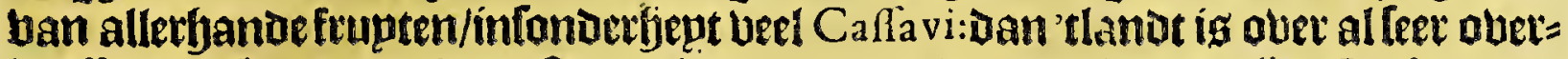
walfen met boomen; 'tmeefte gediette Datter getwonoen wozor zün Cafimanes, Die de Spagmiaetden noemen A rmadillos, noet ometen. Ban Jumio tot (B) tober koumen Daet menichte banfthild-padden/enzer-liaepen: lo dattet een ban de befte

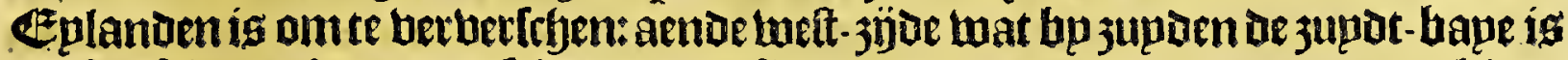

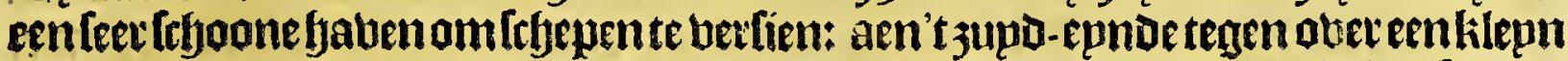

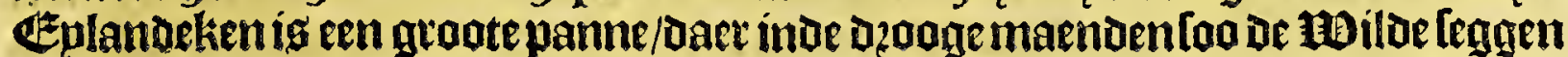
beel fouts inte tinoen is.lGet lant is wel goet om Cobar te planten/maer feer ge= quelt banfekere land-krabben; hoetuel eenige twillenfultineré Datfe maer ontrent Den oeber ente aftuateringen wozoen ghetuonoen/ende dat 'tbinmen-lande daet

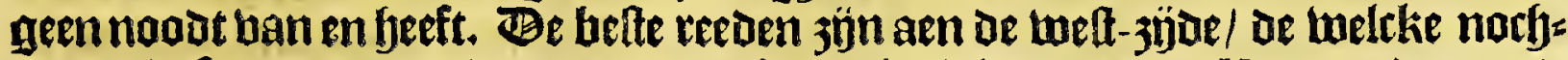
tang niet foa gaed twozoen gewazaeelt bp eenige/als die van $S$ : Vincent; de arona en iffer imede foo frfjoon niet / maet op beel plaetlen buplende tudfigh. Lamende ban St Vincent ig de hours 3. 3. Lw. men let Die bp meften de Begos omme: Defe Begos zün klepne Ezplanoekeng ende kilippen die op eenrije liggen tulferben $S^{r}$ Vincentende Granada, zün [rfyoon; men maglj daec bel dicht bu komen. De in= moonderen zín Caribes van oe felbe larfy alg die bande bu-líggenoe ezplanden/

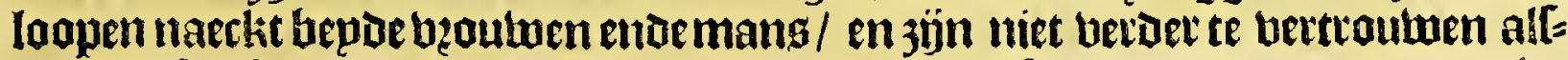
men die liet/feet wyaeck-gierich ende die niet en waetrfyouwen boos dattet aen is; bebben onlangs bertebepoen acten ban yoltilitept glepleegbt tegfen be onfe/ foo op haet epglon Eeplanot als op de naelt gfyelegfiene.

Guadelupe is gheleghen naex 'twelten uan Deffeada, ap be booghte ban I 6

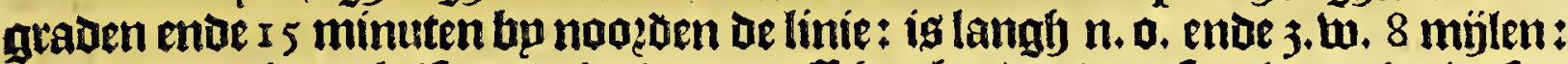

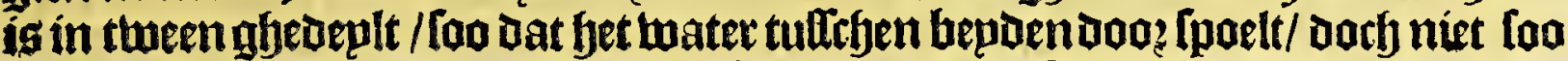
Diep datmen daer Doo: foude honnen feplen: aende ooft-3ÿde maeckt fet fekete ta= felen / Die gínenaemt wazoen bp de ftier-lieden 'tyooge deel ban Guadelupe; ende

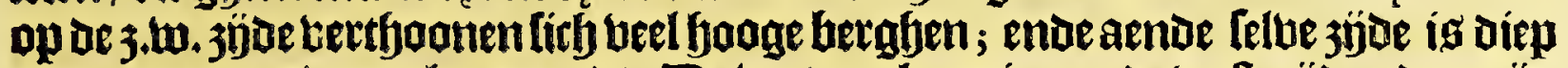
water endegoede ancker gronot. Be water-plaets is aen de welt-júde: Daer jön bee! twilde berckeng ap 't Eplandt/ende Bananas-boomen bp duplenden. Daer

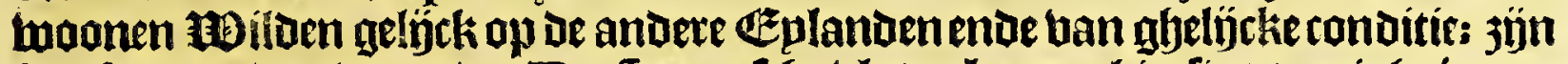

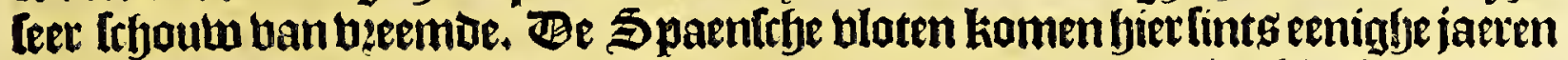

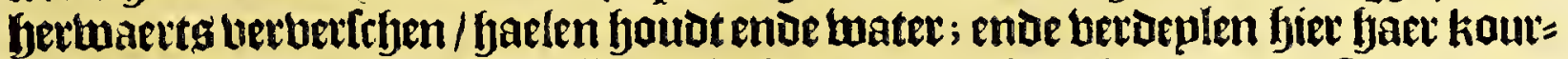
ten / welcklp in booz-leden tjoenplachten te boen inde hauen ban Ocoa, aen't Eplanot Hifpaniola.

Ina de A ves ig gelegen eengront ftuck bp welten los Santos, op oe yoogfte ban

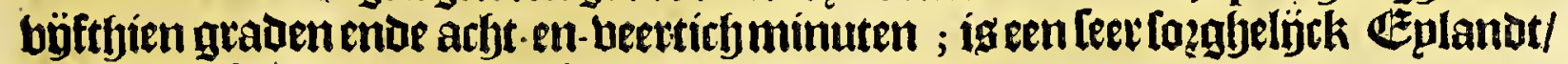
ligghenae bu naer gbeljeks' thater / petg daer op.

\section{Y)et en-en-twintichfte Capittel.}

Van de refterende Eylanden diefe noemen CAN I ALES.

Sleos Blancos jün leket Eplandekeng naer'theltenuan Virgin Gorda.

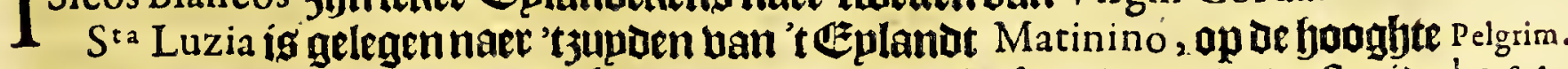

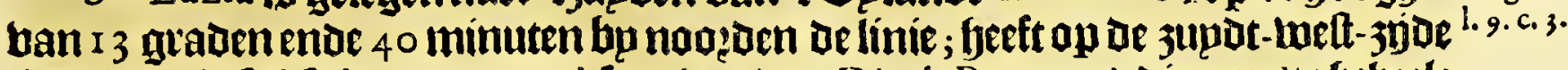
twee booglyelpitle bergen (naer' 'tlegghen ban Dirck Ruyters) diemen'tabebeele landt ober kan fien / ende de ooltelijekfte ig de grootte. 't Balck ban dit Éplandt loapt naeckt/beft lantk fwart hap?/'tlijfroot gebertwet / met roode arcpen wande 
38

Vande Weft-Indifche Eylanden.

oden tot De oogen alg $\mathrm{M}^{\mathrm{r}}$ Purchas getupght; welch Dit Geland ftelt op be foogte

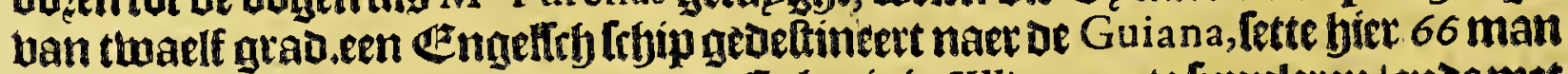
aen lanot / Die gefonden waren omde Colonie in Wia pogo te fuppleren/enter met

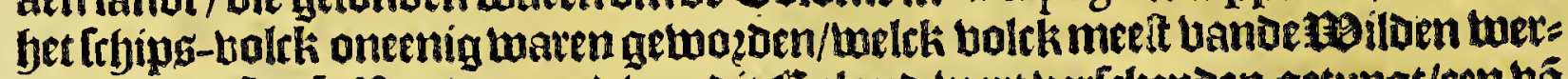

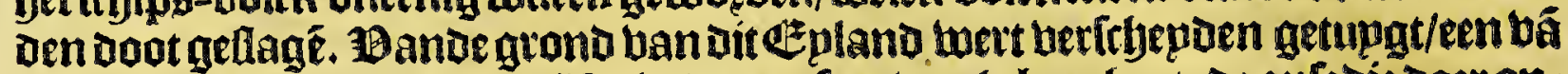

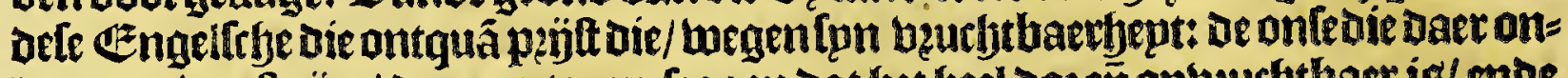

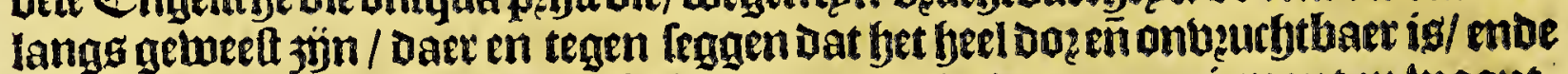

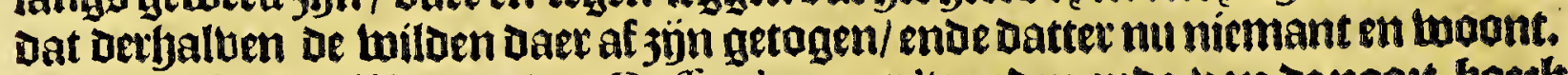

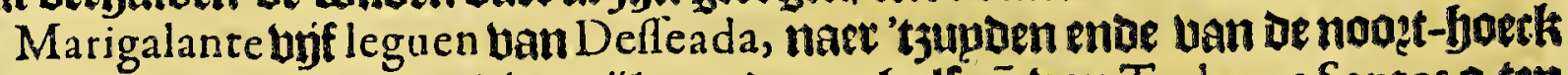

Spaes- ban Dominica n.0. tenn. vier mülen ende een yalf;eñ ban Todos os Santos p.ten fche 11. ontrent büf: op de hoogte ban Is araden ende 40 minuten bp noo den de línie;

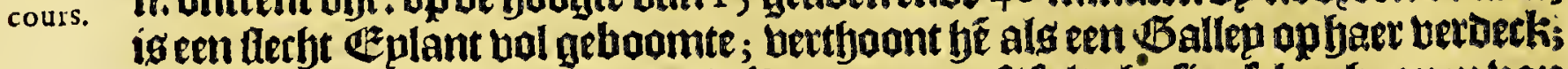

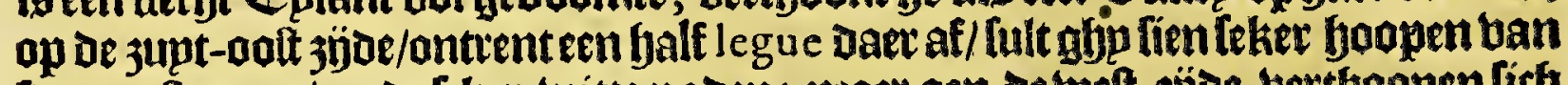
(twarte feenen/ ende leker witte paden: maer aen be welt-joboe tertfoonenlicty fryoune witte fant-ftranden ofte plepnen: ende daer íg gbeen antker qrondt: Diét Epplano als bet bem erettop-ioet/ig agelÿck of de boomen in't bater ftonoen/eñ een jalf mijle daec af ín jee light een klepn EElandeken/altwaer Commige Klippen

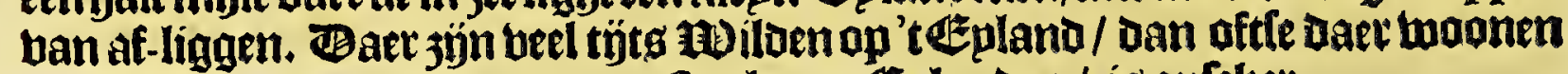
ofte Date daer komen ban de naelt gelegen epplanden/is onleket.

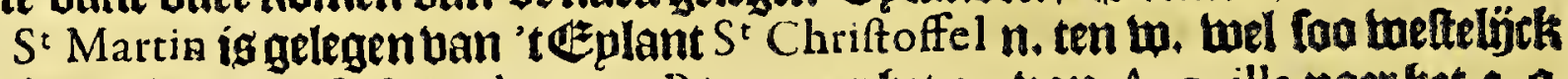
8 of $g$ mälen; ban $S^{t}$ luan de porto Rico naet fet $0 . ;$ ban Anguilla naer bet 3.0 , ende naetfet $n$. w. uan $S^{t}$ Bartholomé : op oe foogboe van 18 graden enoe 15 mis

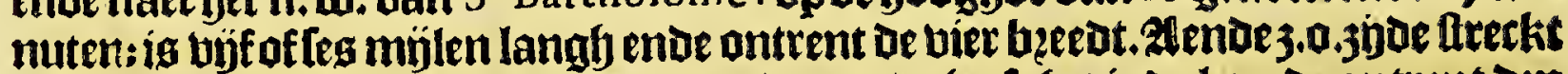
het lant 0.3 .0 . Ban bet 0 . epnoe tot fyet b. epnae beeft bet ínoe lengoe ontent Dep

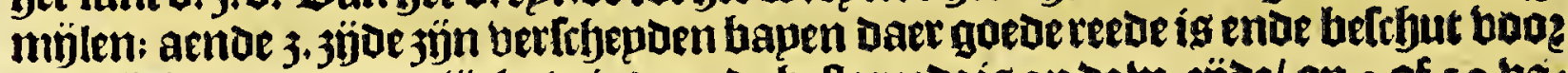

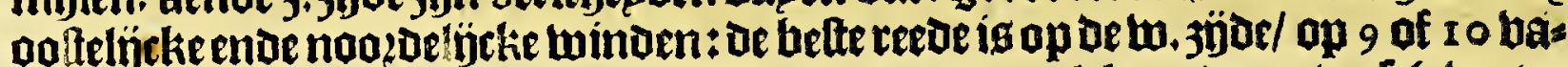
Demem waters goede fanot gronot. Baeren is geen bolck op / geen berfeb watet ofte frupten: Daer is een groote lout panne aen or eene 3 jóde / ende twee tilepne aen

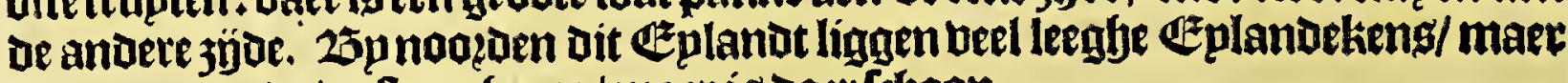
bp jupden ende tweften gheene / maer ís daer tryoon.

Matinino ig aelegen op oe yougte ban beertbien gradenende een balf afte thees aerde naev' tjupoen ban Dominica; is booghende bal bergen/ bebbende in't mios Den Dap heubelg/ waet ban bet booghfte bem vertyoont gelïck De foem ban eenen

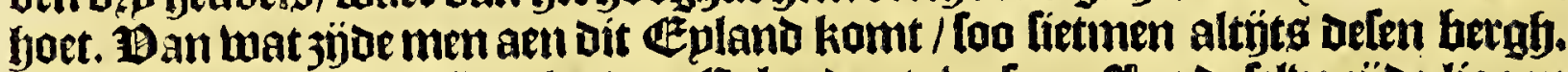

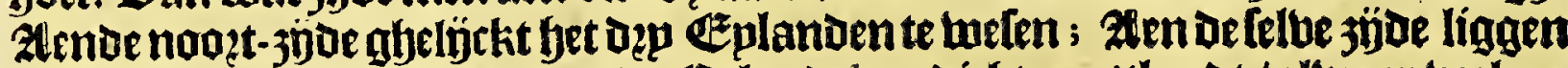

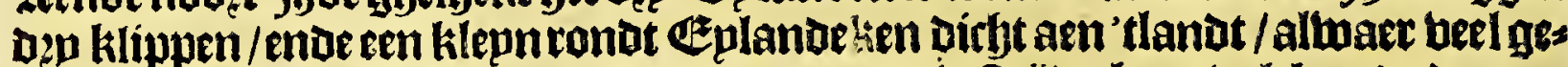
boomte op ftaet. De Miloen die daec twoonen is ftijot-haer bolth ende danges

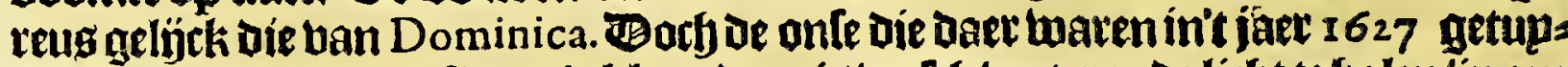
aen dart aeen volck arlien te frebben:Dare is berleb water ende licht te halen/ín een

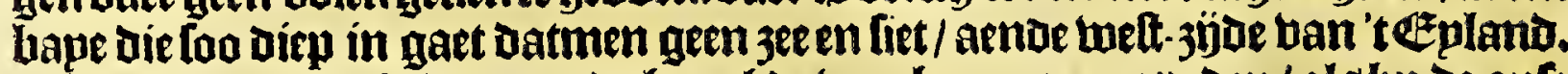

Monferrate is ghelegen op oe hooghoe ban bp naet 7 graden/als bp of anfe

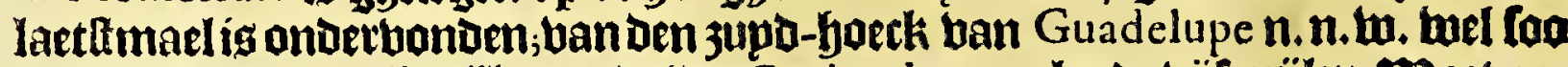

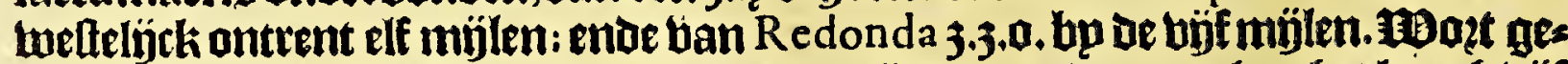

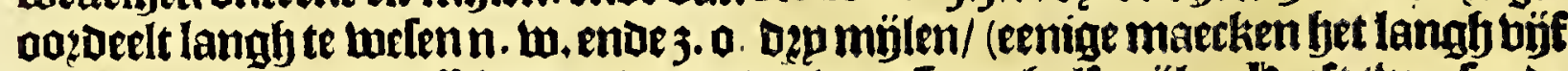

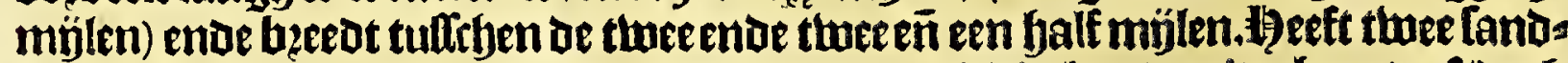
bapen daet gordereede is/eñ in d'eene komt een riebierken ban' tgehergte af/Doch

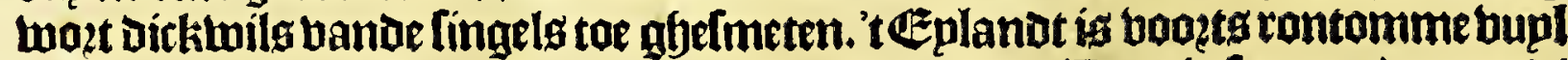
ende met klippen belmet / infonderbeptaen de n.jjoe. Baer ís leer goede grono/

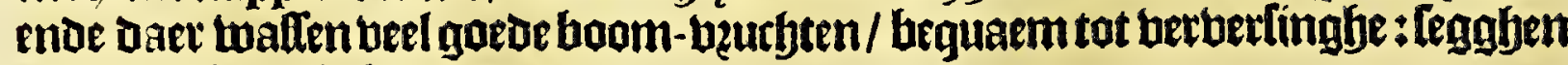
Datter oock pock-fjoubt groept.

Las Nieves, welck bp oe onfe beel töbts twat genaemt Mieves, isgelegen op to

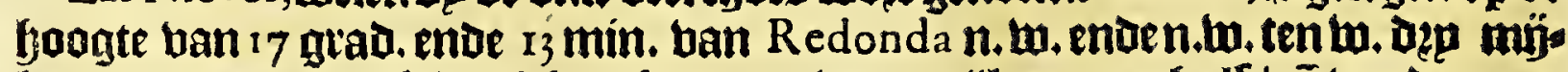
Ien: ban Den 3, boeck ban Monterrate $n, \mathfrak{w}$. 7, müleneneen balf/eñ banden 3, o. baect 
Het eerite Boeck.

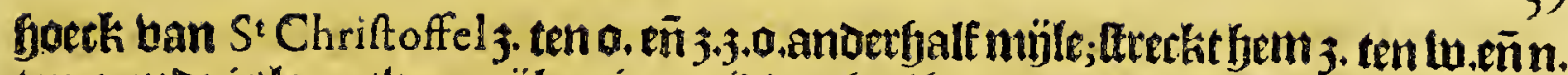
ten o.ende is lang twee mijlen; int midoen fyeel foopg/met een betgh met een fade:

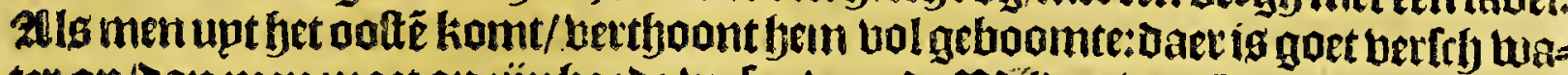
ter op/Dan men moet op jän foede toelen tode de abilden uan Dominica die daec

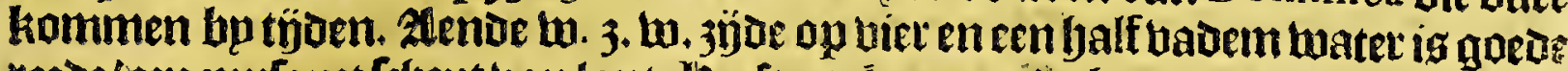
reede/een mufquet fryeut banlant. 1) eeft oarkeen goede bape aen ie nooet-Left-

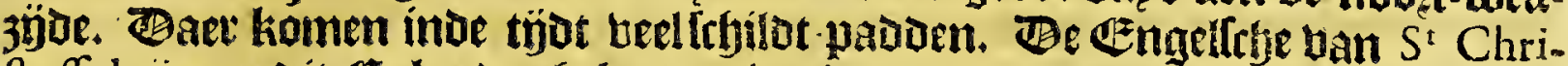
ftoffel sinn op dit Cepland afyekomen in't jaer 1628 .

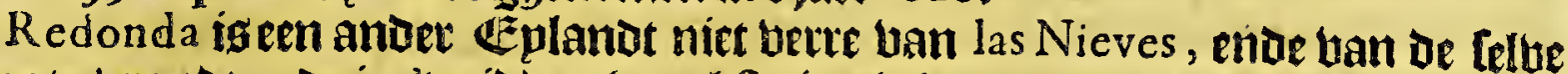

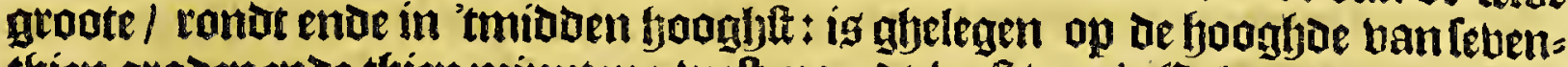
thien gradenende thien minuten: welt noogd-Lelt ban 't $\mathbb{E}^{2}$ plandt Monferrate Dẹp groote mílen naet' tleggljen ban Dirck Ruyters.

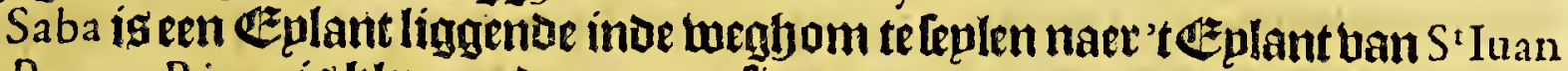
de Puerto Rico : is klepn ende rontom fietmen Den gront / Danmen befoeft Daet bopz niet te fryemen/mant daer en is geen perineliel dan 'tgeene men fien kan: eñ rontom bettyoont bem als boopen ban wit Cand : enoe op de jojoe bertboont bet hem alsenfrhip dat onder $3 e p l$ ís. ZLight op de fooghoe ban 7 graben 37 minus ten / is fjeel boogf ende niet bouen de tluee mịlen groot.

Sanca Cruz is gheleghen uan t' $\mathbb{E}^{2}$ plant $S^{t}$ Iuan de Puerto Rico o. 3.0. (naet Her.d.s. be betindinge ban ae onfe) twaelf mijlen wepnigh meet of min:op oe boogoe ban 1.7 . c. 1.

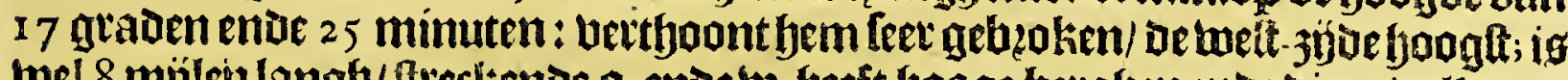

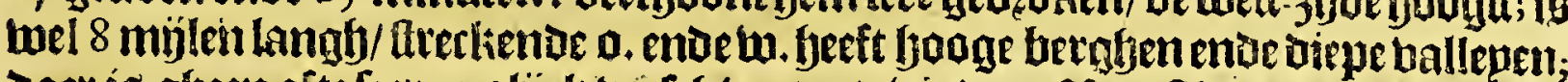

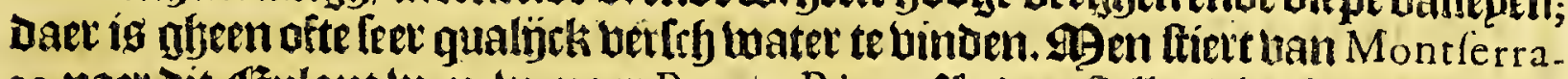

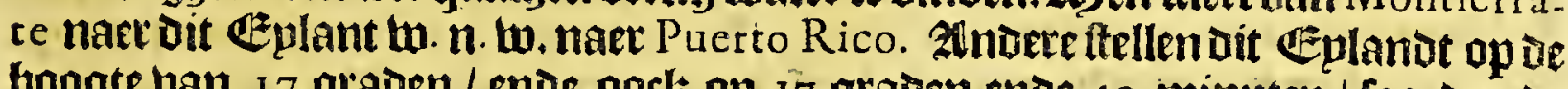
boogte ban 7 graden / ende oock op i7 graden ende 40 misuten / foo tat de

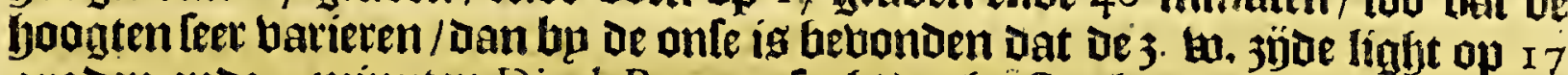
gladen ende 25 minuten. Dirck R uyters feght dat feet tteetkt o.ende to. ende datter

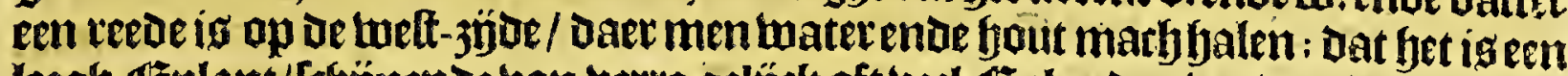

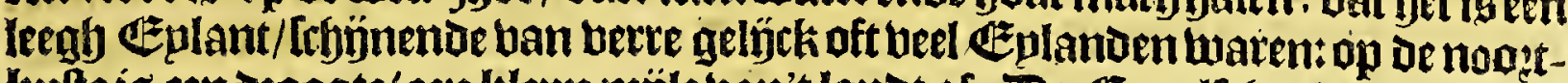

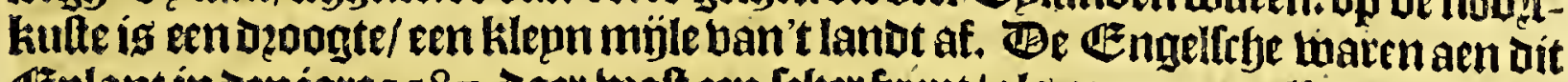

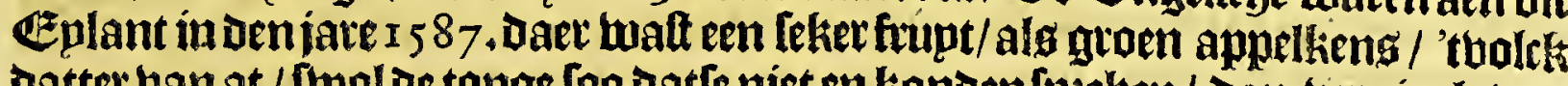
datter ban at / fwolde tonge [oo datfe niet en konoen feetien / Dan terginck ban Celfs binné de 24 uten: bonoen daer upter-mate gropte fryilt-padoen; geen verfth

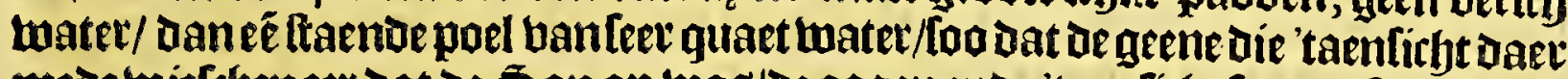

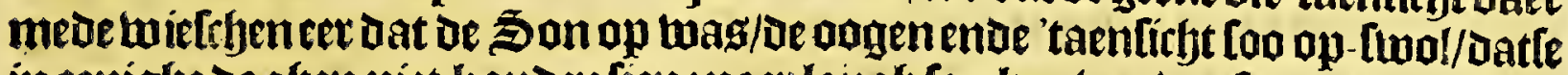
in eenighe dagfen niet konden fien: naer langh foecken bondenfy nacid een fon tepn van goet lwater. Daet woont fonoerlíngh ageen bolck op.

Sombrero igeenkilepn Ezplandeken/bphet Epplant A negada, al omringt ban blarkten/op de fjogghte ban I 8 grad. ende $3 \circ$ min. bu noozen de linie.

Todos Santos (ofte los Santos, alg De kourfen dat noemen) 3 inn 3 ofte 4 klepne Éplandekeng/liggende Ditht bp Den anderen/bp De 3,3 jioe ban't Éplant Guadelupe : Banfier naer Puerto Rico Itiert menn:L. tot aent KEplanat Saba.

$S^{i}$ Vincente ig gelegen op de foogat ban 13 araden (ende eenige mimuten/ [oo

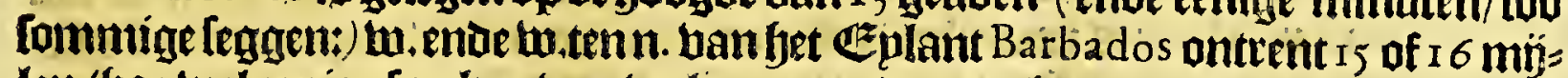
Ien (foe twel enige Lpeken tuan beel(meer) moe naec ljet 3 .tw. ban Santa Luzia.

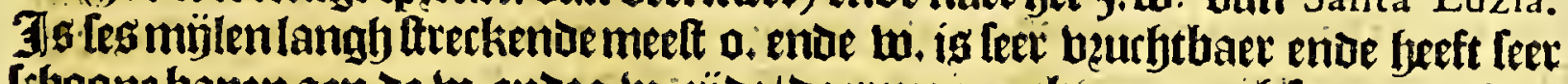
fifgone bapen aen de $\mathfrak{w}$. ende 3 , w. jyjde/ baet men antketen magh foo naer'tlant

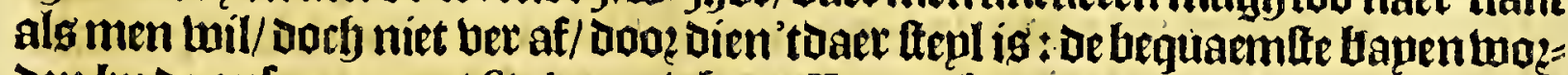
oen bp ae onfe genoemt $S^{t}$ Antonis hape; Kraeck bape; Kael-houcx ofte Cavvynen bape: Trompetters bape /etc. die al lamen bertebe-water-Ioopen febben ofte klepne rievierkeng. Dit Ezplant feeft leet goedegtono; daer is topnigh gedietts.

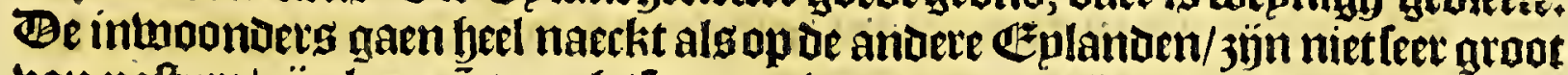

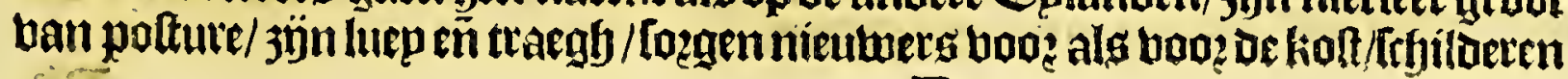


40

Vande Weft-Indifche Eylanden.

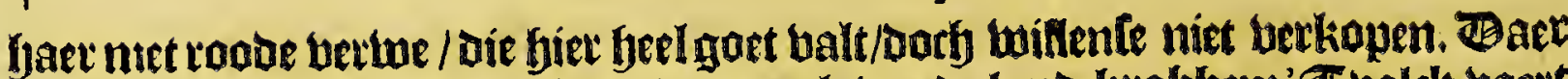
ballen beel foenders: 'tland ig mede gequelt bande lano-krabben:' Co volck baett met fyaer ranoen 35 eñuner mülē ouer 3 eenaer 'tualte land tor fonder eenige $3 e t-i n=$ frumenten/ende beten de (E) planden weder te binden/tot grode bertwonderinge. Bande $\mathbb{E}^{z}$ plandekens twithen Dit en Granada líggenae/is bier bozen gelpzoken.

Her. de- Las Virgines $3 \mathfrak{n}$ twer Eplandekens omringelt ban ondiepten/ende andere 8

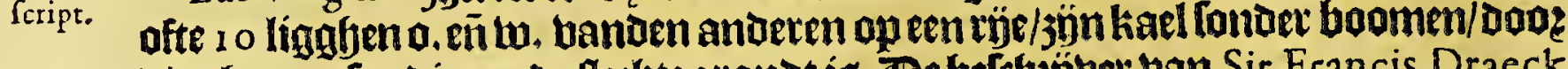
Engel- Dien bet een fandige ende ferthtegrandt í. De belcheñber ban Sir Francis Draeck fche vo- lefte bopaaie getupglyt Daet uan als bolgt. Be E Elanden ghenaemt las Virgines yagic. jüngeatyt geweft angereus / maer top bonden daer goedereede / al thaert voo?

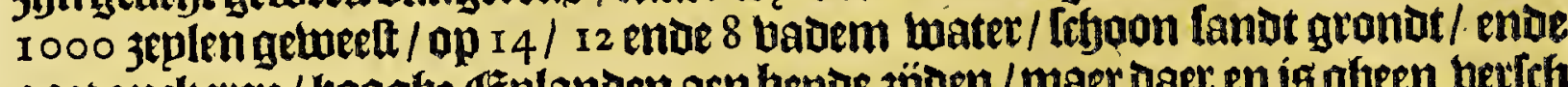
goet ancketen / yooghe Ueplanden aen bepde 3 joon / maer daet en ig gljeen betch water dat wo konoen binden; daer is beel birefy te bangen met foecken ende netten/ oack beelgbevogljelte te banghen: ligghen op oe arbthien graden bu noo:= Den De 2 Linie.

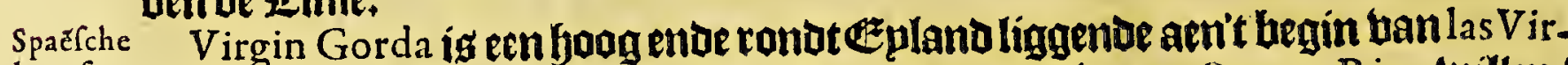

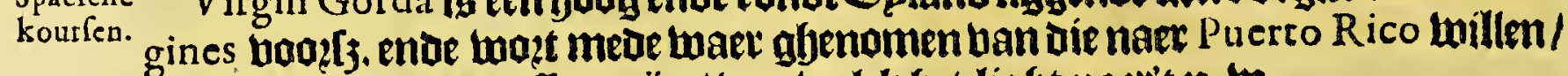
naet datte Saba ghepafleett jün / van welck bet liggt naet't n. w.

Het twee-en-thintirflte Capittel.

Van de BER MV D E Z Eylandeken.

HOe wel het (zpland Bermuda onder dele Eplandenniet kan weroen gferes

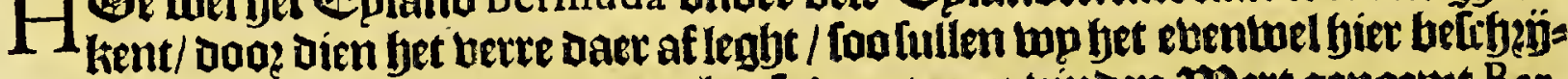
ben/ Doo dien top geen bequamer plaetle daer toe en vinden. Bert genoemt Ber-

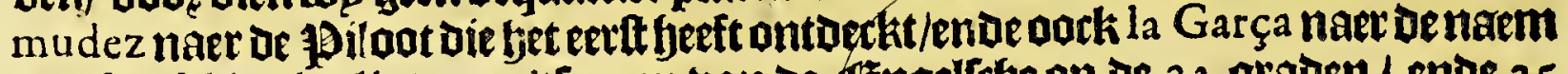

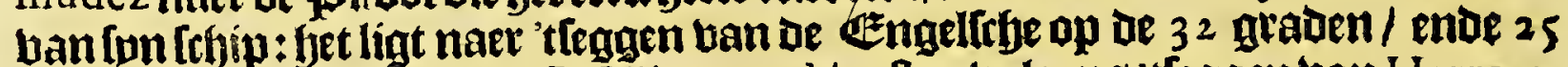

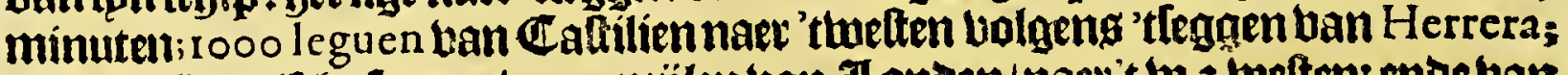

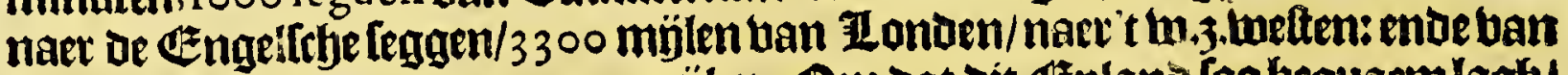

d. 4.1. 2. Roanoack in Virginia 0.3.0.500 mỉlen. Om Dat dit Eplano fao hequaemlagh/

c. 6 . op dekourg die De Uloten bouden komende ban Havana dooz de thate ban Bahama naet \$paegnien toe / foo hadoe den ltoninck ban \$paegnien al inden jare. 1 27. gettactjt daet renigh wolck te planten/ ende een contract tot dien epnoe ge= maeckt met Hernando Camelo \$oztuges / om daet een Colonie ban Spat:

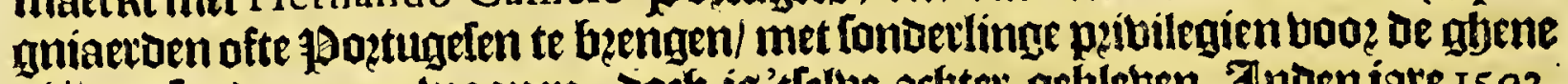

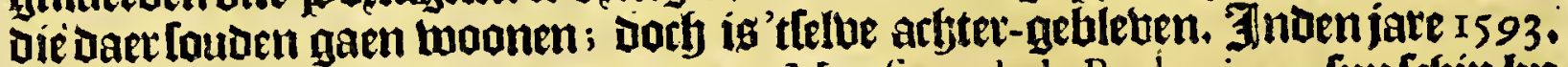
Eacl. betloozen f franteb Capitepn genaent Monfieur de la Barbotiere, [pnfthip be

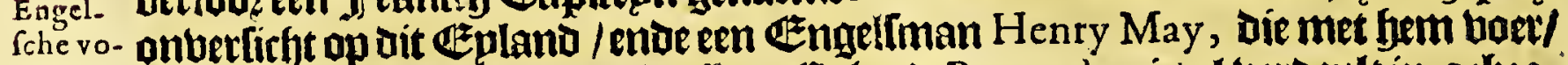

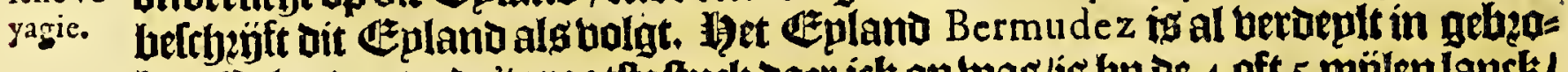

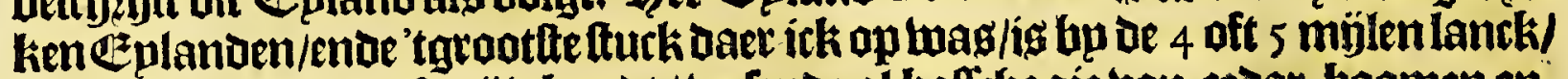

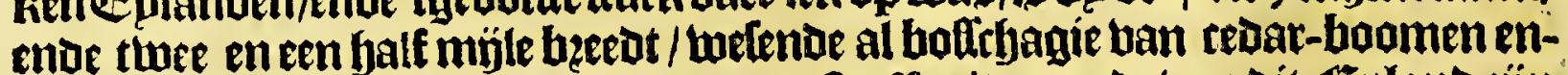

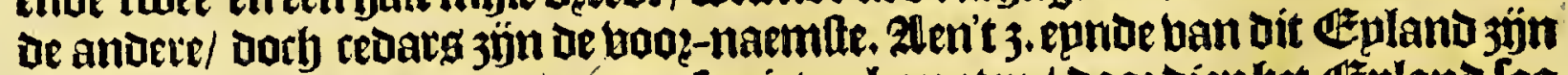
berckens / Doch] [oo maget Dátmen[e niet enkan eten / Dooz dien bet Éplano fad

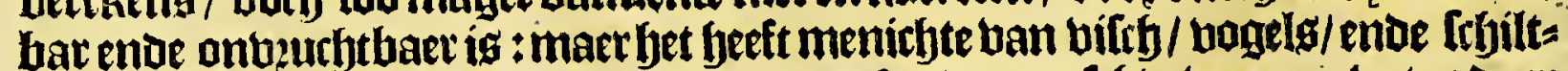

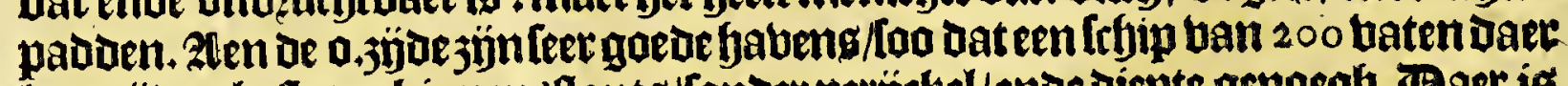
kan rỉoen betloten binnen 'lants/fonoer perijekel/enoe diepte genoegh. Baer is foo gaede peetle-viflecheje als pewers in

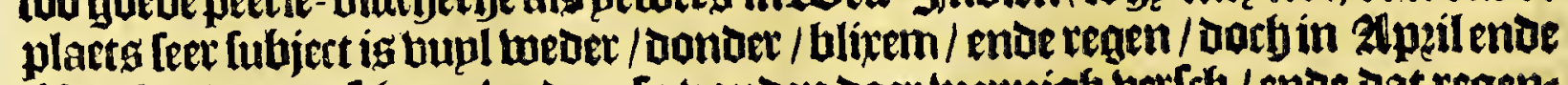

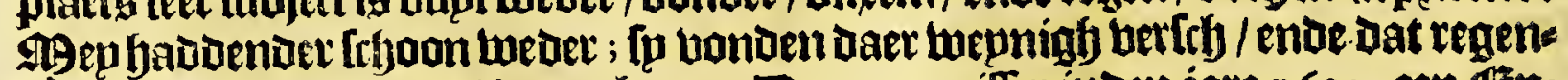
watel: dan daer jön ueel fraepe hapen. Baer naer iller inden jaxe 1609 , een efn=

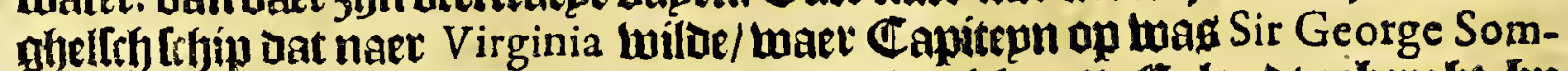

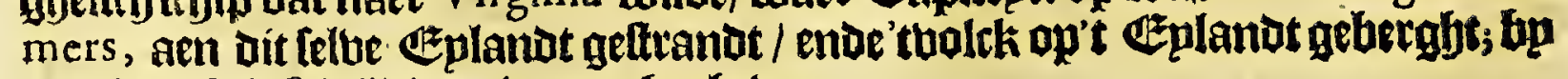
tuelclie oele belcheybinge is upt ghegbeben. 
Dit Eulano/ te Gueten 'tp2incipael Eplano met al De geb?oken Eplantekeng Daer aen liggende / jeeft oe fozme van een fjalf maen / wepnich ronder / enòe bec-

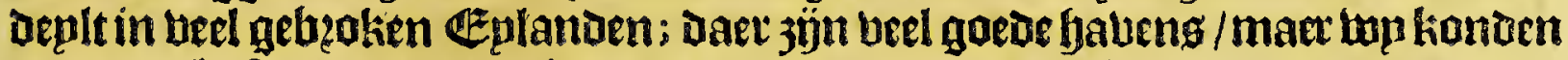
maereen bufonder plaets binoen om in te homen / tweick niet al bag en twas ban Dangier/Daer is Dep badem maters aen't in-Komen/eñ binmen 6.7. en 8, vademen;

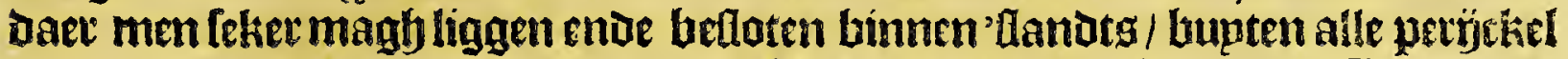

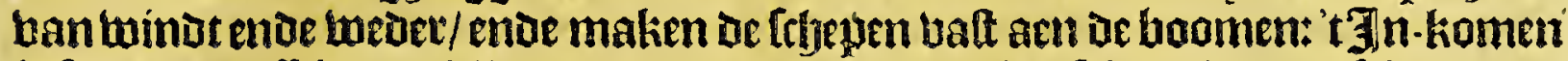

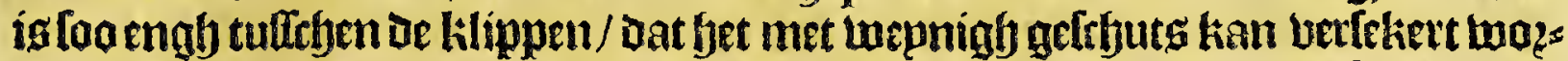
Den. Jaer ís meniggte ban hifry han diberffye footten/ [eer betende fmakelóth. Daer jän beel verckens / cnoe een footte tran vogelg/ foo groot als jupben/ die menichte ban eperen leggen op 'tano/[oo groot als himnen eperen:een ander [ooz=

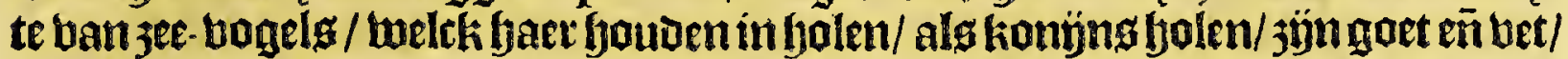
ende baet eperen lwit/ [oo datfe qualÿck ban der boenderen jön te ondertefjegden: oock reugets met menicfte / enoe andere klepne togelkens: men bint daet me-

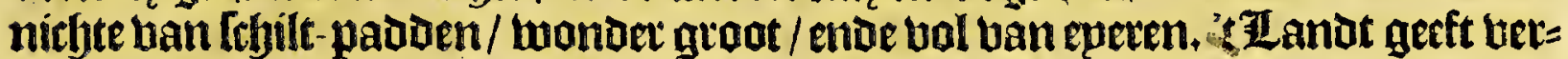

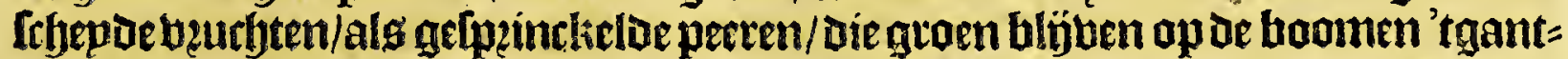

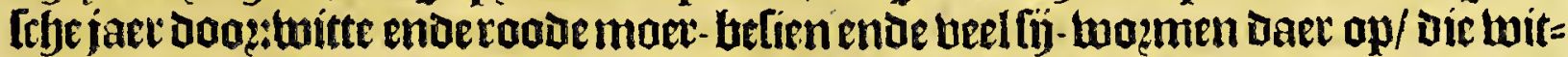

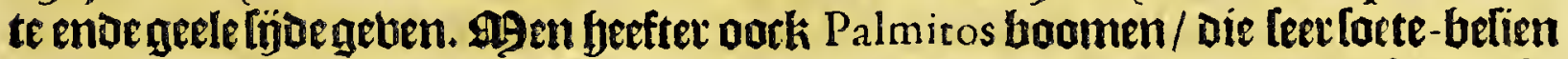
geven/ Daer de berckeng meeff op woeden: ontalligcke cesar-boomen/De tryoonfe ban ie twerelt / welcke een locte-Lelie dzagen/gaet am te eten: men bint daet oock peerlen feet fefjoon eñ tondt / als mede eenigb A mbergr is bande befte footte: groote

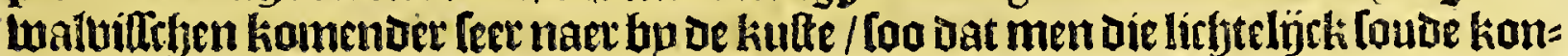

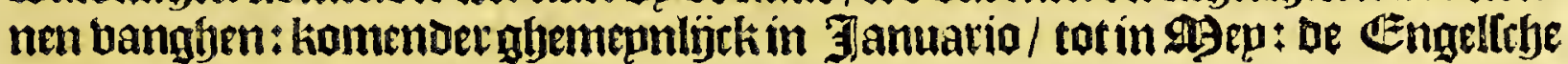
planten Daet nu Tobacco.

Jet Dęp-en-twintichlte Capittel.

Van de Colonien van de Engelrchen op de B E $x$ M V D E $z$ Eylanden.

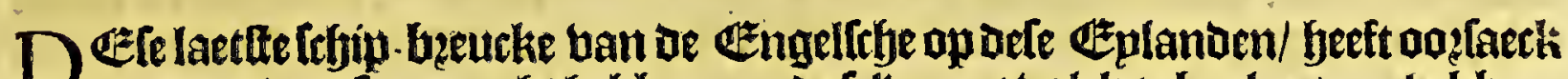

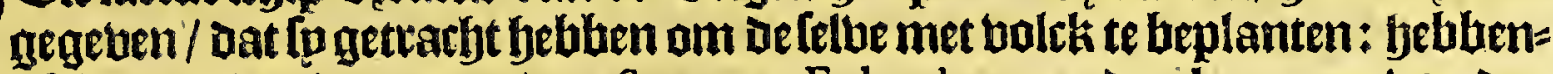
de de Lelue gegeven uen naem van Summer Eylandts, naet den bp-naem ban den

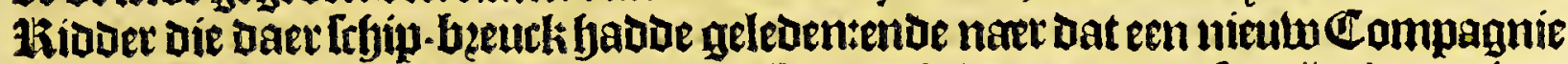

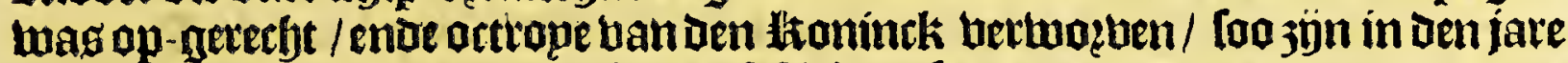

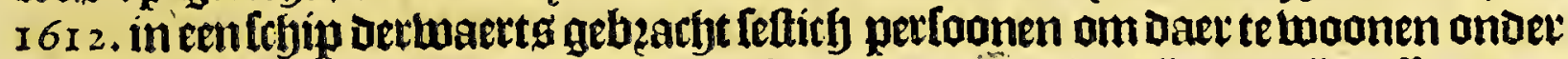
een Gouberneur genaemt $M^{r}$ Richard Moore; entoe ban tjot tot tijot iffer neet

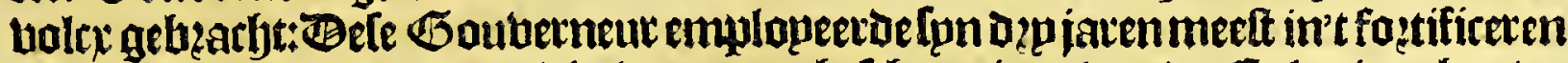

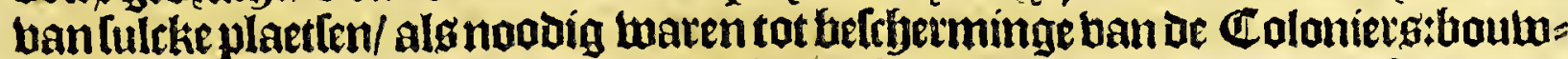
be tot dien epnoe wel negen aft thien fotteffen / ende plante daet glyefchut op :

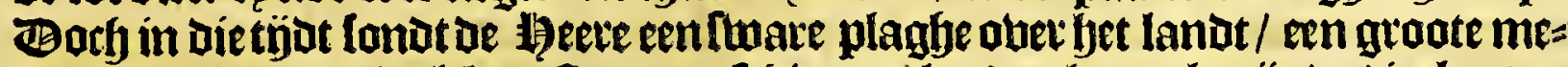

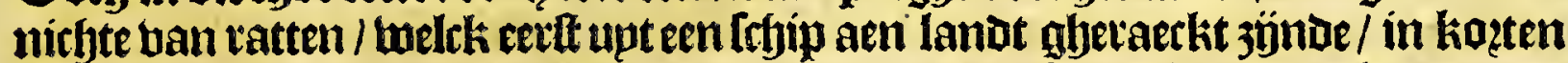
tỉat tlandt loo hebben berbult / Datfe alle de beuchten frbadeloog maeckten; ende

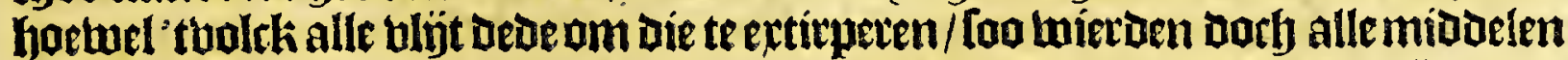

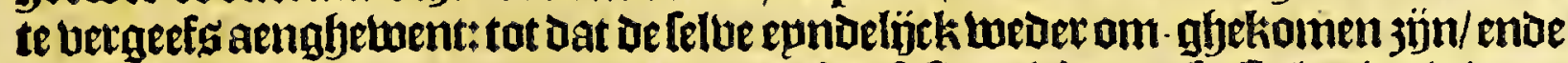

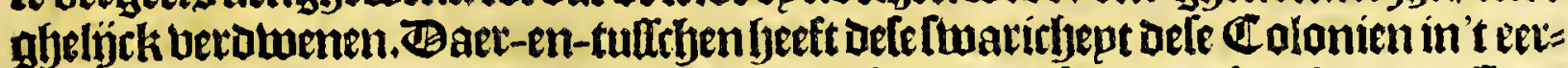
fte feer onder gehouden: Paet 3 jaren is in $\mathrm{M}^{\mathrm{r}}$ Moore fpn plaetle getiomen $\mathbb{C}_{\text {ap. }}$

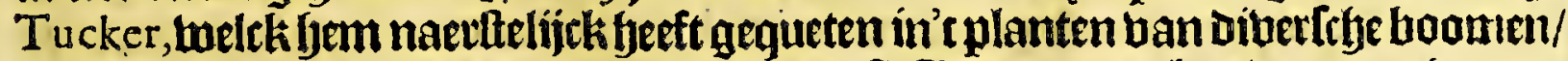

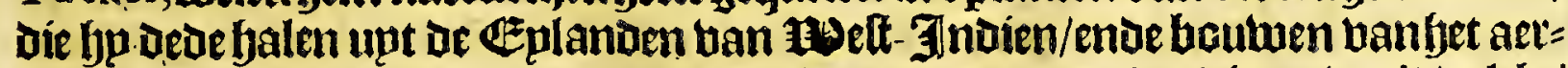

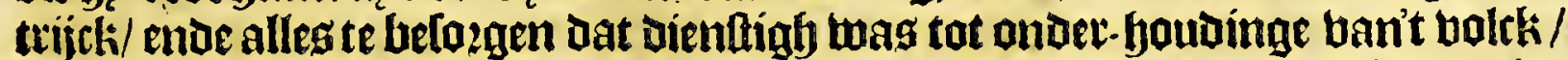
ende de commercien. In fpnen tyjor is mede een berbeclinglye ban't landt ghe maeckt / op dat een peder bande Coloniets ende participanten in of fe Compa= guie macht meten [pu contingent/endefjem begheben tot boutwen ban gup[en] eir berforgen'taene bannoode was tot onder-houbtuan fon familie. Inden jare 1619; ig daet als Goubetneut ghekomen Cap. Butcer, met biet tejepen ende D 3 ba ace 


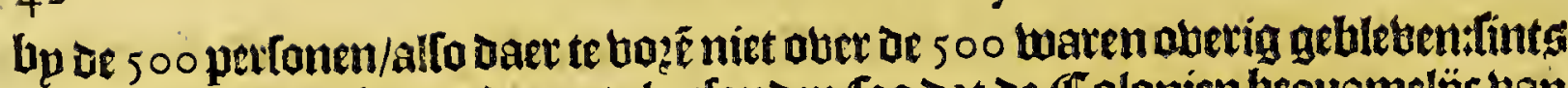
Dic tijt is daet nody meerder getal gefonden/too dat de Colonien hequamelÿc ban bolch booffen/ende alles in feet goede ozoze ig gebzacht:gelïrk 'trelue te fien ig bu

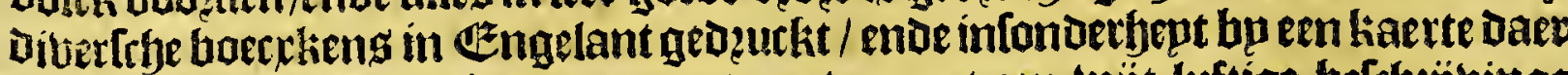

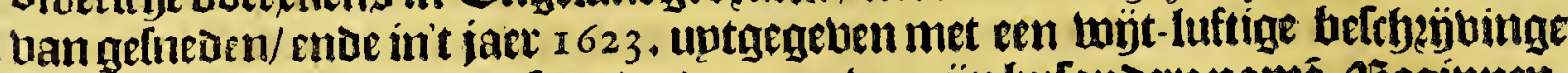
om de lianten bu weltke oele eplanden gegeben jün butondete namé. 25eginnen=

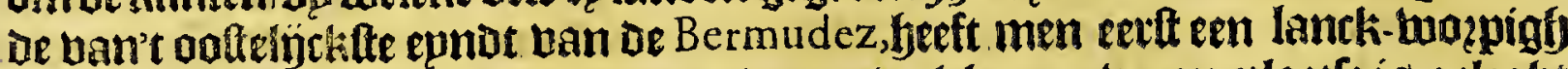

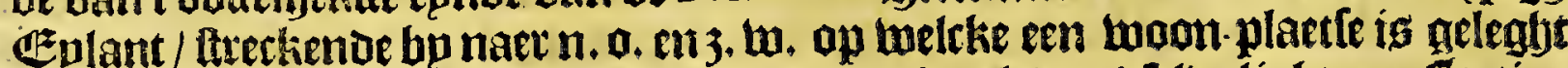
Die [n noemen Warvvyck Fort;ende op de n. o. hoeck ban'tlelde líght een fiotien

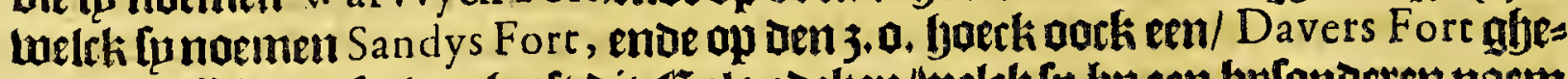
naemt:tullthen oefe thee freft dit Eplandeken/welckfo bu een bpfonderen naem noemen $S^{2}$, Georges Ezplant / [pn meefte beeedtte / ende loopt boozt naer' theffen fmallet enoe fmaller toe tot het weltelýcklte punt / welck fo noemen Burnt Point, ende ig bu naet in't mitouen gelÿck Dooz-gefneden ban een kromme bape / die fu noemen Worfenholm bay, ende bp Burnt Point ap den. jÿue feeft feet een ander filepne bape / Diefe noemen Whalebon hape; teghen ouer oen 3, o. boekk legt een ander Ezplandeken/enoe noef thee ffoetjeng/aiele noemen Cavendish Fort ende

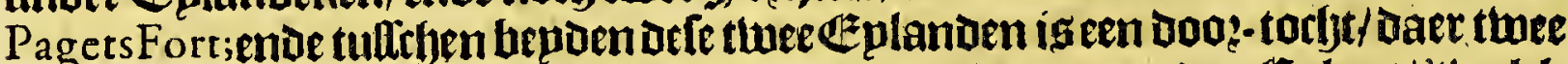
klepne Eplanoekeng in liggen; boozer naer' $\mathbf{3}$ 3.0. Iegt een ander Gplant/'twelck

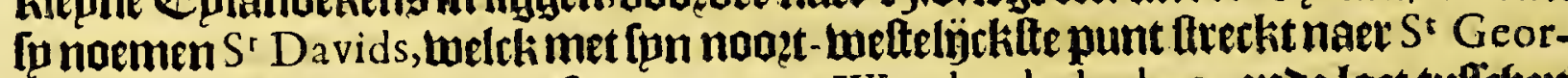
ges $\mathbb{E}^{z}$ plant/ende komt te refponderen op Worshenholm bay, ende laet tuftryen bepoen een binmen-water / in't welcke light een tamelïck E Elanoeken / melckfo noemen Smits Eylane, ende twee ofte dep Kilepnoer ezplandekens. Ban biec om:

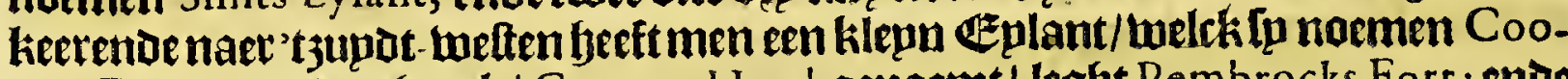
pers Eylant; op den fjoerk/ Gurnets Head genaemt/ leght Pembrocks Fort : ende

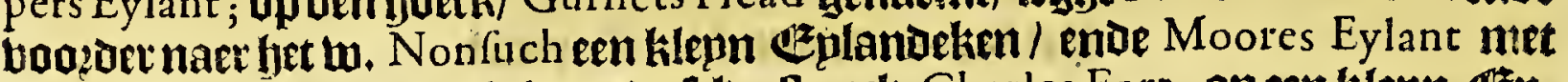

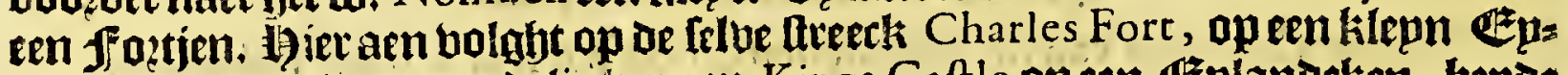

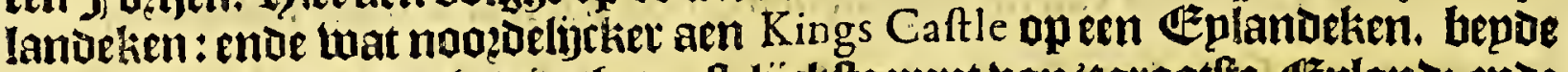

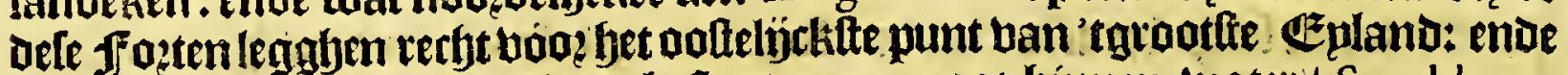

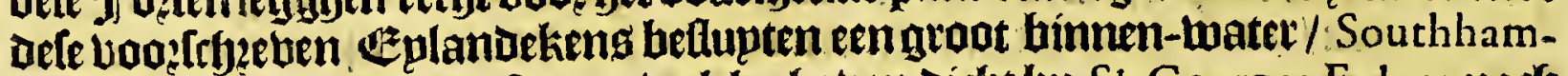
ton Harbour, in't binnente ban weleke haben dirbt bp S' Georges Eylant north

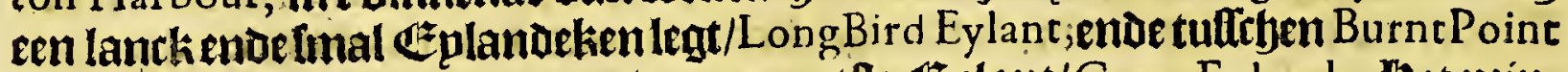

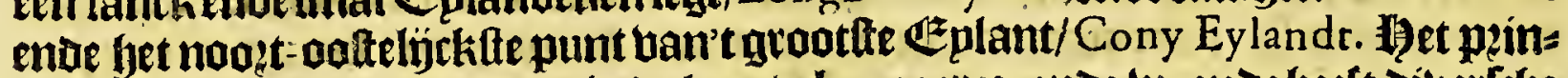
ripaelfte Eplant frectit bein in of lengte bp naer o, ende tw. ende lyeft biberferbe uptftekenoe boerken / kromten enoe binnen-Lateren : fet ooftelÿcklte deel

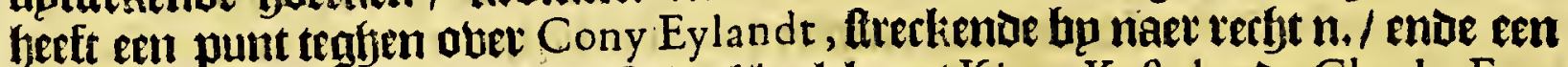

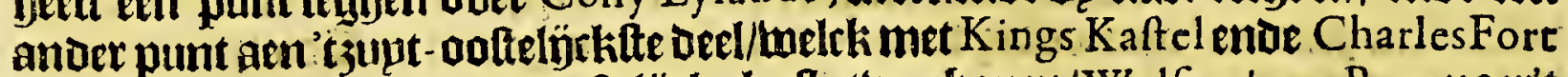
ober een komi/ ende op fun ooftelïcke kutte twee bapen/Walfingham Bayenaert noozoentoe / ende Stokes Bay naer't3upden/bepDe hinnen Southhamtons Baye: ende by Stokes Bay een blerke Tuckers Tovvne. Dit ooltelïcklte Ded ban't $\mathbb{C} \mathfrak{p}$ : lant feeft een groot binnen-water/ Harington Sound, in thelck men kamt baog een feer enge kille/welck fp noemen The Flatts, ftreckente bp naet n. m.ende 3.0 .

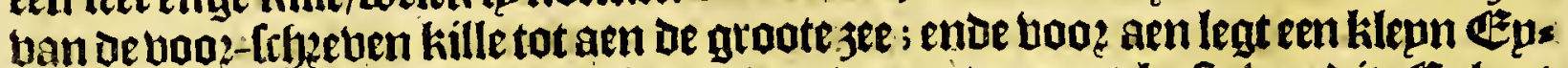

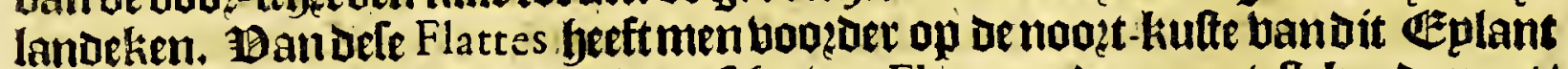
bu naet in't midoen tufteden de booz-[rfyeten Flattes ende een upt-[tekende punt/ (Spanifch Poine) eenplaetfe genaemt Brakifch Pond, Daer een doep bpleght; ende boozts uaer bp het vooily. punt A bbots Bay : dit punt ende de Flattes liggen boat

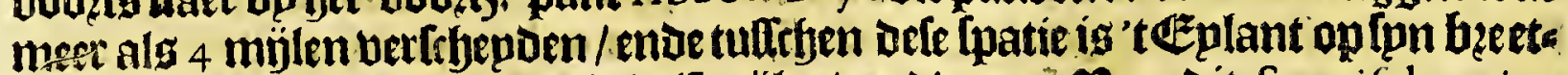

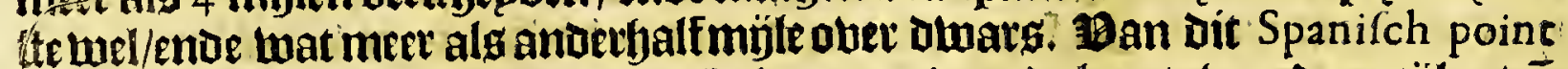

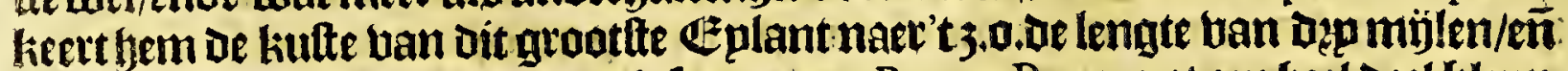

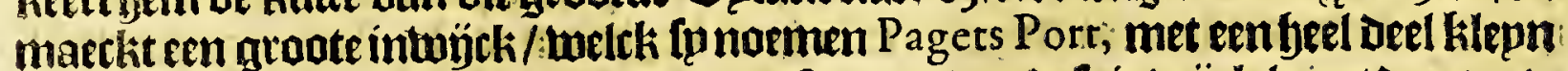

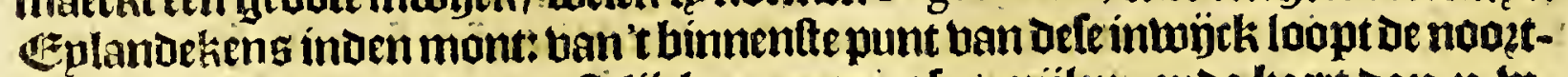

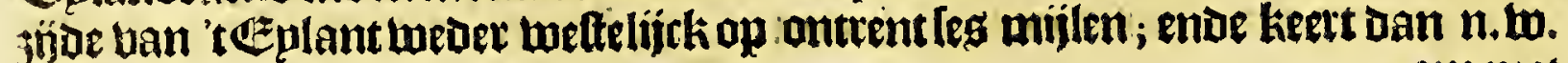




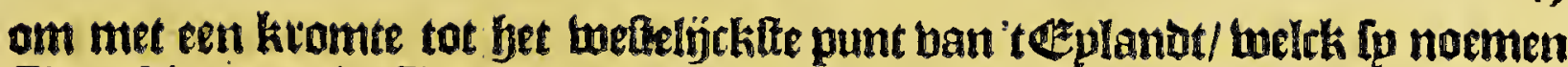
Flemifch Wreck. Tetgen ober dit point naer't n. o. Legt enklepnoer Eplanat/

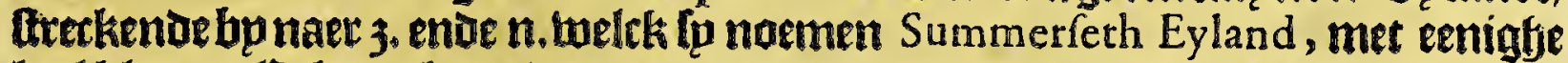

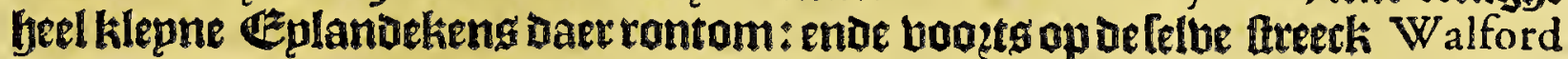

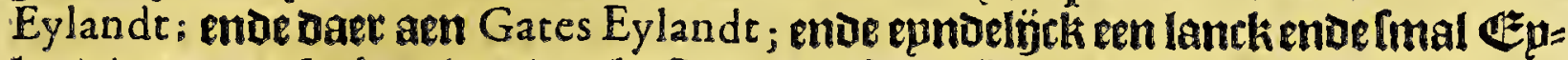
land/genaemt Irelant:ban de 3. Kulte uan dittmal Epland tot aen't Spanish Poine

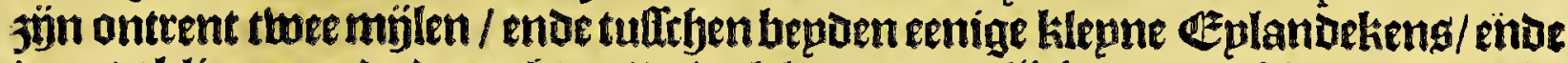
booetg klippen enoe dzooghten / oe twelcke een tamelijcke groote bimmen-lantfobe 3ee beflupten/welck [p noemen The great Sound, in jet welck oock eenige klep=

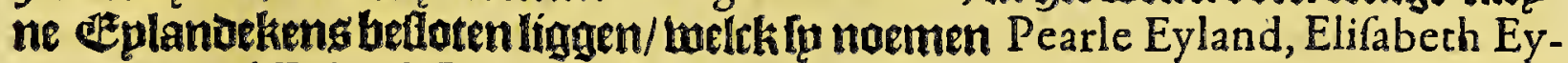
land, Dorrel Eyland, Brothers Eylanden, ende dietgelp̈cke: ende Daer jün noch twee baten / twaet ban oe eene bp naer in'tmidoen van bieftreeck Ieght/genaemt Whithearne Bay ; ende d'ander bp naet aen't epnoe bande kromte George bay:

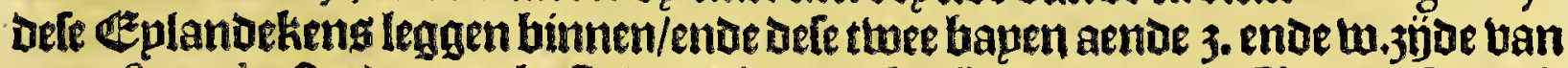
great Sound. Op De jupt-kufte van dit grootfte $\mathbb{E}^{2}$ planat / van Charles Fort af/

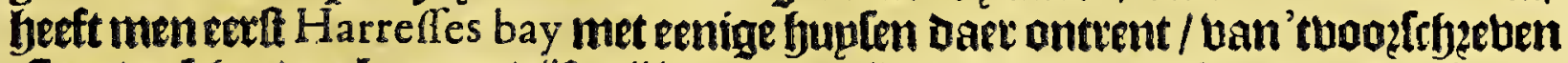

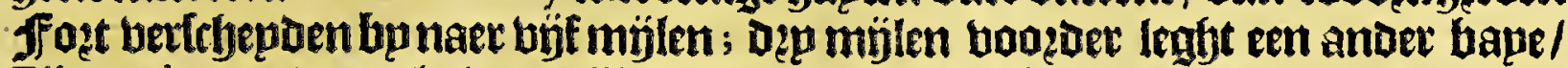
Elbow bay;ende nord twee mijlen voozer naer' tweften Grear Turckle bay; ende

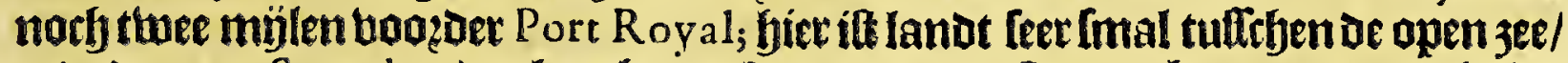
cnoe de great Sound, enoe 'tlant bupgt hem doo? 'twelten om bp naet als een yalue mane tat aen yet Flemifch Wreck. Be 3. w. hoect is fooghen ferbt als de Lyfart, dan luat booger / naet dat bebonoen ig bp ender die in't jaer 162 I. met een

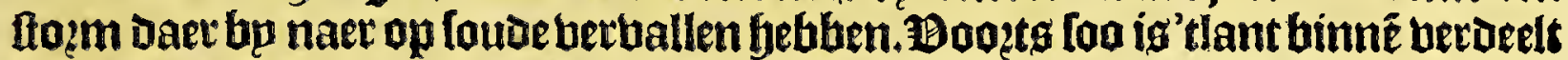
in ander fmaller gedeelten/ Die bup hier fullen booz bu gaen. Toaer bp dan blijctit Dat de Bermudes fertint beel Ezlanden ende ghebzoken landen onoer lief bethatten/ die alle niet beel gronog upt en bzenglien.

Mat viex-an-twintichte Capittel.

$$
\text { Voorder verhael van de gheftalte van'tLandt ende de Lucht. }
$$

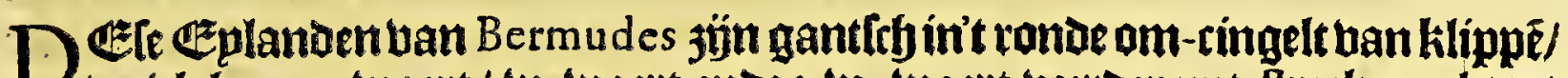

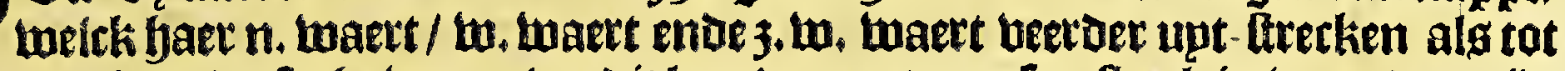

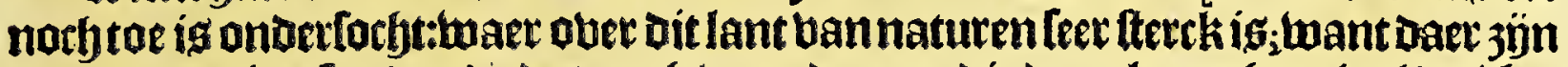
maer twee plaetfen/ (entie dat notg vooz de gene die de gelegentfept geel tuel be=

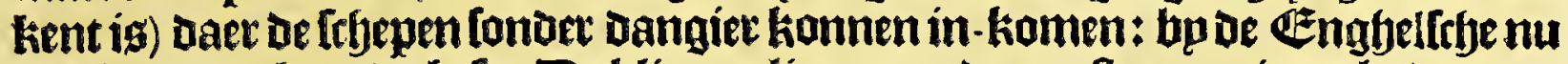
fterck gemaeckt enoe befet. Be klippen liggen op de meelte quartieren bolien met

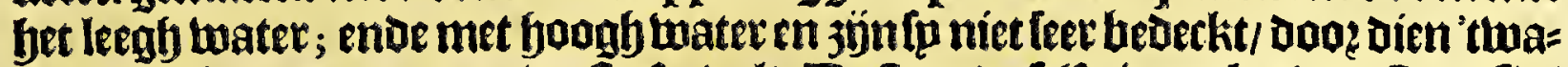

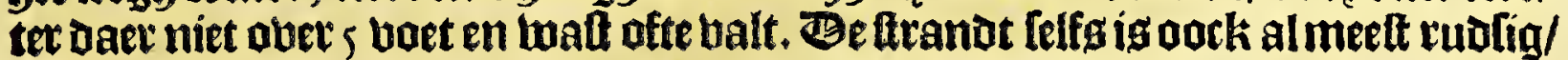

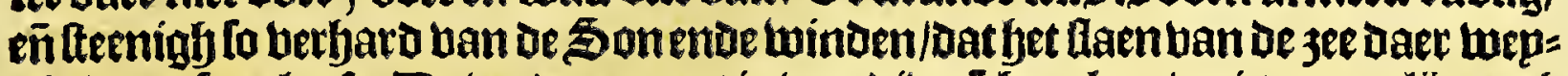
nigb hatte opljeeft. Be boztere gront is ban diberftye coleur/en is epgentlibe norb

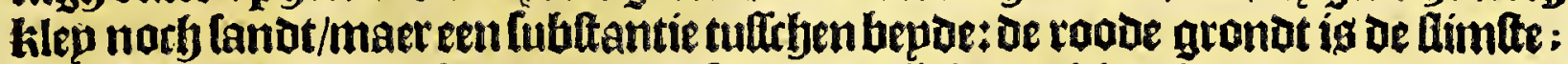
De bleecke gelinckende Lanbe/ ende detharte gelinckende klep/is goet; Dan be beup:

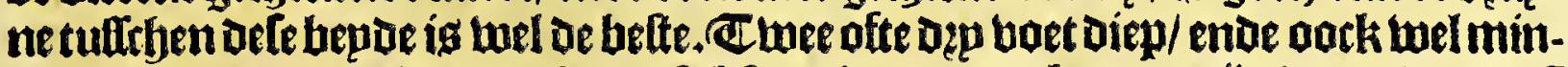

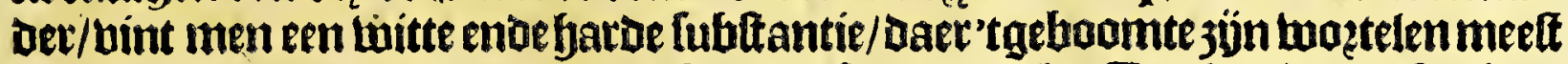
in baftet/entoe oock apparentelijel fpn boetfel upt-treckt. Cen is niet wel loo fart als fteen/endenorbtang harber als tteen-kalek; [pongieus ende bol follicheden als de pumm-lfeen / foo dattet veel borbtichept bat ende lang befjoudt: Jaer iflec oack welcli farder ende bafter ig/te tweten/onder de roode grona/belck op eenlegt

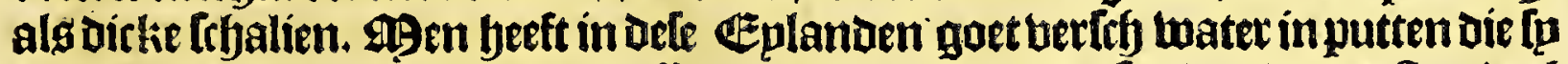
graven/ [ountijots geen 4 oft 5 paften ban oe jee-ftranot; foo dat De meeften ded van dien vloepen ende ebben / gelijck oe jee telfs. Be lueft is doot-gaeng klaer /

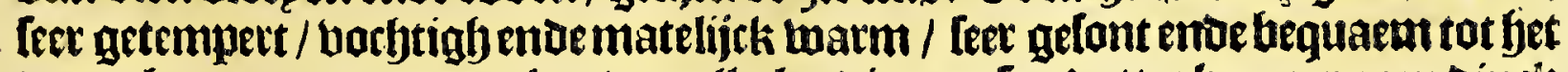
bootc-berengen enoe opqueken ban allerlep dingen; foo datter bp naet geen binck

ban 
44

VandeWeft-Indifche Eylanden.

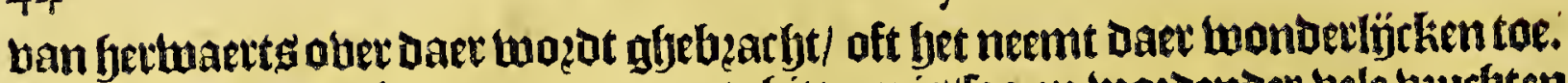

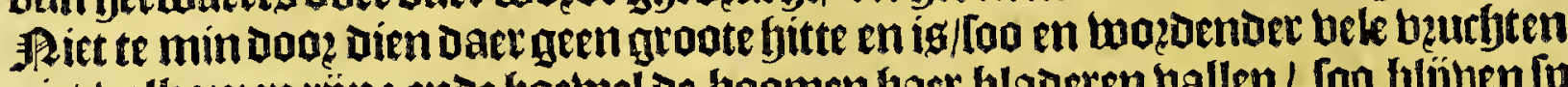

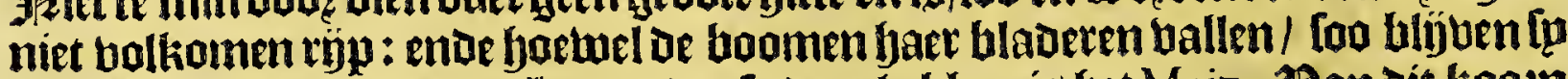

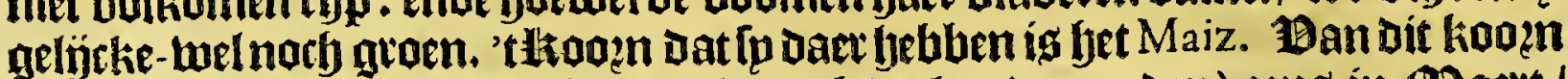

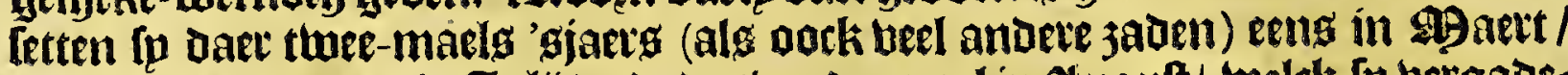

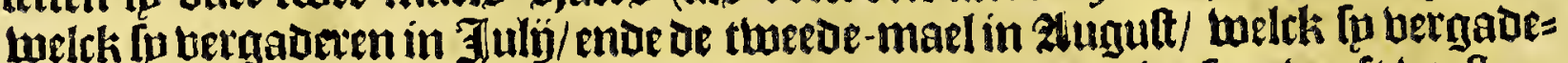

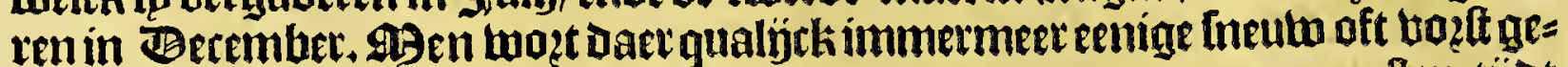

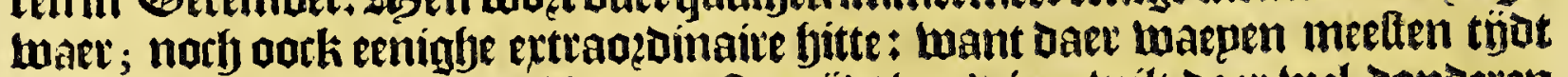

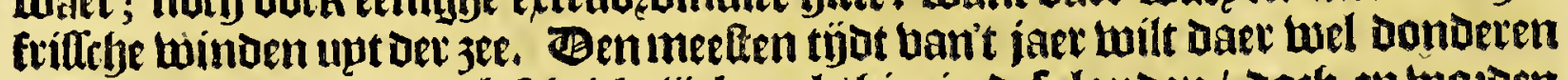

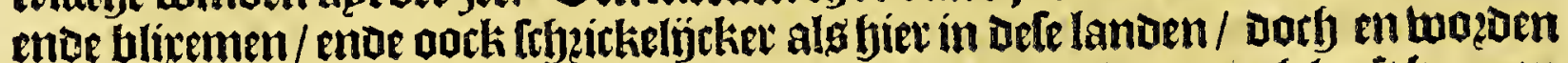

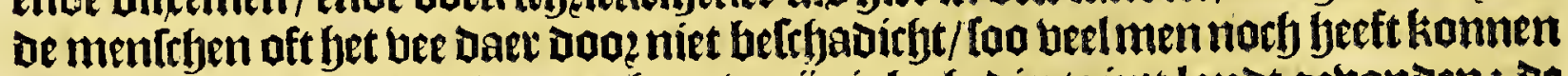

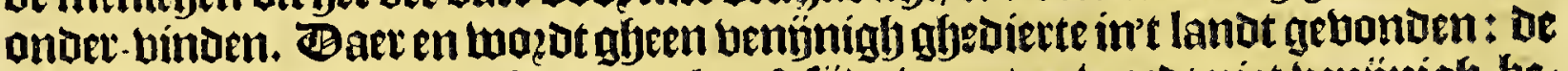

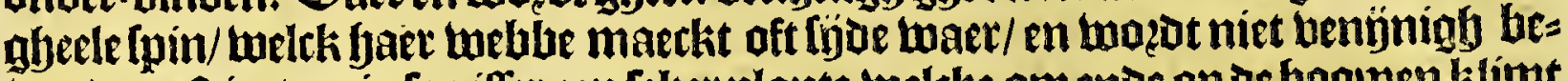
bonoen. Riet te minfoo iffer een feker plante welcke omenoe op oe boounen kímt

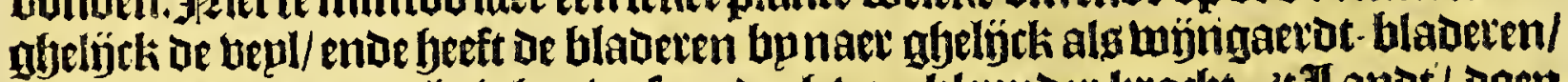

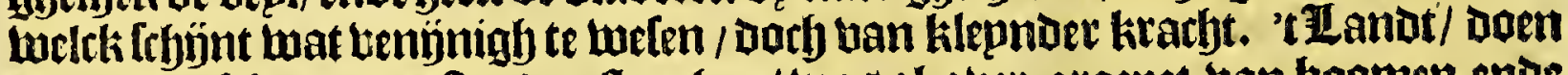

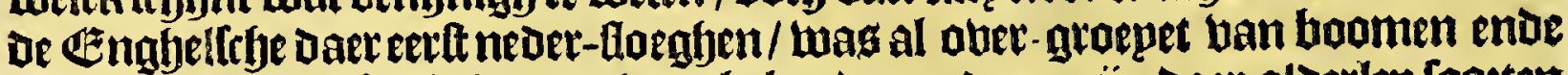

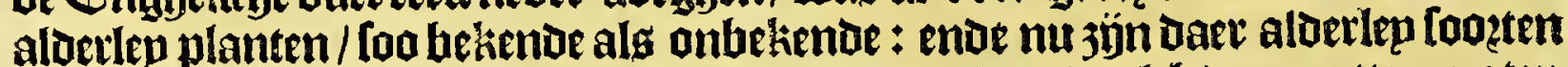
van frupt-hoomenenoe kitupt abeb bacht ende geplant / melck Daer uptter-maten werl toe-nemen. In oe wateren ende de jee daer rondt am / ber is grooten ober=

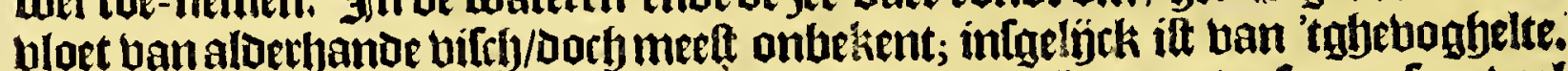

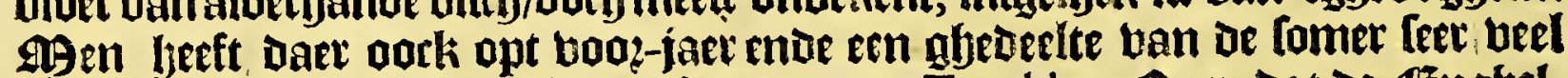

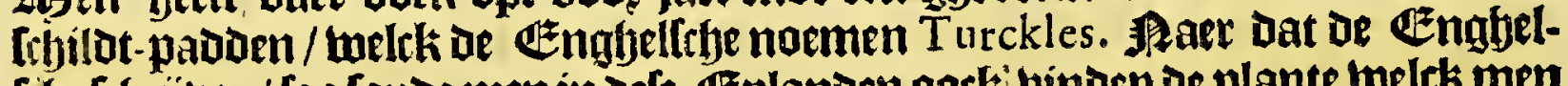
[the fryeyuben/ Loo foude men in Defe Eeplanden oork; binden De plante welck men in Weit- Indien Nuchtly ende oork Tuna noemt / Daer oe Couchenille in Nova

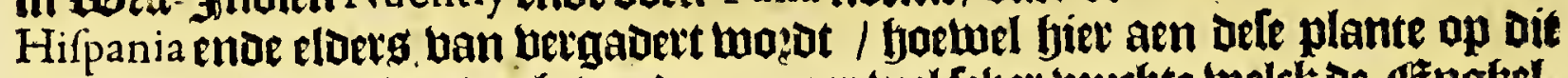

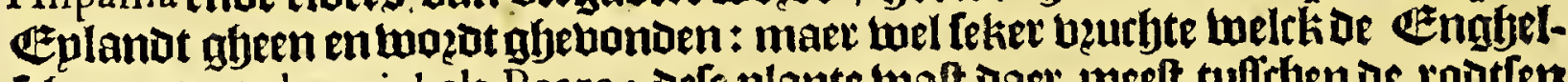
Ithe noemen the prickelt Peare : Defe plante walt Daev meelt tufthen oe rootten

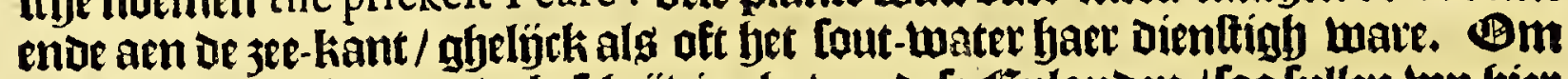

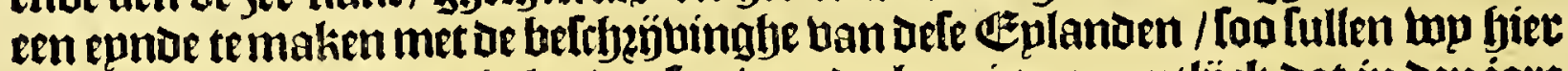

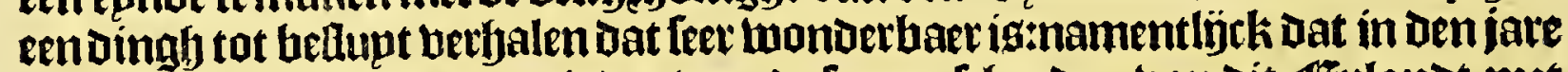
1616. bijf perfconen in't midoen ban de fomer fethepden ban dit Eplanot met

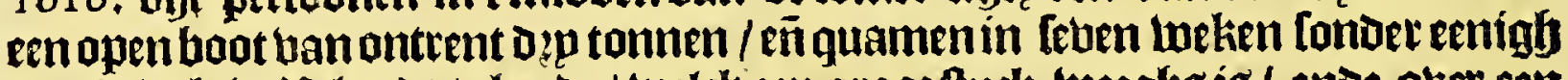

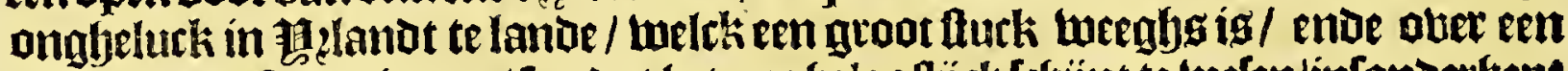

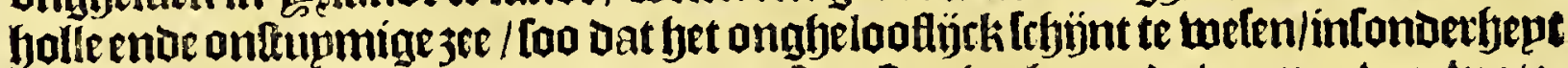

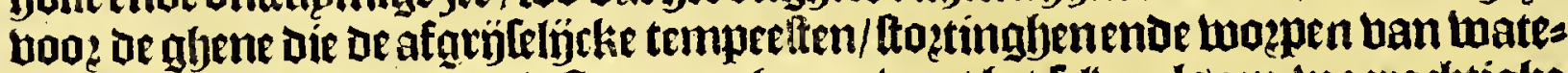

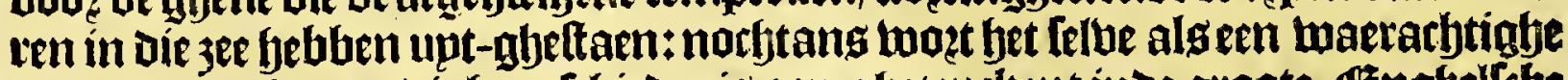

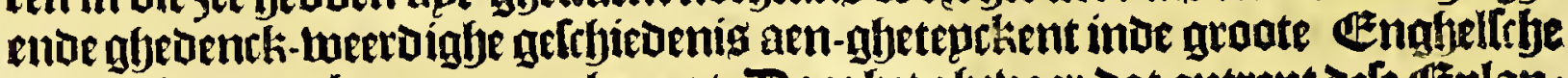

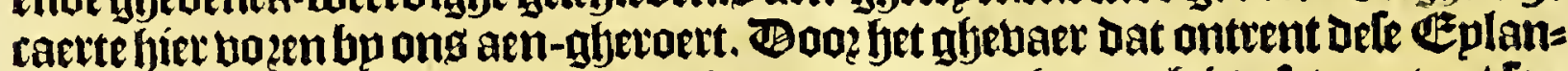

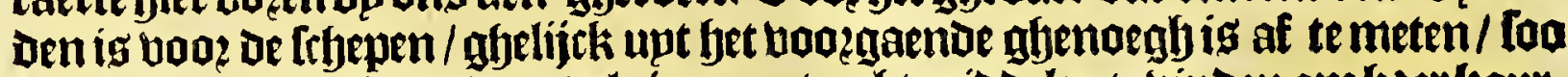

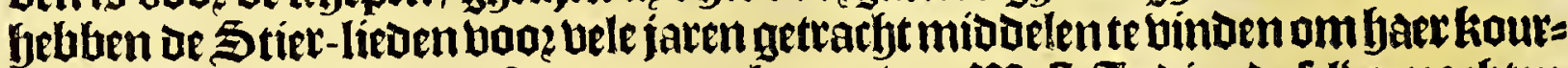

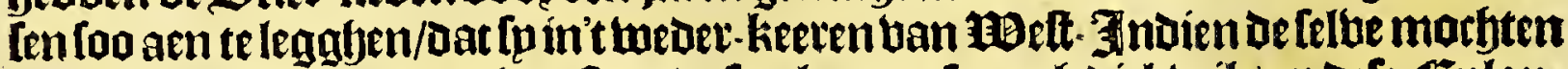

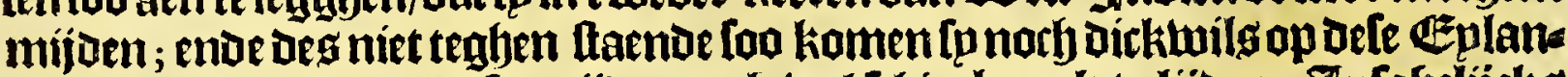

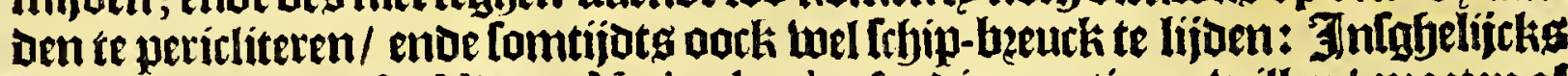
Die naer Virginia ofte Nieu w Neder-lande ofte die quattieten millen/ moetenal

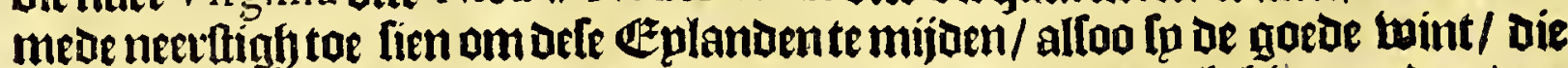

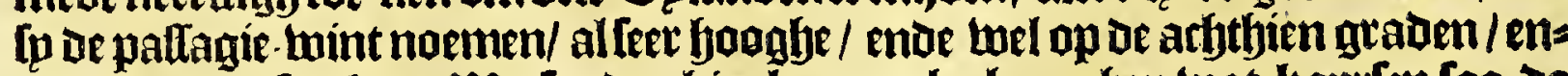
De meer gaen Loecken: ABp fouden bier komnen bu bzengften wat kourfen foo de Spaenuiaetoen als anoere natien hetiben beraemt om dit perȳckel te mijoen enoe tr ontgaen/ dan alloo de take tujot-luftigh is / ende van een verte ander bes

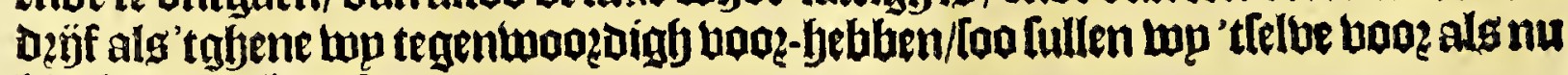
bier bu laten berulten.

BESCHRII- 



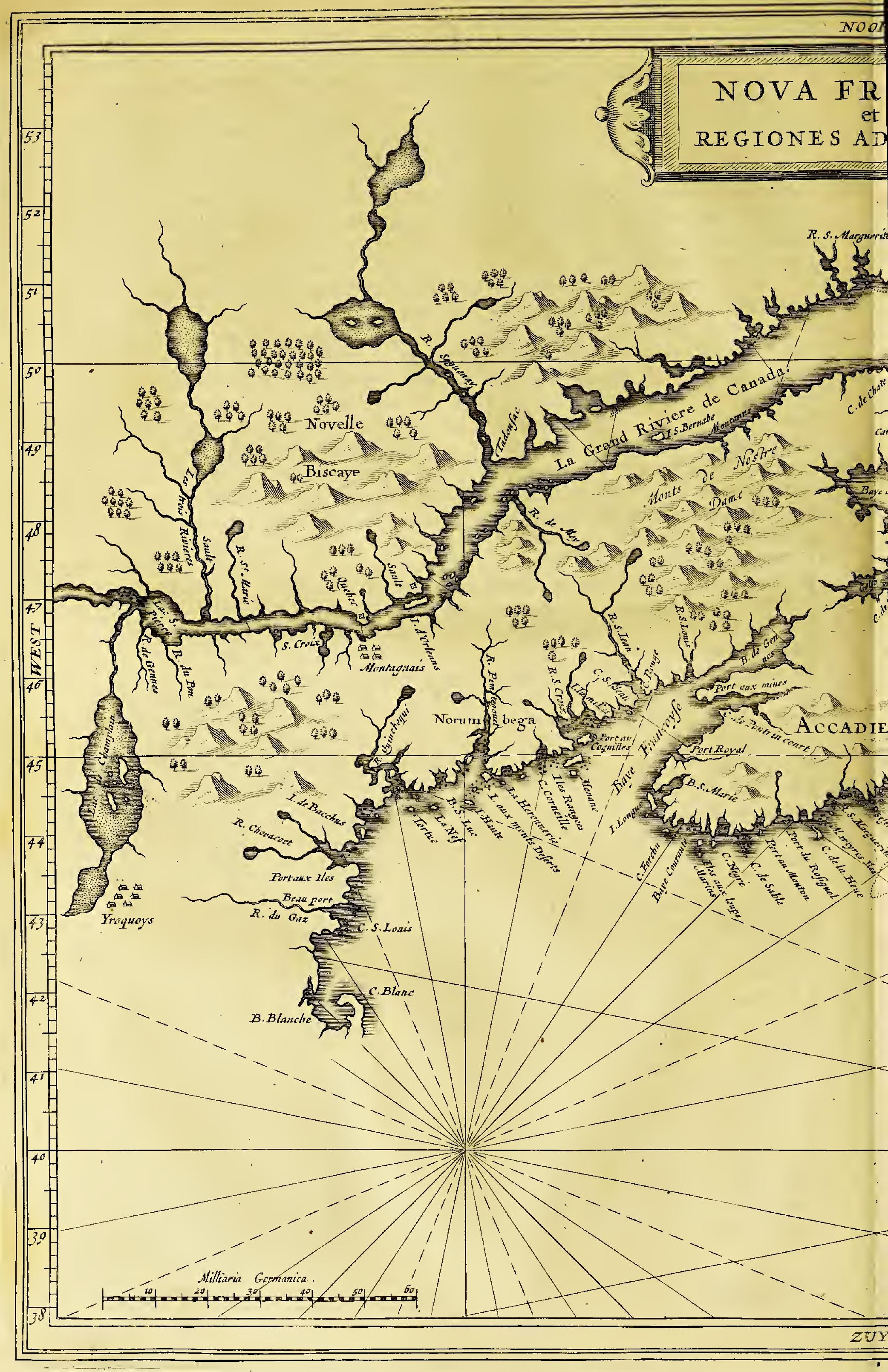



BESCHR IIVINGHE

\section{สan \\ W E S T - I N D I E N}

湔et tweede 15 aech.

\section{NOVA FR A N C I A.}

\section{Inlepdinglye.}

I. 2 bebben in't voor-gaende Boeck befchreven de Groote ende Kleyne Eylanden van $V V e f-I n d i e n$, de voelcke by naer in't midden ende tuf20. S. Schen beyden de tvvee gedeelten van defe nieuvv ghevonden voerelt inliggen: Soo dat voy nu volghens de repartitie bier pooren gemaeckt, fullen voortparen tot de befchrÿpinge pan bet noorder-ghedeelte van VVeft-Indien, vvelck in fich vervat eenighe vrel bekende, doch meeft noch onbekende ofte ten minsten vpeynigh befochte Landen: vvant wyt-genomen bet landt van Nova Hifpania, ende de dependentien varz dien, van de noordi-zee tot de Golfo van California toe, ende de Landen voelcke in de lengte van Nova Hifpania naer Panama toe frecken, voelcke alle redelücken bekent ende door-focbt zïn; foo is de refte van dit groot quartier alleen op de kufte, ende bier ende daer een voeynigh te landtvvaert in, by diverfche natien van Christendom befocht gevveeft: VVy Jullen onfe befcbrïving be beghinnen van' tnoorden, ende fookomen naer'tzuyden, doch niet foo booge, dat vvy daer in fouden trecken de landen aen den Pool gheleghen, ofte de diverfche Straten ende in -vvöcken, door de volcke de Engelfche ende andere natien bebben ghetracht een uyt-komste of te door-ganck te vinden in de zuydt-zee, de vpelcke men tot noch toe niet en beeft konnen rividen; maer. fullen beginnen van de Lainden die op de boogtevan vier ofte rüjf-en-vïftigh graden zïn gheleghen, de rvelcke men ghemeynlijck Nova Francia noemt; niet om dat dit Landt eyghentlijck by de Francoifen eerst ont decke is, p.pant foo voy de eerfte onitdeckinghe wan dit Landt voillen naer Beuren, fullen voy bevinden dat eenighe jaren voor dat die van Britagnien ende Normandien in deje quartieren bebben beghonnente paren, een deel van defe kufte bevaren is by Sebaftiaen Cabota Venetiaen door bevel ende op de koften van den Koninghrvan Engheland Henrick de vi1. ende vpeynigh daer naer inden jare 1500 breeder is ontdeckt ende bevaren by Gafpar Cortereal Portugees, uyt laft van den Koningh van Portugal. Doch is den naem van Nova Francia dit quartier ghebleven, door dien't felve vele jaren by de Françoyjen is gefrequenteert, neerftigonder-focht ende op diverfche tïden met polckis befet gemeeft. Nova Francia dan is dat ghedeelte van bet noorder quartier van $V V$ eft-Indien, (naer't fegghen van

$\mathbb{U}^{*}$ de Fran- 


\section{Nova Francia.}

de Françoifen) voelck tuffchen den veertichsten ende vïf-en-vïffichften graedt noorder breedtte begrepen is; boe pvel het eenig hetot den festichften graed extenderen; fyn lenghte is onbekent naer' tvveffen; ende boe verre de Franogijen tot diver/che tïden zïn ghekomen, foullen voy bier naer verbalen: Ramufio beeft in fyn derde deel een kort verbael wan een François (ghefchreven noer 'tblijckt in den jare 1539.) de vvelcke fegbe dat Cap de Raz, vovefende de oofelïckste van 't Eylandt Terreneuf, legbt op de lengte van veertich graden rovefel ijcker lengbte, begbinnende de gradente rekenen van den meridiaen van de Eylanden varn Cabo Verde : ende dat van Dieppe in Uranckrïcktot de voorfchreven Cabo zï̈n feven bondert ende feftich leguen, freckende meeft ooft ende vveft van den anderen. Dan eer poy komen tot poorder befchrÿpinghe pan Nova Francia, falt van noode vpefen dat woy al vooren Jpreken van de Eylanden die daer voor gheleghen zün, vvelcke met een ghemeyne naem ordinaerlijckvvorden ghenoemt Terra Nova ofte Terreneuf, dat is, niew-ghevonden Land t; hoevvel eenighe vande felve Eylanden oock baer befondere naemen bebber.

\section{TER R A N O V A.}

(get eetfte Capittel.

Generale befchrijvinge van Terreneuf, de gheleghentheydt van 'tEylandt, gheftalte van't Landt ende de Lucht, ende anders.

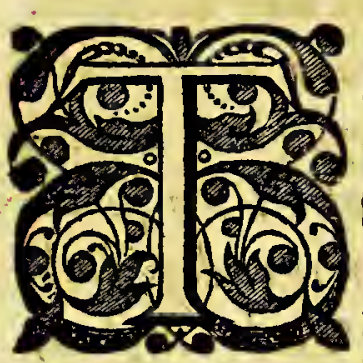

Erra Nova ofte Terreneuf, (welck de Utnahelrche noemen Neuvv-fond.land) if een Equlanat berffreppen van

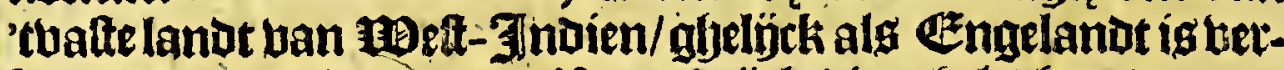

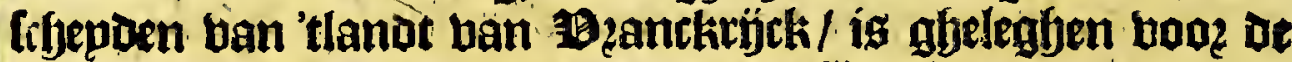
Golfo ban S: Laurens, ende de groote Thiebiere bau Canada, tufleffen de Leg-en-beetricty graden / ende de Dep-en-büfticty gras

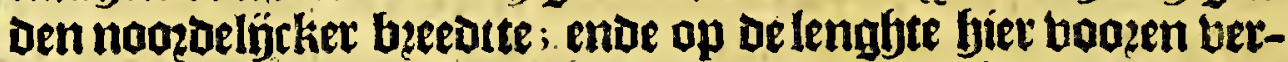

Engelfche ro

yagie derde decl.

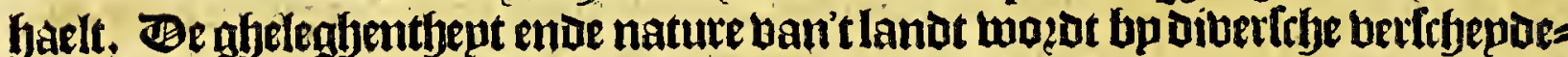
lijek brefryetuen. Stephanus Parmenius. Budxus, Die daer tmas inden jare 15831

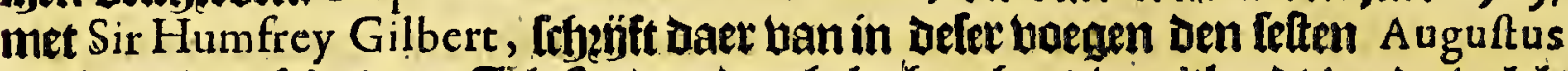

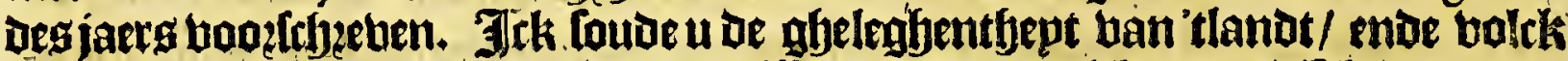
werbalen / Danen fien niet Dan wildoernitten : bier is menichte ban bifth Daer men

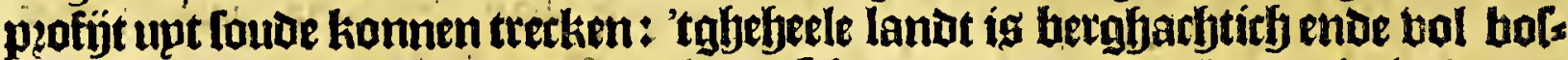

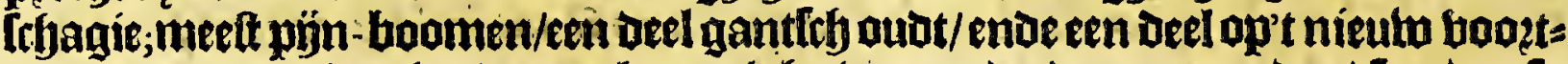
komende / baer legghender aock menighe ban ouberdoum ter neser / loo bat fo

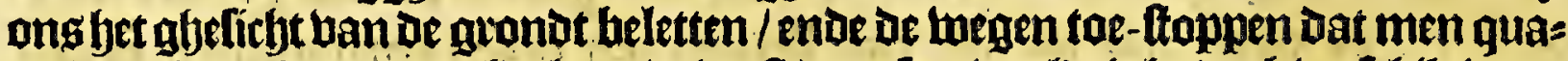

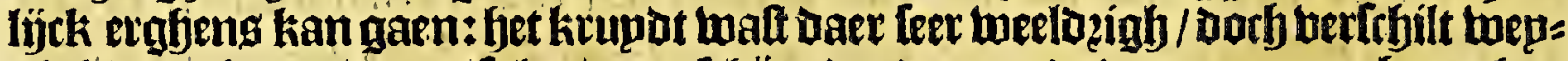

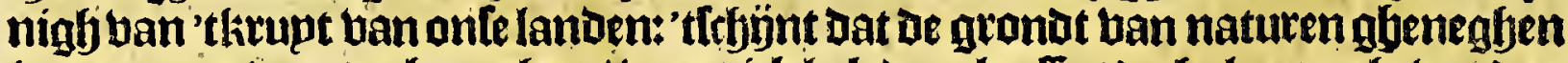

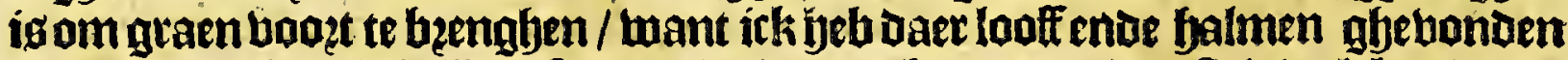

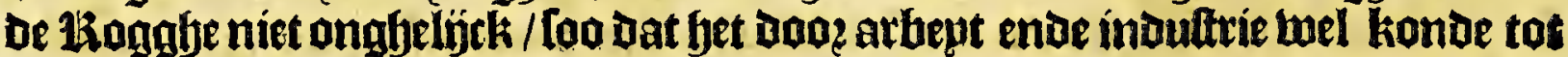
nut ghe boubuet woetoen. Baer komen altemet bepzen ontrent de buplen / Die bp

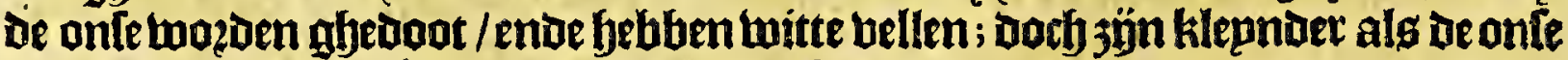

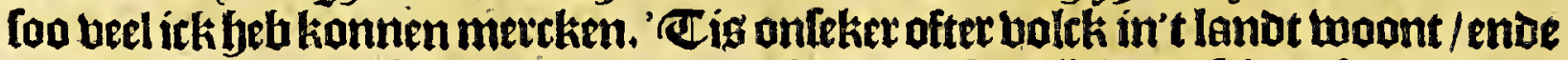

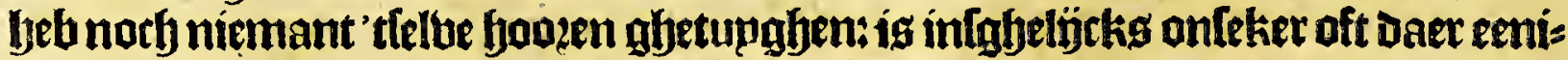

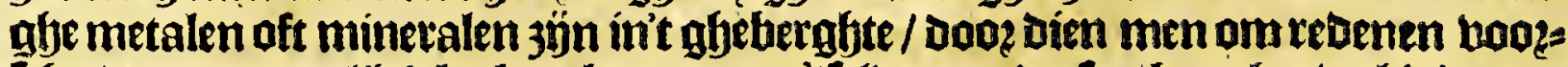
Ifbeeven Daer qualijtk bp kan komen om'ttelbe te onderfoecken: boetwel in't aen: fien lebjunt datter welmineralenmarbten wefen. 
Het rvveede Boeck.

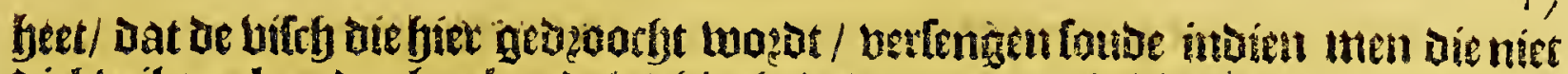

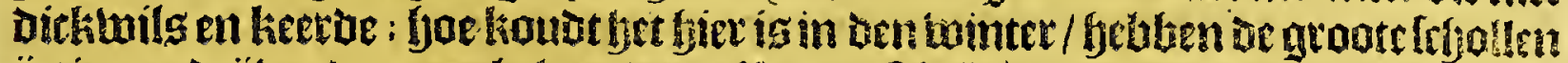

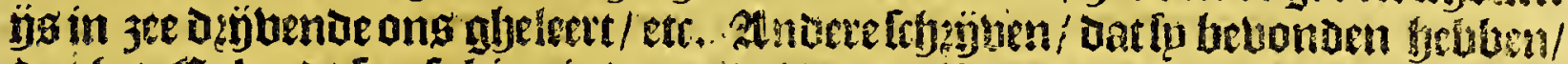

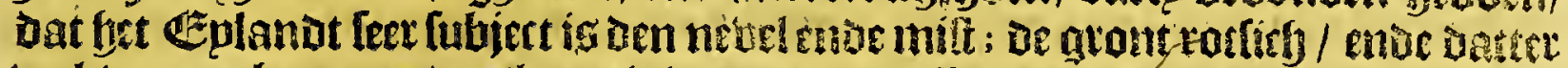

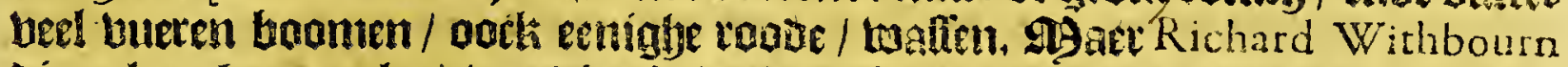

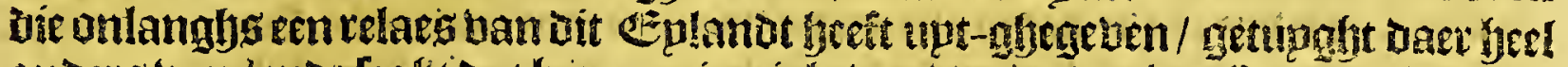

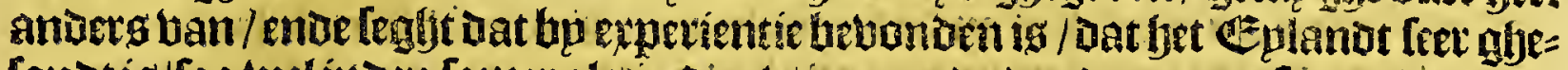

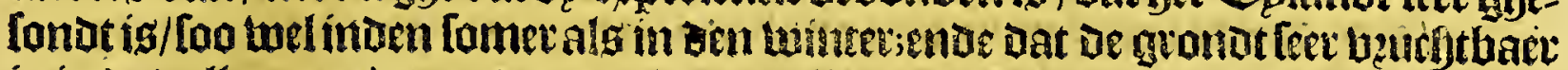

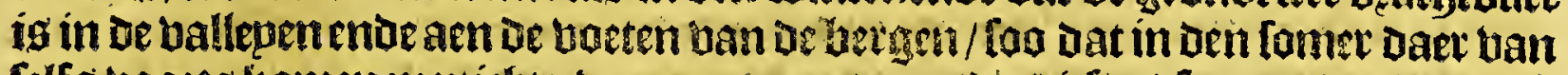
felfs booktg komen meniclye ban graere etten ende bitlen/ foo tonot/ bol ende

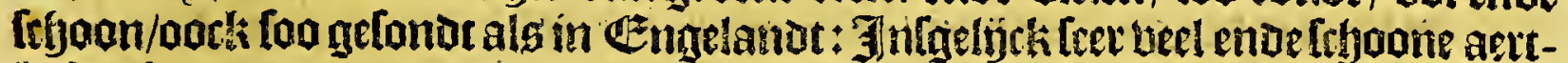

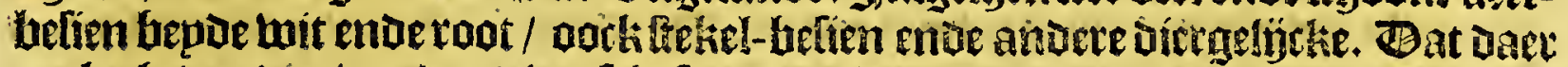

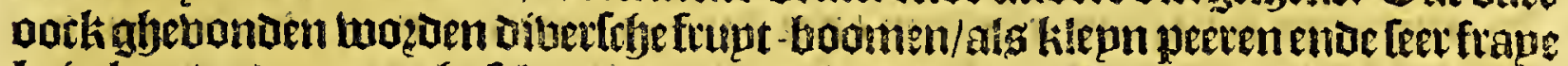

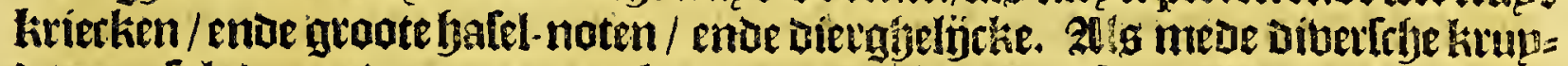

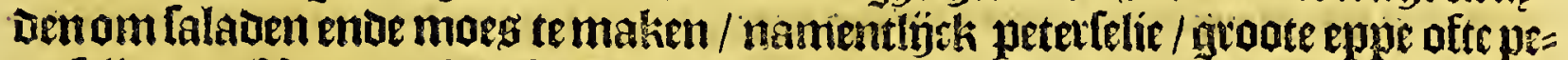

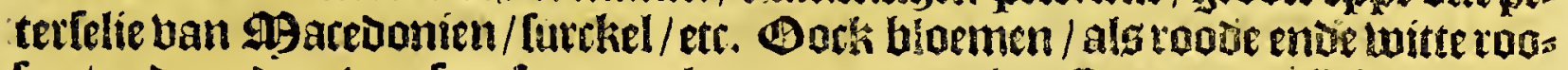

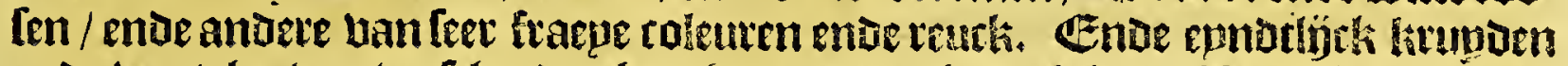

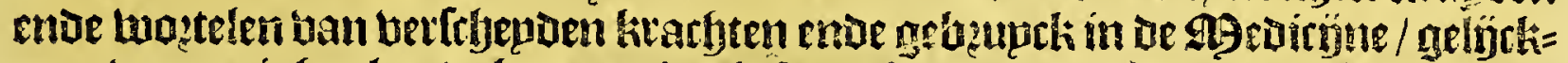
men baneenigbe al vede bp experientie [aude betonoen bebbem/ naer fun feguen.

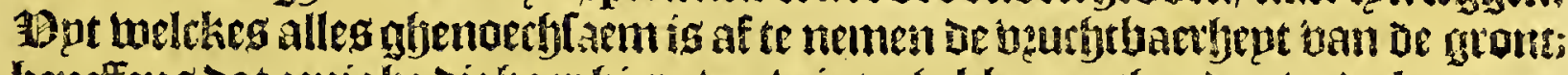

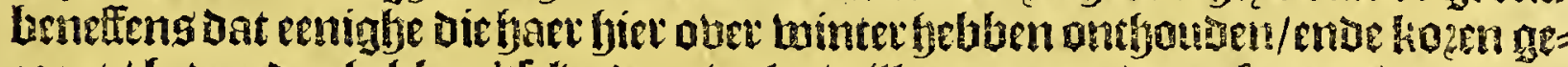

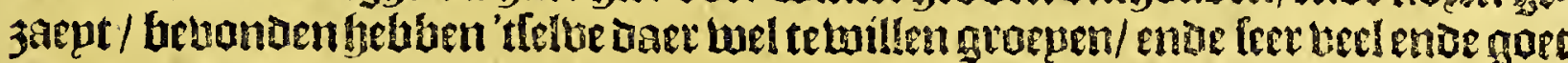

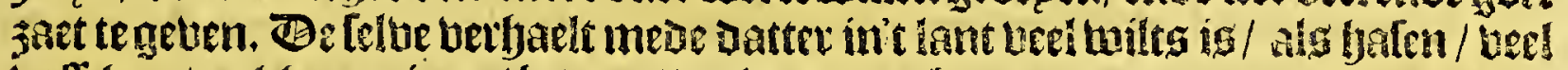

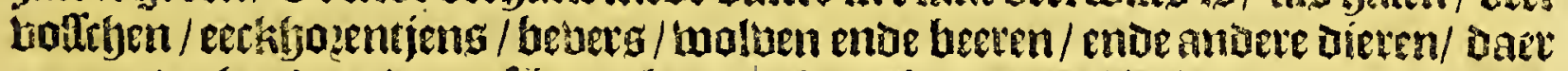

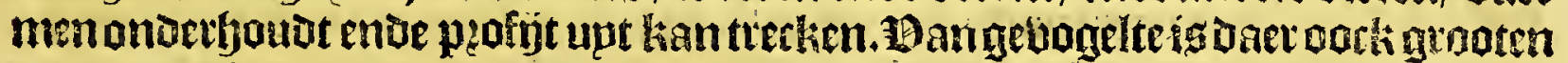

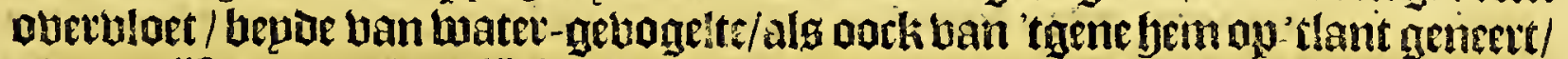

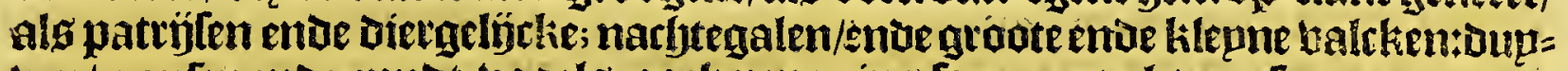
ven/ gan [enende epnit-bogels; oock penguing loo groot als ganfen; enoe ande=

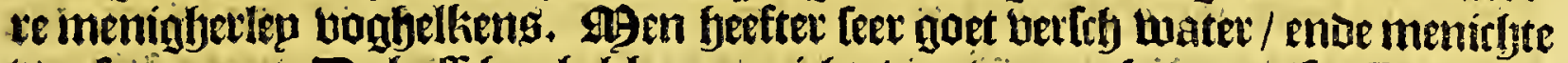

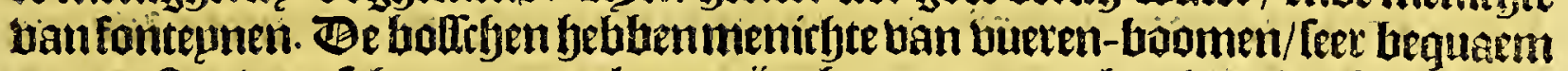

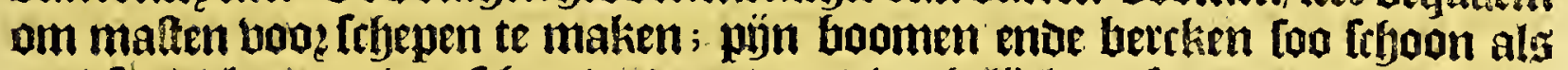

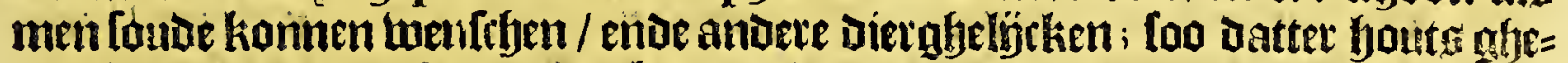

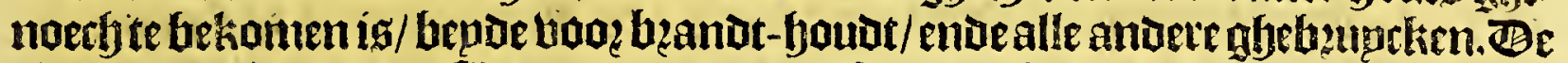

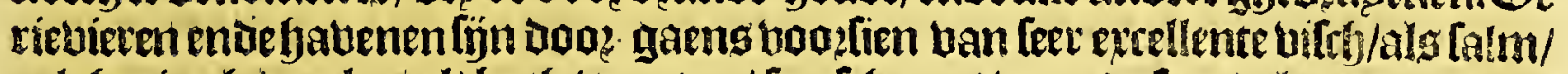

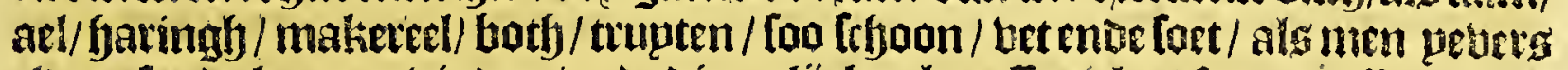
eloers foude lonnen binden / ende diergelÿeke : beneffents kreften/mofielen enue

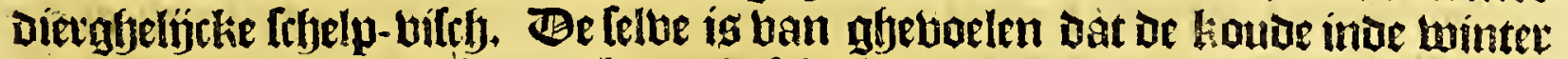

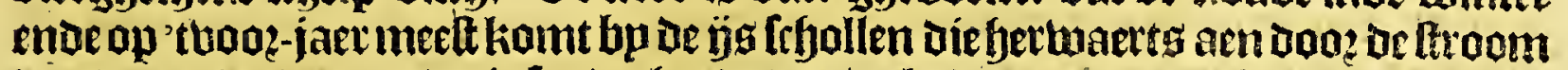

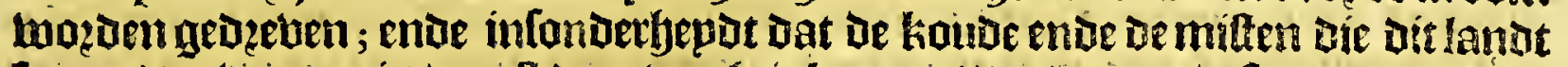

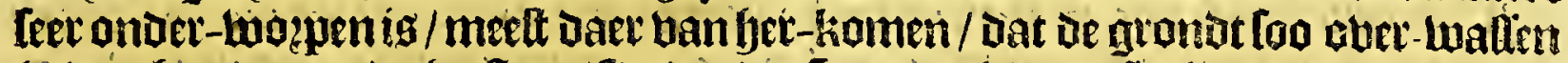
is ban foomen ende beelters / loo dat de Sonne gheen reflexie op de nronot fian

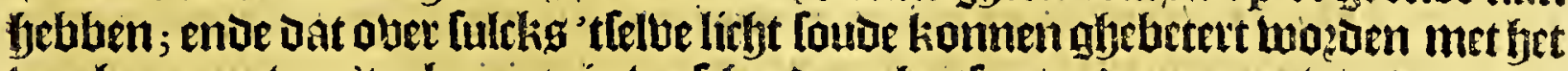

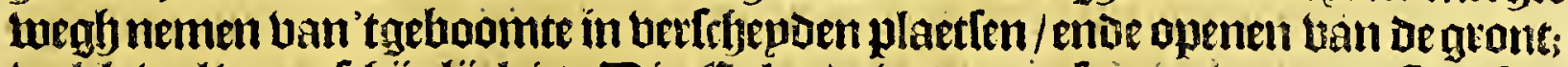

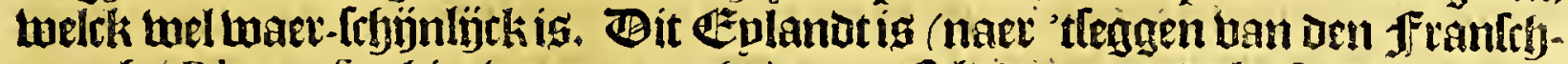

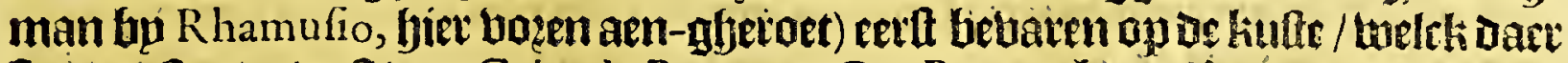

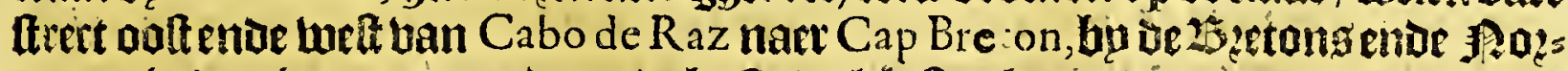

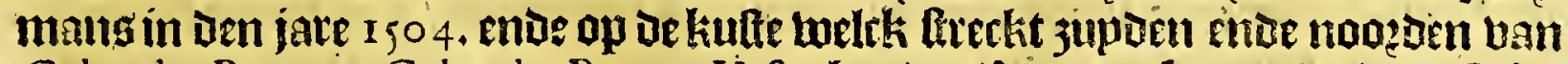
Cabo de Raz tot Cabo de Bonna Vifta bu oe Hoptugerlen; ente han Cabo de Bona Vifta tot Golfo de Chafteaux, bụ de felbe 3 zetang enue Nomang.

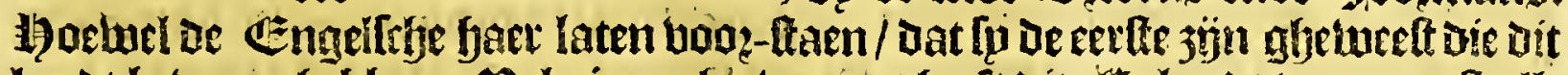

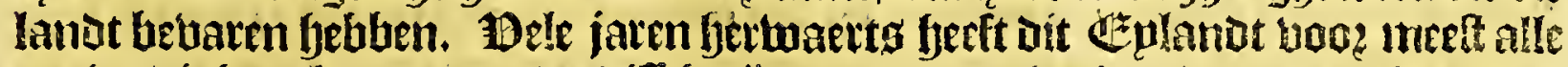

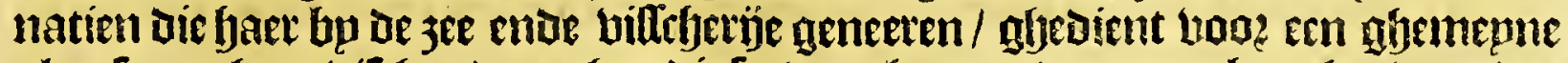

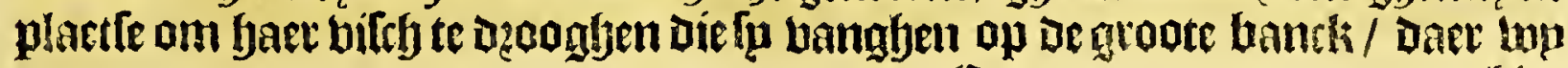
$\mathbb{E}=$

biel 
48

Nova Francia.

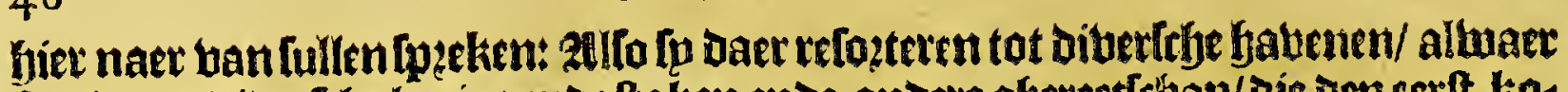

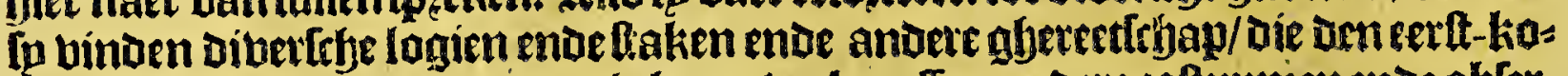
menuen fyem toe-epgent ende abebzupekt; beneffen andere coftupmenenoe ablets

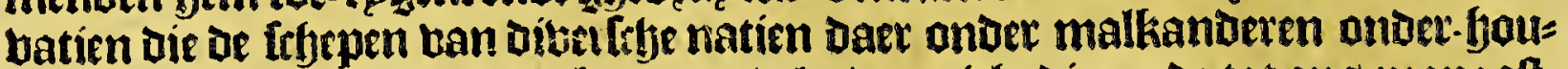

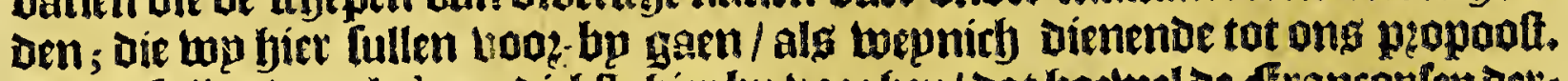

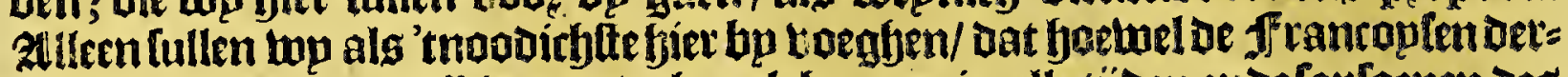

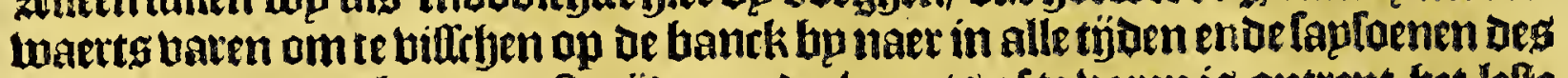
jaers / eben-wel oe bequarmete tijot om Dertuaerts af te varen is ontrent bet leffe ban $M_{d}$ rtio, als Lanneer'tguaedt broer ende de ftomen ter $3 e$ beginnen te refle:

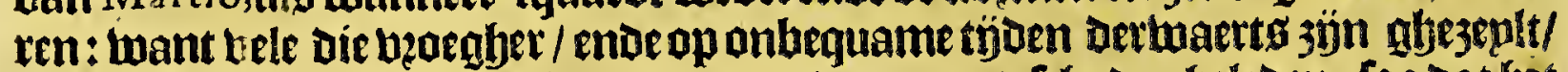
bebluen lthip ende balck berlouen / ende andere groute frbade gheleden; foo dat bet

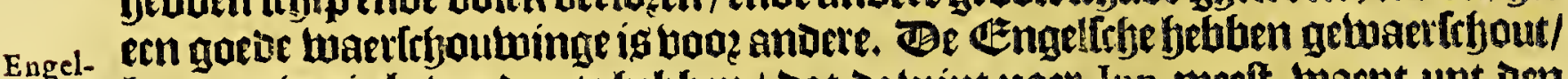

fche vo. bp experientie betonoen te hebben / Dat De wint naet Iun meeit haept upt Den

yagie. weften in die quartieren ban Neuw - fond-land, twepnigh meer als een fteerk te noozoen ofte te jupden batierende/ [oo dat naex lun bet een lange endemoepelÿcke reple valt: Daer in Martio, A pril, en May, men upt Ezenglandt daet gbezeplt beeftin thee-en-twintich Daghen.

Het tweede Capittel.

Van'tvolck woonende op't Eylande Terreneuf, haer gheftalte ende manieren, haer wooninghen ende anders.

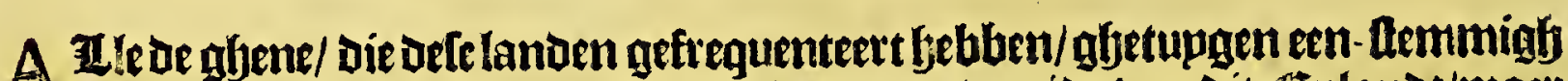

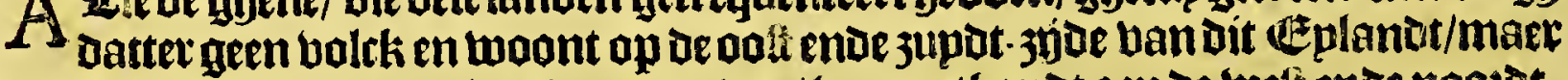
Dat alle 'tualck dat daer twozot gevonden/ fyem onttyoudt aen de welt ende noozot-

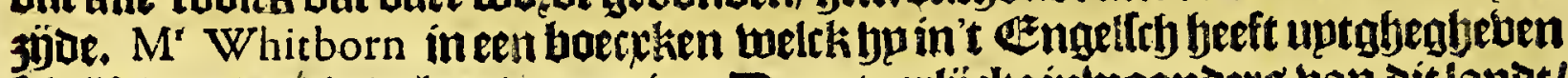
ftyejft daer tan in volgenoe manicre. Be natuerlycke intooonoers ban ait lanot/

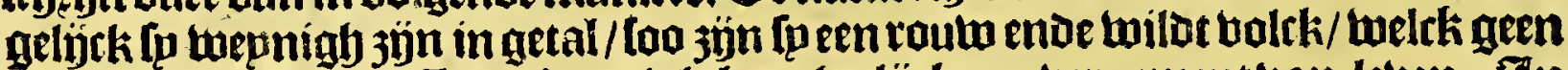

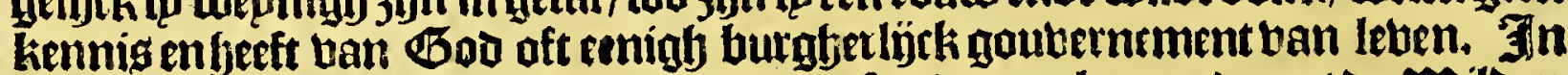

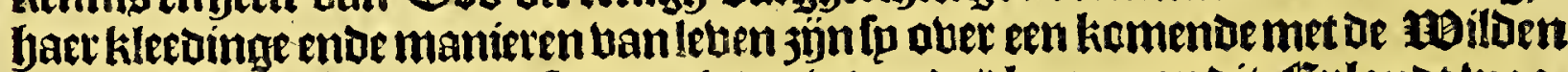

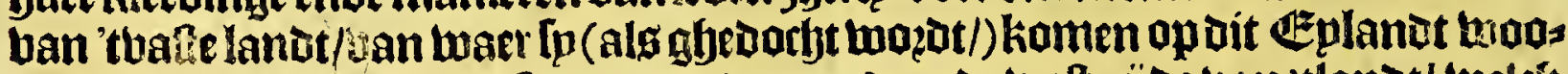

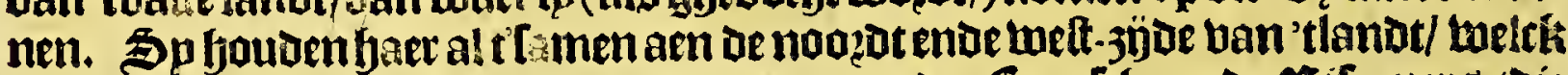

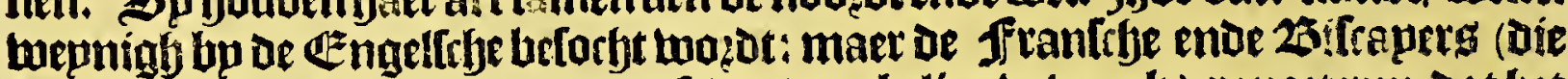
daer jaerlÿks baten op den malbitrty enoe cabeljaum banck) rapoeteren oat lyet een goet enue tractabel bolck ig/als men die bequamelïrk fandelt;

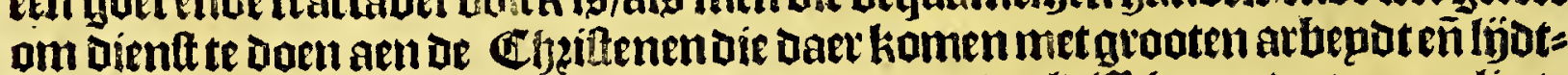
faembepdtint dooden / [njoden ende lieden van de walbitichen ende traen-olie te maken / [onder andere bergeldinge daer boo te gemieten/ als alleen een wepnicf]

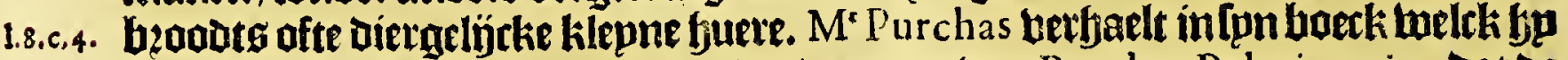
in't Engelfrh hefft upt aegeben onuer ae natm ban Purchas Pelgrimagie; Dat de Ėnaelft; Ien bande foiloen/welck niet anders en waren als Tekere ftaken/ in't rande geftes

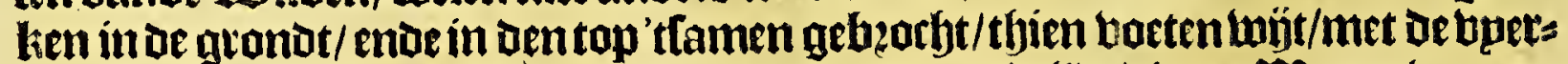

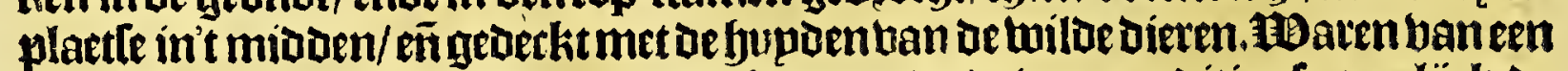
midoelhare ftature ofte lengte / [onder baerden/ende ban conditien leet aeliÿck ie

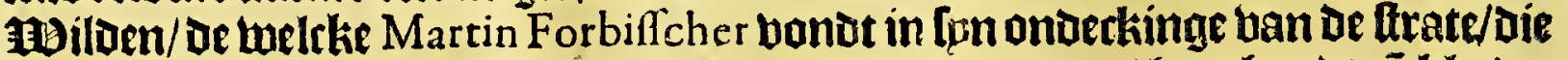

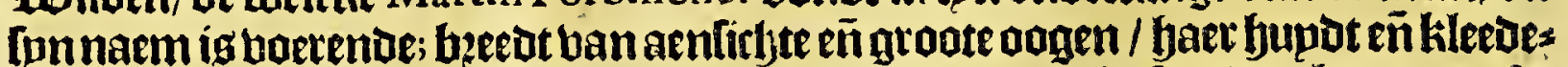
ren geluethet mer rooot oker: faer bootengemaeckt ban balten ban boomen ofts

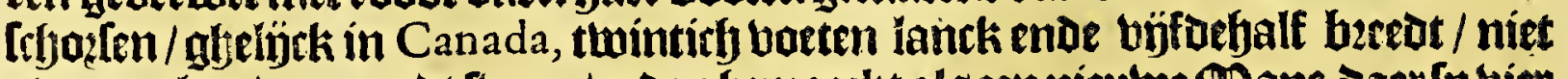

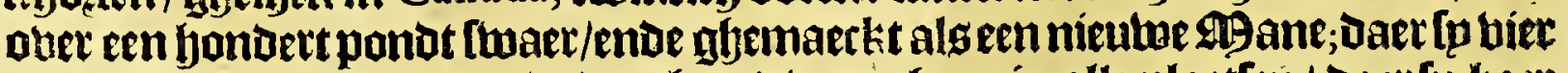
man in konnen boeren / ende dzaglyen die met faer in alle plaetlen/ daer lp baet

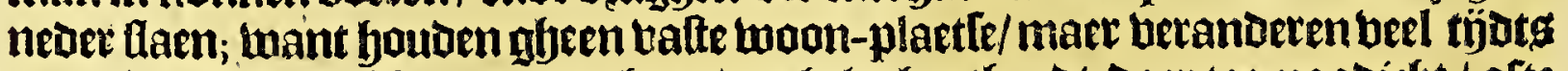

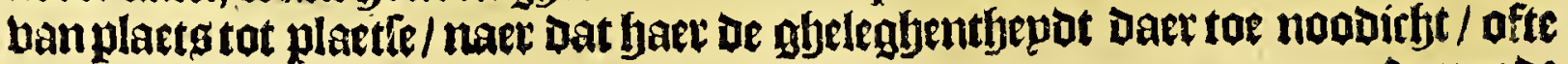
De noods 


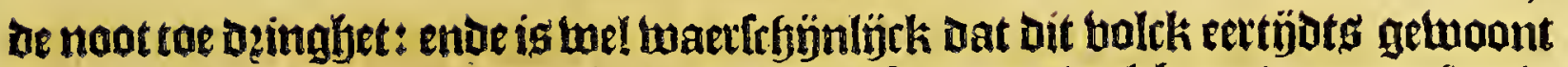
beeft aen 't Jupot-epnoe ban Dit Éplanot / alfoo daer beel beter woonen is als

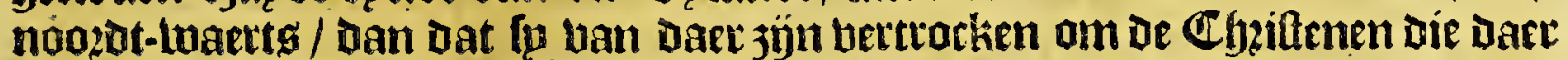

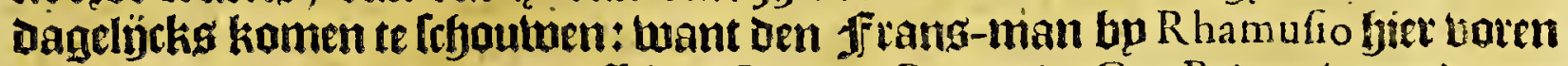
aengferoert / ghetupght Dat tuffryen Capo de Raz enoe Cap Briton woonde een

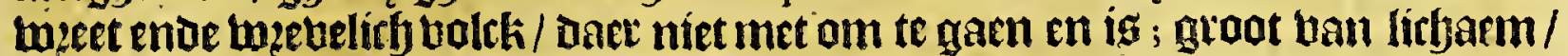
met robben bellen ufjeklect / ende ban andere wilbe dieren / te famenghrbonden/ bet aenlicht gebzant met fekere Arelien / bzupn van coleut naet bet finart trecken=

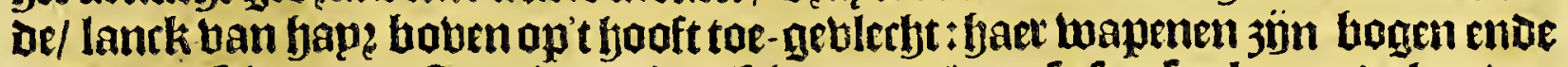

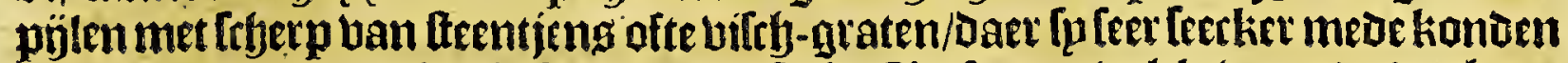
fibieten: Dat ban Cabo de Raz tot Golfo de Chafteaux trolck woande Dat beter was om met om te gaen / ooch minoer in gfetal als op't boot-gaende quartiet)

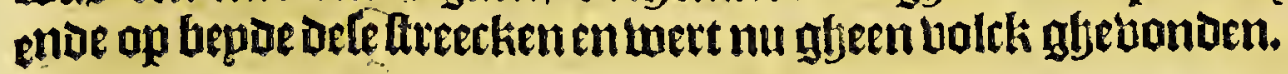

\section{Het ueroe Capittel.}

Van de Havenen, Rievieren, Punten ende Reeden van dit Eylande van Terreneuf.

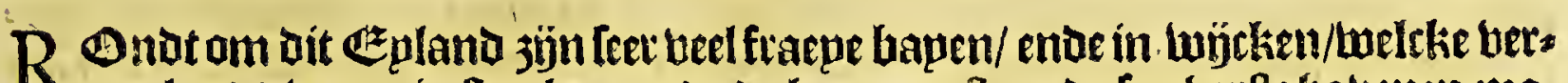
re te landt- twaert in fterlien; ende de bequacm fe ende feeckerfe babenen mas

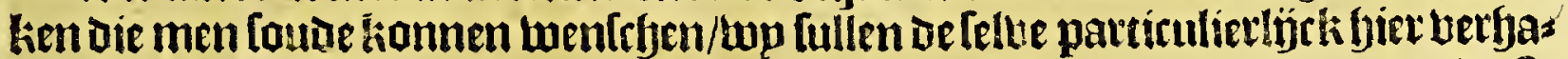
Ien / brgbinnende ban Cap de Raze, ereft noozot - waert / ende baer naer welt-

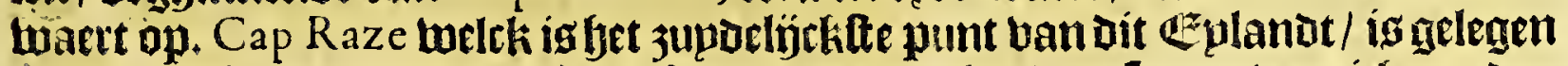

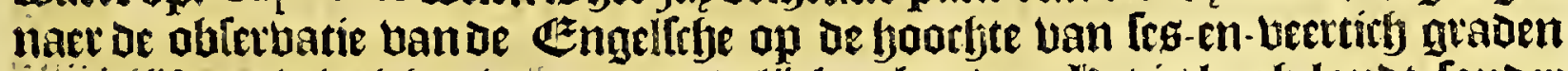

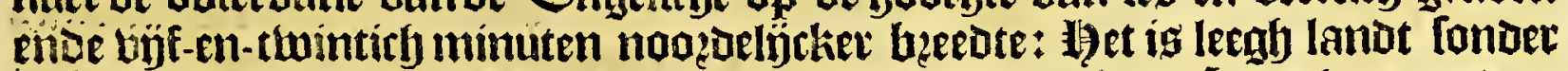
bergen/ende ontrenten yalf legue in jee rịft cen kilipye terbt tege ober bet punt ban De rape/bp twelcke bet gekent moet. Beg leguen ban oele rapenoot- maerts aen íg nelegen de gaven ban Renouze, ofte Roigneule, algde ffrancapten die noemen/

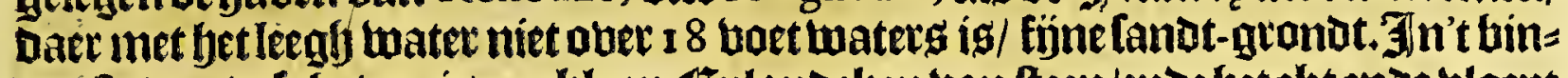
nenlte van aele baten is een klepn GEplandeken van fteen/ende bet cht ende blacpt

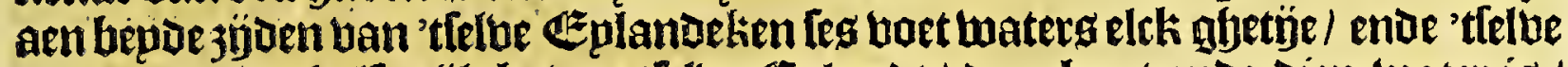
getije loopt een falf mijle boven'tlelue Eplandt / Daer beet ende biep water is /

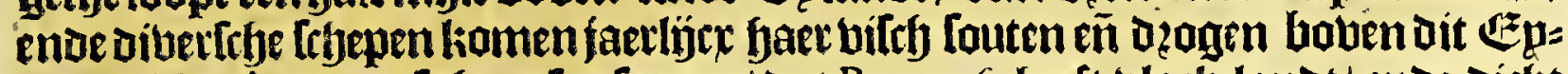

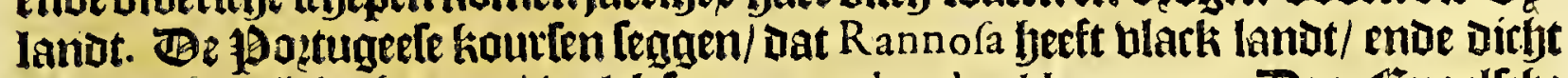
aen jee 2 geljicke bergen/ welckipnaemenlos dos Hermanos. Depp Ẽngelrthe

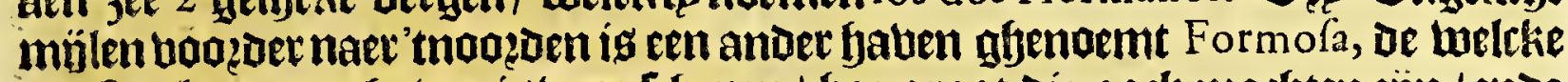

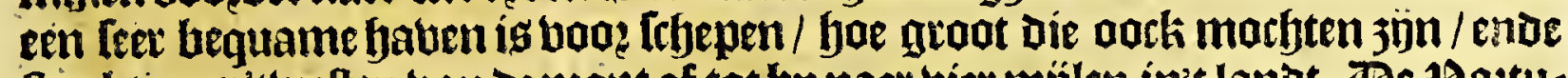
Ifreckt naer' thetten ban de mont af tot bp naer bier mijlen in't landt. Be j\$oztus getle Gourten Itellen die op Les-en-beertich graden ende dz̨p quart. EEen Elepn mül meer noogt- waert legt De bauen A gua Forte, weIclieen naeu in-komen beeft/ende

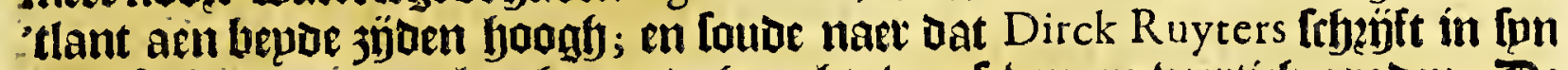
Toorfe der zee-vaert, legghen op de fooghte ban [even-en-bertich gladen. Be

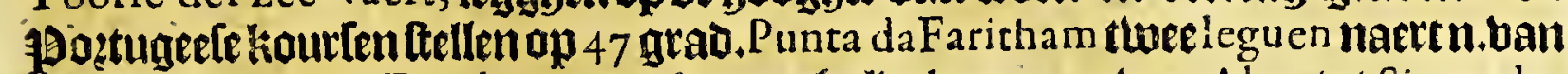
Agua Forte : ban Faritham tot Abra ennfalue legue, $\mathfrak{c}$ ban A bra tot Sierra das

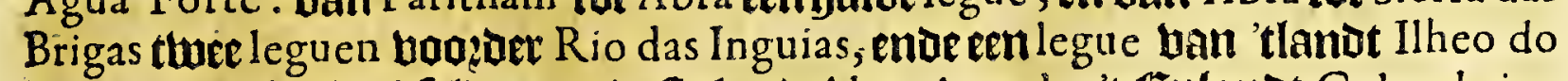

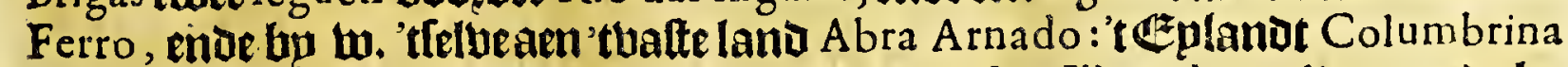
ende daci butw. aen Terreneuf Abra dos Portugefes: Ilheo das galiotas ende bp noozern Abra Augoada. Dele Dęu Geplandetieng liganen n. enie \$. enoe twoz=

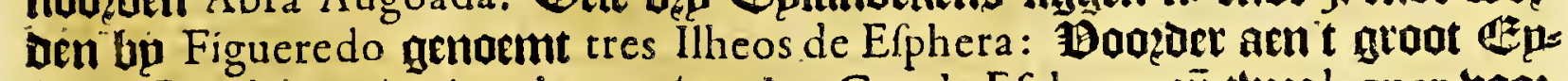
landt Piriabra, ende twee leguen boazoer Cap de Efphera, eñ twer leguen voo: = bet $S^{\mathfrak{t}}$ Iean. Althtyien oft neabenthien leguen ban Cap de Raz op leuen-

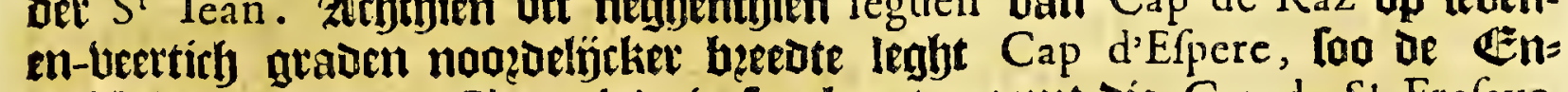
gellclje die noemen; Champlain in Ipn kaerte noemt die Cap de S' Frefaye. 


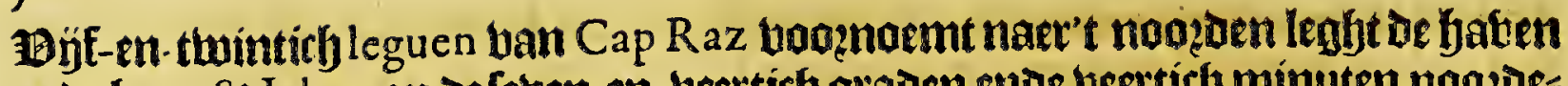

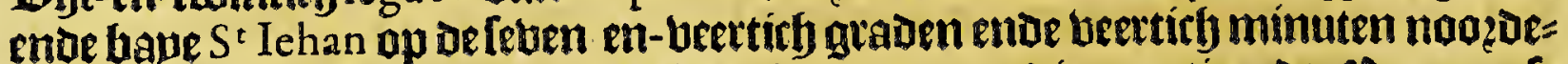

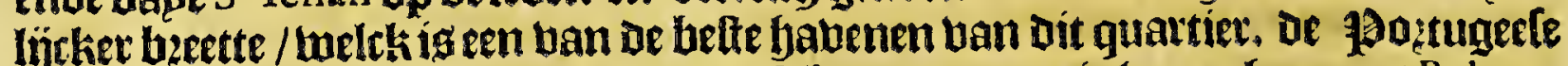

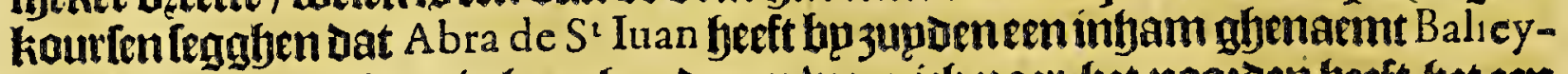
ra :'tlanot ban $S^{t}$ Iuan is hoogb enide een weunich naet bet nooederi beft bet een heubel daet ae zee aen taet/welck [u noemen MonteLouro, en aende voet een klepn

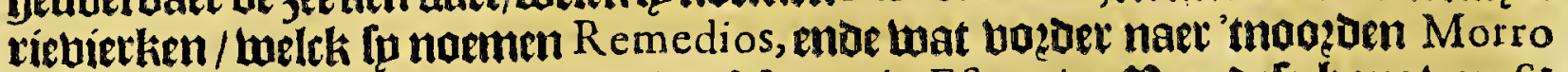
Efpineto/ende norfyeen legue vozider Morro de Eftancia. Ban dete bape ban $S^{z}$

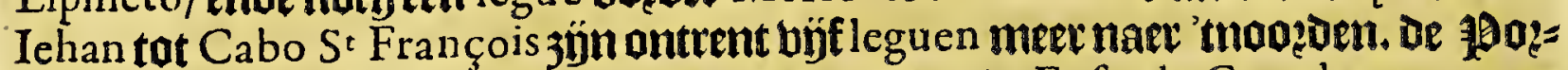
tuneefen kourfen ftellem oele Cabo op 48 graden/ende Enfeade Grande op 47 gra= Den 45 minuten : Dan anuere fegghen Dat bp jupden defe Cape leght efringoten

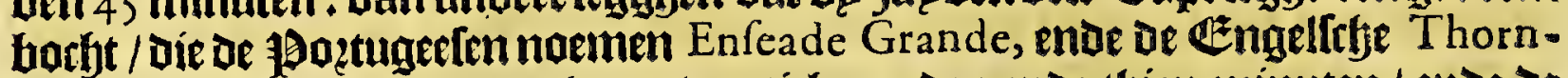
baye, op de hooghte ban atht-en-bertith graben ende thien minuten/entae ve Cabo de $S^{t}$ Francifco, melck is een black af-gaende punt met foummighe tifepne Eplandekeng op De hoogte ban arbt-en-beettich graden ande bÿftyien minuten:

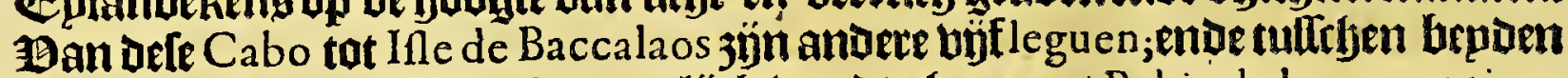
igen groote bape/welck gbemepnlijelk tuozot ghenoemt Bahia de la conception;

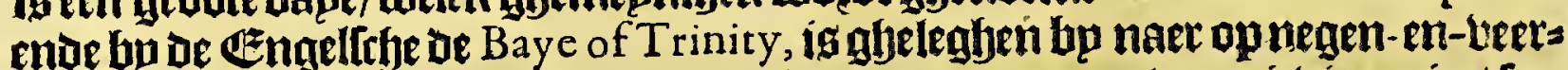

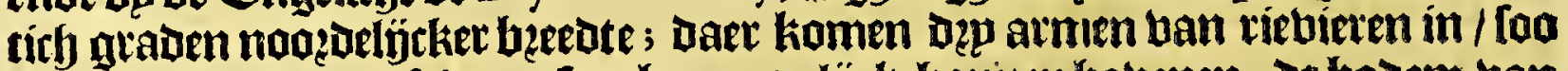

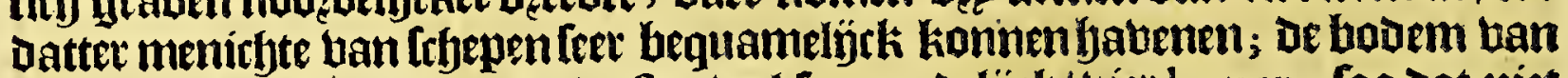

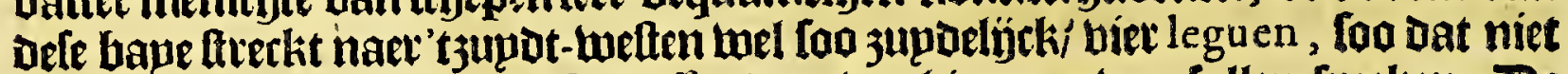
verte en kamt ban de Baye Trepaffez Daer wo bier naer ban lullen fpzeken. Be 19attugede kourfen ftellen twee leguen noozot ban Cabo $S^{t}$ Francifco, Abra Frade, ende daet naelteen groote bape wel byf leguen wït/entoe daer bimneri A bra de Trinidad, de Graza, da Perguiza, op 48 graden 45 minuten : dos Patos, dos Omiziados, endie bp noożen efen yalt legue in $3 \mathfrak{e}$ llheo dos Baccalaos op 49. graden. Boutts Cabo de Bonavifta op 43 graden 15 minuten : ende Abra St Catharina op 49 grad. 20 minuten; hier ontrent eñ vootstsnaer' tnoogedn op't tepnde

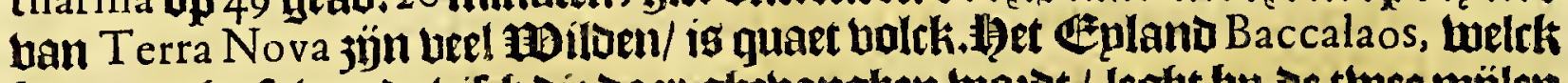

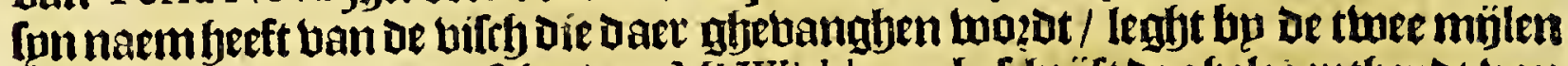

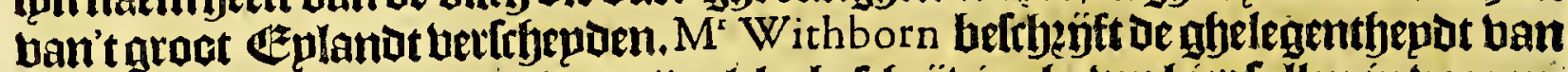

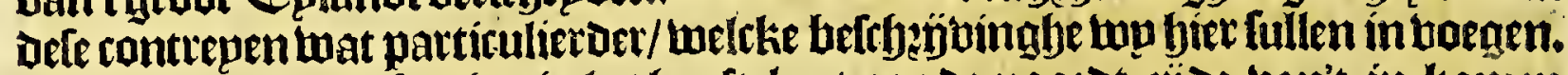
Cap de bona Vifta (fegtfyp) is bet lyooft-lant aen de noogd-3yoe ban't in-komen van de bape ban Trinite, enoe daet is en redelírke goede bauen obenaemt oe haben van Bona Vifta,met eenighe klepne Eplandekens Daer ontrent/ Daer jaer:

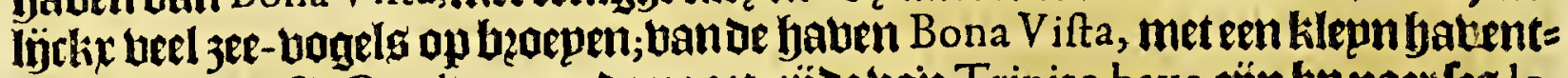

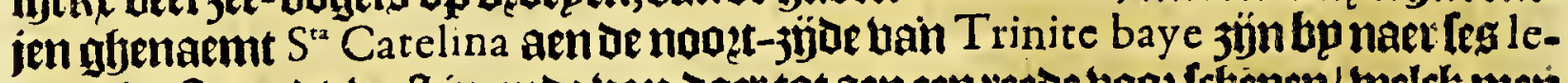

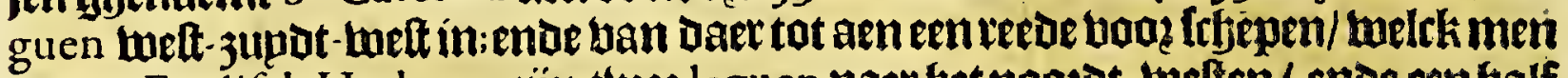
noemt Englifch Harbour, $3 \mathfrak{j n}$ twee leguen naer yet noozot-keften/ ende ectn yalf

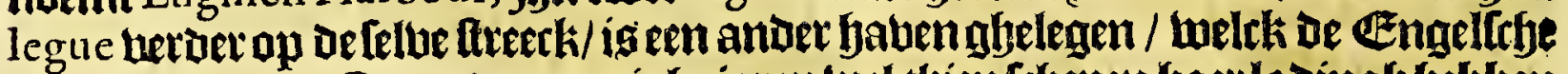
noemen Salmon Coue, daer eenighe jaren tuel thien trbepen baet ladingb bebben bekomen; :en legue ban daet naer 'tweften legt een gaede ree / die [p naemen Robin Hoods baye; $\mathfrak{k e n h a l f}$ legue boożor naer'tweften is de haten ban Trinity, De befte van 'tgantfrye lanot: twee leguen boozer naet 'tweften leght be baben ban Bonaventura, ende twee leguen bogzaer naer' twelten is een rievier ofte in-

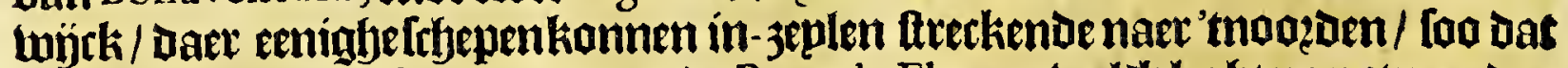

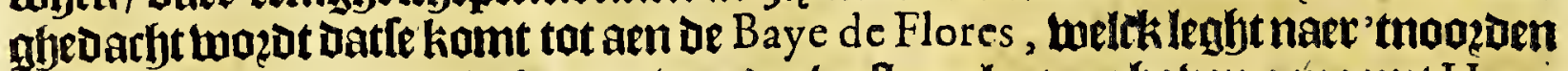
ban de haven Trinity; bier leguen voozed bett aenlegt ent jaben genaemt Hart-

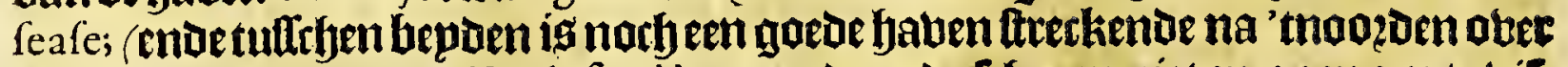
befes leguen, genaemt Hayleford haven, Daer be frbepen niet en gaen om te bifs frfen/ om dat Daer aeen bequaem plaetseníg om te dzoogen) endoe ban Defeplaetfe

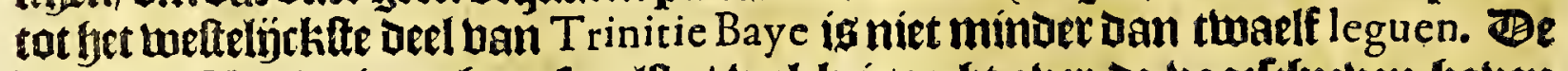

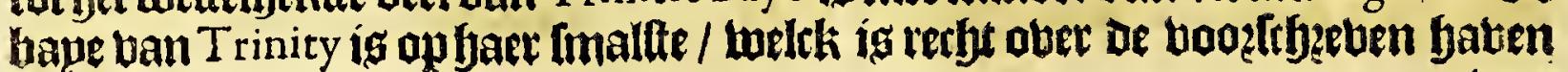




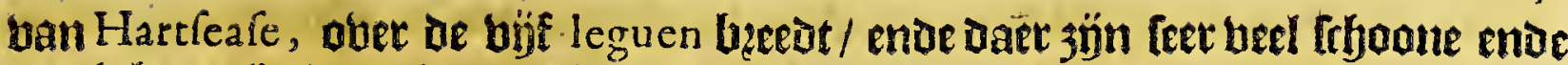

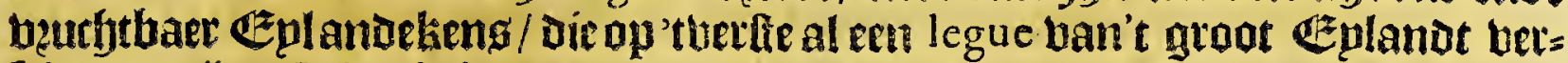

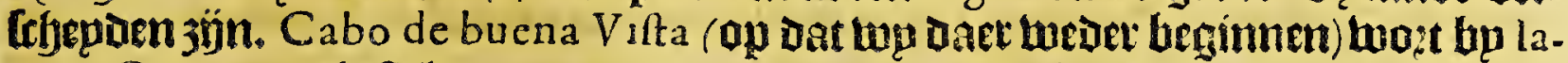

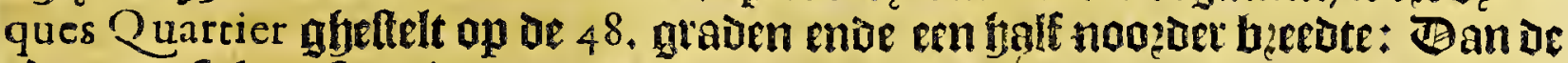

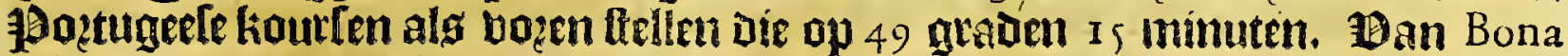
vifta tot punta dos Ilhcos de F. L uis rehenen Ip thien leguen, ende ftellen llheos de F. Luis op 49 ntaden ende 30 mimuten ; ban orte Ilheos tot Ifla das aves reke= nen lp thien leg uen ende ftellen Dat ap $5 \circ$ arauen 15 mimuten;enoe feggen dat ban

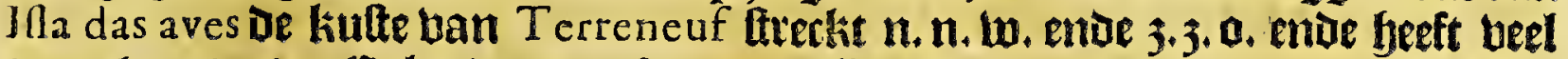

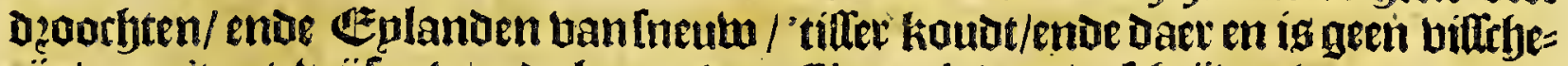

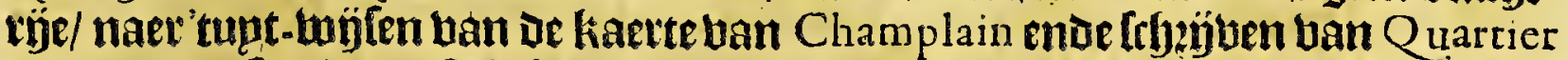
ende andere too ig naelt Cabo de bona Vifta nfelenen de baye afjenaemt Frelaye of Foriland, alg $\mathrm{M}^{\mathrm{r}}$ Withborn die noemt; ofte Farillon, ghelijck andere bie noe-

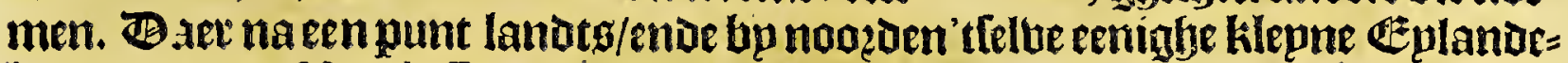

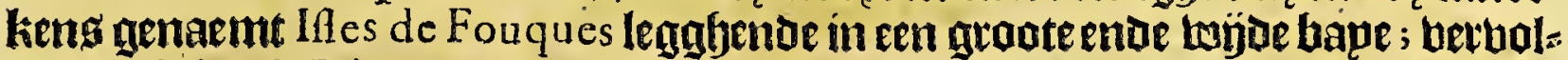

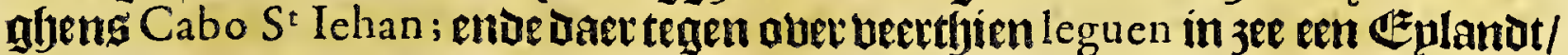
welsk Champlain in fun kaette noemt line aux gros yeux; bp nootoen or $\mathrm{Cabo}$, baye Blanche, ende bouts baye Dorge, Coneh; ende Cabo Rouge, enive epn=

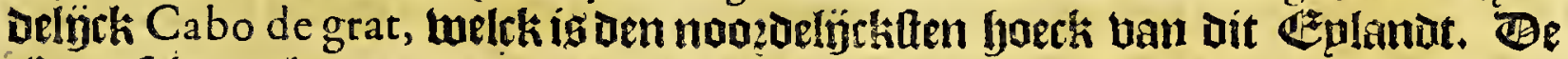

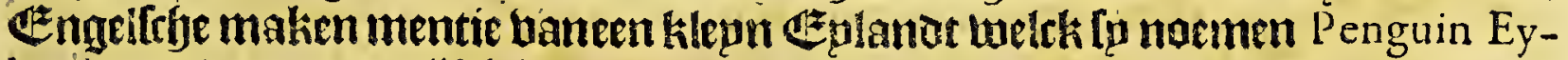
landt, ap oe een-en tujftich graden noozoer beette en fibinnt lyet felfae te twefen welc: Quartier in lpnertle bopagie noemoen lfle des Oifeaux, om dat daet foo

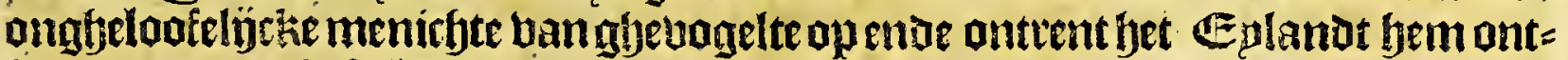

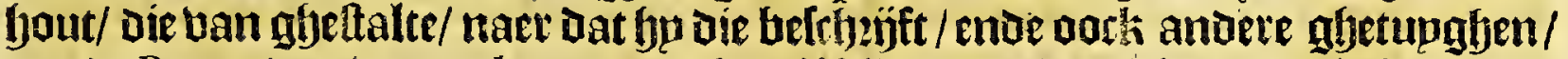

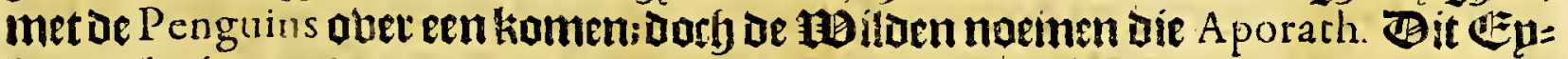
lanot leght op de 49 graden 40 mímuten noozaelïcher beesote. Quartier

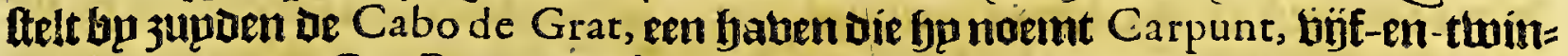
tirfy leguen ban Cap Razo naer't novedon: achte bet Cap Rouge moet twelén: mant Cap de Raz ende Carpunt legghen meer dam bonoett leguen van den an=

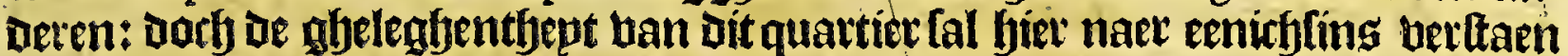
konnen wozben upt de bopagie ban I aques Q uartier, helck tup fier naet fullen

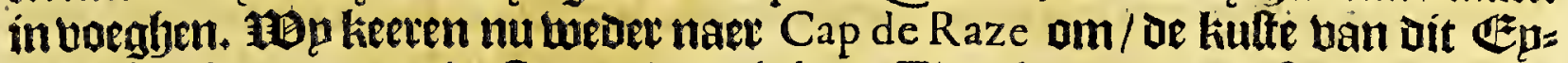

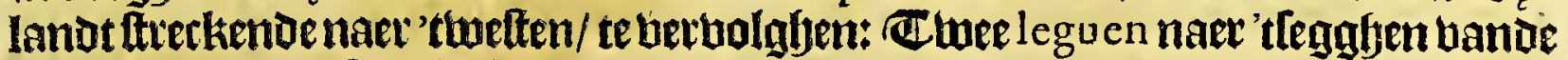

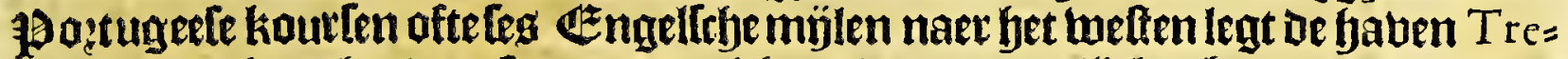

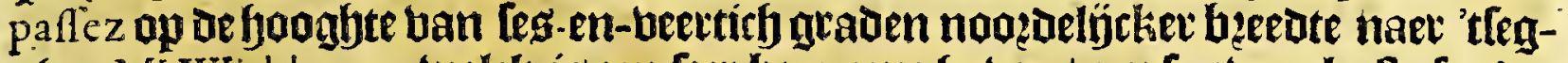
gloen $\mathrm{M}^{x}$ Withborn; welck igen leer heguame gaben/ een luphere kufte fonder

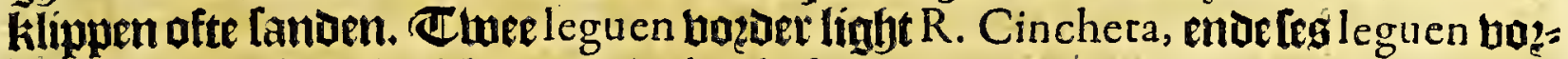
Der A bra $S^{\mathrm{ra}}$ Maria, welckes mondt is biev leguen'beedt/ende binnen ligiteen $\mathbb{E}^{\mathrm{z}} \mathrm{p}=$ lanot welck [u noemen Culuneta. Boozoer helt afjp Cabo de $S^{t}$ Marie, welck legftneghentbien leguen van Cabo de Raz nouzde-weft aen ; enoé is efjelegben aen De volt-3joe tuan't in-komen bande groote Baye Plaicentia, oft Planfance:

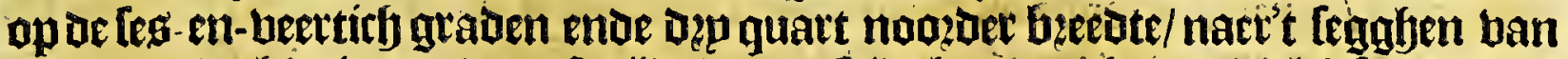

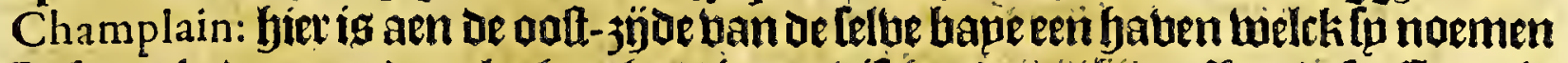
Pefmarck, daer goede geleghentyept is om vifth te dzodghen. Alen dere Cape is mede een bequame hauen. Ban hiec bolghen op de felte kutte eenighe kleune ghe=

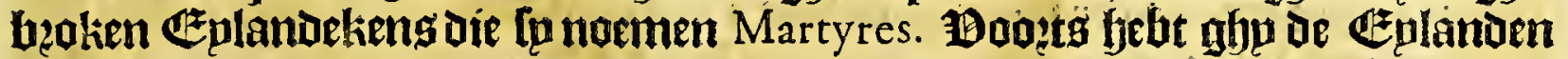
ban S. Pedro, allwaet mede eer leet goede haben is / ende op't eplandet walt al

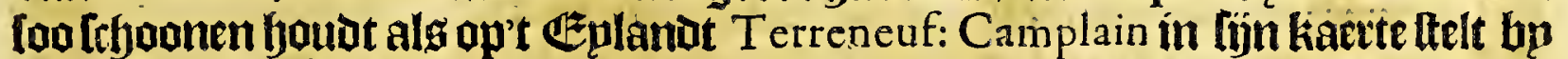

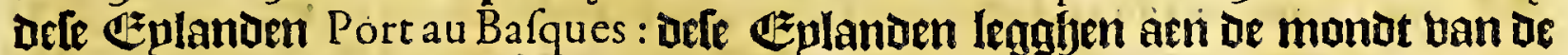
ftrate die men dooz-baertnaer de Golfo van $S^{t}$ Laurence, de kours ig melt-nodet-

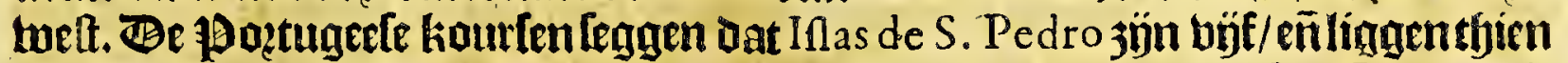
oft twaelf leguen ban Zanot naer't 3 upden/'tmidoelte ig t'arootte. Stellen die

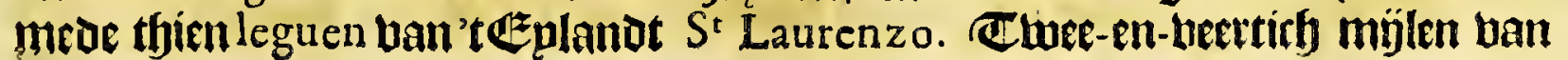

$$
\mathfrak{C E}_{4} \text { Daex }
$$


52

Nova Francia.

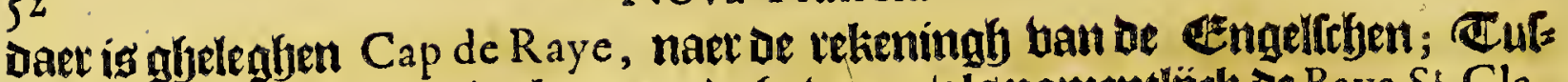

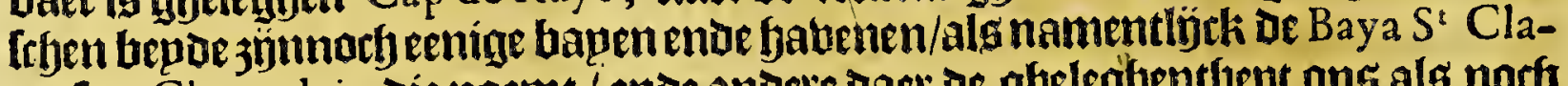
ra, foo Champlain die noemt / ende andere daer de gheleghentfept ons als norfy van anbelient ig. Culleben Cap de Rayentue Cap Briton fetbet rurtent upt naer ljet oolt-jupot-oaften. Ban Cape de Raye tot Caho de Anguille zýn I 2 ofte I3

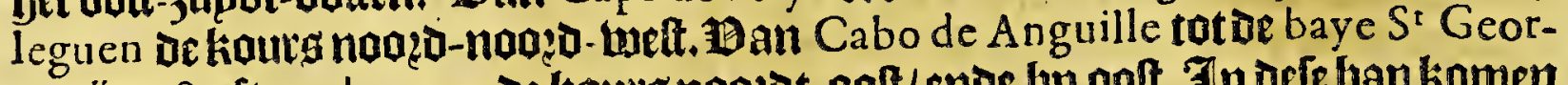

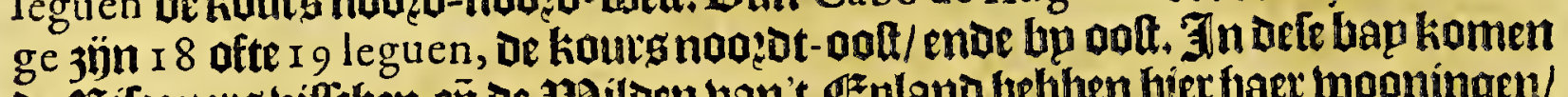

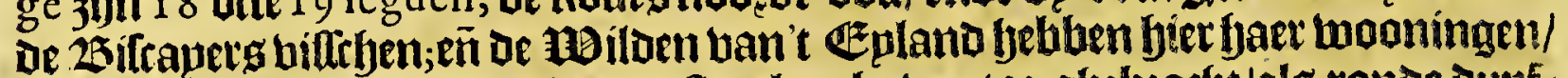

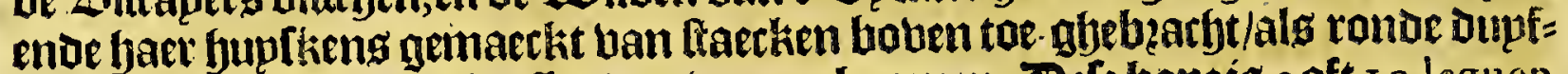

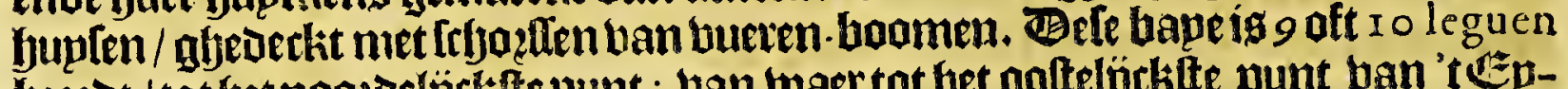

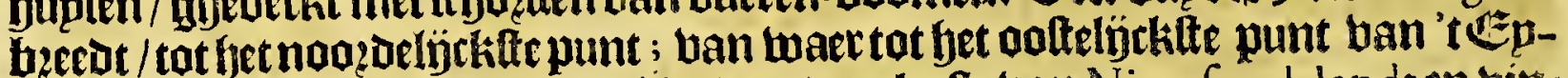

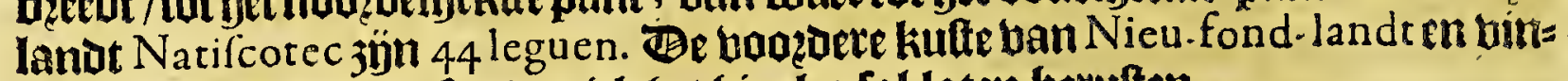
De icknict befrlyetuen / foo dat itk get fiec bu fal laten beruften.

Het bietue Capittel.

Vande groote banck voor Terreneuf, ende voorts van Inle de Sable.

D E groote ende wermaetoe hanck van Terrene uf is wel aen-merckeng waers

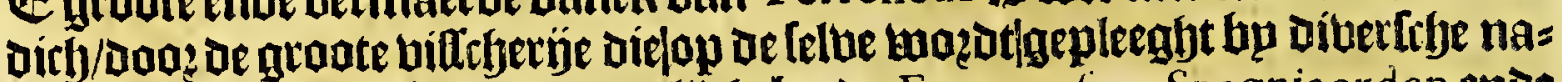
tien ban Europa, ende voaz-namentijck bp de Françoylen, Spagniaerden ende

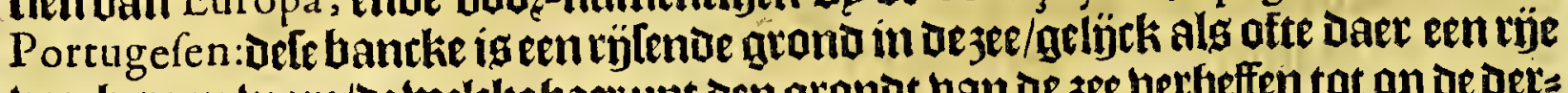
nan bergen ware/De welckefaer upt den gronot van de jee berfeffen tot op de der:

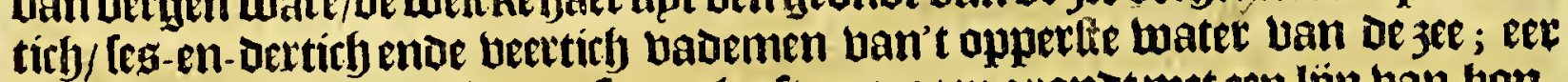
men aen aefelue bantk komt / foo en beft men geen gronot met een lỉn ban bonDert en büftich ofte twee honoert bademen; infagelinck als men daet aber ís tuls

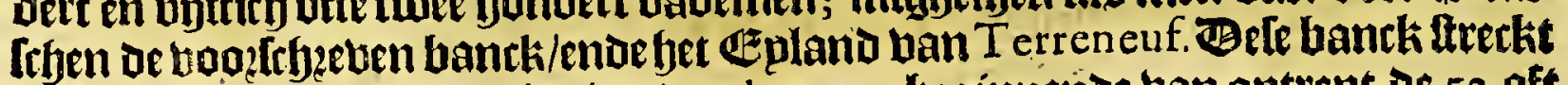
hem in de lenghte boozerenige hondert leguen, beginnende ban ontrent de 52 aft

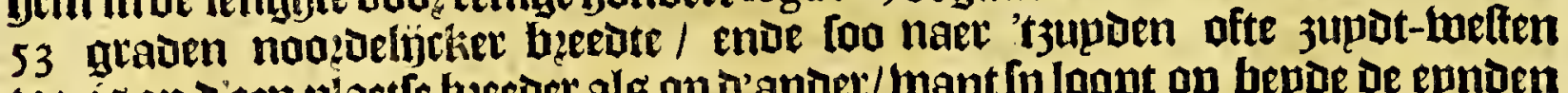
toe; is ap deen plaetfe beedoer als ap o'anoev/ want fu loopt op bepae de epnoen

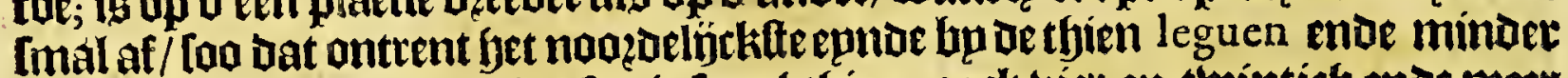

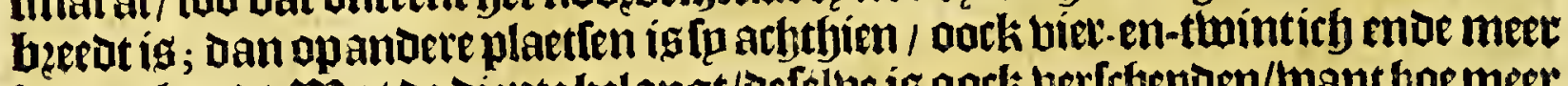

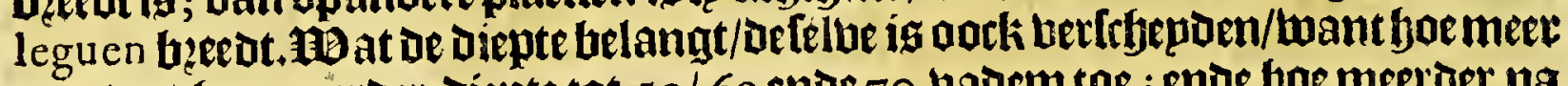
noazden hoe meerder diepte tot $50 / 60$ ende 70 badem toe ; endoe boe meerder na

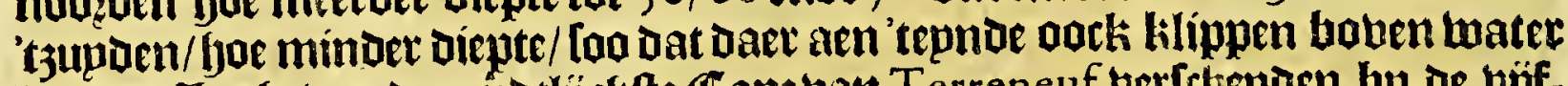

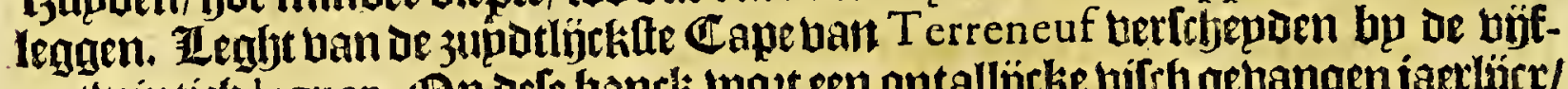

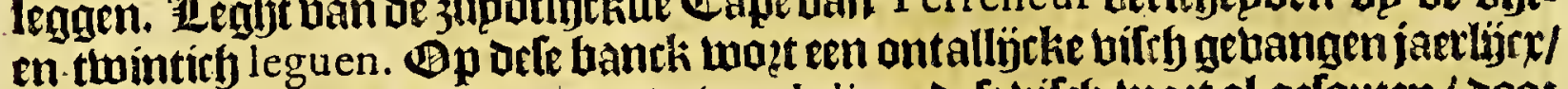

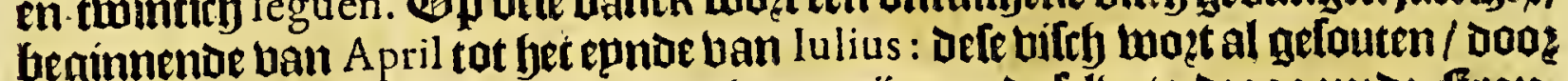
dien daet geen plaetten foo naer geleghen en jön am de felbe te dzoogen:de firans rapten noemen die Morue Verte. Baer tamt jaerlÿrks een groot getal fthepen

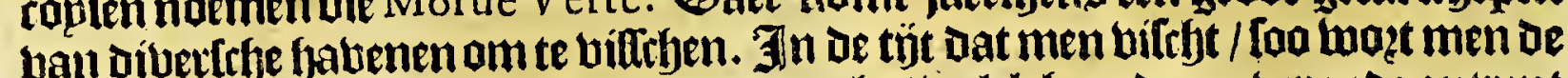
bancke gehaet aen de menichte ban gevogelte / welck fyem Daet ober en oe ontrent ontyouot / hem geneerenoe op t ingewantenoe andere af-bal ban oen biteb die bp

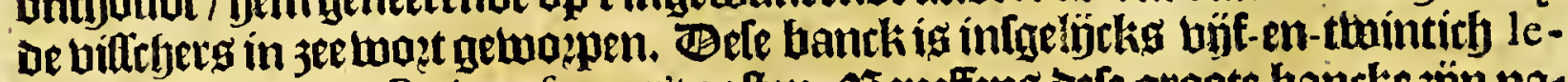
guen uan de haven Roineufe naer't ooften. 25 eneffens bele groote baincke jün nas

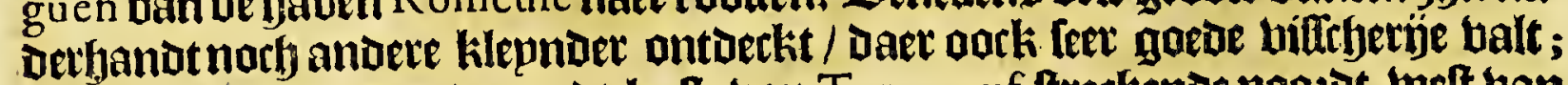
als ene ghelegen boaz oe 3 updt-kulte ban Terreneuf, thetkende noozot-welt ban

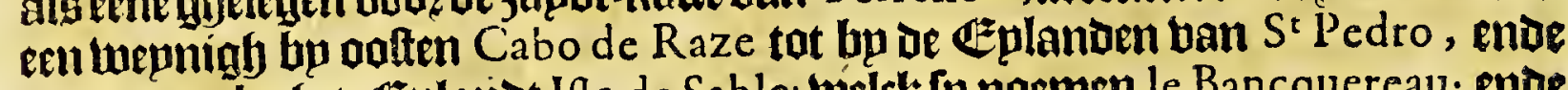
cen andere bphet $\mathbb{E}^{\mathbb{E}}$ planot Ifle de Sable; welckfp noemen le Bancquereau; ende le Bancq laquet, oft/Loo Champlain ftelt infunkaette/le Banc au vert. 25p of onfe

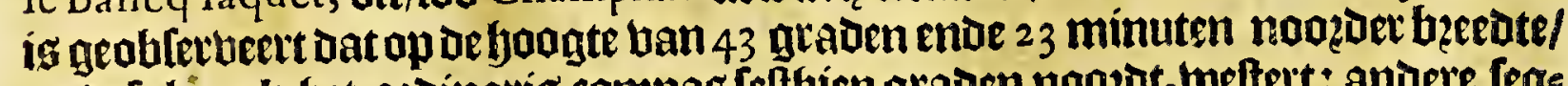
op acfe lanck bet ozoinarig compas feltyien araden noozot-meltert: anoere fege ghen dat de bariatie wel thintich graden beloopt. Paer'tghemepn legghen

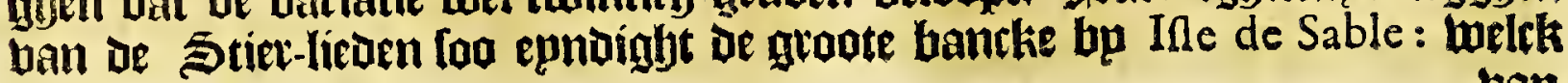


Het trveede Boeck.

ban't Eplanat ban Cap Breton noo?t ende zupden bertebepden is dertify le guen, ente begrïpt ontrent de bijftbien leguen, Imal/maer lank/ op de boothte ban

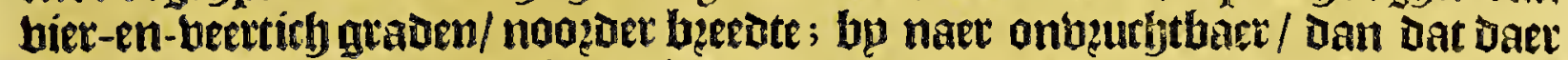

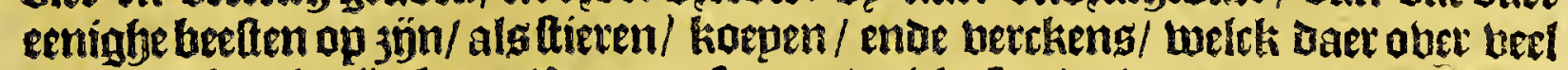

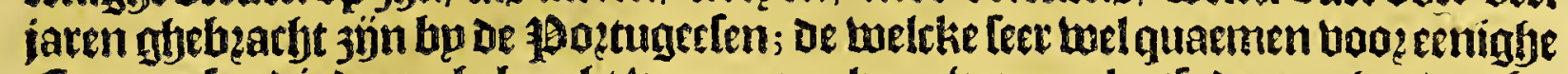

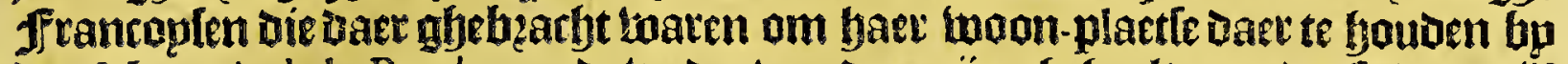

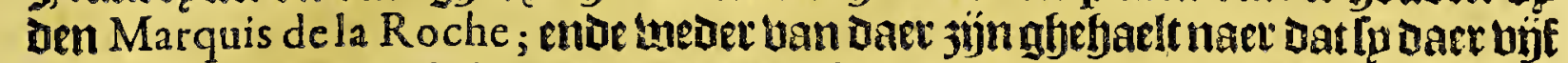

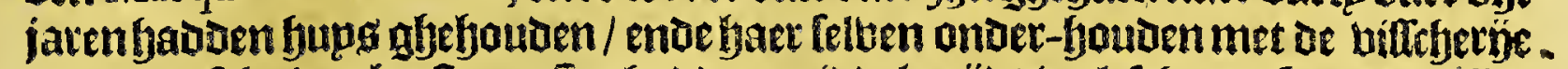

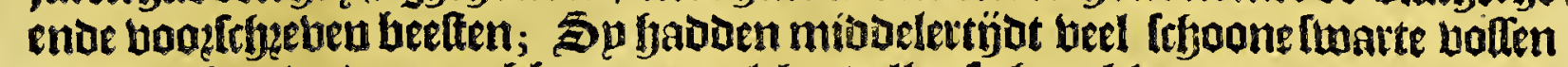
gyeuanghen / endejee-robben met belcker bellenfug baet kleeden.

\section{het vijfor Capittel.}

Van de gheleghentheden van ' $t$ Eylande van Cap Breton, fyn havenen ende reeden, ende manieren van 'tvolck dat daer op woont.

H Ét naelf gbeleghen Eplanit aen Terreneuf, ofte beel eer beel geb?oken Ep=

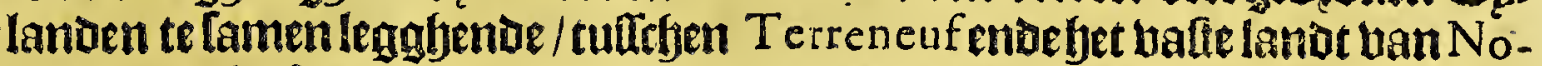

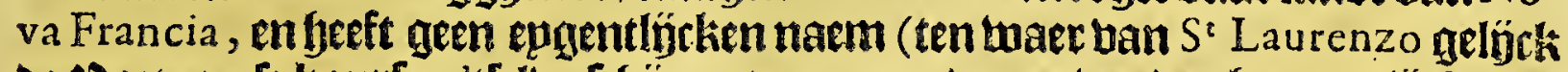

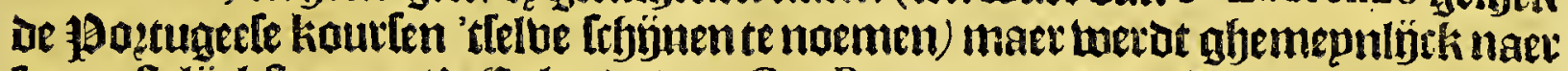

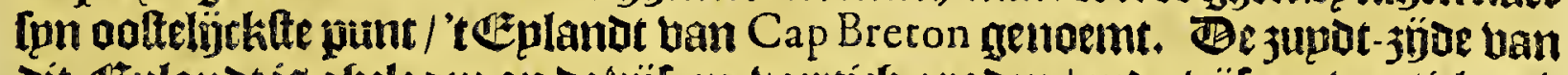
Dit EEplantat is gatelegen ap De vijf-en-beertich graden/ende vijf-en-veertich mi=

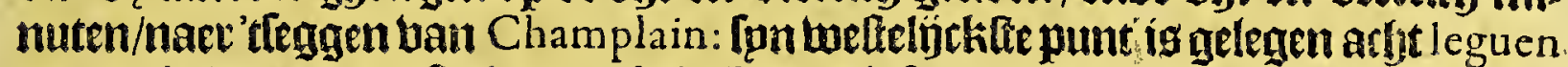
van de lyabe aen 'tuafte landt gheleghen / die fa noemen Campleau; tojoinaice

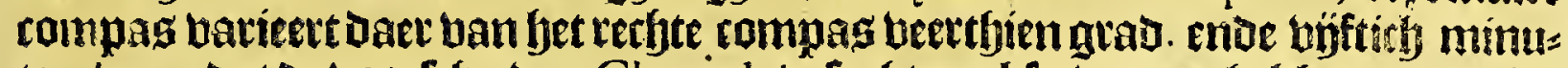

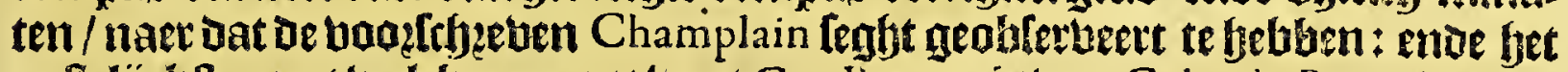

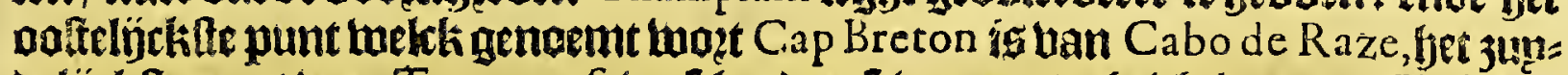
Delijcklte punt ban Terreneuf, berfrhepoen [euen-en-tarbtich leguen. Cuftéten

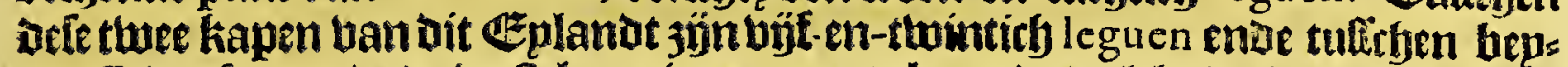

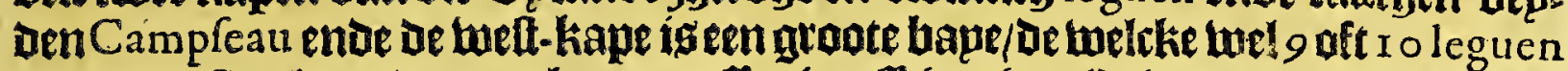
in't lanot ftreckt/ende maecket enpaflagie tufferen bet Epland ende'tbafe land/ lupt-komende in De groote Golfo han $S^{t}$ Laurens, [oo dat men Daer too? han bare

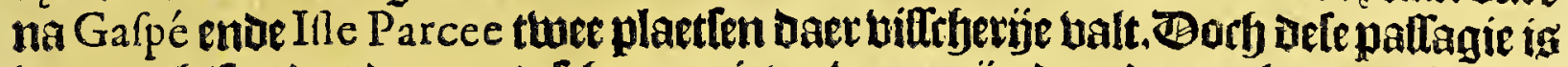

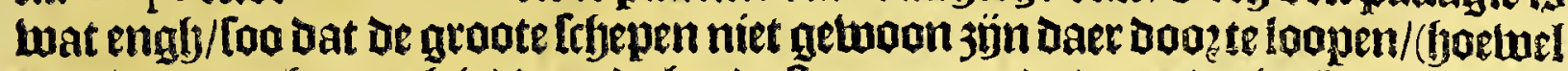

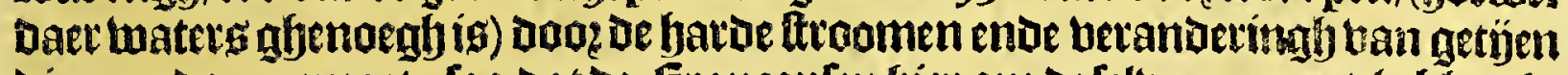
Diemen Daet gemoet: fon dat de friancopten fiec om defeloe genoemt beblen le

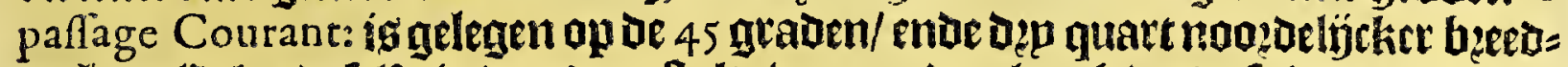

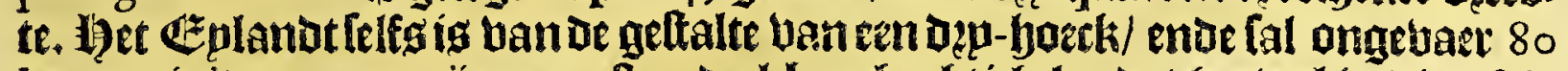

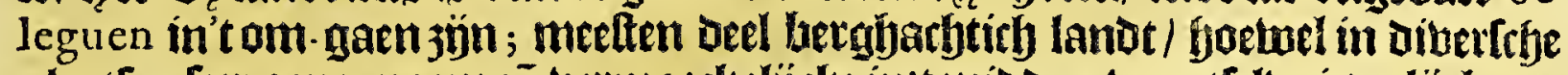
plaetlen feer aengenaemeñ vermaeckelïck: in't misoen ban teflue is gelöck een

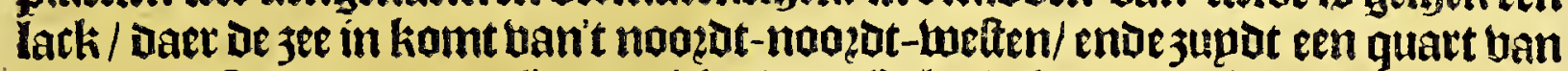

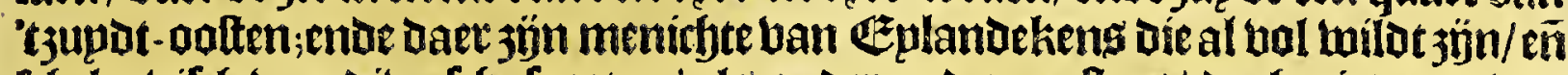

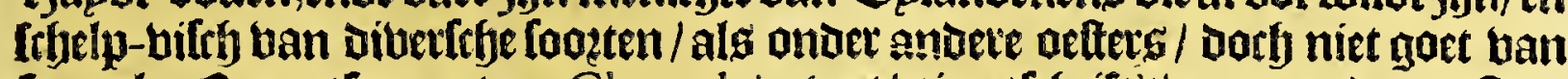

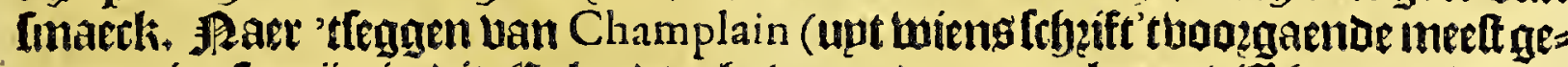

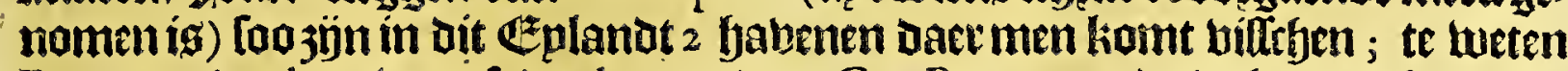
Port aux Anglois twee oft Dep leguen ban Cap Breton, ende be bauen gúenoemt Ninganis 8 oft 20 leguen uan Cap Breton naer't noogden een quatt ban'tnootmeften. (Be)

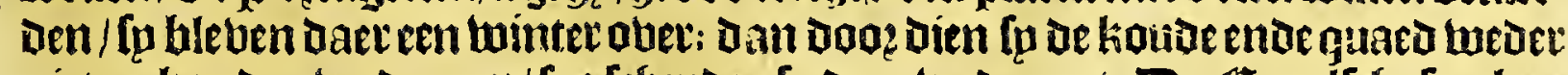

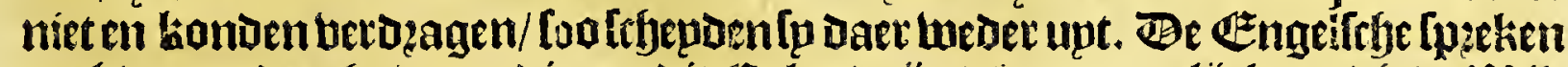

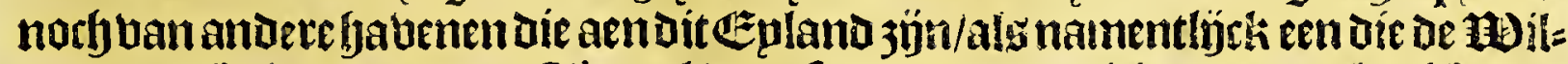
ac bant Geplano noemen Cibo, al maet foo groote menichte ban jee-krahben ig at fet te bethonderenig; adjt leguen ban Cibo ísen ander redelijeke gaede fja=

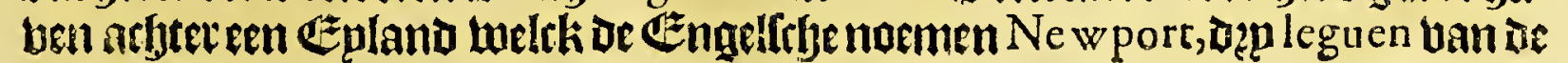


54

Nova Francia.

Enghelfche haven oft port aux Anglois uerthyeden. De noozdelijtitle Capt

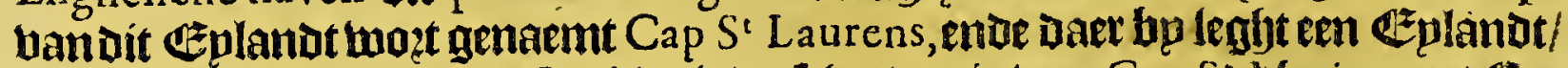

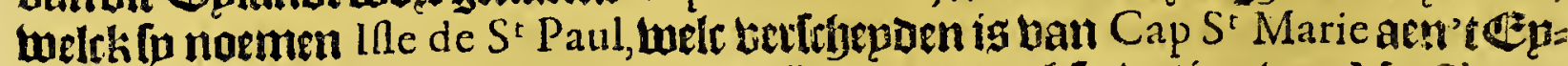

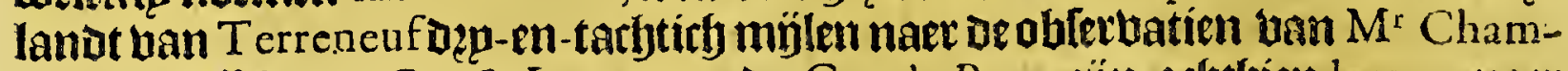
plain. Cuffrben de Cap $S^{t}$ Laurens ende Cap de Raye jün arfthien leguen maer

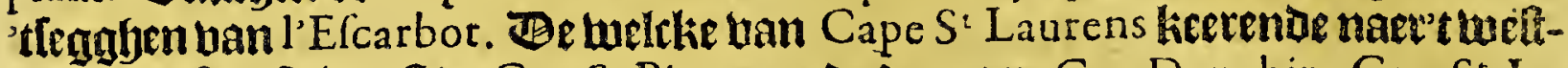
3unot-welten fielt eerit de Cap St Pierre, ende Jaer aen Cap Dauphin, Cap St Ie-

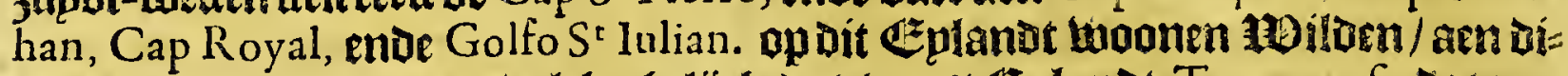

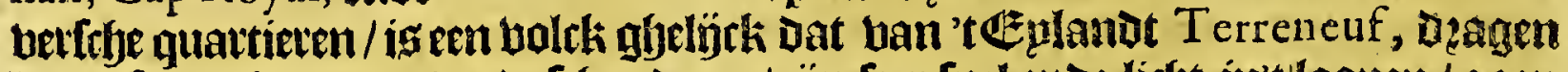

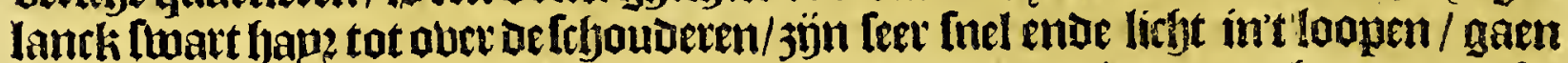

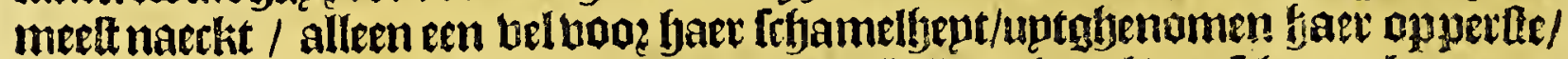

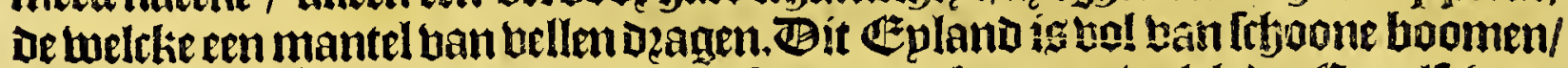

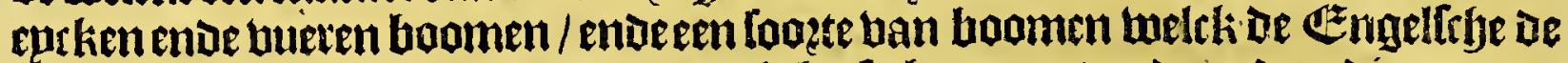
naem gatien han Quickbeame, aock ketle-boomen/ enie andete die ong on=

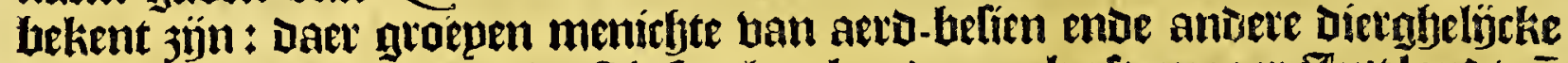

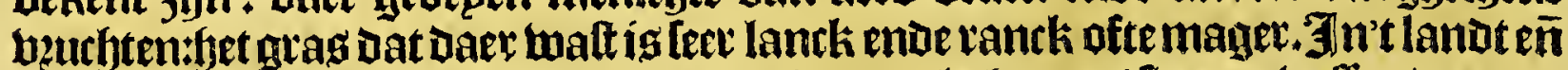

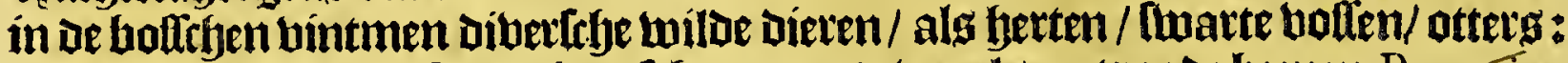
oock beel aebogelte/in[onderfyept felkere groote bogelg metroode henen:Peng üins

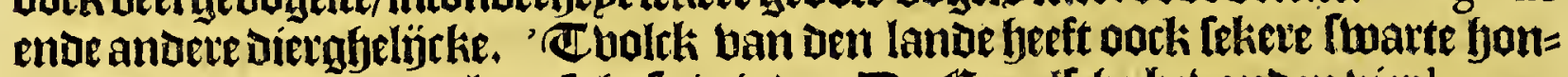
Den/niet wel foo groot als onfe hale- winoen. Be Engelltye bebonton tiet leguen bp jupaen Cap Briton op teftich bademen gronot twart-wafith fant : ende tbien

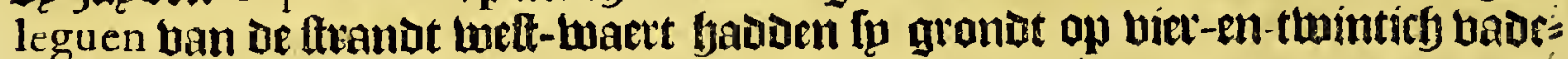
men / ropot fandt met klepne witte ftentieng ghemenght.

Het lefte Capittel.

Van dekleyne Eylanden by 'tEyland van Cap Breton gelegen, ende infonderheyr van'tEylande Ramea, ende de Walruffen die daer gevangen worden.

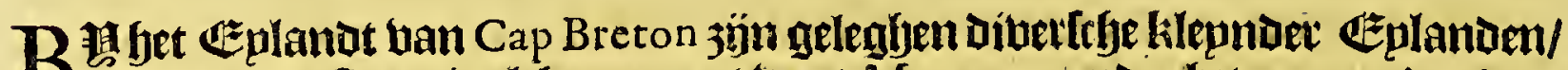

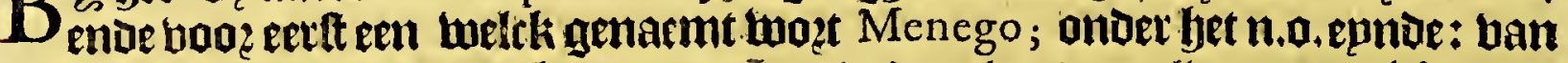
'tfeltue is tamelÿck goede ancket gront eñ I 6 badem materg; allwaet menichte ban

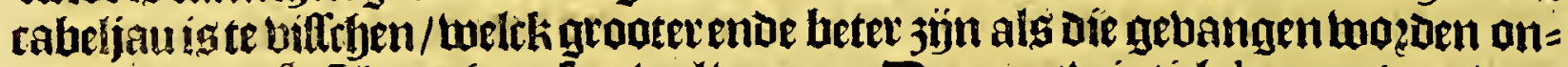

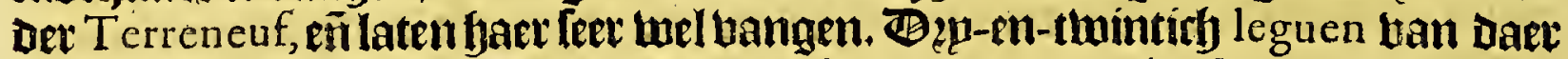

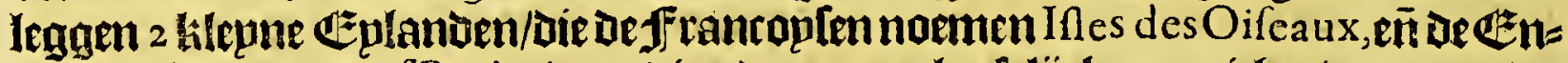
gelfrye the Iflands of Birds, Dooz Dien Daer ongelanfelijtke meniclyte ban bogelen

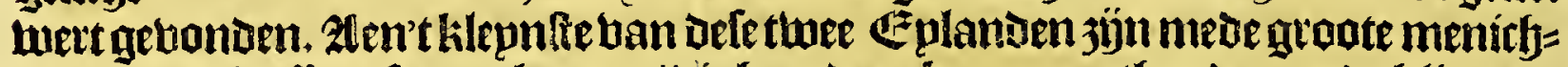

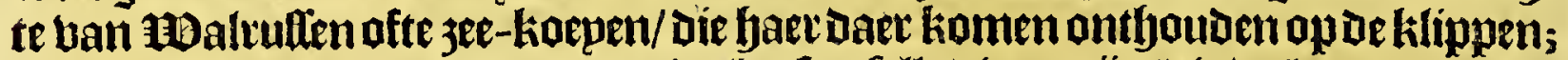

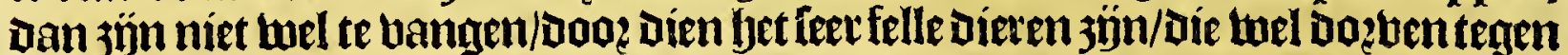
een lloepe aen-liomen/[ao d atmen genoegh te doen beeft om lích daer ban te teode=

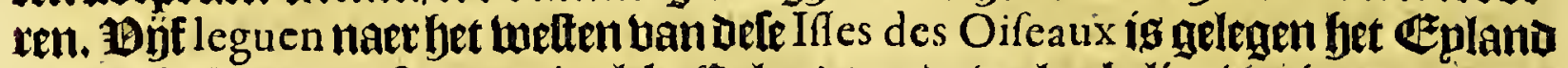

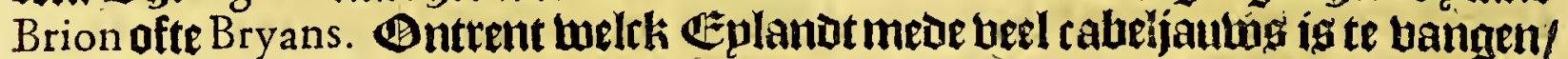
foo dat De \& Engelfrye getupgen/ Dat fu ineen ure tÿts met twee boecken Dael wel

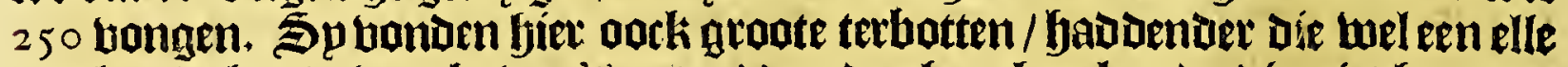

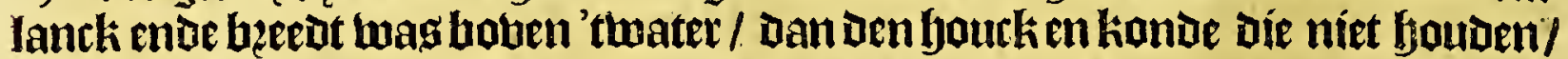

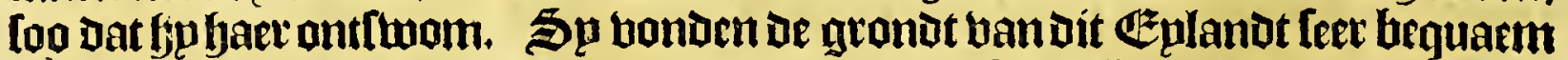

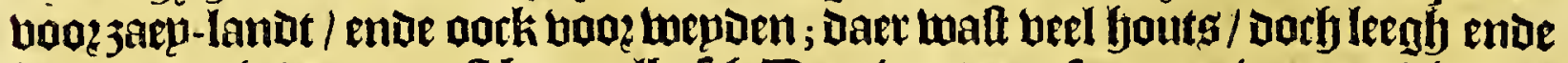

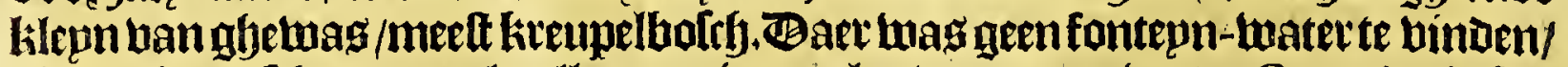

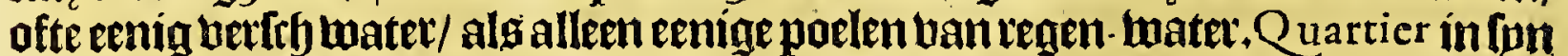
cortte hopagie Las mede aen dit Eplanot / welcke fon noemue lfle de Brion, ende

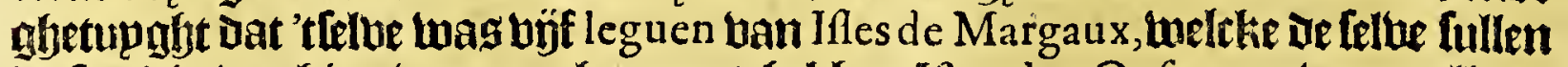
weren Die wp hier boozen ahenoent beblen Ifles des Oyfeaux, want alle de

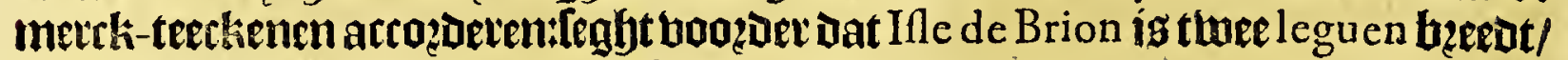

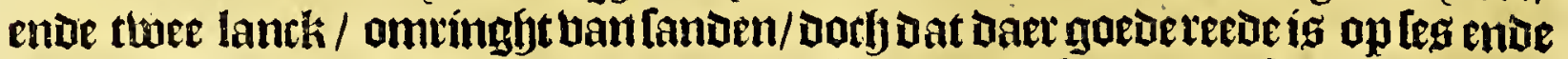

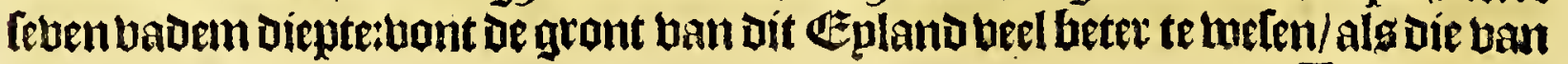

Terreneuve, 
Het trveede Boeck.

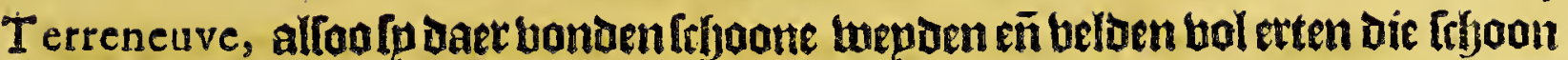
geblaept ftonaen; oock heel minngaeraen/aeti-befien/roofen enue andece ficup= Den ban feet goeden teutke: om ende ontrent bet Eepland bonden [p beel jee. defen

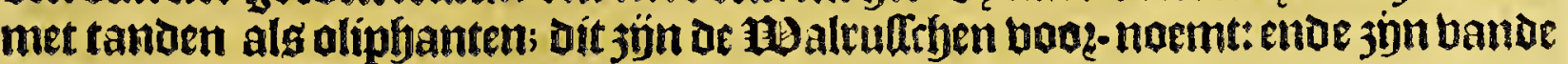
gheiaente alg tolght:

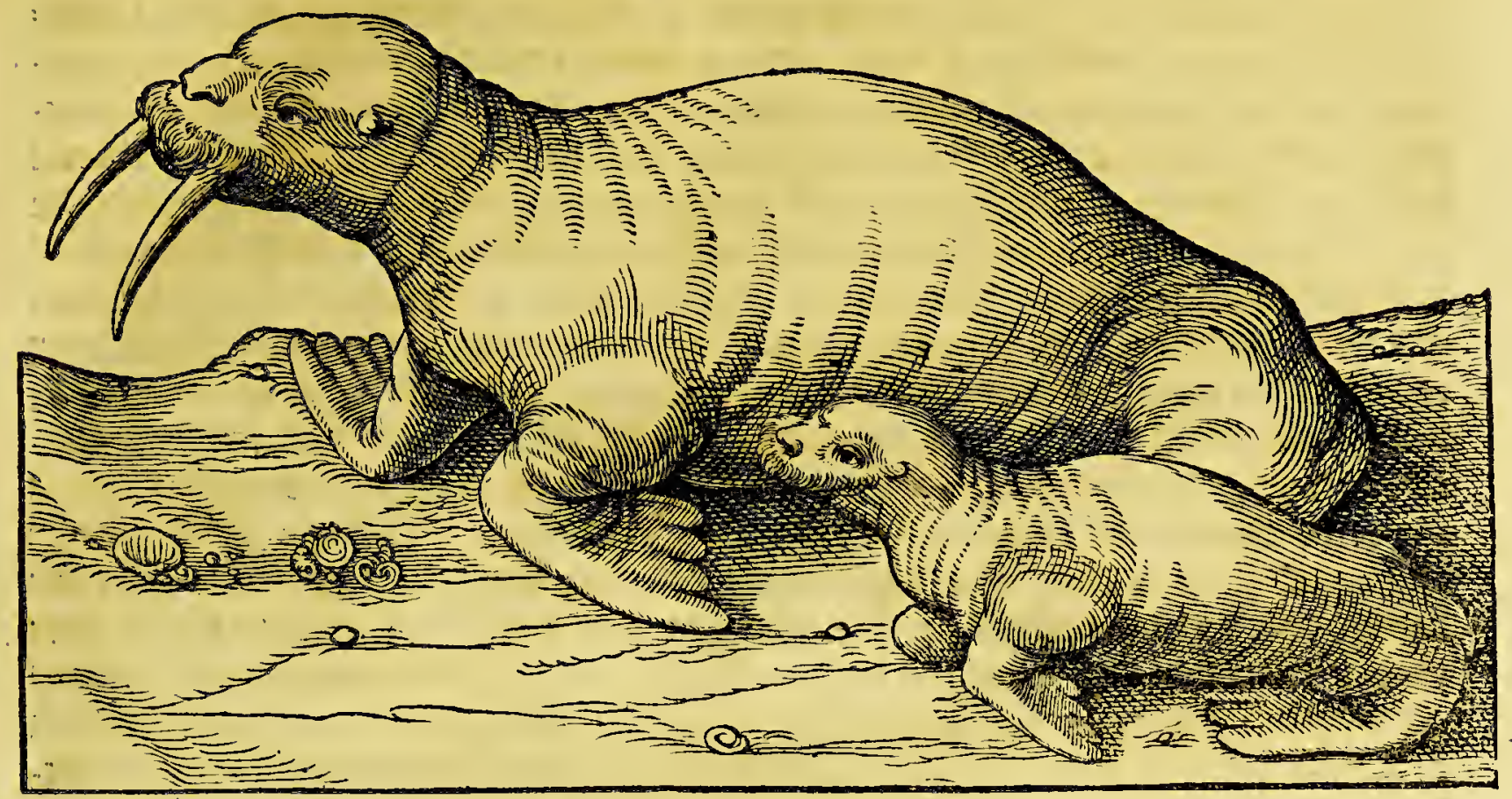

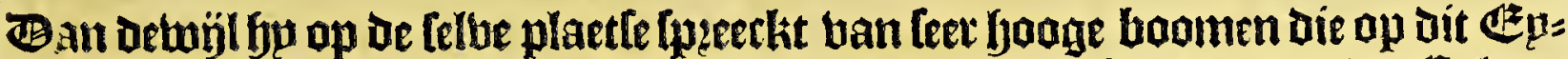

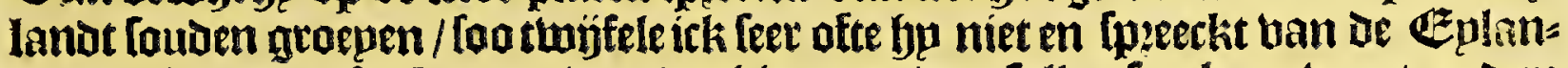
Den de Ramees ofte Ramea, Daer wphier naer ban fulten Ip'etien: want andere

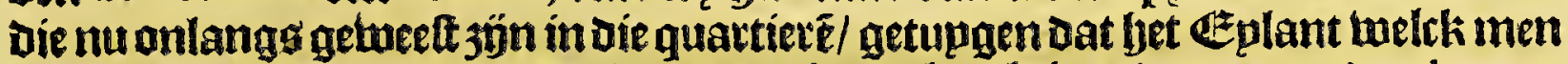
nu gfemennligek Brion noemt / maet een legue lanck is emoe antrent bap leguen in't ronde; ende dat daer beel bueren-boamen wafen / ente dat de gront fandigh

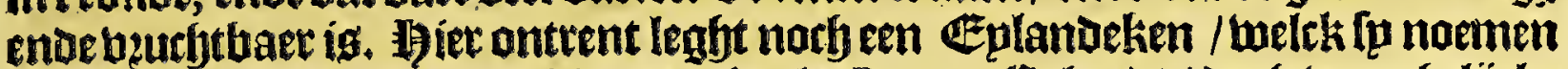

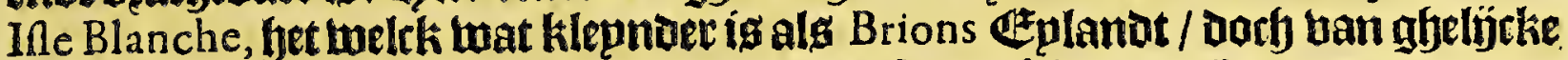

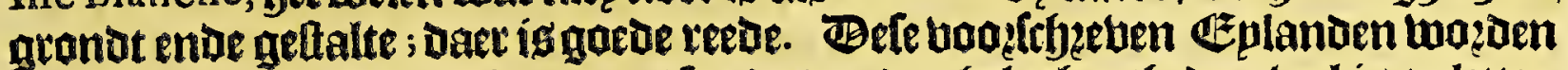
bp andere oork anders ghenaemt / loo dat op de gfelegbentfjeden tael ig te letten om niet d'een booz d' anoer te nemen; want lines des Oifeaux mazaen oock gljes noemt Ifles de A ponath bp andere : ende Champla in in [pn kaette ftelt vier klepn Eplandekent die fyp Ramees noemt/ende een groat Eplandt bu Leften oe Telue/ welel hp noemt Brion, joetwel men upt bet naetboigende fal konnen mercken dat Brion, [oo men fet beaen-daegs noemt / moet bp ooften R a mea legghen. Tit Eplanot Ramea is begommen te bebaren onttent bet jaet 1590 . UEen febip ban $S^{2}$ Malo welck aetwaents toer inden jare $159 \mathrm{I}$, wert in't weder-komen ban de

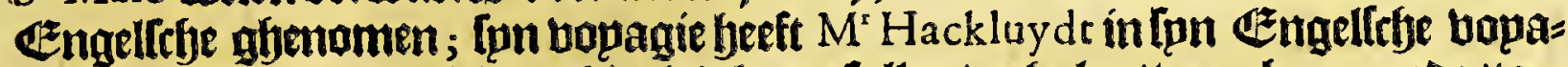

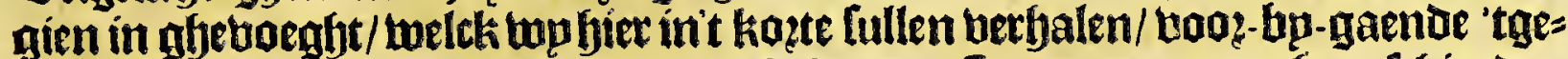
ne totkennis ban dit Eplanot met en beboot. Sp quamen met baer fethip den felten May atn Cap de Ray; ente den Ietuenoen aen de Geplanoen ban A ponath, welck maet acht leguen was ban oe haben die fp [achten/ fa werden soo? ftam te rugghe afiefouden/ende fielentwelelf dagen af ende aen; Dorb quamen epnde=

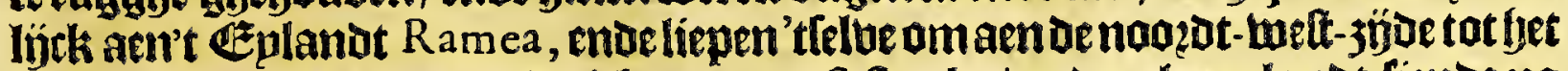

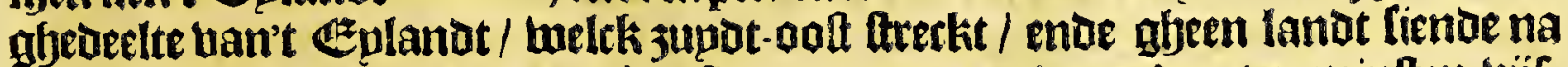
'twelten / liepen'tellue om naer' toolten een quart na 'tmooraen ten mintten büf= thien leguen, ende hondentwel acht leguen ban de twal bijfthien badem waters/

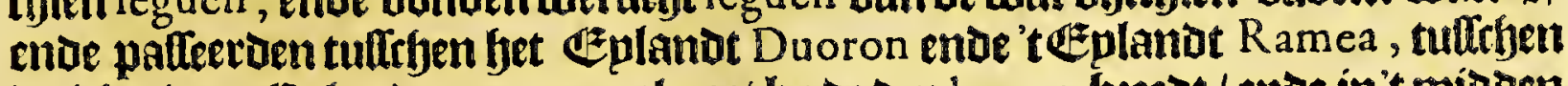
kuelclie tuee Ezplandeneen ranael gaet bp de Dęu le guen beed / ende in't midoen

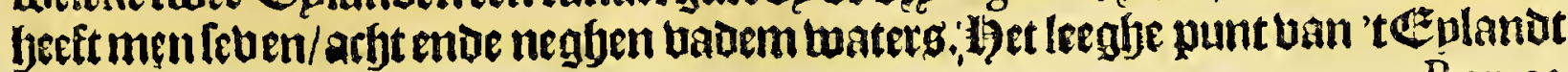




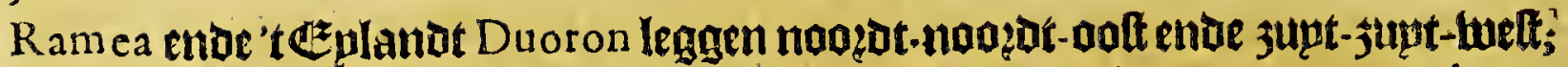
men maet bet leegly punt ban Ramea niet te na komen/ twant een grodete legue vaer van af is maet Dep badem waterg. Je haben ban't $\mathbb{E}$ planot $R$ amea legbt

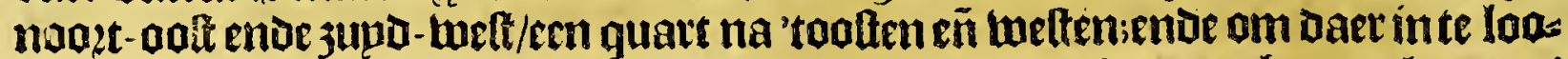
pen/moet mé frem een le gue han oe wal foutoen; lhaet te noteren dat naev' tooft-noot-ooften feker hooge landen leggen die in'taen: hamen fribinen ban betre al Ẽplanaen te Lefen / ende kamenae aen oe jupat-

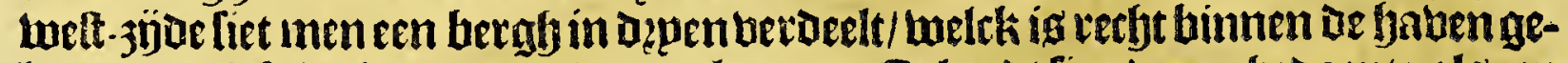
legen : oock fult oljp tot meetoer teecken een Eplanot fien ban alyedacnte als een Ielie / welck ten mintten feg leguen is ban de fjaten; ende dit feplander ende de

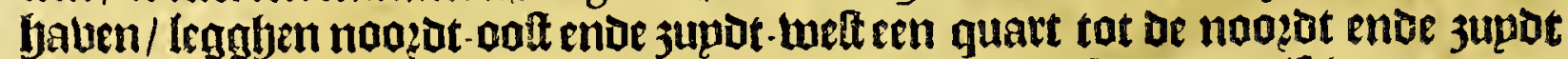

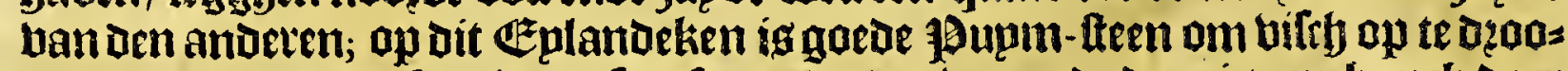
gen: maer naer'twelten is een leet frape lancoutue; ende daet is een banck dact niet ober een baurm materg op is/ welck Daer boos leght de Ienghte ban een rabel;

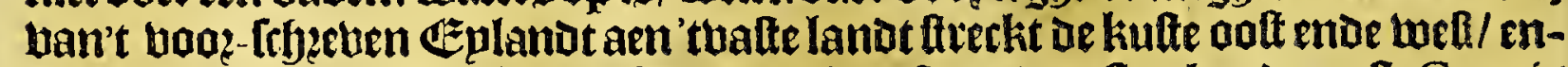

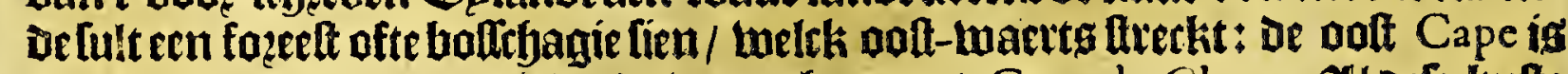

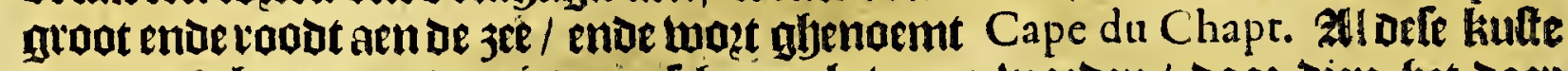

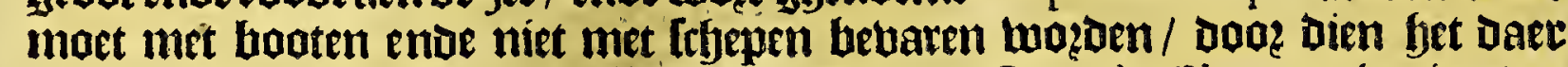
fon Dęogh 1 / / want bp naet anderbalf legue ban Cape du Chape en is niet obet

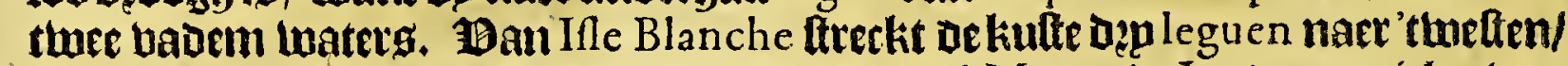

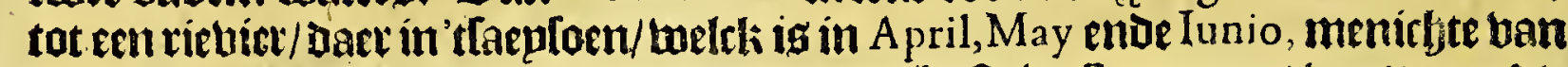

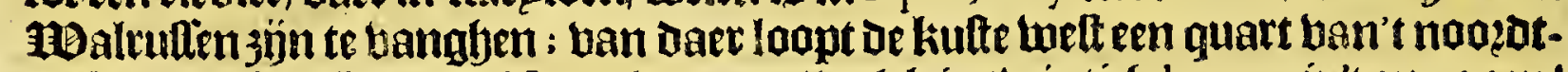

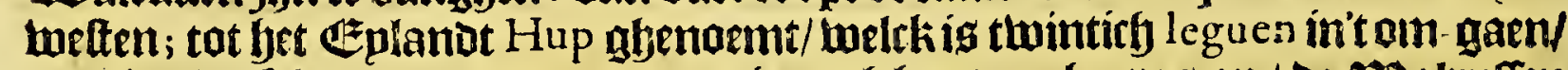

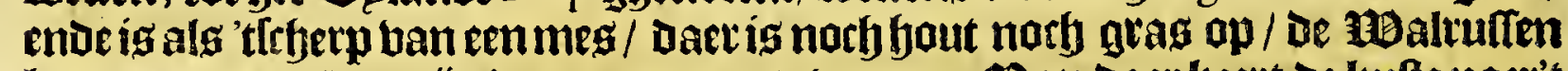
komen daet op/dan jijn daet quaet om te uangen. Ban Daer keet de kufte naer't

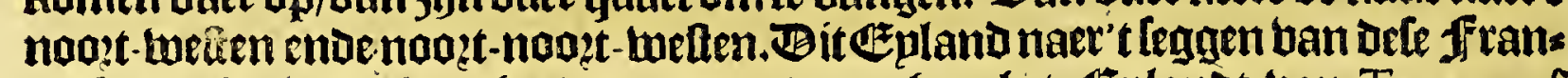
coufen leght op be booggte ban 47 maden achtel bet Eplandt ban Terreneuf ontrent vijftich leguen van oe Grand Baye: ende ig ober De thinticf leguen in't ronde/ende een abedeelte daer wan is niet dan blaclie tanden/ende dzooghten/

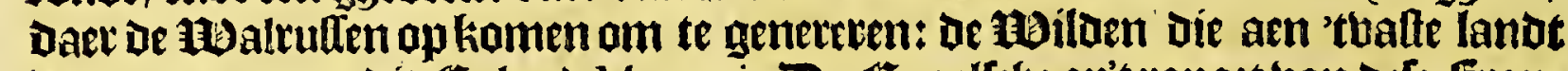

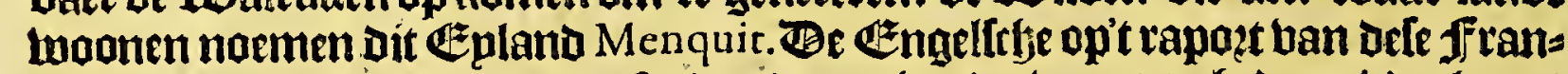
coplen hebluen Date naer twee ofte Dep bopagien Derwaerts nbedaen/ Dorb met klepne bool Lpoet; noemen de peincipaeltte haven Halabolina; ende daer is een ansere nach dirbt bp. Bug ued ban dit Eplanot Ramea.

\section{Het lebeniue Capittel,}

Van'e vafte lande by noorden Terréneuf, ftreckende naer de Rieviervan Canada: ende weft-Kufte van Terreneuf, ende de aen-legghende Eylanden.

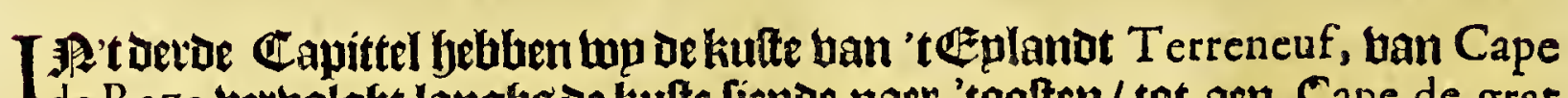
1 de Raze berbolght langfjobe kulte liende naer 'toolten/ tot aen Cape de grat

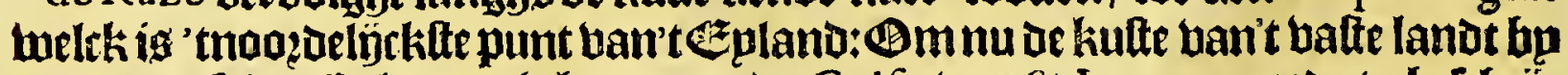

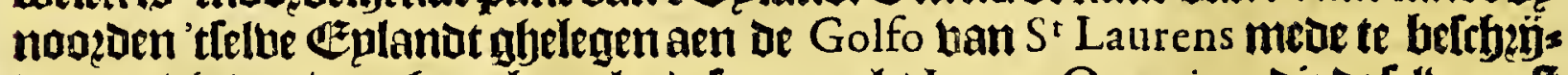

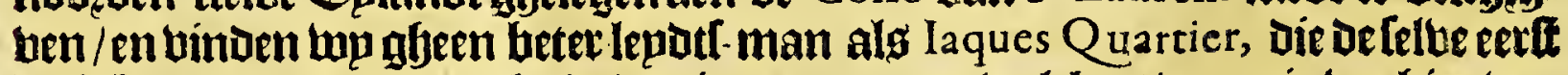
beeft bevaren enoe antoerkt in aen jare 1534 . upt welckes bopagie bu bier ber: bolgens fullen nemen' tgene tot ons propooft is dienenve. 'C is wel foo dat daer Dooz Lal aen-aheraertwazden De welt-jyoe van Terreneuf,ende oe ander Eplan=

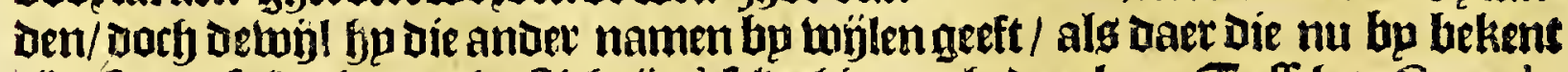

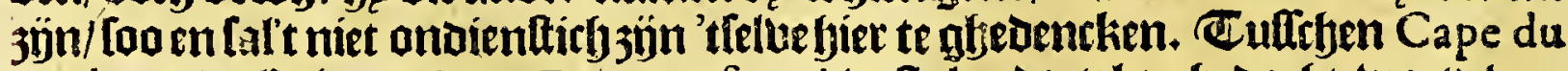
grad, aen't $\mathbb{E}^{2}$ planot ban Terreneuf, en'tuafte lanot (als afyedocht wot) ban America, leghteen 马trate ofte Dooz-torht / Die fu noemen Golfo de Chafteaux, ende pock Baye de Chafteaux: Srbepoende uan Cape du gratende de Golfo in: 
Het rvveede Boeck.

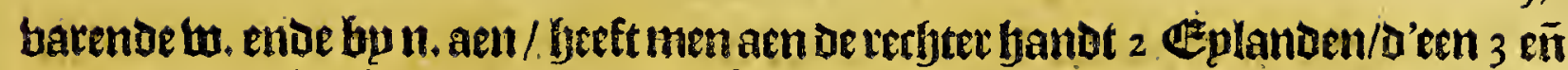
d'anoer 7 (min oftmecr) leguen berfryepoen lan 'tpunt toodrlyetben; is black ende leegb landt/endefcjünt beel eet een gedeelte te luefen ban tuafte landi; $Q$ uartier noemoe fyet Ifle $S^{r}$ Catherine, naev' toolten iften quart ban een mijl ozoogh

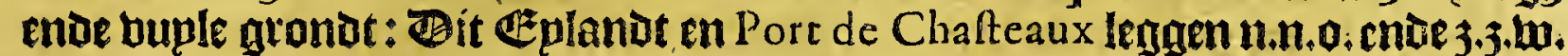
I5 leguen ban oen anderen: 1 an port de. Chafteaux tot porr de Gouttes, welchi ig

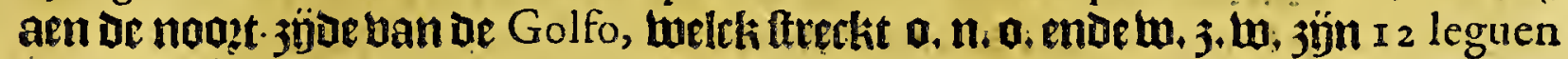
en een balf; ende ban daer tot port de Balances the leguen, tan port de Balances

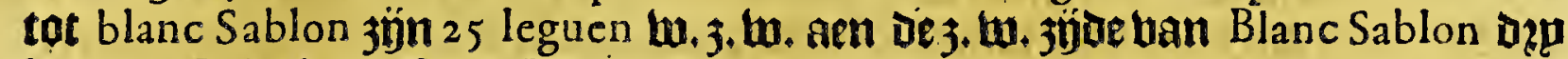
leguen af / leght een fandot boukn twater / algeen boot / Daer men bem booz maet

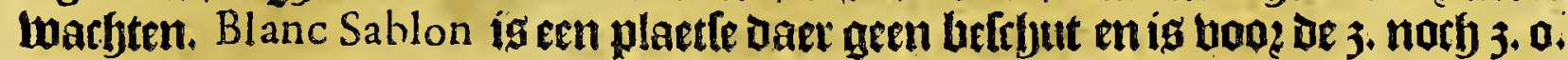

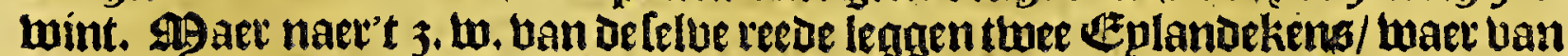

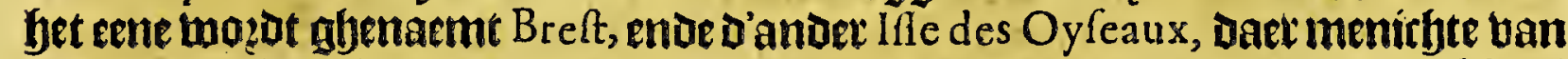
gebogelt op is/onder andete rabeng diecen roade betkende rogde beenen bebben/

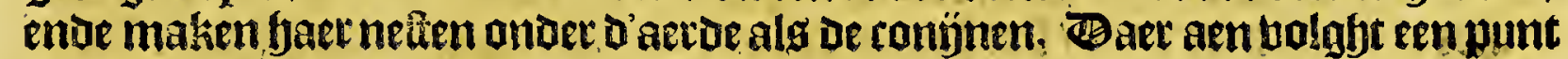
lanjtg ontrent een legue ban Blanc Sablon, voog bo 'telte igeen baven ende pals fagie Dirle noemen les llettes, die beter is als blane Sablon : entie hier balt gaede

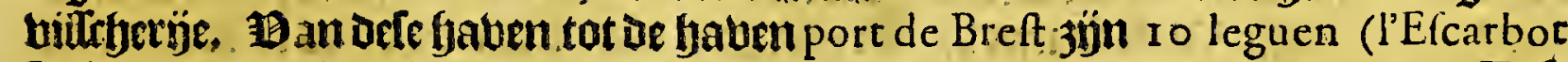
Ieght 18 ) ende ig gelegen ap de fyodghte han 51 graden / ende 65 minuten: Cul:

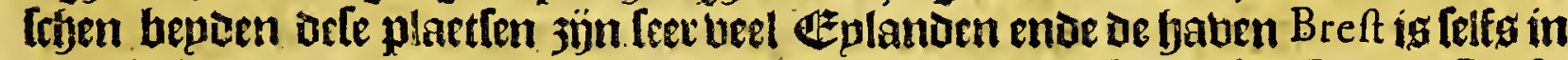

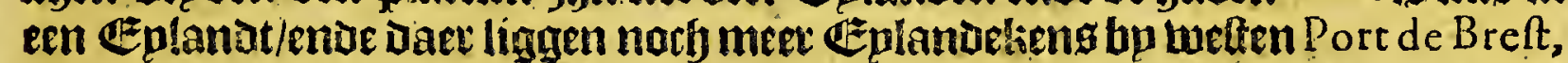

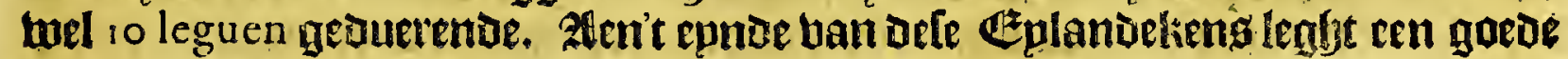
haben / die bp noemoe Port $S^{t}$ Anthoine, ende cen oft thee leguen thoosder aen be

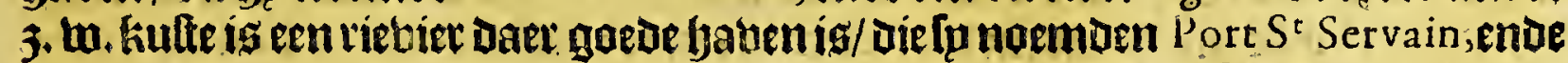

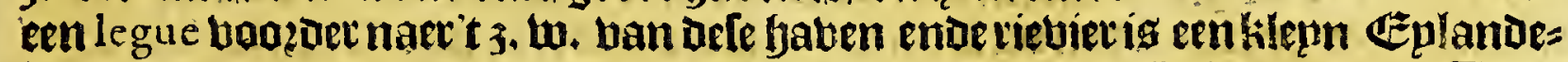
ken randt alseen oben/ om ringt ban andere klepnder Eplandekeng. Clmee leguen booger igen ander rietrier / daer beel falms ig te banglen/ noemoe die

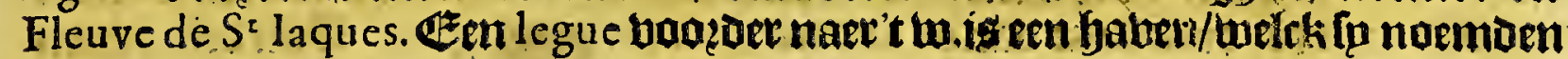
Port de Iaques Quartier, ig en ban de befte babeng ban De lwetelt/ [oo Quartier

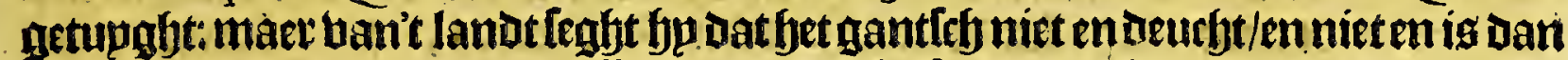

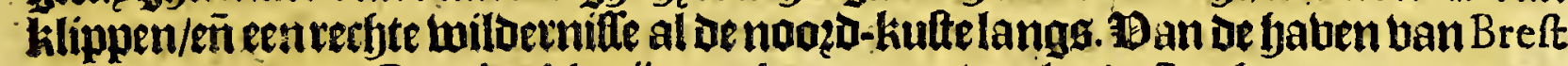

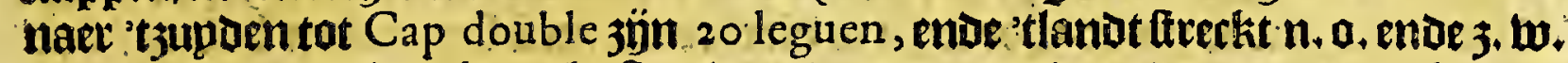
ban daer varende langhg de kulte 3. w. een quart naer't 3 upden ontrent 3 , leguen

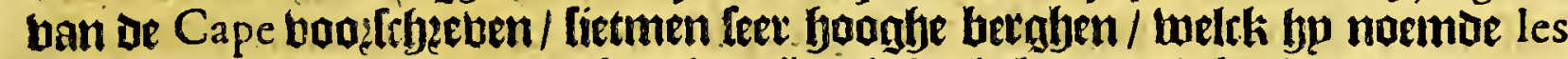
Montagnes de Cabannes; De betuben jïn ghebackeltende gletuzaken / ende naer

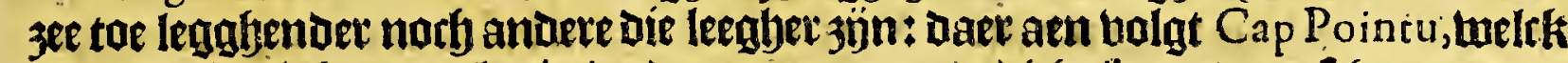
een kape is die bouen plat is/ende naev zee toe epnoirbt lip met een feyeep punt;

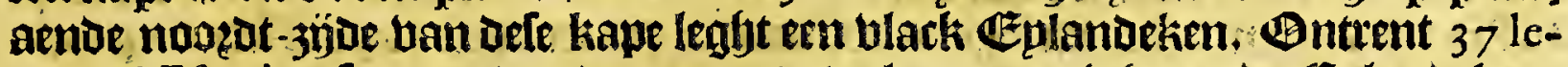

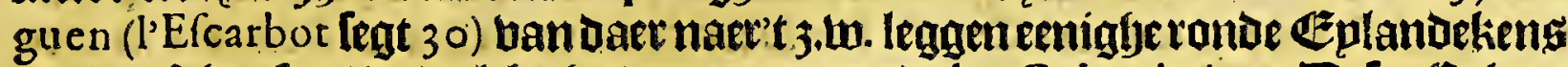

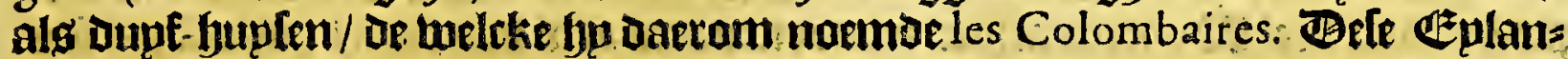
Den leggen in een bape/dere noemen Golfo $S^{t}$ lulian: 7 leguen naer het jupdenten welten is gfielegen Cap Royal; endenaer twelt-jupot-welten ban Cap Royal is

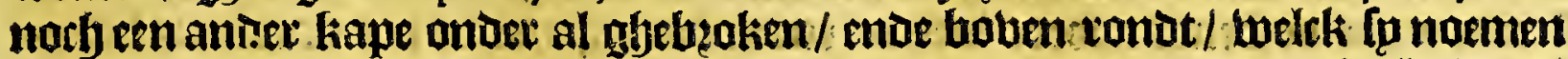
Cap du Laiet ; een balf müle Gan daet naex 'tnoożen leght een leegh $\mathbb{E}$ plandt. (c) wee leguen uan Cap Royal heftmen gronot op 20 badem/ endedaet is en el:

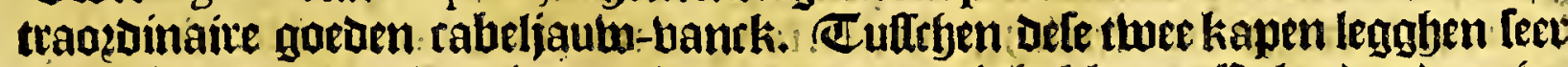

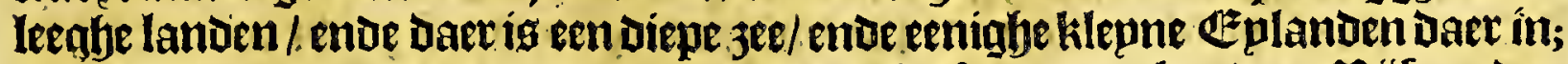

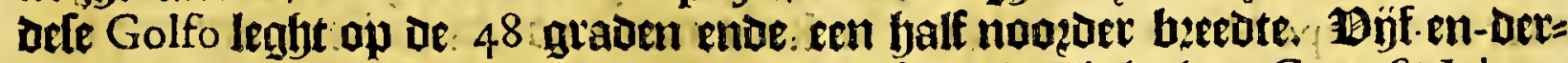
tich leguen van Cap Royal nate't zupor-melten/ is gheleghen. Cape St lehan. Ban uete kapen 3 eploen fo noozot-welt ten welten ontrent leben leguen, ende

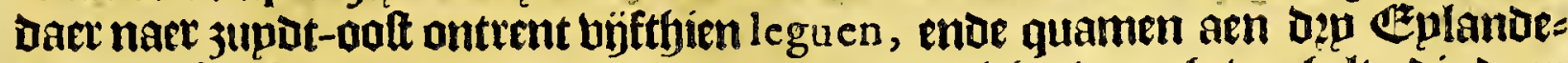
ken's die loo ftepl maren als mueren; Dooz De menirlyte tan ghetuoghelte die daet

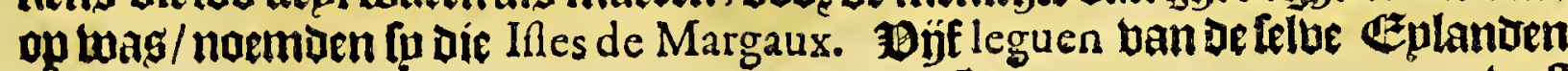

$$
\text { fi. tuelt }
$$




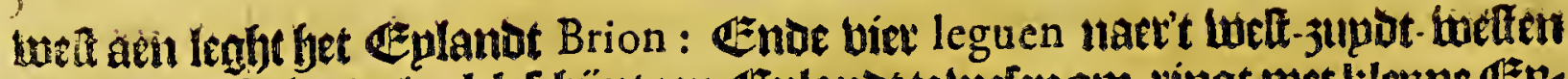

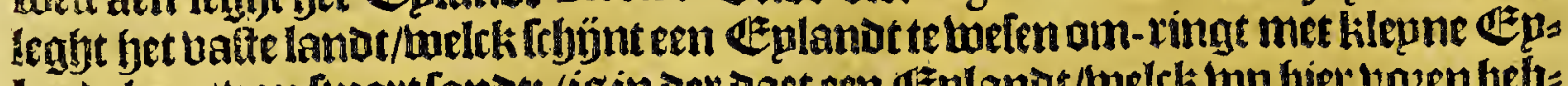

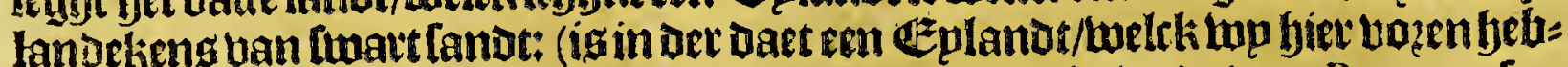
ben ghenomut 't $\mathbb{E}^{z}$ plandt ban Cap Breton : oft bel 't Eplandt ban Ramea, foo

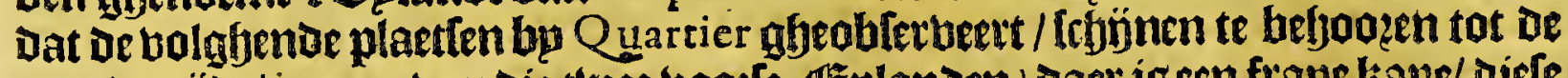

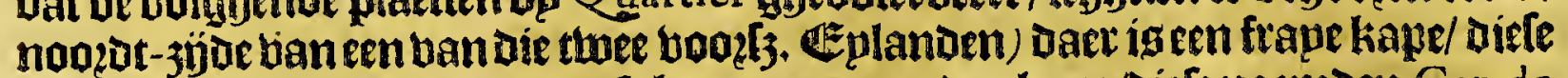
noemben Cap Dauphin:ban Defe hape tot een ander kape foiele noemoen Cap de Sc Pierre, ftreckthet lambt meet welt-jupdt-welt/ende is al leegh land/ende Daet:

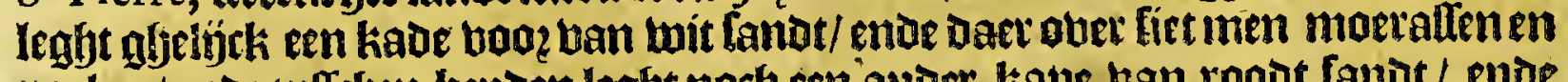
poelen / ende tuffechen bepien leght noch een anoer kape ban roodt famot/ ende

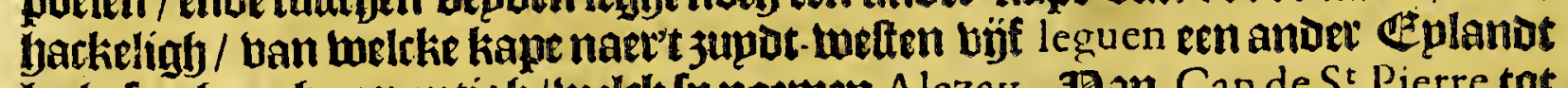
leght feet hoogf enpuntigh/weick fo noemen A lezay. Dan Cap de $S^{\mathfrak{t}}$ Pierre tot het bafte lanot jujnontrent veettich leguen ; twalte landt ftreckt baer jupdt- 3 updtooft/ende noozot-noozot-welt / tot een frape kape ghenaemt Cap d'Otleans : all 'tlandr ig blatk ende leegy/ feet fryoon om aen-fien; bol, ban boomen ende toeps

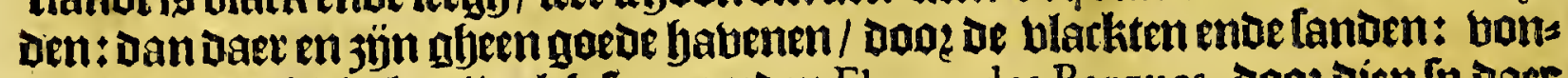
Den baet een riebierken/ melek fp noemoen Fleuve des Barques, Dooę Dien Ip Daec

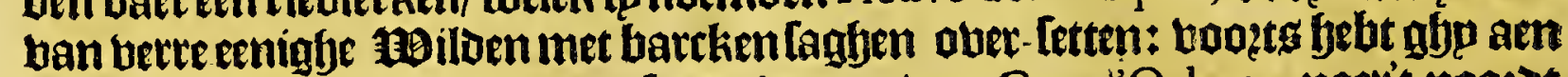
orfelbe kufte Cap de Sauvages, feten leguen ban Cap d'Orleans naet't noozot ten ooften: aenDe noozat-3joe ban oele kape onttent een yalf legue af legtjten rif vanlteen dat leet peticuleug is; eenighe neghen ofte thien mijlen in't ronde is al

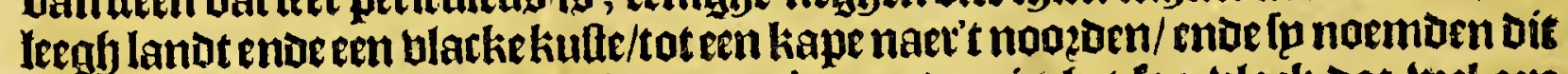
Golfe S' Lunaire; ontrent die kape natr't noozden ig bet foo black Dat twel een legue ban't lanot gheen vadem waterg en íg; naer't noazdt-oaften ban de booz= normoe kape antrent feuen oft arbt leguen ig aen ander kape/tuffeben twelcke beps

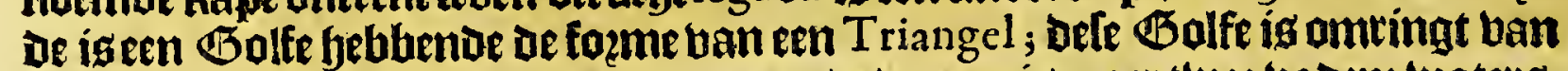
[anden ende blackten booz thien leguen, ende daer en ig mart the badem toatetsis

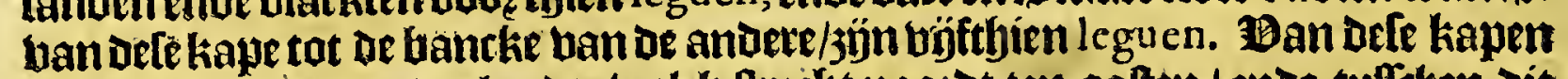
toozder leght een ander lanot: twelck ftreckt noozot ten oolten/ ente tuffeben dit

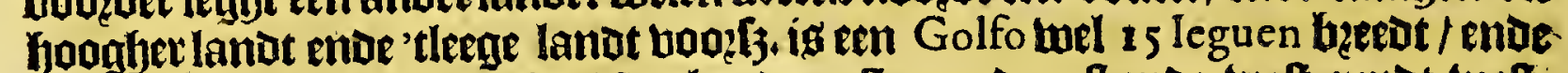
op plaetten 55 vadeinen diep/ ftreckende oolt-noazd-onftende inelt-3updt-weft.

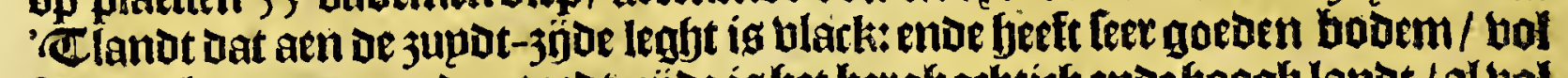

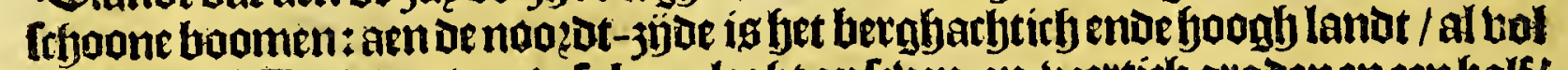

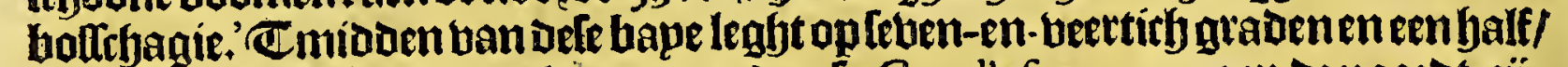

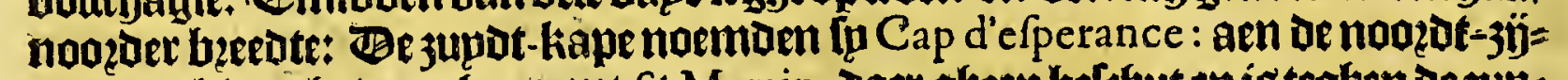

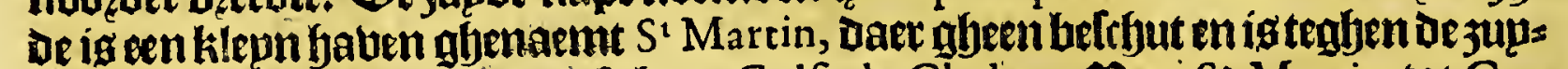
De wint: Quartier noemae dele hape Golfe de Chaleur. Ban St Martin tot Cap

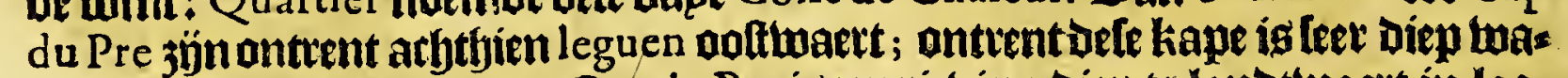
ter: Bjiff oft lest leguen ban Cap du Pre ideen riebiete diep te landtwaert in lon:

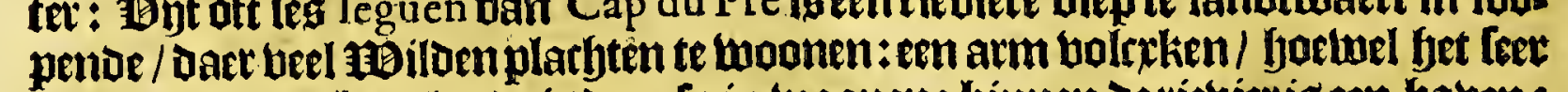
goet ende beuththaer lanot is daer fp in twanen: binnen de riebier is een bauen: ban de monot ban de riebiere beft bet lanot een boctjt algeen Galf maen: ende

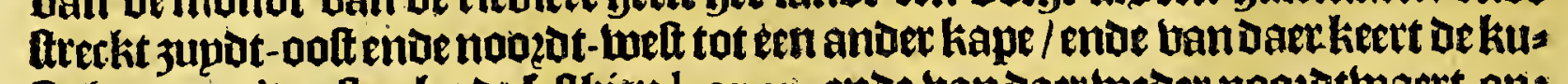

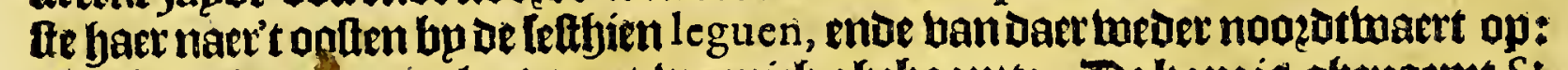

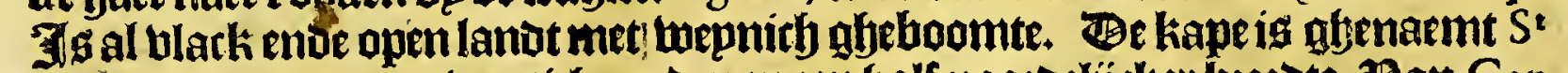
Lou is op de negen-en-beettich gradenen een yalf nowzelötket beedte. Ban Cap

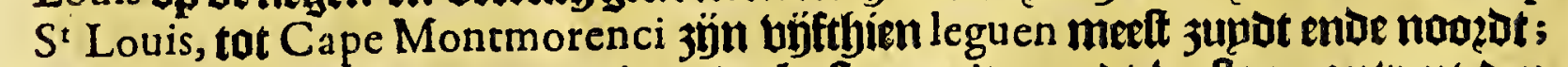
ende van Cape Montmorenci keett de kulte naect noozot-toeften; antrent Dę leguen ban de kape en feeft men gheen grondt met een lín ban 150 . bauemen.

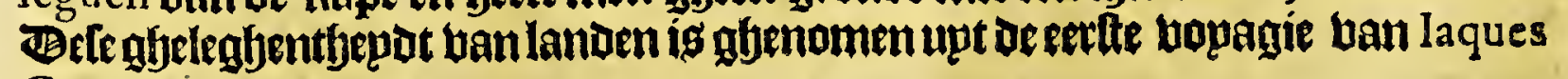
2uartier. 
hot arbtite Capittel.

Voorder befchrijvinghe van de kufte aen de noordt-zijde van de Golfe $S^{t}$ Laurens, ende de gheleghentheden daer ontrent.

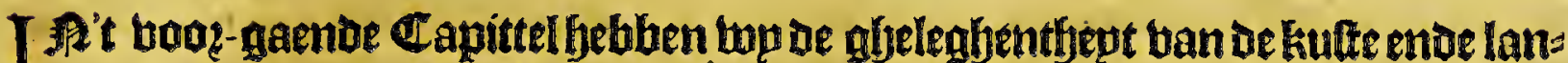

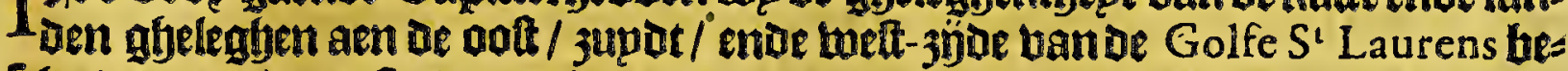

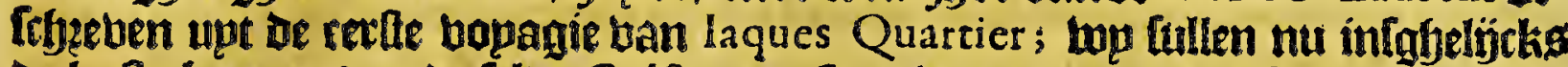
De kulfe bp noozeden de felue Golfo, upt tun theede vopagie belcheijben. Ban Golfo de Chafteaux tot thee (Eplanoen vir fp noemuen Ifles $S^{t}$ Guillaume, on= trent twintiof leguen berfebepoen ban De baben ban Breft, ftreckt De kufte oolt

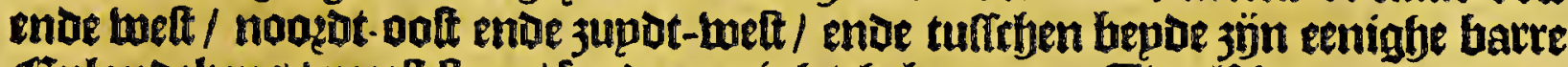

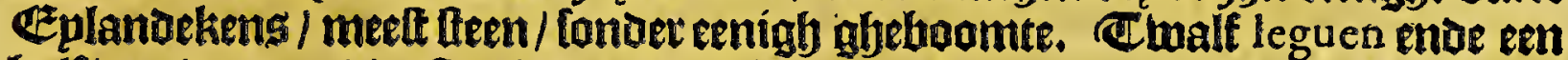

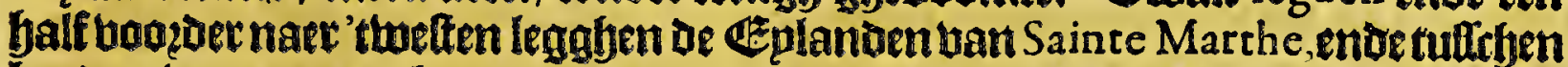

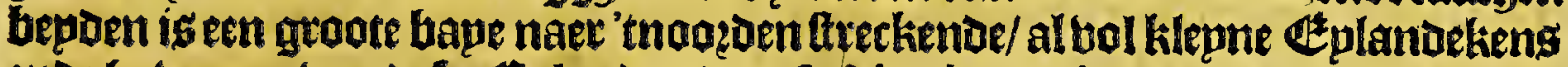

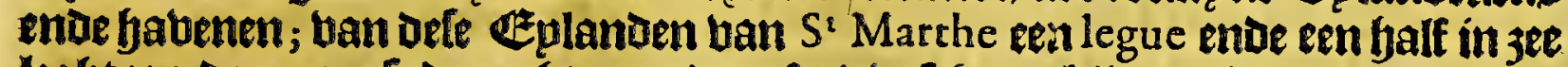

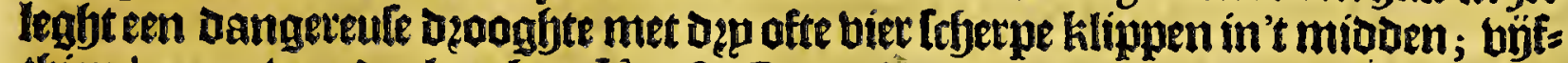
thien leguen boozoer legghen Inles S' Germain, ban welcke onttent oyp leguen

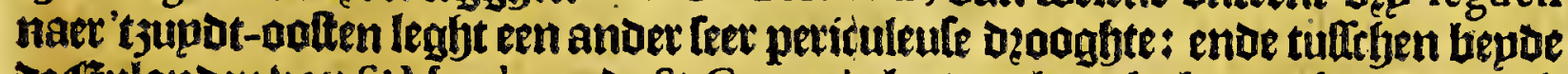
De Ceplanden ban $S^{2}$ Marthe ende $S^{\prime}$ Germain legteen bantke bp de 2 leguen lanck Daer maet 4 badent toaterg op en is. 1Ban be kape ban de efplanden van $S^{\prime}$ Ger. main boostwaett ftreckt de kulte oolt enoe welt/een wepnigh jupdelijckende noo:

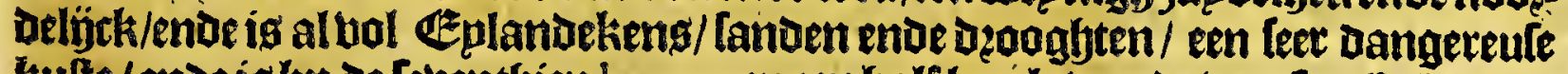

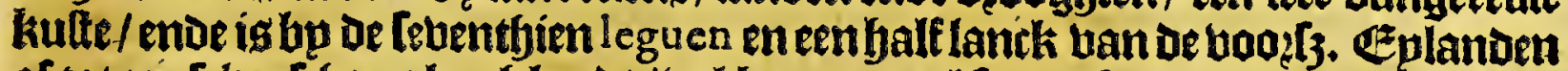
af tot een leker ftyoon leeghlanot / vol hoomen/al landt-frandt fonder habenen/ tot bp Cape Tiennot, ontrent leben leguen ban be lefte Eplanoen naer'tnoogtweften : Seben leguen eneen half boozoer naer'twett-noogt-weften is een klep=

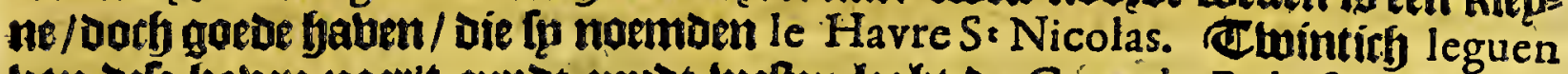
ban Defe baben naer't jupdt-jupot-welten leght de Cápe de Rabaf. Ontrent thien leguen ban bele kape naet't noozinen is een lthoome groote hape bol Eplan=

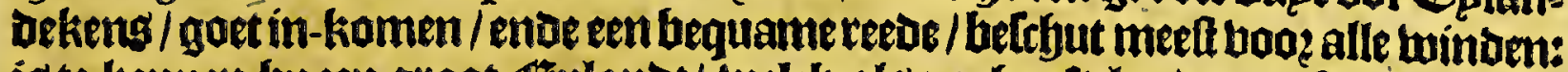

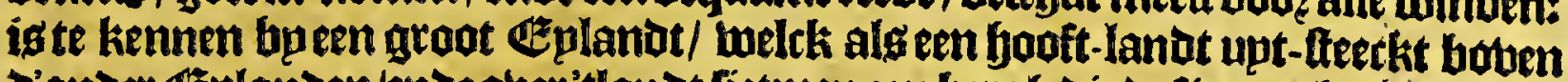
D'anoet Eplanden/ente aber'tlanot lietmen een hergb die de figuere beeft baneen koten-taltfl [p noemben Defe Baye $S^{2}$ Laurens. Ban uele hape ontzent 25 leguen

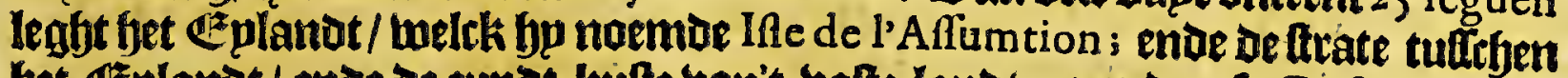
bet Eeplanot / ente de jupat-kulte van't balte lambt noemaen fo Deftroir de St

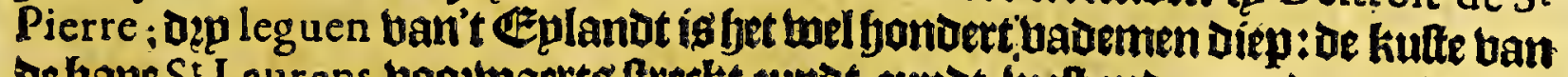

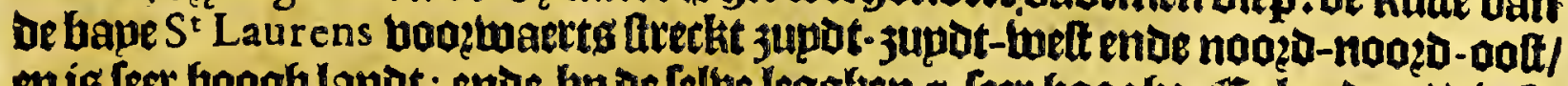
mis teet Googh lanot; ento bp De felte legghen 7 leer booghe efplanden/ die fn noemoen les fept Ifles rondes, antrent dep oft bier leguen ban de kulte/ende ban baet boozts beht gbo leegh landt bol banlthoone boomen / ende en fraep riebiet/ ban Daer ígen blacke kulte hefmet met landen ende ondiepten.

\section{Met neghento Capittel.}

Pertinente befchrijvinghe van dekufte rondtom een goet deel van de Golfo $S^{t}$ Laurens, by IE A N A L F O N S E die Stier-man Was van $M^{2}$ de R O B E R V A L op fyn royagie.

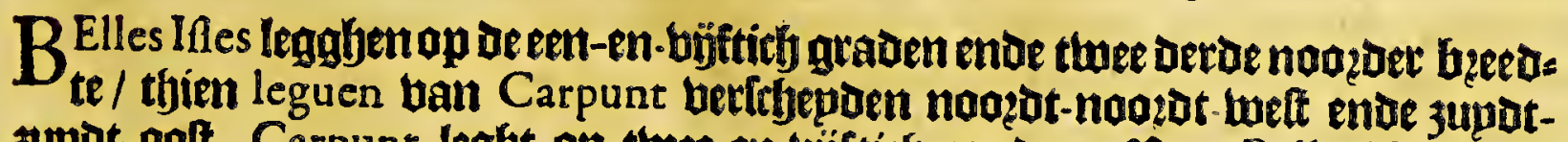
3updt-oolt. Carpune leght op theten-buftich graden. Ban Belle Ine tot te Grand bay is leter leguen n. o. ende 3. W. Get midoente ban oe Grand baye fegtoptture-en-büftighgrad.ende eenbalf/ende aen oe noazat-3joe ig eenklippe/ Ii 2 ende 


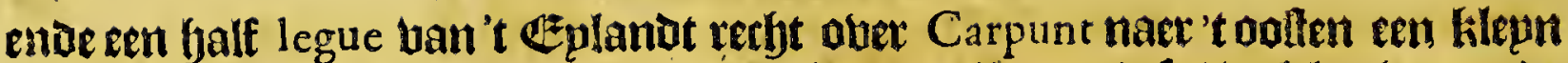
ulack Éplandeten/ enoe aen de noozot-zijoe een platte robtre / welck gbp upt oe

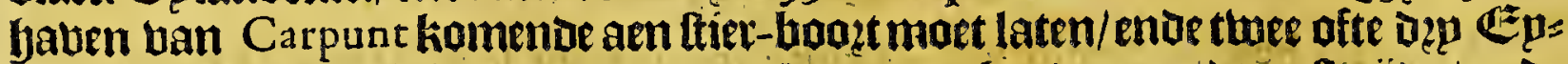
lanoekeng aen bagh-boozor; ende unt-kamende bu be noozot-ooft-jübe / ende loopende langfg oe wal wett-waett aen/ bebt ghpeen blaclite aen u thiet-bovet

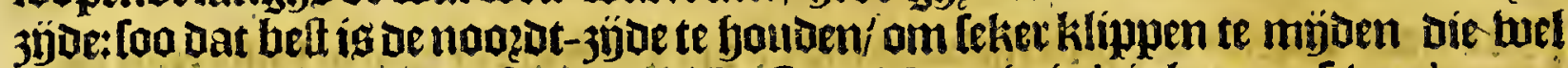
twee tot dzp mijlen in $3 e$ frecken. De Grand Baye is in 't inkomen [euen leguen beet/tot ouer Baye de Chafteaux; ban waer bookwaetts maet ubf leguen beeeds. te $\mathfrak{e n}$ ig. Ban Bell lle in uemonot van Grand Baye tot Blanc. Sablon hinmen

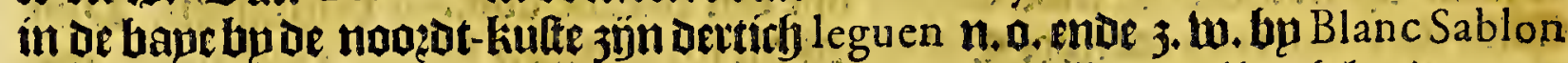
is de bape acht leguen twijot: enoe 'tlanot aen oe 3 unt-jode ig al leegh lanot:maet.

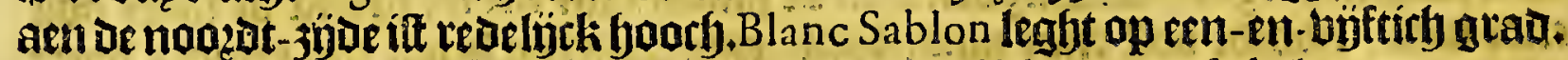
entae thee Deroe: Dit Eplanotende de Eplanden de la Damoifelle leggen o.n.o.

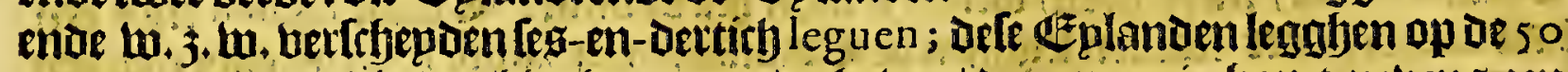
gradenende dep tiende: fier is een goede bauen/ Daer men in tiont nebens een booghe hape die naet' noozot-ootten ftreckt/enoemen mach Daer anckeren in io bademen waters/ontrent twee kabels lengte achter ien yoeck. Ban Defe đeplan= Den tot Terra nova en is de 3 ee niet obel de $36 \mathrm{leg}$. beet/ Dode dien T erra nova tot Cap Breton toe/maern.n. o, eñ 3. 3.tw.enftreckt. Cuffenen bepoen Blanc Sablon ende de Éplanten de la Damoifelle jun meet eplanuenende goede hatenen: I hes

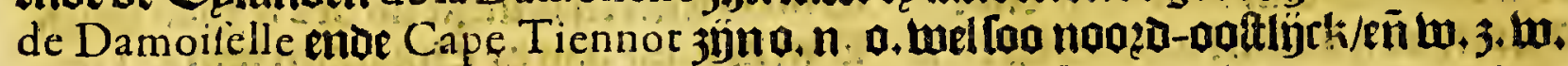
ban den anderen bertffepden arbthien leguen. Cape Tiennor legt op 5 o graden

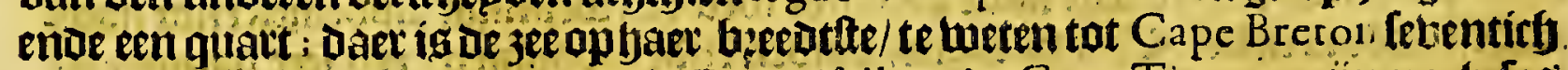

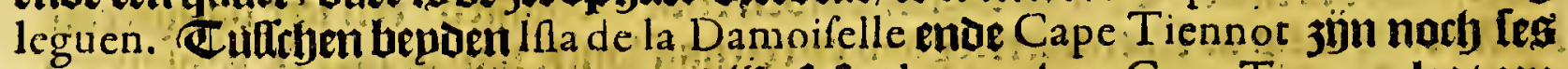
off teben eplandekens, ente ontrent biff oft fes leguen ban Cape. Tiennot legt een

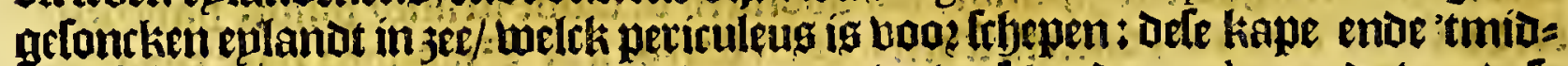

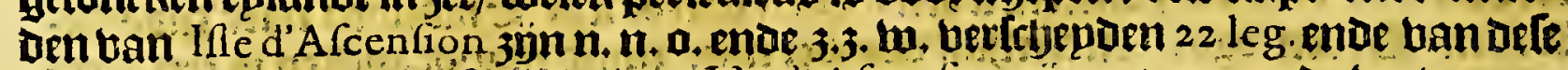

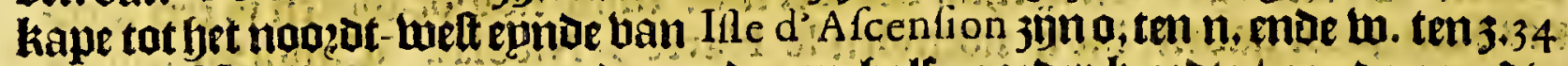
leg. Sept Ines liggen op 50 graden enoe en yalt noogder beedte/aen de noopt-

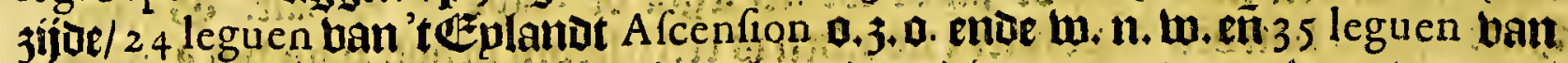
Cap de Ognédoc (ofte Hongoedo, als andere die noemen) n., n.w.ente $3,3.0$. Dan Sepilnes tat Cape de monts de noftre Dame jijin 25 legueng, enden./ han

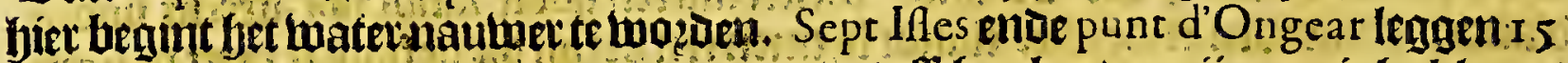

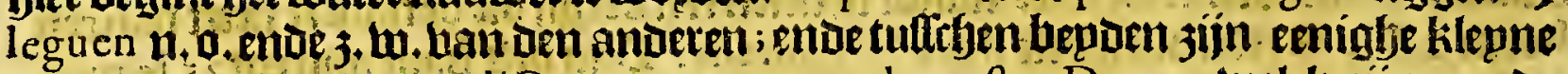
Eplanden , ban punte d Ongear tot monts de noftre Dame, welck 3 ijn aen de

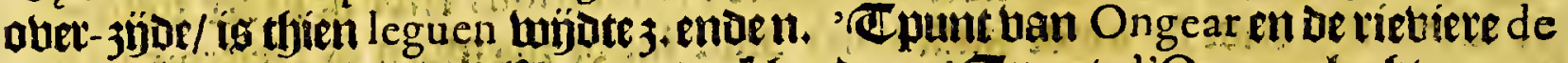

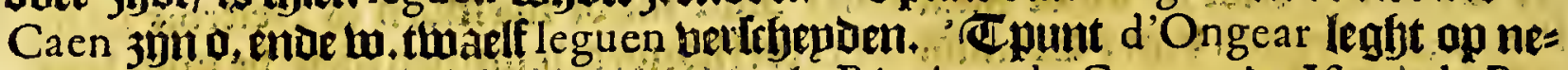
ghen-en-beetich aradenen een bietendeel. Rieviere de Caen ende Ifle de la Ra. quelle leggen n. o.ende $j$, wo twaelf leguen ban den andeten. Dit Eplant ig ges: legen op acht-en-ueetictjaraden ende thoee detoe is een leegh eplandt/ ende legbs naer aen oe zupot-kufte dicht bp een looghe kape / welck twoet ghenoemt Cape de

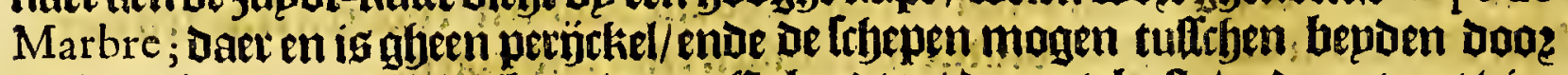
Jeplen:'tíg Daer een legue beet ban't eqplanot tot de jupt-kufte/entoe ontrent bier leguen tot de noozat-kulte. Dan lne de Raquelle tot het brgin ban Saguenay op

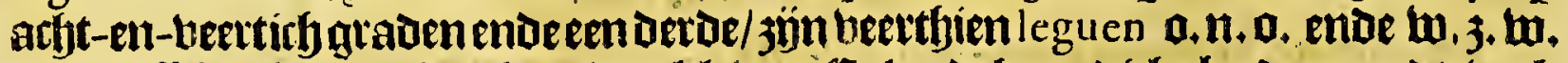

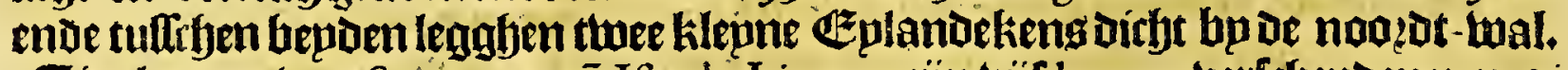
' Cin-komentan Saguenay eñ Ifle de Lievres jün búf leguen berfrbepoenn. n.o. ende 3. 3. w. Tan fier ban fullen tmp fiet na beteder fpzeecken:ende nu bier alleen

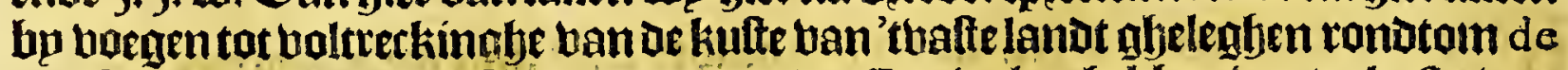
Golfo ban $S^{t}$ Laurens. In oe hoozgaende Capittelen hebben twp de kufte ban 'tualte lant/fagende bp hueften De Golfo belryzeté tot Golfo de Chaleur, Daet aen volgende is een wel-bekende haven/ die lunoemen Gafpé ofte Gachepé, welck is een bape bp defenen oft acht leguen lanck/ biet leguen betet in'timkomen/met een rífuifle 
Het tvveede Boeck.

riebiete die wel dottith leguen in't lanot loopt; op de foongte ban adjt-en-beettich

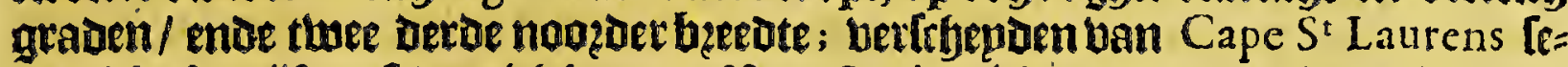
ventich ofte büf-en-febentich leguen. Ban Gachepé fomt men arn baye des Mo- 1'Eccarrues, weltk bp de degp leguen lantk is/ende oock foo beel leguen beted in'tin-lio= bot. men ; daer aen volght Ihle Percee, welck is ghelijck een routfe van bepde jijuen 1.3.c.9.

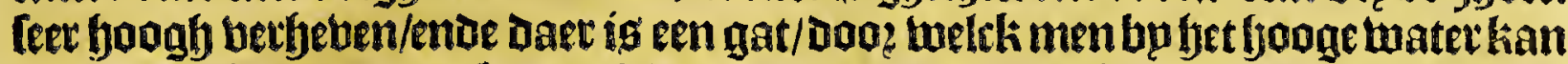
varen met floupen/ende bp leegh matet gaet men tan't Eplanot aen thafte lantot

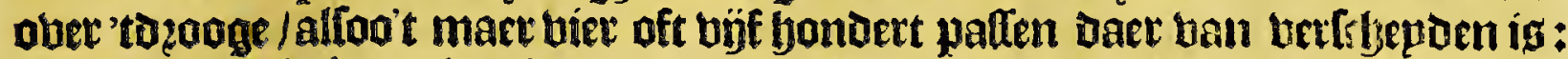
Daer aen volght baye de Chaleur, Daer top fier vozen ban glyelpzolien bebben an=

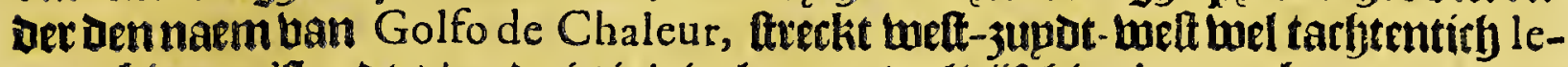
guen bimen 'danotg / ende is in't in-komen wel büftbien leguen beest.

\section{Het thiende Capittel.}

Van 'tEylandt N A T I S C O T E C ofte ghelijck het nu ghenoemt wordt AS S V M T ION; en de rieviere CH ICHEDEC.

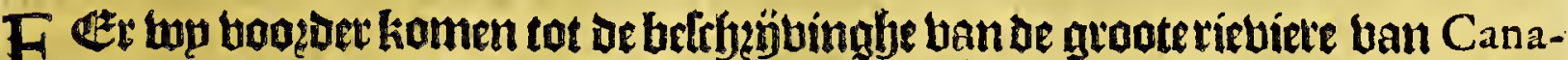
$\mathrm{da}$, Coo fullen twp al boien biex aen roeten bet \& Elanot leggfende aen't in-ka: men ban de feltbe rietuiere / welck oe Ho iloen noemoen Natifcotec, ofte als l'Efcar-

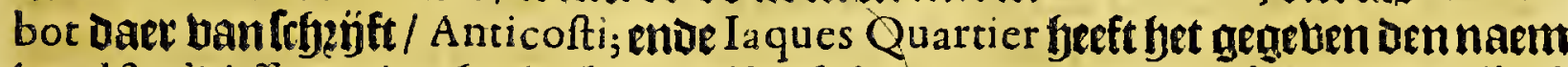

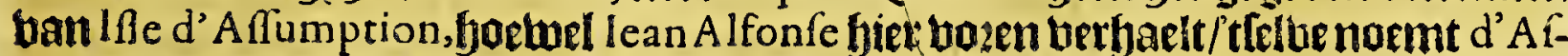
cenfion; bp befrbeyft tet in bolghende maniere. Jet Gepiand tan Afcenfion is fraep/ en beft een lryoone blacke glont / (Londer eenine bergen) ftaende op twitte

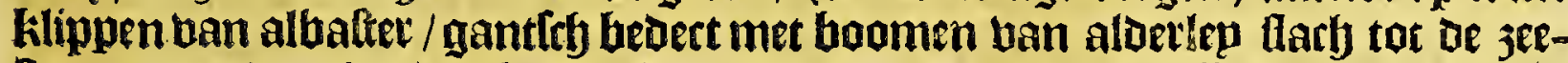
Itranat tae; daer bauden ben ueel wilde dieten/als bepzen/loften/pfere berckens.

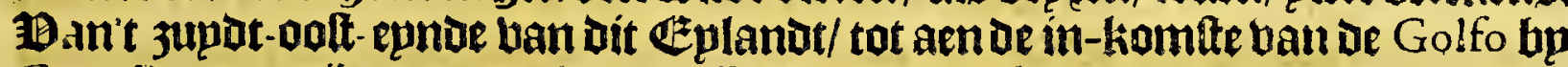

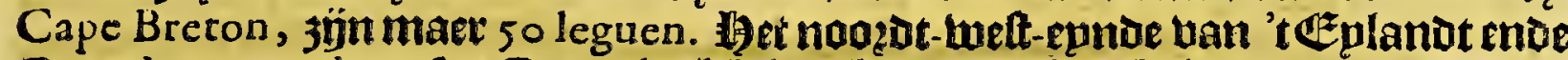
Cape de monts de noftre Dame, welck is gelegen aent' thatte lanot naer'tzupDen/

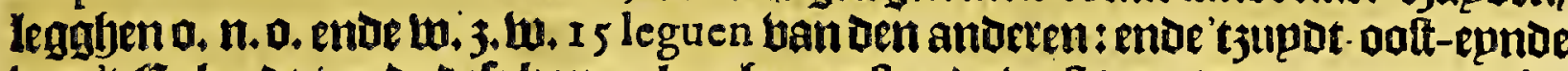
ban 't eplandt / enoe dele hapen legghen walt ende welt ban oen anoeren is leguen. Be feben Eplanden/buelck fp noemen les fepe Ifles geiegen aen de noazd-

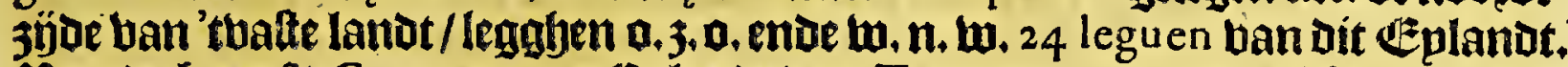
Ban de bape $S^{t}$ George aen 't $\mathbb{E}^{z}$ pland ban Terra nova, naet de abletbatie van

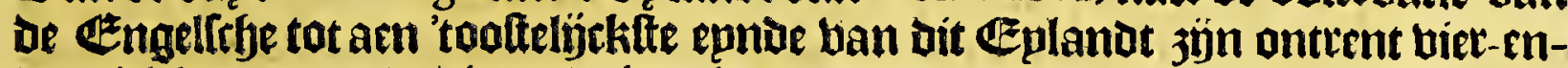
beetticy leguen : enve dit epnoe ís gelegen op oe booghte van 49. alauen bp nooz= den ve linie. Baet is goet antkeren in acththien badem waters / ffboon wit lanot; enoe daer werdt leer groote ende fthoone rabeljau ghebanghen: men fjoubt dat De

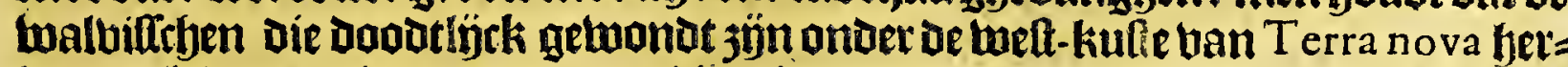

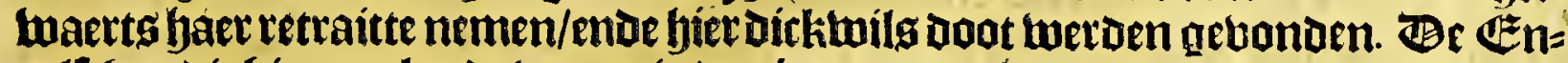
gelletjen die bier aen landt waren in den jare 1594 . ghetupgjen mede dat Daet op't

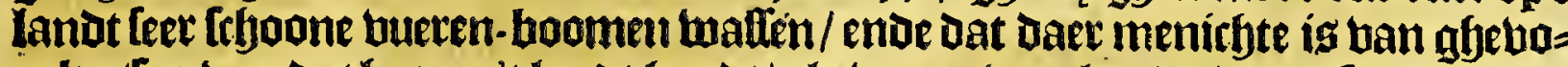
gelte / foo ban Dat hem op t lanot houdt/alshater-bogelen/ende dat fu beel toetîtapen ban dieten in'tlandtgetwaer werden. Cl waelf leguen naer't 3 upden ban

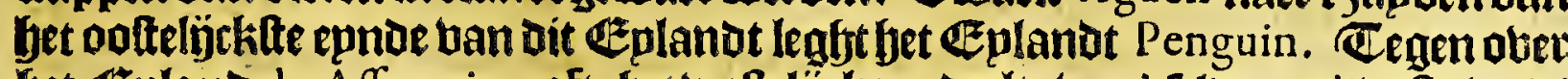
bet Ezpland de Affumtion, ofte bet weftelítke gedeelte ban'tlel he aen' tuafte land/ op de noozot-kufte ban'tlelbe lanotis gelegen cen rieviere/pe twelche la ques Quartier ontoeclite in fon twecoe bopagie / weicke riebiete daer naet oe naem feeft bes bouden ban Chefchedech: de Ielbe $Q$ uartier getupgt dat ban De Teben Éplanden/ weltk gp noemoe les fept Ines, begint een leegh landt/ bol wan fryoon gljeboom: te / ban welck in 3 ee af.-ftrecken Diberlege bancken ban lanot / De fommighe wel

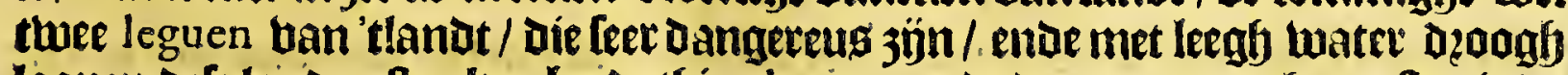
loppen; dele landen ftecken bp de thíen le guen, ende daec aen naer het oolten ig de rieviete / welrk is ban berfet water loo ftelth af-loopenoe in jee/ wat men ff 3 


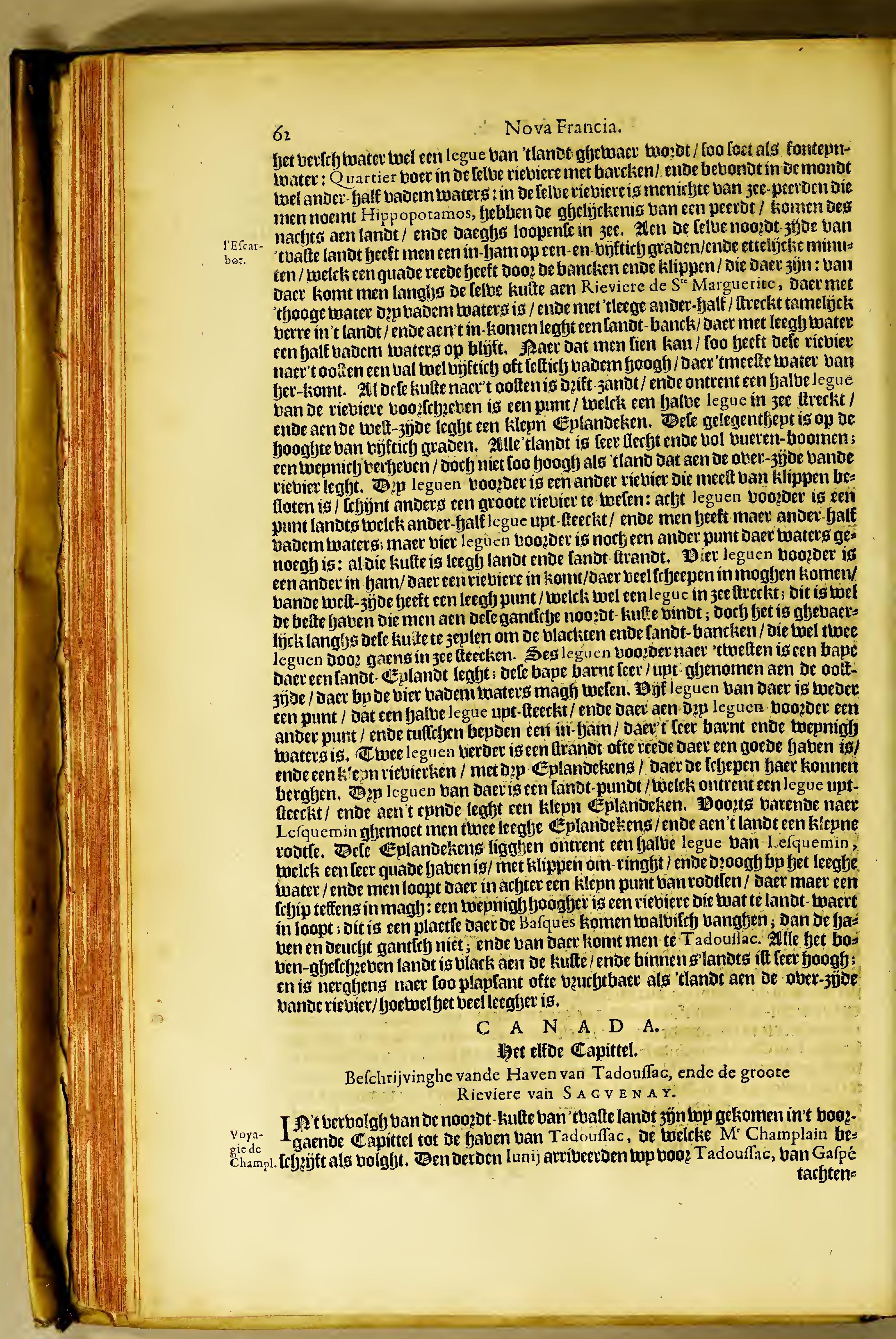


Het trveede Boeck.

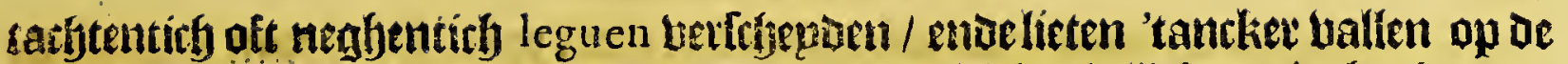

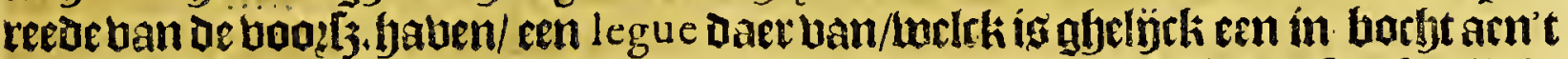

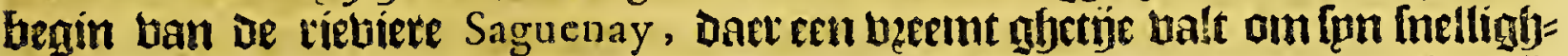

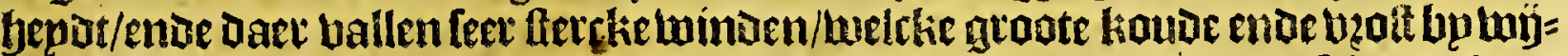

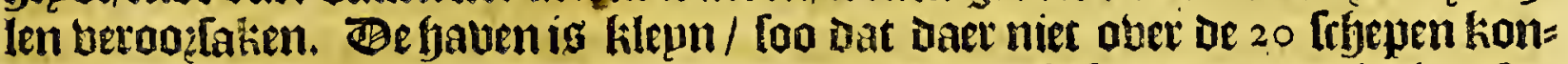

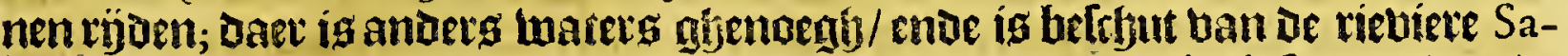
guenay, ente een klepn Eplandelien ban klipuen bp naev af-affetneden ban de

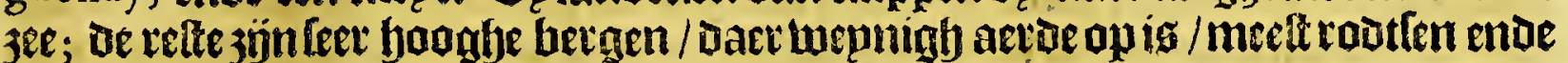
fanden met gheboomte bekleed han bueten boubt; ontrent ae bauen is ecn klen=

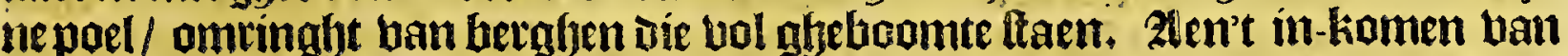

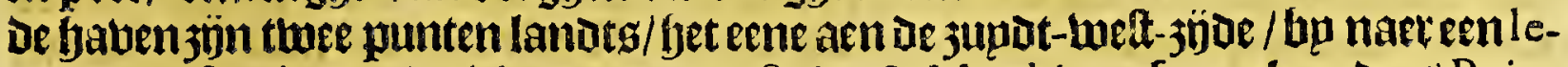
gue in jee ftreckenie/welcts men noemt Point $S^{t}$ Matthieu, ofte oork anders Point

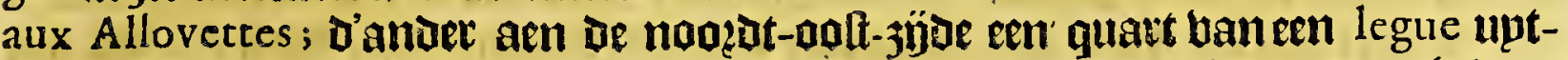

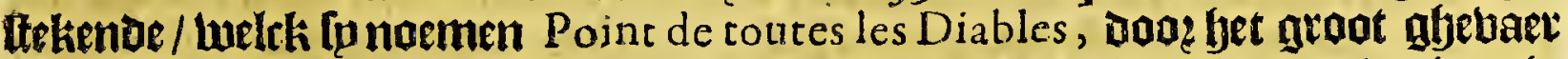

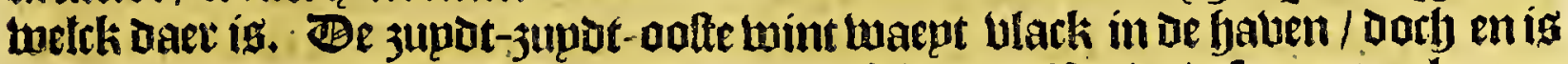
niet te beeren; maer hel aie ban Saguenay af komt. 25ende defe punten loopen Dzoogh met het leegf twatev: binnen in de baven ig thien/ thaelf enoe oock acts= thien ende thintieb uadem maters; in't binnente ban de gaben kome een beke

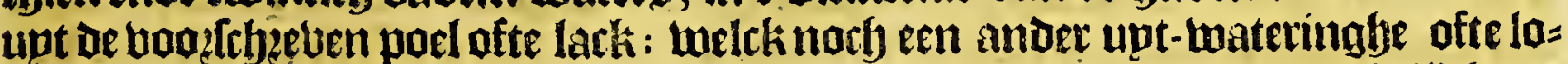

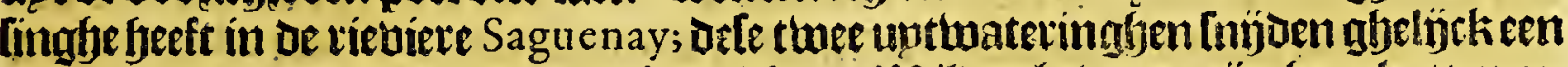

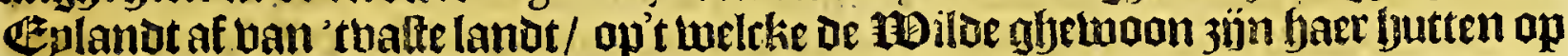

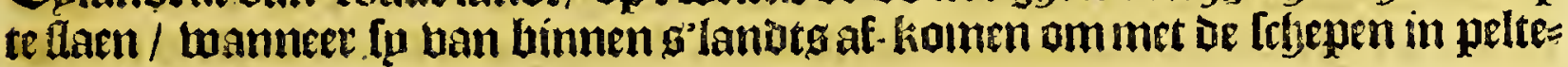
rije te fandelen.

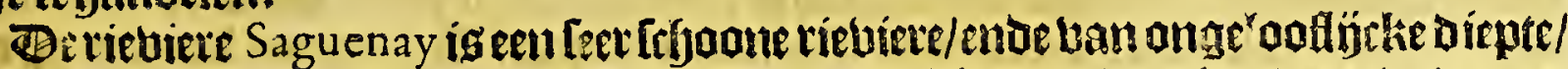

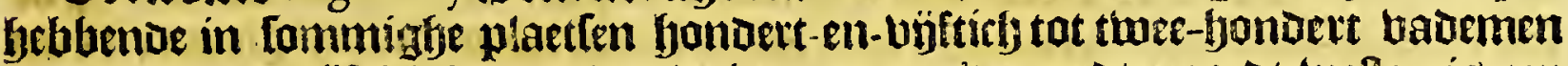

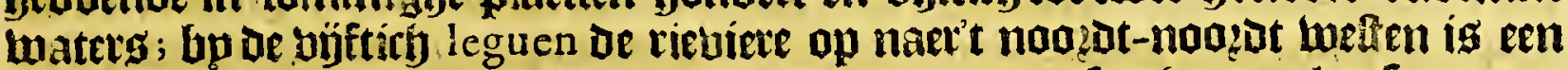
groate af val enoe ltoptinge ban water/vallenoe ban een feer booge plaetfe met een

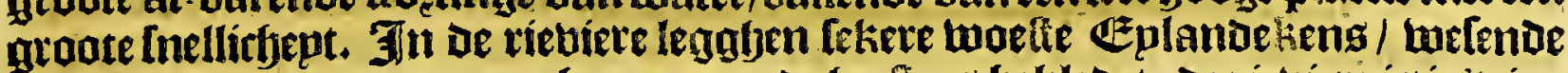
niet dan klippen met Lueten-bogmen ende feefters beliledet; De rietiere is int inkomen een bierendeel ban een le gue beedo / en bímentwaetts op fonmmige fteken

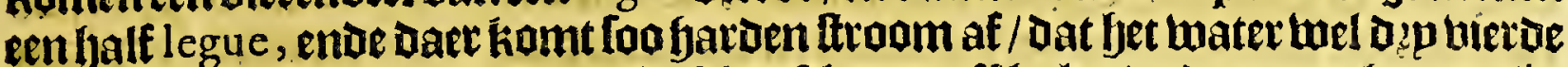
parten ghewalten ig/ Datter noch eble af komt. All tlanot daer om for en jijn niet dan betghen entoe rodten/ de meelten deel met boomen bewaften/ een leer

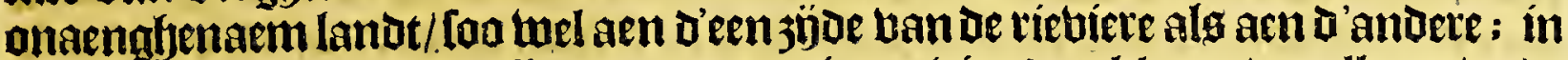
ber daet niet dan wildoeniflen / Daer men niet en bint dan kilepne bagellkens/ente

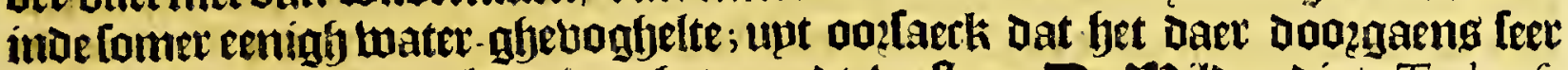

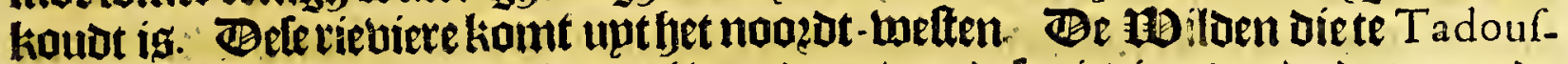
fac komenfyandelen/ bertyalen beel monders ban dele riebiete/ ende dat men de felte eenige dagh -replen op-barende / ende diberlefje van die ballen ende lacken

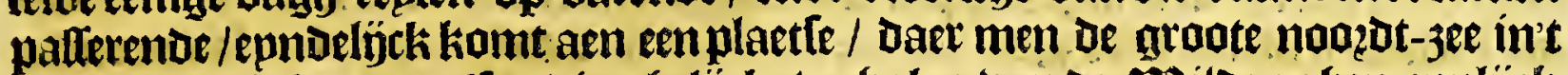

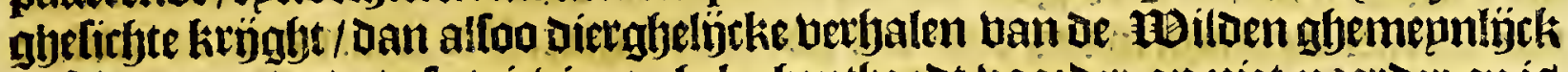
onlelter gaen/ende oefes tietuiers gheleghenthepdt boozder op niet naerder en ís onder vonden/ foofullen tup het hier bu laten beruften/ ende boozt, baten tot oe

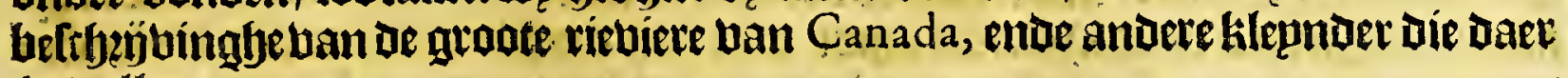
in ballen.

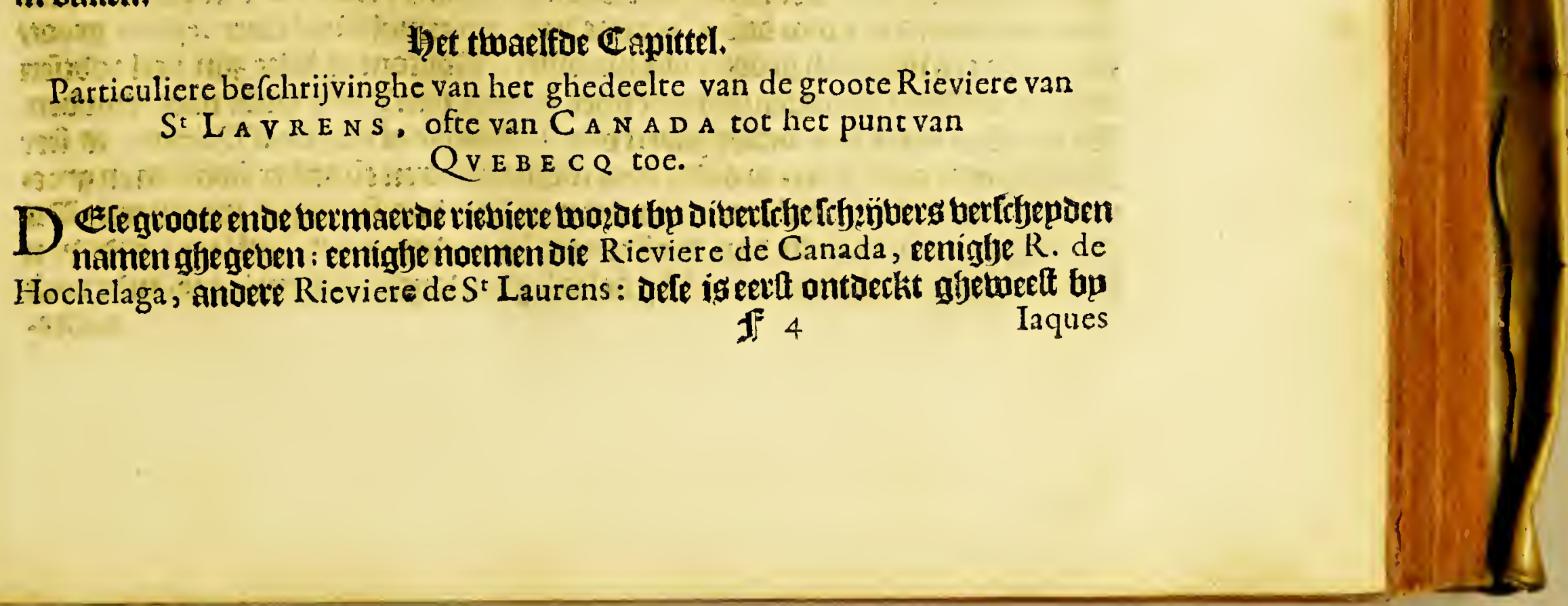


Iaques Quartier op [pn theede bopagie in den jare 5 535. Sp neemt baex epnote

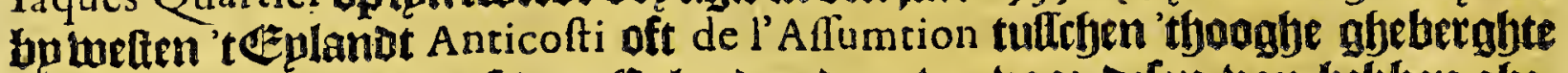

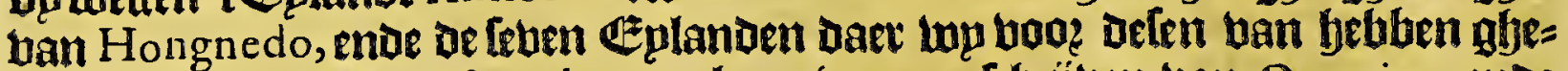
[pzoken; al waer fu 35 oft 40 leguen beet is naert [rbejuen ban Quartier; ende is in't midon wel 200 bademen diep:De meette diepte en [ekerfte baert is lakgg De 3upat-kutte. Aten bepde zjoen han De riebiere is feer fiaep ende bzurlythaer lanot;

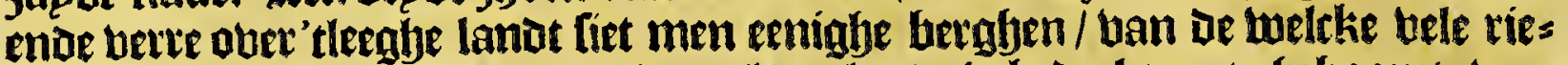
bierkens blieten in de aroote rieviete: al dat landt is bedeckt met gfteboomte ban

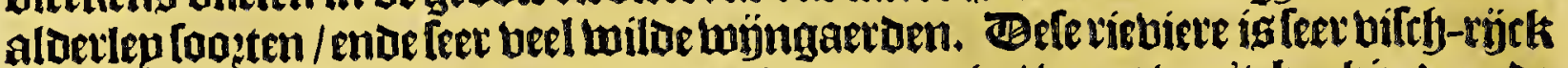

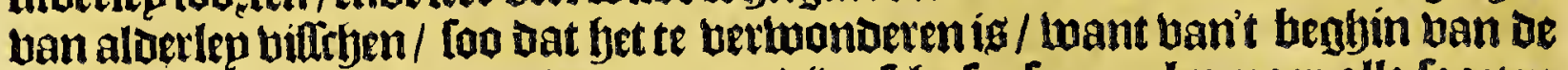
riebiele tot den eynde toe / bint men op diberfthe faploenen bu naer alle fogeten

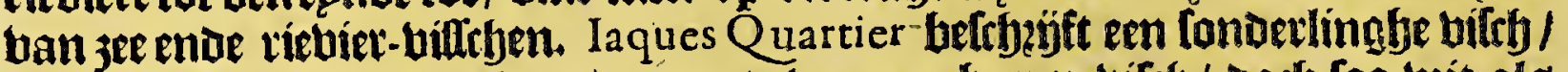

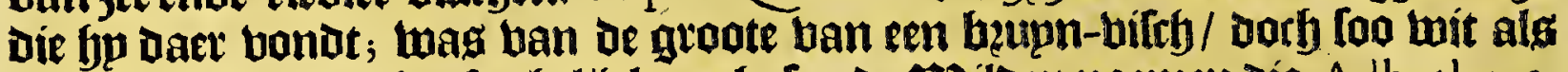

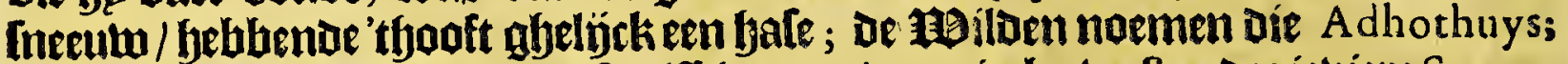
Daet ig aroote menichte ban defe vilichen een wepnig bu weften De riebiere Saguenay; al waer'twater begint verferbte wozoen. Op dele riebiere leggen bedl klepne

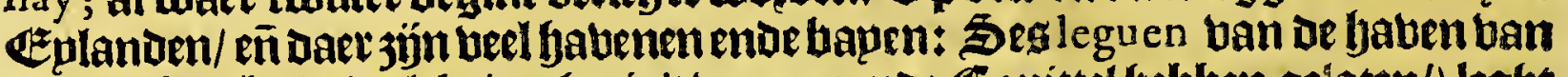

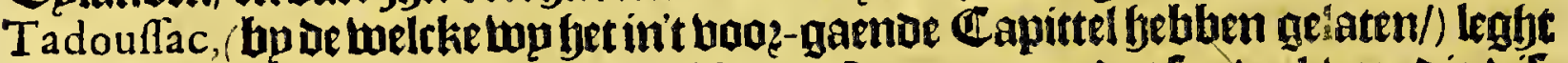
een Ëplandeken melek tp noemen Ine aux Lievres, om dat [oo teel ban die bit=

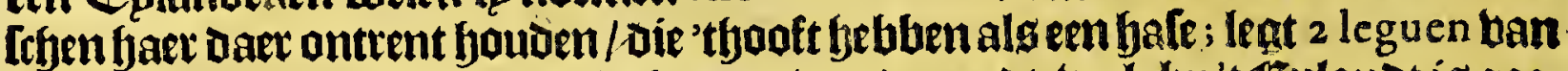

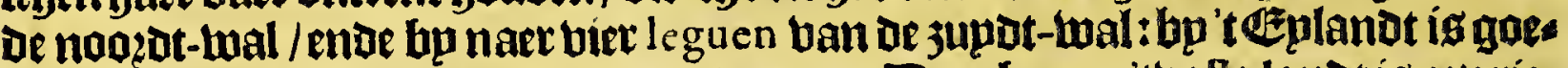

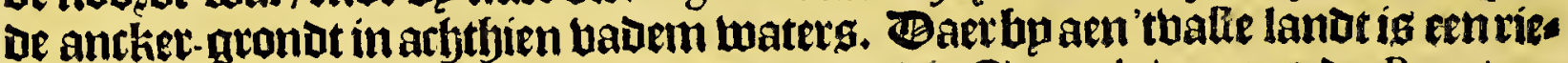
vietken welck alle afetyen $\mathbf{D} 200 \mathrm{gb}$ loopt; weick Champlain noemoe Rieviere

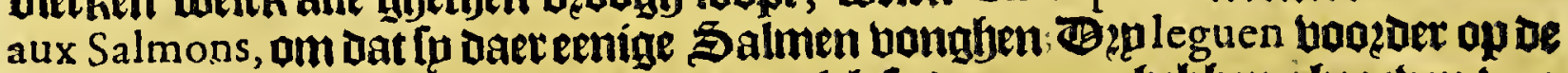
felve noozot-kiulte Iteckt een punt upt / welck fo den naem hebben ghegeben ban Cap Dauphin : enoe acht leguen boozoer is een aneer punt/ welck lpnoemen Cap a l'Aigle, ende tufferen bepoenis engrente in-ham / in't binnenlfe ban de twelcke een klepnriebietken ig Dat Dzoogh loopt met een ebbe: een le gue boozoer Iegt Ifle aux Coudres, foogenaemt bp laques Quartier om datfp daec beel fafelaten bon=

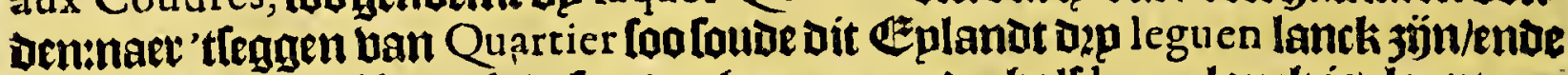
twee beedt; Dan Champlain Legt Dat betmaer andertyalf legue lanck is; loopt aen

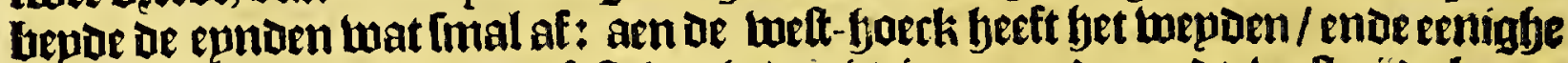

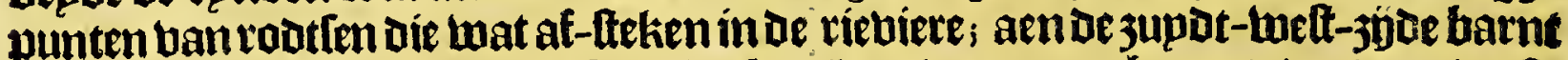

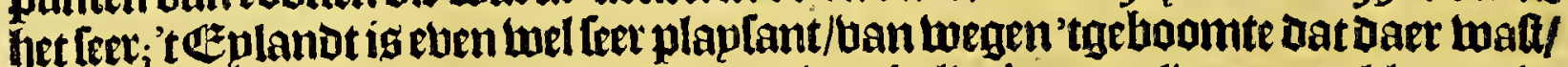
enoe leght bertebepoen ban de noozot-wal een balbe le gue, albaer een klepne ries bier ig/ weltk bep al wetre in't lanot ttreckt; welcke Champlain noemt Reviere du Goufre, Doo? dien bet tufteben'tlandt ende't Ezplanot getweldigb diep is/ende men Daer een rontimuele rabelingh van getỉe beeft/ouck alf ftilig; anders is bet riebier

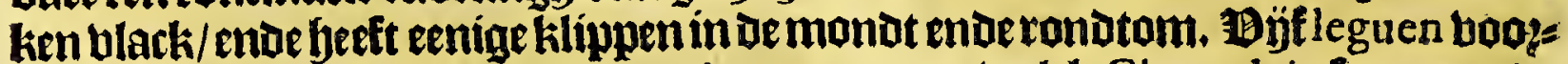
ber heeft men aen be lelbe jijoe Cap de tourmente, welck Champlain loo noemoe om dat met wepnigh wints Daer feet hol-water gaet.

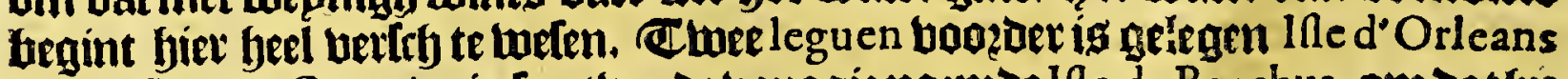
(melck la ques Quarcier infpntweede vopagie noemoe lfle de Bacchus, om Dat bpe

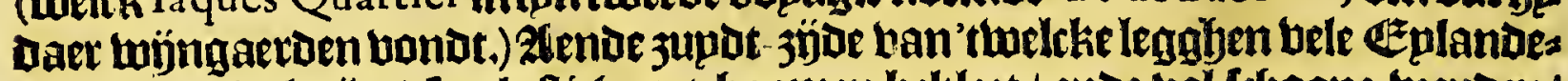
lieng / die black 3 ğn / Leer lultich met boomen bekleet / ende bol ftboone bepden/

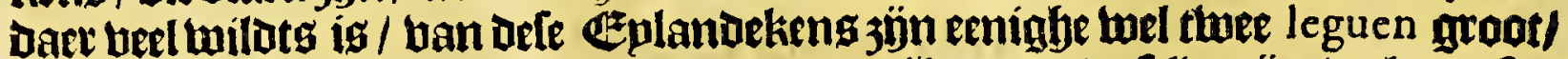
De andere een tuepnigh grooter ofte klepnoer. thontom de felbe 3 ÿn heel rodten cnae gevaetljurke Deogaten/ontrent twee leguen van'tuafte lanot naer 't3upden. Be gantlebe kufte han bepae jujoen van Ta douffac af tot Ine d'Orleans, is leet Lergirfylanot ende ferfhte gronot/ Daer niet dan bueten eñander boomenen grof:

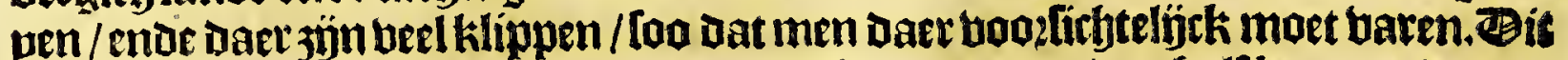
Eplanu legt van oe kulte ban'tualte lanut bp zupoenander-balf legue, ende ban ec nogre-kufte een balbe legue;ig bp de leg leguen lanck/ende een legue, ende aock ander- 


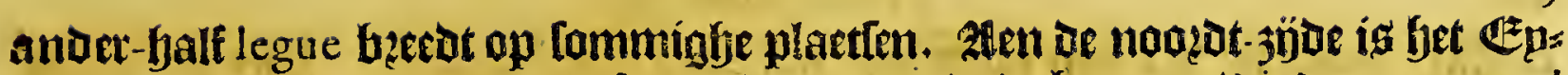

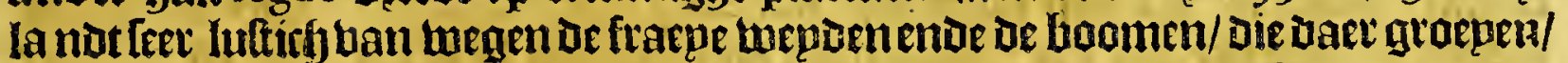

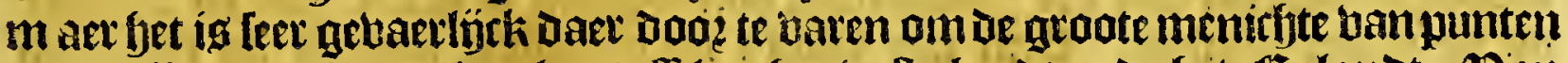

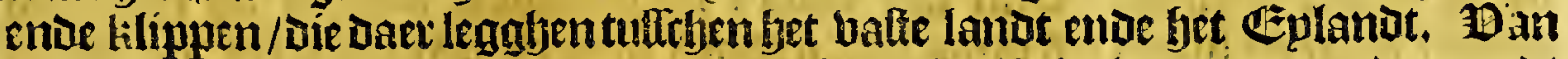

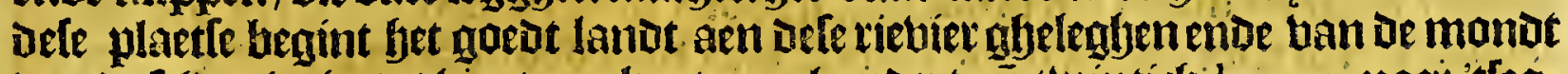

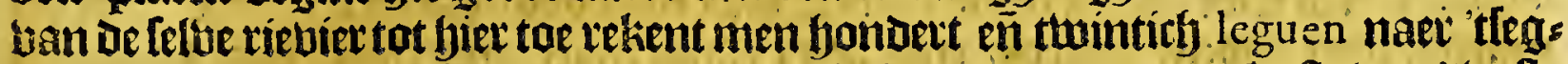

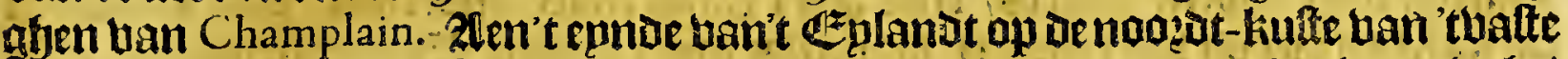

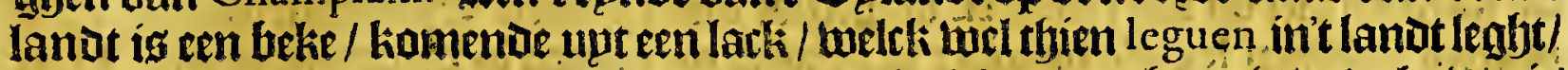

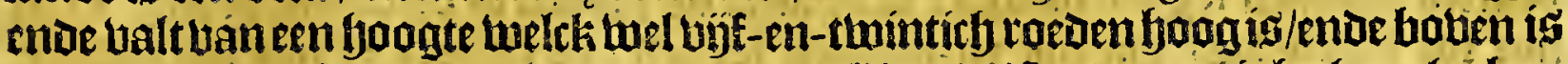

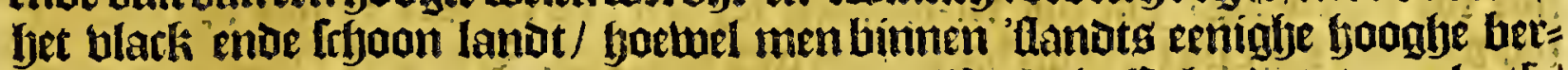
ahen fiet bel vijfthien tot twintich leguen verte. Ban dit Epplanot tat eenplaetle!

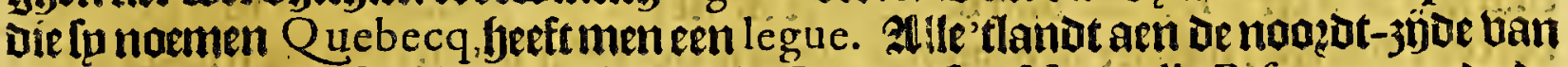
Tadouffac tat bu Quebecq, noemen to firantop[en Nouvelle Bifquaye, ente de boaz-noemoe befe ballende unt fet lack/noemen fo le grand Saut de Mnntmo-

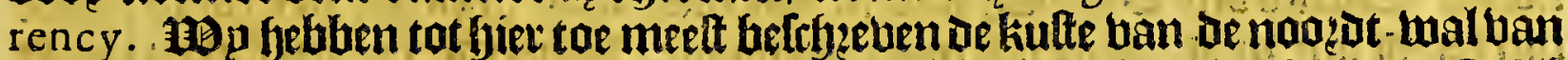
'tuafte lande / en fullen hiet in't kattmese aen-roeten de jupdt-hufte; aen Gafpe ofte Gachepé betuolgtern liape / dé lunarmen Cape de Boutonniers, ende boaz= Der naer tweften Cap l'Evefque enoe Cap de Chate, waet atber fity tertfjoont

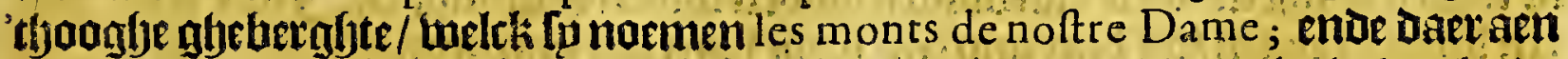

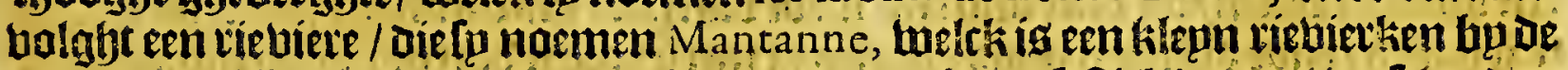

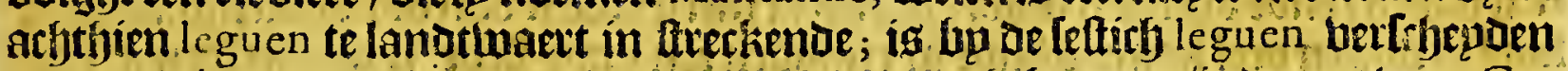

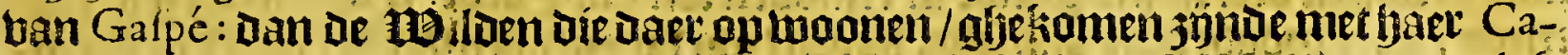

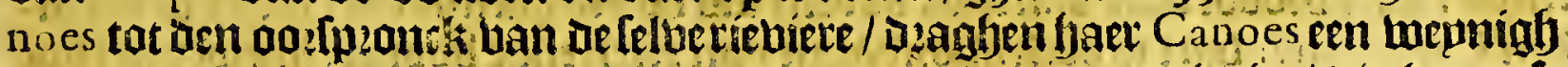
meer algen legue aser lanot/ende komen aen en ander tiebiec/de baer at-

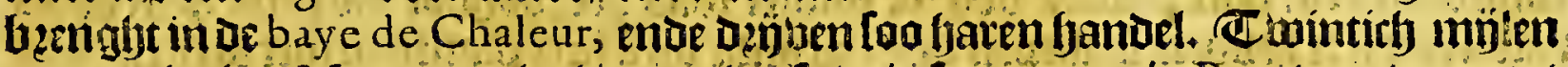

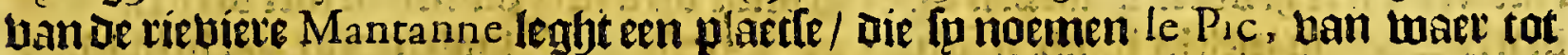

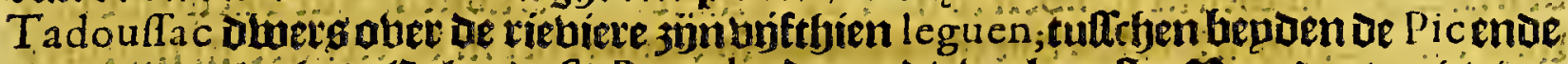

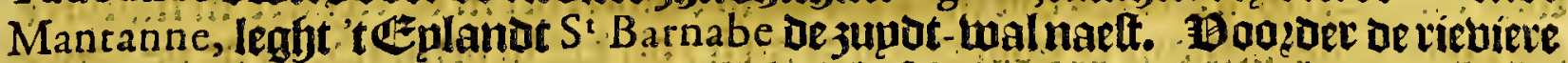
ap/aen de lelve jupot-kufte ftelt Champlain in Lpu haerte Rieviere de Moy, Dorf alloo top oe particuliere gbeleghentbecen bandele viebiete/ alsmede ban de ande re plaetten niet en binden belebeeben/loo fullen wo bet Gier bp laten.

\section{Wet Dertfiende Capittel.}

Voorder befchrijuinghe van de Rieviere van C A N A D A ende van Ho C H E A G A uyt de tw eede voyagie van Iaques puartier.

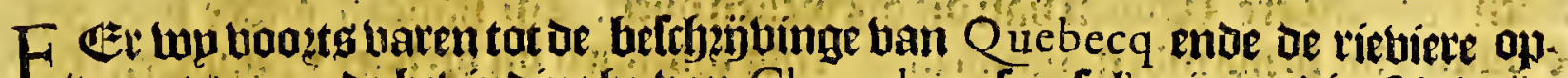

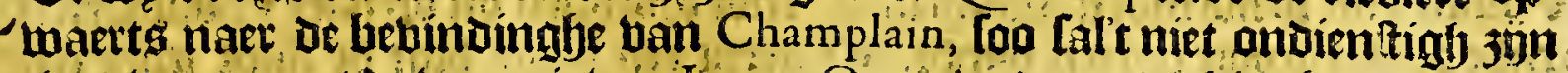
Ijer in te boegen upt de bopagie ban Iaques Quartier de ontoerkingbe ban de tie

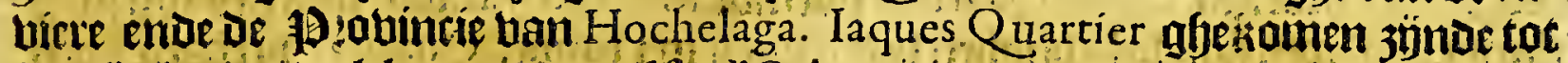

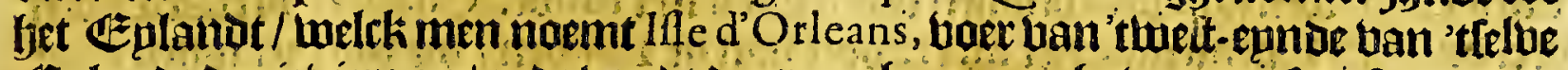

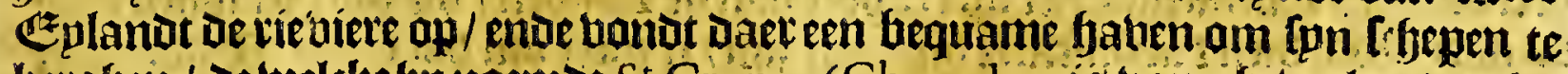

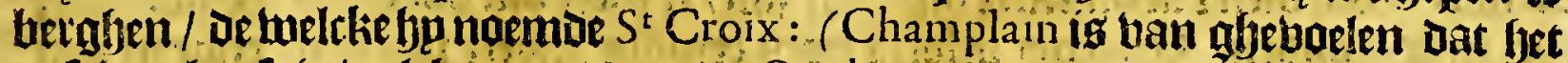
De felue plaetfeis twelch men nu noemi Quebecq) enoe daer twas in die tjot een woon plactie ban milden/, welcli. [u noemoen Stadaca ofte Stadacona; ende

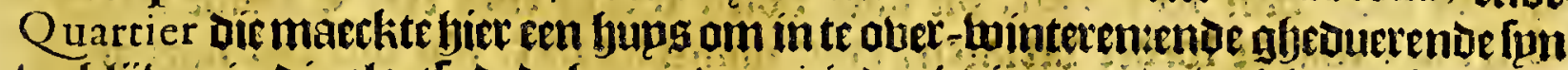
netblijuen in die plaetle dede bpen topagie de rieviete op / oe twe leke wo hiet bet: valgens fullen invaegen. Sp maeckten jepl den negfientjienden Septemb. 535 . ende vonden in't op baren/thandt aen bepde zjö̀n ban de riebiere feer fefoun/ioal fraepe boomen ban alderlep [oo:ten/ oock toungaerden daer dupuen aen waren/ Doch klepn om datte niet ghefauent en lwoguen: oock menifyte ban twooningben

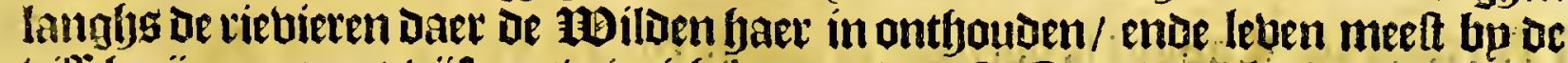

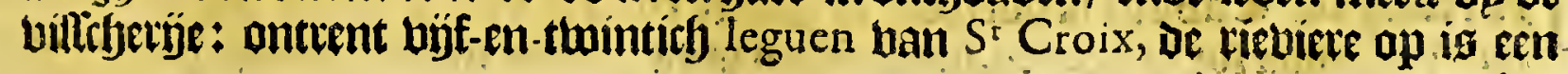


enghte/ melck te milden noemien Achelaci ofte Hochelay, daet ent harde

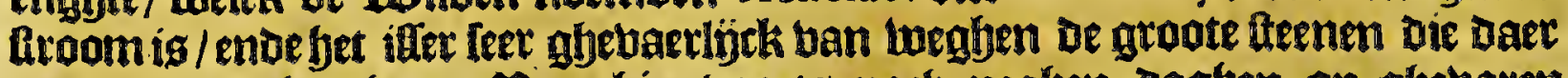
op de grant leggben. Han hier bogts noch neghen daghen op ghevaren 3ynde / quamen Ip aen een groot lack miDoen in oe riebiere/ ontrent bye oft les leguen beetot ende twaelf leguen lanth; daet wag Dop-gaeng wepnigh meer oft min als twee baorm twaters / enoe aen't ennoe maer andertjalf: Daer komen in dit lack wel bier oft büf riebieten loopen/oe welcke fekere Uplanden maken; enoe

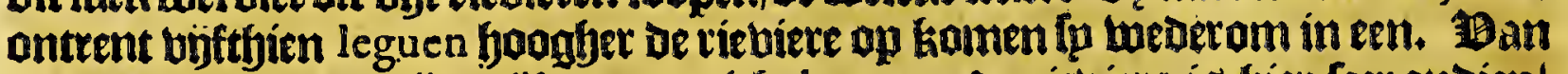
bier tot Hochelaga jün bujf-en-beertich leguen; de rieviere is fier leer ondiep/ foo Dat men Daer niet enkan baren Dan met barcken. De ftabt Hochelaga lagh tuftehen be $6 \mathrm{en} 7$ leguen ban de riebiere af in een feer fryoone ende thel gherultis

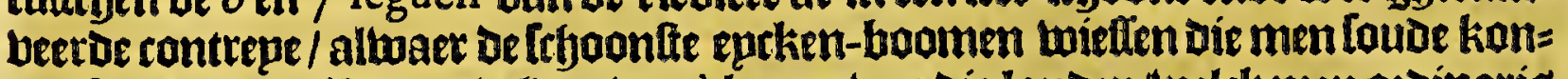
nenlien/ende beel koom-beloen ban 'ttooen ban die lanoen/weltckmen azoinarias

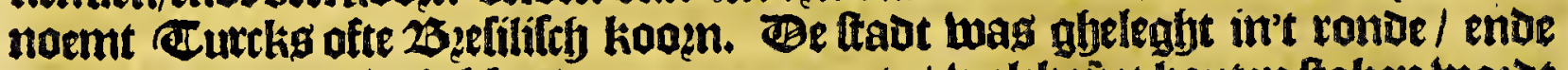
met foudt om-lwalt / bebbendemaer een poozte / welck met bouten ftaken wozte abetloten; be foute-wal is boben plat / ende in maniere ban een rampart / Daer men met leeten aen-klom / ende toas booz-Lien ban fteenen ende kepen tot defen= lie teghen de gheene diele ban bupten [ouben hillen belpeinghen. In oe ftadt toa= ren byftich fup [en/oft Daer ontrent/ meoe ban bout gbetimmert/ lantk bo oe byts

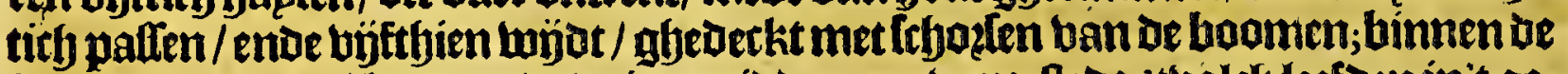
buplen waren beel kamerg/ende in'tmidoen een bupe-ftede; tholtkleefoen in't ges mepn ; baet bzooot wag van feker kookn / als boken/gbemaeckt / weltk fpnormben Caraconny; Daet ís dock abondantie ban erten enoe boonen/meloenen endé

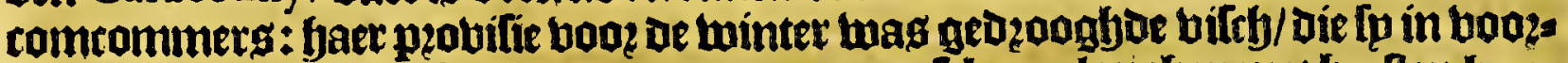
raet maken te bebaen: ip diepen op oe gronot op tekere plantken met beetten bups

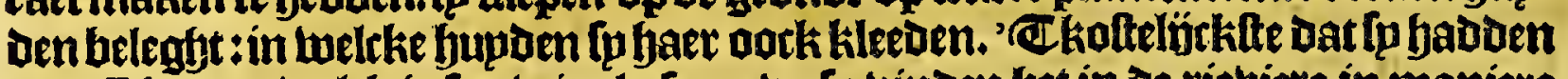
wag Efurgny; welck is too wit alg fneetu; ; uinoen bet in de riebiere in maniere als bolght: als pemant oe ooot verbient beeft / oft Dat [p pemandt in De ooslogbe

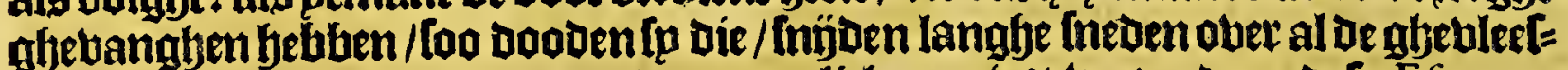
of partigen ban 'tlichaem; ente woepen' tlichaem in't water daer Defe Efurgny valt/ende laten bet daet thien oft twaelf uren in legghen/ende balen bet Dan we= ber upt / ende binden dan'tuoo\{j. Efurgny in Defneden/Daer fp pater-nofters ban maken /ende bouden bet daer booz Dat bet de kratgt beeft om bloet te ftelpen. (Bit

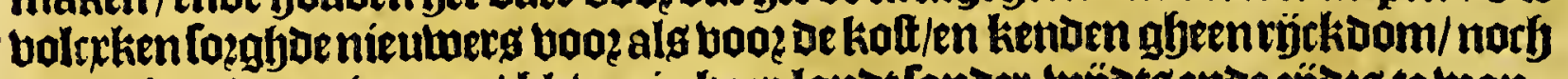
en trathten daerniet naer / bleben in baer lanot conder wjöbtsende 3 jots te twan: Delen/ als andere milden van dieghetweften doen. Sp Gadoen onder baer een Homintk die Ip noemden A gouhanna ; ende begegben die op fjaet frgouteren: lit= tende opeen groate barten-hupdt. Ontrent een legue ban be thaut legbt eenet hoogen berg/meIcke Iaques Quartier noembe Mont Royal, ban weltkeg top men 'tland ronotom kan befithtigften beel leguen in't ronde. Quartier berbaelt norb beel dinghen ban oí quartier op't tapogt ban be BBilden / die Lpp bier fullen booe

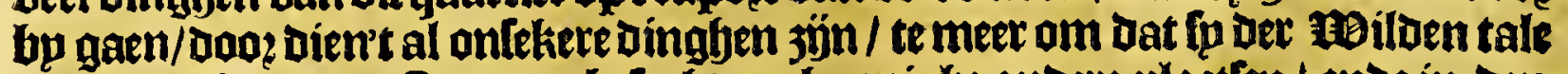
niet en werttonden. Quartier belocht noch eemigbe andexe plaetien/ ende in den jare i 542 . quam in die quartieren als Xieutenant ban be rỷck de borb alles wietot weoer betlaten/ende quam tot niet/ als bup bier naet noch lullen betbalen.

\section{Het beethiende Capittel.}

Befchrijvinghe van $Q \vee$ E B E $Q$, ende voordere ontdeckinghe van de groote Ricviere van C A N A D A by $M^{2}$ Champlain.

IR't twaelfoe Capittel beblen wo de groote riebiere ban Canada ofte $S^{t}$ Laurens berbolght tot Quebecq, welck igeen punt lanots/ welck bolnots-boomen 
Het twveede Boeck.

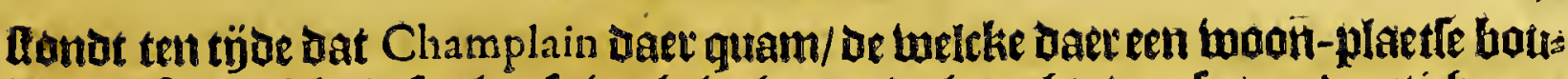
of voot [pn bolck: Dele plaetle is ghelegien op de fooghte uan leg-en-berticfgra:

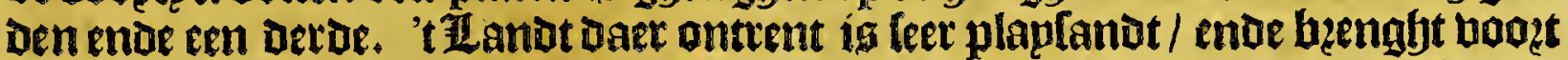

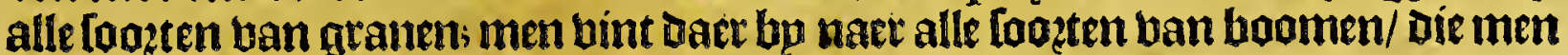

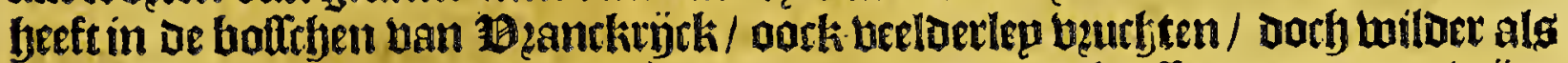

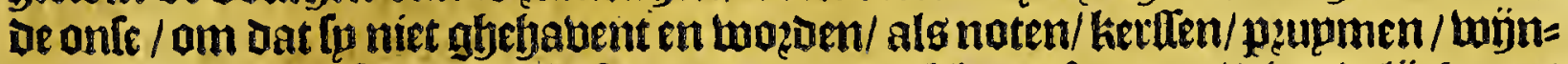
gaetden/framboilen/aendt-befpen/ende andert klepne fuupten/ die redelijck gaet

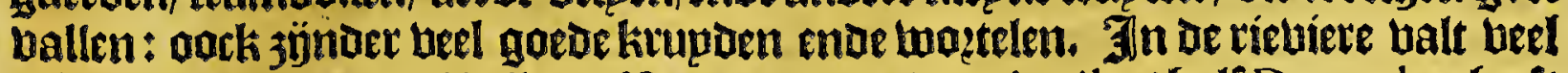
bifff; ende te lanbe weel wilots. Ban De maent ban A pril tot falf December feeft

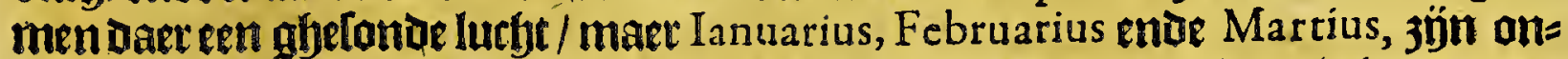

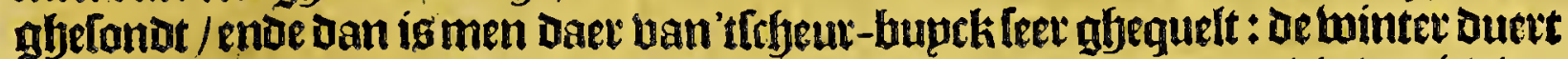
abemepnlíck tot in A pril. Ban Quebecq toozoer de viebiers op / is de vieviete

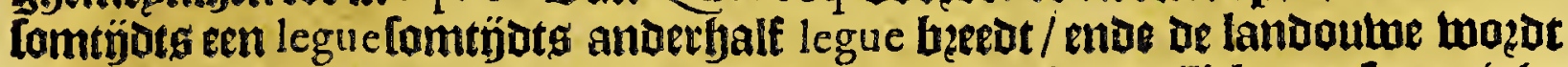

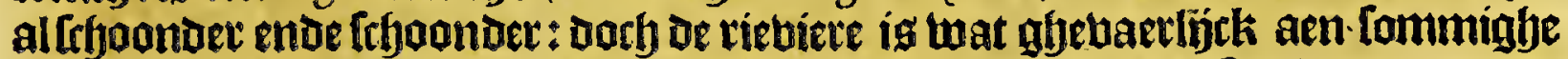
oazoen/ van weghen de bancken ende klippen die daet in jün/ fou Dat men daet

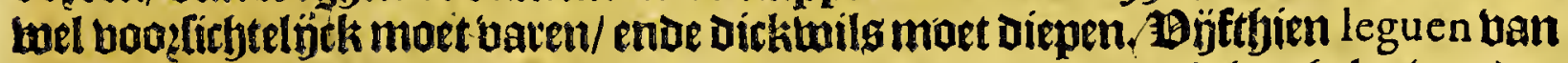
Quebecq is een punt twelch tp naenten S' Croix, al waet ennighe ghelooben tat Quartier [pn winter-plaet fe loude gefjadt hebhen: is een fandt-punt een wepnigh

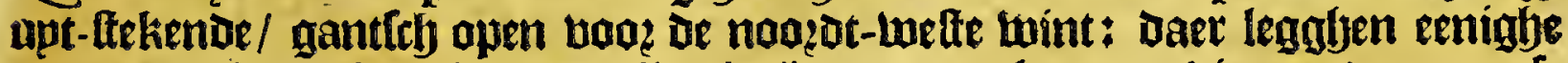
twepden / Die met foogh water alle ghetroden onder-loopen: 'tis een dangereule pallagie van lueghen de robtfen die in de riebiere legghen/ enoe foetwel daet een

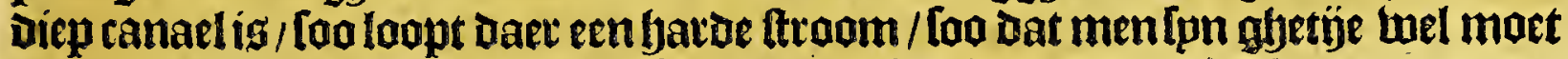
waer nemen om oele plaetle te palleten. Reghen leguen boopdor komt men aen en fraepe riebiet / die Lp noemen Rieviere $S^{`}$ Marie; ende andetfalf legue ban Defe riebiere legt een klepn \&epland/welck fu naemen Ifle $S^{t}$ Efloy, ende narban=

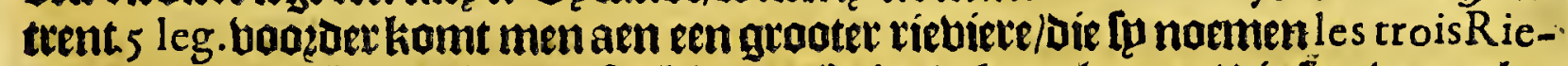
vieres; aen welckes in-komen les klepme Ezlandekeng leggen / oie leer bermakts:

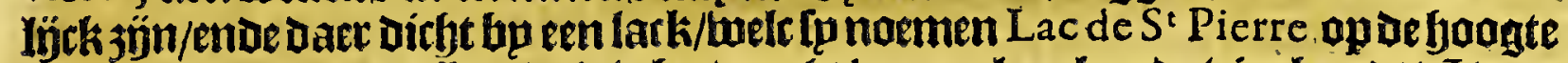

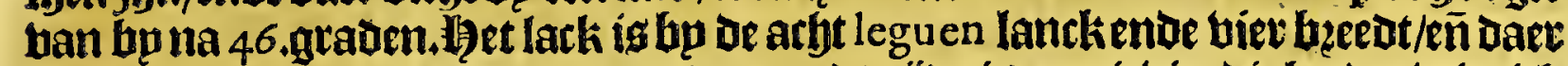

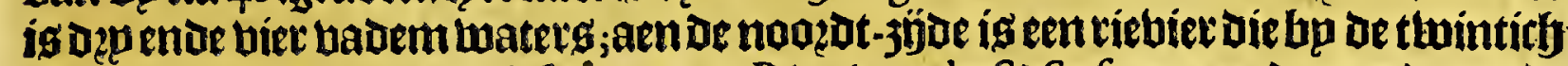
leguen in't lanot loapt/ die [p naemen Rieviere de St Sufanne; ande aen de zupa3 joe 3 junter noch twee / D'een ghenoemt Rieviere du Point, ended ander de Gen-

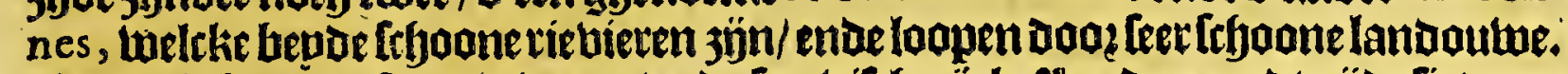

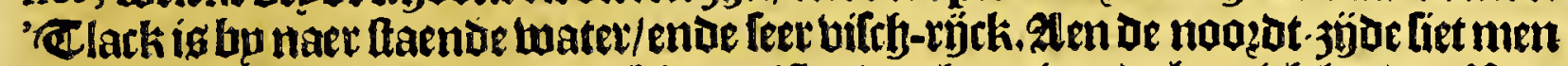
wel twaelf oft ujfthien leguen binnen' landta boogh ende bergich land. Ban

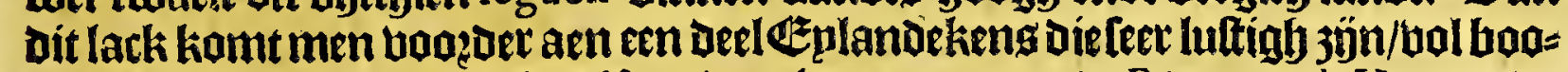

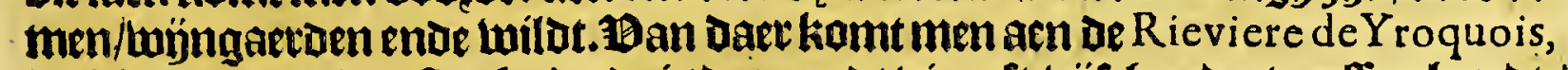

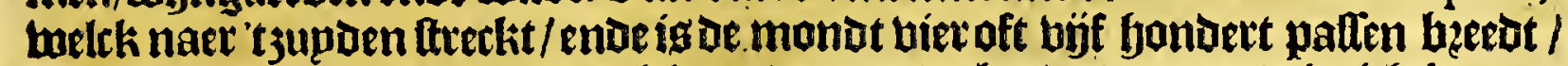
op de booghte ban bijf-en-beertich graden/ ende bp de dep-en-thintich leguen

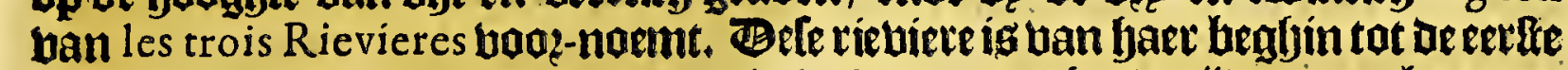
af-bal (welck 3 jun uijtthien leguen), al black ende aen beque jijoen met boomen

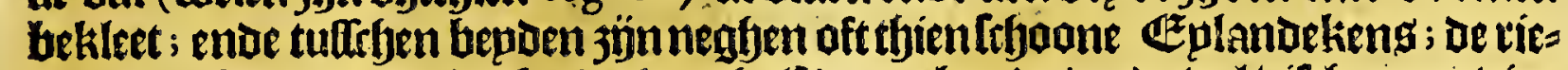

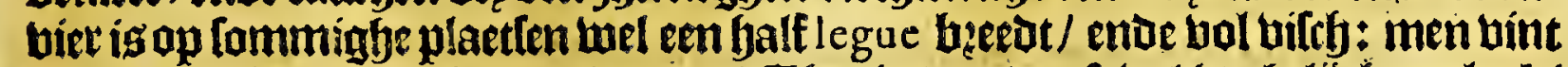
baet niet minder alg bier boet waters.' (C) Jegin ban of af-bal is ghelijekenlack/

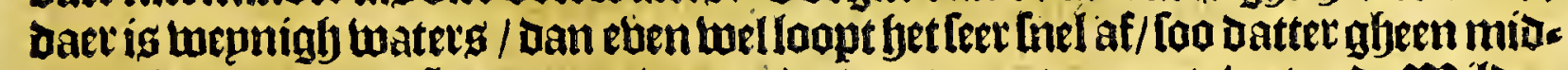
bel en is oin met eentloupe op te baren ; dan met groote moepte weten De mildon bie te palferen methare ranoen: ende foo komt men epnoelyck aen ecn leet groodt lack daet beel rrfjoane Eplandenin legghen: Gier vanght men menirfte van be= bets: sit lack ig naer 'tlegghen ban Champlain wel tachtity oft gonoert leguen

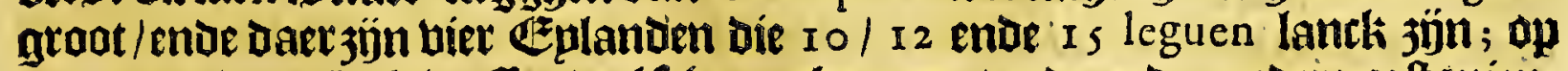
ben oeber ban't lact' wallen beel fchoane boomen/ende ander andeie caftanienboomen/ die men eloers op deriebiete ban C.anada niet en beeft: Daet is beel bifty in't lack/ ende ondet andere een looted / Die fo noemen Chaoufaron, welcket eeni= 
ohe wel thien boeten lanck 3 önthebben een landk bachupg met ten vobbel rije ban

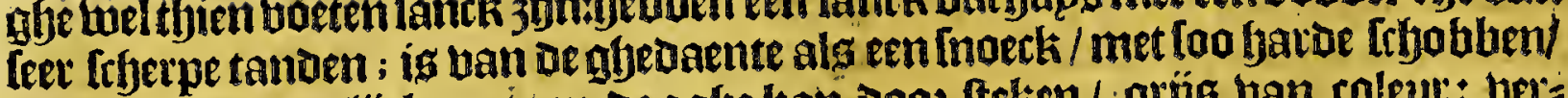

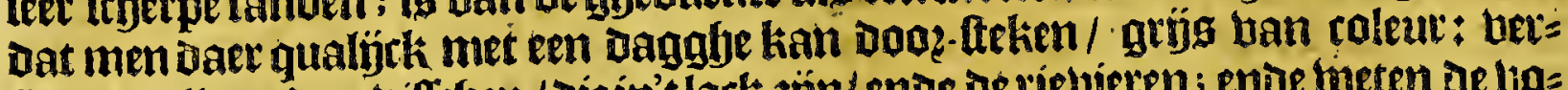

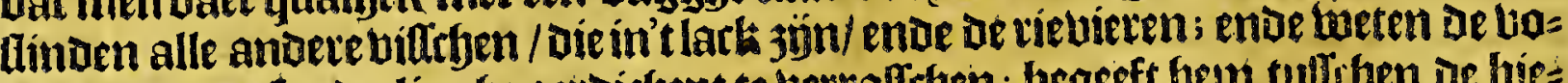

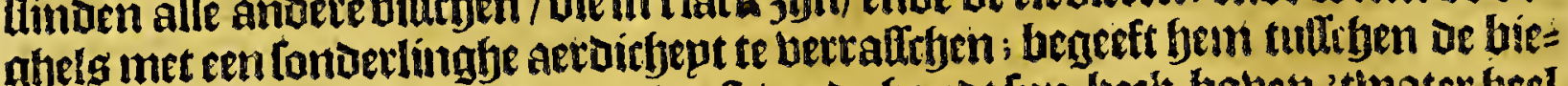

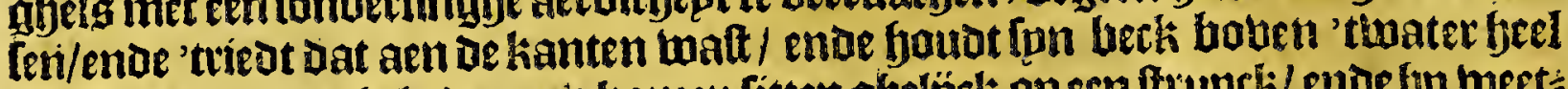

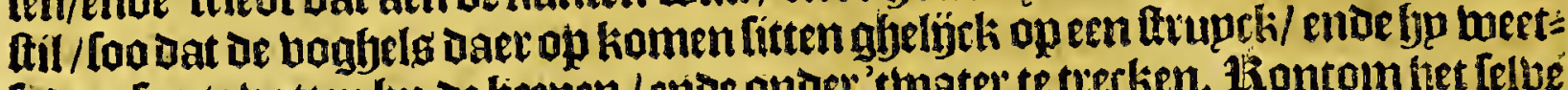

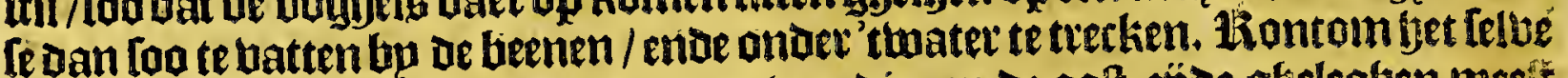

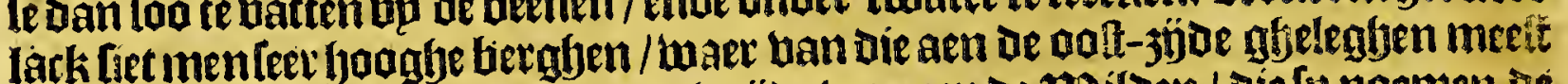

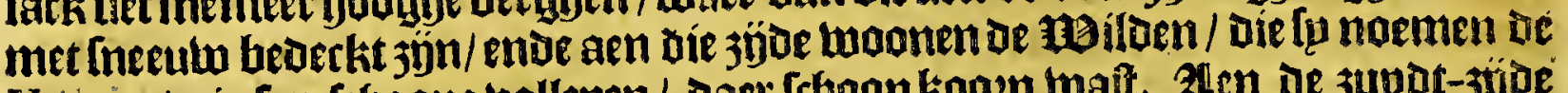

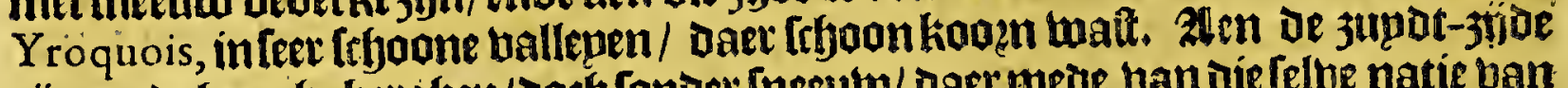

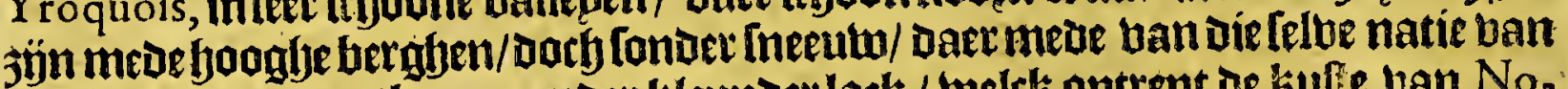
bolcheren twoonen / hp een ander klepnder lack / welck ontrent of kufte ban No. renbegue kount te vallen. "Cgtoote lack wozot oe naem ghegbetuen van Lac de Champlain. Herder-komende in degroote riettiere/[oo liomtmen aen een bal was tetig/ melck [pnoemen le grand Sault $S^{t}$ Louis, ig uettich leguen uan les trois Ríe-

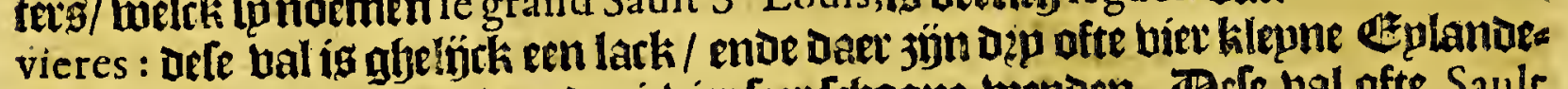

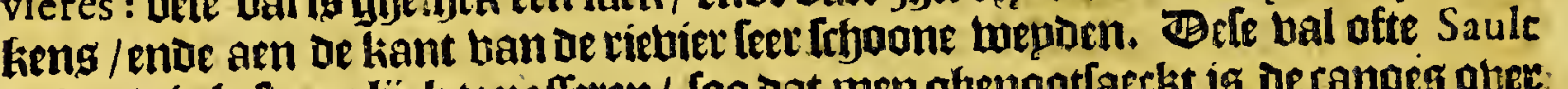

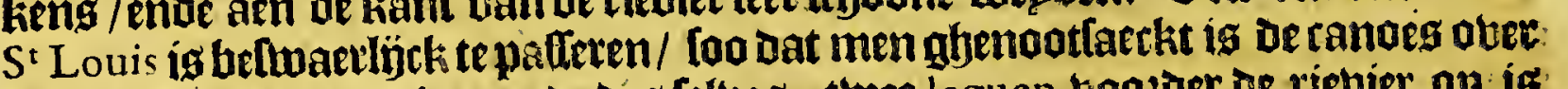

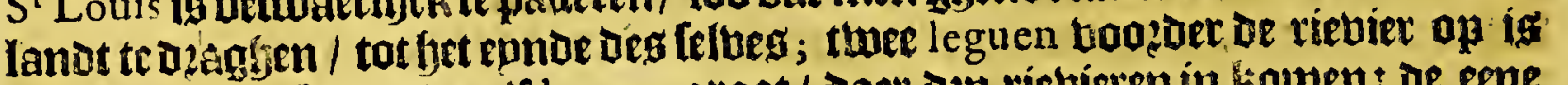
meder ern lack bp oe twaelf leguen groot / Daet dę riebieren in kolnen: ae eene

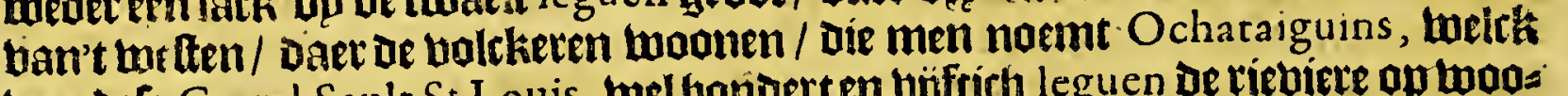
ban defe Grand Sault $S^{t}$ Louis, wel banderten vifftich leguen oe riebiete ap woos:

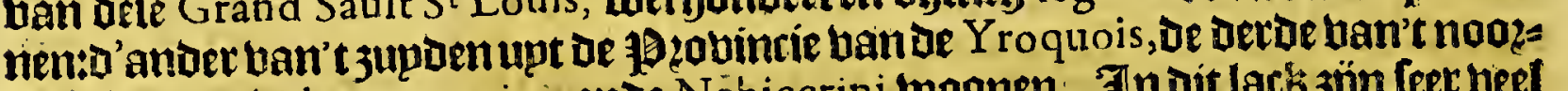

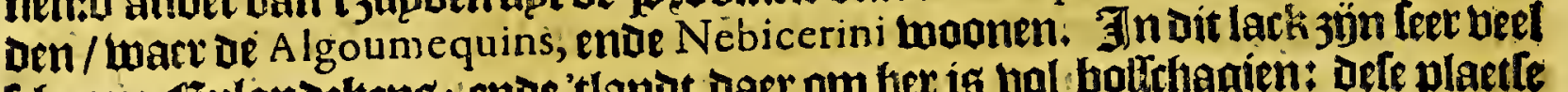
fryoone Eplandekeng: ende 'tland daer om fer is bal boltebagien: Defe plaetfe

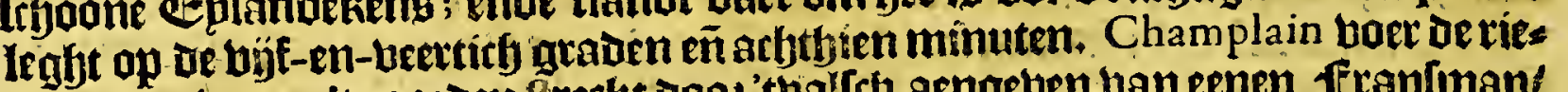
biete op die naer'tnoo?den frecht voo' thalley aengeven van eenen ffranliman'.

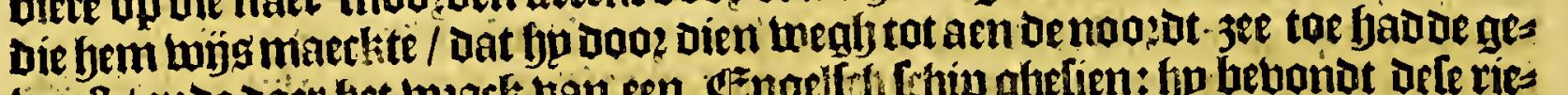

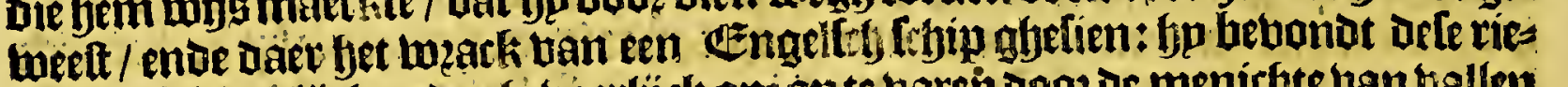

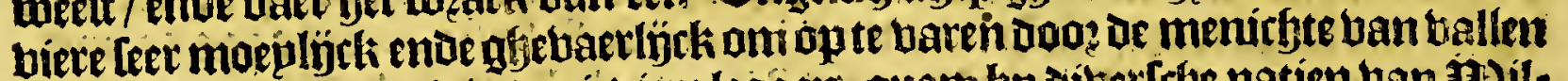

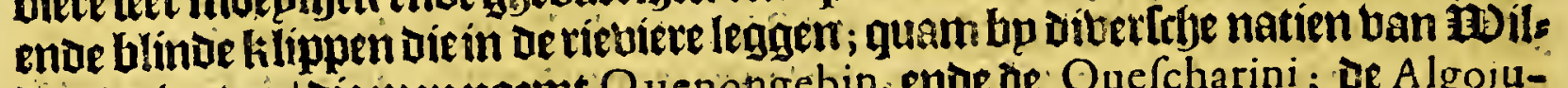
Den / te weten / Die mennoemt Quenongebin, ende be Ouefcharini, te Algoiu-

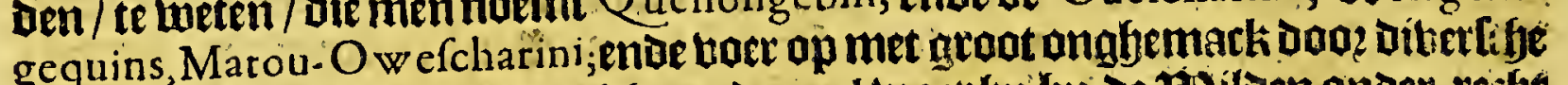
larken tot op de feben en-beettich graden; al waer hp bp oe moilden onder-reihs

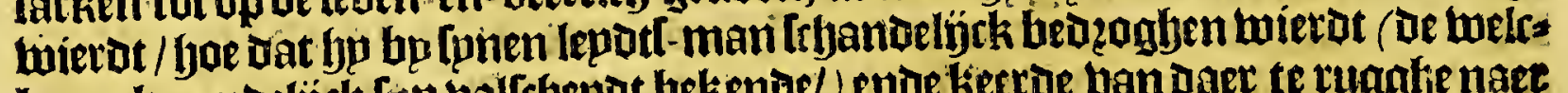

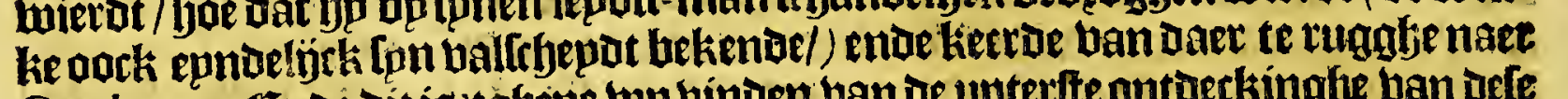

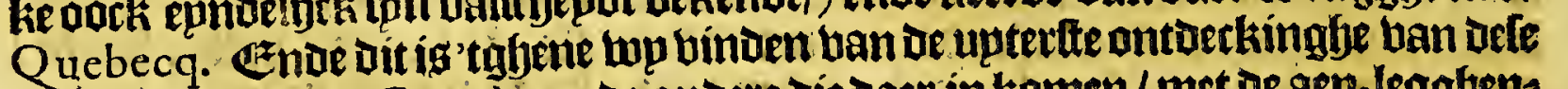
groote riebiere bam Canada, enoe andere die daer in komen/met oe aen-legghens de lackenende andetg.

\section{Het büfthienae Capittel. \\ Van de ghedaente ende manieren van leven van de Wilden die in defe quartieren woonen in't ghemeyn.}

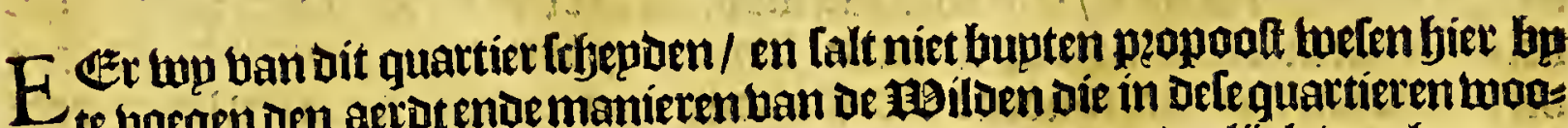
te hoegen den aetotende mamieren ban de Agiloen die in oefequartieten woo:

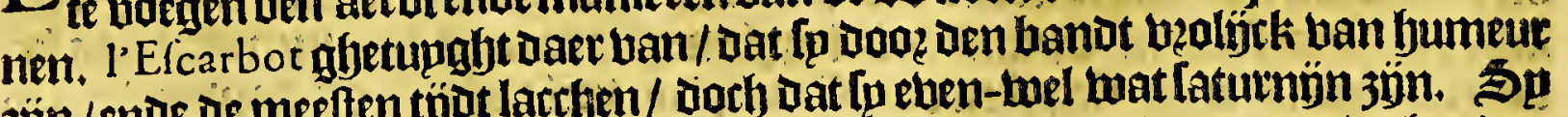

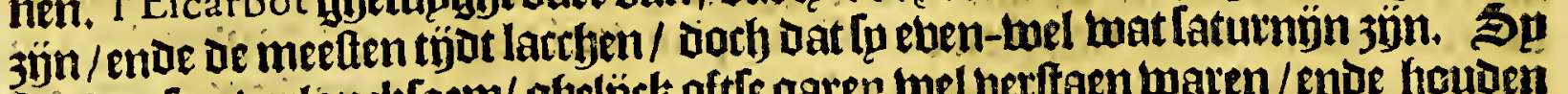

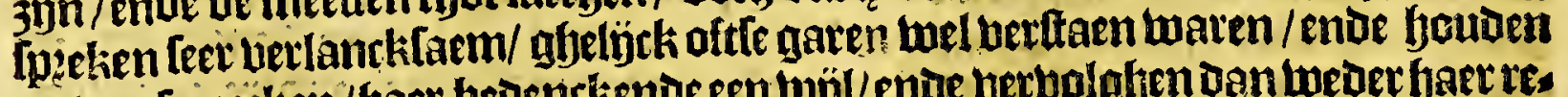
op uan[peetken/baer bedenckende een wöl/enue berbolghen den/weder faer res orn. Su bebhen een ghelwoonte / narr dat Champlain berbaelt / van balf Sep. tember tot Galf Oetober baer te hegbeben tot bet bifichen wan fekele aelen/ oie on: trent 
Het tvveede Bocck.

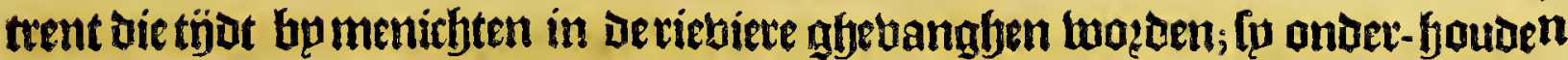
yaer Daer mede/ende dzoogben de felve bogz peobitie teghen den winter/alg wan: neer fp op de jarbt trecken om bebers te banglyen; want daet valt in Die tijot feet

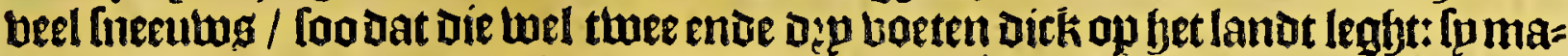
ken Dan fe: tere rahetten/Die fp aen de boeten binden/omniet te fincken in't fneculw.

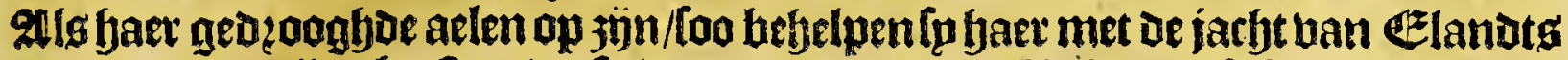

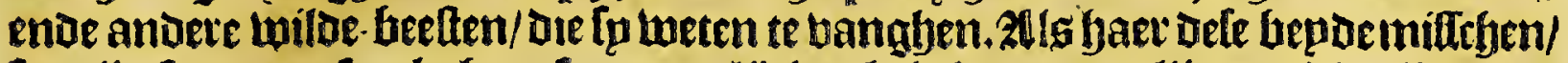

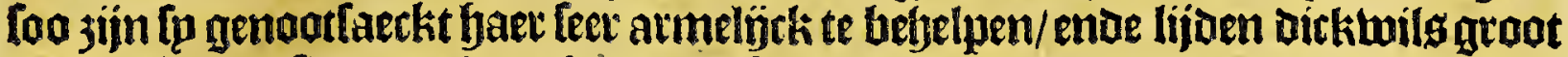

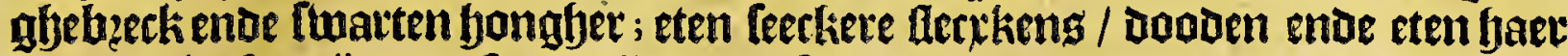

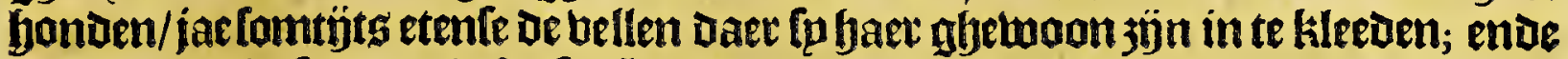
baer en igniet foo bupl ofte fo flaen bet in/ tot buple ftinckende krengen toe: ages Ijek Dan $\mathrm{M}^{\mathrm{r}}$ de Champlain notable exempelen daet ban verijaelt. Sp behlon

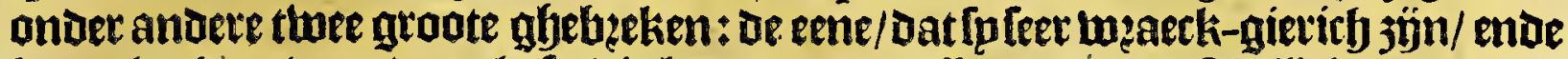

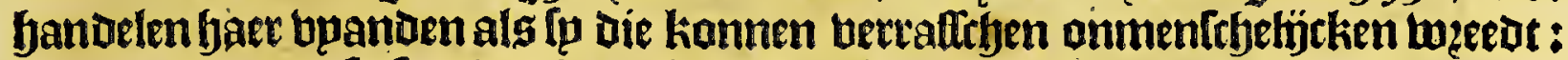

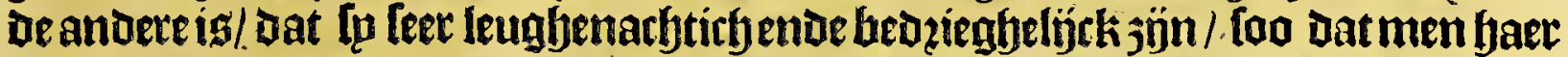
niet en mach bertroulwen / maer altijots wel op [pn baede zün. Den meelten deel en beblen fp gantiry gheen wetten ofte andere coftupmen onder fjact / naet Ieben als triloe-beeften/ Londer entigbe kennis ban Goot ofte Godg. Dient. laques

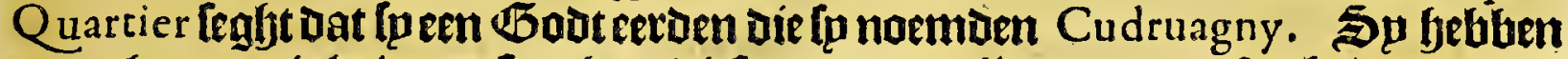
onder fjaer eenighe twaer-fegatiets diefe noemen Pillotois, ende tugfyelooben dat

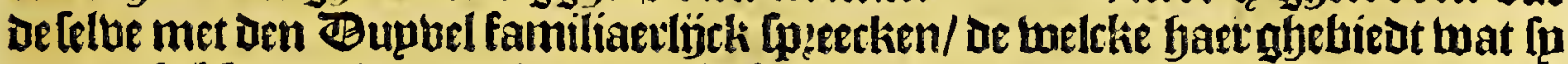

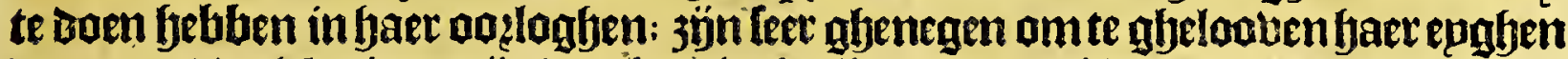
Dyomen/ belck nieten jün Dan bedziegherijen ban den Bupbel. Dit bolck is an= Ders ban lichaem wel gheptopoztioneert / londer eenigbe mif-maecktbept / ende Difponft; fo wel De mang als de beguluen jijn ban coleur bzupn/ofte als een olijbe; Dooe Lekete olpen ende betwen/ Daer [p'tlichaem gfjetwoon zijn mede te befmee=

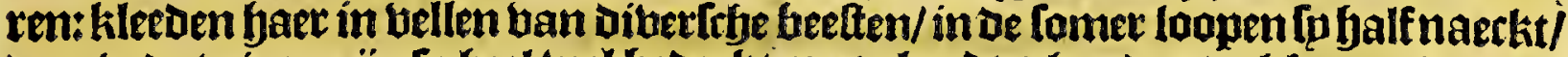

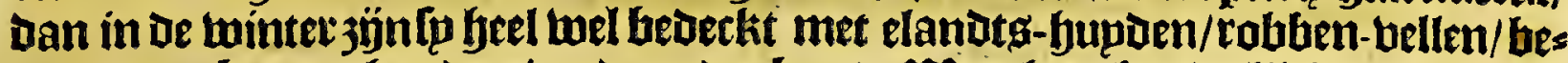
bers ende bepeen-bupden/ ende ander bont. Hat gaer foulwelijeken belangt/ ban dat ve boebters beetthien oft bÿftbien jaren oubt $3 \mathrm{jin} /$ conberferen fp inet alle Die yaet goet Duncken; ende dan't epnde ban bijf oft les jaren/nemen'tp een tot

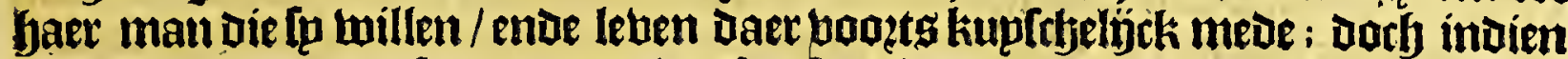
If gheen hinderen te Lamen en teelen/ [oo ftaetljet de man bep die te berlaten/ende een ander te nemen: De mang jijn leer ialoers ober baer bzoutwen; ende geben gfjeftyencken aen de ouders ban de Dothters/ die fo tot beulwen ghenomen beb= ben. $\mathfrak{A 9}$ an ofte bzou gheftogen 3 ijnde/malienle een kupl/ende legglyen daet alleg in twat baet-lieden toe-beljoost/alg ketelg/bijlen/boonhen eñpijten/kleedeten/ctc.

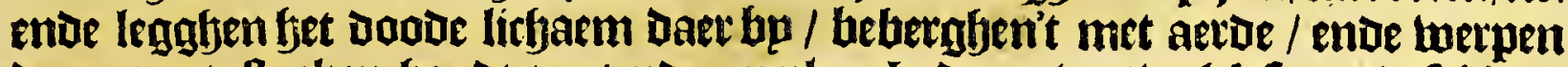
Daer groote flucken foudts op/ende een plancke daet ober / welek fo ropot frgiloe=

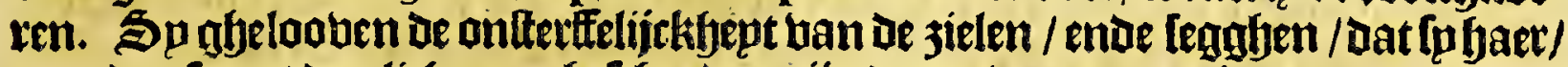

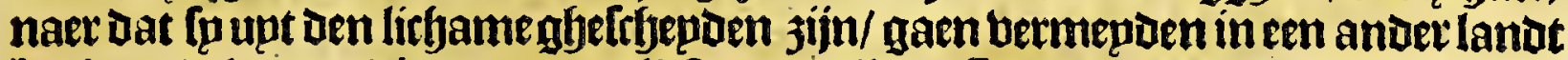

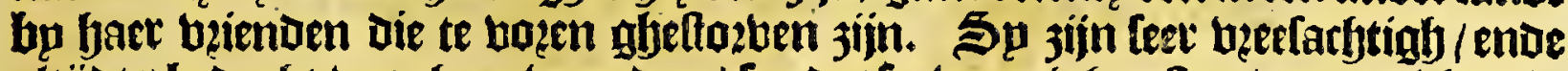

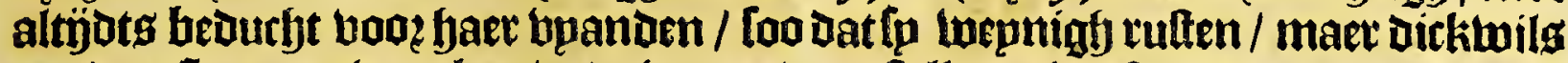
upt oen thaep ontwaecken/ende baer te lweer ftellen/als oft de bpand haer ap't lije ware. In comnta het is een atm ende miletabel bolck; Doch dit en ig niet te betfaen uan alle de geildendie onttent ende in de riebiete twoonen/maer ban die/ welcke aen de eerfte beginfelen ban de riethiere/eñ bp naer tot de Saule $S^{\complement}$ Louis

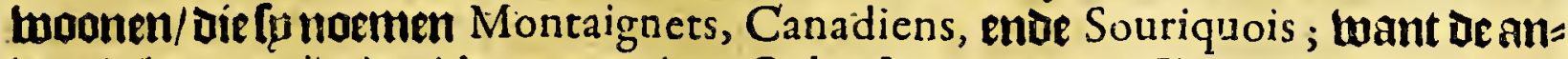
Dete/als daer $3 \mathfrak{y j n}$ de Algoumequins, Ochaiftaguins, enoe Yroquois, de welcke meer in-Laert defe groote rieluiere twoonen/ joe luel lp han conditic ende manic=

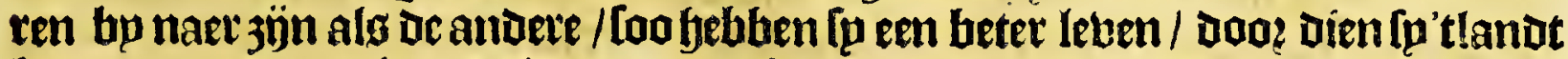

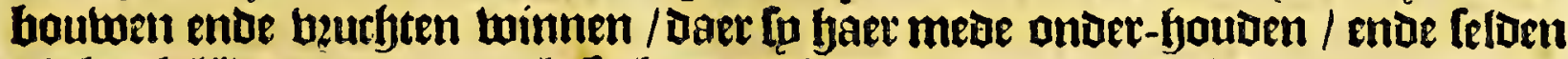

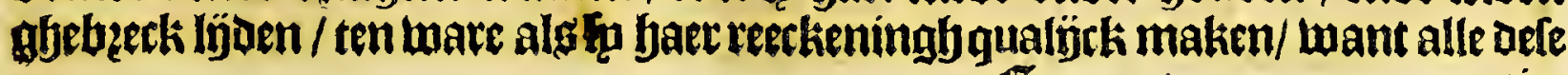


70

\section{Nova Francia.}

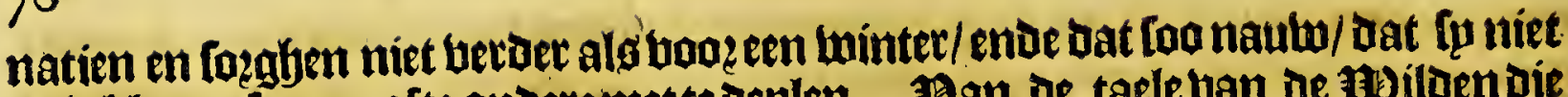
en hebben telparen ofte anderemet te deplen. Ban de taele ban de Hoiloen die in Hochelaga woonoen binae irk dit wepnigbe aen-geteeclient bp Iaques Quartier : De ghetalen beteeckenenlp aloug:

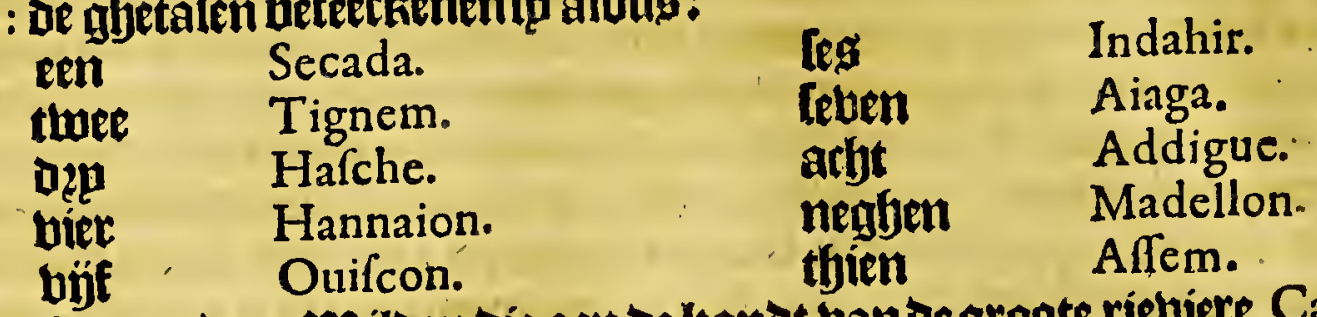

melck de andere moilden die aen de kandt bandegroute riebiere Canada moo: nen/alloo upt-Dzurken/naet Dat l'Efcarbot frbejfft:

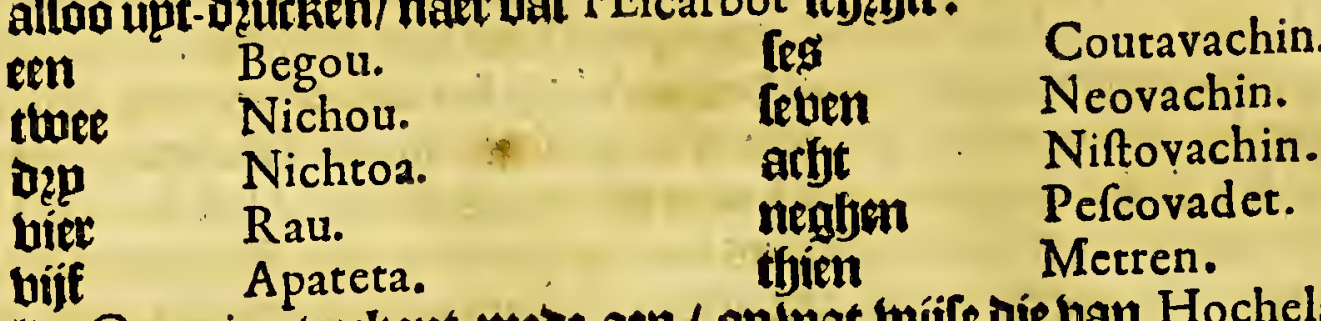

De Telve Quartier teeckent mede aen / oplwat wijle die ban Hochelaga degfies Deelten Deg lichaems noemen:
booft
Aggonzi.
19opz-hooft Hergeniafcon.
Altmen
Aiayafcon.
Dogen
Higata.
25 upck
gipanje
Bopen
Abontafcon.
tonpen
gisonat
Efahe.
Depen
Canden
Efgongai.
conabe
Ofnache.
25 eenen
25 aerat
Hehelin.
stenfiebt
Hegovalcon.
Barten
Efchehenda.
Hape
Agonifón.
loanuen
Bingeren
Agonhon.
Raghelg
Aggruafcon.
Agochinegodafcon.
Hernegradafcon.
Agougenehonde.
Onchidafcon.
Aignoafcon.
Agenoga.
Agedalcon.

Halg

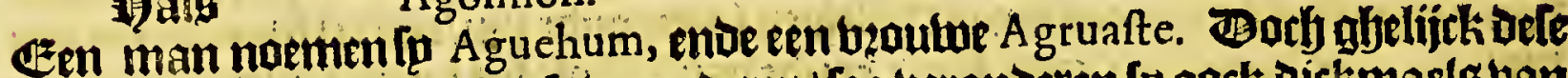

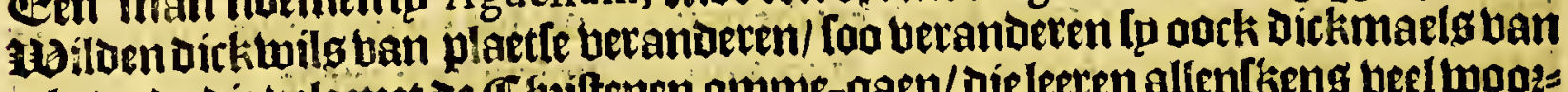

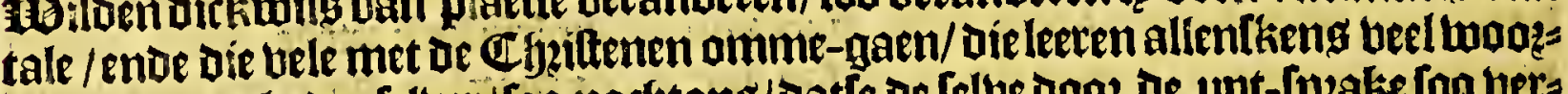

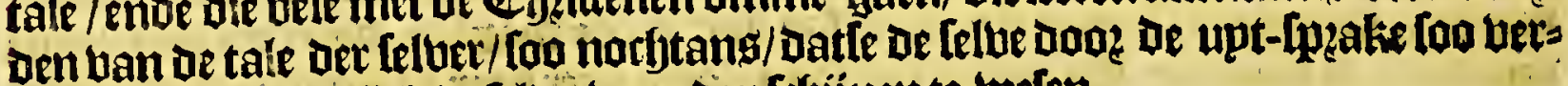

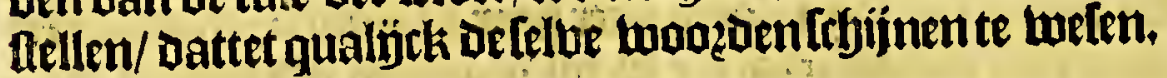

\section{A D I E ofre A C C A D I E.}

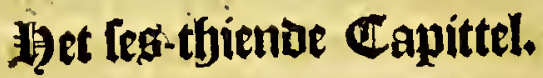

Befchrijvinghe vande Zuydt-kufte van $N$ o $v$ A F R A N C I A, ende eerft van $C A M P S A V$, ende andere havenen en Eylanden op de kuifte van $A C C A D I E$ ofte $C A D I E$, ghelegen tor

C A P, DE SABIE toe.

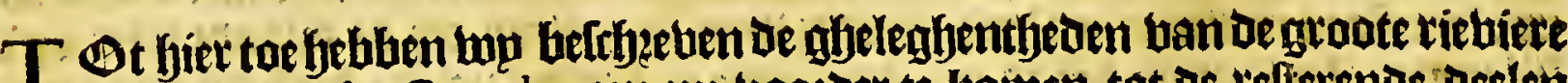

$S^{t}$ Laurens ofte Canada; om nu bogzoer te komen tot de telierende deelen

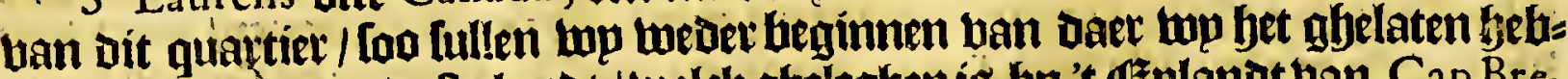

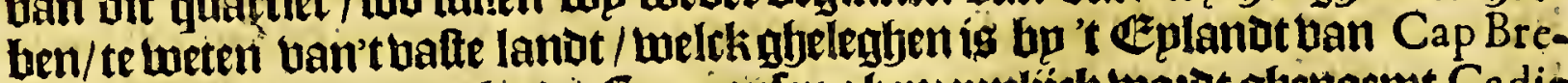
ton; welcke contrepe nubp of francopten ghemepnlijek mozot ghenoemt Cadie ofte A ccadie; welck is eenltreeck lantg legghende in oe lenghte aenbe $3 \mathfrak{e} /$ / wan Campreau af tot Cap Forchu; entoe ban bepoe zifoen loopt bet Imal toe in oe forme ban een triangel; coo dat bet onttent aen't equae van oe baye Fran çoife op Iun Imalte is / ende niet berre ban't innerfte ban oe baye de Chaleur, welek

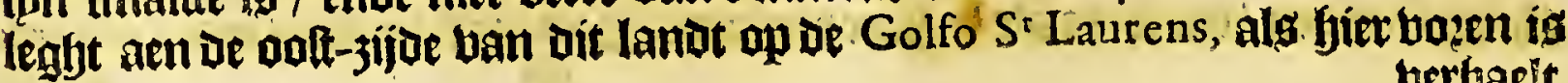
verbaelt, 
bethaelt. Zlen't oolf-epnae / ende beginban dele kulteleght te baben ban Cam-

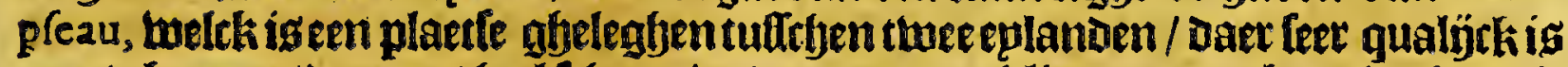
aen te komen/Dan met jeel lchoon lueder / Doog de klippen ende barninghen vie baer 3 ïn ; is gheleghen op de büf-en-bectith araden/endeeen Derdenoogdelït=

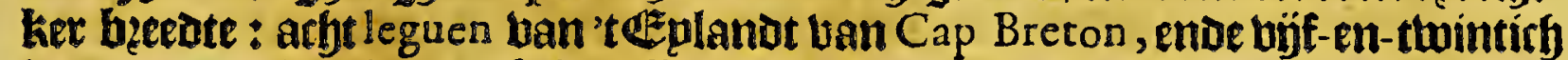
leguen ban Cap Breton felf: tulliben defe hatuen ban Campfeau, ende Dit đep=

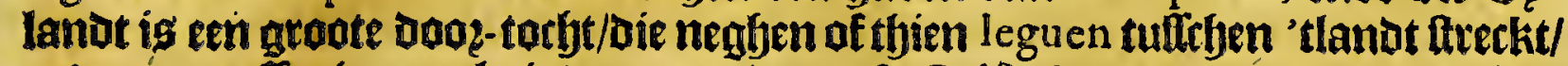

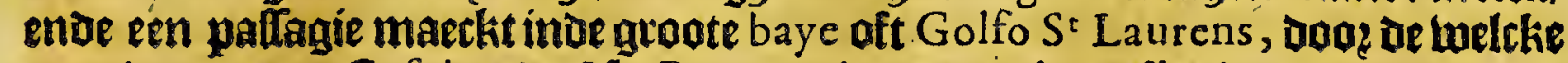
men baett naer Gafpé entoe Ifle Percee : íg een enghe pallagíe / moe de groate

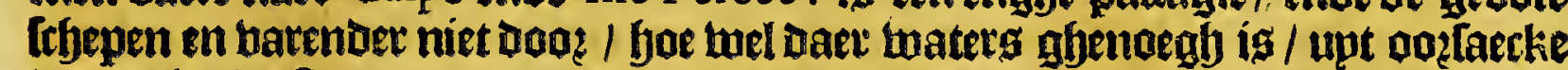
van de harbe ftroom/ende rabelingb tan de ghetjoen; foo dat het daerom oock ghenoemt woget le Paffage Courant, op de fjoachte ban bjf-en-beertich graden ende büf-en-teettich mimuten. Ban Campfeau voozoer naerbet welten tot een baben toe / die fo noemen port de Savalette, 3 j̈n leg leguen, en tuftefien bepden jün feer beel klepne eplandekeng langhg de kifte ligghende. Wan port de Sava. lette tot les Ihes Rangees jün bier leguen, Dit jun uele \&etplandekeng líggende

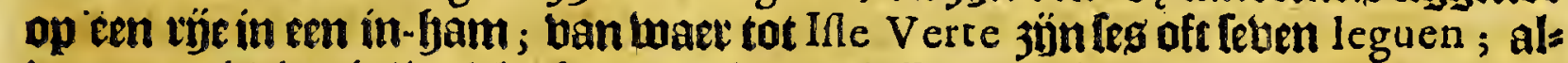
waer een riebiete is/ welck gljenoemt toogdt la Rivicre de l'Ifle Verte, Dooe dien dit groen eplandeken aen oe monot leght ban de Eelve riebiere; endoe is op de 45 graden ende een quart noozder-bereote. Ban ofle ríebiete tot baye de toutes Ines 3 ïn les leguen, ende tufletgen bepaen jün al kíppen die bp naec eenlegue in 3ee fteecken/ende het harnt vaer feer. Ban Dele baepe tat port $S^{2}$. Helaine jijn veettyien oft bófthien leguen, daer oock groot gljebaer is ban wegen oe bancken/

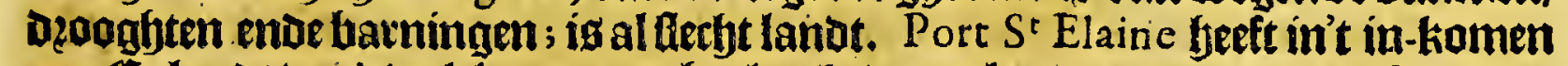

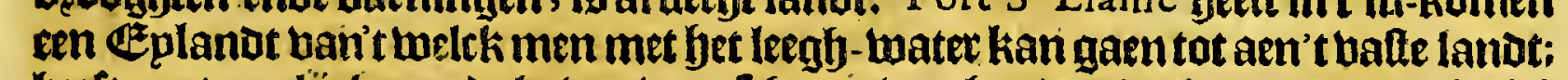
beeft een tamelïcke goede baven boaz [chepen wan yontaert/en bondert en twintich baten/enoe is gfyelegen op de hoorbte ban biet-en-beetticf graten / ende beertich minuten/wepnigh meer of min. 1Ban port $S^{t}$ Helaine tot Sefambre jön acbt leg., enoe tuffben bepoenlegfteen hape/ die Lp noenen baye Saine om dat fp feer fraep

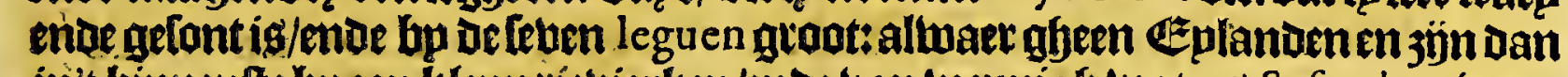
in't binnenfte bpeen klepn rievierken/ende ban wepnigfj waterg.Sefambre isgen Eplandt to genoemt bp die ban S`Malo: banmaer tot Riviere de $S^{\text {tc }}$ Marguerite

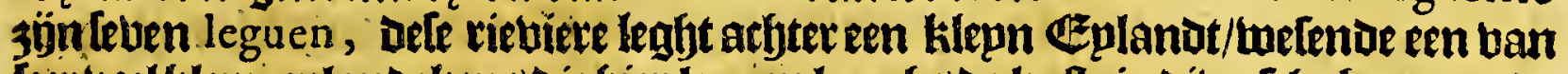
feer beel klepn eplandekens die fier leggen langhs de kulte in dibert be bapen ende in-hammen; be twelcke alle bp de ffrancopfen toozen genoemt les Marty res, om

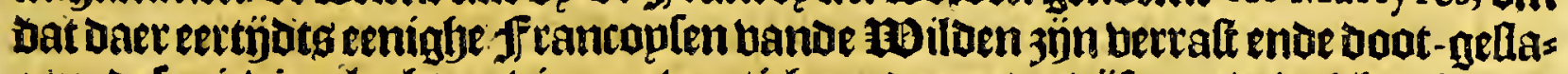

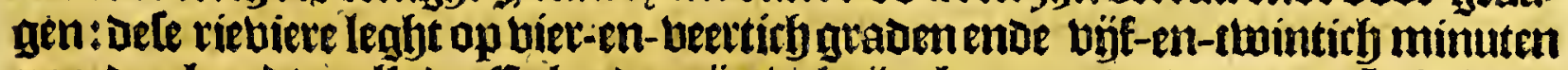

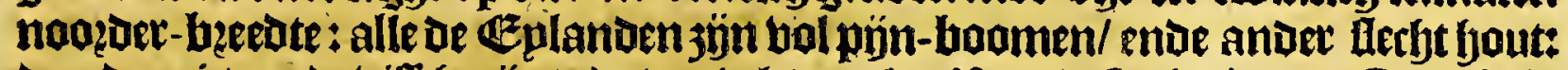

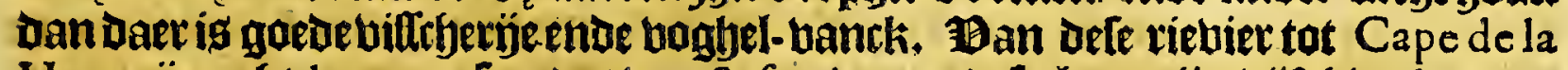
Heve jün acht leguen; fod Dat van Sefambre tot defe kape sijn vífthien leguen.

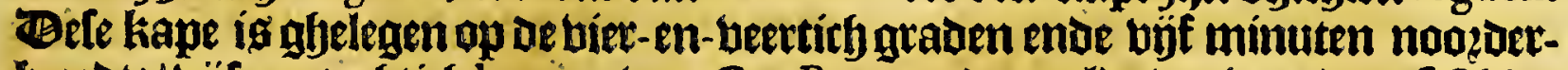

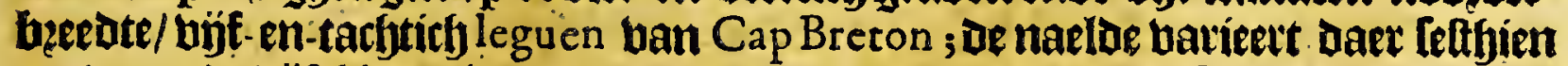
graden enoe bïfthien minuten: bier is een gaede baben/ welck fu noemen port de

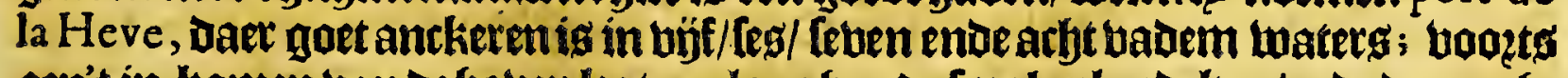
aen't in-kamen ban de haben legt een langhende (mal eplandeken/ende daer acf)= ter bp ooften yanue [elbe haven een bape/met beel kilepri eplandekeng met boomen

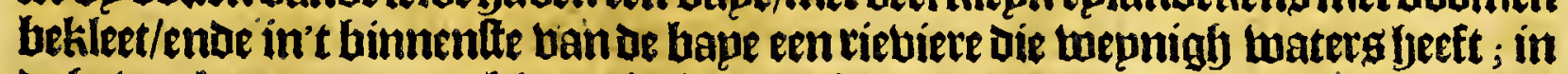
de Gauen komt mede een klepn riebierken ofte kreecke welck Deogh loopt met bet

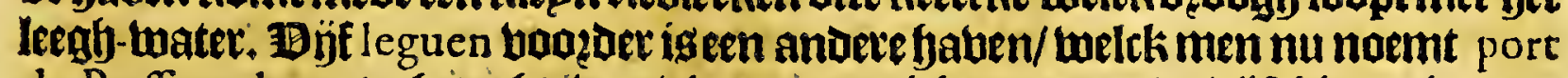
du Roffignol; op de booghte ban vier-en-beertich geadenenoe büfthien minuten. Baet leght een Klepn eplandt booz de haben; ende men beeftin ae felve uan Tes tot thaelf vadem maters/ende bupten beetthien ende bỉfthiew: Daer komt een rievies

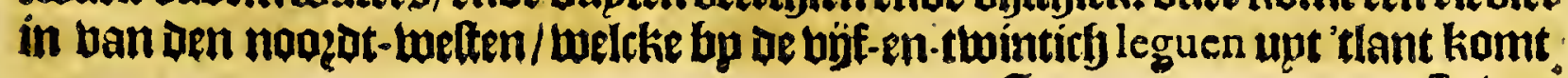

$$
\text { (B) } 3 \text { Seven }
$$


Seben leguen boozer naet' twelten is afjelegen port au Mouron, op de boory= te van biet-en-beetich graden noozor beeeste. Tit is een betloten baben / be naer ronbt; boo? de felbe leght een klepn eplandeken bol boomen/ aen de nogetotzyor van welcke maet twee badem watergis/Dan aen de jupot-3jjoe / allwaer't in-

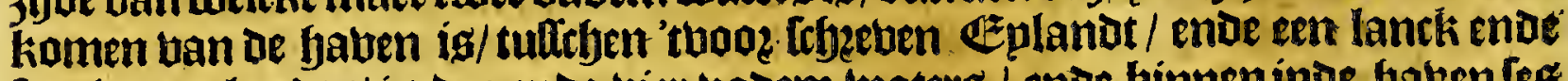
fmal punt lanots/ is oepe ende bier badem twaters /: ende binneninde babenles

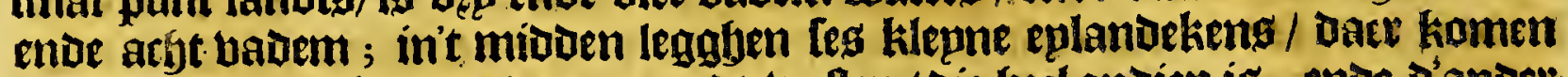
twee rietuielkens in; eene ban't noopd- welten / die beel ondiep ís; ende dandev. ban't 3tupt-welten / weltk komt upteen ftaende poel : 'tlanot aen of ftrandt is bol ban kreupel-bolefy ende beefters : almaer een menichee ban farten is booz ae poelen ende wateren die daer 3 ijn. Ses leguen boozder is een leer gocoe ba: ben/ melek Champlain noemt port du Cap Negré ; ban twegljen tekete kilippe/ Die of abelijckenis beft van een Sluarte / ligghende in jee bpeen Cape die la noemen Cap Negré, berfefjepden ban de boo--naemde baben biet leguen, ende thien ban Port au Mouton. Befe kape is leer ghebaetlifst van meghen of Klippenende rodten die berke in 3ee ftrecken; de kulte tot daer toe is leer leegf ende met kecupel-bofry betwaften; ende be eulandekeng 3 iin al to twildts. Ilen Port du Cap Negré valght enen anderf fauen meltk Champlain noent baye de. Sable, Daer De [thepen konnen antkeren fonoer eenich perijckel. Thee leguen vopeer is Cap de Sable, welck mede qhevaetlijck is van meghen feeckere klipl: pen die weleen legue injer fteken. Zulle de kulte ban Campreau af tor dele Cape de Sable, is tamelijck boogh-lanotende rodtligh/ende mest al met klepne eps: lansen ende gleuarexlycke barningljen belet/Doth daet zön eben-wel eenige gaede

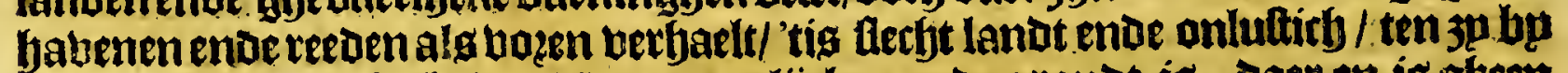
eeniabe rievieten afte beken / Daet tamelincke goede granot is; daet en is gheen twijfer aen ofte de winter moet biec leer koubt 3 ïn/ente Leg ofte feben maenden Dureten.

\section{9et [euen-thiende Capittel.}

Voorder befchrjjuinghe van de kufte ACCA DIE, van CAPE DE SABLE af tot PORT REAL : Befchrijvinghe van PORT REAL.

Valn Cape de Sable (daer wp in't bootgaende Capittel ban bebben ghelpgo: ken) tot een \&zlanot nughenoent lfe aux Cormorans is em legue ; dit ep: lanot woet foo genoemt ban megen oe groote menichte die daer is ban dat ghelos: nelte. Daet aen bolcht een bape die naer't noogen fheckt thee ofte Dęp leguen in't lant/melck (p noemen la Bay C Courante, twee leguen ban Cap Forchi; onttent of welcke bel eplandekeng leggen twee ende dęp mijlen ín 3ee/twaer wan eenige thee/

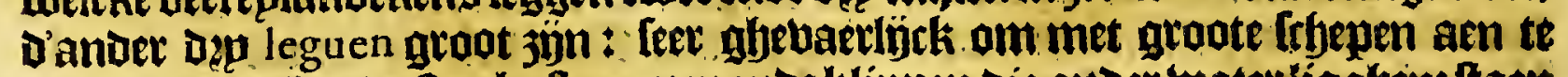
Doen wan weghen of fterke etroomenente klippen die onder water ligghen: taen

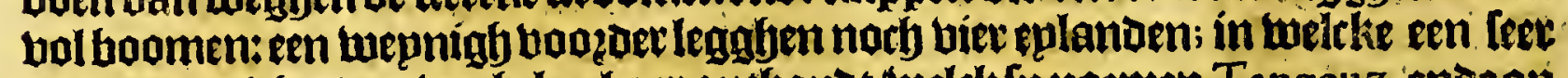
aroote menicfte ban bogbelen baet antbouot/melck fp noemen Tangeuz, tnde op de andere groote menichte ban aloerbande boghelen: d'eerlte noemen fi Ifle aux Tangeux; welck isentyalf legue ban Cap Forchu; eñ d’ander les Intes aux Loups

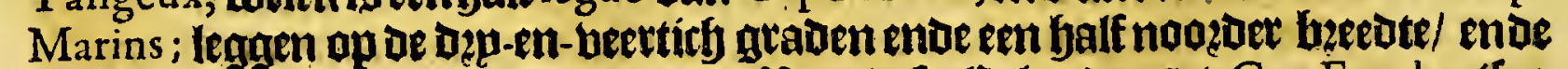
ban'tualte lanot viet oft bijf leguen. Ban Dele \&eplanden tot Cap Forchu (foo glyenoemt naer (pn gbedaente) altuaer een baben is/die lip noemen Port Forchu,

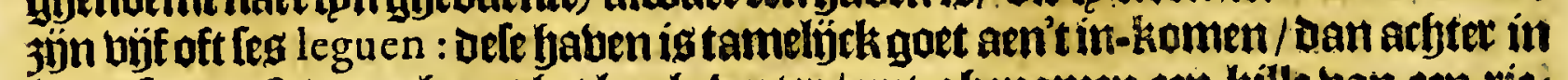
loopt [p imeelt Dqaogh met bet leegh-Loater / upt-ghenomen een kille ban een ries.

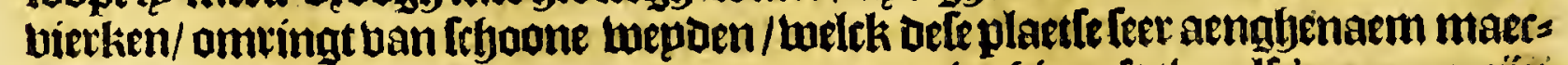

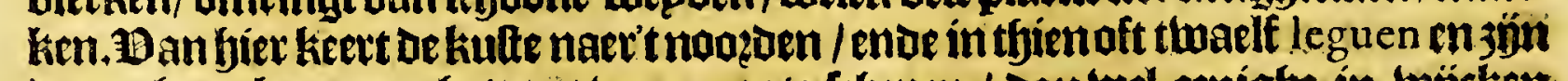
baet gheen bequame bauens booz groote lebepen / Dan wel eninge in-bücken ende fraepe ftranden / ende en fupluere kulte londer eplandekens/ klippen ofte Dzooghten. 


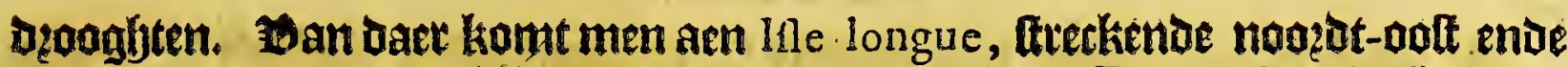

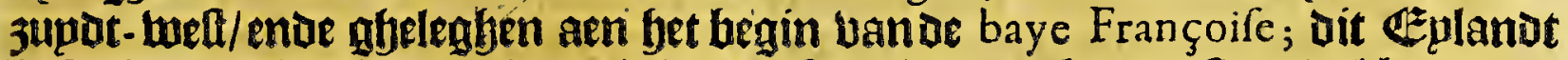
to teg leguen lantk/ ende in eenighe plactien een legue beest : ftart bol boomen: alle de kufte is be[met met lilippen/[oo Datter met trifepen niet en ig aen te tomen;

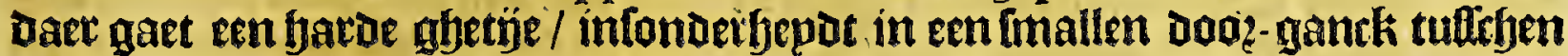
'téplandt ende 'tuafle landt/welck fus daetom noenten le paffage Courant, foo Datter ghen raed en is met frbepen daer Doos te baten. Cuffefen dit Eplandt ende' thafte landt leglyt een bape/ melckifp noemen $S^{\text {te }}$ Marie, daet goede reede íg

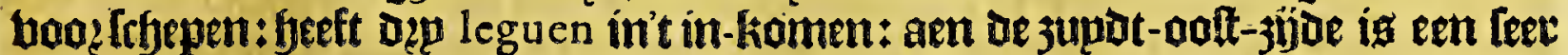
goear haben ghenaemt pore $S^{\text {tc }}$ Marguerite op de yoocfte van vigf-en-veettict gradenende een yalf / ende 'trompag bariect daer leven-tfien graden ende less thien minuten; aen't in konten fegten bantk/ Daet met leegf-water maer anoerGalf badem waters is / dan bimmen beft men dzp vademen/ ende gocae grond: 'twater valt Daer bel dęp vauemen: Daer is feer fraep lanot bp ghelegen; ende aen

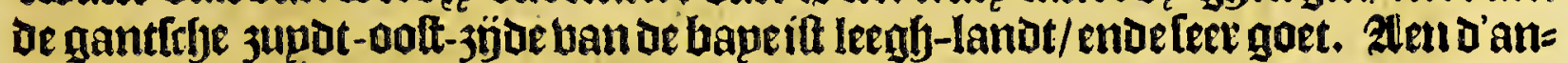

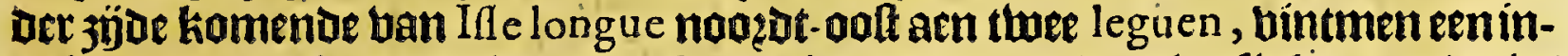

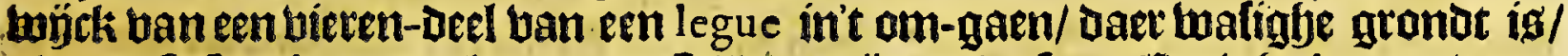

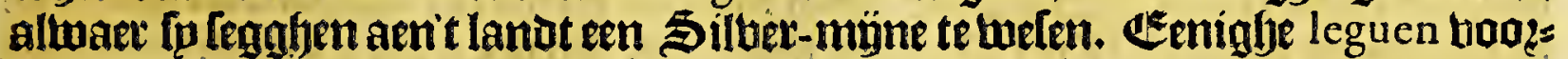

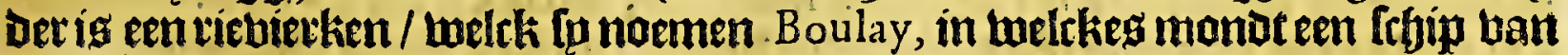
bondert baten bępelïck marh autketen; en quatt ban ken le gue boozoer is een

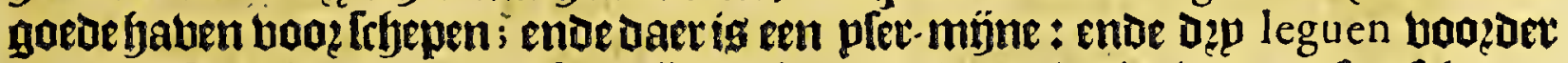
noott-ooft noch een ander plet-mijne/ niet berre ban een riebiete daer leer ltyoone

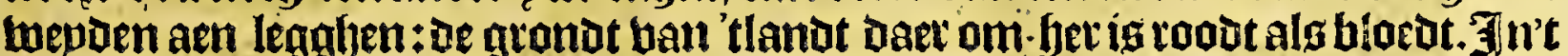
binnenlte uan de bape is noch een riebierken/ welck niet bette en kount ban Port Royal. Seg leguen om de kape / Doot de pallagie ban Ine longue, noozot-ooft

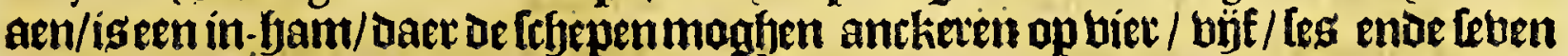

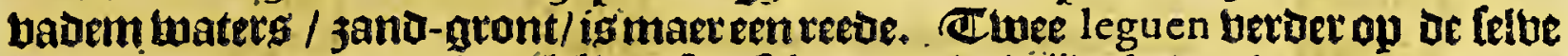

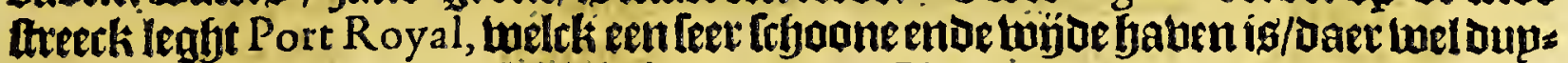

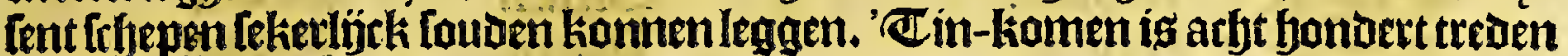

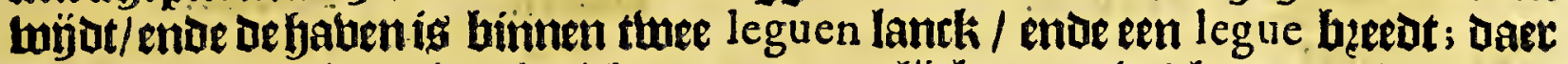

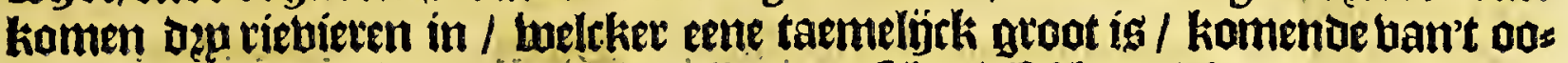
ften/die fanaemen Riviere de l'Equille, naet feker biteglkeng die daet gfetangen wozoen bp menichten: defe rieviere is in de monot bp naer een bieren- deel ban

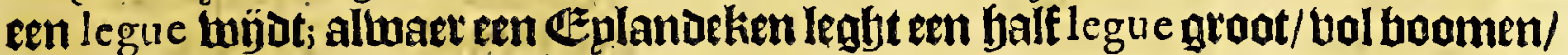
(gelijck bock de landen daet ontrent) ende maeckt dat de riebiete thee in-komften

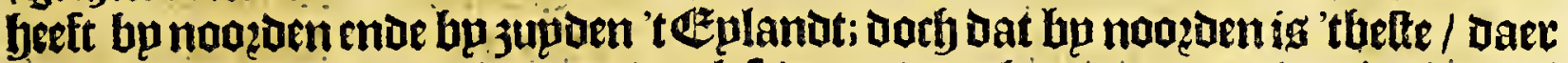

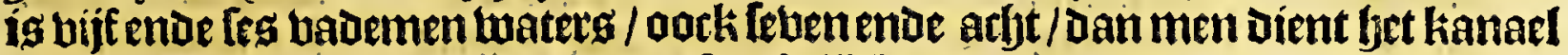

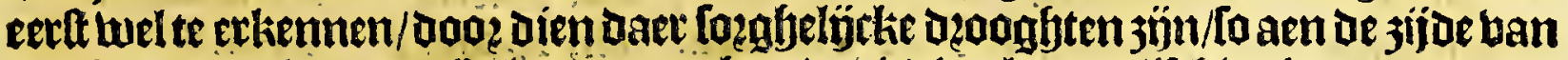
'tuafte landt/als ban't \&eplanut:men kande riebiere bp de biftiften leguen op-vas

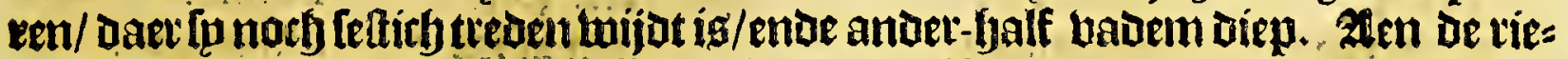

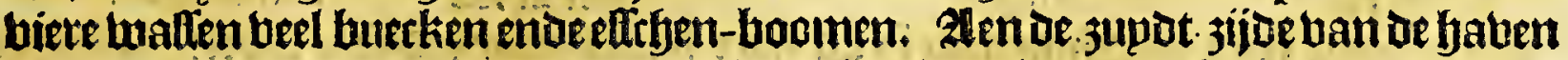
is een ander riebiere/ baer mede en eplandeken bogelegt/twee leguen ban't booz=

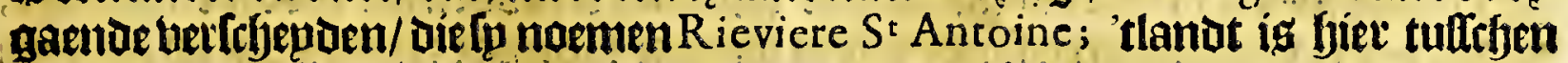
Pore Royal, ende'tbinnenifte han de bape $S^{2}$ Marie, hp de bier leguen ober dwets

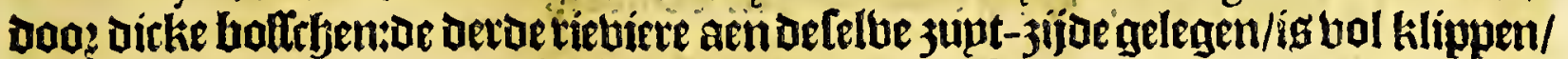
too dat daer niet in te komenen ig/noement le Ruiffeau de la Roche. Drfe baven

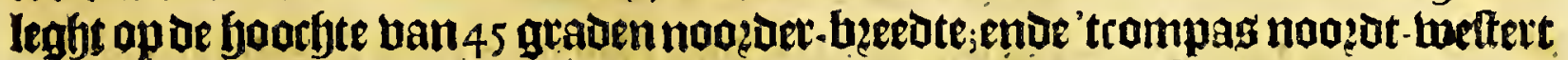
vaer leben-thien graden ende arfot minuten. Be j] tantoplen fadden biet een woon-plaetle inden jare 1605 onder 'thelept thanle $S^{r}$ de Monts, van welcke men

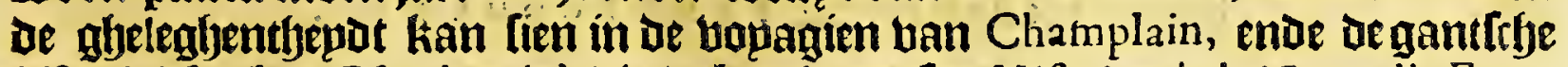
biffazie lefen bu l' Efcarbor ín't tierde hoeck uan fon Hiftoire de la Nouvelle France. Tuolek welck ontent dit quartiet woont/ wogdenghenoemt Souriquois, by de twelcke niet te binden en is dan bebetg bellen/eñ andere diergelïcke pelterñen. 
Dit bolck ig miboelbaet ban thatueve / bzupnban coleur gfelijck of antert

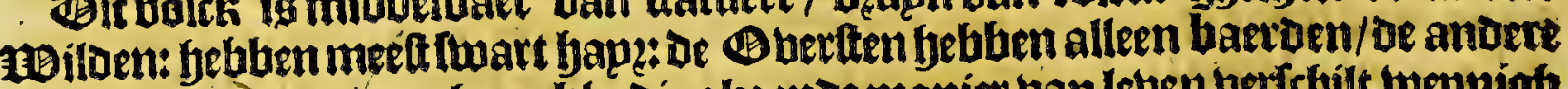
trecken de hapeen upt: baet kleedingle ende manier ban leven betrefilt weymigh

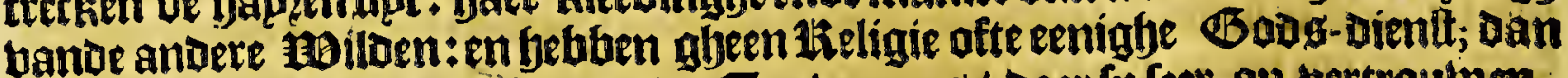

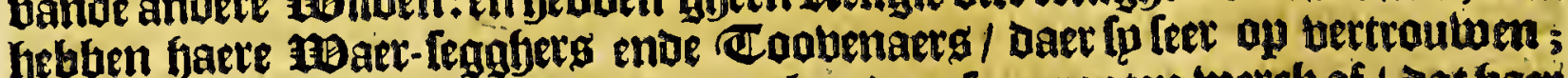
welch ip noemen Autmoins, entemaecken daer foo grooten merck af $/$ dat baet

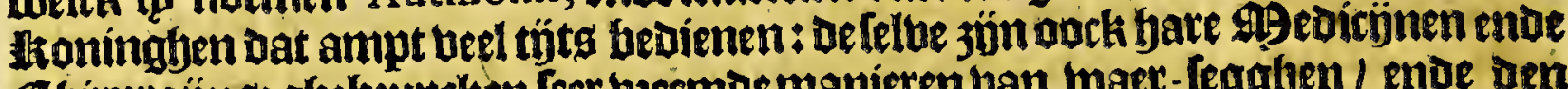

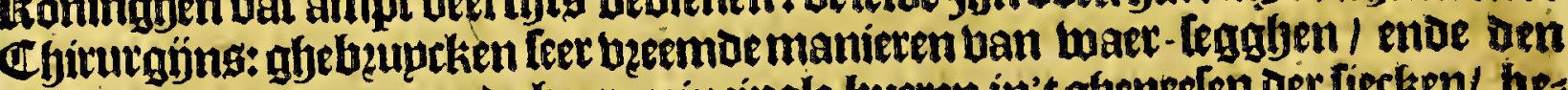
Dupbel op te manen : ende haet pincipale kueren in't gbeneflen der fiecken/ be

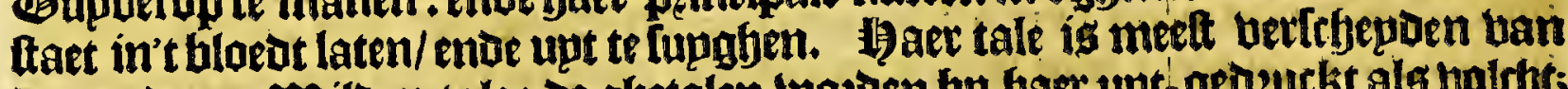

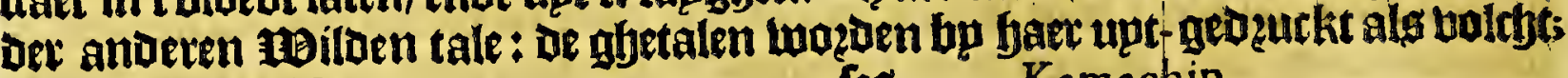

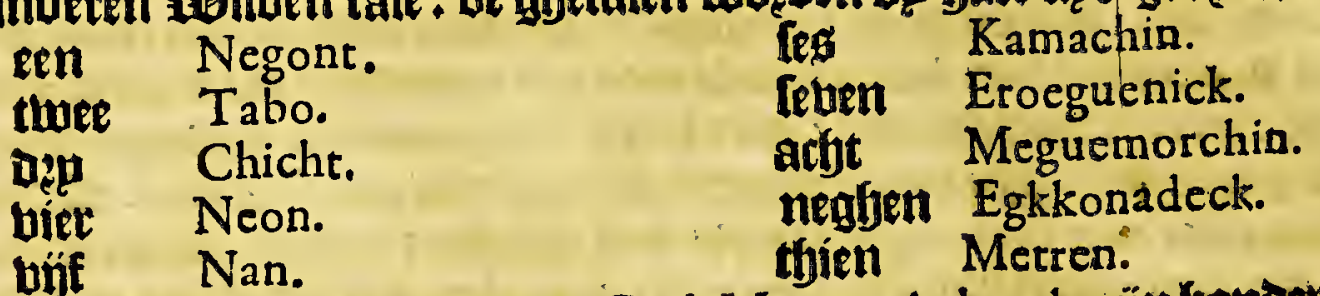

De jaren tellenlu bp De Sannen/ Cach Metren Achreck, 3jn bontert jaten: be

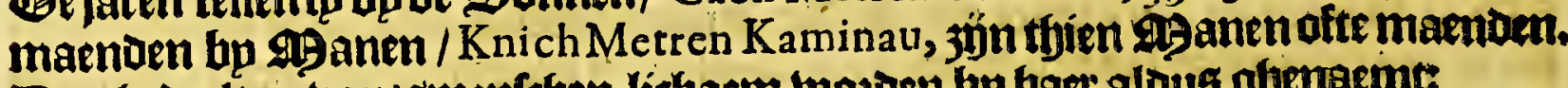
- De ghedeelten ban'gmenteben lichaem mozeon bp baet alous ghemaeme

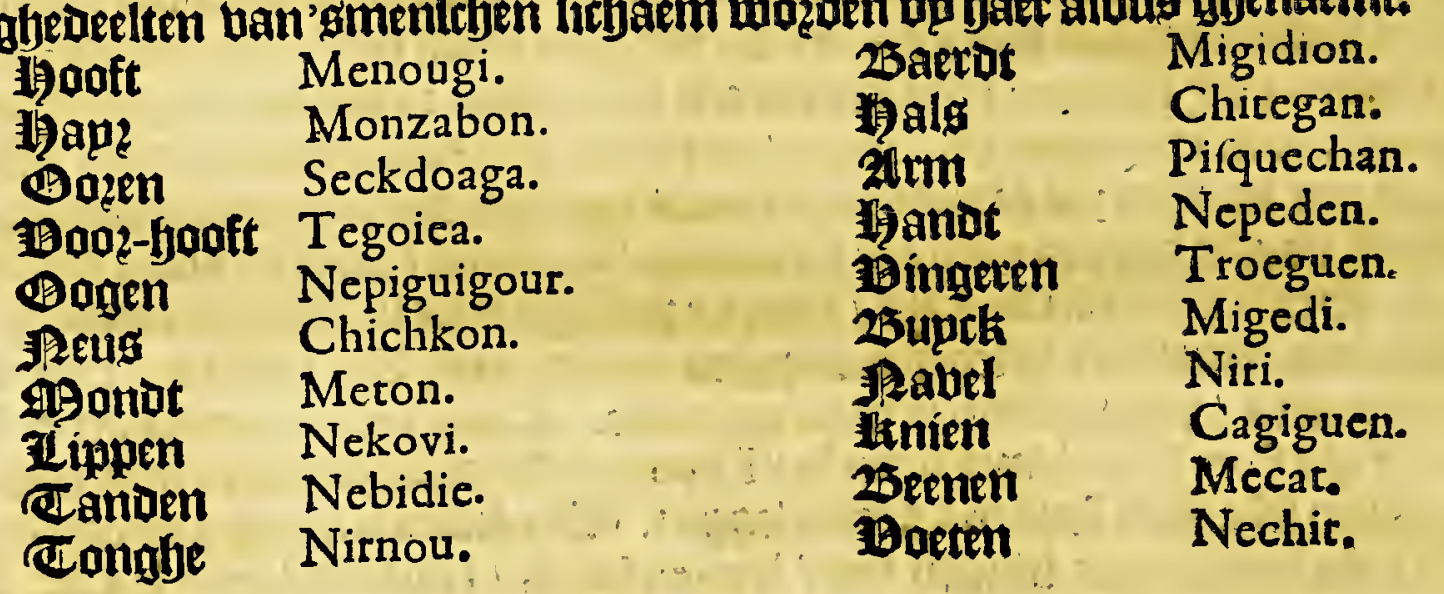

Sp noemen

De MAan een Thoulue

Bader

A9oeder

Metabouiou ofte Keffona.

Sten

Knoudou.

$25 e r d j$

Mebouiou.

23 zoeder

Nouchich.

't Boater

jen lomel

Pamdemouí:

Sultex

Nekich.

be Soune

Orenpeoc.

Sone

Barbter

't Biet

Skinetch.

be g9ane

Ovaieck.

ent Sterte

Achtek.

Knichkaminau.

Kerkooeth.

de zlevor

Nekovis.

Netouch of Pecenemouch.

en 25ooghe

Tabi.

een 1 ijo

een Sheg

Pomio.

Megamingo.

How agan.

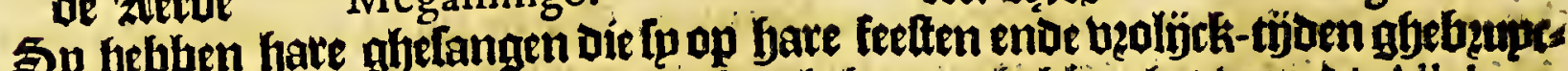
ken / inde belck l'Efcarbot ghetupght ghefoot te feblen bet woozot Alleluya,

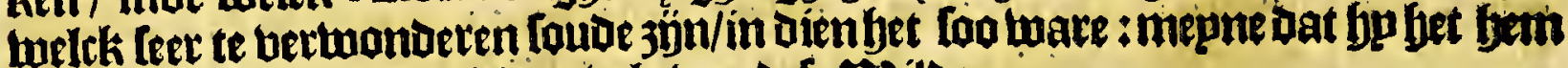
beeft laten vooz-teaen. Jug bele vandele mibilden.

Fet achthiente Capittel.

Voorder befchrijvinghe van de plaeten, Havenen ende Rievieren gheleghen in de groote $B_{A} Y E F_{K} A N$ N OISE, ende daer buyten tot de Rieviere PE M TE G O U E T toe.

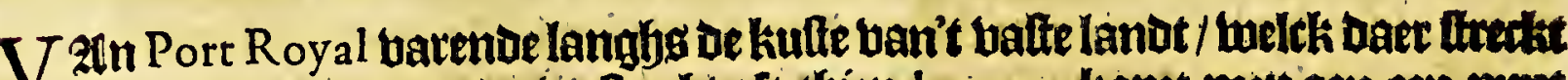
noozot-onft ende zupot-lueft arbt oft thien leguen, komt men aen cen pume lantg / welck [p noemen Cap de deux bayes, joopz dien bet een fmallen reep lants 
Het tvveede Boeck.

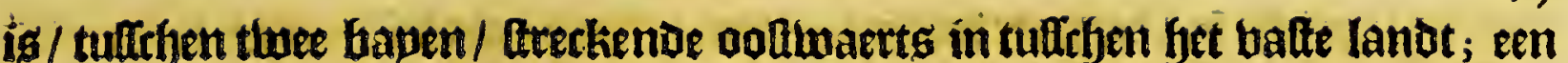
legue in zee ban dele hape leght een Eplanot een legue groot/gantfof omringft van hooghe rodten / upt-ghenomen in een plaetle / Daet cen bycurke is / ende daet bp een poel ban fout water: 't etalanot ís bouen plat / enoe met boomen bebal=

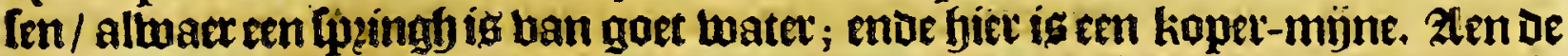

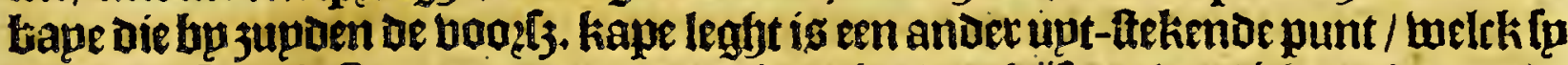
noemen Cap de Poutrincourt, op oe tooghte ban bjif-en-berticl graden enje thee derde nodzer betedte. Bele baue is ontrent thintich leguen int om-gaen/ cnoe in t binnente is een riebierken ban twepnigh waterg: Daet jün norb andere klepne beken; 'twater walt daer bp oe biff badem. Baer is northeen ander baben welck met 'tleeghe twater dzoogh loopt / welck [u noemen Port aux Mines, Dooz Dien baet een kaper-minne is/ porb loopt thee-maels daeghg onder met De bloedt:

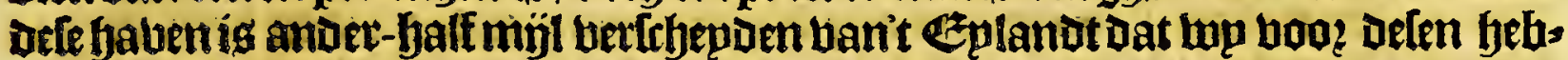
ben aen-afjeroett : ísen bape bp een legue langh/ enoe anderbalf beedt ; men

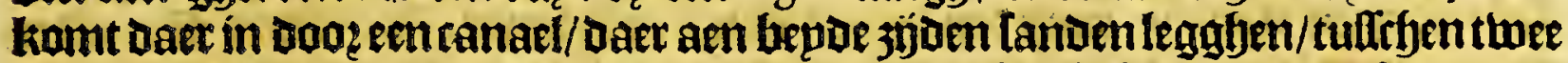
Imal upt-flekende reepen lanots / Die de bape bp ooften bellupten; ende binnen iñ 3̈̈n thete klep̣e beken van twepnigh maters. De baye Françoife loopt ban fiet

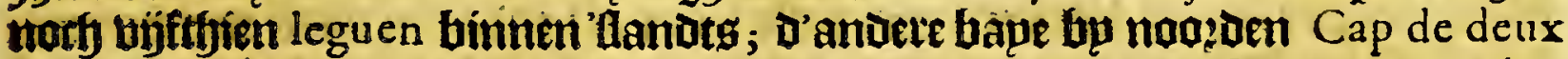
bayes, wotot bu Champlain in Ipn kaette ghenoemt baye de Gennes; Daet ko= men twee riebieren in/De cene ban het ooften naet Cap Breton tos / ende d'ander ban bet noogeten naet Gafpé toe : Dele bape ig in fet in-komen bje oft feg leguen wïot. Alen oe jupot-kufte ban bet valte lanot/ telt Champlain Rieviere $S^{t}$ Louis, De taelche fjp nocfjtans niet en noemt in (pn bopagie/ dan Ipreeckt Daer ban een klewne riebiete / met een leeghe kaep aen bet ín-komen; ende een fooghen bergh binuen '(land t\$) fyebbende De gheljickeníg ban een Cardinaels foedt : allwaex een

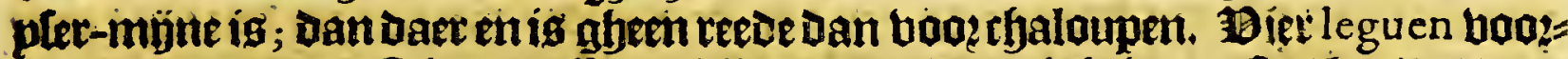
oer twelt-jupot-beeft ig een rif banklippen een twepnigh in 3ee freckende / Daet

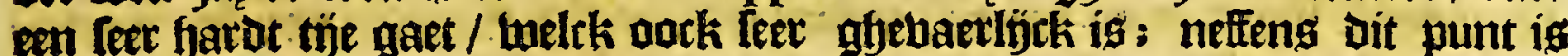
cen in-ham/een balt legue groot / baer oorkeen pler-müne is. Bier leguen hoo?= Der is een Irhoone bape/in de welcke dęp Eplandekens legghen/ende een rodte; oe twee jön een legue ban de Cap Rouge naer't wetten/ moe bet Derde aen de monot ban een fehoone riebiete / welck lp nu noemen Rieviere $S^{t}$ Iean, ende de Tilben naemen die Ouygoudy. Bele riebiete is ghebaetlÿck / indien men niet gaede atft en neemt op lekete punten ende rodten / die aen bepae jyoen leggfen: ip is enghin de monot / ende Daer ig dertbien/ beertfien ende felthien bademen waterg; Daer na woette wijoer tat aen een upt-ltekende punt Daerfe weder nau= wer werdt / ende fieft Daer ghelijek een bal tuftefyen twee bogghe klippen/ Daer 'twater Leer inel af-loopt; Dorty met het yoog water ift Daer wel te palleren; ;nde wert

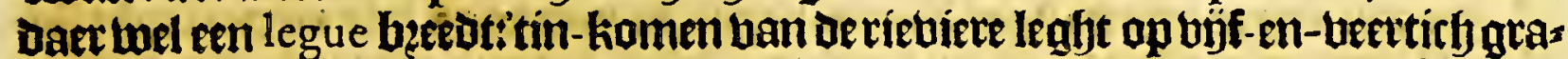

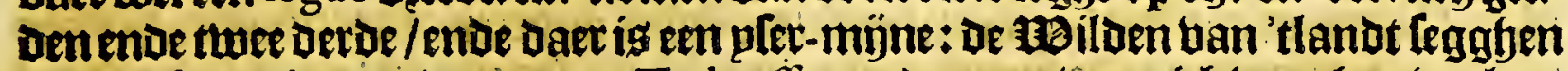
batfe defe tieluiete op baren naer Tadouffac,ende maer wepnich tweeghs ober lant

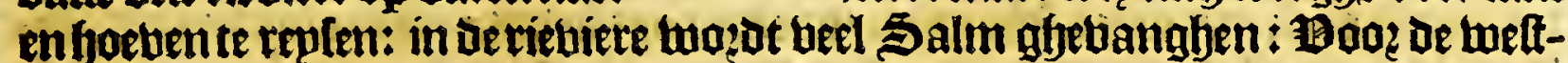

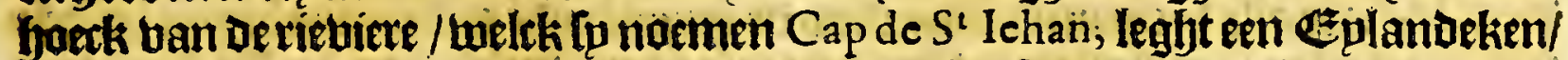
welck fp bar tweghen de gheljekenis noemen la Nef. Ban Daet komt men aen

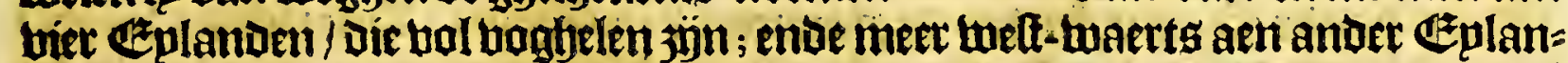

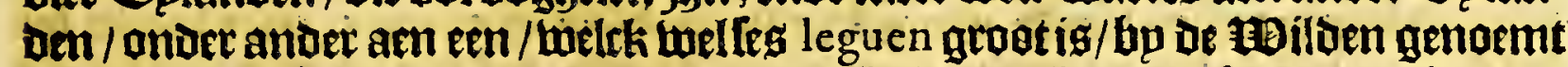
Manthane; enoe naer't 3upden tan't Lelbe deplanot jön diberfthe goede fabeng tulleffen de Eplanden in. Ban baer komt men aen een riebiere / welrk men na De natie uan de Mildon die daet antrent twonen / noemt Rieviere des Efteche-

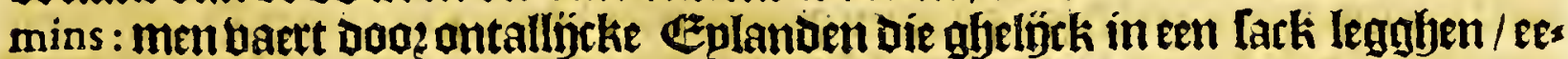
nighe meer oftemin als een legue groot. Champlain noemt Die in [on kaerte Ifles Iumelles. AGidoen Dog orle Eplanden komt men in een rietiere / in't midoen ban de welcke leght Ine $S^{\text {sc }}$ Croix, Daet de ffrancoplen een twoon-plaetle helben

$$
\mathbb{S O}_{4} \text { afdeadt }
$$


nefjadt / woltke fp daer naer tueder werlaten bebluen / als te fien is bu Champlain ende l'Efcarbot. Dit Eplandt is ghelegfen op vöf-en-beertich grauen enoe sent Detde noozder-bzedte / ende 'trampag noozat-Lueliert daer Ceuentbien gradeu

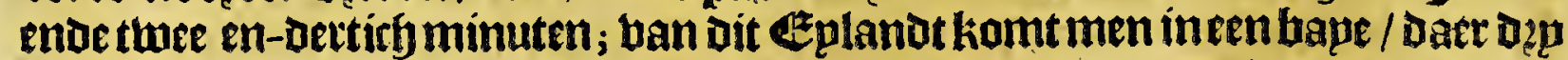

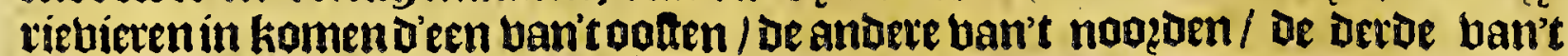
welten/welckis die top bozen bebben trenaemt Rieviere des Efechemins, enoe twee lèguen de riebiete op is een groote val / foo dat de Hoilden baex canoen wel

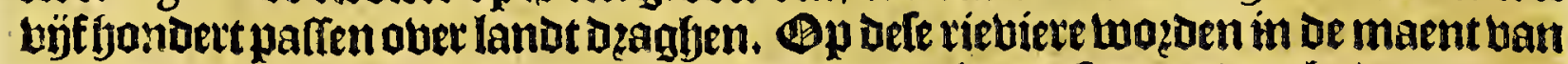
- May ende I un Leet beel baringhen ghebanghen: 'tis een leer goeden bodem/ ende

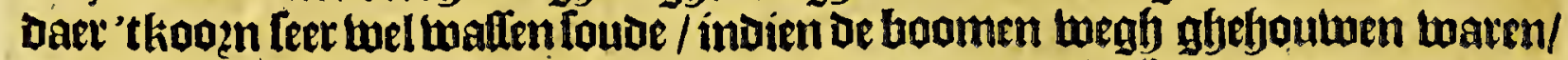
want bet gantfrbe lanot is meett volgheboomte/ende op't Eplandt ende daer ontrent en ontbekten gfoen molquiten. Om ban oeferieviete de $S^{i e}$ Croix te varen naet de riebiere ban Pemtogoüet ofte Norembegue, palfeett men doo: feet bed klepne Ezplanden/ klippen ende landen: ende het Eeplanat / welck de Hoilden lelfs naemen Menane, legft dę leguen van 'tuafte lanot. Be klepne Céplanoen

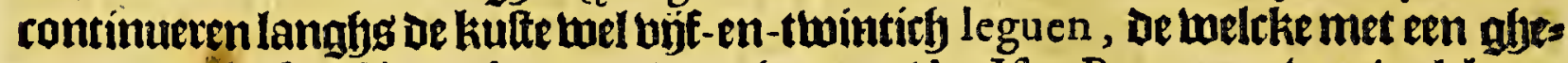
mepne naem bp Champlain woęenghenoemt les Ines Rangees; ban tuelcke 2 s nighe wel bier leguen legghen van't balte landt at: ende zön meelt met boomen ban flecht houbt belet: ende tulleben bepden zön beel goede babenen / doch onluf=

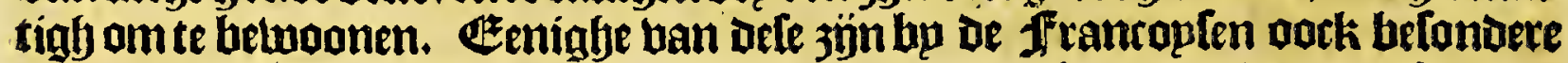

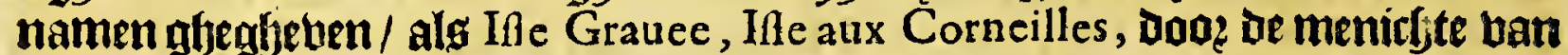
exterg die men daer vinot ; la Heronnerie, ende dierghelijcke. Cen epnoe van Dele EEplandekeng komt men aen een Geplandt/ meltk wel bier oft bÿf leguen langh ig/ ende en leght maer twepnigh tweeghg ban de kulte ban 'tbalte landt; is

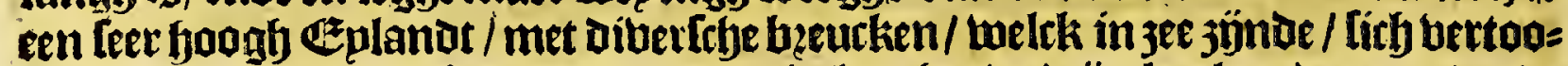
nen als feven oft acht bergben op een rỉe leggftende / jün kael op Den top / ende niet Dan roitlen; Champlain noemt het Inle de Monts deferts, is ghelegben op be jooghte ban biet-en-beetrich graden ende dertich minuten noozder-beetorel ende aende monot ban de tietiere Pemrogoüet; Daer kop nu boozoer fullen van Ipeken.

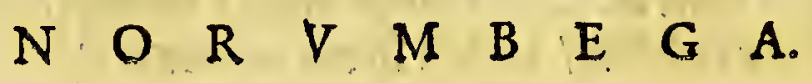 \\ Iet neghent-hiende Clapittel.}

Van de Rieviere by. de Wilden ghenoemt P E M I O C o' ü E T, welck fchijnt te wefen de Rieviere ende Contreye die men noemde No R V M B E G A.

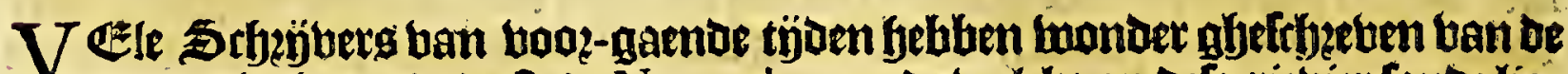
groote rieviere ende de ftadt Norumbegua, de meltke op defe riebiet Loube lig:

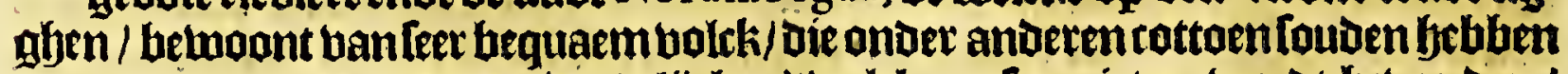
ende tottoene gaeren enoe aiergbelöeke; thelck nu foo niet en lwozat bevonden/

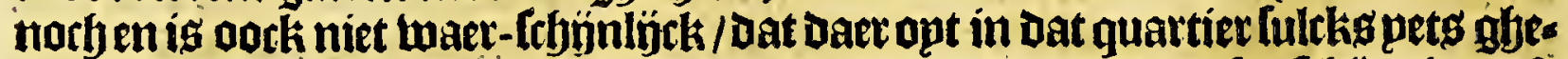
weeft is; naer alle de circumttantien ban oe boogte en be anders/[oo febynt bet ofle

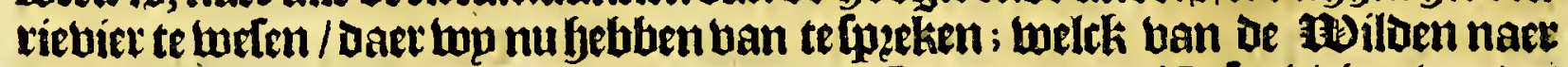
'tfeggen van De ffrancopfen mozot ghenoemt Pemtegoüer: Bele rieluiere woędt/ naet itk Kan meteken / bu de Engellebe Pennobfcot ghenoemt ; enoe woz̧ot hp $\mathrm{M}^{\mathrm{r}}$ Champlain in fun bopagien naer Nova Francia beftheten in voeghen ald bolgt. Fn tín-liomen ban de riebiere Ieggen feer beel Eplanden/thien ende thaelf

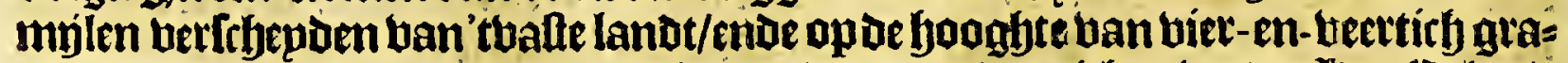

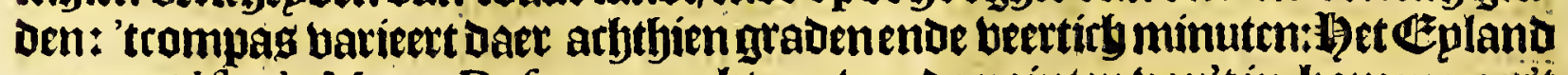
genoemt lfle de Monts Deferts, maetht een ban de pointen var't in-komennaer't ooften toe / ende d'ander point iseen leegh-landt/ welck de Boildennoemen Bedabedec, leggende aen oe twelt-3ÿbe/ende ż̈n dele twee painten ban oen enderen turtchtess 
Het trveede Boeck.

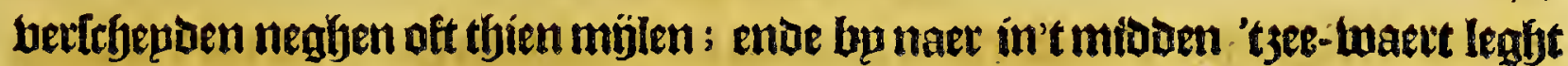

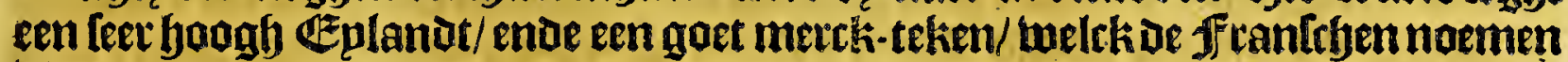

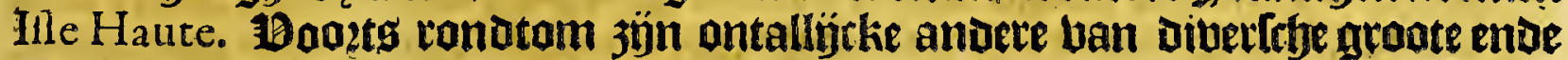
hyecate/maer 't EE

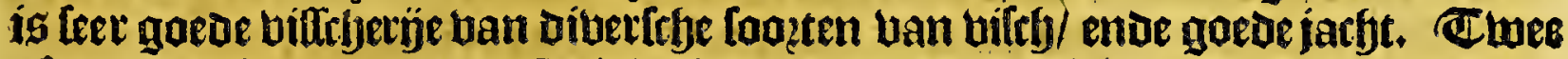
ofte dep mỉlen van't punt Bedabedec, Jaapende lancke'tlanot naer't noazden/ legghen leet fooghe landen / luelck men met fyeloer weder mel twaelf ende büfthien mülen in jee kan fien. Homende aen't jupten ban Ifle Haute, ende daet

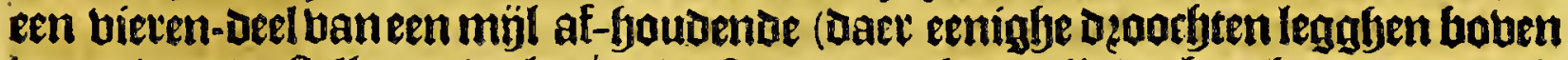
water/) enoe ftellenoe de kotirg welt / tot dat bem alle de berghen openen die noożt ban't Eelbe Eplanot legghen/ ende Dat abp Dan komt telien de acfjt oft ne= ghen bzeucken ban Ifle de Monts deferts, enve die van Bedabedec, fao bebt ghjp De riebier apen booz u: ende om Daet in te loopen/ [oo moet men be Cape noazden banfich bzengen/welck ig boben de hougfte bergen tan Bedabedec;'ende en fult geen [Eplanden booz u fien/ende moogt Dan fonder foege in loopen/want Daer ís waters ghenoegh/ boetuel ghp beel barningfen fiet / ende Eplanoen / enoeroot=

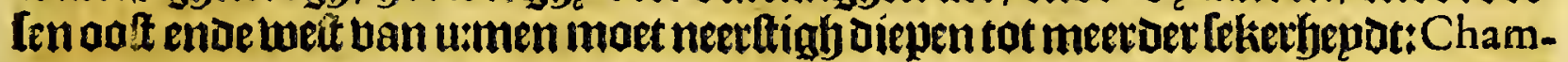
plain mepnt dat baet gheen ander in-kamen is als dit/vonz aroute febepen/ Dan Lel booz klepnoer afte chaloupen; want als bazen Daer legghen Lao beel. EEplan= Dekeng / klippen / bantiken / ende barningfen / Dat bet te vethondeten is. Defe

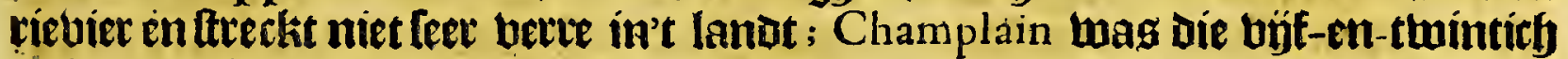
imjien op oft tuepnigh meer / ende bonot dat derievier daer een bal badoe. Lap ge:

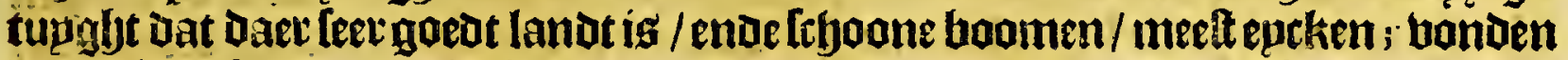
baet gyeen lteden / nach gleen apparentie ban opt ghetweeft te bebben/maer hel

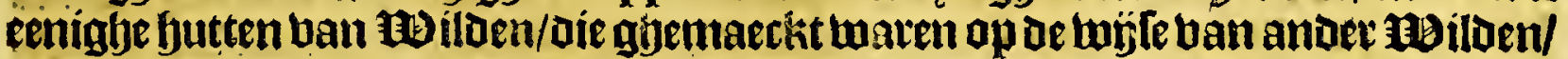

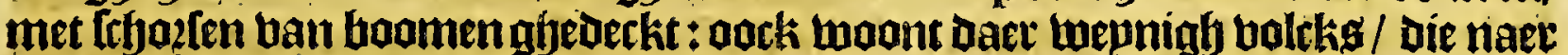
Tpn fegghen Erechem ins twozden genoemt: 'tig bolck dat gheen uafte boun plaet=

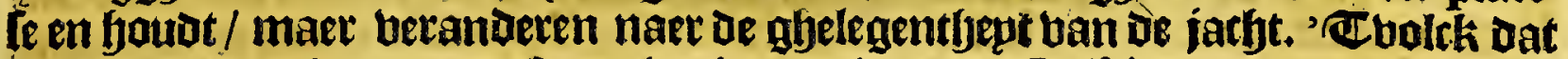

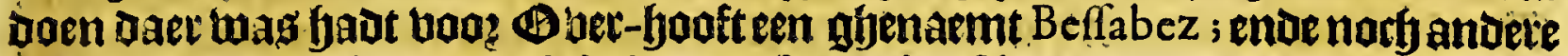

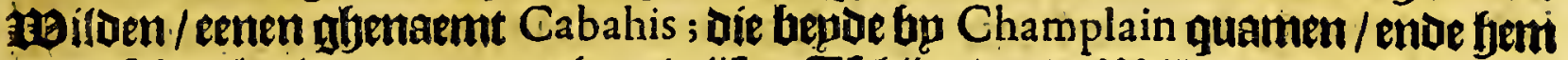

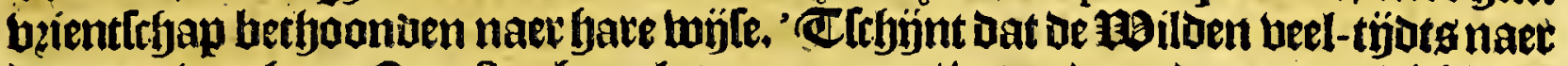
Denaem ban baer Buetiten faer laten noemen / waer booz de namen dicktuils

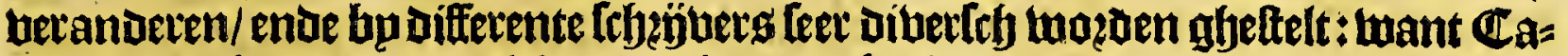
pitepn Smith noemt de baleketen / die aen Defe riebiete twoonen / T arentins; foe: tuel bp oock mentie maeckt ban Beffabez, qbebende Den naem ban den obertten

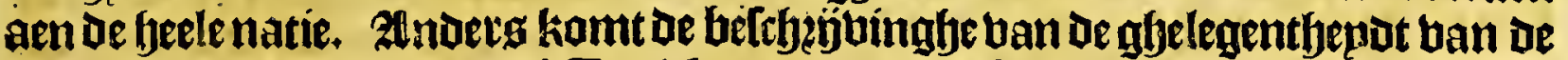
riebiere tamelijck ouet een. "Chalck dat ontwent dele vieviete twount ig ban de [els be glueltalte ende maniere han leven alg de Canadiens ende Souriquois, ende klee: ben baer in beteig enoe andere bellen.

Fet thintichte Capittel

Vervolgh van de kufte van NOR V MBEG V E en de befchrijvinghe van de Rieviere $Q$ V I N I B E QV.Y, ende de plaetfer daer ontrent gheleghen, uye $\mathrm{M}^{\mathrm{r}}$ Champlain.

V Alin theltelijtktte punt van be riebiete Pemtougouet, welck ald bozen ghe= naemt wozat Bedabedec, tat de tieviere Quinibequi ofte Kinnibequi, tekent

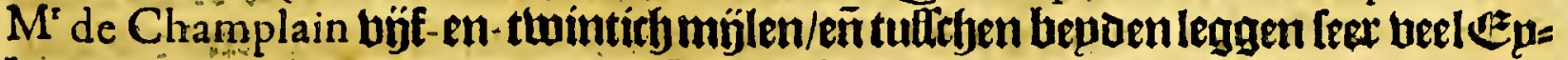
Ianden ende kilippen;ende aen't balte lamo bp naet in't midoen ban bepde dele rie: bieren legft een groote in -wojtk / afte hape/ al bal klepne ende groate Eplanden/ tuelrk de bookj. Champlain in [prikaette noemt Baye de Si Luc. Leetht aber de riebiete Quinibequy legft een tamelötk boogh Epland / welck of ffrancoulent

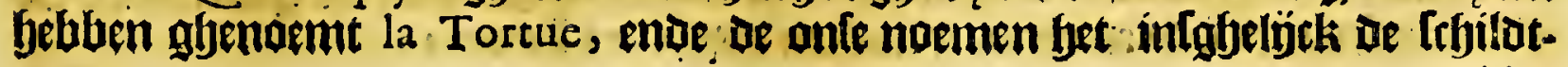

paube; 


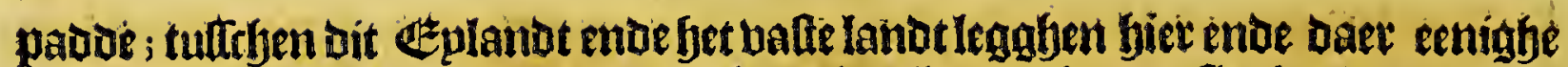
flippen/ die met get boogh water bedeckt 3 jun/ boty men liet bet water daet op tarmen. Dis đEplanot la Tortue legbt met De ríevier Quinibequy jupd-jupd-

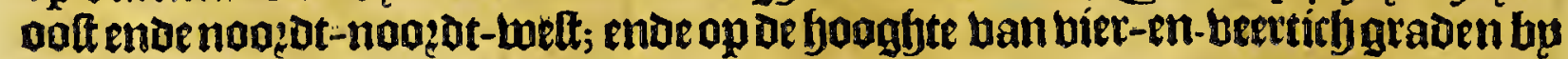
noozaen oe linie; t'compas barieert baer neghenthien graben ende tbaelf müu= ten volgbeng De obferbatie ban Champlain. Aden'tin-komen ban De riebiere Ieg=

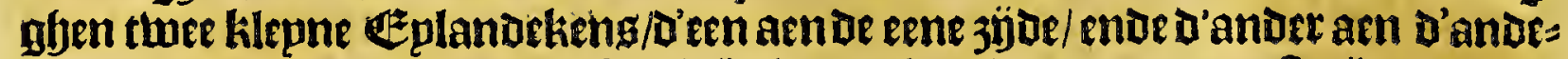

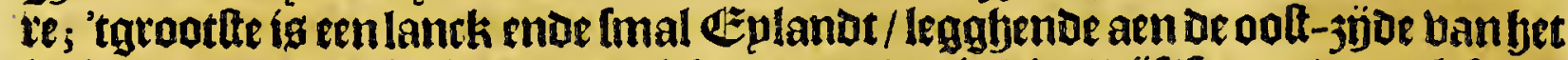
in-komen ban De tíedietre / ende Dirfyt Daer onder is bier / büf/ [es / ende oock feven vademen waterg; enighe dep fondert palfen meer intwaerts leggben twee rodt= [en/ Daer gfjeen youd open ís/ maet alleen luepnigh groente: tegben ober bet grootfte \&eplandt vooe-noemt Iteeckt fyet balte lanot met een punt upt / hobbende

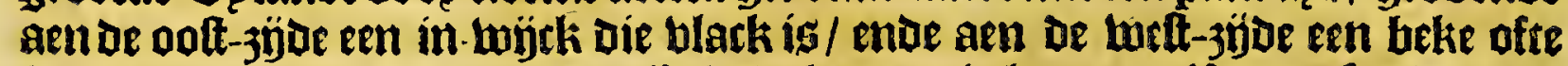

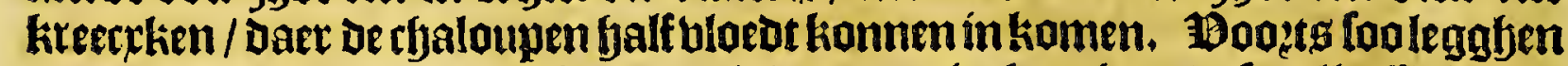

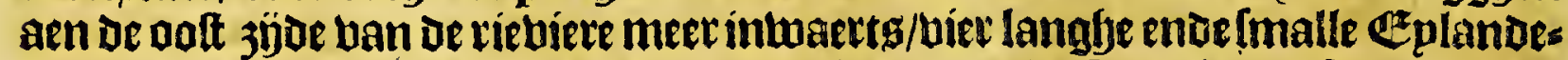
kens; ende aen de weft-jijoe ig een in-wijtk/ welck wett-waett in Areckt / enoe

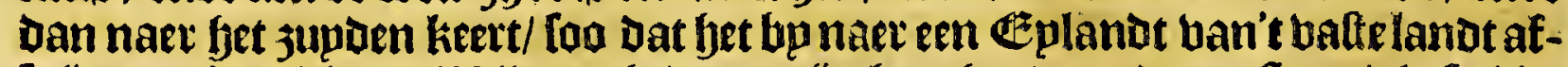

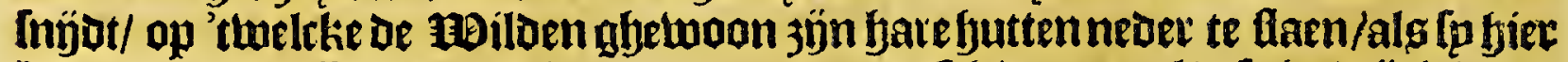
komen om te billeben; Daer íg een panne van vertry watev: al dele ín-mück is on:

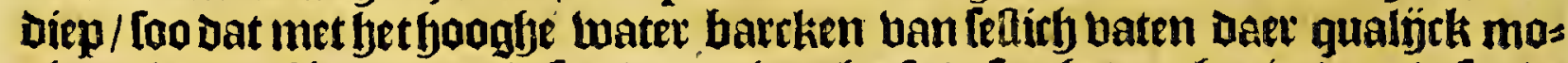
ghen bloten. Champlain infun vopagien gheeft oefe gffetupghenis ban Defe ries

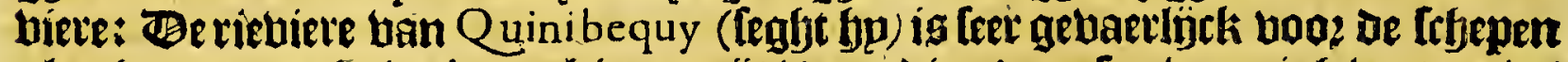

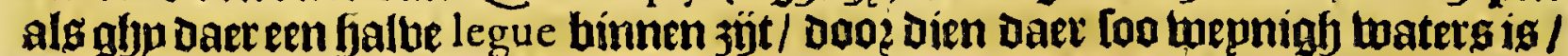

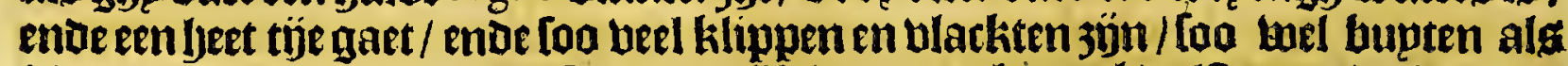

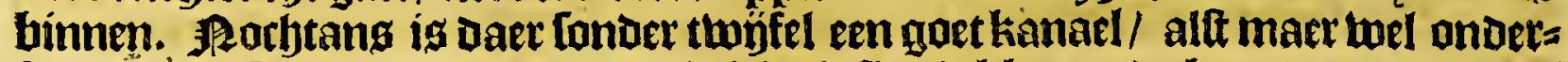
fortyt wate, \$oo mepnigh landtg als irk ghelien yeb be aen de kant ban de riebiete isleer dechte gronot / niet Dan roorten aen alle kanten. Baer wallen menichte ban leeglie epcken / enve daer is Leet wepnigh landts dat bequaem is om te bejaepen.

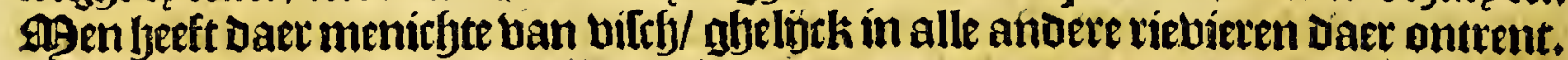

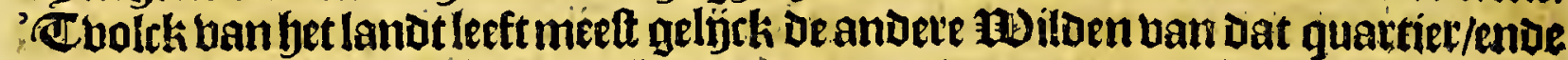
bet'yaeloen ong dat' tudick/ welck glyetwoon is Maiz te jaepen/ Ieer terte te landttwaert in twoonot/ ende dat [p naet gyelaten bebbente zaepen loo naer aen oe ku=

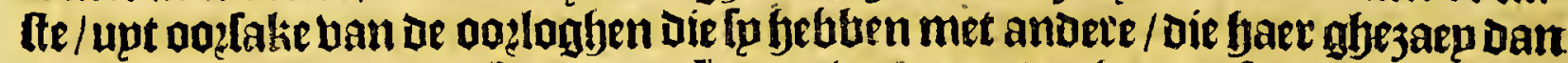
quamen berderbenende berooten. 1)p terbaelt boo zoer foe dat fu met oe rhalous pe eenighe mijlen de viebiet op baeren/ende berlpalien daet een van de Oterfe ban de Millen / Die Iu noemoen Manthoumermer, Die baer wan twee andere $D_{\text {s. }}$ berften bermaende Marchim ende Sazinou, díe buel de boog-naemlte twaren op

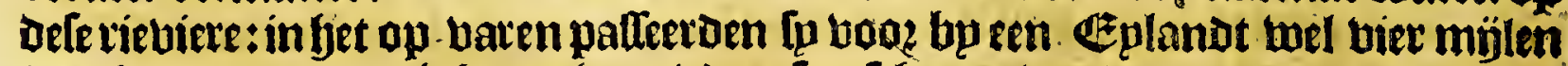

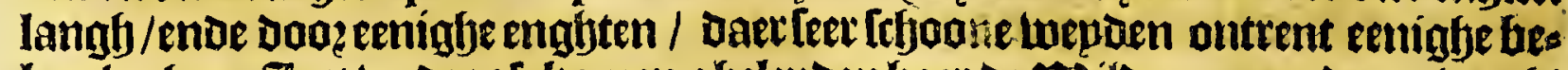

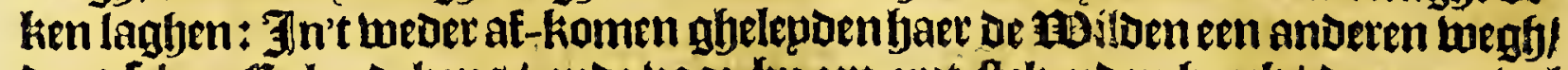
booz teker [eplandekeng/ ende booz-hp een upt-ftekenden foeck/ Daer een bal

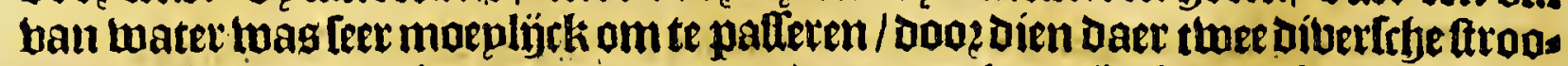
men malkanderen ghemoeten: quamen daet naer in een lark ołe ofte vier mỉlen langh / Daet eenighe klepne Eplandekeng in legghen/ende daex komen twee ties bieten in/ namentligck die ban Q uinibequy, welck ban bet noozot-noożt-notten af-komt/ ende een ander welck komt ban'tnoozot- weften. Paet trapozt van oe Moilion' foo kan men langfge de le vieviete komen tot aen de geoote riebier ban

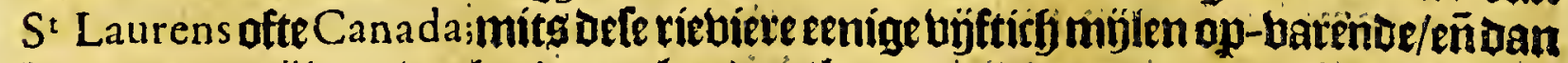
hu de twee mülen ober landt tteckenden/komt men aen een antoer riebrere dic in oe groote vieviere komt niet berte ban Q uebecq. Be Gengellfhe noemen dele riea

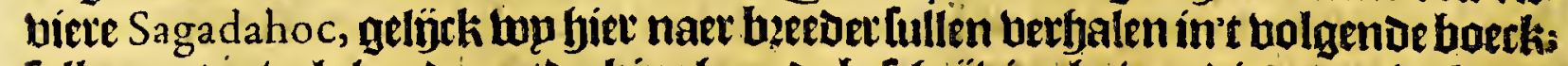

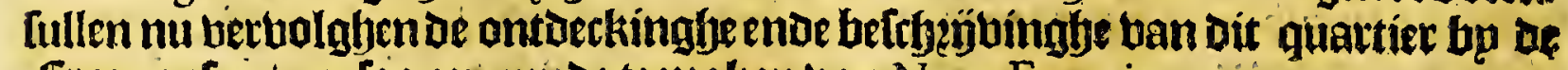
ffranroplen / om too een epnoe te maken uan Nova Francia.

婹战 


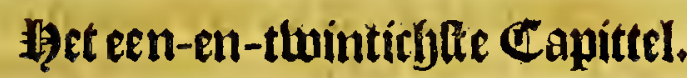

Vervolgh van de kufte van $Q v$ I N I-B E $Q v$ I Weftwaerts, ende van de rieviere C H O V A COE T, ende de gheleghentheydt van de plaetfen

daer ontrent; de gheftalte ende manieren van de Wilden

die men noemt A L MOV CHIQVOIS.

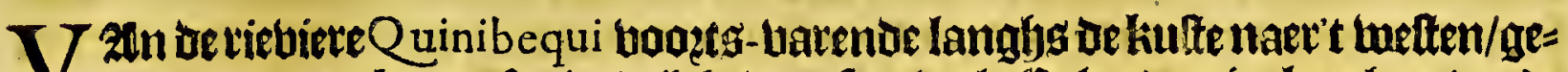

maet men een bape ofte in- wijek Daer feer beel Eeplanden in legghen/ ende men fiet daer feet boogbe herghen naer' tweilen toe. Befe hape ís han de riebiete

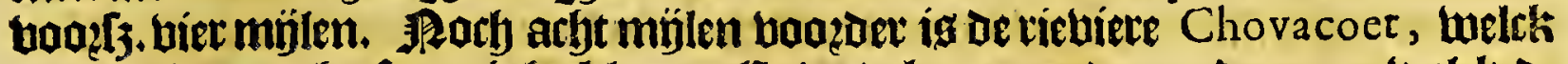
in't in.komen beeft eemighe klepne Gzplandekeng; onoer andere een welck ie

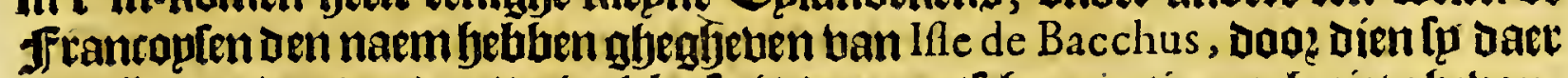

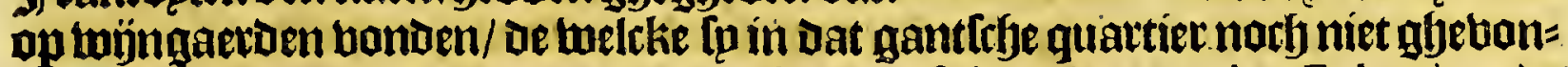
aen en hasuen; de anfe noemen't om de felue oaelake Wijngaerden Eylandt, ente ae hape twelck aen't in-kamen ban Defe riebiere is / Graef Willems baye: naet 'tlegghen van Champlain too ig dit een teer vermakelíck Eplandeken/Daer Leet Ichoon ghe hoomte op twatt wan eprken enoe noate-boomen / ende fraep lanot ap igom te bejaenen: ig ontrent thee mijlen ban de viebiete. Defe viebiete ban Chovacoet is maer een klepne rieniete / ende beft een batre int in-liamen/ allwaet met 'tleegfe water maet een balf uadem maters ig/ ende met 'tjoggbe ander-fjalf

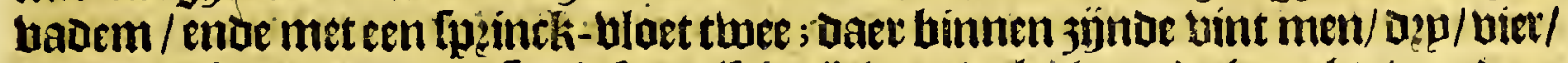

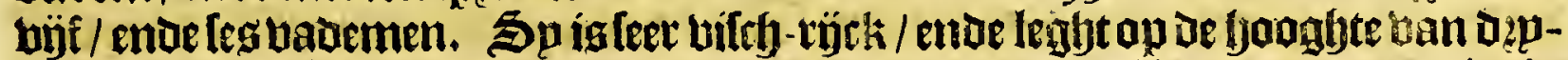

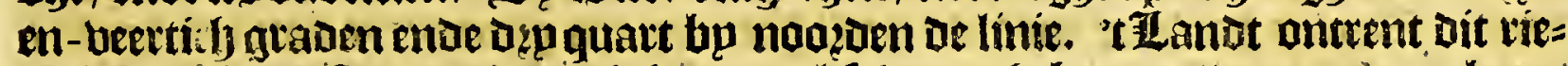

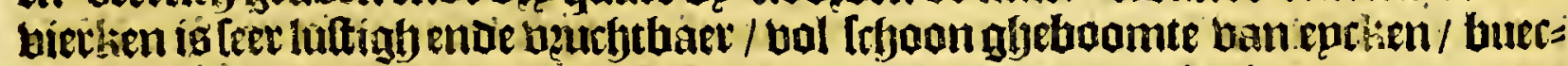
ken / ende aimen. 't Bolck dat daer twoonot is een ander natie als de voos-gaen=

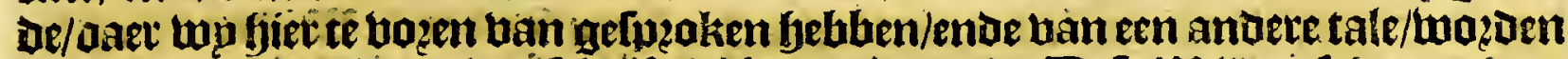

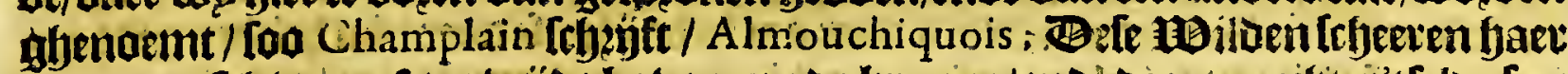

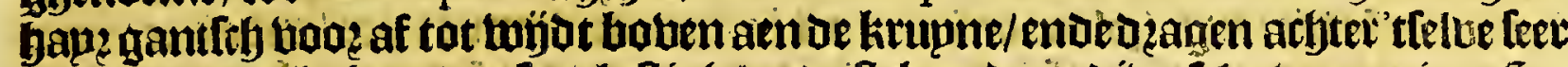

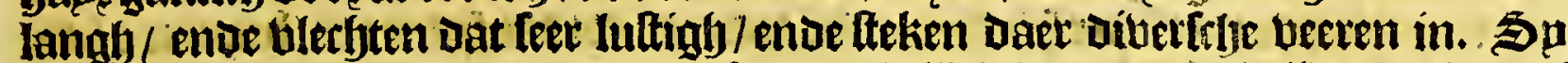

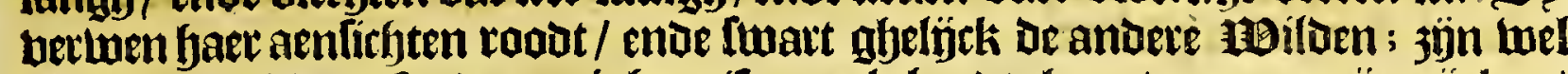
gheltelt ban leden / conoer eenighe mif-maecktbepot; baet wapenen jün pücken/

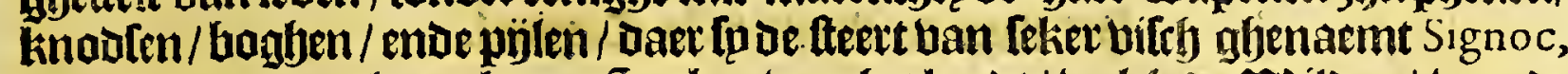

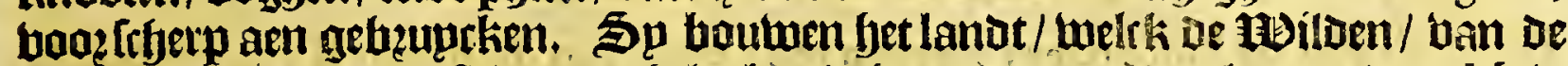
quattieren van bier watt-waetr glyeleghen/ niet en boen:entoc planten daet Maiz ende 25etilítge haantiens ban diberfrbe coleuren ander den anderen/ Coa dat

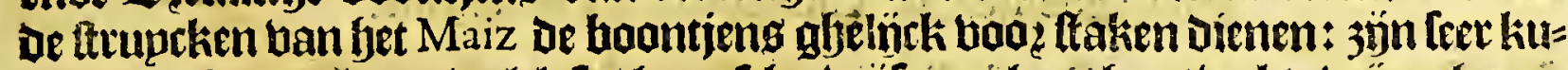

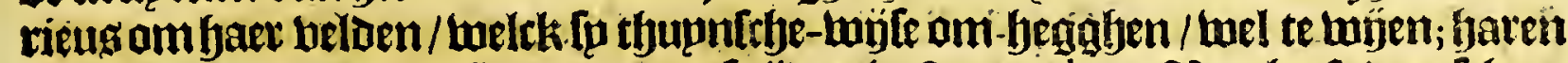

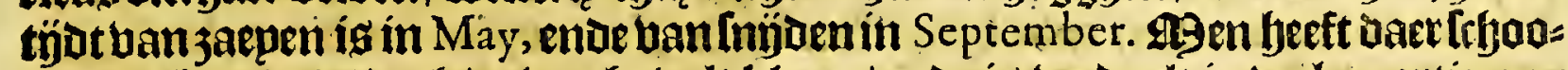

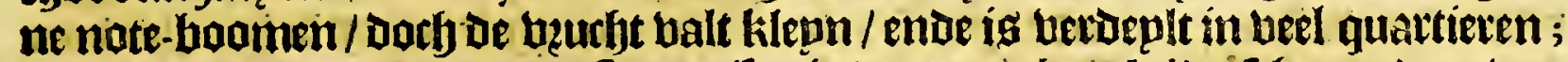

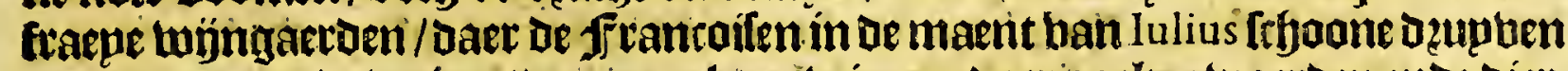

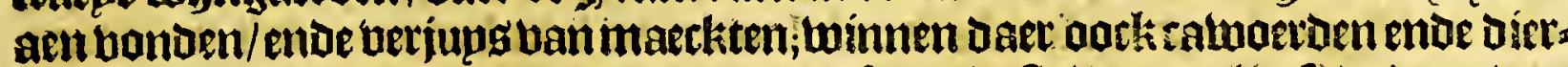

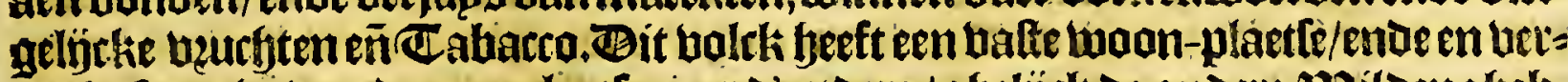
treckt loo niet ban de eene plaetle naec danuere/ ghelijck de andere moilden: feb=

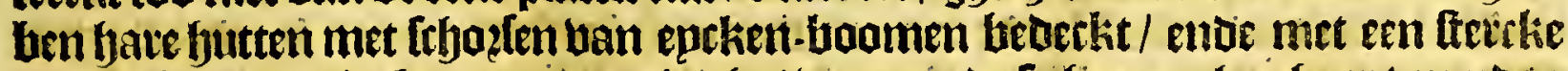

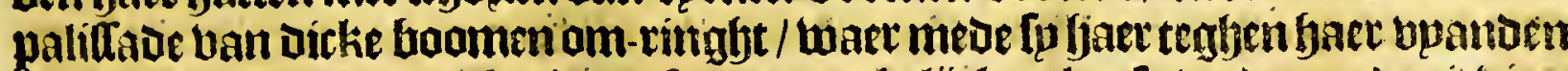

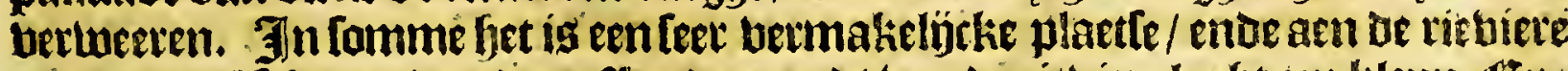

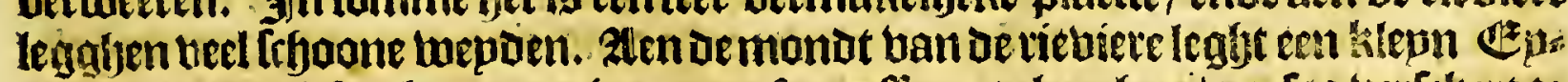
lanbeken welck teer bequaem is an een faztrefte op te legohen / am foo vertetient te weten tegijen alie aen-ualien. Eepnich berber bupten de tiebfere fegagen nocts

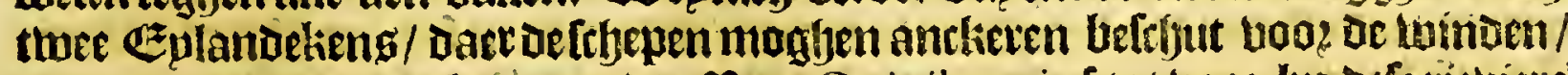
ende daer is goede autker-grandt. 19an Quinibequi af tot boo bp ofe riebiere

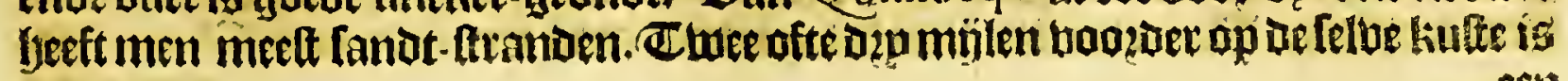


ecn kape/ende daet bpen baben die goet is boa lchepen ban bonbert baten/welc

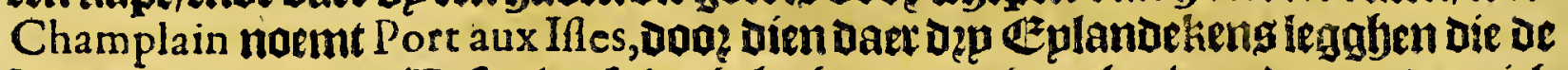

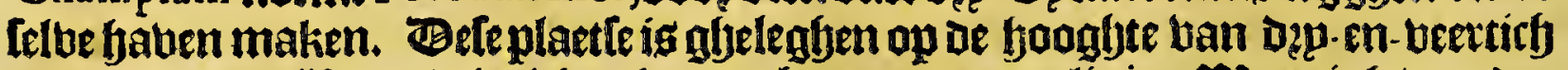

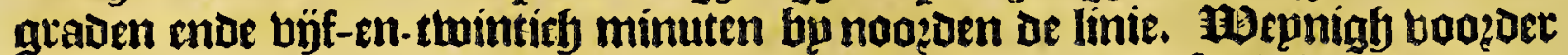

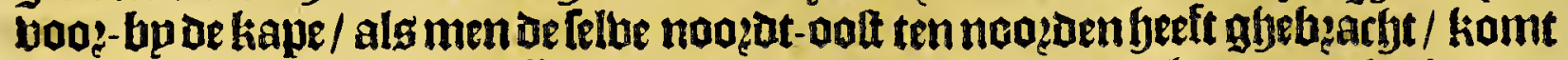
imen in een anoer yaben tuflefyen Eplanden/ die maer een in-komenen yeeft/Daer

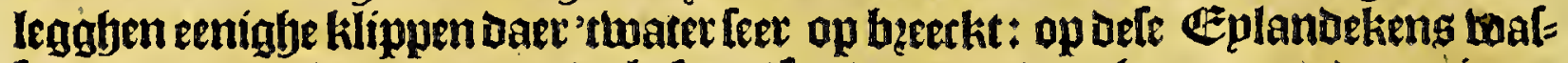
fen uptetmaten beel roode aetot-befpen/ too dat meri daer bu naet anders niet en fíet. Be kulte is booger aen meet blackende lanoigf. Baet naer komt men aen een ander kape / welck Champlain noemt le Cap aux, Ines; ende tuftirgen bepden. is een in -wijck / welcke ftreckt naer't welten; ende daet legghen twee oft Depp $\mathbb{C}^{z} p=$

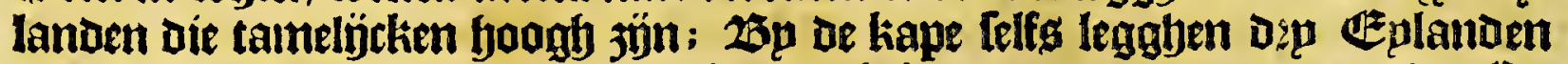
Dirbt bp thafte landt / volban aloerbanoe gheboomte; ende een anoer plat Eps.

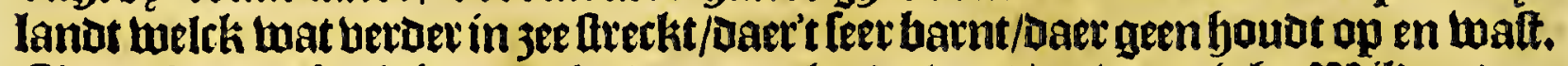
Champlain berhaelt boe vat fjp daet aen landt was / ende eenighe milden ber: fpeack bp teeckenen; dat daet beel wijngaetden waren/ende veel note-hoomen/ Docf of noten niet grooter als een mulquet-loodt. 'CC bolck jaepdot ende plant alg'

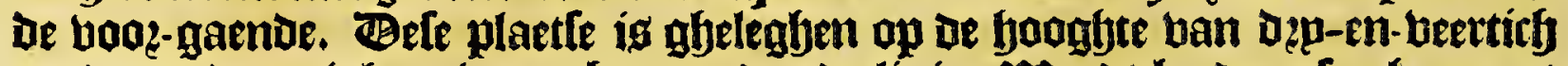

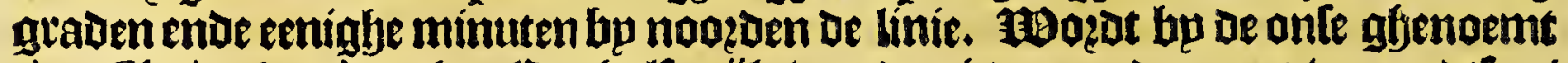
den Ghebroken hoeck. EEen balf mijle boożer iseen anoer punt ban rodten/ welck de firancoplen daeram bebluen ghenoemt Cap de Rocher. Eulteben bep=

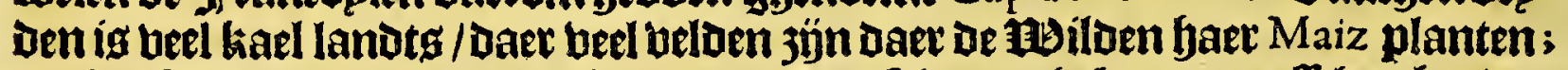

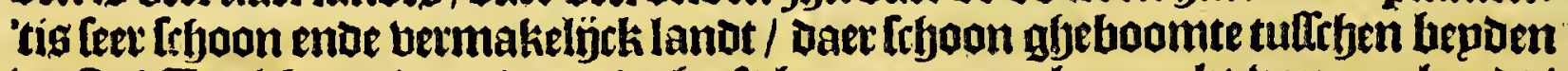
walt. 'Cuolck Dat Daer woonot beeft baer ranoen ghemaeckt ban een boudt/ meick feer litht om flaen / ten $3 p$ men die boozlichteljock weet te ftieren. Be moil= Den maken Die van Leer groote hoomen / welck fo tweten te bellen met bijlen ban

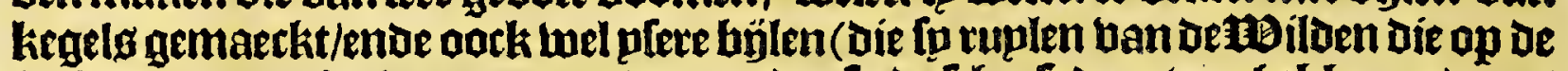

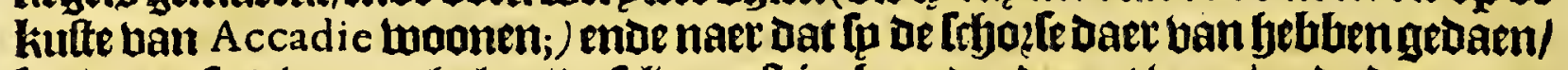
foo taetenfy die upt te halen / de felue eeclt in-bzanoende met bper / entoe daet naet upt-Icheabbende met felter frbelpen ende anders / tot dat If die en luzquame bols lithepd abegheben bebben.

\section{Het thee-en-thintichlte capittel.}

Vervolgh van de kufte naer'r zuyden toe: ende van de haven B E A V P O Ri $T$, ende C A P St Lo u is, ende andere plaetfen daer ontrent ghele. ghen; ghelijck $M^{5}$ Champlain die befchrijft.

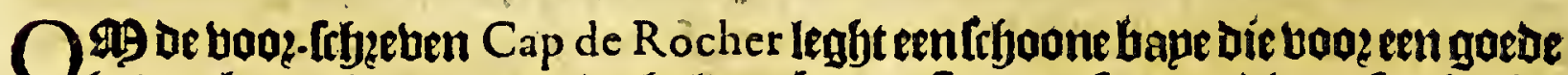
bauen kan dienen/ ende dertyaluen bp de friancouten om die oo: laeck gbes noemt werdt Beauport, ende bu ante Schoone haven, gbelegen op de hoogfte ban Dep-en-beettich graden. Defe bape ftreckt noogot-waett in/enoe jupot-waett upt; aen de woft-jy de loopt een Imalle fteeck landts bol ban boomen: in't in-komen ban de bape feeft men in't midoen Leben / acht / ende thien badem twaters / ende

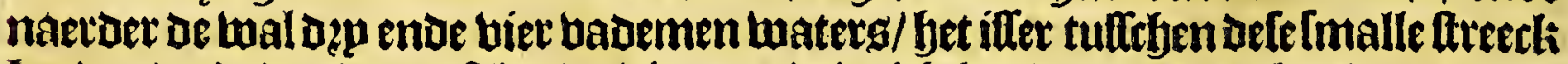
Ianots / ende'tander baft landt bier-en-twintich yondert roeden beetot: Daer ig goet antlieren acteter een klepn efelandelken/ welck bp naer balf wegljen de bape leght / altwaecmen befrgut kan legghen booz de lainoen. Baer woont beel tolcks

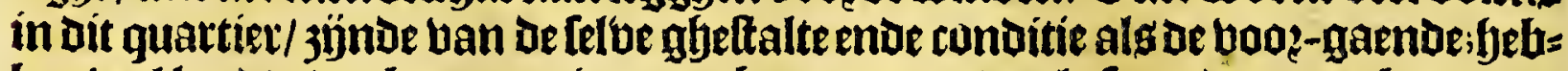
ben beel lanots dat bequaemig om te bejaepen; ende als fp anoer meer bequaem millen maken/Loofoutuenlp de boomen maet af tot hen naet dęe boeten bouen ot grondt/ende fteken den bzanot in De tatken/ende maken loo een klaten bodem. In Dele bapen komeneenighe klepne beecrkeng blieten/ baet leboone toepoen on. trent legghen. Ben oberten ban dit quattiet wag ten tijue ban Champlain obenoemt 
Het twveede Boeck.

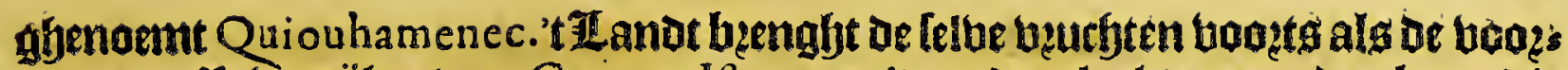
gaenoe. Zltbr miglem ban Cap aux Ifes naer't jupden legbt en ander kape die Champlain noemt Cap St Louis, de onfe noemen Die Wijngaerts hoeck; Dan ken möle hp noożen Defe kape is norbeen bape/daer beel klepne fyuttekens aen lanot

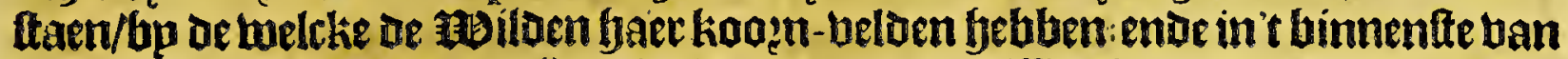

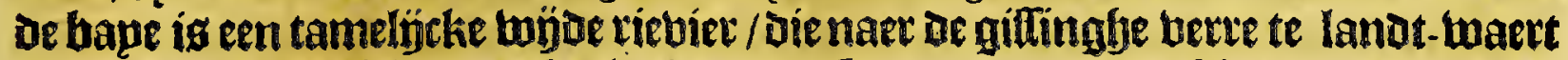

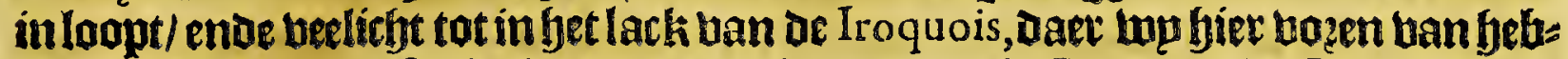
ben ghelpzoken; ; defe vieuiere naemt Champlain; la Rieviere du Gaz; entue de onfe noemen die de Sandt-rieviere, ende defe hape/ de Witte-baye. De Cape St

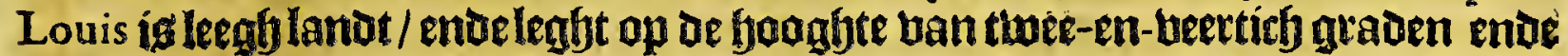

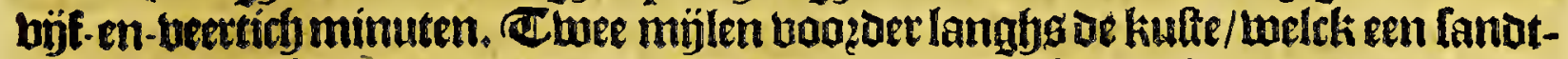
Atranot is / beeft men een klepne belioten bage / welck Champlain noemt port da Cap St Louis, enoe Iegfyt top naer op oe felbe boaghten / Itreekt twelt in / enoe ooft upt; aen ie nowidt-3bae ban't in-komen igeen upt-ftekende reep landts / boog

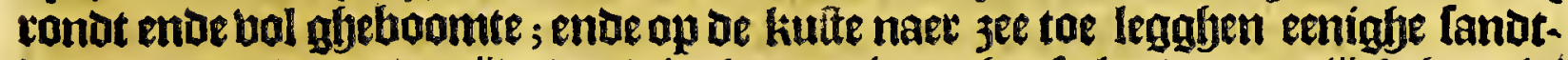

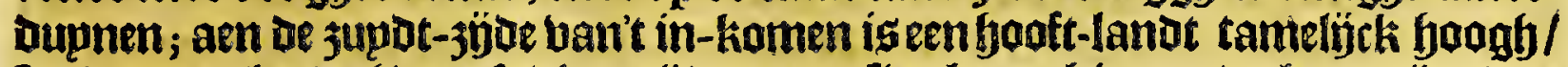

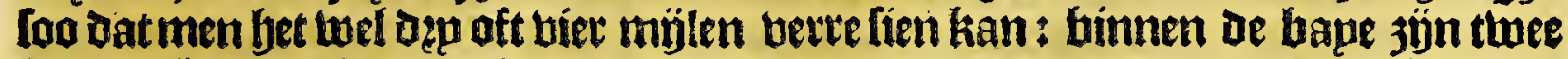

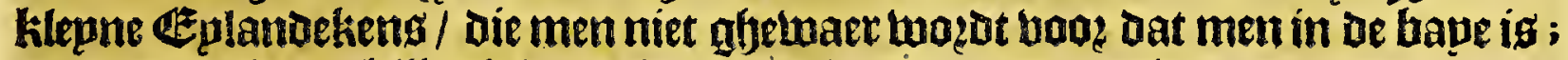

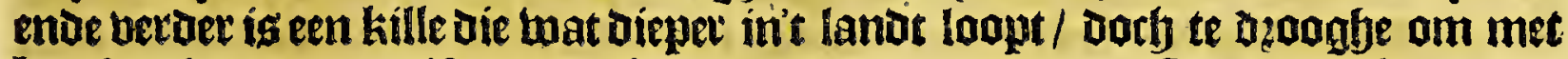
barcken in te baten. Bandaer komt men aen en andere Cap, Die Champlain noemt Cap Blanc; de Eengelfrye noemen die Cap Cod, enoe de onfe noemen Die Staten-hoeck; ende oock twell fountijots de Witten-hoeck: ban Lelcke top hiet:

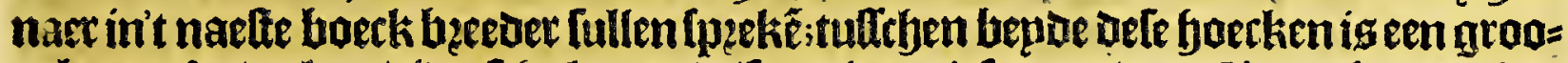

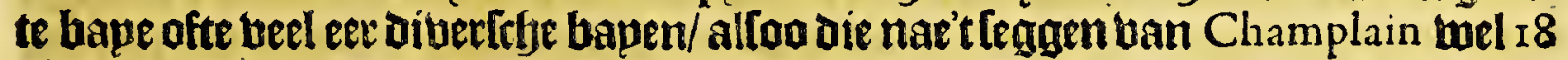

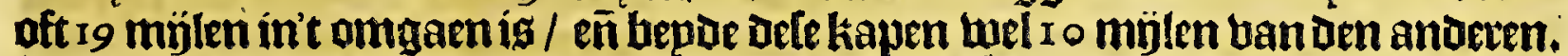

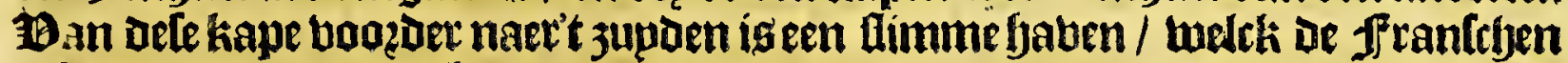

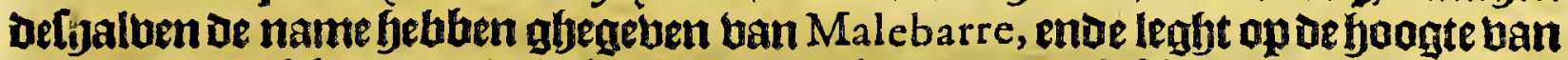

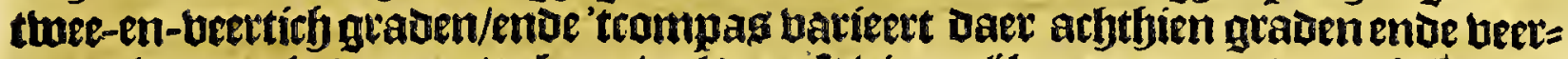

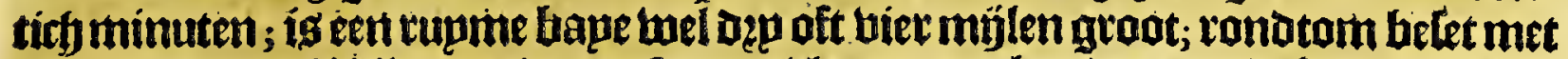
buttekens ban Foilben; die daer loo veel fants om beplanten als fin ban noode

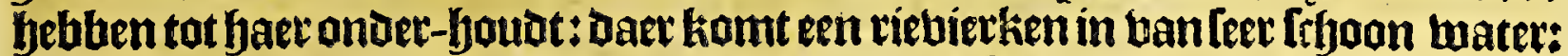
is anders feet ondiep in de biape / ende barnt Daer Leer aen alle kanten. 'Clandt

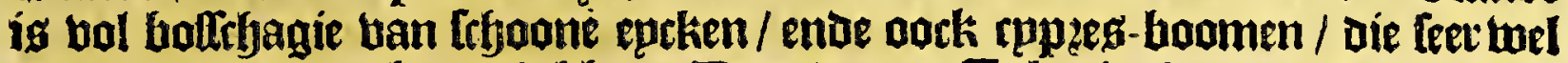

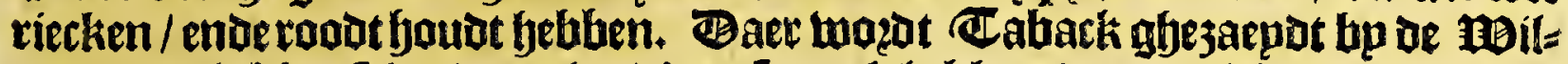

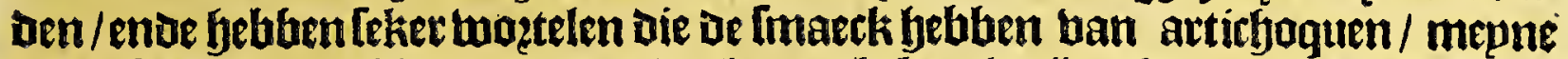

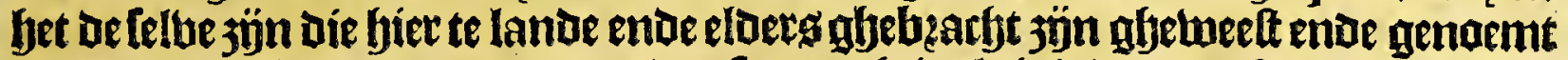

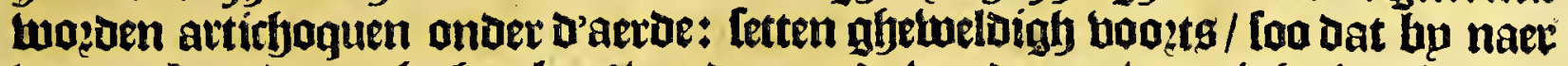

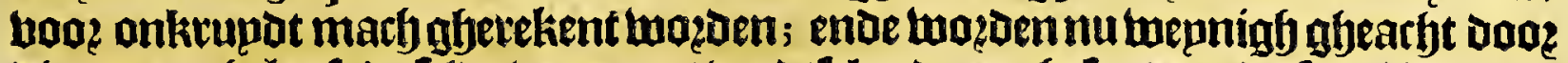

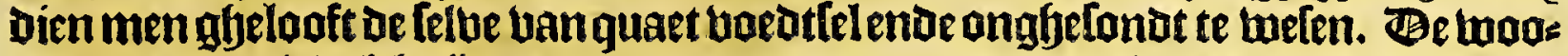

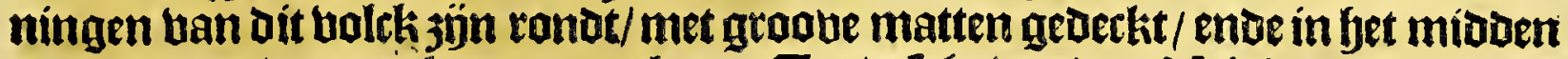

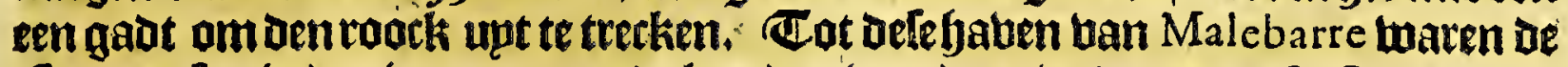
francopfen in benjare 1605 ende keetsen ban daet twe der naer $S^{t}$ Croix, ban waer [p gluekomen waren: Champlain befrfyegfteng de kours ende diftantien in

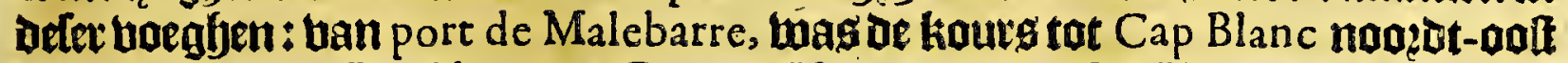

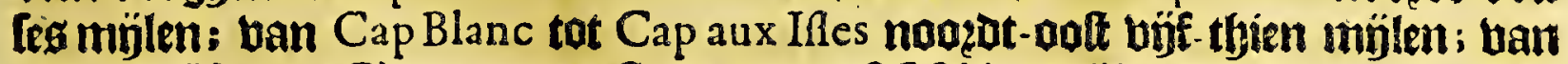

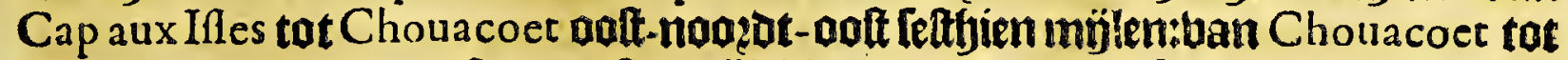
Quinibequi noozdt-ooft ten ooften bijfthien; wan Daer tot Ifle Haure oalt-jupot-

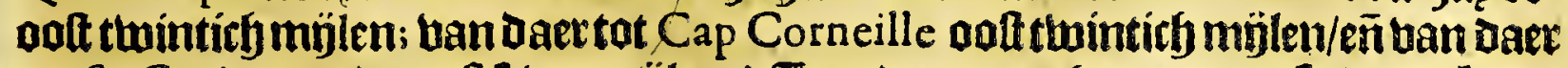

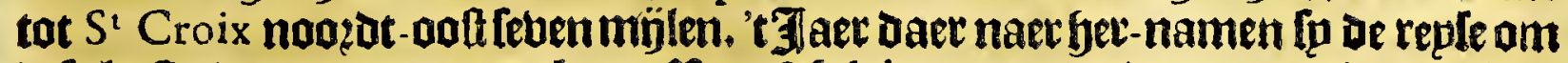
defe kutte boozder te ontaecken. Ban Malebarre 3updt-twaert aen is al black 3ee-ftrandt / welck Leer Dangereus met frbepen te ghenaken is / enoe niet goet met

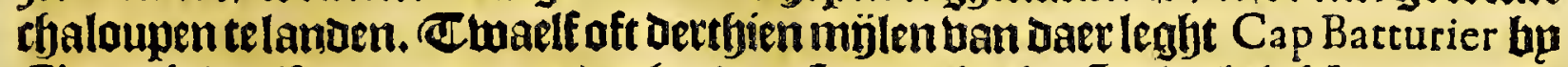
Champlain allo genoemt om dat fet Daer foo onoiep ig/en getweldigh barnt; baant 


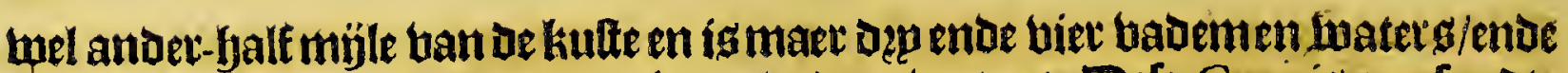

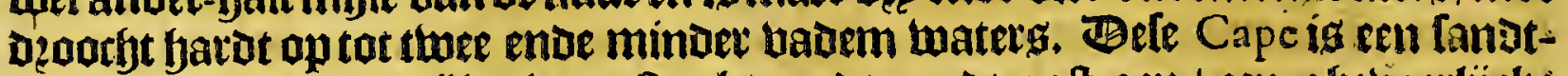

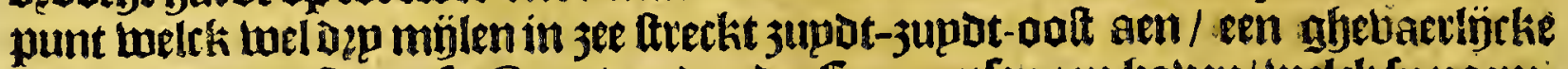

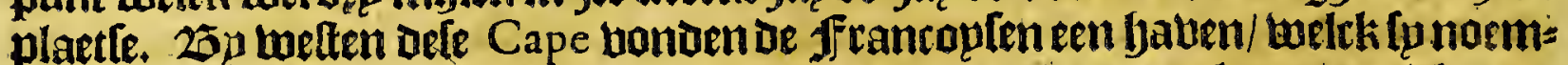
Den Port fortuné, Dooz dientu daet eenigh volck aen landot berlazen/ weick ban

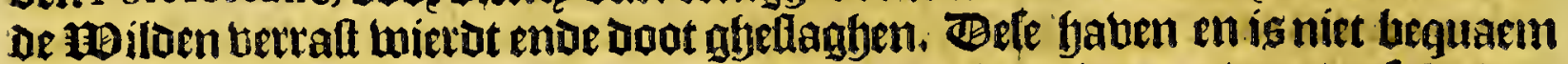

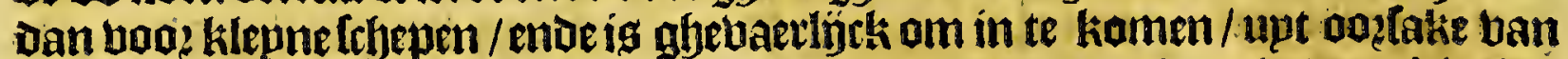

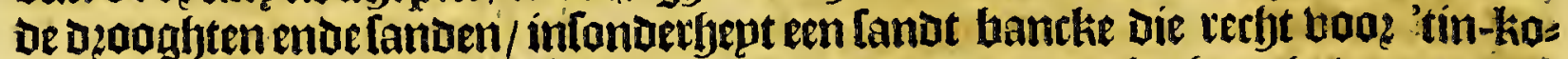

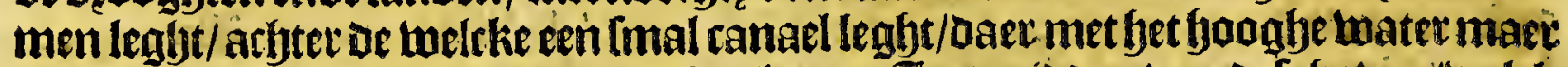

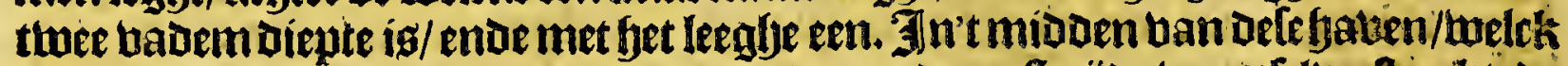

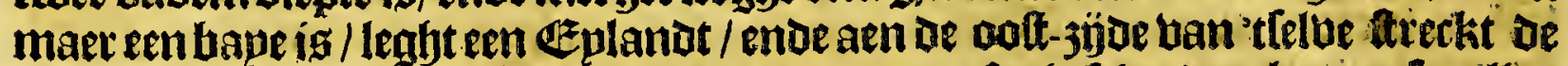
hape noo:at-waetot in / welck ban oe jee wozot af-ghetryepoen bp cen fmallen riem lanats / welck niet dan fanot- dupnenen jijn. Ontrent defe haten twoonen beel moilden / ban welcker glelegbentbepot wo bier naer fullen fp?eken. Dete plaetle legft op de fooghte ban een-en-ueettichgadanende een aerde. Ban daet

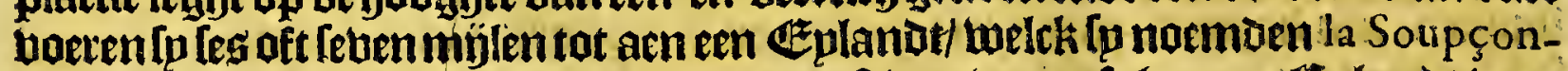
neufe, doo soien [o in twijfel marenghetweelt van verte oft bet een Calanot wag ofte balt lanot. Ban bier voots boeten [p langhg oe kulte naet't 3upot-welten eenighe twaelf múlew / ende ontbecten een riebiete / of twelcke ktepn wag/ende quaet om aente komen yan weghen de blackten ende klippen/ die daer boo ligs ghen / welck lp noemoen Rieviere de Champlain, ende keeruen ban baer naer PortFortuné. Bit ig het upterlte daer de framcoplen als doen quamé in lyaex ont:

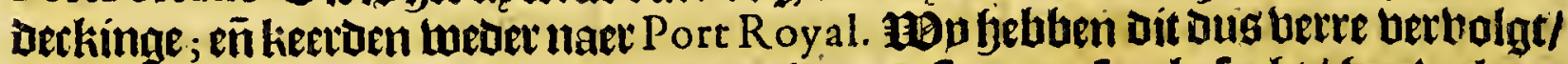
om fier mede teffjepden ban de landen bo of frantoplen beforgt/ joe wel een

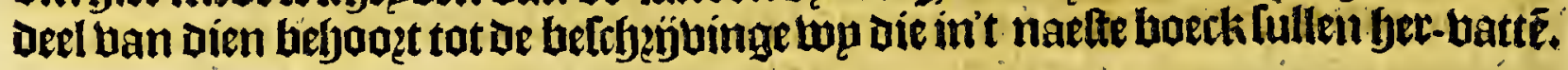

Tet ๖ę-en-twintichlte Capittel.

Een kort verhael van de proceduren by de Françoyfen in defe quartieren ghehouden; als namentlijck by laques $Q$ uartier ende andere van den jare 1534 . tot den jare 1544 .

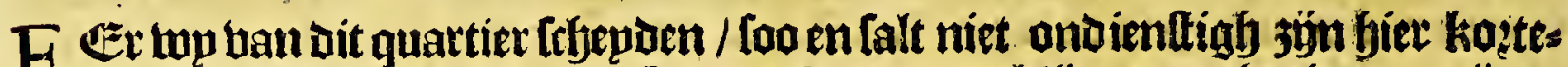

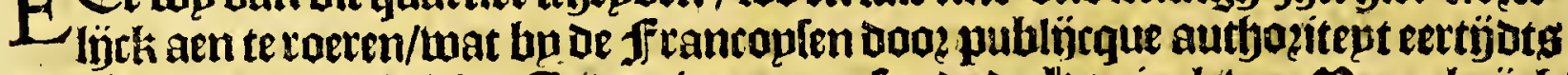

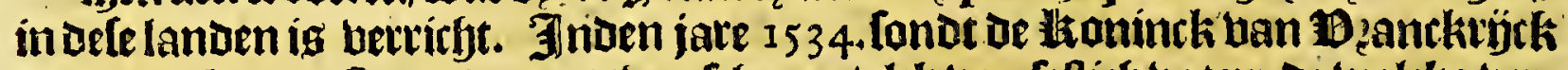

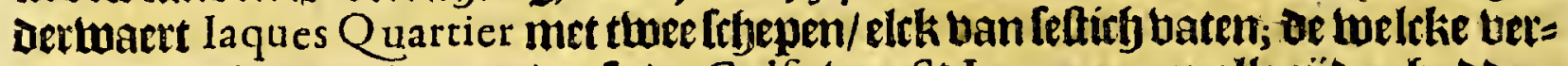

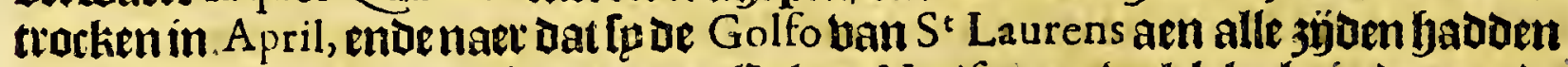
aenghefocht / ende ontuerkt tot aen't Eplant Natifcotec, welckleglyt in tae monot ban be groote riebiete van Canada, keerden [p beder naer fups/ende artibertoen

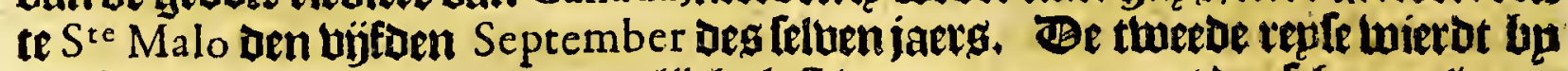

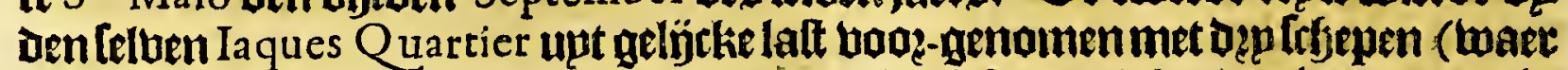
ban't klepnlte maer wag ban ueertich baten) in't lefte ban May des jaerg 1535 . in melcke hopagie bp of groote riebier ban Canada bogeder ontoeclite tot Hochela. ga toe; ober-minterae op de felue riebiere ineen plaete/ wele fjp noemoe $S^{\text {te }}$ Croix, allwaer een onbekenue liecte quam onoer [pn bolck (is nu ghenoegb fekent / ente

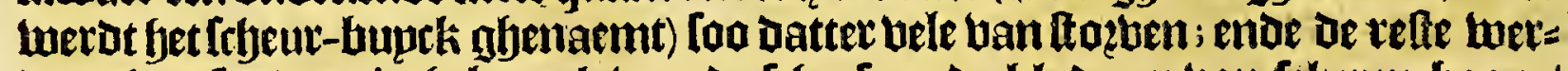

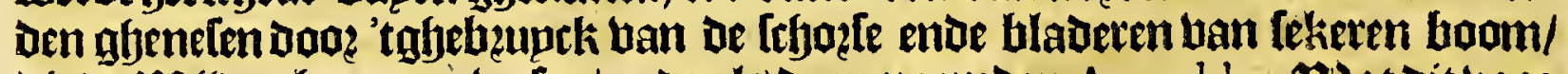
Die de mildenhaet aen-melen/ende als doen noemoen Annedda : Al at dit booz

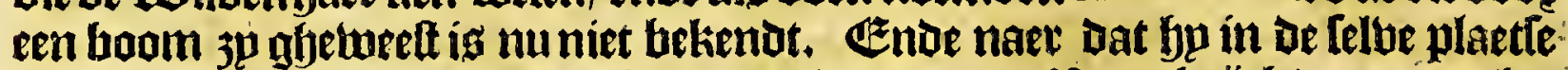

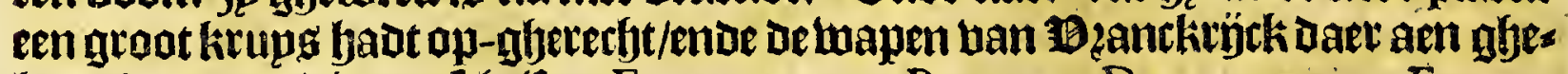
banghen met dit op-lefyeift: Franciscvs PRIMvs DEI Gratia FranCORVM REX REGNA T : [oo nambp met liftichepDt Den pincipalen loere tan Dit quartietmet namen Donnacona, ende noty eenighe andere ghebangfen /ens.

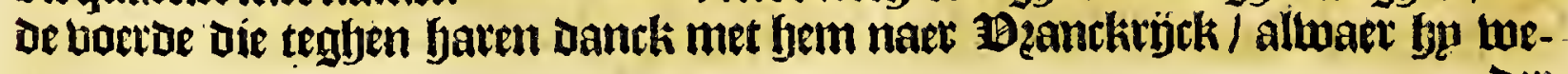

Det 
oer quam benteften lulij Desjaets 1536 . Taer naet in ben jare I 440 maer bat be abilden / welck Iaques Quartier als bozen fadde met abebzarbe / meelt al in

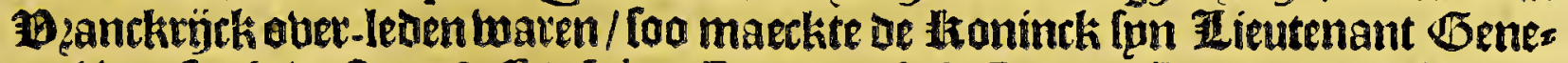
rael in dele ghelueften Mefire Iehan Fran çois de la Roque, likete van Roberval,

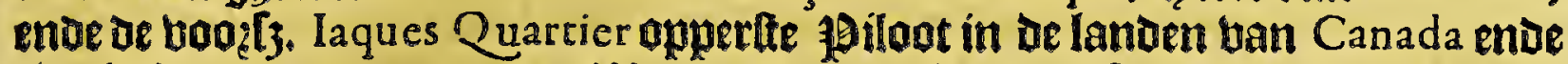
Hochelaga, tot Saguenay tot. 1 Aart op laques $Q$ uartier fun oeroe bopagie bontnam in den jate 154 ende atritterdoen in te haben ban $S^{*}$ Croix in de imaende

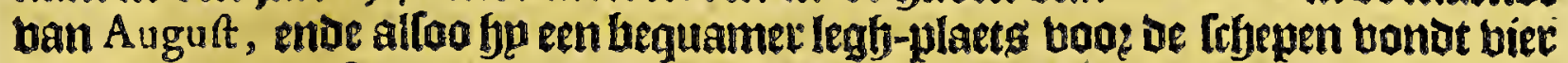

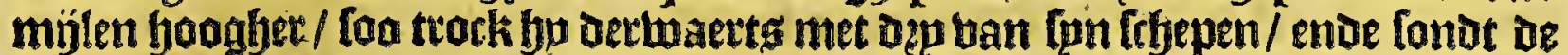

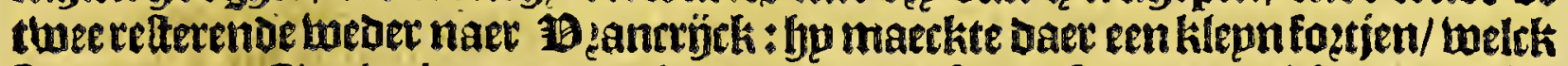
Ip noemben Charles bourg Royal, daet jp met fen refterenoe bolch doen obet-

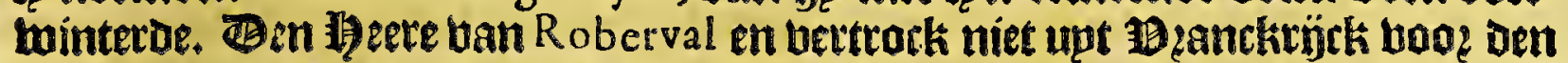

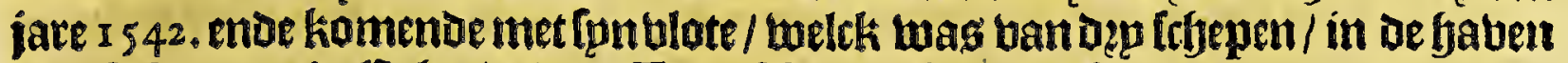
bat St lean aent Efplandt ban Terra Nova, ghemoete fem daer de book-noem=

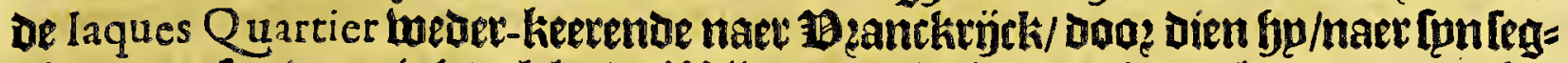
ghen/met foo toepnigh bolcks de noilden ban de lanoe niet en konae onber be=

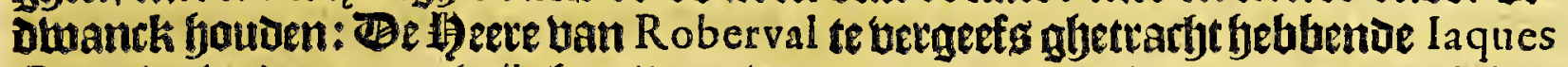
$Q$ uartier beder met te kijghen / woer bogets / enje quam inoe maent ban Iulius bier mỉlen bouen Ifle d'Orleans, alwaer bo een foẹt maeckte welck fo noemben France Roy op de fooghte (naer dat lean Alfonfe betklaert) ban 47 graden;enoe naet fpn feggen/als het te Rochell midoath is/foo enishet te France Roy maet een yalf upge ouernegfenen. B $\varepsilon$ ligere ban Roberval bleef in dele platten een rupme

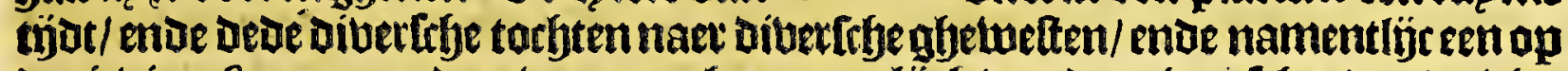
De tieniere Saguenay; dan wanmeer fjp epgentlijck ban daer is geffefepsen/en bin-

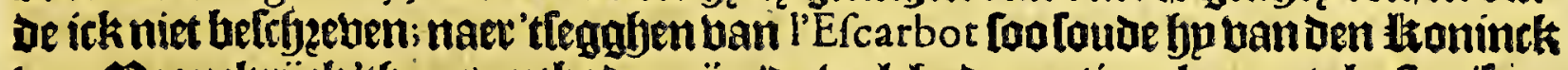

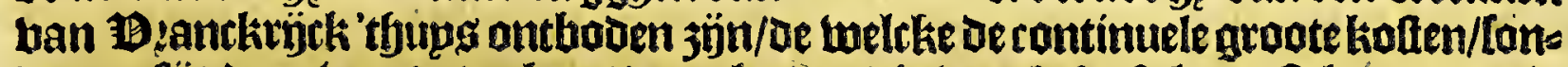

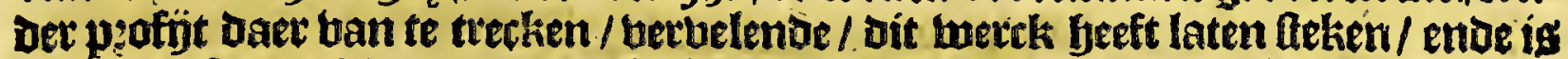
beel faren foa berbleben / tot dat fet tweder is fyetwat in Den jare ujf-tjien yondert ende adbt-en-neghentich bp oen Marquis de la Roche, Doch met alloo dechte upt-

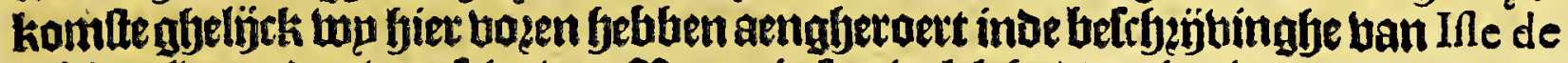

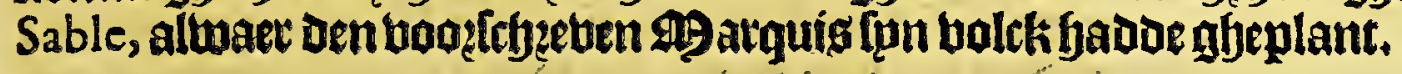

\section{Set biev-en-twintichte Capittel.}

Voordere proceduren vande Francoyfen in verfcheyden andere quartieren van $N$ o v A FR A C I A, ende infonderheye op dezuydrkufte te $S^{t} C_{R}$ orx ende PORT ROY A $\mathrm{L}$.

De bopzgaenoe bopagien op ofle quartieten loo onveuchthaerlÿck af -gbeloo:

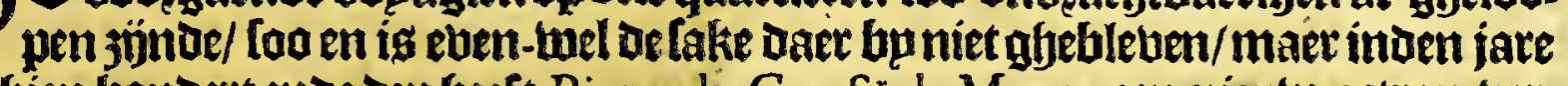
Celtfíen yondett ende aęe beeft Pierre du Gua $S^{r}$ de Monts een nieutw ottrop vet=

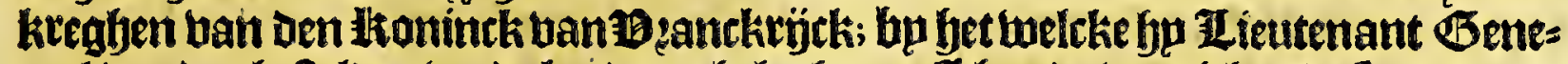

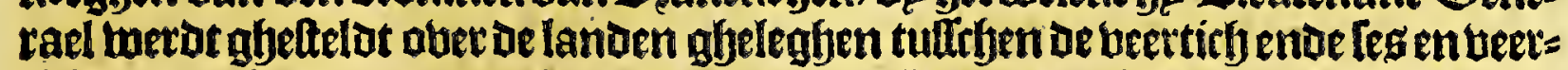

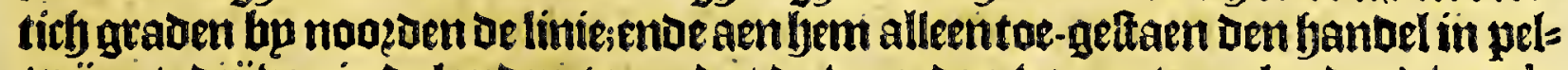
terijen te dijuen in de lander (naet dat de twoogoen van octrope lupden) ban la Cadie; Terre, en Cap Breton, Bayes de St Cler entae de Chaleur, Iffe Percee, Gachepe, Chichedec, Mefamichi, Lefquemin, Tadouffac, ende ann hepde as

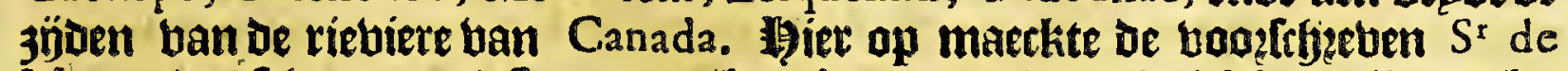
Monts thee friepen upt/ eñ nam met bem bondert ende twintich bupg-lieden; by

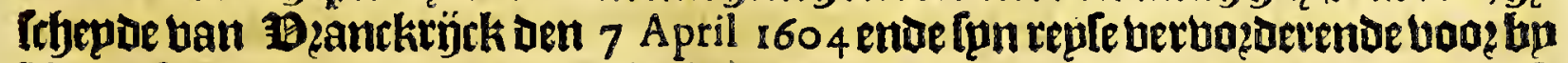
Ifle de Sable ende be kulte han Cadie ofte Accadie, nam jün eertte twoon-plaetle in port au Mouton : twelcke hp kozts daer naer beder betliet / ende naer Dat ly be bape $S^{2 e}$ Marie hadoe helorft / floeth bem neder op bet Eplandt $S^{\text {re }}$ Croix odelegfom aen de mondot ban de riebiere van de Ëechemins op de booghte ban 2 unif- 
84

Nova Francia.

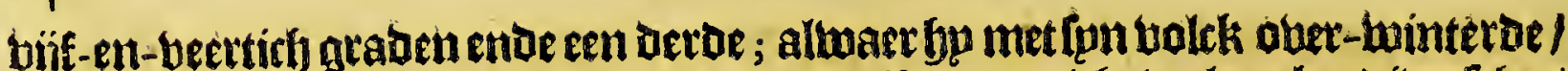
ende ban negben-en-feventich pertoonen bijf-en-bertich berlaze bp diuerftyent fiecten: Jn lunio Deg jaers I 605 , quam bem bertefy volck toe upt Beantrijck/ende naet Dat fp bequamet plaetfe om te twoonen badoen ghelocht/(want bevonden bet

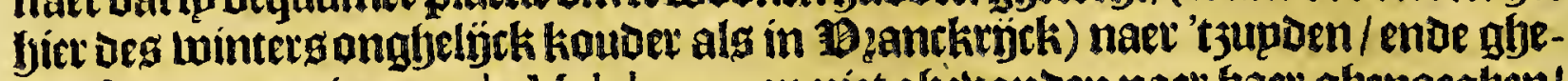
weelt waten tot in port de Malebarre, en niet ghetuonoen naet baet gbenoegben/ foo verlietenfe dele wooningfe han $S^{\text {ie }}$ Croix ende trangfetectoen die naer port Koyal; allwaet jp uijf-en-dettich man in betettingye liet ende keetoe felfs naet

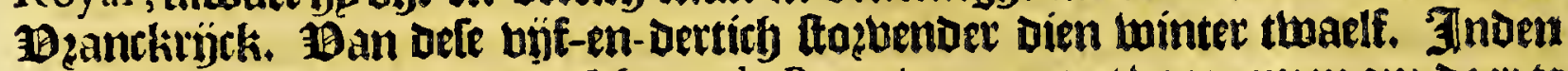
jate 1606 , foo boer Detwaertg Mons ${ }^{\mathrm{T}}$ de Poutrincourt met booknemen om daet te woonen/ enoe inoe maenot ban Iulius komende bp Champleau, fonot ge een betcke langbs de kulte / welcke daer bu gbeual gbemoete bet ouerigh balck van port Royal, die de plaetle verlaten batoden ende batt oe gbelegbentbepot forb:

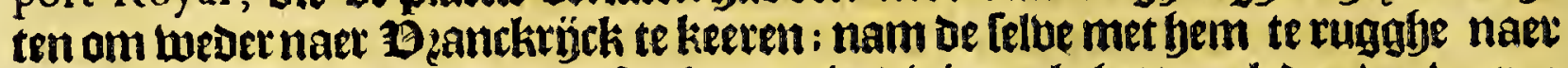
port Royal. Betwinter en luas too bardt niet oit jaet als bet voo lleden/ en waren

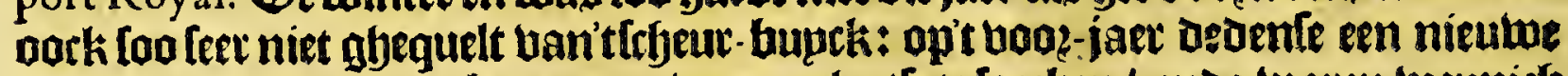
torbt nael't jupden om beguamer woon-plaetle te loetken/ ende waren mepnich verder alsMalebarre tot een faben diefenoemden Port fortuné,ende keet den ban Daer weoer naet port Royal: altwaerfe dien lwinter tamelnick goet weder baboen/

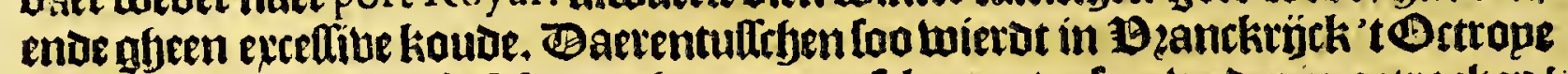
als topen aen Mons ${ }^{r}$ de Monts ghegetien op feker petenfien weder in-getrocken/ ende den fandel in de pelterīen aen een peder wederom open ghefteldt/waer over bat bp gbeen midarl liende om de beboeften bande Colonie langfer te terballen/. 'tuolck welck hp in port Royal gelaten bad meder t' fuph onthoodt; foo dat pore Royal weder betlaten wer de in Den jare 1607 . Ban Mons ${ }^{r}$. de Poutrin court beft

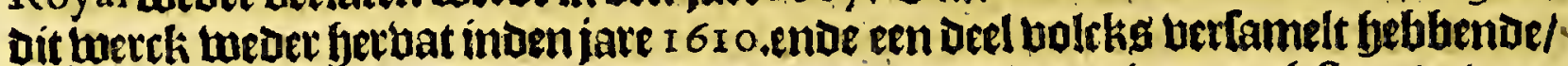
bzorlyt dic te porr Royal, alwaer fo haer boogetenae twooninge norty thaenoe bons ben (upt-ghenomen de Daecken) ende alle oemeublen die daer gbelaten waren/: nochoplyaer oude plaetle: Raet dat Mons ${ }^{2}$ de Poutrincourt 'tlanot hadoe doen bejaepen enoe alles wat tot onderfoudt bande Colonie bejoufoe uetlozaben/loo

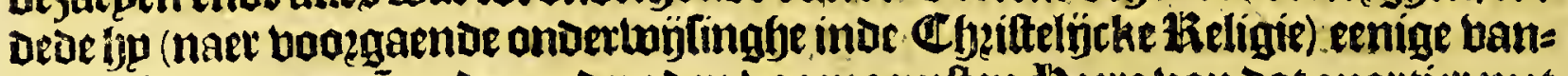

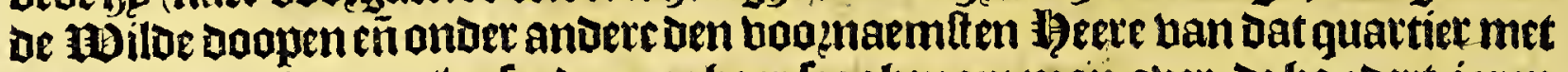
naemen Membertou (wefende naer baer fegglyeneen man ober we bondert jaten

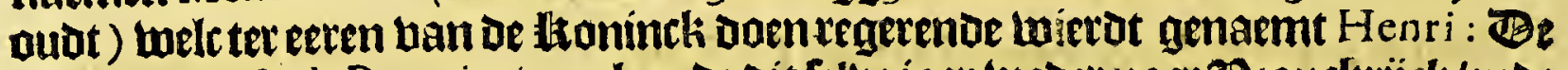

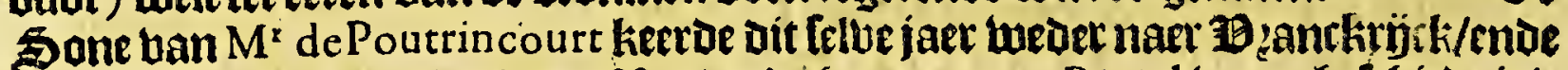

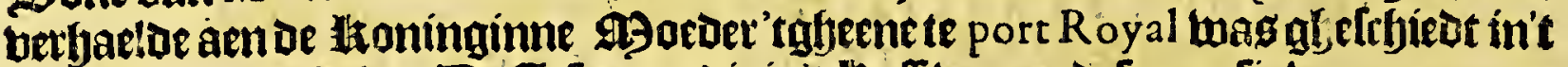

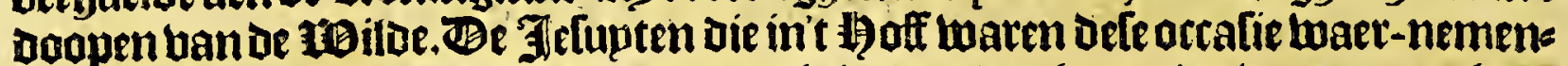
be verforbten aen de Loninginne dat eenighe ban den baren derbaerts mocliten wazden gatefonden met een penfioen van twee duplent ponden/booz-gbebende

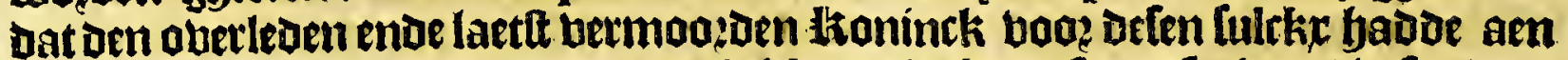

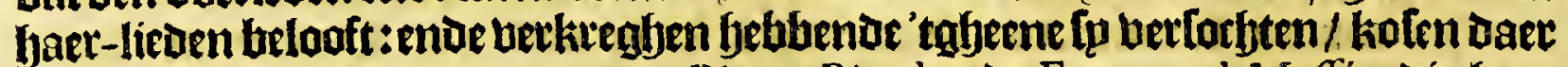
toe twee upt oen yaren met namen Pierre Biard enie Euemond Maffe; Die baer naer Diepe begauen / altwaer twee lapp-lieden/ De belcke met $M^{r}$ de Poutrin-.

Echar- court in compaanie Imaren ghetteden/een Irbip beetoirb badoen. Alls defe koop-

bot.1.5. lieoen ghetwaer mierden Dat Defe Jectupten met baer bagagie Itheep billoen gaen om mede ober te taren/ loo en wiloen fa 'telbe niet lijoen/ fegghende dat oe

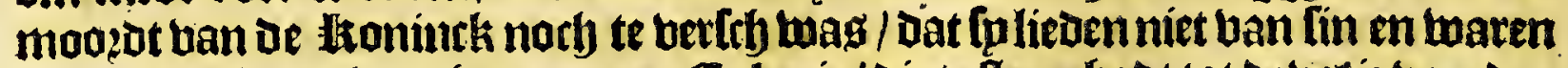
haer midoelen te banghen aen een Colonie/ dieke ftaen yaut tot debotie ban den Spaegniaerat/ ende dat fp haer goederen niet betfekert en bieloen in't abefels

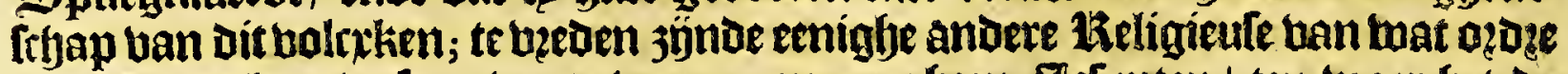
[p aock machten wefen ober te boeten; maer gfeen Jefupten/ ten twaer bet be

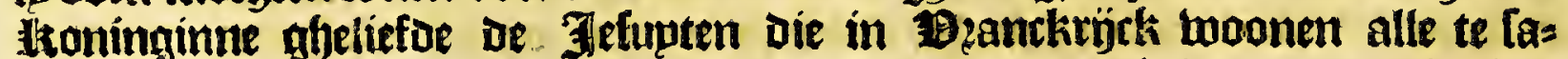
men oertwaerts te lebicken; Dat fo anders baet upt-gbelegboe penningben begberts 


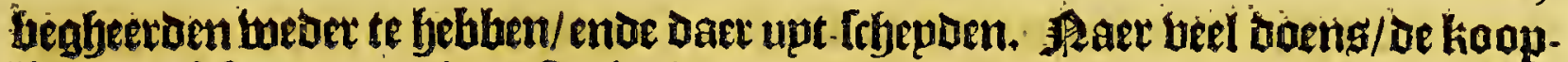

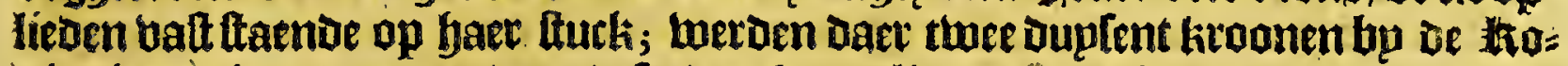

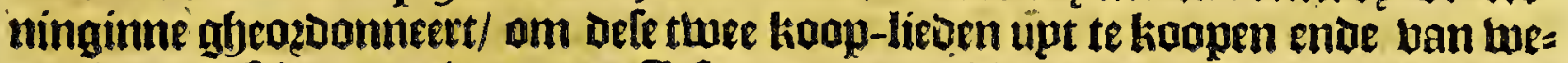

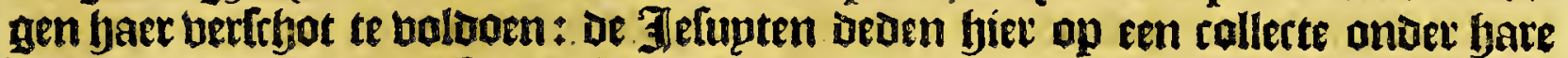
beienden/enoe kreaben feer beel gibegheven; kathten de koop-lieden upt/ende tra:

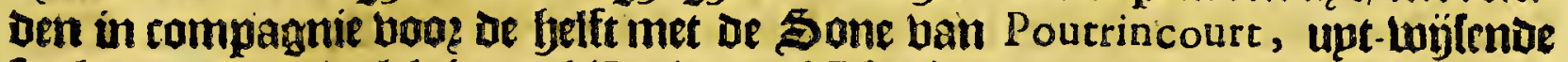

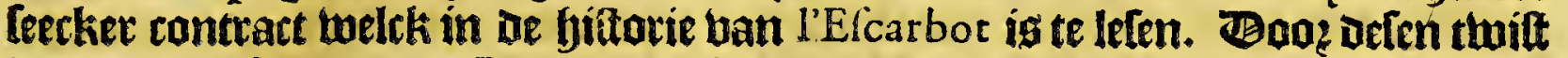
werot de reple naer port Royal eenighe maenden beractetet//[o dat De Some ban Pourrincourt met de Jeflupten eetf han Diepe 'tzepl ginck in Ianuario 16 II. ende

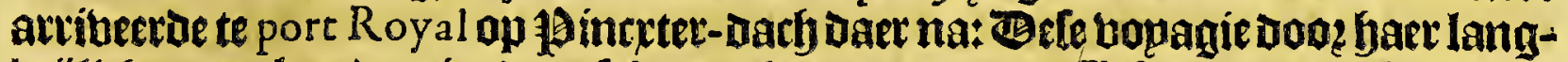

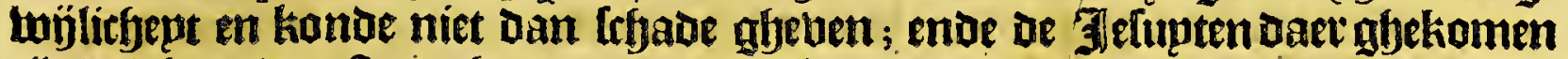

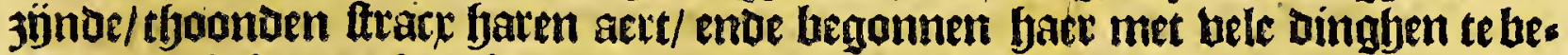

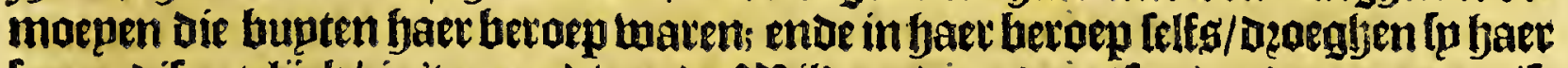

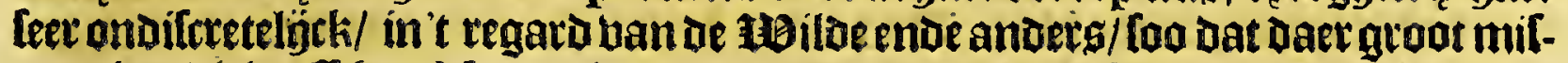
noegben biel tuffeffen Mons ${ }^{r}$ de Poutrincourt ende faeer. Hiev op lieeroe Mons ${ }^{r}$ de Poutrincourt felfs naer 19:anctück/ ende liet aen fon Bome 'tgoubernement

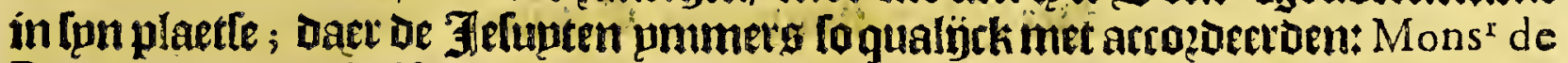

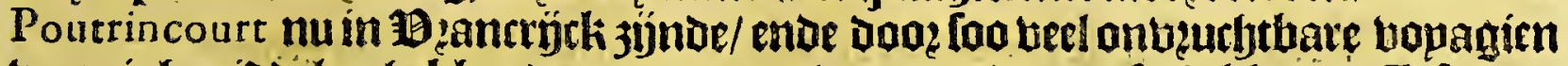

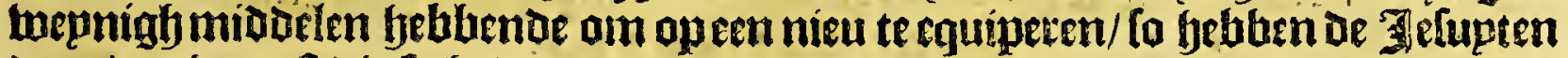

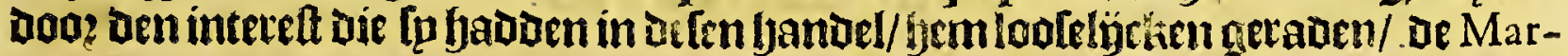
quile de Guercheville meare in te laten in den bande!/booz sen fétere fomme gelts;

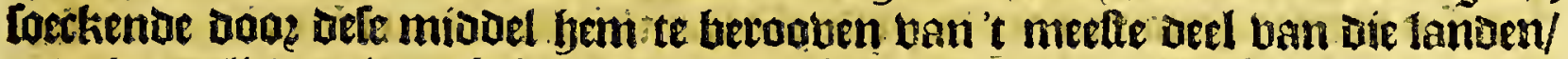

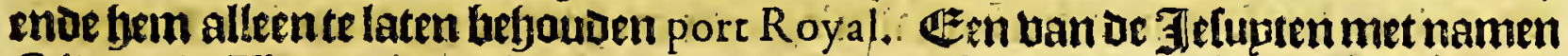
Gilbert du Thet werot tain de Marquife Dertwaetts ghefonden om van baren

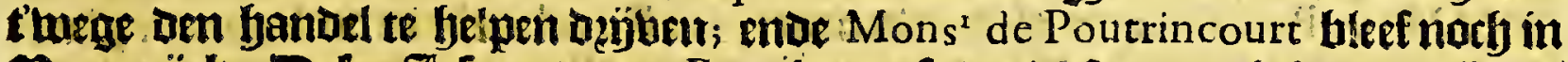

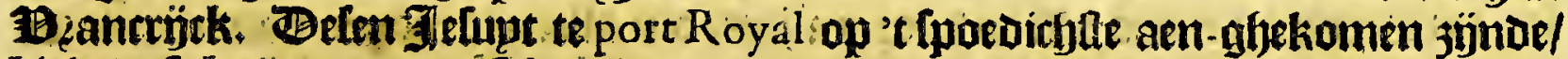

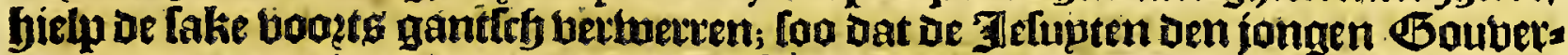

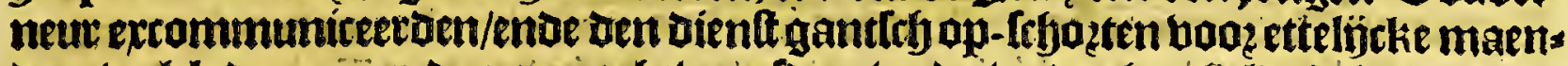

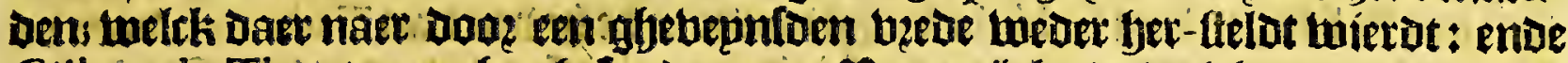

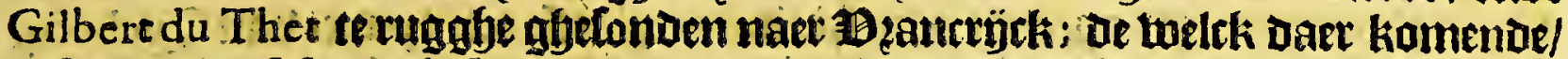
De Taken tian Mons $r$ de Pourtrincourt oj nieutus in't bettmett ftelde/ foo dat fet

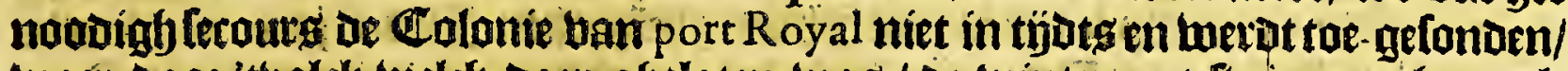

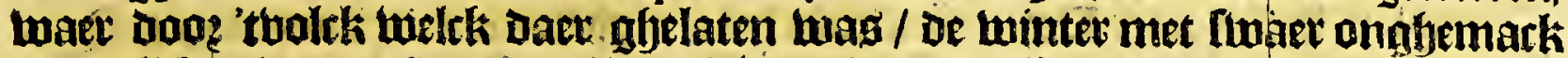

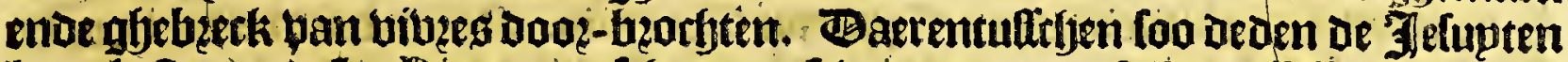

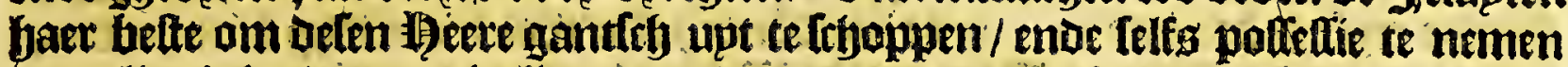
banalle die landen/ Doefyafleg ondoer den naem van De Marquile de Guercheville

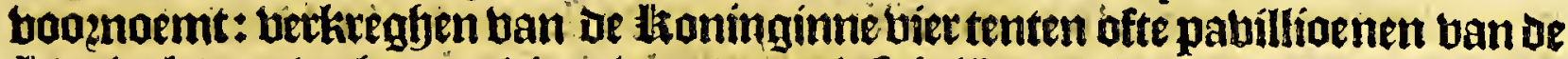

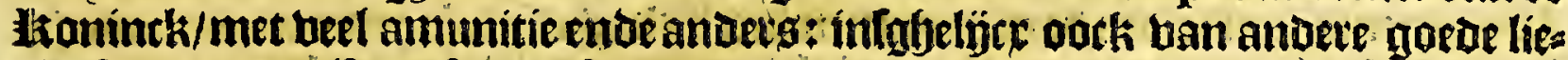
Den feer groote giften: foo datfe in Martio 16 13 een Deel balcks ober-boerben; nas meneerlf poffeflie booz de Marquile aen Cap de la Heve: enoe quamen boott te

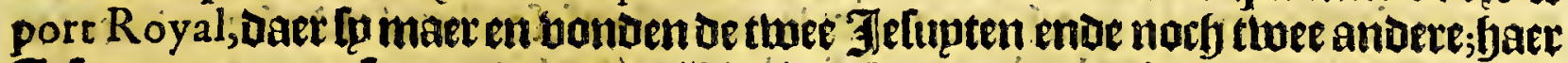

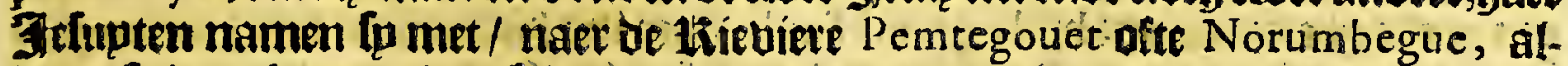

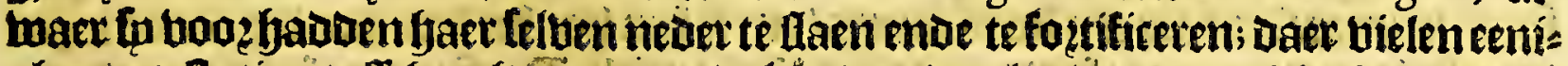

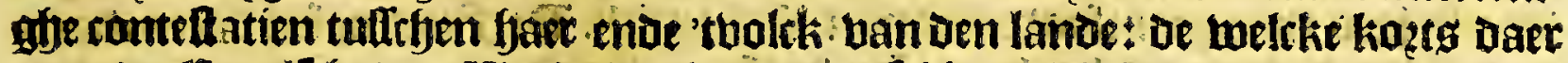

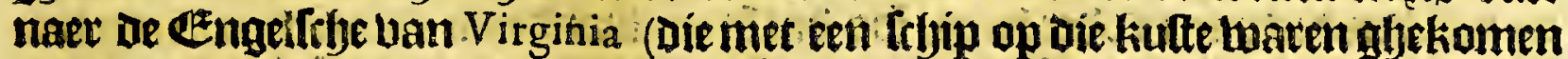

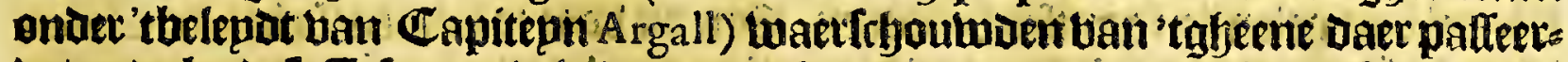

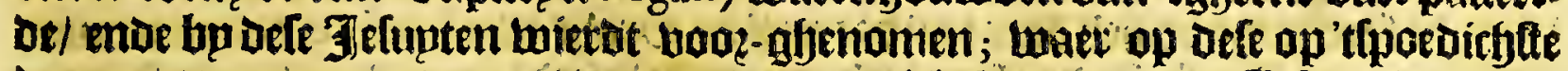
vaerna toe quamen/om te vernemen wat balck bet twas; Den Yeflupt du Ther,

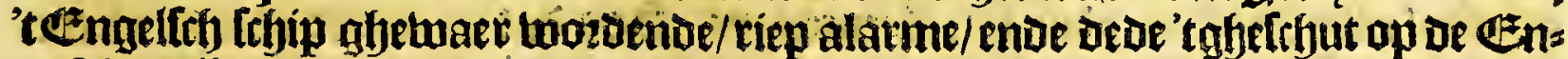

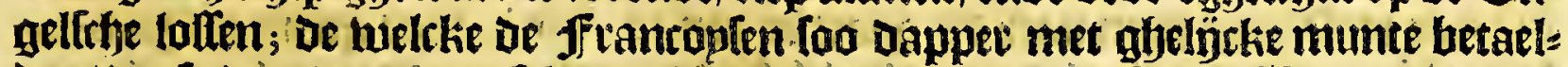

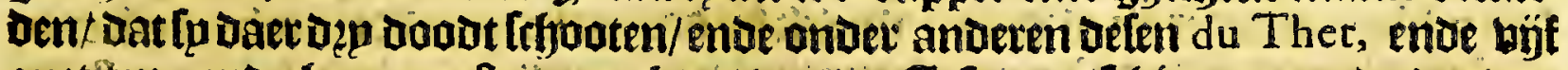
quetiten; ende gaer meefter maeckten bander Tefupten frbip/ nemente ae twose

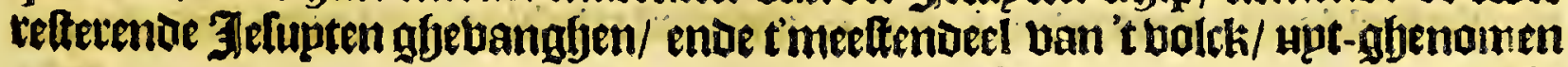




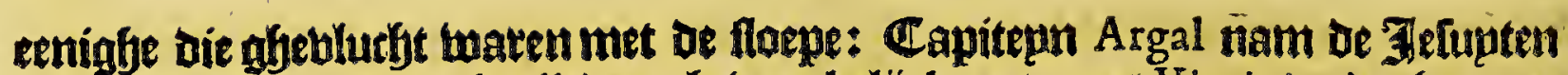

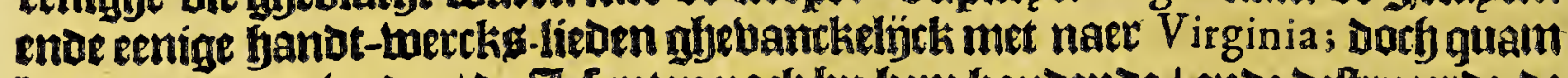

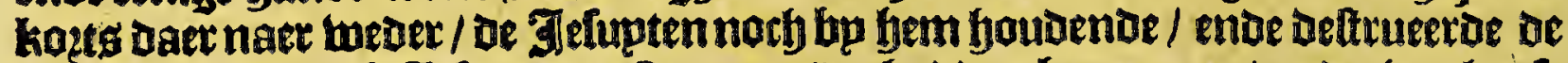
fortifitatien die defe Jeflupten te Pemregoüet badon begonnen / ende in plaetfe

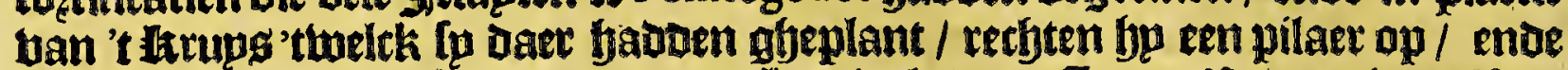
toegb Date aen De bapenen ban Den Honinck ban Groot-25yttanmien. Ban

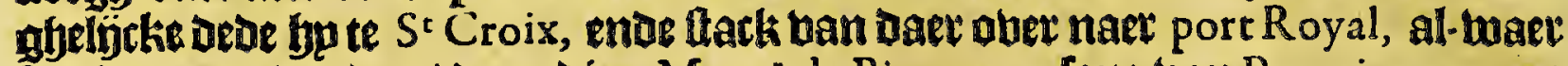

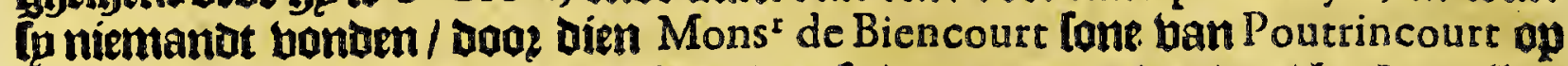

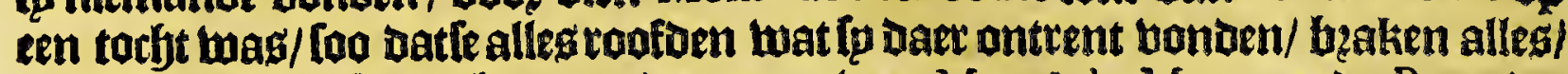
ende ftaken de reffe aen bzanat; de namen ban Mons ${ }^{x}$ de Monts enue Poutrin-

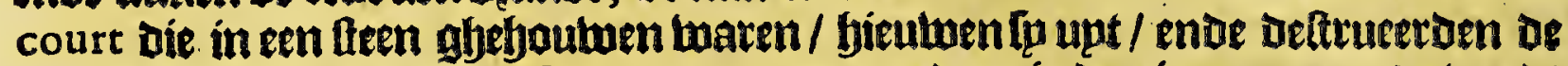
gantffreplaetfe. Mons ${ }^{5}$ de Poutrincourc quam Daer ín Den jare 1614 , ende tonot

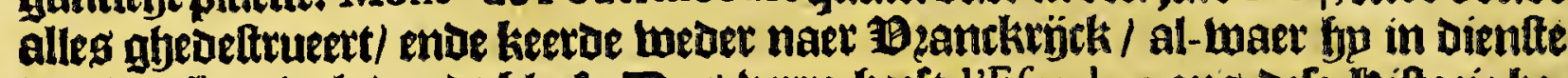

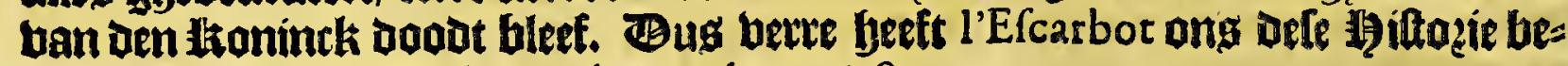
chyecten/ende ugt-ghegheben in den jare 1618 .

$$
\begin{aligned}
& \text { Verhael van deproceduren van de Françoyfen op de groote } \\
& \text { Rieviere van C A N A D A. }
\end{aligned}
$$

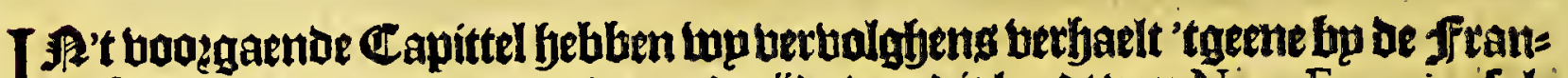

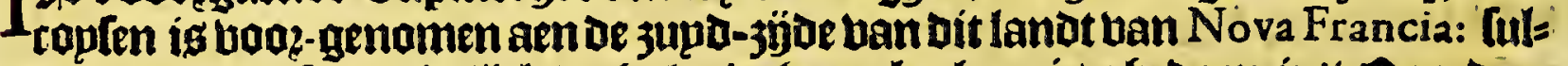

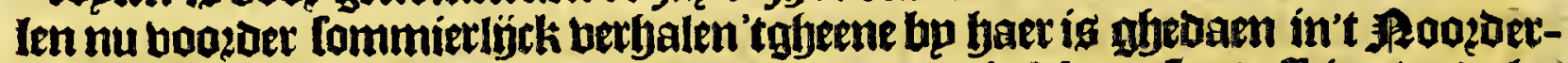
quartier. FIndenjare 1608 verander be de Marquis de:Monts fun Deffeing/ende las tende $M^{r}$ de Poutrin court ghetwerdenmet port Royal, ende de omleggende plaet= Len; berkreenf op nieus ottrop booz een jaer/ om alleen te magen Gandelen in te pelteryen ap oe groote riebiere ban Canada : maeckte Monst de Champlain fpn

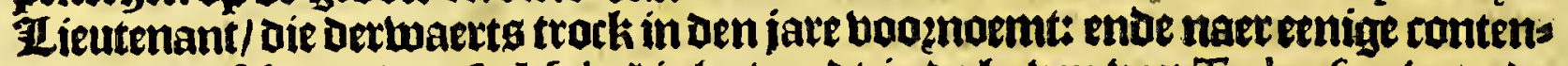

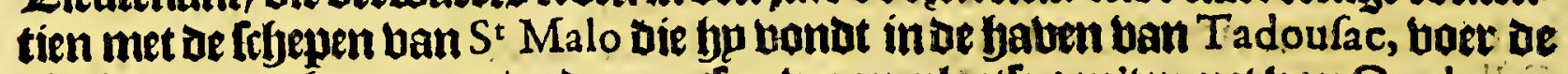
riebiere boots thouger op/ende nam [pn twoon-plaetfe atn'tyumtt ban Quebecq;

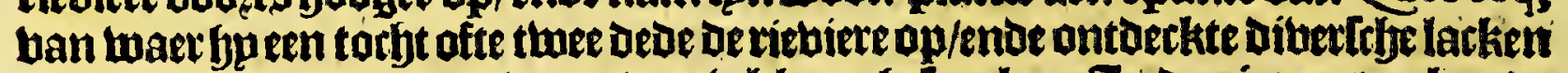

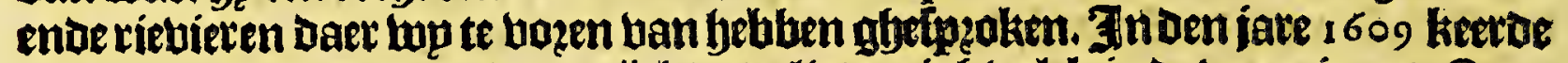

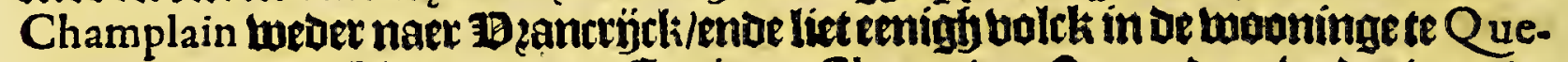
becq onder fet gethiedt ban Den Capitepn Chauvain. Buam Daer twe ber boot de

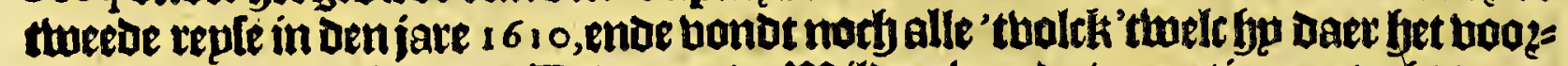

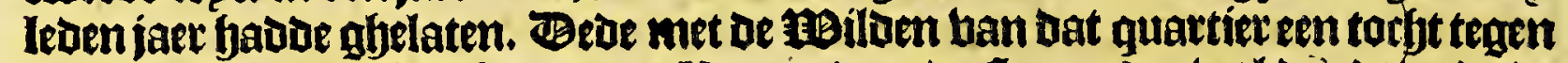

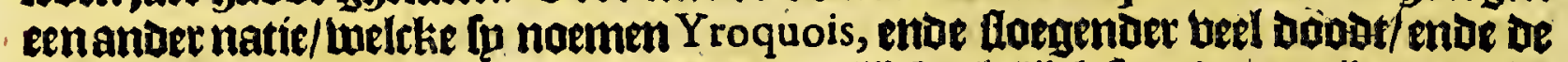

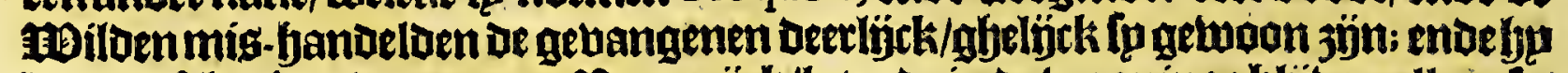

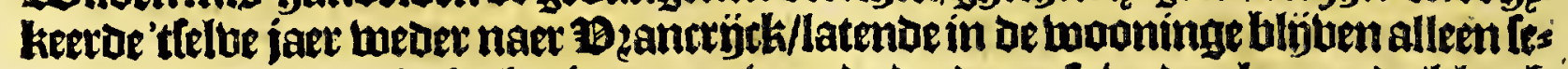

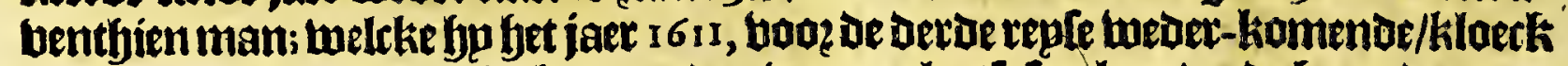
ende ghefonot bonot: ginck een ander twoon-plaetfefoetken/ ende koogs Daer toe

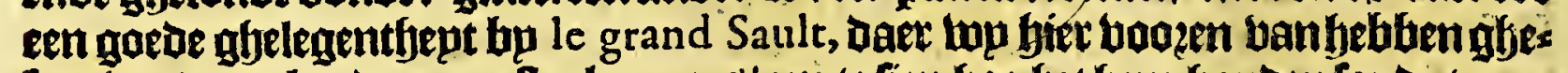

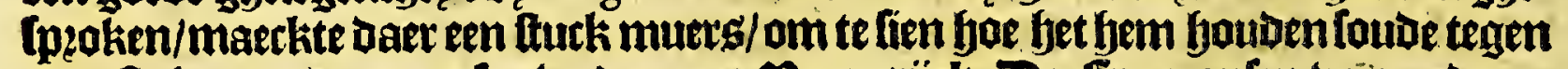

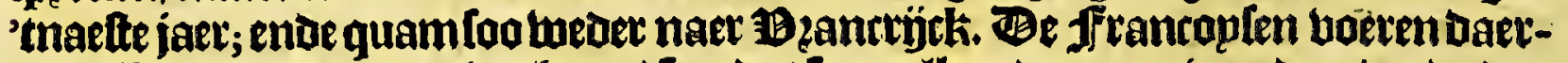

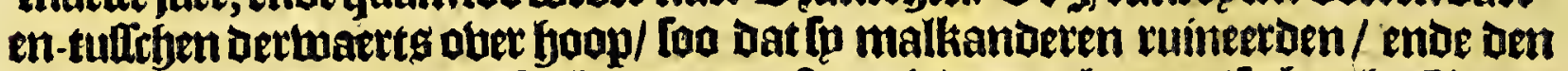

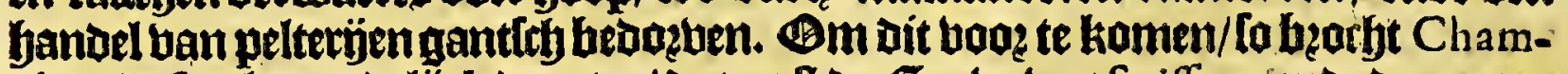

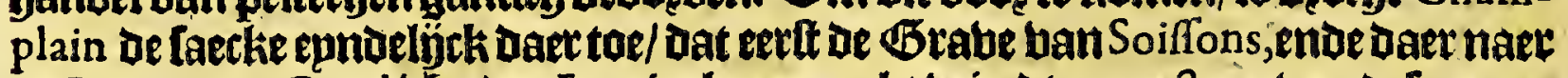
De Prince van Condé bp uentltoninck gemaeckt toierot protecteur ban defe entrec

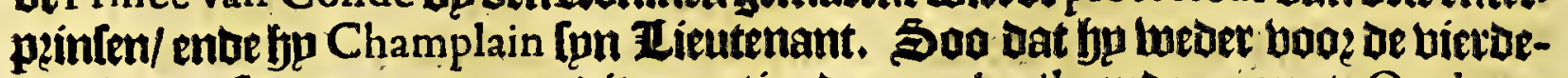
mael oe reple booz-nam naer dit quartier oen 10 April, ender quam te Quebecq

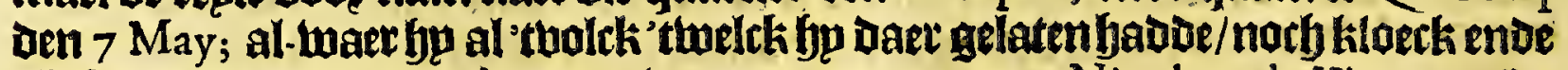
Gfjelanot bonot; endoe op't rapoęt bameenen met namen Ni colaus de Vigneau, (be

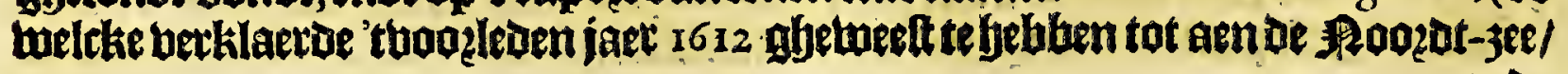
ende 


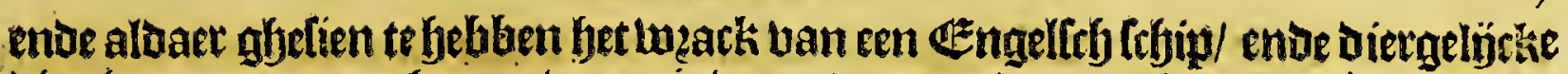
binglen meer) nambe een bopagie bozen/ om een deur-tocht naer. China te bin= Den/Dan naer langhe moepte ende beel tyots uevloogen/ foo berot hp de balfefjept

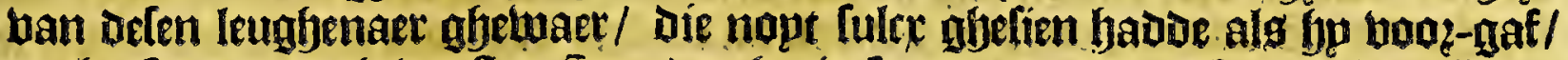
norbtefoo betre ghetweelt; Soo dat be in fpn booz-nemen bedoghen zundel

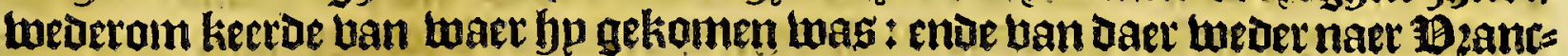

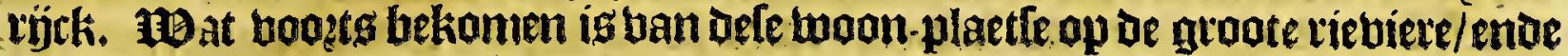
of de lelbe daer nacb continueent / en binde niet fekers ban te leggben: allecnlp̈ck

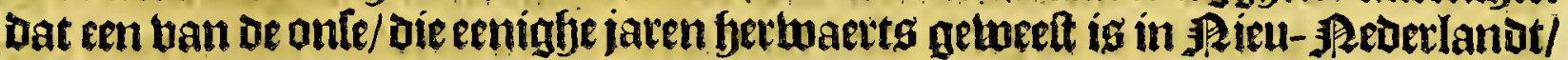
ghetupght dat daet milien quamen aen't ffoet bp de onfe ghemaeckt/ Daer wo biet naex fullen ban [pteken/ Die entigbe lappen ende ftucken banklecoeren met

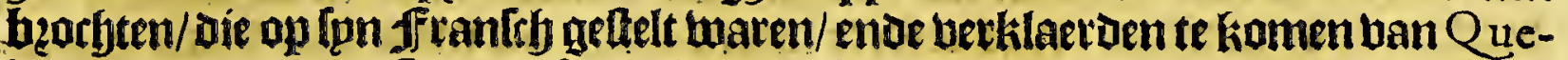
becq, ende eenighe ffrancoplen in faet glefeltryap gbebadt te bebben/ dic ander-

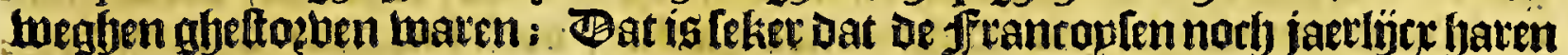

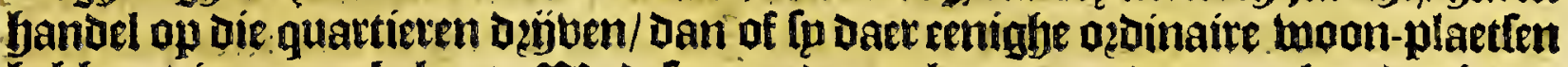
Gebben / is mp onbekent. Alot dete poceduren kan een peder mercken dat fet te

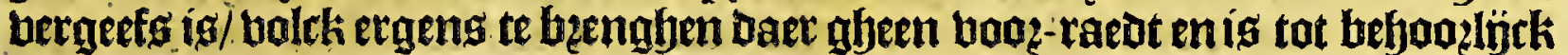

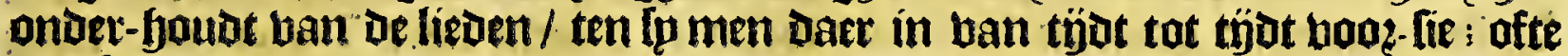

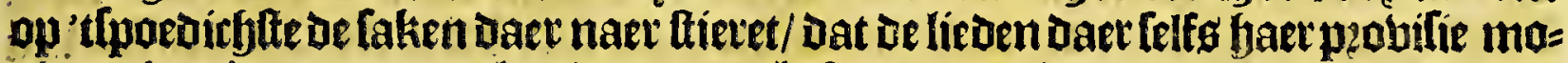
oben glsetwinnen / Dooz t boumen ende befaepen van'tlandt: Oock Dat bet niet ghenaegh en igeen lake te beginmen/ Dan dat daer mibdelen moeten jön ghereedt/

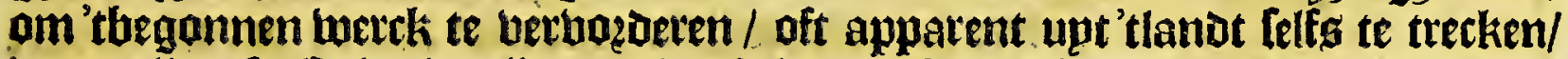

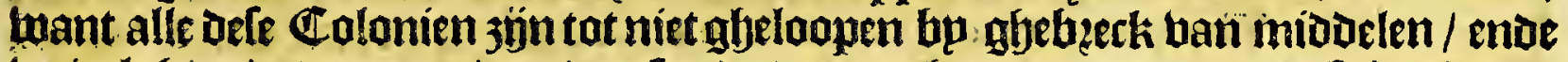

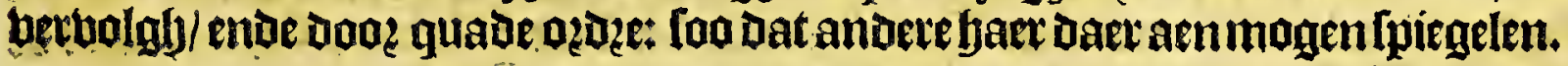

\section{A P P E N D I X \\ Van Nieuvy Schotland.}

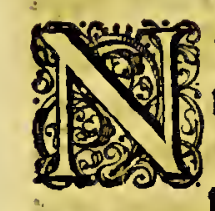

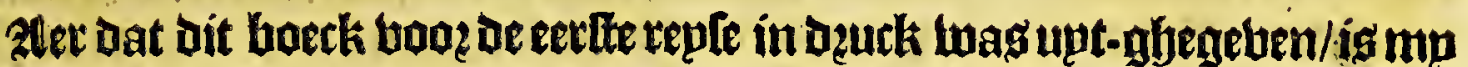
ter banot gfoktomen den grooten baeck ban $\mathrm{M}^{\mathrm{r}}$ Purchas, bu fem in't Etngelfy upt-ghegetuen in Den jare I 625 in melckes bietoe ghedeelte wazot bethaelt hoe dat den marftigen lioninck ban Groat-25itannien

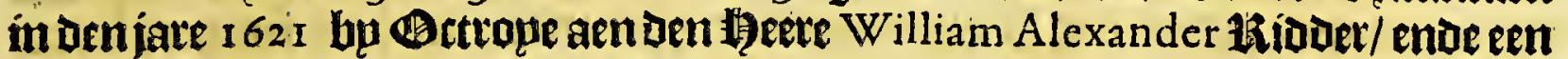

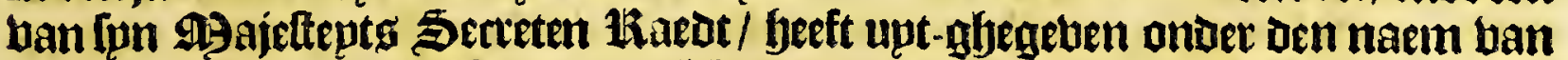

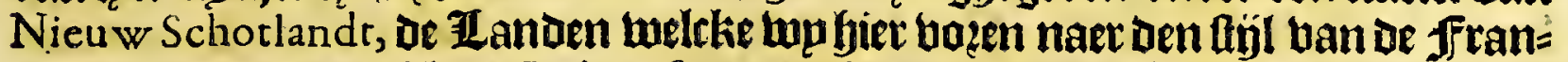
coplen glyenoemt hebben Cadie ofte Accadie; beginnende van Cap de Sable,

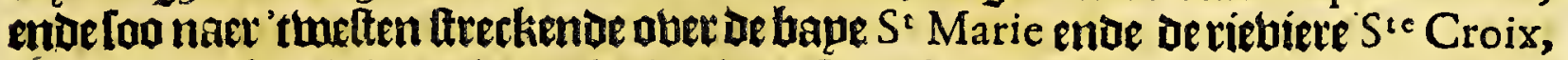
Doaz een tertyte línie tot in de riebiete ban Canada ofte $S^{\mathfrak{t}}$ Laurens; ende ban Daet naer' tooften langg den aever ban de felte rietuiete tot aen Gafpé afte Gachepe;

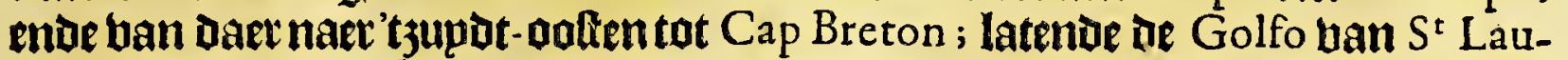
rens ende Terreneuf aen de Glinclket-fjandt legghen; ende tweder-ketende naet 'twelten tat Cap de Sable vooeftyzetuen; met beettich leguen berte in jee naer 't jup: ben ende zupdi-aoften / Daer in begrïpende Ine de Sable ontrent dertith leguen

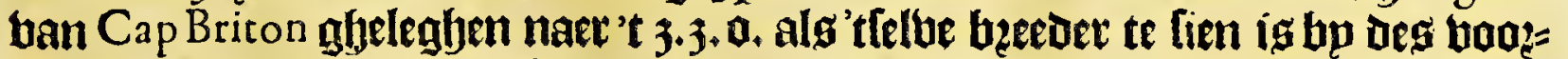

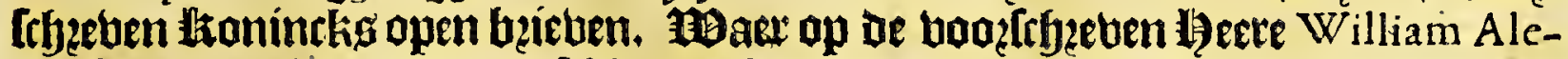

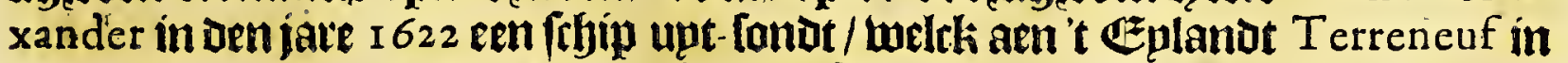
$S^{t}$ Ians haben aber-winterde/ ende in den jare 1623 Joeten [p naer Nieu w Schotland, ende quamen eerlt ín de haben bp de ffrancoplen genaent port au mouton, Daer fp dep fraepe bauenen ontoeckten / ende ginghen aen oe eene te lante/

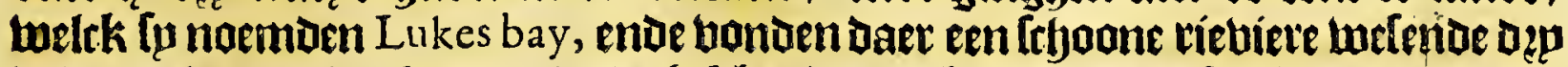
badem diep met leegh water/ende bebbende aen bepoe aeberg leer fraepe twepoen/ baer 
Nova Francia.

daet roobe entie witte roulen groepden/ ende cen loote han toitte lelpen bie fect

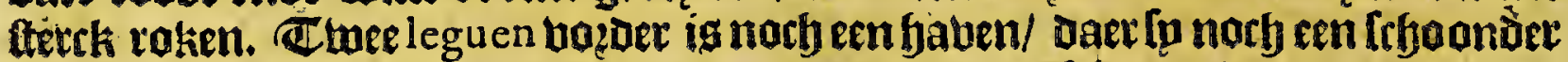
tievier volloen/ bier badem diep met leegh twater/met lffoone tmepden daer aen fegghenoe als boozen; enve opzeelden dit een leer bequame plaetfe om tolck te

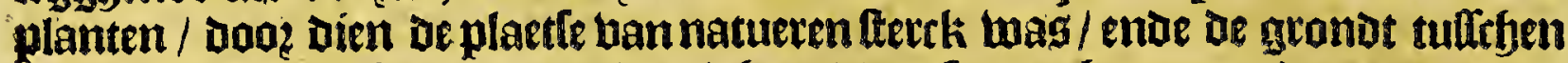
bepoe ae riebieten feet vet ende beuchtbaer/ende fonder boamen; Daer groapoen han [elfa/menichte van aela-belpen; boottg/ttekel-befpen/hinne-befpen/ende dier= gbelijcke: oock een Loote ban eerten; ende foo [p Lcheguen in faer \$ournael/ eenis ube apen ban tarbe ende gerlt. Sp noemoen arte viebiere/porr Iolly; ende boes ven ban fier langg de kufte naer port Negro, thaelf leguen boozerc/ bebindende

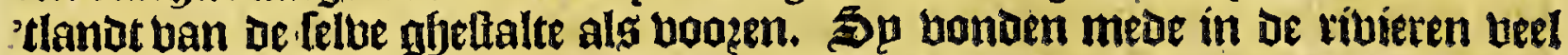
liteften ende malfelen / ente andere klepne bifry; ald mede veel water-ghebo: ofelte/ niet alleen in De ribieren/maer oock op De kutte/ te breten / beeloetfan=

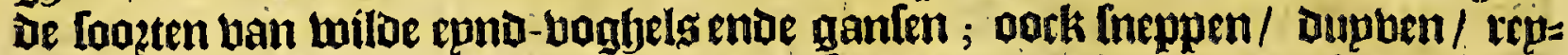
getg/ ende andere onbeliende voghelen. Jn 3 ze is menighte ban rabeliau/ ende

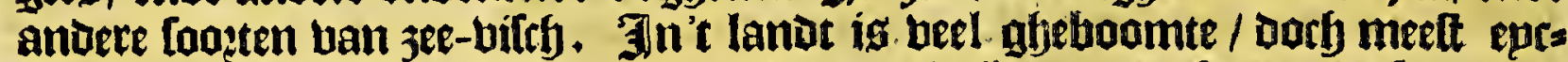
fen ende Denne-boomen/bercken/ende diergfelijcke/ dan ftaen niet feet dirbt bp Den anderen: quamen ban daer weoer te vugahe naer Terreneuf. Hat

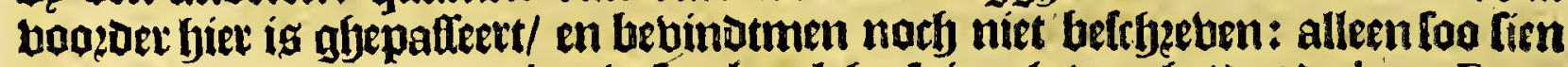
mp de Haerte die $M^{\mathrm{r}}$ Purchas in Inn boeck foeft in-ghebaegbt/ Dat De baye Françoife daer abenoemt mazot Argals baye; ende de 13 zountie van Cadie, The province of Caledonia; ende het noozdelijcke gljedeelte aen oe groote rietiere uan Canada, The province of Alexandria; ende datte de riebiefe ban Sie Croix ofte ieg Etechemins, naemen Twede; ende die van $S^{t}$ Iehan, Clyde; ende de baye de Chaleur binnen ide golfo ban $S^{t}$ Laurens, Forthe.

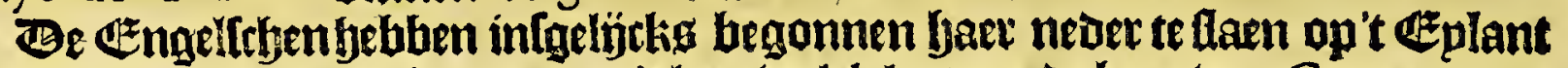
ban Terreneuf, in Den jate 1610 , op't lant welck legt aen de bapeban Concepcion,

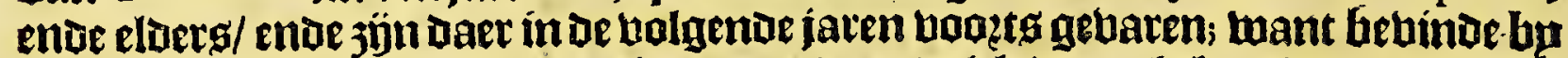

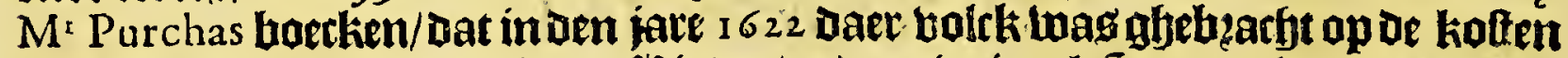

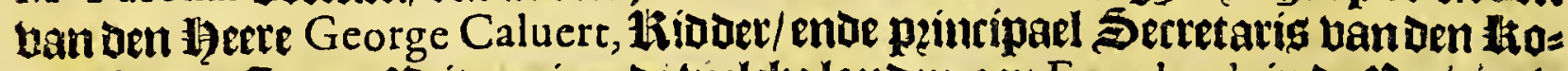
ningh ban Groot-25itannien; de welcke landen aen Farryland, in of 19:obincie ban A valon, Loo [p die noemen. Ben Bouberneut van dit bolkk Ediard Winne, frbeifft in Auguif Deg felben jaerg/ dat haer gheluag ban tarwe/ gerft/baber ende

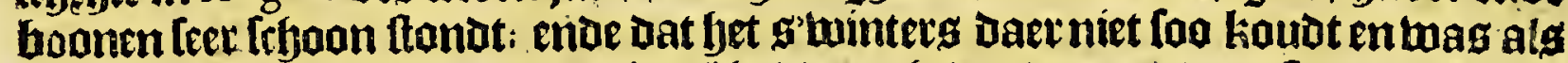
menglyemepnt badde; dat Ip middel fadden ghebonden om daer feer goet fout te maken;ende dat alle jaden/boomen/wöngaerden/ende andete planten Daer ges bzorfyt/Leer wel toe-namen. Een anoer berjaelt dat de bolieben aen bzanot lasas

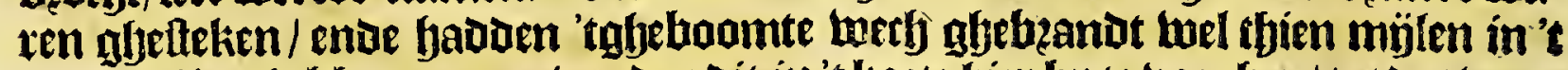
rande. nop bebben gaet gebonaen dit in 't kazte biex bu te boeghen/ tot dat boozs

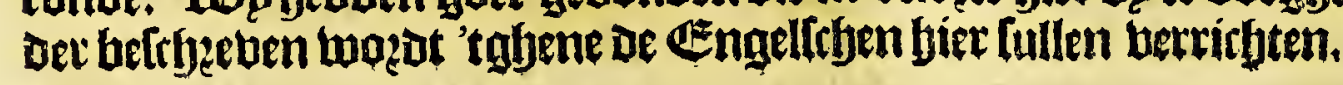

BESCHRII- 



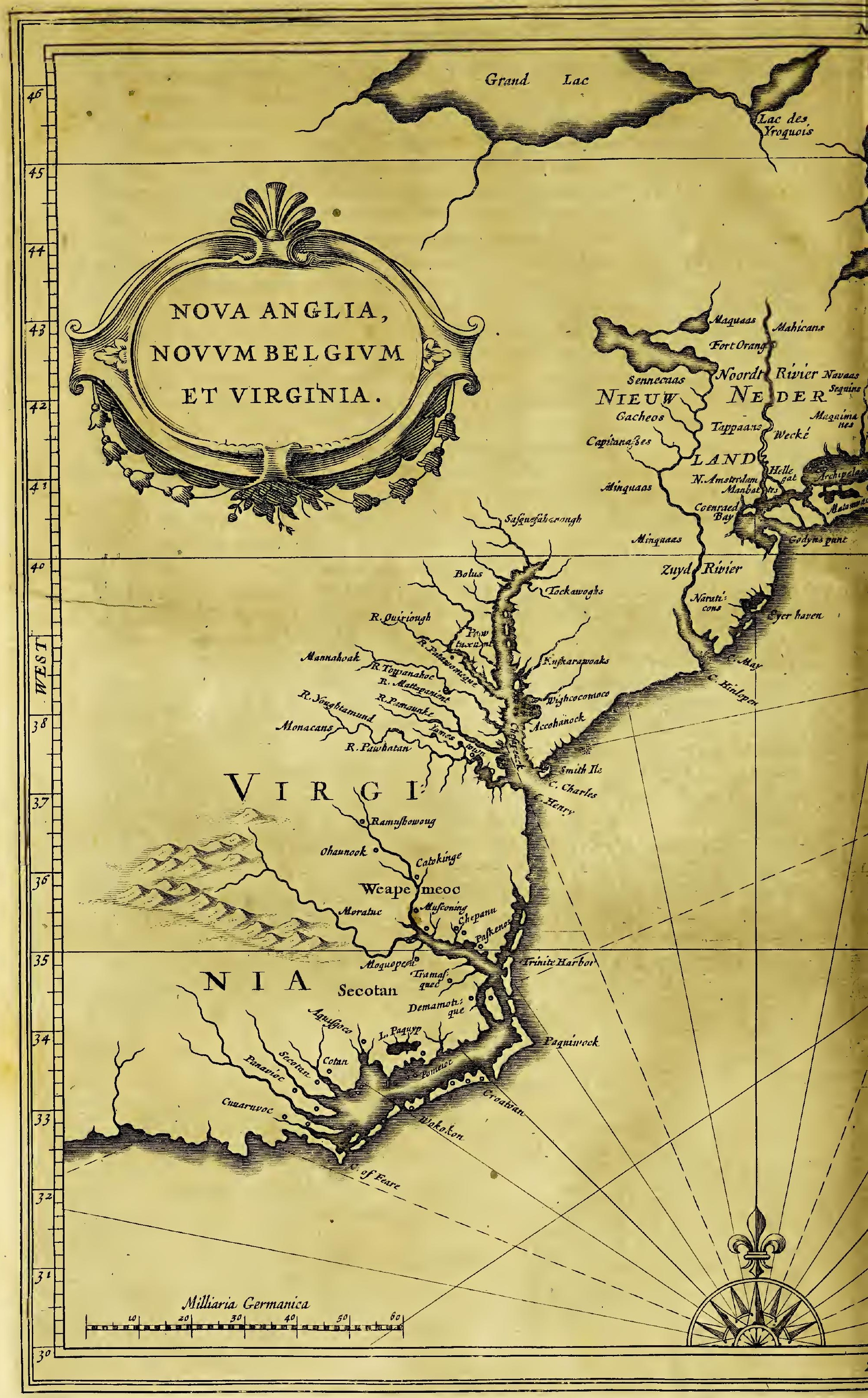




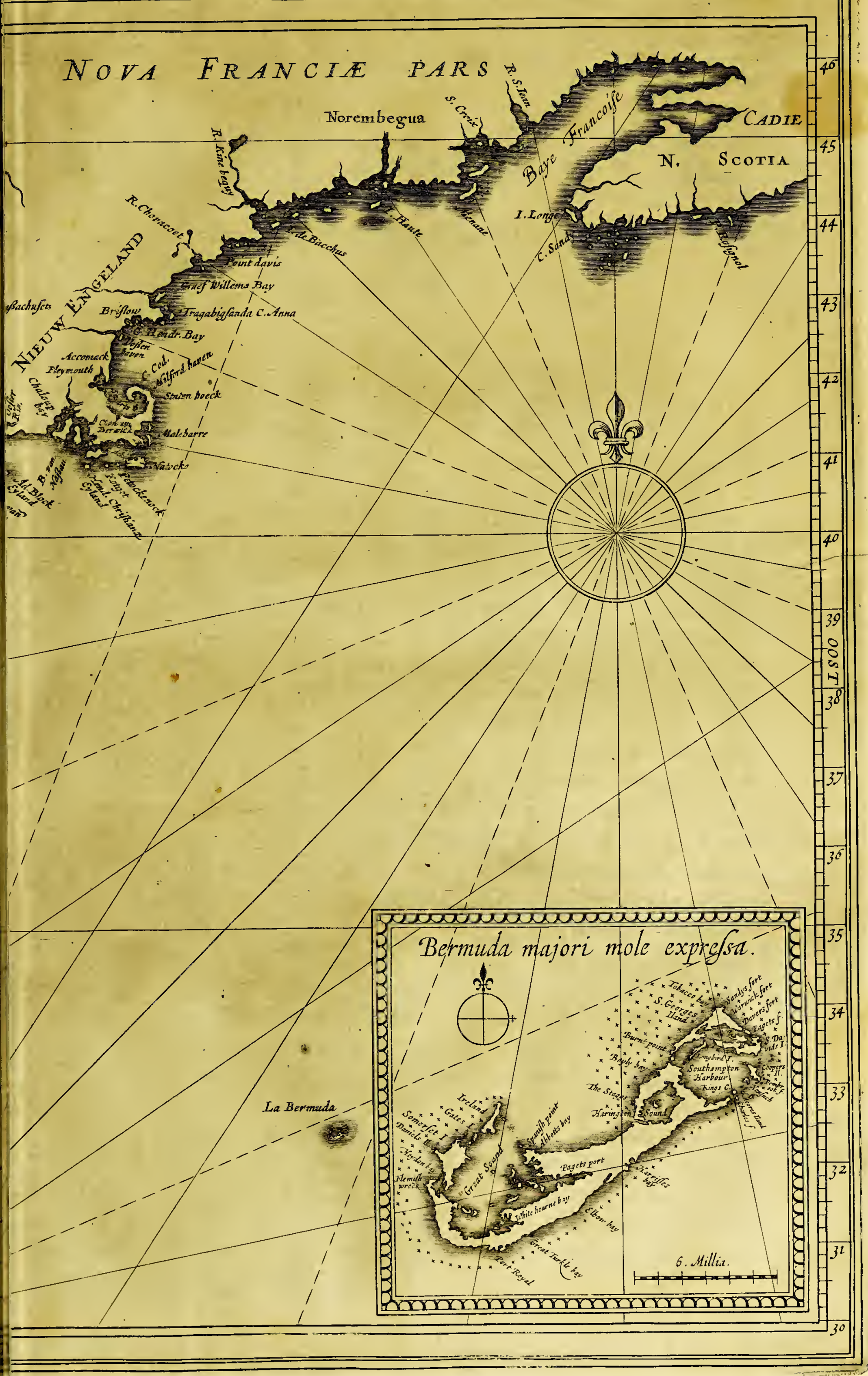



B E S C HR I IVINGHE

\section{Uan}

\section{W E S T I N D I E N. Het derae 25oeck: \\ V I R G I N I A.}

Inlevoinglie.

20 Ena Francia paelt bet landt; vvelck nus eenigbe volghende daer 1. In ile gbemeyne fïll; ende de directie vande Engheljche \{ die dit quartier eenige jaren berwaerts ferck bebben bevaren, ende oockeein deele bebben ontdeckt, in't gemeyn noemen Virginia; bepaels zünde tuffchen de boochte vans pier-er-dertich ende vier-en-peertich graden by noorden de linie: bebbende aen de cost-züde de groote zee; aen de zuydt-zïde de Provincie van Florida; ende aen de nourdt-züde de Propincien ruan Nova Francia; aen de voest-zïjde de limiten noch open ende onbekent. Dan om eyghentlijck te preken, foo en freckt fich den naem roan Virginia foo verre niet, maer is een verre kleynder gbedeelte, confinerende met Florida aen de zuydt-zijde, ende voorts voor dry ofte vier graden, freckende naerit noorden; te vveten dat quartier, vvelck door Sir Walter Ralegh in den jare Is 84 is aen-ghevangen te ontdecken, ende met een ofte meer Colonien van Engelfche te belaen, als voy bier naer Jullen verbalen; docb door dien dat de felve ontdeckinghen eenighe jaren fill geftaen hebbende, daer naer vveder zün ber-pat by de Enghellche Virginiaenfche Compagnie ontrent den jare 1606 , is een quartier meer naert noorden ftreckende, (te pveten op de booghte van. feven-en.dertich graden) fo is het, dat men dit deel nu ordinaris Virginia noemt, ofte prel beyde defe deelen, te vpeten ruan dry oft vier-en-dertich graden of , tot de negen-en-dertich, voelck voy bier naer particulerlïck fullen befchrïpen; ende. bet voorder deel van dit quartier tot de limiten van Nova Francia toe, bebben onfe. X (ederlanders rvoor een feker ghedeelte ghenoemt Nieu-Nederlandr, door dien' 't felve by de onfe eerst ont deckt ende bevaren, endeoock bevroont is geweest; ende ${ }^{2}$ noordelïcksie ghedeelte bebben de Engel/che nu eenighe jaren her. pvaerts Neuvv-Engelandr begonnen te noemen. Ende boe-vvel vvy dit laetSte ghedeelte in't voorgaende Boeckten deele hebben befabreven, volghens'tgheene de Francoifen daer van in druck bebben uyt-gegeven, foo fullen vvy niet te min bier by voeglien cen naerder befchrijvinge, gelijck als defelve by Capiteyn Iohn Smith is uyt-gbegheven; docb eer voy daer toe komen, foo en bebben voy niet voillen vioor by gaen de ontdeckinghe van defe quartieren, eertïdts ghedaen by Iean de Verazzano Florentïn, door bevelende op de kosten vanden Coninck van Vrancrïck, vpelcke voy bier vervolghensfoullen in-voeghen. 
Het erette $\mathbb{C}$ apittel.

De voyagie van Iehan de Verazzano.

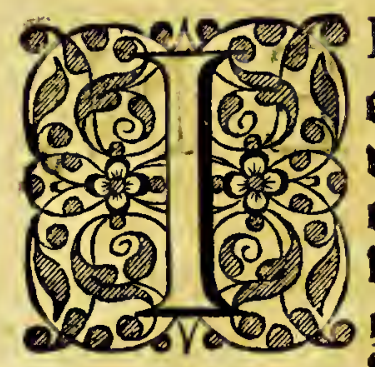

E н a N Verazzano

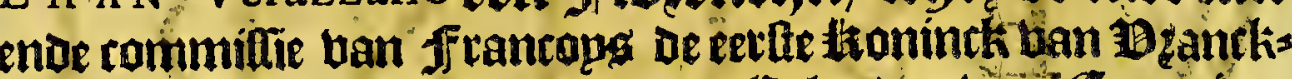
rijek/ Den I 7 Ianuar. 1524 ban be Eplanden ban Canatien; ende nam fon kourg Boelt-waetts met ken frboonen ooften

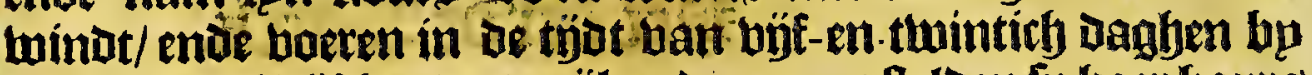

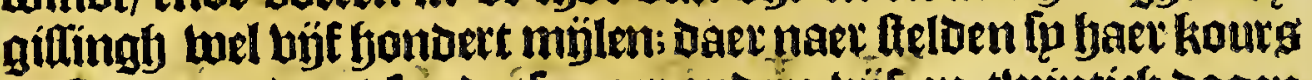

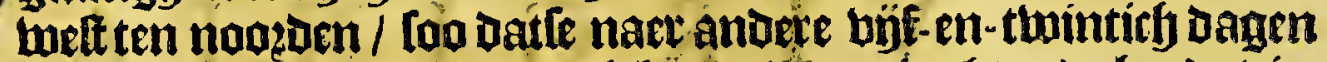

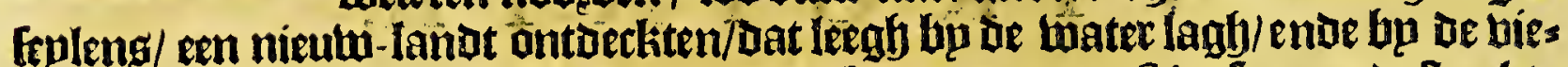

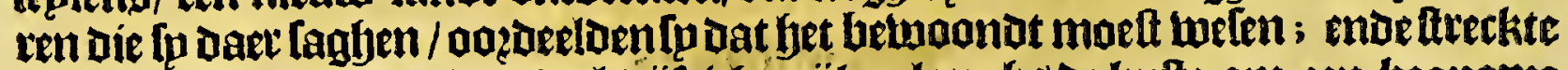

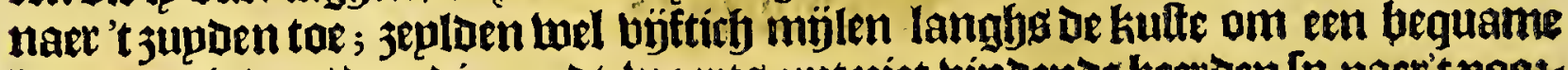
haten te binden/Dan Die 3upDt-waerts upt nict bindende keetden [p nact t node

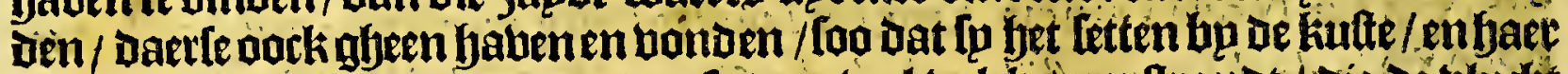

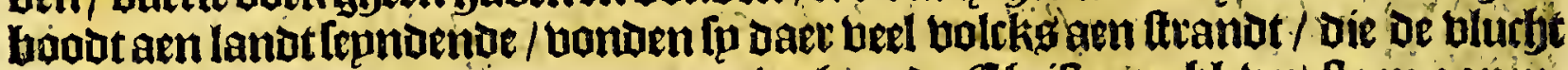

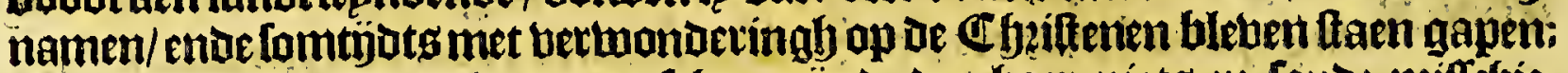

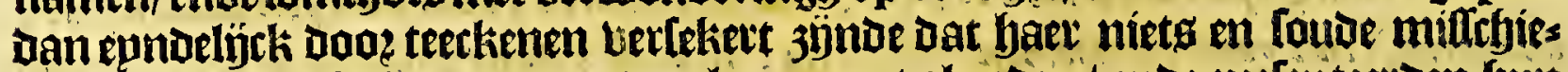

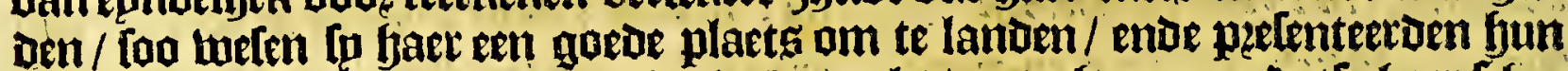
oock nan yaer bittualie." "C nolck ginck naeckt / upt-ghenomen Datfe baer ffba:

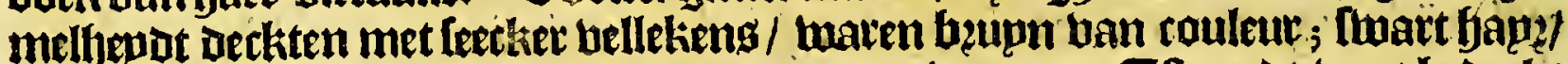

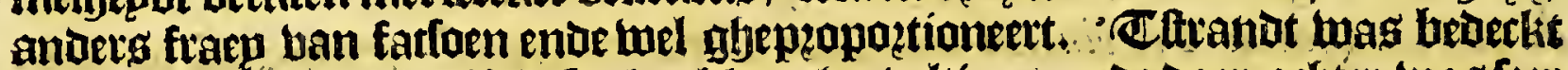
met fijn fanot / weick right in feecker klepn beubeltjends ende daer achter was feet

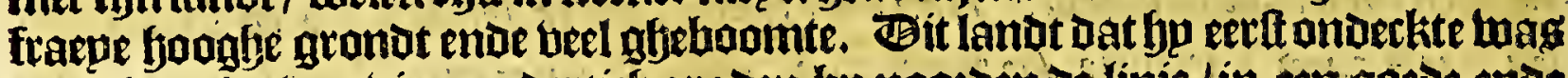

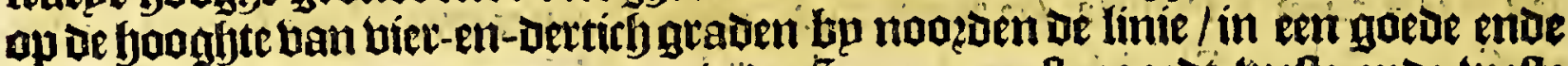

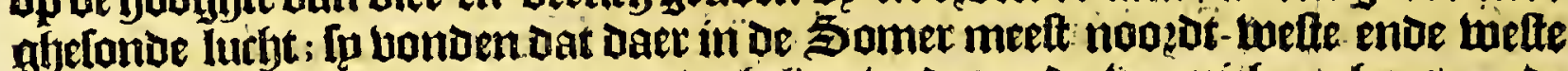

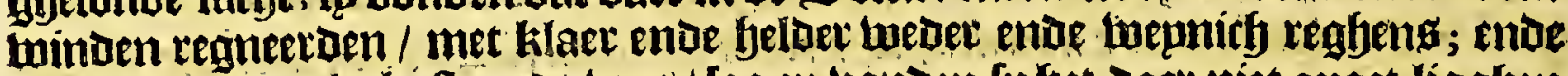

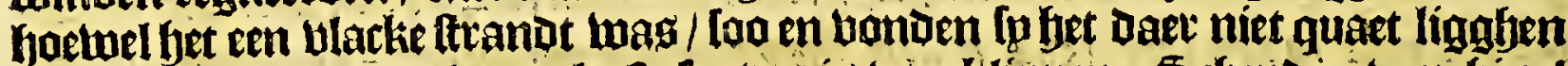

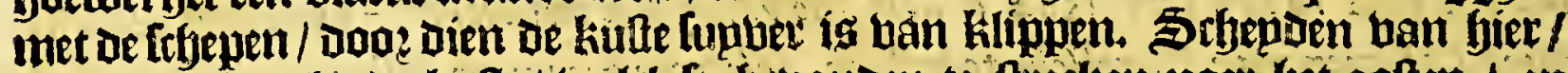

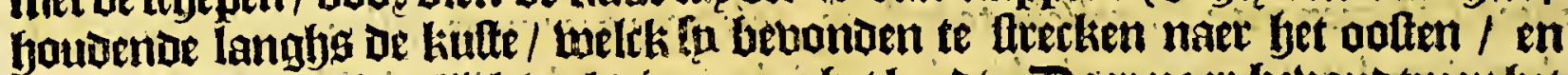

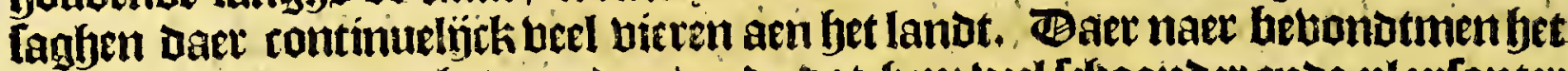
landt te ftrecken naer fyet noozden / ende bat fem beel Irfjoondere ende plapfantes

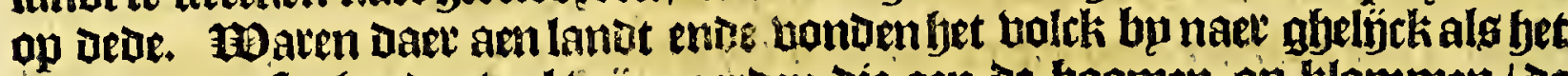

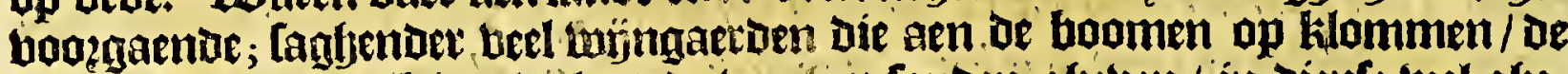

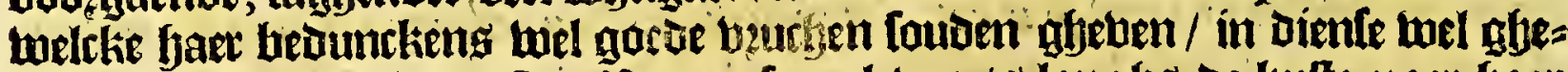

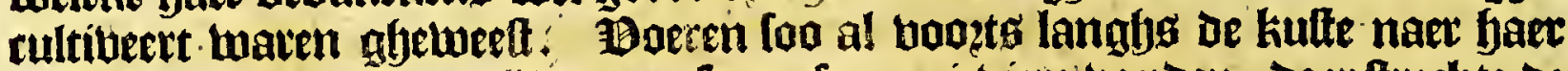

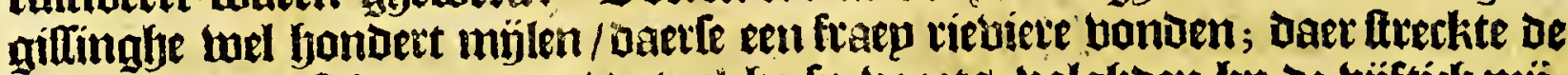

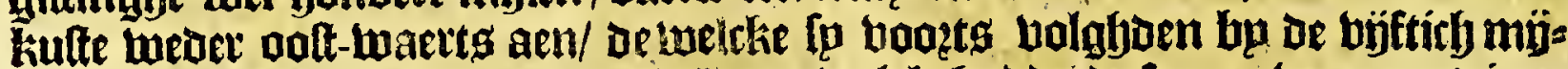
Ien/ende ontoeckten Doen een eEplanot welck yadoe de forme ban een trians whel / ligghende thienmijlen wan het valte lanot / wol ban berghen die dicht met

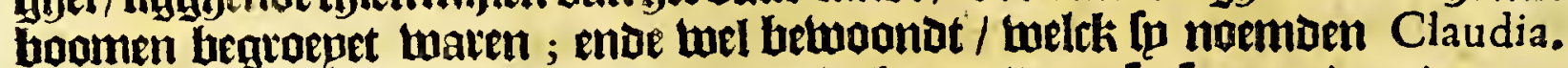

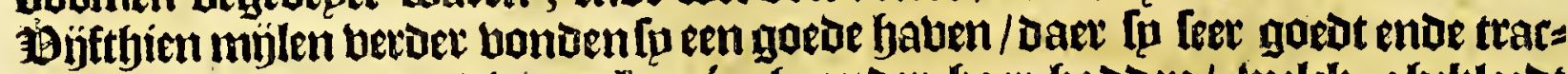

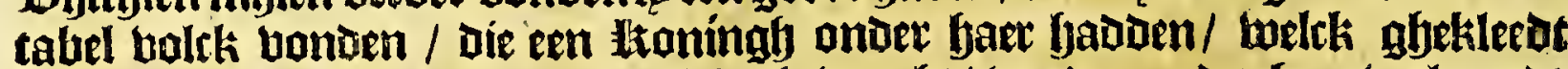

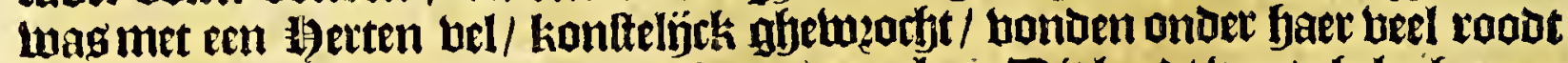

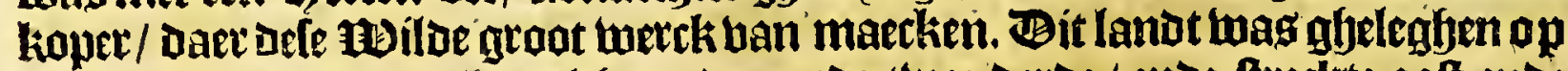
oe fooghte ban een-en-jeertict) graden ende thee Derde / ende ftreckite ooft ende

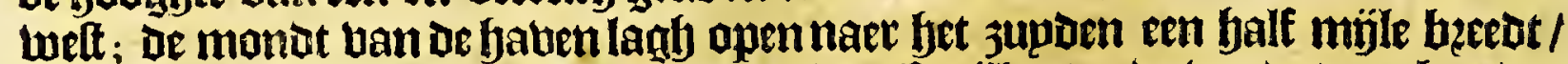

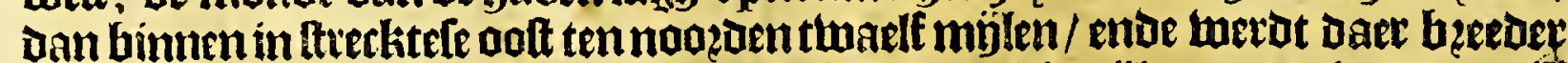

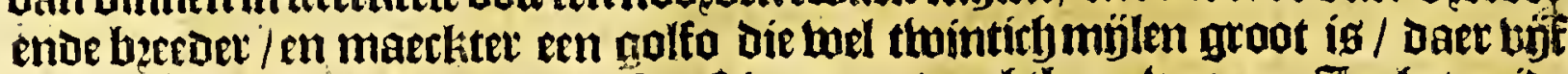

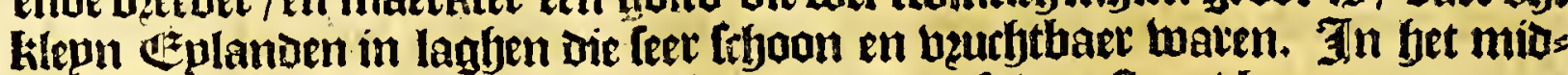
ben ban fret in-fiomen ban dele baben is een rodtfe ban fteen / bequaem om een

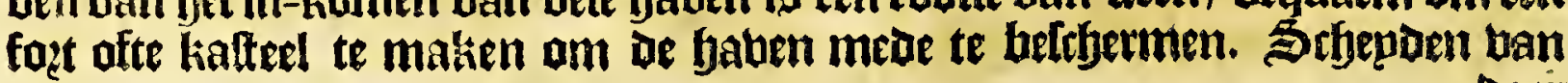


Daer Den bïfoen May, ente liepen boots langhj de kufte bel fonbett entoe büt:

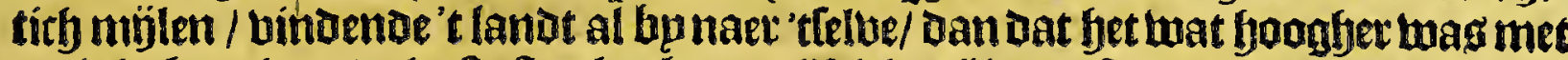

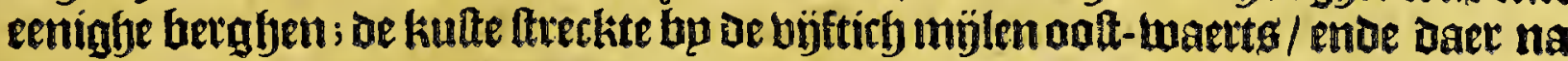

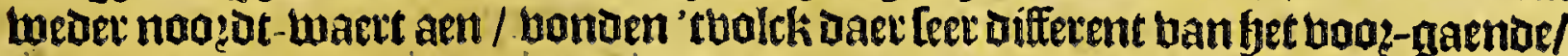

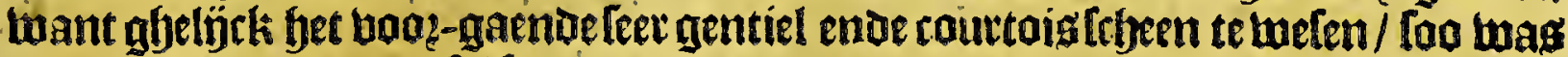

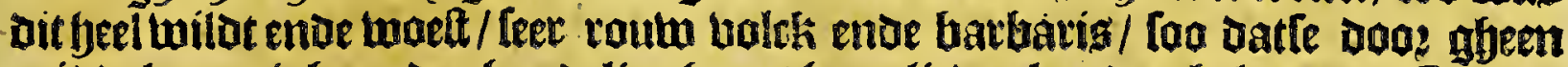
mi boeleneenighe andet-bandelingy met fjaet-lieden konden bekomen. Spua= ren abekleed met beeren-bupden / attergende jee-rohben/ ende andere bellen: Gaelden baer boet tel / [oo berre fo konden mercken / bp bifichenende jaghen / ende

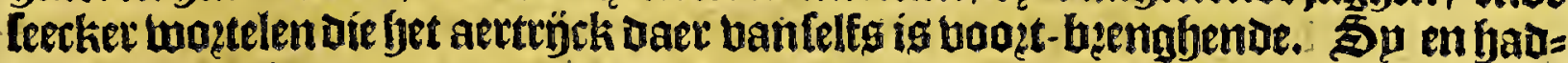
Den ggeendeclep graen/ente en boumbende aetde oock miet/ oock en lefjeen fet

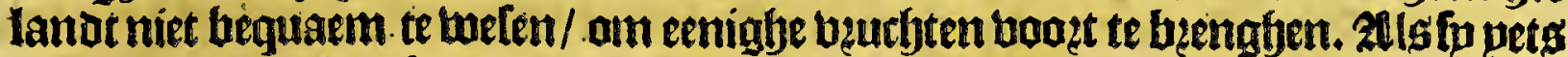
wilben mangfelen / foo quamen fp op de Kilippen ende lieten af 't gfteenfp wiloen/

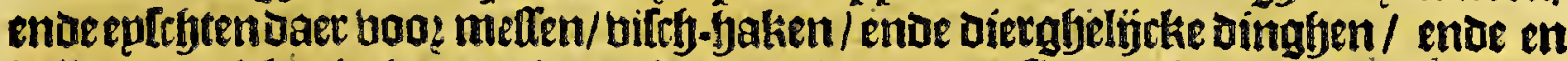

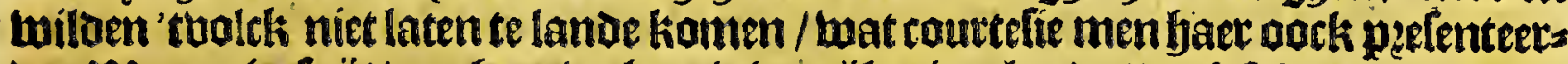

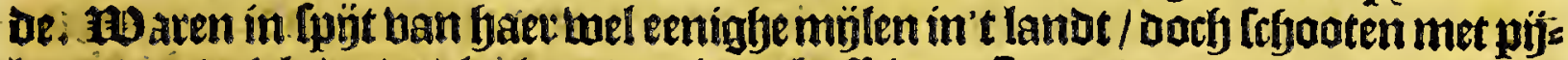

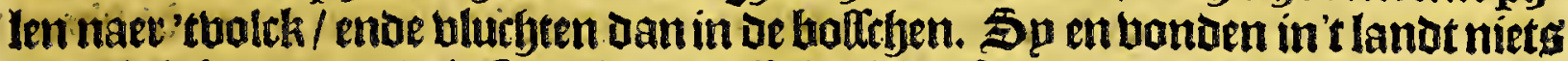

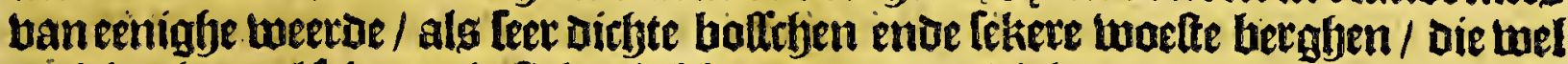

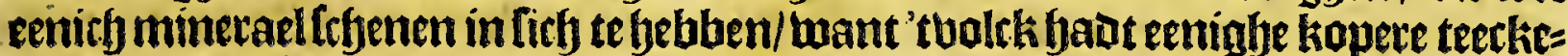

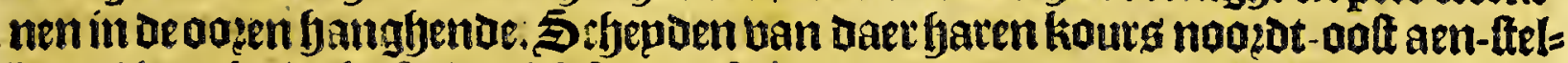

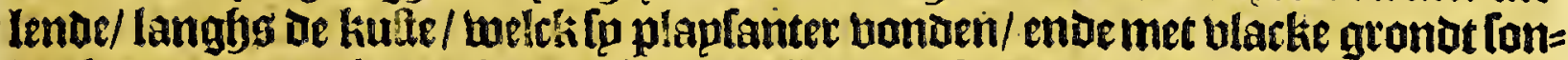
ber boomen/methooge beigen bimnen 'fandts ; fu ondecktentwel 32 Geplanden/ al dicht bp het bafte-lanot ghelegen/zjöne klepn/met beel ktomten/makenae beel

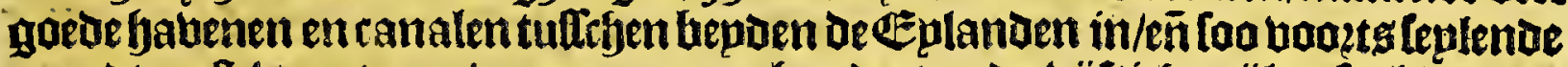
noozot-ooft-tuaert aen/ quamen naer bondert enoe bÿfticf mülen fepleng aen

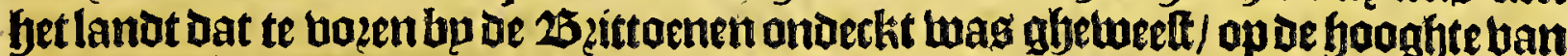

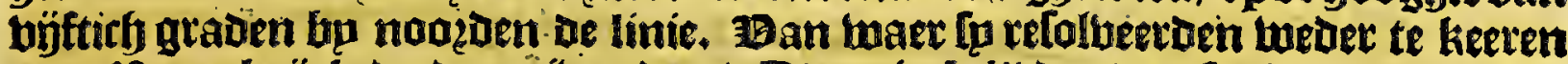

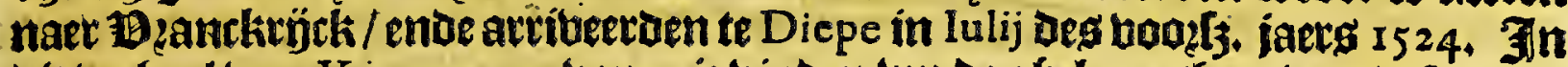
Dit vetfael ban Verazzanos thopagie binuen top te gfelegentjept van dere gant:

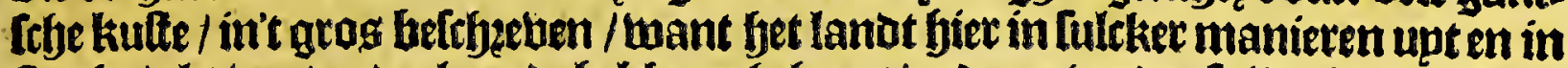

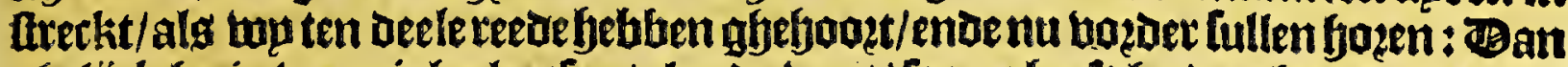

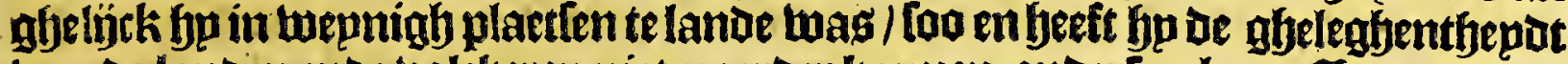
ban de landen ende bolckeren niet naetder konnen ondertoecken. Laet ong nu bogoer fien wat de erengellebe / ende de onfe baec banbeblen onder-bonden/ enje in't litgtgfebzacht.

\section{N I E U W.E N G.E L A NDT.}

Het thetede Capitte!.

Degheleghentheydt van dit deel van A ME R ICA welck do Enghelfche nu noemen NEW-EN $\epsilon_{A}$ A D, by

Capteyn Smith befchreven.

T'Bhedeelte (Tegft lyp) welck twp naemen Nevv-England, isglitelegen tultefyen Confe-

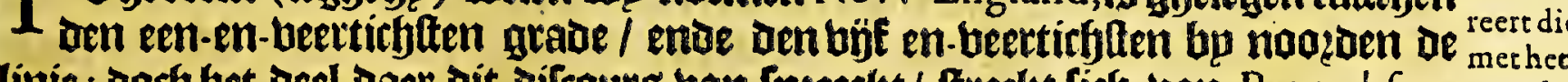

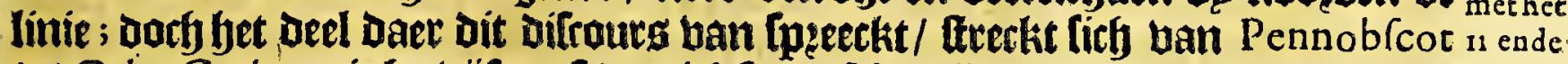

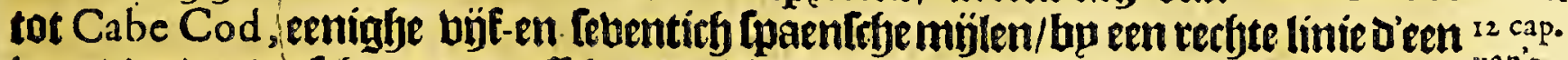

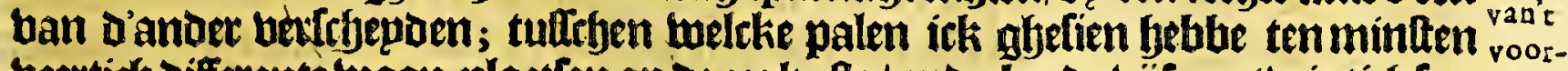
beertich differente woon-plaetten ap de zee kulte / enoe bo oe byjf-en-twintichleet gaende

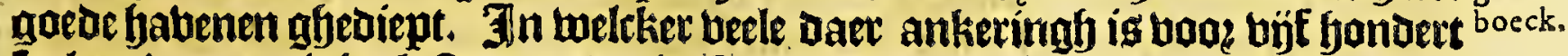

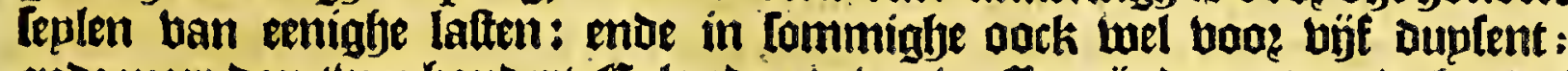

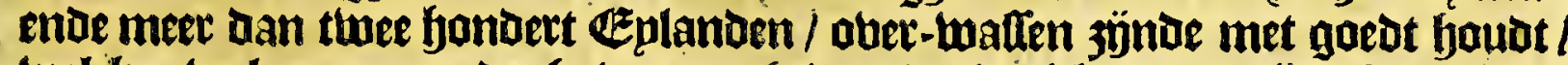
welcke beel meet goede fabenen gijeben / als ick boen tijot badoe om 
92

Virginia.

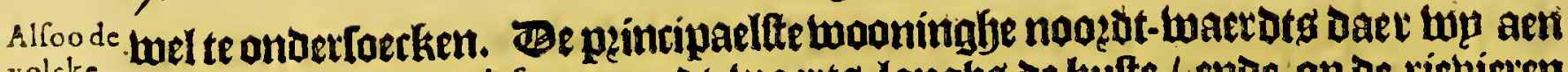
volcke- maren/was Pennobfcor: : Jupot-waetts langhg oe kufte / ende op de riebieten haer banjen wop Macadacut, Segocker, Pemmaquid, Nufconcus, Kenebeck, Sanoemen ' ga dahock, entae Aumoughcavrgen;ende tot dele tontrepen behoozen ae volckeren na hare ban Segotago, Pagkhuntanuck, Pocopaffum, Taughtanakagnet, Wabigganus, fooen is Naffaque; Mashecofqueck, Wavvrigvveck; Moshoquen, Wakcogo, Palsharaniette nack, \&c. IA deré dar Paffataquack, "Aggavvom, ende Naemkeck: al Dele foo vet ítk könde fpeuren de namé oiffereten luttel in tale/ manieten enoe goubernement; bae mel 'tmeelt heertrbap=

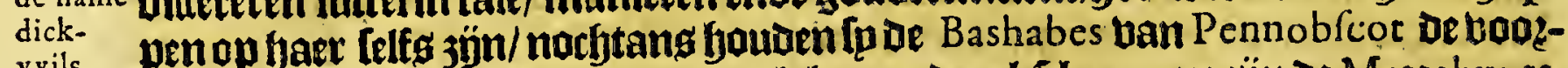

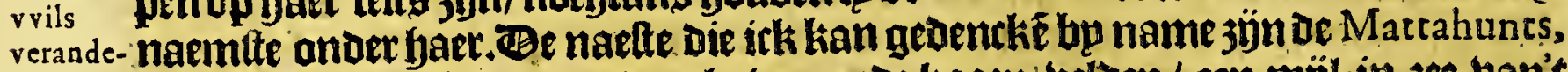

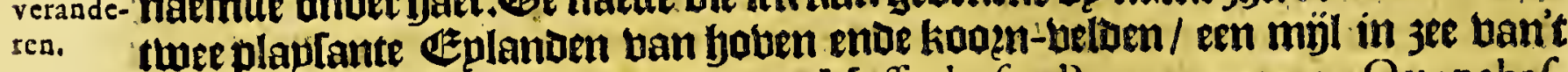
balte landt af-ligabende: Dan Totant; Maffachufet, Pocapauvvmet, Quonahaffit, Sagoquas, Nahapaffumkeck, Topeent, Seccafauvv, Totheer, Nafcocomacak, Accomak, Chavvum, De anoze jön al glenaemt Maffachufets, ban een ander tael/humeur enoe conditie/aen-langende baeren Gandel ende koop-man Ichay ; tot elck van baet wooningben beboozen diberldye boupen enoe volckeren) enoe bp haer relatien ende befrbejuinghen/ meer dan twintich diberfefye toonplaetfen ende riebieten/ Die berre te landt-waert in thecken/ Lelfg tot diterffye aroote lacken/ daerle de meef ban haer bebers ende otter bangben en booden. Ban Pennob/cot tot Sagadahock is Defe kulle al bergich / beel Ezplanden ende groote radten/Darb belwaflen ban alle fookten ban fraep hout/tot oen boum ban

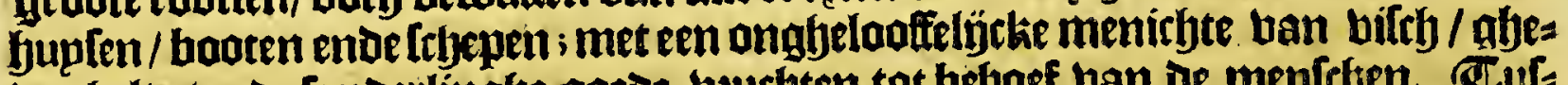
boghelte / ende conderlinghe gaede bzuchten tot bejaef ban de mentefen. Cut= [chen Sagadahock ende So w ocatuck, gịn maet Dep oft viet landt-bapen / matr tuftelyen dat ende Cabe Cod leet beele; infondertyept de kufte ban de Maffachu-

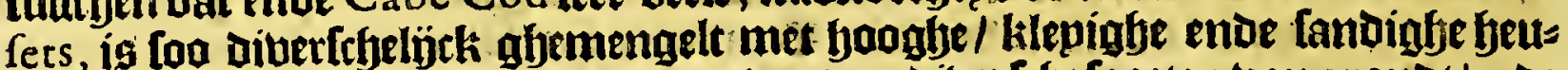
bels in een plaetfe;ende dan lange itreeken uan biberfryefouzten uan grondt/ende bier-kanten ban fteen op ander plaetfen/ fon beemaeibek berdeelt met aderen ofte beunen ban bibertebe kouleuren als bert-fteen tot timmeragie/ /ribalien booz

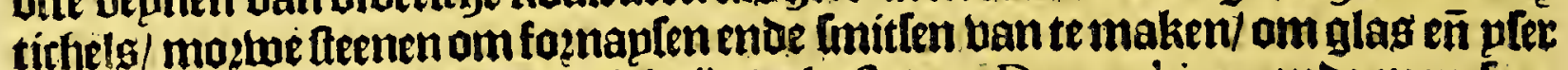
in te fmilten; foa aatle leer gheligck zïnde kufte ban Deuonshire; enoe men fous oernaer mün mepningl fulcke lïm. Iteen kammen maken; oft foo fu niet en 3 jön van gelficke qualitept/ Loo kamen fpleet na bp: ende dit alleg bouten de andere ad: bantagieufe ahelegentbeden die ick Daer geablertueet bebbe/ Dat in bien ljet mine= rael Loo goet plerende that wot beuonden/als isk weete't felbe te welen/binnen be palen ban bet lanot; [oo doęt ick mün yooft te panoe ftellen (bebbende maet balck die twetenfrhap hadoen om de Simplicia die daer groepen te henefíieren)te binden daet alles twat noodicf is tot maken en upt-reeden ban gaede [thepen/ endegoede waren tat baer bzacft / in't compas ban thien afte beerthien mïlen. Boozwaet

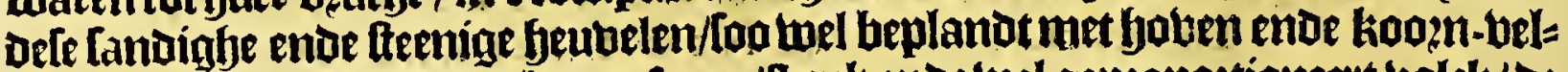

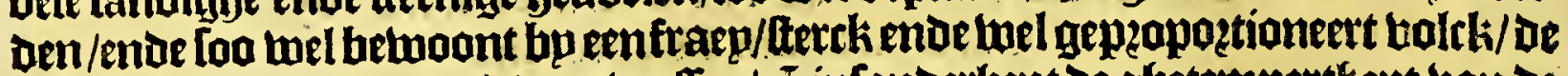
atoote ban de boomen die daer waffen/eñ infonterbept de ghetempertfept ban de

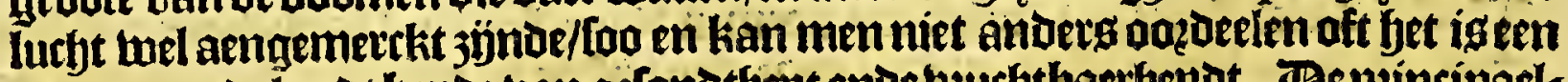
upt-nemenoelanot bepoe ban ge[ondtbept ende beuchthaerbepdt. Depeincipaels fte thapel Daer men boozerttrekeningh foube kommen opmaken/is biffy. Hier is oock al [oo gaede gronbt als cenich matbligghen op be booghte ban een twee en

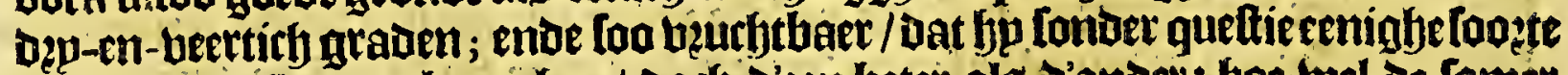
ban graen wil boot-benghen / Doch d'een beter als D'ander: hoe tuel be fomet

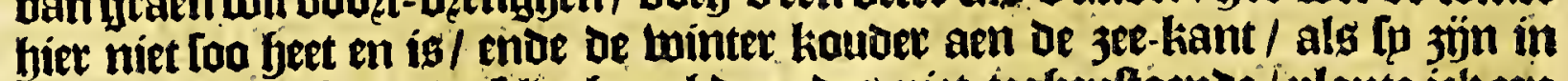
Europa ende A fia op de Teloe foogboen: des niet tegfenftaende / plante ick een thupn/aen de top van een klippich Ezplanot op of foughte ban depp en-bert: tich graden en een fialf/ bier mijlen ban 't balte landt/ in Majo, welck loo toe- 
Het derde Boeck.

nam/bat fet ons in Iunij ente Iulij dienve ban Lalaet ktupben: ento al footen tuan

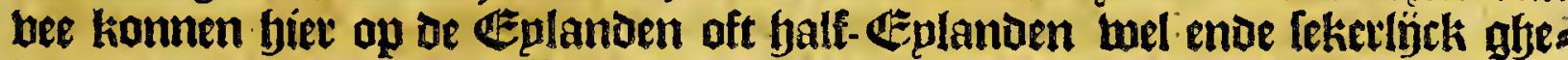
boedt Luozoen. Mat oe bififfingh belanght; in Mart; A pril, May, en half lun ig Giex abundantie ban cabelíaulw; in May, I un, Iulij, ende Auguft van Iteur/ welcker rogben de Cauiar ende Potargo gleben; en ban baringh is daet en an= upt-\{pekelycke menichte op de kulte. In't epnot van Auguft, September, Octo-

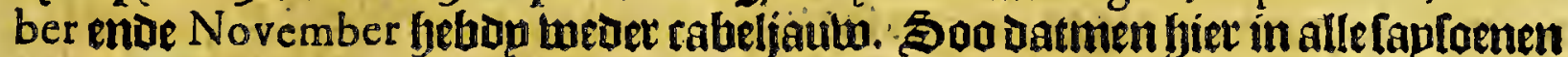
bem kan dienen ban viffy. "C is bupten twöfel dat Daer ghenoech fouts fal kan = nen twerden ghemaectit / ende bijl men de pannen peactifeet / kan men ben dies

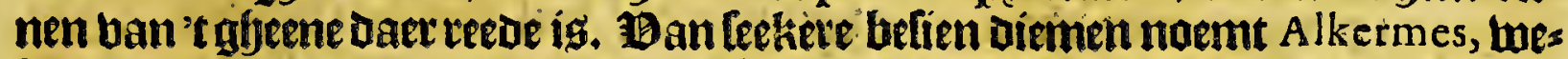

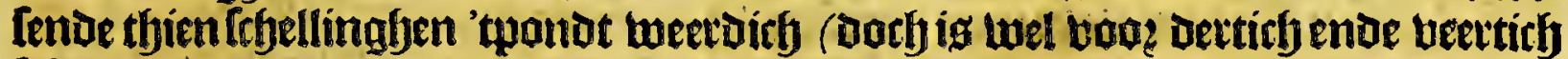

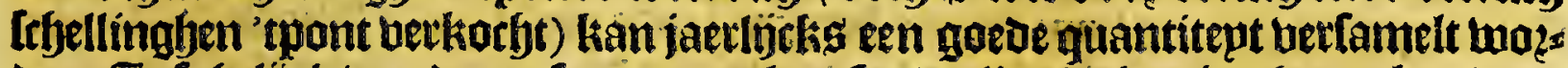

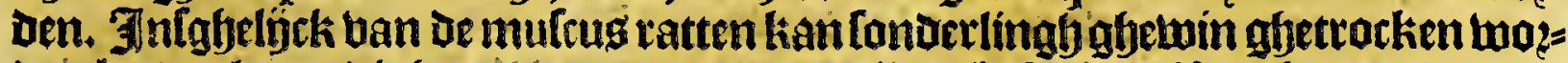
oen bp de abeene die haet moepte daet aen willen befteden. Ban bebers/otters/

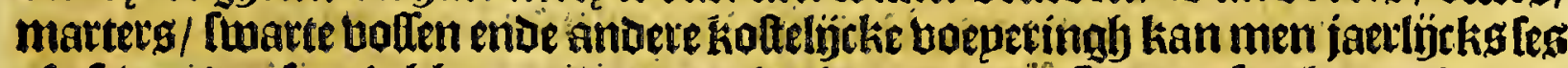
oft feven oupfent febloen: eribe meer indien men de ffrancoplen haren bandel

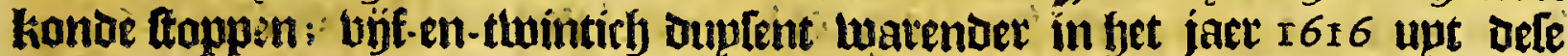

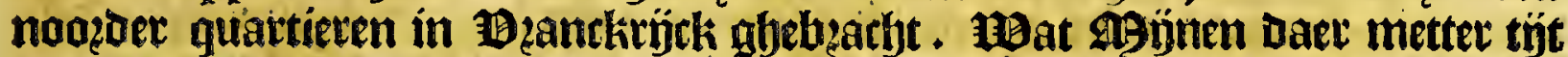
Couben konmen gbebonden wazden / moet oen tjot leeten; De appatentie is feet groot.

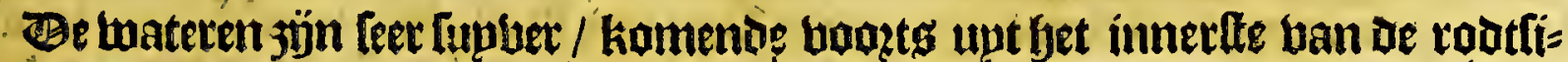
Gre berghen.

De krupdenende buthten 3 g̈n wan siberfhe Loaten; als Alkermes, coetenten

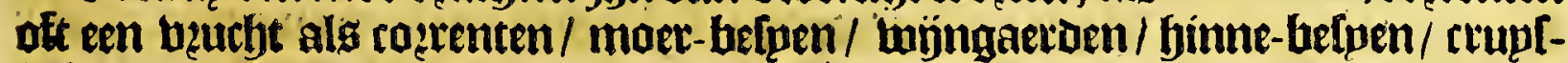
belpen / pupmen / wal-noten/ bale-noten / etc. Jampoenen/aett-befpen/ boos nen / eetten / ende Mayz; een loote afte thee ban blafty/ Daetle baet netten ban maken / enoe lignenom te bifichen.

Beeloerbande gbebogbelte: beel foozten ban vifeb: ende beelderbande biettoetigfe dieten.

Het berbe capittel.

Particuliere befchrijvinghe van ' $t$ felve quartier.

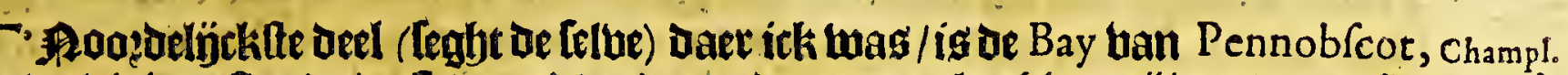

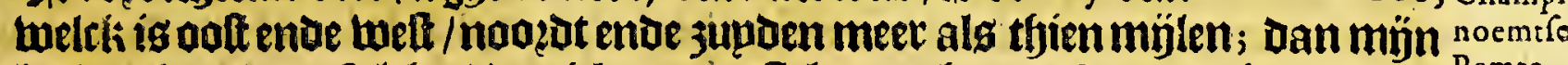
abelegbentbept was fulcks / dat ick mp molt laten gljenoeghen met bet bethatl ${ }_{\text {goiier. }}^{\text {Pente- }}$ ban de gfoene die ick daet inoe bap bonot; alg te tweten dat Die riebier feet ber te lanot waett in liep / en twel bemoonot was bp beel bolcks / dan datte van hupg waren / ofte om te bifleben tuffeben bepoen de Eplanden / oftete jaghen in de lac=

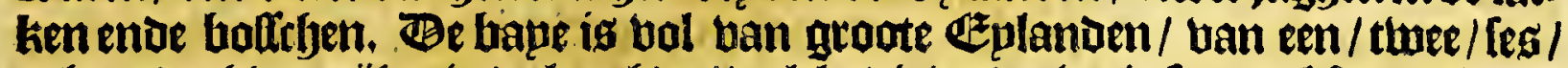
arbt ende thien mülen in de lenghoe / welcke die berdeelen in leer beel fraepe have= nen. Atent oolten ban Dele bape twoouten de Tarentines, Joot buanden ban't

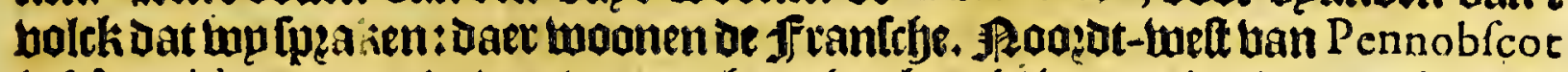
is Mecaddacut, aen de boet ban een booghen betag / in maniete van een foztrelle tegben de Tarrantins, gfelegben aen defoogge berghen ban Pennobfcot, daet de

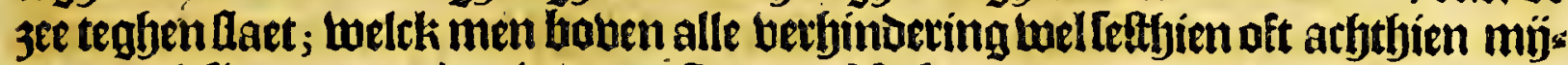
len math fien. Segochet is be naelte/ Dan Nufconcus, Pemmakid enae Sagada-

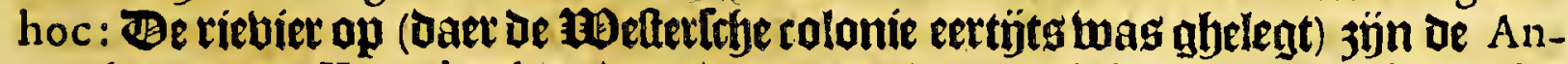
muckcavvgen, Kinnebeck, ende andere meer/ daer enighe veloen met kooen be= Champl.

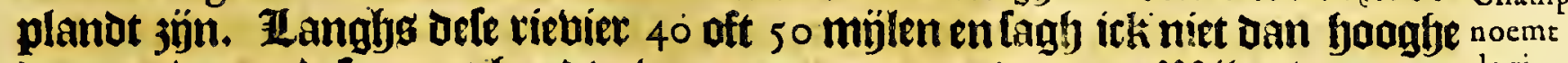
Dupnen ban rodten met baubt aber-groepet; maet daer oe milde twoonen/de rie-

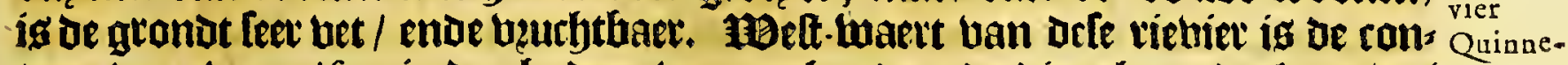

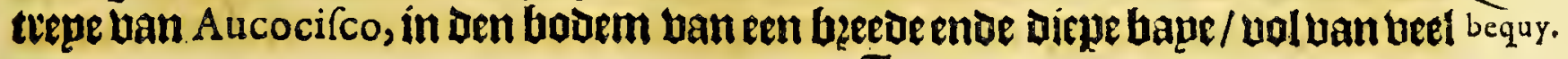

$$
\text { I3 gionte }
$$


94

Virginia.

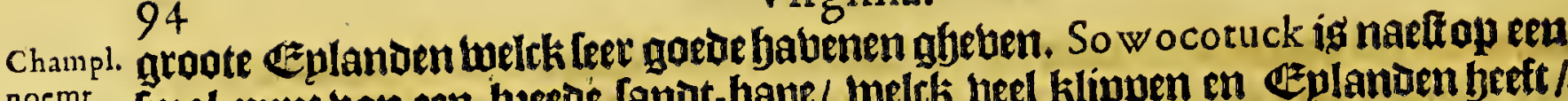
noeme Imal punt ban een bzeede lanot-bape/ welck beel klippen en efplanden beeft/. de maer twepnich gaede haveng/alg booz Wercken. S9aet al dele kulte tot Pennob. Chova- fcot, en too verre als ick tien konde oult- waert aen / is niet dan lulcke backelióhe kliffsende rotten en ftenighe CEplanden/ Dat te bertuonderen is boe too groote boomen daer konnen wallen. 'Cigen lanot om eer ban te berfeyeicken/als op

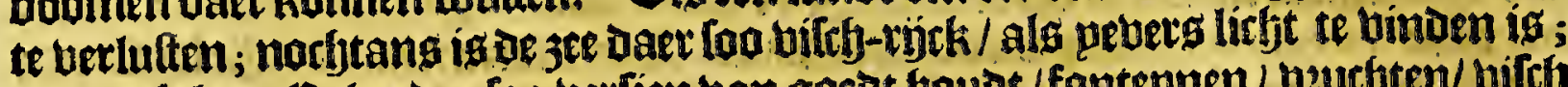

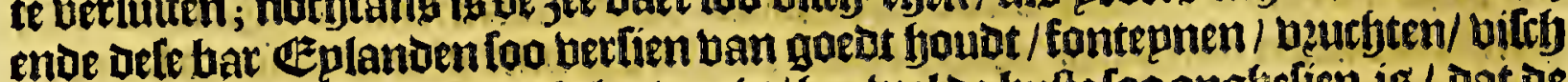

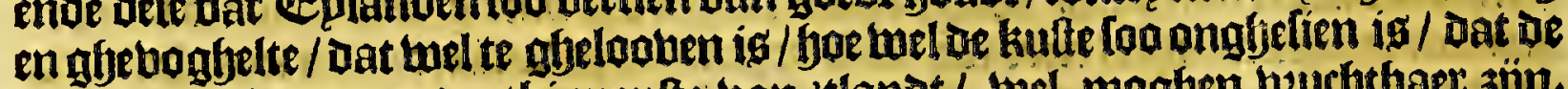
ballepen / plapnen enoe thimmentte ban 'tlande / wel moghen bzuchtbaer 3 ün.

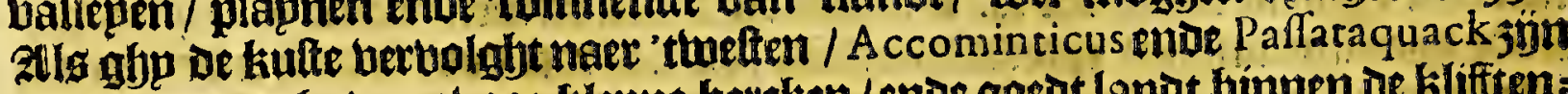

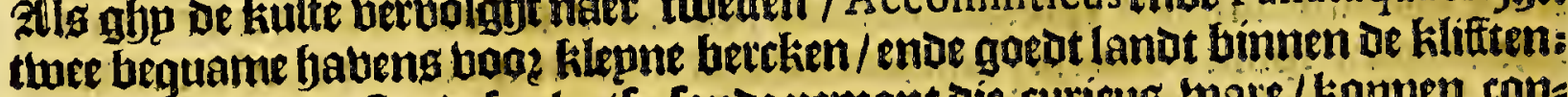
Angoam is de naefte; Dele plaetfe loude pemant die chicieus bare/konnen contenteeren / Doth daer jün beel Canden aen tin-Komen van de bauen / ende de bape

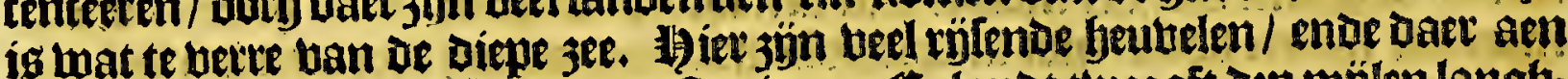

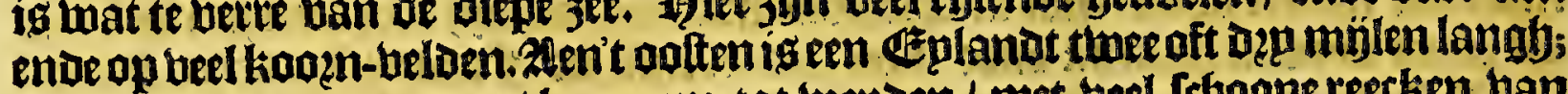

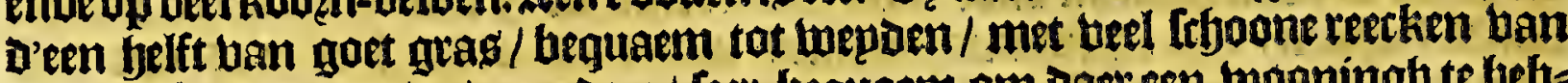
moet-belie-boomen/enve andere / leer bequarm om baer een wooningh te beb= ben/ Dooe dien oe hauen feer [eecker is. Naimkeck hoe wel bet rotfigbet gronot is/ (Lant Angoam ig Tandich) is niet gheringhet/ [oo veel oe baben/ oft pet anoevg

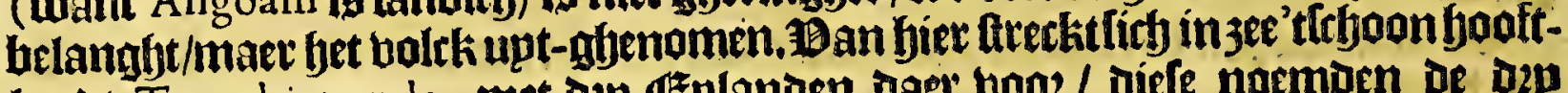

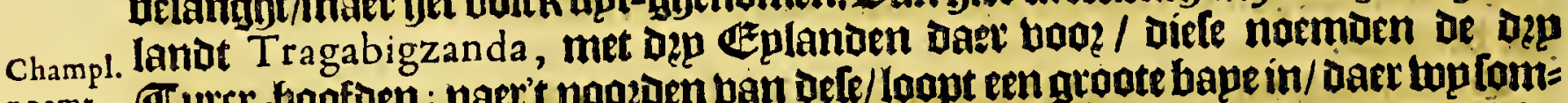

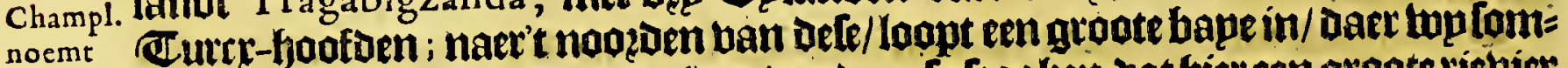
het Cap migfye woninghen en koogn-betoen bonuen; [p legghen wat bier een groote riebiet

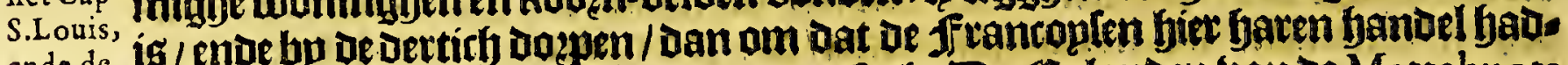

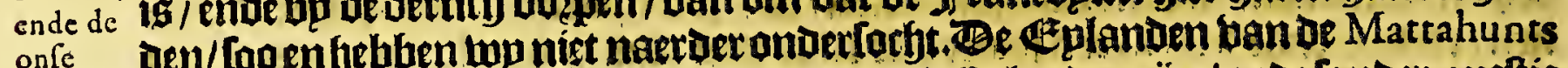

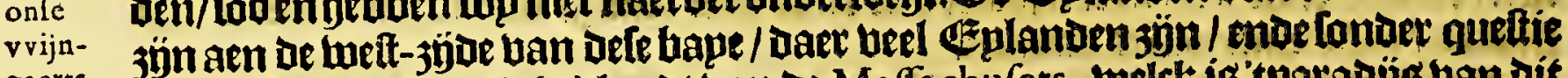

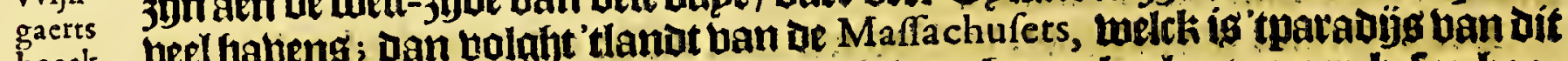

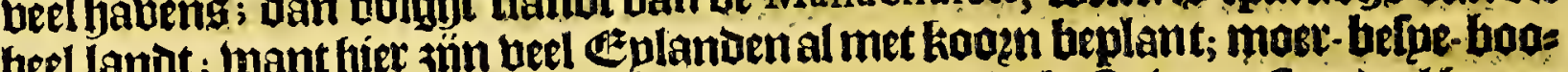

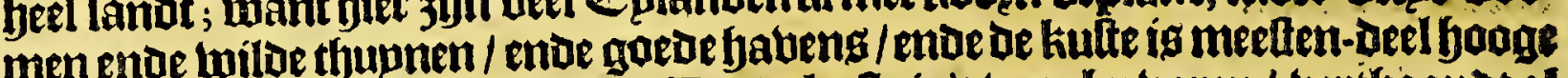

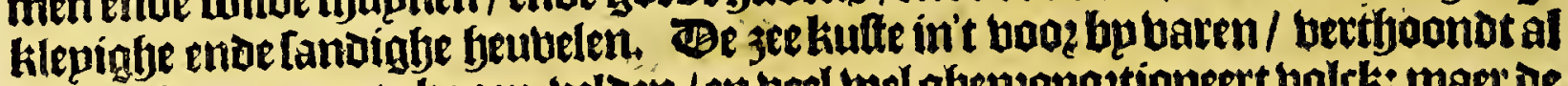
langhghenen groote koo zn-beloen / cn veel wel gbepzopoztioneert bolck: maer de Frantehe dief hier wel fes beken waten gfebleben/ en badoen ong niet ober ghe= laten om de TBibe ober te examineeren; te tweten/ ofter bel oze mentefyen op

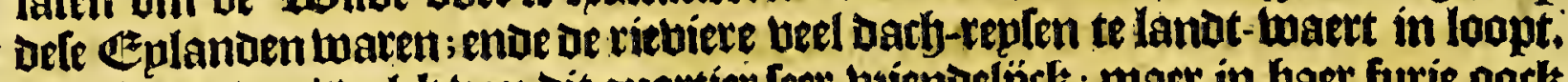

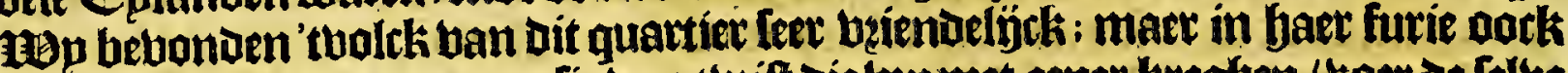

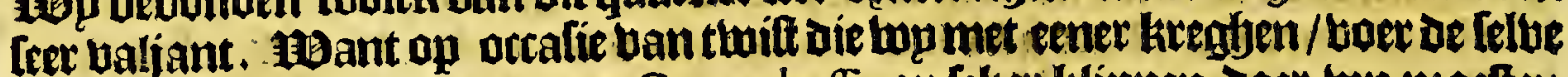

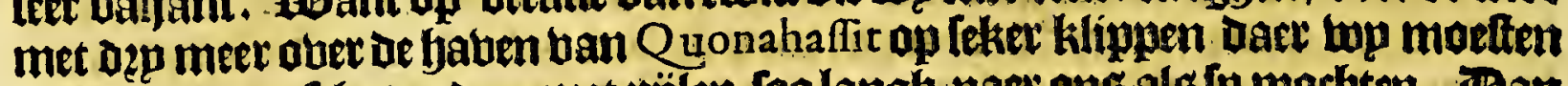
palteren / ende feljoten daer met pijlen foo langh naer ond ald fu mochten. Tam

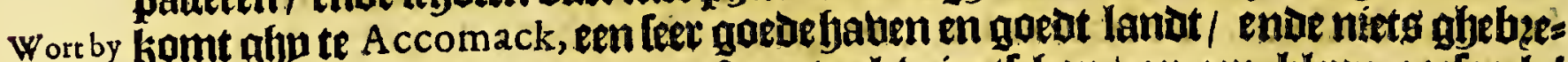

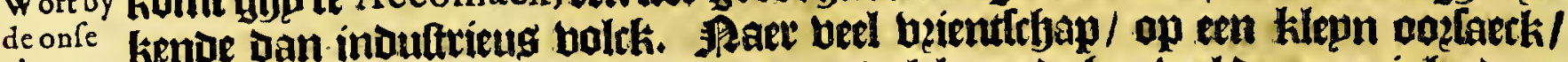

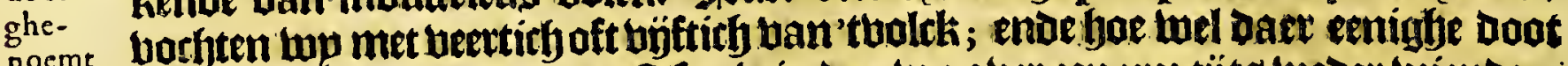

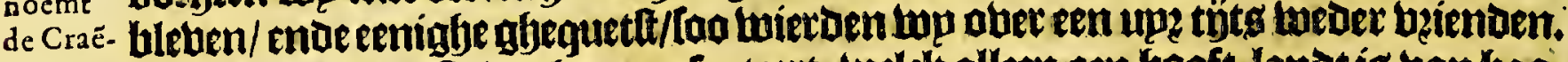
bay. Cap Cod is'tnaelte wat hemperenteert; twelck alleen een booft-lanot is ban boo:

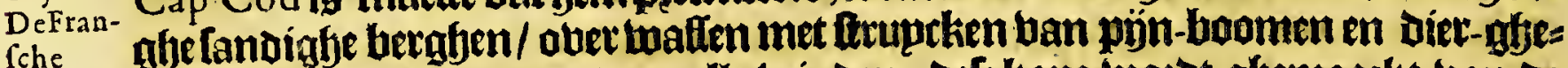
noemen ligtk / een excellente haben booz alle twinten; Dele kape wo tot ghemaeckt ban of

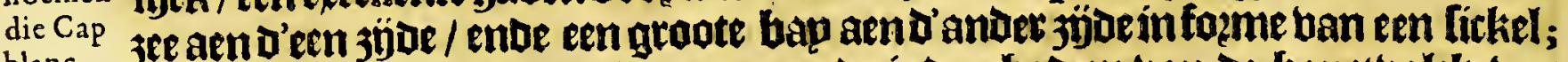
blanc.

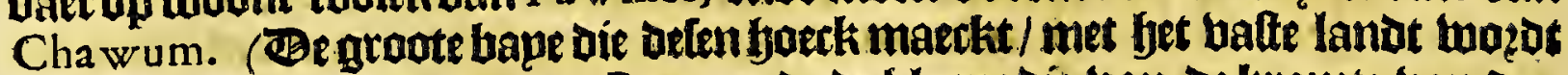
bp de onle ghenoemt de Staten Baye, ende de klepne die ban de kxomte ban den hoeck Telfs merdt ghemaeckt Fuyc Bay.) 25immen dere bap is een lupbete kuftel Dan blark / loo dat men wel een míl daer ban bient te bljuben; Champlain met

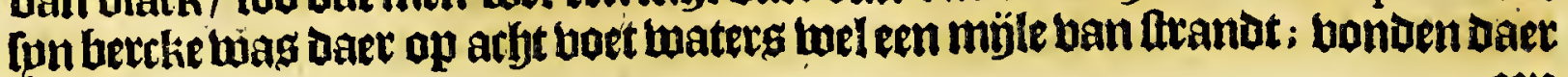


Het derde Boeck.

een goede haben lolck fp noemien port aux Huifres op de booghte ban tweeen-beettich graden / büf mïlen ban Cap Blanc, melcke kape ban aere haben

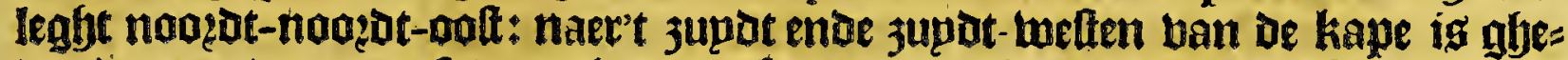
nonden een dangeteule Dzogghte ban tanden ende klippen. Asaet foo betre alg ick bet [elbe om-boet (legft Smith) bonot ick dettich vadem diepte vicht onder ftranot en een ftercke froom; welck mu Doet ghelooben dat daet een canael moet

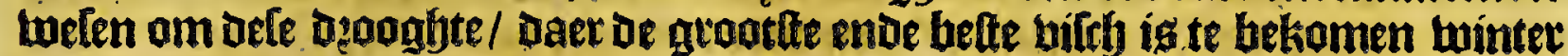

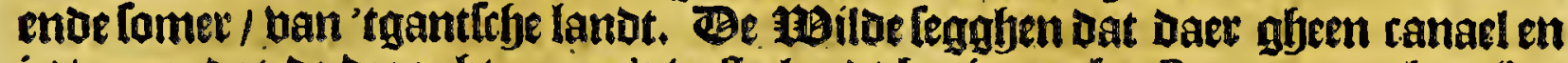

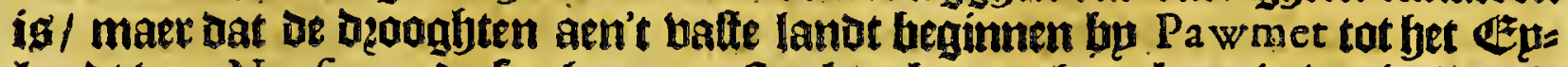
Iande ban Naufit, ende foo bem upt-ftrecken bupten baer kennis ber in de 3 ee.

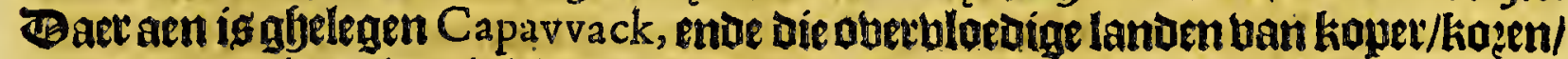
bolck/ende mineralg; die ick tlaetftejaer ginck ontoecken; Dan mifte mỉn weglj. Sp verbalen dat de Maffachufets fomtiototo poylongen met de Bashabes ban Pennobfcot; en 3 ijn ootk niet altijots beienden met die ban Cha wum endefjaet gye= allietde: dan nu jünte alle bzienden/ ende bandelen met den anderen / op pe= Dets frontieven; want en maken gheen bopagien als ban Pennobfcot tot Cabe Cod, feloen tot Maffachew fet. In't noo zoer quartier bigonoen fokodente plan= ten/Daer die ban't3upder quartier futcken abundantic ban hehben/ Dat fp daek

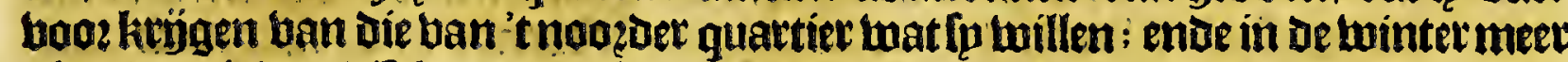

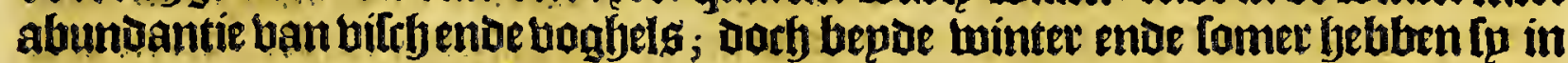

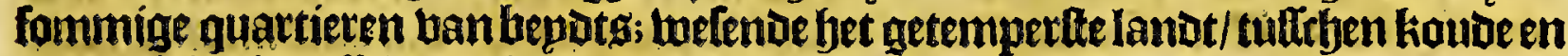

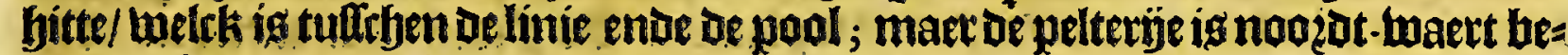
ter/ en abunbanter als jupbt-waents.

Be pyincipaelfte Eplanden ende betahen bod lantot-martken jün Dele; bet DeFran-

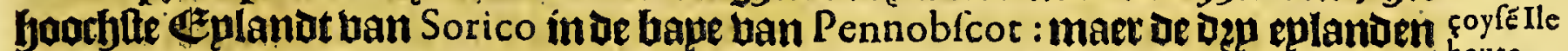
en een klip ban Mattinnack jün boozoet in $3 e e$; Metinicus is intghelícks dzp blacke eplandenende een ropte ; tulteben Mattinnack ende Monahigan: welck is

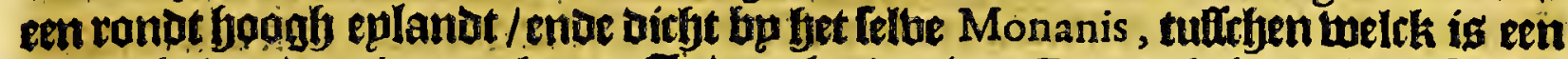
klepne faben daer twp anckeren. Into eplanden ban Damerils ig noch en fulcke:

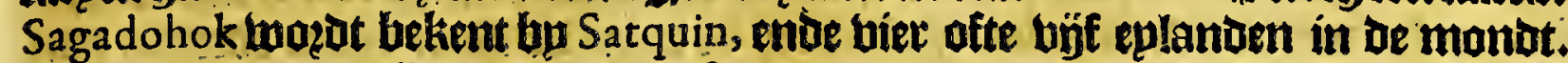

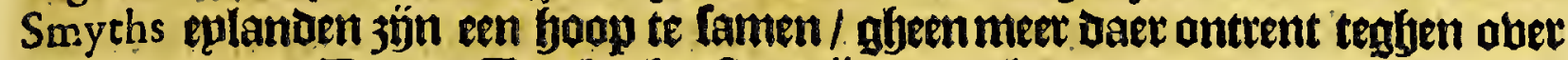
Accominticus. Be dęp Curcks-fjodtaen jün depeplanden/ die men betre ter zee-

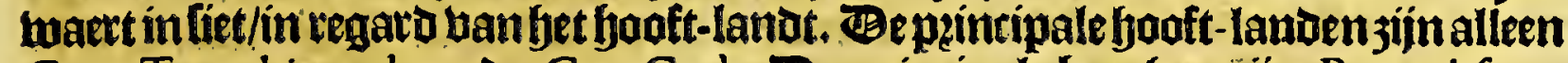
Cape Tragabizanda enve Cap Cod. Be peinripale herghen jijn Pennobfcot,

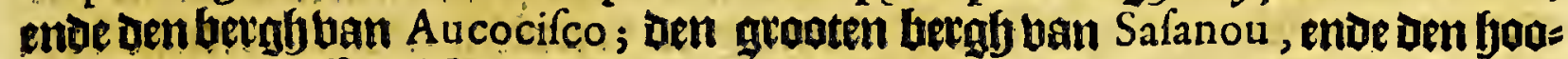
gben betgoj Maffachúfit.

\section{Nat bietoe Capittel.}

Verhael van't ghene eenighe jaren herwaerts by de Enghelfche is voor-ghenomen in dit quartier.

De Enghelichen hebbenthiet begonnen met ozoze te handelen ban Den jaete Difcour: 1606 af; 2llg wanneer patenten bp oen thoningh wietoen ghegheden om of Nevv 't zupat ende noozoet quattier tuan Virginia te populeren / met expess beuel / Dat fu England

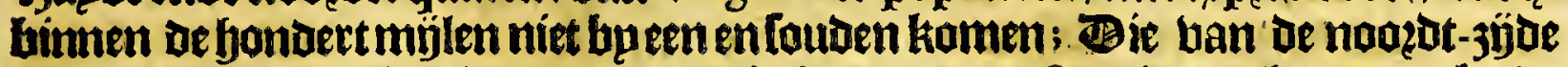
Contaen daet eerit Capitepn Henry Chalons, dan defe wietst gbenamen bp de 5 paegniatroen. Bntrent be felve tỉot fondt Sir Iohn Popham, Lord Chiefe Iuftice ban \& Enghelandt/eenfrhip/twaet abet tommandertoe Capitepn Thomas Hzman, welck jeplae naer de riebiete ban Sagadahok; tot aftittentie ban den book-[clyeetuen Chalons; Dan Den [elben Daet niet bindente / ontoeckte dekufte ende fabenen/ende quam foo weder'thupg. In den jaere 1607 mag een woon- $\mathrm{purch}$ as plaetle ghelegt op De ríebier ban Sagadahok, entoe fjanoert lanot-lieden dertwaerts pelgrim.

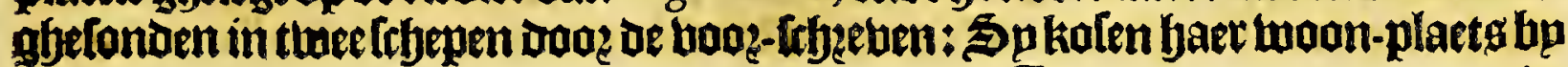




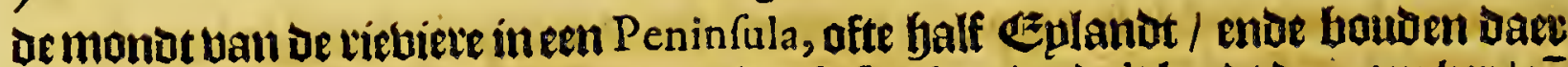

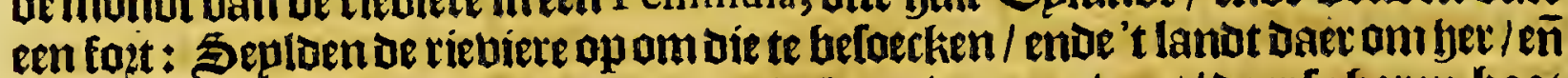

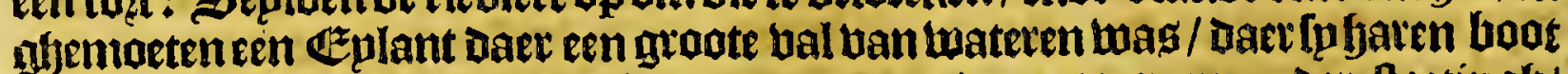

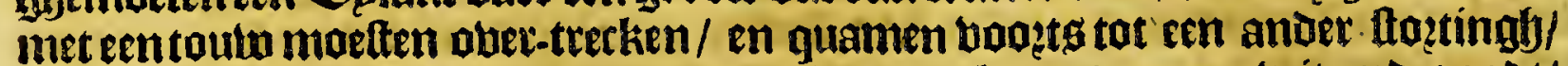
Daer niet oher was te komen. Bonden't lanot bol ban Dupnen bit enderoodt/

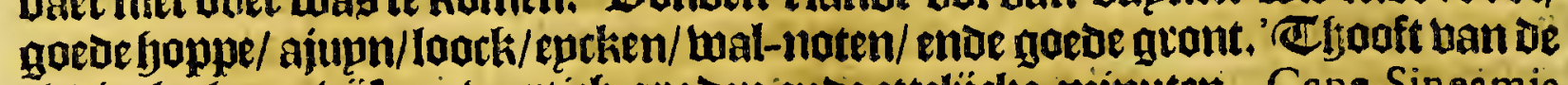
riebier leght op ujf-en-beettich graben ende etteligcke minuten; Cape Sineamis

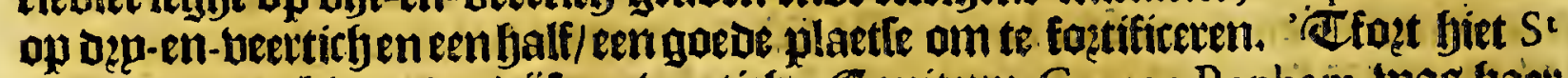
George; daer blevenuer bijf-en-bertith; Capitepn. George Popham tuas bat:

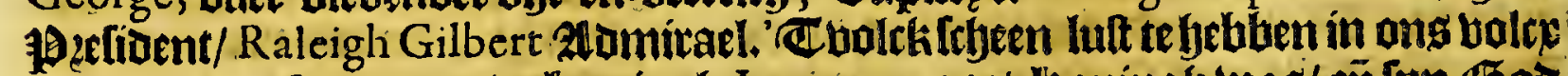
Devotie / ende [epden Dat de ltoningh lames eengaet Honingy was/ eñ [pn God

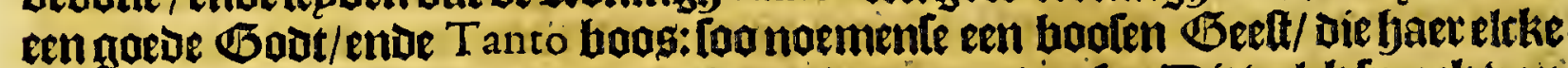

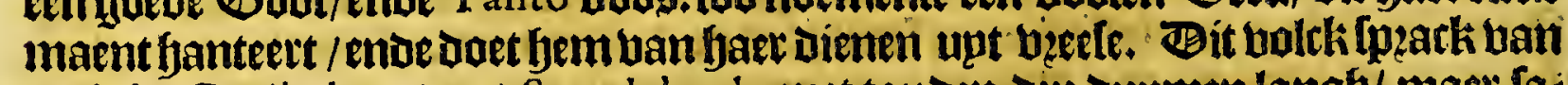
eenighe Canibals onttent Sagadahock, met tamoen Depe Dupmen langh/maet [a: genfeniet. In de vievier ban Tamefcot bonden fo oefterg negben dupmen langh/:

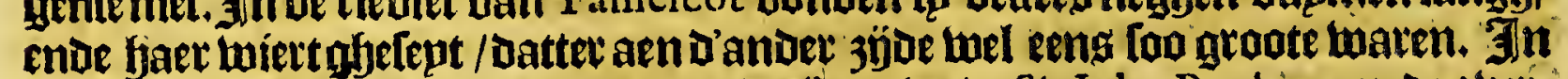

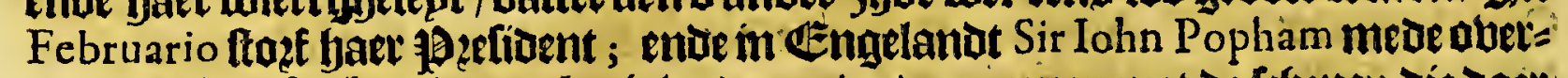

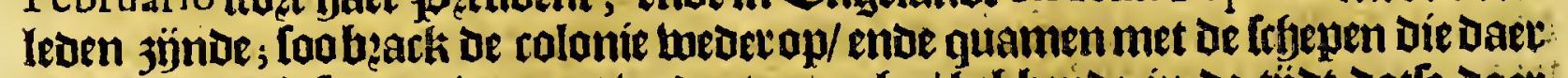
'tnaelte jaer ghelonion maren / weder te rugghe / behbenoe in de tyjot Datle daet. afjetwoont gadoen eenttercke barcke ghetimmert / die faer in't meder-keeten wel te palle quam. Bit Difcouragieer de De participanten foo / Dat Daer inlamglgeen

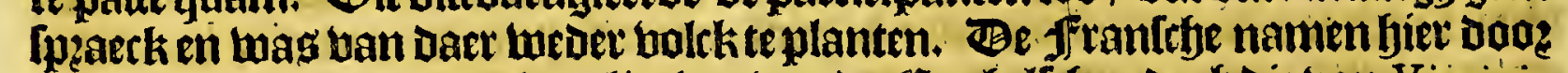

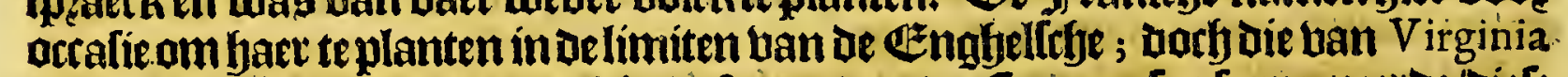
fonden Sir Samuel Argal, welcke de foeten uan oe Jirancaplen lurpeneerde/oiele ghehaudt hadoen hp Mount Manfel, Ste Croix, ende Port Real: nami baer gefrly ut

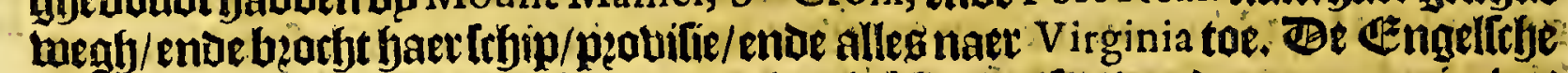

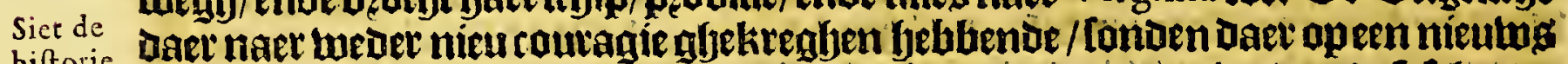

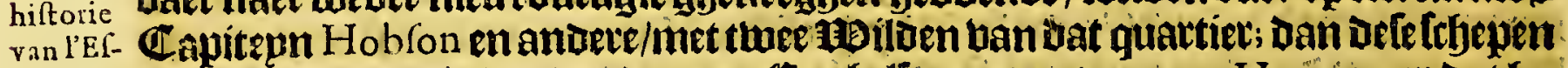

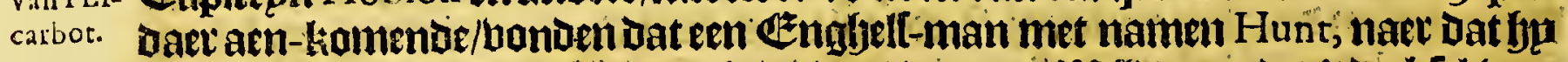

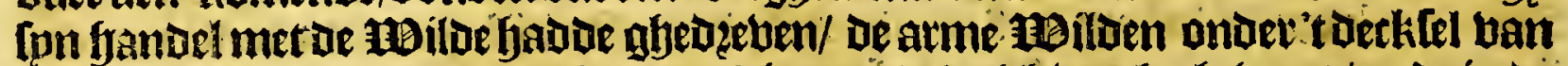

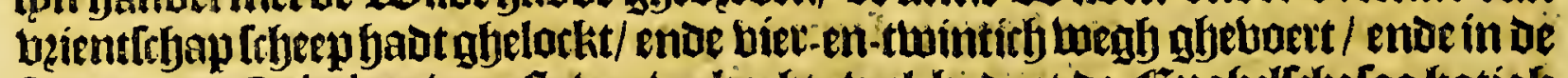

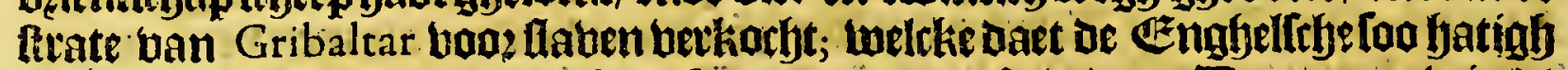

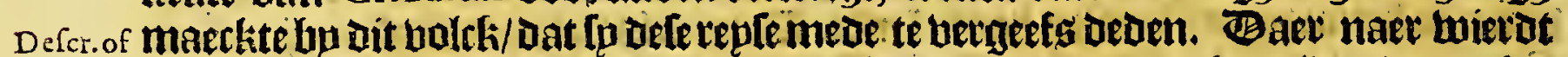
Neuvv Datr ghelonden Capitepn Iohn Snith, in onen jate I 614 , welck arribeetde aen bet Ey

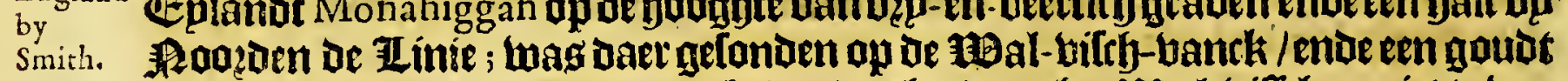

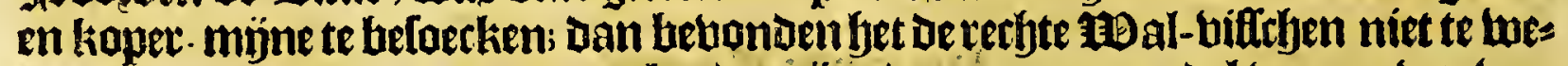

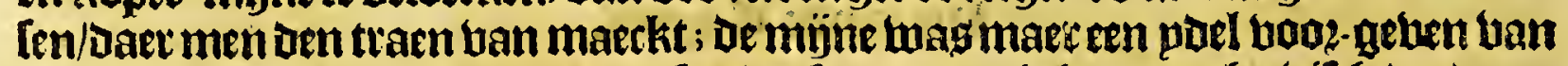

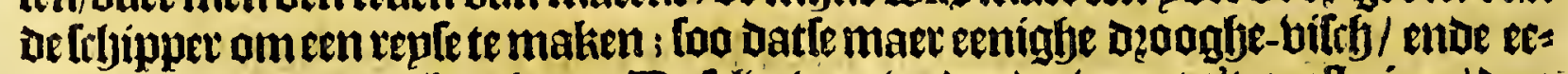

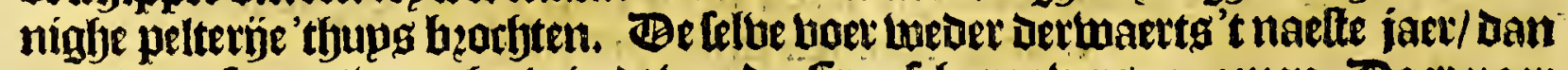

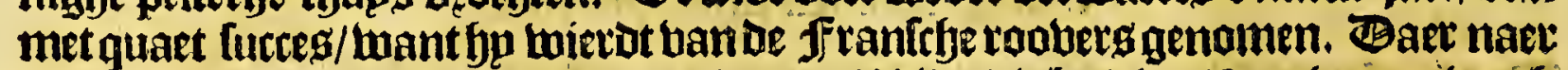

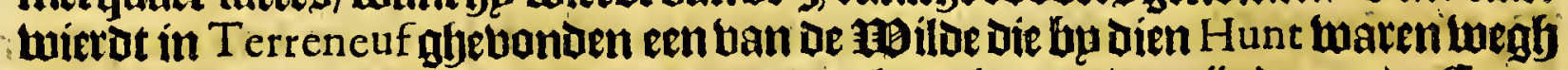
gevoert met namen Tafquantum, waer ban kennig gegeben jünoe aen de Com: pagnic bp Capitepn Darmer, met vertoecli van bulp tot fpn boaz-nemen; fonot de tompagnie Dertmaerts Capitepn Rocraft; tan alloo Darmer Daer-en-tuffichen goet gewanden badt foffa naer 廷ngelandt tekomen/ Rocraft Daer aen-komende/ ende bem niet binoenoe / was han fpn fteck; nam een J franlebe bercke die daet

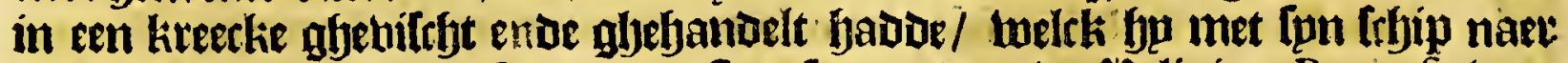
Ezenglyelanot lonot / melende eren freant-man ban de Jieligie; Rocrafe boet boot met de bercke / ende dooz canlpiratie banfpn holck loag bp naet om bals/

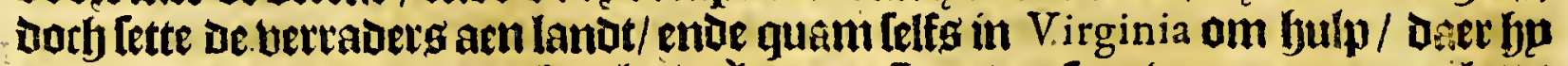

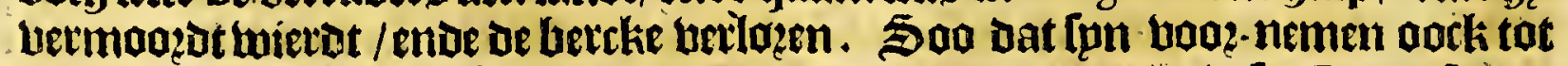

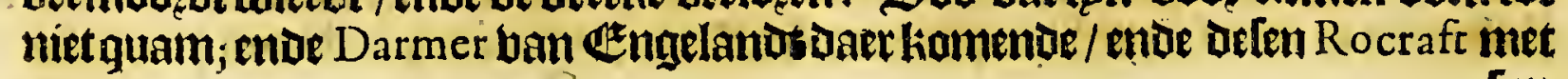


Het derde Boeck.

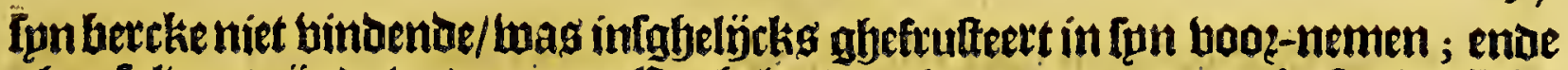

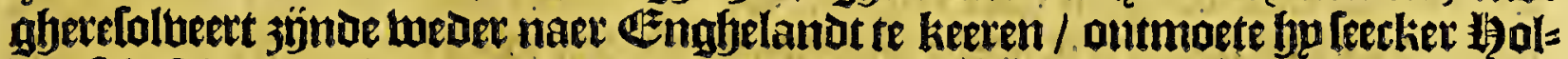

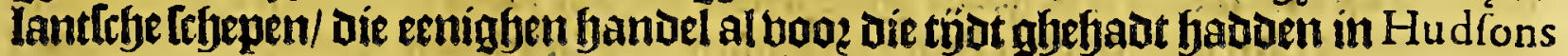

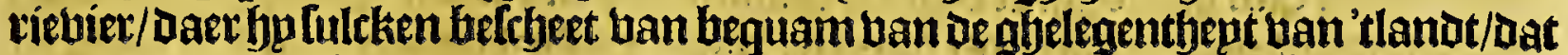

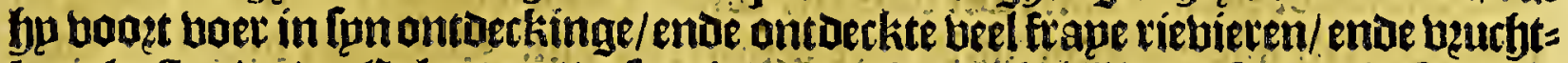

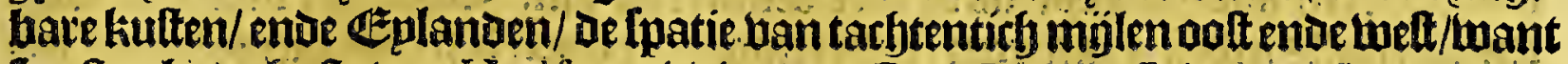
too ltreckt de kufte ban Hudfens riebiere tot Cape Iames. Hier op toiert goet ge=

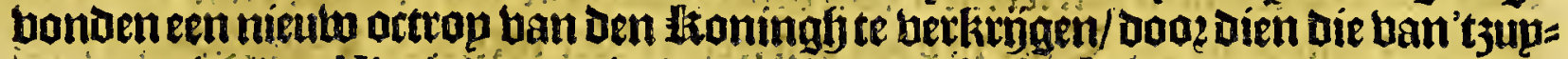
berquattier ban Virginia een nientw octrop reede fadoe bekomen/ende yaer lími= ten foo uertekert/ dat de defe gljenoegflaem upt-ghethaten/ ende berlaten twaren.

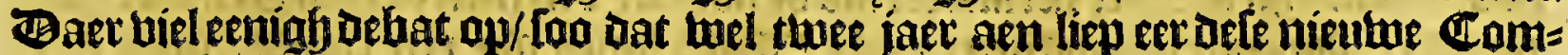

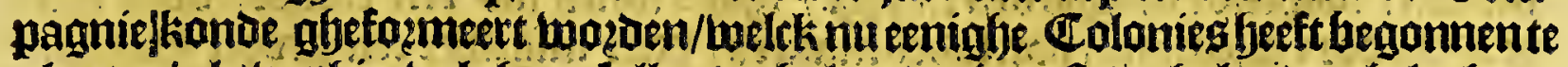

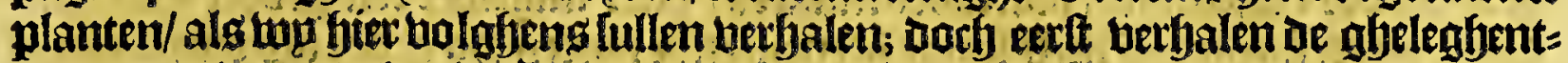

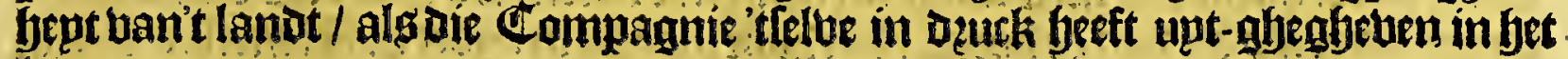
Jaer 1622.

\section{Het büfoe Capittel.}

\section{Ghelegentheyt van NEVV. ENGE I AND (als het nu vvort genomen) uyther relaes van die Compagnie.}

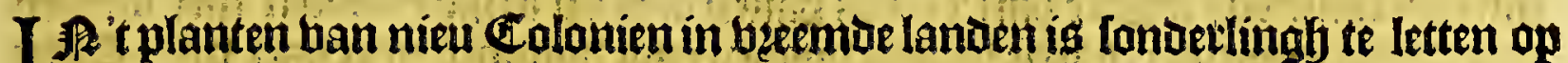

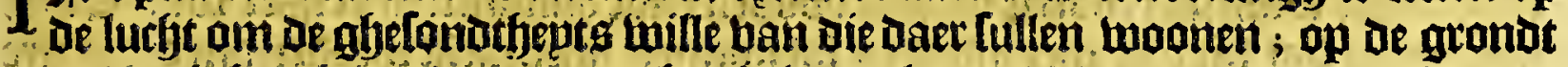

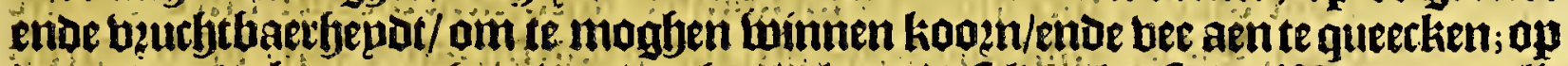

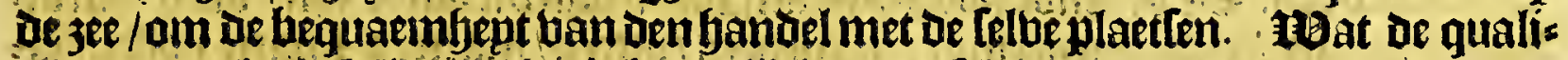
tept ban de Jucht belangt / get ig lkennelíck dat de felloe boazt kant afte upt ae ges netaele difpolitie ban't Climaet/ofte han oe particuliere gheleghenttlepat ban de plaetle. Haat fet Climaet belanght/ bit lanot ig niet alleen gbelegen inde getemis

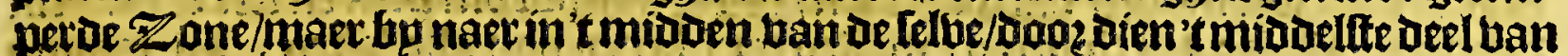

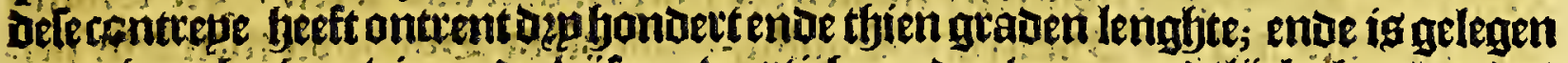

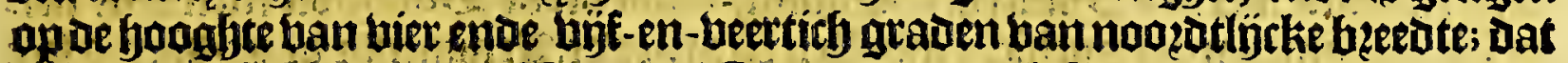
is twintict graden ban oe. Tropicus Cancri, ende oork to beel ban Circulo Arcti-

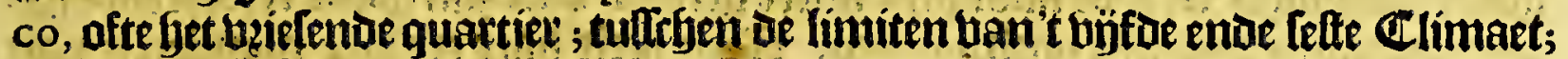
Daer 1 eanckinck ende I talien mede ander legaben. Hat de conttitutie van de plaetfe belanght (welrkis bp de twee-en-teftich graden bp jee uan ong batte landt

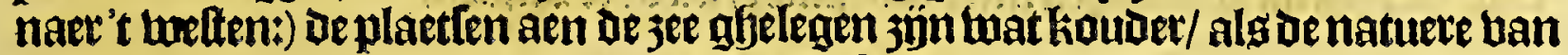
'telimaet anders mede beengt; Dooz oren oe thalen ban de lonne berflapt wozoen/ eenfoeds Dooz de ongheftadigye belweginge van de 3 ee/ als mede doo de menich=

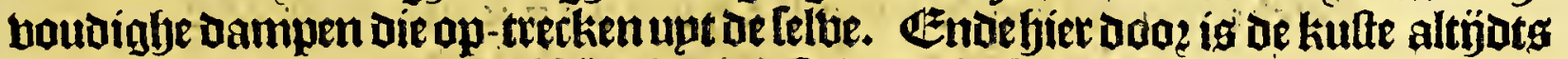

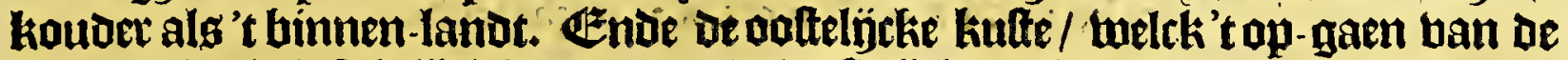

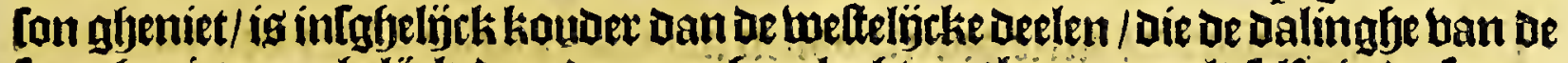
Con gftenieten; abelíck dan oe motghen-luctiten (bo exempel) felfs in de fomer

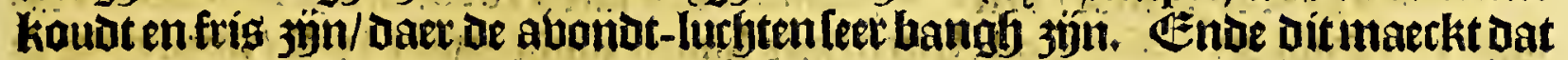
befe quattieren beel beter obereen komen met de natuere tom ong bolck/ oie geen contentementen binden in kauder lueften/noch gberontbept in heeter. Soo dat Dit climaet/ welek lo getempert is / [eer bequaem mot betonton boo anle natien.

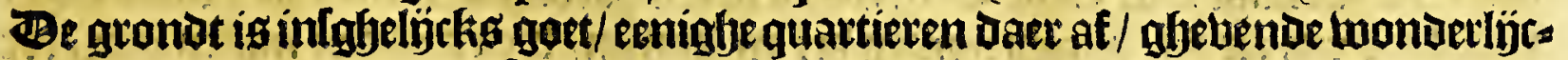

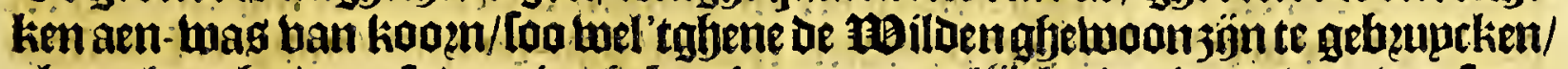

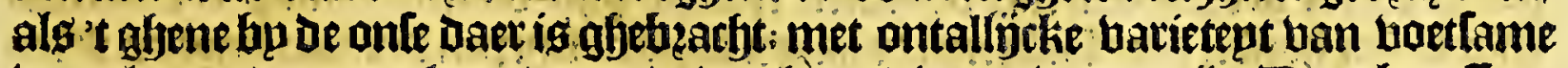

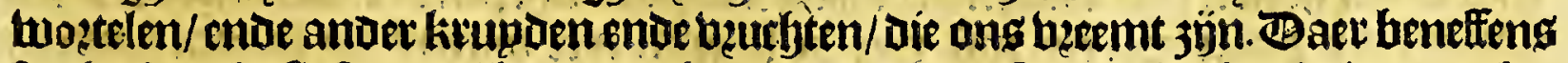
[oo heeft de kulte [eet beel bequame baueng / bol ban [ondetlingfe Ezplanden/be= quaem an tuolck op teplanten; betbult ban alderbanoe boumen/alsepcken/ $\mathfrak{t e}=$ Deen/bueten/pïn-Loomen/wal-noten/caltanien/Saffafras, peupm-boomen/Calamus Aromaticus, \&c. Het bolek ídtrartabel (fomenle niet en abuleert) ommet te ban= 


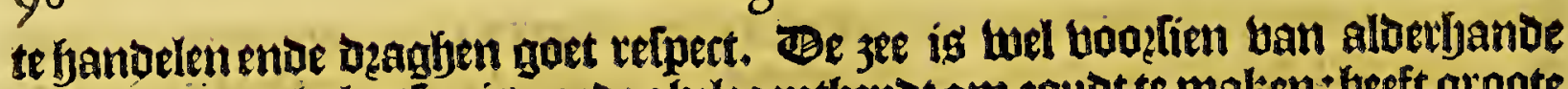
bilch/en op beel plaetlen is gatod gbelegentbept om joubt te maken: beeft groote abonoantic ban gheboghelte binmen' handts / alg calcoenen / patröfen / fwanen/

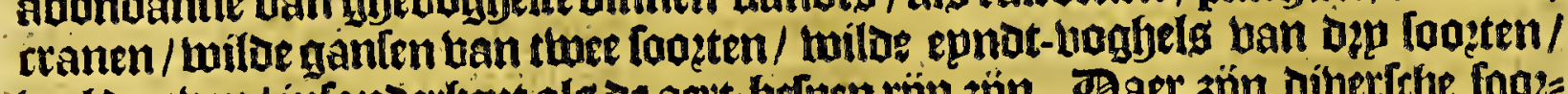
ueel Dupuen/ infonderfept als de aett-belpen rijp jion. Baer jön dibertebe foo:=

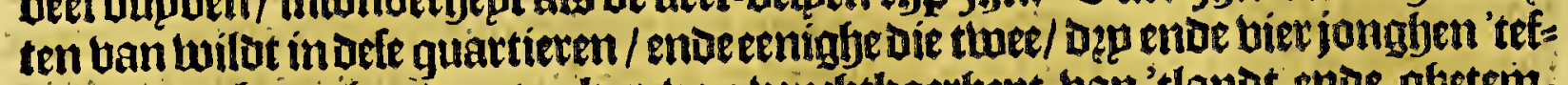
fens boozt-benghen/ een teecken ban bęuthtbaerbept ban'tlanot ende ghetempertfept van be lucht. Baer is oork een leecker diet welck de in-ghebooene noe men Moffe, is loo groot ban ligfals een as/'tbooft als een bock met een buetoe booen/welch bp alle jaet betandert ald be bocken/Den neck als en hett/met kote manen / loopende langbs ben rugibe / thape lanth als een elanot / ooch beter

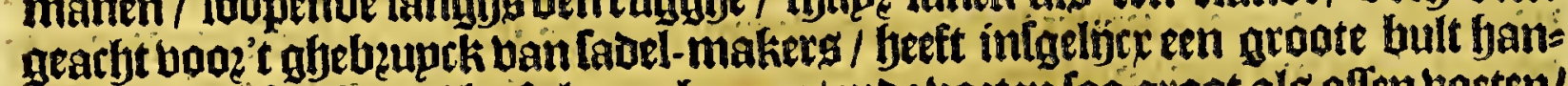
genve ondertunftroot/ hesft lange beenen/ende boeten loo groot als oflen toeten/

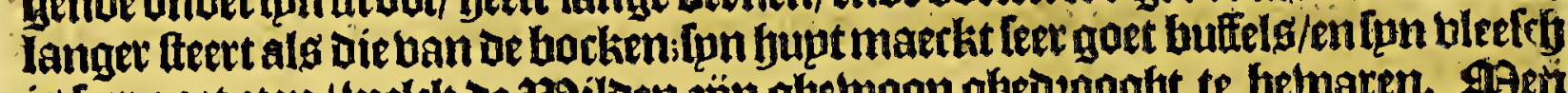

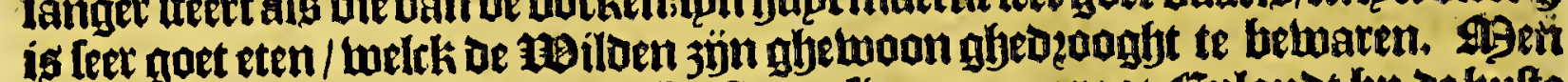
heeft een grootemenichte ban dele beeften gelien op een groot Eplandt bp be kulte

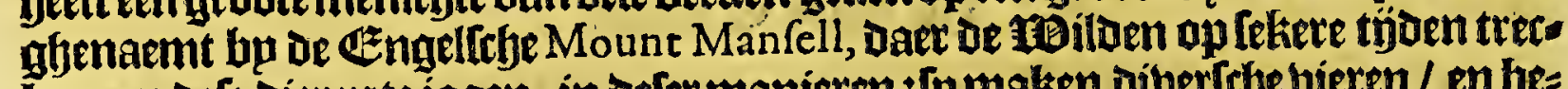
ken om dele dietente janen; in deter manieren: [n maken Diberiche bieren/en be=

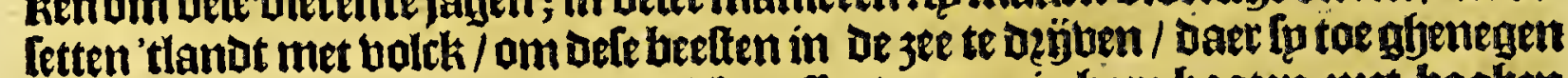
jün ban naturen / andere uan 't wolck paften daer op inf jare booten met bogben ente ander wapenen / daerle diemet dooden ende vanghen naer faer wil. 'C is te gheloouen dat dit diet met inoultrie Lal konnen ghebzarbt twozoen om dzoinaite

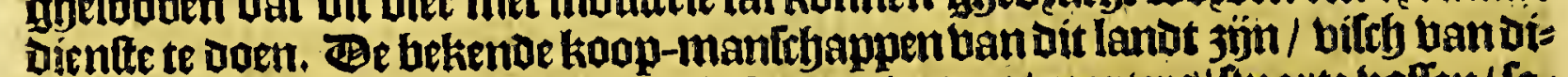

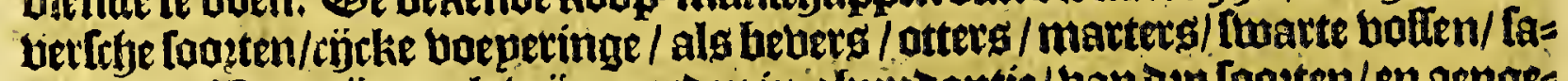

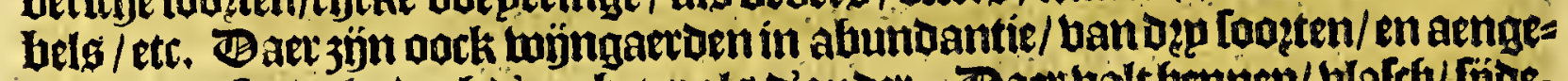

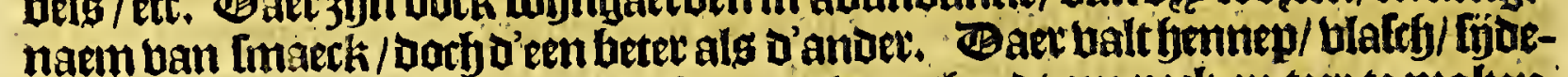

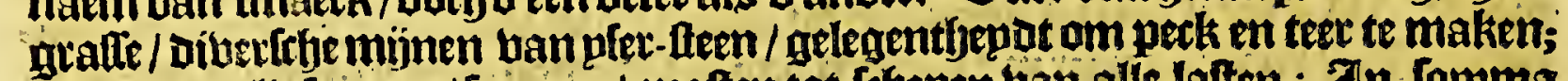
Delen uan alle loogten / fparten / maften tot fryepen ban alle latten; In fomma

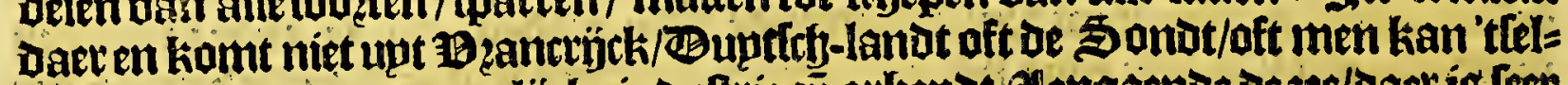

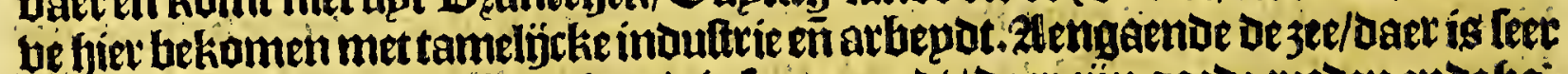

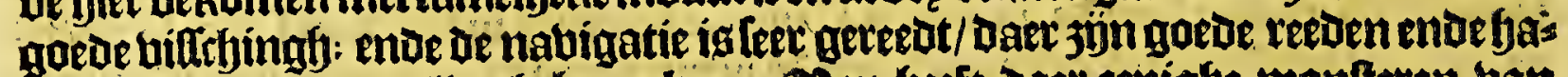

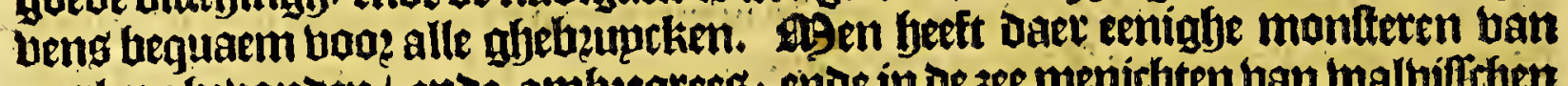

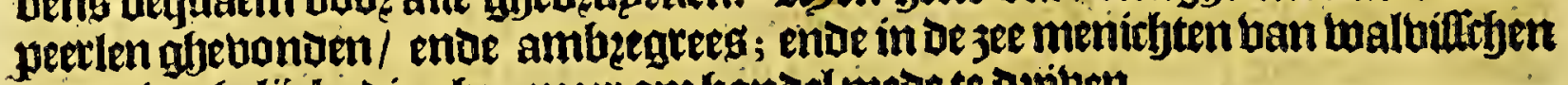

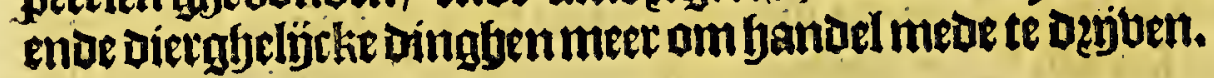

Het lefte Capittel;

$$
\begin{aligned}
& \text { Befchrijvinghe van N IE W-P L E Y MOU T H een ftadr ofre } \\
& \text { vlecke in NEW-ENG A N D gheleghen. }
\end{aligned}
$$

T'Bolck gedeltineett omte gaen moonen in New-England ftyepon tran Pley: 1 mouth in Uingelandt / Den 6 Seprember Des jaers 1620 . Den 9 November la:

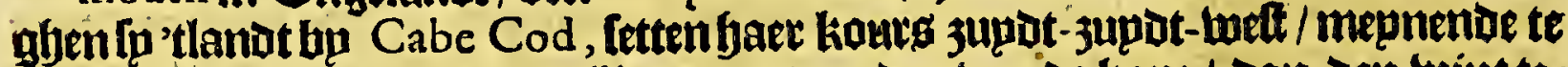
barennaer een riebiet thien mïlennaer't jupden ban de kape / dan den twint tes ghen krïgende waren genootlaeckt weder te keeren/endequamen den elfien aen antkel in de bape wan Cabe Cod, welck is een goede fauen ende plaplante hapel ronot als een rirkel / uptahenomen bet in-komen / welck is bier mỉlen mp̈t / tot aende zee toe al betwallenmet boomen/epcken/pön-boamen/iuniper/ fallafragl

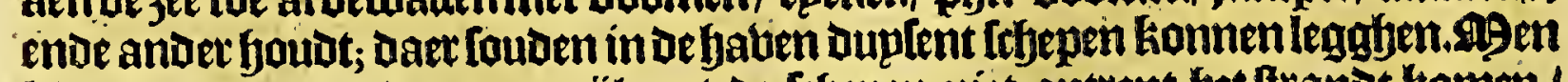
lian op dep quart van een mỉl met de lcbepen niet ontrent het ftrandt komen/

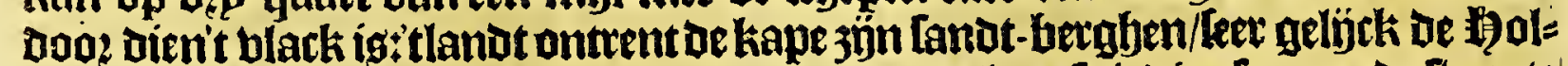

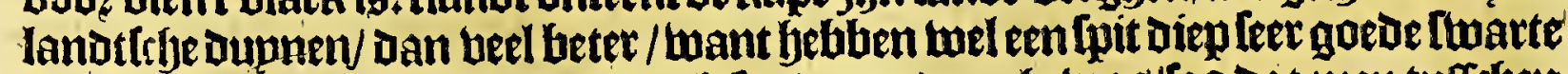
aerde/al met boomen begtoept/boch Londer onoer-ghetwas/[oo dat mentufretyen

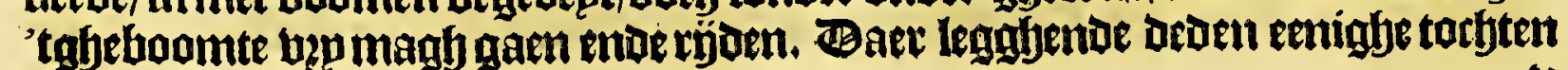


te lande / om een bequame toon-plactle unt te Toecken / tonoen entahe bupten/ Doch fonder bolck ende oockernigh fozen ban of lande inde gronde fegraben in

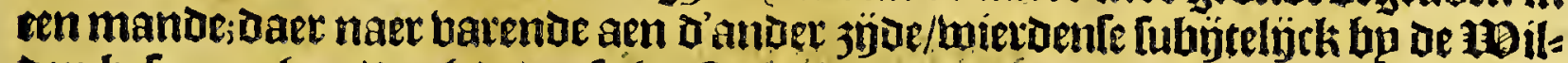
Den be[pzonghen/ doef Dedenfe baele bluthten. Bonden daet naer een ander ha: ben welt-twaert ban Cape Cod, daet Ip naev toe zeplaen den 16 December. Dele baben is een bape grooter als die uan Cabe Cod, omringft ban feliet fraep lanot ende binnen de bape twee fraepe eplanden oubetwoont / paer niet op is als boas

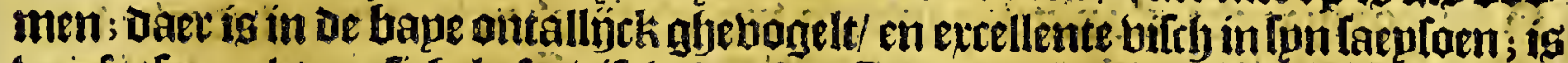

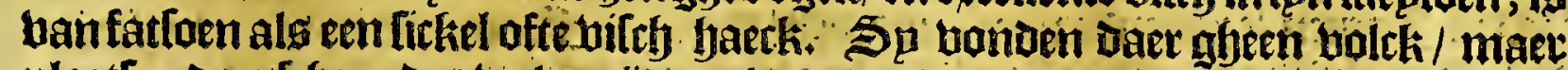

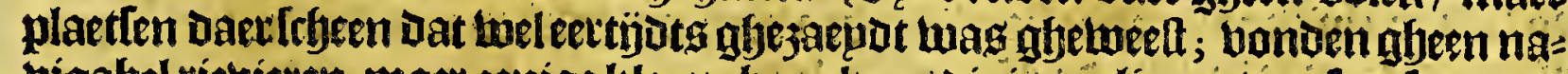
vigabel riebieren; maer eenige klepne beertiens bie in 3 ee liepen van feer loet ente

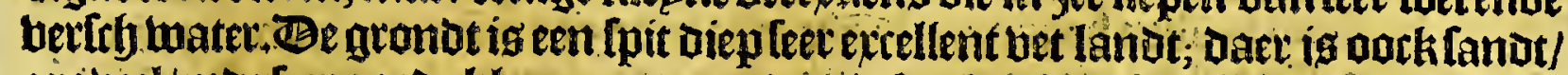
grabeel/entue feet goede klep om patten ban te backentende Daer is fraep geboomte/ende beeloetlep krupden als bozen inghenete is berbaelt. Jn Dit quartiet aen't balte lanot ig gelegft Nieuvv. Pleynouth, opeen boagle aronot/Daer beel lanots

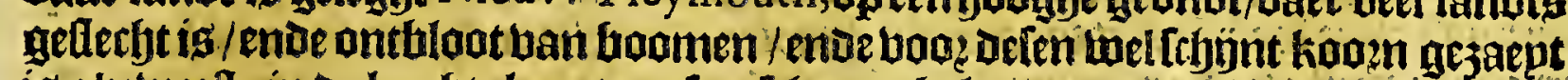

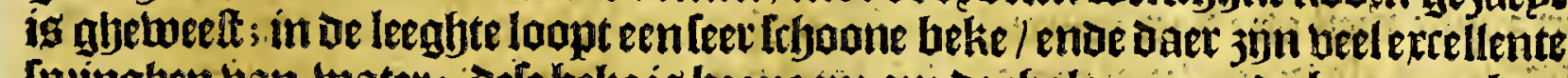
Ipeingben ban twater; Dele heke is bequaem on oe chaloupen ende booten te bet:

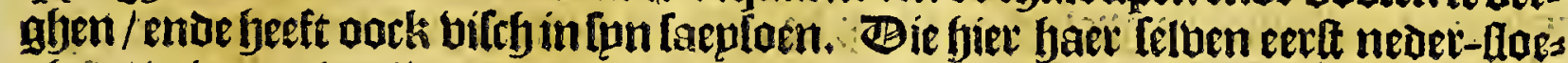
ghen / wietien in alleg ghereduceet tot negentjien familien/ deeen-loopighe gjes fellen baer tot d'een ofte d'ander boeghende; maetkten thee rỉen ban bup fen om

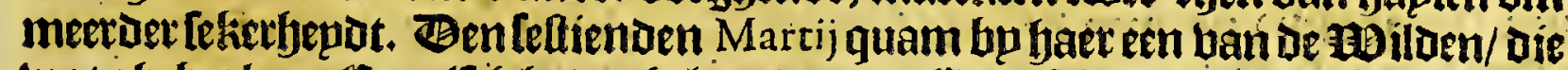

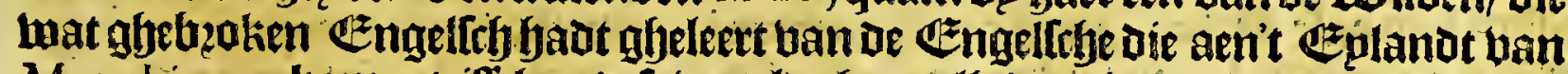
Monehiggon komen vifithen; dele verteloe baer alle de gelegentyepdot ban't landt) enje dat de plaetfe daer fubet begiepen baboen gbenaemt was Patuxet, ende dat antrent vier jaren gheleden alle de intwoonwers baren geltoęen bai een extrao:=

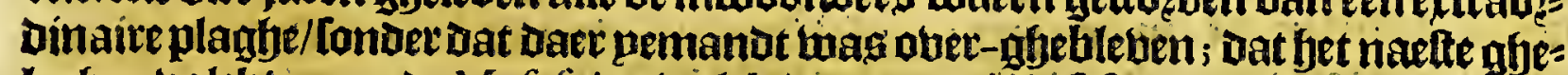
leghen volck haren de Mafafoits, welck wareneenighe Tefticlyman fterck; ie Naufites zön mede naer't jupot-paften ban baet/ ende jandert man fterck/ Dit ualck igs

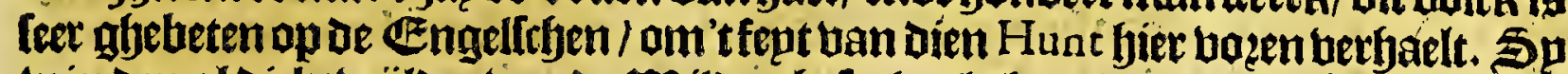

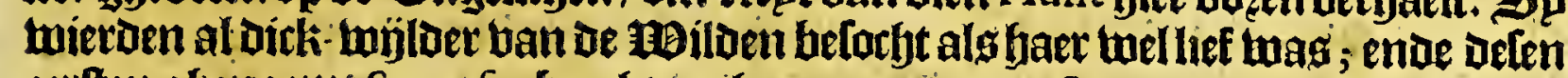
eerten gfenaemt Samofet bzach nodyeen met namen Squanto, oft Tifquantum,

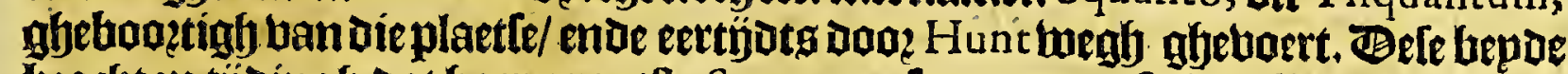
bzachten tijoingh dat faer grootle Sagamos (Joo noemen fu haer (yetren) Mafa-

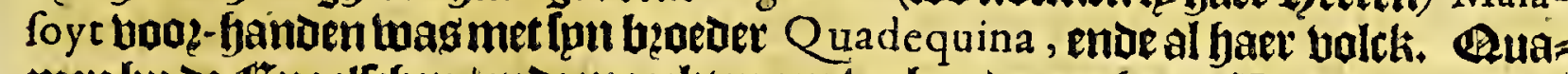
men bp de $\mathbb{E}$ ngelthen/enoe maeckten een berbond met faer. Baer naer is defe tolonie noch aen-ghelwallenmet nieutw toe-boer ban bolck. enve naer oe fieden

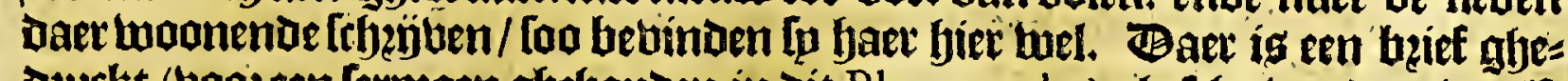
Deuckt (boazen lermaen ghelyouden in oit Pleymouth :) ghefryeeten Den twaelfs oen December I 62 I upt befe plaetle; als mede een bethael ban dagh tot dagh wan't gheene ghepaltert is in't begin ende boatt-gancts ban Defe colonie / welck

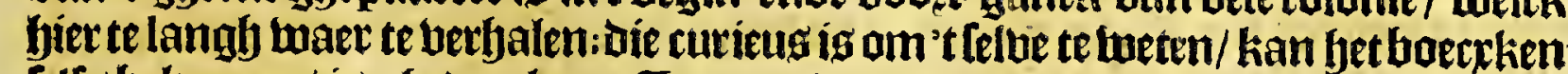
Lelfs betamen/is gheduckt tot Londen in'tjaet I 622 gheintituleert; A Relation or lournall of the beginning and proceeding of the Englifch Plantation Setled at Plimouth in Neuw-England, \&c. Mophebuen oock eenighe beieuenghelien ban

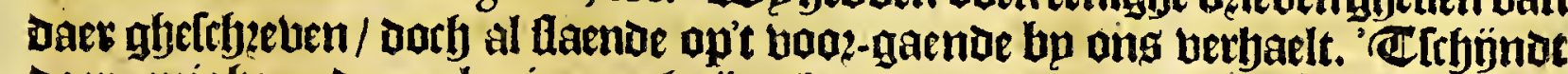
daer eenighe andere colonien noch jijn gheplant / Dan doo dien twi daet gheen particuliere kennis banen bebben / foo fullen lup bet hier bp laten.

NIE U W. 
Het rebende Capittel.

Eerfte ontdeckinghe ende ghenerale befchrijvinghe van't quartier welck by de onfe NIEU W-NEDER I A N D T wordt ghenoemt:-

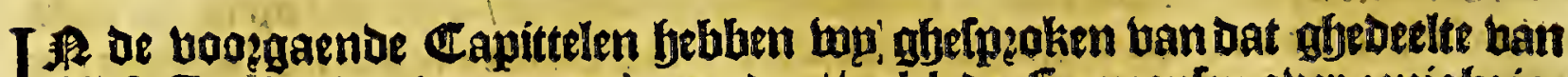

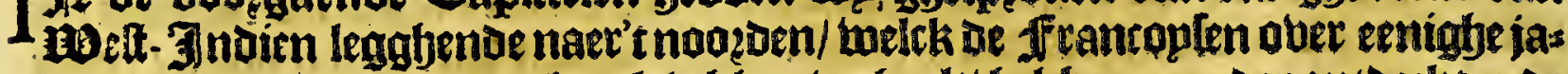

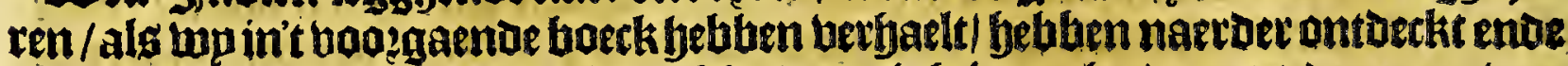
onderfocht; ende welcke of Engellebe wepnigh jaren betwaerts de naem ban Neuvv-England jeblen begonten te gbeven: enoe zön alfoo gbekomen tot Cap. Cod, als de ez ngellfhe die noemen; ende in't veozgaende boect tot Cap Malebarre, ende Porr foreuné, volgeng de antideckingbe ban de firancoplen: Ban

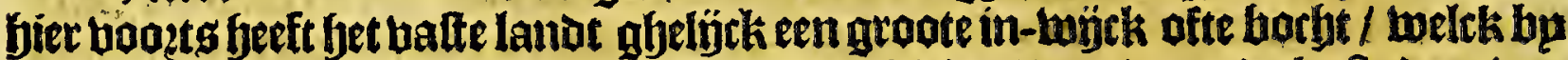
naet oolf enoe twe fiteckt tot aen een groote rietiere/ ban maer oe kufte dan toes Der zup ot weff ofte daet ontrent ftreckt tot bet epnoe ban Florida toe: Dele kufte Aterkenoe als boen / met eenighe Eplanden ende thee feet groote riebieren/ han

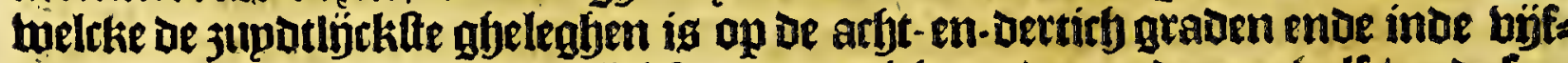
tich minuten/ ende de noozoelïckite op veertich graden ende een ljalf / ende feet

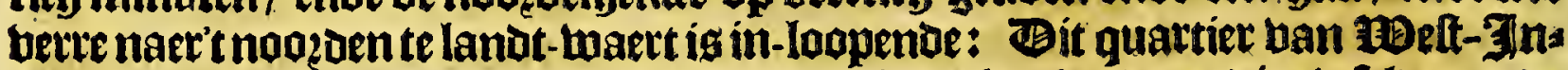
Dien (feggbe ick) noemen de onfe Nieuvv-Nederlande, Doog dien't felbe ap de

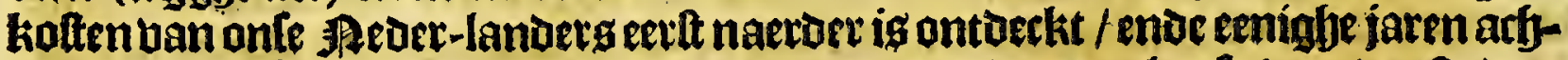
ter den anoeten bevaren / ende meteen fortjen ende woon-plaetfe ban de Reder-

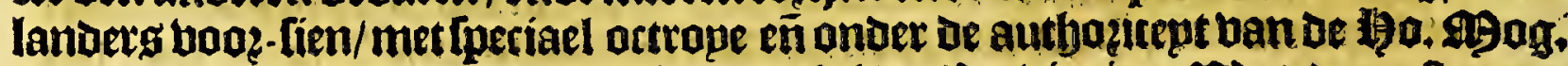

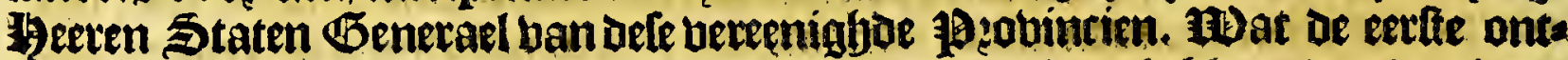
Deckingbe belanabt / in aen jare 1609 fonden de 25 eluindt-bebbers ban de gyeacs

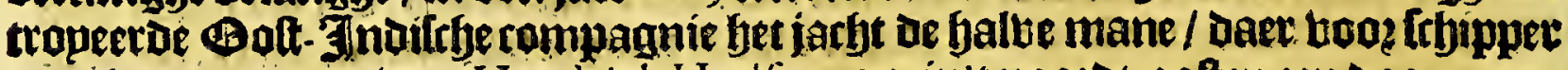
enoekoop man op boer Hendrick Hudfon, omin't noozot-anlten een booz-ganc naer China te [oeckenidanifo beranoerden ban kourg/ endeftaken aber naer Nova Francia, ende de banck ban Terreneuf ghepafleett bebbende op de 43 graden

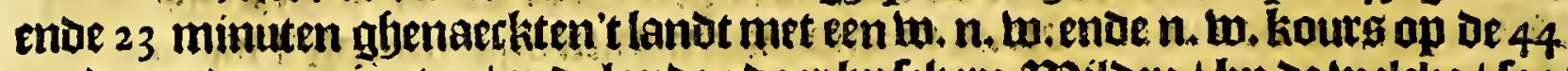

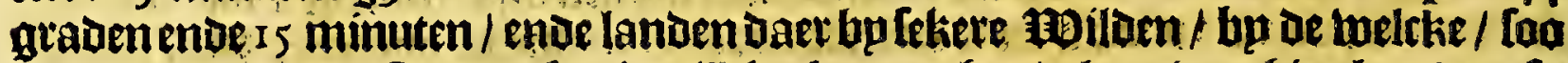

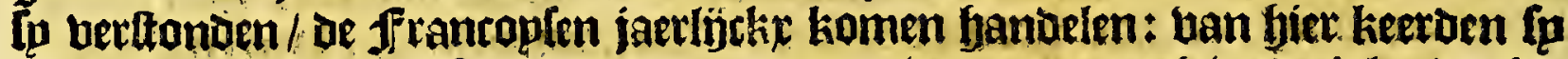

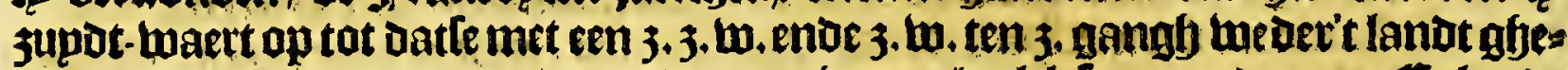
waer bieraen op de 4 I graben enoe 43 minuten/wetek fp mepnoen een Eplande te welen/ende gabent Den naem van Nieuvv. Hollandr, Dan betonden Daer naex bat fet Cap Cod wag/enoe bat het naer haer belteck toel büf-en-[ebenticy/mülen weltelijcker legbt als in alle kaerten gbeltelt wozot. Ban bier berbielen fp tos

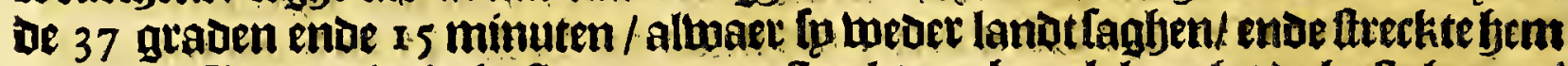

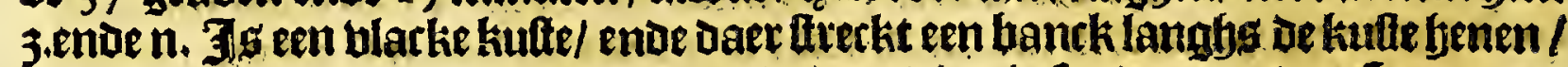
waer binnen bet $8,9,10,11.7$ ende $6 \frac{1}{2}$ badem dien is tandt-gronot: $5 p$ noeme ben defe platfe de drooghe Caep. Baer naer noped twaert aen loopende/ghes naetkten 'p hedoer' tandt op acht-en-bertich graden en neghen minuten/enoe was een wit lanot-Aranot/ende binnen bolgroene boamen/artetkte daet n.n.o. ende 3.3.w. onttent afbt mijlen/ende danj, enden. feben mülen/ente bodet $; .0$. enoen. w. byjf mülen: jeploen al langhs oe wal noozoen aen / tot dat fo aen een

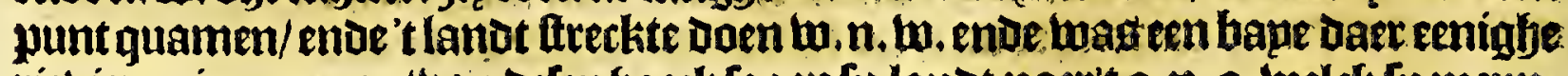

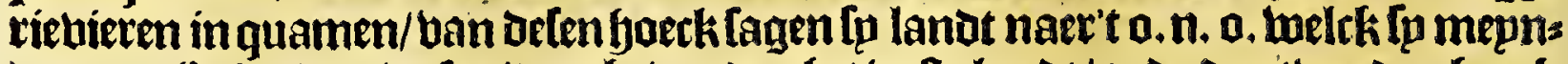

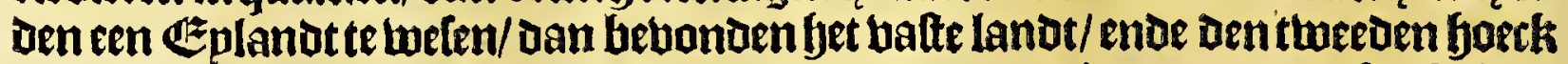
ban die bape / op oe boodjte ban 38 graden ende 54 minuten:ende alfoo fp haec kours n. w.tenn. aen fteloen/ bonoen fp faer felben in een bape berleplt/ ende ghemarten beel barninglen / foo dat [g 3,3,0. weder upt-ftonden: [p bermoeden

Datter 


$$
\text { Het derde Boeck. }
$$

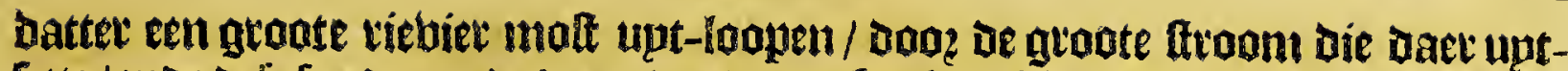

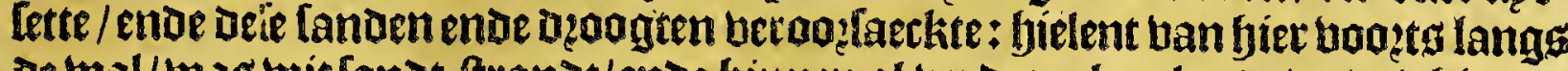
De wal/wag wit fandt-ftrandt/ende binnen al berdentken lanot/ende't binnen

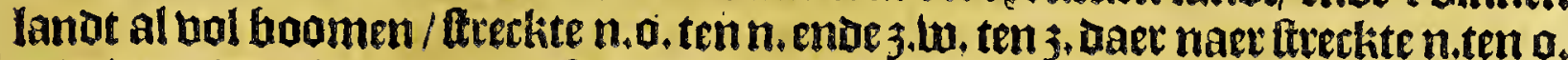
ende was boogfer lanot alg (p noch gbefien hadoen/tot aen eenen fooghen fjoech/ achter de welcke een bape leght / altwaer [p op de reeden liepen/ atbter een lceghen landt-baeck / op de beetticl graden enue acfethien minuten; daer quamen thee

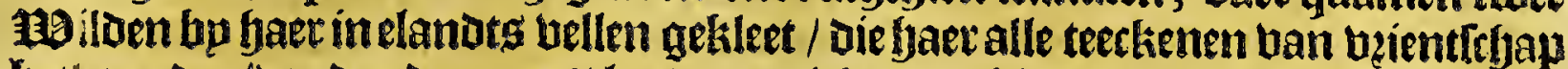

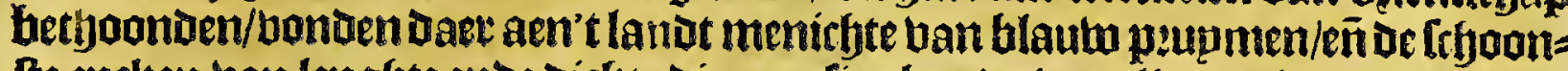
Ite epcken ban lenglte enoe dickte diemen fientionoe / poplieren / lonen / enoe als

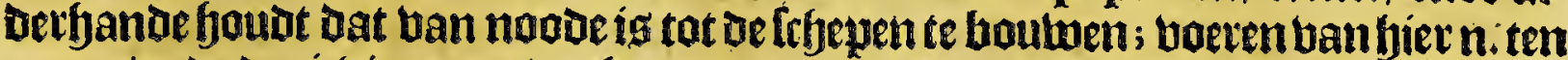
o. aen/ende de riebieten op/tot bp de 43 graden bp noozoen de linie/ altwaer de rie -

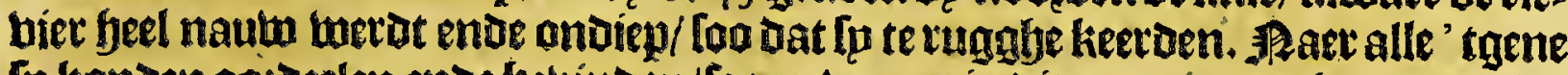
Ip konden oo:deelen ende bebinden/[os en toaten in oit quartice noth nopt eenine

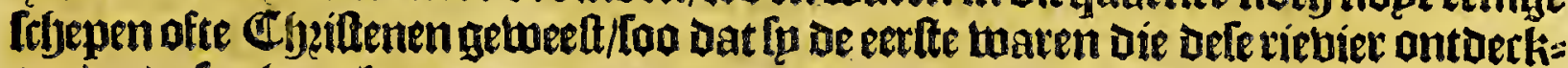

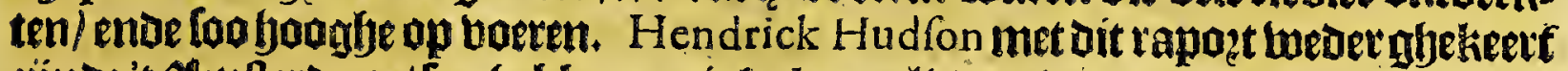

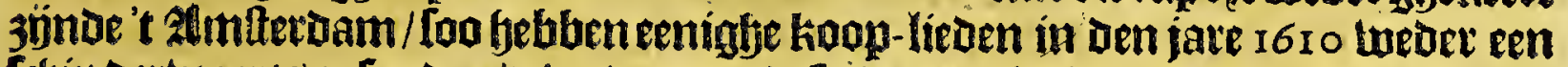
fchip berbaerts gefonoen/te tweten naer dele tweede riebier/ae belcke fo oen naem gaben ban Manhattes; naet de natm ban de foilden die aen 't begin ban aefe rie=

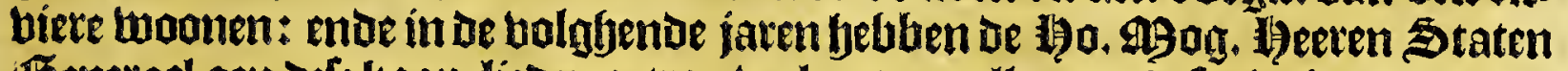
Benerael aen ofle foop-liesen octrop betleent om alleen op befe rieviere te Inogen

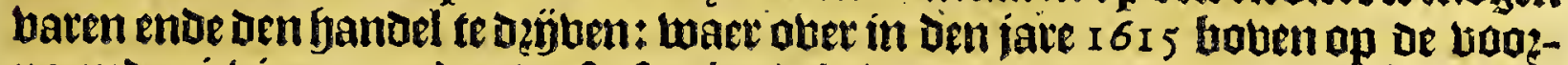
noembe riebiete een reboute ofte foxtien bierd geleght met een kilepn befettinghe/

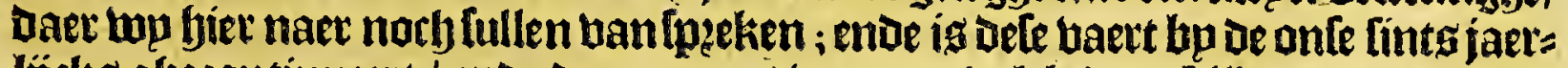
lýcks gbecontinueert / enoe boge-naens ban ong bolkk Daer blyben leggben om

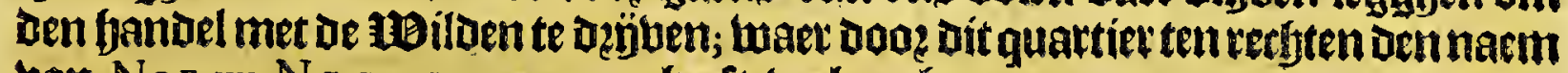
ban NIE W-NE D E R I A N D T beff berkitegben.

\section{Het achote Capittel.}

Gheleghentheydt van de kufte van N I E V V-N E D E R I A N D I, van de PYE B Y E aftot aen de groote rieviere DE MONTA I NES.

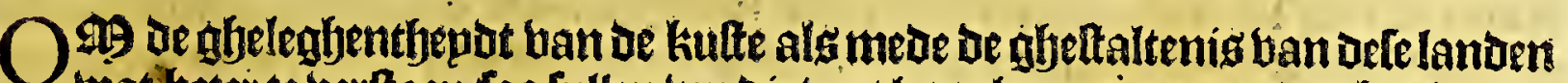
wat beter te bet:taen/foo fullen top die wat hoogher naet' tnoozenen beginnen/

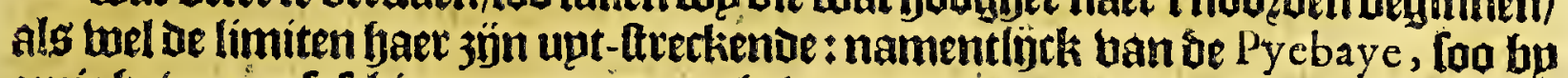
eenigbe wan onfe frbippers genoemt; ghelegen op de booghte ban twee-en- veertich gladen entae dertich minuten, ban be weleke (naer of bebindinge ende belteck ban

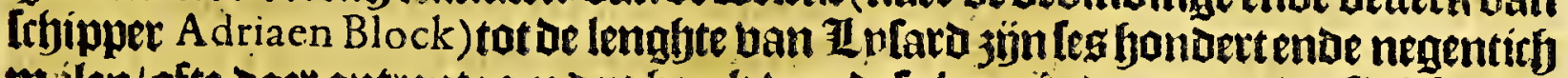
mjlen/ofte daet ontrent: om jen boeck tan dele bape ig de grandit waliggland:

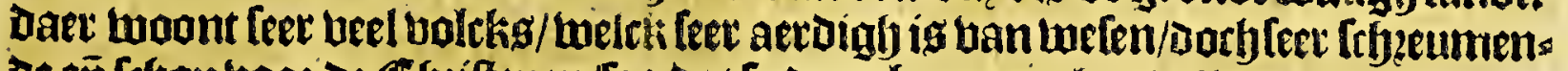

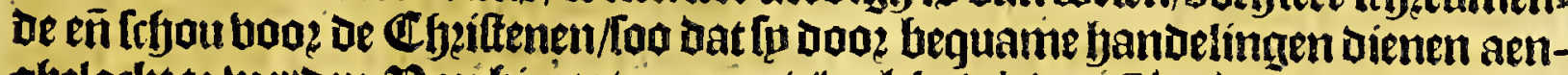
gbelorkt te werden. Ban bier tot eenpunt (welck Adriaen Block voo -naemt/Den naem freft ghegheben wan kaep Bevechier, Dooz dienfe foo goevegeibckenis heeft met Bevechier, welende klebiab landt/ende niet leet hoong) imersouer de Wyckbay (een ander bape bu de onfe foo ghenoemt/ oe twelcke juptot-oplt op ftrecke) jün

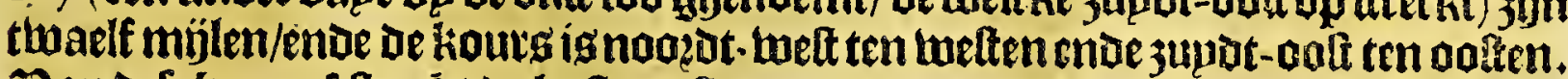

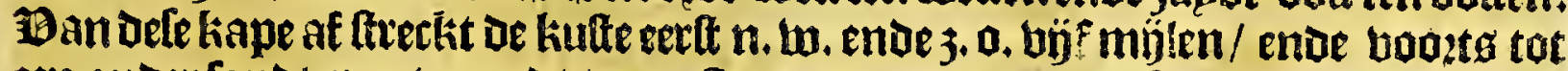
een ander fanot punt noozot ten oolten ende jupot ten wellen fes múlen: Ban waer tot liape Malebarre jän neghen mijlen/ ende de Ateckinglye is n. o. ten n. ente 3. w. ten 3. Tefe kape woest by de onfe oock afienoemt de Black-

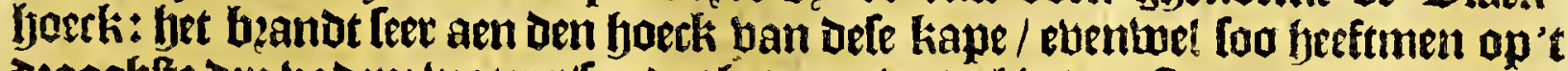

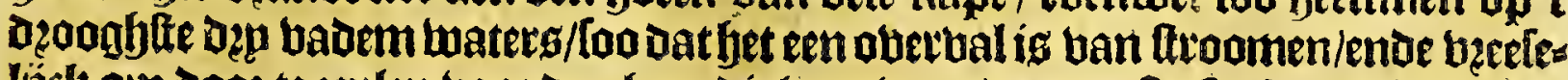

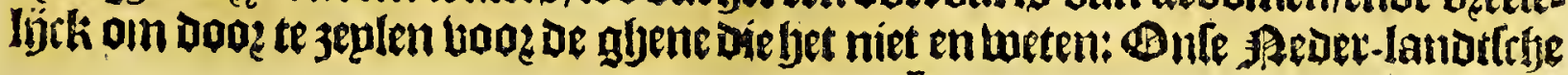




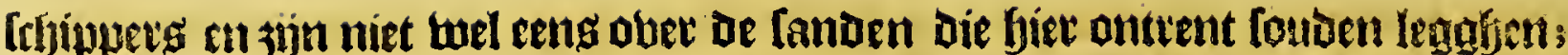

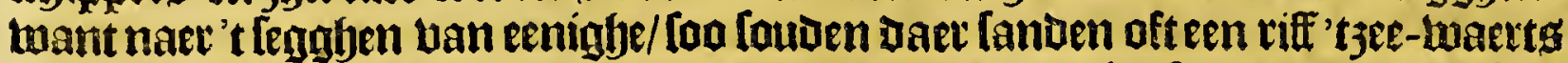

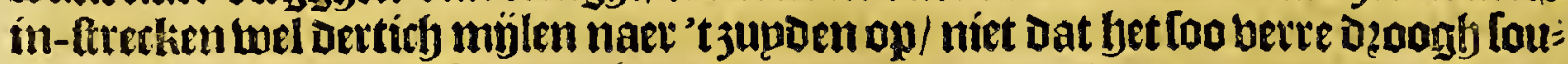

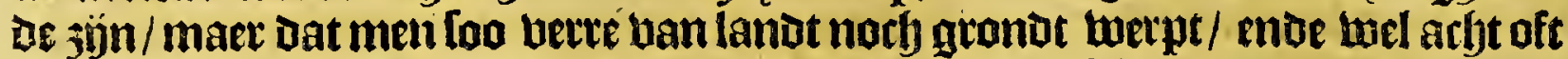

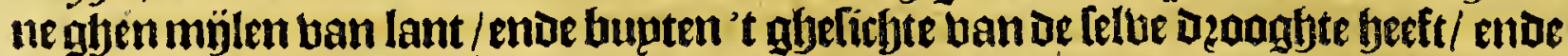
ferr oneffen gront / foo Dat men lomwölen Dertich badem beeft met d'een werp/

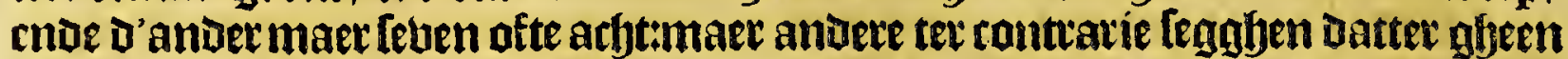
Canden ofte riff by zupden iele kape loo betre in $3 e e$ en leght / maer wel oalt- waert ban De hape ofte Port de Malebarre; wp fullen Dit Dode naerder bevindinglye on=

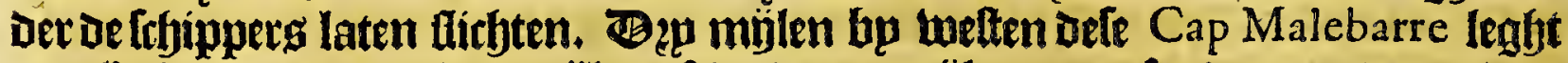
een Eplandt antrent twee mílen at / enoe een mỉle groot ofte Daer ontrent ; dan als men Daer that verte af is/ foube men mepnen bat bet gheen Gpland en wael; moz ot bp eenighe / foo ick gille / Petockenock gfjenaemt; de ftrectkingbe ban't ba=

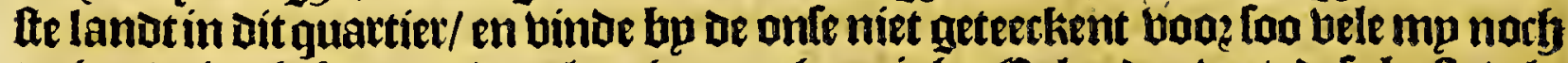
tex hanot is ghekamen; daer legghen nach eenighe Ezplanden vooz dele kutte/ alg

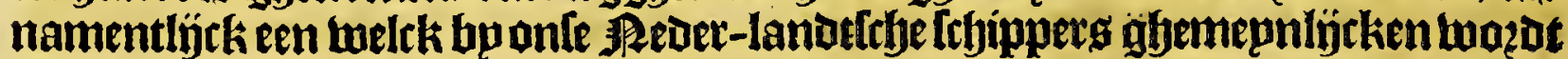
ghenaemt Texel, ende bp andere Cape Ack; dit is een groat Eplandt/ende Doet

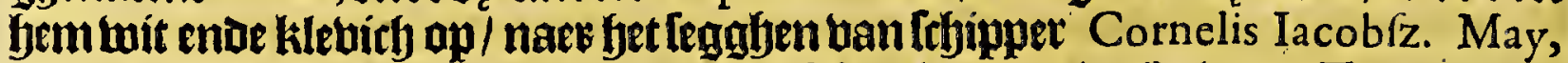
cnde ander-half mijle van aen 3updt-tweft baeck ban Dit Eplandt Texel, leght een ander Geplanoeken welck bp de anle wozot ghenoemt Hendrick Chri-

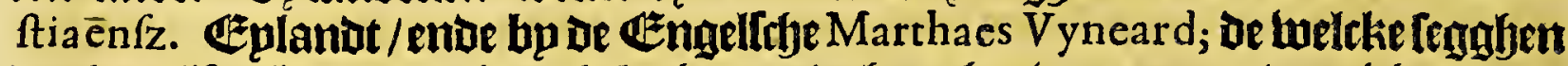
Dat bet bỷf múlen groat ig ; gheleghen op de hooghte wan een-en-beertich graden

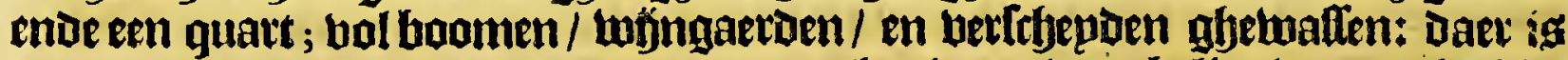
menighte ban ghe bogelte op; ende daerom her is gaede rabeljaulw bangh: biet:

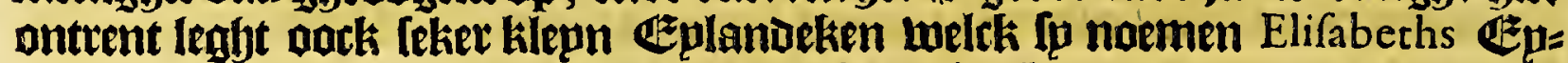
landt/ welck men kamende ban ise tiebiete afte bape ban Naflouwen aen ftierboozot abemaedt; enoc am hupten Hendrick Chriftiaenfz. Utalantat am te loopen / maet oe kours jupdt-antt wet den ghefjouden. Bartholomeus Gofnol

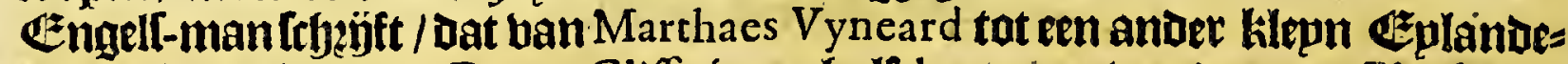
ken bp bem ghenaemt Dover Cliffe ig een half legue, en van Daer tot Elifabeths

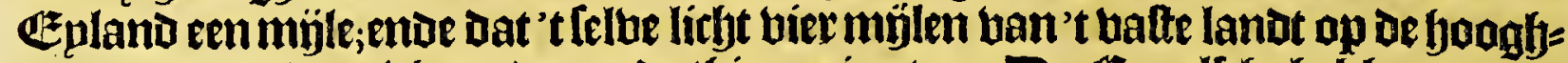
te han een-en-beertich graden ende thien minuten: De Ezngelfefe bebben op dit

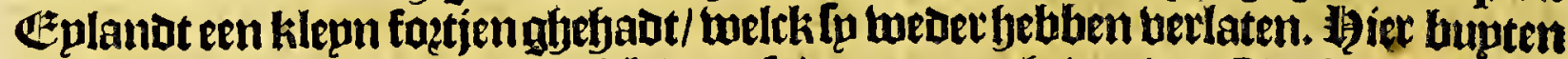
af leght mede een Geplanot welck de anle den naem abeben ban Blocks Ezplanot/

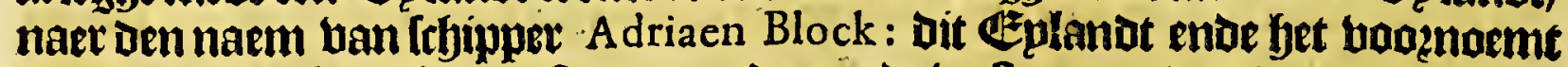
Eplandt Texel legghen anft ten noogden ende helt ten 3 upden van malkande=

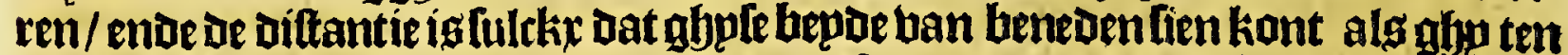

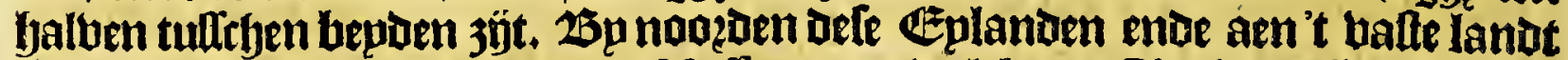

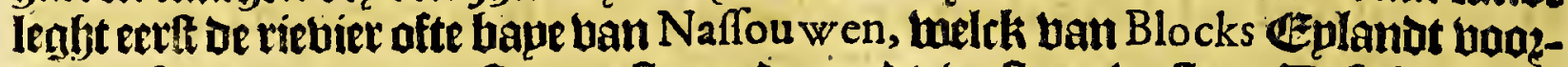

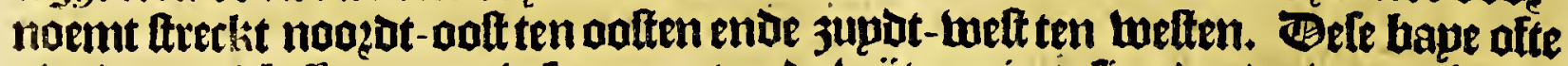
tiebiet ban Naffouw en, is leer gront ende twĭt am in te lien/ ende is naer't leg =

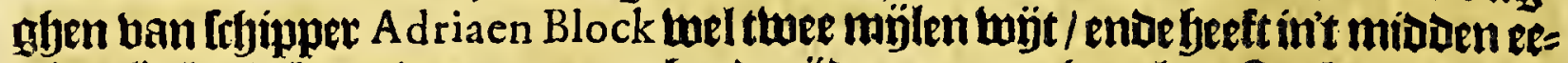

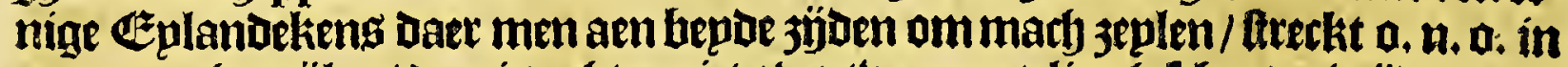
ontrent adyt mälen / Dan is adjter niet ober thee geutelingh feffeuten mijot / ende

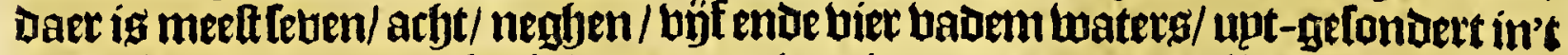
arbterte Daereendzoghte is taan negen boet watex/opeengeutelinch frheut na bu een Eplande

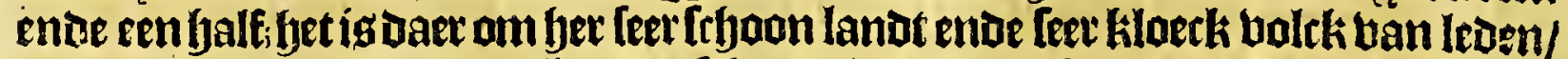

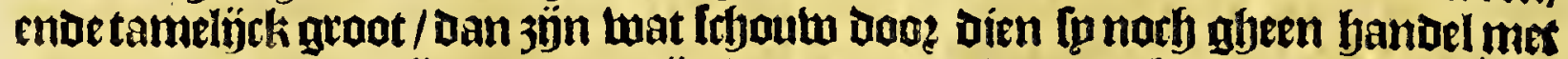

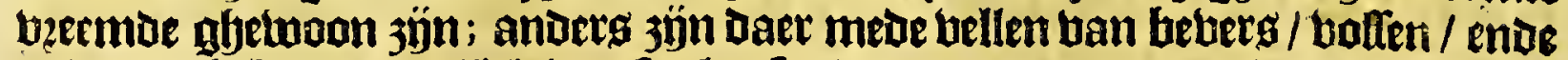

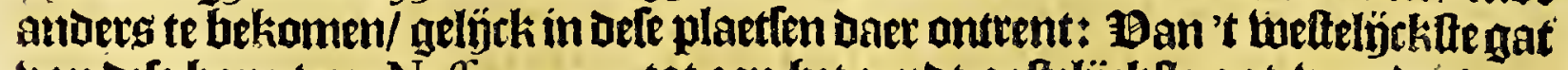
ban Dele bape ban Naflou wen, tot aen fet jupdt-poltelijcklte gat van be Anc-

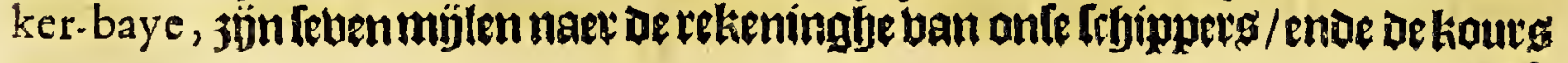


oglt ten jupten ende welt ten noogen: Dele bape beft by de onte thee naemen

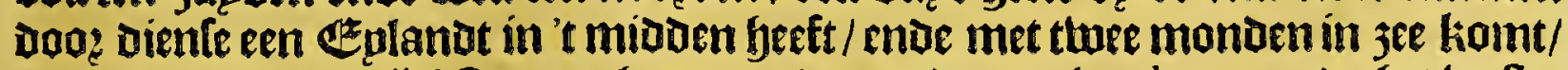
Luaer ban het ooltelïcklte gat gbenoemt woz̧ot oe Ancker-baye, enoe het weftelïcklte de Sloep-baye: De jupot-oaft-wal van dele hape aterkt bem n. a. ten $n$. ende n. n. o. inden bodem ban de haue woonen de Wapenocks een natie ban de Hilden alg de refte; Ithippet A driaen Block noemt bet bolck welck aen de weltjjoe ban dele bape twoont Nahicans, en faten Sagimos Nathat tou; enoe een ans

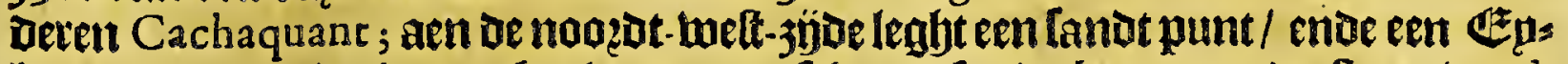
Iandeken n. tentw. in den bocht met een frfoone fanot bape; op oe fteert ban't

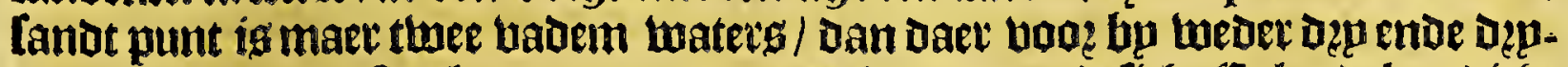

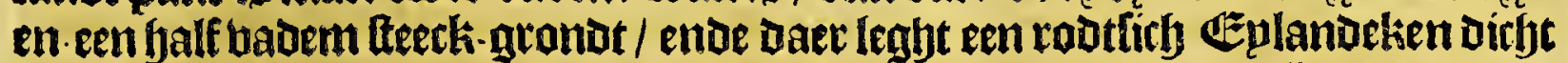
bp. Ban De Sloep-baye afte het tweltelỉcklte gat ban Defen in-wijck tot aen ae groote bape/jijn aclit mijlen; dele groote bape is ghelegen tuftegen fet balte landt/ ende feker ghehgoken landt ofte Geplanden die haer ftecken tot in oe bape luelck leght aen oe mont ban de groote riebiere: Tn Defe quote bape legghen bele ende berfchenden EEplanden Loo groot als klepn de welche gheen fondertingenamenen

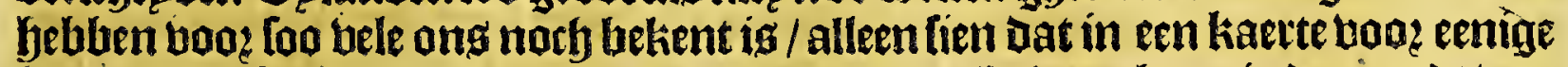

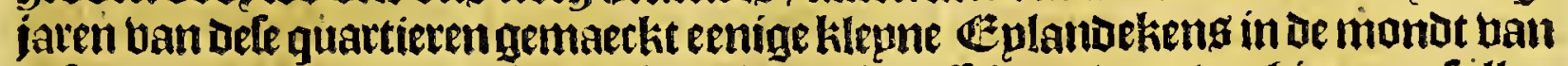
Defe aroote bape/liggende bp Den hoeck van de viffchers, Daet wu biet nare fullen

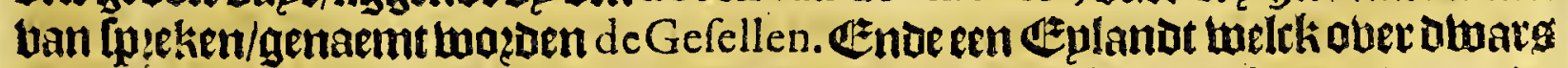
boog De bape leght/ 't lange Eylande, om 't welcke te mijoen men komende om de Viffchers.hoeck am naer' $\mathrm{t}$ Vriefch-rievierken te foopenmenn.tw.moet laten in-

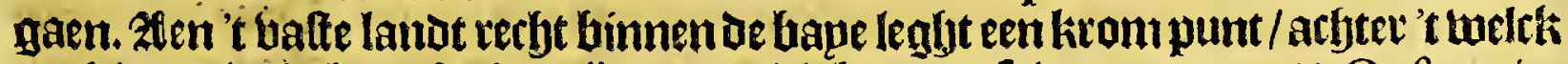

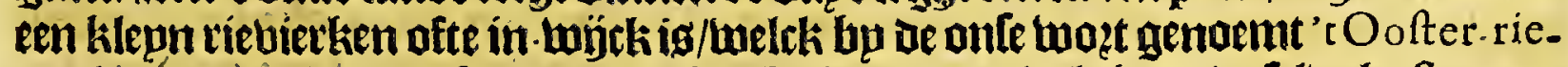

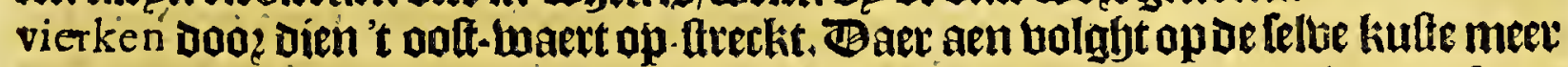
naer 'twefien een ander klepn rievier/me!ck bp de onfenaer de naem ban de Sagimos ofte Sacmos luetot geheten Rieviere van Siccanamos:Daeríg goede reede aclj= tex een lanot punt ontrent ken fyalf mỉl in/aen de twelt-wal op twee ende een falf badem luaters: De rievier ftreckt meeft noozot ten ooften op/ enoe is tot fommige plaetlen [eer ondiep/maet negen-Loet twatev/ende daet weynigh/ftroam/ende tot

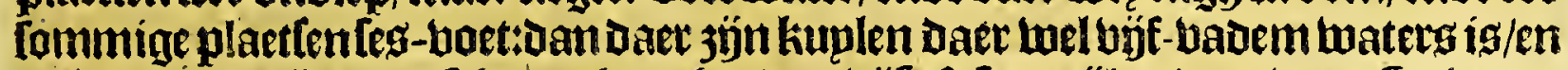

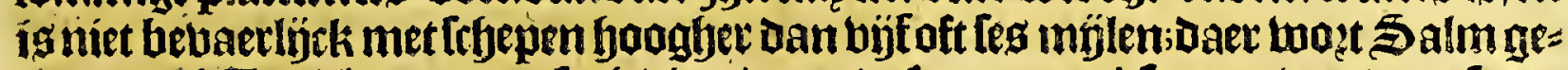
bangen: 'C bolck dat op defe riebieve moonot foude naer'tleggen ban de onté ge= noemt boezen Pequatoos, ende buanton jín uan de Wapanoos. Ban deferies

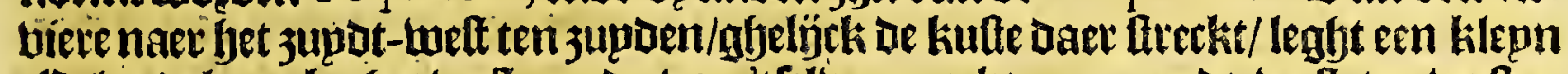

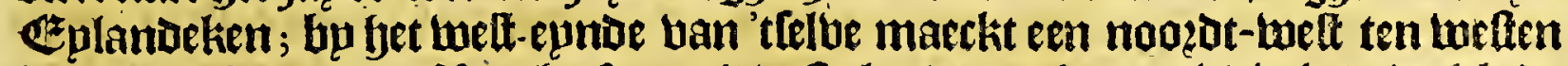
maen leegly-bater. MYen beeft aen 't balte lanot roed een riebierken welch de onle noemen' ' $t$ Vriefche-rievierken, al waet ooct eenighen handel valt met be HBilde / Die men noeme Morhicans. Jaet aen bolght op befelue zupot-kult/een

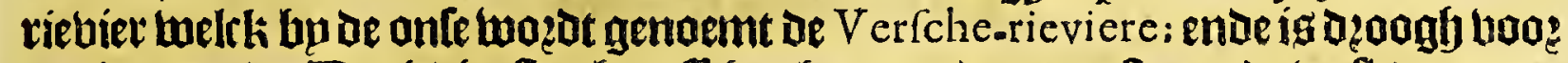

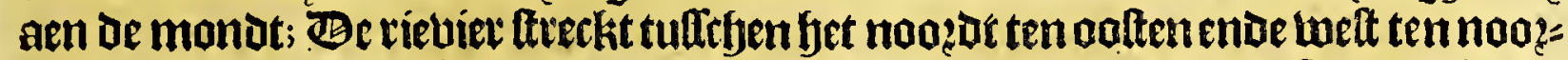

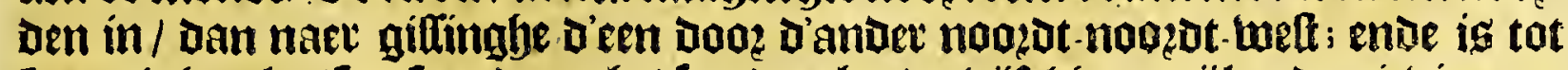

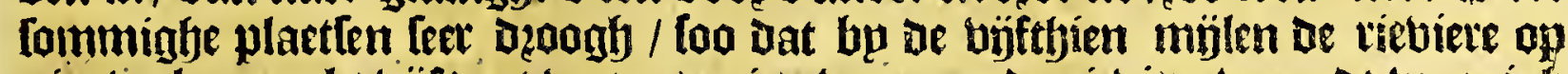

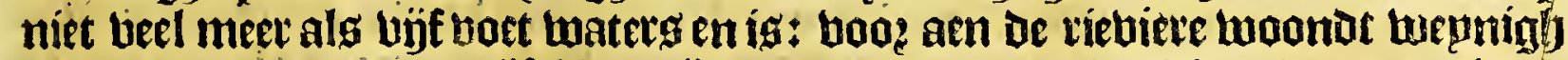

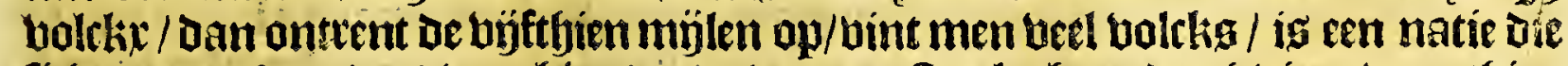
fith noemt Sequins; ban ljier boozt-waerts ftreckt hem de riebiere voos thien

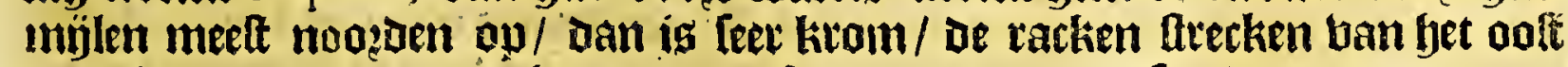
naed bet noozen om/ tot feet jupot.welt ten juboen toe / foo dat men met een toos-winot alle racken niet zeplen en kan/ ende is neeft al diep acht / neghen/ oock thienende twaelf boet waters/ oock fomtijots wel plaetfen ban viev ento hijfbadem diey; Dan meelt al atht ende neghen voet: ie hoilden faepen daet

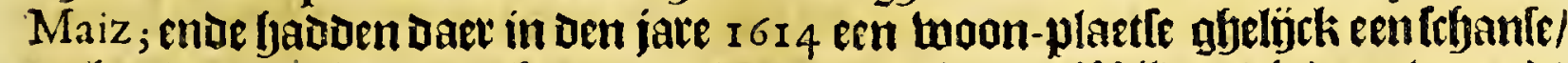
egljen Den aen-loop banjaet upanden; de natie van ADiloen die daer woonot Ii 2 woglon 
$104 \quad$ Virginia.

możen ghenaemt Nawaas, ende baren Sagimos wag doen geljeten Morahieck: \$p noemen in baet tale bet bzond ban Maiz gbebarken Leganick: Dele plaetle is gheleghen op oe fooghte ban een-en-beetich graden ende acht-en-brertity mis muten; men kan deriebier niet ouer De twee mijlen joggher op 3 plen met jarb= ten / want wozot Daer feet ondiep ende fteenighe gronot. 25innen in bet lamot moundt een ander natie van noilden/ melck fe noemen Horikans, die defe rieviet af-komen met camoen ban baften gbemaerkt. Dele riebier loopt altít af/ Too dat. de ftroom in't op zeplen niet en kan belpen/maermen maet de goede bintot baetnemen. Bande Verfche rieviere tot een ander/ welck fu noemen Rievier van

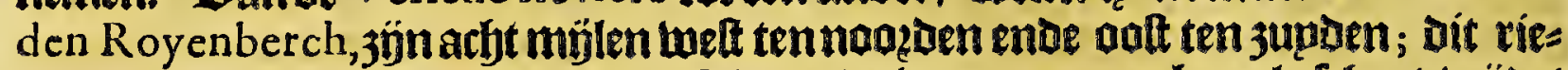

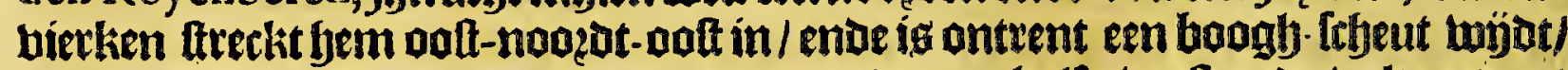
enoe daer is met foogh water dep badem ende een balf; walt ende balt ontrent een badem op endeneer; een zupdt-opet ten jupDen maen maeckt booe dit rietier= ken foogh water. De Hilden die aen bele rieviere woonen woeden gbenormt

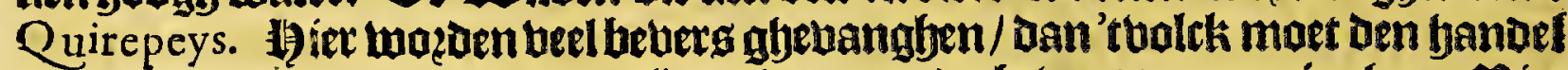
eerftghemonn wazoen / anders jün te leup om de hebets te gaen jaghen. Bies

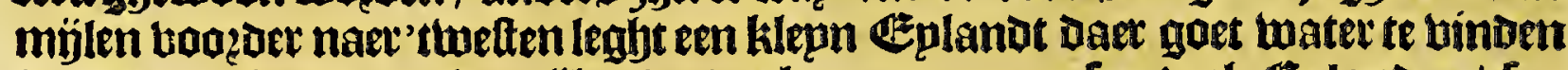
is; ende narb andere vier mp̈len bozoer kamt men aen feer veel Geplanden/ foo Dat Lthipper Adriaen Block de Lelte Dennaem beet ghegeten ban Archipelagus; oe groote hap is daer antrent biet mülen wöat. Aten de kufte ban 'tuafte lantot is een kilepn riebierken / melck niet bouen een balf mïl op ftreckt / enoe ig daee beel dzoogly. Be Hailde die bier moonen mozen ghenarmt Si wanois, enoe

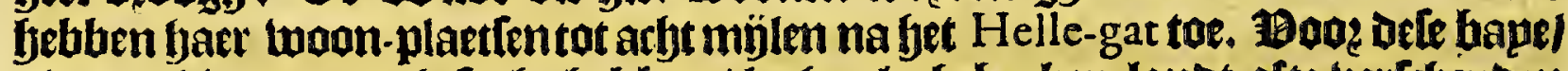

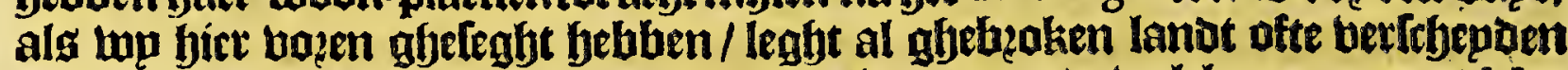
Éplanoen / op oe tweleke een natieban tibiloen moondt helck men noemt Matou wax, gheneeren haet met bifichen binnen de bape/ waerom den ooftelj̈ckften

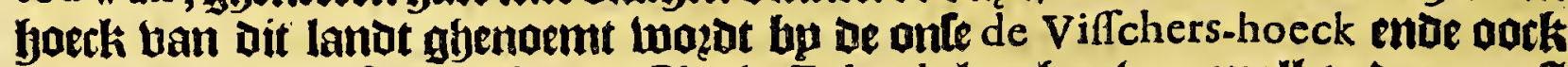
Cape de Baye; defen boeck enue Blocks Eylandt legghen ban malkandeten ooft ten noażé ende wett ten 3 upoen ontrent biet mílen. Wet Helle-gat bp den onfen ghenaemt is een ander riebier naer bet legahen ban frbipperi Adriaen Block, welck in oe grooteriebiere komt ban de groore Baye, ende of bloed komt baer ontrent [eben-en-derticf mílen naer [pn Legghen bp aalten oe groote riebiet/ende hepoe de bloeden han oe groote riebier ende dit Helle-gat ghemoeten malkandes ren bufet Noten Eylandr; kamente ban ae groote riebier naet oe bape toe / foo ftrecken de racken aoft ten noazoen ente aoft-nodzot-oaft ende oock ooft-jupot-

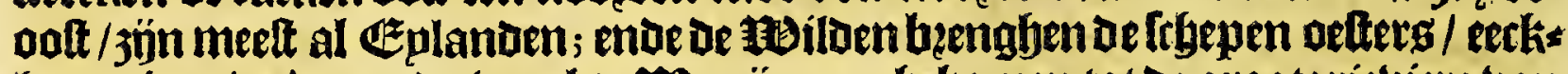
botentiens/ende epnat-bogels. FBp jün nu abeliomen tot de gucote riebiere ban De belcke wa betbolgheng fullen lqetken.

\section{Het negbente Capittel.}

Van de groote noordt-rievier van NIE UW-NEDER I ANDT, ende gheleghentheden van de felve.

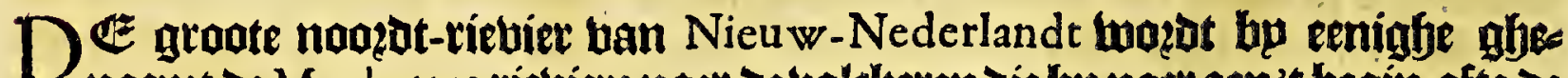
noemt de Manhattes riebiere naer de bolckeren Jie by naer aen't begin ofte de mandt van oe riebiere woonen; bp anuere ack Rio de Montaigne; darb bp of onfe wazot meeft nfienoemt de noordt-rievier: Alten be monot afte't in-komen beftte

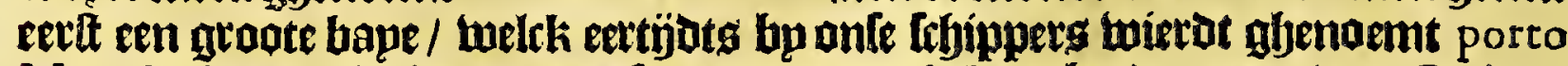
May : beeft aen 't in-komen een lanot punt nu bekent be de naem van Godijns punt, ende booz de ooft-boeck ban oe riebiere ftreckt een riff af twelck leet ftepl is/ want als men twaelf vademen ghetwoepen beft/ loo beeft men t'ander boup büf oft leg / enae dan wel anoer-balf ofte batt. Ontrent ander-balf müle binnen Den boeck van de riebiet den ooft-wal naeft / legbt een Eplandeken Dat niet 
Het derde Boeck.

beel meetoet als etn falf mijle groot is / ente bozot bu de onle ghenoemt fot Noten-Eylande, doos bien daet leer veel lifjoone note-boomen op twallen. Alen de ooft-3ýde up lyet bafte landt woonen de Manacthans, ken quade natie

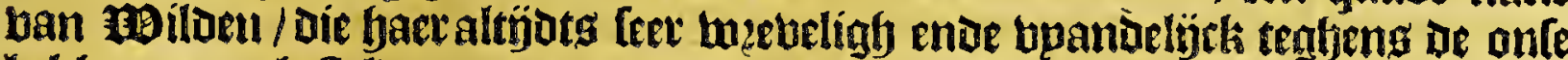
bebben aen-gheltelor; aende twelt-jübe woondt de natie ban ie Sanhikans, de= Lelcke doodt bpanden jün ban de Manatthans booz-f(t)etten/ende een ber be= ter bolck : Dele als mede de Aquamachuques, moonen binnen oe fanot-foeck/ ende al langbj of bape/ente oock te lanot-waert in. Het in-komen bande rie= tiete leght op oe googhte ban beettich graden enoe arbt-en-twintiry ofte oettich minuten : teghen aber get Noten-Eylande tirfit be de twelt-wal legghen viev andere klepne eplanden; oe viebier is aenfee in-komen treethien ende unfthien bademen diep / ende continucett too op die diepte in't terfjte canael; pe vievier

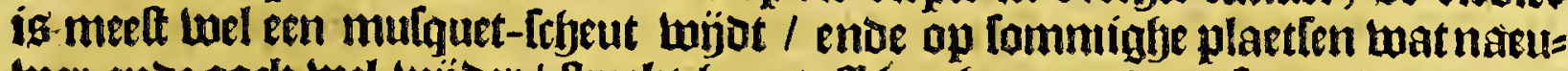

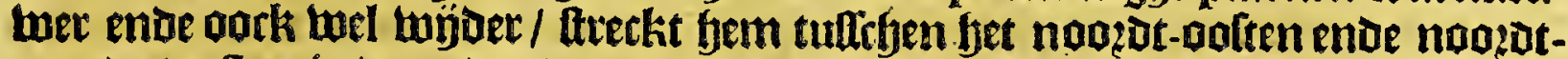
noozot-melten in/naer dat de rackenloopent; binnen het eetlte rack aen oe weltwal leght fet laghe-land/ al-waer een natie ban tbiloen moond / detuelcke ghenoent bozaen Tappaans : de rieviete is in't midoen dzoonbla / ende bep=

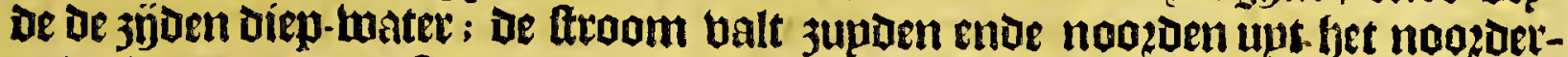
gadt / cen jupot-aolte endoe noozdt-welte maen maeckt bet boogble watel; ontient een mijle inme twaetots is een hape boo? alle tuinden befrbut / ongfye= baetlïct les miglen ende een galffin't ronde; daer gaet een ftertke bloeot ende chbe / Dan balt niet boben de bier boeten / Doos de menichte han 't inater tuelch

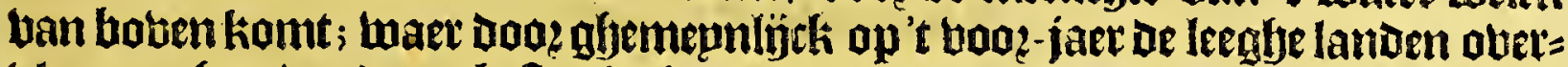
vlaepen : fet tweede rack ftreckt bem nootdt-welt op/tot een englote welclie de onte naemen Haver-ftroo; daer aen balght bet Seyl-makers-rack bp de onte abe= noemt: bootseen krom rack/ or foume baneen falf-mane/ bp be onfe bet Kocks. rack quenoemt; daer naec het Hooge-rack; ende bet Voffen-rack tot aen oe Klinckers-bergh; ende boottg bet Viffchers-rack; altwate aen Den oott-wal ban de rie= biere een natie ban failoen twoond die [u noemen Pachami: dit rack ftreckt frem op de tot een ander enghte allwaet aen oe weft-jyjoe een fryatp upt-ftefende punt is met hooghte

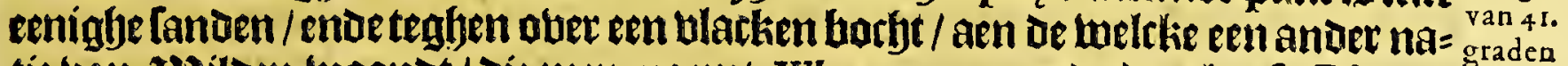
tie ban willaen twoonat/ die men noemt Waoranecs, enoe ae plaetfe Efopus. is minu-

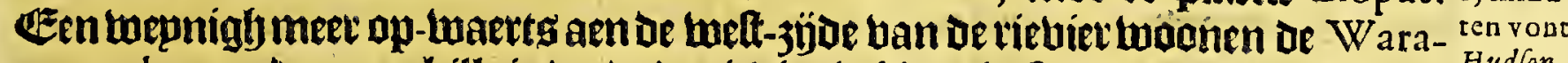
navvankougs, baer een kille ig/ ente de rievier ig bier niet foo diep ald boeen/ende ${ }_{9}$. grad.

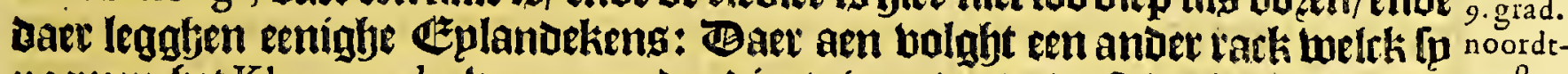
noemen bet Kleve.rack, waet meerder diepte is onder De twelt-hual; aen de ooft- vrefte3joe legghen eenighe landen. Bootts foo bolght daer aen fyet Backer-rack ende Ian Playfiers-rack; bet Vafte-rack tot aen Den Hinnen-hoeck: alle bele rarken zön leet be[met met fanden ende ondiepten/ loo aen be oolt-twal/ als mede in't midoen ban de rieuiere. Bolgyt bet Herten-rack tot aen be Kinder-hoeck, hier enoe ban bier boots en ig de rieviete op't dieplte maer biff badem diep/enoe meeft

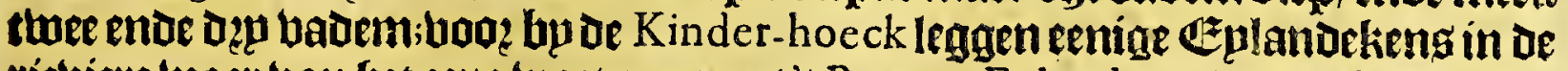

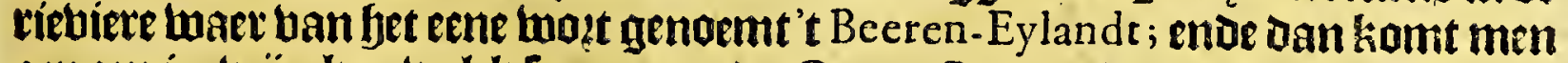

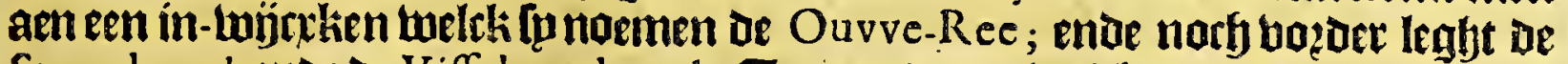

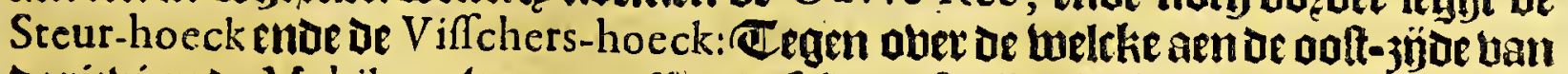
oe riebiete de Mahikans woonen. Zlen De Telbe ooft-jüue Ieght een lantl geb?oken

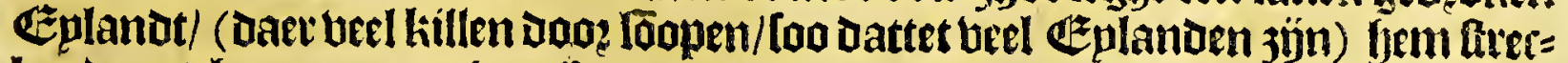
kentoe tot bu naex aen het Gplanot Daet bet frotien op twas gheleght/ op de hooghte uan 43 graden; ende tot hier toe komt de bloet aele rieuiere op; ende tot

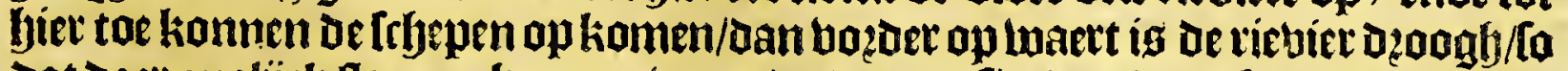
dat daer qualijck lloupen konnen baren/ende men fiet ban betre feket foogh ghe berghte Jaer 't meette water ban offeriebiete af-komt: naev alle apparentie foo komt dele rievier tot aen de groote rieviere ban $S^{\ulcorner}$Laurens ofte Canada, twant It 3 oule

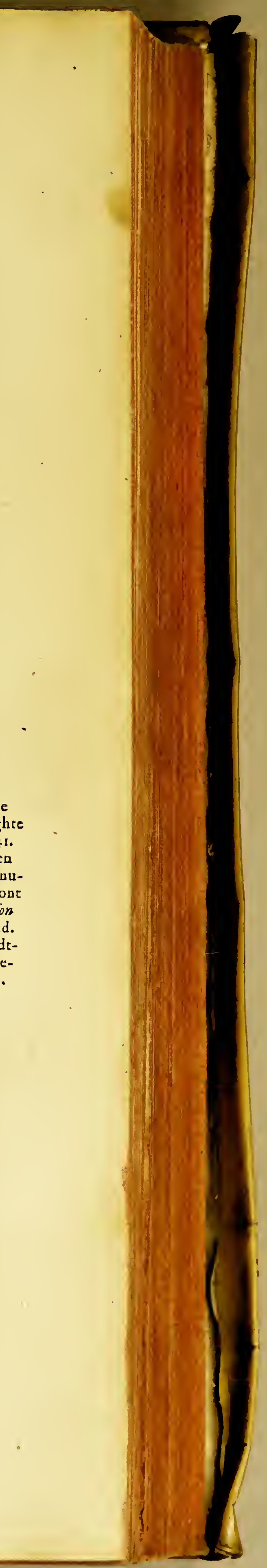




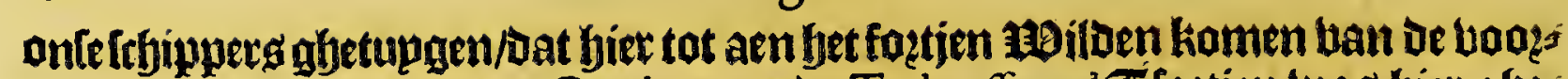
noembe rieniere / ende ban Quebecq enue Tadouffac. 'Clfoatjen was hier ghe leght inden jareleftyien bondert ende veerthien/ op een Eplandeken aen de keltmal ban de riebiere / Daer een natie ban 3 Eilden moont diefe noemen Mack-

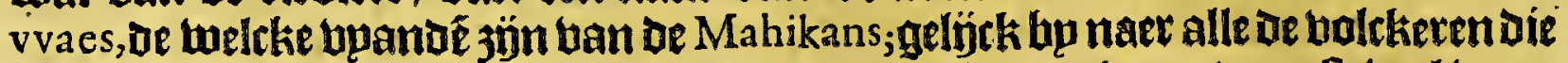

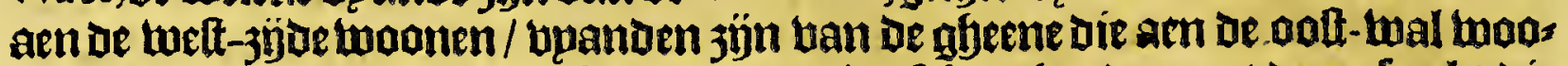

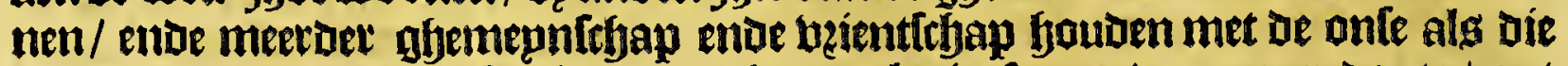

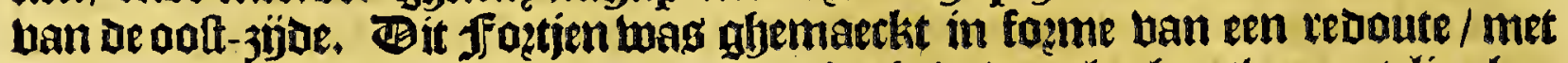

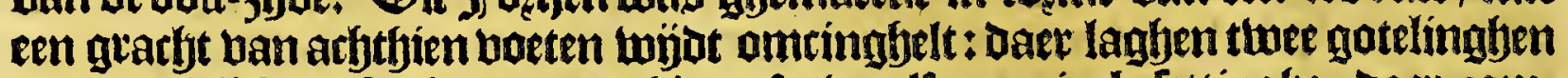
op/.ende elf fteen furken / ende thien oft twaelf man in betettingbe; daer cam= mandertoe cerft Henderick Chriftiaenfz. ende in fun ablentie Iaques Elckens, ban weghen de Compagnie die het octrop inden jare 1614 voot-noent ban de

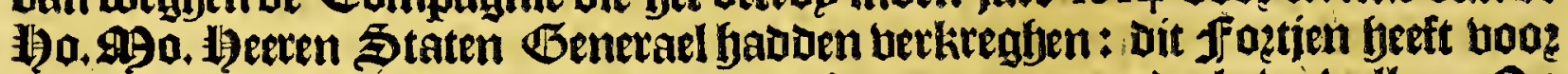
Depjaren ghelfadigh befet ghetweelt / ende is daer naet ten oeele berballen. Op

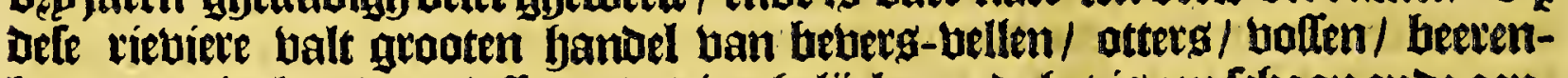
fupden/mincken/ tattelollen ende dierghelÿcke; ende fjet is een ftjoon ende aen= gbenaem lanot/ bol ban [eer leboon gheboamte enoe oock wijngaerden/ daet en abebeectit niet dan den artepot entoe indultrie ban mentefen/ om een ban be Ifboonlte entoe buththaeulte landen te telen ban dat quartier: Dan de milden die

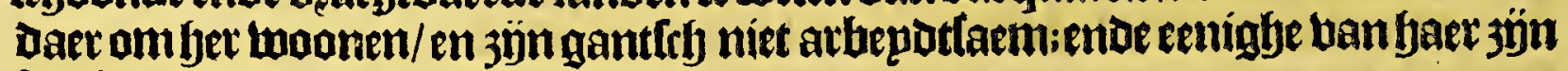
feet Inoode dieben/ende quaet balch.

\section{Wet thiende Capittel.}

Van de gheftalte van 'tlandt ende manieren van't volck aen de
groote rieviere de MON T A I N S.

HEndrick Hudfon die dele riebiete eerft beeft ontoeckitende alle die naerderH fyanot daet bebben ghetweet / weten wanoer te fegghen ban de lefoone boos

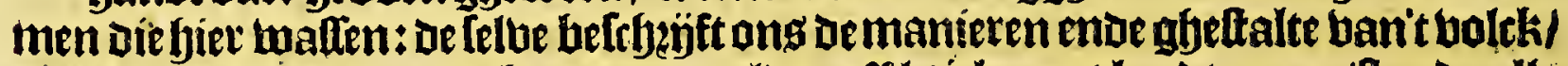

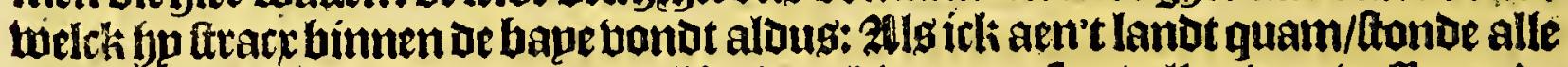
ite Sivartenen fonghen ophare wijle; faer kleederen fon bellen ban boden ende andere beeften die fy berepden / ente maken kileederen ban bellen/ ban aller

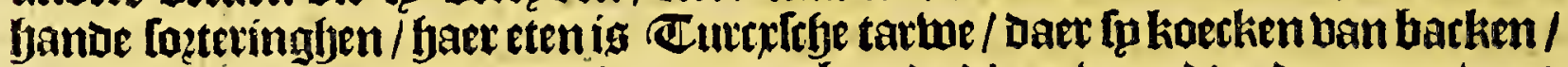
ende is goet eeten; quamen al temetaen boozot d'een yoog d'ander naer / met

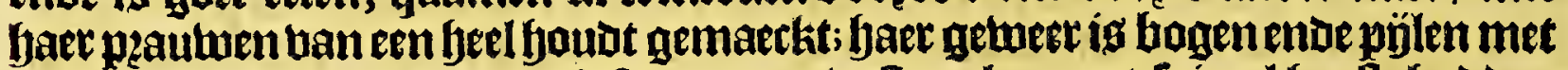

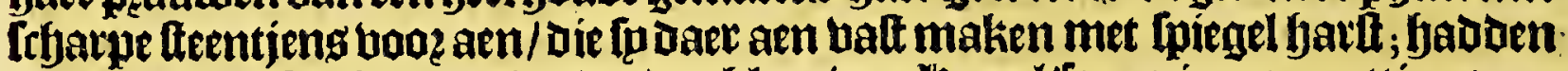

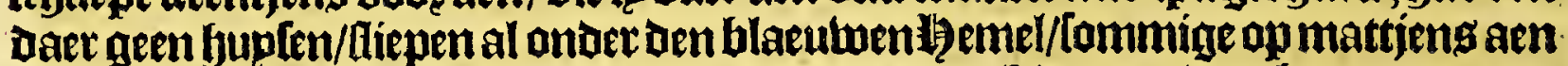
mallianderen gfelwzocht ban bielen / lommighe op Gladeren ban boomen/Dza=

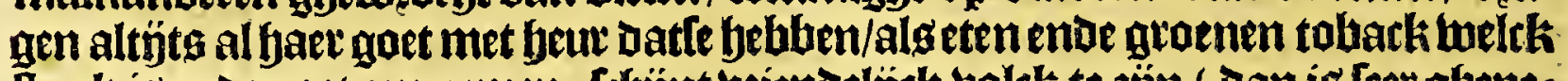

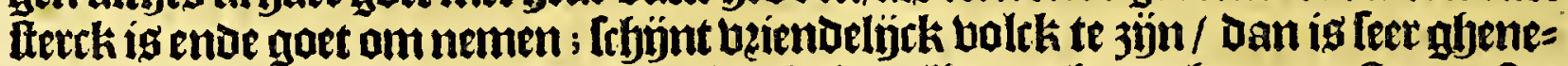

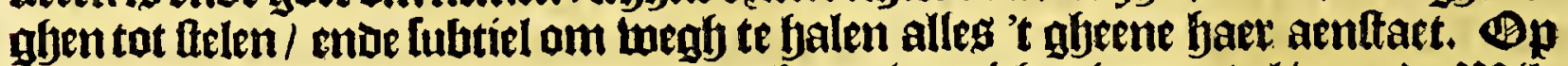
De hooghte ban ueertich graden entue acht-en-beettich minuten / al waer de mils oe feer feboane aetters aen Ipn frbip bzarbten/ afjetuptgt de vooz-noembe Hudfon ban 't lanot aloug; $\mathfrak{7}$ s loo ftyoonen landt als men met boeten betieden mary/ obet-uloedigf ban aloerbande boust / om ltyepen te boulwen / enta om groote baten ban te maken; 't valck bajoe daer kaperen toback pyjpen / waer upt ick bermaede dat Daer koper moet jün/ als oork pler naer Der mailoen lueduus

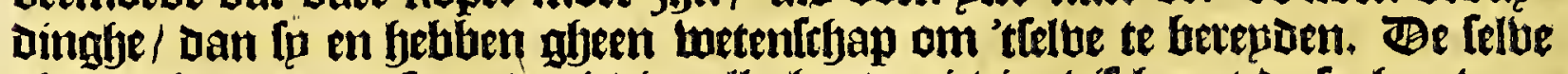

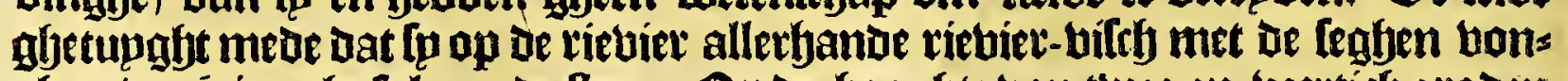
ghen / ooch jonglye falmenoe fteur. Op ove hooghte ban thee-en-beettich graden

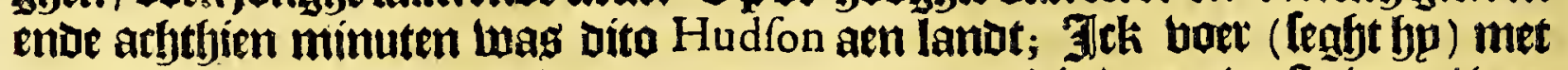
een uan fjaer pzatuen aen lande / met een oudt man die daer obertte was / van beettich mang ende febentbien bzoutuen/ die itk daer lagh; in een bupg van 
Het derde Boeck.

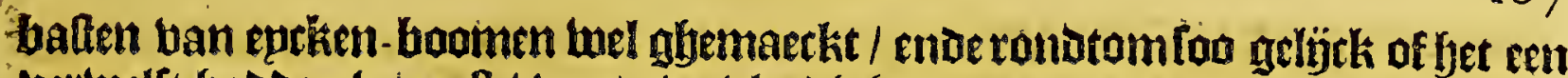

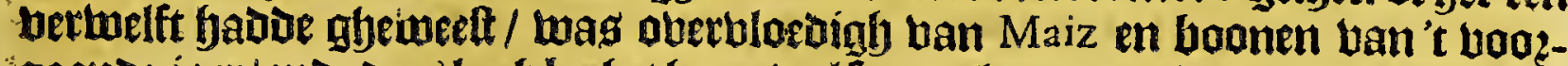

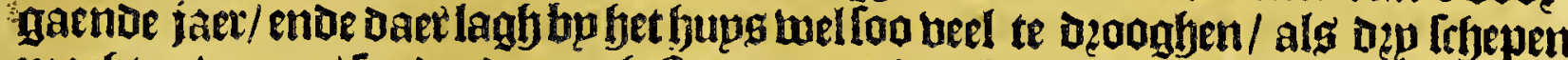

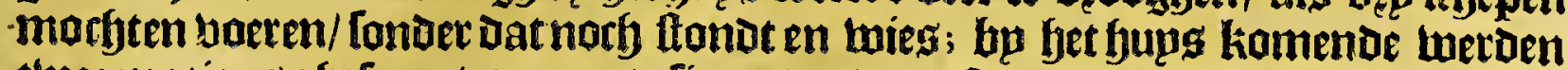

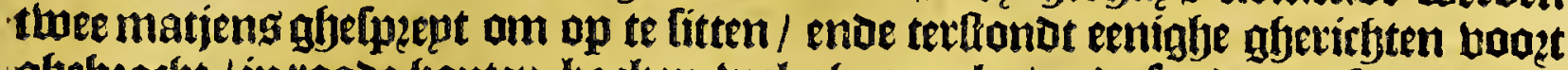

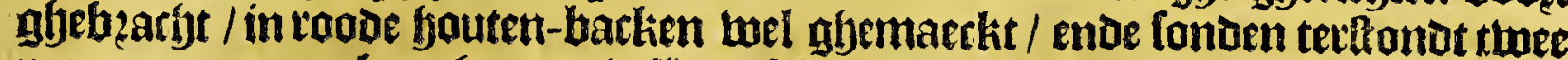
mannen upt inet booghen am wilot te frbieten / bzodjten twee Bupben die fa wel

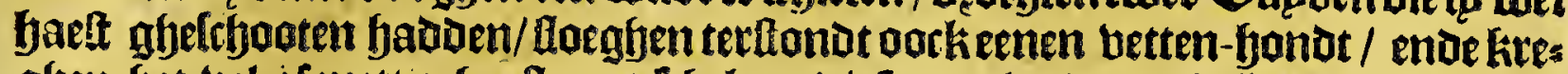

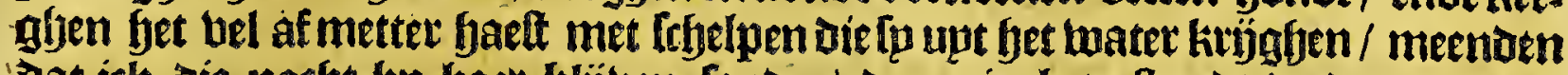

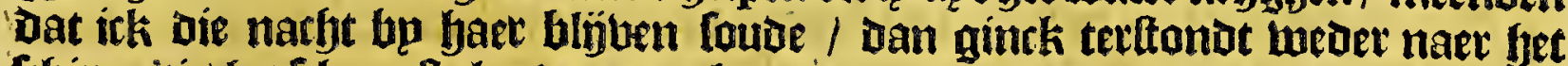
felyip; 'tis bet fryoonlte lanot om te boutwen/als ick opt mín leben met boeten betradt/ende oork ban alderfjande boomen; ende isleet goet bolck/mant doen [p

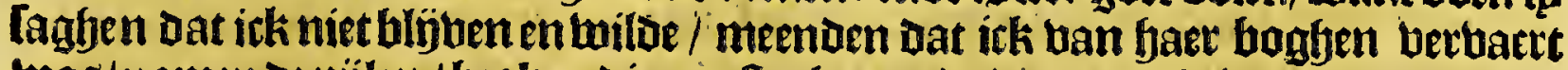

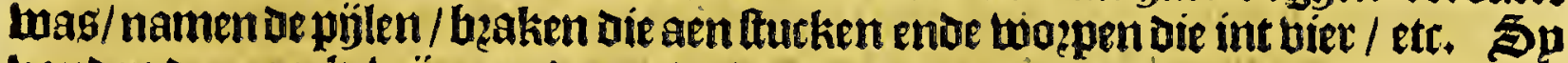
bonden daet oack twingaerden ende bupben/ pompoenen ende andere buachy ten. Ator weltkeg alles ghenoed faem is af te nemen Jat bet een leer fefoon ende beurfjthaer quartier is / ende goet bolek/als fet maer mel gfyefjandelt wozot; bach feer betanderlijek/enoe ban den felben aecot als alle fiet bolck ban die noozder

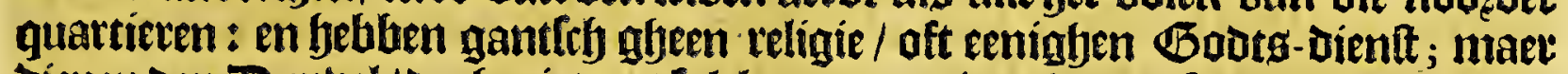
Dienen Den Duphel/ Dach nietmet fulthe retemomien als de A fricanen; [u noemen bem Menutto; ende alles wat wander ende beemt is oft het mentryelinck berftant te baben gaet dat noemen fp al mede Menutto : beel minder febtuen fpe enige pa= litique regetinghe / alleen Datfefyaer wherlten febben welck tp Sackmos ofte Sagi-

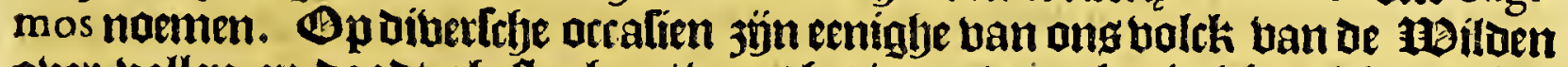

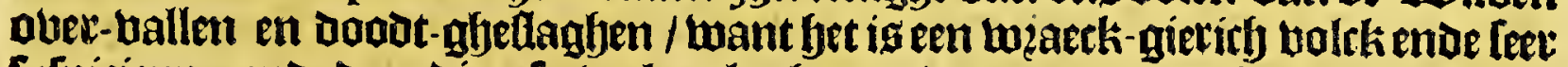

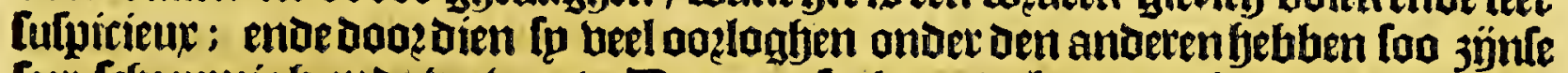
Ieer fefyecumigh ende berbaert. Ban net factete ende bequame fandelingbe/ende

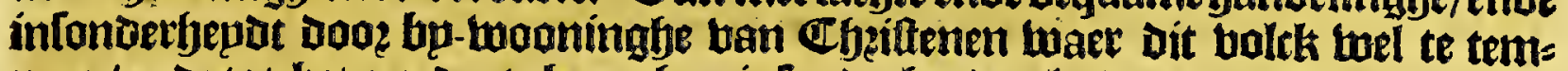

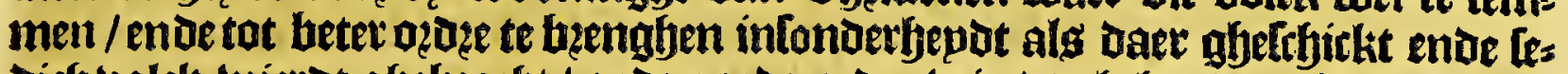

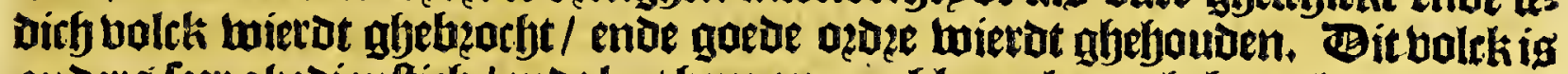
anders leet ghedienftich / enae laet fem om een kleme loonghebuupcken tat beele

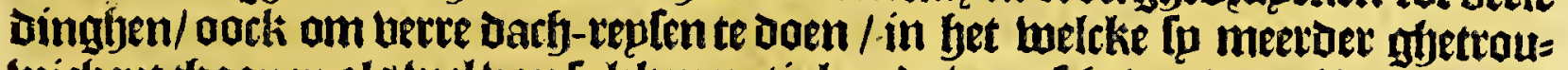

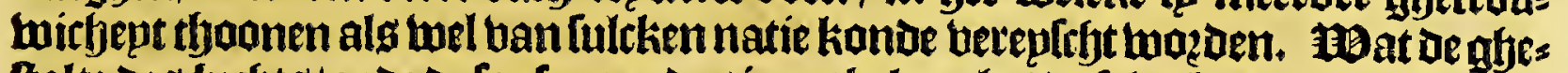

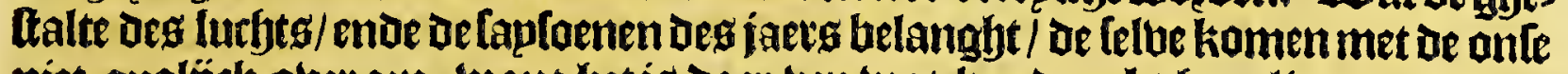

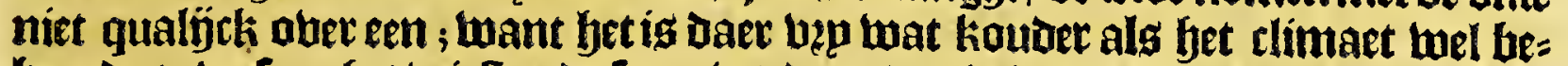

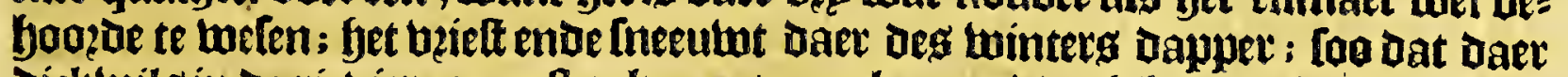
dickmils in de rieuier eenen ftercken ps-ganck gaet/ Doeth bet een jaer meet als

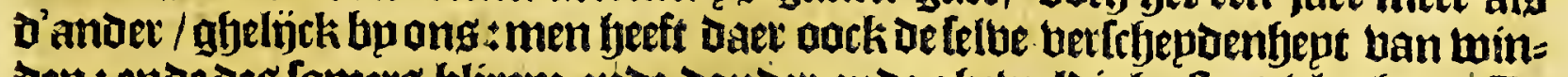
oen: ende des fomers blixem ende bonder ende ghetuetoinge foet-blaghen. Jin comma het is een lanot oat feer bequaem is om bp onfenatic / onoz ghelintkfepot

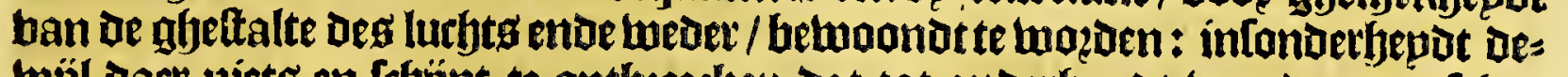
wijl daer niets en frfínt te ontbeerken dat tot anderfjoubt ban des menfryen Ieven ban noode is / Dan tam bee welck Daer licht twaet te benghen/ende boats

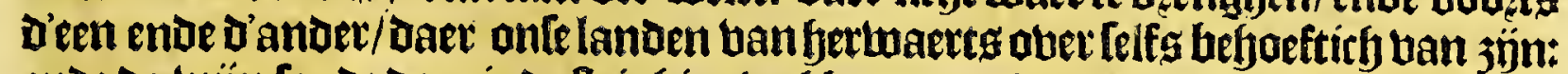

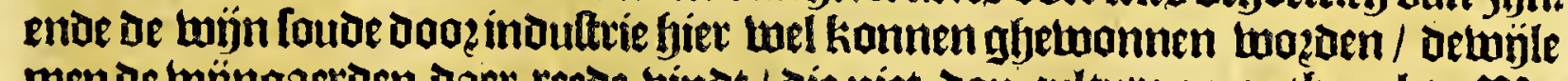
men De twijngaetoen Daer reede bindt / die niet dan tulture en ontbeerkt. Hap

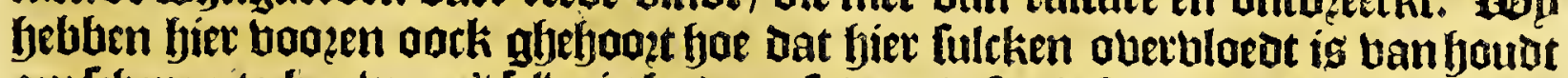

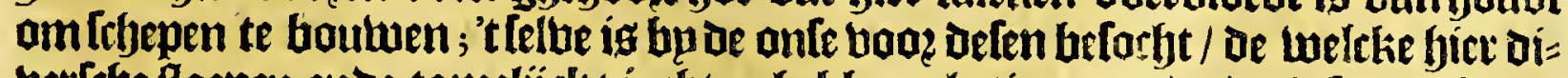

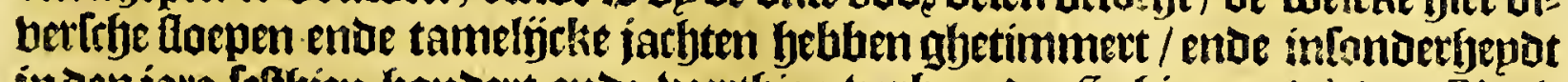
indenjate fettyien fandert ende beetthien berbzande Srghipper Adriaen Block

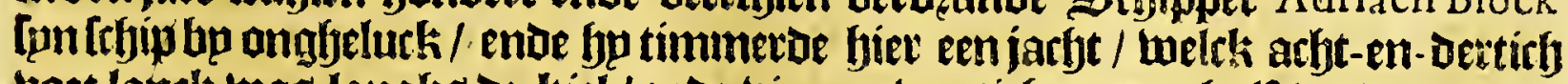
toet lancli was langlys de kiel / ende bier-en-beetticy en een balf boedt ouer de

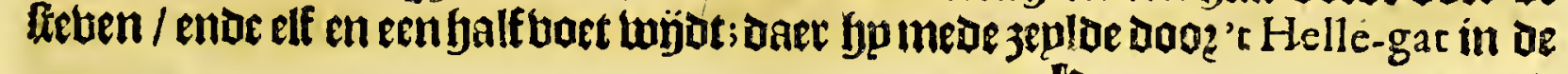

$$
\text { 保 } 4 \text { groote }
$$


groete bape ende belocht alle ae plaetlen daet ontrent/ ente boet baet meto tơt aen Cape Cod, ban waex ypmet't tefip ban Hendrick Chriftiaenfz. naet hupg quam/ ende liet de jarbt Daet op de kufte om bozoet te handelen.

\section{1)et elfoe Capittel.}

Vordere befchrijvinghe van de kufte tot de andere groote rieviere; ende vañ daer vorder tot op de acht-en-dertich graden: ende 'tgheene by de vrije Nederlanders aldaer is verricht.

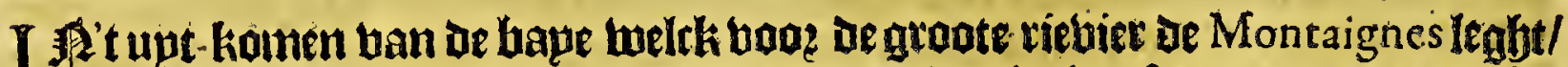
1 ijeft inen een tamelinck diep kanael / als men oe riebier ofte den manot Det-[el= ben noozot ten oaltent uan bem beft/ ende den upt-boerk van't booge lanot ban oe bape zupdet ten ooften luan fem: ban de landt-boeck ban de bape afte port May tot den hoeck van de Viffchers ofte't aoflepnoe baut gebzolken landt Daet de $M$ a.

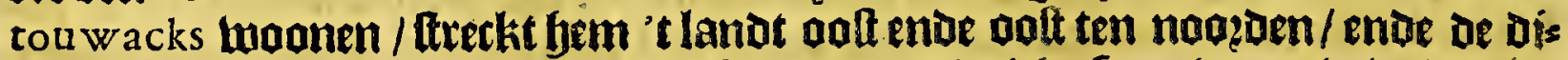

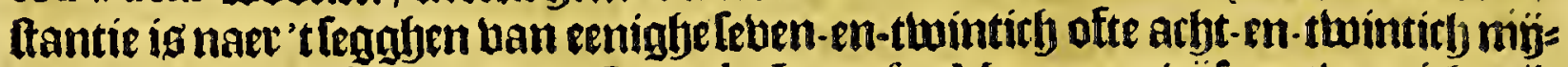

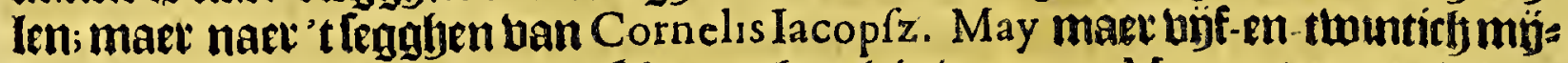

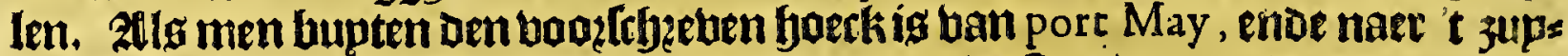

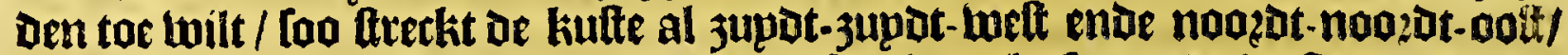

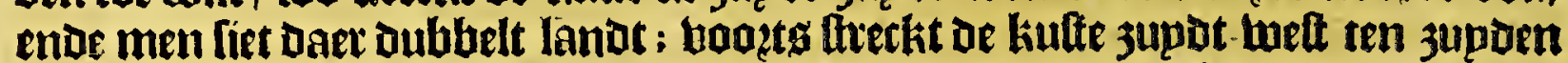
ende noozot-oolt ten noazoen/en is een lefjoane ende diépe kulte / ende tameińcke yooglye bupnen / ende't binnen-lanot aen't haoz-landot balt; dan twat berder bp Jupden wąt het landtleeger/ ende is maet een baet ftrand/Daet men bet binment water aber heen lienkan/ende lier en Daet een Dupntjen: Wat hazoer gemoet men cen gat ofte in-bzeucke: ende wat bozaet norbecn ander gat op oe joogte ban ons trent neghen-en-dertirfy graden ende búfthien minuten/ welck bp de onle berot genoemt of Ey er-haven, ofte oock de Baye-haven, igenn klepnrieníetken aftekillel en binnen al ghebzaken landt/en binnen debape leggen Dibertebe klepne Ezplan=

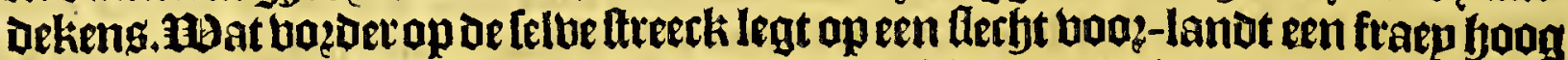
bofef;ende dan een flecbt fantet-ftranot met beel klepne ende leege dupntjens/ende

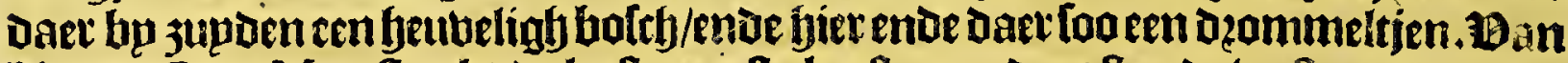

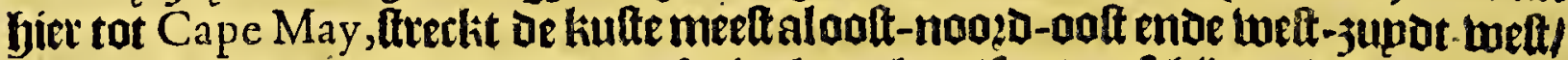
en men liet op de kufte beel gaten aftein-beucken/ Loo dat frbÿnt/alie klepn mijle tíeng/bunaer een gat in Jet bodz-lanot; Danmen en dient oe kufte niet feet te na:

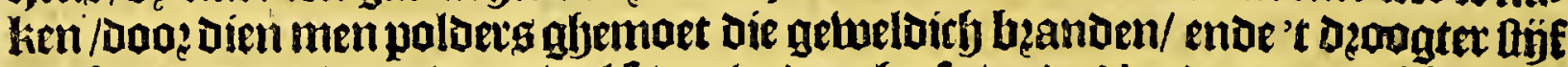
op /Coo dat men D'een wozp wel Coven badem beeft / ende s'ander maer bijf / ende De der de maet depe eñ minder. Mat naerder Cape May ftreckt de kufte toeft-3upd-

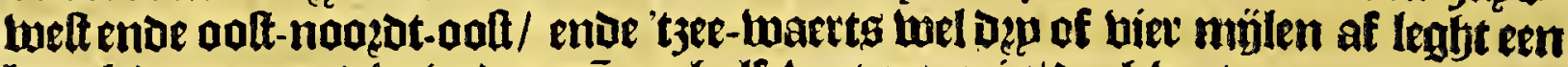

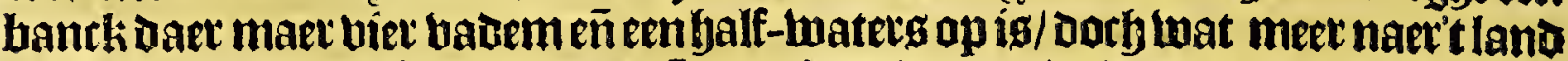
toe feeft men lueder feben badem eñ meet. De theede riebier legt binneneen graa: te bape / weltk bp de onlegenoemt tugęot Nieu w port May ; dele bape beefe thete hapen ofte yooft-lanoen/ de noazdelátkitte wozot ghenornt Cape May, ende de 3upotlijetkfte Cape Cornelius; afte mede Cap Hinlopen, ende bepde offe hapen

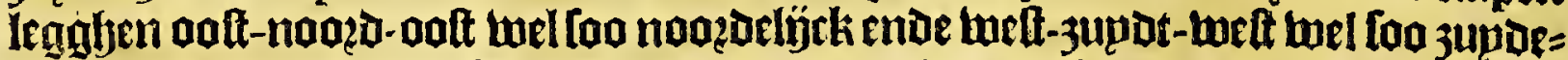
lijek han Jen anderen / [oo uerre als men pas ober oaghen math: De noozorlïck= Re kape light ap de atht-en-dertich graden ende bijf-en-büftity minuten. Ban Cape May fteerken eeniqfe bantken af 3 upot-weft ouer naet Cape Cornelius

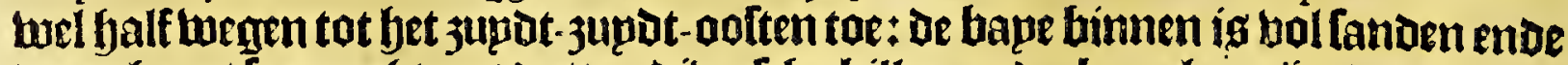
Doougten / foa nochtang datter diberfrhe killen ende kanalen jün/ dan men dient dare niet te komen / ten [p men Daet bol bekent is / want igen gfebaerligss the bape. 2 Binné dete bape legt ue andere gloote rievier die de onte naemen de 3 uporícbier/Daer wop in't fevenoe Capittel ban bermaent fyebben/eñnatbeenigeklepn=

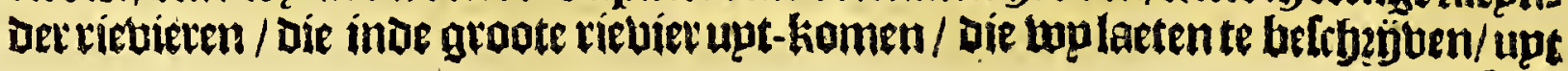
ooţatas 


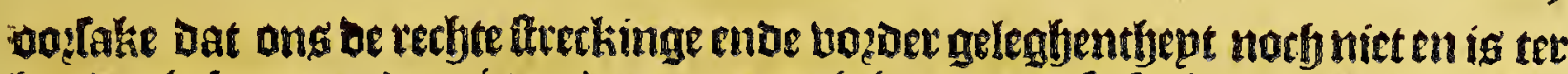
banot gyekomen; ban ig anters aen eenighe ban onte frippers afyenoecly be= lient Die of re riebieren al ower enighe jaren jebben ontdeckt ende beluaten. Op

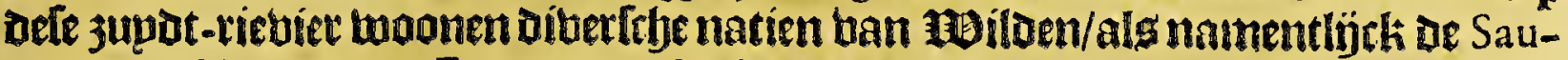
wanoos, Nararicons, Ermomex, Sankicans.

Be Minquaas, Capitanaffes, Gacheos, Sennecaas, Canomakers, Konekotays, Matanackoufes, Armeomecks, ende Diergelýcke/ wopnen beruer in'tlandten op een ander riebier; ig norfjonleker aft Defe mede kamt inde zupit-rievier / oft Dat

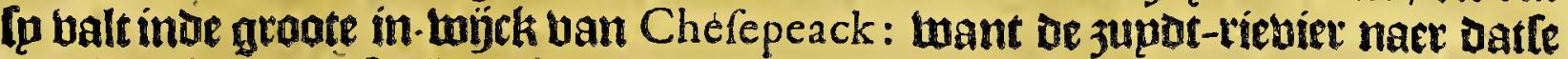
met baet bape een ftuck weegyg nootat-wett op íf geloopen/Loo heert fu met een

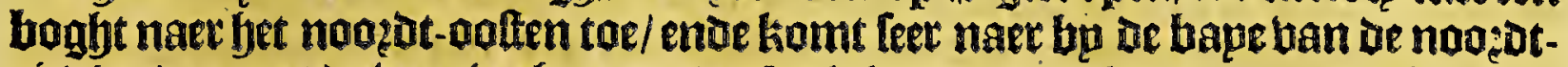
riebiet / ontrent de woningfen bande Sankikans ende Matovancons. 25p naet al ban een geftalte ende conditie als de gheene daet wo hiec bozen ban gefpzoken bebhen; belaepen't landt ende bebluen beelMaiz enoe oock boontjeng/ente boots

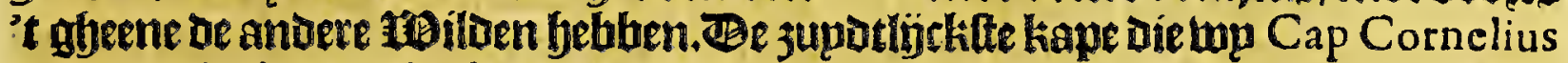
naemen / beeft een twiat blenchken/ende saec loopt cen riff af jupbt-zupot-aott in 3ee: Ieght op de arbt-en-dertich graden ende viet-en-byjtity minuten. Bier mï: len ban Defe kaep legtet een anber kape welrk oe onfe noemen Cape Hinloopen; ende de ftrechingte is noo bt-ouft ten ooften/ ende jupot-welt ten welten. Ban

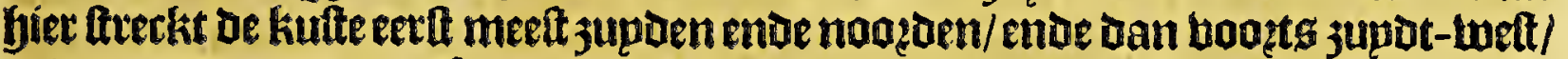
endenoozot-noozat-poft / ende oock jupbt ten tweften/ende noozot ten ooffen; men magh bel langs oe hal fenen loopen in fes ente feuen badem waters/ende

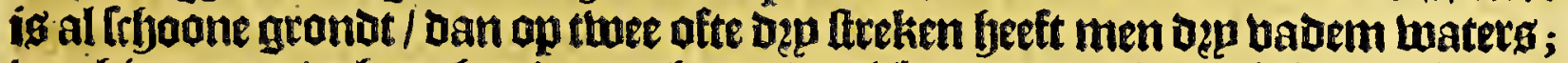
banljier tot op of boagfte ban arbt-en-Dertich graden ende arbthien minuten

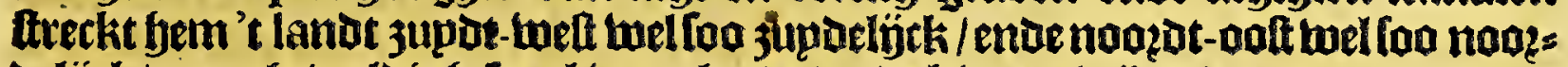

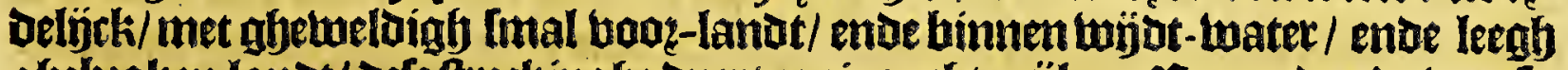

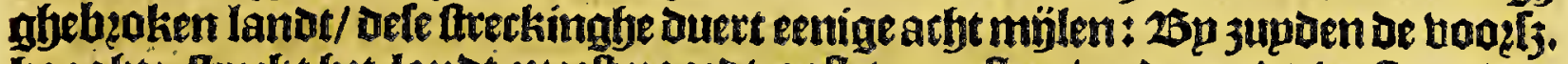

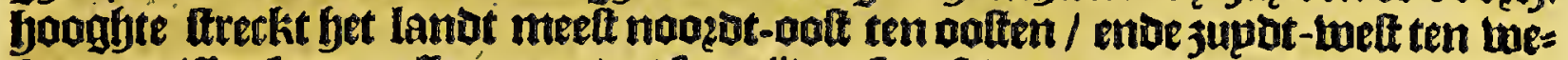

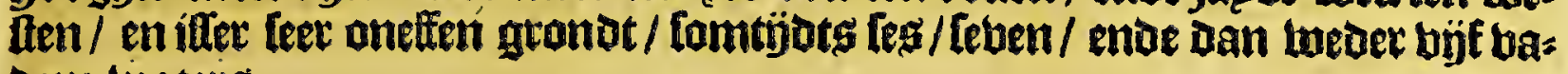
Dem tuaterg.

In Nieu w-Nederland ende op bepoe dele riebieren bu ang inde tooggaente

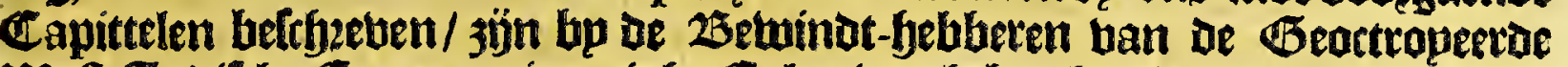

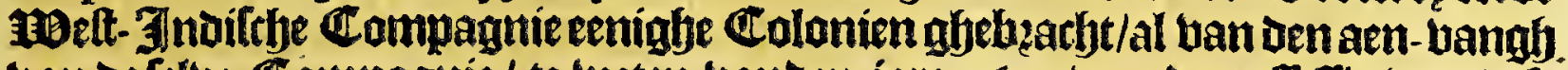
ban De felbe Compagnie / te lueten banton jare I 623 / am de poltedie ban defe guartieren te continueten/ente den hanbel ban pelterijente onder-bouden. Sp beb hen daet in't bimnentte ban de nooget-viebier ende op de hoogfjoe han dęp-enbeetrich graben ofte baec ontrent een fotetjen luelck oe onle noemen 't fort van

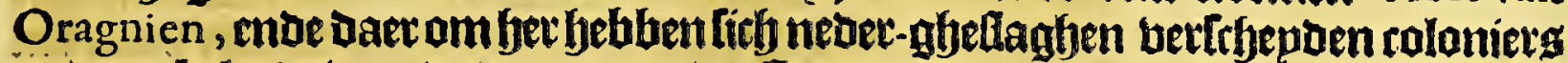
onder't belepdt ban De booz-noemoe Compagnie. EEnoe fueder een ander fout

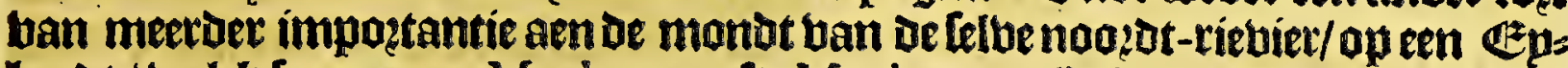
landt / welck [p nomen Manhatres nfte Manharans Ezlande / Doozdien 't felue Dele natie ban moilden beft toe-ghekomen ende bu baer aen of Compannie ís

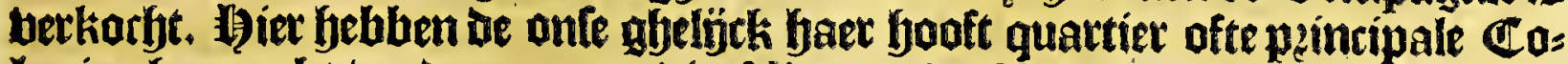
Ionie ghemarckt / ende noemen die Nieuvv-Amfterdam; be frbepen die jaer.s

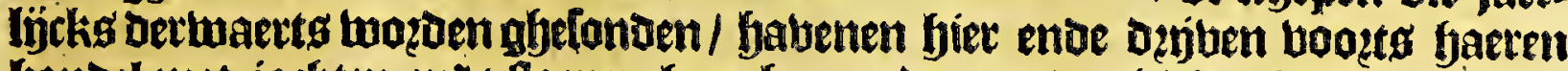
Gandel met jatbten ende flatpen foogher ap de noogot-riebier / in be juubt-rie= biet ende in alle de andere riebieten ende bapen biet boen bp ong belch?eben.

VIRGI- 
Het thadfoe Capittel.

Degheleghentheydt van VIR G IN I A daer de Engelfche nu vvoonen, befchreven by Capiteyn Smith.

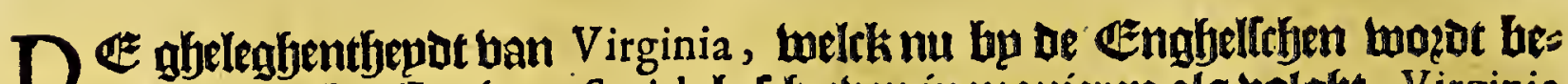
moondt / ig bp Capitepn Smith heftyed ben in manieren als volgyt. Virginia welck bp onfe EEnghelche is heplandt met bolck inden jare 1606 , is gljeleghen op De boongte tan leben-en-dertith graden/ tot de booghte ban negben-en-dertich graden bp noozen de linie. Be lomer ig daer too beet als in Spaegnien/ ende

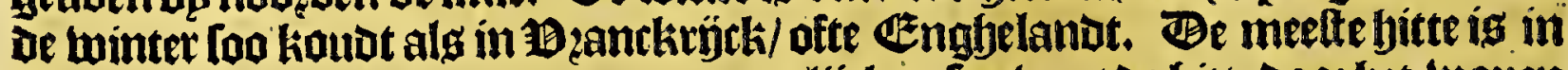
Iunio, Iulio, ende Augufto, maex gemepnlijeken foo waet de fitte Doo? het wapen ban de koele bifes ofte winden upt oer $3 e$ / wat gebzaken. De peincipaelle koude bebt gfjp Daer ban December totbalf Martio. De koude is upter-maten ltberp/

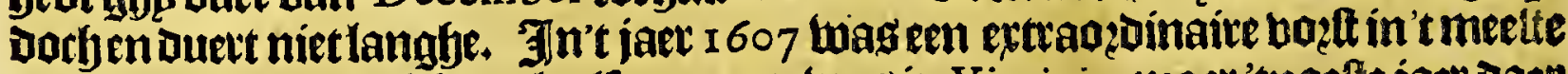
deel ban Europa, weltk oock allo extreem has in Virginia, maet'tnaefte jaer daet aen tegljen acht oft tfjien dagen bupl-weder / Gadoe men daer wejer twel beetthien

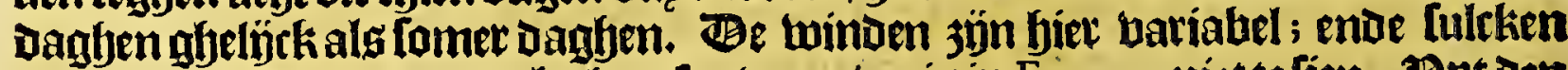
Donder ende blikem/ om de lueft te lupberen/en is in Europa niet te lien. Bpt Den jupdt-welten quamen de grootlfe flach-reghenen met Donder en bitte: Denoozatwelten winat daer en tegen is koel/ende benglyt thoon-beder mede. Ban't noozs Den liomt De grootfekoude ende han't oolten / ende jupdt-ooften (ghelijck ban de Bermudas af) liomt milt ende reghen. Somtröots iffer aroote Dzooghte ende fom:

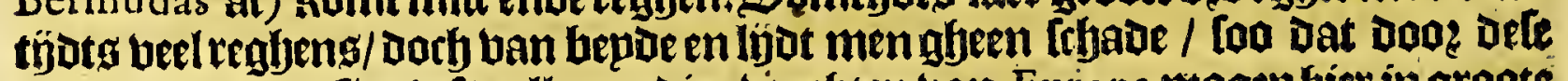
reden wp niet en fín/ ofte alle noodige beurfen ban Europa mogen bier in groote abundantie ghetwonnen wozden bp de indultrie han mentthen/ als blÿclit bp ie ghene die wo fier alteede geplant bebben. Baer en is maer een aen-komite hp jee tot dit lanut /ende dele is bp De monot ban eenleer ftyoone hape/weltk bp oe atfs

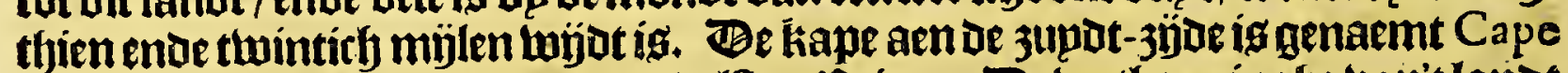
Henry, ter eeten van onlen aloer-edelften joince. De bertbooningle van't landot

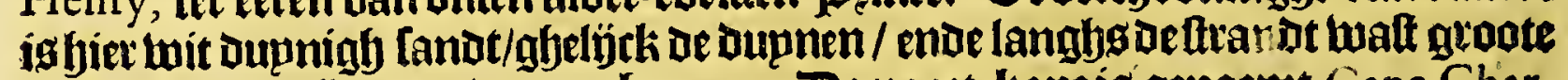
menictyte uan pijn ende bueren-hoomen. Be noot-kape is genaemt Cape Char-

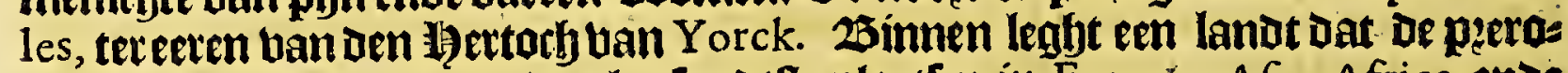
gatibe magh bebben ban de plaplanotte plaetfen in Europa, A fia, Africa ende America, van weghen de wijoe ende frjoonenabigable riebieren; hemel eñ aerde en confpireeroen nopt beter omeen plaetfe bequaem te maken tot de bekooningfe booz lichamen ban onler complexie / indient ten bollen bearbepot ende betwoont ware bp insultrieug bolck. Hier jün berghen/ Geubelen/plapnen/ ballepen/ ries tieren/en broecken/alle leet liltich loopende in eenleboone bape/omínght aen de

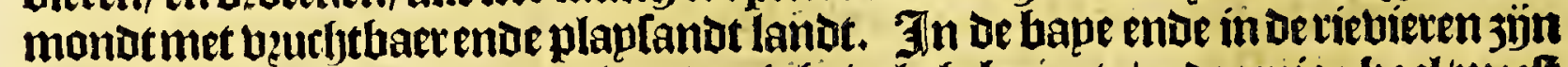
beel 选planoen foo groot als klepn/ernighe bolgheboomte/ende eenige kael/meet leeghende onbetwoont. Befe bape ftreckit nootende jupden/ in oe twelcke bet was

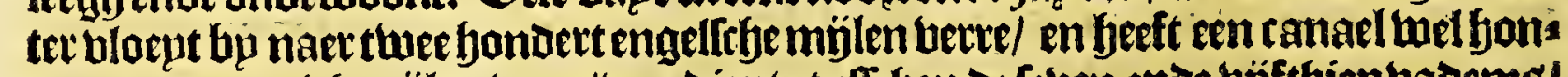

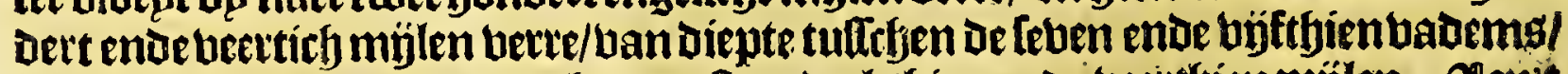

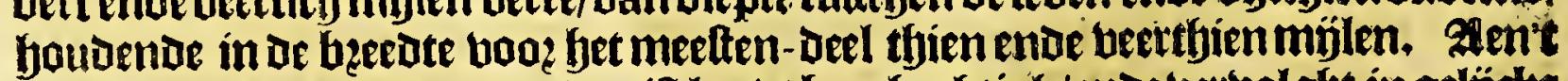

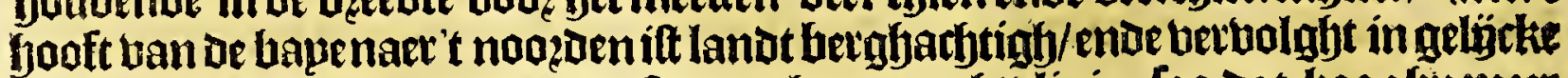
manier ban daet naer't 3 upot-welten toe bpeen rectje linie; loo dat boe afjp meet jupdt-waert komt/ orfe bergen te beroer af legghen ban oe hape; ban defe bergen homen díberf(ye belien af/ welck ten laelten tot büf peincipale ende nauigable ries

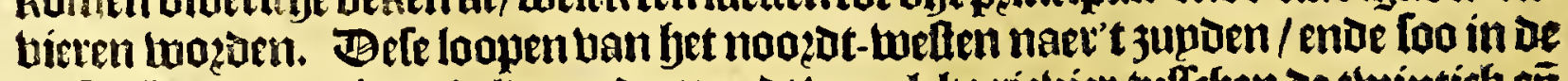

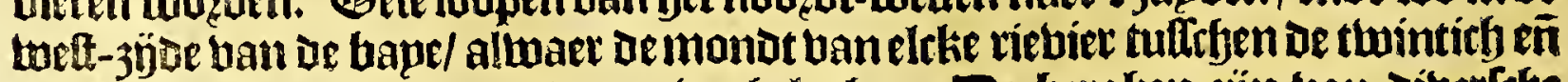
bijethien miglem ban Den anderen ig ghelegben. De berghen jon ban diberffbe gheltalte; 
Het derde Boeck.

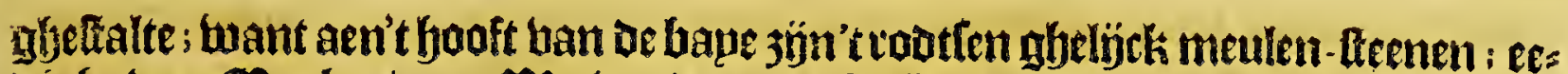

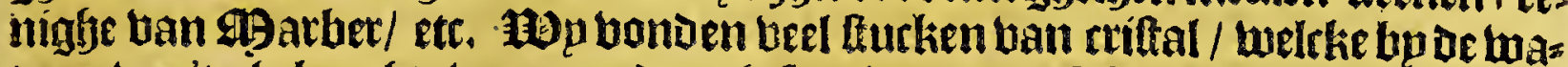

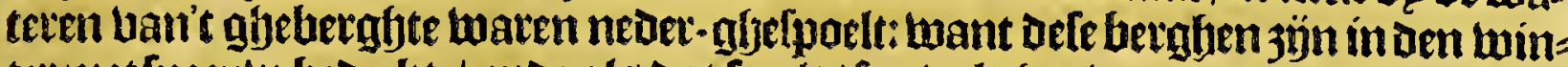

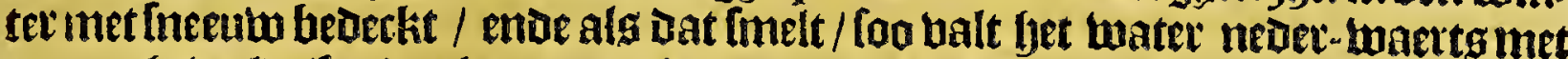
groot ghetwelot/[oo dat het groote inundatien rauleett in de naeulve vallepen/Dan komende in de rievieren wozot nautuelijskg gljemerckt. Befe Lateren wallechen ban De betofien af fulcke glinfterende couleuren/ dat de grond in eeninge plaeten

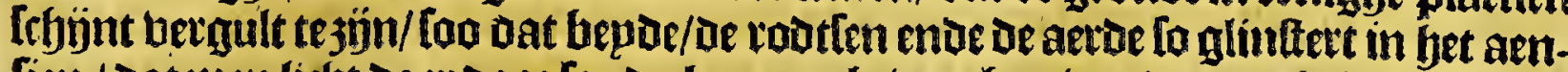

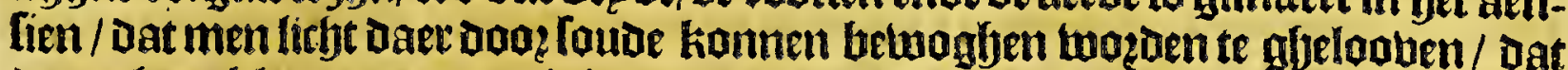
Daet ghen klepne apparentie ig van goudt. Telueklecoingtbe van degronot geeft

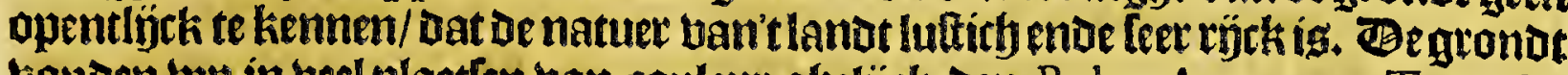
bontuen top in beel plaetien ban coulcur gbelïtk den Bolus Armenus, Terra Si-

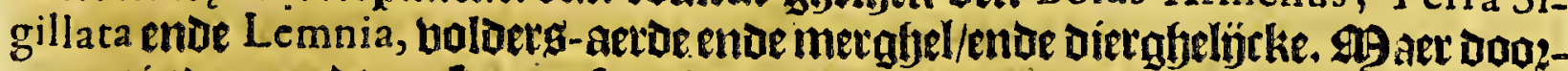

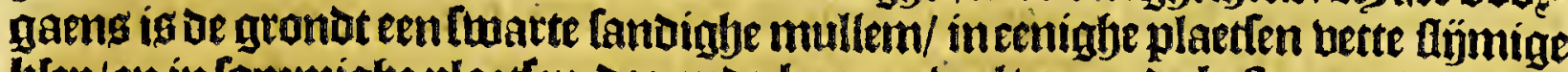
$\mathrm{klep} / \mathrm{en}$ in fommighe plaetten doe ende bat grabeel/maet de befte gronot wozet

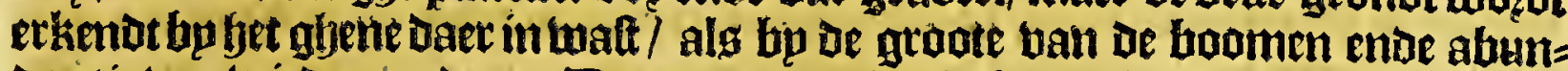
Dantie ban wied en anderg. Be contrepeen ig niet bergigh noch oock leegh/maec loo plaplante exien beubels ende beuchtbare ballepen / Deen D'ander krupflende/

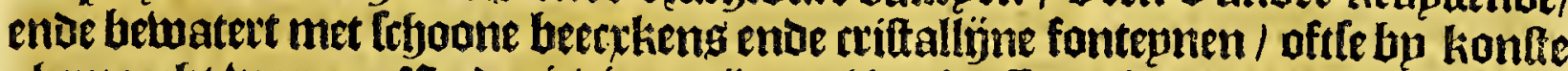

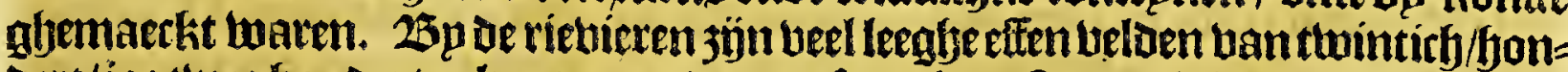
oett/jae thee lyondert ackers gleot/ meet ofte min. Open plainen jün daev lueps

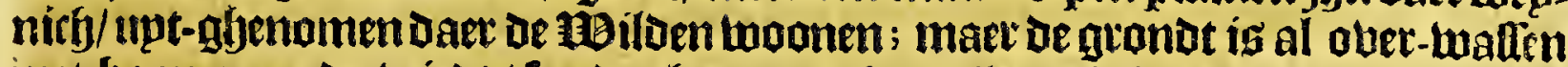

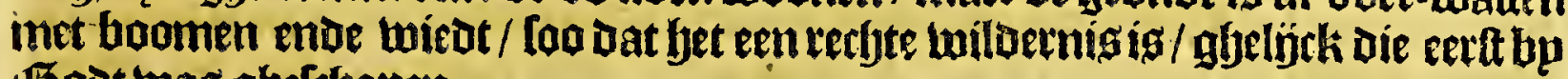
Bout wag gherljapen.

(1)et Derthiende Capittel.

Befchrijvinghe van de by fondere rievieren ende volckeren van' $t$ lande van VI I G I I I A, daer de Engelfche nu vroonen.

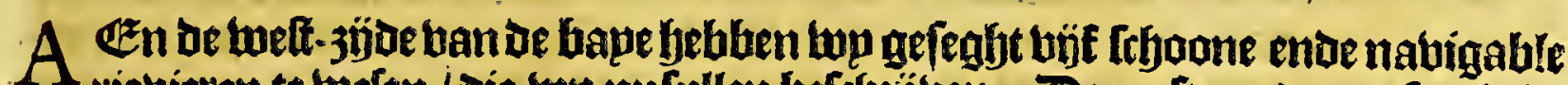

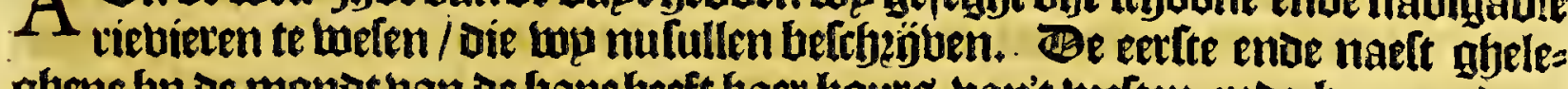
ghene bp de monot wan de hape heeft faet hours ban't weften enoe bp noozen: buazot ghenoent Pau watan, naet dennaem ban't peincipael landt dat daet aen paelt. Be monot ban oele rieviere is bp naet dep mijlen beedot / nochtang doo? de

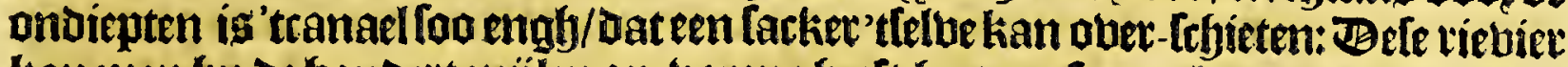

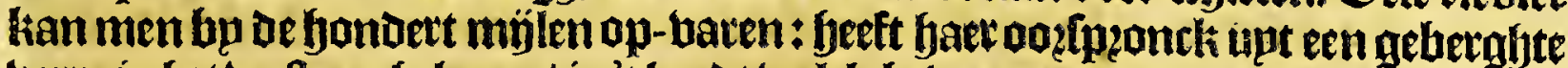
berte in fet lueften gfyelegen / in't landt welck betwoont wazot bp de Monacans.

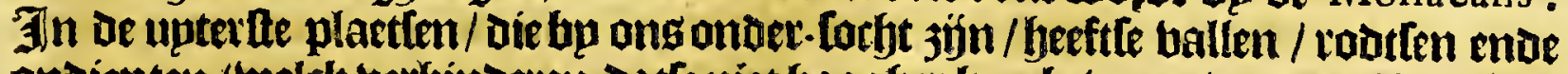
ondiepten / welck berfinderen datfe niet foogher kan betaren wo?den. Ban daet

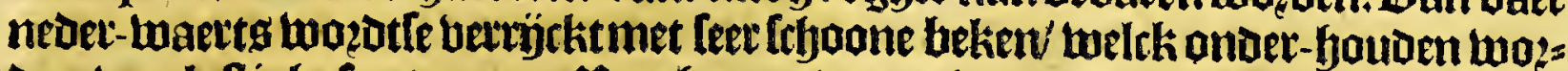

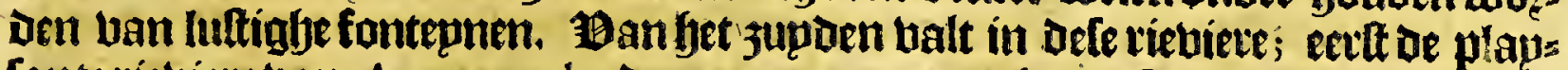
Inte ríetiete ban Apamatuck : Daet naet meer nae bet oolten komen in de Telue twee riebieten ban Quiyoughcohanock : een tmepnigh boozoer is een bape/ in de

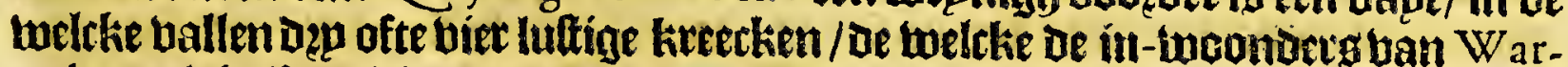
raskoyack half om-ringhelen: Daer naer De riebiete Nand famund; endeten laelten

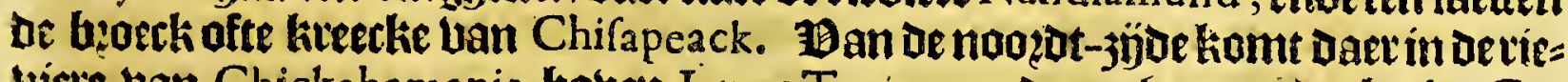
viete van Chickahamania boven Iames Tow ne:ende noctyen ander bp fiet $\mathrm{Ce}$ dar Eplandt Daer top thien wekenleffoen bp de oefters; ende dan ig Daer een be: guame haven boo: bifferferg booten te Kecougtan, twelrk fem bequamelijck toend enor dzaqut in bapen ende kreecken / dat bet deplaetfe feer bequaem maeckt om

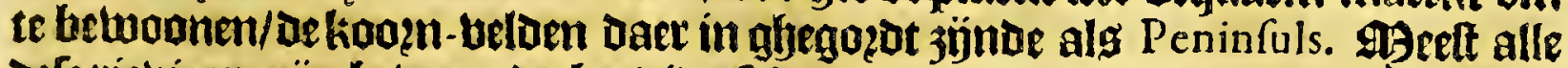

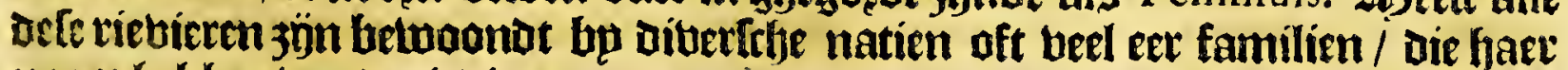
แam febbenbanderiebieren; ende beblen in eleke plaete faet Gouberneurs nfielÿck 
Virginia.

atyelinck als haet thoningben / welck [p noemen Werovvances. In een Penin.

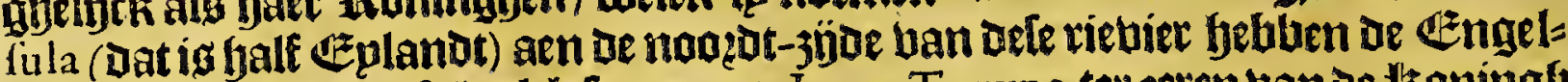
fcheneen woon-plaetfe/welck fpnoelnen Iames Tovvne, tel eeten van je ltoningf van Groot Britannien:aen twelcke jyjo beel boleketen woonen on Det baet Werovvances. Be ectete ende naefte bp de mondt ban de rítuiere jön de Kecougtans, Lelcke beneffeng fjaec bzoutwen ende kinderen gheen thintich lkijotbare mannen

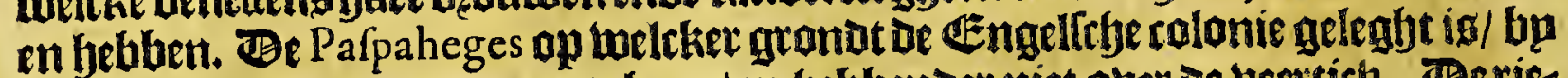

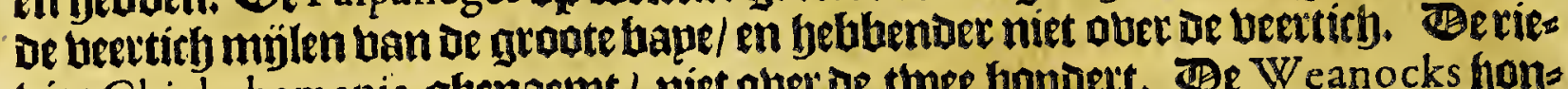
bier Chichahamania nbenaemt / niet aber de thee bondert. Be Weanocks jon=

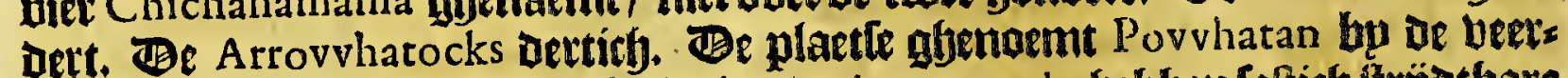

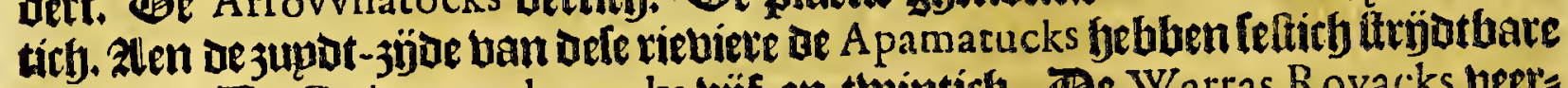
mannen. De Quiyougcohanocks büf-en-twinticty. Be Warras Royacks beet: tich. De Nandfamunds twee hondert. De Chefapeacks en moghen gben bon= Dert upt-maken. Ban defe plaetfe beeft de bape baren naem. In alle dele plaet:

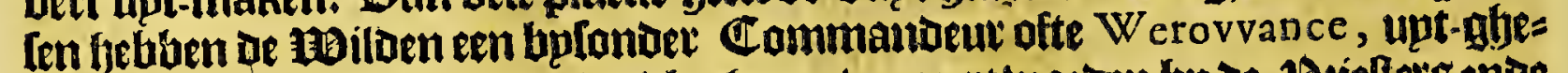

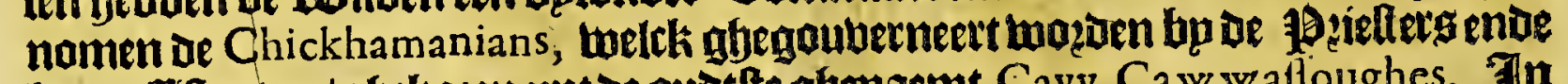
haet alliftenten / gljekoten upt oe puotte ghenaemt Cavv-Ca w walloughes. Jn

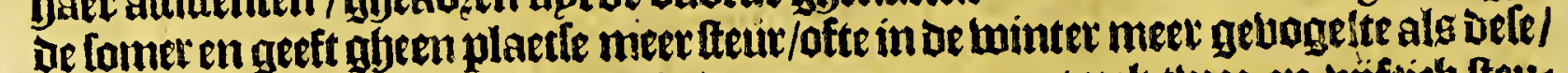

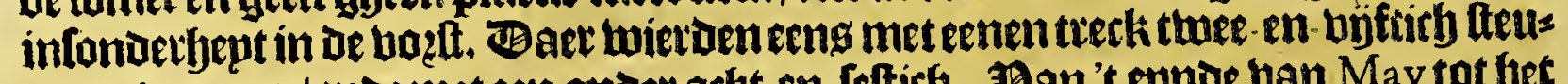
ren gebangen / enve met een ander atbt-en- [efticf. Ban't equae ban May tot bet

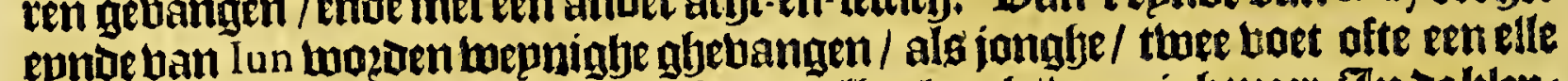
lanck. Ban balt September thee ofte dege ellen lantk/wepnighmeer. In be kleps ne riebieten is al 't jaet dooz abumbantie van klepne bifty/ Loo dat men die met of engfel aljenaegh banghen Kan. Srbipper Cornelis Iacobf. May, die ap dele riebier was in Den jare I $620 / \mathrm{gbetupght} \mathrm{Dat} \mathrm{bet} \mathrm{eerlte} \mathrm{rack} \mathrm{ban} \mathrm{bele} \mathrm{riduier} \mathrm{ftrerkte}$

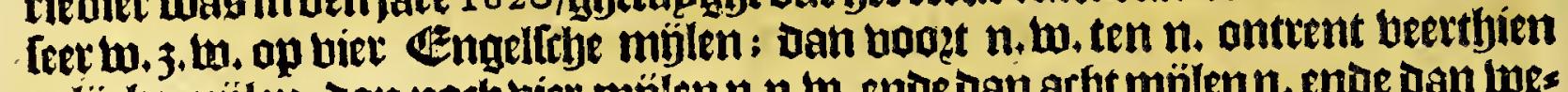

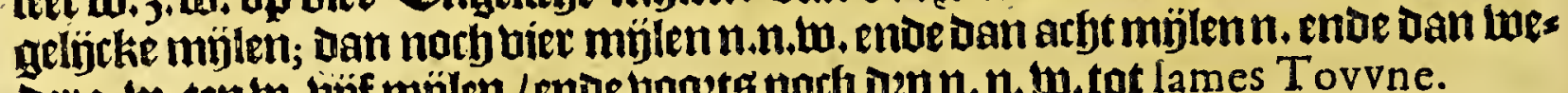

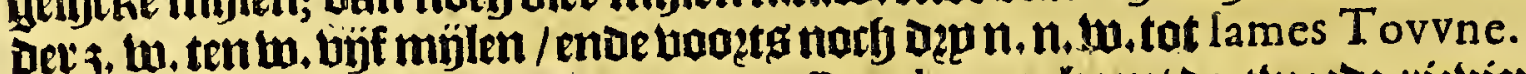

Beetthien mílen noozotmaert ban Povvhatan, Komt de twetde riebier upt/ welck fu noemen Pamauncke, die tuel lefticfy oft febentity mijlen op kan wozs

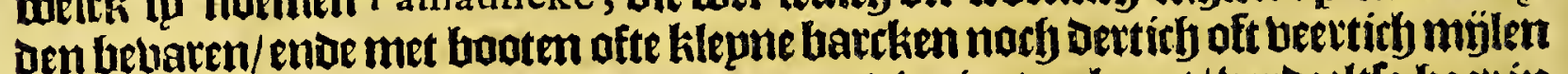
boozoer; daer oe blokdt ban'tzouot-water ozoinaire toe-komt/berdedtle baet in twee fryoone armen. Flen De jupDt-3joe woonen de Yougtanunds, welch bp de feltich ftrijotbare mannen beblon. 2len De noozot-arm de Mattapaments, weick

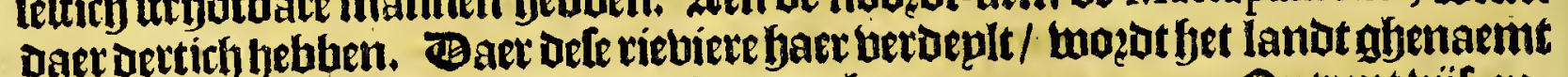
Pamaunke, endeboed bp naer oep hondert bequame mannen. Ontrent bijf-entwintich mülen leeger aen de noozot-zijoe ban defe riebier is Weravocomoco, Daet haer groote Honingh bem onthielde doen Capitepn Smith tot hem gevante kelijck wietat ahebzatjt; norftang en jijnber gheen beettirf ftrijotbare mannen.

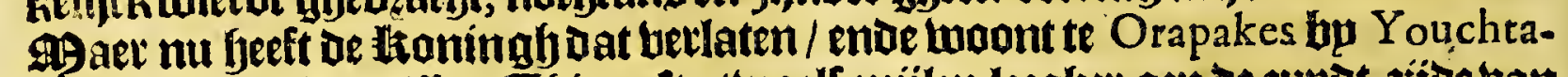
nund in oe huildernite. Chien ofte thaelf mijlen leegher aen be jupbt-jijoe ban Defe riebieve ís Chiskiack, welck beeft by de beettich ofte bifttich man. Befe als alfoo A pematuck, Irrohatock, enoe Povvhatan, 3ijn haer groote ltoningljo

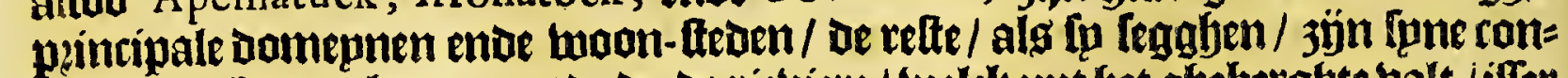

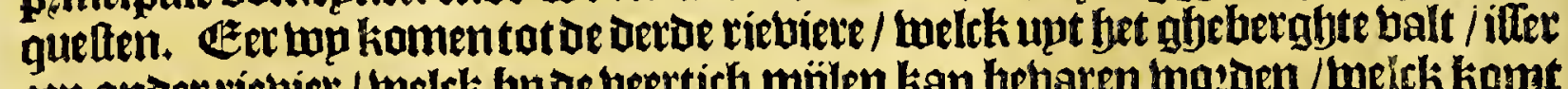
cen anoer riécier / welck bp oe ueertich mijlen kan bebaren wozden / weick komt tan fet in-lanot/ae riebiere is gfjenaemt Payankatanck, de in twoondecs honnen bp ae beetich ftrijatbare manmenupt-maken.

Je derue natuigable vietuiere mozot ghenaemt Toppahanock, Defe kan Jjondert en dertich mülen betuaren wazden. Alen' topperfte woonende balkkeren genaemt

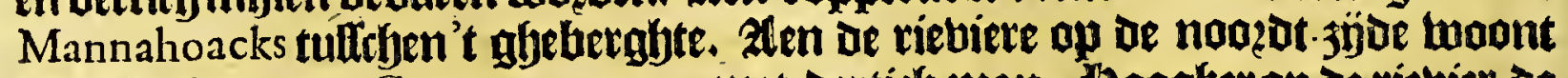
't balck ghenaemt Cutratavvomen, met oertich man. Moraugtacunds, met tathtentich man. 25oben baer be Toppahanocks, met hon= Dert 
Het derde Boeck.

Dettman. Alen't 3upden/berte binuen De tiebiete is Nantaughtacund, met fon= Dert vịftiç一 man.

De bierde viebiete ig ghenaemt Patavomeke, en isfeg oft feben mülen bzedt/

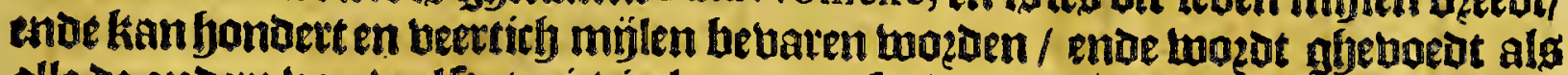
alle de anoere ban betloete riebieckeng ende fpingen/weicke kamen ban te aen-

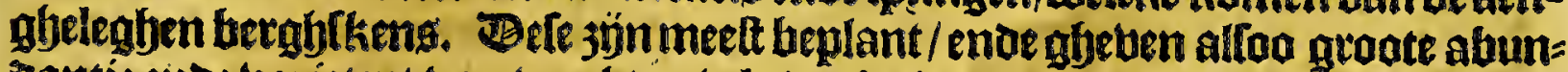

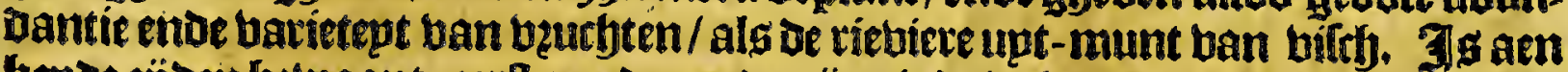
bepoe zyjoen bthoont; eetit aen ae jupDt-3ÿue in't in-kamen leght Wigcomoco; Daer bp of yonderten detticfyman ig; Daer aenSekaco wone met derticfm man/ende Onavvmanient met Gonbert. Ban Patavvomeke met fondert ende feftich man. Fier berbelt bem de riebiere in Deg ofte bier bequame riebieten / De groptfe ban

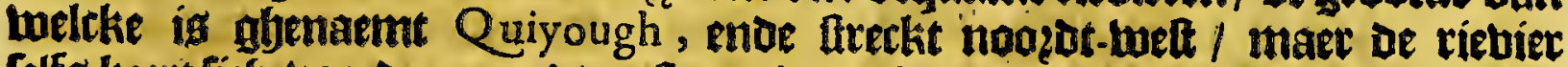

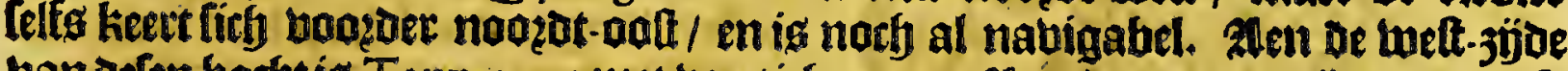
van Defen bocht is Tauxenenr met beertich man. Zlen de noozot-3joe van Defe riebier ís Secovvocomoco, met beertichman: that voager Potapaco met twints

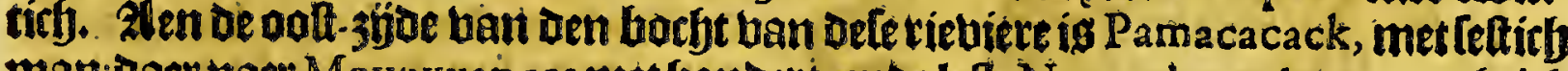
manidaer naer Moyovvances met fjondert; enteleft Nacotchtancke met tachtich

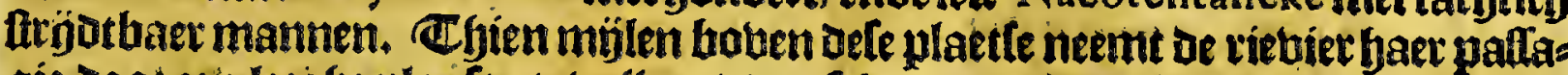
gie Doot een leeghe plapiante ballepe/ober-frgabulwet in beel platten / met ontals lijcke Iffjoone ende plaplante waterliens die daet af blieten.

De vôftoe riebier is gftenaemt Pavveuxunt, en íg klepnder als de anderen/Doch bet canael ig in lommighe plaetfen feffien ente acbitbien basemen diep. Hier ig

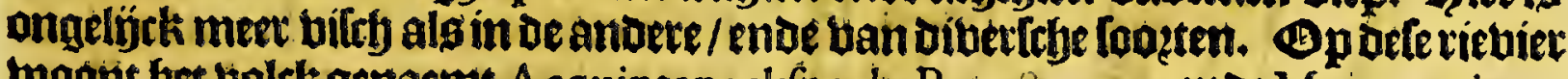
moont bet boltkgenaemt Acquintanackfnack, Pavvtuxunt, ende Mattapanient; die [oo beel men mercken konve ten upterfien 200 imankonoen upt-biengen. Ban woonen betet by een/ente niet loo berftopt als de antoere ; ente woęden de alder

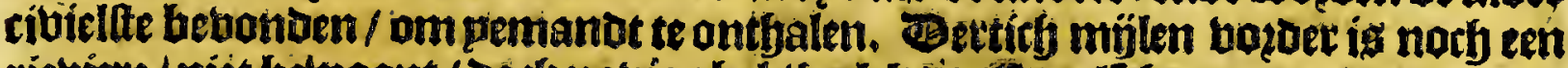
riebiere / miet betuoont / Dorb nabigatuel / wellck de e engelfefe om dat be klep Bo-

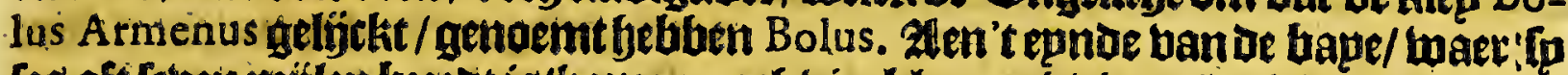

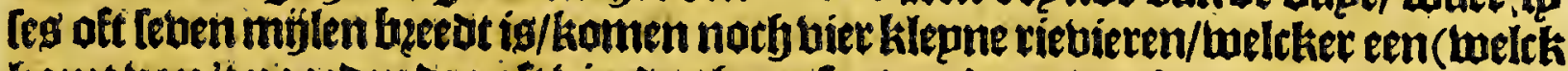

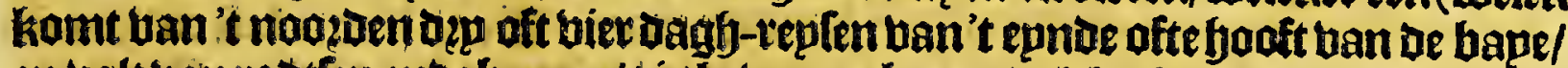

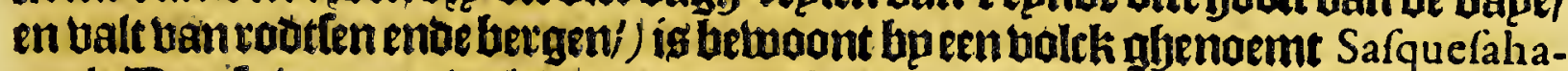
nock. Dan fp woonen wel twee dagt-leplen yoogher als de betcke konoe komen: (belc twas uan twee latt/entebadose twaelf man in:) Seltich oft Daet ontrentban

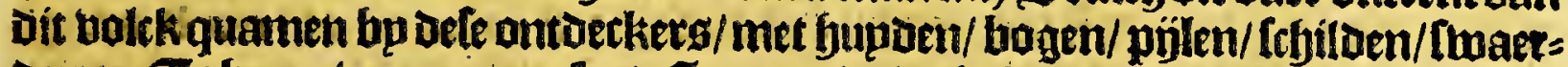
oenen co abacta boo een pelent. Groat ende wel gbeptapationeett bolck/want

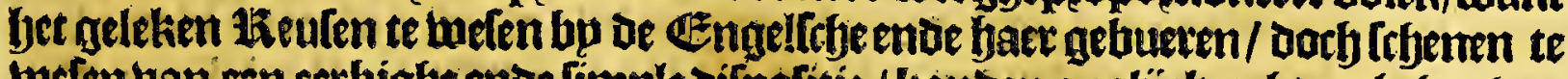

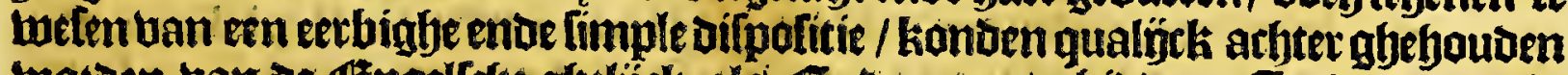

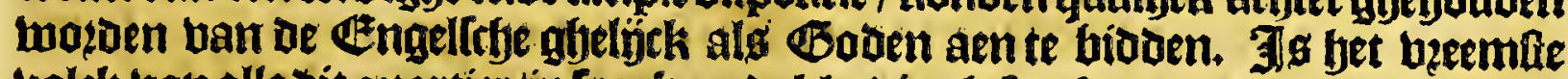

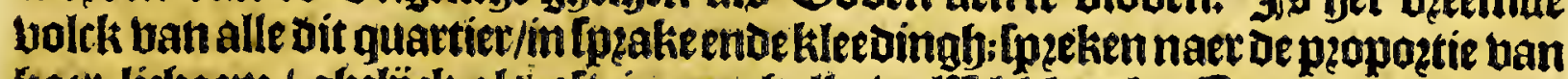

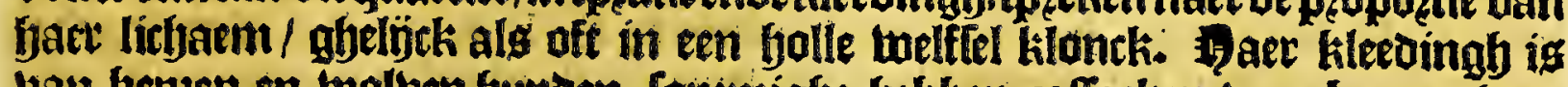
bat beper: en twolben bupten; [onmigbe bebben caflacken ban bepen bup= teri / met booft en al / too dat baet bals gaet booz Des bepess bals / ente des

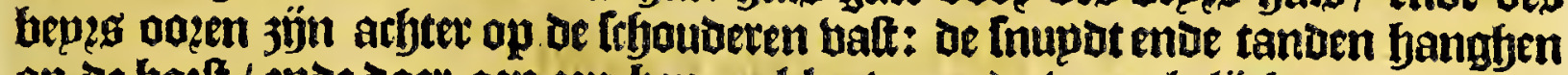
op de boeft / ende daet aen een bepzen-klaulw; ente ban ghelijcken op den at: men tot Det elleboglje toe. EEen van Gaer baut een tuolfa-booft banghende

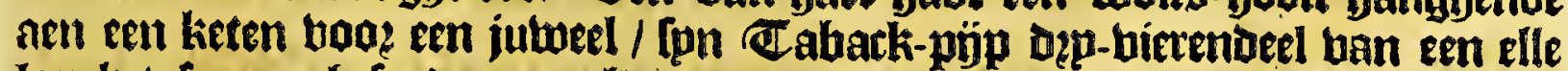
lanck / fraep ghefneden aen ljet opper epnot / fterck ghenoegf om pemanot Je bertenen upt te fimỉten; badoen booztg booghen / pjilen ende knobtten naer

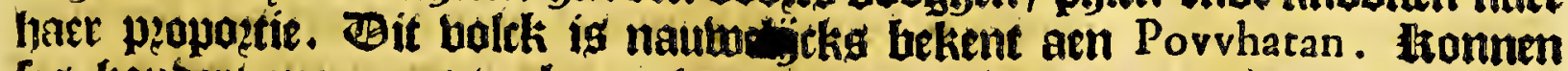
les bonoert man upt-maken / baet bospen jün met paliflasen omringelt

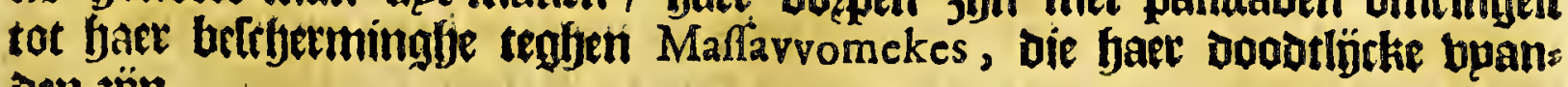
Den jün. 


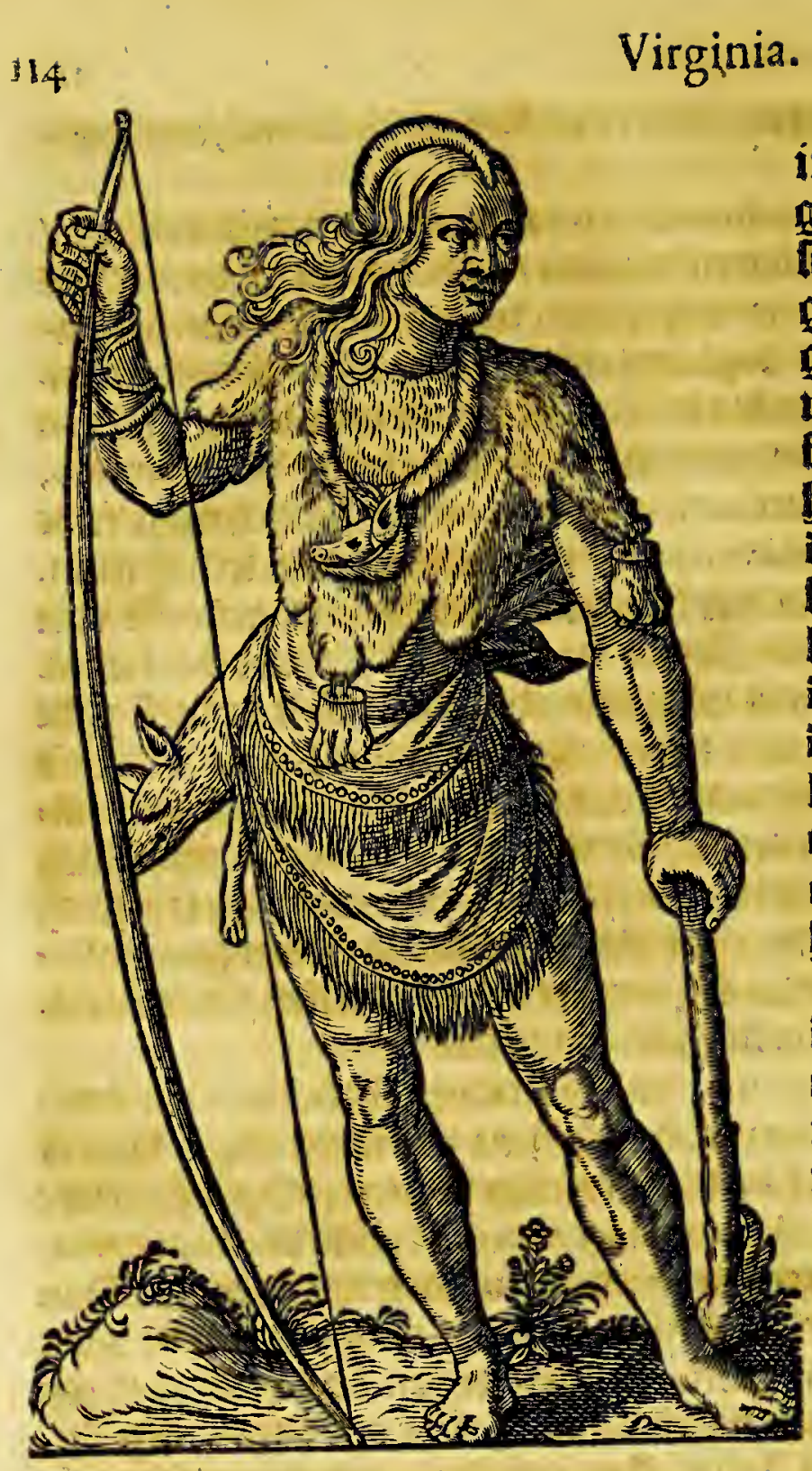

App feblen gact gbetonden hiel in te voegen upt de haerte bande $\mathcal{C E}^{2}=$ abelfine de af beeloingtye tan een de=

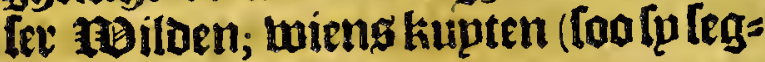
ghen) baren Dęp bietended ban een gaetbe dick/ende de reft van fon leden naet aduentand/ foo Dat bet sen feet fracp man was om aen te lien. Spn

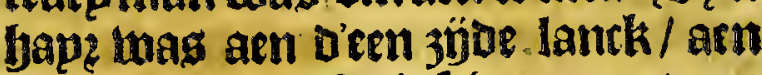
Danoet bieft af-glyeftyozen met eet Itreeck ouer fon krupn als sen banenKam. Spn pujlen waren vỉf-bierenDeel langh/ met fryerp van fteen een. Dupm beerot enoe ander-fyalf Duum langh; lacltke fop in ten wolfg thel. op Den rugh Dzoegh; I Ipn booth in De eene / ende fun knodle in de andere banat.

Alen ve voft-jüoe van oe bape ig De riebiere Tock wogh, enve Daer aen eenbolck welck yonoertmankan upt maecken / diefeuen mülen biumen de riebiere woonen; daet fo een fort helbs hen twel belet met palithaden. Jaec naeft leght Ozinies met lefticlyman: meer naer't jupden ap oe fellue ooltjübe van oe bape/ oe rievier Rapahanock, Daet De riebiere Kuskaravvaock naelt ghelegen íg. Op twelcke riebiet een oo ph ahelegen is met twee hendertman. Taet aen bolght de riebier Tants Wich cocomoco, ende een boup van bondert man. 'Quoldk ban bele riebiete ig ban klepne ftatuete / ende bebluen een ander tale / ende jün Ieer roulw. glgaer die Lam De rietiete A cohanock met veertítyman/ende die ban Accomack met tacb= tentich man/ zün te uerghelijcken met de landen ban Povwhatan, enderlyeeken oork

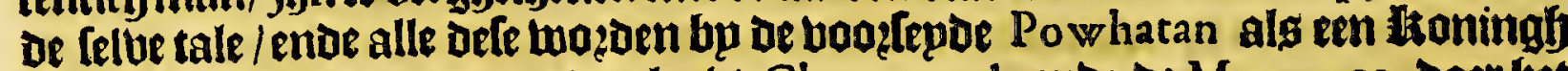
gljetegeert. As)er naer't jupden legtjt Chavvonock ente de Mangoags, daer bet bolck ban Sir Walcher Ralegh was: want van orle plaeten af tot be blecke vam Chifapeack was yet eertijotgontoeckt by $\mathrm{M}^{\mathrm{r}}$ Heriots ente Sir Raph Lane. Bn= Det dit bolck jün Diberlebe natien ende talen; foo dat om-ber Povwhatans lanot/ ae Cha wonocks, of Mangoags, oe Monacans, de Mannahokes, de Mafa wo ome$\mathrm{kes}$, De Alquanachukes, oe Toghvvoghes ende de Kuskazavvaakes, D'ent'ander: niet en berftaen dan by toleken: welcker wooningh-platten beeder te fien zün bu of kaerte.

\section{Wet vertffiende Capittel.}

Van de eyghen vruchten van VIRGINIA, die daer van felfs vvaffen.

H Oe-wel (legft de Lelbe) Dat Virginia booet-beenght beel fraepe [oo lebende als

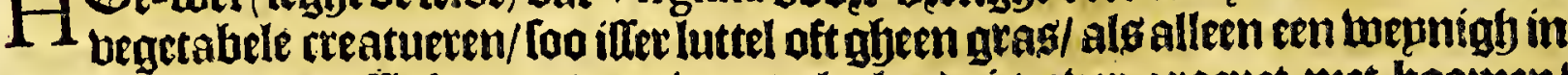
Ieenfe ende moerallighe gronden; mant al 't lande is ober-groevet met boomen; melcker continuelen ozop't gtas tot wieot maeckt; oan dit waer licht met arbepot

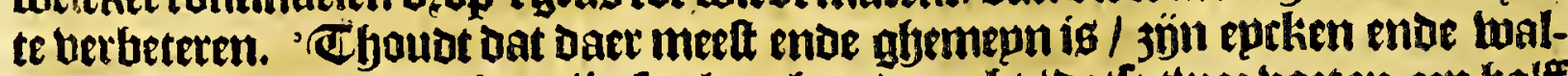
noten : beel ban jaec epcken jujn foa langh ende recht / oatle twee boeten een balf viet-kant 
Liet-Kanot fullen upt-benghen ende dat of lenubte ban thínticb graben; ende

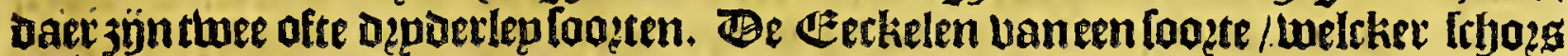

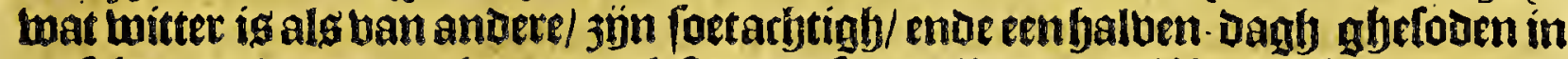
neritgepden twaters / gheven ten leften een foete olie / Die de Moilden betwaren om Gaet leden met te fmeten. Be veurfte etenle tot bzoobt gbematckt / ende anders.

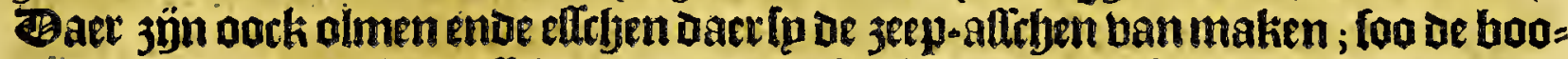
nen groot $3 \mathrm{jin} / \mathrm{balt}$ de altrben goet / ende linelt tot groote bzocken/ maer foo fo klepn zijn/, Too woęot fjet maer pulber/ende niet foo goet ald't andere. Baer zijn mal-noten ban twer ofte depoerlep footten. Bockeen foots ban boomen/ Die wp

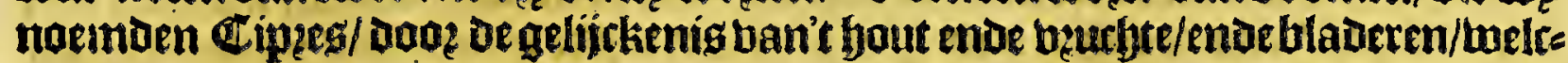

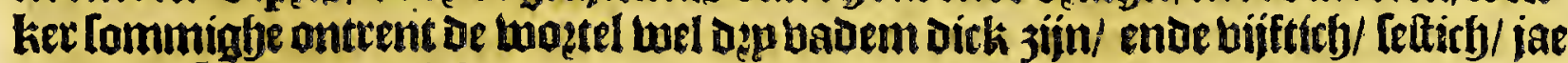
tachtentich boet boogh fonder eenighe tacken: (uele geben een roodt ende leer we!-

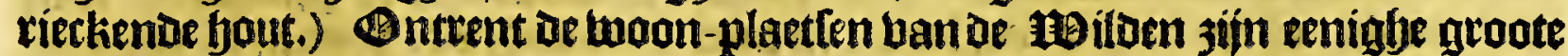

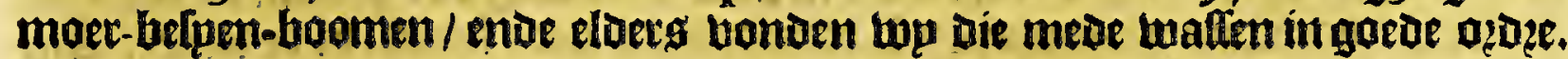

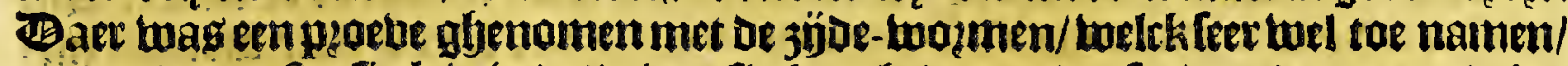
tot dat de meefter fieck wierd/ wieng fieckte gheduevenue / [p ban be ratten twiet: den op-ghegeten. Sp wonden oock hafenoten in lomminge quartieren/ welckers

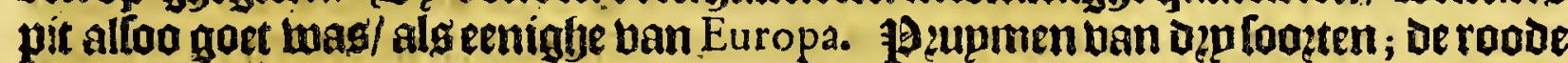
enoe twitte 3 in als de peupmen die op de hegeren watten; maer De andere welck fo noemen Putchami ns, twatten foofooobals Palmiten; be beucht is als een mitpe!/

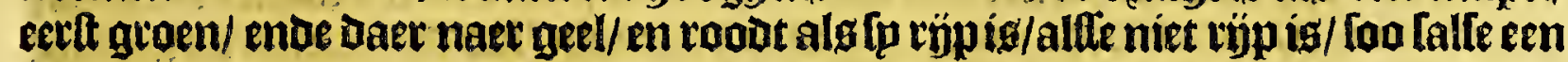

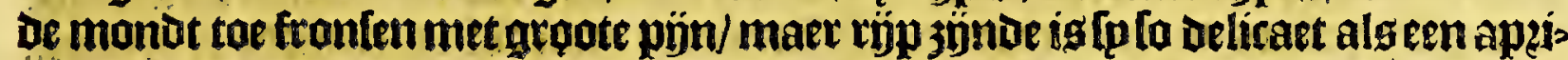
rock. Htiecken foo groot als kroofkeng; : wepnighappelkeng/ ende díe leet kiteun ende bitter.

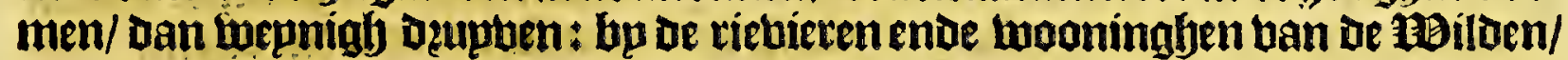

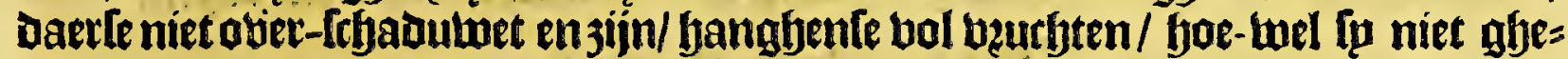
Inoept ofte ghefhabent en twozoen. Sp maecktenvan oele dzupben leet naet twin= tich ftoopen wijng / welck alloo goet twas als een ffrang 25 fittoeng wìntien ; en oe voo - feker foude daer goede tojn vallen / twierden de twijngaerden ghebabent.

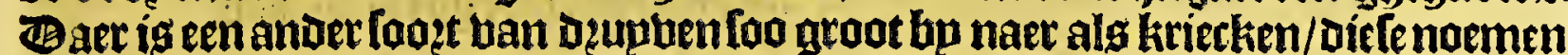

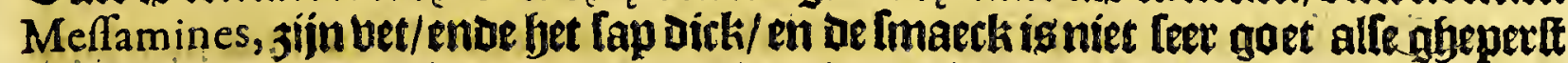

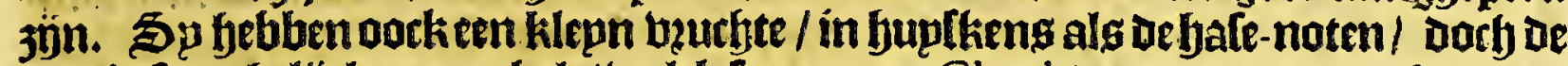
beutht leet âthelírk een eeckele/ welck [u noemen Chechinquamins, ende foudent

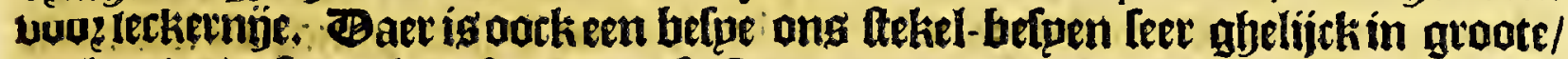
couleur/ende [maeck/ defenoemenfp'R avvocomenes, en eten bie raulw/ende abes

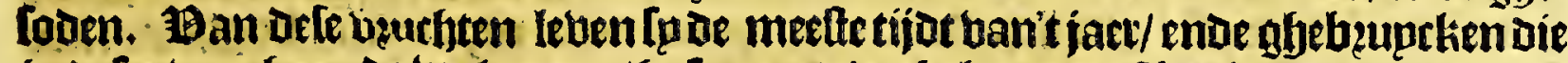
in defer voegfien; de twal-noten/hale-noten/ eeckelen mae Chechin quamins, wo:=

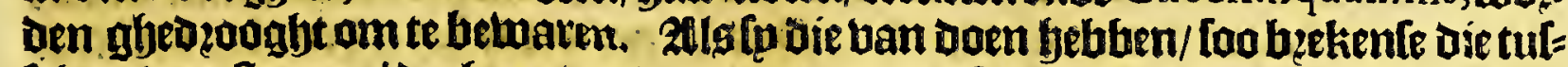
fibentwee fteenen / Doch een part han de mal-not-[ryel bliffter aen -bangben: dan ¿zoogbenfubet tweder op een mat legglfende aber een furdel; ftonten bet boots klepn in een fouten moetiev; mengbeler bet met Later dat be frbellen mogfen fincken: dit water twozot alsmelck/ heldk tu noemen Pavvcohifcora; en betwaren

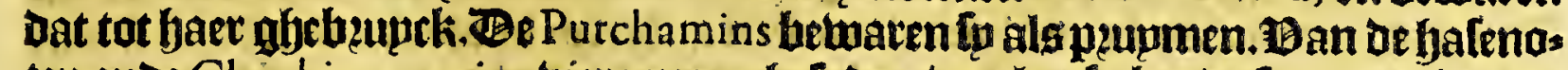
ten ende Chechin quamins bier upten ghefoten/makente bepte lop enoe bzoodt

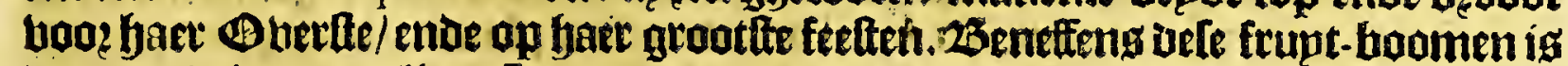

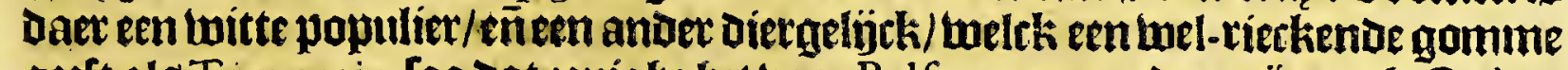
gefft alg Terpentin, [oo Dat eeninbe bet booz Balfem nemen: Daer jün oork Ceders ende Saffa fras boomen: Daer ballen oockeen wepnigh gammen. In oe waterarb= tige vallepen waften belpe / welck Ip noemen Ocoughranamins, Je kappers ferr ghelÿck; defe dzoughen fp in De [omet: als [p die twillen eten / [oo fieden fp die bp naer ren faluen bagh/want anderg berferbillen fp wepnigh vanfenïn. Mattoume

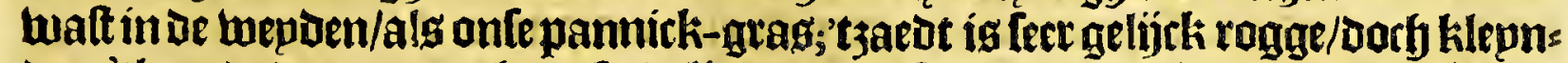

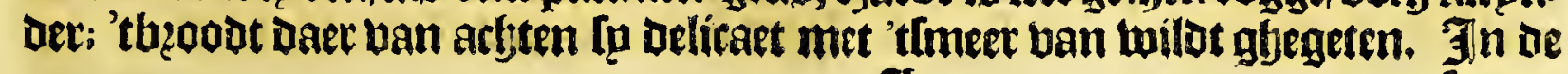
ZL 2 Tomer 
Cometheft men baer / ofte aetot-belien/ welcke ryppen in April, ofte mogt-befiet in May en Iun, enoe een vzuchte weltk fo noemen Maracocks, welck een frague

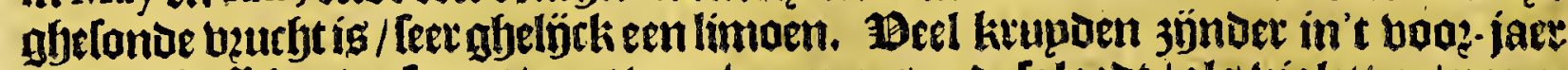

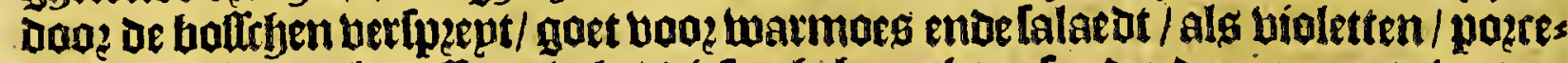
lepn / lurick / etc. benefteng bele / Jiele gyebzuptkten lonoer oen naem te toeten.

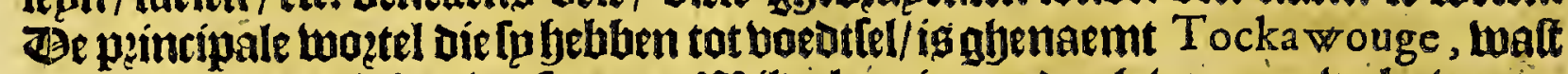

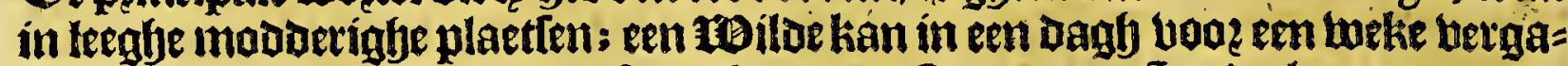
Deten; jön uan de groote ende Imaeck dan de Potatoes. Sp Decken een groote menichte met epcken bladeren ende vapten/ende aetde daet ober/in maniere ban een kaal-put / enoe leggben daet gaet uper aen bepoe jjoen / twel 24 uren langh/ eerfe die derben eten/ want raubu is bet niet beter als benÿn; ende tuefende ghes

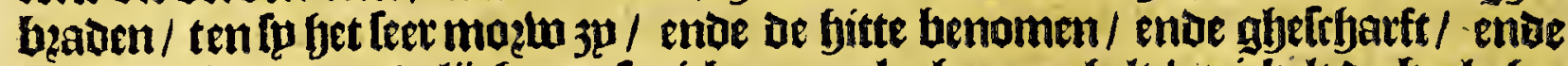

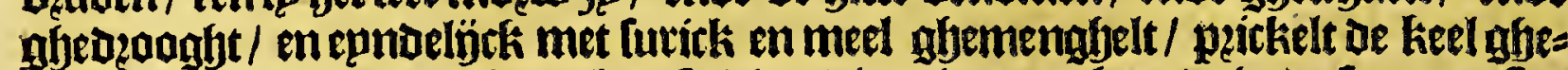

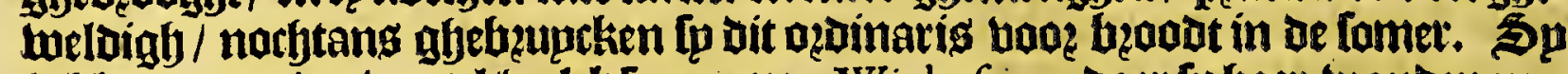

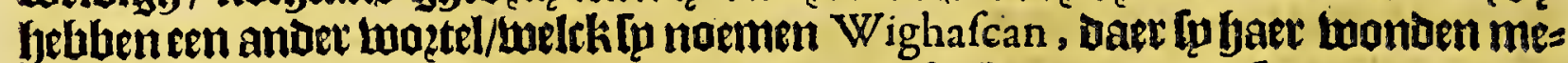
be ghenelen/ ig een klepn waztellien / welck fo beeken / ende foo op de twon=

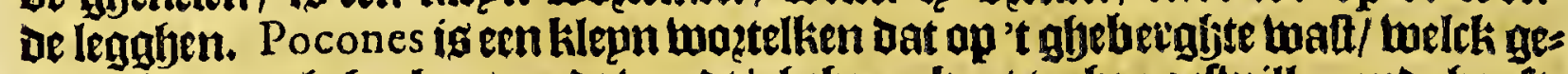

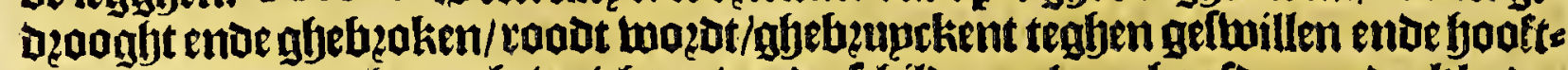

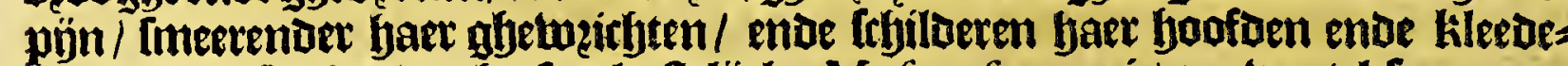
ren mede. Spyouden bet leer kaftelïck. Mufquafpenne ísen tudetel foo groot als een binger/ ende bloedt-roodt; als men't beooght / [oo bertwelcket lip naer tot niet; gebzupckent am yaer matten/[cfilloen/ende ander dingfen mede te vertwen.

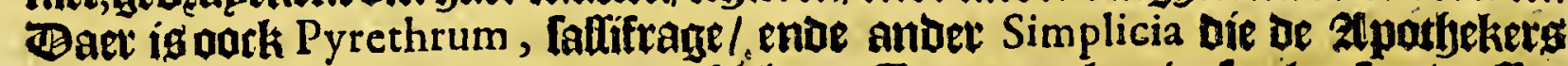

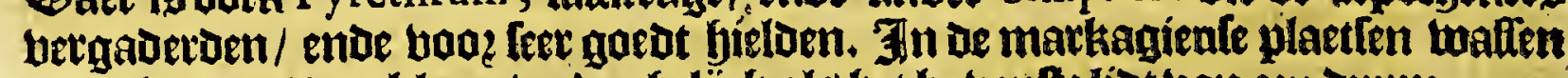

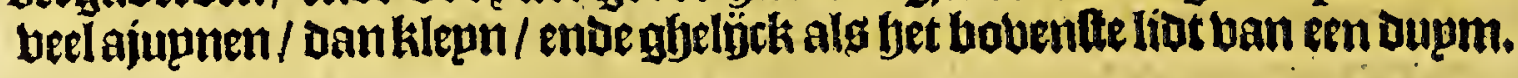

\section{(9et büftbiende Capittel.}

Befchrijvinghe van de byfondere vruchten, die by de Wilden van den Lande ghevvonnen vvorden; hoe fy die planten ende ghebruycken.

D Ex Birginiaeng berdeplen baer jaet in uñf faeploenen; delwinter noemen fam: mige Popanovv, 't booe jaex Cattapeuck, of fomer Cohattayough, als fjaet koom begint te apen Nepinough, Den betfit ende ballen ban 't loof Taquitock. Ban September tot midoen ban November febben lu yaer pincipale feetten en factificien. Ban bebben fp abundantie bankrupot / Fa a bel gbeplant als 't ghene

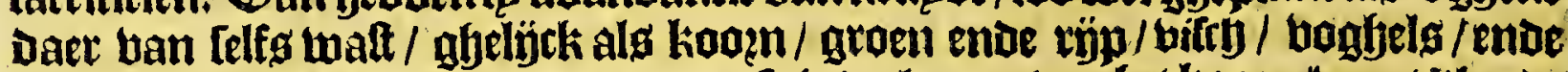

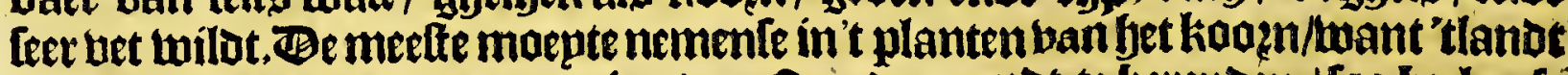

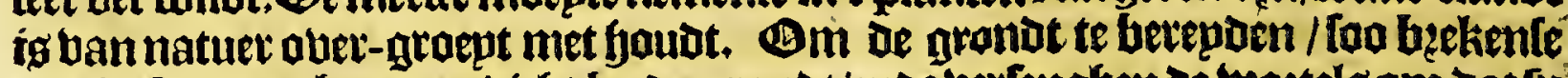
Den balt bam de boomen dicht bp de grondt/enze berfenghen be waztelg om dat lie

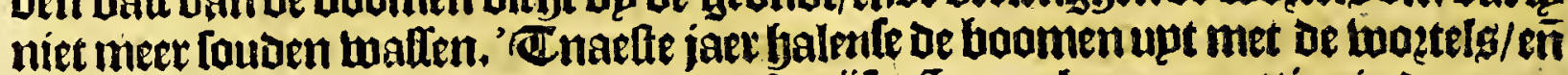

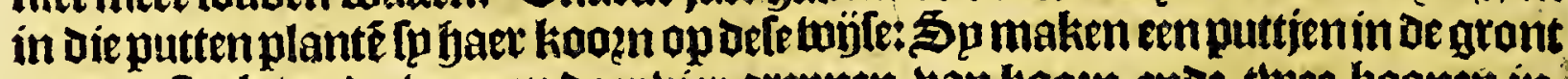
met een ftock / enoe weepen daer bier grepnen van kooen ende thee boonen in. Bele puttiensi maken [p vier boeten ban den anderen/ oe bzautwenende kindeten onder-houden fet gejaep cantinuelijeken met wieden/ende allt op-getryoten ig tat oefyelft/ [oo aetoenfp dat aen. Jn A pril beginnen fp te planten/ oochpeincipalijck in Mey, eñ loo continuetente tot falf Iun; wat fp planten in A pril, Dat vergaderen fpin Auguft; ban May in Septemb.ban Iun in Octob. Eticke thaec ban baet kadu Dzaeght gemepnlÿck 2 aft 3 apzen/ welmin ofte oockgeen/maer Teloen meet;ende elck apt heft ban 20 tat 500 grainen: De ftaecligroen welende beefteen loet lap/

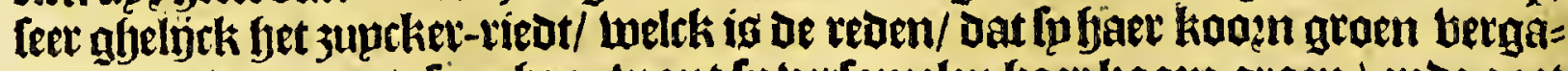
deten ou de canen te fupghen; want fu bertamelen baet koazn graen / ende gaet

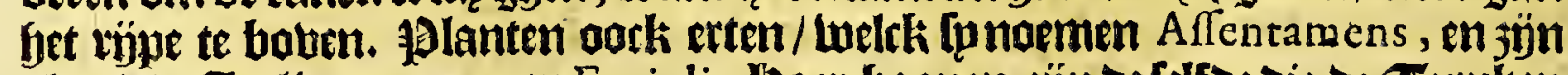

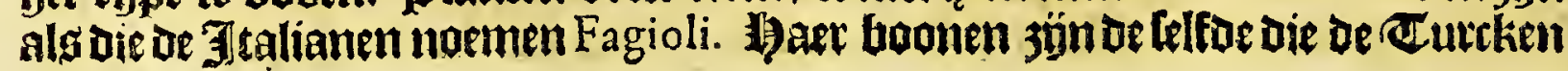


noemen Garuanfes, Defe boutenfe tooz cen Delicatelle. Sp rooffen baet hoom groen in de apze/ ende betken yet in een moztier/ enoe rallen fet op in de bladecen ban 'tfelbe kooen / ende fieden bet foo toog en lecternije. Enoe her fiopen dat te laet gfjeplant ig / ende niet wil rjpen / roaften [p onder beete aftefjen/ ende belua:

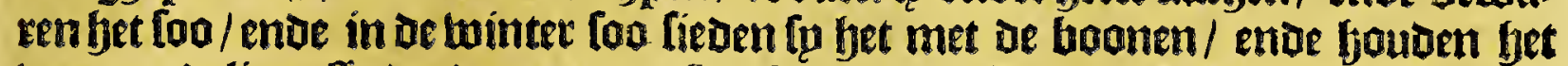

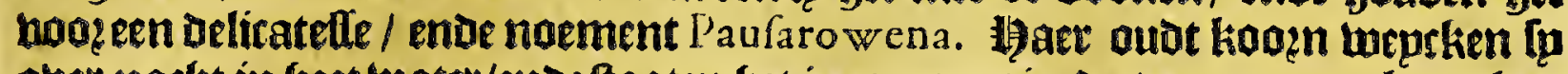
buer natbt in feet water/endeftooten het in een moatier des mazgeng;gebzuptken

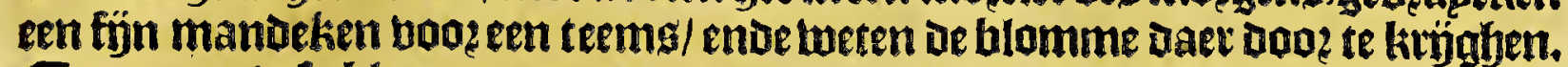

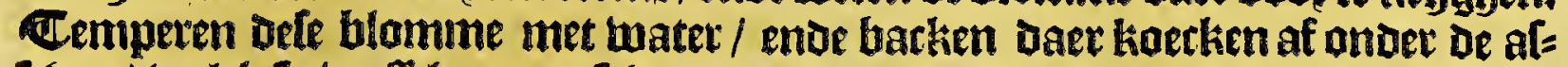

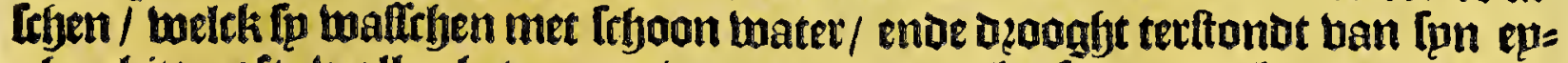
ghen bitte: ofte wallen bet op met water / ende eten bet foppe met bzood belck fo noemen Ponap. Be grutten ende ober blinffels ban't koden glyetwannet in of

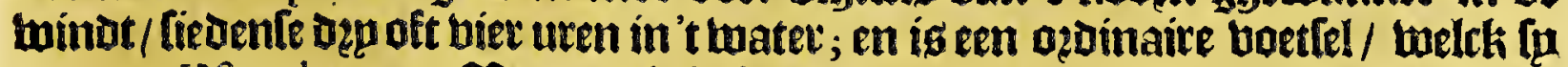

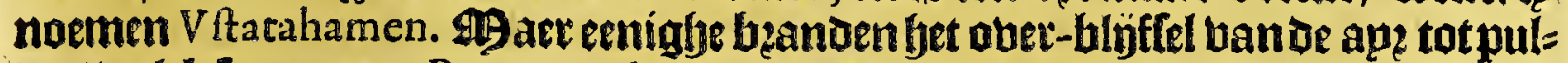
ber/ welck [p noemen Pungnough, en mengfelen bet met baer meel/maer fmaecht niet wel noct in bzoodt / noct in loppen.

In de May planten [p oacli ander baer Koom pompoenen / entoeen beurbt/ge=

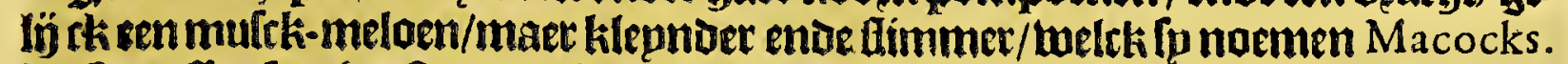

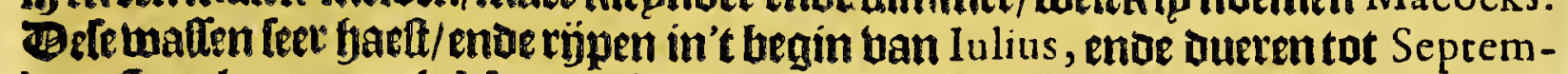
ber. Sp planten oock Maracocks, een wiloe bęudyt als een limoen / Die ghetwe! = Digh aenuaften/beqinnen te rüpen in Seprember, ende Dueren tot October. Alg al baet buebten zün ingefamelt / [oo plantenfp tuepnigh anders; ende dit wozot al gedaen bu De beoumen enoe hinderen ; ende dit en ftreclit gaer niet langh/want Ieer naer de dep derde partein van 't jaer / oblerveren [p de tỉoen ende jaep[oenen/

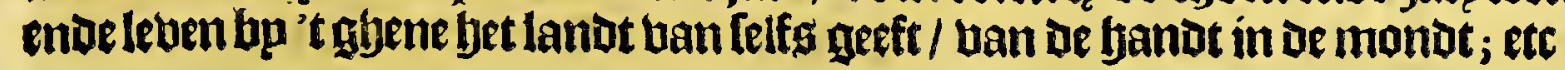

\section{Het [effiente Capittel.}

Befchrijvinghe van de Dieren, die men in dic quarcier van VIR G IN I A vindt; vier-voetighe Dieren, Voghelen, ende Viffchen.

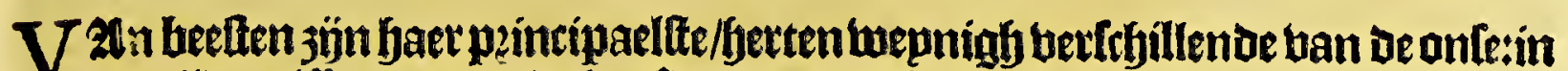
De wilderniffen ontrent de boofden uan deriebieren jonder beel/maer tuft'jen be rievieten wepnigh. Baer is een beeft welck fo noemen A rough cun, leer geligek

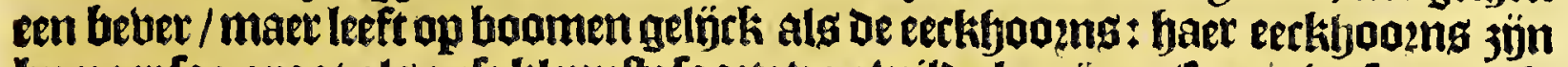

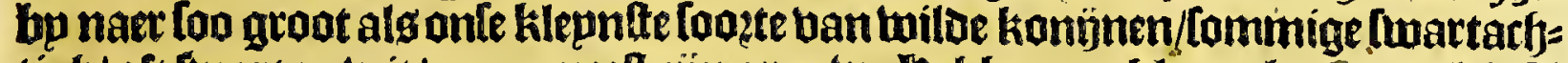

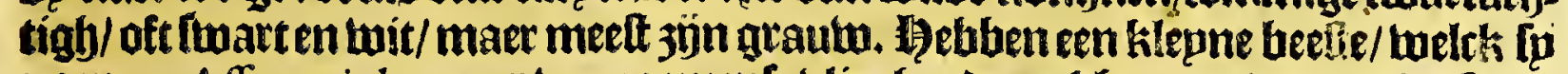

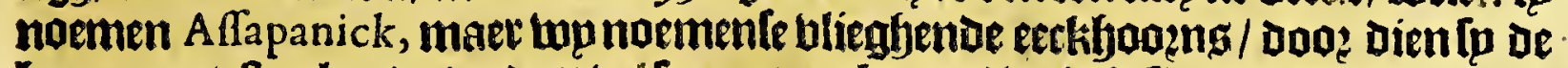
beenen upt-Atreckende / ende't bel foo upt-rerkende / wel gherien twogeden 30 oft 40 roeden verte te blieghen / ban den eenen boom ap den anueren.

Opafom beefteen booft als eentwinn/ende een fteert als een rat/ende is ban de gtoote als een kat: onder Den buurk beeft [p een fack/ Daer lp baer jongben in bzaeght/ende boedt. Muffafcus is een beeft ban de ghedaente ende hature ban een water-rat / maer beel rieckenfe frer naet mulrug. Haet bafen en $3 \mathfrak{j} n$ niet

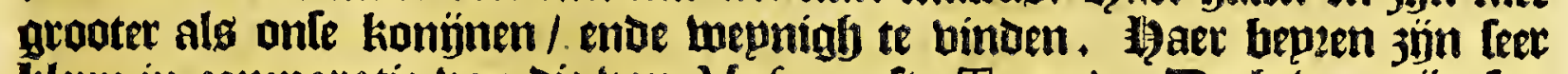
klepn in compatatie ban die van Mufcou ofte Tartaria. Te bebers jün foo groobt als ożinaire water-fonden/ maer be beenen kot / ae booz-boeten als een bondt / ende de arfterfte gftelíck als ban een fuaen/ de fteert bu naer als een racket / naeckt fonder hapz; of mailoen achten bet bleftef een goedr eten te melen. Sp bebben oork beel otterg / be welcke fu ghelïck als de be= bers uanghen met ftricken/ende bouden de bellen voos een rieract; enoe al bele dieten eten fp / als fp die kanmen uanghen. Baer is oock een dier / welck (p noemen Vetchunquoyes, ban gfeoaente als en milbe kat. Haet boften

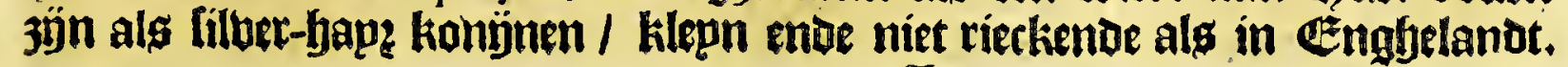




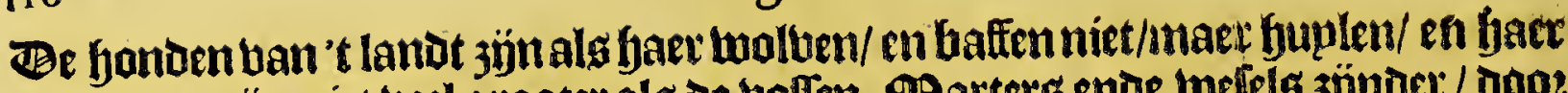

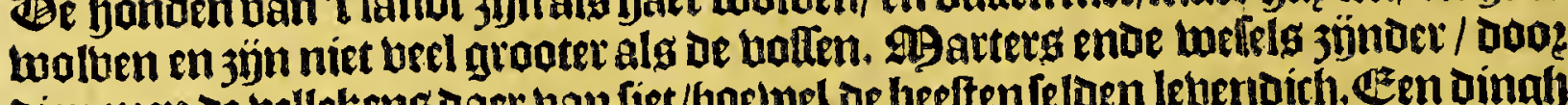

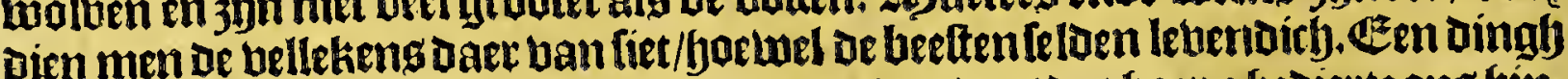

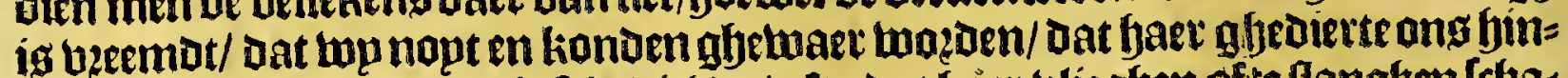

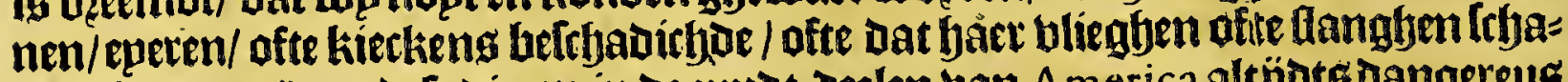

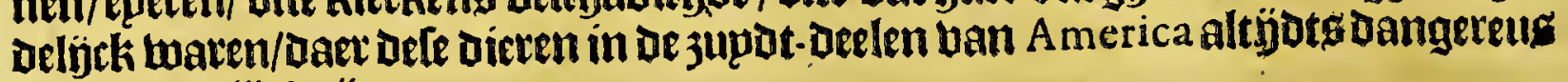
ende Doadutlïck jün.

Ban ghebogbelte jön daex arenoen / ende dibertebe topeten bar balcken : ende

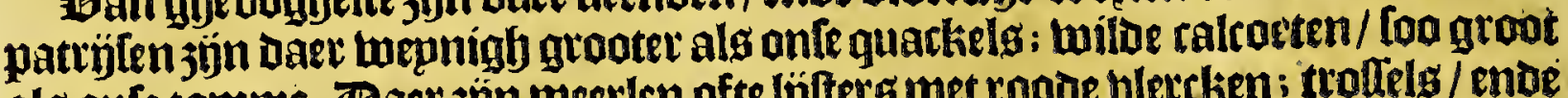
als onle tamme. Baer jịn meerlen oftelijltets met roode bletclien; trolels/ ende diberfthe foozten banklepn gheboghelte / senighe roodt / eenigbe blautu / gualj̈ck foo groot als een koninctken/maer wejnigh in of fomer. Jn de bointer ifter groo= te menichte han Imanen / cranen grau enoe wit met fivarte bleuglyels / repghets / ganโen/epnoen/papegapen/enoe bupuen. Ban alle oefe Loozten groote menichte ende andeve beemae footen/ van welcke dennaem ons onbekent is/maer in den fomer júnder wepnigh afte gheen wan alle defe te lien.

mat bifth belanght / Gadoen oe bette kennig ban fteux / beupn-bilch/3ek-kalf/ fteech-rogh/mieng ffeeck [eet dangeteugis / betten / meulenąrs / witte Balm/

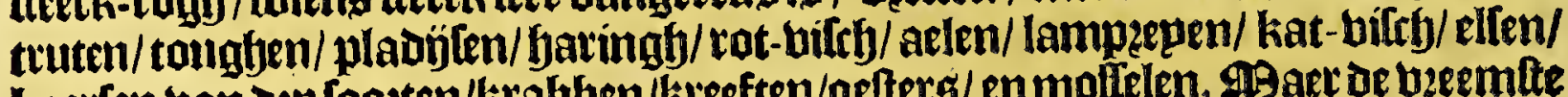

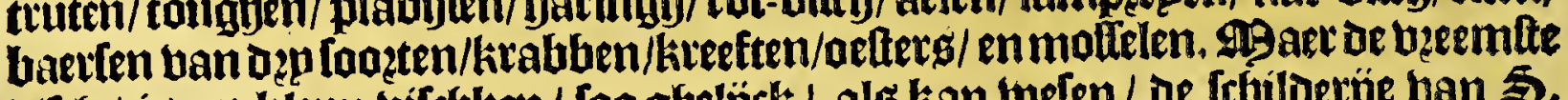

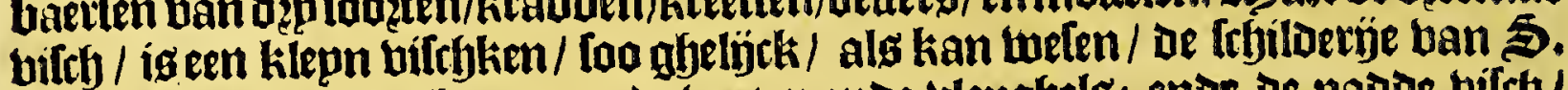
Joeís Braeck / upt-ghenomen de boeten ende vleughelg; ende de padoe-vilfy/ welck in De lucht kamende tat bertten tae ap-liwillet.

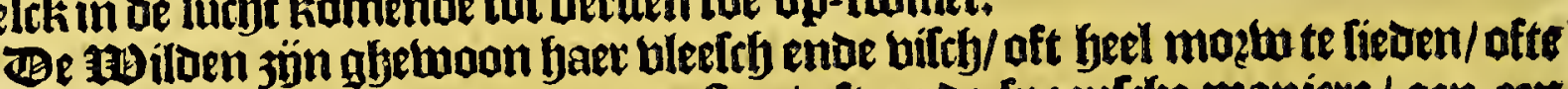

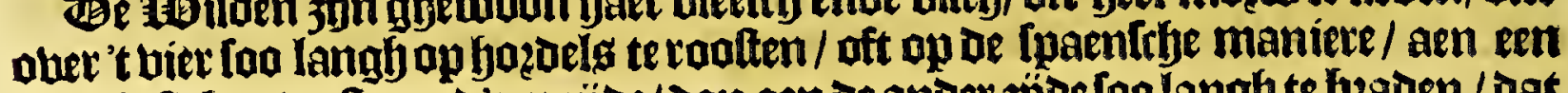

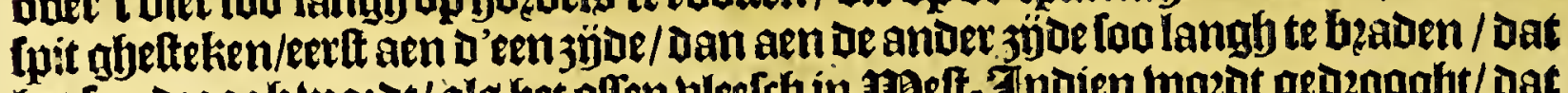

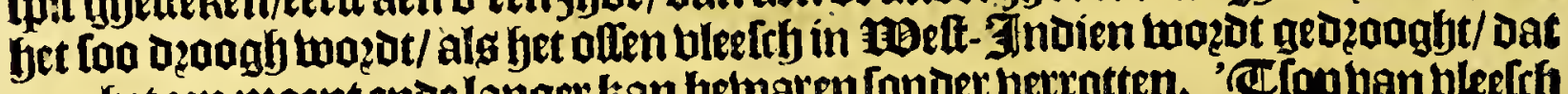

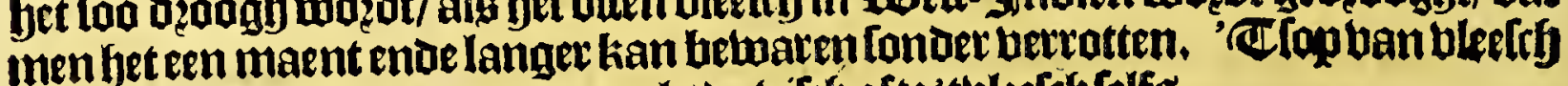

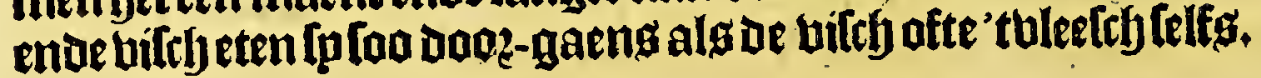

\section{Yat Leventbiende Capittel.}

$V$ an 't volck van den lande, haer manieren ende gheleghentheden, kleedinghe, wooninghen, politie, ende fuperftitien.

HUt lanot en ig niet bolck-rürk/mant de mans jün wepnigh/ oe meeften foop zün bzoulwenende kimbeten. Ontrent lames Towne inde fefticly mijlen in't vande zijn antrent letten duplent lieden / maer ban ftrÿdtbare mannen niet ater be

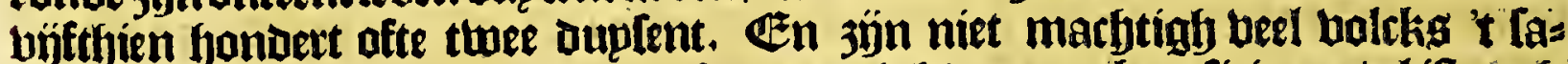
men te boeden / om Datte baeclanot loo mepnigh meten te beneficieren / al ift noch foo buchthaer; Ses oft feben fondert bp een / is 't meelte dat men ghelien beeft ) ioen fo haer berlameloen om Capitepn Smith te Pamaunke te ober-ballen! hjo maec bjfthien man bebbende am baet te weder-ftaen. ban ftature enoe tale / eenighe beel groat / als de Sefqueshamocken, anter leet kilepn / als or Whigcocomocos; maer Done-gaeng langhen rank / wel ghepzo=

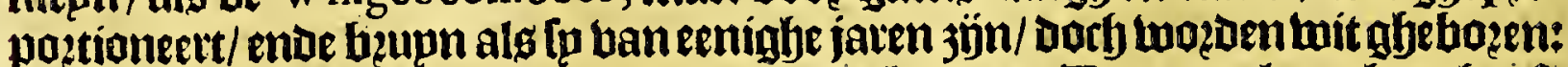
baer hap? meelt fwatt/enoe wepnighe heb ben baerden. De mang laten baer booft

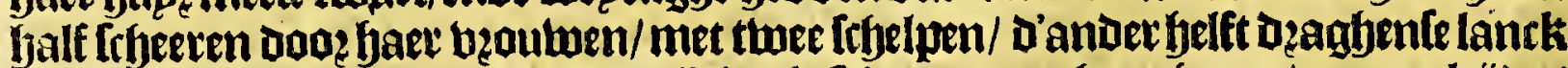

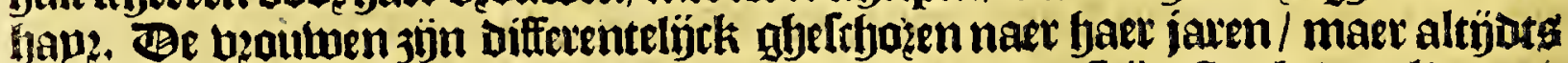

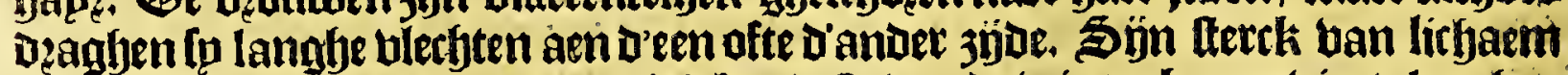
ende rast/konnende verdzangen in'tkoudetlte ban oe binter bp een bierte legghen

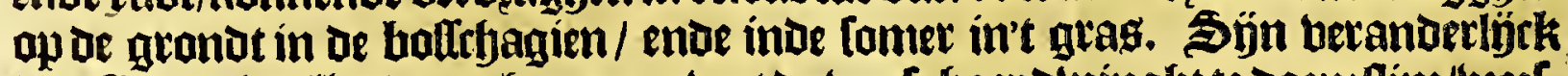

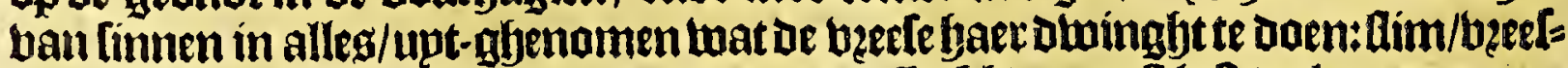
achticls / en ban fnelle appecfenlie / ingenieug, Jebben meelt lutt tot koperen rans Dekengl 


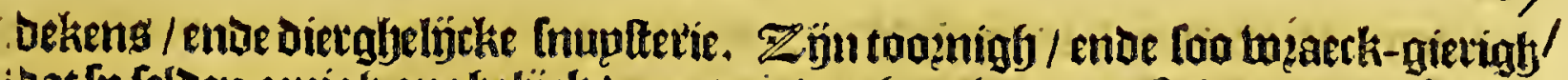
ibat fo feloen eenigh ongbelijck bergeten; warijten yaer uan dtelen/am dat ti bees=

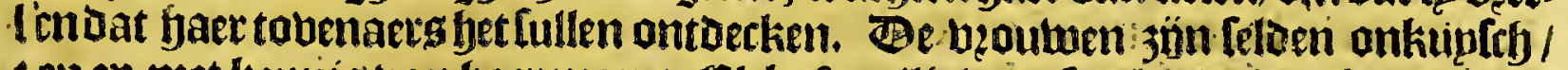

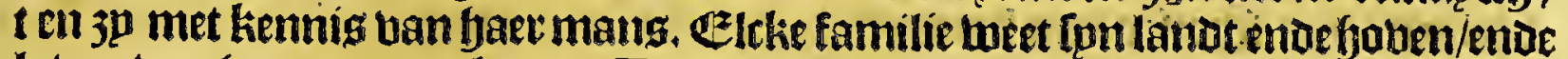
I even ban yaer epgen arbepot. Cot kilecoeten gebuptken fp uellen uan wildo bee=

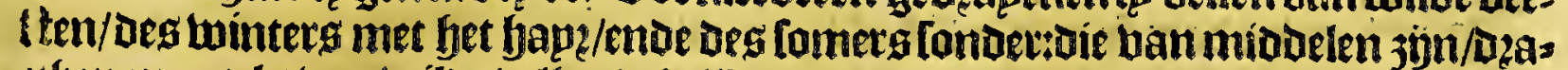

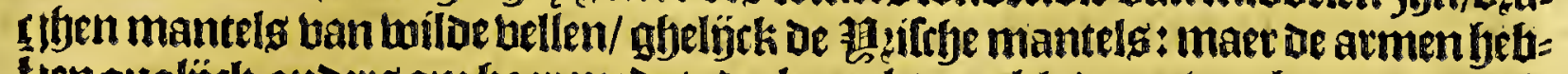
fien qualíck anders om fjaer meoe te decken alg met bladeren ban boomen/grag/

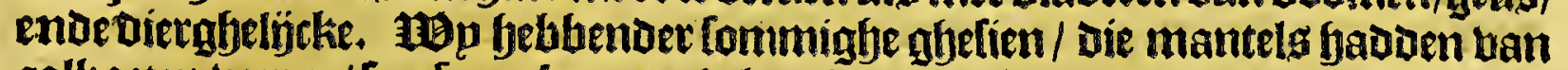
calkaeten beeren / loe fraep bp een glebeaclyt ende ghenaept / Dat men niet als de tertenkonde fien; feer warmende fraepe. De veoumen jiin altifot bedeckt om Demidoelt / ende jijn beffjaemt indien mente andors fagbe. De bzoumen baet beenen/ handen/ boutten/ende aenlicht is al gbepickelt met fuarte ftipkens/ende

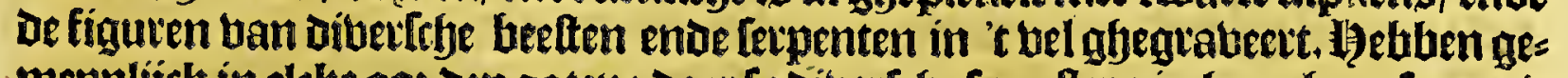

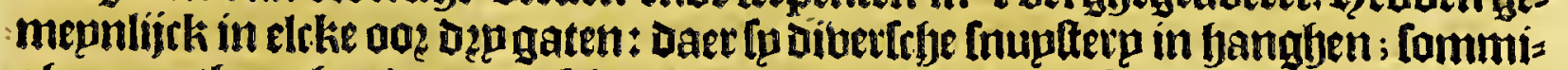
ghe mang banghen daer een klepn gwaen ende geel tangeflien in/ bu naev een balf

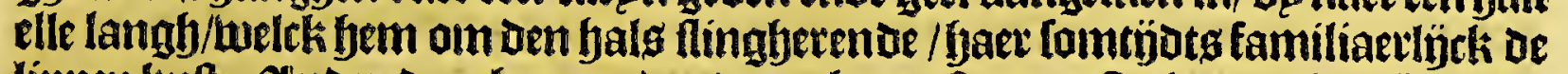

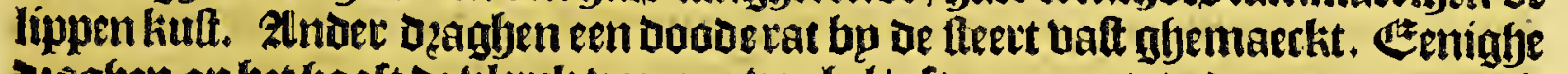
beagden op bet jooft de blerch ban een boghel/oft een moote ueder met eenrattel;

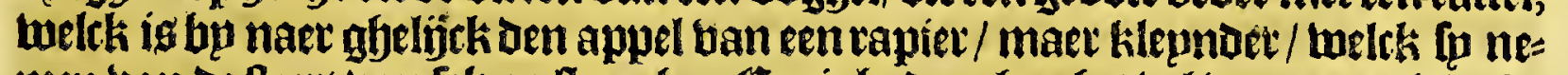
men ban de lteert ban [ekere tlanghe. Eenighe dzaghen bet bel ban eenualck ofte ander beemae boghel; pock een bzecoe kapere plaet; cenighe oock wel de bandt ban baec upanden gbedooght. Dert met ù Loptel Pocone, gepulberifeert/enoe itet alie gemenght/ welck Ip hou=

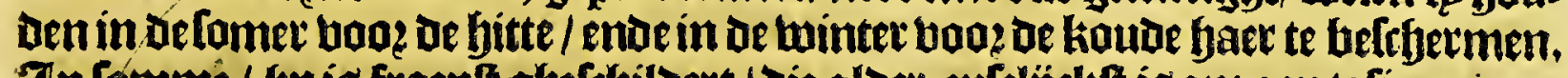

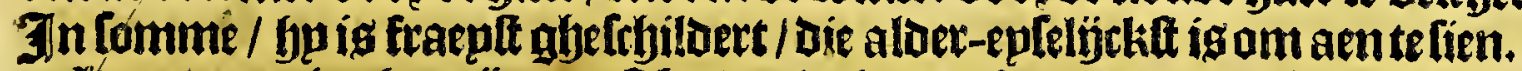

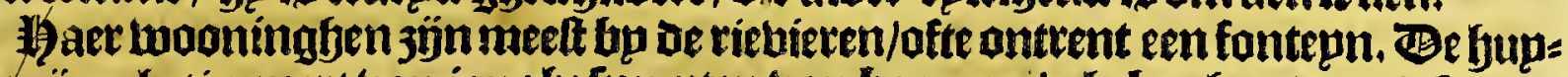

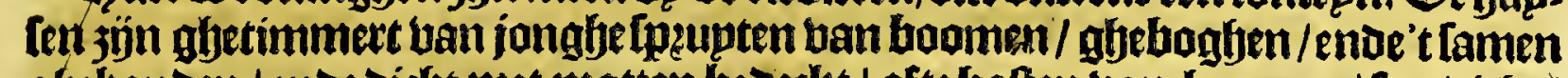
ghebonden / ende dicht met matten bedeckt / ofte batten ban boomen / [eer dicht)

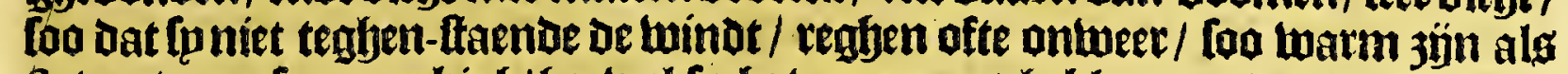
flouen/maer feer roockigh/foetwel fo baben een gat bebben am oen roack upt te trecken. In dée buplen legghen fp ranatom bet uper op rieten burdelg / bedeckt met een mat/op ftaken aber fjaer legghende/een boet ofte meer ban de gronat: ban fes tot thintich in een fups: haet juplen ttaen meeft in't midoen ban baet boben/

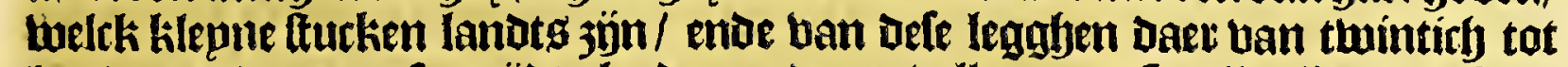
hondert ende meer fomtijots bp enen anderen / alleen met fmalle rijen ban boa= men ban Den anderen berdeelot. Bntrent baer twouningben bebt ggje meet

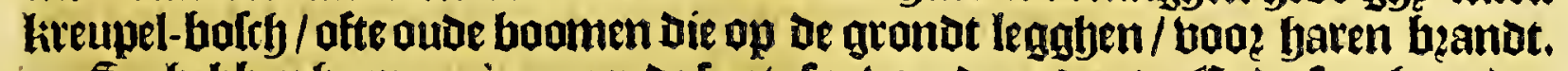

Sp bebben yaer namen naer De fantafpe ban de oubers. E⿺辶de legghen/dat

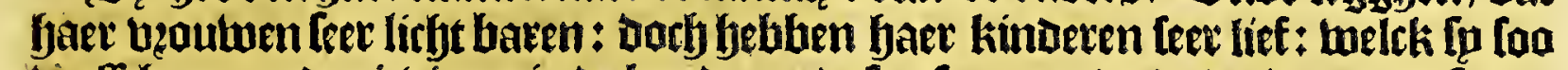
twalthen aen de rievieten ín de kaube / ende foo fmeeren/ende bertwen/ dat fueen foo barde hupd bekomen/ dat gfeen weder baer kan beftyadighen. Be mans

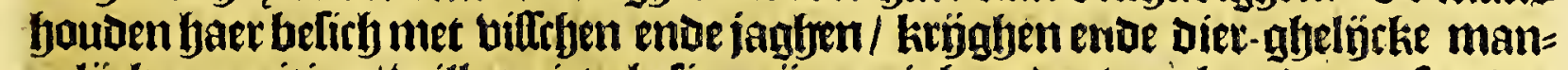

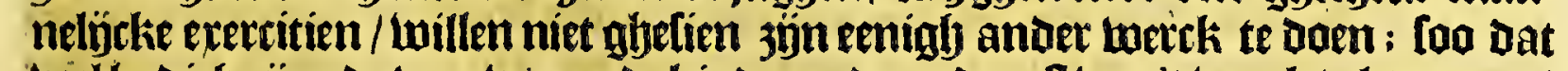
beel leedicl 3 j̈n; de beoutwen ende kinderen daen de relt ban't weerk/als matten! haeben/ potten / maztiers te maken/ bet koazen te bekien/ bzoaut te backen! Jet hooen te planten/ende te bergaderen/alle lalten te dzaghen/ende dierajelingtie.

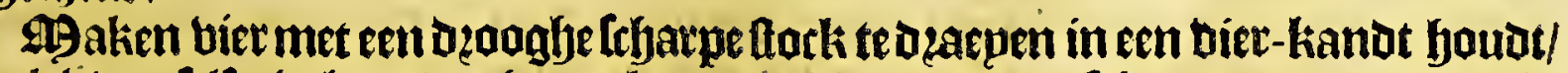
welck banlelfs in bzanot gheraeckt/ enoe bladeren/ moity enoe andere azoogbe Itof aenlteeckt : gaer bogen maken lo doog 't ftheabhen met een frbelpe ; ende haet pijlen ban jonghe loten ban boomen / daer fp uoag eert frbetp been aen Daen ; oock van rieden/ Daer fy punten aen maken ban frgerpe fteenen/ fpozen van 
kalcaeten ofte berken ban boghels die balt. hindende met of zenuwen ten twilot:

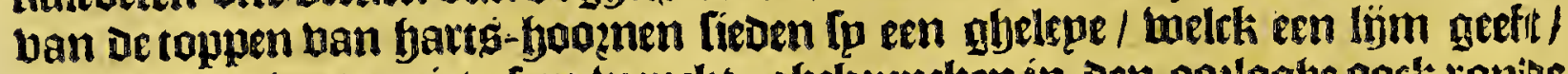

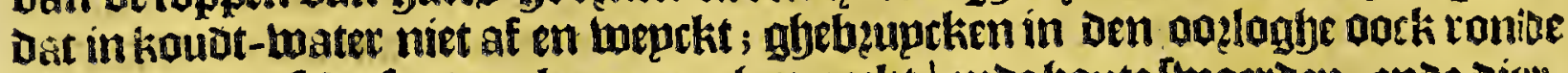

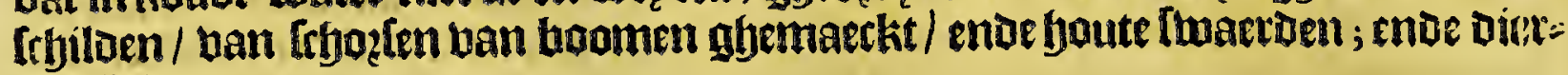
gacligcke.

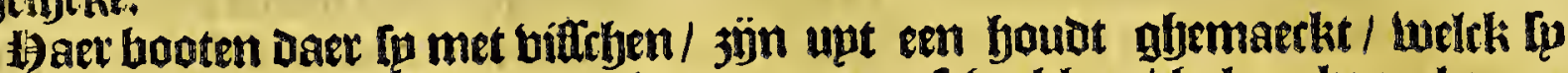
met bzanoen/ende de kolen met fchelpen upt te fetjeabben/ jol maken ald el troch. Sommigbe jijn een elle diep / ende beettich ofte büftirfy voeten langh/enibe Daet magy in Lommighe wel beertich man baren; Dan meelt 3 ïn [p klepnoev/om thien tot twintich man in te laten; roepen met baet berbers ento thocken foo talty als de onle met riemen. Be bzoulwen jün getwaon te Lpinnen baften ban boomen/ 3enumen ban berten/ ende felier grag helck fp noemeu Penmenauvv, daet fo leer eften Dzaet ban [pinnen; Die tot veel Dingbente pag komt/in[onderbepdt tot netten/ diele naer oe groote foo fïn tweten te beepoen als oe onfe.

De lieligie ban dit uollk ig / al aen te bidoen mat baet quaedt kan doen/ [on= Der dat fp het hooz-komen ofte berhínderen konmen/alg bper/ water/blixem/

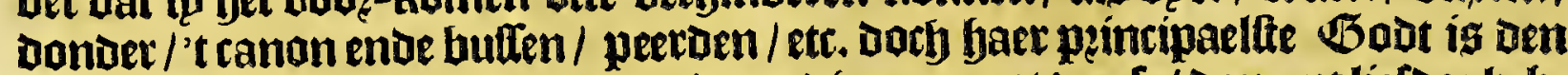

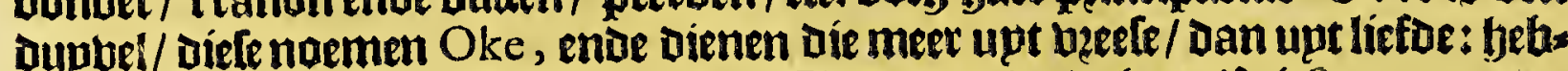

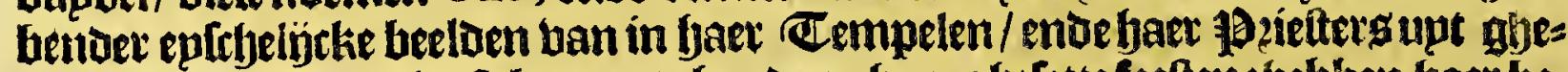
oteken als fulcken dient betaemt; bouben gheen gbelette feetten: bebben faer bes

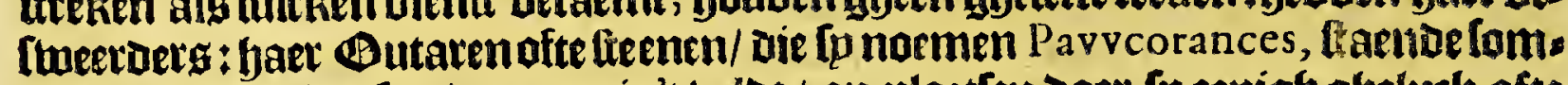
migbe bu gaer fup [en / and ere in't belot / op plaetien Daer fpenigh gheluck ofte groot onghelurk beblen ghebadt; daerfe bloedt / jeetten-\{meer / ende Taback op afferen; als [p banuen krigh oft jarbt weder keeten. Abp berkoęten. Dele dingen] om Dattete teuicus jon om in't langh te bertyalen.

zolleen fullen wp bier bp boeghen of foeme ban baere regeringe. bolck foo mildt ende barbaris ig loo bebben lp norbtang eene regeringh onder baer / beter alcmen onder fulcken boop foube konnen tertwactsten. Sp febben

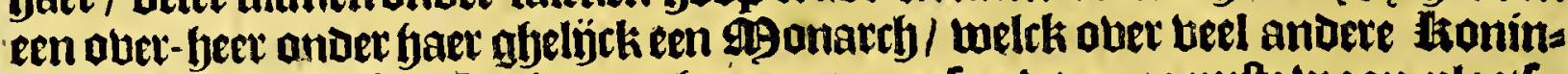
gben beerfelyet. Dele is Pouhatan ghenoemt naer fun boos-naemite woon-plaetfe; anders is funcughen naem Wahunfonacuck. EẼenighe [nnet lanton/alg Pouhatan, Arrohateck, Appamatucke, Pamauncke, Youchtanund, enoe Mattapanient 3 junfpne erf-lanoen; de andere beeft he met ghemelot aen andere afgheno= men. Spn vooz-naemtte woon-plaetle is Orapacks. Hp beeft foo beel bzous wen alg hp wilt / wan melcker een als bp op fun lenget light / altyots fit aen lpn hooft-epnoe/ ende een antor aen't boet-epnoe: maer als bp op-fit/[op fit o'een aen

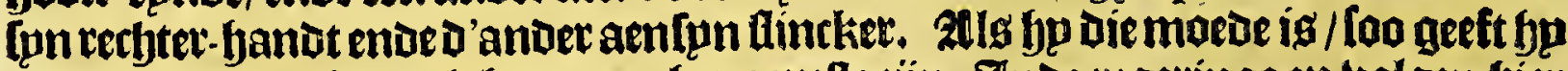
Die over aen be ghene die hem aenghenaemfte zijn. Jn noe regeringe en bolgen bier niet oe kinueten ofte fonen / maer eert Des ltoninghg bzoeders / ende daer naet [on fufters / wan de oubtlte tot de jonglte. Sp en bebben gheen gferette wetten/

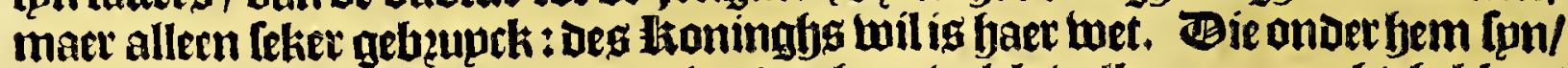
wozoen Weroances ghenoemt / Die doer baec bolck bolkomen marbt bebben.

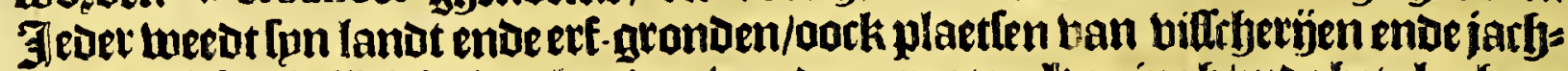

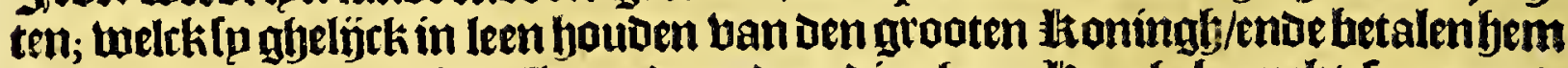
Thattinghe daer boos in vellen ende andere singlien. weresthepot in't ftraffen van die tegben bem milsoen / Loo dat fp ghetweloing han alle' t volck abeuzeet werot. Somtijots doet bp die banden ende boeten binden/ enoe ranotom baer bier legghen/ende bzaed die foo lebendigh. Somtjots doet gp haer boofoen leaghen op een altaer-fteen/ende joet baer be bertenen upt-klop: pen meteen knoofe ; famtíts Doet bp Die aeneen boom oft thaerk baft binoen enos

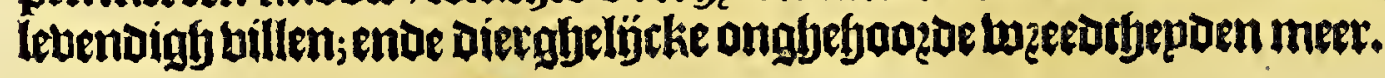


Het derde Boeck.

het afjthiende Capittel.

Kort verhael van der Engelfche proceduren in dit quartier van VIR GINIA, fints den jare I 606.

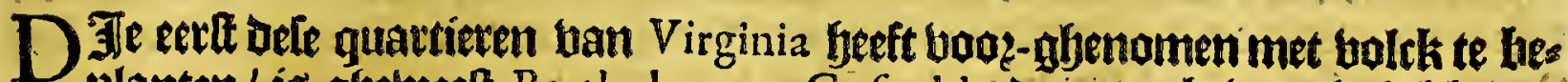
planten/ is ghetweelt Bartholoneus Gofnold, Daer toe betueeght febluende naec langh-wijlen tetbolgy eenigbe bau [pn bienoen/ende onder andere Capi= tepn lohn Smith, ende dan notheen deel Goelen enoe loop. lieden:ente ban ien

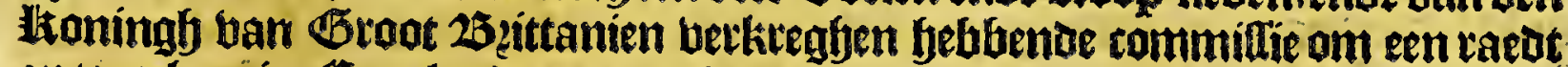

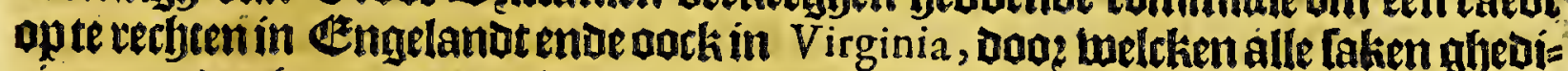

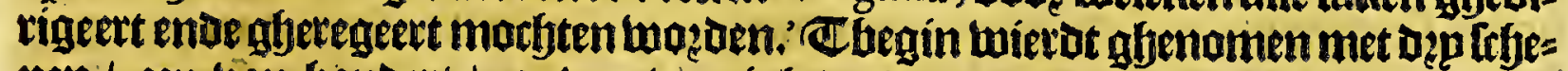
pen/ een ban gondert / een ban beertigh/ende een ban thintich lalt / ende bet

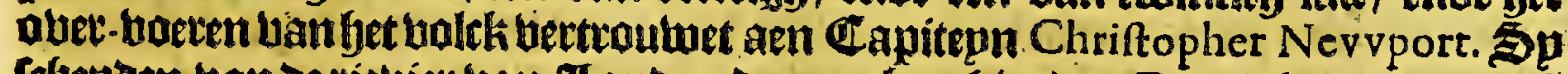
Icljepten ban te riebiet ban ZLonben den neghenthienton December 1606 ; Docti

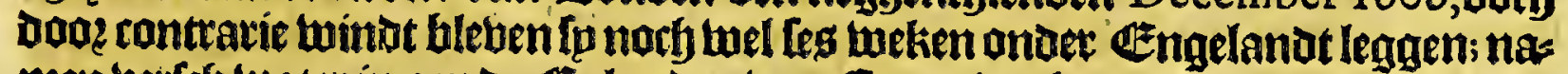
men bevfry Later in aen de Epplanden ban Canarien; fjandeloen met de äbiloen

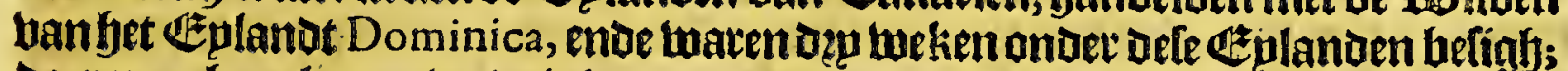
daee naet haet kours betbolghente naet Vir ginia, thierden fp 't lant onterfiens

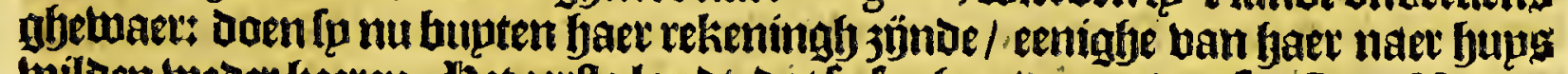

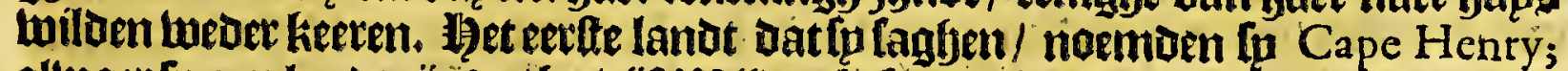

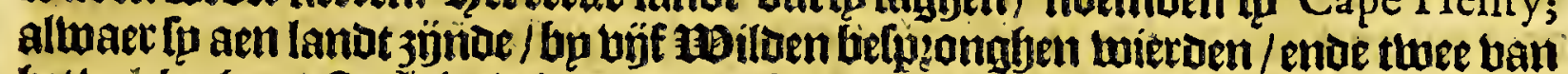

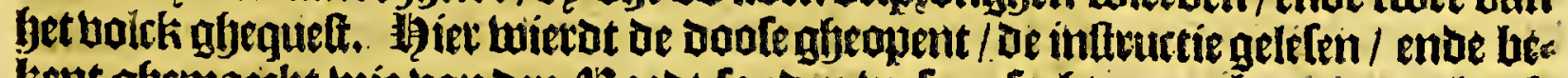
kent gfemaeckt wie ban oen Haedt fouben welen; fochten een bequame plaetfe

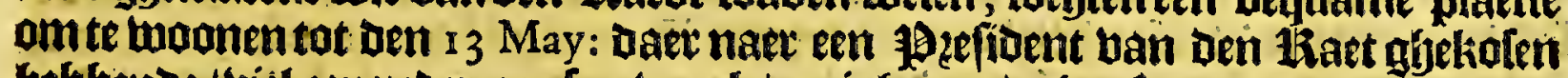
bebbende/ biel een pedor aen [pn werck/eenigfe om de huplen ende bet foet te inas

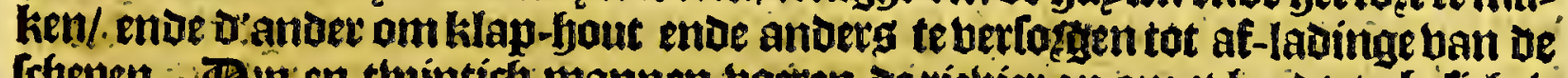

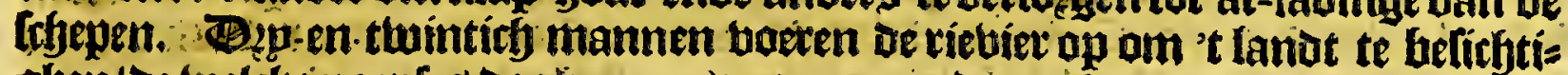
ghen/De toelcke naer fes dagben quamen aen een dogp gbendemt Povvatan, ban

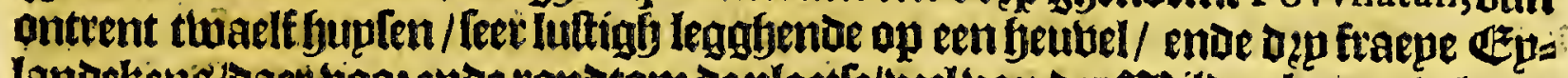

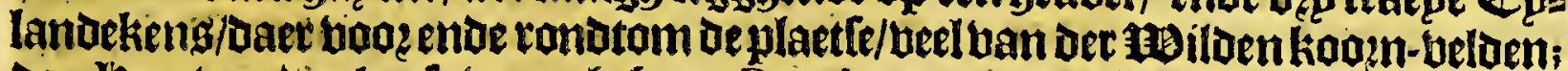
Den Heer ban oe plaetfe was gheteten Pov vhatan, ento fon volck Povvhatans:tot

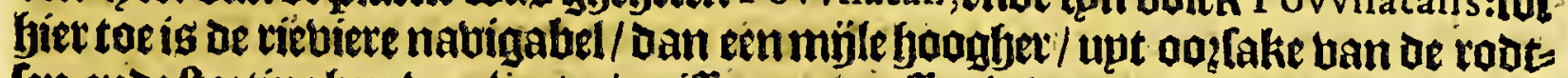

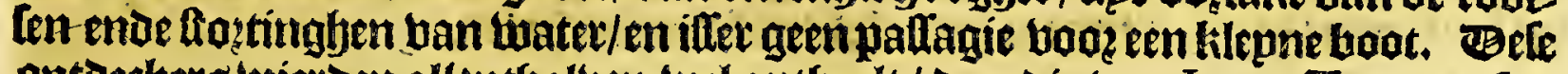
ontoeckers twierden allentfjalben Luel ontfjaelt / dan die van Iames Tovne (foo

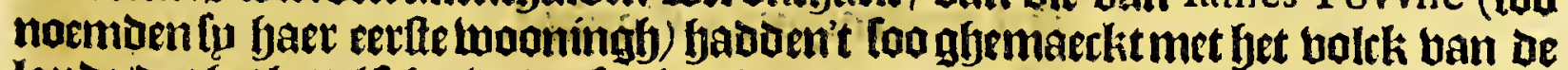

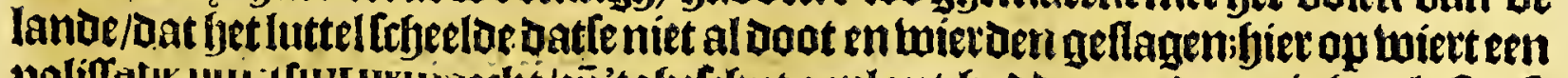

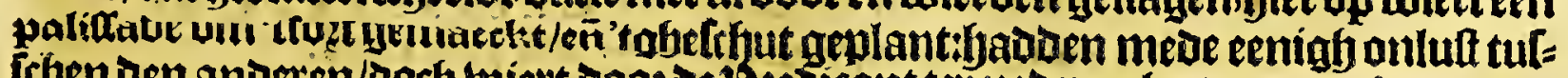
tiben Den anderen/borb wiett Dooe de 1 ?

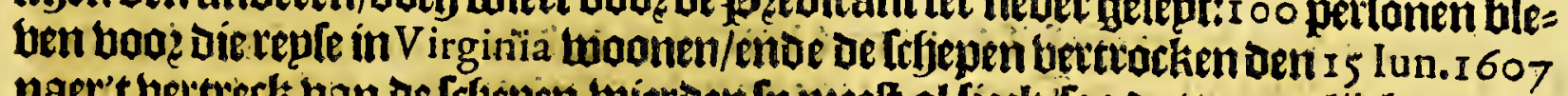

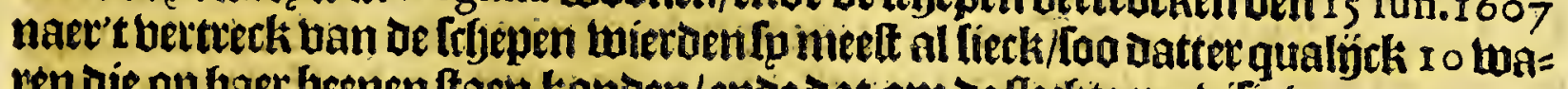
nen die op baer beenenftaen konoen/ende dat om de flectlete probifie ban eten ente

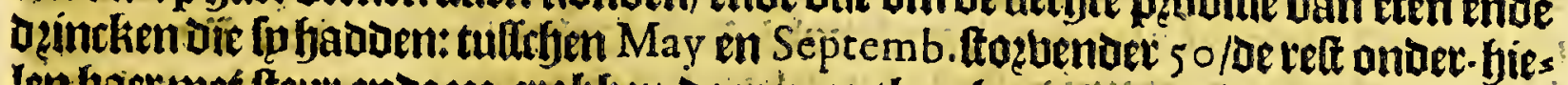

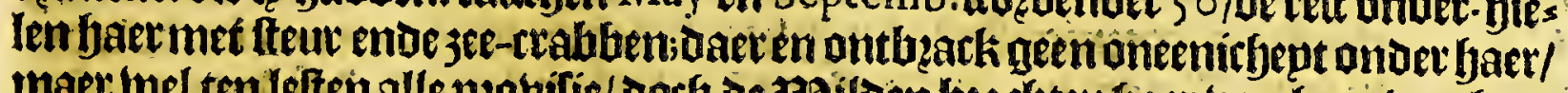

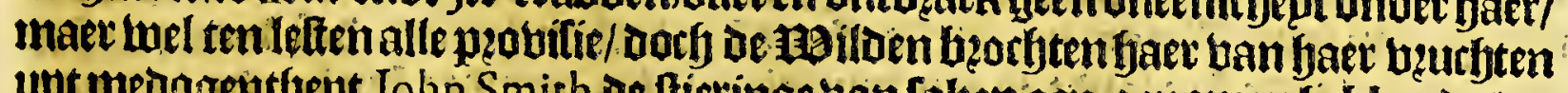
upt medogentfept. Io hi Smith de fleringe van faken aen genomen hebbende/of=

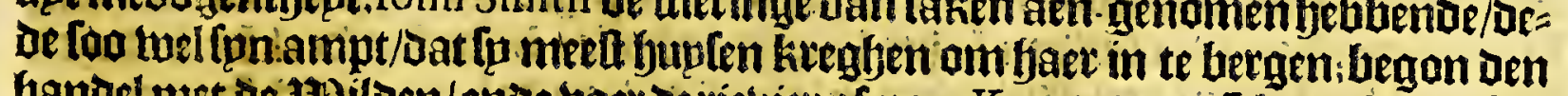

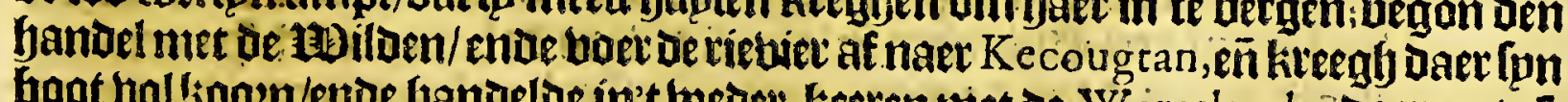
boot bol!iooen/ende bandeloe in't beoer-keten met de Weraskoyks; Daet en tur= fofen badoe die ban de ftad oe miloen lo bethult met faet maeren/ dat fp die niet

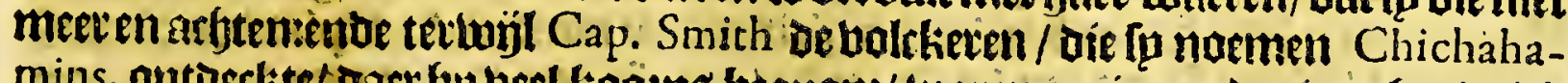
mins, ontbeckte/ daer fjp beel koozng bequam/ waten eenige anber ban bet bolck Doende om de pinas tuegh te yoereii/ende daer mede haet hung te kerten; dan dit 


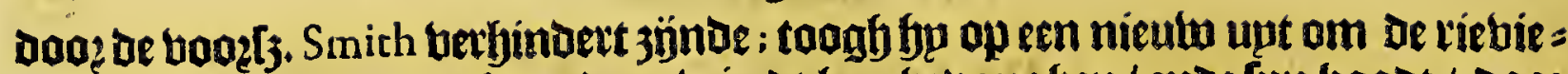
te Chichamine te ontoecken; Daet wierdet bp ghe uanglen / ende fun boodt / Doo?

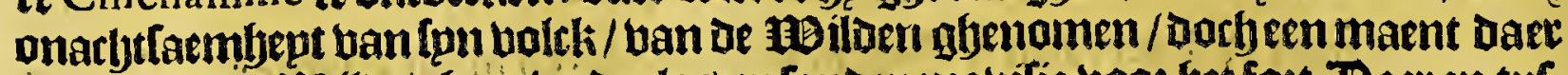

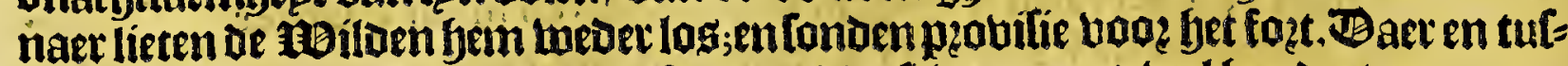

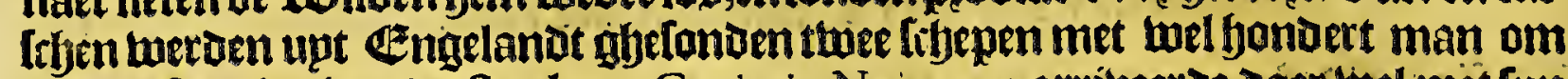
Defe eette colonie te betterelken; Capitain Newport arribertoe daer wel met fpn

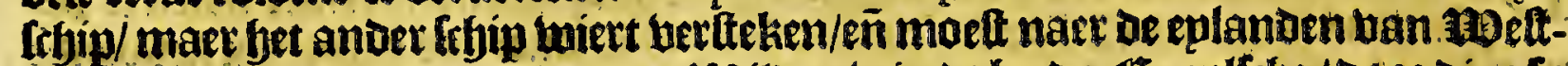

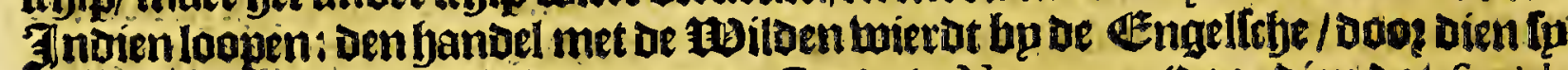
niet bel eens en waren/Lelfg beooteven. Capitain Nevvport (doog Jíen Dat Smith

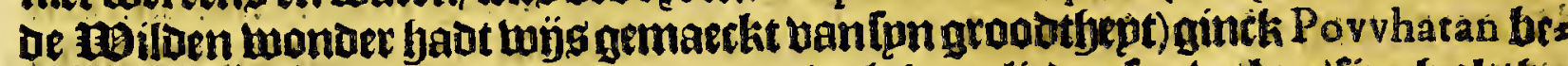

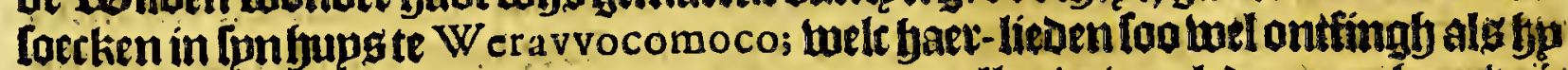

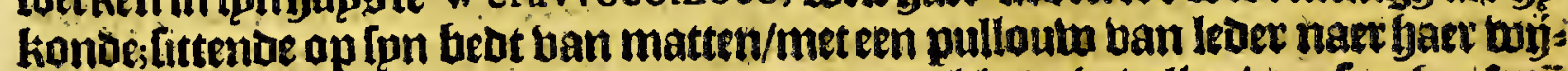
fe gebozouert/met peetlen ende lwitte teeckenen/gekleed in bellew/aen fun fooft ên

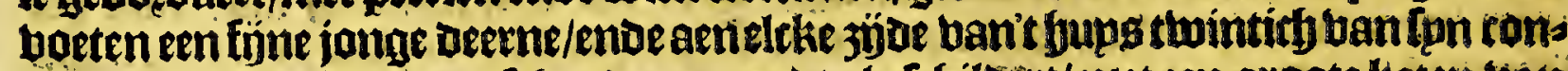
cubijnen/'t jooft ende de lrbouaeren roodt gherchiloert/met een groote keten tian twitte hralen om Den hals: Cap. Nevvport gaf aen Povyhatan een jougben/ende Povvhatan aen bem een ban fon gettoutwete dienaets genaemt Namontack : toog luepnigh blauto kralen kreegh Smith ban delen Povvhatan cen groot Deel kozen: ende inlgeligck ban Spechanchynough De lkoningy v an Pamaunke; ende ketroen weder tot baet foet. Raer dat De nieulo-gbeiomene baer mede baer logementen waten beftelt/geraeckten den hzanot in oe huplen/ Loo dat [p meeft al af bzanden/ ente een goet Deel ban oe palifladen / enoe beel pequifie. Bit ghelthieden in den winter Deg jaers 1607 . Het Lebip bleef Daer beetthien weken legghen / en conlus

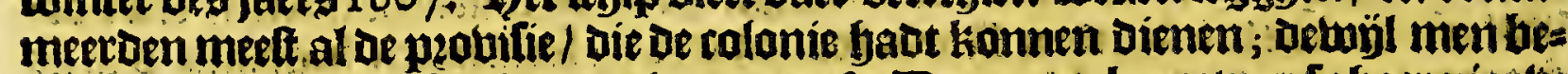

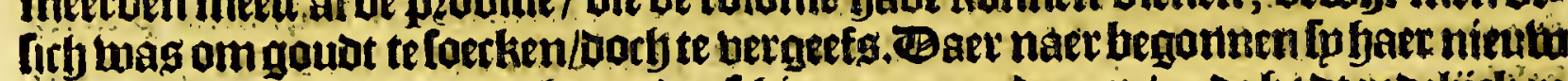

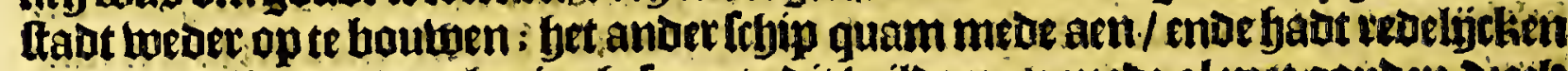
bet bictualie booz de colonie gjelpaert sit wilbe men mede al met gouben biech

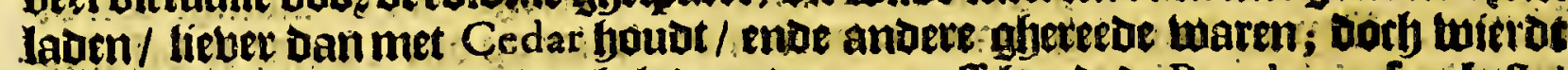

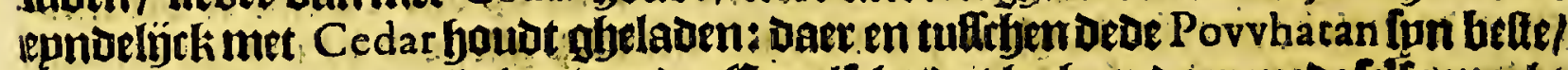

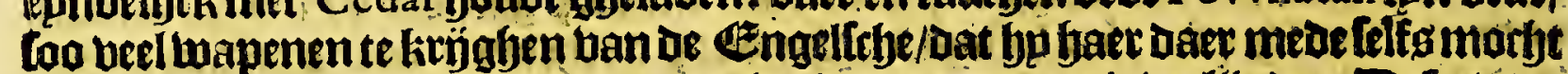

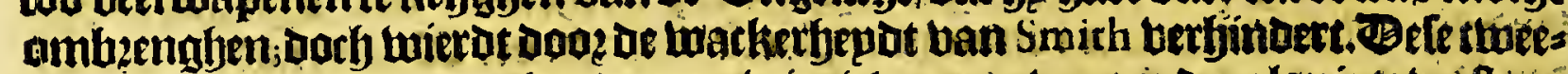
oe rep fe quamenoer bp oe fyonderten thintich man ober om of colanie te berftere ken. Daernaer nam. Smith de ontoethingbe ban oe groote bape van Chefapeack bp der banot / gbelötk top nu betbolgbeng (ullen berbalen.

Het neghentbiende Capittel.

Byfondere ontdeckinghe van de Baye van C H E A PEA CK. by Capitain Smith vonr-ghenomou iu den jare 1608 .

Apitain Smith berghelelichapt met beetthien andare febepden den tweeden Clunij 1608 ban lames Town met een open barcke ban twee laften/ende krups.

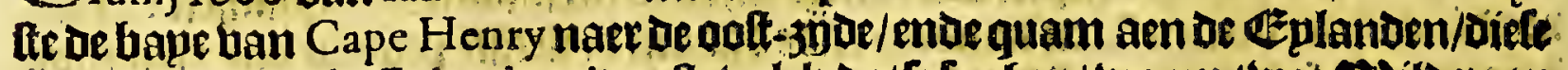
nu noemen Smiths Ey landen; teerlte voldk datte fagben/ waren twee zBbiloen op Cap Charles, die naer eenige ttrebelingh Gaer bechten tot A ca wmacke, oe woos

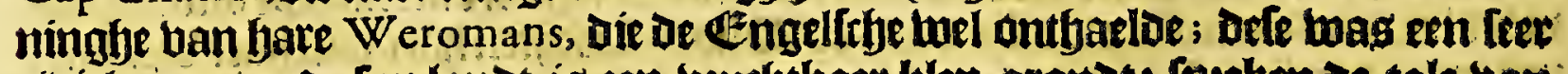
cibiel man enoe fon lanot is een beutbthaer klep-gronot: queken ae tale bari

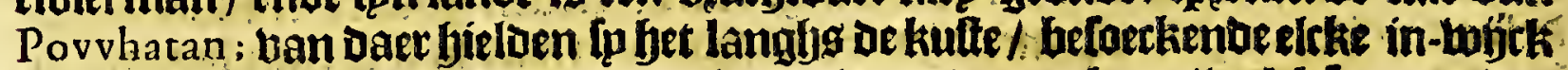
ofte bape / en laghen beel Geplanden in't midoen ban de bape / welckle noemben Ruffels Eylands, ende hadoen daet een groot ontueder bantwinot/regen donoeren

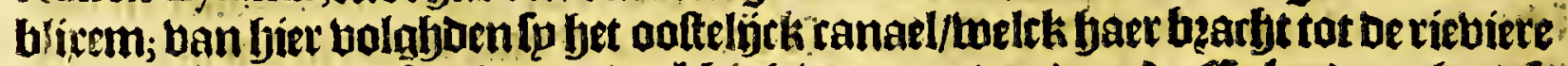

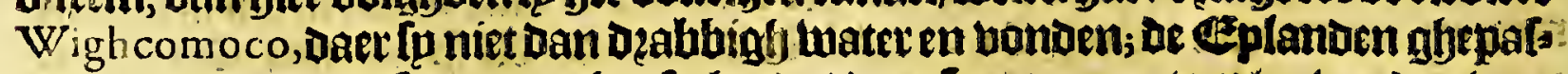

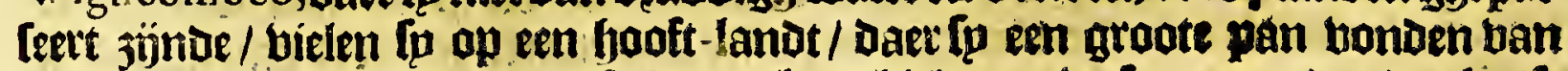

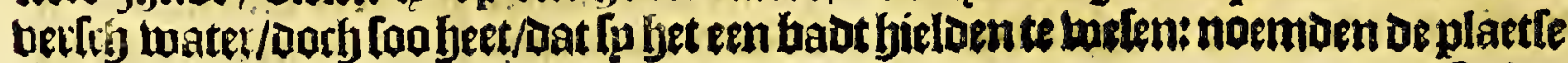

Point 
Point Ployer, tetten doen ban't valte land aen andere onletwoonte Ethlanoen/

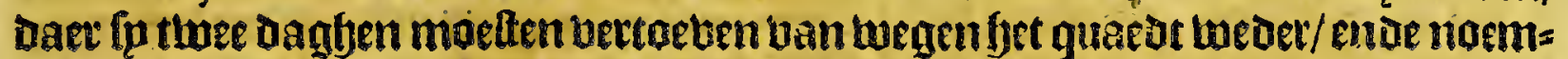

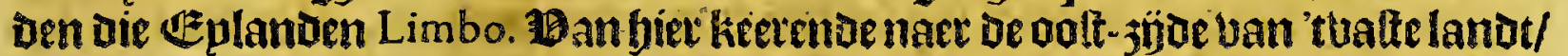
quamen fo aen de feboane rieviere Kuskaranaocke, Ju belck de volekeren ban Soraphanigh; Naufe, Arfec ende Nautaquack woonen/ De twelcke wonoer wiften te fegghen ban een groote natic diefe noemden Maflavvomekes; un twelcke natie te loecken fo toeder keetion bp Limbo, dan bindende dele kufte ulack / ende beel

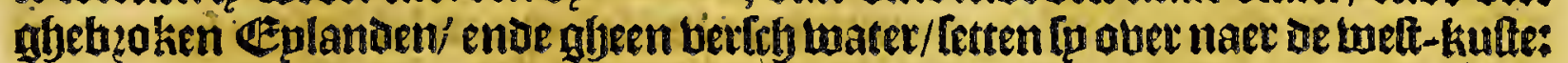
De bape is bier foo beecot / Dat men uain de ooft-3joe qualïck lien kan of groote

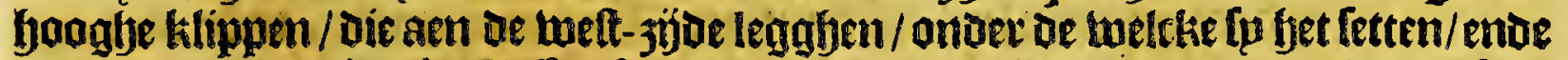
noemoen die Richards Cliffes; [p jeploen detticj mijlen neet noozdtwatt [on:

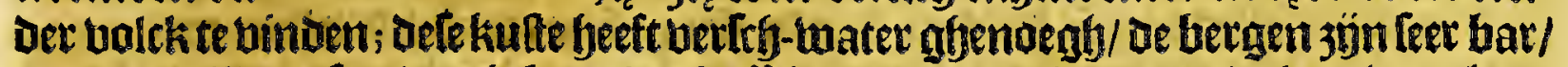

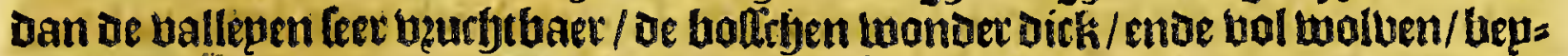

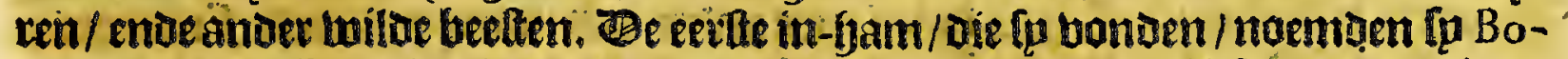

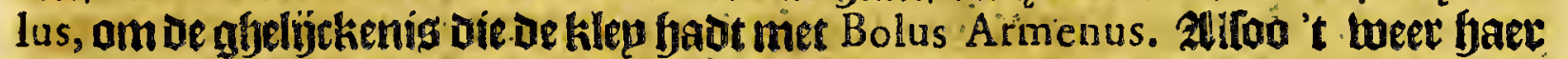

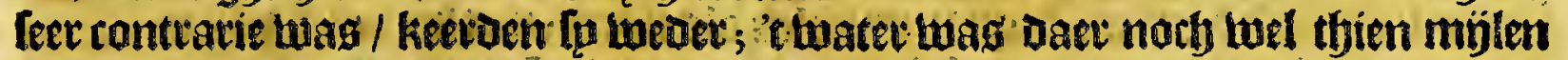
becert/ende neghen of thien badem diep. Ben I 6 lun quamente aen de riebiete ban

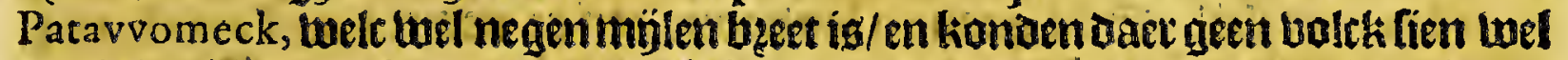

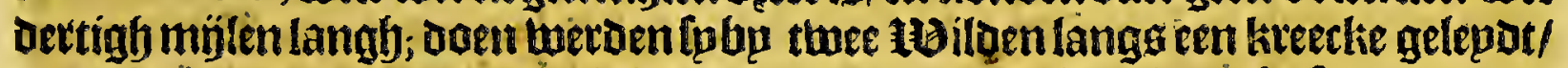
naer Onavvmament, daer eeniabe honderden uan to iloen in embutcade laglen/

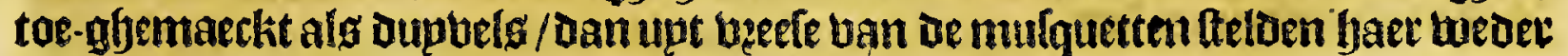
beel beiendelijck aen/ende bekentoen/ Dat Porv hatan ghemilcontenteert jünoe bp

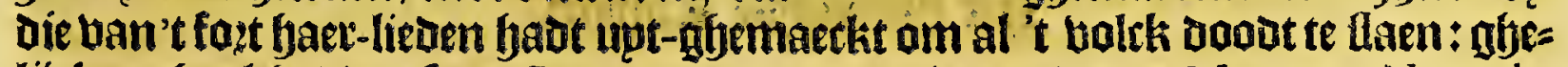

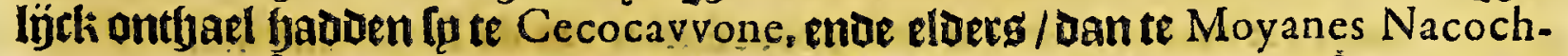

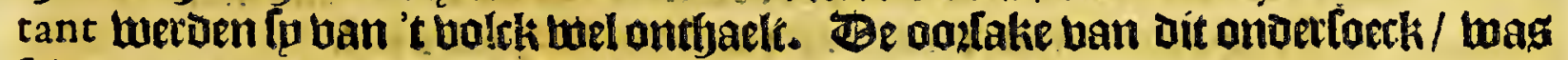
Ielkel minetael/ welck de moilden lepden te beblen ban Patavvomeck ( luelck Cap. Nevv-port wilte fegghen balf fiber te twelent) ende om boazoer te fien te ge: leghentbept ban 't landt. Sp vonden die müne negen oft thiernimílen in't lanot/ Dan twiert bebonden niet's tweerding te wefen. Boogts bonden fu otters/bebers/ marterg/ende fabelg/ende fulthe aliumbantie ban bitry/Dat te betwonteren loag. Spquamen boo bp Toppahanock, Daerfp mepnoen opte baren/Dan getaeckten op de deaoghten Die in de monat leggen/ende Smith laierat Daer affefeken in Den

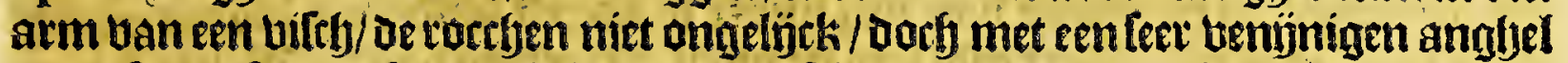

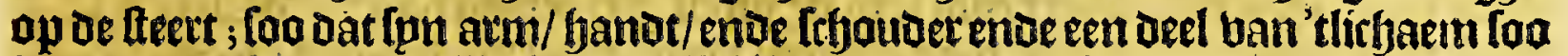

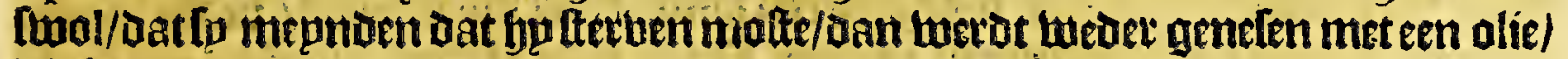
Die fy't alle affelucii mede hadoen: noemoen de plaette Stingeray Eylandt. Leer= Den foo tueder vooz bp de rietuieren Pyankatack ende Pamaunke naer Kekoughtan, ende den 2 I lul. tat lames Tovvn, Daer fp al tualektietk bonden/ende [oo qua:

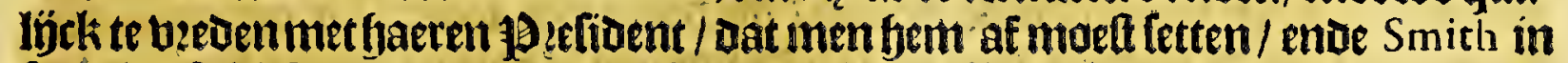

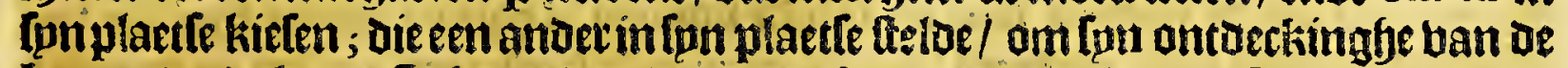
bape te bertuolgen. Sefjepden tweter ban't fostmet twaelf man/ente Ke coughtan

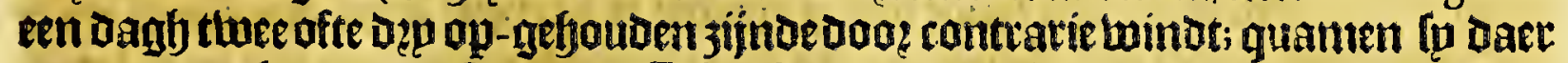
naer ten ancker onoer Stingeray Eyland; ende maeckten groote haeft tot aen de

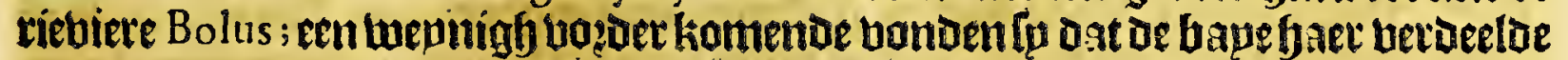

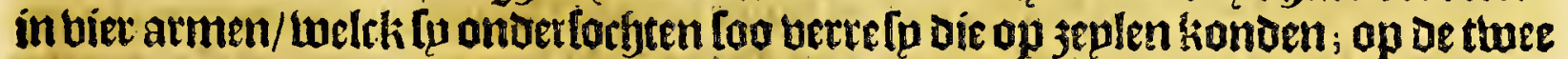

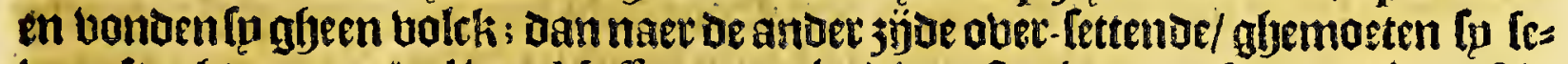

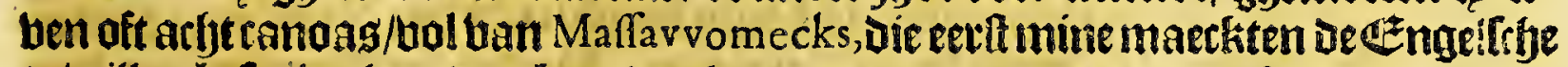

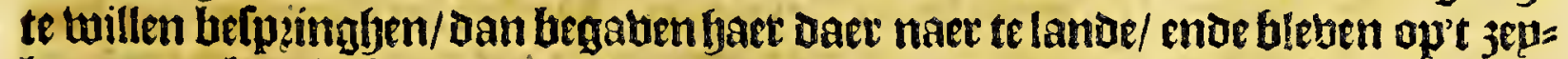
len van de barefie (taen gapen/ tot dat die vecht aber faer anc letos. Splorkten de Hilden aen boogtot die eert twee ban be baer fonoen / daer naet quamen fp ailel

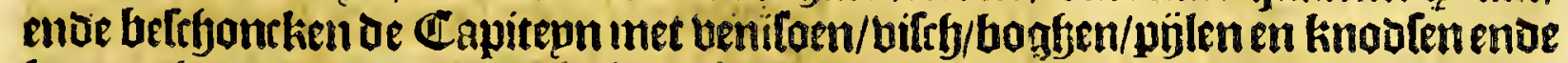
bepen-fupden: gaven bp teectienente kennen / bat fu ingbebecht warengetweef met oe Tockvvogs; Deg natbts trocken fo wegly/ enoe en quamen niet weder. 


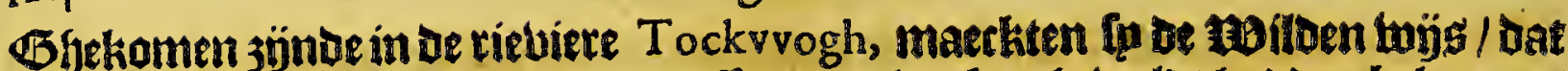
fu dic bogben enoe pỉlen ban de Maffavomekes bu gbeluelot badoen betiomen!

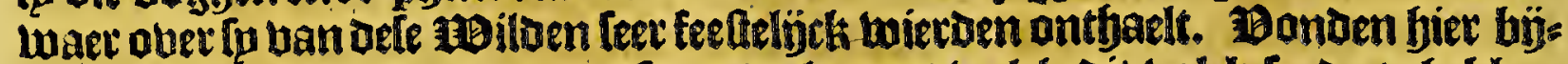
len / mefien ende ftucken ban plet ente koper/ melck dit bolck fepDe te behben uan de Safquefahanockes, die Joobt-bpanden jön ban de Maffavromekes; ende woonen op Den bierden arm ban de bape/ wel bier dact-xeqfen boogher als fo met yaer barcke haoden komen komen ; I noodicboen bp een boose bit bolkt /

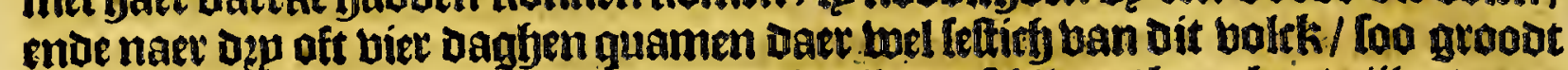

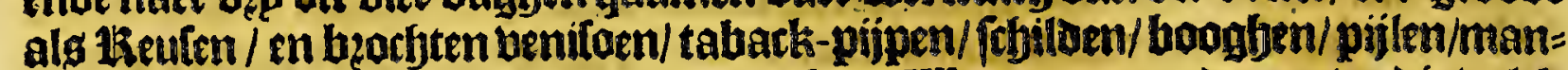
bekeng / enue daet quamen bel büf ban faer Weroances mede; moe dit bolrk baden de Engelfefe feet am baet te twillen tweectien ober de Maffa womekes,

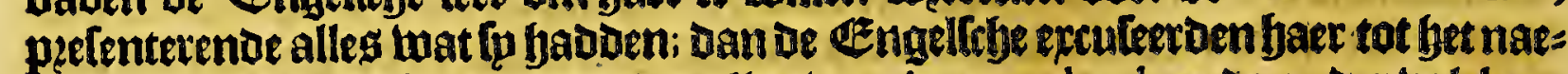
tte jaet; Dit bolck twift tuonder te bertellen van A tquanahuck, ende ander bolcken; ghebende te kennendatie baer bÿlen enae ander inftrumenten ban oe francoplen Gandeloen. Ban biec keeroe fi te rugghe om de riebiere Pauwtuxunt te onders [oecken/ vonDen daer veel bequamer volek als eloets; met bet bolck ban de riebiet Tappahanock badoen eenig onlutt/Doozdien't een bielenatie is/Doch beroen noch

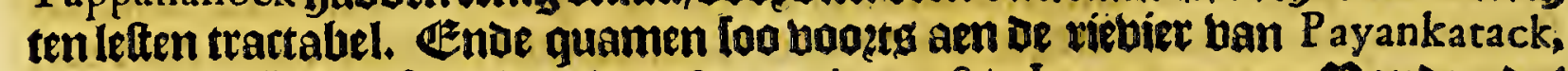
ende epnoelïck de febenden uan Septemb. I 608 te. lames tou wn. Bomoen Dat baer al een oeel gbeftoeven twaten/ende een part noch fiect; ende de probifie feer bes fryadicbt banden reghen.

\section{I) thintichlte Capittel.}

Kort verhael van de vordête proceduren van de Engelfche in dit quartier van $V$ I $R$ G I I I A fints den jare 1608 .

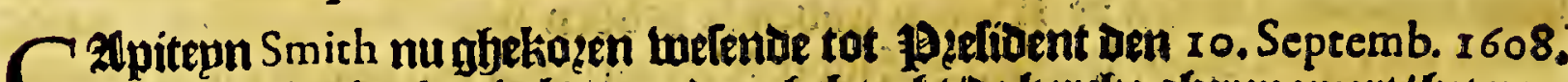

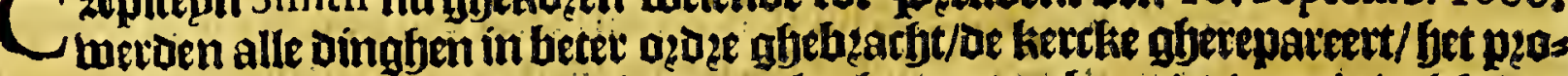

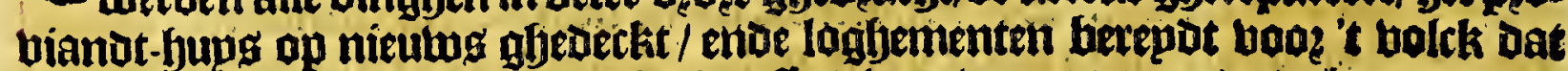
noch te komenbadt: ende 't bolck gbeaeferit in se wapenien; ende be boaten beet: Dich ghemaeckt om te handelen met oe ta iloe; dele gemueten in' upt-baren $C_{a}$ pitepn Neuport, tuelcke quammet bet tweedef lupplement ban bolck boge be colos nie; ende met een rommilie ban niet weder te keeren fonder een klomp goudto mede te bengen;ende lekerbepot ban of zupot-3ed oft een ban Sir Walter Ralegs

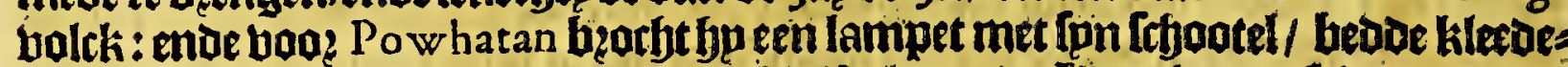

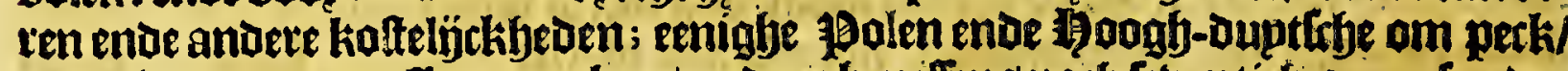
tar / glag / en 3eep-alien te maken / en Daer beneftend nach Lebentich man; conder

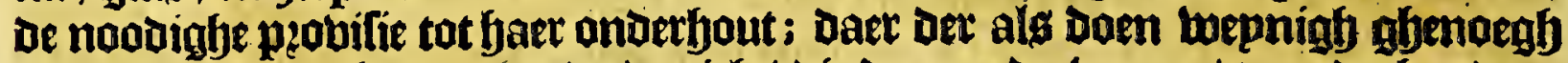
pegobilie was om bandert ende dertich / die daer reede waren/ te onoerbouden;

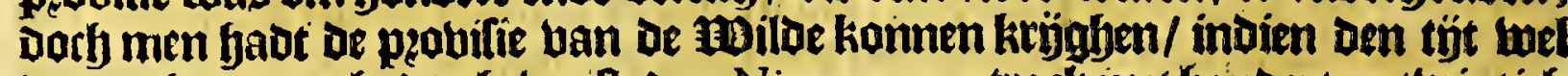
luact-ghenomen badt ghetueelt: Dan Nieuvv-port track met bondert en twintiry man Povvhatan te kronen/ende defe peelenten te gljeben; ende om gheen töt te vetlielen trock Smith met twepnigfe om Povvhatan te berloecken dat bp te Iames Tovva wilde komen/ende daer de peetenten ontfangfen; Dan Povvhatan loas wel foo boogfmoedigy dat hp niet en wilbe komen/ fegghende bp was mede een

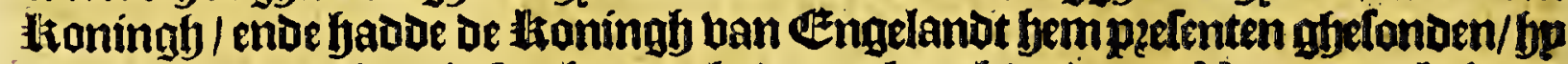
wilde Die bertwathten in [pn bupg acht dagen langh/ ende dat Nevv-port beboazs ie totfem te kamen/ende nietfjp tot Nevv-port. Boper berklarende/ bat boos

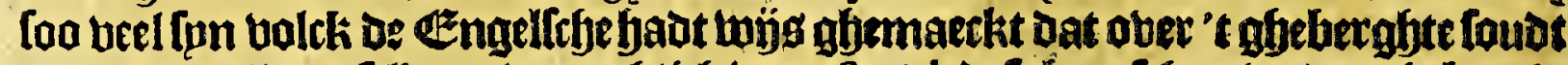

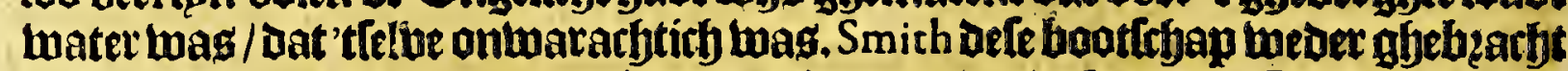
Gelbende/ trock Nevv-port te lande dertwaerts / ente kroande Povvhatan met beel baeng / alloo dele pilde fem tot'fulcke kleederen ende anders niet konde

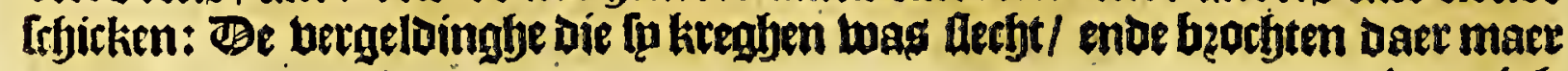


Het derde Boeck.

tmeunigh Kapeits wan. Newport Gadt booken bet lant tuan de Monacans te ontoecken/ berforft daer toe ban Pow hatan gbelepoets, dan bje in twiloe beu niemant gheben als alleen Namontack Die met Nevvport meder upt Engge= lanot was ghekomen. Hier op trock Nevyport met al Den liaed ende bon

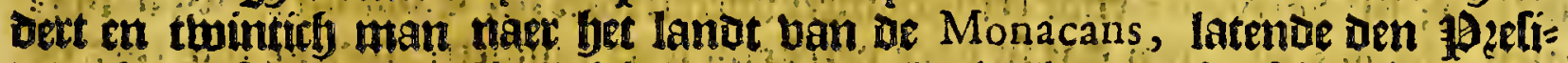
Dent in oe ftaet met tachtentich man om de ladinghe ban bet lchip te boges:

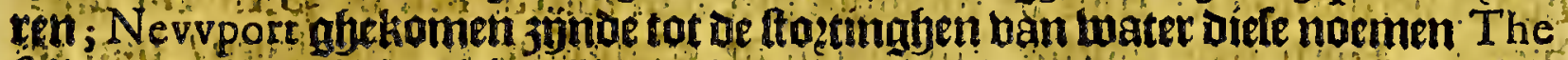
failes, trock noch beerticf mulen te lande / ende tonot tbee doepen tan de $\mathrm{Mo-}$

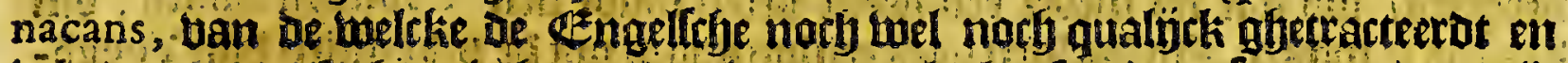
tuiernen onoentorbten in her toeoer keeren beel plaeten taer 'p mepnoen mij= ren te binden/ bielen aen fet graben enoe refineren enoe den refineur lepae

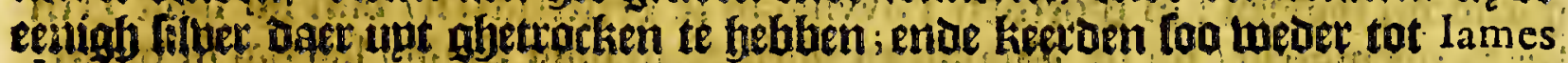

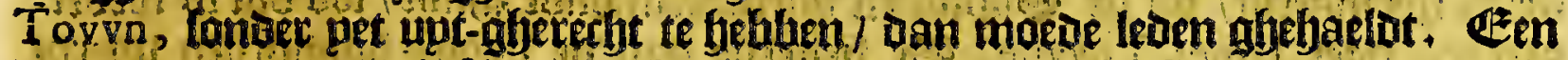

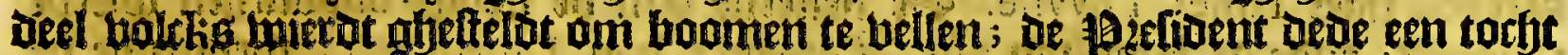
vaer Chick hamina, welck bolck met ozepgibementen too derte ghe bectit wierot/

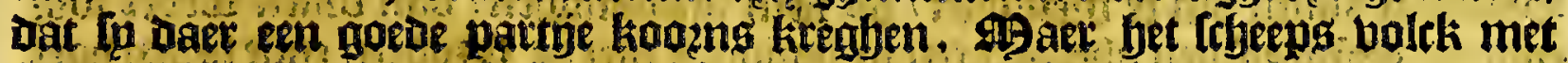

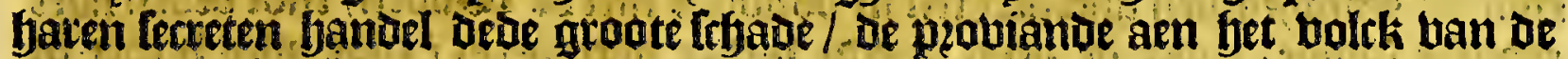

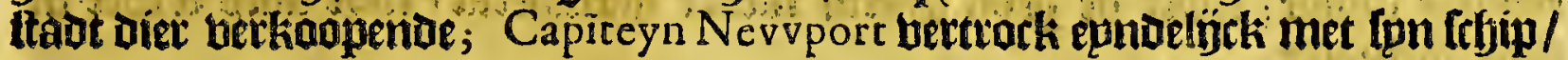
latenoe in de calonie thee bondert man/ met die bp ghebzocht badoe; Imaer

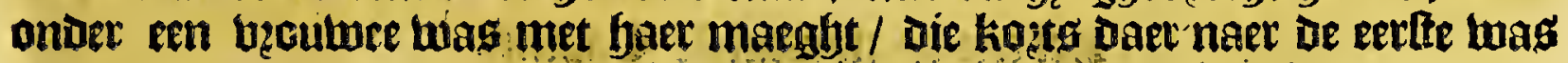

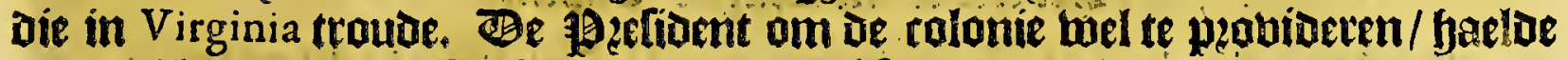

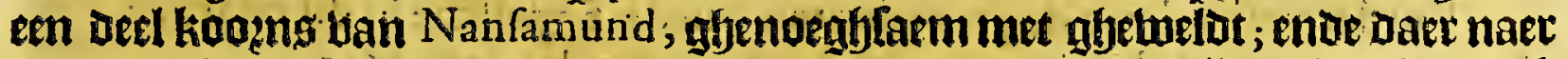
ecn mepnigh vain Áppamatuck, met gyemoepe. San' bit alles nist gbenoegf

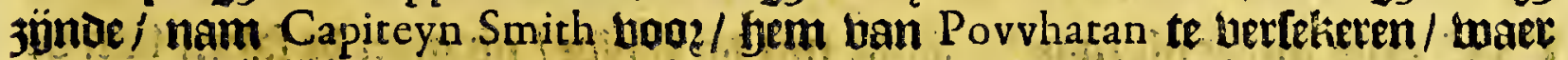
toe wel te pafle quam/ Dat Povvhatan eenigf bolck berloctit bat ou fjem cen bupg te timmeren/ ug̈ttich touactoen / moe eenigbe dinaben meer. Den neghenen-twintichten December trodk bo met adbt-en-beertich man naet Weravvocomoco toe t enue logeerden den eetiten nadbt te. VVeraskoyack, daet tu faet

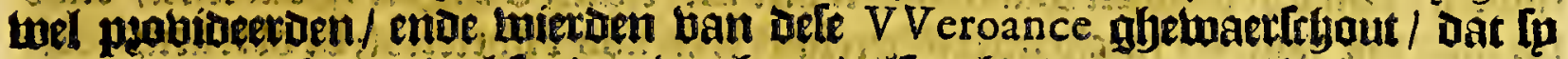

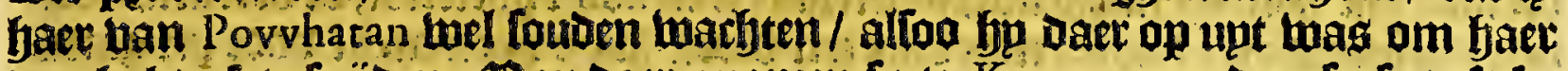

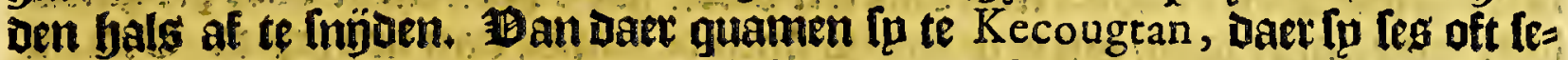

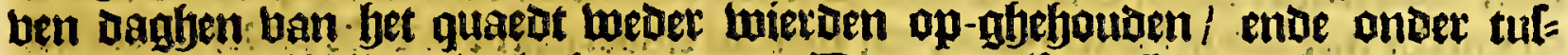
Itben yan oe Milden tuel ghetcacteett. Ben thaelfoen Ianuar. quamen fu te $\checkmark V$ eravvocomoco, waer oe riebier bel en lalf míl ban ftranot abevzolen was / foo datte met gloot onghemack aen lanot gberaetkten; ende Povvatan

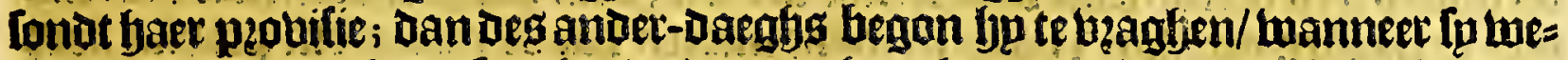

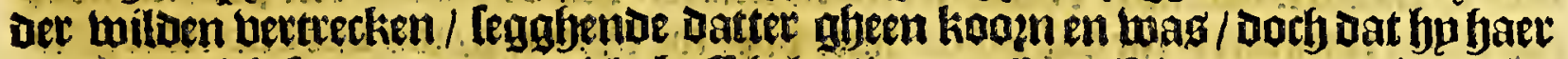

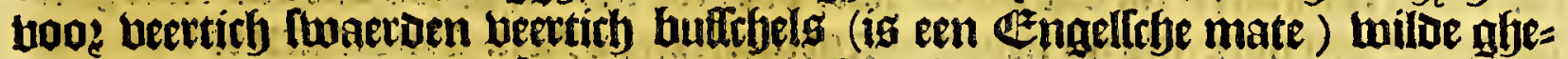

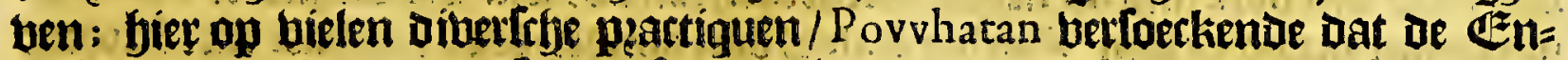
gellche baet ghemeer te trbeep fouben laten: te meer om dat en wan de

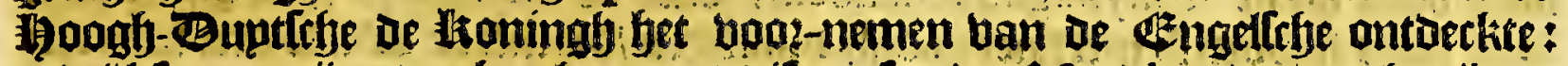

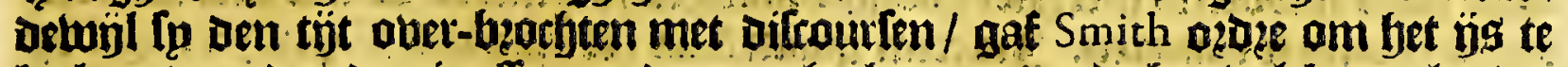
beteen / op dat oe pinate naeroer morbt komen / enoe bet boldk aen landt:

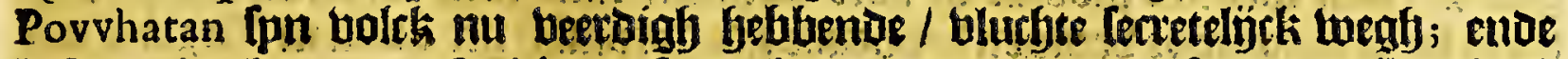

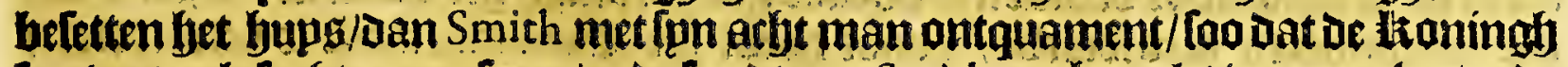
Ipn bertreck [ocfte te exculeren/ende tondt aen Smith een bearelet ban peetlen/ende

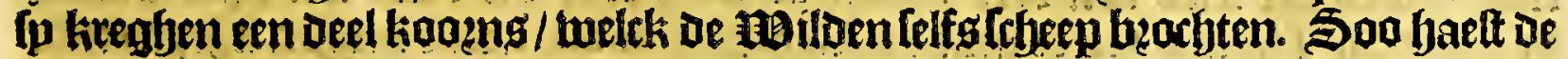

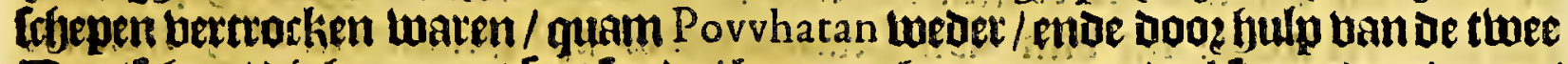

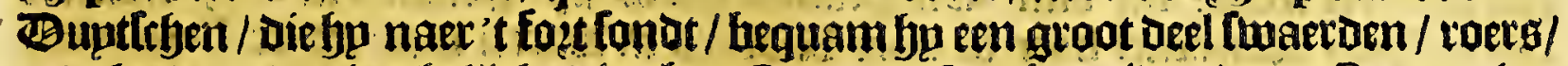
endeloodt/ende dietgheligcke dinghen. Capiteyn Smith arribeerden te Pamaunke, baet de Honingh Opechancanough baer forlyt te berrafteben met tuel les oft

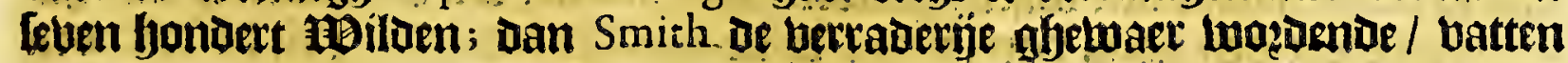

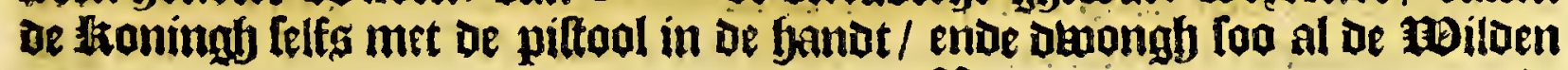


be wapenen neter te legghen; Dody mepnoen frem baer naer meter in bet bupg

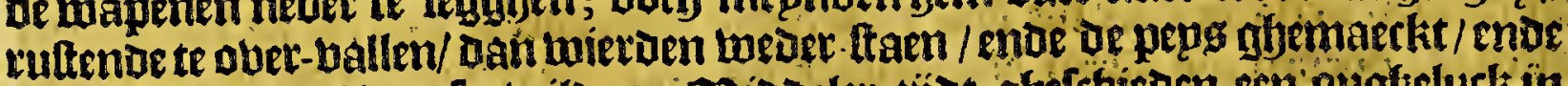

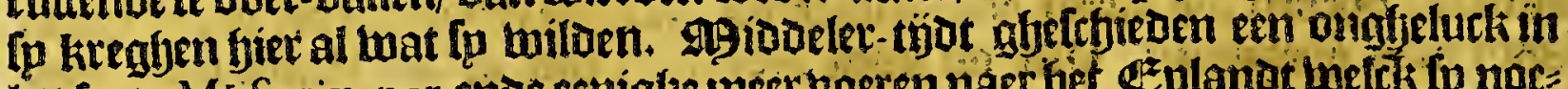

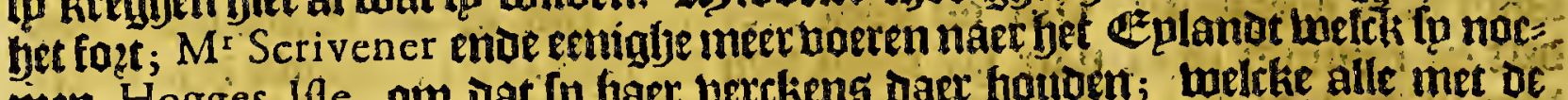

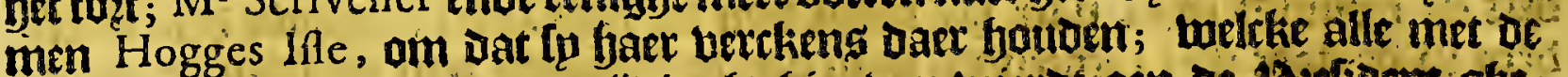

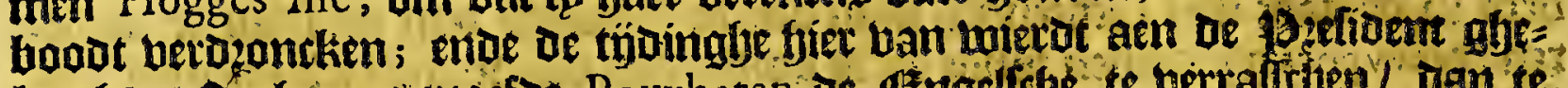

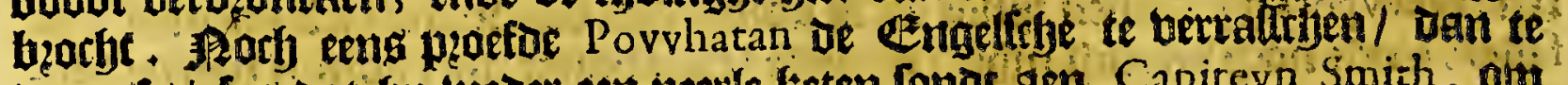
bergetg/ Too dat hp weder een peerle keten fonde den Capiteyn Smith, oin oe pepg te maken. Sp gaetoen oock ennigh kooen upt oe pzobneien ban Yough-

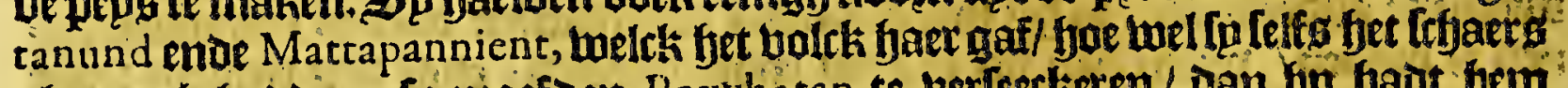

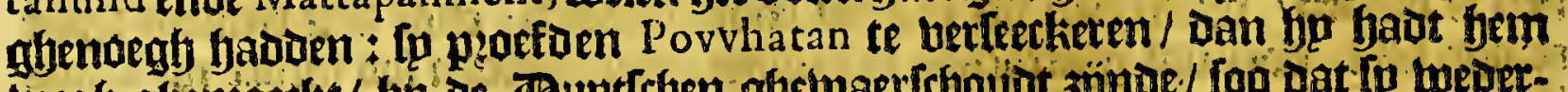

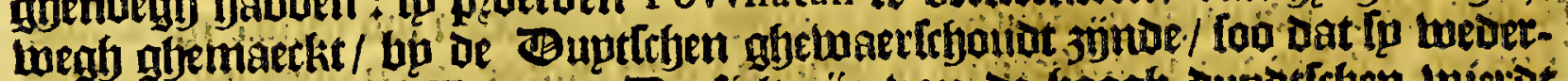

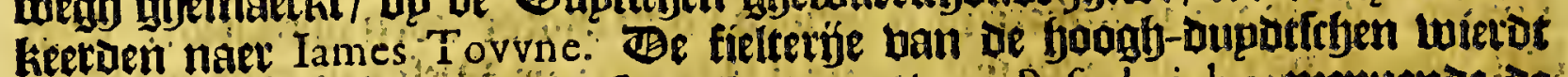
ontocktit; enoe be thaning ofte Weroance ban Pafpaheigh ; mepuende de

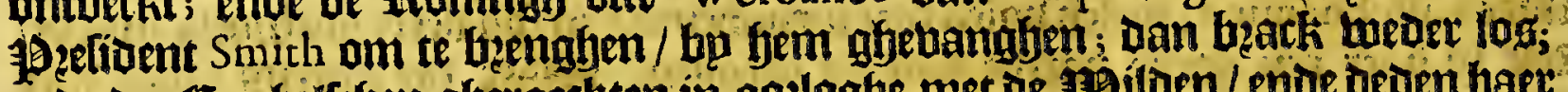

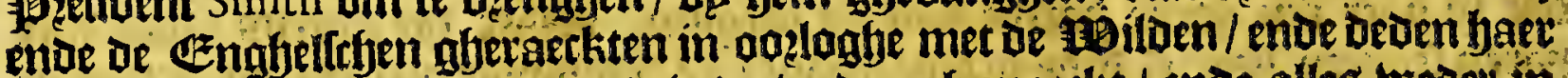

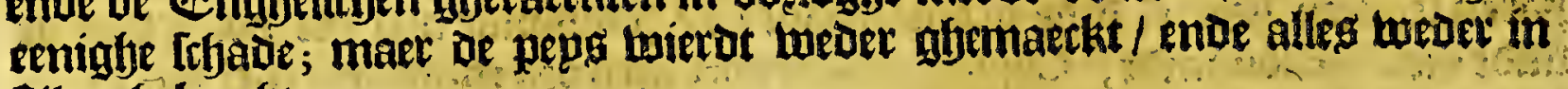
tailte ofgebzactjt.

\section{Het een-en-twintirffe Capittel.}

Vorder verhael van de procedueren van de Engelfche in dit quartier tot ip den jare 1612 ende voorts tot den jare 1621 .

$\mathrm{D}$

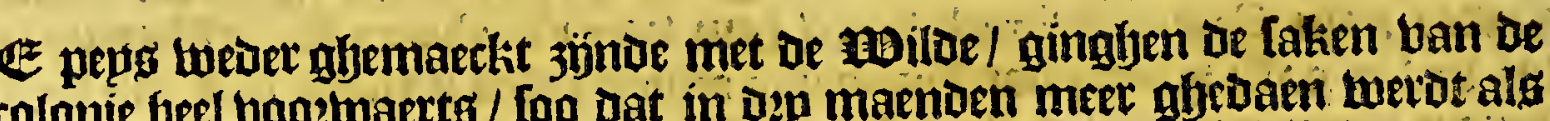
colonie beel booztwaerts / foo dat in Deg maenden meet gfjedaén wetot als in de voozgaenoe dye jaxen, fo maeckten ozp oft bier lalt peck ende taxte: enoe pot-aftben ; maeckten een boen-put in bet foet / ende timmeraen wel twintidj juplen; Lan ofp feugberi waren in een jaer we! lellich biggben afjetiomen/ende

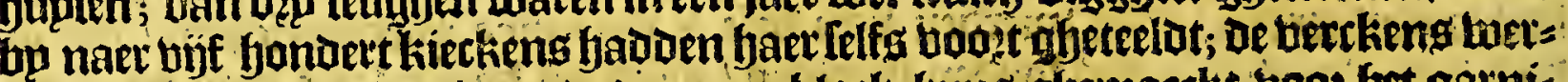

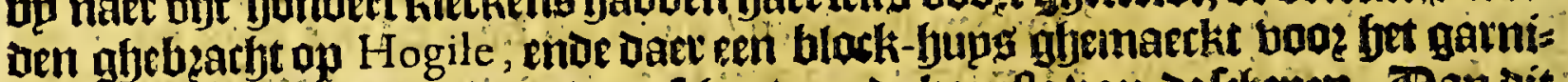

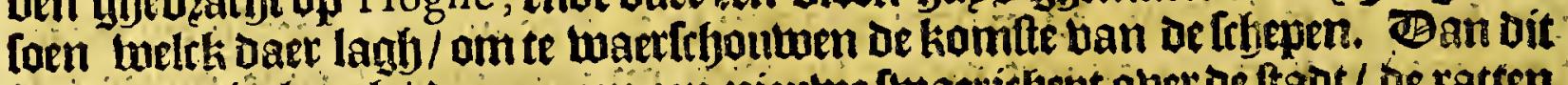
en Duerde niet langh / Daer quam een nieutue [tuaerityept ober de ftadt/ be ratten aten fjact kaden / ende daec en twas in fjet lanot gheen anoer te krtjgtjen / foo dats men bet bolck hieten daer molt verdenlen om de kalt te foecken; een partige leffoe

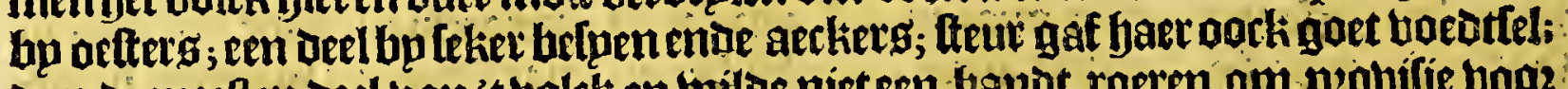

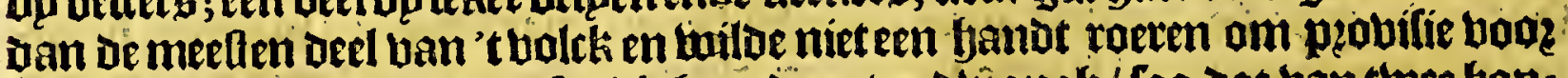
haer Lelfs te maken / tot dat Smith Gaer baer toe okwongh/ foo dat ban twee fons.

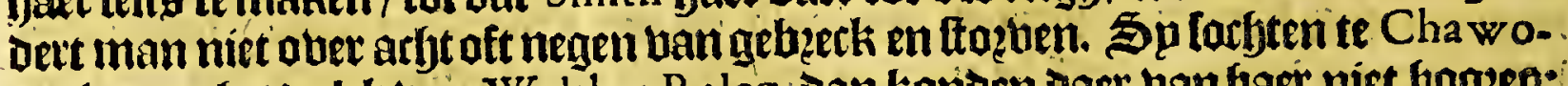
nock naer bet bolck ban Walther Raleg, Dan kontuen Daer ban fjaet niet bogzen: noth oock bu of Q uiyoughquohanocks, Daer oe Mángoags haer ghelepten.

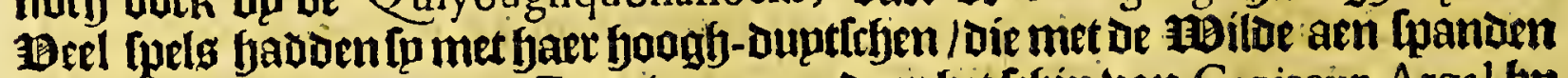
om de rolonie te tuineren. Intevim quam daec het frfyp van Capiceyn A rgal bp

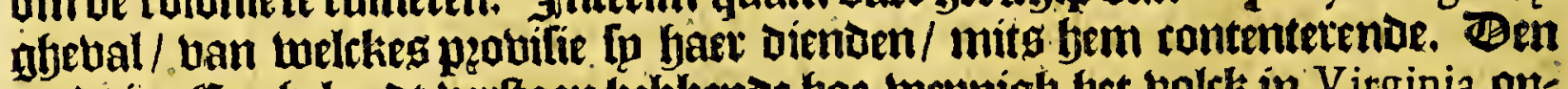
raed in Ezagelande bertaen bebbenoe hoe wepnigh het tolck in Virginia ons oer den andeten accozderde / randt gaedt Get Goubermement te veranderen/ ende raben get lelbe aen den Baron de-la-Ware; bie booz Ipn gfodeputeer= ae conbt Sir Thomas Gates ende Sir Geórge Sommers, met neghen frbepen ende büf honoert man; die ban UEngbelanot onoer $3 e p l$ gingben in May maent I 609. Den zlomirael baer of twee Hibders in waten bleef op oe. Bermudas; d'ander fefepen quamen twel obev / Dan הic daer op waren voos Capitepng/gljes

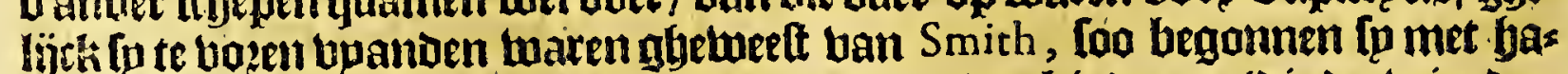
ren onghereneloen boop ban jonghe luitte-bzoodts kimberen (die ac veienden upt Genthelandt badoen toedj ghelonden upt beefe wat lp anders aen een gals abe 


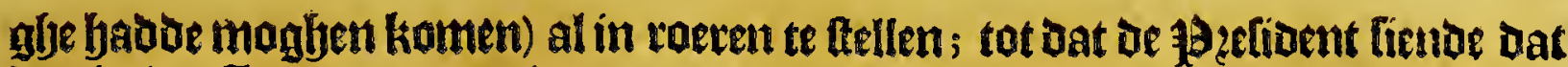
de nieulu bouberneurg niet en quamen/ fun tanden thoonae entae eeniglye bp

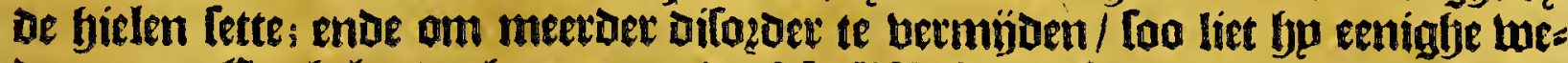

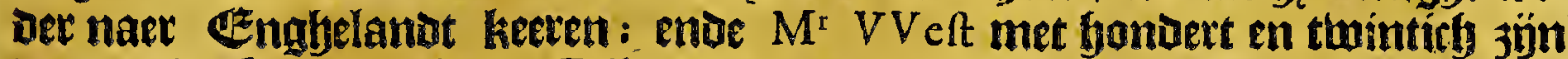
twoon plaetfe nemen bp de Falls; ende $M^{r}$ Martin met oock foo beele te Nanfamund. Bie fem Doos [pn couardife foo Dzoegh/ Dat een Deel ban bet bolck bp

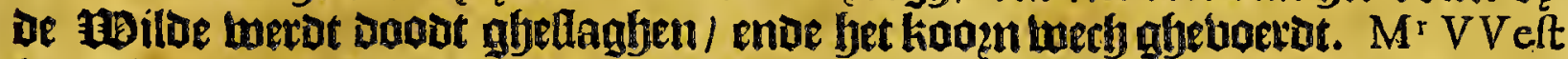

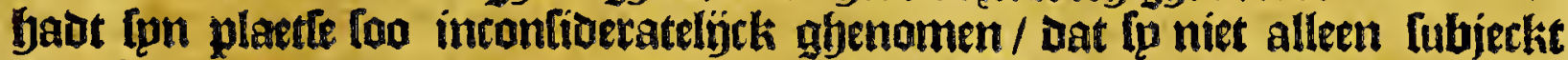
mag 't obevloopen ban be riebier / maer oock bonuert andere inconvenienten:

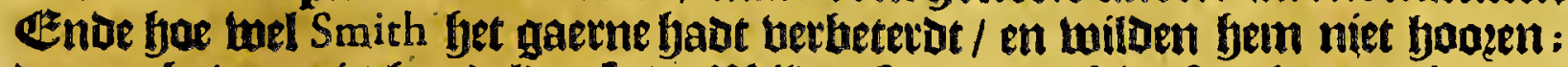

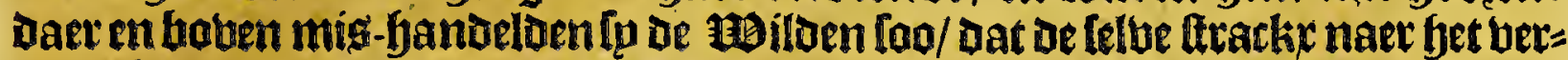
treck ban Smith baer berpzonghen enoe eeniafye doot doeofen: twate aber Smith tweder-ketente faet lepae op een ghewenichte plaette / die fye noembe Nonfuch; wan trocken tueder naer yaev ande plaetfe die fu noemoen VVeft fore,

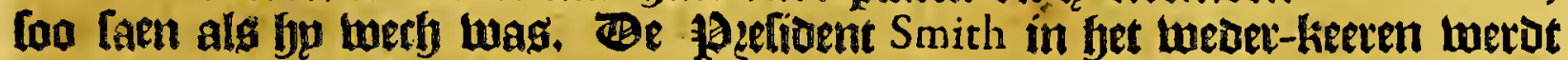

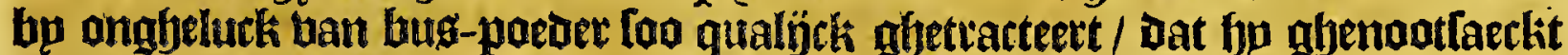

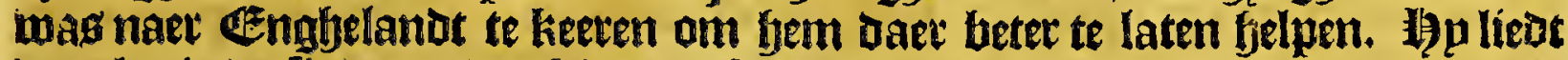
De calonie berlíen met been fobepen/ feuen booten; beel twaten am met te ban=

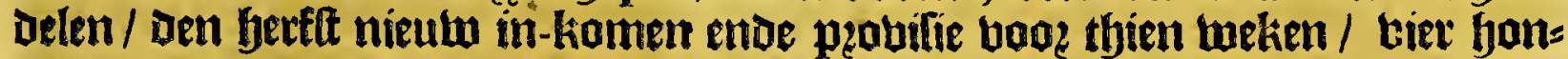
Dert ende tneeghentich perfoonen / biet-en-twintich ftucken abelcfuts / Dep jon = Dett musketten en roets / vootg piecken / fwaetoen ende alle noodigbe ammus

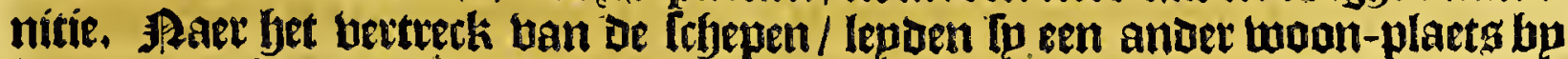

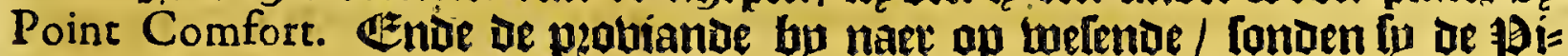

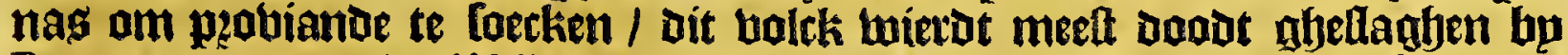

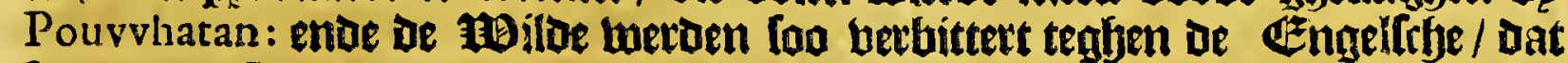
Iu al boot loeggen baet fo bu konde kamen; foo dat de bjif bondert / in leg maenoen tỉdts gheronfumeerot tuaten / tot op de feltich feer milerable lie= oen: midoeler tijots quam waer aen Sir Thomas Gates ende Sir George Sommers uan te Bermudas met handert ente büftich man; die taer abeberabt

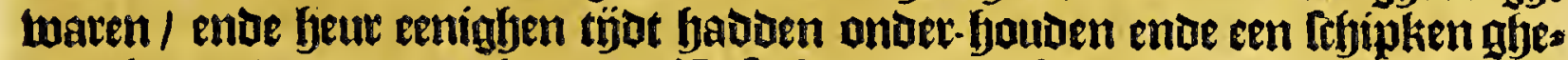
maeckt om van Daer te komen. Befe fiende oe miferie ban fet bolck / fouden

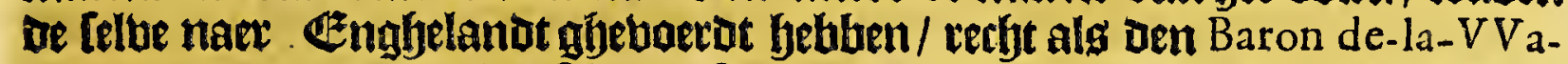

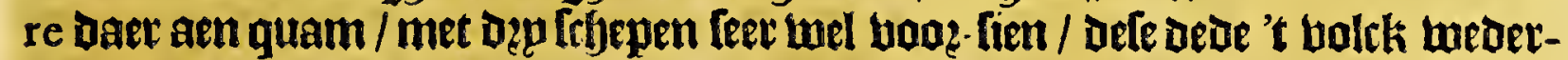
keeten naex Iames Tovvne Den 9 Iun. I610 Condt Sir George Sommers ende, Capitayn Argal, om te Bermudas aen te Ioetken; ende Sir Thomas Gates naev

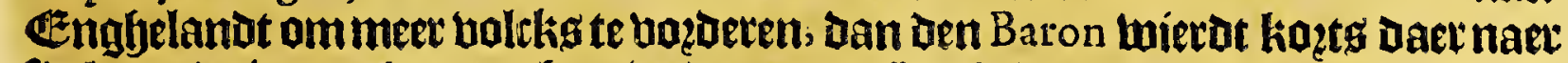

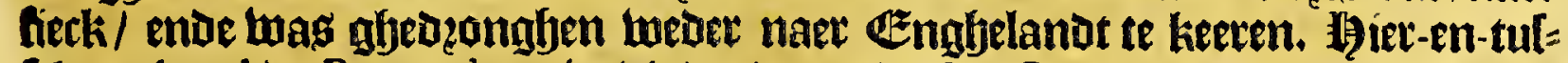
Irben Argal de Bermudas niet bindende; ende Sir George Sommers betlopen Gebbentie op de $3 \mathfrak{k e} /$ quam te terballen op de kufte ban Sagadahock, Daet bp een

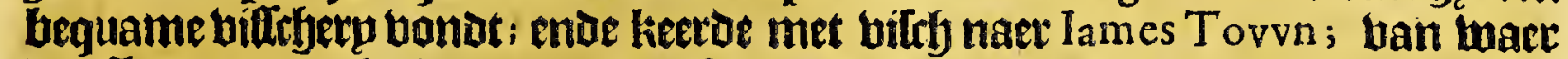
De Gauberneur de-la-VVare hem fonde op de riebiere ban Patav vomeke, Daer

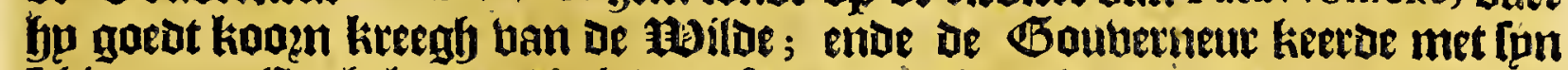
Ifhip naet EEnghelanot; Doch boo? fun vettreck arribeetio Den ro May I6I I Sir Thomas Dale met dęp [rbepen / boldti ende bee ende al antoet noodighe pro= bilie. Baet naer waren noch ghelonden les atoote fefepen onder bet abse biedt van Sir Thomas Gates, met dęu bondert man ende hondert flucket groot bee / met ammunitie ente noodighe pzobilie / die twel atribertode enen Iames Tovvn Den eerten Auguft. Baen twerat oe calanie met nondighe THetten

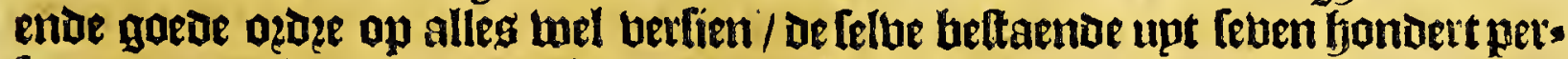
foonen ban aldethande konften enve ambachten: een fout ig gheleglt bp Cape Henry, onder bet ahebied ende commantement han Capitepn Davis; ende een ander twoon-plaetle ig ggelegfte tarfetentich mijlen boben Iames Tovvn, 
op een hooghe ende wel ghelegen plaetle ghenatmt Henrico, daetle bequatu

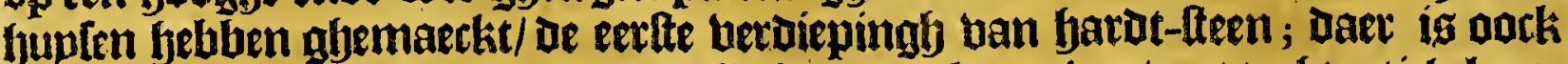

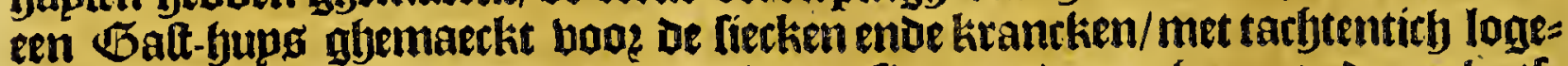
menten ban bedaen ende anders bel booz fien : ende noch een andere plaete diele naemen Bermuda, ontrent büft mílen onder Henrico, bu lanat te reecke:

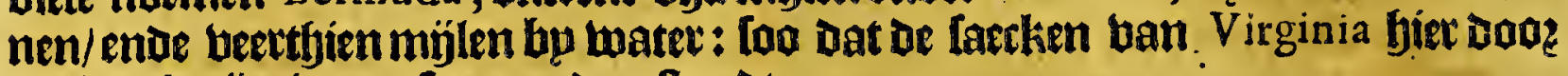
quebeatyt 3 ju in een Leer goeden ftandr.

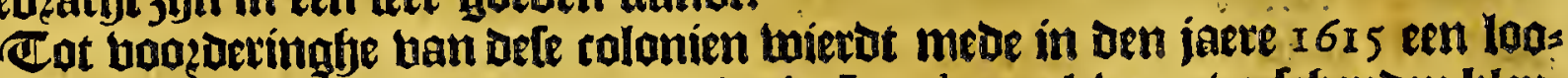

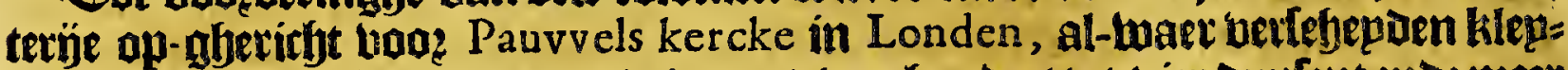
ne ende groote pej̉en waren te winnen/ ban bondert tot bier ouplentende meet kroonen meetioe.

De groote Honingl Pouvvhatan ttierf in Den jaexe 1618 ende in Ipnplaetfe

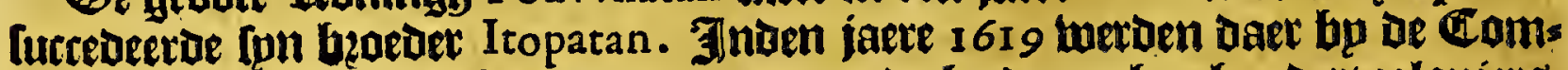
pagnie gheLonoen acht frbepen/ente daer mede bu de neghen bondert coloniets; enoe ouer oe hondert beeten / befjaluen bet bolck oat bu particuliere mierdot ghe[onoen. Bit felue jaer zön berlefepoen giften ghedaen bu particuliete / tot boozetingh ban het begonnen merck. Gende Daer twierden beele particuliere octrapen betrumat aen berfrbepden pertoonen. Daer naer ż̈nder noth meer

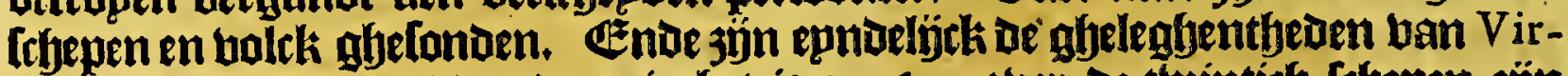

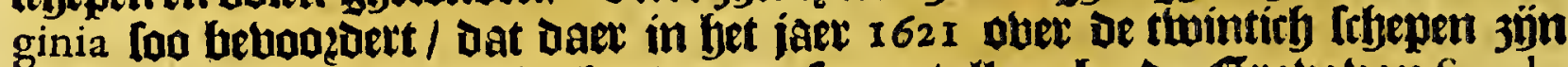
ghetonden/met mel derthien fondert perfonen/alleen bp de Grabe tan Suyth. hampton endede Compagnie; beneffeng andere die glefonden zýn bp particus:

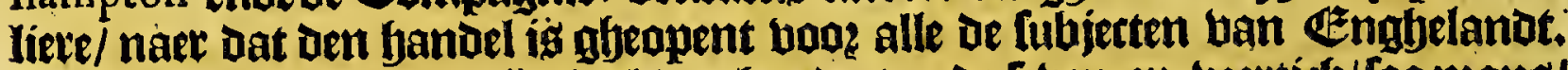
Doch inden jaete 1624 jín mel dep bandert ende leben-en-beettich/[oo mang) bzuluen / als kinderen; die bier ende daer moonden [onder arbter-dencken]

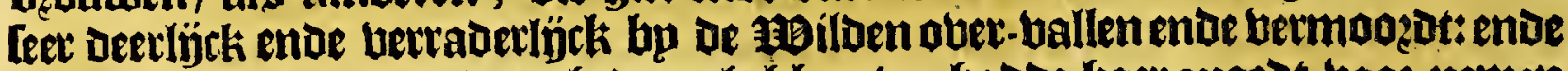
[ouben noch meer quaedts glbedaen bebben/ en badoe haer quaed booz-nemen twelck fu hadoen op de ftaot lames tovvne, niet bp een Moiloe die Chyeitten loag

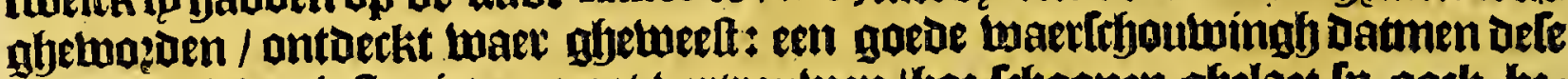
barbaren intminfteniet en maet bertroulwen/boe frboonen ghelaet la wack be= thoonen.

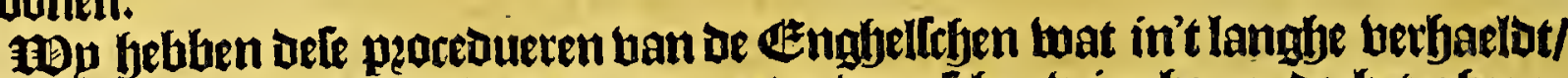
booz dien dat baer mis-flaghen een goede waerlfyoulwinghe; ende bet gfeene

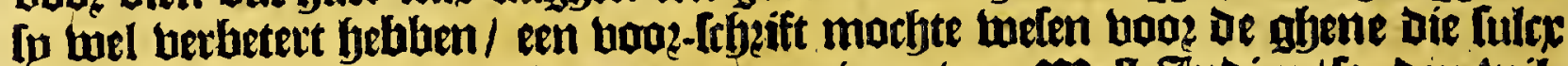

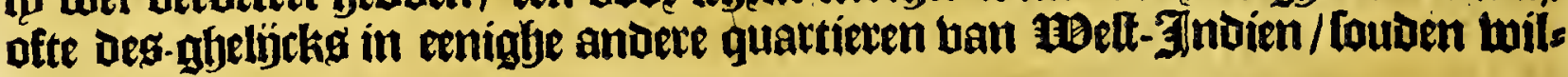
Ien booz-nemen.

\section{Set twee-ent-twintidblte Capittel.}

Befehrijvinghe van VI R G I I A door Sir Walther Ralegh cerft ontdeckt in den Iaere 1584 , ende vervolghende : eenighe vruchten van den Lande, ende ghedierten.

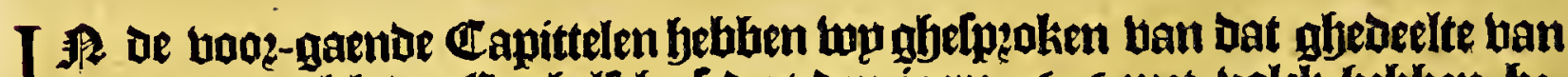

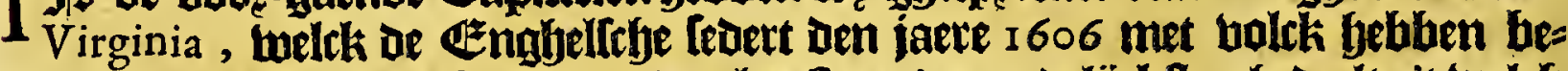

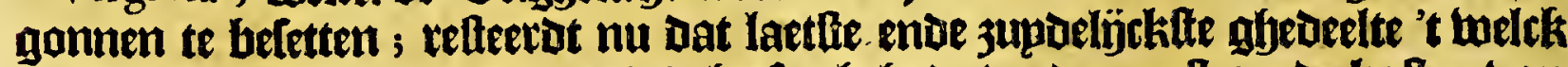
alder-eerlt den naem han Virginia beeft ghefabt / ende meelt ap ve kolten ban Sir Walther Ralegh in den jaere 1584 ende berbolgfende is ontoeckt; begin= nende van den bier-en-dertichften gtaedt bp nopeden ie línie ende foo voouts

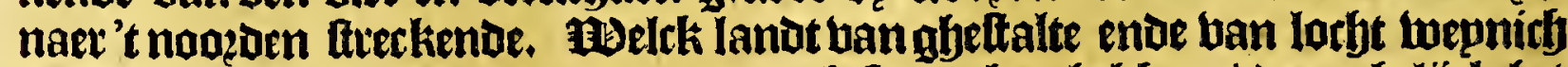
differeert ban't gfjene daet wp nu ban gloépeacken bebben / dan gbelíck bet meer naer't zupden ftrecket / foo is bet daer wat warmer. Zllfoo $M^{x}$ Thomas 
Heroit, de gheleghenthepot ban dit lanot wijot-luftigh in't Gengelfobleft be=

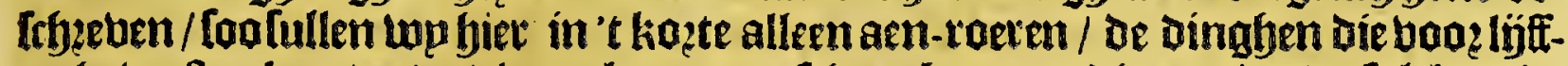
torht berftecken / ende die tot kaopmanfryap konnen dienen / ende lulcke dies ren/ bogbelen ende bifichen als fp berfryepden fyeblen ban andere quartieren/ban Dit ghe twelte.

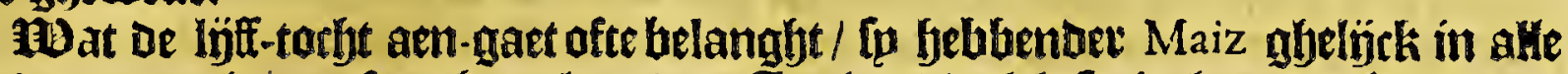

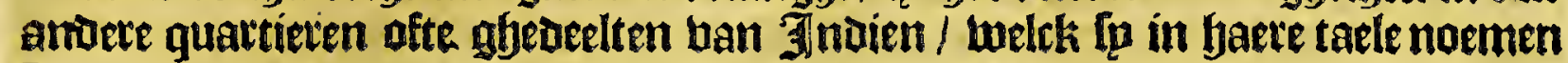
Pagatowr.

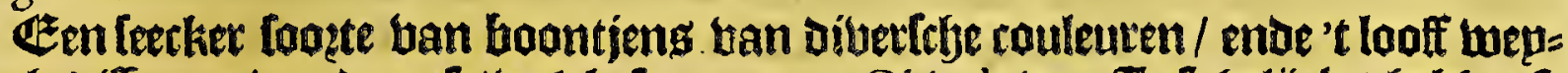
nigl bifferent ban de anfe/welck [p naemen Okindgier. Tnfgbeljetkg bebbente eenloote ban eetten welcklpheeten Wickonzour, pompoenen/meloenenende tamoerden ban differente footen ende ban feet goeden fmaeck/ bie fp noemen Macocquer. Borb andere jün uan ghetuoelen dat Macocquer een beturbt is op

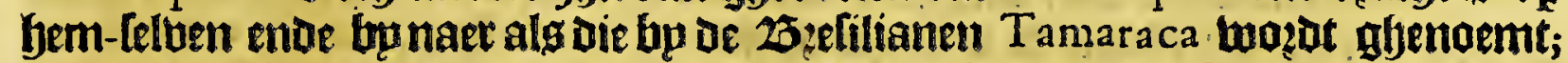
Defelue ig befétetuen bp den bermaeroen Dutuen als bier onder:

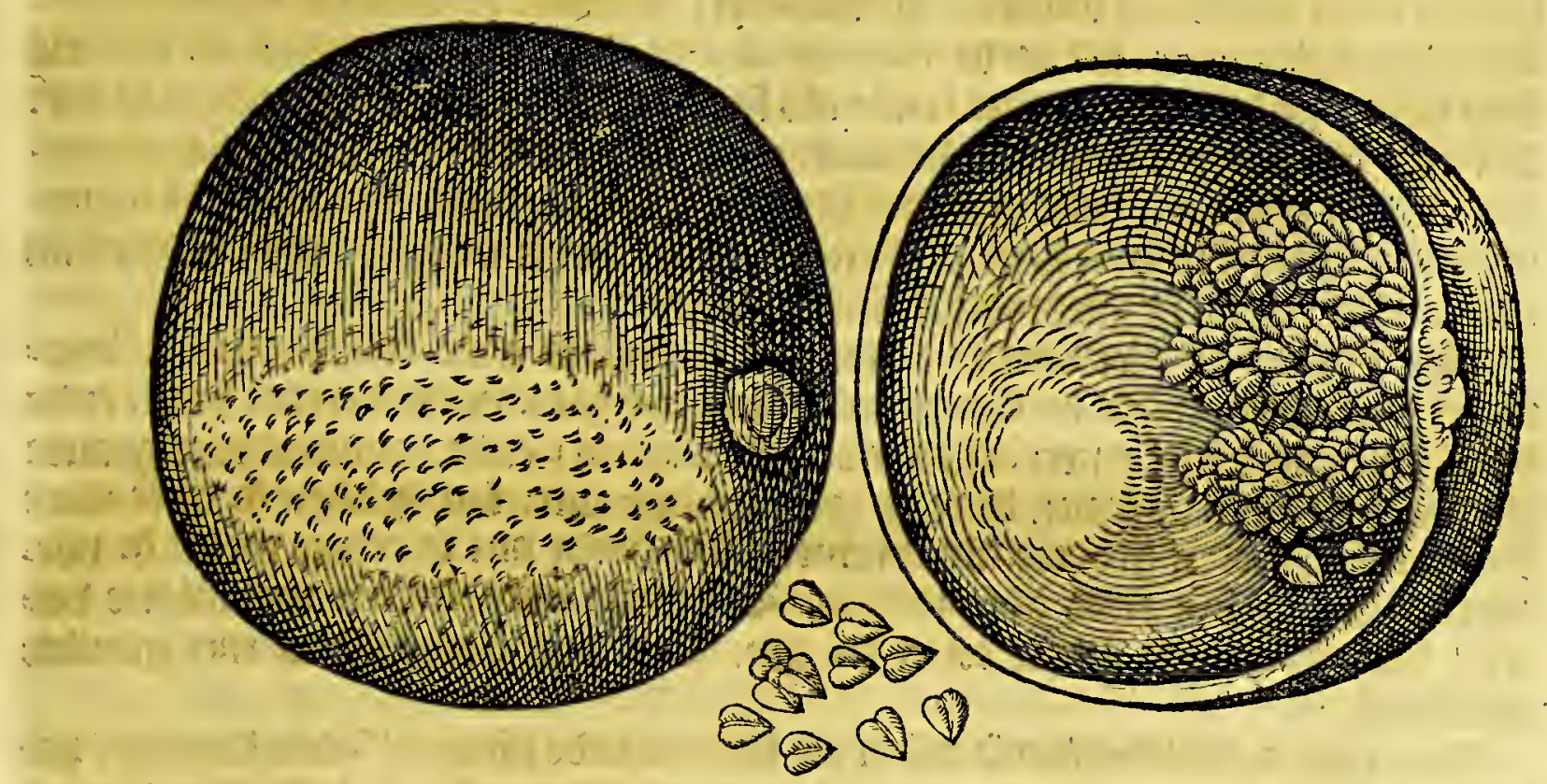

Den Taback twas daec groepende in gaede abundantie / entotu ghebutucks ten die doos pjupen / ende noemoen dat feluiglye kitupd Vppovvock. 23entefens Dele grainen ende krupoen die fp daer gljelwoon 3 jun te jaepen ende te planten/

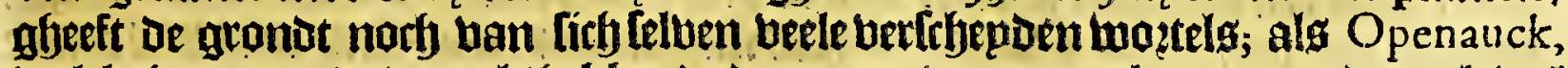

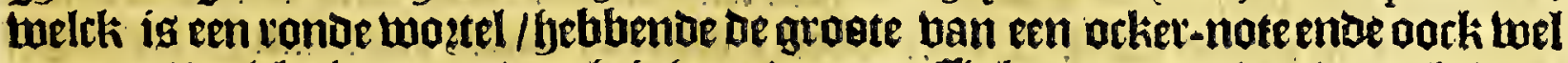
grooter / welcke in natte / bochtigle ende morallight gronoen toozen gheton= Den / veel bp ten anderen / ente ghelíck met een ttengh aen deu anderen valt/

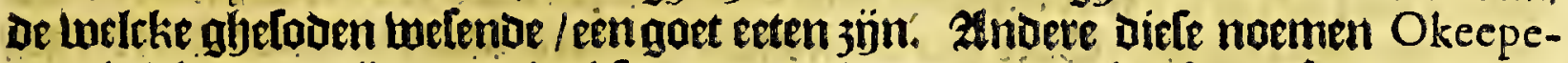
nauck die tondot zýn ende tuel loo groot als een mans-fjonft'; Defe twozden in byoghe gronot agebonoen; Dan jijn loo goed nocly oock foo fmaeckelijck niet

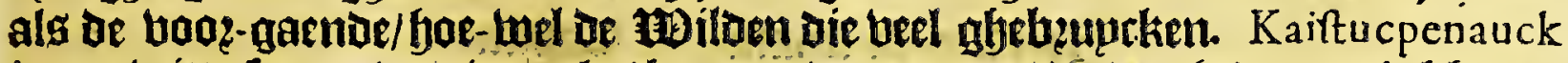
is een witte foote ban woetels / hy naer ae groote ende be glyedaente febluenoc ban ên lyinmen-epe / dan jün nict loa goedt ban fmaeck als de boaz-gaende. Thinavy leet gheligch de radix China, tmaftende met sliftets te lamen/gheeft een

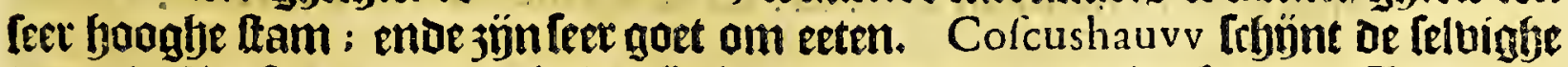
toptel te turfen daer men in de Ezplandenende andere plactlen ban Jndien de Caflavi ban maeckt : want het mozoc op of telue maniere ghetuzupdkt als de Yuca: Defe twoetelen twalten in modoerige/natte ende borbte gronden. Habafcon is een wotel bp nare gljelibth als de paltinalien/Dan is beet op de tongfe. STen

Ag 3 vint 


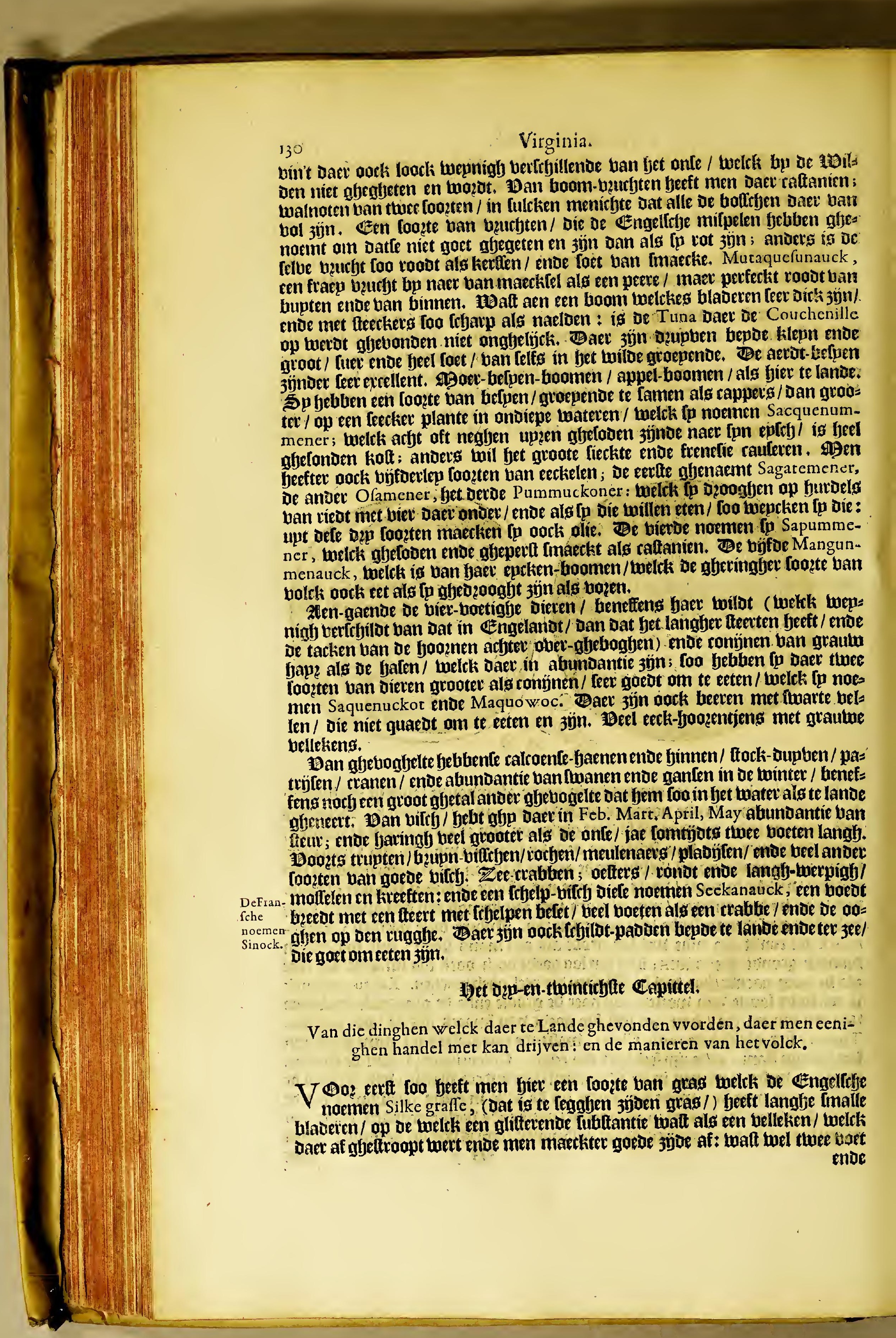




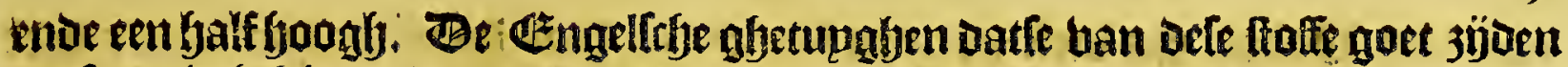
ntof-grain hebben gljemaeckti ende date beneffeng dit noch fraepe jube-twoemen in 't lamot fobben ghetonaen.

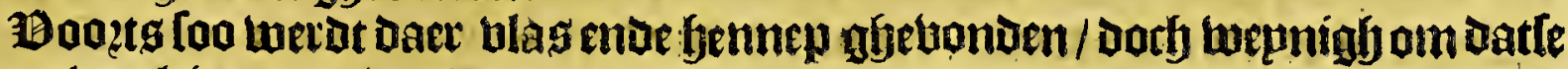
niet gberultibert en twożorn.

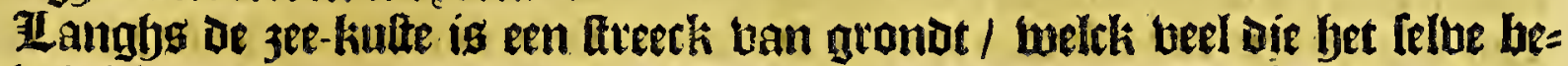
Corft fjebluen ghetupghen goet allupu te glfeven. Wapeigh is een fooute ban aer= of bu de in-ghebooene foo ghenoemt / Ieer ghelÿcl of Terra figillata, ende

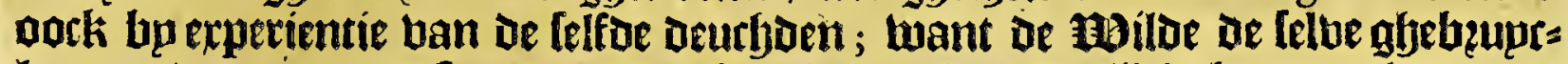
ken om twonoen ende feeten te gyenten. Baer jün ontalliöcke foomen bequaem om peck / taute / ende tecpentün ban te maken. Saffafras welck oe Milde noemen Winauck, is een foubt ban [eer tetcken/ goeden ende [oeten reuck/ ende leet nut teglyen oiberfefje fieckiten; fae nutter als lyet pork-boudt ofte Guaiacan. Cedar youtat ig daet mede abundant ban feet goeden reurke ende bequaen om eenigh dimghen ban te maken. Hoign mepnt men daer te kon= nen maken van de dzupben die daer van felfo groepen. De abuntontie ban

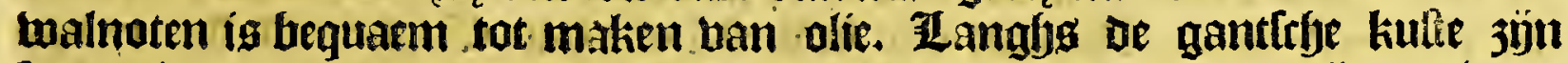
feet beel otterg / welcker bellen goet pzofjet konnen ghetuen: Daer jïn oock ap:

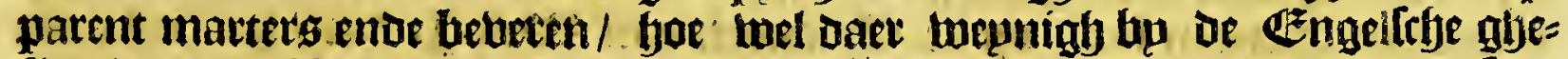

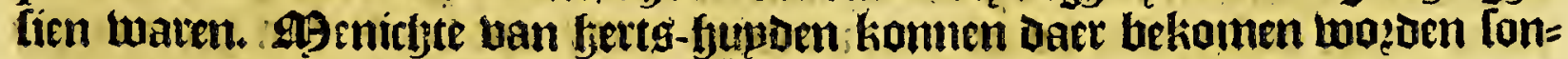

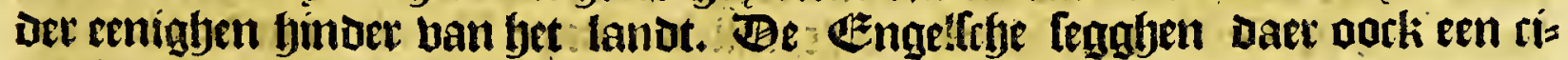

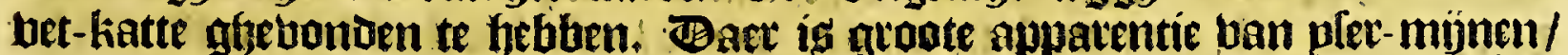

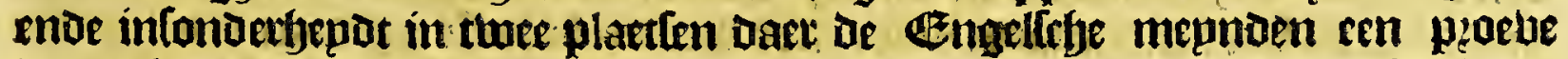

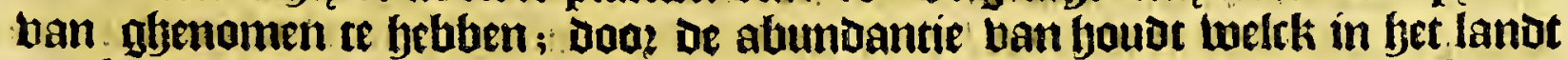
is/ Couden Defe mijnen met abantagie kannen ghebentficent wozoen. Hoper

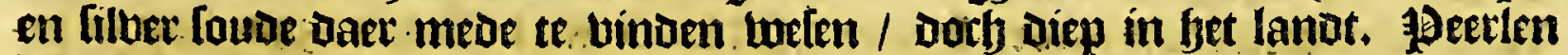

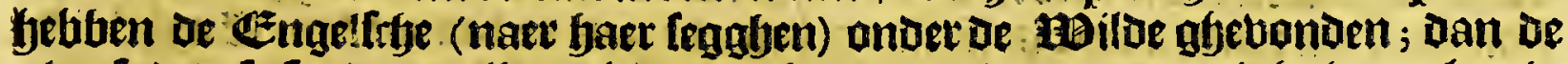
plaetle daette fouden vallen niec ontoeckt; upt-gbenomen eeniglje veagghen in

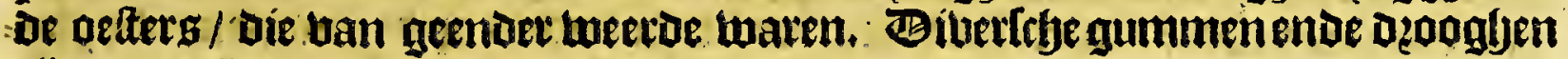
jÿnaer te binden.

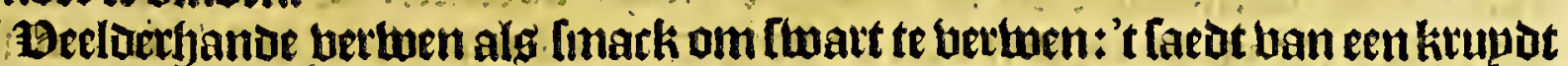
welck fu noemen Wafebur, klepne tunne mpteltjeng gfenarmt Chappacor, choe den baft ban een boom diefenoemen Tangomockonominge: welcke al dibeiftherogot bertuen ghet ben.

t1Bolck van de lande gaet gheklecot in lolle mantels gan bellen/ban wilot

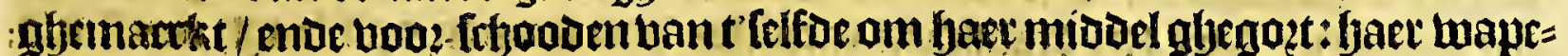

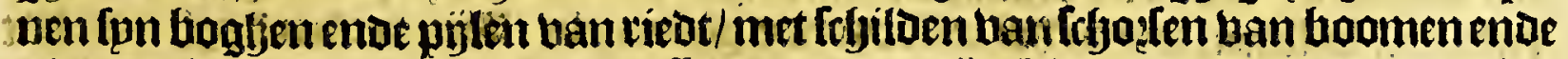

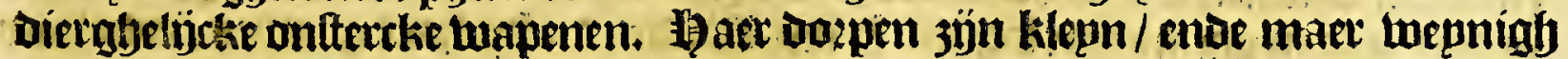

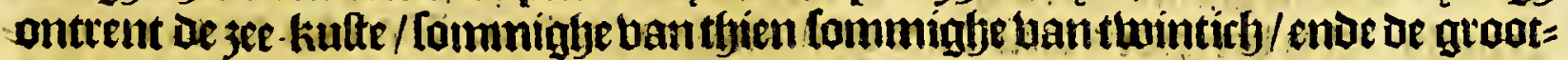

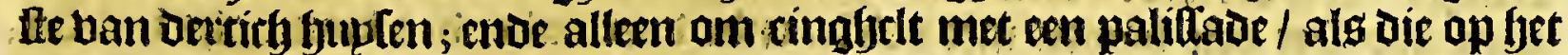

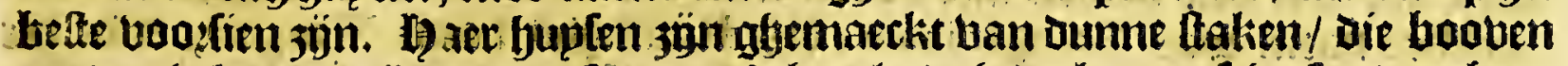

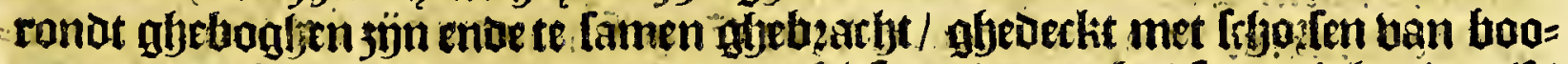
nien / ende foumininge met matten van biefen quemaecke/ Commighe thaelf / foummiglye featjien tot bier-en-thinticty rocoen toe langb/ende balf foo beecot.

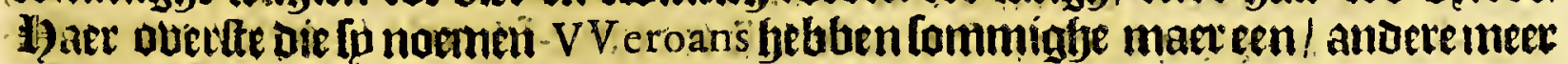
Dojuen onder fjaer; oe groutte daer oe Gengeldfe mede bandelden/ en fad= ate maer athtfien ontuer ljem. Be tale differeet ban placts tot p!aetle / ende foe betoer ban den andeten gfelengen fyoe meetder verfenil. ende glyeuecljt is meet bp furpti[e/ ober-ballen dieen ben anderen bp nacht oft in't beectien ban ben Daglie-taed ; [eloen vechten fu met oen anderen in't open velot/

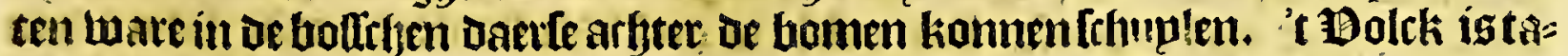

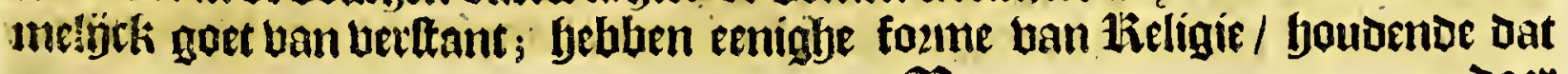
$\mathfrak{g P}_{4}$ Dakt 
Date beel Gaden jän diele noemen Mantoac, han biber Ifye qualitepten enbe

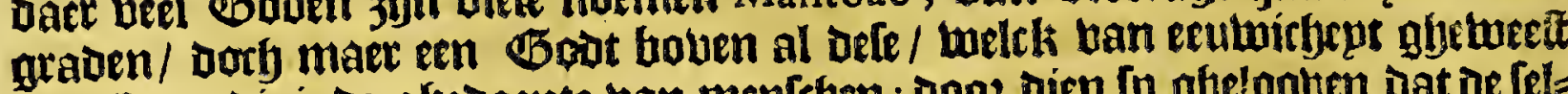

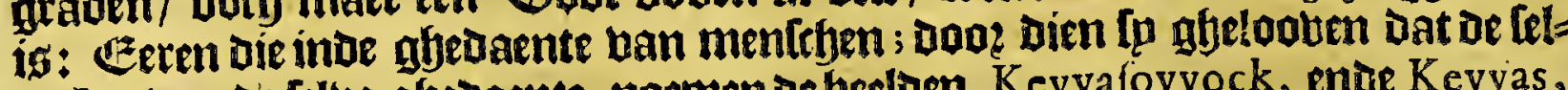
be Imn ban de felbe abedaente; noemen de beeloen Kevvafovvock, ente Kevvas, enoe Letten Dis in buplen Daer toe gheapptopeieert / diefe noemen Machicomuck.

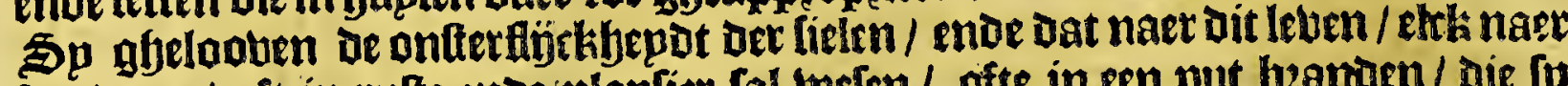

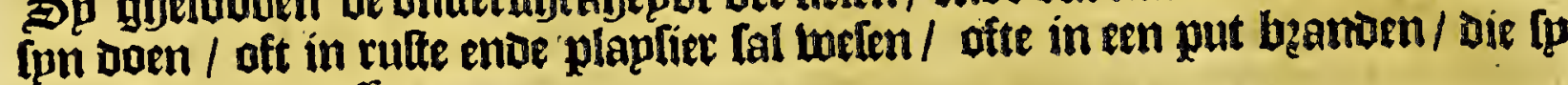
noemen Popoguffo.

\section{(3) biet-en-twintichlte Capittel.}

Kort verhael van de proceduren van de Engelfche in dit quartier van VIR GINIA tot in denjare is86.

$\mathrm{D}$ EE eerfte hopagie naer dit quartier merot boor-ghenomen op de holten ban Sir Walther Ralegh in oen jare 1584 met twee harcken/ onder fet belept van $\mathrm{M}^{\mathrm{r}}$ Philips Amadas; tryepoen ban oe helt-kulte ban Enghelandt Den 27 van A pril, enoe quamen oen tbienden May in of Eplanden uan Canarien, ende bet: viekn Den thienden Iunij op De Geplanden ban meft-3]noien/ baudende een meer jupot-oolterlïcke kours Dan noodigh was/ upt beete ban bet current/ welck upt of Golfo ban Mexico balt/tuffchen kape Florida ende oe Havana: oen tweeden lulij quamente in onaiep batec/ ende kregljen oen reuck ban fret

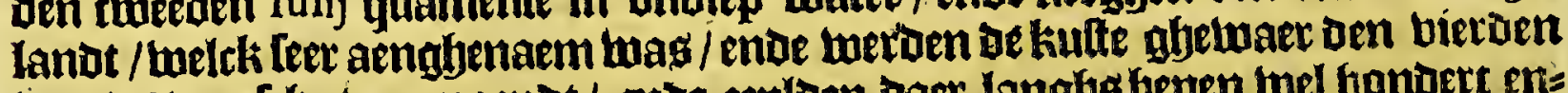

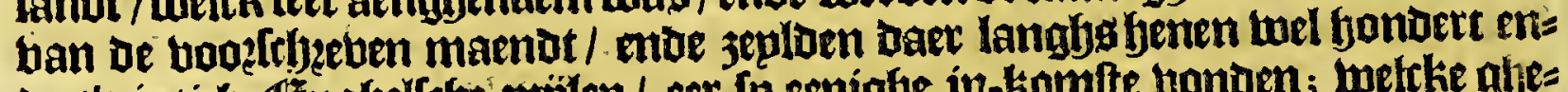

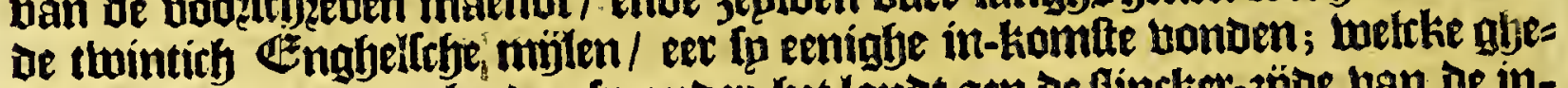

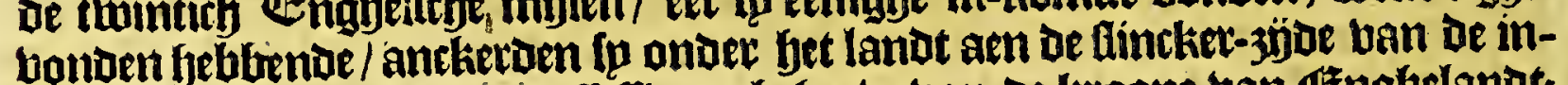
homlte / ende namen Daer polleflie ten befjoebe ban oe kroone ban efnghelanot; yet lamot daet fu eerft landen wag leegh ende landigf / ende vonden daer twijns

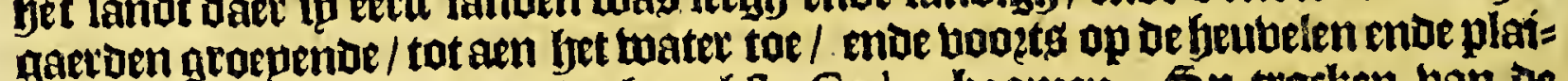
nen/ ende tilimmente op ofe booglyte Cedar boomen. Sp trorken ban be 3et-kandt tat op oe toppen ban de berghen naelt aen glyelegben / die niet leer boogh waren / enoe ontoeckten ban de felbe oe jee aen bepoe jyoen naet bet. nooson ende zupDen/ Conuer epnot te lien; dit lanot ftreckte bem melt; ende

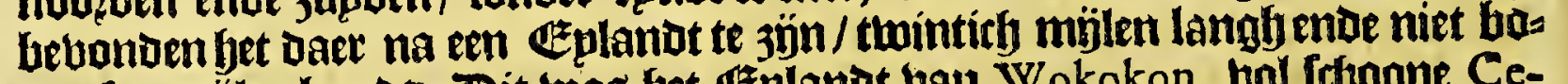
ven les múlen bzeedt. Bit was het Geplanut bau Wokokon, hol fthoone Cedar boomen/ Daet een ontallícke menichte ban kranen op bloogh meet lwits

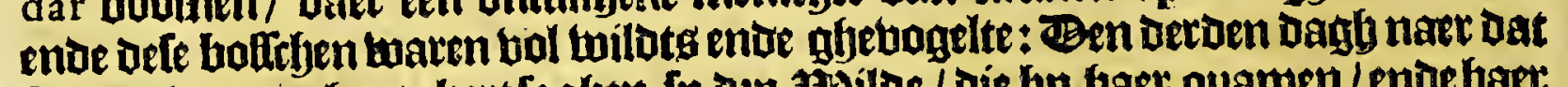

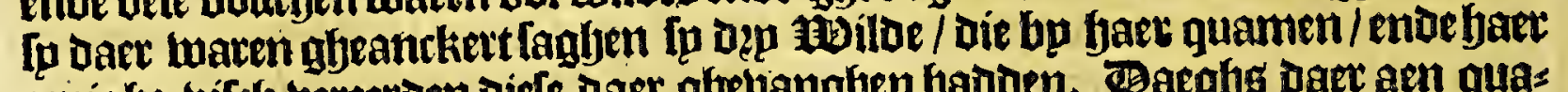
enighe bilch bereeroen diele daer alfebanghen hadoen. Daeghs daet aen quas men daet feer vele boaten met bolch / enve daet onoer des lloninghg baecoer; hrelckeg naem mag Granganimeo ; oes lkoningfy naem Wingina, ente fyet

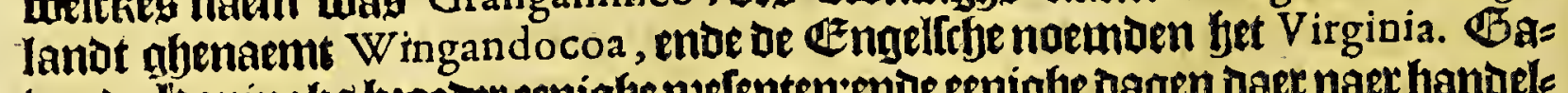

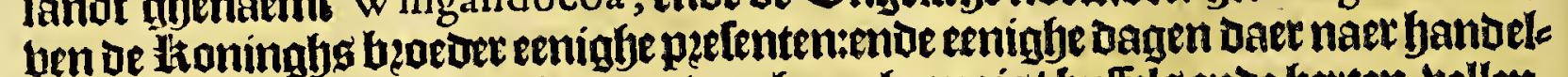

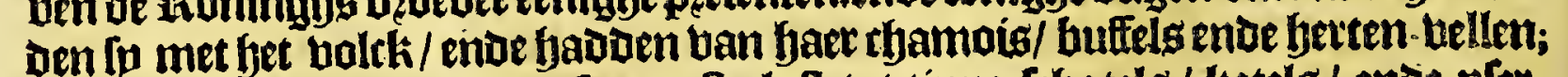
boten alle Dinghen yadoen fo meelfe lult tot tínne-letyotelg/ ketels/ ente plex-

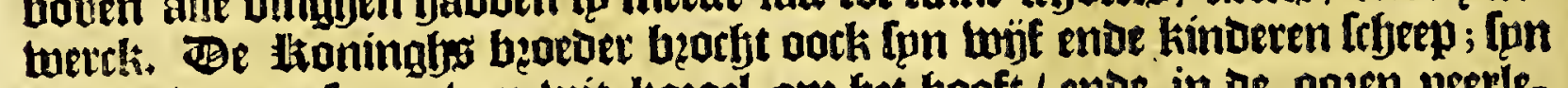
winf hadt een Inoer ban wit kozael om feet hooft / ende in oe oozen peerle-

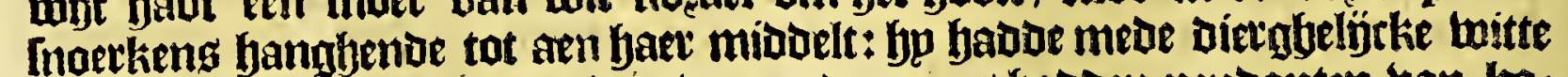
hozale-[noetkens. B'ander beuluen enoe manz haoden pendanten ban los: per in oe opeen fjangfien; ende des ltoninghs bzoeder baot een plate van gouds oft fín koper op fet looft. Het bolck is geel ban houleur / ento llwart ban

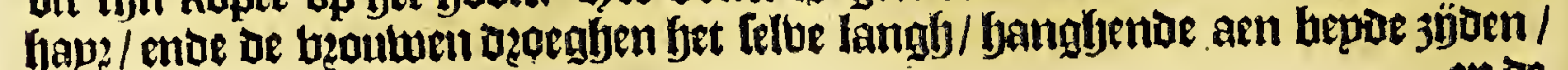

en te 


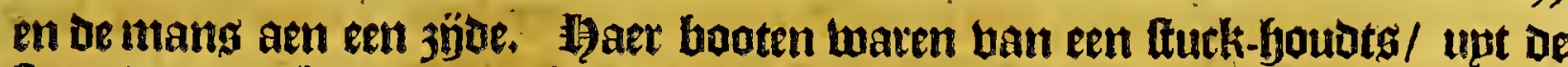
fam ban een boom upt-ghegoolt met bzanden. Be Enghelfehe boeten Daer naer een rieviere op diele noemen. Occam, ende quamen baex aen een $\mathbb{E}^{z} \mathbf{p}$

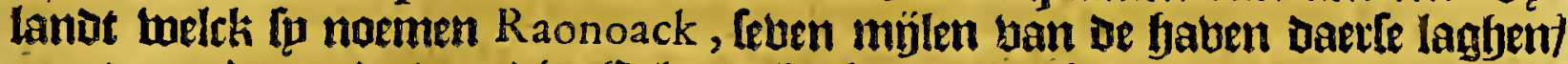
aen't noozot-epnde ban Dit Eplandt lagh een Doupken van neghen huplen/ met een palidade om-tinghelt / Daer Des ltanimabs bzocder twoonde / welches

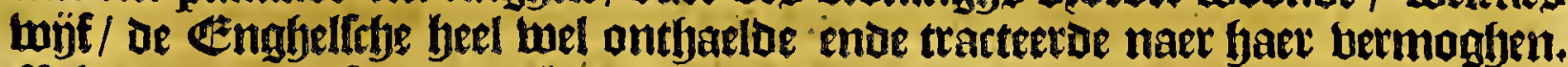

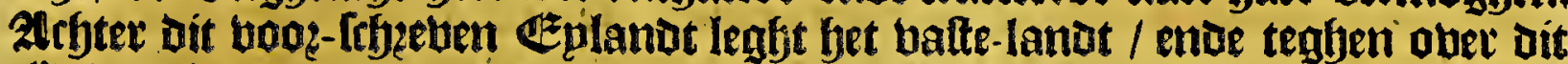
Eeplandt is de groote rietuiete Occam wooz-noemot/ maet het dow Pomeiock leght / ende ontrent fes bacf. replen de vieviere op / leght haet guotite ftad Ski-

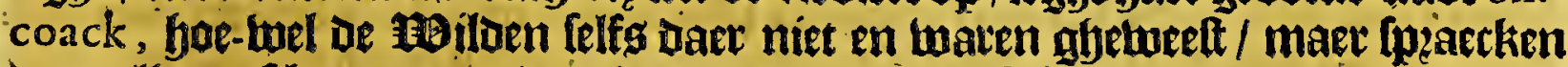
baer alleen af bu trapozt ban baer boot-ouoers. Zn dele riebiete balt een an= ber riebier ghenaemt Cipo, alwaer groote molielen/met peetlen Daer iil/ met= Den nfebanden: bock noeb een ander riebiet ghenoemt Nomopano, aen mele= keg een 3übe legft een groot bazp Chavvonook gbenaemt / wieng lgeete luag

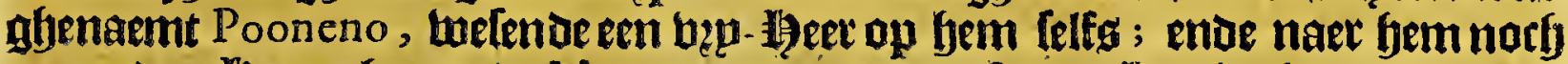

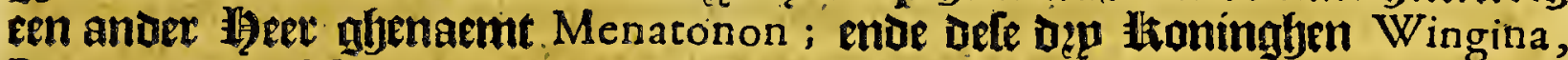
Pooneno ente Menatonon, waeren te famen in verbandt met den anteren.

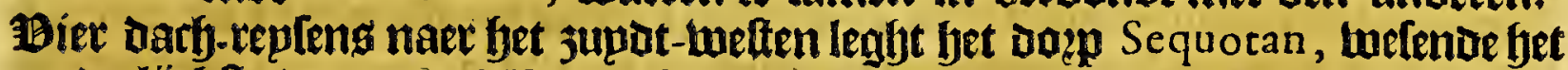

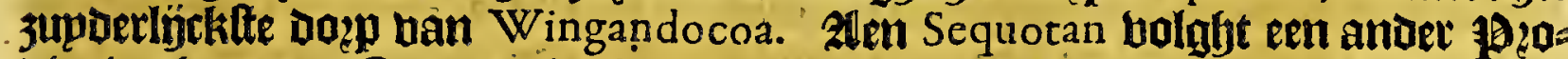
bintie ghenaemt Pomonick ofte Pananvaiock, de lioningh is gljenaemt Piamacum : ende naer bet meften paelt baer aen $\mathrm{New}$ frock, op een traepe ríebier ghenaemt Nëus gheleghen. 1Berder alg Roanoack jün beel luftigfe eulanoen

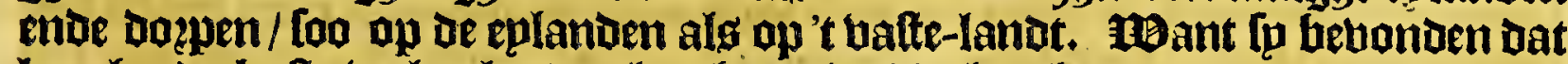
langfg de kulte beel eplanden legghen / wel be lenghoe ban thee fonoert en=

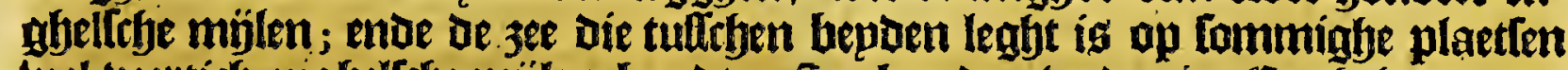

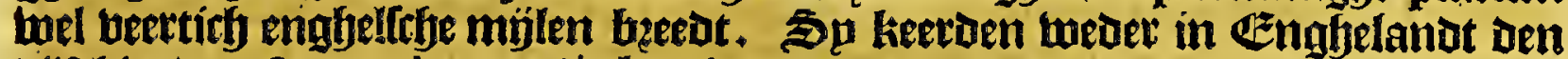
büfthienden September, endie bzarbten thee stBilden Wanchete ende Manleo ghenaemt/met haer.

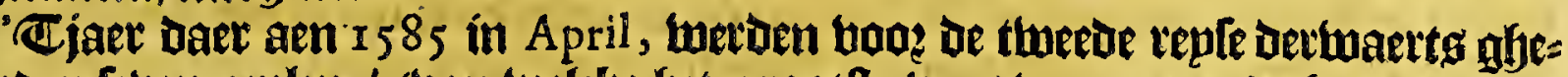
conoen fetten 3eplen / (van twelcke het grootfte was ban ontrenot hondert ton= nen) onder bet belepde van Sir Richard Greenville, Doot Sir Walther Ralegh. Befe fefjepden ban Pleymouth oen negfenden April : ende ben beetthienden barenfe in de canarien; ende den fenenden May aen ljet Geplandt Dominica, ende oen thienden aen Cotefa een klepn Eplanot bp Porto Rico : ende den thaelfoen quamente ten andket in de hape de Mofquites in't felte Eplandt; lan=

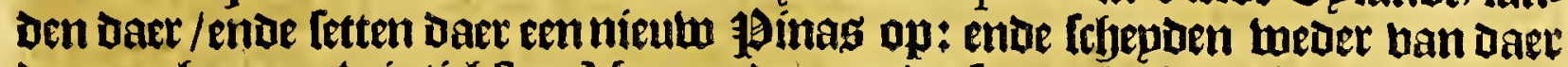
ben neglen-en-twintichten May : endenaer datte aen Hifpaniola, de Caycos, Guanima, Cygateo, waten aen gftetweelt / berbielen Den twintichlten Iunij op

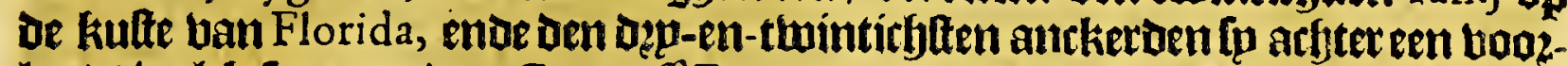
landt thelck fo noemben Cape off Feare, (on be beete van fthip-betuck die fu Daer badoen) ende quamen foo den [eg-en-thinticfiten te $V$ Vocokon, ende ber= lozen daer boo onuerfitht bet fryip ban Den Admirael : [onden aen VVingina te Roanoack; ende wock naer Croatan, daetfe eenigfj ban faet bolck bonden/

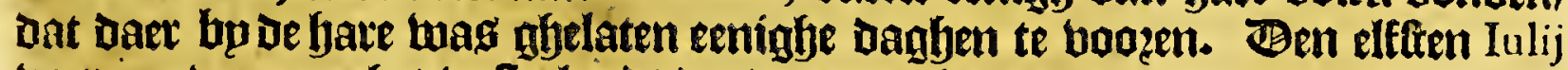
boeten ober naer bet bafte-lantot / ende ontoerkten de dogpen ban Pomeiock, A quafcogock ende Secotan, als mede't groote lack tuelck de wilden naemen Paquipe, ende meer andere plaeten; ente keerden foo weder in de blote : yeb= benae al hoozen die ban Aquafcogock baer koom bethzanat / om Datfe een fil= beten kap gheftalen hadoen / enteniet en twilden tweder-gheben. Ben en-entwintichiten boeren lp ban VVocokon naer Hatoraske, ende quamen daer des ander-daegly aen ancker; ende den darh daetnaet quam Grangino de beoeder 


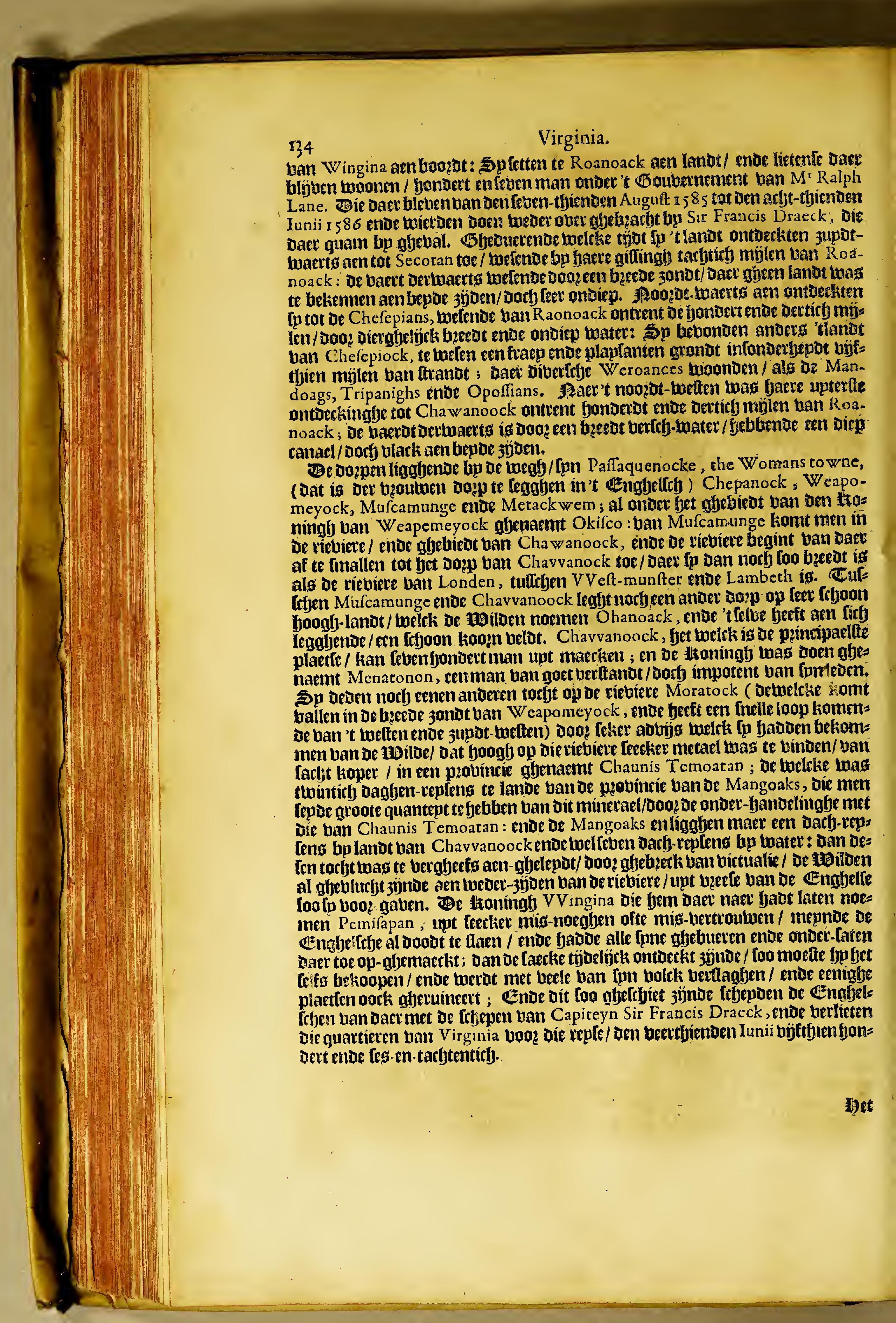


Het bij-ent-thintichate $\mathbb{C}_{\text {auittel. }}$

Vordere procedueren van de Engelfchen in dit quartier vath VIR G IN I A, van den jare if 86 tot den jare 1590.

S Ir Walther Ralegh habt in Den jate 1586 en frbip unt-ghemaeckt am fpt

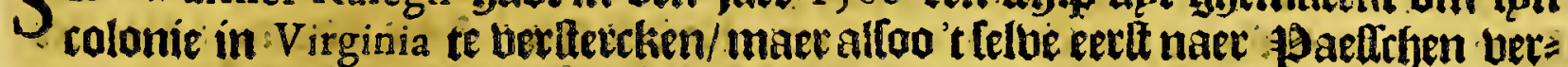
trock upt Gisghelandt/ foo quam't juplt in Virginia naet dat het bolck al weder was vertroeken met De Iffepen van Sir Francis Draeck, alg boojen werfaelt is/ eribe keeroen beudjt-loos weder naer bupg: Sir Richard Greenvil eenighe da= ghen Daet naer mede in Virginia arwibectende tot bet felbe epnue/keetoen oork

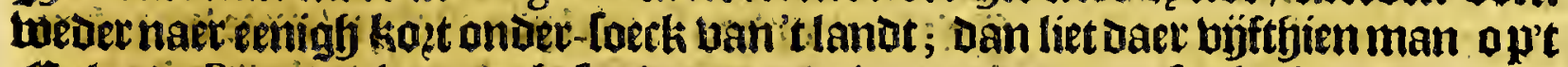
EElanot Róanoack omot belettinge te continueten/ende berlagh die met monot-

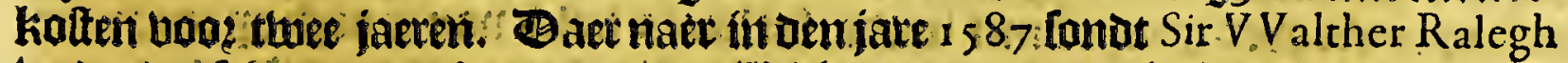

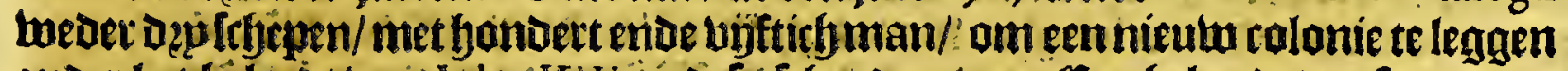

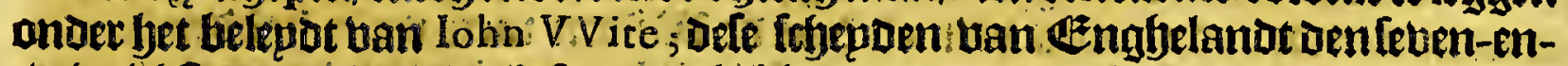

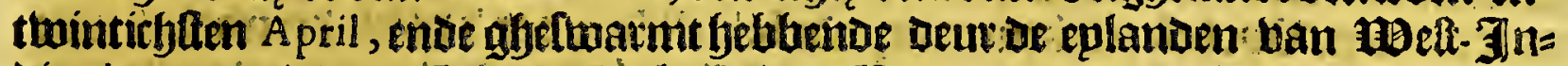
Dien/quamen oen 16 Iulii aend de kulte ban $V$ irginia, ende ancketden epndeinck

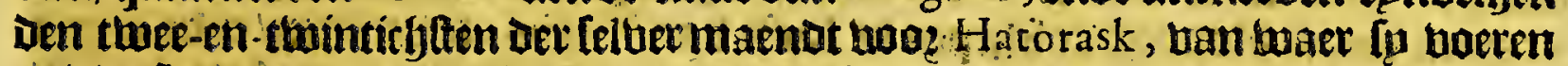

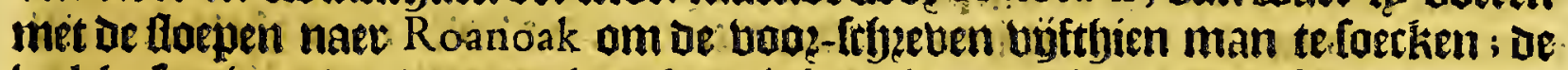

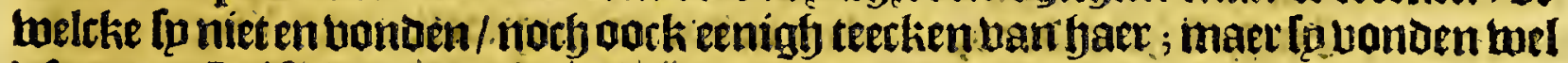

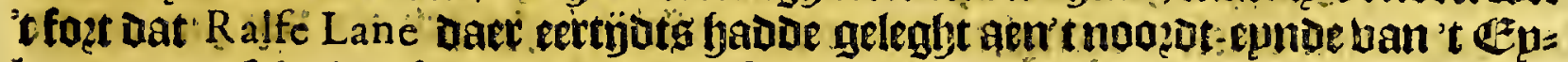

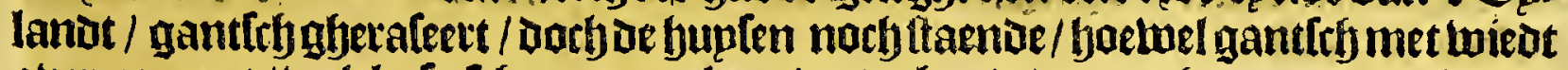
ober-groepet / welcke fp fthoon maeckten/ ende boubuden norb andere ap nieulwg Daer bp booz faer mooningfe: (Sir VV alther Ralegh badoe baet wel bp lpne in= Iturtie helaft / Darle fouden gaen moonen in de hape ban Chefepeach, Dan De

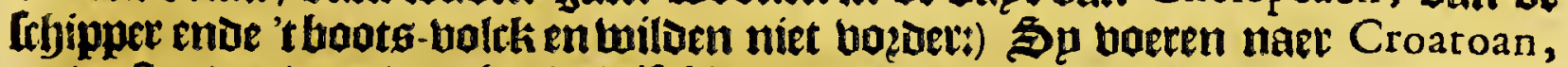

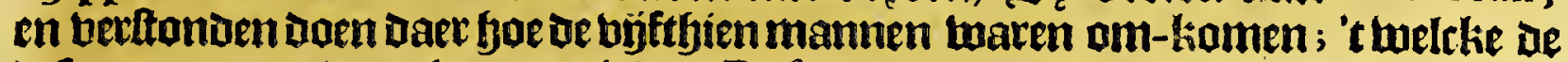
Delemepnoen te wyeecken op die ban Dafamonquepeuck, De luelcke de moozd te

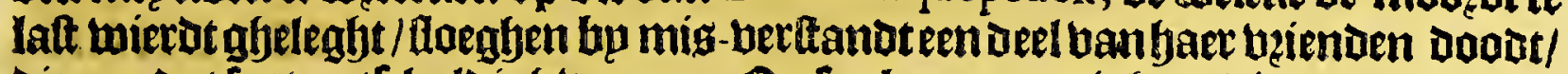
die aen dat fept antfrbulaigh waven. Opteeckete oneenighept die ander' $t$ volck

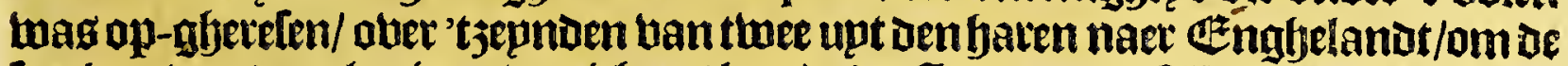

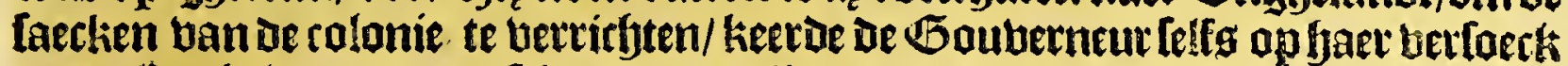

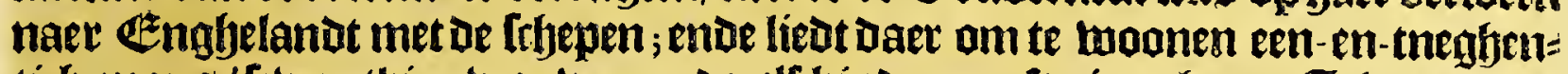
tich mang / [even-thien bzoulwen ende elf kinderen ofte jonghers. Jles en binae

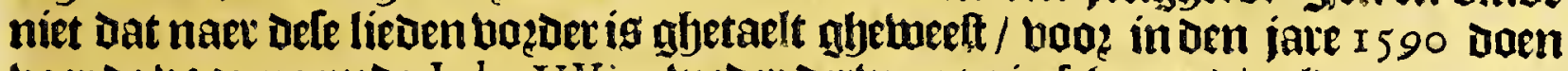
baer de booz-naembe Iohn V. Vite lueder Detwaents in fobepen die eloers toe ghe= Deftineert waren/ende soo faueur ban Sir Walther Ralegh gheowongtien wier= Den am die kulte aen te Daen/ende lohn VVite Daer te lanien: Befe lrbepuen in Martio upt Enghelanot/ ende twarmoen foo langhe Dooz de eplanoen ban abelt-

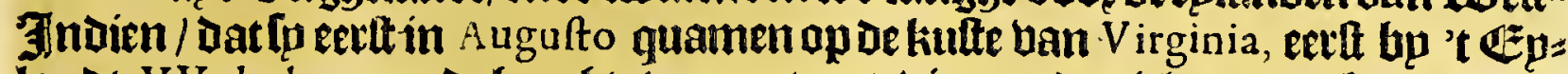
landt $V V$ okokon, op oe hoorbte ban ontrent viet-en-iertich graden bp noozoen

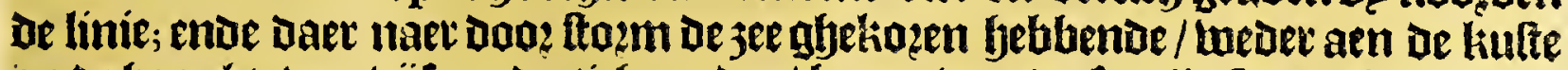

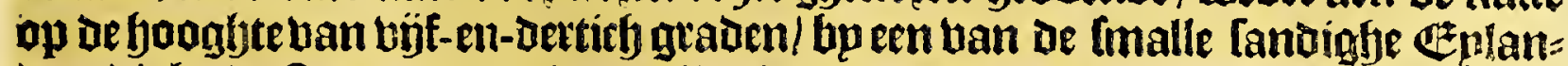

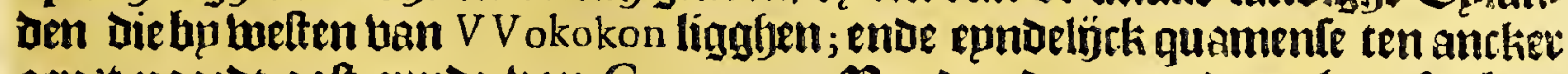
aen't noo'dt- ooft-epnde ban Croatoan : Bonoen Daer een Dzooghte ofte bar:

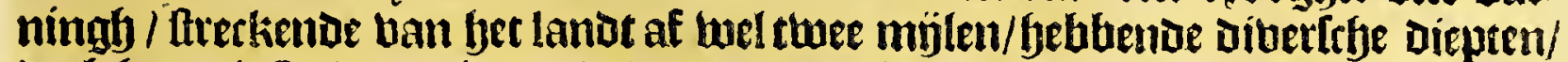
borf fot minfte water is Dep bajemen; welcker noozot-aolt-epnoe ban dit $\mathbb{E}_{\mathrm{p}}=$ lanot leglyt op bÿf-en Detticl graden ende een yalf. Jen bujfthienoen Augufti

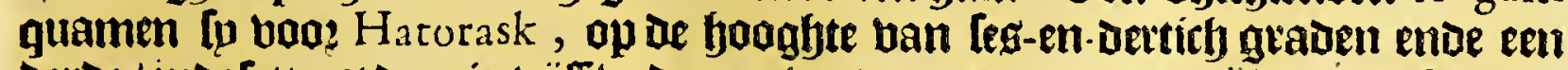

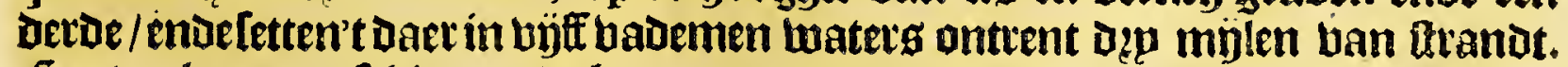
Sp trackenupt't frbix met de bootennaet't lanot toe/ ont te Roanoack fret bolch

van 


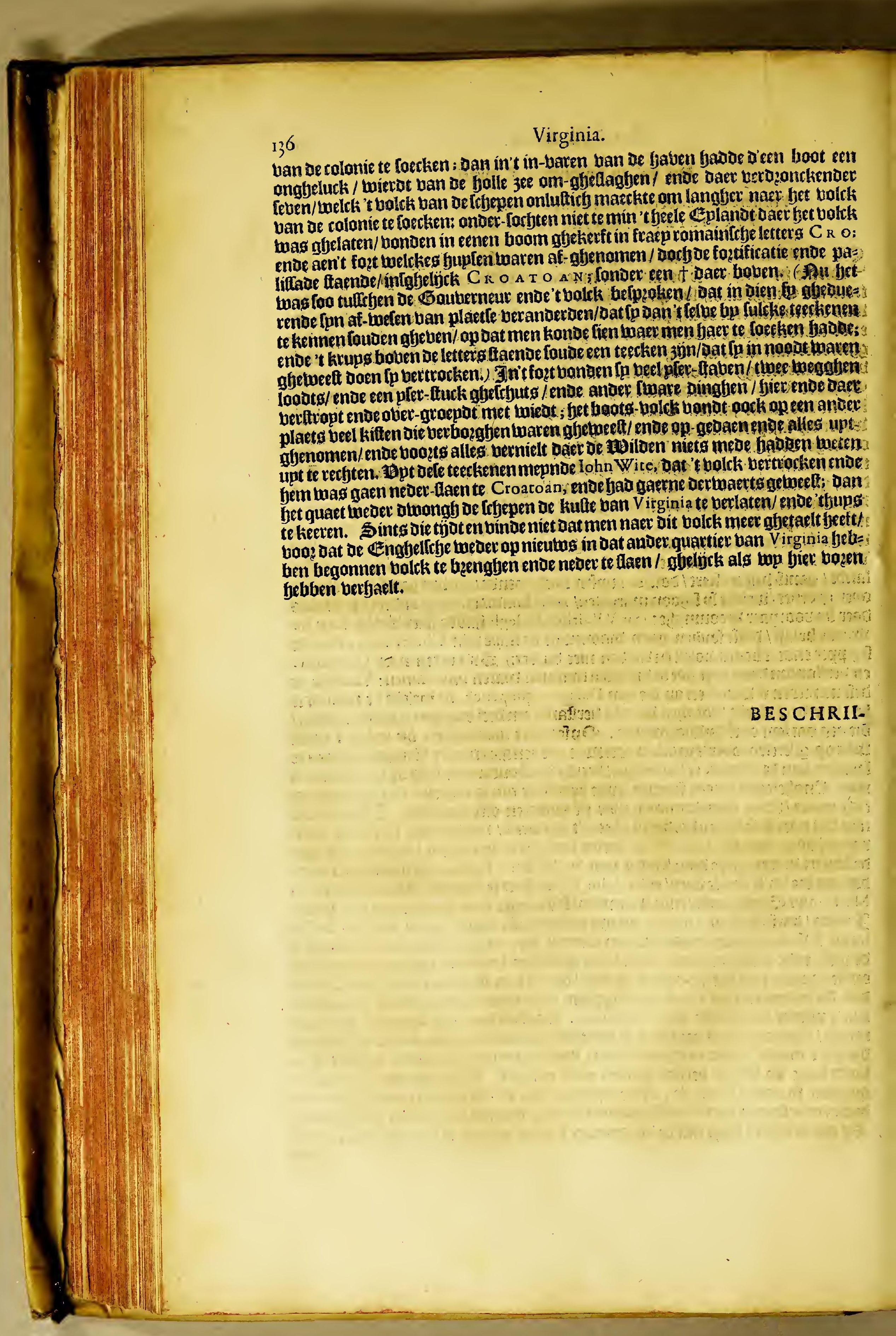





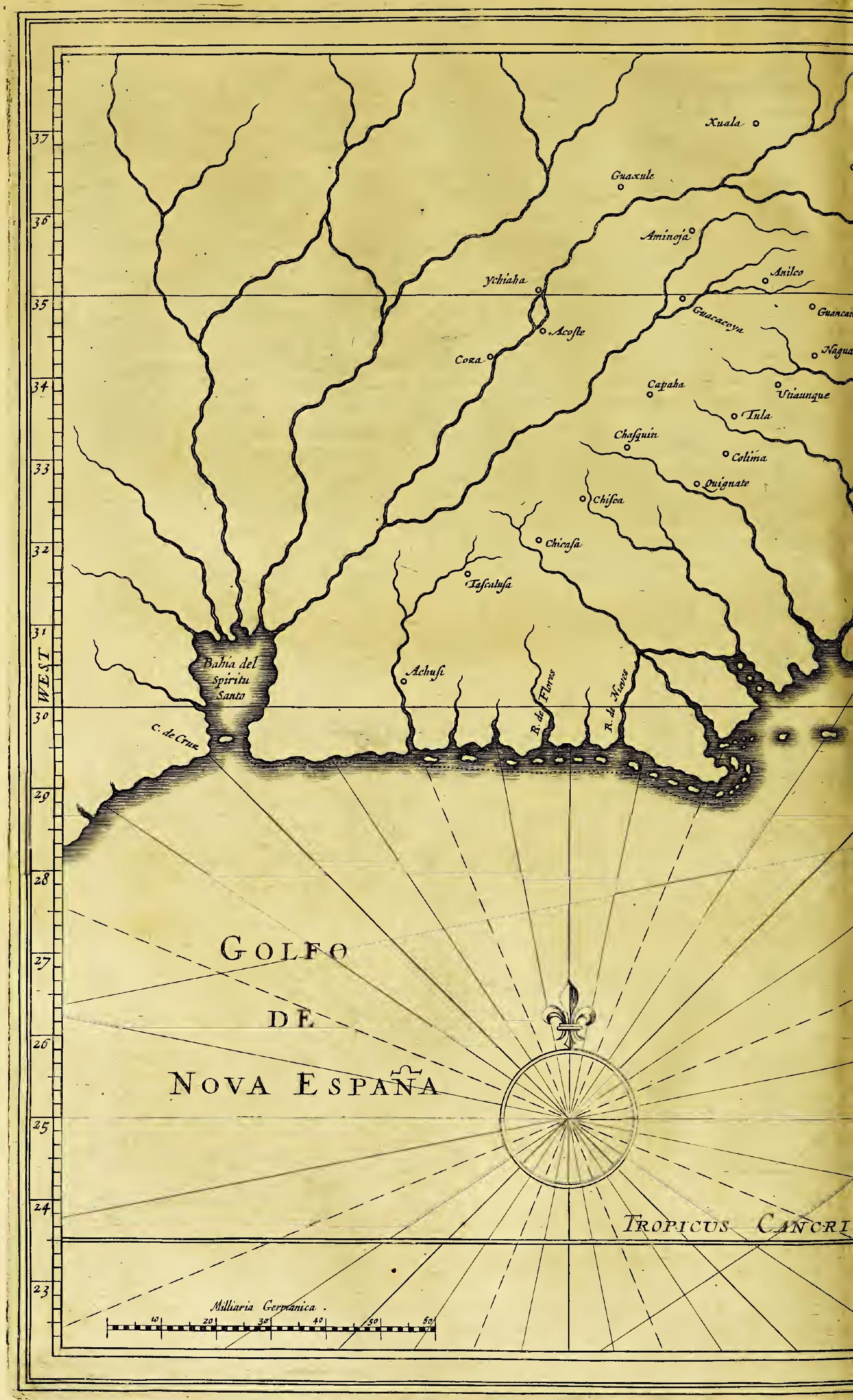




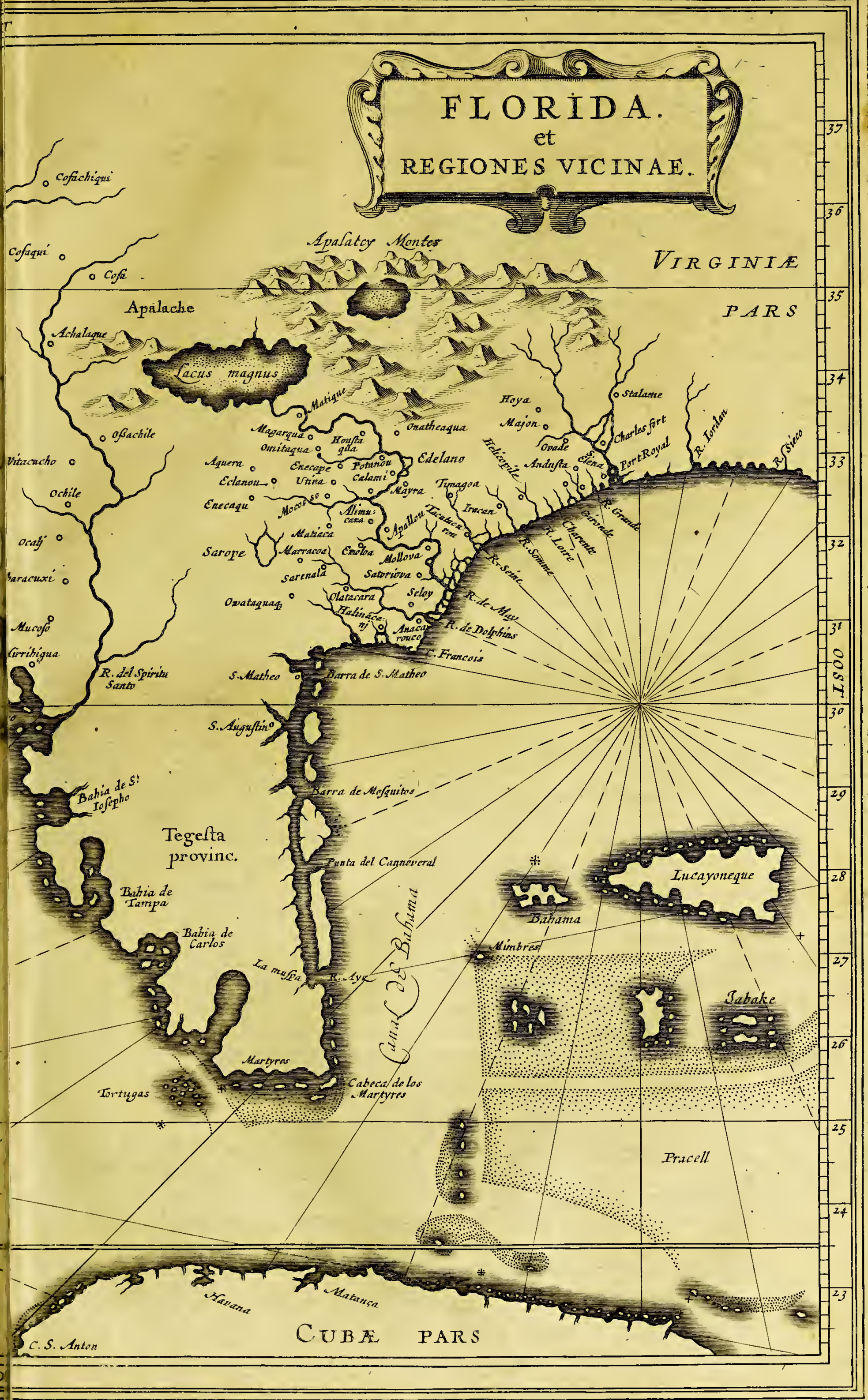




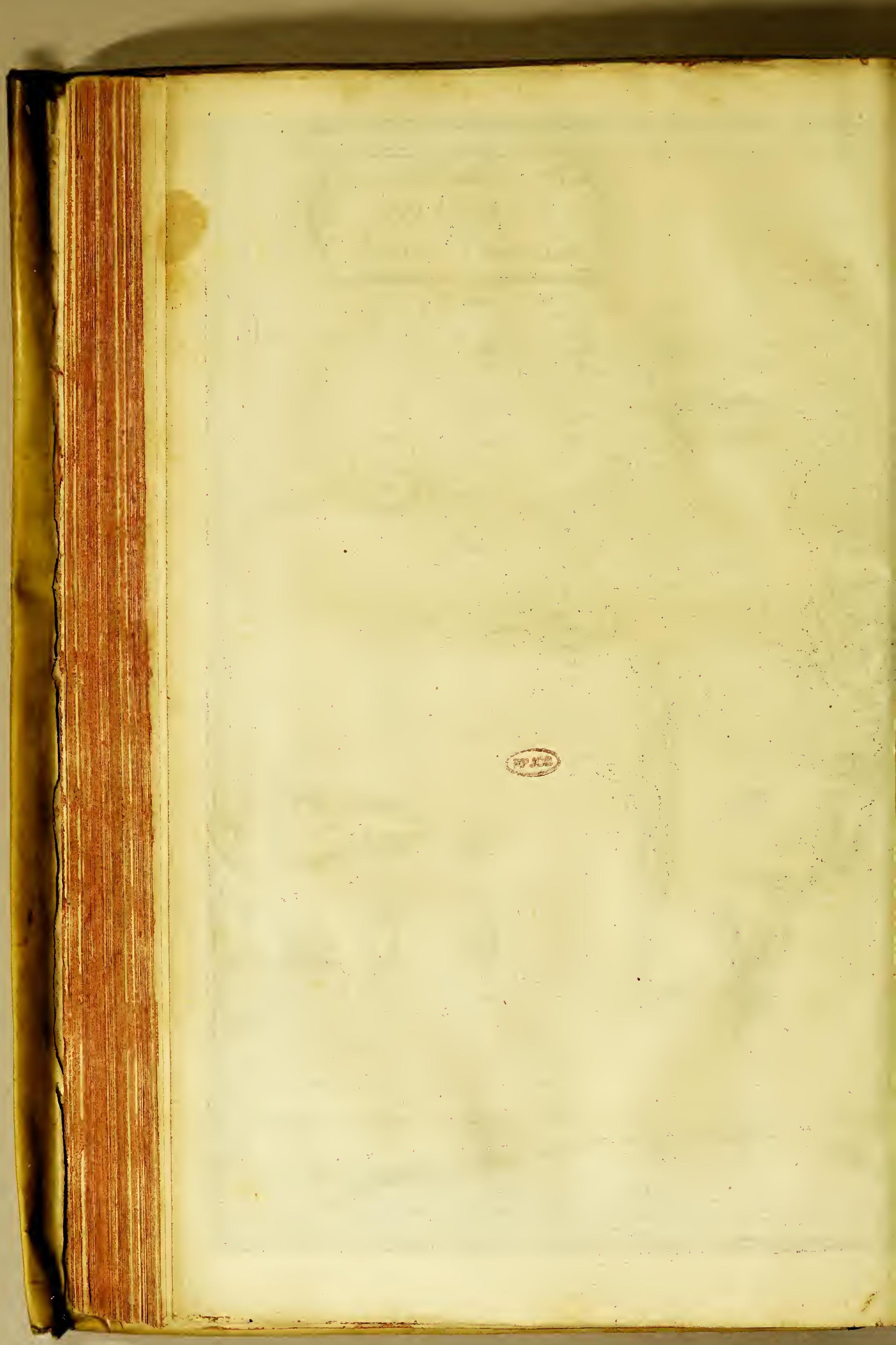


BES CHR IIVINGHE

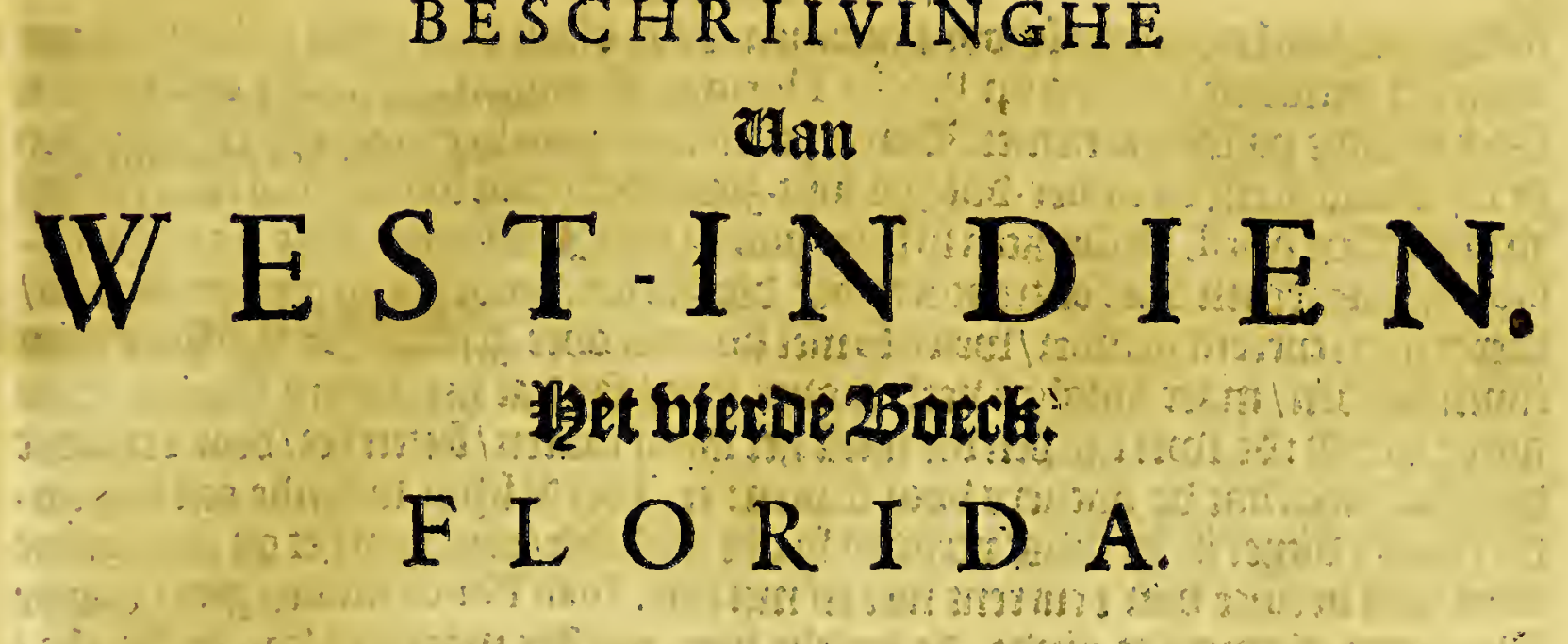

Het cetite Capittel.

De ecrte ontdeckinghe van $F_{I} O R$ I $D$ A.

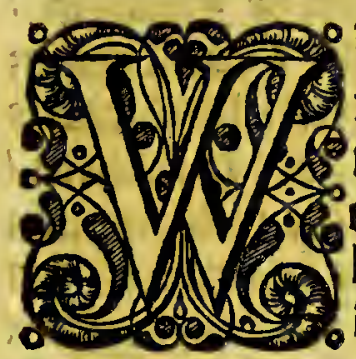

职 fon nu ghekomen tot bat gluedeelte ban bet

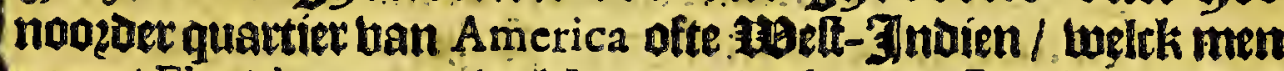
noemt Florida, om't welcke te ontoecken ae Spaegniaetaen enta firancoplen fonderlingfe blibt beblen aen-ghewent. Cot Geter berttantot ban de gfelegentbept ban t' telbe quartier too op

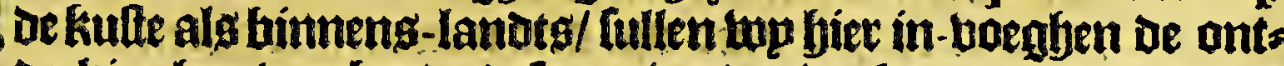
Deckingben ban bepae defe natien/eec bup komen tot een punts tuele geagraphilthe delineatie ende betrbejuingtbe ban'tlelbe. Be ontoeckinghen

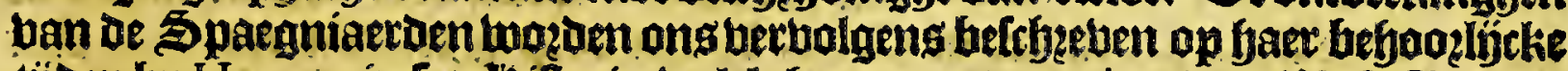

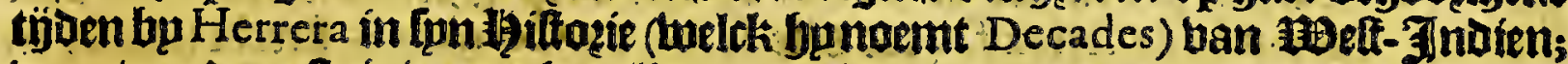

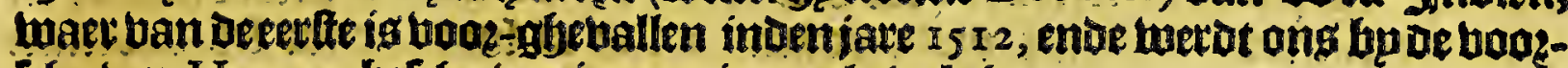
Itbetuen Her rera belcheeben in mamiecen alg bolght:

Iuan Ponce de Leon gettegen jónde ann nieube lantente ontuecken/maeckte onglchepen ghereet/ende berlozghoe die tan noodighe bictualie/ammunitien entoe volck. Srbepde ban 't Éplandt ban St Iuan de Porto rico Den Derden Martij Deg jaets I 5 1 2, te heten upt debaben ban San German; ende twag aen de A guada om ban Daer [pn kours te Itellen; ftack han daet in see naer't noozot-noozot-weften/

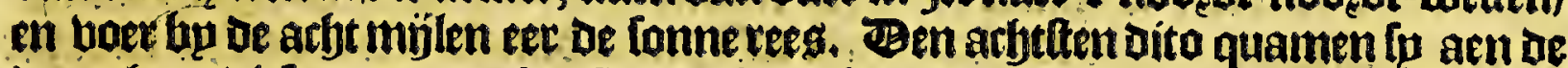
Dzooghten diefe naemaen los Baxos de Babueca, op een Eplandt tuelck men noemt del Veio, gheleggen ap de booghte ban thee-en-twintich graden enderen

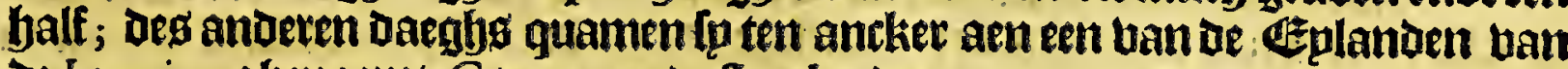
de Lucaios gbenaemt Caycos; ente trackx daet naet aen een anoer gbenaemt Yaguna, op de booghte ban bier-en-twintich graden. Ben elfften guamen lp aen

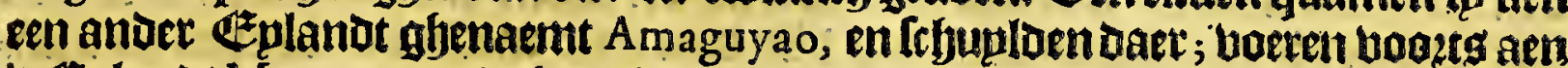
t Explandt Manegua op de fooglyte ban biex-en-twintich graden en ren yalf; den neettfienden arriueeroen fp aen Guanahani, op oe foogbte ban 25 maden ende 40 minuten; Dit is het Eeplandt exte bn den Ammirante Columbus ondetkt ende San Salvador ghenoemt. Stelden ban Giet baet kours nootat-welt aen ende Den Leluen-en-twintichfen wefende jaeficfen / welck fo noemen de Flores, fagbenle een Eplandt / Datle niet en befochten; bieloen noch twee Dagfen de felve kourd : ende badoen daer naer quaet heoer tot den tweeden $A$ pril; ftierden Welt-noogat-weft / bet twater minderende tot op neghen bademen/ enmingle ban

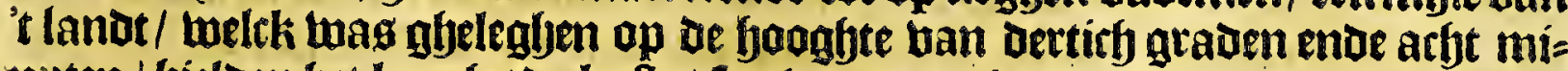
nuten / bielden bet langbs de kufte / foerkende een batuen / ende aeg nachts ant= keroen lp onttent bet landt in atht badem waters. EEnde mepnende dat Dit lanot een Eplanot wag / noemoen bet la Florida, Doog dien bet een 
$13^{8}$

Florida.

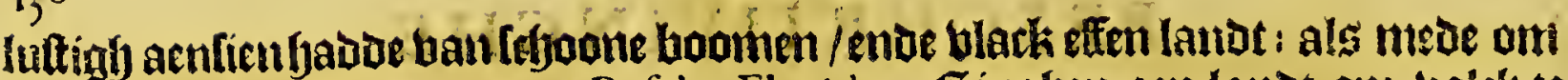

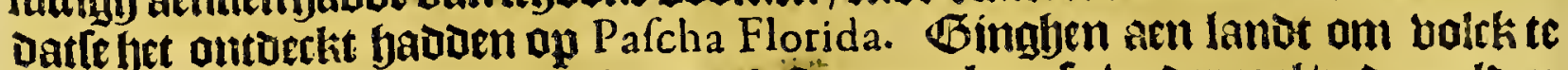

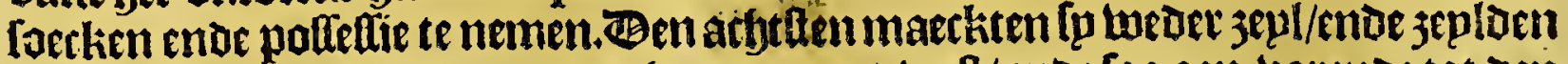

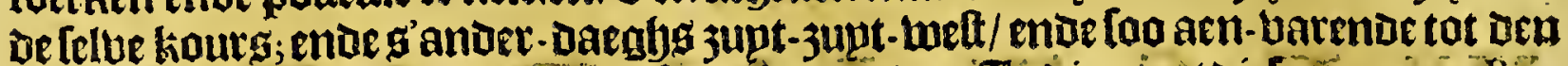

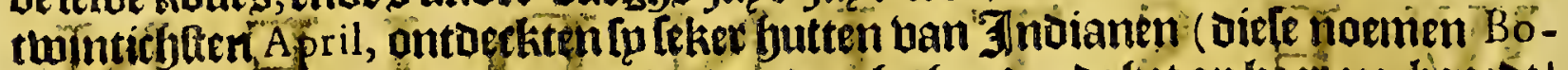

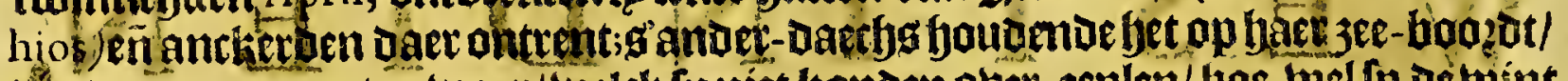

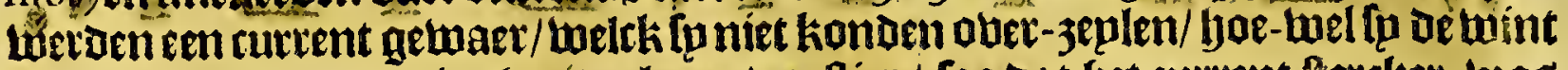

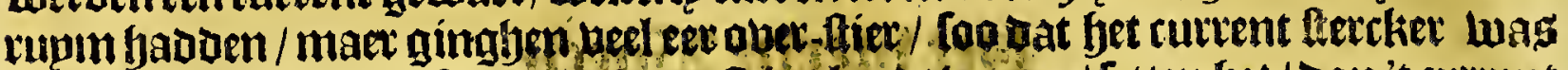

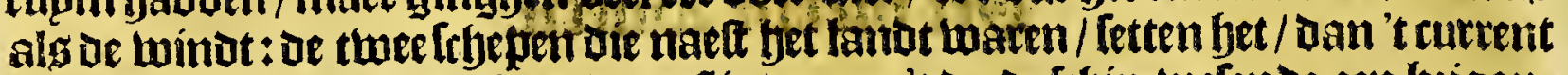

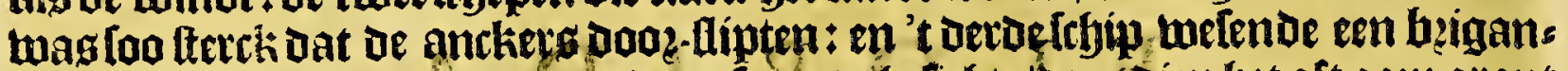
tin / welck dieper in 3ee wad verloeen fp upt ghelithte/boos dien bet oft geen gront bont/ofte de toze van't rurrent niet en merclite. Iuan Ponce landen biex / wan de

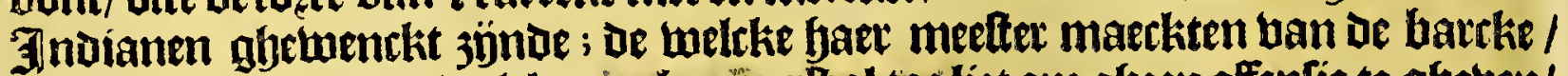
tiemen enoe wapenen/welck men baeceetltat toe liet om gheen offentie te gbeben/

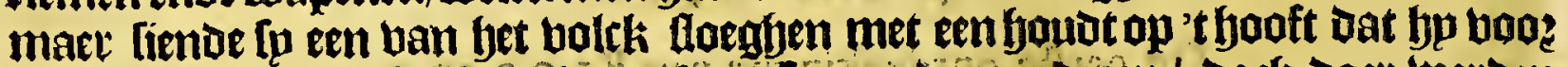
boodt daet neder viel / lod gberaeckten Ip aen ben anderen/ Dorb daer berden

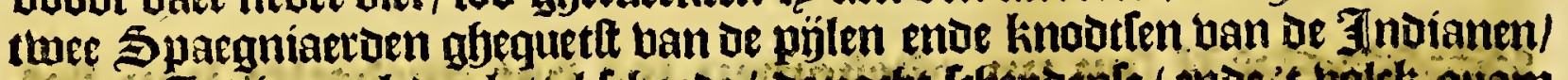

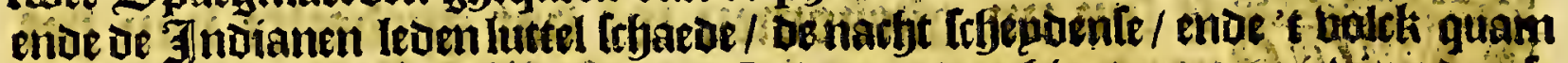

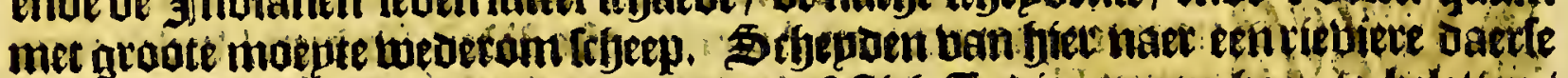

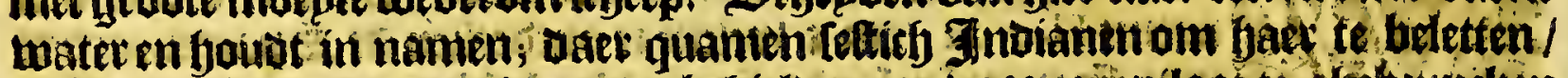
ban oe weltke[p ten kreghen enoe behielden om bool cen piloot te g]etoupcken

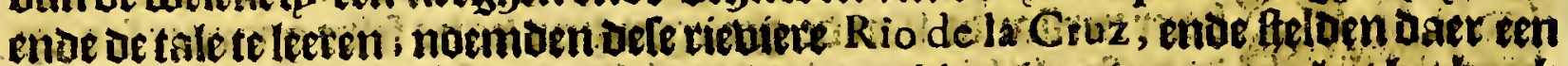

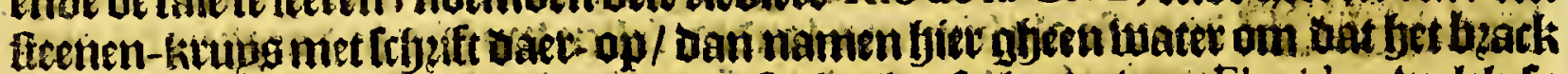

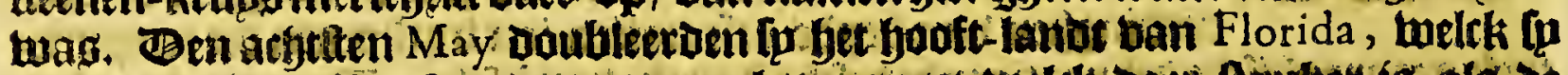
nocmoen $C a b b$ de Corriéntes, om bet cutent weldt baet forcher ig ald be

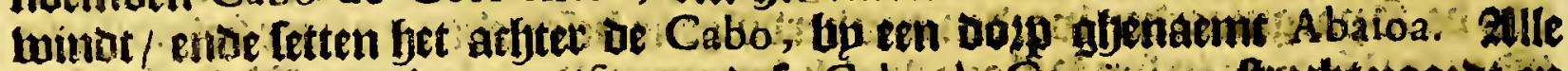
die fiutte van punta de Arrazifés tot oele Cabo de Corrientes ftretkt noozot en

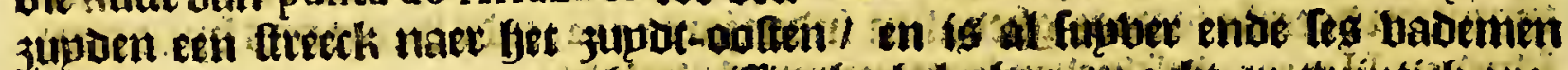

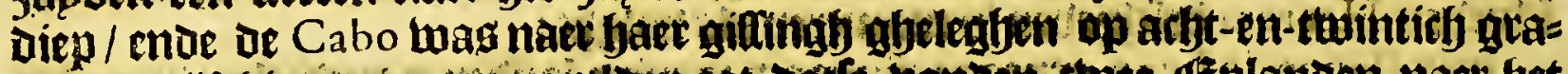

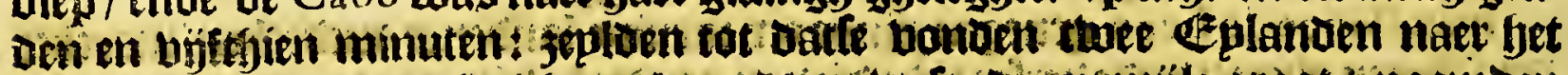

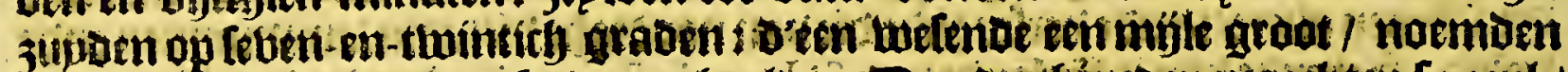

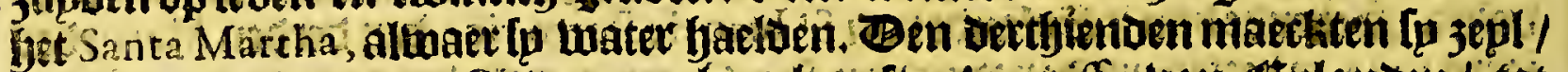

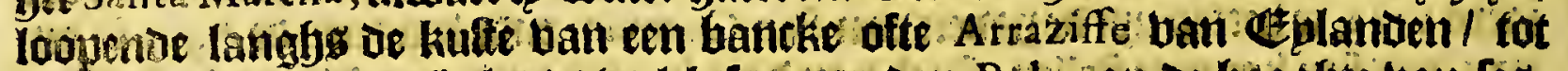
op be reese ban een etalandt welek fo noemoen Pola, op of boogfjte tan lés-

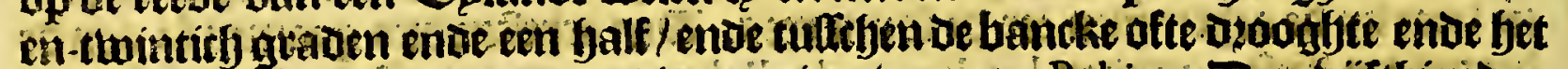
bafte lanot gaet eer groote zee / in maniere ban en Babia. Den býfthienden May liepenfe langhe oe kulte tuan de Geplanoekens tbien leguen tot thee twits

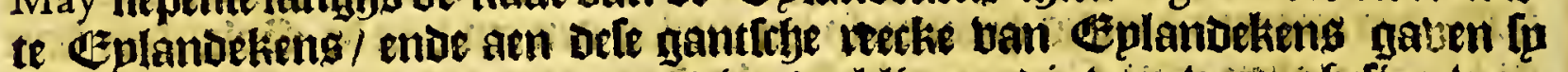
oen naem ban los Martires, Doo dien be klippen die bain bette gfefien twoze

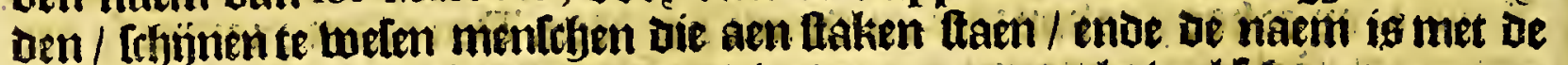

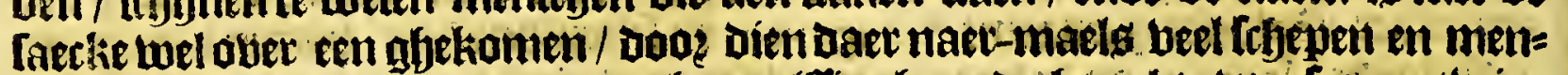
fryen zón bergaen; laeglen naer baer gillingh op oe booghte ban feg-en-thin= tich graden búfthien minuten: Boeten lomtýts noozden aen/ ende fomtïts nooedt-ooft tot ben Dep-en-thintichften May, ende oen bier-en-thintichften

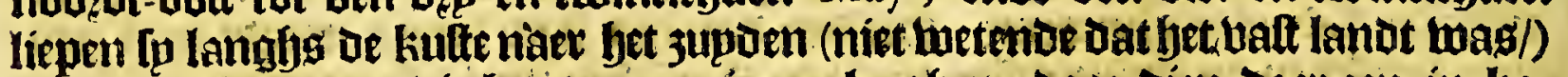

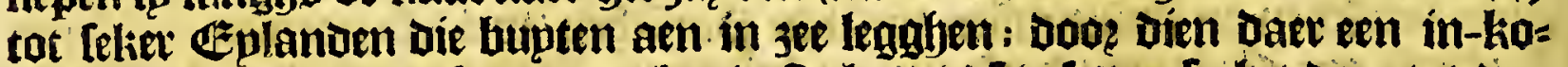

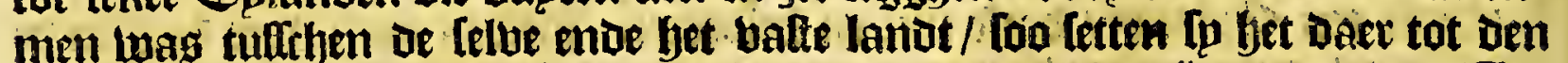

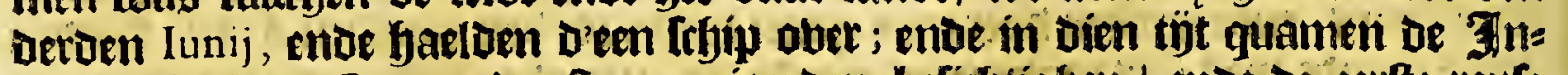

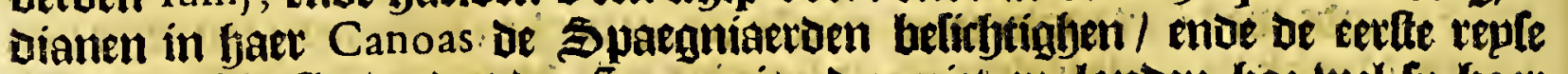

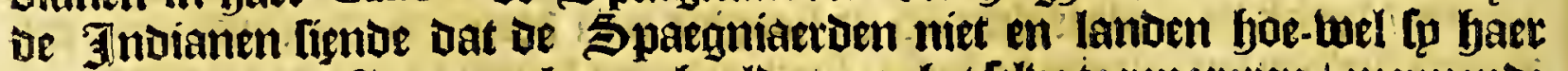
riepen / enoe dat ló een ancker op baeloen om bet lelue te repareven / mepnenoe oat lo lwegy wiloen baren/quamen met baer Canoas, ende doeghen banden aen be kabel om bet frbip naet haet te trecken; waet om to bartke onder baet werdt 
Het vierde Boeck.

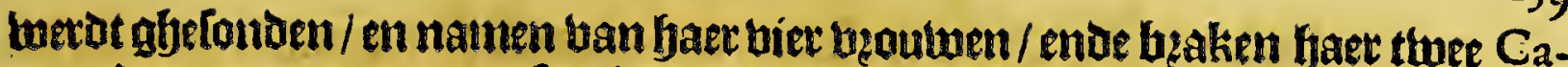
noas; daet naet en quamen fu niet meer tot berften/doos dien fo geen midodel daét toe en faghen/maermangeloen fupden ende Guanines : Be Spagniaetion bad: Den daec naer biec eenighe refcontres met oe 3 noianen/ende fonder pets nozuerg

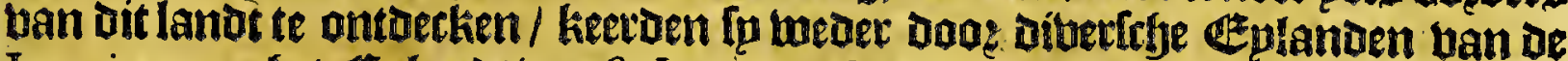
Lucaios naer het \&ulanot ban St Iuan toe: I uan Ponce mag onoer andere volas ken oock tot Dete topagie betmoghen Doge fet rapot belck of Jndianengaben ban oe fontepn ban Bimini, ende een riebier aen bet balte lanot waet dooz de

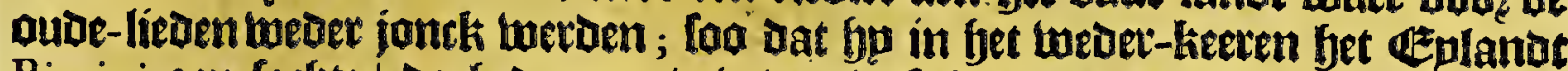

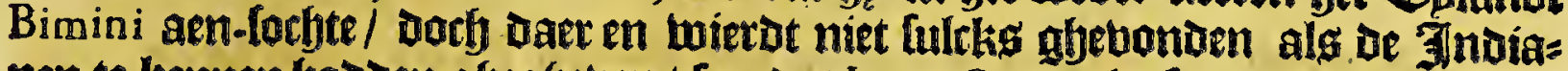
nen te kemen badoen ghegheuen / foo dat luan Ponce in fon uoge-nemen be= Dzogben twag.

\section{Het tweede Capittel.}

Tweede ontdeckinghe van de landen van $F_{L}$ OR I D A by de Spaegniaerden.

TR Denjate 1520 maeckten ten Licenciaet Lucas Vafquez de Ayllon neffeng andete/ twee fofepenupt ban Puerto de Plata, in fiet GEplamat Hifpaniola om d.2.1.10.

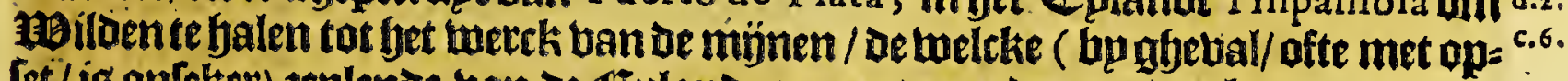
fet / is onfeker) 3eplente ban De Eplanoen naer't nopzuen toe/eenlandt ontoeck: ten/genaemt loo fp doen uevifonden Chicora ende Gualdape, op ¿e foogfte vam 32 graden/ tuelck fp nu noemen Cabo de Santa Elena, ende Rio lordan. Be $\mathfrak{Z} \mathfrak{n}=$

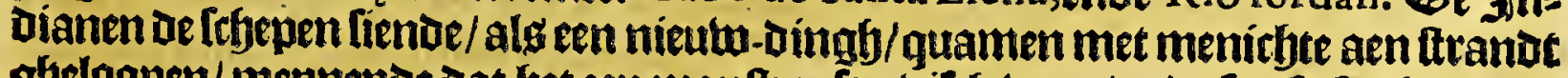

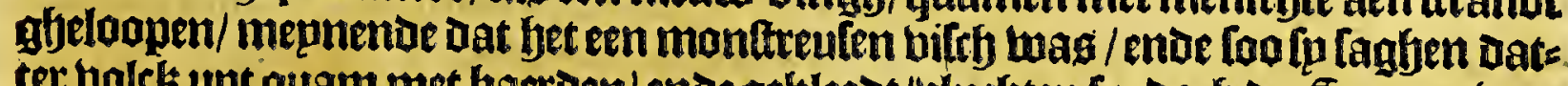

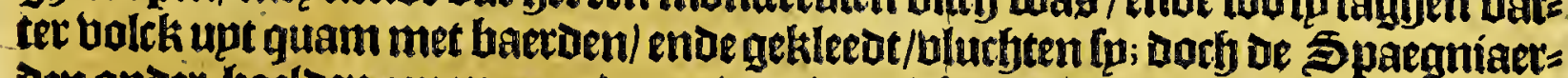

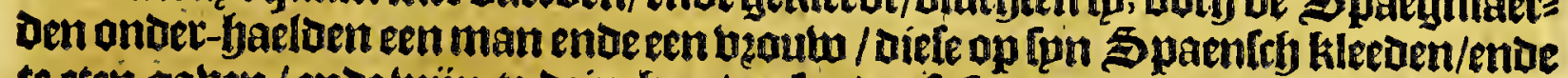
te eten gaben / ende tujn te dzincken / en fondente foo meder aen land. Be Ito=

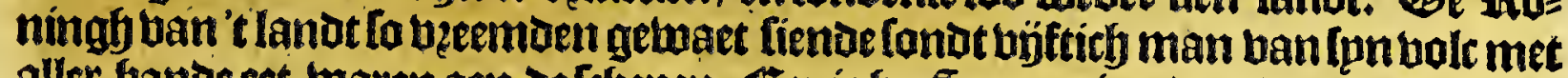

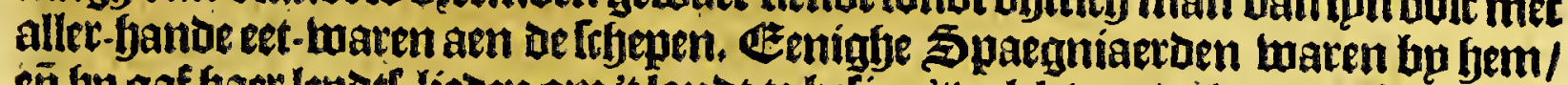
eñ by gaf Gaec lepotf-lieden om 't lanot te befien;'tuolck ban de lande gafte te eten/ ende eenige pefenten ban goutot ende peetlen/ ente oockeenige dingen ban filber/

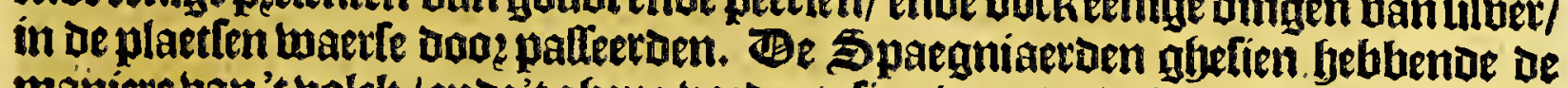

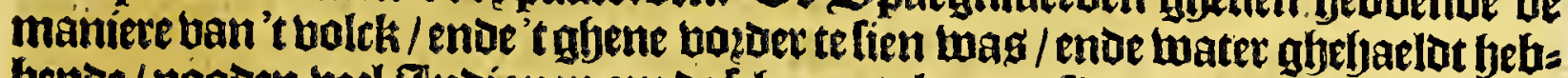
bende / nooden beel Indianen am de fryepen te komen fien; welcke fonder athters Dencken in de lejjepen abekomen 3j̈nde/trocken fp de zeplen op/ende baerden die megh. Ban'teentrhip uerginck bu de wegb/ende de neette Jndianen ban't ander

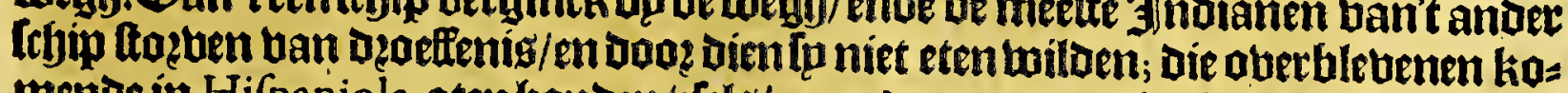
mende in Hifpaniola, aten bonden/etels/en anoete carongnien. Bit wag eenfnoo= oe daedt/ ooch gínck al ongheftraft beenen; ende den Licenciaet noet naet 5 paes

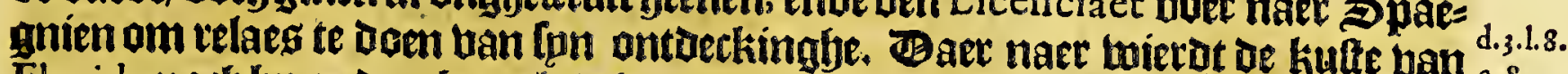
Florida noth bp andere bejeplt / als meae bp Eftevan Gomes, die oock eenige da= ben ban Daer bzacht/ende men wiert gewaer Dat bet baft landt wag. Énie Lucas Vafques, die artrop badoe berkireghen/Lonot meder aerwaetts fchepen in den

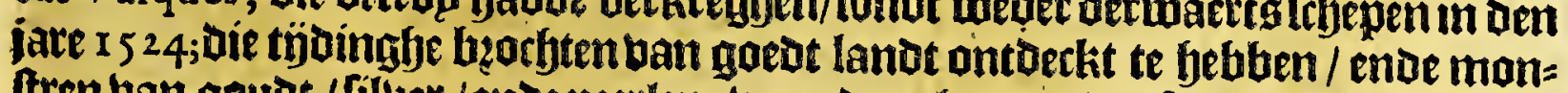

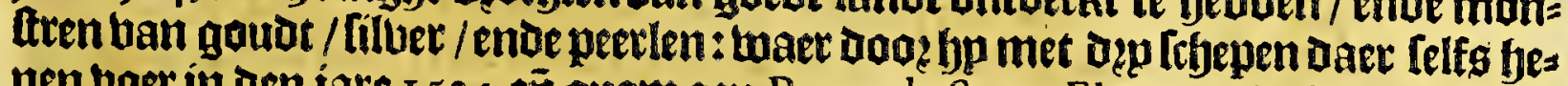
nen boer in den jare 1525 eñ quam aen Punta de Santa Elena, ende in de riebieke lordan, Daer bp funeen frbip berlogz; ende fpn booz-nemen berbolghende / fette

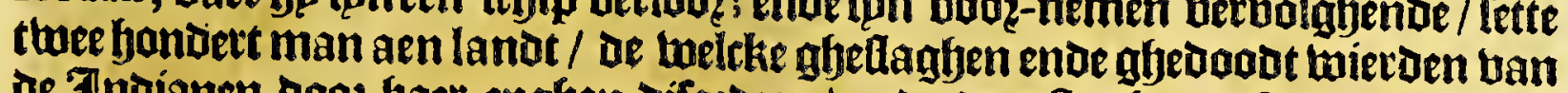

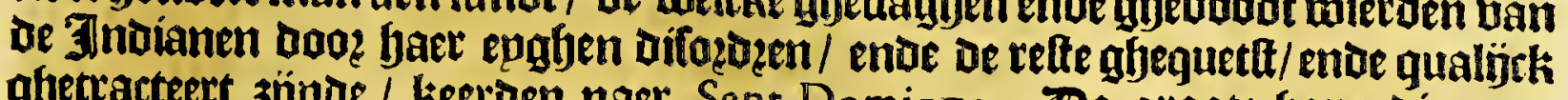
ghetracteert 3 junde / keetuen naer Sant.Domingo. Be aroote hope die men ban dit lamot yadoe / quam Dooz dit quaed ghevolgh feet te berminderen / boog dien Dat bet felve bolck dat fp Doen-maelg daet taghen / Ifjeen een leer 
140

Florida.

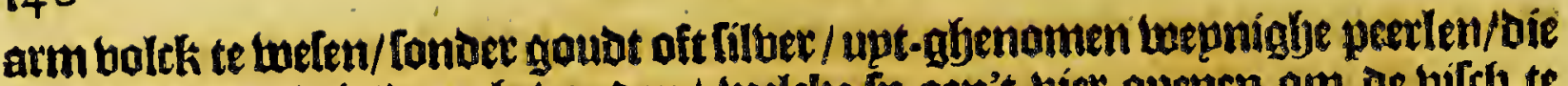
in 3ee. frbelpen wierden gbebanaen/ welcke fo aen't bier apenen om de vilfy te eten; en 't gout ende filuer datte bonden/ en thas ban daer niet/ maer wel feftich

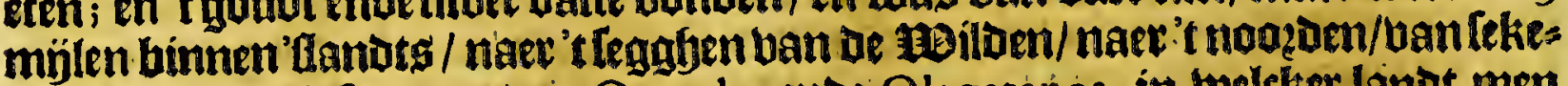
re uolckeren/ die fp noemben Otapales ende Olagatanos, in telleker landt men berltonot münen te twelen ban goudt/ riluer/ ende koper: oft ten mintten de wiloe maeckten fulckg de Spaegniaetoen bujg/ ooos dien Ip fagen datte fulckg forften,

Het aetae Capittel.

De derde ontdeckinghe van de Landen van F L OR I D A by de Spagniacrden voor-ghenomen in den jare 1528.

d.4.1.4.

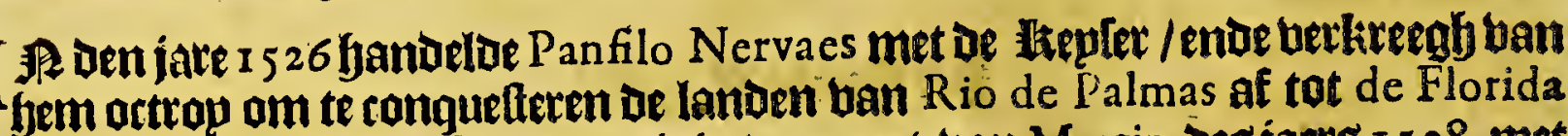

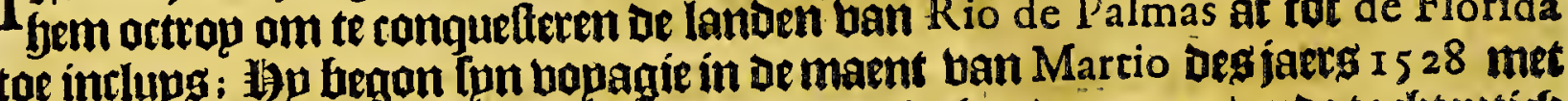
bier Lthepen ende een beigantin / ende daec op bier bondert man / ende tachtentich

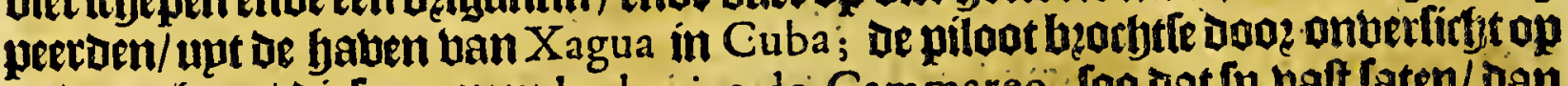
de Dzooghten/ dielenoemen los baxios de Cammareo, foo dat fu balt faten/ Dan

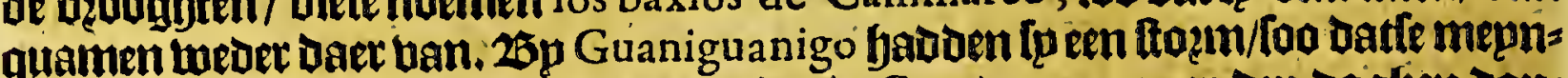
ben te bergaen/ende een ander aen Cabo de Corrientes : naet Dęp dagfen dou=

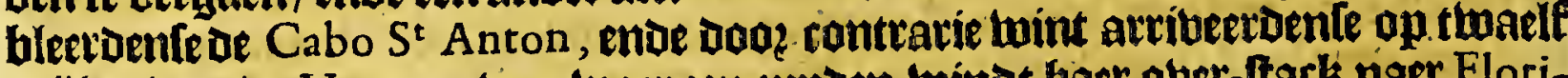
mülen ban oe Havana, ban lwaet een jupuen lwimot faer aber-ftark naer Florida, Daet fu quamen den I2 April, ente fetten bet in een bape/ wan twaer fu eenis ghe tooningben ban Jndianen ontoeckten; kiteghen ban yaet bp mangelingf

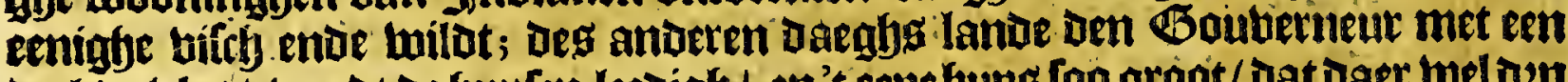

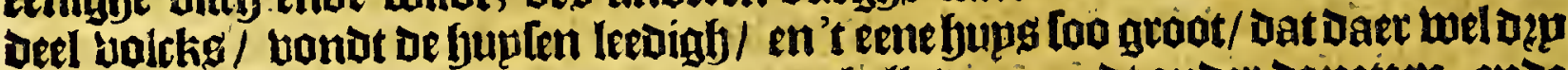
bondert pertoonen in moebten; hondeneen belle ban goud onder de netten; ende Den Dagh Daer aen nam De Gouberneur poffeflie ban 'tlandt boǫ Den ttoningl/ ende dede meer boletis aen landt komen/ende de peetoen die tot op 42 twaten ghes kamen: of $\mathbf{J}$ ndianen quamen bp haet/Doeb men konde die niet bexfaen/Dan alleen Datte Irfyenen te deepgben / ende te begeeren dat de Spaegniaetoen bertiet= ken fouden. Be Gouberneut trackte landt-haet tin/ende bondt en grootebape/

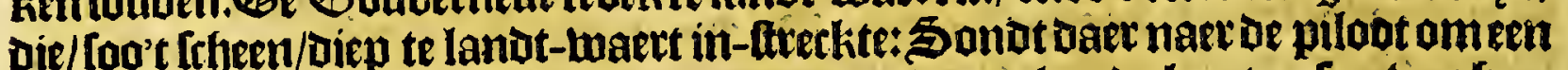

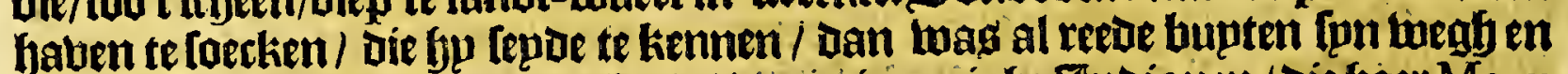
kennis; kitegben biet leguen te landt-Laate in eenighe Jndianen/ die baer Mayz thoonden; bonden Daer eenine raften ban koopmanícbappen/en in elck een Doodt

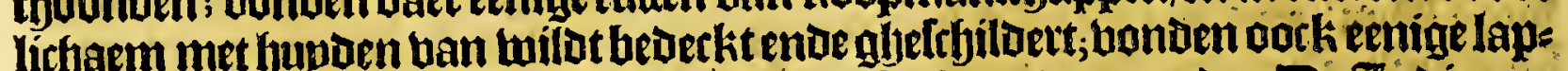

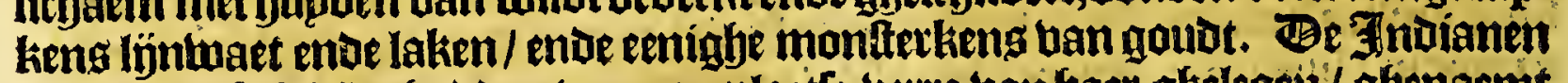

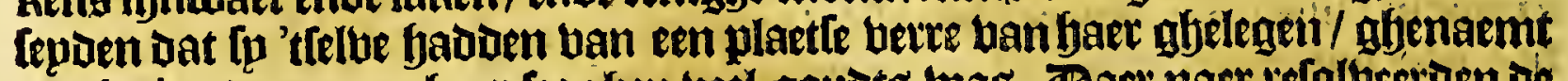
A palache, Daer naer haer fegghen beel gounts luag. Baer naer velolbeerden to

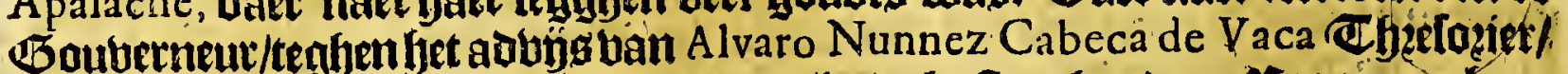
ouet lanot te trecken / ende de frbepen langhg de kufte te fouden. 25egonnen later

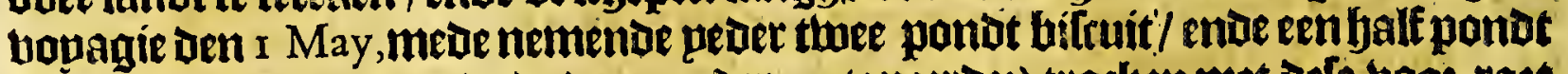
[perk; (waren $300 \mathrm{man} / \mathrm{en}$ be daet onder 40 tepeer be:) trocken met dele book-raet

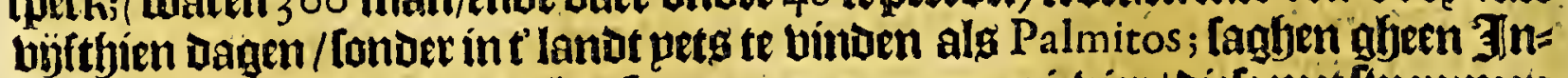
Dianen buplen / ofte woon-plaetlen ; quamen aen een rieviev/ diefe met lwemmen ende op blotten pafferden; ende bonden aen d'ander 3 joe thee hondert India:

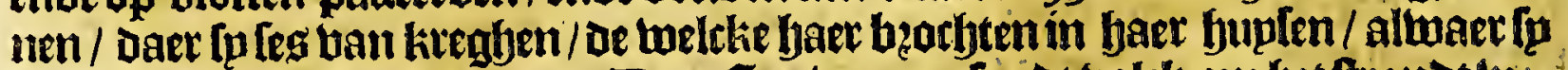

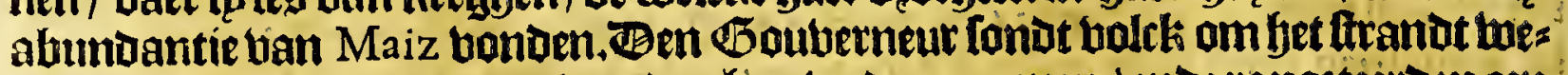
Der aen te foetken / die nate twee dagfjen lueder quamen/ende rapozteerden een grooten in-fjam abebonden te bebben/ ende een blacke kufte Conoer apparentie uan bauen. Crocken ban hice booktg andere büftjien oagen fonuer pemant te

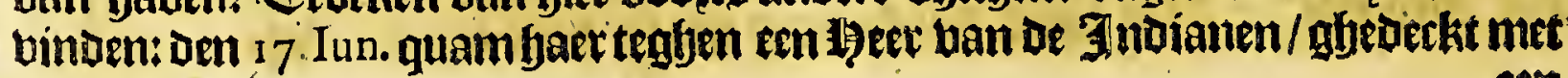


Het vierde Boeck.

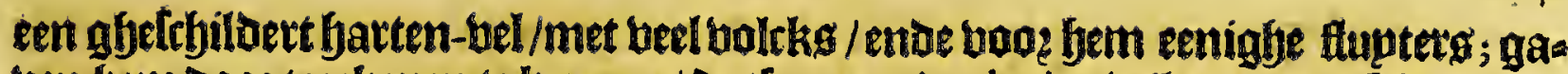
ven bem Dooz teeckenen te kemnen / Datfenaer A palache twiloen; en 't feben Dat bp anthoozoe vpanot te melen ban dat lanot. Baben fem bellekeng ende an. Derefnplteringh. Daet naet quamente aen een diepe en lnel-1oopende rietiete / foo datle een Canoa moieften maken om te paftecten ; aen de blecke komente ban

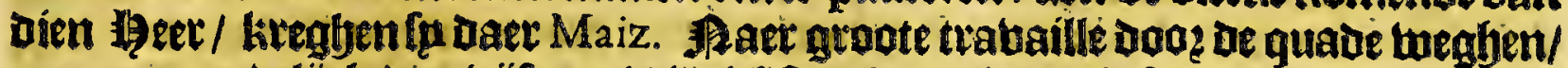

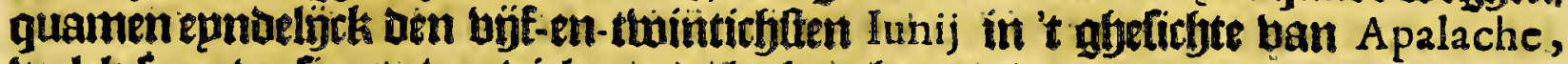
wetck fp anbertiens aber-bielen ende in-kteghen/en vonaen daer beel Maiz; hups ben ban milt / mantels ban bzat / en moztiens om fyet Maiz in te ftooten ; de blet= ke was han beertich leegfe buplen / in een plaetie die boos oe winot befribermt

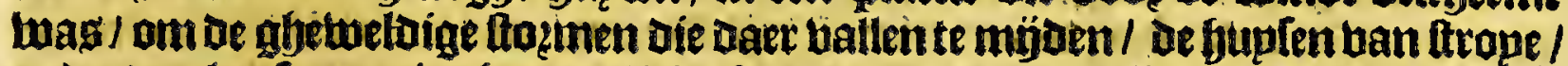

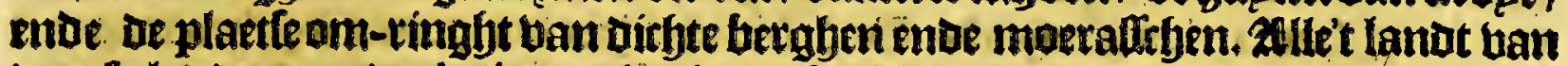
Daet fu landen tot A palache toe is black / Tanuighe gronat en balt lanot/ met beel groot gheboomte ban note-boomen/ laurieten / liquifoambar / rebsen/ fauel-

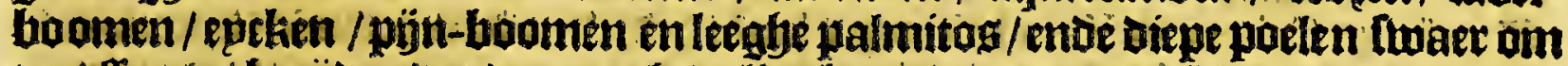

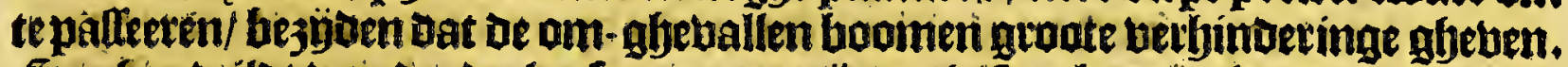

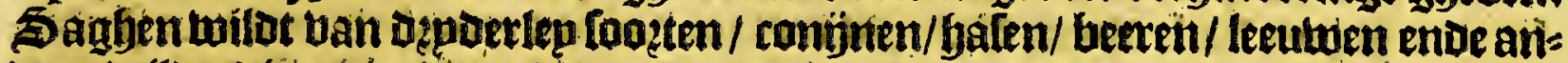
Dexe tuilde dieten/ ende onber dien een dat fph jonghen in een fark Dzaeght:

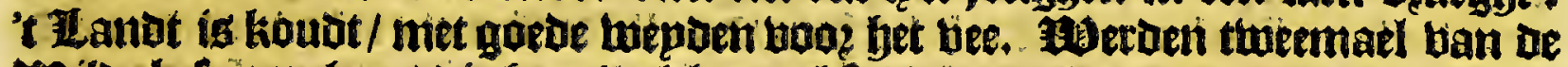
toilde befugonghen / die baer 't elckemael falbeetoen intoe paelen ente moeraf.

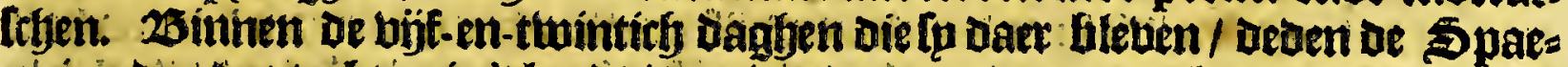
ghiaerden bep tocteten in't lanot/ dan banter maet arm bolck en feer quade wes glyein; Den Cafique die fo ghetuangen fielden/ fepoe fjaec dat dit be grootte blecke

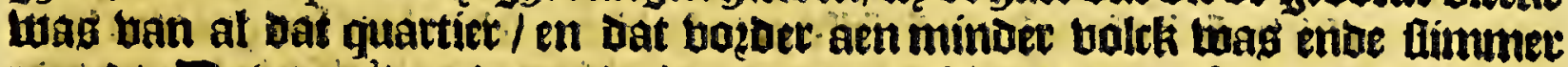

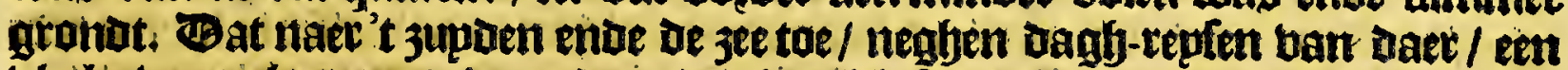

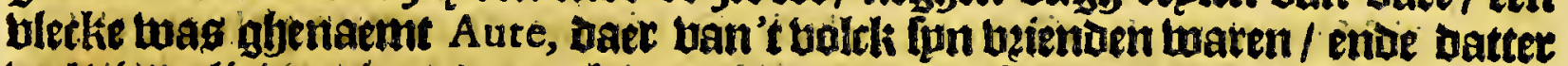

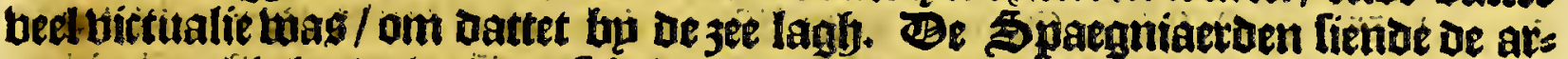

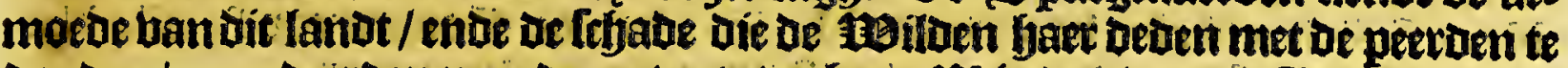

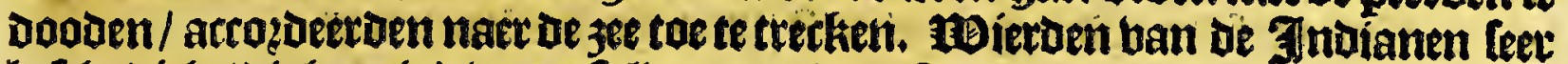

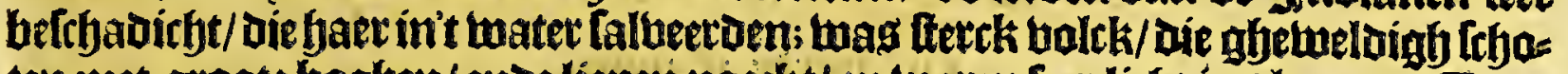

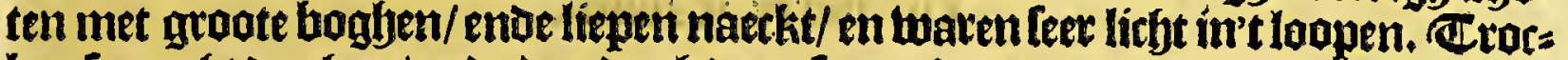

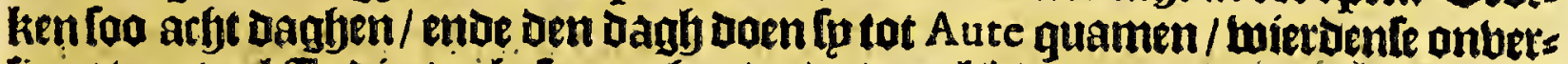

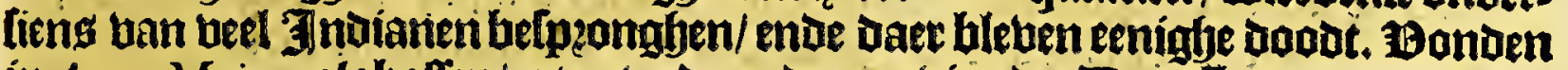
in Aute, Maiz, ralaballen/erten/ende ander pzobiande; ;en Bouberneur conde Cabeca de Vaca om ae zee te be[oecken/ welck naer oze daghen toeder quam/ en

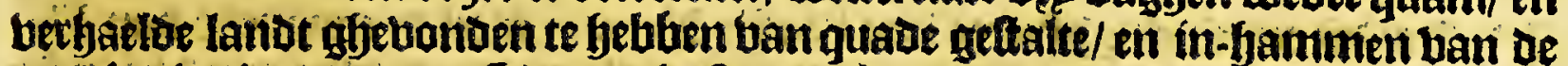

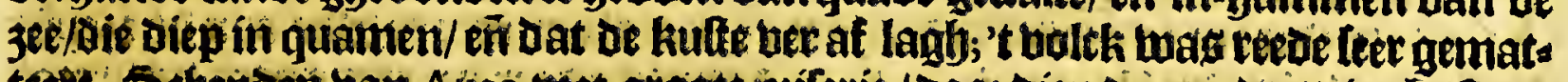
teett Sthepten ban Alité met groote miferie/ ood dien de peerden hiet baftant

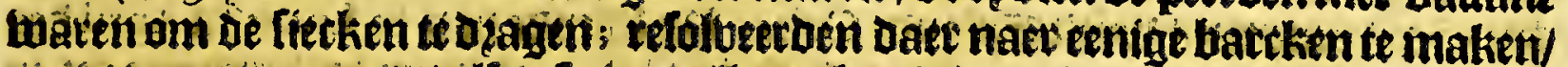

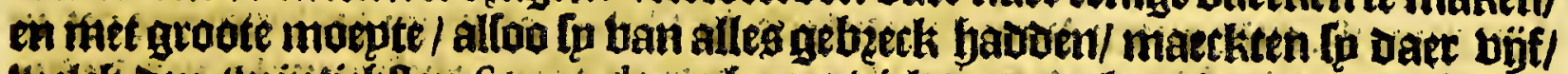

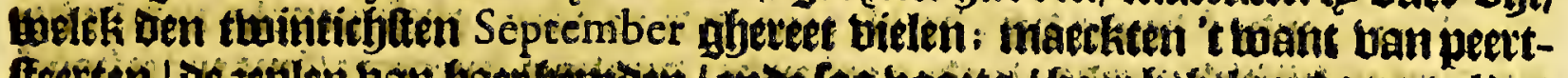

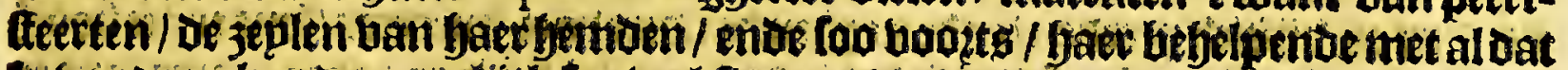

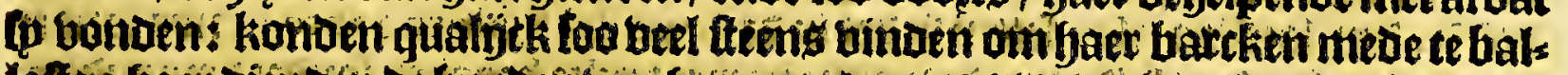

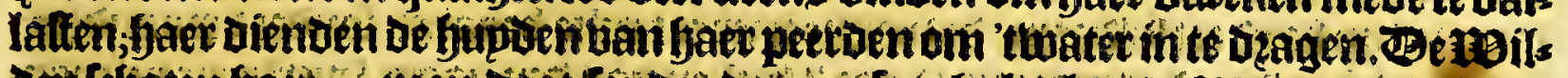

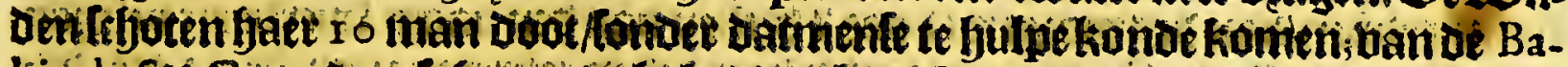

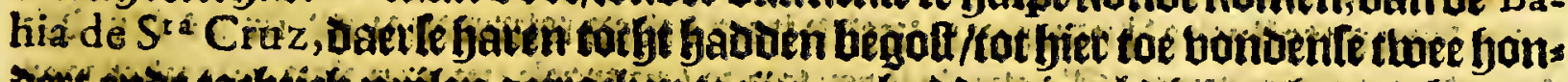

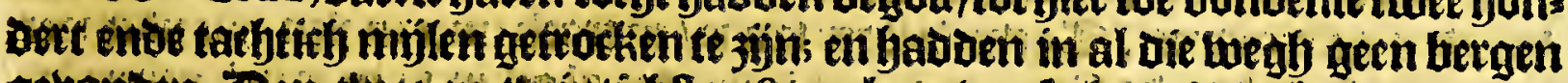
gevonten. Den thee-en-twintirbten Sépt: begaben fo haer in de barchen/ende

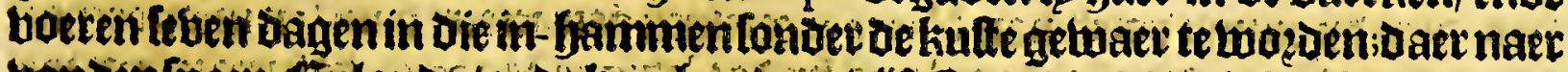

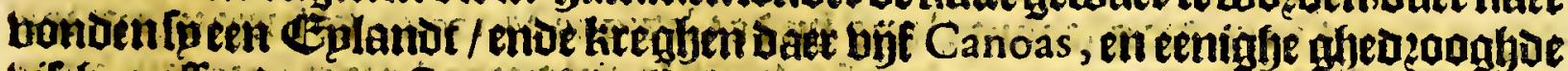

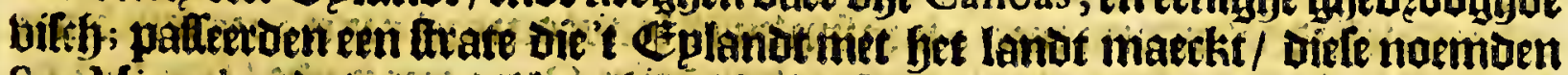
San Miguel, enve boeten al langhos de kitle nater Rio de Palmas toe/grooten do?

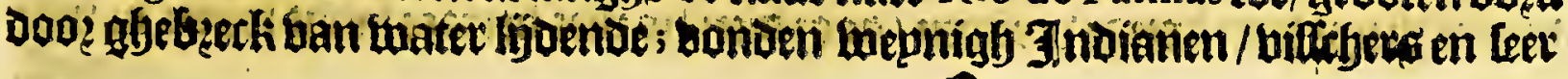


arm wolck. Baet naer een punt ban'tlanot met groot perÿckel te Loben gheko:-

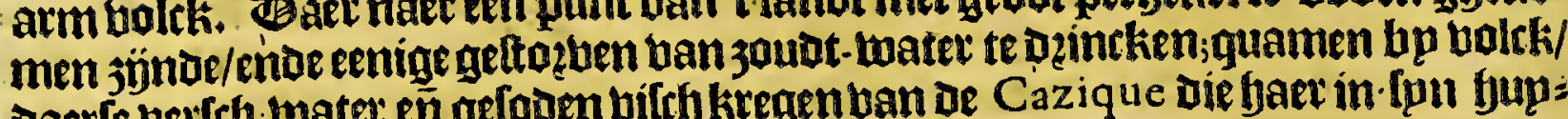

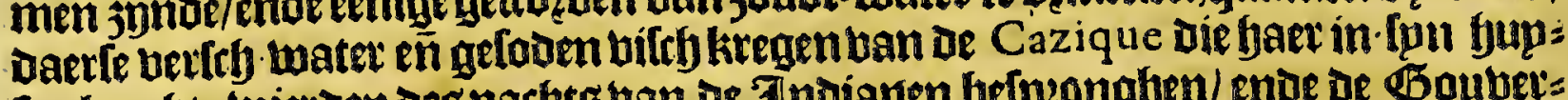

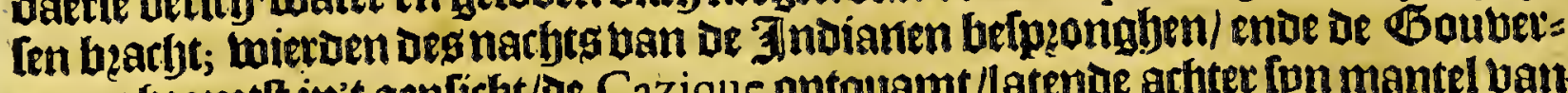
neut gfequett in't aenficht/oe Cazique onfquamt/latende arfter fon mantel van Tahelg/bie feet naet Ambar roork; geraeckten met groote moepte heoetom Icheep; boeren dzę daghen; en bertielen weder in't Ielpe gbeberk ban water. Bonoen

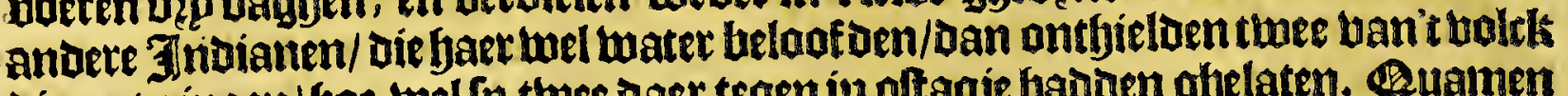
vie met gingen/goe-mel fp twee daer tegen in oftagie gadoen ghelaten. Quamen

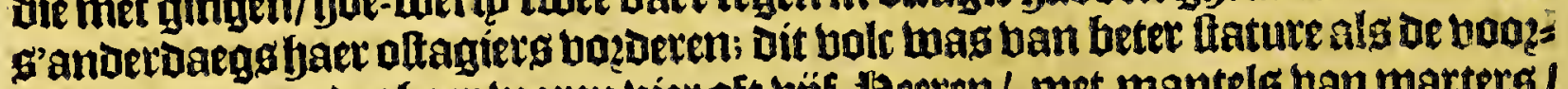
gaende / ende onder faer waren biec oft bijf 1 eeren/ met mantels ban marters/ met langh fjapz en los fjangenoe. Booz dien bet fier dangereug legghen twas met

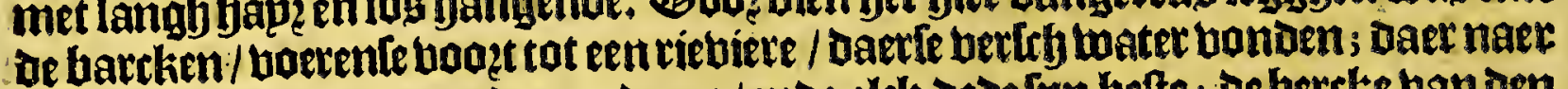

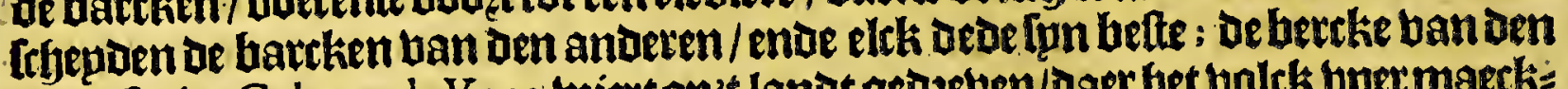

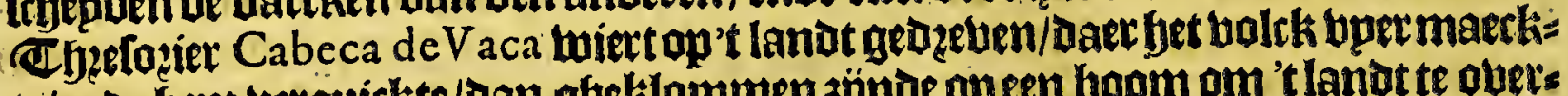

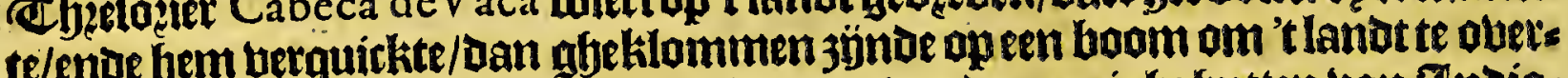

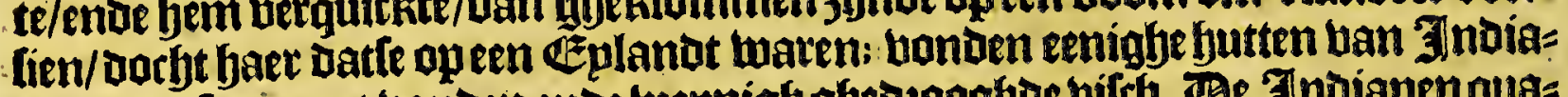

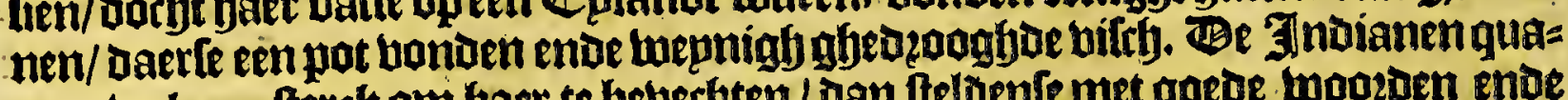
men wel roo fterck om haer. te bebecthten / Dan fteldente met goede wouzden ende eenige giftienster neder/[oo datle de Spaegniaerden tot diberlehe rep fen ban baet

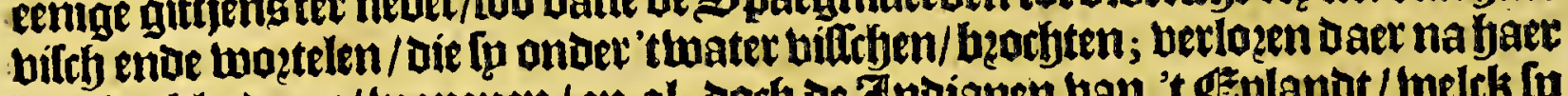

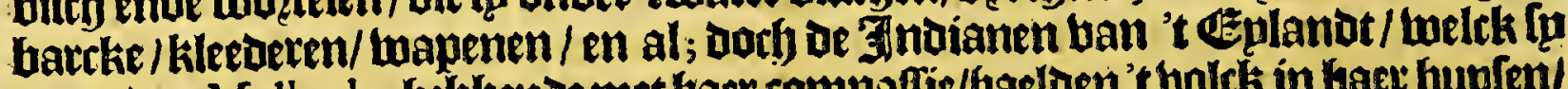
noemoen Malhado, hebbenoe met fyaer compafle/fyacloen't bolct in Gaet buplen' ende onderbielente foo langl als fo felfs yetg badoen; leoen bier foo arooten bon=

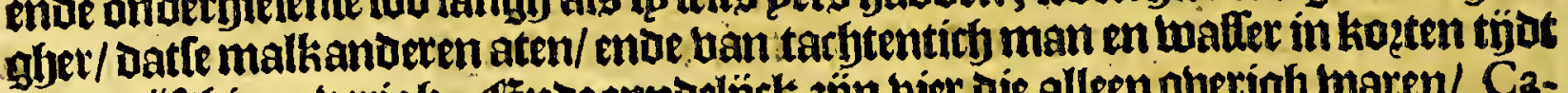
maer büfthien duering. Ende epndelïck jün viet die alleen oberigh waren/ Cabeca de Vaca, Caftillo, Orantes enue Eftevanico; aber lantot gberaeckt tot in Nova Galicia, ende lon tooztonaer Mexico ; van de Bouberneur Panfilo Narvaez en ig nopt felter tảdinghe ghetecelt / waet fyp om-komen ig.

Het bietoe Capittel.

Vier de ontdeckinghe van 'tlandt van F L O R I D A, by de Spagniaerden, onder 't beleydr ende ghébiedt van Hernando de Soto

in den jare 1539.

DOoz dit ongelucking fuctes ban Panfilo Narvaes, bleef te conquelte ban Flo-

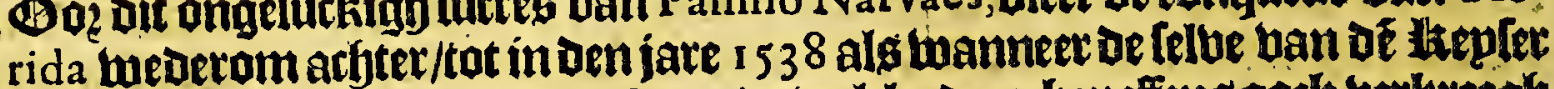
berktegen miert bp Hernando de Soto; De welcke Daec beneffeng ootk beckreegh

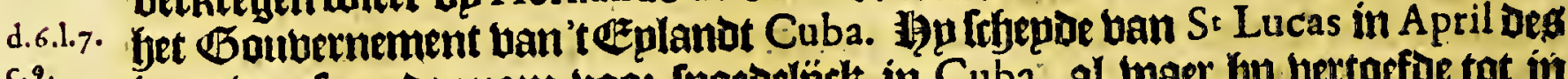

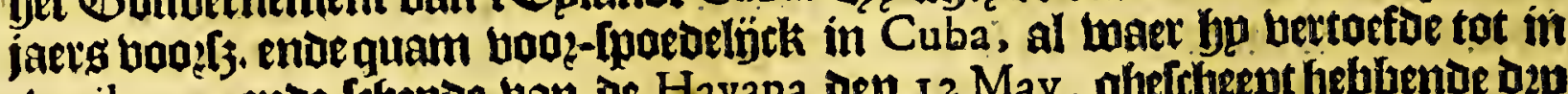

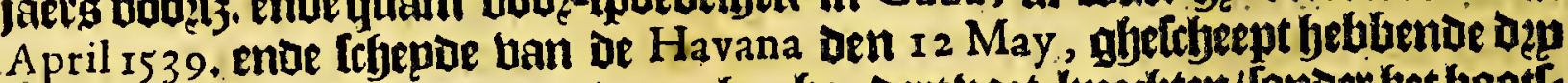

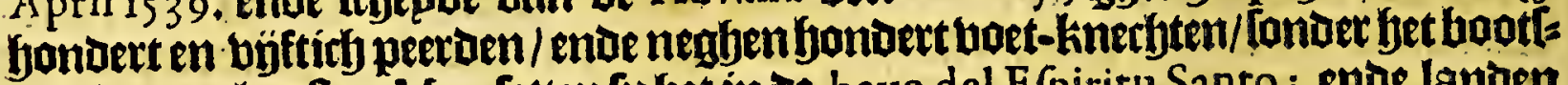
volck ; Den laetften May letten fubet in be baye del Efpiritu Santo; ende lantaen fracks dep fondert toldaten/De welcke fyaer tot rulte begaben fonder pemand gets

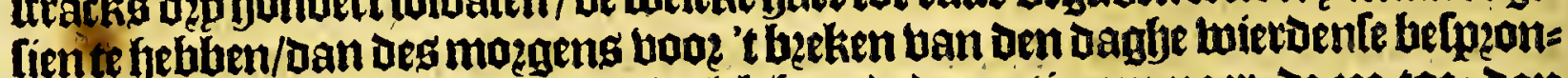

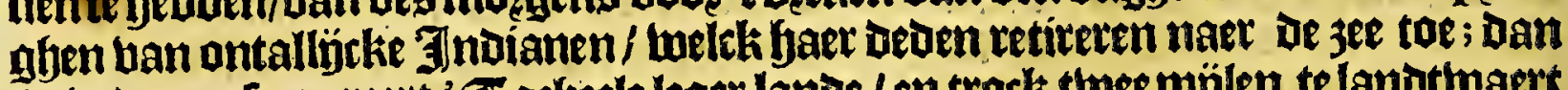

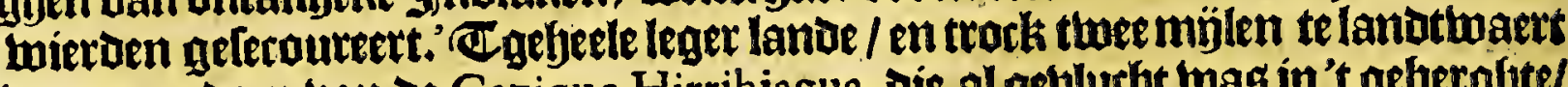
in aen een Dow uan de Cazique Hirrihiagua, die al getlutht was in't gebernfte/

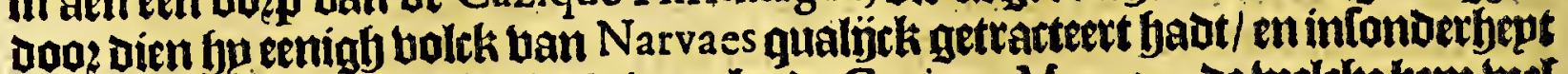
enen Iuan Ortiz; die glfeblutbt wag bo de Cazique Mucozo; de twelcke bem wer

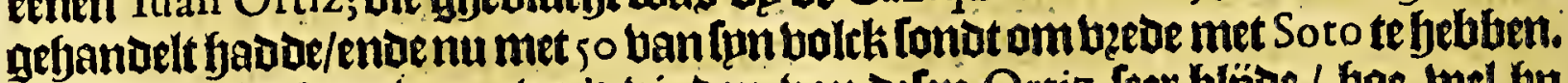

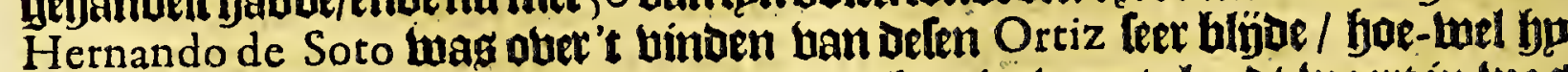

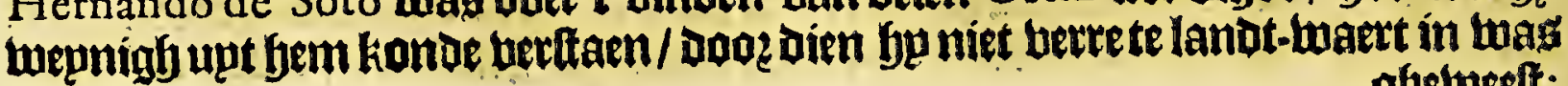
afdetetef; 


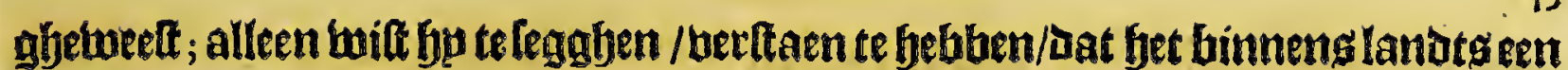
goede ende beurbtharengront thas. De Gouberneur fepnt fpn fobepen twegf op

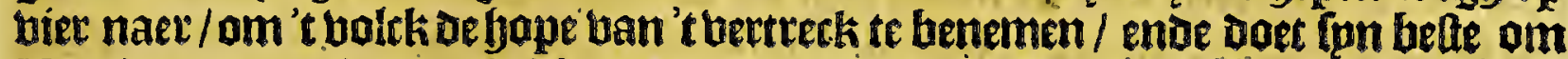
Hirrihiagua te beiende te febben/ doo dien fp naeff gheleghen was aen oe bape/ ban voyerde niet. Sondt daet naec feltich te peerde ende feltich te boet naet oen Cazique ban Virribarracuxi ghelegen bootoer aen van Mucozo, Dan bonden het

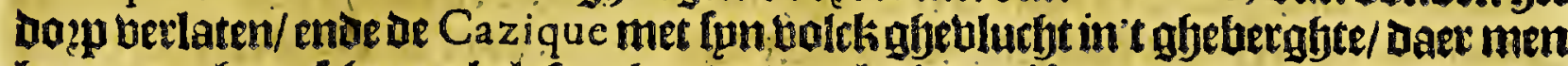
bern met gheen fegoone beloften konoe bat locken. Bonden in dat lanot milde Lujngaetden/note-buamen/moel-be[pen/ker[e-boomen/ pjin-boomen/epcken/ enfeer fefoune beloen. Baben aubýg fier van aen Hernando de So to, we welck tot bewaringe bande refteerende frbejen en birtualie/Daer liet de Capitepn Caldefon met beetich lancen/ met ozde de Indianen gantleb niet te mifooen; trock boozts booe't lantot ban Mucozo, en ginck almoot-nooet-oolt aen//onoer tlanot te teeckenen; baer gp en groote faute in begingf. Bfethomen 3 gnoe in'tlanot

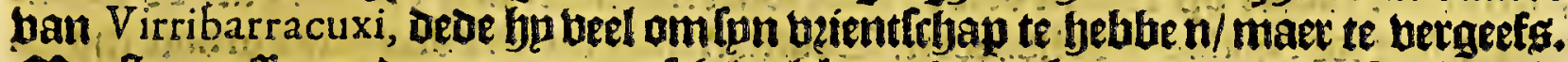

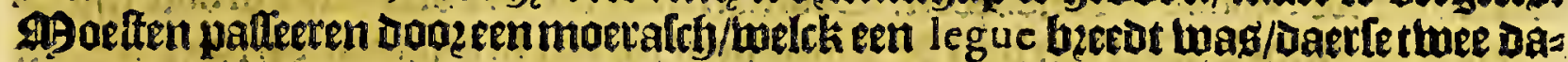
ghen mede toende waten: De Jnoianen quamen baet befpeinghen / ende enige

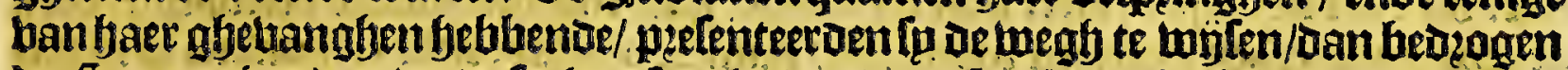
de Spaegniaerden/ende forftenfe te lepoen/Daer [p niet upten fouden konnen/De

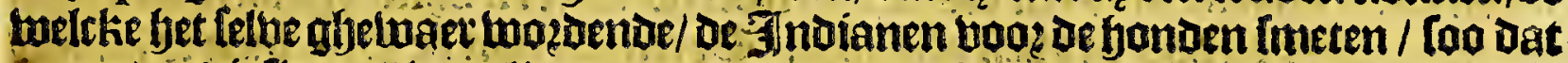

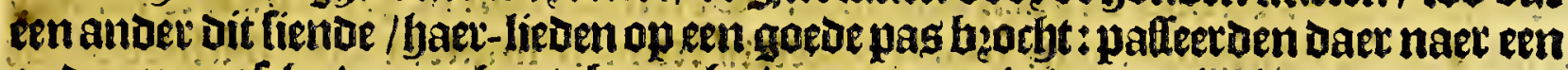
ander moetalth ober en boute bugabe / en quamen in de pequintie van Acuera.

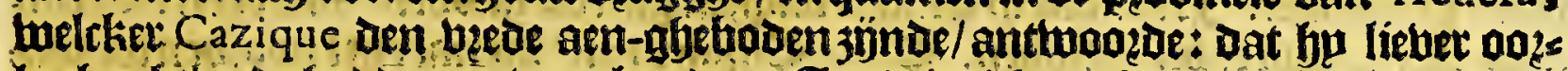

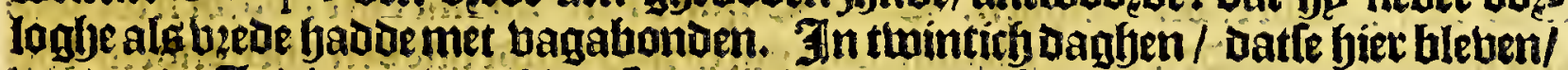
Dooden de Indianen toerthien Spaegniaerden/oie lo al'tyooft af ineden / ende

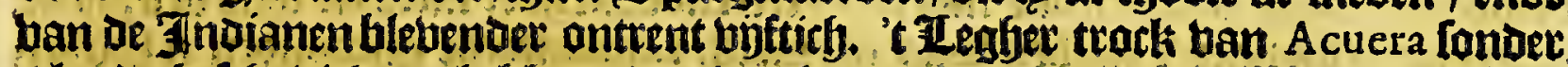
thanot befrjadicht te bebben / ben toegh nemenoe noozot-waet to een luepuigh

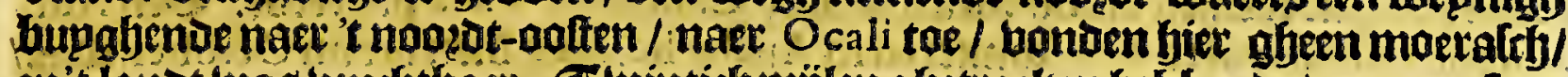
en't lanot was beutfethaet. Clwintichmilen gfettocken behbende/ quamen[e te Ocali, ken plaetle van feg hondert buplen / met abundantic ban Maiz, etweten/

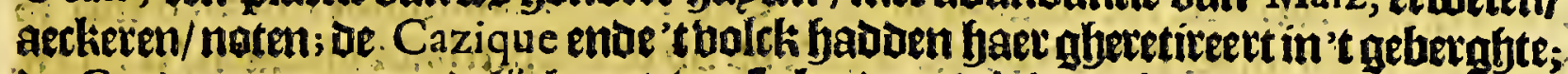
De Cazique quamepnoelock met bge le bp den Adelantado; boch met bem gfes

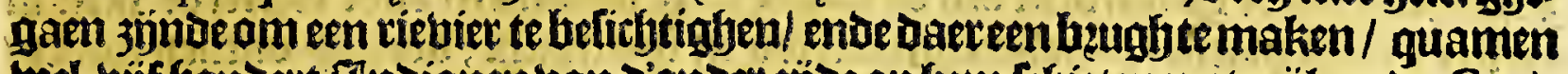

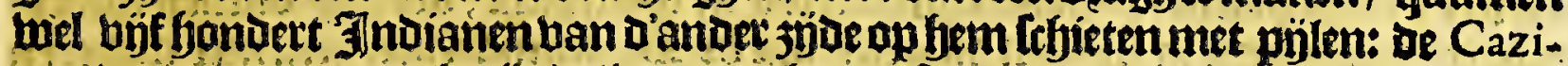

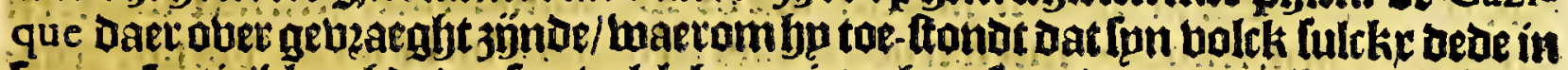
Inn prefentie/klaeghoe dat fpn bolck bem niet geboolatmbe/om oat bp beientegap badoe ghemaerkt met oe Spaegniaerden; maet ober oen Adelantado fem liet

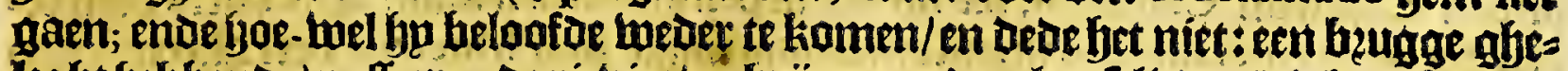

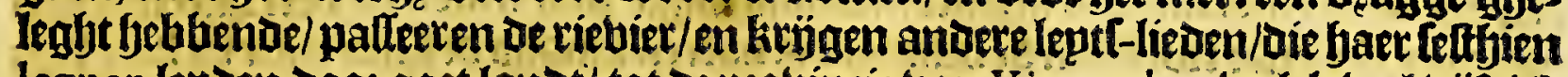

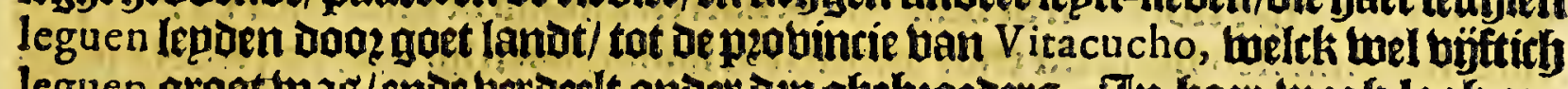
leguen groot was/enoe berdeelt onder dep ghebzoederg. Jn baer twegh lanf een blerke genoemt Ochile, diefe onberfieng ober-bielen/ moe naet enighe refiftentie be Cazique met gemack in fanden kregenttratteeroentem wel/ento bp thack met Gaer tot cen ballewe/die twel betwoont was/hoe-wel oe huplen hier en daet berthopt laglien: dele Cazique tont twoozt aen fon bzoeders/oatte de Spaegniaerden lous ben laten pafferen / alloo [p gheen quaet en Deden/maer alleen pzobiande begeet: Den; den eenen brocoer gaf goede antwoot; maet Vitacucho, die de oudtite ende

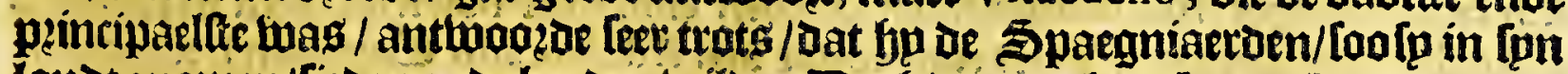
lanot quamen/lieden ende bzaden biloe. Docb oact nabem bedenckende/ quam

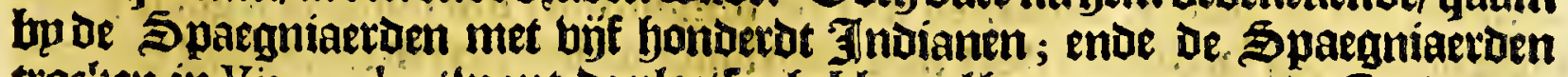
troctien in Vitacucho (want be plaetten betben albaer naem naer de Caziquen)

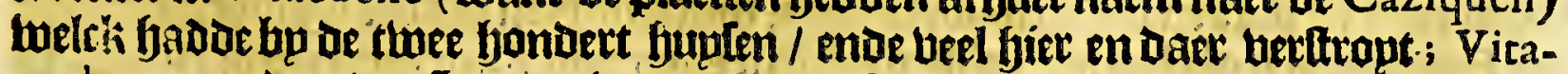
cucho mepnoen de Spaegniaerden onberfieng te ober-ballen ende jood te 
144

Florida.

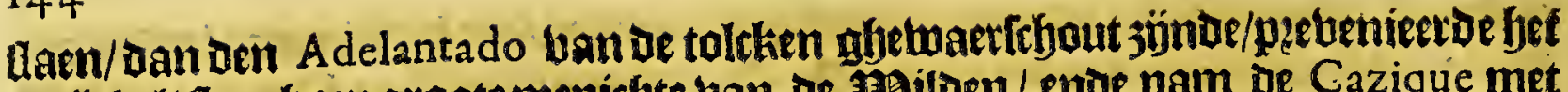

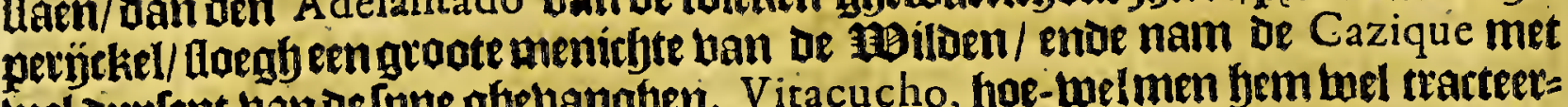
wel Duplent bandefone ghebanghen. Vitacucho, boe-welmen bem tuel tracteet=

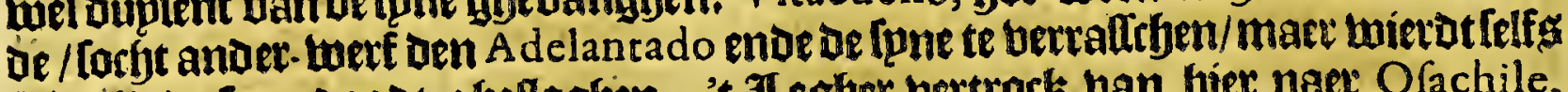
met alle de [pme doodt-gheflagfien. 't Legher bertrock ban bier naet Ofachile, maeckente met groote moepte een beugh ober een ander riebier / ende ghepalfert

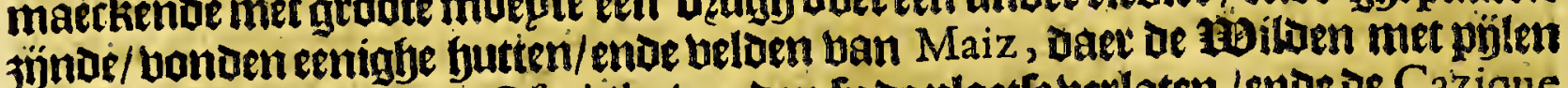
upt-Iffjoten. Homendete Ofachile vonoen [u de plaetle berlaten/ende de Cazique

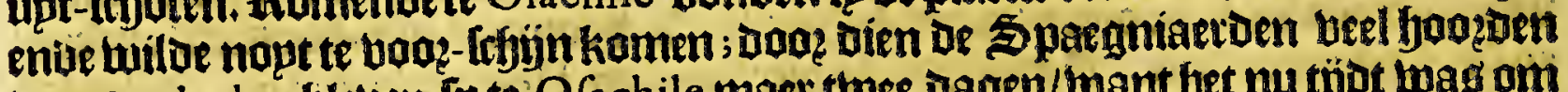
ban A palache, bleten Ip te O fachile maet twee Dagen/want bet nu tïbt luad on naeen winter-Leger te dencken. Cracken I 2 leguen Doogen wiloetnig/en banden

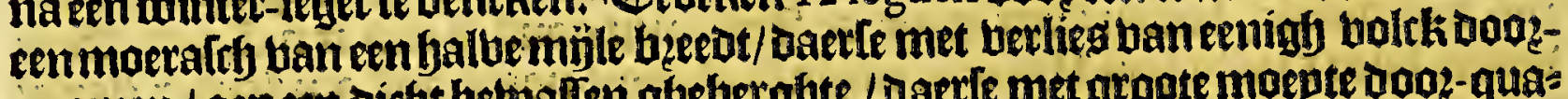
quamen / aen een bictyt betuallen ghebetghte / oaetle met groote moepte dooz-quas

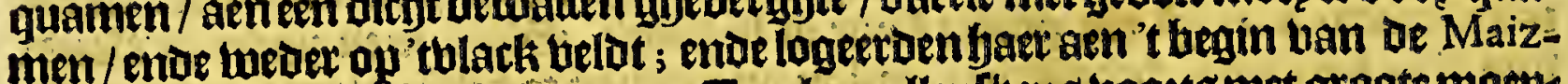
beloen/aie tot A palache befjoozoen. Cracken allenlkens baokts met groote moeps: te/ endecontinuele allaulten ban de 3 ndianen/ tot dat Ip quamen op thoee leguen

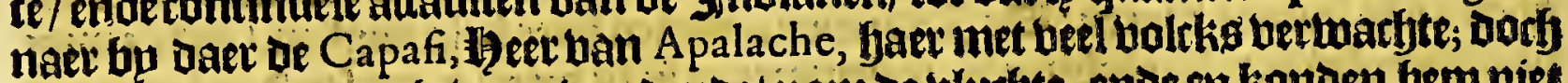
oe Spaegniaeraen ghetwaer twozoende/ nam de bluchte; ende en konton bemniet Gekomen. A pala che mas een blecke ban twe hantoet en büftirf buplen/beneffeng

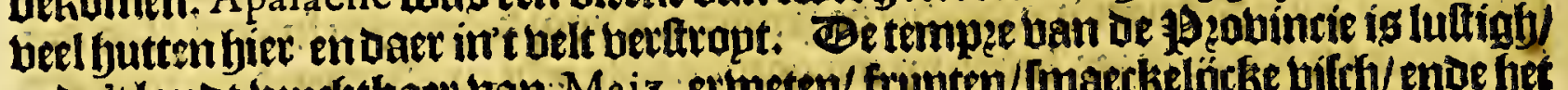

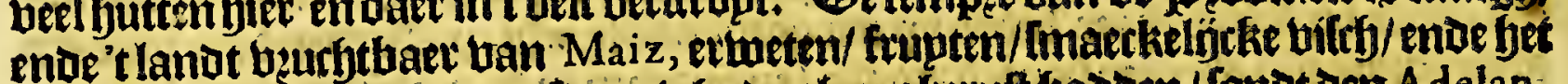

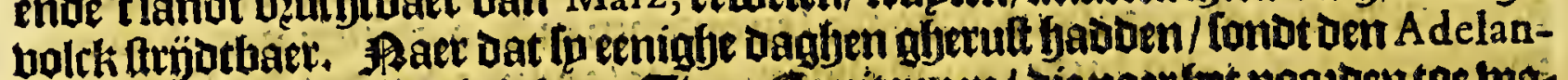
tado om 't lanot te befirytighen. Celuet Capitennen/ bienaerlyet noozdentoe bat:

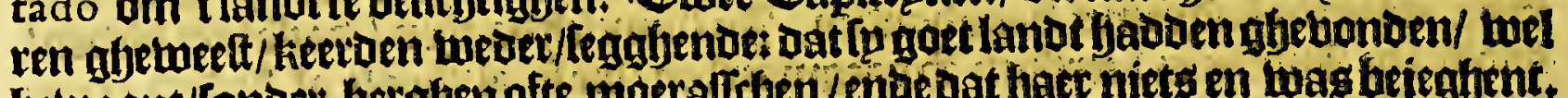
bewoont/Lonber bethen ofte moeralthen / enbe oat bate niets en twas bejeghent.

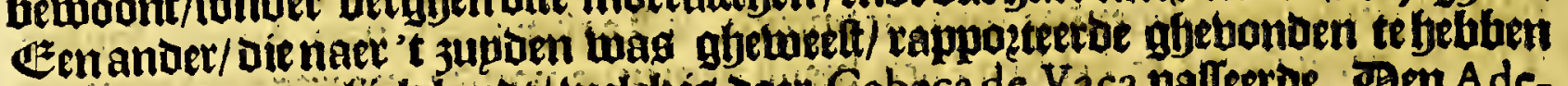

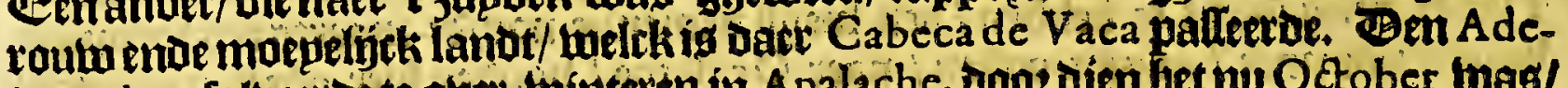
lantado relolbertoe te ober-tointeren in A palache, pooz dien bet nu October twas/

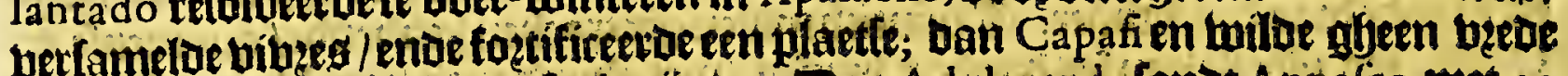

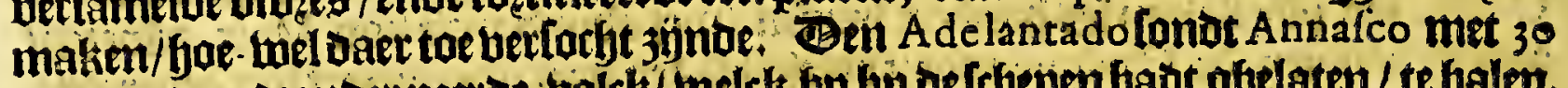
peeroen/ om d ander peerde-bolck/ melck bo bp be tebepen fabt ghelaten/ te balen.

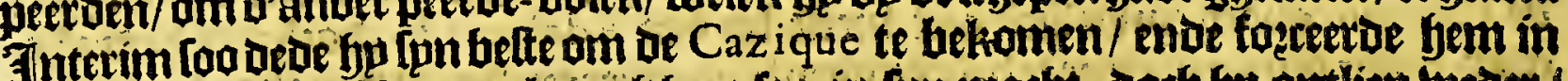

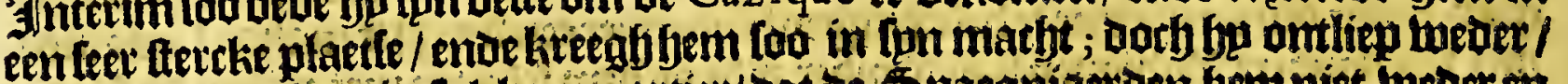
ende retíteerde fyem in Lulcken quattiet/ bat oe syaegniaetoen jern niet webex en

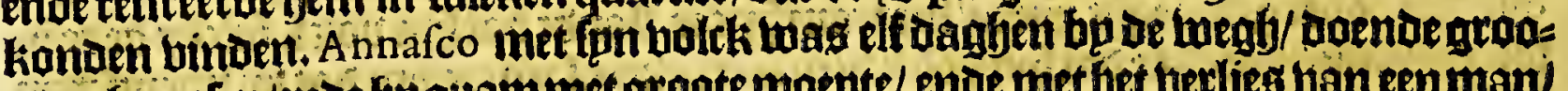
te dach-repten/ento fjp quaim met groote moepte/ ende met bet beelies ban een mani

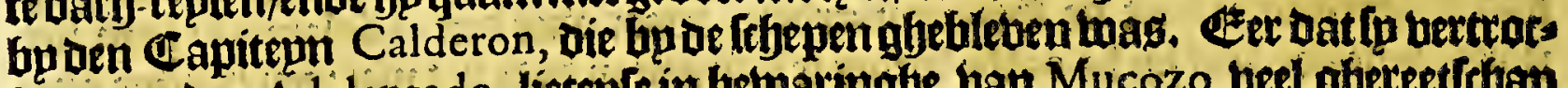
ken naer den A delantado, lietente in betwaringbe ban Mucozo beel gbereettegep ende probifite; ende twee ban de byiganting hoeren langhg be kufte naer ue Baia ban

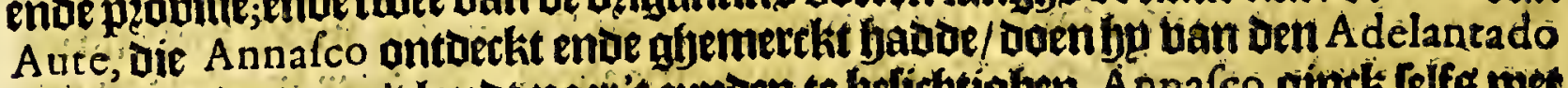

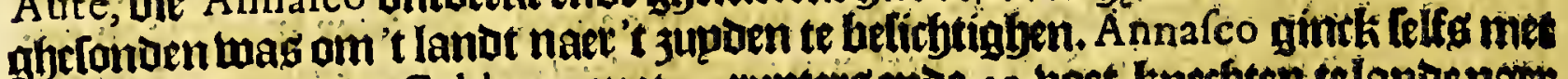
oe beiganting/ende Calderon met 7 o ruptersenoe so hoet-knergten telandenate A pala che: pafteetoen bondert en býf. en-Dertich leguen tot aen bet moetaley ban A palache, fonder eenighe refiftentie; dan ban daer bogts tot A palache toe toier:

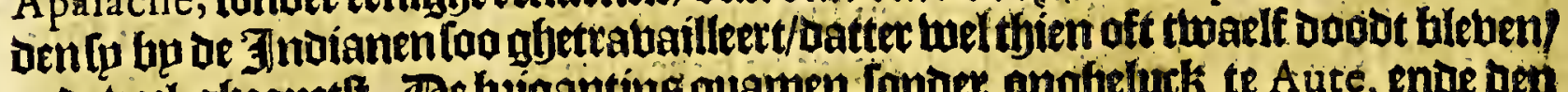
ende beel gheguetle. De beiganting quamen tonder ongfelurk te Aute, ende ben

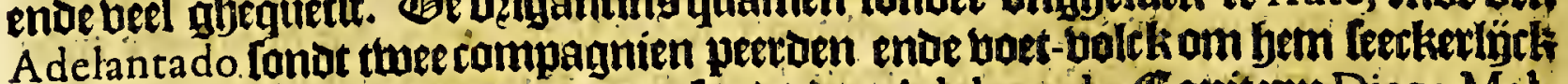
te A palache te benghen. Baer naer lont den A delantado Capitepn Diego Mal. donado, om de kufte te beloetken met de beiganting / dze bonoert leguen naet's weften/enoe dat fip Gimen thee maenoen loude beder-keeten met relaes ban alle

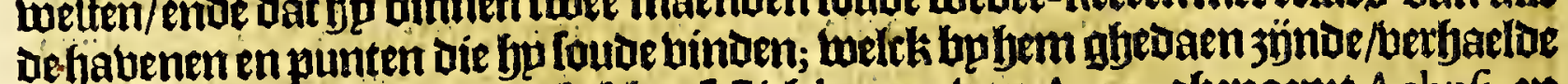
een traepe haberi ghelaten te bebben Teltich leguen ban Aure, gfenaemt A chufi, en byocht thee Jndianen ban daet mede: daec naet Conot bphem naer Cúba, om de tỷoingly 


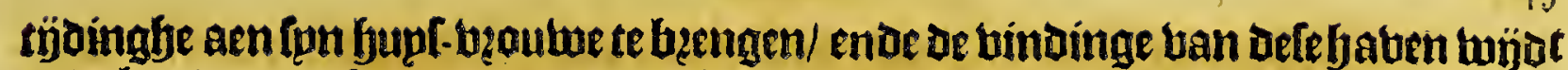
ende beedat te uerfpeepoen / om 't bolch te betwecken om Daer te kamen woonen. 2Hlle Dentyot dat den Adelantado bertuinteride in A palache, informeet of bp bem ban de ghelegentfjept ban't lanos/ dat twelt-twaert aen lagh; ende verftondt onder ander ban een jongh- man die de 3ndiaente koop-liedendiende/ dat Derthien oft beethien Dagh-replen Dien wegf upt/melck bo den Adelantado thoonde/ghelegen

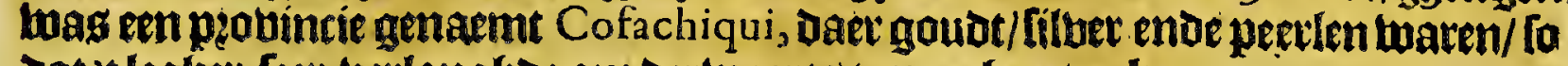
Dat't legber feer berlangboe om dertwaents te moghen trecken.

\section{anet bütoe Capittel.}

Vervolgh van de vierde ontdeckinghe van 't landt van $F_{L}$ OR I D A onder het beleydt van Hernando de Soto.

$\mathrm{D}$

En Adelantado Hernando de Soto, ober-tuintert bebluenot in Apalache,

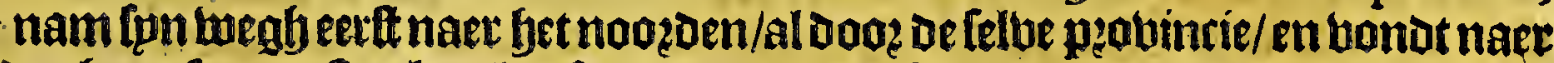

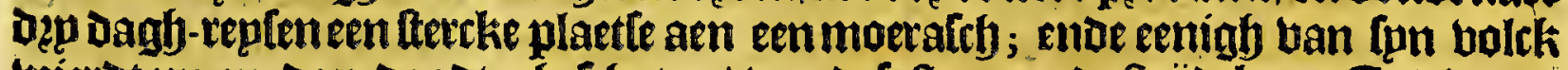

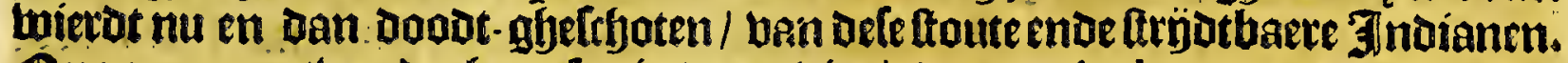
Quamen naex thee Dath-replen in Dewzobincie ban A tal paha, en bonden de eerfte

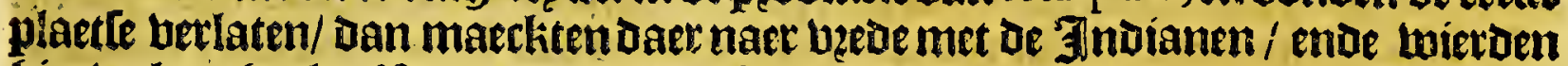
bier Lel ontbaelt. Ban Daer trocken [p thien Darfj-replen noozdt ende zupot een

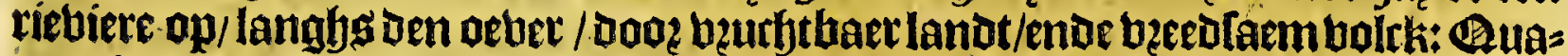
men in be plobincie ban Achalaqui, arm/ onveurfitbaer/ende qualísk belmoont/

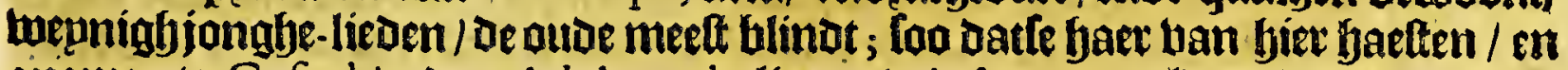
quamen te Cofachi; Den Adelantado liet te A chalaqui en eloers bettheng/ om boots te teelen/ oe twelcke Daet leer bermenigffulbirfjt jön. Baer naer quamenie aen de peovincie ban Cofa ende Cofaqui, twee gbeboeders / ende twierden ban

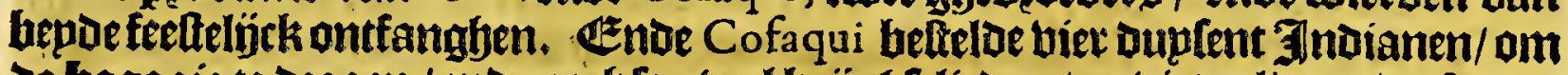

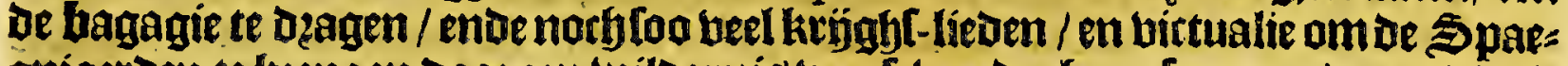
gniaerden te bengen dooz een twildernig ban fehen darf-repten naer be pzodincie van Cofachiqui. Ben DetDen Dagh naer datte gljefrbepden twaren uan Cofaqui,

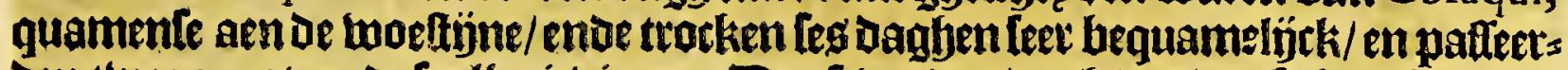

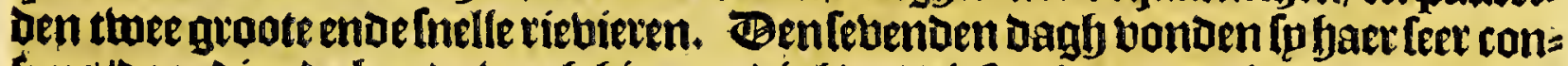
fupg/booz dien de bzeede twegh fier epnoighoe / diefp abenomen badoen/ ende fp niet en wiften werbaetts gaen/ ende de 3hdianen felfs twaren upt lyaer begh en

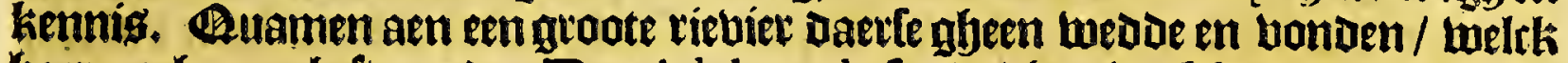
baet nothmeer beftwaetde. Ben Adelantado fonot biet Diverfere troupen upt om te berpien; waer ban de dep niets en bonden; De vierde onder den Capitepn An. nafco, daet de Benerael ban de Indianen met upt was met Duplent Jndianen/ trock de riebiere op / en tonot aenden oetuer ban de 3 joe Daet le waren een blecke / ende veel twarender boots de rietuiete op / foo dat gp daer ban wo ozot fondt aen ben Adelanta do; daet-en-tufirfen bieloen de Jndianen die met hem waren ellen:

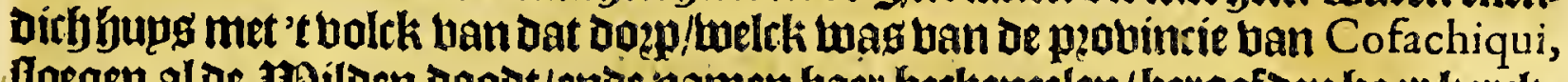
doegen al de Hilden boodt/enoe namen baet beckeneelen/betoofden baer kerck-

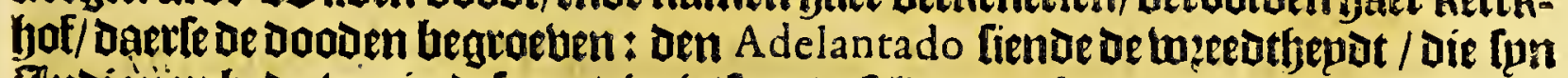

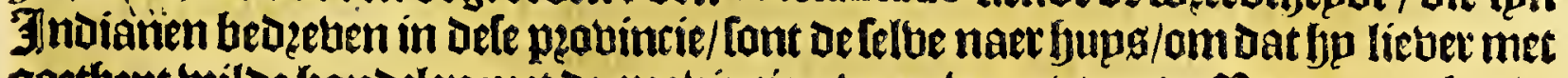
goethept wilde bandelen met de pzobincien boaz-twaerts upt. Baots trecliende bonoen de plaeten al levigh/ Doog dien als bozen de Inuianen van Cofaqui tholc boot-gyellaghen hadoen. Annafco meder boo upt-treckenoe / naet dat jp toat meer als twee leguen gfotogen was/ bondt een blecke/borb lagh aend'ander jñe

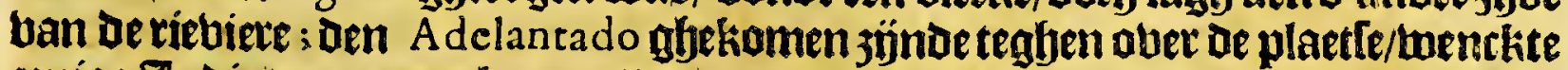

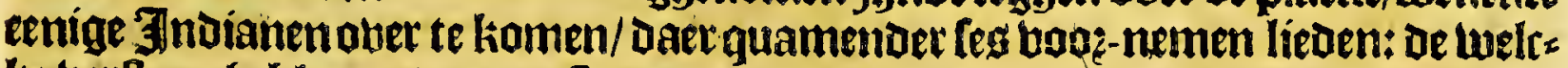

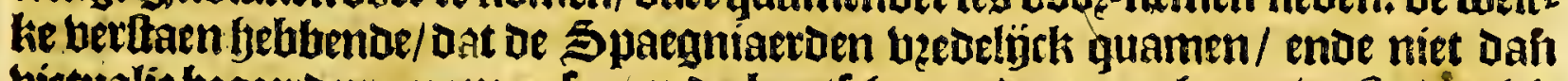

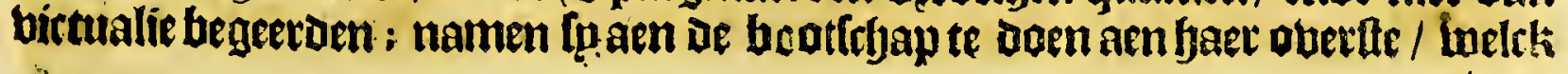


246

Florida.

was en jonahe ongetroube maeght ; Dele quam obet / en berefjonck ton Adelanrado met eentnoer peetlen / enoe bp yaer met een rabju-rinclis; klaeghoe dat of

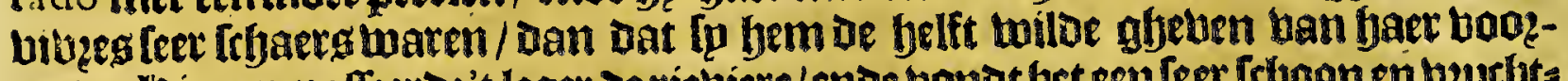

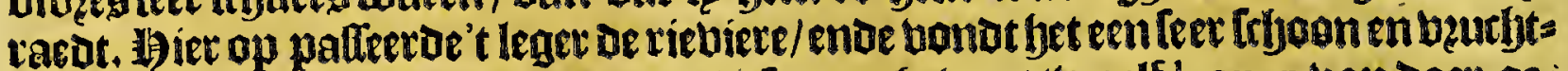
haer landte Lefen. Be moeder ban dele maerht was twaelf leguen ban daet ge

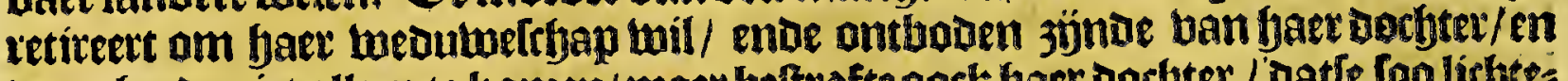

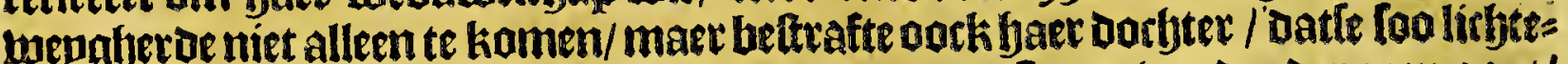
lifek dit veeemot bolck in baec lanot badde ghelaten. 5y en bonoender geen gout/ a anlioper ban loo hoogen couleur / dat het goudet Icjeen te welen / en ftucken ban

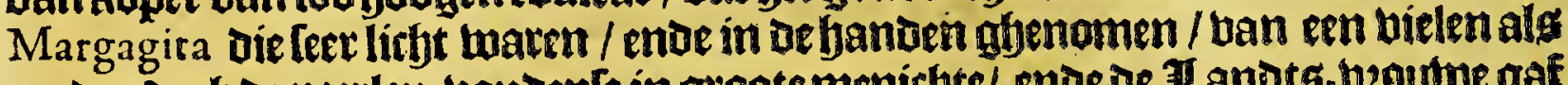

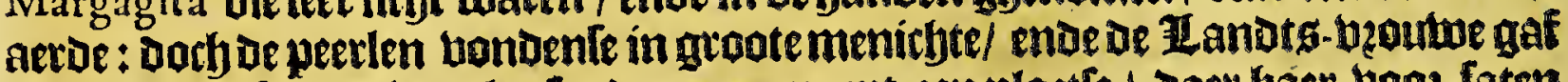
licentie datfe foo beel peerlenloudennemen upt eenplaetie / Daet baer booz-faten begraben waren / alg fp wifoen; oe officiers ban den knoningh die woeghen ín

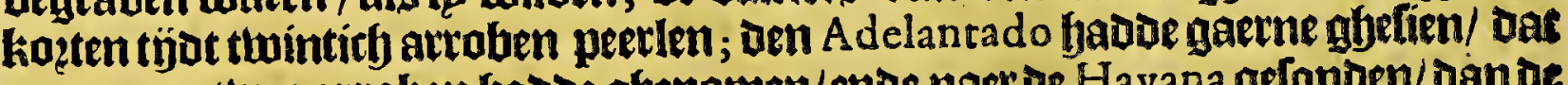
men maer twee arroben fadoe ghenomen/ende naet se Havana gefonoen/dande offííerg ban den lsoningh wiloenfe al met packen; baex waren peerlen foo groot als Gravances, ofte ertweten. Quamen aen een ander blecke/genaemt Tolomeco,

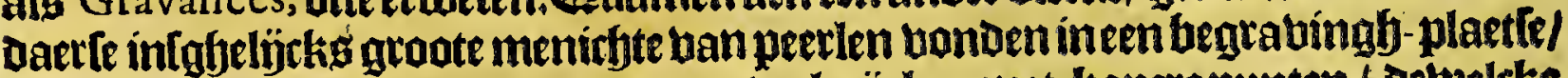

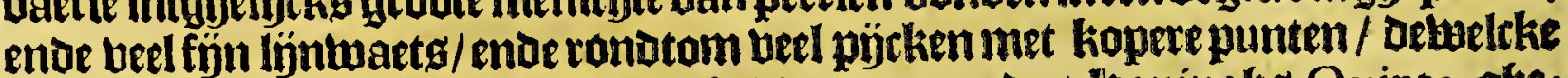

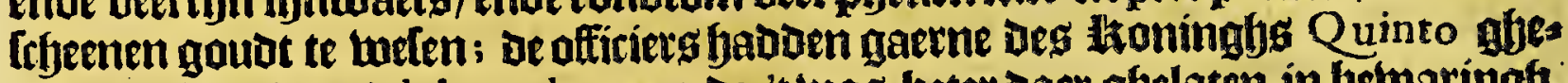
nomen/ Jan oen Adelantado mepnoe 'twag beter Daer ghelaten in betwaringf.

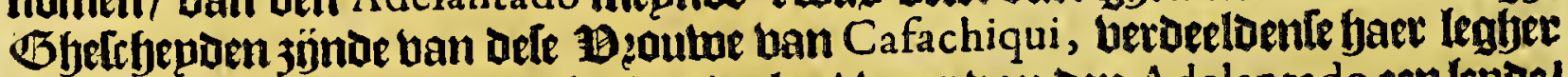

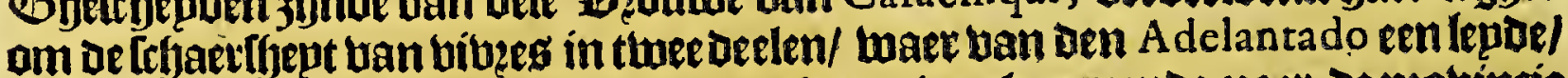
ende't ander Balthafar de Gallegos; ende faren twegh nemende naex de peobintie

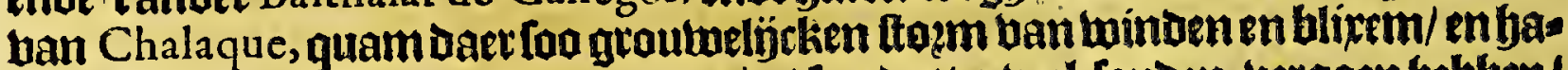
abel-tteenen [oo aroot algfinmen-epereit / loo datter veel louben uergaen bebluen/ hadoen de boomenniet belefubt. Den teften Dagh quamente aen be balleqe Xuala naer't noozat-noożt-ooften/melck was goedt lanot. Spekende ban ae groote rieviete ban Cofachiqui, mepnoen't varende boldk/ bat fet de lelfoe was die inde nooz-jee upt quam/en Santa Elena Daer woet genoemt; ende naer de reeckeningf

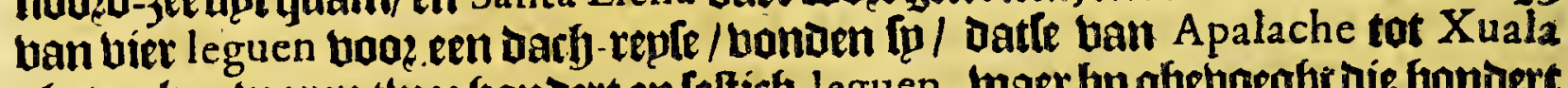
ghetracken waren twee yon dert en [eltich leguen, waer bp qfeboegfor die fondert en vinftith van Baia del Efpiritu Santo, tot A palache maeckt bier Gonoerten tbien leguen. $\mathfrak{A g e n}$ vondt in De probintie ban Cofachiqui beel beembe flaten/aiefe bers

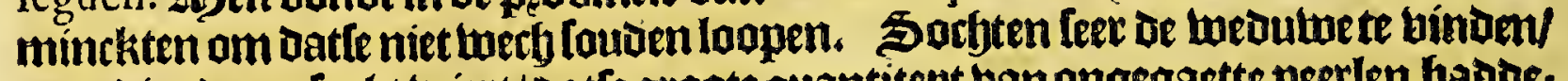
Doo2 Dienoer geleght wiert/ Dat fe groote quantitept ban ongegaette peerlen babde;

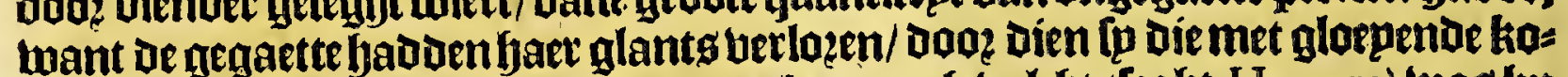
pere priemen boozdon. Bitrelaeg/en'tabene noch boleht (legbt Herrera) was bp cen minne-bzoeder afiepzelenteert aen den oppertten raedt ban Indien/ die tfelbe Icpoe te fyebben ban Mexico betomen/ vaneen Capitepn die ín oele ontoeckíngfe twas $\mathfrak{g}$ fetweet.

\section{Het rette CLapittel.}

Voorder verhael van de vierde ontdeckinge van't lande van FLORIDA, onder het beleydt van Hernando de Soto.

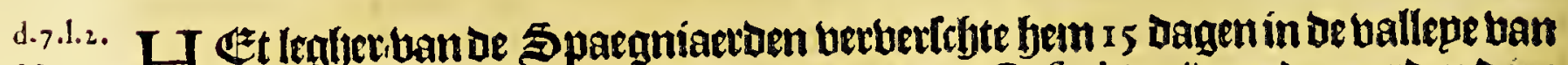

Xuala (melck bejooet tot de beevlíthept wan Cofachiqui) om de peetden daet te betten Dooz de abundantie ban't landt. Baer na trock bet legher een Dagh Doos goet lanot/en uñf daghen ouer een anbetwoant gfeberghte / ooct fraep / met beel

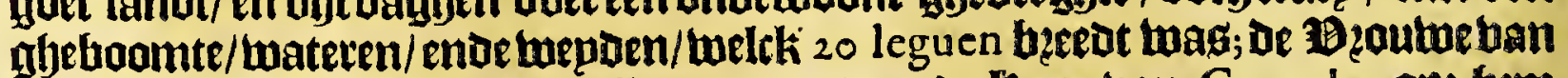
Cofachiqui fondt bier ban baer Heren met/aen de laeere ban Guaxale, om bem te boottchappen/Dat fjp de Spaegniaeroenluel Couoe tracteeren/ oft Dat lo bem 
Het vierde Boeck.

moets be dollogbe fouden aen fegaben; een met namen I uan Teron bondt een lackken met groote ongegaette peerlent/ Dan lmeette begly/ en andete fameloen die

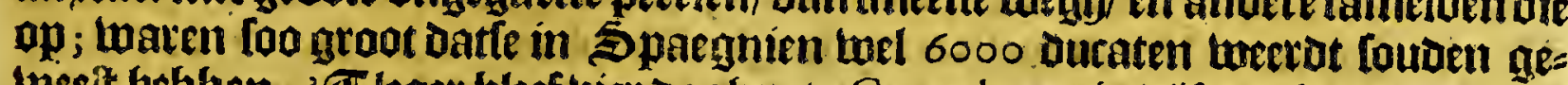
tweelt bebben. 'Cleget blecf vier daghen te Guaxale, en in bujf dagben quamente

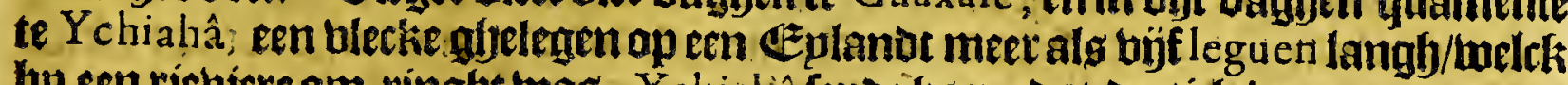

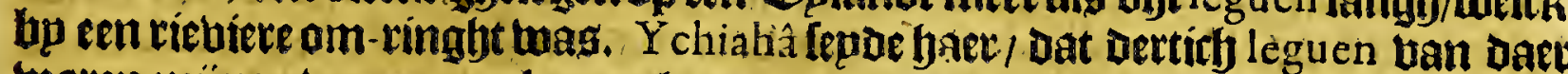
tuaren mïnen uan een geel metael/ Daec ben Adelantado luan de Villalobos naer toe fonot , De Cellue Cazique gaf Den Adelantado een fnoer ban grootepeerlen/ Die

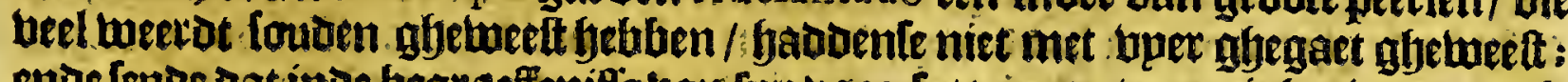
ende Lepos dat inoe begraeffenifle ban (pn bao-faten groote menighte was/baetle

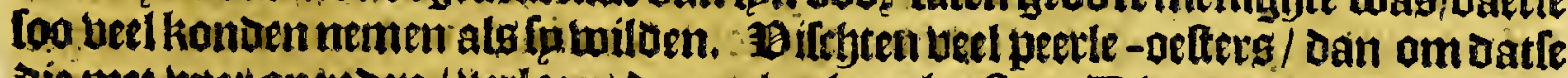
die met bper openden / berlozen de peecten baer lupiter. (B) na de minen waren

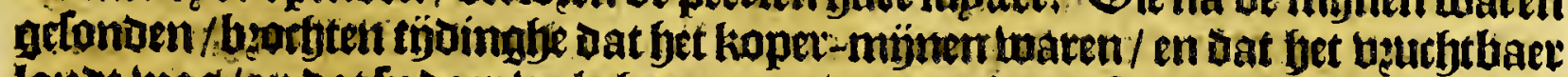

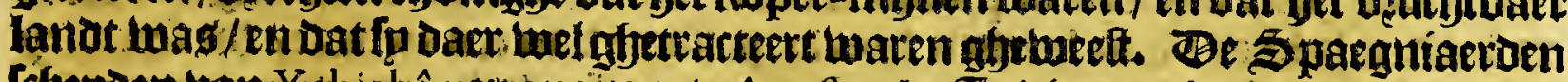

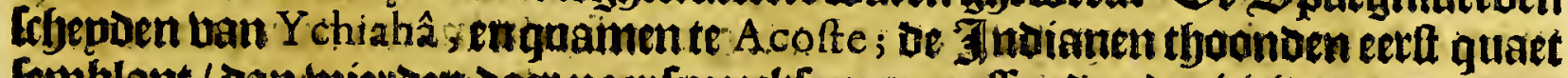

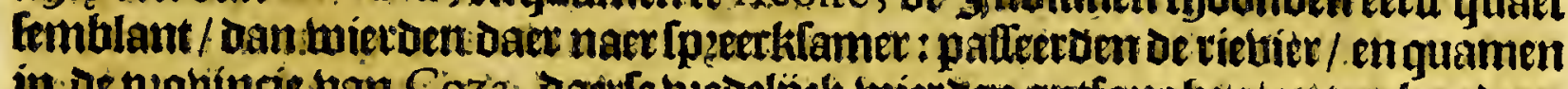

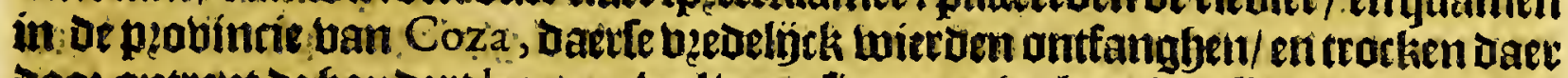

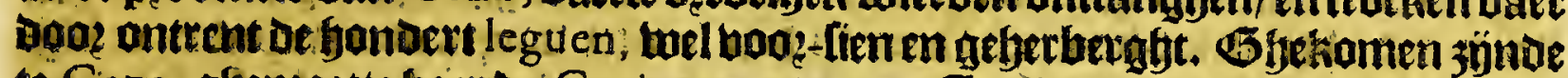
te Coza, gfemacte haer de Cazique met I 000 Thuianen met plupmagien bet: ciert / ende mantels ban rücke boepetingbt. To blecke was ban 500 Juplen bp ben oeter ban een riebiets de Cazique baot fraer tatle baer fouben ober-minte=

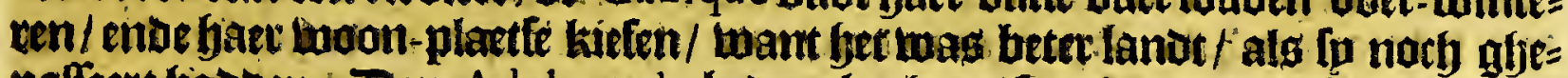
palfeert fiaboen. Ben Adelantado bedanthte bem/legghenae / aat fin voo?-nes

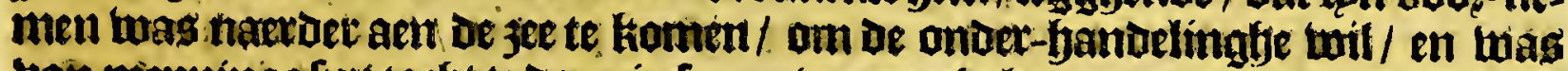
yan miepuinge fun tocht te doen in fopme bam een yalbe maen/ enoe de baten ban

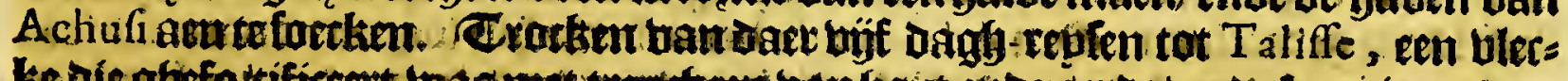

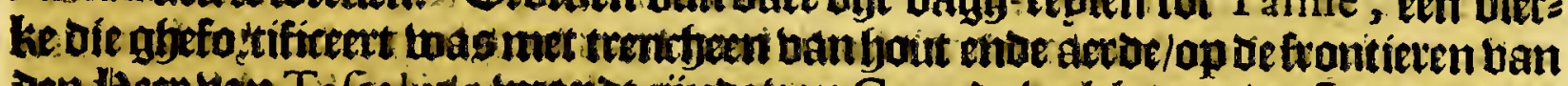

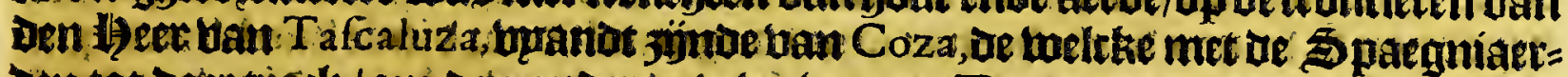

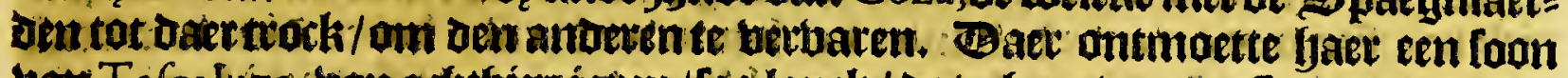

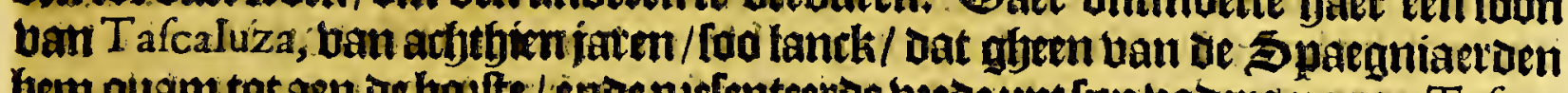
bem quam totaen de boulte/enoe perfenteerde bze oe upt [pn baders naem. Tafcaluza ontfinck oen Adelantado mer groote magnificentie/ littenoe in fon ftoel tot Dat Den Adelanitado felfs quam/ mag noth langher als fpn foon / foo Dat hp een

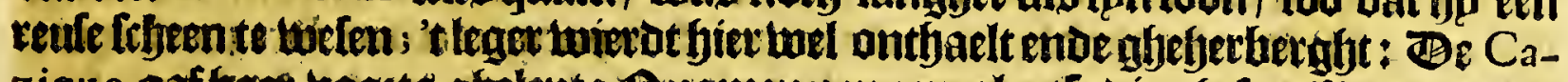
zique gat fage boots ghelept : Duamen aen een plaetle bie ghefoetificeert was/

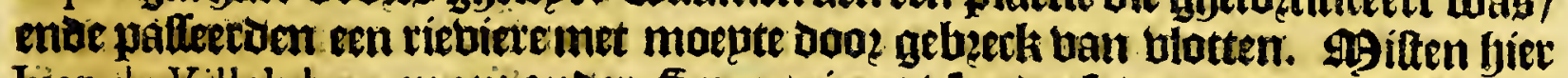

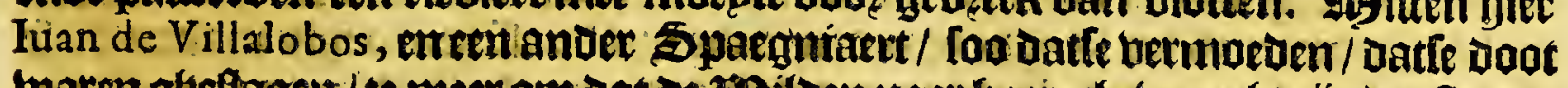

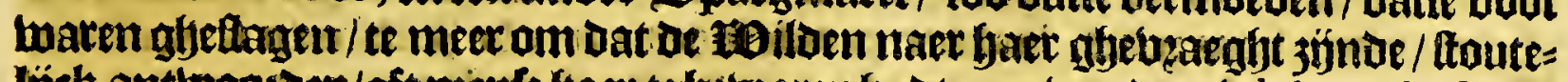

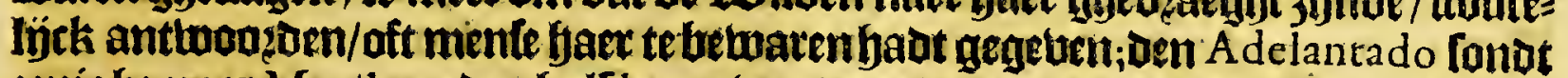
entigfe naet Mavila ander-half legue tran daec / om ma baer te 3 ien / want be Cazique haot daer bolck faten bergaren/om't leger foo bp voo?-gaf beter te tratterent; of [e bzocften tijoinge dat Mavila cen alloo fterdke platte twas/als [p noth in

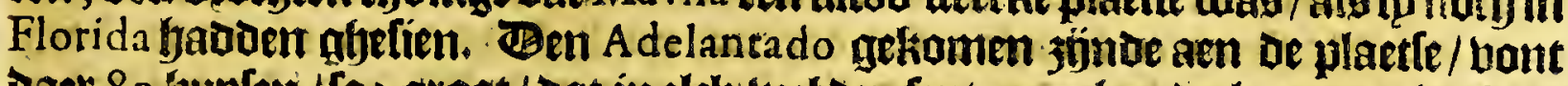
Daet 80 hupfri / [oo gloot / tat in elch wel oupfent mankonoe logeren; lagd op een plain / om-ringelt met palifladen / en tufferjen bepden met aevoe gfjebult / [oo dat bet eenmuer fryeen te weten/ enoe alche 80 palten twas een toom / Daer adst

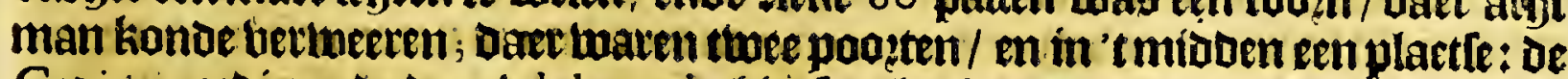
Cazique opdineetue oen A delanta do bier fon loghement. Be Cazique twas ban

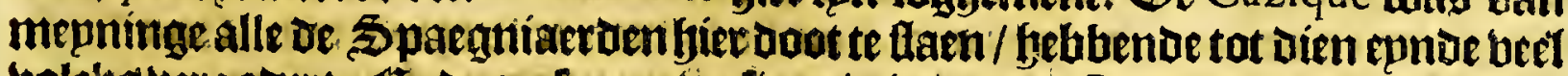
bolcks bergatert. Enve op fpn ontierfieng twietzen de Spaeqniaerden wel ban

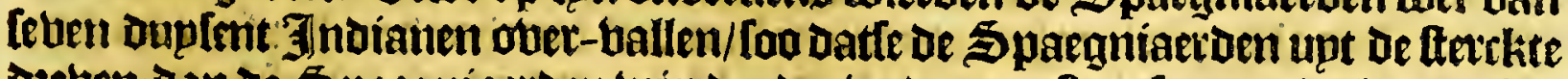

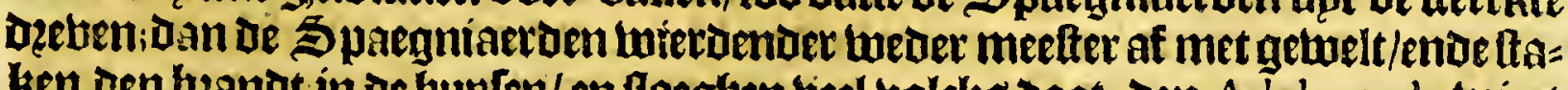
ken ben bzanot in oe bupten/en toeghen beel bolekg Doot; Den A delantado hiert 
felfg gequettifun bagagie berbzande meet in oe fterchte/en baet bleten loo in be bataille / als nader-Land ban de monden 83 Spaegniaerden/ende 45 peerben. Ban of 3 ndianen blewen wel naet gillingh elf Duplent / want bupten de plaetle Lierden tuel 4000 Dadden gevonden/ende Dael ander Den foon ban Tafcaluza, 't lityaem van Ta caluza felfs en twietut niet gebonden/en men lyoudtoat 't felue betbzanot was. Hernando de Soro mas ban mepninghe enen ftaot te houtwen in Achufi, endeeen ander thinticty leguen te landtwaert in; Dan fan bolch en wiloe niet / [egabenoe datle te wepnigh twaren om Loo belliceulen bolck te hed wingyen/

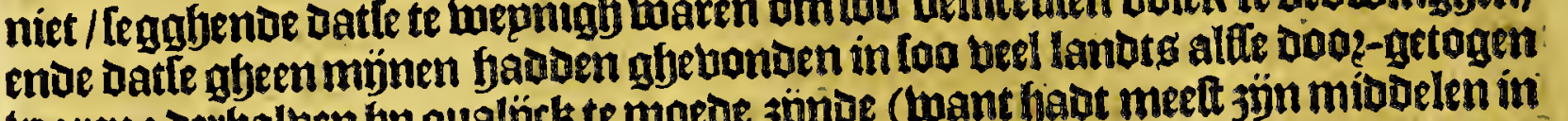

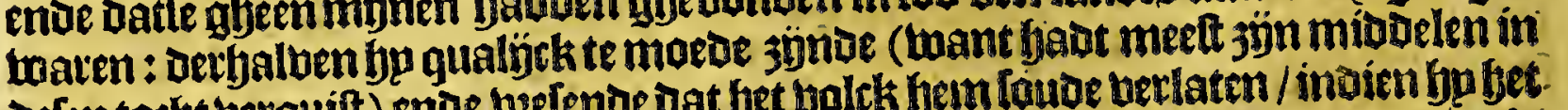

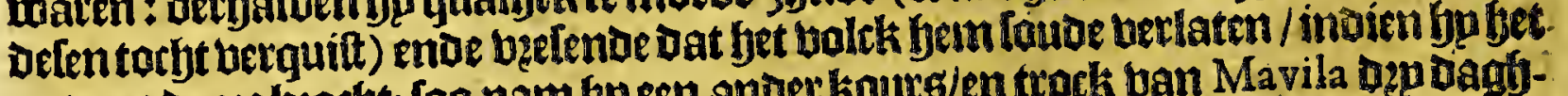
ontrent de jee bzacht; Loo nam bpeen ander kours/en trock ban Mavila dęp dagfj-

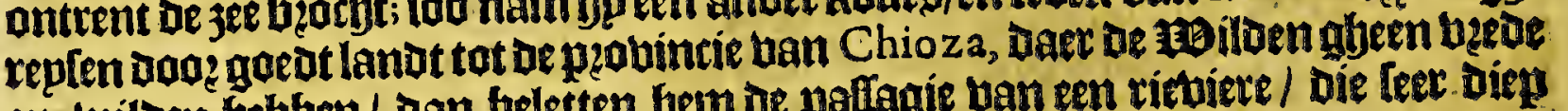

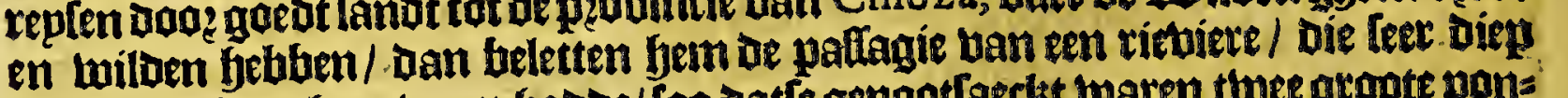
twas/ende hoogfe aeleten fadoe/ Loo datte genootfaecltt waren twee groote pons ten te maken / baerle eqnaeligck met greote moepte mede ober quamen; naec biet Dagh-repten van daet quamen fo te Chicoza, een wel gfeleghen plaetle tultryen belienende beel frupt-bogmen/ daer [p Den luinter booztg ober mepniden te bij=

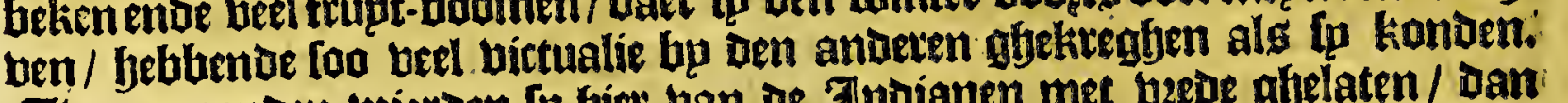

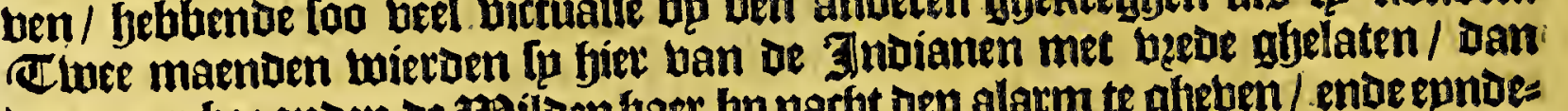

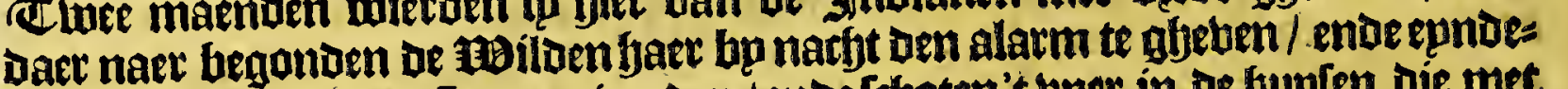

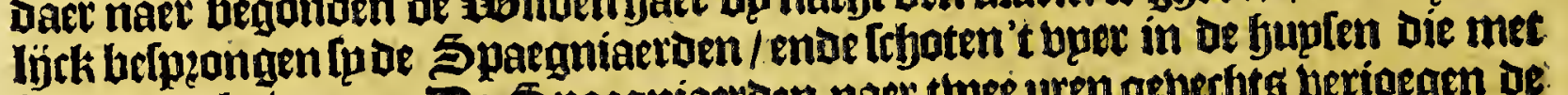
froo gedetht waren. Be Spaegniaet den naer twee uren gebechts berjoegen de:

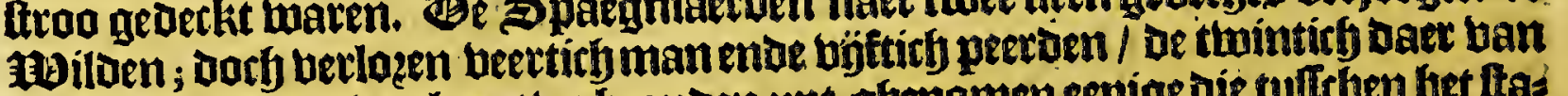
uerbzanden/yaer berckens berbzanoen upt-gbenomen eenige die tullechen bet ftas kettel booz getaetkten. Ben Adelantado betanueroe fon logement naer Chica-

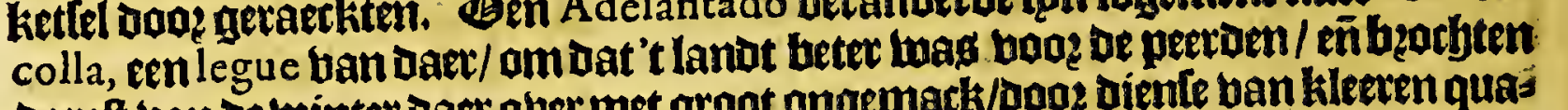
oe reft wan be minter daet aber met groot ongemack/booe dienfe ban kileten quas

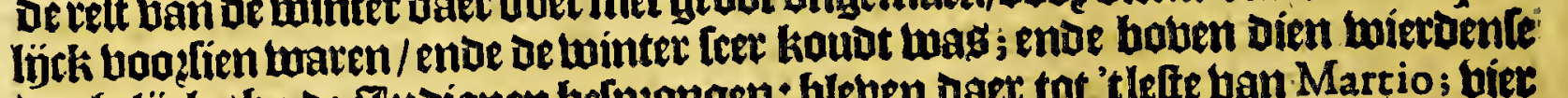

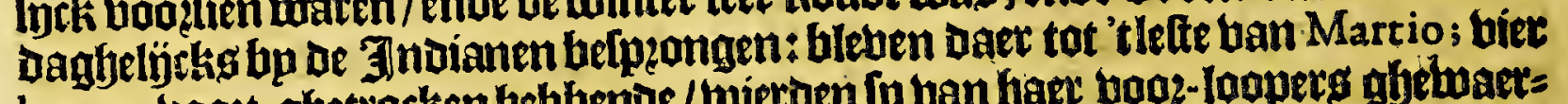

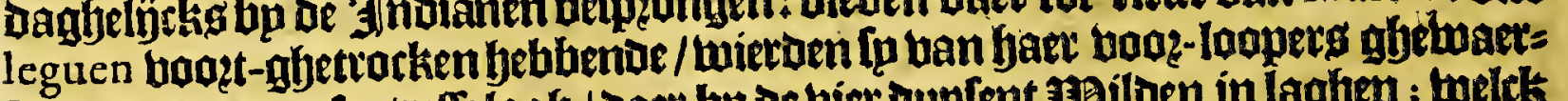

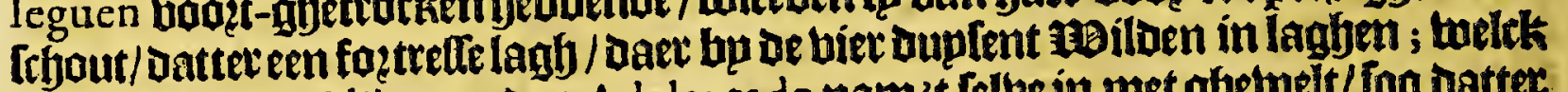
was ghenaemt Alibamo; Den Adelantado nam't felbe in met ghelweit / foo dattec

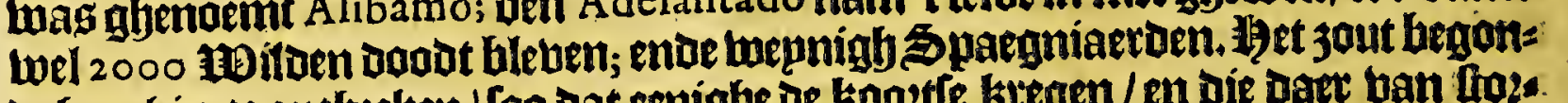

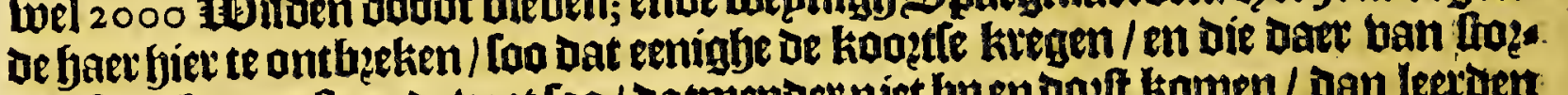
benftoncken op ftaenoe boet foa / Datmender niet bp en doeft komen/ Dan leerdent ban of Jnoianen leket krupot beanden/ ento met os alichen loogbe maken/diere.

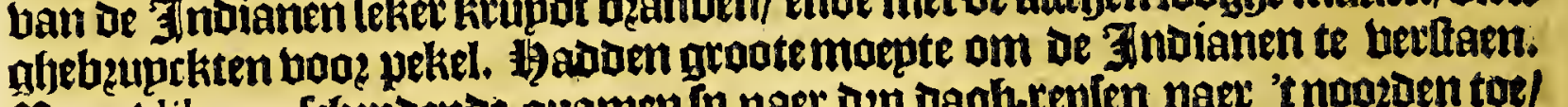
Ban Alibamo frjepdende quamen lp naer oep dagb-replen naet 't nonzaen toel te Chifca, neffens een riebiere diefe noemben el Grande, om dat bet of groptife:

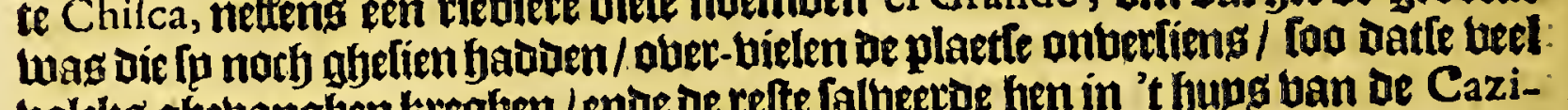
bolcks ghebanghen kreglen / enue de relte falbetwe ben in 't fupg ban be Cazique, welck lagh opeen booghte / foo dat daer qualíck mas aen te komen; bocf

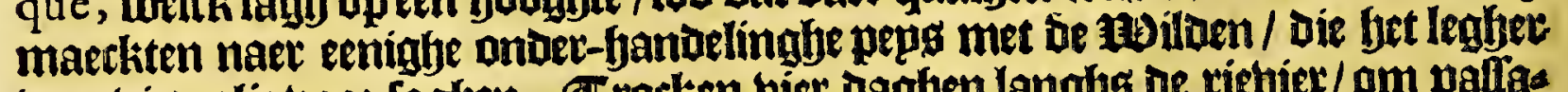
ban bictualie booz-Lanfen. Frocken bier dagfen langlys be riebier/ om pallas gie te binuen/ want lp twas met booghe betghen betet; de Cazique in wiens:

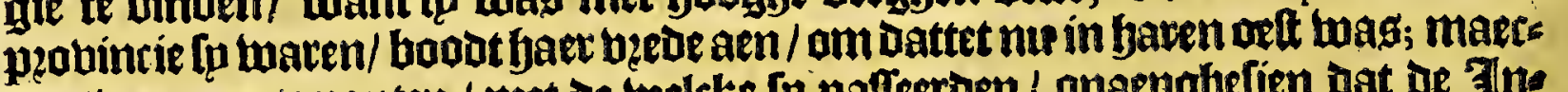

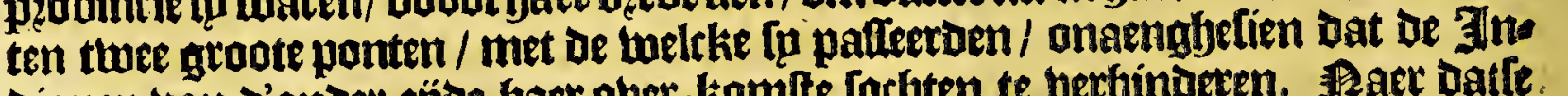
dianen ban d'anoet jübe haer ober-komete forbten te berfindeten. Parer datte. be rietier aber waren/ ende bier bagh-kepleng Gadoen ghetrocken/antbecks

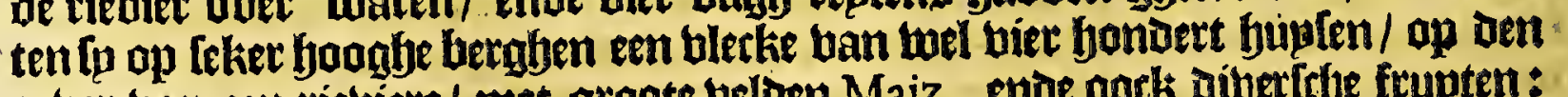
oeter ban een riebiere / met gronte beloen Maiz, ende oock diberf́ye frupten:

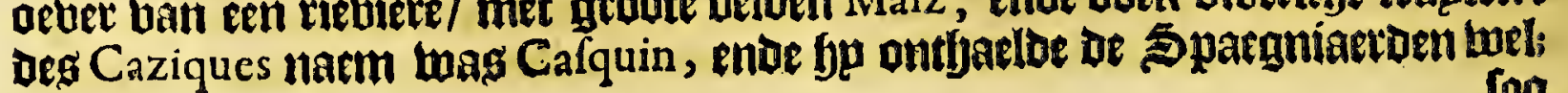


foo Dat fo daet feg Daghen bleten / en thocken oe riebiete op / binbente oberbloes bigh lanot / ende wel betuont. bp bem ujf buplent milden; om dat de naelt-legghende Cazique fon upande was / votht bp goet hem van Defe occalie te dienen; naec datle dęp daghen ghetroc ken fadoen paflectoen fu een moerafdy / ende dęu Dagfen daet nae quamen fu in het ghefichte ban Capahâ, welck quefoetificeert mas met een grachte/ wel thien bademen diep enoe beetticly beerot/ baet get bater in quam ban te vies

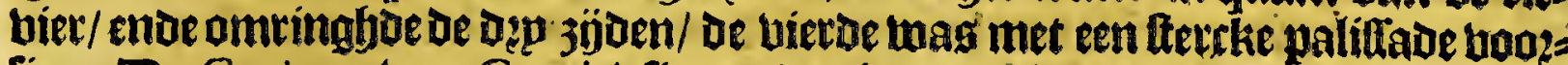

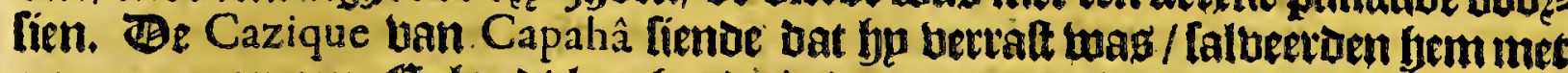
een canoa op een Eeplanot legghende in De groote riebiete/ bet welche bp the fottificert badoe: Die ban Cafquin floeghen fier fot bolck boo? or banut

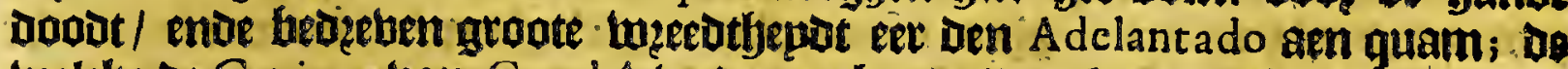

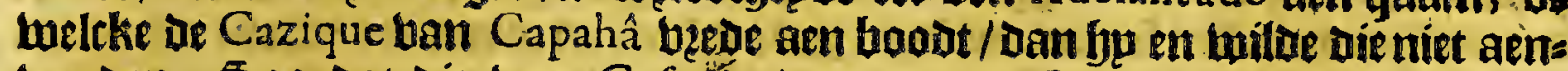
beeroen. Son dat die ban Cafqứin toet ranoas beochten / ente de Spaes gniaet den twonnen den in-ganth ban fyet Eplandt/ Dan Daet naer ban die ban Cafquin berlaten jünde/ (Disupt becefe met beettich canaen tegh liepen) maec ten tụ uzede met Capahâ; mate ben Adelantado bebzenictoe de twee Caziquen mede / foo datfe beienden lwierden met Den anderen.

Het teuente Capittel.

$$
\begin{aligned}
& \text { Vervolgh van de felvereyfe var Hernando de Soto, door de } \\
& \text { landen van F L OR I D A. }
\end{aligned}
$$

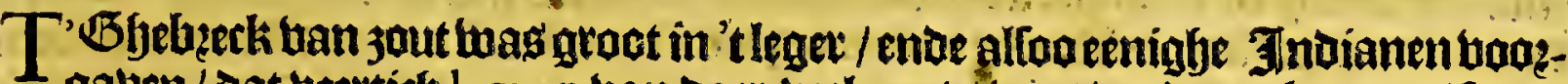

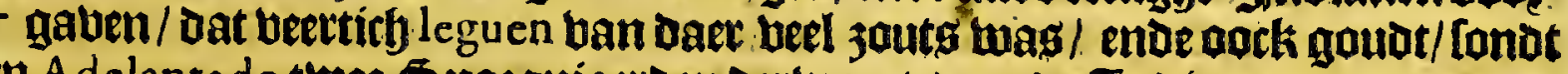

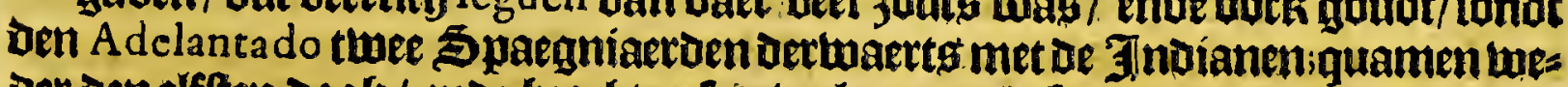

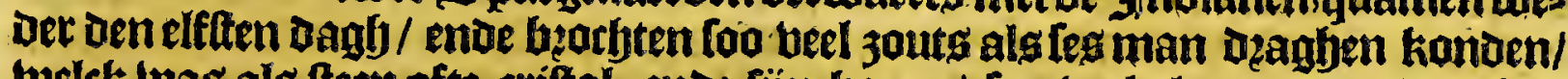
welck Las als fteen ofte criftal; ente fün koper / foo veel als eenman dzagfen

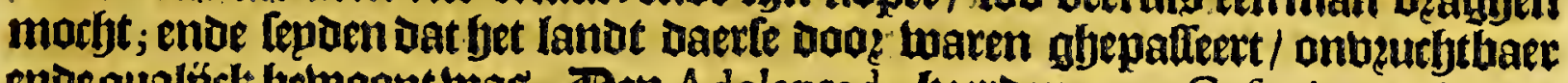

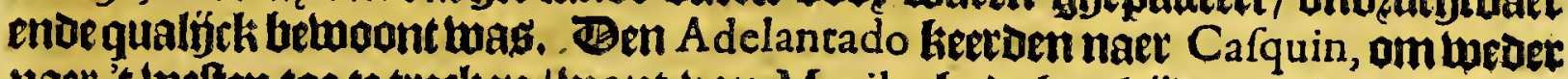
naer 't welten toe te trecken / want ban. Mavila baot bp altijot noozen aen ghes. tworken/amban oe zettezún. Ban. Cafquin trockente bijt Dagh-replen de rievieve af tot Dep?obincie ban Quiguate; Den lebenoen Dagh Iffepdende upt Quiguate, chue den býfoen dagh daer aen/quamenfe te Colima, altyotg oe riebiete af/Datrfe

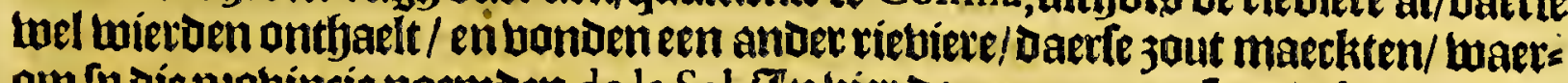
oun fp die peobincie noemoen de la Sal. In bier dagen quamenfe te Tula poos twils

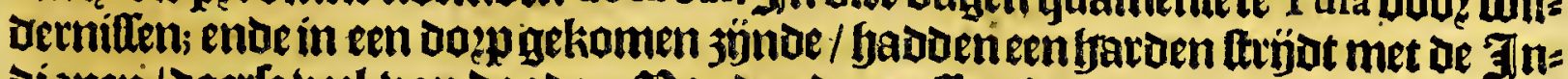

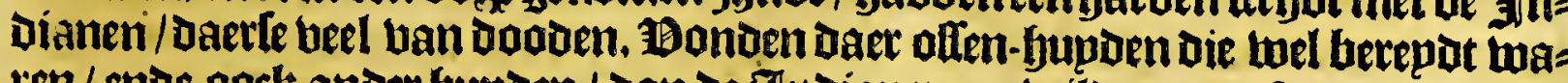

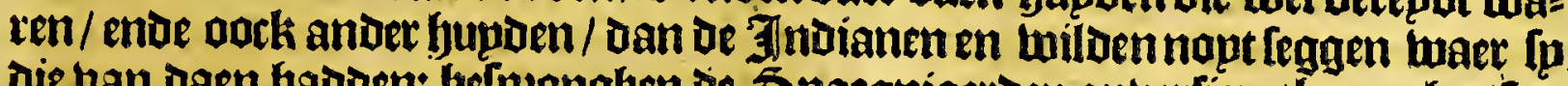
die van Daen fadoen: belpenghen oe Spaegniaer Den onbertiens bp narfte/toa

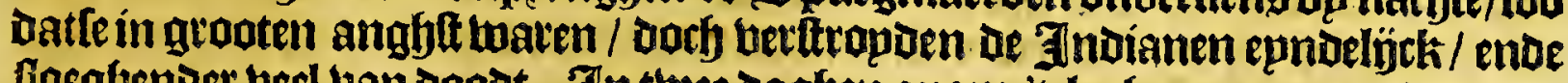
faegfender beel ban boodt. In twee Daghen quam 't legher aen en ander peas bincie ghenoent Vitangue; bonden oe bletke berlaten/ente de $\mathbf{3}$ ndianen bielen

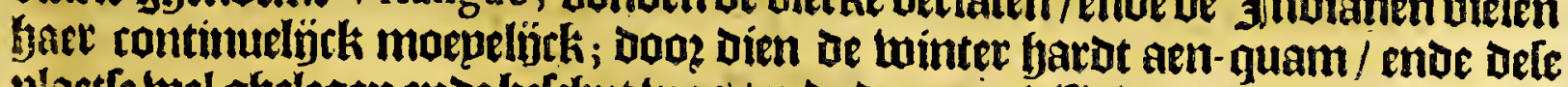
plaet te wel ghetegen ente belebut was / entoe daer pzotifie was boo? menteben en

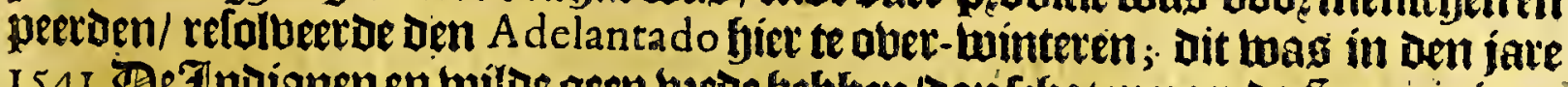

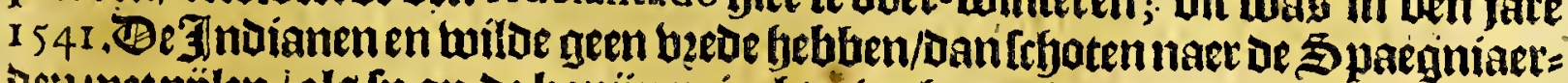

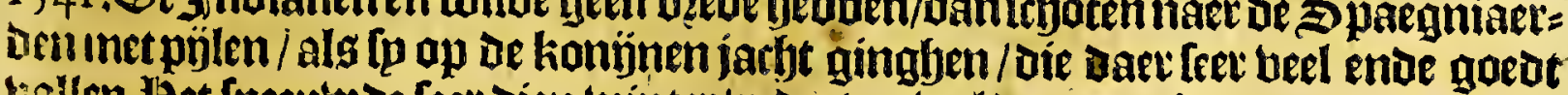

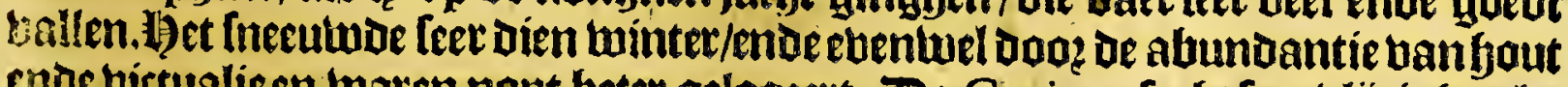
enoe bittualie en waten nopt beter gelogeett. Be Cazique forljt feet blijtigh geles

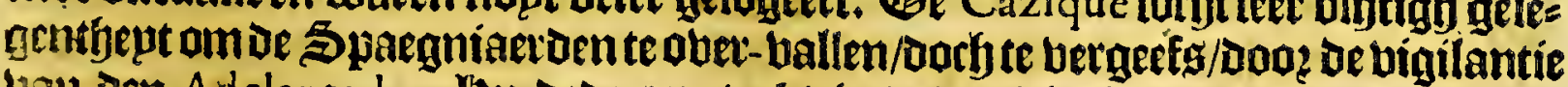
van oen Adelantado: Hp Dede een tocht in oe plobinfie ban Naguatex, ente botht bel bolcks gheluanghen. In A pril trock tleghet op tan Vitangue, en in Q 
150

Florida.

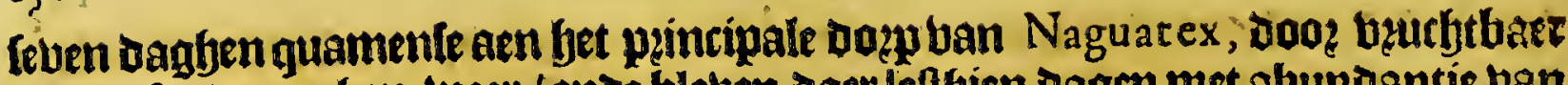
lanot / fonder tegben-weer / ende bleben dacr leabien oagen met abundantie ban

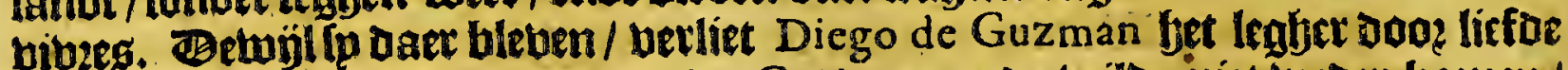
ban een Tnoiaenlcbe Dorbter ban de Cazique, ende wilde niet meder-komen/

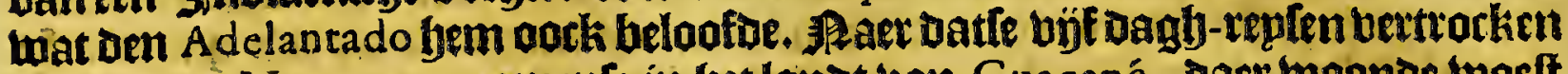
waren ban $N$ aguatex quamenie in bet lant ban Guacané, dake boonde worft enve ftrïotbaer bolck / oie geen veede met oe Spaegniaeroen en begeetoen / ban= oen in alle Guplencrupfen ban bout/welck daer waren gebleben fints Dat Cabeca de Vaca Daer was getweett. Hernando de Soto thas feer begeerigf om een moon= plaetfe te legaen / en ae bem berdzoot leer t felbe niet eer gedaen te bebben/ alloo bp numeer alg ae belft ban fpn bolck mitte; en forbt boeder naet Rio grande, berou

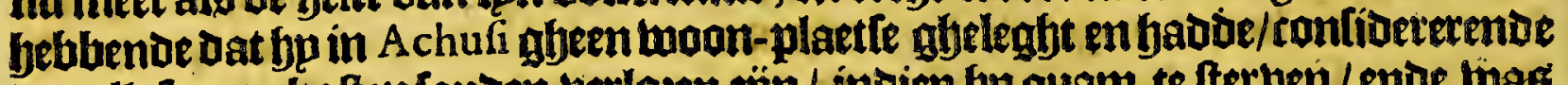

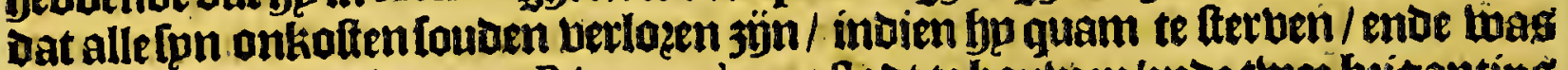
Daetam uan mepninge aen Rio grande eenltadt te boutuen/ende thee beiganting

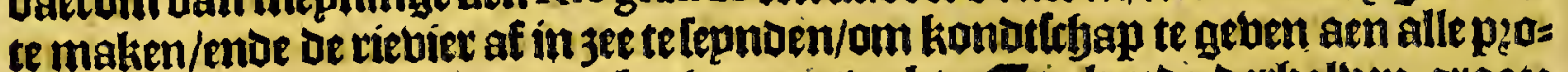

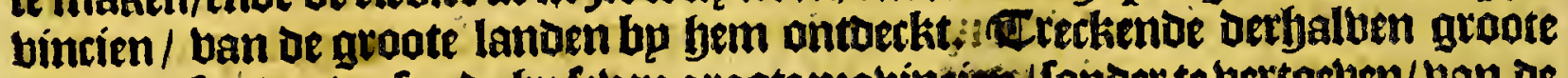
Dagh-replen / traberfeerde bp feben grootepzobintien/ fonder te bertoetren/van de

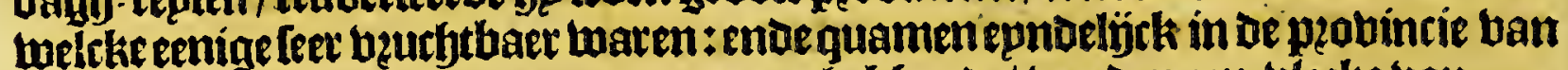
Anilco, ende 3 o leguen daet Doas getogen behbende/ bonoen een bletke ban 400 buplen / met een groote plaetle daet het palais ban de Cazique lagh op een berag

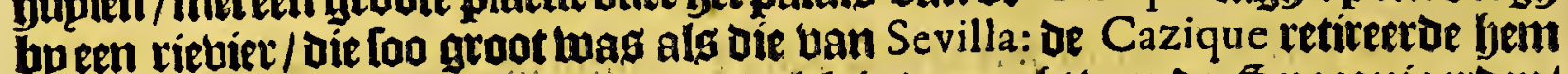
ouer de riebiere/blighenoe eenigh ban't volck in oe mactst ban de Spaegniaerden/

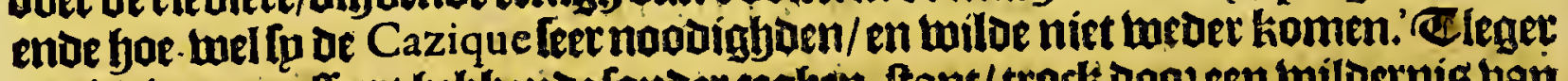
De rieviere gepalfeert bebbende fonder teghen-ftant/ trock doosen wildernis bain hooghe bergen/enoe quam in bepzobincie nan Guachacoya, enbe of eerfte plaetfe Daerfe aen quamen/ wag be booz-naemite/ op den oeber tian de groote riebier/ges leghen op feker feubelen;bertatten oe plaetie/ende de Cazique blurfte ater de ries

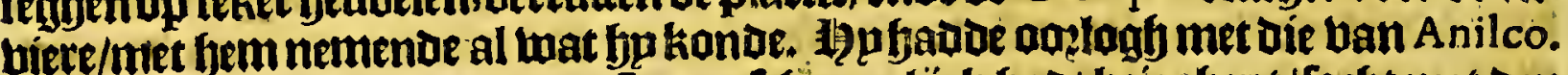
enoe tuettaende/ dat Anilco de Spaentefje quaijek baot bejegfent/ forbt met Den Adelantado te bandelen / endequam bp fem; ende betweeghoe bem Anilco te bes ftrïden / lettetoe daer toe beel ranoag/ en trocken foo met beel Indianen nate

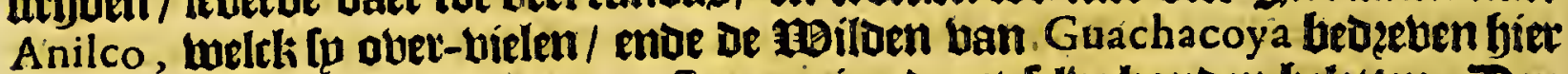

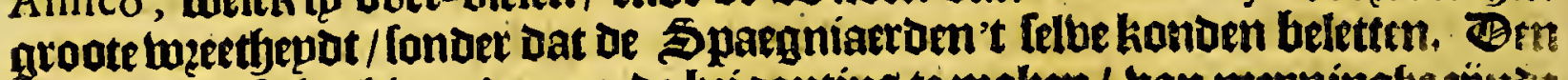

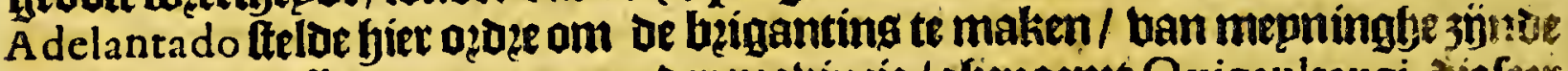
oe riebiere te palleeten naet een ander pzobintie / gbenaemt $Q$ uigaultaugi, biefeer

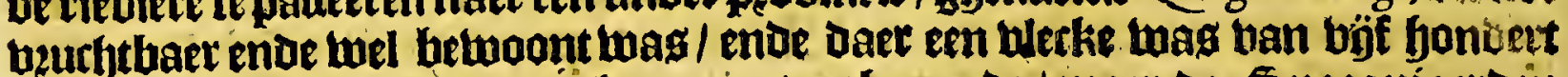
huplen; hoe-twel oe Cazique ghetn pepg en begeeroe / maex of Spachniaeroen feet Deepghoe/ niet tegben-ftaende oen Adelantado bem forfyt met alle bequame miooelen te beiende te krỉghen. Hernando de Soto wierot bier fieck ban een kootte / enoe in Lonplaetie gheftelt bebluenoe Luis de Mofcofo de Alvarado, enoe alle't bolck op't hooghte gererammanoeert bebbente den bzede eñ eenighept ons oer den anderen/literf oudt 3 jonde 42 jaren/ende wiecot in een kiffe geloncken in de riebiete/ die wel negenthien bademen diep wag/eneen quatt ban een legue bzet.

(3et acbette Capittel.

Vervolgh van defen toche door de landen van F L O I I D A naer de doode van Hernando de Soto, onder 't beleyde van Luis de

Mofcofo de Alvarado.

$M$ et De Doot ban oen Adelantado beranderden Degenegentheden ban 't bolck/ endefiende haer onfterck tegben loo belliteufennatien / refolbeerden't lant te

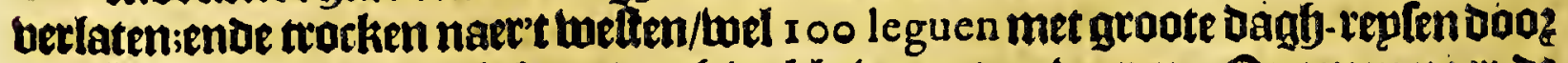
probincien die nach bzucfithaet/noch wel betwoant en waten. Quamen naer as hondert 


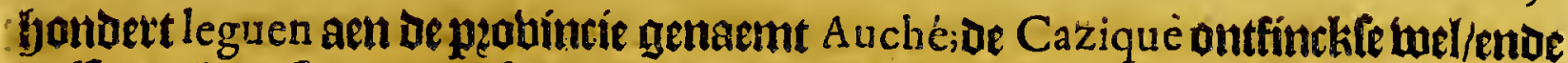

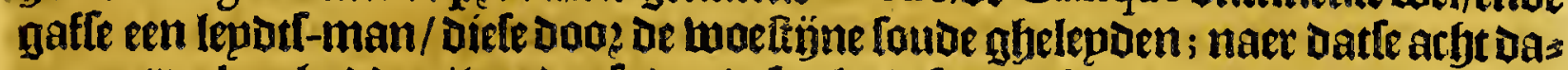
gen gettorken badoen/ bonoente dat defen lepdtf-man baer mir-lepde; waet ober

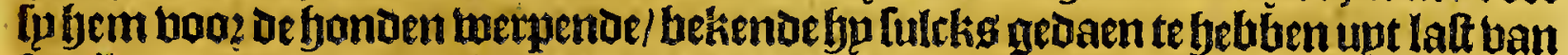
fun Heete/ op datle daev moghten om-komen/ende pelenteerde fjaet himnen des Dagben weoer op De rechte wegh te bzengen/ Dorb lieten bem ban be bonden bet-

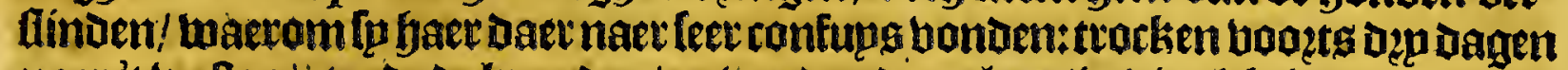
naer't tweften/etende ae ktupden/en bonden doen lant/in't twelck/boetwel bet on=

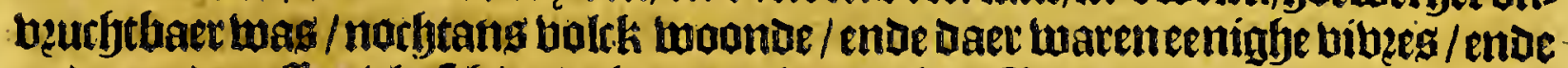

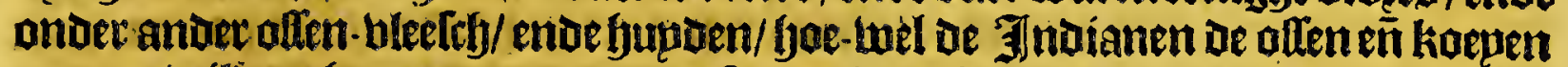

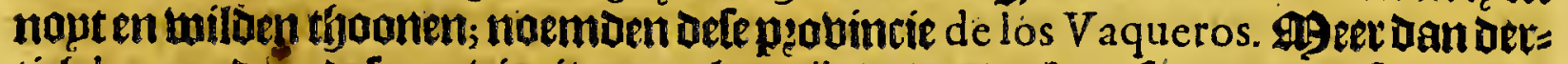

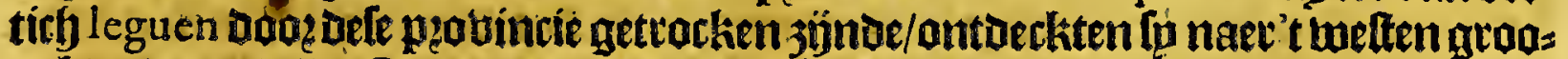

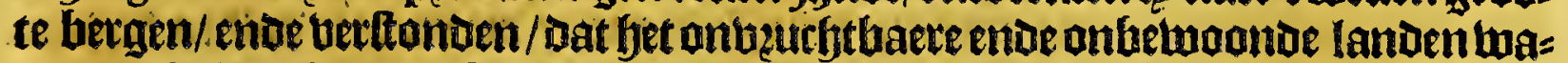

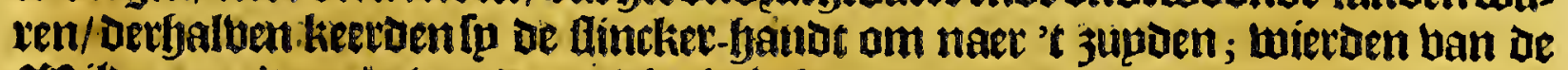
TBitoen aen't epnoe ban de pzobincie de los Vaqueros een tuepnigh betchadiagt.

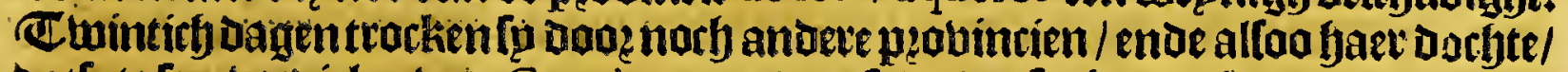

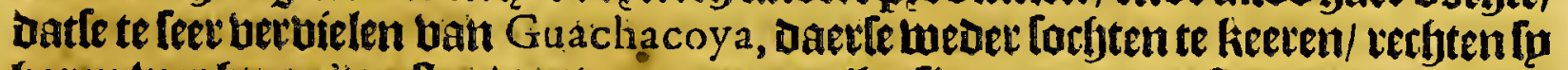

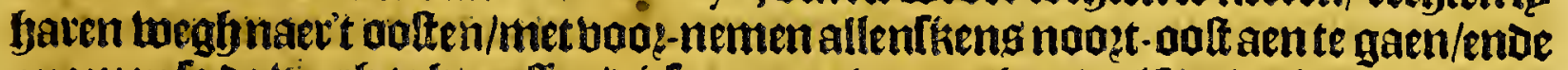

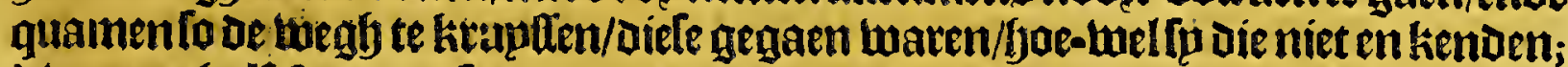
twagnubalf $S$ epr. eer fp aen dien pas quamen/ende fadoen dep maenden befich getueelt fints Datle bau Guachacoya Thepuen; enDe hae-wel fp geen geberbten en

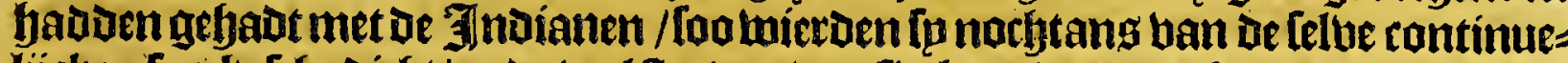

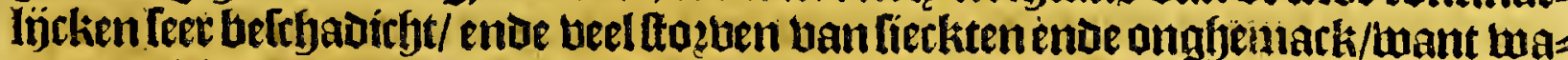
ten ban kleederen armelijek berlien/ ende badoen ban alles groot ghebzeck. A9et Dele aimaede quamen Iy den leften Novemb. aen Rio Gran de, bebbenoe int gaen ende komengetracken dęu yondert en uỷftich leguén, ende beclozen fondert iman ènoe tacljtenitich peetaen/fonder ar Junoianen tot baten sienfte beboozende. Zlen

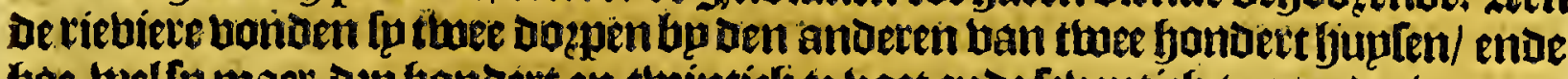

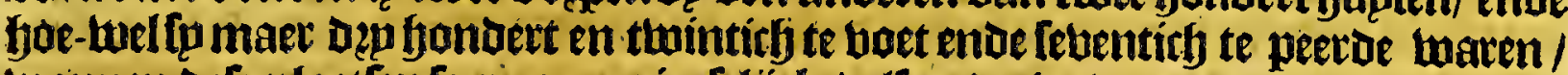

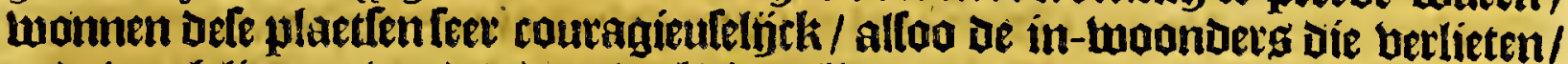
ende tweghliepen; honden taer beel hictualie / en ebentwel tozuen daev beel ban't

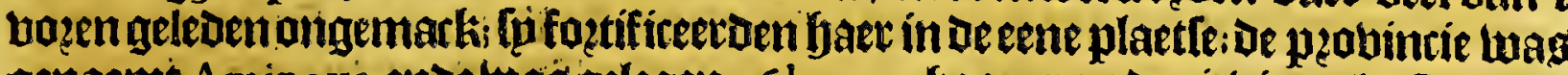
genaemt Aminoya, ende twas gelegen I 6 leguen booger op oe riebiete als Guachacoya, Daer fu naet toe twilden ketren. In't lefte ban lanuarius begonden fp't fyout tepzepareten tot de bzigainting;

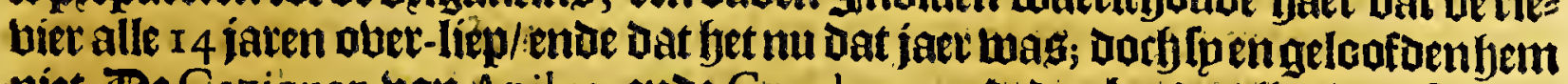
niet. Je Caziquen uan Anilco, ente Guachacoya deden bevoe allés wat Ip konts Denom de Spaegniaerdente beiende te bebben / infonderbept die ban Anilco, die Jaer bet Tagh banmantelg tegen de koube; melcke gemaeckt wievon ban kitupot als malbe / geb bende dzaepent als blas : Daer. fu ouch faet twanter ban maeckten.

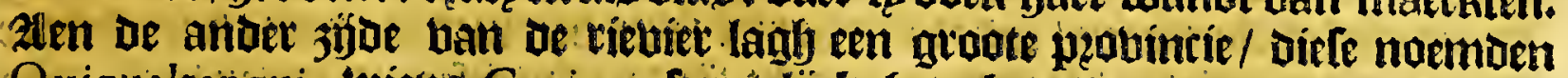
Quiqualtanqui, miens Cazique ferretelïk bem betepde om oe 5 pactniaer:

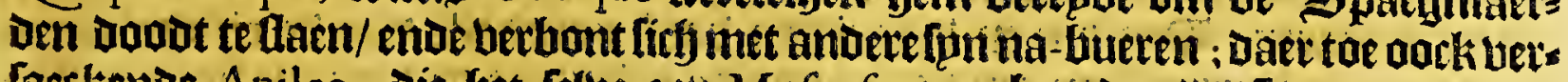
foectsende. Anilco, die fyet felve aen Mofcofo openbaet de: De Spaegniaetden

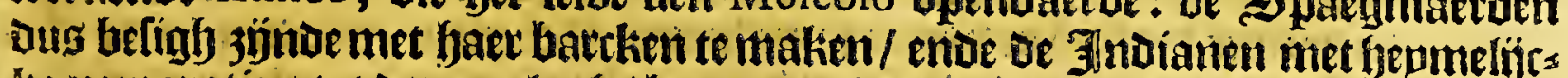
ke pzeparatien tot den aozlogh / hegan de rievier te haflen den tljienden Martij, foo datfe den achthienden ter poozen in-quam vait de plaetfe daet de $\Xi$ pae= gniactoen twounden/ende bet lanot liep lual thinticly leguen bijot ende jijots ander/dat men daer met ramoas aber boer. Ben leften April begon fjet water te ballen / dan foo betlanghfaem dat den twintifflten May men de tweglen

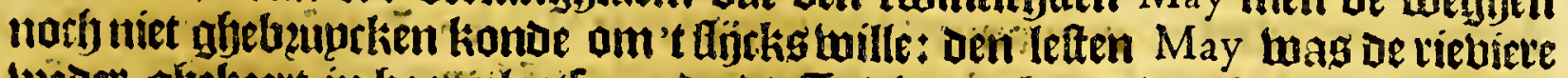

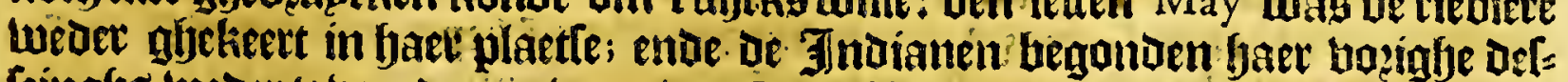

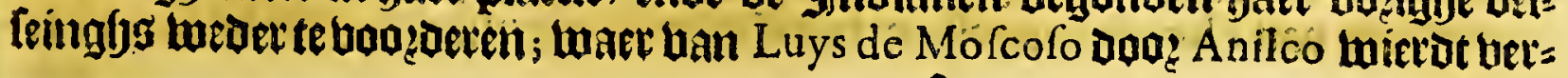


$15^{2}$

Florida.

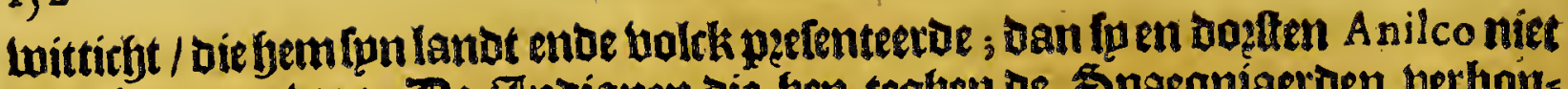
te beel vertrouben. Be Jnoianen die ben teghen oe Spaegniaeroen berbon=

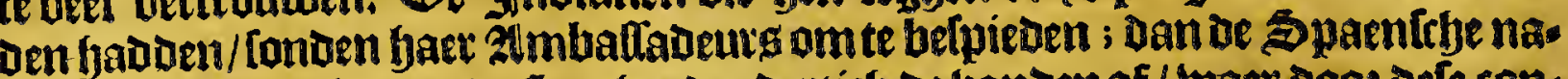
men Die gfjebanghen / ende floeghender Dertich De handen af / waer dop defe ron:

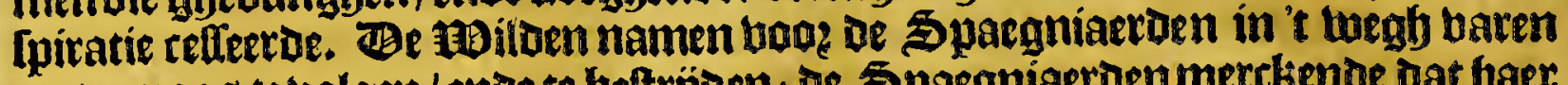
met ranoag te bolgen/ende te beftrijoen; of Spaegniaeroen merckende dat baer befoubenifle Daer in gelegen luag/ Datte baer baelt ban bier maeckten/feloen yaer feuen fryepen toe ten beften dat fp konden; Dooden baer betckens/ upt-gyenomen aththien; ende gaben aen bepoe de Caziquen elck een paet om boote te teelen;pzoc bideeruen ranoag om 33 peetoen/ diefo noch aberigh badoen in te boeren; ende ine Caziquen ban Anilco ende Guachacoya bebeediche hebbende/embarqueeroen Ip in oefe feuen barcken tot dep fondert en büftich Spargniaerden/ en in elcke bp

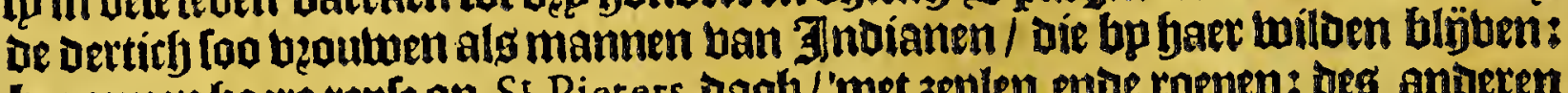
begonmen faere reple op $S^{t}$. Pieters.Dagh/'met jeplen ende roepen: ofs anderen Daegbs wierdenโp gelwaec een blote ban bel ouplent ranoag/ Die tegen baer quas men/ enoeeníghe loogroot datte aen elcke 3 jo büf-en-twintich riemen badoen/ ende bolvolckis/ diegfjetueloigy in't aen-komen op de Spargniartoen met pj"s

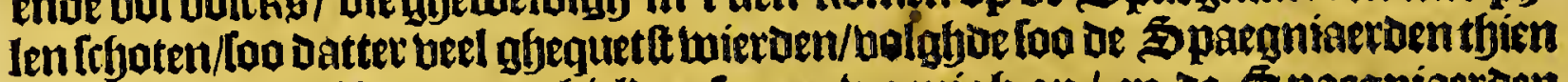
Daglyen langh. Daer naet hieloen fe een leepnigh op/ en de Spaegniarroen [etten r o o man met 8 peeroen aenlanotom biveses te balen aen een klepn Doep/ or

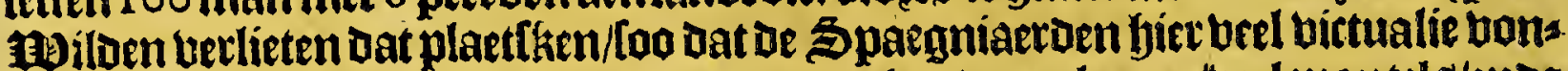
Den/ende beel Chamoifen, witende van aloerfande coulcurett/herl mantelg/ende eenlijfte ban fïne marterg / al met klepne peetlen ghegarnicert: Doch de Indias nen quamen weoer [oo lubitelijck aen/Dat fp gaer moelten't Iryeep begeben/ente

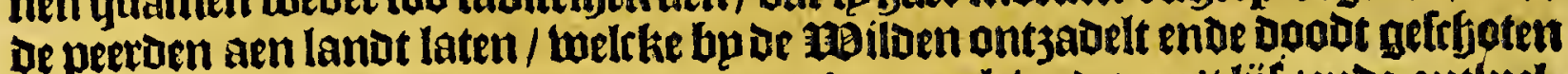

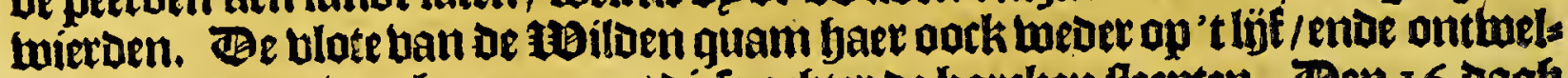
bingoe baer een ban haec ranoag diele achter de barcken flecpten. Ben 16 dagf uan haer bopagie berlozen fo pooe de temeritept baneen Spaegniaert (Die bem

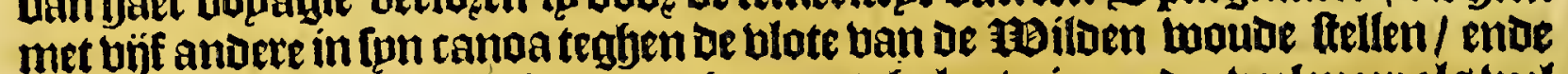
alloo de Generael eenighe Lonut am bem op te balen/ gingender beel meer als wel

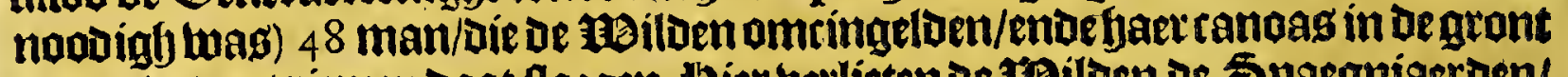

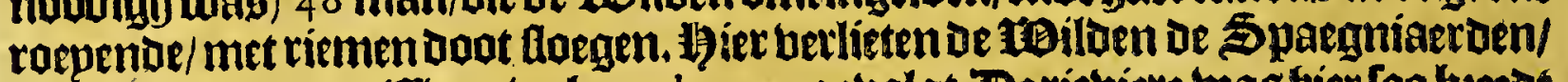
hedbende nu naer gillinge wel 400 leguen gebolgt. Be riebiese wag hier foo bąerot

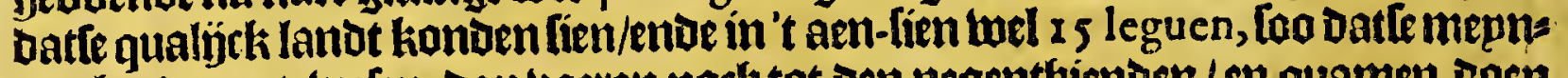
den lu de 3 ee tewelen; Dan voeren noclj tot Den negentbienten / en quamen Daen aen Jee / ende een Eplant daer bolkt op twoonde / Daerfe toot-namen eenige das

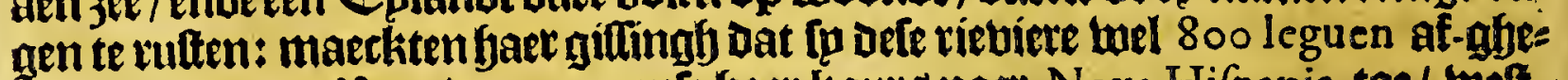
fomen waren. Ban daec namenle haer kourg nate Nova Hifpania toe/ weet-: waett aen/hebbende Florida op De rechterfhand, - Den büfthienoen dagh bonoen

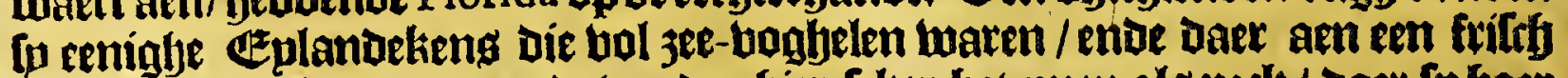
ftrantot vol gheboomten / enoe bonton bier feker betumen als peck / Daer fu baer betclien met calefaten / laghen maer acht \$ndiamen diefe niet eens en bzaeghoen waer [p warell. Den Dep-en-býftichtlen Dagh naet Datle ban of rievier waren

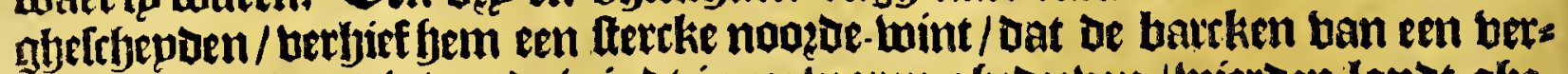
ftropoen; De twee die ban oe twinot in jee waren ghedzeten / wierden lanot ghes maer Daer [p op aem-hieloen/enoe fetten bepoe de bartken op Deogh//en gheraeck. ten op't landt: Conoen twee man noch oes natbta om de anoere büf barcken te loecken; ende te lanot-waert in treckende / wonden frberben wan aerde frfotels als in Spaegnien gbemaeckt moeden / ende daer naer een Fndiaen die fpaenlef berttonot / welcke haer bertekerde datte waren ín oe pzobincis ban Panuco: water fo epnuelïck al te lamen quamen/ende ban daer te Mexico. De Capitepnen Diego Maldonado ende Gomes Arias, haduen met faer fchspen Dęp diberictje repten op de kufte ban Flosida getweeft om den Generael te gemaeten;ende dit jaet 1543. 


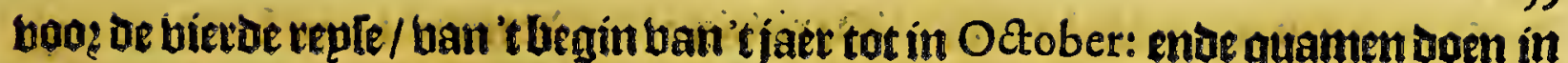
teljaven ban Vera Cruz, en betfonden de dopat uan Hernando de Soto, ende t ghene taer bozoer gheyalteert was.

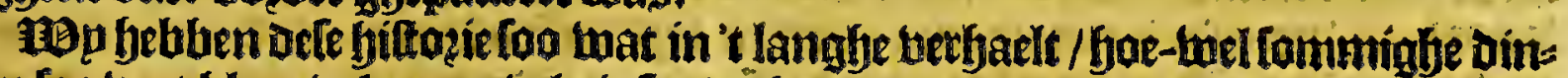
gen foo bat blaeutu komen/als inlondetbept de groote menighte ban peetlen/loo

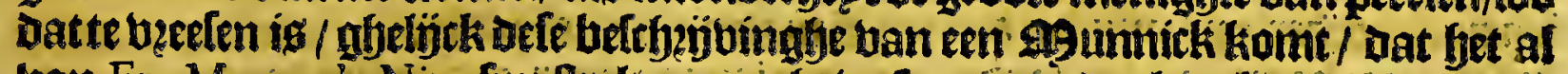
ban Fra Marco de Niza fort fteken mongt weien een peder Kan bet gelooben met

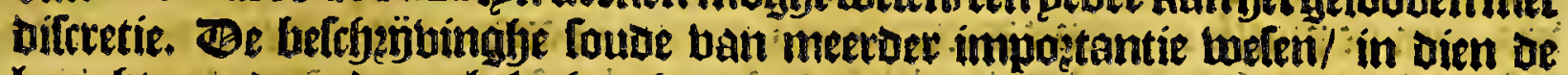
booghten ende andere gfolegbentheden ban oe plaetlen wat beter twaten aenghe

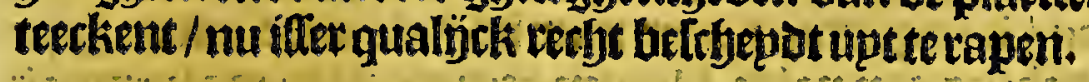

1) neghende Capittel.

De ontdeckinghe van F $L$ OR I D by de Francoyfen voor-ghenomen, onder het beleyt van Iean Ribault.

I Pe booz-gaente Capittelen bebluen wu bethaelt bet luces ban ben tocht ban

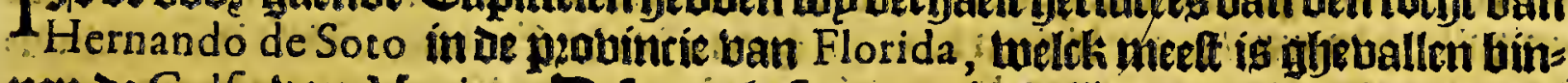

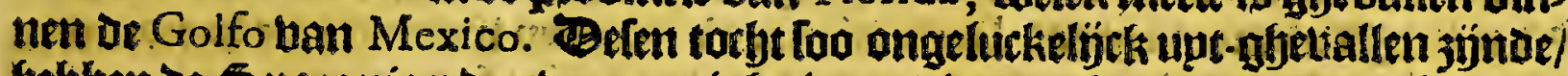

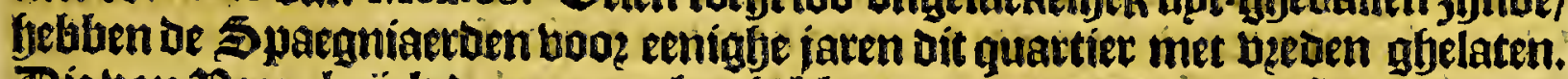

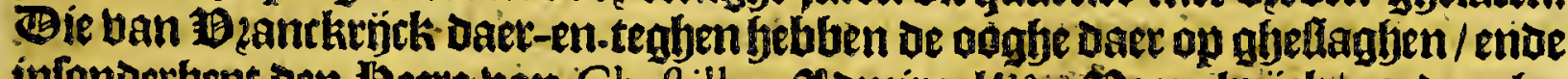

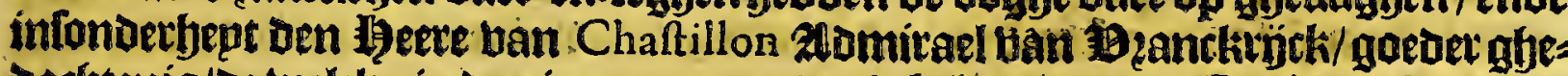

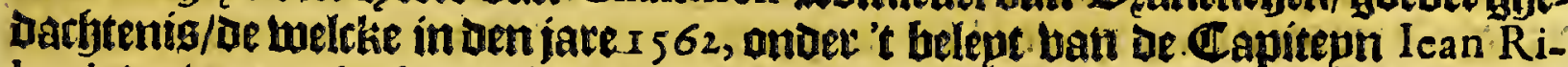

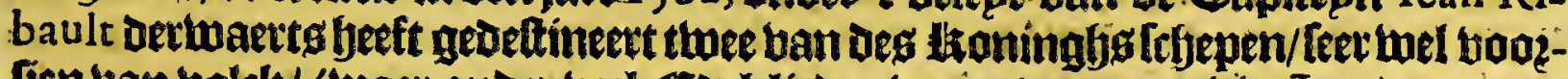
lien uan bolkk/ (waet ander beel Eedel-lieden twaten) ammunitie eñ andere noots faeckelïckfyeden. Dele jeploen upt sancktyok in Februario, enoe naet twee

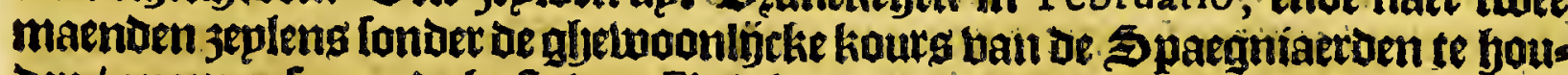
ben / quamen lin aen de kulte van Florida, aen een kape welckfe noemoen Cape

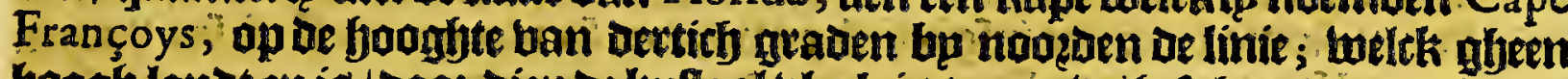
boogh lanot en is / oooz dien be kulte al black is / maer berbeft bem Doo? de booge

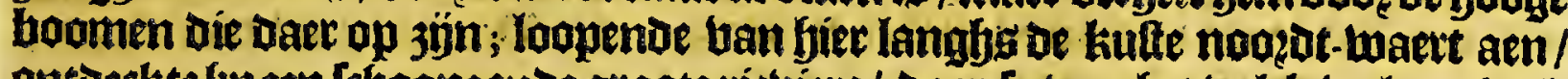

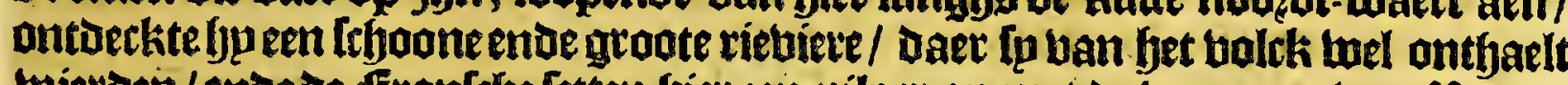

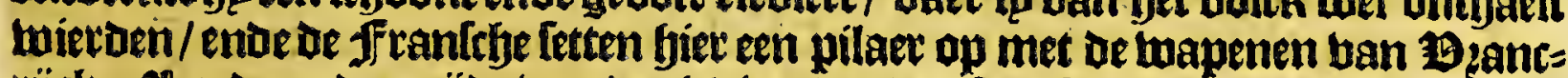

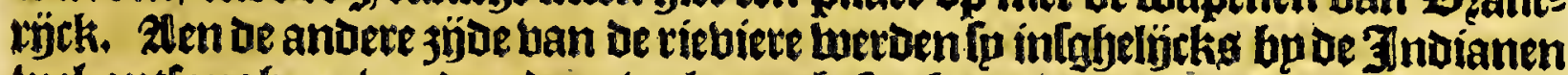
wel ontfanghen; bonden daer beel maetbelpe-hoomen toobt en wit / ende beel

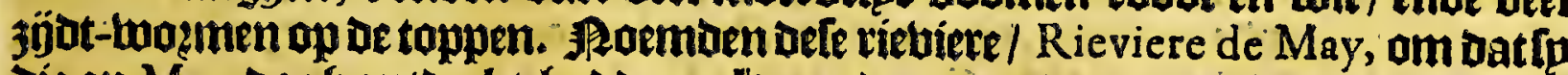
die op May-daghontoeckt baoden. Hozts daer aen bouts jeplende / bonoen fo

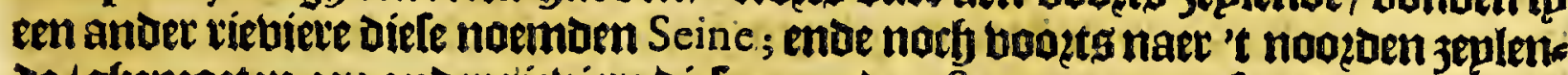
we / ghemoeten een ander riebiere diele noemaen Somme; ende fes mülen bozat

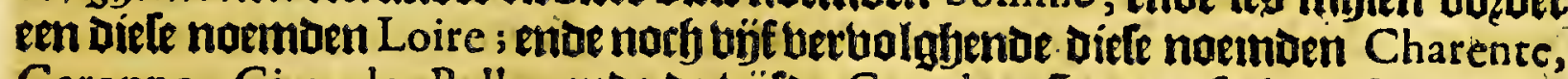
Garonne, Gironde, Belle, ento de büfoe Grande. Soa datle in de luatie han minder als feltich mijlen bonben neghen ricbieten / ende beel andere veetmoiche = Den. Boeren al boott noozot-waett aen om de riebiete Io rdan te forcken; ente naet dat lu loo mat ftoems badoen upt-gbeftaen/, uonden fo een riebieve diefe

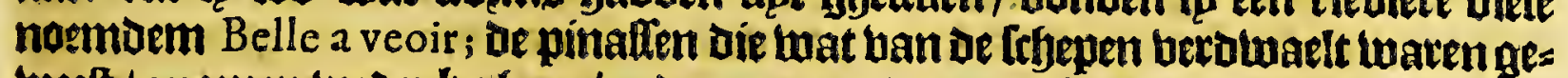
beeft / quamen weder bp faer/ ende rapoeteerden een riebiete ghe bonden te fetb: ben noch grooter ende fejoonder als de boo gaende / Daetle naer toe bielen/ ende antkerden in de Ielbe pp thien batem waters / noemoen defe riebiue Port Royal, Whelegen op be fooghte ban twee-en-Dettich graden. "Clands daet ronbt-om is tronder plaplant / bol ban groote boomen / loo epsken als redar-boomen/ente lentilcus onder aen de gronot / ghetuende een leer goeden reuck ban ben: ín dele boficfjagie lwarew menichte ban talcaenlche-baenen / ende boendeten / pattiflen ende ander gfjebogelte; ende beel wilde dieten: in te riebiere wietot feet goede biffy gljebanghen / ende inlonderthept een fookte diefe noemoen Sallicoques,

(1) 3 melcke 
154

Florida.

trelcke foo groot 3 inn als kitetten.

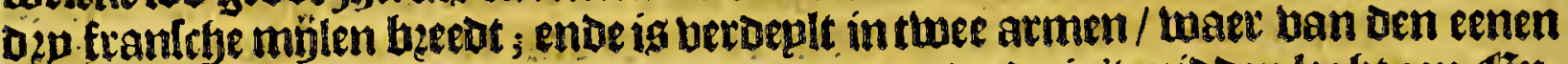
loopt naer't toeften/ende dander naer't noogen/ende in't midoden leght efn ezps

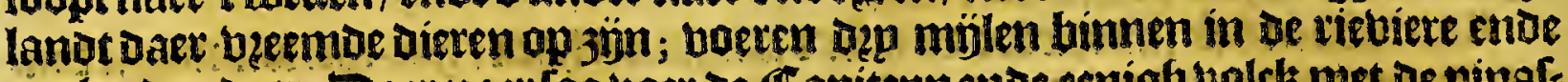
anckeroen Daet. Baer naer Loo voer ue Capitepnende enigh boldk met de pinafs

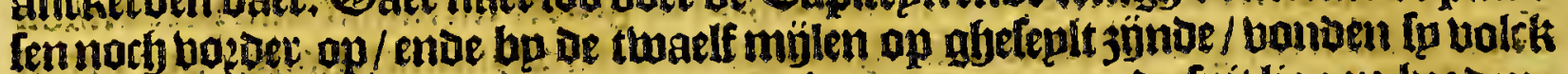
welc't voop baer bluchten/ende lieten cen jongen otter aen be fjit liggen bzaden; waevom De vlaptle genaent hiett Cape lucerne; bondeneen ander arm ban de

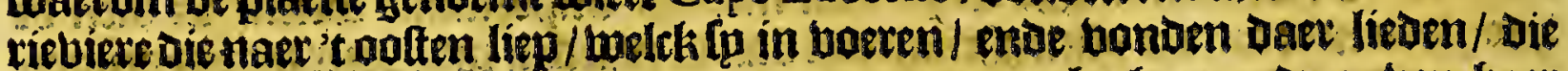
cett trhouw van yaet waren / oan quamen daet naet bu baec ende gaben gaec

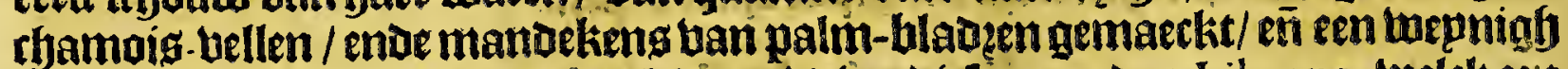
peetlen. Banden nocheen ander klepun riebiere diefenoenden Liborne, welckeen fraep Éplandt maeckte / waetle mede een pilaer fteloen met de wapenen ban

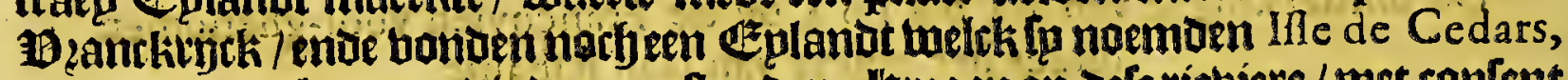
om De frhaome boomen Die daer op ftonden. Itregen op Defe rietiere / met canfent van de Haningh van dat quartier/ twee Jndianen am met te nemen/die eeth leet onwilligh twaren/maer bletien daer na geetne bp de frumfebe. Defe wifien wons

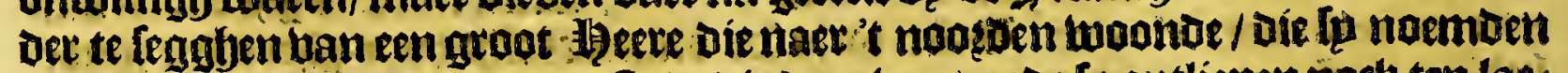
Chiquola, ende een aber quete ftad Die daec bag:ende fo ontliepen noct ten lae: ften met de boot. Capitenn Ribaule gaf fier aen bet bolek te beritaen / Den dierilt

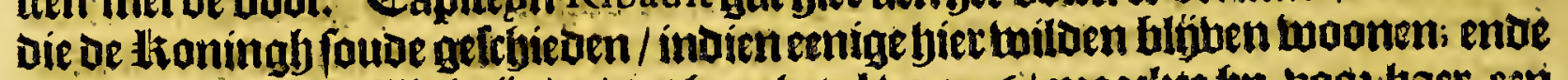

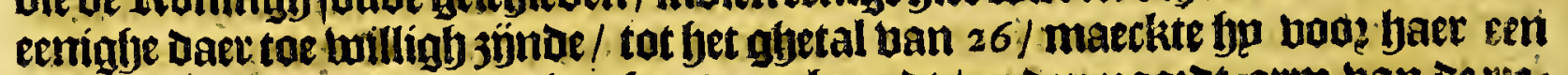

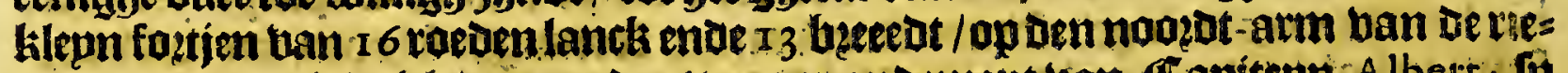
viev/ entoe liet dit bolch daet onoer 't tommanoement van Capitepn Albert; in noemben 'tfott Charles Fort, ende de viebiere Chenonceau, Ban oele Port Royal

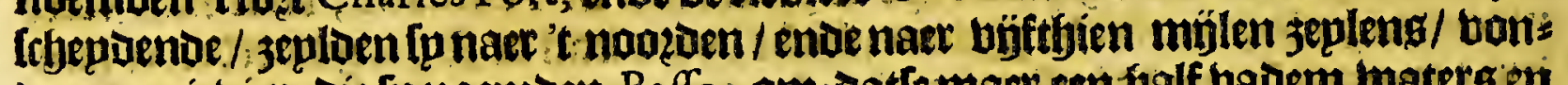
aen een rieviere die [p noemoen Baffe; om datle maex een yalf badem watergen

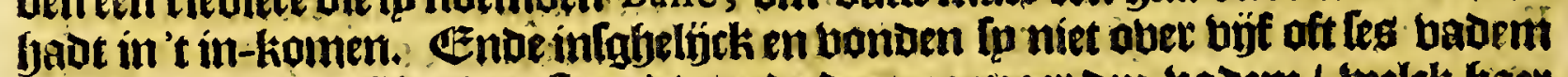
waters / welles mịlen ban ftranot; enoe baet na maer Dęp badem/ welck faet

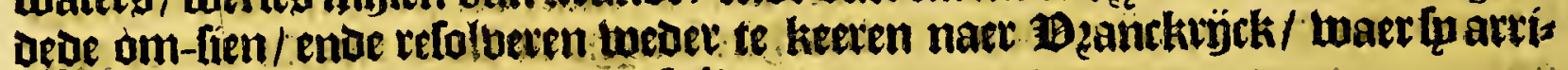
veeraen [ander tegbenfpaet den 20 Iulij i 562 .

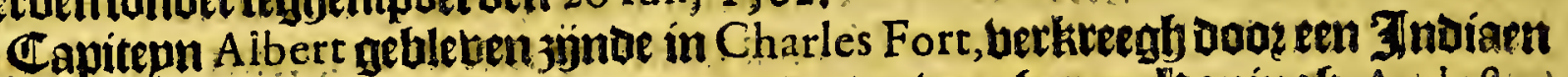

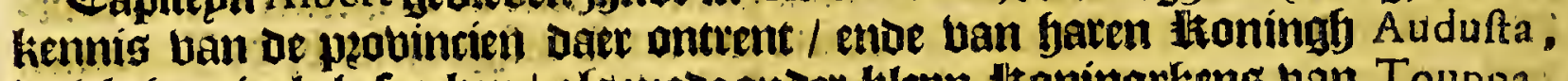
welch hp ginck beloecken/alg meoe ander klepn thoningxkeng ban Touppa, Maion, Hoya ende Stalame, van welcke alle fju mel onthaelt wiett; eñ de beiertte

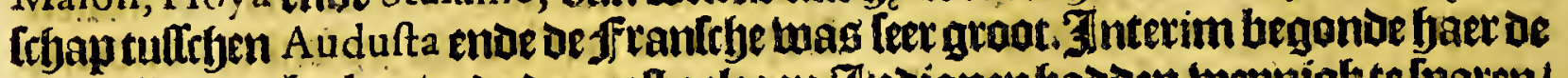
victualie te ontbeken/enoe oe naelt gelegen Indianen fadoen twepnigfs te Laten/ want maetten felfo baer nautw befelpen met woetelen/. ende andere dierghelǵcke

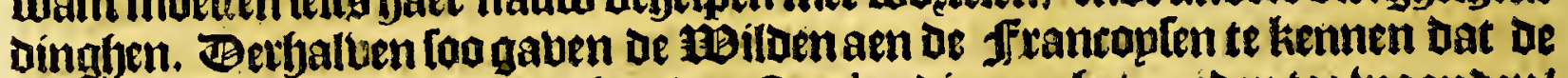
Honingh Covexis, ende Ipn bzoeder Ovade, dienaex fet jupden toe twoonden/

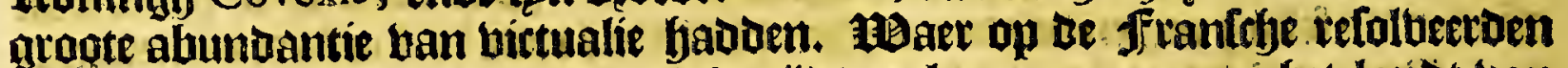
Derwaet te 3 eplen/ ente naer eenighe tijot jepleng quamen aen fet lantor ban Ovade, welck is ofbeleghen aen be rieviete Belle. Su wietaen wan Ovade wel onthaelt/vonoen fon bunghel behangen met tapjt ban beeren die gevertwet was rent liregen baet pinalle bol ban Maiz ende hoontiens / enoe lieetaen fon toedec

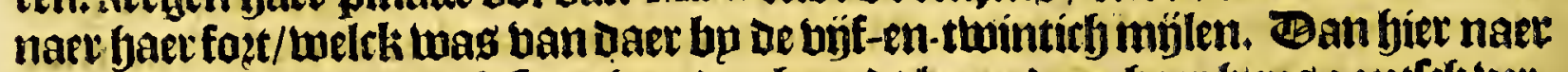

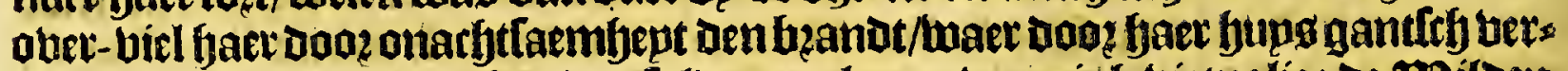

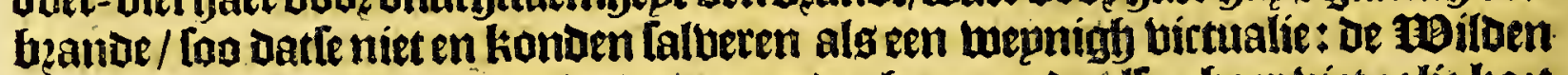
timmerten faer in een dagh weder een ander fyup; ende alloo fyaer bictualie toet upt quam/ baerenfp weder naer Ovade, die haer meder peabidertue ban Maiz enee boonen/ende benefteng dat gaf noch eenighe frboone peetlen/thee füne ftes= nen ban rriftal / ende [eecker minerael ban filuer / welck bp lepoe dat wel thien Dagh-replen van daet ghetunden wierdt aen feecket ghebergbte. Defe beder gbetio: 
Het vierde Boeck.

ghekomen 3 junde te Charles Fort, quam daer een mutinatie ander't bolck doog to bardiclyepot ban De Capitepn/loo dattefem Doodt-dioegben/ende kolen een ander Capitepn met naeme Nicolas Barre, pie hem feer tol queet in funchatge : Dan alla

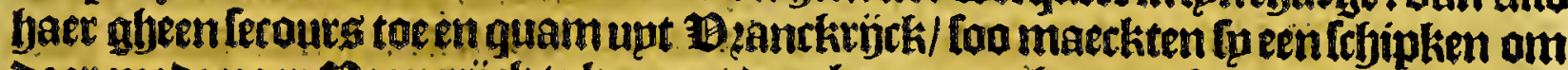

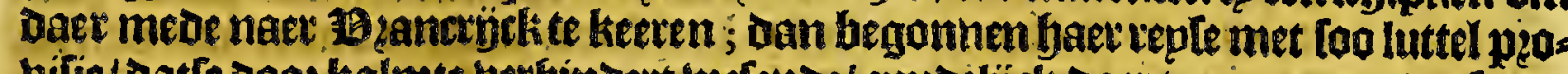

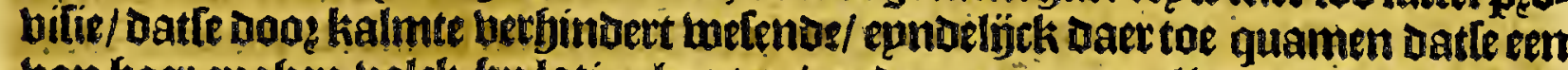
ban haer equgen bolck bu lotinghe aten/ enoe naer grote ellende quamen noch

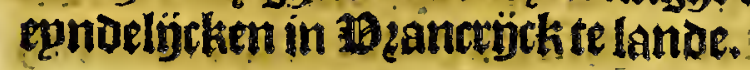

\section{\$2t thiende Capittel.}

De tweede voyagie van de Françuyfen naer $F L$ O $R$ I $D$ A onder het beleyt van de Capiteyn Laudoniere.

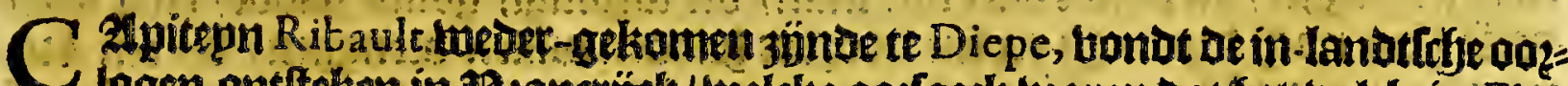

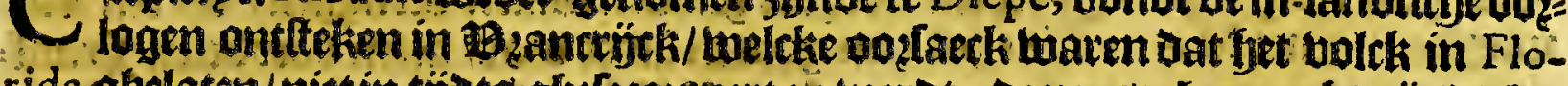

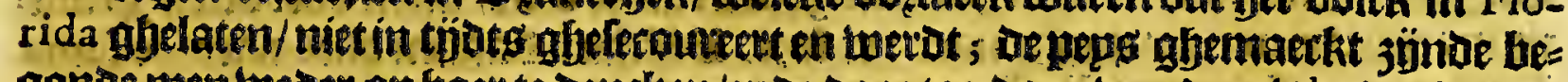
gonoe meritueder op fage te dencken/ende dooe toe-Jaen ban ben A dmira el voo-

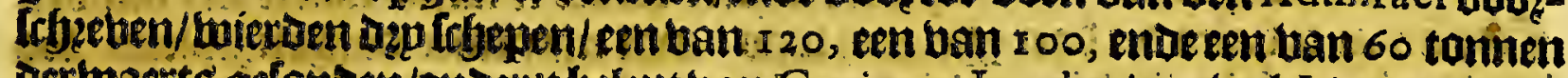
dertmaerts gefonoen/antet't belept ban Capiteyn Laudoniere, fuelck den $22 \mathrm{~A}$ pril

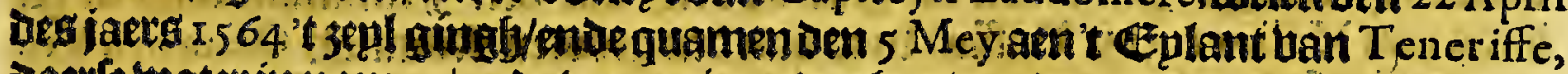

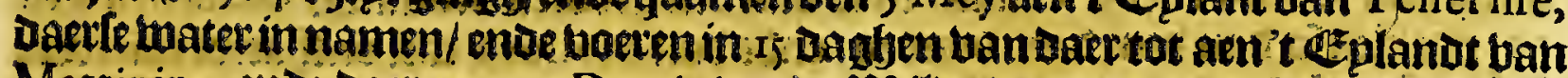

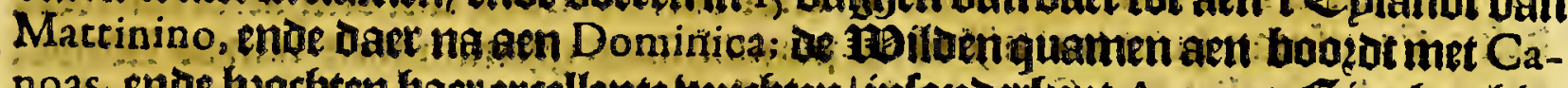

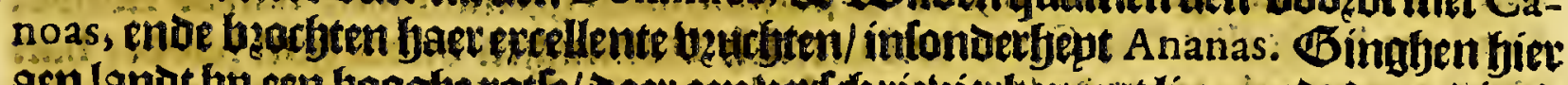

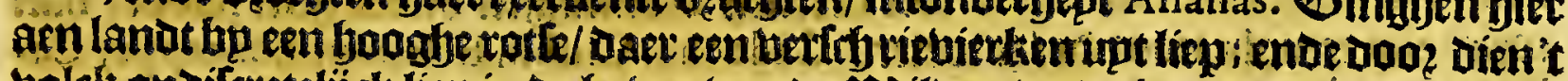

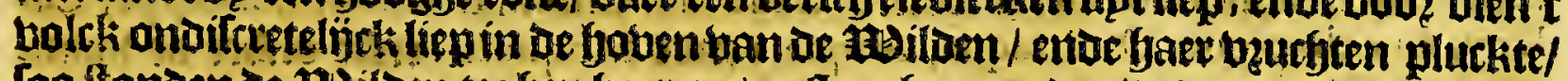

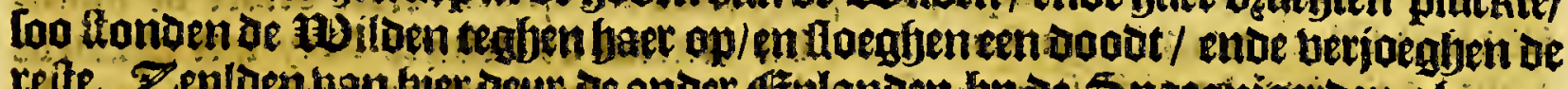
reite. Zeploen ban bier oeur ue ander Gulanden bp oe: Sparghiaeroen ghecon: queftert/ala $S^{t}$ Chriftophoro, Santos, Montferrate, la Redonda; Anguilla ento Anegada, entoe quamen bet1 22 Itn, enhanden in Florida aen ent klepn ríeviere

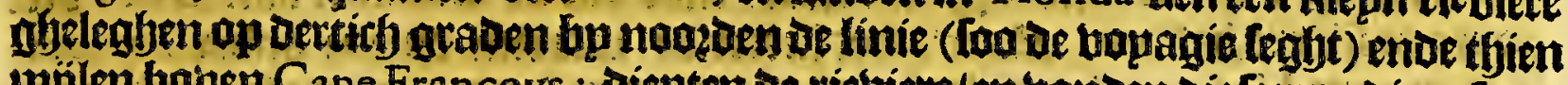

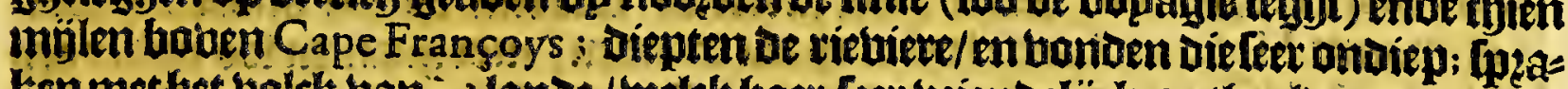
kenmet bet bolck ban , lande / welck faer feer beqendeligek antfjaeloe / noemoen

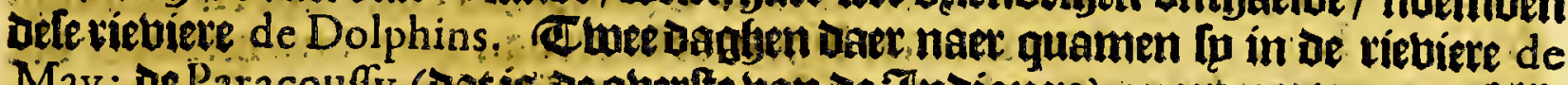

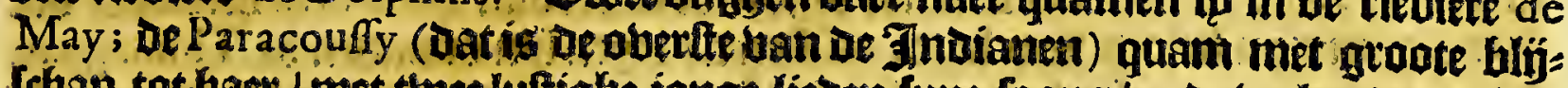
lchap tot haer / met thee luttighe jonge-lieon (pne foons/ ente beel ander bolcx; thoonden haer de pilaer bo Ribaulc op-gbevirgt / diefe met lauvieren ghektoont badoen: oe Paracouffy fon naem toag Saturiova, enbe fpn outte loons naem A thore; welck aen Laudpniere gafen logghbe ban filber. Boetent oe riebiete op om die te ontoecken/ be miloe contimuelíck roepende Ami, Ami. Quamen bp een

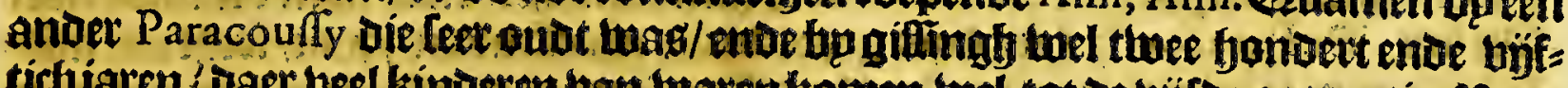
tichjaren yaer beel kinteren ban watenkomen wel tot be biffoe genetatie. Bon= Den fier en feer plapfanten bewb/ al bal cedats / palm enbe fautier-boomen:

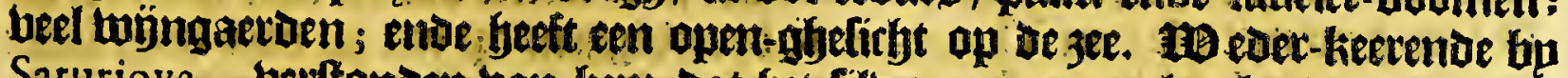
Saturiova, berftonden ban bem Dat fet filber quam upt bet landt ban Thi-

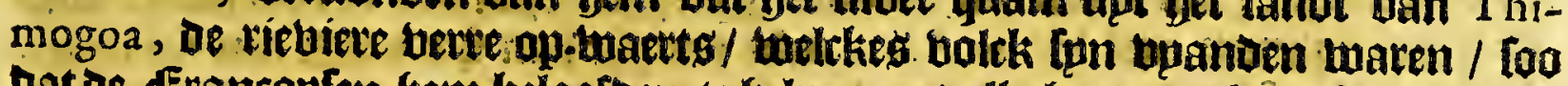
bat de ffrantopten fem belooften te felpen met alle baet matht oelen Thimogoa befpeinglen. Boeren ban grier biex mibten naevoe riebiete Seine, ende teg

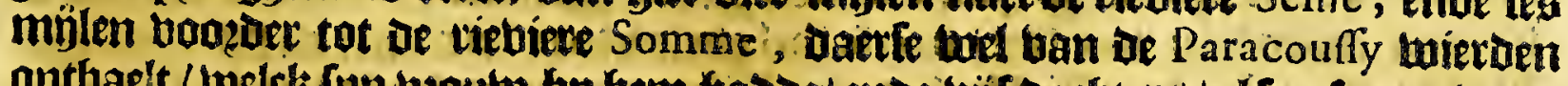
ontbaelt / twelck fun uzoutu bp bem faboe/ ente bóf bocljters / al feer fraepe bzou= twen. Be bzoutue gaf aen Laudoniere feecter litberen ballekeng. Jangberelol= beet beblentefyaer neder te than ontrent Rieviere de May, om dat daer abun= Dantie ban victualíe twag/ende fo goeden apparentie om fier naer filluer ende gout

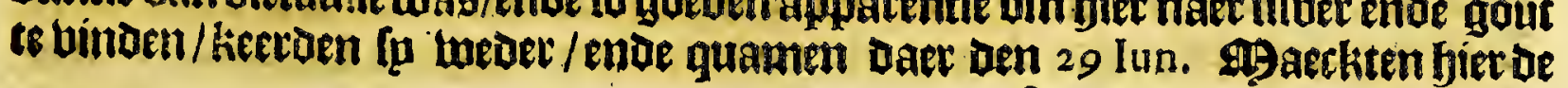


$15^{6}$

Florida.

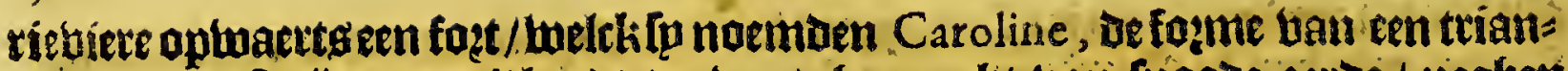

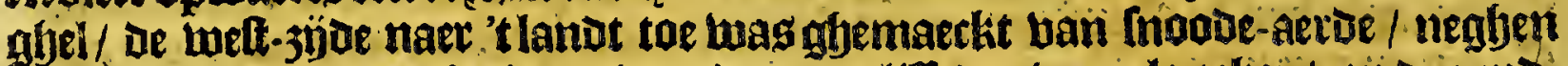

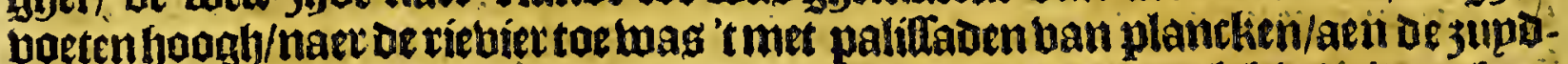

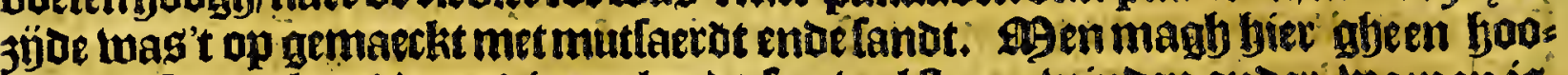

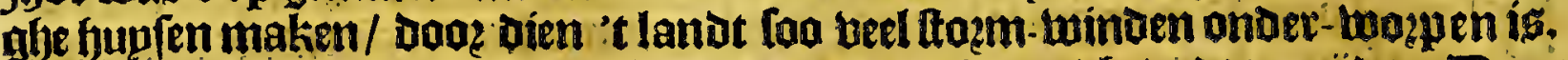

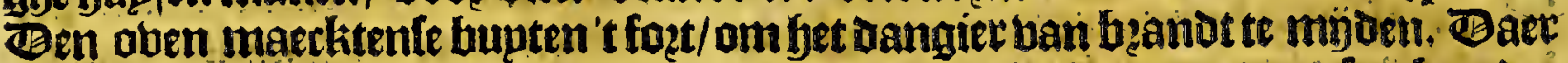

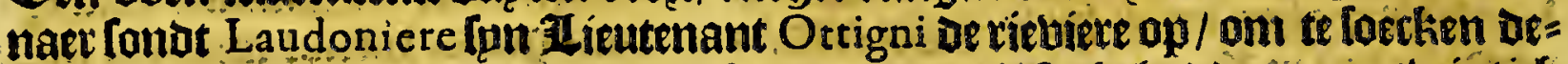
Ien Thimogoa, daet fem Saturiova loo beel van abjefeght jadoe ; thaet thintich mijlen weeghy/bondenfu eenige van dele Thimogoas, daerle in onder-bandelingh

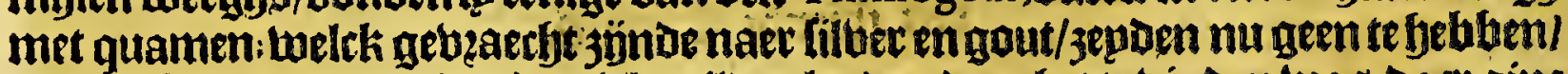
Dan Datfe wel pemant ban' walck wiloen!epoen daer bet te binoen twag; daer ginc en foloaet met faer/Dan alloo gp wat langber bertoefoe/boer Ortigni norf thien mijlen foogher / en bonot baet tun man / die toepnigh gouts badoe / ende fepoe

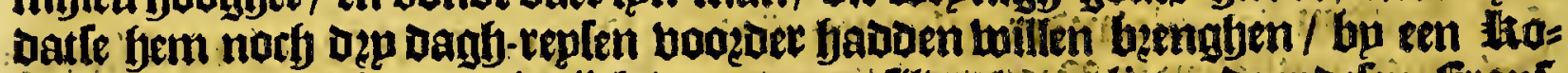

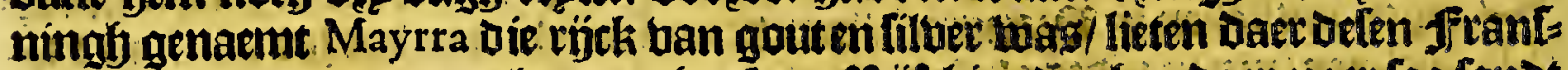
man/ende voeren te rugghe naer bet fott. Sigfthien Daghen baet vaet foo cond Laudoniere Capitepn Vafecur, ente antere tieder te lanot-waet in / om Den franfman te falen die Daer ghelaten twas i ende naet thee daghen jepleng/ foo

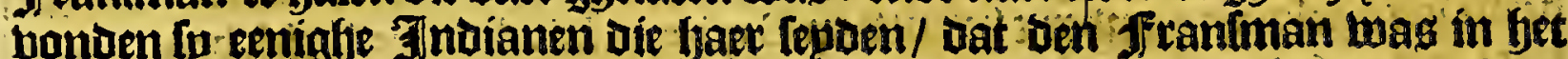
hupg ban Mollova, (dic 1Daflael mas banden grooten Honingh Olata ova Vtina) gbelïrkfy dan bem daec bonden/ente tan Mollova twel ontbaelat twierven:

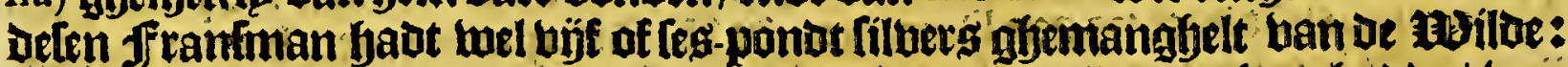

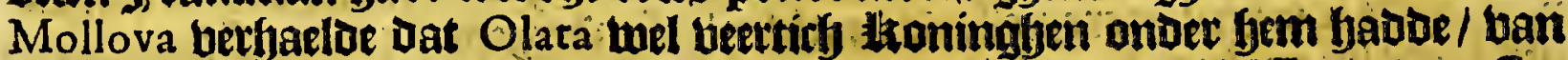
welcke hp eenighe noemoe/ te tueten/. Cadecha, Chilili, Eclanou; Enacappe, $\mathrm{Ca}$ lany, Anachataqua, Omittaqua, Aequeia enoe Moquofo : ente onder de upam= ten ban Olata' noembe ba Sacuriova, die ontrent de riebiete May Ipn ghebied

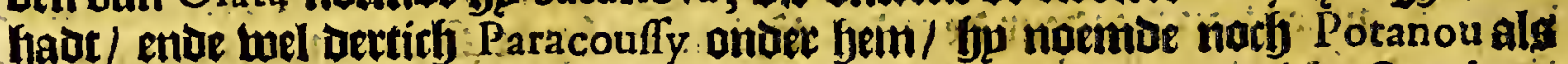
upanot van Olata, allmeoe Onatheaquá ende Houftaqua, van twelcke Onathea's

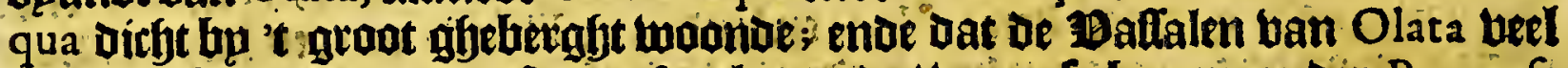

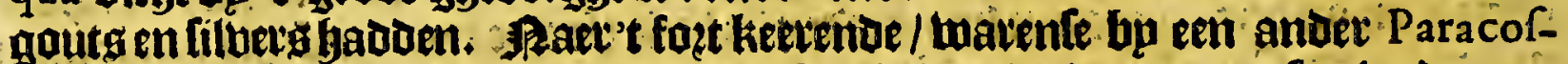

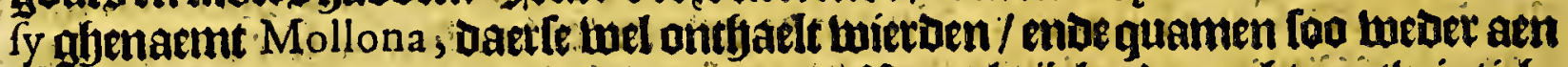

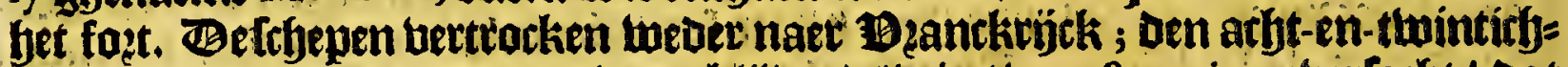

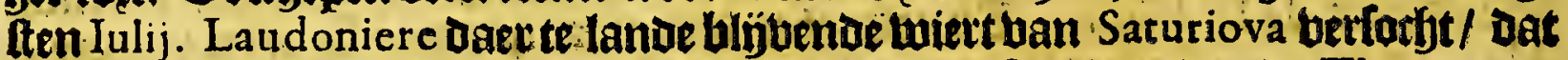

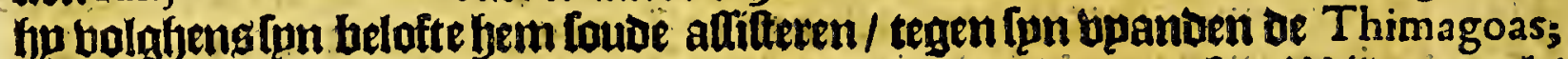
Dan Laudoniere exculeerue bem / Loo Dat Saturiova alleen met lon railoen trock/ ende bet loegf veel ban de bpanoen/ende beght eenige gebangemen't fupg. Laudoniere epfoftte twee van de ghetuangbeng / Dan twierden bem ghetwepghert; waet op hp met thintich foloaten trock in 't fupg ban Saturiova, ende beoc de

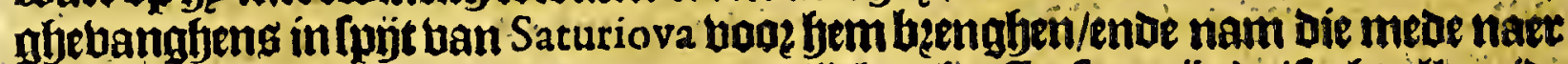

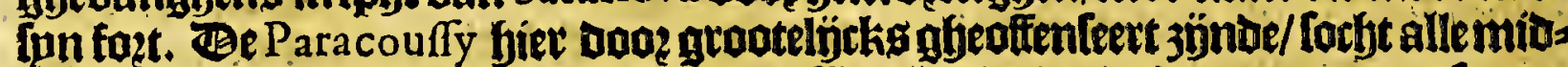
Del am fem te rebengeren/foe-wel bp diflimuleetoe/ ente doot-gaeng pzeTenten

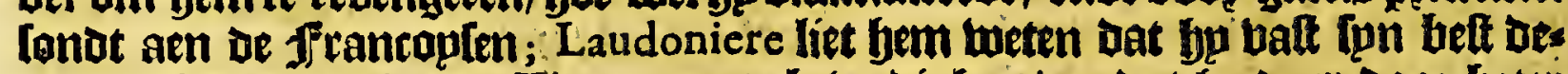
De/am fem met die ban Thimagoa te bebecoigfen/op dat fu daet booz beter

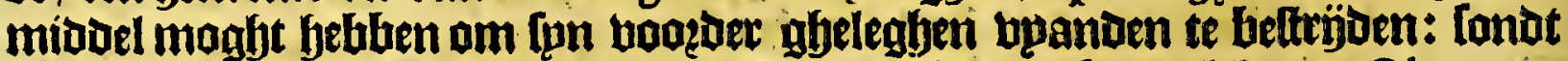
oe glebanghenten met $\mathrm{M}^{\mathrm{r}}$ de Arlac ende eenighe ban fon bolek aen Olata ova $V$ tina. Arlac Ithepue ban bet fotet on thienden ban September, ende boet de riebier foo berte op/Dat fp quam aen een plaetfe ghenaemt Maiarqua ontrent de

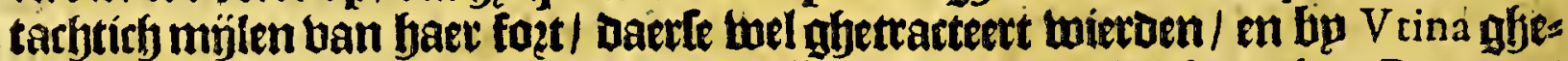
bzargt: Die Arlac bewilliggoe bem te aftifteren in de odelogfe teghen Potanotr; wiens plaetle fp ober-bielen/ bele doout laegfen ende eenighe gebangen litegen: ende Arlac quam Daer naer thupg/ende hagabt eenigf filber/ wepnigh gauts! ende andere dinglen meae/. Die V tina boo? pefenten fonot aen Laudoniere: - Barr naer foo complatteetoe een met namen Genre tegheng Laudoniere, Dorh

wietit 
Het vierde Boeck.

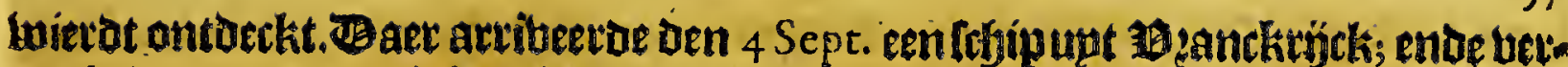
frock tueter met eenigh voles / bat Laudoniere niet en boeft betroutmen. De

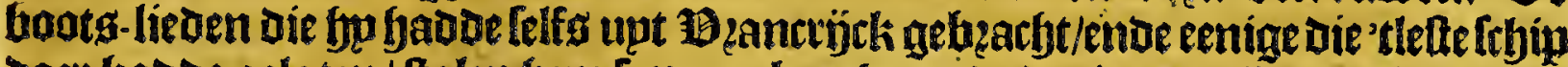

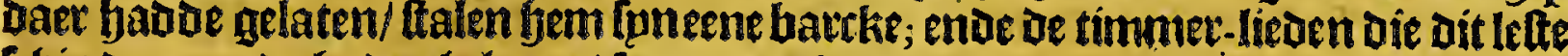

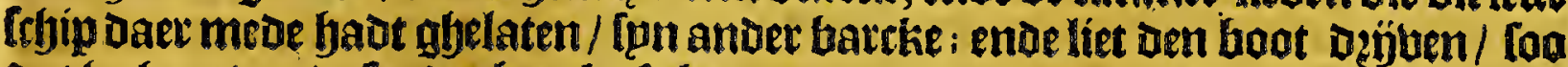
at bp hem bonat Conber batck of boot; bit volck ginckbier met rapben ontrent

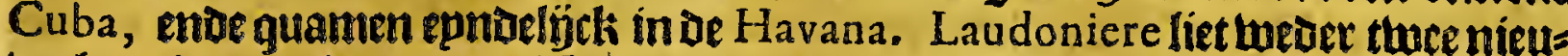
twe barcken maken/ban bjif-en-Dertich toet lantk op oe kiel: Dan defe thierden

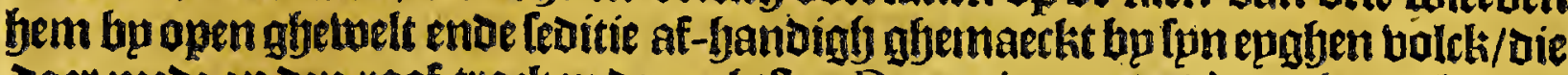
oaer mete op oen roof trocken Den achteften December, ende d'een gheraeckte tat in Ianaica, Dan wierot doog de induftrie baneenighe weder agebzacht op of kufte uan Florida, enue [oo naer't fozt / Daer Depeincipaelfe muting gbeftraft lueruen/ anter tot een exempel. Detuji dit bolch wegh was/biel bem Laudoniere befich met 't fout wel te booz-lien / ende en ander barckete maken / die in achthien das

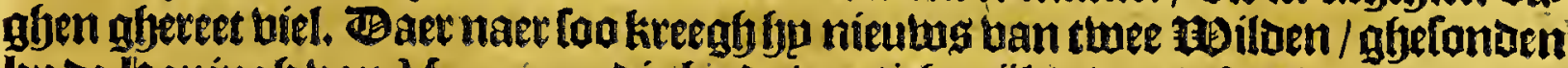

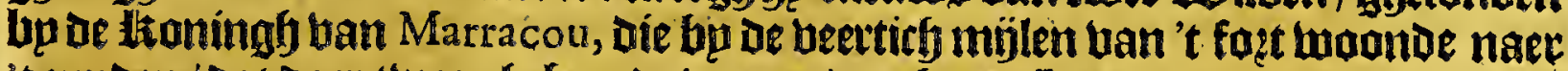

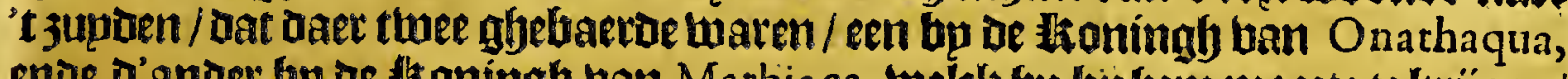
enoe d'ander bp de thoningh uan Marhiaca, welck fp bp fem maecte te krögen/ twaten thee 5 paegmiaetoen/aie büftbien faten geleven neffens andere gelalteert waren / upt dęp tefepen die ou de Martyres bleben tenen obet Calos, berfjelden twonder uan de macht ban den litoningh ban Calos, die de gaederen van dele

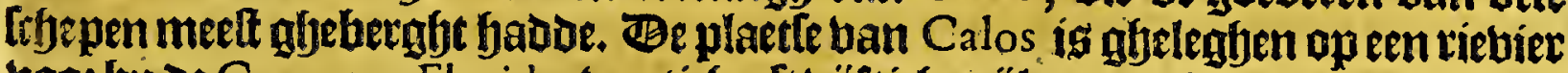

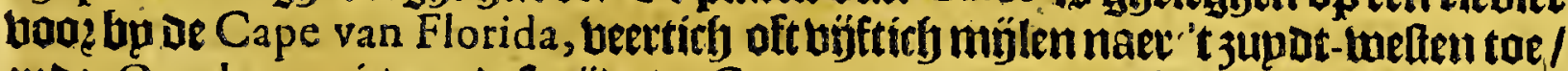
ande Onathaqua is aen defe 3 jud de Cape naer 't noazden / in een plaetle die in de kaetten werot gfonaemt Cannaveral, op' de hooghte ban acht-en-twintich gtas

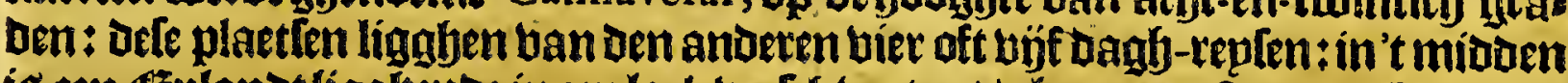

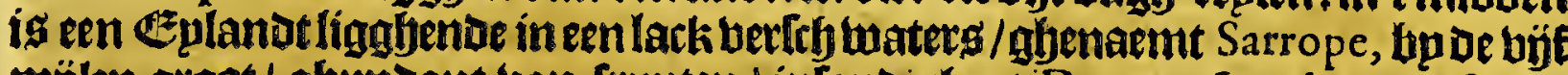
mölen groot/abundant ban frupten/infonderfept Dayen. Laudoniere contot

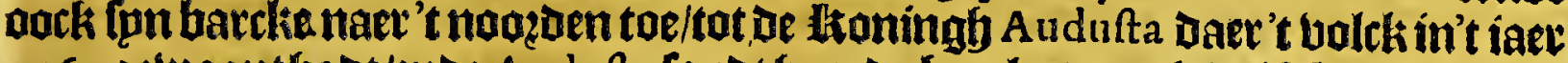

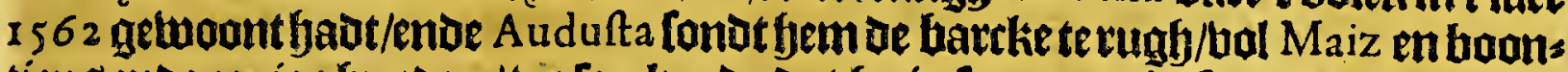

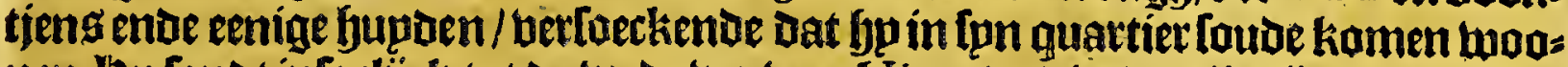

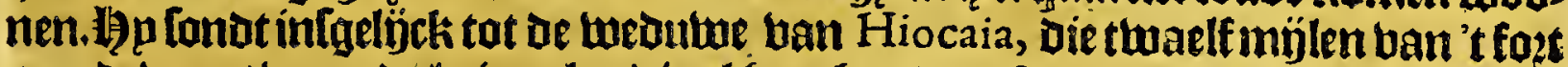

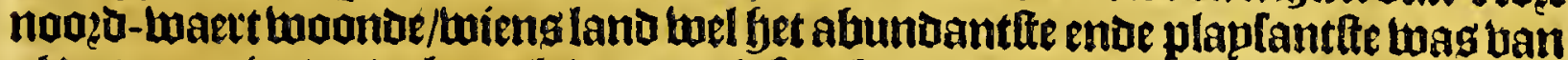

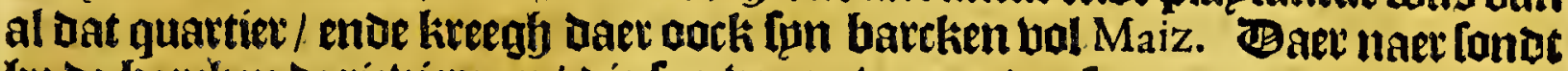

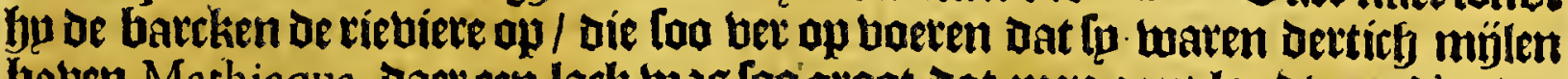
hoben Mathiaqua, daet een lack was loogrout dat-men geen lanot aen Dandet

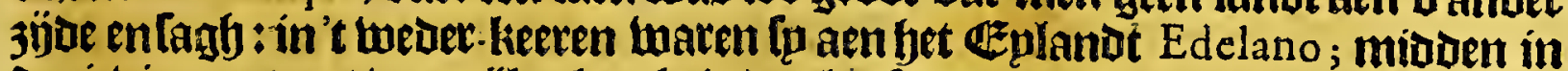
De riebiere ontrent Dap mijlen lanck is oeplapfantle plaetfe ban de twerelt. Ban daet quamen li naer Eneguape, Daet aen te Chilily, bandaer te Patica, ende ten Ieften te Coya, ban daer nimghen fp telande V tina befoecken/ende daet bleven ceniglye op Ipn berloeck bu fyem. Befe berfyaeloen ghetweelt te jön in fet landt ban de thoningh Hoftaqua die leet machtigh wag / ente naelt ghelegfen aen te berghen ban A palatci, aen weltker boet een froom upt-komt/ aaet de kBilde fil=

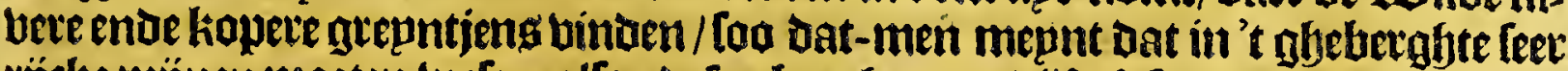
rýrke münen maeten twelen:alloo delen betofy maer büt oft les dagen meer naer' noozat- weften twas gfjelegen/[ou mepnoe Laudoniere, fun wooningh twat meet

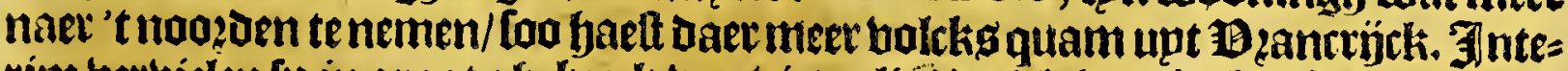
rim berbielen [p in groot gfjebeecl ban birtualie / welck haer bp blef ban't begin

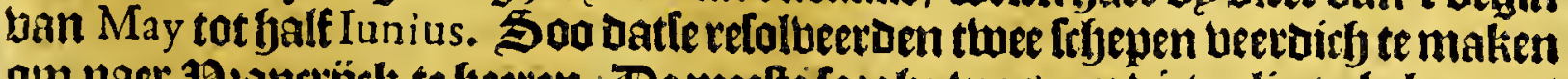

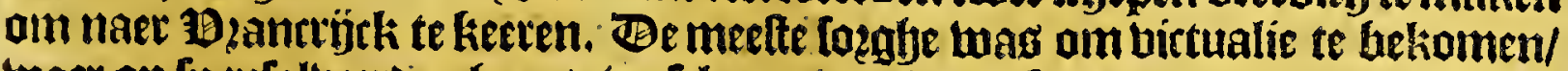

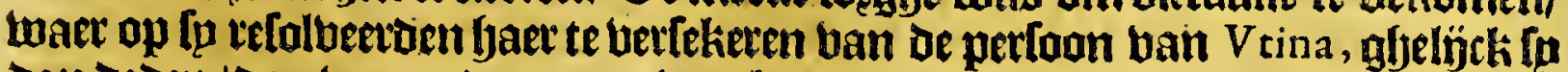

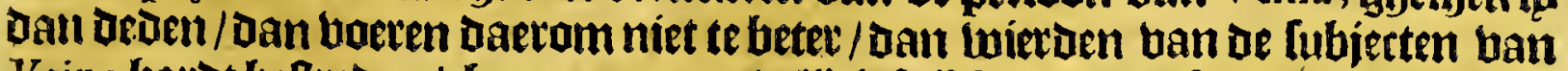
$V$ tina barot beffreden/ bequamen equdelícli luffitante peobifie ban Maiz, mee 
$15^{8}$

Florida.

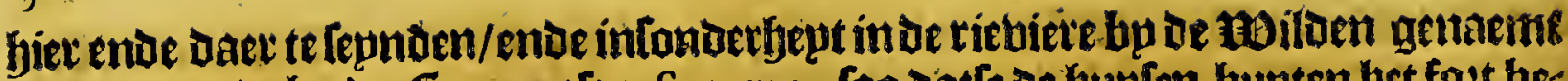
Iracana, ende bp de frantoplen Somnse; foo datte de fupten bupten bet foet be: gonnen af te beeken / als mede de palifiade aen de water-jyoe: Dus doende jündel

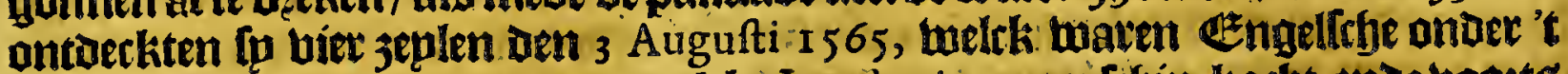
belept ban lohn Ha wkins; tran welcke Laudoniere. en lrhip korht ende boots beel bittualie/ ende anoer noodinge dinghen bequam/ende maeckte bem foo ghe= reet om naet 1 gantkrińtk te keeren.

\section{Het elfoe Capittel.}

De derde voyagie van de Françoyfen naer Fror ID A, onder's beleyt van Capiteyn Iean Ribauld.

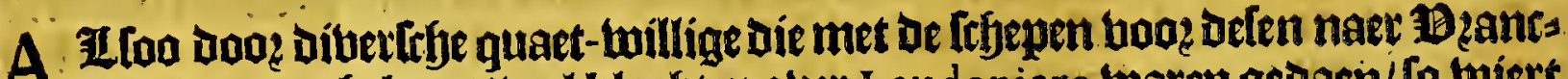

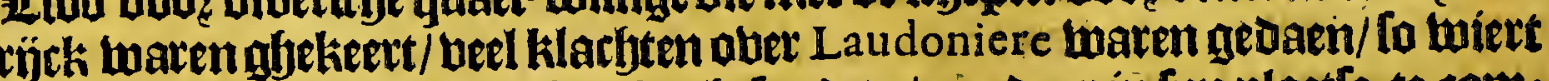
Capitepn lean Ribauld naex Florida gbelonden / om daer in fon plaetle te com= manieren/ende hem naer bupg te [epniven. Bele arribeerde daer aen 28 A ugufti

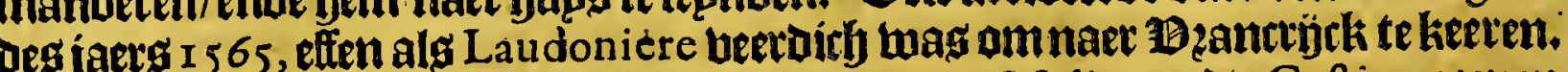
De livaninghen Homoloa, Seravarri, Alcmacani, Malica ende Cafti, quamen

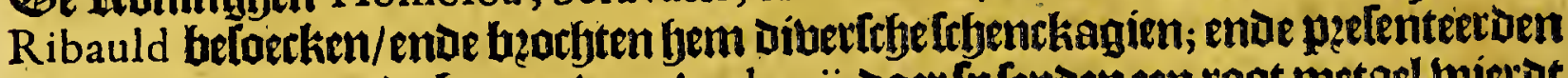
bem te beengenaen de bergen ban A palarcij, Daer fo fepden een root metael wiet ot

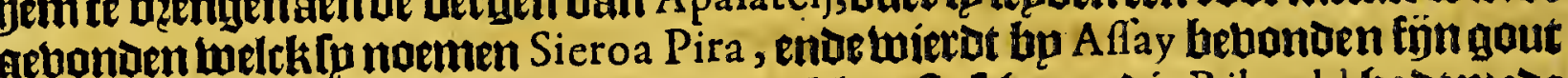

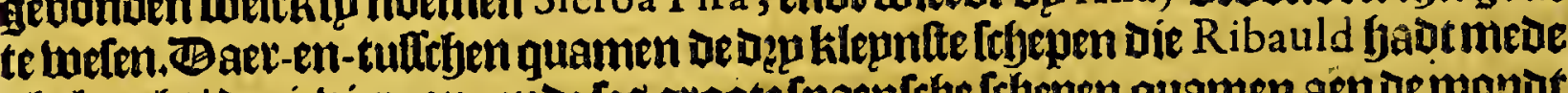
ghebzatht/ De riebiere op ; ende les gronte Lpaenlebe frbepen quamen aen oremanot ban De riebiete/ende fetten't neffeng de biev groute frbepen ban Ribauld, baer alle

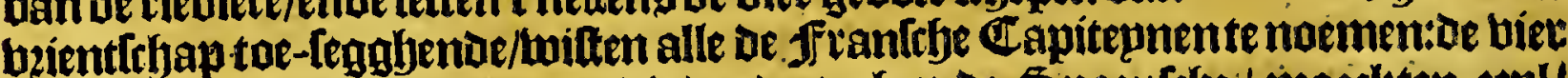

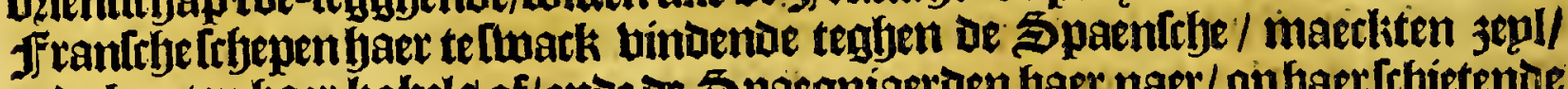
ende kapten baer kabels af/ende we Spaenniaerden baer naer/ophaer [rbietente

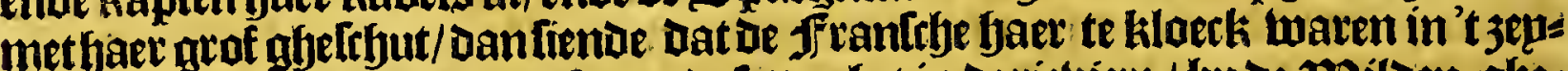

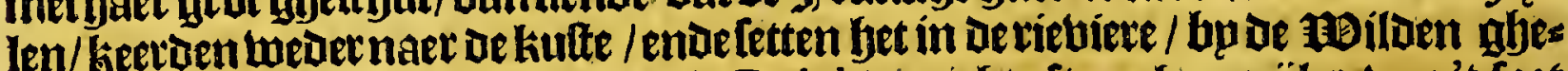
noemt Seloy, ende bp de frantege de Dolphins, actit oft neghen mïlen uan 't foęt

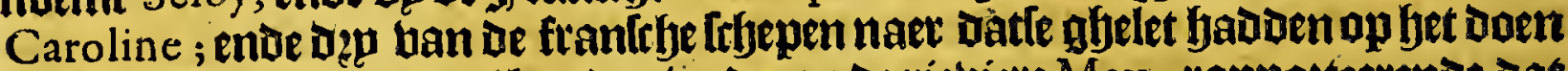

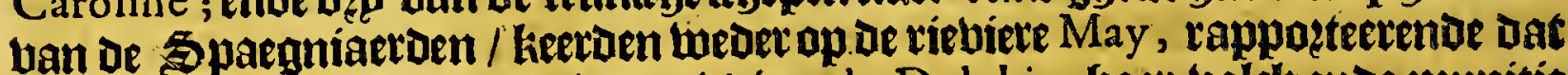
Dep ban de [paenlche frbepen in de riebiete de Dolphins haet bolck ende munitie hadoen ghelandt/ende dat dander dep bupten op de reede lagfen; berftonden

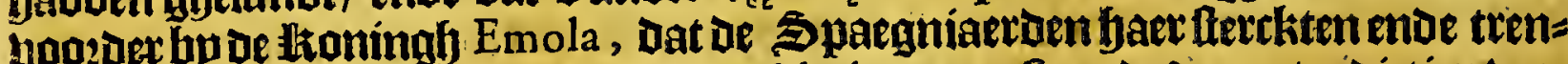
theen op- wierpen. Eaer op dan R ibauld niet tegen-ftaende de contradittien van Laudoniere, ende beel andere/ refolbeertien de Spaegniaerden. met al lpn Irfjes pen ende gantlebe matht te gaen belpeinghen; te meer om dat onder den bzief

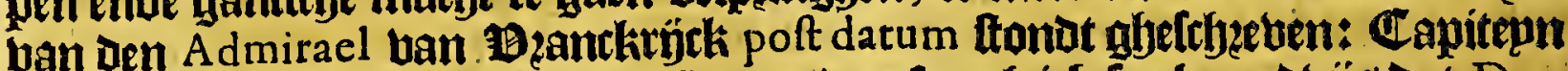
lean Ribauld, foo ick delen foude flupten/ ontfangh ick feetket aovijg dat Don Pedro de Melendes bertretkt upt Spaegnien naet De kulte han Nova Francia; fiet toe dat hpu geen boozoed af enliet. Ribauld Dan nam al 'tbolck met yem/elfs t befte balck ban Laudoniere : ende frbepoe ban de ríeviere den thienden Septem-

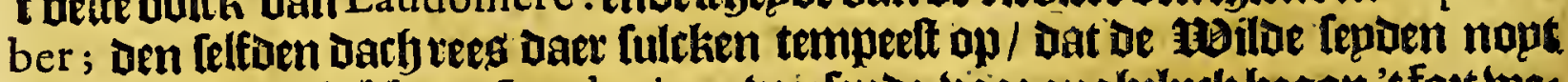
fultkg ghelien te bebluen. Laudoniere beelente booz ongheluck began't foet we: Dex te faztificeten ten belten hp konde; hem en waren bp Ribauld niet ghelaten/ oan unff-en-tarbtich jielen / Loo mans / bzouluen ende jonghers/ente daec ondes:

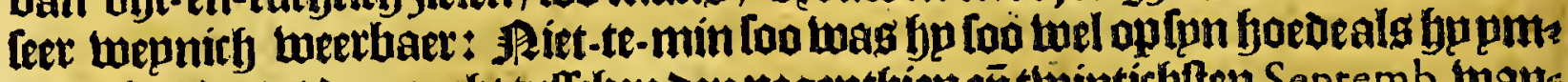
mers konde; tot Den nacht tufthen Den negenthien ent twintichten Septemb. wan:

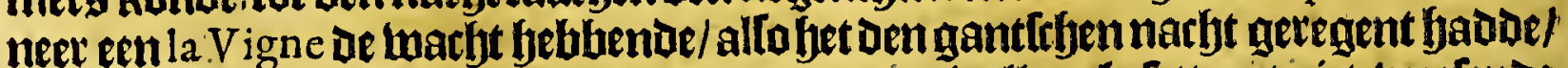
hem retiveetoenaer [pn logement / fonder de centinelle te befetten (niet beerlende dat oe Spaegniaeroen komen [ouden in fulcken wedert) maet een tan't bolck ende Den trompetter pets te doen bebbende bupten't foet / L wievaen een troepe ban Spatghiaet: 
Het vierde' Boeck.

Spaegniaerben ghetwaet/ die ban en bergh af quanten / ento gaben'talatm

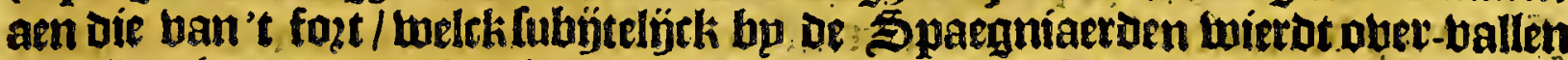
ende ín-gbenomen. Laudoniere ende eenigbe meet falberden baer in or bof

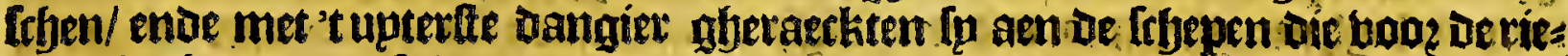

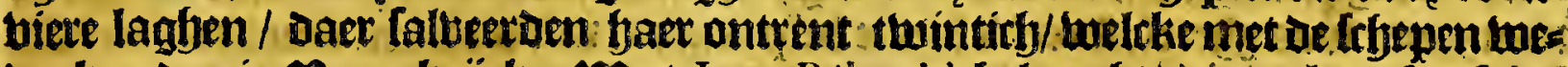

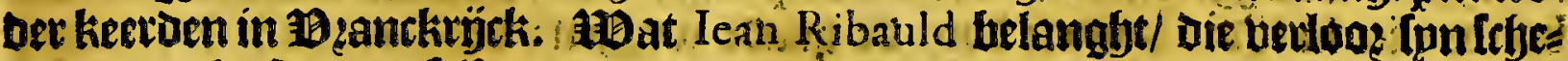

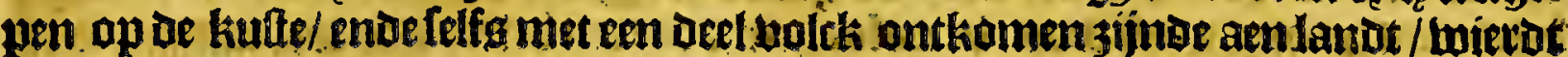

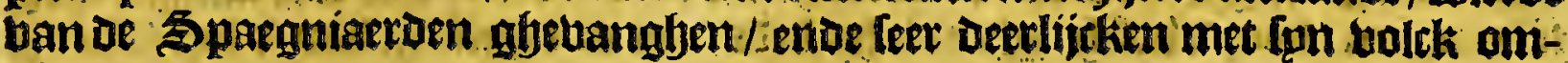
obebadjt.

$$
\text { Tet thaelfoe capittel to }
$$

De vierde voyagie van de Françoyfen naer $F$ i $b$ id $A$ onder het beleyt van Dominico Gourgues.

T Den jare 1567 nam oe Capitepn Gourgues een mannelỉckejelolutie om

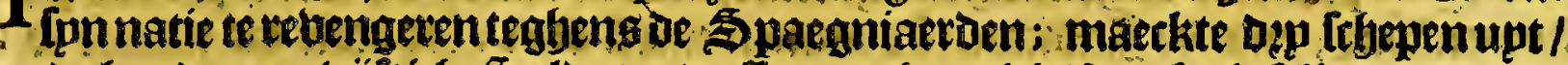

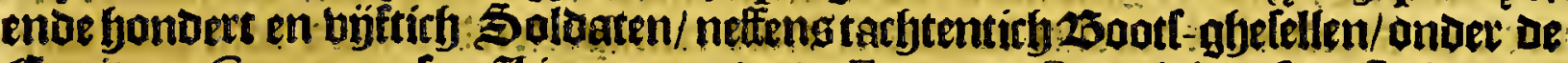
Gapitepn Cazenove fpn Lieutenant/ende Françoys Bourdelois [pn Schippet:

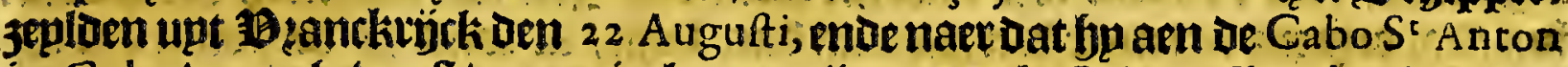
in Cuba mag ghetheelt/quam in koten tijot op De kulte ban Florida waer de

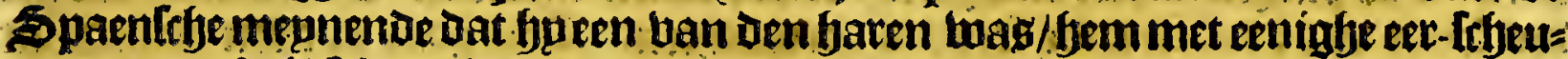

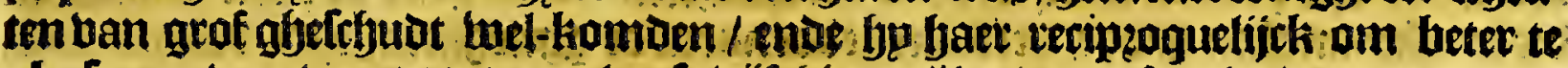

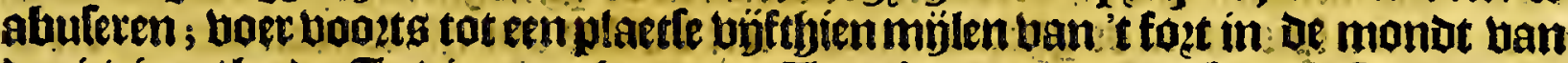
oe riebiete / bo de Indianen gbenoent Tacadocouru, ende bp De frantoplen

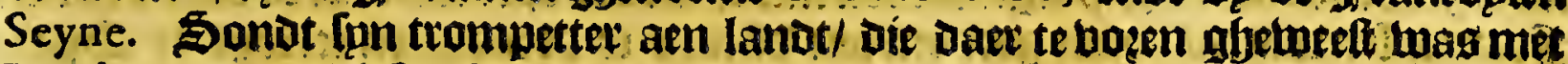

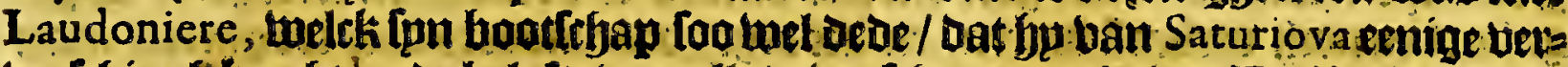

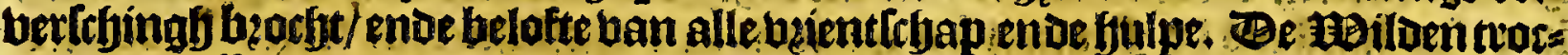

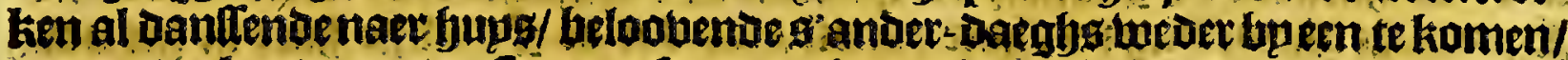
om een tietbonot met de : fr tancoplen te maken : ghelpekle gander- Daeghs niet en faelgeeroen te komen /: te groptlte Paracouffi Saturiova ende sacadocouru, Halmacanir, Athore, Herpaha, Helmacape, Helicopile; Mollova, envemert an=

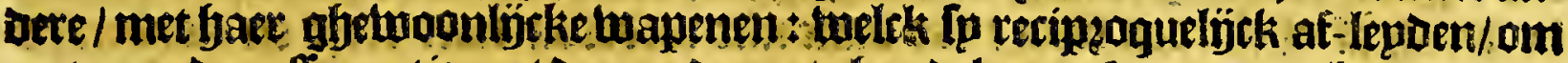
met meetiet affutantie met den andeten te bandelen; Saturiova gbemoetenoe

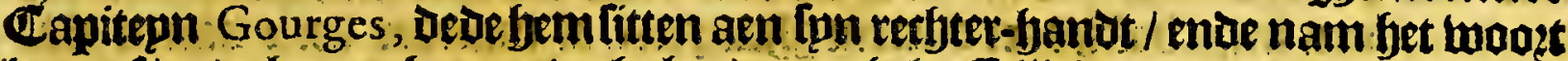
bem af/ende begon yem te berbalen de ongfyelooffelibeke ongheligetien ende ous

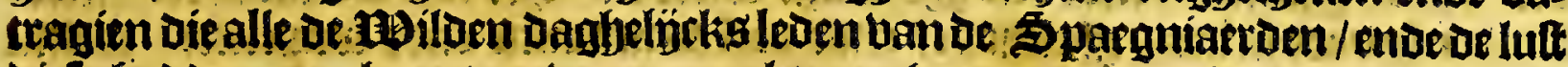
biele badoen om baer te rebengeren als men yaer naer en wiloe belpen ; waet

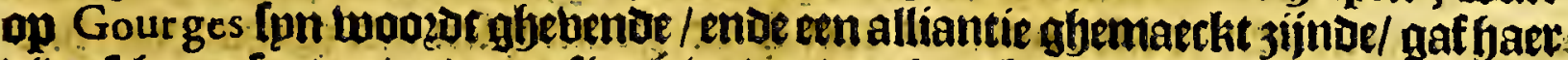

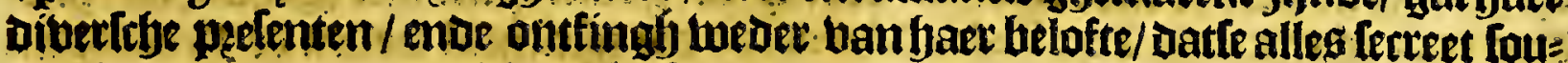

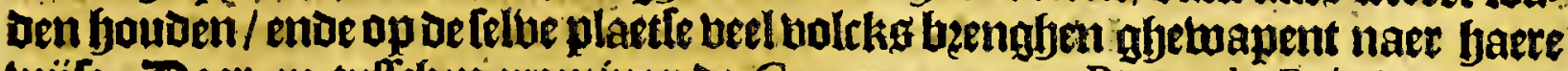

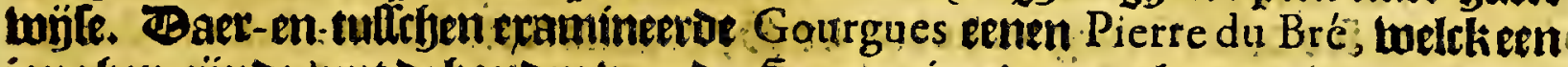
jongben zjöne / upt De hanton ban de Spaegniaerden ontkomen wag / Doenfe ifoest ban de firancopten betobet Den/ente alles bermoozoen/endefints bp Sa-

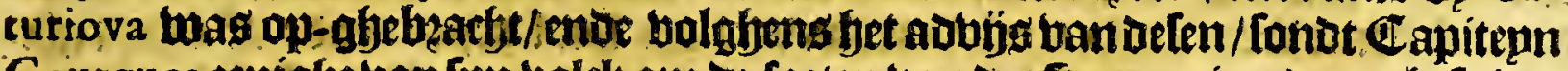
Gourgues enighe ban fpn balkk om de foten bander Spaegniaetdent te be[pien/ quoer bet gfelept ban Olotacara ive touffín ban Saturiova. (Ben aen-flach nuge=

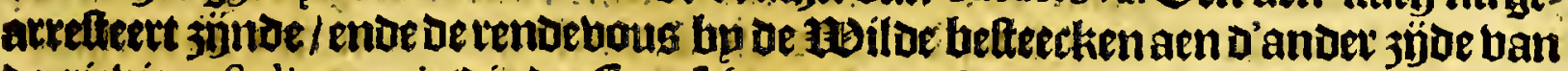
oe risbiere Salinacani, (Die or f rantefye noenten Somme, doef de vopagie van Laudoniere noemt Somme in't Tndiaens Iracana; ) wancken (p allemet groote Colemnitept der miloen doanck/gfenaemt Caffine, die ghemaeckt worot ban

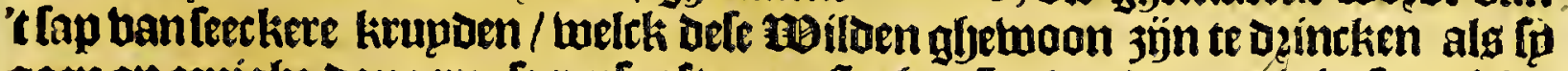
gaen op eenighe dangeteule reple ofte aen. flach. Sp vonoen eenighe twariche= Den ende verbinderingben bp de wegf dooz den regben die daet ghetuallen twas:

ende 


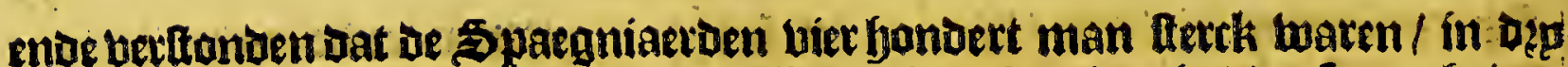
fopten op de riebiere May : (want beneffeng 't foęt Caroline baboenfer noefy the

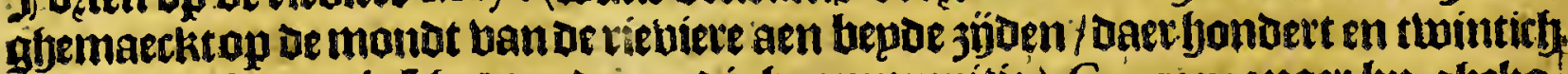
man in taghmet gfyelchubt ende noodigbe ammunitie.) Gourgues naet bp gheko:

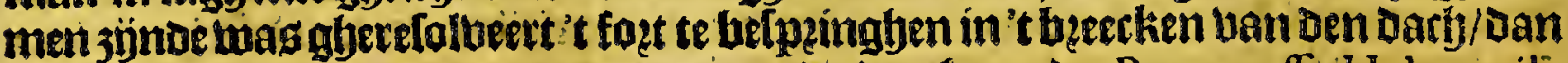
konde niet in tijots koment doog de quade wenfen! De Paracouffi Hely copile

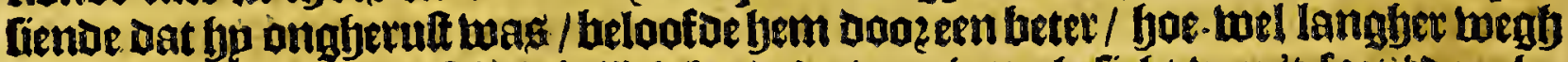

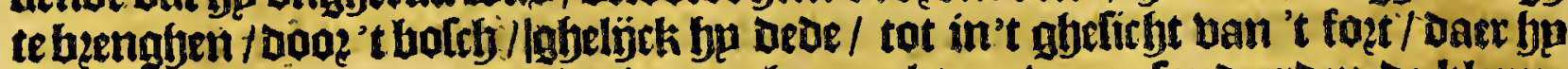
Geuroe eenquartier Dat noch niet op-abemaectit en mag: Conoeetoen de klepne

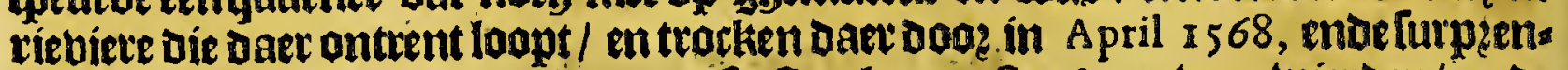
neerden't fort in lulcker boeghen / oat fu fracks meelter oaer ban wierden/enve van feftich Spaegniaetoen die daer in laghenen mamen fpoer maer büfthien gbes

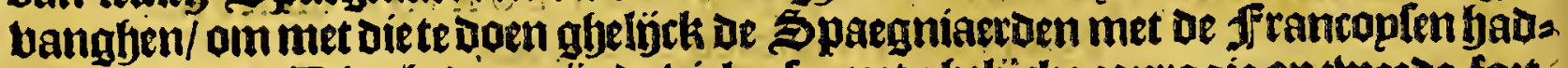

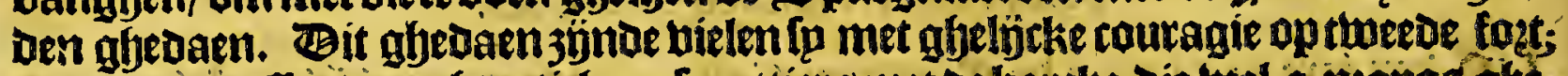
Gourgies palleerio tachtentichmulquettiers met de barcke die wiel a popos ghts

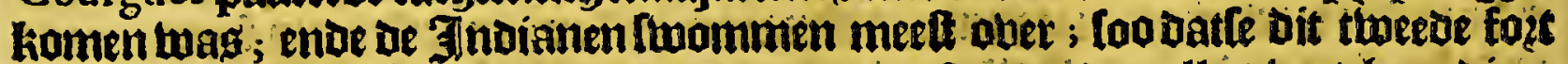

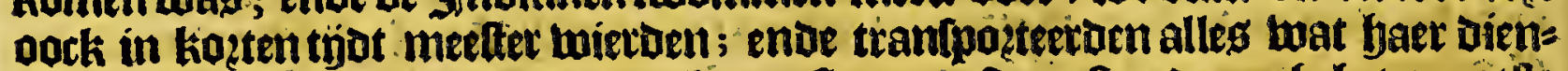

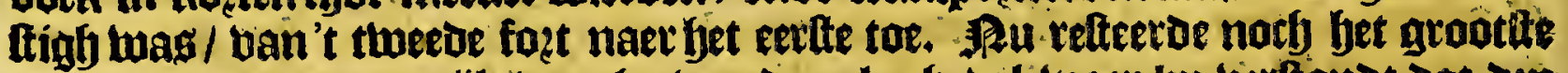
foet / oat ontrent een mijle weeghs ban daer lagf / al-maer bp bertionot bat dep bondert Spaegniaerdenin lagben/ onder eenen kloetken Gouberneur die bet wel Loude upt-houden ende Iecours verbuarten. Gourgues upt een Sargeant

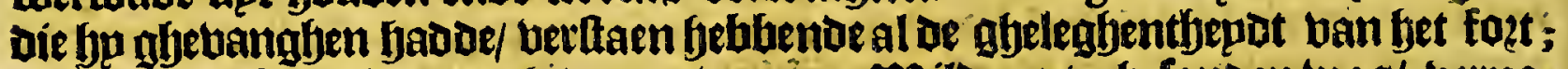

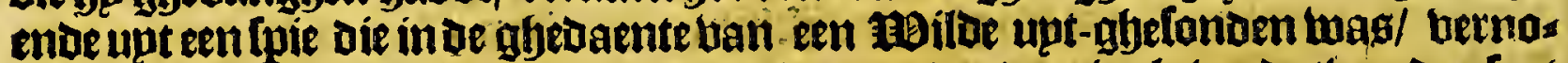

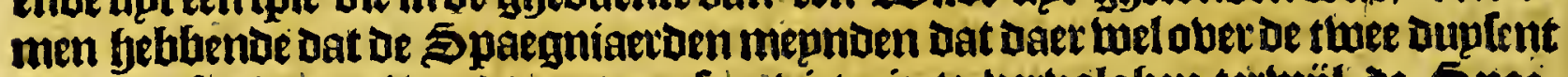

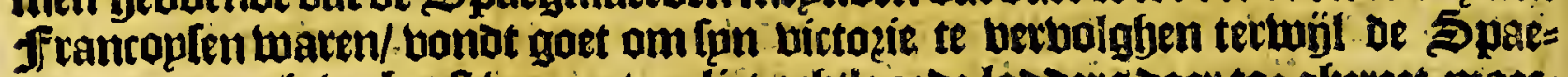

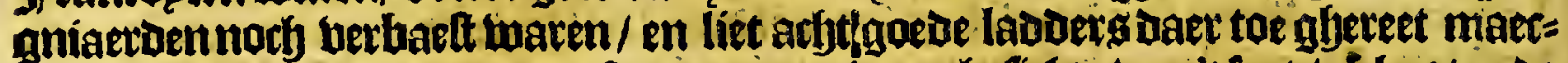

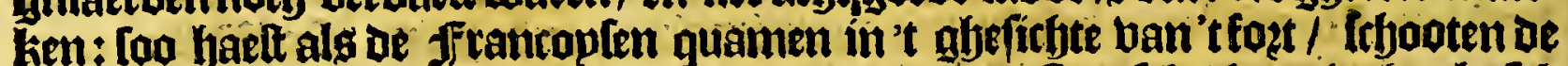

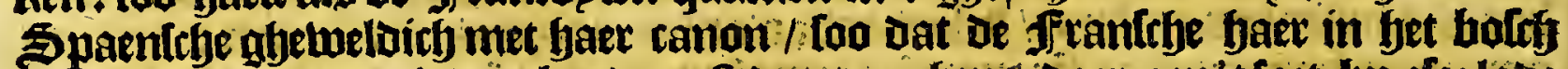

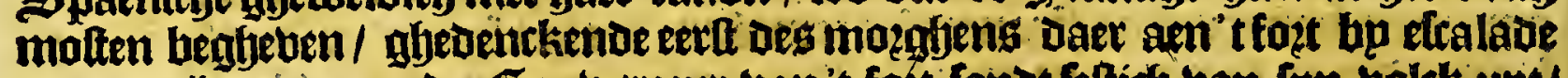
aen $t e$ arijpen : maer ae . Gouberneur ban't fort tonot feltich ban (pn holck upt/ om't abetal tuan of ffrantebe te belichtighen/ ae twelcke (alloo baer bu Cazenove

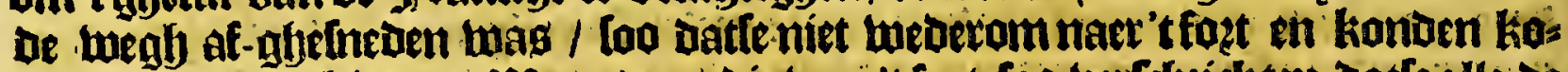

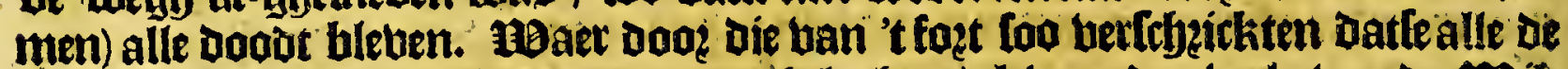

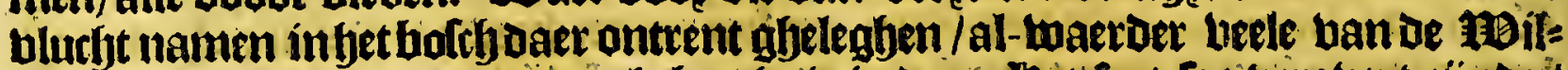

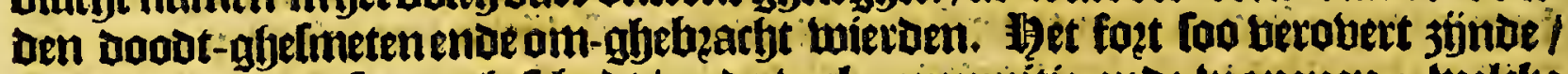

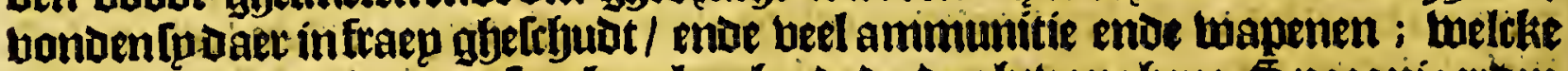
Gourgues al dede laden in ipn bartke: bp dede ue ghetoanghene Spaegniaectoen ou-hanghen / aen De felbe boomen Daer lo de J rantopen aen ghebanghen bads

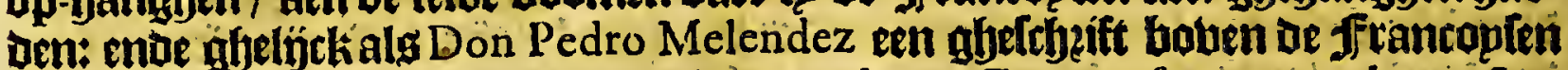
hadoe Doen fjanghen; Ick en doe dit niet als aen Françeyfen, maer als aen Lutheranen: foo Dede Gourgues haben be 5 pargmiaertan ftellen; I Ick en doe dit niet als tot Spaegniaerden, maer als tot verraders, dieven ende moordenaers. Bindende hem alte lwack ban bolck om de fozten inne te bouben / Dede bu die

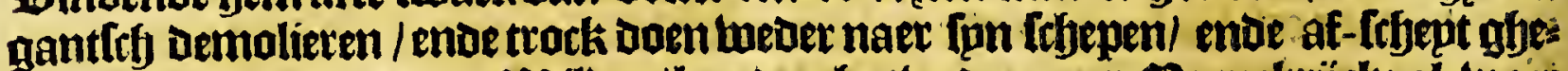

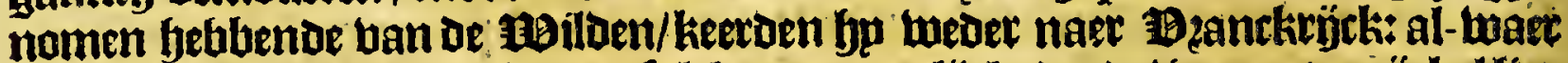

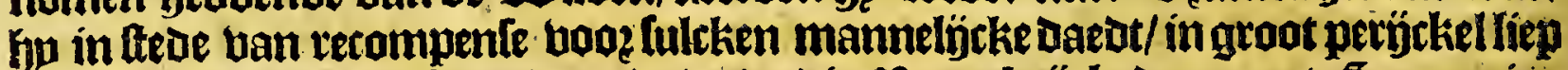

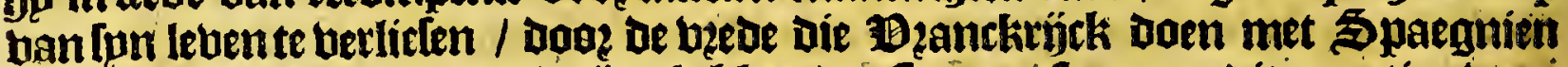

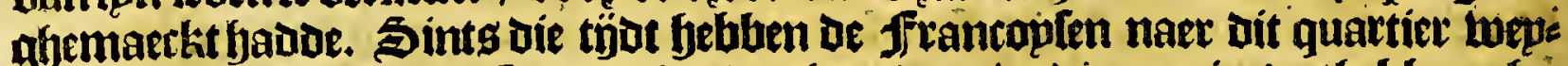

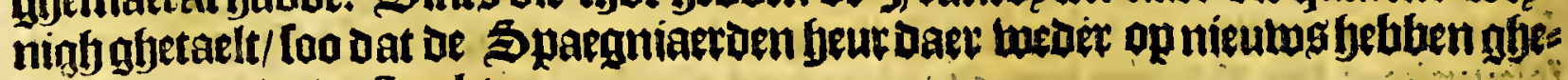
foutificert ende bertterckt. 
Tet dertbienù $\mathbb{C}_{\text {apittel. }}$

De limiten ende gheleghentheyt van $F_{L}$ O R I D A, ghelijck als Herrera die befchrijft.

D E 13 gabincie ende 't Goubernement ban la Florida, welck igen aenfianghfel ban de Audientia ban Hifpaniola, bolghens de limiten die bp den lioningh ban Spaegnien geoctropeert waren aen Don Pedro Melendez, begrïpt intich alle't landt mekt 3 ïn beginfel neemt van Rio de las Palmas, (confineerende met 't Joubernement van Panuco in Nova Hifpania, ende belangente tot oe Audientia ban Mexico, ) welcke ig atelegen bp den Tropicus ban Cancer, op de booghte ban 22 graden bp noozden de línie Equinattiael/ ende epndigbt aen't punt van Baccalaos, welck gelegen is op De booghte ban atft-en-beertich graden endeeen

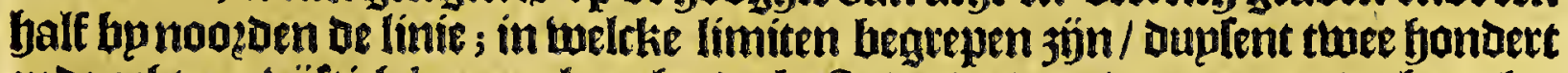
ende atbt-en-unjftich leguen langhs de kufte / ende van daer tot op oe boogfte

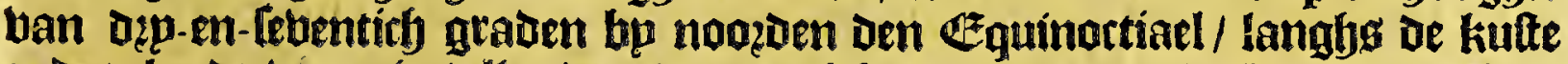

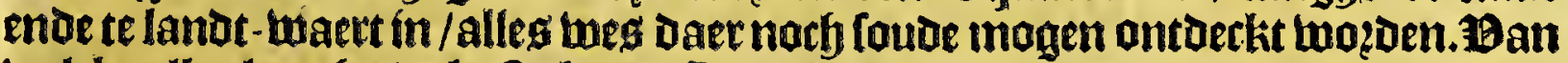
wolcke alleg langfs oe kulte bp de Spaegniaeroen ontoerkt $3 \mathfrak{y} n$ / De landen ban Río de Palmas at/tot aen. Punta de Santa Helena inclupg/ende De rievier Iordan,

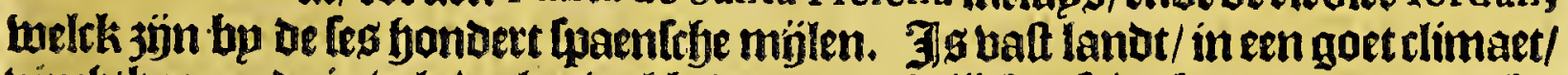
viuchtbaer ende in bele oeelen wel bewaont / gheligth't felbe betonoen laetat bu be ghene die Daer boot-ghetogen bebben met Don Hernando de Soto, in den jare

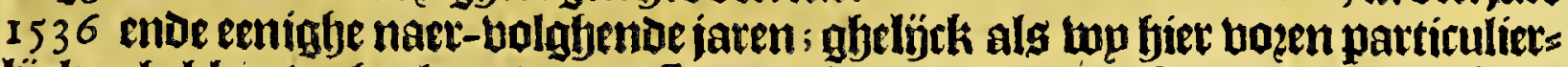
lijcken bebluen bertbaelt; enoe een Spaegniaertmet namen Iuan Pardo, gfjeboo= ren van Cuenca in Spaegnien / replde te lande ban la Florida af / tot in Nova Hifpania in minder als in twee jaren. Bit landt is ban alle de landen ende peos bincien ban Moeft-3ndien naeft gfyelegen aen Europa; ende is ban gelijeken ont= Deckt van oe Bahia de San Iufepe af / tot aen Terra Nova : twerende Dele hape ban

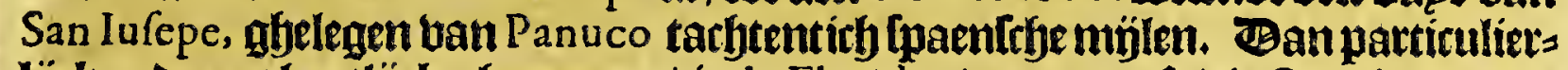

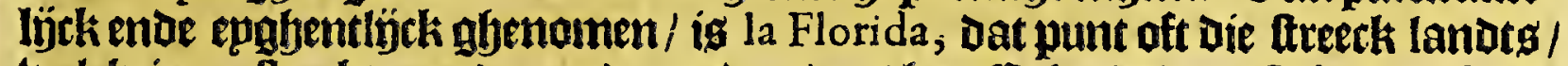

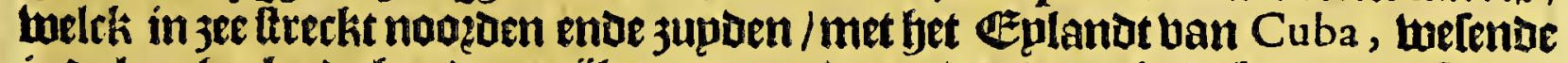
in de lenglte bu de fyondertmýlen nooet ende zupden/ende in ae beedte ooft ende

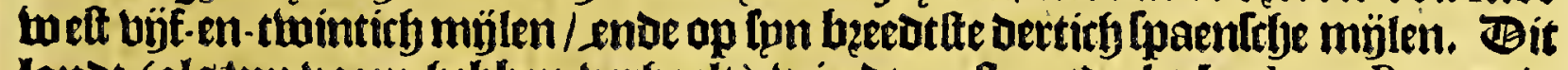

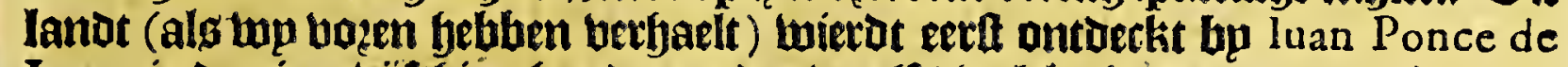
Leon, in Den jare tüfttien gondert ende twaelf / welcke het De naem gaf ban la Florida, om de redenen boozen berfaelt: De felbe keetoe daertwederam in Den

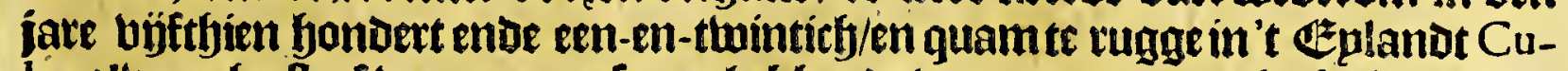

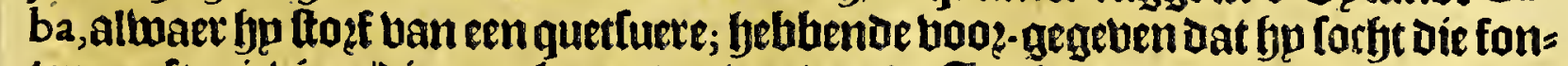
tepine ofte rieviere/oie naer bet upt-geben ban be Jindianen/De oude-lieden jongh maeckte/met frem Kelluen in't water van die fontepne ofte riebiete te wafiffen ende baden. Befe pzohincie ban la Florida epghentlijek too ghenoemt / is ban tempze

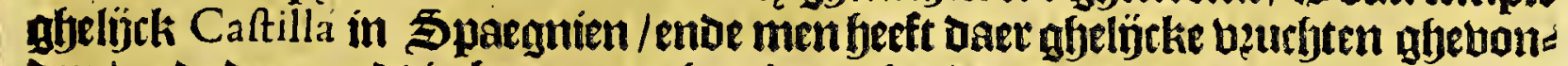
ben / ende de gronot ig bequaem ghearbt tot bet boeden ban bee/ ende tot tarke telacpen: Taer en balt gheen gout / en ten fefyñt oock niet dat de in-gheboozne

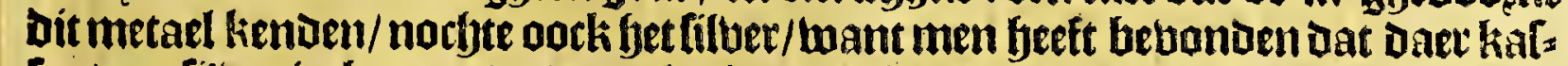
fen van filber in barren / enoe oork ghemunt filber op oe kufte is blijben legghen/

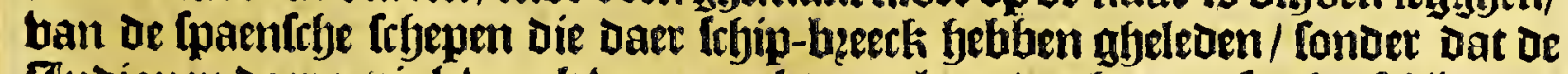

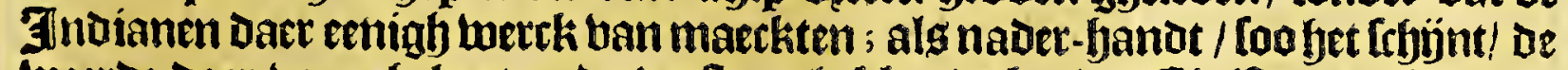
wertde daer ban gheleert ende berltaen bebbende bp de Chyiftenen; bae- ine! Hernando de Soto hinmen in fjet lanot in oe rieviere die hp noemae R io Grande, gffeluonien frfönt te bebben upter-maten groote menithte ban peerlen; als top bict toden in bet langhe bebloen betjaelt / balghende bet velaes / dat Herrera in

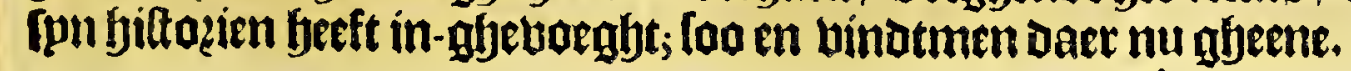


Het bertthiende Capittcl.

De natuere van ' $t$ landr; de gheftalte ende manieren van 't volck van FIORIDA, ghelijck die by Laudoniere

befchreven worden.

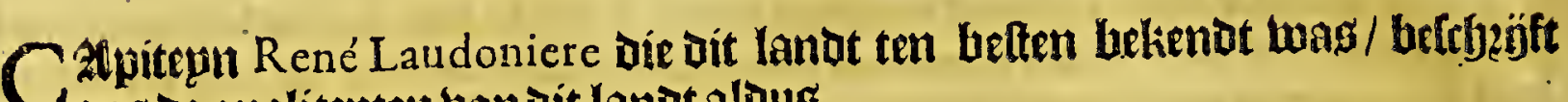
ong de qualitepten ban Dit lanot aloug.

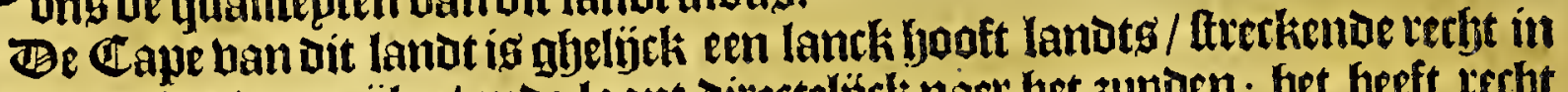

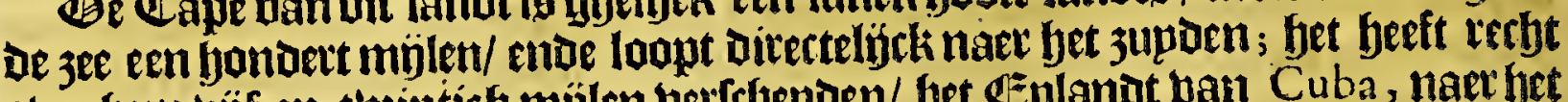
ouer fem bujf-en-twinticf mijlen werfryepden/ bet Eplanot bail Cuba, naer fet

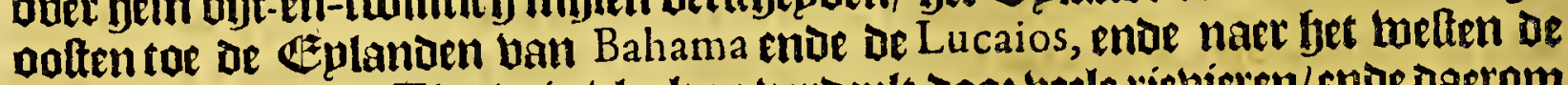
Baye van Mexico.' Clandt is black en uetoeplt doo zueele viebieten/ende daerom

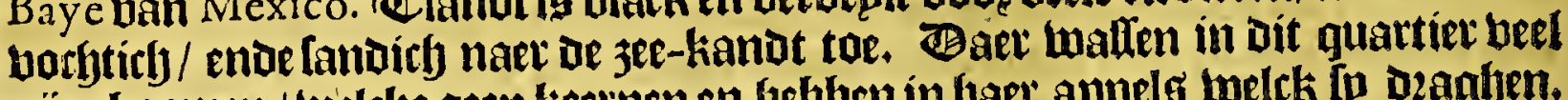
ün-hoomen / Luelcke geen lieernen en bebben in baet appels twelck in dzaglen.

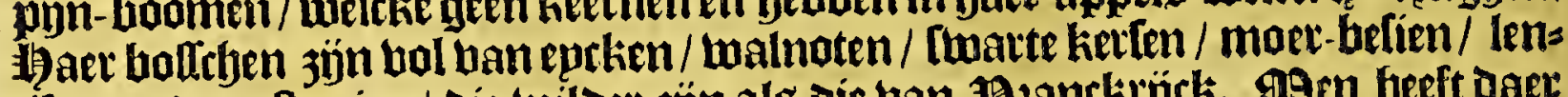

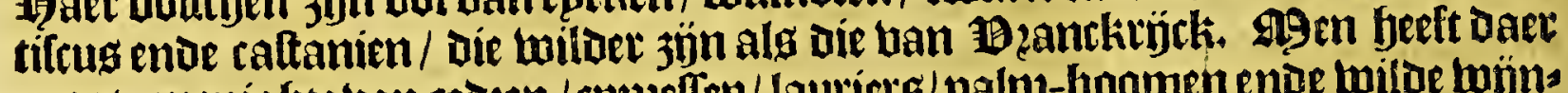

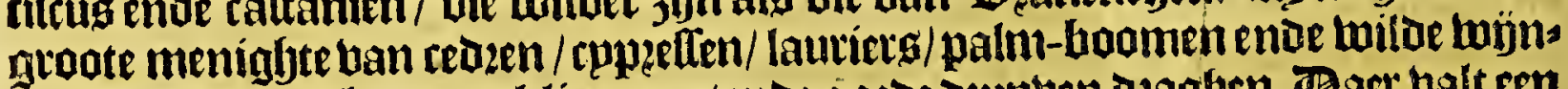
gaetoen die in de hoomen klimmen / ende goede decupten azaghen. Baer balt ken

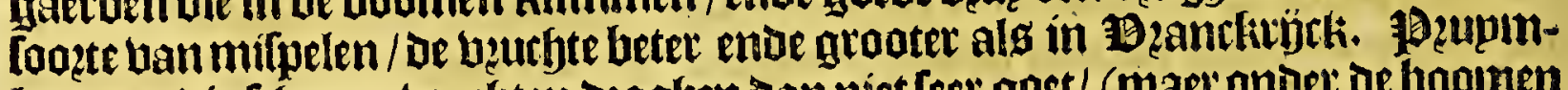
boomen die frboone bzuchten dzaghen dan niet leer gaet/ (maet onder de boomen muntupt/die de mbiloen Parame ende de francoplen Saffafras noemen: dit is

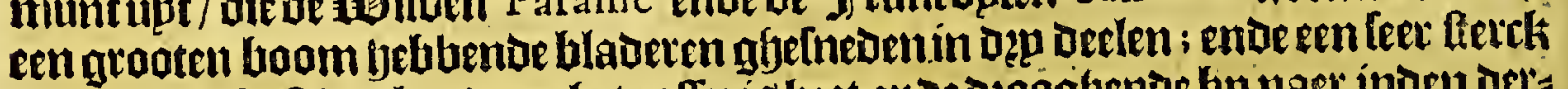
rieckenden balt/treekende op het rolle: is heet enoe deooghende bp naer inden oets oen araedt; ende ig dienltigh tegben aecolike; ende een lonoerlingf remedie tegen

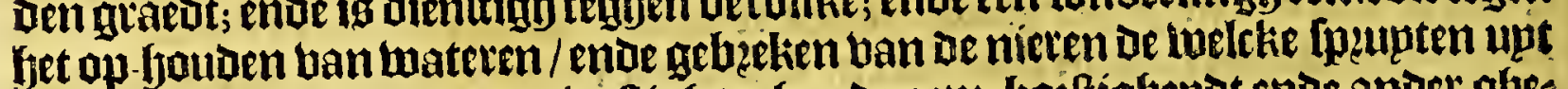

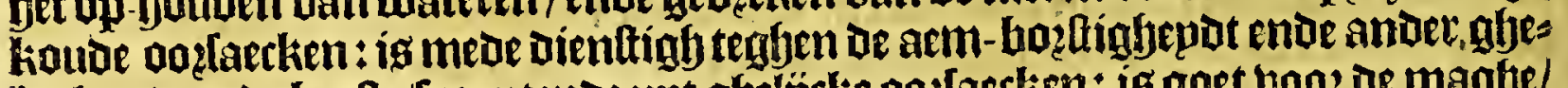

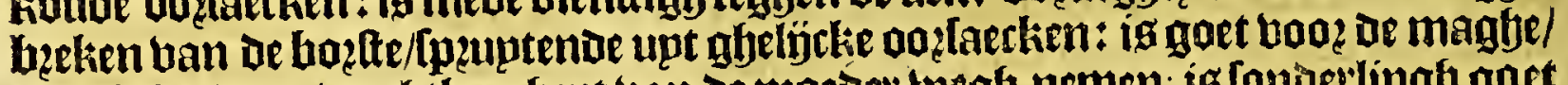

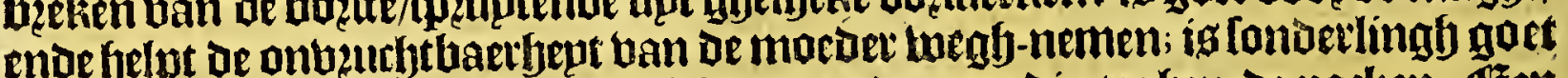

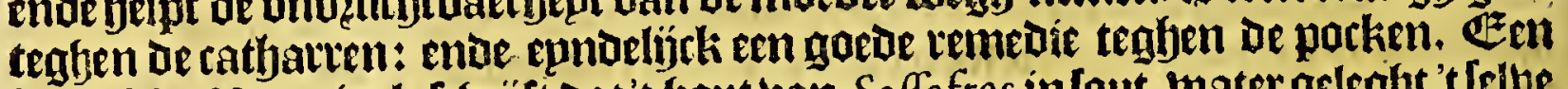

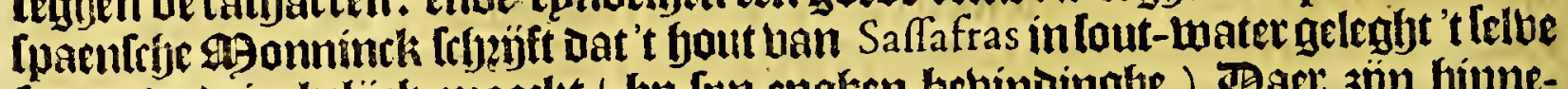

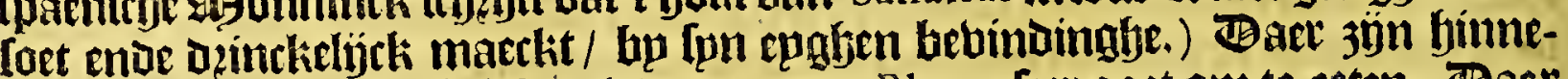

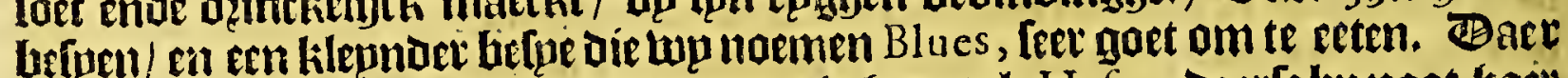

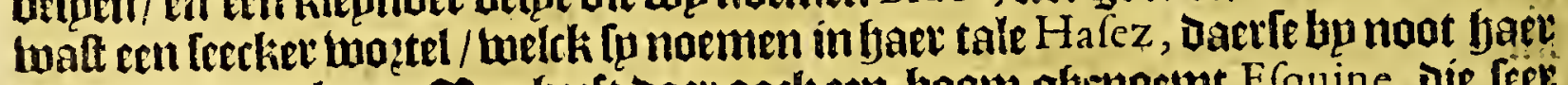

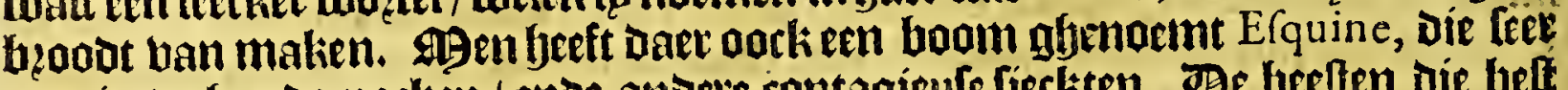
noet is teglen ae porken / enoe andere contagieule fiectiten. DE beelten die beft belient $3 \mathfrak{j n}$ in dit lamot / [un barten en binben/gepten/ dier / luppaeroen/on=

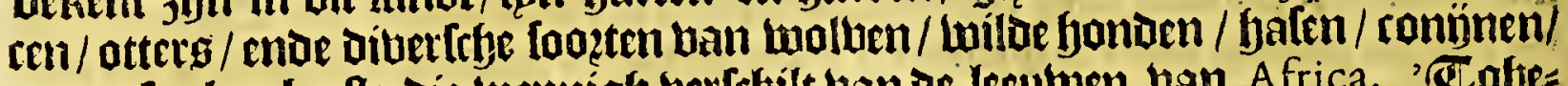

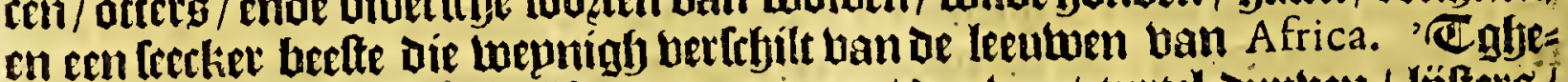

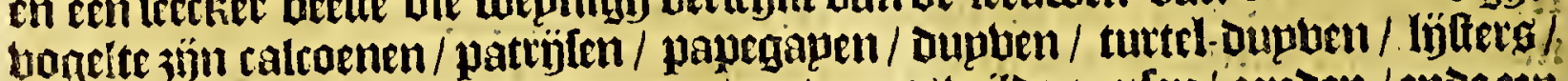
Fraepen / balcken / repgetg / kranen / ouebaets / wilbe ganfen / enden / ende een

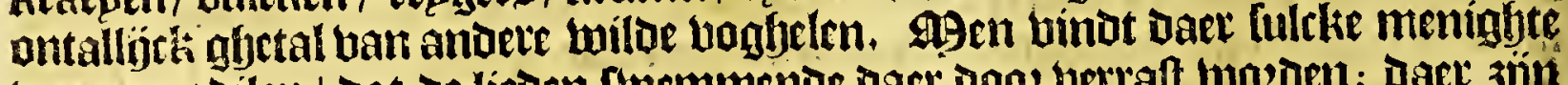

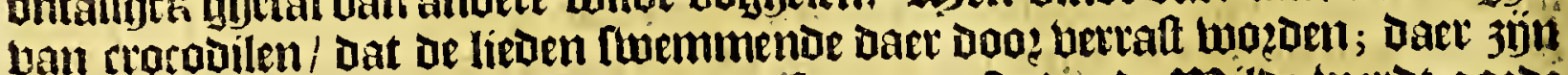

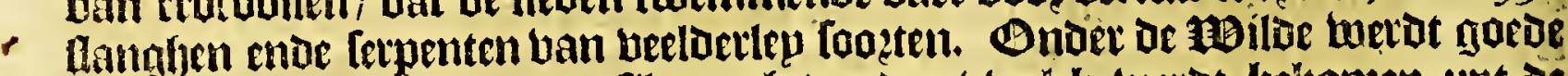

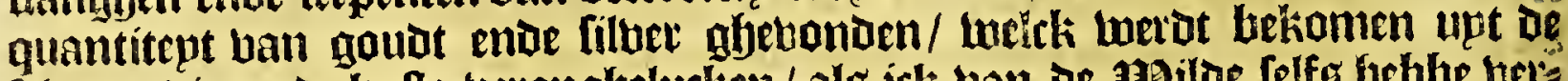

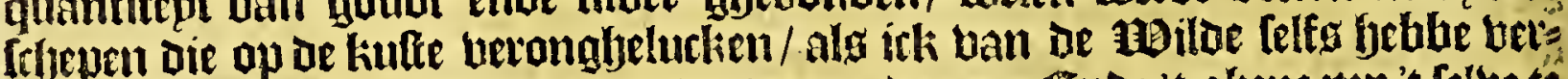
faen: \$u trafiketen daet mede onder ben anderen. Ende't abene mu't lelue te

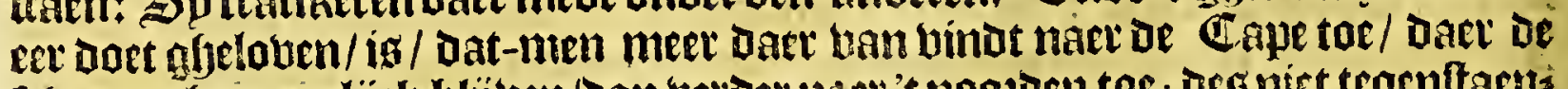

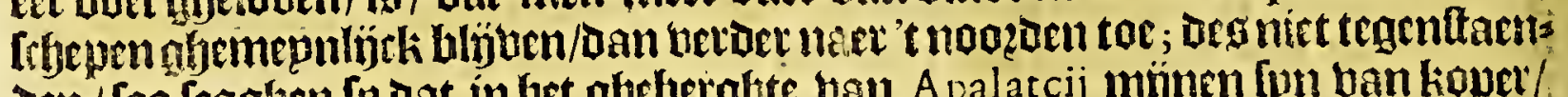
aen / foo ferahen fo dat in het ghelerghte ban A palatcij mïnen fpn ban kopel/

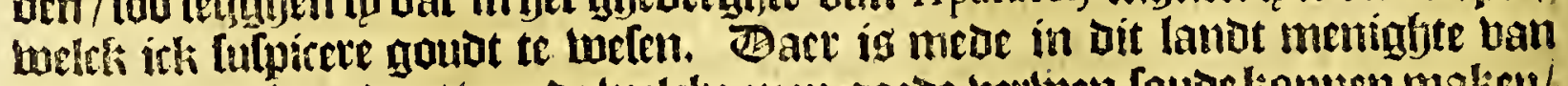

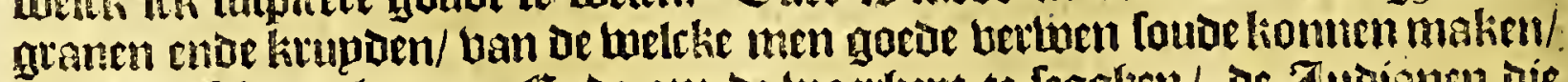

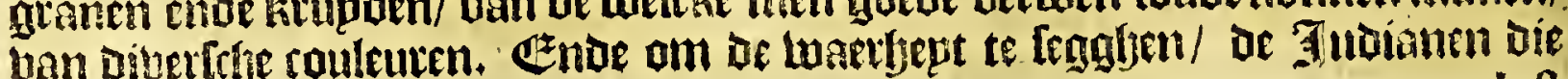




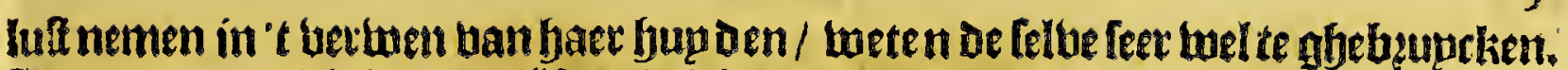

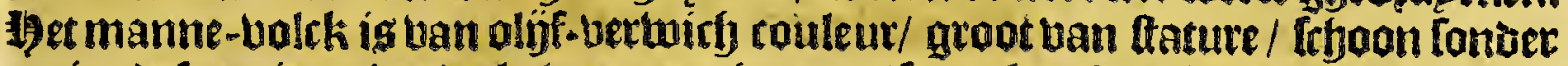

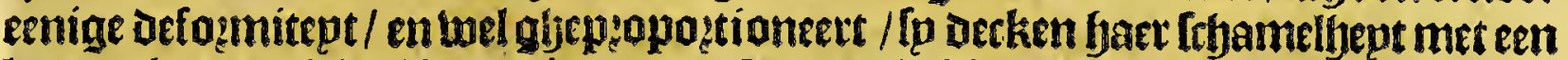
batten bupdt die wel berept is; de meeffended bebben haer fichamen/atmen ende open gbefrjildert met fraepe debifen/ wolck nimmermeer en tergaen/ Dooz Dienle

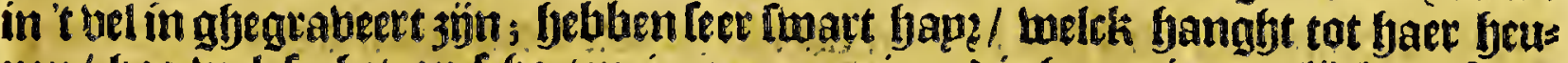
pen/ boe-wel fp bet op fefozten in een maniere die gaet niet qualjeth en tact.

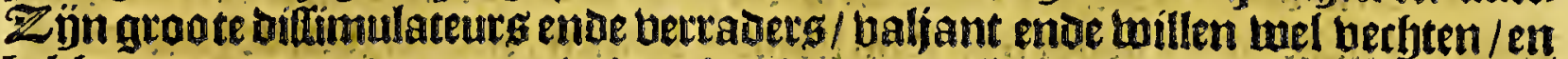
bebben geen anoer wapeng als Gaer boghen ende púlen:maken oe peten uan faer boghen van de barmen ban de harten / ofte baet bupot / metckfo foo hel tweten te

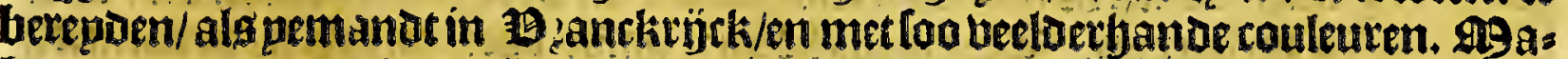
ken be punten aen faer pijlen ban tanden ban biffelen enoe feenen / Diefe fraep weten te accommoderen. Sp oeffenen baer jonglye-lieden om wel teloopen / en maken een torot-[pel / welek ghetuoninen twetos bp Die oe langhten adem be eft:

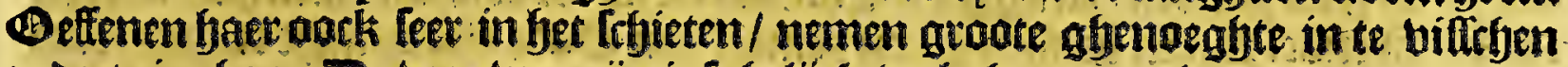

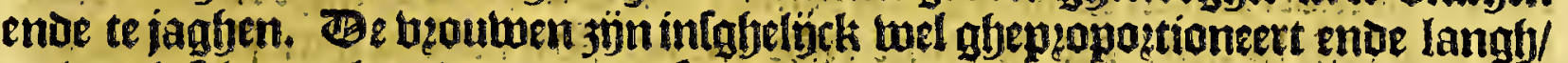

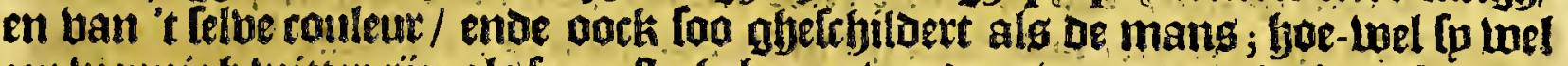

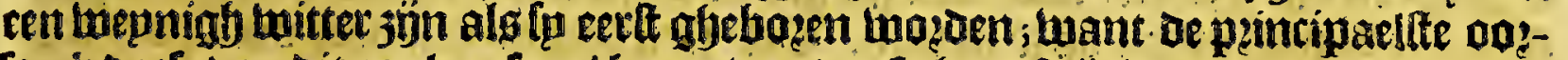

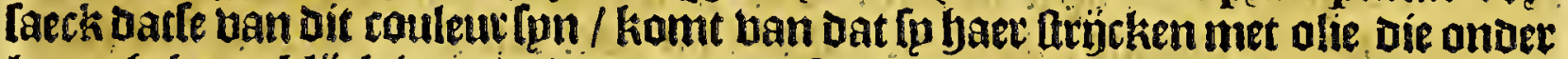

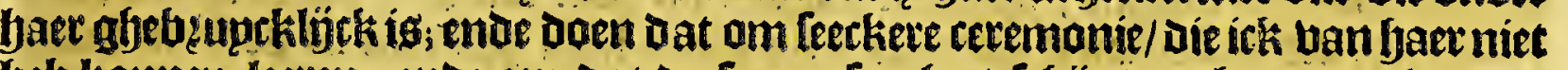

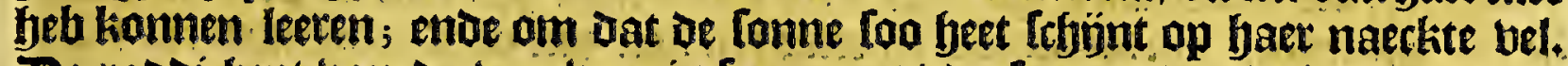

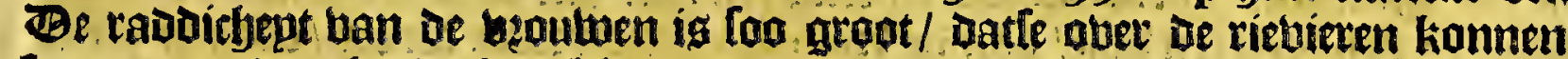
twemmen/Dzaghende baer kinderten op haren eenen arm; kliminen oock feet

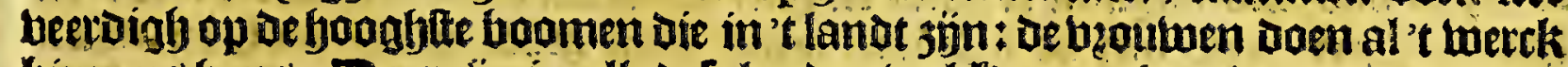
binneng fups: Baer 3 tin in alle dele lanoen beel germaphzoditen / Dat ismans enoe vzouluen teffeng / aie oe meette laften ozaghen / ende oe birtualie naec voeren als [p te Itrijde gaen. Sp taepen Jaer Maiz tweemael os jaers / in Martio ende in Iunio, ende al in de felue grondt: te felve Maiz en is gemegnligek maer dęp maen. oen in 't walten; laten de gronot to andere leg maenden ruften. Hebben oock Ler fthoone pompoenen en feer goede boonen. Spen melten baet lanot nim= mermeer / dan als fp bet betaepen wilien/ foo tteken fp bet wied aen bantot melek Daer die leg maensen op ghegroepet is/ enoe tuerbzanden bet al. $S p$ beecken De gtondt met een fouten intrument/gbelÿck als Daer men in 19 zantk: rỉck de bujngaetden mede boubet/ ende fetten thee guepnen Maiz te famen.

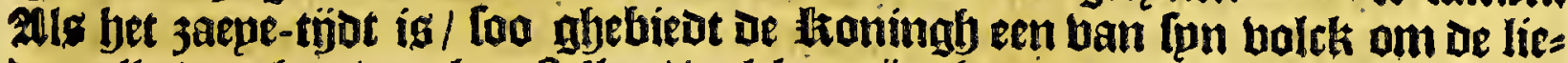

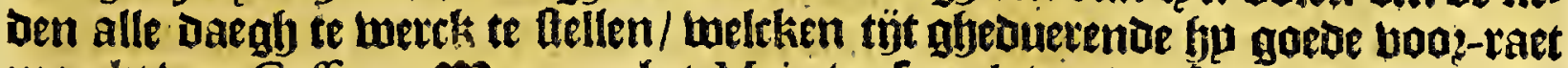
maeclit ban Caffine. Manneet bet Maiz verfamelt wozot/ loo beenghen fp bee

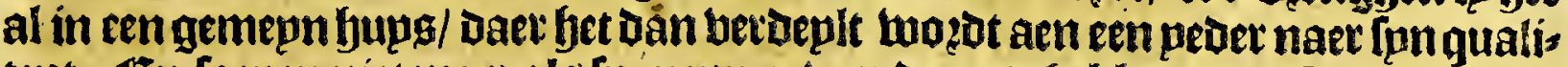

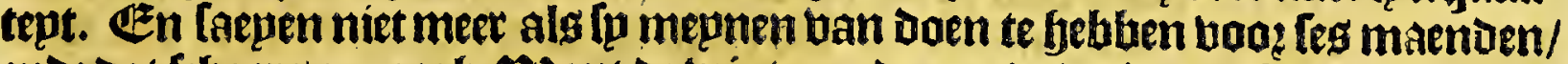

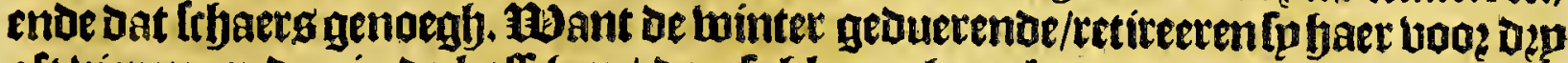
oft biet maenden in de boflefyen / Daerfe klepne buttekens maken van palm-tace

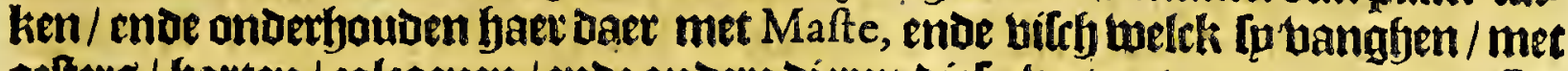
oefters/ barten/ calcoenen/ende andere dieren diele lueten te attrapperen. 3 p eten al baer kolt op kolenende in ben roock gbelkoackt/welck fp in baer tale noe: men Boucaned. Eten geern fyet bleelch ban trocobilen/ bet welck booz-baer ffhoon en wit is / ende ten ware bet foa feet naet mulfus roock / wp fouden daet Dictukils van ghegeten fyebluen. Sp bebben een ghetwoonte als lp lieck [pn/

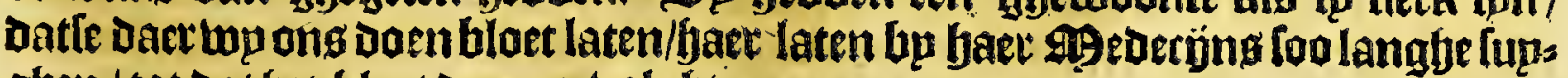
ghen / tot Dat bet bloet Daet ap volght. 


\section{Get bijfthiendae Capittel.}

De Regeringh ende Politie van defe Indianen van F I OR I D A, ghelijck die by den voorfchreven Laudoniere worde verhack.

$\mathrm{D}$

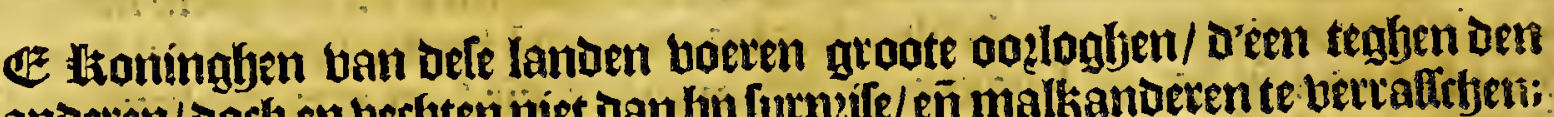

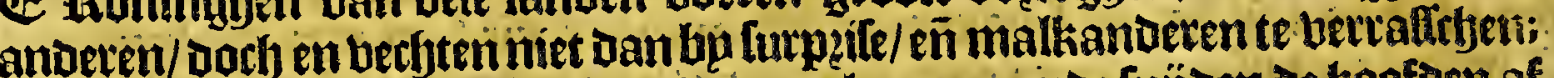

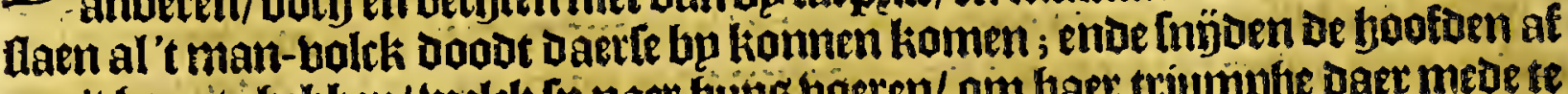
om't fapę te fobben/ welck Ip naer bujg haeten/ om baet triumphe daer mede

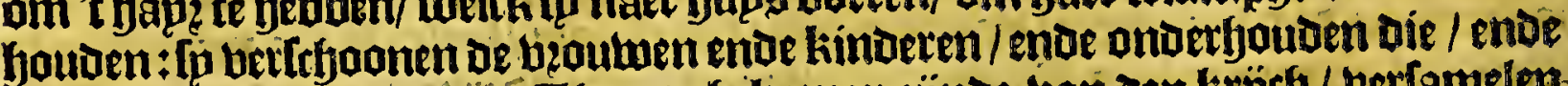

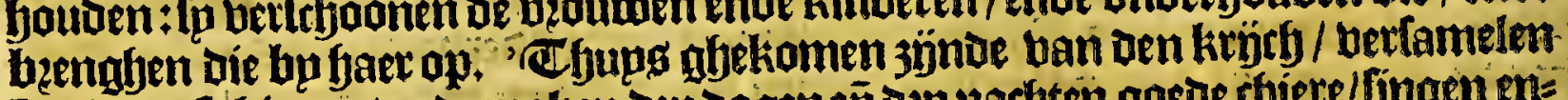

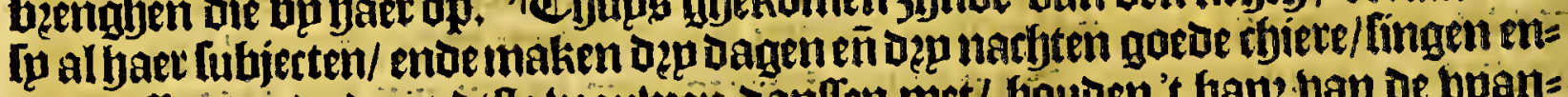

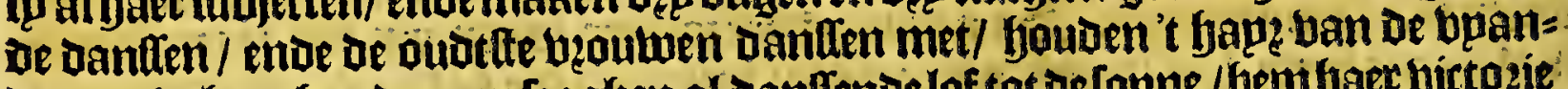
ton op in haet yanden; enfegghen al danlfende lof tot de [onne / henibaec virto eie

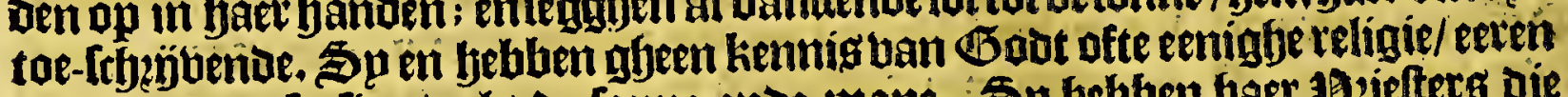

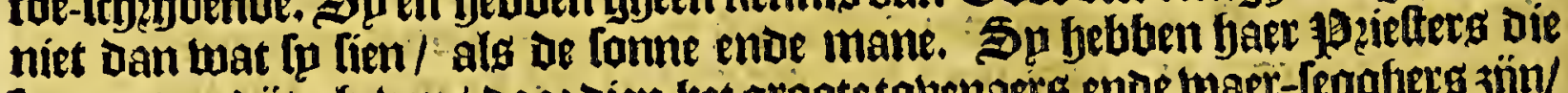

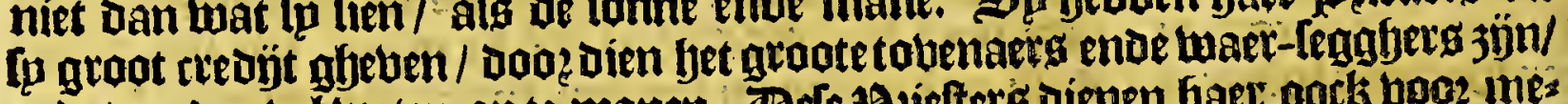

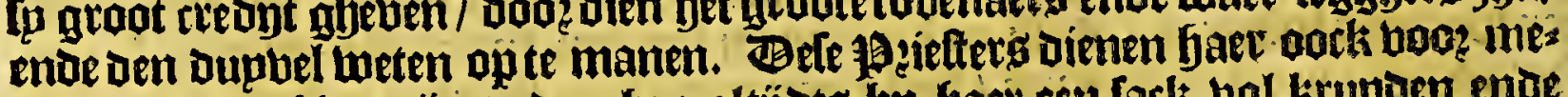

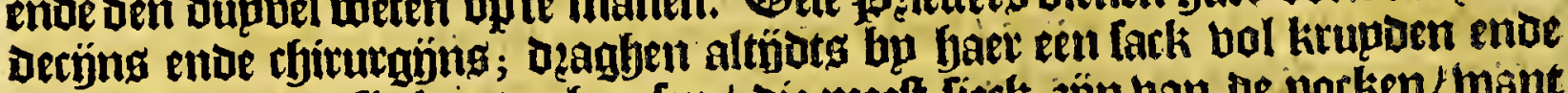

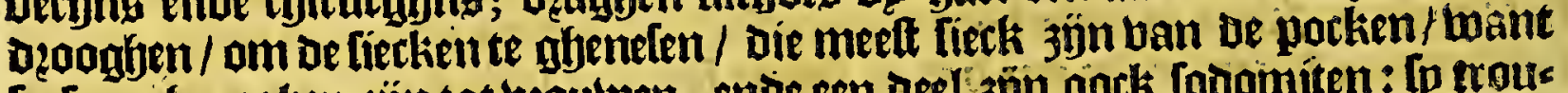

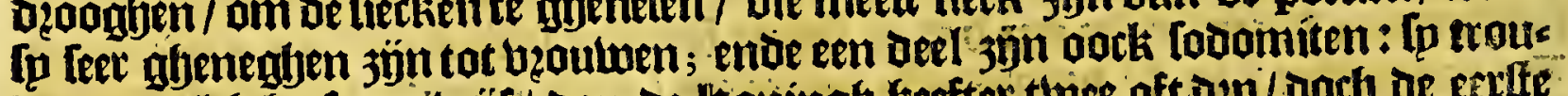

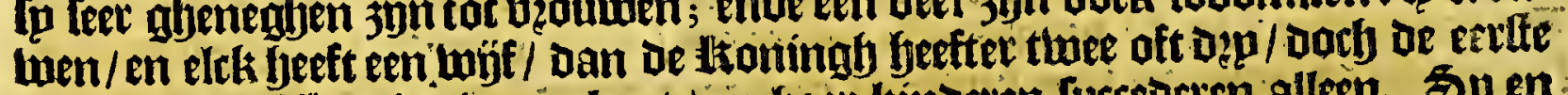

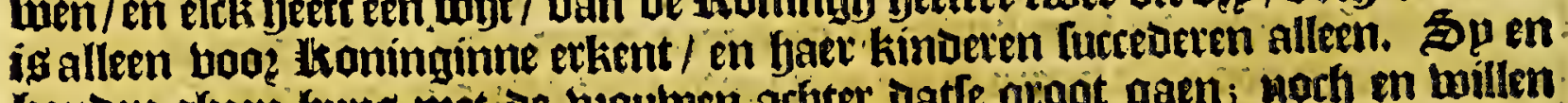

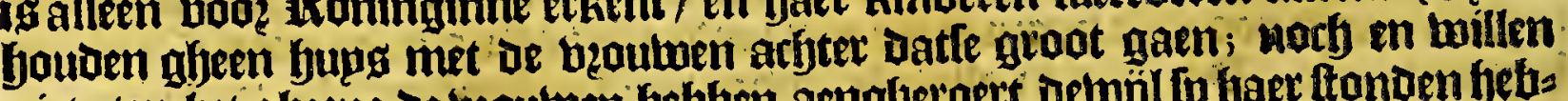

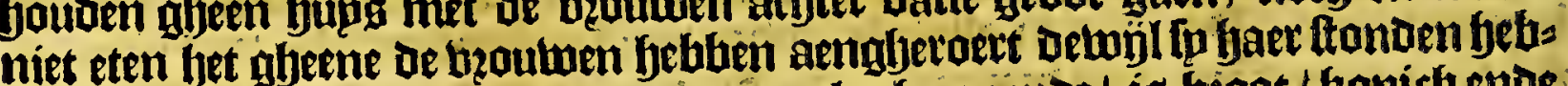
ben. Be bietualie diele met nementen oplogfe gaende/ is boot / bonitb ende meel ban Maiz ghemaeclit / Dat bu het bier gheboeften íg: Dzaghen oock Comtn̈ts

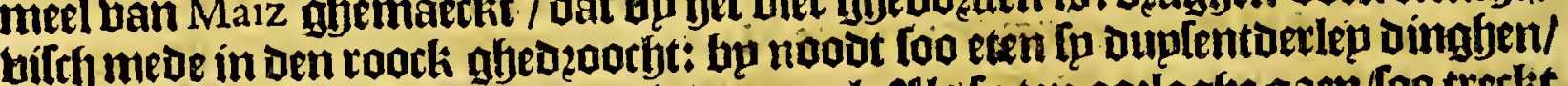

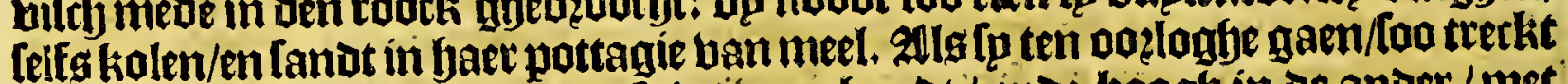

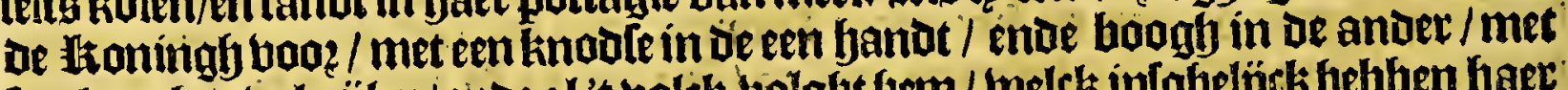

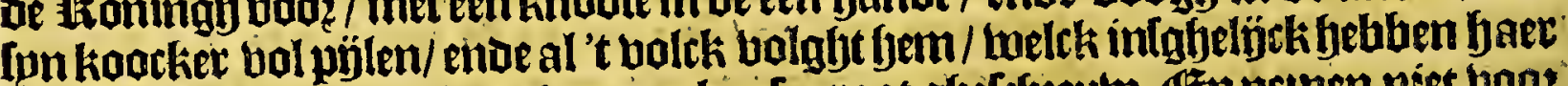

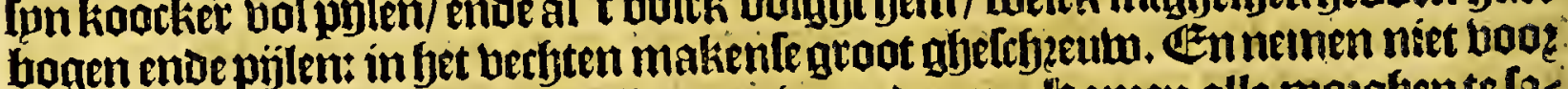
fonoer jyaten raeot daer dickiwilg op te betgaderen. Homen alle mazghente lae men in een groot gemeju bupg/Daer de loningh komt/entoe let feim neser op een

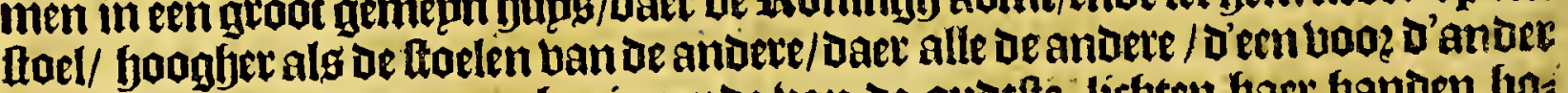
naer/hem komen gtoeten/beginmenoe ban de oubtfte; lieften baer hanoen bo: ven baet fooft/ legghenoe ha, he, ya, ende de relte antwoozt ha, ha. Bit gljes

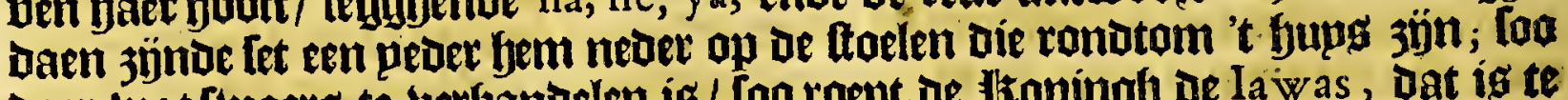
Daet wat (twaers te bethandolen is / foo roept de ltoningh de la was, oat is te

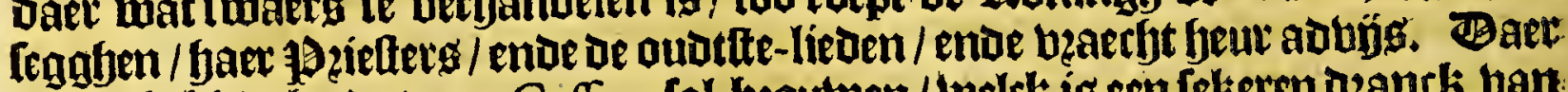

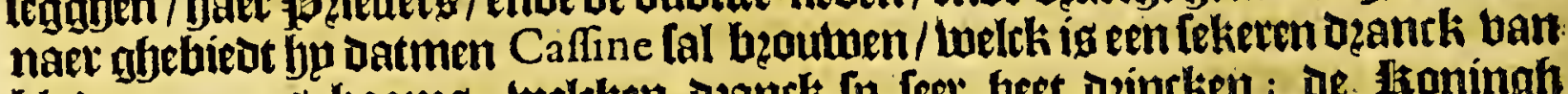
bladeren eenes booms; welcken dzantk [n feet feet Dzincken; de laningh

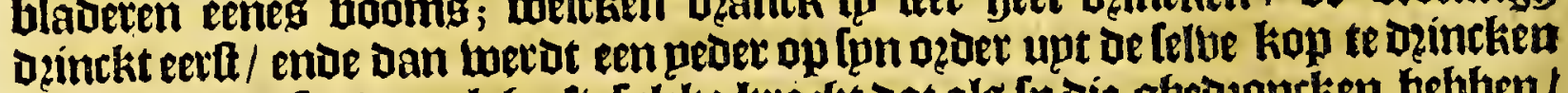

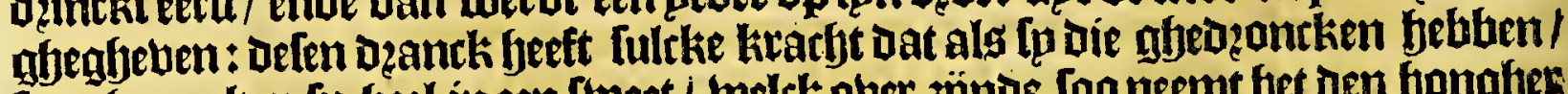

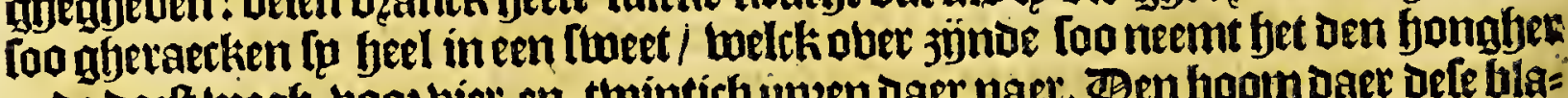

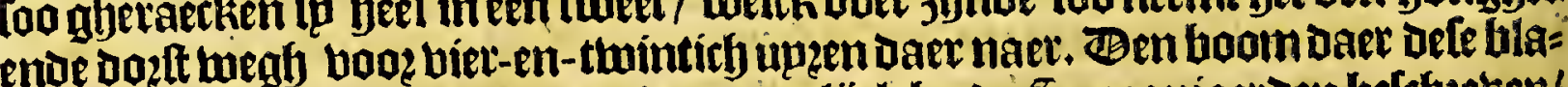

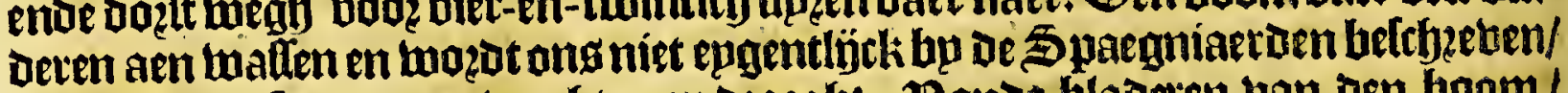
alleen feggen fo dat geen veuchten en dzaeght. Banoe bladeren wan ben boom/ mozt de Caffine ofte Cacina aemaeckt op defer wijle: Doen de bladeren groen in een grooten aerden bat/ende houden daer een bzandende fout oluer ende raecen de

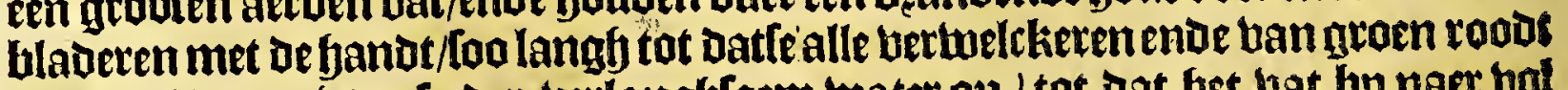
wozeden/ Dan gieten fu oer berlanghfaem twater op / tot dat bet hat bp naer hol merot; therlien ban't nat af / welck is ban couleur als clatet-wign / moe fchupms 
Het vierde Boeck.

$i \sigma_{5}$

als be Chocalate: deren bzantk Dzincken oe moilden ljeel twatm/'tuele de Spae=

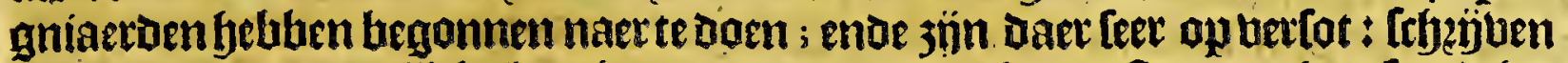
oen Dzanck wonderlijcke krarbt toe / om de grabeel ende feen te ghenelen / ghes

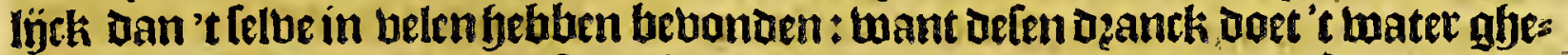
weldigly loofen/ jae foo oat: fp terffalen van fommigbe die naer datle een goede

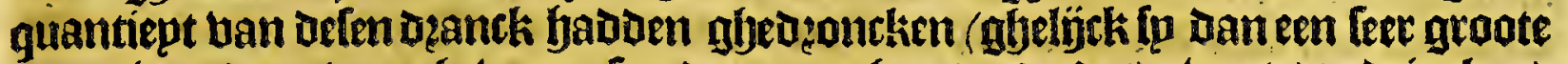
quantitept daet ban ghetwoon [pn Des mozghens ende Des abonts te déncken)

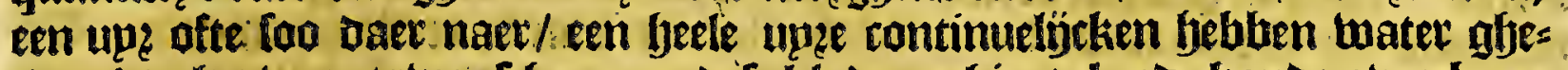
maeclit: bet ware te menleben men dele bladeren bier te lande konde ober-ben=

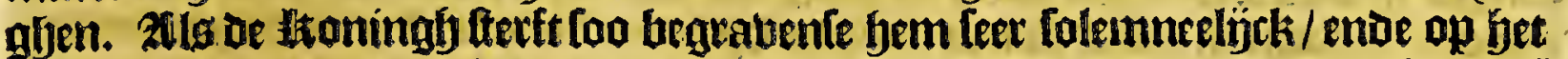

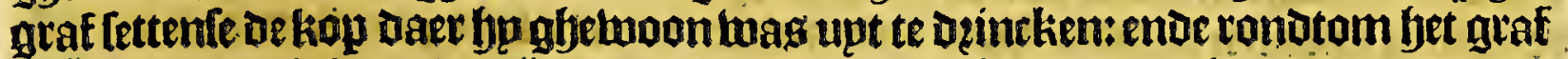
flectkenle menighte ban pjilen/ en ljuplen/en baften dęp daglyen naer den an=

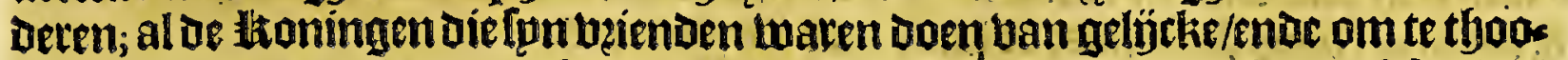

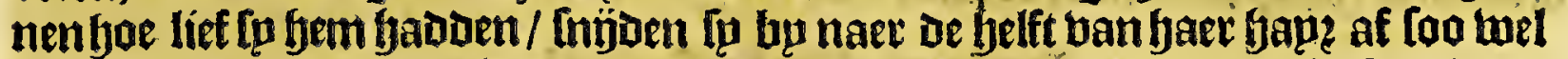
mansals veouluen. Stlle de goederen ban de ltoningh/ weroen in fon bups

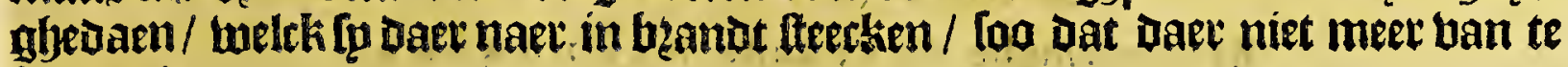
lien en ig.

het tedibutue capittel.

\section{Befchrijvinghe van de tweefterckten, die de Spaegniaerden teghen-} woordigh noch hebben in F I O RID A.

DUE Spaegniaerden en bebben inbelepeduntie maer twee ferckten met bolck Her. des

ingarnifoen lígghende / die alle bepoe ghelegfen jún aen De liufte die naer fiet boften toe liet ; bet eene gbenaemt Sar Mattheo, aen bet punt ban Santa Elena, by de fondert leguen van de Havana; ende fyet ander Sant Auguftin; welck fyet.

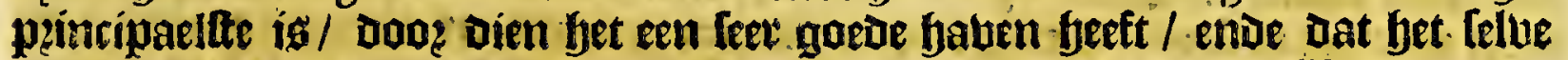
naevoet ngeleghen ig aen de ftrate ban Bahama; is ghelegfen vijfticly leguen van los Martyres. Dit Ielte foet mietot ban Sir Francis Draeck in Den jare 1585 , coo jp quam ban fet in-nemen ban San Domingo ende Cartagena, beto=

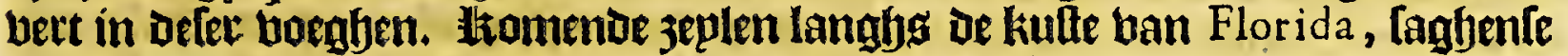
op bet landt een booghe ttellinglye in fozme ban een baecke/ op de hooglte ban Dertich graden ofte daet onttent; waet op [p oe pinallen manoen/ ende aen landt voeren om te fien twat daet twas; aen lanot jünde togfen fo langlys de hant ban de riebier op / bu naer een mijle; ende twietoen nhetwaet aen d'ander:

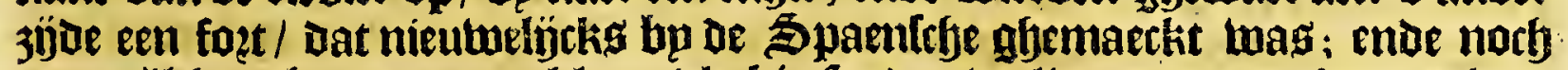
een mül hoogher was een klepn bleckje fonder mallen enoe met houten bup=

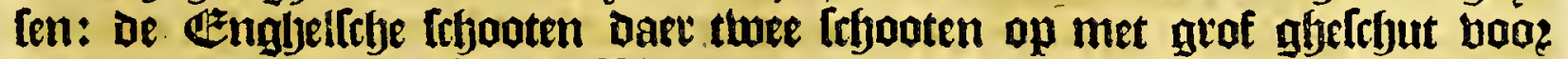

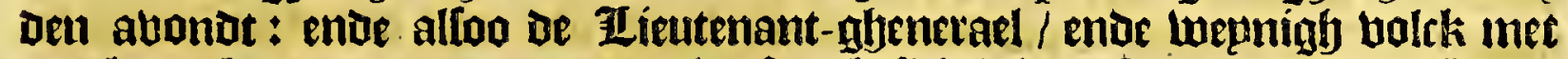
een boodtken ouer-uoet om de plaetle te befirbtigften/ foo mierden de Spae=

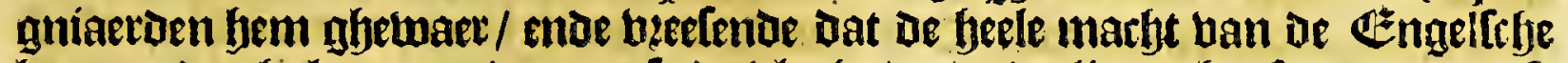
baer op den fjals quam/ namenle de blucht / enoe verlieten bet fout naer datfe

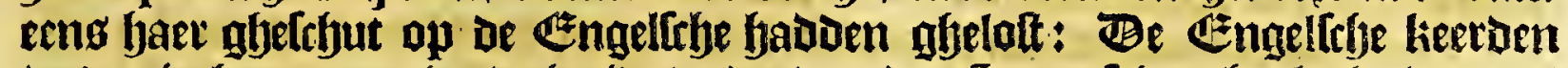
tweder in lyaer quartier / niet metende oat de Spaenfrye gheblutjt toaren / tot dat een frranf-man die bp de Spaenfebe ghebanglyen baot gletweelt / olet quam in een bootien lpelenoe op [pn pyjpe/ oen toon ban bet liedeken

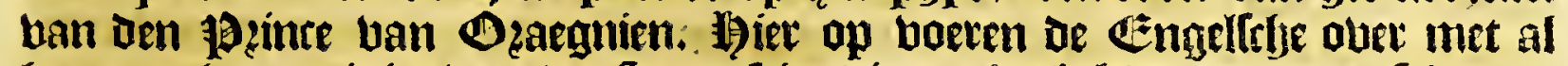
Gaet macbt; eenighe ban de Spaenlebe bic noch ghebleben waren frbooten

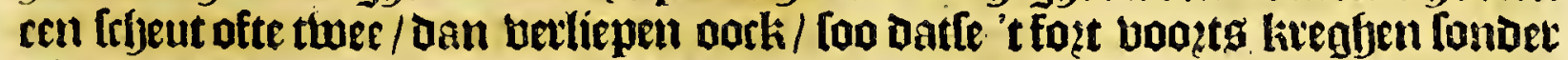
renighe teghen-weer: Bonoen't foet al ban boudt ghemaeckt / De wallen niet an=

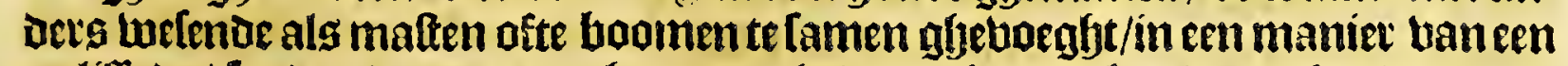

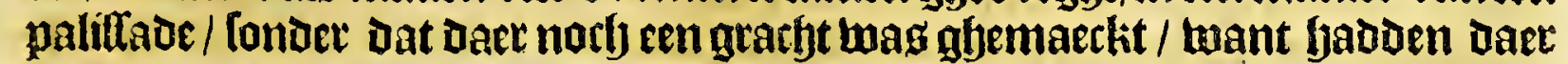
maet Dep oft biet maenden met Doende gftelueelt ende Dethaluen en twas de platte 
166

Florida.

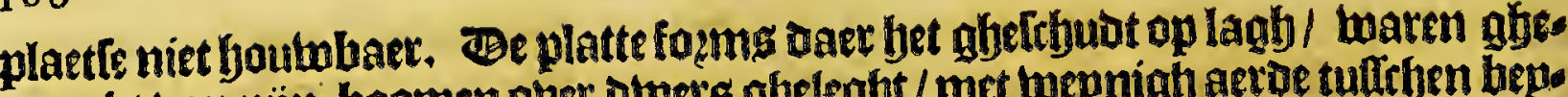
maeckt ban pün-boomen ober dwets gheleght / met wepnigb aexo tufteben bep. Dew/ Daer waren thien oft beerthien groore metale ftucken; ende een kitt toag daes gljebanden met ontrent De tuintich bup fent guloens / om De Loloaten Die Daef las

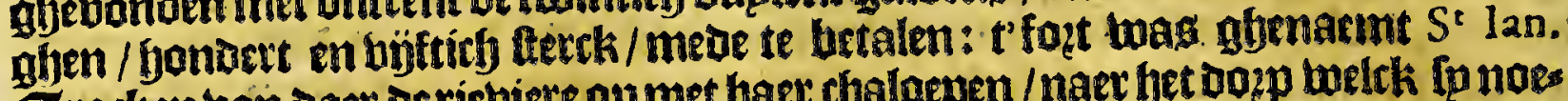

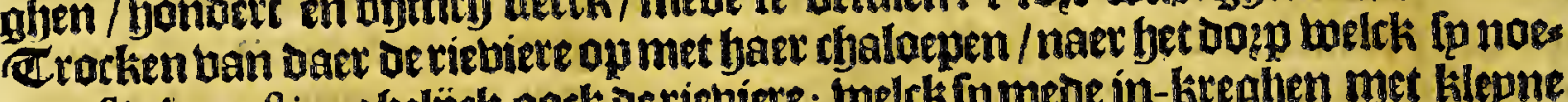
men St Auguftin, ghelistk oock De riebiert; melck tumede in-laregben met klepne. refiftentie oe Gouberneur Pedro Melendez een ban de ertle bluctrende. De Engelirbe berftonden fier oat De Spaegniaeroen / bp de twaelf mülen meer naet tnoozden/nocheen ander plartfe jadoen bu Santa Helena, daet oack honoert ens of bijftich [oloaten laghen. Iffen/ Dan vindenoe in toertwaertg 3 eplen / oe kufte foo vlack ende Dangeteus/ foo lieten fo bet Dooz-Itaen naer dekulte ban Virginia toe.

Yet feuen-thiendo Capittel.

\section{Befchrijvinghe van de kufte van FI O R ID A.}

Her. defcript. 19 oe kufte van Florida zön ban fonderlinghe controeratie de Eplandekeng

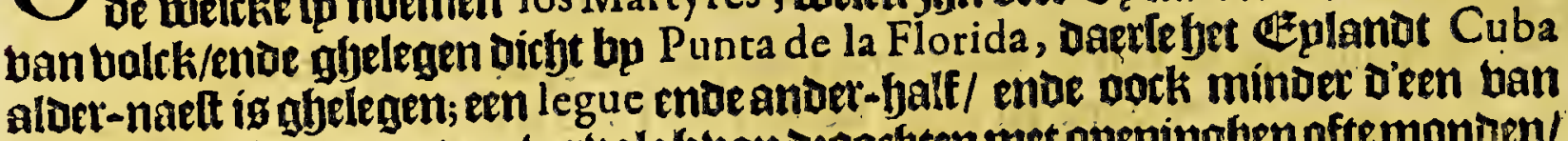
D'andex ligghende/met een berbolghban Deoochten met openingben oftemonoen/

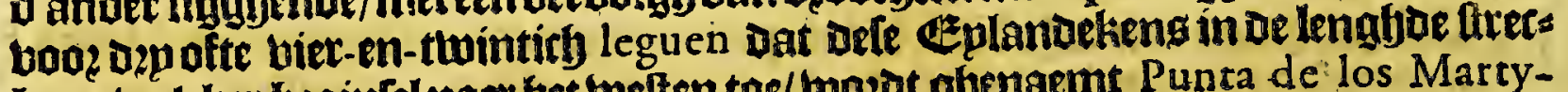
Ken ; melcker beginfel naer het welten toe/ bozot ghenaemt Punta de los Marty-

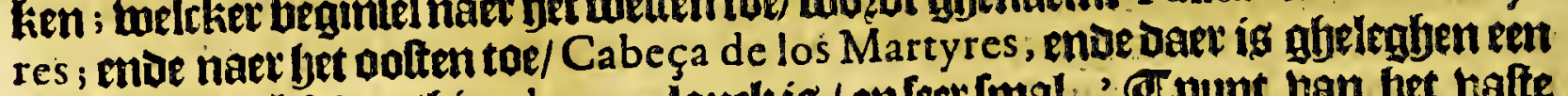

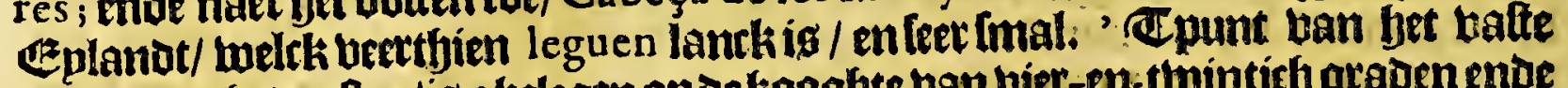
landt naer bet ooften/is ghelegen op de booghte bam biet-en-twintisf graden entoe een half / Daet eetrijtseen moon-platte ban Spaegniaerden was gheleght / oeth

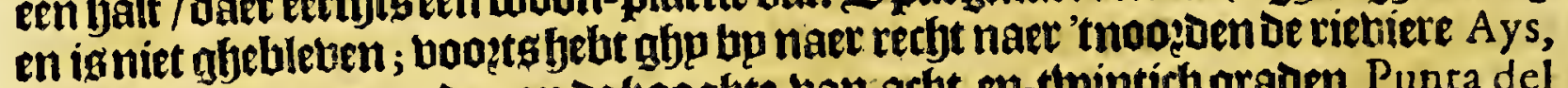
ende meet naer 't noozoen op de hooghte van acht-en-twintích graden Punta del Cannaveral, welcti andere trellen op atyt-en-twintígh graden en een deroe ofte ooc een fjalbe graet/entue nocly bozael Rio de Mofquitos, eer ghp komt aen Rio de la Matança; de welrke Lo genaemt wozt/ uan wegen de flarfter die Pedro Melen. dez bier debe aen Capitepn Ribauld ende ae Jirantoplen: (melck top bier toien bebben verfaelt.) Baer naer la Punta de Sr Auguftin, op ue booghte ban negfer:en-twinticf graden ende Dep quart: De Barra ban $S^{2}$ A uguftin líght op Dertict gra: Den Lefjarts/ende ftreckt noazot- Left in/ende zupdt-ooft upt: ende thien leguen noozoer de riebiere $S^{t}$ Mattheo, ban waer de kuifte baer bonot naet bet noozot-

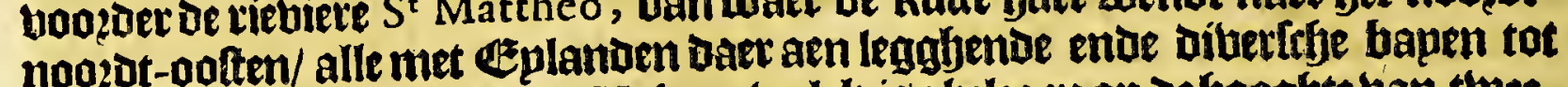
aen oe Cabo ofte Punta de $S^{t^{2}}$ Helena, welck is ghelegen op de hooghte van twee-

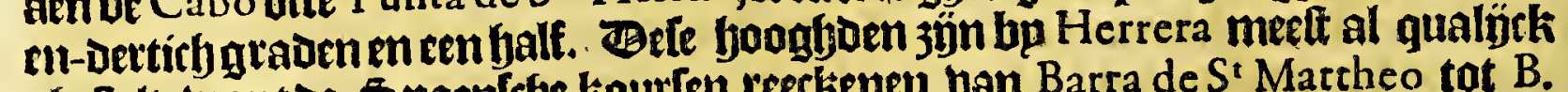
afieftelt: want oe Spaenlefe kourten reeckenen ban Barra de $S^{t}$ Mattheo tat B. de $S^{t}$ Pedro op or jooghte ban 3 I graden arbt leguen, enve ban oaer tot Barra de Balenas vïf leguen, be kult ftreckende noozot-nodzot-ooft/ende ander-half legue boozder Alacanij ofte Qualaquinij: ban Daer tot Saon noozot-noozot-oolt bje

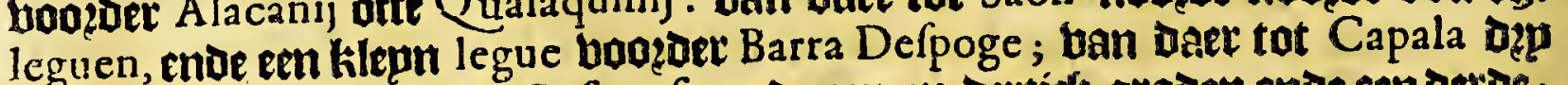
leguen, ende twee boozert Cofonufo op de en-en-dertich graden ende een detae; Depleguen vooyder Barra de Afopo ; van daer tot Bahia della Cruz aerde-bale legue, tot Bahia dos Baxos Dap; tot $S^{t}$ Elena tujf/op to booghte ban twee-en-der tidf gradenen een balf : ban bier tot Oriftan fes leguen; tot Barra de Oftano biez leguen: tot Cayagua adyt/ De kulte Areckt oolt-noazot-oolt ente welt-zupt-twelt/ light op oe twee-en-Dettich graden en büftich mínuten: ende Rio lordan op Depen - Derticlj; Cabo S' Roman op vier-en-Dettich geadentbien minuten/ende thien leguen 
leguen uotoer Rio de Barachadare; we liufeftreclit nootot-noazot-oalt: Cabo de Tros-falgar op bujf-en-Derticf graden: Bahia de St Madal ena op \{eg-en- Dettiff gladen rupm: ban fier ftreclit oe hulfe noozot-noozot-belt tot Bahia de $S^{t}$ Iago arbt leguen, ente ban daer tot Xacan oft Bahia de Madre de Dios ap de hooghte ban feben-en-Dertich graden / leten oft arbt leguen noazden ende zupuen.

Op Defe thutte ban Florida Lualck naet bet lueften toe fiet/jijn be Tortugas gijeleghen/[eten oft atht Geplanockens bu den anderen; ende naev't noojoen ban Punta de los Martyres, aen bet valte lanbt la Mulpa, ende derthien leguen meet nooldt-maert oe Bahia de Carlos, anoers afenoemit de Iuan Ponce de Leon; ende norb foo beel leguen boozer de Bahia de Tampa, Dep-en-Dettich leguen uan Tocobaga, Díe men anders noent del Efpiritu Santo, ofte de Meruelo, op ve fooghte bau neghen-en-twintich gtaden en en balf/ Daer bet begin is ban

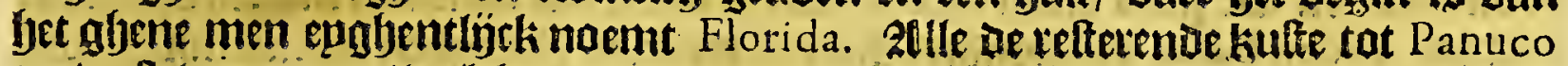

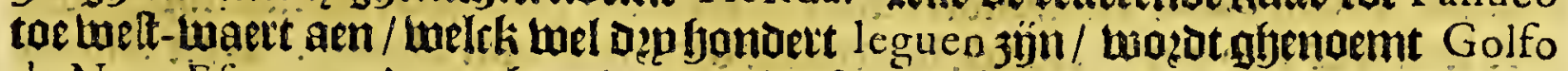
de Nova Efpanna, Daer gbeen moon plaetlen en 3 ju ban Spargniaeroen/fyoewel bet in Boubernement was gfenlieven aen Panflode Nervaes, nno Hernando de Soto, enoe noth te Lozen aen Francifco de Garay : enoe ban fun boltk infonderfept beiftonotmen/dat bet en aim lanot is/ban vibzes gualjel boa:fien/ende miferabel bolck / [oo dat-men Daer twepnigh werths banmaeckte/ joe-

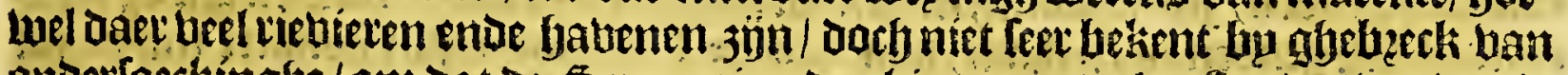
ondertaeckingfje / om dat or Spaegniaeroen biec mect teghenltanotg bonden in

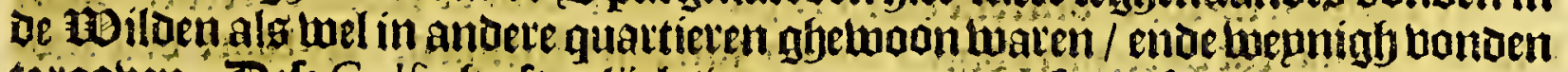

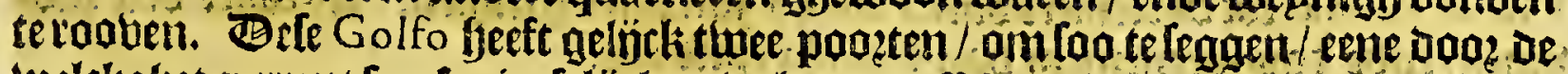

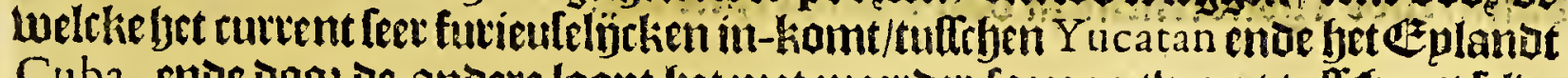

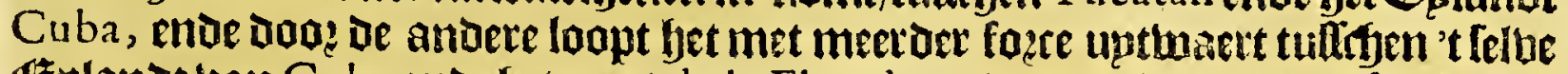
Eplanot uan Cuba enoe bet punt de la Florida, enoemartit Daet met fpn kourg

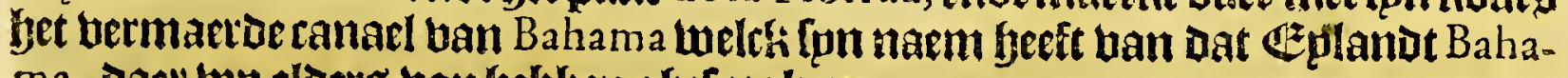
ma, Dael top eloers ban beblen gutipzaken.

\section{() ach atbienue Capittel.}

\section{Andere befchrijunghe van de felve Cufte, uyt Ian Huy- ghens van Linfchoten.}

V Zfn Santa Helena tot Rio Secco, lekentmen betticf Spaentfye mülen / welcket Ietentyienen een balt een githed maetken/ende defe rieviere legbt op ac looghte ban een-en-dertich gladen loan R io Secco jün twintich múlen tôt

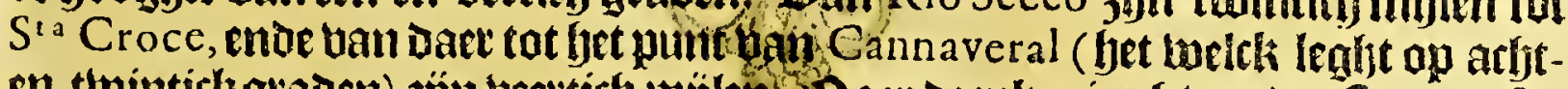

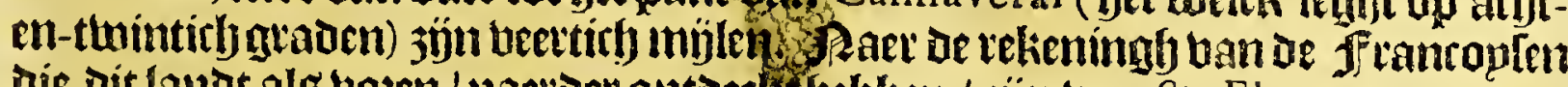

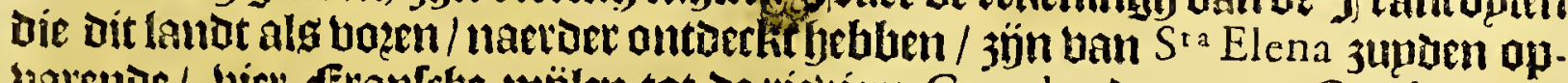
batende / vire ffranlibe mijlen tot de ríeviete Grande; Dapt nacr Guade, fnde voozder Belle, ban daer tot Gironda, wajbet tot Garumna, moe vopts tot Charente, han Charente tot De Loire, [es mijlen; ban ie Loire tot Axona, in welctier

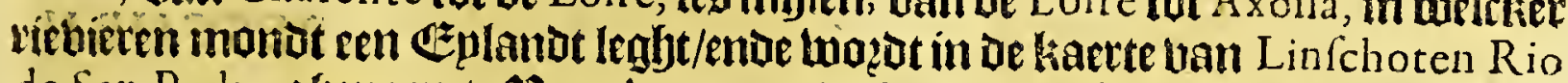

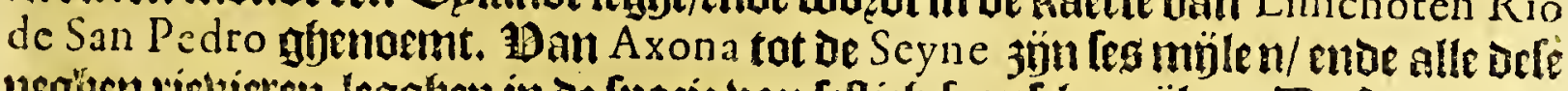

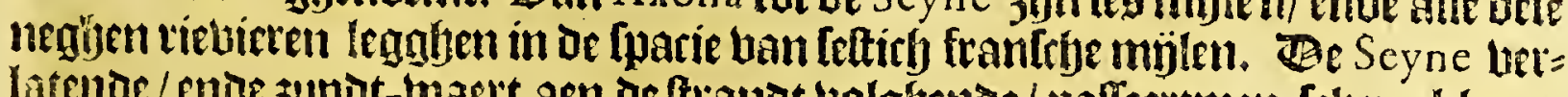

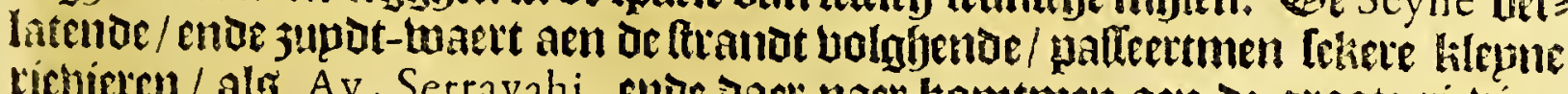
ríctieten / als Ay, Serravahi, ente Daet naer komtmen aen be groote riethiete Majus. Ban idfe riebiete komtmen aen en Golfo, die wat te lanot-braett in.

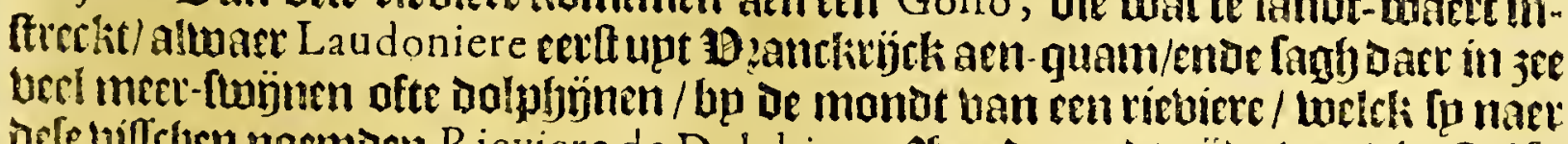
oefe biffryen noemoen Rieviere de Dolphins. Aten de 3 mpot jyoe ban die Golfo

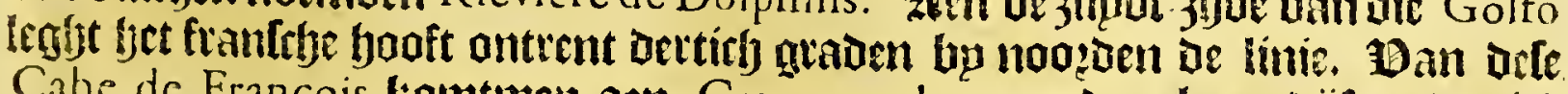
Cabe de François thamtmen aen Cannaveral cen andere hape bije-ent-Detticl) mïlen 
mij!en ban d'ander gfeleghen. Be Spaenfthe kaerten laten ecniglie van defe Hleque riebieren affer / ende de groote gbebenlp andere namen/ bant díe ban May, notmenle de Matança; De Seine, $S^{t}$ Auguftin : De Garumne, $S^{t}$ Mattheo, ende de Grande, $S^{t}$ Pedro. Dan Cannaveral tot Cabo de la Florida leeftmen

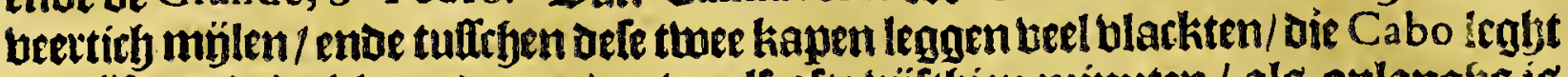
op bïf-en-twintich graden ente twaelf ofte biffthien minuten/als onlangug ig hebonuen: booz die Cabo legalfen beel blackten ende klippen/ diefe los Marcyr es noemen/ welck jün beel blacke Êplanden/ ban twelck bet uptetfte ghenaemt Ca-

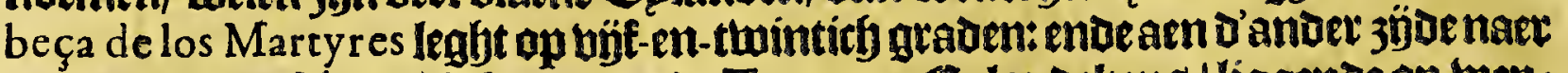
oen bortht ban Nova Hifpania toe oe Tortugas \&zplandekeng/ liggenoe op weps

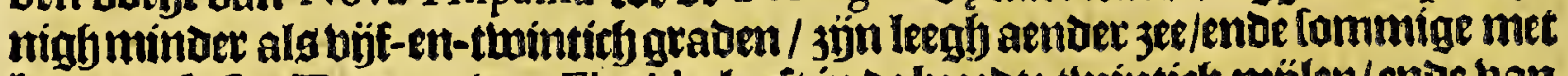
boomen belet. Je punt ban Florida beeft in ae beeedte twintich mïlen/ende ban

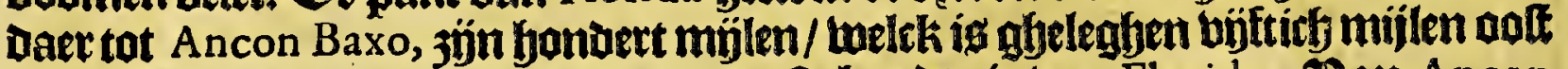
ende twelt met Rio Secco, welck degroottet beedte is ban Florida. Ban Ancon Baxo tot Rio de Nieues, jün bonuert millen. Ban Daet tot Rio de Flores, thins tichmílen ofte watmeer. Ban Rio de Flores tot Bahia del Efpiritu Santo, jijm Tebenticfjmijlen/aiemen nock anders neemt la Culata, enve is in't in-komen oettich mijlen bzedt. Ban defe Bahia (melek leght op de booghte vanneghen-entwinticy graven) zijn leventity mijlen tot $R$ io de Pefadores (welek leggt op arften-twintich graden en en balf/) ban Rio de Pefcadores 3 jin fondert mijlen tot Rio de Palmas, al-waer ontrent aen Tropicus ban Cancer beenen freckt. Bant Rio de Palmas tot de riebiere van Panuco jủn uertith mülen. Aal-waer dete pqus bincie/ende 'tgaubetnement ban Florida epnoietht.

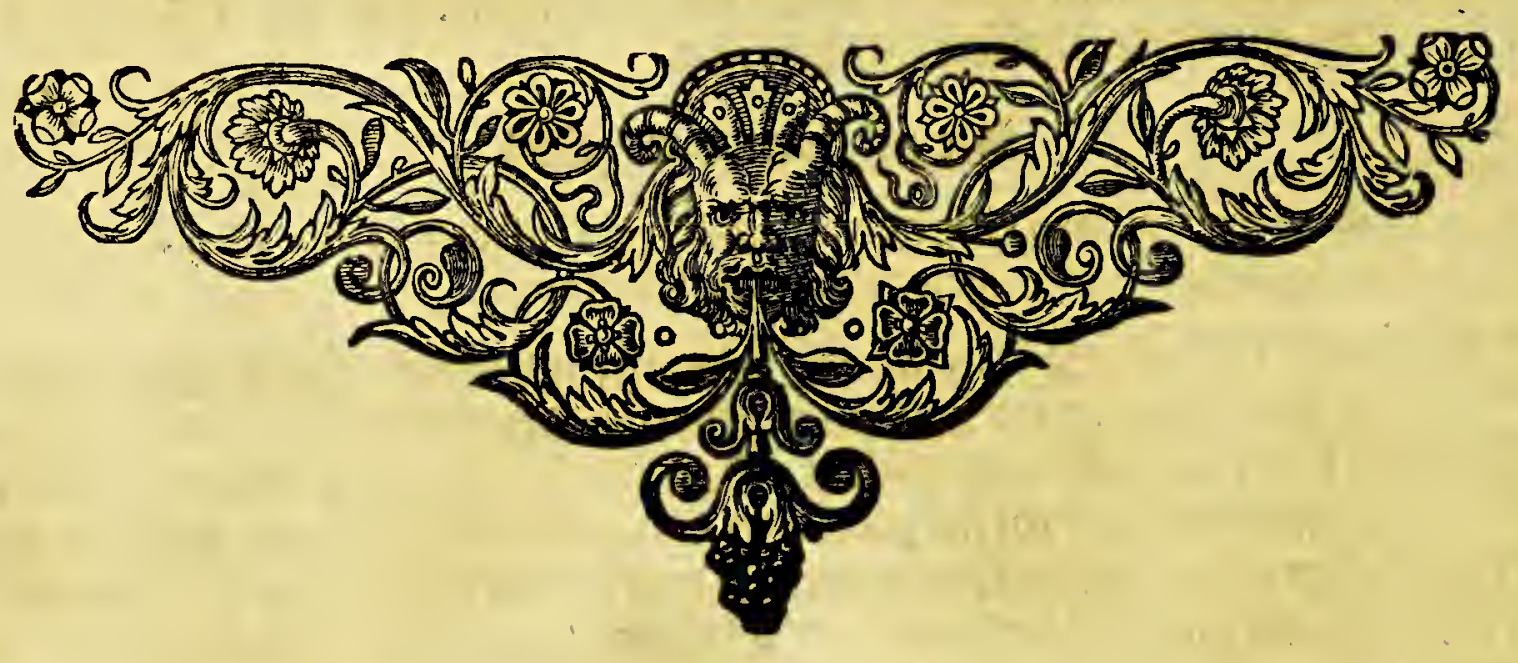

BES CHRII- 



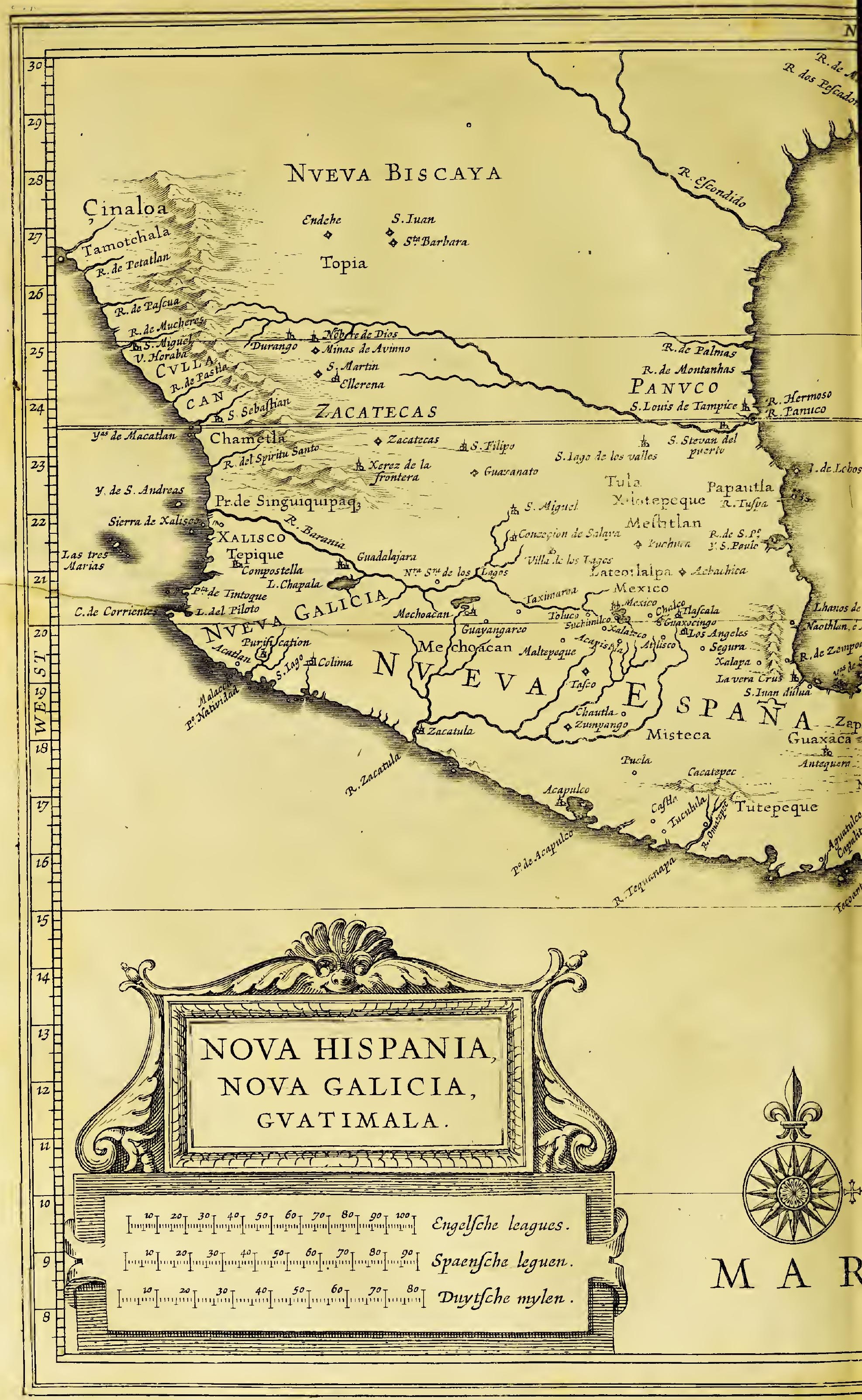




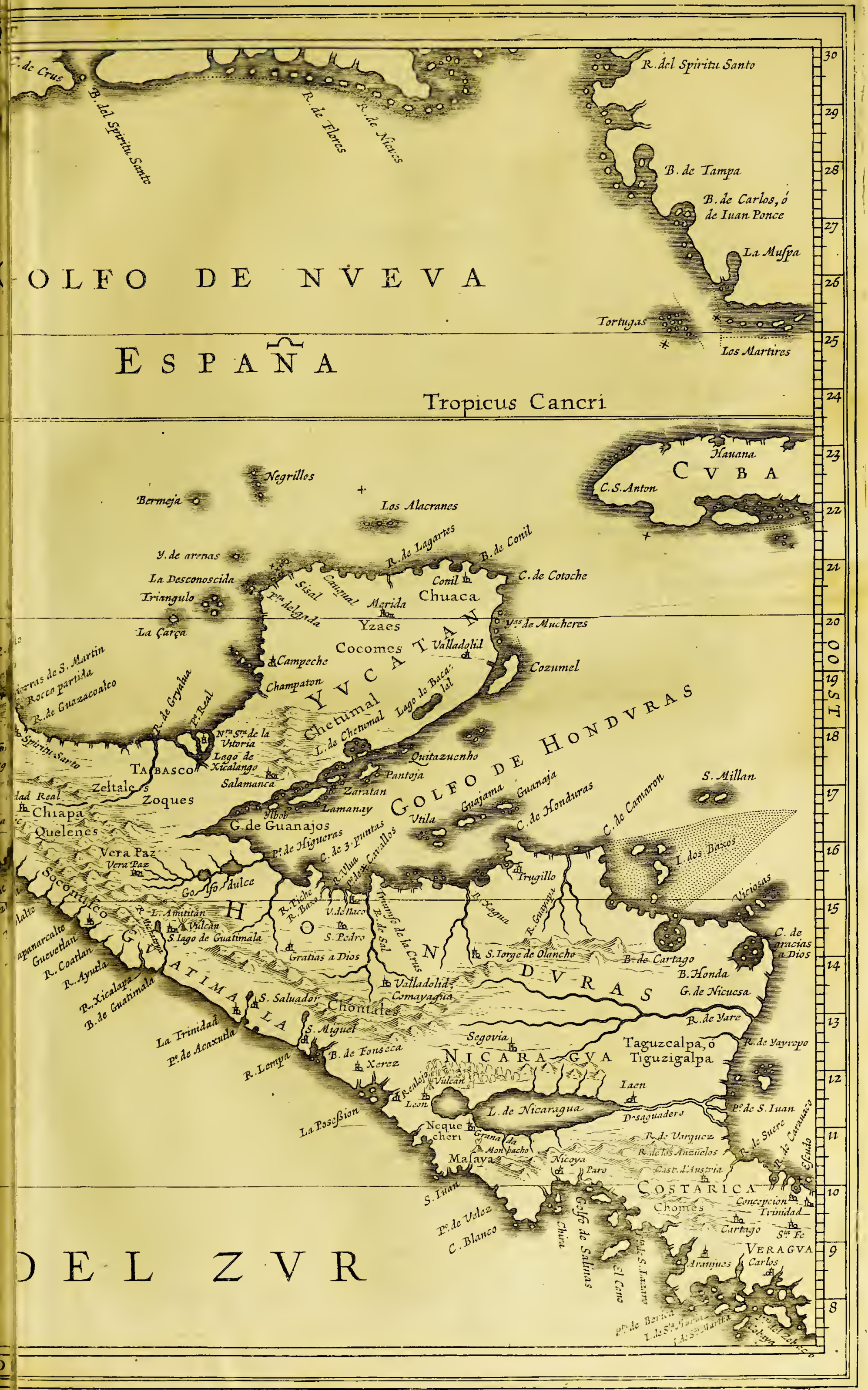




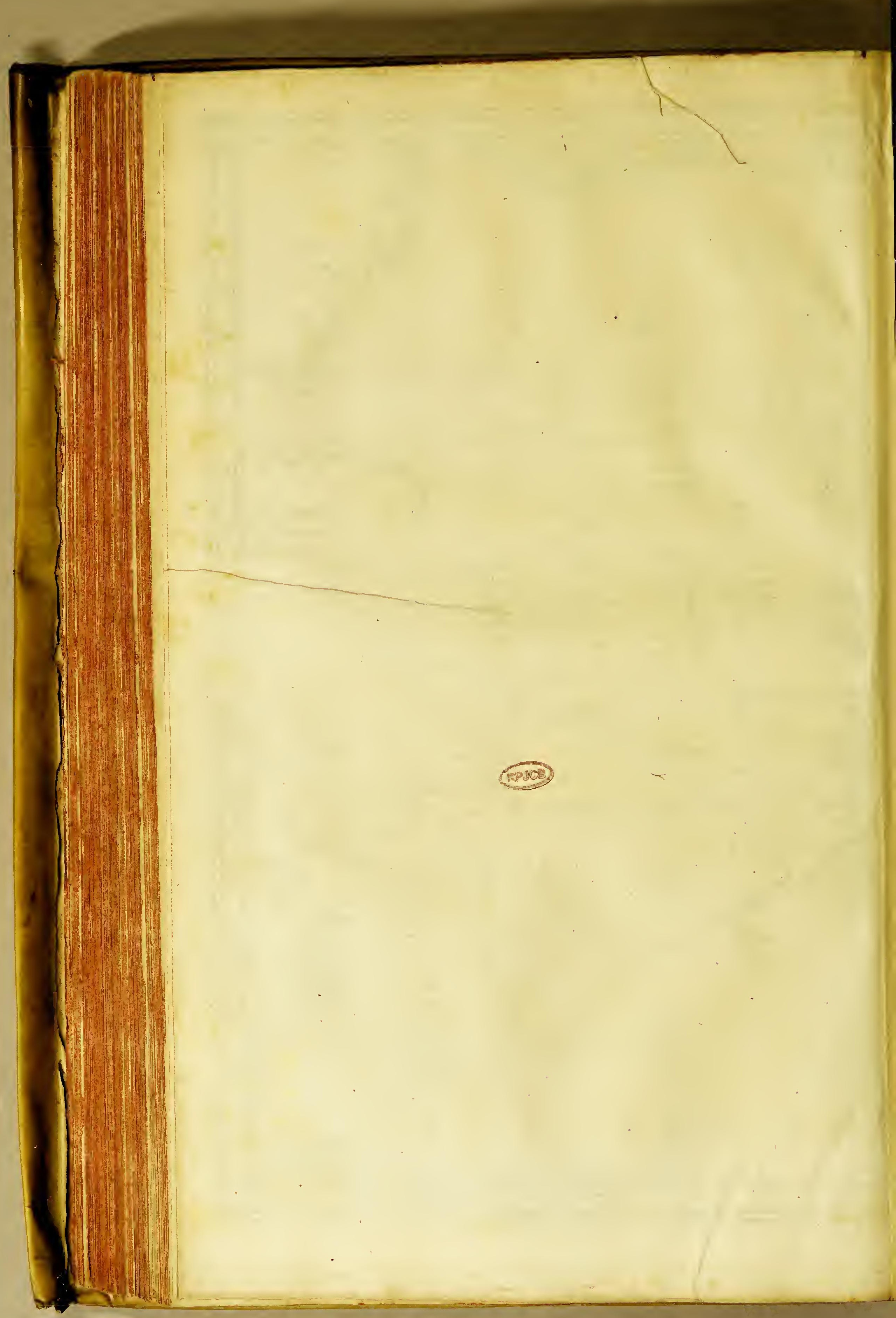


BESCHR IIVINGHE

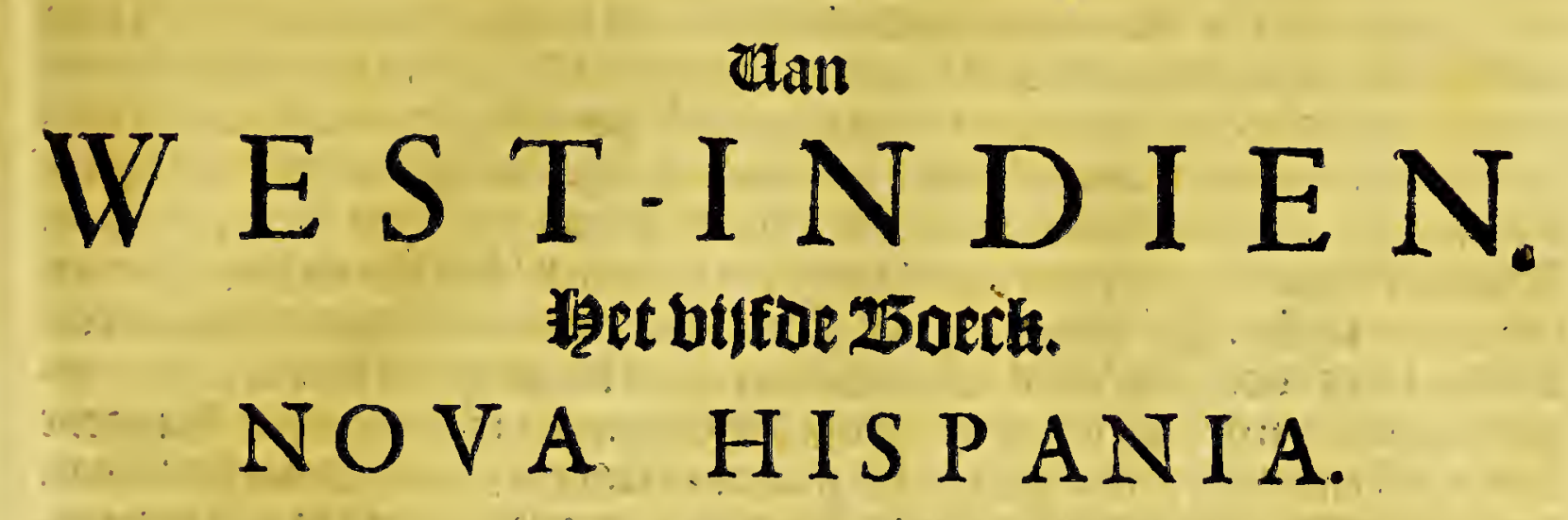

Het eatite Capittel.

Befchrijvinghe van de provincie van Nov A His o a i a in't ghemeyn, de gheleghentheydt van de verfcheyden landen ende volckeren.

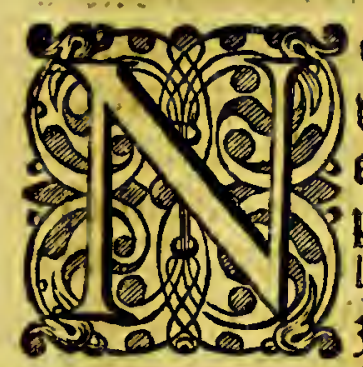

VA H I's A N A, Weicl lot pincipaclife deel is

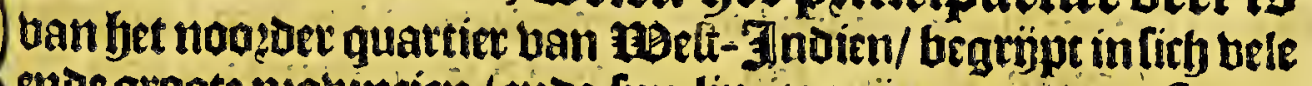
ende groote peabintien/ende fpn limiten 3 jun naet bet ooften De p zobincie ban Y ucatan, ende naer't weften depeduincienuan Colifornia enue Nova Vizcaia, ende andere;naer't 3 upden de zupot$3 \mathrm{ee} /$ ende naer 'tnoozaen bele ende groote lamben / Die noch niet te degben bekent ofte ontseckt en jọ / loo dat baer limiten aen

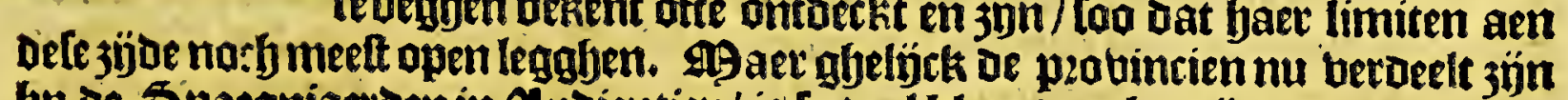
bp oe Spaegniaeroen in zludientien/ is fp veel klepnder; begrijpende nu de 2 lus dientie uan Nova Hifpania, ten deele't ghene epgentlibel gbeen Nova Hifpania en is / als de peobincie ban Yucatan, ende ten deele daec bupten fuptenoe/ bet

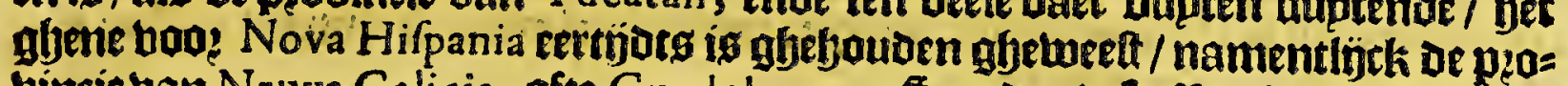
bimcie ban Neuva Galicia, ofte Guadalarara. Soo dat ocle zludientie van Nova Hifpania gheligr tot bet welten / bp de bier Gondert leguen, ban bet ooltelïckfte deet ban Yucatan, tot daer of peobincie ban Mechoa can baet af-fchepot ban of limiten ban Neuva Galicia ; ende in oe bzecote ban fet nopzoen naer fet jupaen bp de twee jondert leguen; ban fiet noojdt-epnoe ban feet Goubemement ban Panuco, tot aen de zupbt- zee / blijbenoe fun limiten niet te min open naer bet noazoen toe als voen

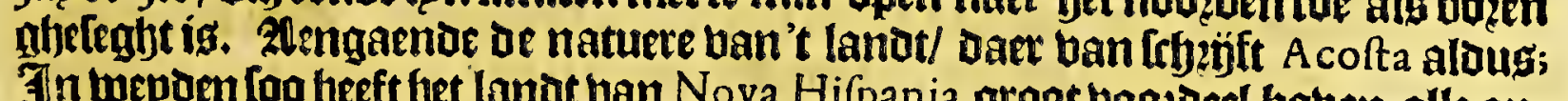

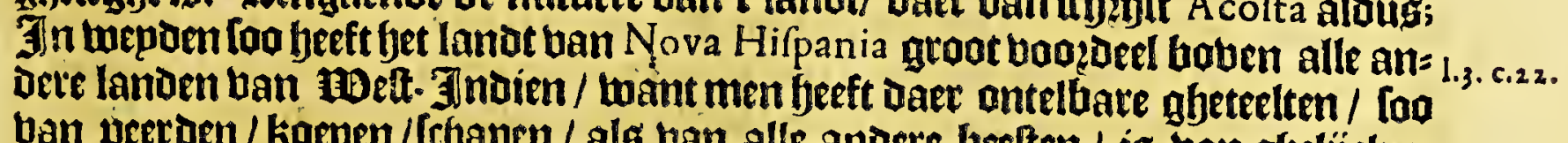
ban perden / koepen / frgapen / als ban alle andere beelten / is ban gbelj̈clien

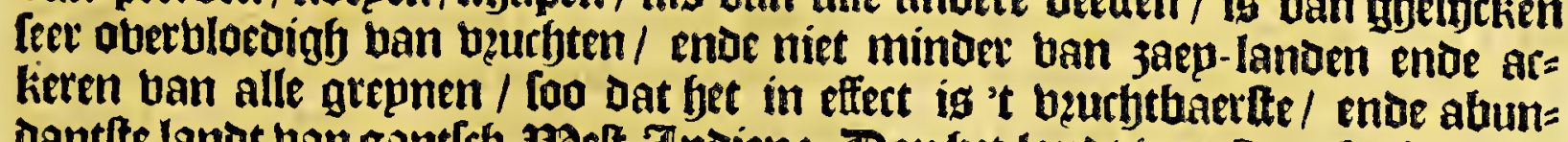

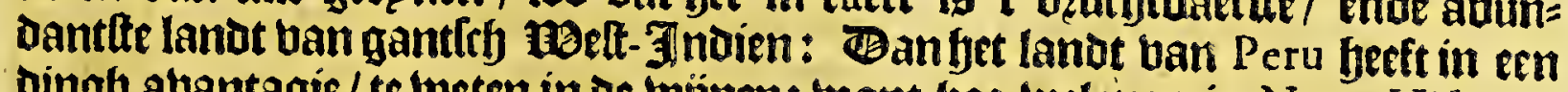
bingh abantagie / te weten in de wijnen: want boe-lwel men in Nova Hifpania

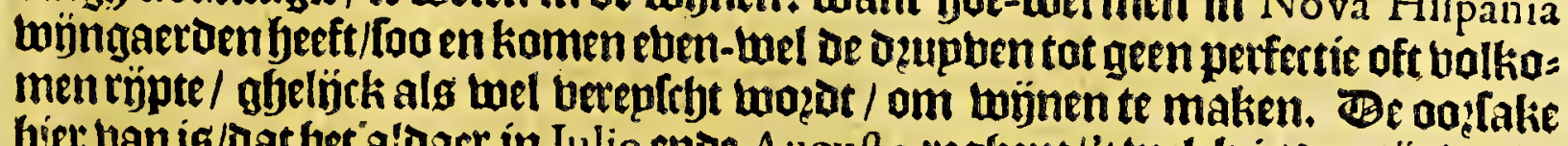
biet ban is/oat fet aldaer in Iulio ende A ugufto reghent/'t welck is den tút dat de deupben rijp bebooken te wozoen/waerom fp niet tot bolkomen rijpte en geraken/ ende foo men daer met litacht ende met beel neerftithept eenighe winn wiloe ma

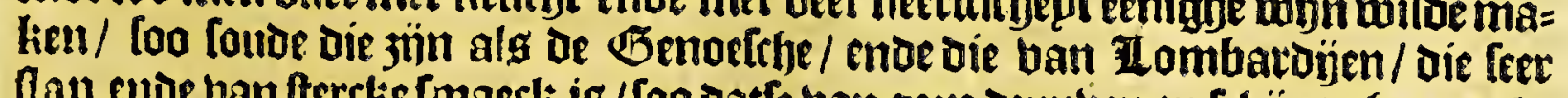
flap ende ban ferclie fmaeck is / [oo datfe ban geen deuptien en l'bünt ghemaecht to welen. Ben lében A cofta oblerbeett boos een gheneralen regel/ aengaende alle de lanoen die naer ljet noozden ban be limie equmortiael gheleghen jün/ ende ouer fulcks loo palt get feloe mede oy de lanoen ban Nova Hifpania, 


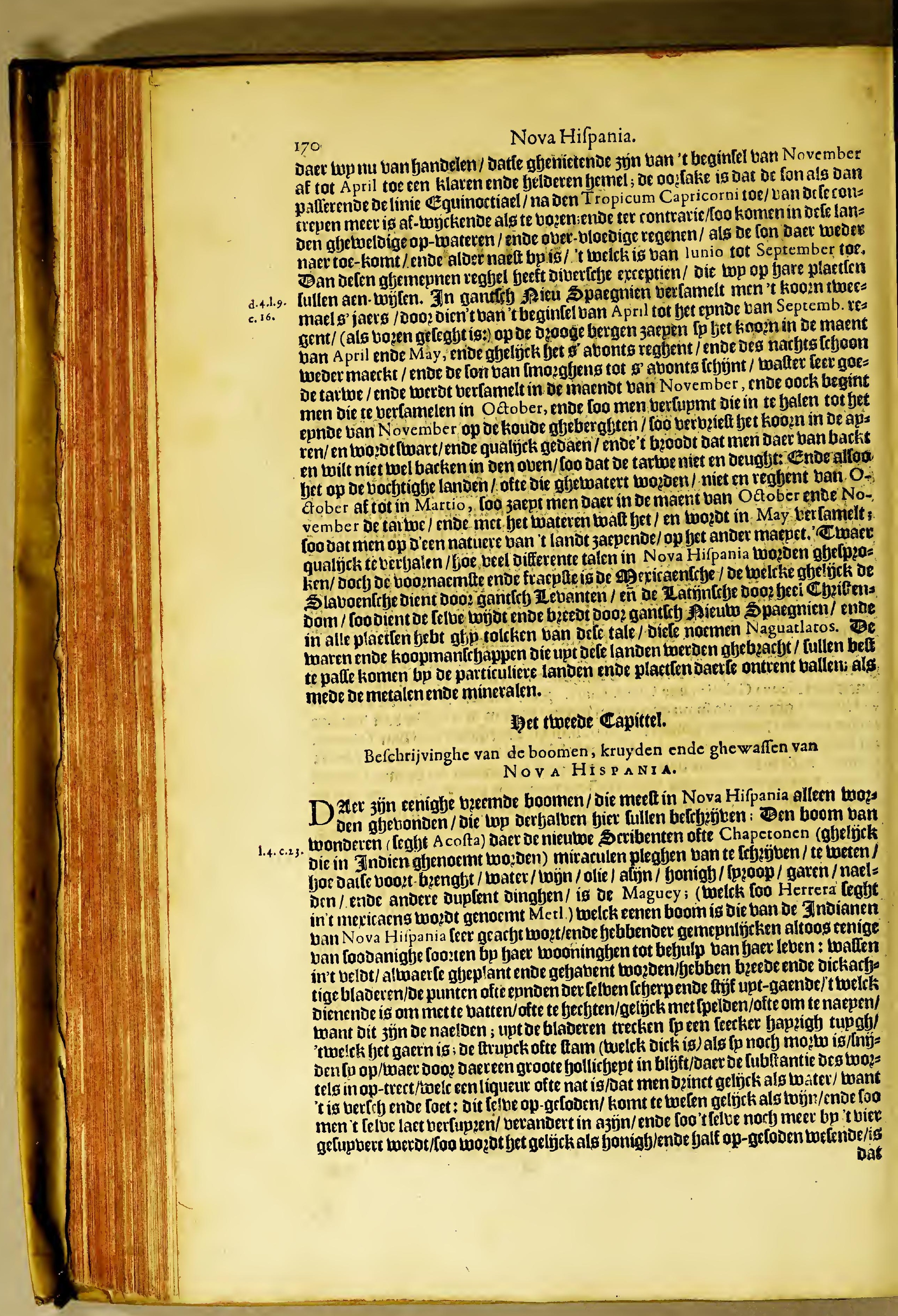


Het vijfde Boeck.

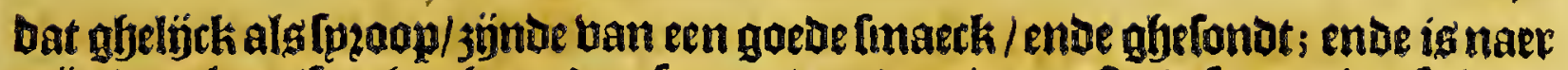
mïn Duncken (legt gp) beter Dan fpzopp ban Dzupben. Op Defe maniere fo tooz:

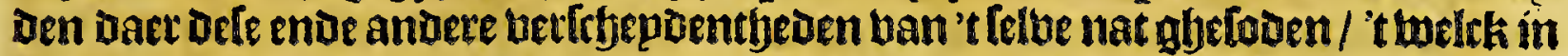
groote menicfte boot komt / want krïgfen bp wölen ettelifske kanten bol ies Daegys daer ban. 'C fout ban defen boamig bol enoe [pongieus/enae dient om

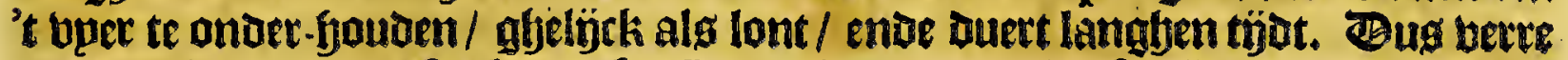

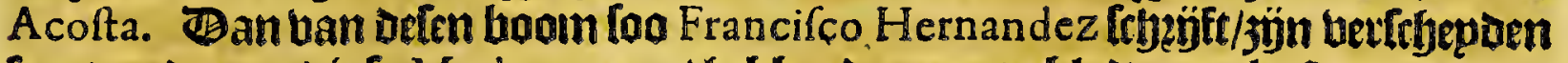
foo:ten; oe eene die [p Metl noemen / jebbente groote bladeren als Semperniva,

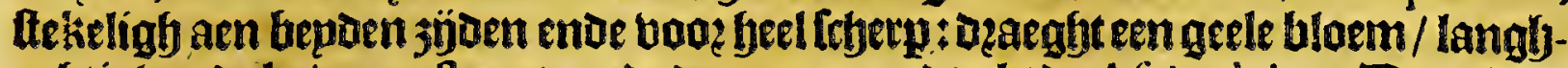
athtigh ende boben gefterret; ende daet naer 3 aed als de A phodel us. TBe andere welct [p noemen Metl Coztli ofte Coztic Metl, beeft blaberen filepnuer als oe tooz-gaende/ ende met minder dooznen be[et/ die ftuart 3 ön/ende de bladeren aen

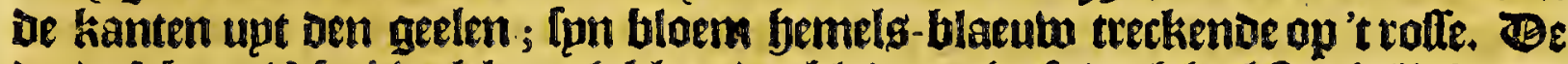
Derde Mexcal Metl, weltk noth klepnder blaveten yeeft Docb beel fteeckelighende Doncket-groen. EEnoe noch andere meer bier te langh te berfaelen. דan is te noteten dat Francifco Hernandez ende Francifco Ximenes dele planten geen boomen en noemen / maer onder de krupden beftheijuen / gae twel fu fegghen dat de eerlte foozte twel op-lrfieot tot de fjoogfte ban een tamelijeken boom. Be Tuna is een anderen bermaerðen boom ban Rieulw-Spaegmien/ foo men betern boom marb geeten / een bos bladeren ofte looten die d'een boben b'ander upt ko. men/waet in ljp 't beeemtite fatloen ban alle andere boomen beeft/want Daer twatt eetit een bladt/upt bet welcke komt een ander/ende ban dat weder een ander/ende allo boouts tor het epnot toe / uptaefondert dat fo gelíck als de blaven boven ofte bejÿorn beginnen lipt te komen/alto beginnem de benedentte te betdicken/komen= be bp naer $t$ fattoen ban de bladeren te berliefen / eñ makenoe cenmanier ban een

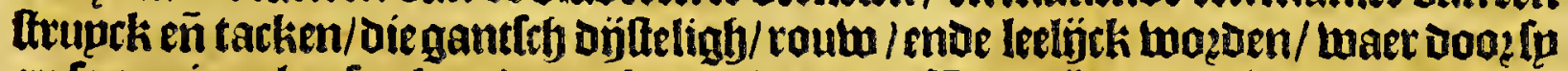
op commige plaeten kaerden geberten toogden. Baer 3 gin ooc wiloe kaerden ofte

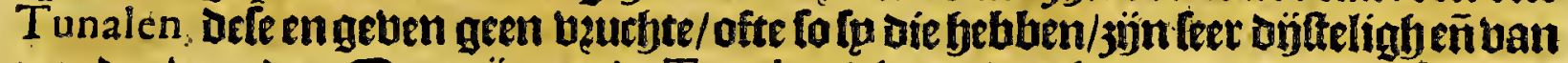

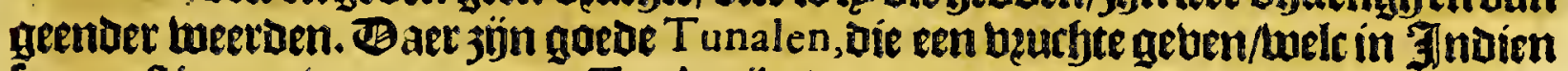

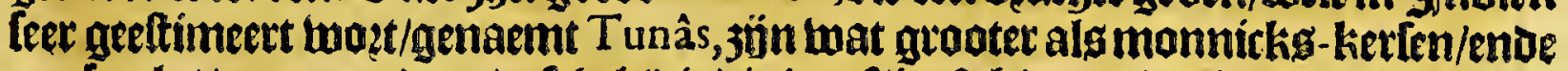

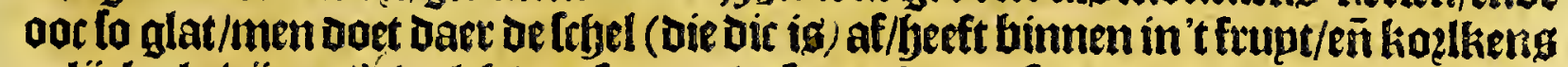

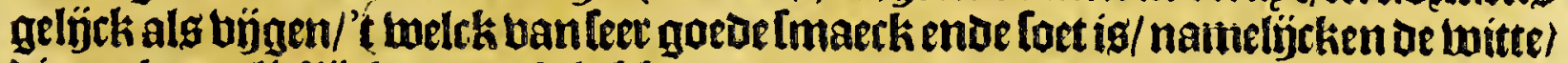
die oock een lieflïrken reuth bebben / ae toode en jün gemepnligrtien lo nact niet.

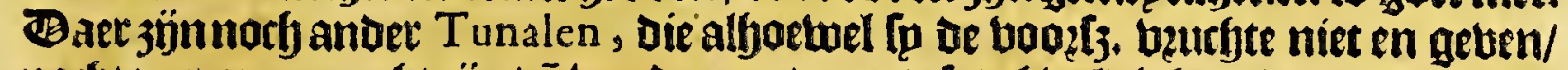
nocbtang meet geacht sïn/eñ bożen met groote fozghbulioighept waet-genomen eñ gebatuent; want van dele Tunas komt't greun ofte Cochenille; (De gigericanen noemen Defe Nocheztli nopall ofte nopal Nocheztli) Daer groepen onoer in De bladen ban deten boom alfe wel gefjabent is / fekete twozmkeng / die saer aen ge. tileft / eñ met een leker dun blieflken bedeckt jün / De welck oe Jindianen daer feer

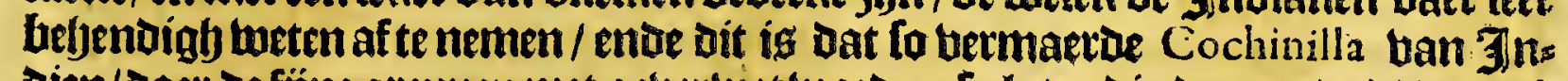

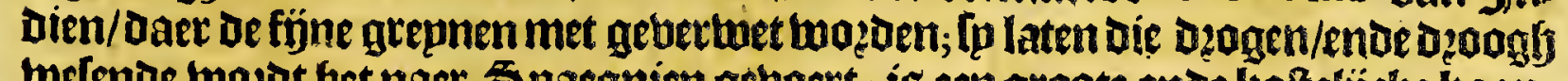
belende wozot fet naer Spatgnien geboert; is een groote ende holtelijtke toops mantryappe. Tn oe bloot van't jaer 87 quamen daer 5677 aroben Cochinilla. welck beliepen 283750 Pezos, ofte Ziealen ban achten. Dele Tunalen twallen in

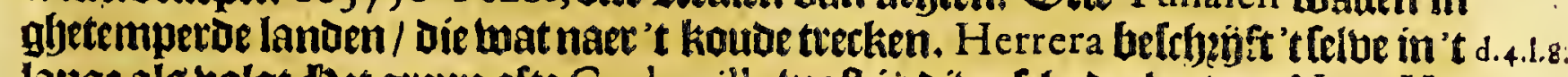
lantge als holgt. Bet grepn ofte Cochenilla twaft ín diberftye deelen uan Nova $\mathrm{Hi}_{\text {. c.Ir. }}$ Spania, aeneen boom welc Ip noemen Tuna, (de g9ericanen noemen Die Nocheli) twelc feer grobe bladeren beeft; twott ban dep bladeren geplant / in plaetfen daet oe Roopde-winot de lelbe niet en kan beffyadigen; de Cochenilla is een letendigh Jingf / De maniere ban een ronde woem / van't farloen ban een tereetj-Iup[e/entoe

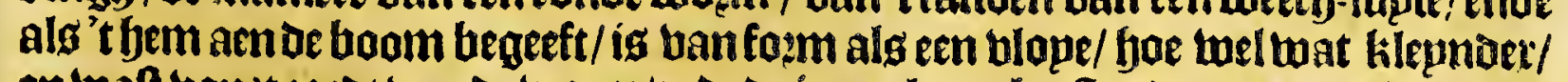

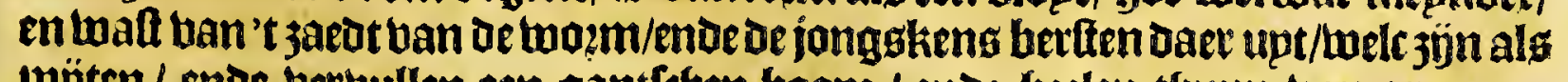
mÿten/ ende betbullen een gantifben boom / ende beelen tbupn ban grepnen; Q 2 komt 


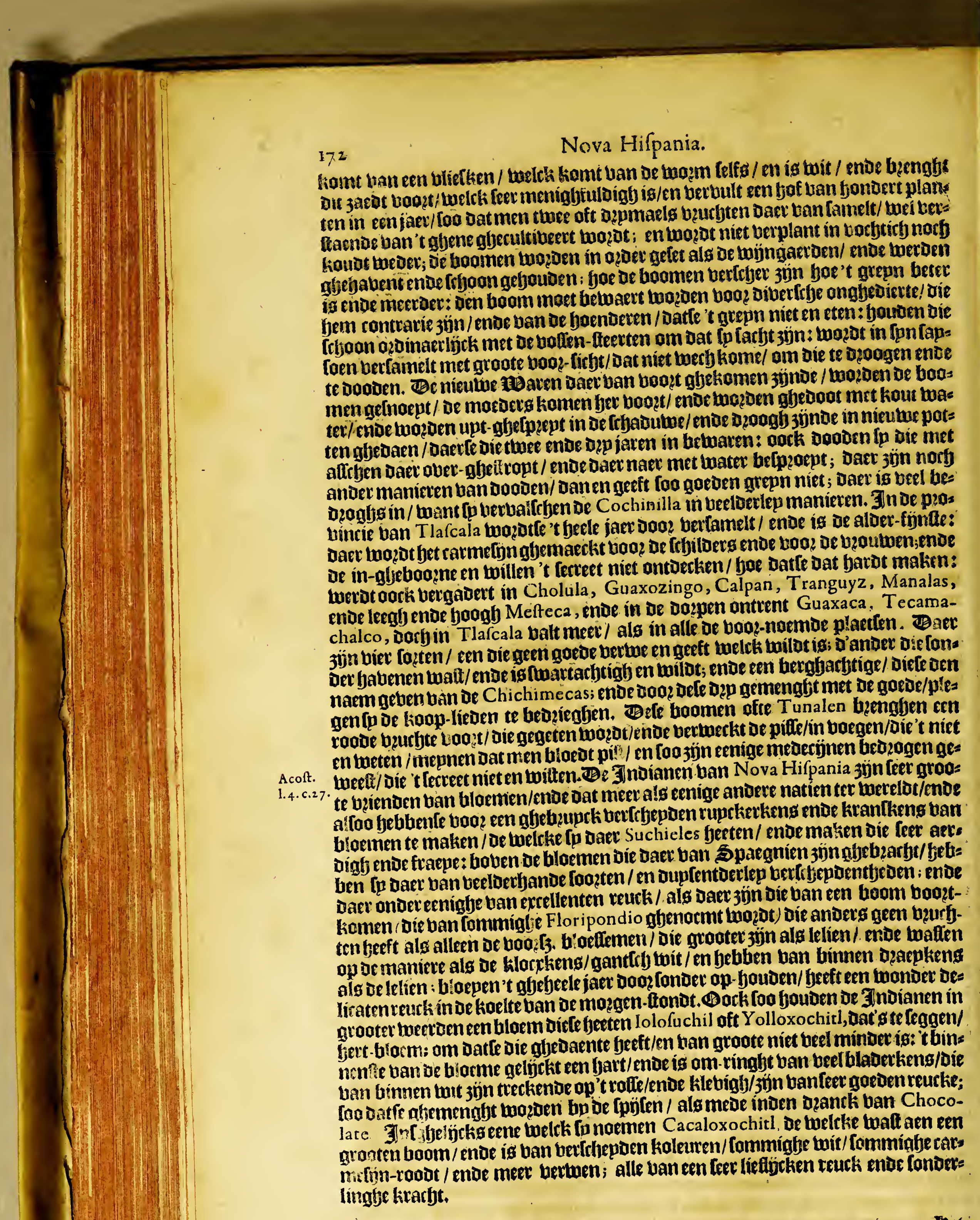


het Detoe Capitiel.

Van verfcheyden Herften ende Gummen dic in Nova Hípania va llen; ende verdeelinghe van defe Provincic.

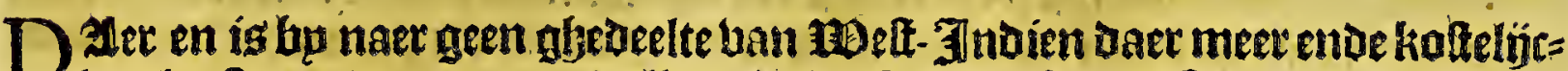
ker berten ende gummen ballen alg in Nova Hifpania, loo dat bet de pyine

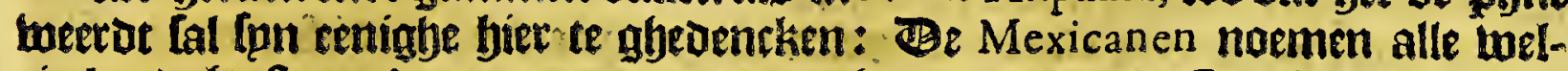
riectiende ferften ende gummen met eenen gijemepnen naem Copal, ende naev de berffyepdentfepdt der boamen die de feloe bookt-bzengen/ioo doen fp saer een bp. narm toe om die te onderlefyepoen:Doefy den berlt die boomementipek Copal wert

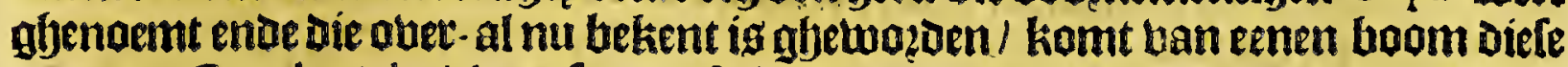

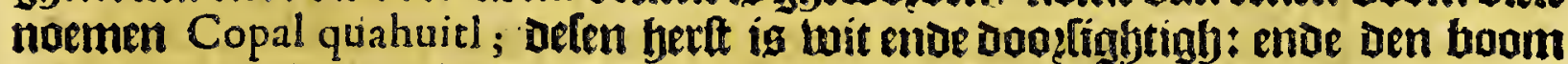
baet bp upt-bloepet / Geeft blaoeten det epchen bladeren niet ongelijek dan dats fe grooter fpn en langher; Den frett komt foments ban felf ae teten die in oen balt woeden gheliteden: is watm bp naer inden detoen grae at/

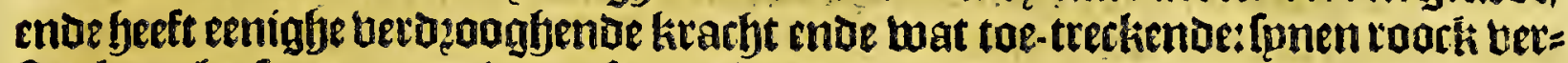
ferckt oe hetfenen; enoe ia een fondetlinglye temedie teghen alie quaelen die upt koude boot-kommen. 20meffeng dele vindtmen bier andere boomen die mede ben naem borten ban Copal quahuicl met cenigh bp-beeghfel:taelcker bladeren berfrbillen in groote ofte lengfte ban den boge-gaenden ; als die fp noemen $C_{C-}$ pal quahuitl patlatmac; om dat die beeeder bladeren beeft; enoe fonen beth is fwattarftigh/ende tuozot bp ue Spaegniaet den gbenoemt Incienfo de las Indias,

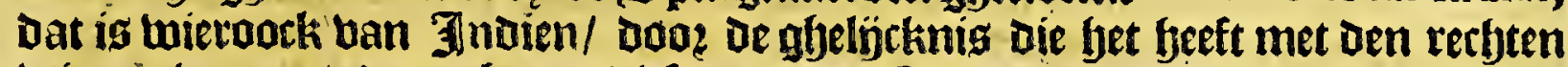
twietoocti: een anderen boom diefe noemen Copal quauhxiorl die langher ende klepnder bladeren feeft ende cenen loften baft; defe geeft feer twepnigij bert: een oerue diefe noemen Tepecopalli om datte op de bergben groepen/ Dele Deaegdit

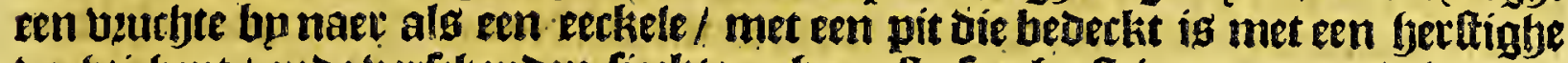

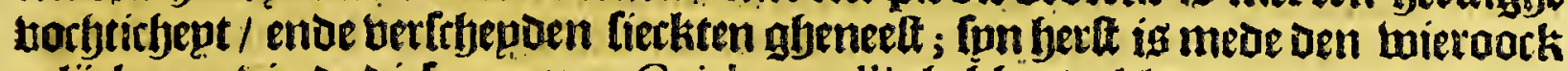
gelïct: e en bierde diele noemen Cuitlacopalli, bebbende klepne ronae bladeten/

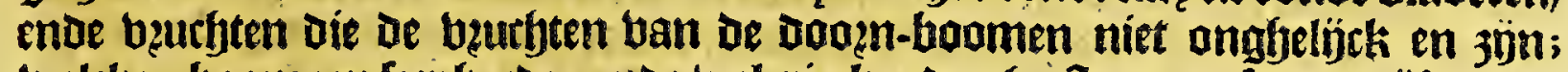

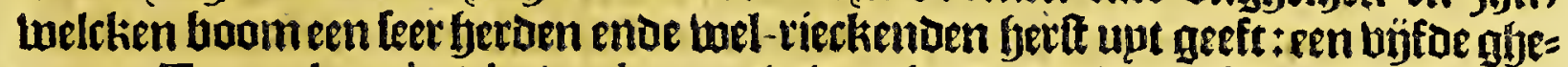
naemt Tecopal quahuitl pitzahuac, twieng bladeren kiepn fpn ende fubtiel;

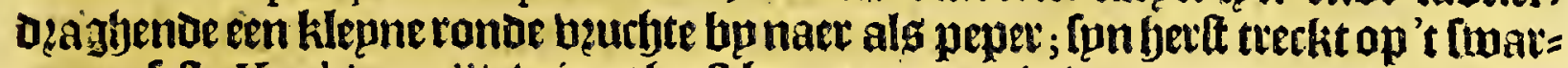
te : een Lefte Xochicopalli, wiens hertt bp naer ąangie is; ende een reuck heeft feer ghelïck oe limoenen: ende epnoelijck Mizquixochicopalli, wiens bladeren oe

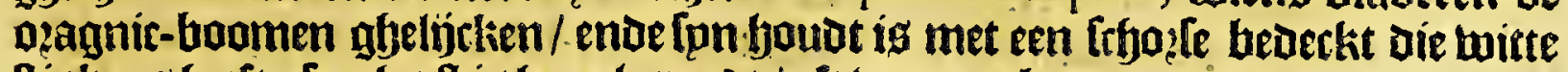
ftipkens beeft; [pn berte is foogh-roodt / oft ban een byandende kouleur.

Jaet ig een andere fopte ban berft die de $\mathbf{J}$ nuianen noemen Holli, ende de

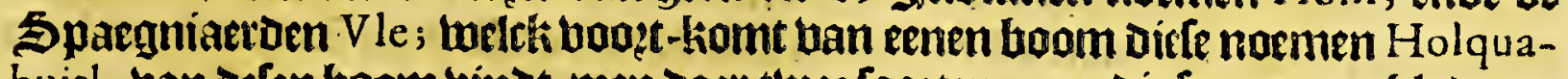
huicl, ban defen boom binot-men baex twee foozten; eene die feer groote bladeren beeft / ende de ftronci gladt / ros ban uetwe / ende ban biumen pittigh moe lpme= righ / enoe benght cen beuctite boost aen De tacken die ronot ig / met een pit oen bale-noten gljelöck / met een bitter / geel uelleken beueckt : Des andecs blaueten jijn oe ozannie-appelen bladeren niet ongtjelijck / mact grooter; oen baft ban

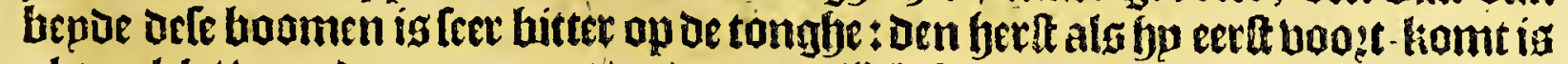
als melck / woet daer naer ros / enoe epnoelijek lwart; [amelen die in ronoe bal:

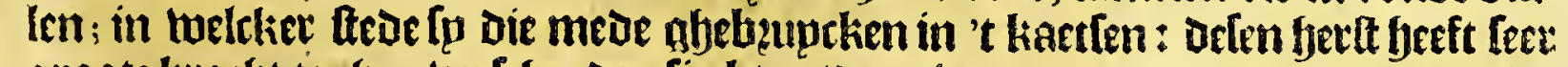

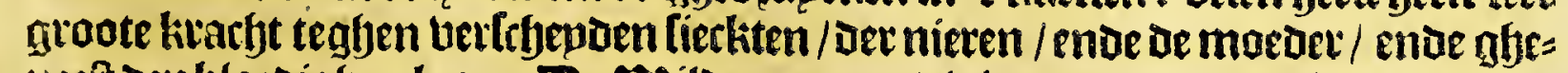
neet Den bloedighen loop. Be poilden nemen die in met $A$ xin / (melck is een bet ban feker toomen die hiet aen boamen tuozoen ghevonden) ende fegghen dat de Ieden daer radt ban twozoen / ende dat de beenen [elfs fagbt mogden/ foo datmen fe bughenende dwinghen kan waetwerts men wil. 
De veroe loote banberlt is de Tecomahaca, welc boot-komt ban eenen boom Die [p meelt Tecoma hiyac noemen/mie oock Copal hyac ofte Memeyalquahuit, welet is eenen grooten hoom met rande ende ghetertelde bladeren: den

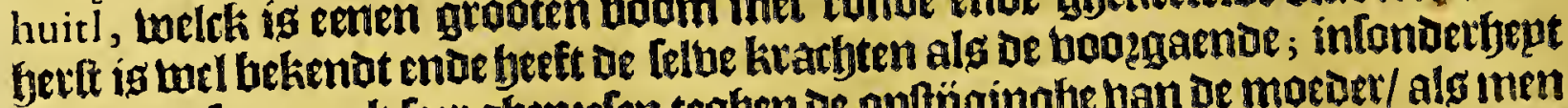

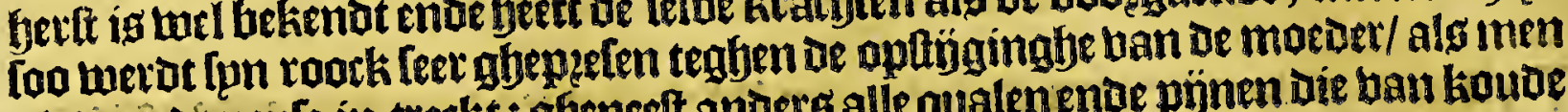
die Doo se neule in-treckt : gheneeft anders alle qualenende pÿnen Die bau koude ende toefjtigfe aoflaecken wopet-komen.

Devierde fooste is de Caranna, wilck bloept unt een boan diele noemen Tla-

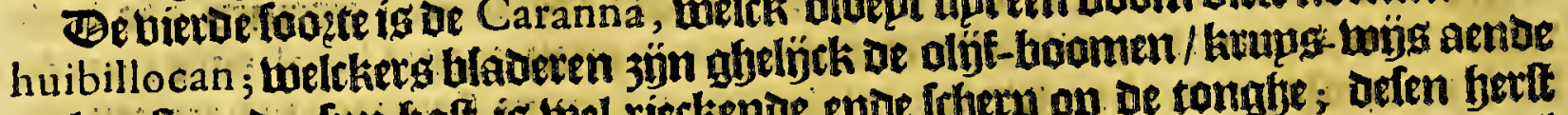

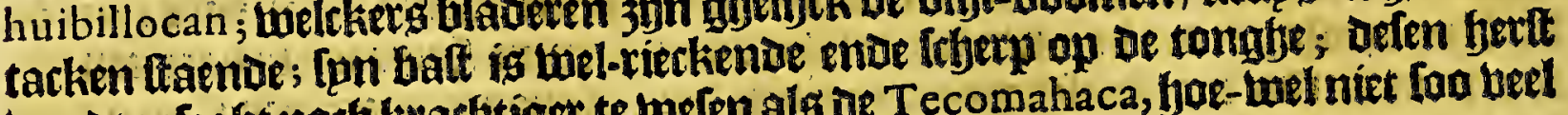

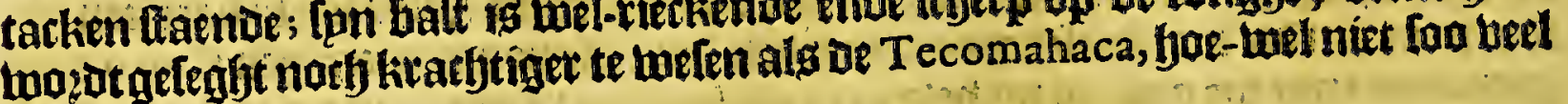
abebelight en wazot.

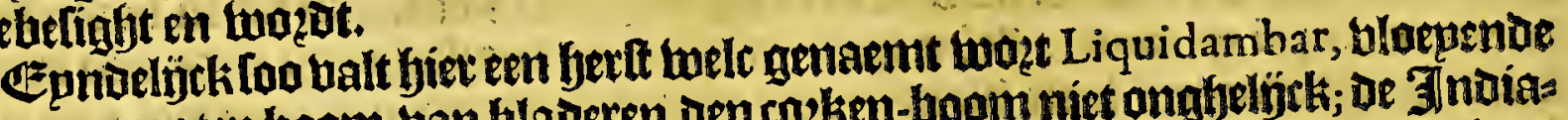

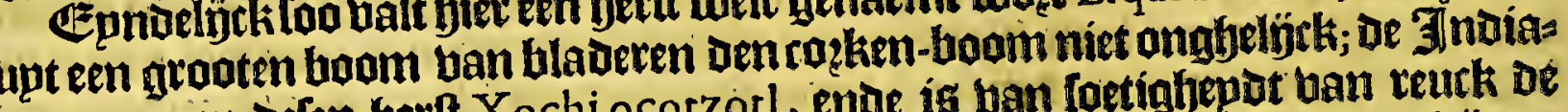
nen naemen defen bert Xochi ocotzotl, ende is dan foetíghepot ban reuck oe

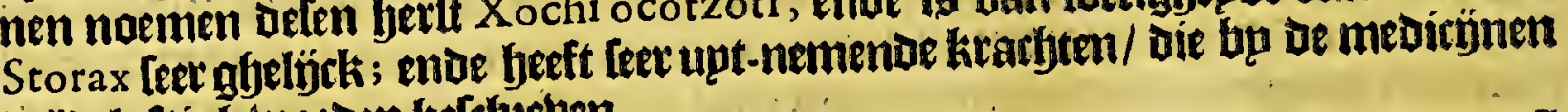
wijotluftigh wożen belcheeten.

Baer ballen noch berteyepden andere bertenende olpen; als een witten bert boozt-kommende ban een hoolm die fo noemen Quauhcopaltic xixio, ae welcke

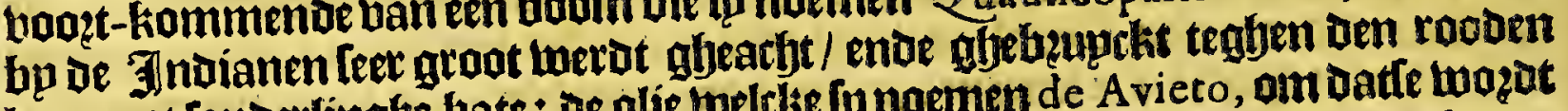
loop met londertingfe bate: De alie welclie fo noemen de A vieto, oin datte wazgt ghetrodken upt het foust met kradyt ban biew / ban emen boam de denne-boom

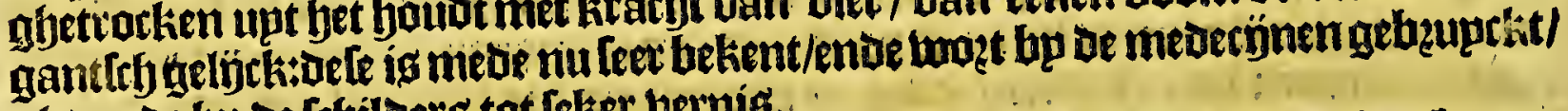
alg mede bp De Irfiloers tot leker bernis.

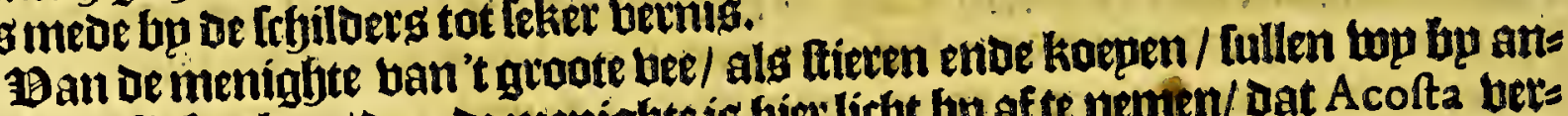

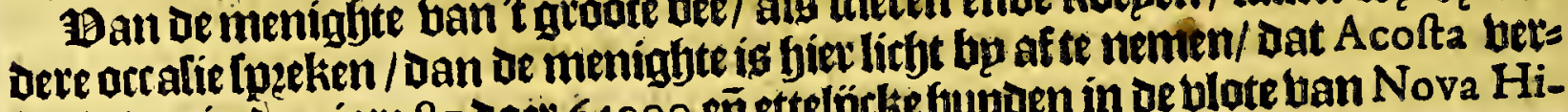

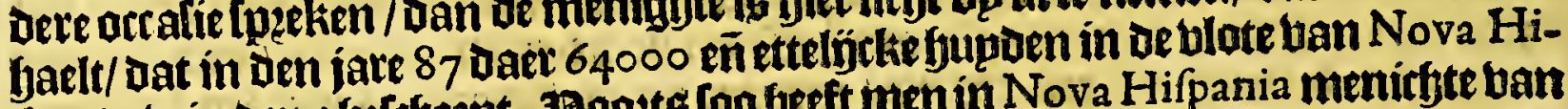

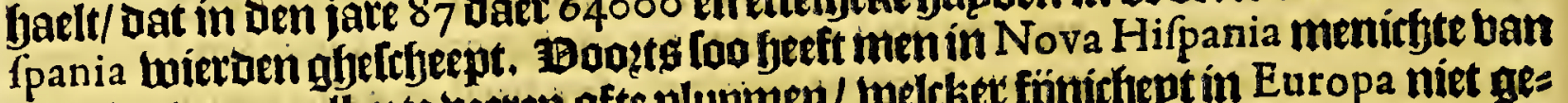
bogelen vanereellente veeten ofte plupmen/ welcker fönichept in Europa niet ges bonden wozot; ghelï̌k men lien maet aen oe beeloekeng die van plupmen ghes

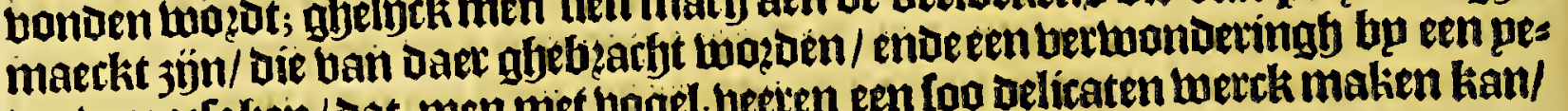
Der beroos[aken / Dat-men met bogel. veeten een fon delicaten werck maken kan/ Dat het ganttry ende gaer met het pencel letjönt gbetracken te welen.

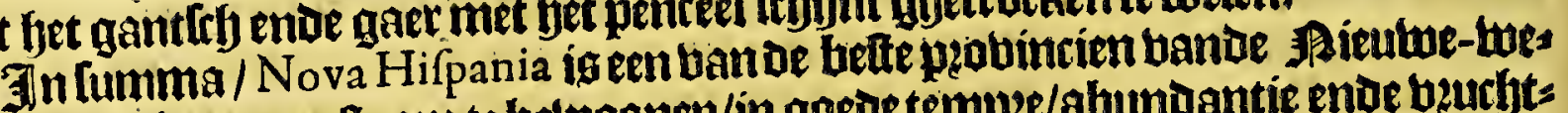

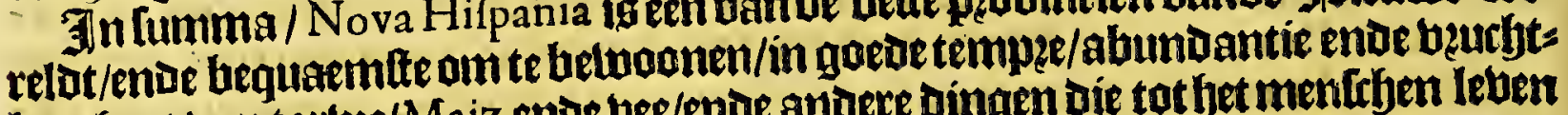
baerfept vantartwe/Maiz ende vee/ende andere dingen die tot jet menifben leben

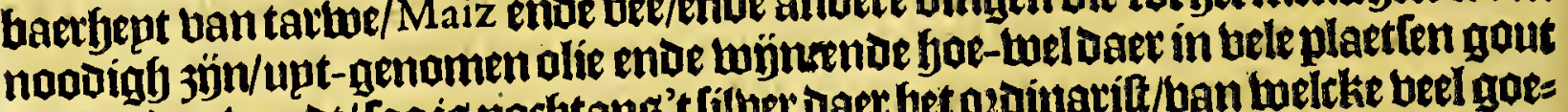

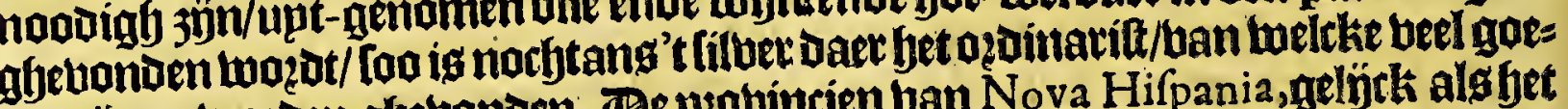

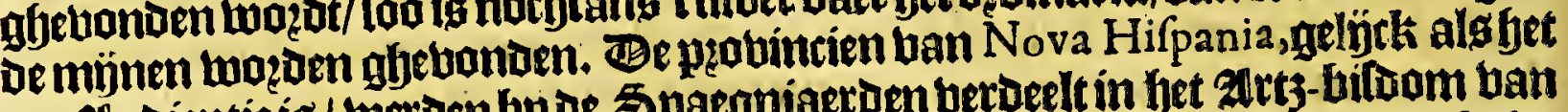

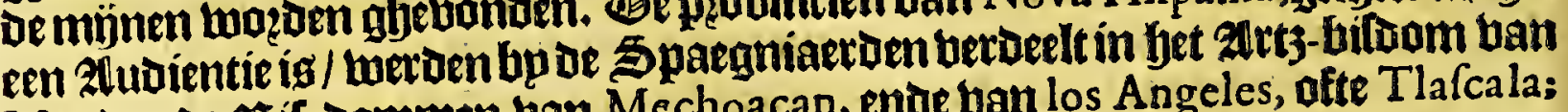
Mexico, de $2 \mathfrak{F i f - D o m m e n ~ b a n ~ M e c h o a c a n , ~ e n t u e ~ b a n ~ l o s ~ A n g e l e s , ~ a f t e ~ T l a f c a l a ; ~}$ uan Guaxaca ende ban Chiapa, ende de Boubernementen ban Panuco ende Yu.

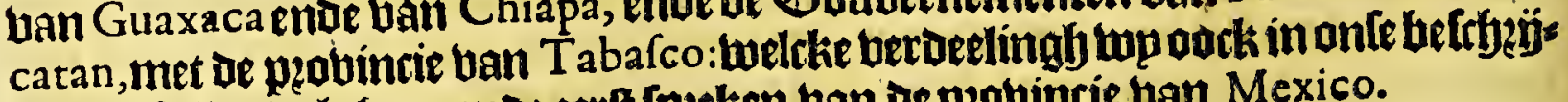
binglye fullen bolghen; ende eerf fpetken ban de pzobincie ban Mexico.

$$
M \quad E \quad X \quad I \quad C \text { O. }
$$

Jet bierde Capittel.

Befchrijvinghe van de provincie van $\mathrm{MEX}$ I $\mathrm{Co}$ in't byfonder, de verfcheyden landen ende volckeren daer onder begrepen.

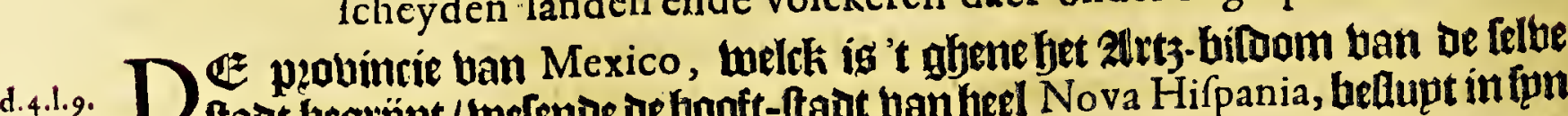

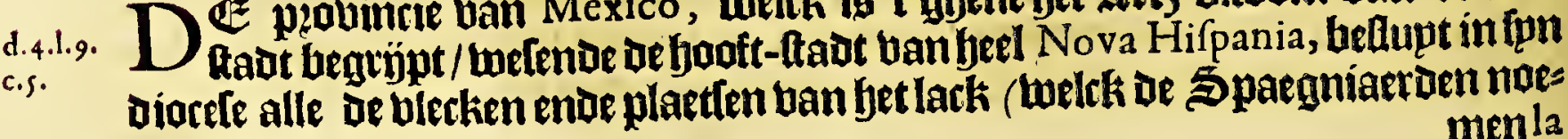
menla 
Het vijfde Boeck.

menila Laguna, ) febept fun limitem ban bet witoom ban Tlaccala, op gaende Doof de peobincie van Chalco, welch is ghelegen Leven leguen van Tlaicala, enee negen ban Mexico, ende ftreckt tot aen de P ico hande Sierra Nevada (t fneculo. gheberghte) Die tu noemen el Volcan sou Dat bet zurt, biloom ban Mexico

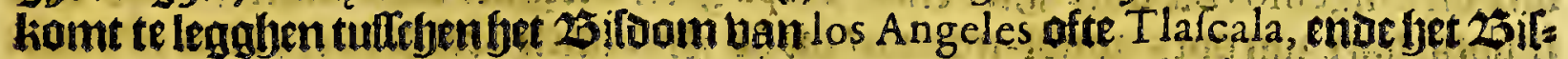
Dom ban Mechoa can; beft in de lenghte noozon ende 3upoen fondert ender ort:

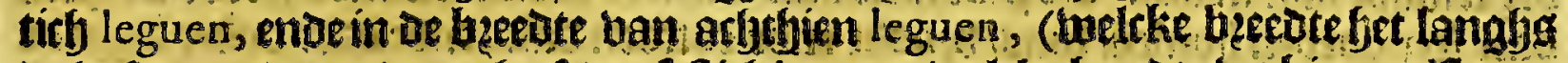

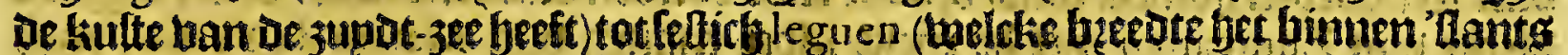
beeft; ) in twelckejün begrepen oe probineion ban Mexico, enue naer t noofotaolten ban defelue Lateotlalpa, Mezcitlan, Xilopereque ende Panuco, welck if De bert gheleghente ende naet t tuefen Matalzingo, narlt gheleghen bu Mexico, enve Culrepeque, aloen bert daet af gbeleghen: naer bet ooften Tezcuco, naeltaen Mexico ghelegben; naet het 3 uput-eoften Chalco, mede aen Mexico;

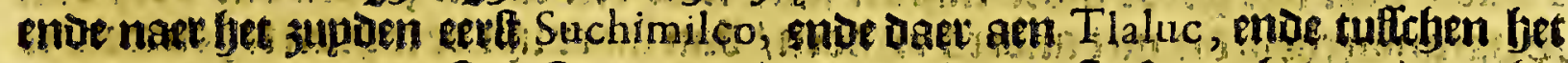

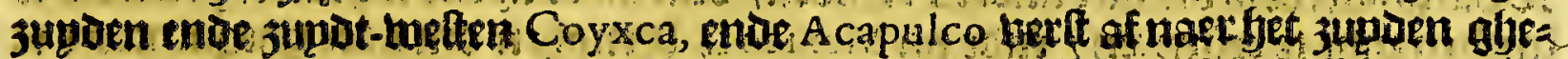

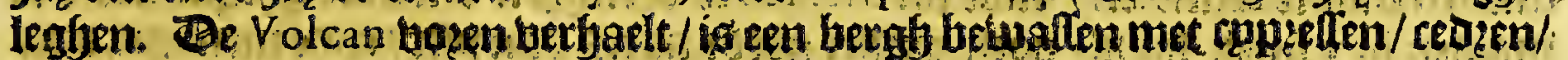

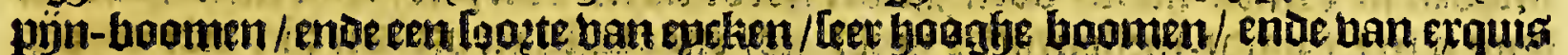

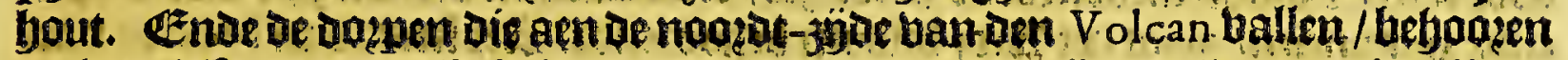

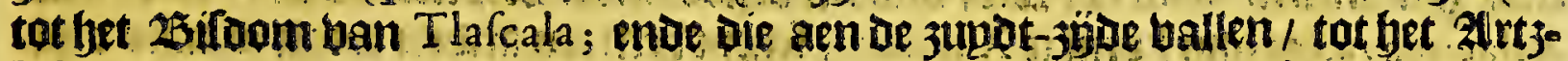

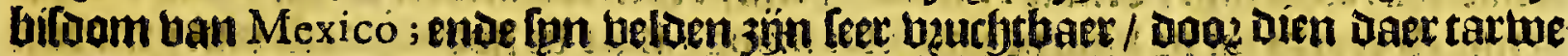

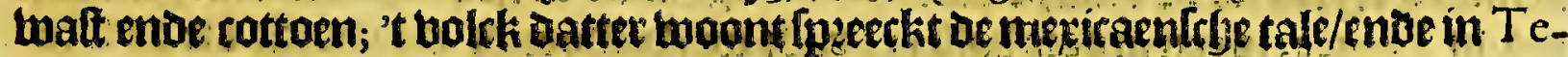
pexco balt feer goet alupn/wit endertiftalin. Dele plaetle ig gholegen aen oe boet ban een bergh / ban tuelete een plepen begint / wetek loopr naer Chiautla, cen

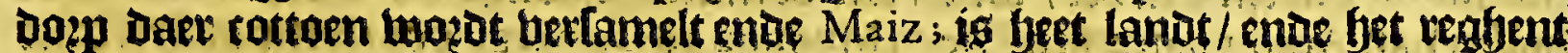

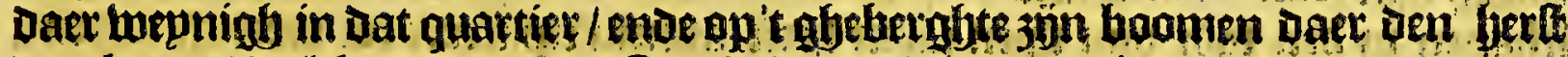

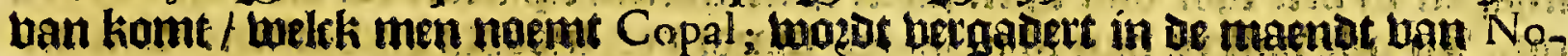

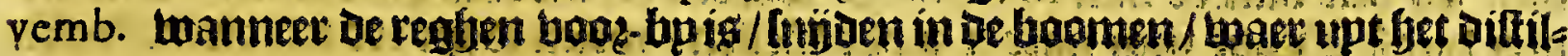

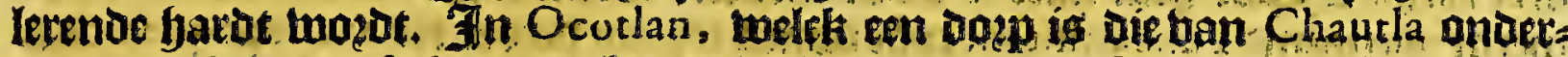

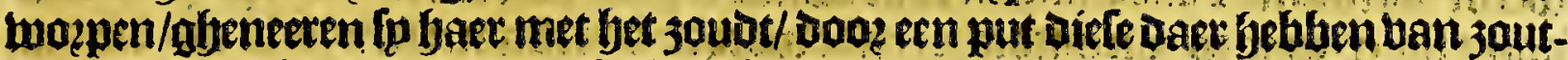
water/ welck leet goet $30 u$ tgeeft; ban hier gaet men naer be Doppen uiefe noemen Contecomapa, ende Gualtepeque; De in-woondeten fpetien of Miftefe tale/ Daet is een bergh die lafpis geeft/ die een leer excellent groen kouleur foefe/treckende naet bet Porphyr ; bebben feer beel Maiz, gfelijek die aock ban Patonala, weles Kes balck íg ban oe [elfoe tale: ende Tecomottla, ende Pucla, welch tot fet 25:[= jom ban Guaxaca befoogen/ Daet Motezuma garnifoen onoer-hielat / ende den

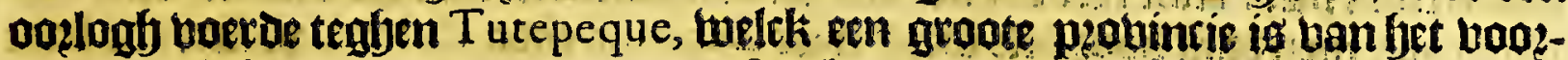
Itheeven 25itoom van Guaxaca, enoe ttreckt tot aen oe jupot-3ee / enoe bet bolck is ban een anoer tale. Ban bier homt men te Caftla fetthien leguen, latenoe tule

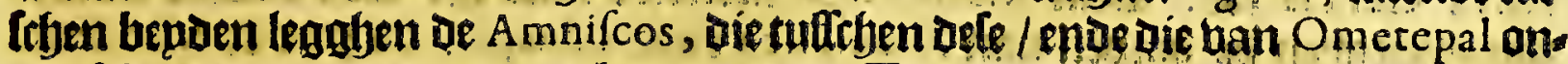
Der-frbenoen; ende Daer naer komt mente Tuculala twoe leguen uoetor/ Daer

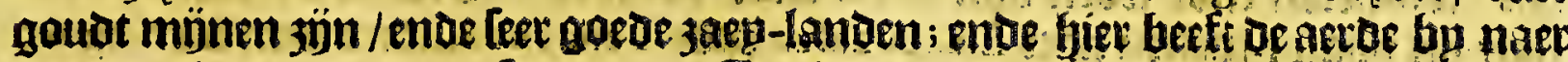
tweemaels ter maenot/ foo dat de Thbianen fiet geen hupfen met mueten on boutuen / maet leven in hutten/ diete noemen Boios, leegh enoe met trape gbe: Detkt / ende ban foden ban aet de ghemaech / om meat befbut te jon teghen oe

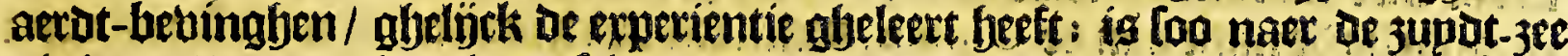

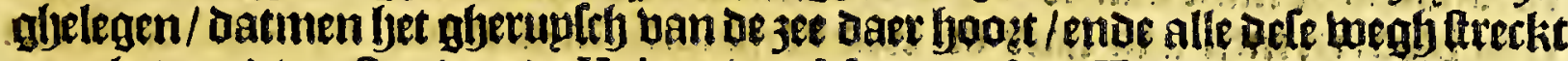
naet fet zupdt-ooften uan oe Volcan ban Mexico af tot Tuculala ende de jupd-

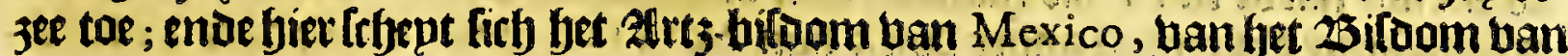
Guaxaca. Ban de ftaot ban Mexico keetende naet bet 3upden/3yn gfyelegfien oe blectien ban Coautruaguacal, A capiftla, Guaftepeque ende Autepeque, die den Marquis del Valle toe. behoozen/elf leguen ban Mexico gelegen//rect goede plaet= [en/in beet landt / enoe gyetempert Dooz bateringfen/ waer Maiz ende cottoen walt; enoe beel bloemen ende roolen feer twel-rieckende ban diberfebe footen: a 4 Defe 


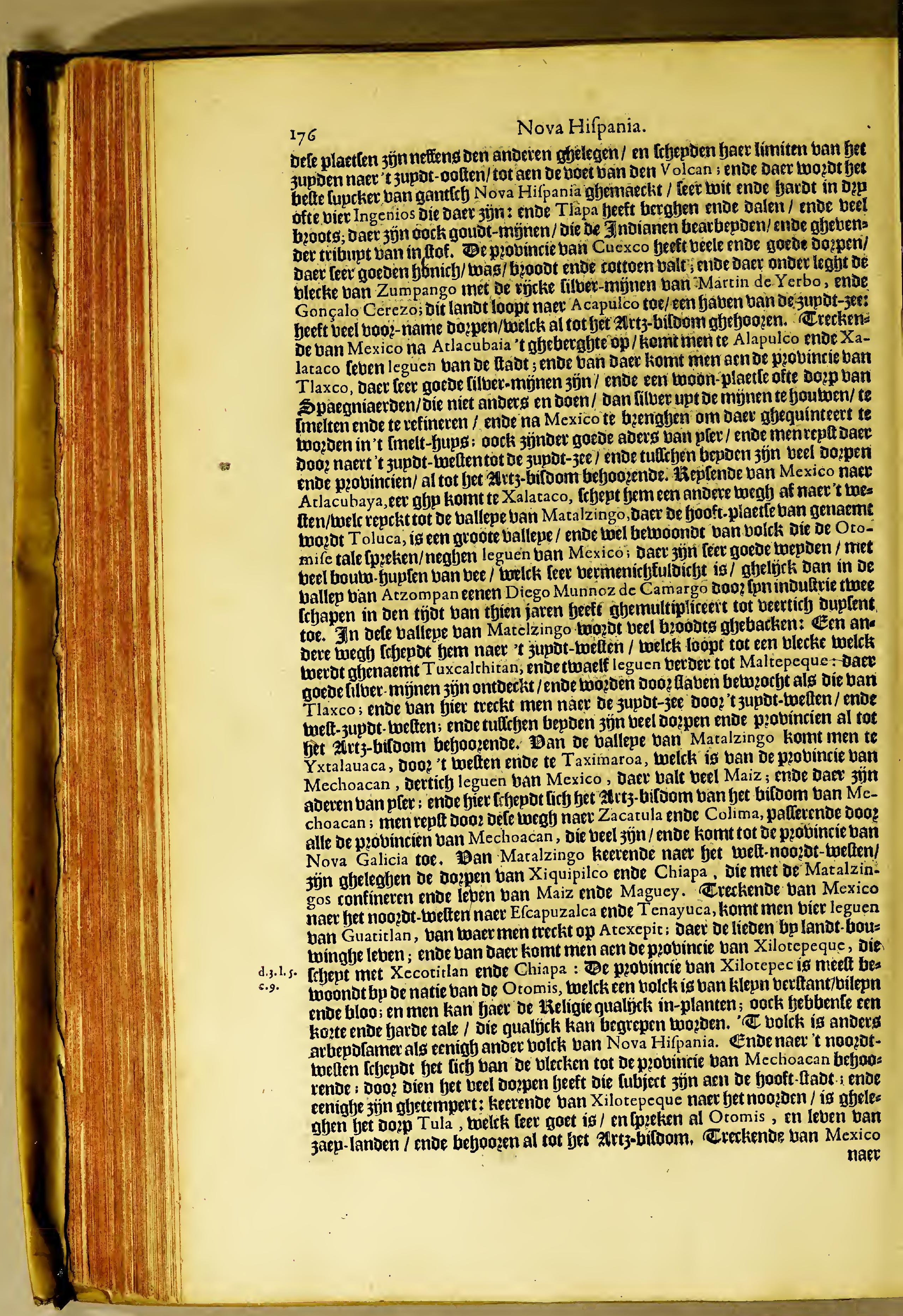


naer het noogden/ komt men te Tepeaquilla, ende ban vate te Ecatepeque ende Atotobilco, Tulanzingo ende de peobincie ban Metztitlan, bjef-en-twintich leguen Dooe Get quattier ban Xilotepeque : In Mezitlan talt tert not crifta= lijn-alupn / ghetonien Dap? Bartholomets de Zarate Kiegeerder ban Mexico:

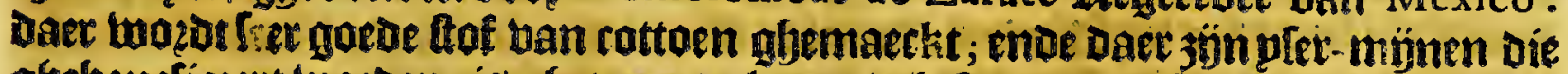

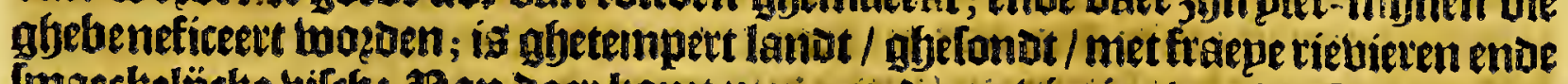

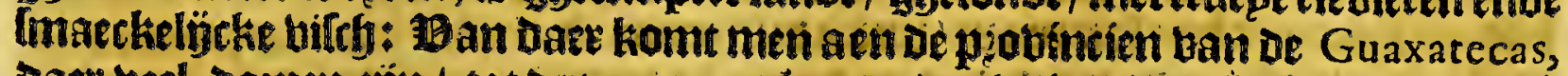

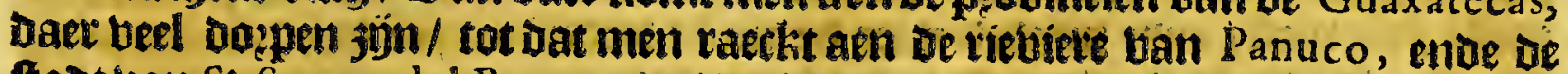

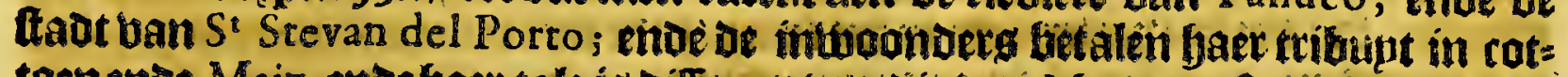
toenenoe Maiz, ende baer tale is different bandie ban Mexico. Paei bet noozotpoften leght Otumba ende Tepeapulco feer biquame doinen/enoe daet teel jaep-

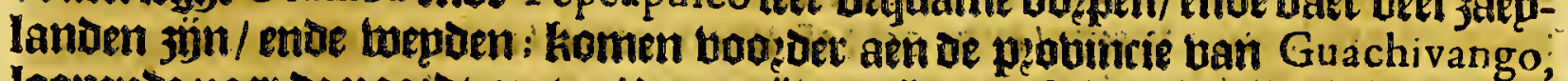
lopente naet be noogot-jet toe / daer müneti jün ban filber / entie ban daec komt men aen de pzobincien ban Papautla ende Tupax, toelets is de tieticte Tuxpa; $t \in=$

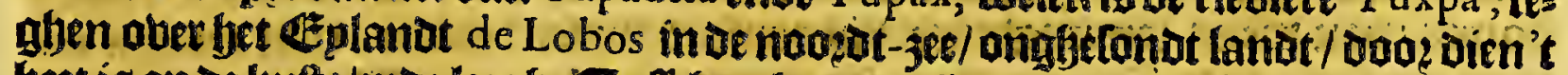

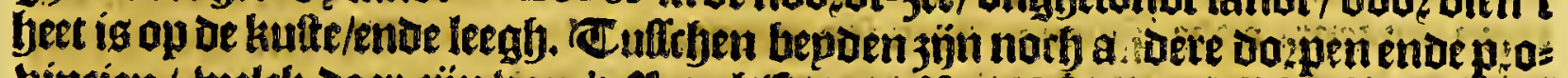

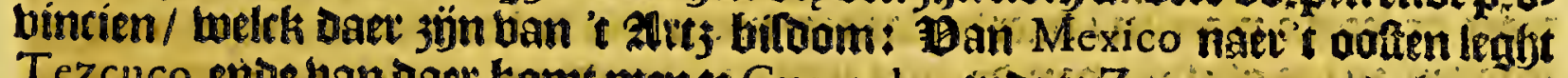
Tezcuco,ente ban baec komt men te Gueytul pa entue fe Zacatepec;enoe ketrent

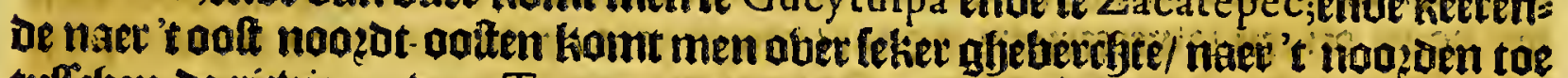

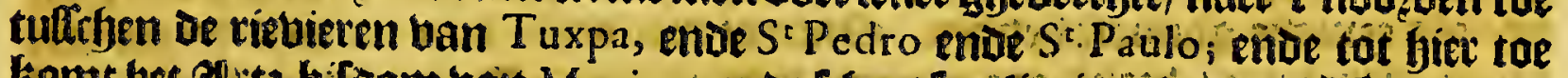

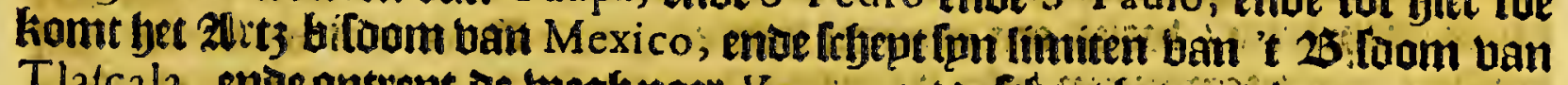
Tlatcala, enoe ontrent de tueghnaex Veracruz toe febét jet mot Ategotepeque, Her. de.

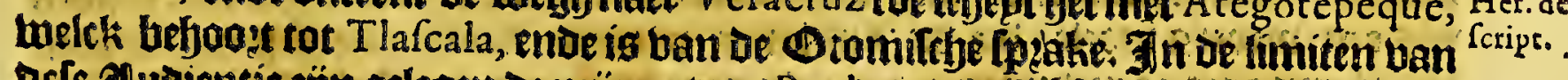
bele Zludientíe zïn gelegen de mïnen ban Puchuca, leekthien leguen ban Mexi-

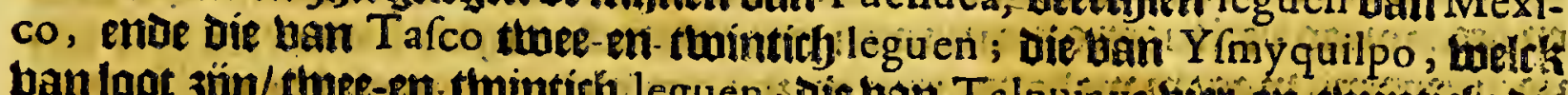
ban loot $3 j \mathrm{~m} /$ thee-en thintith leguen; die ban Talpuia va bier en-thinticf: die

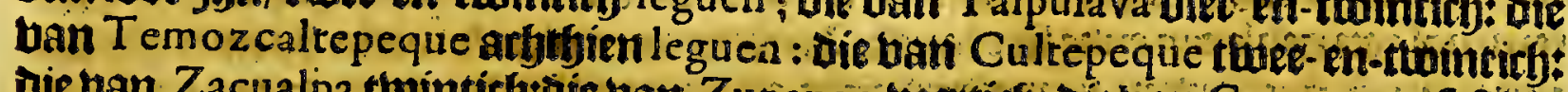

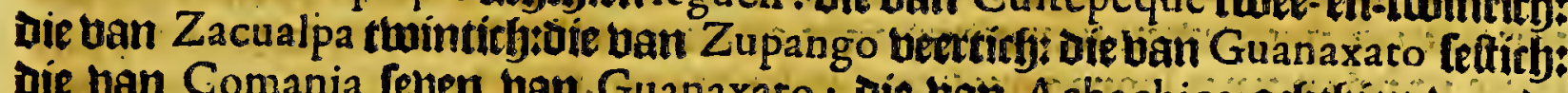
die van Comania feven ban Guanaxato : vie bain Achachica acfithien van ue thaut de los Angeles; die ban Gautla ofte Zumatlan, entie $S^{t} L u i z$ de la Paz; ende

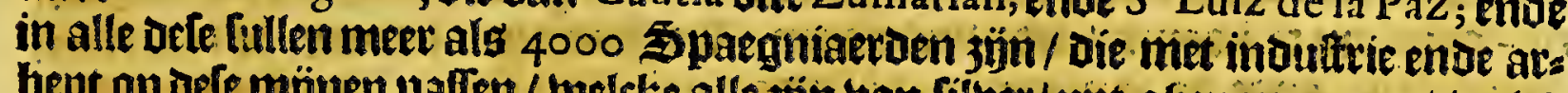

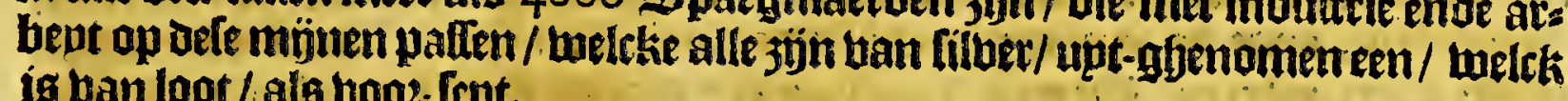
ig ban loot / als boo?- Tept.

\section{Wet bijtac Capittel.}

\section{Befclirijvinghe van de groote ftadt M E X I C 0 , welck de hoof- ftadt is van gantfch NOVA H IS P A I A.}

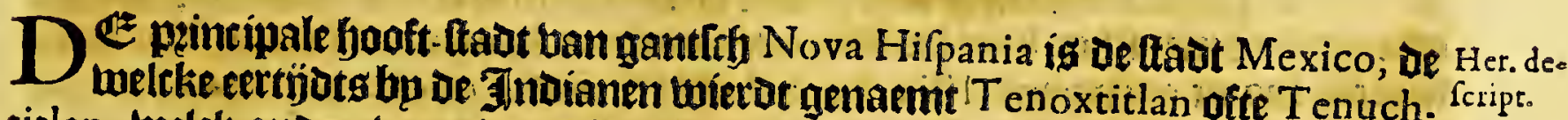

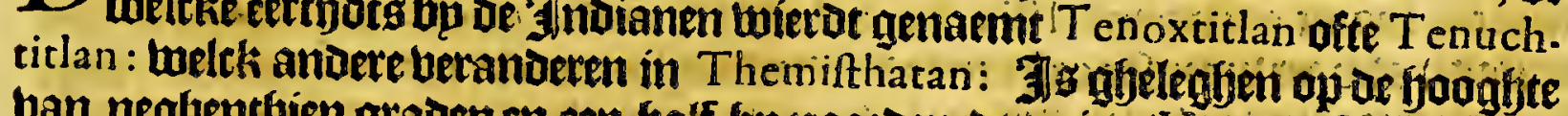
ban neghentbien graden en een balf bp nooson de 3 imie: (Herrera feght efoets in Lun biftocie datfe legft op de booghte ban twintfty graden tot thinticf ento d.3.1.9. een balf /) enoc bit komtmet de kaerten ende viftartich uan andete befr ober een/? ende heff de lenghte ban jondert ente dep graden op den neribiaen ban To-

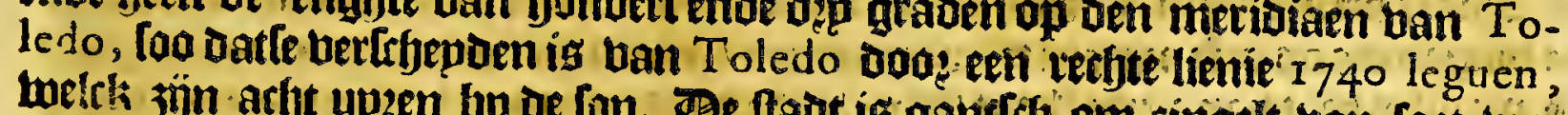

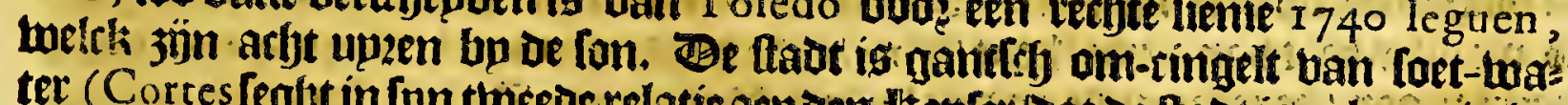
ter (Cortes leglyt in [pn the de relatic aenden liepler/oat be thabt ig gelegen in fet

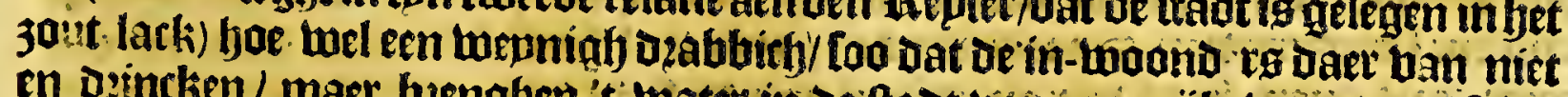

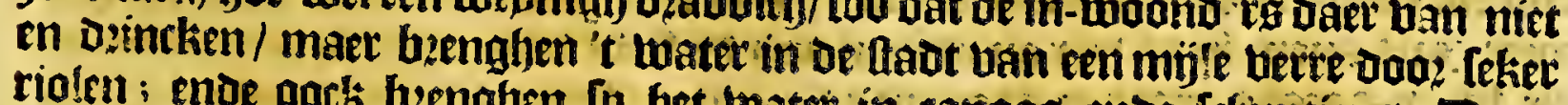
riolen; : ende oock bzenghen lo bet toater in tanoas ende Irfuptjens. Boo?

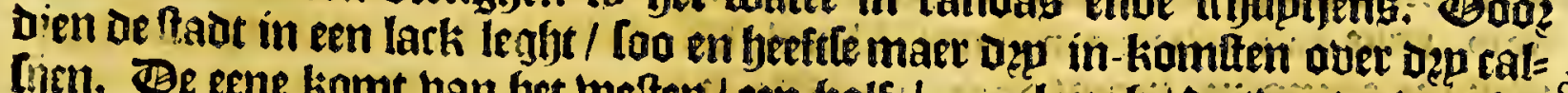

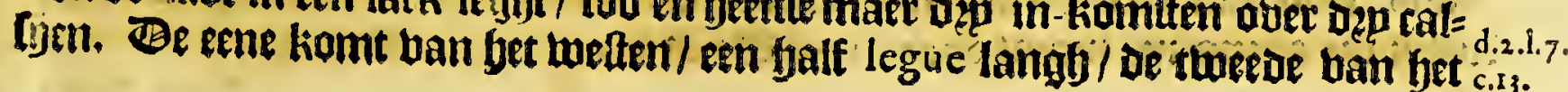
nopzon/ 
$17^{8}$

Nova Hifpania.

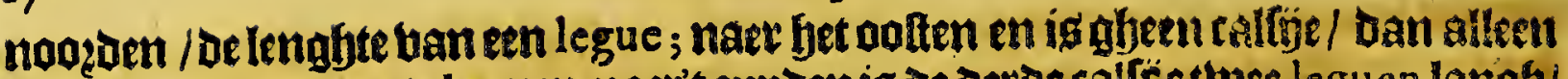
tanoen om daer aen te komen; naer't zupuen is de deroe callóse these leguen langh/ baer Cortes endefpn uaick langhg in de ftadt quamen. Eenoe is te tueten/ Dat

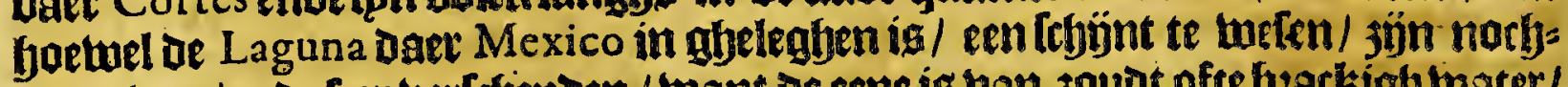
tang twee / enoe leer berltyepton / want oe eene ig wan joud ofte bzackigh twater/ bitter ende quaet / ende daet niet en groepet / norb gheen bifth ter werelot in en

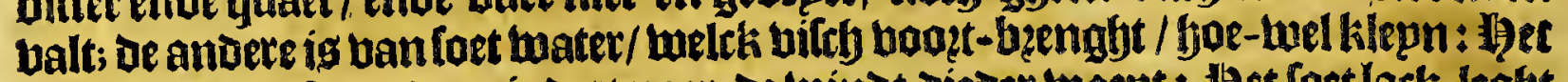

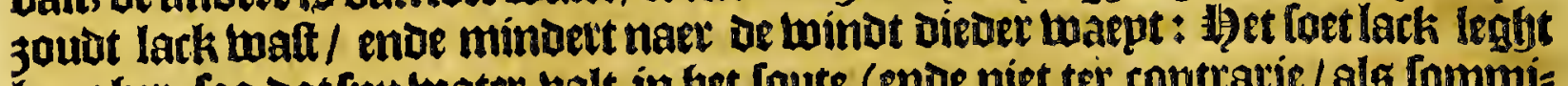
jooghet; foo dat [pn water balt in bet foute (ende niet ter contrarie/als fommi=

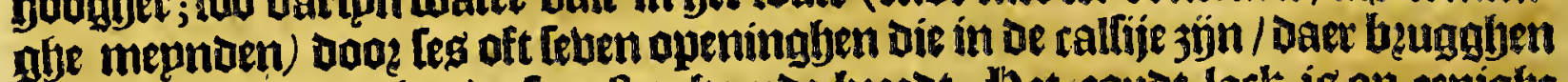

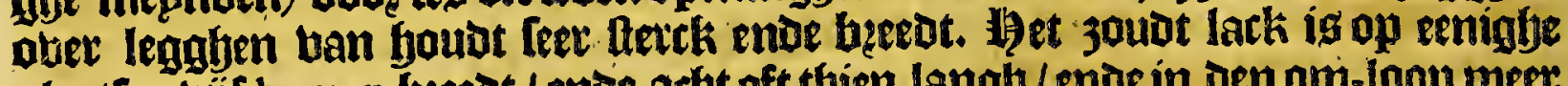
plaetien bỉt leguen beedot / ende arft oft thien langb/ende in den om-loop meet Dan bijfthien. 19et loete lack is pmmers foo groot: enoe 3 jon bepoe in bet om-gaen meer dan Dertich leguen, bebhen ban binnenende op den oeber meer dan bjiftich

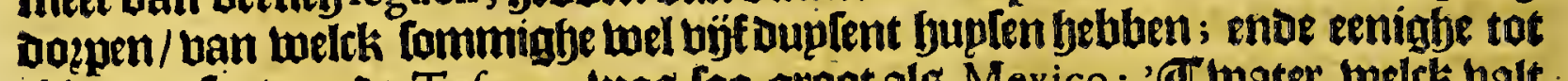
thien duplent; ende Tefcuco twas too groot als Mexico; 'C water twelck balt naet of leegbe plaeten / daer bet lack is/komt ban de berdben af-loopen / melck leggben in bet ghefirbt van de ltad ende waer ronotom; welck water dooz dien

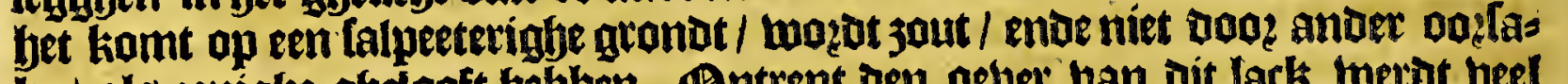
ke/ als enighe ghelooft beblen. Ontrent Den oeber ban dit lack twerot beel 3ouot ghemaectit/ welck een grooten bandel geeft. Baer 3 jun ozoinaris wel bondert ouplent tanoen in / ofte barckkens ban eenftuck / welck zïn ban fatloen als etn webers Loele/ die de Jnoianen noemen Acales; de Spargniartden upt ghetwoonte noemuente canoas / alg men die bett in ue Geplanoen. Be thaot

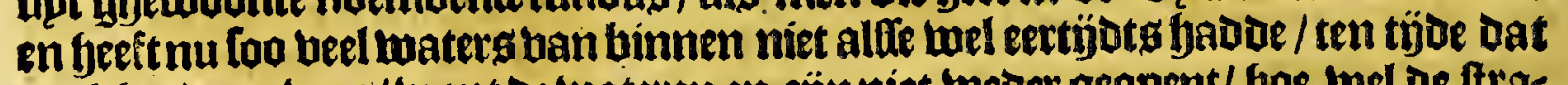

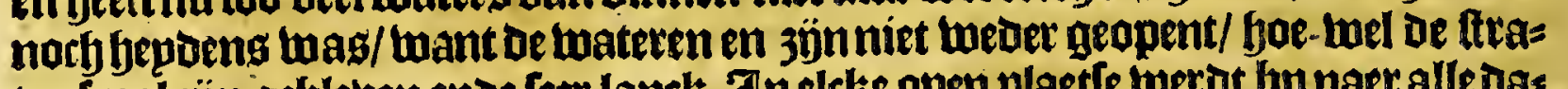

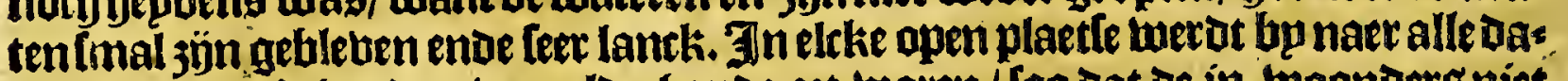
abe marckt gfyefouden ban alderfyande eft-waren/ loo dat de in-woonters niet berie en befjoeuen te loopen om baet fuplen te booz-lien: boben defe jün daer dęp peincipaie martkten / Daer Ceker Daghen in De weke groot gbetal ban Jndianen toc-oopt om te koopen/ende berkoopen. Be Indianen noemen oe marckten Tianguftly, ende de Spaegniaeroen noemente Tianguez, conoer oen ouden naem te beranderen. De eene Tianguez ofte marcktis in Tatelulco, welck tent vier-kante plaete is/ aen oe dzp jüben om-tingelt ban gaelberÿen ende tenten; in fet midoen van def plaetle (melck is een van de grootlte der werelt) ltaet bet gericht/ende een [eer tejoone fontepn die de Spatgniaetaen bebbenghemaeckt: oe andere legft binnen Mexico, en lwogtot fedent-daegfg glyenoemt el Tianguez de $S^{t}$ ltian, weltk oock een groote plaetle ig; [oo dat in oefe twee platten wel hon= Dert duufent menteben baer konnen laten met baer koopmantrbappen. De derde marekt mozot gbenaemt el Tianguez de $S^{t}$ Hippolito, (tuelck oe patroonis ban

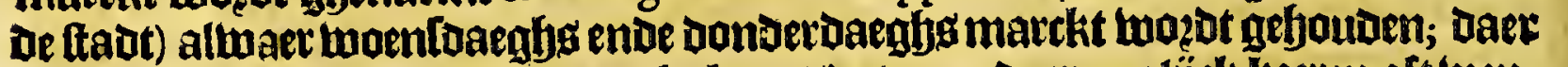
fulcken ontallÿcken bolck te marckt komt/oat men daet qualj̧ck keeten oft wen=

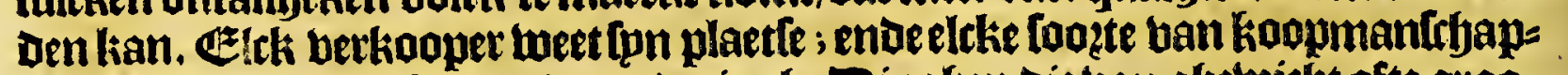
pe beft [pn quartier [onder beranderingh. Binghen die van gfelwicht ofte groos te hefommetingh 3ijn / latenfe aen de kanot ban't water in de canoas. Beande

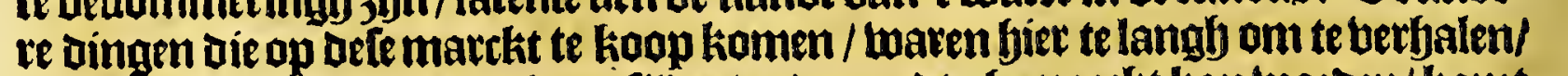

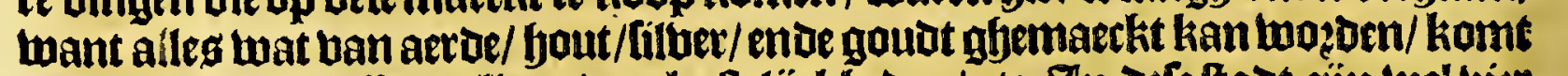

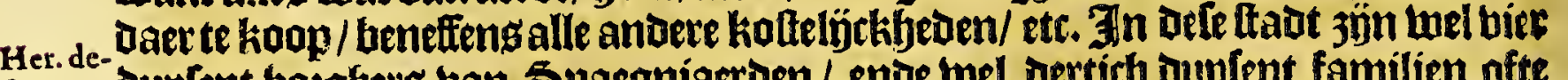
Script. Duplent bozghets ban Spargmiaerden/ ende wel dertich ouplent familien ofte meer Indianen; in de biet quartieren baer be ftad ban oubts in berdeelt bas / oie feden-daeghjs twozaen ghenoemt Sant luan, Santa Maria la redonda, San Pablo, ende. San Sebaftiaen, ende Thatelulco, is bet wel peintipaelfte quartierl

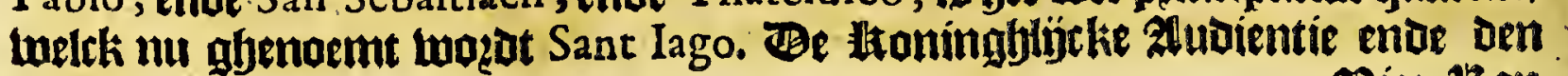

Bice- khop 
Het vijfde Boeck.

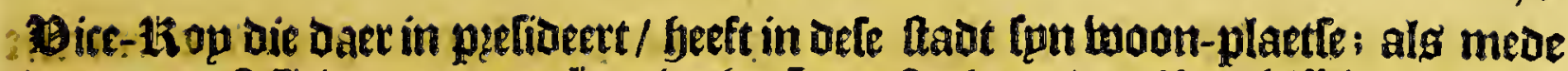

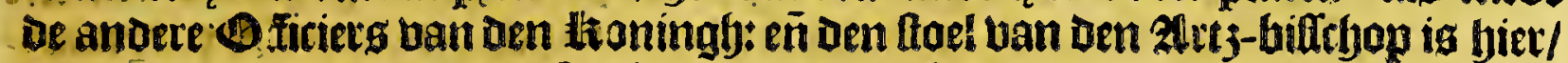

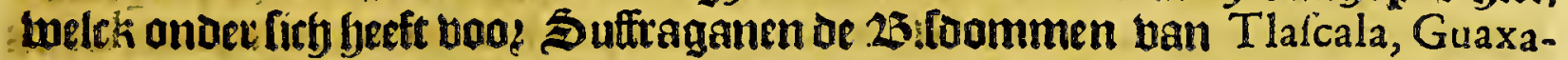
ca, Mechóacan; Neuva Galicia, Chiapa, Yucatan, Guatemala, Verapaz, enie de Philippinas: De Catfedsale liercke wierot begonnen by Cortes, enoe boats ap-ahehout bu Don Sebaltian Ramires de Feunleal.

In de Ladt ban Mexico jön divertrbe flooftets ban Bominicanen / francif canen/ Ztuguabiner/ De compagnie ban 3elus/ Carmeliten/la Merced, 25ats

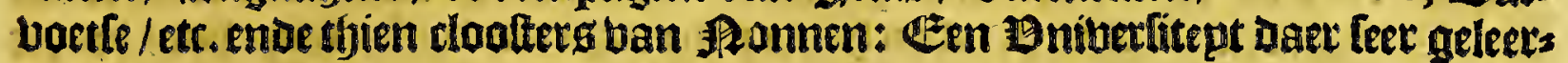

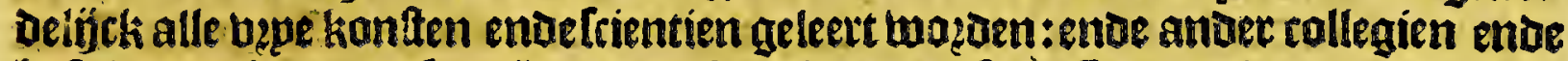

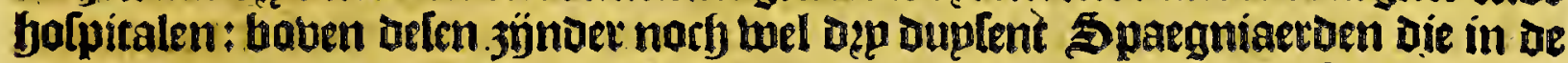

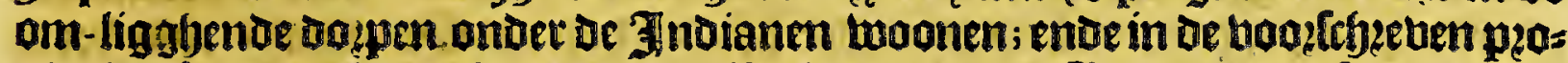
bincien fullen tuel twee fontert en büftich do:pen uan 3ndianen buefen / ende in De felve/al s mede in de lantot-huplen (die de Spaegniaerien Eltan cias noemen)

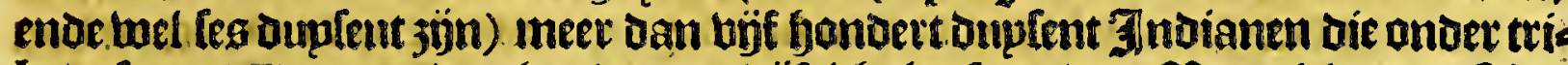

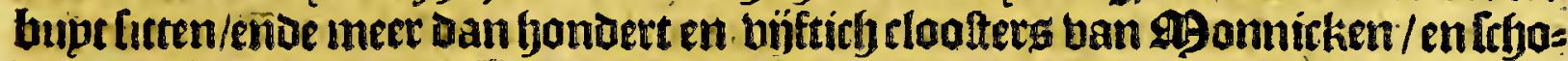

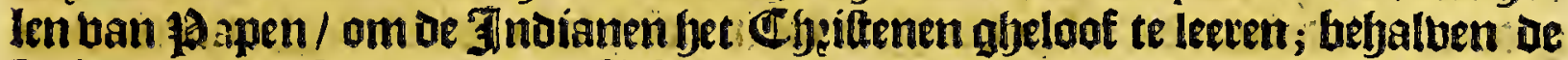
Padres uan De Sorietept van 3 : flus / ende andere burtlingfen: oack loo heeft oe

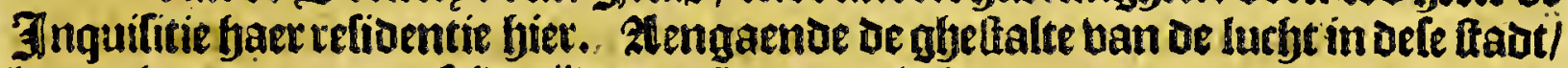
bet regbent daer op de felbe tijoen en thonden alg in andere quartieren ban Nova d.4.1.9. Hifpania, Doth met de noozoe-Linot des abonts endeniet des mozghens: maet ban lunozgheng tot 's atronots if daer bel der ende klaer weder. Fes abonts loa berbeft bem aen't noosden op oen bergy de Tepeaquilla een legue ban oe ftaot/

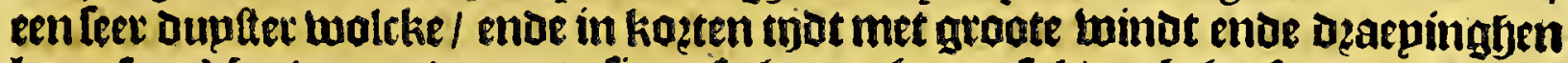
komtle te Mexico : ende om te lien oft bet teghenen fal/en befjoeft-men maet te

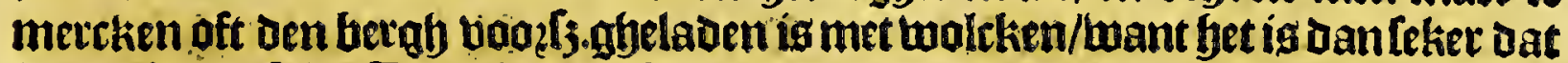
het regbenen fal. Ten troe dat fet reghent / is bet in Mexico luftigh ende gbes funot / maeckt fraepe mozghen-ftanden / enoe botbtighe abonoen/ enoe De nacf: tengheftattet enoe feboon tueder. In oe maenden tan Novenber; December, Ianuarius, Februarius enoe Martius, tot dat Den reghen komt/ghelg̈ek bet Dan

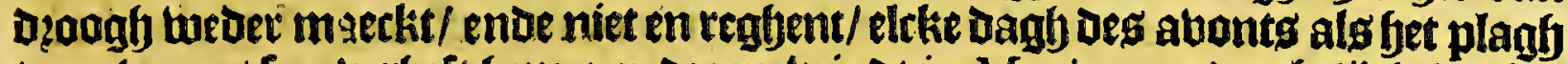
te reghenen / foo bertheft brm een Dzaep-winot in Mexico, enoe gbelỉek bet fal peetrich landt is / loo blieghter too oirften ftof / ende loo dupfter/ dat men bp wij: Ien malkandeten niet fien en kan/enoe ouett den gantfoben abonot gfelíck den regíjen / loo dat in lpn plaetle libünt te kamen; dan de narfjen alg bozen jün leex heloer. Befeftaf is leet ongelondt/ende fjoe men naetder aen Martio komt/ende het lanot dzogber is / boe trbadelïcker/ want bliegfen te neufe ende te monoe

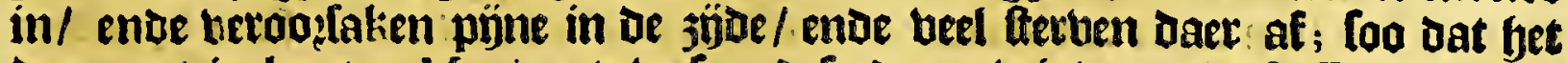

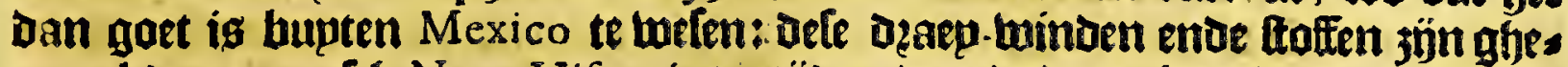
neracl pooz gantlfh Nova Hifpania ter tżden ban de dzooghten/ oactjen jön loa If havelijck niet alg in Mexico: tie in De ftadt op baet ghetontbepot willen leven/en

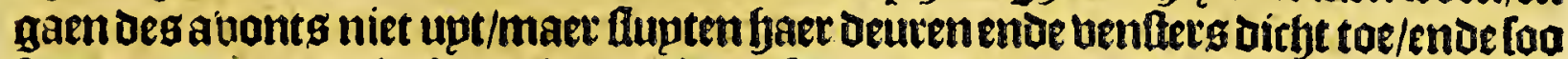
fo ooch of abanot-lurbt twillen genieten/ foo gaen fy in gaer boben enoe in't belot.

Wet lelte Capittel.

Befchrijvinghe van de andere plaeten ontrent de ftadt MExico gheleghen.

V. Oas Defen bebben wp aen-gferoert te menighte van plaet ten die ontrent de taot Mexico legglyen / lullen nu eenige ban be p'intipaelfte plaetlen belchyej= ben / onder de beleke upt-munt Chulula, meleke een groote blecketwas in booz-

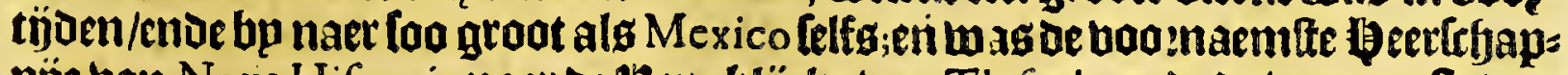

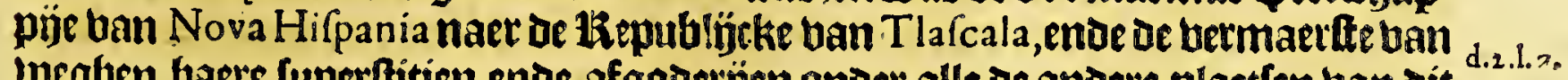
uneghen baete luperthitien ende afgodetyen onoer alle de andete glaetfen ban dit ${ }_{c .2}$.

gantid] 
180

Nova Hifpania.

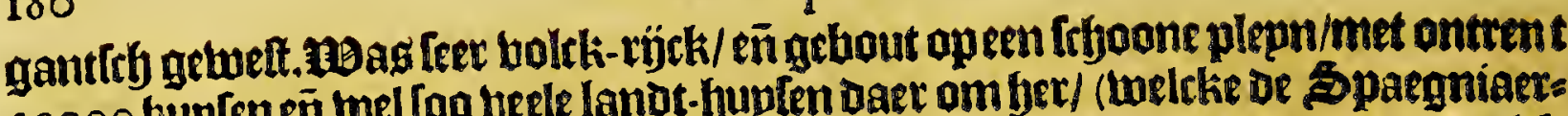
20000 buplen eñ teel (oo beele lanot-bupten daer om her/ (welcke de Spaegniaer: Den normen Eftancias,) met beel fryoone tooms op oe krreken ofte tempelen/welck men leght wel foo beel geweeft te bebben/aller dagen in't jaer jün; foo datter naet

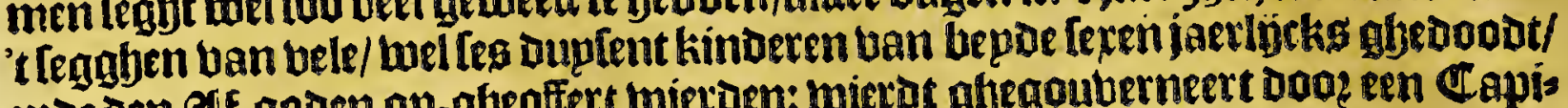

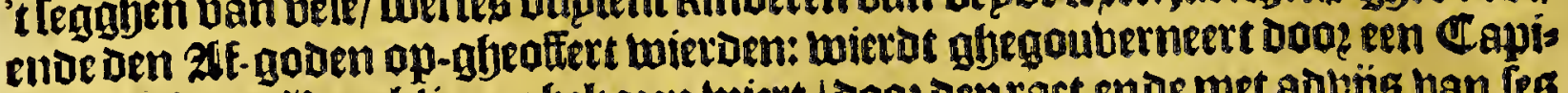

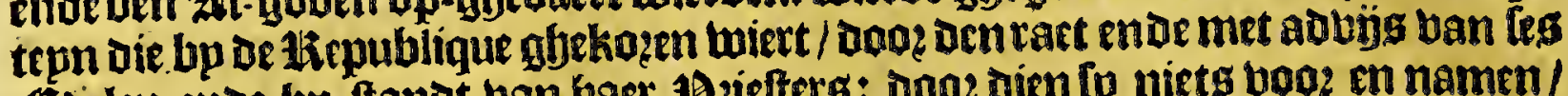

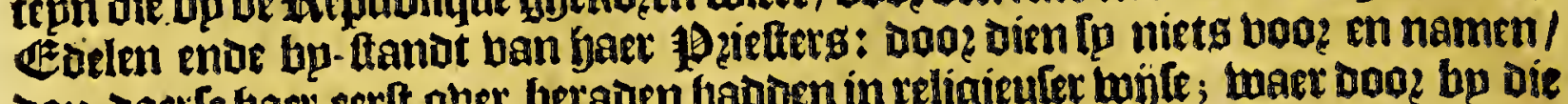

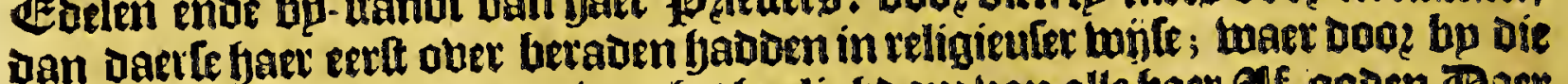
natien orfe ftadt gjenaemt wietot bet yepligboom ban alle baer zAf-gooen. (Baer:

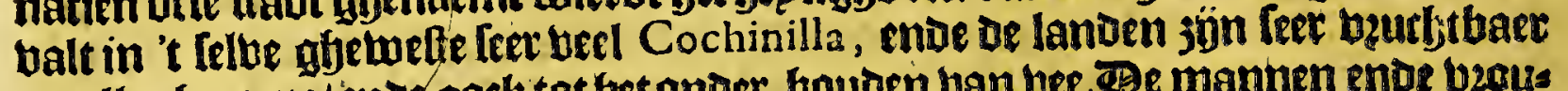
tot allegyejaepe/ende oock tot fet onder-houden ban bee. De mannen ende vzous

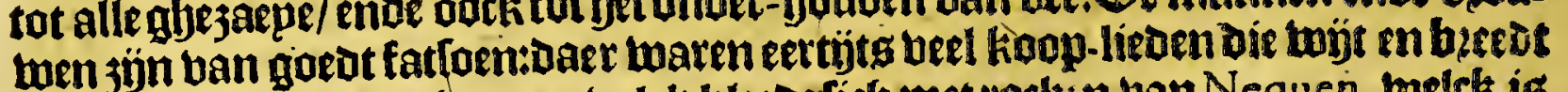
baren yandel deeben: fyet arm bolck kleede fich met tockin ban Nequen, belck is bet lïnmaet Dat ghemaerkt woęot ban de Maguey, enoe de rijeke in rorken ban rattoen/met randen bau plupmen ende cock bankonïne velletiens. Baet biel feer glooten fandel met diberflye dingfen die in ofle blecke wierden ghemaecktenoe. gbebunian.

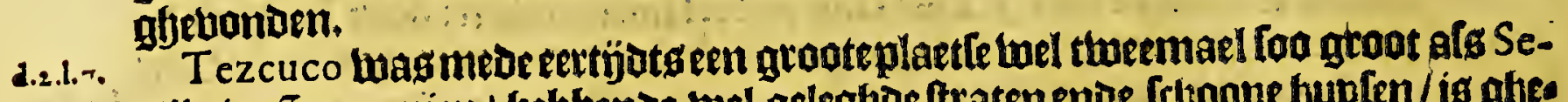

c.4. villa in Spargnien/bebbende wel gelegboe fraten enoe frboone buplen/is ghes legben op een plepn/aen de kant wan't jout-lack ban Mexico, ende beeft niet te min 't loet-water in alle plaet fen/ welck dart gelept wot boo diterfeberioien ban 'tgebergljte af: do Cortez legft in Ipn derae bertjael / lou light Tez cuco leg leguen ban de ftadt Mexico langhg bet lack.

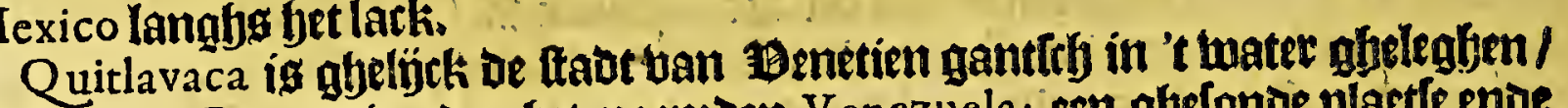

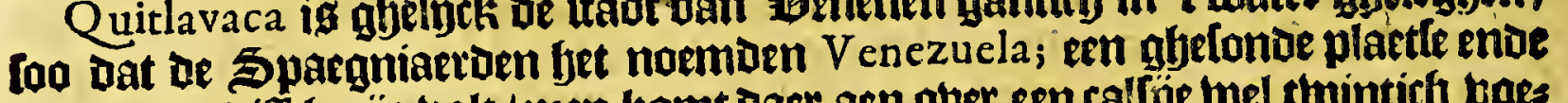

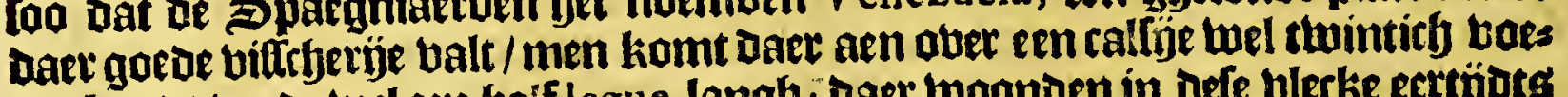
ten bzetot / enoe wel een balf legue langh; daer woonden in defe blecke ectröbts mel twee dupfent familien.

Yztacpalapa wag cen blecke wel ban thien suplent buplen / balf glyeboubt in bet jout-lack/ ende balf op 't balte lanot; pnoe daet waren berlebepoen bivers han foet water/met beel bitely daer in; ende een fontepne op den begly nact Me. xico toe ban gact water / ende om-ringelt ban Leer fjogghe boomell. Beff plarife Ieaft twee leguen ban ae ftaut Mexico, ende leg leguen ban Tezcuco; enúe men therlit naer de ftadt van Mexico langhys encalfýe / Daet wel arbt te peeroe neffend

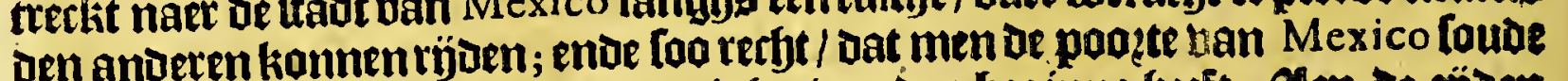
konnenlien / ten warceen kromte die het ban den beginne beeft. Sten de zäjoen van Dele plartfe was gbeleghen. Mexicaltzingo, een boex ban viec buplent bup: Ien/al in't water; ente Cuyocan met wel leg duplent buplen/ al op 't bafte lantot

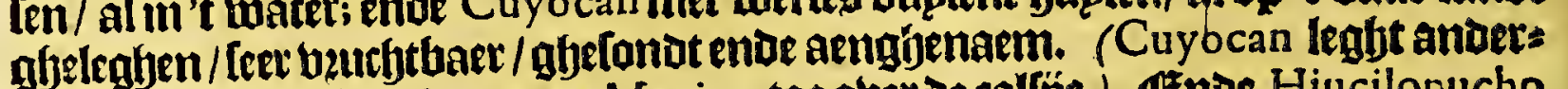

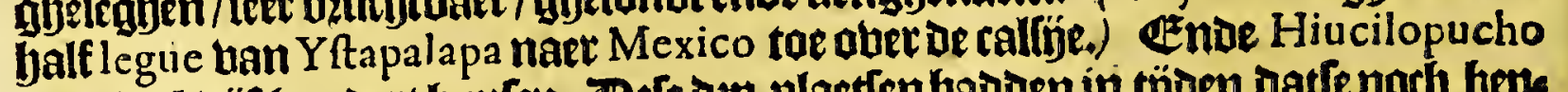

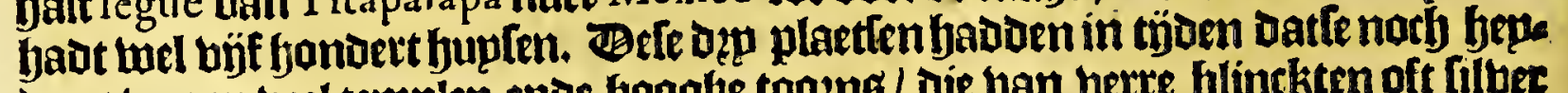
oens maren beel templen ende boogle toozng / die van berte blinckten oft filber

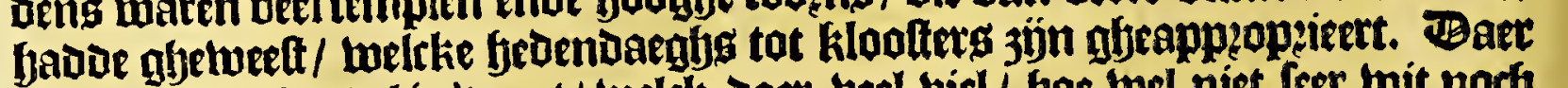
wag grooten fandel in't jout / welck Daet beel biel / boe-wel niet feet mit notf

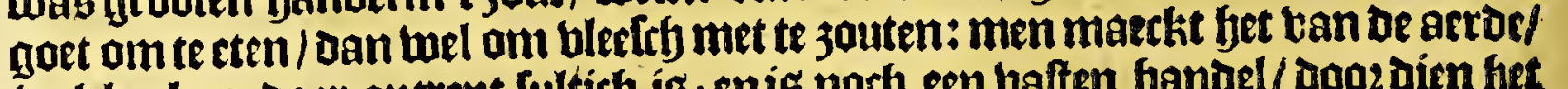

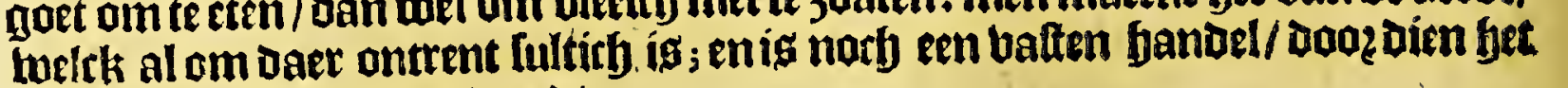
wojot en berot berboert wozot.

Guatitlan legft bíer leguen ban Mexico ; ende Tenyauca twee leguen; Efcapuzalco enn legue, al aen den oetuer wan 't lack. Tacuba dicht bp Mexico.

d.3. 1. 2. Suchimilco is een frapeplaetle gheleghen in 'troete lack bier leguen ban Me.

c.10. xico naer't zupden; inde twoel leguen ban Cuyocan. 
F Queretaro it een platte gheleghen in be peobincie tan Xilotepec, Daet een

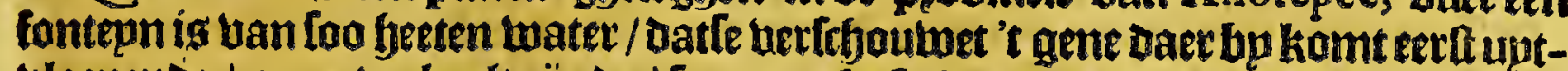
bloepende / maer berkadit jünde / foo maeckt fp get bee bet / ooog dienfe gelont ig: In de felbe probincie is een fontepne ban feer goet water / welck bier jaten loopt/

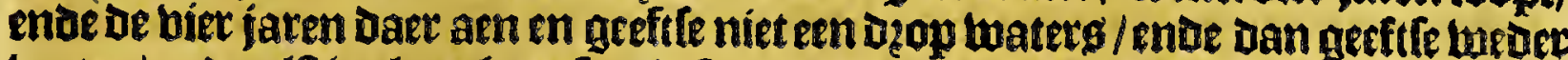

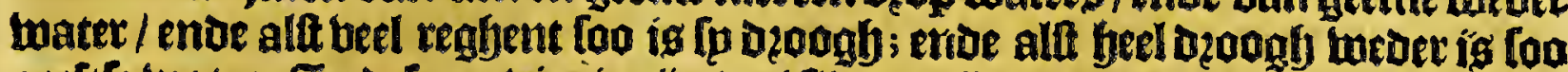

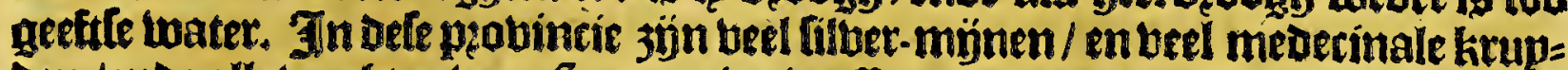

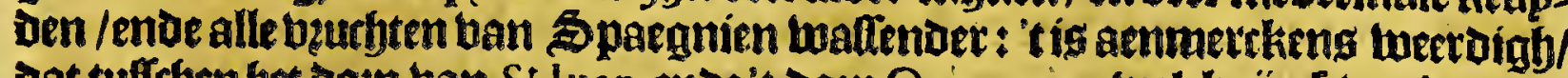

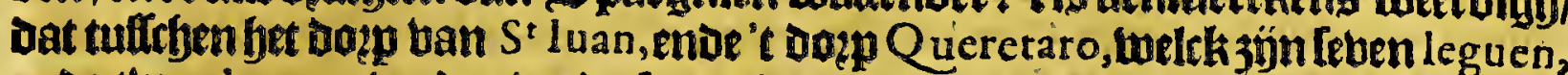

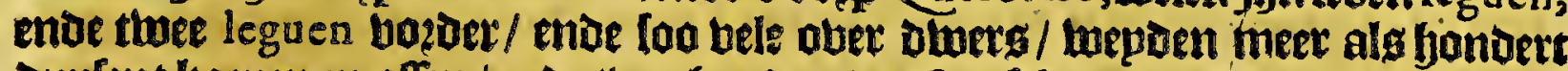

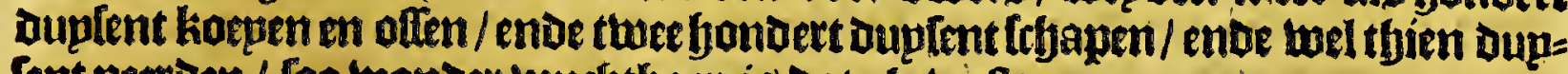
Cent peeruen / foo honoer beuchthaer is dat ghelwefte.

\section{het leuente Capittel.}

\section{Befchrijvinghe $\operatorname{van} A \subset A P \vee I C O$, welck is de haven van de provincie} van MEXICO, gheleghen aen de zuydr-zee.

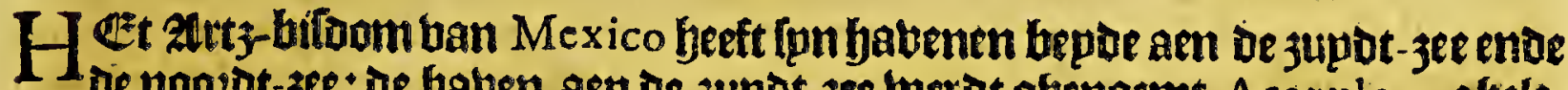

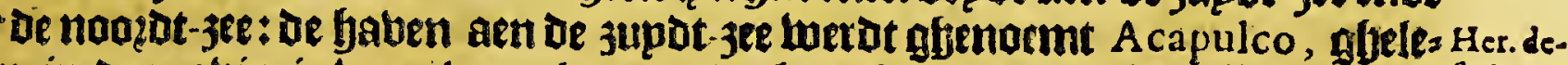
ghen in de peobincie ban Acapulco, op of bogghte ban fetentfien graden bp fcript. noozende limie; naet't legghen ban Herrera : waer mede ober en tiont een aenteeckeningh ban oe kulte bp Den Generael Spilberghen in een fpaens frfjp gfo: bonoen. (Thomas Fuller teftefe op be booglyte ban febentbien gradenen twointich minuten; Olivier van Noorde, op (ebenthien graden/Dertirf minuten.) Begle-

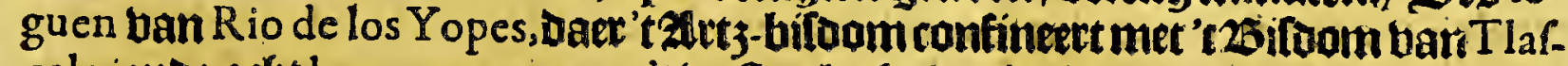
cala, ente acht leguen meet naer't welten leght de riebiete Cirala, entie noch viet

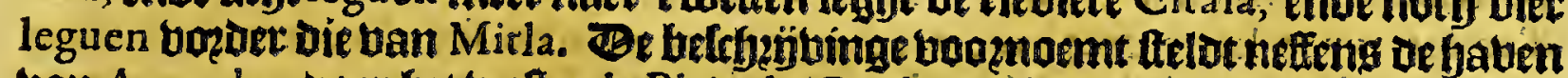
uan Acapulco haer bet welten la Plaja de Citala, weldk twel 24 leguen ourt [on: Der beubels oft klippenaen jet tranot: tekent 9 leguen tot Boca de Mirla, ento 4 leguen tot A puraqualcos, van Daer tot Petatlan fteltfe la Plaia de Tefpa, bol kilepn gheboomte ende palmiten: ban Petatlan tot De haben ban Ciguatanejo I3 leguen, eñ bain Daer tot Rio de Zacatula i 2 leguen. Be Gaben uan A capulco befft d.s. $L .6$.

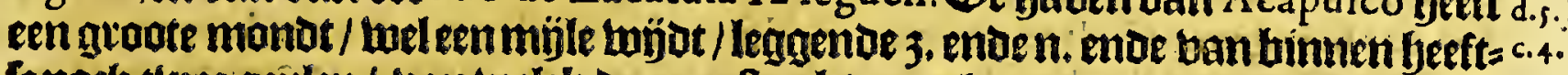

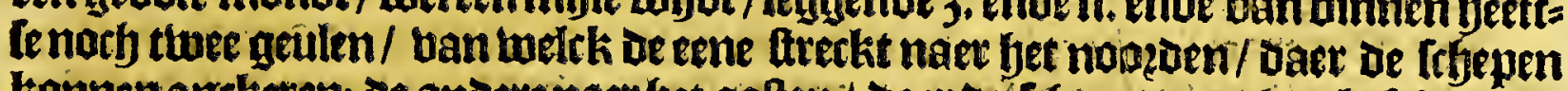

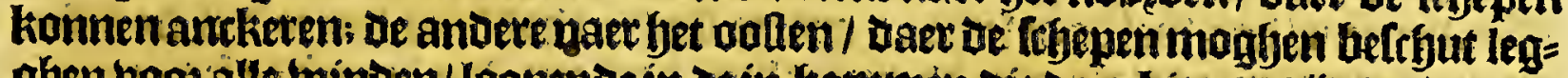

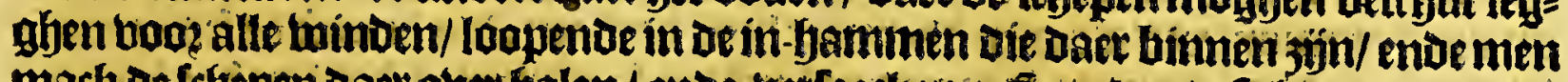

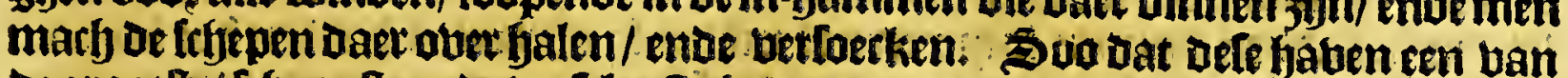

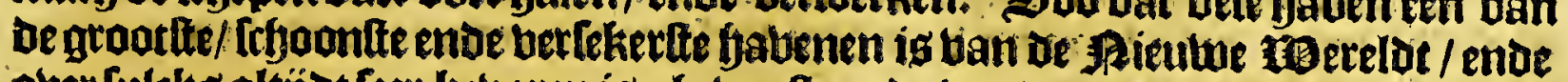

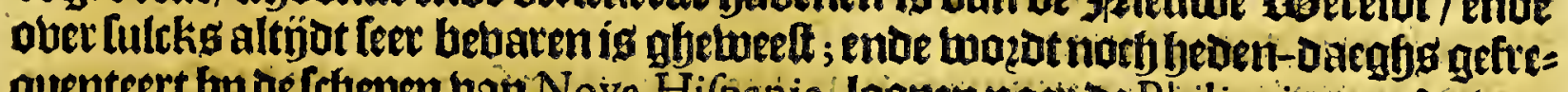
guenteett bu de fetjepen bait Nova Hifpania, loopen naet oe Philippinas, ende van baet tweder-keeten naet Nova Hifpania. 2len be wett-joeck ban de bape light eet

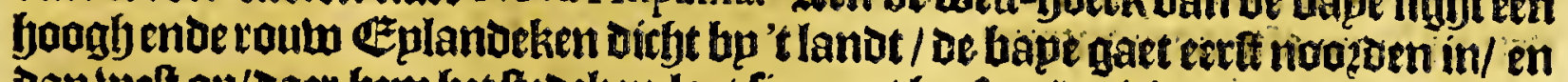
Dan tueft op/oaer bem fjet ftedeken laet fien met bet foet /welck maer een lege bouft beringfen badoe daen ong bolck daec twas met Spilberghen: de fobepen hionnen tot op een mulquet-lebeut bp of buplen ende bet fott loomen. Het fedefien aen Dele faben gheleghen/ is ban Mexico targtentich leguen, (naex'tleggfen ban Pedro Texeira die de felbe bereplt beff) een quaden ende feer periculeulen tuegh ober

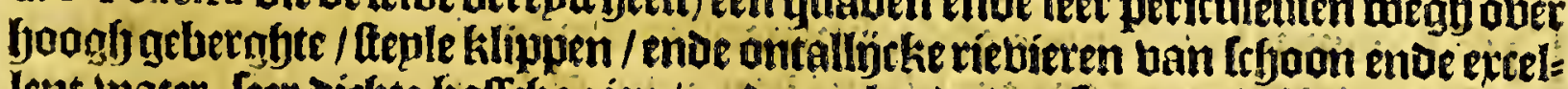

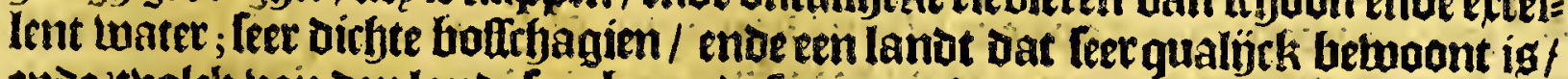

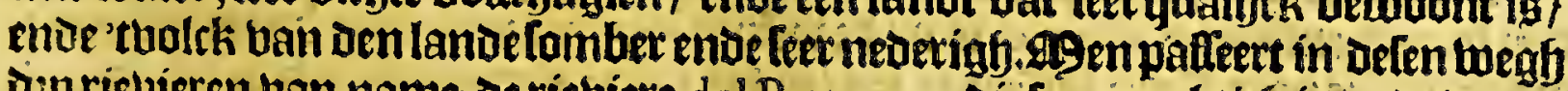

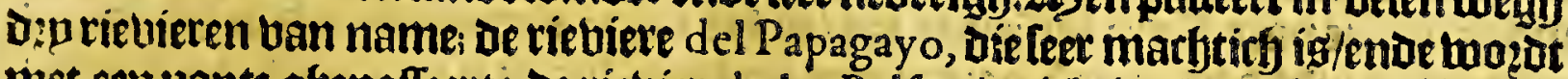

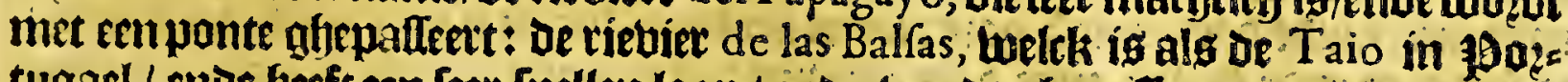
tugael/ enoe beffeen leer Inellen loop/ ende toozot gbepalfeert met blotten ban 
182

Nova Hifpania.

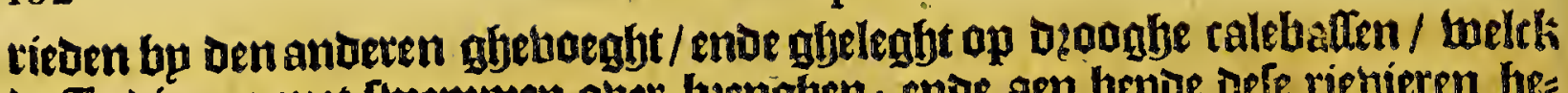
De Invianen met fwemmen abet-benghen; ende aen bepoe defe rievieren be= taelt men fun pallagie. De Derde is oe riebiere van San Francifoo, de telclie boetwel fp groot enoe macftich is / heeft haer medoen in eenigbe plaetfen: al aelen wegh lamghs is men leet gheplaeght ban oe Mofquitos Dattex qualijtk

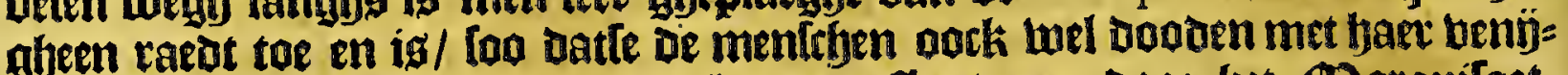

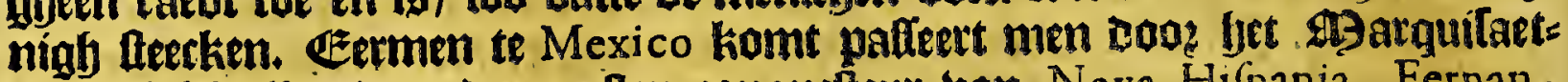
frhap del Valle, Daer ben eertten tonquelteur van Nova Hifpania, Fernan -

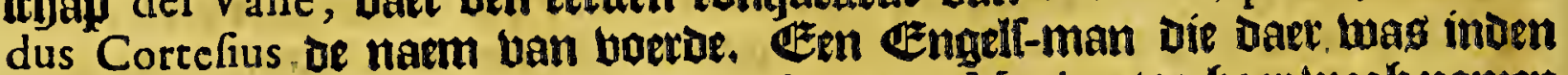
jare I 603 ghetupght Dat Ip uan A capulco naer Mexico toe baer Legh namen

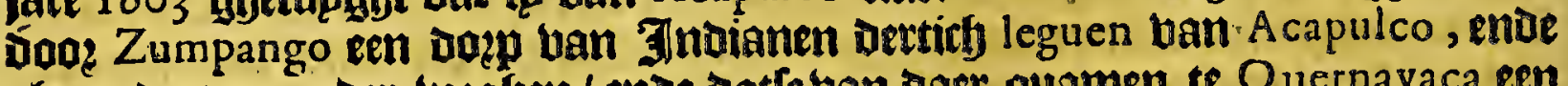
gheen boepen onder-tweghen/enae date ban daer quamen te Quernavaca een

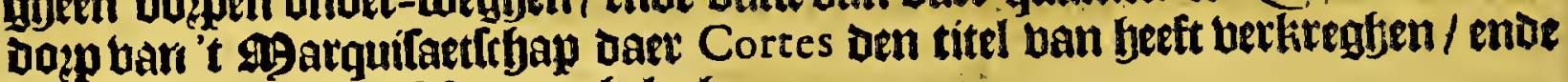
Dertbien leguen ban Mexico gheleghen.

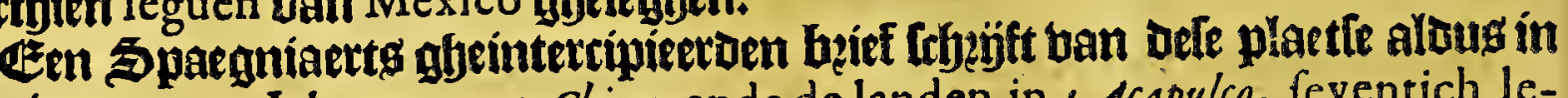
Den jare 1590. Ick quam van China, ende de landen in Lapulco, feventich leguen van Mexico, welck is de haven daer de fchepen legghen die naer China varen; alle koop-lieden van CMexico brengen haer koopmanfchappen neerwaerts tot defe haven, om wegh te fchepen als voren. Her is een van de befte havenen van alle de havené van $N o v a$ Hipania, ende daer de fchepen alder-feeckerfte konnen rijden fonder eenigerhande ghevaer; want fy leght onder een hoeck landts, ende een groot punt. Ende hier zijn vier groote fchepen, te MNexico toebehoorende, van fes hondert ende acht hondert vaten't ftuck, die alleen dienen tot de vaert naer China, ende vvederom; ende gaen tvvee teffens naer China; vvelck is over de tvvee duyfent mijlen, ende zijn ghemeynlijck derthien ofte veerthien maenden uyt; ende als die tvvee vveder-ghekomen zijn, foo loopen d'ander tvvee korts daer naer vvederom uyt, gaen nu feer fterck van foldaten voorfien. Een dingh kan ick u. 1. verfeeckeren; dat tvvee hondert ducaten in Spaenfche ende eenige Nederlandefche vvaren die ick dervvaerts yoerde, vveert maeckte daer in ' $t$ landeveerthien hondert ducaten, ende maeck rekeningh dat. de zijde-vvaren ende andere koopmanfchappen die ick in plaetfe heb mede ghebracht, my hier in CMexico fullen vveert zyn vijf-en-tvvintich hondert ducaten; foo dat hier groot gheltte vinnen is, allmen behouden mach over komen.

- Ben Benerael Spilberghen wagh fier in'tiaer I 615 ; enoe arcoydertoe met ben

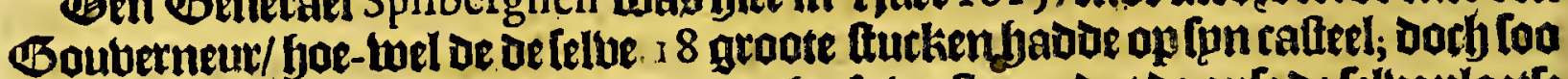
qualïrk ghemonteert/als men Daer naer beeft berftaen; dat be onfé De felbeplaetle

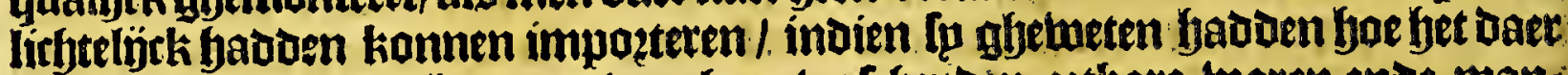

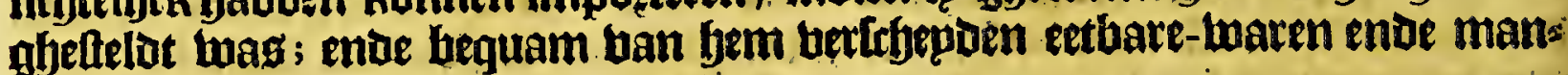
glyeloe fpne ghebanghenen.

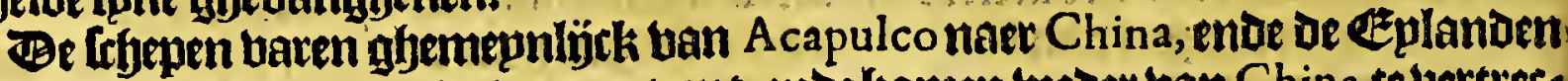
Filippinas, in Martio ende daer onttent; ende komen tweder ban China te vertrecs ken in Iunio ofte daet ontrent.

Het achtite Capittel.

De gheleghentheden van de provincie van $P$ A $N$ v co, ende de fteden in ' $t$ felve quartier gheleghen.

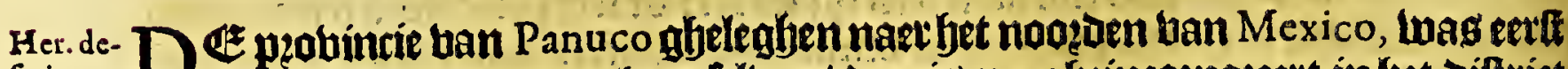

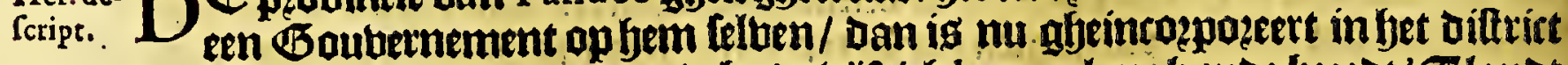
ban oe audientie ban Mexico, is bp de biftich leguen langhende bzecot. 'Clandt

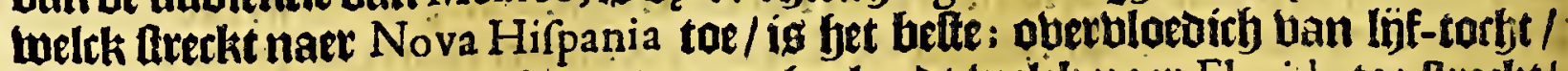
ende men binot daet eenigh gout: maer bet lanot melck naev Florida toe trecks/

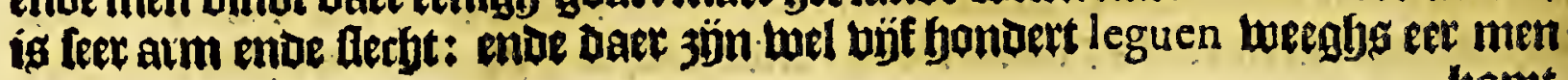

fomt 
Het vijfde Boeck.

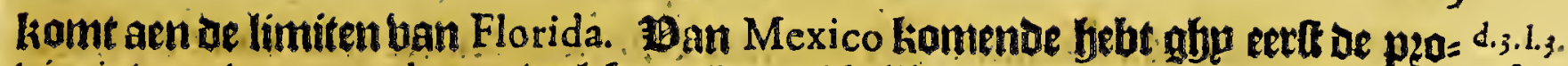
bincie van A yotuxtetlatan, belek centỉts bol belliqueus boick twas/ende wietot c. ร8. van Don Hernando Cortes geronqueiteert in Den fare 1522 , met groote lachter

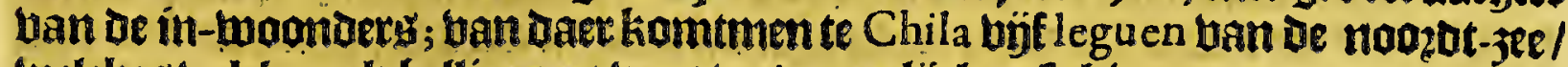
welckes uolck oock be!líqueug twas / entoe qualïck te Iabjugeten/ upt ooelaecken ban diverfhe lacken die in de felbe peobintie jän; foo dat Cortes beel te doen had: De oin die te ober-binmen. Be Spaegmiaerden beblben nu ít dit 5 anbernes Her.de.

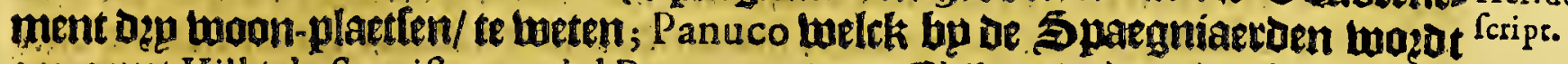
genoemt Villa de Santiftevan del Puerto, antent Chila enoe vaer de riebiete ban Panucoít de zee loapt i gbeloulut bu Don Hernando Corres naer dat fjp die tan Panuco ende Chila bavoe' tonoer-gebratht/ende faer twoon-plaetfengedelturert;

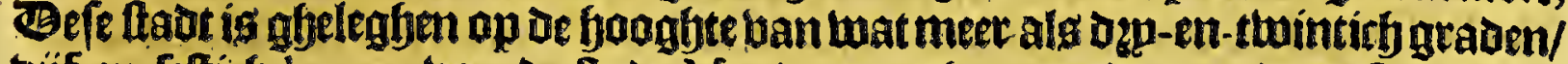

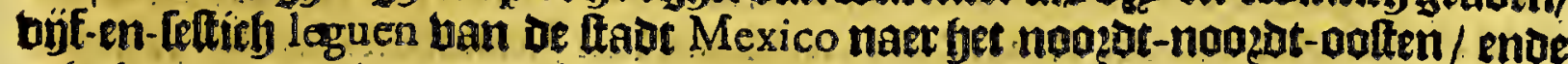
acht leguen ban de 3 ee / neffeng en riebiere tuelcke bet in-liomen maeckt ba De haben,

Be theeve that íg gftenoemt hp te Spaegniaerden Santiago de los Valles, is gljelegben bimmen landtg bje:en-tbintich leguen ban Panuco naet bet tuelten toe:

De derde ig de ftadt St Luis de Tampice, actyt leguen ban Panuco naer'tnoozt.

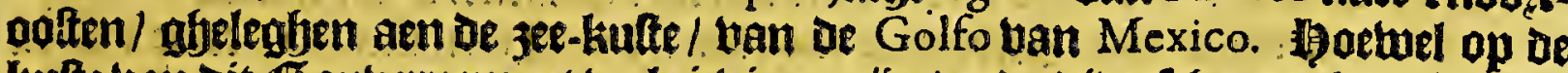

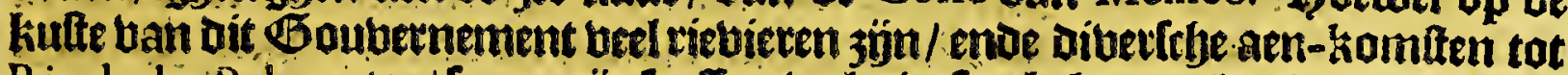
Rio de las Palmas toe / foo en jünte effen- wel niet feer bekent / als alleen de riebier ban Panuco; ende fpn baben / welck oock niet feet goet ofte feecker en is.

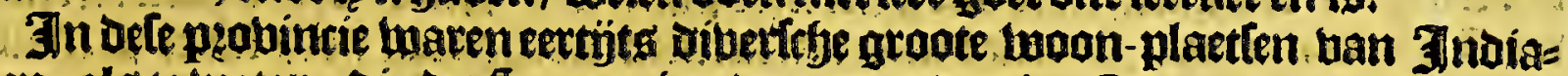
nen; als te meten; die de 5 paegmiaeroen noemben las Caxas, enoreen andere d.3.l.s. ghenaemt $Y$ xicuyan; mole Nachapalan, ende Taquinitl, ende Tezetuco; al feer c.7.

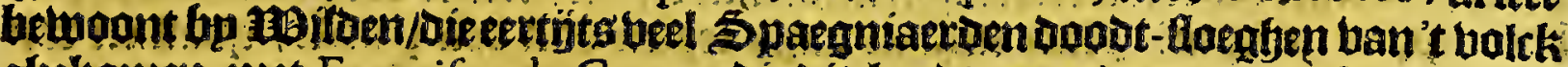
gbekomen met Francifco de Garay, wie dit lanot mepnoe te ronquefteren/ ban was daet in too - obethomen bu Corres.

Tn pe prouincie uan Panuco, alo Oviedo ghetupgft / bogot abetronden een sommar leecker Bitumen, tuelck feer bequaem is om de icbepen mede te perken; wetck nen c. 8 . oorkeloers in fonden binot.

Zlen de noqut-jýde ban de riebiere tegen ober Panuco, lyehlaen de Spaegniaet: Engel-

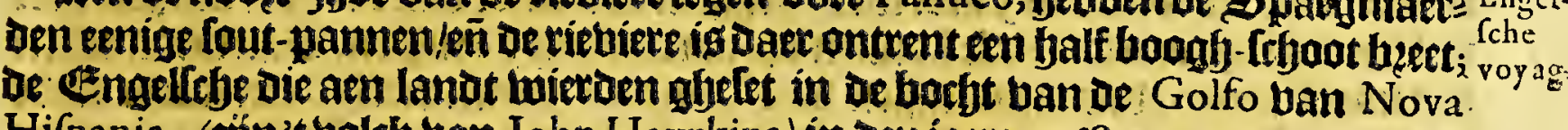

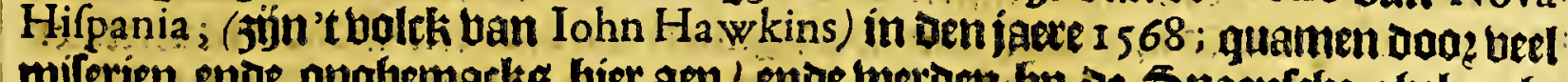

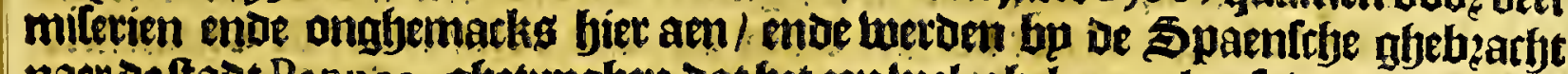
naer de fadt Panuco; gbetupglien dat bet een luel-ghelegen plaetfe was / wel bets lien ban alle looten ban frupten; ende beneffens beel Jnoianen/alg boen be woont be outtent thee bondet Spaegniaeroen/ bebalben noch de Stwatten.

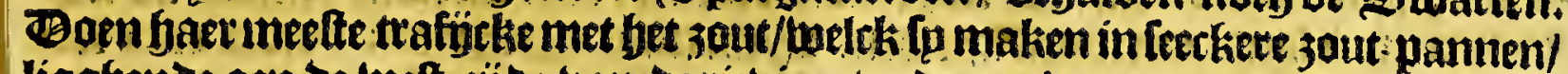

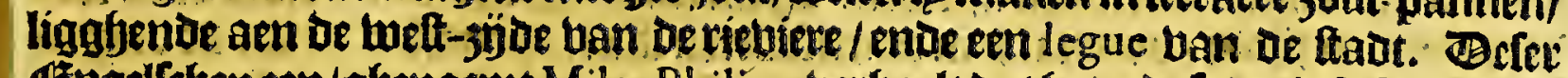

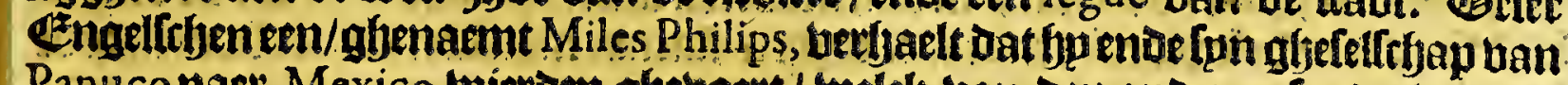

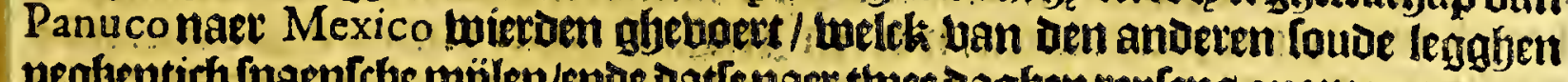

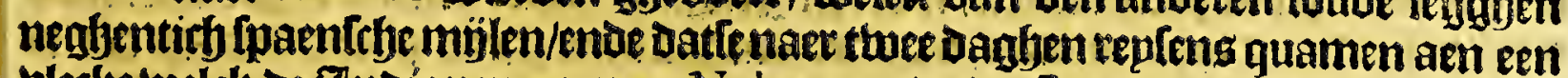
blectie telck de Indianen noemen Nohete, ende de Spaegniaetoen Santa Maria, daet een kloolter ban 9gunnicken ig; Daer naet quamente te Meftitlan beer. tich leguen ban Mexico, Daer cen hupd íg ban Graeub-munnicken/ ende daer

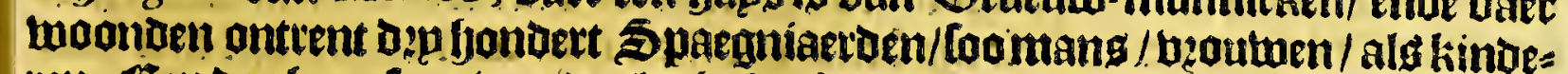
ren. Een dagl-replens vooegder legft Puchuca een ftedeken/ende de münen van Puchuca leggfen ontrent les leguen ban daet naet't nooet-Luelten.

Sot naerder ontoeckinglje ban defe probincie / fullen wo hier bp baeghen bet berbael ban Iohn Chilton, als t telbe is upt-gbegeben bp $M^{5}$ Richard Hackluye

in 2 inlon




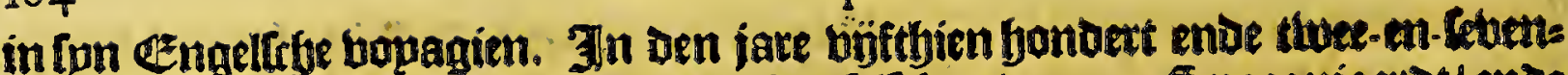
tich / (legbt bp) quam ist: te Mexico, in'tgdelicfap ban een Spargniaerot/ enise up trocken te famen naec de peobincie ban Panuco, buelck legto op oe kulte ban be noozot-3et/enoe naet ozp Dagh-repten quamen lopin een fradt gbenaemt Mefticlan, daer maer twaelf spaegmiaerts en woonuen/ende de Indianen die daer moonden waten bp of Derrich duplent. Bele plaetfe leght op leerker boogfe bers

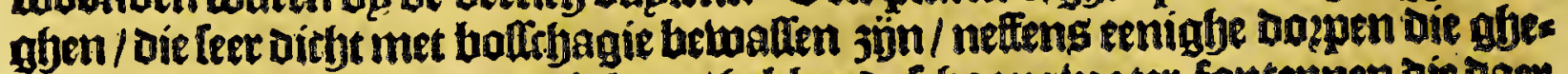
font ende luftigh jon / en buthtbaev / bebbende fefjoone water-fontepnen die daec

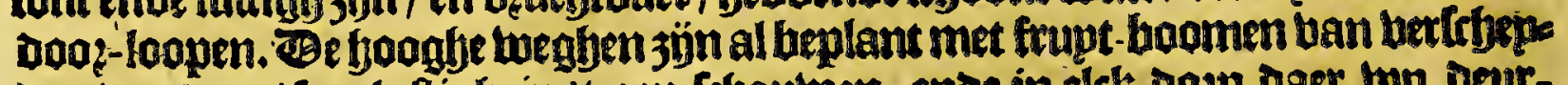

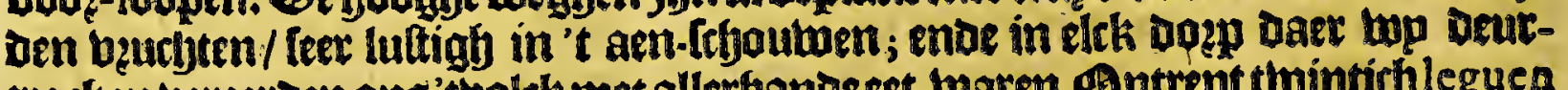
tracken bereeroen ong' tbolck met allerfyande eet- warem. (Bntrent twintirb leguen ban dele platte is een ander ulecke ghenaemt Cianchinoltepec, toldk een ejolman toe befoo:t/alwaec ontrent de beettich duplent Indiamen twopnen:ente ons

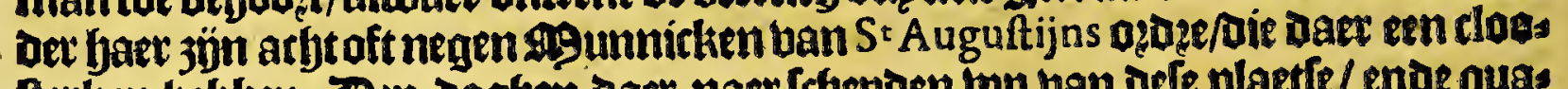

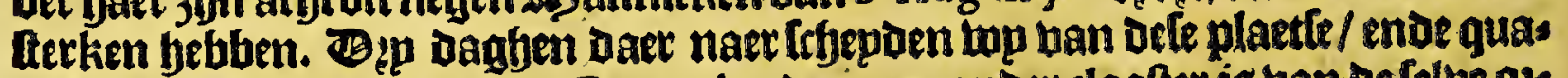
men tot een blecke ghenaemt Guaxutla, Daer een ander cloofter is ban de felbe oze ber; ente daet waanen ontrent twaelf Spaegniaetoen. Ban defe plaetfe bootswaerts begint of peobincie ghenaemt Guaftecan, welck is black Lanot fondec eenigh gbebexgfte. Beeerlte blecke Daev top aen- quamen ig ghenaemt Tancuylabo, daet menichte ban Jndianen twonen/langh tan ftatuere/ mbe't löf al

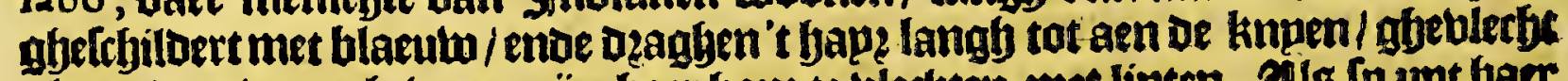
als oe bzoutwen ofetwoon 3ïn baet bap te blecten met linten. 2als lp upt baex

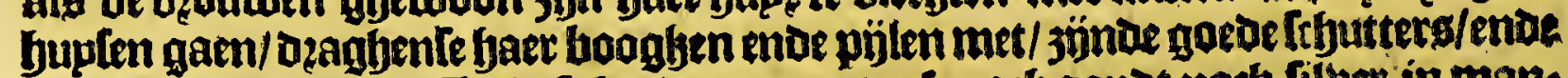

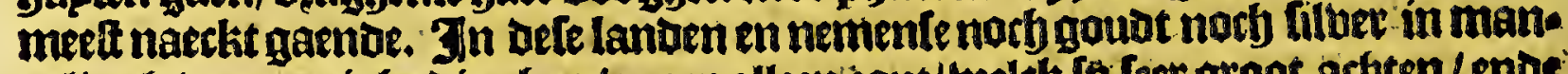

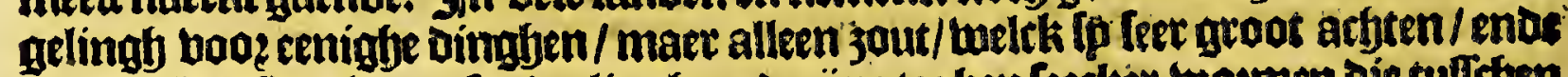

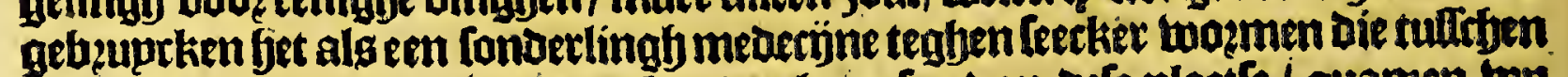
baer lippen groepen. Faer nogben oagb-replen ban dele plaetle / quamen wp tot een ltedeken ghenaemt Tampice, welck een baben-plaete is op de zee/ daef.

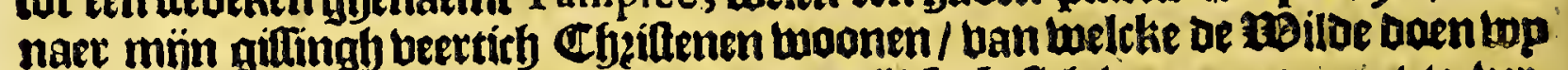

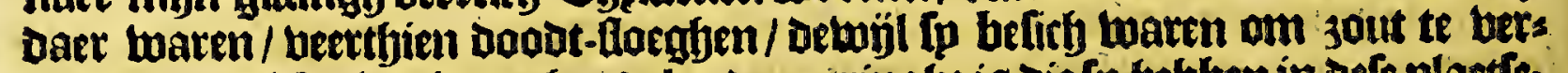

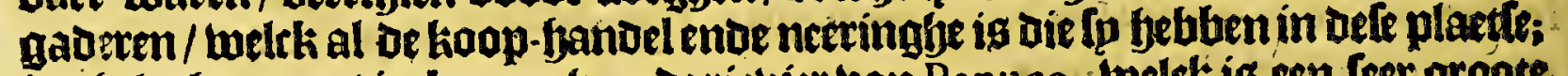
is gheleghen aen 't in-liomen ban de riebire ban Panuco, loelek is en feer groote.

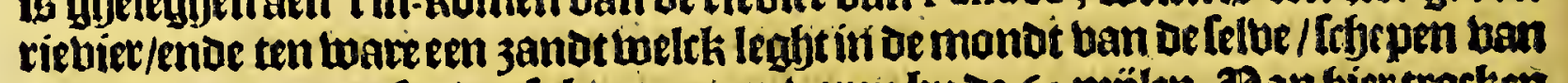

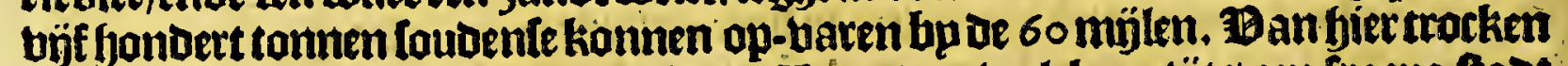
wp naer Panuco, beerthien imílen ban Tampice, welck eertüts een fraepe fadet is ghetweet / en be de thoningh ban Spaegniengadt daer een Gouberneur; maet

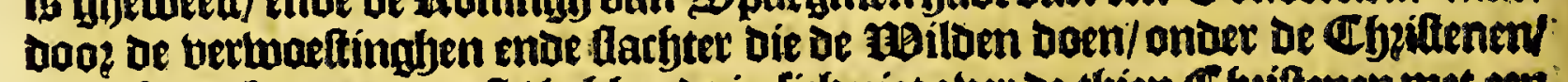

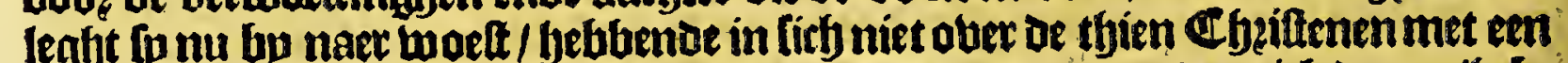

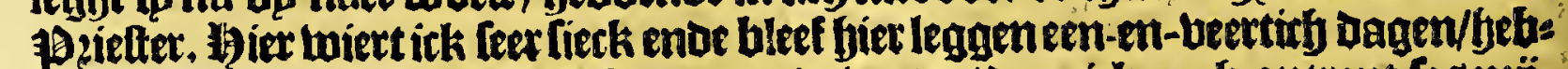
benoe gheen ander boettel als fruptenenoe water / baer ick noct ontrent les mige:

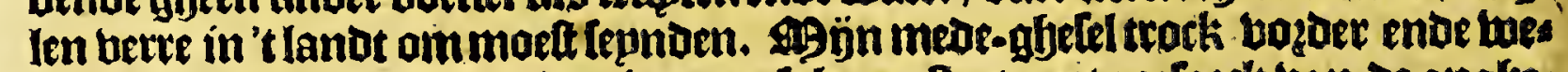

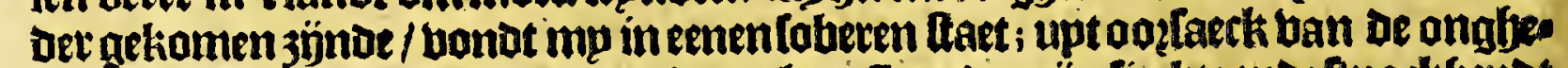

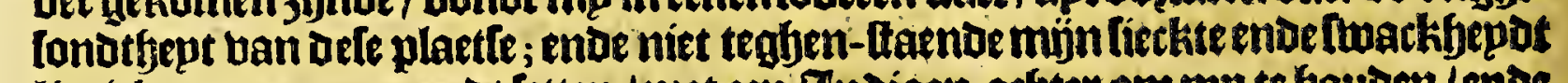
liet ick mp op een peerot letten / met een Indiaen arfter om mp te bouden / ende

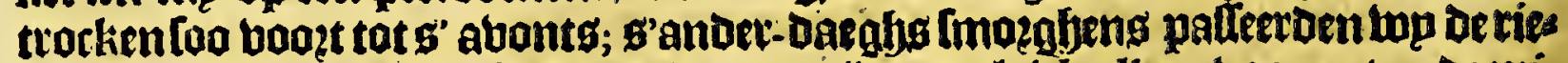

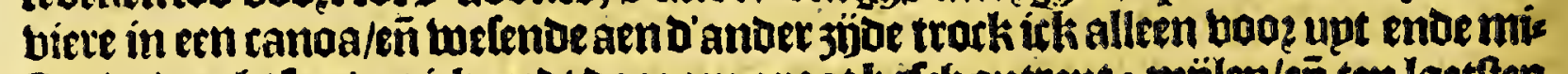
ften De wegf/ foo dat ick reedt Dooz een groot bơfch ontrent 2 mijlew/eñ ten laetten viel isk in banwen ban de noilue ban dit getuefte/oie daer woonaen in leetker bets tiens ban ftroo gemaeckt : Dele mp fiende quamen beur twintighen upt met baex boongen ende pyjlen/ende Ipzaken mp aen in bart tale twelck ick niet en berftonot/ enoe ick gaf baet met teeckenen te kennen satte mp ban mijn peetot fouden

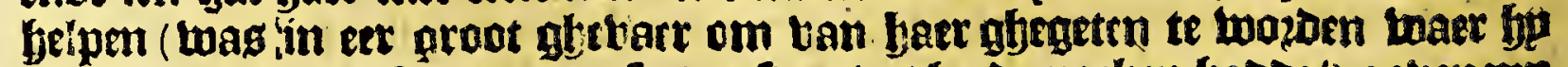

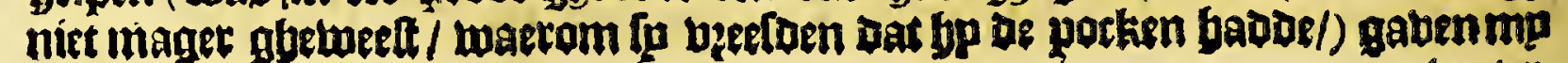
mater 
Het vijfde Boeck.

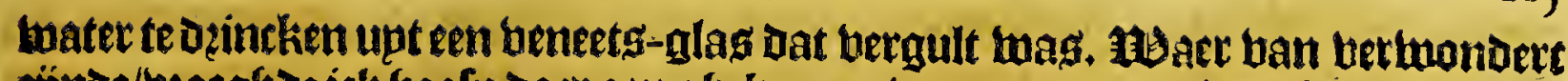

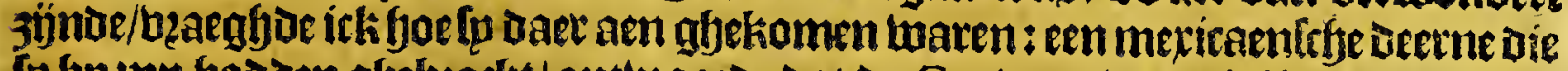

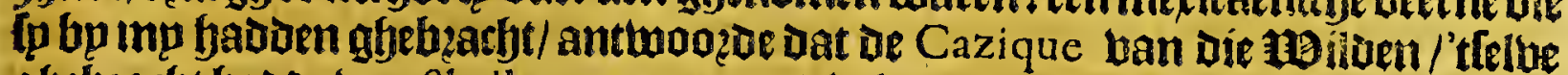

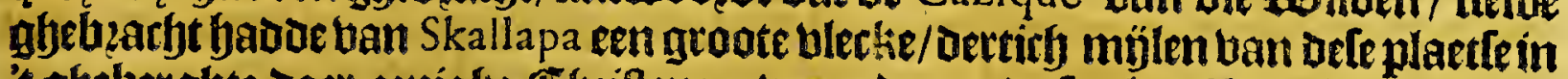

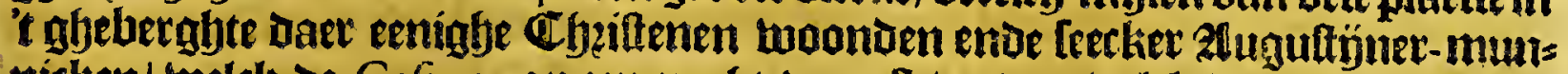
nicken/ welck de Cafique op een narbt vertalt / ende 't ualch Dooot-gfyeflagljen

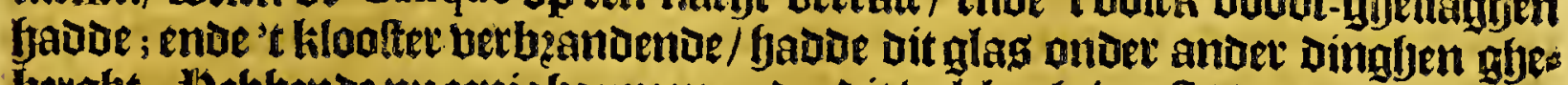

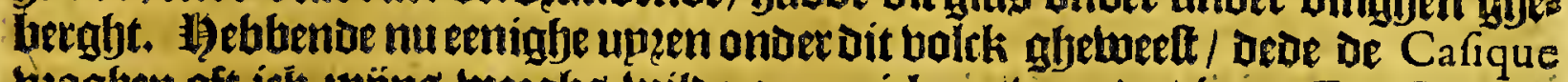
bzaghen oft ick mings tweeghs luiloe gaen; ick antwogzoe / jae. De Cafique liet twer ban fpn bolck met mp gaen om mp te gfelepoen / díe naecht bog mp gingben met jaet booghen ende pjilen bu de dępmiglen/ tot datte mp bectjten op Denlyoghen weth/enoe gaben mu met teeckenen te hennen dat ích baelt coube komen aen een faot daec Cijzifienen woonden / welck is ghenaemt St lago de los Valles, gljeleghen op Glacke teloen cnoe om-ringht met en aeroe tual/tabe= tal ban de C fyttenen die Dake woonden/ en waren niet bouen be biet oft bijf-enthinticly/ die de ltoningf van Spaegnien Dowen ende Jndianen gheeft om tee

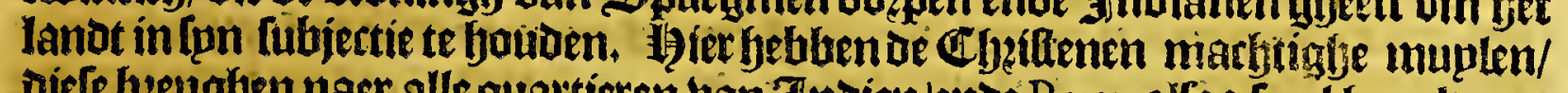

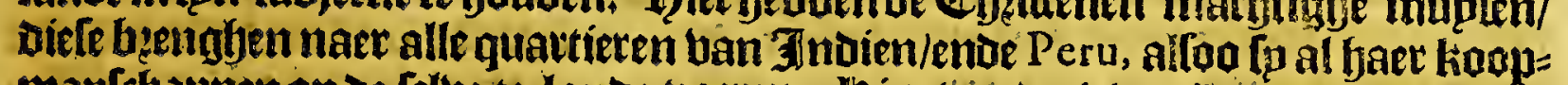

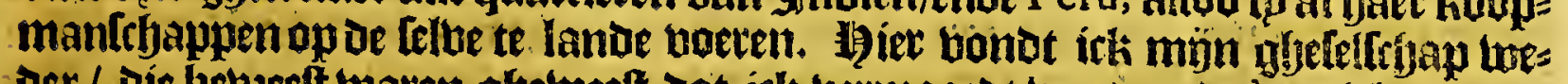

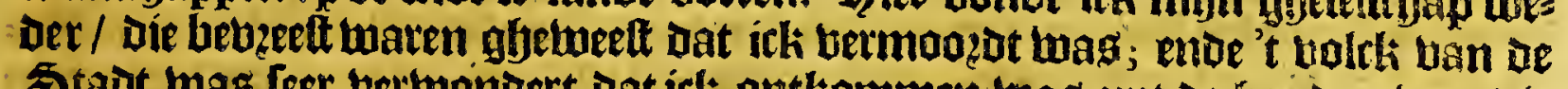

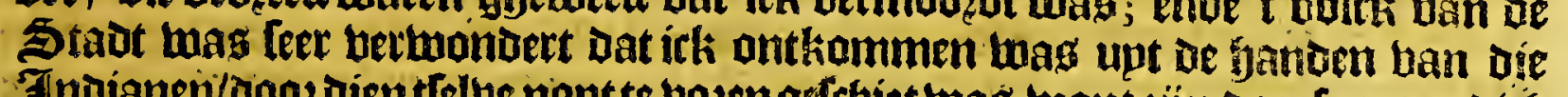

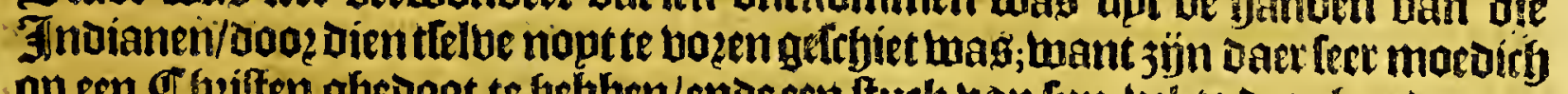

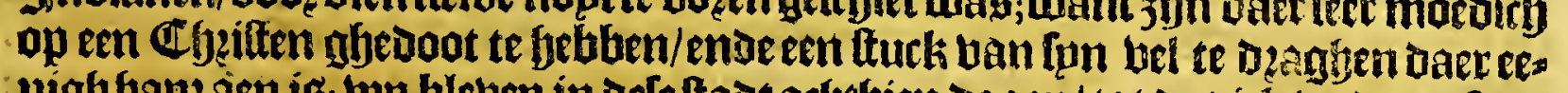

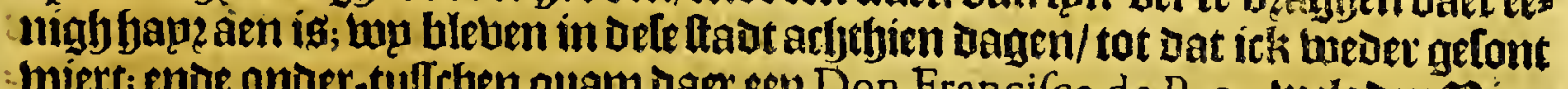
- wiert; ende onder-tufthen quam daer een Don Francifoo de Page, wele ten 1)ireTop Don Henrico Manriques foud gefonden yoo? Capiteun-generael/ om te on:

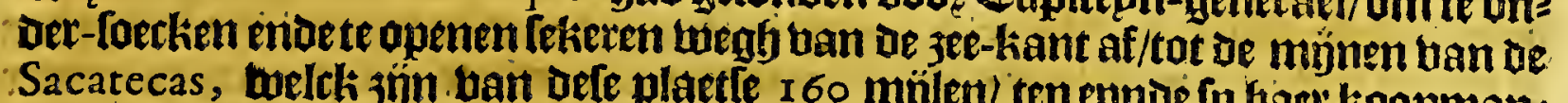

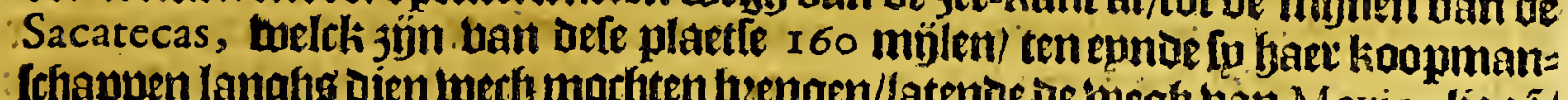
Ichappen langhg dien wech moethten beengen/laten be de wegh tan Mexico liggêf

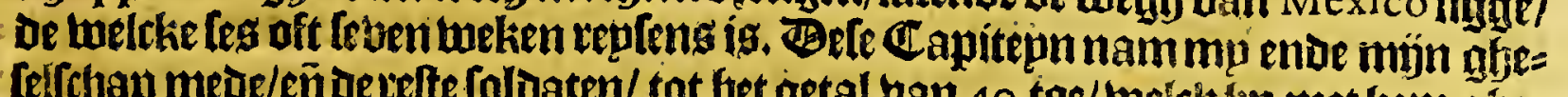

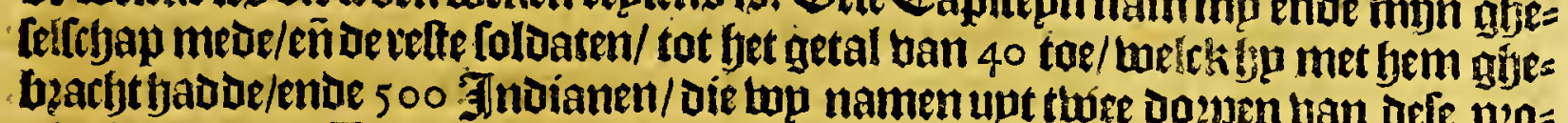

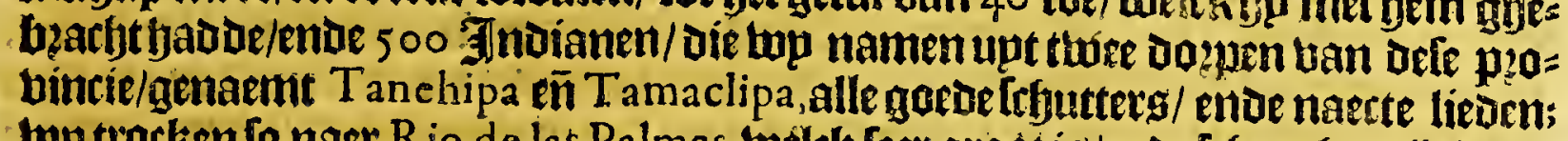

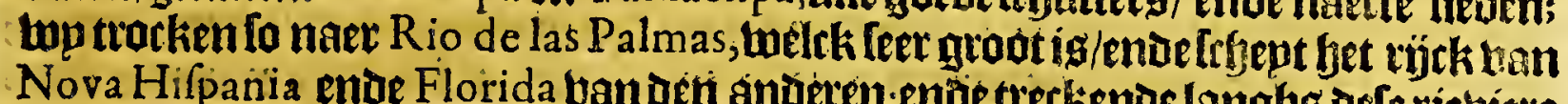

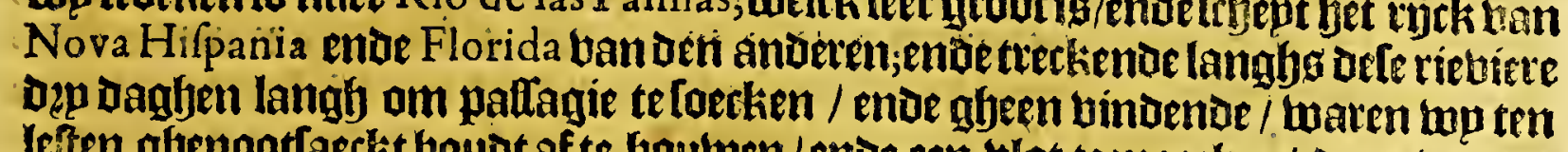

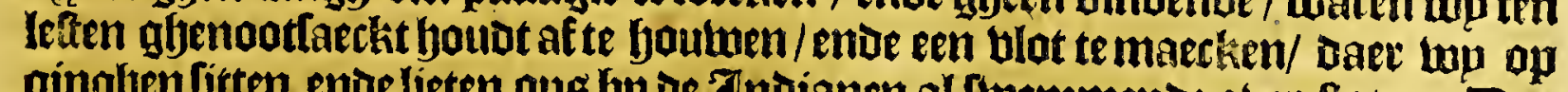

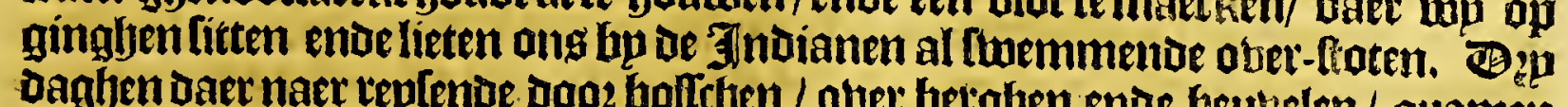

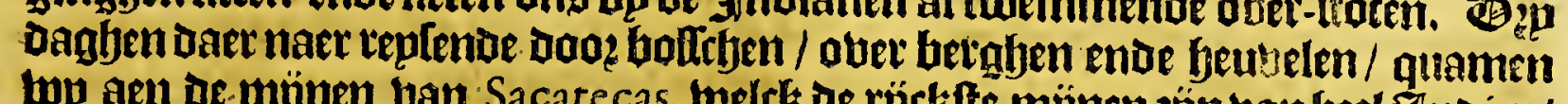

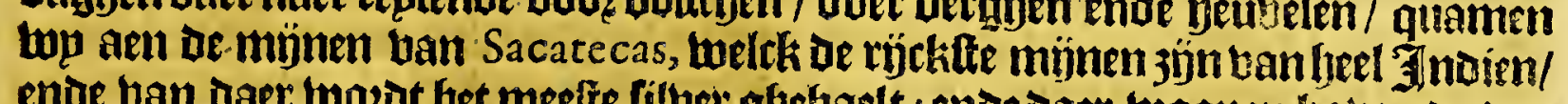

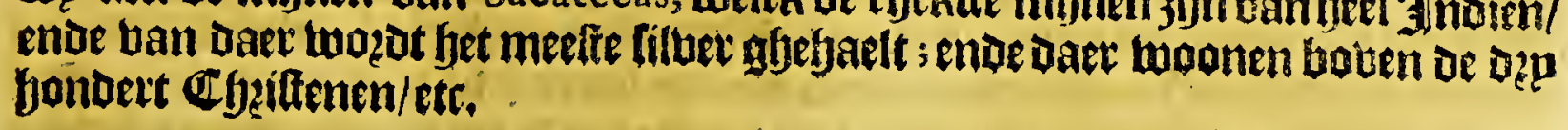

\section{Het neglyende Capittel.}

Van de manieren van de Mexicanen, haere tale ende regeringhe.

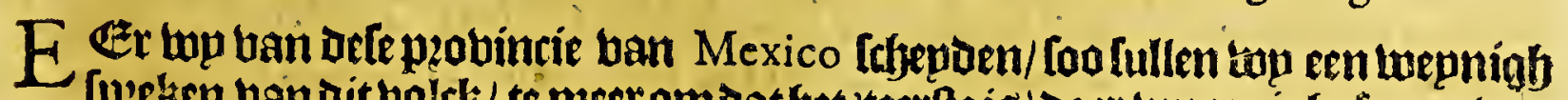

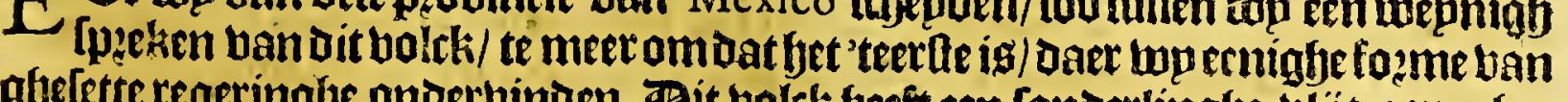

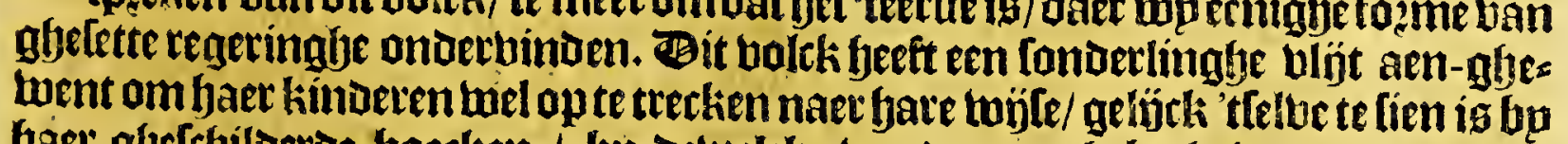

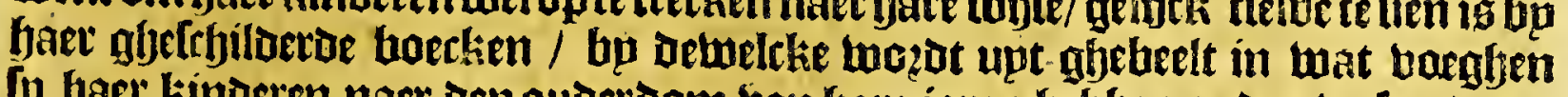
tp baet kinderen naer den ouderdom ban hare jaren hetben onter-melen / ende naet baet bernuft te loerclie gbeftelt/ ende of lweder-[pannigfe met tware ftraffen

$$
\text { 1i } 3 \text { ghetemt: }
$$




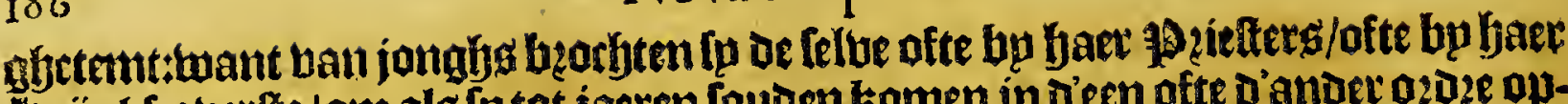

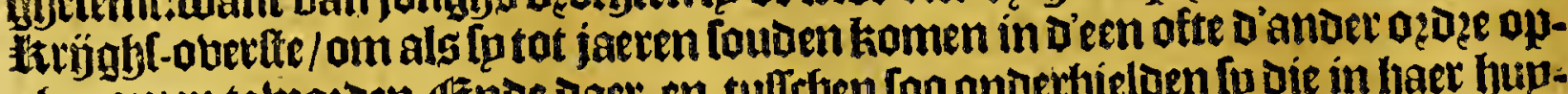

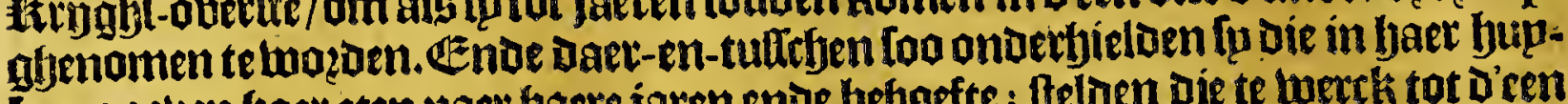

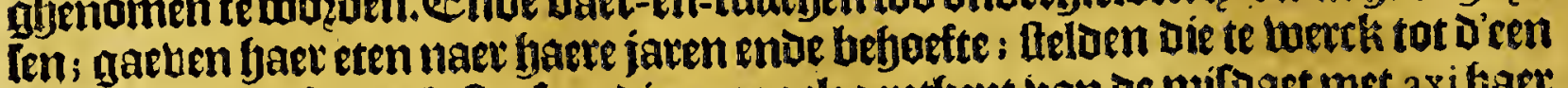

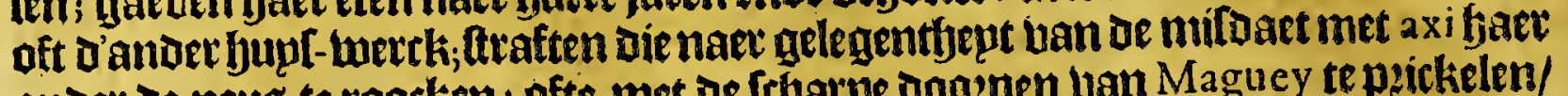

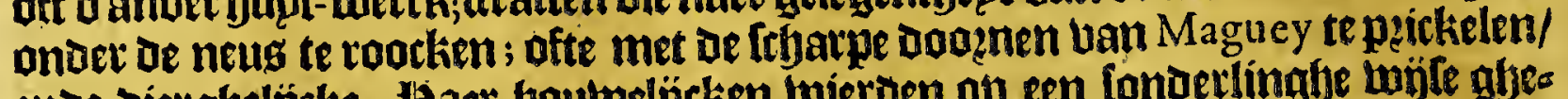

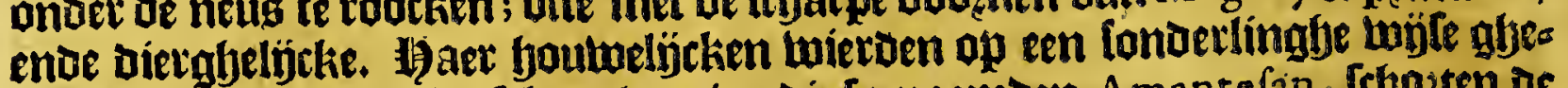

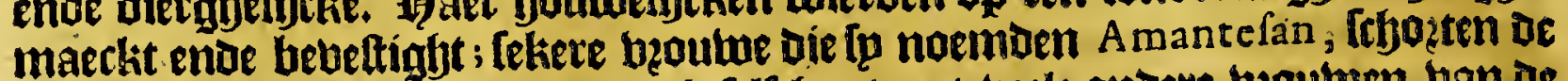

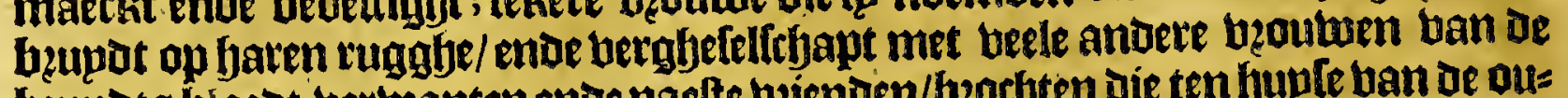

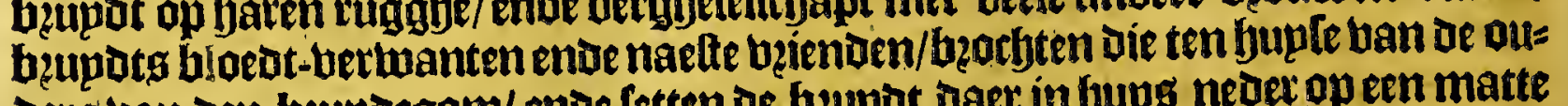
Dersiban den bzupoegom/ ende fetten de beuptot baer in bups neder op een matte neffeng den bzupdegom/endeknoopten de kleerderen baride bzupot ende den beups segom aen ben anoeren ; men offerie Daer naet Copal aen of aff-gaden/entoe

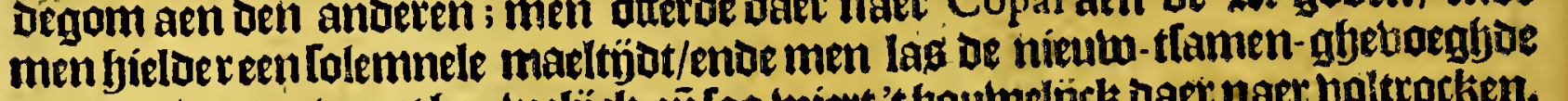

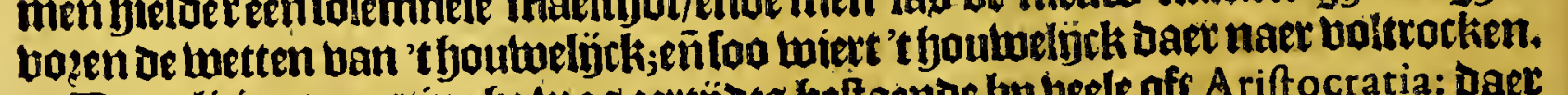

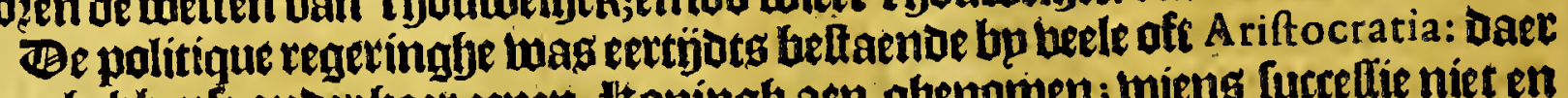

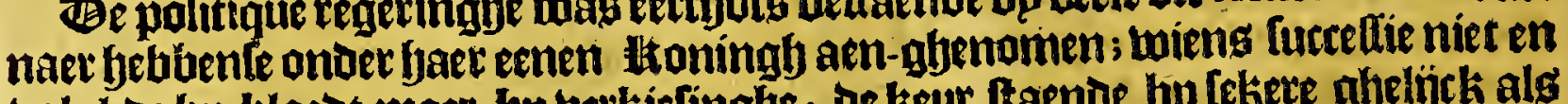

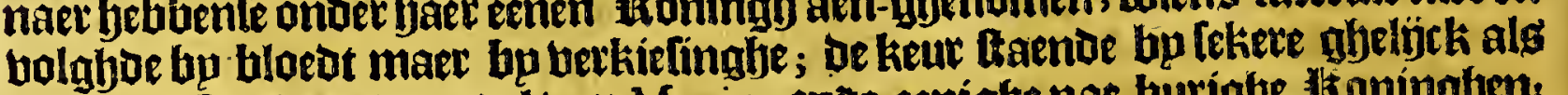

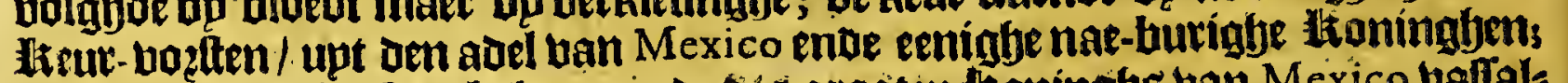

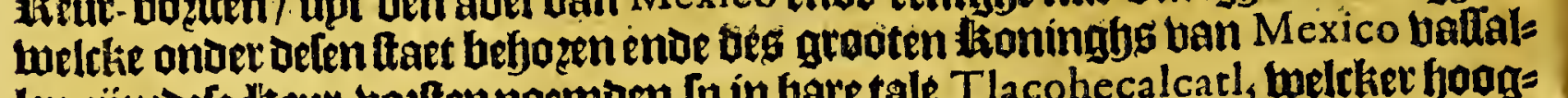

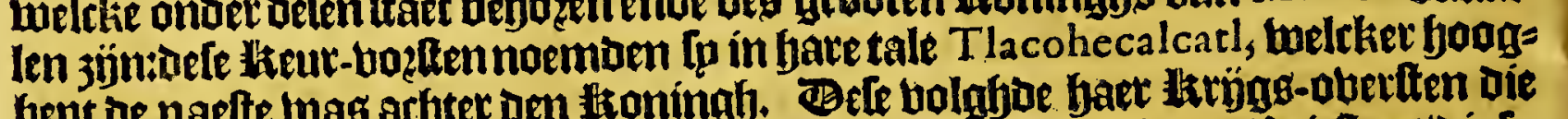

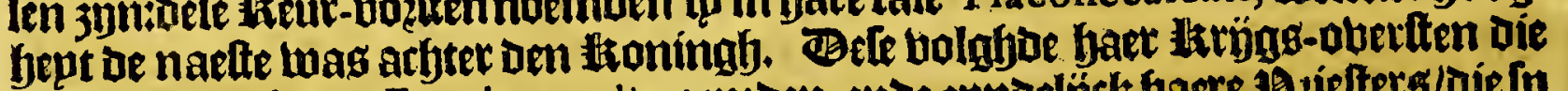

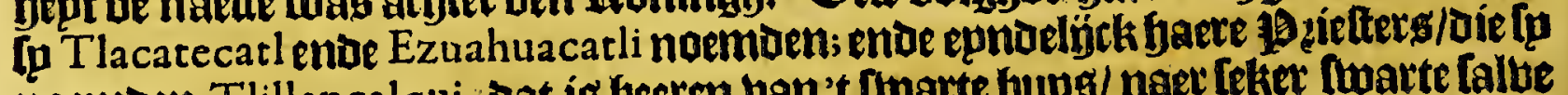

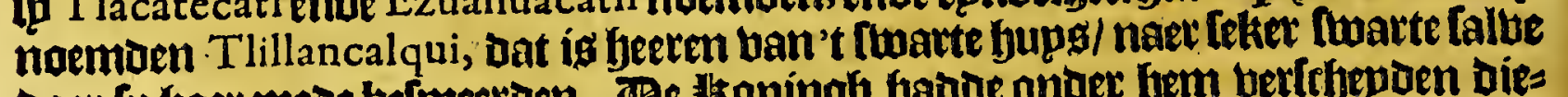

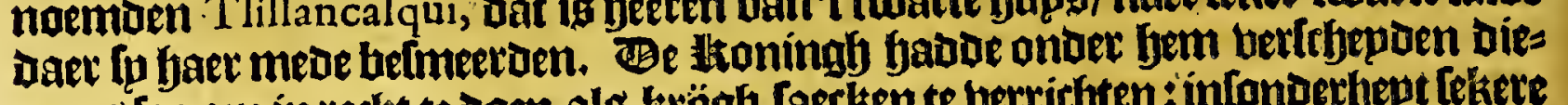

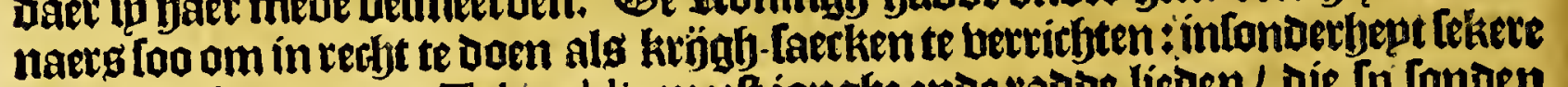

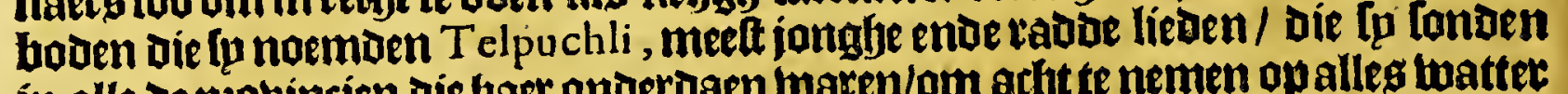

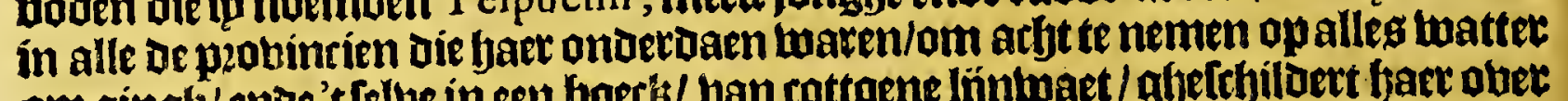

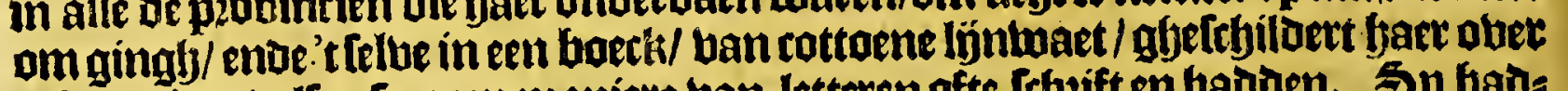

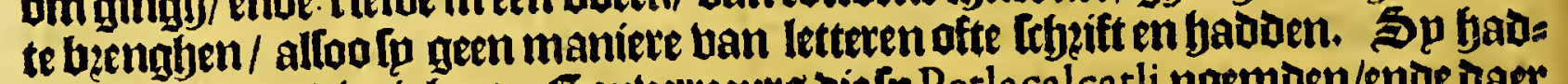

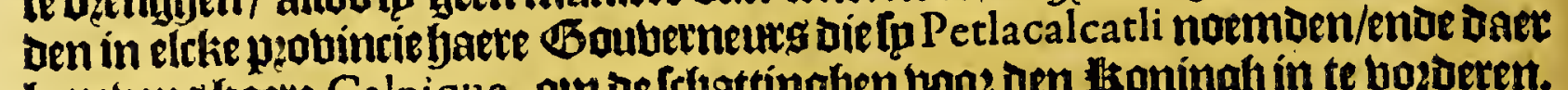

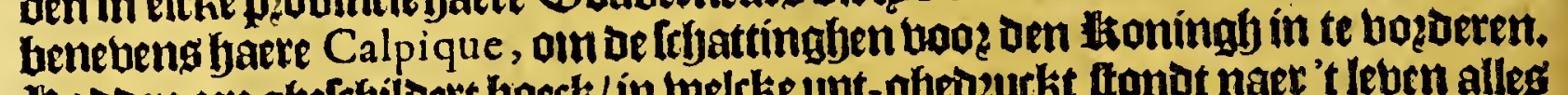

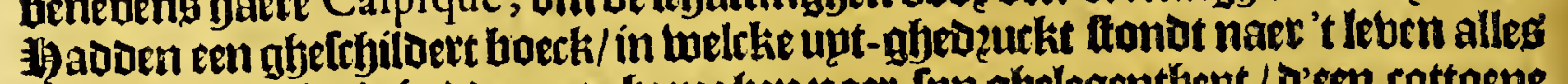

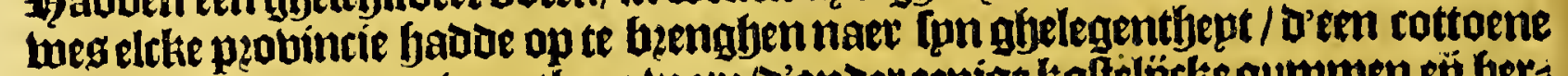

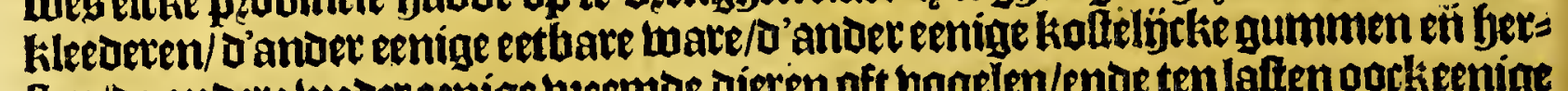

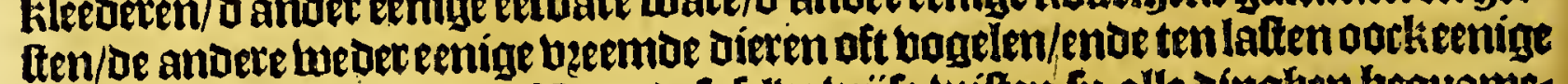

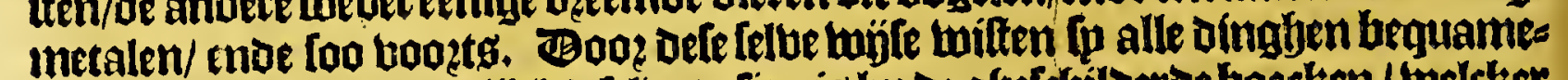

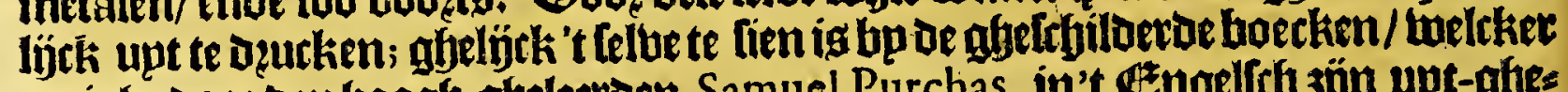

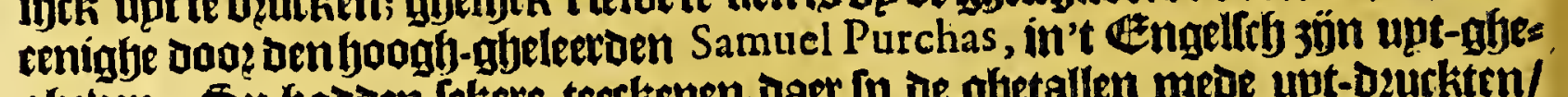

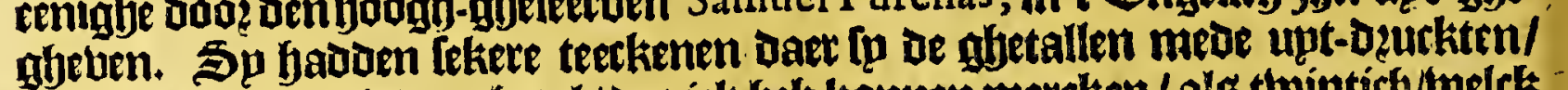

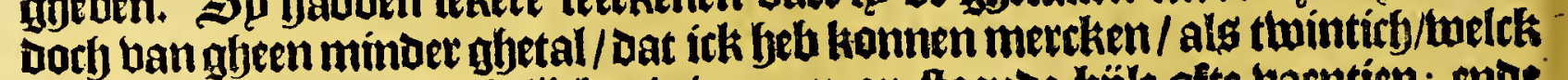

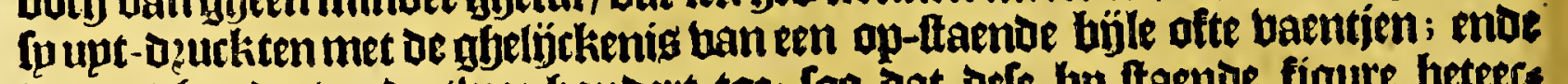
dat tot fonoert enoe twee Gonbert toe; foo dat befe bp-ftaende figure heteers

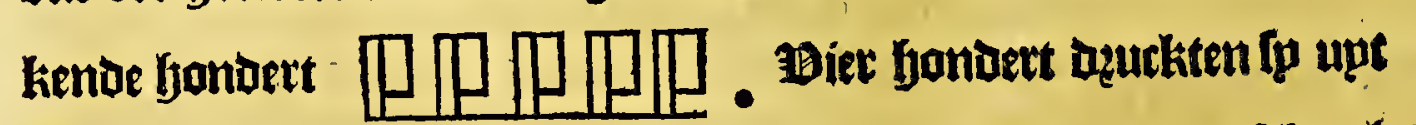

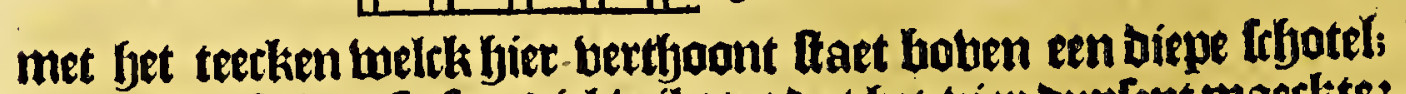

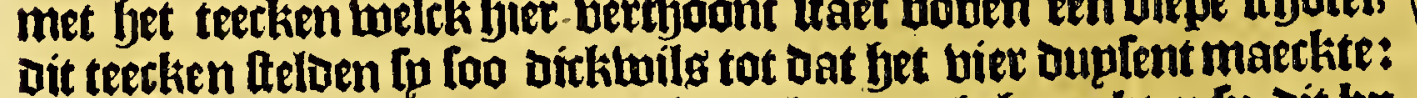

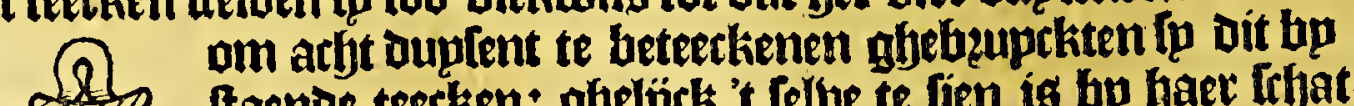

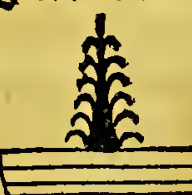

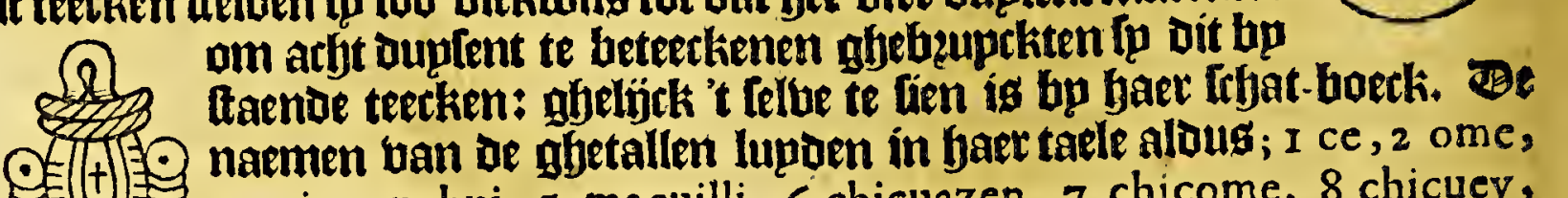
道 3 yei , 4 nahui, 5 macuilli, 6 chicuazen, 7 chicome, 8 chicuey, of 9 chicunahui, Io machtlaalli, 20 zempohualli, 40 ompohu-
alli, trt. 


$$
\text { Het vijfde Boeck. }
$$

Sp begounen faer jaer ban onten Maert,ende bet deeloen flaet jaet in achtjien maenden (als Gomara ftjęjft) ende gaben elck maent een beloniere naem meeft ghenomen ban yaer feeften die elche maenot amquam; ense elcke maenot berdeelen [p in twinticy dangen/ Die oot haer belonoere naemen badoen ban beelten ente anders/ met twelcker beeloen lp die upt Dqurkten. In't op rekenen ban jaeten gle: beupckten fo cen wetke om loo te feggijen uan dertbien jaeren/De tuelc= ke lo upt-beeloen alg in be bu ftaende. figuete/ in oe twelcke maex

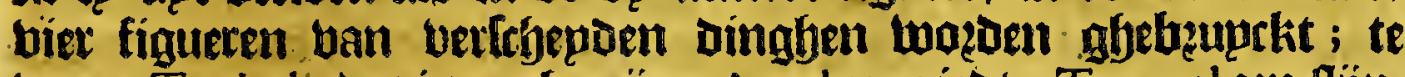
weten Tocheli, dat is een tionün: A catl en riedt : Tecpatl een añp-

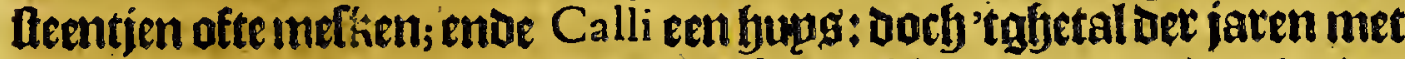

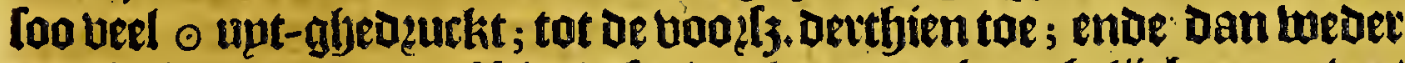

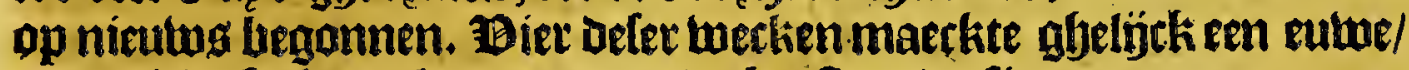
oe twelcke fo beteeckenden met oe bpeftaende figuete;

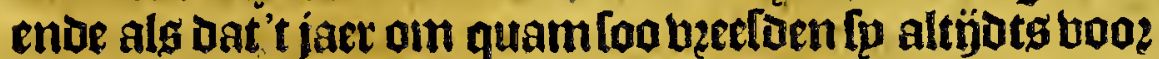
eenighe groote teranderingy/jae mepnien dat de wetelt in fulch jaer badoe te bergaen/ [oo dat [p Deg abonots te bozen alle baer potten betbzaken ende haer. vier upt.blufte eñ loach

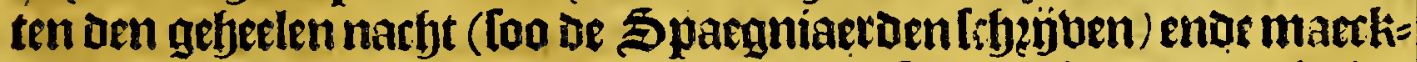
ten Derbalben groote feetlen naer dat Den eertten dagh ban een nieutwe

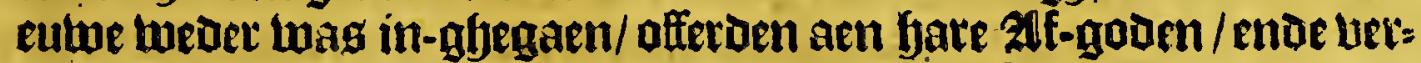
Cagfen yaer tweder ban potten ende nieutenen bup -raedt/ende baelden

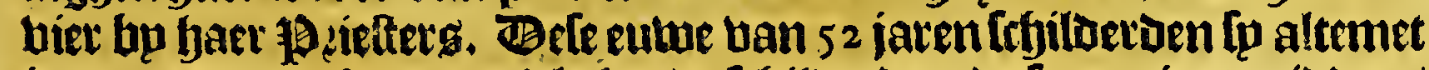
in't rande; tracken een cirkel ente frgilderden de tonne in't midoen/ ende berdeploen den ritkel in bier ghelýcke ghedeelten : ende elcteg ghedeeltes om-loop uerdeeloen fp in oerthien deelen als boozen; ende als daer wat fonoerlimags in s'een ofte o'anoer jaer gelbeuroe dat beel= ben fo met figureten upt ten beften als fo kanoen/neffeng de figuete

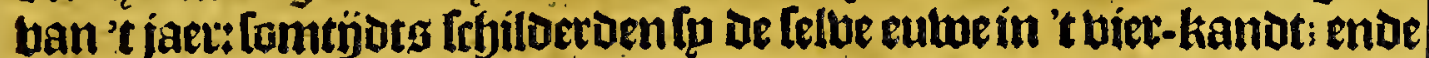
in 'tmidoen oe ghefrbiedeniften.

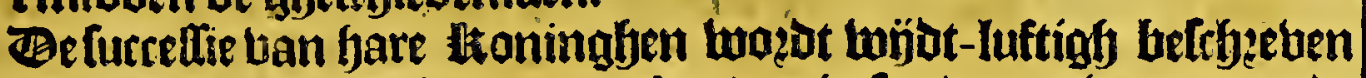
bp A colta, twiens boeck in peders banoen íg/[oo Dat 't niet ban noode

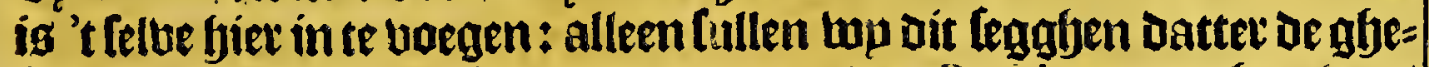

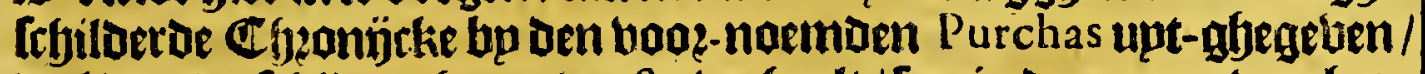
beel ban bertrbilt 't ghene A cofta berfaelt / [oo in oe namen ban bare foninghen als in 't abetal hande jaeten yaerder regheringhe; ooch en fullen dat fier niet naerder onder-foecken; alloo Dat ftoningh:

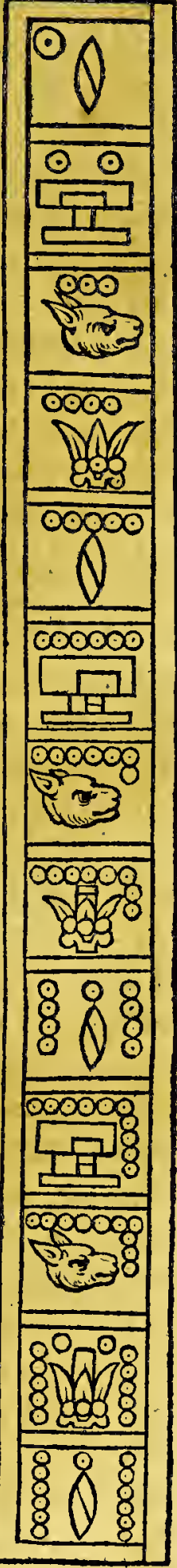
tỉck nu dooz de Spaegniaerden ten equoc is gbebeacht. Sullen nu boot baren tot oe andere probincien.

$$
\text { T L A S C A I A. }
$$

Het thiente Capittel.

De ghelegentheyt van de provincie van T I A S C A I A in't ghemeyn,

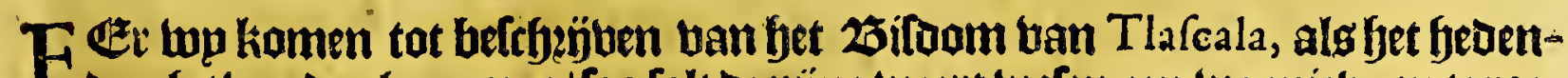

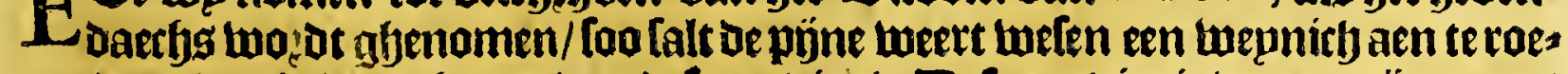

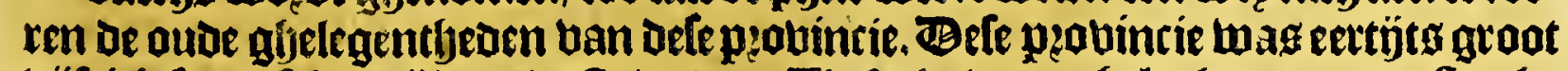
büftich Lpaenfrbe mölen; of ftadt ban Tlafcala was gheleghen aen een ftercke

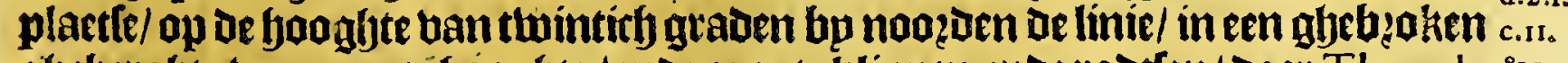

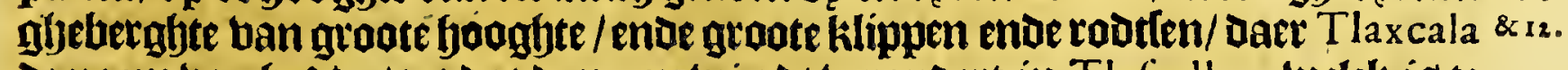
De naem ban fadoe / tat dat denaem miet ot betandert in Tla fall an, welck ig te

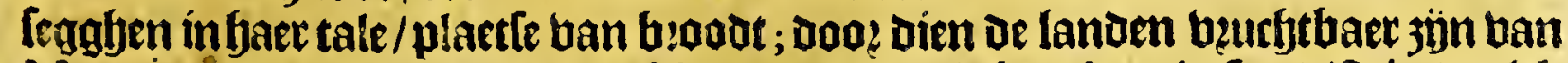
Maiz enoe andere ligf-tacljten; behbende groote ahebergbten in [pn Diftrict/welck in 4 vect 


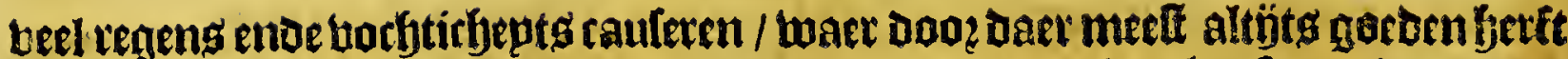
balt ban koon; is twoonoen meelt op ftercke ende booghe plaetlen/ die dacrem oock hout waren. Ban yetquattier ban Xicotencalt lpingljt een lertioigy ban betafjen / welcke beginmen ban de ooft-jïbe / enoe thecken naer bet beetten / ente maken een langen rugghe / Deo? miooen van telck palleert oe riebiere Zahuat, welck fomtints obet-loopt / enoe boetot ae buplen ende ghelaepe toegl/ enoe in oe

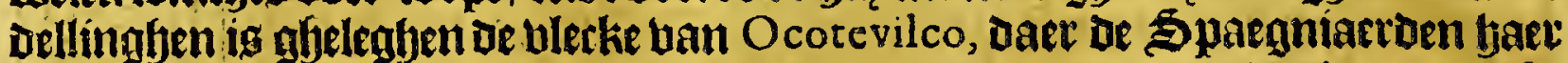
eref neder-Iorghen/ om helchut te mozoen ban Maxicatzin die baer groofte

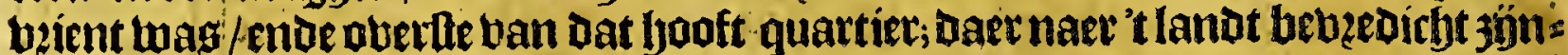
oe / om De in-ghebooene tot politie te beenghen / boutoden fp bart wooninglen

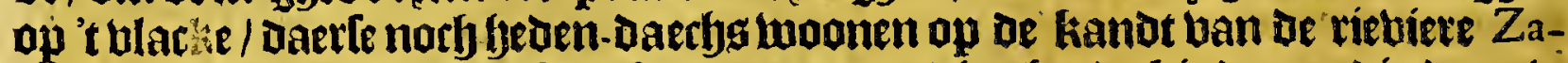

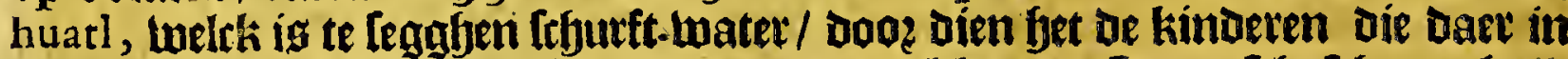

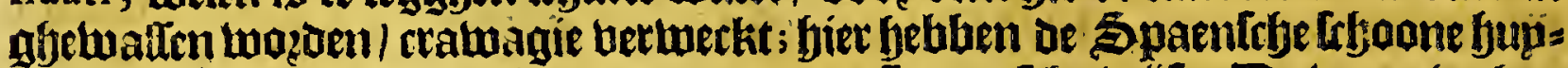

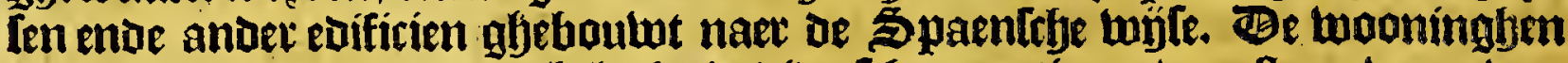

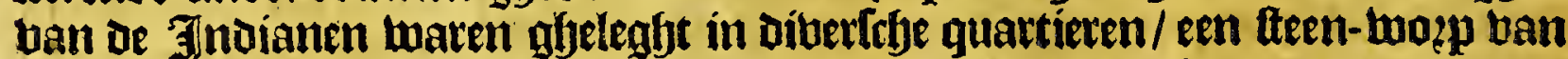
Den anderen/ende beel bupten bn oen anderen met enge ftraetjeng/met beel krom: ten enoe keeren. Be buplen ban aevoe gbemaeckt / ofte van boutot / entighe cack vat ften; meelt leegh / met groote falen uan lizeemt fatloen: dan nu timmeren ie

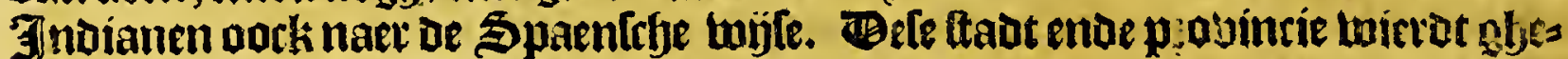

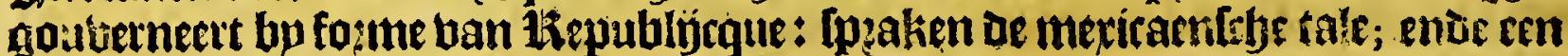

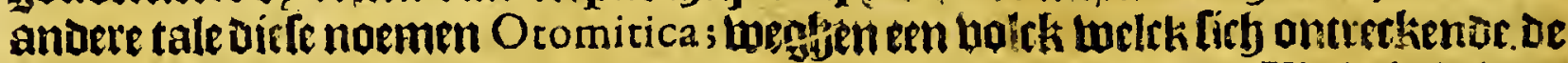
regeringh ban Mexico, ende daer tegen rebellerenue/ban die ban Tlafcala wictit

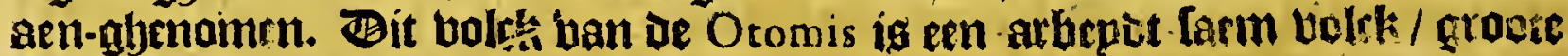

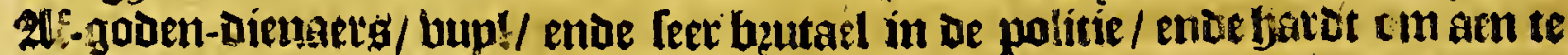

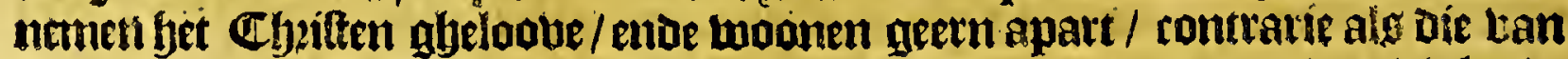
Mexico, die polüt jón ende feet leerlarm. ban Tlafcala fulcks is / Dat het bolck ten oeel naeckt gaet / ende die baer kiceten/ abeen tuetanderingh en maken ban kleedeten in De fomer/noty in be tuinter; foo beft bet norftangeen ghelwelt welck kouder is/boogher op-obeleghen naer bet

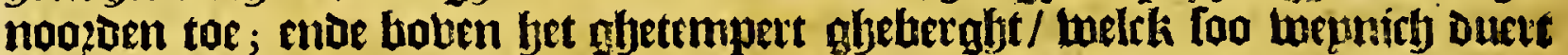

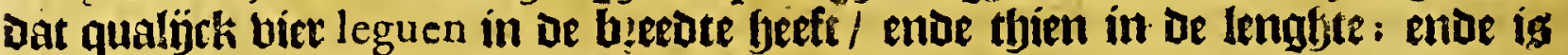
oterbloeding lanot / vetufftbaer ban Maiz, ende andere betuchten ban dat lanot) enoe van Sparanien. Spn Ienghte treckt tan bet ooften naer bet beltrmint teer beel woor-plaeten; ende ban ie blacke lanoen begint een ander gletla:ke

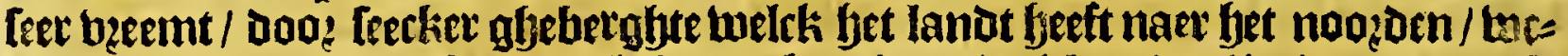
tenoe een Cordillera ofte terbolng han berghen/ heicke al de limiten tan irle

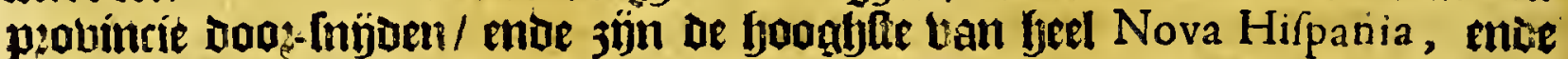

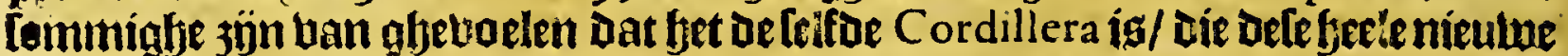

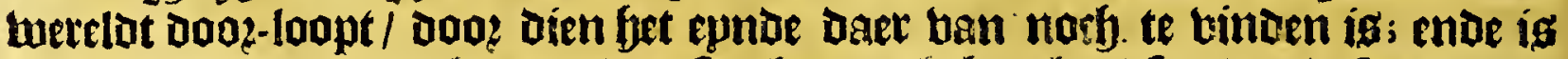

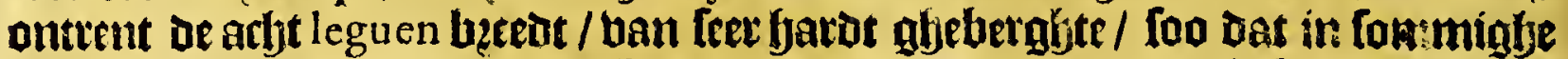
plaetlen onmonbelíck is die te betwoonen afte hanteven: ende is for ceafjenarb=

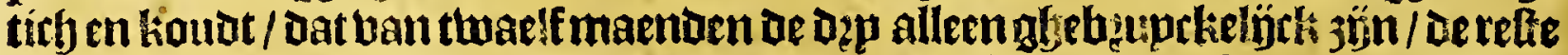
zün continuele dampen / miften ende reghenen/ loo dat ve conne Daer felden

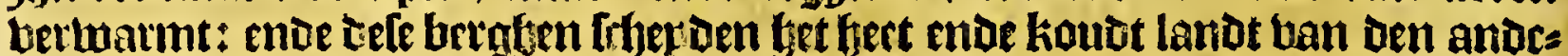
$\mathrm{ren} /$ in boeghen dat dele acht leguen glsepafleert jünue men naer fiet noozoen Daelt / te weten jer-lwaett / ende na de beete lanoen toe. Alen D'ander jioe ban 't giveluerghte begint lyet koude landt / welch is goet ende aboronot / ente tie wa: teren loopen naer het zupden ban de toppen van het gheberglte af. 2ul het aljeberabte is betheed met boomen / enoe ombzagieus / ende daer zinn twiloe.

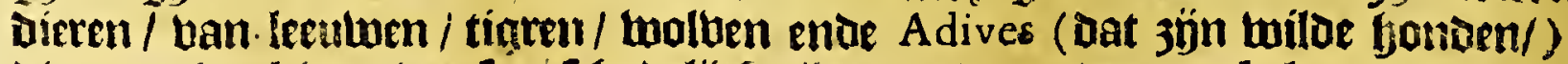

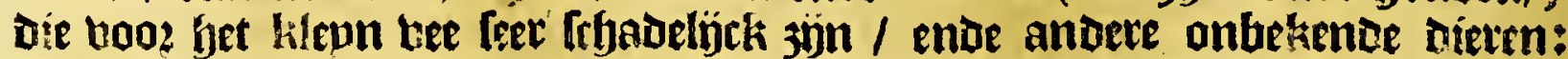
flanglyen ende biperen groat ende klepn; harten / ende ander twild ; ende mes

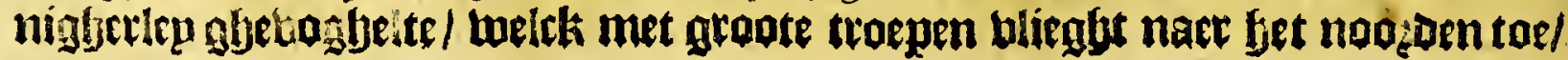


Het vijfde Boeck.

too tarmen 't fllue fet pafieten ober ae Havana. Baec ig groote appatentie ban

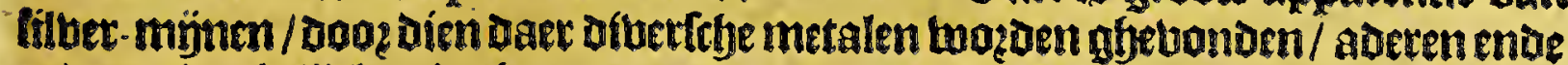

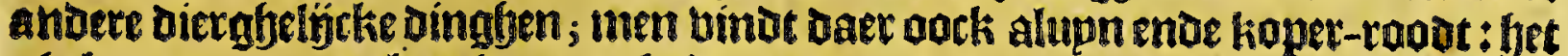

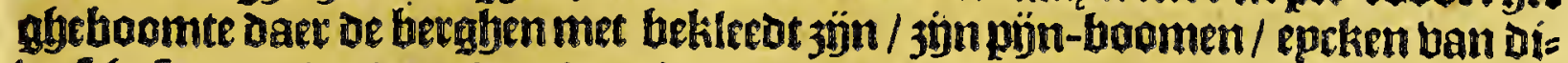
berfóne foaten / ende andere daet de Anime ende Liquidamber ban komt; enoe in cenigfe plactifen twozot Manna gfjevonden/ boch niet fon foet ofte bequaem om

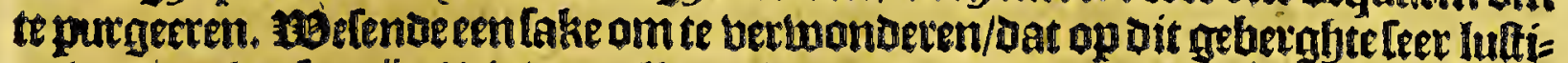

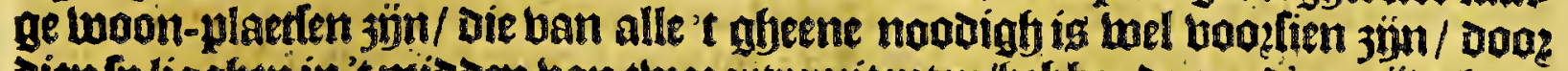

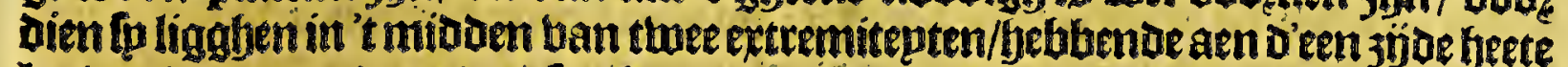

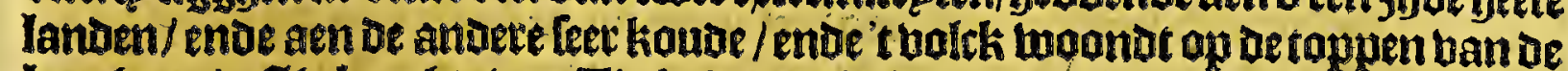
bergfen. 't Gfyeberghte ban Tlafcala taelcke bp die ban Nova Hifpania genoemt

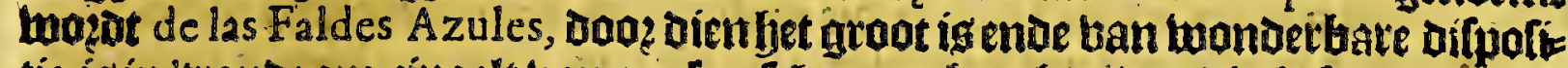

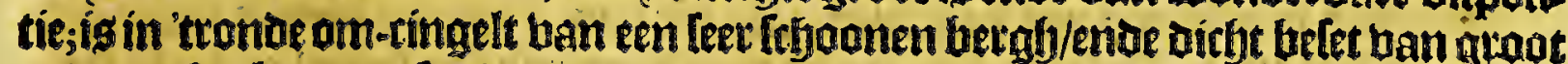
enoe grof geboomte/ fonder bat daer pets opert ig als alleen 't fooghfte deg felves/

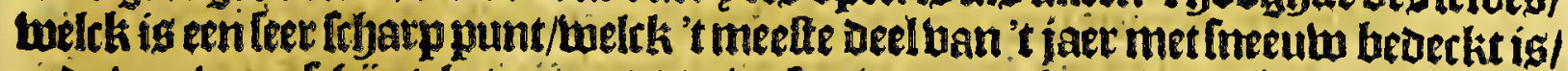
enoe ban berte fefjint get een rotg te twefen ban $A$ zul rouleur / foo perfect ende afjelÿtk als de naturete die foude konmen maken; entoe tuetot abjenoemt la Sierra

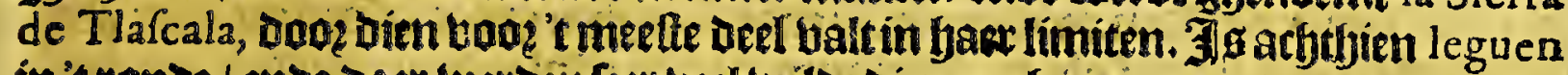
in'tronde / enoe daer werden feer beel twilde dieten gfegeneretrt / enoe pock beel theren ende koepen die die Spargniaerden daer bebben gebparbt / enoe nu bilot

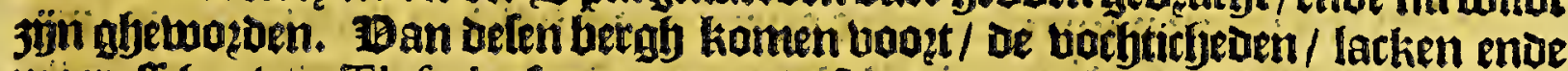
moeraftenen ban Tlafcala, fontepnen ende feec goede toateren :ente in de tÿt ban

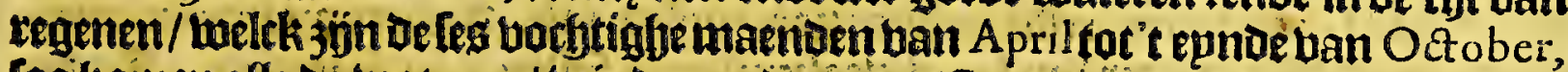

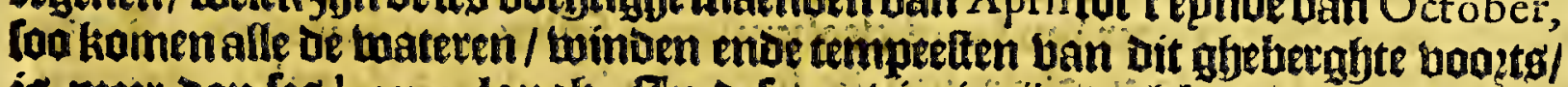
is meer dan feg leguen langf. In befe plobincie jun ued baoen boot fiecken.

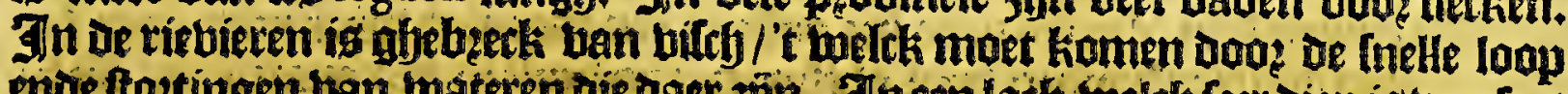

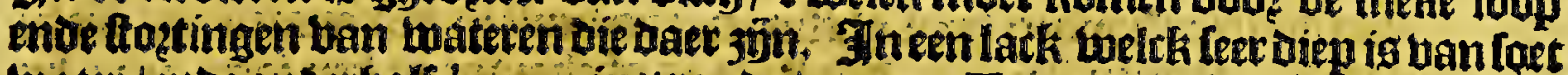

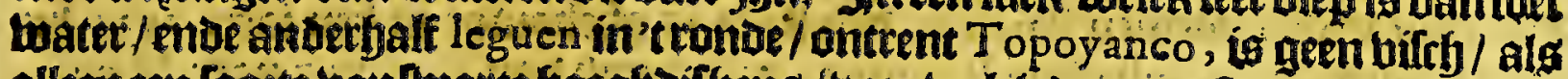

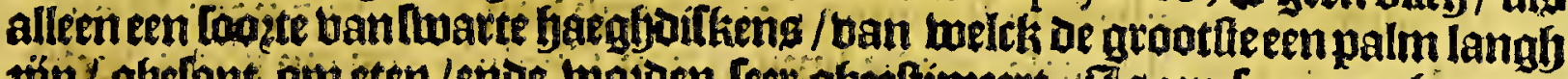

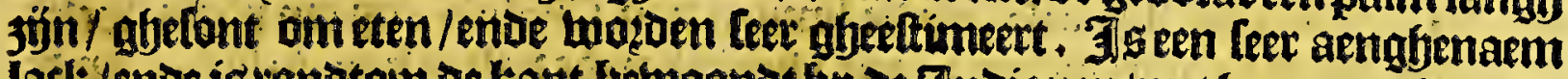
lacli/ende igtonotoin de kant betwoonot bp of Jndianen/met baer jaep-lanoen/

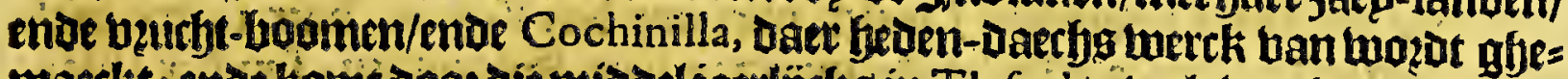

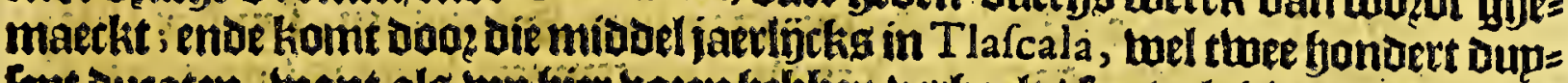

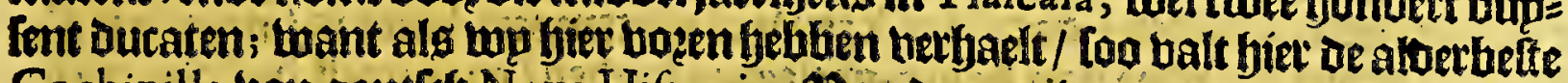
Cochinilla ban gantfef Nova Hifpania. 'San demanieren ban dit wolch in baet bepdentom en fullen wp niet toeren/als alleen batfe garle tbleetch ban bare bpan= Den aten/naet Datte die glelackificeert gadoen aen baer alf-goden; ende allen[s keng Daer toe waten ghelkimen batle vock malkanderen aten/ende openbare

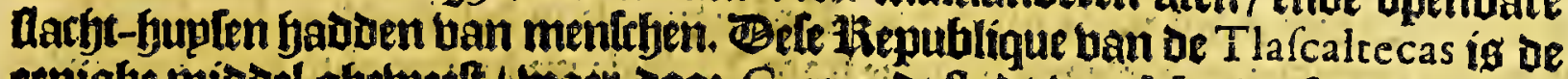

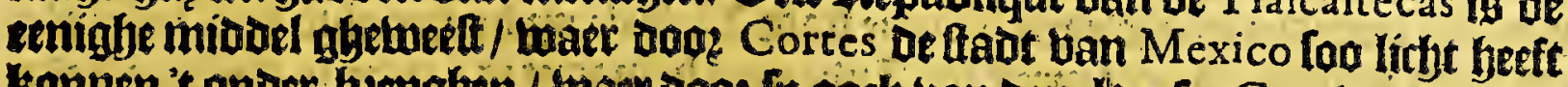

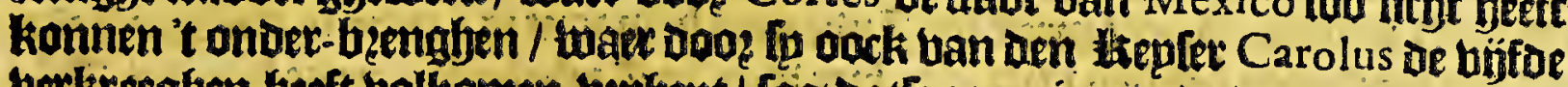
beckteeghen beft bolkomen beptyept/ too tatfe aen niemanot / naer de maniere

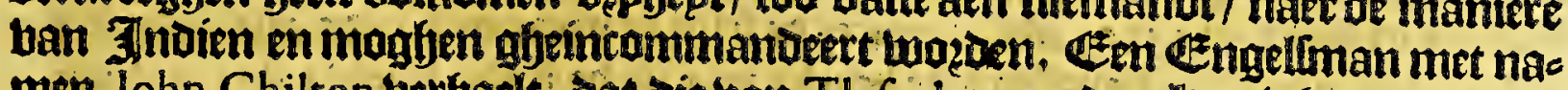
men lohn Chilton verbaelt; bat bie van Tlacala, aen den thonigf ban Spaz= gnien jaerlígtks booz tribupt betaelen eci banot bol tartwe elck mentrh/ welck beloopt tot Detthien buplent Haneguas in bet jaer, SR-en-Dettigg ban de Haneguas maecken een laft, Atmitterdamithe mate. 
190

Nova Hifpania.

Wet elfete capittel.

Van 't Bifdom van T I a S C a I a, ende de Stadt daer in gelegen genoeme Puebla de los Angeles. Ende van T l a S C A a woon-plaetfe van de Indianen:

Herrer. H Et 25idonmban Tlafcala, ofte de los Angeles gelïckmen bet anders naemt/

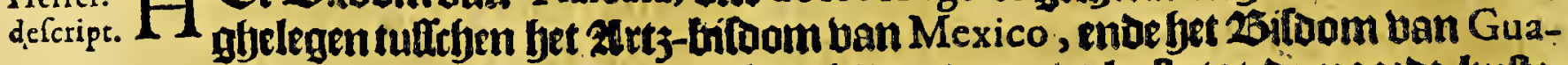
$\mathrm{xaca}$, is jondert ende meer leguen langh/ ban de zupot-kulte tat oe noozot-kulte;

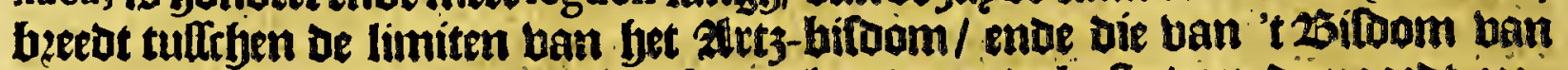
Guaxaca tarffentith leguen, ende coo beel mede op de kufte ban de nopzat-jee:

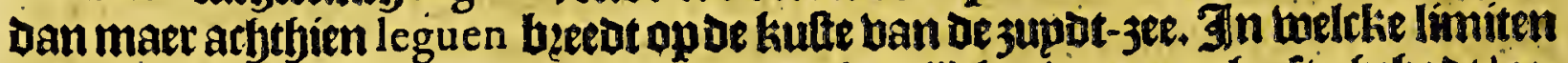

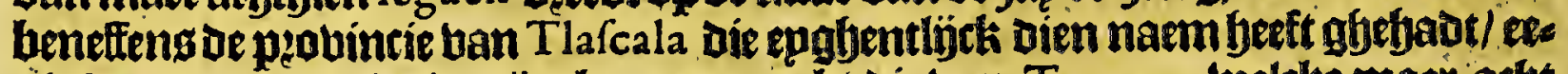
nigbe anoere pzobincien 3 ju begrepen; als die ban Tepeaca melcke maer acbt

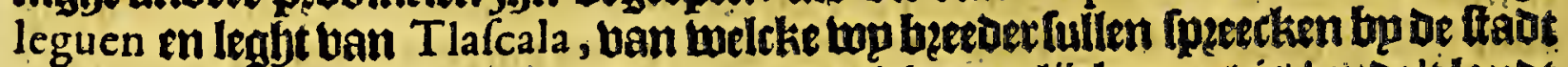

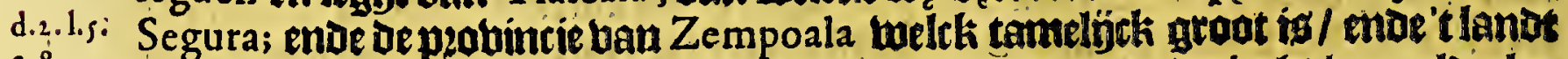

c. 8. beutfthaer / meet al black lanot met goede wepoen / ende jarbt ban aloerlep

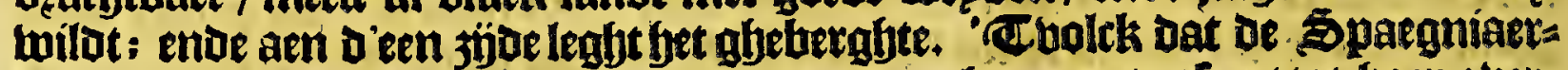

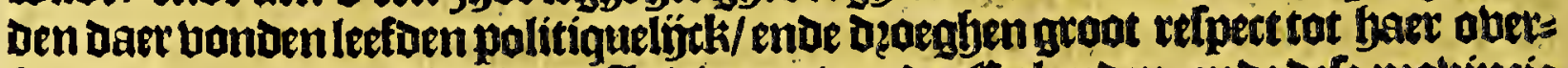

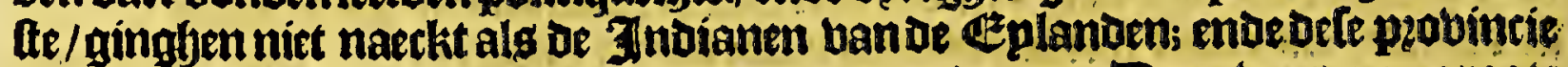
leght op fet naette ander. half legue ban de noozot-jef. Baer was een groote blecke ban ben Lelben name gheboutwt op een plepn tulteben thee ríebieren / met

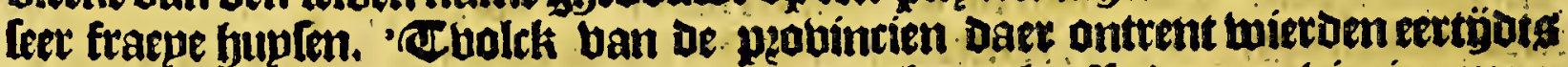
gfenoemt Tutonaques, ende badoen baet epaben tale. Zindeteprobincien meet

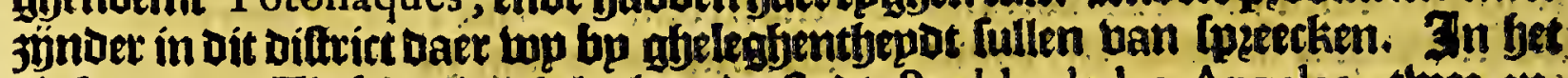

Her.der. 25ifoom ban Tlafcala is ghelegten ue thabt Puebla de los Angeles; ther-entwintich leguen ban Mexico naer bet oeften/ een tuepnigf twóckenoe naes bet

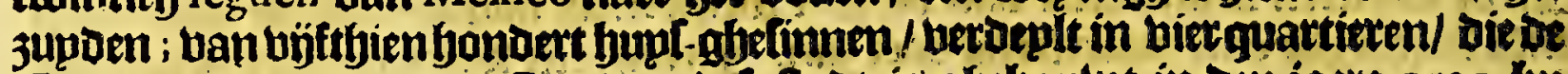
Spaegniaetoen noemen Barrios, defe fad is ofjeboutut in ben jaete 1531 bp

d.4.1.9. Den 19erident Don Sebaftian Ramirez, moe wegh ban Veracruz naet Mexico

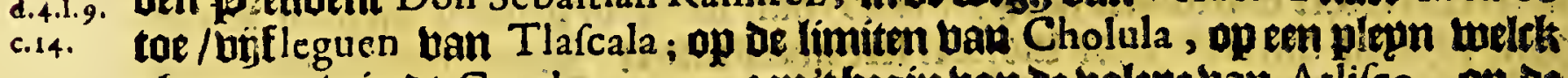
ghenaemt inierot Cuetlaxcoapa, aen thegin ban oe balepe ban Atlifco, op of Kant van een kilepn riebietken / welck bliet upt Jen Volcan, baer tartue twall

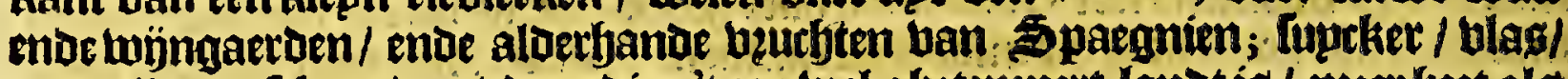

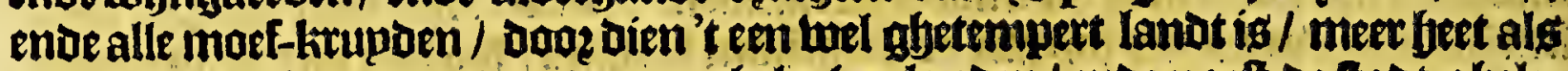

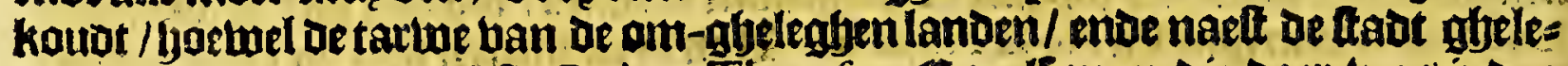

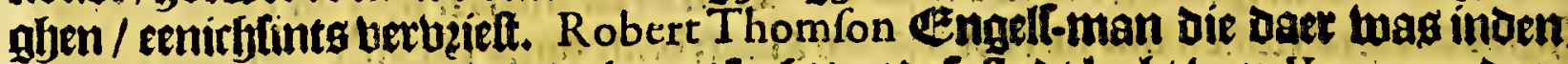

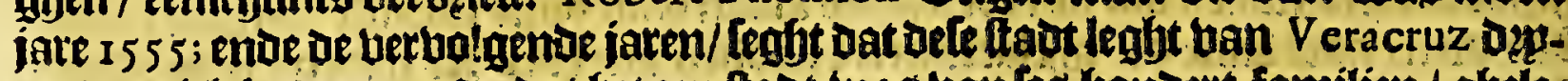
en-treertich leguen, ende dat bet een fad was banles bondert familien / gbeles. ghen in een [eer plaptante lamboultit; 3 ijt leguen ban defe thadt de los Angeles, naer fet noozoen is afjelegen de oute ttaot T lafeala op oe boughte ban meer ales

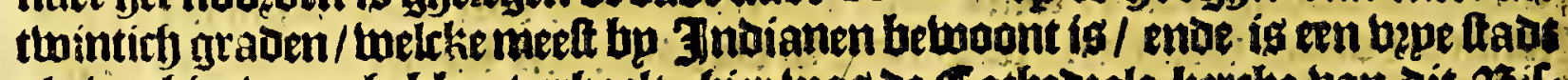

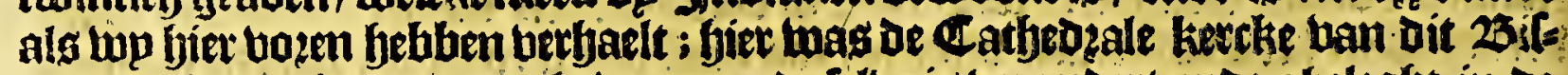
bom tot in Denjare 1550 , als twannet de letbe is berandert ende gheleght in de Itadt de los Angeles; beneffens oe kercke jän in oe thadt Puebla de los Ange-

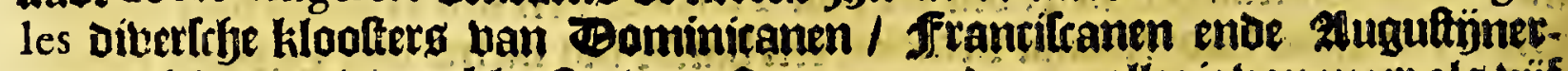

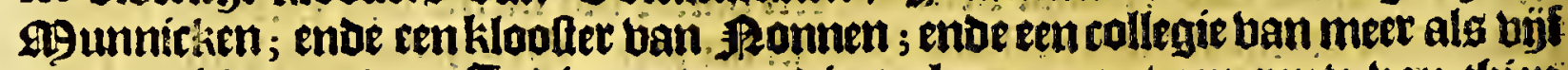
honoert kinuers ban J noianen/ om die te leeten: met een rente ban thien Duplent Pezos, affelticht bu de 19elíbent Ramirez booz-noemt: niet betre ban Tlafcala ӟ̈n de fpeingben ofte fontepnen ban een rietiere / welcke komende tutatben los Angeles enbe Cholula matfrigh twozot / enoe fonder bilfy/pals leett Dooz de peouincien van Mechoacan, enoe loopt in de zupdt-3ee dook Zacatula, enoe daer zijn loa vele Caimans ofte rrorodilen in / datle entighe plaetlen ghedepopuleetc beblun. Dele fteden bebben be ballepe ban Atlifco, weick 
welck ontrent andertyalf legue bect is/Daec fet kooen nimmermeet en bethiedt ende daet way ot bouen De honoert duplent Hanegas jaerlïtks getwonnen/ende

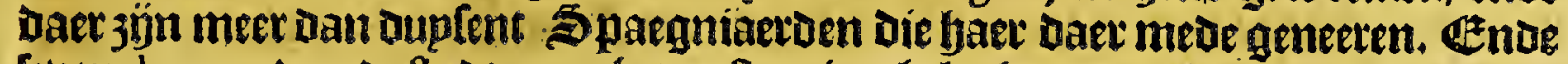
feven leguen ban deftade naer fet oaften íg gheleghen de vallepe uan Ocumba afte Otzumba, toelck faet begintel beft ban de Venta, tuelclifp noemen Del Pinar, tot de Venta Die fu noemen Del Perote, weicke twintichleguen langid/ $\mathrm{ens}$ De thien ofte wepnith min aber slwarg; fier in is mede geiegen bet Doep Napaluca, welc fun beginlel feeft gefjadt ban een Stmarte/genaemt Iuan, die eenlanot-fjupg gadoe in iefe vallepe/ oaer bp berckeng bielot/ende lockte tot fich [eker 3indiamen/ die op een boogbte woonoen / foo dat bpe in Kozten tijot de plaetfe papuleeroe met ouplent in-twoonders : bet bee is in oefe quattieren foo feer bermenichfuloicht/ Dat fet ban noode is ghetweelt een racot op te ricten / belck be Spaegniaerden noemen Conlejo de Mefta, met lpn Alcaldes moe nodighte officieten/Die alle jaer faer bu cen-Komlte houden te Na paluca, in beballep ban Otzumba.

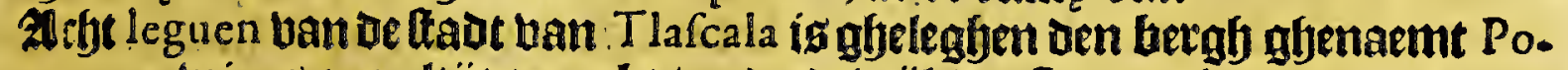

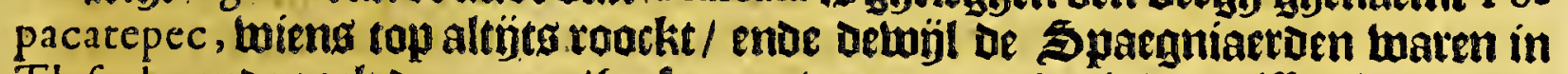
Tlafcala, ende oock daet naer / fjeeft meer vperg upt ghegheten alfe placlyt / met

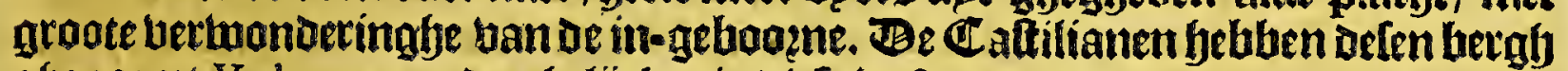
ǵfenoant Volcan, om oe ghelijckenig diele beft met Den Mongibelo ban siri= lien. II foogoagh datmen dien ban bele mijlen liet/ ende bet fneeuto en gebeeckt daer nimmetmoer/ ende daer om her ig bet landt meelt beboont/ende't beucht= baculte van gautrey Nova Hifpania. Be naeft gfelegbene blecke is Guaxocingo, groot/beuchtbaet ende plapfant/ welck is aen oen boet ban den felluen bergh. Des fen bergh toas thien jacenlonber roack upt te gheben; ende in 't jaer 1540 ketrde tot fpn oude ltandt / met fulcken ghedeupg ende roock / aat bet alle die bier mülen

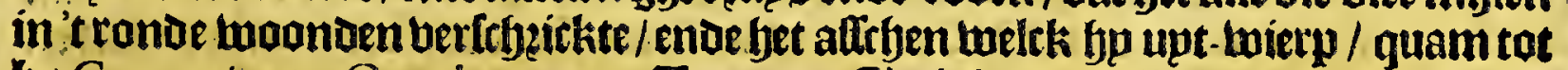
up Guaxocingo, Quetlaxcopan, Tepeac2, Chulula ende Tlafcala ; berbzandede moeg-ktupuen / t gfebonmte / ende dede andere frbaden/ daer de om-legghende bolckeren loo ban verlebeickten/ Datte mepnoen 't lanot te rupmen. Ben Capi= tepn Diego de. Ordas Daozeen mannelÿcke touragie/gingh dien belitjtigen/ende quam tot hoben op den bergh/ande belaty de monot welch frbeen ranot te hefen/ ende eenige mülen in'trande. Baet naer inden jate 1522 trocken Den felten betgh op Montanno ende Mefa; met noch eenige Spaegniactaen ende Jindianen/met d.3.1.3. groot perjeckel/ende leden groote koude: quamen aen de openinghe ban den Volcan, ende lieten Daex eene ban den yaten in/twelck lwas Montanno, die in Les rep: fen daex upt-haelde ontrent acht arrobas ban fulphux; ende een ander naer bem in les replen infahelÿtks / Gaeloe daet wepnich meer als biet arrobas upt; met melcke futweder naer beneden quamen/ ende byorbten orfe lalphur bu Cortez; Luelcke gherefineert júnoe / bleef thien arroben fün fulpfur; die baer wel te palfe quain/om pulber van te maecken/ vaer de Spjegniaetoen gebleck ban badoen.

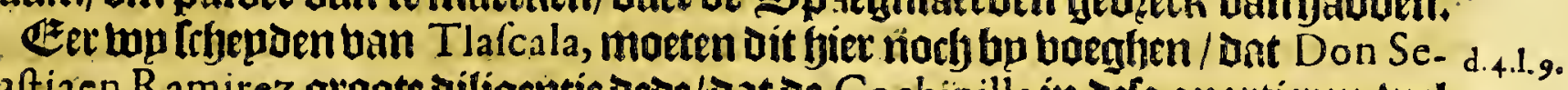
battiaen Ramirez groote viligentie seoe/ Dat of Cochinilla in Defe quartieten wel c.14.

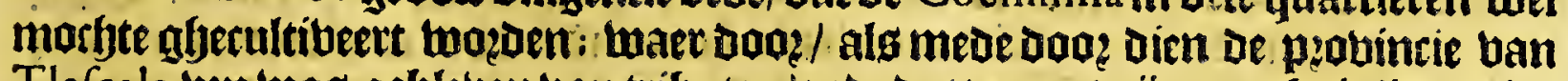
Tlafcala beg was gebleben ban tributen/ende datter een beje martktig/:oint get

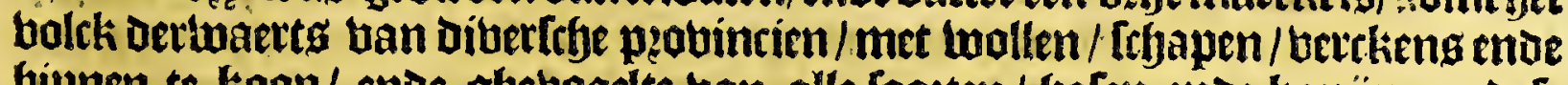

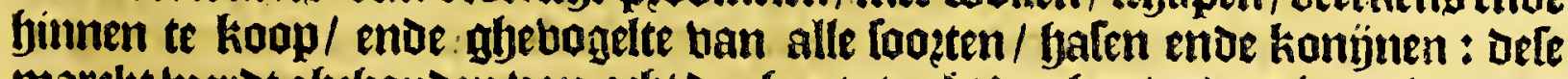

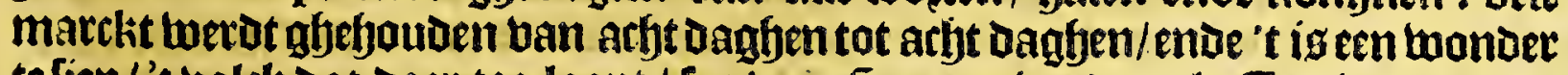
te lien/'t volck dat daet toe. loopt / foo ban Spaegniaerden alg Jinoianen; ende aen deen 3 jijoe ghelet oe lijf-tochten (welende een feker oingh/Dat in de ttadt alle

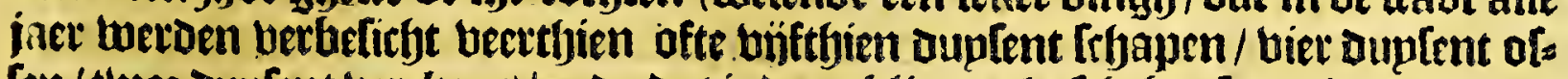
feil/thee duplent berckens/ende dat inde publique bler (1)-buplen;) Komendaet beel dzooghen / ueel Liquidambar, Cochinilla; infumma daer tuerot loa groo= ten rïrtioum in-ghebzocht / als qualÿck te bedenctien is / na. De-nael daer veel

filter- 
192

Nova Hifpania.

filber-lmeden jön/ende goudt-Imeden/ ende beel koopmanfebappen; ende groos te quantitept van fpaenfthe wönen/ boetwel mon ten in-ghehooęne niet toe en laet

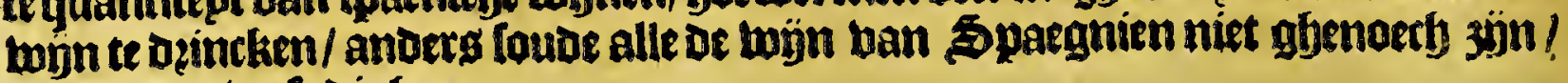
ou baer te berfadigfen.

\section{Fet twaelffe Capittel.}

Van de ftadt $S$ E G V R A, ende de gheleghentheden van de provincie TE P E A C A, in de welcke defe fadt gheleghen is.

N Zlex Dat Don Hernando Cortes met groot berlies ban tolck wag gbejatobt

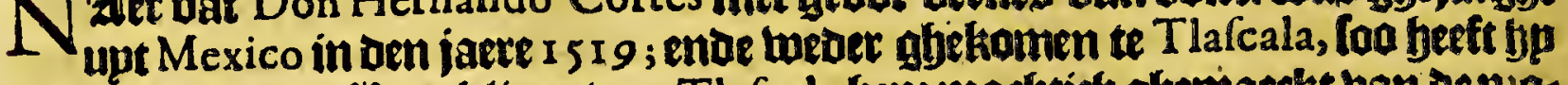

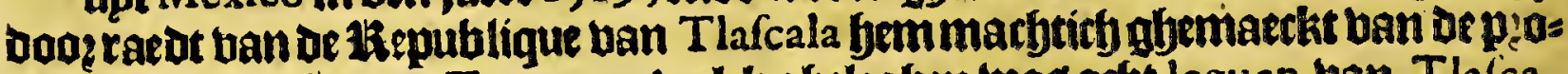
bincie ende blectke ban T epeaca, melck gbeleggen was acht leguen ban Tlafica-

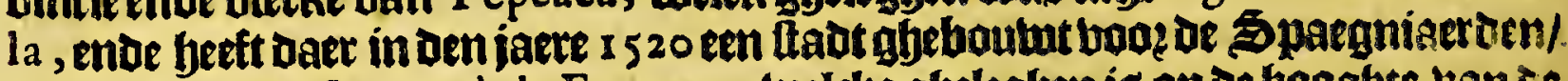
d.2. 1. ro. Die bp nuemben Segura de la Frontera, welcke gbeleghen ís op de boogbte van te c.28. neghenthien graden min een derde bp noogedn oe línie; is gheboutut in een goste ghelegentfepot / met feer bequame buplen ende goede ataten/Daer te toozen de ftadt ban de Jndianen gbelegfen mas op een yoaghte/ Daer als nocty eenigte tan

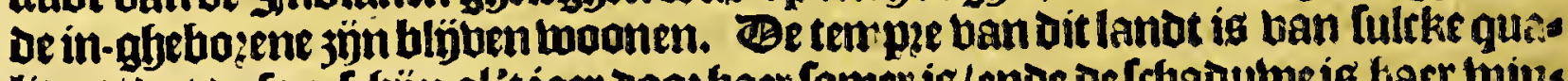

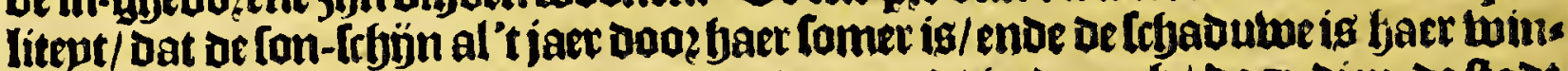

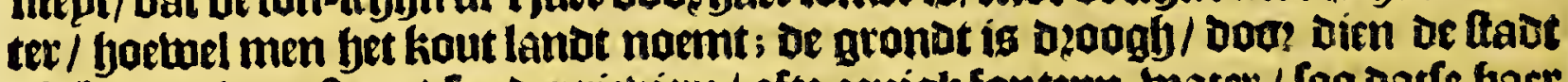
afeboutut is op teen / conoer riebiere / ofte eenigh fontepn-twatex / foo Darfe bact met regben-water moeten befyelpen; boetuel datfe een balf legue ban oe fact een (pxingh hebben uan luet-water als die ban Almagro in Caftilien/ die upt de clip: pen boopt-komt. Ben regben begint daet gbeligck in beel Nova Hifpania, ban A pril tot in Seprember, ende in D'ander maenden is bet daer kout / ende de fon en bzandr loo leer niet/ ende dan waepet daer Den noozoen windt; ende bp bothtirf

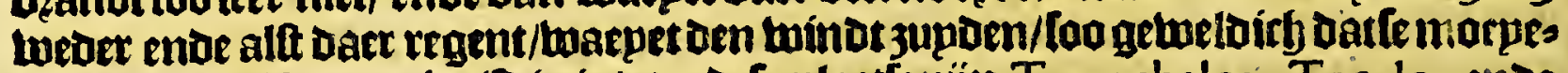
lijeken valt. Ban de jurifdictie van defe plaetfe zín Temachalco, Tecalco ende Chacutlac, en Arazingo. Temachalco isglyelegben aen de hoet van eenen berob/

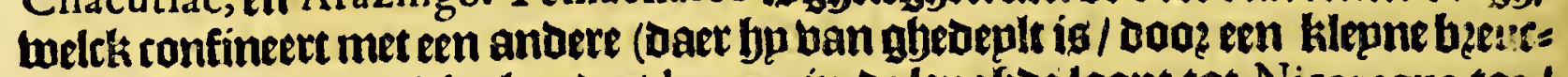
te) bulck meer dan bier bondert leguen in de lenghoe loopt tot Nicaragua toc / ende berber naer ae opinie ban beelen: Dooz de dzooghte ban dit lanot febben de Spaegniaerden't water oetwaertg ghe!epot ban feket water welck blíet ban den berag ban T lafcala, ende hebbent boos lekete buplen ghebsacht / tot op oe marc ban be ftadt. than ribierkeng / geeft niet-te- min beele goede twepoen/ Doo dienfe thinticly le-

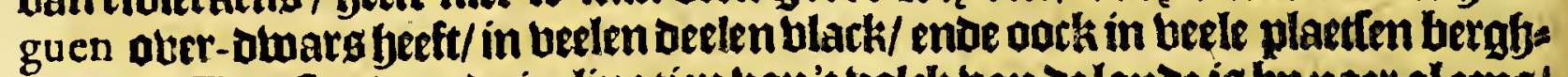
achticl.' "C bertanot ende inclinatien ban't volck tan of lande is bp naer al cens/

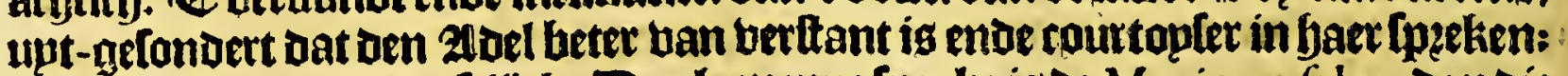

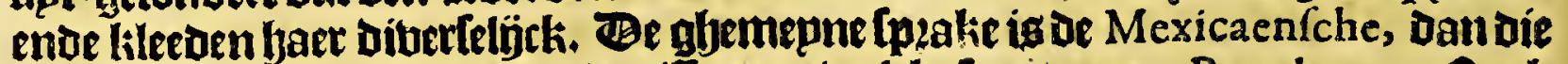
't tolck doozgaeng Lpzeckt / is different ; melth lp noemen Popolucan. Gock

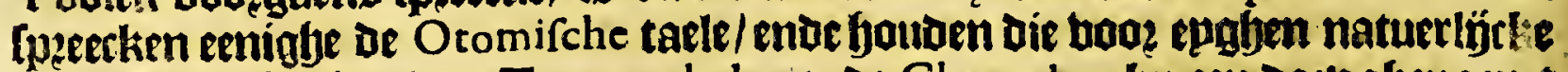
tale. Op de limiten van Tecamachalco enue Chacutlac, bp een dopg gfenaemt A ly oxucan, op 't googbe ban eenen betag / is een lack twelck ban be booghte tot

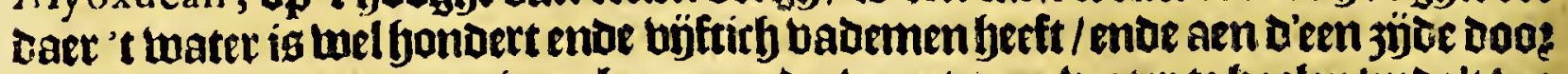
efn tilepn patien gaen oe in-gebozene neortwaetts om twater te haelen/ende't bes om te osincken. Daer en graepet geen vilth iri/of ander onghediette/en berdeniet loonfer net fet winter-water / norf mindert niet met oe dzooghte des lomers: men befter geen arond ghe vonden / en men peefumeett Datter een ríebiere onder: paficert / Die unt komt thien leguen ban daer in leegher lande / weltk fp noemen A olizapan. 'C Mater ig leer kout en blaeutw ban couleur/ moe booz dien't twas ter ban die riebiec ban gheljekte couleut ig/ boude men die peclumtie booz leker.

Inde 


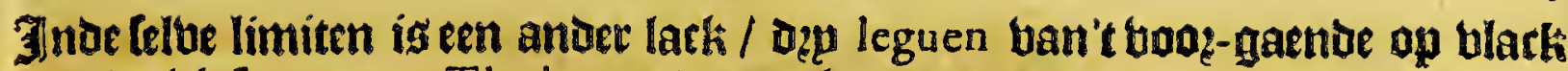
lant/welck [p noemen Tlachac, ende men kander om-gaen/ende De peerden daer upt te Deincken gheben. Jo seen le gue in 't ronde/ en ig foo diep dat men Daer geen gronoten bindt ; Daer genereren feectier twitte vilthleng foo groot als een binger/

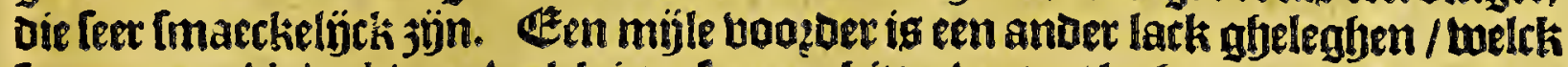
Ip noemen Alchichican, welck is te leggen bitter water/leght op een plapn/enoe is thee leguen in't ont gaen: fret bee deinckt daex af /enoe twozot daer bet af ; men binter gheen gronot/ende t'igleer filaer water/en geneteert geen bilch ofte ander

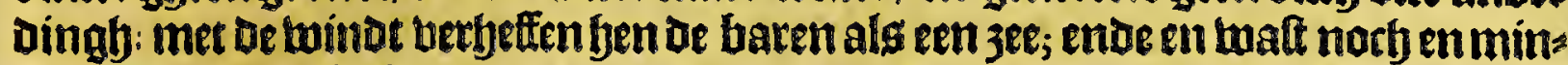
Dert oock niet als bet voo:-gaenoe; vaet onttent $30 j n$ twel twaelf leguen black lanats / met groote fjeubelen ende twepden boot [ctjapen. Boos de aroote abun= Dantie ban bofterben ende bergben jünoer beeloerlep [ooten ban wiloe boomen/ be bezcht-boomen jün ketten / quelighk die ban Spaegnien/ upt-gbenomen

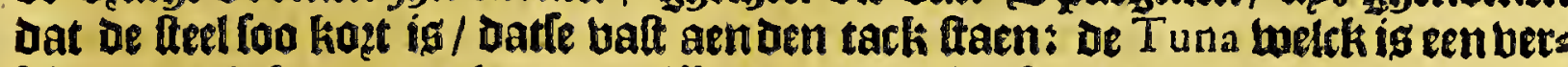
Icfeende ghelonbe beucht ; Daer iffer twitte/geele / cwarte ende incarnate; aen oelen boom als bozen/komt of Couchinilla. Infabelijcks foo twillen de beurfys ten van Spaegnien fiet twel waften. Be imwaonoers onoer-fyouden baer met Maiz, ende andere 3 aden ende krupden. Be tartue waft daet oock leer luel; daet is in defe peabintere en ballepe diele noemen de San Pablo, Daer ontrent lefticly Spaegmiaerien woonen) (Herrera feght infpn Defcripcion de las Indias, Dat Daer wel Derthien bonoert 5 paegniaerden in defe ballepe woonen in diberfrge Eftancias) Die ontrent twee fondert ende bier bondert Hanegas jaepen/ende bers gaderen ozbinaris tachtentiff duplent Hanegas bangoede ende feet fware tartwe.

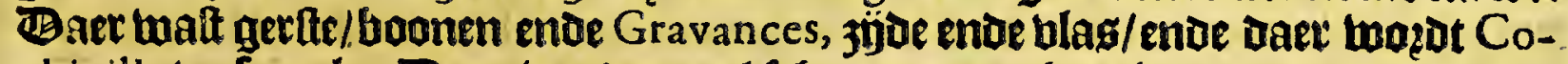
chinilla berlamelt. Baer wogoen beel fryapen aen-gbeteelt/ gepten en bertkeng. Quteeckenaer peerden ende muplen. Bp't gfteberghte ban defeptobincie / en ins

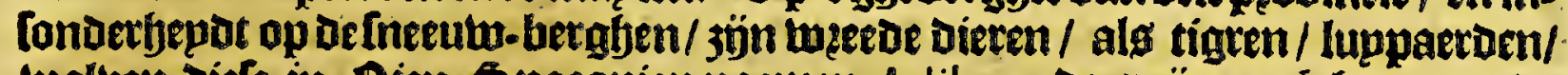

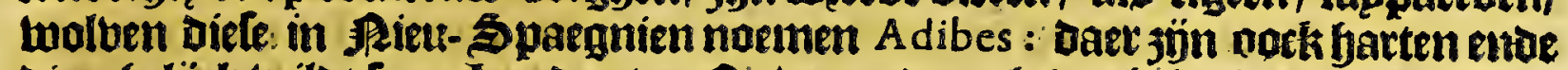

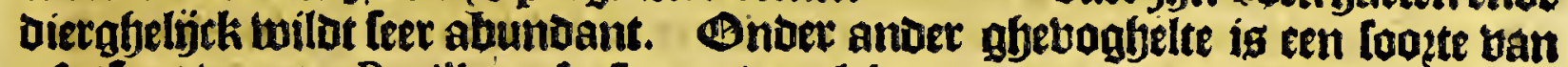
't fatloen ban een Papillon ofte fomet-bogeltien met een langben beck / en fraep ghekouleurde beetkeng / aie feet wet: Denggeeftimeert tot be torerken; en

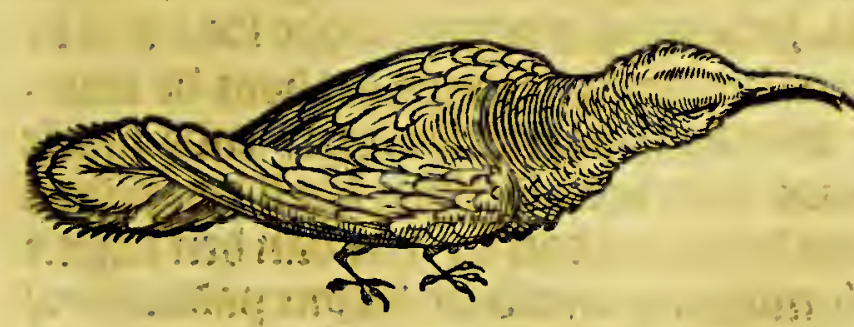
eten niet dan bloemen oft den dauto ban dien als be been; alg den regen op boubt ende de azoogfte home/ [oo becteten le baex aen den boom met ben beck / ende blijben daer iond: enoe 't naefte jaer met ben regen twet: Denfe weder levende: Bit bogbeltien is ban ghedaente als fier ís upt-ghe: beelot. eten legue ban Tepeaca is een fteen-rodte ban jafpis ente marmos/ Dat Leer gheacht wozot. Baet en balt gheen fout noch cottoen / maet Daer wanels

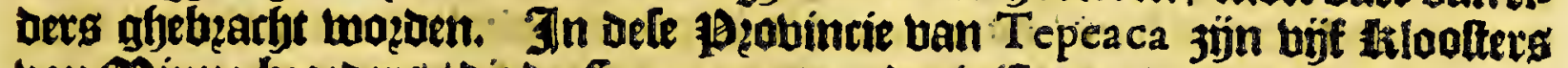

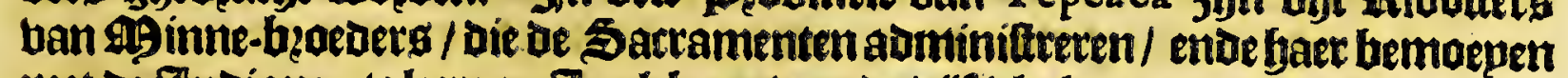
met de Indianen te leeten. Tnelek een ban oe bijf blecken ban befe probincie is een bolpitael daer de arme in-gheboozene twozden ghenefen. Bele j9zobincie is feet gheleghen om de werb ban Vera Cruz naer Mexico te berfeetketen/altoofo bepoe de paften commandeet / waer ban D'een twozbt ghenoemt Siculchima, Daer oe \$ paegniaerden eerft doog in't landt quamen/ende ae andere Ginochula

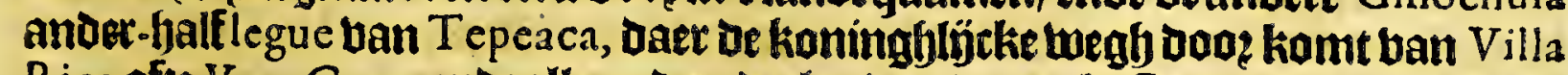
Rica ofte Vera Cruz, enoealle andere deelen ban oe jee-kufte/ naet Mexico toe. 


\section{Het derthiendac Gapittel.}

Van de Stadt Ver a CRvZ, ende de voornaemfte haven van Nova HisPanIa, welck ghenoeme voordt $S^{t}$ I I A N de Viua.

Her. de(E) Staut Vera Cruz, die oock anders ghenoemt mietdt Villa Rica, is afte= leghen op oe hooghte ban achthien grawen een wepniǵg meer/naex 'tiegghen uan Herrera; maet oe directie ban kourten bp of Spaegniaerden upt-gheghes ven/ ende bu $\mathrm{M}^{\mathrm{r}}$ Hackluyc bertaelt / Itellen Villa Rica op negenthien graden ent een balf/ende. Vera Cruz een tuepnigh naet het zupot-oolten ban Villa Rica ber=

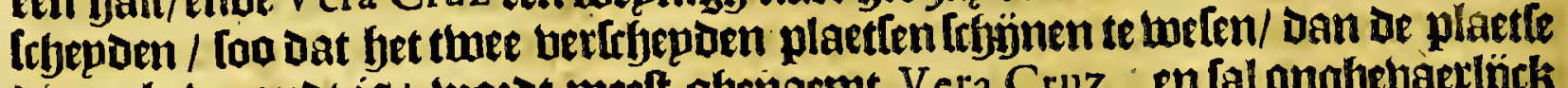
die nu betwoonot is/ mozot meeft ghenaemt Vera Cruz, en fal onghetuaerlÿck

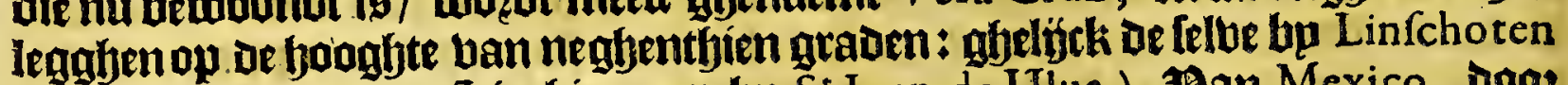
oock gheltelt wozot. (Siet hiet naet bu St Iuan de Ulua.) Ban Mexico, Dove

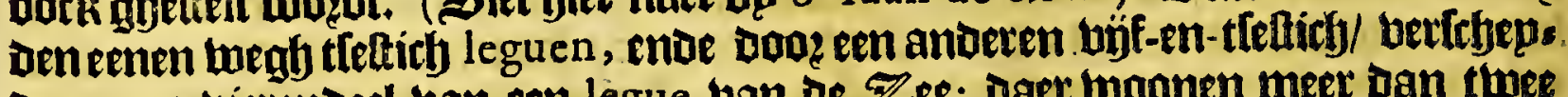
Den; een bietendeel van een legue van de $\mathbb{Z} e \mathfrak{e}$; Daer woonen meer dan twee

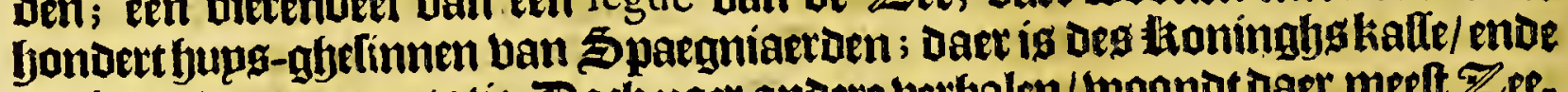
en bups van contrattatie. Borb naer andere vethalen/woondt daet meet Z-erbarenot bolck / enoe die haet geneeten met goederen 'tfrbeep ende aen lanot te benghen: Dooz dím dat hiex alle of bloten pleghen te antladen/ende waren biet

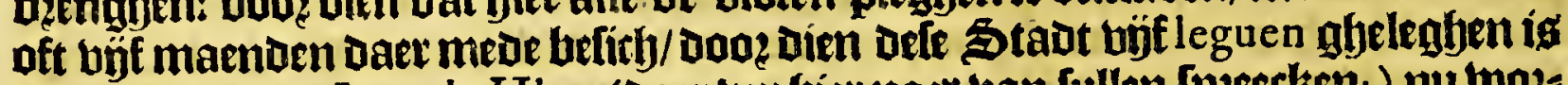
han oe haben St Iuan de Ulua (Daer wo biev naet ban fullen [peecken; ) nu woz= Den of bloten meet ontladen in een plaetle ghenaemt Buytron, die maet tarb= tentich palten en is ban de bookfryeeben yauen/ welck foo gbenoemt wo zot naex een herbetghe die daer was / ban begint nu een fraepe plaetfe te beroen. Be

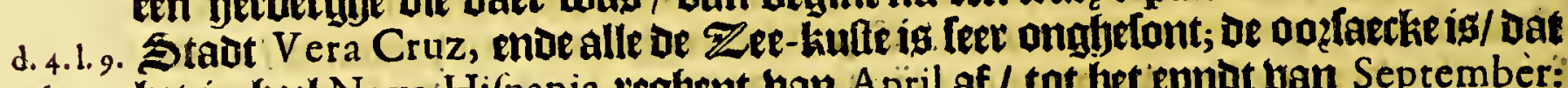

c.6. het in heel Nova Hifpania reghent ban April af / tot bet epnot wan September: enoe te Vera Cruz, ende op de gantlefye noozat-kufte/ reglyent bet met een oofte

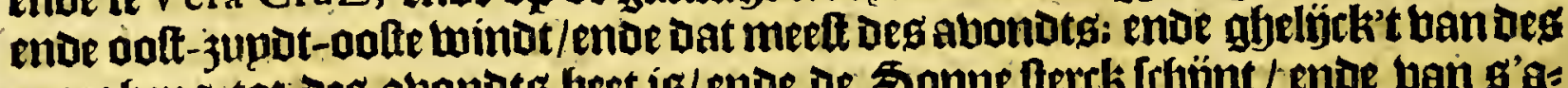

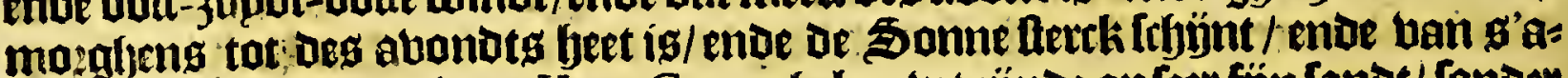

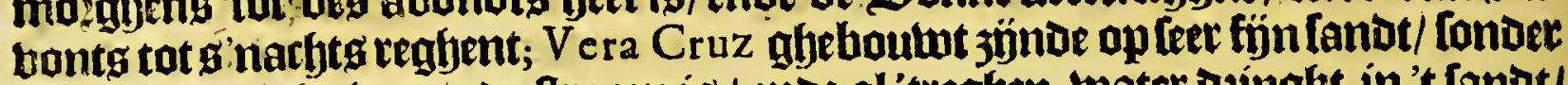
Dat daet eenigbe loopenoe froom ig / enoe al 'treghen-water decinglyt in 't lanot/

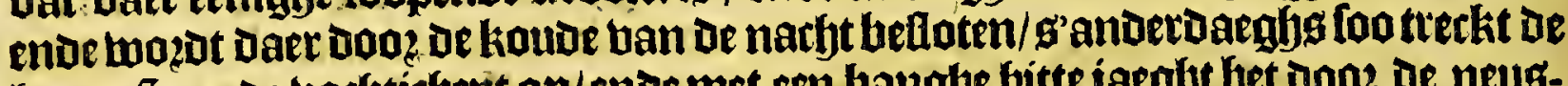
heete Son de vorbtichept op/ende met een bangbe fitte jaeglet bet Doo de neug-

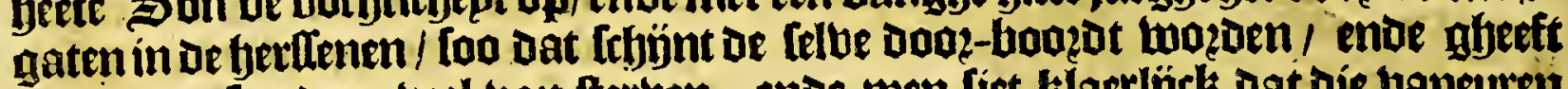
heete koostlen Daer beel wan fterben; enoe men liet klaerlÿck dat Díe bapeuren

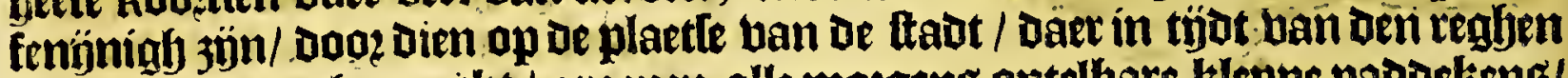
een poel werot ghemaeckt / groepen alle moegens ontelbare klepne padoekeng/ met fterten ende voeten/ende in wepnigh daghton ballen baet oe fteetten af/ende

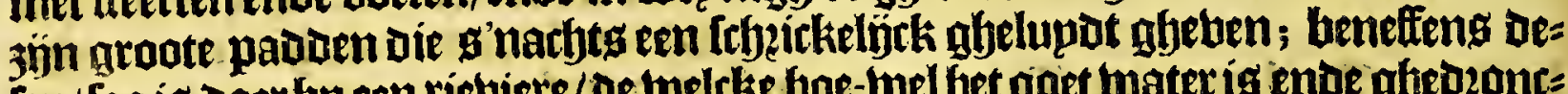

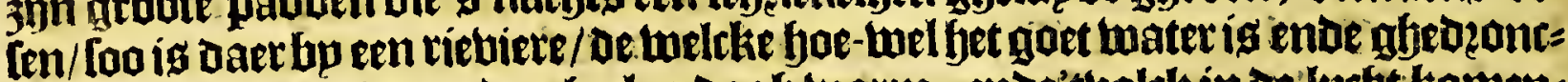
ken wozot/is nothtang Den beelen Daab warm; ende'tuolck in de' lucfjt Kamen:

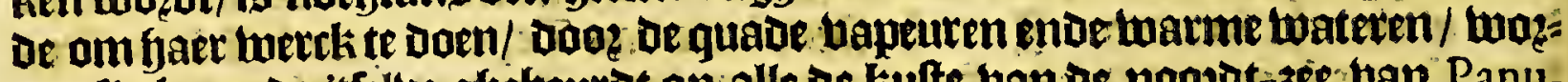
oen líeck; enoe 'tfélbe ghebeurot op alle de kulte ban de noożot-jet ban Panu. co af tot Guazacoalco toe. In de maenot ban November tot het epnoe ban Martio en regfent fet niet een ozoppel / enoe daer waepen ftercke noozde-wins

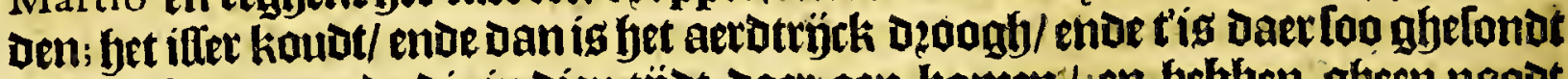
als in Mexico, ende die in dien tijot Daer aen-komen/:en hebluen abeen noadt

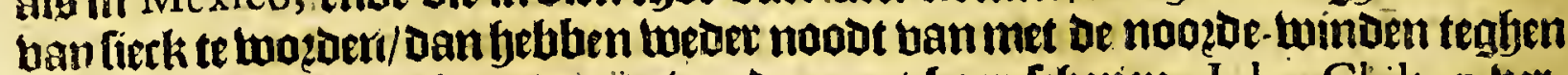
be wal om turken ghedetuen te wozoen met baer fryepen. Iohn Chilton ber: haelt Dat Vera Cruz leght bu een rieviete/ ento dat alle of farteurg daet woo= ten om de goederen die ban Spargnien kamen/te ontfanghen / enoe or blote weder te laden. Zün ontrent bier hondert in't ghetal/ Dorb en blÿben daer niet 
langher ban tot tat de bloote ontladen moe weder ghelaten is/ welch is ban bee epnoe ban A uguft tot Iret begin ban A pril ; ende oan frbepoenfe ban Daer om de

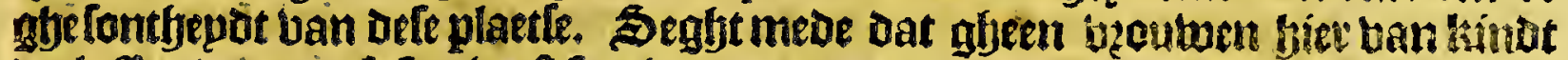
berlofen / Dan datle foo baed [u ghetwaer bogoen groot te gaen / jaer in bet lanot

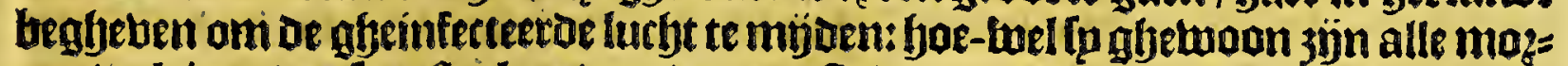

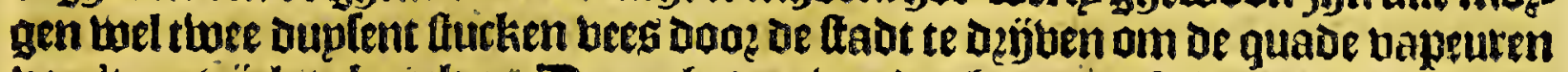

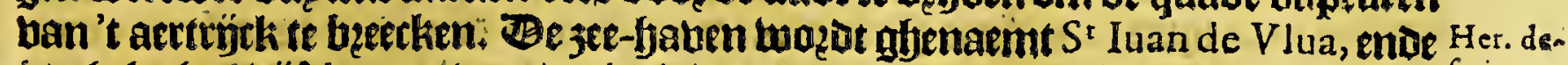

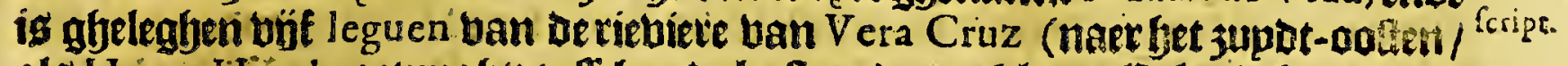
als Henr.y Hä wks getupght) tuffiben ac kufteende een klepn Galandeken/weick ontrent een legue in t om-gaen is/omeingelt banklippen ende ofecnrobten/ente foo lecgf dat de jee't felve met oe bloet lomtídts bedeckt/ teghen ober de mondt uan de vietícte ban Vera Cruz. Agen komt in Defe baten toog the rana=

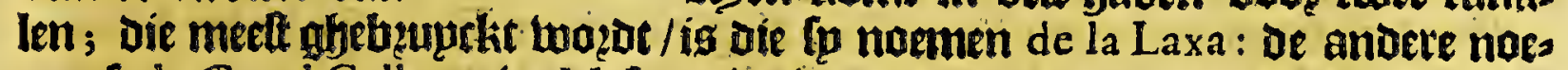

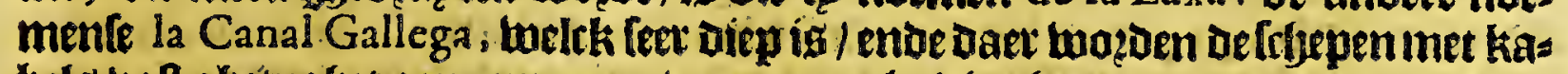
bels baff gbetugfet aeneen mupz uan meer als biet hon wert boeten/aen hopes ren ringhen / ende als oe nopezo- winot ferck waenet / foo ligqbenfe daer niet feet

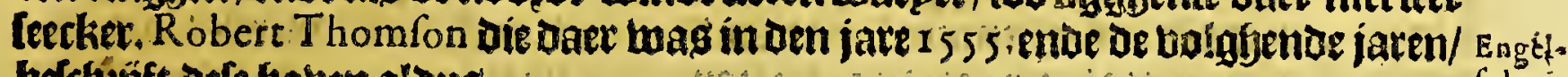
befrejenft defe gaven alous.

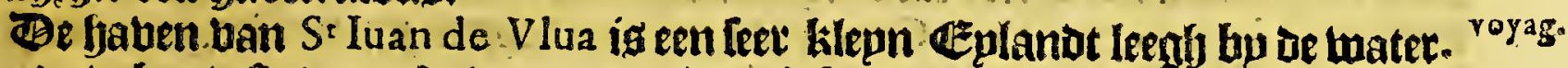

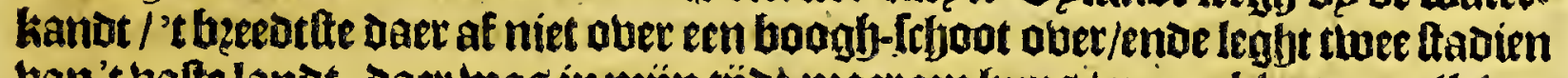
ban't balte landt; Daer twas inming tïot maer een fupg / en een klepn capelleken

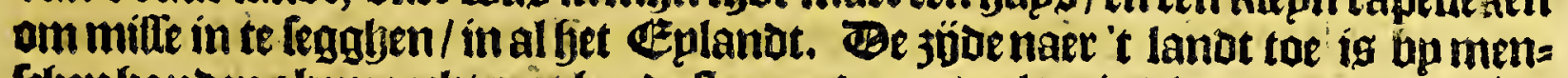
frben banden gljemaeckt mitt harde fteen ende graueel/et ig bier badem disp resht

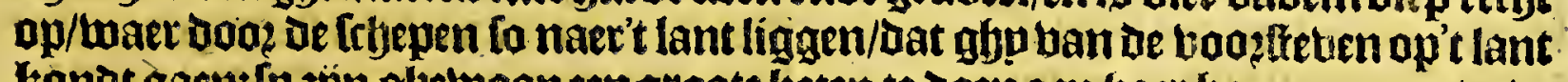
Konot gaen:It jơn glbewoon een groote keten te daen aen yaer boepe-reepen/znde

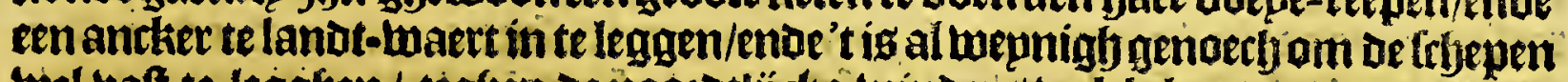

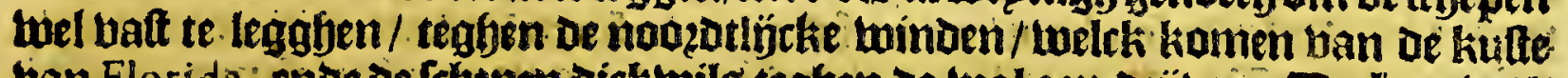

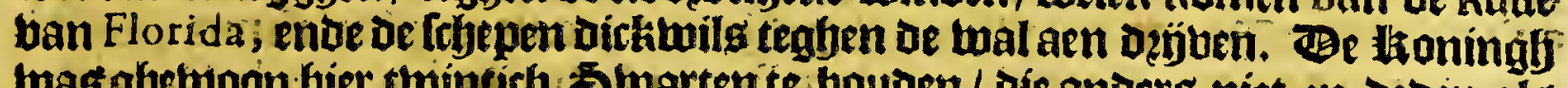
twas gbetwoon fjer twintich Stwartente bouben/ Die anders niet en Deden als

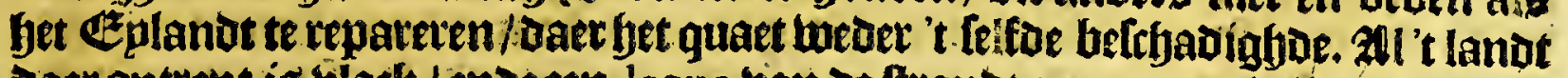
vaer onttent is blatk / endeent legue ban de trandt een groote twiloernig / met beel wildots Daer in / foo dat bet bootf-bolck als fet baet lult / Daet been trecker.

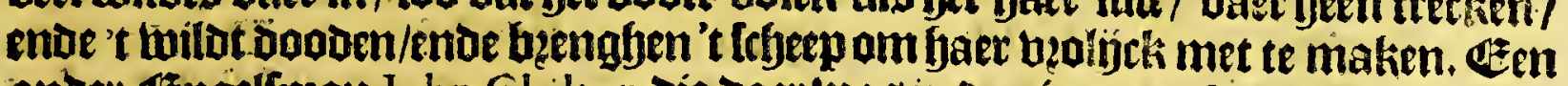
antore $\mathbb{E}^{z}$ ngelfman lohn Chilton die daer was in den jare 1568 , ende de tertud=

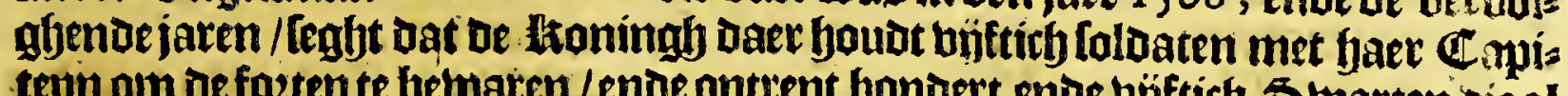
tepu oin oe foetente bewaten/ende ontrent bandert ende büftich Stwatten die al 'tjaer langf beficf $3 \mathfrak{y} n$ met teen te deagfen uod de timmeragien ende ander gbe= buupk / enoe om de tebepen die daer in liomen / met barr kaluels balt te maken.

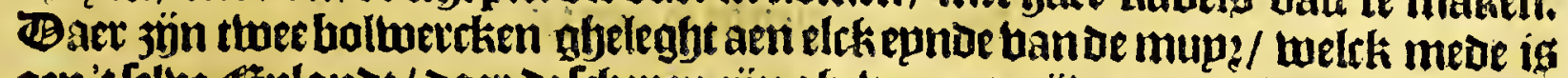

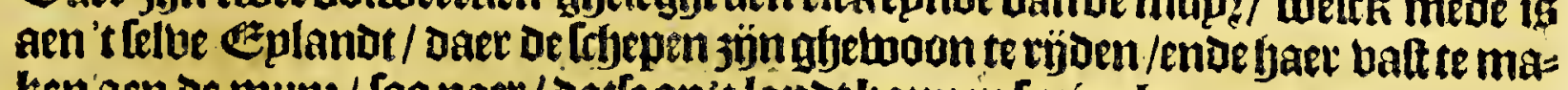
ken aen De mupz / foo naet/ Datfe op't landt konnen quanghen.

Henry Havvks die daer was ín Den jare 1572 [egft tat de Spaegniaeroen naet

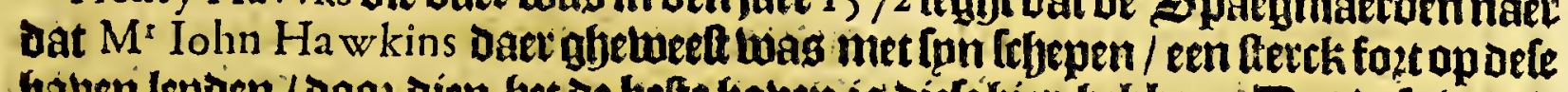
Gatuen lepden/ Doo: dien get de befte jaben is diefe hier bebben. Bat Dele baben

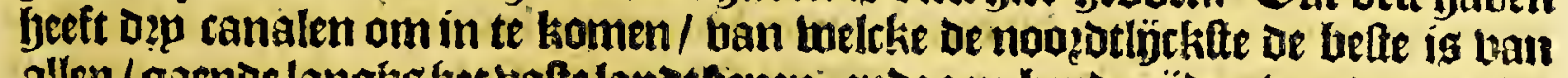

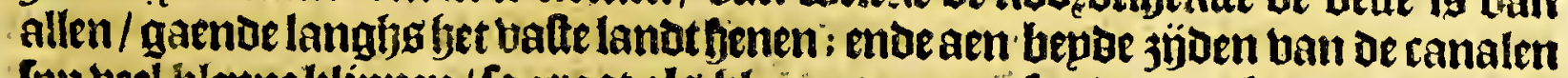
fpun beel klepne klippen / fo groot als klephe tonnen; foo dat een bedencken geeft) Dan daer en is gfeen vecere ban te bebben.

$\mathrm{M}^{\mathrm{r}}$ Iohn Hawkins was Daer gljemeet in Den jare 1568 ; ente quam in defe

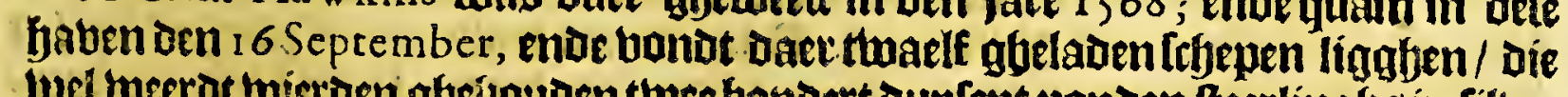

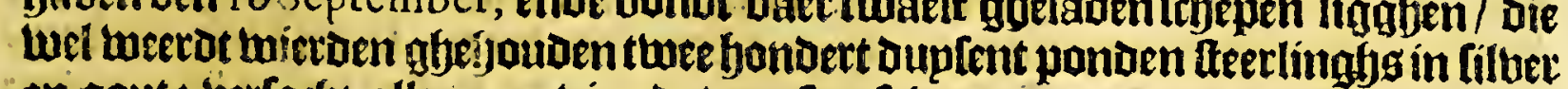
en gout : berforgt alleen peobiande boos [un frbepen /ende dat voa waren: den 17 quamen daer bettbien frbepen/ ban be bloote twelck quam ban Spaeguien/

$$
\text { S. ende }
$$


196

Nova Hifpania.

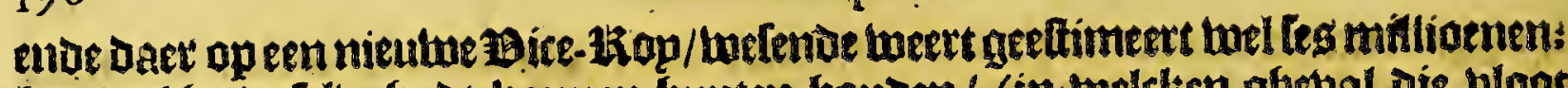

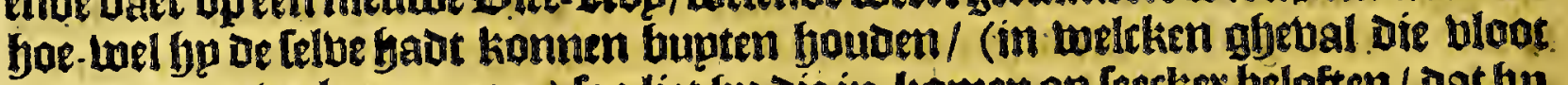
bad moeten berloogen gaen) foo liet ge die in-komen op feecket beloften / Dat by

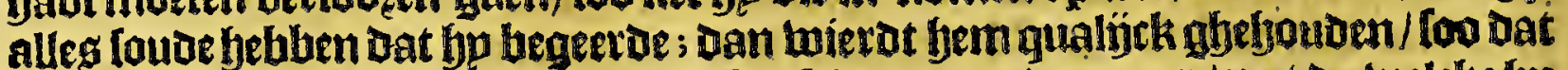

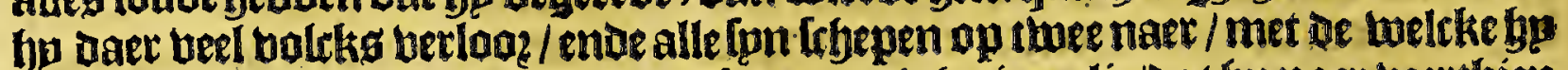
ontquam/ Jorb coa reboeloosen met loa toepnigh victualie/Dat Go naer neerthien

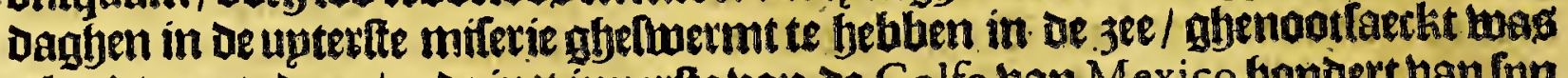
't landt aen te doen/ente in't inmerfte ban of Golfo ban Mexico honitert ban fpn volch aen landt te fetten / Die nace beel miferien/ende eenige ban or toiloe boontgljeflagfen/enoe alle naeckt upt-ghetefyut bielen in fanoen van de So paegniaets

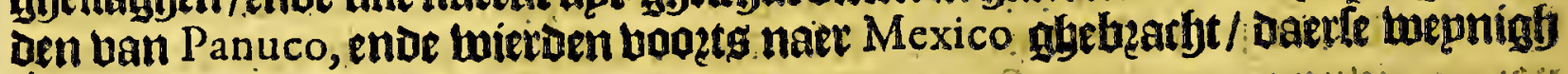
upt-ghenomen allengkeng pm-quamen.

Een falf Dagly-teple ban Vera Cruz (leght Robert Thomfon) naet Mexico toe / is een ferbargb-plact te ban uñf oft les bup [en / genaemt la Rinconada, bet ig

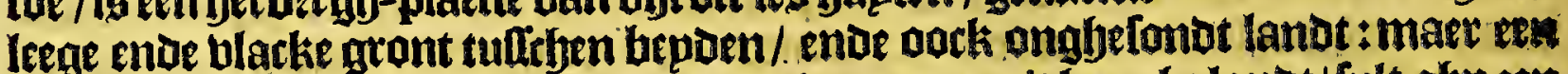
falf bagh-rep [e voozer coo gfjp begint te komen aen't boogbe lantot/ fult ghe een

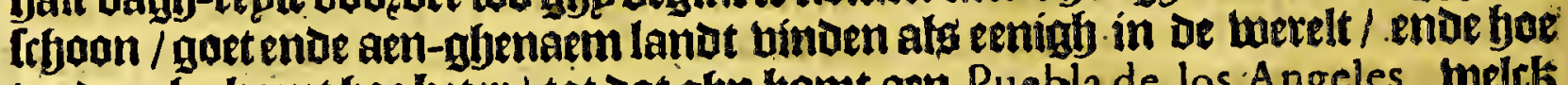
terwer abp kamt boe beter / tot Dat gop komt aen Puebla de los Angeles, . melck

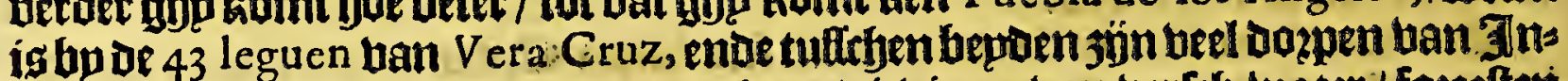

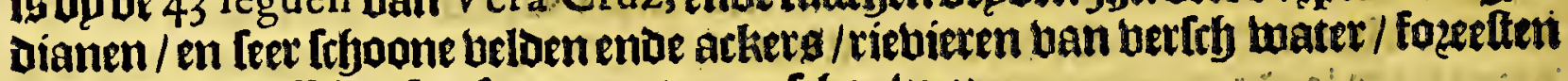
ende groote boltchen leer fraep om te aen-frboulwen.

Iohn Chilton beftyejft lpn reple te lande aloug; 10an Vera Cruz komtmen te

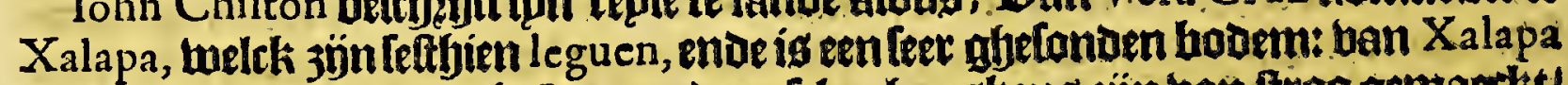

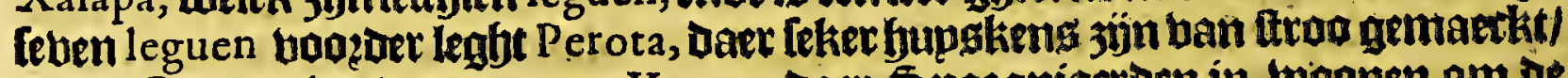
die de Spaegniaetden noemen Ventas, Daer Spaegniaer den in-woonen om de reptenoe man te berbergen; is gelegen in een groot bolch banpïn endecedar-boos

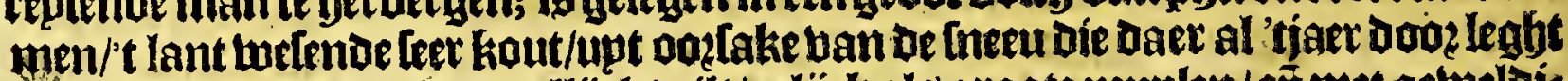

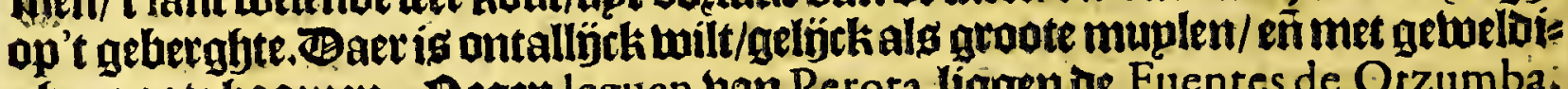
gbe groote fjooznen. Regen leguen van Perota liggen de Fuentes de Otzumba;

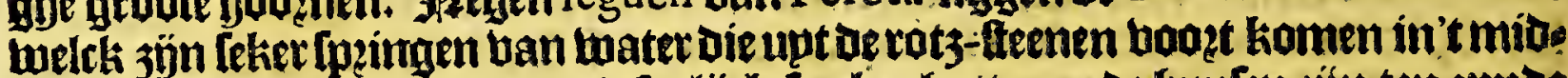

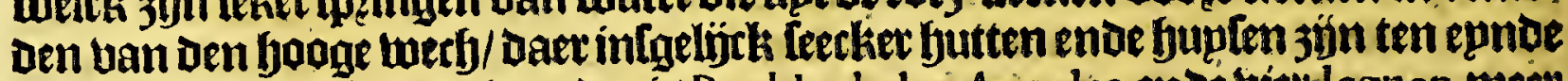

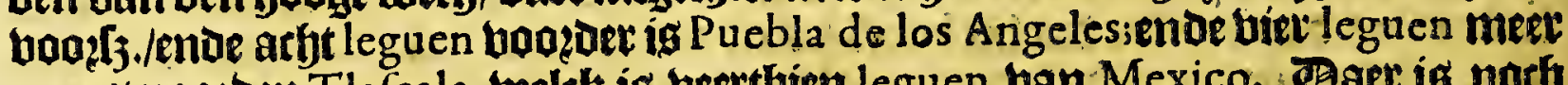
nart'tnoozoen Tlafcala, weltk is beethien leguen ban Mexico. Daet is notf een anoer blecke een legue van daer ghenaemt Chetula, daer wel leftich dupient Tndianen woonen/ende niet boben thaelf Spargniaerden.

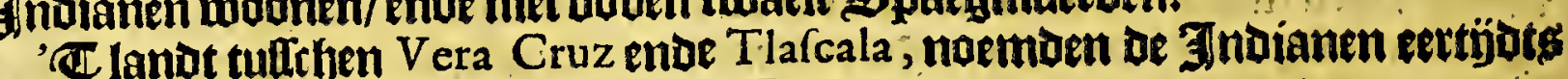
Cotaft, enoe is afyeligck Andaluzia in Spargnien.

\section{Het bertbiende Capittel.}

Befchrijvinghe van de kufte van 't Bifdom van T I A $C$ A L A aen de noordt-zee, met de Eylanden daer onder gheleghen.

H Uet 25itoom ban Tlafcala beeft op oe noozot-kulte be riebiete Alvarado, Daet fpn limiten fryepden ban't 2aftoom ban Guaxaca : Defe riebiere wiecot ont.

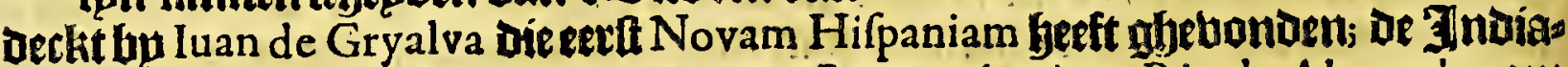

c.9. nen moemben de Lelle Papaloava, enoe de Spargniaerden Rio de Alvarado, out

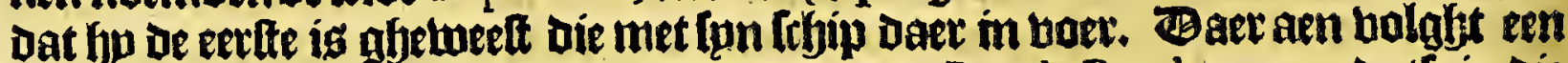
andere riebiete die de Spaegniaerden noemisen Rio de Banderas, om datté in die eevlte ontoeckingbe van oe in-woonders ghelockt wieroen met bitte laeckens

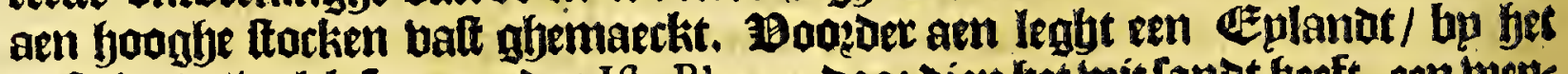

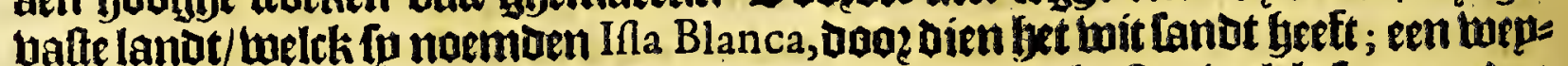

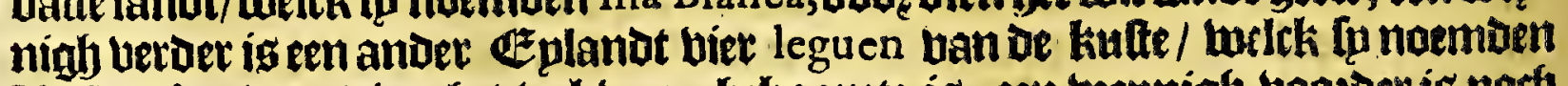

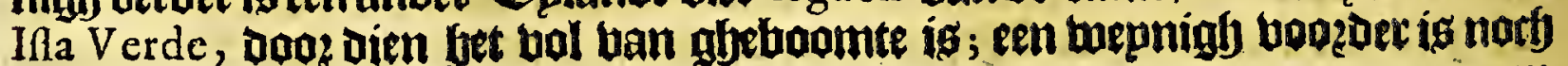


Het vijfde Boeck.

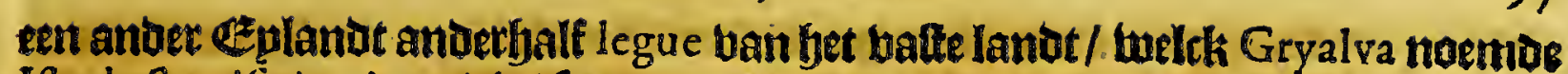
Ifla de Sacrificios, doog dien fp ọaer gelïck een autaer bonoen / enoe meniffen die onlanghs greffert thaten/ oe boetten geopent/ de armen ende beenen af-gerneden/ ende de tmanot al met bloet belpienght. Henry Ha wks feglt Dat of Spaegniaer:

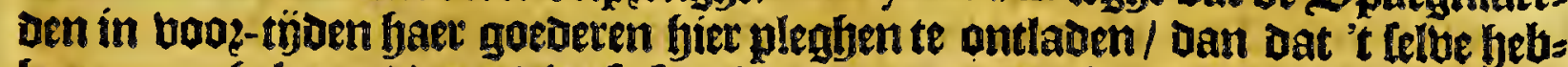
ben naex-ghelaten / poos dien lp legaben Dat daer gheeften Domineren; Dorb de

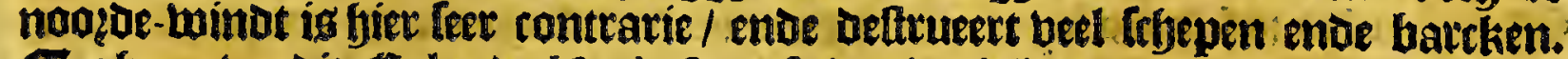
(Cegljen over dit Eplanot Ina de Sacrificios, is gbeleghen een rieviete die Her-

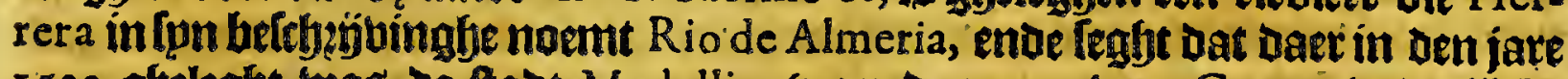
I 522 gheleght was de ftadt Medellin (naer te naem tan Cortes baderlícke d.3.1. 3. ftadt) Deg leguen ban Vera Cruz; Dan defe ftadt wierdt weter te niet ghedaen c.r6.

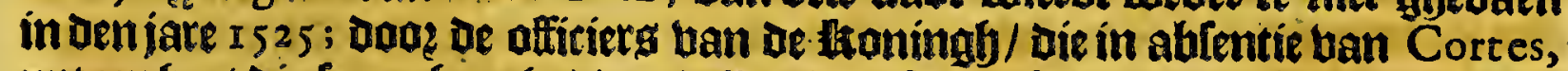
upteen baet die of op bem fadoen / alles in difozoge fteloen. Duts ffelt Herrera Almeria bp ooften ban Vera Cruz; daer andere / ende fyp felfs op andele plaetten legbt / Dat Almeria loelck de Indianen in baer tale noemaen Naothlan, gelegen is twaelf leguen ban Vera Cruz naet Panuco toe; Geeft faet ool [pzonck upt de Her. de; Cordillera bie aber fanghg loopt / jooe de pzobincien ban de Totonaques ende fript.

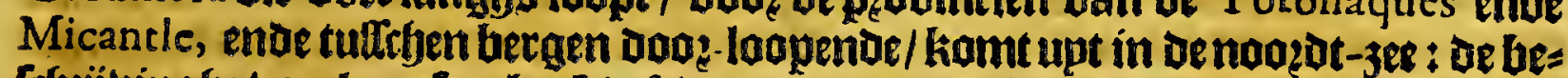

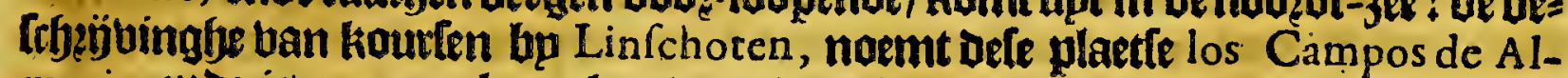
meria, ente is een merck teecken boos be piloten / en is ghelengen op thintich gladen/ofte als Figueredo infpn Roteiro ftelt op thintiff gcauen en een balf.

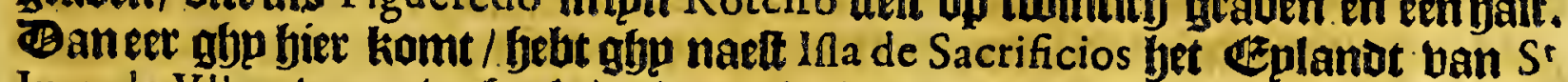
Iuan de Vllua vozen verfaelt / enoe de rietuiete ban Vera Cruz; welck Ieght ban 't Ezplanot ban $S^{\prime}$ Iuan de Vllua naet 't noozot-wetten als bozen berfjaelt; ente langgs defe riebiere byenghtmen de goederennaer of 3 upt-3ee toog be riebiete ban

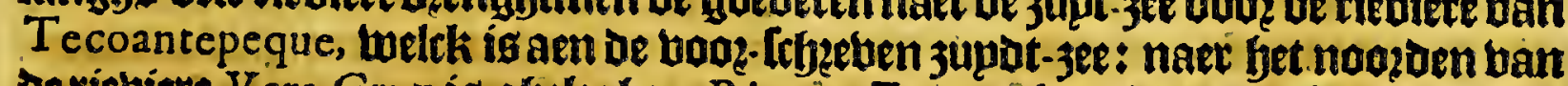
be viebiete Vera Cruz is ghelegben Rio de Zempoala; (Herrera frbeb́tt in fun biftozpe dat oe blecke ban Zempoala gheleghen is bier leguen ban Vera Cruz) ende noch boozoer Rio de San Pedro ende San Pablo, welck mede faeren doz= fpencls beeft in oe Cordillera ban't gbeberghte baet wa fier bozen bebben ban gljelpzoken; ofe riebiete is gheleghen op de booghte ban een-en-twintich graden naer bet legghen bau Linfchoten in be befrlyejuinghe ban be kaurlen. Be Spaentrbe kourteri bu Hackluydr upt-gbegetuen ttellen tutitben Zempoala enive Rio de San Pedro, ente San Pablo, Punta deHidalgo ofte Punta Delgada, enve legghen bat oe kulfe tot daer toe ftreckt noazot-onit ende 3upot-weft / ende norfj voozedr Rio de los Cazones, enve daet aen Tufpa, enderepndelijck Tamiagua ontrent bet Goubetnement ban Panuco. Be Spaenfebe kourfen noemen Rio de los Cazones, Baya de los Caffones, enoe legghen Dat het is een diepe Bahia, daermen fem moet ban warbten/ende dat daer epnoinfen de bergben ban Tufpa, welck jön fooghe bergben legghende binnen g' landts/ ente freckende nooget-oolt ende jugbt-belt.

$$
\text { G U A X A C A. }
$$

\section{Het büfthiente Capittel.}

\section{Particuliere befchrijvinghe van' $t$ Bifdom van $G$ V A $\times A C A$,} ende gheleghentheydt van dien.

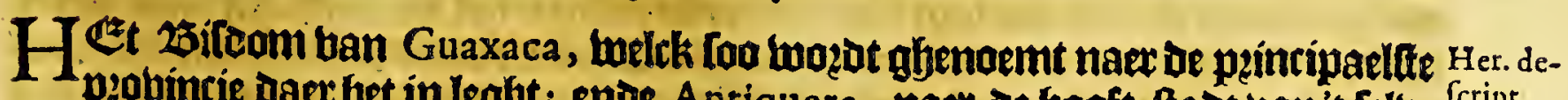
pyobincie daet bet in leght; ente Antiquera, naet oe booft-ftaot uan't felbe fcript. 25itbom: is ghelegen tufichen't 2 bitoom de los Angeles, ende or 25 iboummen than be zlludientie ban Guatemala ; beft be lenghte ban fondert en twintirf leguen

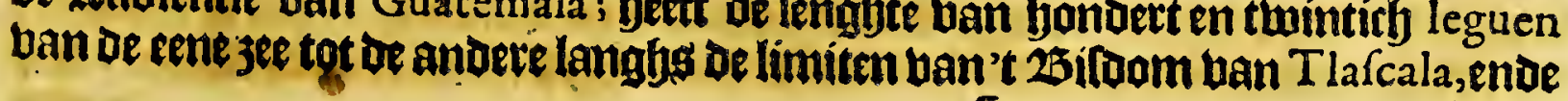


198

Nova Hifpania.

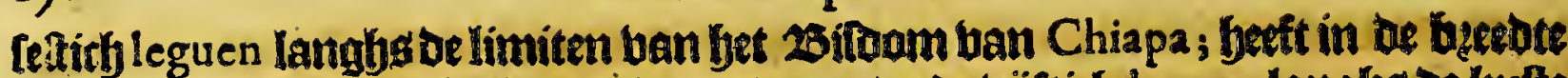

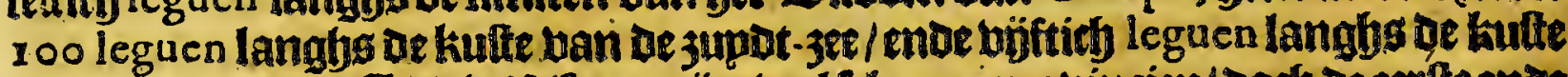

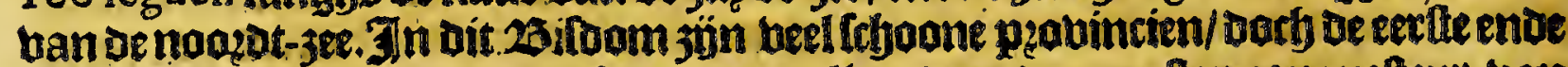

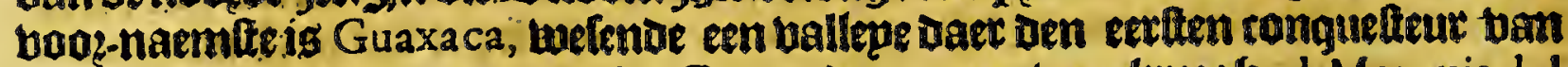
Nova Hifpania, Don Hernando Cortes uen naem ban kreegh el Marquis del d.3.l.3. Valle; oefe hallepe begint ban oen bergh ghenaemt Cocola, op of limiten ban

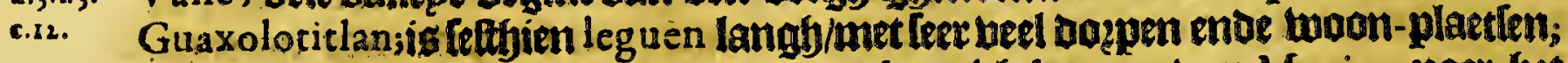
op of goaghte ban acbthien graden/ tachtentich leguen bam Mexico naer bet

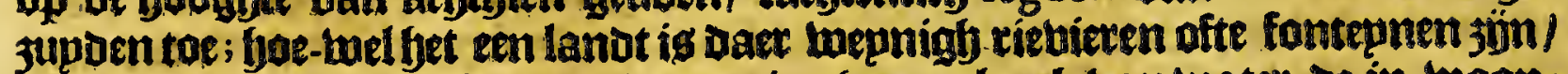

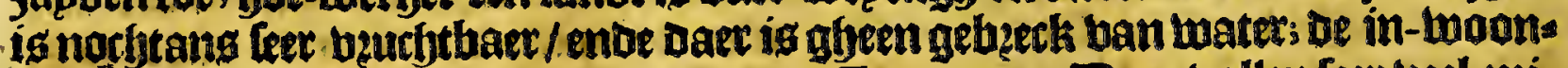
Dets van Defe ballepe fpetken be tale van oe $Z$ apotecas. Baer vallen Teer beel mix necalen/ baerfe filber ende noubt upt fineren/ criftal / hooper-roodt; ende beel ges tteenten van diffetente couleuren/ tegben 't grabeel ende bloeden/ oock bejar-fteent

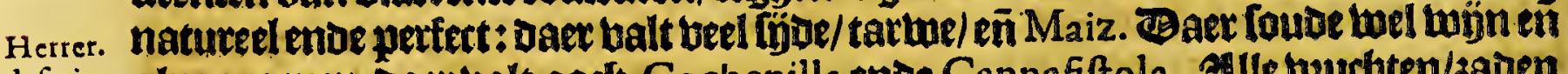
defcript. olpe groepen; Daer valt oock Cochenilla ende Cannafiftola. 2Alle beturbten/3auen ente andere krupden ban Spaegnien willen wel Daer bookt-komen: en 'tuee ban alberlep loozten tiert baer feer bel. In't gantltye 25iloom hain Guaxaca en is niet aen rieviere ofte baeten balt gout in/ende be Indianen en Louben geen dingh gres

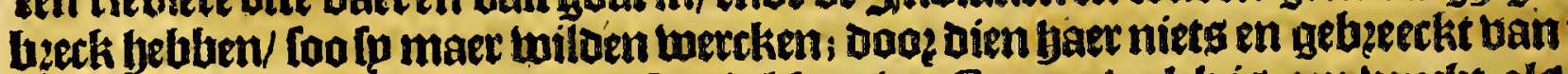
eet-maren/ende omte kilezoen. Sp beblen bet Cacao, welck is een veurbt als amanoelen/ die daer boaz gelt dient;:[p maken daer oock wijn af; ende ghebzaden] jín feer goet om eten; ende wozoen booz een goet boetlel gbefouden. Baer wait feet oberulaedich een kruppenoe beefter / welck de TBildenoemen Huitzpacot, met puntige bladeren: ozaeghtklegene roode blomkens ap een trolken aen' tupters

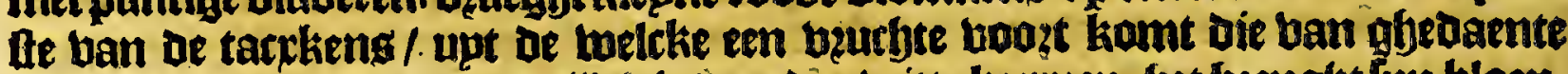

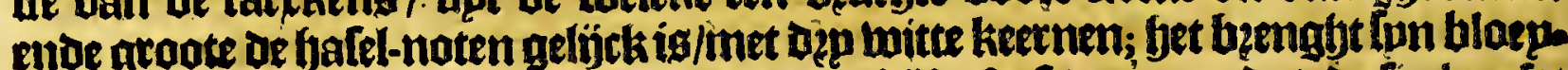

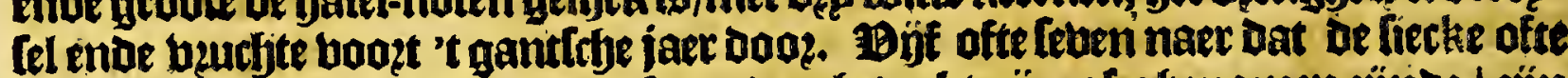
per[oon ftetck ig/'t vliefken oaerfe mede ofjedeckt 3 ïn af-gbenomen zönoe / zón leer keachtigh om te purgeren alle fegmatike enoe gallige bumeuren/beque van

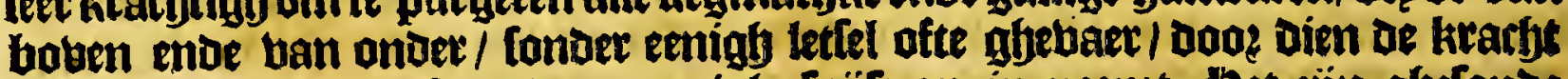
terttondts bergaet a! (men Daer ennighe ipigle op in-neemt.

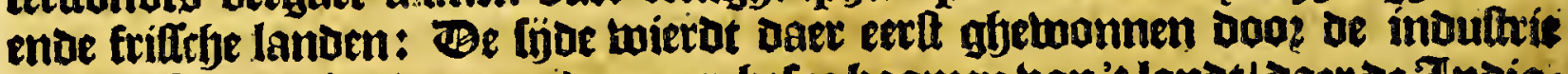

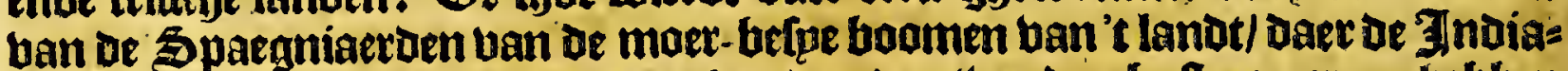
nentwaten gfetwoon pampier te maken van oen tweeden baft : maer nu bebben de Spargniaetom daer foo ueel moer-be[pe-boomen gheplant/ dat daer ontals

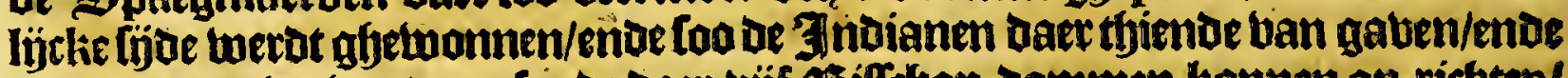
bam andore oingljen / men foube daec bijf 25iflefjop-iommen konnen op-richten/ dan nu er betalen de Spaegniaerden maet alleen thienden. Bit 25 flopm begreght

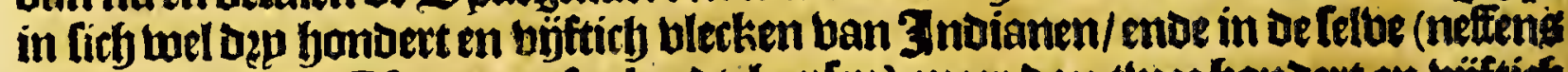

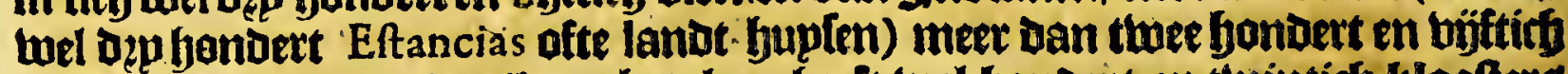
Dupfent Fndianen die tribupt betalen: Geeft bel bonbert en twintich kloofters

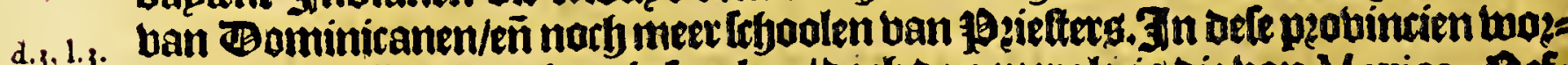

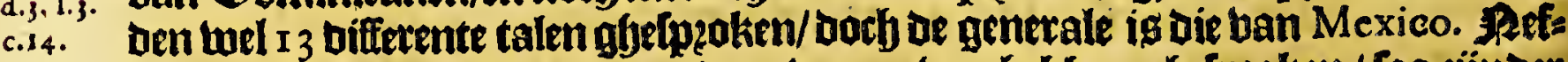
feng oe peobincie uan Guaxaca, daet twp nu ban bebhen ghelpzaken / foo jändec

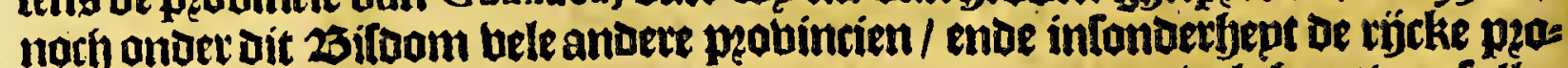
vintie Lan Mifteca, Tutatepec, ende andere daer wop nu becbolghens tanfullen

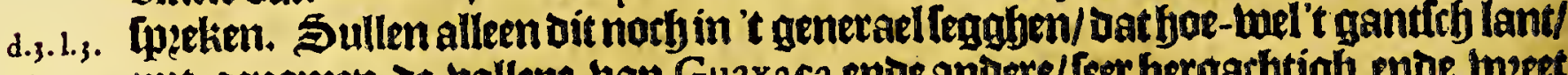

c.12. upt-genomen oe ballepe ban Guaxaca ende andere/ Feer hergarbtigh ente twzest

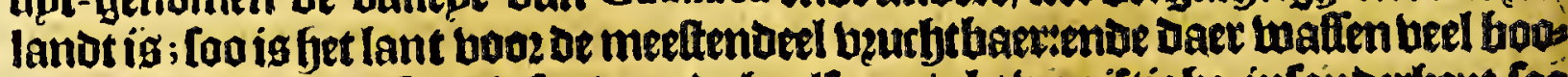

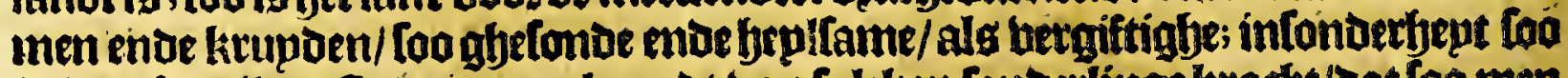
is in of (e ballepe Guaxaca een krupot ban fulcken fontuerlinge kratht/bat foo men begeert een menirfy te jooden binnen op jaers/ loo geeft men bem dat te deineken

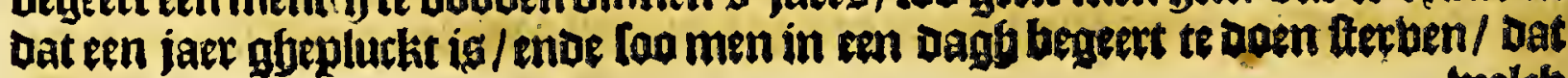
tuelck 
Het vijfde Boeck.

199

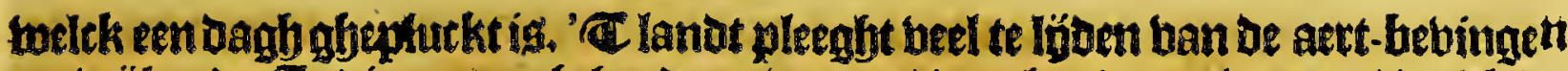

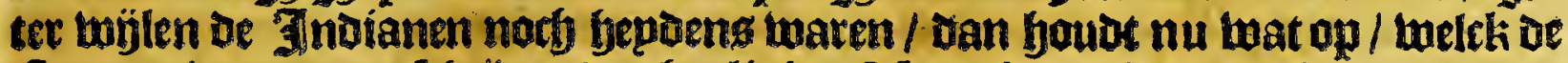
Spaegniaerden toe-froejuen oen beplighen Martialis, die oe kertke ban Antequera booz faren zlobotaet beeft.

\section{1) Tetfliende Capittel.}

Befondere befchrijvinghe van de Provincie van M I T E C A, ende andere Provincien daer aen gheleghen; behoorende tot de Provincie van $G$ V A X A C A.

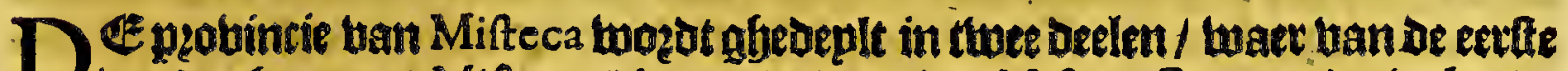
wozot gfenoemt Mifteca Alta, ende de ander Mifteca Baxa, ende in bepde Iptaken de lieden faet differente talen. Mifteca Alta is gfelegfen tufteben Mexico enbe Guaxaca, beettitb leguen ban Antequera naet't twelten. Mifteca Baxa leght

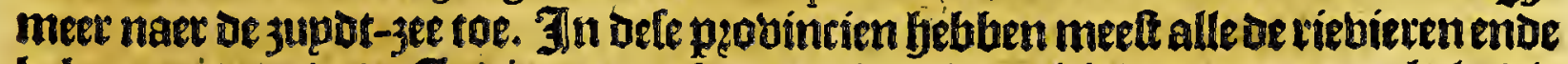
beken gout; ende ae 3 naianen trecken met beutu en kinderen naer een beke die baet nael ghelegfen is/met plobiande vooz thien oft twaelf uaghen/en vergades ren met gemack foo beel gouts als fo konnen/ welcke fp in pulber in fekere fthach: ten ban boenderen betwaren/ ende trecken daer mede op oe marckten daer men toffen ende bities berkoopt / ende mangelen Daet tegen' tgoubt wat lp ban Doen bebben / enve kerren naer baer wooninghen / enoe en ballen niet eer tueder aen't bercken booz dat faer pzotiante op is/en willen miet jaepen/ of petg ter banoen

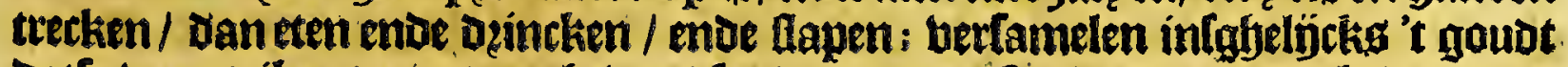
batle booz tribupt moeten gheben/ fondet datmente eloerg kan toe belweghen/ want billen anderg niet doen / feggfjende dat haer kinderen moghen boen als fp quedaen bebben. In de blecke ban Cuatrithlan toaft grode menichte ban of woxtelen die men noemt Mechoacan.

In be Jlutifoictie ban de blecken ban Cuertlavaca entie Tequiciftepeca ig een leer booghen bergfy/coaer een [pelonthe in is/Dis boog een Dominicaner monnick

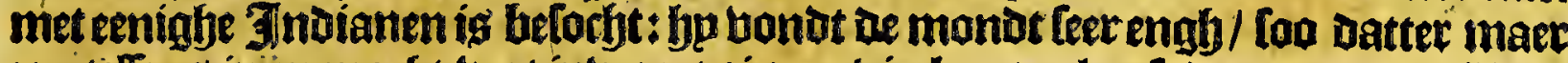
en teffens in en motht: wat intuaterts is een bieckante plaetfe ban ontrent vifftich hoeten; ban jönoer fekere putten/met rrappen/enoe baer begínt een wegh met

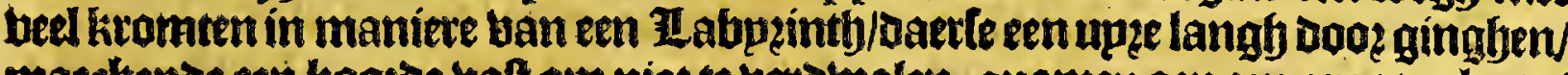
maeckentoe een kodege baft on niet te verobalen; quamen aen cen moote plaets/ in't miboen ban welke is een fontepne ban gaet water; ende langhs oe eerie

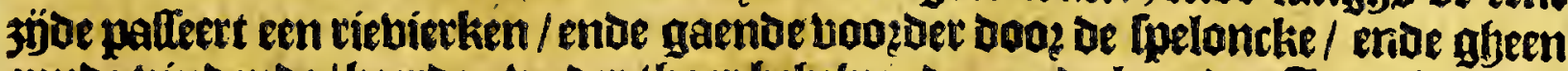

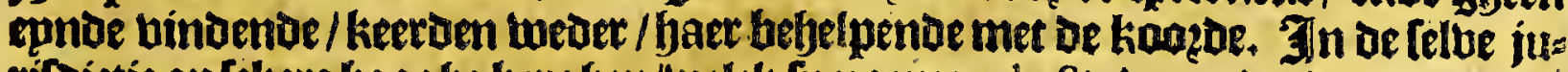
ridoictie op fekere hooghe berafen/beldk fp noemen de $S^{t}$ Antonio, moonen eeni= obe Indianen in fetere putten tulithen oe klippen / welck ban thien tot twintich boeten langf enoe beect jün/enoe berer folle-putten iller meer dan bondert/ baer fy met bzouben ende kinderen in twaonen/ ende men kan die met geen mid=

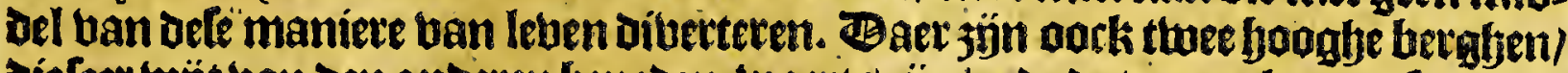
bieleer wijt ban ben anderen beneden-baerts 3 ijn/ende de toppen komen foo naec boben bp den anderen/Dat men met den eenen baet op dieen/ente den anderen boet op D'anoer kan ftaen.

Alen of peobincie ban Mifteca confineren fekete woon-plaetfen bp as Spaes gniactoen genaemt Pennoles, tuslcke 30 th les/gbelegen d'een naer den anderen/

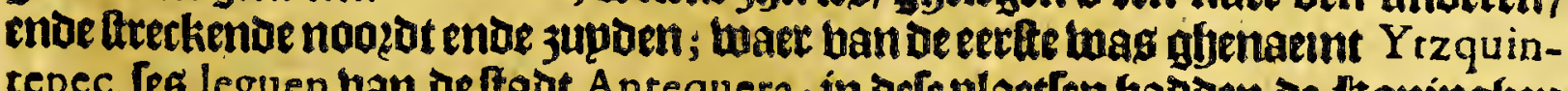

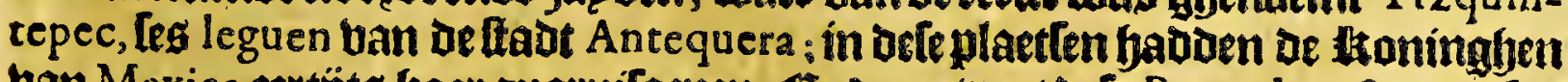

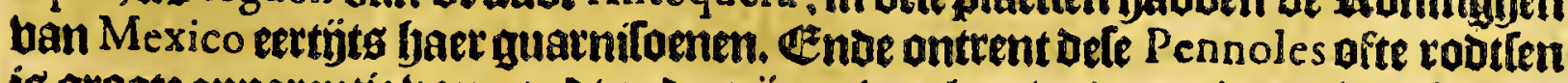
is groote apparentie han gouot ende mijnen ban loot/ende een luattel die bequas

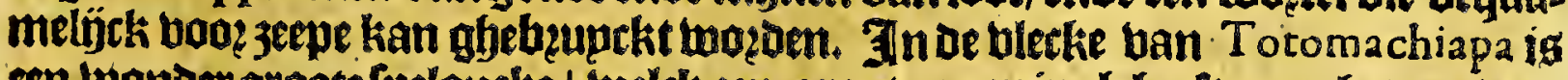
een luonber grootefueloncke/ welck een groote openingh beeft maer bet zupden/ 
en ftreckt in naer'tnopoen: men freft Daet luel een balf mïle ingfegatn / maec

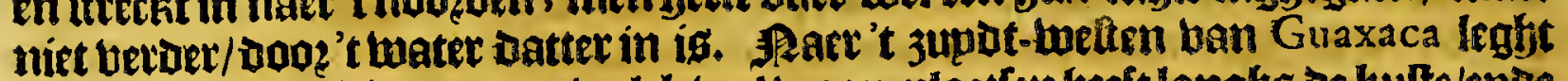

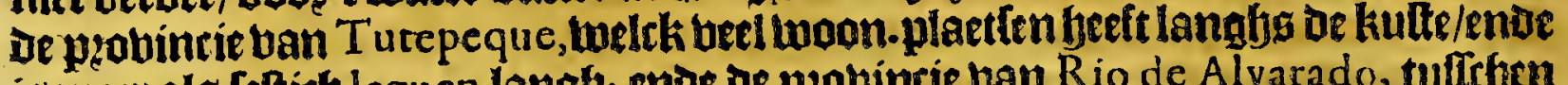
is meet als teltirb leguen langt; ende oe peovintie ban Rio de Alvarado, tufterfen

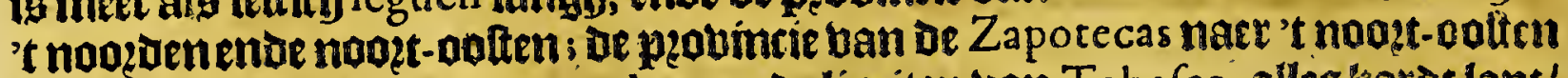
ban Antequera; tnoe Guazacoalco, op oe limiten ban Tabafco; altes harot lant/

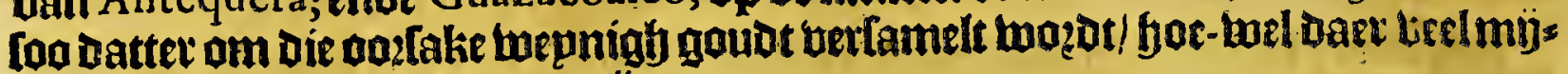
nen ban goudot in 't telbe landt $j \mathfrak{y} n$.

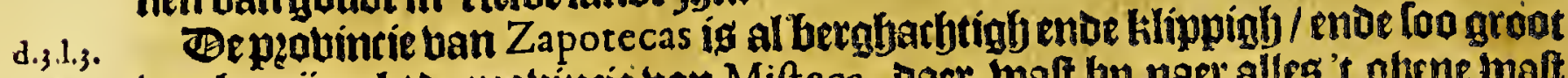

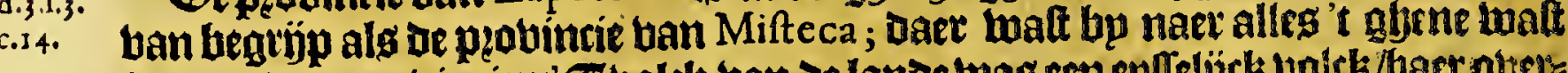

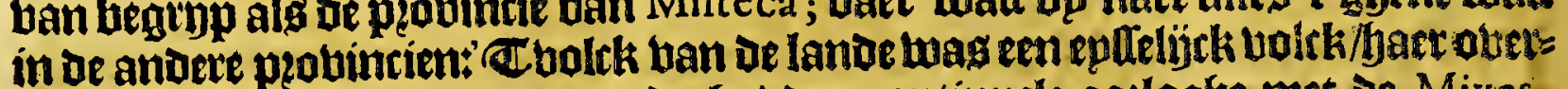
Ite hoonden te Teozapotlan, ente babden continute oologhe met de Mixes,

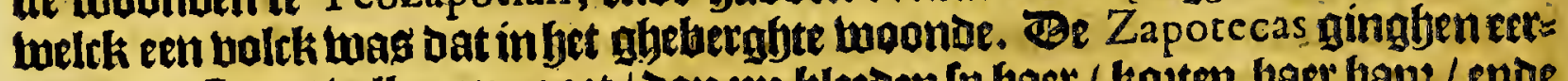
tjotg meelt met bellen am-goet / dan nu klecoen fo baex / koeten baet bap? / ende Desagljen meet foeiden.

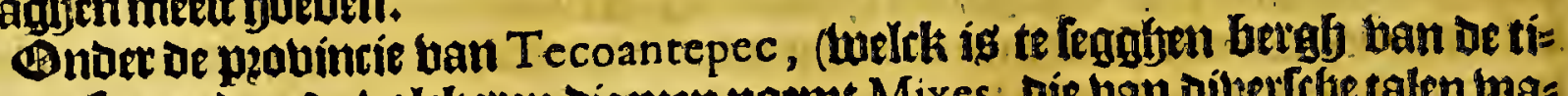

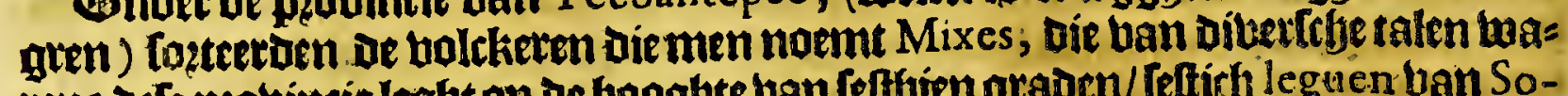
ren: Dele p2obintie legbt op be booghte ban feftien graden/ Teftith leguen ban Soconufco: In die probintí loozot Liquidambar ghetronden. Ban de pzotintie ban oe Miges fullen wp hier naer lpetken / bp ic faot ban San llcfonfo.

In de probincie ban Guazacualco ende Yluta, als mede in de peotincie bart

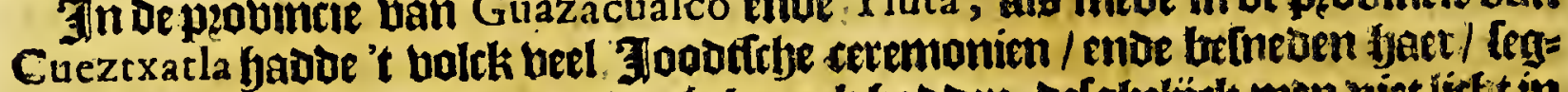

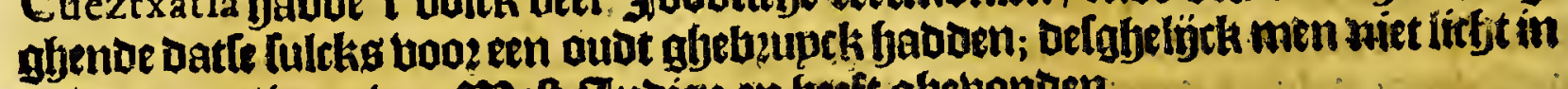

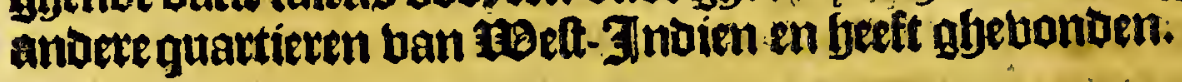

\section{Fet [eben-thiende Capittel.}

Befehrijvinghe van de Steden der Spaegniaerden in defe provincie van GVAXA CA.

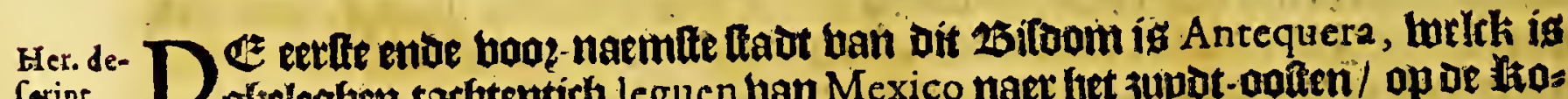

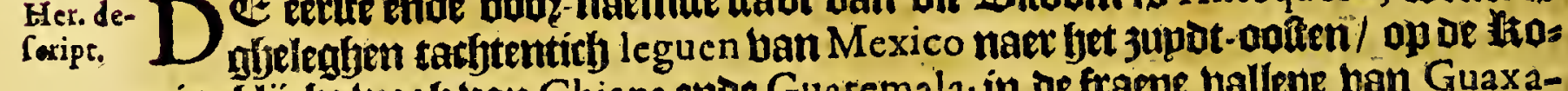
ninghlïelie tuegh uan Chiapa ende Guatemala; in oe fraepe ballepe ban Guaxaca. Be rieviere ban defe ftadt tpupt van onder de aerde / teglen ober Cimatlan, ende neemt baren loop naet't gbeberghte ban Coatlan twee leguen ban daer/ende oock twee leguen ban Guaxaca. Exen balf míle ban oe fladt / teglen aber enten.

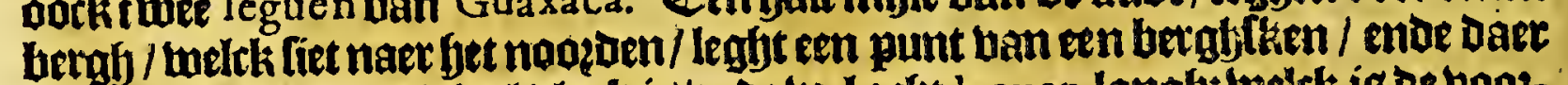
loopt een ballepe af die beel black is/enoe wel actyt leguen langh: Welck ig be boozIfyetuen plaplante ballepe ban Guaxaca, ghetempert ende ban teer gfetonoe lucht / Daet aluetbloedeligck alle bingfen boat-komen/ ente inlonderfepot leet

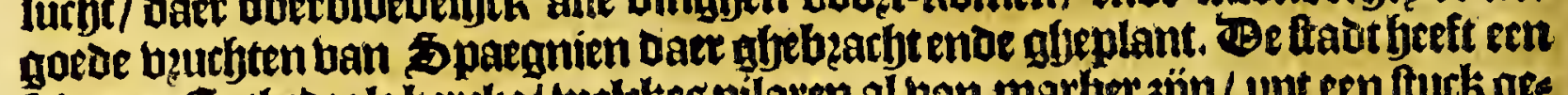
fefjoone Catjeozale kercke/ twelckes pilarm al ban marber zjön/ upt een ftuck gec Gouben / feer groot ende dick: Baet ' ouden naer' tegghen uan Herrera in dere fabt bier bonoert fupl-gefímen ban Spaegmiaeroen woonen. Dan Iohn Chil-

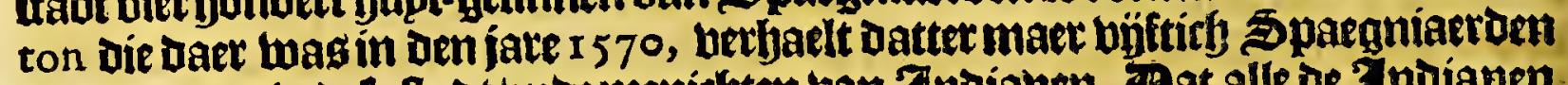
en woonden in dele ftadt/ende menichten ban Jindianen. Bat alle te 3 noianen ban defe pzobintie haer tribupt betalen in mantels ban cottoen mbe Cochinilla, welck leet abuntoant groepet in dit gantich quartiex.

Her.de- Detweede ftadt mozot ghenaemt $S^{r}$ llifonfo de los Zapotecas, twintich le-

frips. guen ban Antequera naet bet noozot-ooften; men hantelt dare met gouot/ rottoen ende Maiz, ende daet 3 jijn meet dan dertith buplent Tndianen die ons Der tribupt litten.

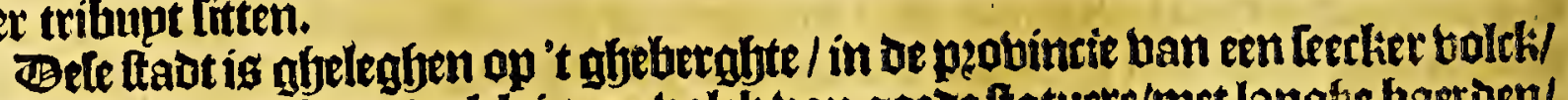
die men noemt Miges; belch is ent bolck ban goede fatuete/met langhe baetoen/ 
Het vijfde Boeck.

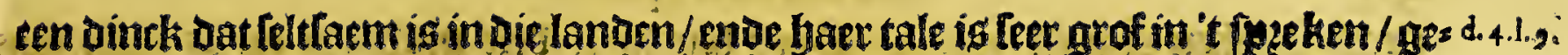

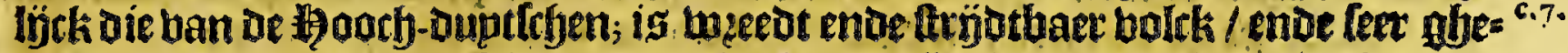

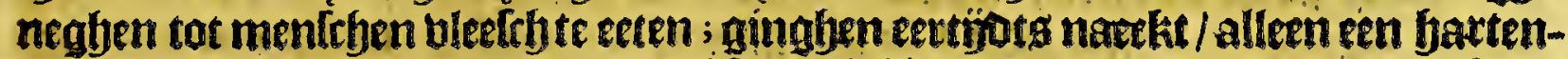
bel om de beupen gljegoet / welck bel feer bit ig / enoe bel herepot met mentefen

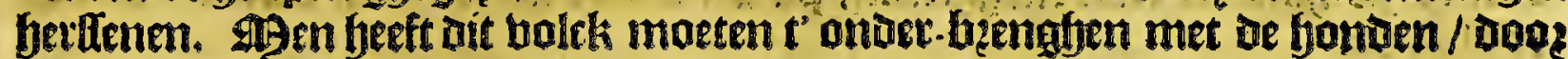
dien men daet te peetdeniet bp en math; - In be ftadt ban lle fonfo en twoonden eetríts niet meer dan 3 o. Spaeqniaetoen in butten ban ftoo; De trelcke bet Daer finaerlïck Couben freben konnen fouben/ten ware dat baet bonoen bate ban de

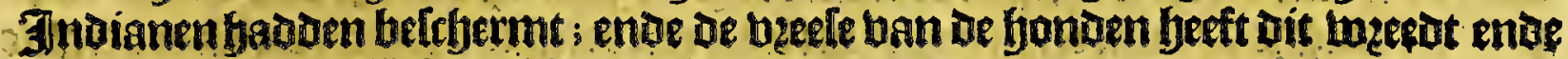

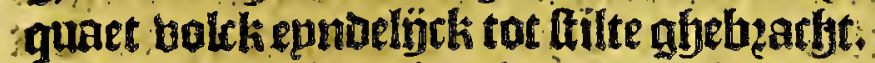

De ieroe fraot íf abenoemt $S^{\text {ta }}$ Iago de Nexapa, gheleghen in de ballepe Her. deban Nexapa, thintirf leguen van Antiquera naer bet ooften / in of twegh uaer fcript. Chiapa ende Guatemale. Iohn Chilton Die daer voog veptoe in den jaere i 570 .

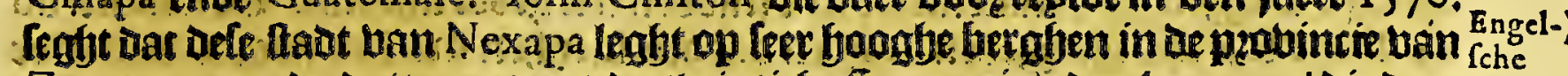
Zapotecas, ende datter ontrent de twinticf Spaegniaerden woomen/ Die Daet royag. legghen upt bebel han oen lloningh van Spaegnien/om bet land baet on=

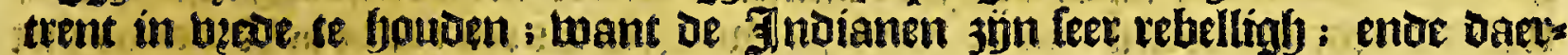

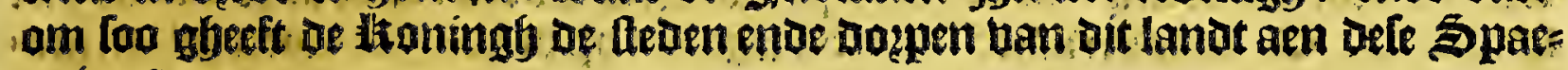
gníaerden.

Be bieroeftadt uan oftepquincie ig la Villa del Elpirizu Santo, in ae pequin= Herrer. rie van Guazacoalco, ap of kufte ban be noozor-jec/ op de límiten ban Tabaf- defcripr. co, theghentiry leguen tan be ftad Antequera; if glebout in ben jaere 1522 ;

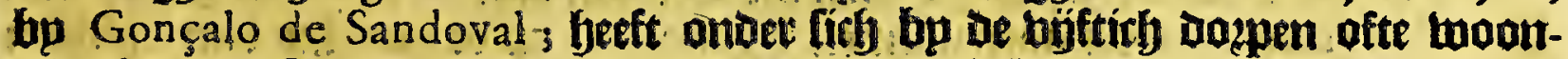
plaetten ban Jubianen/ende ig gltelegfen aen oe hanot ban oe riebiete / naet bet ghelwelte ban Chiapa toe/ Dap leguen uan oe $3 \mathfrak{e}:$ Don Hernando Cortes d.3.1.3: gaf aen de eette bozghers ban dele ttaot beel bietken ban Jindiamen en Enco- c,1r.. mienda als oe Spatgnjaeroen bet noemen/enoe inlonoethepat Guecollan, Cuiatlan ende Quezaltepec; tueltke bolkketen bee moepten frebben ghekoft om

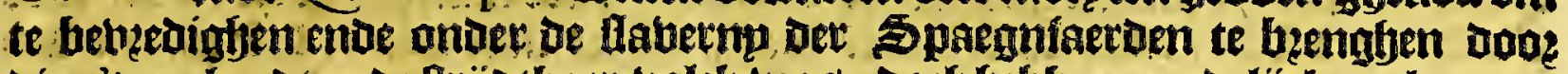

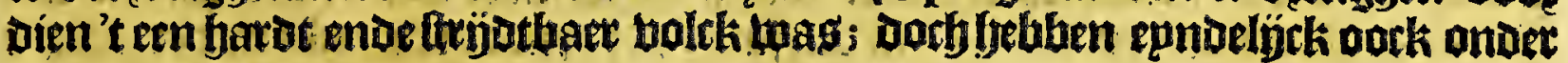
c jock moeten buyghen:

\section{It achthiende Capittel.}

\section{Befchrijuinghe vande kufte ende havenen van GVAX.A C A, beyde} op de noordt-zee, ende op de zuýdt-zee gheleghen.

D Ez Kulfeban dit 25itoom ban Guaxaca aen de noozat-zee hegint aen Rio de

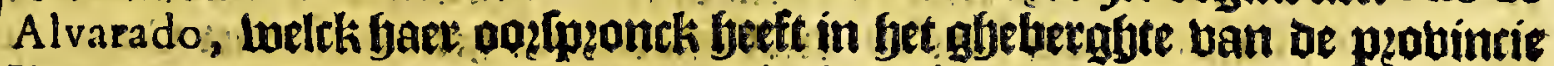
Der Zapotecas; ende ander anbere pectuintien/ hamt gheloopen boo de p2as

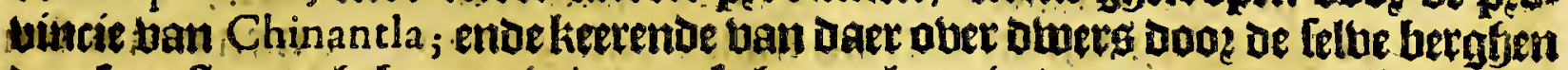

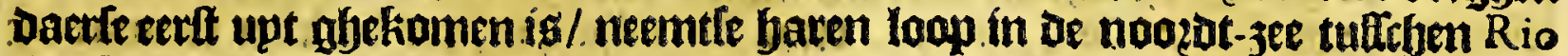
de Guazacoalco ende S! Iuan de Vlua. De riébiete Guazacoalco íg ent leet groote vieviete; Don Hernando Cortes londt in benjare 1520 ; Diego de Ordas d.2. l. .

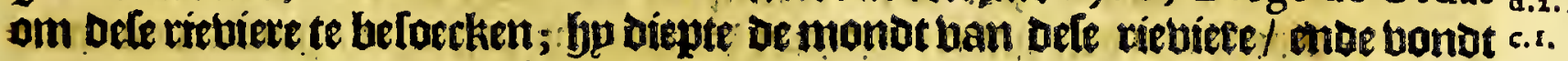
rupm dęp bademen maters in'tin-komen ban de riebiere / ende hoe men meet de

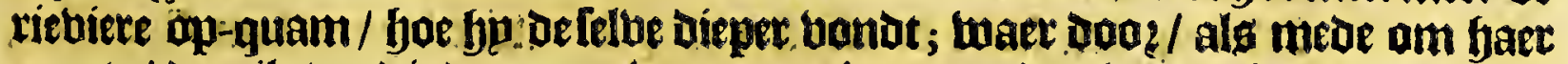
gloote / oe piloten die Daer met baren/opineeroen dat bet een Crate ofte booz-

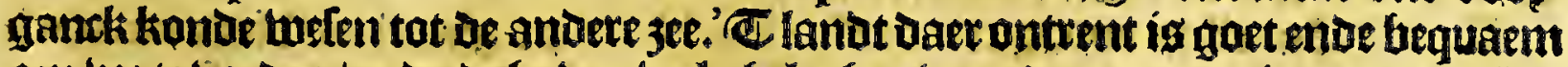

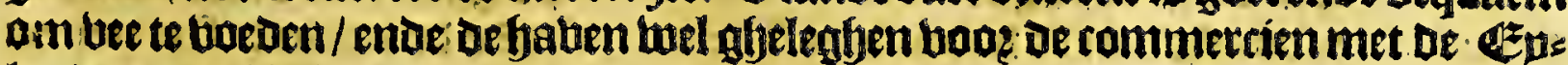
landen ban Hifpaniola, Cuba ende anuete / foe-twel wel hondert ende twintich d.3.1.6. teguen berichepoen íg ban Mexico. Herreta leght eloer dat fet hondett ende c.Ir.

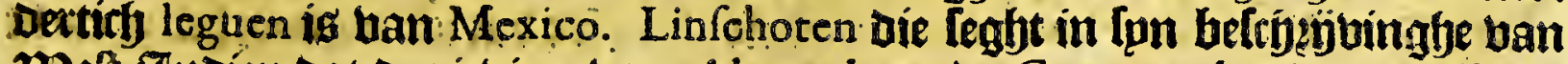
Meft-Indien dat de vieviere ban Alvarado ente Guazacoalco ban malkan= 
Deren legghen büftich leguen. Dock Loo beeft dete plobincie op be kulte ban oe noozot-jee of riebiete $/$ twelck Herrera in fon Defcripcion de las Indias d.31.6. normit Agualulco, entoe elders in fon biltopie A quiavilco, melck cen balf mp̈le

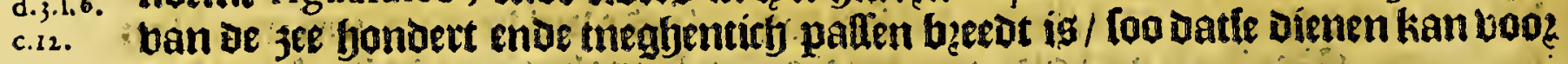
en baben.

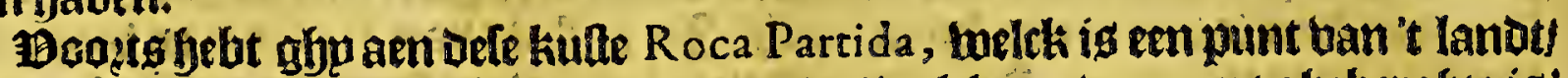

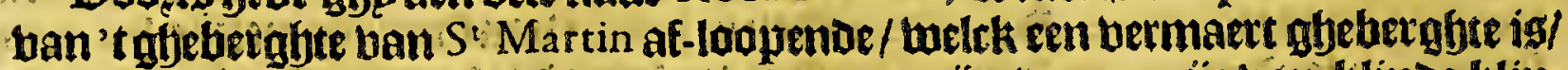

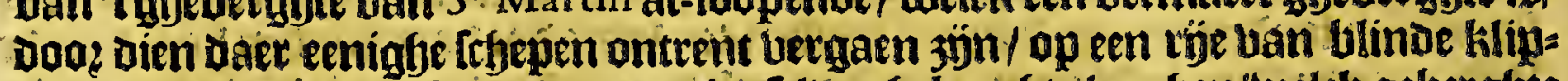

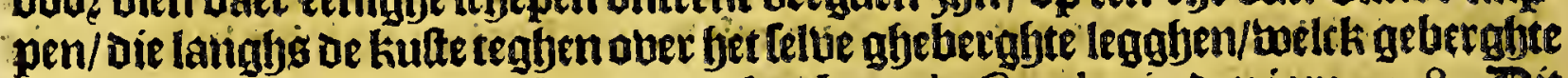
too is glyenaemt bp den eerten ontoecker Iuan de Gryalva in den jare 15 I. Dit abeberabte is een fonderlingh mertk-teerken boog de abene die defe quartieren twillen bejeplen: oe beldjęjuingbe van kourien bp Linfchoten, leabt dat bet thee

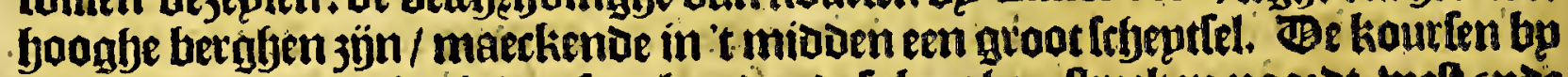

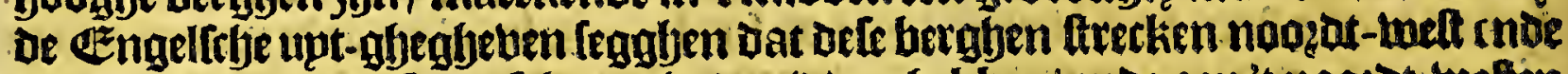

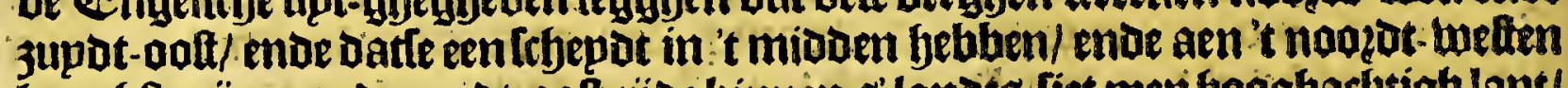

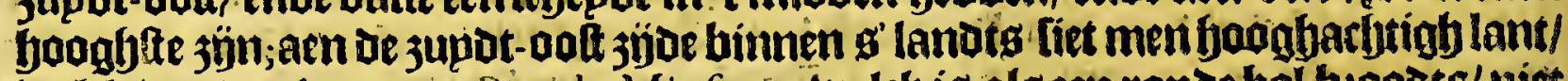

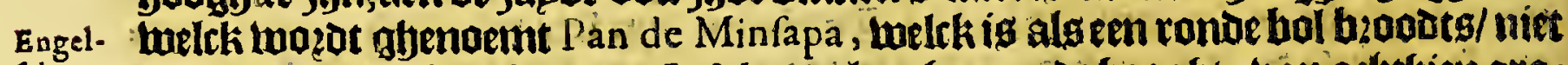

fche feet boonb. Be berghen uan $S^{t}$ Martin legghen op ae booghte han arbetyien gras

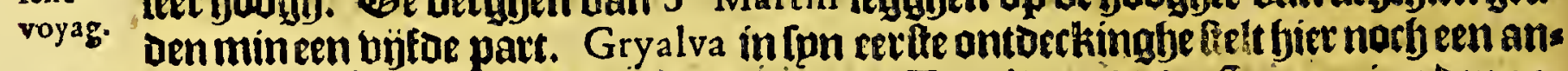

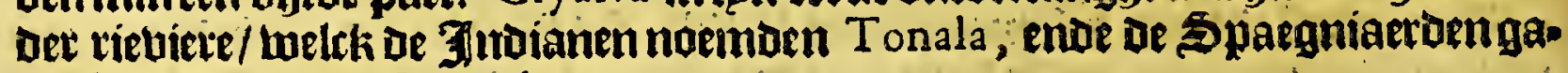
venle de naem van $S^{2}$ Anthon.

Herrer. Op oe kulte ban de zundot-jee beeft dit 25itoom ban Guaxaca de batuen ban defrripe. Guatulco (welck andere oock noemen 'Aguarulco) op de boogljte ban bijftyin graden en een balf naer fet feggjen van. Herre ra; ende naer bet legghen ban de

Engel-

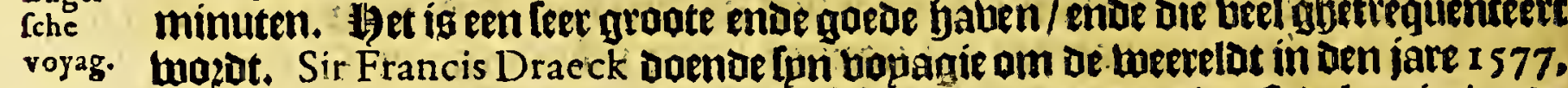
bopagie ban Thomas Candish, op de fooghte van böfthien graden ende veertirf

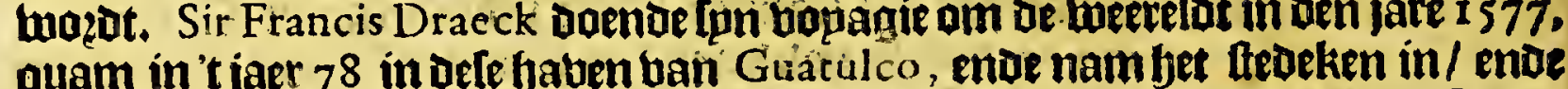
plonderde 't feitue / enoe trock tweder 'wegl). Baer naer mierat defe plaetle twes berom in -ghenomen bp Can dish in oen fare 1587 ; enoe toetbzanot met oe kercke

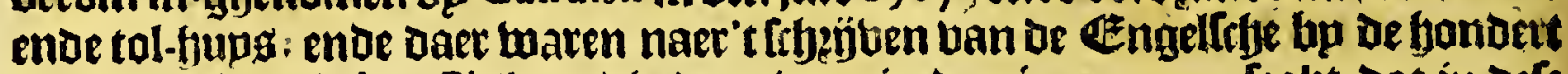
Gupfen. $\mathfrak{A g a e l}$ Iohn Chilton die Daer lwas in Den face 1570, leght Dat ín Dele plaetfe niet oter bier oft bujf Spaegniaerden en woonen/ende een deel Swarten/ Die de lloningly daer onderfjoudt; ente dat hier alle de goederen wozoen gbeladen die naet Peru ende naer de Honduras twoęen gfjetoett.

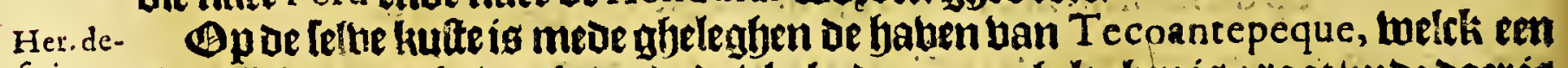

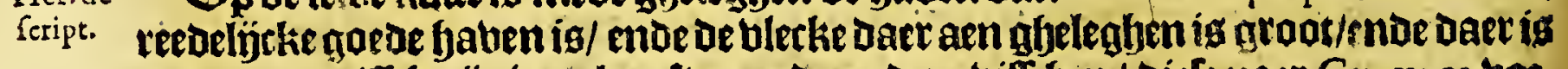
een glante billfyern̈e van kieeften ende andere bififben / diele naer Guaxa ca boes

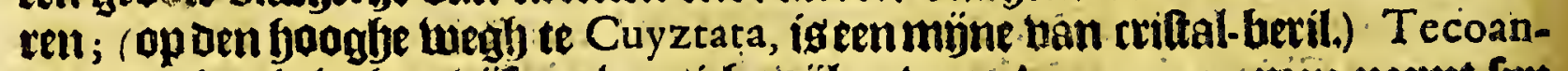
tepeque is glyeleghen bijf-en-beetricl mijlen ban Antequera; men neemt fon

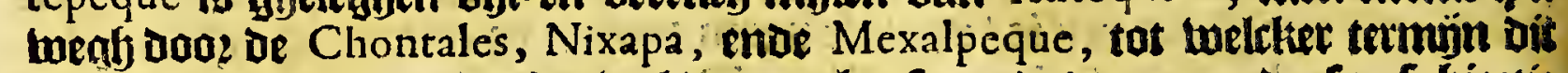

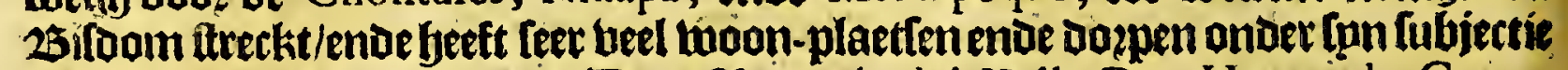

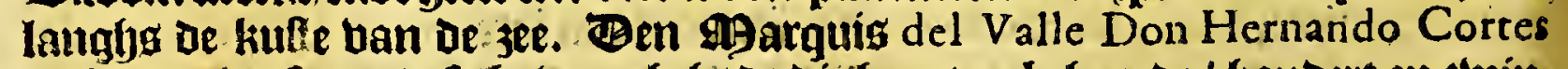

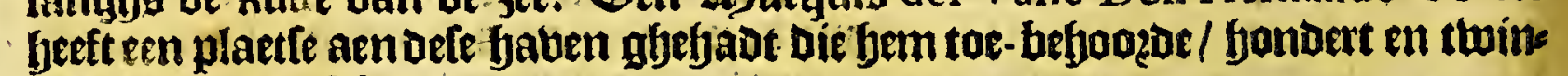
tifyleguen van Mexico.

Candish telot op dele kufte oe vietsiere Copalita thee leguen ban Guatulco, Daer Ep antkerde in thien badem waterg.

Tndefe Engelfebe vapagien Doo: $\mathrm{M}^{x}$ Hackluye upt-abegeben/binae sen pettik

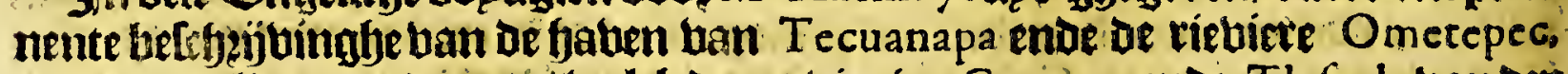
met de orn-lixgende doipen/ tuelch de prohintien Guaxaca ende Tlafcala handen

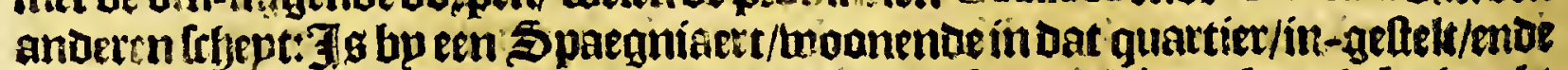
aente Bire liop uan Nova Hifpania phrfonten; foo Dat ick ooghoog beb ghearbs of felte bier en te boegben/ ende lupdt als volggt. 
De haten ende fmalle recos ban Tecunapa ljeft in 't deonghlte ban de fomet

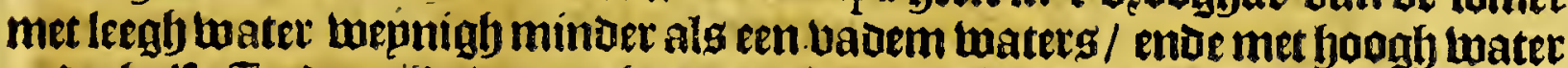
anjerljalf: In den tijot ban regbenen dęp thademen enoe neer. IL eght naex 't twe: Iten daet de 25 ifoonmen ban Guaxaca ende Tlafcala ban oem anderen fefrepoen: twee mijlen ban daer/naet Punta de Intla oft Dorda ci torigeen bape/saer oe febe= pen bp noodet rỉden konnen/ goe-tuel 't geen conterlínghe reede en ig. Defe bape maeckt aen de rechter-banot naer 't noozoen toe/ een lack wat beetot en diep on= trent be kil / inlonderbept aen be zjoe ban Cuahintla, anders ondiep aen bepde jojoen: palferende tufryen de jee enoe leket bofty ban ozaengie-boomen/ente an=

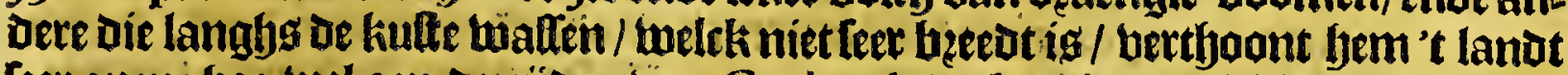
teer open: goe-wel aen de jijoen ban Cuahintla de bergben beel klepne kreecken gljeten / ende een klepn lack ghenaemt Tulaningo, cinde men kan baet niet reps fen / oan tulthen be 3 ee / ende't epnoe ban dit lack / luelende ontrent twee mijlen Candighengrontot. Zlen de noatt-3joe ísen andet klepne kreeck/ ende gaende

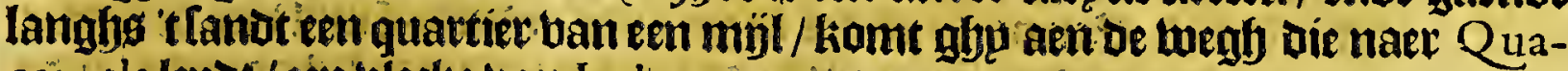
capotla lepor / cen blecke ban Intla.

Be viebiere tian Omerepec, welck de booz-naemlte jo die in defe hatuen kant/ beeft baer beghin in de baghen ban Xicayan de Tovar, ontrent vier-en-twintich leguen ban Defe haben/ upt feter paelen die ban bet gheluetghte ban Cacatepec bookt-konien/ ende baer beneden een doey Suchiftlavaca in en boeghen/ wan

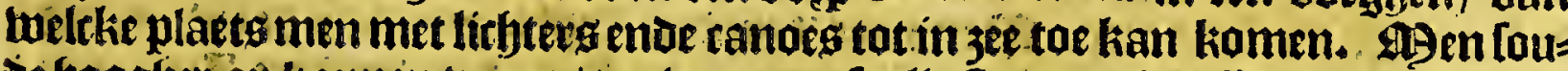

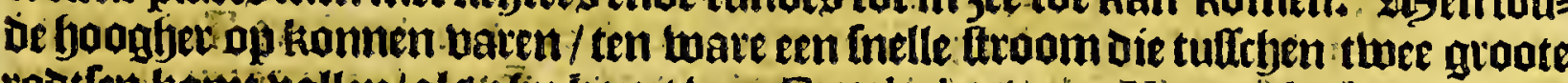

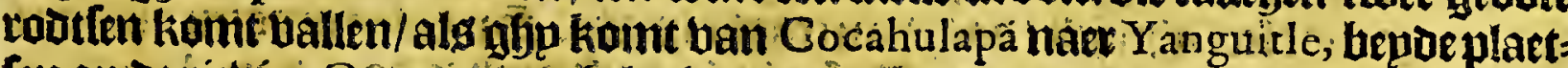

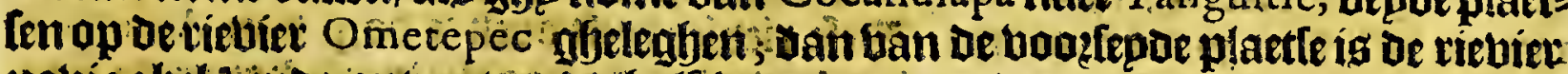

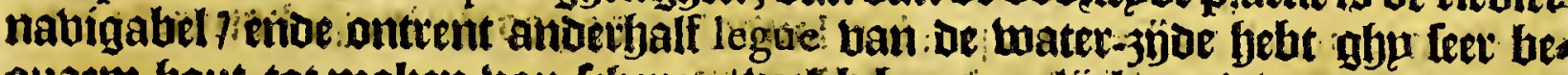
guaem bout tot maken ban frbepen/ helck bequameligh aen't twater kan twozs

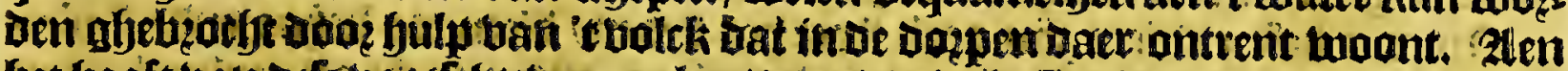

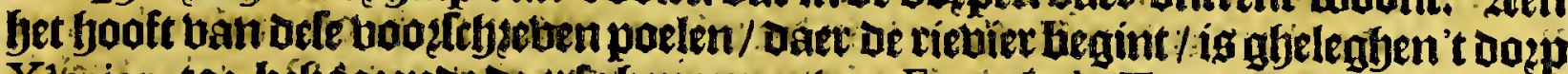

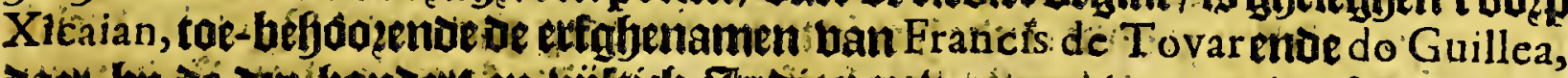

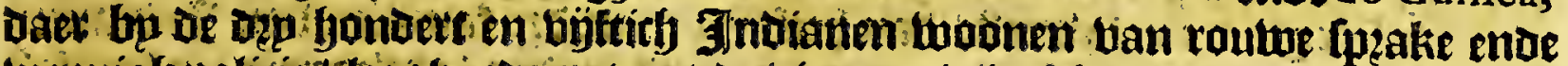

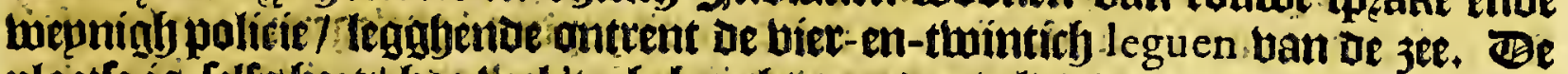
placte is relfg fiert/ hoe-thel't gheberghte tanatom tiombt is. Bier leguen ban Xicaian, ente thintich ban de zee/legljt jet doef Aioanapa, toe-befjoozende de ext-

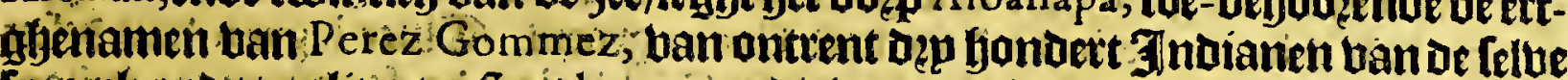
Geack-ende qualitept Ses leguen nederbaert nate t jupuen is de blecke Su-

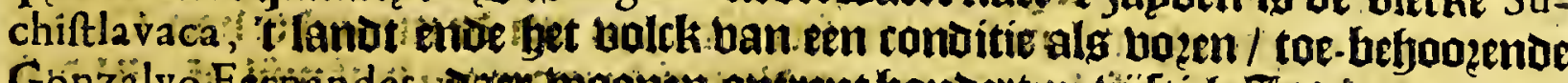

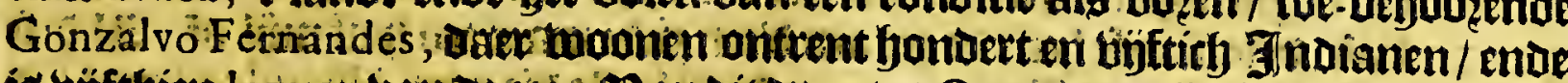

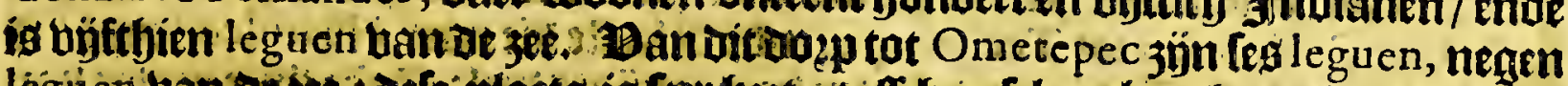

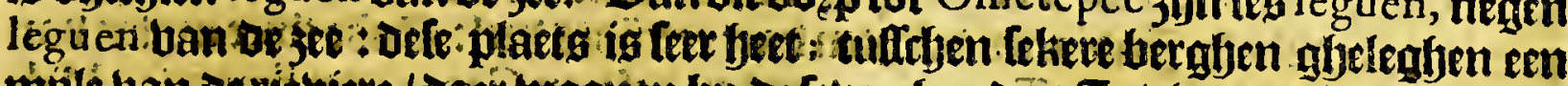
mijle bain oe vieviete / Daer twoonen bp de leuen gonoert Tndianen die de tale ban

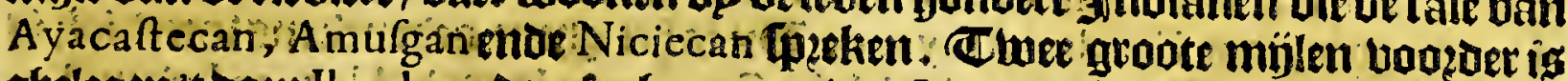

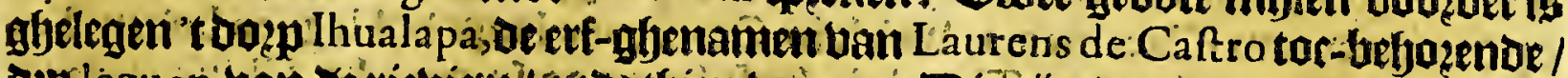

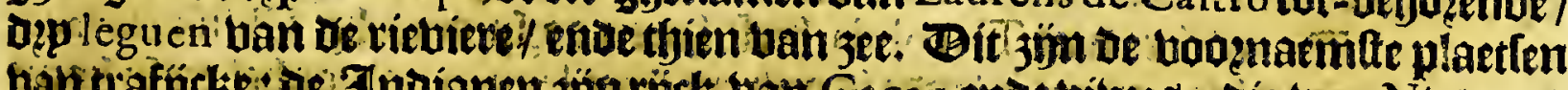

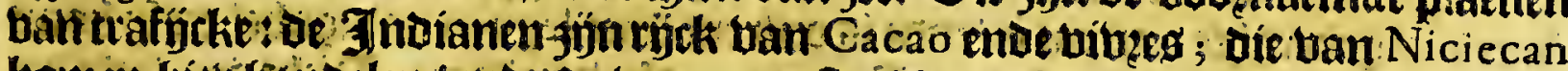

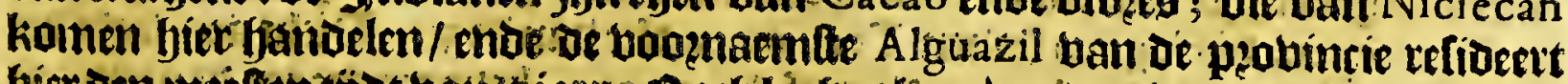

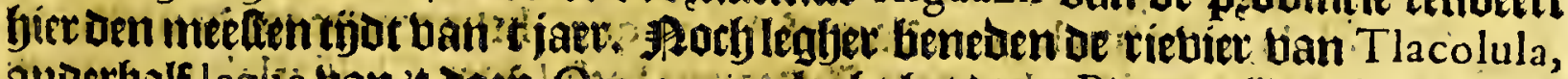

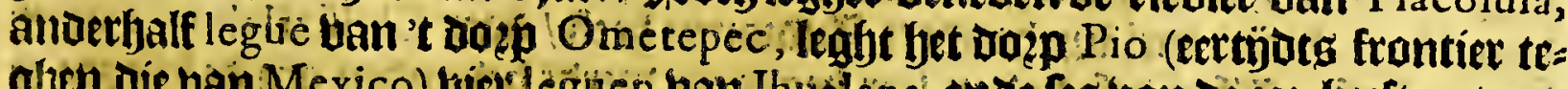

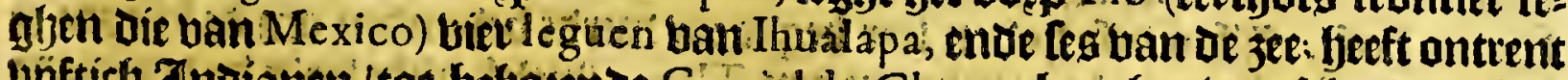

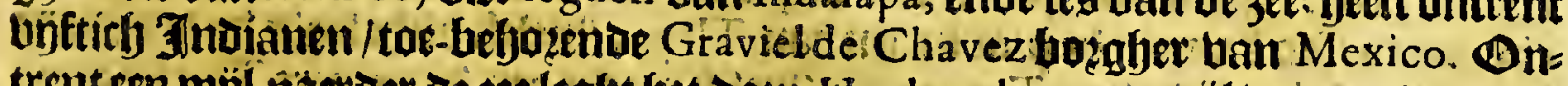

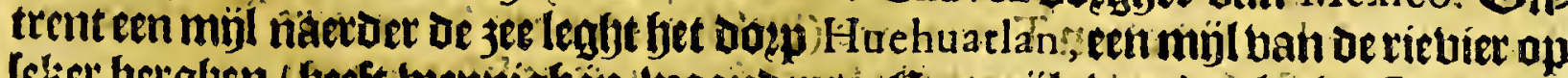

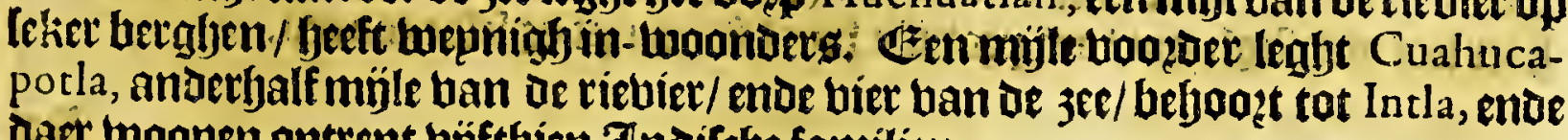
daet twoonen ontrent büftbien 3 ndiftbe familien. 


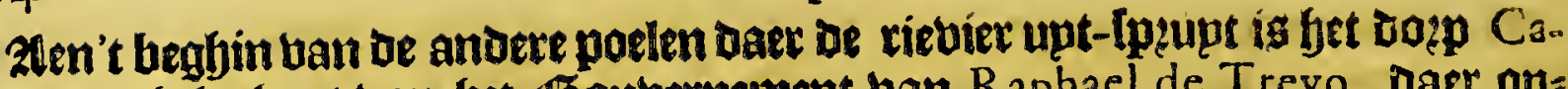
catepec gbeleghen/ ban bet Goubenement ban Raphael de Treyo, daet on= trent feben bondert Jnotanen twoonem ban de Niciecan tale/ twee-en-thinticly leguen banjee.

Te rieviere ban Tla camama lpeupt upt de betgben ban Atoy a que ende A mufgos, Letentbien leguen ban de jee. Ber maeckt het een bolkomen rietriere die met ranoas ende lichters bebaren kan wo woen tot of 3 ee toe; te weten/ ban een twep:

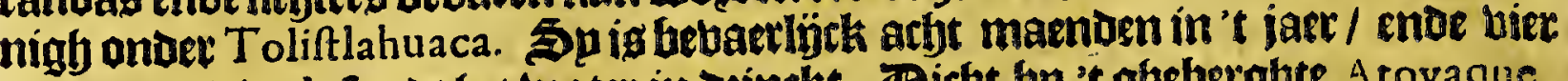

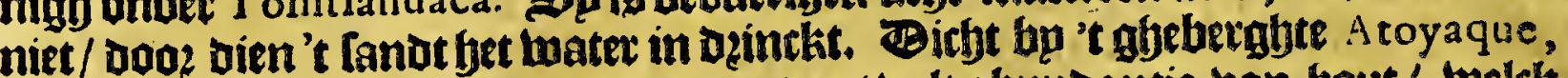
Cacatepec, ende Amufgos, ende Daer ontrent balt abundantie ban bout/ welck licht kan af-abebzocht woz̨oen na Tecuanapa. Be le riebiere beeft mede veel Dožs yen daec aen loterende / eerd aen de boet ban de bergben bet dozp A toyaque, Den Janingly enoe de erben van Pronetto toe-befjodzende / víftbien leguen ban te

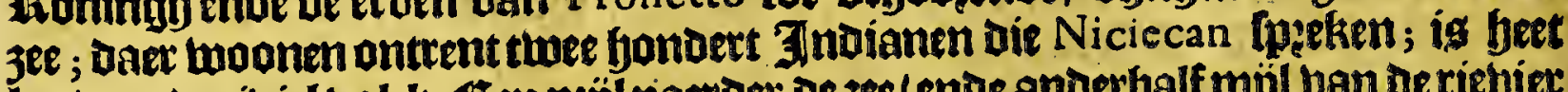

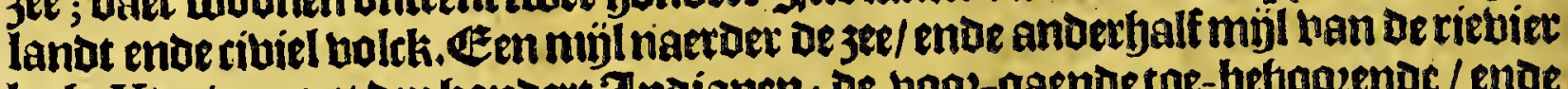
leght Xicaian, met dzp bondert Jndianen; oe booz-gaenoe toe-befjoozende / enoe

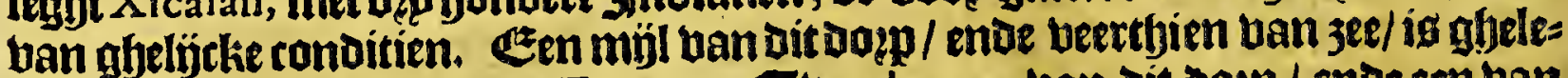
ghen Pinotefpan lubject aen. Tutepec. Clmee leguen ban dit boep/ enoe een ban Xicayan, enoe oertffien ban T ecuanapa, enoe dep ban de riebiet/ ig gbelegben of blecke Tlacamama, daet feer ribiel bolck waont/ ontrent fondert Indianen/ Die

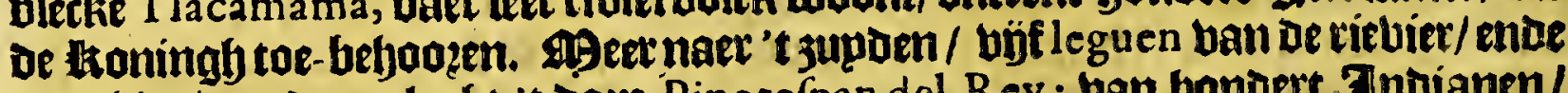
beetthien van oe jee leght:t Doep Pinotefpan del Rey; ban bonoert Jnoianen/

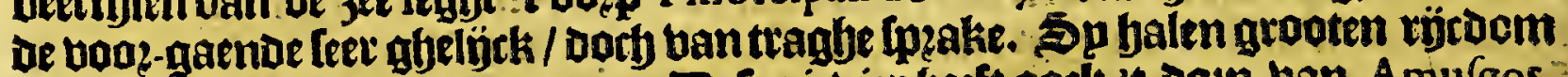
upt een lack daer joubt in groęt. Befe riebiet beeft oock 't boy ban Amufgos, aththien leguen ban. Tecuanapa; beet lanot / op oc boogbe wegb komentoe ban Nicieca, heeft onttent biet yon Deet Indianen.

Bntrent dele riebiete jun oock thee fof-teden/ o'een toe-beboozente Pedro Bravo; ende d' ander den zutbeur ban dit relaes; ontrent atjt of negben leguen

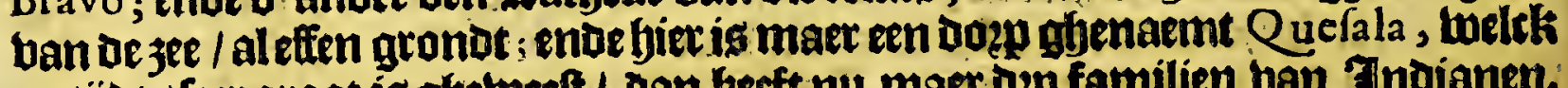

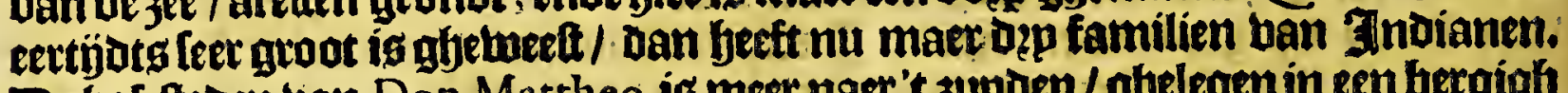
De hof-tteon ban Don Mattheo is meer naer't Junden/gbelegen in een bergigf

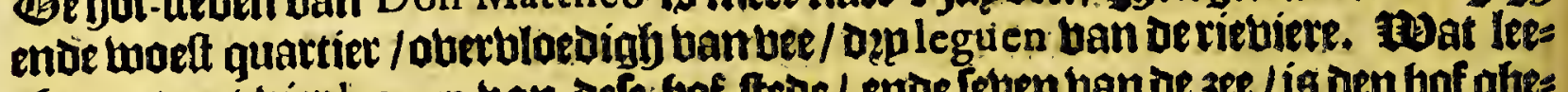
gber ontrent bier leguen ban dele bof-atede / ende leuen ban de zee / is den bof glje: leghen ban Alonfo Pedraza daer beel Cacao groept. Cluee leguen ban delen

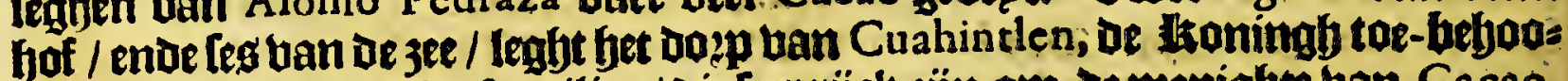
rende / ban negfenthien familien/ die teer rüct jün om de menighte ban Ca cao, die daec balt; dele plaetle beft oe zee aen d'een jyoe maet een balf míl af. all defe kulte ban Cuahintlan tot Tecuanapa, ende de turfte die naer Huatulco loopt / is

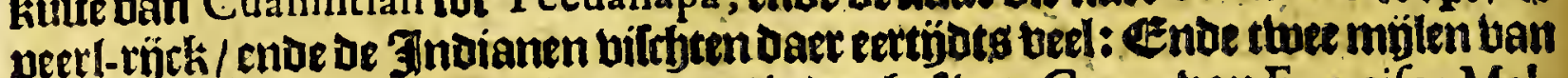
Cuahintlan ende biet ban Tecuanapa; íg den bof ban Cacao ban Francifco Maldonado ghenaemt Cacahu-A toyaque. Bit is het gbene gedenckeng tweeroigh is op de riebier van Tlacamama, welck in Ometepec loopt bj̈f leguen boben Tecuanapa. Be riebiere ban Tlacolula beeft baren opelpeonct bp Chilfiztlavaca, vaet veel geberghte ontrent ig/ enve is antrent thee leguen nabigabel eer fo komt in Ometepec, bijf leguen boben Tecuanapa ofte ban be zet. Bicht aen leabt bet Do2p Tla colula, ende dep leguen daet af Azoyoque; behoozende tot Depeobintie ban Tlapa, welck wel dep bondert Indianen beeft/ Daet Chilfiztlahuaca maet

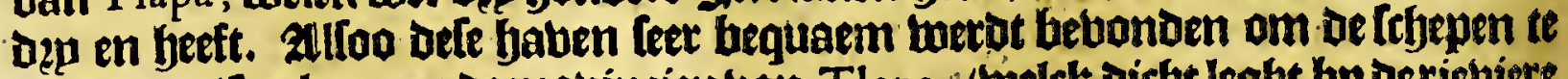
timmeten/too konnen De pzobincien ban Tlapa, (welck dicht legbt bp oe riebiere ban Tlacolula, ) enoe ban Tututepec (tuelck raeckt aen de riebiere Tlacamama)

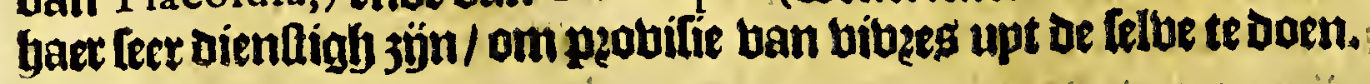




\section{$\begin{array}{llllllllll}M & E & C & H & O & A & C & A & N\end{array}$}

Het negfen-thiente Capittel.

Befchrijuinghe van de Províncie M E C H O A C A N in'eghemeyn.

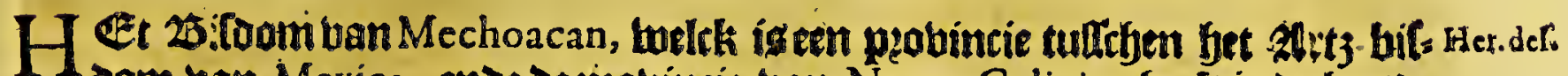
Dom ban Mexico, ende de pzobincie ban Neuva Galicia ; beeft in de bzetds

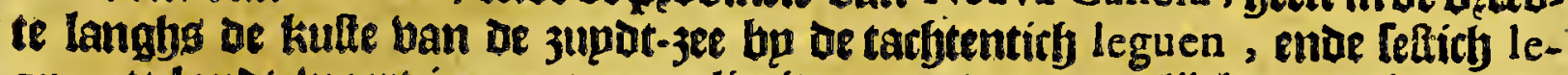
guen te lands-twaert in ; met open limiten naet de nodgaelïcke quartieten/alwaet bet bem berte upt-freckt onder de balckeren aie men noemt of Chichimecus; ente Mechoacan is in oe mexicaenictre tale foo veel te fegghen als een d.3. 1.30

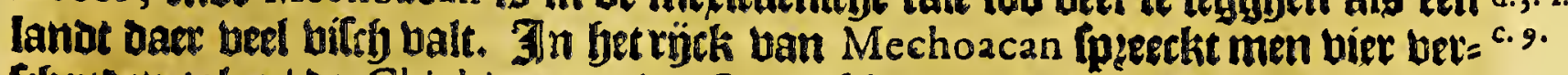
frbepoen talen / of Chichimeca, of Otomifche (booz dien die generatie van of Jnoianen Daet in gropt ghetal is/) De Mexicaenfche, die ghemepn is in

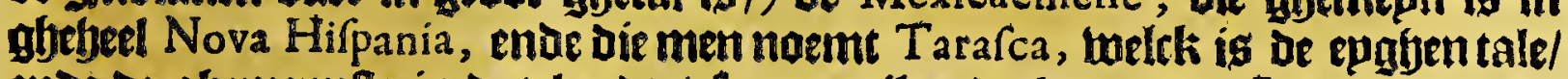
enoe oe ghemepntte in dat lanot / feet gentil ende kopt; of Spaegniaerden

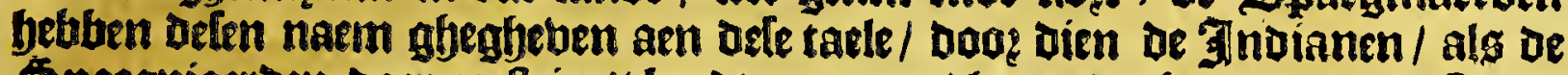
Spaegniaeroen daer eet in 't lanot quamen / baete borfters aen of Spae. ghiaeroen gatten / ente Tarafcue is foo beel bp baet te legghen alg trbooncone / enoe daec ban beeft bet balck oe naem bejoution van Tarafcos, enve de

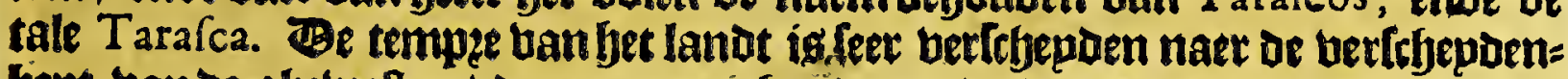
bept ban be gbebelten / De eene meer koubt / ende de andere meerber gbetem= pert / ente cenighe oock leer beet; dach alle leet ghelondt ende ban een goede lucijt / foo Dat daer groote toe-loop is ban alle quattieren / om daer van bituers Iche lieckten gheneten te wogoen: Baer is groote abundantie ban lacken ofte poelen/ ende riebieren/ende fontepnen ban loet twater / klaet ende gfjetonot /

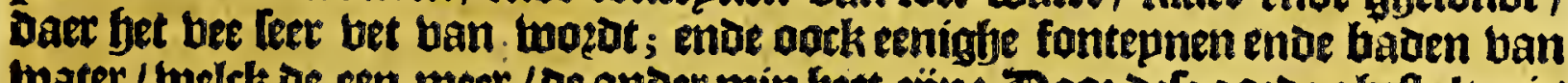
loater / tuelck de een meer / oe ander min beet 3 jon: Doos befe goede gheftaltenig Des lucfits/is bit landt upter-maten benchtbaer/met leer groote blacke beloen

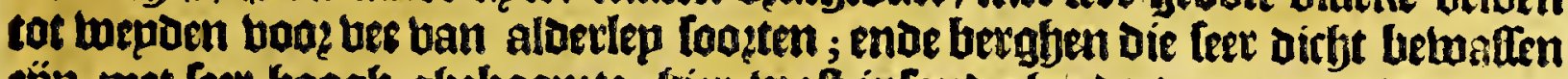

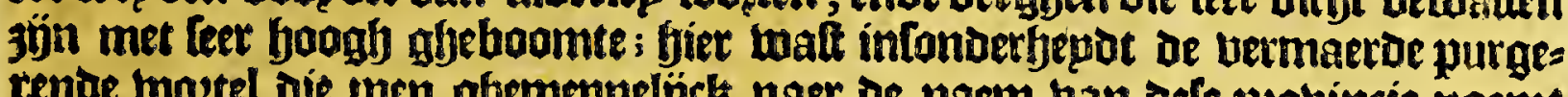
rente woetel die men gfemepnelíck naer de naem ban dele plobincie noemt

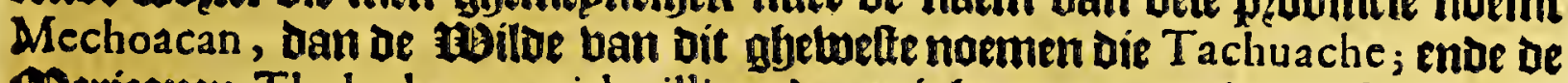
igexicanen Tlatlanla quacuitlapilli, enoe eenighe andere natien Pufqua. Ban befe plante binotmen bier ende eloets bep loaten; oe eene beeft een birken ende langhen twoetel / klimmende tacrkens / blaeders bie klepn [pn ban oe gbes daente ban cen fardt / langbe ende raode blocmkens / een beuchte ban groote

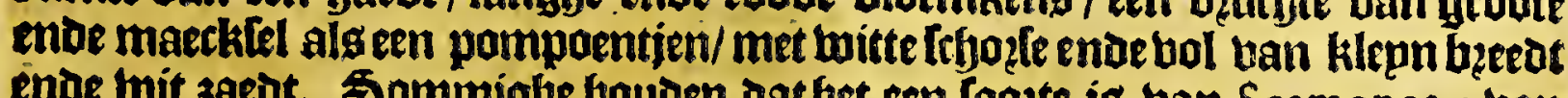
ende wit 3aedt. Sommiglye bouden datbet een lopte ig tan Scamonea : van

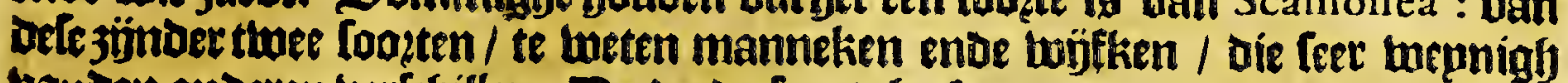
banden anderen bericfillen. Be derbe loote beeft een aumner wastel enoe waft inftenachtighe plaetlen/ Dele purgeett beel larbter. Ban de eerlte foozte twoztter bock eene ghetronoen die booz fenín twogatghebouben/ foo datter naum acht moet werben op-ghenomen. Baet is noefj een andere foate die fp noemen

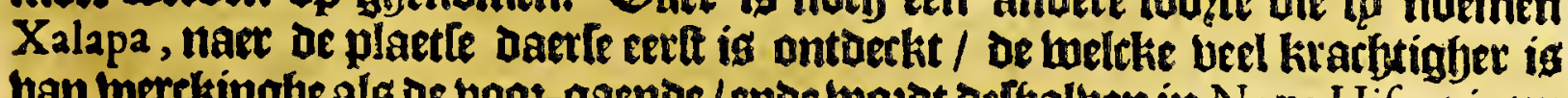

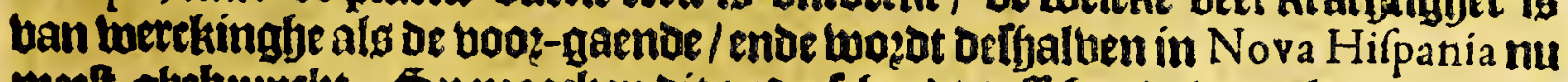
meelt gbebeupcht. Sp maecken dit andertebepor tuffeben de wotelen; of aroof: te wottel noementp Matlalitztic ; de naelte Mechoacan; de flepnoer is be tres nünigfe/ ende de alder-klepnlte doch langhtte oe Xalapa. Be twaztel is loatm

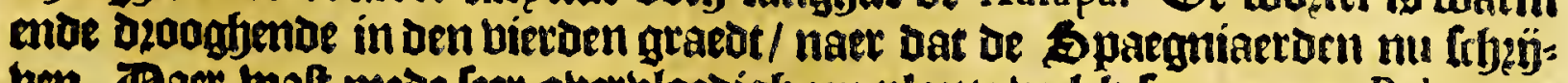
ben. Baer twalt mede lree oberblaedigh een plante belelt fp noemen Pehuame be Ariftolochia niet ongheligck/met lilepne bladeren/hebbende be gledoaente ban 
ecu batot / purpure blocmkeng / een langlen ende groben twotel met cen rooden

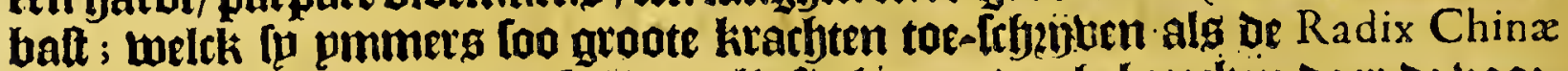
ofte Sarzaparilla, in 't gbenelentuan alle lieckten enoe ghebeeckitn daat oe too:[epae toe ghebeupckt wozoen/ende infondertyept teghen oe lieckte ban de porken. 1)et lanot is oberbloedigh ban aloerlep noobtopuft / enoe inlonoerbepot bau tarme/gerfte/enoe andere graenen ende zaden ban Spaegnien; in fulcker boe=

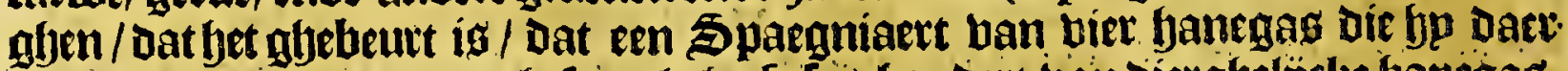
ahe zaepot hadoe/ weoer ghelamelt feeft tes bondert ban diergbelinclie banegas. Daeren glyebeeclit niet een frupt-boom ban Spaennien / gheen foote ban hof-krupoen/enoe oe dzuphen jün daer leet excellent: De Spaeqniaetoen beth: ben Daer bock moer-belpe-hoomen ghebzacht ende gheplant / waer Doo baer feet goede fpoe balt; ende abundantie ban Annil om mede te betwen! men heft daer een butfte alg tarroben/Dienende boo Imacke / ende bet krupot tot glag. Paer bet quartier van de Chichimecas toe/ (Daer wo bier naer ban fuls Ien (perecken) walt Cochinilla.

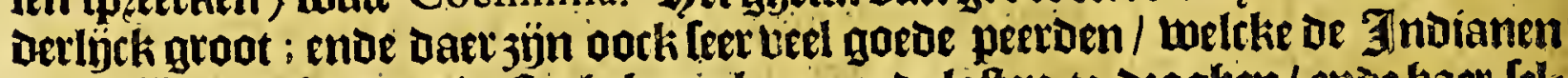
nu ter tijot tot Garen Dienth ghebzupelien om oe laten te Dzaghen/enoe baer [els wen niet meer op den rugabe te laten belalten als beelten: Daet 3 jun beel gep= ten enoe berkens han s paegnien / Daer Der oock beel bp troupen tan in't thitoe looperi boo de bofityen; ontallipeke boenoeren ban Spaengien/enoe ringh-

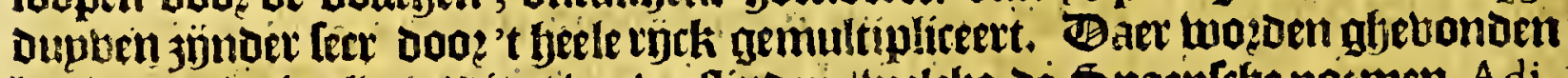

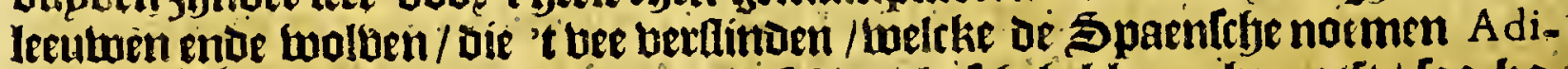

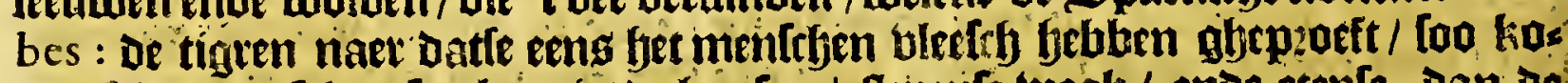

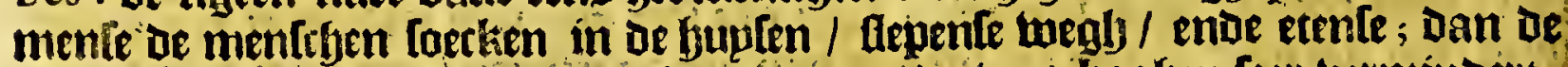
Spargniaeroen febben die nuet haer roers enoe boet-bogben [eet betminoent;

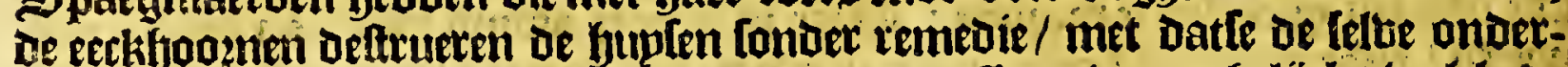

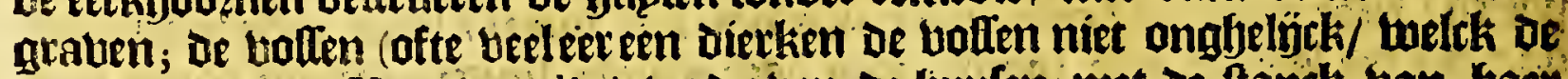
zibiloe noemen Yzquiepatli,) beroethen de buplen met be ftanck ban haex water ofte pilfe / welck wel teettich daghen blgft Dueren/ende de kleeperen daer bet op komt jön foo berootuen / oatfe netafjens toe meer dienftigh en jún / mant

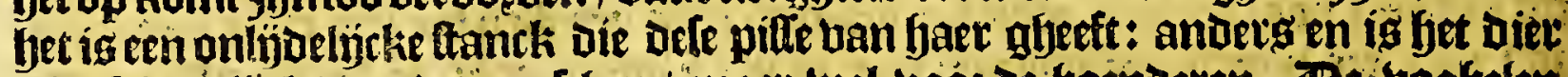
niet Ichadelíck booz de menletyen / maer tuel booz of boenueren. Be vonfelen.

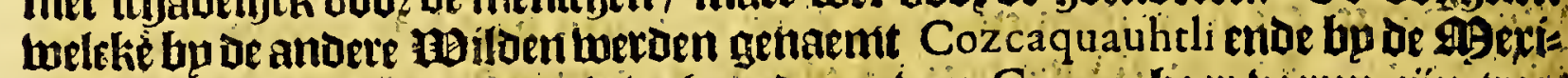
tanen Aura, jijn loo aroat alg de goenderen bain Creta, faer beeren Jón trecs

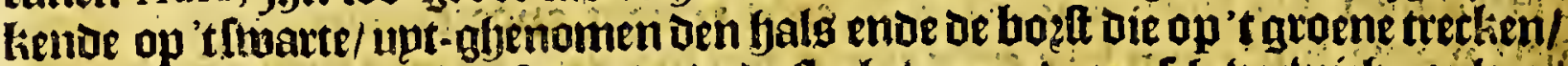

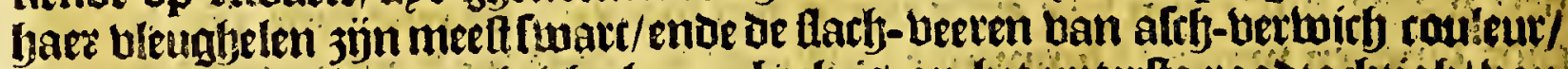
en van binnen purpurachtich: baren bets is op het upterlte roobtarbtigb/ bau

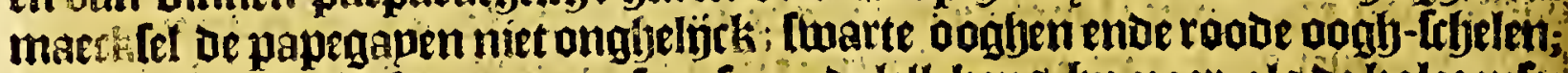
boben ten beck 3 inte rood met fronten ende lellekens bo naer als be kalcoente-

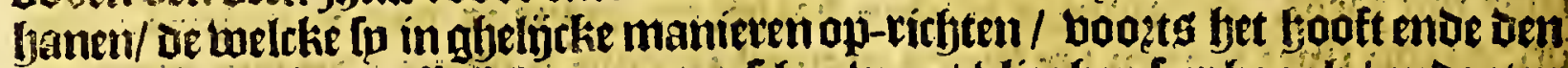

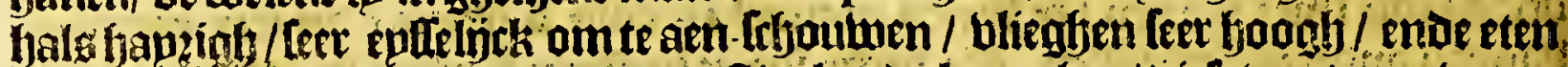
niet Dan tlanghen/ratten/Dzeck ende ftincken de krenghen/ Diele ban berte lueten

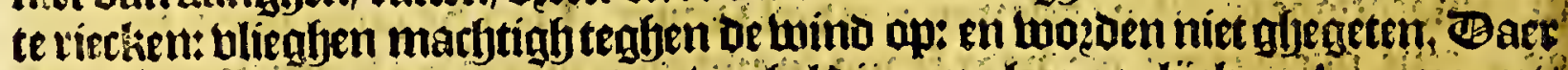

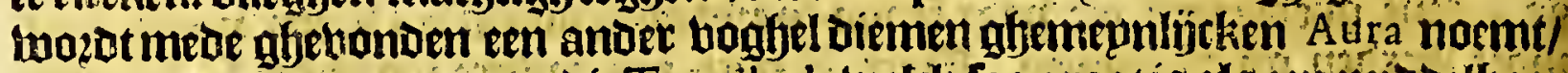

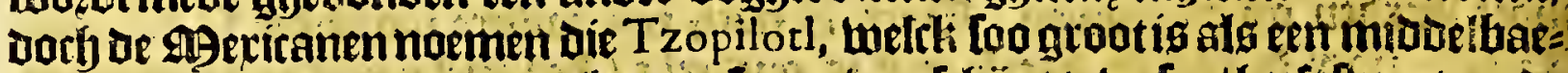

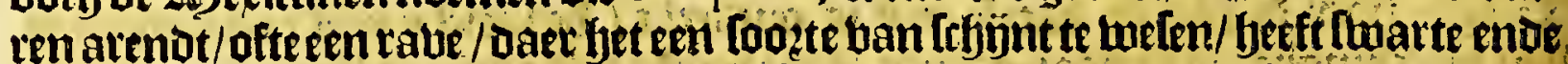
Gromme klautwew/ beupne beenen / Den beck alseen papegape/ oftern beeren opt

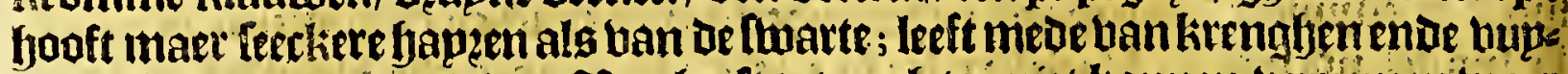

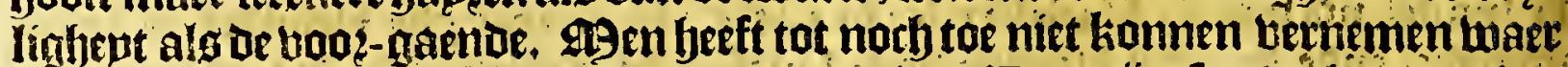
Ip haer eperen leaghen ofte jonghen boot-teelen. Baer jün leet beel andere bo= ghelen / Die daer naet al hegb thecken naer feet noozen toe / ende fomen op baet

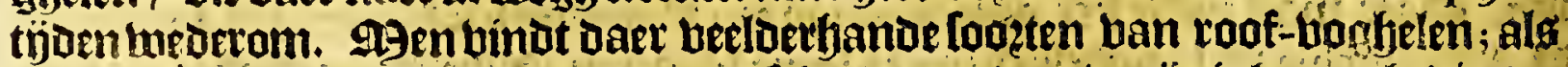

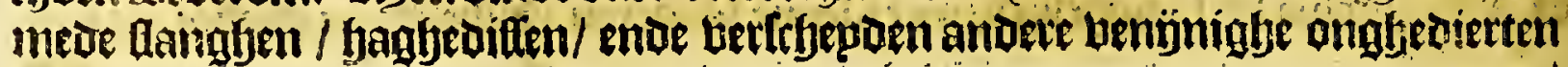

meer/ 
meer / woth niet too bet als in ander quartieten. De betckents ban bet landt

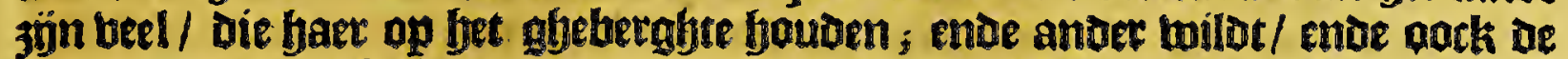
dieten Daer men feabt Dat ben Bezar ban komt. Berle feentn wogoen in bere lantoen ban Nova Hifpania ghebonden in berfebepden dieren/als namentigeth in een dier be betgh-gepten niet onglelintk turlek fo noemen Theotlalmazame, die

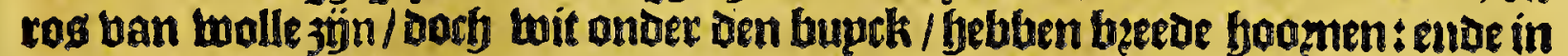
een ander bier belck fp noemen Mazaltchihileic ofte Themamazame, welck

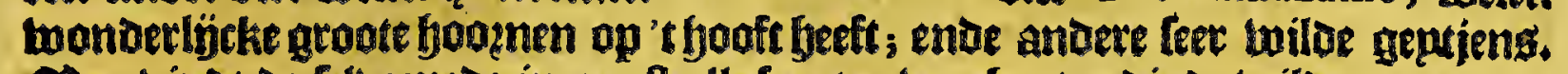

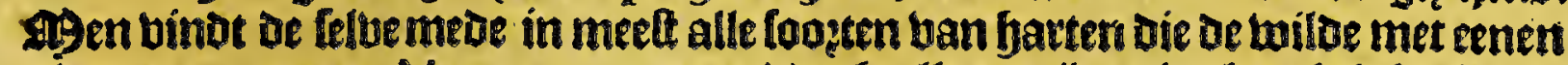
abemepnen naem Mamazas noemen/ ooch alle en jün niet krarbtigh ofte en bebben die facultepten niet die men in fret ghemepn defe fteenen tos-[rbejft / dan alleen dîe belcke ghenomen twozoen upt oteren oie op ernighe meoirinale ende kractrigbe ktupten loepben; foo dat bet ondertefepot groot is enoe foaet om tupt te binden.

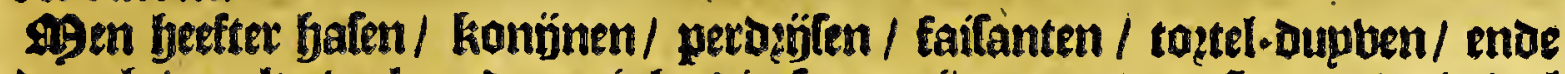
ander ghebogelte beel; ente enigbe die fraep jijn oin ou te fupten/ Die beel twel ende leet fraep fingten.

- Cholck ban of lanoe gaet nu al glyekleed in cattoen ende molle-laeckenen ban Spaegnien / enoe btel op fpn Spaentey / Dzagfen al boedens enoe in beel beelen fpreetien de bzouwen moe mang ie $\$$ paentche taele. bele kontten ente ambarbten gbelectot / enoe upt ootaeclie van bet finn bta:

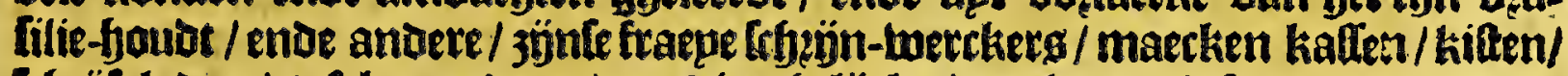

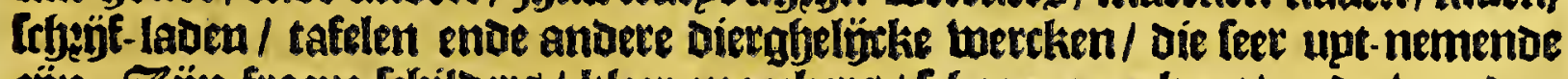

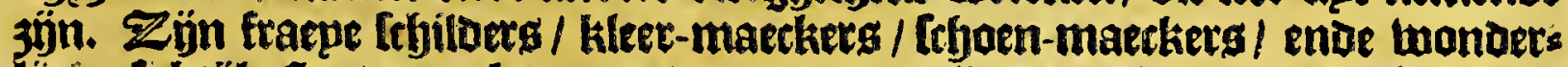
lijche lubtÿle doot-maeckers; ende ban een minne ban koper belck fp weten te beneficeten/maectenle beel bingfen; als oe befte ketels ban de teerelor/

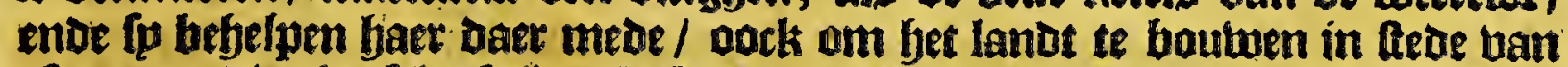

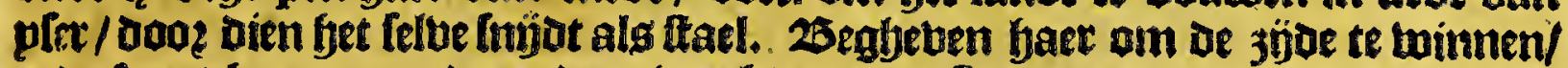
ende frupt-boomen ende ambere beutjten ban 5 paegnien te cultiberen. 10 oes oen frbapen / koepen / ente betfebepoen ander vee / pork peeroen: maecken

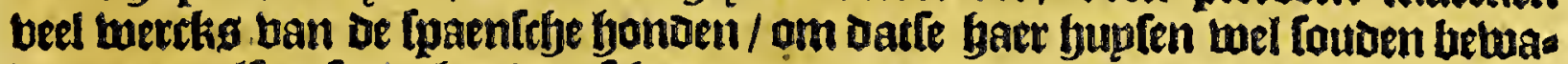
bert / oan alfoo fo de bonden frfaets te eeten gaben/jünoer beel naer bet ghes

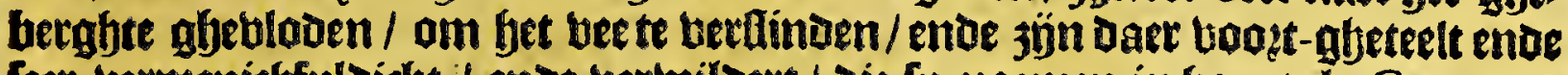
feer betmenithfuldicht / ende bermildert / Die fo noemen in haer tale Cimarro-

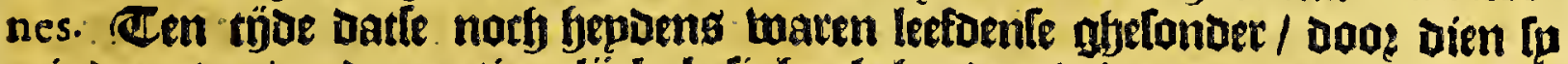
minoer aten / ende continueljek beligh gheljouben wienden ban baer Caziques: Cat notb toe en betf men baer gantefy niet kannen at-raden bet baden in 't kouot-water / welek faer pjine raufeert in be 3 ijoe / ende beel tijots oe

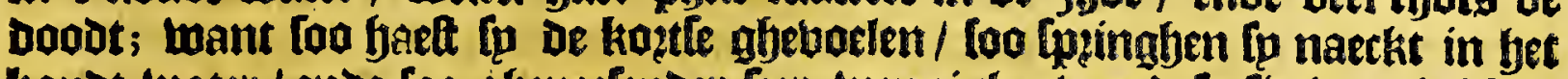
koud-buater / enoe loo gheneelenuer feet mennighe ban dofe liectite: bebben wonder beel kxupden ende twotelen daer fp haer felfs met cureten/ Die ban fon

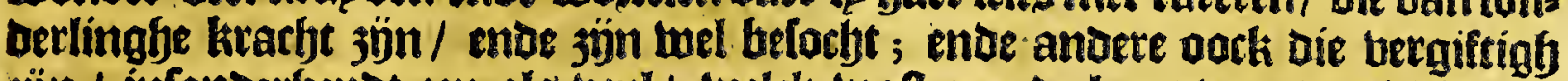
jön / infonocrbepot een als bepl/ twelck wat aen de kant van be riebieten/ onoe foo pemanot Daer quam fun water op te maecken/ Doet De fryantelfepos
op.twellen.

Dit thijck ban Mechoacan, is nu tot een $2 B$ itoom gbemaed / / ente baek 3ün tuel bondert ende Dertich blecken / loaet ban be bier-en-tmeghentirb baere

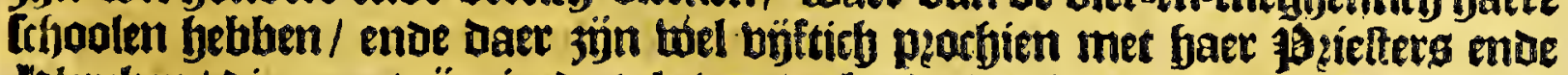

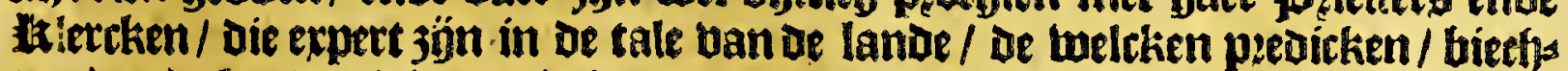
ten/ enve bet balch leeren in bace taelen/ upt-abenomen in oe D tomilche tale/

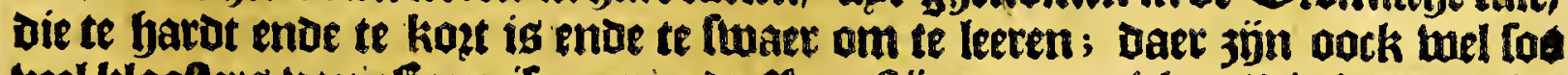

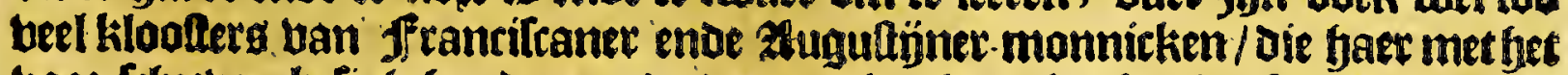
booz-frbetoen beligh bouben; ende daec en is gheen booft-placte / ofte daet ig 


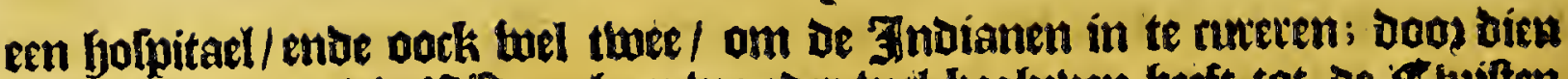

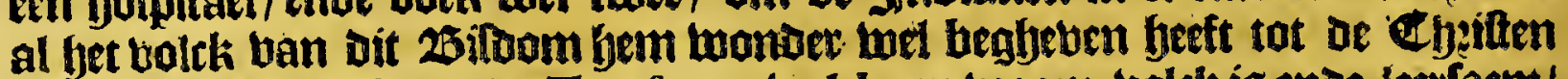
Kieligie; infonderfepat of Tarafcos, welck een begom bolck is enoe teerfaem/

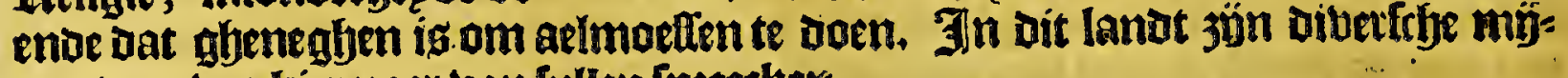
nen Daer wp bier naer ban lullen ipeectier.

(om dit Capittel te bellupten fullen wptjier bp baegfen yet ghene A cofta bets

1.4. e.37. batl: De befte plupm-heeloekeng (Teght bp) botoen ahemaeckt in te pzobin= cie uan Mechoacan, in de blecke ban Pafcaro : De mamiete daer ban ig / met eeri nj̈p-tanghghen De plupmkens te vatten / Die alloo upt de Doode hogelkens trees hende/ ende als dan met een aelicaet ligmisen (twelck fp daet toe-jebben) in oen anderen te boeghen met groote radoicbepot ende perfertie / nemen defe too hlepne enae perfecte beetkens ban de bogeltiens diefe in Peru noemen Tomeneios, ende anoere biergbelijcke/ te melcke eenupt-nemende kouleur in haer bee ren bebuen. it bogeltien bebt ofje Gier boagen in't twaeffoe Capittel.

醇t twintichlte Capittel.

Van de particuliere provincien begrepen onder dit Bifdom van $M E$ CHOACAN, endevan de CHICHIMECAS.

T'25itoam welck nu Den naem boert ban Mechoacan, begript onder fít]

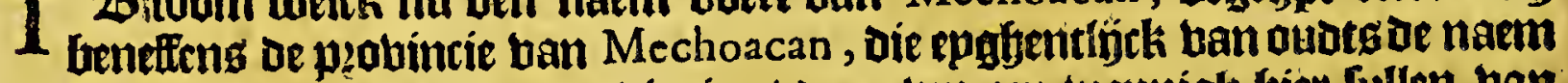
beeft ghetuett/ noch ander pzobincien / Daet wp een wepnigh bier fullen ban aen-raeren.

d.s.1.3. Be probintie ban Mechoacan begint ban een plaetfe gljenaemt Taximaroa,

c.3. (alyelegljen van Mexico uettigfy leguen naet het welten ghelïck top in't theete Capittel bebben aen-glyetoert) Daer ae Spaegmiaetıen naer het beroberen van

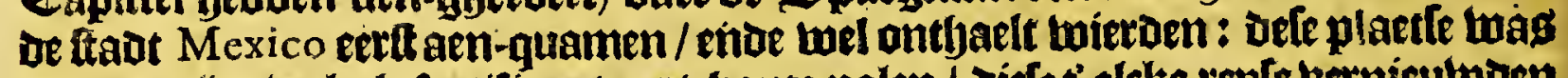

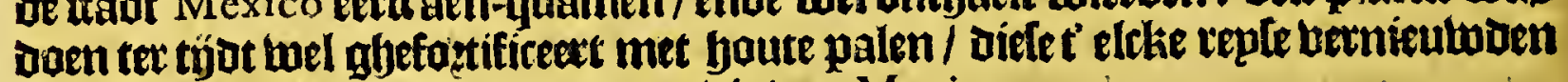
boos of ooslogibe diefe voetoen met die ban Mexico.

- Bit 25 foom begrípt voozoer in licly de peobincien ban Zacatula enoe Colima, welcke bepde legghen op oe kutte van de zupdt-3ee. Als mede de ptobin= rie ban Chilchora, in be welcke wonnt (loo de Spaegniaeraen leggen) een balck bat gantfoh gheen bercken maeckt van balfelye eeden te lweeren.

mo bebben in fet booz-gaende Capittel ghelegft Dat icle pzabincie naet bet tmosion confineert met de Chichimecas, Dethalben lal bet ban noode 3 j̈n een d.8.1.6. tuepnigf van dit bolck ende de lanom diefe befitten/ aen te roeren. De begins

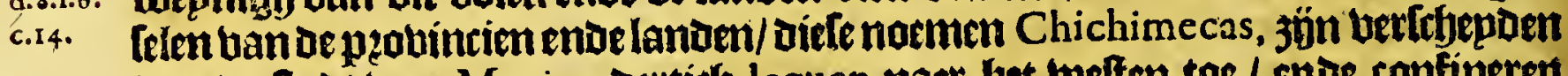
ban de ftad ban Mexico dertity leguen naer lyet welten tae / ende confinerent met Queutaro, Acanoaro, Yurirapundaro ende Sichu. Pe pequincien ban jefe Chichimecas ftreckem noozot ende jupoen: naer het jupben jün oe lane

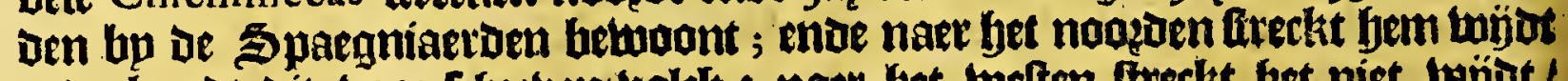

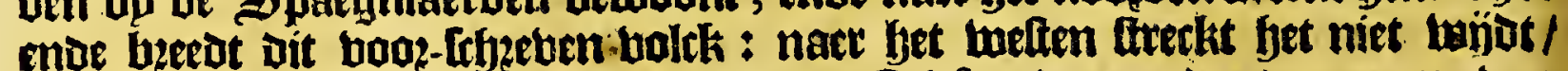
om ae gloote in-bijck ban ae jee bp ofe Californias; onder aen naem ban Chichimecas mozoen begrenen vele natien wie different 3 jon ban tale / als Daer zün ue Panues, Capuzes, Samues, Zancas, Maiolias, Guamares, Gua-

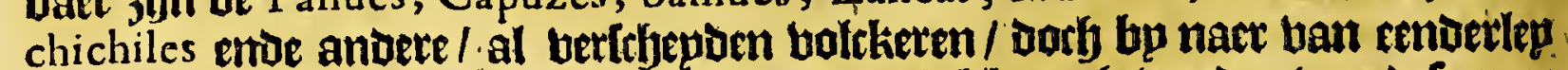

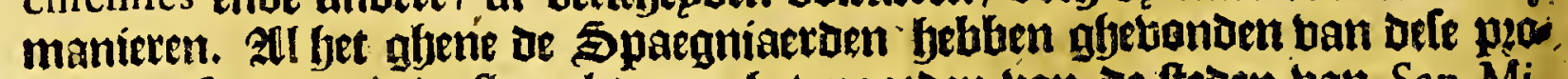
bincien/ loo naer 't weften als naet jet noozen ban de fteden ban San Miguel ende San Felipe af / jojn meer oan twee bonoert leguen, al leer beutfits bare gronot / enoe ban goede ghetemperthepot / meer loubt als beet / entu

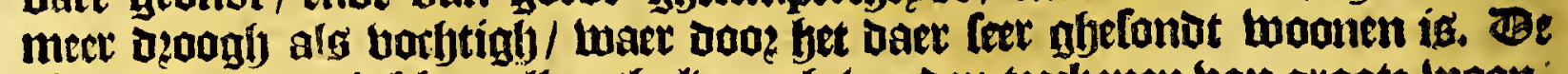
Spaegniaetoen bebben allen-thalben gfretonoen teeckenen ban groote lwoonplaetten/ 


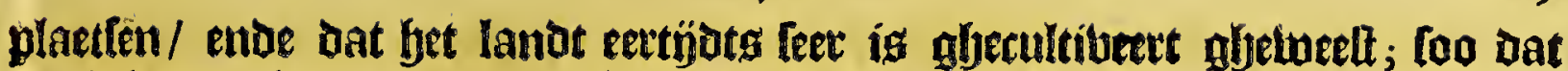
te gfeloouen is / Dat Daer eertyots bolck ghelwoont beeft/ Dat gheneghen load oul te arbepoen/ ende bet lanot te houluen/ente buplen te timmeren; welck alles dele Chichimecas ontbgeeclit/ want en beblen gbeen bupfen/ norh en werckeu niet/ ten mare feer twennigh in eninge quartieren: (eenigfje fon van

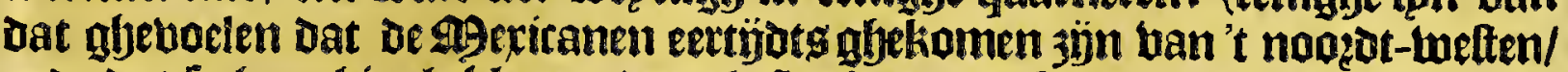

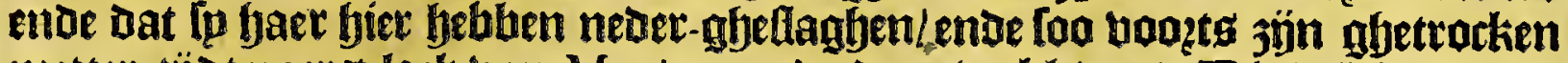
metter tyot naer $t$ lack ban Mexico, ende daer berbleben.) Bit volck en heeft

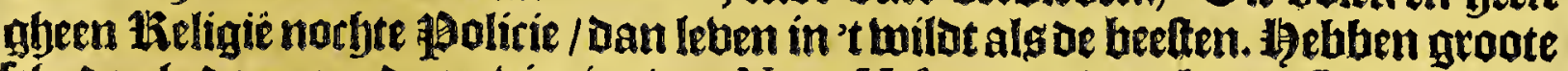
fchade glyedaen aen de probincien van Nova Hifpania, die nu bp de Spaegniaer=

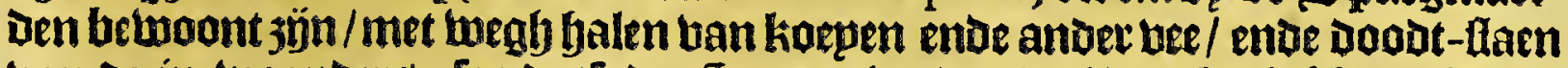

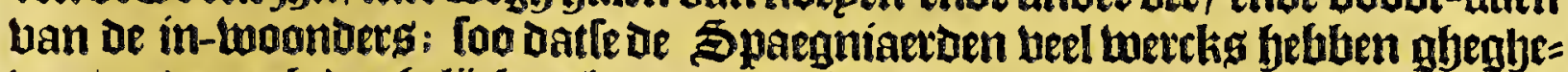

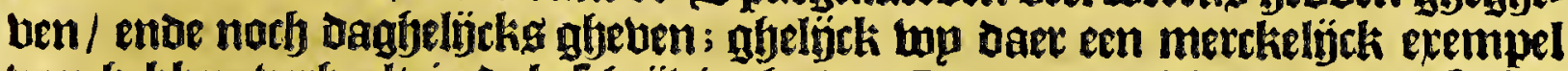

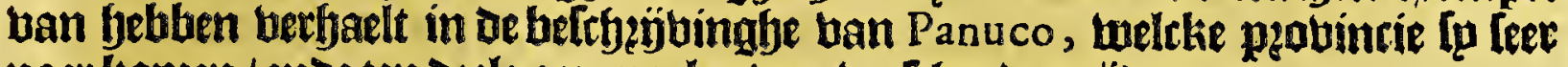
naer kamen / ende ten deele aen-paelen ban berlthepden jp̈ben.

\section{Het een-en-twintichlte Capittel.}

Befchrijvinghe van defteden by de Spaegniaerden bewoont in defe provincie van $\mathrm{ME} \mathrm{CHOACAN}$. De ftadt ban Mechoacan ofte Pafcuaro, is gfolleghent op de fooghte ban muten te belen/ want alle be kaerten ftellen aele ftait foo boonf / ofte boogber

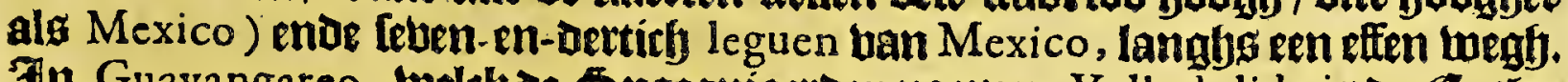
Jn Guayangareo, melck de Spaegniaerdennoemen Vallodolid, ig be Catjes

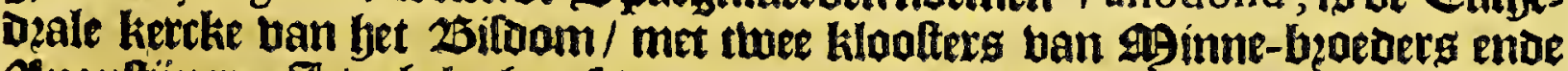

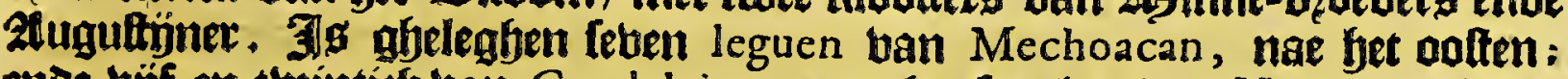
enoe bje-en-thinticf ban Guadalaiara, naer bet fegoben ban Herrera, die feet

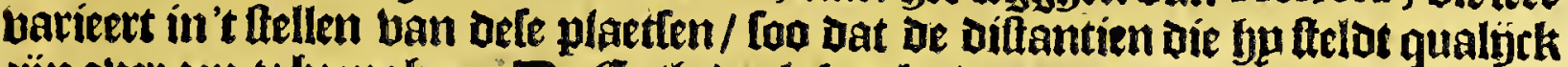

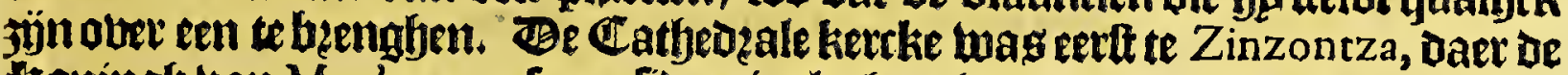

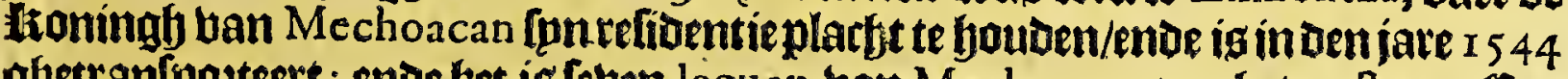
ghetranfupeteert; ende bet iff feben leguen ban Mechoacan nae bet ooften. EEen quart ban een mïle ban de ftaot feeft men een lack / welck eenighe legothen groo= ter te wefen als dat ban Mexico, oaer beel tanoas in baren/ente ourkenigbe

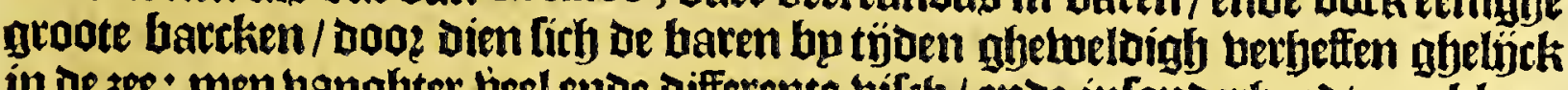
in de zee: men banghter beel ende difterente bifith / ende infonderbepde een klepn

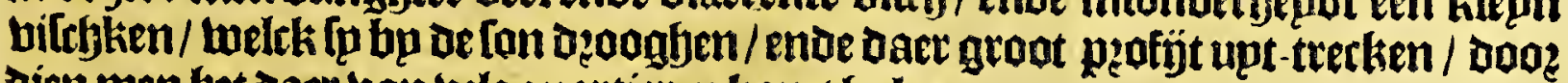
dien men bet daer ban bele quartieten kamt halen.

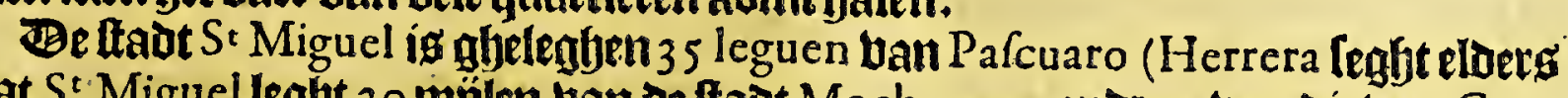
Dat $S^{t}$ Miguel leght 30 múlen ban de taadt Mechoacan, ende 23 van die ban Gua- d.8. 1.ro.

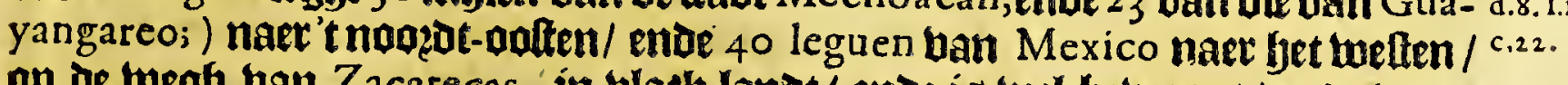
op oe wegh ban Zacatecas, in black lanot / ende is bel betwoont / enoe boo?fien ban beel boum-fjuplen booz beeften; bet ig daer goet replen tot bp feker kee=

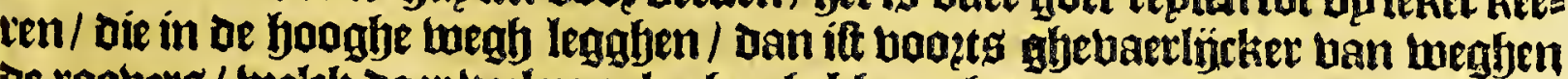
ae roobers / twelck daer beel meet-laghen fjeblen ghedaen / ende rooberijen / Dooe dien fet een Dterets. wegh is / daetle dooz quamen / konen ban baet lanot / ende 't afjebergbte af / welcke men noemt del Vizocho.

De ftadt $S^{t}$ Felipe is ghelegljen bujftith leguen ban de ftadt Mechoacan nae Jjet noozoen / enoe twee-en-treftich leguen van or ftadt Mexico, naer bet nooedtweften / in een onbeuchthaet ente kout lanot. 23epoe defe feden $3 \mathfrak{j n}$ experfte=

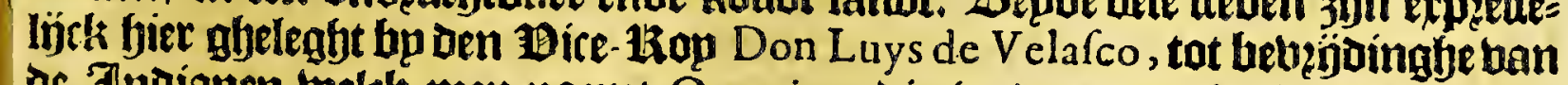
ac Jndianen weltk men noemt Otomies, die in dat quartiet moonen/ente tlandt ban Xilotepeque, enoe be Tarafcos; welck al feer ghequelt wierden van 
De Chichimecas, wierden berooft banbaet goederen / ende 't bolck twetf geboert ban deten milden boop. bandoe bee/ foa ift norbtang bequaemit boos ftieten ende koepen; mant dit lee/

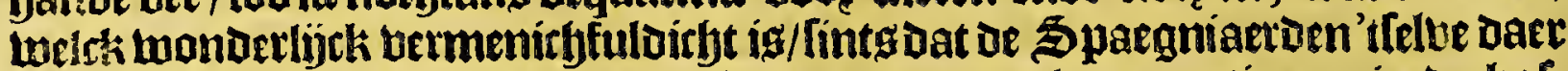

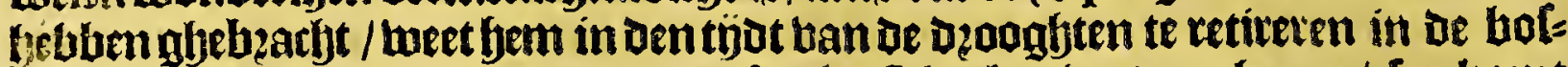

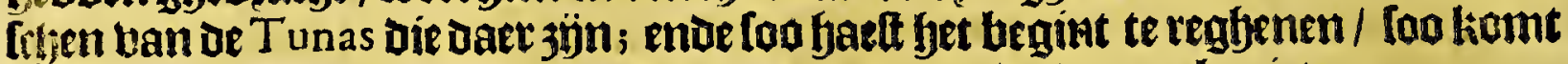
fet weoer naex bet black landt/ om de goede wepde weder te ghenieten.

Her.der. De frabt Concecion de Salaia, gheleghen acbt leguen uan San Miguel, ende unf-en-dertich leguen ban de fooft-ftadt Mexico, ende febenthien leguen

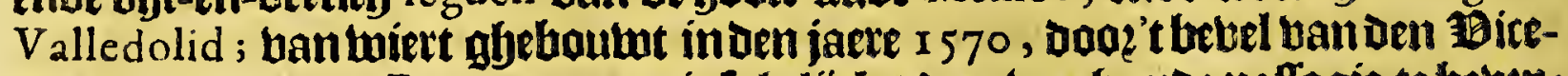

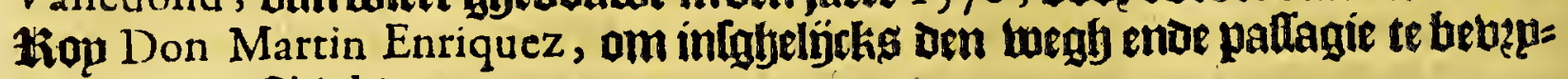
ven vooz de Chichimecas.

d.4.1.3. Deftadt Leon meer dan Ieftich leguen ban Mexico gfelegben/ende bier-en-

c.9. twintith ban Valledolid; in tuelckers límiten groote aoers ofte teeten jünghe:

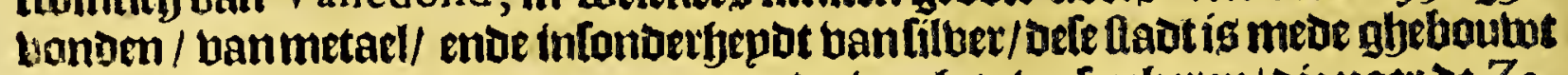
ten feltuen epnoe als oe booz-gaende/ om de twegh te berfeecketen/oie naer de $\mathrm{Za}$. carecas lepdt.

DE that Zamora Detthien leguen ban Puzcuaro gheleghen.

Villa de Lagos aertify leguen van Valledolid uettehepon.

d.3.1.3. De mỉnen ban Guanaxuato 3ïn gfteleghen arbt-en-twintirb leguen ban

c.9. Mechoacan (ofte Valledolid, alg Herrera eloers Leght) naer het nowosen/ ende oe Zacatecas toe/altwaer bel leg fonbert Spaegniaetben fullen welen in twee leghets/:uelck [p daec hebben) om de mỉnen te belwextien.

De minnen van Talpuiagua jön ghelegben ontrent bier-en-twintichleguen ban ve hooft-ltadt Mexico.

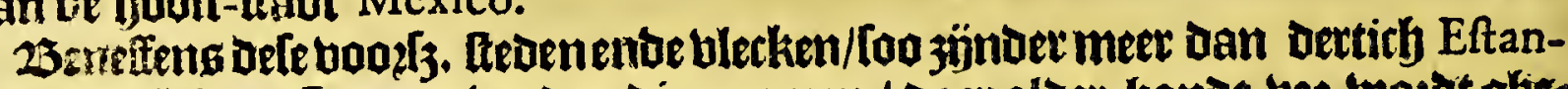

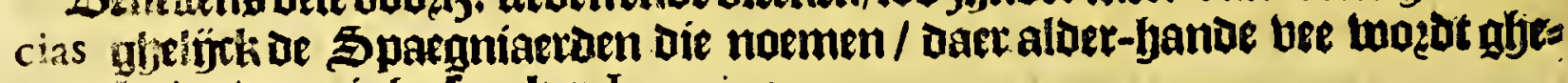
queetkt / enoe eerigige lupcker Ingenios.

\section{Het thee-en-thintichlte Capittel.}

Befchrij vinge vande havenen ende kufte van defe provincie van ME CH O A CAN; aen de zuydt-zee ghelegen: ende noch eenighe fteden ende vlecken.

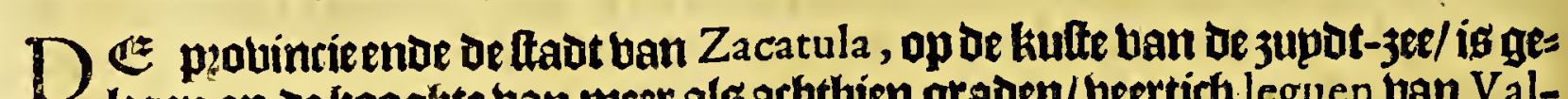
legen op oe yooghte ban meer als arththien graden/beetich leguen uan Valledolid de Mechoacan, naer fat jupذt-meftew/enoe neghentirb leguen, wepnicf

d.3.1.3. meer oft min ban Mexico; De thadt wat ghenoemt Concecion; is gheboukt aen

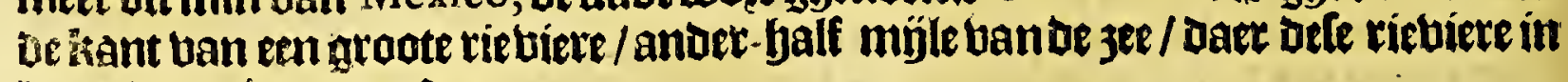
loopt ooo? there monden.

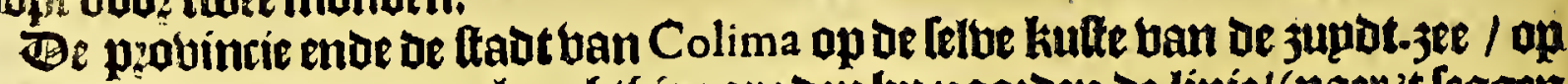
or hooghte han wat meer als arfthiengraden bp noozonen de linie/(naer 't leggen ban Herrera, dan naer't ftrecken ban de kufte en be aenlwölinge ban caerten light hoben de negentfien graden) op de limiten ban de peobincie han Neuva Galicia,

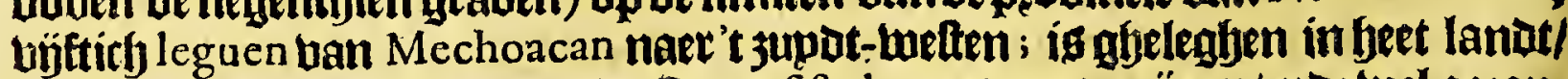
ende beurbtbaet ban Cacao entoe Cannafiftola, met gout-mínen/entek wel gecone. ditionert wolck. Beden in 't eertte groote refiftentie aen de Spatgniaerdem neffens die ban Ympilzingo, dan wietaen epnoeligrk tonort-ghebzadyt; entoe dels ffadt wiett daer ghebout in oen jare I 22 , light thien mỉlen binnen's lanots bp ooften een Volcan.

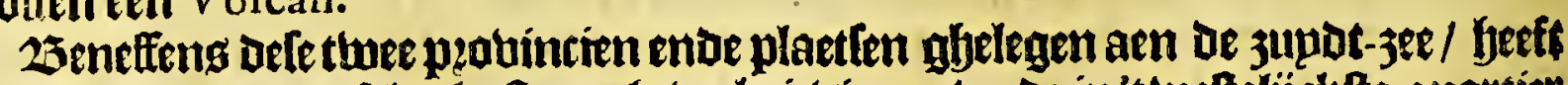

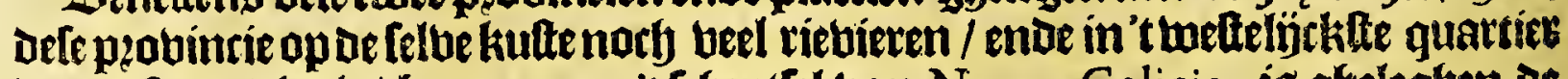

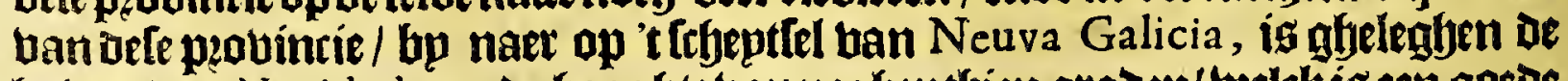
baten ban Navidad, op be booghte bannegbenthien graden/welckiseen goede baben 
Het vijfde Boeck.

Gaben/ende die beel ghebuptlit wozot/enoemen baett ban baet naet oe Filippi-

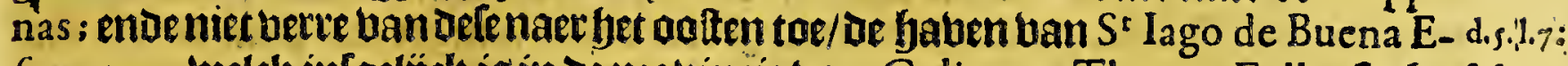
fperanca, welck infgelijck is in of pyouincie ban Coliman. Thomas Fuller [eght $/{ }^{c .30}$ Dat San Iago leght op arbthien graden ende bÿftich minuten / feben mülen ban

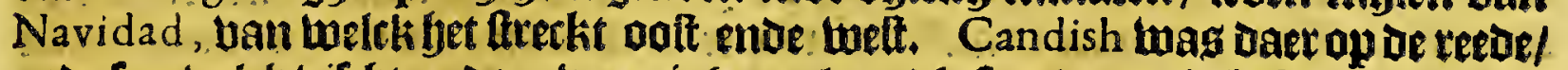

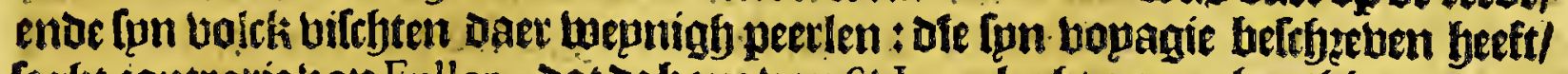
cegbt contratie ban Fuller; sat de hape ban $S^{2}$ Iago Iegft op negbenthien graden

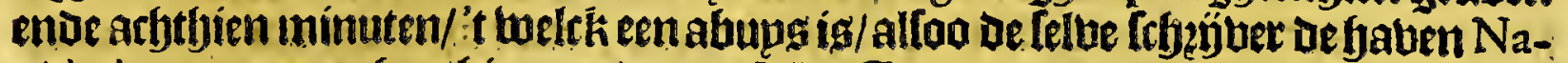
vidad maer op neggenthien graden en ftelt. In Dat quattier jyn feer goede mï: nen ban koper/ oaer De abiloe monderbaere baten van maecken/ Doog dien bet

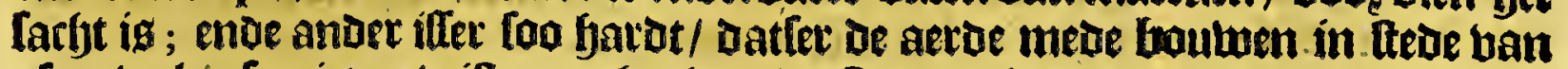
pler : tuelch fo nieten wiften eer bet baet de Spaegniaeroen tyoanden. Candish was in de bauen ban Natividad, berbzanoen oe bupten die daet ftonden/ende twee nieulwe Ititepen/ die vaft gfyetimunert wierden / elck ban twee bondert ton= nen. $p$ boer ban daer in de bape tan Malacea, een müle weelt-waetts ban Navidad, Daer een goedereede is ; twee mijlen binmen's lanotg leght een doyp ban

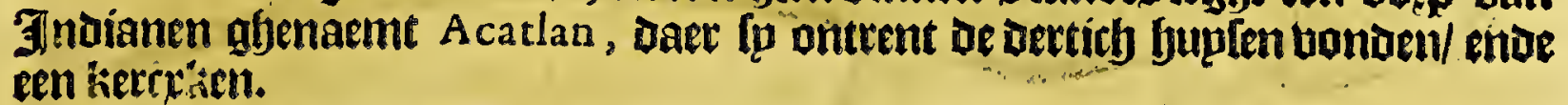

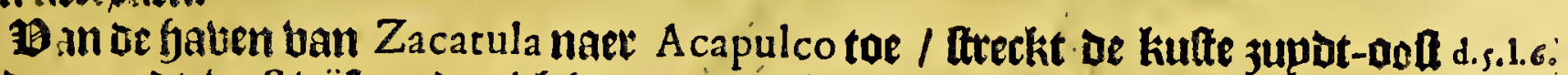
ende noozat welt bjif-en-bertich leguen, endedan boots oolt ente beatenbe is c.4. al bough landt / ende bimen 's lamot gheberghte dityt met boomen belet / ende daer $3 \mathfrak{i n n}$ ueel in-bammen ende bapen : ten epnoe van de bje-en-dertich leguen is een grof punt als ofteen Geplandt waer daet De jee leet op beerkt/ende ban daete

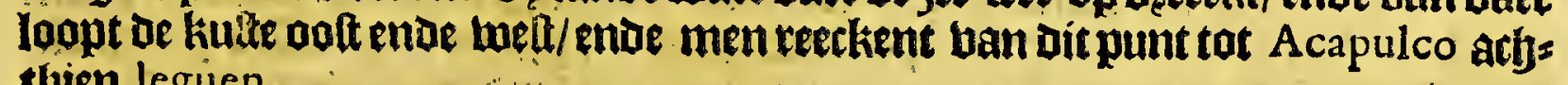
thien leguen.

- De aenteeckeninghe uan de kulte taan Nova Hifpania vozen aengheroert ftelt ban Rio Zacatula melt-twaerts eenmidoelbaet hoogh ftrand/gbenaemt los Mo-

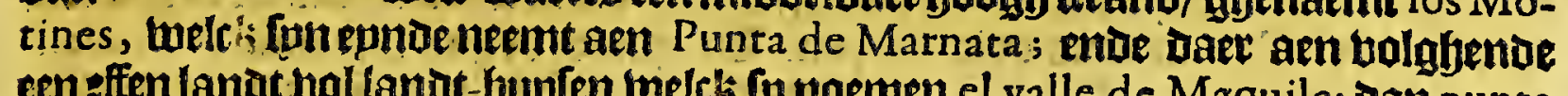
en effen lanat hol landt-buplen twelcti fp noemen el valle de Maquile; dan punta de Suchiff, ente thee leguen bootder Rio Alima; enoe baneen binnen-water welektp noemen las Pefquerias de Colima; ente baetaen $S^{t}$ Iago enve Salagua ende bier leguen boozoer Natividad.

Fuller in [pn. Memorial ftelt van Acapulco tot de haven ban $S^{t}$ Iago tatbten= tich leguen weft ten nookden/ende ban $S^{t}$ Iago tot Natividad feben leguen ooft
ende beft.

$$
Y \text { U C A } T \text { A } N \text {. }
$$

(3et dep-en-thimtichte Capittel.

$$
\text { Vande Provincie van Yu Ca t a N in' } t \text { ghemeyn. }
$$
De plabintie ende 't Goubernentent bam Yucatan, fo ghenoemt bp Capi ban de eerfte ontoeckets boo? een eplanot gbefjouden/ doos dien't bp na ban de jee om-ringht wozat/ in boeghen/ dat bet met recteen Peninfula madh genoemt

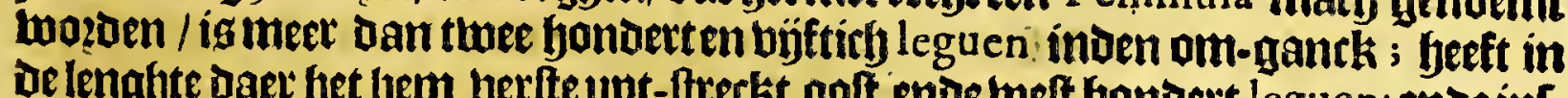
oe lenghte daer bet ljem berlte upt-Itreckt poft ende twelt bondert leguen; ende ints

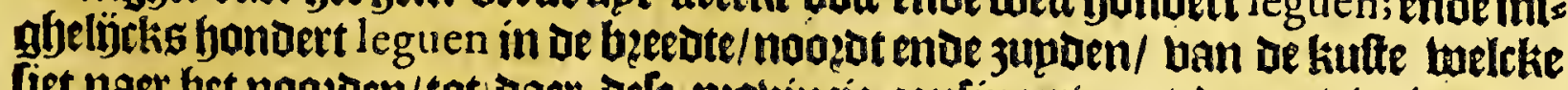

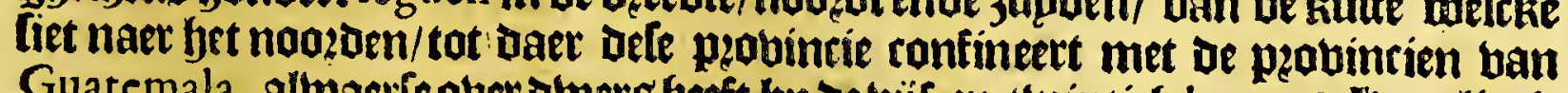

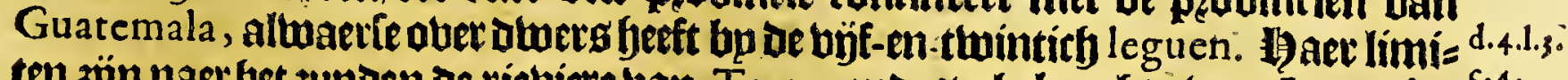

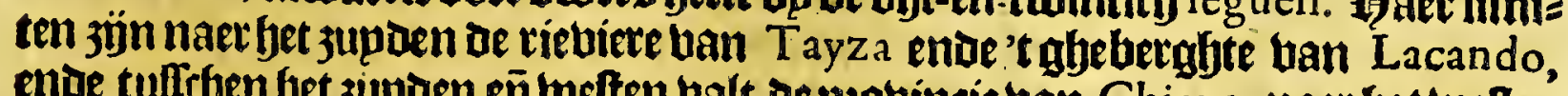

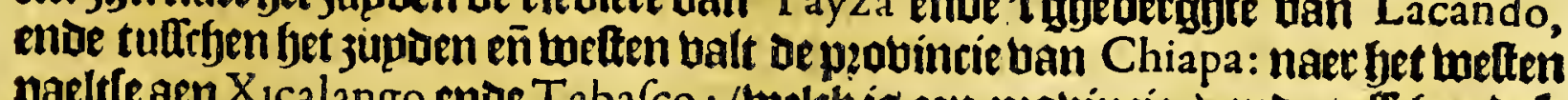
paelte aen Xicalango ende Tabafco ; (welck is een p?ovincie;) ende tuffetgen defe (4) 4. 


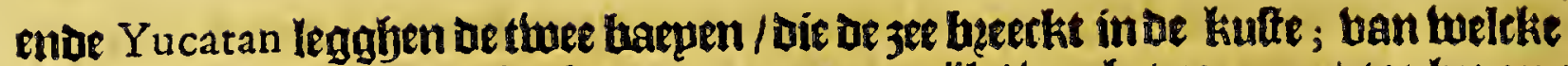
oe groatte beft een apenimghe ban een groate mijle/ ban bet en punt tot het ans

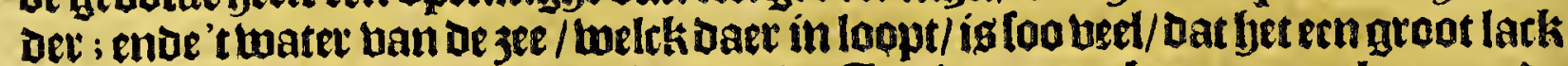
maeckt vol ban eplanoekeng / foo dat de Jnoianen teeckenen maecken acn de boomen/om de twegluniet te miflen/ ende te bertoulen / alg fo dast boos baren

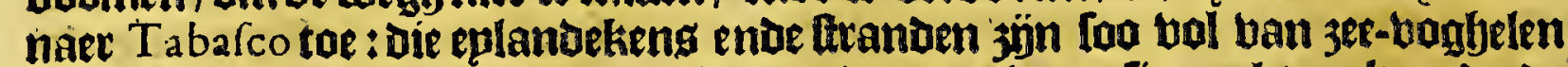
ban foo vifferenten gheftalte / Dat bet een wonder is om lien; als oock mede de jaght die baex is bankonïnen / wilot / berckeng / ende apen die daer jün; ende baerom komen oe 3 Indianen ban andere quattieken om daer te jaghen; Daex

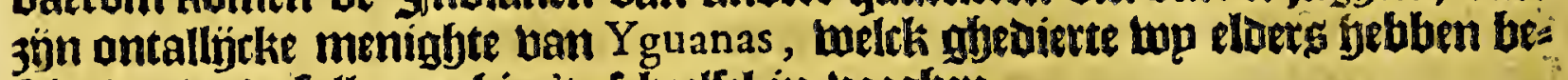
ftbeben/ende fullen nubier't af-beelel in-boeglen.

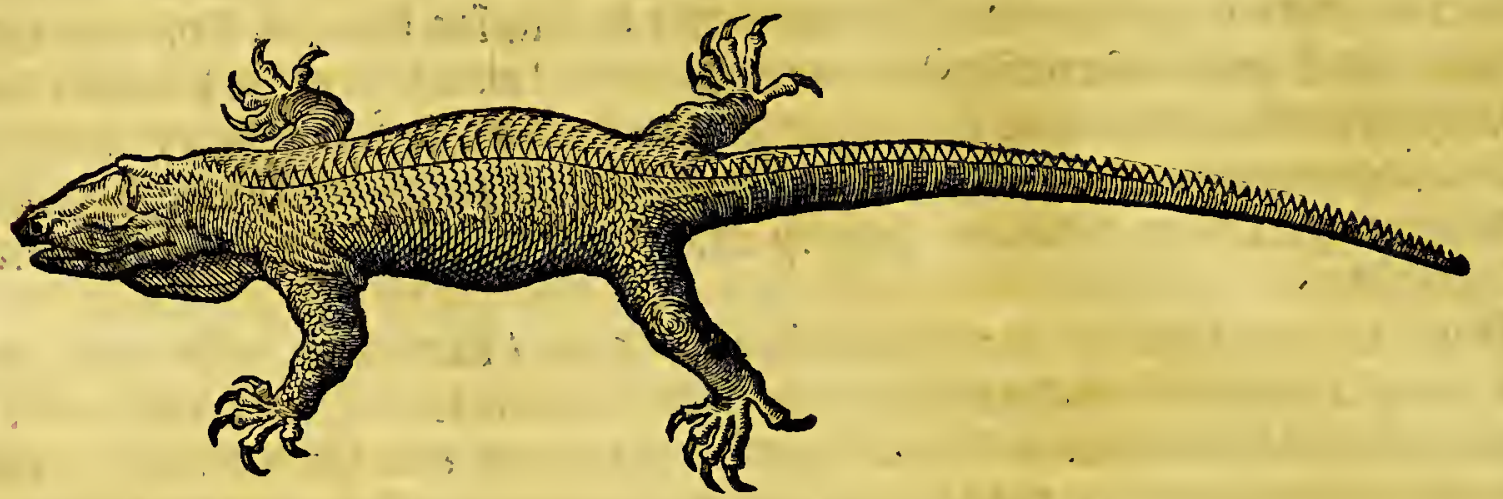

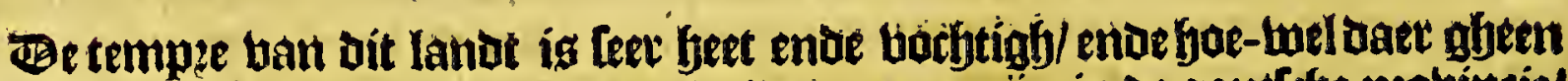

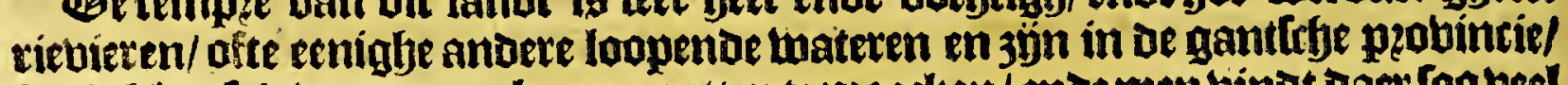
foo hebbenle't mater naet by om putten te maecken/ ende men binot daet lao beel

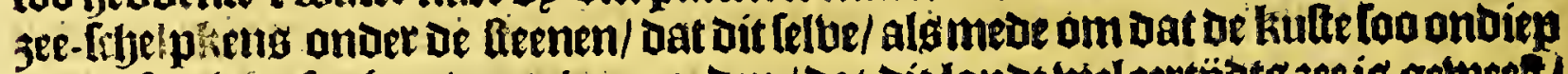

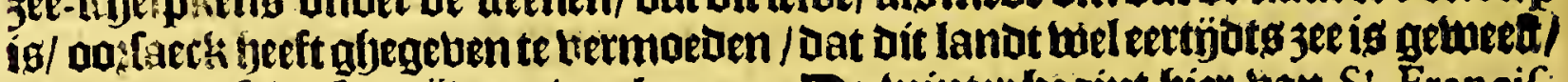
ofte tan de leilue lomtindts ober-loopen. Be winter begint bier ban $S^{2}$ Francif-

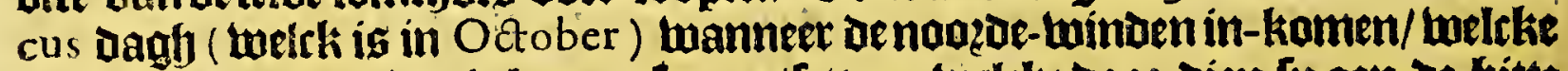

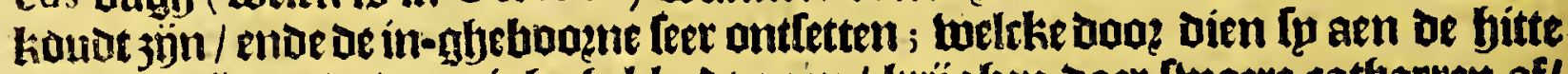

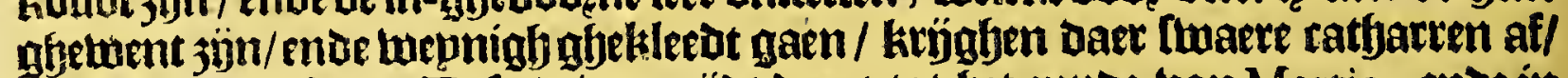

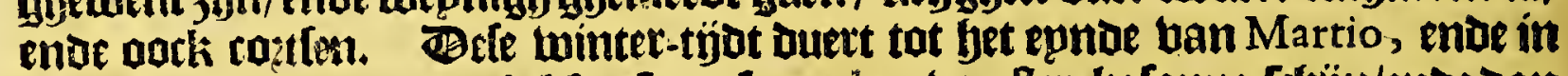

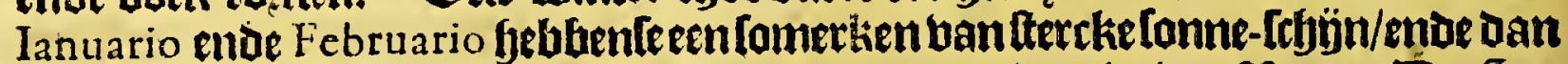

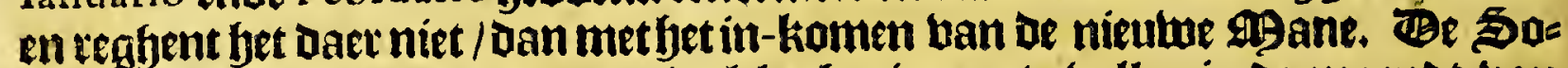
mer is den tijot ban reglyenen / welcke beginnen te ballen in de maentot han A pril, ende Dueren tat het epnoe van September. Bie tijot gheduerende / werot

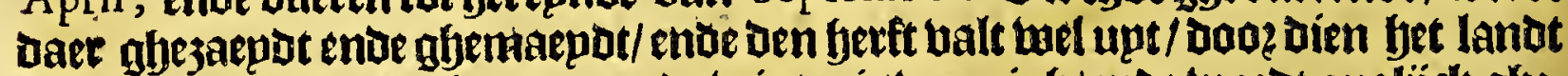

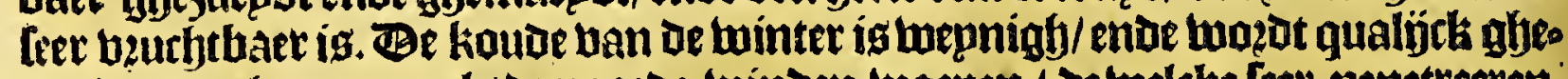
boelt/unt-ghenomest alg de noozo-binden baepen / be twelcke leet penetteeren. Her.der. 'C gantrye lanot is befloten ban berghen/ Daee en walt gheen tartwe ofte andet grain uan Caltilien : Daer en is gheen goubt ofte cenigh anter metael te bins Den; loo dat daet upt licht ig af te nemen bet erreur ban oe gfjene diefobben ghe fibeben/oat de Spaegniaetoen been fueerlt bier quamen/ daer vonden crupen van latoen; welck metad men nopt in eenighe peobincien ban Indien en beefs ghetuonuen.

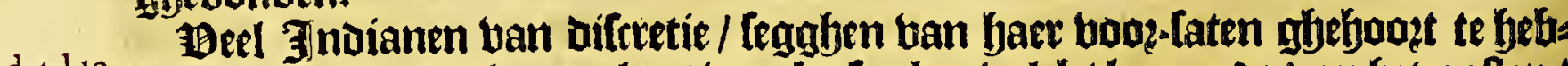

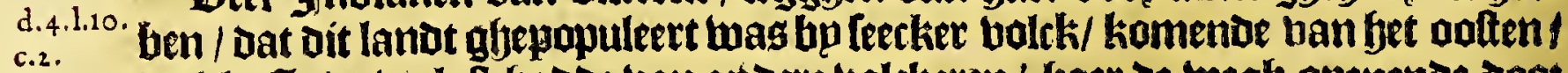
welck Goot berlaft gaode ban andere bolckeren/ haer oe wegh openende boo be jee. Het is een laeclie leet aen-merckens lueerding/ Dat be Spaegniaerden alleen in dele peobincie gebonden bebben een maniete ban Boop; naemben die

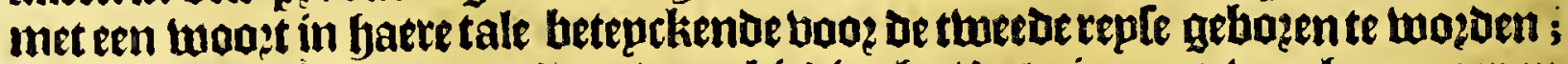
hajden die in fulcken lueer be ende eerbiedinghe / bat niemant ban faer naer en liet diente ontfangben; lieten baex booz-ttaen/batle daer doo? ontfinghen een bol.komen 


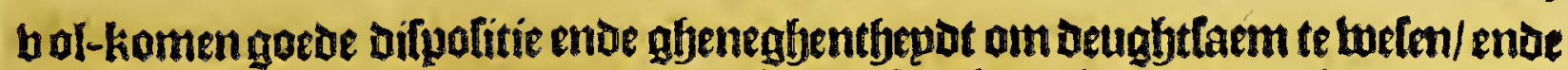
niet verdoemt te bogden ban de duphels ; ontfinghen dien ban ofe jaren oudet: Dams op. waets tor twaelf toe; enue fontor dien ontfanghen te beblen en traus De niemandt; kofen Daex een Dagh toe die niec ongheluckighen twaer / ente of ouderg die baften Dze Dagfen te boozen/ende ontfieloen baer ban de bzoutuen. De Spaegniaerden bethaelen boottg beel ban be manieren ende touftupmen

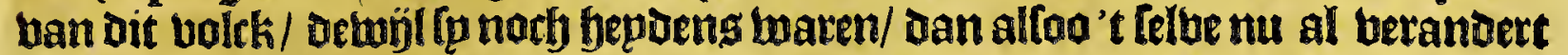

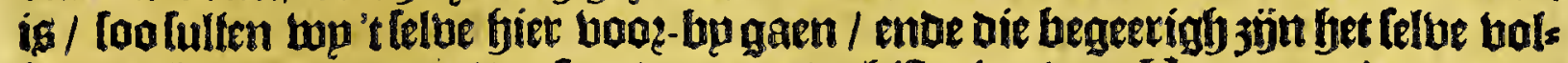
fomentlightier te weten / verfepnden aen de biftoęien ban Herrera ende anoere Spaegniaeroen. De tale ban Dit booe-[tbeten bolck was al eens / boe-twel oe gheene die op oe kufte toonden/yaer befte deden om met meerder curiofitept te fpererthen.

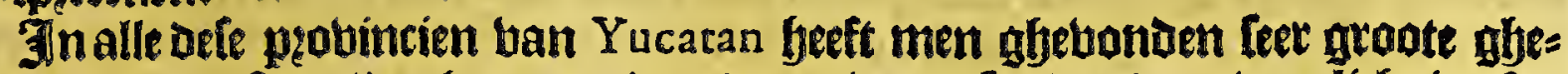
boutwen ban ffeen / Dat bet te bertwonderen toas / cou Dat daer ban lifyt is af te nemen dat fet landt is ghelweeft ban fonderlinglye lupfter; en is te bertwonderen foefe foo grooten gijeboulwen bebluen konnen maecken / aenghefien men baer

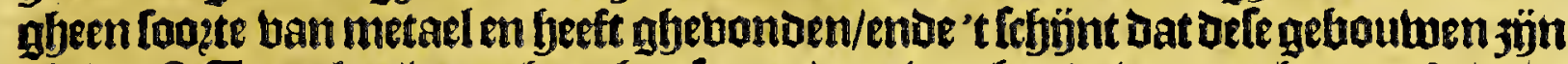

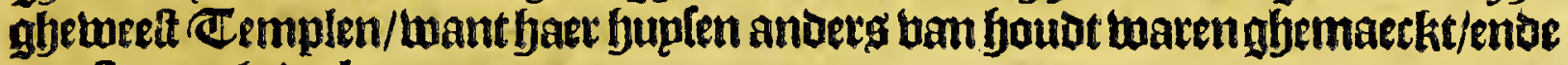
met itrope gheartkt.

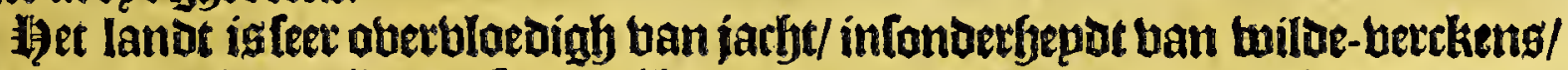

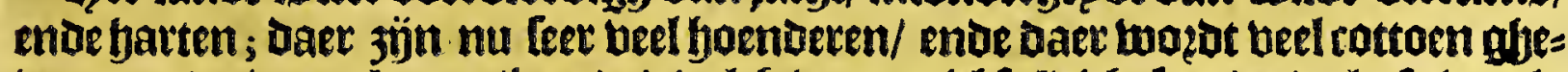
twonnen/ende oock Annil; ende't bolck bermenichfuldidgt feer/ ende lefft langh: bebben nu aloerbande bee van Cattilien/enofgoede peerden.

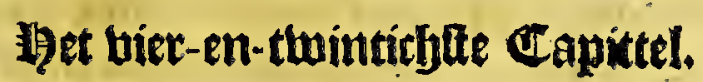

Befchrijvinghe van de particuliere Provincien die onder Yuc a t a v verden gerékent; hoe, ende by wie defe landen eerft zijn ontdecke geweelt.

D Boze gantefye pzobintie ban Yucatan loopt een klepn gheberghte ban ten d.4. 1.3. eenen foetk tot den anderen/'t helcle begint ban bu Champoton, ende ber: $=$ c. 4 . volght tot aen oe ftaot ban Sala manca, weltk is Den rontraxien joeck ban Cham. poton; Bitghebergbte berweplt dete landen in twee deelen; bet Deel naer bet 3 up= oen/weick leggt naer Lacando toe/ente Tayza mag twoet ende onbetwoont ges

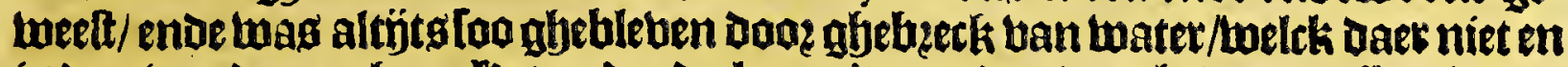
is Dan van den reghen. Let ander deel naer't noozden was betwoont: Het is beet

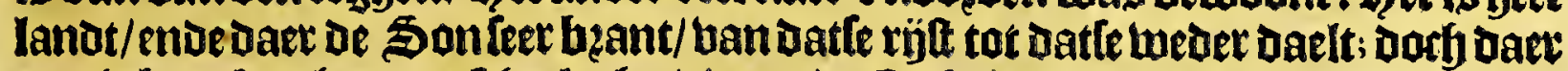

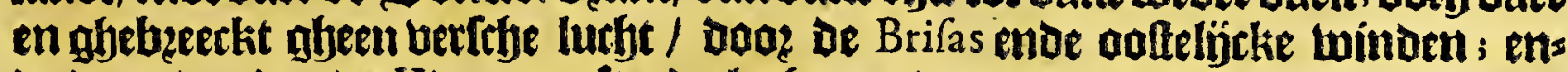
de des aboutots de Virazon ofte oe lucft upt ber 3 ee / Die de bitte feet tempert.

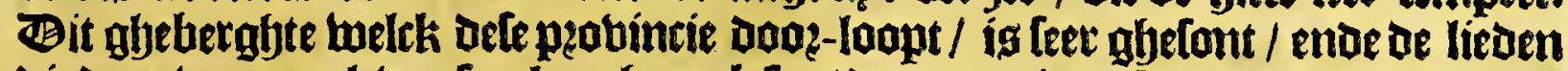
Die daer lugonen leben leet langh; oock [oo/ dat een minne-bzaeder/ weetoigh om

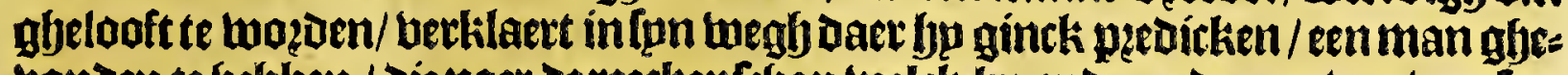
vondent te frebben / Die naer oe reeckentrgap tuelck bp ende andere gaben uan fon

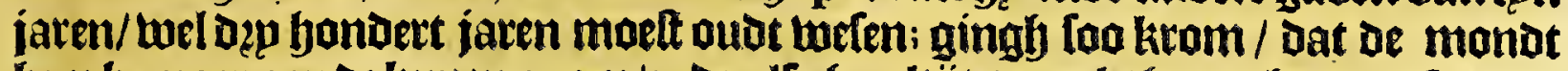

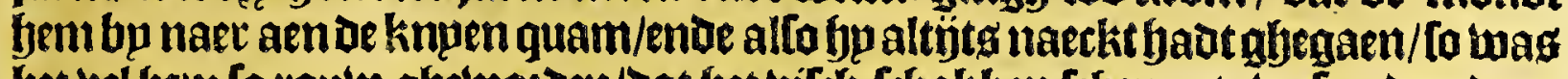

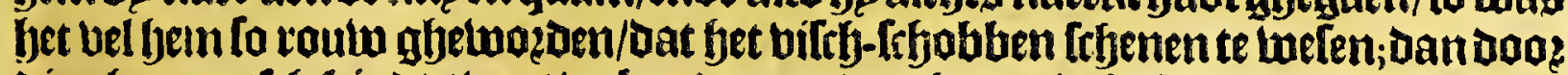
dien ljp gantedy kinots was/enkonde men ban bem niet bufonders berftaen; beel andere oude lieden binat men in'tlelbe quartier.

Bit lanot miert eerlt ontaectit toos Francifco Hernandez de Cordua, welck d.2.1.2: met lun frgip aen-quam aen een punt ban't lanot / welck fp noemoen Cotoche; c.17. ooos dien de Cazique ban dit quartier ue Spaegniaerden aen lanot lockende)

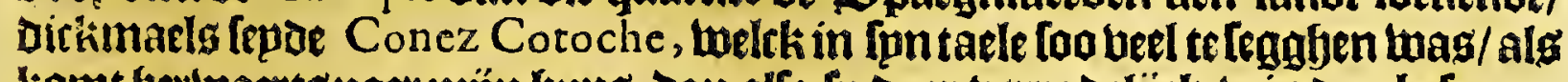
homt bertwaetts naer mün bupg; Dan alfo fp daet vetradelijeli wierden befpzon: gljen (als mede in een ander quartiec/welck be Indianen noemoen Quimpech,

(d) 5 
214

Nova Hifpania.

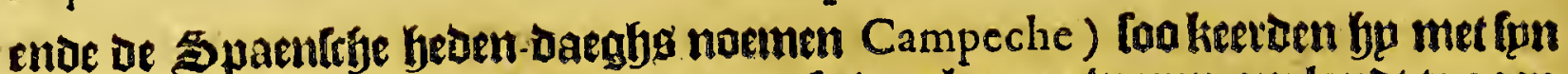
trolck weore naer't Eplanot Cuba, Daer fp ban komen waren om landt te gaen ontortien. Baer naet was aen dit felve landt Iuan de Gryalva te tueten aen ot

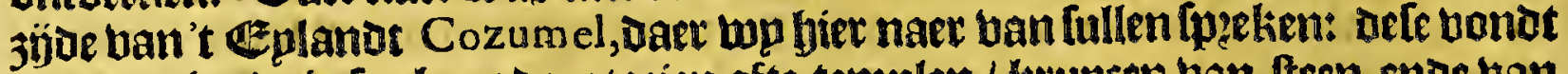
Daet aen lanot in leetket adopatopien ofte templen / hrupen ban fteen ende van

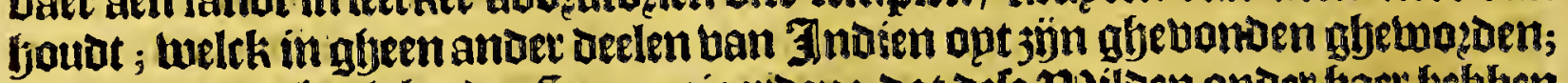

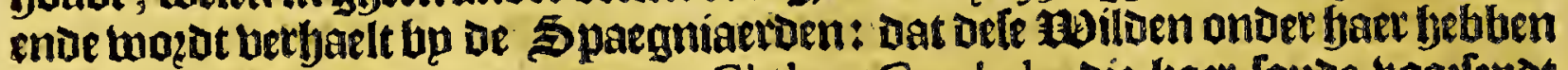
ahehant een 19 ?opfeet met namen Chilam Cambal, die baet foutde voorfepd hejuen de komete ban een beemot bolck upt de quartieren daer de fonne op-gaet

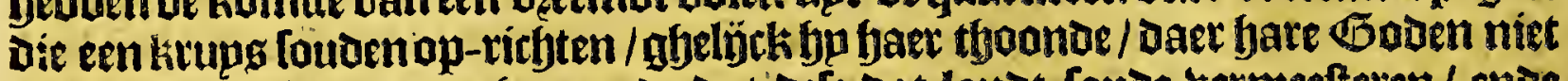
tegljen op en fouden moghen; ende dat orle dat landot Coube bermeefteten/ ende

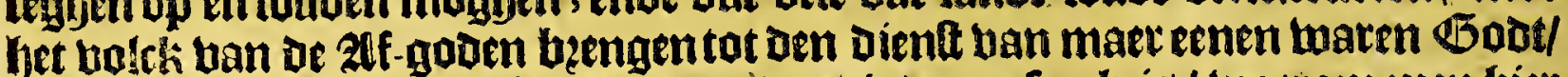

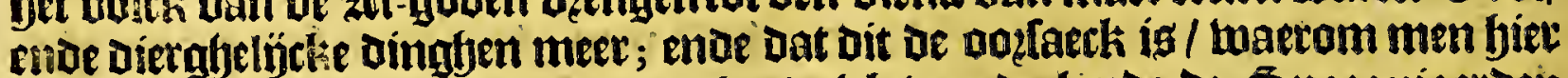
Defe kitupen tonot/ ende thaerom bet bolek ban de lande de Spaegniaeroen in 't aen-kommen veaeghoen of Ip quamen ban bet quartier baet ofe fonne op gaet. 1 a abozdeerue in eenplaetle ghenoemt Potonchan, Daer bet bolck.ban

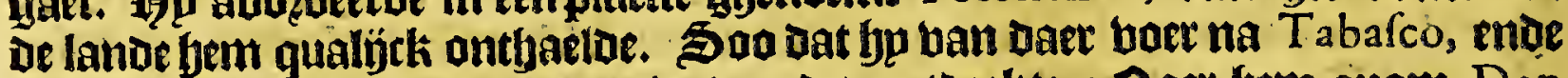
in Defe probincie ban Yucatan niet voozoer ontseckte. Saer hem quam Don Hernando Corres mede te Cozumel, ende afberaeckte daet aen den tolkt Geronimo de A guilar, die bem grooten dienit dede infjet ontoecken ende ronquelteren ban Nova Hifpania; dan uoer nopzoer naer Tabafco ente be rietuiete Grialva.

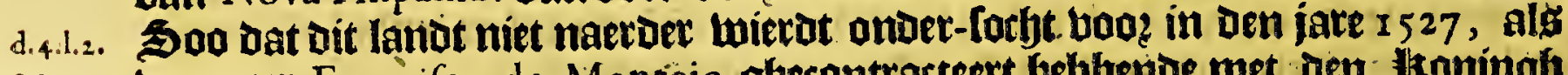
manneer Francifco de Montejo ghecontratteert beblento met den luoningh ober de ontoeckinge ende conquelte ban Cozumel ende Yucatan, oaer aen quam/ namentlijek eerft aen't [eplanot Cozumel,ende daernaer aen een Dozp genaemt Xamanzal: enoe boe-wel bet bolck ban't lanot/ welck ftrïd-baet is/bem tuelt te boen a a / loo trock bpeten-wel boozts langhg de kulte tot een plactle ghenaemt Conil, alwaer bp fem quamen de regeeroets ban een yzobincie ghenaemt Chu2ca; ende naer neerthich onder-foeck bertondt bj dat de peimcipaelfte platte ban Defe probintie Las gljenaemt Tirroh, Daet leetlete Heeren gouberneerden / ghes naent Cheles. Gier twas eertijots noclyeen andete fraepe bletke / ghenaemt Cid.2.l.3. lam, abelegljen beetticly mülen ban Campeche. Crock boots naet en an= Dere peouincie ghenaemt Aarrinchel, welck oock ghenoemt wozbt Yzamal, Daec fo wepning teathen-Itantots bondt; ende be pzobincie ban Tutulxin, welckeg hooft-plaetfe mas Mini, ueetthien leguen van daer nú Merida is ghebout ; dit bolck ontfinglyem beecoelijek om baingem ghetjolpen te jün tegfen be Cocomes; melcke een ander natie was/ende boandt ban ae booz-gaende.

Boots is in Yucatan of probincie bam Chetema, Daer Salamanca nu Yegfjt; moe extröbtg was gheleght Villareal, weltk wedor wiert verlaten; Campeche elloe Champoton, daer oock en ftabt ban Spaegniaeraen ig aheleght. Daer naer de probincie ban Cochuaque, Daet een moon-plaetle ban Indianen thas ahenaent Tulma, at berghen ende fteen-robtligh lanat:ente een lileckeghenaemt Chable, Daet of Spaegniaetaen eertijots mepnoen goutot te timben/ Dorb te verneff. Lier aen paelt de peouintie Guayamil.

'e volek welck te Chicheniz a woonde/ waren ghenaemt Yzaes, welctie noth een ander ftadt bouden/ Diefenoemoen Mayapan, daet nu de thad Merida gfes Ieghen ig.

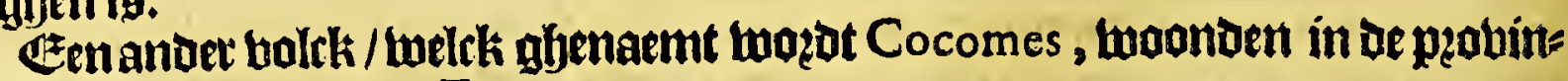
rie dieghenoemt wozot Zututa.

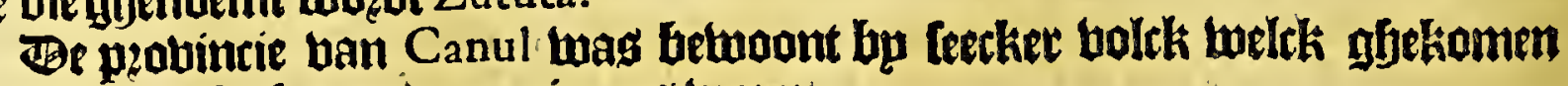
Luas ban Tabafco, ende mexicaens haren. 
Het uäf-en-tmintitylte Capittel.

Befchrijvinghe van de fteden by de Spaegniaerden bewoont in defe provincie van Yü C A T A N.

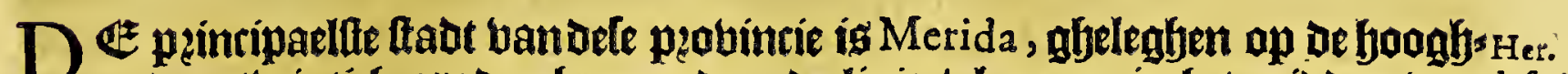
te ban twintirf graden bp noogen of línie / bp naer in bet midoen han defrips.

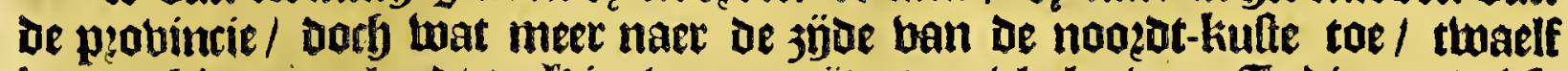
leguen binmen g landts. Hier was eertyotg een blecke ban Jundanen / diele noemben Mayapan, daet beel gropte ende aude edificien waren ban fteen gijes maecht / in oe belcke glefjoulwen waren figueten van naeckte menteben / upt

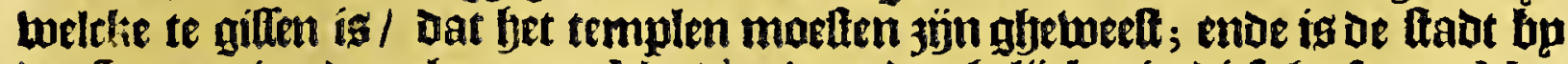

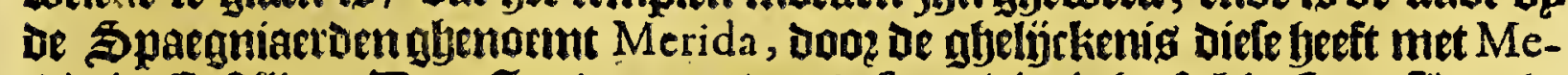
rida in Cafilien. Ben Gouberneur ban bele plabintie beeft bier [an relidentie/ neffents de Officiers ban oes loninghs in-komften/ende kalfe; Dater is mede de

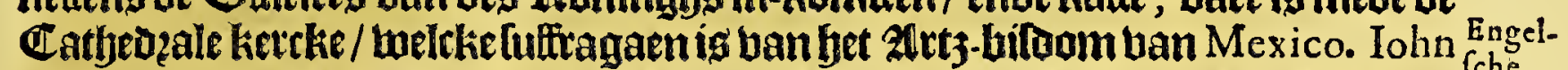
Chilton die daet was antrent denjare 1570 , Ieght dat in Dele ftadt Den $25 i$ illifop voyag. tuoont/ende bp be bondert Spaegniaetoen.

Be tweede ftadt is ghenaemt Valledolid, isgheleghen en-en-Dettich leguen Her. ban Merida, naer bet jupot-oolten / beeft een Leet fumptueus kloolter ban gin in= defript.

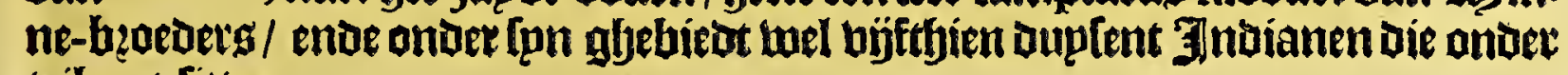
tribupt fitten.

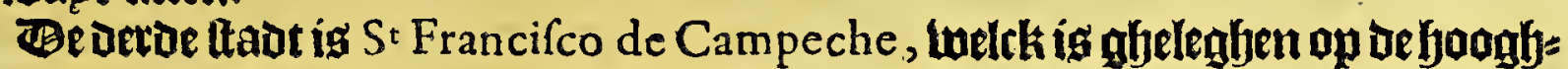
te ban thintich grauren / (naer het Teggben ban Herrera, dan Figueredo ftelot Die op negtyenthien) op de kulfe luelck liet naet Nova Hifpania ; bp de büftich leguer uan Merida nact bet weften/ een luepnigh declíneetende naet bet jupden; beeft een redelÿcke baten / boe-twel van wepniab diepte / aoo dien bet een bape ig. Ban bier twozot aljelauen bet camperbe-boutot daer men mede berwet.

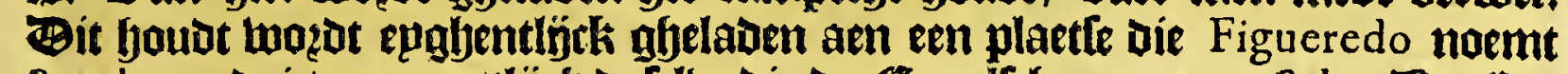

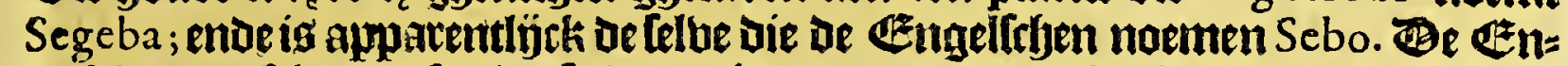

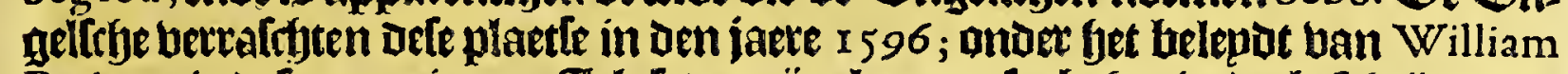

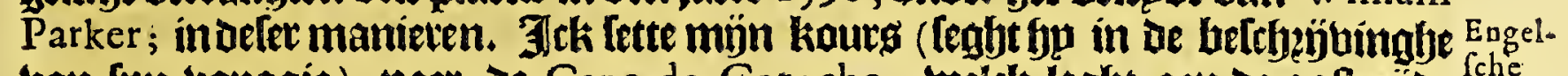

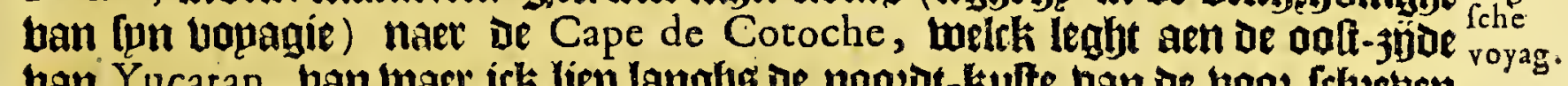
ban Yucatan, ban waet ick liep langhg oe noozot-kulte ban de booz-frbetuen Cabo uan Yucatan, tot dat ifl quam bp Cabo Defconofcido, Daer Ittte itk

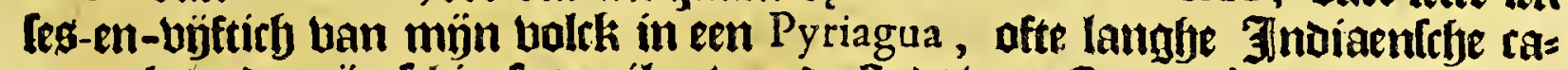
noa; latende mign lefíp fes mýlen ban oe ftadt ban Campeche; ende lanten ten Dep up:en fmozgbeng dicht bp get kloofer ban $S^{2}$ Francifco, ende nam oe

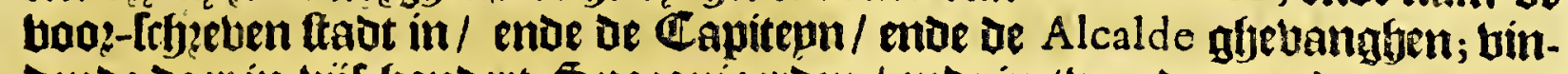
Dende daer in býf yondert \$paegniaerden / ende in there do:pen daer onttent gheleglen / wel acfit ouplent Tndianen. Be Spatgniaerden oe welcke ghebloden haren op mỉn ertfe aen-komfte / antrent ten tijien upen in den mo:

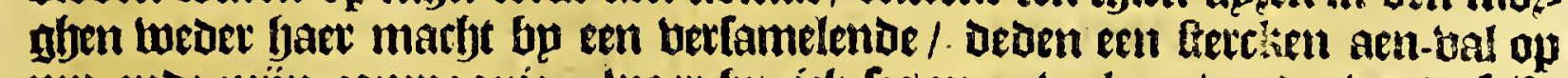
mp ende minn compagnie ; waet fu ick les man berloos / enoe twetor felfs abelchooten met een loot onder mïn laincke-boztt / welek loot noef is legghende

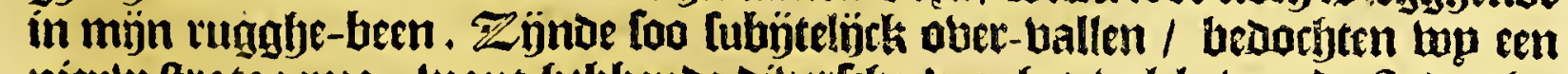

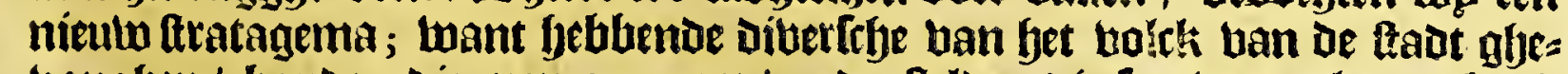
banghen / bonden die arm aen arm/ enoe ftelden die foo boos als een bari= cade tegljen fiet febieten ban de bpanot; ende trocken foo met blieghende ven= bel/ ong leg dooden met nemende/ in goede ozoke naer oe haven; daer top een frigat namen/ welch daer op ancker lagh/al glueladen met oes ltoninghs

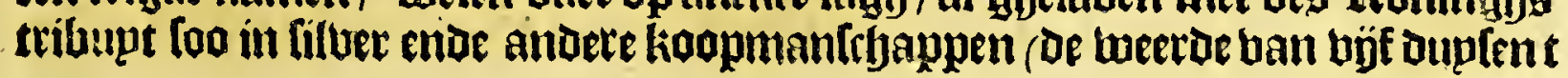

ponout 
216

Nova Hifpania.

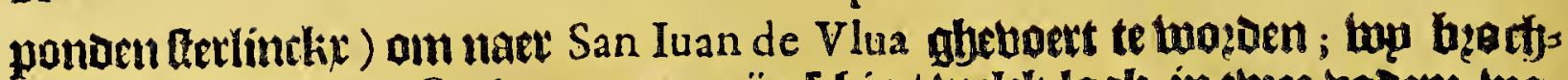
ten Defrigatte thet of Pyriagua naer mün Ichip / welcli lagh in twase baden toa:

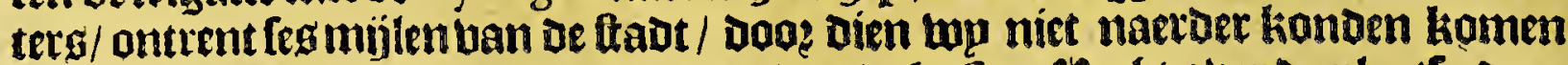
Lan werisen de deooghte ende ondiepte ban de kulte. Hietbt aber de plarte daet

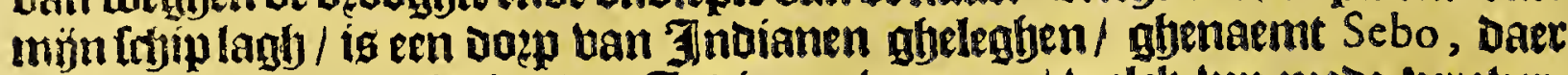

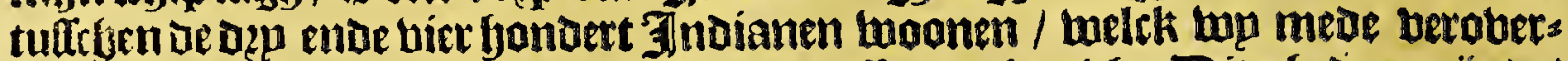

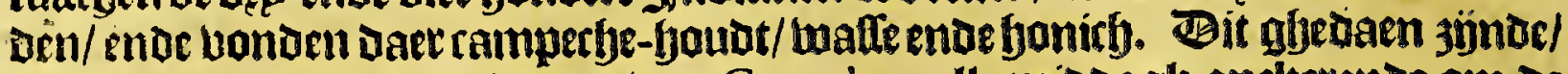
fiet'oen lop weder naer' t punt ban Cotoche, alle midoagh anckerende om de Brifas wille/etc.

De laetfte ftadtig Salamanca, gelegenintepgobincien wan Bacalar ende Chetemal; (eventict)leguen vandeftadt Merida, zupot ende noazden/bellende naer't

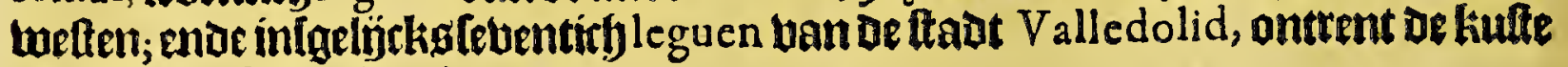
van ae Golfo de Honduras.

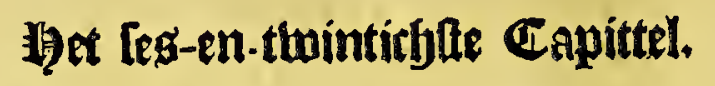

Befchrijvinghe van de kufte ende havenen van defe Provincic van Y U C A TA N.

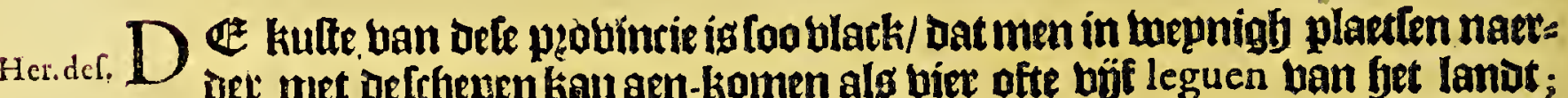
oet met oefrhepen kan aen-komen als bier ofte bǘt leguen ban fet lamot;

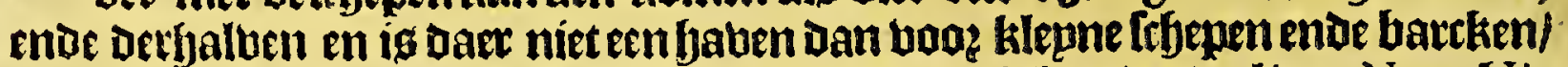
ende de jee die elut ende bloept bier meer dan in eenigh ander deel ban Nova Hifpania. Piet alleen is Dele kufte black/ maer oock bet ftrandt lleght ende lonoer d.3.1.4. berafjen/foo dat men'tellue upt de Jee komente niet en liet / boos dat men daet heelaicht bp ig/upt-ghenamentufthen Campeche ende Champoton, Daer men: eenighe bergblkeng ontueckt/ ende intonaerbepdeten bergb diele naemen Morro de los Diablos. Be grooter fefiepen fyouden van't lande af/ Dooz dien oe kulte bes. fmet ig (baben de voos-[these ben blackte) met klippen ende barde rodten / die de

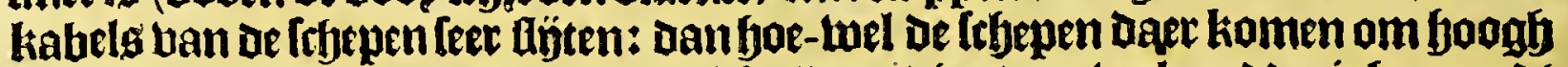

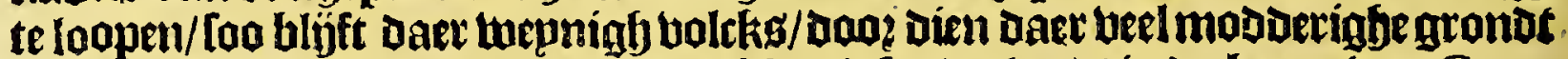
ig : Daec valt fulcken aljetweldighen ebbe / infonderbeptot in de baepe ban Campeche, dat fet dicktwils gly beutt datter een balf le gue wijote ban de felbe baepe

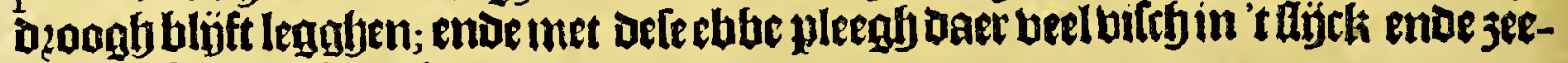
aras te blÿuen bangljen.

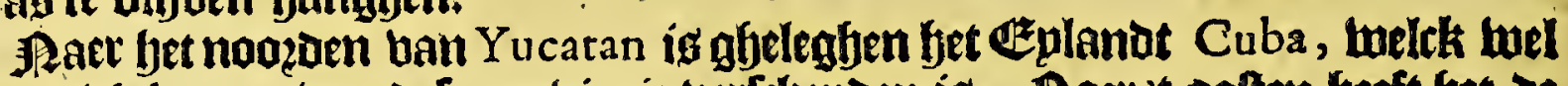

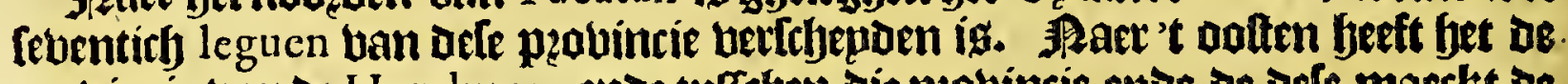
yeobincie vande Honduras, ende tuffethen die plabintie enve oe defe maeckt de jee een grooten in-Gam / oe welcke den Capitepn Gryalva naemDe Bahia del Afcenfion, is aroot / ende bol ban klepne eplandekent; ; bier jön beel frbepen veroughelutlit: infonderbepot ban oe bandelaerg tufteben Yucatan ende de Honduras.

Fan lieginmende de kutte aen de zöbe daetre paelt aen Tabafco, foo febt gfjp baer def fauenenuan Cicla ende Telichaque, Cical ende Cauquil, melckeen rie: biere ig met thee monoen / ende de Gauen uan Campeche op de kulte naer Nova Hifpania toe-fiente; ente tropet Cabo Delgado, van twaec de kufte fich begint:

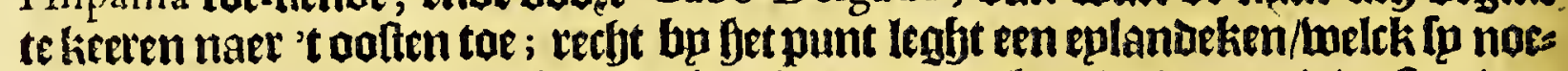

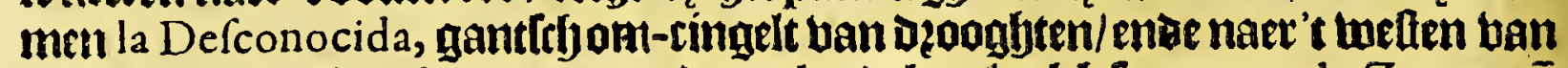

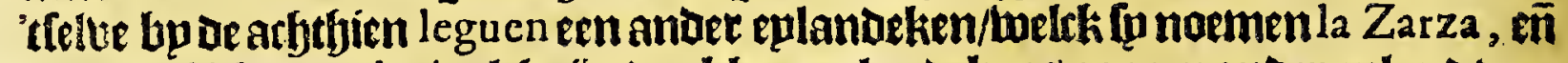

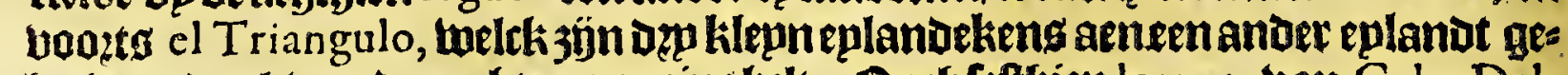

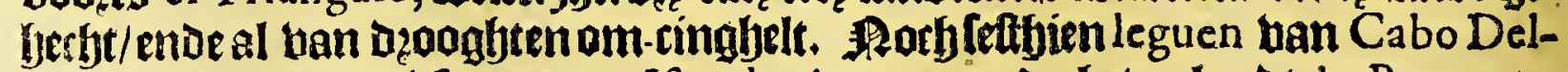
gado, de eplanden diefe noemen Inas de Arenas, enoe bet eplande la Bermeya,

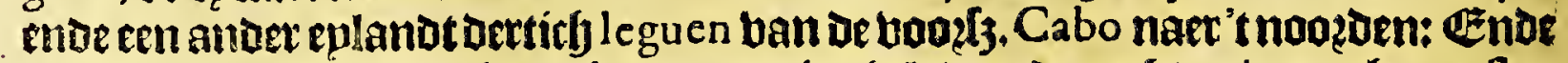
los Negrillos jijn dęp eplandekeng/om-cingbelt van dęoogljten/ naer bet oolten 


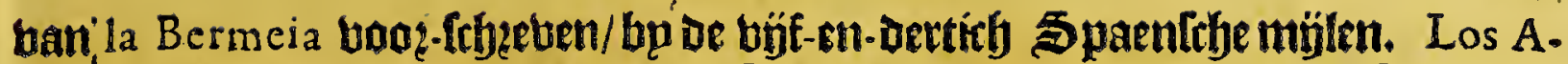
lacranes, thintity leguen bande kuffe/ noozat ende jupden/ met de ftad Merida : Ontrent dele eplanden jün beel lilipperi/ Daermen bem ban moet matb= ten; enve men neemt funkouts ban Cabo Sant Anton naer Nova Hifpania, bupten ofte binnen Defe eqlanden ban Los Alacranes, als be de directie ban kourtente fien is.

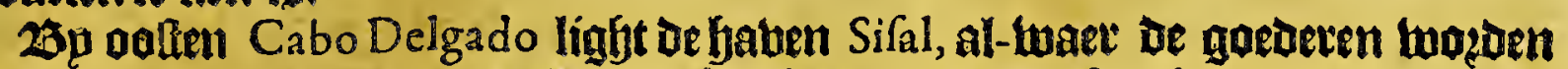
ontladen die naet Merida twillen/ bart defe haben naet 'tfeghben van Figueredo

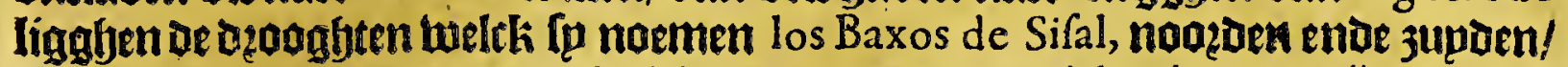
op De booghte van een-en-thwintich graden ende beettich minuten/zjon ontrent ozp mijlen laingh/ftreckende noozot-welt enoe 3updt-onet. Be Alaeranes naet 't leguen van de Cabo $S^{t}$ Anton, enoe bonuert bujf-en-bujftich leguen ban Villa

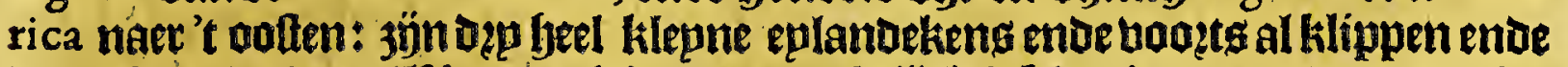
Deoghten mel twaelf leguen in't ronde / ghelïck t felbe is ondet-uonden / in=

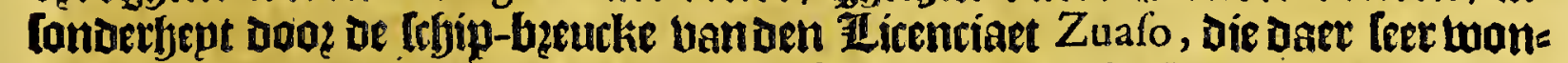

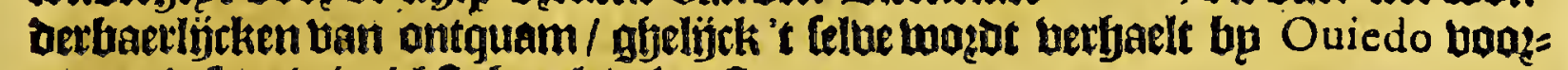
noemt in Ipn twintichfte boeck/' tlaetfe cap.

Cabo de Cotoche is jet ooffelỉckitt punt ban Yucatan: Ouiedo leght Dat Cotoche light op een-en-twintich graden; Figueredo feght op en-en-twintich geaden ende thinticf minuten: bp de boots. Cabo foude en boep ligghenvan Indoianen met een kerecken ghenaemt Igreia de Icao. Ban Dele Cabo legghen

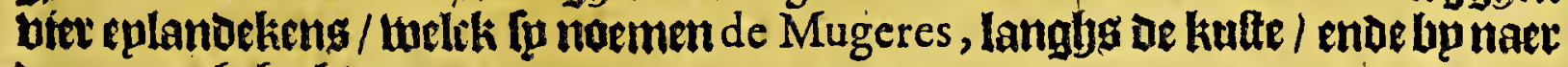
baet aen afyefuetht.

Baer aenlight fyet Eplant Cozumel loo ghenaemt/naer eenfameus abozas totie ofte tempel/uan een afgoden-beelot 'twelck daet was / Daer alle be natien

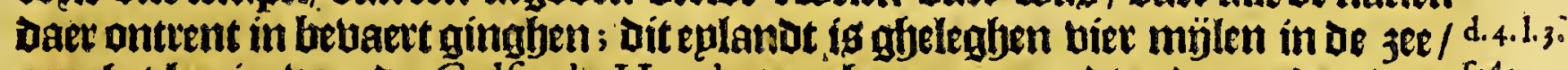

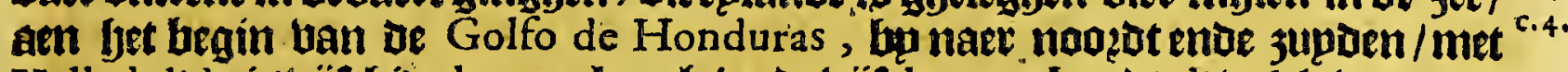

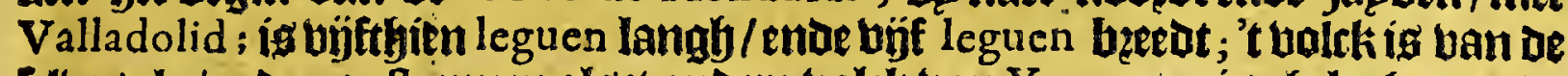
Ieloe tale / ende coultupmen als't andere bolck ban Yucatan; isglieleghen op de booghte ban thintity graden; ofte als andere beb ben onderbonoen/get noogdo:

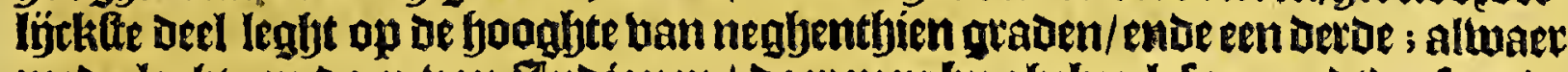

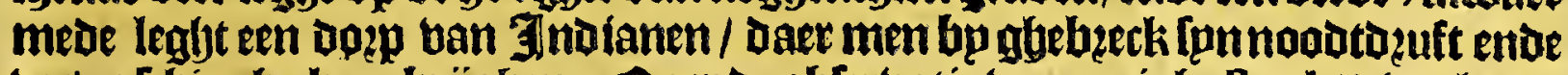

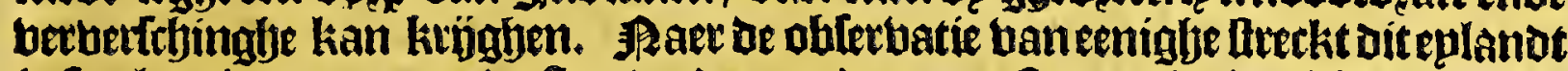
in lpnlenghte jupdt ten wetten / enoe noozot ten oolten / ende is al lieght lanot. Ouiedo leght oat Cozumel light büf-en-thintich leguen by jupoen oe Cabo de

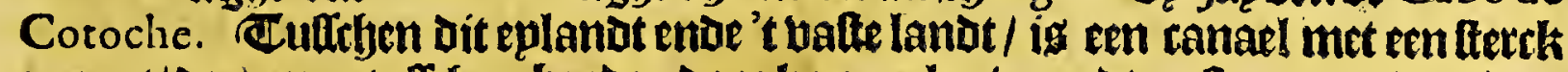

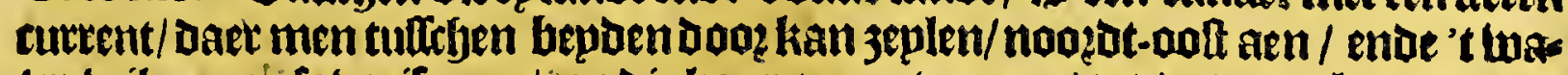
ter tuil eeneti faboziterten/ombie kaurs aen te gaen/tot Dat men kount op de Googhte ban biet-en-twintich graben/ baet men be diepingljen kighght ban de Tortugas.

If)er inte-Laarts in de Golfo de Honduras, legghen dęu eqlandekeng met ondiepten om-tingfyt / (bie Herrera infunkaecte noemt Triangulo doa? dien die in een dap-boeck ligghen/) be naet in'tquartiet van bet lack uan Bacalal, wetck binnen'slanots leght Dettich leguen van bet lack van Chetemal; be tulfe is al belkleed met eplanoekeng tot Salamanca toe; waec ban fret eerlte werdt genaemt Pantoia, neffeng een ondiwte toelck Ip noemen Quitafuenno, welck is loo veel te fegghen als Slaept niet / Imaer liet boo: $u$; jet tweede is gbenaemt Zaratan; enoe een ander Lamanay; enoe ten leften Ylbob in't imerfe van de Golfo booz-Irlyze ben.

TA. 


\section{T A B A S C O.}

Fet feben-en-twintithte Capittel.

Van de provincie van $T$ A в a s c $O$ in't ghemeja.

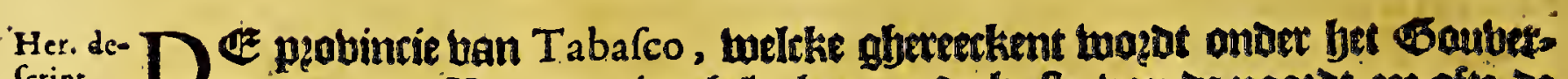

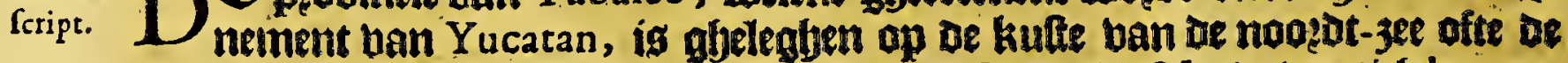
Golfo ban Nova Hifpania;beft in te lengbte uoft enve totef bp de beettich leguen, ban de limiten ban Yucatan, tot die ban Goazacoalco, met belck Tabafco confineet naer bet weiten toe; ende beeft oodk too beel leguen in de beecote

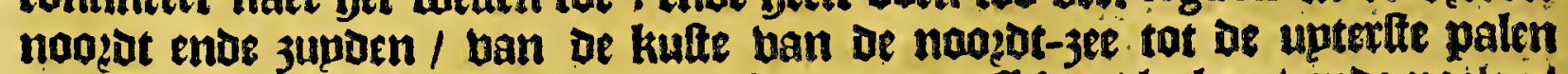
uan Chiapa. Jg al black lanot / bol ban moeraffichen/lacken/ enoe poelen/ Daer men ober baert met kamoen ende bartken/ enoe daet beel groote bitsh

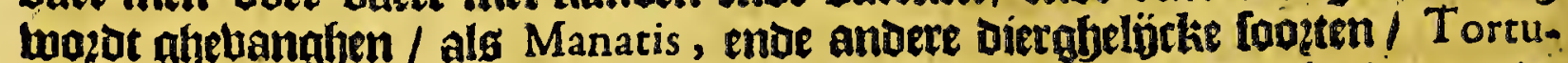
d.3.1.7. gas entue Yguanas. I Lanot is leegb ende bal bzatilie-hoomen / teden ente

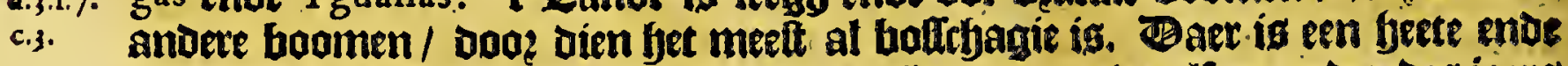
botbtigbe lutbt/ con datter beel Mofquices zön: ban de thaelf maenden Des jaerg vegbent bet daer wet neghen. Jn be bofichen is gropte abundantie han be beutjen ban bet lanot / gbelísk als Mameyes, Zapotes, Aguacates, Gua-

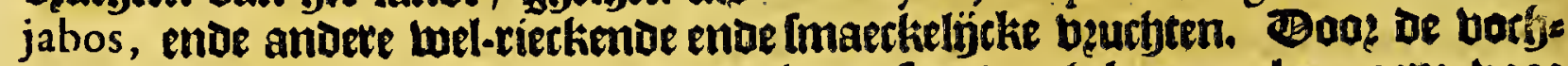
tichepot enoe bitte oes lanots is dit lanot leer bechethaer en bequaem boos luepinen ban groot bee; tot Marz ende Cacao, welck is den grootlten rósks bom ban't land; bier in betalen lp laren tribupot/ ende gbeben jaerlích twet duplent Xiquipiles van Cacao, elcke Xiquipil is acht Dupfent amans

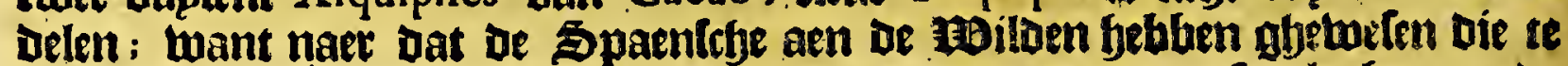
cultiberen / foo bergaderen lp jaerlightis meet quantitept oan fp pleghen; ende bet volek beeft bem feet begbetuen tot twepden van groot vee / ende bet plauten ban of fuarnffhe buthten: waer doos baet groote meningte is ban tujngaers ben/ unghe-boomen/ lpmen/limoenen/ ende ozaegnie-appelen. Baer balt beel Maiz, ende werot dep ofte bier replen bes jaers berfamelt; ende ten minften twee. maels: ootk loo walf het rỉg baer mel/ ende birs/ ende aloerbende bof-'̌rtupden uan Spaegnien. Dock Jeeftmen oaer groote diberfítept ban mes

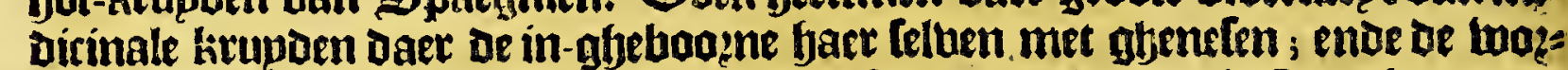
men Dooden / enoe daetle bet bloed mede ftoppen: als daet is Picietl, anders ngenoemt Tabaco, twelck de püne twetb neemt die dooz koude gfetauleert is!

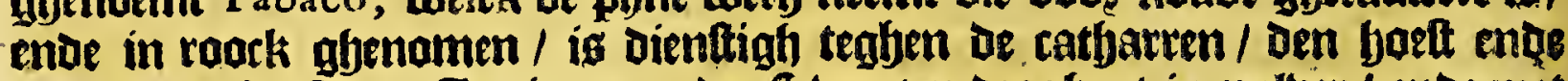
benautude boefl; of Fndianen ende. Stwarten Dzagbent in pulber / ende met

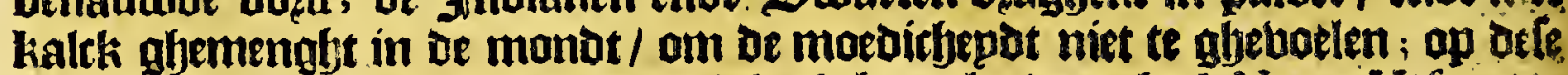
maniere twozot bet leet menighfuloigh ghelbuyckt oooz beel Nova Hifpania, komt daet op alle marckten te koop/in oe bladeren ban bet Maiz op-ofies

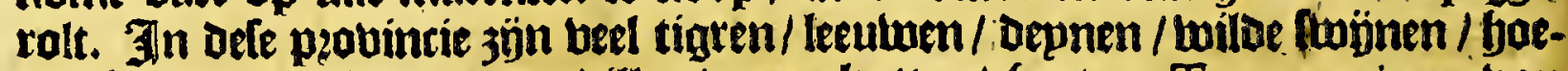
wel kilepn; konjunen/ armadillen/ meer-katten/ gatten; Tepeyzquintes ban fatloen als en biggegken/ enve gecouleutt als be bucken ofte tepmen:men bine baet trel aroote frbilot-padoen als ronualen/ Yguanas, ende ander onghes Dierte: faplanten/ paeumen enoe papegapen ham beeloerlep fooeten/ quarkes Ien ende alderbande groot ende klepn gljebogelte ban Differente couleuren : beel

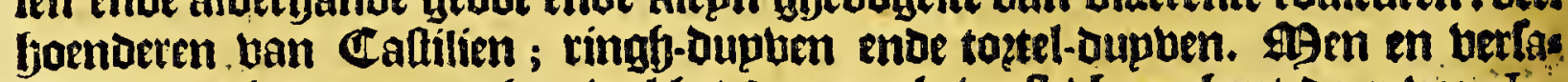
melt daer gheen cottaen yoe-wel bet oaer back malt / beengbent Daer ban Iucatan, als mede andere ftoften om in te klecoen / Doo? Dien 't bolck oe cottoen niet enl kan beneficeren/ belich jünoe met kaepen ende berckens te boeden/ Daete groot nut upt treeken; ende naer bet Cacao te lien; mant norb op oe boomen thaende / foo komen of apen ende erch-boogntjeng ende ander gbediente bet 
Het vijfde Boeck.

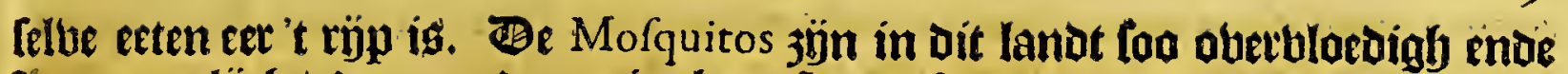
foa moepelýck/ Datmen Daer niet kan lapen conoer pabillon. Baer toag eet:

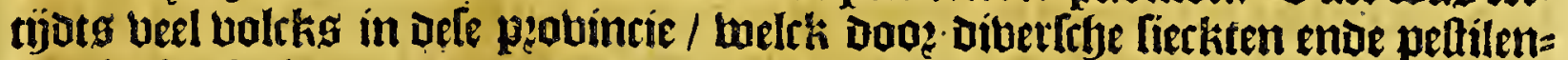
tien yeeft af-ghenomm/ te meer om dat dit bolrk gftewenot is in bet water te baoen / wat fieckten In oock hebben; ende alfoo haer bp of twetten ban bet Clyeiten abeloabe niet werot toe-ngelaten meer dan een beoulwe te bebluevi / foo en kan loet bolek foo niet meer termenighfulbighen. Sp aten feer bepnigh/en

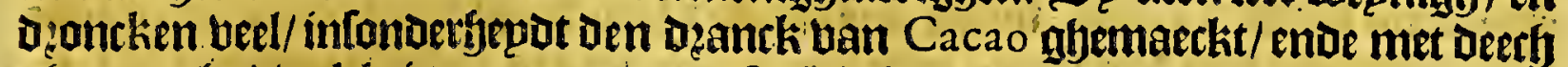

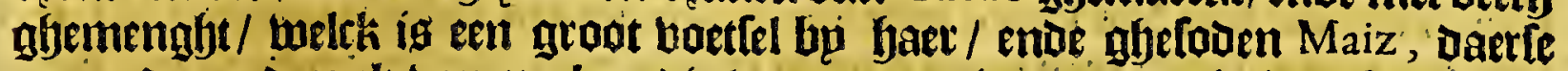
een anderen dzanck ban maken die Lat amper is/ enoe oerbaltben [eer berfen om in oe bitte te deintien. Sints datfe de palitie ban Spaegnien bebben be= gounen aen te nemen/ Iebente te gader bu doepen/en eeten op baet beftembe

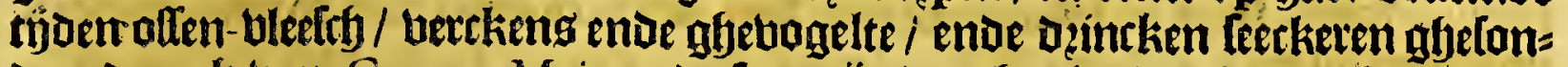
Den Dzanck ban Cacao, Maiz ende fpecerýe ban bet lande gfyemaetkt / welck

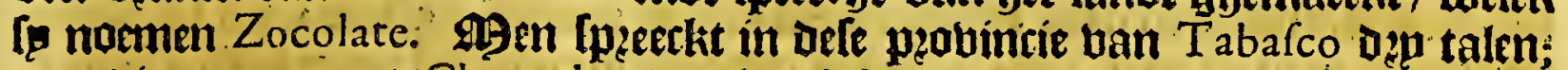

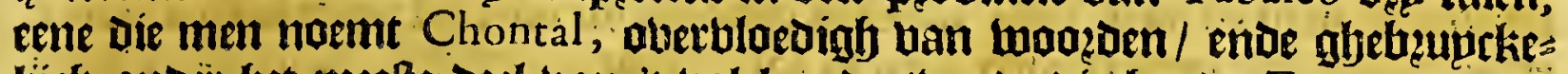

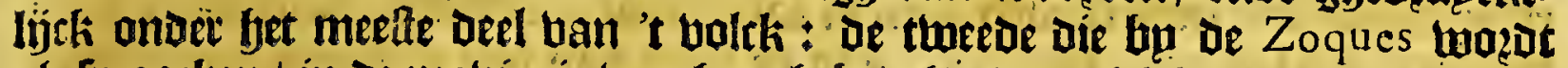

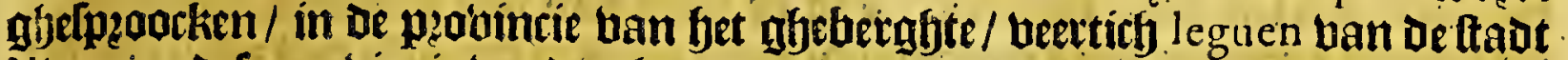
$\checkmark$ ittoria, Defe pyobintie twetor ghenoent la Sierra; om datle confineert met de betghen ban Chiapa, Daer de felte talc merdi ghelp!olien; want Daer loopt

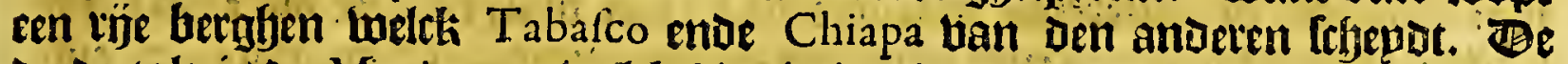

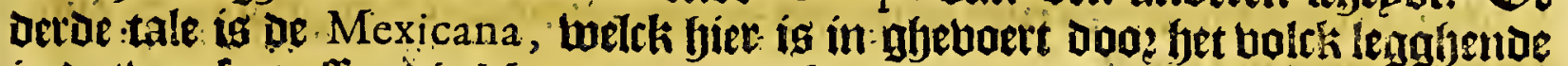
in De tluee foettellen die Motezuma in Defe peobincie bielot / Zimatlan ende Xi-

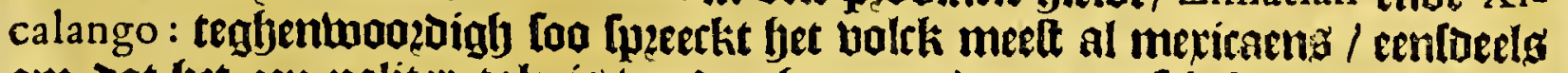
om dat het een politer tale is / ende ghemepn Dooz ganttry Nova Hifpania;

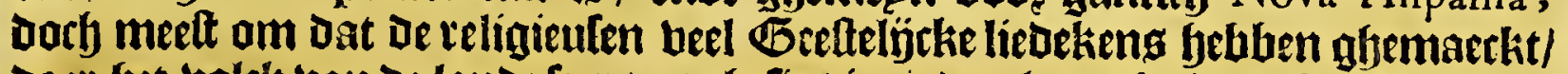

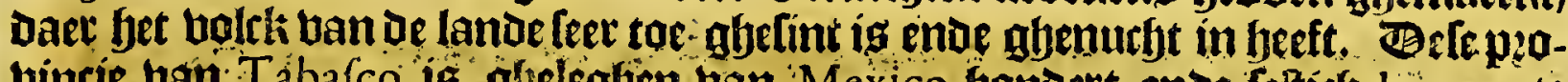
vincie tain Tábafco is ghelegfen van Mexico bondert ende feltich leguen te lanoe/ ende te water langhg Vera Cruz honbert ende beerticf: Ban Merida baet de Goubetneur ban Iucatan ende Defe peobincie fem foutot / is bait oele pzanincie bertebepoen tachtentich leguen. Ban Campeche, langbs de jee uj̉ts tífy leguen.

\section{Wet acht-en-twintitylte Capittel.}

\footnotetext{
Befchrijvinghe van de ftadt by de Spaegniaerden bewoont in defe provinciez ende van de rieviere, ende zee-kufte van defe provincie van $T$ A B A s co.
}

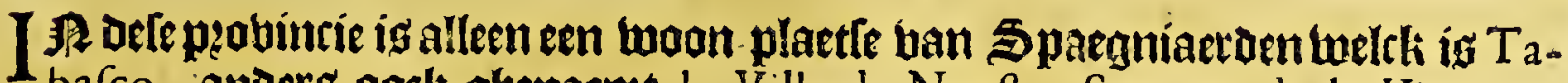
1 bafco, anders oock ghenaemt la Villa de Nueftra Sennora de la Vittoria,

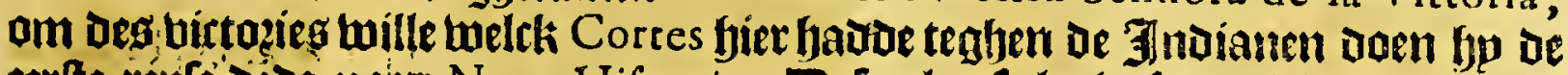
extfe reple dede naer Nova Hifpania. Dele plaetle leggt febentirf leguen ban Cuidad Real de Chiapa, ende men traet naer Chiapa de riebirre Gryalva op beetticy leguen, ende de refterenoe dertich leguen repltmen ober bard ghebergh: te / Daec beel riebieten $3 \mathfrak{j n}$ / ende koubt lanot. De riebiete ban Gryalva ke!ck in sen jare 1516 de naem kreegh ban Iuan de Gryalva, ig mactytigy/en b.m groote diepte/ mant binnen de barte beftle hel acht baden luaters; Dan in ite

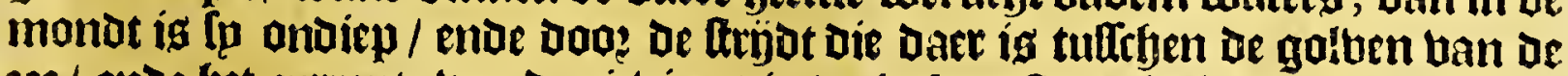

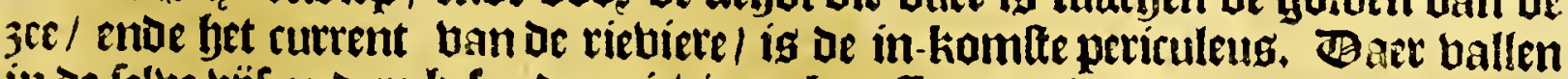

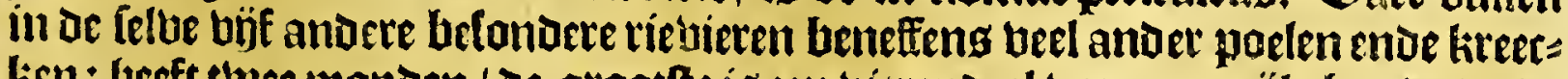
lien: Geft these monoen / De grootte is een bierendeel ban een mijle beesot / ende

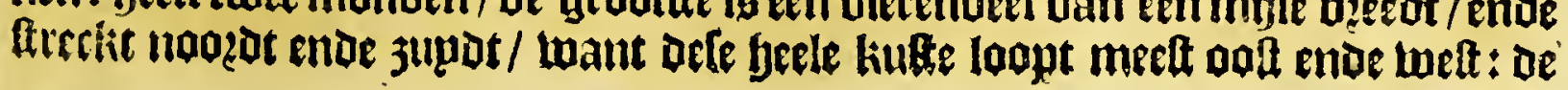
andere 


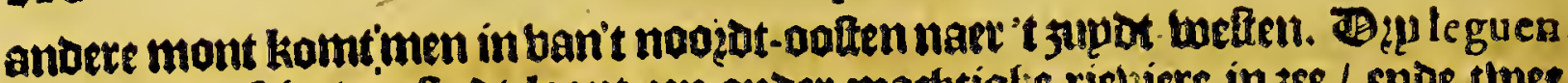

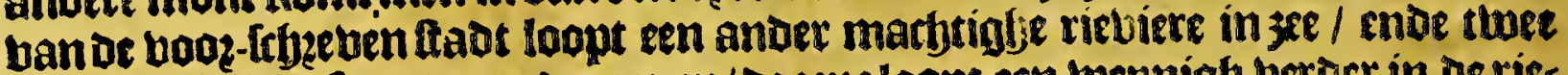
treecken toelcke fo noemen de armen/ De eene loopt een bepnigh beroer in oe ries

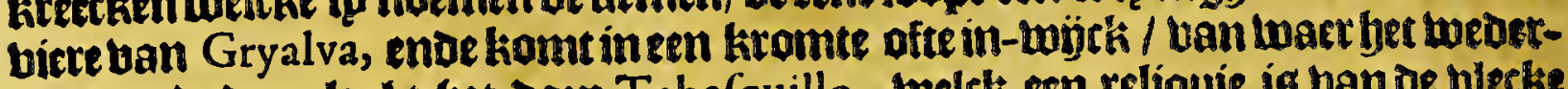
keert/ende daer legbt bet Doup Tabafquillo, welth een relíquie íg ban de viecke Pontonchan ; Daer Marina de talcke aen Cortes wierdut gbeperenteetr. eegben ober Dere blecke/aen D'anuer 3 joe ban De riebiete Gryalva is een ander kreethe/Die gyenoemt wozot Tacanis, welck Dooz leecker lack loopt op't boogbe/ legghende naer de rieviere ban San Pedro ende San Pablo, welcke riebier marbtigh is / en heeft ken engbe barte; men komt daer in noozot ende 3 upaen / ende íf leet diep

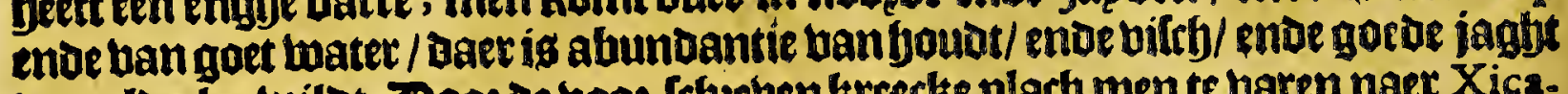
ban aloerlep wilot. Booz de booz-[chzeben kreecke placty men te varen naer Xicalango, welck mas de frontier-plaetfe ban de mexicanen: De Spaegniaerden noemoen dit oock El Lago de Xicalango, ende Puerto Real, welit groot ende Ipacieus is/ende beeft thee eplandetiens in De mondt. Ende noch berder op koms Daet in De riebiete Yztapa, die feer groot is/Die naet bet 3upot- ooften freckts ende langhs dele riebiere baert-men in canoen toc oe blecke Xonutla toe/alfmen booztgreplen wilnaer Yucatan. Op de kutte van bele peobincie regneren of

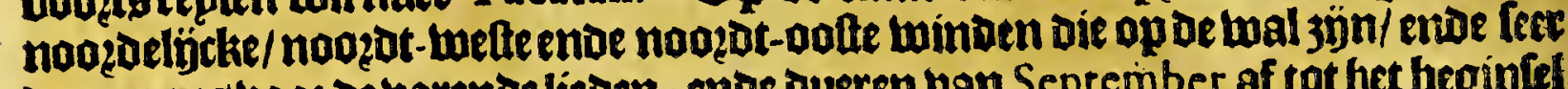
Dangereugbooz de barende lieden; ende dueren van September af tot bet beginfet ban April toe; de relteetende maenden ban't jaer maepen daer ooffeljëke ende

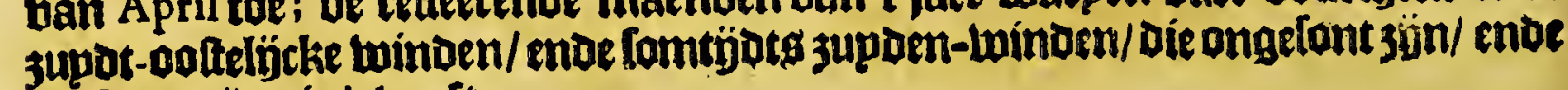
cauletenpinge in't booft.

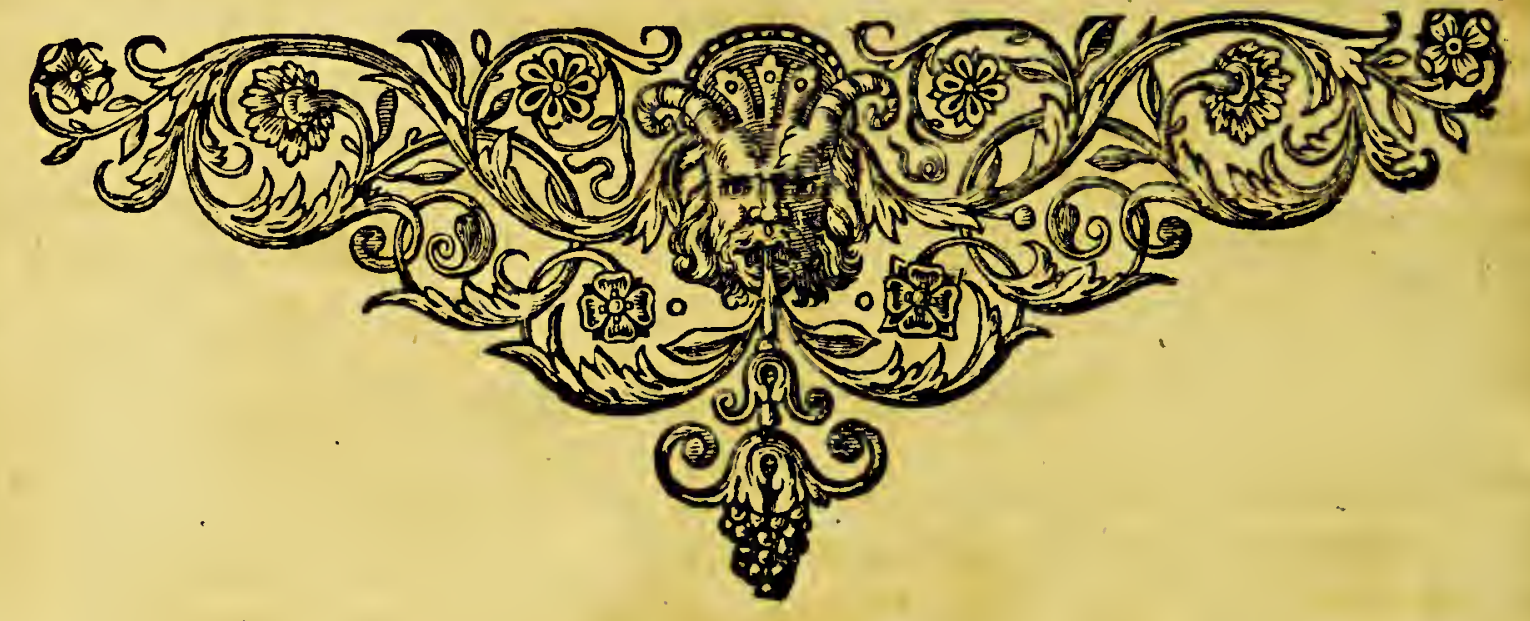

BESCHRIT 
BESCHRIIVINGHE

Uail

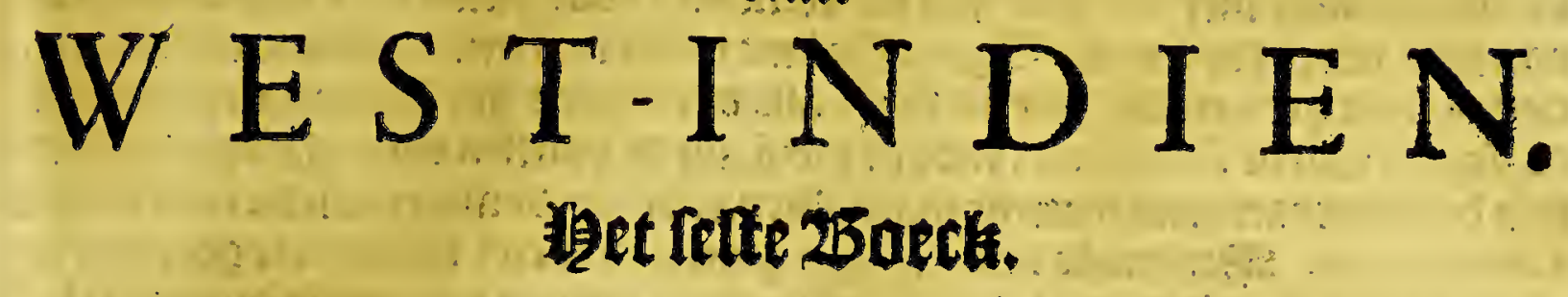

Nova Galicia, ofte Guadalaiara,

\author{
Let eerte Capittel. \\ Befchrijvinghe van de provincic in ' $t$ ghemeyn.
}

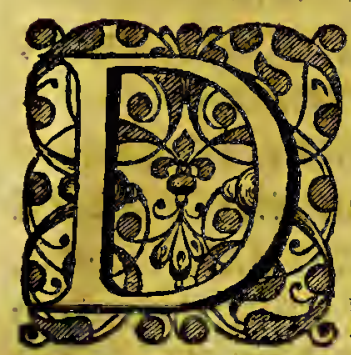

probincie wan Nova Galicia, welck oock glye= noemt wogot Guadalaiara, naer de píncipaelfte fjooft- Itadt:enoe Her. deoock de Xalifco naer een booz-nemen pzolintie onder de leline ve:

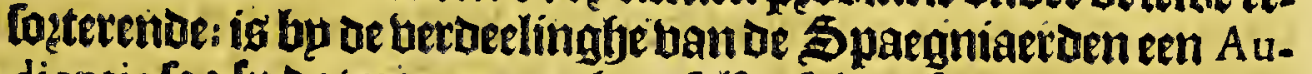
dientie loo lu dat noemen op hem felfs; Ichept fun limiten ban oe limiten ban de Audientie ban Nova Hifpania, ontrent de haben ban Navidad, ende bet lack tuan Chiapala;replente naer't noozot-

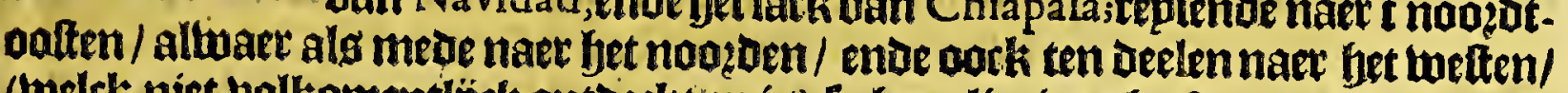
(belck niet bolkomentlibck ontoeckt en is) [p baer límiten beeft open legabenoe/ ente de relfe naer't welten is al zee: 't gfjene daet betwoont is aen d'een kant/ ende

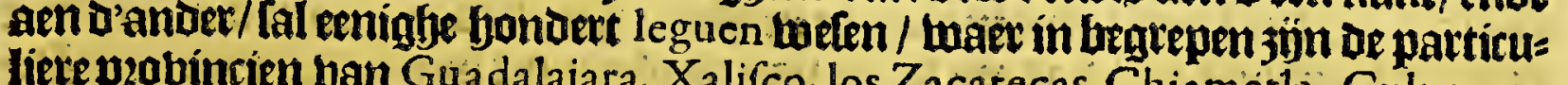
liete pzobincien ban Guadalaiara, Xalifco, los Zacatecas, Chiametla, Culuacan,

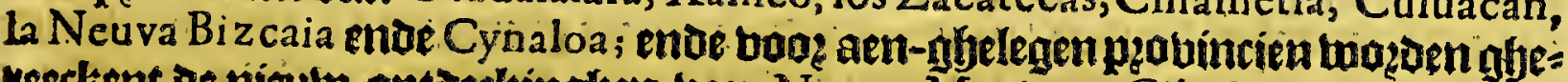
verkent oe nieulu ontoreckingten ban Neuvo Mexico, Cibola ento Quibira.

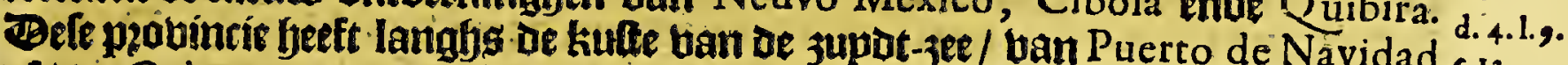
af / tot Culuacan toe / twel bep honbert leguen in ue lenghte. Be gfjeltaltenisban oe lucht is meer ghetcmpert als kouvt / get regbent ende Donoert baer beel in ise maenden ban Iunius, Iulius ende A uguftus; men beeft daer groote aerdt-bebin=

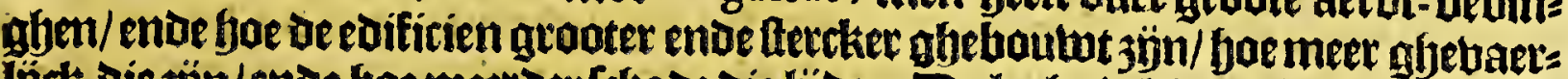

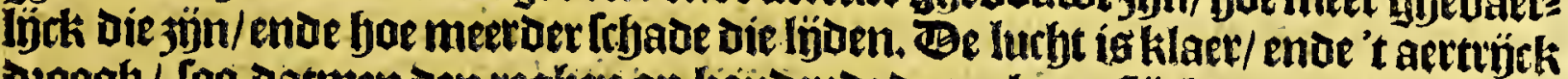

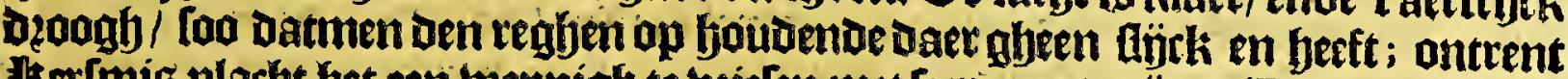

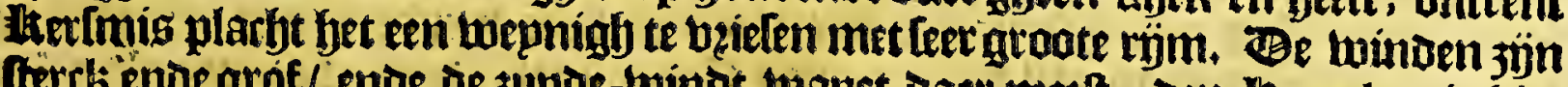

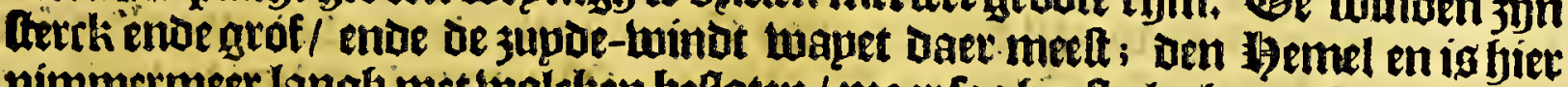
nimmermeer langly met wolcken befloten / maer foo baelt als bet op fout ban res

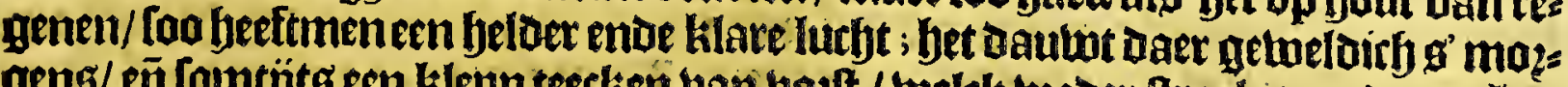

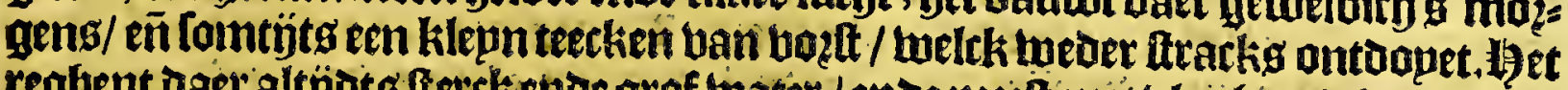
regbent daet altyots fetcliente grof water/ende meelt met blagben; 't beele quar=

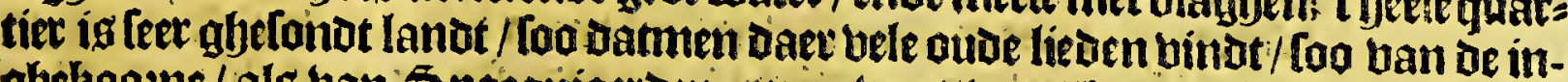

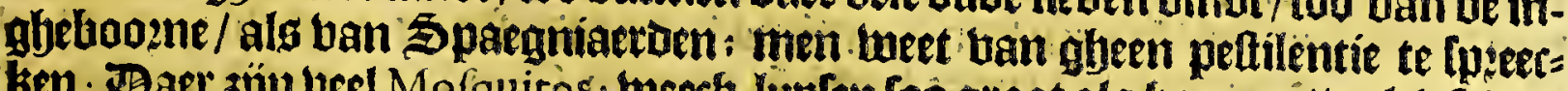

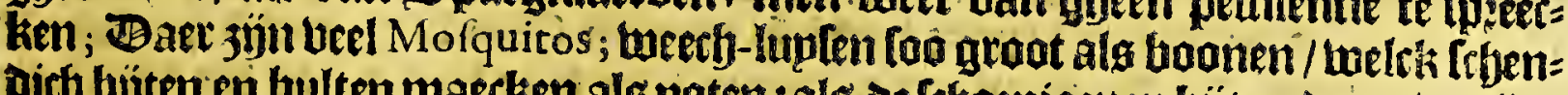

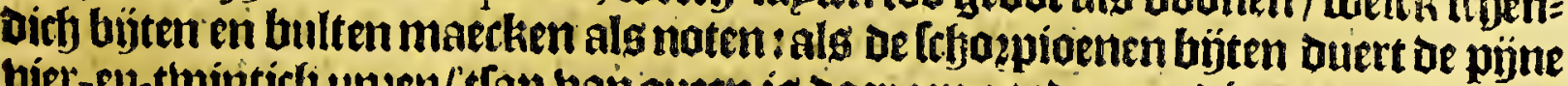
biet-ell-thinticlf upken/'tlap bain queen is Daer een goede remedie tegen/ente men on ferft uali die beten niet. (C) landt is meet boagh ende bergich/ ald effen ofte

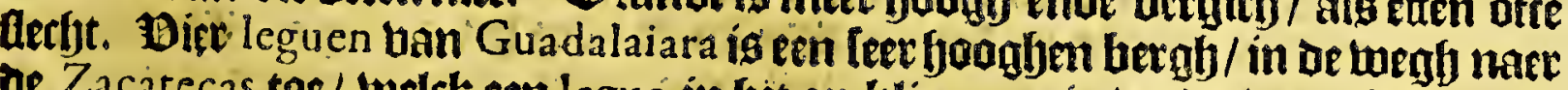
oe Zacatecas toe / welck een legue in bet op-klimmen is/ende ban ghelñ ke en legue in't af-komen/lon datimen daer te peetoe niet en han replen; ende bootg bet gljeberfjte in al Dat quartiet is leer barot/met groote boomen belet / als pÿn-boomen eptisen ende andere; Daer menighte ban moltuen in loopen die

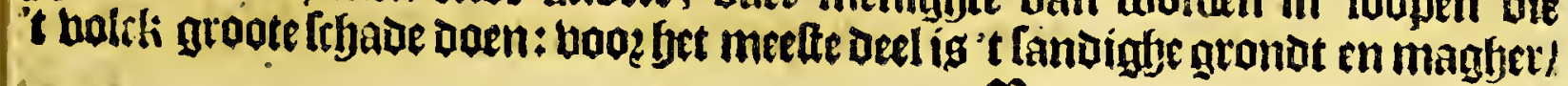


enoe in tuepniqgylaetfen is flet klepe ; bet aten-klippen: ten tetiónt niet dat Daet

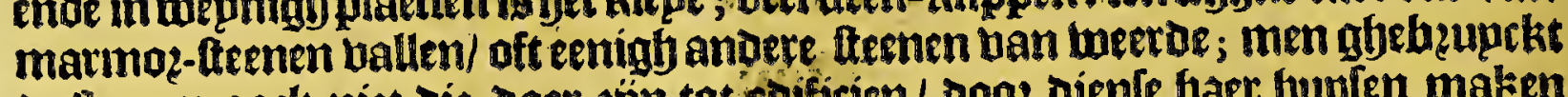
De ltenen oork niet die vaer jun tot edificiem/ Doog dienle haer bupten maken ban leem ofte aeroe-werck: Sgantiche lant ís bol van metalen/filber ende, kopet;

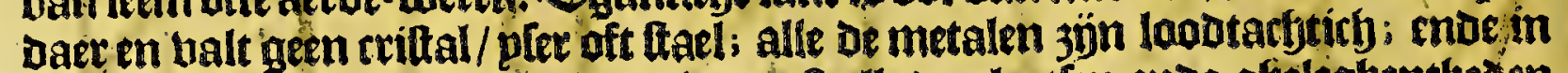
oe mijnen van oe $Z$ a catecas, enoe in meelt alle de plaetien ende gfjeleghentbeten ban dit lande raeckt men aen de margatiten/ende aen de mineralen die men noeme Chalchivites. Agen binot baer eenigbe groene fteenen/ welcke leet gart jön te=

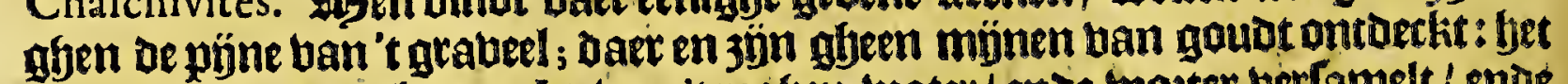

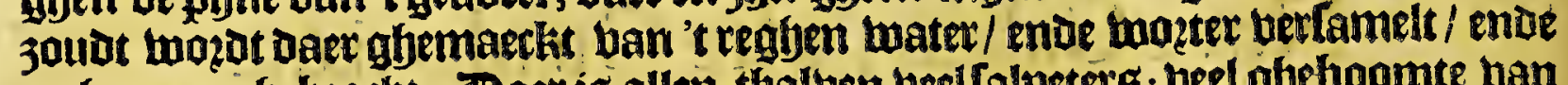
op boopen ghebzarbt. Baer is allen-tjalten beel lalpeterg; veel gbehoomte ban Tunas, welck geft een wonderlícke gaede butbte/ ente beel Cochinilla, boe- - wel

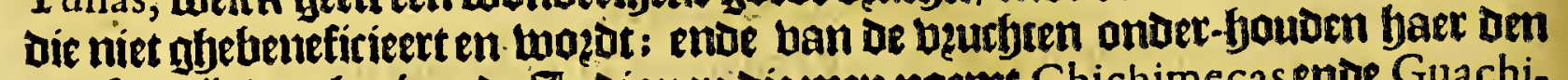
meetten tj̉t ban fjet jaer of Indianen die men noemt Chichimecas ende Guachi-

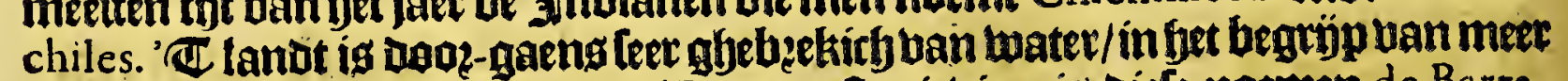
ald fettich leguen blacke groviot. De grootte rietuiere is diefe normen de Barrania, welck haer oof [pzontk fyeft upt het latk ban Mechozcan, enve baer upt-twas

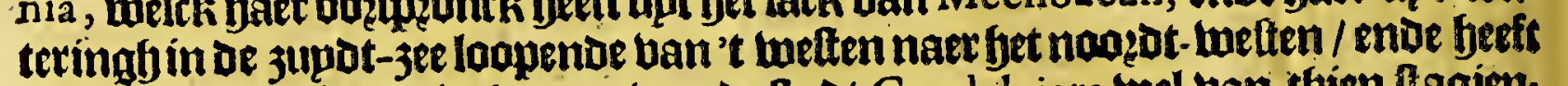
en bal ofte foztinge bier leguen ban be ftadt Guadalaiara wel ban thien lagien;

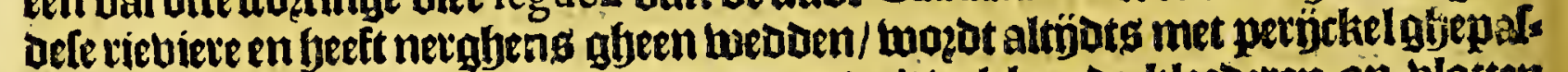
feert / De pertoen daer ober lmemmende / ende 't bolch ende kleederen op blotten

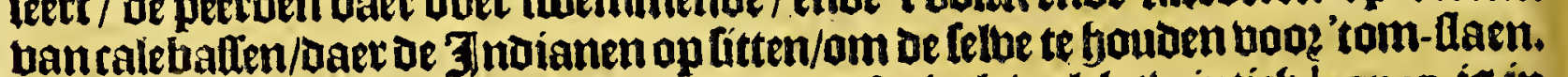
- Dntrent't lanot ban Y catlan, is een mepe ofte lack melck thintich leguen is in het om-gaen/ende een ander $Z_{2}$ cualco, dat thaelfleguen ísin bet om-gaen/moe rontom sön feet goede lwepden too de peerden. In alle de ballepen ban dit lanot

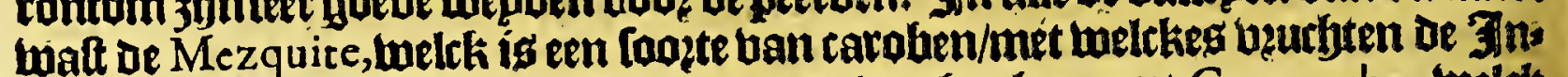

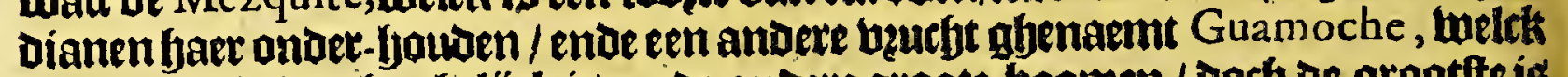

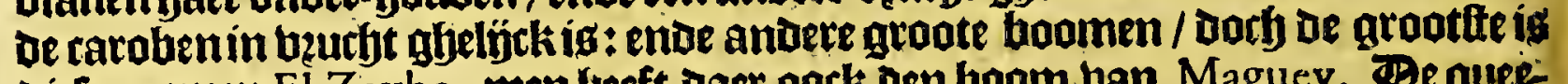
diefe noemen El Zeybo; men ljeft daer oock Den boom ban Maguey. De quebappelenenoe peeren / granaten/ büghen / apgicocos / perfen / melocotong/ ende

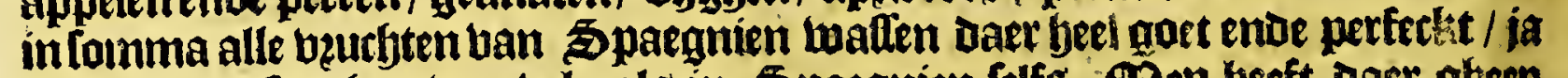
beter naex 't leggljen van bele als in Spaegnien felfs. 9 Sen beeft baet gbeen liriecken nodjte kerfen / Doos dien 't landt loo bucthtbaer is / Dat die boomen loo weeloerich loof ente tacken maken/ datfe gheen beuchten konnen boozt-bzen= ghen; De oljuenen willen daer oork niet wel waflen/ Dooz dien de mieten Dic bes Ithadighen. Het aertrürk is leet obetbloedich ban mepuen booz aloerfande bee : entoe daer is eentwotel diele noemen Coftannuela, welch de berckens al fou

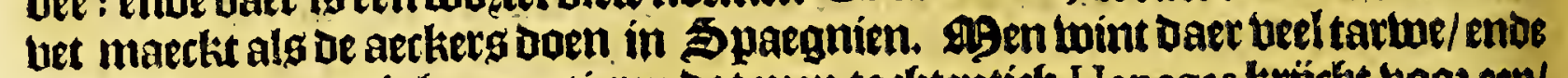
bet ghebeurt in eenighe quartieten dat men tarftentích Hanegas krtücht toae een/ enoe ban Maiz wel twee hondert ende meer. Be peulen ende andere mae- - ktup:

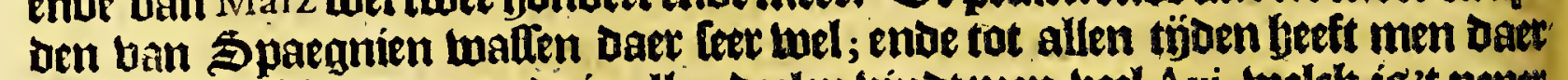

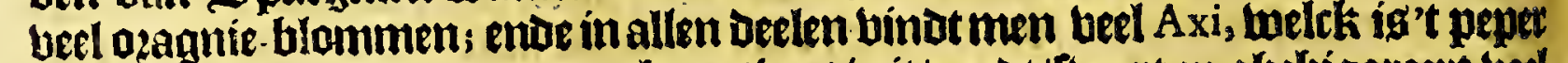

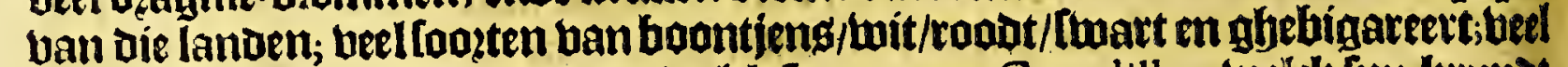
Calabaffen; baex ig een frupot welck fp noemen Cevadilla, weick inn ktupat ende apze beeft; de Spaegniaerden dienen baer daer ban om de wonden ban oe peeroen te abenelen. Be gerfe ente rogghe wil baer oock twel wallen/ ban

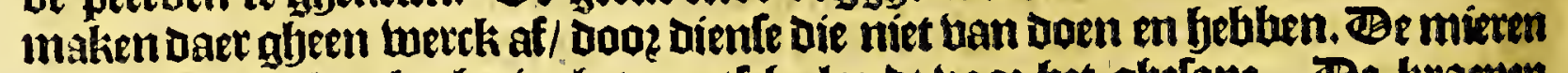
is ecn gljenetale plaghe in bet gantlebe landt booz bet ghelape. Be kraepen

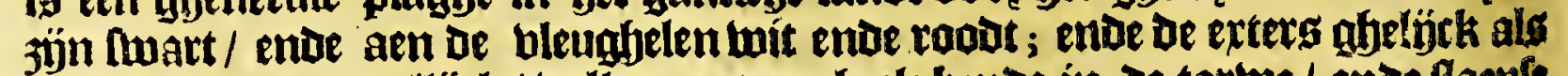

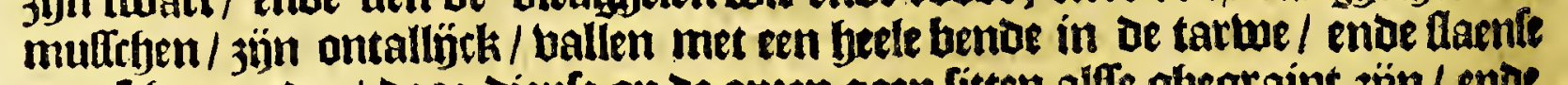
gantfry ter neder / woos dienfe op oe apeen gaen fitten alfe ghearaint zijn/ ento

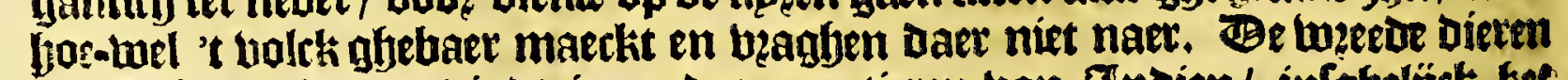

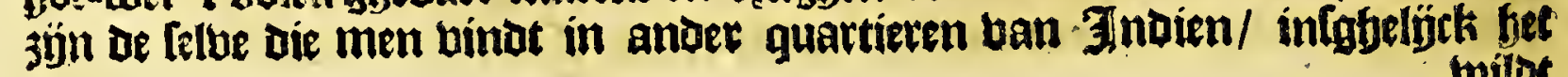
willor 
Juilor tot oe jactyt: De bertkeng/ frfapen enoe gepten geneteren als in Spatgmien/ ende met minder moepte/ ento dart is groote.menighte/ als mede peeroen/ftieren

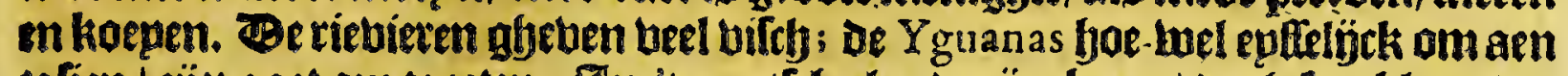
te fien/ 3ön gaet om te eeten. In 't gantfebe lanot jün bpen/ Dorb feer klepn/ent tereken niet / maken baer boniry in De bolte ban de boomen.

\section{Het thetar capittel.}

Van t'volck van de lande, ende de Spaegniaerden die daer woonen.

\section{$\mathrm{D}$} An meeffen-ded ban de Spaegniaerden die faet ím dele landen onthouden/ d. 4. l.9. leven eentoeels bucontractatien ofte koop-bandel/anoer-Deels bp't benefice $=0.13$. ren ban de mïnen/ende ten derden bp jet boeden ende boott teelen ban bee/ ende bouluen ban bet landt. S9en wint Daer gheen fupcker / boe-wel de rieden Daer

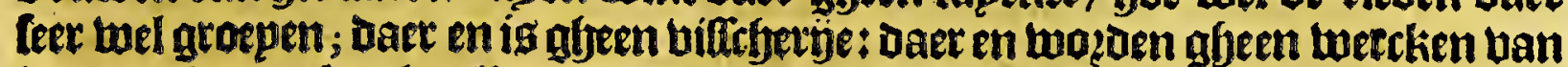
beeten ghemaeckt als alleen waepers om oe blieghen te beroejuen: Daer is eent Tunal ofte bolety ban Tunas hoomen / wel in de biftich leguen langh / Daer men alte jaer wel thien ouplent atroben Cochinilla fonde kommen bergadeten. $\$$

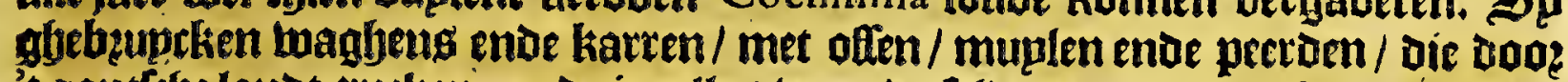

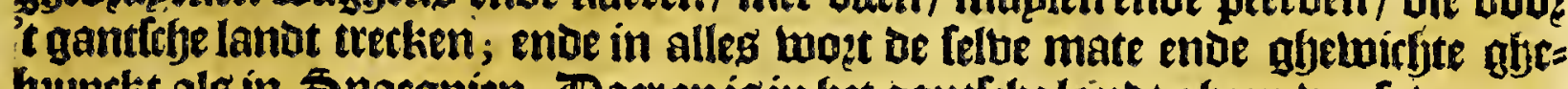

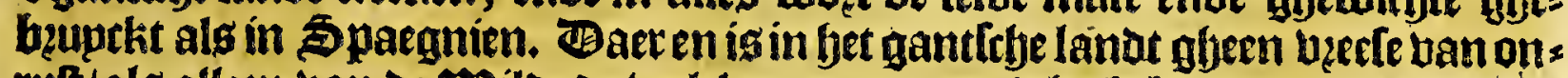
rult/als alleen ban de Hilde oe welcke men met eenigh gheloulu ban belen ente fparren kan tegbenftandt boen; haer twapenen jịn boghen en pülen/ Macanas, dimglyers entoe frbiloen; de Spatgniaetuen ahebeuptken Efcaupiles tan cottoen/

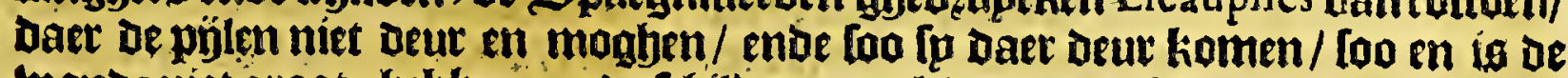
bonde miet aroot; bebuen goede frbilion van ledex/ ende lyelmen ban het lelue ; alle de Spaegniartien 3 in meelers om Gaer mapenen felfs te too?-fien/ ende baer peetden. Be Indianen jün leer lichtbeerdich ende on een kleque fake betla= tente baet twoon-plaetle in o'een bopp oft d'ander/ende daen baer tweder neder Daerfe eenigge ghjereetlfyap binden om baer futten te maken; ja loopen in de twils

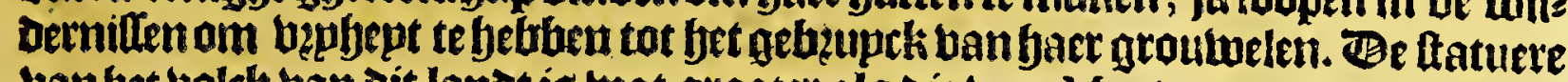
ban yet volck ban dit landt is bat grooter als die ban Mexico: nemen oe Chyi=

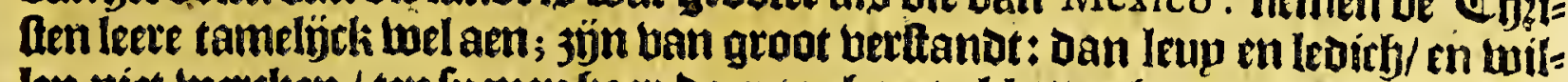
Ien niet wercken / ten fp men faer daer toe buert: klecten baer met gemben ban cottoen / enoe bietkante mantels / met twee knoppen op oe ftyouberen ban tot= toen ofte Maguey, weltk is baer oude kleedingh: dzaghen onder-bzoecken; frboe= nen met folen: Jaer bedoen jün matten ban biefen / rnde Deeckeng van cottaen ofte twalle: baer rieraet jïn groene fteenen/ Recken-buthens om de beenelt enoe

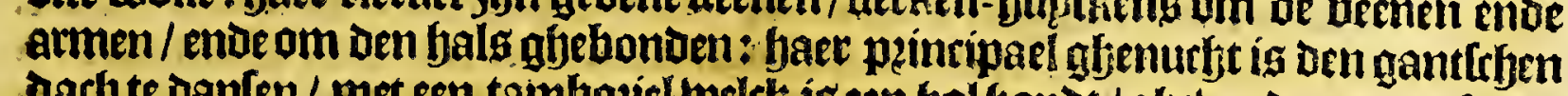
barb te danten / met een tamboziel belth is een hol boubt / ghebende cen grof glje= lupot/fingende/en baer frbilderende/ ende baer fracp makende met beel plupma=

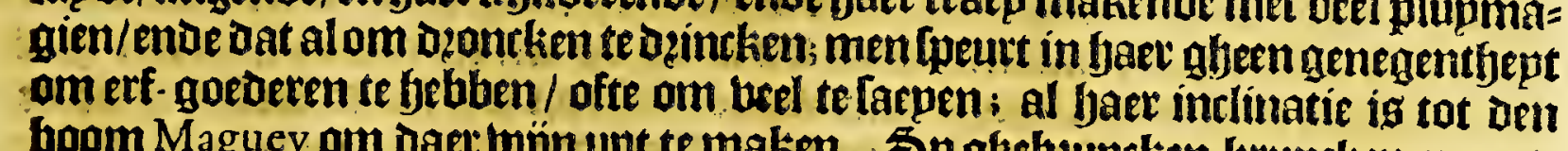

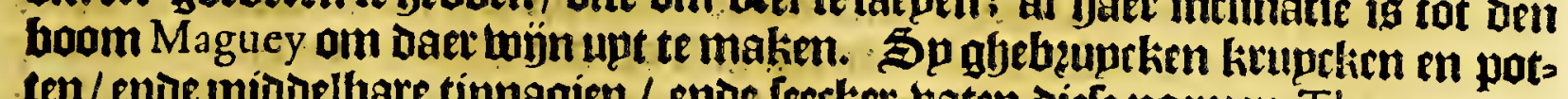
ten/ende imidoelbare tinnagien / ende leetker baten diefe noemen Thecomares,

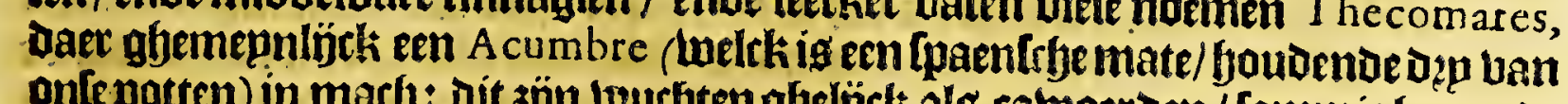

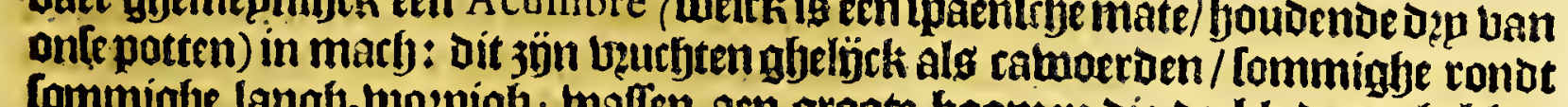
fommighe langh-moppigh; twatien aen groote boomen die de bladeren bebben als moer-belpe boomen/ende woet bp be Spaegniartoen Higuero gfenoemt; beten op/ om Darfe toepnigh moepte bebben; eeten Maiz tot bzood ghebac= ken/cnde oock gherooft; drincken de tuṕn ban Magliey, ende banCacao, ende de Cacao met bet meel van gyerooftet Maiz bermenght / ig oork bare fpjef ide

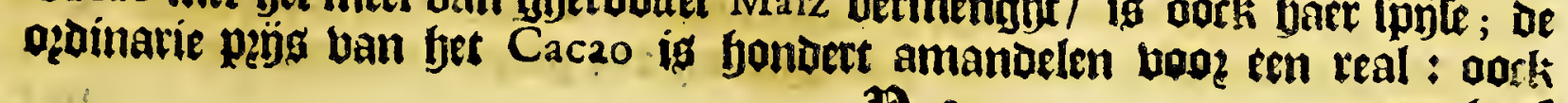
102 metighente 
menabenle oe Cacao met peper/ende't lamen ghemalen met bet Maiz, becetkente 't [elbe in water ende deinckent loo; dele mengbelinghy ban Cacao, Maiz ende pe:

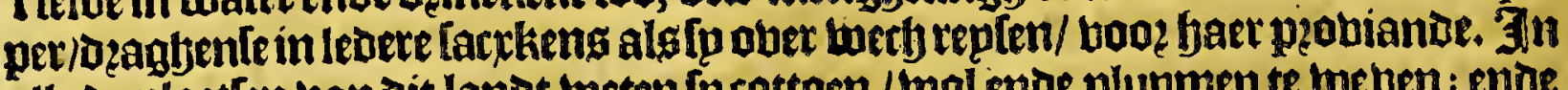
alle oe plact Ten van dit lanot wetenfp rottoen / wal ende plupmen te toeben; ente 'tlanot ís bequarm om rottoen boots te beenghen/ maer fp en willen haer daex toe niet begbeben/ om den arbept te Ichoutwen. Be intrumenten Daerfe of aront

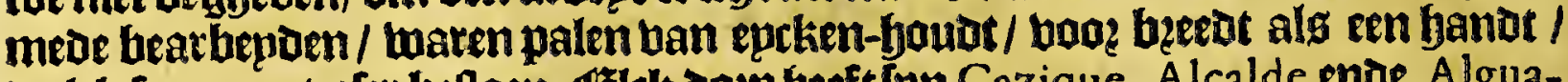
welck fo nu met pfer bellaen. EZIck ondp heeftipn Cazique, Alcalde ende Algua-

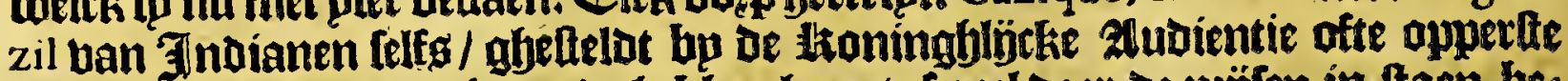
Alcaldes van dat quartier; ende bebben baer tafereel daer de peỹen in ftaen bes groot ban oe eethare waren; de Caziquen wozden bp lucceflie ghenomen. The meelte aftrante die men baet Doen kan / is datmenfe ftbert; ende baer meelfe

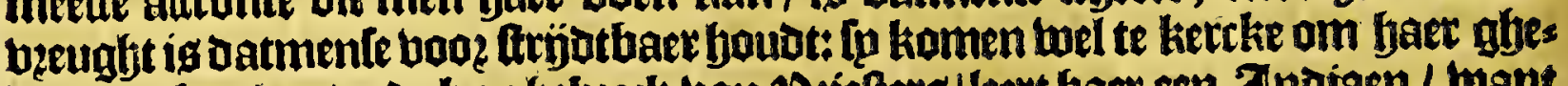

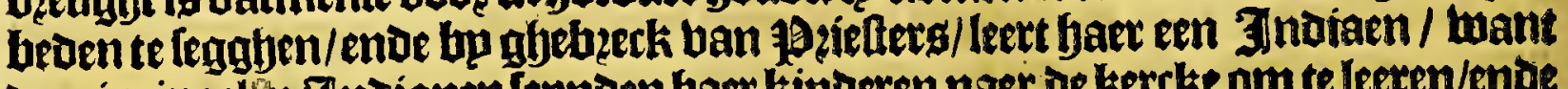
Depeincipaelles Jnoianen lepnoen haer kinderen naer de ketcke om te leeten/ente boo2 99 onninstient te dienen. Cot bet jaet twee-en-tachtich toe / waren daex

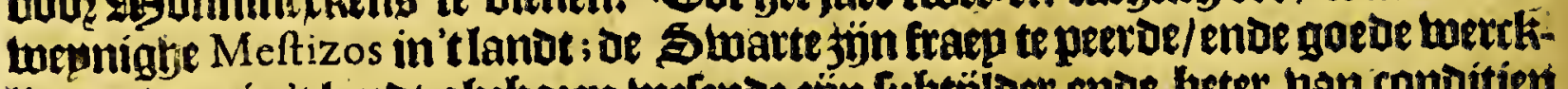

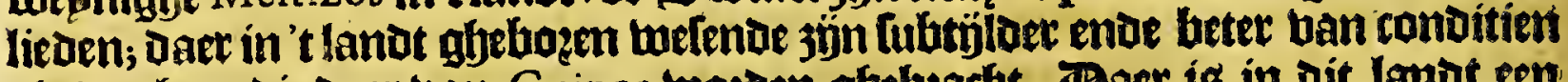

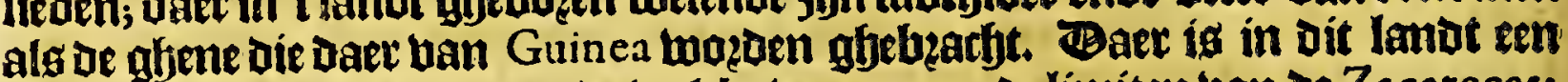
natie diele noemen Cazcanes, De toulcke moonen op de limiten ban de $Z$ acarecas:

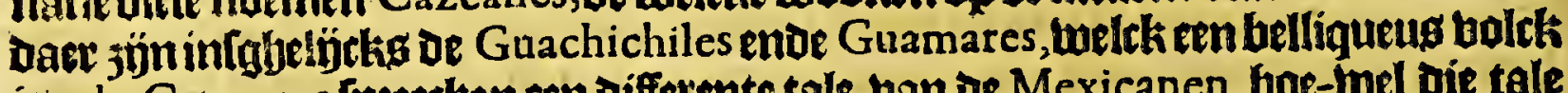
is: de Cazcanes Ipteetken een differente tale van de Mexicanen, boe-wel die tale ban Mexico Daer oock bertaen motor / ende dat vaet allent-halbe tolcken ban 3jön: Guachichil íg oock different ban bet mexitaeng / ende de tale ban Guamara

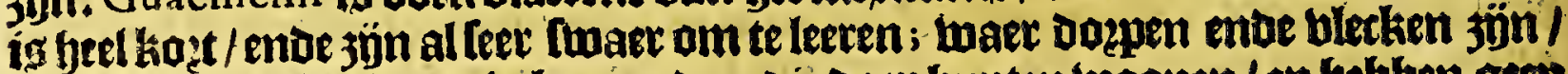
Daer eben ae Indianen in beter ozoge; Die daex bupten woonen/en bebben geen Iuft om haer iaer toe te boegben/ op datte te beter bet bee fouden konnen fteelenl Dakte Leer toe gyenteghen $3 \mathfrak{g}$.

政et berde Capittel.

Van de provincie G V A D I A I A R A in't particulier, ende de fteden dic in dit deel by de Spaegniaerden nu worden bewoondt.

$\mathrm{D}$

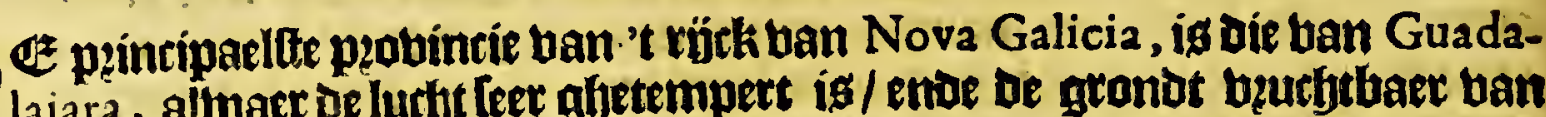

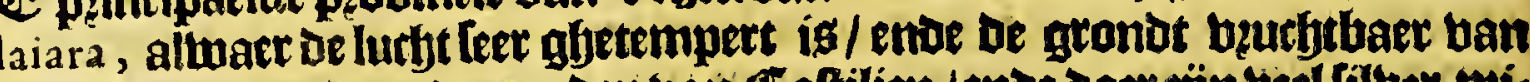
tartwe ente Maiz, ende andere jaden ban Caltilien/ente daer jün beel lílber-mi= neralen;enoe de naer volgende plaetlen bp oe Spatgniaerden als nu betwoonot.

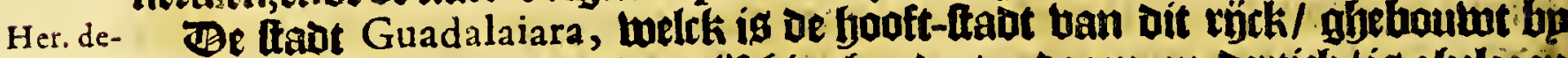

fcript. Nunno de Guzman in Denjare büfthien bondert ende ent-en-dertich/is afelegen op of hooghte ban twinticl graden en een deroe bp noogen be limie/ naer 't leg. gijen tan Herrera (De kaerten ftellen die meel op een-en-twintith en een Galf

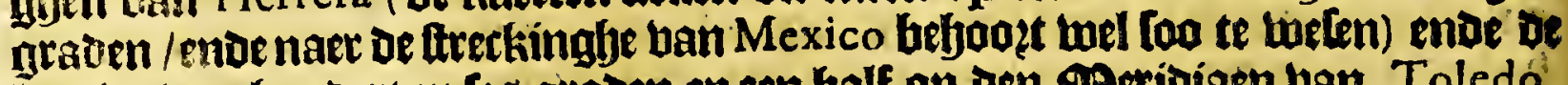
Ienahte ban fondert en leg graden en een balf op Den ageridiaen ban Toledo,

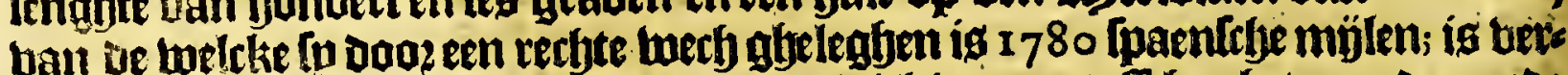

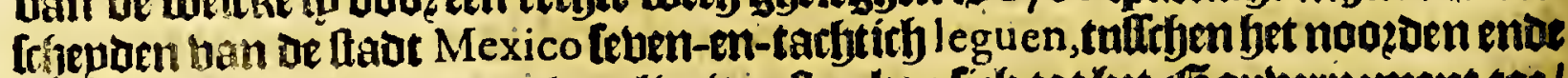
weiten/meer welt-waets; ; haer limiten ftrecken fich tot bet Goubernement toe! melek [u noemen de Francifco de Yuarra, han welcke bet bem af-Lrbept naet het

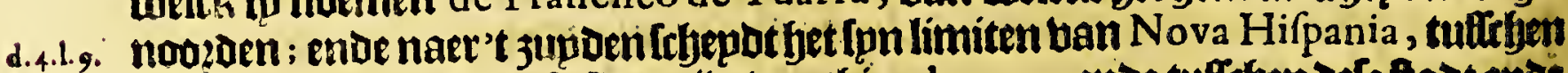

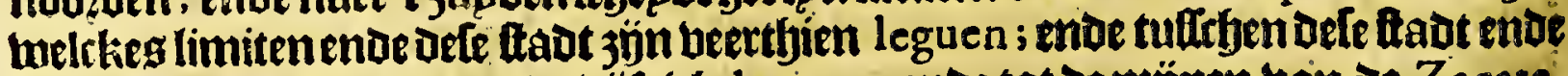
Culuacan twee bandert ende bỷftich leguen; ende tot be münen ban de Zacatecas zïn biet-en-twintich leguen; (Herrera [eghteloers beetrich/ welck rertht ig) tot

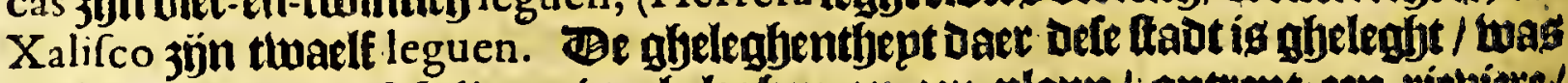
eetribtg ghenoemt Molino : is ghelegfen op en plapn/antrent een riebiete/ 
Het fefte Boeck.

met quede fontepnen / wateren ende twepoen / ende goede jaep-landen / ende gheberghte om your te betiomen/ende goedematerialen tot de edificien; De geftalte ban

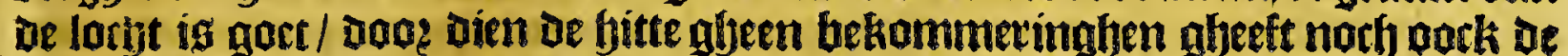
koude/ ende daet en ghenereert gheen onghedierte; De tarbe ban Caftílien lualt

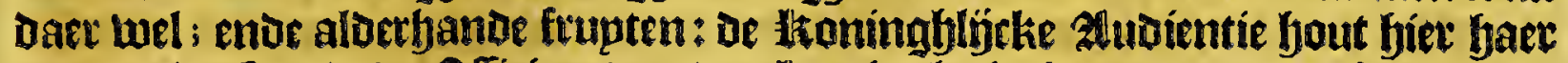

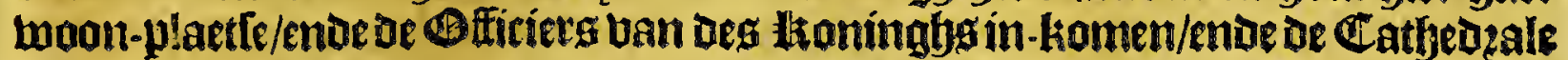

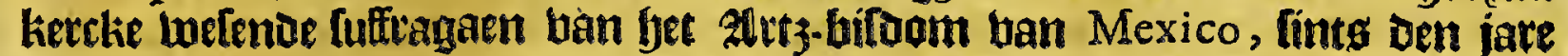
1.570; welck eerth twas gljedzineett te leggfjen in is ftat Compoftella:

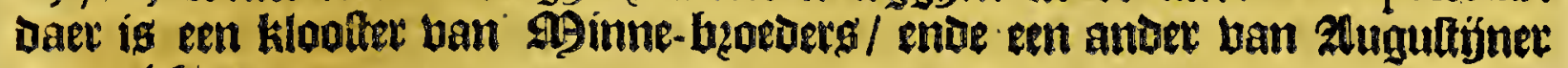
mamnicken.

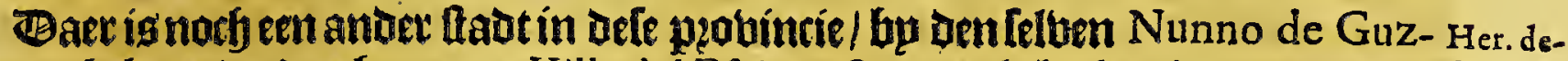
man ghebout/ ende gfenaemt Villa del Efpiritu Sanco; gbelegfen in De peobincie fript. han Tepique.

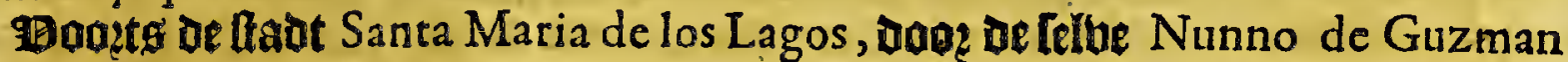
gbehoubut / Dertith leguen van Guadalaiara naer't zupot-poften / Daer een Alcalde Major refideert; oefe ttadt mierdt fiet gyelegbt om lich te berfeeckeren tenflen de Chichimecas, twelck woonen in die landen tulleben bet noozoen ende oolten/

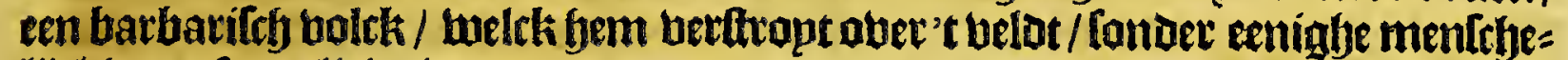
lijckljept ofte policie/ lebende in tabernen/ende in oe boffefagien als willo bee ften/enve faec onder-fjoudende ban de jacht/ende alderfjande wilbe beuchten/en

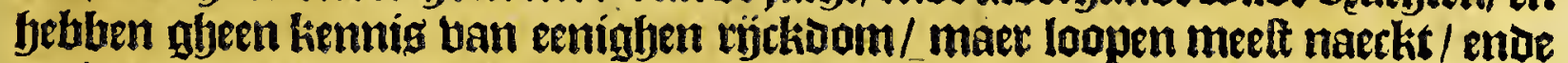
oock tuel eenighe met beefren-bellen be Deckt; baer wapenen jün bogben ende pij: len: jün anders fraep ban lichaem/ groote vzaten ende dequckaettg / maken Dzanch ban feechere hoetelen / Daerfe fraer bolin fuppen.

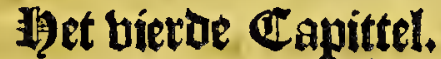

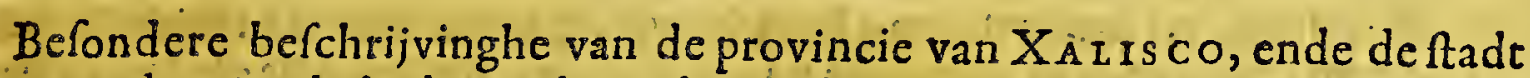
daer in gheleghen, als mede van de provincie CHIA METLA.

De theede probincie ban dit rỉck is ghenaemt Xalifco, welcke bed butuctjts

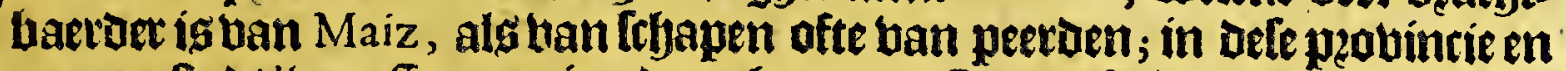
is maer een ftast/ ban Spaegniaer ben ghenaemt Compoftella, ghelegen ontrent Je jee-kufte / op de boogljte ban een-en-thointich graden (naer' $t$ legghen ban be

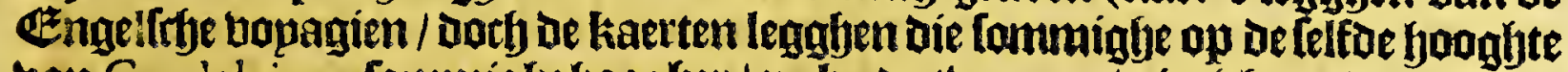
ban Guadalaiara, [ommigfre boogfer/en bp de thee-en-thintich graden /) Dzpen-Dertity leguen ban Guadalaiara naet het twetten * is abeluaulut bu Nunno de Guzman in oen jate bijfthien bandert entoe een-en-Dertief / op een plapn / onttent

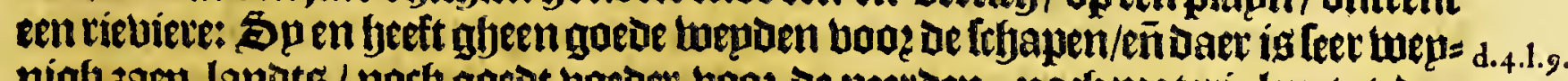

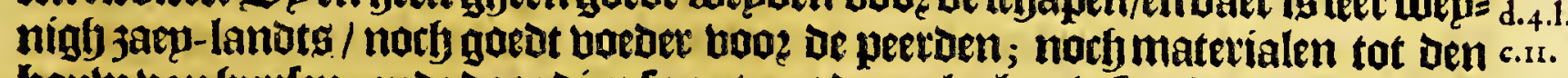

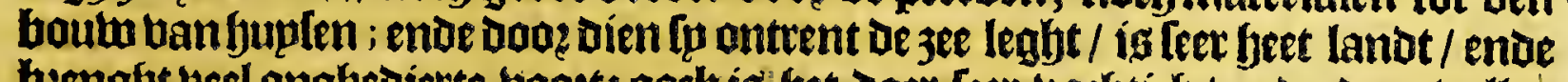

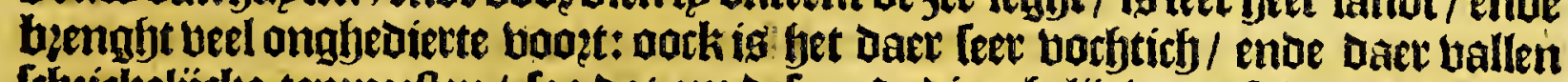

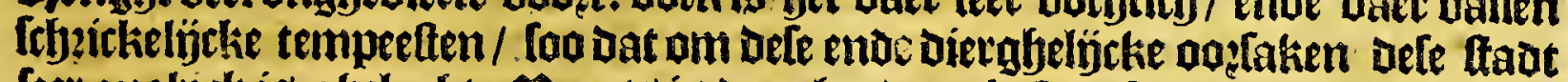

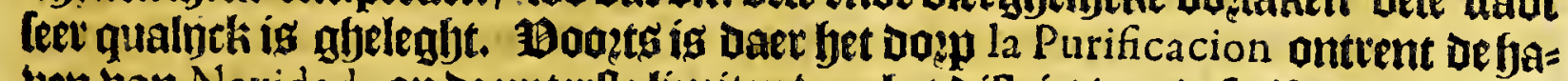
ben ban Navidad, op de upterffe limiten ban bet diftrict ban Defe zftraientie ende die van Mexico, in een feer hete contrepe ende anghelonot. Be kufte ban Xalifco is gfyeleghen op of fooghte ban wat meer als twee-en-twintich graden bp noozoen of limie: naer 't legghen tan Herrera.

Ilen de pzovintie han Xalifco confineett of plobincie ban Chiametla, thin: tich leguen langh en lueect / op de kufte ban ae 3 upot-3ee gfeleghen bu de beettich fpaenffije mülen van Xalifco; is een groote p2ouintie; ende daer woande eettijots d.4.1.8.

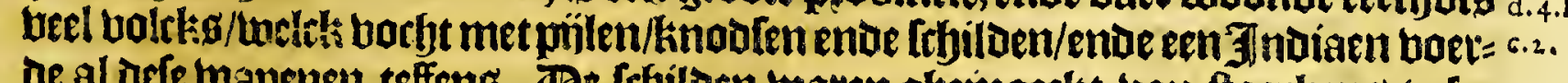
oe al defe taapenen teffens. De frfilben waren ghemaeckt ban ftorklieng te las

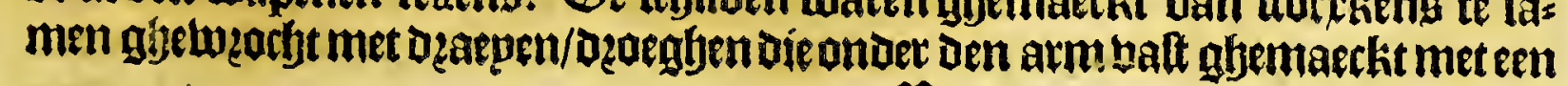




\section{$226 \quad$ Nova Galicia ofre Guadalaiara.}

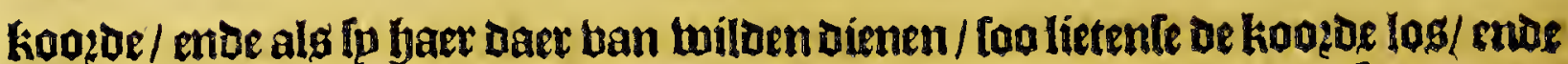
diende baer bope en lebilot / ende waren oaer mede bedeckt; ende als fp ban een man te peerde berbolght toerden/Loo legghen fu baet nedet op de gronot ende der len yaer daer mede; bet moet een fterche lancie jijn die de telve palleren foude?

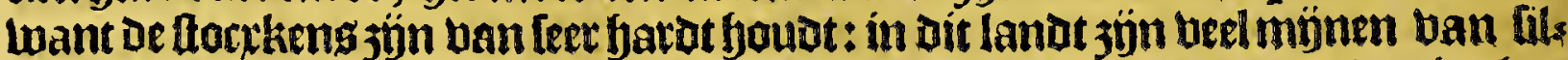

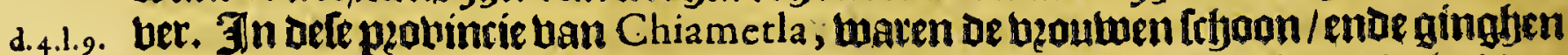

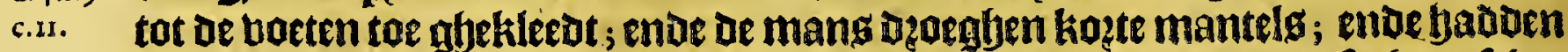

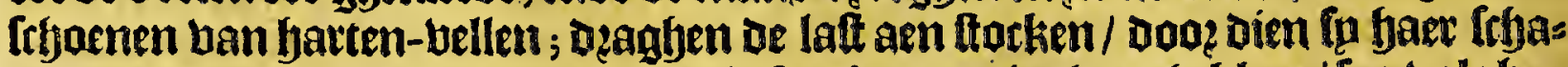

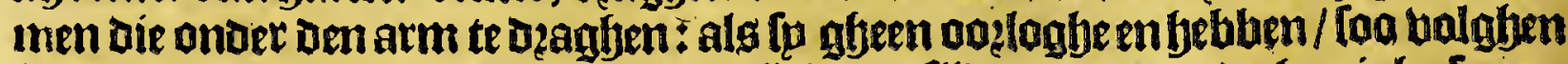

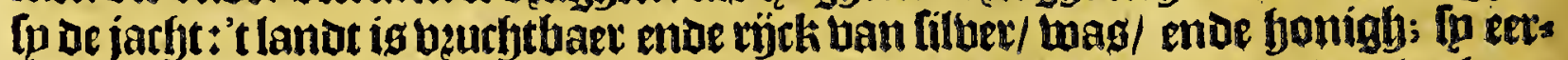
ben eertijotg de afgoden-beeloen/aten menlchen-bleelch/ende hadoen beel ans

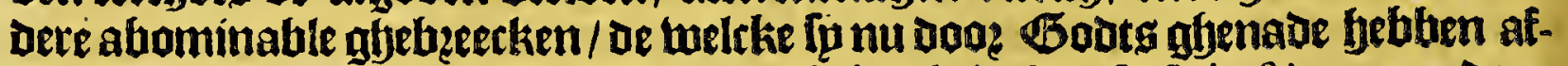

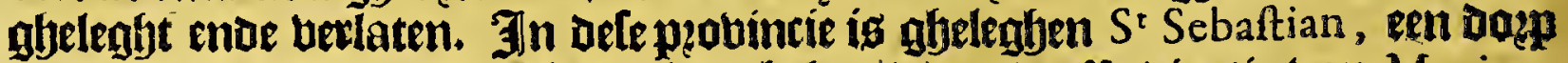

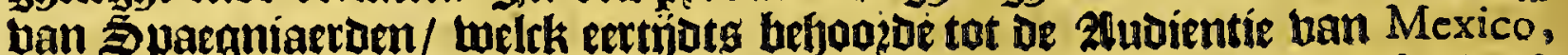
ende is gelegen op de hooghte banmeer als twee-en-twintich graden. Befle plaet te was gheleght bp of Capitepn Francifco de Yuarra inden jare 1554, enae daet

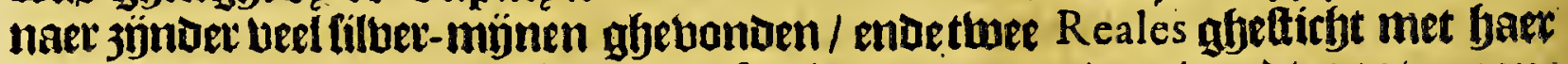
noodighe Ingenios han molens/ende fmelt-abeng; ende daet hozotgroote quans titept ban filtuet ghebeneficieett.

Set bütae Capittel.

Particuliere befchrijvinghe van de provincie van $\mathrm{C}$ V L V A C A N, ende haer eerlte ontdeckinghe by Nunno de Guzman.

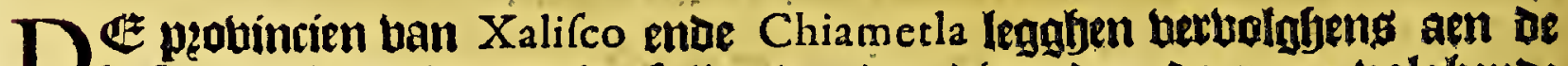
kufte ban be jupot-jee / foo fullen wp dan die andere daer aen bolgfende

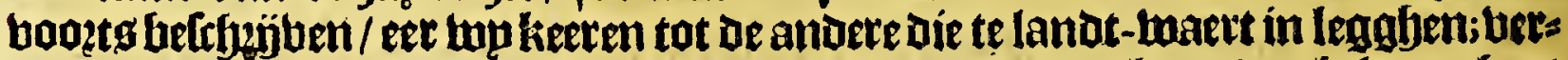

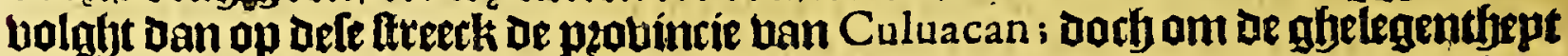
Daer ban beter te berftaen/ [oo lullen top in't kotte aetr-roeren ae erette antarckin= glye ball dit quartier bu Nunno de Gufman verricht in den jare 153 I. Ban Chia-

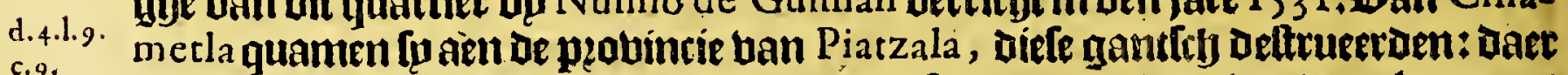

c.9. na aen een andete glyenaeme Zapuatan, daerfe meer beoumen bonben alg mang/

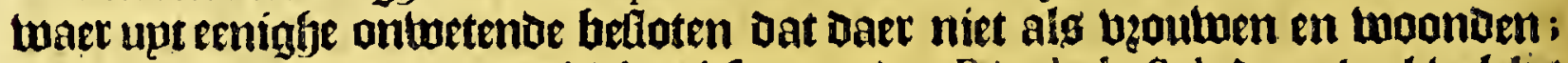

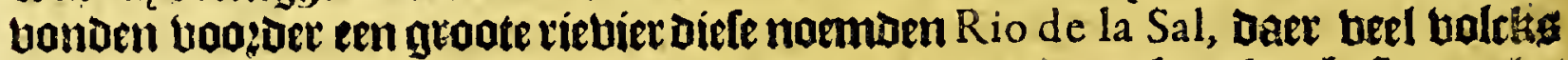

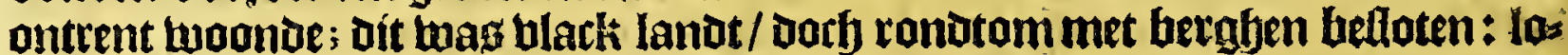

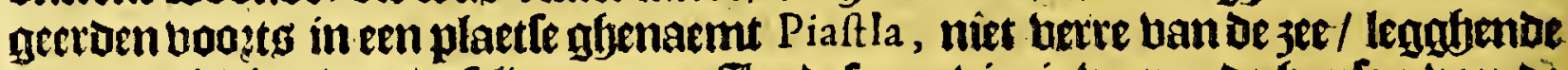
aen een riebiere ban oe lelbe naem. In Dele pzobincie twaren de buplen than de

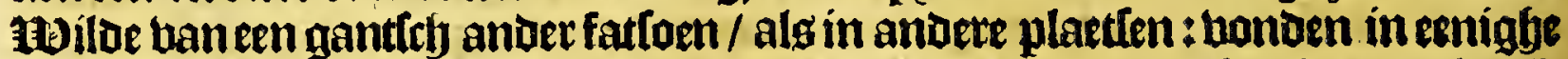

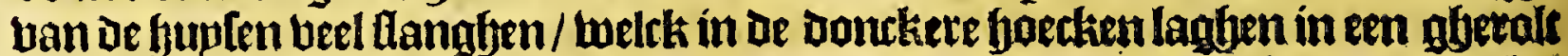

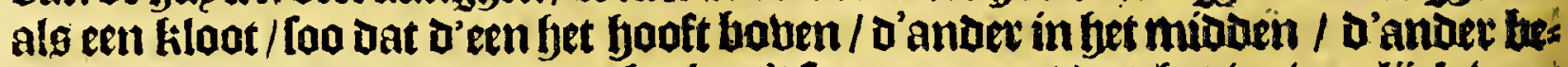

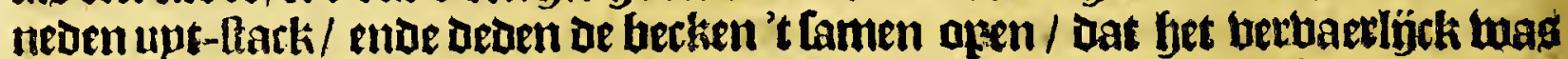
om fien / oocf oeden anders gheen quaedt; de Indianen namente in haer bans oen/en atente/ende fjadoen die infonoerlinge refpect boos dien den wupbel baer in

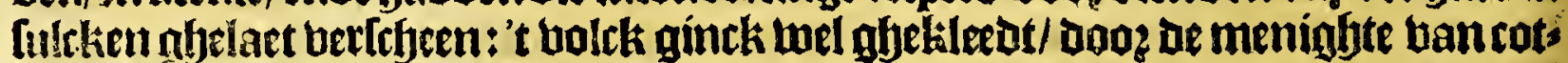
toen diefe fjebben/ende daer mag fraep byoutwe bolck. Ban 't balck ban Nunno de Gufman deftutertien al 't lande. Crecken han daer naer Bayla, ende quamen bookder aen een groote rieviere diefe noemben Rio de Mugeres, om aat lp daet nist aan bzoutuenen lagfent; 't landt baet antrent is bal ge boomte ende leer dichte

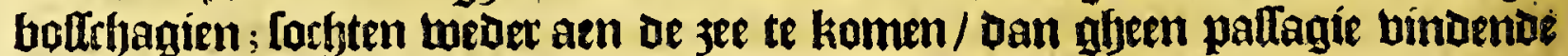

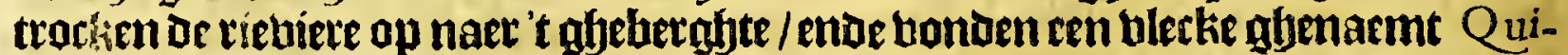

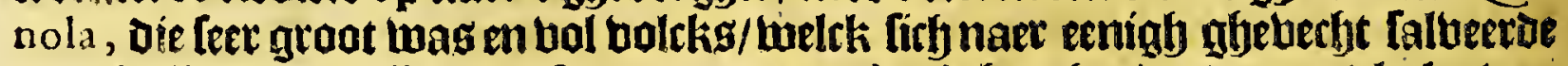

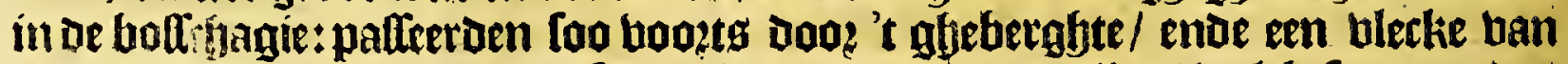

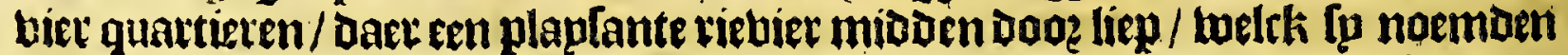


Quatrobarrios, om be biet quartieren wil ; ghelötke een ander noemoen Leon, om datfereen lecutw bonden. Bit lamor mas vol woon-plaeten / ende leer beurbt=

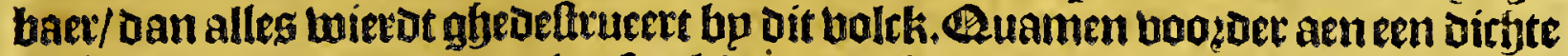
bofryagie daet beel woon-platten bimuen laghen; enterden de felte / ende wiet= oen die meeter met veriles van eenirb bolck:trocken al dieper in bet gyeberghte fonder upt-komfte te binden / foo datfe grooten jonghet leden / enoe waten epnt= lijek ghedzongfen te keeren naer Culuacan. Be pzobincie ban Culuacan ig en Her.de-

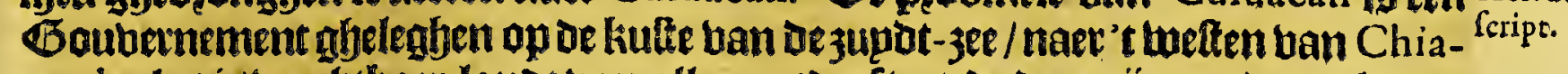
metla : bet ig buthtbaer lanot ban alle nootouft; ende daet jún goede teeckenen

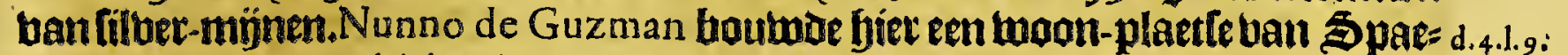
gniaerden/aen de rietiere tan Orala, om de commoditept yan de naeft ghele=c.11.engben rievieren $R$ io de Sal moe Rio de Piaftla, ende noemae de felbe San Miguel; de s.c.8. enoe is ghelegben oy de booghte ban bier-en- dertich graden bp noozoen de linie/ naet 't fegqfen ban Herrera, die fent fiet Letabuleert / want kan niet bouen bóf-

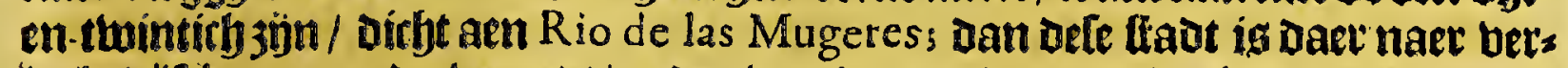
leght bijf leguen nedertwaetts / ende twee leguen ban de $j e e /$ in de ballepe ban Horaba, om Dat Daer beter gbeleglenttjęt is ban jaep-lanoen/frupten/ende an=

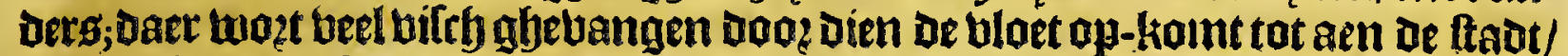

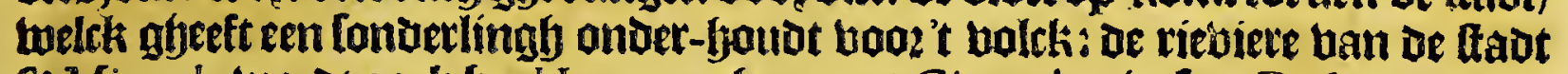
$S^{r}$ Miguel, mazdt aock bp Herrera ghenoemt Ciguatlan in fpn Defcripcion de Her. de.

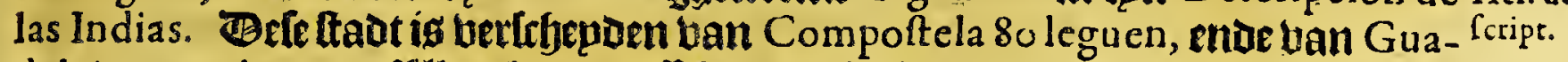
dala iara 103 leguen. Zflle't lande tultrben de riebiete Piaftla, ende devietuete $\mathrm{Cu}$ luacan, isfeer duerbloedigh ban virtualie / met beeloetlep frupten ban dibertige

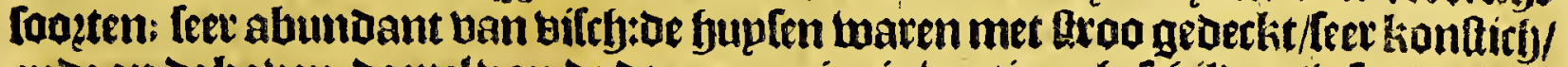
ende op de boven- Daspel ban de deuren eenige intentien ghelchildett/inlondethept

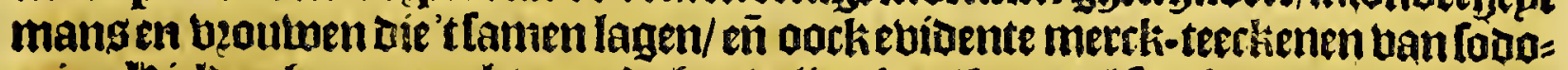

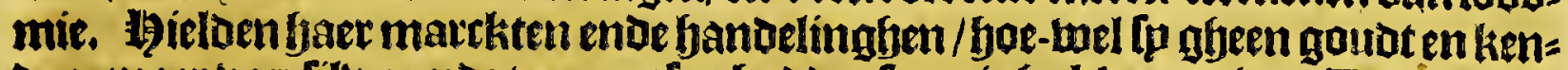

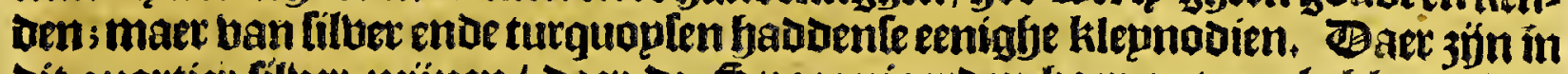

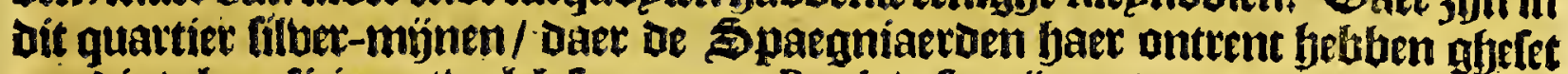

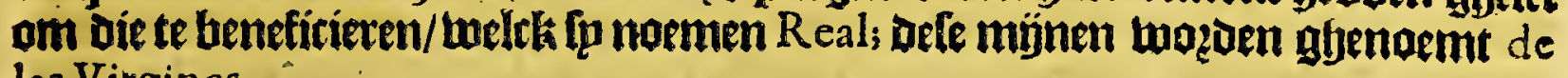
las Virgines.

\section{Het tefte Capittel.}

Befchrijvinghe van de provincie van $C_{I N A} O^{\prime} A$, ende haer cerfe ontdeckinghe by Nunno de Guzman.

N2lelt De pzovincie uan Culuacan is ghelegen de pyobincie ban Cinaloa, welck Her. de. ig de lelte ende noożelÿrkfte van Neuva Galicia, twee-en-beerticf leguen frript. vam Culuacan, ende fonoert en büftich ban Guadalaiara, naet bet noozoen/fjon=

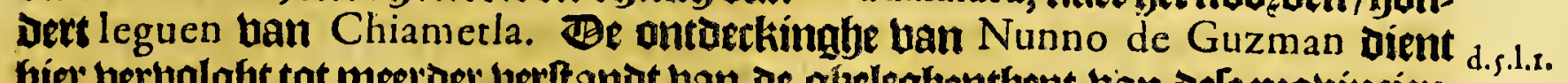
Gier beruolght tot meet der berltandt ban de gheleghentbent ban dele peovincien. c.7. Nunno de Guzman trock in Den jare 1532 ban Culuacan boozoer aen/ende quam boop eerlt aen de rieviere Petatlan, welck jón ujufticl leguen weegba; noemben

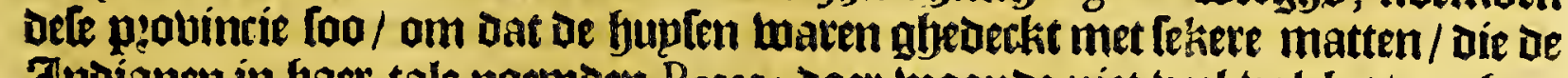
Jndiamen in baer tale noemoen Petat; daer woonde niet beel bolclis/ nocf en badsen gbeen laecken/lketden baer met bereque bellen han yarten/aen denande: ten gfenaept ende onder de armen doas-gebacht/ ende de beoulwen deckten teclit

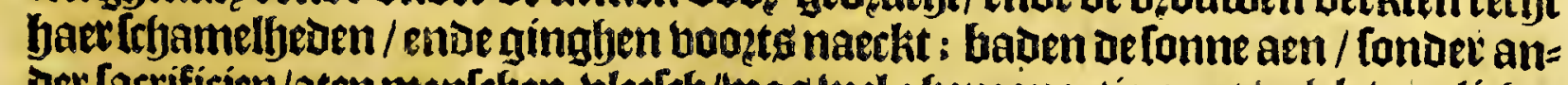

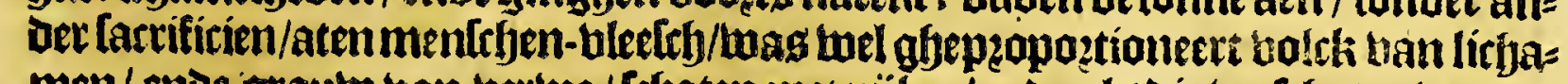

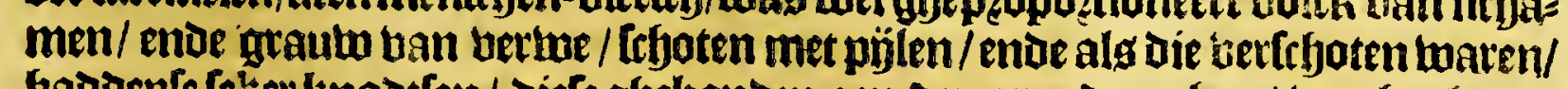

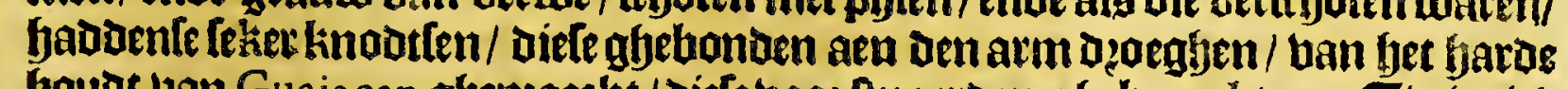

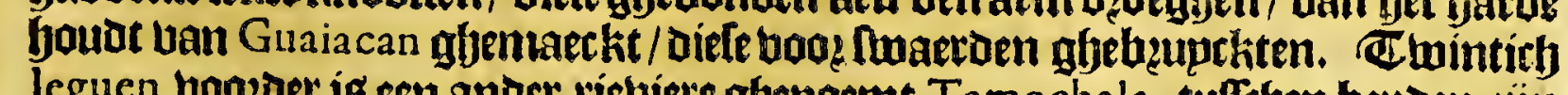
leguen boożder is een ander viebiere gbenaemt Tamochala, tuffrben beyoen ign 30 Dicbte 


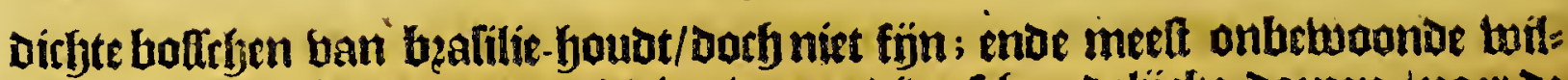
uecuiffe: aen De kanot ban de riebiere twaxen diberfefye redelýcke dospen / naer de wijle ban Petatlan. Ban't treginfel ban oe peouincie van Tamochala tot aen De jupdt-jek jün legleguen, waer wan de bïf betwoont jïn. Dan fier trockente

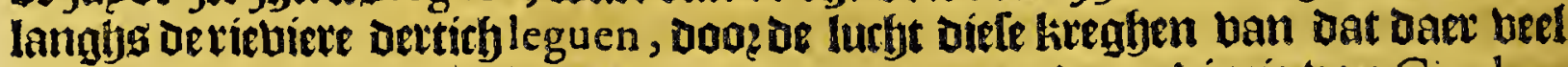
woan-p!aetfen enoe goet lanot twas endequamen aen oe peobincie vari Cinaloa,

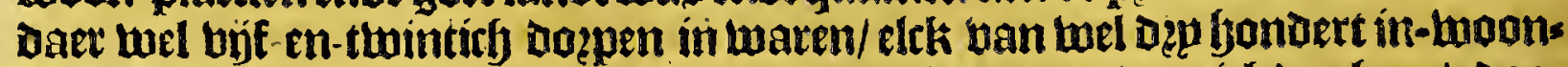
aers. Be Spaegniaetien vertoefoen bier twel thee-en-berticly daglyen / Dooe

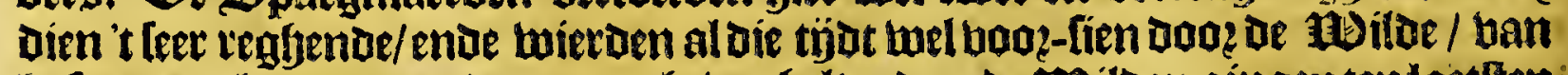
bafew/ toztel-oupben enoe anoer gbetoghelte: Dan de moilden gingenten laetlten ona: ende de Spaegniaerden pafterden De riebiere/ ende togben dertich das.

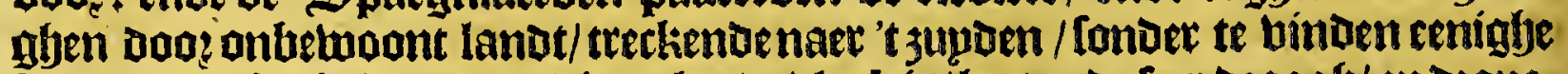

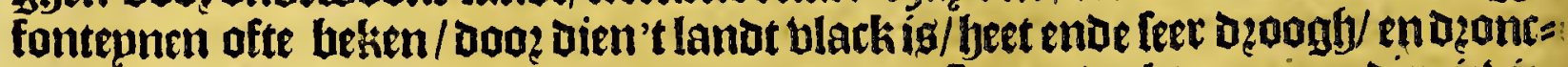
kenalleenupt feket plafen ban renfen-mater. Sp ontoeckten een anoecriebie-

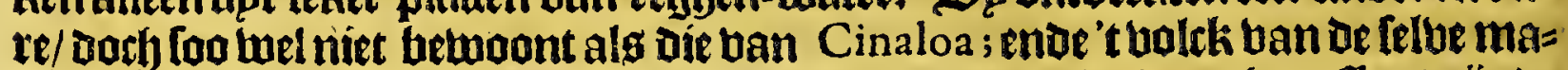
nieren/ghetwact/entoe tale als die van Cinaloa. Be viebiere gyepaliect jünde

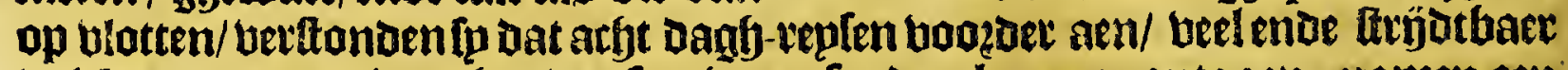
bolck woonoe/ wiens handen [u niet en louben komen ontgaen; namen een

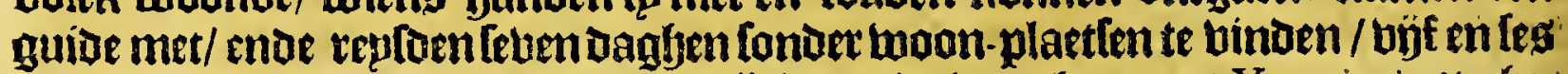
leguen darglis/ ende vanoen epundelijck de riebiere obenoemt Yaquimi; 't ahes

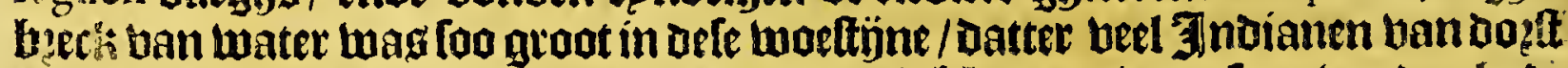
fosten/ende daer foubender meer gheltozuen bebhen/ten warefo gebonden bad: Den teier katboenen ban yet fattoen ban de Tunas, welcke af-ghebarkt 3jnoe/ Coo ueel laps gaten/Dat't uolck bem daer mede berquickte: palteersen de riebiere fonder ernigh helet/ en bonden een bevlaten bogp ban't welck een beede bogh

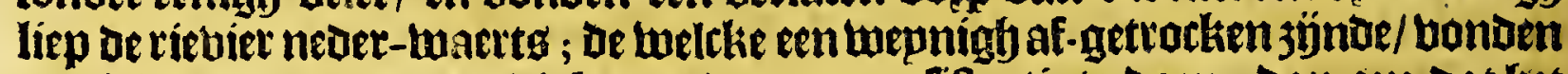
volck in oe wapenen / welck berept was om refiftentie te boen; dan om dat fet black landt mas Daer oe Spaegniaerden met baer peeruen abantagie fadoen/

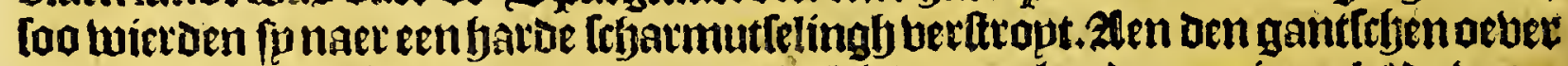

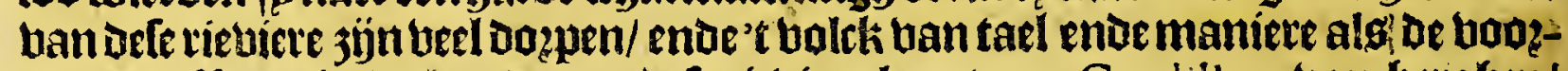
gaende. Ilanghs or kanot ban ofle riebiere loopt een Cordillera ban betghen/

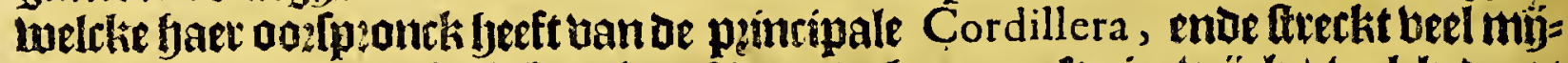
Ienin $3 e$; ende ban ditghebergbte af loopt ox kromte ofte in-wijek / welck buete tot Xalifco toe/ twelck jỷn meer dan twee Gondert leguen; ende ombat bit point foo dicp in jee loopt / foeftmen eettúts ghemeptit dat bet een Gplanbt bas. Je Spaegniaerden keerden ban fier weder naer Culuacan. In't ganttrye land tul= foljen ae twee riebieten Petatlan ende Yaquimi is't tuole bebben aeenfrupten/noty Batatas, nocb dievghelírke dinglyen/alg cilleen feecket meloenen/Maiz, hoontiens enoe ander klepn zatt deer fp bzogot ban maken/en

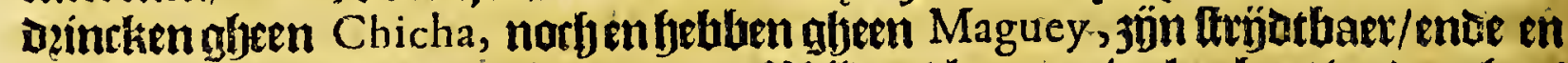
maecken meengheffyeecu als de andere milden/kommen bel arbept betozaghen/

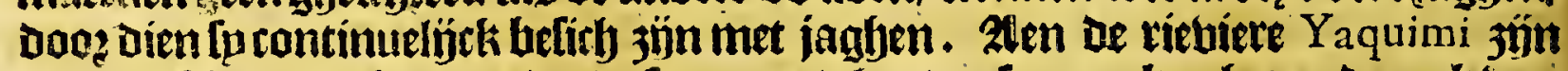
ennighe ltieren/ en lioepen / enoe feet groote barten; fumaecken baren bzanck ban feet:er Hilepne Carobes, die aen de boomen waften die funoenten Mezquites, nes

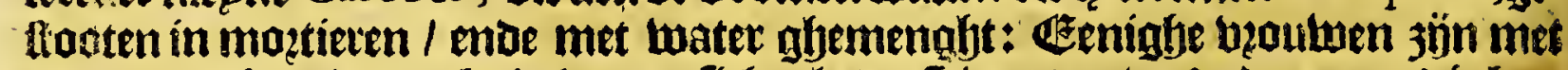

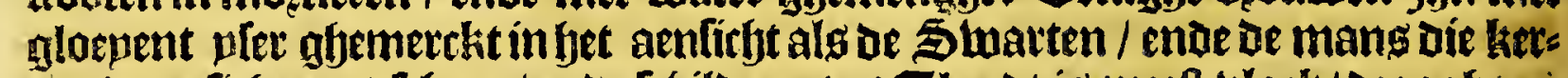

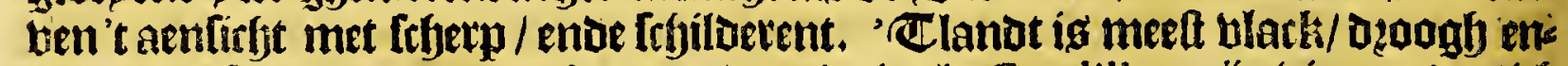

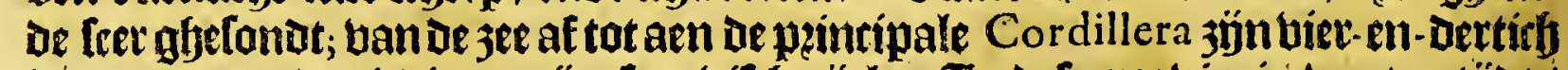
leguen, ende de riebieten jün feer bifrb-tijek. 3n defe probintie maseertijots een moon plaetfe tuan Spaegniaerben ghelenfjt / diefe noemben San Iuan de Cinaloa, da: en febben oie niet wel kannen fouden / foe-wel dat Francifco de Ybarra defe plactle op nieutus ban boltk berfach / enoe alles daex liet beenghen

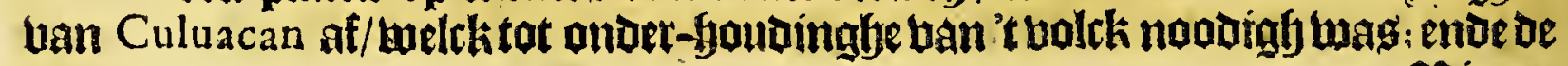

SHinne- 


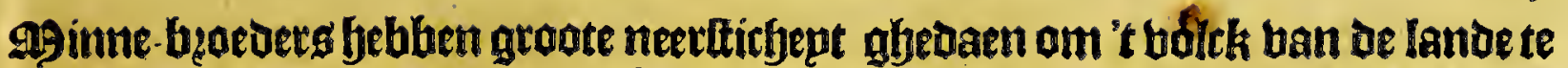
betheren. Binde cen naerder beftbejbinge tan defe plobintie in eenen befef ban

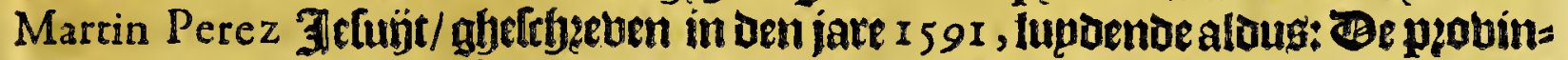
rie ban Cinaloa is 300 leguen ban Mexico, ende ftreckt baer naer 't noogen:

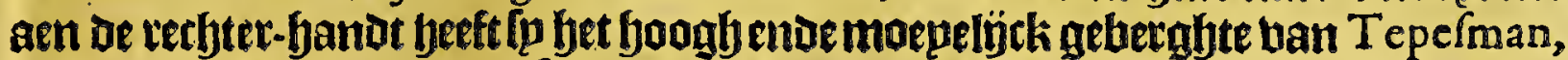
ende aen de thincker de Golfo van California: naer 't weften de peobinmie ban Cibola; naer't nouzden Neuvo Mexico, welck maer twee dagh-replen light ban De

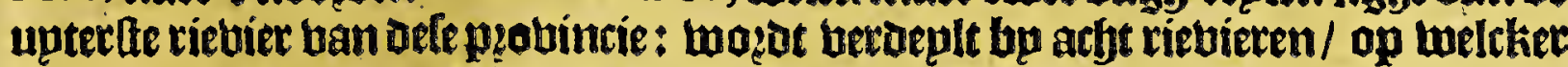
aebers alle de Doepenende twoon-plaeten ban de Jndianen gheleghen jijn om De biffcherye tuille. De grondt is bet ende dzaeghfaem/ enve daet waft licht alles wes daet ghelaept twozot: Daer is een beloze ende ghelonde lucfit. Hebluen abet: bloed ban cottoen/oaer fo hare kleeten ende mantels banmaken; de weleke fu

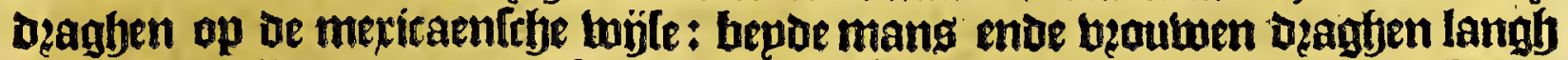

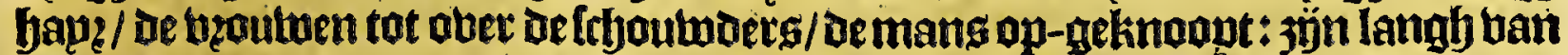
Ctatuete ende in naer een handt beedt langher als de Spaegniaerden; fterck ende Itrijotbaer: Gaet mapenen jün boghen ende betgiftighe pílen/knodtien van Garot boudt; ende kotte pjoken ban roodt boubt: ie Spaegniaerden hadoen beel te Doen/eerle dit bolck tot thilte konde beengben. De telbe maeckt gljebarb ban fet ftedetien $S^{2}$ Filippo ende lago, ghelegen aen de theede rievier/ 42 leguen

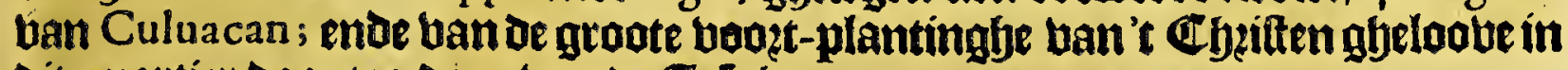
dit quartier bog toe-Doen ban be \$eluiten.

\section{Het Tetuende Capittel.}

Befchrijvinghe van de provincie UX I I I A , ende hare gheleghentheydt.

TOt noth toe beblen wp terbolgft de particuliete pzobincien ban Neuva $G_{2}$.

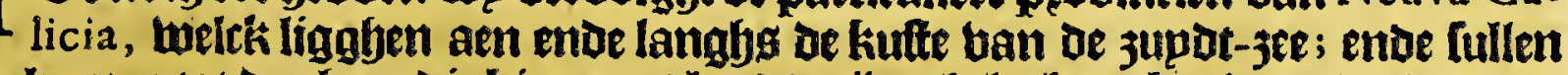
nukomen tot oe ghene die binneng' lanotg jün gfelegben; beginnende han een probintie die naer $t$ Goubernement uan Panuco toe ofbeleghen ig. Cen tijot boen Nunno de Guzman han Mexico betteploe naet oe ontoeckingtye ban de d.4.1.9. peobincien bie nu Neuva Galicia twetben ghendemt / weltk was in 't faet 1529 , c.12. liet fjp in bet Goubetmement ban Panuco daer be epghentlöck Gouberneur ban wag/booz lpn Lieutenant Lope de Mendoça, met expefefe ozoze/ bat bp em tocht Coube Doen te landt-waett in/ naer't quattier ban V xitipa, om 't lanot te ontore= ken/ ende bolck te planten/ loo twanneer bp bequaembepot banplaette ende an=

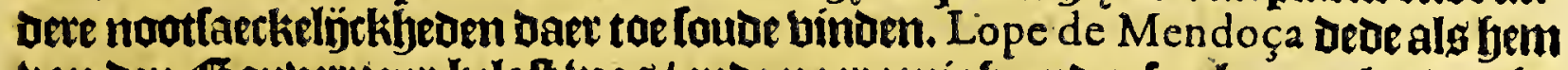
van den Bouberneur belatt twas / ente naer eenigy onoer-foect populeerden ljp in be ballepen ban V xiripa, gelegen tivintichleguen ban de ftadt $P$ anuco,en tadot welck fjp noembe San Luyz, te lanot-waett in/ naet be peobincie ban Xalifco toe/ onter welckes Boubernement bet if ghebleben/oock naet dat oe ltoningb van Spaegnien 't Goubernement ban Panuco, telck eerlt op fem felven was/ ons

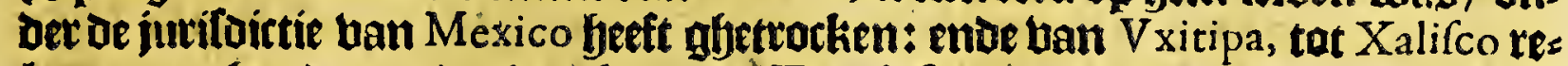
kent men bondert ende thee leguen. - Be gheftalte ende manteren ban's bolck

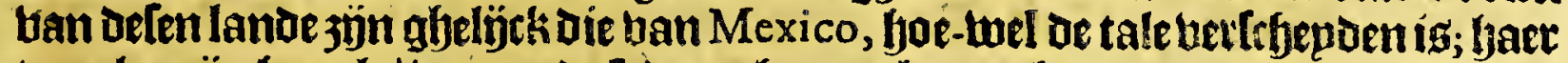
templen jün foogh / ban aeroe foden ghemaeclit met baet trappea : Kleeden haer met mantels als dit ban Mexico; yebben bare footen ban gbemaeckte wyjnen om op fjact feetten te deincken. 'Cl landt is monder abetbloedigb ban frupten' ende ban jacljt ban Ijarten entie andere twilde bieten: beel boenderen wozacndev nu ghetonoen/ quackelen/perdeg̉ [en/totteloupbenende andere ghebogelte/ende in fomma aloethande liff-torht in oberthloet. 10pt oele peovincie fpeupt eengroote

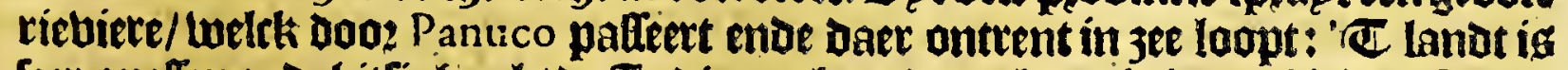

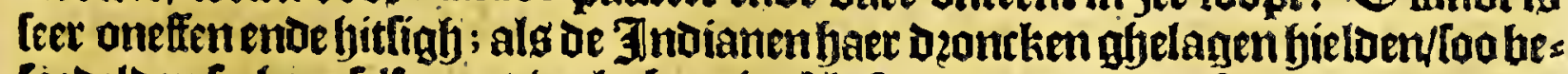
foedeloen lo brec felfg met beel abominable fonden / enoe datfe dooj de monot 
230

Nova Galicia ofte Guadalaiara.

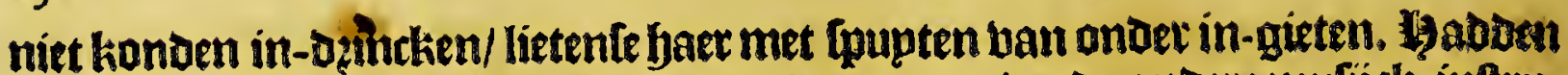
baer manieren van flupten / trompetten / couznetten / ender andere muljicki-inttrus

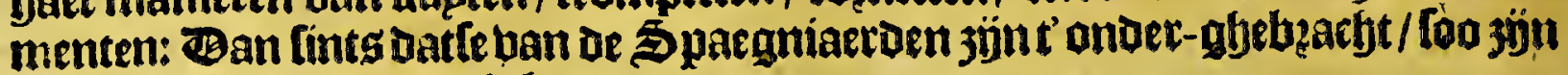
DeEe grooffe faute wat gyebrtert.

Wet arbette Capittel.

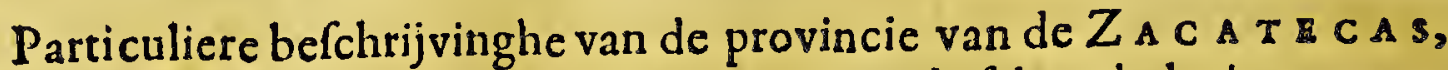
ende de verfcheyden filver-mijnen in de felve gheleghen.

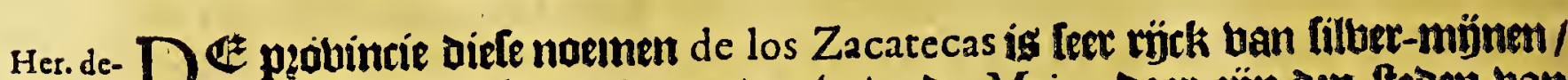

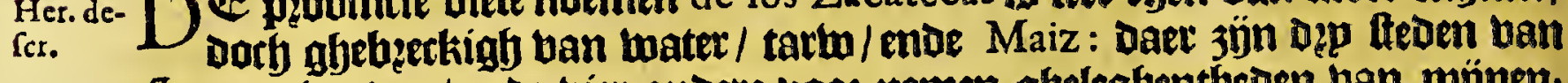
Spaegniaeroen/ende biec anoere booz-nemen gbeleghentbeden ban münen; ban tuelcke mïnen oe peincipaelite jijn die men roemt de los Zacatecas, beettirb [paenlche mülen naet fet noogeen ban Guadalaiara, ende tarbticy mijlen ban de

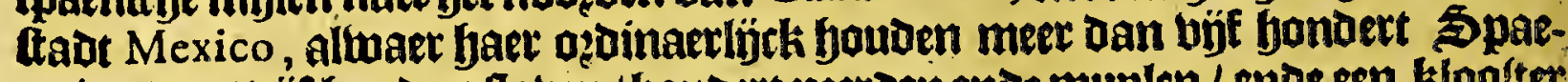
gniaerden / buje fondert tlaben / bondert peeroen ende muplen / ende een klooltet

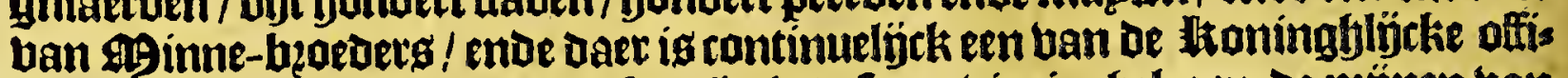
tiets ban Guadalaiara. Dock loo zjön in dele probincie gbelegen de mínen van Avinno, op de limiten ban de Zacatecas. Bele wieroen ontaeckt de mijl Don d.8. L.ro. Luys de Velafco Bíce-1iop twas ban Nova Hifpania, onoz bet beleput ban Franc. 23. cifco de Ybarra, in oen jare 1554 : welcke fefepaen de uan oe mïnen uan Zacatecas met een goet ghetal Coloaten / wel berfienmet wapenen/peeraen/flaben enoe

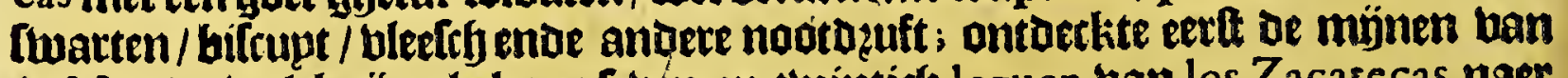
Her.de- $S^{\imath}$ Martin, welck jön gbelegen feven-en-twintich leguen van los Zacatecas, naet

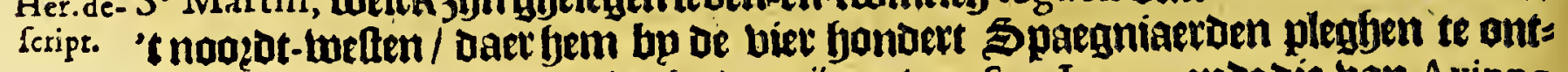
houden: Baer naer ontoeckte bp de minen van San Lucas; ende die van A vinno booz-noemt / enar andere meer Daer onttent/ Deer groote quantitept van filloer ig upt-gheljaelit; enoe beneffeng dele wietaen mede antoeckt in de juritoictie ban $S^{:}$ Martin, Deminnen diele noemen del Sombrerete; ontrent be melcke gbeleght is De ftadt del Erena, bujf-en-twintich leguen ban los Zacatecas naer'tnoozat-mes Iten toe. Booktg oe minnen de los Ranchos ende de los Chalchuites, ende die de

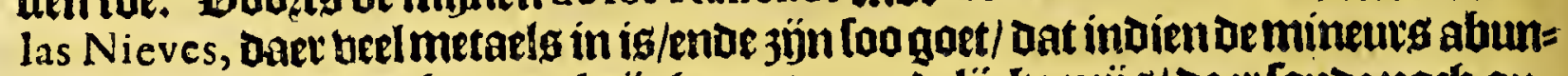

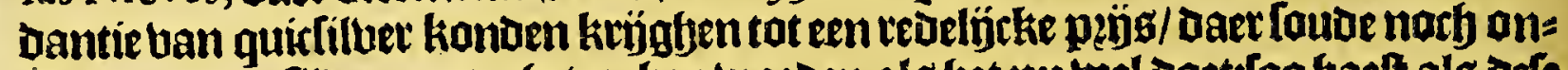

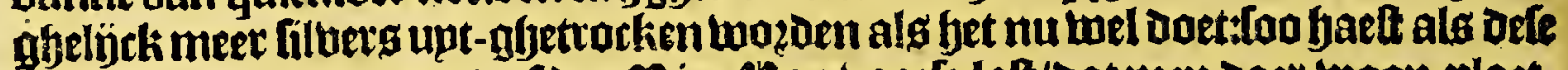

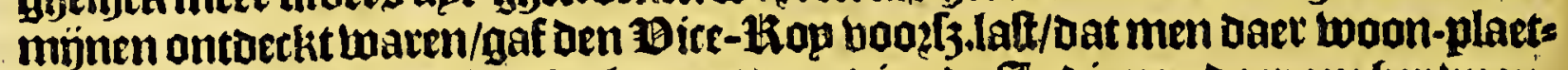

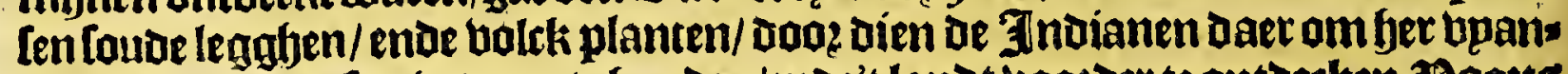

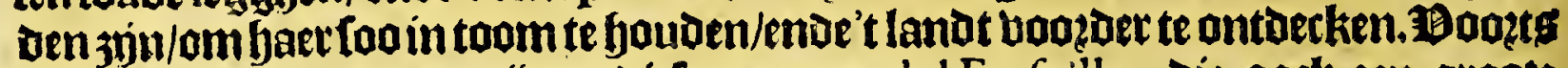
tuierden ghebanurn de münen diele noemen del Frefnillo, die oock een groote

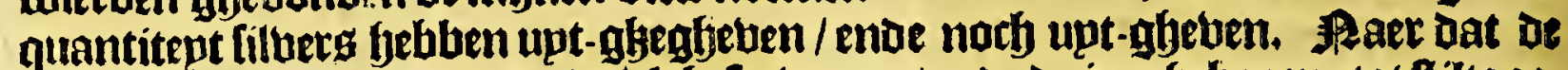
mijnen ban San Martin met bolck befet waren/ende de in-ghebooene tot ffilte ges bzadt / quamen Daer Ieket religíeulen ban De ogzoze ban $S^{t}$ Francifcus, met rom: mitlic ban den Bice- Hop / om te landt-maett in te trecken/'t bolck ban de lanoe to befoecken/ende fjaer bet Etuangeliumle petdiken; Francifco de Ybarra bem latenoe vooultaen / dat defe פgonnicken perijekel foude loopen / wiloe met haet trecken met goede compagmie ban foldaten / ende lp ontoeckten díe tequfe de bals Iepe ban $S^{t}$ Iuan, ende de riebiete de las Nacas, ende ten feluen töjoen rebelleeraen

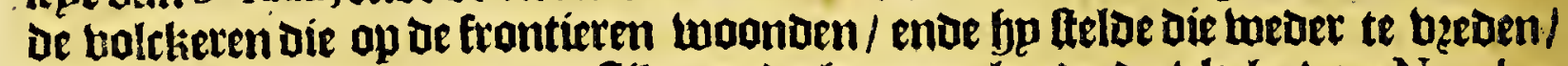
Herier. enoe bzarfteule loo tmeder tot ltilte: ende hp populeerde oe blecke van Nombre

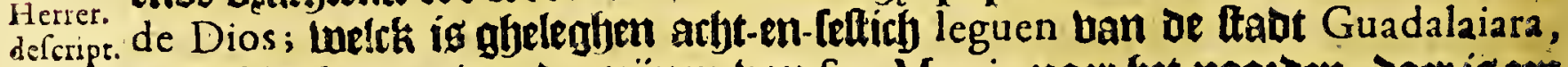
ende thien leguen ban oe mỉnen ban San Martin naer bet noozden; Daer ígen hiloofter ban ginne-bzecoers; het lanot is oberbloedigh ban Maiz enoe ban

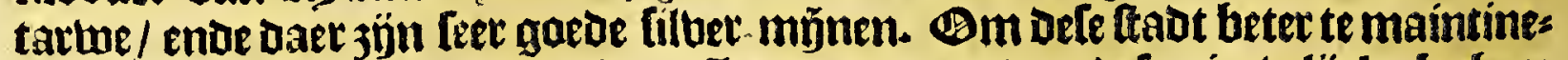

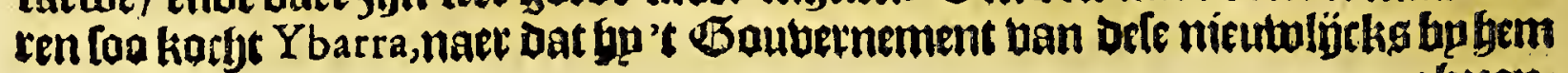
abecon: 


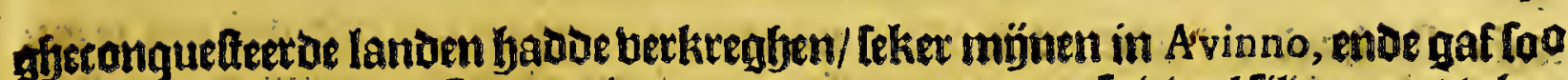
thel oe 3ndianen als Spaegniaetoen bepoom om oaer foo beel filbers upt te bas

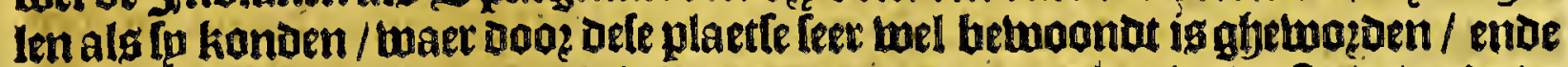
't bolck ball de lanoe in bede ghejouden / ende de bpanden mederfaen/ende de

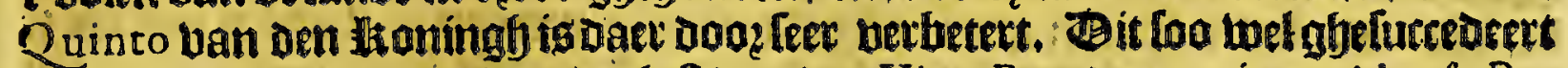

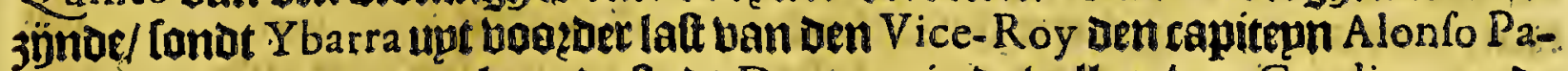
checo, oun te gaen populeren de thadt Durango in of vallepe ban Guadiana, ente gaf bem mede ren groot gfetal ban koepen ende ttieren/peeroen/[stapen/Maiz,

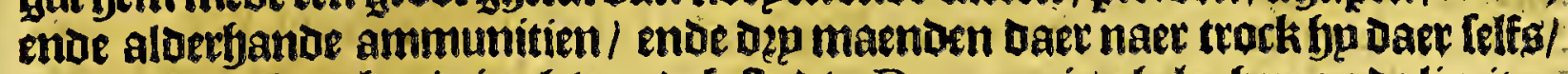
ende bol-trock de boulwingh ban dele ftad. Durango ís gheleghen op de limiten Her. devan de mínen ban San Martin ende de ballepe van San Salvador; atyt leguen. ban de blecke Nombre de Dios ; ísen ghelonoe ofjelegentheqt/Daer jün beel ries:

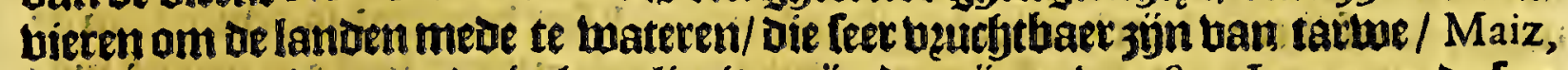
ende andere vibes ; ente in yaer limiten jün de mijnen ban San Lucas, ende leer goede zout-pannen: men beefter beel Eftancias bfte bou-fjupfen booz groot ende. hlepn bee/ doot de meniggte van de riebierkeng ende wateren/bergben ende weps.

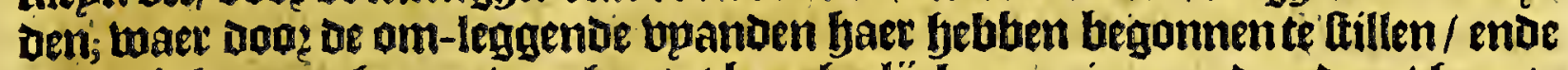

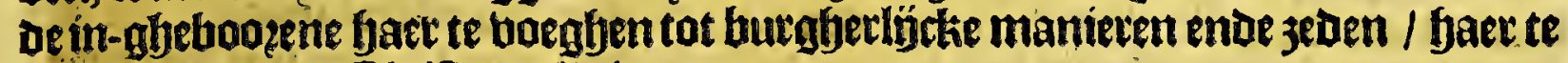
Kileeden/enoe de Cofeiften religie aen te nemen.

Tn de peobintie de los Zacarecas, ig noetjeen ander plaetle bp of Spaegniaer $\mathrm{Her}$. deDen betwoont / ghenaemt Xere z de la Frontera, Dettich leguen van Güadalaia:- fcript. ra, naet bet noozden/ente thien leguen ban de mïnen de los Zacatecas, ente op oe wegf die dertuaetts loopt. De Indianen van wit quartier waren langh in od lagbe in bele plaetten / ende de Chichimecas ende Guachachiles deden groote ftyade op of wegh tufferfen Guadalaiara enoe los Zacatecas; Dit beefteen kolte.

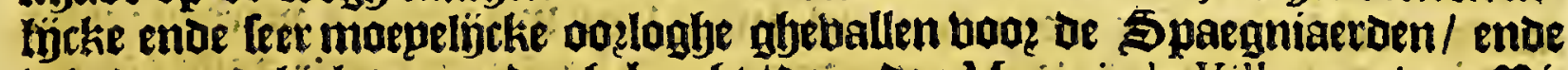
mierot epnoelinck ten epune ghebzactgt/Doen Den Marquis de Villamanrique Bis

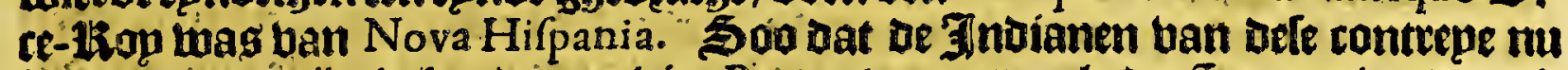
Ghereparteert jün in fondert en vier Repartiementos,alg de \$paegniaerden die

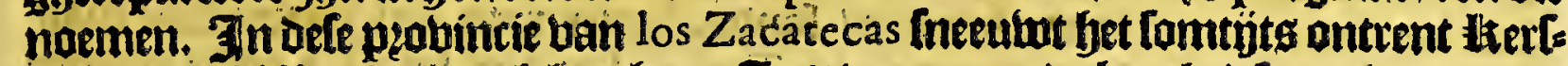
mis / dan bligft niet langh legghen. Jin't booz-gaende boerk / peectiende ban

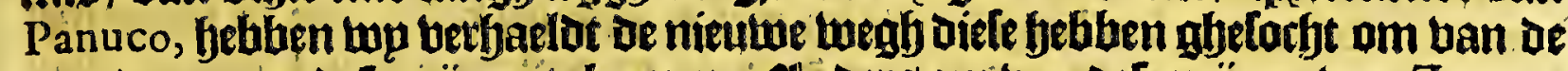
noozot-jee aen dere minnen te komen. Alnders om ban dete müpen ban Zacatecas naer Mexico te komen/ neemt menifpn luegh (naer't berbael ban lohn Chilton die daer feeft gherepit) op $\mathrm{S}^{\tau}$ Miguel ; ente tan daer naer Pueblo Novo; ende dan boug de peobincie ban Me choacan, ende foo bootg naet Mexico toe.

\section{N O V A V I Z C A Y A.}

\section{Set neghende Capittel.}

Particuliere befchrijvinghe van defe provincie, ende de byfondere filver-mijnen daer in gheleghen.

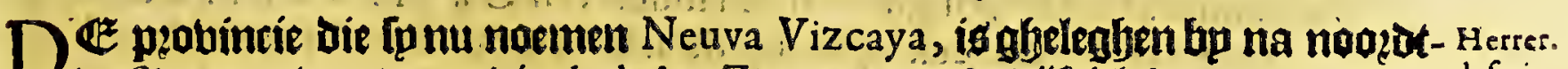
wettmaerts ban oe peobincie de los Zacatecas, enbe vinttich leguen ban baer defcripr. betrfjepden: is een lanot daer abundantic is ban bibeg/ enoe beel bee endegoe=

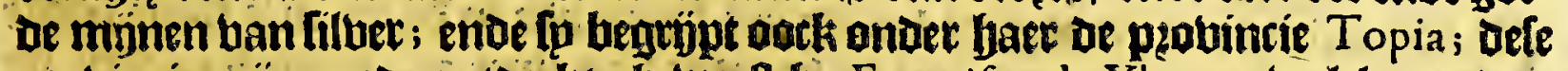

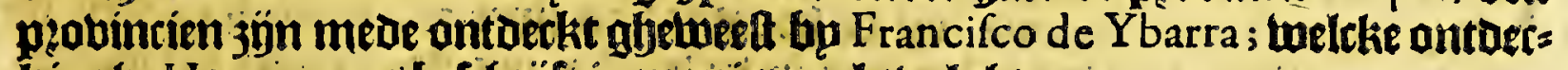
kingbe Herrera ong beletjegft in manieten als bolght.

Francifo de Ybarra, bem bebindenoe met banoert en dertidy foldaten/naer d. 8. 1. o.

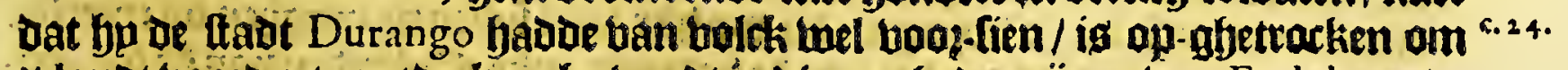

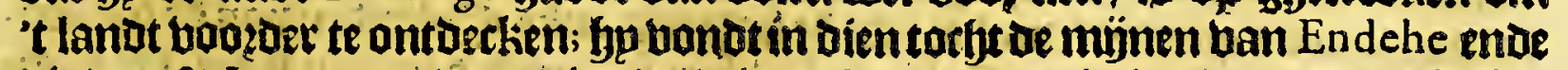
die ban S Iuan; dan Doog dien de winter bem op den bals quam/ bede fup fun 


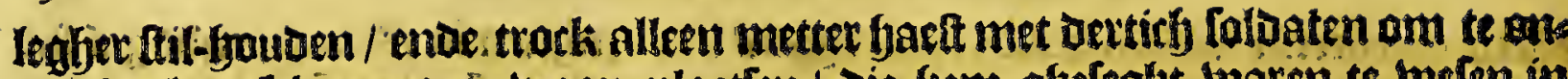

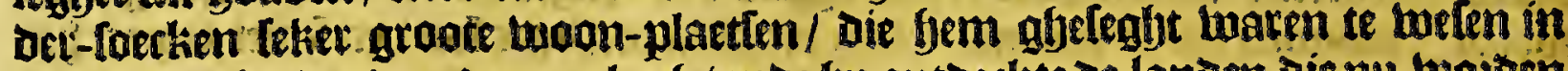

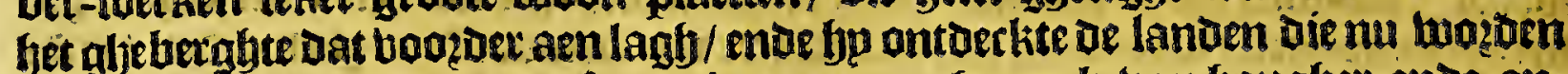
aljenoemt Topia; leed op offen tocht groot onghemack ban bongher ende an: Der ghebaer: want waren gfenoortaeckt eenigbe peerden te larbten om die te eten; ende ban Daer ghekeert 3 jöno / Lonot bp of Capitepn Rodrigo del Rio, om

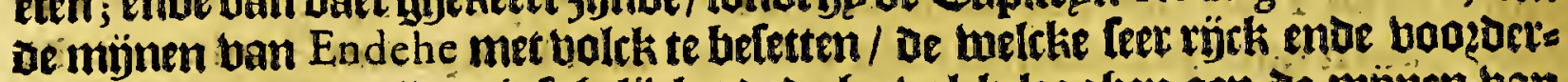

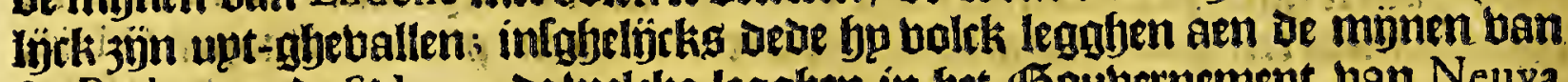
S: Barbara ende $S^{t}$ luan, de wellke legghen in bet Goubernement van Neuva Bifcaya, dip leguen deen ban d'ander; enoe thintich leguen van oie ban Endehe, tuelck de upterlfe jön ban bet glyene tot nu bp oe Spaegniaer oen is hetwoont

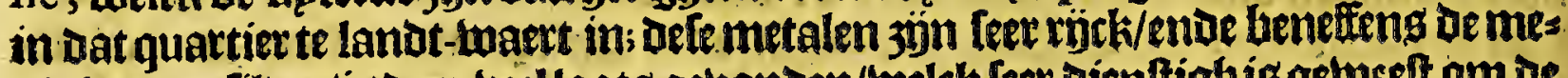

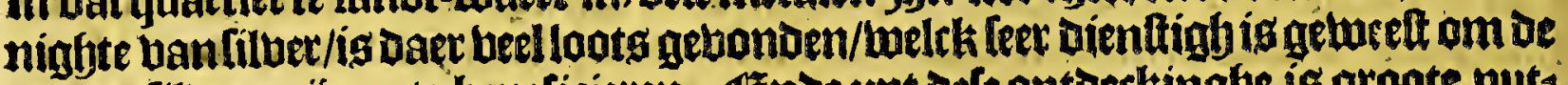
andere filber-mijnen te beneficieren. Énde upt oele ontoeckingbe is groote nuts

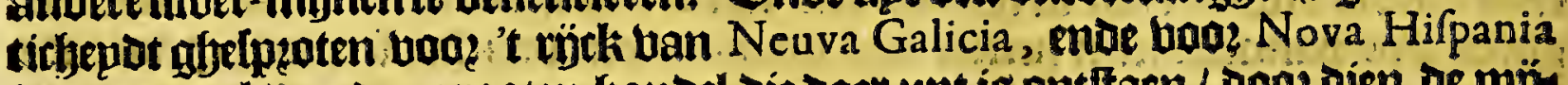

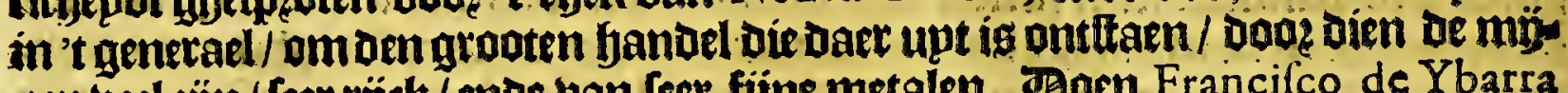
nen beel jün / feer rürk/ende van leet fíne metalen. Doen Francifco de Ybarra leetde naer de ballep van $S^{2}$ I luan, om Daer te guer-minteren/maeckte bp een

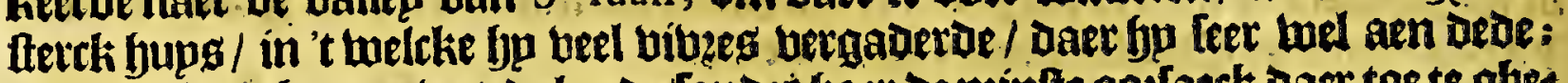

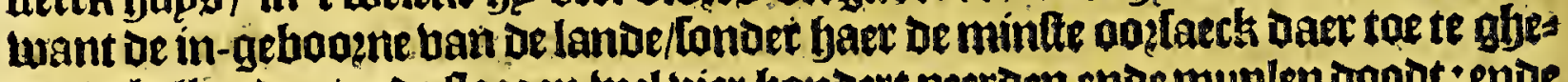
ben/cebellertaen/ende tlaegen twel vier handert peerden enoe muplen oood : ende

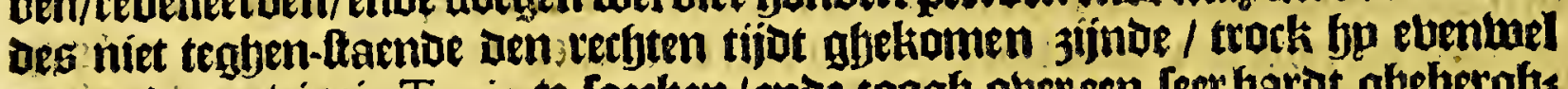
op om de probintie Topia te toecken/ende toogh plereen leerbaciot gfyeberghs te/Daerle altemael groote armaede leden/ openende oe megh met faer handen

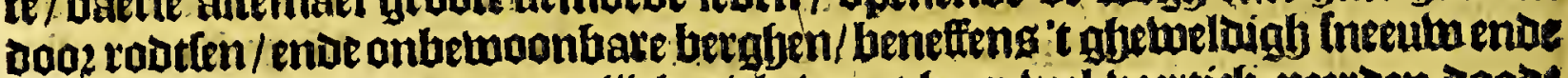

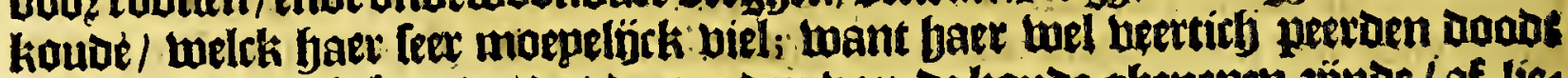
beolen : ende't ghebeurde / at de peeroen ban de kaude ghenepen zünde / af-lies tente wepden / ende quamen loopen in de bperen die de Spargniaetien baboen

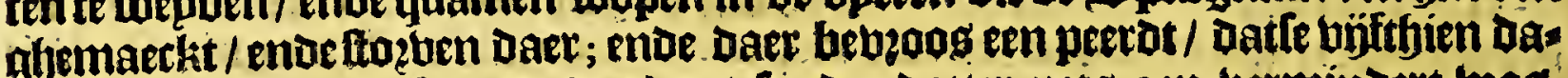
ghen daer nae norh flaenoe bonjen/ Conver datter pets aen berminoert twas. Ghekomen 3 intoe in of plobintie ban Topia, boe-bel bp in ' $t$ eerte eenighe

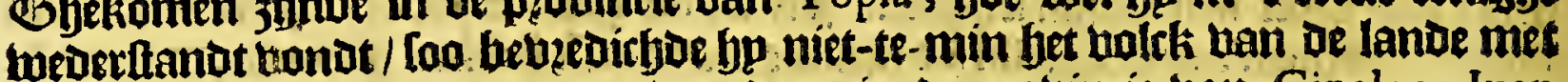
Carbte banoelinghe; enoe quam ban oaer in oe peouincie ban Cinaloa. Iuan Gonzalez in Ipn hiftozie van China fegft dat de munen ban $S^{\text {ta }}$ Barbara legghen bondert en lettich leguen ban Mexico ; ende Dat leventicf leguen ban defe mïnen voozoer / Iegghen oe fteden / die de Spaegniaetoen noemen las quatro Cienegas: Daer wa gheen voozoer beldjepat als norf ban bebluen oin: Der-bonden.

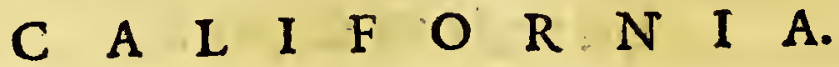

Het thiende Capittel.

Particuliere befchrijvinghe van de landen van $C$ A I I F O R N I A, ende haer eerfe ontdeckinghe by de fchepen van. Don Hernatido

Cortes, ende andere.

Herrer.

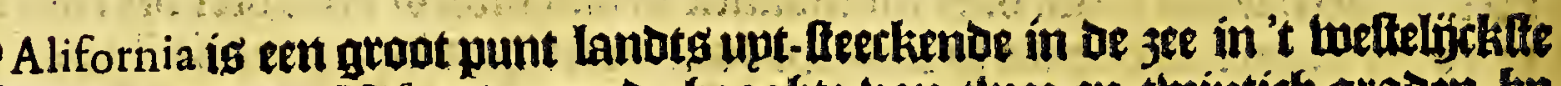

Deel bain Nova Hifpania, op de booghte ban twee-en-twintict graden bp noozoen de linie; ban waet yet bem in de lengbte upt-ftreclit naet bet noogt-

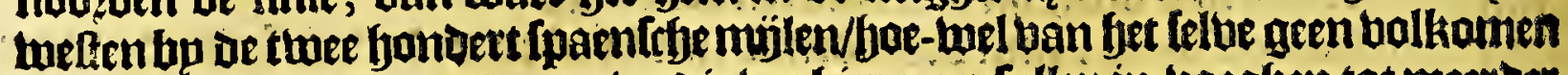

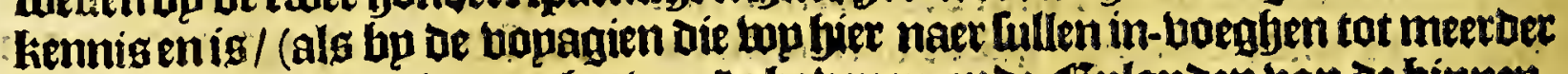

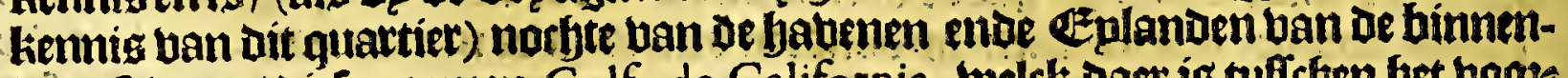
lanoutebe zee / Diele noemen Golfo de California, welck paet is tufficten bet booze Ityeghen 
Irjeetuen punt/ ende be landen ban Nova Hifpania, ende baer ftrectit naet fet noogat-belten; in ie welcke 3 j̈n beel tiebieten/caben/pumrten/endeplaetfen Daet men landen marb/ Daer men abeen Conderlinglye kennis ban feeft / Doo? diente wepnigh beforbe mozoen. Allen theginfel ende in-komen ban defe Golfo leglyt

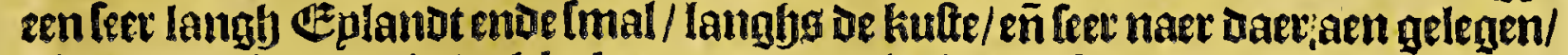
ghenaent Guayaval, twelcke komt ban de viebiere Diefe noemen R io de nueftra Sennora, ofte oot de Sebaltiaen de Bora, tot de ricbiere Pafcua toe in oeplobin: tie ban Culuacan: want dit Eplanot ofte [pn baten ig onttent de achthien mij= Ien van Si Miguel de Culuacan. Ban om beter te herftaen De gheleghentbepat ban dekutte ban Nova Galicia ende California, toofullen wuhier in-boegfen de nabigatien op De felbe kufte ghedatn/ foo Dooz ozgege ban oen Marquis del Valle, alg mede uan den Bice-Hop Men doça. Don Hernando Cortes fonot in den jare

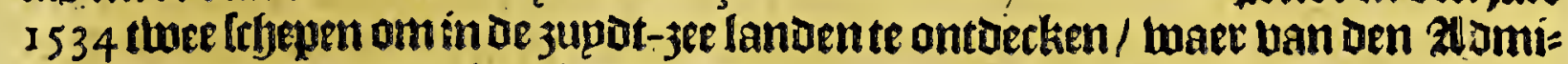
rael ban fet ander berdmaeloe/ ende om-quam; ende bet lchip S' Lazaro, helck

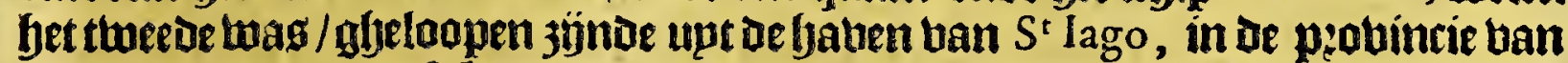
Coliman, bielot meet fpn kours jupdt-jupDt-wedt/ tot op de booghte ban Der: thien graden eneen yalf ; ende daer nace welt-noozdt-weft tot ou de booghte ban

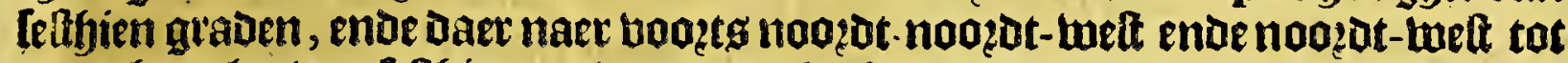

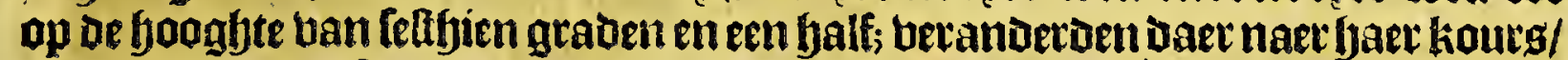
enoe gingben ooft-jupdt-oolt arn tot op de hooghte van Lelthien graden; Daet

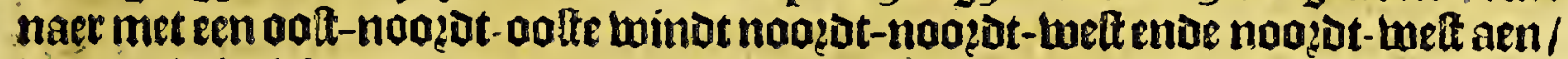
ban oe thintich gladen tot de Dep-en-twintirh graden en een balf; ende foo boots

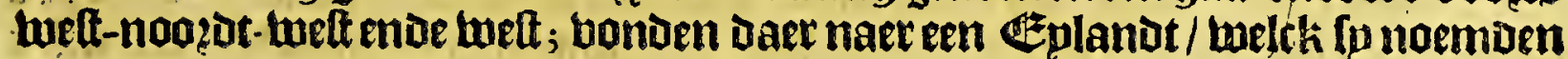
Santo Thomas, gfyelegen op de hooghte ban twintich giaden en een derde/ hels bende in't am-gaen bp of vif-en-twintich leguen, vol gheboomte; aen de zupotjö̀e beeft fjet een [eer boogen bergh/eñ daer is gaet ancketen/ een mufquet-frbeut van landt in bijf-en-twintich badem twaters / wit ende twart zande / ende bet

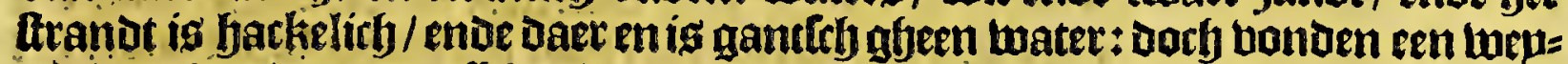
nigb reghen-tuaters tulfeben te klippen in/. Dat noch half bzack wag. Steloen

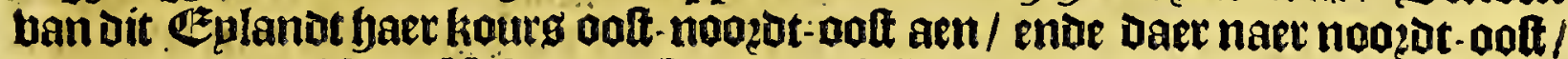
om't lanot ban Nova Hifpania te bejeplen / blíbente al meelt op ae hooglyte ban ontrent thinticharaden/ op twelcke hooghte fpoock bet lanot abetwaer mierden/ ende quamen aen ancker dęp oft viet leguen ban Ciguatlan, op de boangte ban

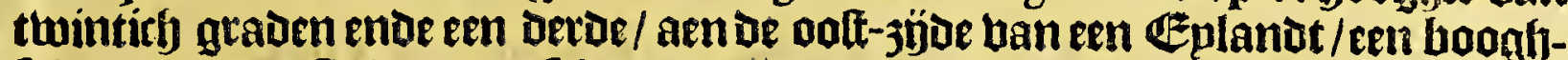
Icfjeut ban 't balte lanot berfrjepoen; quanen Daet naet in oe baben taan Xuclu-

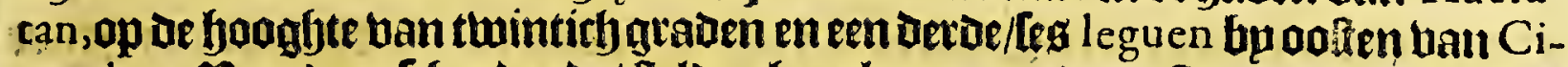

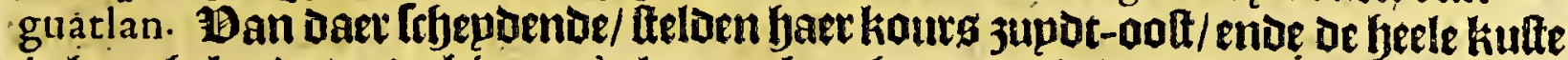
is boagh-landt / ende binuen 's lanotg berghen bol gfyehoomte / ende daet naet

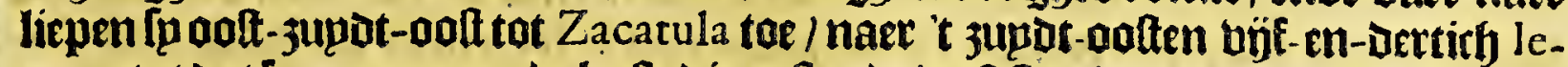

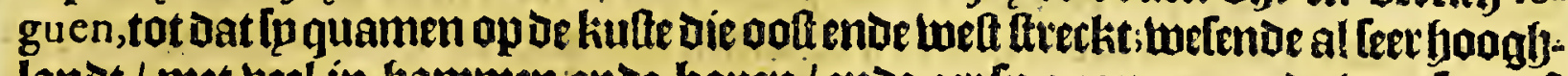

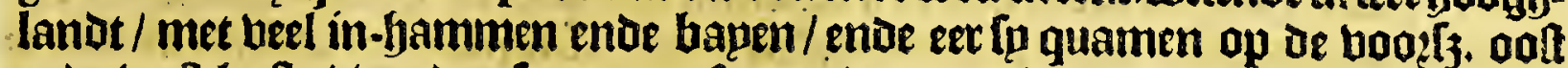

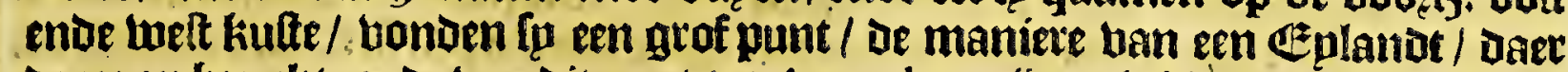
de 3 ee op beeckt; ende ban dit punt tot A capulco, 3 ín achthien leguen ooft enoe wef. Bell zlomirael die top bier boozen bebluen berfaelt ban dit frín bet: owaelt te tuefen / quam in de Baya bam $S^{2}$. Cruz, altwaer 't volck ban de lanbe

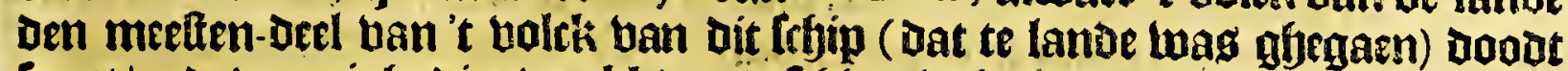
Imeet/ende wepnighe die ober-bleben/ttiffip niet kanmende regeeren/betloozen 't felbe op de tufte ban Nova Galicia. Den Marquis del Valle hier ban bertuittifft d.s.1.8.

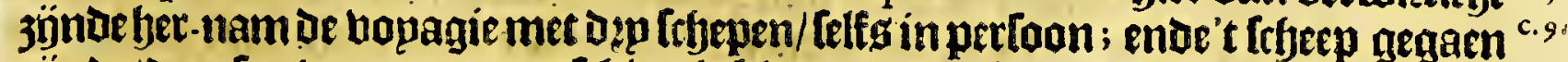

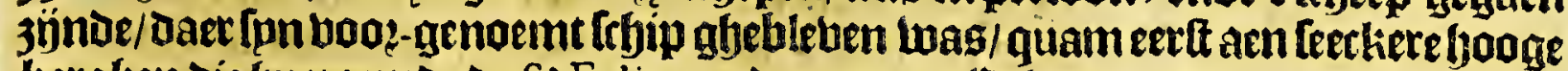

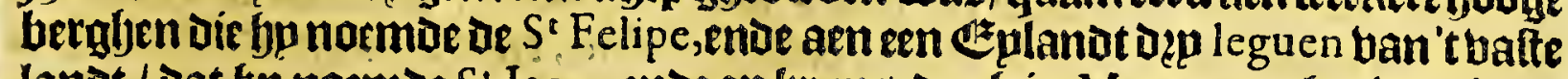
landt / Dat fjp noem de $S^{2}$ Iago ; ende op krups-dagh in May quam bp in oe bape

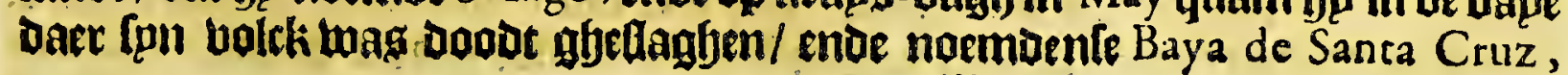


234

Nova Galicia ofre Guadalaiara.

welck igen goese fraben/ belchut boos alle minoen/ op de booghte ban bę-entwintich graden en een yalf bp noo zoen oe línie; mepnende de bape ober te krupt: fen/ ober-biel haer fulcken ftom wat fp upt haer kours gheraeckten/ enoe voeren De bape op tot aen De twee riebieren ban $S^{\star}$ Pedro ende $S^{\prime}$ Pablo, ende vertoefoen

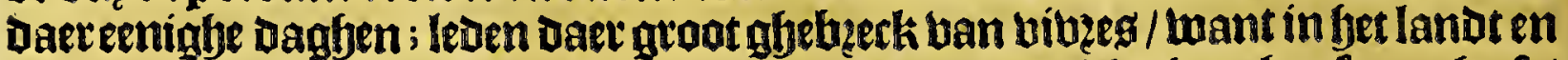
is gheen booz-raedt/ Dooz dien bet een milot bolck is welck gheen buplen en beeft/ noch jaep-lanoen/ende leeft alleen opfrupten enoe krupoen ban't velot/ende ban

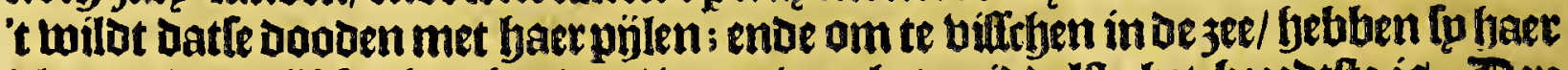
blotten ban bijf fucken bouots / waet ban bet misoelfte bet beesotte is. Den Marquis daer naer met bet klepnete lethip (dat alleen bp bem was ghebleben) lav: penoe wel büftich leguen langhg de kufte ban Nova Hifpania, bonot bem op een mozghen tulfefen klippenende dzooghten Daer Is niet wilfen upt te homen / foo Datfe met fyet loodt Diepende/'t lanot naeckten bp een in-wörk/ ende wieruen ghes maet een ander fefip dat ontrent twee leguen bam Daer baet lagh/ welckeen ban Ipn anoer twee Ichepen was / ende de piloot ban 't Telbe frbíp bzacht bem bimen/

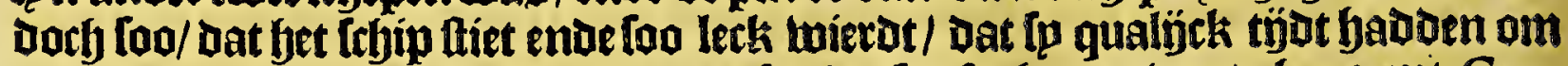
baer líf ende goederente falueren. Defe plaetle ofte haven was ghenoemt Guayabal; entoe $S^{t}$ Miguel de Culuacan Ieght ban fier actitbien leguen naer 't weftent. - De [tfepen bier wat bermaeckt behbende/verbolghoen fo baer bopagie naer be booz-noemoe Baya de S' Cruz, baer den Marquis eenigh bolck gbelaten fadode;

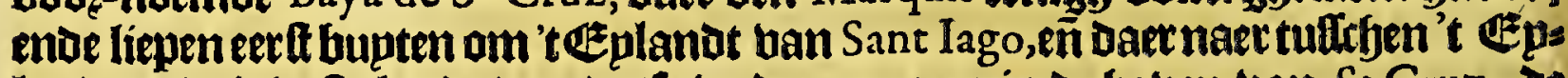
lanot ende 't balte lanot / tot datte toeder guamen in de baben ban St Cruz; de mont ban 't kamael ban dele haben is engh/Dan binnen ig thanael toel een mỉle beedot. Den Marquis liet bier eenigh balck onder orn Capitepn Francifco de Vlloa met bictualie booz een jaer. Ban allos daer oscalien booz-bielen / buate booz eenighe lefjepen moeften ghebzupckt twozoen tat lecours ban Den Marquis

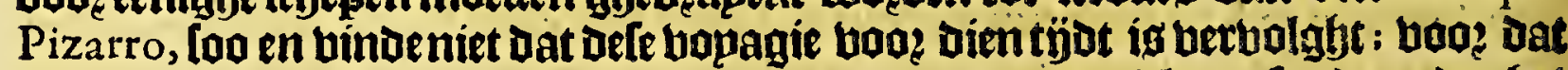
den Marquis del Valle naet $\$$ paegnien keerde / ende een bloote fonot onder bet

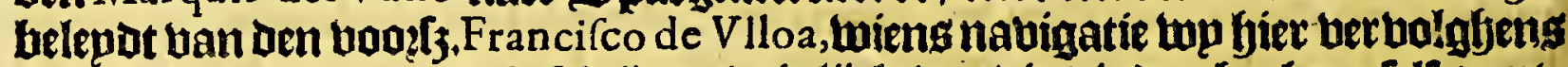

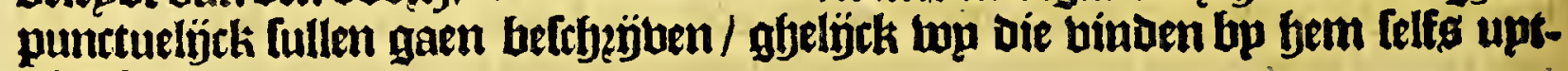
glyegheuen.

Het elfite Capittel.

Befchrijvinghe van de voyagie van Francifco de Vlloa.

St ginghen't tebeep in de baben ban Acapulco den 8 Iulij in ten jare 1539 ; cnte jeploen langlys de kulte ban Sacatula enoe Motin (welck is foet entoe plaplans Dooę de menighte ban boomen die daer groepen/ ende de rietuieren die Dooz bet lanot loopen) ende quamen foo tot de faben ban $S^{t}$ lago in de pzotintie ban Colima: waren tuffechen bepoen befich thintífy Dagfen / en bletien daer feben-en-

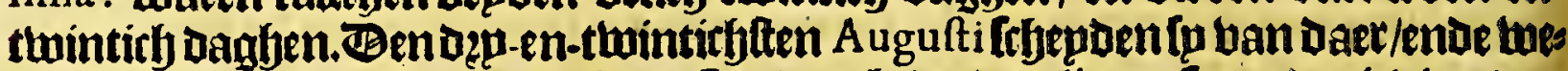
Iende Doo een extreemtempeelt op eñ neder ghedeeben/liepen fo tot De rieviere bat Guayaval in De pequincie van Culuacan. EEnDe Dod Dien Depinatte $S^{2}$ Thomas

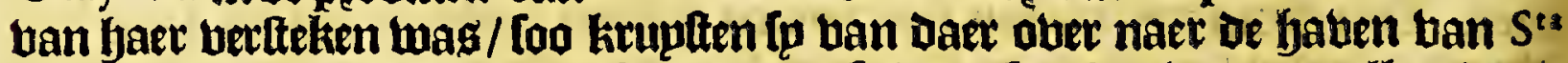
Cruz in de pzobintie ban California, baer Ip booz--Lpzoken twaren malkanderen

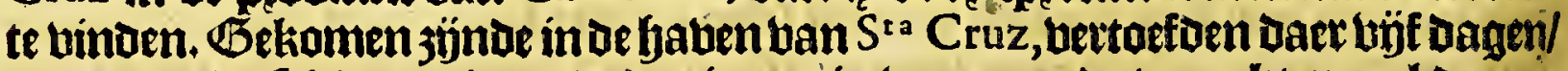
en namen verfeb water in; ende de pinas niet bernemende / maeckten 3 epl den 12

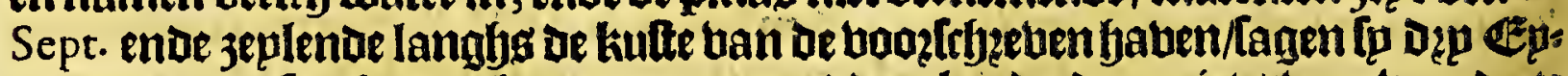
landen / Daer [p gfeen arbt op en namen/ Denckende Daet niets ban weerde te binden. Zeplende loa ober de Golfo ban California, quamen in thee Das ghen eneen half tot Rio de $S^{2}$ Pedro ende $S^{2}$ Pablo, ende vonden een kilepn Eps. landt booz de monot ban of riebiete / vier ofte bỉf. leguen ban fet bafte lanot: zlen bepoe jijden ban De rietuiece lagben [p leboone ende groote plapnen bol ban

groene 


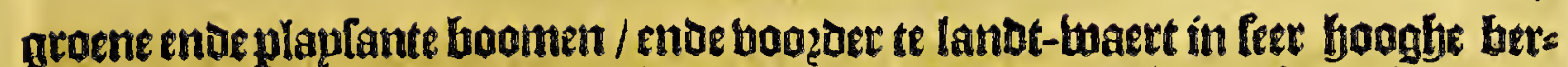
ghen vol ban algehoomte/ feer luttich om te aenfchoutwen. Ban defe riebiete jepls.

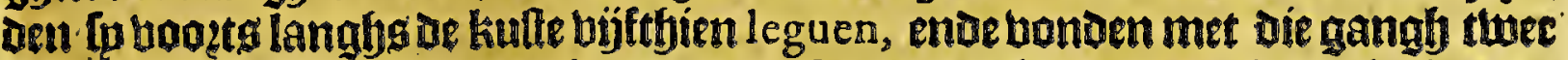

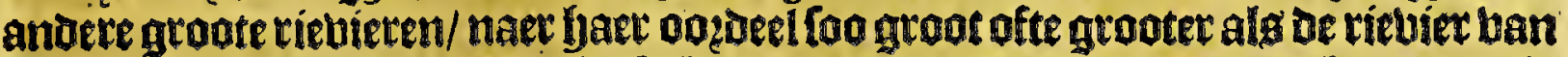
Sevilla in Spaegnien. Alloe kufte bp Defe riebieren íg black ende bol boomen alg

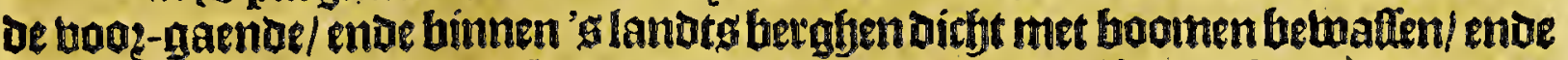

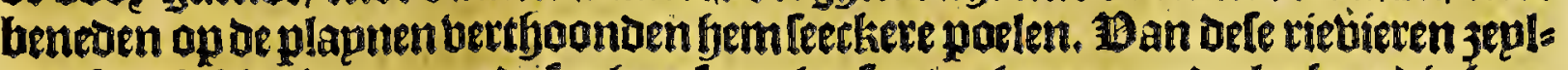
ben fo achthien leguen, endélagben feex plaplante plapnen ende lacken die baer

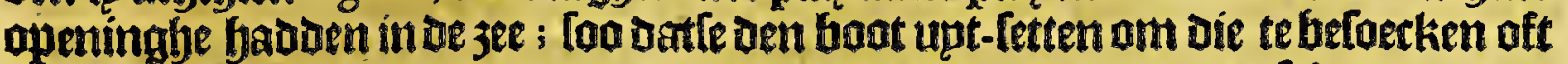

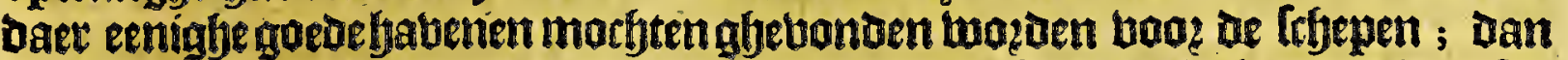
bonden de kufte black/ ende de monben ban de booz-lcherben lacken ondiep/ foo Datter niet op te atbernen twas/anders twag bet feer fraep landt : Gies laghen fa eenighe Inoianen aen'tlandr/ende pock bperen. Befe twee riebieten legghen twee leguen van den anderen/ende jän Irec groot; gbekomen zúnde aen de thees.

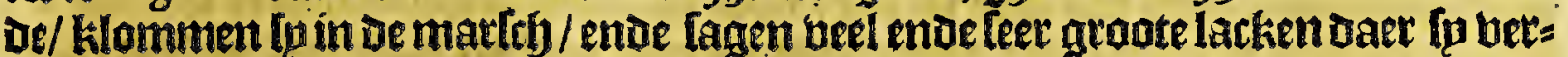

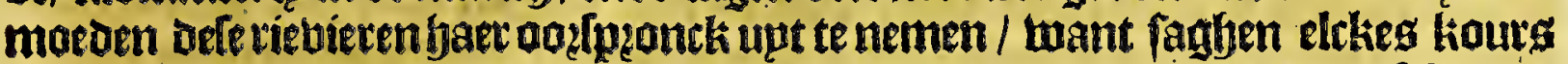

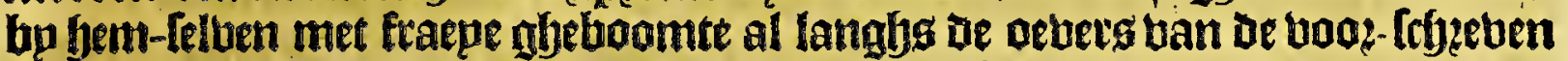
riebieten groepente. Irffepden twopoen/ende aen te monoen twietden feecker ftaecken ghefet om die te bekennen / entoe 't ftrandt is black ende jandigh/ende't landt luftigh. Defen dagf zeploen Ip langhg De kulte lettyien leguen; ende in 't midoen is een Ichoone bape

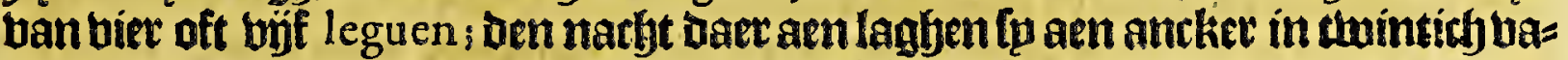

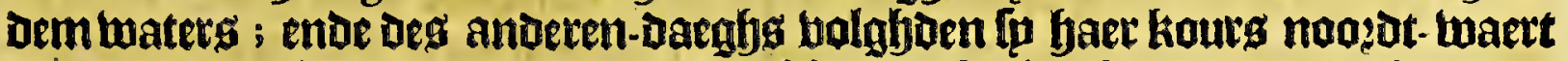
aen/ende dęp oft vier leguen abezeplt fyebbende / laghen fo dep openinghen ban lacken welck te landt-waet inftreckten/ende twierden daer thaende poelen. Sp reden een múl ban de boos-lebzeben monden ín les badem luaters / ende conden ben boot upt om te fien oft daereening in-Komen wag boog baer frbepen / want een balf mijle ban't lanot en badoen fon niet botren een ofte twee badem twaters.

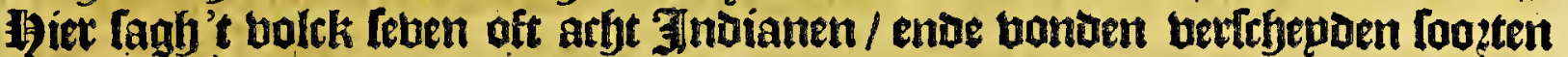
ban groene krupden/betfifillende ban die ban Nova Hifpania; t lanot is blatk/ Dan berre binnen's lanotg faghen [p groote enoe klepne bergfien bie een groote weghbenen ftreckten / enoe twaren leer plapfant om aentefien/ den bolghenden

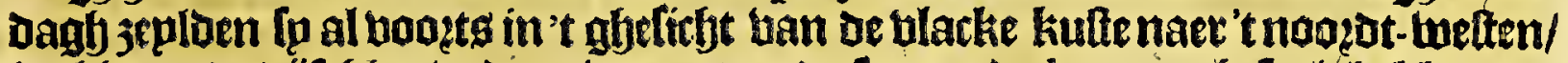

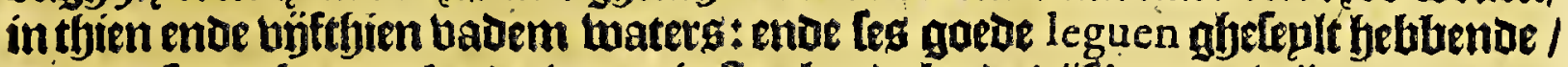
bonden [peen bape te lanot-waert in ftreckente bp oe bijfleguen twijt / van waer

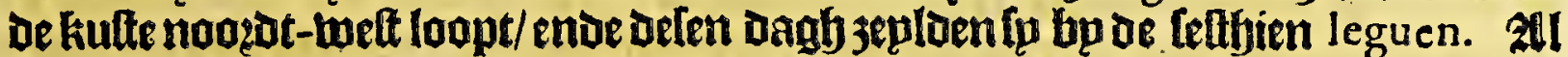

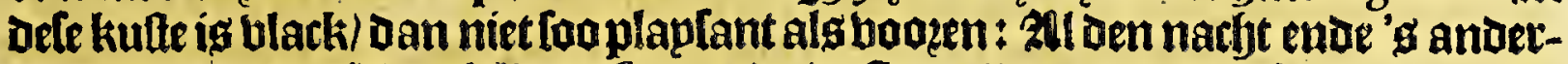

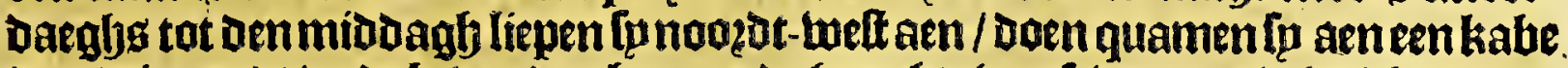
ban wit zandt/ende bebonden baet ap ae googfte ban teben-en-twintichgrauen

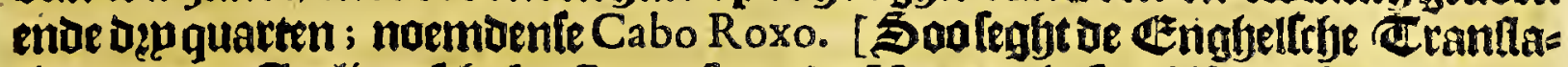
tie: maer oe Italiaenffje bp Ramufio ende Herrera in Ipn fittogie ftellen Cabo

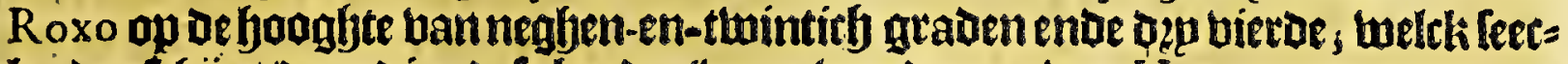

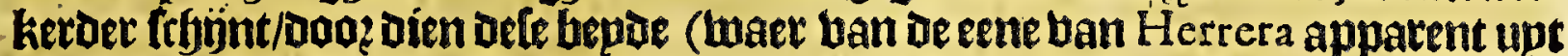

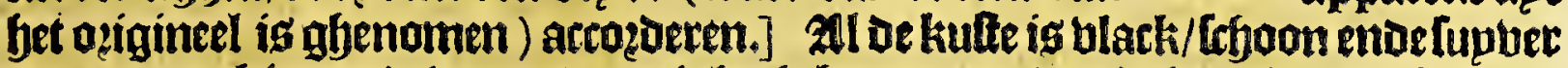
3andt / ende binmen's lands twepnigh gheboomte/ endeniet hoogh / met leeckere berghen enoe gheboomte / Dep ofte bier leguen ban de boot-febethen kape; enve bier berthoonoe bem oock een monot ban een riebiere/ bebbende een lack binnen 's landts/ende de riebiere febeen ondiep te welen/ Doos dien de 3 ee daer feer baan= De. Hier laghen lp in't land depp oft vier riebieten. Dus jeploen fa al nooz̧at-

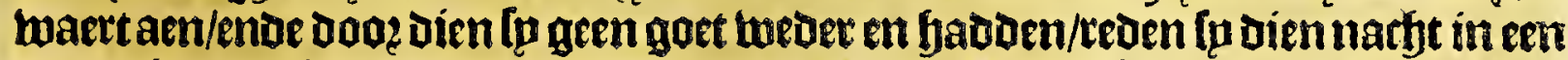
groote baten die in haten wegh lagh/ waer fp aen tranot leeckelplepnen fagfen/ ende bimen' 'slanots geberghte dat niet feer boodfen was. Bervolghendefaren

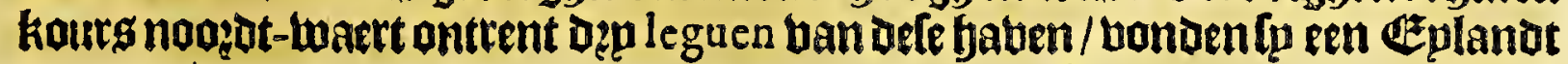


236

Nova Galicia, ofte Guadalaiara.

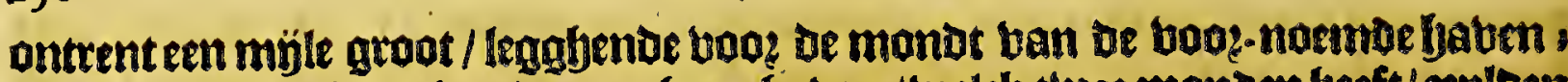
tnde boozder jeptende bonden norb een bauen / welck twee monoen beeft/ 3 eploen ae noozotlijelifte monot in / welck feeft thien oft thaelf badem taaters / ende Deoongt op tot op ujf baorm/ daerfp ancketarn in een poel welck of jee maeckt/

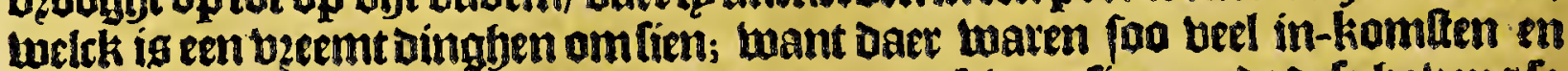

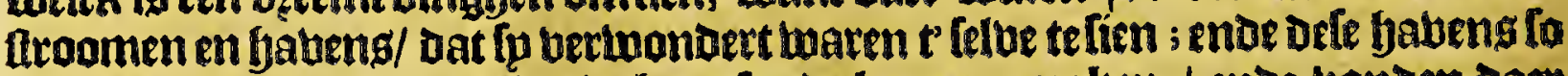
bequaem/ bat denatuete die niet beter foube konnen maken / ende bonden daet oberuloet ban biffh. Lier anckeruen fo/ ende de Capitepn ginck aen landt / ende

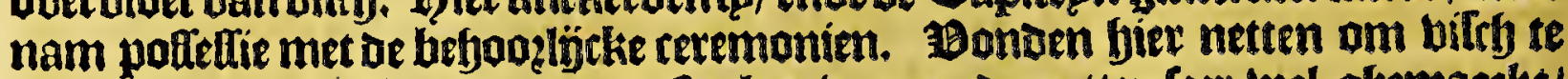
vanghen / enoe feecker koten ende fucken ban aetoe potten leet wel gbemaeckt/

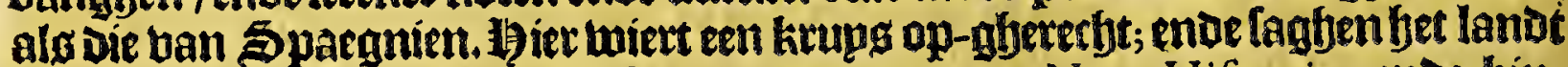
bol ban grom gras / bottuel berfehepoen ban dat ban Nova Hifpania, enoe bin= nen's landts groote ende groene berghen. Srbenton ban dele batom/ ende gir: ghen aen noozot-welt met goet weder / enoe ban bier begonmen fo te fien arn te franot fooghe beraben met witte [potten/ ende Iaghen daer betl gbebogbeitel welck fpn netten fadde in feecker bolen uan de rodten / ende 3eplaen thien leguen voo der 3 ommen ander-ganck/ende twaren des nachts hekalmt. B'anoex-Daeghg

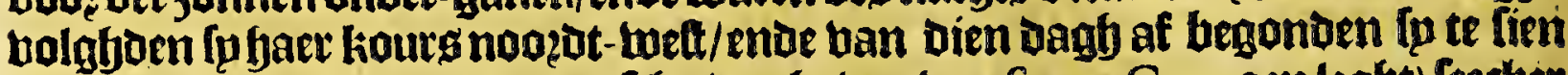

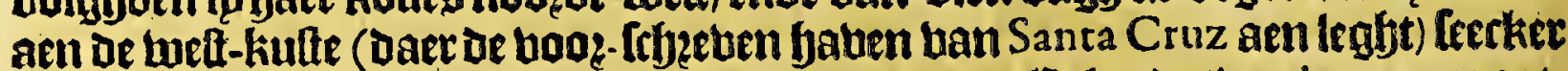
Eplanden ofte haoghe landen; ende gbemaeten een Eplandt twee leguen groat;

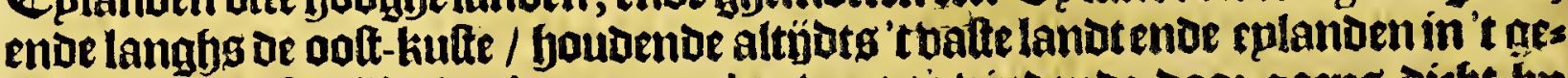

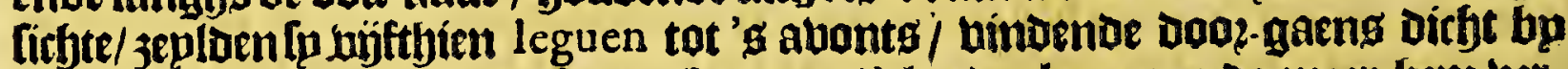
frande leet joogfie bergben fonder boomen/'tlandt al meer ende meet lom bet: thoonende aen oe welt-kulte; waer doof fp brgonden berffbepoen banghetoelen te beten / eenighe mepnende dat of kufte ban Santa Cruz wag baft landt/ende Dat fet paeloe aen't batte landt ban Nova Hifpania ; andere gheloobenoe datbet maex eplanden en waten. Eende Loa boerenfp boost aen) bebbende 't landt aen

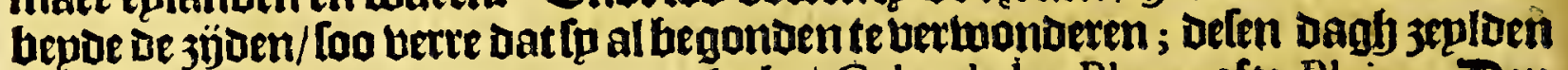
[u büfthienleguen, endenoemben dekabe/ Cabo de las Plagas ofte Plaias. Ben naeften dagh 3 eploen [p iwel twinticy leguen; 'Cl tranot is al langhs benen tal klepne lyeutueltiens fonoer arag oft boomen; ende anckeroen dien narbt in twins tich badem waters; Deg andet-Daeghs begonden fu te komen in ern frate nootswelt-waert / welch in oe monot tmaelf leguen beetot mag/ende badt twee exlans Den/bier mijlen ban den anderen berfebepden; ende fagfen dat bet lanot daet black was met teker bergltheng/enoe dat Daer een water alg een bzoecke dooz oe plapn fenen liep. Eele frate foo berte als fp fien konton / was feet diep / want ip en kanden afjeen gronat binden/ende taghen bet landt frecken aen bepae jijoen/ende de weltelijeke jijoe ban Santa Cruz was fooger lanot/ende feer kaele

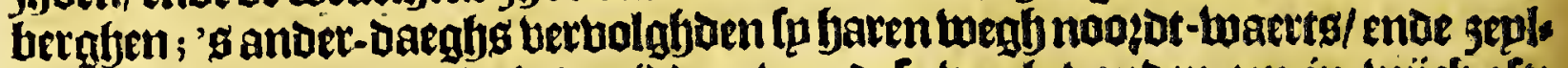
denbriftyien leguen, ende in't midoen van dele wegh bonden een in-lujjek ofte bape/mel feg leguen in't lanot lereckenoe met beel keecken; Daegbs daer aen jeploenfpthien leguen, de kutte was al boogh gfeberghte ende kael. "Ce is feec

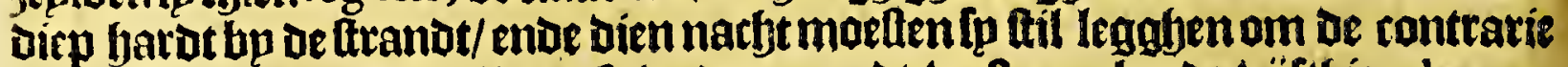

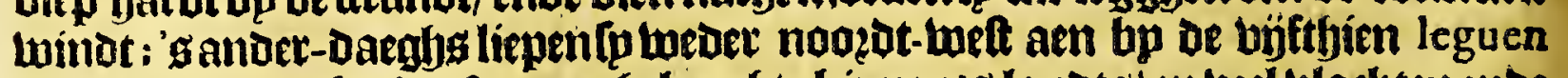

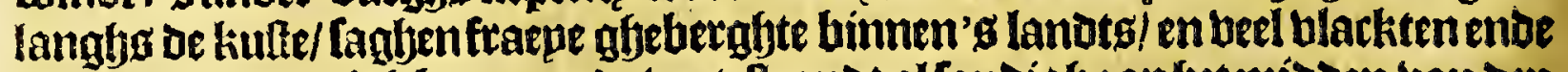

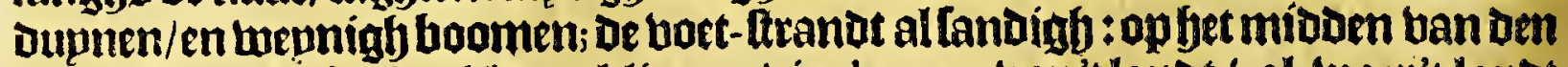
dagh bonden lip leecker klepne klippen vier leguen ban'tlander/ al-baer't lanot een grootepunt maeckt/ daer fp bleben legghen/ende badoen dien nacht een gbes

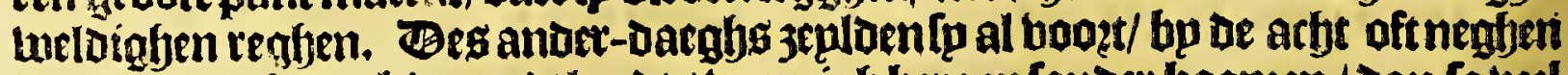
leguen, ense fagen bimmen' s landts twepnigh bergen Conder boamen / Dan fo beel

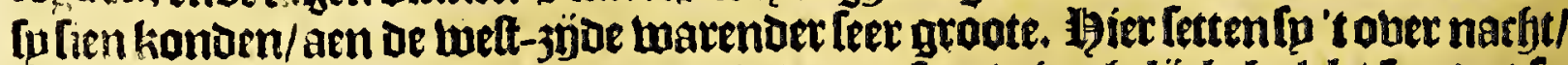
Doo? dien bet daet ondiep mas/ende 't water feer wit ghelörk kalck/ [oo dat fo

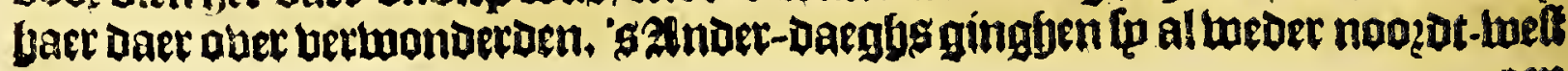




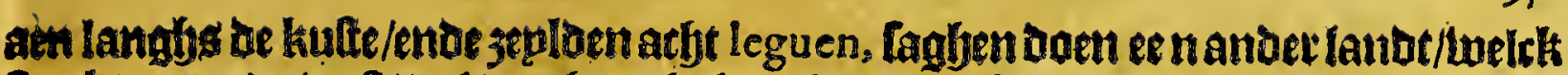

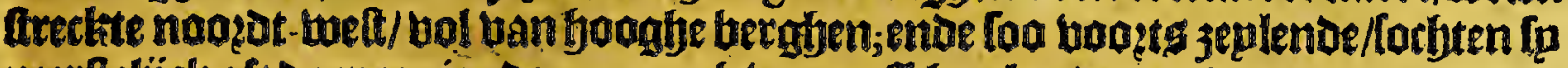

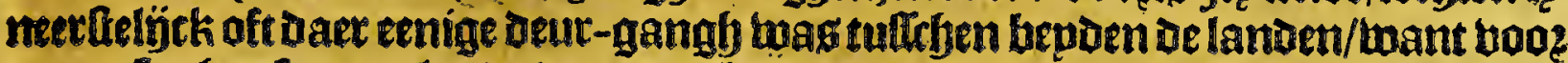

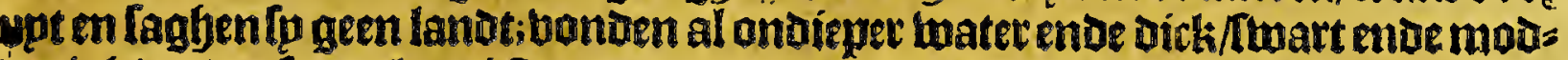
berigy/tot dat lp tenlangbeten quamen in bijf badem tuatevs/enoe hebonoentoat

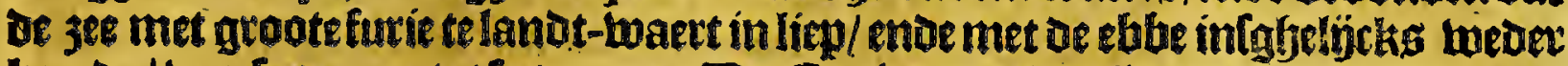

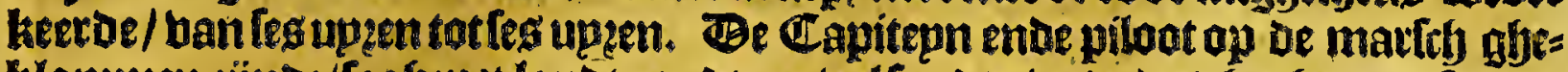
klommen zỉnde/Laghen't lande tondtom vollandtg/ende dat bet bem te famen

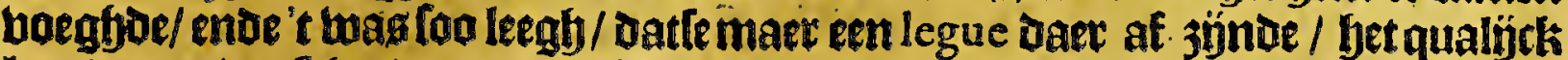
konden onoer-frfepden; enoe'tffyen Datter een in-laet was ban feeckere lacken) baer de zee in en upt liep. Siende dat vace gheen deut-gangf en twas/ofteenigh bolck twoonde/ ginck de Capitepn aen lanut/ ende nampofrelíe Daerban. Ten Celben dagf met be ebbe bielen fu naer de andere fulte toe; boe-loel fu altijots in

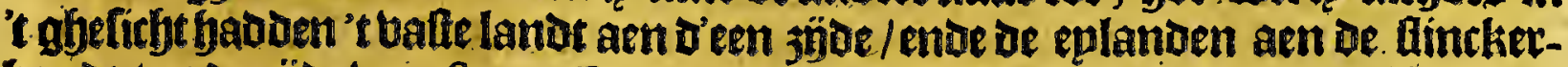

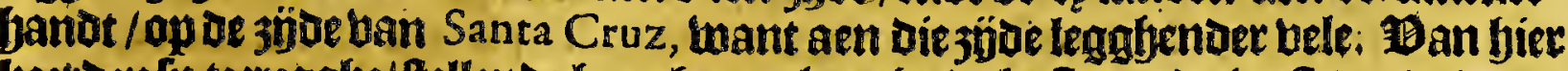

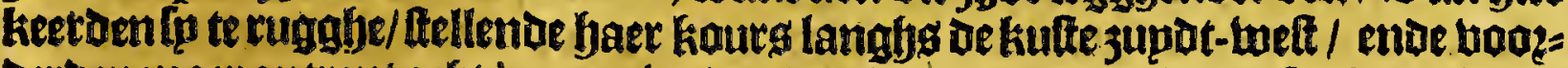
Detoen maer ontrent arbt leguen in twes Daghen booz of kallnte; Caghen 't lanot bol ban booghe ende naeckte berghen/ ente aen de flinclier-jübe een ulack lande/ ende in be nacht eenighe beten. Deg anderen daeghs haer kours tolgbenoe/a= ghen lp een groote baben met een Ezplanot in 3 ee/ een boogh-[cheut ban lanot/en

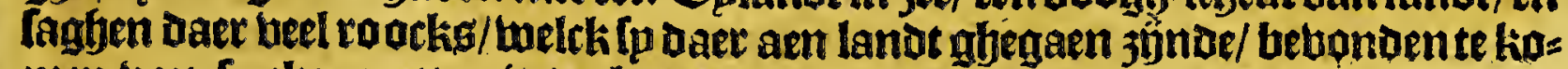
men van feecker putten in de bergben tan berbzande aerde. Op dit Gplanot waren menichte ban jee-robben / kreghen hier oock een Jndiaen ban feven oft

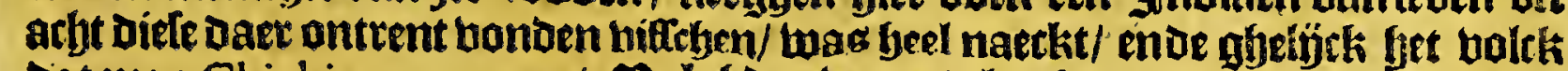
dat men Chichimecas noemt. Bolghoen yoozts al de telue kufte/ ende paftertoen

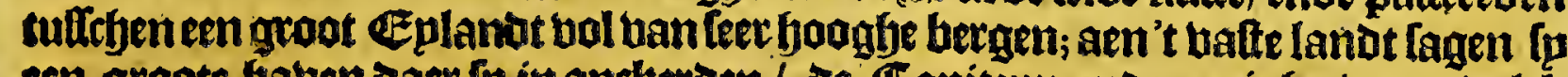

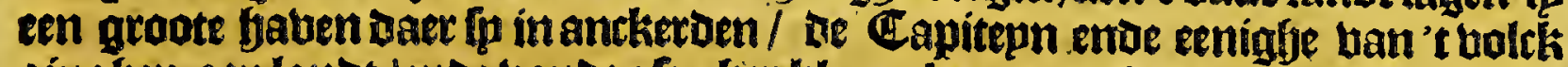
ginghen aen lantot /ende bondenfeetker klepne koten met bope objedeckt; 't landt

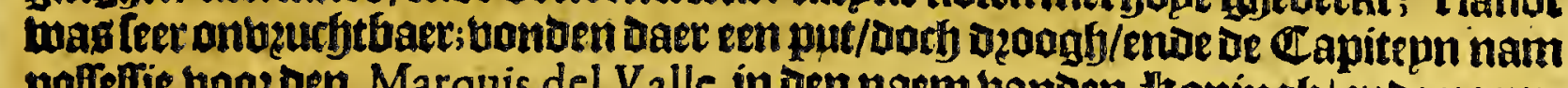
polielie voog den Marquis del Valle in Den naem bannen thoningly/ende noem= ben bele haven Puerto de Sant Andres; lagben bier ontrent thee Indianen ban feer groote ttaturé. (Be Eugffelferye trandatie ftelt Ancon de Sant Andres, op Her.d.6.

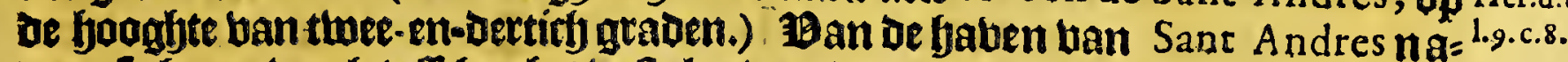

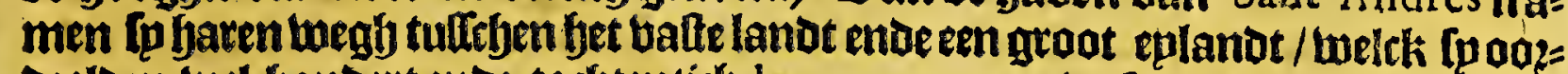
beeloen wel honuert ende tachtentich leguen groot te wofen/ ende lagh een ofte twee mijlen ban't baftelandt: Dep Daghen 3eploen [pmet frbaerfe minot/enoe fet

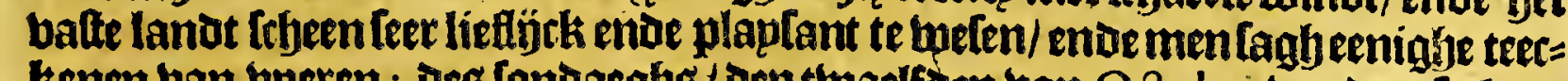

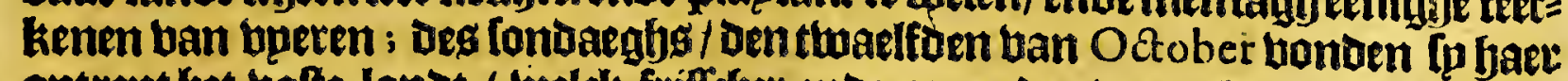
ontrent bet bafte landt / welck friffrber ende groender was als t booz-gaende/

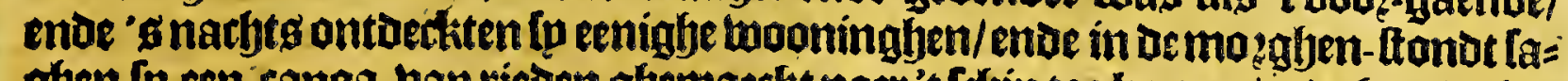
ghen fp een ranaa ban tieden ghemaeckt naer't frgip toe kamen/ende foe- wel be Indianen [pzaecken/ foo en tuerfetentmenfe Docf niet/ foo datfe tweder-keetoen; ende fracks quamenoer noch bóftanoag ban 't lanot/en quamen een fteen-wo:p na bp fet tebip/Dan en twilden niet naetber kamen/ ende alloo tweder wegb boe = ren / fond men faer de floupe naer dic een ban de canaas onderbaeloe enoe enters

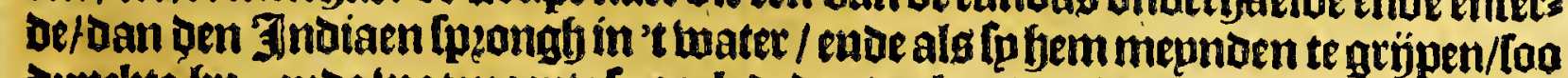

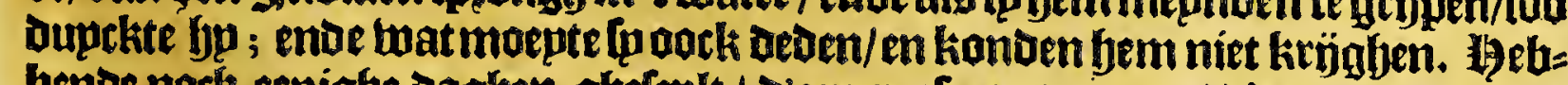
bente norly eenighe daghen gfjeteplt / d'een rep[e met rupme / d'ander repg met

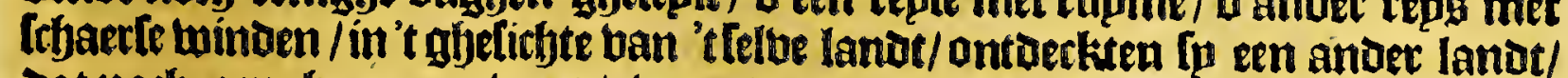
dat noch aengfenamer was / twaet boos eenighe riebieten in $3 e x$ liepen. Be Capitepn qingy aen lant met les man/ende bonten licteeckenen ban bolck/ ende beel frupt-Loomen/eñ den felthienben Oat ober bonden fa baer ontrent een punt ban boogb geberefte/eñ boozts barendequamen teder in de baben ban $S^{t a}$ Cruz 
Den achthienuen Oatober, ente blebentaer acht Dagfen/in-nemende batet ende boudt / ende haet berbertryende. De Capitepn lonot thadf man aen lanat om

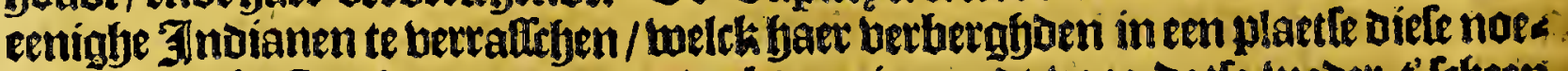

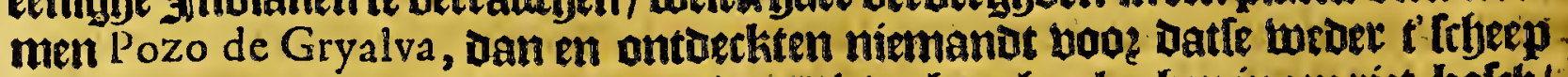
fouben gaen/ ooen ontoeckten [user twee/Die berbozghen lagfen in een riet-holch) om de Spaegniartoen te vertpieden/Dan twaren foo fnel in 't loopen/ Datmente niet enkonde adyter-balen.

\section{Het twaelfte Capittel. \\ Vervolgh van de Navigatie van Francifco de Vlloa.}

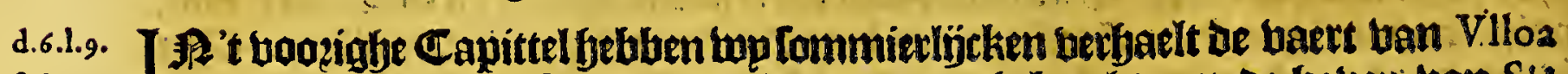
c.9.

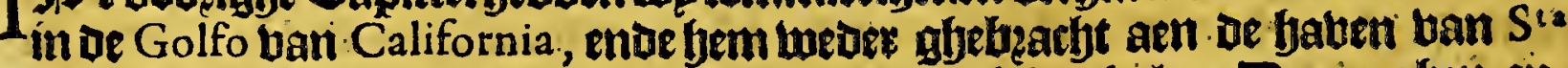
Cruz; fullen nu fpn boozzoere bopagie langhs oe kufte bexbalen. Den negben-entwintichften Octob. Lorbten Ip tueder ban $S^{\text {ta }}$ Cruz'tzeple te gaen/maer onoz dien

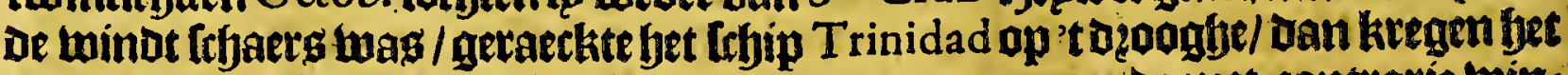
met groote moepte daer beder ban/ ende naer $3 e e$ pozende met contratie mins. $\mathrm{den} / \mathrm{keglyen}$ ende blicem / ende groote buplternis / en kanden in arbt daghenniet upt-komen/ ofte het punt Doubleren/welende ingroot perbeliel/om datteloo naer aen 't lanot tuaren. Den levenden Novemb. Laemoe bet weder / ende fp jeploen langhs oe kuffe / ontoeckende feer bermaeckeljick lanot/-met frjoone plainen/:

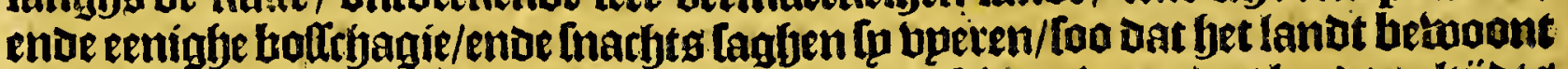

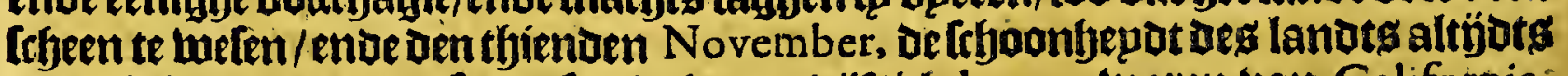
betbolg'sende / vondentp datte al biet-en-büftich leguen waten ban California; onzarelenue dat het lanot wel helwoont was/enoe al die kufte is ftepl/ booz diente

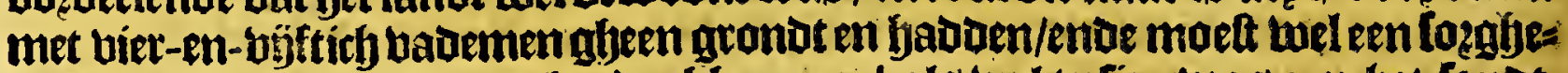
ligcke kulte weien/ enoe een barbe ebbe gaen/ als luel te fien luas aen bet fanot. 12an den elfoen Novemb. tot Den uiftthienden en zeploen fo maer tbien leguen

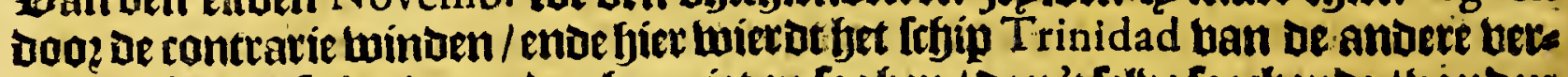

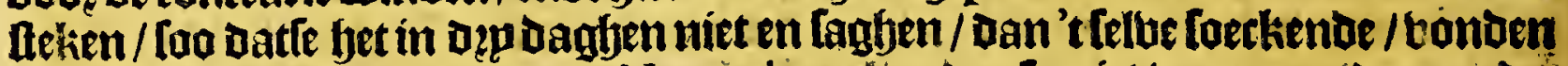

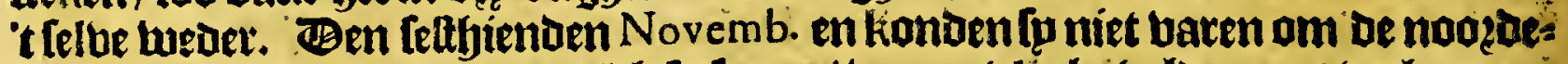

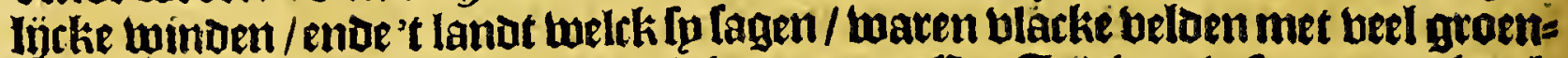

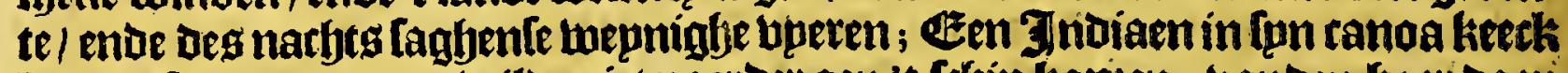
haer baft aen / maer en miloe niet naerber aen't febip komen; bonben baet boen te helen [etentich leguen ban. Santa Cruz : gheen Jepl kunnende maken tot Den [es-en-twintichften / ende boo? dien De nooze winot fetck tuaepoe / (waec Doog

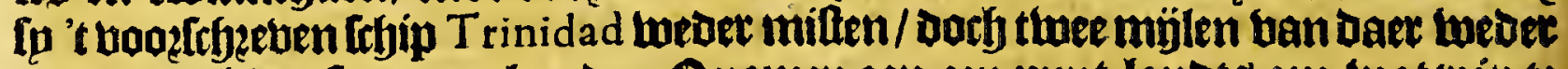
vonoen /) Ieoen Ip groote koude. Quamen aen een punt landtg om loater in te nemen/ dan de noozde winat meer op-fteeckende/ moelten de zee kielen tot ben

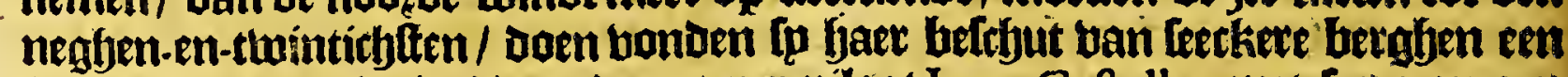
falf legue van't lantot / baer ben opper-piloot Iuan Caftellon mot les man aen voer / ende bonot daet biet 3ndianen leet groot ban lithatm/ welcke blucteten als farten; ende aen tweeden Decemb. namen fy thater in/ ente de Capitepn trock een ftuck weedfe in't lanot / en was berghatytigh enoe klippiof / met bele

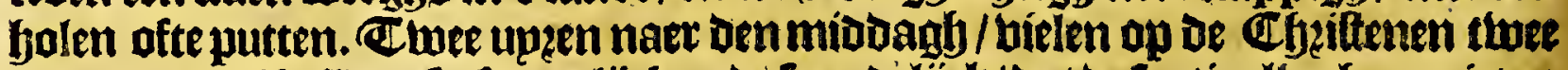

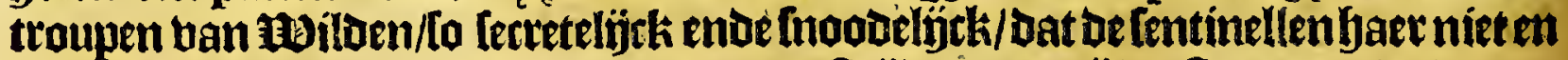

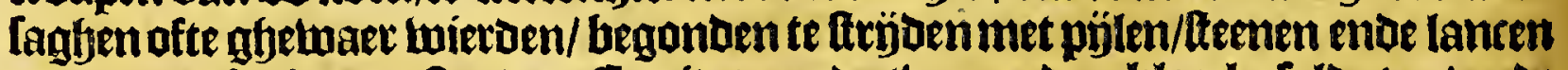
met groote furie; quettenden Capitepn ende twee andere kloecke [oldaten/ mot

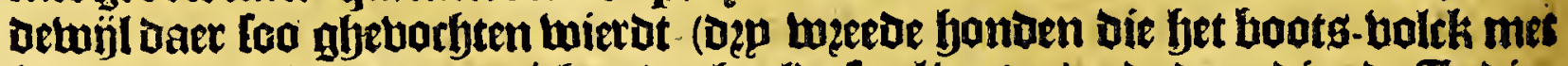

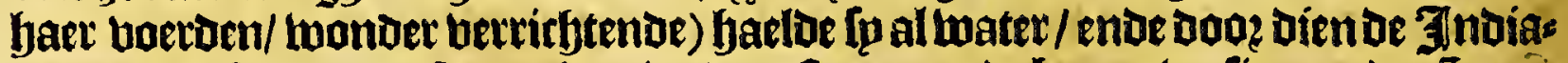
nen al danfende ende feljeetulmente / met fteenen ende bogen berfien op de Spaes gniaeroen aen-bielen/tepoen Francifco Preciado, Dar oe MBiloen trotfigf wierden/ om datmenfe niet lelfs batber aen en biel; ende de Capitepn roepenoe Sant 
Iago, en tot yaer in / bielle met ecnighe foldaten foo fterth aen / Datle baet retireerben naet haer andere troupe/ maer [p fhaet ftil bielden/ende groote bueren

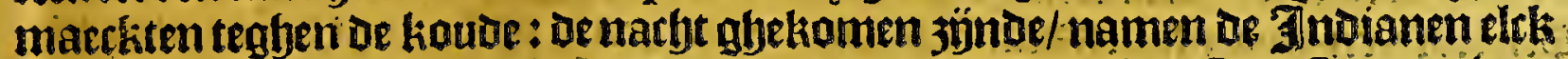

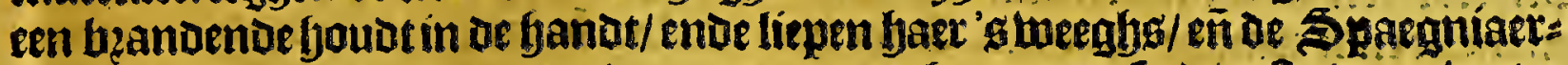

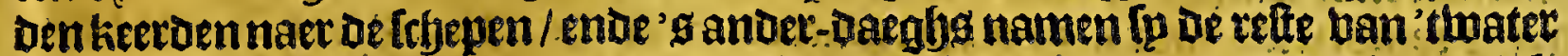
in; ende den opper-piloot gintk ander-foecken de montot ban een lack / welck

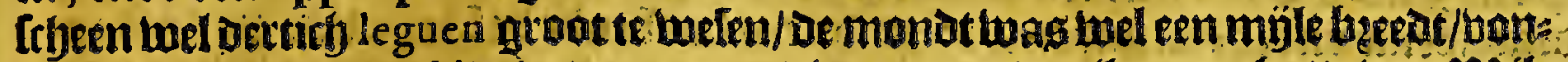

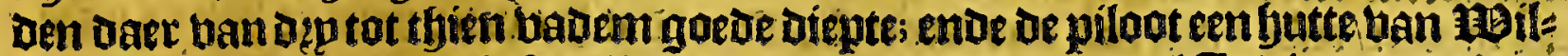

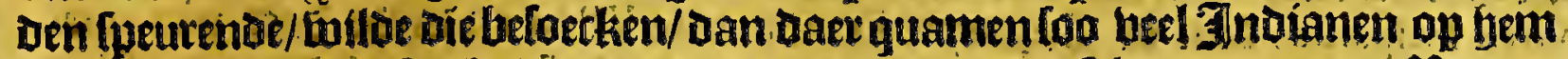

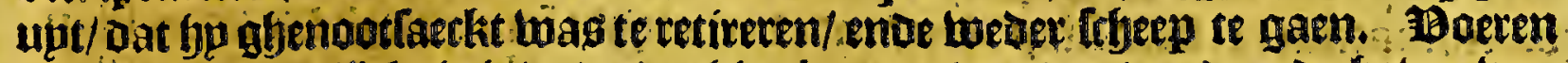
boots met matelöeke tointot/ende thien legụ en boozoer bonden de baben ban San A bad, welck een goedefjaben ís/ ende goedt lant Daet ontrent t tot den $n e=$ ghenten December ontoeckten fp al fraep landt / met frjoone groente / fuftigfie

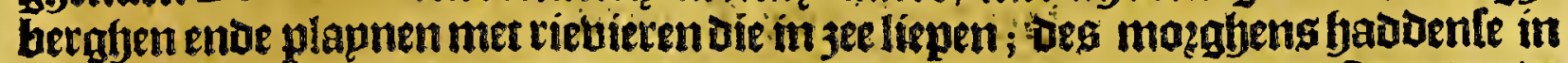

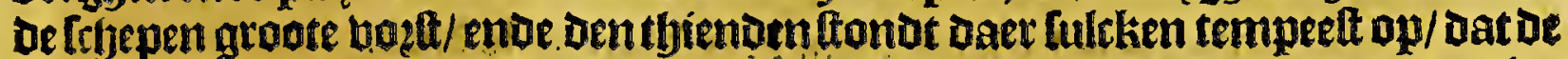
twee Ithepen baex seplen febeurden/ende berlogen twee anckers/ ende waren ghes = nootfaeckt te feeten in Debabern uan San A bad; Doen be bindt af-nam/ retols:

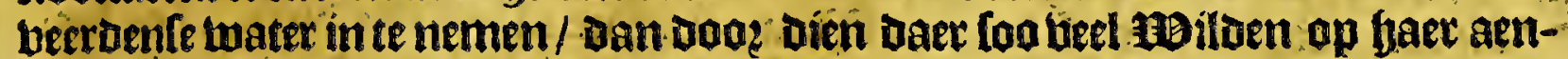
quamen/enoe ophaer frfyoten/en kanoen [p bet Dien abonot niet gbedoen;'gan-

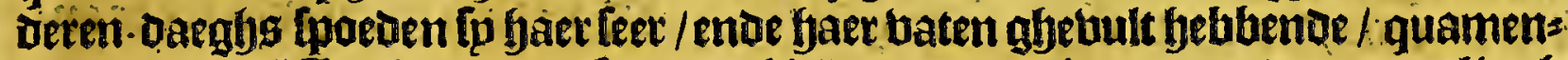
Der tueder veel Inoianen / dirfe onder-fitelden met teectkenen / ende mangelingh

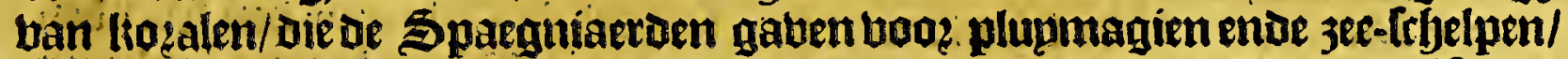

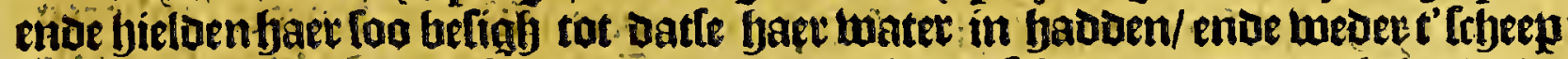
keerben. Boos vien be Indianen meer dingfen eptchten om te manghelen/ende

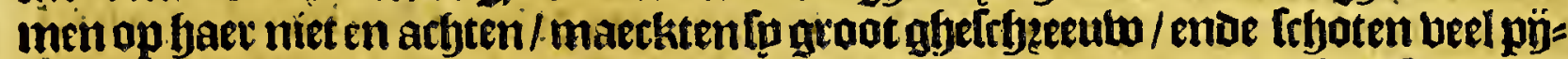
len naer bet hootr: bolck die oe andkers op baetoen/ waer boge men belaften thee

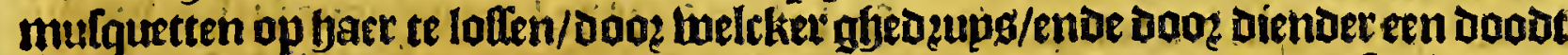

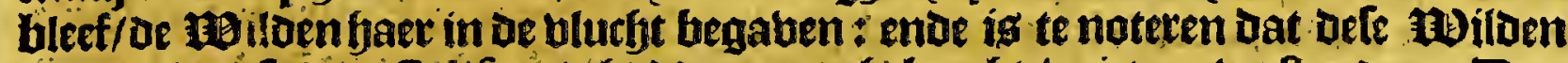
onvitolck diele ban California fjadoenmet gfebzarht / niet en berttonden. Ben

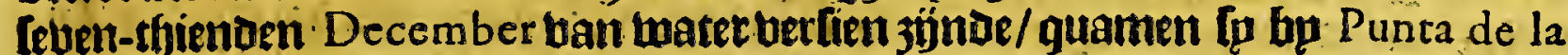

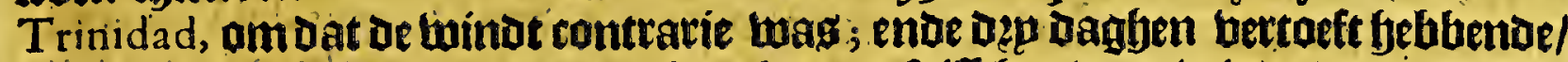

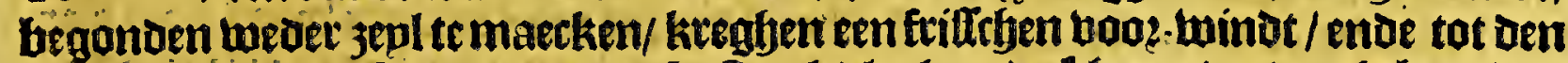
[even-en-twinticfften bonden de kulte al black ende frboon/ ende ghelberghten binmen's landts; boeren tot nieu-jaet -jagh des jaets $154^{\circ}$, bertich leguen

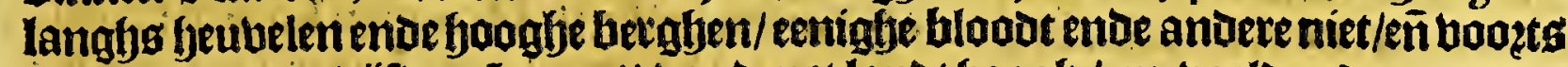

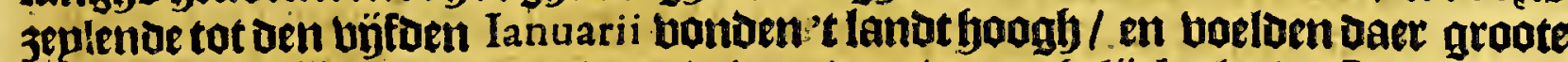
kaube / foo datle merckten/ oat oe twinter baet was gljelijek als in Spaegnien;

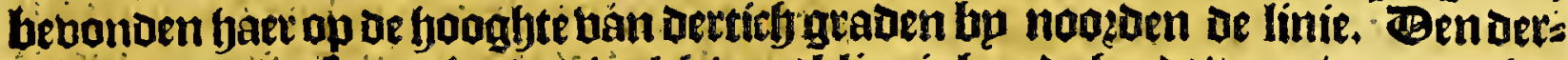

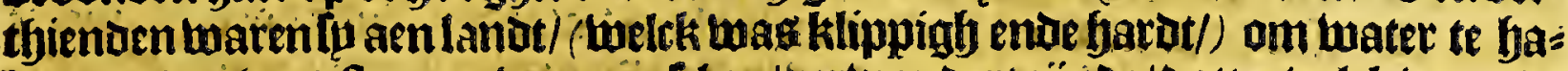

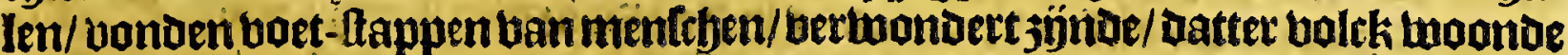

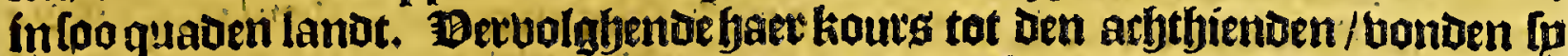

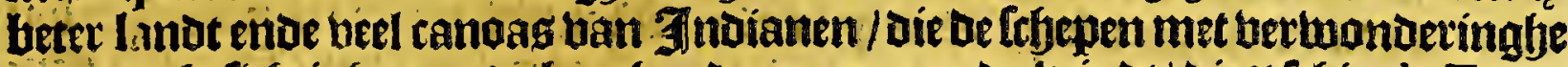

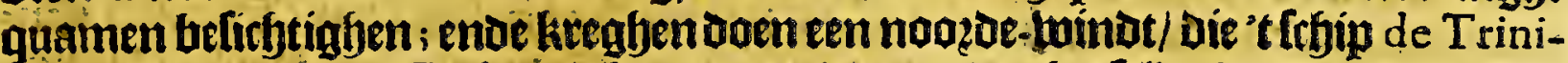
dad, uan D'ander verffack / Doeb quamen 's abondts Get lelbe beder te lien; Den

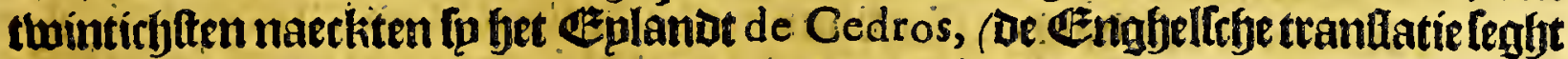

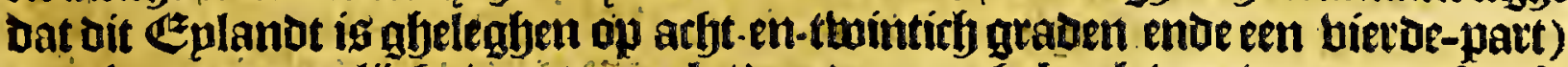

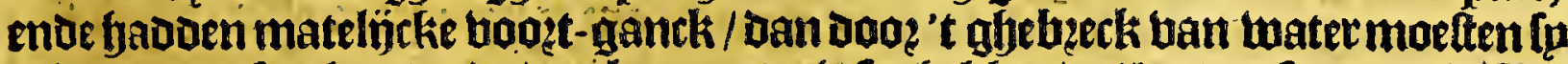

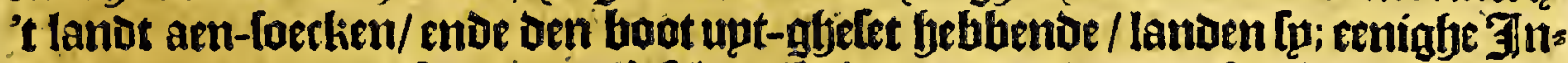
bianen mierpen met fteenen om 't clbe te beletten/ Dan nae datle die ghedeepgyt hadDen tefrbieten/vlodenfp meet / ende de fonden achtet-fyaelden twee / die de Tapitepneenigbe [nuplteríengaf / enoe tweder liet loopen: twater in-ghenomen

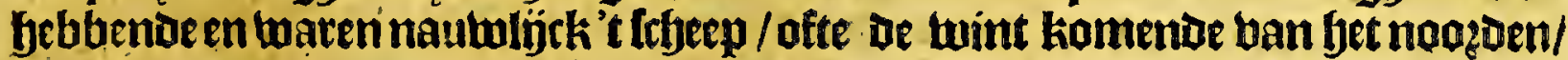
befefte beder op'teplant de Cedros, Daete bertoefoen tot Den achteten Februarius, 


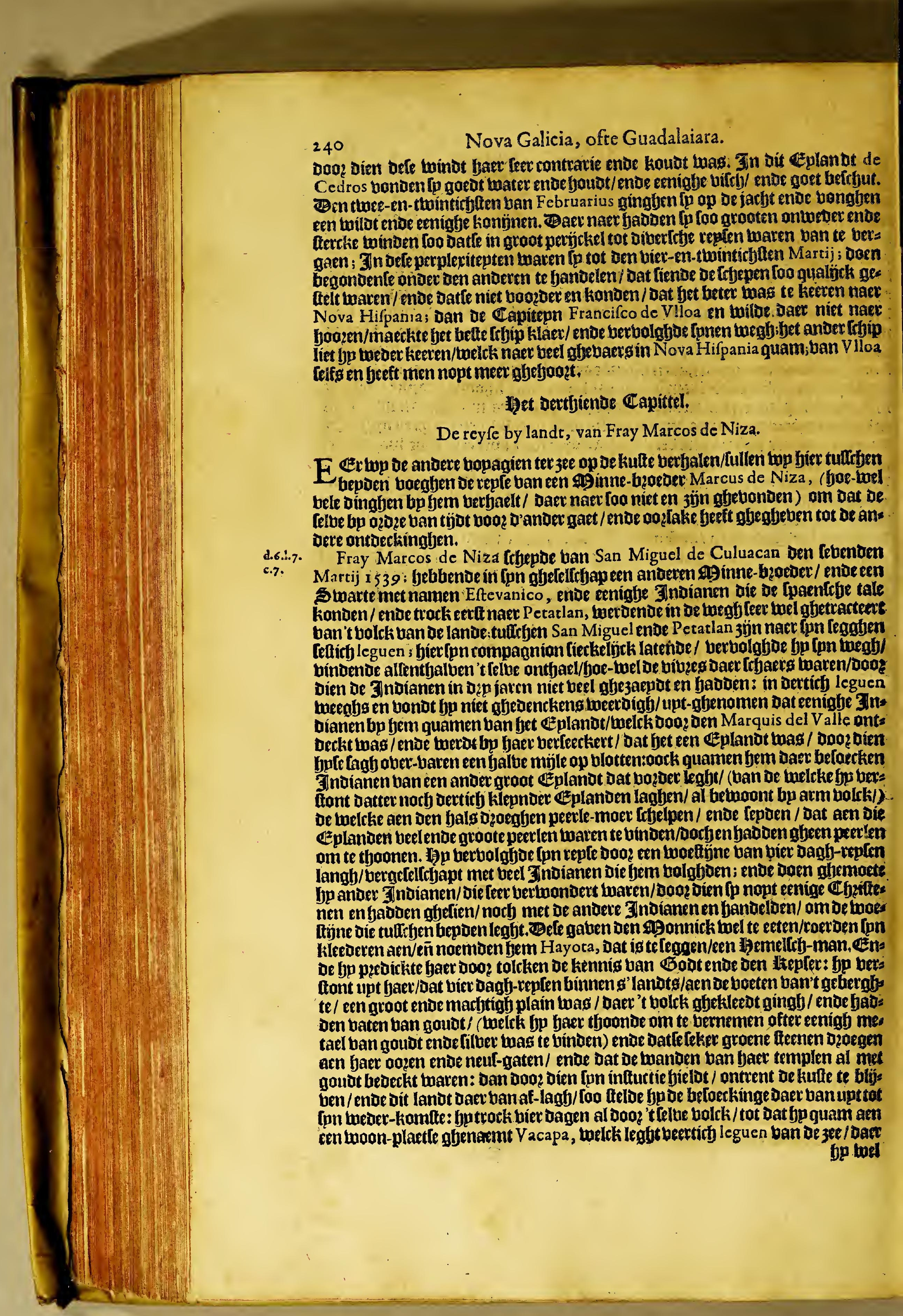




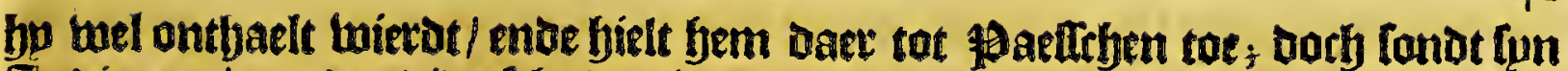

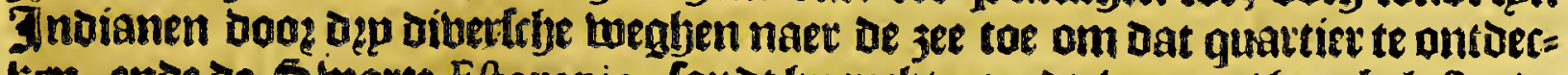

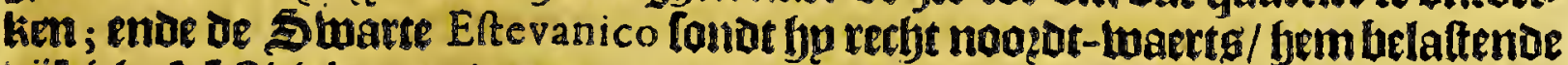
vijfrich oft teltich leguen bootts te trecken tat dat bp pets ban impotantie bonot)

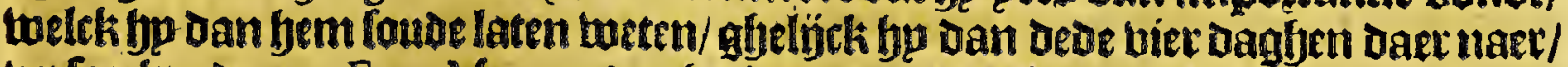

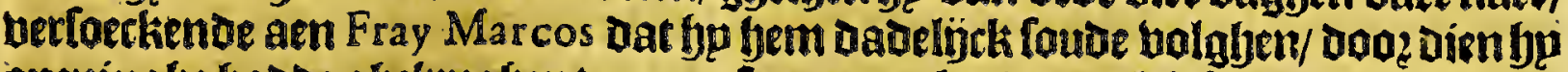
openingfe hadoe ghekreghen ban cen feer arout lanto / welck fp noemben Cibo.

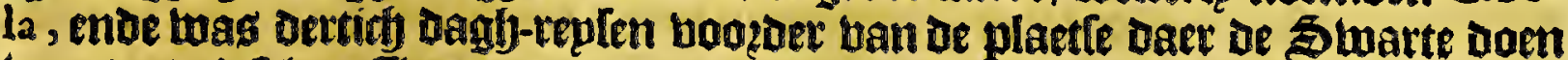

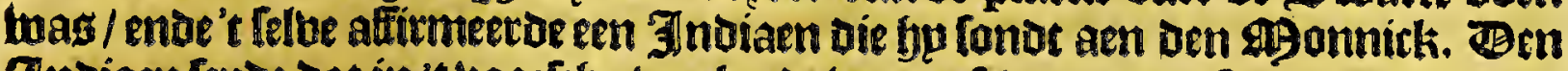

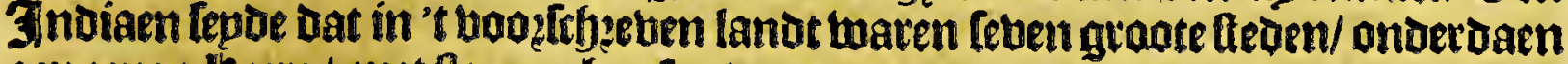

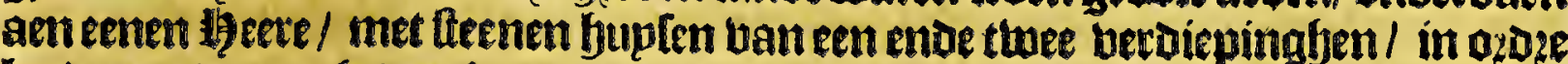
bp den anberen gfeboecht / ende de deuten bercient met turquoplen; dat bet bolck

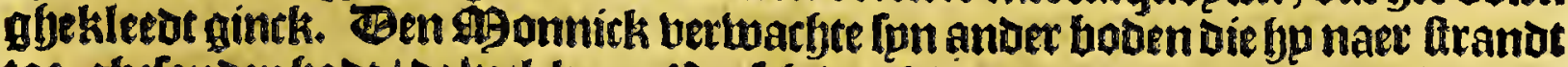

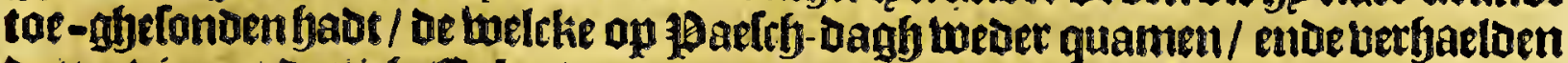
Datter bier-en-Dettich Eplanden haren / ende balt't telfoe als bouzen; ende imet Gaer quamen eenighe ban de Eplanters / Die den fsonnich pgetentertoen rans dallen ofte fthiloen ban oflen-Irever / wel berepot / Daer fu't beele lisfaem mede

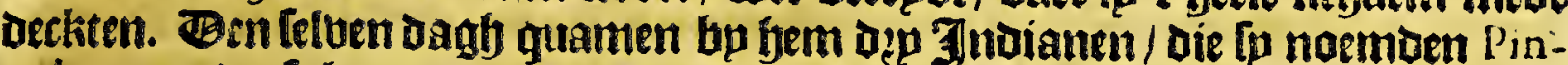
tados, om datte baer armen enbe bojften frbiloeten/welcke woonen naet bet ods

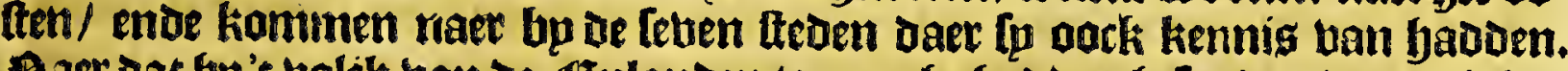

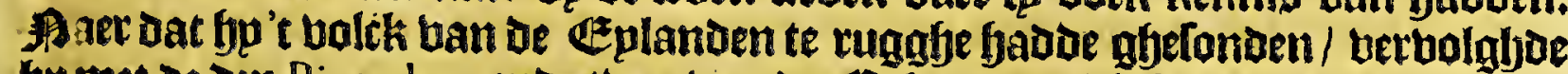
bp met de dep Pintados, ende twee ban oe Geplanders (die fem tiog? eenighe da: gben willden accompagneren/) den twegh die Eftevanico hielot/en ghemoete daet meder boden uan bem/die hem baden te baeften/ ento haft 't lellue relaes gaben als de boo:-gaende; ende dep daghen daer na weder anaere / die hem wonder fep:

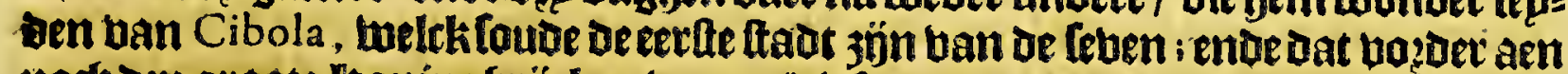
notb dep groote ltoningbrifeken maren/aie fu noemoen Marata, Acus ende Ton-

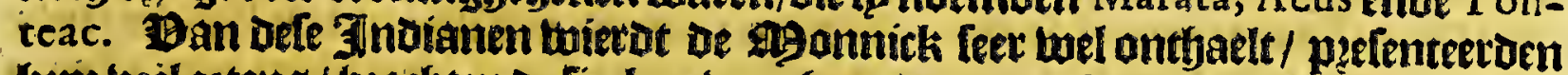
bem beel ecteng / bzochten de liecken booz bem/ om uan bem ghenefen te lwozoen: gaben fermbupdentuan Cibola die feel wel berepot waren ; in een anoer plaet(e) (be Pintad os bem altijots bolghende) wietat gp mese twel ontlyaelt / enoe gaben bem kundtchap ban Cibola, ende boñot een groot krupg / welck Eftevanico boosen teecken jasde ghelet / Dat de mare ban bet goeve lanot oat boos upt was/ bermeeroerde ; ende't boick [epoe dat fp woozot fadt ghelaten den 99 onnick te

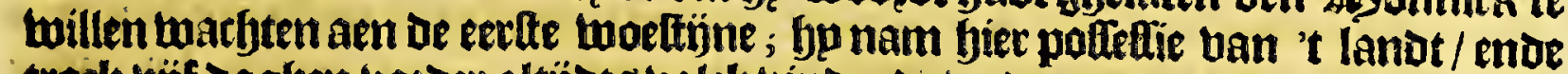

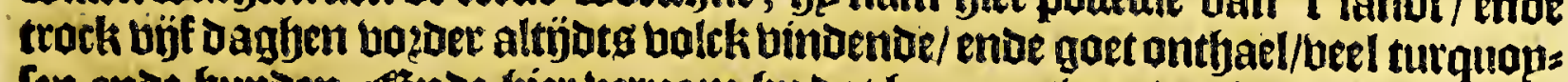

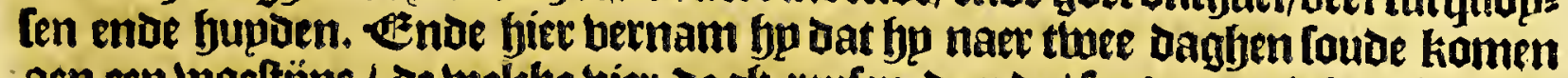
aen een woettỉne / de twelcke bier dagfj-repfen duerbe / fonder eenighe lijf torbt / foo dat fu daer boop-raet ban maeckten;eet fp aen de twoeltỷne quamen/bonoenfe een friffrbe plaete/ daec de jaep-lanben met tootjens en greppen nfetwatert luiet: Den / ende beel mang en byoutwen quamen fern te gbemoet / gaekleet met cottoen'

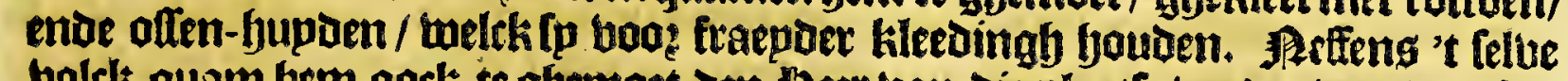
bolck quam bem oock te qbemoet den bzoesers / wel gbeklect in tottoenen tofte / met bals-kraglen ban turquopten /

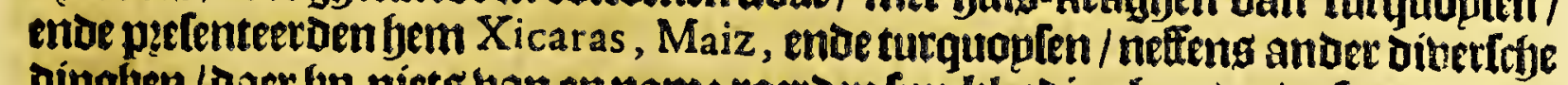
dinghen/Daer fjp niets ban en nam: roerden fon kleedinghen / ende fepden Datmen banfulck ghetwaet beel bondt in Tonteac, ende date 't felte maeckten ban

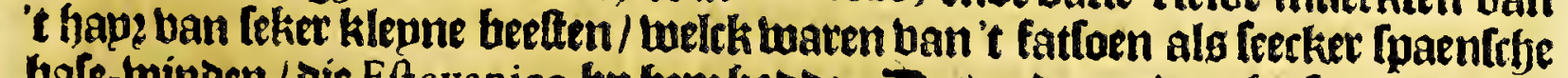
bate-twinden / die Eftevanico bp bembadoe. Bes anteren-daeghs foo track Den

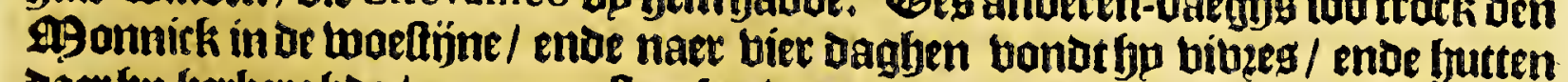
daer fy berbergboe / en quam ftracks daer aen in een ballepe daer beel bolcki twoonde/ ende aen de eerlte plaetle ghemoeten bem teel bolcks/gekleet als boozen/ met turguoplen om den bals / ende aen de neul-gaten enoe oogen / enoe gp bonot 
242

Nova Galicia, ofre Guadalaiara.

[oo graaten kennig ban Cibola, als in Nova Hifpania han Mexico, mbe tret bolctis dat Daet whetweelt badoe. Bonat Daec oock relaeg ban't wollem-laecken tan Tonteac : ende bod dien de kufte feer frectite naer't nopzoen/ begeerde by diete befien / ende bonot batfe op of leg-en-Dertity geaden baet lieeroe naer ljet

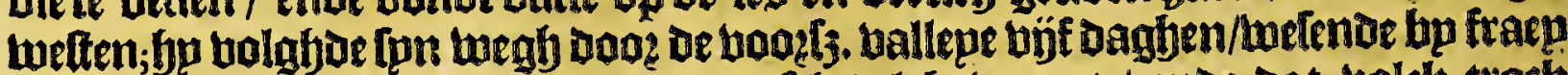

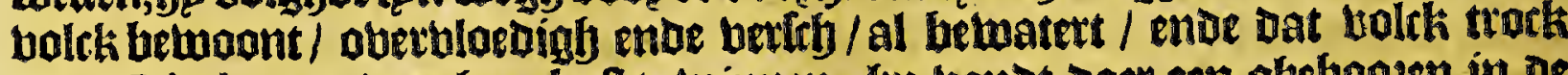
naer Cibola, om daer haer haft te winmen; hp bonot daer een abebooten in de

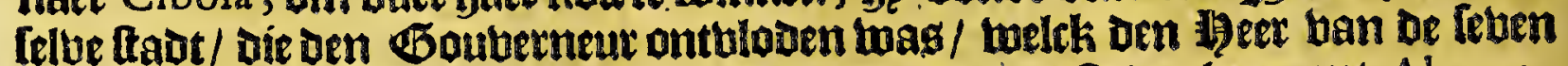
fteoen Daet gheftelt badoe / Die [on relioentie bielot in of ftad ghenaemt Ahacus:

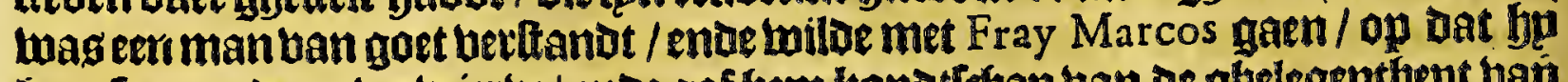

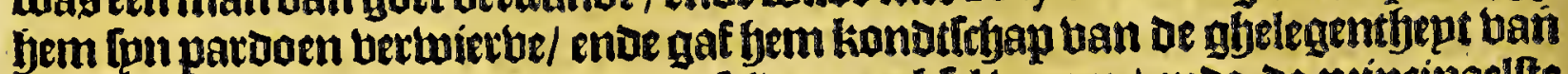

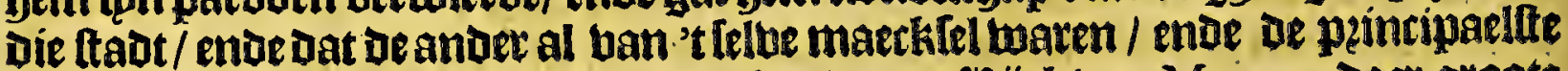
A hacus, ende Dat naet't welfengfeleghen was't thöck ban Marata, Daer groote moonínghen pleglen te weín/met buplen ban fteen ende kalck/ als die van Ci-

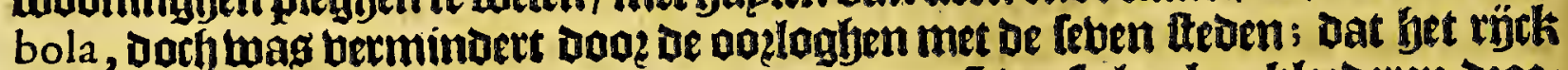

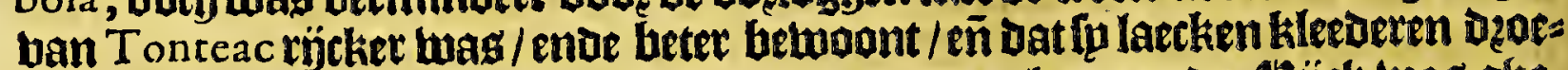

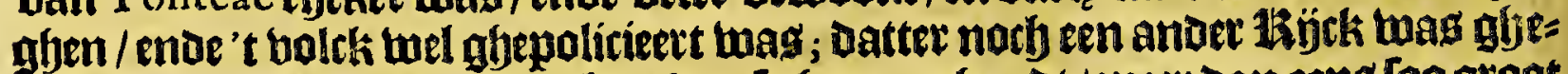

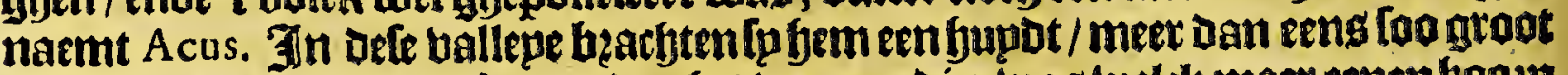
als die ban een os / ende fepoen dat bet ban een dier was belck maer eenen booph badoe in't boo:-booft / krom am gfeboghen naer de boeft toe / moe dat Daet een rechten yooen upt-quam / Daer bet diex groat getwelt mede honde Doen / 't koulcut alg een bock / ente' t bape een bingher lanck : fier kreegh by aduÿg ban Eftevanico, die bem bootthapte dat fop of Jndianen nopt op leugeng en badt bebonden/

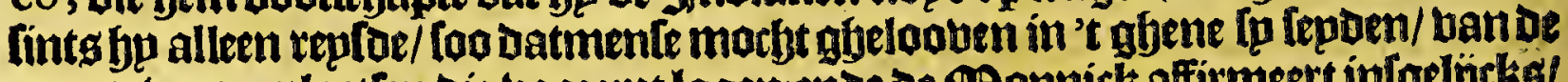

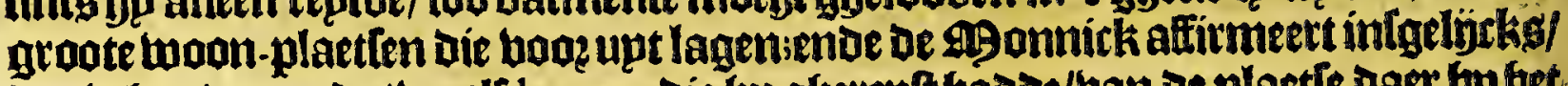

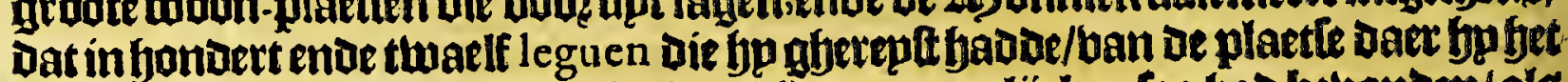

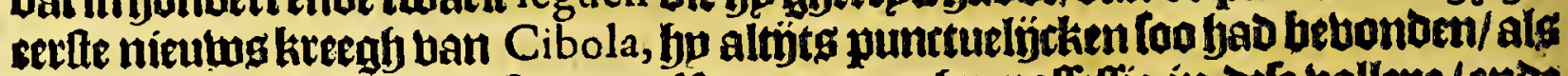

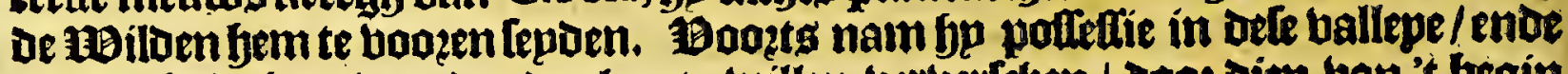
't volsk baot hem oaer app daghen te willen betberfeben / doos dien ban't begin

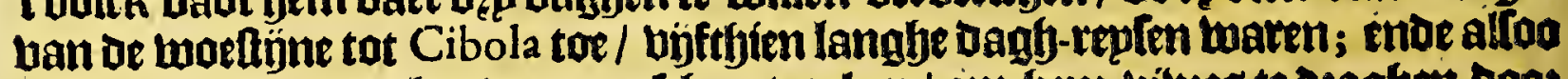
met Eftevanico Dep hondettmentehen tracken / om bem bibess te dzagfen boo: De lwoeltïne/ Dat lp oock met bem wiloen trecken om fem te bienen/ bertreutwen=

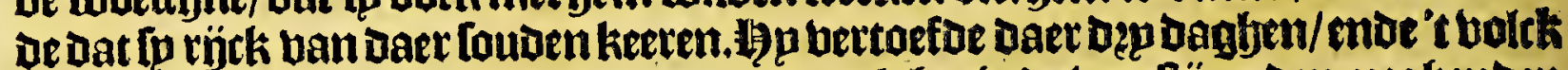

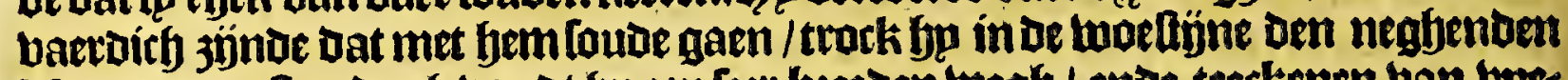

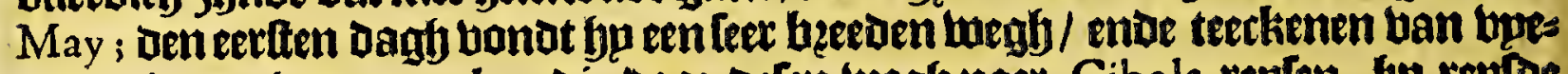
ren / die de ghene maecken die bode delen twegh naer Cibola teplen; be reptoe

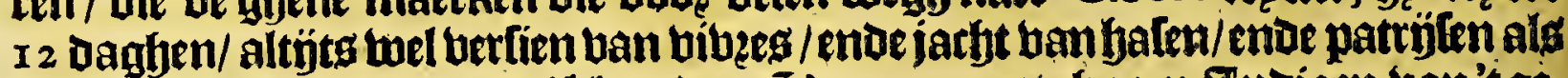

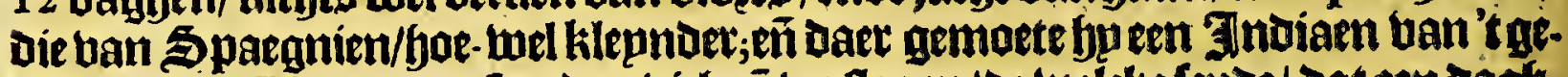

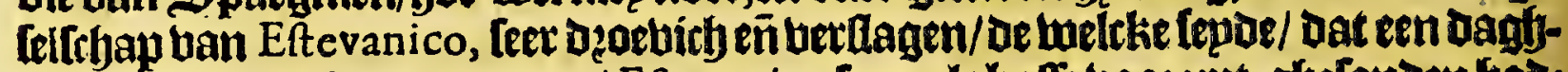

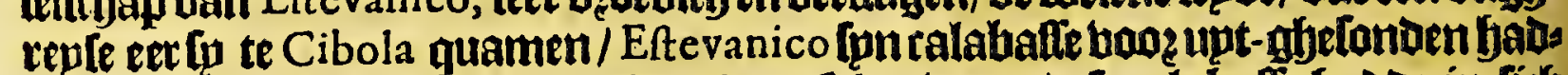

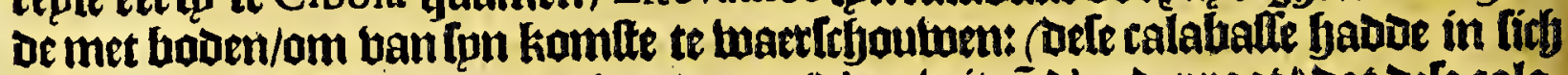
een [noer ban bellekeng/enoe thee beeren/o'een witeñ d'ander roat/) bat bele ralas balle ter hant was geftelt/ban den Gouberneur ban Cibola, ende dat fp die fien De/met groote gramtehap de felbe ban frem gfetmoepen had op d'aerbe / leggente tot de booen dat bp fulck bolck wel kende/oat [p teegh louben trecken/ende niet in Cibola komen/ Dathple anders al toude boot lmïten; Dan Eftevanico dele booits frhap ontfanghen febhenoe / Icpoe aen [pn rompagnie Dat op fulck feggen nirt en was te pallenibertulgoefpn reple eñ quam te Cibola; dan die ban de ftaot en lieten hem niet binnen komen/ Letten bem in een groot fups/ endenamen fyem af al that

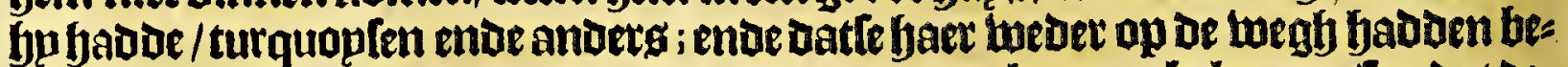
aeten/ende in daghenbe natht geen eeten en badoenkonnen betiomen/too dat des fen J ndiaen ban Doet halben/hem begheben bebhende naec een riebietken bat

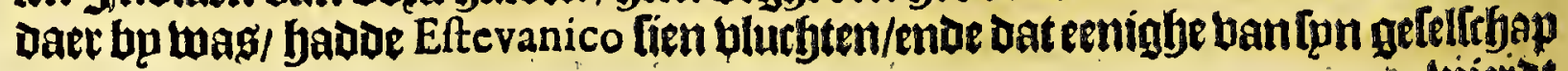
tuieritst 


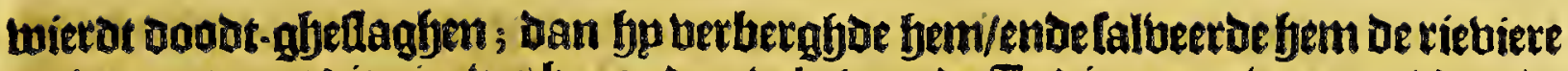
op-Loerts: met dit nieutws begonden bele ban de Indianen te weenen / Dan ute 9gonnick bertrootte baer/Leggende/ dat dit niet en was tegbelooben; Dan fiende

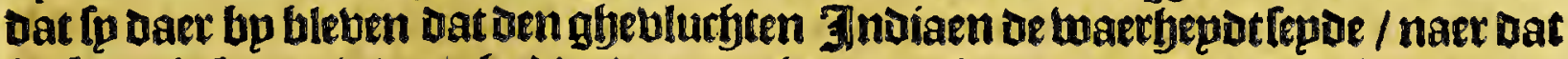
bp lpu gbebeot ghedaen badoe / opende bp de malenente verdeeloe de koopmans Itbappen onder de pzincipaellte/ ende animeetdefe boogder met bem te trecken :

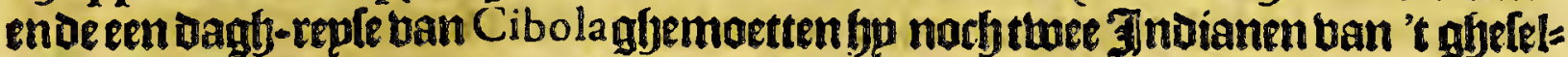
febap ban Eltevanico, dic feet beblocotende ghequett waten/waer boo? op nieug een groot gyebupl onder haer-lieden ontftond: Ben פgonnick wat tot bem-fels ben ghekomen jinde / ghehoodt Defe twee datfe berbalen fouben yet gheene daex

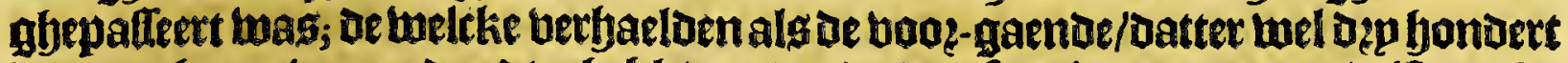
ben den faren waren Doodt-gbebleben / ende bat fp niet anders en wiften ofte

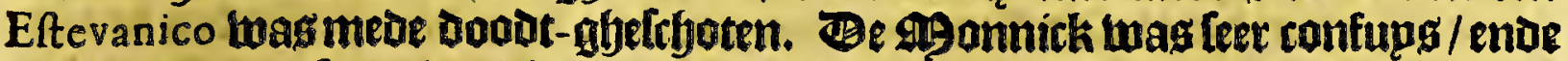

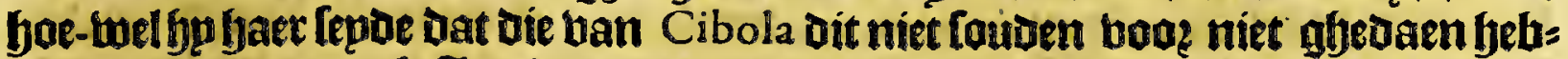
ben/[oo en waren dele 3ndianen daet mede niet te thillen. omte bidoen/ende bedet-tomende/waertffoude femeen mexicaen met namen

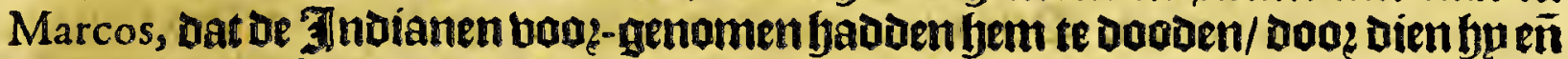
Eftevanico optaeck waren ban bet om-kommen ban baet bolck. Omoit te ont= gaen foo oeploegp onoer Gaer unt oe refterenoe koopmanfrbappen / enoe fepoe baet dat fo tuepniglypefít fouden doen met bem te dooden/ mant de Cbeiftenen

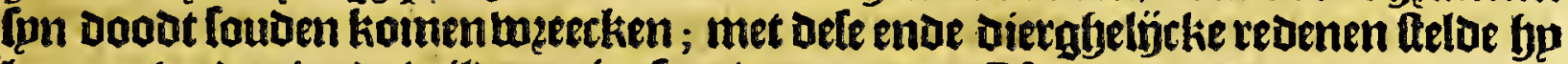
baer te becben/ende wilibe eenige fepnoen om naer Eftevanico te gaen bernemen/ dan niemant en wilde gaen: Derbalben ginck bp felfs met thee ban oe peincipael-

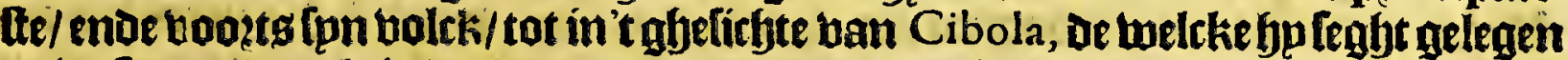
te turfen opeen plain/aen be boet ban eenronden bethb/Loo fraep in't aenlien als cenigge ltaot in die quartieren/met fteenen bup [en enoe daecken/na dat bp konbe lien vaneen bergb/ Daer bpop klom oin tie te fien; ente tat de faod grooter wag als Mexico; berfyaelr bat jp feer ghentghen tuas om Daer inte gaen/ban bzeefende

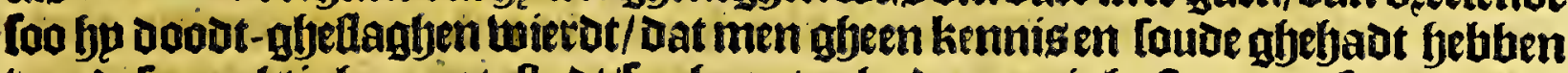

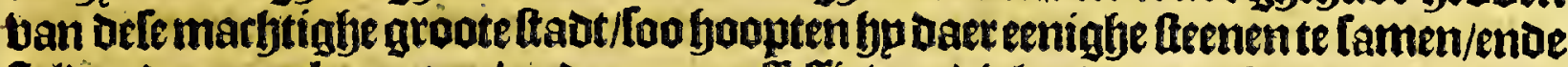

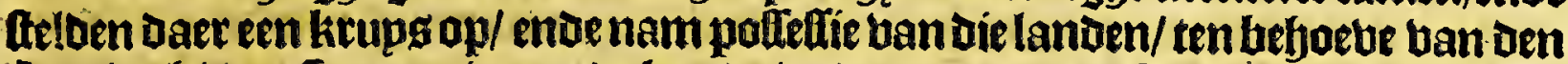

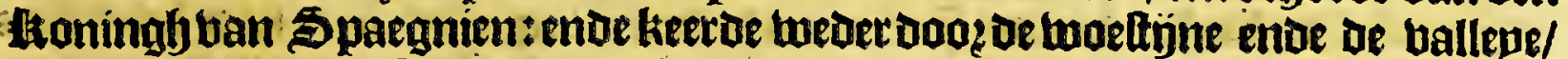

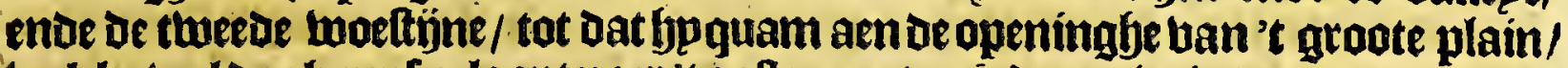
twelcke beel oagh-replenlooptnaer't oolten; en trock daer niet in/ om't peryckel te frtyoutwen/ hoe- -wel bphan daex af feben tamelibtke woon-plaetien lagh in een feer fraepe ballepe/ente ban goede gronot / ente berttonot dat oe intwoonoers beel gouts baboen; ban trock foo voottg naer San Miguel de Culuacan ende Compo-

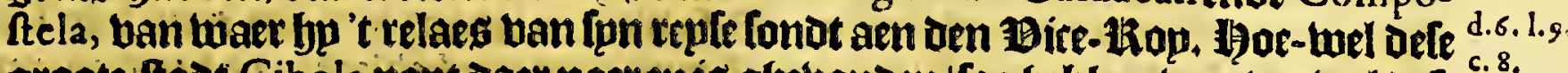
groote ftad Cibola nopt daer naeren is ghetonden/foo bebben top eventuel dele reple ban Fray Marcos bier goet gbevonoen te berbalen / om dat men macf lien/ that gheloobe daer te gheben is aen relatien ban ggonnicken/ die'tgheene Lu ban

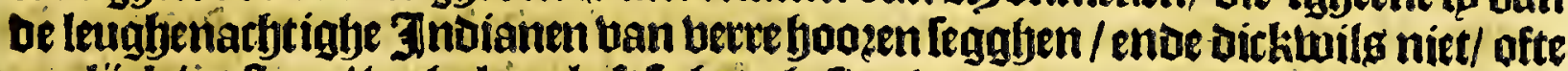
qualíek betfaen/ berbalen al oft fo fet ghefien hadoen.

\section{Set beertfiende Capittel.}

Verhael van de Reyfe by landt van Francifco Vafquez de Cornado, uyt bevel van den Vice-Roy Don Antonio de Mendoça.

F Rancifco Vafquez de Cornado Gouberneur ban Nova Galicia, ooo latt ban d.6.1.9. DentBice-liop Don Antonio de Mendoça, bp den anderen bebliende bandert ${ }^{\text {c.r. }}$ en byjftich man te peerde/ban welcke beel tweepeerden badoen/ende twee bonoert boet-linechten twel gelwapent met fuffilante ammunitie/eñ eenige belot-ltutekkeng; groote probilie ban berckens ende frhapen/ neffeng andere bictualie; trock ban 
Culuacan, in de ntaent van May 1539 , ende vonot naer bier dagf-replen te ries.

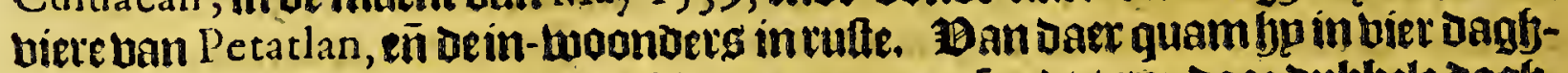
repfente Cinaloa, uan twaer bp thien rupters upt-fonot / om Doog bubbele dagf: replenmet Deu haelt te trecken naex de Cedar-beke (Arroio de los Cedros)ende te

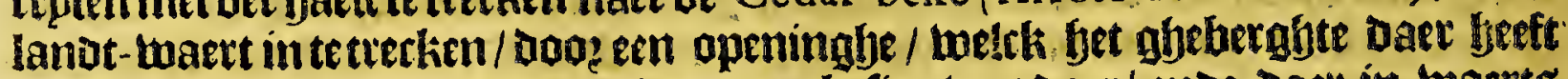

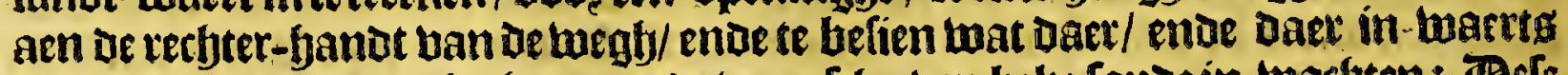

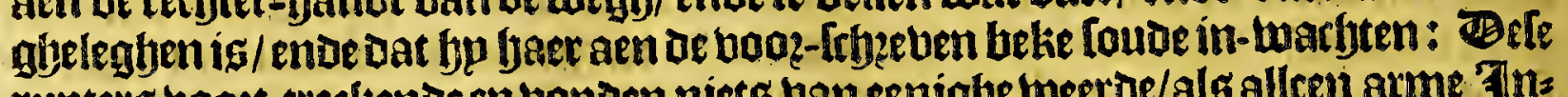

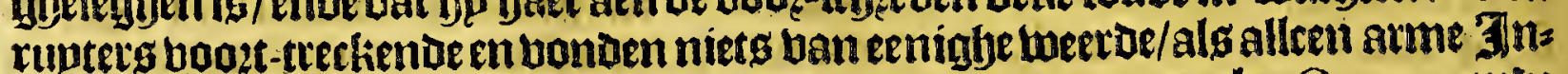
dianen cot oe belie de los Coracones toe (foo eertijots genaemt bp Orantes entue Cabeca de Vacca, upt ooplaecke van eenigh in-abetuanot ban witor vat baet

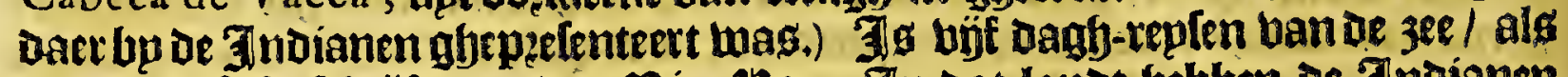

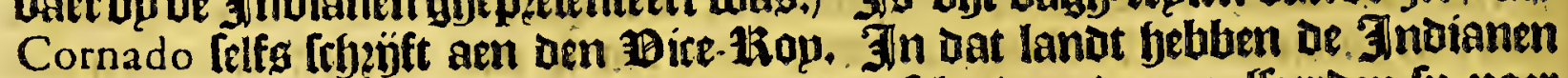
Maiz, etweten/ende calabaften voos baet voetfel : ban daer pafteerden fu naet De ballepe welck fu noemen de Sennora, welck is al 't feltue lande: t tuolck ban vefe

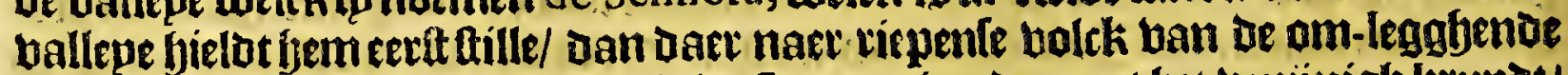
quartieren te hulpe/ Doodenoe eenighe 5 paegniaerden met yet veng̈nigb krupot/ welck fp gbebupeken. Bele rupters bedel-gheteert jünde met relaes van fet

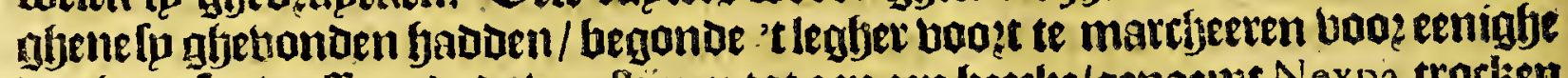
Danf-repten/palietende de boeltynen tot aen een beecke/genaemt Nexpa, trocken

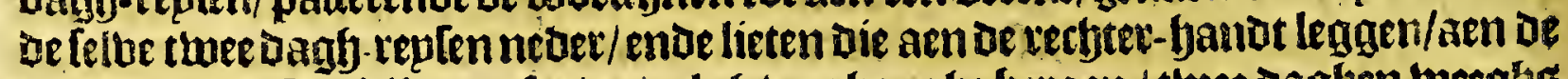

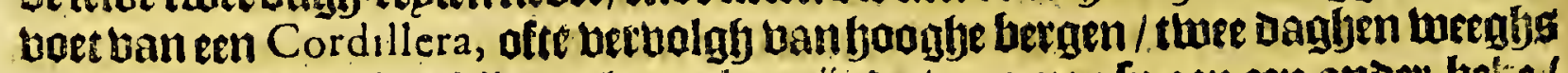
daernaer aber de Cordillera gljetrochen jijnde / quainen fo aen een ander bet:e/ die leer diey mas/ende met riet betwallen/bonoen waterenoe grag boo? oe peets Den/enoequamen in dep oaglen aen Rio de San Iuan, welek fp foo noemoen om Datte ap S'Ians-dagh Daer maren gbekomen. Jn thee daghen daer naer quamen ip aen Rio de las Balfas, welck fo loo naemoen om batte vlotten moeften maken om die te pafteren; s'ander-Daeghs warenle aen een bele genoemt del Pinar, bels bende groot gebeck ban bictualie / foo dat 't volek bem moelt befelpen met krup:

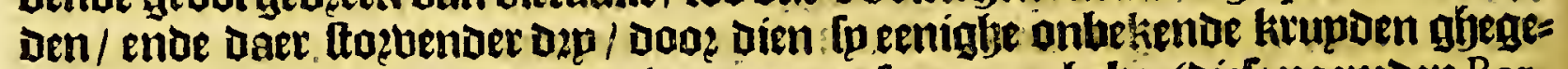
ten hadoen. In andere twee daghen quamente aeneen beke (diefe noemoen Ber-

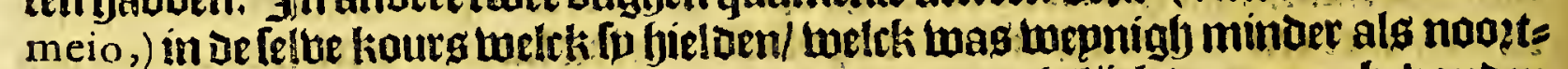
ooft / ende fjer faghen fp twee Tnaianen de tuelcke (gljelíct Daer naer behonden

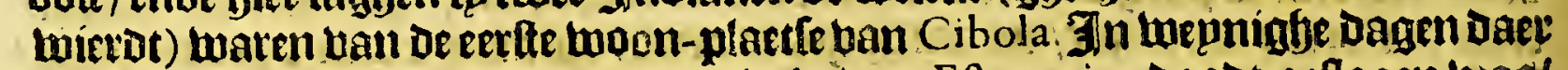
naet quamen lp aen de limiten ban Cibola, Daer Eftevanico toadt-gethagen has/

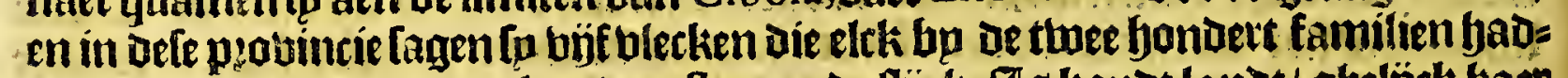

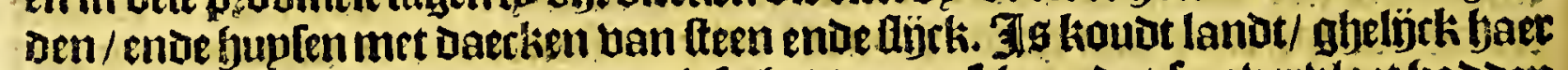

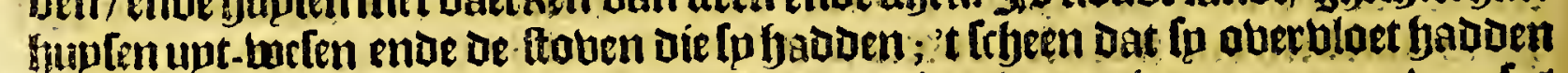
ban Maiz, extweten ende calabaften. Befe blecken leggen in 't om-gaen van feg Jeguen, het lanot is fandigy/ende niet feer met groente bekleeot / De bergben jön met fabel-boom belet /. 't bolck klecor bem met harten-fupoen feer buel betepo!/ cnoe oock ollen-fupden / ende bedecken faer daer mede in manieren ban rocken

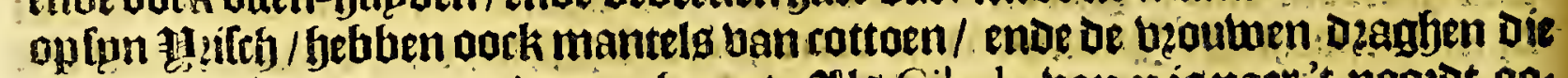
om de natel/o ber oen anderen ghegoet 2lis Cibola ban u ig naer't noogt-og: ften wepnigh min als bujf dagh-replen / ig taet en ander p?ovincie gbelentyen die fo noemen Tucuyan, welck beeft teuen blecthen/ouerbloedigher als of boo?-gaens

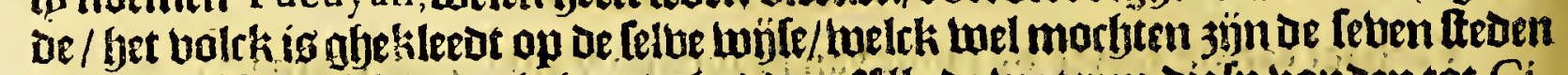

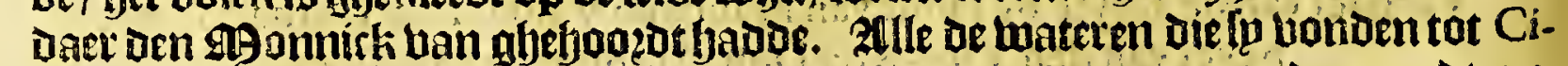

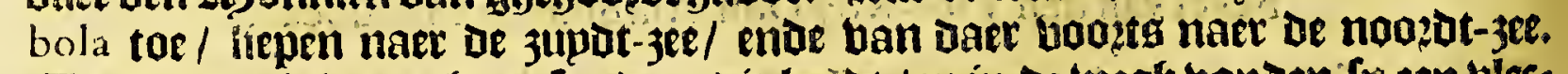

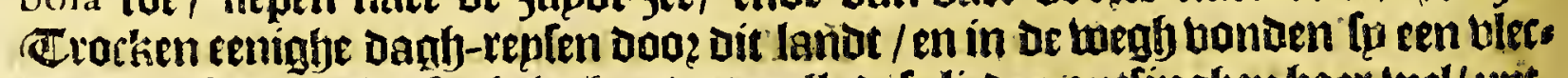
ke op een ftertke plaetle gheleghen/ende alle dete lienen ontfinghen baer inel/ upt. rifenomen die van de erefte blerke ban Cibola. Gyekomen 3ynde aen Rio de Huex, hebt abp langly de felbe in de Diltantie ban thintich leguen, wel bijfthen toion-plaetlen met fteenen-bupfenende met daectien; ende aen ander befen 


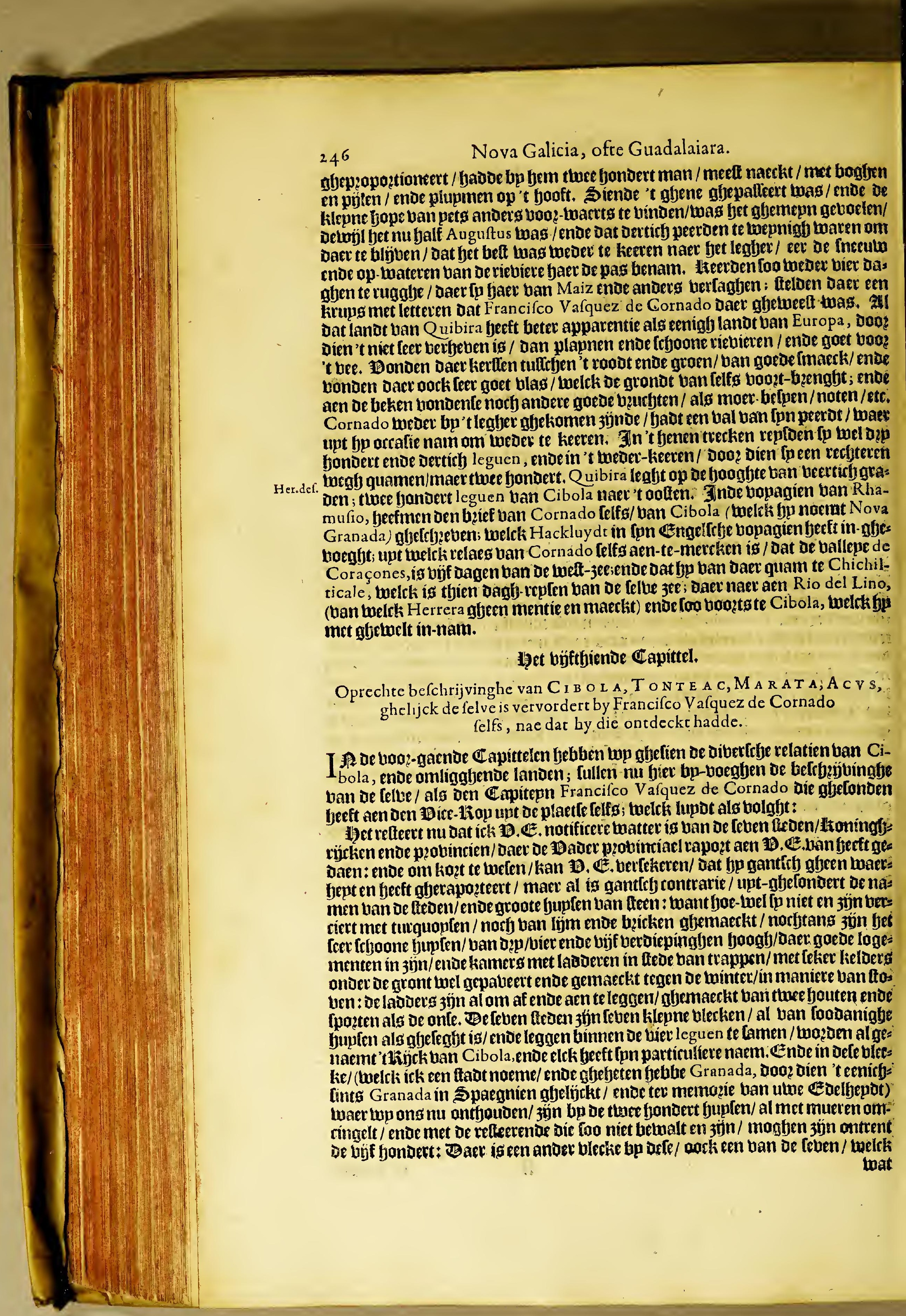


Her felte Boeck.

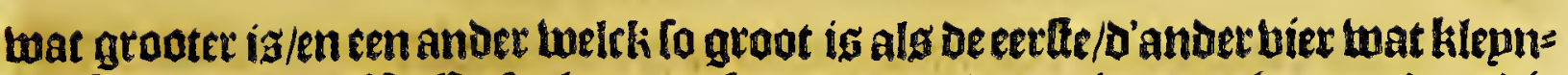

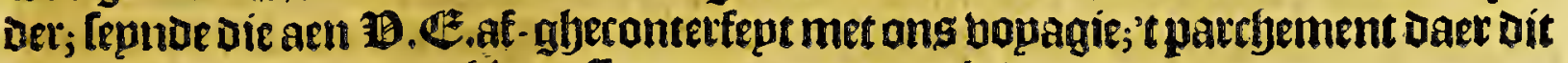
op ghefrbilaert is/ was fiet neftens andere meer gbetonden.

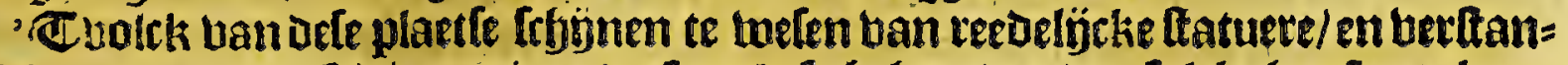

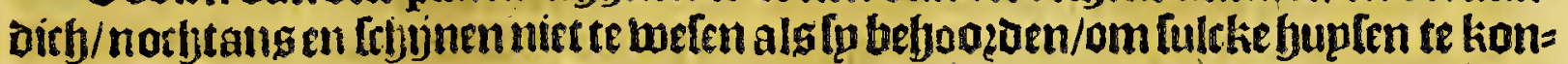
nen timmeren. Want gaen benmeeften - deel al naerkt/ upt-ngenomen yaerlefjas

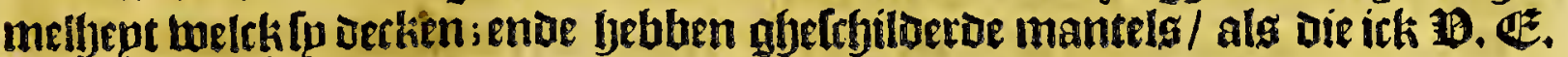

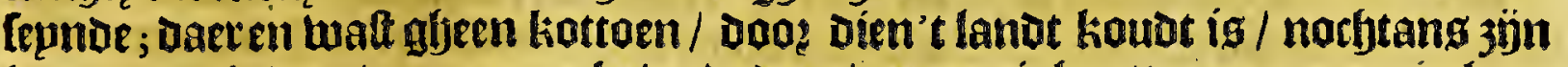
baer mantelg daer ban gemaeckit/ ende baer tuett eenigy cottoenen-garen in ljate

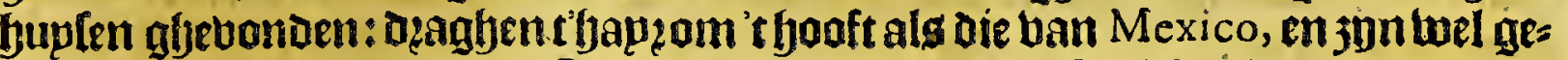
boedt ende geconditioneert : Su hebben turquoplen /en foo icliachte goede quans.

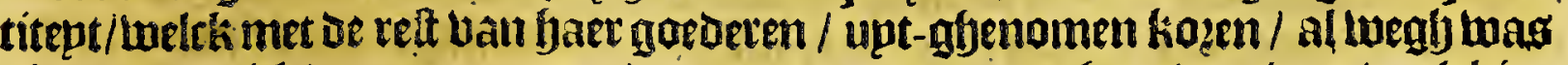

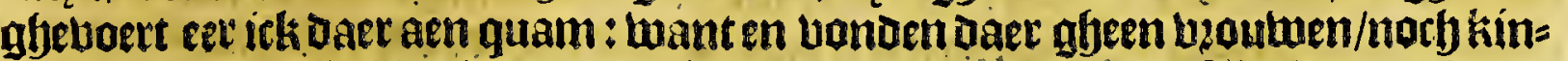
Deren onder be büftbien jaren oudt/ nach oude-lieden boven be [etfiry/ upt-ghena: men twee ofte Dep/ Die daer twaren abebleven am de tefte in de onjloge te gouvet: neren. Baer waren glyebonden in leectier papiet twee putten ban emerauben/

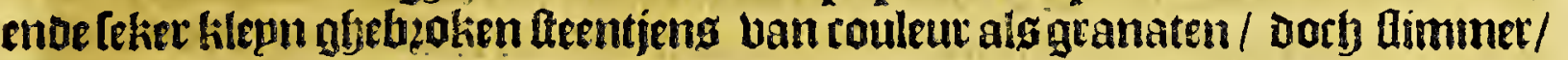

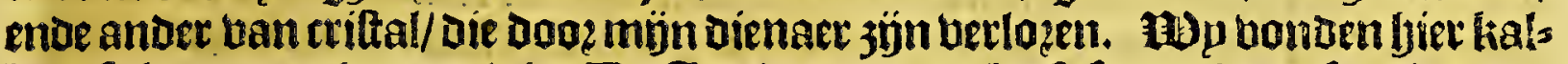

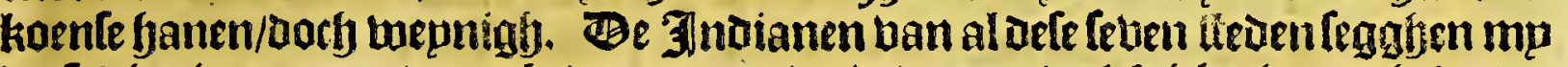
datte die niet en eeten/maer betwaren om de bederen; teslck ich niet en gheloobe/ mant jünexcellent goet/ ende arooter als die ban Mexico. De lapfoenen entre temperature ban oe lucfjt is gljeljéck te Mexico, mant fomtÿots is ljet bet/ ende tomejuts reghent fet; boe-mel dat ick het tot noch toe niet en fyeb fien regenen/als eng een blagle met luint/al\$ bet getwoon ig in Spaegnien. De fneeuende hoube

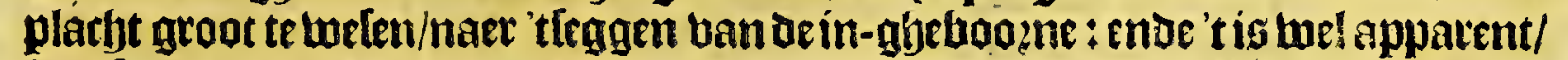
in refpect ban de ghelegentfjept ban't landt / ende't fattoen uan faec bupfen/ ende De troeperingfende andets/ melck't holck in booz-raed beeft teghen de koude. Daer en ż̈n gljeen frupten/ofte frupt-boomen: De gront is effen ende black/ende

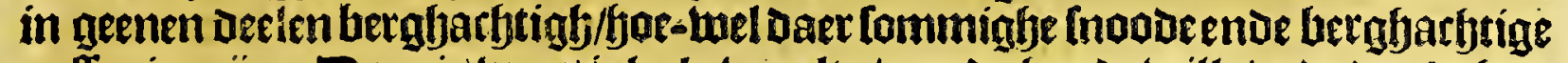

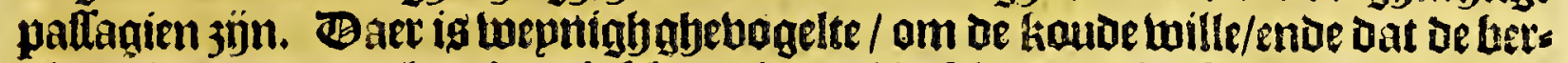

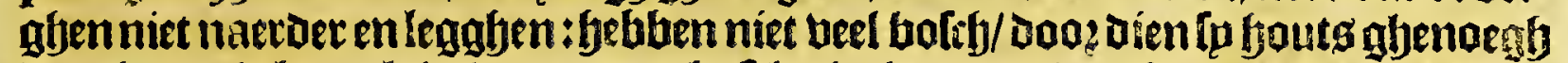
booz baer abebzupck jalen/upt een.bofch vier leguen Jact af/welck is ban tilepne tedar-boomen. Baer is feer goet grag een quart ban een möle van bier / om onfe peerden te luepden/ ende oock hope te maken / welck ong toel te pas foumt / alloa ons peeroen fier feer weeck ende af gedaeft quamen. Haer birtualie i Maiz, daer

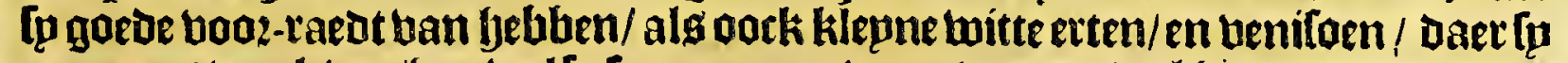
apparent van leven/fjoe-wellp [eggen neen; want bonoen beel bupoen tan wilat/ balen ende tianinnen. Eeten be belte koecken die ich opt tagh; hebluen oock de be= quaem tee inaniere om't hazen te malen / als wo opt elghens langen: enoe een bzoutw ban dit landtal al loo bed malen als vier veoutwen in Mexico. excellent jout in grepnen/welck [p aen een lack balen/een bagh-replens ban bier. Een febben abeen kennis ban de noozdt-jee / noty bain oe beft-jee; en fian.ock

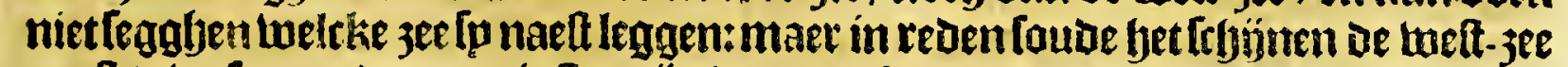

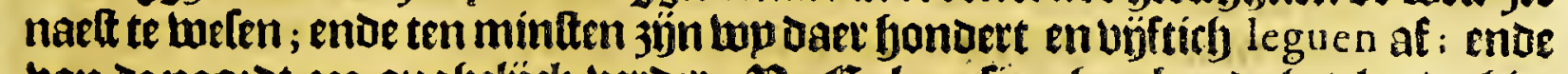

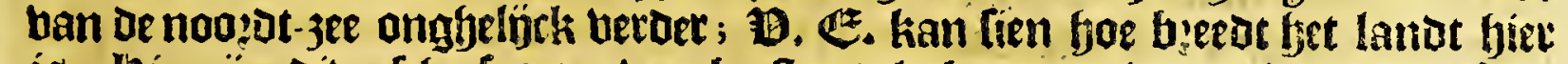

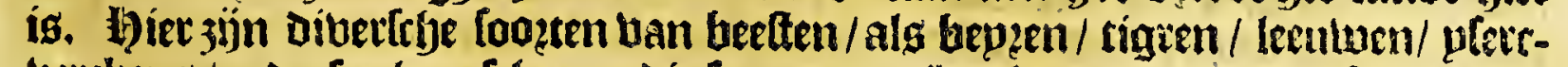
berckeng / ende leeckete lrbapen díe fod groot 3 jun alg pertoen/ met leet groote

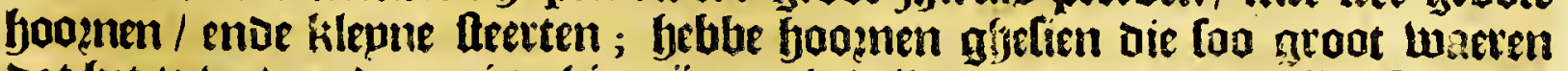
Dat bet te tertwonderen is : bier jün oock twilde gepten / ende tuilde fuÿnen. Baer jün oocli groote hatten. Sp replen acht dang-reulen tot leecket plap. nen naer de noozda-jee toe. Agen binot hiet bupden die twel berepir $3 \mathfrak{j n} /$ ende fp berepden ende febiloeten die ter platte daet to de ftieren dooden / too als fo regghen. 


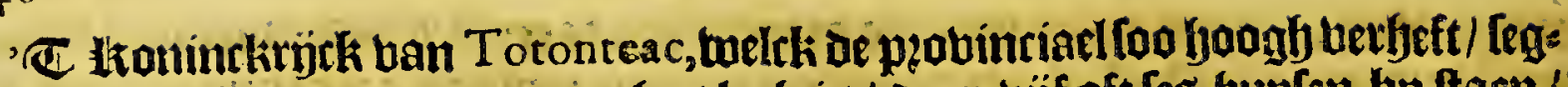

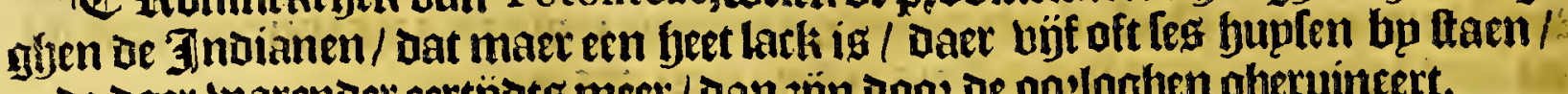

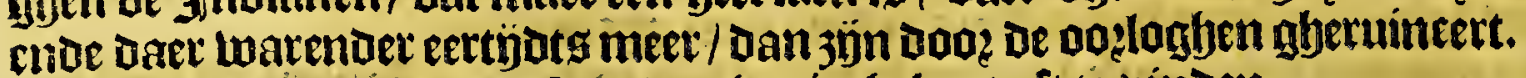

; If Ioninckentk ban Marata en ig niet bekent oft te binoen.

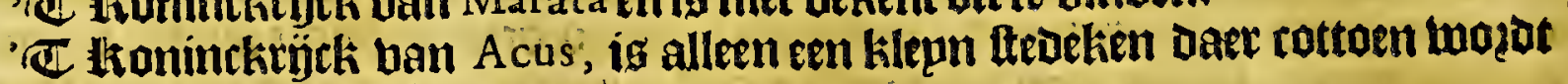
Letradert / welck dele J naianen noemen A cucu.

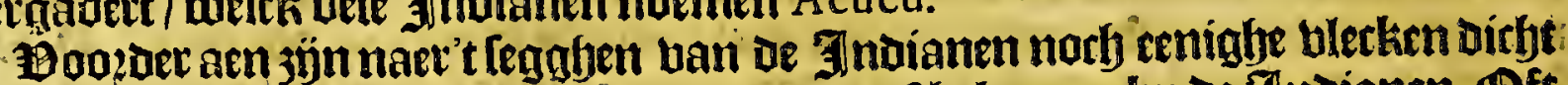
bu cen rieviete/ aie ickljeb ghefien/ende rapast af bekomen bp de Indianen. (Oft

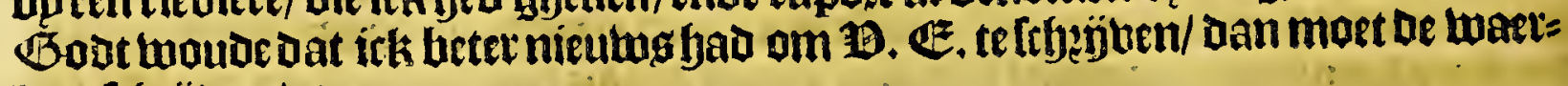
bept trbyëten/etc.

Gomara legft dat Cibola leght op De booghte ban Teben-en-Dertich graden en cenlyalf / bp noozoen de linie; (loo ue frantelye ober-lettinghe leght / maer in yet

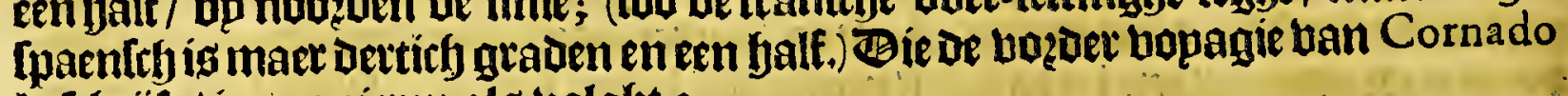
belchenffe / in manieren als volght :

Defoldaten fiende dat Dit landt [oo qualijek betwoont wag/ ende den rückbom

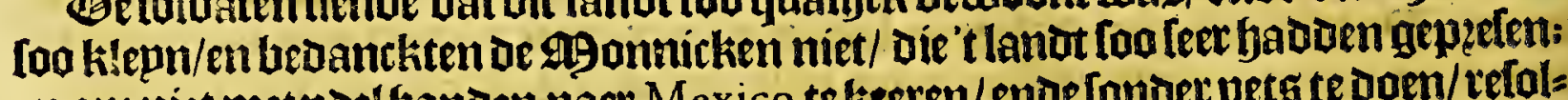
en amniet metpdel banden naer Mexico te keeren/endefonder petate doen/refol=

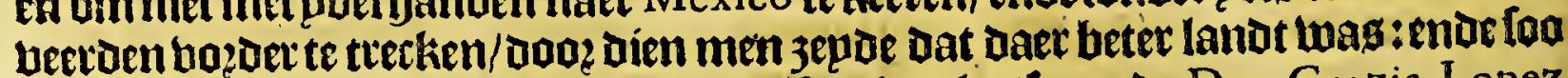

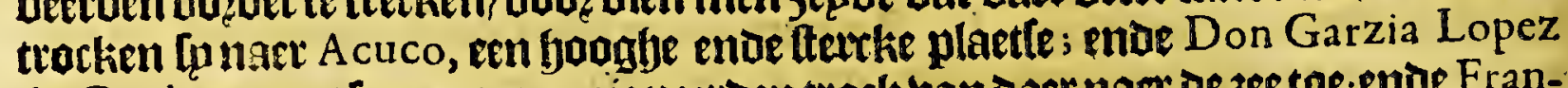
de Cardenas met[un rompagnie peetaen trock ban daer naer de jeet toe;ende Francifco Vafquez met fiet refterende volck naev Tiguez, welck leght aen een groote riebiete. Etreghen baet meug uan Axa enoe Quivira, daer men zepde een ltos ningb was met namen Tatarrax, een gyebaert man / wit ende tỉck / die aen [pn 3ijoe a zoegheen beacamart/ ende [un ghetieden oede in een klepn kapelleken/aenbiadende een lirupg/ende de tioningine aes 1 emels. Bit nieus betheughoe de

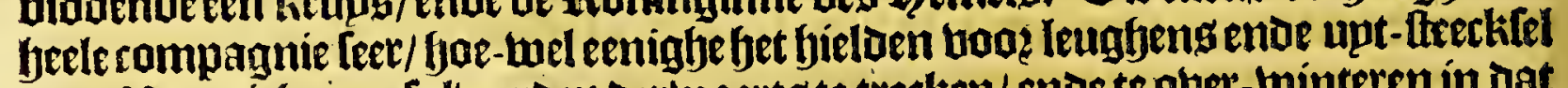
van ghonnichen: velolbeer den Dertwaertg te treeken/ende te ober-binteren in dat

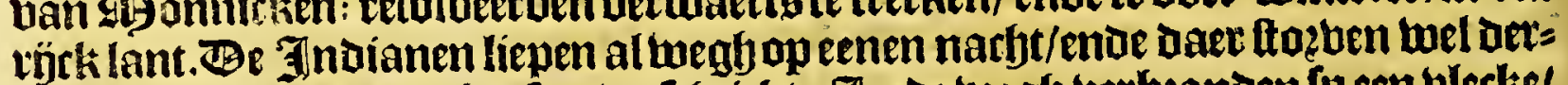

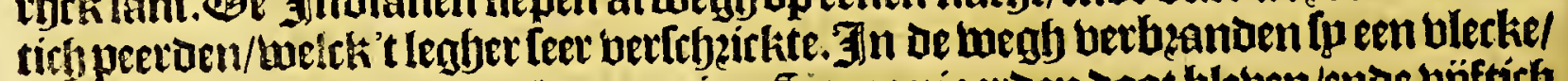
enoe belp?ongeneen ander/baet eenige Spaegniaerden bout bleven/ende büftich

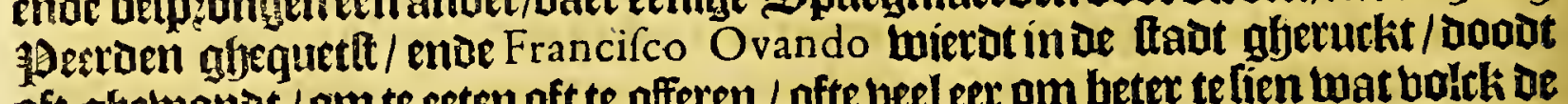
oft ghelwand / om te eeten oft te offeren / afte beel eer om betex te fien wat botck oe Spargniaeroen waren; want menin al dat quartier gheen teeckenen beft ge= vonden bandat[p menlchen fouden offeren. De Spaegniaeroen belegheroen oe plaetle / Dan kon Den die niet vooz naer vijf-en-beettich dagfen tetoberen. Be inmoonoets dzoncken Ineeu bp foute han water / eñ fienoe datfe berloozen waten/ maeckten een bper daer fu al haet mantels / turguoplen / ento andeten rúckiom in berbzanden / ende aeden een upt-bal / bebbende baet bzoutwen ende kinderen in't midaen; maer twepnigh ontquamen de Teberpte aeg tueerots/ende de furie ban de peetden/ende beel berdeconcken in de rieviere die daee ontrent thas; in dit ghes berlyt blewen leven Spaegniaerden Doodt / endo taclytentich gfjequetef / ende beel

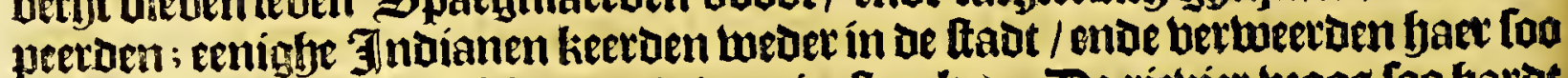
langh tot dat ae Spaenfflye Daer't bper in ftaecken. De rievier begog foo fyarat toe / foe-twel fpmaer en isgheleghen ap leten-sn-bertiry graden/ dat de peetoen

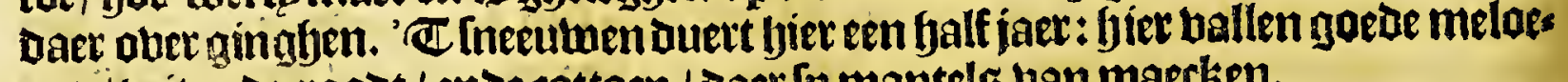
nen / wit ende roout / ento cottoen / Daer Lu mantelg ban maecken.

Dan Tiguez trocken lo in bier Dagly-replen tot Cicuic, welck is een klepne

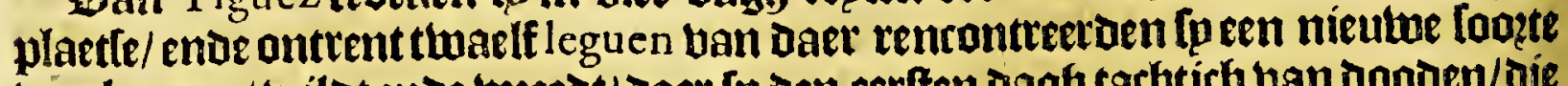

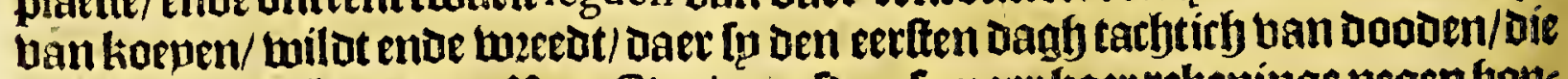
't leaher [eer wel quamen. Ban Cicuic rep[oen fo naer baer rekeninge negen fon:

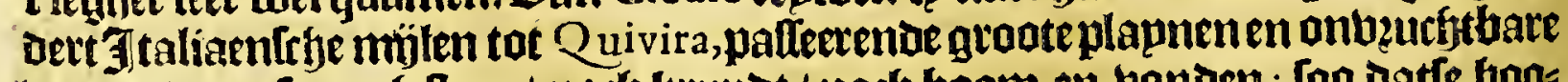
landen / Daer [p norf fteen / noct krupdt / norb boom en bonden; [ foo datte boo: pen maeckten ban den dzect han de koepen/ om ljaer wegh in 't weder-keten 
niet te milfen. goet ghebonoen bet af-beelfel Defer koepen bier in te boegen. all defe plapnen zün bol van Defe ghebulte tierenenkoepen/ gyelinck la Sercría in Spae= anienuol is banfchapen/maet Daet en is gheen boick Datle boedt: arte boos-ftyetuen bee= ten luaren groot lecours booz Den bongleet / wantengadoen gheen bzood meet. Baet biel

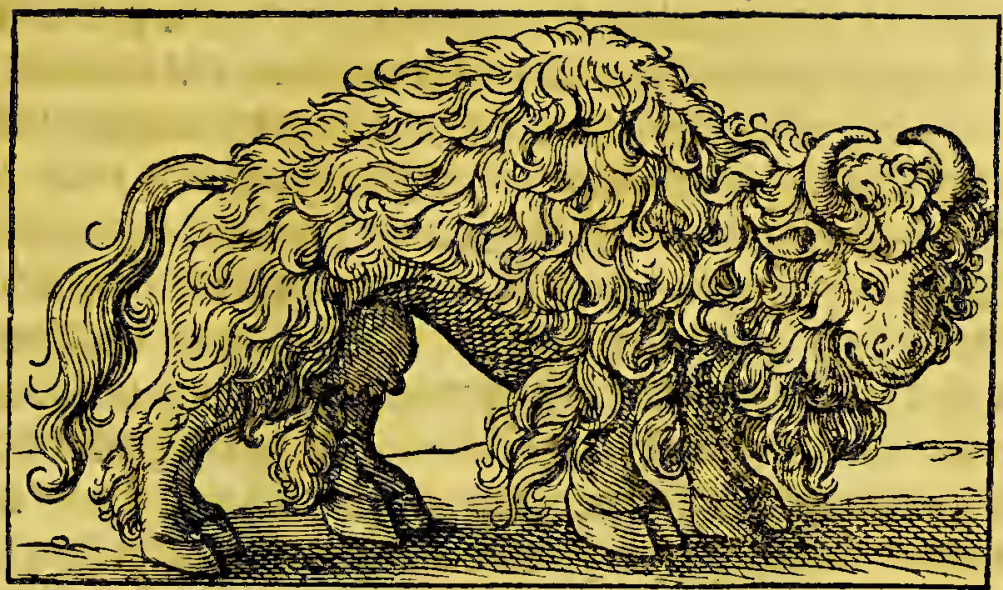

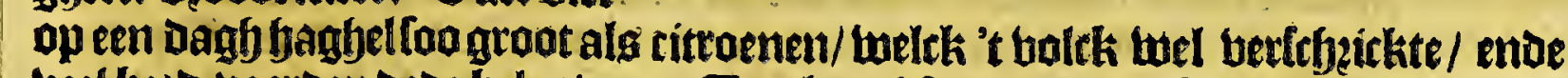
beel beto baerden dede belooben. Cen langytten quamen fo te Quivira, ende

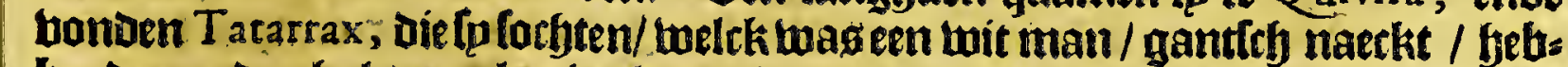
benoe aen Den bals eenplaetjen koper fanghen/welck twag al fpn rijckom. Be

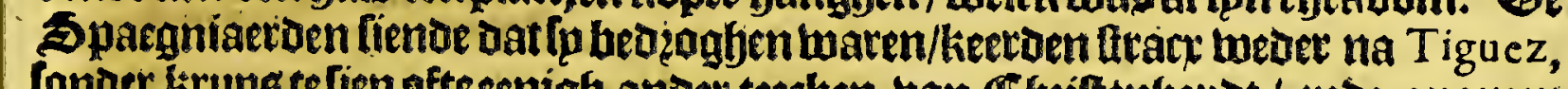
fonoer krupg te lien ofterenigh ander teecken ban Cypiftenbepot / enoe quamen daet naer te Mexico in't jaer I 542. Q uivira is op ueettich graden/ een getempert lanot/ berlien uan goet water ende fryoone wepoen. SOen binot daer prupmen/

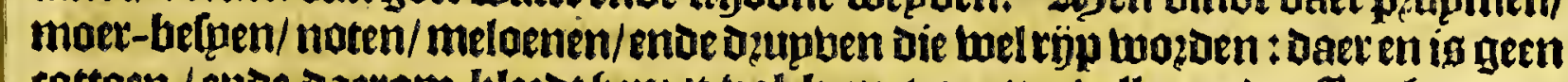
cottoen / ende daerom kleedt fem 't volek met gepten-bellen ende oflen-bupden. Ong volck Tagh op den aever uan de $3 e$ / trbepen die de vooz--Itebens bergult ende berfilbett badoen/ende waren met koopmanteyap gbeladen; mepnden dat fp van Cattay oft Sina twaren/ Dooe dien't bolck dat daet op was met teeckenen te ken nen gaven Dat [p Dertich Daghen ghezeplt baoden. 25:oer Iuan de Padilla bleef te Tiguez, meteen anderen monnick / ende keetoe naer Q uivira met twaelf India= men uan Mechoacan, enoe Andrea d'Ocampo poetugets ginck mede. Hu nam bee met bem/en peerden/met pzobilie om te leben / trbapen ende hoenderen ban Spaegnien/endemigh-getwaedt. Haer die ban Quivira dooden bele arme mon= nicken/ende de poztugees ontquamt met eenighe ban Mechuacan; Dan lnierdt ghebangljen / Daer fjp thien maenden boot daef diende/ ende ontquamt daer naet met eenigbe fonden ; bp quam aen't lanot ban de Chichimecas, ende foo boots

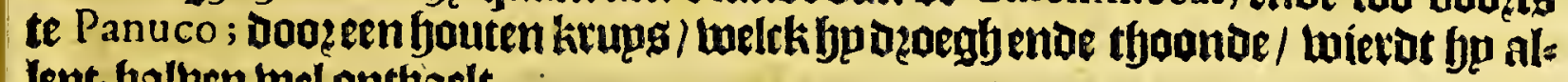
Ient-balben wel onthaelt.

\section{Het lettjiende Capittel.}

De voyagie van Hernando de Alarcon by zee.

I Deleltue tÿdt Dat de Bice-1kop Don Antonio de Mendoça Den Goubernetie

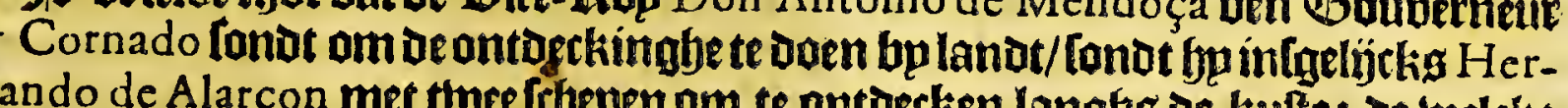
nando de Alarcon met thee frhepen om te ontoecken langhg De kuffe: oc toelcke ghekomen jünde tot De dzonghtenende ondiepten ban de Golfo, Daet Vlloa ban

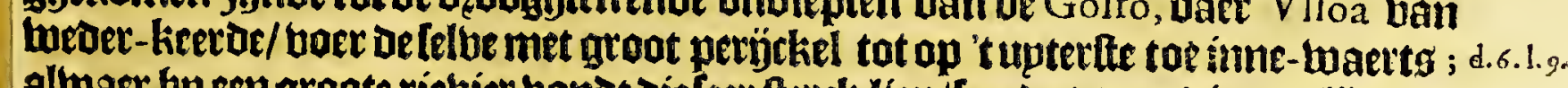

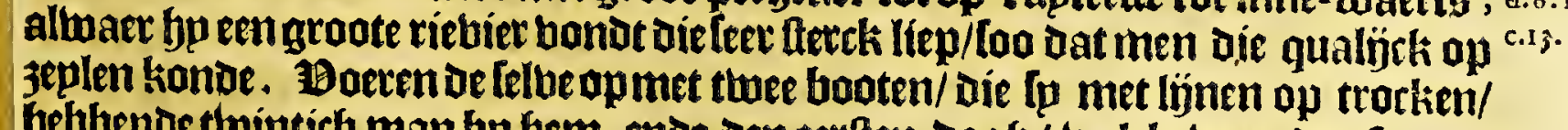
bebbenoe thinticly man bp bem; ende den eetten dagh/ welck wag den feg-en-

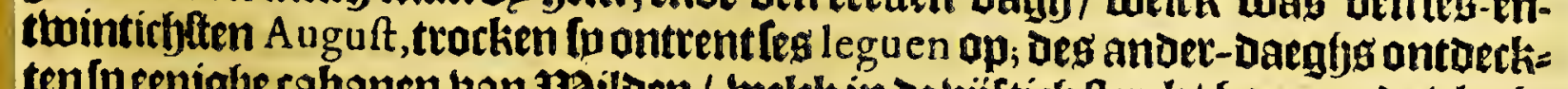

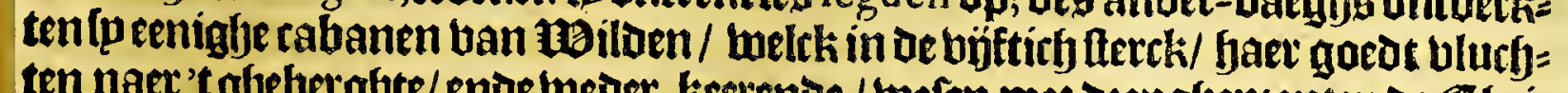

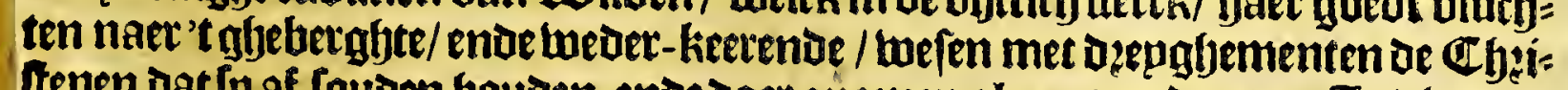
tenen dat fp af touben youden; ende daer quamen al meet ende meer Indianen; borfy Alarcon bont miodel om jaer ter newer te ftellen met teeckenen ban beede/eñ d'een ended ander fnupfterp met baer te nanglgelen / foo dat fo ten laetlen bem

$$
3 \text { noodicb: }
$$




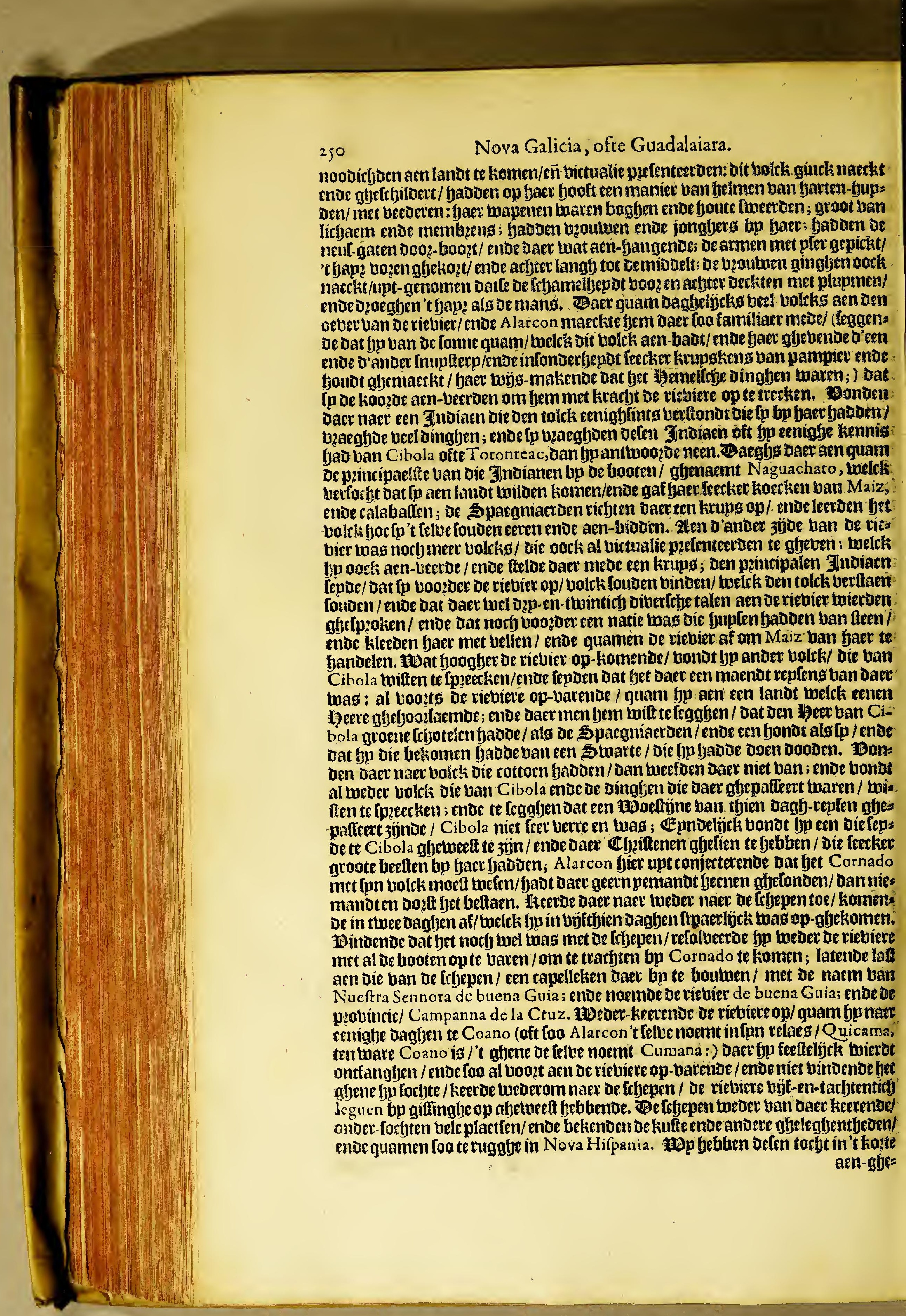


aen-ghetoert / upt welcke niet beel lichto en is te itheppen / am Dat top be boogfy= ten ban oe plaeten ende ftreckinglen ban dien niet aen-gheteeckent en hin= Den/ noty in oe relatie ban Alarcon lelfg/ notg ootk in oe biftazie Dop? Herrera daet ban belryeetuen.

\section{Het [ebentfiente Capittel.}

\section{Een ander Voyagie voor den Vice-Roy op de kufte van No v a}

Ga LICIA ende CALIFOR IA.

D Ën Bice-1kop Don Antonio de Mendoça uede beder thee andere frftepen gherext maecken/Daet bp booz Capitepn op lette een 1 10ztugees/met namen Iuan Rodriguez Cabrillo. Defe tebepen liepen upt de bauen ban Navidad oen 27 Iun. I 542 des midoaegbs/ ende waren des anderen daeghs fmozghens aen de

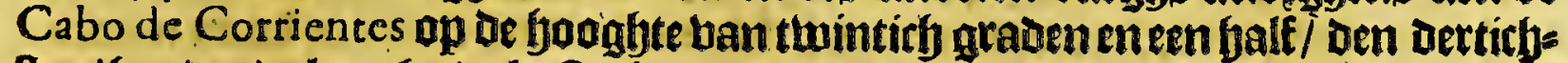

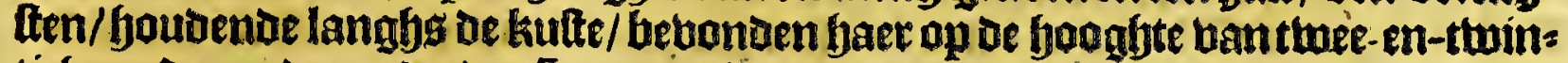
tich graden ende een derde: Sondaeghs den tweeden lulij op de fooghte ban birten:thintich graben zupm/ ende etkenden de baben ban oen Marquis del Valle, Diele noemen de la Cruz, twelck to De kufte ban California. Den arheten dito vons Den lief op de fooghte ban bỷf-en-twintich graden / welcke is t punt de la Trini-

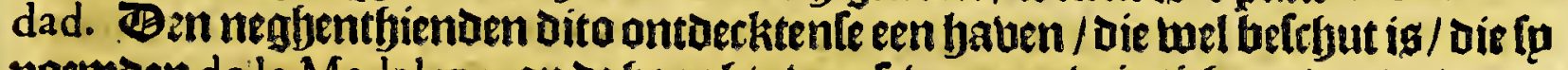
noem den de la Madalena, op oe fooghte ban feuen-en-twintich graden/ende nas men Daer berfey water in: Den 20 A uguft bondente haec aen Cabo del Enganno, op oe booghte ban 3 I graden. Den I 4 Sept. lagen ln op ancker/ aen een Cabo Die Ip noemben de la Cruz, melende lfepl / joogf enoe kael lanot/ op de hoogfte ban Dę-en-dertity graden. Ben thienden Oetober ontaeckenfpeeniglje woon-plaets

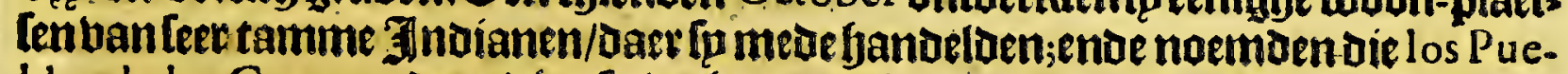
blos de las Ganoas, Dooz dien lp Geel canoag hadden: op de boonfte ban 35 gra=

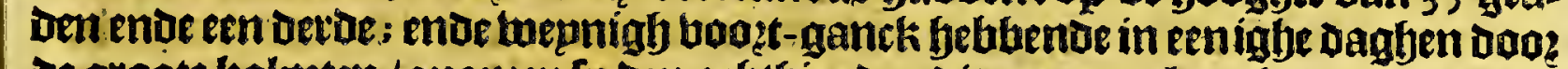
de groote kalmten / quamen fp den actitfienoen dito aen een langh punt/wele een Cabo marckt/ende Dodacten't langhis als een galep/noemdenfp bet Cabo de $\mathrm{Ga}$. lera; op de booglte ban les-en-iertich graden ende eenhalf; ende dooz den kauben

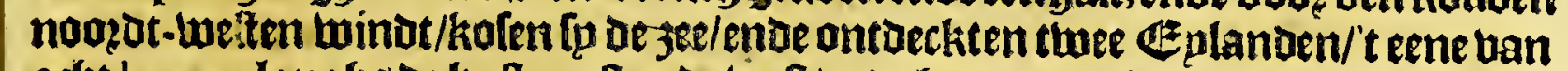

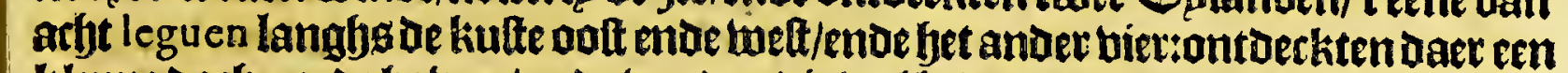

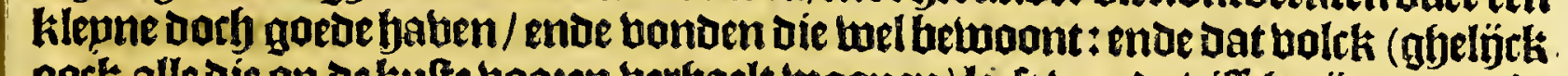
oock alle die op de kufte boozen terfyalt woonen) left ban de bificherỉe; ende jün Ghelegben thien leguen ban Cábo de Galera, wett-noopot-wett aen. Foierden de atht daghen diefp daet bleven ban 't bolck mel ghetracteert / welck naeckt loopt / enoe behben de kaecken ghewertwet / in maniete als dam-ftecken / noemoen orfe bauen Puerto de la Poffeffion. Jen bujf-en-twintichtten dito f́bepoenfp ban

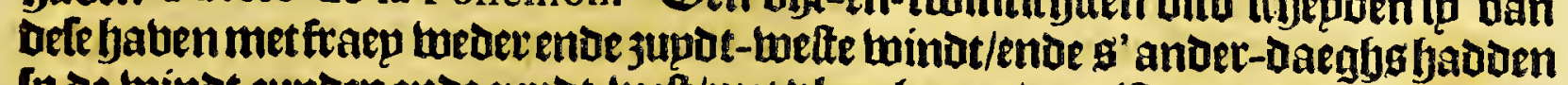
Ip oe twindt jupden ende jupdt-welt/met blaeghen ende mitten/ende bonden Gaer in noout/ boog dien of himbt op se wal was / weick baet alte naer was/ende een

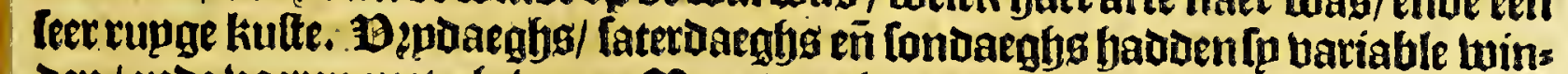

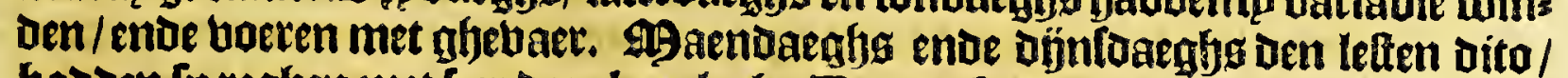
basoen lo regben met leer donckere lurfyt. Den eerften November badoenfo gftes weloighe winot upt Den noozot-weften/Loo dat [u gheen 3 epl konden troeten/ende keerden weder naet Cabo de Galera, welck goet belchut feeft teghen dien windt. Ben tweeden maren fp aen Puerto de Sardinas, enoe naerderden een quartier lanots/ welck boos beettich leguen twel betwoont is bp feet goet bolck; enoe van een plactle daet ontrent gbelegen/quamen eenighe ban de pyintipaelte in be ftyes pen/ ende danten op den trommel-tlarb/ende diepen febeep; ende Daet-en-turt Icfjen berfanben of frgepen baer ban water ende boubt; dele mbiloen badoen groote buplen bp de Later-fiandt/ende baet begrabingten met planckien rontom

$$
\text { 想 } 4 \text { botet. }
$$




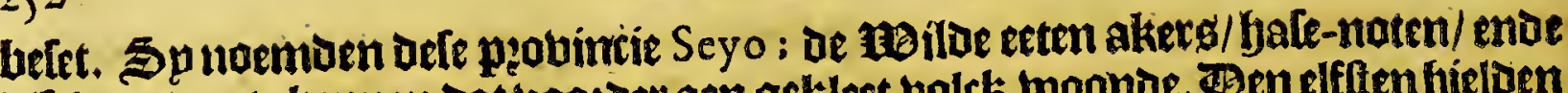

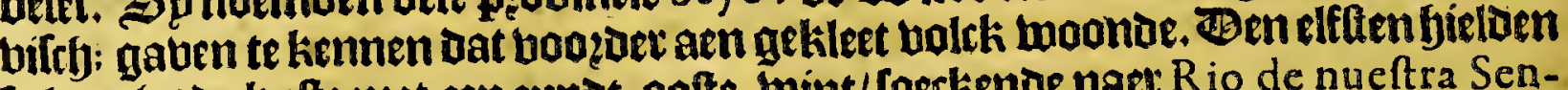
[planghs de kufte met een 3 updot-oofte-bint/ loeckende naet Rio de nueftra Sennora, de belckefuniet en konuen vinden: dan fyaer glyemoete een berbolgh van [cer booghe berghen/en vol gheboomte/ die fu noemoen las Sierras de San Martin, op de booghte ban [eten-en-dertich graden ende een balf/ende aen of toet ban of felbenaer't noozt-weftenmaetke 't lanteen Cabo, op de booghte wan acht-ent-Ders tich graden / weltk fp noemoen Cabo de Martin; nathts te vier upzen begon de

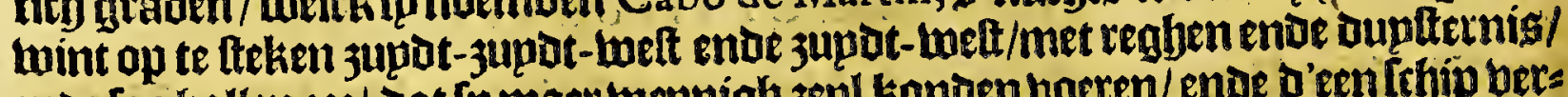

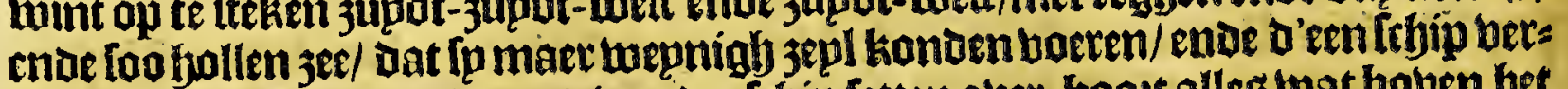
Dtwaeloe ban het ander/ ende dit ander tehip letten ober-boot alleg wat boben bet berdeck bas; ende die van Den zemirael beloofoen een bede-baett: Den aerthien=

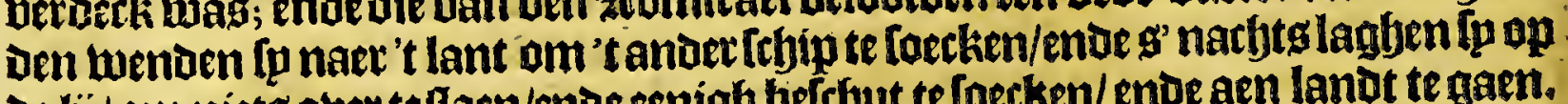
De lij/ om niets ober tellaen/entoe enenigh bef́chut te loecken/ende aen landt te gaen. Daer ttectkteen Cabo in 3ee / met leer boogbe pün-buomen betwaflen/ welck is noemoen Cabo de Pinos, ende bonoen yaer op oe boogbte ban beettich graden ende meer / naex't noogat-weften / van waerip meer als bufftbien leguen ftrandets

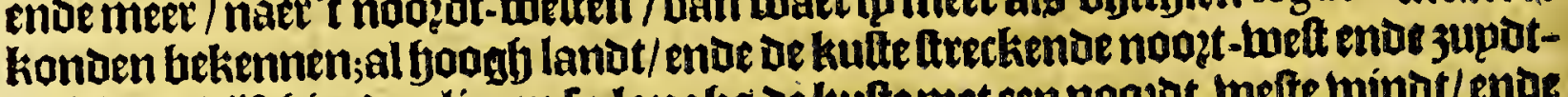
ooft. Ben büfthienden liepen [p langhg oe kufte met eennoazat-loefte winot/ente 't maeckten foo grooten koutue dat fo het niet en konden verozaghen / enoe lagfen alle be beraenmet fneeulw beoeckt/enoeg abonots bonoen[p het ander [thip/welek in grooten noot was dooz dien fyet Tert leck twas getwozoen: Ben [eethienoen quas men [p aen een groote in-ham/ helek [ebeen een baben te twelen/ ende noemoenle Bay a de Pinos. Den arththienden Lachtenfp baben/ontoeckende felker beineeulus.

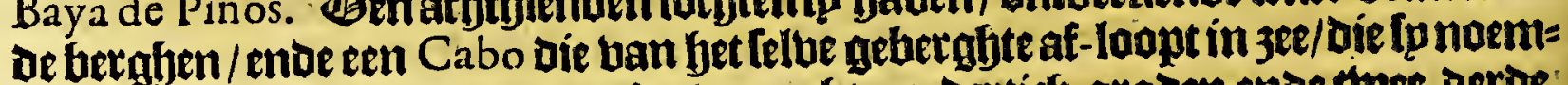
Den Cabo de Nieve, op oe yoogfte van actit-en-Dertich graden enoe thee deroe:

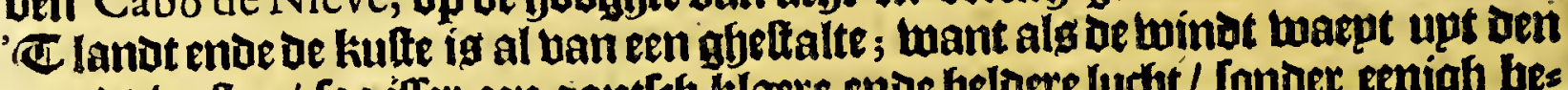

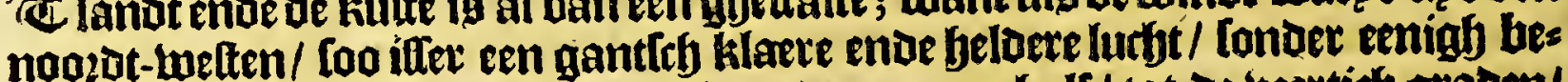

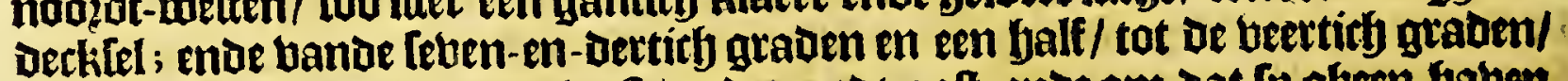

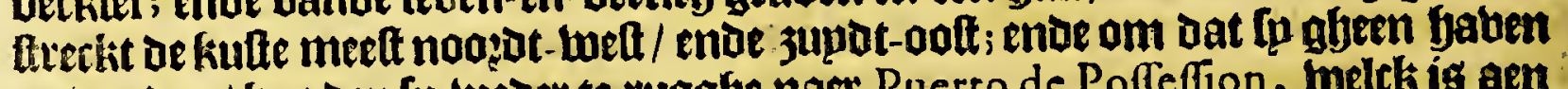
en bonden/keetoen lp weoer te rugghe naet Puerto de Poffeffion, twelck is aen

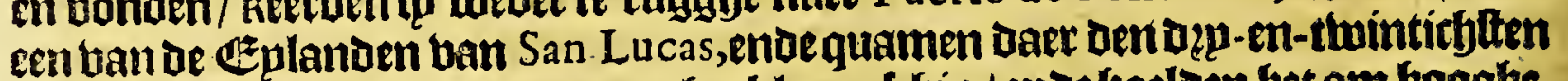

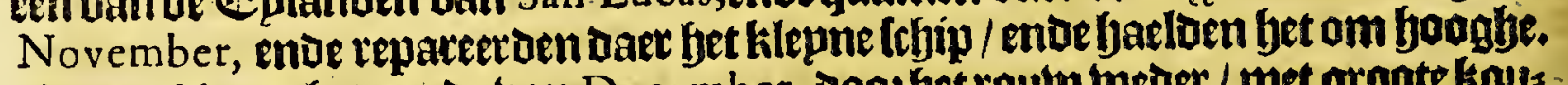

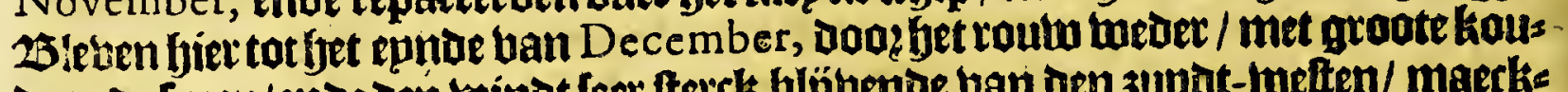
De ende [neeu/endeden winot leet fterck blíhende ban den jupdt-tweften/maerke ten bet bier foo ballen water / vat fo / boe-wel tp in een belloten bauen lagben / in

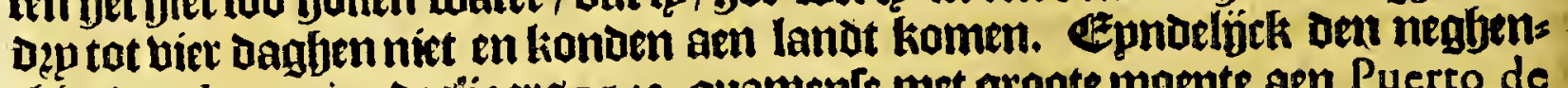
thienoen lanuarius oeghaers 1543 , quamenie met groote moepte aen Puerto de

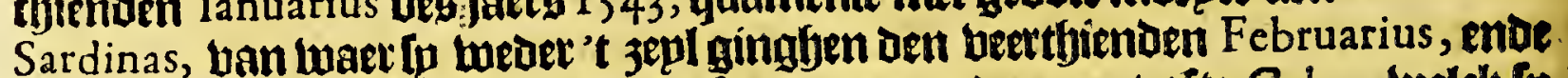
Den [eł-en-twintichten dito waren fp aen een ander punt ofte $C_{2}$ be, welck fo noemoen Cabo de Fortunas, op de booghte baneen-en-beetticly graden: ban den feg-en-twintichten Februarius, tot den erttten Martij, liepenfu groot perïtkel

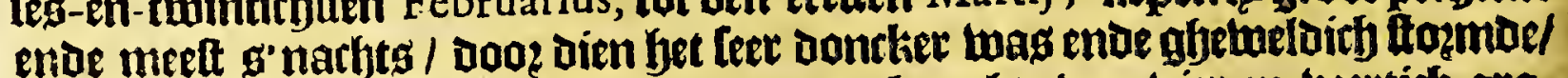
enbe bevonden faer oen eerten Martij op de booghte ban biet-en-beettich gras

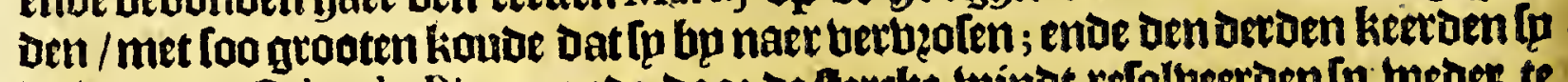

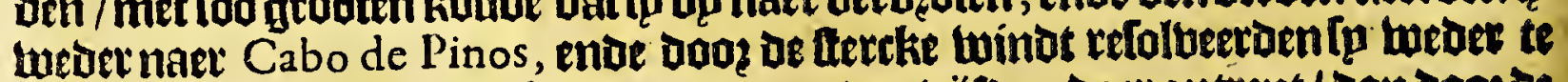
keeten naet Puerto de Poffeffion; quamen oen bỉfoen baet ontrent / Dan boge de

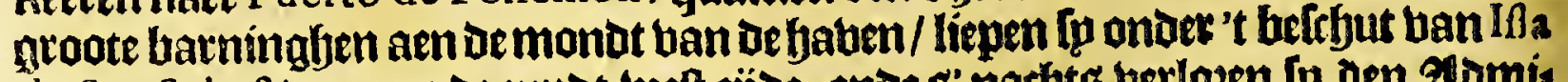

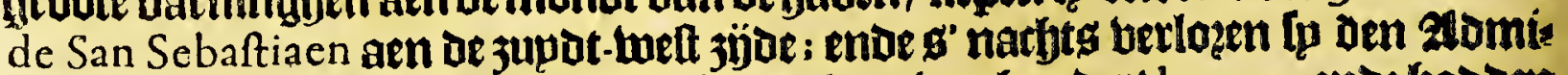

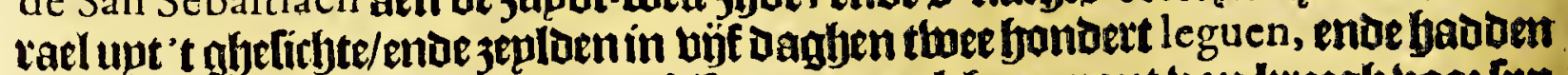

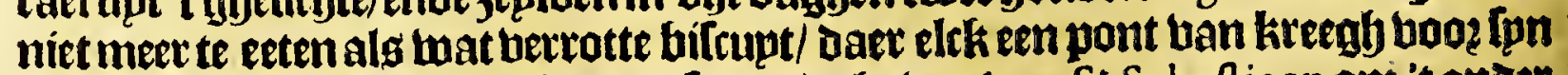
paztic. Den achtften dito [chepuen fpupt de haben uan $S^{t}$ Sebaftiaen om 't andere

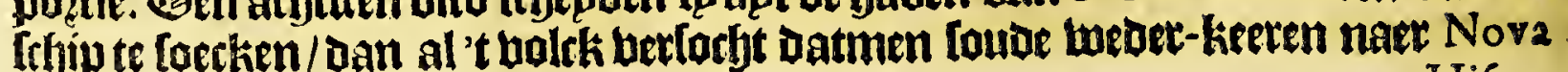


254

Nova Galicia, ofre Guadalaiara.

heen beel Eplanden leggen/al foe-bel Dat fu kilepn jön/ euentuel foo ig bet fontace

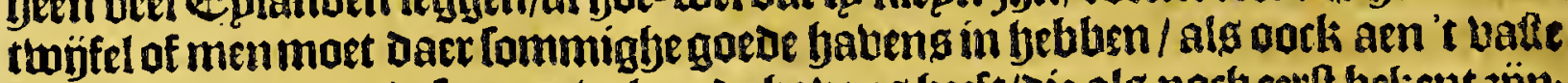
landt/al-waet men dele naet-balgende babeng beft/sie als noch eetl belient 3 ÿn;

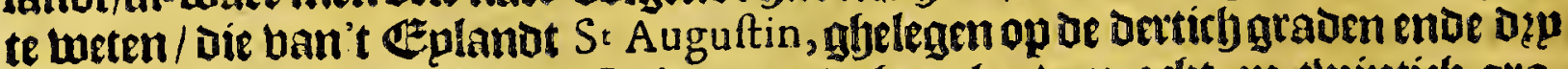

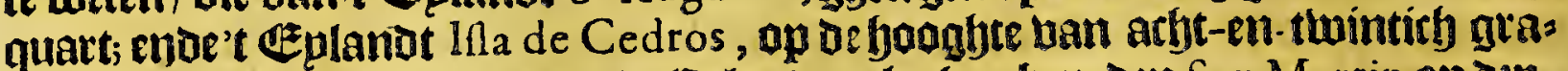
oen ende een quart fobaetg; ende't Eplanat geleghen beneden San Marcin op depen-twintity ende een balf graden / alle dele kulte ende landoube is mÿng bedunc:

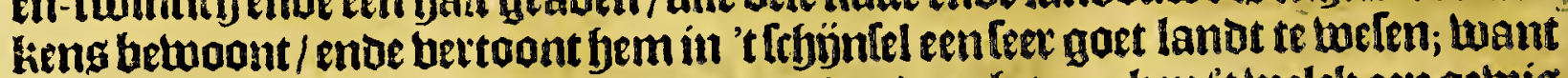

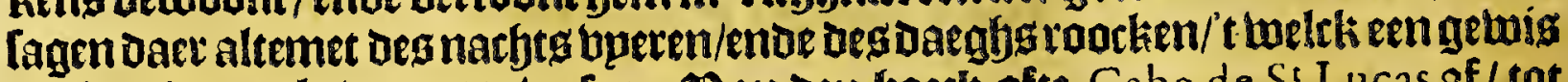
teecken is ban betwoont te Lelen. Ban aen hoeck ofte Cabo de $S^{t}$ Lucas af/ tot naer d'anoer zyue van't 3 upot . ooften ban California toe/ oeden onlen kours ooit-

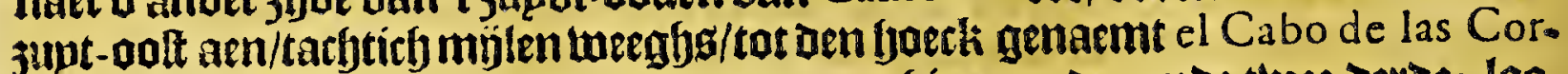
rientes toe/abelegen op de hooghte van negentfien graden ende twee Deroe; loopende op defe kours enoe twegb/ Lagen in 't noozacn ontrent efn mijl ban ong af /

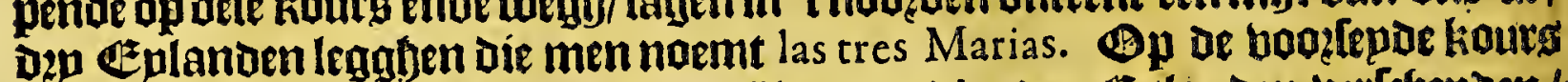

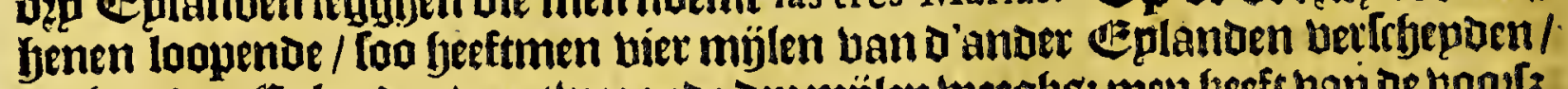

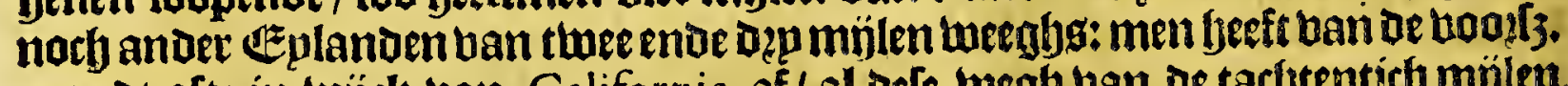
monot ofte in-tunek ban California af / al aele wegh ban oe tactstentich mülen heen/atoote froomen aie treft-maertaen.loopen. Ban oen boech ofte Cabo de las Corrientes af / Deden onfen kauts jupdt-oot / ende bu wölen jupot-ooft ten bolten aen / hondert ende oertich mijlen meenge tot in oe laben ban A capulco,

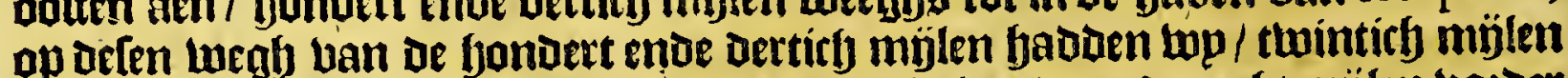

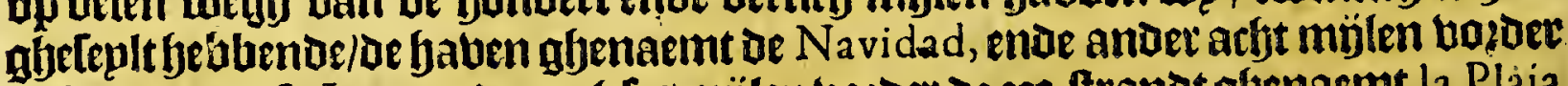

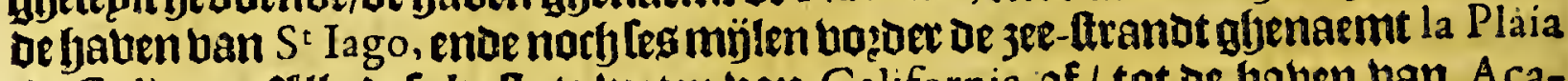
de Colima. aulle bere hulte te beten ban California af/ tot oe bauen ban Acapulco toe / is betwoont ban boleti diemet of Spaegniaeroen beede ende alliancie bebben / sijn ban conditie ende qualitept ald't volch ban d'ander tufte ban Nova Hifpania, \&c. Defe vopagie wast bol-epmot in oenjare 1584.

Het negben-thiende Capittel.

Extract uyt de Voyagie van Thomas. Candifch, voor foo vele de felve defe kuite van CaLiFORNIA ende Nova HisPania is betreffende.

W Alullen bier noch bp-troegen't afjene dient tot onfen pzopoofte/ upt de tropa-

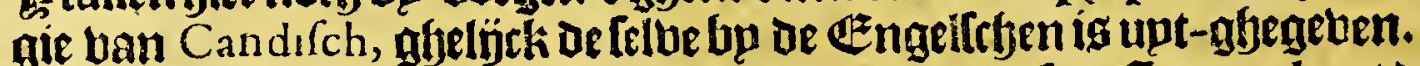

Den viet-en-twintichthen ban Auguftus 1587 voer onlen Generael met berticly man in ie pinalde tot een faaten gifenaemt Puerto de Navidad, Daer top betftaen badoen ban Michael Sancius een pinalfe te Ieggen; maer eet wp Daer kanden kas men/ was oc pinalte bertrocken twaelf mälen voozoer am peetlen te billetben/als

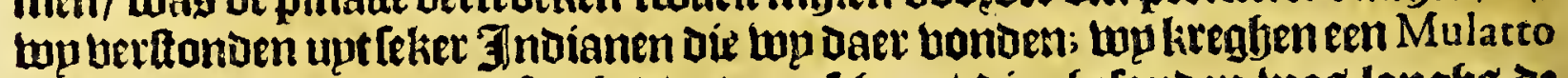

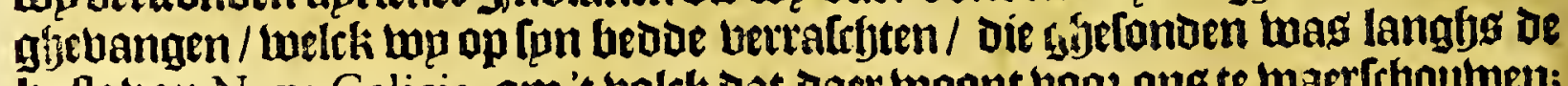
kulte ban Nova Galicia, om't volck dat daer twoont voos ons te waerfthoulwen;

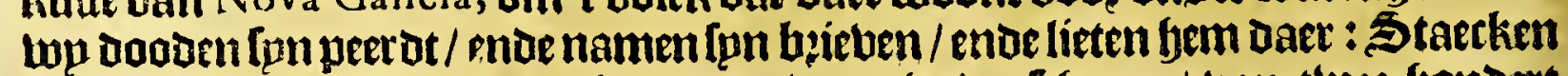
't bper in De fuplen/ ende berbzanden twee nieutwe fibepen/ban twee fjondert tonnen eick / Die dare abetimmert wierden/enoe quamen weder aen ons frbepen.

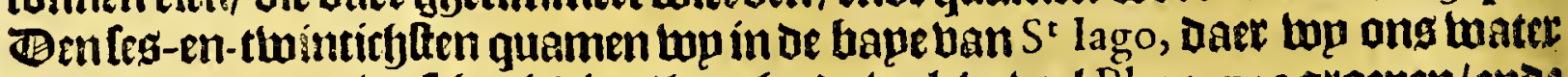
in-namen upt een betishe rieviete/langhs de twelcke beel Plantanos gl'oęen/ende abundantie is van bertebe vifry:daer waren oock eenige ban be onfe die naer peets len [odjten/ende bonoen daer maer eenige tweunighe. Ben theeden Septemb. bets

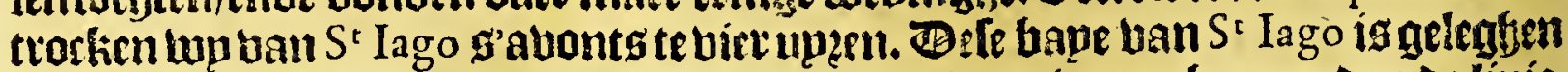
op defjooghte bannegentbien graden ende achthien minuten bp noazden de línie. Den oeroen dito anckerden top in een kilepne hape/ een mülen twett-waerts ban Puerto de Navidad, ghefjeeten Malacca, is efn goede reede: Des midoaegly botr 
Het fefte Boeck.

255

boer onten Getretael aenlaw thet ontyent Dettichman/entee trock naet een ban Der Jndianen Doepen/ttwee mijlen ban de reede gijenoemt A catlan : daet antlent

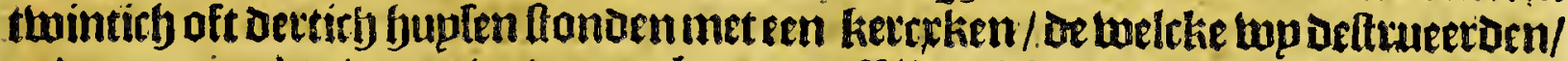

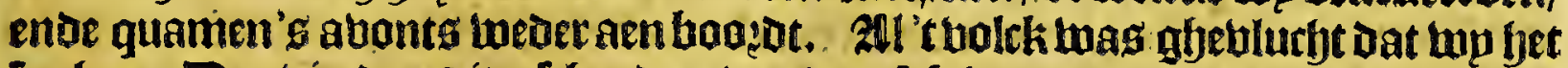

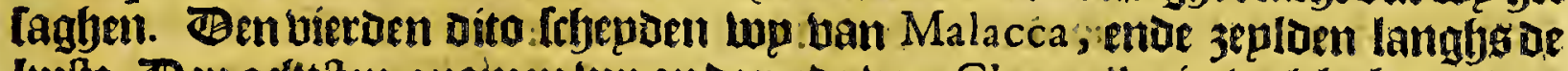
kufte. Den aciftiten quamen top op oe reede ban Chaccalla, in tuelcke bape twee klepne hup thens ftaen bp de tuater-3joe; ende dele bape is achthien molen ban

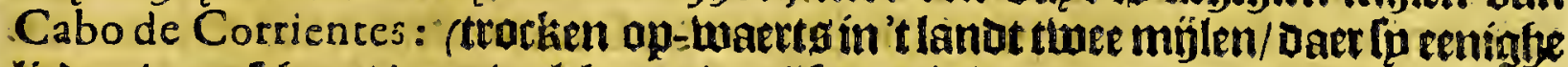
lieden bertafryten/ oop . weleker midoel fu eenigfje betuerfthinghe bequamen.) Dentwaelfoen oito quamen wo aen een filepn eplanot ghenaemt lna de Sant

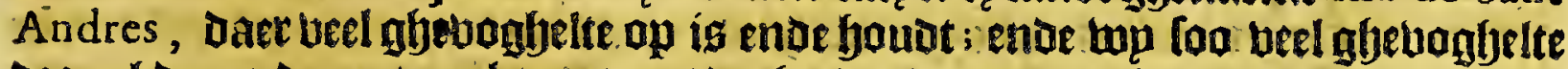

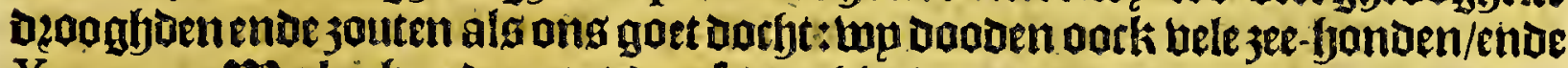
Yguanas. Alop laghen Daer tot Den letuenthienden/ende uertrocken Doen. Ben bier-en-thintichfen atritueetioen tup op de reede van Mafrat an, op be fooghte

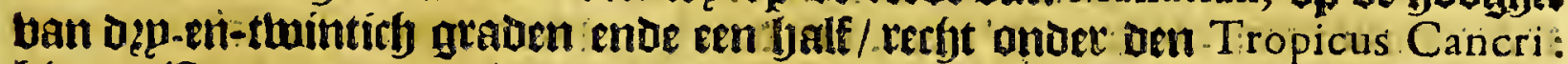

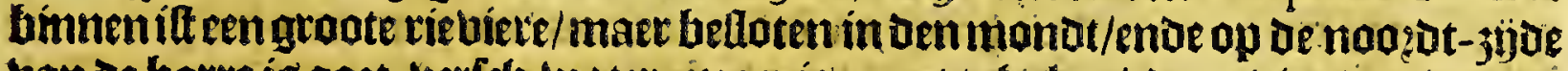
ban de hatre is goet bertey: water; maer is quaet te halen/, woo dicn dat get met

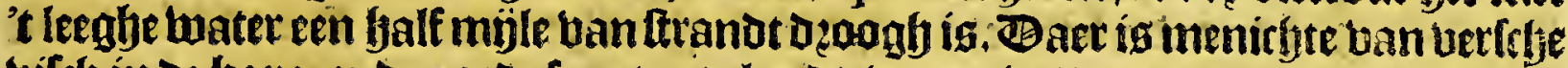
bilch in de bape; ende goede fuuten te lantot-maet in / Daer wp entighe ban kites ghen/Doch niet fonoer períckel. Den 27 bettrockentup upt oe reede uan Maftat-

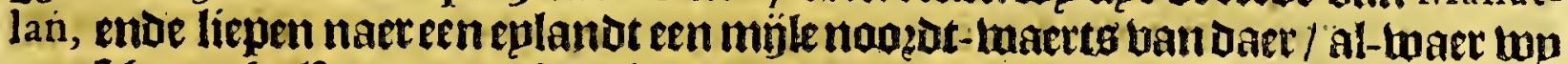
ons Tchepen kalfaten/ende fer-timmerden ong pinafle; enue daer igen Eeplandt

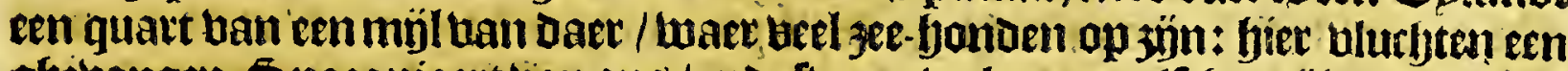

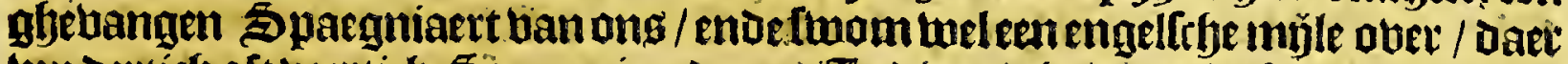

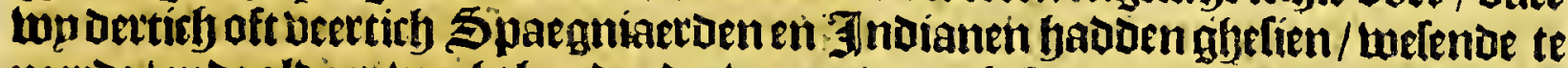
peerde/ende aldaec wacht houdende; tharen daet gletiomen ban Chiametla, efri ulecke elf mig̈len binnen 'g landts leggfenoe / naer't feggen van Michael Sancius.

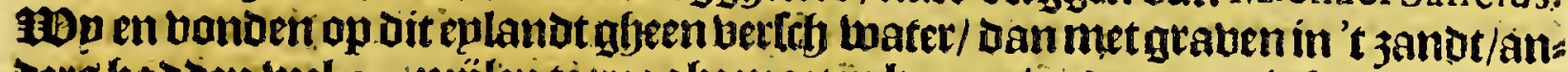

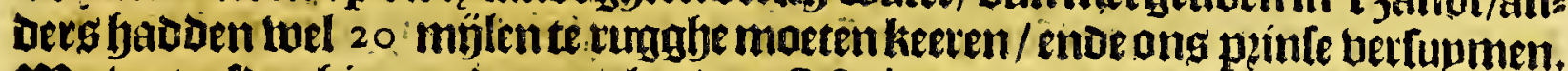

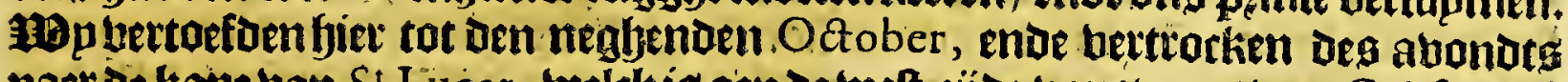
naer be kape ban $S^{t}$ Lucar, twelck ig aen de welt-jöjoe ban't punt ban California. - Ben beetthiehden hieien top op de kape ban St Lucar; meith feet gbeljek is de naelde by 't eplanot ban Wight; ende bimnen de hape is een groete bape / bp te

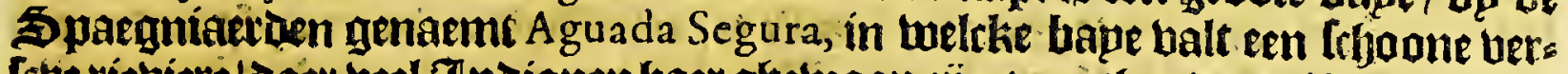

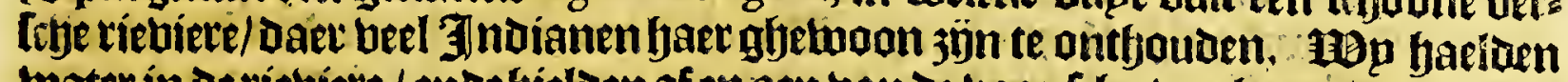
water ín de ríebiete / endefjeloen af en aen ban de boaz-Irbeeten kape de $S^{t} L u c a r$

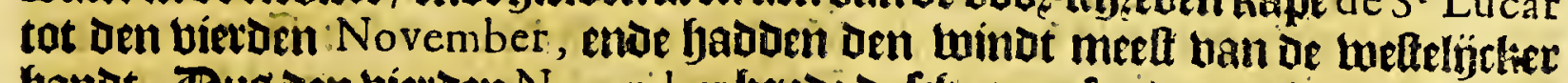
Gand. Bug den bierden November bepoe de fefjepen af ende aen ljoutande ban bet vooz-lanot ban California, ghelegen op oe booghte ban ozp-en-thintirf gra=

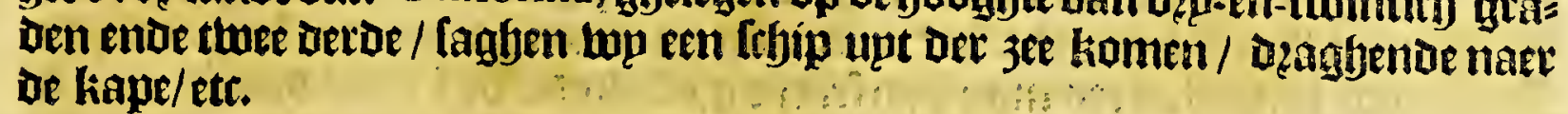

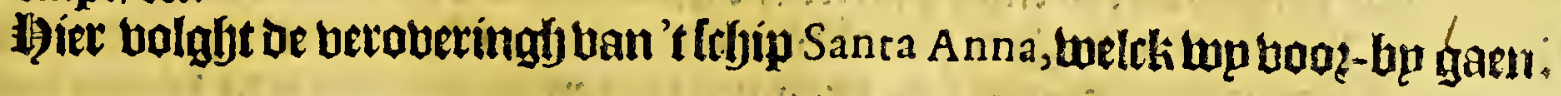

\section{Het thinticflte Capittel.}

Befchrijvinge van Nov A A r B I ON uyt de voyagie van Sir Francis Draeck door de Strate van Magellanes, gelijck de felve by de Engelfche is uyt-gegeven.

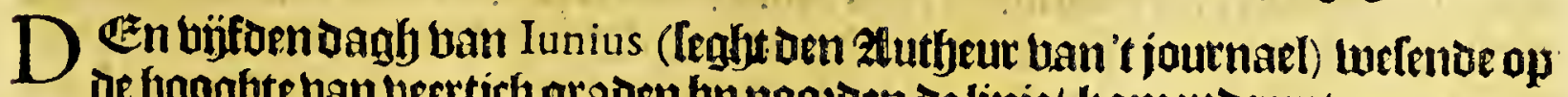
be fooghte van leettirb graden bp noozden de linie/ Komente unt eetl gropte

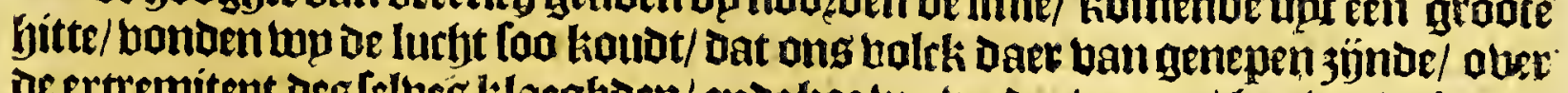
be extremitept oes Teloes hlaeghoen/ ende bae top berder boeten/ hoe top de lioude

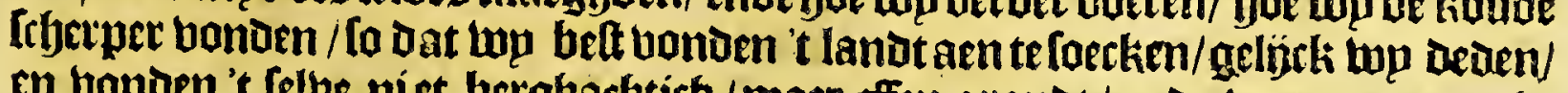
en banden't felbe niet berghadbtich/maer effen granot / ento boeren te cugglys

folitier 
conber te landen / tot Dat wo quamen op asht-en-Dertich graden bp noo?den de

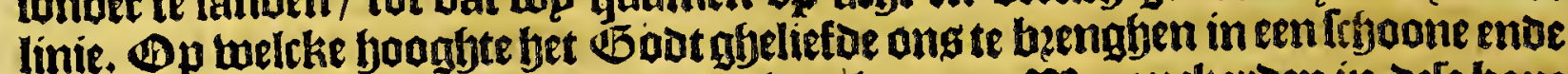
goede bape / met goede winot om Daer in te loopen. Top anckerden in dete baue

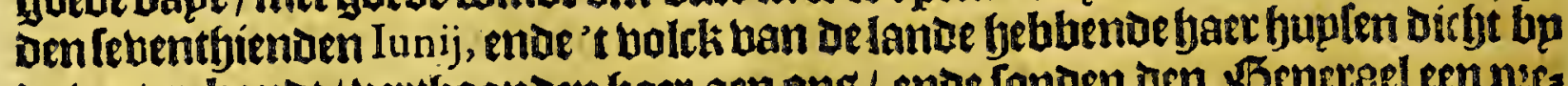
De water-kanot / berthoonden faet aen ons/ ende Conden den benersel een pss [ent : Lanneer fp tot ons quamen / verbonderden fo fjaet feet ober de dingfen die

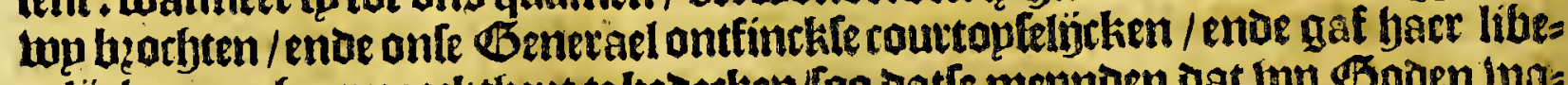
ralyeken om fyaer naeckthept te bedecken/foo datte mepnoen oat wo Boden lua:

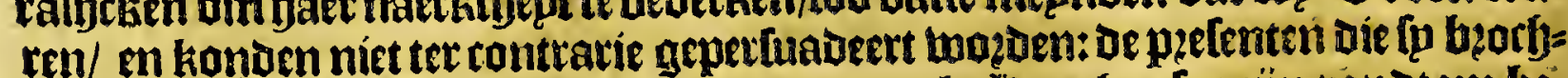
ten/waren plupmen ende ktaghen ban net- werck. Haet huplen jön rond tom be:

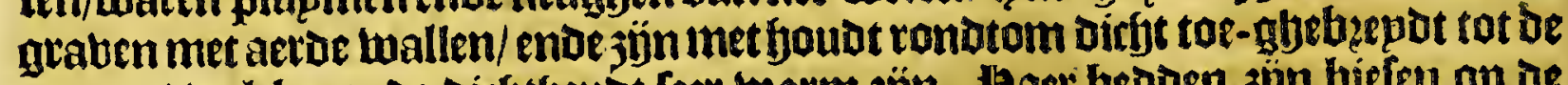
top toe / welck om de dirfthepot teer warm jön. haet bedoen 3 inn hiefen op of

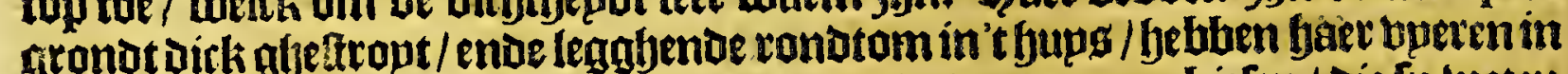
Demidoen. De mans gaen naeckt / ende de bzoutenen nemen bielen / die fo beten te arcommoneten als bennip/ eñ maken daer baer kleedingen af/ welcke te lamen aljeknoopt om haer imidoelt fangfien neoer-waetts/ tot ober faec feupen/ cnoe

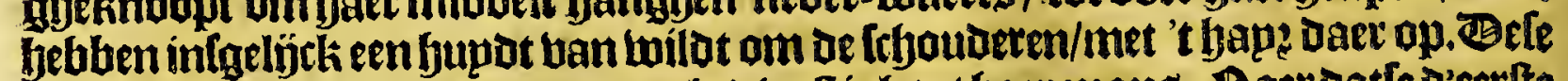

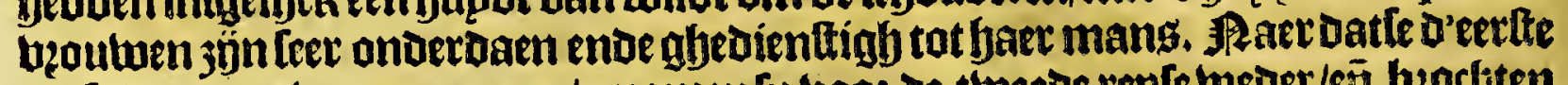

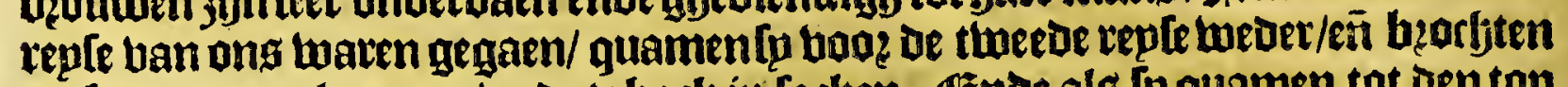

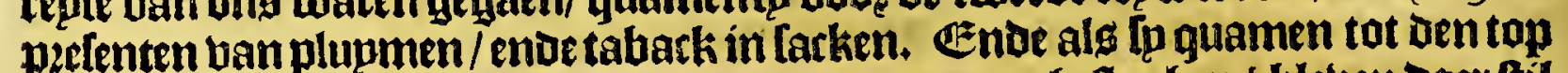

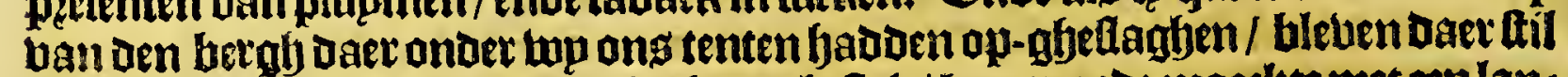
ftaenoe / almaer eener / Daer toe bp baer ghefteit/ bem moede maerlte met een lan=

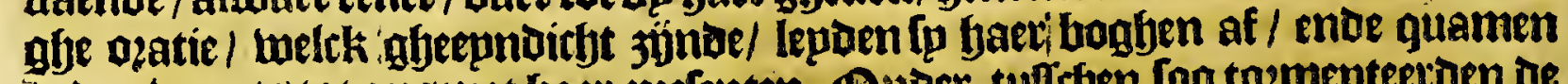

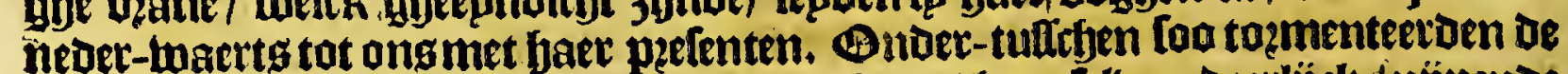

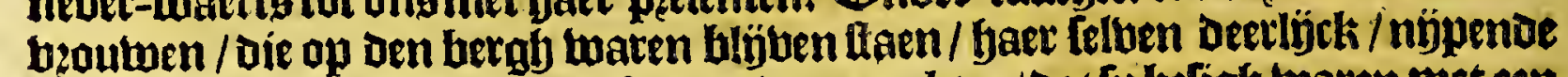

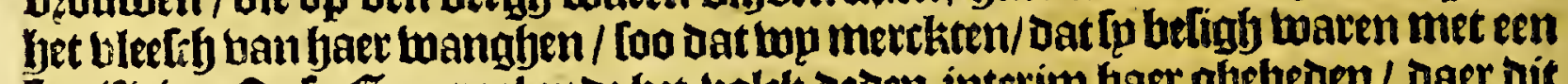
tacrificie. Onfe Generael ende het bolck Deden interim haet gbebeden/ oaer dit

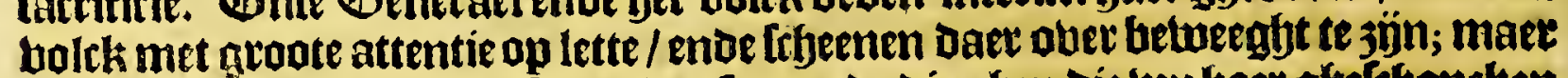

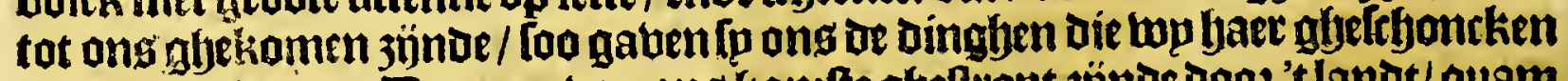

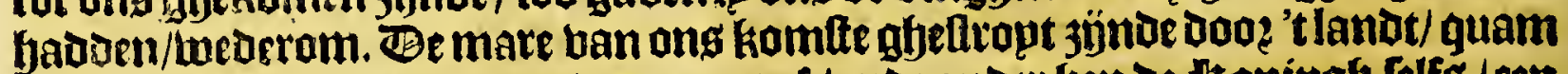
bet boick bat rondtom woonoe tot ond at / ende onoer ben be Itoning felfæ/ cen man ban fraep flatuere ende ghebaer/cnde beel langhe enoe ftrötbare mannen

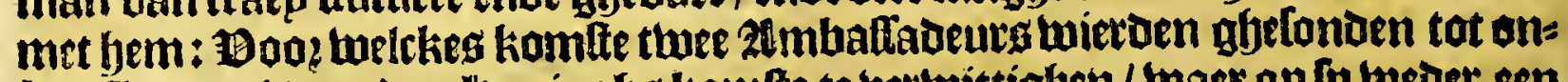

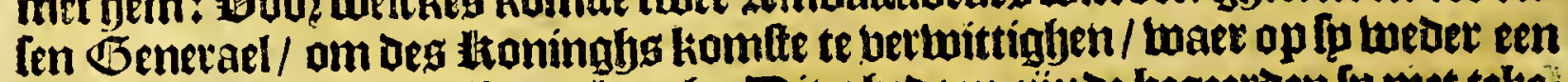

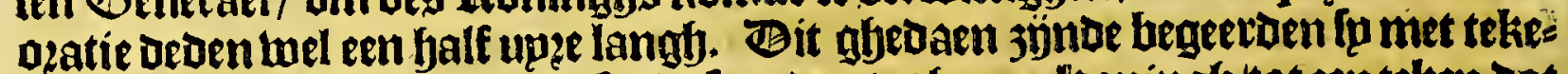
nen/Dat onfen Generael pets [oude [epnden lot baren Honingh/tot een telken bat hp in bzede tot fjaer mocht komen; welch ghedaen 3 indoe bu onlen Benecael/ketr= ben fo met bin oe boottryap tot faren ltoning / welck boozt aen marcheer oe met

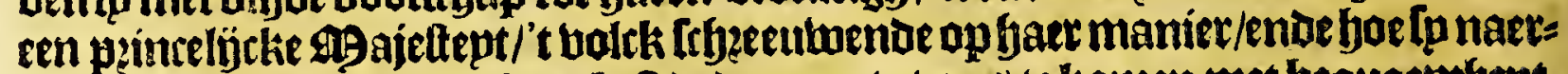
Der quamen / hoe [n meet fyat beft deden om tot ons te kamen met bequaemfept.

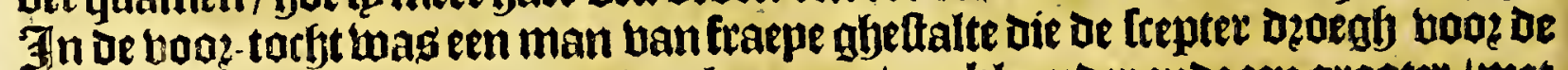
Honingli / waer aen honghen twee kroonen / een kilepnder ende een grooter / met Dep keteng van groote lenglite; De kroonen twaren ghemaeelth ban berren kon,

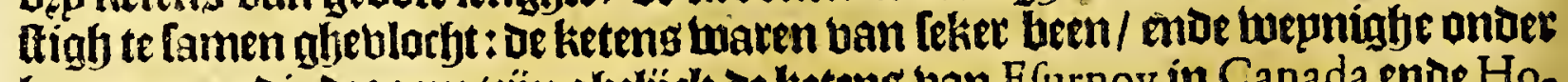
haer monen die dzagen: (jün ahelíck de keteng van Efurnoy in Canada ende Ho-

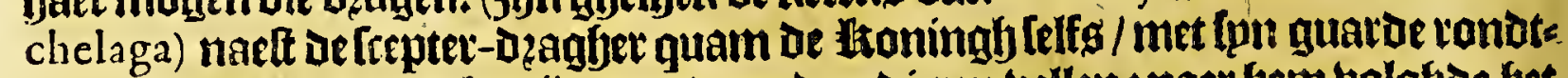

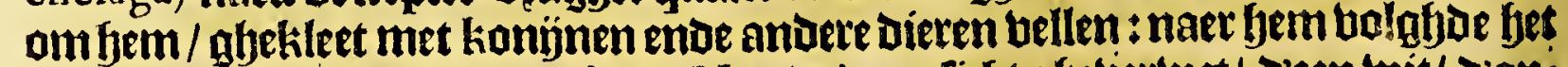

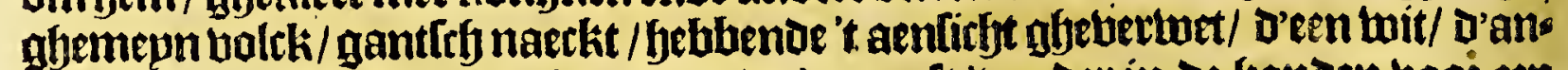
Der fwart/ choe andere Liouleuten / ende 'teen oft' $t$ ander in de lyanden too? een pefent / niet foo ueel als de kinders / die oock al wat bzocthten. Bnder-tultren berfameloen den Genekael [un bolck be een / ende martheetoen tot faet in flactnozden; de falutatie ghedaen jünde / was daer een neoute thilte. Boen jede de

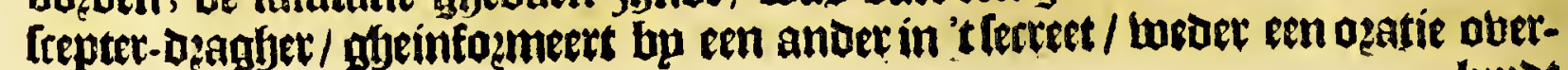
lupbot 


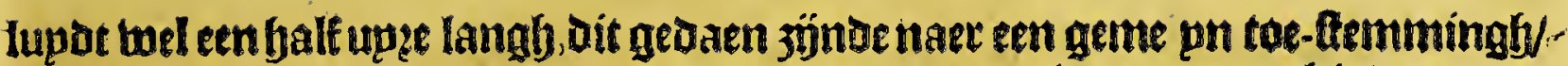
quam de ltoningf met de mang Ende bequenen (upt-gfenomen de kindet:) ne=

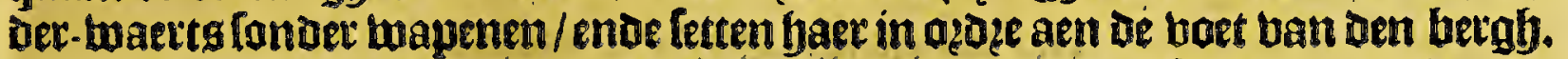
Homenoe naer ons bolberclienende tenten toe / begonde de feepter-Degegber een

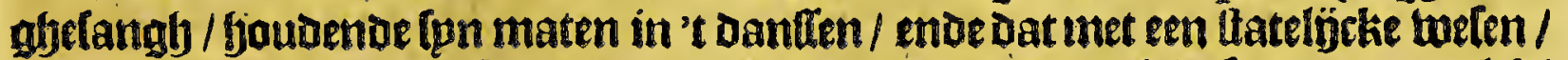

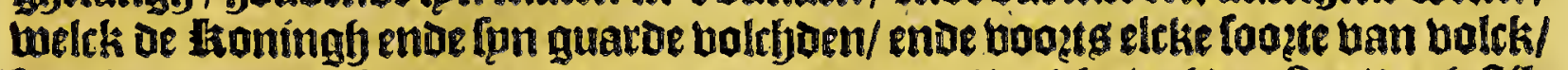

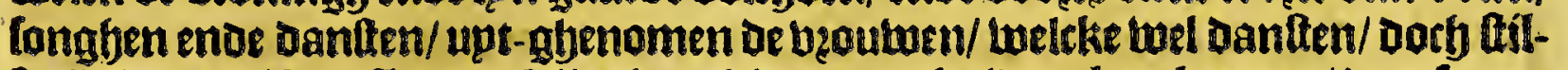
twajghenoe. Be Generael liet baer binnen de bolwetcken kamen / Daer fp efn

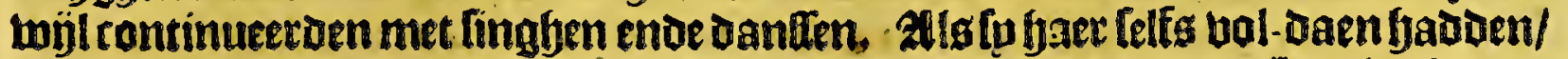
begeetoen fp dat onfen Benerael foube neder-fitten/ tot welcke de lloningbento

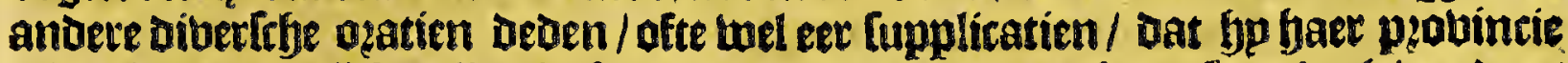

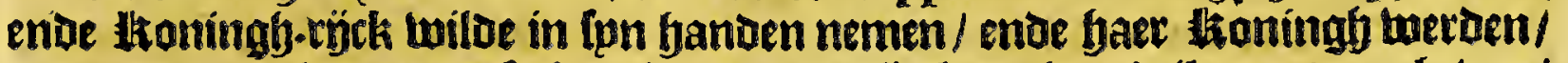
maeckende teeckenen bat [p faec lanot enoe tijtel aen fem wiloen ouer-gbeben/ enoe [un fubjecten werden. Cot welcken epnoe ae lsaningh ende de refte fjem met groate reberentie dandende ende finghende of kroom op 't booft letten/ende de ties tens om ben bals bingben/ende beel ander dingben perentertaen/yem beteerents oe met orn naem ban Hioh; welcli onten Gुenerael hiet en ontfepde / niet weten-: oc wat boogeel get in tíben en wijlen aen ons landt konbe geten. Berbaluen foa: nam gy in be naem ende ten behoebe van baet g9ajeitept de frepter/ oe kroon/. ende de bignitept ban dit landt in fpn yanoen/ wenfépende dat ven rijckoom loo tuel konde naer baer lanot gbetrantpoteert mazoen/als be fel be twel in femfeltuen

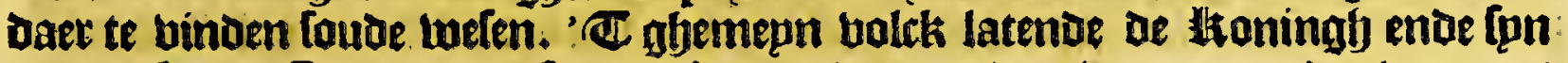
guarde bp oe Benerael/ uerfpecpde ferm onder ons/naum op een peder batt ong. lettende; endefulcke als baec bett betyaegoen (weltk waren oejonghtte) om-ringfs:

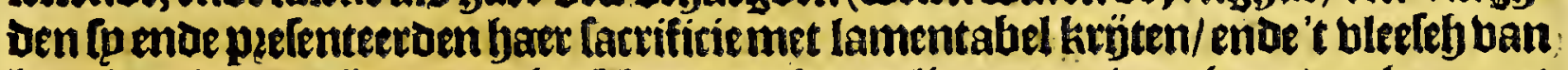
baer kaecken te njopen/ Dat bet bloet daer benen liep: maer wp thoonoen baer mee

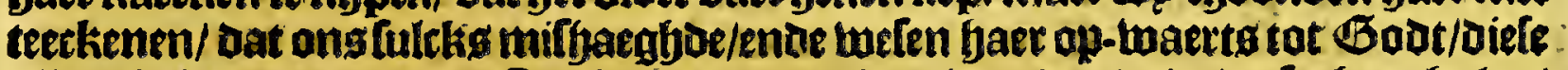
alleen bejoozoen te eeten: Sp tboonden ans faer wanden/ende berfochten bulpe/ twaer op twp baec plaeftets enoe talben gaben/ biodenoe Baot haet te millenges

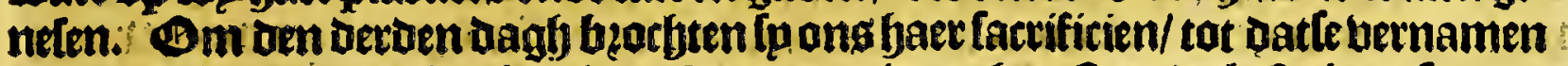
bat twp daet gheen befagben in en yadoen ; niet tegben-Itaende befacjten fp ons

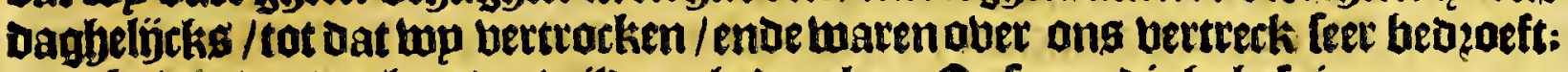
enoe traden bat wp haeraer wildenghedencken. Onfe noodigfye beloignen geepn= Dicht 3önoe / trock ong Benerael met ton rompagnie in 't lanot tot baer baepen/ oaertwp beel twilots bonoen/tot Dupfent bp een / welck groot enoe bet ban lije waren. Eop vonden dat bet gantefy lanot was als een twarande ban een beem.

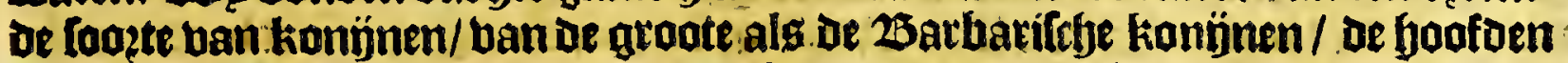
als be onle / oe baeten als mallen/enoe fteerten als ratten [eer langb; onoer of $j \ddot{j}=$ toen aen bepoe jöben een fark / Daer fo baer eeten in bergaderen/als fu oen bupek

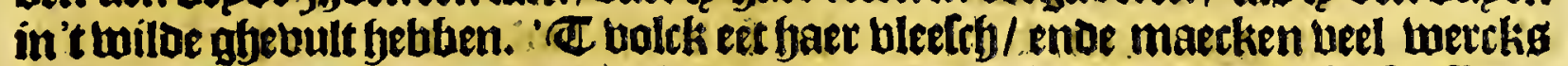

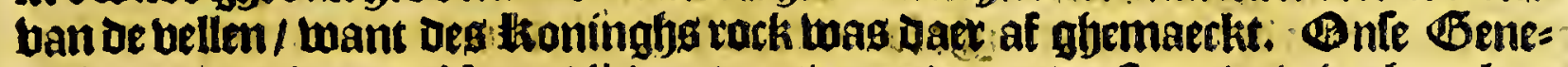
rael noembe oit landt Nova Albion, om thee vedemen/ rextf um be bitte banthen ende cliffen die naer $3 e e$ toeleggen; tenandeten/ op Dat feteeníge aftinitept noocht bebben met ons landt/ Dat eetrijots A lbion twietot ghenoemt. Agen kan qualÿck

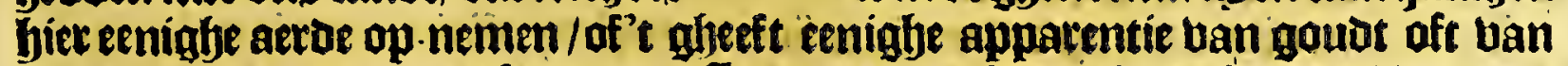
fituer. Bp ons bertreck Cetten oen Benerael een gbedenck-teecken op / van oat wo dant ghetweeft waren/ namentlïck een plate aen een poft ghenaghelt met

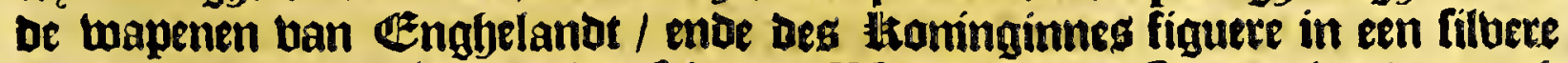

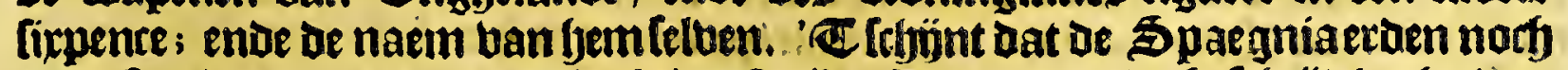

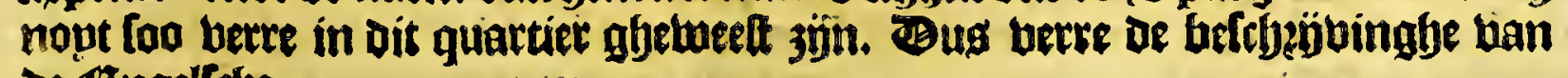
or Gingeliche. 
$25^{8}$

Nova Galicia, ofre Guadalaiara.

N O V O M E X I C O.

Het en-en-thintitblte Capittel.

De eerfte ontdeckinghe van de landen van N o v O ME x I c o, voor-ghenomen in den jaere duyfent vijfhondert ende dry-en-tachtentich.

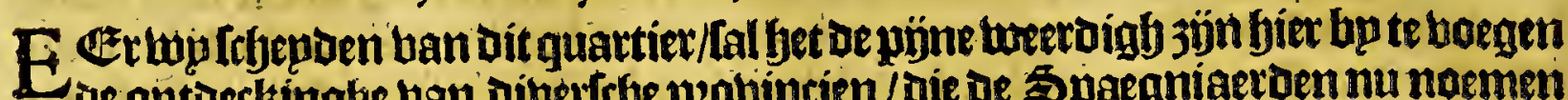
De ontoeckinghe van dibertebe pzobincien/Die de Spaegniaerden nu noemen

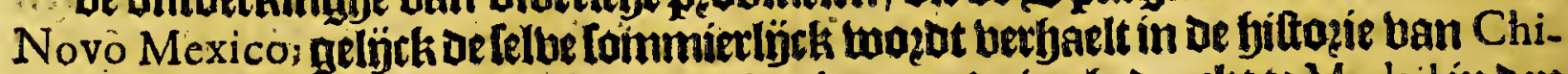
na, befthecuen bu Fray Gonçalez de Mendoça, ende íg gloedurtht te Madril in Den jate 1586 ; ente lupot inmaniete als bolght :

$\mathbb{E}^{*} \mathfrak{e n}$ religieug ban de azdoe ban $S^{`}$ Francifcus, metnamen Fray Auguftin Ruyz, bem onthoubenoe in de ballepe ban $S^{t}$ Bartholome; in oen jaere 1581 , berftaen Jehbenoe dode'trelaes ban feker 3 ndianen/ die mennoemt Conchos, (De twelcke communicatie fadoen met lekete bare na-bupeen/genoemt Paffaguates;) Datnaer

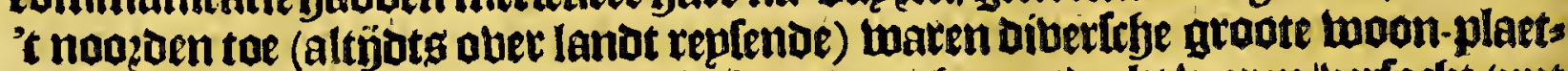
Ien/Die bu onfe Spaegniaetoennopt bekent nochte antoeskt waren/berforfte (upt enen plet am de zielen te betlollen/cantent aen Conde de Corunna, díe Doen B is te-1iop wag ban Nova Hifpania, ende aen fpnen obertten/ betwaertg te mogen

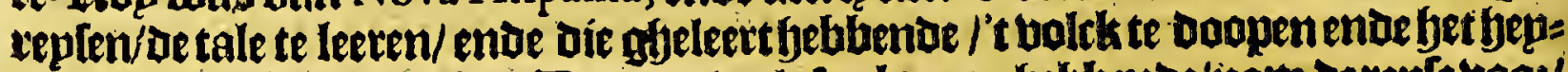

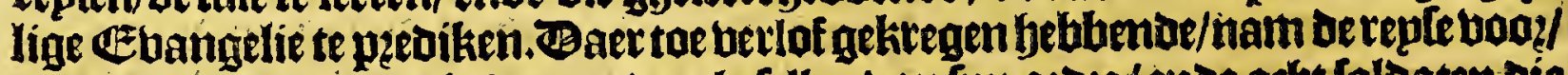
met hem nemende norf thee mede-ghefellen ban Ipn azoze/ enoe acht faloaten die

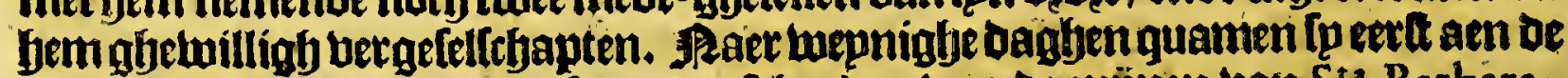

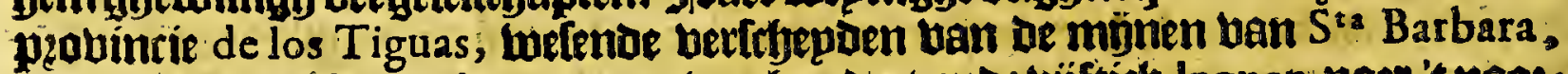

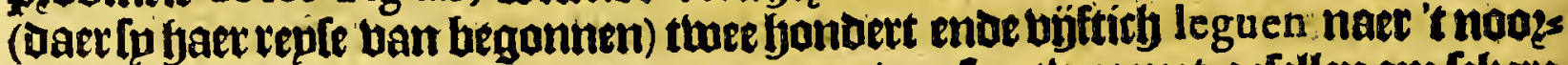
ten; in welckep pabintie de in-woonoers een ban fpn twee met-getellen om fekere

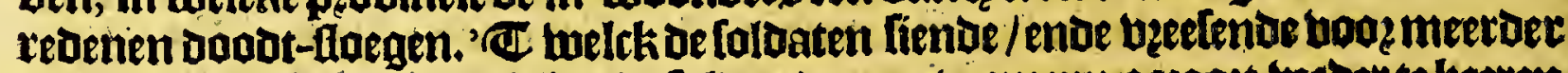
Iwarighept die mochte bolghen/ refolbeerben met gemequ actooet weber te keten naer te minnen Daer fp ban gekomen waren; boo al confioererende dat fo te torps

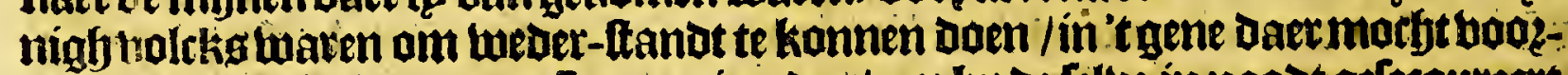

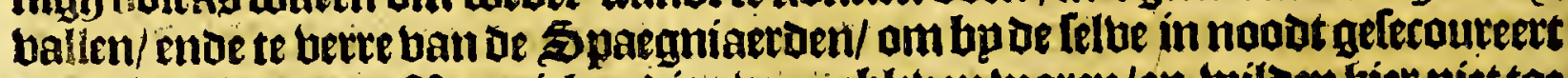

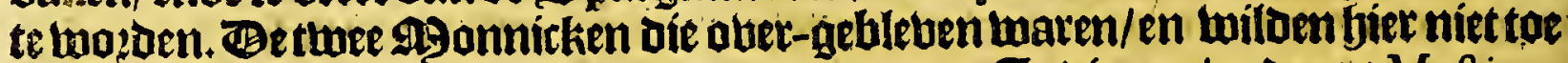
berttaen/Dan blever iaer met ofpiongelingen ban 3 noianen/enoe een Meftizo, viefp imet fadoengenomen/faet latenoe booz-Itaen/Datboe- wel fp alleen bleben/

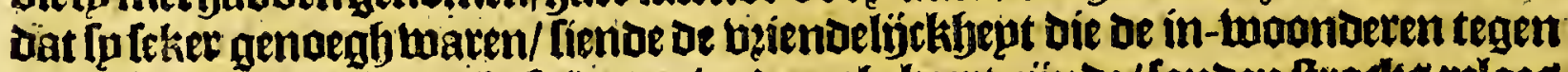

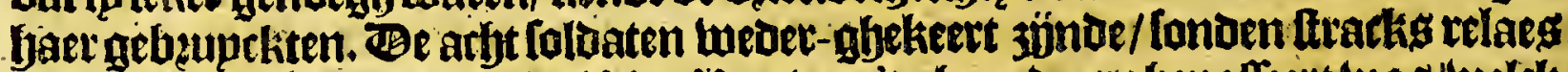

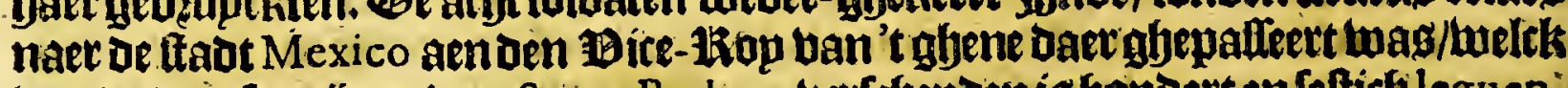

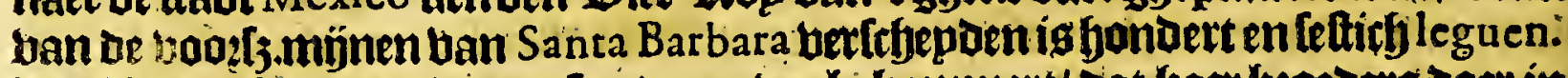

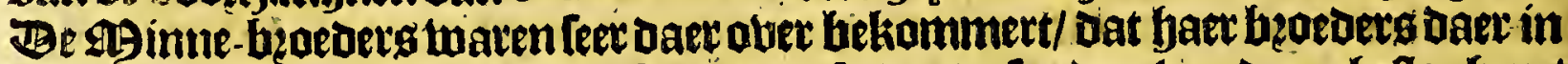

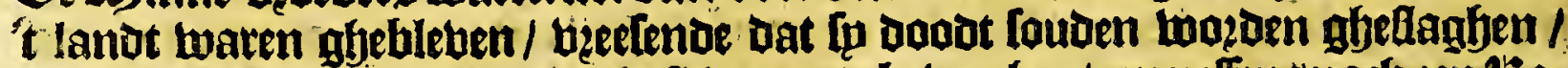
ende beganden derbalben eenigje foldaten to betweghen/ om neffens noct een lites lígieug ban be lelve ozoze gyenaeint Bernardino Beltran, weoer te treeken naet

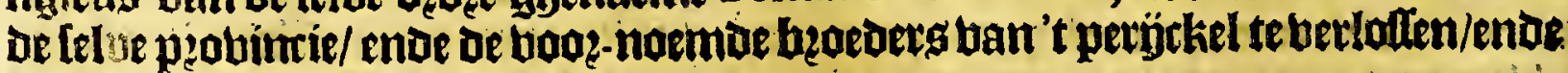
ae hegonnen fake te betwozoeten.

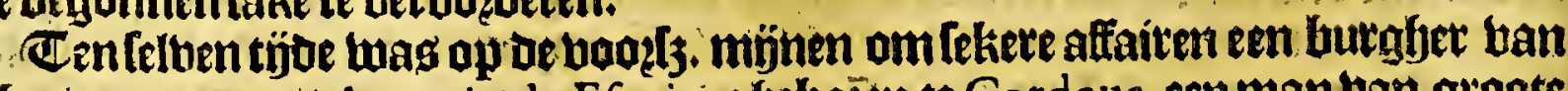
Mexico, genaent Antonio de Épeio, ghebozen te Cordoua, een manuan groote

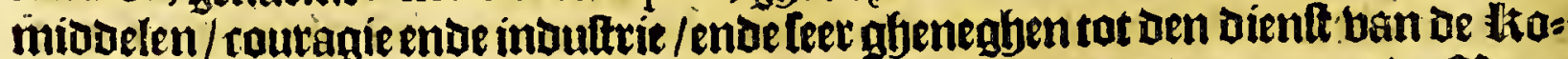

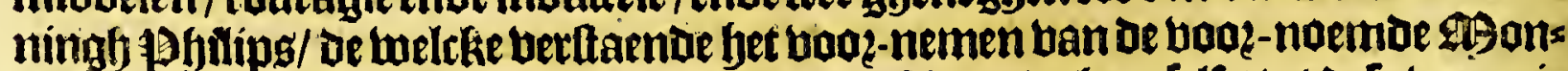

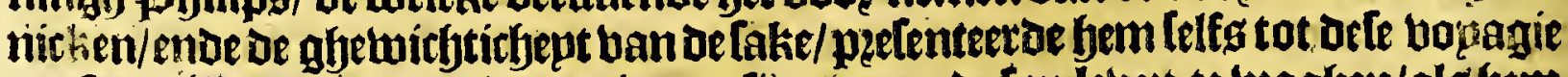

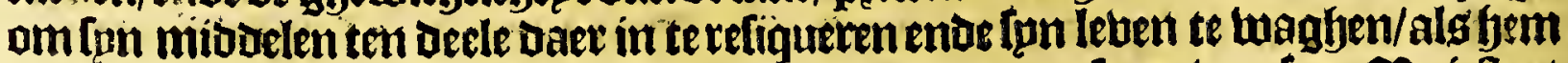

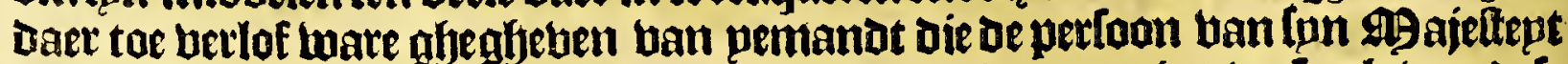
repzetenteeraen/ welth canlent bem ghegheben twierdot op bet berlaeck ban ocle

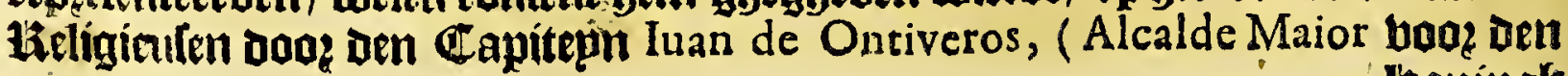


Honingh in de blecken / ghenoent las quatro. Cienagas, welcts jün ghelegen in't Boubernement uan Neuva Vizcaya, 70 leguen van de boos 5 , minen ban $S^{:}$

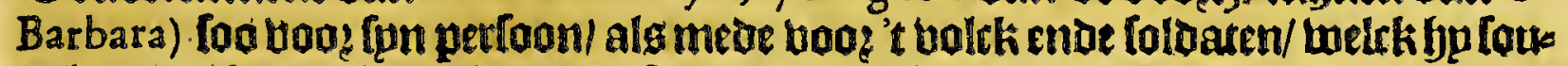
be konnen be een benghen. Dele Antonio de Efpejo nam be fake foo ter fierten/

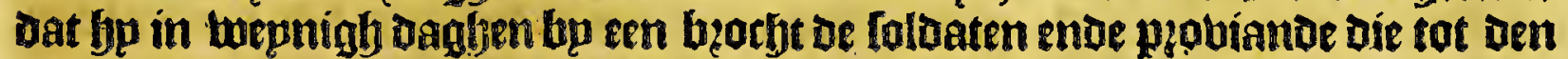
tocbe noodigh waten/ een goet deel vanfunmidodelen daer aen te koft legghende: enoe frbeptoe imet alles upt de vallep ban $S^{:}$Bartholome Den Io Novemb. 1 582 ; metbem boerende i is fapeetoen alg muplen/ende beel wapenen/ammuntie ban

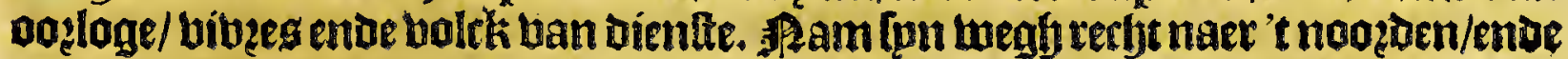
naer twee baten bont fop ved Jnoianen/ Die mennoemt Conchos, woonenoe in

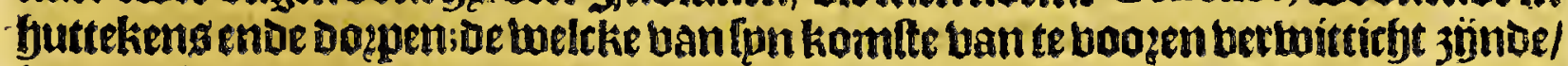
bem te ghemoet quamen/om bem met bljichap te ontfanghen. Iset onoer-fouot ban befe Conchos ente antere dic in befe groote ende boefte peobintie woonen/ jün konjuen / jalen enoe barten / welck daev zön in groote abumdantie : bebben oock beel Maiz, calabalten ende meloenen met menighteः daet jün beel riebieren

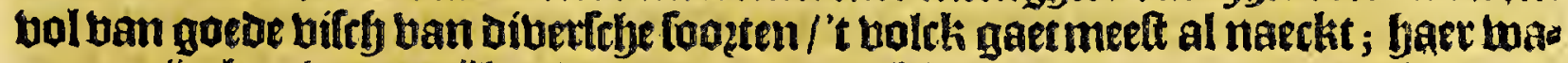
penen 3 gn boghen en pölen; Ieten onder bet gebièt ban Caziques, als de merita= nen :en bonoen baer gbeen beeloen/nothen konoen niet bernemen satfe pet aenbaben; waer Doos fu litytelïck toe-ftonden dat de Chiftenen baer krupren op-

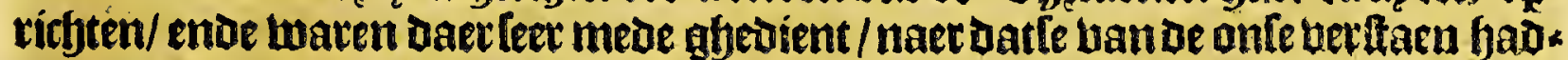
ben watyet te leggen was; 't welck gefebiede boog tolcken diele met faet boerden;

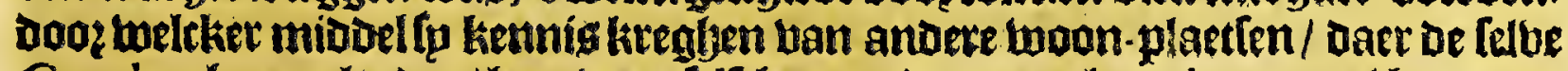
Conchos fyaer gelepoen/ haer bergelelfrbappenoe meer alg 24 leguen, al bewoont

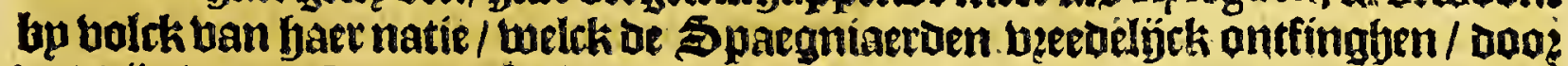
't adougs dat oe Caziques fonden band'en plaetle tot de andere. Paer dat lo oefé 24 leguen waren boott-gfetrodken/oonden fp en andet natie genaemt Paflagua -

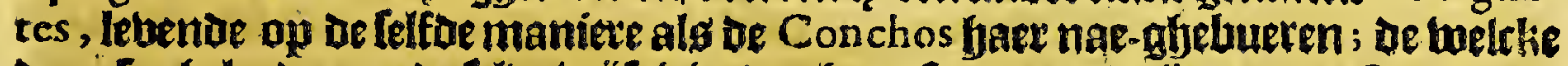

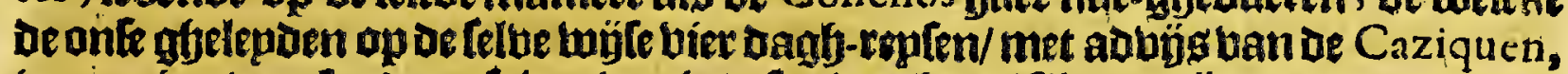

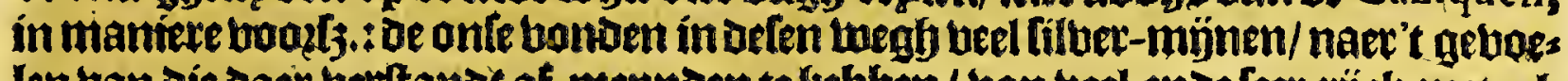
Ien ban die baer bettambt af mepnoen te jebhen/ ban beel ende feer rijek metael. Een bagh-reple boogder bonben (p een andere natie/ ghenaemt los Tobofos, be welcke de onfe gfetwaer wozdende / bladen naer het abebergbte / latende baer

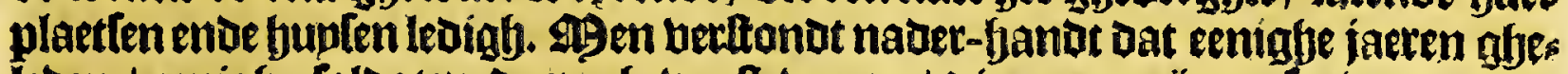
leden / eenighe loloaten daer ghemeeft waren/ die naer münen lorbten/ ende

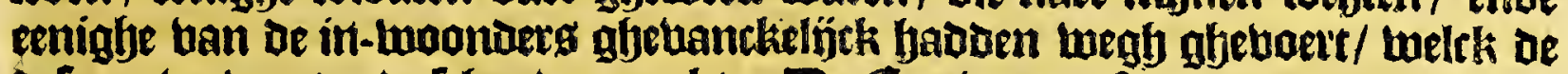

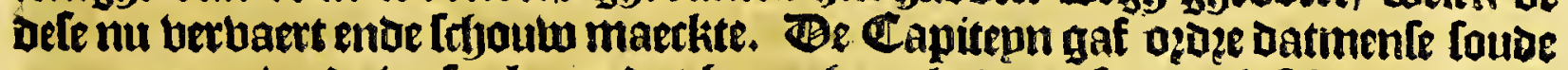
gaen roepen/ende berfeeckeren dat baet gbeen leedt en foube ghefrjieden/ende maecteten het foo wel bat daet hele quamen/ oie bp tarefleerbe enoe giften gaf/ baet Dooe den tolck te betfaen ghebende/ Dat fp niet ghekomen twaren on pes manot quaest te boen; thaer Doog 't bolck bem liet ter neder fetten / ende confens teetden dat daer krupten fouben op-gheretht werden/ende ae mepningle daet ban berklaert / ende tjoonden daer goed ghenotgben in te bebben/met dat fis be onle gingen accompanneten/als baer ofjebueren badoen ghed aen/ tor dat fp baer bzorgtenín een lanot lip een anber natie belwoont / van bet haere berf fyepden bp be twaelf leguen; dete Hailoe ghebzupeken boghen enoe pjilen / enje gaen voopts al naeckt.

\section{Wet tbuee-en-thintitbfte Capittel.}

$$
\begin{aligned}
& \text { Vervolgh van de felve ontdeckinghe van No v o MExico, } \\
& \text { by Antonio de Efpejo. }
\end{aligned}
$$

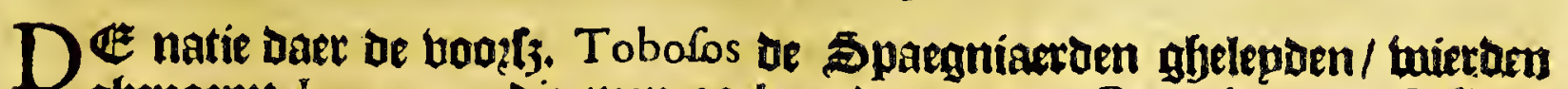
ghenaemt lumanos, die men oock andets noemt Patarabueyes, belitten 


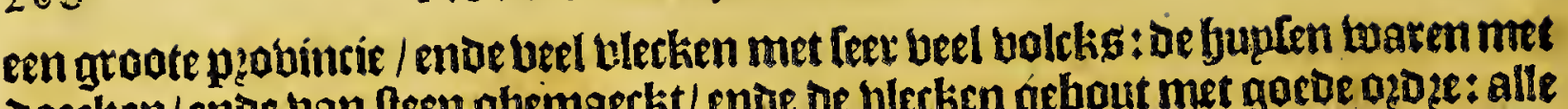

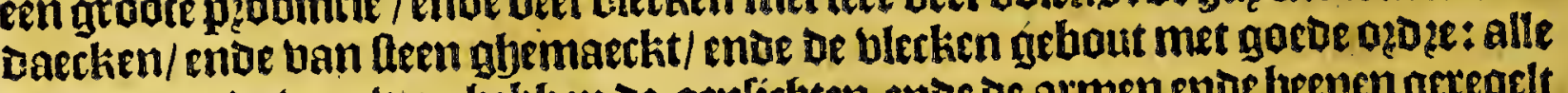
oe mang ende bzoutwen behben de aenfíthten ende of armen enoe beenen getegelt

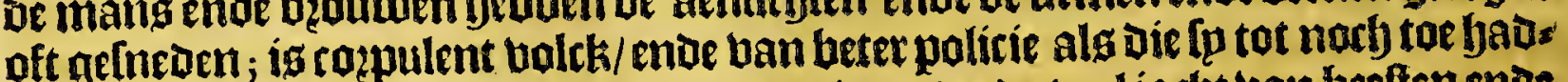
Den ghe vanuen: hadoen abumbantie ban vibeg / enoe veel jact van beeften ende

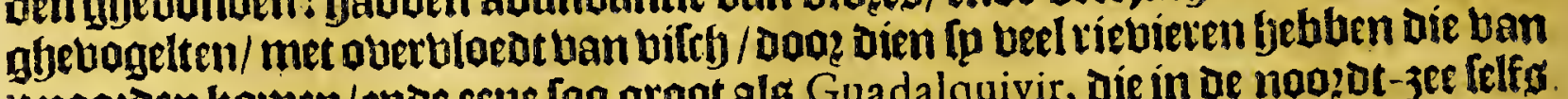
'tnopzen kounen/ende eene [oo groot alg Guadalquivir, die in de noo?̨ot-3ee felfo. loopt. 19ebben beel lacken uan 3 out-water/welck harot woet cnoe caaguleert cenis

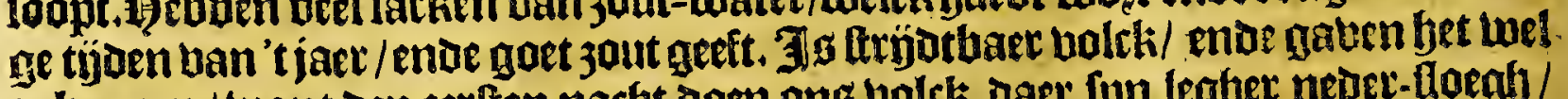
te kennen / want Den ereften narbt Doen ong uolck Daer fun legher neber-floegf / Ifhotenfp fel met pÿlen/Dooden bủf peeraen/ende quettender narb foo uele/ende en foùden niet een lewendigly gelaten bebhen/sen ware de warbt die bado beffyermt. Dit ferft onthael gedaen bebbenoe / verlieten fo haer plaette / eñ liepen ap een ges berghte dat traec bu was / mettwaerts des moggbeng de Capitepn trock met buje welgetuapende foldaten/met een tolck genaemt Pedro, ende een Jnoiaen ban as Celfoe natic / die met goede reoenen yaer te byeden ftelde / doende baer tweder af-ko. men naer foer blecke ende bupten/ ende haec boozoer betuegende advijg te willen geven aen baet gebueren/Dat of 5 paegniaerden een bolck mag die niemant quaes.

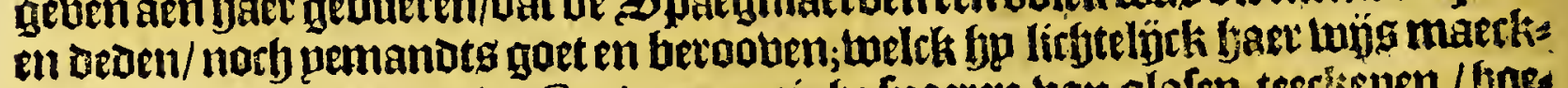
te / midts ghelentie aen de Caziques eenigbe fnoeren ban glafen teeclienen / goes

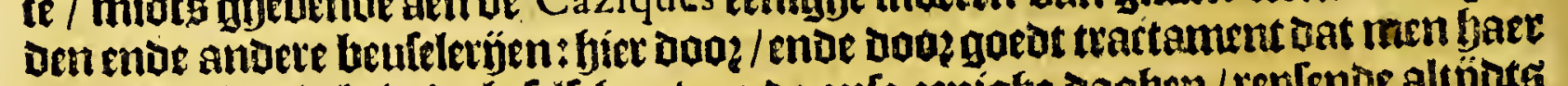

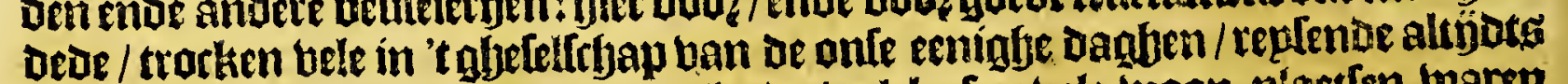

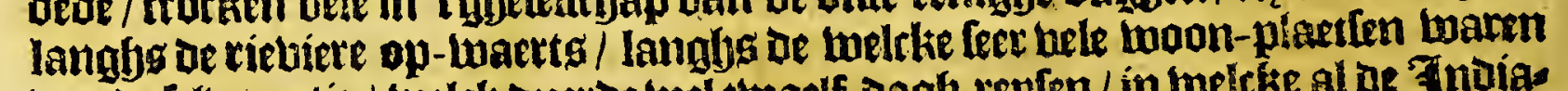
ban de felbe natie / weles ouerae hel twaelf dagh-repfen / in twelcke al of Jndia nen ghelwaerfefjout jönoe uan oe Caziques, వ' een naer o' ander upt-quamen om

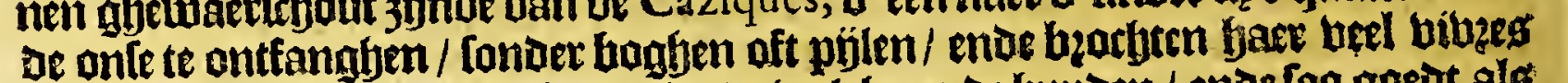
enoe andere giften / ende infondertyepot wel-betepoe bupoen / enae foo guedt alo

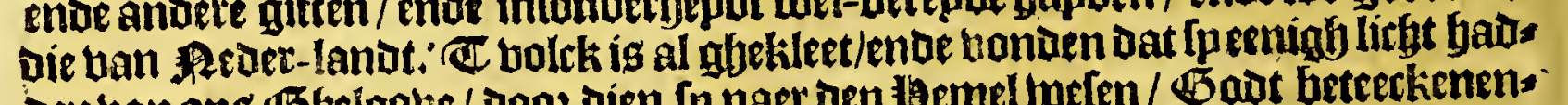

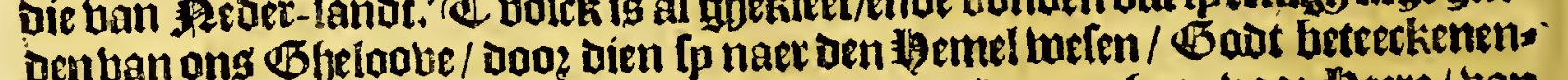

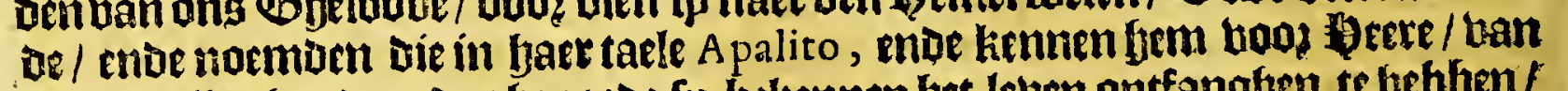
miens unitoe banor ende ghenaede lp betiennen bet leuen ontfandben te behlien/ ende de tjoelficke noederen. Taer quamen beel tan laak beuluen ende kindes. $\mathrm{ren}$ / on ban Den keligieug gheljeplichy te hogoen ende de beneairtic te ontfans gijen; De welkke haer bzaeghoen ban wien lp oele hennifle ban fort hadoen

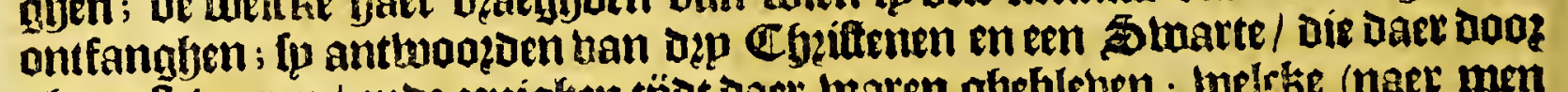

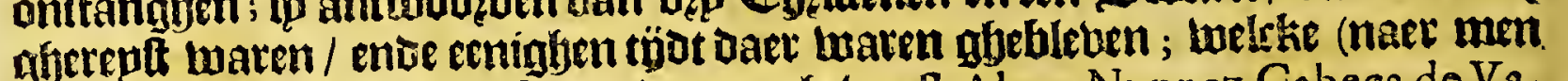
ha De teeclienen kande beritaen) waren ghemeel Alvar Nunnez Cabeca de Vaca, Dorantes, Caftillo Maldonado, enae een Stwarte/ Die onttamen warem ban te armatie daet Panfilo Nervaes mede track in Florida; ende naet dat ip

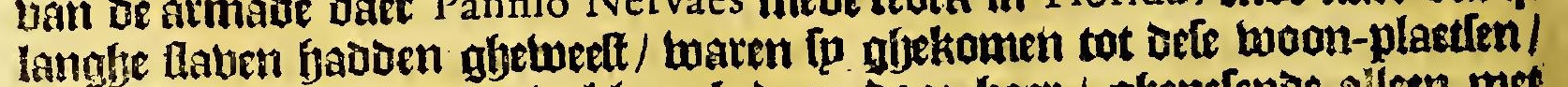
ende Godt hadoe beel miraklem gbedaen soos baer / gbenefende alleen met fjet aen-roeten ban haer handen bele fiectien / waer boa fp een groote naem

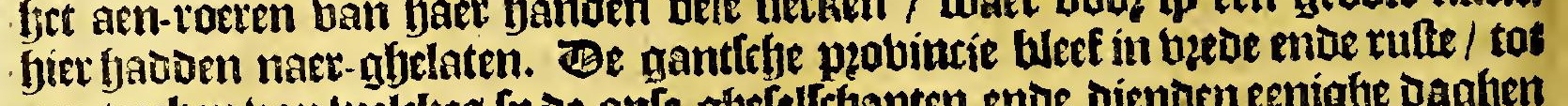

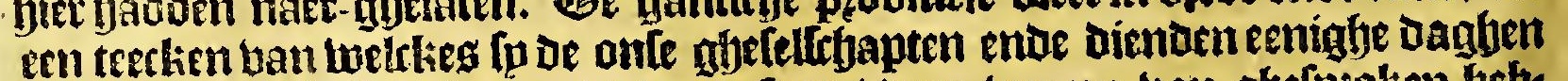

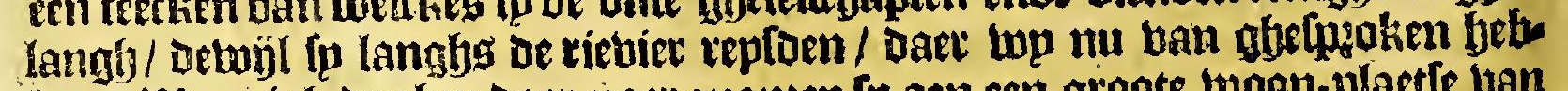
ben. 1Bepnigh Daghen daer naet quamen fp aen een groate twogn-plaetle han Indianen / die fyat quamen ontmoeten Dod bet nieutws dat fp bau baet ghes bueren yedorn ontfangfen / ende bzorgten faer beel curieule dinglen banplups men tan biberldye kouleuren/ ende veel mantels han cottoen ghebigartecth

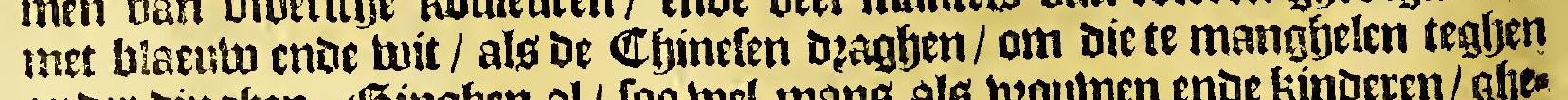
ander dinghen. Binghen al / foo wol mans als beoutwen ende kinoeren/ ghe lifed met betaenen beel wel berepot / enoe nopt en konoen ife onle betfaen

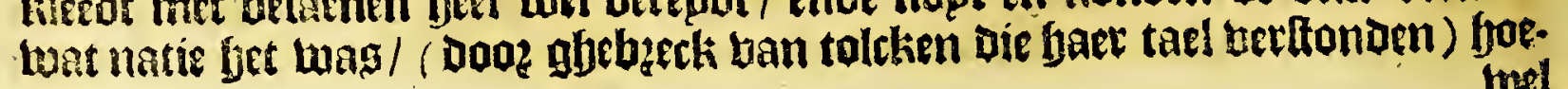




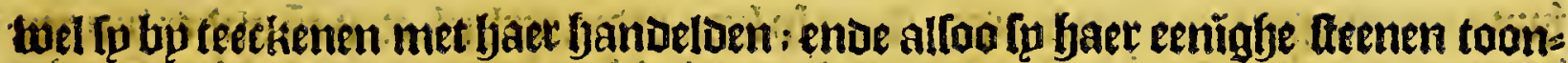

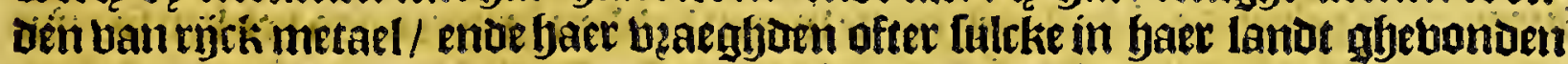

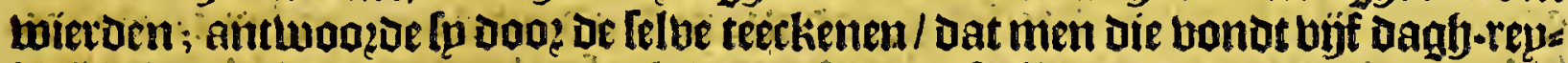

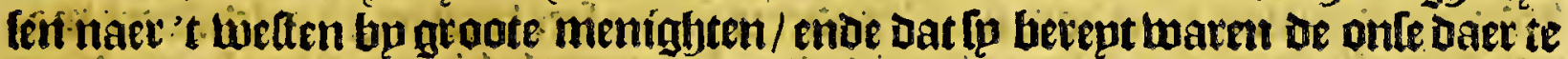

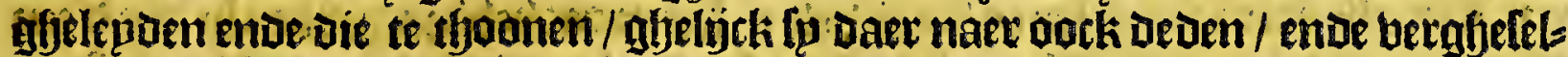

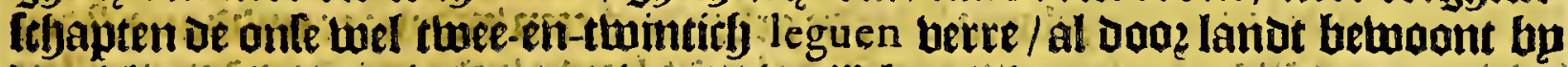

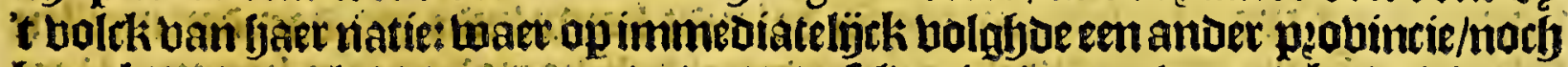

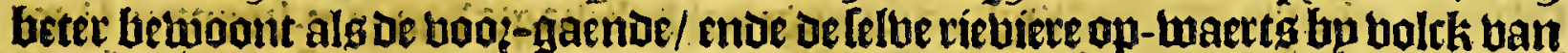

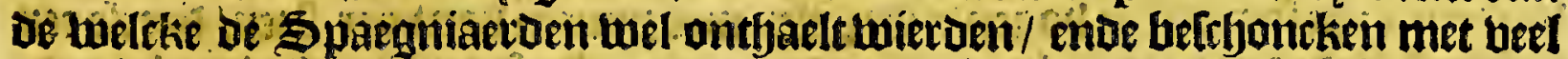

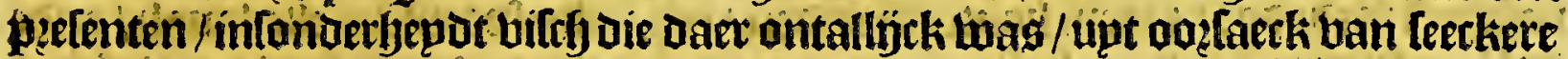

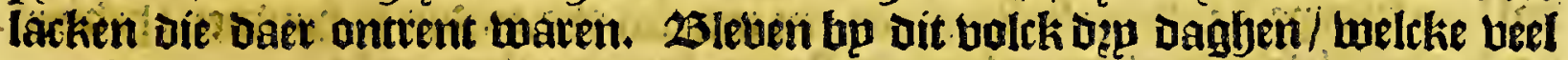
danfen opljaet maniec aen-ftelden Dang en nacht/met bemanltratie ban groate

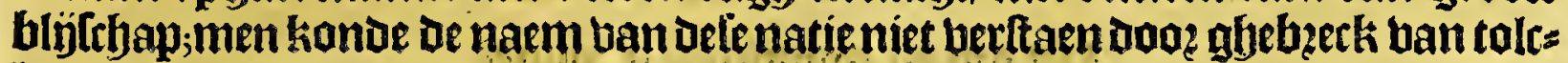

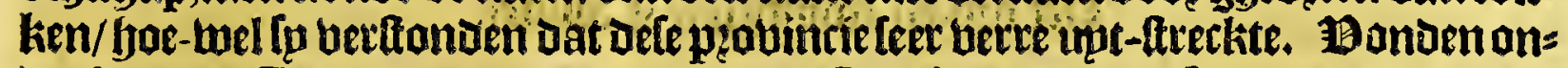
Det haer een 3 noiaen uan de natie ban de Concho's, die baer Tepde en met teeckes nen te kennen gaf/Dat büfthien Dagh-tepten van saer/ na't tueften/een [eet beet lack bas / enoe daet om-her belé woon-plaetfen ende hupfen wan D?p en bier bet:

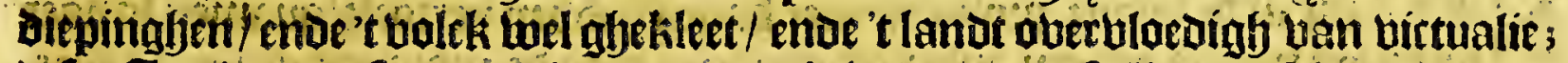

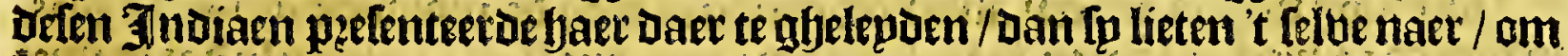

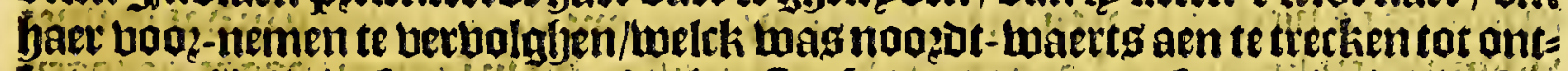

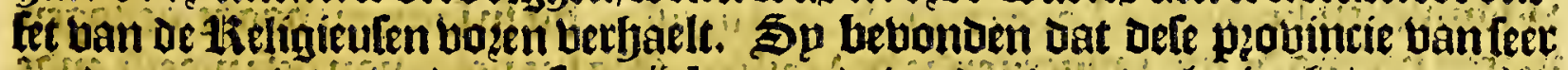
goede tempere twás/ende een leer roncke gronot/en dat oaer beel te jaghenen te blice

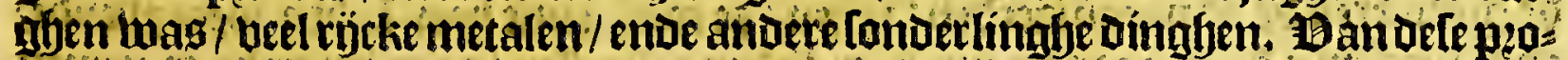

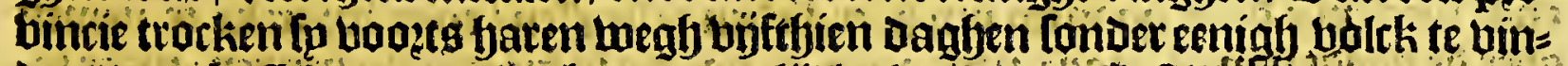

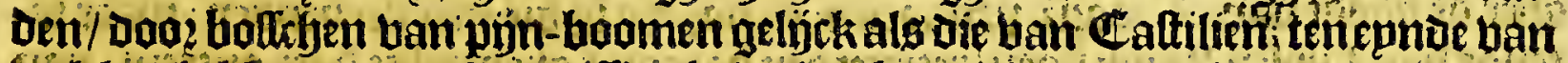

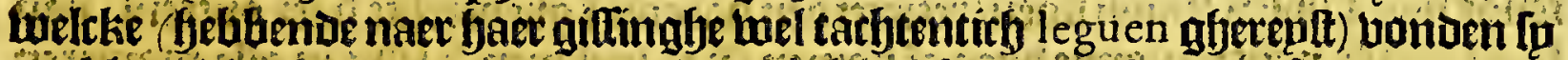
en klepn blectken ban butten met wephing tolck ten it faerbuofikens die arm

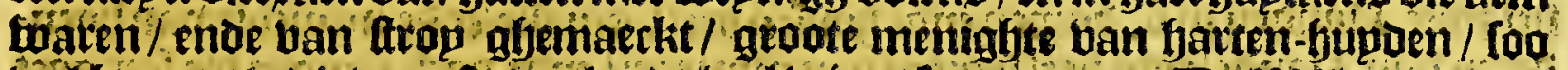

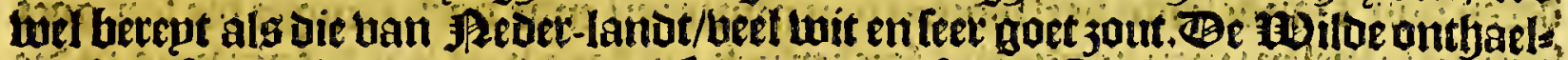

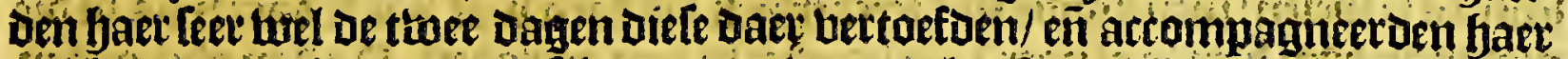

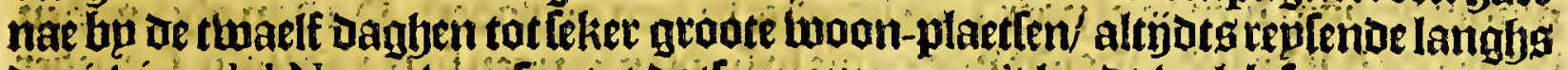

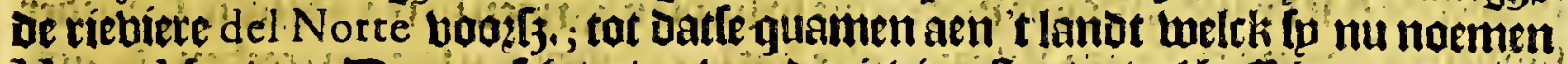
Neuvo Mexico. De gantlehe oeber ban dé rieviere ftonot bol bofferen ban abelen/ae tuelcke op commighe quattieren wel biet le guen beet waren/ende inlafes: tóck ban bele note-boomen/ende wimugaet denals die bain Cattilien. Raedatlp

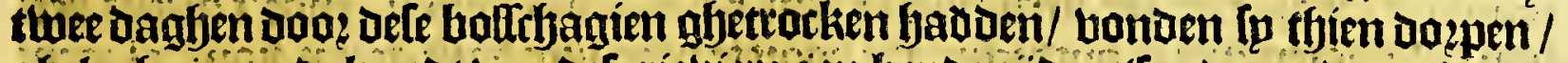

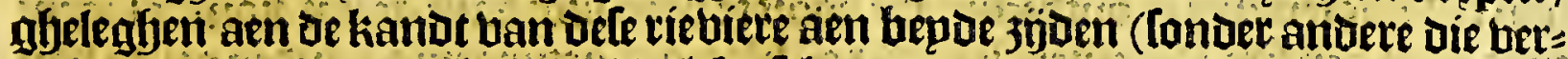

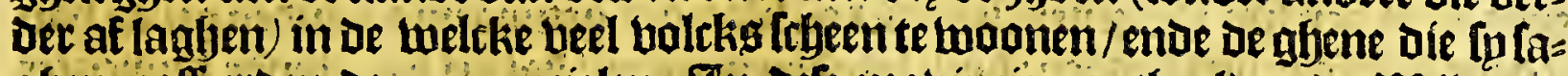

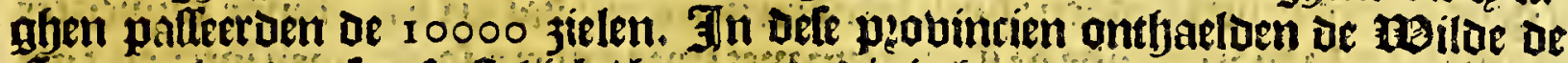

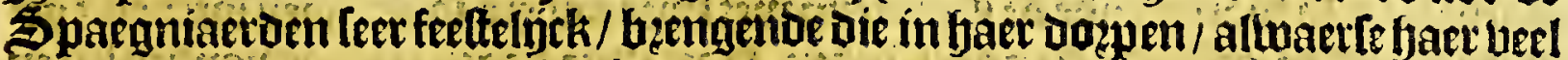
thrtualie gaben/ypenderen ban't lanot ende andere dinglyen/en dat met leer goeve twil. Bonden bree bup[ert wan vier berdiepinghen/ wel ghetimmert/ en met fraepe

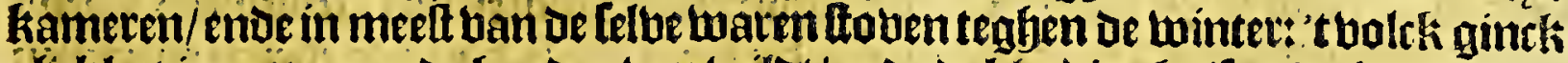
otjekleet in cottoen ende fyupoen ban wildot/ende de kleedinghe/ foo wel ban byo:s twen alsmaing/ was nae de wije ban de Tnoianen ban Mexico: ende't gigene de Spaegniaerden meet dedo betwondeten / wag / te lien Dat bepoe mang en bzous wen gheleljoept waren met lrboenen ende leerfen ban gart leder/ende de folen van afen-ljupoen/'t gene menelders nopt en hadae gheuanden, Je beoumen dzae:

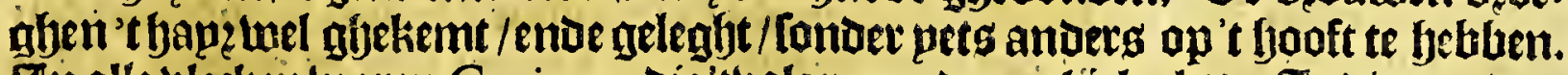

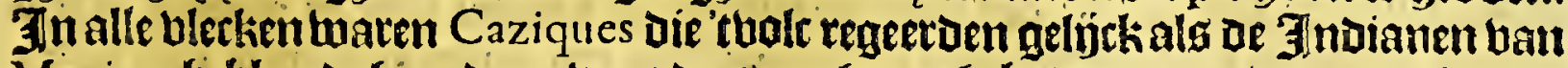

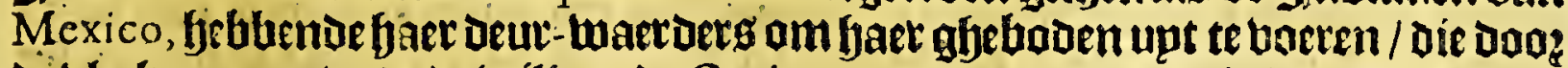
de blecken gaen/ende de wil ban de Caziques upt-roepen / ende in 't wetck tellen. Bonden daer beel beelden die de Bilde aen-baden/ende badoen bu naer in elc:

$$
\text { ? } 3 \text { bups }
$$


hupg een tempel too? oen oupbel / Daex fo bem ozdinaeclïck eten eñanber bingen

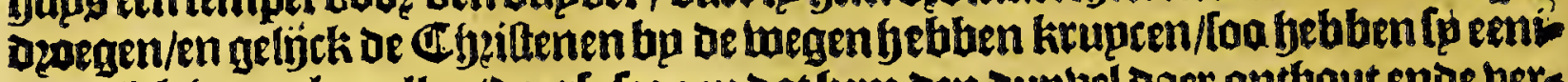

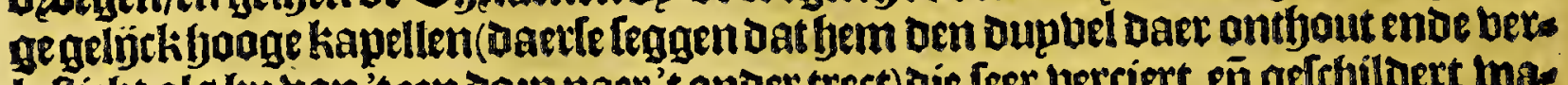

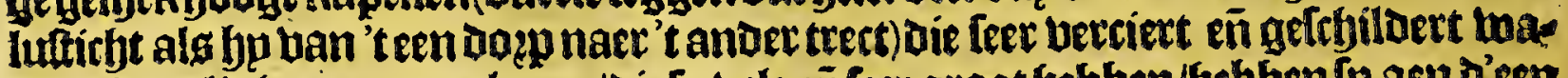
ren. Atem alle baer jaep-ackeren/Diefp bele eñleer groot bebben/beb ben fo aen t'een

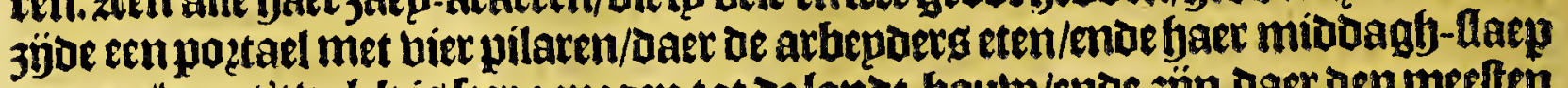

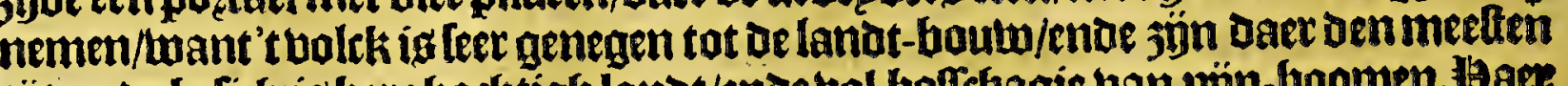

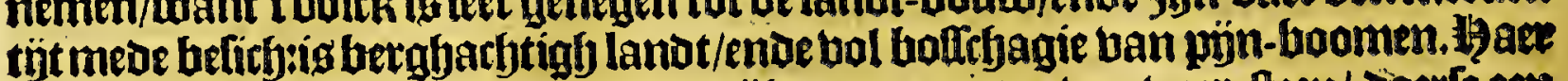
wapenen 3 j̈n Ieer ftercke bogen/endepölen met punten ban uper-fteen/ Jaerfe een

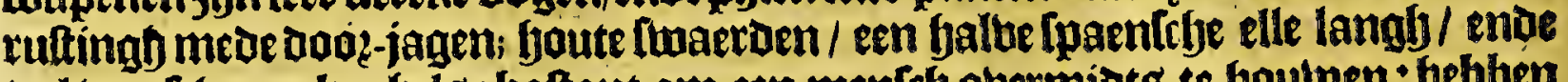
bol ban frhetue keghels / baltant om een mentch obermiats te boulwen : bebben oatk gheljeklthiloen ban onberepae ftieten-bupoen gbemaeckt.

Het Dęu-en-twintichlte Capittel.

Voorder verhael van de gheleghentheye van de provincie van NEuro Mexico, ende 'r ghene de Spaegniaerden daer faghen.

N

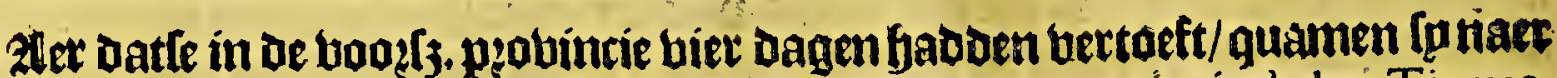

wepnigh weghs aeneen ander die genaemt was de pzobintie de los Ti guas; in melcke I 6 bleclientwaren; in luelcker een/genaemt Poala, bonden [p vat oe twee Agommicken Francifco Lopez ende Fray A ugultin, Die [p Lochten/ Doodt-gellagen barenneffent de dep jongersenoe de Meftizo. Alla bet bolck ban dele plaetle ende

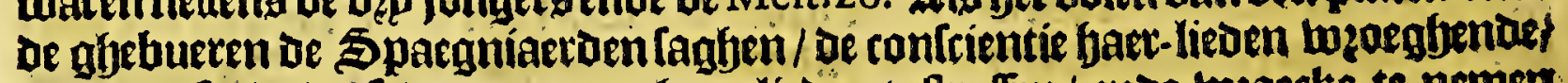

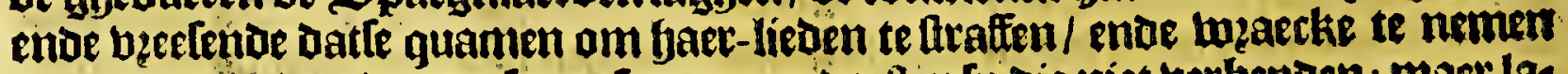

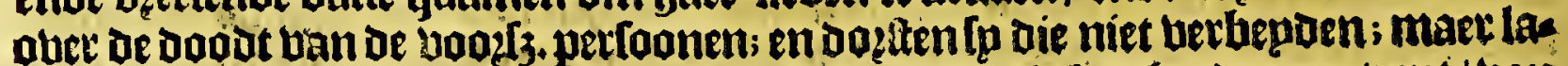

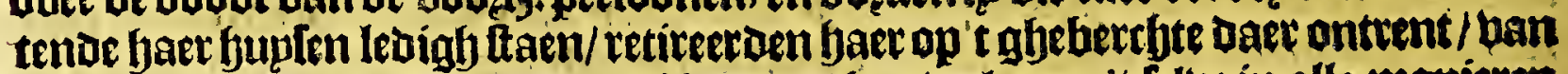
waer menle noptenkande doen af komen / boe-wel men 't felue in alle maniecen beforfte. Bonden in or dowpen ende buplen beel bictualie/ende menictyte ban foens: Jeten ban't lanot/ente beel looeten ban minetael/ ende aack eenighe die feer goet

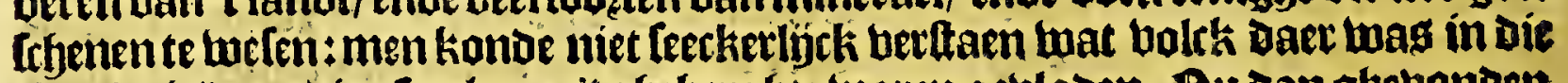

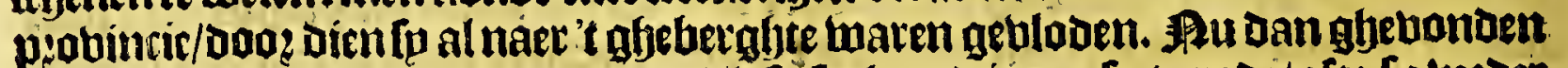

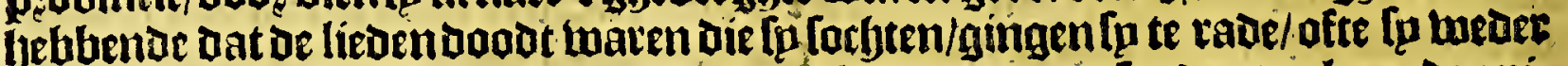

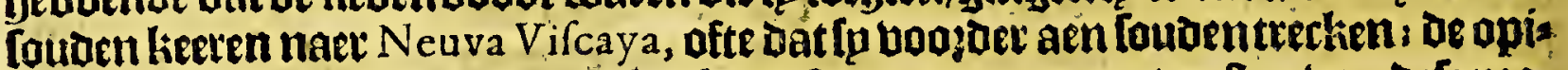

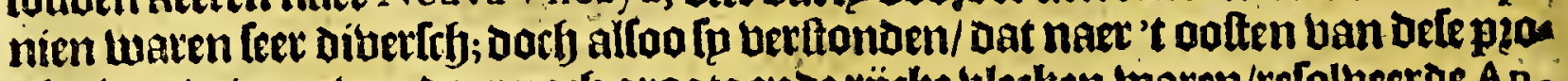
bíncie/ende betre van daer noefy groote ende vöcke ulecken toaren/refolbeeroe Antonio de Efpejo met toe-ftemminghe van Bernardino Beltran, ende't meefte deel Jan be fol loaten/met oe ontoeckinghe boozt te varen/tot datfe de upt-komtte fagen/ ente alloo aen fpn $\mathfrak{g}$ Gajeltept fekerder eñ klaetider getupgenis konoen geten ban

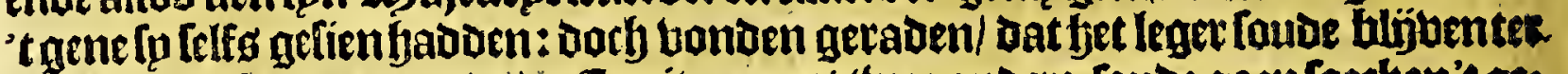

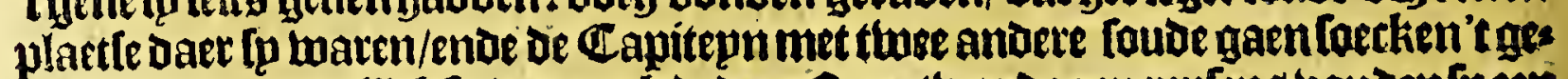

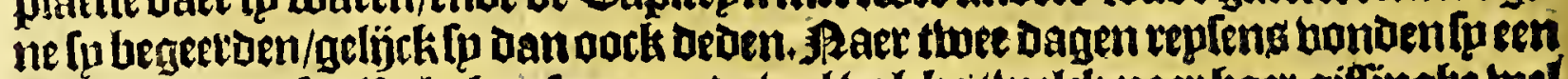
peobincie daet Ip elf blecken lagen ende beel bolcks/ welck naer baer gillingthe wel

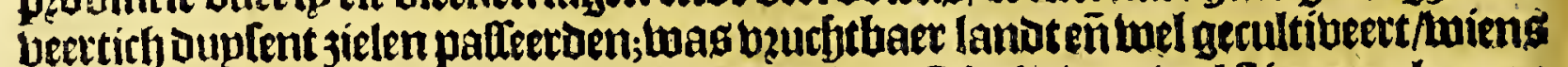
limiten immediate!jekf faer boegen met die ban Cibola, daer beel fieten en koepen 3ijn/ met tuelcker bupaen lp Gaer kleeden/ende oock beel cottoen; valgende in baer

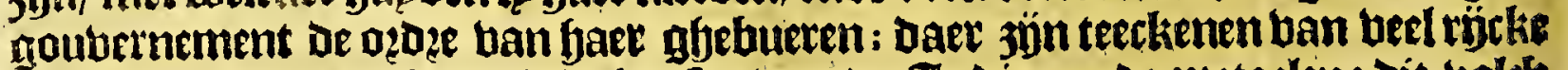
mijnen/ en bantien in eenighe buplen ban de Indianen de metaelen: dit bolek feeft beeloen die fp aen-bidoen; ontfingben oe Spacguiaetaen bezoeliöck / ente

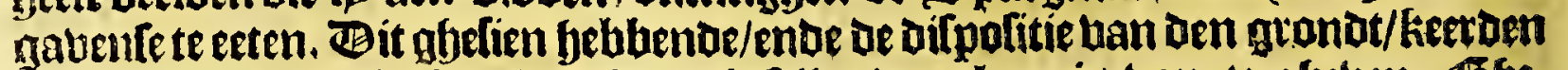
Ip Leder naer bet legher/ om baer ghelellen daer kennig ban te gheben. Bgls thomen jünoe in't legber kreghen fp kennis ban een ander pzobintie ban bolk

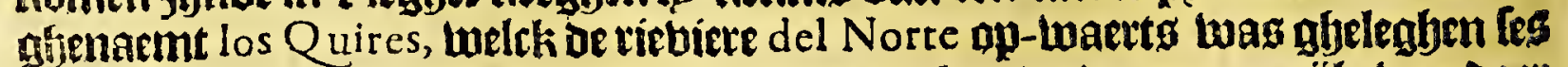

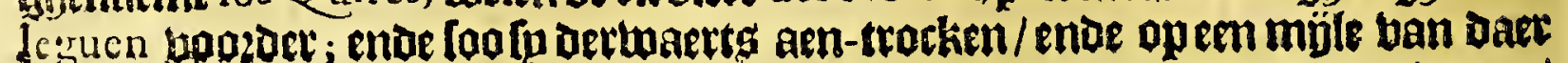
warend 


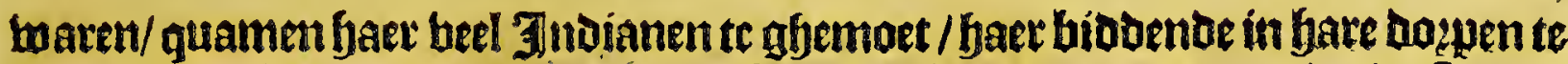
homen/'t welek Doende/ wierden Daet [eer wel ghetrartegrt enoe antbaelt. Fagen in die peovincie alleen büf woon-plaerfen baer veel bolcks in thas / enve die fp fa: agen yallerden de büftbien duplent zielen; bebben beeloen die lp aen-bidoen als baer ghebueten. Bonden in een ban defe blecken een exter in een kope / als men Doet in Caltilien/ende van die Tirafoles, als men upt China bzengbt/met de fon ende mane ende ftetren daet op ghe[cljiloert. Pemende de booghte / vondentjaet op de 37 graden en een falf. Schepden tweder upt otefe peobincie / foudende de felue kourg: naer veerthien leguen uonden Ipeen ander pequincie ban een tolck ghenaemt los Cunames, Daec fp uj̈f blectien faglen/ende de grootte ende pinci= paeltte was ghenatmt $\mathrm{Cia}$, welck foo groot wag / bat oaer acht marckit-plaetten waren; de fuplen twaten met kalck ghettreecken / ende gefthildertmet kouleuten/

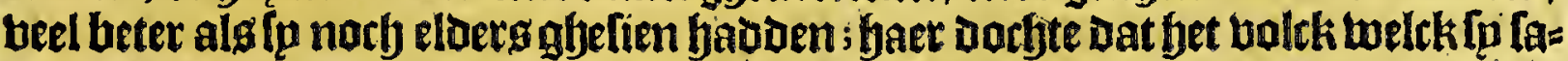
ghen/palfeetde de 20000 jielen: Tchoncken be Spaegniaeroen Ueel curieure man=

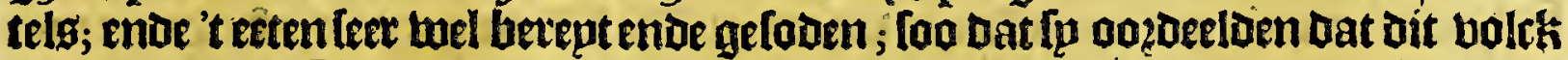
rurieuler twas/eñ beter gepoliticert als [n nothernigh habon genonden;thoonden rÿcke metalen/ende de betgen Daer antrent/ upt de belckefp die baetoen. Biet kre= gen lplucht ban een ander pzobintie naer't noozt-weften toe gelegen / Daer fp naer toe trocken;enje quamen daer aen na dat foleg leguen gerepit yadoen/buelcke pzas bincie thazt genaemt de los Ameies, bebbende fevengroate blectken/eñ in oe felbe/ naer baet berlant/wel 30000 zielen, Een van Defe biecken lwag naer baet Leggen feer groot ende lefoon / Dan lieten naet't felbe te gaen befien/ [oo om oat fet arfuter

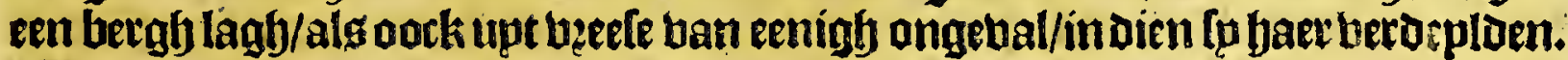

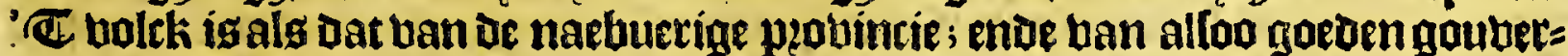
nement. Bijfthien leguen van defepzovincie / treckende naer't teeften toe / bon= ben [p een greote blecke gfyenaemt A coma, ban meet alg leg Duplent jielen/ende was ghelegen opeen booge klippedie meer als bjftich ftagien loogh was/gheen

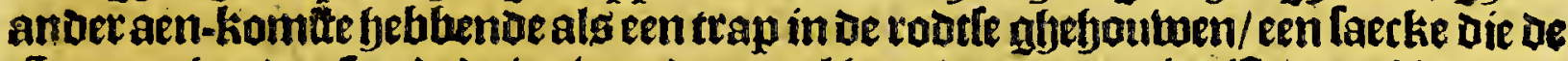
Spaegniaerden feer dede bertwonoeren; al baer water twas in rifernen. Depin-

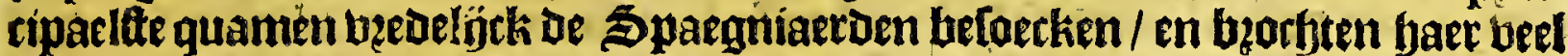
mantelg/en belanen twel berept/en beel bíbzest febbende jaer ge3aep thee leguen ban Daer / ende lepoen bet water om oe felbe te begieten upt een kitepne rieviere Daer ontrent/op meleties oever fp veel ronfelaten laggen alg die ban Spaegnien.

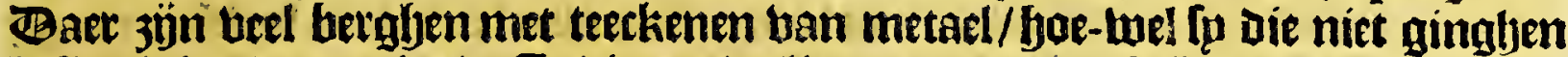

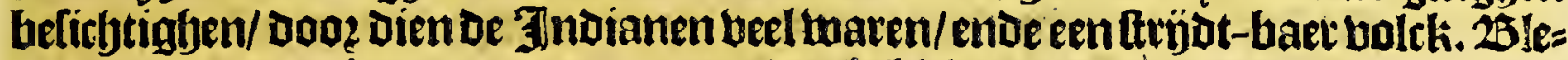
ben daec dey daghen / en op den eenen Dagh bielden de noilden een Colemnelen Dang/ dantende met fraepe kleederen/ente feer ingenieufe lpelen / daer fp faer in bermaecken. Biet-en-twintich leguen naet het weften/ quamen [u aen ren pza=

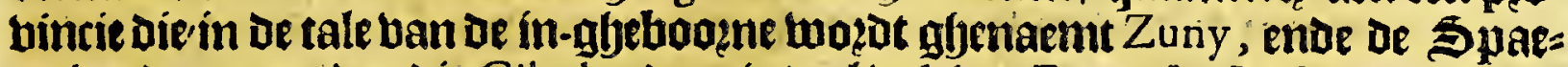
gniaeroen noem den die Cibola : Daer ig ued boleks: Francifo Vafquez de Cor-

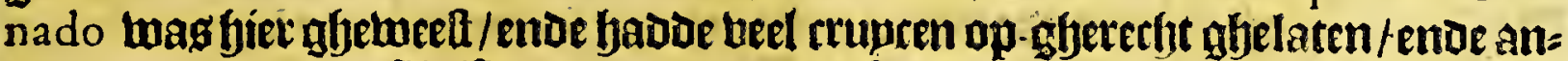

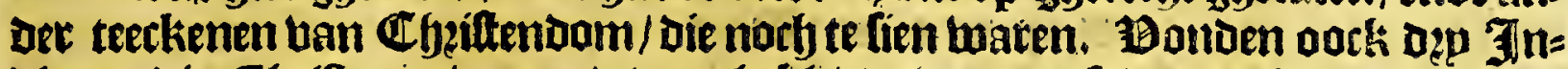

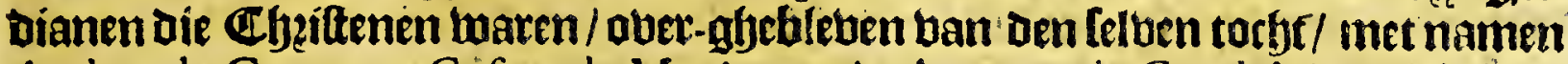
Andres de Cuyocan, Gafpar de Mexico, ende Antonio de Guadalaiara, Die faeer epghen taele bp naer bergeten badoen/:ente konden die uan fyet landt leer wel [pteecken/ yoe-wel lp naer wepnigf tjots malkanderen wocoer wel uertanden.

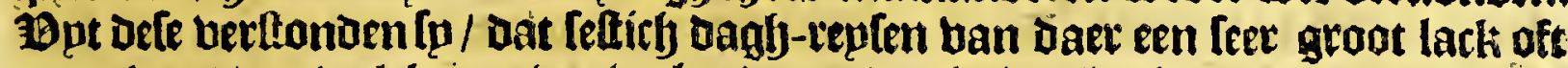
meps twas / op lue!rkes oeluer beel ende goede blecken lagfen/ ende dat 't volck

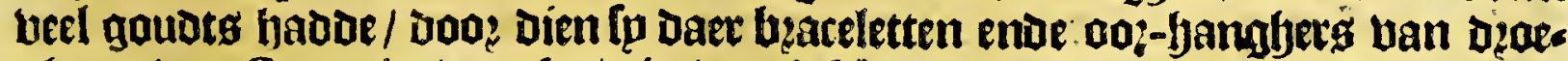
ghen: Dat Cornado Daer kennig uan bebbenoe/ oertwaerts was ghetrocken/

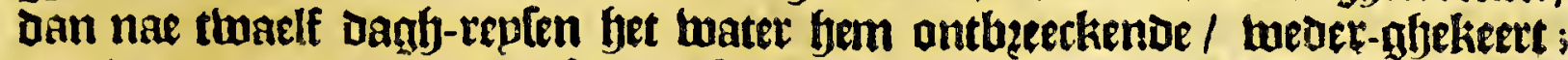

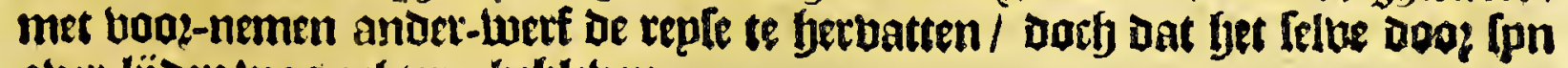
ober-lÿoen twas actbter-ghebleben. 
(het bier-en-twinticflte Capittel.

\author{
Vervolgh van't $t$ elve verhael van NIE U W MEXICo.
}

19 'tnieus ban dele rïck aammen bopen bethaelt/was Antonio de Efpeio fert begerity om dertwaettg te trecken / ende fyoc - wel eenighe ban fon bolkk

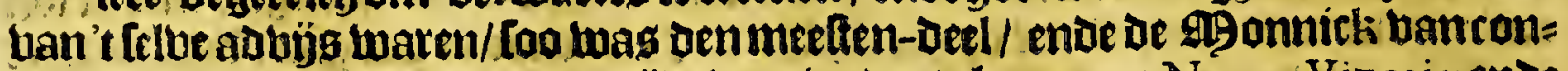
tratie gevoelen: leggende dat nutjot lwas lweder te keetenna Neuva Vizcaia, ende

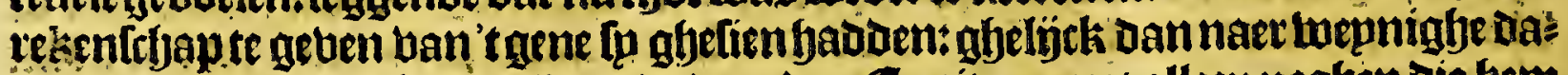
gen Den meelen-Deel Deden/iatende daer den Capitepn met alleenneghen oie bem wilden bolgben. Be welcke na dat bo bem wel geinfoemeert fadoe ban oen rÿck= Dom ban oeptobincie bozen betfaelt/.ende datter [eer beel goede metalen laatew

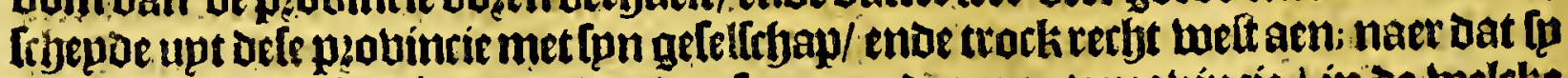

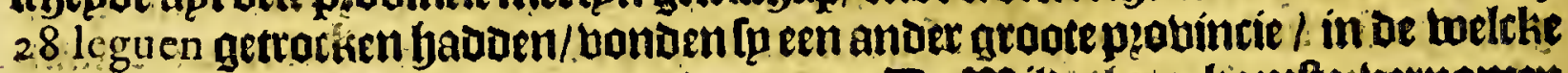

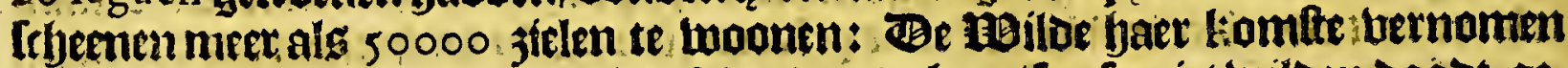

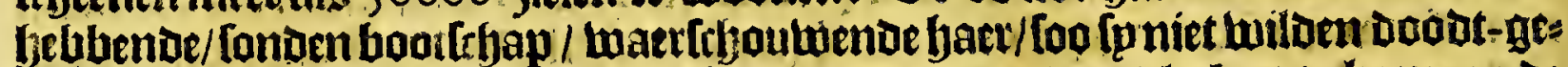

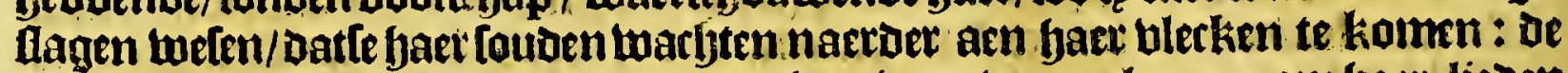
Capitepn gat faer boot antwoozoe dat bp niet en wag nekomen om yaer-lieben

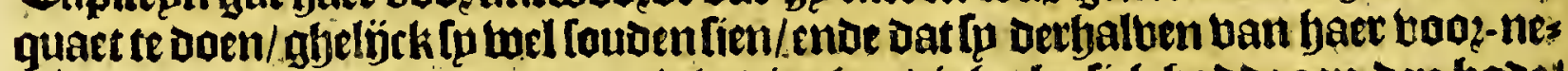
men wilden af-Itaen/gebende eenigbe dinghen die by bplief badoe aen ben bouel

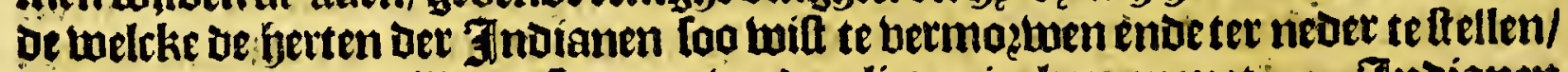

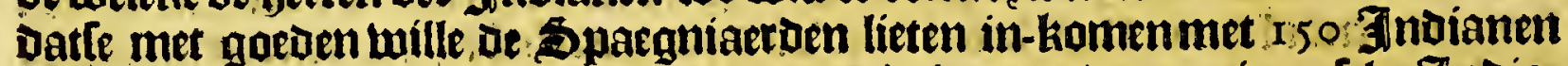

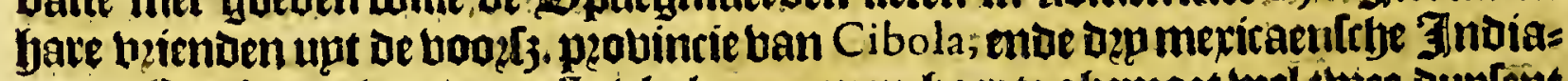
non. Een legue ban de eerlte blecke quamen baet te gljemoet wel thuee duptent Jindiauen aeladen met bittualie / vie de (Capitepn eenige dingen gatban klepn:

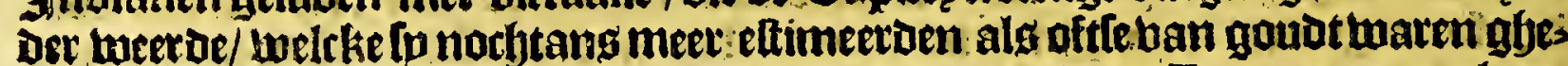
wee?t. Do blecke naerder komenoe / melck ghenaemt wot Zaguato; quam baer

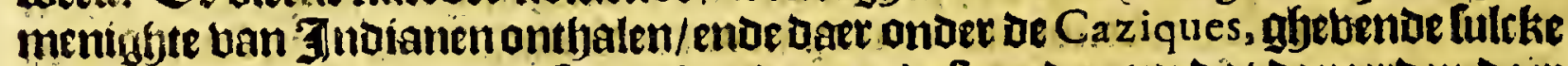
teeckenen ban bip[rbap/Dat fp meel op de arondt ftopoen om dat be peerden daex ober fouden treden; met ofle feelte deden fp baer in-tree ; ende twietien feer twel

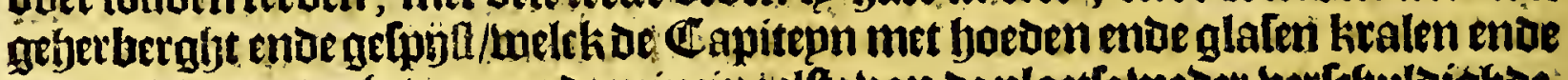

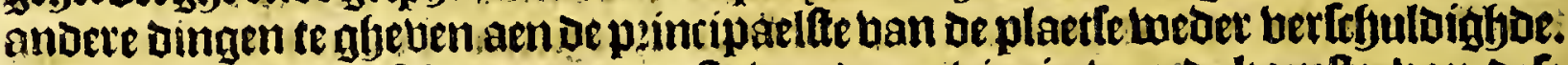
De Caziques lwaerfryaumoen de refte ban de pzobincie ban de komite ban defe

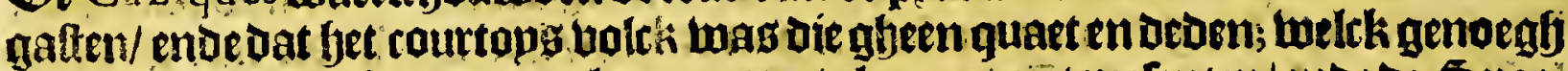
was om alle or refte te uritoecken om toe te loopen met peelenten/ende de Spats gniaerden tot haer plaetente noodighen; daer de Spaegniaerden oack gingben/ borb met om-ficht. Be Capitepn ghelbupdkte bier.en [onderlinghe Xifticljepat/ enoe maeckte de Caziques luijs/ bat dooz Dienfu te boozen abedetphyt baboen be

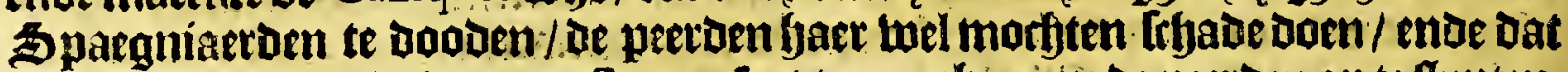
derfjaluen ban noode twas een lteenen fort te maecken om de peetoen op te flupten. De Gaziquen dit geloatrende/Deoen in kottentyot foe beel bolcks bp ken kamen/

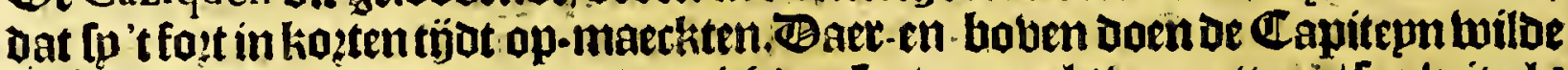

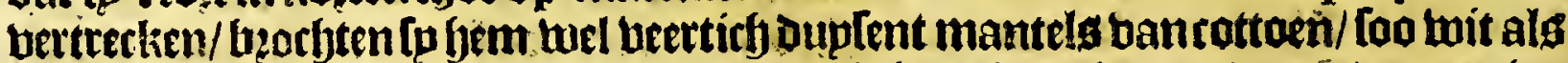
Adrechildert/ende veel ander dingljen/ende rücke minetalen/ onder ánoere cenige Daer litel libers in febeentelwelen. Bonoen Daer groote kennis ban bet mep? woeen berhaelt/ confoem bet rapoet ban dander/belangfende den rïckioom enve abuntantir ban 'tgoudt. Be Capitepn frm bertrobubende op fyet goet fert ban

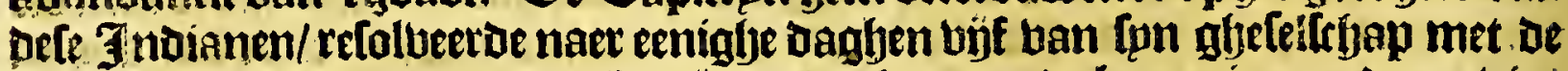
Inoianen [nn bienden te rugghe te laten trectien met de bagagie naer of p:obin: rie ban Zuny, ende felfs met bier abelellen inder baeft te trecten op oe ontoeckinge ban leecker rï̌ke müner daer bp kundtldyap ban yadde; ende met lpn guiden

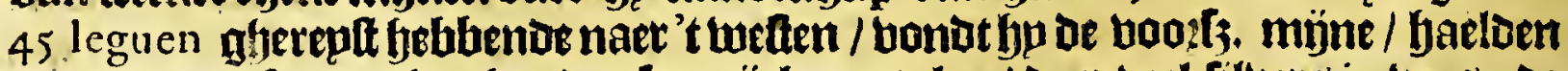
Daer upt met fon epglyen fanden leet rärke metalen / Daer beel cilbers in twas: De 


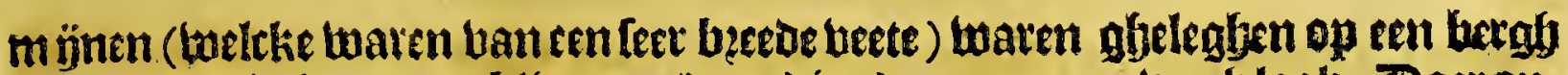

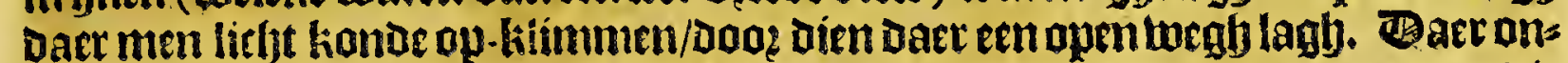

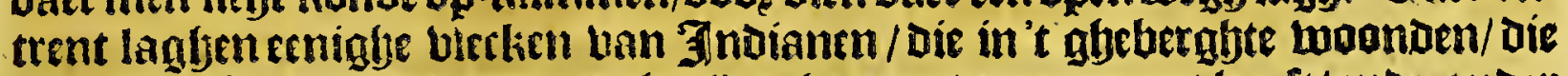

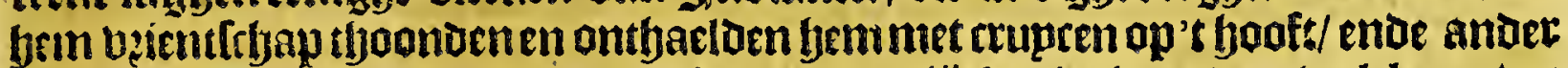

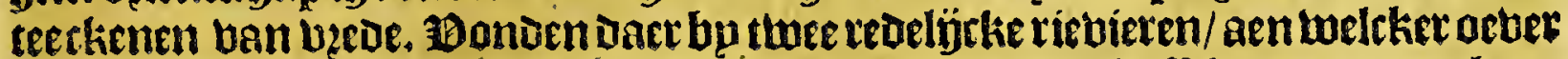

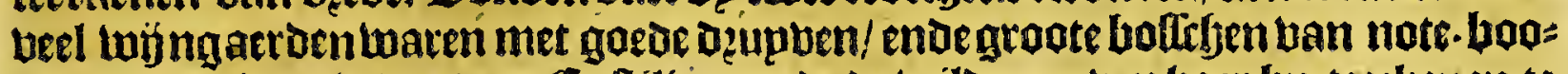
men: beel ulas als Dat ban faftilien; ende de twilden gaben baer bp teeckenen te

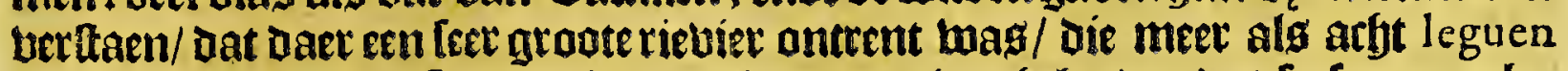
beerat was / Dan ae Spaegniaerden konden met ghelooben dat fp loa naer bp

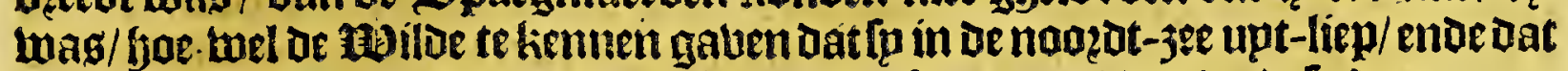
aen bepde de zjön uecl woon-plaetlen waten loo groot / Dat de dele jaet maet buetten bp en maren. Raec Dat De Capiteqn ban alles kennig badoe ghenomen/

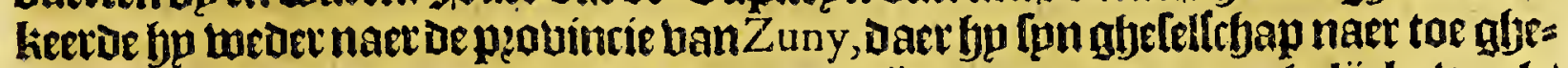

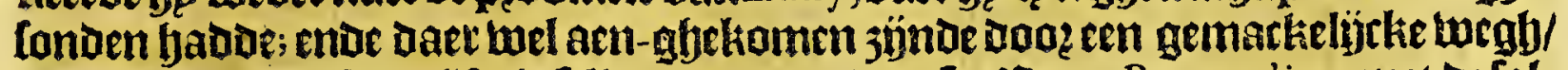

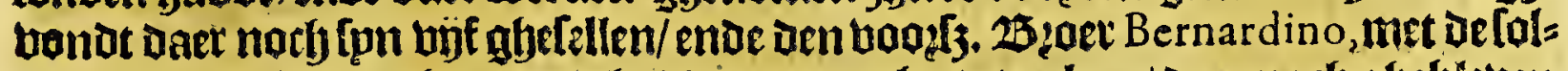
Daten/ die twel woo:-ghenomen badoen terugalje te trecken / Dan noch ghebleven

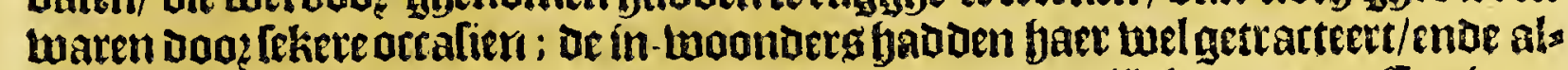

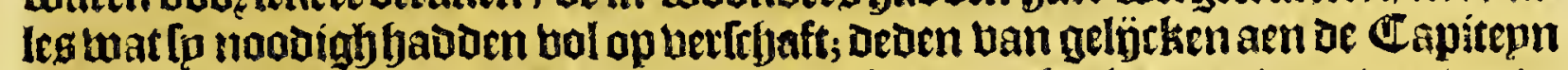
ende die met ferm quamen; welch fo met blüfthap ontfyaelden/ende gauen ben oe

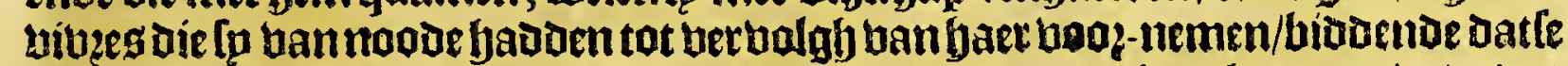
hae it tweder toiloentiomen/ende beel Spaegniartden met baer bzengen/ende Dat

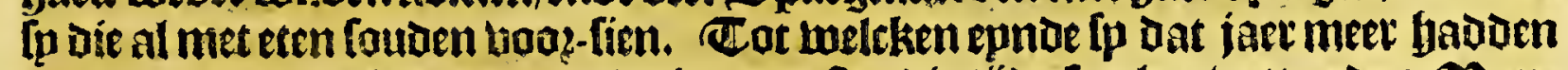

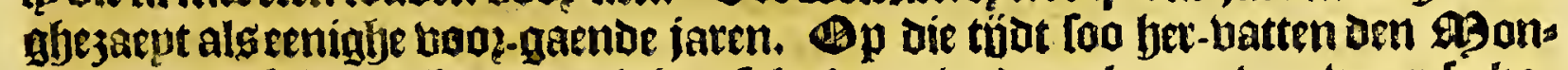

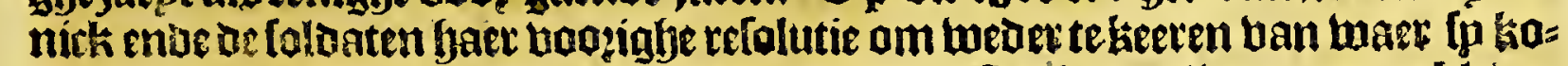
men waren; ue welche vertradten jünde ende de Capitepn alleen ouet-gebleben met acht foldaten : refolbeerde bp 't hegonnen werckte berbolglyen/ende ae rifs biete del Norte op te trecken: gbetrocken jünae ontrent de 60 leguen, tot aen de

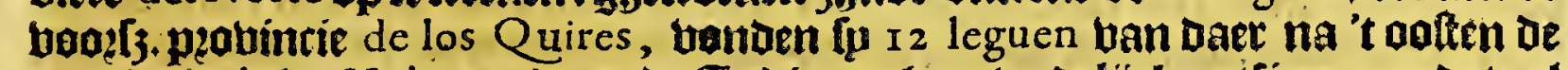

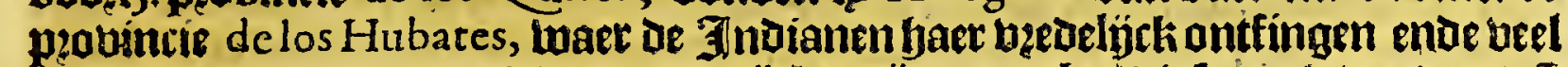

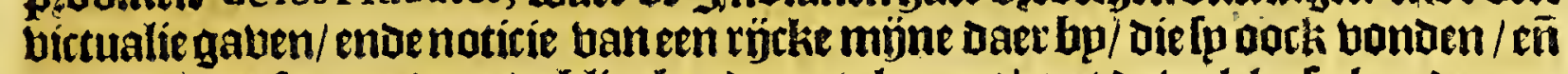
baeloen daet feer goede ende blinckenoemetalen upt/ met oe tweleke fp keerden na

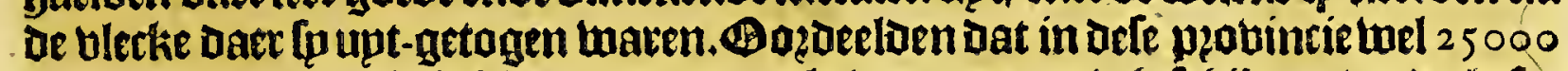

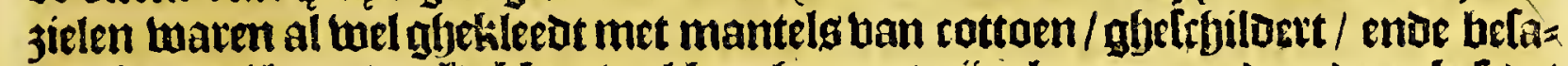

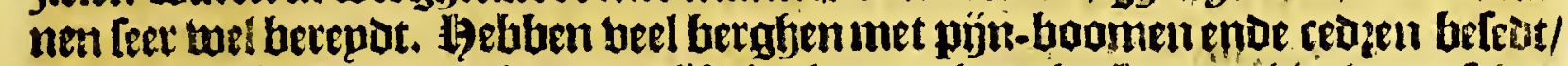

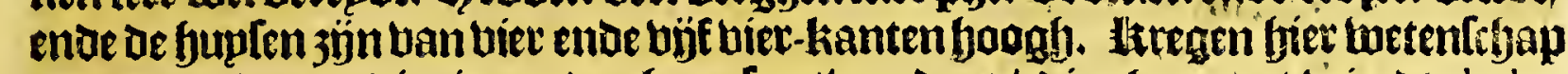

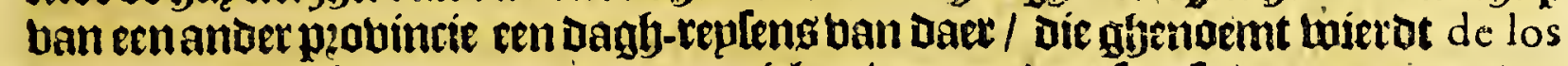
Thamos, in tuelt: e meer tain 40000 jielen twaren; dan foo [p Daet quamen/en wilde 't volch ban de lalloe baer niet 't eeten geven/norb yaer in baer woon-plaets

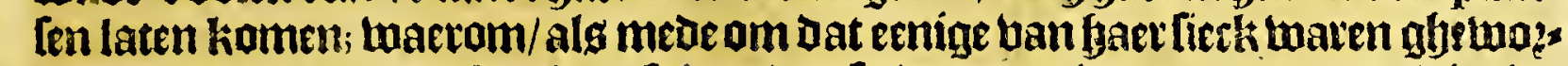

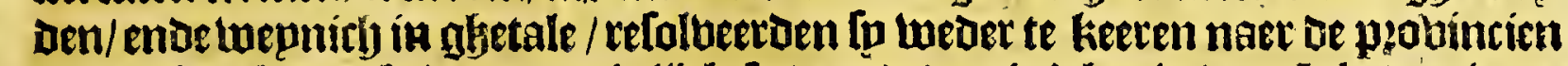

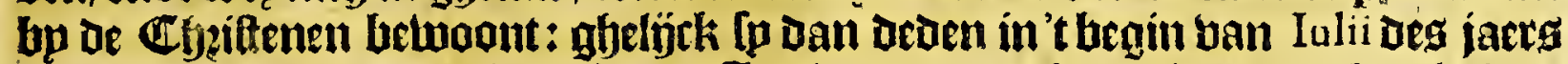

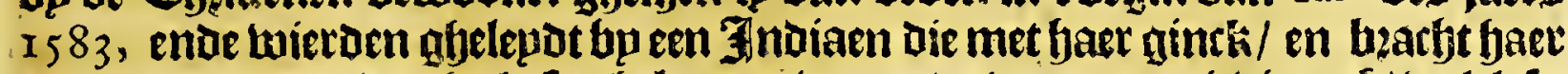
aoge een anderen twegh als [p ghekomen waren/te weteneen riebiere af / welck fp noemuen $R$ io de las Vacas, Doog dien daer fullken meniefte van dat bee aen beps de de oevers twas/ langijs twelckelp fondert ende thintirh leguen marcfeerien/ al bele wegly de ftieren ende lioepen pz̨ainatis bindende: Ban daer quainen fp aen De riebiete de los Conchos, waet doos fp in-agetrocken waten / enoe aen oe vale Iepe ban S' Bartholome ban waer ip de ontoeckinghe eerlt hadoen begonnen; ende als [p daer arribeetuen / honden dat 25 eer Bernardino Beltran met lpn ges fellefap daer beel daghen te boozen was aen-koimen / ende ban daev gyetrocken naer Guadiana. Ben Capitepn maeckte hier een vergae! van alle'tofeenc by ge:

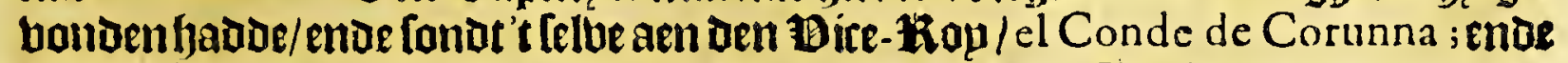

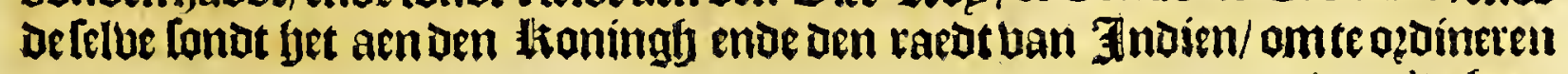




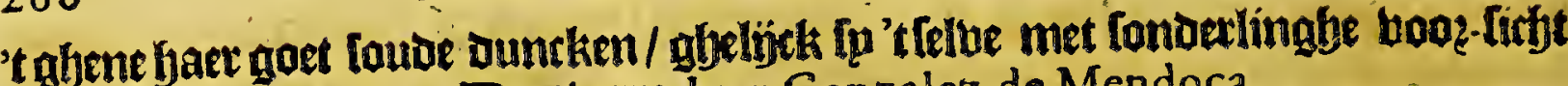
reforfebben ghedaen. Bug uerre luan Gonzalez de Mendoça.

een geintertipieeroen bief ban een Spaegniaert Bartholome Cano, gefryes ben upt Mexico aen $30 \mathrm{May}, 1590$, Iegft als bolght: Daer zijn vertrocken uyt Mexico ende enighe fteden hier ontrent, door bevel van den Vice-Roy, 500 Spaenfche Soldaten, onder het gebiedt van Rodrigo del Rio Gouverneur van Neuva Bifcaia, om te gaen vvinnen een groote ftadt ghenaemt Cibola, vvelck is gelegen 400 leguen van GMexico naer hec noordt-vveften, midden in' $t$ landt $:$ ende is by raport een feer groote ftadt, fo groot als Mexico, ende een feer rijck landr, beyde van filver ende goudt-mijnen, ende de Koningh van 't landt is een machtighe Prince, ende en vvil hem nier geven onder fubjectie van den Koningh van Spaegnien. Dacr vvaren eenighe Ambaffadeurs van den Vice-Roy dervvaerts ghefonden; ende 't vvordt ghedacht dat fy daer doot zijn gheflagen, door dien men gheen nieuvvs van haer en verneemt. Hat bozoer in dele ontoeckinghe ig boo?gheballen/enlyeble tot noch toe niet tonnen bernemen.

\section{(jet vijt-en-thintirjtte Capittel.}

Verhael van den Tocht van Don Iuan de Onate, naer $\mathrm{N}$ o v o MEX I C $O$ in den jaere I599.

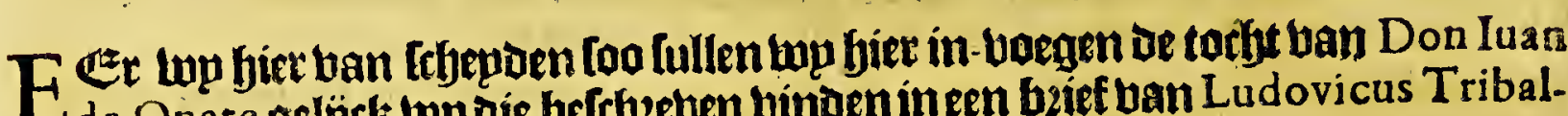

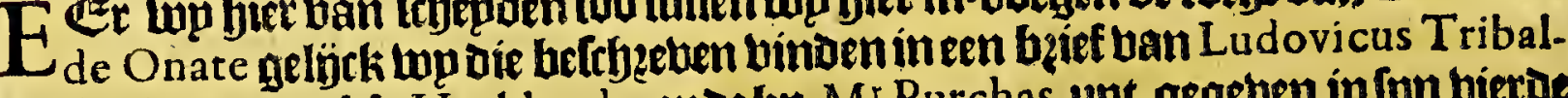
dus Tolecus aen $\mathrm{M}^{\mathrm{r}}$ Hackluydr, ende bp $-\mathrm{M}^{\mathrm{r}}$ Purchas upt-gegeben infon bietoe turk han Inn groot werck.

Don Iuan de Onate lofepde ban Mexico in Den jaete 1599 met een legherban 5000 pertoonen [oo Soldaten als andere/bzoutwen/jongers ende kinderen; nam beel bictualie met bem/ beel ltbapen ende gepten/olfen ende peeroen; beel twapes nenende ammunitienende andere noodr-faeckelijekfeden tor fulcken tocht; ende

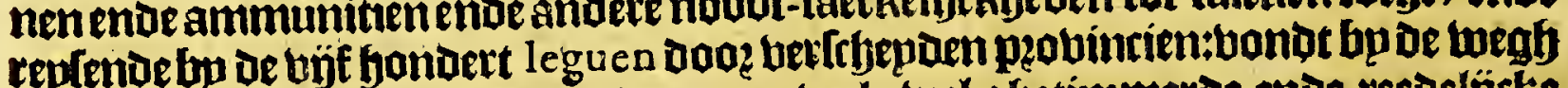
uerfebepon bolct:eren ende natien / met beele thel ghetimmerde enoe reedelijcke

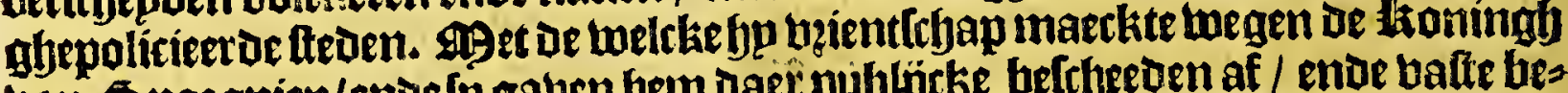

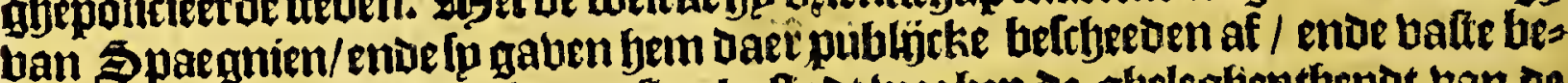
loften. Cot dat hp quam bp een ftetcke ftadt wedjen oe gheleqfientyept ban de

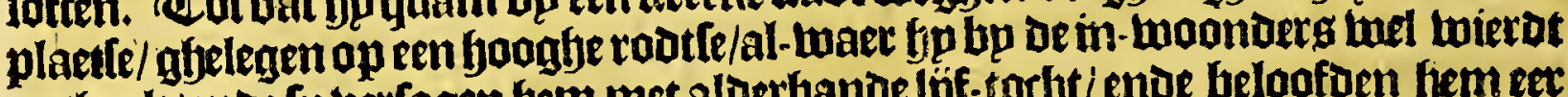
onthaelt/ende fu verfagen bem met aloerbande líf-todjt/ende beloofoen bem eet langh fo beel te leteren alg bp tot een bozoeren torgt foube uan naode beblent; Den

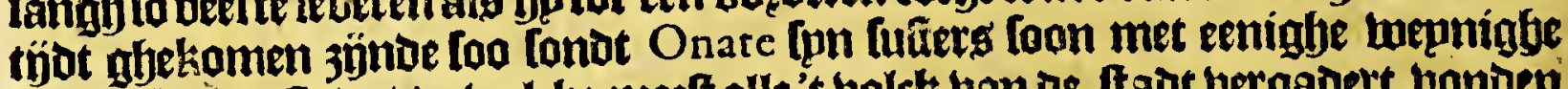
foldaten in de ftadr / de welcke meelt alle's bolck bau ae tadt bergadert bonden op De marckt; enoe Detwijl fn daer befief waren met hoopen 't ahene [p noodicty

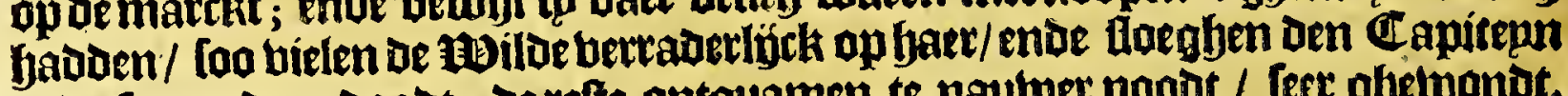

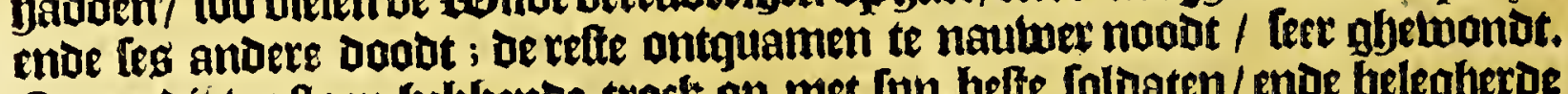
Onate dit uerftaen behbenoe trock op met lpn beffe Colbaten/ende beleaberde

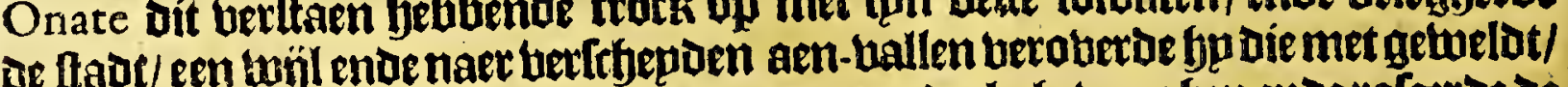
ende hermoozoe meef al't bolck/ ende nam een Deel ghetuanghen enoe ratertoe de

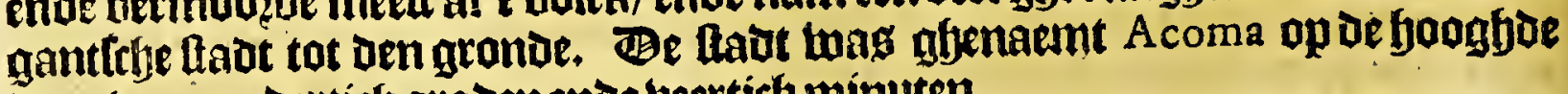
van twee-en-Dertity graden ende veertich minuten.

l)p trock met gemack boolts/ tot oat bp quam aen een marfitiabe grooteltaot

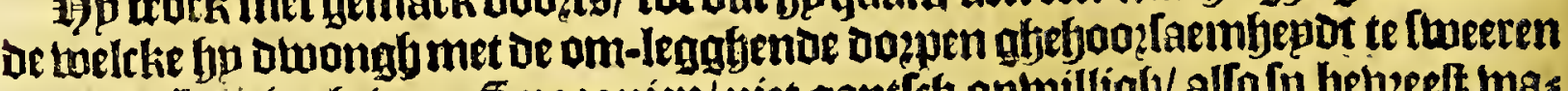

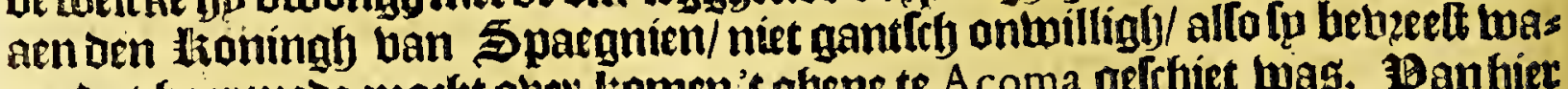
ren bat gaer mede morlyt ober-komen't ghene te Acoma getefiet was. Ban bier

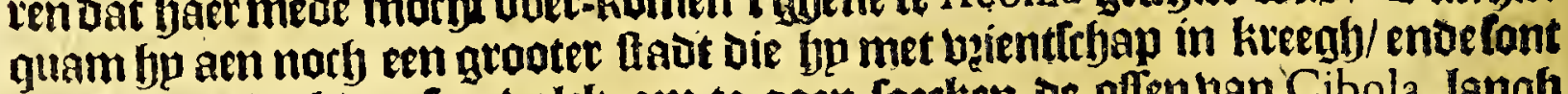
banfiereen teel banfun bolck om te gaen foetken de often wan Cibola, langh bode orfen befient gemareckt doo? Vafques de Coronado ende andare. De belcke tonel 


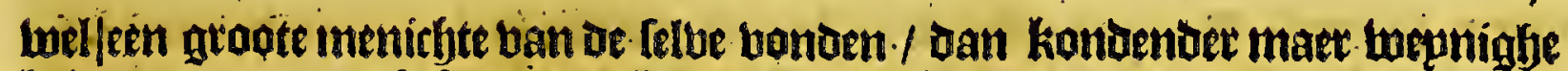

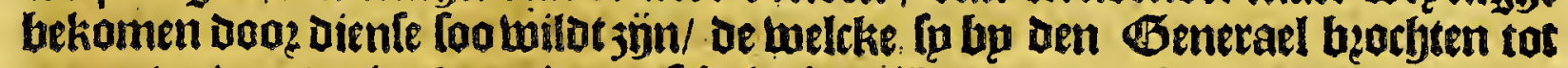
groote betwonderingly ban't gantfrbe Iegher. Baer naer gheraden vimbende te

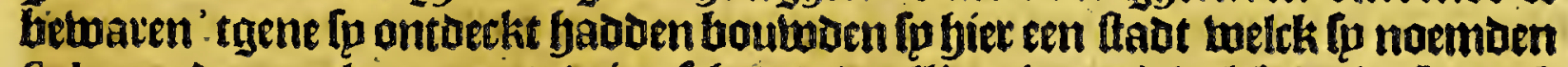
St lan, ende maeckten groote beientfobap ende alliantie met' $t$ tolck welck Ip laetfit

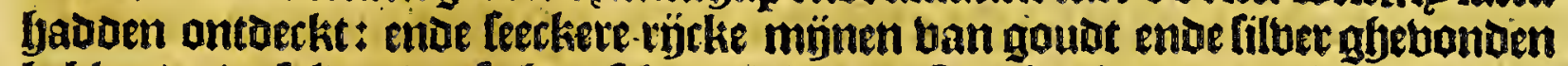
Gebbende / refolbeetoenfp yaer felven daer tot rufte te beghebenende fage neerfice

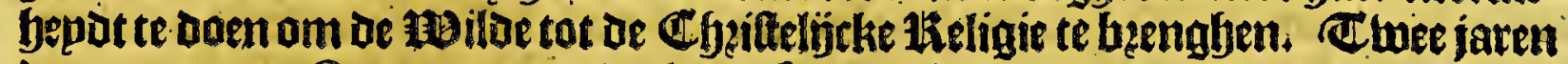
baer naer nam Onate met een Deel ban fpn balck een anderen torbt hooe naer de

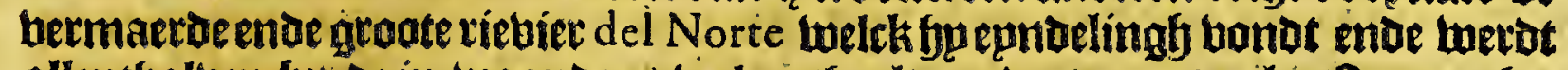
allentbaluen bp de in-woonders thel ontbaelt: ende quam ten laetfen aen bet lack Conibas, op twelckes oeber fp een ftadtanfien bp oe feben le guen langh ende

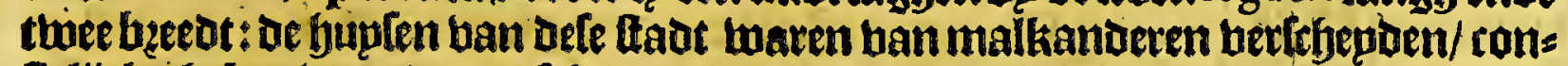
Atelíck gheboutut ende met fofjoon gheboamte ende fraepe bouen betciert / ende oock fomtyjots met water ban den anderen berdeelt. - Baer en bertjoonde hem gheen volck; entoe Onate niet bettien jünoe ban brquaente marbt / [onot alleen

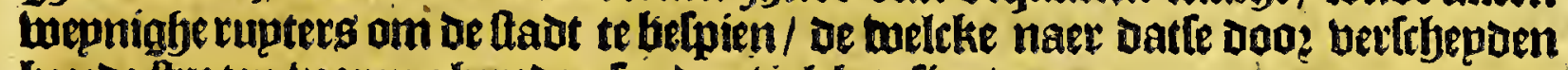
beede ltraten twaken gbereden fonder bialck te fien/quamen aen ern groat enve

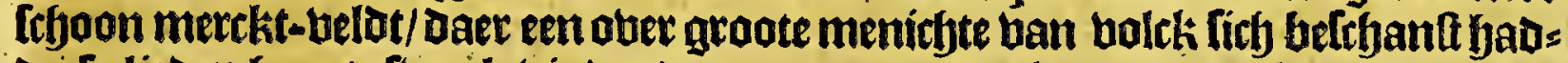

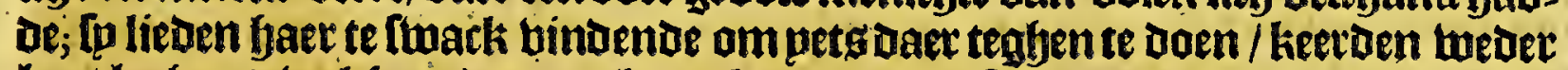
bp 't legher; 't twelclis mede naer bupg keerde/, upt-ftellende den aen-tocht op loo grooten ende boldk-ribckenltadt tot op een ander tiobt.

\section{(1)et [es-en-ttwintitytte $\mathfrak{C}_{\text {apittel. }}$}

\section{Belchrijvinghe van de kufte van Nov $A$ G I I C I A, ofte GUADA TAIARA op de zuydr-zee ghelegen.}

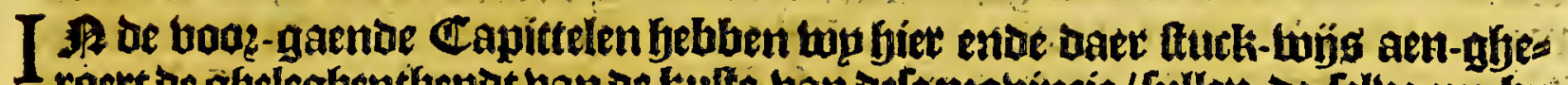
1 roet be ghelegfentbepot ban oe kulte ban oele peobincie / fullen be felloe mu bp een uerbalennaer 't gfene dat Thomas Fuller op oe vopagie met Candifch, ende: De bouagie oock[elfa berbaelt. De haten han St Igo ftelt bp op 18 graden $50^{\circ}$

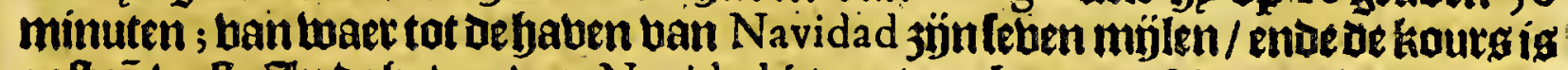

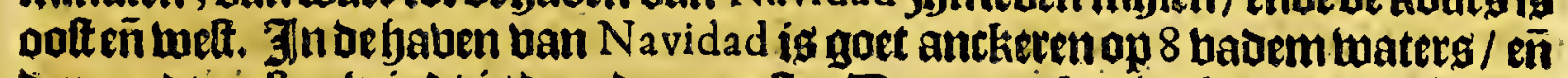

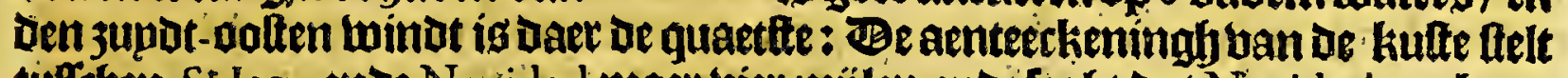
tufteben. $S^{t}$. lago ende Navidad maer viet mỉlen;ende legft Dat Navidad een bape

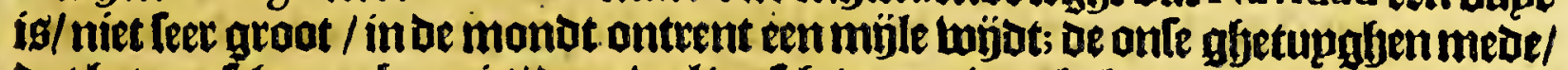

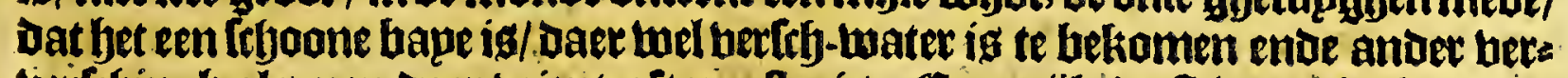

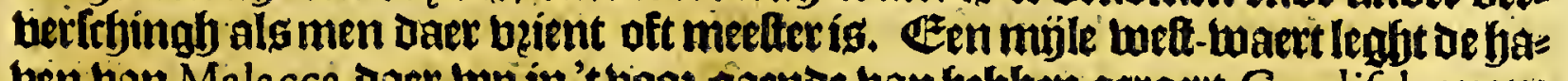

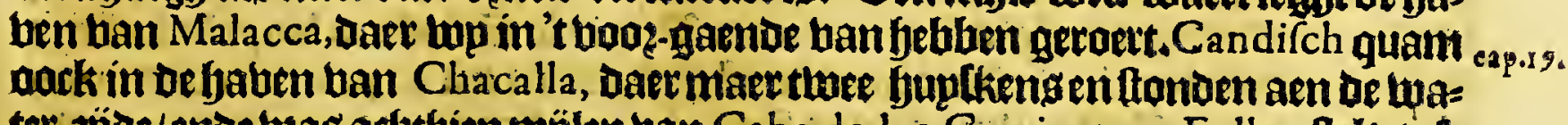

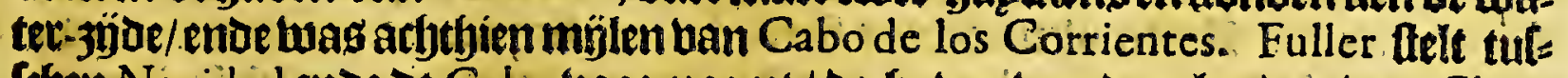
fgen Navidad ende de Cabo tooz-noemt/ be Gaberi ban de eplanden ban Chiametla, ban Navidad r onjilen/entae theckende ooft enbe taeft: defe eplanden jün nafpn Ieguglien berlchepaen ban Cabo de los Corrientes 30 mülen/ende de kourg

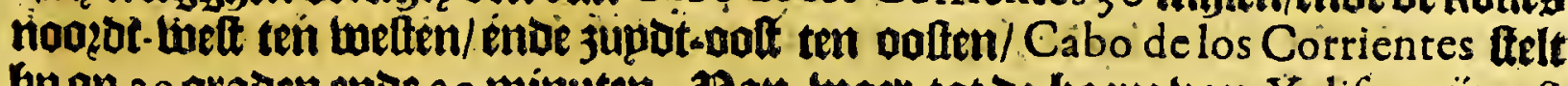
hp op 20 graden ende 30 minuten. Ban twaet tot de haepe ban Xalifeo $3 \mathfrak{y}$ mijlen/ oele bape legghende op de foogfte van 21 gradeneneen balf / ende daet is goet anckeren in neglyen baoem waters ; of tweft-3upot-Lefte winot ig daet de quactte. De eplanden las tres Marias ftelt fjp op 2 I graden ende 20 minuten/tot de

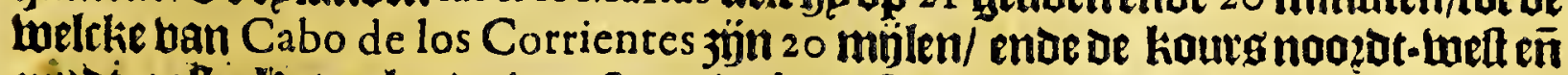
3upot-oolt. Het eplanot ban Sant Andreas ftelt bpop 22 graoen; welch ist een

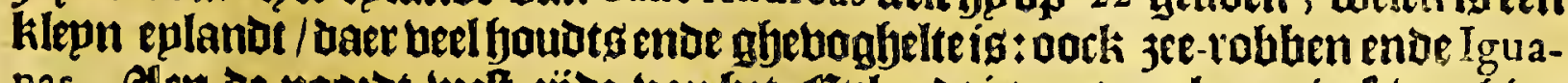
nas. Alen de nougd-welt-jijoe ban bet explandtig goet anckeren in febentbien badem 


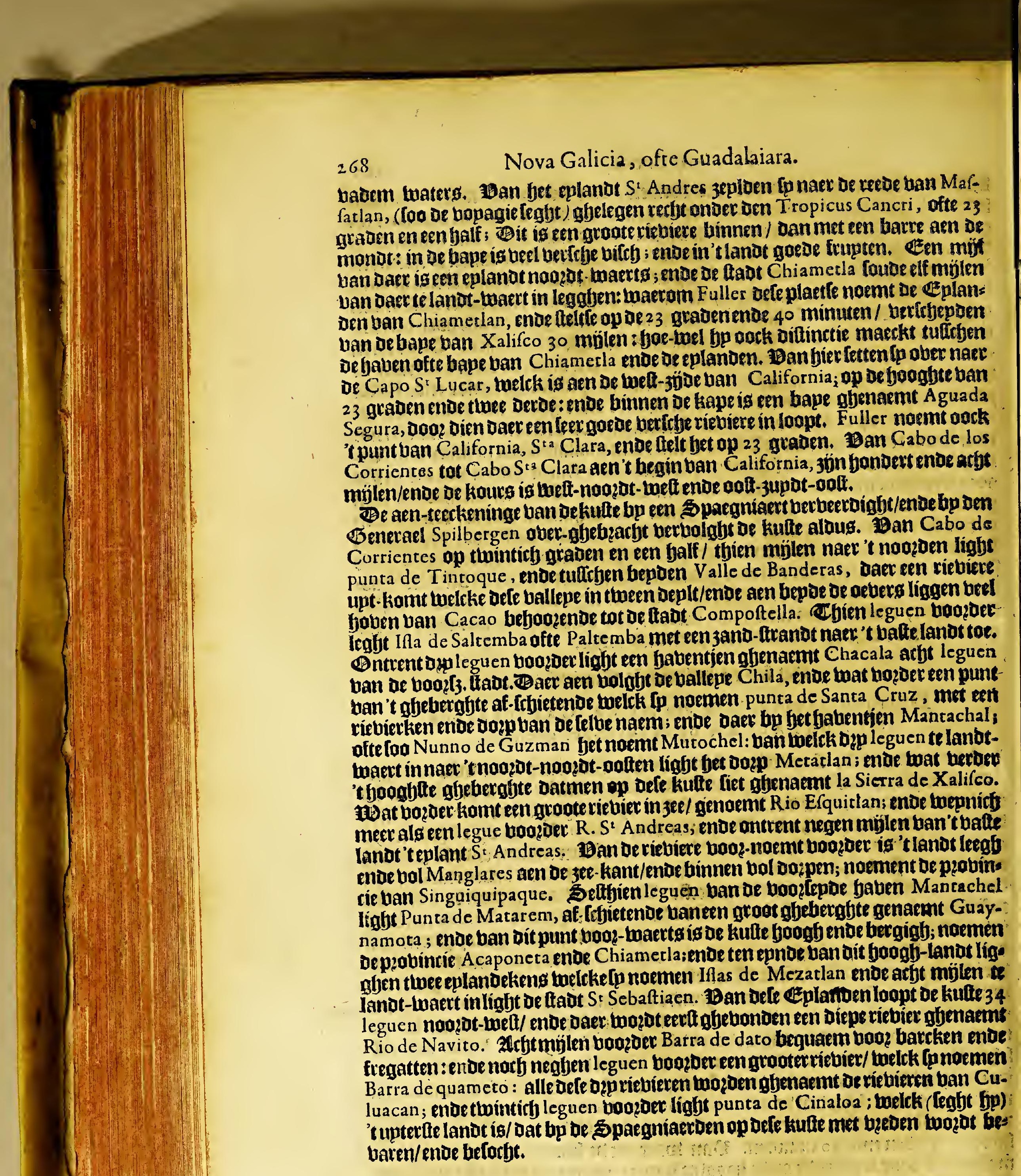

BESCHRIL 
đan

\section{W E S T I N D I E N. Met tebende 25 oeck. \\ G V A I I M A A.}

Wet terlte Capittel.

Befehrijvinghe van de Audientie van GV A T MA I $A$ in't ghemeyn.

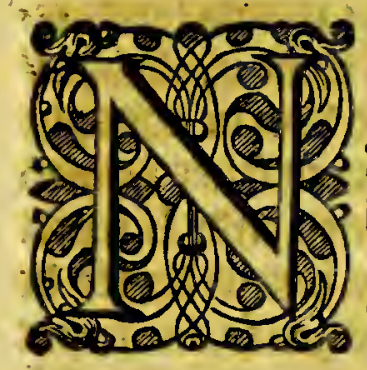

Aelt de Zubientie ban Nova Hilpania, Daer wp

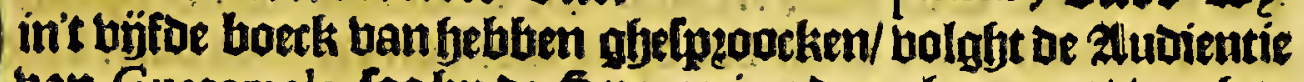
ven Guatemala, foo bp be Spaeguiaerden ghenaemt/ wegten

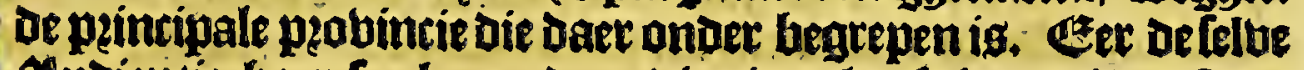

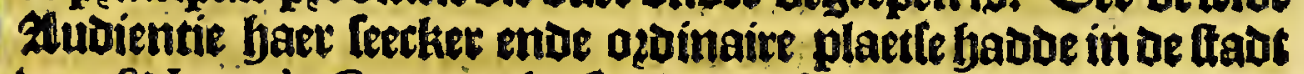
ban S' lago de Guatemala, foo twietotfe ghenaemt de los confines, entue begreep alleenonderfich de p2ovincien ban Nicaragua d.4. 1.s. enoe Guatemala ; Dan nu is baer begripp grooter/mant hegint van ve upterfte pas Itn ban Tecoantepec, endoe neemt Gaet epnoe aen De laetfee palen van Cofta rica;

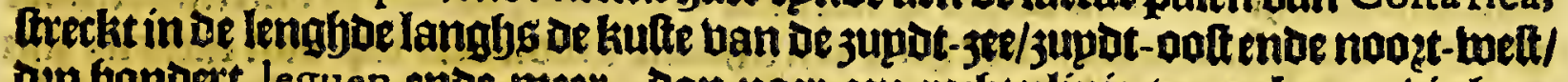
Dap fonoert leguen enoe meer; Dan naer een recbet linie te reeckenen/isf faer

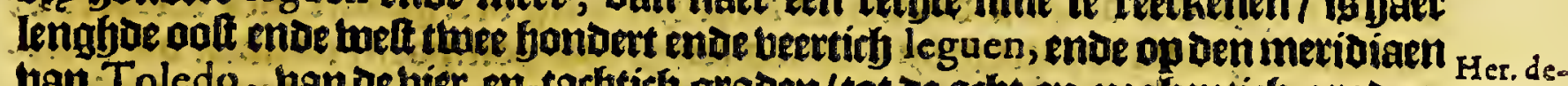

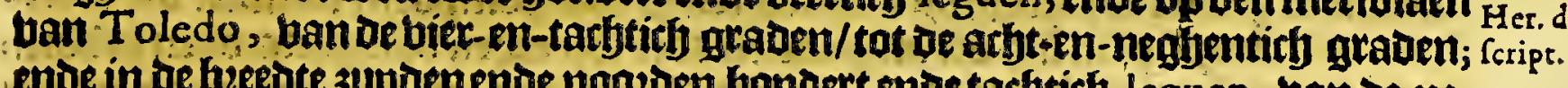

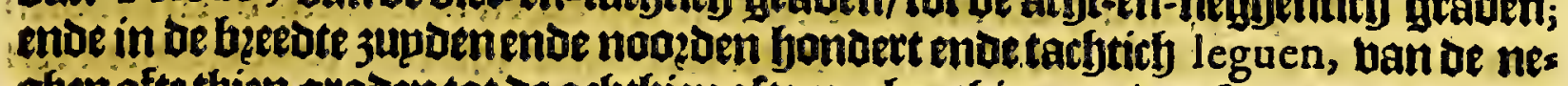

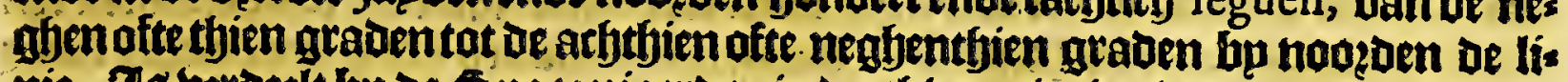

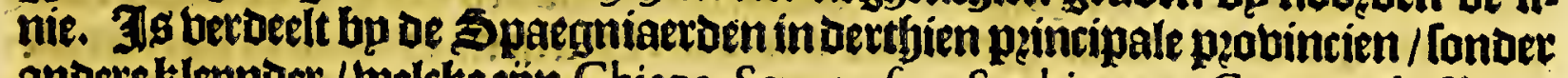
andere kilepnoer / melcke 3 inn Chiapa, So conufco, Suchitepec, Guatemala, Verapaz, Ycalcos, San Salvador, San Miguel, Honduras, Chuluteca, Nicaragua, Taguz galpa, ende Cofta rica: In alle oefe probintien lpeeeckenfe differente tae:

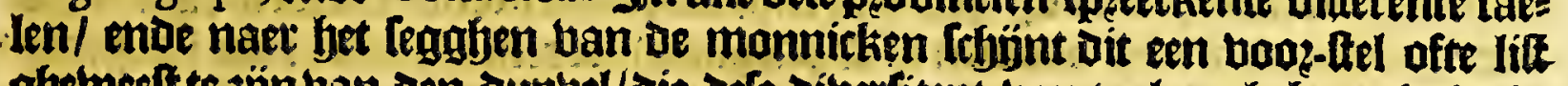

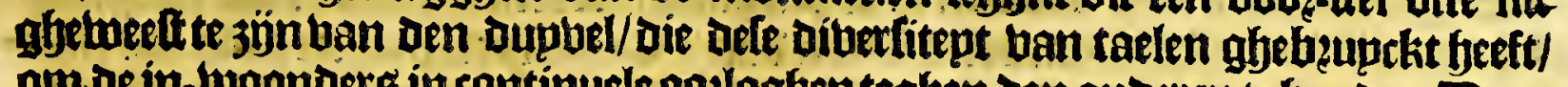

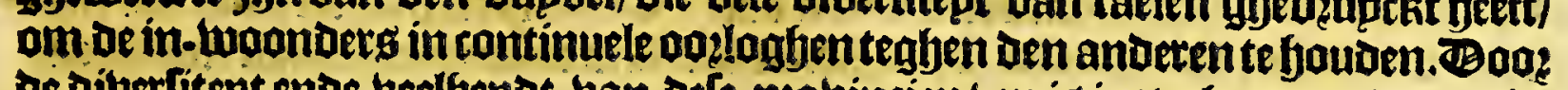
oe diturfitept ente beelfeptot ban dele peotincien/ en is in't gbemepn daec niet bplonders ban te fegghen / maerfullen de epghenlefjappen van't lanot berfalen

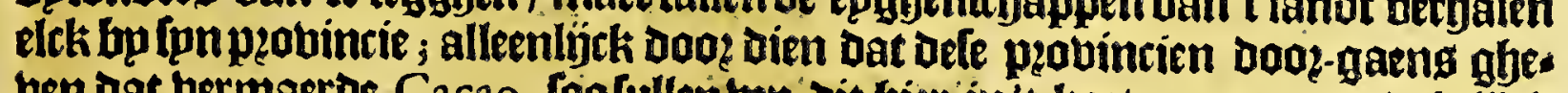
wen dat bermaerde Cacao, foofullevibu bit hier in't kote aen-roeren/ ghelfipck

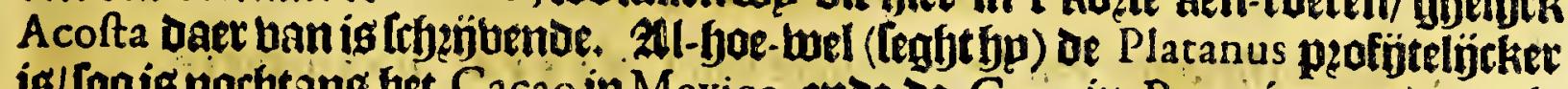

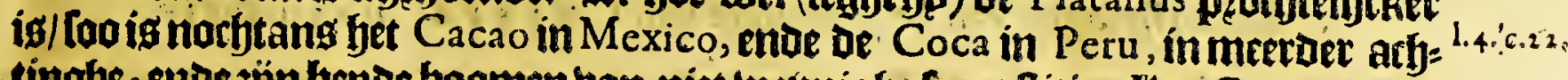

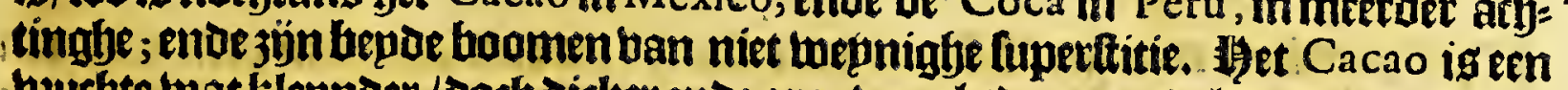

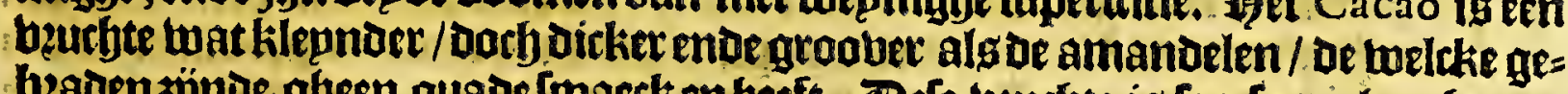

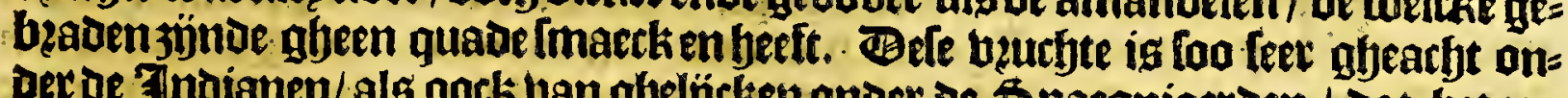

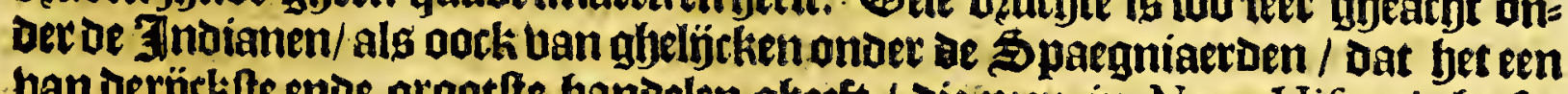
ban Derijethete ende grootle banoelen qbeeft / Die men in Nova Hifpania beeft:

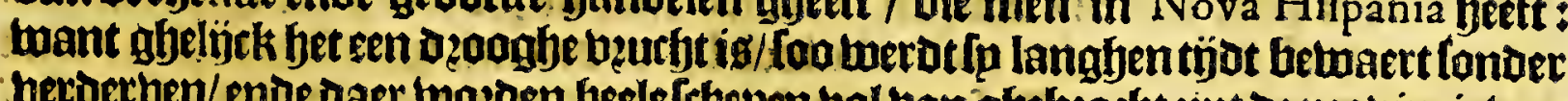

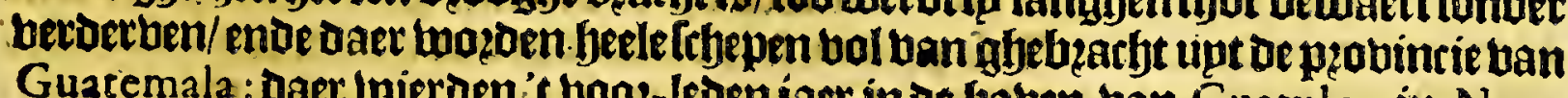
Guatemala : Daer Laierden't boot-leden jaer in de Jaben ban Guaculco in Nova Hifpania meer Dan fondert Dupfent balen betbzant baneen engelffibe zef-roober: 
270

Guatimala.

(Defe was Thomas Candifch, oie in [pin Joumael feght / Dat by bier bontert fare

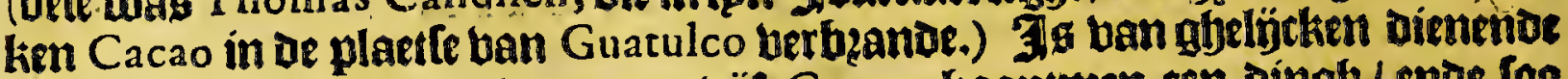
in de platte ban munte / want met un̈f Cacaos kooptmen een dingy / ente foo

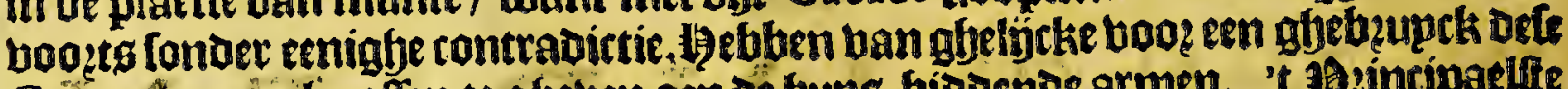

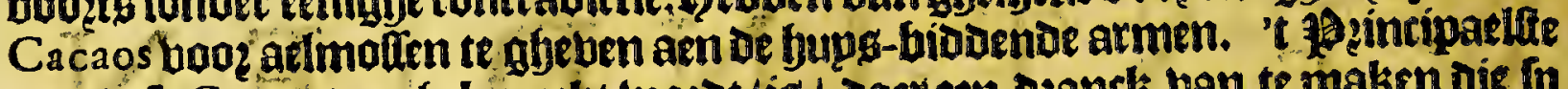

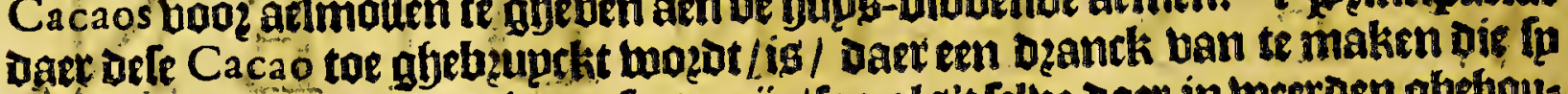
Chocolate noemeri; ente is een lotternije/ foo ald't telbe daer in loeetorn ghefjous

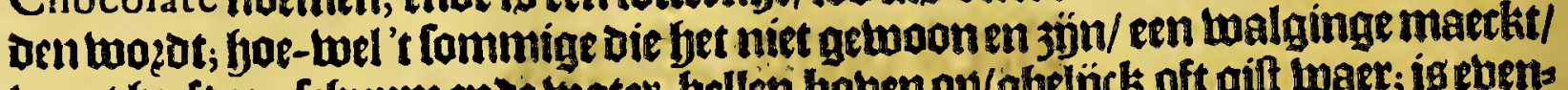
want beeft een lcfupm ende water-bellen boben op/oghelïck oft gilt waer; is etert: wel ben petieulen ozanck daec oe Spaegniaerden ende Indianen foo begl ban

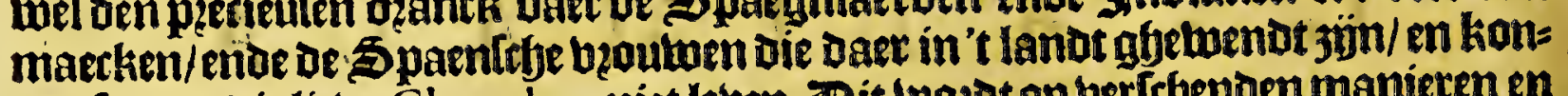

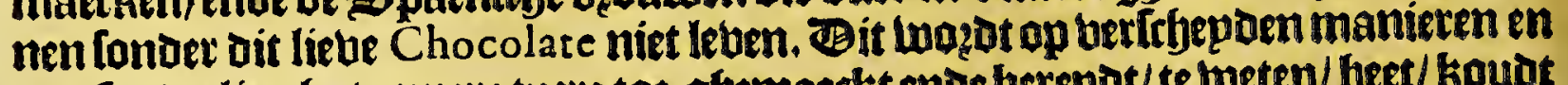
met fonoerlingle temperatuere toe-ghemaeck ende berepot/ te weten/ beet/ houd enoe aetempert; Doen daet oock lpecerye ente veel Chilos Dat is 25 zeflilitrye peper onder: maecken't wan ghelÿrke in een pafte / welck fu boen in Doofen enoe andere baten om te betuaren/leggen dat bet goet is boos oe boeft / vooz oe magbe/ ende tes

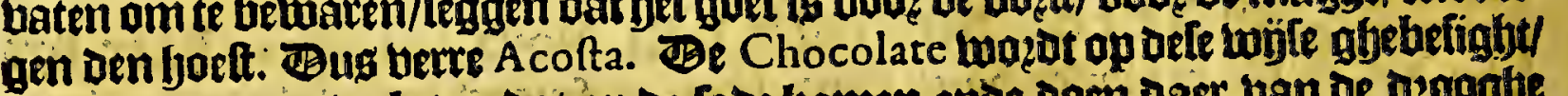
nemen water ende laten dat op de fode liomen ende Doen daer uan de deonghe Chocolate in foo beel als baer goet ounckt; ende roeten bat met een feker bouten menilentien [oo fp't noemen/tot dat de Chocolate ganitfib berfmelt entoe fich met

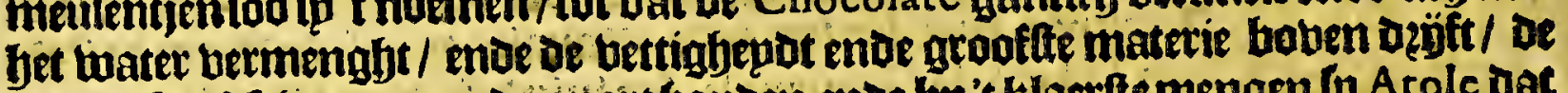
welcke fp af-Crjupmen ende apart bouoen;ende bp't klaerte mengen fo A tole dac is leker comporitis than be blamme van bet Maiz, ende als Ip 't willen Drincken/oft

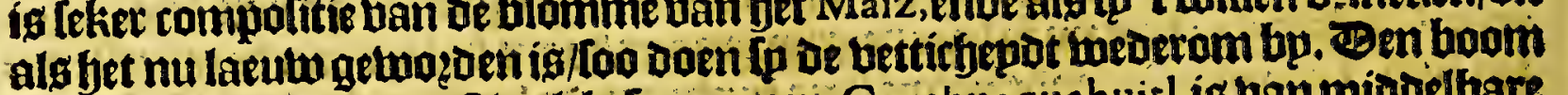

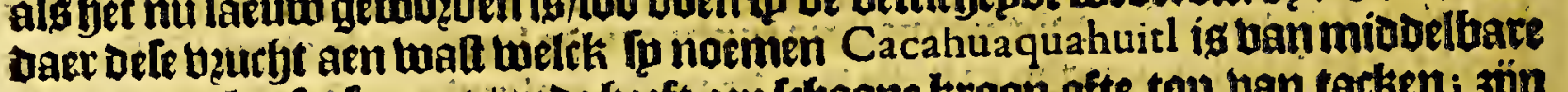
groote / mel gefattometert / ende feeft een foboane kroon ofte top ban tacken; jön

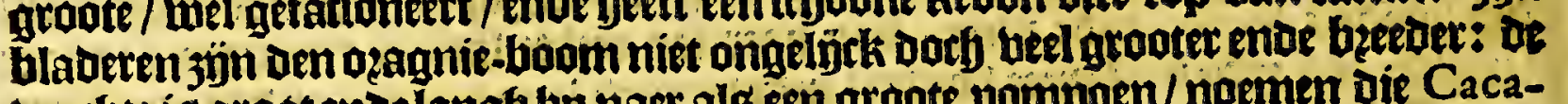
beuthte ís grootende langh bp naet als een groote pompoen/ noemen die Caca-

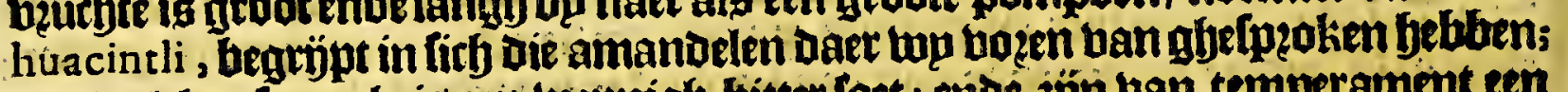
oer welcket Imaerk is een wepmiaf bitter loet ; ende jýn ban temperament een

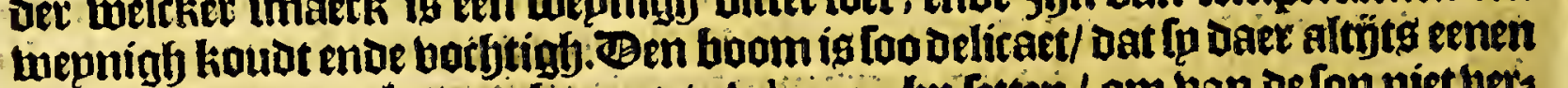
anderen grooteren boom gljeriaemt Atlynan, bp Ietter / om wan de fon niet bets bzandt te wozoen/ Den welcken alleenligrtken dienende is/ om ferm frbaoulwe te

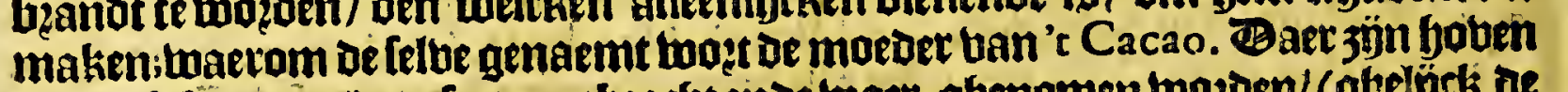

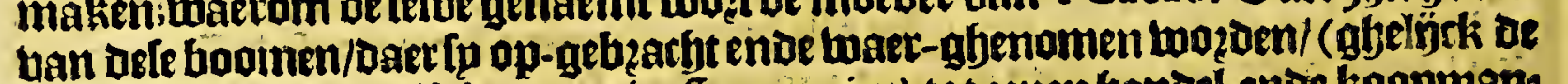
wïngaerdenende olije-boomen in $\$$ paegnien) tot eenen bandel enve koopmans

d.4. 1.8. Tchappe. Herrera Teght/Dat de [en boom ban't Cacao heeft bladeren ald een caftas c. 9. nien-boom/boe-wel grootec / bengbende bloeffemenoe beuctiten alle maenoen.

\section{C $\mathrm{H} I \mathrm{~A} \quad \mathrm{P} A$.}

\section{Het tweede Capittel.}

Befchrijvinghe van de provincie van C н I $A$ P A, in'tghemeyn.

D ¿z peouincie ende fyet 2sifbom van Chiapa, welck [un naem beeft naet een plaetfe ghenaemt Chiapa, welck de peincipaelfte is ban bele peobincie; is een

Her. de- midoelanteche pzobincie/tulteben de probincie ban Soconufco, die ghelegen is aen

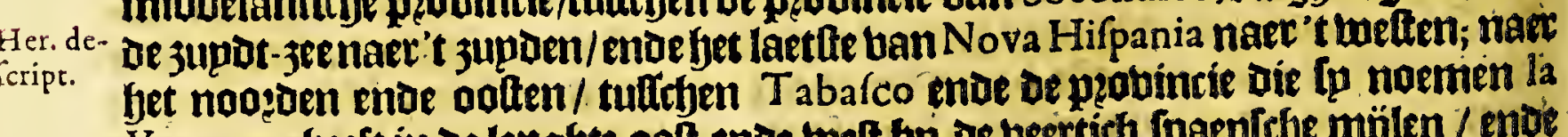

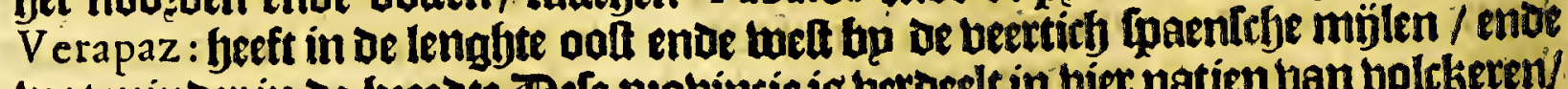

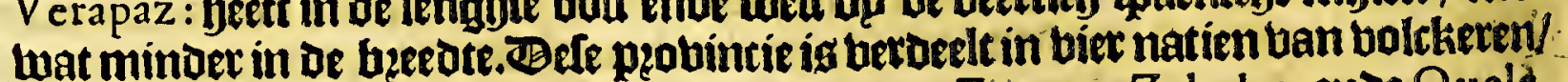
d. 4. l. . o. Die different jün ban tale / te tueten Chiapanecas, Zoques, Zelcales, ende Quelè-

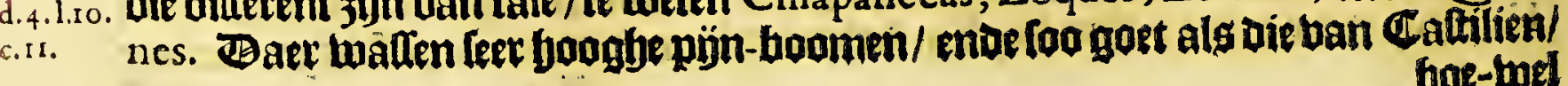
bag-bod 
Het Cevende Boeck.

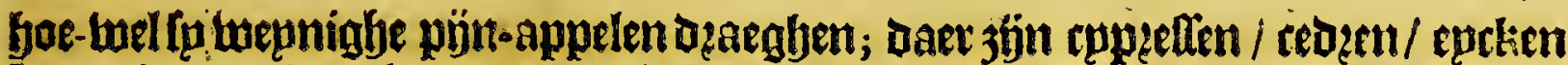

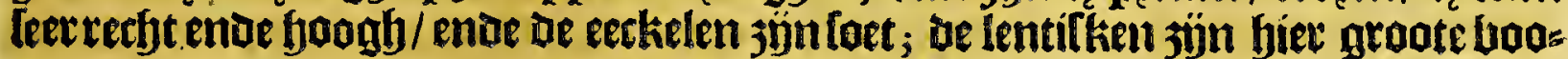
men; de Myrtus is een kilepn boomken ofte beefter/minder als de Lpaentrbe/ende oe beuchten grooter : De haegh-appel boomen jÿngroot / enoe de beuchten kileun. De frupt-boomen ban Spaegnien twalten daer Leer wel:Daer jún oocknote-boo= men/ loo bel van Spargnien als ban 't landt/ De berghen gantfly bol/ hoe-wel

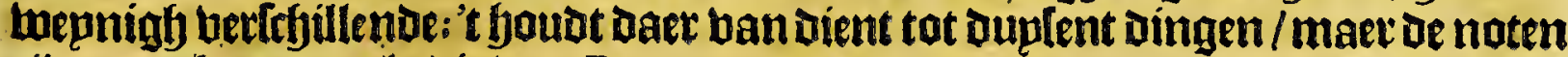
jän meer benepen als die ban Europa: de dzupben luozden ríp op faer fap[aen/eñ in Dien daer meer wijngaet ben waten aheplant/ [ouden lwel peofpereren; want

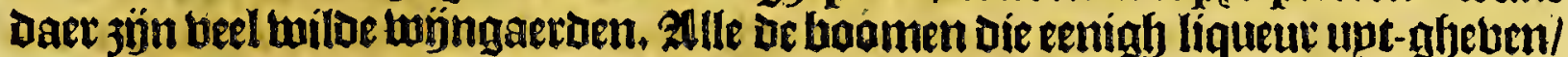

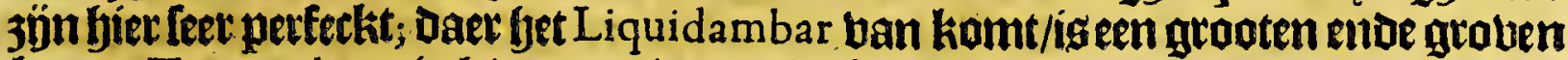
hoom: Tecomahaca is kilepn;eenige der ferlten jön wit/ander graeu als thierooc/

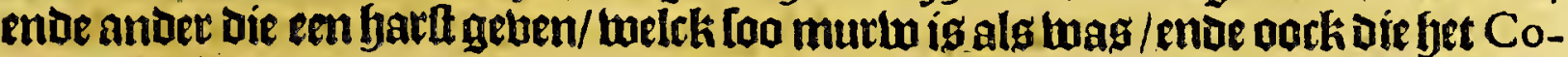

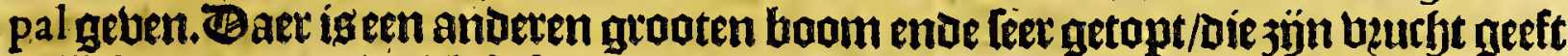
gelfick als pepet / twelck lp legghen te tueten oe Malagueta, die de Swatten in Guinea gheluguptken/ welck wa noemen grepn/ (Dan jün Daer in hedzagen) ende

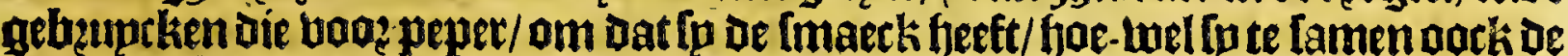
tmaeck feeft uan de nagelen: Daer haft groote menighte ban Caca onde andete boomen/ die ae in-gebazene ende de Spaegniaerdenghebzupcken tot Dzancken: Daer ís ahundantie ban Guayacan, welekig een groaten boom met wepnigh bla= veren: Bock Cannafiftola : enoe in Copanavatzla is een toomken tueltk eenrao=

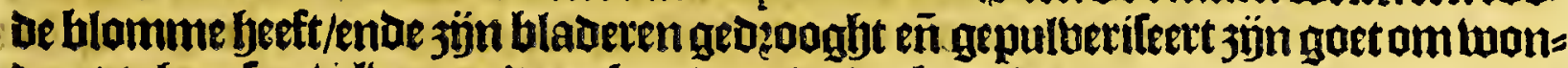
Den te gfjenelen/albaren't oock oude ende berkancker oe wonoen; enoe't water

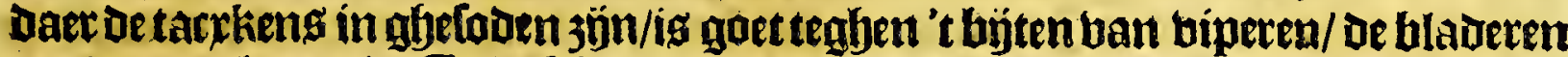

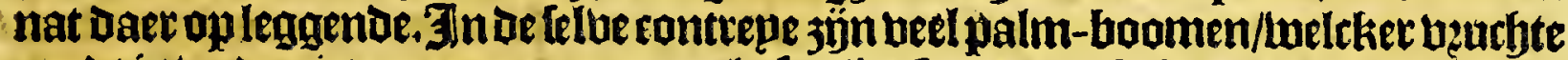

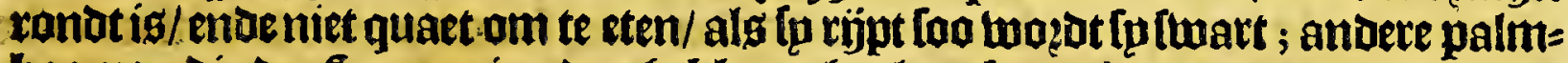
boomen die ote Spaegniaerden fehluen aheplant beenghen goede dapen boat/

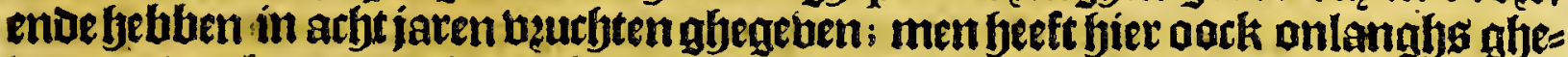
bonoen dy boomen die een hatf gbeben als Storaque, boe-wel beter ban kou= leur: andere groate boomen die blommen Dzaghen als Azahar (Dat jún ozaz= gnie-bloemen) ende die oock (o a riecken/gbebupeken die in den dzantk die fo ban de Cacao maecken /ende binden die gaet te twelen boas de maghe: In Chicomu-

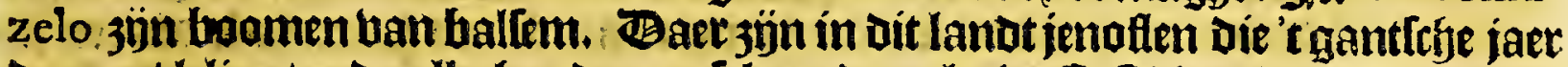
tueren/lelien/entoe allerbande moer-krupden als in Caftilien; de boonen eens ghelaept / bueten beel jaren/endebebluen't gantechiaer boos bloemen: Daer sün

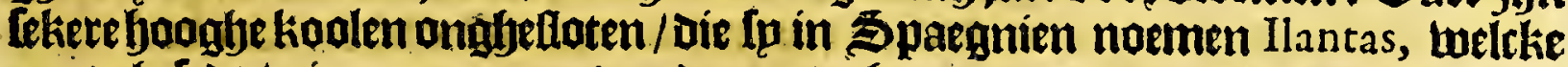
eens ghetedt / nimmetmeer en moęden upt-ghetoept / ende maecken een ftam als een boom/endejön loo foogh dat de bogfelen daer in neftelen/cnde men frijot

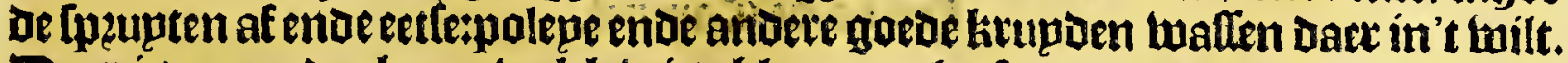
- Baer is een ander krupt twelck twitte blommen beeft/ende de twoetel als faftiaen/ welck men ghebupekt in oe fipjle: een ander met een mitte twoztel welck lachts iens purgeert: een ander luelck leer klepne bladeren heeft / welck als gljp fot aen-raet betwelckert/ende als ghjpaer af gaet weder betquickt. A9en binde

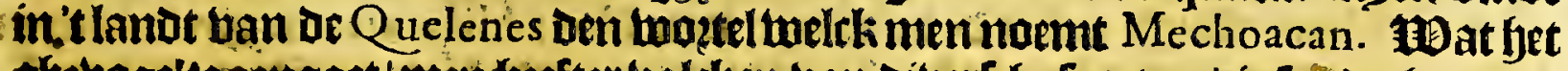

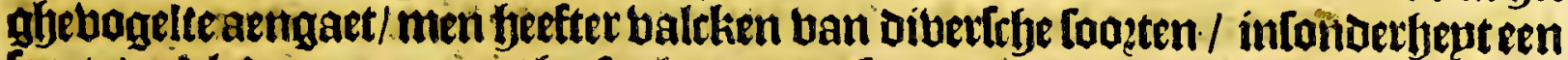
foozte welch Den eenen poot heeft als cen ganfe / ende d'ander als een valck/ gaen

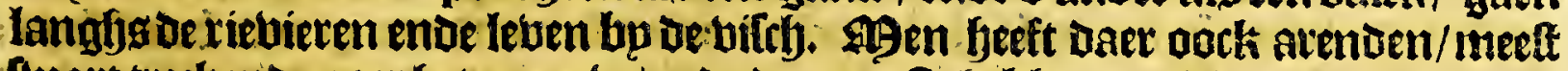

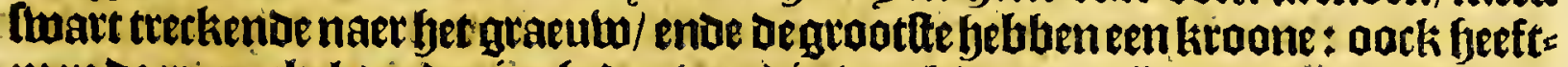
men daerquackels enoe ringlj-dupten die watklepnder zön als die van $\mathbf{S p a e s}$

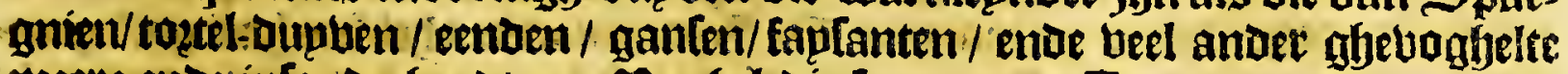
meex: ende inlondertgepdt een Boghel die [u noemen Totoqueztal, ( Doen fo

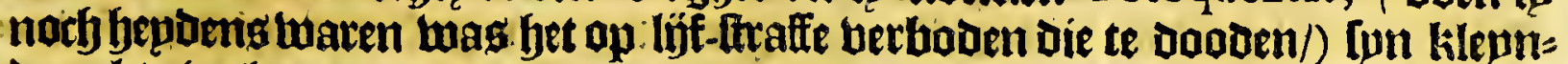
oee als rimgfj-dumben/met graene beeren als bet heliotropium / ende die van 
272

Guatimala.

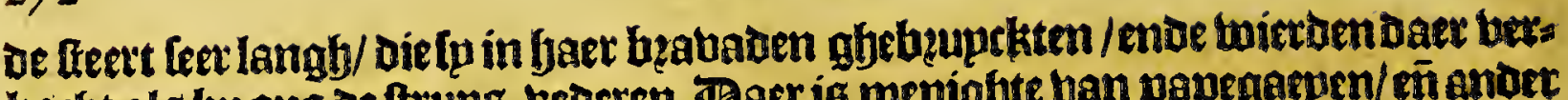
kotjt als bp ong de ftrupg-tederen. Baer is menighte ban papegaepen/ on ander bogelg die fo noemen Guacamayes, jyn roodr enoe blaeula / ban't maecklel ban een ganle ban Peru. Be peeroen die daex vallen jün foo goed datte de beulend

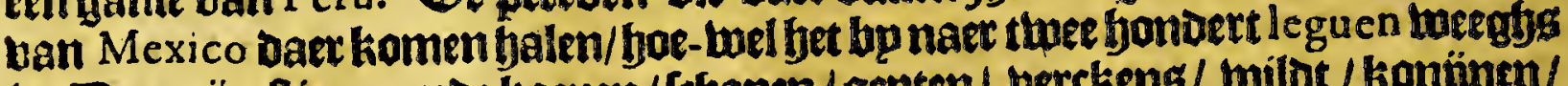
is: Daer zün ttieten ende koepen/ trbapen / gepten/ berckens/ wilot / konïnen/

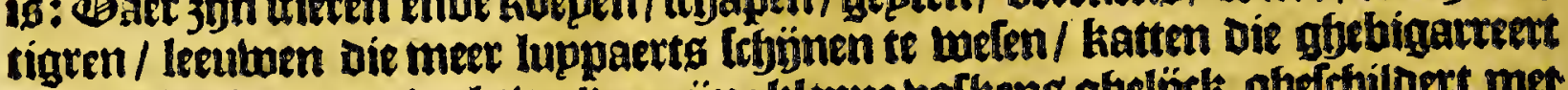

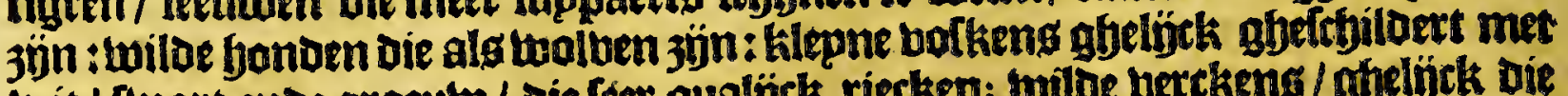

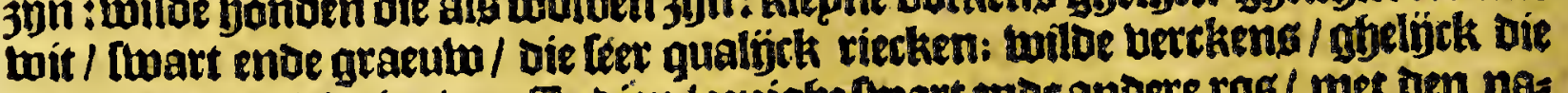
van andere pzobincien ban Indien/ eenigbe twart ende andere rod/ met den nas vel op Den rugghe/ welck qualijck rieckt/ en behben gbeen theerten/enoeloapen in troepen: Daer $3 \mathfrak{y ̈ n}$ oock Armadillos; enoe eeckbozentjens ban Dępexlep looten: men binot oaer een anber bettien welek gljenaemt twoetot T laquatzin, is als $\mathrm{cen}$ biggbeliken / met een langhe Inupt / beeft aen Den bupck een lack Daex 't fpn jons

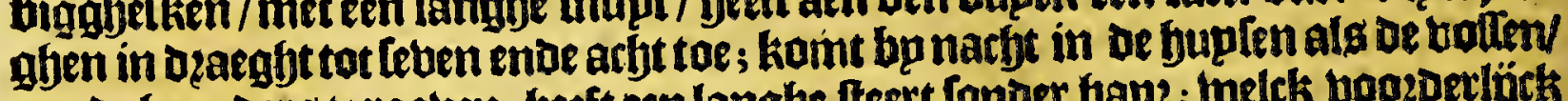
om de boenders te roouen; heeft een langhe fteert fonoer bap? ; torick boozderlöct

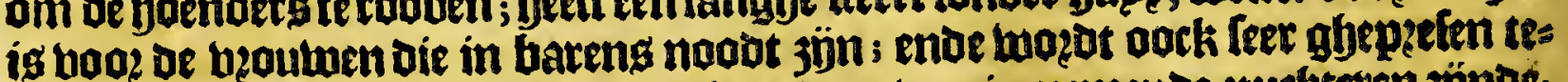
gyen fet grabeel ende fteen; een dzagfjme daer van in-nemende nuchteren jónde;

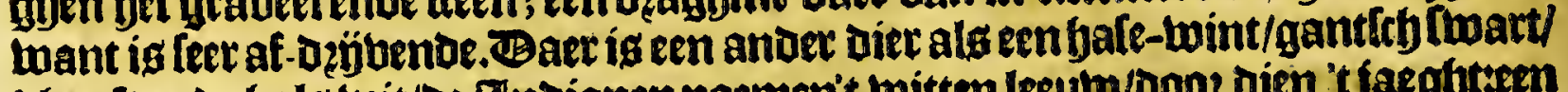

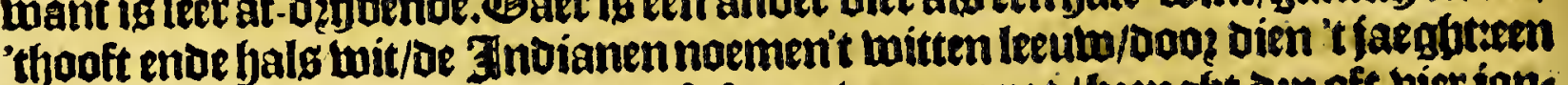
ander ban fattoen als een konjun / oft foeme ban een rat / bzenght dzp ofe bier jon: gen boot /ende als 't upt treckt om eeten te foecken/ too klimmen be jongen op fin rugglje / ende gaet loo gfbeladen met fonjongen: men vindt daec beel anber diecen te langf om te berfalen. In oit lanot jôn leer beel dangen ende andere bergiftige

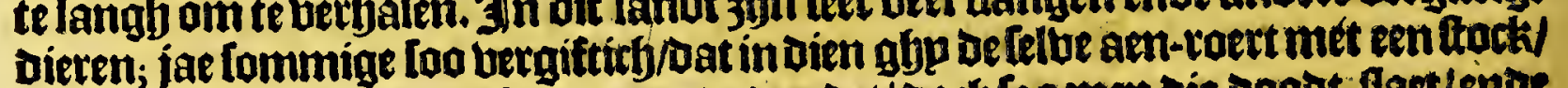

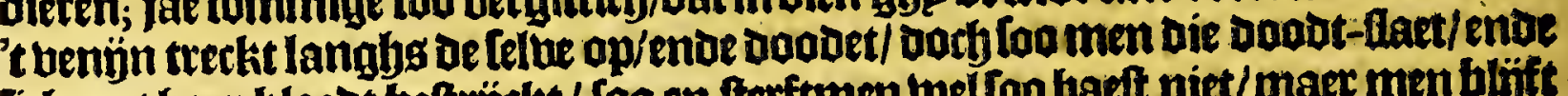
fith met baer bloed beftriekt/ loo en ferftmen wel too baef niet/maer men blöt:

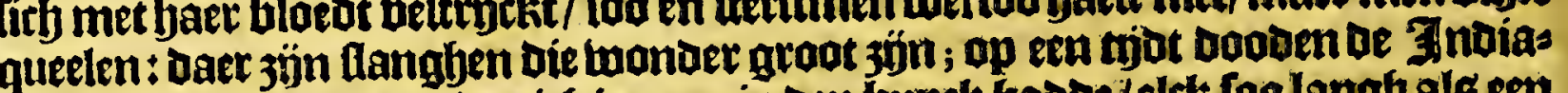
nen baet een die een-en-dertich jongen in Den bupek baboe/ elck foo langh als een binghet/ enve kropen ftracks boogt; twas meer dan thintich boeten langf; de

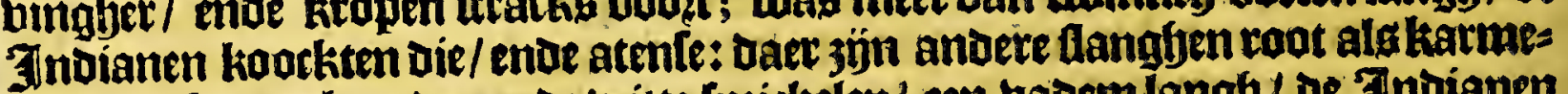

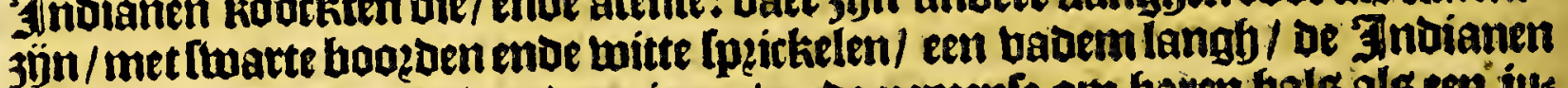
noemen die de moeders ban be mieren / ende nemenfe am Garen fals als eeri jus beeltjen: ontrent een doup ghenaemt Ecatepeque, ban de Lptaecke van de Que-

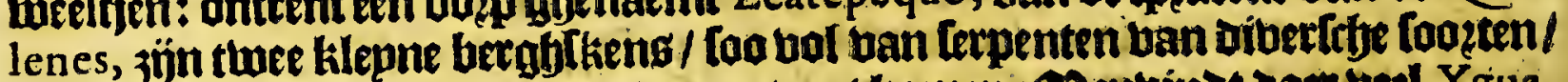
Dat de 3 indianen Daer niet en derben ontrent komen. Apenbindt daec beel Yguanas, die oock jön in alle quartieren ban Nova Hifpania.

\section{Wet Derde Capittel.}

Vorder befchrijvinghe van do provincie CH I $\mathrm{A}$ A in't particulier, ende de fadt CIVDAD RE A I daer in gheleghen.

d.4.1.10. T' Bolkk nan be blectke Chiapa, welck een ban be bier deelen ig ban beie probin

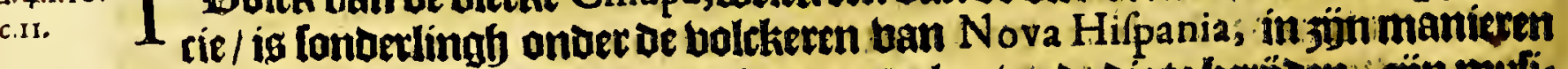

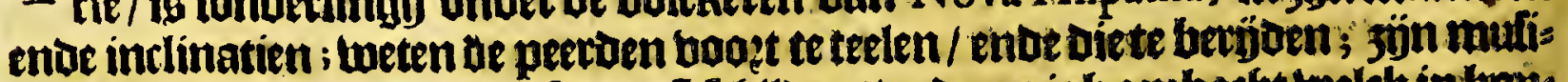
riens in alle looeten ban mulique/eñ letgiloecs/moe eenigh ambarbt toelcts inliome

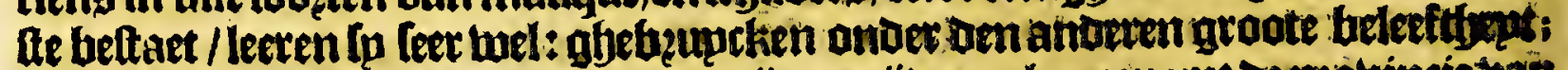

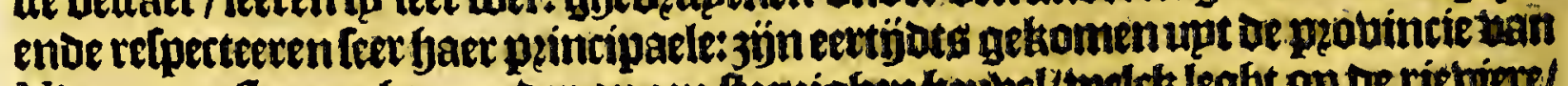

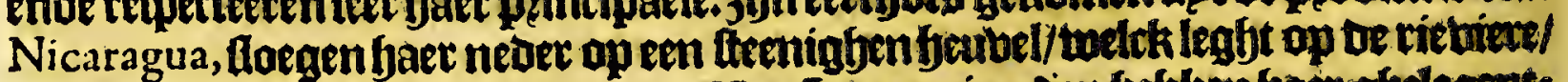

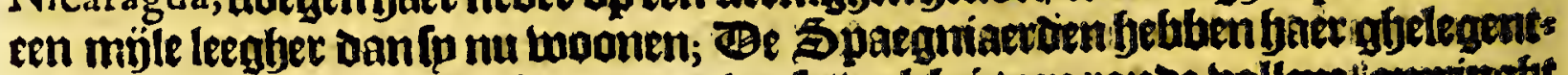

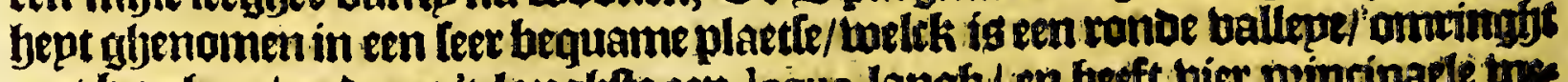

Ier.der. met beraften / ende op 't langhfte een legue langh/ en beeft bier peintipade to

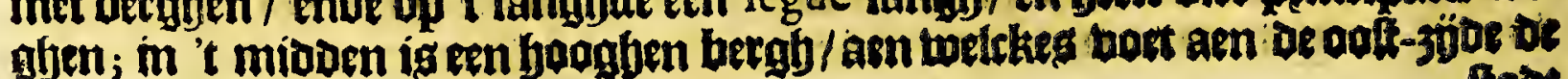


Het fevende Boeck.

faot is gheboulut / weiche ac Spacaniaeroen noenten Cuidad Real, feluenticf

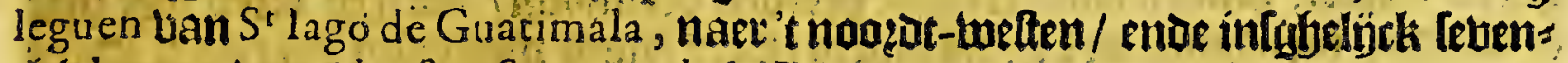
tirbleguen ban Nueftra Sennora de la Vitroria, in De pzobincie ban Tabafco; men necint uan Tabafco jijn lough ueettich mülen de rievier Gryalva op / ende de

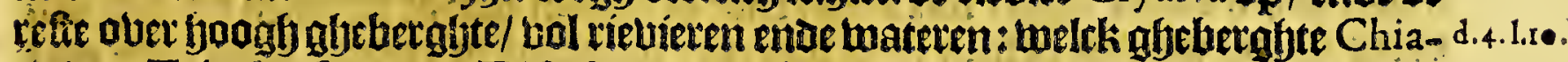

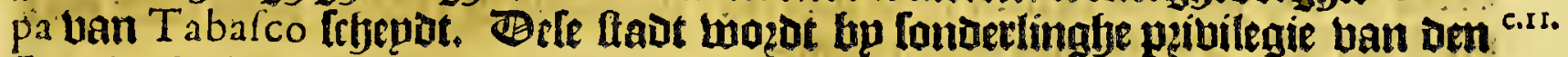

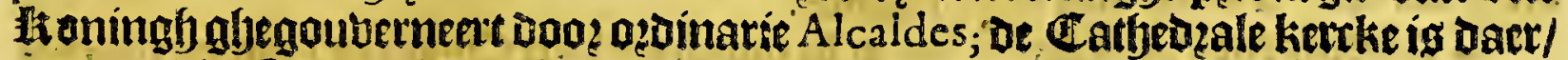
met een kloofer ban Jominicanen/ met beel Doepen ban Jnoianen in fpn dic

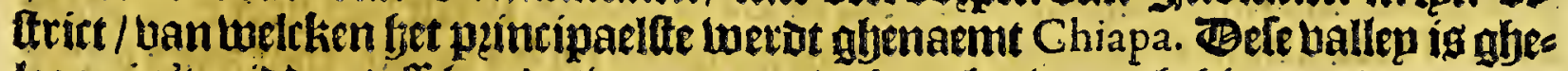

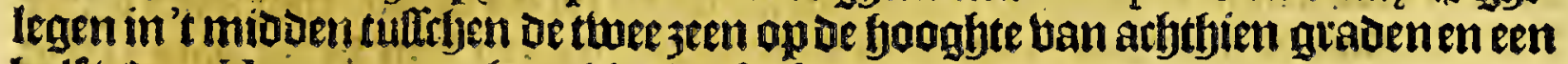
balf/ (Dan Herrera moet fem fier in abuleren / want ten kan niet arcoz̨deren met

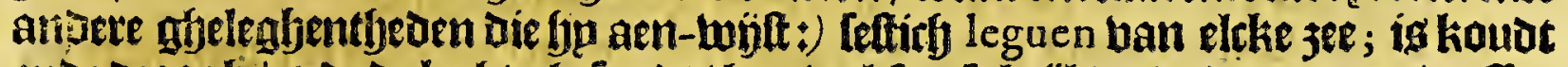

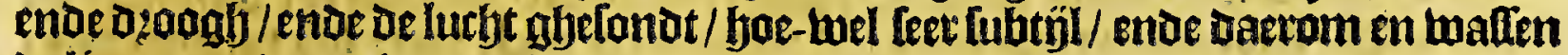
oe limoenen daet niet / noch de dzagnien/maer wel peeten / appelen / queen ente perfen'/entoe andere beuchten die in koube landen wallen; de kerflen dzagen wep: nigoj/ente de kriectien en rípen niet wel; oe tartwe groepet daet wel/ende bet Maiz

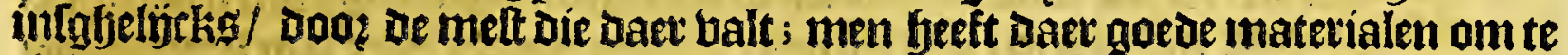
timmeten. Deprobincie ban de Zoques ofte Zoaques beeft búf-en-thintich doz= pen ofte blectien / ende bet pyincipaelfte is Tecpatlan, daer be Jominitanen een

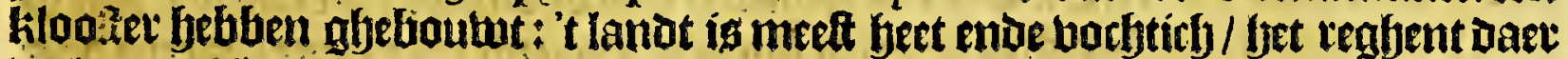
beel / ende 3ïn quade weghen; ende beeft beel riebieten / waer booz bet beel bifth beeft: De Zeltales hebien detthien ulecken / Die een populaer goubernement ontor fjaet feblen: ig beuththate gronot / ende feer abundant van Maiz, waer

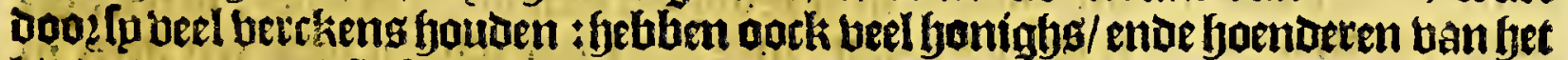
landt / ende ball Cattilien; beel Cochinilla, boe-welip die niet anders en benefis

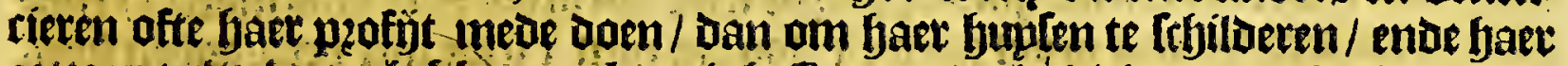

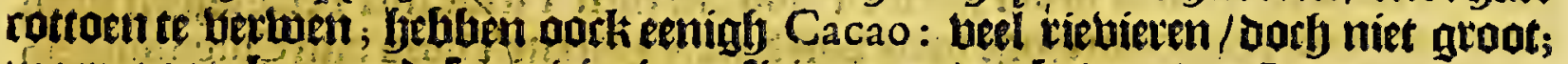
maer groote betgen oele pzobincie confinetert thet den bobem ban Lecandon, met be Zoques, enoe Yucatan. De Quelenes febben bij-en-twinticlj doppen/ende bet peincipaelfte is Copanavaztla, groot ende abundant ban alles: daet is en Eloofer ban Dominicanen ; is feet bain tempe ende dzoonb: in enighe ban de

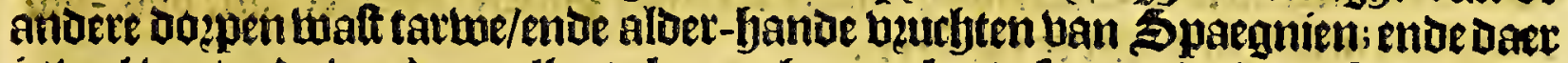
ig heel bee/ende wozot excellente kaes ghenaeckt: Defe peouincie confineert met Guatimala enpe Soconufco, met oe waeftünen van Lecandon ente Chiapa. En=

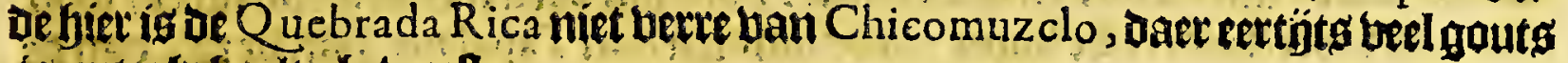
is upt-abeljaelt obeweet.

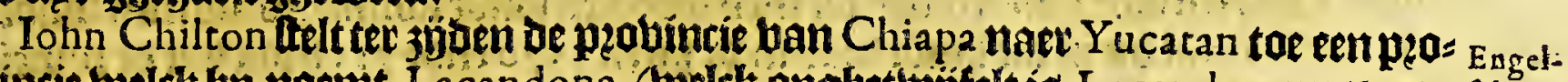

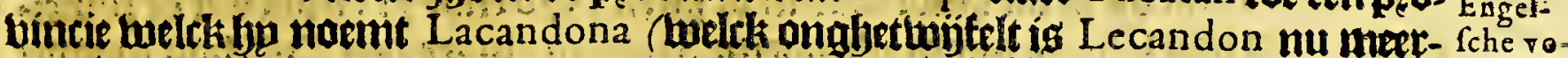
maels be ons aen-ghetoert upt Herrera) ende feght dat of Jndianen die daex yage.

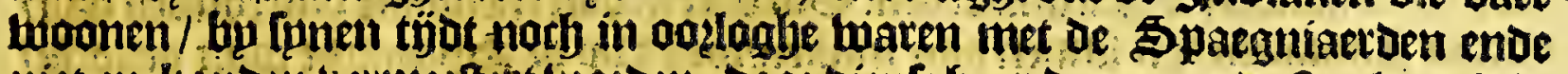

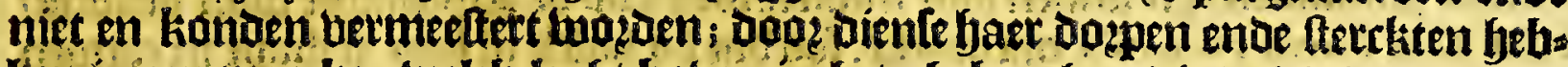

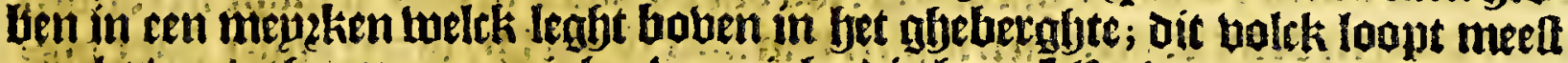

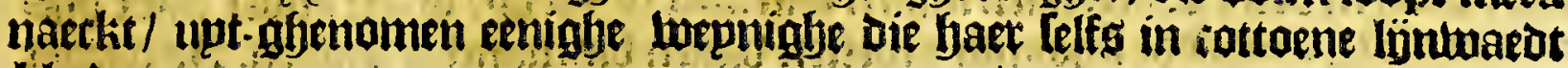
treeden.

De riebiere ban Chiapa loopt naer, nooedon toe/owerg doog de pyobincie ban Copanavaztla, enoe komt in be noogot-3ee upt / langlyg Tabafco ; Daer komen

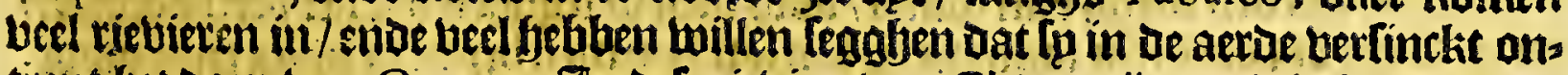
tient lret oozy ban Oztuca: In dele riebiere ban Chiapa jün enighe beelten ghelijtlials groote apen/met een langlen feett/ghebigarieert als de tigren; bljuen Altijots onder bet luater / foo batmenfe daer nimmemeer bouen fiet; ende de Indianen die daer pallecten doof 't watex/laen fp be fieert om de beenen/ende trechen die loo onder 't thater / ende berlmoosente; eenighe alloo bet groote fwem=

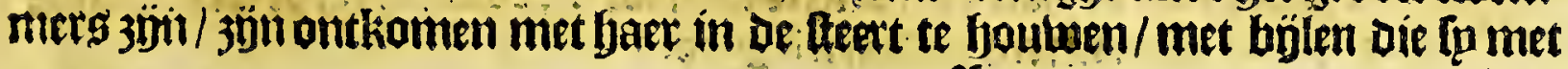


274

Guatimala.

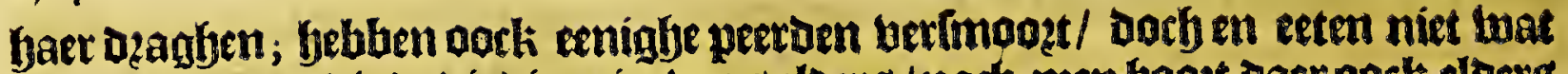
Ip oooden; men binde dit dier nieuluers eloers / nath men boost daer oork elders niet ban. Beriediere die Ip Daer noemen Rio blanco, bedeckt enigh dingh bat langh in fpn water leght / met fteen ; ende de tarken ban de boomen die aen Den oeluer ftaen / 3än met de felbe fteen bedeckit; nochtang ig't thater klaer ende oet om deincken/ende en doet gheen lchade.

Ce nobelfte ende bet fraeplte dat in de pzobincie ban Chiapa is / jün be fontep. nen; anderfjalf möle ban Ciudad real, in Caza cual pa, is een ban goet ento klaet water / welck waft ende bermindert van fes upen tot fes upzen; ende alloo ophet booghlte van de pzobincie / ende meet dan bijttich leguen uan de 3 ee legft / $\mathrm{cm}$ ig niet te Dencken dat De zee fulcken bloed ende eb be beroog faeckt.

In Tafixa is een ander/ welck Dęp jaren acheter en/ jae-wel bet twepnigh res ghent/Loopt; ende andere dęp jaren/al reghent get oock beel/ too berdzoochtfel is ban goet water : vöf leguen tan de felbe ftadit is een ander/ welck in be lomet beel waters geeft/ende in de twinter gheen. [Een yalf mïle ban een opep/genaems Cinacatan, ig een klepne fontepne/welck ig goet omlieckten te gheneten die cogeta libe oft bandende medectynen bereptetben; ende de bogelg daer ban dzinckende; fterben; alsmede 't vee ende andere dieren. Baer zjön in defe plabincie oock beel baden ende feete lpingben. Baer de rietieren ban de ballepe ban Chiapa, aen D: boet van een booghen bergh in oe aerde fincken/makenle een groote caterne daet: wel twe bondert pertonen in fouden magen; ende aen Den ooélpzonck ban de eene bam dele riebieren ígen ander/Daer wel thee bupfent in fouden mogfjen. One trent het Doup bau $S^{\prime}$ Batcholome, in de pzahincie van los Quelenes, is een ope: ninghe in maniere ban een boen-put; men leght bat allmen daet een feen in woept loo groot als een ozagnie-appel / oe Teloe een groot gbedgups maeckt / ende Itracks Dondert foet met groot gheluelt / foo dat men't telue niet berozagben kan; ende men foo te de donteringe betre ban daer. Ontrent't doup ban Chico omucelo ig een anjer caberne/ op de maniere ban cen grotte/ende binnen de Lellue een groot

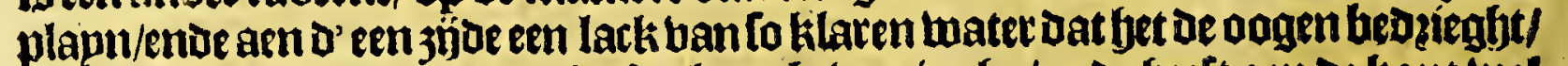
Irtjinnende jandt te welen/en beeft gbeen betweginghe / ende heeft aen de kant bel

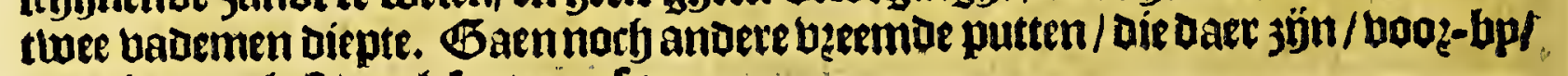
om gbeen onliut den leter te tauleren.

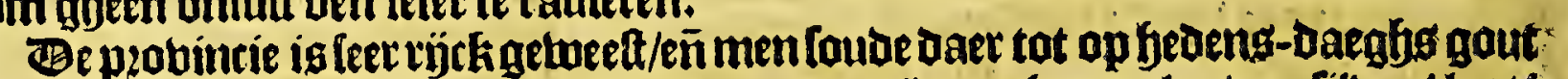
binden / Loo de dabenniet en ontbzaken: daer jön oock metalen van filbev / loot/ thin/ quicfilber/plet / ende koper; in de liimiten van Tapala pa, ban De tale ban de

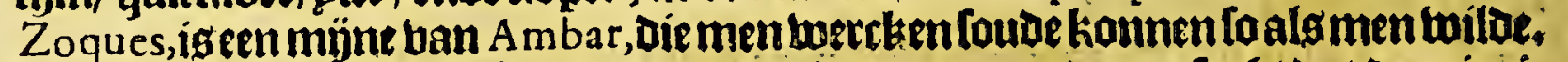

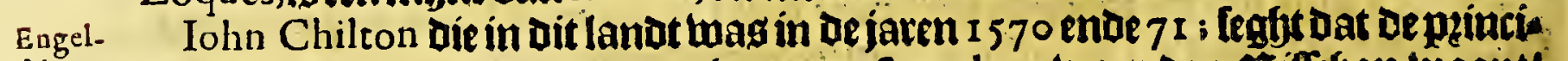

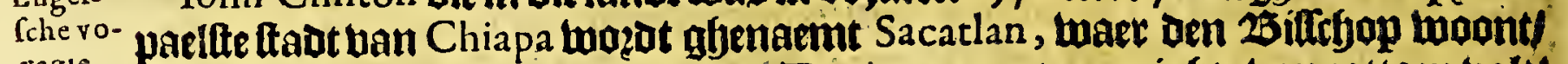
yagre. ende bp de fondert 5 paegniaetden. Bat daet aroote menigfte ban cottoen balts.

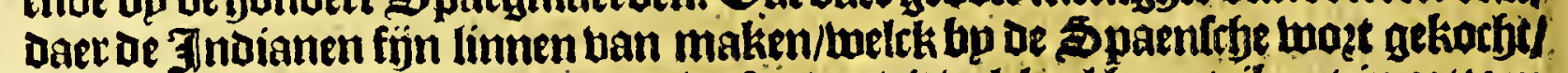
ende naer Nova Hifpania abebzacht: loo Dat dit volck al baer tribupt in cottoen

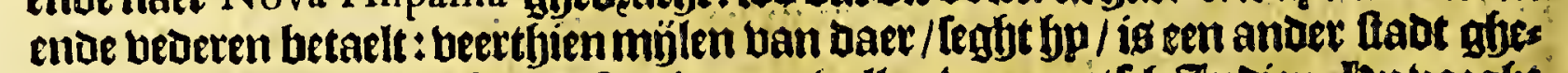
naemt Chiapa, daer de frboontte ginetten ballen uan gantffy Indien. hiet bp / Dat thp ban Chiapa at/al ober berahenenoebeubelen reptoe tot bet epnot

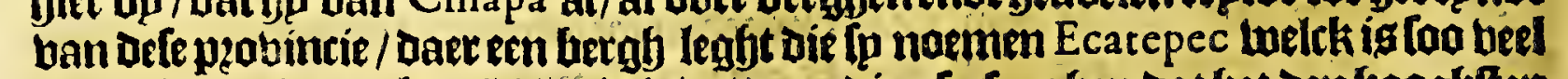

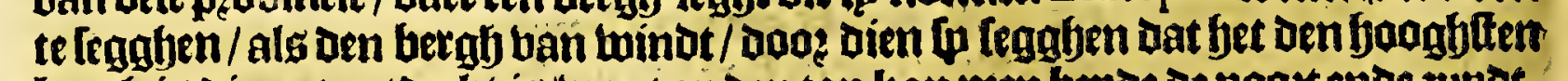
bergh is dic opt ontoeckt is/want op den top kanmen bepoe de noox ende juppt-

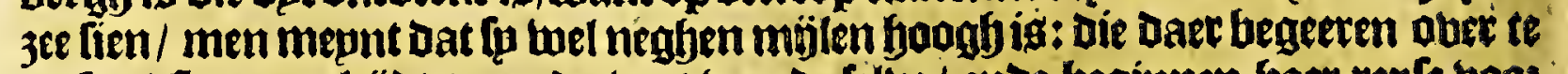

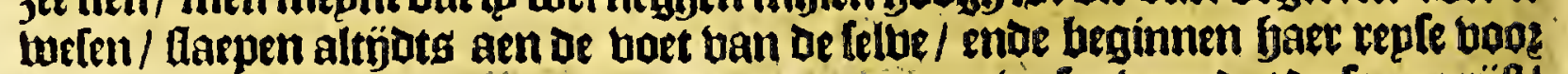
midoer-nacht / am des ander-daeghs op den rop te welen booz dat De lonne rijtt/.

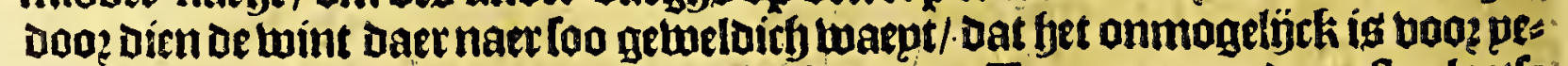
mand optegaen; ban de voet ban delen hergh tot Tecoantepec, of extfe plaetfe in Nova Hifpania zjón ontrent büftbien leguen.

soco. 
Het fevende Boeck.

SOCONVSCO ende SVCHITEPEC.

Wet bierdae Capittel.

Partículiere befchrijvinghe van de provincie van $S$ o c o N V S co ende S V CHITERE C.

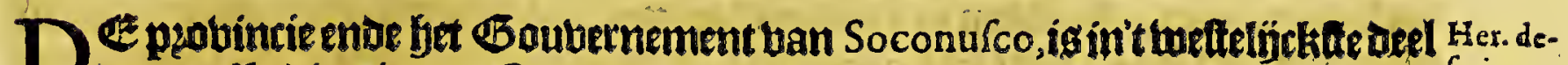

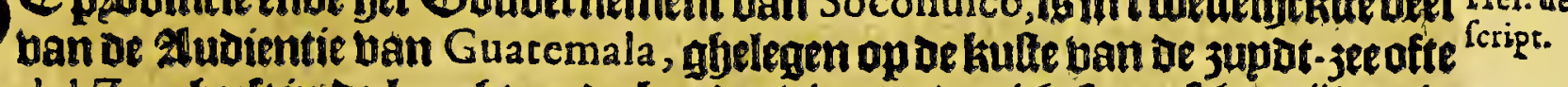
Mar del Zur, beeft in be langfte ende bzecote biet-en-bertich Lpaenfrbe mílen; is Teet burchtbaer ban Cacao, waet met den peincipalen bandel aldaer wert gfedege ben; ente baer wott bam alles ghefaept ente ghetwonnen/upt-gbenomen tarke; Daet en ig in Defe ganteby probincie maet een blecke bp Spaeqniaeroent betwoont/ belcke ghenaemt mozot Guevetlan, eetrijots gheboumt bp don Pedro de Alvarado, al waet Den Bouberneur ban bele pequincie són moon-plaetfe foubt.

Iohn Chilton die in dele lanten wag in denjare 1570 legbt in jón vopagie ban Mexico naet Guatemala toe/aloug: betlatenoe Tecoantepec, repfoe ic's al boozts Engellangfys de 3 upot-3ee / ontrent I 50 mílen in be moelte pqobincie ban Soconufco, jagie,

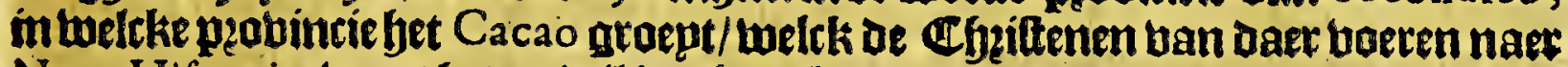
Nova Hifpania, want bet en wil in gbeen koude lamaen groepen. We Jnoianen ban bit lanbet betalen yaer tribunt aen aen ltoninghin 'telve Cacao, ghevende bem bier fonbett Cargas, ende elcke Carga ig bier-en-twintich dup[ent aman-

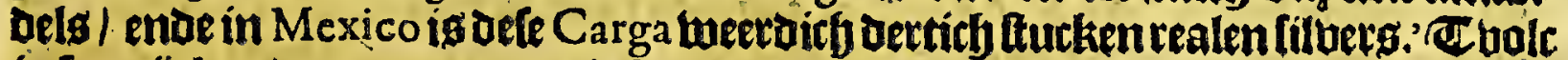
is leer röck ende met eenen oock leet trots i enoe in alle defe pzobincienen boonen gheen thintich Spaegniaet ben. Befelbe gbetupgdt mede dat bet in defe peouin= tie / wan April tot September Ieer reghent / loo dat bet water wan de bergfen bals lenoe naer be leeghe lanoen / maeckt dat bet in dien tyot Daec niet en is te teplen] ende dat men detbalben kamente van Nicaragua fpn wegb elders moet nemen/

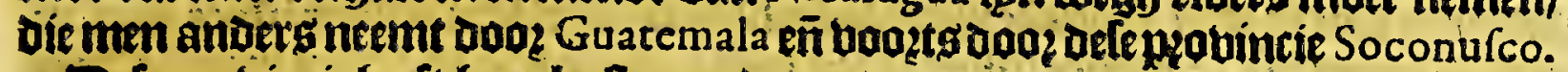

Defe pobincie beeft faet kulte aen de supbt-jee / ente neemt baer begin leven leguen ban be riebiere die fo noemen $R$ io de Aiutla, naer' tweften; ende beft daer aenbe bolghente riebieren / Coatlan, Capanercalte, Colatl, Haztatlan, Amatituc, ende Quizatatan. Ban de belcke top als noef niet bulonders en belaben be=

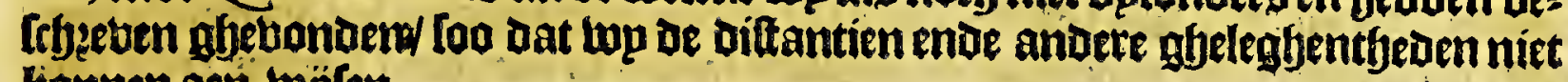
lionnen aen - wộten.

Raelt dele peovintie io nfeleghen to peobintie ban Suchitepeque, ento Guafa- Engel-

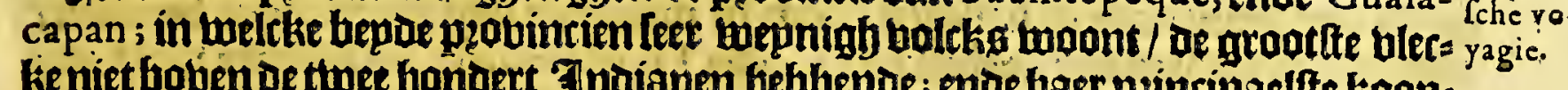
ke niet boben de twee bondert Jnoianen febbende; ende baec peincipaelfte koop= manichap is Cacao ; ald de booz-noembe Iohn Chilton gfetugght.

$$
\text { V E R A P A Z }
$$

Fet bijtot Capittel:

Particuliere befchrijvinghe van de provincie $V$ E R A P A $z$, ende de woon-plaetfen van de Spaegniaerden daer in gheleghen.

De peotincie ban Verapaz (welth bie naem is obegbeben bp oe Bominica Her.der.

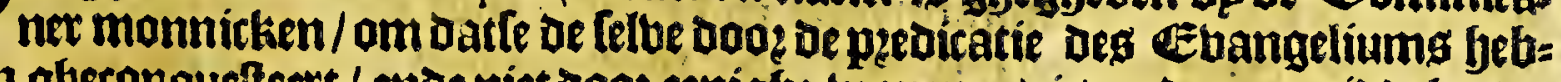
ben ghetonqueftert / ente niet doos eenighe topenen) is mede een miodelanot: frbe peobincie/ tufferen de limiten ban de probincien ban Soconufco; Chiapa, Yucatan, Honduras, ende Guatemala, ís dettich leguen ober-Dtwets/ ende fon beel leguen infgelÿrks gelegen ban de thadt $S^{t}$ Iago de Guatemala: Befe probincie werot gbelchepoen ban die ban Guatemala Dooe oe riebiere ban Xicalapa, banbe

$$
\text { at } 4 \text { melcke }
$$


$27^{6}$

Guatimala.

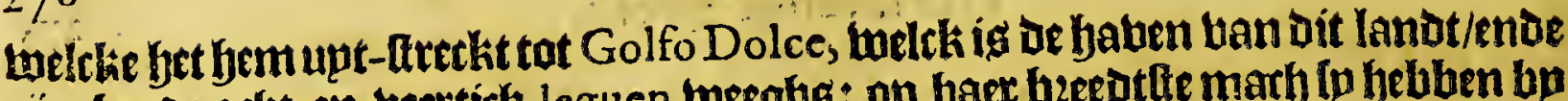

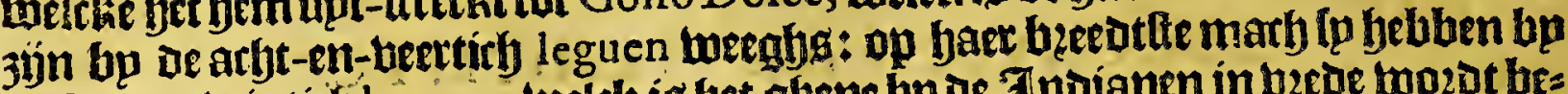

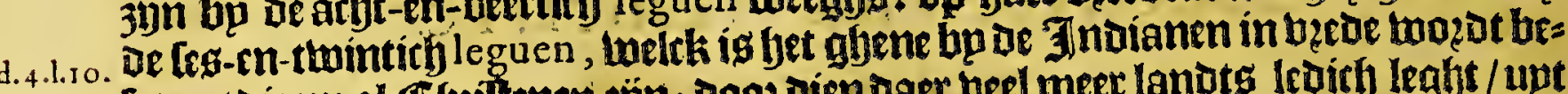

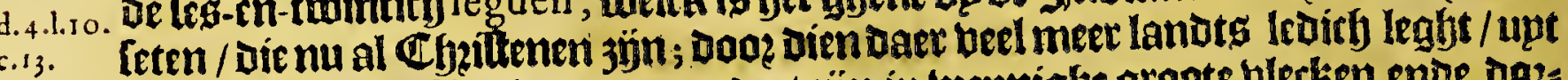

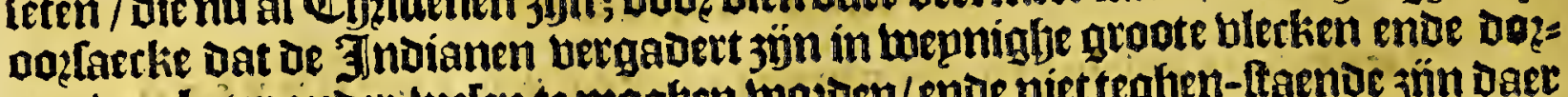
yen / om beter onder-Lelen te moghen mozoen/ende niet teghen-ltaende jün Daet noch beel onglyeloobige ofte bepoenen / als daex jÿn die volckeren díe men noemt

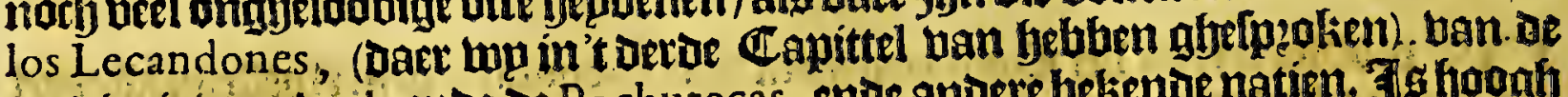
probintie ban A cala ende oe Pochutecas, ende andere bekende natien. 3 g goong

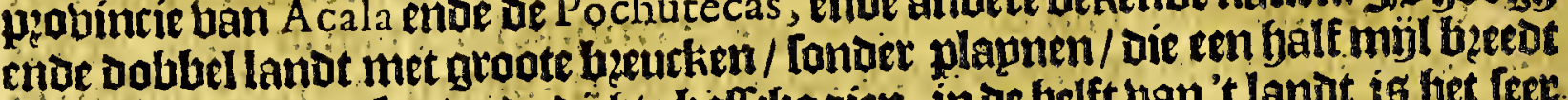

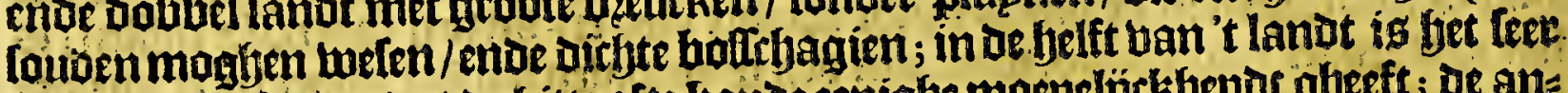

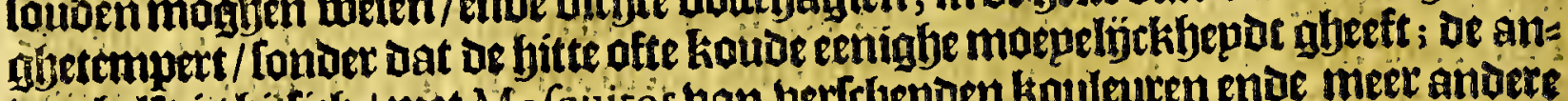
Dere felft is hittich / met Mofquitos ban berfhepden kouleuren ende meer andere

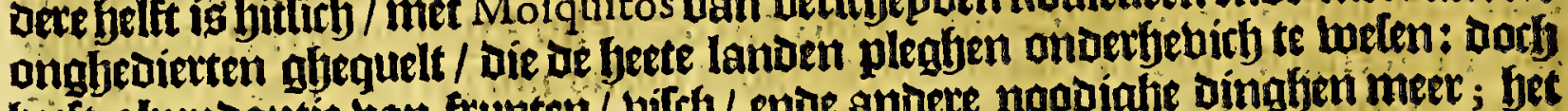

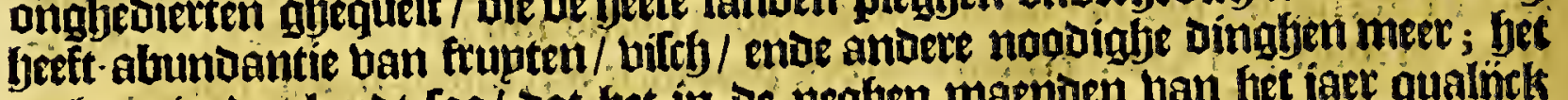
reghent in dat landt loo/ tat bet in De negfen maenten ban bet faer qualinek anderg doet als regljenen/ ente in De andere dep maenden beft men oock di:

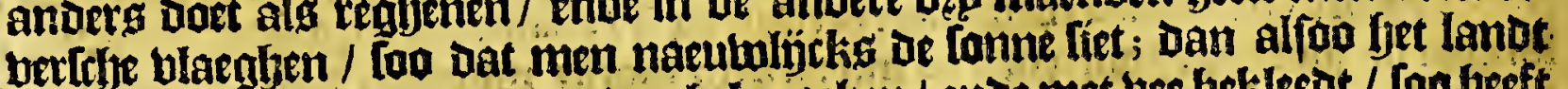

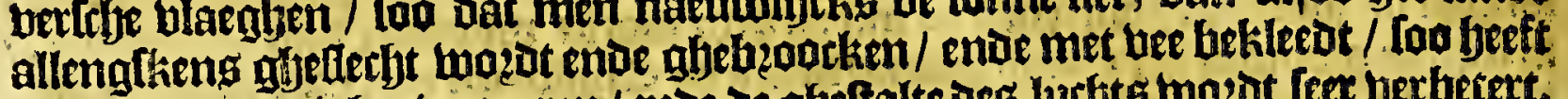

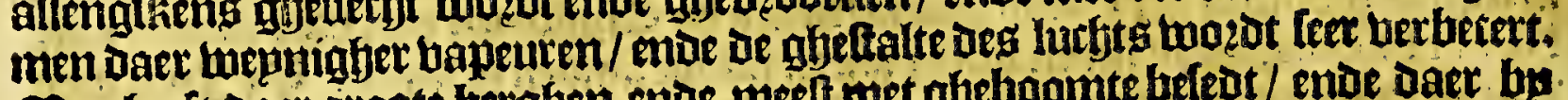

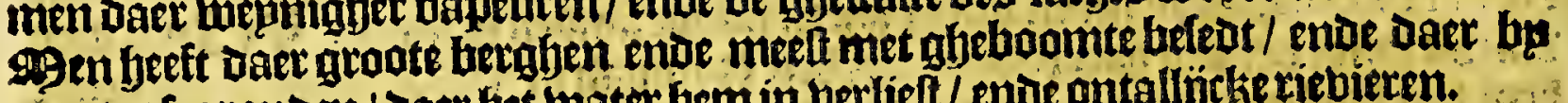

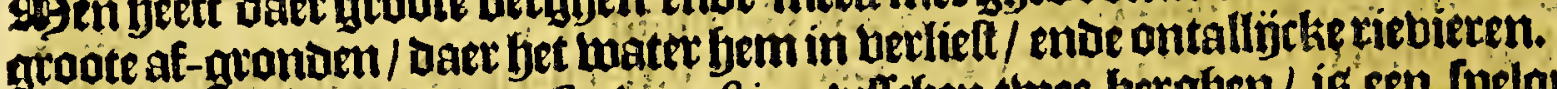

Dntrent de blecke ban St A üguftin, tultchen twee berghen/is cen fpelontke baer men beel bolcks in foube moghen bergfen/ is ban feen/ enoe beeft een groote

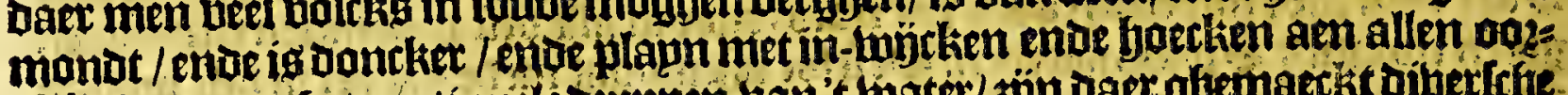

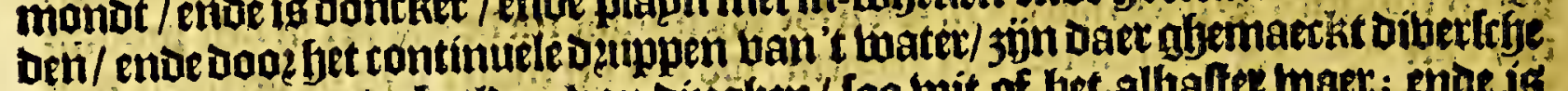
pilaren/ bulten ende beeloen ban uinghen/Loo wit of bet albatter waer; enoe ig.

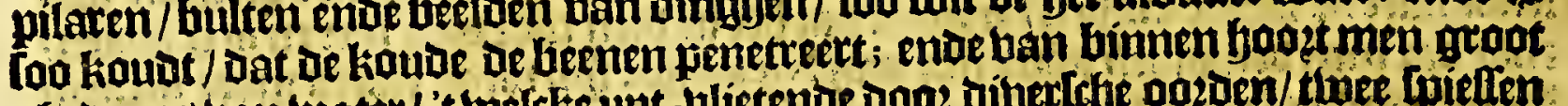

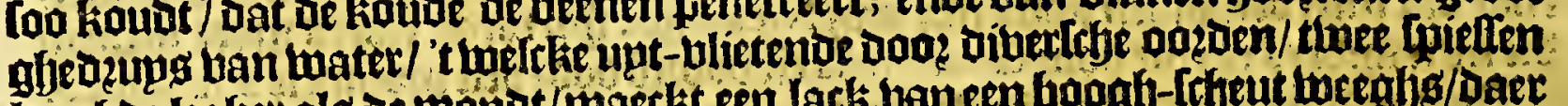

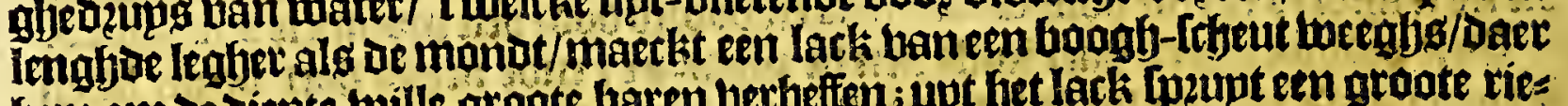
hem om De diepte wille groote baren berbeffen; upt bet lack [peupt een groote ries

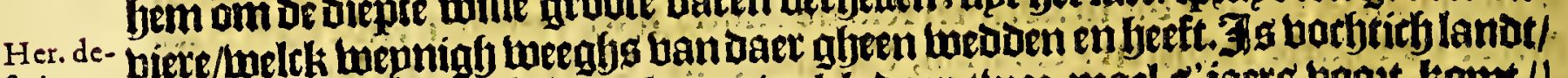

frript. ende daetom beter uoo? bet Maiz, (welcls daet twee-mael s' jaers boot-koint/)

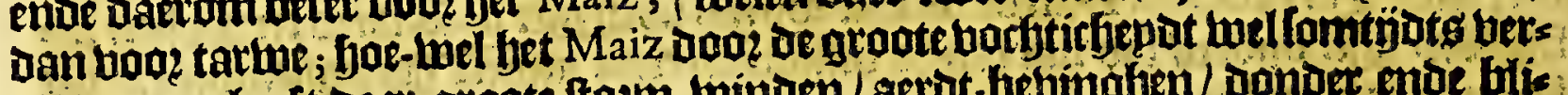

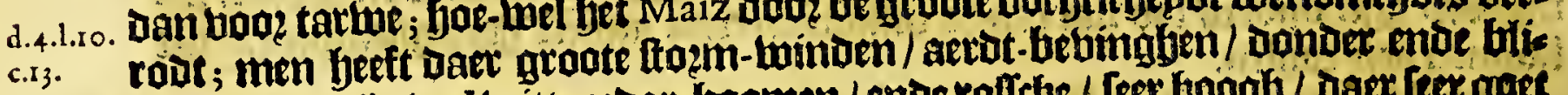

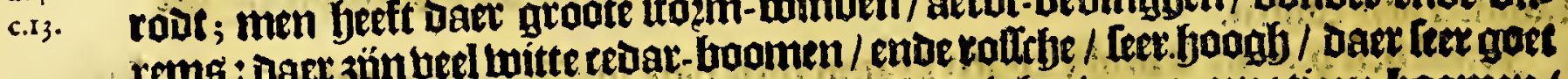
houot ban komt; alle de bolldyen / Doop oe menighte ban aromatigue boomen/ jún altijots vol tanlect goeden reuck. De Liquida mbar, welck daer beel balt/

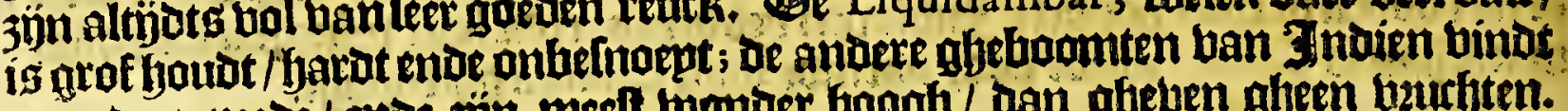

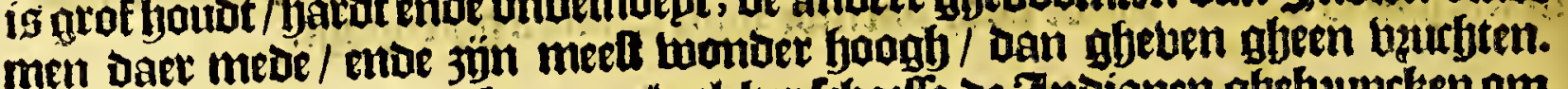

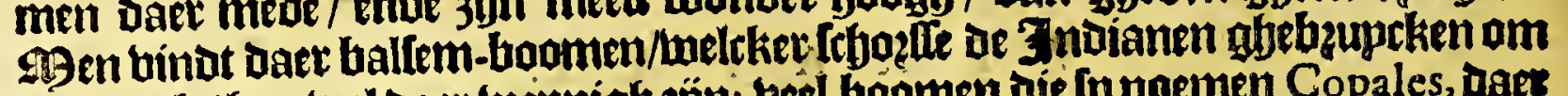
Den reurk / hoe-wel daer wepnigh ján; besl boomen die fu noemen Copales, daet het Anime bankamt / ente Xuchicopales; weltk gheplanutwoguen in beete ente varljtighe landen / om fet peofït ; enoe oock fịne Maftick-boomen/ende be boos men daet fet Sanguis Draconis, ofte Degetken-bloed wan komt. O9en beft baet

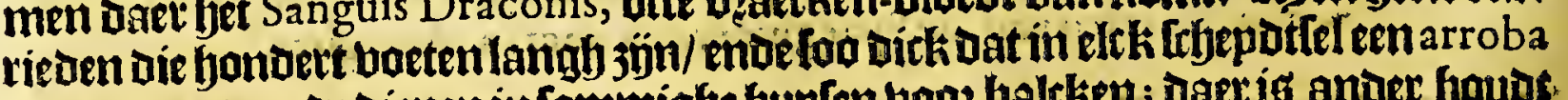
watets gaet; ende dienen in fommighe fup [en boos baltken; daet is ander bouds:

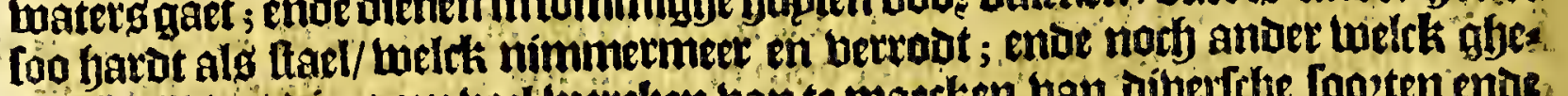

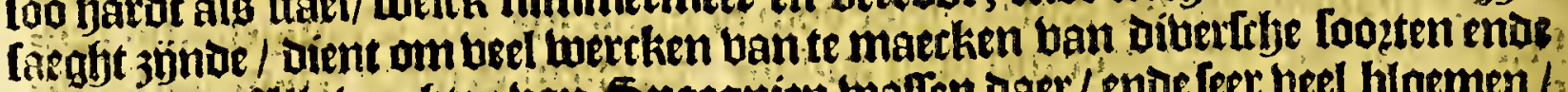

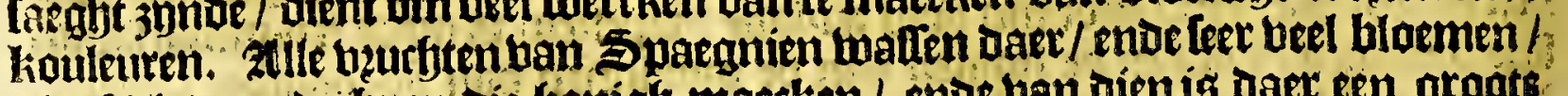
dientiticly uoo se bpen die fonigh maecken/ ende ban dien is daet een groats

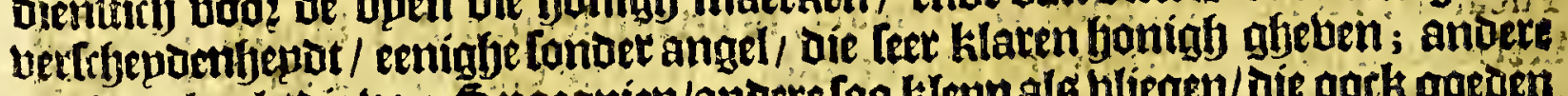
met angrlg alg die ban Spaegnien/anbere Loo klepnals bliegen/bie opeck gaedén. bonig6 
Het Cevende Boeck.

hantub ghetur; andere twieng banigh oe menlefen be finnen betifoot; ente euns

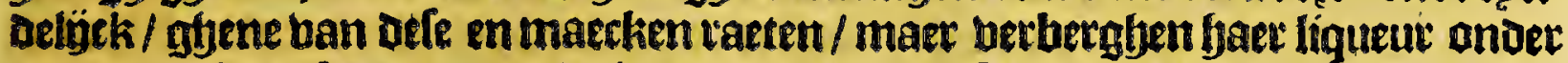
de aeroe / in be boumen / cnue in be boetelen der felbe: Den jonigh is feer bun / ende treckt naex 't fuete; ende in londerbepot ban de bpen die ghelijck bliegen jün:

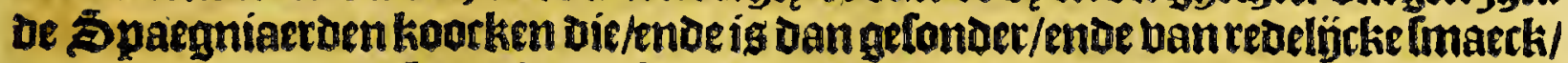

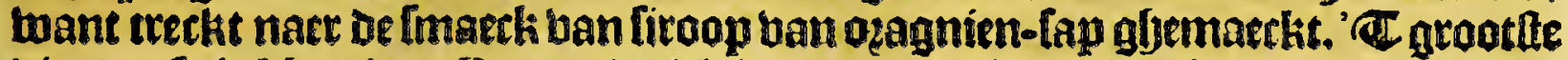
Dier dat fp febben is of Danta, twelck ig als eenkalf/ Dort beknopter / leegh ban beenen enoe knpen/De abelozitfiten leegb/ende bp oe boeten/als oe olifanten; aen be boozlte betnen feeft bet bijf klaeulwen / Dąp boos / enoe twee arjter aen Den ents kel / aen be arfterfte beenen en beft bet maer vier; een langh booft / ende 't boo:-

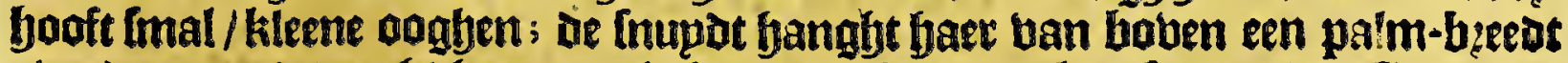
obet den monot; tectjt bem op als bet gram ig / ende laet fun tanden tien / ende

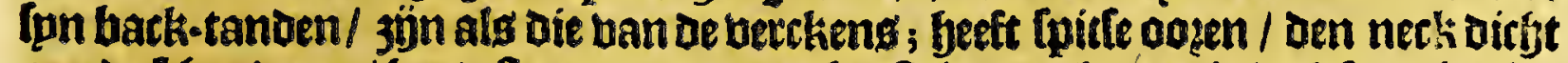

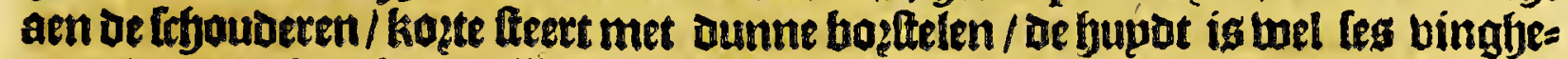
ren dick/men kan fet qualjek batten met de handt/enoe youot tegben alle wapes nen in 't frijoen; boed op gras ende ktupdt: De Jndianen eeten't vleefey/ende

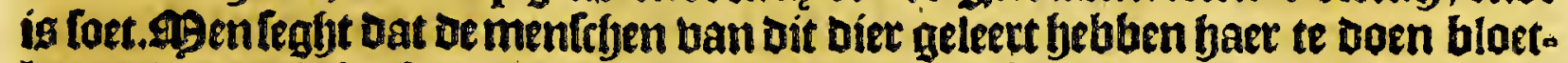
laeten/want ald get bem oberladen bindt ban bloet/ loo quett bet frem aen be bee= nen op de klippen / ende laet bem felben too beel blocotg af / als tiet noodigb is.

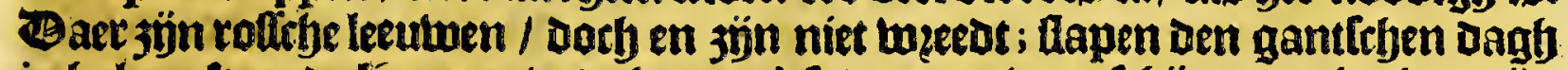

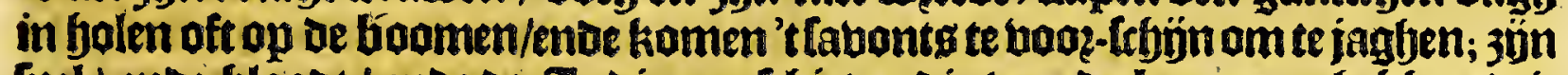
Inel/ ende blood/ ente de 3 noianen fejieten die ban de boomen; bebten wit bleeleb ende dick/ende de Thbianen eeten die voosen delicatefle; betwaren' t fmeer tot (eeckete mederijnen / ende de beenen tot baet Danflen. De tigren jün grooter)

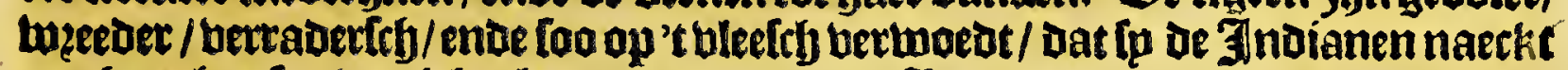
upt faer fupfen twegh baeloen; ente waee de Tnvianen die ghemoetten / bielen Daer boos op baer knpen/ oie boudende bno Gaden; ende baden dat [p baer boch niet en bilben op-eeten/ende werden niet te min ban De tigerg terfefeurt. BBant in gantlrb Nova Hifpania berticheen ben Dupbel in be gheoaente ban een tiger/ moe bielaen die in groote eerbiebinghe / feggben bat fp vergift bebten tultiben Gaer klaeutwen / ente dat die daet mede gbetmanot jön / nimmermeer en beelen.

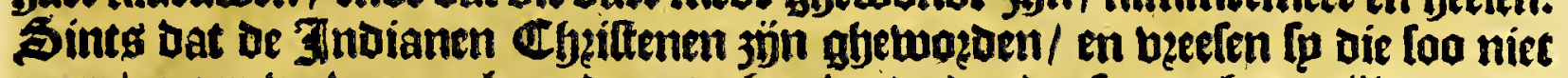

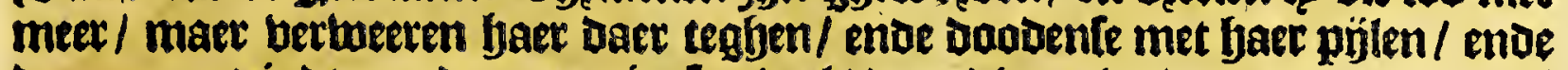
baerom en bindtmen Daer nu niet too beel/ booz dien 't lande nu meet apen is /

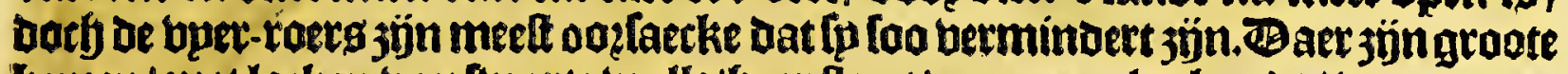
bepen/ met lacken van lwarte wolle/baer fteert ban een palm beeds / boetenenoe banoen als menlchen/hebben een plat backbups als een ouoe mogiaen / Conder bape ende betfronfelt. Be Indianen verfalen dat Daer een groot dier is als een peecot / met een ronten fooen in't booz-fjooft. 3nfghelïcks jün daer beel apen ende meex-katten van differente groote/kouleur/enocindinatien. Be twiloe gepten jün als die ban Spaegnien/boe - wel lp den bals bebben als barten; Daer zịngroo: te betckeng/ban welcker jupotit of Inoianen trommelen maken. Agen binot oaet oock plete-betcking/hat biffertnt ban tie ban Africa ; enoe Armadillos enoe ans

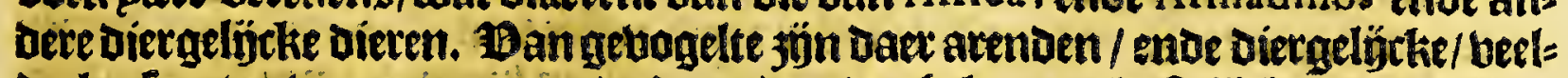
Declep toozten ban papegapen/ende anbere bogbelen met koltelïcke decren. S9en heeft bier oock Ganghen enbe ferpenten / gbeligek als in oe peobincie ban Chiapa. - Baer is loo beel waters in 't lantat / vat bet ghebeurt dat men berticly riebierkents beeft in Dep leguen beegfys / enve fontepnen uan oelicaet berteb enoe klaer twas tex / oorb tuepnigh bitry; dan de Bominicanen hebben in een lack ghelet eeninge

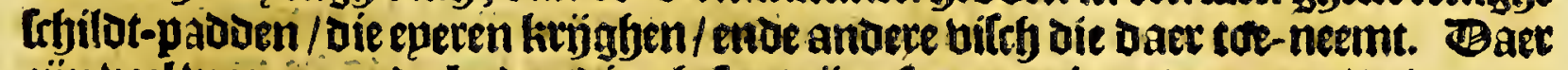
jün beel wateren ende baben die ghelont jön; tontepntjeng ban root / wait / enore blaeulm toater / ende andere onaenghenaem uan fmaeck / Doos dien fp doos plete-

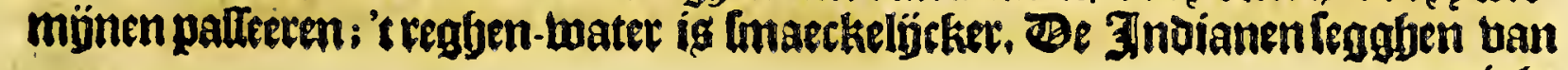
eenighe 
278

Guatimala.

eemighe monltets ban goutd/ filber/ enoe andere metalen / Danmenenbindtyet niet met der waetbepot/alsmen't komt te onoer-Loecken. Be berghen traen tal uan Zarçaparilla, beel radix. China, ende Mechoacan; ende fp leg̣hbendat Daex

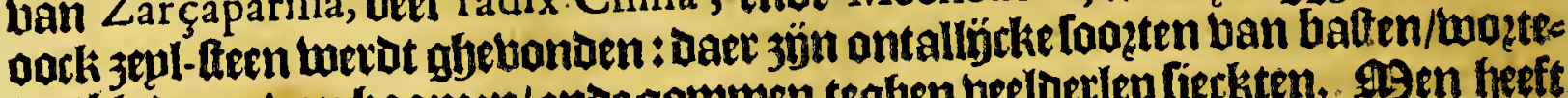
Ien/bladeren ban boomen/endegammen teghen beelderlep lieckten. Asen beeft bieroock cottoen/ enoe eenich Cacao.

Het telfe capittel.

Voorder befchrijvinghe van de Provincie van VE R A A $Z$, ende

GOIFO DOICE.

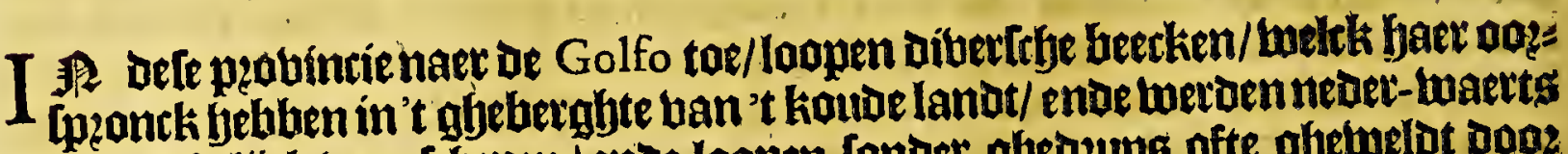

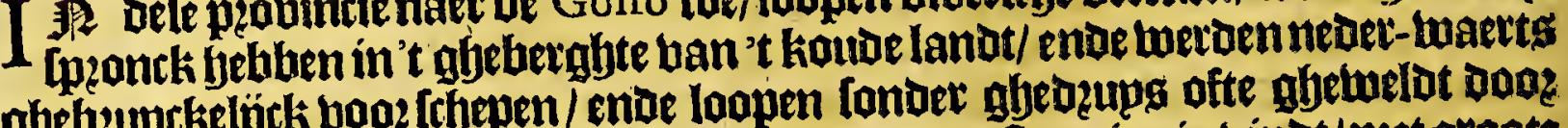

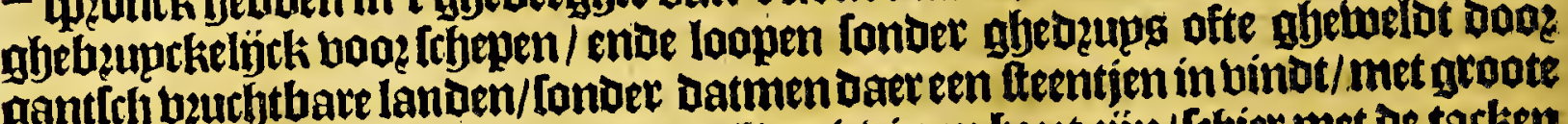
ende dichte boomen/ de tueleke fjae-wel ae riebieren beet jön/lebier met de tacken

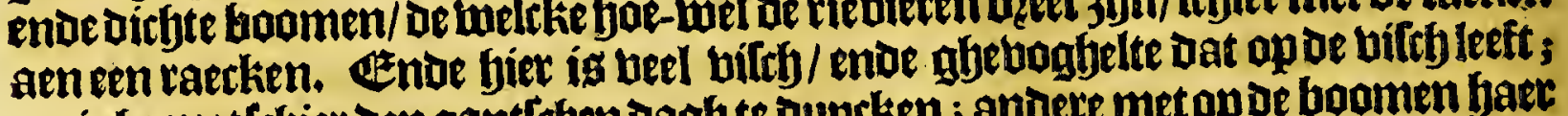
enigbe metcthier den gantthen Dagh te Duprken ; andere met op de boamen baer Gach te wachten / ende als lp de bilth fien/ baec op te ballen; andere die met baet

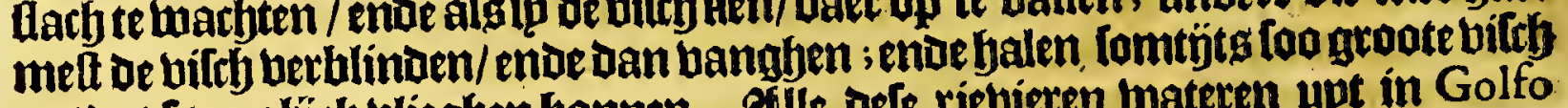

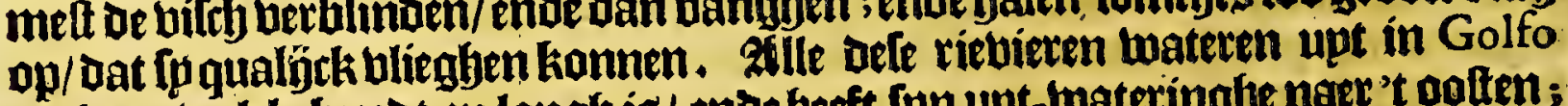
Dolce, welck beetot en langh is/ enoe beeft fpn upt-inateringbe naer't doetten; ende wojot fooghenaemt om dat fon water loet ís / hoe-bel troebel enoe lmaex:

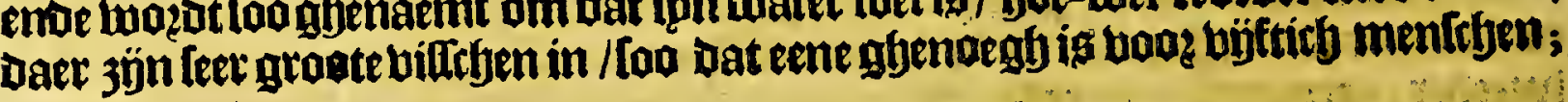

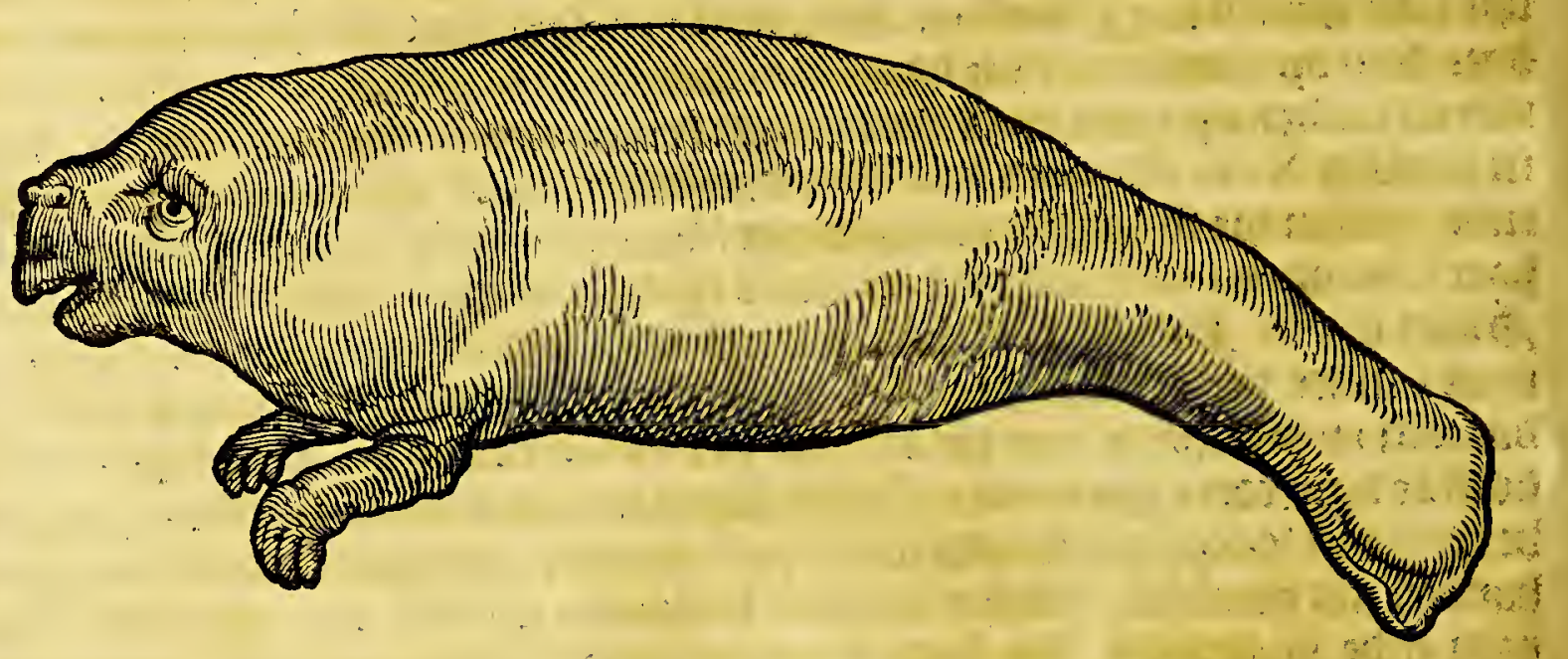

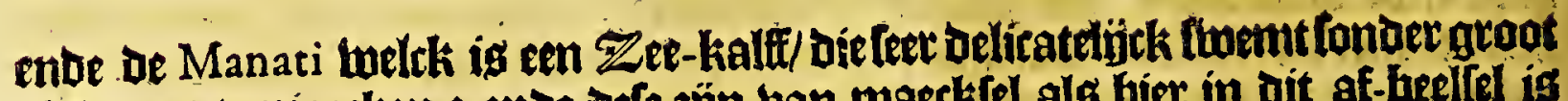

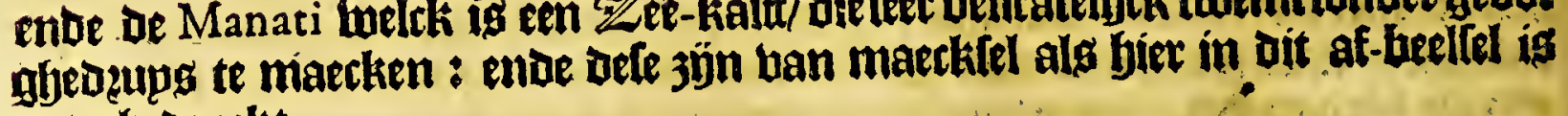
upt-abedeuckt.

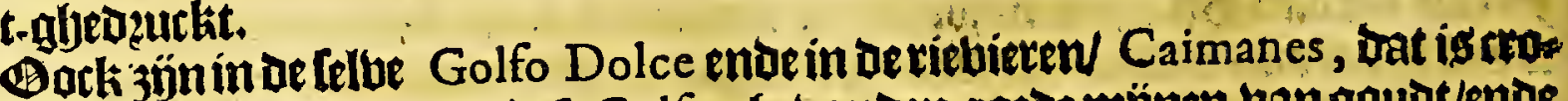

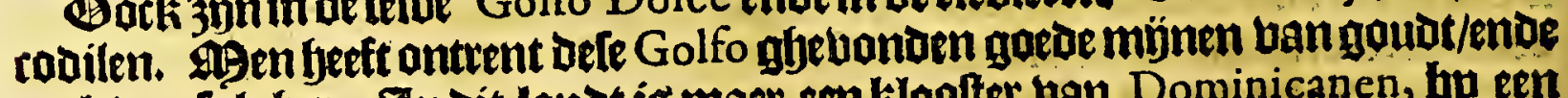

Her.der. oock ban Lulpher. 3 nd dit landt is maet een kloofter van Dominicanen, bu een blecke ban Jindianen/welende een van de Lebentbien klepne doepen diemen daes

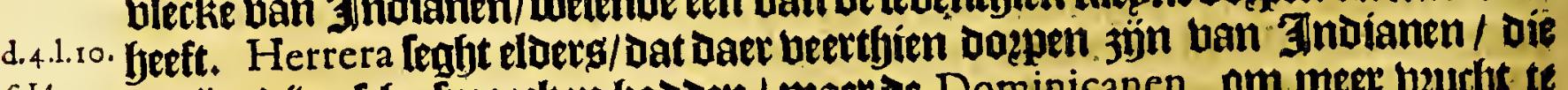

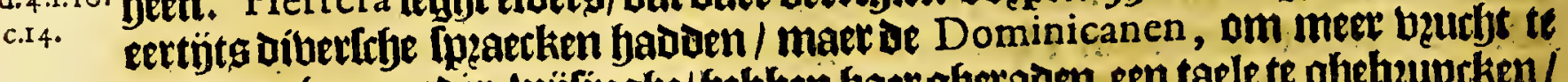

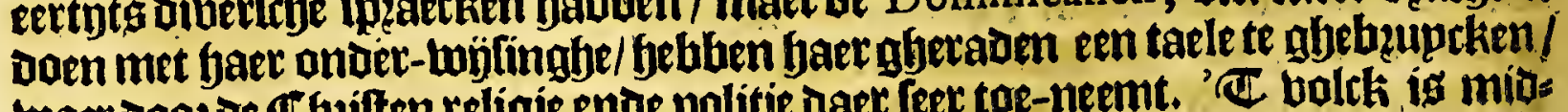

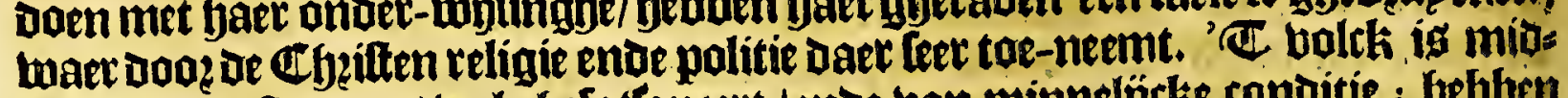
Delbaer ban ftatuere / wel ghefatfoneett / ende ban minnelïcke conditie; bebben ghebzeck ban bzoulwen/ Dooz díen de bzouluen kozter leven ald de mand; want

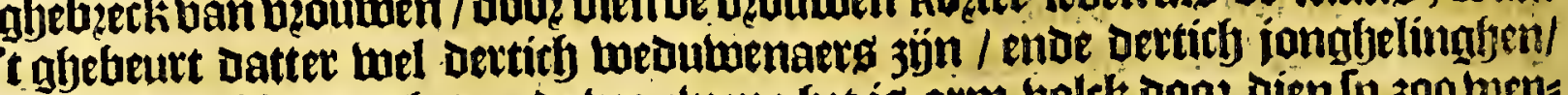

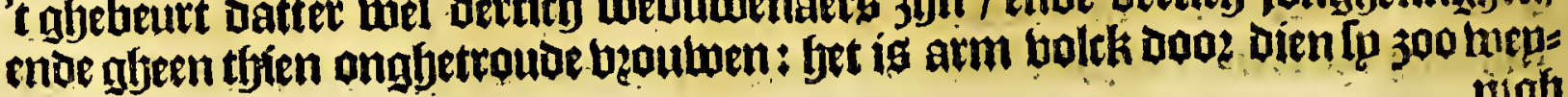


Het fevende Boeck.

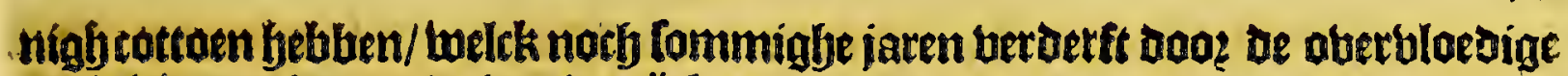

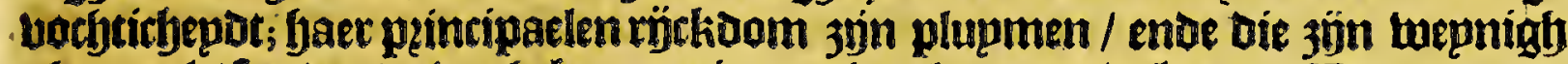
gbenoent/ too dat oe in-gheloopene in continuele armosoe leben. De beoumen baren alg gepten/Dickbilg alleen/ op oe gronot upt-geftreclit; andere bp de twegh/

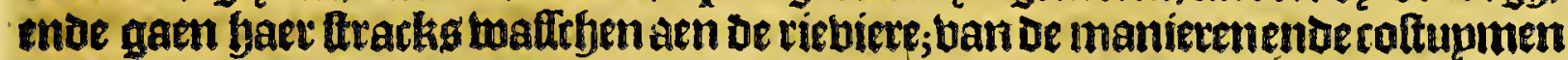
die fp badoen ten tỷde ban baet bepDenoom/en is niet ober-ghebleben ban de Danlirn. Sp maeckenfeer fraepe twetken tan plupmen; ende hebben baer nube= geben tot andeke ambarbten te Ieeten. Befe probincie en geeft geen Bouberneur। als alleen ljeft Ip een Alcalde major, die Daer geftelt bozot bp de Aludientie ban Guatimala.

Eter wop hier af-frfjepoen / Cal fyet gaet welente berfjalen't glyeene Sir Anthoni EngelSherley, entoe William Parker ig wedet-baren in't andert-foecken ban Rio Dolce. Fche vo. Bele naer eenigbe andere attentatenop de kufte ban Honduras, ende bet berobes yagic. ren ban Puerto de Cavallos, namen boo te onder-Loteken defe plaetten van Rio Dolce, faer felben in-beeldende dat baer defe riebiere op / (melck balt in Golfo Dolce) een enghte wag te binoen ban landt / waet ober men lictht foube konmen pafferen met uolck/ ende een barcke in ftucken mede boeten tot aen de jupbt-jee. Seploenmet be grootelebepen tot aen Cabo de tres puntas in $t$ innerte ban De bape/ende lieten baer leftepen Daer legghen/ enoe boeren met booten naer Rio Dolce, twelch Dlwers in fyet lanot loopt. Baeren be felberiebiere dooe diberffye keerenendekromten bel dertich mïlen enoe meer op-lwaertg; bonoen Daer een

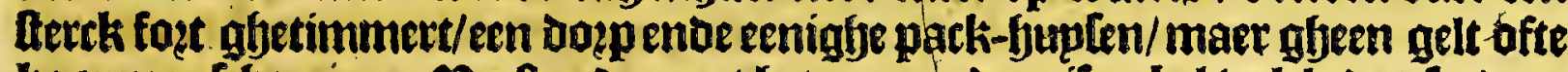
hoopmantebappen. Bextronden upt Get arm moe miferabel bolck dat [p daet

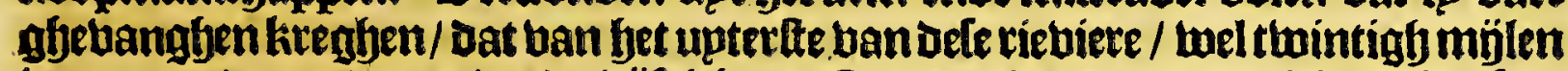
twaren tot oe jupot-3ee/ enve bijftich tot Guatemala, enve beettich tot Sonfon. nate, entoe derticfy tot Sacatocaluca, melende alle plaetien daer Ip foopten naer toe

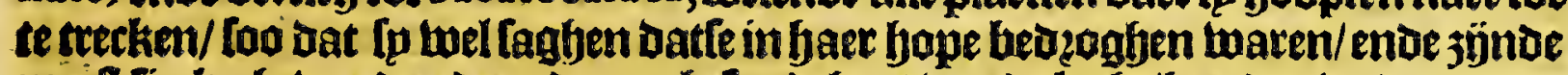
meeft lieck ghemozaen dooz de onghefonatbept hamae lucht/keeraenwederamna

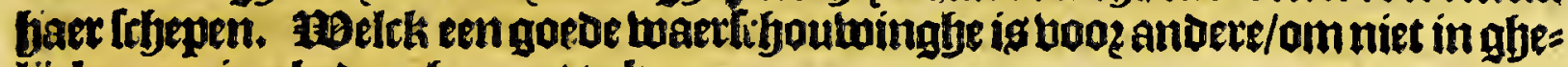
ligcke maniece bedeggfen upt te komen.

$$
\text { G } \quad \text { V A } A \text { T E } \quad M \quad A \quad L A .
$$

\section{Het Lebende Capittel.}

Byfondere befchrijvinghe van de Provincie, die eyghentlijck de naem voert van G V A T E MA I A, ende hare eygenfchappen.

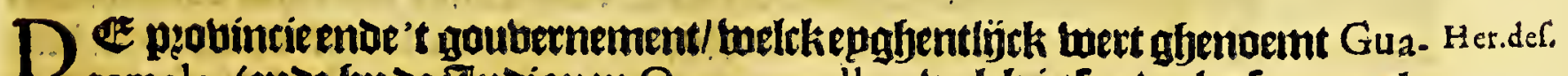
- temala, (ende bp de Indianen Quautemallac, twelck is foo beel te leggen als eenen berrotten boom; ) is ghelegen op oe kulte ban de jupot-jee / op oe lenghte

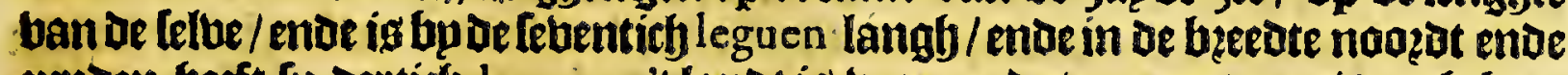
3upden beft fo oertich leguen; 't landot ig ban goede temperatuere / beutfjtbaer ban Maiz ende cottoen; ende tartwe walt daer feer oberbloedigy / gbelïck oack

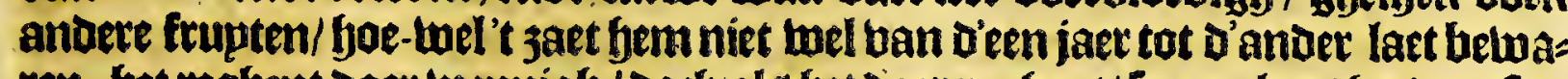

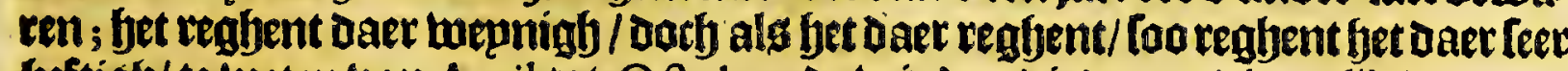
beftigb/ te weten ban A pril tot Oetober, te twinden die daer azoinaerlict waepen/

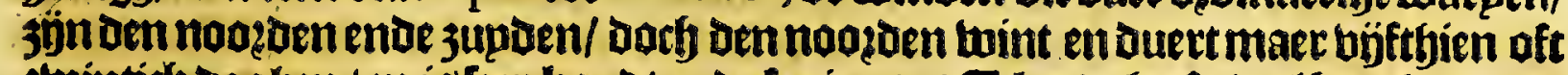

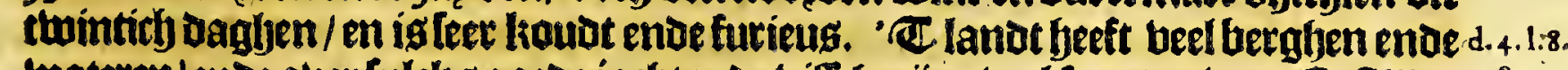

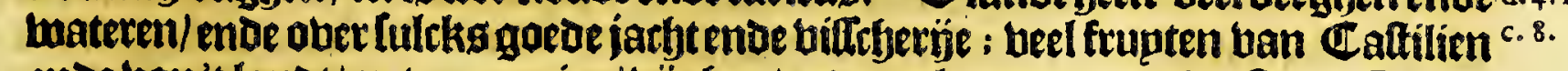
ende ban't lanot/met ozaeguien/ bijgfien/ende meloenen : oaer balt beel Cacao;

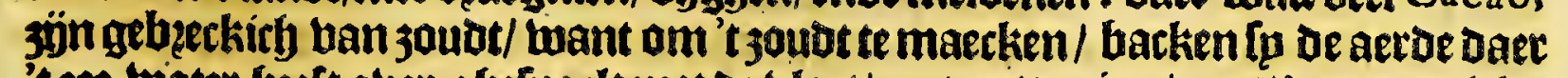
't 3 ee-water fyeft aber-ghelpoelt met oe bloet/met potten in ouens/ Doa? menichte banbout/ende trecken daet fo defeltichept upt om't $30 u t$ van te maken/met groote 
280

Guatimala:

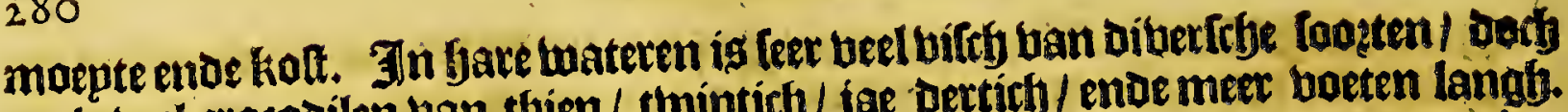
oock veel cracodilen yan thien/ twintich / jae bertich / ende meer boeten langt. - Be kufte ban defe pebincie begint ban Michatoya, ende epnoight aen Aguacha-

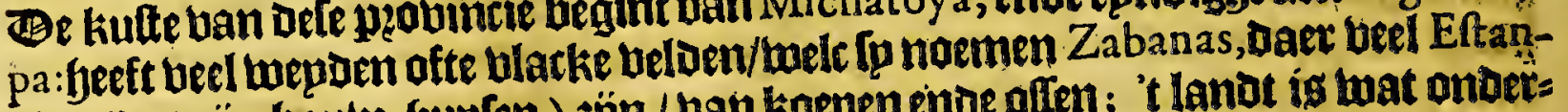

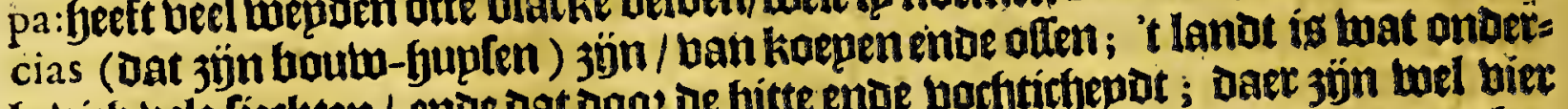

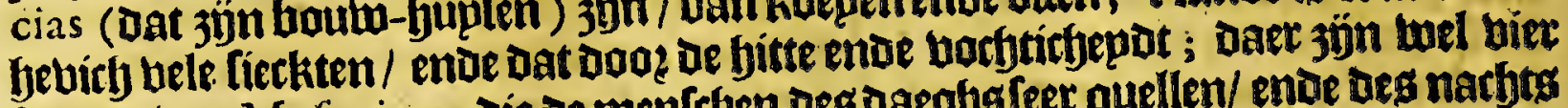
footen ban Mofquitos, die de menteyen Des daeghgfeer quellen/ ende des narbts

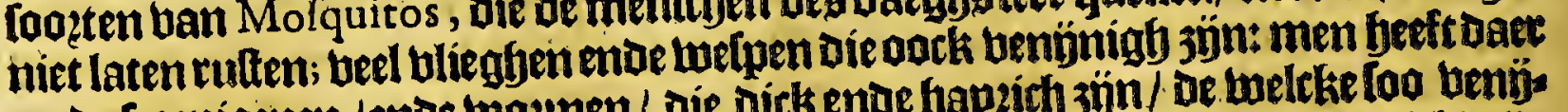

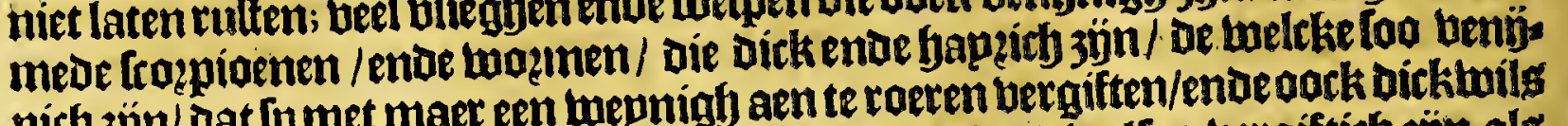

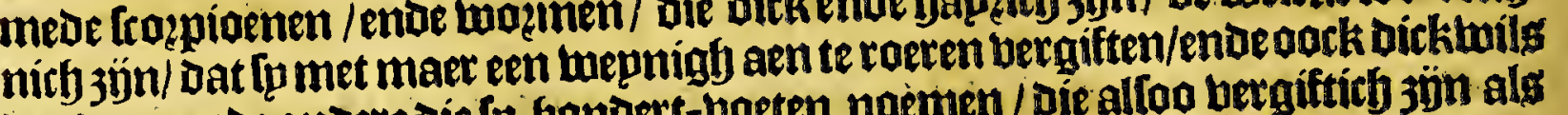

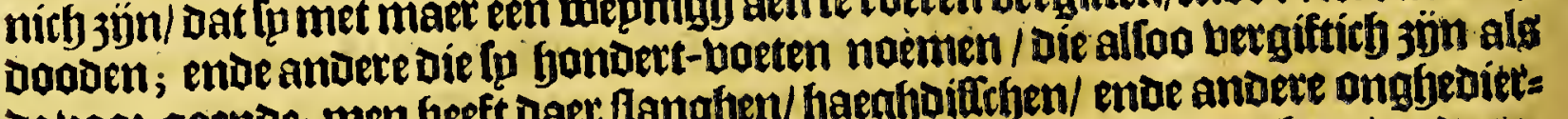

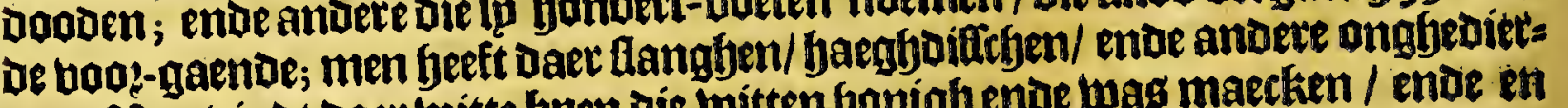
ten. Agen bintot Daer witte buen die witten Gonigbende was maecten / ende en tteecken loo leet niet als de andere. Baer balt veel ballems; ende een leecker lis d.3.1.5. queur als alie: (Gomara [eglyt dat dit líqueur vliet upt een bergb:) Daer is fulpfur

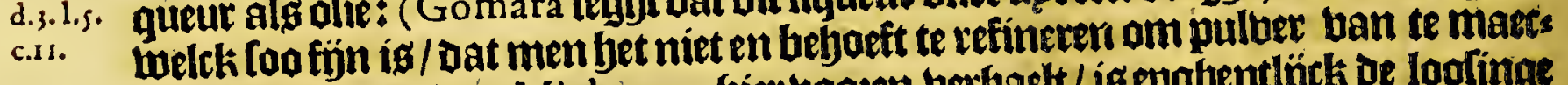

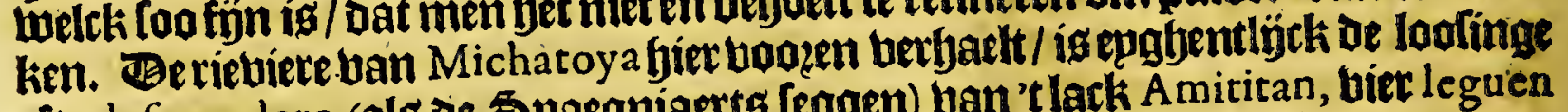
d.4.1. ofte defaguadero (alg De Spaegniaertg leggen) ban't lack Amititan, bier leguen

Wan de that ban Guatimala gbelegfen/ ende om in oe peobincie te ballen / does foo boaghen Lpenga/ Dat men met een roet lao boogi niet en loude konment

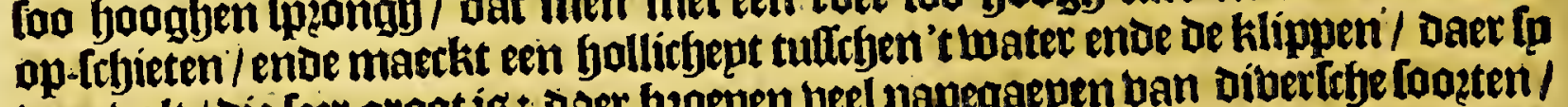

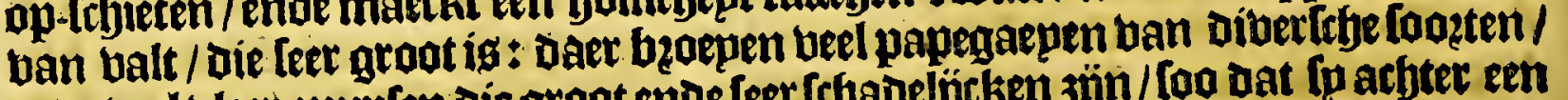

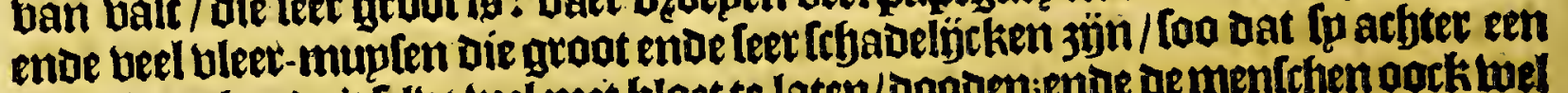
half getactkende't telue wel met bloet te laten/Dopoeniende de mentchen oock bel mede / foo fp die thapende binden: ende in dele caverne fanghen dele vleet-muplen D'een op oen anoeren/ento maecken turfen grooter als een foet / ende booz de

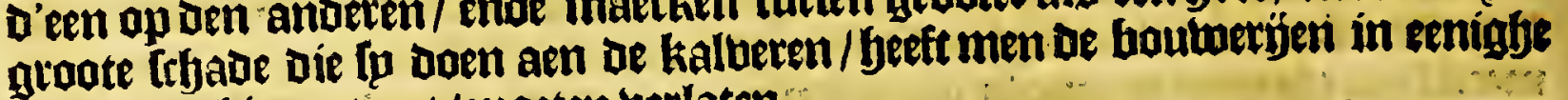
quartieren biet ontrent / moeten verlaten.

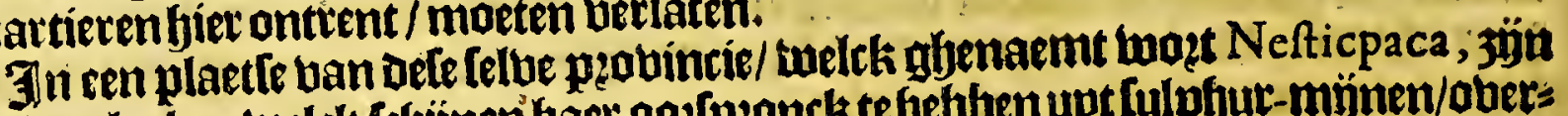

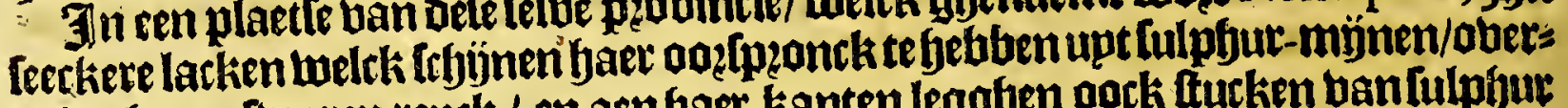
mits baren lwaren reuck / en aen baer kanten leggfen oock ftucken ban lulphus te Lamen ghegraept Dooz De Dickte ban water/ ende ouer lulcks leer ghelupbert;

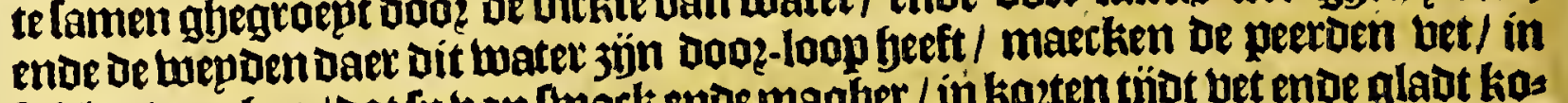

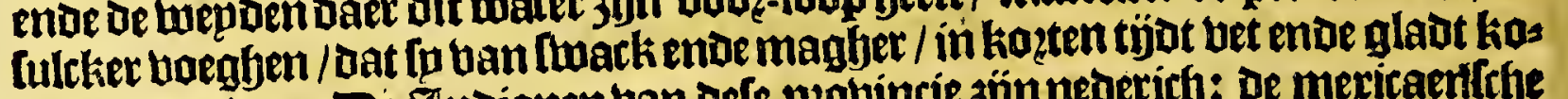

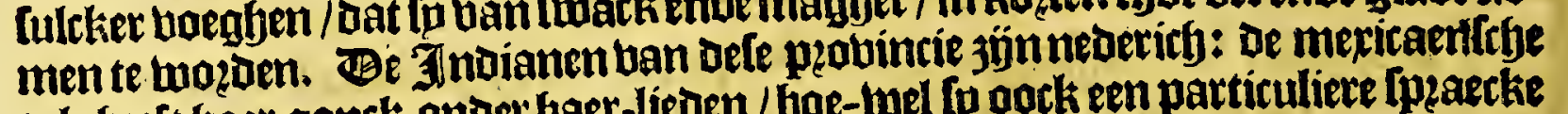
tale feeft haer ganck onder fjaer-lieden / boe-wel fp oock een particuliere Lpzaecke frebluen: $\$ p$ nemenmeer toe als andere in de religis ende politique conberlatie / worb met de minfte naerlaticfept wan wel op haer te letten/foo berballen fo in fyaer voozigbe blimbtfept. De bzoulwen zön groote fpinfters enoe wel abelebickt: of

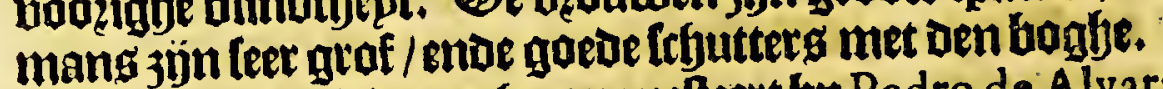

Defe peobincie was gheconquelteert by Pedro de Alvarado in ben jare bijfthien

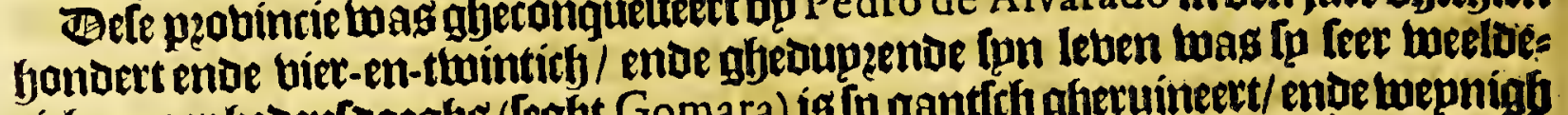

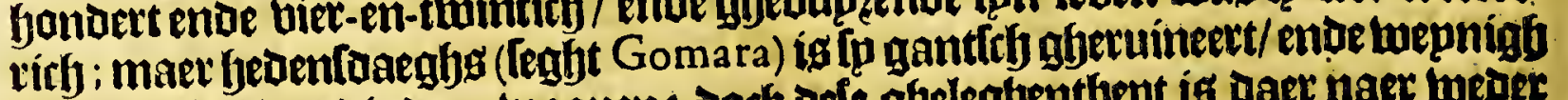
Spaegniaerden die daer woonen: Doeb Dele glyeleghentbept is Daer naer weder veranoert / ghelỉck die dinghen gaen.

- Bele pyatincie (leabt Herrera) en beeft maer de baben ban Yztapa, ende die en

d.3.1.7. is noch niet foo gaet ald Ip twel befyoozde te twelen. Herrera ftelt eloerg R. Yztapa bo

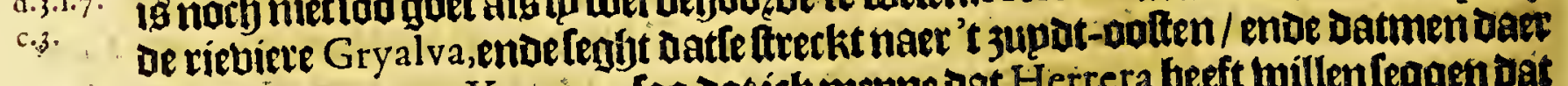

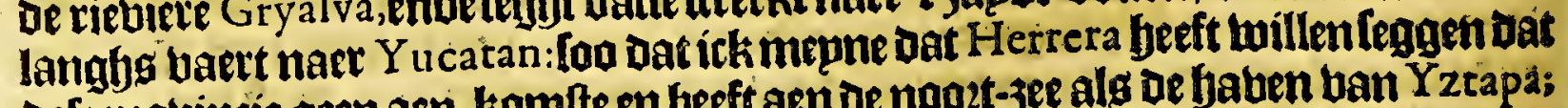

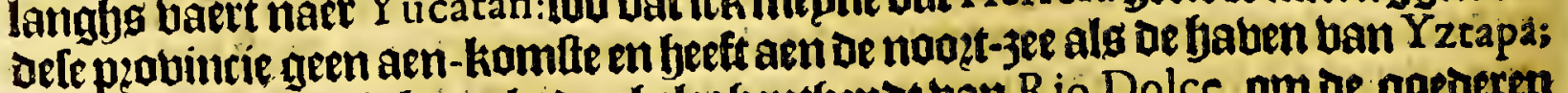

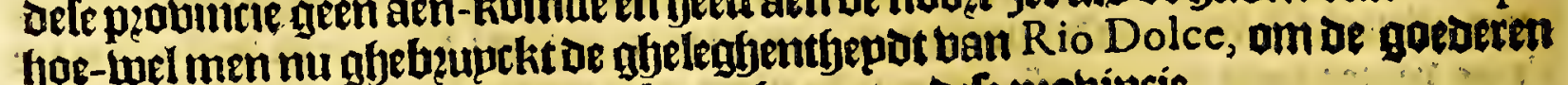
fommende ban de noozot-jee te bzengben naet oele pzobincie. 
Het adbette Capittel.

Particuliere befchrijvinghe van de Proviticie van YzA I cos, ghelijck de Spaegniaerden die noemen.

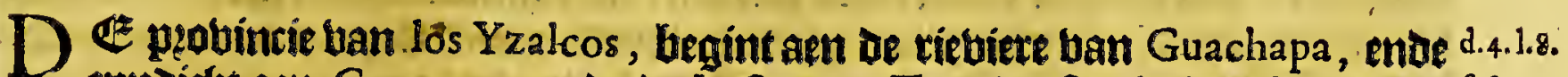

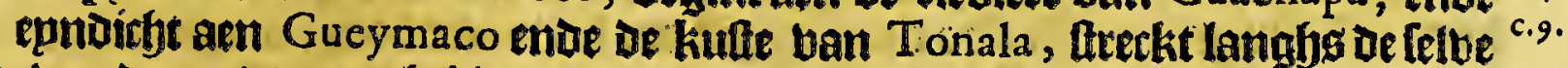
kufte bande jupot-jee achthien leguen, beeft bp naer be felbe qualitegten ban bo: oem ende lucht als die ban Guazapan, ende oberbloedirfept van de [elue dingfien/ enve beeft beel Cacao, foo dat'taheene naet Nova Hifpania wozot abebarbt। ende't gheene fp ingaer equben fuplen verbefigben/ in de bier placten ban los Yzalcos, alleen meer dan böfticf Duplent Cargas beloopt/ (Dat ig foo teel als een

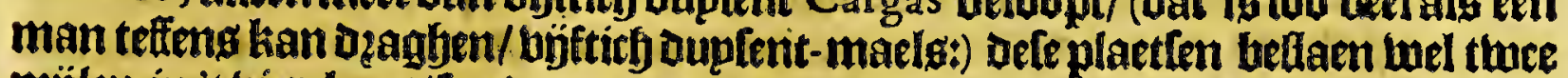

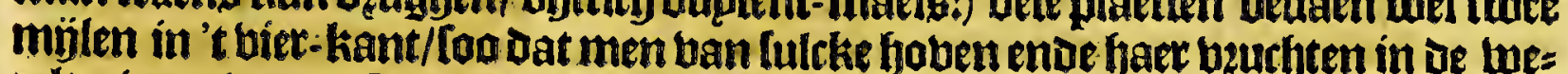
relt niet en weet te fperecken. Sp teflen yet Cacao bp Contles, Xequipiles, en Cargas:een Contle ig vier bondert amandelen; een Xequipil twee jondert Coneles, bat is acht ouplent amanotls; ente een Carga Deg Xequipiles; ende op Die maniere tellen ip oock alle baer andere dinghen. Daer watt nocheen anoeren boom luelck of Jindianen in baete taele noemen Cochiz-tzapotl ende de Spae= gniaerden Zapote, if en grooten boom / wieng bladeten be ogagnie-boomen bladeren niet ongelïck en $3 \mathfrak{j n}$; dzaeght klepne geele blommekeng/ende beenght een bzuchte bootg als ten quek-appel ofte peete foo banmaetlitel alg tan qroo= te ; welck twel goet ban Imaeck ig/maer niet ghelonbt/ enoe beeft een ften in / Die niet beter als benifn is : defe beuchte gljegeten maeckt de mentrben daperigh/ waerom oe Spaegniaerden de telue noemen Zapote fonifero. Jen booghgheleetoen Carolus. Clufius maeckt in fpn boetken tan te upt-heemlefte kutup=

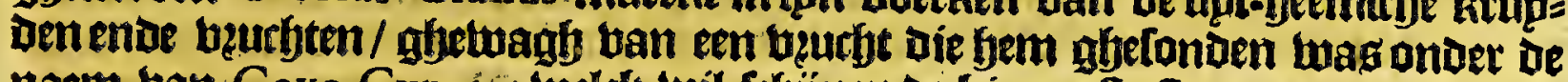
naem ban Coxo Cypote; melck wil fthínen te himnentte teen te jijn ban defe bquchte.

In dele plobincie is een Volcan die altijotg roockt / welck of in-gheletene

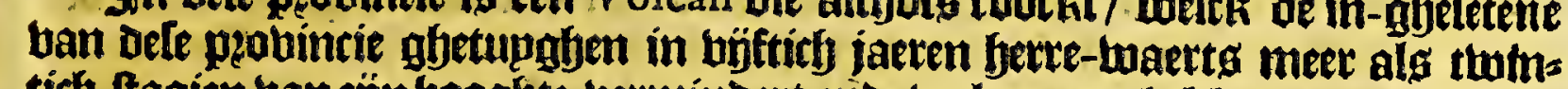
tich ttagien ban jön booghte bermindert ende berlaozen te bebben; ende op fom= mighe jaeten feeft be fulcken menichte ian alleben upt-ghetwoupen / dat bp bet lanot daer mede eenighe mijlen in 't rande bedeckte; dede fer: groote lchade in de boben ban 't Cacao naet het jupoen gbeleghen/Daec bet lanot leeghtte is; daet ballen ban befen berglj beel berfegenden twateren af / welcker enighe leer goedt jón / ander leer quaedt entae thinckenoe ; daer iseen leecke onder andere / bie met Iteen bederkt alles wat daet in balt; ende bier ontrent in een plaetle ghenaemt Tupa, bebt gljp noth een delghelijeke / als mede een in de plobintie ban Chiapa. Ban de Yzalcos klimt men Dep leguen tot een plaette die fu naemen A paneca, belck bouen maten koudt is : Daer mozoen eben-wel granaden getwomen/enoe antere bututen ban lpaegnien/ ende inlonderfepdt tathe: een mijle van Daex is een anoer plaetfe gfienaemt A taco, ban de felbe temperatuete ende uptel-maten mel booz-lien ban alderfande jacht; in fet gheberghte feeft men Jet ghediette dat men feght den Bezoar boozt-beenght: Daer is oock een loozte ban klepne oieten

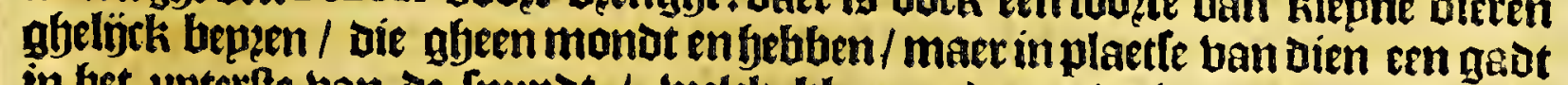
in bet upterte ban oe Imupot / tuelck klepn enoe ronot is / met ern langfe tonghe/ban binnen bol / daex [p den bonigh mede in fupgljen / enoe balem die baerfu die binden konnen; ende als baet die ontbeetkt / foo gaen fo aen oe mie= ren-nelten / enve therken haere tonghe daer upt als oft eenried waer/ ende lor= ken de mierenlo daer in. Baer jün beel dainen ban diberffye couleuren / ende beel $25 \mathfrak{b}$ Differen= 


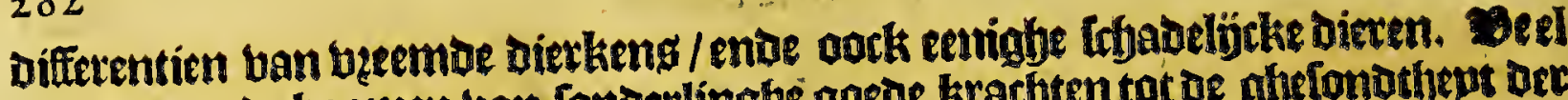
kitupoen ende boomen ban conderlinghe goede krachten tot of glyefondthetet oer mentryen/als ban maftick/ Dzaecken-bloet/ ende boomen ban Anime, bp groote menichten. Foat boozder ban Daex is. Guacapa ghelegen/abundant als de boosgaende/ Daer oe bzoulven fonder eenighe inftrumenten feer goede aerde baten ma: ken; ende in't water van feeckere belke/let bem leecker fubittantie bie roodt is als Cochinille, daer [p f aer baten mede bertwen / enoe ghelooben dat het bolus arme.

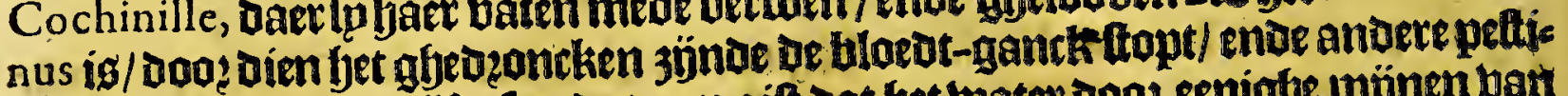

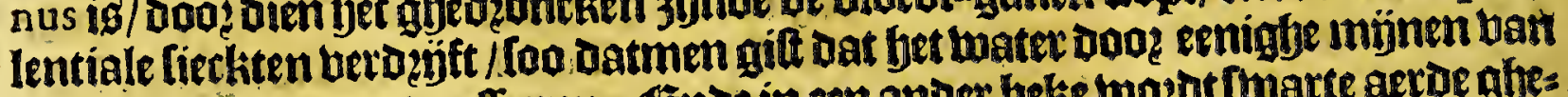
bolus armenus moet palfeeten. Ende in een anoer beke mozot fwarte aerde ghe:

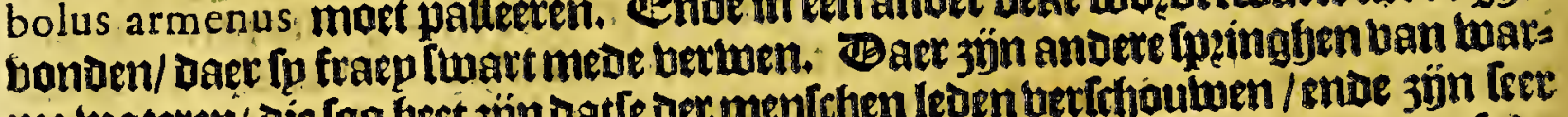

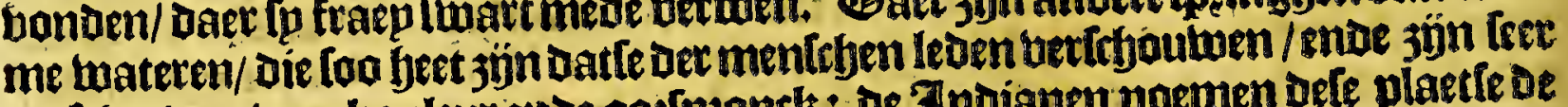

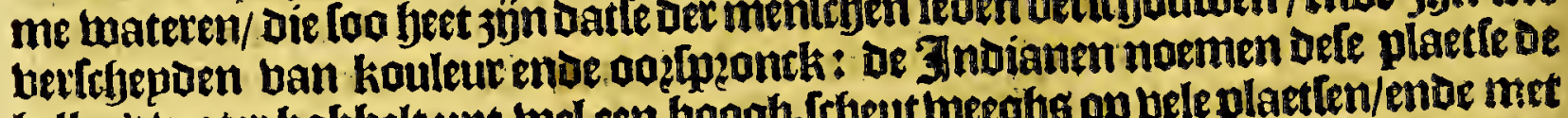

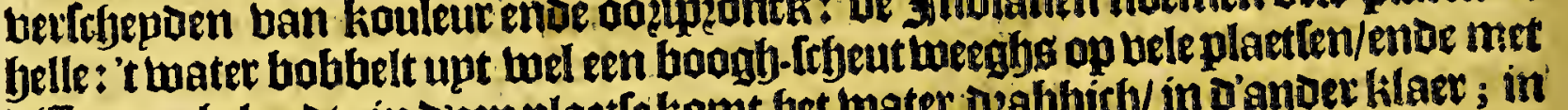

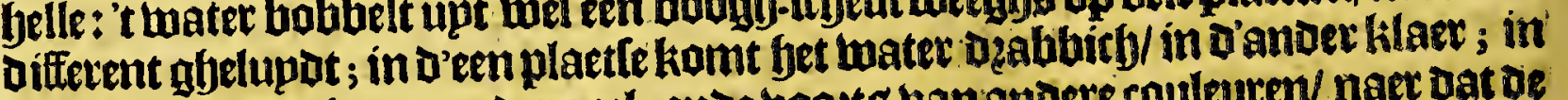
een ander roout/ in een ander geel; ende boaztg banandere couleuren/ naet dat de mineralen jün daet dele twateren dooz palteeren; epnoelíck van de dampen vie baer upt kamen/komt leecker betumen, ban leet berfebepoen rouleuten/ melcke coube konnen dienen am mede te fehiloeren ; ae 3 nbianen pleghen gaer patten te Ietten aber dele fpinghen / am die te doen fieden. Ban alle defe fpezinghen kams voost deviebiere die de Sparguiaeroen noemen Caliente, dat is beete/ want als Jit mater mel een half legue gheloopen beeft boo? De gronot/ ban oefe plaetie af/

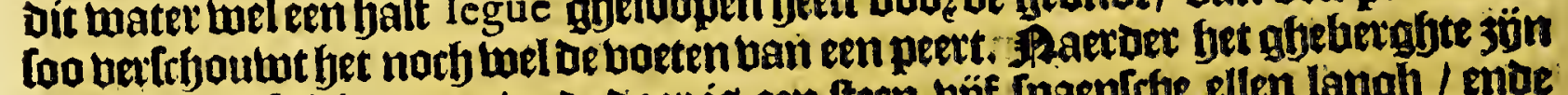
nochandere fulcke gaten/ende daer ig een lteen büf Laenictye ellen langb / enoe

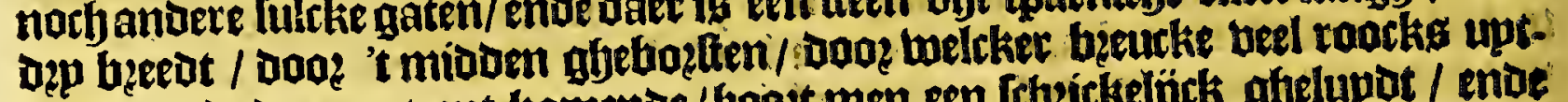

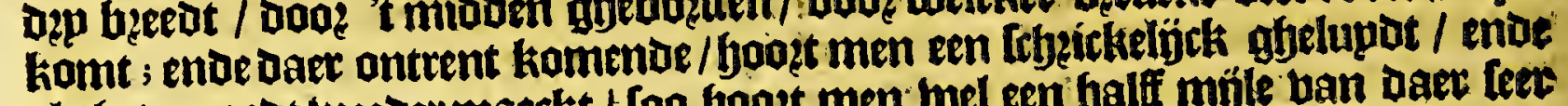

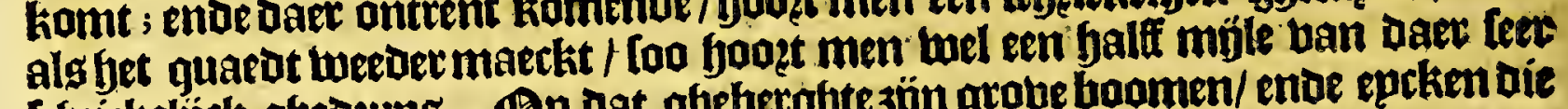

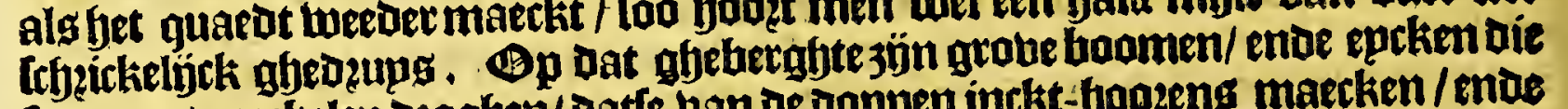
foo groote eectielen dzaghen/Datte ban oe doppen inckt-fjoozeng maecken/ento

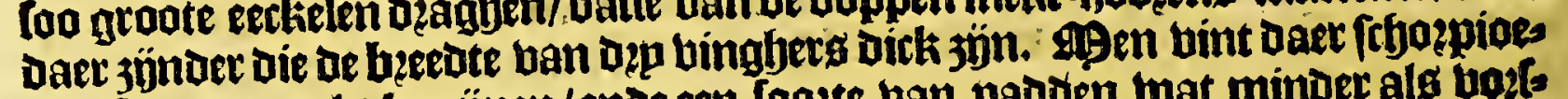
nen too groot als trong̈nen/ende een loozte ban padoen wat minder als voefo Ifben / die op De boomen Ipeinghen/ ende baet daer onthouben gfelp̈ck als bos abelen / ende maecken in tijoe ban regfenen leer groot ghefrbal. Be mieren jún daet wonder groat / ende de in-moonders eetenle/ ende berkoopen die op baere marckten.

\section{SAN SALVADOR, SAN MIGUEI, ende CHULUTECA.}

\section{Fat meghenoe Capittel.}

Particuliere befchrijvinghe van de Provincien van San SALvador, SA N MrgVe ende CHVIVTECA, ende hare byfondere gheleghentheden.

d.4.1.8. Detouincie han San Salvador, neemt baet begin aen oe blecke ban Ati-
c.10.

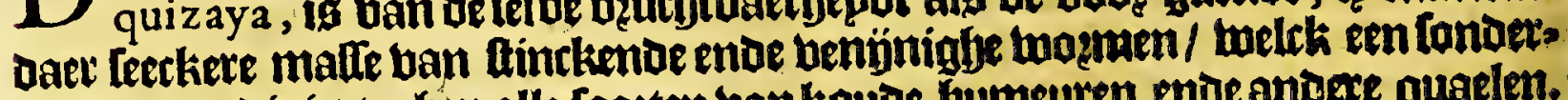
lingle remedie ís teghen alle [ooeten van kaude bumeuren ende anowe guaelen.

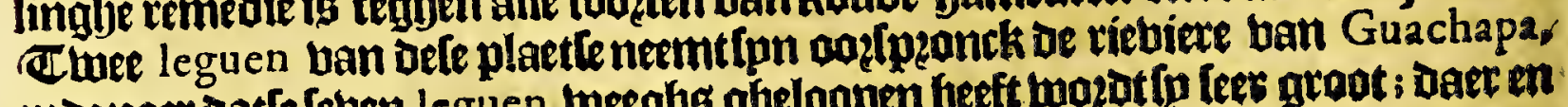

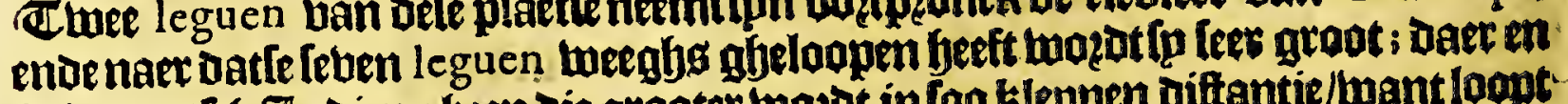
is in gantley Indien gheen die grooter mogot in foo Elepnen diftantie/want loopt maer derthien leguen, ende komt loo in de 3 upat-3ee. In de blecke ban Santa

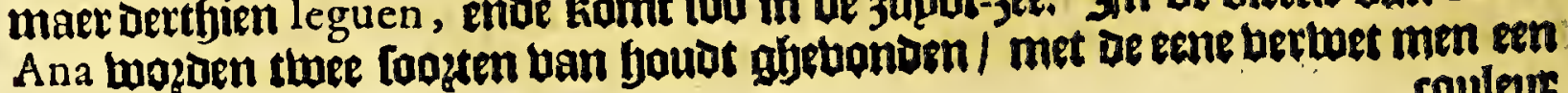
couleut 
hauleut welck fo noemen Leonada; ente fet ander in't water werpende/ maeckt fefjoon blaeuw. Alen oe boet ban ben Volcan in t booz-gaende Capittel berbaelt / ditbt ap Coatan, is een lack gfelegfen dat beel diep ig/ vol ban trocas Dilen/ende een Eplandeken in't midoen; De 3 ndianen die [p noemen Pipeles, gheloofoen Dat gheen mentch en mocht fien twatter op Dit Eplanot twag / Dan

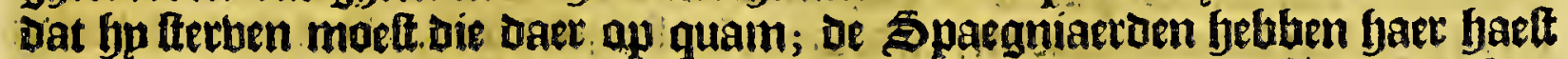
tan defe bombent ontlait / maeckten blotten am daet aen te tiomen/ ende lere= kete Stwarten fowommen daet naet toe / enoe bonden op bet Explandet eengroot

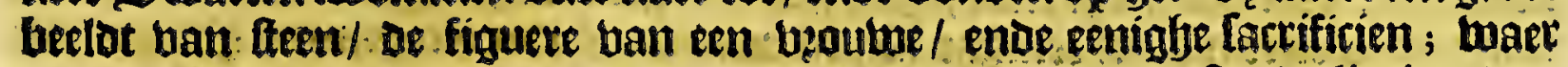
boos oc . Indianen faghen oat bet maer fabulen en waren. Op oc limiten van De blecke twelck Ip noemen Guaymoco, jün groote boomen ban ballem (als

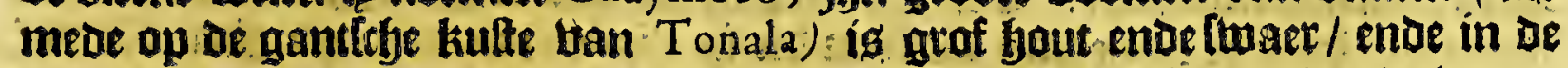

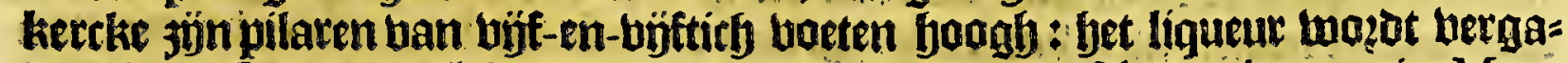
Dett in De fomer/. welck Daet Duett ban de maendt November tot in May;

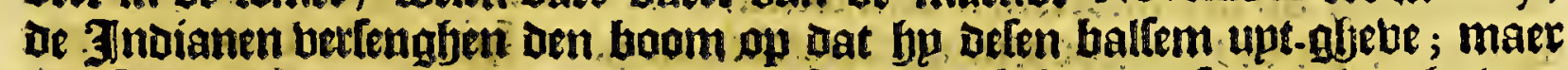

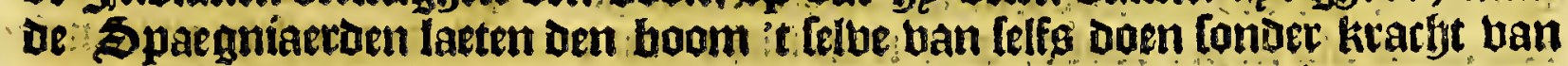
vper. Ben boom betnght feeckere beucften boots als amantielen / daer een

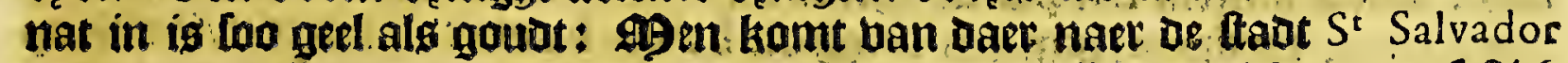
book een engfte / waor langhs men een riebieve pafteert bel loben-en-feitich mael/tot aen de boet vaneen grode $V$ olcan, die gheen vper meer upt en gheeft/

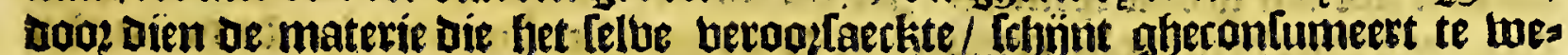
fen; ende maet kten loa groaten monot ten tijoe batle bzanoe/ Datfe meer alg een balf mijle in bet ronoe was / ende luonaer diep jende eet ghp beneoen komt/ foo beeftet twee plaetlen ghelýck ald be kalck-puens; enoe upt oe dieplte komt norbozoinaris roock die loo lwaer rieckt / Dat men abelien lyeeft een Spaes gniaert daer ban te belwijmen / om bat bp Daer te naer was gheknmen. Ben bergh is ban beneden tot boben bol ban cedar-boomen/pjn-boomen/ende meer andere / oork gfedierte / ende berbzande ftoffen ban den bzandt die daec pleegh te tweten. Bepp leguen ban bet upterife ban offen Volcan is glbeleghen te blecke ban Nixapa, Daec een ftuck is ban eenen dozeren bergh / die fo naf= men el mal pays, beltaende upt fteenen/ ende berbzande aerde ouer-foop legs = abenoe / ende is te bertwonderen ban waer dele aerde magh abeltomen zijn;

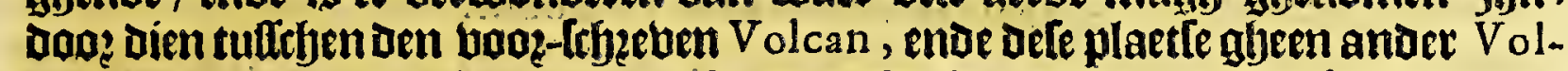

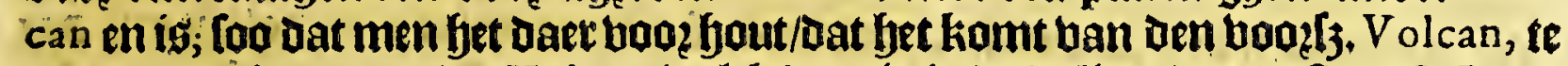
meer Dooz dieneen anoer Volcan welck daer is in de valleve ban de ftadt $S^{t}$ Iago, ban berte upt-Imït groote betghen ban beter ende fleenen; : ende een andeten die upt- bozte enoe begon te bzanden in Nicaragua, fimet met ghetwelt een betgh uan bouen tot beneden ober een feeckere ballepe daer eenighe tooningten waren ban

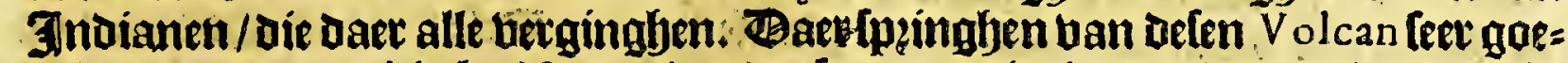
be wateren/ende dicht bu Nixapa wazgenfe tot een riebiere; ende daer is een beke

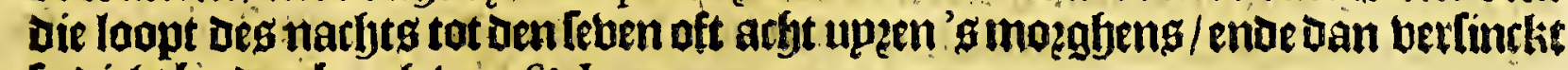
Ip vicht bip oen bergh ban $S^{2}$ Iuan:

In oe peouincie ban Chuluteca isten ander fontepn/welche bloept tot mios Dagh/en verdwignt Dan. Zlen de boet ban defen Volçan is een ronden put die leet

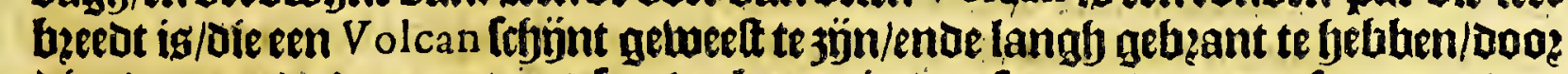
dien de grondt Daer ontrent leer berbzant is / nu fpzupt Daet een fontepne tan feet goet water / Daer oe blecke bant Cuzcatan met yooz-[ien wozat / oie bp de kant ban deten put ís gelegen: ende daet bp íg oock ghelegen oe ftadt $S^{:}$Salvador.

Op Defe kulte yan de jupdt-jee tot of riebiere Lempa toe/ palenoe aen de provincie van $S^{t}$ Miguel, jün plapuen ende oberbloedt van toepden/ ende ge= nity the: aen een jyoe bp oe boet ban pen boogge Volcan legghen bier blecken ban Indianen/ Daer too beel Eacao twatt als in oe pzobincie van Ycalcos.

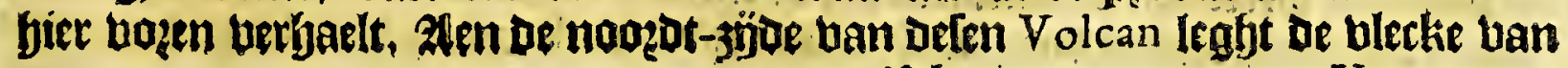




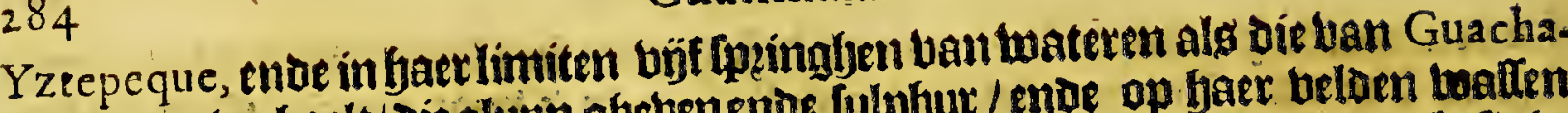
pa toosen berfaelt/ die alupn ghebenendo lulphur / ende op haec beloen toalten uecl boomen ende krupden/ oie tot beele gaeae ghebzuptken konmen ghebefigbt tmotzen. De berghen ttaen bol van de medirinale wotelentwelck fo noemen Me. choacan; enoe bandie platte af beginmen De bolcketen diemen noemt Chonta-

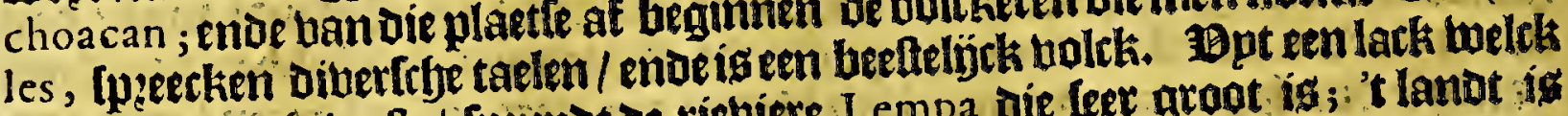

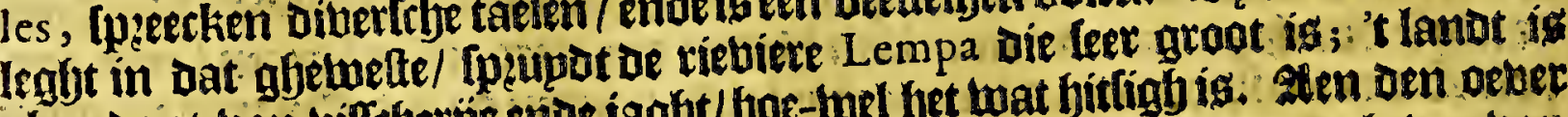

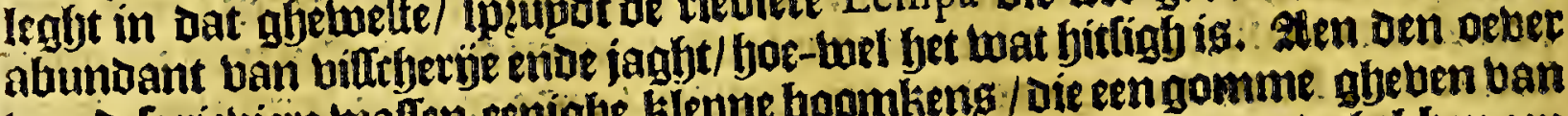
uan Defe riebiexe twatten eenighe hlepne boomkens / Die een gomme. gheben ban

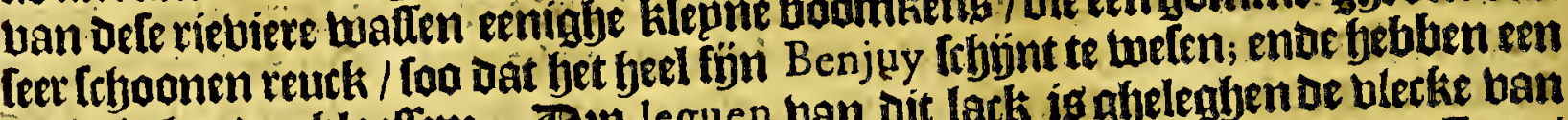
weI-rieckenton bloeflem. Dep leguen ban dit lack is gheleghen be blecke ban

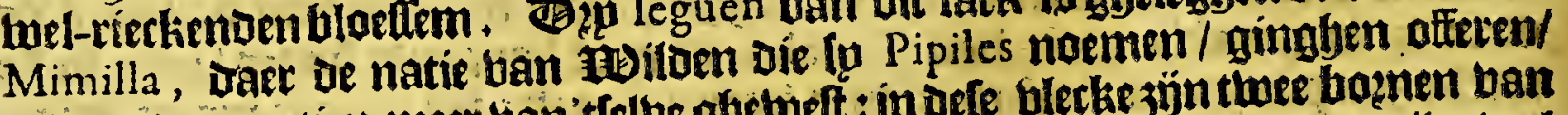
ende andere natien meec ban'tfelbe ghetueft : in oele blecke jün twee boenen ban

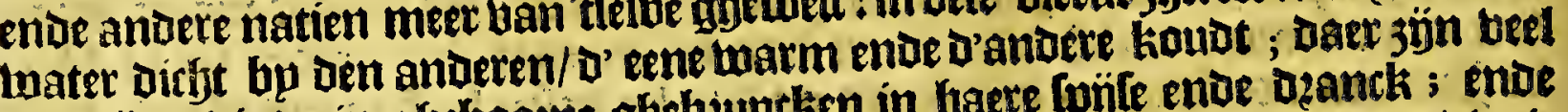
[pecerijen die de in-gheboozne ghebututken in yaere fpjife ende dzanck ; enoe efn aerde als koper-rooot / Daet men inckt ban maeckt be ganttrbe peobincie

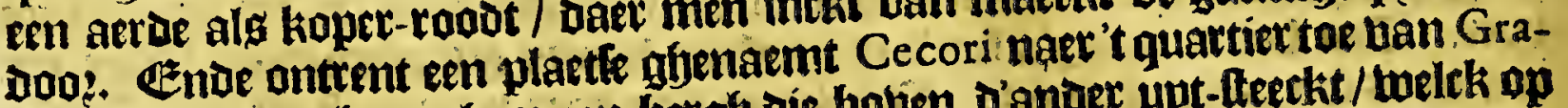
cias à Dios, bertfoont bem een bergy die boben Dander upt-lteecht / welck op den top een groot lack beeft ban foet-Luater/ Ceer diep / welck Itjýnt boozt te komen upt een groote lpeingh. $31 n$ dit lanot binot men leet beel danten; Dit

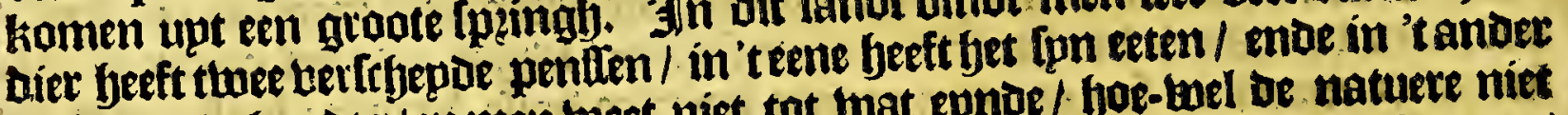
beel betrodtyoubts/en men toeet niet tot wat epnoe/ boe-bel be natuete niet

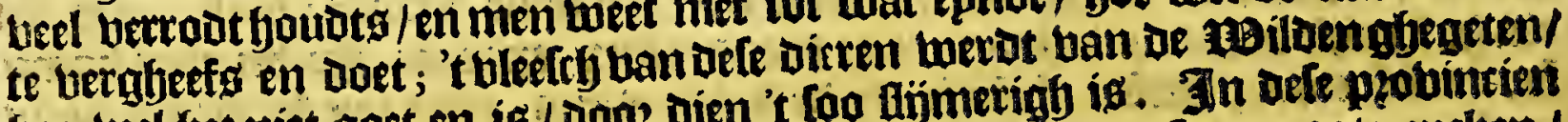

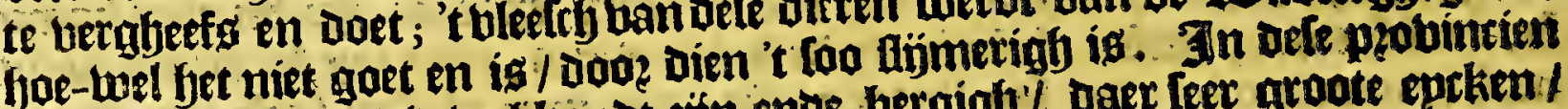

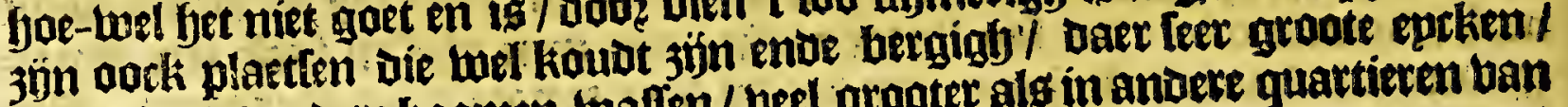

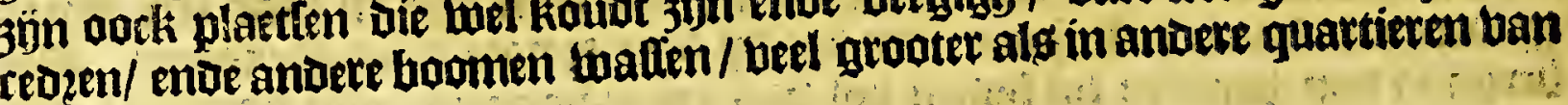
Dit afjetwelte.

\section{Het thiende Capittel.}

Befchrijvinghe van de Stade $S$ A N I A G O DE GV A TE M A I A, welck is de voornaemfte die in dit quartier by de

Spaegniaerden worde bewoont.

Her.der. WW

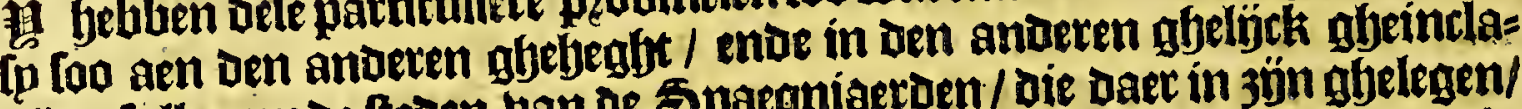
beert $3 \mathfrak{g n}$ : Cullen nu de fteden ban de Spaegniaerden/ bie daec in 3 g̈n ghelegen/ berbalen / beginnende ban oe peincipaelfe / welckegbenoem two of s' lago de

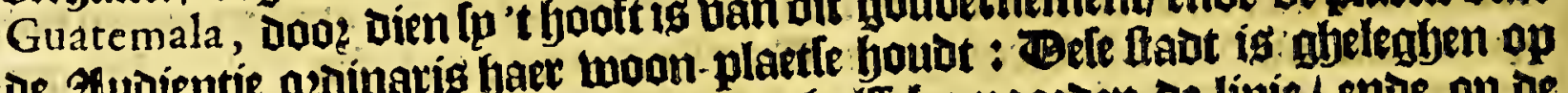
de 2 fudientie ozoinatis baec boen en een halff bu noozoen be linie/ ende op de be booglyte ban beertbien graden en een ban den meridiaen ban Toledo; is Ienghte uan Dęp-en-tneghentigl graden men noemt Mar del Zur; ( Herrera

d.3.1.5. gheleghen twaelf leguen ban in het mitonen ban een ballepe daer een riebiere c.ri. Teght eloers büfthien legue

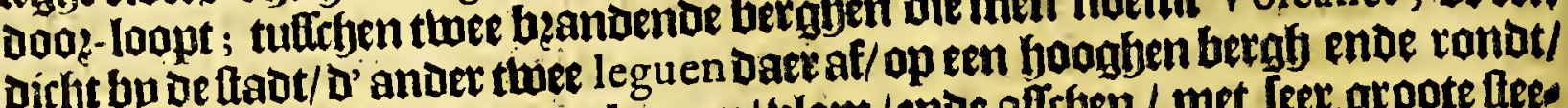

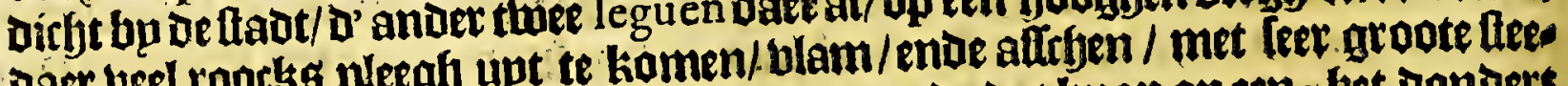
Daer beel roocks pleegh upt te komen/be leer / ende Dat knap op een; lyet dondert

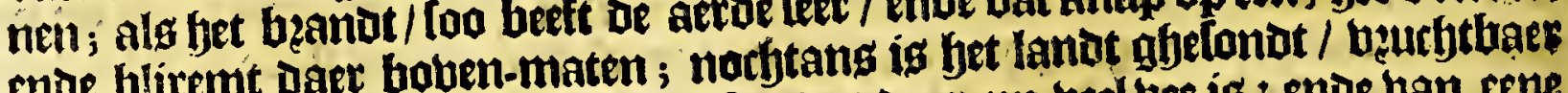
ende blipemt daer boben-maten; noct oat daet nu beel bee is : ende ban ene

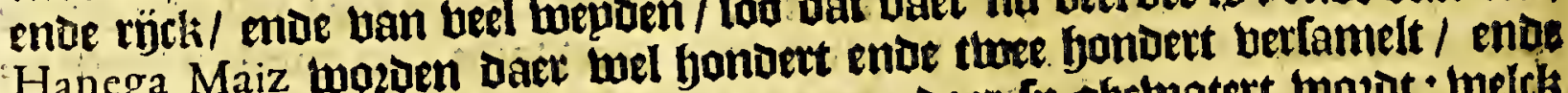

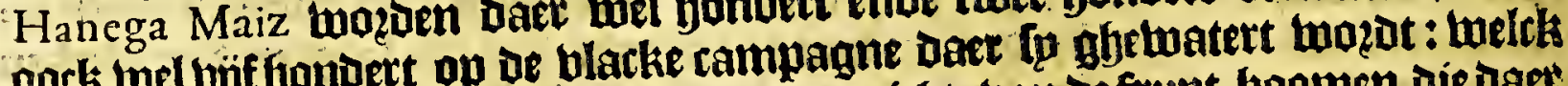

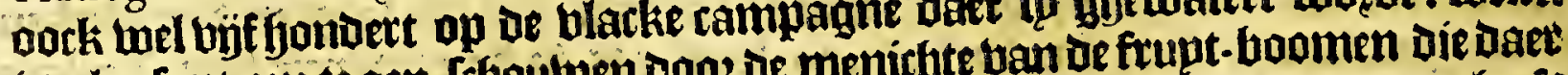

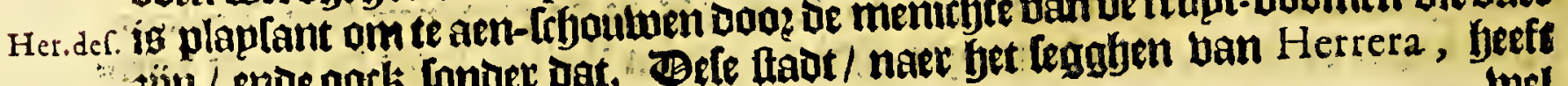

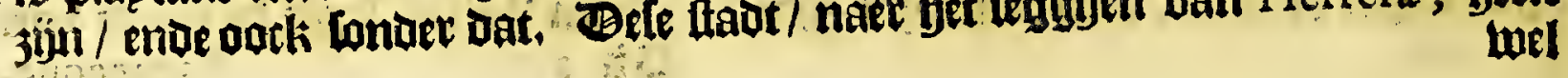




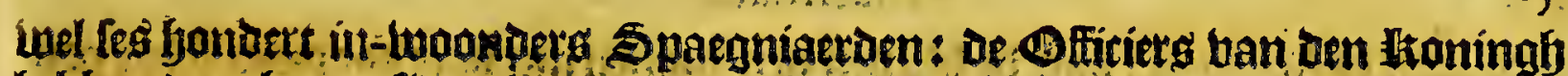

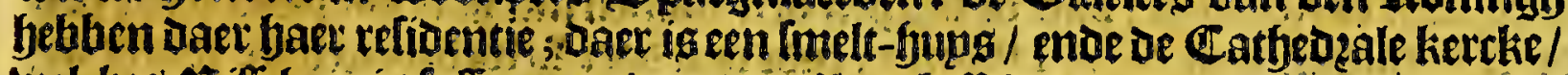

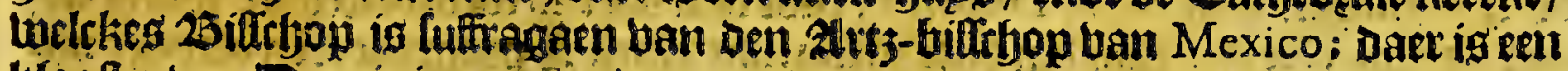
kloofter ban Dominitanen 7 ende een ander ban de ozdoe de la Merced; ende een bolpitael; enoe in baer limiter woonen wel büf-en; fluintich Dupknt Invianen Die tribupt betalen; de thaot is ghelegfen in en feer bermaeckelijcke ballepe/ ende beeft abundantie van fuputen ende alderhande victualie. Dele ftadt is gheleghen twee bondert en fettentifh leguen uan Mexico; Den loegl dertwaerte ban Me-d. 4.1.7.

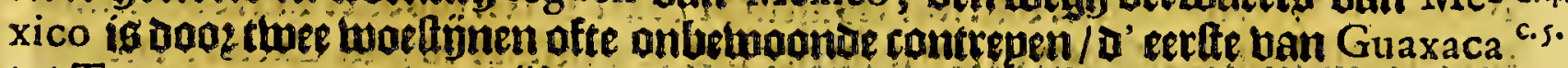
tot Tecoantepecque ban bót-en-beetticf leguen; enoed anoer ban baer langlgs Soconulco, ban leftich leguen, enoe ban balf May tot falf November enteplt men nies / Doo bien bet meeli alle dagben reghent / enop men de riebieren en paelen

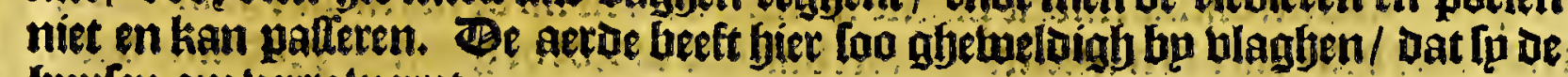
bupten om berte luerpt.

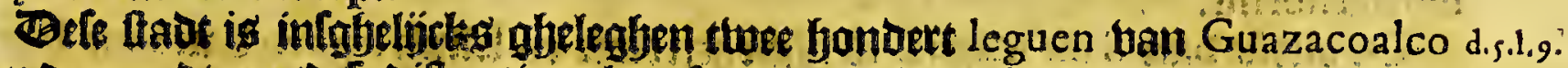

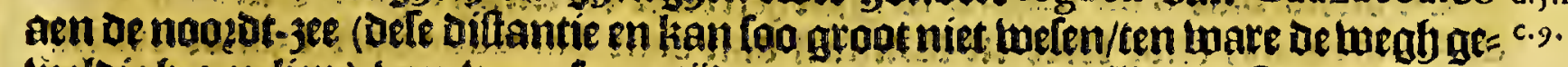
toeloigh om-liep) ban tuaer fo ecrtopts met groote trabailie moeften balen bet gbene lo ban de noozot-3ee ban doen jaouen. Banbebben daet naet een naet= Deren tuegl ghetonoen dooe de vallepe ban Naco in de pebincie Honduras welck maer bu de viftich mijlen ig ghelegften ban $S^{t}$ Iago de Cavalleros ofte Guatemala.

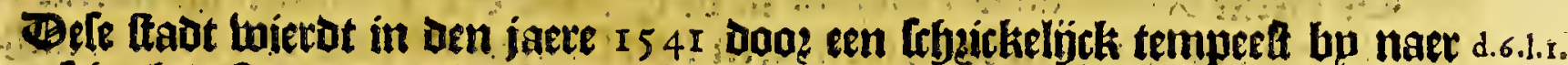
ganteb ghedeffiueett / welck lpn oof fpeonck nam unt oen Volcan, welck legbt c.8. boven oe ftadt / ban maer bes nacbts ten twee upeen onterliens foo grooten water-bloed (met bem boerende ghetweldigbe freenen / beel bouot ende gantflye boomen /) quam in de ttade met fulcken ghetwelot / dat lo de mueren ban de

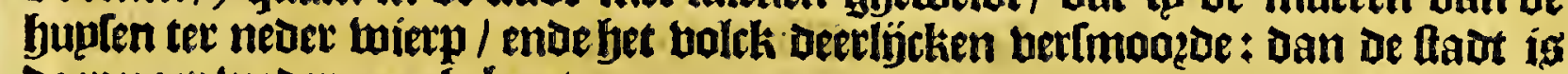
Daer naer tueder op-abebout.

Iohn Chilton die daet was in ben jaere 1570 legfit bat bp funet tijot in Dele EngelItaut maer woonoen tachtentich Spaeguiaeruen; dat lp leght beetthien mílen fche vo. ban de zee binnen's landts; ende leer rijck is / ban lueghen het goudot datfe gaen yagie. Galen ban de kufte tan Veragua. Boch gheloabe datter een goedt Deel ban ba= ren rỷchoom kamt ban Den Indigo ofte Annil die Luonoer fün is / lo date boben allen leet gfeacht wożt.

\section{Wet elffte Capittel.}

Befchrijvinghe van de andere fteden van defe provincien, te weten, St SALVADOR, LATRINIDAD, St M I V VI, ende XEREZ DE LA FRONTERA.

De ftadt $S^{t}$ Salvador, de tuelcke de Jntrianen infare tale naemoen Cuzcat- Her.dor.

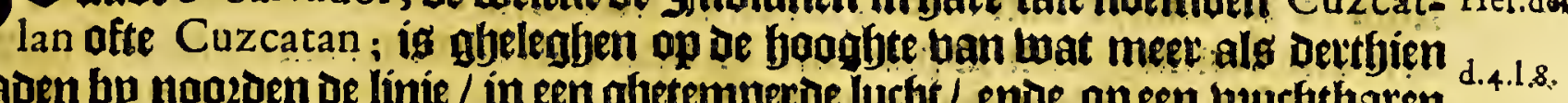

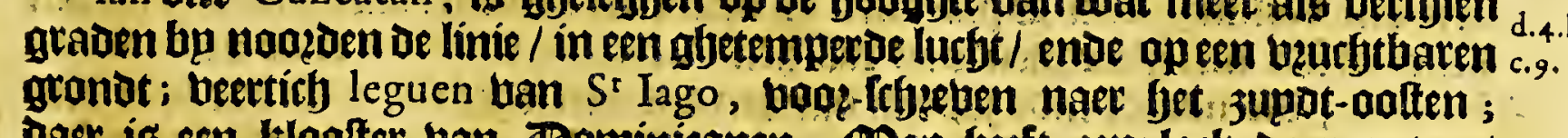
baet is een kloofter ban Dominicanen. 9 gen beeft een lack oaer onttent belck bijf leguen in 't om-gaen is/ met wepnigh biff daec in: de aude $\mathbb{I n}=$

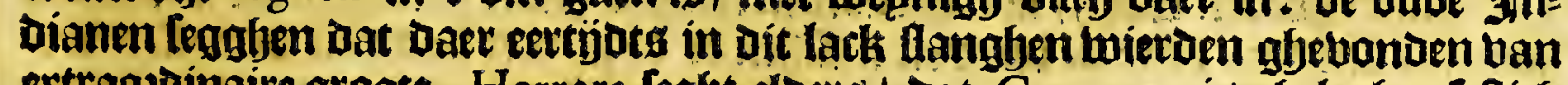
extraozoinaire groate. Herrera leght eloers/ oat Cuzcatan is gbelegfen [elticly leguen ban Guatemala: Ban bet eetlte komt beter met ie gbeleghentbegot ban to fteden ober een.

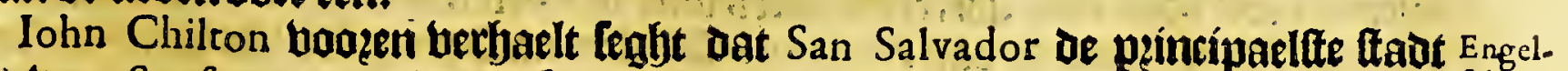
is ban Sonfonate, ende Datle gheleghen is teltich leguen ban Guatemala fche voende feben mijlen ban of zupot-jee / ende een batuen op of felbe kulte/ die yagie. 25 h 3 gbenaemt 
ghenaemt is A caxutla, baex of Ichepen aen-Homen met baex koopmantebaxpen die lp betnghen wan Nova Hifpania, ence ban Daer Ip twederom baer bearbt innemen van Cacao : ende dat daer in fpntijot teltich Spaegmiaerden oft daet ontrent woonden.

Be blecke la Trinidad; welck in of Indiaenifbe fpzake wozt genoemt Conzo. nate, is gheleghen Les-en-twintich leguen van $S^{t}$ lago de Guatemala, enoe vier leguen van de haben ban A caxurla naex' $t$ 3upot-meften/ woet ghetegeert by een Alcalde major, upt naem uan (pn 9 ) ajeltept / baer is een Kloolter ban Dominica: ner monnicken: is gelegen in een quartier dat befuchthaet ig ban Cacao, ende de

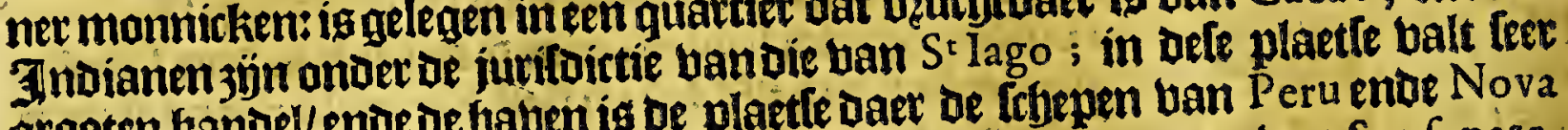
grooten bandel/ende de baben is be plaetfe daet de frhepen ban Peru ente Nova Hifpania komen ontladentiele plaetie is meelt bekent bo de naem uan Sonfonare,

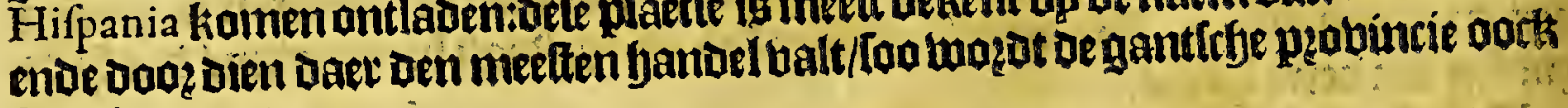
foo gbenoemt.

Be blecke ban Sant Miguel is ghe'egen twee-en-Leftich leguen tan Sant Tago de Guatemala, entue twee-en-twintich tuan Sant Salvador naex't juput-adten/ (loo dat alg bier boozen Sant Salvador maec beertigh leguen ban Sant lago moet

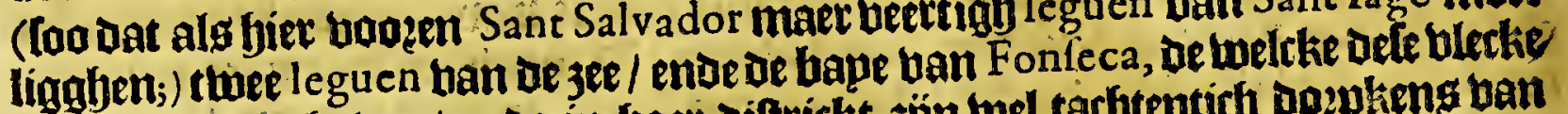

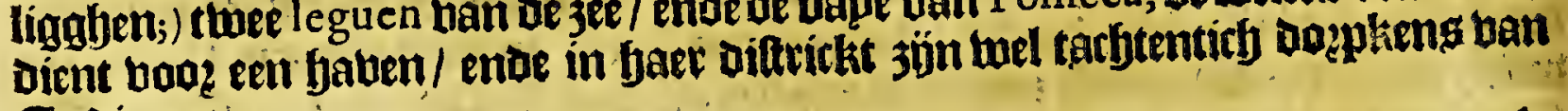
Indianen:

De blecke Xerez de la Frontera in De Lpzaecke oer Jnoianen obenaemt la Chuluteca; is glyelegen op de frontieten ban Guatemala ende Nicaragua, tacts

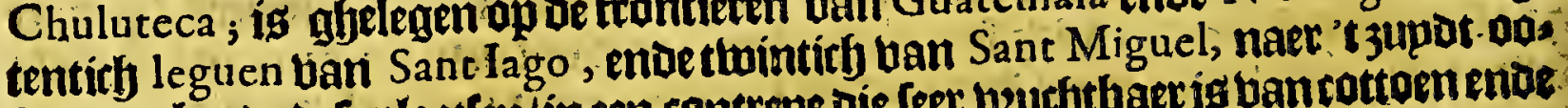

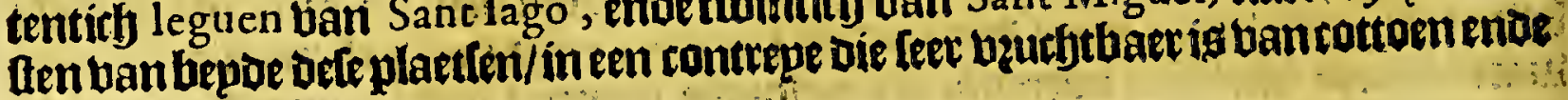
ban Maiz.

\section{Het twaelfue Capittel.} De gheleghentheyt.van de havenen ende kufte aen de zuydt-zee van
dit gouvernement van GV A T E M I A.

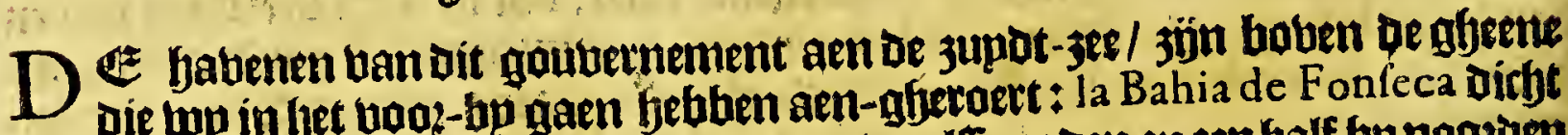
die wo in bet boa-bp gaen bebben aen-gfyecoert: la Bahia de Fonfeca dirbt bp de thade Sant Miguel op de fjooghte van twaelff graden en een falf bp noozuen

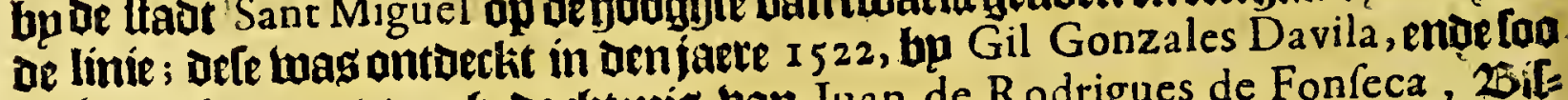
bu bem gfonaemt ter ghedarbtenis van Iuan de Rodrigues de Fonfeca, 2 if: Ichop ban Burgos ende peelident ban den raed ban Jnoien; himnen in de bape

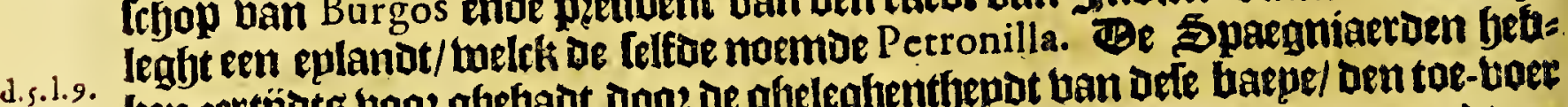

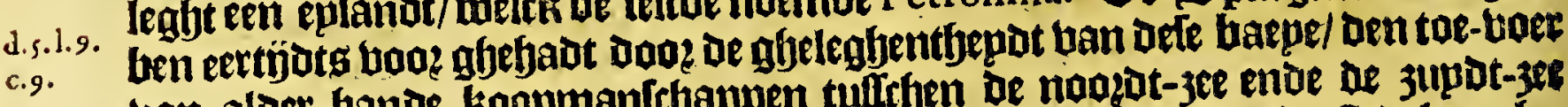

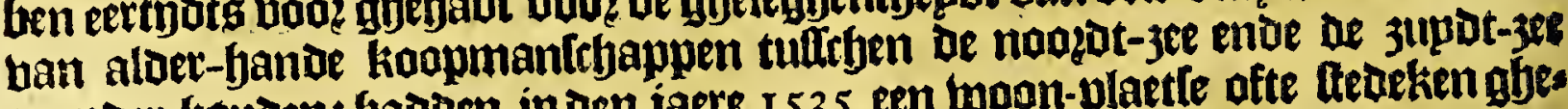
te onder-bouden: Gadoen in oen jaete 1535 een woon-plaetle afte tedekengbes legbt in de vallepe van Naco, welch fu noemoen buena Efperance; ende gas

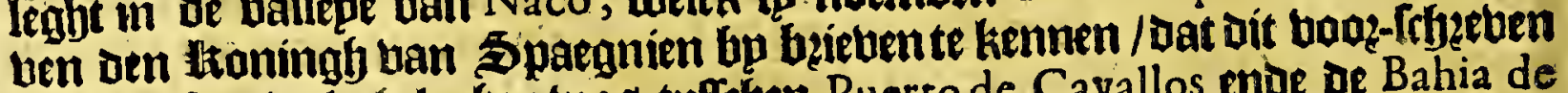
ftedeken leer buel ghelequen twas tuftrhen Puerto de Cavallos ende be Bahia de Fonfeca, die noozot ende zupden uanden anderen leggfen/ enoe dat baet van

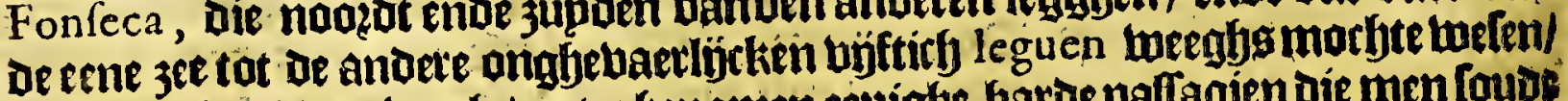
enoe meeft goeden twegh / upt-ghenomen eenighe baroe paltagien die men [ouves kounen flechten / ende de weafien tufitjen de dirft met boomen betwafien bets ghen openen. Bat oork den bandel op Peru veel bequamer ende peofitabeloet honoe gftedetuen woesoen aber dele Bahia de Fonfeca, als twel ober Panama; Dop? dien bet bee! beter ente ghereeder uaren was ban defe hape nart Peru als han $\mathrm{P}_{2}-$ nama: eñ getreder baten van Puerto de Cavallos na $\$$ paegnien/alg ban Nombre de Dios: Doo: Dienmen ban Puerto de Cavallos intmaelf tot ueerthien oaghen zeplen konve tor in ae Havana. Glotupgyen oock ata oefe Bahia de Fonfeca 
Het fevende Boeck.

it ten leer grootente leeckere fyaben / Daet de baben uan Panamo niet en is bp te ghelṕtken. Thomas Fuller feght in fpn ableruatien ap ae trapagie van Candifch: EngelWat in to Golfo han Fonfeca (foo noemt bn die bape) Iegahen thien Geplande= y agie.

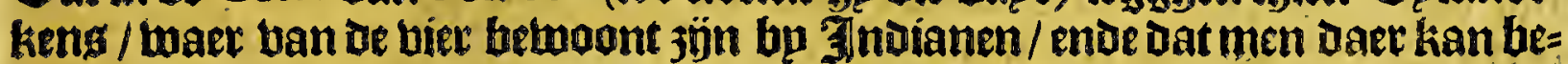

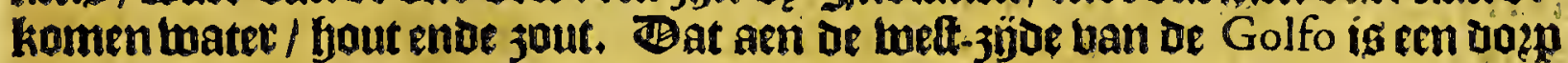
ban Indiamen/ belck is ghenaemt Mapal, daet menighte ban ollen ig. Steit Rio Lexo op oe booghte ban twaelf graden ende beertich minuten; ende feght dat De bape ban Fonfeca leght van Rio Lexo (achte bp mepnt $R$ ealeio in Nicaragua)

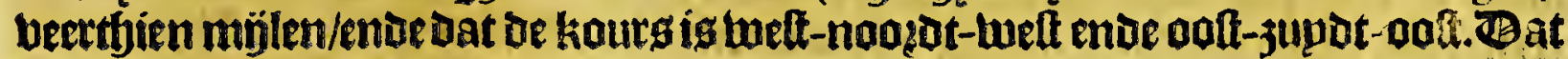
ban Rio Lexo tot de baupe van Sonfonate ie koutg ig ooft ende belt / ende de di= ftantie Teltich mỉlen.

De tweede baten ig Acaxutla bp De blecte Trinidad ofte Conzonate, op oe Her.der. booghte ban twaelf graden bp noozoen de linie; (Dan naer upt - wojfen ban oe parkaetten foube wel op derthien ligghen:) welck is de booenaemfte yauen ban bit Eoubernement boaz de trafätke op Nova Hifpania ende Peru. Be bape ban Guatemala is twaelf leguen boozder naet fot wetten; ende Rio de Xicala pa norfjtes

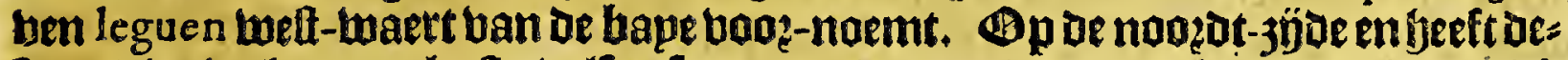
te pzobincie gyeen 3 ee-kufte / alloo fp tot aen be 3 ee niet en raectit / op toel beertirls leguen naer/bu een landingh plaetle / welck fu noemen el Puerto de Golfo Dolce, ban twaer de koopmantehappen (die ban Spaeguien komen langhg de Golfo de Honduras) te lande twoeden glyevoert naer Guatemala, San Salva dor ende la Trinidad; enoe twaelf leguen ban Guatemala, bp aen ljoughe twegh ban Mexico legft fyet lack uan Atitlan, welck thien leguen is in't am-gaen/ende-bier leguen beetot / [onoer dat men daer gronot beft konmen lerwen.

\section{$\begin{array}{lllllllllll} & H & O & N & D & U & R & A & \text { S. }\end{array}$}

Wet Dertbiende ciapittel.

Befchrijuinghe van de provincie de HON D V RA A.s in'tghemeyn.

DE probintie ende bet Goubernement de Honduras, Iffepot lpn limiten aen d.4.1.8. d'een jübe met de pyobintie ban Guatemala langyg de fteden ban San Salva. c.3. dor ende San Miguel, ende be blecke ban Xerez de la Frontera : ende aen D'an=

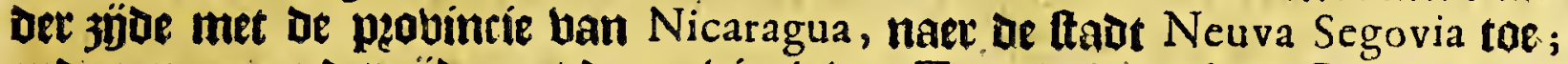
enoe aen eetr ander 3 joe met de probincie van Taguzcalpa, die de Spaegniaer: Den nu noemen la Neuva Eftremadura, ende booits leghtte aen oe noajot-jee; Her. de.

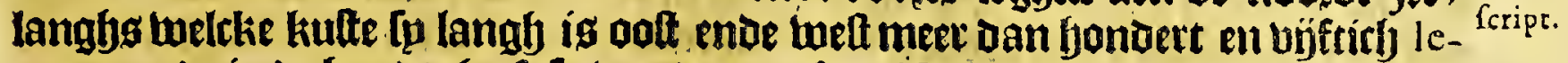
guen, enoe in de beedte feeft fp han be 3 ee af tot Nicaragua, enoe tot be pyouin= cie van Guatemala in lommighe quattieren tactitentich leguen, enoe in loni= mighe plaet ten meer ofte min. 'Clandt beeft teer beel bergben/ente frgoone en

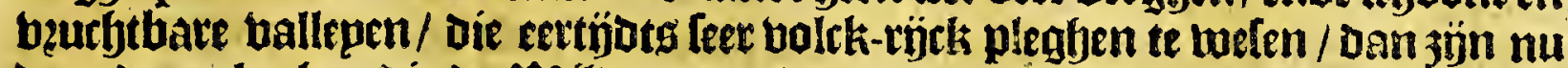
book de aologhen die de thilde onder den anderen bebben ghevoert / feer omghekomen ende bermindert, Daer ż̈n hepnigh plapnen in regato van de groote moe hoogfe berghen. Befe ptobincie ís feer uzucthtbaer uan Maiz ende tarbe

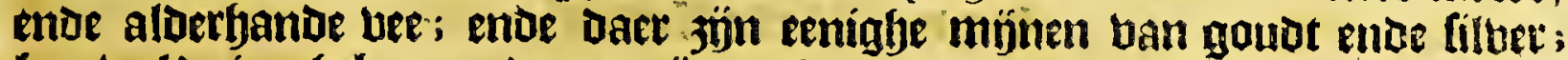

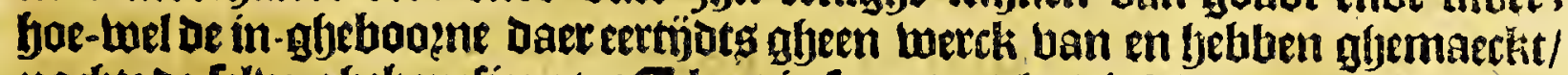
nochte de lelte ghelieneficeert: 'C lant is feet oberbloedigh ban bictualie; gnoe rïck ban yonigh ende wafij. Baer walfen talaballen in ntoote abumbantic/ waer doop de eerfe ontberkers ban dele kufte / víndende in de jee veel van defe talaballen Dẹuten / weltke men in't Epplandt Hifpaniola ofte Sant Domingo noemt Ybueras, dele $3 \mathfrak{e}$ noemoen Golfo de las Ybueras, ende de pzobuncie nan gelÿrke las Y bueras; (joe-twel daerna om de groate diepte dic De ftier-lieden thonden ontrent een $C_{2}$ bo ban Defepgobincie/lg De naemgekregen ende befouden beeft de $25 \mathbf{b}_{4}$ Honduras. 
Honduras. Heft oe rietier Haguaro naex't quartier ban Truxillo toe/ die groot endefrboon is/aen wieng oébeten [eer beel woon-plaet fen waren ban Indianen/

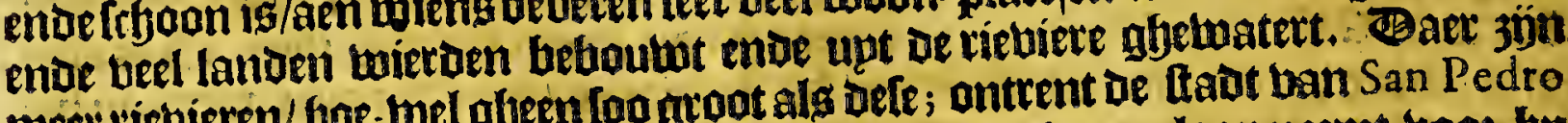
meer riebieten/ hor-mel gleen foogroot als defe; ontrent de ftadt ban San Pedro loopt eentiebiele diefe noemen. Chamalucon, iuelck baren loop neemt booz-by Camayagua. Be ríeviere Vlua beeft twinticty leguen in ae lenghoe met [eerffyoo:

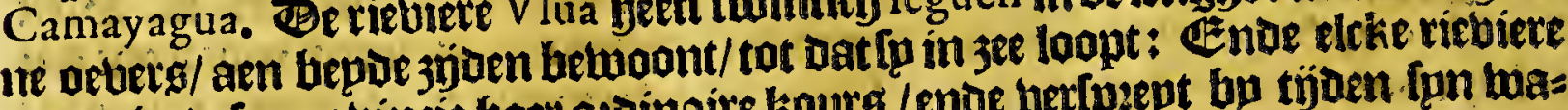

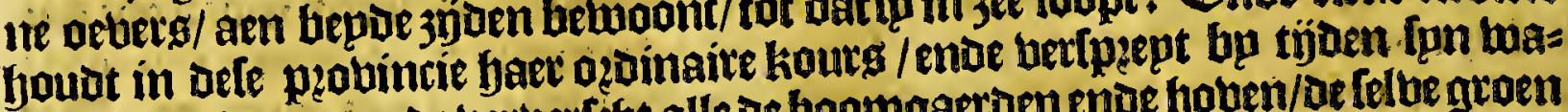
teren/ enve twatert enue berturtht alle ae boomgaetoen enoe foben/oe folve groen

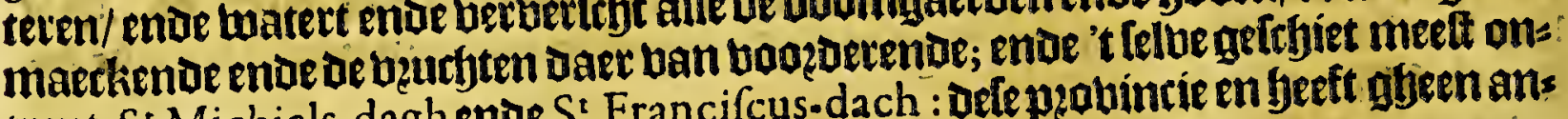
trent $S^{t}$ Michiels-daghende $S^{2}$ Francifcus-dach : Defengabincie en yeeft ghen ans oer fantepnen ofte wateringhen amberm bante dienen.

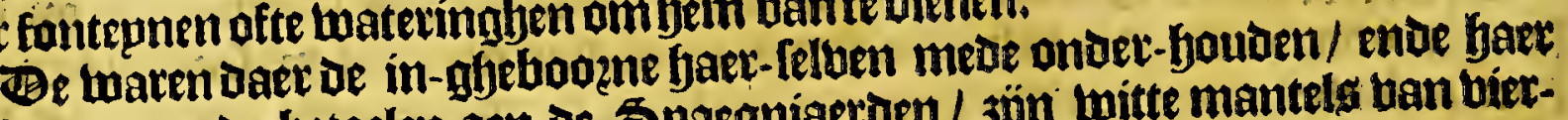
tributten meor betaelen aen oe Spaegniaeroen/ zön mitte mantels ban bierotaet; beel fonigh welck [p tergaoten in aroote holle boomen/ ente ander te aetoe op-nemen/ Dooz dien lp gheen andete bpe-kozoen en beblen: fo febluen ouck Chille ofte Axi ende Batatas; [u jaepen Maiz ende extweten Dapmaet Degs jaets. Sproeroen de aetie met leerkere langhe paelen/ ae meleke bebben twes kromme tacken / een op-waerts ende D ander neder-waerts om ghebogfen / om

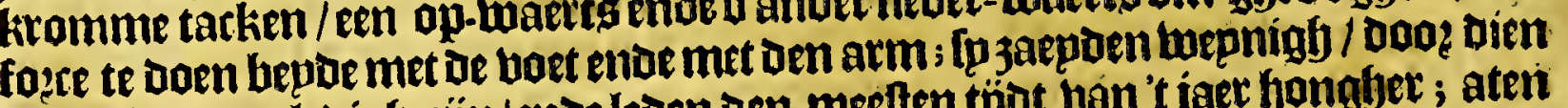
Ip leer lup ende ledigh $3 \mathfrak{y} n /$ ende leden den meetten tyot ban 't jaer fongher; aten

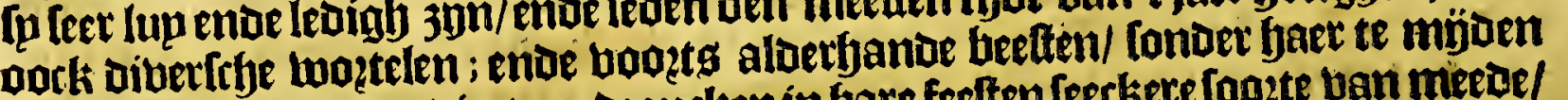

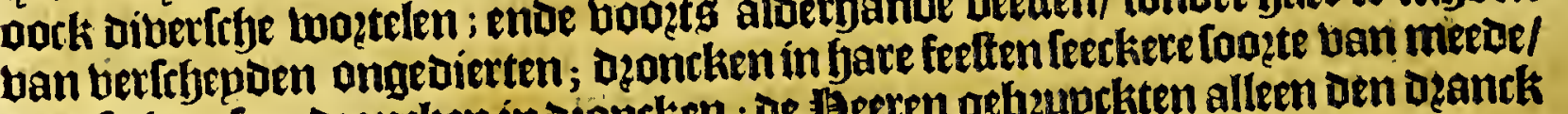
Daer fp yaer Leer Dzontken in Dzancken ; De Heeten gebzuptkten alleen den dzanck ban fet Cacao, nudzincken [y alle 't felbe; Dan alle die quade couftupmen nefteng Dibertrye abominatien die fp onder den anderen pleeghaen/ zón Dooz oe combet: Latí bail or Spargniaetoen leer berbetert. Sphadoen onder faer differente ta=

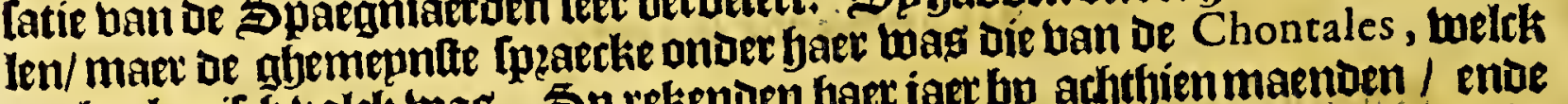
enn harbariffy volck was. Sp rekenden baet jaet bp achthien maenoen / enoe noemuent Ivalar, Dat is te tegghen een dinck dat boos-bp gaet; ende gaben elcke maenot twintirh oaghen/hoe-wel fp niet en rekenden Dan by nachten/ende fo ftels

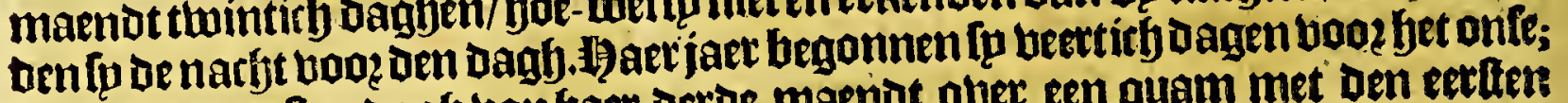
foo dat oen eerten dagh ban yaet deroe maenot ober een quam met oen eetifen Ianuarij naer onfe rekeninglye.

Den Wifterop ban Chiapa, Bartholomeo de las Cafas beklaeght bem aenien

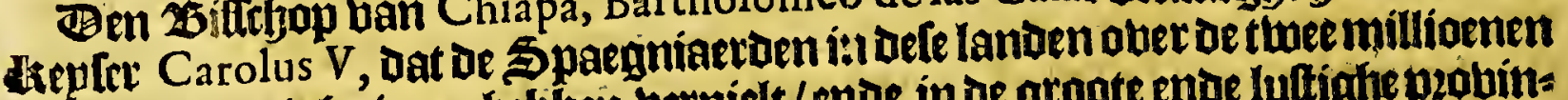
jielen in wepnigfe jaren bebiben bernielt / ende in ae groote ende luttighe peobin: cien bp naet gheen bolck ober ghelaeten. Befe peobincie beeft biet fteden ban Spargniaerben ende twee blecken/te tueten Valledolid, Gracias à Dios, San Pedro, puerto de Cavallos, Truxillo ende San Iorge de Olancho, wetcke tup pars

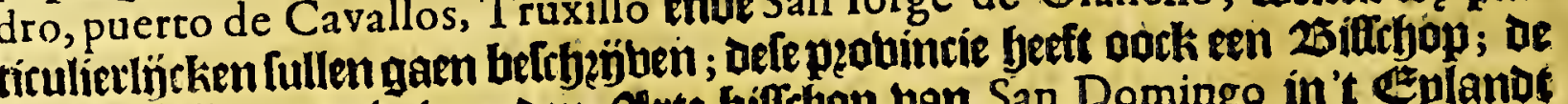
welclie fuftragaen íg ban Den Aftrt-biffetyop ban San Domingo in't explands Hifpaniola.

\section{Het beethiende Gapittel.}

Befchrijvinghe van de Stadt V A I A D OIID in Honbvras, ende de Stadt Gracias a Dios, ende St PEDko.

İer.der. DE Etadt nieulu Valladolid, welck de Jndianenín haer taele noemen Comajagua, is ghelegen op de fooghte ban meer ald lettyien gradon bp noozs Den de linie ; (naer't [egghen uan Herrera, diefembier in moet abuleren/na-de-

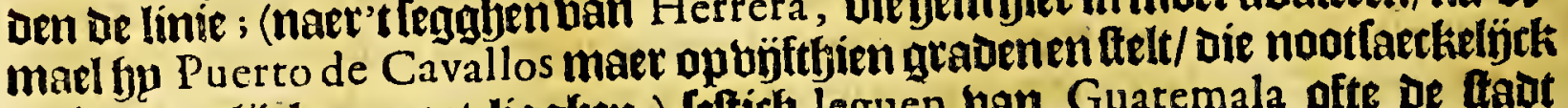

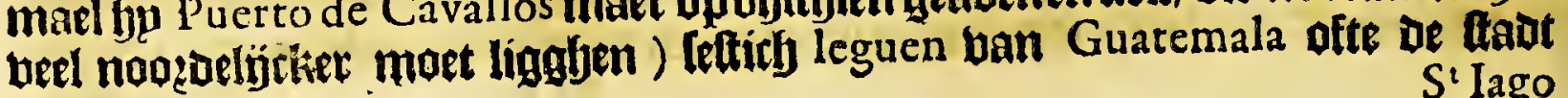




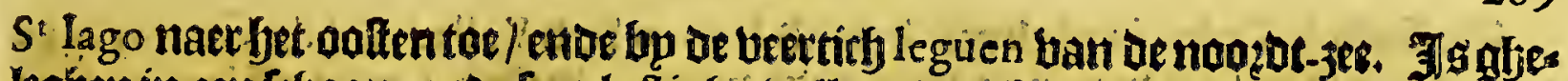
leghen in cen ftheone ente leer luftighe ballspe / een fraepe gheleghenthepat ban gheremperde ende'fer geconde lutbtiti baer beloen beft men menighte ban bee/ belck Daer faer beeft toe-ghenomen; : ende men beeft in baer oiftrick bork gaede

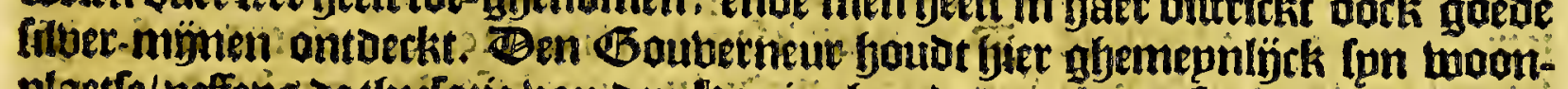

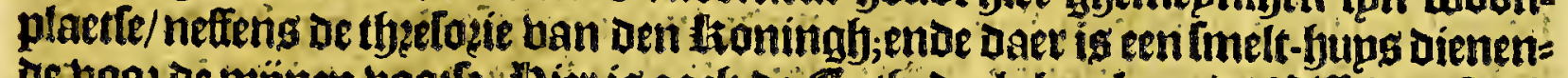

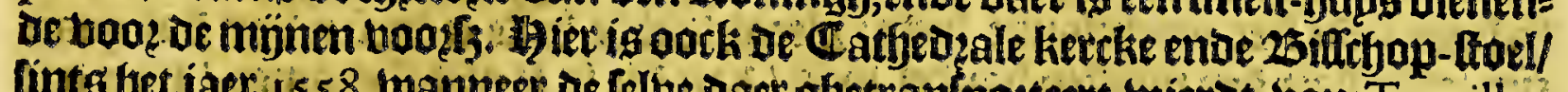

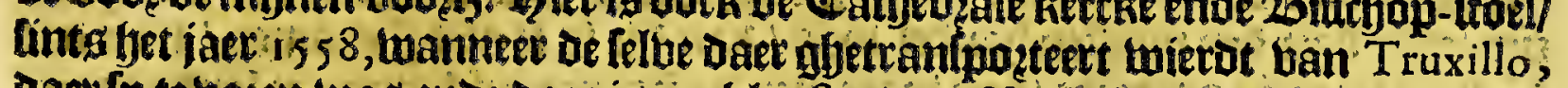

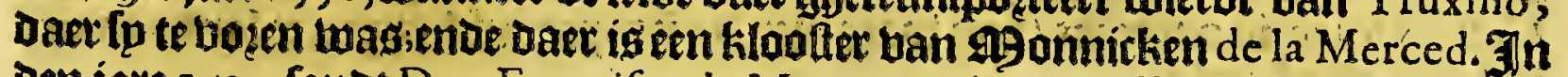
Den jare 1539 fonot Don Francifco de Monteio, dete toen Jbauberneut was ban De Honduras, frn , Zlieutenant Alonfo de Caceres met entigh uolck / om een

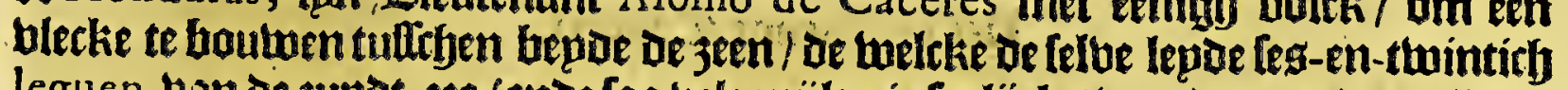

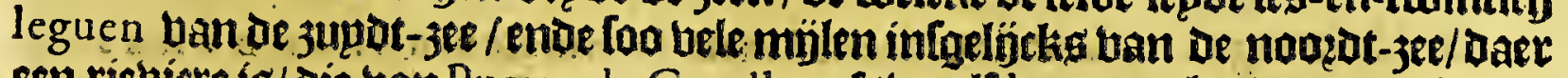
een rieviere ig/ die ban Puerto de Cavallos af twaelf leguen te lanot-uaert in met tanoag han bevaten wogpen tot een boup ban Jnoiaten / ende ban dit Dołp tot Dele vlecke / welcke fu den naem gaben van Santa Maria de Comoyagua, jün

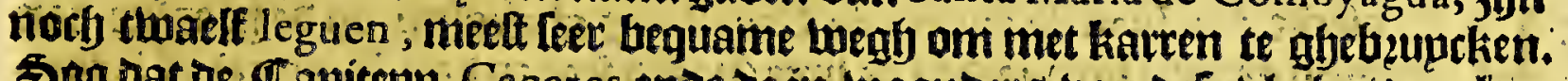
Soo dat de Capitepn Cacer es ende de ii-twoonders' ban dete blecke/ ben tho: ningl te kenuen gaven / Dat dere plaetle een goede ghelegbentyept afa tot ae an=

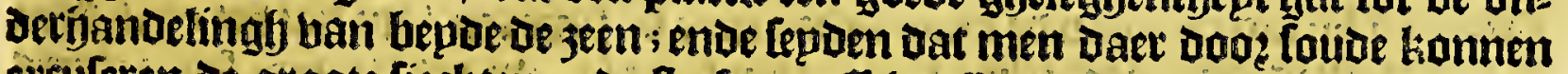
extuleren oe groote fieckten ende iterften tulftjen Panama ende Nombre de Dios book-ballende ; aftirmetende dat de natigatie die menfoude Iegghen in een placts

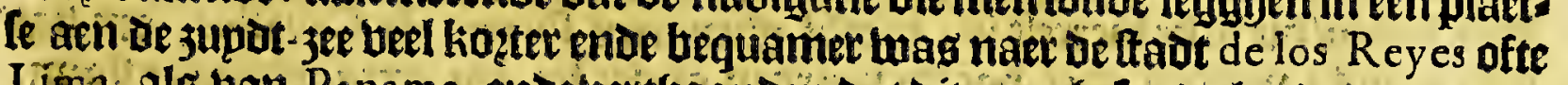

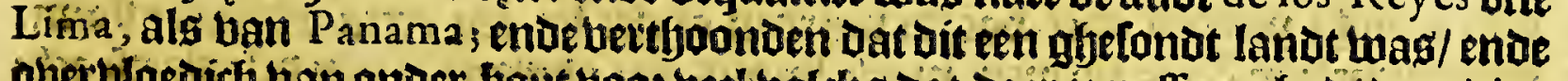

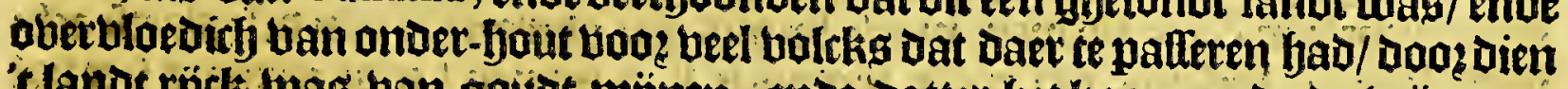

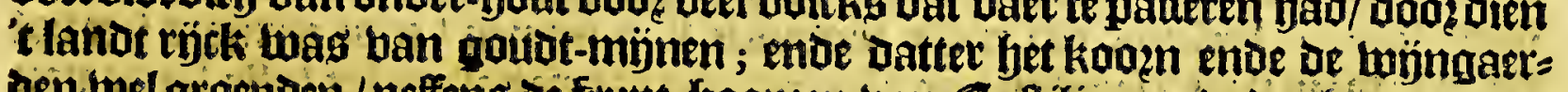
ben wel groepoen / neffens de ftupt-boomen ban $\mathbb{C}$ altilien, ente dat bet bee daet

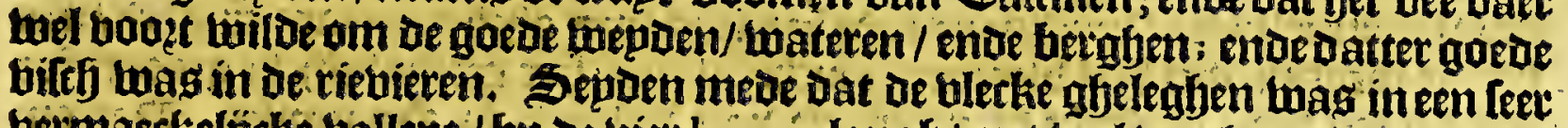

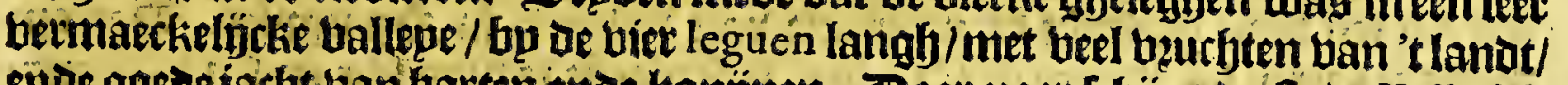
ende goede fatht ban harten ende konỉnen. Baer naer fthỷnt de ftad Vallado-

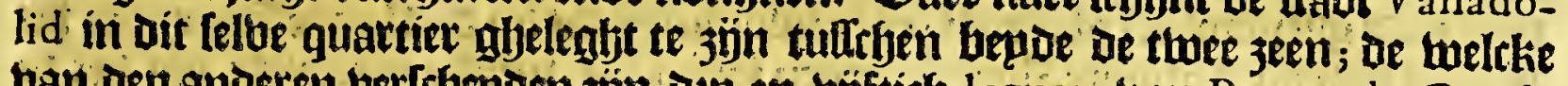

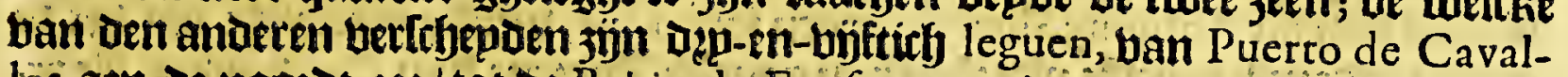

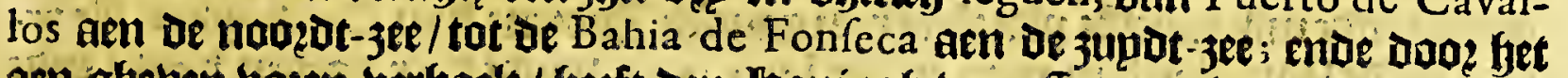

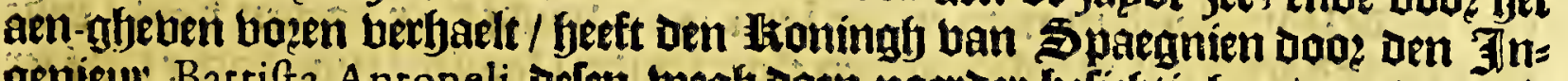
genieue Bartifta Antoneli belen twegly doen naerder belieftigfen / om dat bele Her.der. bardot deven dat dien wegh bequamer twas wooz oe onoer. Ganoelinghe ban bep= de de $3 e e n$; maer bp betonot dat daer beel inconvenientem in de twegh waren/die berbinderden upt te boeren't ghene bande Spargniaetoen van dit ghetwefte nu meet-maels den ltoningh ban Spaegnien twas aen-gfedient.

De ftadt Gracias a Dios is abeleghen Dertith leguen ban de ftadt Valla. dolid boo'-noent bu naer naer het welten; wietot ghelsoutut in oen jaete 1350 boo: de Capitepn Gabriel de Royas, om de minnen ban gouot te heneficieten

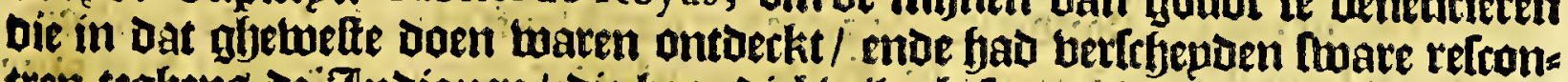
then teglyens de Indianen/ die bem dicktwilg belplongben in een fot dat fp daer ghemaeckt hadoe; maer alloo bp ban be Bouberneurs ban Honduras ende Nicaragua niet beboolijet en wierot glbelecoumeert/ was bp abenootlaeckt ie

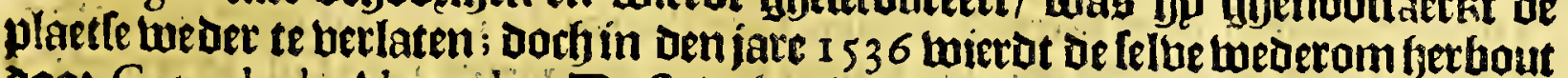

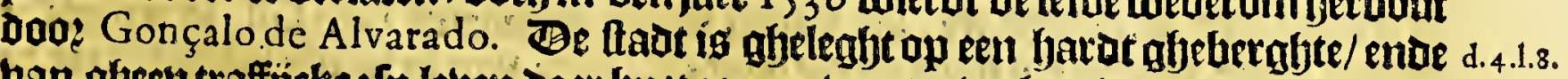
ban gfeen traffijthe: [p leben daer bp 't jaepen ban tartw; boe-Inel't landt om fpn c.43. baroichepot met moepte gheboumt mazot : Daer twoęoen leer beel muplen ghe teelt / met de beleke lp de tartwe die daer wat voeten naer San Salvador ende daex ontrent /endefebben oock goede peetden/ die [p daet aen-telett. 


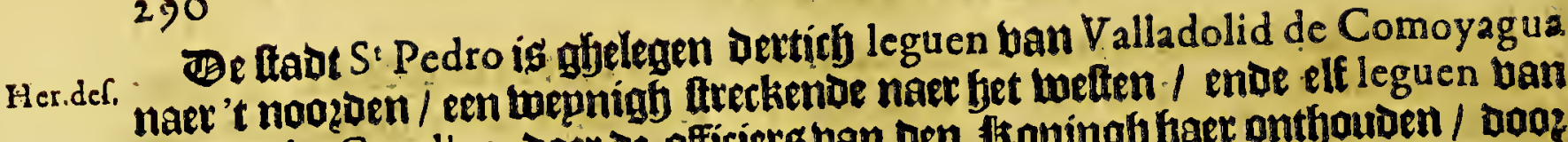

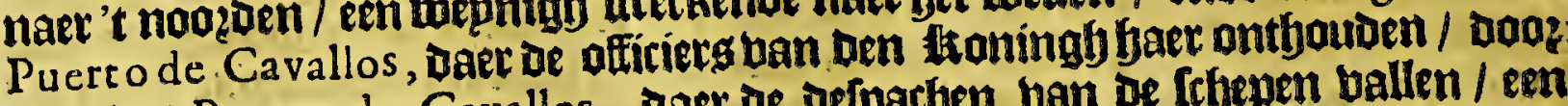
dien dat Puerto de Cavallos, vaer de Defparthen van be frbepen ballen / een leet onghe fonoe plaste is; Jan naer 't fegghen van Herrera eloers in fungt:

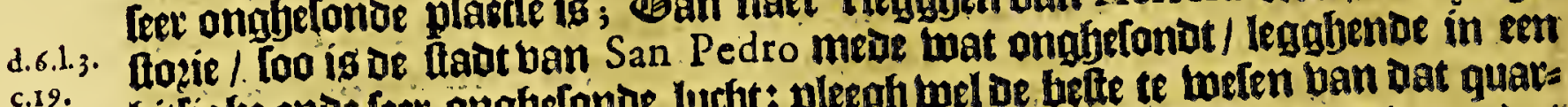

c.19. Gitligbe ende feer onghelonde lucht: pleegh wel de befte te melen van dat quat: tier / enoe daer den meelten jandel was / dan bit is te nít ghekomen / naer dat: Golfo Dolce is ontoectit / ban waer men de koopmantebapen te landt-Laert in-boet met barcken.

\section{Het büttbiente clapittel.}

Befchrijvinge van de andere Steden in de Provincie van Ho v D $\vee$ \& As gheleghen, te weten PVERTO DE CAVAIIOS;

TRV́XILLO ende St IORGE.

Her.der.

D Ulecke San Iuan de puerto de Cavallos ig gbeleghen op be booghte ban bujfthien graden bp noogzen de línie (naer'tleggen ban Herrera) elf leguen ban San Pedro, ende beertich leguen van de ttat Valledolid de Comay agua ; if bemoont bu farteuns ban de koop-lieden ende bo fmarten / om dat bet een baben is diefmack is) Doch gaedt/boe-wel bet em bape is ; (mant Herrera [egft elders

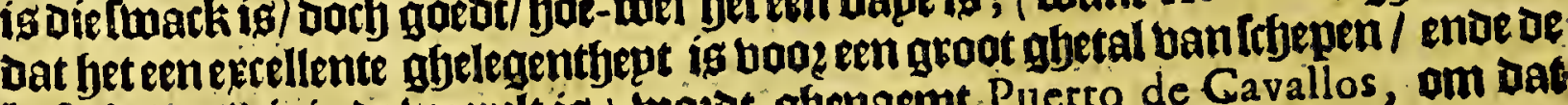
hette batien/Die in oe tweerelt is ) wazot ghenaemt Puerto de Cavallos, om dat d.4.7. Daer eenighe jeerden olaer-boozot mierden ghelet bp een extra-dzoinaire ttozm.

0.3. De vallepe ban Naco numeer-maelg bp ong aen-ghetoent is ban bele plaetfeacty tbien leguen, wetende een rïthe peabincie ban minen/ ende eetrjots feer vol

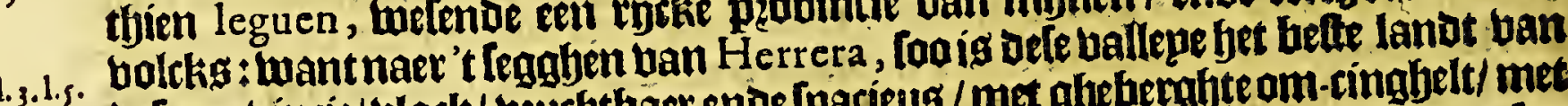

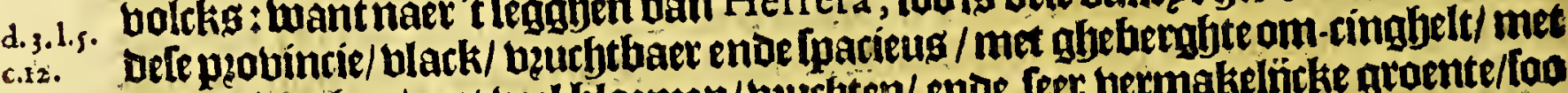
beedae tweghen/met beel bloemen/beuchten/ ende feer bermakelijelke groente/foo Dat bet ten Deele ghelýckt of p2obintie ban Valentia in Spaegmien. Ban om weder te keeten tot Puerto de Cavallos, Jeleplaetle is divertefte replen in-ghenos

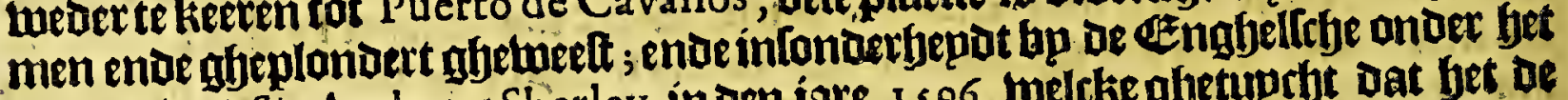
belepot van Sir Anthony Sherley, in oen jare 1596 , welcke alyetupebt dat bet of armifte enoemilerabelfte plaetle is ban ganttch 3ndien: Dan Chriftopher $\mathrm{New}$ porr die de felue plaet te in-nam in Denjaere 159 I bont daer goeden bupt / ende ghetuught dat bet een plaette twag ban twee hondert buplen/ ende datter dat jaet

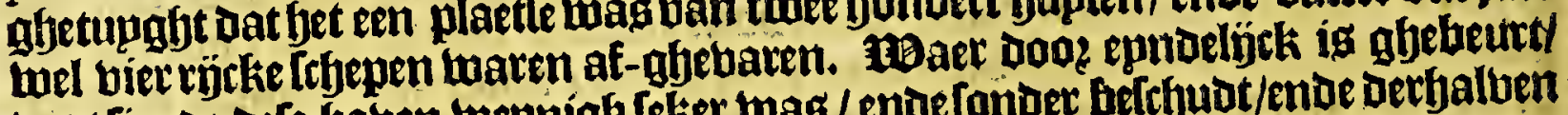

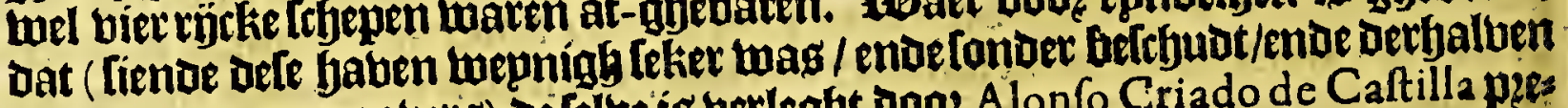
open vooz oe 3et-roobers) de lelue is uetleght booz Alonfo Criado de Caftilla pets lioent ban be Zluoientie tian Guatemala, ende den bandel ghehaght opeen andes plaetfe/twelck men noemt A matique, aththien leguen ban de book-gaenoe puerso de Cavallos, ende íg genaemt San Thomas de Caftilla, welcke blecke heeft aloer Gande gbelegentbeden/ ende de noodiabe lecuritept tegen de bpanden; fon dat den

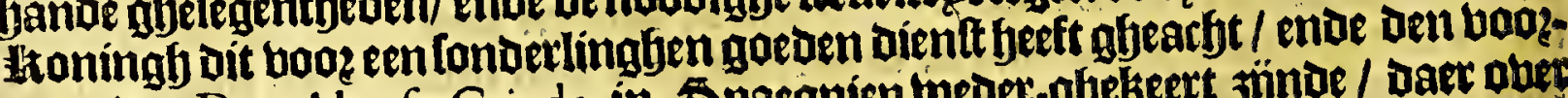
noemoen Don Alonfo Criado in Spaegnientweder-ghekeert jünoe / Daet ober thaeotg-1)eet afjekozen in (pn appetften raed ban Jndien.

De thad T ruxillo ig gelegen Teftigh leguen ban de booft-ttaot $V$ alladolid naet

Her.def. tnoozat-aolten/ ende beertich leguen ban Puerto de Cavallos naer foet ooften; eenmijle ban de noozot-jee; (pn bauen luogt gfienaemt Iuan Gil, is een goede Gaven / (boe-welfet een bape ig/ oie doodt ig) ende ban de winot belefjut/ oaer to

18. Trbepen berli ontladen afte aen-kamen die boazts na Giatemala twillen. De ftad

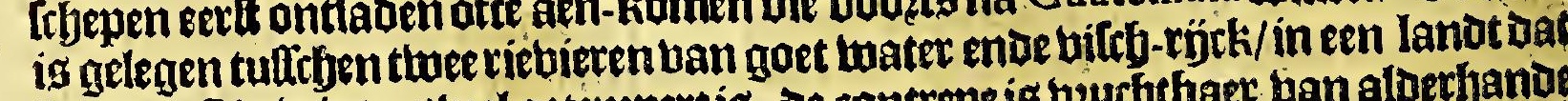
Comerg eñ 'g hinters wel getempert is; of contrepe ig buchethaer ban alderbanas lïf-tarht: 


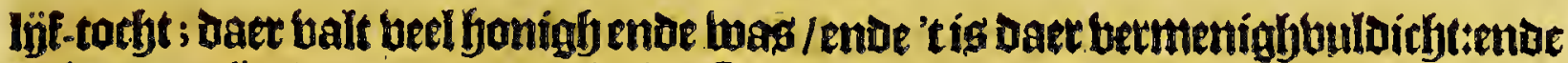
be koepen zön daer grooter als in Spaegnien; de twp̈ngaeroen Deagben twee:

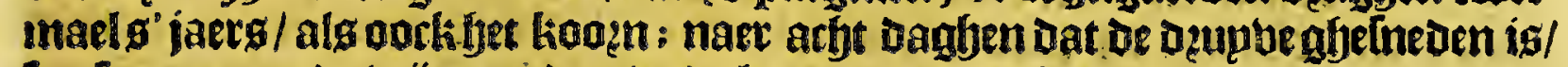
foo fnotpt men de wỉngerden/ende loopen op een nieu upt / ende gheben tueder beupben ontrent kerfmis : De limaenen ende oragnien/ ende in fomme alle andes

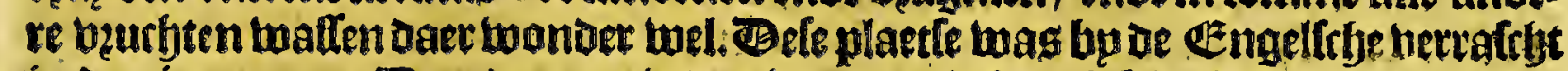

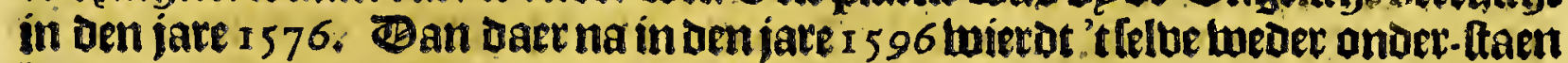
bp Sir Anthony Sherley ende William Rarker, Joef te bergeefs; thant twierden

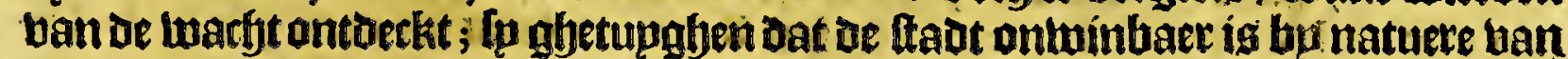
oe plaetfe/ leggfende opeen teplen berafj dicht bp oe zee / am-ringht met bolfhas

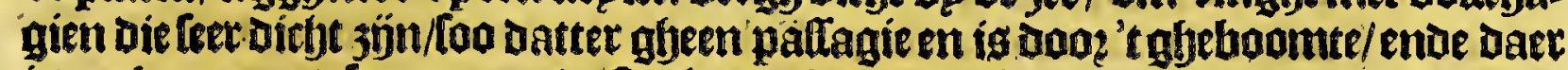
is oock maer een feer enge ende fteple begh naer de ftadt toe-gaenoe / aen melckes

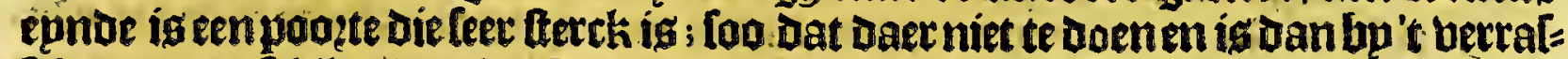

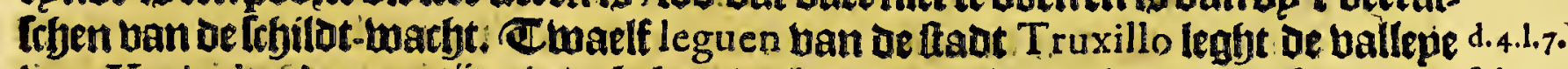

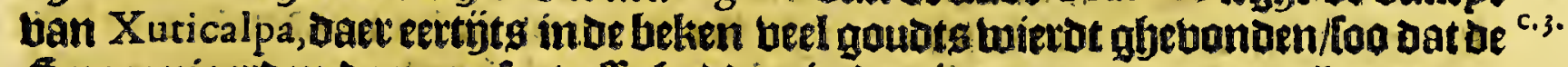
Spargniaeroen daet een foettefle gaoden in den jake 1530 ; om de münen boo aen-loop ball oe 2 Biloe te betchutten.

Be blecke $S^{2}$ Iorge de Olancho is gheieghen beertich leguen ban aeftad $V$ al- Her.der. ledolid de Gomayagua, maet het ouifter I (Herrera feght elders meer als dertigh; liet fier naet) Daer woonen eenighe teertich Spaegniaetoen/ enoe in haet Diftrickt wel fettbien Dupfent. Indianen Die onder trifupt fitten/ baer balt veel goitotg/inTonoerbept in be rieviere tuan Guayape, die thaelf leguen leght ban dele

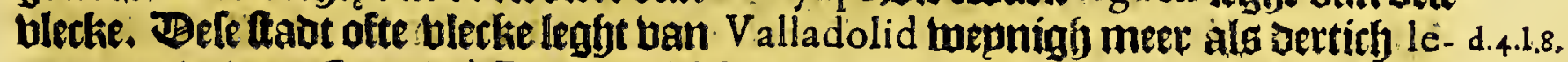
guen, ende ban Gracias à Dios Dertich leguen meer; ende uan Truxillo infgyes c.3. lijcks dertich leguen; [oo dat de wegh wepnigg bertefilot / ende iele ftaut ende de teden Valladolid, Gracias a Dios, ende San Pedro legghen gbelfock in een trians

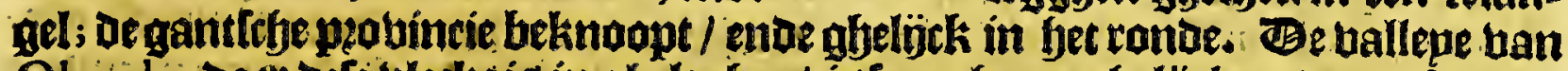

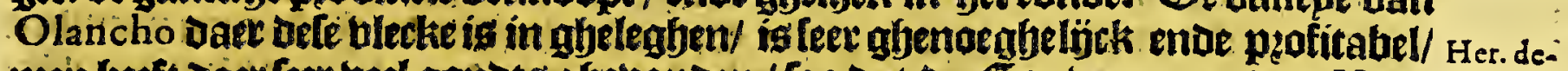

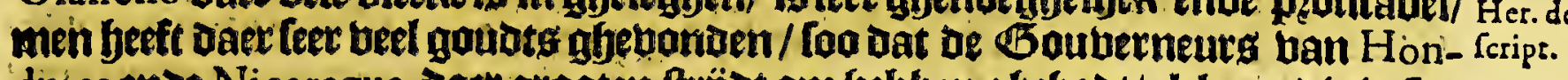
duras ende Nicaragua daet groaten ftrijot om fehben ghebadt/ elck een die in lpn

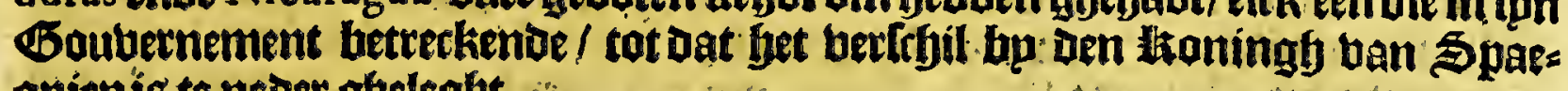
gmien is te neder ghelegjt.

\section{1)et telluiende capittel.}

Befchrijvinghe van de kufte, havenen, ende Eylanden van HoNDVRAs.

$\mathrm{D}$

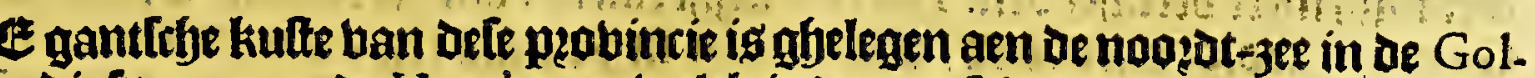

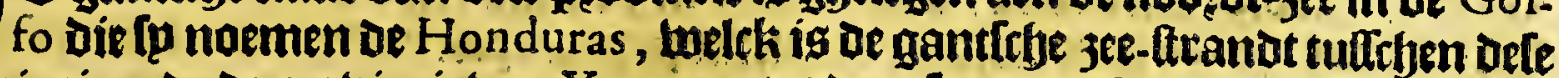
peobincic onde depequincie ban Yucatan, tot daet [u aen de felbe paelt / langfg de peobincie ban Verapaz, al maet jet be naem beeft ban Golfo de Guanaios toe

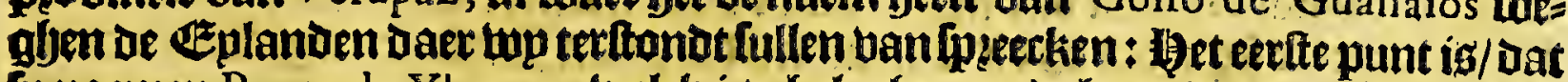
fo noemen Punta de Ybueras, toelck is gfoleghen op oe fooghte ban fetthien gra= ben bp noozoen de linie (afte naer upt wujlen ban oe kaette op böfthien graden en uiet-en-dertich mimuten; ) neffeng Golfo Dolce, trelch de Gaben is boo? de pzobincie ban Guaremala; waer eectijts ghebout was een plaetfe / gbenaemt San Gil de buena Vifta, neffeng de Cabo de tres puntas, naer't ooften ban Golfo Dolce. Sigeer naex't oulten bebt gbp de rieviere Piche, enoe Rio Baxo, ende de ries biere Vlua, die oock anders glbenaemt wogdt in be Jndiaenlége tale Ba lahama, cer gbj komt aen puerto de Cavallos, twelck is ghelegfen op De booghte van büfs thien graden. Figueredo ftelt Rio de Lua bp oolten puerto de Cavallos Dirft bp puerto de Sal. Linfchoten ftelot tuffeten punta de Ytueras mae puerto de Cavallos dertich mülen. Baet naer bolagt be rietuiere ente bet punt de la Sal; ende Daer by puerto de Sal. Figueredo in fun Roteiro rekent ban puerto de Sal tot puerto 


\section{Guatimala.}

292

note ftelot tuffeffen beptoen Morro de Baibas, Dłe puerto de Cavallos uñfleguen, thovallos, enoe daat aen Triumpho de la Cruz, leguen bp palten de ou punten/Daer Chriftoval deOlid inden jare 1524 eenblec: lie fadoe gfeleght/ Die bp Too noembe. Boozere legbt Rio Hulma, ofte of Xagua,

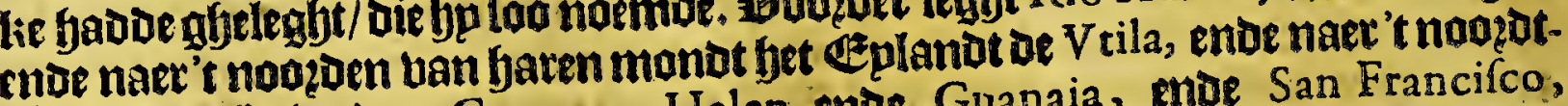
ooften de Eplanden Guyama, Helen ende Guanaia, moe San Francifco, noozot enoe jupben met punta de Truxillo ( welck jön de Geplanden de los Guanaios:) fiet booz-(rhetuen punt mozot oock anoers ghenaemt Cabo Delgado ofte de Honduras; Figueredo in Ipn Roteiro naemt bet oock punta de $\mathrm{C}_{2}$. ftilha : Linfchoten ftelot tufftyen Triumpho dela Cruz, enoe Cabo de Honduras Dertich mijlen/ ende wan isaer tot Cabo de Cameron twintirly mülen. 25p

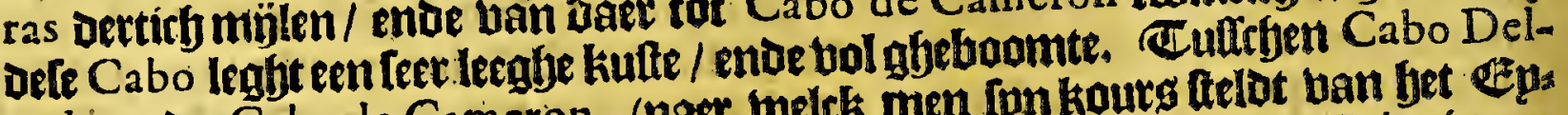

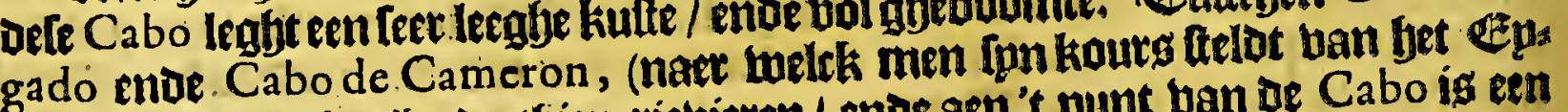
lanot Iamaica af) jôn Dettfien riebieten/ enoe aen't punt van de Cabo is een

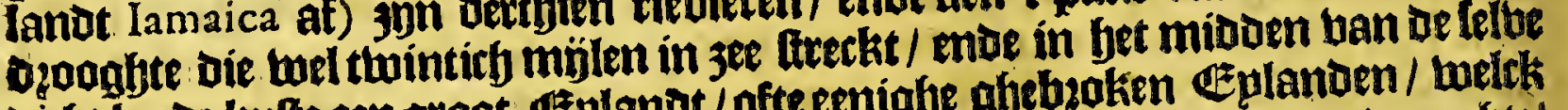
bicht bp De kufte een groot Ezplanot / ofte entighe ghebzoken Eplanoen / weick [p noemen de los Baxos, enoe een ander naer bet noogoen ontrent oe ozoogftel

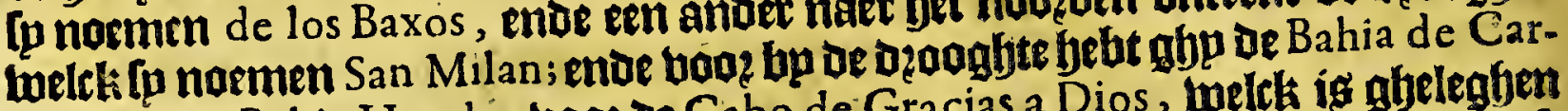
thago, ende Bahia Honda, booz oe Cabo de Gracias a Dios, welck ig gheleghen

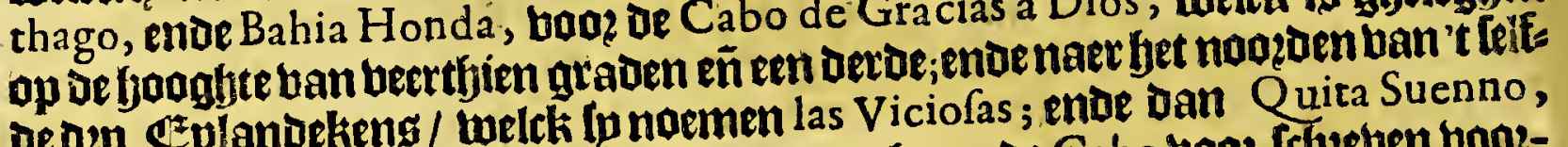

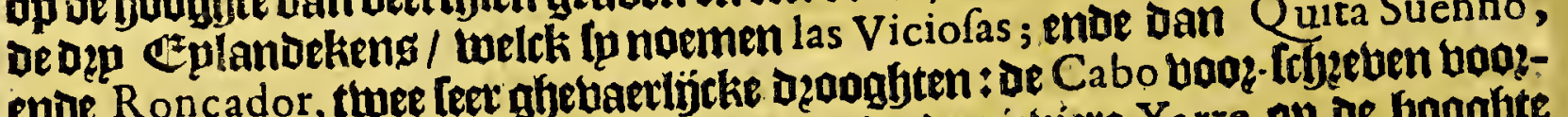
enoe Roncador, thee Golfo de Niquefa; mae oe riebiece Yarre op ae booglyte bp 3ynte Geth / duras ende Nicaragua te lamen komen.

De Eplanden Dienen noemt los Guanaios, wietden ontoectet by Den eetfen Ammirante Don Chriftoval Colon in Den jaere 1502 ; thant daoe tempeeft gljes

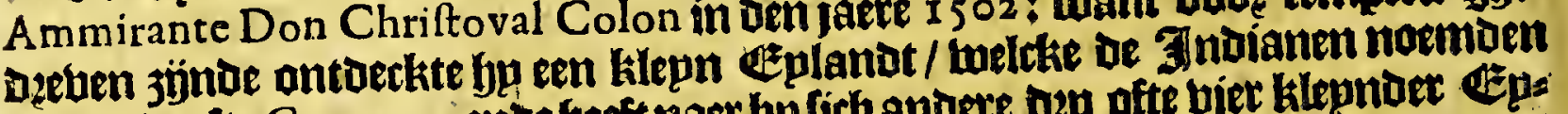

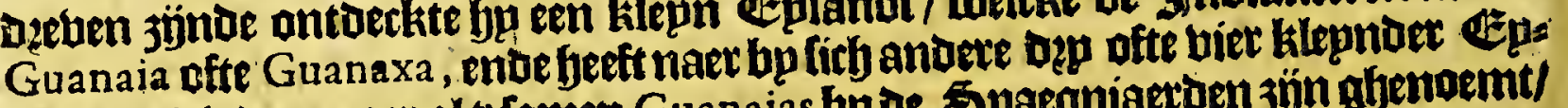

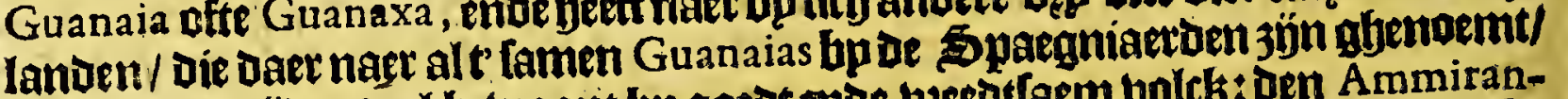
en waren eertijots wel becwoont bp gaedenoe beectlaem bolck: den Ammirante noembe oit [eplanot Ifla de Pinos, om dat daer beel pijn-Loomen waren/ cnoe leght wan Cabo de Honduras naec 't legghen uan eenighe / büf mílen supot ten tueften ende noozdt ten oolten/ ende ban de frad ban Truxillo naer't tegghen ban Herrera twaelf leguen, entoe ig ban't lanot ban Yucatan bertich leguen ofte Luepnigh meer bertetyepoen. Herrera leght elders ; Dat bet theede fiplanot welck

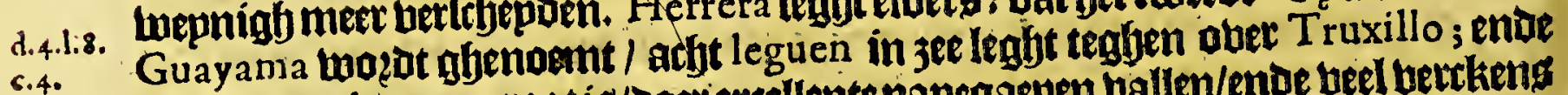

s.4. Guaya twe leguen groat is/baer excellente papegaepen ballen/ento beel betckeng Dat het twee leguen grover

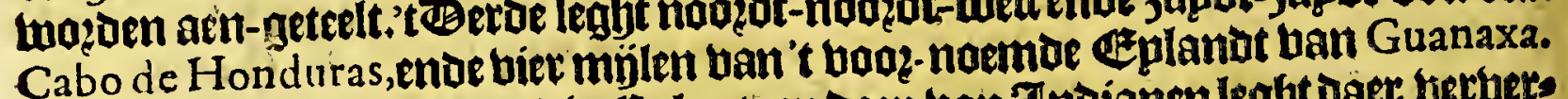
Dirck Ruyters feght dat op oit Eplant een Dopp uan 3 noianen leght daer tetuets

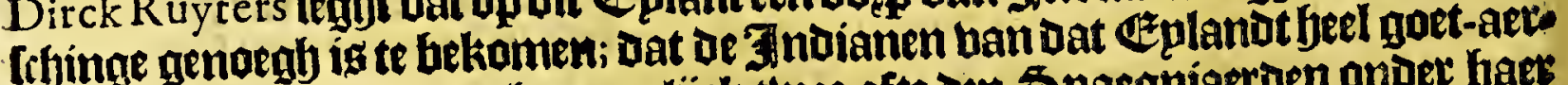

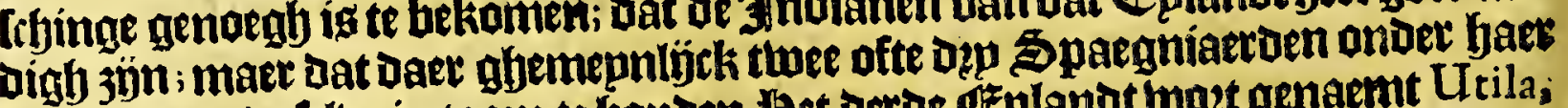
woonen om de felbe ill toom te houden. enoe is arooter / enoe leght i 4 leguen uan Puerto de Cavallos. Dirck Ruycers

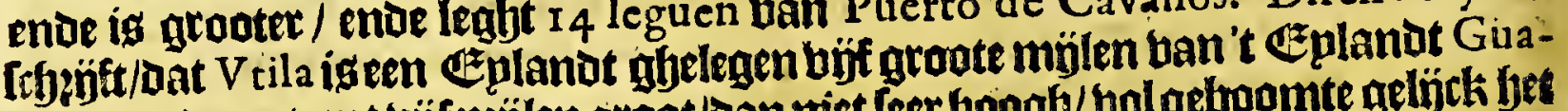

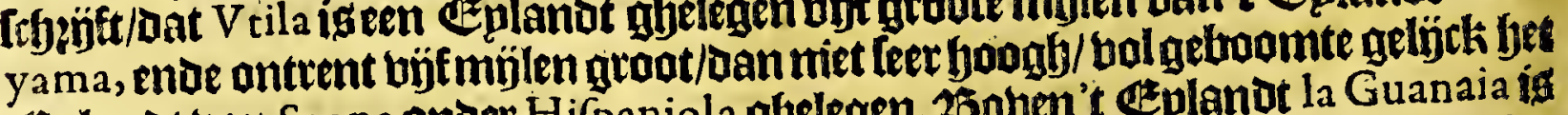
Uzplanot wan Saona onder Hifpaniola ghelegen. 25oben't éplandt la Guanaia id

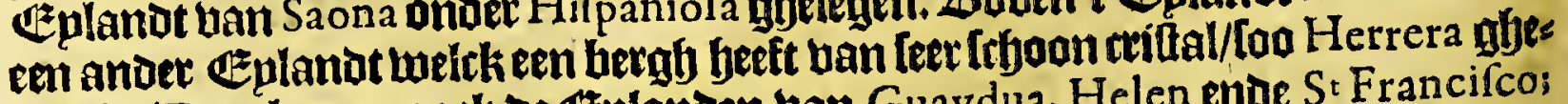

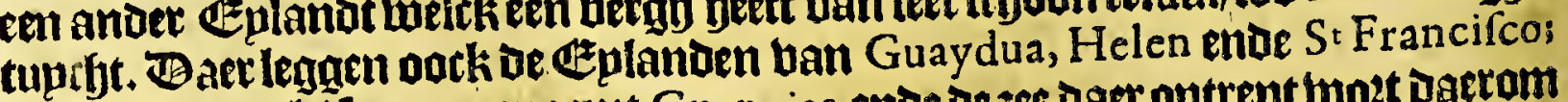

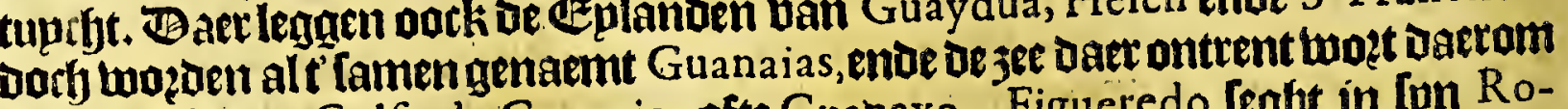
mear glyeferten Golfo de Guanaio, ofte Guanaxo. Figueredo lengt in Inn Ro-

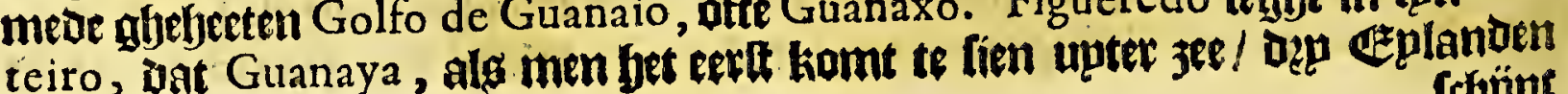
Ityönt 


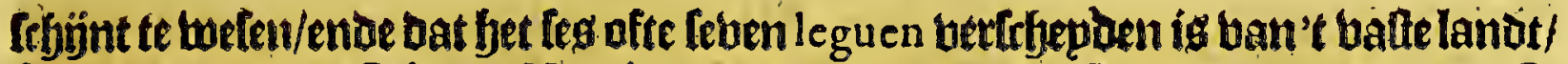
freckenoe met de Cabo de Hon duras noozot-noozot-weet enoe zupot-3upot-ooft: aen be oolt-ljoe is het al hoogb eñ effen/eñ daer bp komende nopgot enoe jupden/

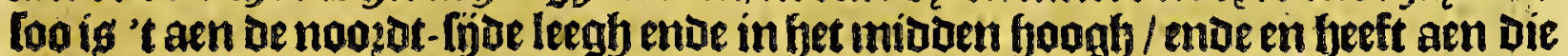

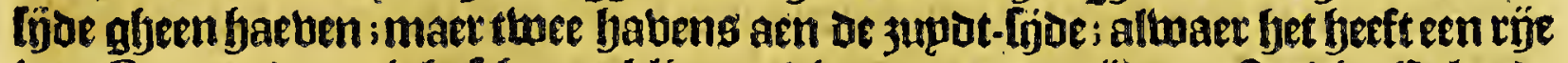
ban Cajos ende eenighe trharpe klippen die men moet müben. Bp dit Epplands beft men berthens / boenderen / papegaepen ende Daer woonen opdinaris thes

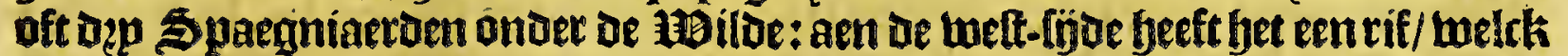

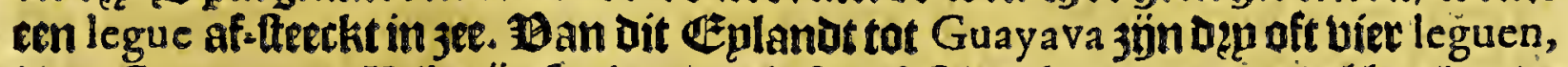
ban Guayava tot V tila zijn fes leguen, is [eg oft feuen leguen groot/ al leeghende bol boomen; aen be ooft-fijde feeft bet eenronden beubel als een bzopdt/endenaex ' jupst-Leften een klepnen ljeubel/Daer eenige palm-Loomen op ftaen; eñ vootets een grooteren feubel met een punt/welck black is; ento thee leguen ban daer een

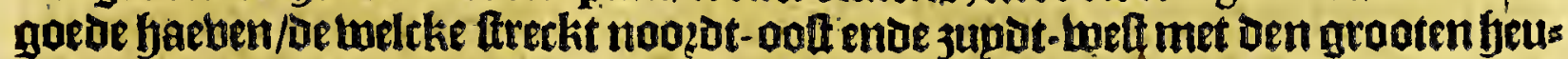

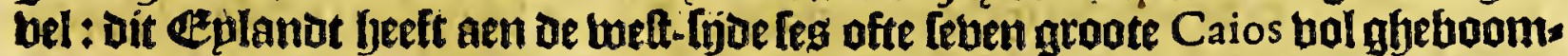

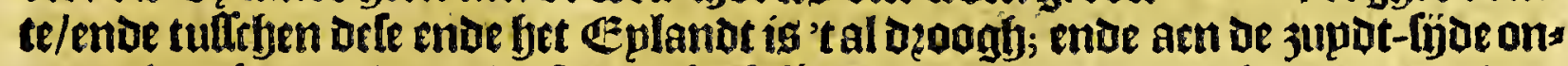
trent thee leguen wan't weft puntheft fjet twee Caios ende en bancke daer 't op

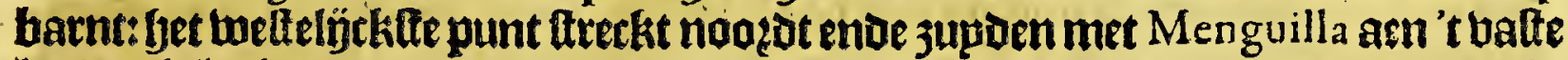
lande gheleghen.

\section{$N$ I $\quad C \quad A \quad R \quad A \quad G \quad V \quad A$.}

\section{- get fetuentfiende Capittel.}

\section{Befchrijvinghe van de Provincievan NI CAR $A$ G A in' $r$ ghemeyn.}

De pqubincie ente't Boubernement ban Nicaragua, welck be Gouberneut Her.def. Diego Lopez de Salzedo eertt nuemibe Neuvo Reyno de Leon, paelt naet het ueften met of p?ouintie ban Guatemala, naet 't noozden met de pequincie ban

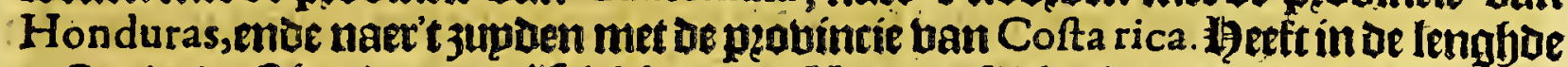

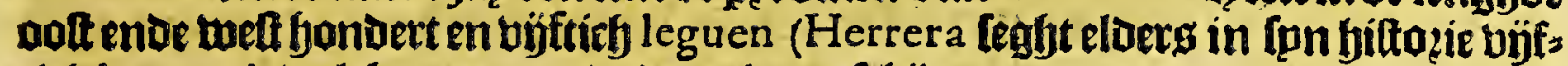
tich leguen, 't twelck meer met oe waeubepot frbïnt ober een te komen) enoe tacfy=

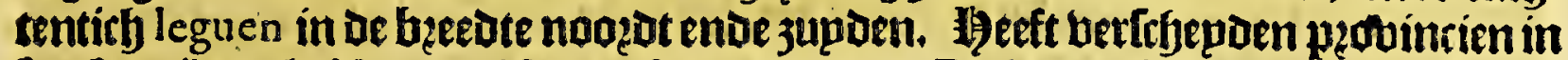
(pn begrip / als Nicoya, Nequecheri, Mabyte, Diria, Mafaya, Managua, Cacaloaque, Ceveaco, ent gfjedeelte ban De bolckeren welck men naent Chontales,

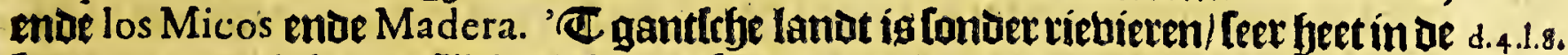

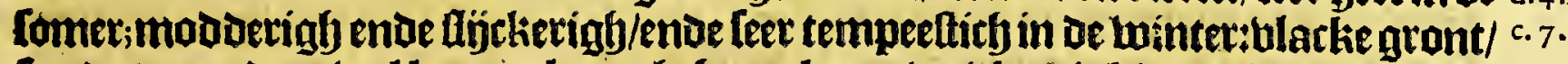
coo dat men dowr wel karren kan ghebeupcken: oberbloeding ban aloerfande lige:

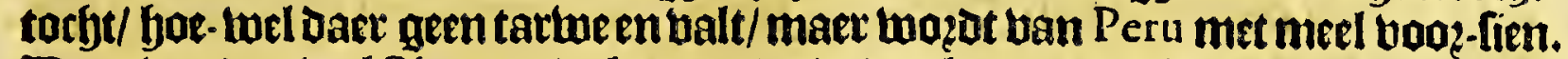
Daer wozden beel tticken ende koepen / ende berckeng aen-ghequeeckt / ende pack enighe gepten; maer men en beeft daet gljeen ftbapen. Baer is leer veel biffy: (1) maecken baer beel entoe leet goet jout; daer en jún gbeen peerlen ofte andet:

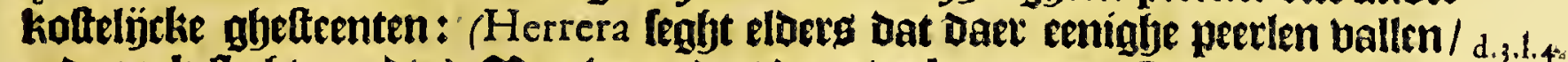

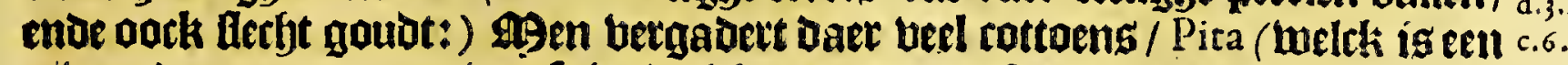
getwas daer men gaeten ban [pint welek uptetmaten ftercli ig) beel bonigh/Maiz, Chille ofte Axi, ertweten: Ip betalen baer tribupt aen de \$paegniaeraeil met

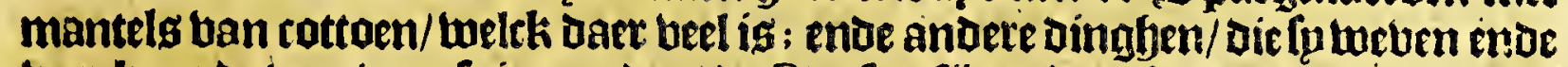

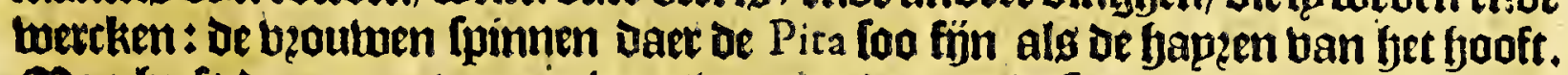
g9en beeft daet grooten aen-Luas ban peerden / ende [eer groote muplen / enos twozben ban fier getbert om in be Caravanas gebupekt te twozden die van Nombre de Dios trecken naet Panama om't filtuer te baelen. Baer is beel bolltyagie in 't landat/\$oaz dien't abeboomte daet lect groept; intonuerbept Den boom genacmt Zeyba, wozot daer Iomwijlen loo dick / Dat bỉfthien mang die bandt aen banot baudevide niet an konnen om-bangben. Daer jün boomen die fekere rooue kerfen 


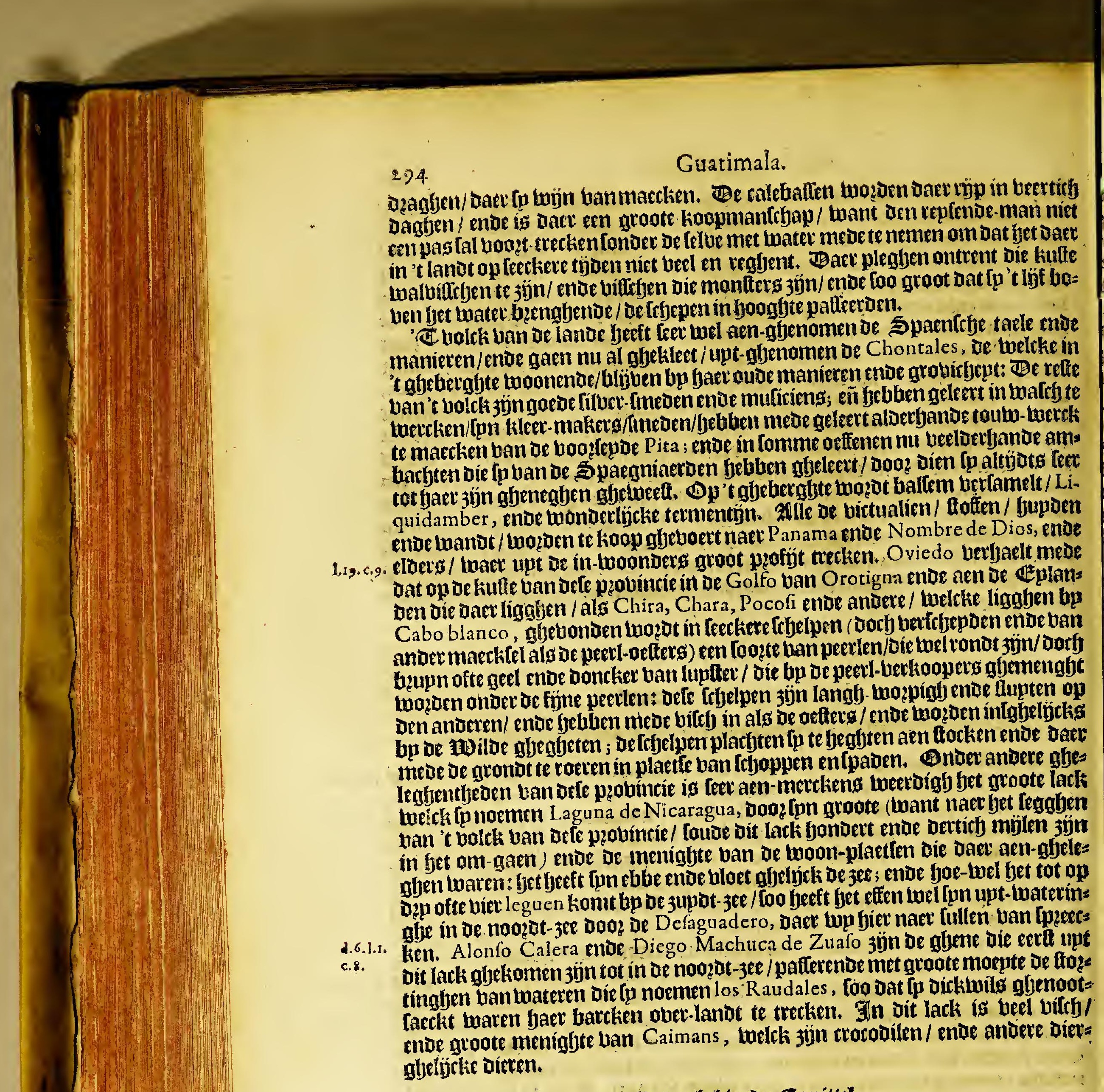

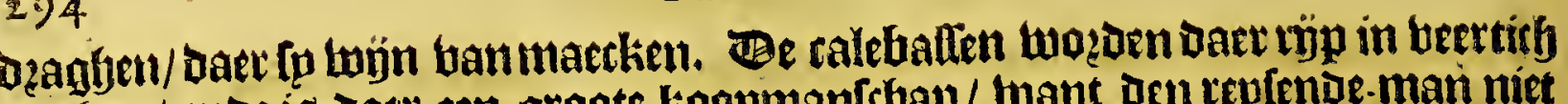

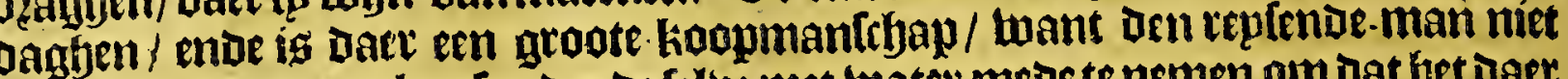
boot-sreckentonoer de telue met water medeter 年

Cholth uan de lanoe beeft leer wel aen-gbenomen oe Spaentrtye tade enoe Chentales, oe welcke in

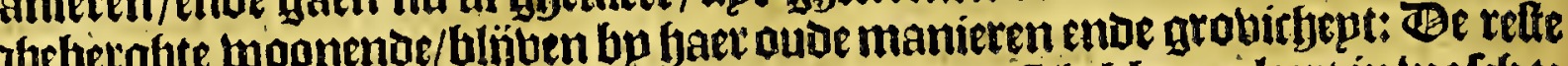

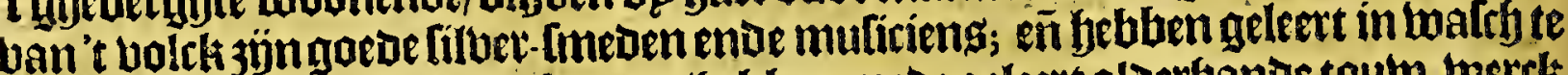

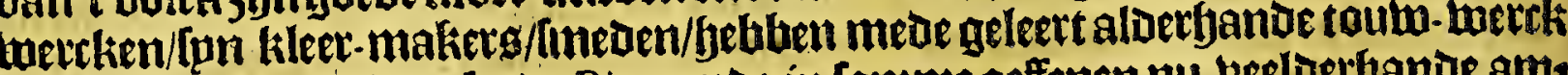

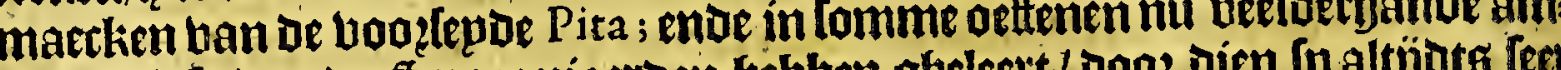
(a)

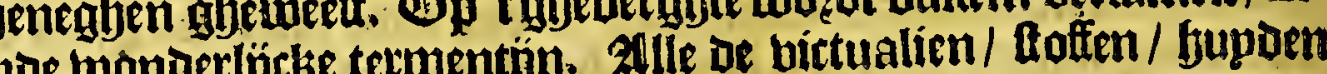

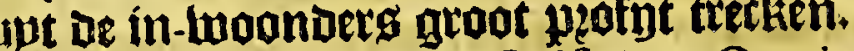
Dat op oe kutte van oele pzouincie in de Golfo ban 政

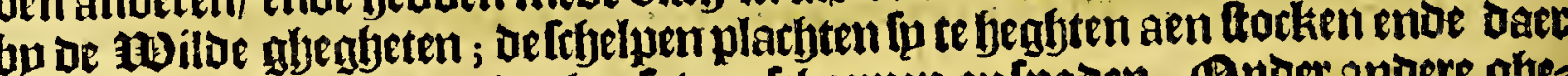
mede ae gronot te roetenin paete ban tchopuen enlpaden. Ordoes andere gye(t)

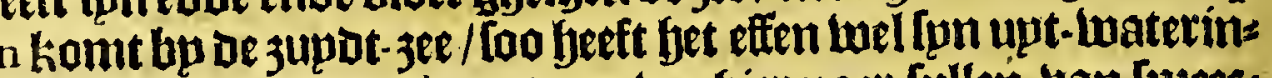

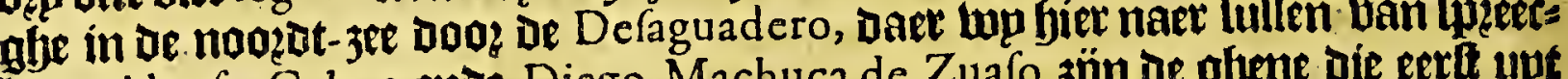
choe groote menighte Lan Caimans, welck 3 nn rrocodilen/ ende andere diet: glyelïrke Dieten.

\section{Het arfthiente Capittel.}

Van de fteden van dit Gouvernement, LE ON DE Nicar A GV A, GRANA D A, Neuv a SE govia, I a en ende de vlecke Realeio.

$\mathrm{D}$ Ce extte ende píntipadlte ftadt han bit Baubernement is Leon de $\mathrm{Ni}$ caragua; gheleghen van $S^{t}$ Iago de Guatemala yonoert ende bier leguen bp nae naer bet zupot-ooften/ thaelf leguen ban oe jupot-3ee / Dicht be bet boo2-[rtyetuen aroote lark ban Nicaragua; in dele ftabt boubt ben Bouber neur fon relidentie/ende andere officiers bain oen ltoningb/ende bier is mede of

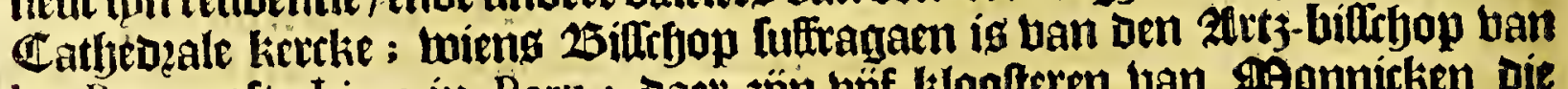
los Reyes ofte Lima in Peru : Daet jün büf kloolteren wan Sonnicken bie

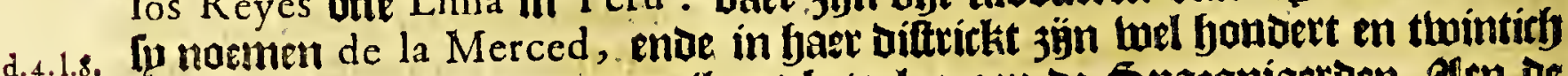

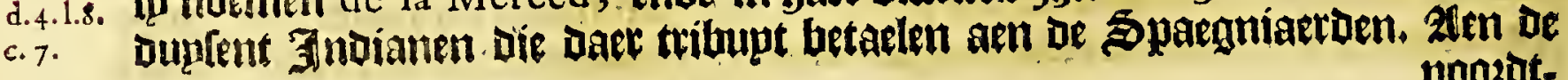
nooget- 


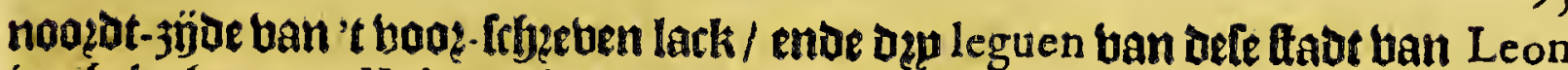
is ghelegben een Volcan die wronderlijethen foogh is en bouen frherp/ oe welctie

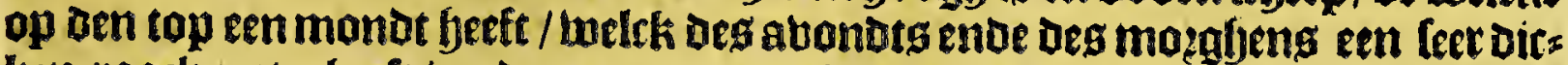
ken roock upt-gheft/ ende groote quantitept ban fulphet-Gteenen uptolwerpt; ende alsmen de aerde ban defen Volcan bermenght met bet water van Nacolot, (welck is of beutfete ban een hoom ban dit lanot / welck mede bozot gfye= bonuen ín Nova Hifpania, enoe wozot daet gftenoemt Xahuali; fpn beuctite ig bp nare tam gbedaente als de man-koppen; de Foilden butken daer een nat

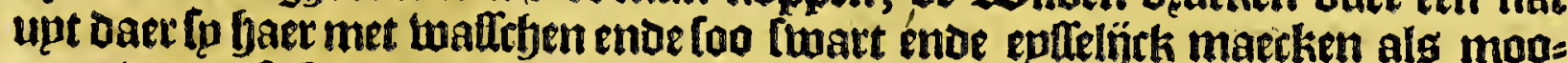
ren; Dan ofe charte berlwe bergaet weder in beertfien dagfen; ere en hanfe

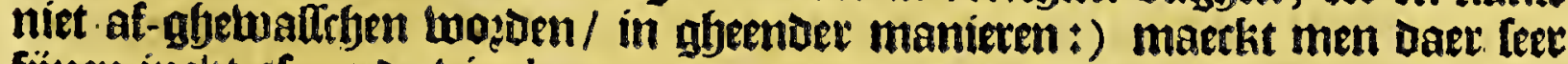
fÿnen inctst af; enoe vier leguen voogser in de probincie ban Mafaya, is een klepnoer lack/rondt/ ende ban't bobentte ban oe grondt tot aen bet water/ is bet tuel duplent ltagien boogb/alle te Jnoianen dalen daet in om water te faes Ien / met kruptken daer wel twee artoben in gaen / ende bet op ende af klimmen is foo recht ende ftepl als een muec/ al ban barde klippe / daer jün gaten in ghe maeckt daet fo be banden ende boeten in bouben / en klimmen loo af ende twe ber op met baer krupcken / Dat bet een lwonoer om lien ís; enoe bet is gleleghen bp naer aen be boet ban den Volcan ban Mafaya, of ineleke naer bet leggben van Gomara thienleguen light ban Leon ende dąp ban Granada. De ftaot tan Leon leglt op een fandigbe gtondt / enoe if gantfeb omringlyt vat en Dicbte bofichagie: (Die de Spaegmiaeroen noemoen Arcabuco,) In oen jare 1527 gas ben die ban Nicaragua te kennen aen den feptex Carolus V, Dat tufferhen be flabt Leon ende Cabo de Honduras, welck legghen 3 upot ende noozot van oen d.4.1.s. anderen / waren febentich leguen tweeghs/ enve be vallepe ban Vlanco in bet ${ }^{c} 7$. mioden; foo dat bet een feeckere twegh was/om den banoel tutfhen bepae de zeente onder-bouden.

De thaot Granada de Nicaragua ís gbelenben teltjien leguen ban Leon, op Her.der.

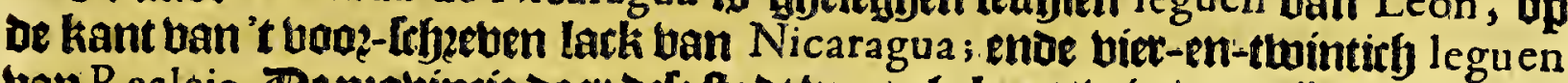

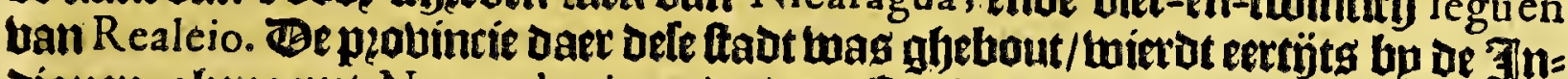
vianen qljenaemt Nequecheri : entue oen Capitepn Francifo Hernandes de Cordua maeckte daer een fraepe kercke ende een foztrelfe tegben be India=

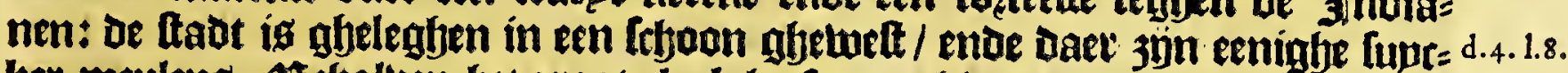

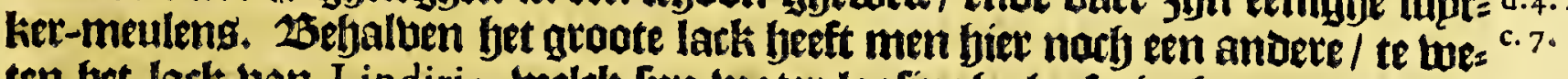
ten bet lack ban Lindiri ; welck [nn water-loolinghe beeft in bet groote lack.

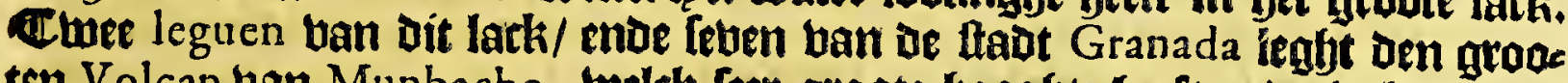
ten Volcan ban Munbacho, weltk leet groote boogfte heeft ente is betwallen met beel frupt-boomen/ wan welcke de beele probintie leet twel booz-lien is / ende de belte daet ander jún Capotes, Platanos, ende Anones, welck jün ban

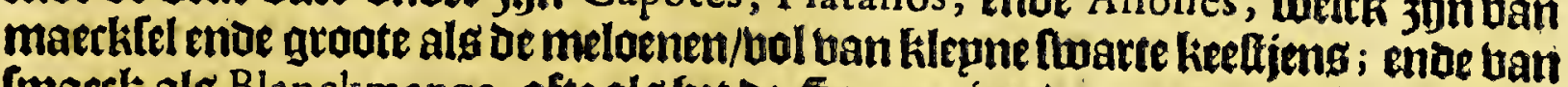
fmaeck als Blanckmange, ofte als jet de Spaegniaetoen noemen Maniar blanco ; doch en zün uiet feet ghelonot om te eeten / doos dienfe beel twinden bertuece ken/ende facljt boedtel gheben / de 2 gexicanen noemen oefen boom Quauhtzapotl; maer be Spaegniaeroen noemen die Annona. Boote freftmen baer wonderlÿrke meloenen / milpelen / gbelíck als fupcker-tanoilch / kerten ende

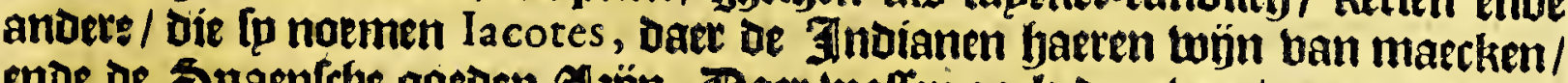
ende oe Spaentebe goeden âtjün. Baer wallen oock dęuben / queen / grana: ben / ozagnien / limoenen / ritroenen / bjgben : Daet is groote jacht ban aldet-
banbe wilot.

Jee ftadt Neuva Segovia Yeaft dertich leguen ban Leon naex's noo?den / ende oock loo beel mïlen ban Granada bpkants naer 't noozoen; in baet dilticlit toozot veel goubts berlamelt upt de mipnen.

De ftaot laen legbt betticty leguen tan oe nooz̧ot-jee / aen bet epnoe ban

$$
C_{c}{ }_{2} \text { 'tgrome }
$$


t groote lack / onttent baer of upt-wateringlye welck fo noemen el Defagnadero begint; Doo: toelcke de koopmantryappen komende ban Nombre de Dios (nu porto Belo) wozoen op-glbetoert naer andere plaetfen ban oefe pgo: bincie.

De bleckevan Realeio een legue ban de baten de la Poffeffion, welck men ghemepnlÿcli noemt del Realeio; is gheleghen op oe hooghte ban eff graden enoe een baif; (Thomas Fuller in De vopagie ban Candifch ftelte ou twaelf graden enae beertíly minuten / indien bet de ylaetfe ig die lye noemt Rio Lexo:) ende biet-en-twinticy leguen van Granada booz-noemt. Jlo maet een kltwn plattaken/ende meet betwoont by barendt volrk; oe baben is ban de bette ende [eerliette habenen ban alle die langhg de lelbe kulte wozoen ghebonoen/ enoe daer wozoen goede frbeyen aljetimmert / Dog de gaede gluetertrobap ban bes quaen lyoudot / welck men daer licht kan bekomen. Jn dit Boubernement jón Ueel doepen ban 3 ndianen die den meelten- deel onder tribupt fitten.

Het negben-thienoe Capittel.

Befchrijvinghe van de kufte, punten ende havanen van de provincie Van NICARAGVA.

O De lutte ban defe pzobincie aen of noozot-3ee / beeft men naet de ries viece Yare, welck defe pzouintie frbepat ban de pzobintie de Honduras,

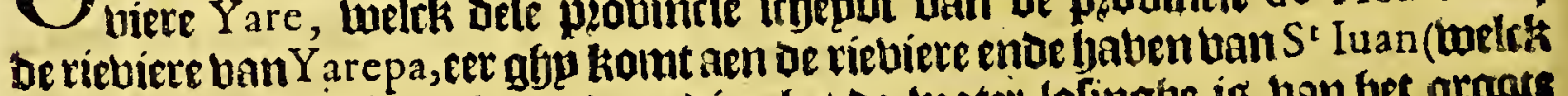
Ip noemen el Defaguadero, Dooz dien bet de water-lolinghe is han bet groate Lack ban Nicaragua) met een gloot Gzplanot in de manot / ende daer naer noff

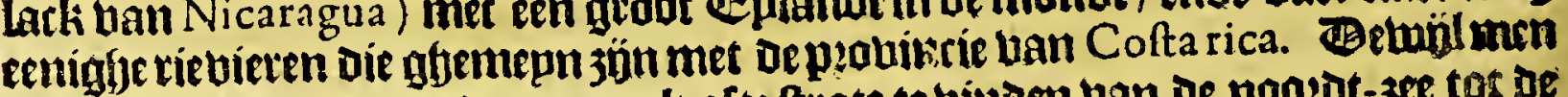

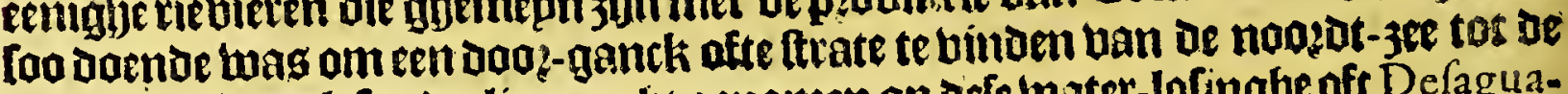
3 upDt-jee/ is oatk fonderlinge atbt genomen ap defe Later-Lofingbe oft Defaguadero, melch is een rieviete [oo groot als die ban Sevilla, aen lrepore de aeteren be: moone bu bertryepoen natien / foo dat die ban Nicaragua in den jare 1534 dent

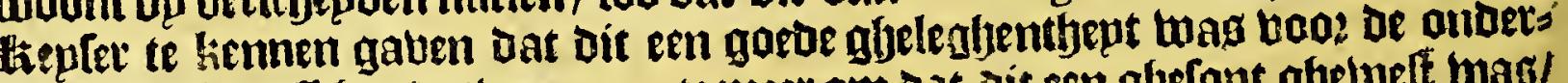

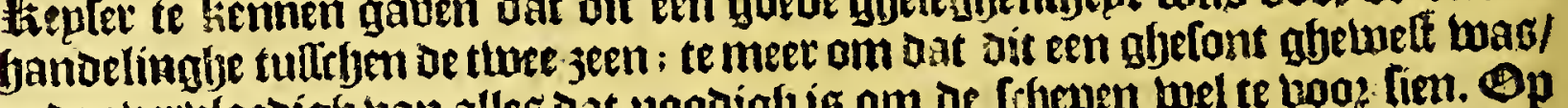
ende oustuloedígij van alles dat noodígh is om of fibepen wel te boos fien. Op d.2.1.2. De hulte ban Mare del Zur beeft Defe pzdaincie naer De baten ban Realeio Daet

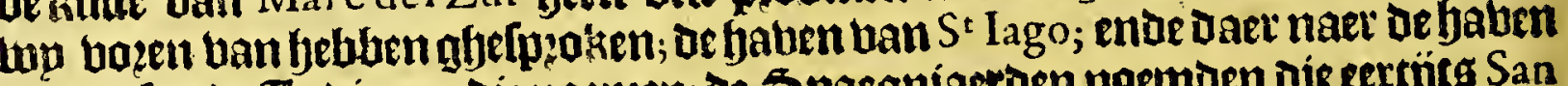
Chira, [oo de Indianen die noemen; de Spaegniaetden noemoen die eertíts San Lucar, ende nubeet mendie Puerto de Nicoya, (welck is eenparticuliere probincie

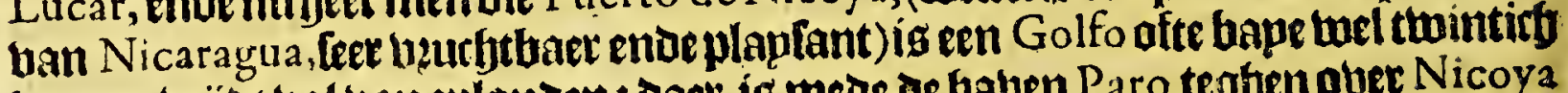
Her.def. leguen wijot bol baneulanden: Daer íg mede de hauen Paro teghen ober Nicoya in be Golfo die funoemen de Salinas cer ghu kamt aen Punta de San Lazaro, enos Cabo de borica, ban twelcke naer bet oolten ghelegben jün of etplanden ban Sanra Maria ende Santa Martha, Cobaya ende Sebaco, ap de limiten ban Vera d.2.1.9. Gua, enoe befoolen oork tot de kutute ban Cofta rica. Defe eplanden uan Zebaco c.16. jün wel Dertich in ghetal/ coo groot alsklepn/ leftich leguen ban Panama gbeles ghen; Daer was eetrijots treel bolcks op defeeplanden. Thomas Fuller in de hopas

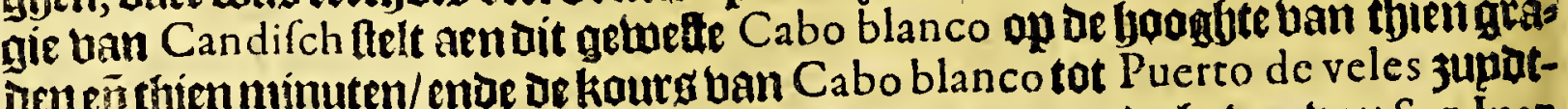
lueft ende noozot-aolt atht mijen: ban Puerto de veles tot de haten ban San luan

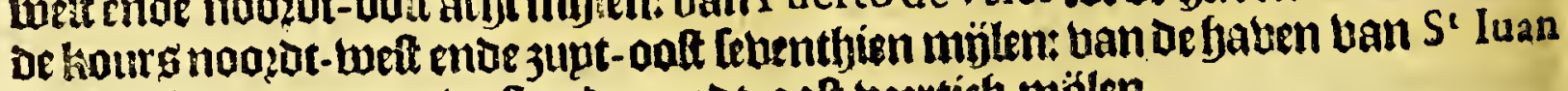
tot Rio Lexo, noazor-tweft ende zupot-auft veertich mijlen.

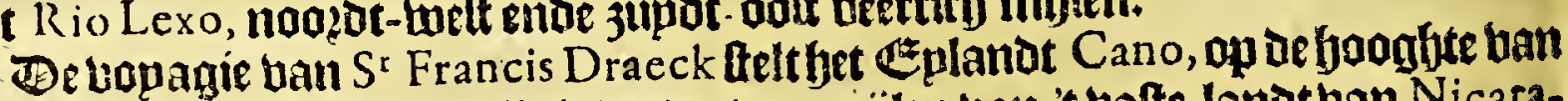
acht graden bp noazoende linie/ ende twee mülen uan 't halte land ban Nicaragua : Dit eplanot feefteen klepne bape (alg Nunno de Silva gfetupght) Daer men

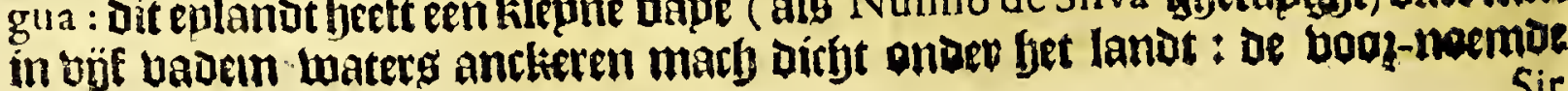


Het fevende Boeck.

Sir Franeis Draeck ancketoen tullegen het fellue eplanot ende' bafte lant ontrent een rievier / bp ontlade ende kiel-haeloe fon fehip/entoe berfagl'telbe ban twater enoe bzanot-boutot / enoe anoere noodtosuft die oaer te bekommen was. Te

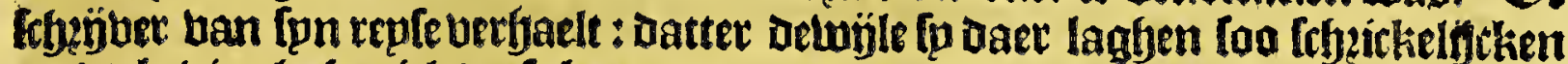

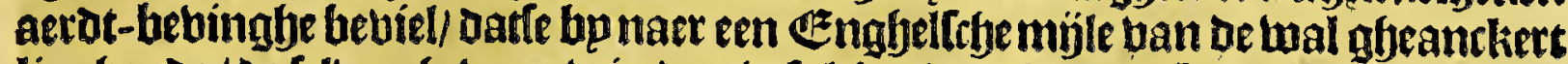
ligghende / oe fe!tue gfelwaer twieroen in fulcker boegben Dat hepsefpn fchip ende

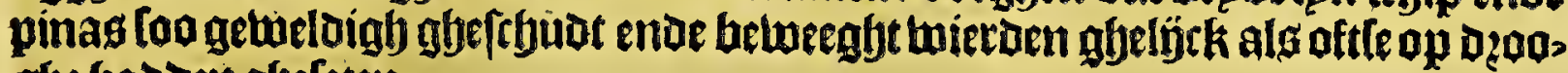
ghe badoen garleten.

\section{O S T A R I C A.}

\section{()et twintichete Capittel.} Befchrijvinghe van de Provincie van Cos t A R I c A : ende de
plaetfen der Spaegniaetden daer in ghelegen.

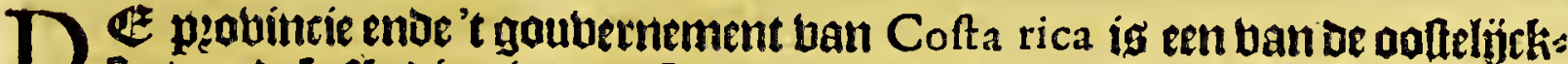

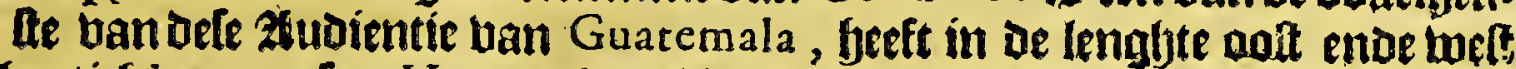
tmeghentirf leguen. ([oo Herrera jem biex in nieten beraif) ban be upterfe pa= Ien uan de plobintie ban Nicaragua, aen de welcke bet paelt langhs tnoozoen ende 'luelten/tot de límiten ban de probintie ban Veragua : $7 \mathfrak{s}$ tamelijek goet

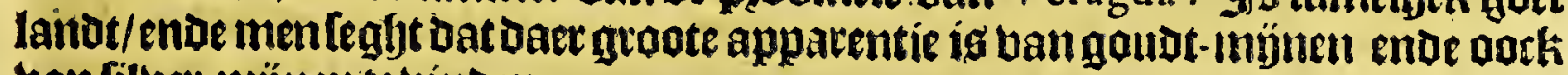
ban filver-mïnente binden.

Daer jün twee plaeten betwoont by Spaegniaetden: b'enghenaemt A ranivez, bj̈f leguen ban't landt bp een natie ban Indianen betwoont diemen naemt Chomes, welcke blecke beboott tot oe juriloictie ban Nicoya. Gende de ftadt Carthago, beettirfy leguen ball Nicoya, ende twintirf leguen ban de $3 \mathfrak{e e} / \mathrm{bp}$ naer in'tmidoen ban oe probincie/welck feeft baer baben enoe ontladingbplaetfe bepoe aen de jupdt-jee ende aen de nooget-3ee; op oe welcke eenighe rievieren leggtjen tulfetjen Nicaragua tnoe Veragua, die met dit Goubernement glye: mepn зйn.

Op de limiten ban 't goubernement ban Nicaragua ente ban Cofta rica ligft mede Nicoya, actjt-en-beettich leguen uan Granada, op de kulte ban Mar del Zur, is een Coregimiento (als de Spaeghiaeroen bat naemen) in 't tuelske/als mede in bet eplanot Chira, (welck befjoot tot fun jurifoittie ende ig aheleglyen acht leguen af in De $3 e e /$ ) woonen leer veel Inoianen dic tribupt betalen aen of Honing

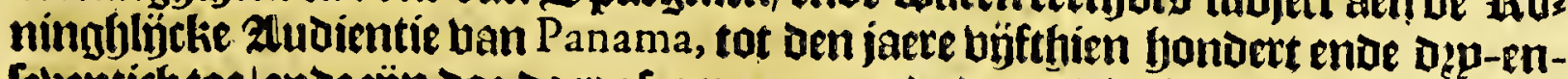
Celuentich toe/ entae $3 \ddot{j n}$ doe daer af-genomen ende de pequincie ban Coft a rica bugbevoeght/welckeg Gouberneur baer een líeutenant ftels/ende oen 25 iffetjop ban

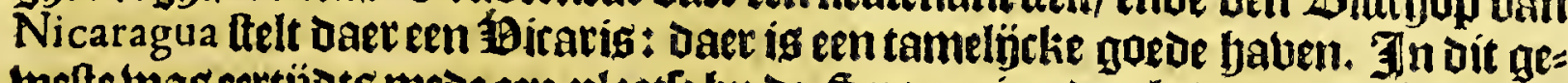

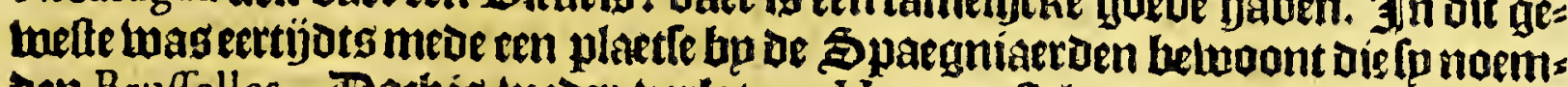
ben Bruffelles. Dorbig weoer berlaten. Herrera ftelt mede in tpn kaerte on=

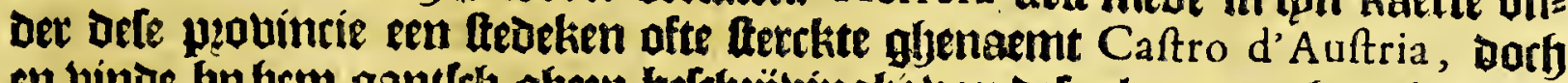

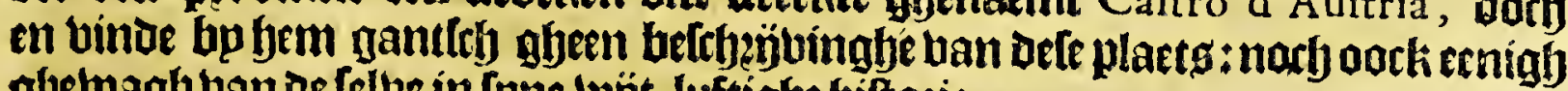
ghetuaglj ban oe felue in lpune Luńt-luftighe biftozie.

Lopes Vaz feglyt dat Cofta rica is een lergharftighe cnde defolate lan= boume / loo dat de naem met de laecke felfs qualijtk loude aber een komen. Bp dekulte uan de noagdt-3eefeeft dit goubernement de Bahia de San Gieron mo ende de Caribaco bp oe limiten ban Veragua. 
$\because 9$

Guatimala.

$V \quad E \quad R \quad A \quad G$ U A.

Het een-en-thintitylte Capittel. Befchrijvinghe van VERA GVA, haer cerfte ontdeckinghe
ende gheleghentheyt.

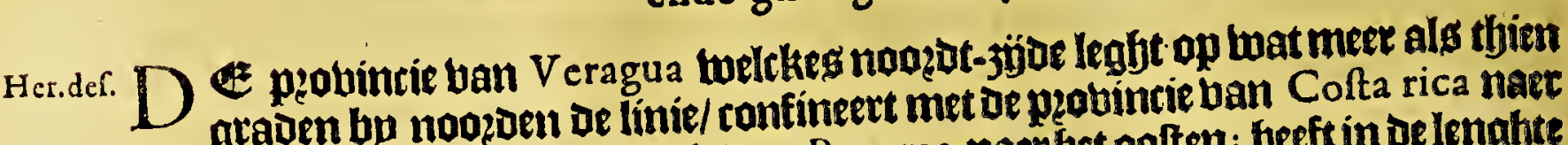
het wetten/enoe met de plobincie van Panama naerbet oolten; beeft in de lengbte

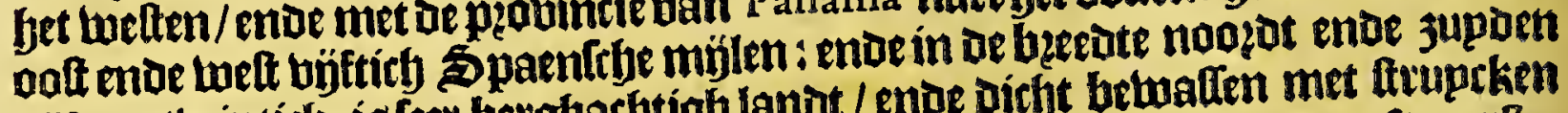
vijf-en-thintich; is feet berghjachtígh lanot / ende dicht bewalten met ftrupcken ende abehoamte/ Conoer twepoen ofte bee; Daer en walt gheen tartwe oft garte; yeft wepnigh Maiz, endetwepnich bof ofte moes-kwupen; Doch is aber-laeden

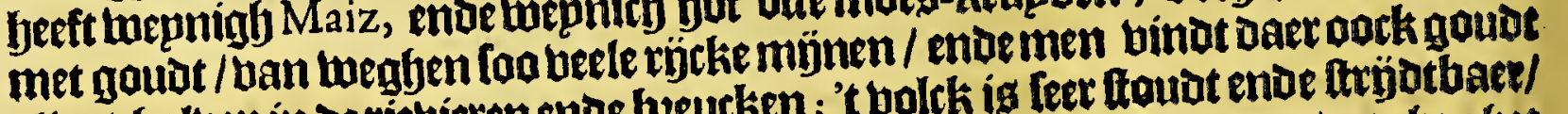

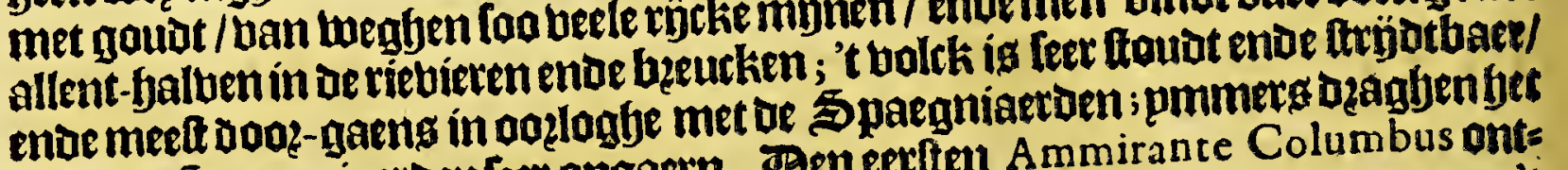
tort der \$paegniaetoen leer ongaern. Ben eetten Ammirante Columbus ont:

d.r.l.s. Deckte dit lanotín den jare 1502 , komende ban Cabo de Gracias a Dios naer't

6.6.87. poften toe; yp quameert aen een eplanot ahenaemt Q uibiri, enoe een plaetfe aen 't balte lanot gbenaemt Cariari, daer [p't bette bolcli enoe foo goroen bodem bons ben/als fp noth opt gbelien badoen/weghen de aenghenatmbept ban oe bexgew/ werflitbept wan oe riebieren/ende feyoonyept ban oe boomen/ende 't eplamoeken

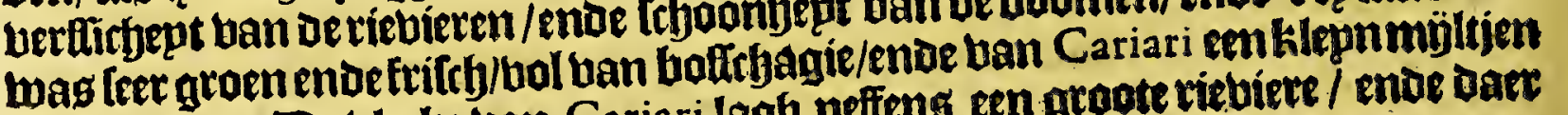
berlybepaen. De blecke ban Cariari lagh neffens een groote riebiere / enoe oaer

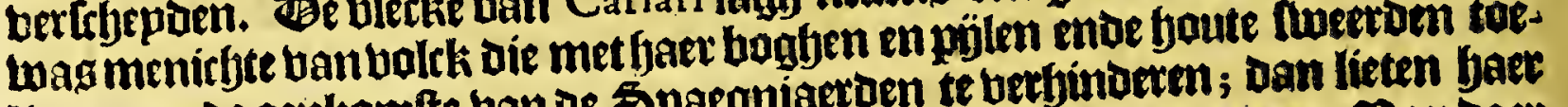

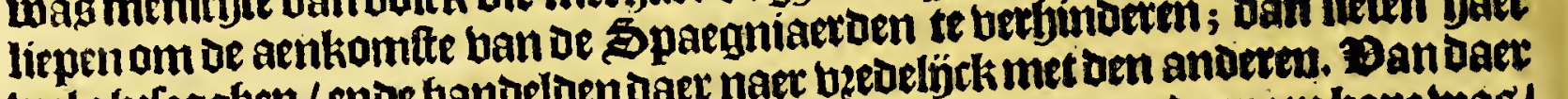

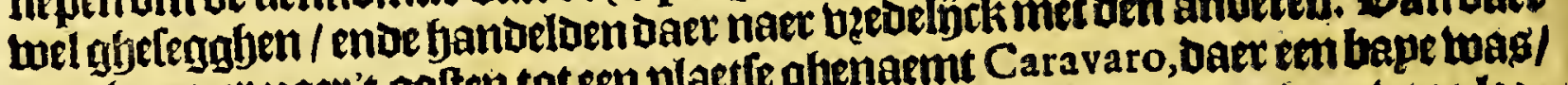

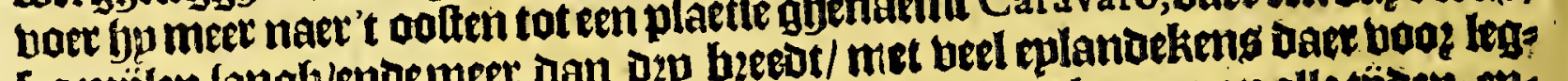

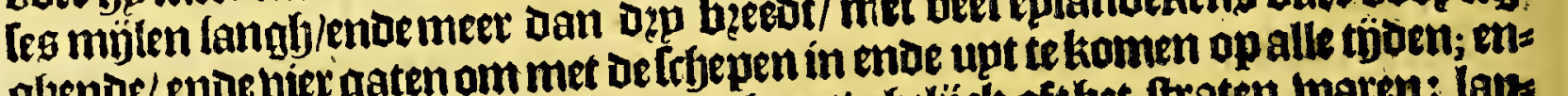

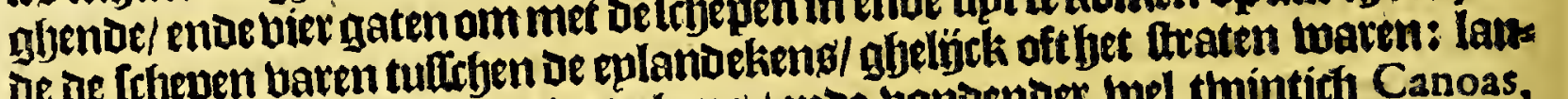

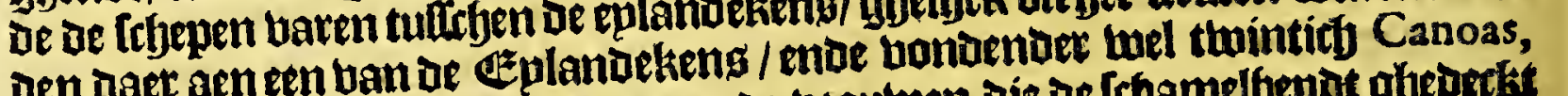

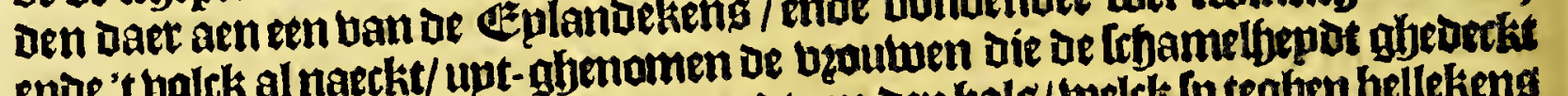

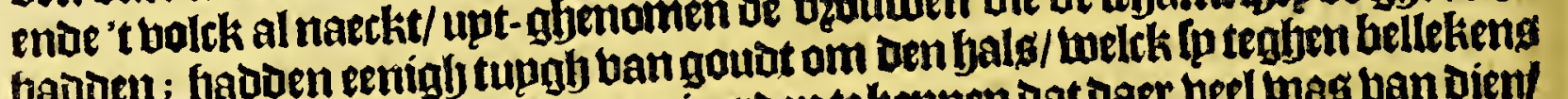

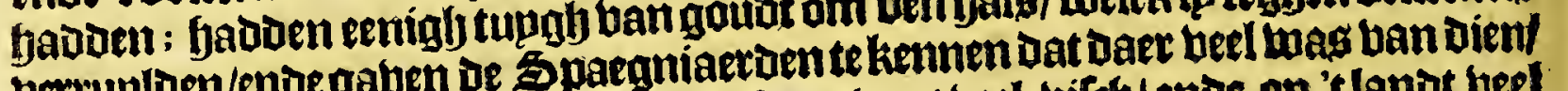

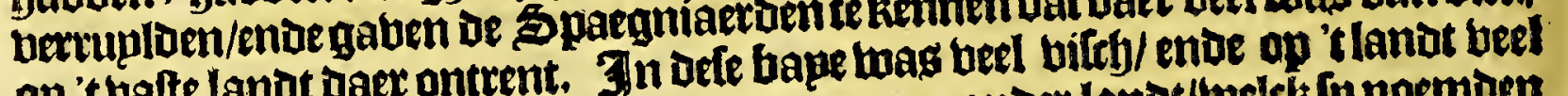

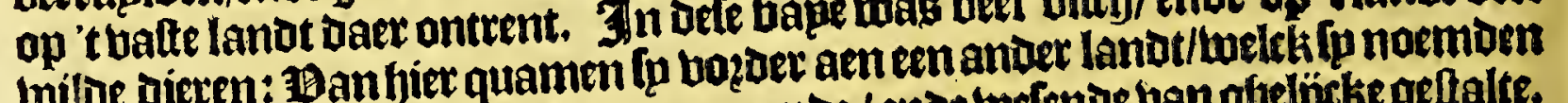

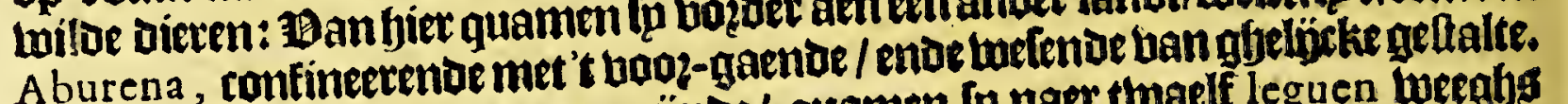
A burena, confineerento met on Ban daer lueder in 3 ee gel oupen

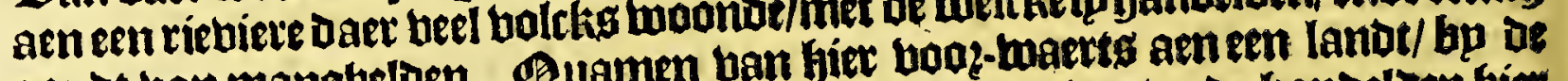
gouot ban mangheloen. Quamen bat ben in een rieviere / enoe banaeloen bies

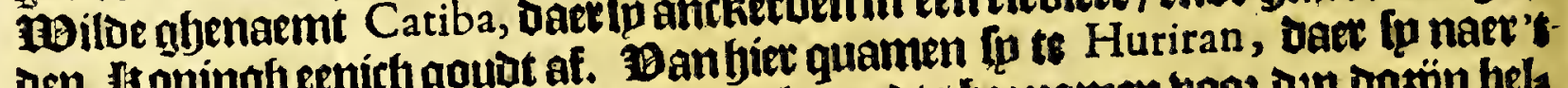
oen Honingheenict goudat at.

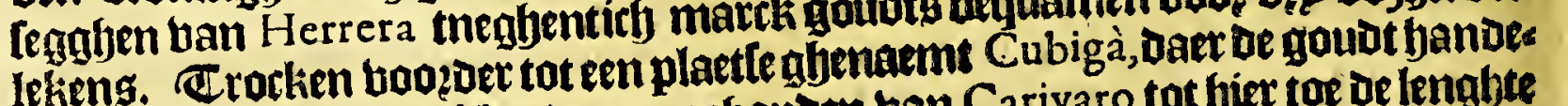

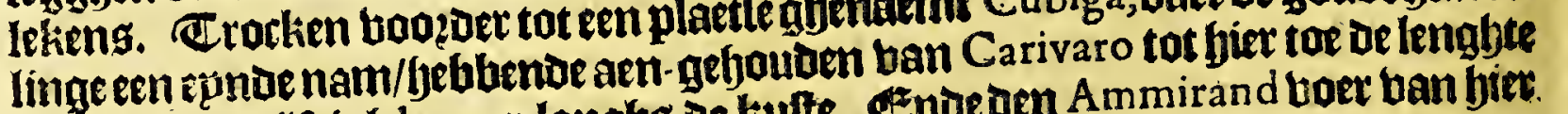
linge een

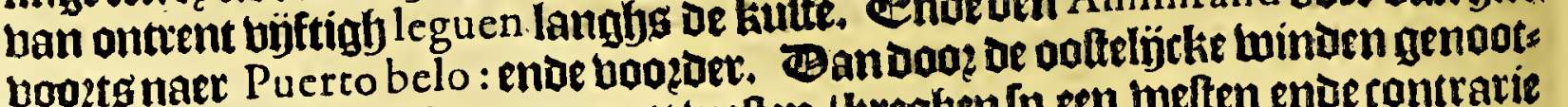
faeckit jünde weder te keren naev' t weften / kreglyen fp een weften enue contrarie winot/ (met foo graubelijcken tempeedt / dat [p al mepnoen te bergaen/) mel

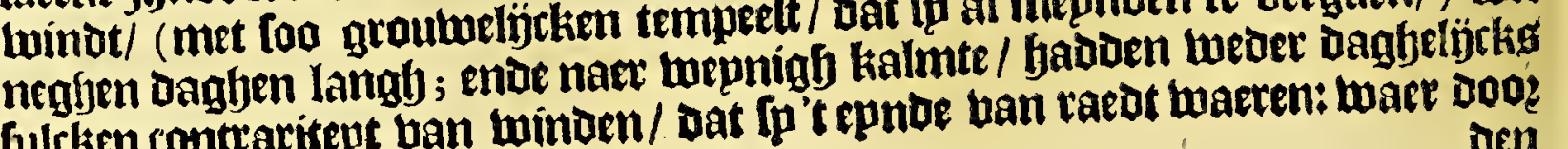

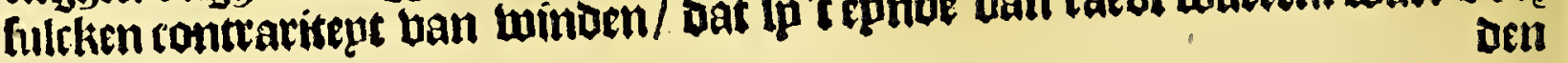


Den Ammirante bele kufte uan Veragua noemde/ Cofta de los Cöntraftes. felten lanua ri desjaets 1 503 , quamen fu in een riebiete die de Jndianen noem-

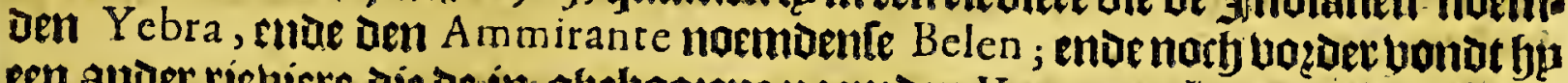
een alloer rícbiere die oe in glyebogene noemien Veragua.

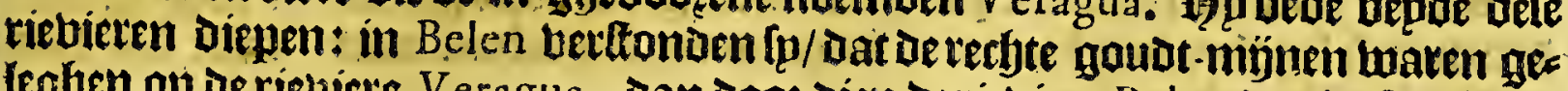
Ieghen ap de riebiete Veragua; Dan dooz dien de rieuiere Belen de diepfetwierat betuonden/refolbeerde den Ammirante daet inte baren. Sondt fpn beaeder de riebiete Veragua op met barcken/ be twelcke quam tot aen de woon-plaetlen van

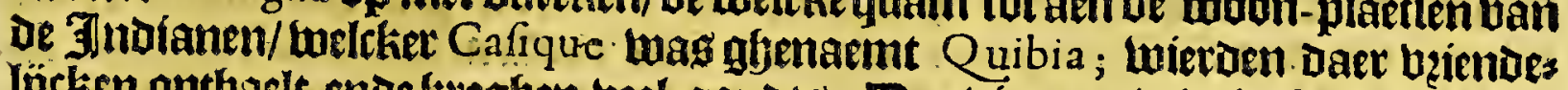

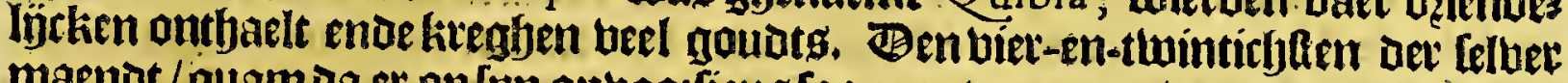

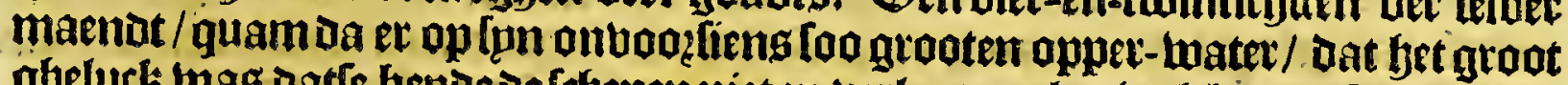
gbeluck was date bepdedeffepen nieten betloozen; bet welcke moeft boot-ko= men ban eengrooten dagh-reghen op t theberghte ghe allen/ welck legft bouen Veragua foo joogly datmen ljet ban twintich le guen bette lien kan / Den A mmirante noemion aitgheberghte $S$ an Ghriftoval. Sonot daer naer fun b?oeder wes oet de rietiere $V$ eragua op (tuelck een legue bain Belen leglyt ineernaer' tweften)

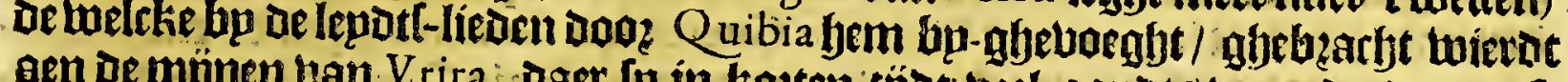
aen de mijnen ban V.rira, daer lp in katen tijor beel goudts uergaderden / ture

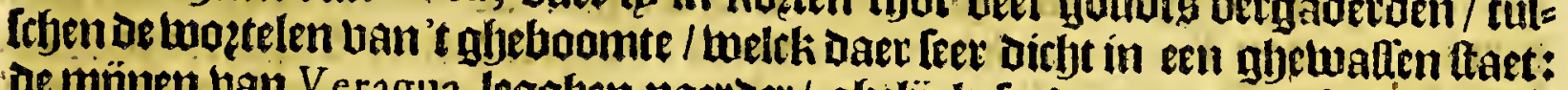

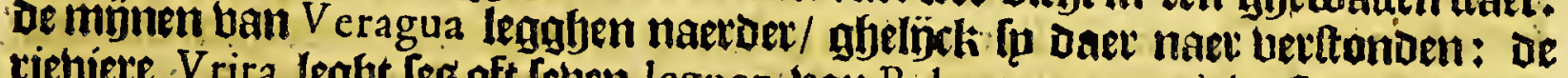
riebietre Vrira legbt fegs oft leven leguen ban Belen meer naet's luelten: daet onttrent was noclyeen ander woan-plaetle gbenaemt Dururi; enoe eet anoer glye naemt Zobraba, al-haerfp veel lanots met Maiz belaepdot bonden. Ben Am-

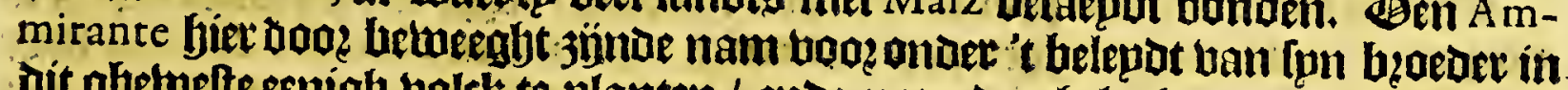
Dit ghetuette eenigh bolck te planten / ende nam de ghelegbentfjedot neffens oe riebiere Belen, bp naet aen't in-komen / op leeclket booghte; fiet-en-tultefyn booe bet deogh weder was bet water ban de riebiere foo gbeminoett / aat oe Trfepen niet blatten en konjen ober oe batre bande riebier / foo datle ghenoot: faeckt waren te bertoeben/tot dat den reghen de riebiere weder fou de Doen wallen:

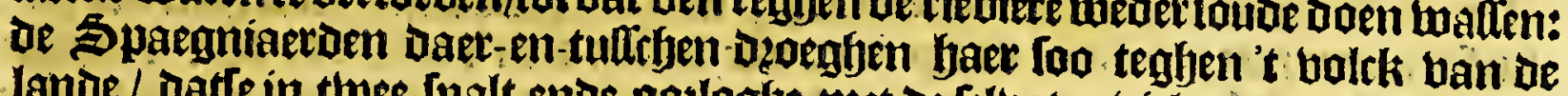
lande / datte in thee- Lpalt ende pollogle met oe felbe betuielen / entoe naer faere

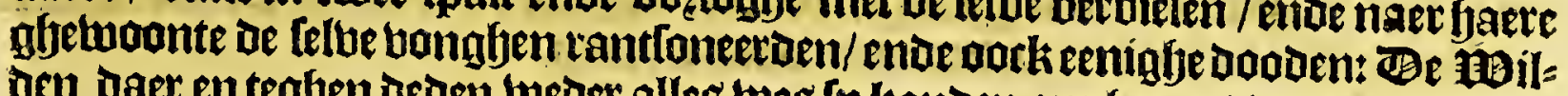
aen daer en teghen deden weder alles tues fp konden on yaet té beetken / ende toegfyen mede eenighe Spaegniaerden doodt/ ende namen lyaet de thaloupe: Soo dat de Spaegniaerden fiende dat fyet fier gheen goet blíben en lwas/ gljo noegblaem tegígendanck ban faet ouerte de plaetle betlieten ende beder ber
trocken.

\section{Het thee-en-thinticfofte Capittel.}

\section{Befchrijvinghe van de Steden ende Vlecken die by de Spaegniaerden nu bewoont worden in de Provincie van VER A G VA.}

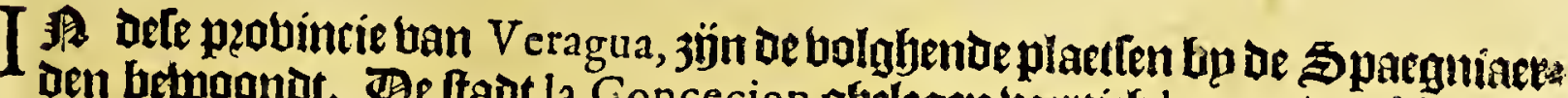
de Dios naer 'twetten tae lager

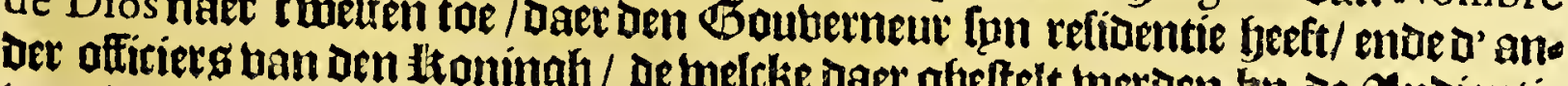
uan Panama.

De blecke la Trinidad, fes leguen naer fet oolten uan la Concecion langfjs de

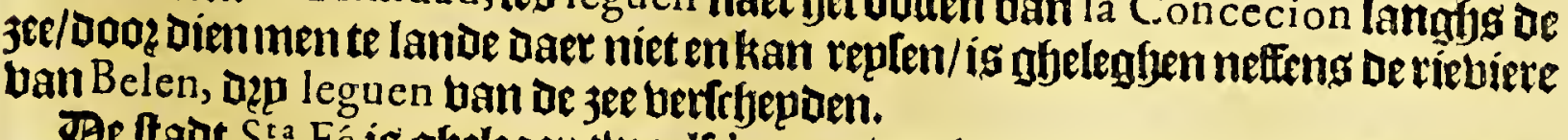

Be ftadt $S^{\text {ta }}$ Fé ig ghelegentwaelf leguen banla Concecion naer fyet jupDen/ met eenfmelt-fupg ende onder-afficiets ofte lieutenanten van de officiers ban den
Jtoningf. 


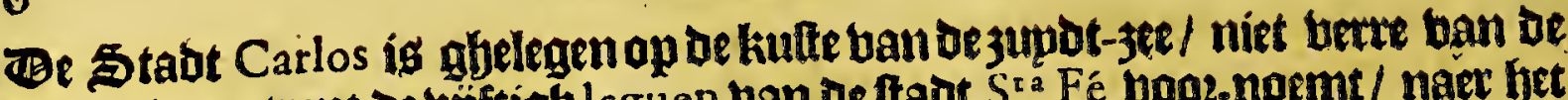
Itrand ende ontrent de väftigh leguen van De ftadt $S^{\text {ra }}$. Fé vooz-noemt/ naer bet welten toe.

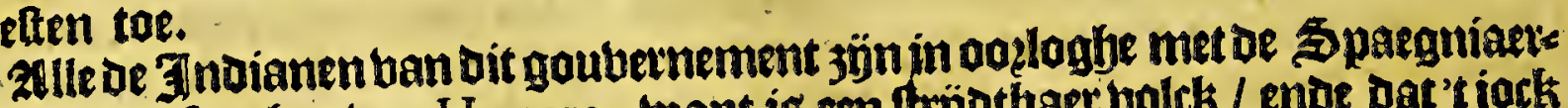
Den/naer't fegghen ban Herrera : want is een lrijotbaer bolck / ente dat 't jock niet tuel wil Dzaghen.

Daet en is gbeen yaben vanemigbe contuetlinghe weetoe on bepoe de kulten ban dit goubernement; alleen op of kufte naer't noozoen beeft men Bahia de $\mathrm{Ca}$. rabaco, ofte ban $S^{r}$ Geronymo; ende meet naet 't oolten/Rio de la Trinidad, ens De Rio de Concecion ende de Belen, Daex aen eerfen Ammirante fun moon. plaetfe bad gelegft alg boozen is berbaelt/ Die niet bequaemen is booz ictonen bain eenighe groote: Too dat miet en binde dat bier eeniglje fonderlinge baert balt.

Anton. Op de kulte ban de 3 upot-zet hebt abp Cabo de Santa Maria, ende Punta de Gal va- Guerra; welcke punta eenighe ftellen op de bougfte ban twat meer als Ieg graden bp noazoen de limie/ende Ieventicy leguen yan Panama naer't twelten lon Gomara getupgbt: enoe meer naex 't melten Punta de Borica, op de boogboe ban arbt gra: aen/ende bondett leguen ban. Punta de Guerra too Gomara trtyenft: ende Cabo blanco, op de hooghte ban acht araden endeeen falt/alg Gomara legbt:ende bon: oert leguen ban Borica: welcke Cabo wo in't negbenthiente Capittel upt oe abis fervatien ban Thomas Fuller bebben gefelt op tfien graden enoe tbien minuten; vorb altmen Loude oozdeclen naer deghelegenthepot ende frecking be ban't landt/ frhint dele Cabo op arftgraden enoe een balf te legghen.

Dp defe kufte ban Dele pzobincie naex't noozoen/ legft een Geplanot welck fi Engel- noemen Efcudo, íg gheleghen ontrent detticly leguen van Nombre de Dios traet 'twelten: $S^{5}$. Francis Draeck was daet aen infpn laettle bopagie; anckerwen aen

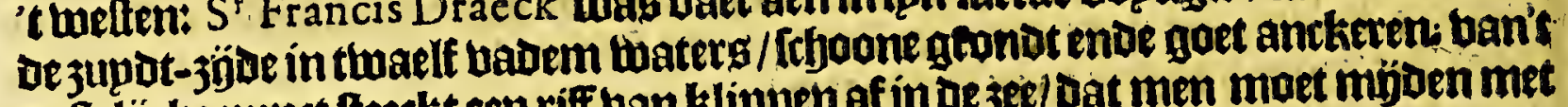

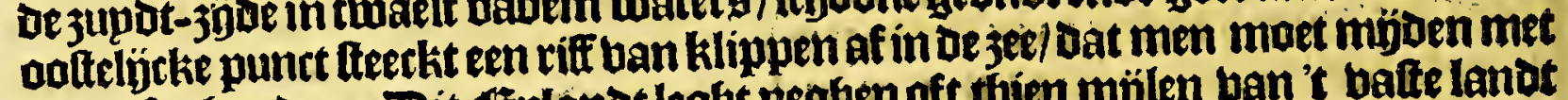
wat af te bouben. TBit Ezplanot legbt neghen oft thien mijlen ban't bafte lanot af/ende en ig niet ober twee leguen langh/ thaet bol geboomte/ ende beeft feet gaet betth water met oberbloet in bp naet alle beelen ban't eplanot: Dan 't climaet en is niet onghelonot/ende gljenegen tot beel regbeng : $S^{z}$ Francis Braeck lwiecos bier kranck/ende ftiert koetgdaer naer ban den loop. 



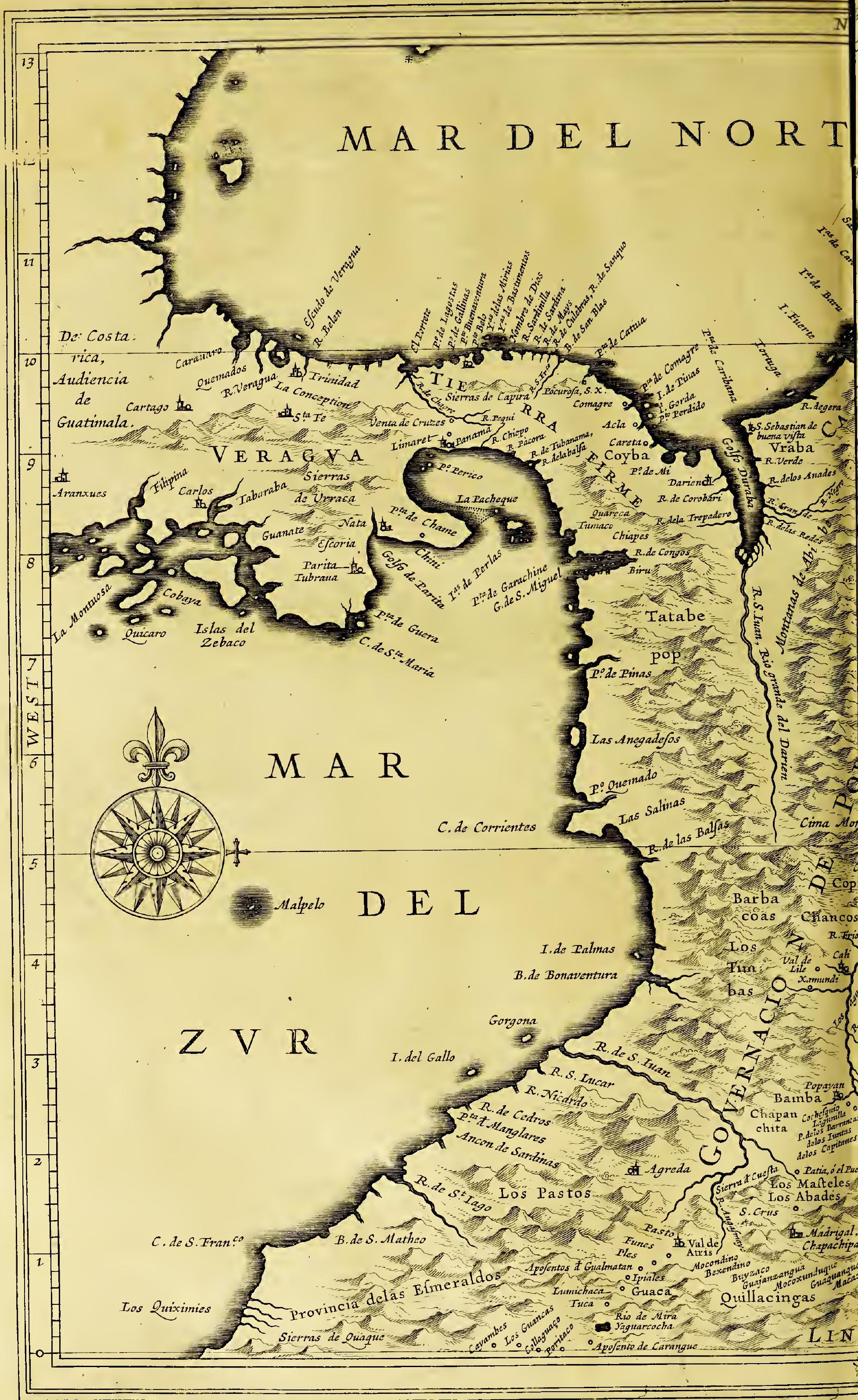




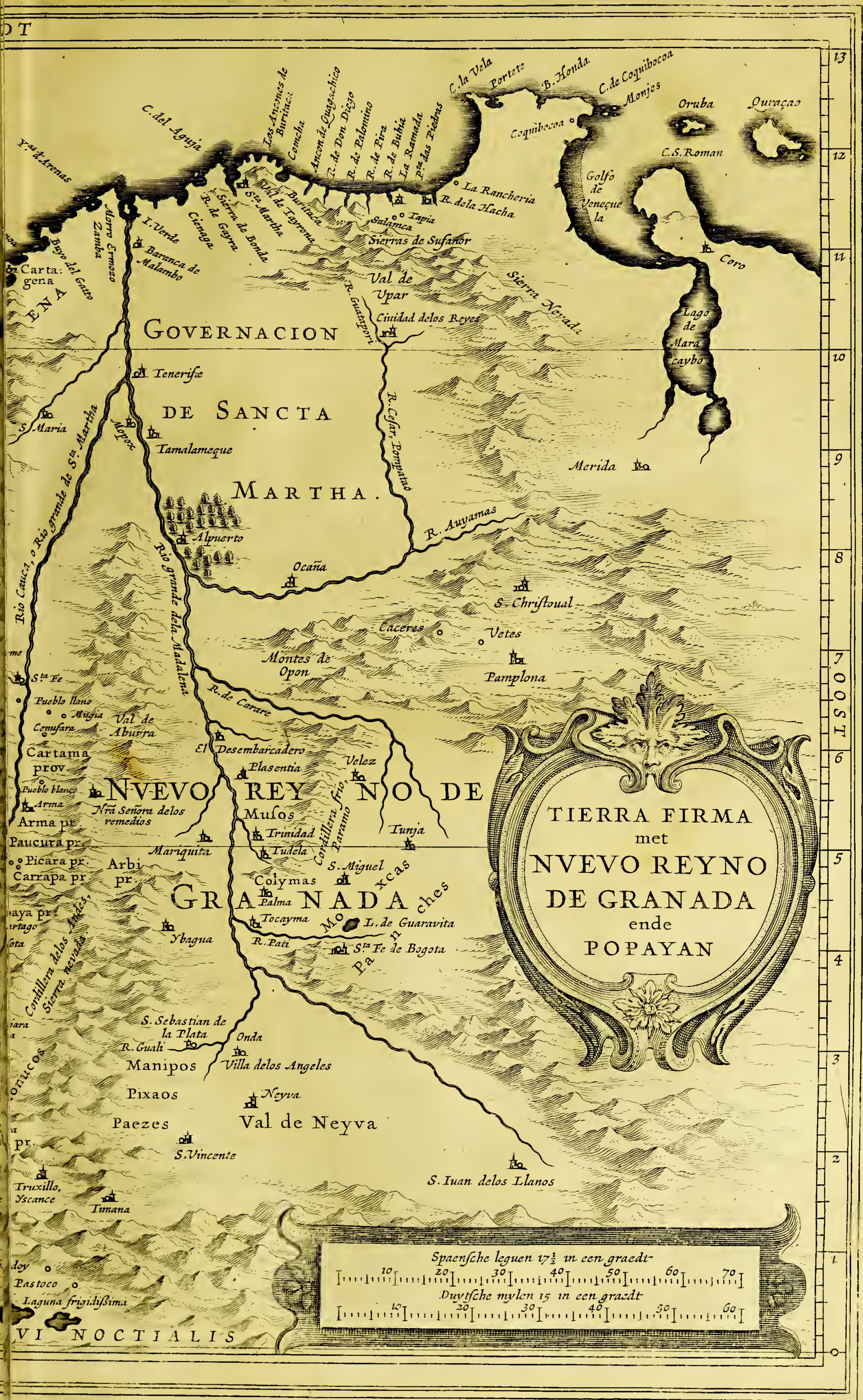




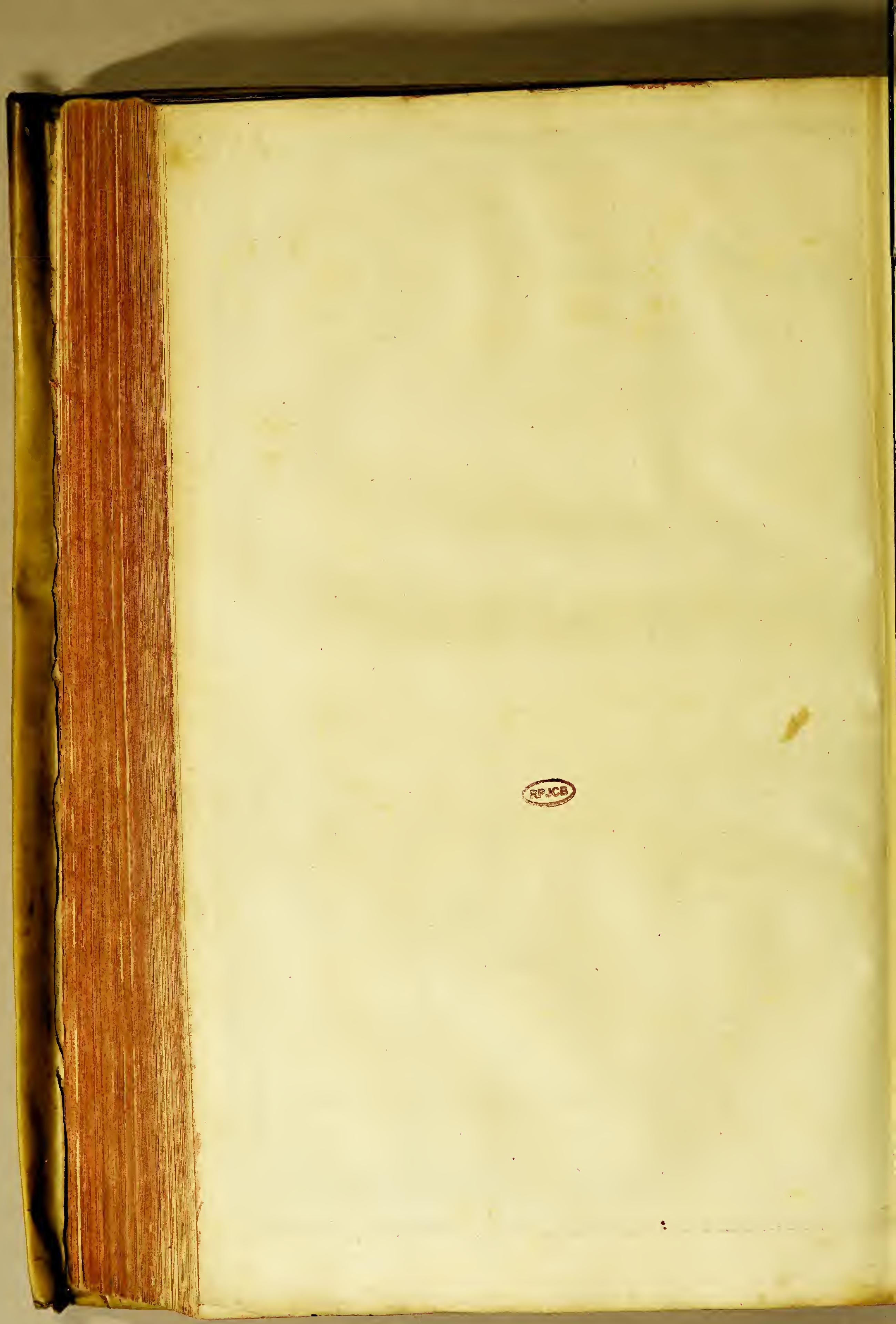


B ES CHR IIVINGHE

Jan

\section{W E S T I N D I E N.} Vet achtte $2 B o c k$.

\section{TER R A F I R A.}

\section{Inlepdingbe.}

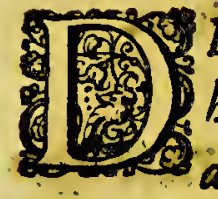

E vaste Lariden van VVest-Indien dien voy bier voren perdeelt bebben, in die van't noorden ende die naer ' 2 zuyden, zün aen den anderen ghelïckgbebecbt door eenen fmallen reep landts, op de vivelcke. ghelegen zün de tpvee vermaerde plaetfen, Panama, ende Porto Belo, gbeliyck eertijdts Nombre de Dios; eer voy dan komen tot de befchrÿving he van bet Zuyder ghedeelte van VV eft Indien, foo fal't noodich poefen, dat wry al vooren $\beta$ preecken wan defe Provincie vvelck bedens-daeghs bekent $\dot{x}$, by den naem voun Panama; ofte oock by een gemeynen naem Terra Firma by de Spaegniaerden pvort ghenaemt : pviert certijdts onder Caftilla del Oro begrepen, doch Caltilla del Oro beeft dickmaels pan limiten verandert, foo dat ${ }^{2}$ felve eerize duyferbeytgheeft int lefen van de oude, Schrijpers: In den jaere igo8 povert bet Gouvernement, ofie veel eer bet veroveren pan dit landt, ghegunt aen Diego de Niquefa, onder den naem ruan Caftilla del Oro, ende de limiten ghestelt van de vUest-züde van de rieviere Darien in de Golfo de Vraba, tot Cabo de gracias a Dios by de. Honduras: ende van de ander züde pan de rieviere voor-fcbreven naer't ooften toe, tot Cabo de la Vela, voerde. bet paste landt de neem van Nova Andaluzia. Docb defe bepalinghe van defe Provincien en is niet langhe foo ghebleven, maer de limiten van Caftilla

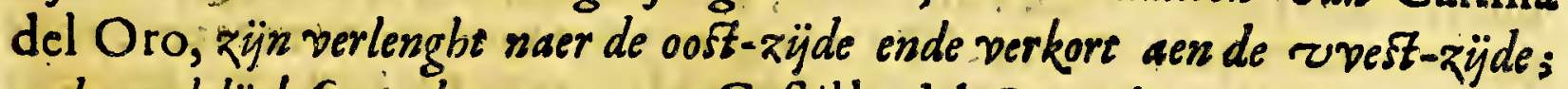
enderyndelÿckfoo is den naem van Caftilla del Oro ghenoeghfaem uyt gbebruyck ghekomen, ende de naem pan Panama de over-bande ghekregen: voelck voy bier aen roeren om dat ordinaerlyck in oude, ende oock beden daeghfche kaerten den naem van Caltilla del Oro feer breet faet; fichuyt-breydende, oock over Provincien over de vvelcke fy noyt en vvas gheftelt, voor foo veel vvy uyt de Spaenfche Historien bebben konnen bevinden; op dat ons niet tot onvvetenbeyt en voerde gherekent, van defe Provincie onder de naem van Caftilla del Orogbeen ghevvacbite maecken.

In de befchrÿuing be van dit zuyder ghedeelte van America, fullen voy als vooren ghefeght is, beginnen van de Provincie van Panama, met 't ghene daer aen past is, ende dan voorts vaeren langhs de kufte, vvelck naer' $t$ noorden aen de noordt.zee is ghelegen, ende al-daer poor eerst befchrijpen de. Provincien van

ad

Carthagena, 
302

Terra Firma.

Carthagena, ende Santa Martha, ende Rio dela Hacha; daer raer fullers vvy komen tot de binnenlandt fche Provincien, die päelen met Cartagena ende Santa Martha, te preter bet Landi dat ghenaemt vvort Neuvo Reyno, om foo te komen aen de zuydt-zete, al poaer de rijcke Landen van Peru ernde Chile legghen, ende foo voorts vaeten door de Strate van Magallanes, ende langhs de ooft-zijde van America, poor by Rio de la Plata, Brafil, ende de Provincien van de Caribes, vreder-keeren tot Rio de la Hacha, daervay bet met dit boeck laten follen.

\section{P A N A M A.}

\section{Jét eet Ite Gapittel.}

$\checkmark$ an degheleghentheydr, palen ; ende gheftaltenis van de Provincie ofte Audientie van PAN A $A$.

Her.der.

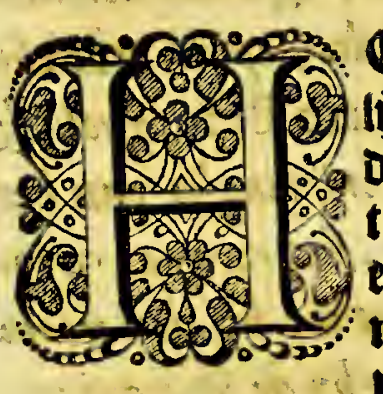

(et begrijp ban de 19 zovincie ofte Atudientie (ge: ligch be Spaegniaerden die noemen'ban Panama is niet groot/ Doa: oien oe Zludientie Daer alleen yaet ontfoutos om de bloten te dilpartjeren / endide recbt te boen aen pe koop-lieben die gaen ende fomen ban Peru; feeft in de lenghte oof ender welt bp De mentuan . Cartagena ende Popayart, tot aen Caftillo de.Vera-

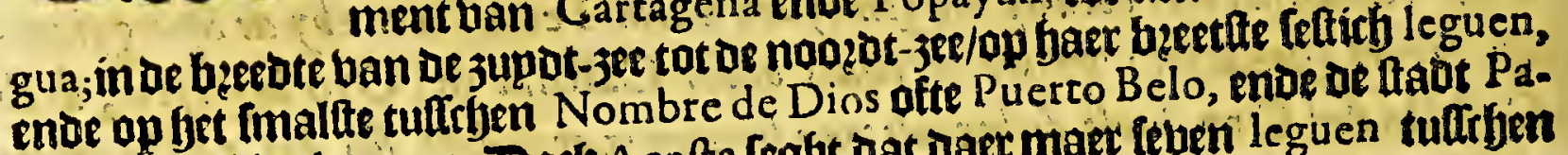

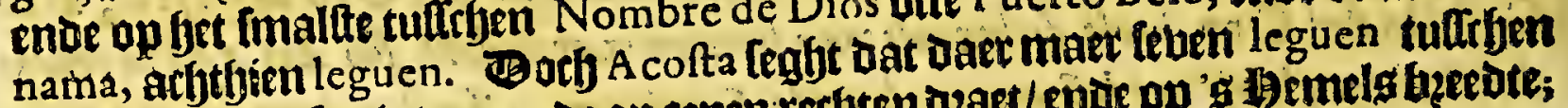

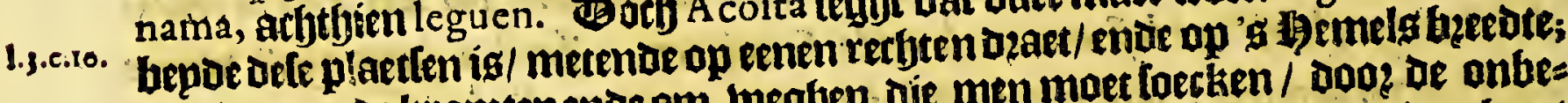
Dan dat om De kromtenende om-megfen die men moet foecken / Doog de onbe=

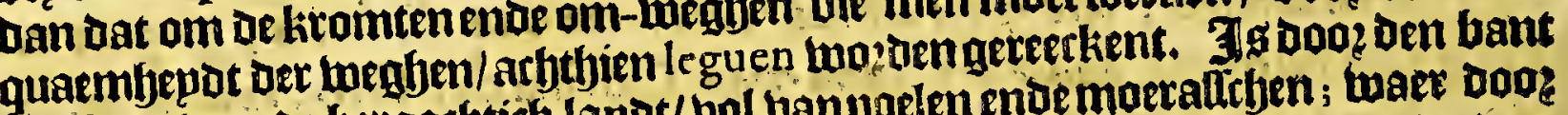

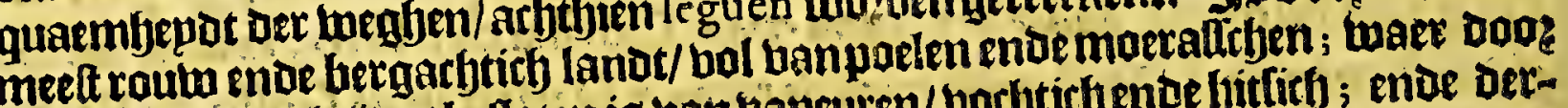

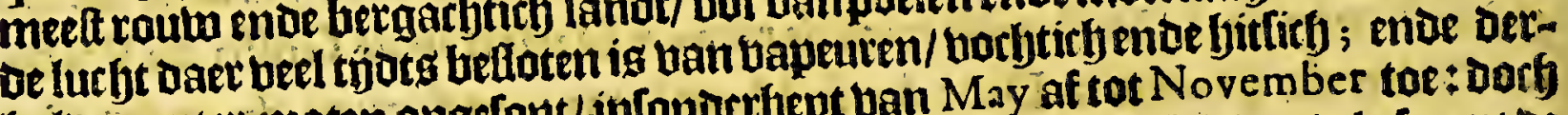
balben upter-maten ongefont/ infonorryept van May af tot November toe: Doefy

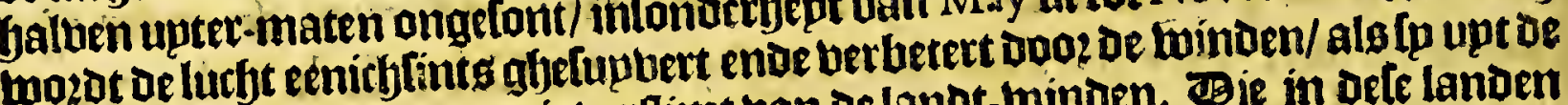
zee komen / ende ter contrarie vertlimt van de landt-winden. Bie in oefe landen

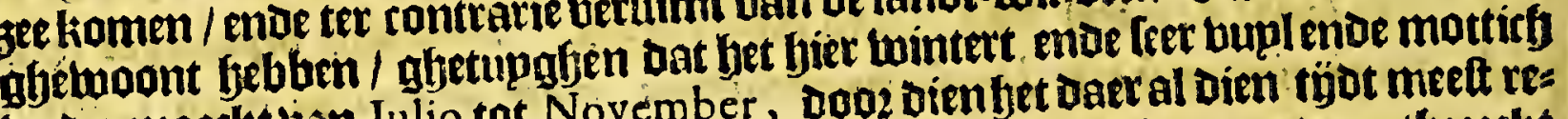
meoer maeckt van Iulio tot November, Dooz Dien bet daer al dien tijot meeft re=

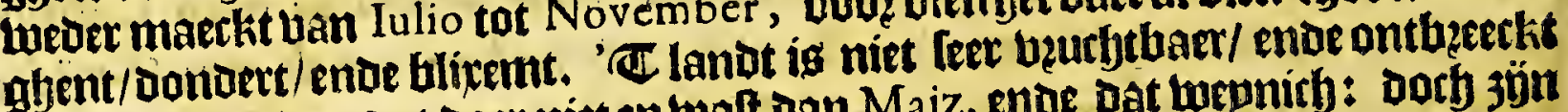
beele dingfen / om Dat Daec niet en walt Dan Maiz, endee dat wennirb: Doct 3 g̈n

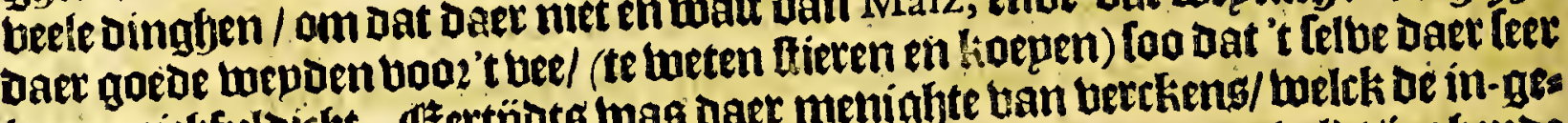
bermenichfuldirbt. (Eertīots was daer menighte tan berckens/ welck de in-ges

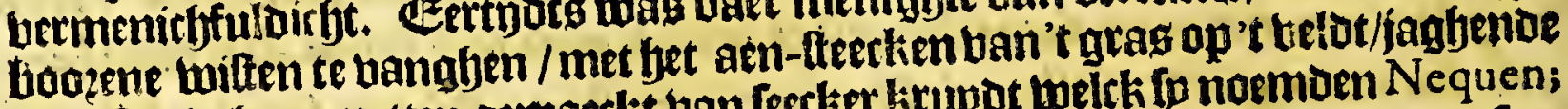
oie altao in baere netten gemaetkt wan feetker hrupot weltk fp noemoen Nequen;

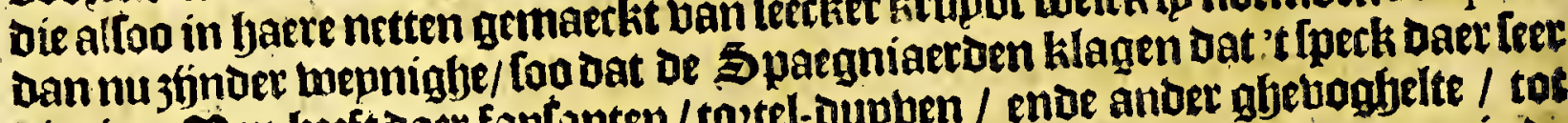

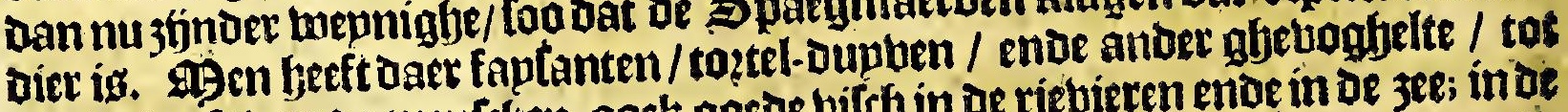

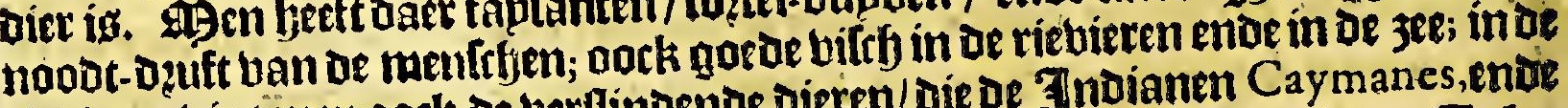
riebteren bint men oock de berlinoende Dieren/ Die de Indianen Caymanes,enue

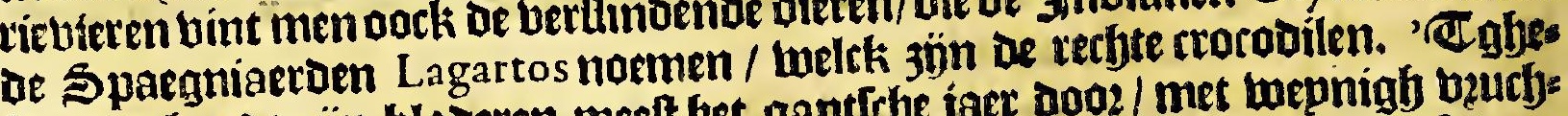

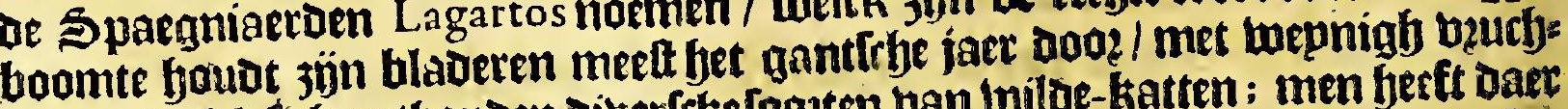

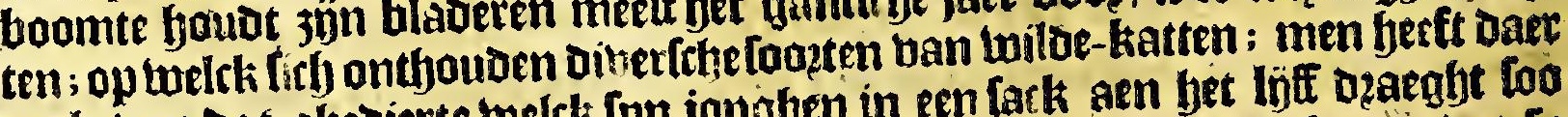
oock tan dat ghedierte melck fpn jonghen in een fack aen bet linft dzaeght loo

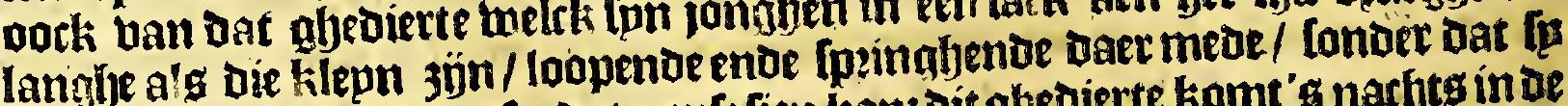

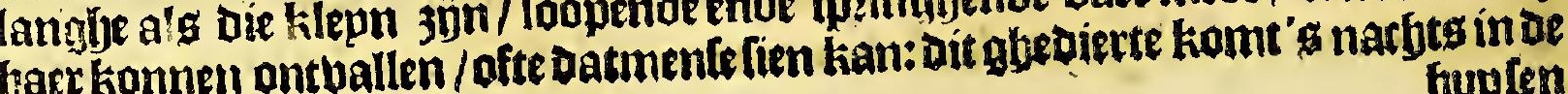
buplen 
Het achifte Boeck.

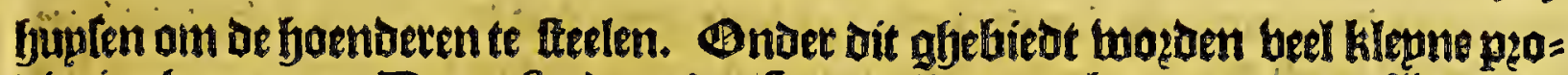
bincien begrepen. De eerte daet ie Spaegniaeroen begomen't protigt upt te trecken/enoe daet fo brientefjapende onthalinghe bonoen/was die van Careta, bertirbleguen ban Darien: ende te pzobincien ban Acla, bjif leguen boozoer.

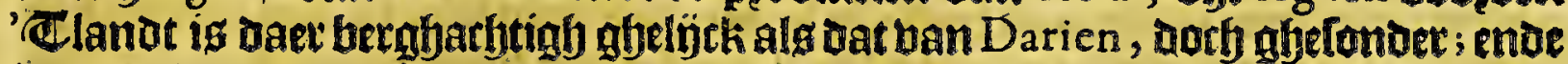

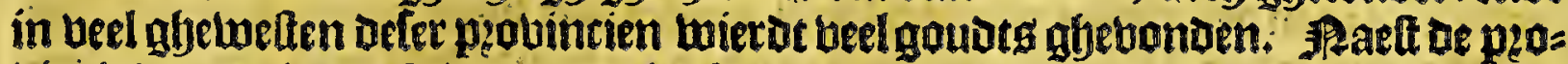
bincie ban Acla, wett-waert aen lagf Comagre, al-waer bet black landt begint/

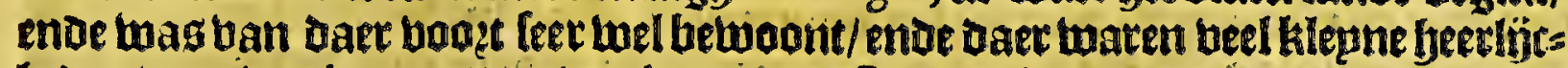
beden ban twee leguen, tot twee leguen; de Spargniaeroennoemden dit gantth quartier tot Peruquete toe/Cueba ; ente de aen-leggende lanten (Dooz Dien baet

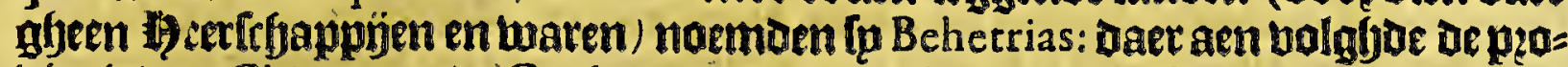
bincie uan Chiame, ente Coyba, ander be twelche Pocorofa begrepen twas/ wate eerttjots bu de Spaegniaerden een plaetfe toas ghelegfot die fonoemoen $S^{\text {ta }}$ Cruz. $25 p$ tuelten de ftaut Panama twasgelegen tepzobincie Chame, ente feven leguen

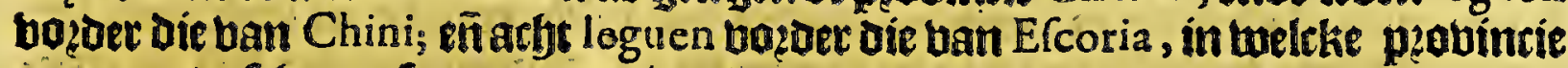

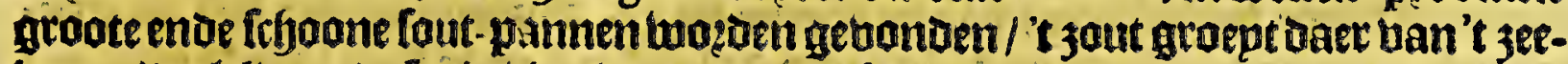
water/ welck met de [p:ingij-bloedtkomt in leeckere pannen afte lacken/ende bers

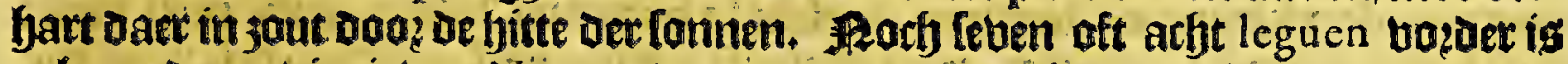
gelegen de y abincie ban Nata, ende boyer oe peobintien ban Tobre ende Trota,

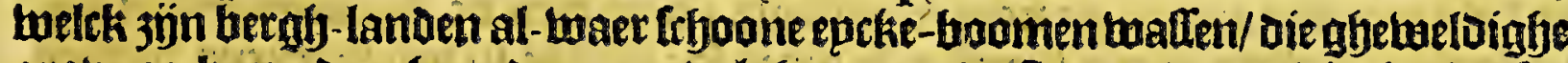
grobe aeckeren dzaghen : daet aen bolght naer' $t$ weften toe de probintie Huy fia, ende Burica, op oe palen bain Nicaragua. elwaelf leguer ban Nata naer't meftnookt- - wetten tor/ has de plobincie van Paris, wieng Cafique De Spaegniaerden

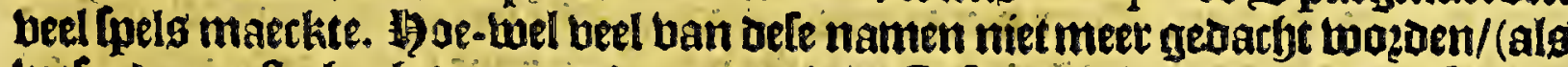
befende meef ghegbeben naer den naem van Cafiquen die joen Daee jeetfoften)

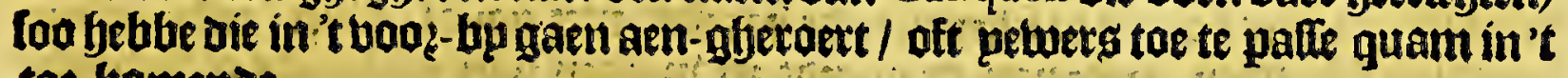
toe-kamenoe.

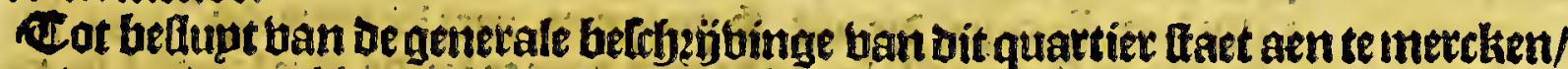

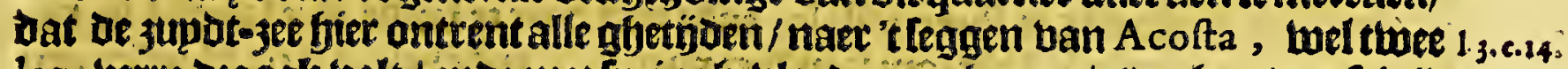

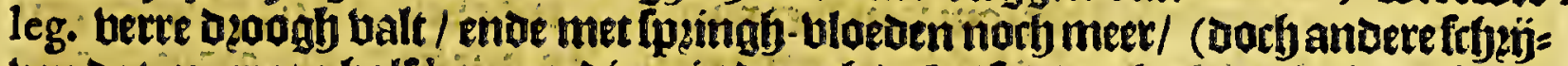

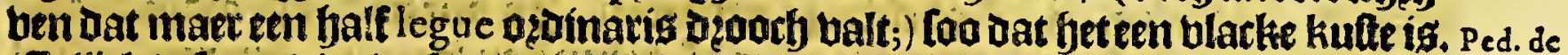

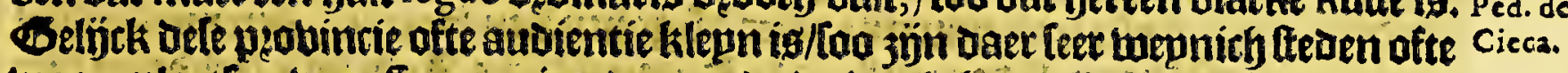
moon-plaetren ban Spaegniaerden, ende de in-ghefiooene ban de lanoe jün al

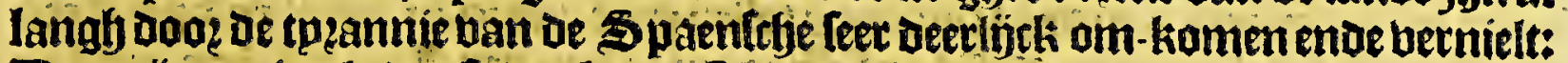
Daet jón nu in alg dęp ftèden bp de 5 paegniaeroen betwoont/Panama, Puerto

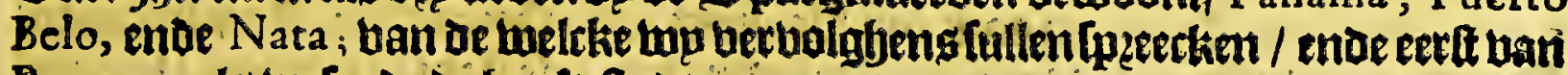
Panama, als twefende de booft-ftadt.

\section{(yet theede Capittel.}

$$
\text { Van de ftade P A AMA. }
$$

D Eat Panama daer bele pgotincie de naem ban beeft/. legft op be kufte

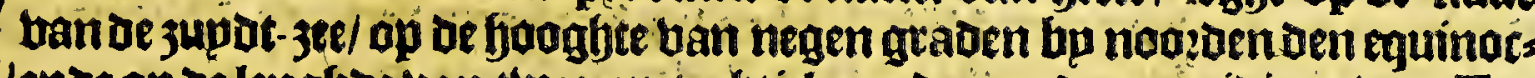
tiael/ende op of lengfoe van thee-en-tachtich graden op Denmeridiaen van To. Her.der. ledo, naer't leggfen ban Herrera. Be fraot ig klepn van begrijp / upt oolaecke ban een lack welckle om.ringht aen eene jojoe; enoe doos de dampen die daet upt ${ }_{1.9}$ c.16.

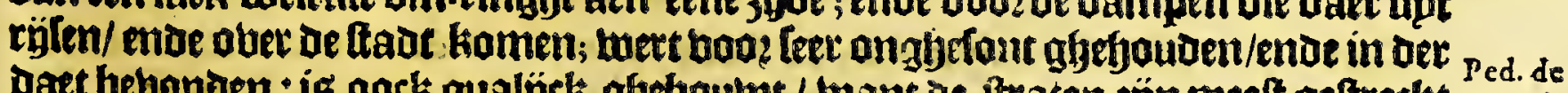

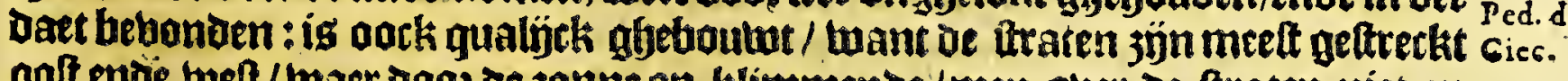
oolt enve twel / waer dooe de jonne op-klimmenbe/men aber de fraten niet en kan gaen/ doos dien daet gbeen fchadutue en is/ ende de bitte treft loo gbetwel:

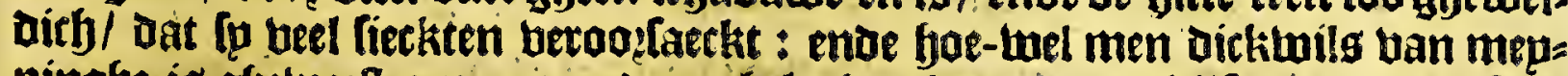
ningfye is afetweelt am een anorte ghelegbentbepot te berkiefen / ende bele te

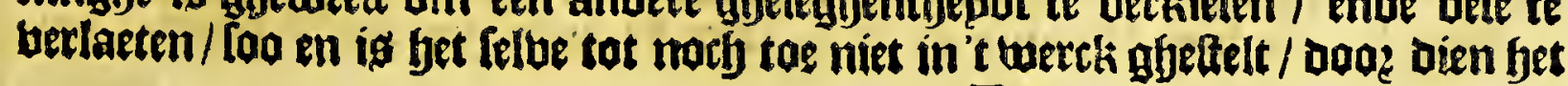
\\2 - timmes: 


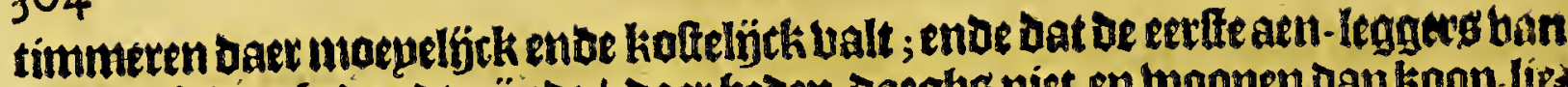

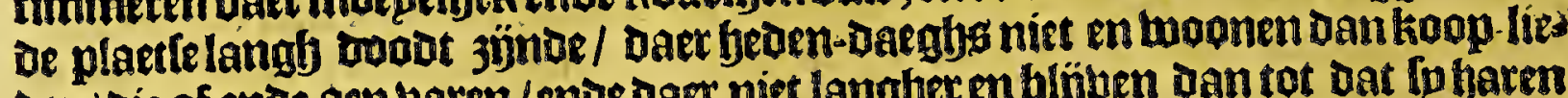
Den/Die af ende aen varen/ende daer niet langhet en blöuen dan tot dat fo baren hantel beluben glyedaem / ende rijckdom bergabert. Ontrent of tadt loopt een riebiere welck baer oglpench beeft upt de beroben/ ende daet komen beel klegne beecken in : aen dele riebier zön beel landot-buplen ofte boulwerÿen gheleght (oie

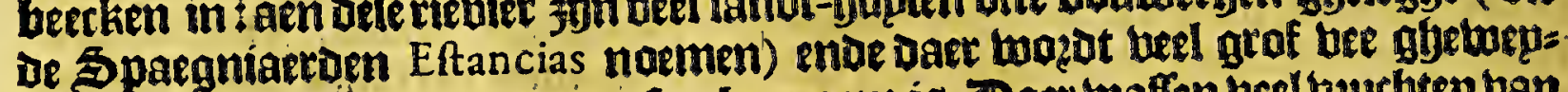

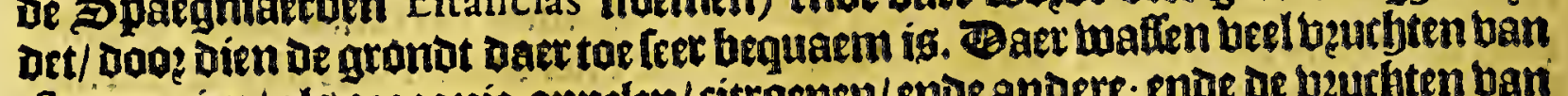
Spacgnien/alg ozaegnie-appelen/ritraenen/ende andere; ende de beurbten ban de lande ballen baer oark feer gaet; alg daer jün wel-rícekende Pinnas, Platanos, Guayavas, Caymitos, Aguacatos, ende diergbelp̈llie. De Itabt ís altijots thel

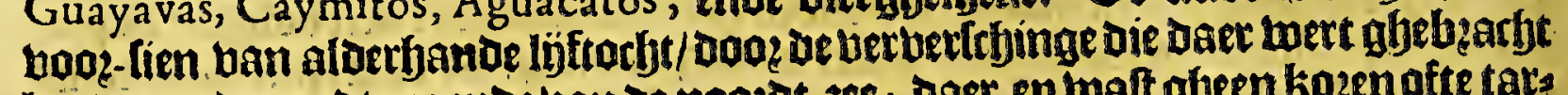
bepoe upt de 3 upot-jee ende van de noozot-zee; vaet en walt gheen kozen afte tars ine/ maer toel Maiz; het meel mazot baer oopz-gaeng ban Perti ende oock upt Spaegnien gheblarht ; de riebieren gheben beel bilch/ende de jee beeft oock feer.

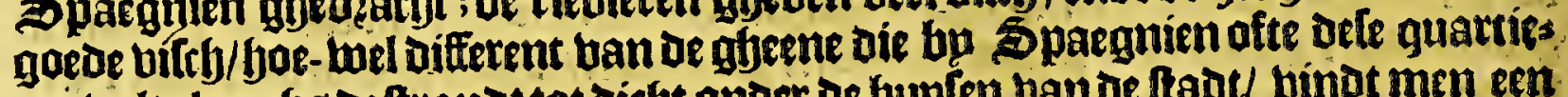

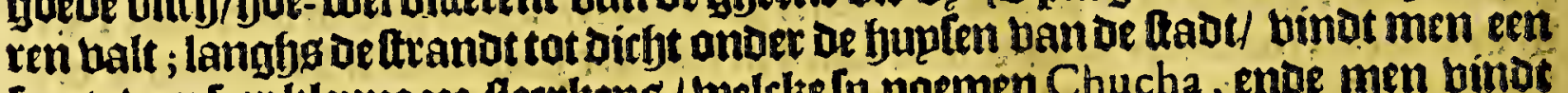

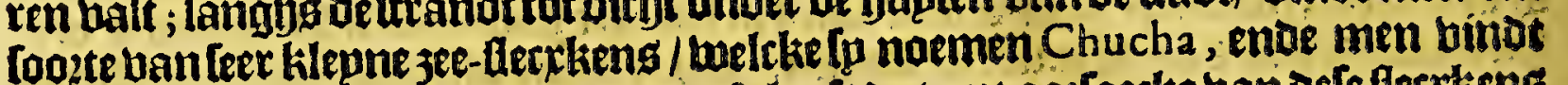

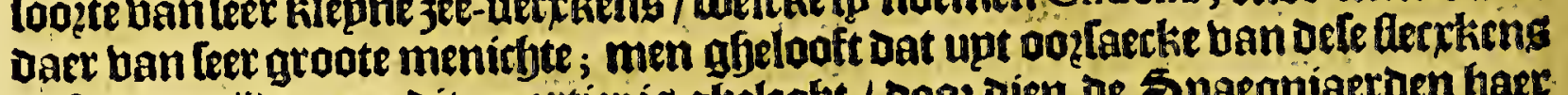

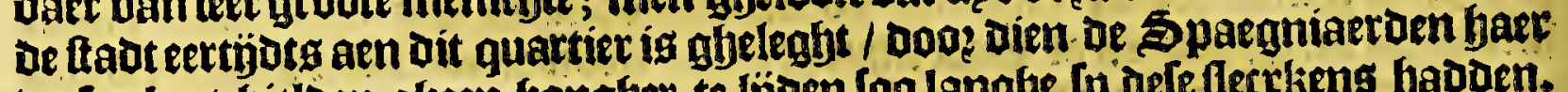

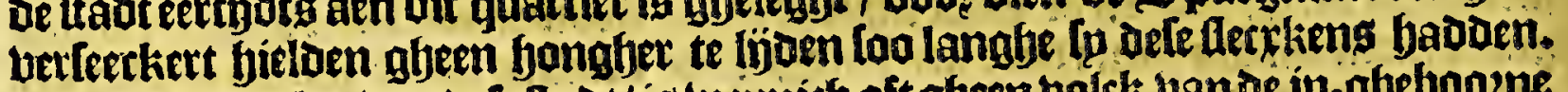

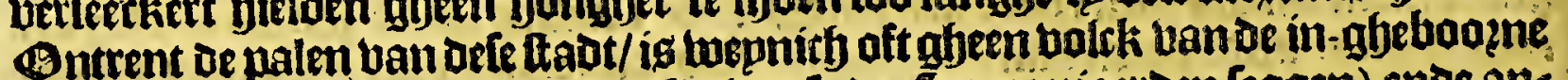
ban de lande/poog dien dieal opoefiectite (lo de Spaggniaetden legaen) enoe ans

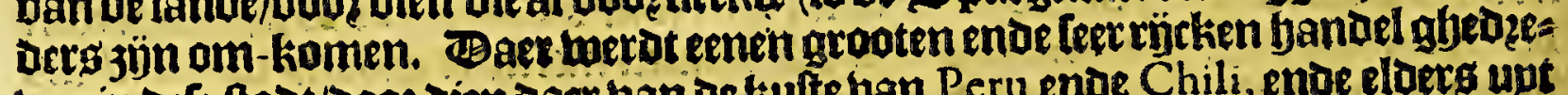
ben in defe faot/00oz dien oaer ban oe tufte uan Peru ende Chili, ende eloecs upt de zupot-jee aen-fomen de lebepen ente barcken met goubt / filber / ende andere Hoopmantryappen; ende ban oe noozdot-jee topzoen daet gbebzacht aloetbande hoopmantéappen ban Europa die upt Spaegnien met be blote op Terra Firma toozon abebzacht te Puerto Belo, ende uan daer te lande afte langfjs de rie. birte Chagre naer dele ftadt/ om wan biernaec Peru ende bele andere plaetfen aet

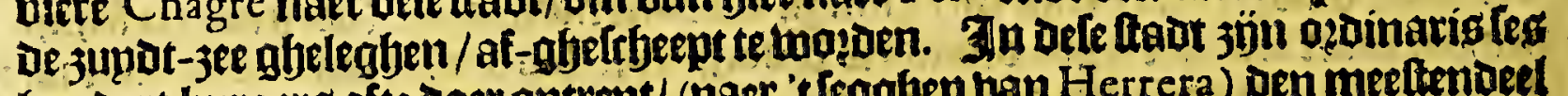
honoert burgers ofte daer ontrent/ (naex 't feggben ban Herrera) Den meettentoel

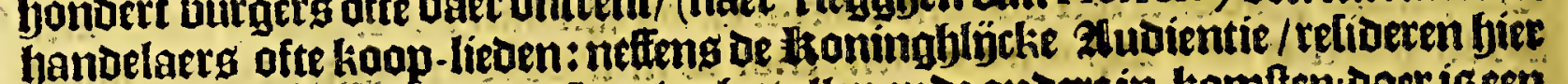
mede be ontfangers ban des Joningbatolien ende andere in-kamften; Daer is een

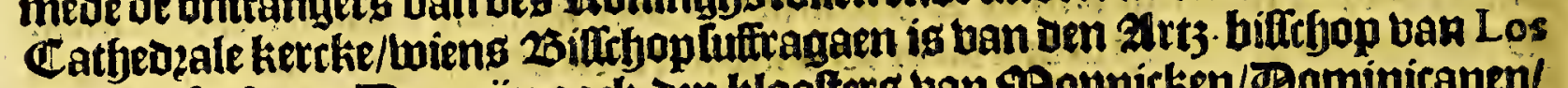
Reyes, ofte Lima: Baer jün oack oz̨p kloolters ban 99 onnicken/Bominicanen/

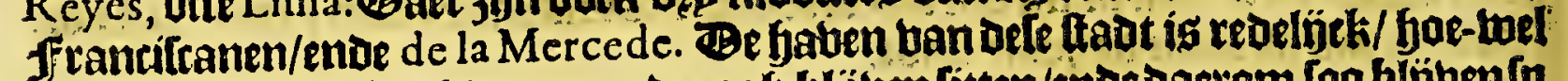
De [chepen met bet leegh watex op dzoogh blighen litten/ende daetom loo blijben [p in ae tomer op't black leggen/eñ in de winter loopen [o in of baben Perico, welck twee leguen ban ie feart leght. S9en loude een bequamet ghelegenthept/ gelonder

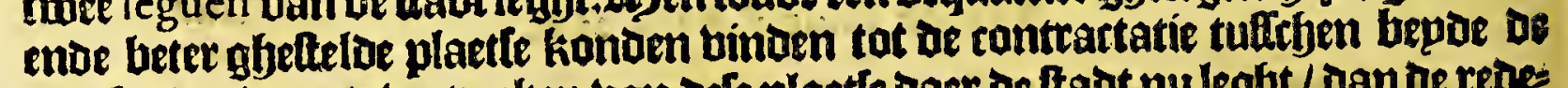

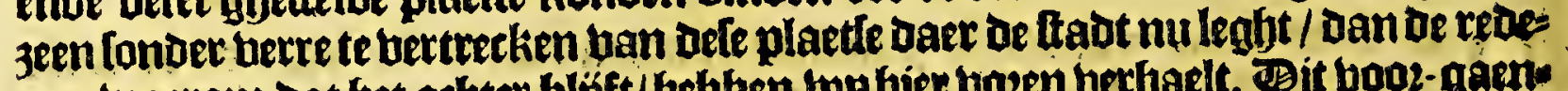
nen waetom dat bet arbter blíft/bebben wp bier bozen berbaelt. Bit booz-gaen: of lobben lop nubpen gbelozacht upt Pedro de Cieca, moe Herrera.

\section{Iget bexoe Capittel.}

Pertinente befchrijvinghe van de ftadr Panama, ende alle aen-komften; 'door Iuan:Baptifta Antonelli Ingenieür, ghefonden aen den Koningh

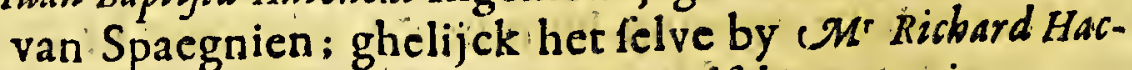

kluydt is ghefteldt in de Engellche voyagien.

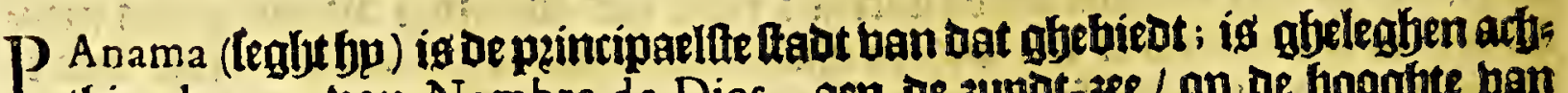

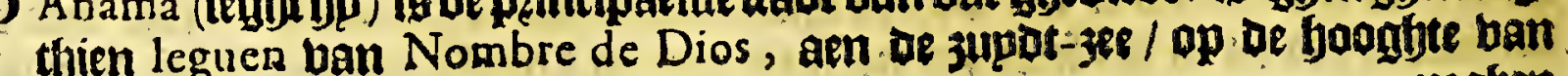
negben 


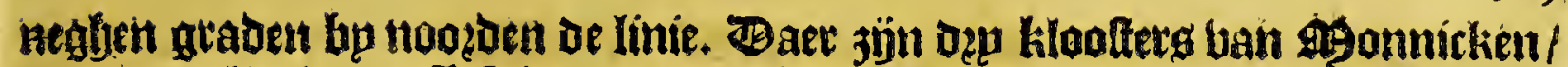
ende een collegie ban Jefuiten/ende of ltoningblibcke Audientie luogat hier ghe: bouden. Be ttadt is gheleghen dítht bp oe jee aen een zandt-baue; [oa dat de eene jöbe ban de laot om-ringht is bp De jeelelfe / ende aen dander jöje bpeen arm

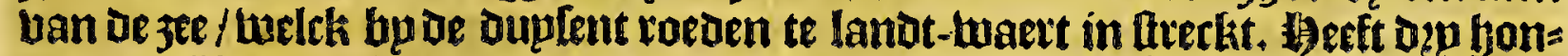
bert en bufftich huptett / al van ljout ghetimmert; Daer jün fes bandert in-Loons bets/ende acht honoert Loloaten met het bolck ban de ftadt/ enoe bier honoert Swarten ban Guinee, twaer onder eenighe bep-lieden jön: darr ís enn ander de= Delien ghenaemt Santa Cruz de la real van Swarten Simerons, die meel ghe=

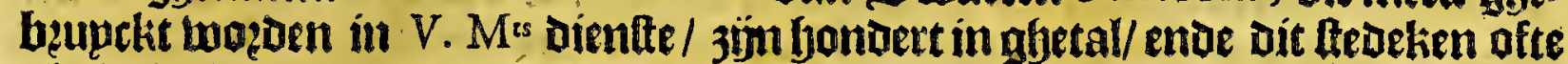
ulecke legbt een legue ban oefe that / op oe kant van een groote riebiere/een legue van de $3 e$ /ende recht tegen ober de bauen uan Pericos. 9 Gaec daer en ig gheen re kininge ofte bertroutwen op Defe 3 wartén te maken/maer moeten ong daet too:=

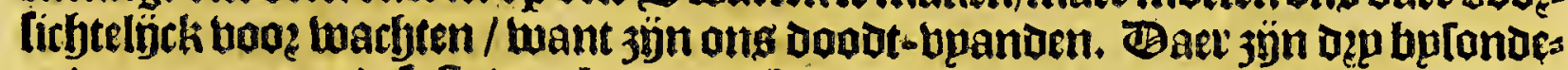

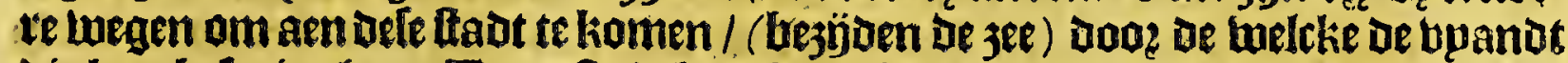

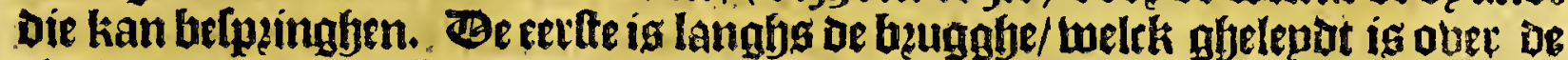

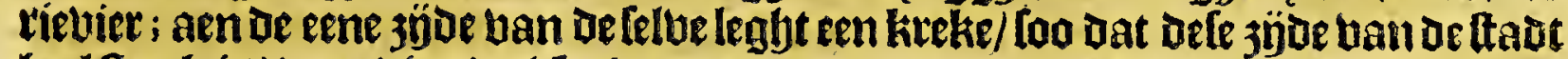
beel fteck is/ booe dien't al latfte ende modoerige geonot is; Daer men in gheen: Der manieren op gaenen kan. EEnde reclyt tegen ober legbt de rievicte/twelck ig als een grachte/ ende aen de anter jübe ban oe riebiere leght een groot lack ofte pan/ welck oe gantfelye winter ende een oeel ban de lomel bol twaters is / Too gat dit

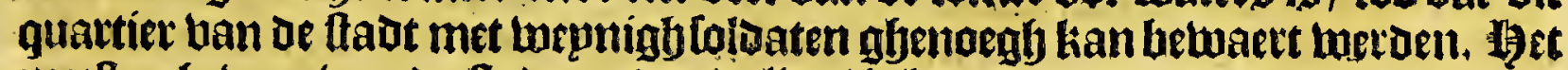

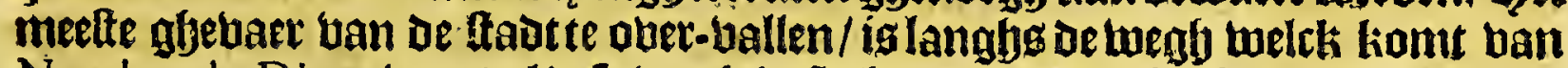

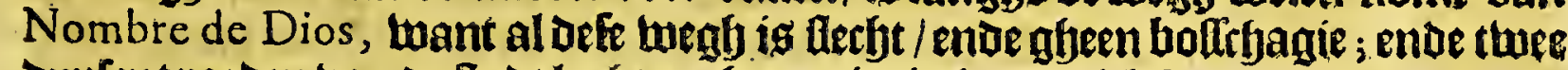
oup[ent roeden ban oe ftaut legfyenocf] een riebietken inelck [p noemen $L_{a}$ vende-

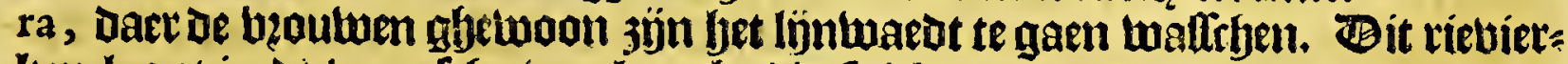

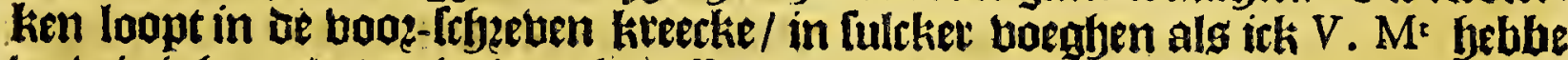

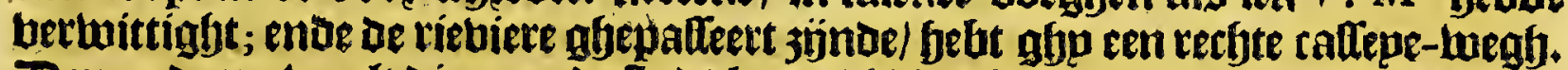
- Ben andeten twegh die naer de ftadt loopt / is leegtee naer de jee toe / bpeen ftee: nen beugghe / legghende in be twegh viemen daet gaet naer oe baben ban Perico. Befe thee wegfen en konmen niet belwaent metDen/Doos Dien fet aldaer

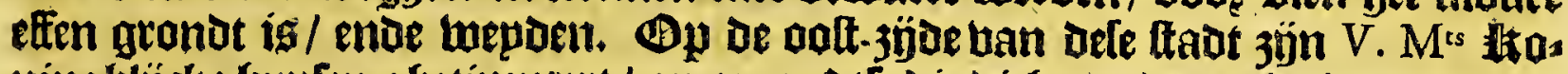

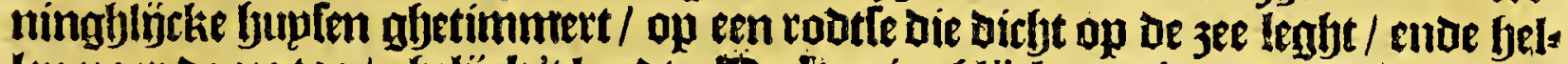

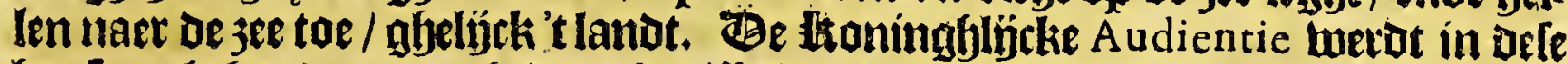

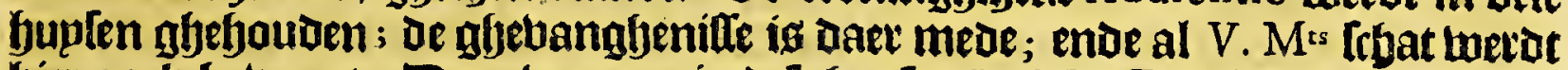

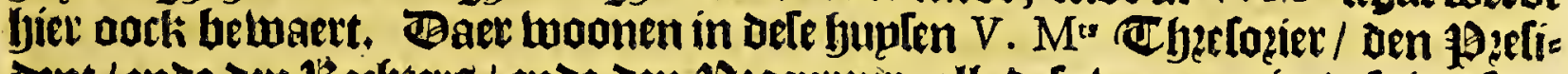

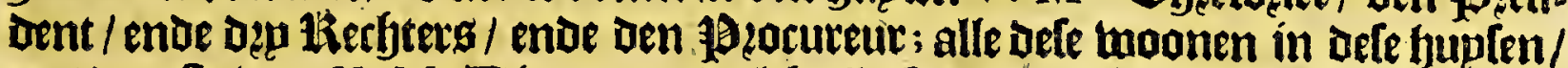

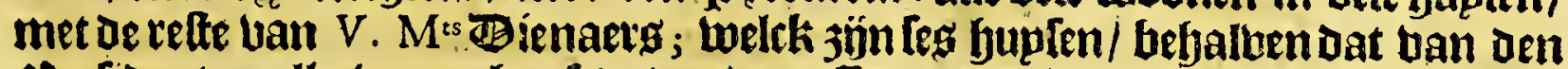
Agefident; alle woon-huplen / ende neffens aen aen anderen gijetimmert

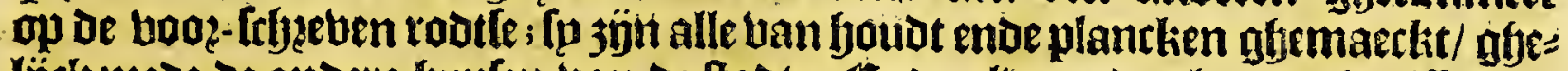

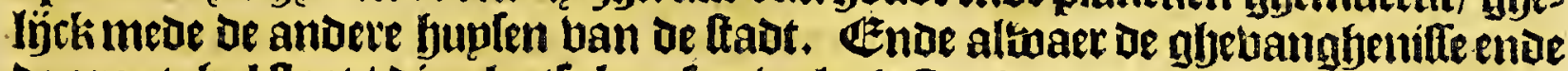
oe groote fal ftaet / die plaetle kan feet wel ghefterckt weroen / Dod dien fu daer

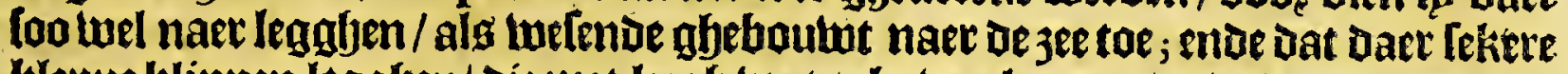

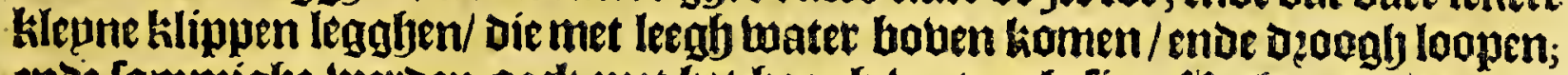

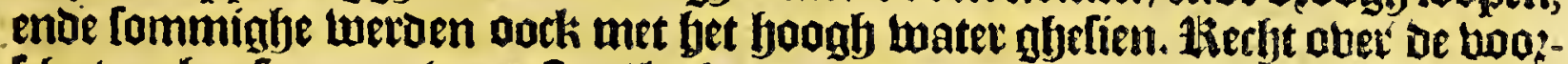
frbecuen hupfen naet bet oolten/legbt een Geplanot ontrent viff bondert raedert Uan de felbe / bebuende de ghedaente ghelïck als een balue maen / ende in oflev boenfien loopt bet al langhs benen tot bp bet balte lanot: aock foo legft ober ofle loupten de bauen daer alle oe frbepen jün gletwoon op ancker te legghen/

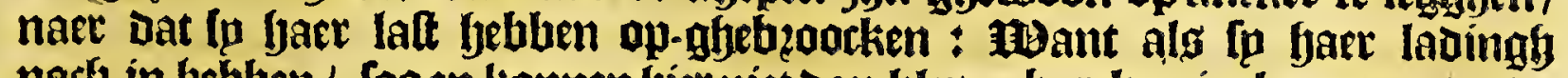
notb in beblen / loo en komen bier niet dan klepne barchen in-komnen / enoe met yet leegbe mater foo lítten alle oe febepen op bet azoonge; moe loo is al oc lpacie by de dettich roeden van dele buplen: ende rectyt daet teghen ober D. 3 leglyt 


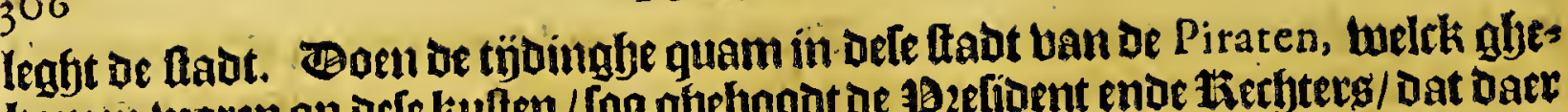

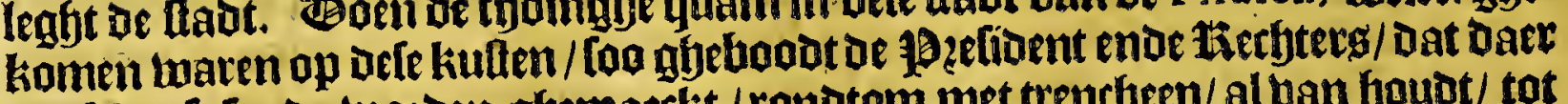
een [cljanle Coude wozoen ghemaecht / ronotom met trentfieen/ al ban houdt/ tot

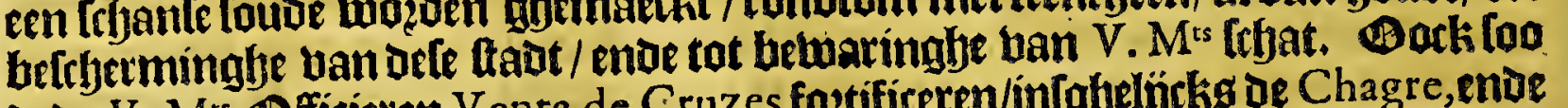

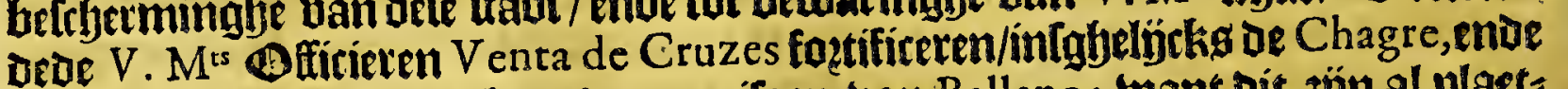
Quebrada, ende berlterelkten 't guarmitoen uan Ballano; want dit jón al plaet= fendaer de bpandot kan landen/ ende bu delen míadel 't lande gantfeb berooben.

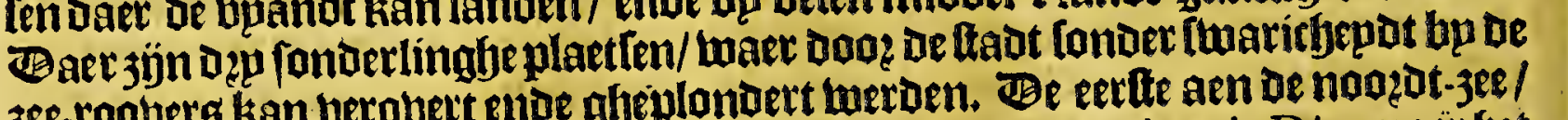
jer-roabers kan berobert endoe gfeplondert werden. Be eertte aen de noozot-jee / in een Ieerkere platte welck leght veerthien leguen han Nombre de Dios, naer yet

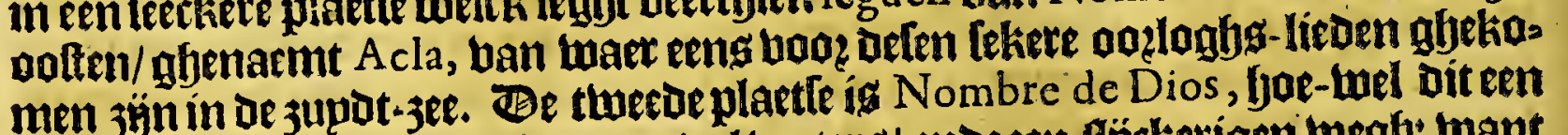

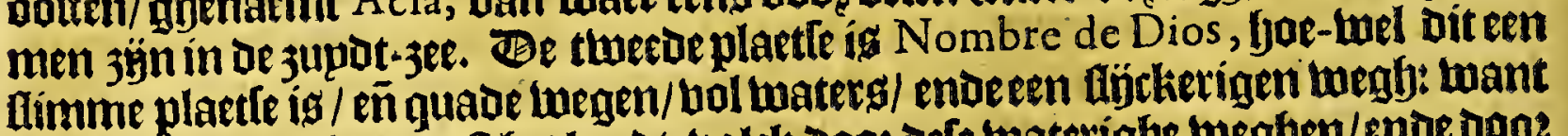

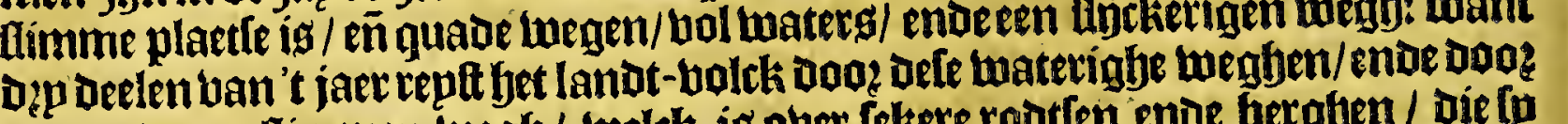
ech anderen tlimmen wegh / welck is ober fekere rodten ende berghen / die fu maeten op-klimmen / t tgheherghte ban Capira gljenaemt/ bp oe ozp quarten ban

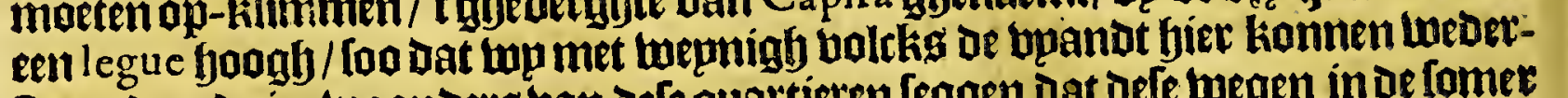
ftaen: dan De in-moonderg ban defe quattieten feggen dat Defe wegen in De fomer

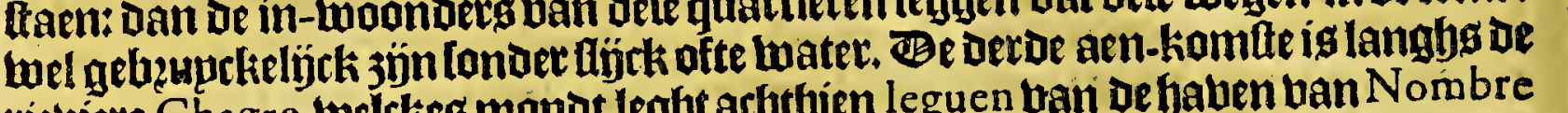
riebiere Chagre, weickes manot leght achthien leguen tran oe yahen wan Nombre

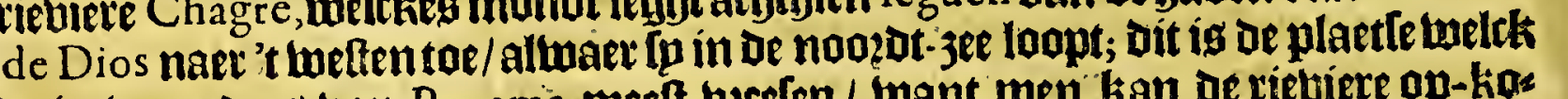
oe in-Loondels ban Panama meeft beefen/ want men kan de rietuiere op-kos

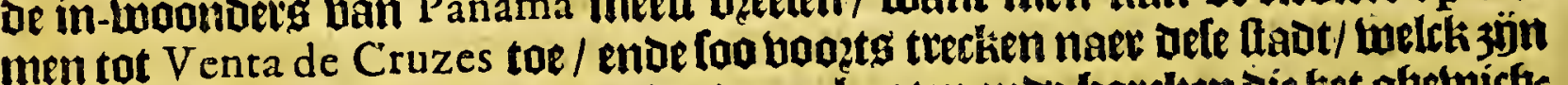

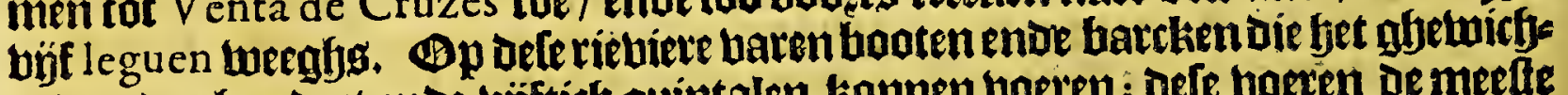
te ban dep hondert ende bïftich quintalen konnen boeven; defe boeren de meefte tioopmanfryappen welck ban Spaegnien werden glyebzactht omnaer Peru ber: boert te werden; han Venta de Cruzes imeruen [p gbeboent naex Limaret, weick

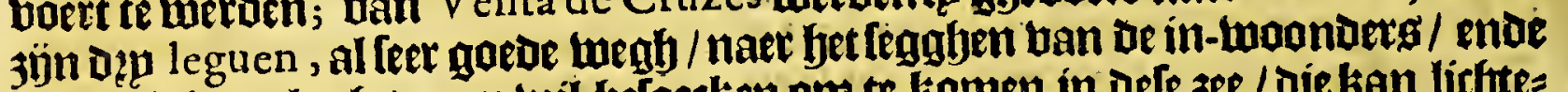
foo eenigh oollogfg-man wil beloecken om te komen in Defe 3 ee / diekan lirftes= ligck dele vieuiere op kamen tot Venta de Cruzes toe / ende ban daer trecken naet

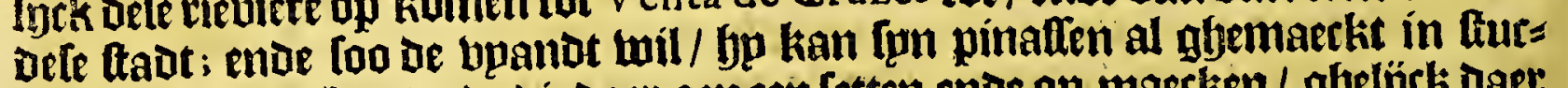
ken mede beengljen/ende die daex aen een letten enoe op-maecken/ghelïrk Daet nefeght wozdt dat Francis Draeckend foude ghedaen bebben / ende kan ong too berpeinghen bepoe te water ende te lanoe. Eênae alloo bet meeften-ded ban ong.

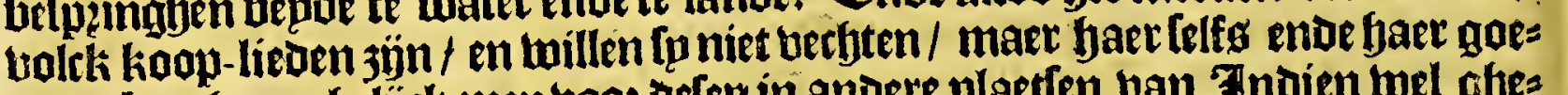

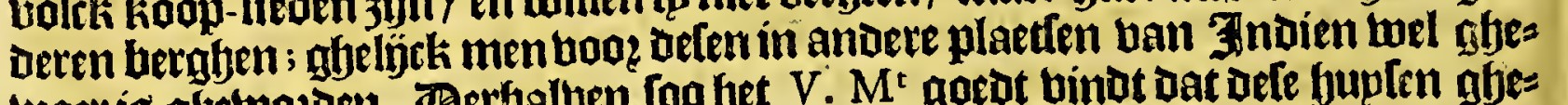

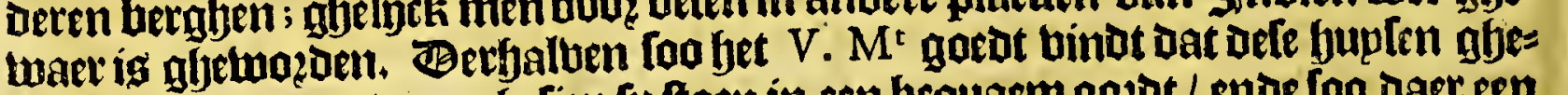
foztificent werden / aen-ghefien fp ftaen in een bequaem oozot / ende foo daec een Iubijte alam morbt komen/kommen de in- woonders faer goederen bies in blurfys ten/ende foo de veefle voo? de buand ontgaen; oock foo wil dit een feeckere plaets

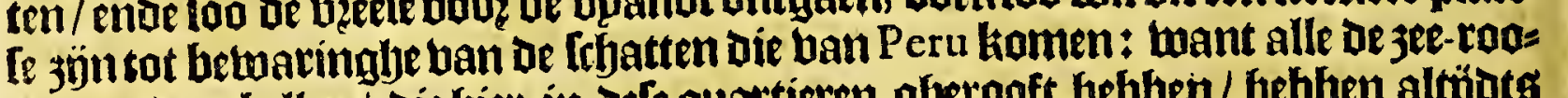

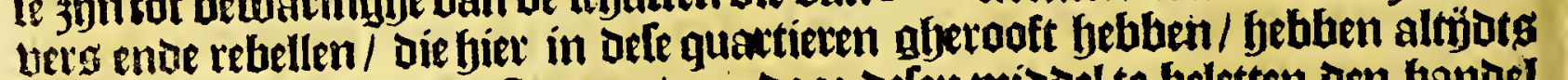
ghetrarht defe pallagie te ftoppen / om dooz defen midodel te beletten den bandel.

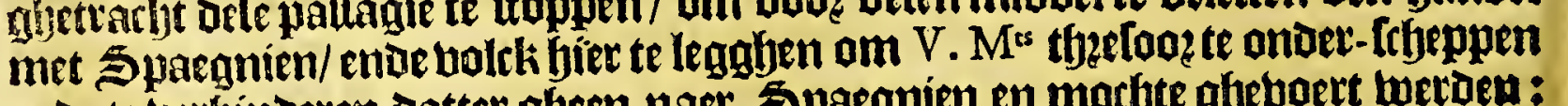

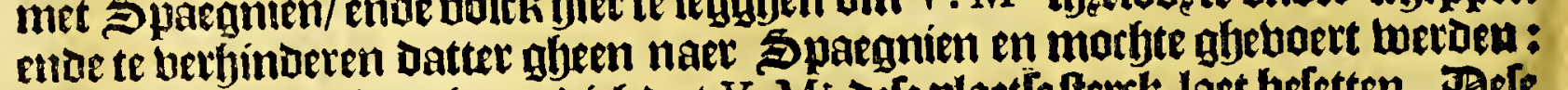

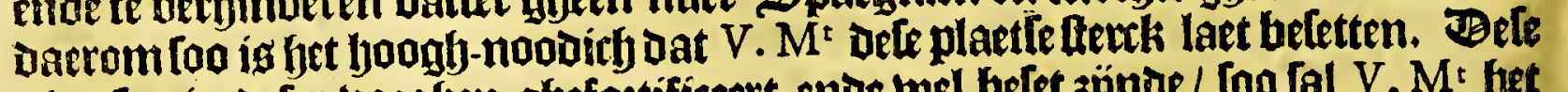

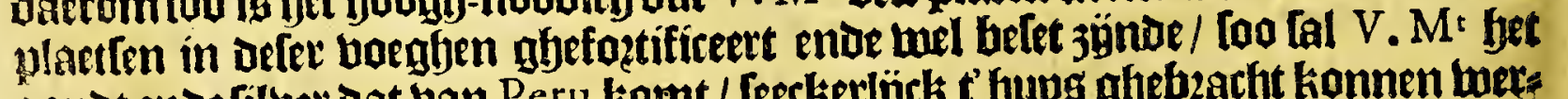

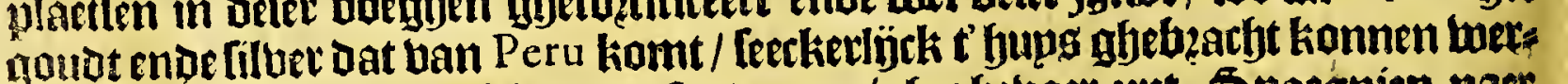
Den: ende alle koopmanfryappen fonder eenigh ghebaer upt Spargnien naes.

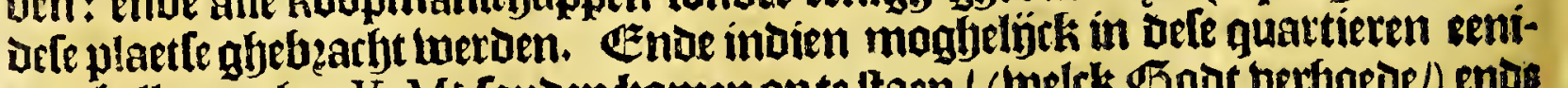

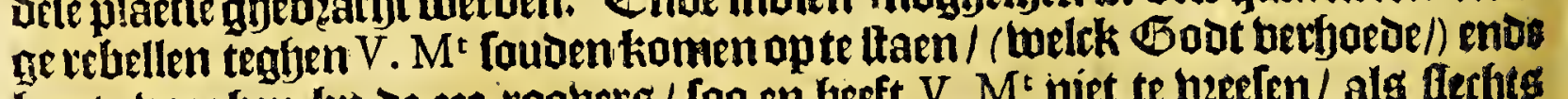

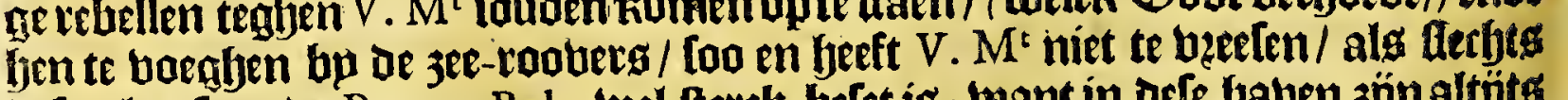
orfe plaetfe ende Puerro Belo wel terck beret is; want ín offe yauen júnaltịts 


\section{Terra Firma.}

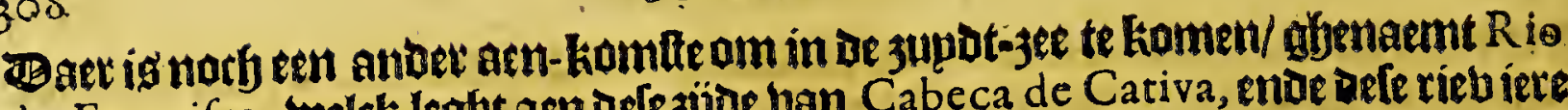

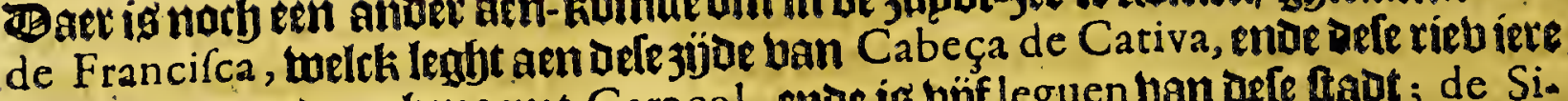
komt in en anoer gbenaemt Caracol, ende is bujt leguen yan dete ftadt; de Si-

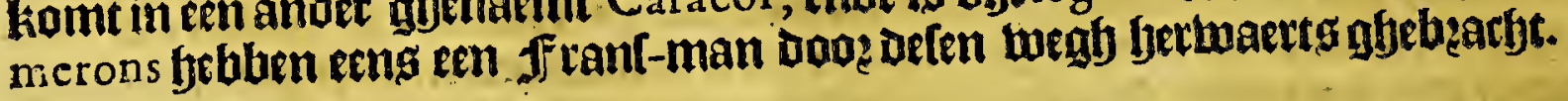

Het bietoe Capittel.

Van de Stadt NOM BRE DE DIOS.

D E tweede Itab ban dele peabincie taas abenaemt Nombre de Dios, ente hatemel defelbe nuglyecuineert ig / ende berleght op Puerto Belo, foo fal bet

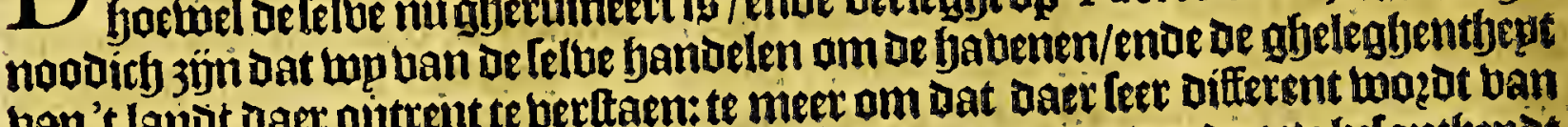
ban't lanot daer bintreint te berftaen: te meer om Dat daer feer differsnt mozot ban

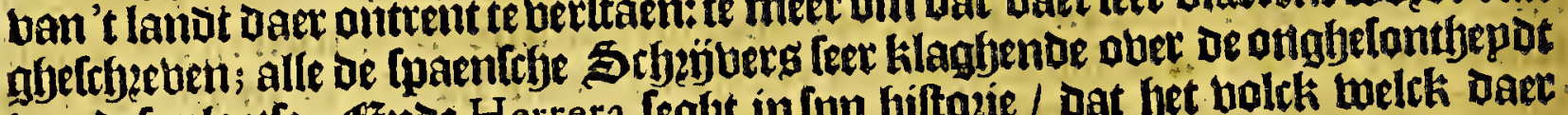

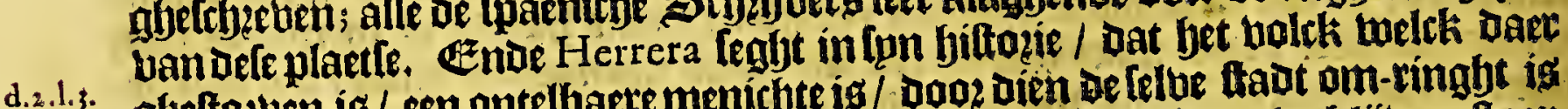

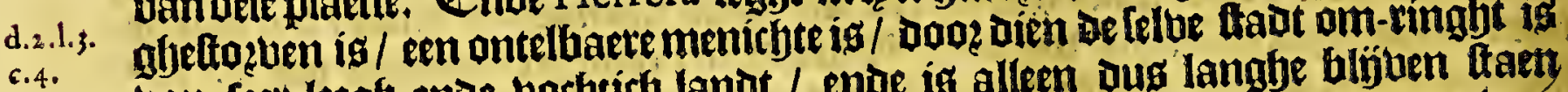

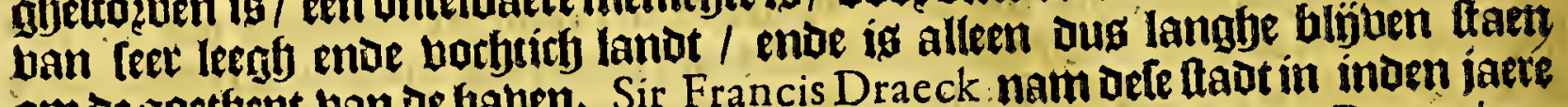
om de graetfeet ban be haden. Sir Francis Draeck nam-twintichtten December.

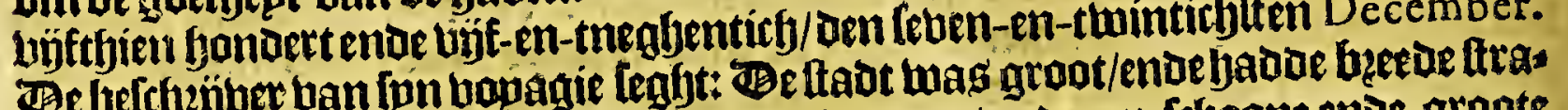

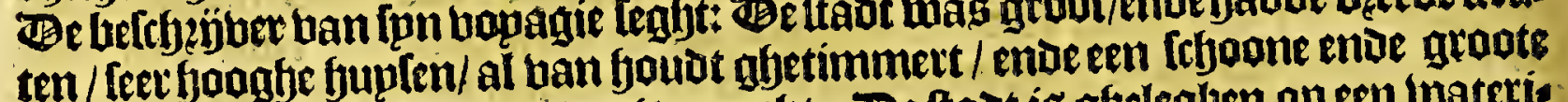

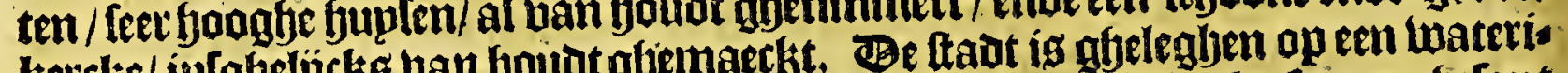

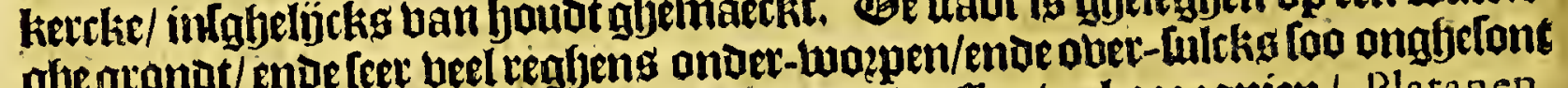

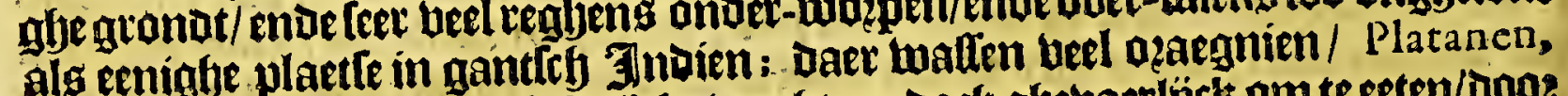
als eenighe plaette in gant

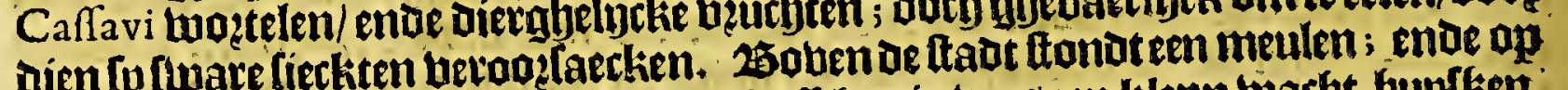

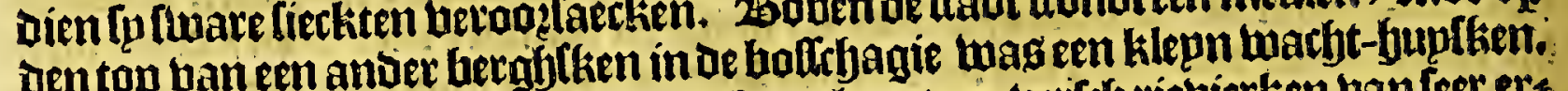

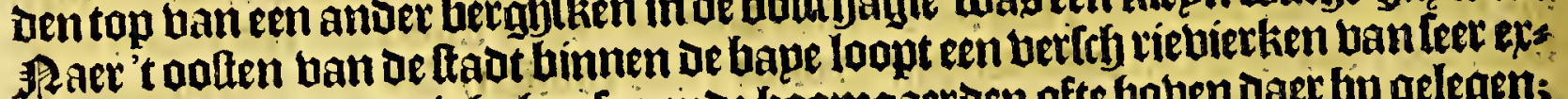
cellent water/met eenighe hupfen enoe boungaeroen ofte boben daer bu gelegen;

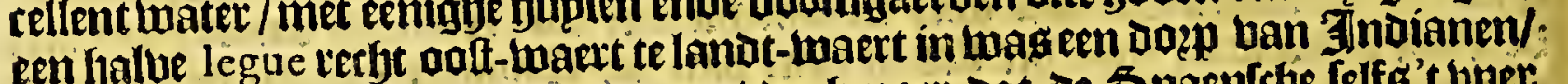

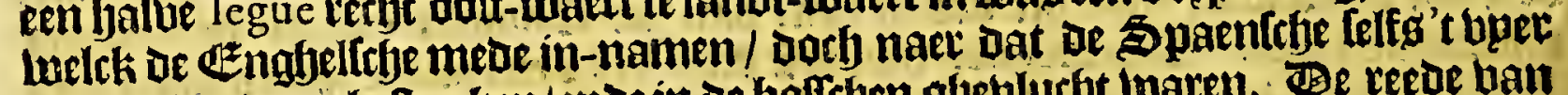

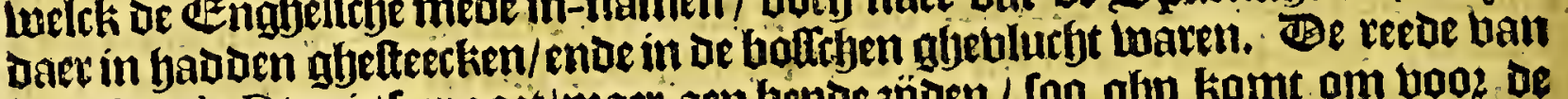
Nombre de Dios ig feet goet/maer aen bepae 3 joen / foo aljp komt om vooz of

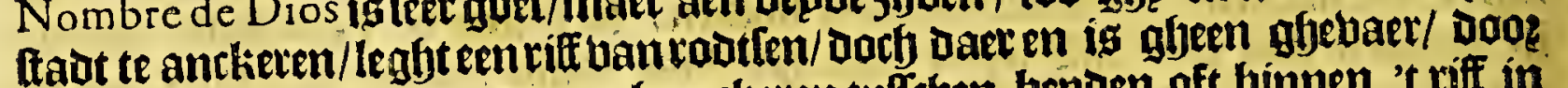
dien men diefien kan /ende magh anckeren tufferien benden oft binnen 't riff in Dep oft bier hadem waters/ofte bunten't riff in acljt oft thien badem/ oaer noch

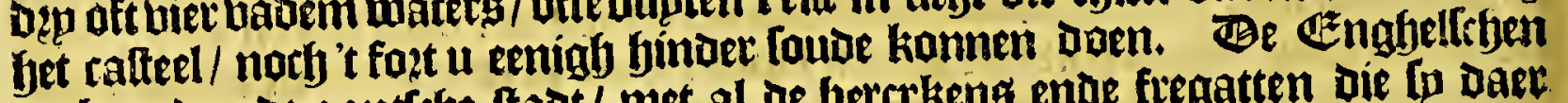

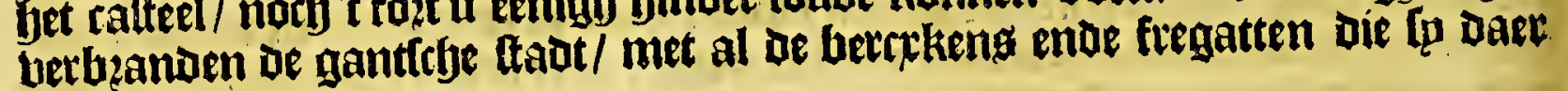
vonden.

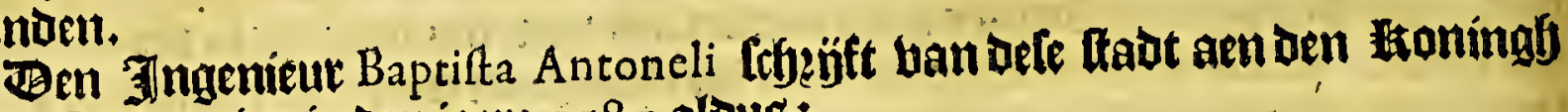
van Spaegnien im oen jaere 1587 alous:

Nombre deDios ís ghebaumt aen een jandt-bap dicht bp de zee; fet is een ftedeken van ontrent dertich familien :haer huplen jün gyebout van foust/ende

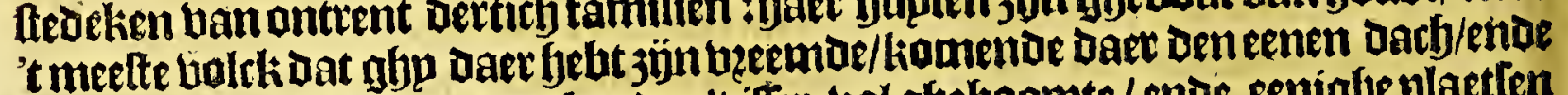

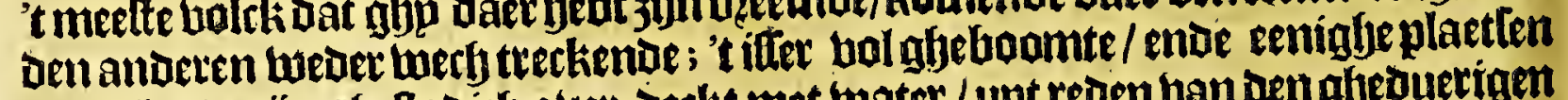

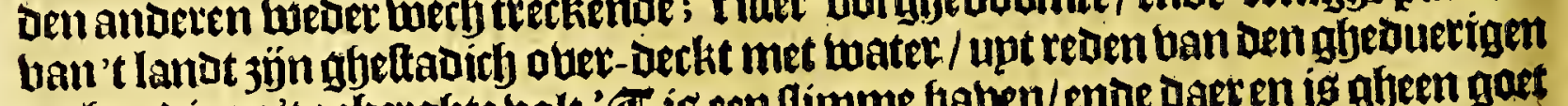

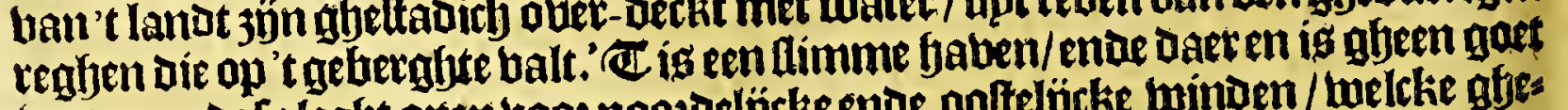

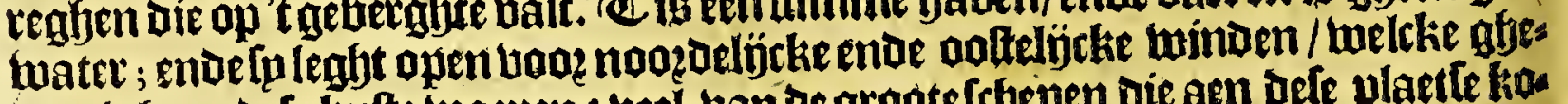

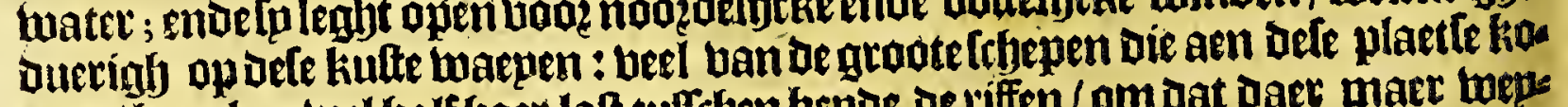

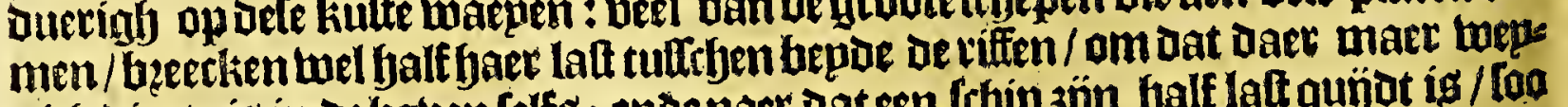

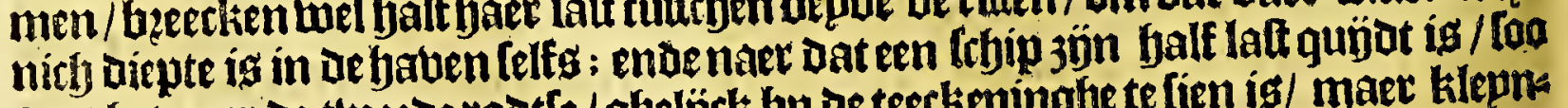
gatt fet naev de tweede rodte / ghelïck bp oe teeckeninghe te fien is/ maer kleprs Dex fifyepen komen met al haes laft / tot aen een anuer klippe aen de weft-syou.

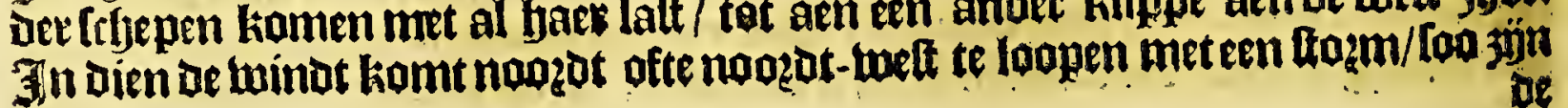




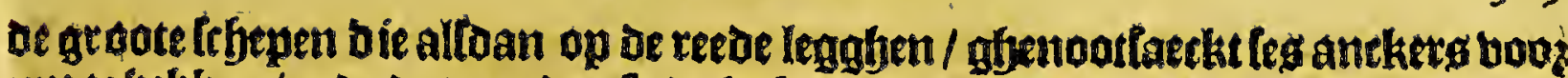
upe te hebben / ende dat om dat fp oe tiabels niet en oazben ghenoegh biecen/ we ghen de janden enderoutten die op bepde oe plaetlen legafen: foo dat oe Lfyepen gfetweloigh arbepden in de[e bauen / Doos dien daex een bolle jee gaet / twanneer bet bupl beder maeckt/ enve dicklwilg beecken de fabelg/ ende be roets twozon upt-gelitgt / Doos dien baet foo wepnigf waterg is / ende foo bollen zee. Be fadt is tuel ghetimmert ettde wel gbeleghen / Dat de haben maer goet waer / legohends aen be oalt-jijde opeen rodte / daer men een ferck foet foude konnen leggijen tot befchermingfe ban de bauen; maer aen-gbefien bet een flectite hauen ig/ on ons Diep toter; foo foube ick het noodeloog tat V. M' eenighe kolten foube doen om Dele platte fterck te Maken/maex Dat daet alleen een trentyee twerbe ghemaeckt/ ban aerde ofte klep / maer mede oe in-mopnders fun-felben mogben bertweeren/ tegben Dep afte bier fchepen.

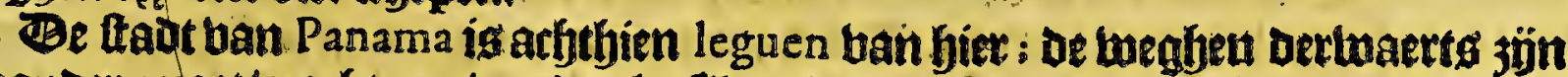
monder quaet/ narbtans wozot al 't filuer doot defe wegh gheblacht naer Nom-

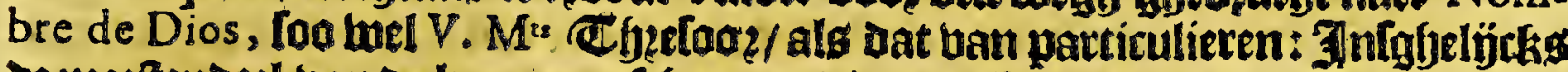

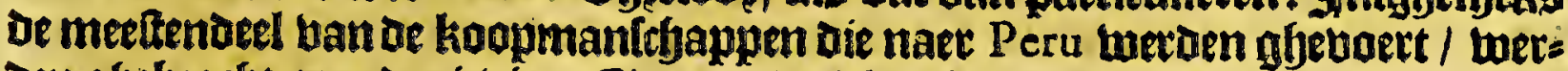
aen ghebzarby naer de riebiere Chagre, welck is bu ue achthien leguen van dete

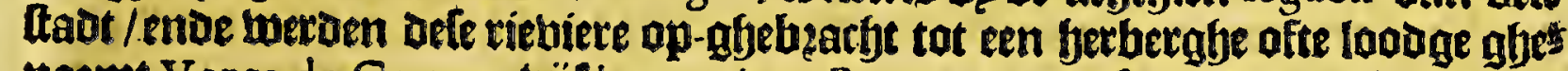
naemt Venta de Cruzes, bjef leguen ban Panama, ende foa bootta te lande met muplen. Den yooghe wegh die ban Nombre de Dios naer Panama gaet / kan

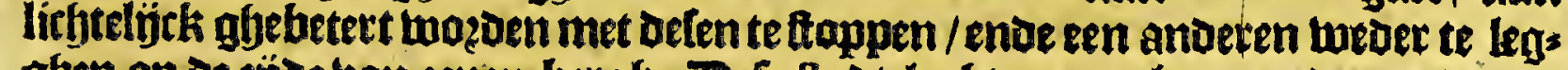
ghen op oe zỷde ban eenen betgh. Defe taad leght op neghen graden enoe een

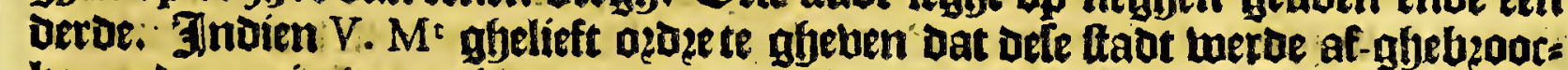
ken entae opnieuths getimmett in Puerto B elo, foo maeft daet een nieulae wegf gemaeckt wozoen oon't getuergfte ban Capira, oooz vien d'anoer wegen gantif bupl zön / ende konnen met wepnigh ankotten gbettopt ende op-ghebzoken wo:=

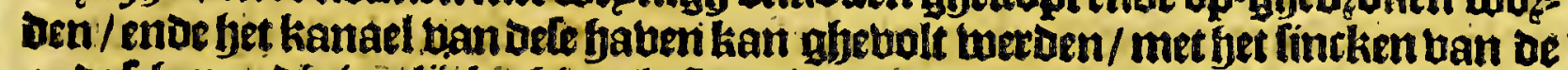

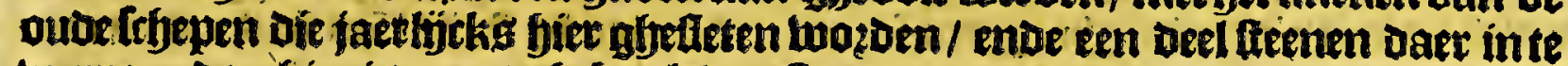
merpen: Dan bier is groot gfjelizeck ban fteenen/ om oe Ithepen meae te ballatten/

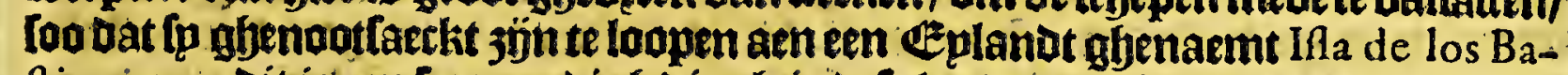
ftimentos, dit is een letr noodigh dingh in dele landen/als ick bp experientie beb be beuonoen.

Dele belchejuinghen ban be etngelfebe ende Spaentrbe/ loopen loo twat tegen Den anderen: Doch't ffejhnt defen Baptifta Antoneli de ftadt ende baven ban Nom-

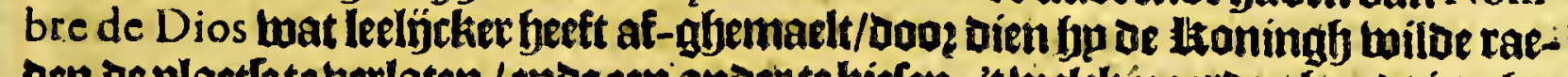
Den de plaetfetetuetlaten / ende eeriandertekiefen; 'twelck naecoer-fjanot is gbes

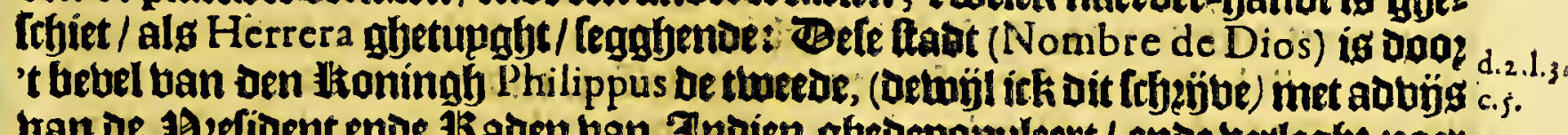

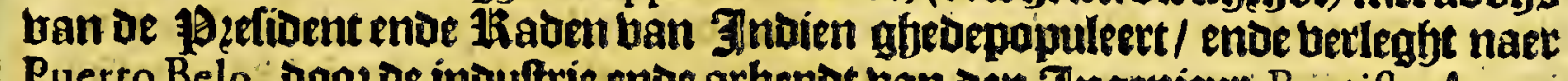
Puerto Belo, Doo de inoultrie ende arbepdt van oen 7 Ingenieur Baptifta Antoneli ; oie bet felve langhe hadoe gheraden/ende de experientie begint te tboonen bat men twel ofjedaen beft ban plaetle te beranderen.

Iset vító capittel.

Van de gheleghentheydt van Pue R TO BELO, uythet Raport van Baptifta Antoneli.

PUerto Belo leght bijfleguen tan Nombre Dios naer bet toelten toe : is een leet bequame baben / waer feet beel frhepen konnen lenghen/ beeft gaede antker.

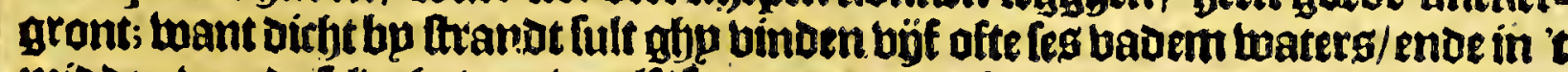
misden ban de Lelbe babentwaelf/ leet goede ende fupbere grond ofte [andt/ fone

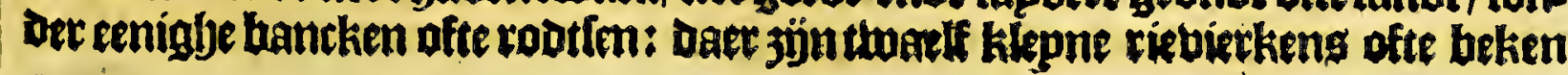


Dietat bele hauten hehoosen/ento al in een kamen; [oo bat te blote tot allen tijoen baer ban vertch water kan verfien/ loo bel als Ip felts willen. Oock foo is in Defe platts beel boutg om tchepen te timmeren/ ende teen om ballate in te ne ${ }^{3}$ men: oock fos en heeft [s gheen Dangiet in't in-komen / als alleen twannest de

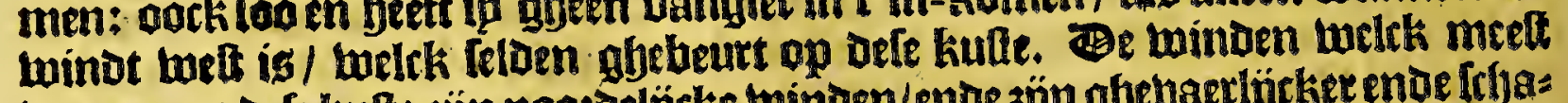

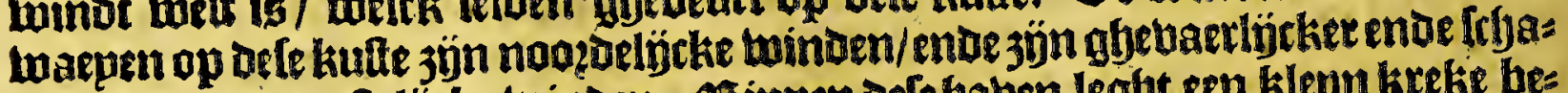

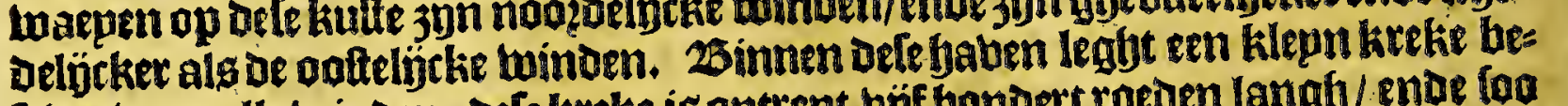

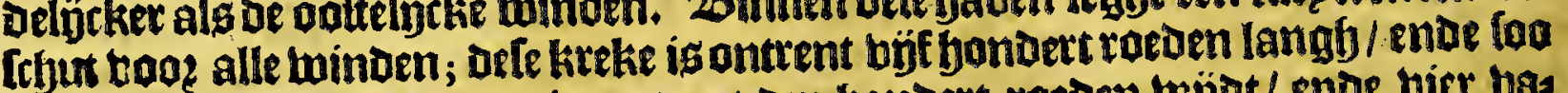
besed / enoe bet in-komen is antrent Dep bondert roeden wajot/ endee birr bas

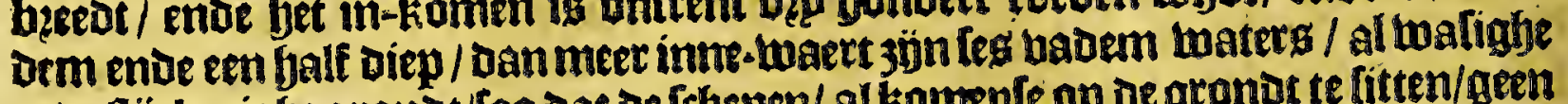

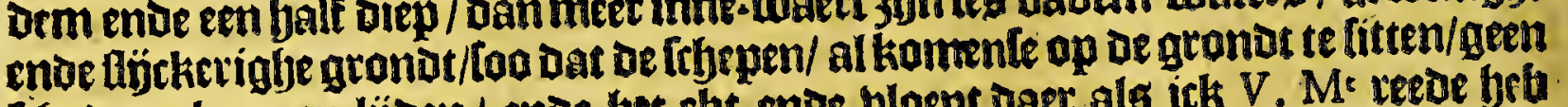
frjade en lionnen lijden/ ende bet ebt ende bloept daer als itk V. M* reede bra

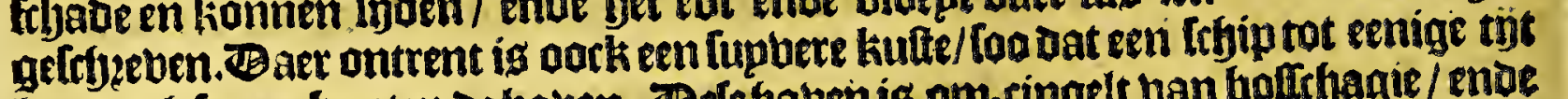

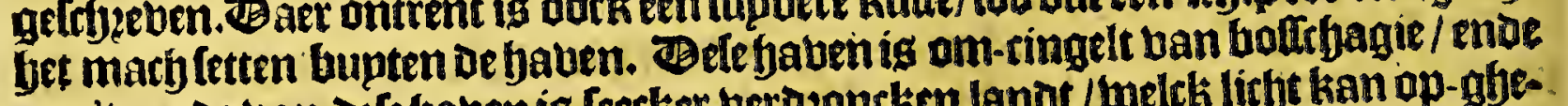

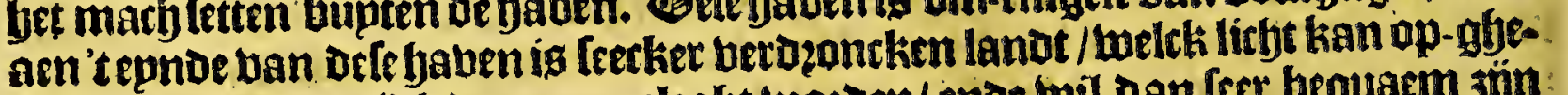

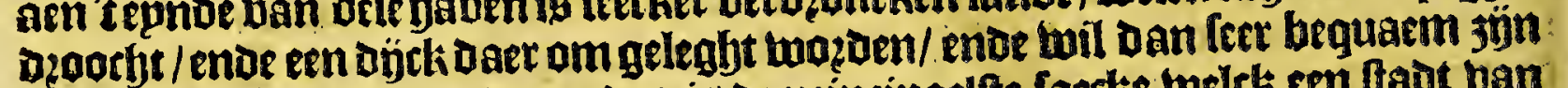
om beeften te wepoen: want dat is de peincipaeltite faecke weltk ren ltaot ban

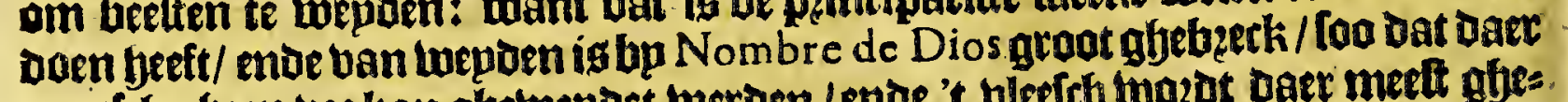

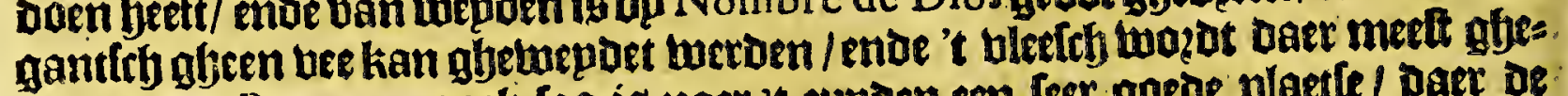

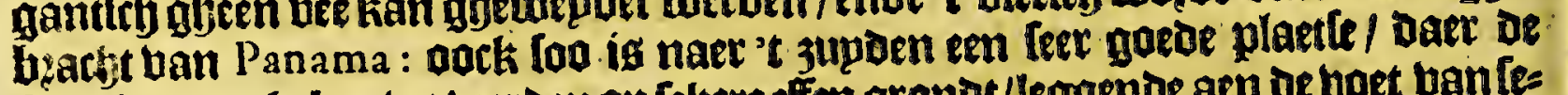

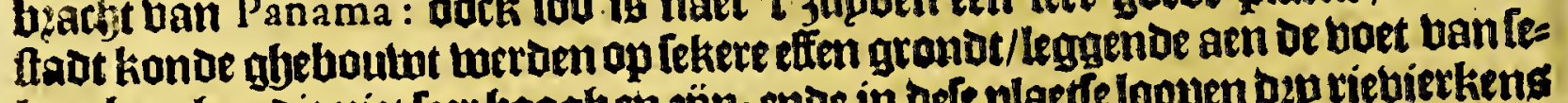

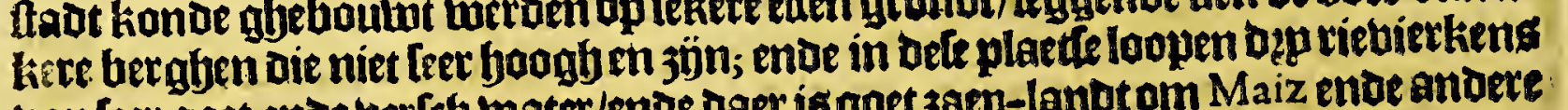
ban feer goet ende berffy water/endee daer is goet 3atp-lantot om Maiz endee andere granen te twinnen.

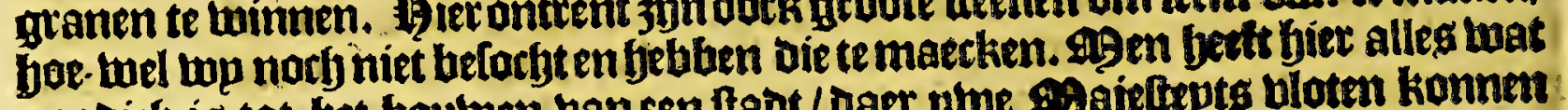

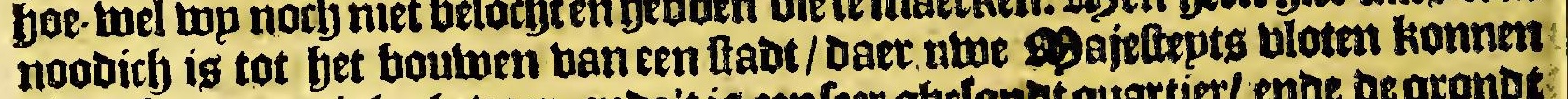
rijoen fonder eenigh ghebaer; ende't is eenfeer gftlonet quattiet/ ende oe gronde

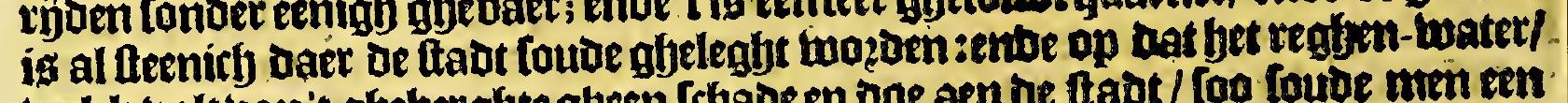

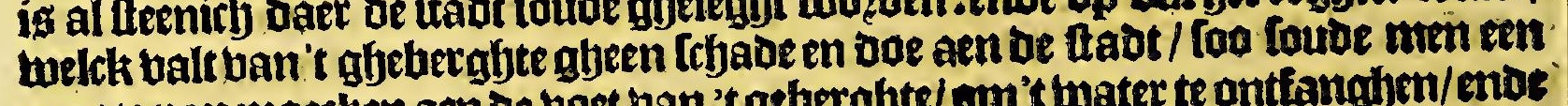
groote pan maecken aen de voet wan 't geberghte/ on's twater te ontfanghen/enae'

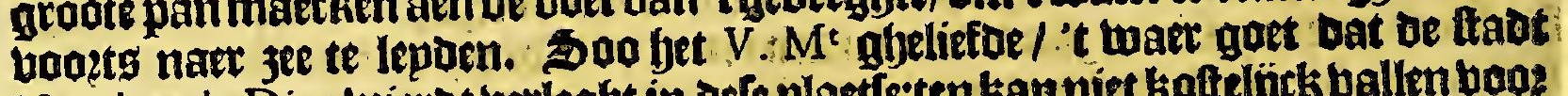
Nombre de Dios thiertot betleagt in defe plaetfe:tenkanniet kafteljitk ballen beo?

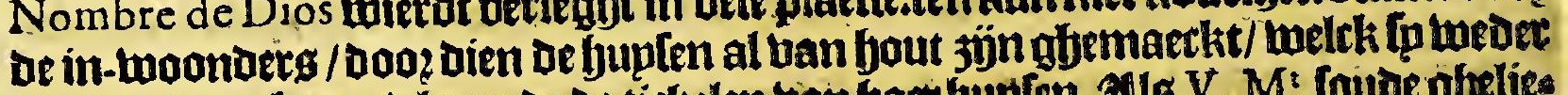

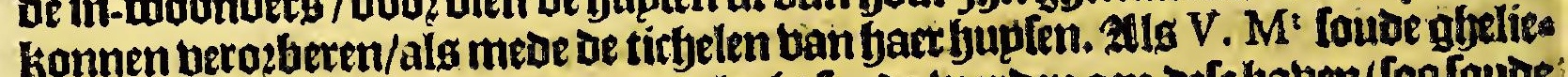

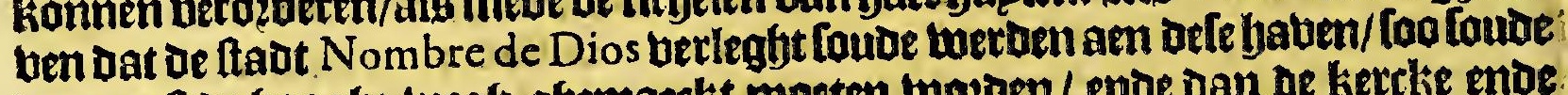

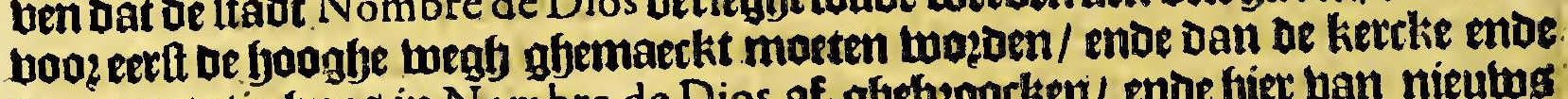

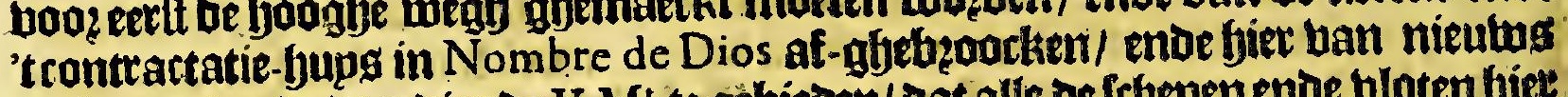

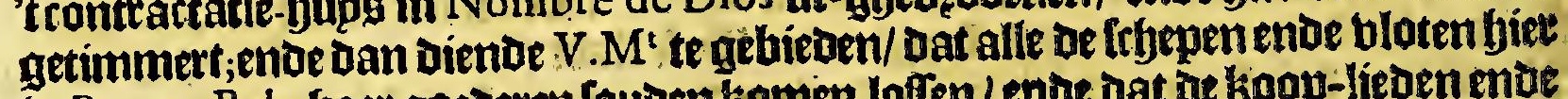
in Puerto Belo baer goederen [auden komen loften / ente dat ae Koop-lieden enoe factrurs die nu haer te Nombre de Dios antfouden/fiet op't nieutu fouden parks gupten komen timmeren / om de goederen in te ontfanghen: Loo Lal De plaetfe in

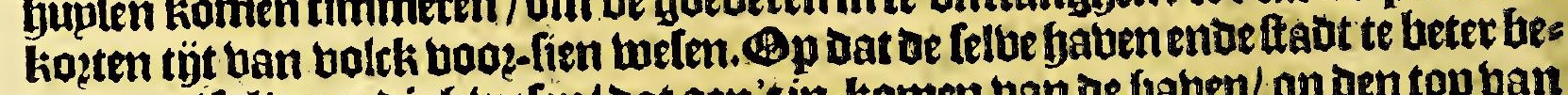
waert 30/ Tal't noovigh weten/ Dat aen'tin-komen uan de fjaben/ op oen top ban eenen bergh/ welck noozot-waetes leabt / abemaeckt weroe een klepn bier-kant

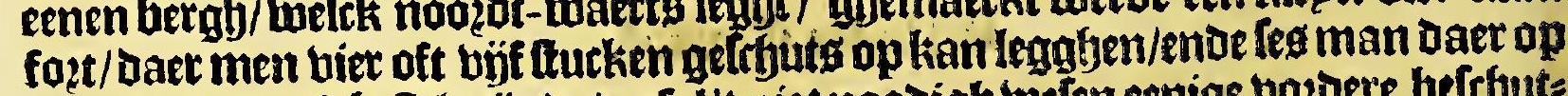
laten waken; dit beftelt jünde/en fal' t niet noadigh welen eenige vozoere befrfuts tingbe te maken/ Dooz dien't lanot vol klippen is/ende quabe tweghen/ende dat de

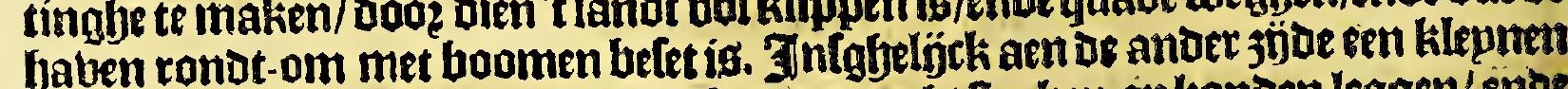

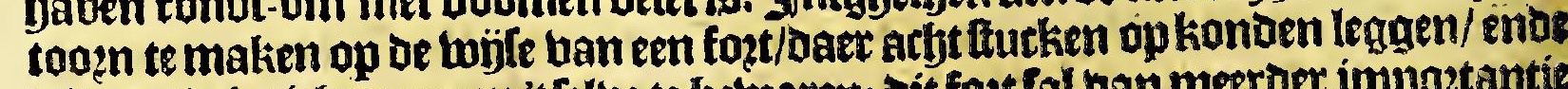

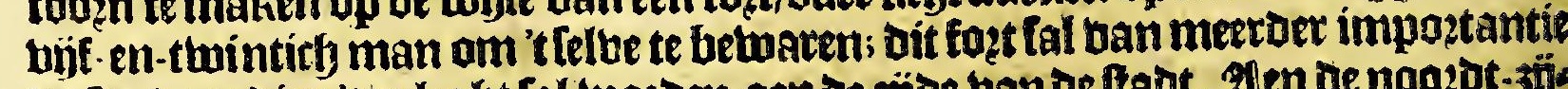

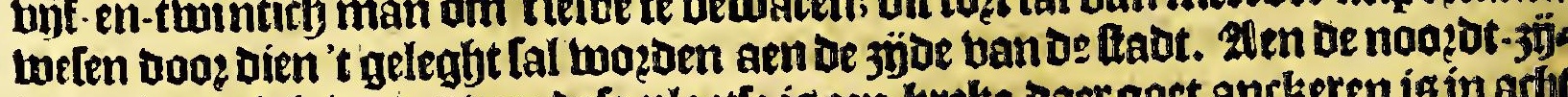
De een twepnigh vozaer uan Defe plaetfe is een kretke daer goet anckeren is in arty

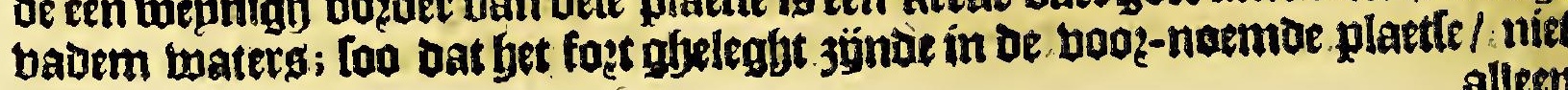
alleer 
Het achtfte Boeck.

alleen be ti aot tal befthermen/ maet oock of bpanot befthadighen; ente be kus

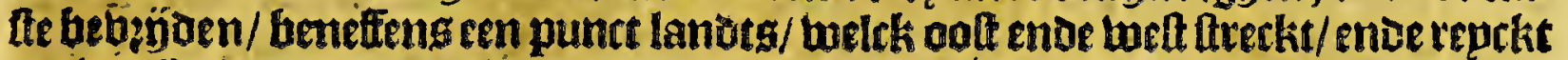
tot bet Eplanot Buenaventura. EnDe ghenomen't fost wekls is ghetimmert aen D'ander 3 joe / quame te berballen / ofte bp of bpanot in-ghenomen te twetoen/ foo kan men met dit theede be ftadt eben-wet ghenoegf berchermen / want met twintith mulquetiers te legghen ap een betgh weick ouer jet foet legbt / [al men een grooten joop upanoen ghenoegd af-keren. (B) ele bauen legbt op negfen yras aen ende een deroe. Sigen konde de luegf tweldk naer Capira loopt/ Itoppen; ghes lïck oock de refterende begljen die van Nombre de Dios naer Venta de Cruzes loopen/ want ot fiwaten Simerons frebhen mp betklaet Dat oeten weah niet

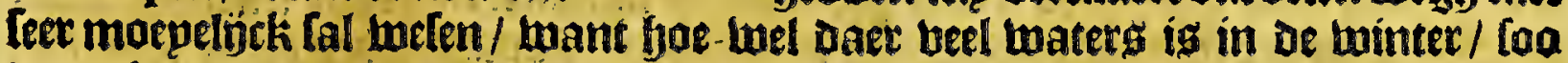
vzooght bet boch in be tomer op; enve daet fyet niet op en Dzogght / Daet konde men een trate legghen; daer is fteen ende bouts ghenoegh daer toe dienende; Dele tuegf konde gfemaetkt wozoen met bet gfeene $V . M^{t}$ in Panama ende Nombre de Dios ontfanght boos tol $\%$, welck jaetlïckg twaelf oft veettfien buplent Pezos bedzaeght /ende liande tot maecken ende ander-jouden ban defe wegben ftectien.

\section{Aget tefte Capittel.}

Van de nieuwe fade by Pu $\mathrm{R}$ T O B E to gheleght, ende hoe de felve is inghenomen gheweeft by de Enghelfche; ende van de ftadt NA T A.

I.

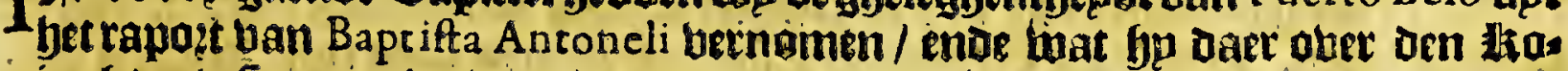
ningh ban Spaegnien toas radende; Delen racot is bp den lloningh get ghes

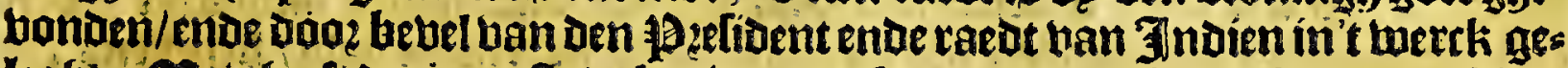
legft. "Agen beeft daet een ffadt beginnen te boutwen / die fu S' Philippe bebben

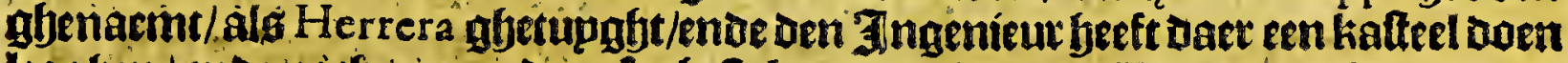
Iegaben / ende noth ten ander at-gheteken aen d' ander 3 goe van be bauen / om be felbe tegfyen alle invafien beter te betfekeren. Aaer dat Sir Francis Draeck, Numbre de Dios bao in-genomen en De gfedeltrueert/quam bp met de blote mede

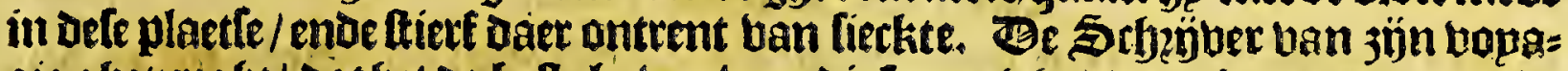

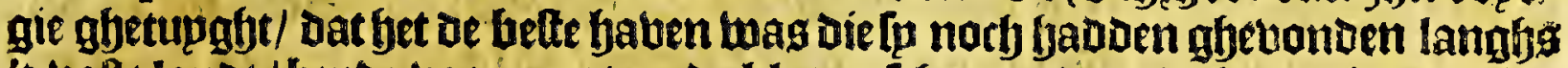

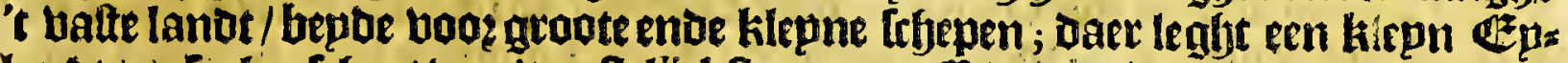

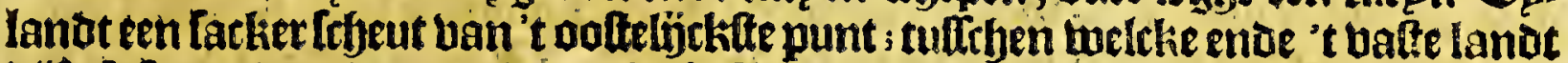

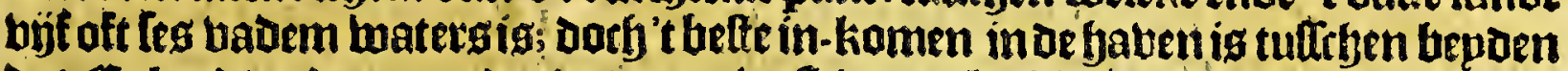
dat Eplandt ende een moer dat meer toelt-waert leght met een rif ban klippen. Sp bonoen daer boen maer arbt ofte tbien fuplen/ beneftens een groot fjupg daet

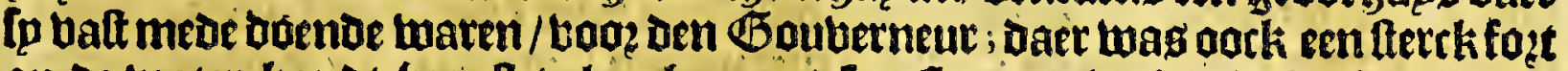
op de twater-kandt begolt te legghen met lpn flanqueringhen/ abentaeckt ban groote balcken ende ftenen/ ende tulfefen bepoen met aetoe ghebult; Sop oat naer apparentie oele plaetfe feer bequaem enoe tterck is glemaeckt / te meet naer dat 't volck ban Nombre de Dios, naer 't berbzanden ban baer fraut bp of $\mathbb{E}_{n=}$ gelftye / oertwaerts is gfreb2acht. Be koopmantchappen tweroen ban ofle plaetfe

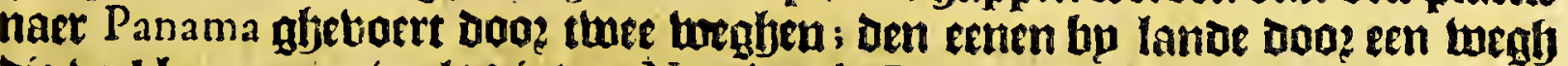
die beel bequamer ís als die ban Nonbre de Dios was/ento is achthien legtien meeghg: oen anderen langhs de jee tot oe riediete Chagre, tuelct jön uertfjen oft bertfjien leguen toe? -waert aen; enbe ban De riebiere op tot Venta de Cruzes; ende ban daer bootg te lande naet Panama.

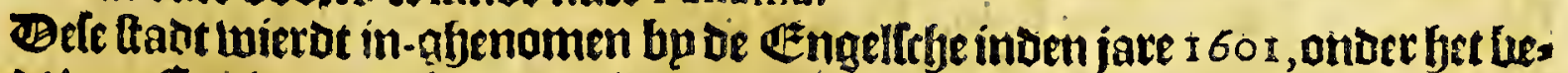

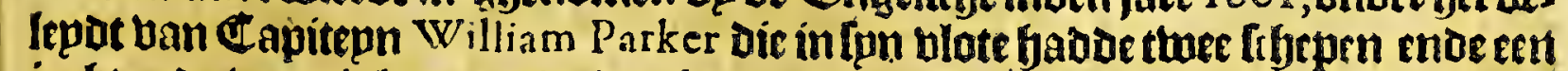
jarbtende toepnigh meer als thee fjondert man: gp fettent onoer fjet Eeplanot de Baftimentos, ende manden dace twee pinallen ende thee thepen/die bp in furketi bados 
$3^{12}$

Terra Firma.

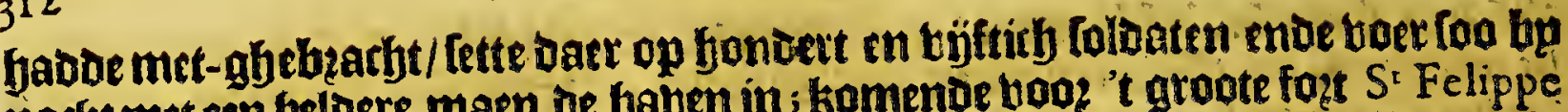
natfet met een beloere maen de baven in; komende hoog 't groote fort $S^{r}$ Felippe

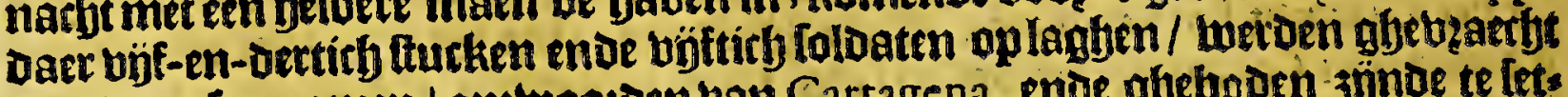
ban waer [p quamen / antwoozoen ban Cartagena, ende ngeboden jonde te lets

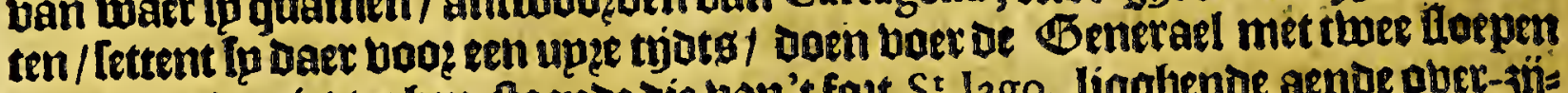

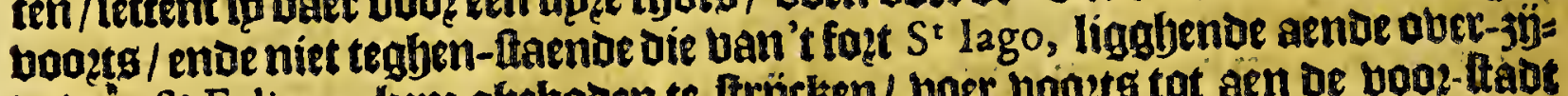

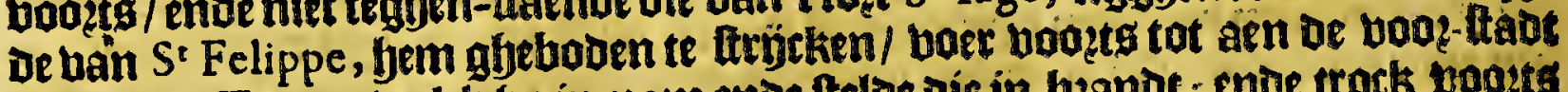
ghenaemt Triana, weltk bp in-nam ende fteloe die in bzand, ende trock boosts

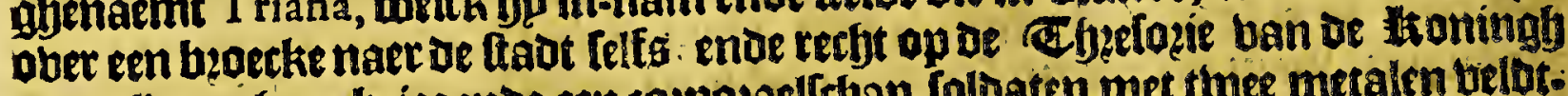
aen/alwaer fem bejegenoe een roepposalltbap Coldaten met thee metalen tielot: ftucrkeng/aie lp bemaghtighoen/enoe Tetten booets troutelijck aen op oe Coloaten: Daer-en-tuffeben quamen de twee pinalten met bonoert en twintich man oock aen: of Bouberneur Pedro Melen des feltich foloaten bo een abekreghen bebbens be focht baer te ftutten aen een bugghe/ dan twee manten ontlanghen betbente maeckte bem fterck in een bups / meirk de Engyelletse in-kreglyen naer bat to is Bouberneur noch arbt wonden badoen gheabeven/ enbe namen bem ghebant:

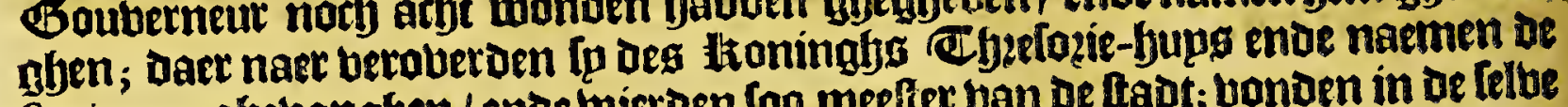
Scrivano ghebanghen / ende wierden foo meefer ban de ftadt; bonoen in de Telbe

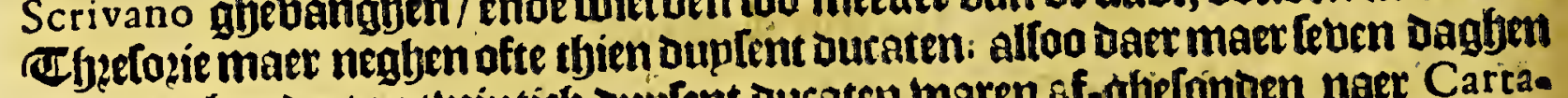

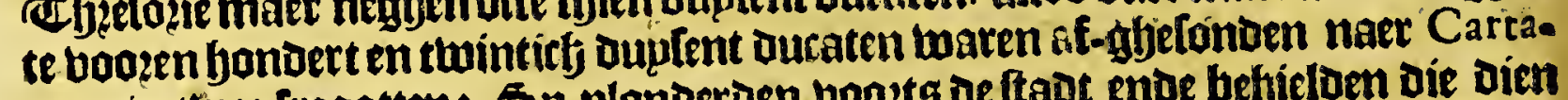
gena in thee fregatten: $5 p$ plonoeroen bookts oe ftad ende befjieloen die dien Daghin; ende oes nachts retireerden faer weder naer oe frbepen/ fonoer be ftad bozoer te betrbadigben / ofte in't af-trecken eenighe fonderlingfye frjade wan be fouten te lïjon. Paer baer berklaringhe [oo twaren in be ftabt twee kercken bal. timmert/ les ofte teven Rraeten met buplen / Daer aller-bande ambarftr-lievet

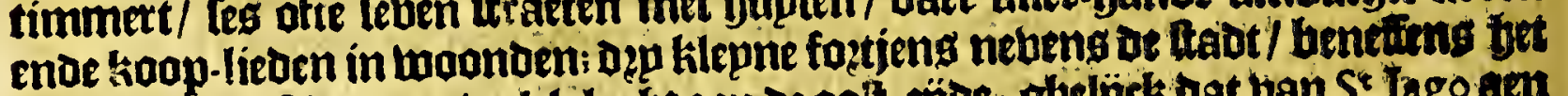

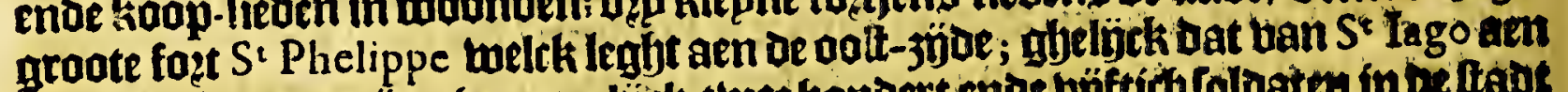

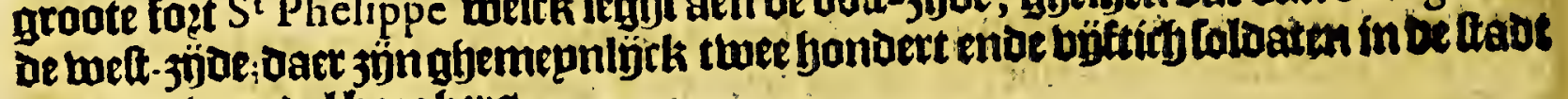
ende een vaendel bozghers.

\section{Uan de Staut Nata.}

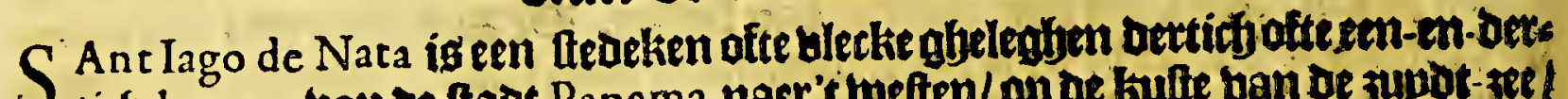

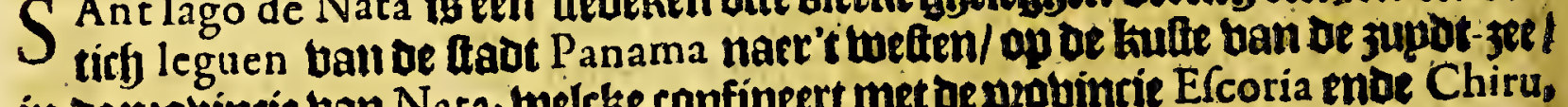
in de psovincie ban Nata; twelcke confíneert met de pyobintie Efcoria entoe Chiru,

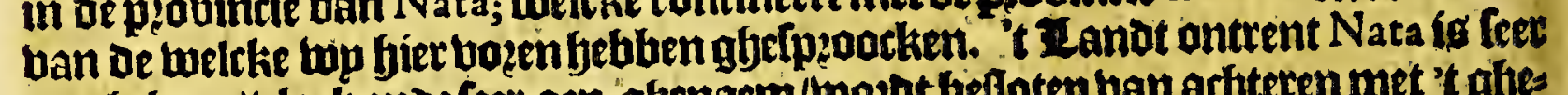
veucbtbaer/black ende leer aen-ghenaem/mozot belloten ban actjeten met 't ghes bergbte ban Viraca ofte Veragua, welck altjots be naem beeft ghefjabt banfeet

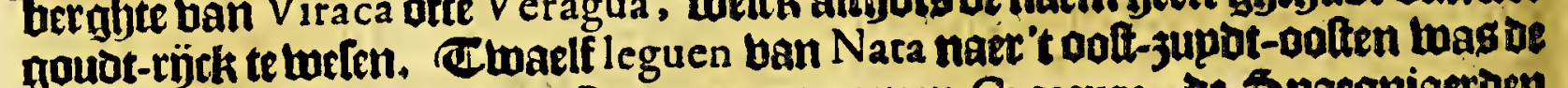
pzovintie ban Paris, mieng Cazıque met namen. Cutatura, be spaegniaetoen eertijotg beel [pelsheft gbemaeckt.

Fet Tevende Capittel.

Van de Rievieren van defe Provincie.

D E primtipaelte thietuier ban dete 1320 bincie is die men noemt Chagre, ento oock eertyts bp de Spaegniaerden Rio de los Lagartos: Ieght op de booghs te banneghen graden ende twintich mínuten bp noozoen be linie / beeft baer uptwateringbe in be nooptat-3ee / achthien leguen van Nombre de Dios, ende oers tbien leguen van Puerto Belo. Ban De mont ban be riebiere tot Venta de Cruzes, jün aththien leguen ; al-maer de goederen enoe koopmanldyappen mozeen ontladen/ende vooztg opmuplenghebzarfht naet Panama, welck ban daer bet: Irfepden ig büf leguen. Bele rieviere beeft beel waters in ben winter-tijot. De bercken die tot dele riebiere befjooeen/ jün dooe-gaens ban leltbien baten/ende konnen 


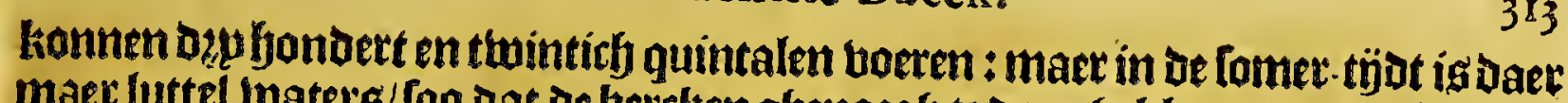
maec luttel luaters/ foo dat de berchen ghenoegh te doen beb ben om op te komen/ enve jün ghenootlaeckt in beele plaetfen een deel ban haer goet te ontladen / enve

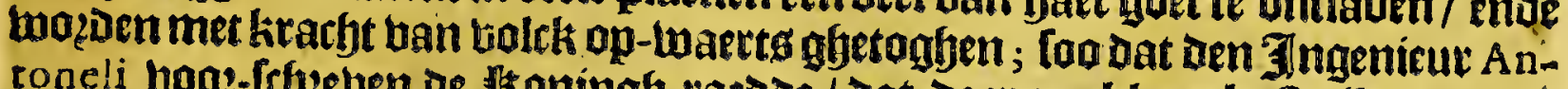
monot ban defe rieviere foune ghelegedoe / dat daet een klepn kalteelken aen be Puerto Belo Daer intere loude gljeleght wazoen / om de gaederen kamende ban Puerto Belo daer inte berghen; ende kilepnder bercken te timmeten/ om in be lo: mer-tÿdt de goederenmet op te boeren / latende de groote bercken boo oen thin:

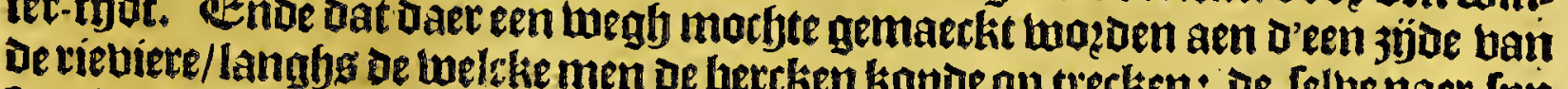

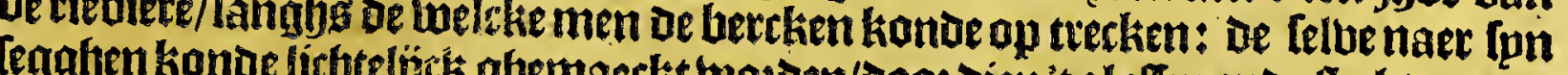

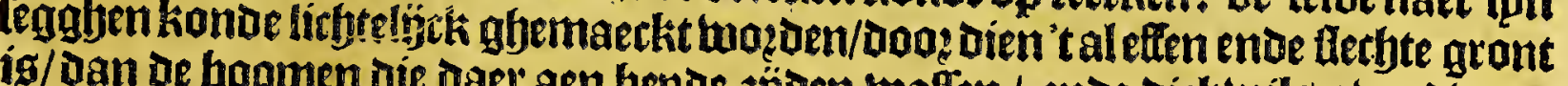

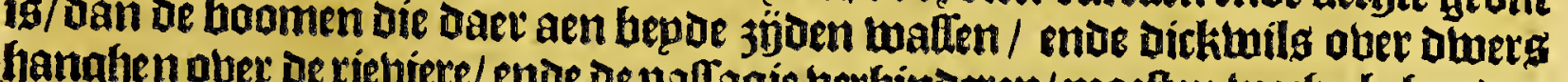
tozoen. Je mondt ban town leer goede vilth op aefe richte/ endecenigh berchut boo de Brifas. Agen bangft

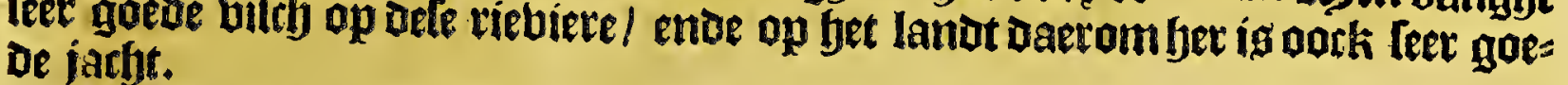

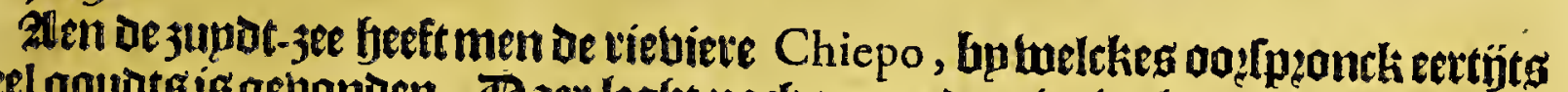
beel goubtg ig getonden. Baer legft noch een ander rievier by oofen Panama, Die fu noemen Rio de las Balfas, Daer feet gaet houdot valt om berelien endelfbepen ban te timmeren; want Daen Bafco Nunnez de Balboa de jupDt-jee eerlt badoe ontieclit / ende boo?-nam de landen daet aen legghende te beloecken/ loo betepde

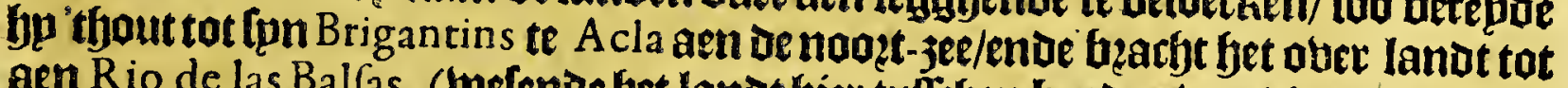
aen Rio de las Balfas, (welende fyet landt hier tulthen bepoent ban o'ene jee tot de andere maet tbee-en-twintiry leguen beedt/naet bet feggen ban Herrera) maer d.2.l.s:

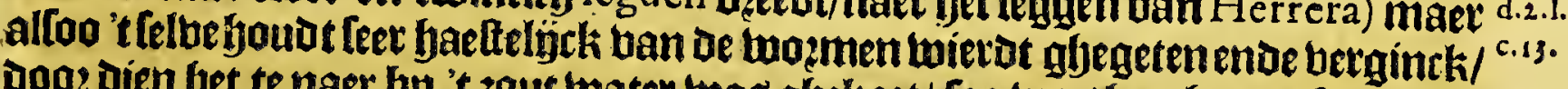
oog Dien bet te naer bp 't 3 out water twas ghekozt/ foo was bp ghenootlaeckt bp ocle riebiete de las Balfas op nícutus fjoubt te bellen; gfelijck fjp dan 't felbe oock geluckelÿrken upt-boerde / ende maeckte fier kenige Brigantins, Daer hp de jupDt3ee eerlt meoe bejeploe. In defe rieviete fiamt bp tyjoen loo groaten op-water/bat

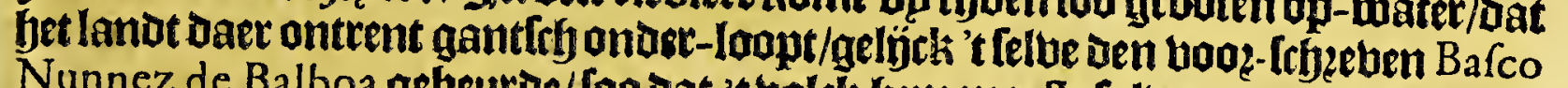
Nunnez de Balboa gebeurde/ foo dat 't bolck hem moette talteren op de boomen/

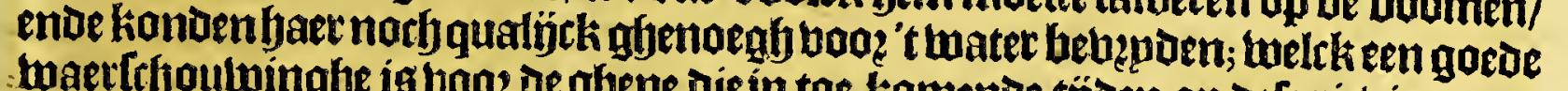

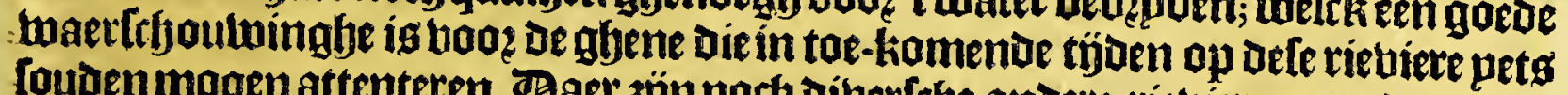
foubenmogen attenteren. Baer 3 j̈nnoty diberfebe andere riebieren aen de 3 upot-

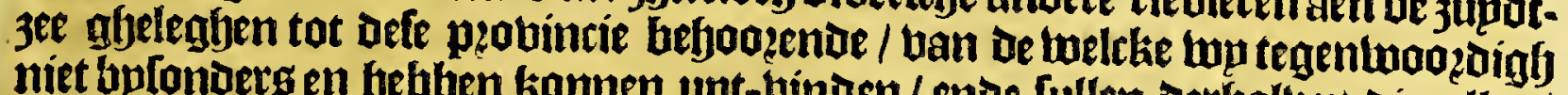
niet bpfonders en hebben komen upt-binden / ende fullen derfyalven die alleen

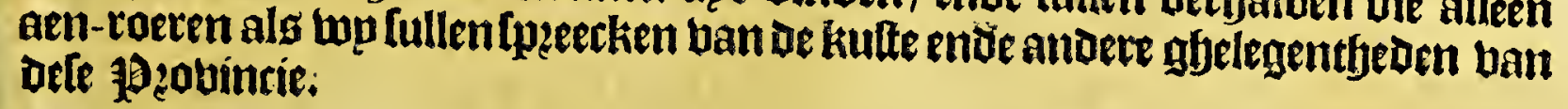

\section{Wet achtlte Capittel.}

Van de Rieviere Darien, ende de Provincie.

$\mathrm{D}$ Ez Liebiere Darien leggt in't inmerle wan oe Golfo die de Spaegniaerden noemen de Vraba, ende is fet trjept tufthen oe probincie ofte audientie ban Panama, eñ de plobincie ban Cartagena; is gelegen aen de twef-jujue van de lelte Golfo, ende aen de rectjter-bandt/ fo gljp uie in-komt/ iseen groote viebiexe ende

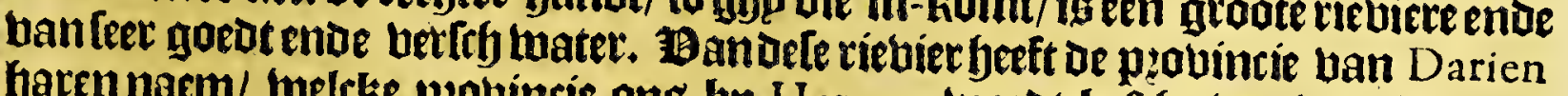
Garennaem/ twelcke peouintie ang bp Herrera wazot befthetben in bolahende maniere. Be gbetemperthept ban Je pzobintie Darien is wonderhaer/ want de d.r.l.ro.

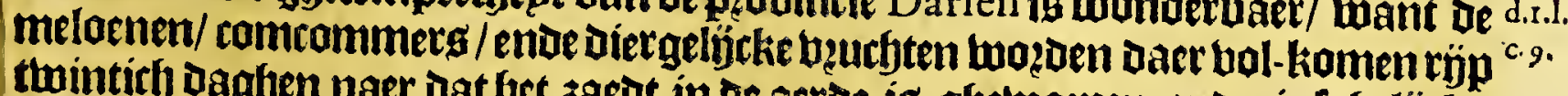
twintirly Daghen naer dat jet jaed in be aerbe ig ghetwoppen; enoe infobelijeks alle andere moeg-krupden. De bijngaerdenende boomen geben baet beuchten 


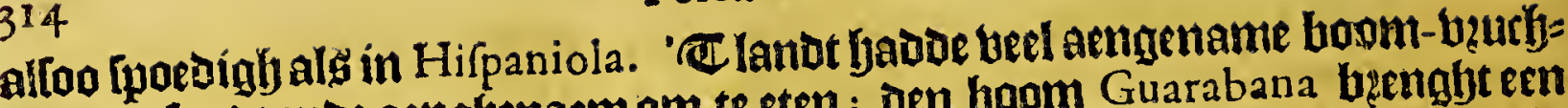
ten / gljetonat ende aenghenaem om te eten ; den boom Guarabana benght een

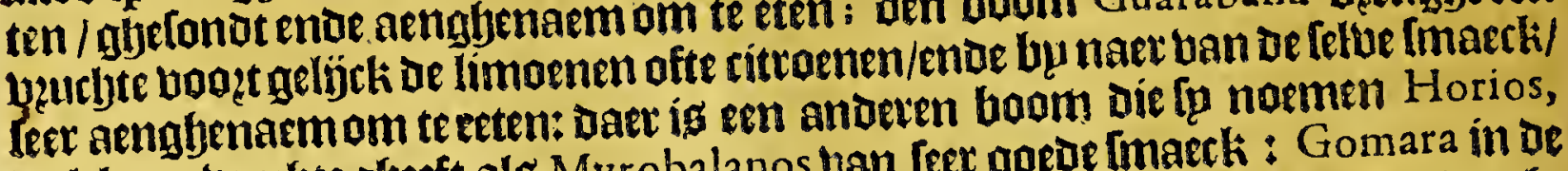
welth een veurbte gheeft als My robalanos van leet goede [maeck : Gomara in De

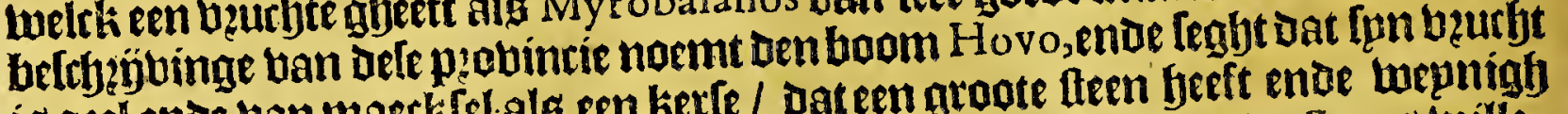
ig geel ende van maetkfel als een kerle / Dateen groote tteen heeft enoe wepnigh bleff(d); datle getont is om eten/ Dan quaedt boo? de tanden om de lteens twille; Dat Defen boom een water upt-gheeft dat feer aen-ghenaem en gefont is om dęint=

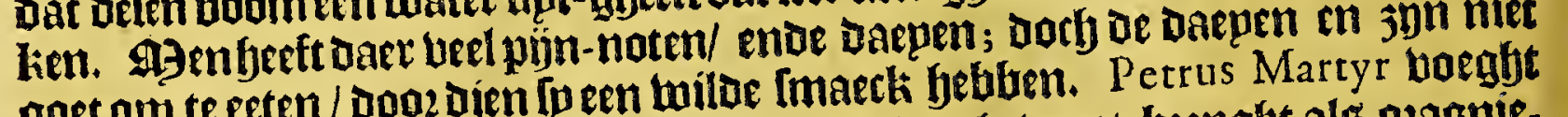

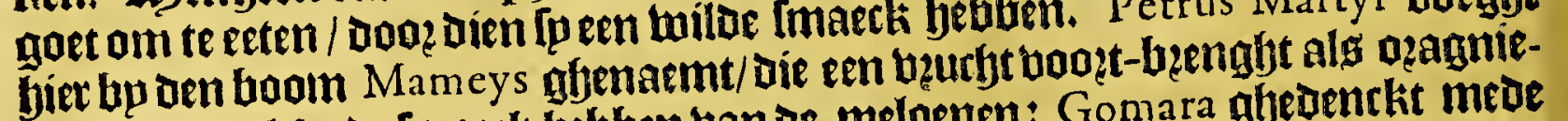
appelen / welrke de Imaeck bebben ban oe meloenen: Gomara ghedenckit mede be Mamay, ende Iegft dat heteen Lchoonen luel gljetopten boom ig/bp naer als de noote-hoom/ende dat [pn Jeuryt groot ende rondt ís/van Imaeckals de perten;

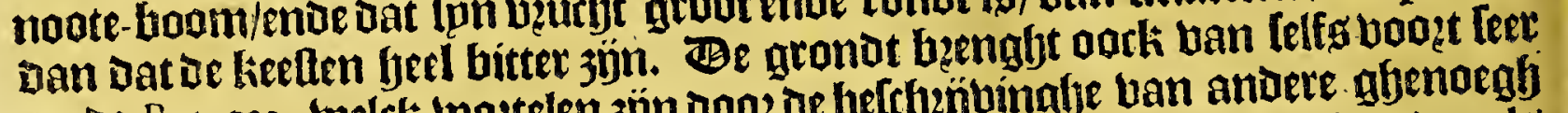

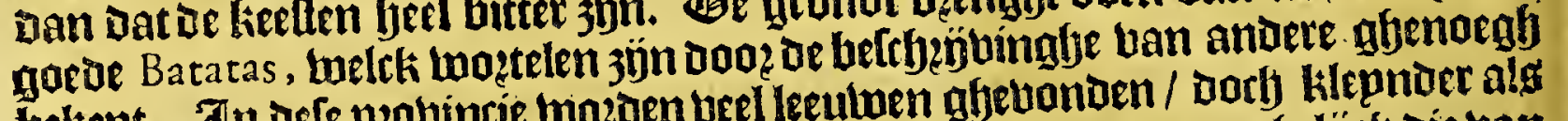

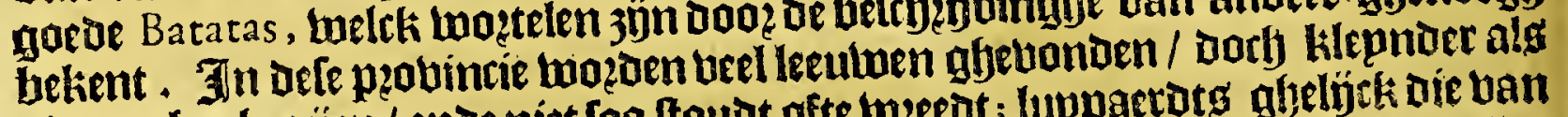

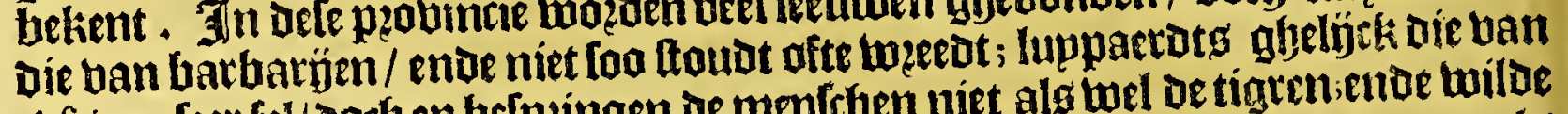
A frica, [eer fel/ Darty en be[peingen de mentchen niet als wel De tigren; entoe wilde katten grooter als tighen/enoe we! foo fnel in't loopen; mentyeeft daec hatten als

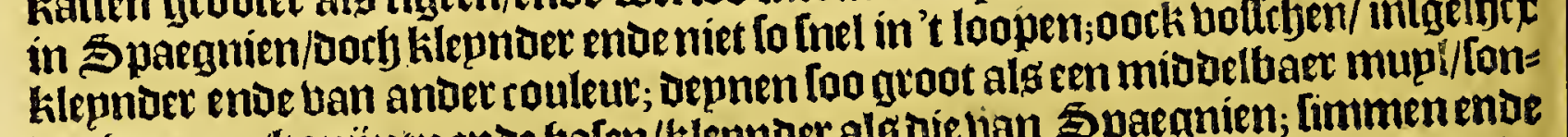

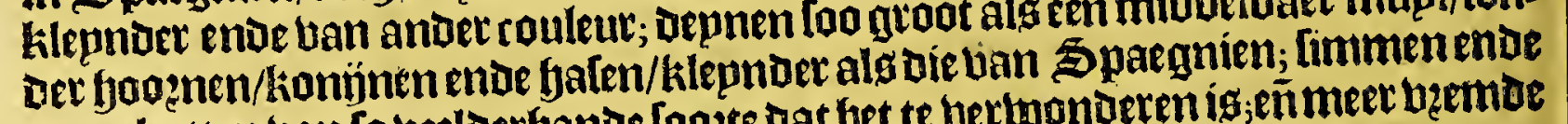

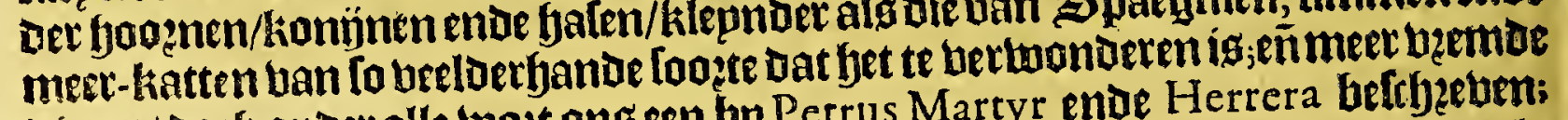
Dieten/ Dorfj onoer alle wopt ongeen bp Petrus Martyr ende Herrera befibetuen; is een beefte foo groot algetn olle / hebbende een Inabel alseen oliphant/bapz als

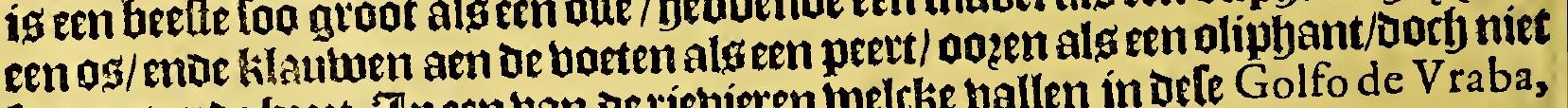
fo groot ende beet. 3 neen ban de rievieren welcke vallen in dele Golfo de Vraba, welch fu noemen $R$ io Grande, Dooz dienfp hel twee leguen wijot is/binot men memichte ban rrocodilen;ende aen ot kant ban dele rieviere/welck ober-loopenoe beel poelen ende moerattefen maeckt / hint men beel faplanten ende parutwen ban beel anoer couleur als die ban Caftilien/enoe ander gevogelte feer goet ende aen-

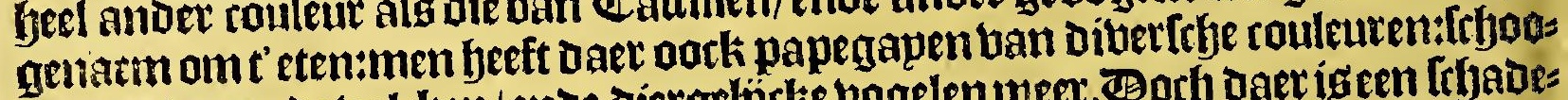
ne arenoen ende balcken/ende diergeljerke hogelen meer. Borb daer igen fryades Ijek gebogelte uan bleer-muplen/ die de menifyen in oe theenen ban de boeten/eñ bingeten/ende eloers büten/ende haren bert is leer fenínigh/ende laet beel bloet g; se remedie baet tegen getwonden/ is't bloet te Itelpen met $3 \mathrm{ee}$ - water/ ofte met heet

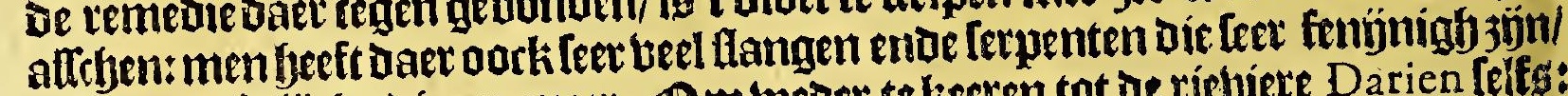
ende bietghelÿcke dieten meer. Ombeoer te keeren tot de ríebiete Darien felts: Petrus Martyr getuphht dat fjetmaex een Imalle eñ ondiepe riebiete is/[o dat daet niet als canoagentionnen op baren:maer de riebiere hier bozen aen-geraert/Die fy noemen Rio grande, ende $S^{\mathfrak{t}}$ Iuan, is een marlytige groote riebiete'endenaer 't teg gen ban Marcyr mel een legue beetende leer diep/ig gelegen in't binnenite ban of

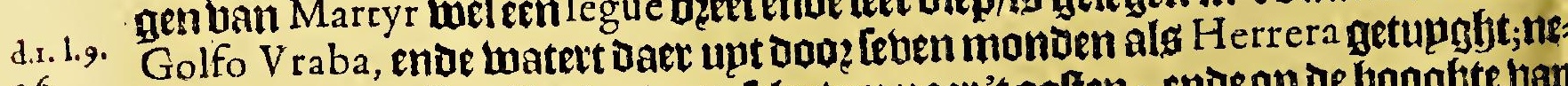
gen le guen wan Rio Darien booe-Irbeetuen naer't aolten; ende op de booghte ban ontrent [eg gladen; Dorf kan niet welen Dooz dien de Golfo loo berre niet in er frecht. Baer bu is norfi een ander ende klepnjer rieviere die de Spaenniaerder

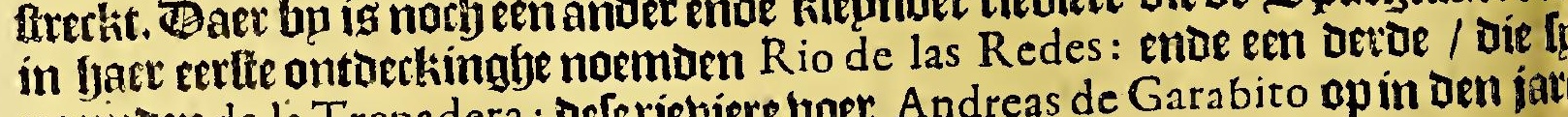
noentuen de la Trepadera ; deferieviere voer Andreas de Garabito op in den jar I 5 I 4 tot aen 't hooghe geluerghte/ende ander 't lelbe rebergljte hande by een ande riebiere luelek fun loop hadoe tot in oe zupdr-jee. Oock loo was oaer een antoe rieviere die In noemoen de las Anades, Daet in Spaegniaeroen tuel eertijot 
een twoan-plactfe fadoen begonneri te leggfen feg oft leben leguen ban Darien, in een butbtbaer ende plaptant quattier / ontrent een peobincie ghenaemt Ceracanà, daer doen een Cazique regeerde/genaemt Abraybe,ende de Mildentwoon= ben vaer in bupskeng boven op de boomen. Herrera maeckt aock ghetwagb ban Rio de Corabari, tuelck ontrent Darien loude legghen / in een luequame p'atete ende glje[onde lutbt / foo dat de fiecken ban oe lfadt Darien derluaetts trocken om baer bodzighe ghefondtbepot te beter weder te hekomen.

Fert neghende Capittel.

$$
\begin{aligned}
& \text { Van de fteden die eertijdts zijn gheweeft in ende ontrent } \\
& \text { de provincie DA R IEN. }
\end{aligned}
$$

I R't booz-gaende Capittel bebben wp by gelegenthept vande rievieke Darien,

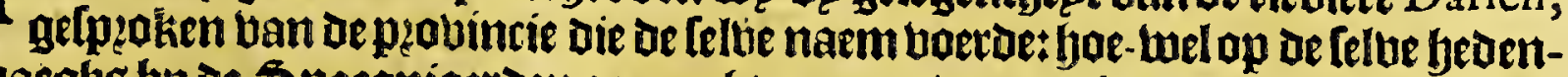
daeghg bp de Spaegniaeroen geen acht meer en twozot ghenomen / enoe daer nu geen Iteden ofte woon-plaetlen ban Spaeghiaerden en wozedn betonoen / [oo

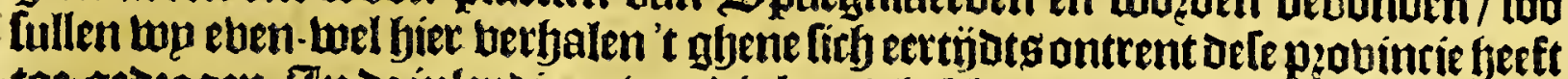
toe-gedzagen. Fn de inlepdinge ban dit boeck bebbe ick aen-getwelen/ boe dat dit ofedeelte ban Terra Firme eertijots was beroeelt in Caftilla del Oro ende Nova Andaluzia: Ban oe welcke Caftilla del Oro in fich begreep oe eene zijoe ban oefe riebiete Darien naer't wetten toe; ende Nova Andaluzia, De ander jyjoe naer bet polten toe. Thit abetwefte foo Gomara feljeyft waseert ontoerkt bp Rodrigo de Baftidas in Deri jare 1502 , die Daer ober begiftight wierdt atet een jaerljëke rente ban thee fyondert Ducaten. Be bozoer ronquelte ende 't Boubernement ban Nova $A n$ daluzia twietot in den jare 1508 ban oen Honingh ghegeben aen A lonfo de Oieda. Befen Oieda met fun fryepen gheliomen jünae aen 't bafte lanot ontrent daet Her. d.t. nu Cartagena leght/ende een dappere neer-lanfye geleden hebluende bp de nailoen ${ }^{1.7}$. c.16. van dat ghetwefte/ naer dat bp bem met bulpe ban Niquefa daer ober gfjetzoken Gaode/ig bp met fon frhepen geloopen in De Golfo de V raba, om aldaer te loecken de riebiere Darien, die onder de Induiamen den naem fadoe ban wonder goudt-

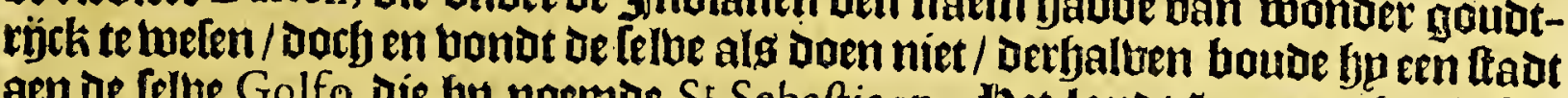
aen de fellue Golfo die by noemde $S^{t}$ Sebaftiaen. Het land baet om ber is leet beuthtbaer ende abumbant ban bibets naer't fegghen ban Herrera. Terfe plaetfe

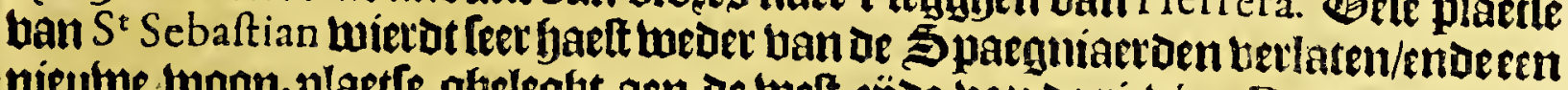
nieutwe waon-plaetle afreleght aen oe twelt-jijoe ban oe riebiere Darien, altwaer Encifo een tad boude in denjare 1510 ; endegafle den naem ban Santa Maria el Antigua del Darien, welcke in katten tijot leet toe-nam/[oo dat daet een 23 iloom

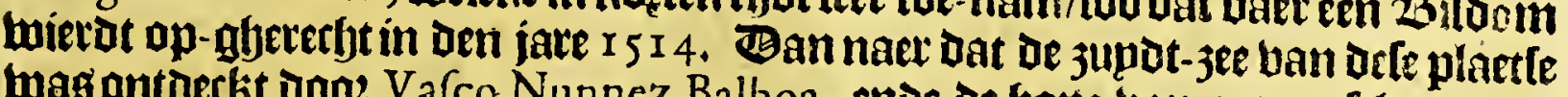
wag ontoeckt boog $V$ afco Nunnez Balboa, ende de bope ban groote fegatten in

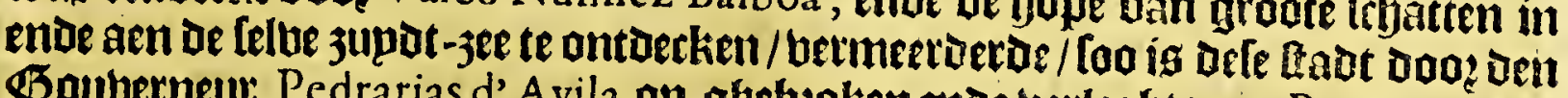
Eouberneur Pedratias d'A vila op-gfebeakenende berleght naer Panama, in't d.2.1.4.

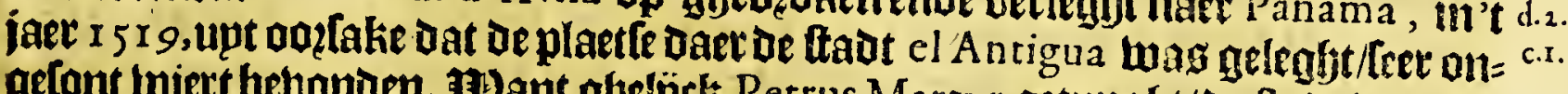

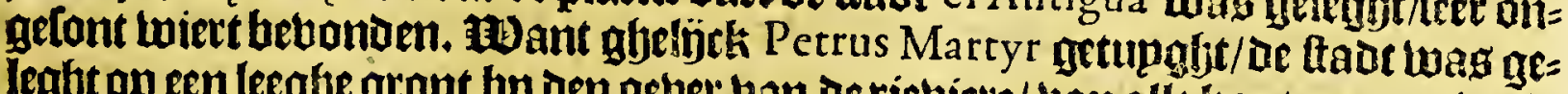
legbt op een leeghe gront bp den oever ban de rieviete/ uan alle kanten om-ringlit

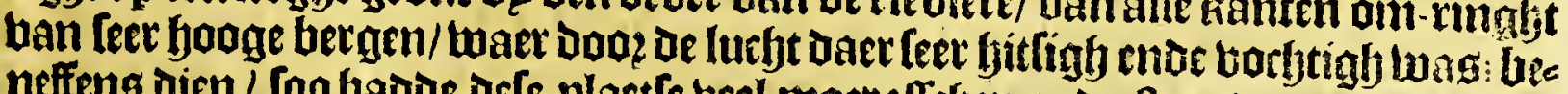

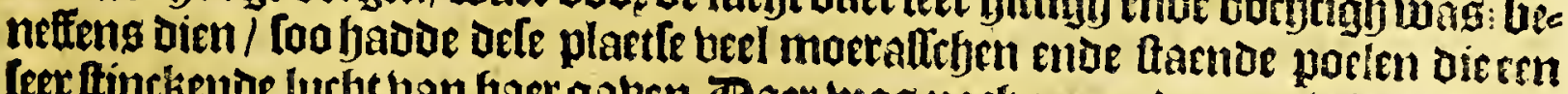

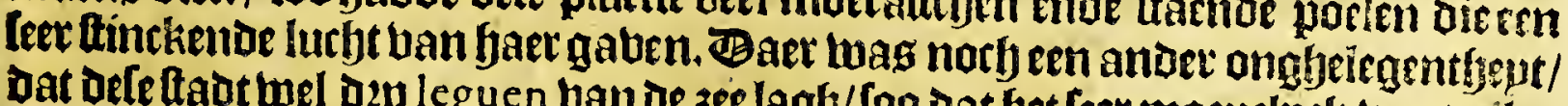

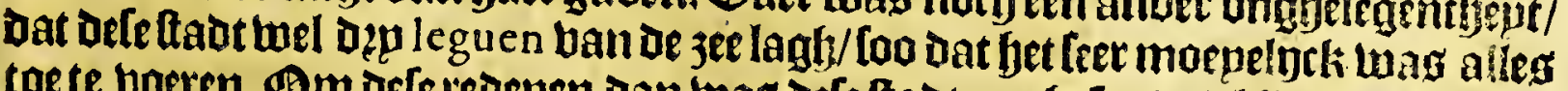

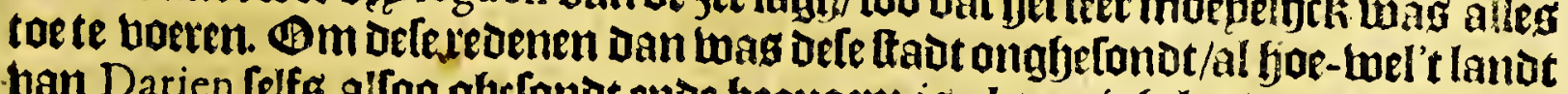
ban Darien [elfs alloo ghefonot enoe bequaem is als efnigh lanot Dact om-ljer/ naet 't leggen uan Herrera: dan Gomara getupght daet hedl anderg ban/ $/$ ñ leght

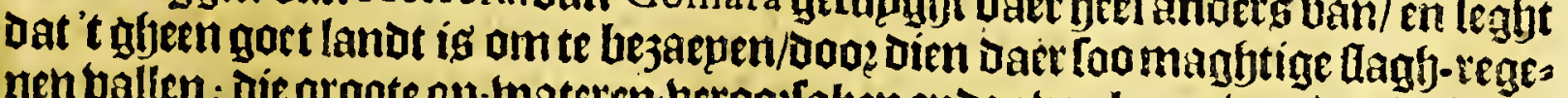
nen ballen; diegroote op-wateren berooklaken ento aber-lopen ban be riebieren;

$$
\mathbb{C E}_{2} \text { Dattet }
$$


316

\section{Terra Firma.}

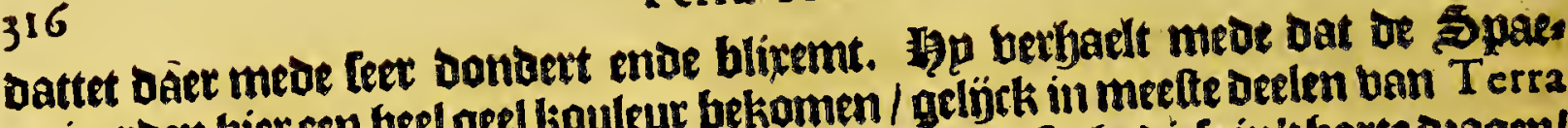
gniaeroen bier een yeel geel liouleur bekamen / gelp̈rk in meette Deelen ban Terra Firma ; bet kan weten (teght be) Dat de groote gaubt-furbt diefe in 't barte dzagen/ haer Dit kouleur upt-llaet ende de bupot ban berwe doet beranderen. Een ander Itaat wierds in arfe contreue ghelectyt bp de Capitepng uan Pedrarias d'A vila, in d.1. of probincie ban Pocorofa, bpeen riebiece diefp noemoen $\mathrm{S}^{22} \mathrm{Cruz}$, Dan wiertot

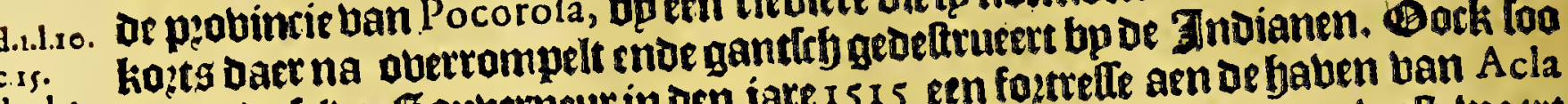

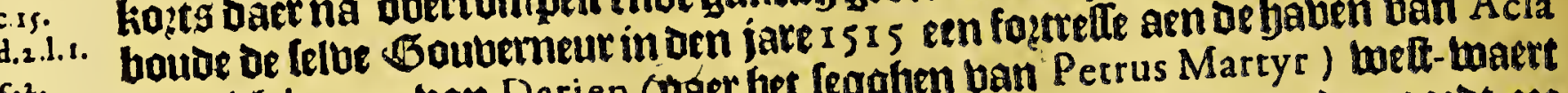
d.2.1.2. twinticly leguen ban Darien (naet bet fegaben ban Petrus Magaen oe noozot-zee

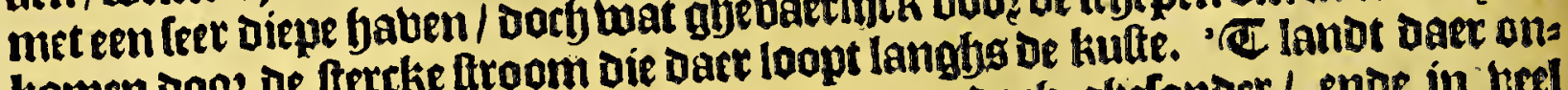
komen Doo? oe ftercke troom dat ban Darien, Dorh gfjelonder/ ende in teel

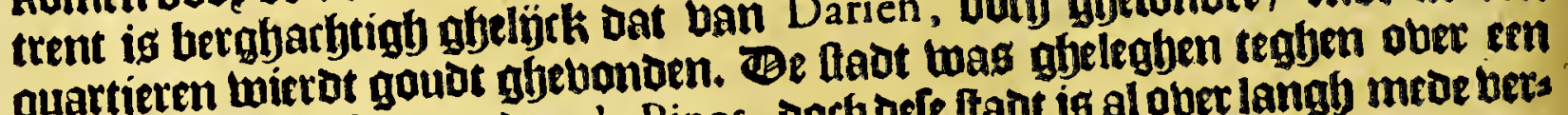

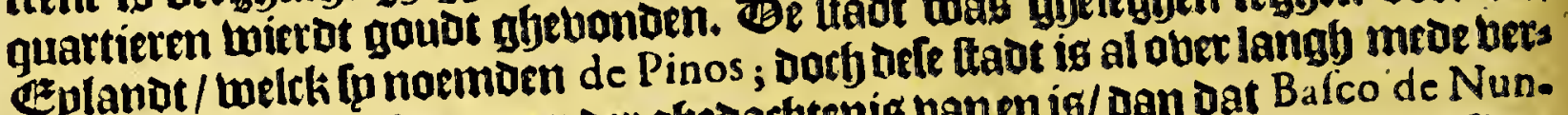

Her.der. Eppland / welch (p noem meerder ghedarbtenis venen is/ Dan dat Bafco de Nun.

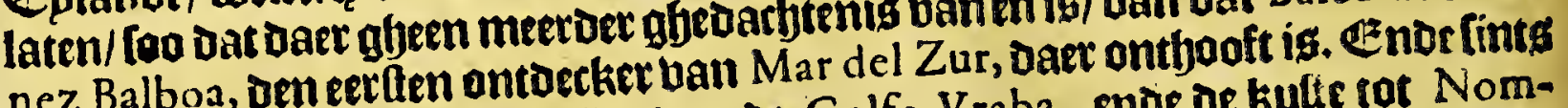
nez Balboa, Den eetten wetefor bre de Dios toe onbemoont ghebleben bp of Spargniaeroen; ban of ooft.

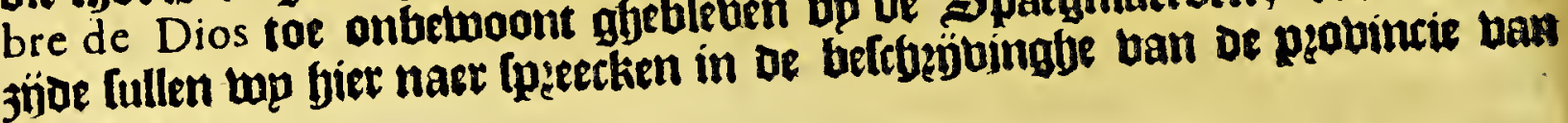
Cartagena.

\section{Set thiende Capittel.}

Van de kufte, havenen en punten van defe provincie van PANA MA.

$O$ of noozot-zjoe van orle pyobintie enoe zudientie ban Panama jön de naex-bolgende babenen ende kapen/beginnende ban de riebiere Chagre, daet

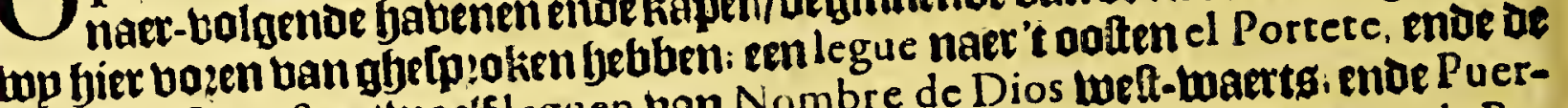
haven de Lagoftas, twaelf leguen uan Nombre de Dios Lett-maertgi enue Puerto de Gallinas negen leguen van Nombre de Dios lall naventura leg leguen; $\mathfrak{n}$ dide Puerto Belo bnf leguen

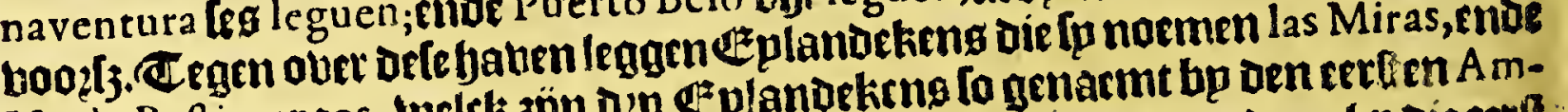

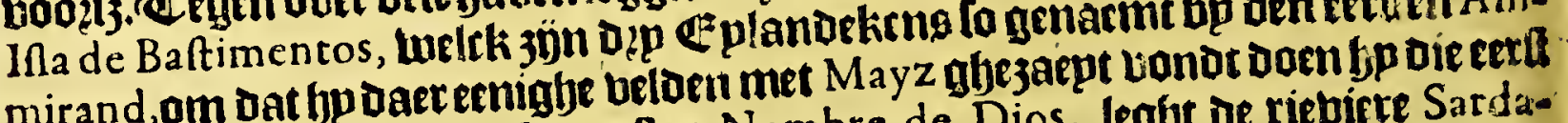
mirand, om dat gp daeternighe belten Nombre de Dios, leght oe riebirte Sardanilla, entoe vier leguen oie ban Sardina; vooets Rio de Maiz enoe de Cul-bras: enoe arbt leguen voozoer Rio de Francifca, (welth is of riebier daer oen Ingee nieur Antoneli ban Lp:eeckt in't lelte ban fun abtÿs ober bet foztificeten ban de fast Panama:) aen 't begin ban de Golfo van V raba. Bopzoer fert purt tran't

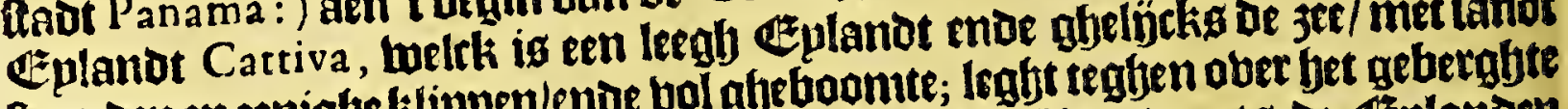

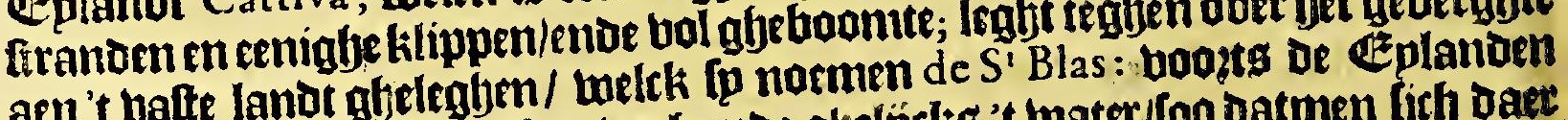

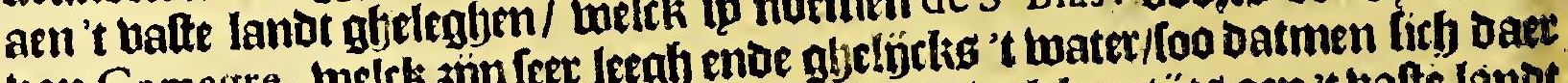

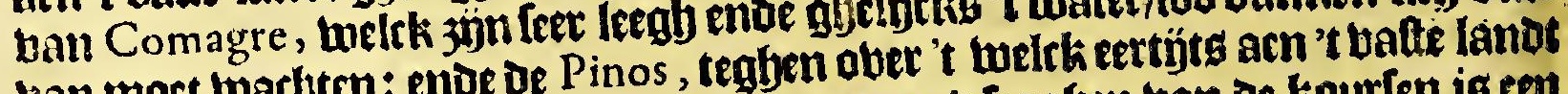

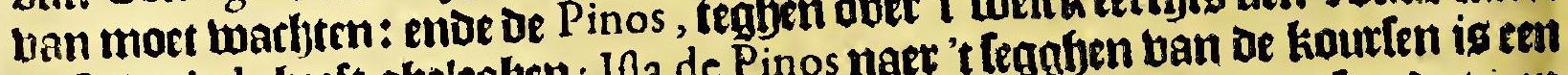
De ftadt A cla beeft ghelenben; ina de

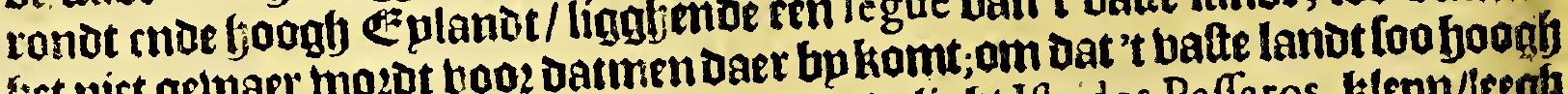

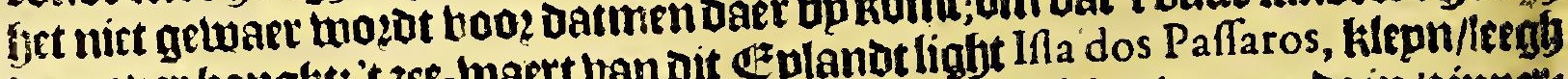

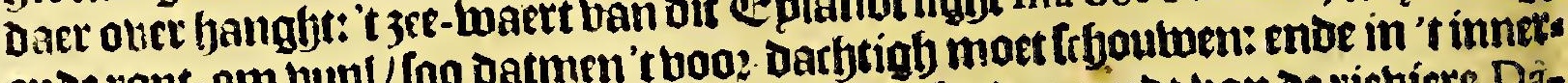

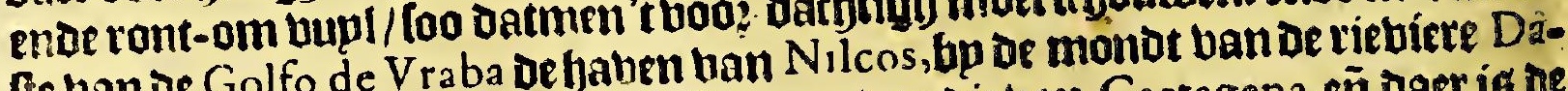
fe ban ie Golfo de Vraba De bahrn Dan Na ban die ban Cartagena, eñ Dart is de

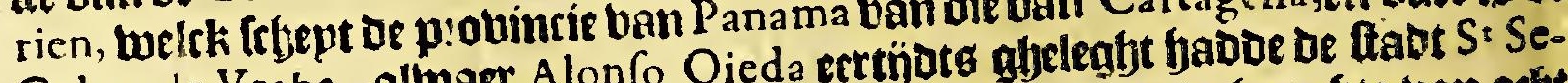
Culata de Vraba, almaer Alonfo Oieda tere Golfo leght op oe boongte van artht

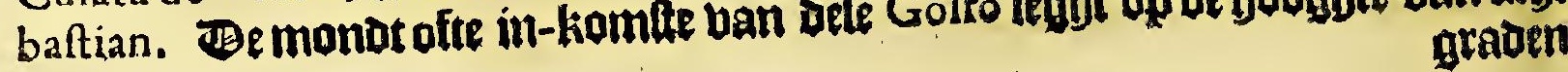


traben by noogden be linie / enve ftreckt in oe lenghte beerthien leguen te lanot

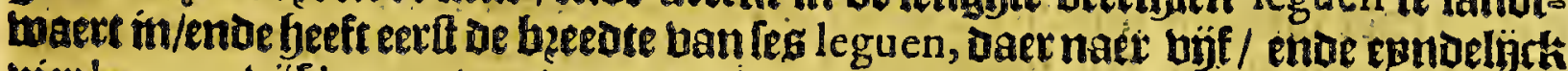
biet leguen; byff leguen ban de mont ofte begin ban defe Golfo naer't 3 upderi wag

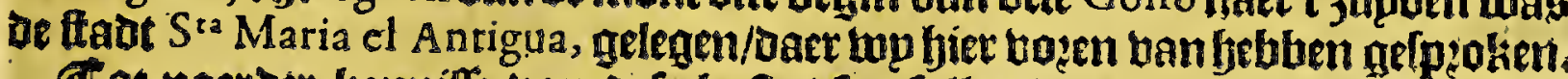

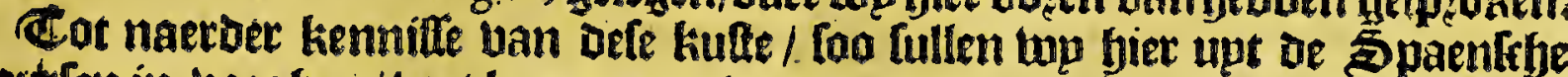
koutren in-boeghen/ wat kours men fout om ban Cartagena te loopen naer Nombre de Dios. Noillende naer Nombre de Dios baren ban Carragena af /

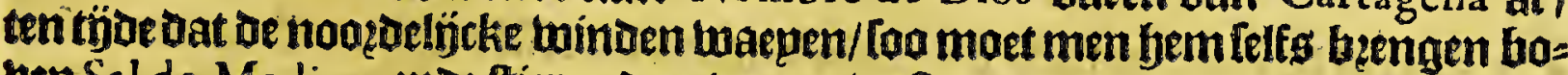

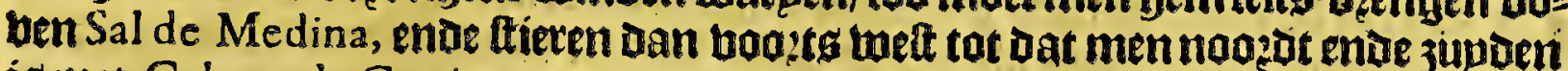
is met Cabeca de Cattiva, ente dan jupde-welt ten luelten aen-gaen/ om te val= len op Rio de Francifea, welckeg merck-tekenen jün feher lanor niet feer boogfy) ende binnen s' landts eenighe fooghe berghen fteeckende volt ende twelt ende aen

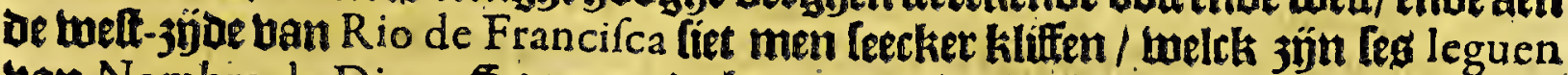
uan Nombre de Dios. Soo men de bouen-berbaelde kours boudente komt te

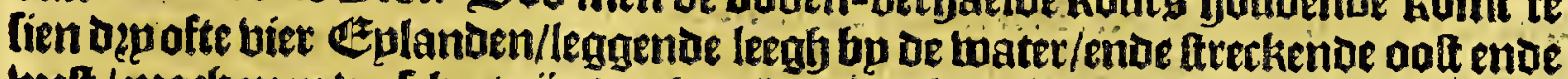

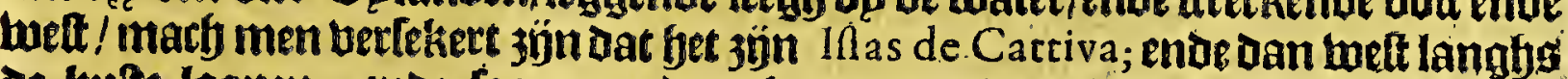
oe kufte loopen; enoe foo men ban komt een punt ban leegly lanot te fien/ mady men [an rekeningl maecken / dat bet is Punta de $S^{t}$ Blas; ende men Cal baet op fien een rije ban rootfigbe bergben/ belch fu noemen las Sierras de Santa Cruz.

2ten de jupdt-3ee lyefut gljp van Panama twelt-waett aen Golfo de Parita ofte Paris, alwaet de ftadt Nata leglit; Punta de Chame, 't landt ban de Cazique

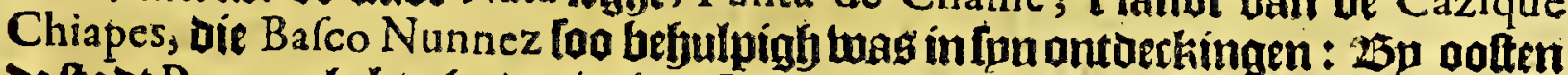
oe ftadt Panama bebt ghjp de vieviete Coquira ofte Chepo, enoe bozder Rio de las Balfas; boots noef jupot-maert aen Golfo San Miguel, ende in't hinnentte bari Dele Golfo, Rio de Congos; in Defe Golfo gaet een feer hol mater doo? De menighte ban deplandekeng / Landen ende klippen die daet in legghen; fet fiter quaett te urlen in de maen ien ban Seprember, October, November, December, ghelizht:

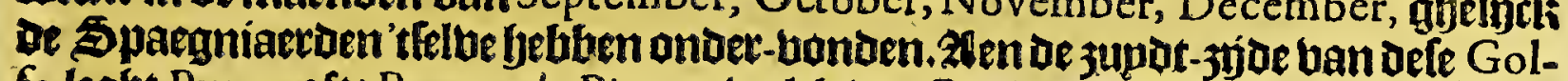
fo legbt Punta ofte Puerto de Pinnas; twelck ban Panama biftichl leguen luettchep= ben is naer't tegghen ban Herrera, ende twintich leguen ouer-duers ban V ra ba : 't Zandr is bol berghen entue klippen; 't regljent daet ben meeltentÿt ban bet jaer met ghetweldiglye ftoet-ulagben/weick niet alleen op 't lanot en ballen/mare oock acht ende thien/ jae thintich leguen in zee; enue't lanat is foo ditht met boo men belet ende ober-groept / Dat men daer niet gaen en kan; daer leght eer riebier

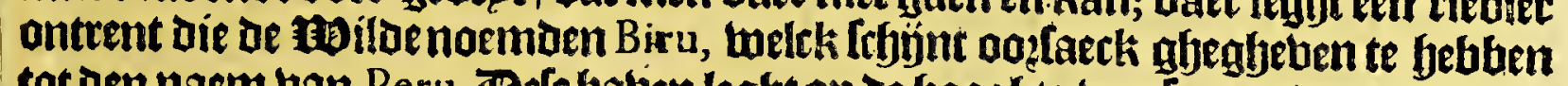
tot Den naem uan Peru. Dele jaben legbt op de boogfte ban leg graden ende bijfthien mímuten bp noozoen de línie. Baex aen bolngt Puerto $Q$ uemado, dirlyt bp Cabo de Corrientes, op de yooghte ban büf graden: moetot oork anderg ghe= naemt Pueblo Quemado; ig vijf-en-twintich leguen ban puerto de Pinnas, 't landt is bol gheboomte tot den oeber toe / welck fo noemen Manglares, ende foo onderbevigh den teghen ende blixem als bet hoos-gaenoe; in de eerte ont= deckingfe ban Peru fjeeft bet bolck ban Pizarro beel gheleden in dit quartier/ende

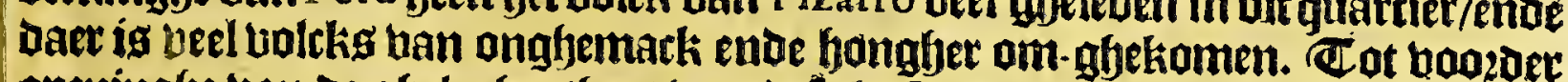

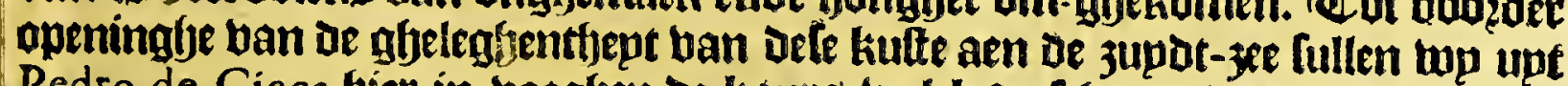
Pedro de Cieca bier in-boeghen oe kours belck de fchepen ban Panama naev Peru barenoe ghemepnlizek houden. Defefepen (leght by) barende han Panama gaen eerte erkennen las Inas de las Perlas, gheleghen op arbt graden frfaers; ban

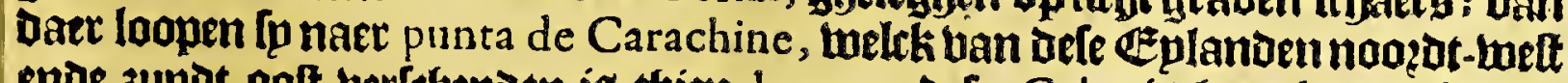

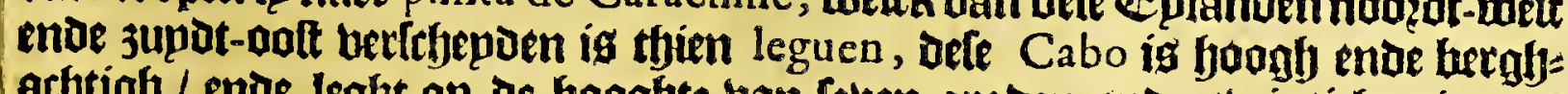
acbtigh / ende leght op de booghte bai leven graden ende tuinticly minuten bp noazaen de linie: ban dit punt tot Puerto de Pinnas ftrecht de kulte 3 undottereten zupden adjt leguen; ende Puerto de Pinnas legbt op de fooghte ban les

$$
\text { dét } 3 \text { miadin }
$$


$3^{18}$

\section{Terra Firma.}

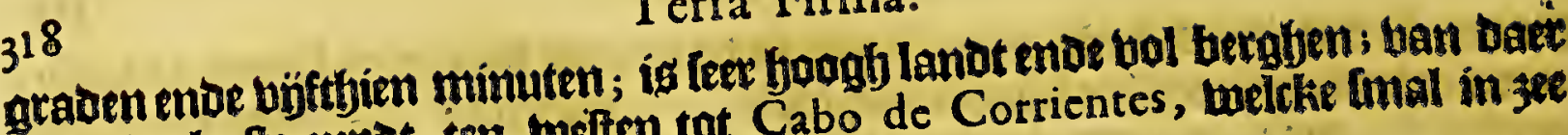
loopt de thufte zuptot ten tefiten tot Cabo de Corrientes, welcke Imal in zee loopt.

\section{iget elfite Capittel.}

Van de Eylandekens ontrent defe kufte.

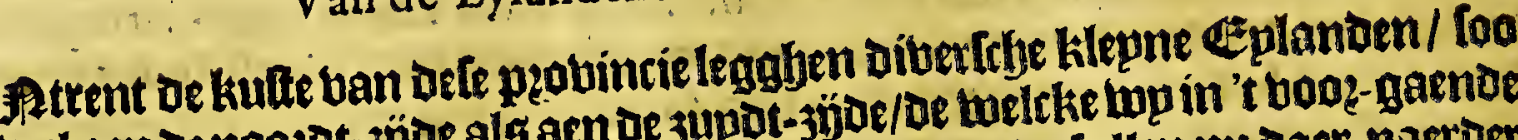

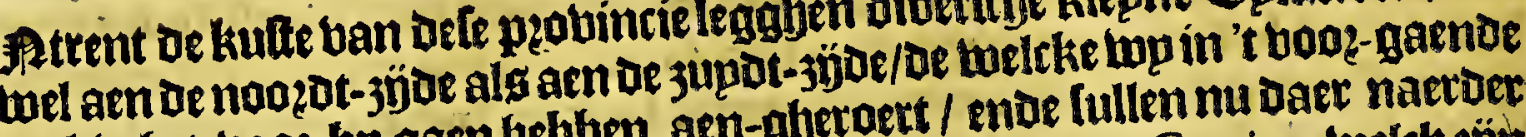
Capittel in bet booz-bp gaen bebben aen-aberoett / moe lullen nu daer naetser banfpeecken. Op oe noozot-kulfe legghen de $\mathbb{U}^{z}$ plamoen ban Cattiva, welck jün leeglye Eplanoen/met witte lanot-franden/ ende Itaen bal guseloomte; men moet bem warbten oe lelde niet te naer te kamen/ want bet fller buyle glond tho met fteen-kilippen beimet; ien boeck die [p noemen Cabeca de Caet ' boogbe gheberghte

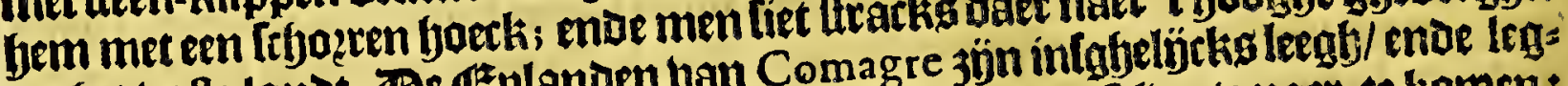
op lyet balte landt. Be Eplanden ban Comagre jon be Telve te naet te komen:

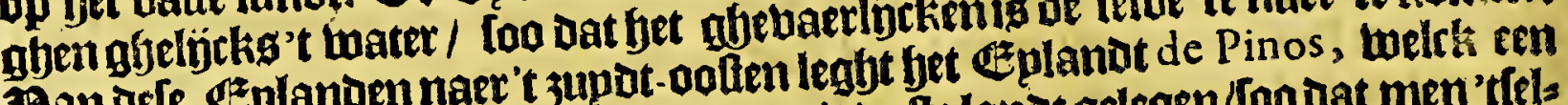
Ban dele Eplanoen naer't zupot-oolten leg befte lanot gelegen/lod dat men'tlels

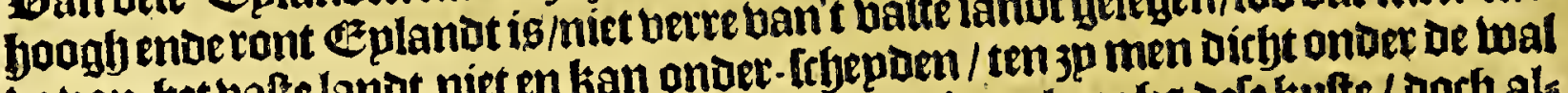

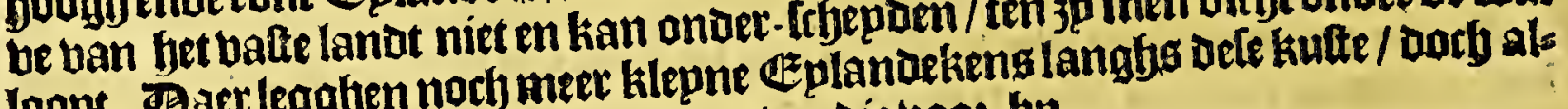

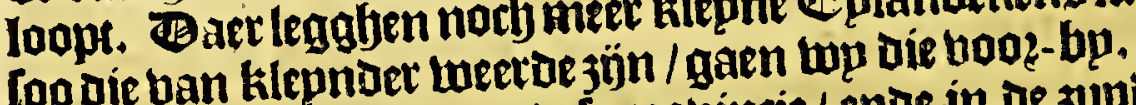

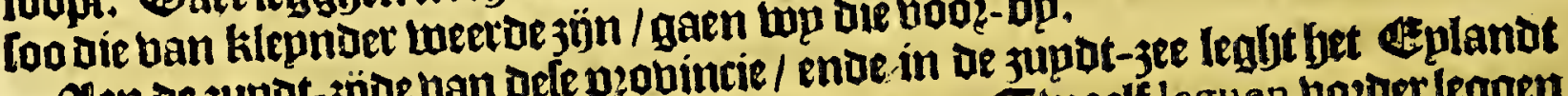

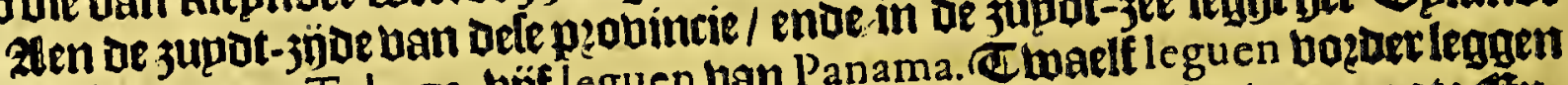
welck [p noemen Taboga, byjt leguen ban Tamentan Herrera jọn twee groote Eps

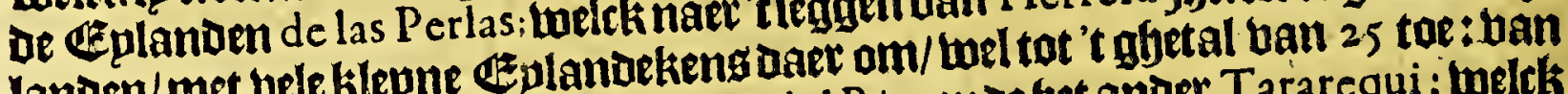

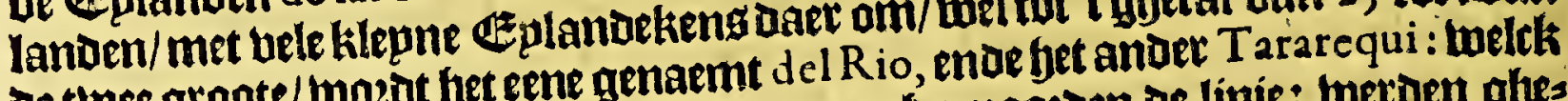

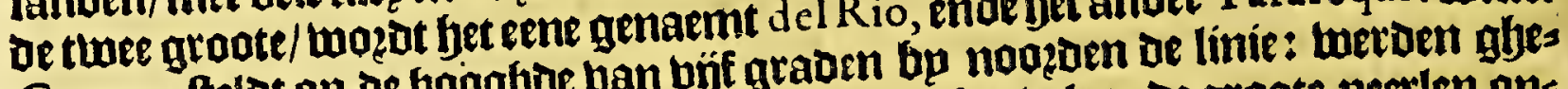

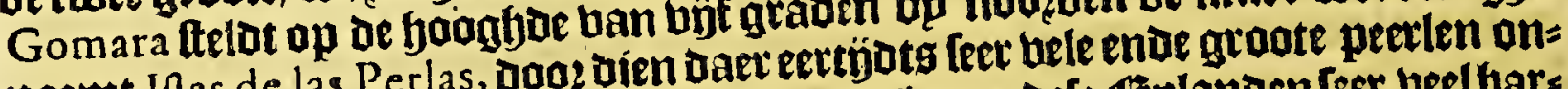

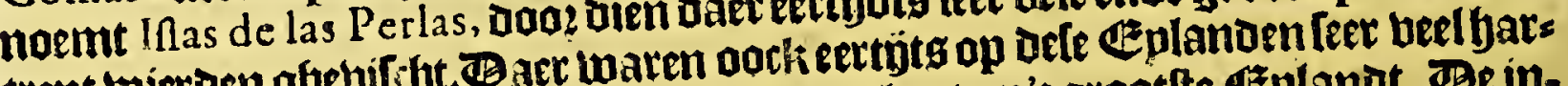

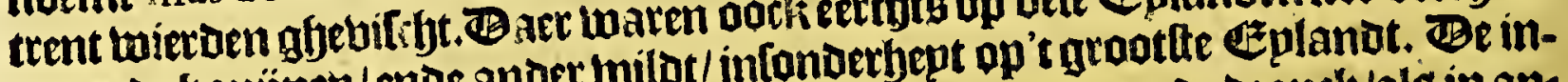
tenende fonjünen/ende ander wila /

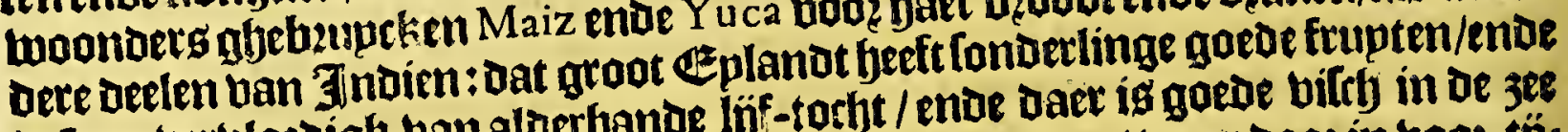

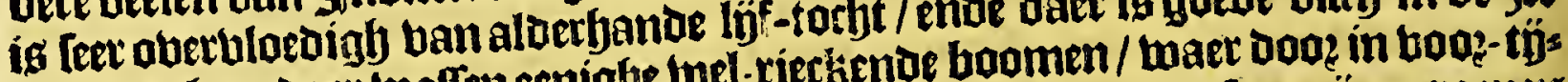
Daet om-her ; daer watten eenighe welDeneenige ao zeetaen/oorfy

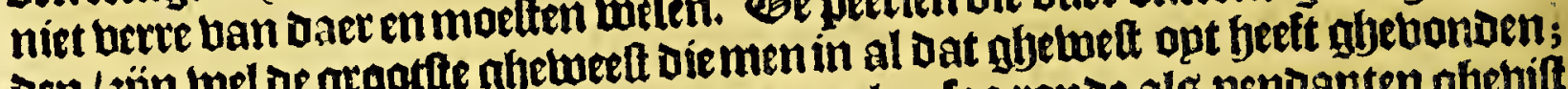

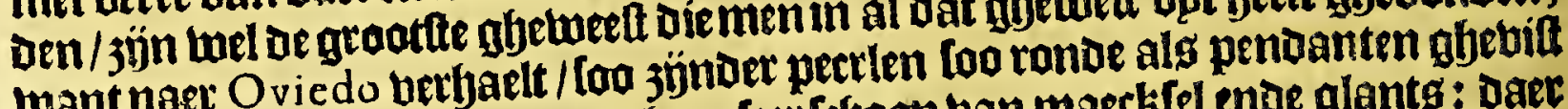

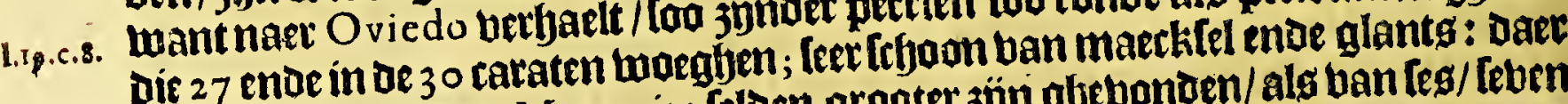
dic 27 ende in be up Cubagua entae de Marga ende acht caraten; ende die noety lelderen feer bernuftich in 't bificten ban de lelbel in-gheboozene ban de 《epland

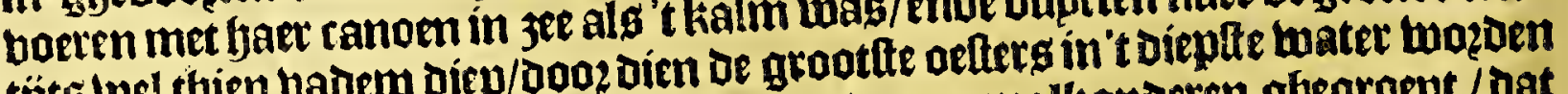

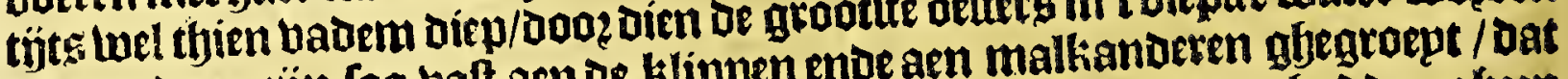

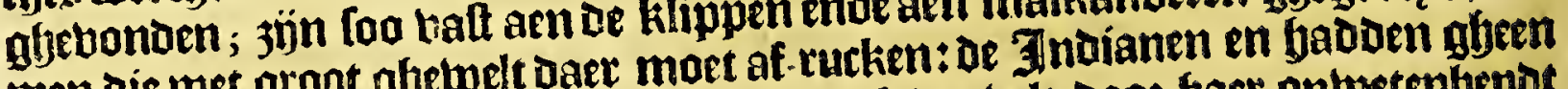
men die met groot ahelwelt daet mor af oat Ipoer bele Dooz haet ontuetenbepot

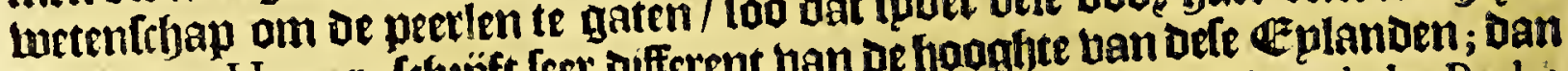

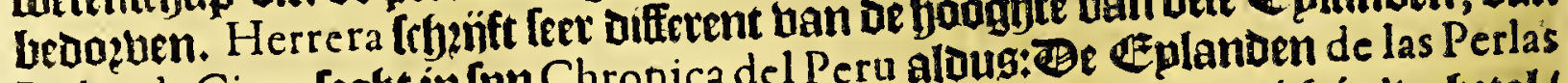
Pedro de Cieca leaft in [nn Chronica del Perb-en-twintich oft dertich in 't ahetal/

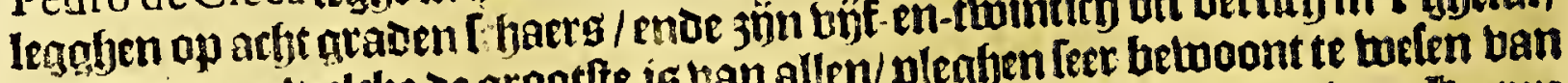
ronot oin ern trelste of grootte ig than allen/ $\mathfrak{p}$ /eghen

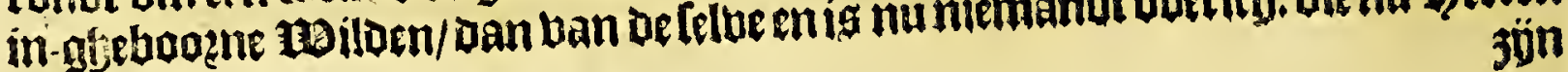




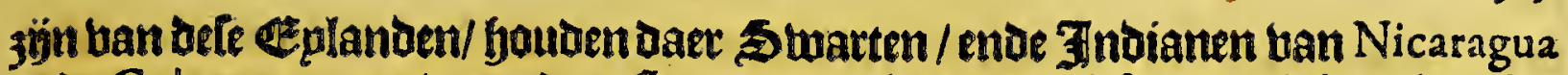
ende Cubagua, om't vee gade te flaen/enoe't lanot toelck feer beucffthaer iste be= jaepen. Be peetle-biftcherije ig daer nu gantfry ghedaen / loo dat gljeen afte leev bepnigfe daet wazoen gebonden. Sir Richard $\mathrm{H}$ a whins noemt een ban dele Eplanoekeng la Pachera Dicht bp't vafte landt abelegfen acijt oft thien leguen ban Panama zupdet ten trefen; bet is een ronden geubel niet boben een legue in bet om-zaen/Doch feet buththaer; bet behoost een particulier man toe die met fpn neerticffepat ende oen atbepot ban eenighe Stwatten baer loo bele buchten winot/ dat fop daer Panama feet mede berliet ende groate bop-irelen upt-treckit boog bem-feltuen.

\section{Het thaelffte Capittel.}

\section{De voyagie van Ian Oxenham Engelfman.}

T Oren beflupt ban be belchejuinghe ban defe yebincie tuan Panama, foo ig

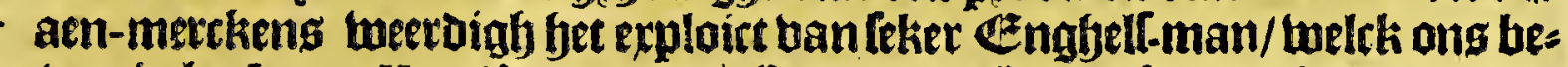

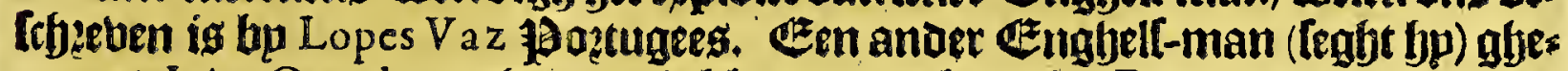
naemt Iohn Oxenham glebpoot bebbenot wat bupt Sir Francis Draeck in den jaere 1572 , ghebaelt hadoe op dere kufte / mam een uopagie boo: an't fel be mede te onoer-winden. Spn febip wag van ontrent I 20 baten/ cnie bjad daet op lfs benticf man; quam Daer mede aen de noozot-kutte van de probincie uan Panama, ende badoe onderlingbe conferentie met de ltwarten die in defe quartieren

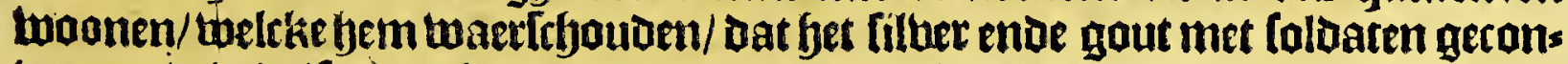

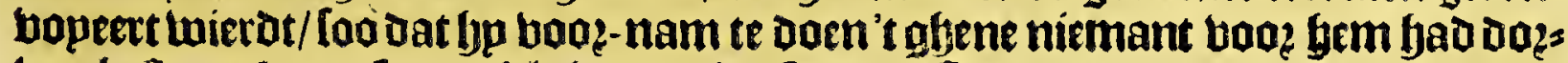
ben beitaen; lande [pn volck in een plaetle daet Capitepn Draeck te vozen twas getwet $/$ b:ocht [un Lrbip op 't dzooge/ ende bedeckte bet met tacken ban boomen/

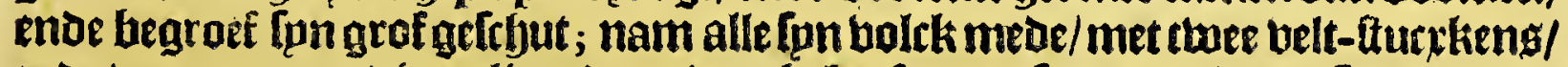
ende boozct roerg/bictualie enoe andere behoeften tot funen torbt ; De [warten ges

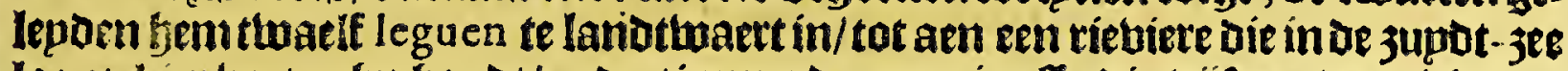

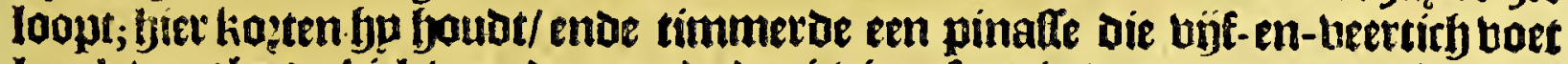

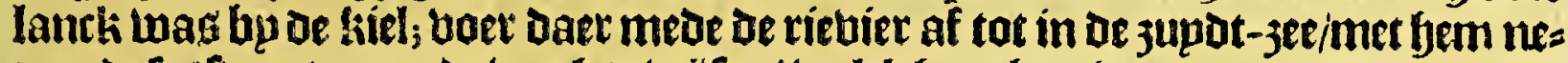

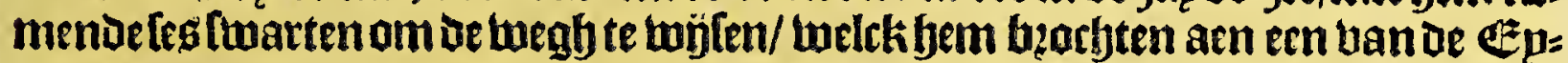
lanoen de las Perlas, welch in ae zupot-3ee leggen rectyt in se vaett van Peru naer Panama toe: naet dat bp fier thien Dagfen badde gewacht/ quam Daet een klepne

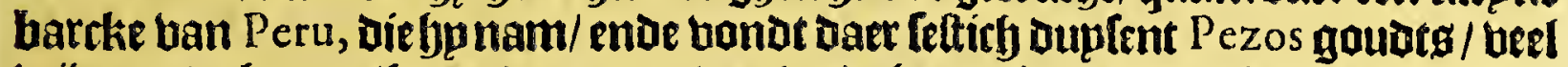
mijns enoe bzoots/kogtts daer naer beroberde be noct een ander barcke komende ban Lima, daer bp in vondt yondert duptent Pezos in filtuere baren; welch alles

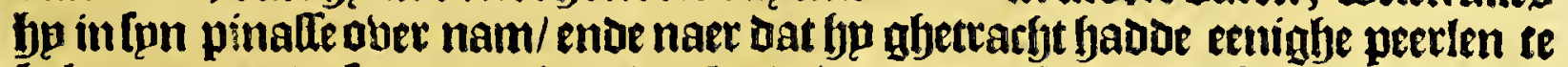
bekomen han de fwarten die op 't eplandt woonden/ ftelden bp fpn kours tweder naer de riebiere daer yp af gheliamen was/ende liet oe twee teberphens die gp ge= nomen badoe ledigh weeth varen. Be fmarten die op 't eplant de las Perlas tooo: nen/ boeten ltracks naer fpn vertreck met bare canoen naer Panama toe/ om oen Bouberneur te bootrtbappen't gbene Daer paltertoe. Haer op of Gouberneur twee dagen Daer naer bier barctien fonot met bonoert foldaten ende entige ftwat: ten om die te raepen ; ben Capitepn ban dit volck glenaemt Iuan de Orrega boer eett naer de efplanden de las Perlas om te betnemen wat wegboen eEngelfman Gadoe gbenomen / daer natr ghemoetenoe de twee barcken bp den Eznghelfman berooft/herftont fyp dat oe pinas de riebiere luag op-gebaten. Ben Spaenniaert aen oe rieviere lamenoe/was in twöfel welcken arm ban de dep daet de riebiere met in jee tiomt / hp op baren faude/ tat dat ljp den klepnften arm af [agh dijocn boenose teeren bie oe Eenghe the geplurkt baoden enoe met groot onberficht in't water ghetwoipen: boer derthalben delen kilepntten arm ban de riebier op/ enoe

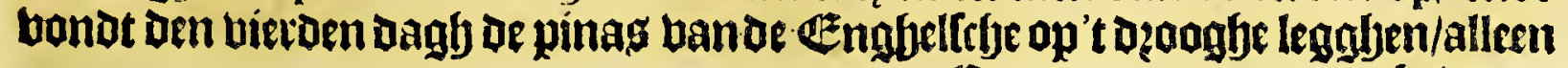




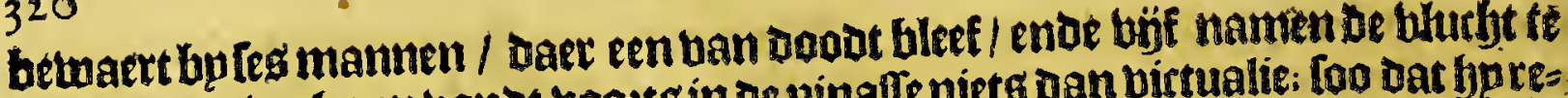
lanotmaert in; bp en bonot boozts in oe pinalle niets dan virtualie; foo dat fjpres:

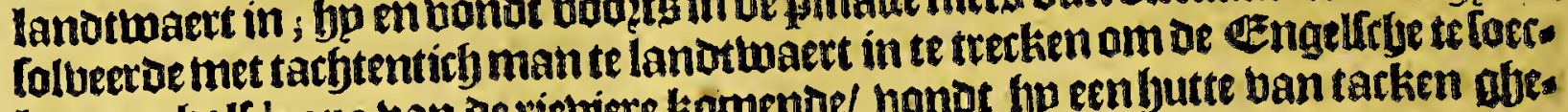

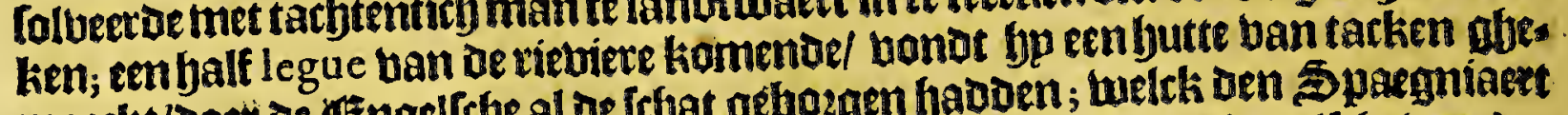

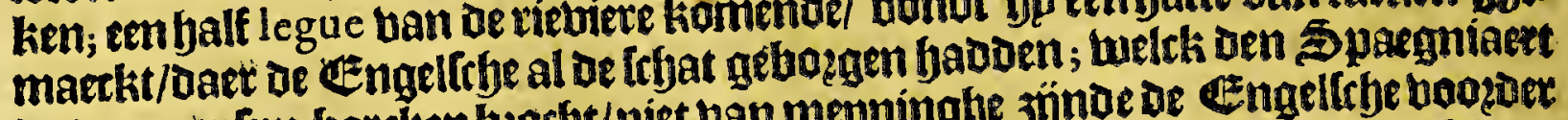

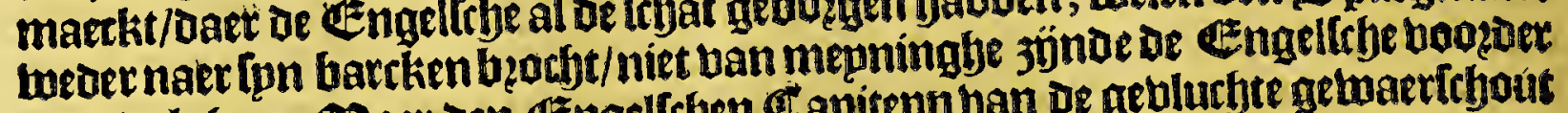

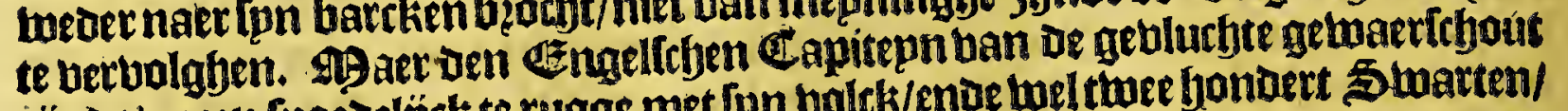
jünde/quam fuoedelïck te rugge met [pn bolek/ende toel twee bonbert 5twarten/ ende lette met groatefurie op oe Spaegniaerden; De tuelcke baer dienende ban een

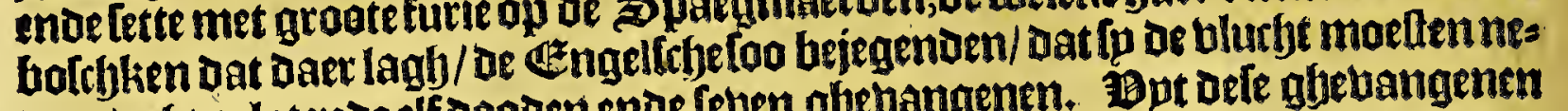
men/atyter:latende elf Dooden ende feven ghebangenen. Bpt oefe gliebangenen

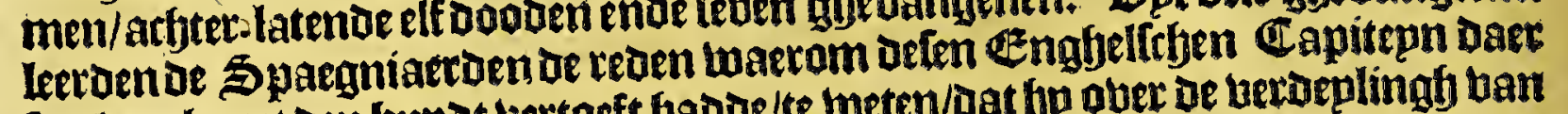
fou langh met oen bupot vertoeft hadoe/te weten/Dat fop over oe ueroeplingh ban

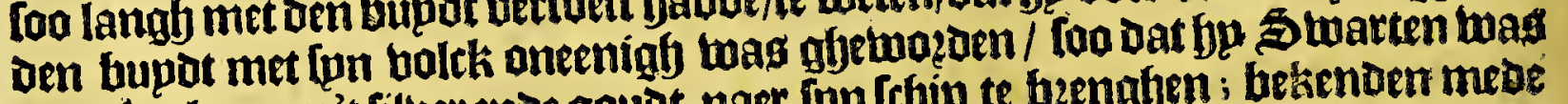
gaen loecken om't filber ende goubt naer fon lehip te benghen; bekenden meoe

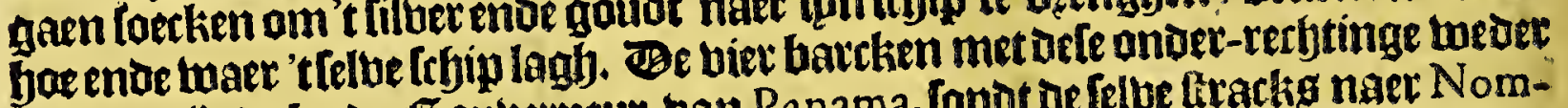

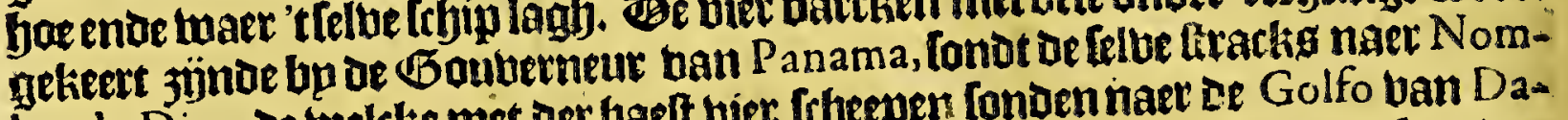
bre de Dios, de welcke met der baeft vier frbeepen fondennaer ae Golfo van Darien, ende haeloen Daer't Lchipenae 't gbeftbut. EEenigen tíjot baer naer font Den

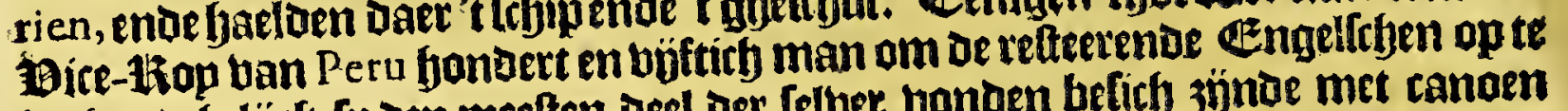
jaghen/ghelïck [p oen meeften-Deel der felber banben beficy jünoe met canaen te maecken/aaer mede fp in oe noozot-jee d'een oft d'ander barke morfyten bers.

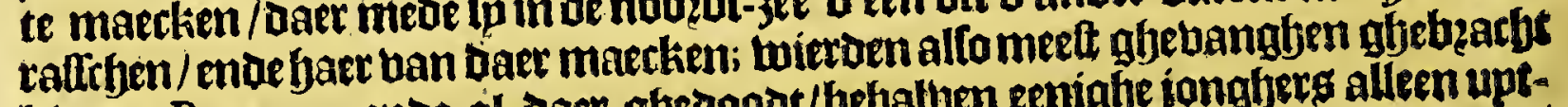
bímen Panama, ende al-daer glbedoodt/bebalben enigbe iongbers alleen uptghenamen.

\section{$\begin{array}{lllllllllllllll}C & A & R & T & A & G & E & N & A\end{array}$}

\section{Het Detthiende Capittel.}

Befchrijvinge van de Provincie van C A R T A GE N A, in't ghemeyn.

$A$ IIn De plobincie van Panama paelt naex 't oolten de pzobincie ende' 't goubers nement ban Cartagena, welek de naemnaer ipn yooft-thadtheeft berkirgen. ente wett uan Rio Grande, ofte de la Madalena tot aen ae riebiere Darien in de Golfo de Vraba tarfytenticfl leguen, ende oork tan veel in'oe beetote noazot ende zumaen / van oe noozot-zee af tot aen de palen ban Neuvo Reyno de Granada :

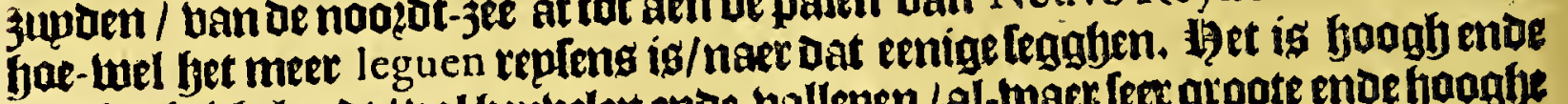

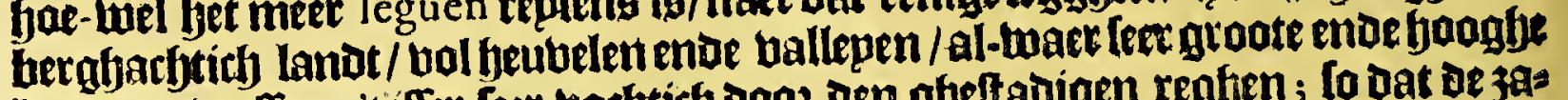
hoomen wallen; 't ifter feer vorbtich Doos oen gheftadigen rengen; fo dat at 39

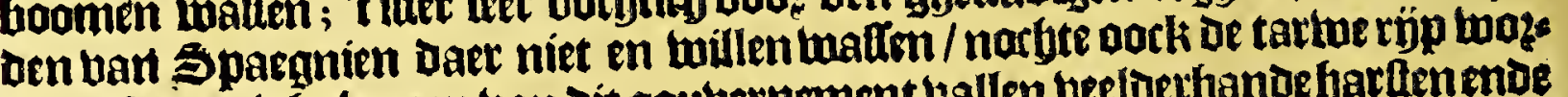
aet1. Opeenigbe bergen van dit goubetmement vallen veeloetbande barfenende acomatique gummen/ende ander liqueuren die fo upt oe boomen teten te tret: ken: groote abumbantie ban dzacken.bloedt / ende ballamen than feer excellens

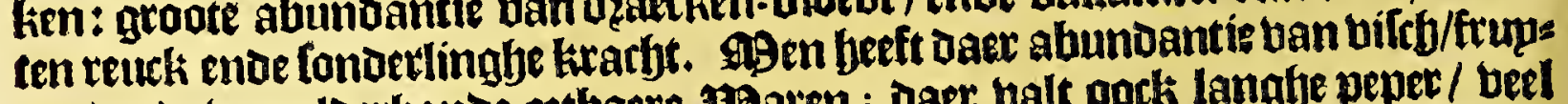
ten / ente ban aloerbanoe eetbaere maren ; daec balt oock lamghe peper/ beel

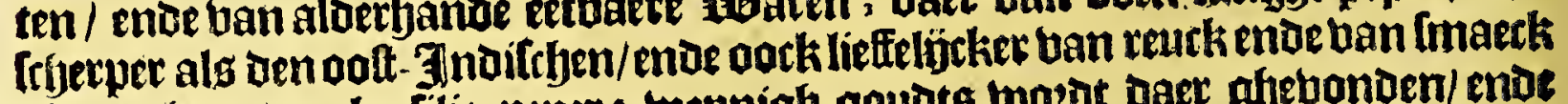

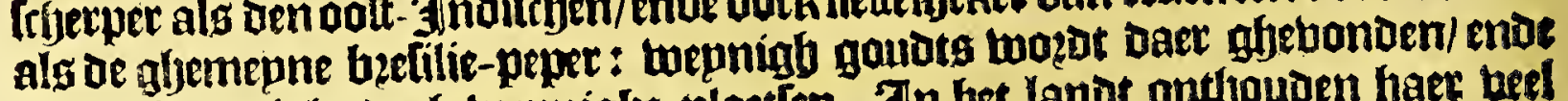
alleen in eeniabe docb lexpnighe plartien. In bet lanot onthouden baet beel

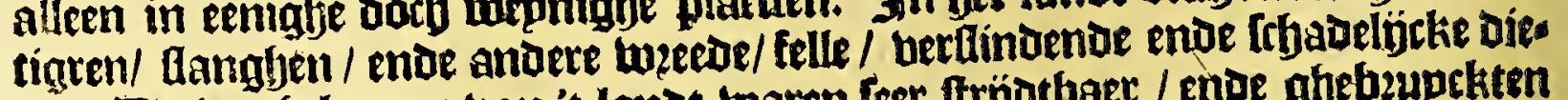

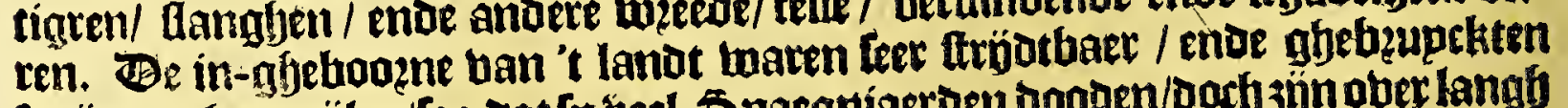

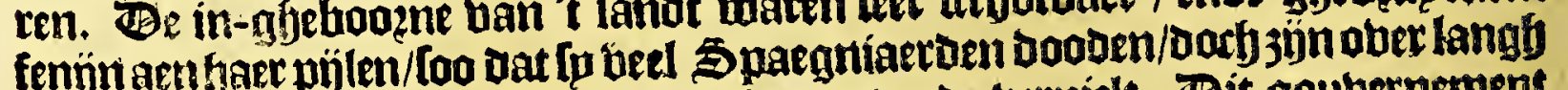
meet al ban De Spaeginiaeboen upt-gheroept enoe vernielt. Dit goubernement begröp 
Het achtite Boeck.

legrijpt onderticl eenighe particuliete plotintien; als namentlïck naet 't toelten

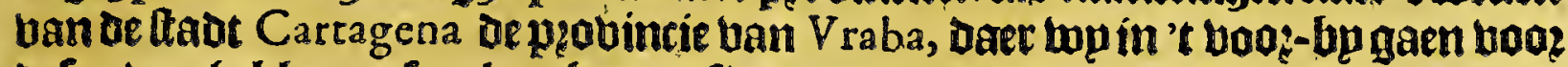
aefen van bebben gelpzoken bp occafie ban Darien, Daer't met confincert : Dele peobincie/ naer'tlegghen ban Pedro de Cieça, is teet bzurbtbaer/ende oberbloe=

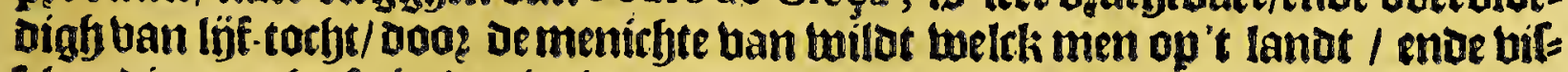
frjen die men beeft in de riebieren / ende op de kulfe. Ban dele p:olvimcie komt men aen't gheberglyte welck fu naemen A bibe, welck is een bertolgh ofte Cordillera, als oe Spaenfrfe die noemen/ ban leet foogbe berghen/Areckende naet' tuelten/De lenghte is onbekent/Dan is op [ommige plaet fen twintich leguen biet/ op Commige meer/ende apeenige min; beeft leer quade tweghen / ende bp naer on: beupckbaer booz de peerden: op't bobente ban't gebergbteen twoont gantleb geen bolck; maer ín be ballepen die leer beel ende groor 3 j̈n / woonden eertijots beel ualckg/Leer rijek ban goubt/melck [p bonoen in de riebieren ende beken die ban 't boogbe gbebergljte af wateren / ente jaer kours belt- waert aen-nemen. regbent den meeften tjot ban't jaer in dit gheberghte / enoe of boomen azuppen contimutligck ban't water datter op goeballen is/melek berbindert Dat daer geen

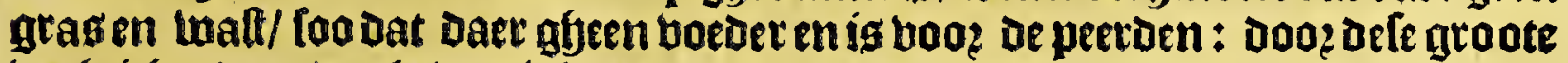

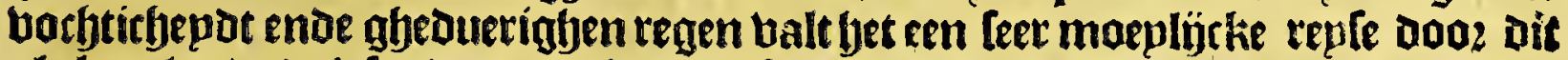

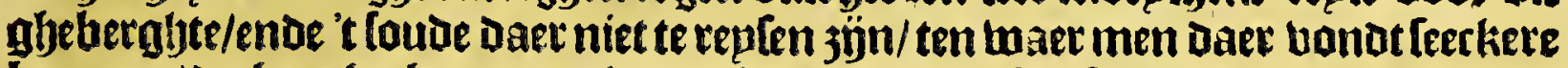

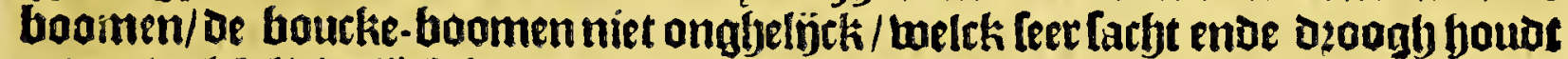
geven/tuelck lichtelïrk bzant/waer doog de replende lieden baer konnen D200gen/ want't ander fout dooz de nattichept is ontequaem om bper te maken. Zlen de boet ban dit gheberghte als ghp die ober jüt ghetracken naer't jupden / leght oe pzobincie Tatabe, daet wel eertijots leer ueel bolcks moonde / dat rück ende oock ftrjotbaer was / ende dit bolck befloeghyet meelten deel ban fet lanot van bier af tot aen de jupot-3ee. Alen defelbe jube van't gbeberghte leagt de plovincie del Guaca, ontrent Dertich leguen ban de ftadt A ntiochia, Daer wp jier naet fullen ban fpeeecken. Dan om twe der te keeren naer oe kufte/ bp depeobintie ban Vraba bebr gfp de pzouincie van Zenu, bp naer ban oc felve ghelegentbept ende gbeftalte als die ban V raba; defe probincie was eetröts als een gemepne begraefplacts/ Daer ueele natien / oack verte ban daer moonende/baer booben bzoctjen/

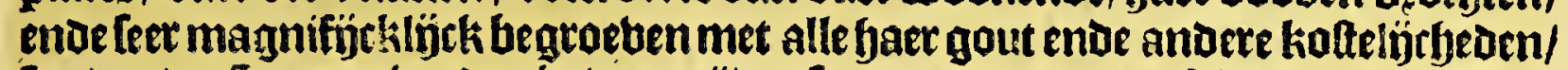
too dat of Spaegniaerden in toos-tyjoen feer beel gouts ende lryatten upt dele bes araeffeniften bebben gebaelt. Gomara hetbaelt ban oele p2ovincie Zenu 'tabeene feer aen-merckeng weeroigh is ; dat de Spaegniaerden daer eert-komende aen

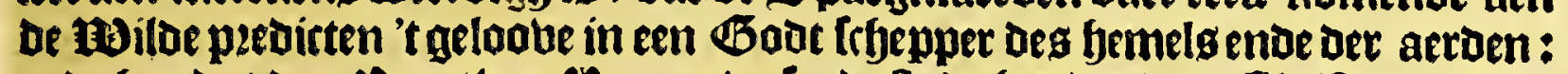

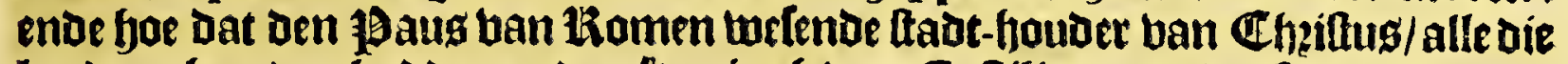

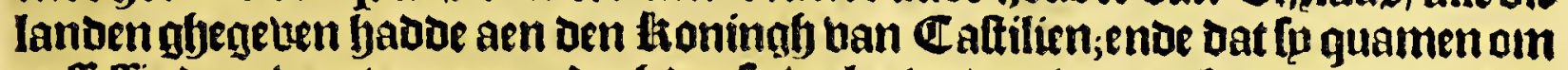
polfelie daer ban te nemen; doch Dat fp twel te beeden waren yaer daer te laeten

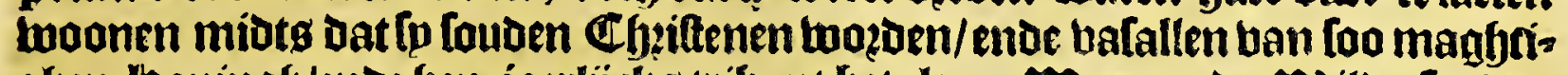

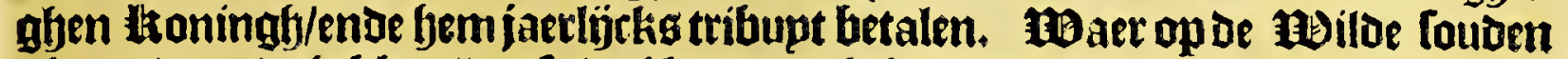
gbeantmoo:ot gebben/bat [p wel konden ghelooben Datter maereen Godt was/ Dan Datf Des niet tegben-taende twiloen blijuen bp faer religie: Dat oe faus al te liberael wasin't gheven oat hem niet tos en quam; dat de ltoningh moef

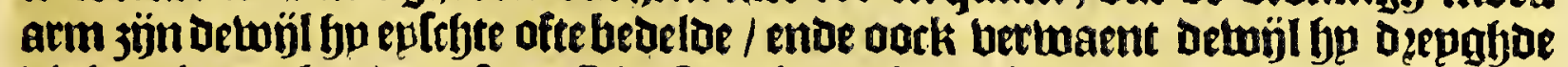
die bp niet en kenoe. $\Re$ Rer Rio Grande toe/bp oolten de ftadt Cartagena, beeft men de ballepe Zamba; ende baogder de probincie ban Mopox.

Het beettjiende Capittel.

Van de Stadt C A R T A G E A.

C Artagena be booft-ltadt ban ofle probincie beeft fyaren naem ban be ftadt

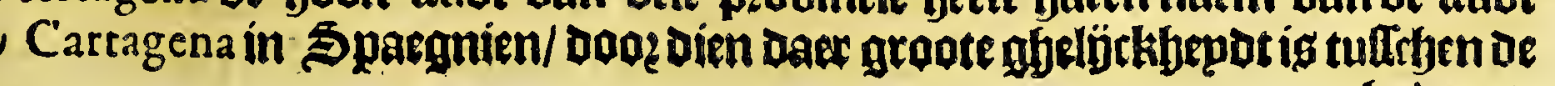
Gabenen 
322

Terra Firma.

babenen ban bepde Dele plaetlen: Ieght aende nooget-jee/ twee leguen bain punta de la Canoa naer't wetten/op de booghte ban I graden bp noogen de linie/ende op de lenglte ban 76 graden uan oen meridiaen ban Toledo naer't legghen ban Herrera : De welcke leght dat daet wel soo bup[-ghelinmen woonen/enoe daex onder wel 2000 vzouwentaen Bouberneur ban de peouincie woont darer/ benef=

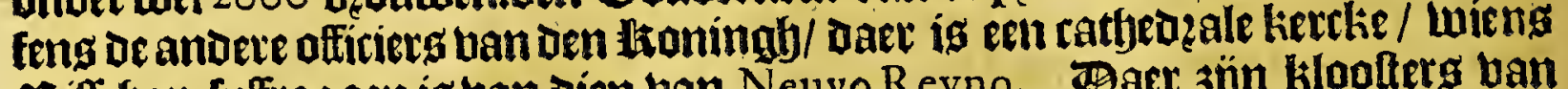
23 iltrhop luftragaen ig ban dien ban Neuvo Reyno. Baer 3 j̈n Hloofterg ban Dominicanen ende minne-bzoederg : Ieght ap een blacke jlepn / welck bp nace eeneplanot ís / gelubende aen de noozat-jöbe de zee met een blacke ende ondiepe

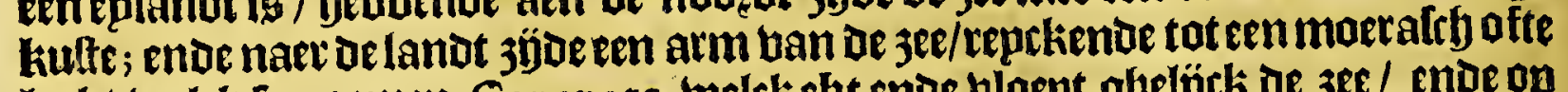
lack/ welck [p noemen Canapote, welckebt ende bloept glyeljock ae 3 ef / ende op

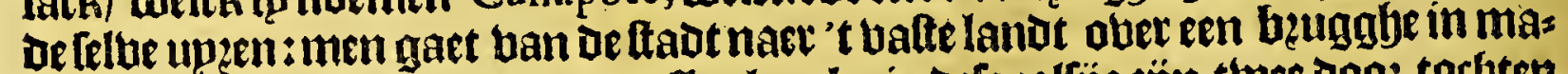

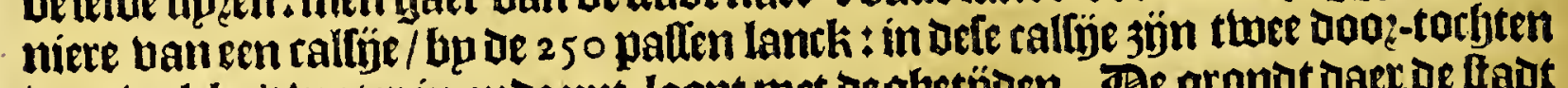
Joo welcke't water in ende upt-loopt met de ghetróben. De gronat daer de fradt

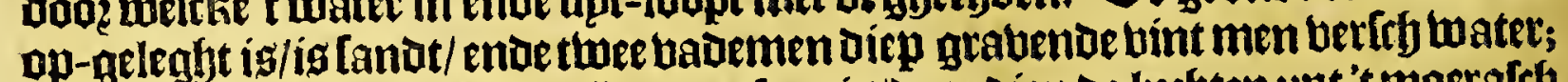

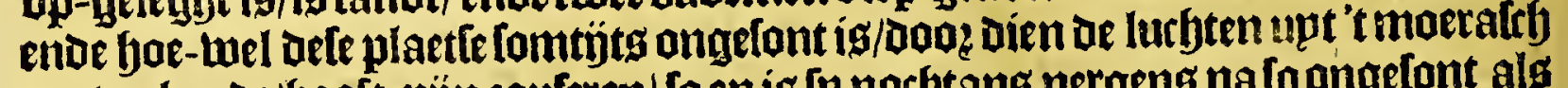
op-treckende/yooft-pýn rauferen/ Lo en ig [p nothtans nergeng na co ongelont als Nombre de Dios, maer madj naer oe gelegenthept wan oí quattieren tuel booz ge

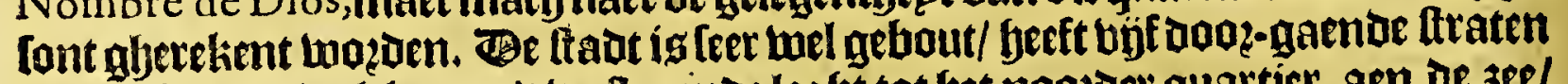
van de baben / welcke aen't welt-epnoe leght tot Get nowezer quartier aen be jee/ welckes ftrant tot bp oe huplen kamt: elcke ftrate is bo de 600 palten langh / beb= bendeleer bequame wooningen met baer plaetlen enoe boben:doo? ae beetate bau

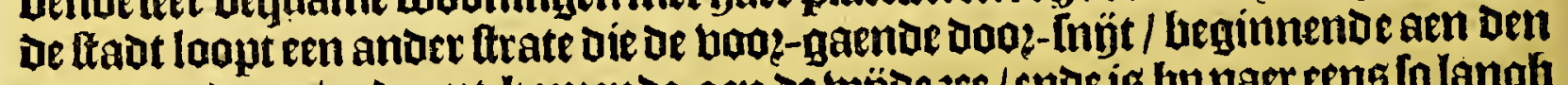

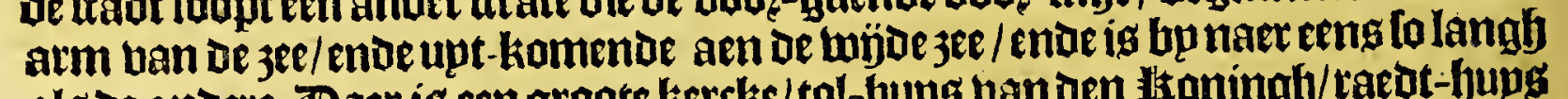

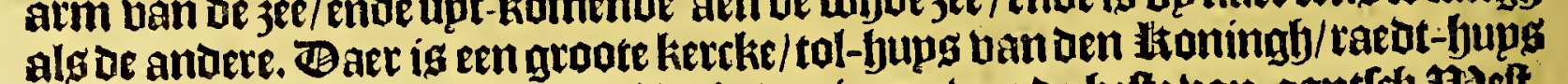

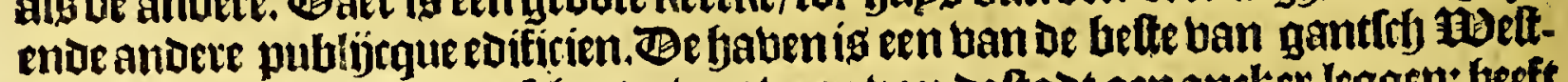
3noien/hoe-wel ae groote fryepen lwat berte ban ae ftadt aen andker leggen: beeft aen bet in-komen een eplanot / ghelïck dat ban Efcombrera bp Cartagena in

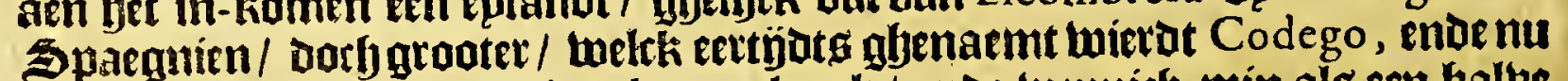
noeme men bet Carex, is twee leguen lanck / enae wepniry min als een balbe

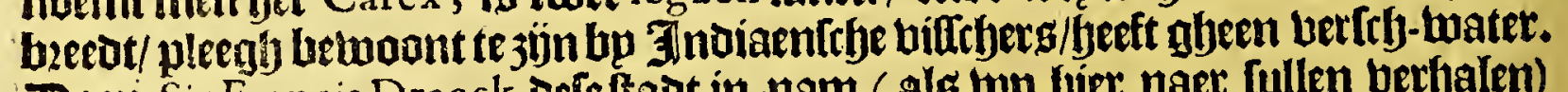
Doen Sir Francis Draeck beie fadot in-nam ( als lup lier naet fullen berbalen) bonet fju op dit eplanot een grooten baen-put/upt oe welcke ljp Ipn felyepen ban

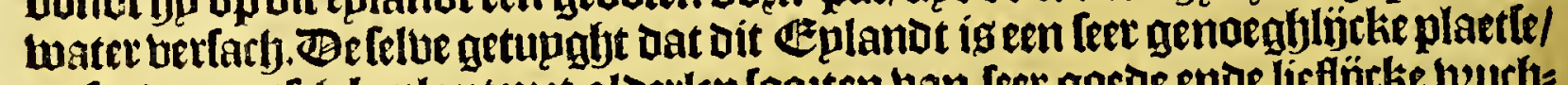

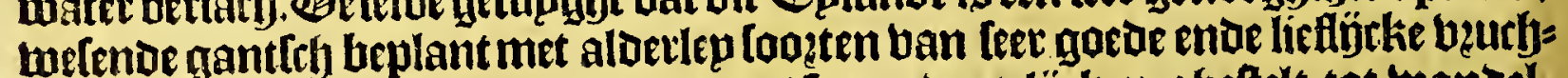

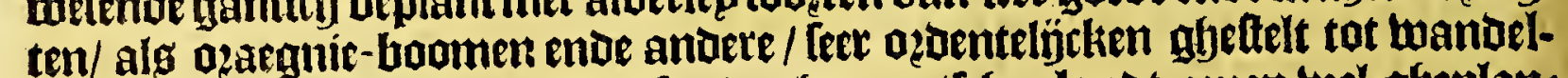
weahen wan feer groote lengboe/ loo dat fet gantldy eplanat eenen twel-gfeplans

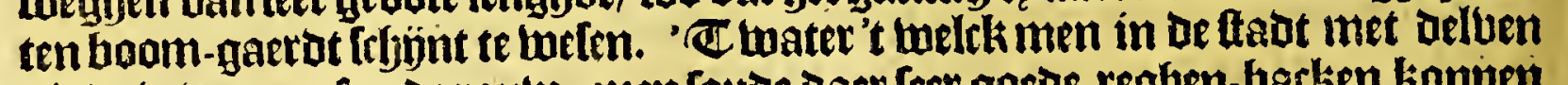
bindt is taat grof ende raum; men loutae daer leer goede regben-barken konmen bebben/ want het reghent daer beel: De Staot en kanniet oberrompelt twozaden Dan langhs de yaben / ofte langhg den arm ban of jee; ofte langhg te kufte ban

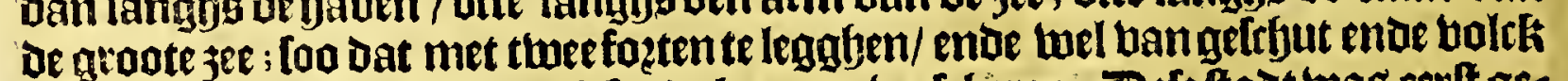

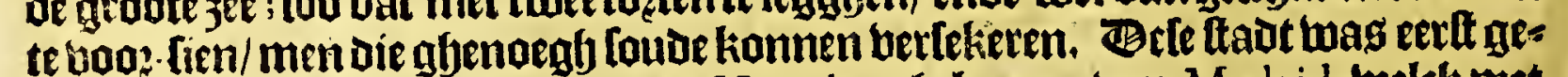
bout in Den jare 1532 , bp Pedro de Heredia nlyeboozen ban Madrid; meltk met

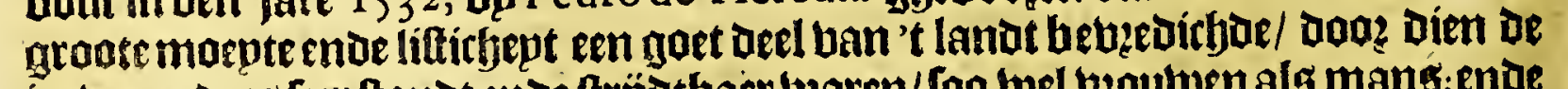

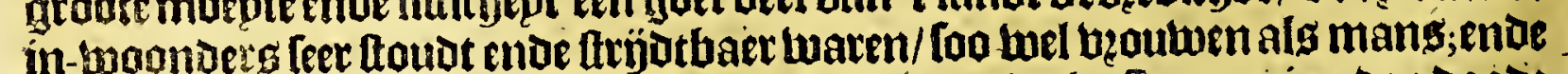
men fieft gefien dat een vzou ban artytbien jaren lwel arbt Spaenniaerden boode met fyer pij"en/ cermente konde bermeelteren. Deltadt is leer op-gekamenende

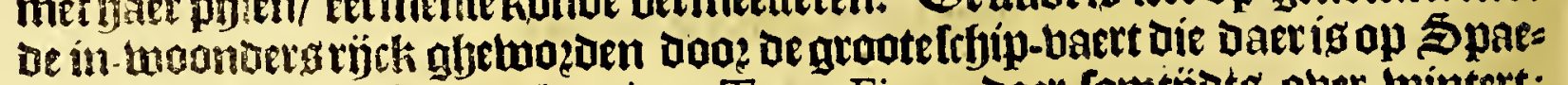
gnien/ende doo dien de blate van. Terra Firma daet fomtÿotg ober-wintert;

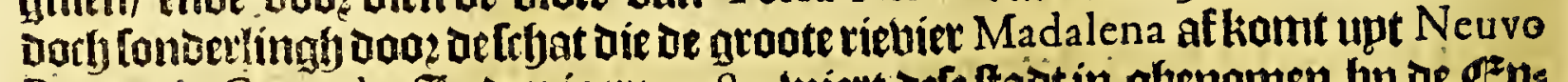
Reyno de Granada. In Den jaere 1585 wiert aele ftátin-ghenomen bu ae Ẽns aelfrye onoer't belept ban Sir Francis Draeck, foe-welfy de [elbetwel boo-tien/ entoe 
ente op haer hoede bontit / want waten hel een maent te boosen boos fun liomte

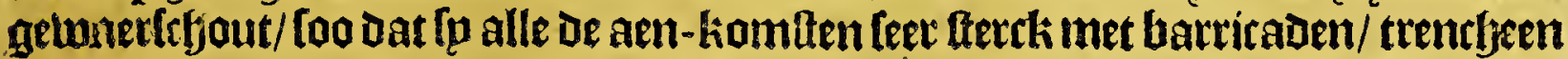

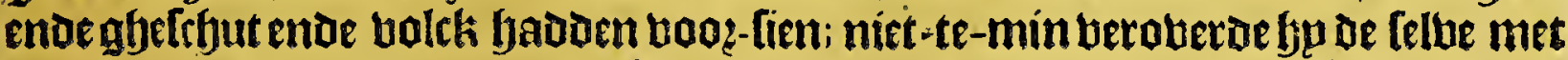
feer mannelïcken rouragie/ betbzanie daer een oeel ban/ende rantoeneerde de

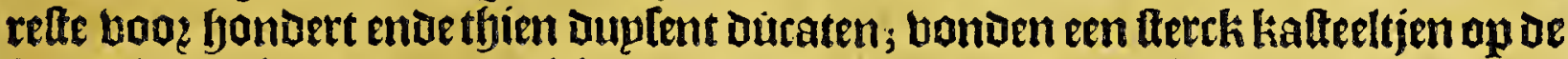

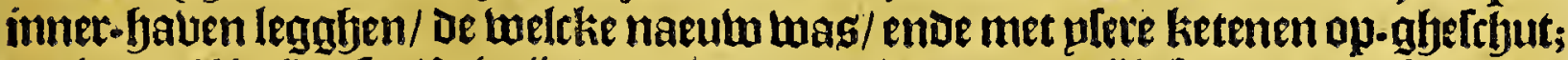

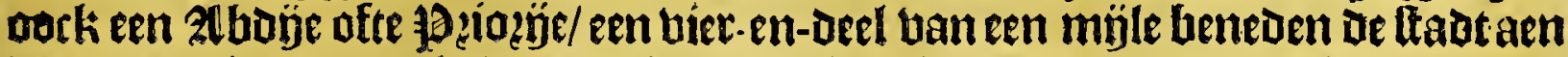
be wattr-jüoe ban de bauen / wefende met een tteene mupe om-ringht,

\section{Get uñftriende Capittel.}

Naerder befchrijvinghe van de ftadt met haer aen-komften, by den Ingenieur Baptifta Antoneli.

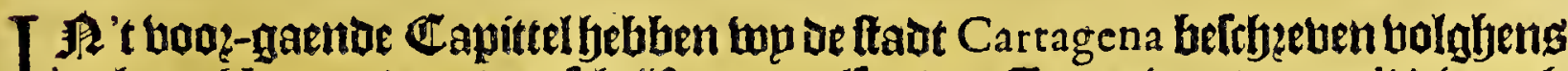

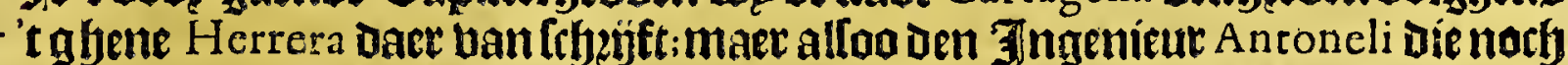

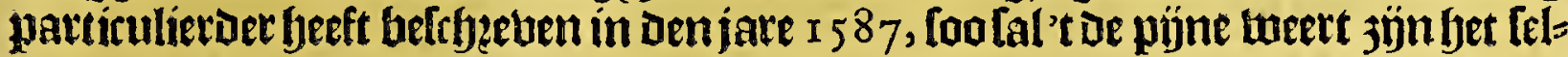

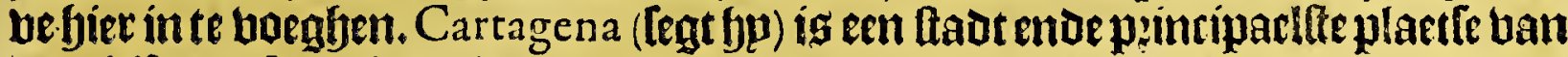
Dat 25ifoom, fu legft 40 leguen van Santa Martha, op oe booghte ban I o graden Ictjaers bp noozden de linie; is ghelegen op een landt-banclie ofte bape gelijelt eet

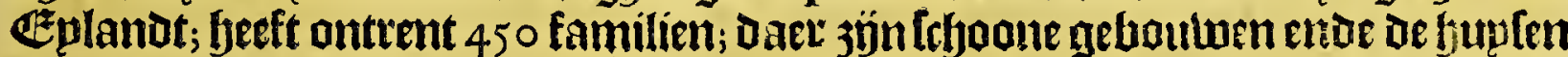

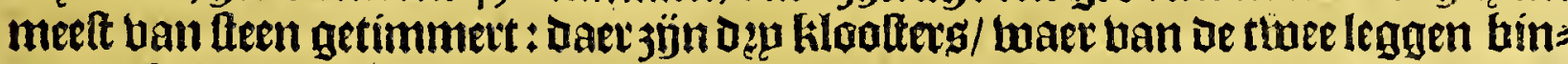
nen de ftadt/ende d'ander leglyt bupten/ende am na't Telbe te gaen/moet men gaen

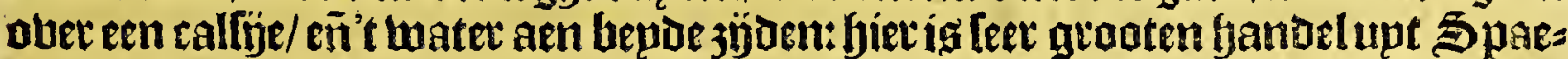
gnien ende upt bet nieu Lijetk Granada, ban Peru, upt de Eeplanden/ ende alle de kulte ban Terre Firme; 't is een leer gefonoeplaetle. Befe ftad beefteen leet goede baben/ enoe bequaem om beel frhepen te berberten; de haten heeft twee in -hom=

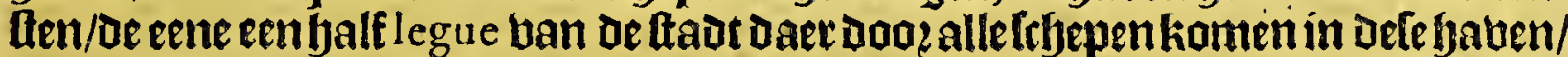

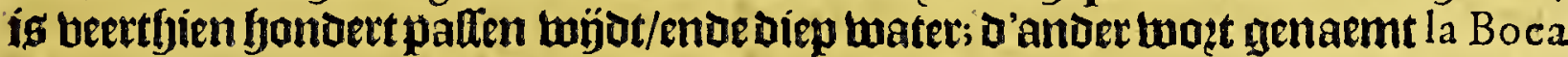

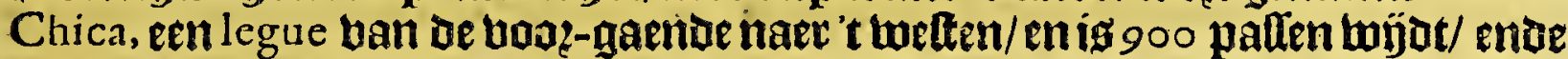
beft in't midoeneenkanael 200 toeden twït/entoe I 5 tot 20 bademen diep op foms mige plaetlet / min ofte meer: om in de hauen te komen moet men baren dope dit

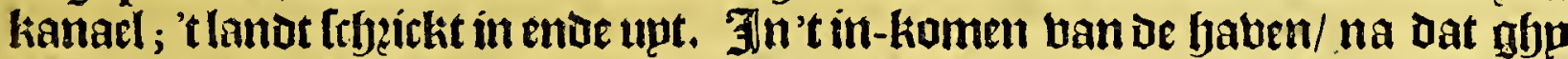

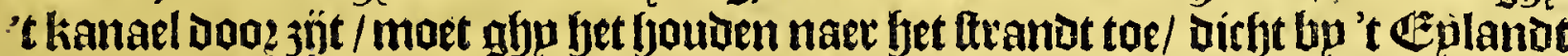

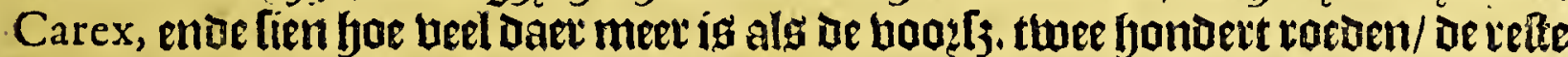
3ijn al rifen tuan klippen/ bedeckt op den top met thee ofte dzp boet matevs/ meer ofte min: Soo dat de Lrbepen diefjier willen in-komen/maeten goede loots-

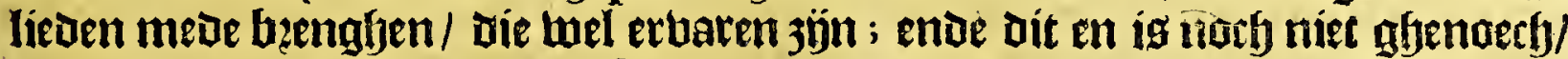
maer dienen't boot boos upt te [efjicken met bet 'oodt/ om te diepen twaet fjet mese the watet ban 't kanael leggt om in te komen. Baer jijn dęe plaetlen ontrent Dele ftadt langhg de welcke de bpanot han attenteren te landen. B' eene is daet oe bpandt in quam ende lande / meltk is en landt-bancke; aen oe eene jijoe is de $\mathbf{j e e} /$ ende aen de ander jüje een groot lack / welck ftreckt naer de bauen.

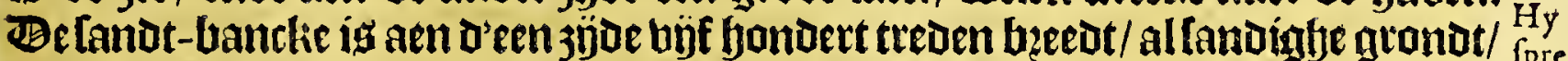
[onver boomen; [oo dat oe buande aen-vallende ban defe plaetfe ahenootlaeckt van

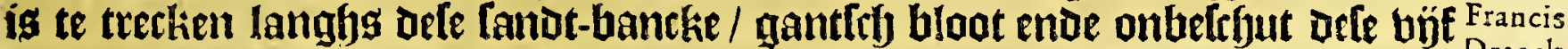

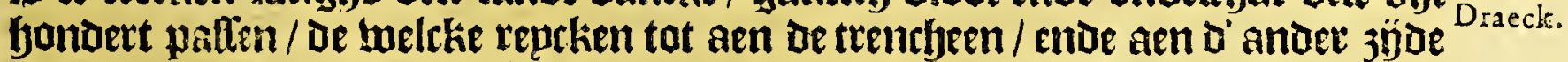

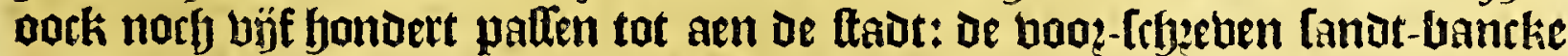

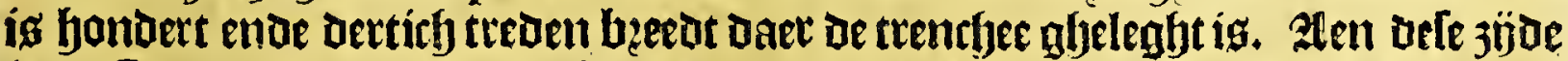
ig de ltad tot twee-mael toe bp de buande in-ofjenomen; Daerom bebben tap hier in de grond ghefepot een [eer groote menieffe baut palen / welkl loopen tot bÿftich treden in 3 ee / ende dit hebben top gljedaen om dat yet een Dangeteure enoe buple liutte is. Eende beneden in den bootem uan de vallepe hebben wa een

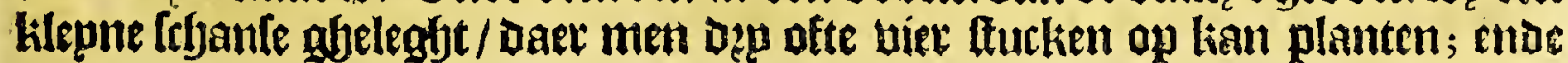


$3^{24}$

\section{Terra Firma.}

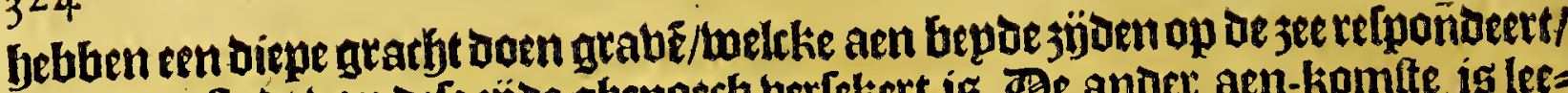

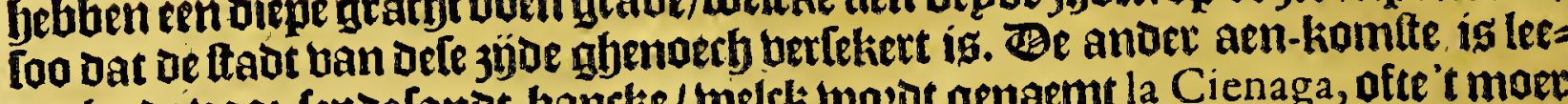
ger bu de booz-lepde landt-bancke / welck woęot genaemt la Cienaga, ofte't moet

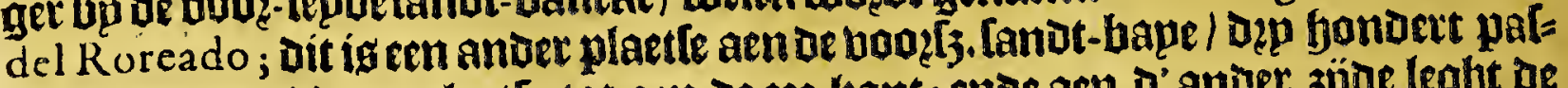
Ien byecot ban d' een placte tat aen oe jee-kant ende aen d' anver jöbe leght ofe Cienaga, welck ig een fuck landtg Dat't gebede jaer booz onoer bater legbt. Soo.

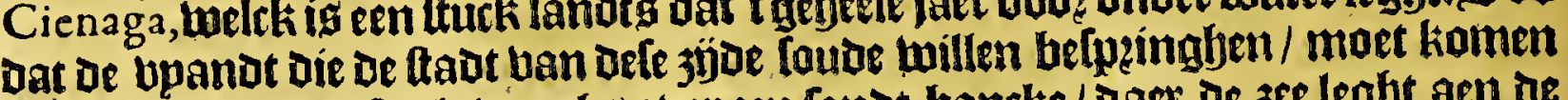
trecken een groot fuck weeghs ouer een Candt-bancke / Daer oe jee leght aen of

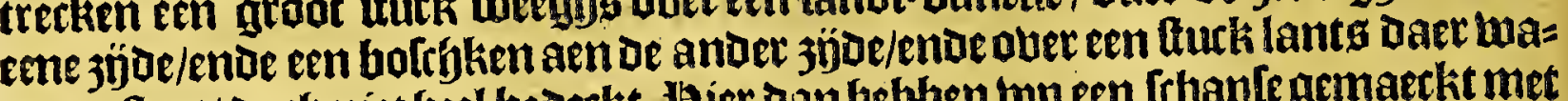
tet op ftaet/ Doch niet heel beoeckt. Hiec dan bebben wp een [rban[e gemaeckt met

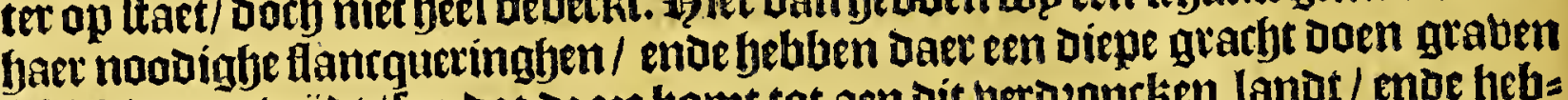

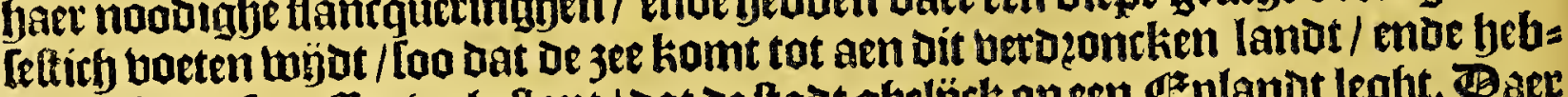

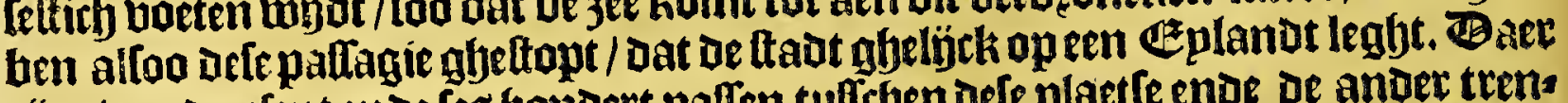

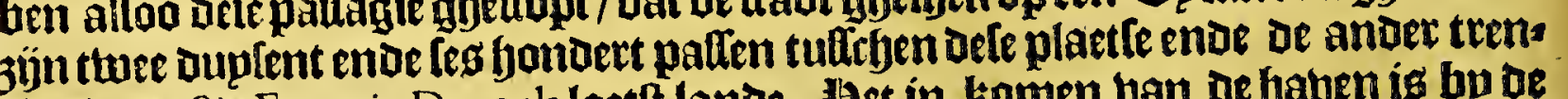
chee daer Sir Francis Draeck laetlt lanoe.

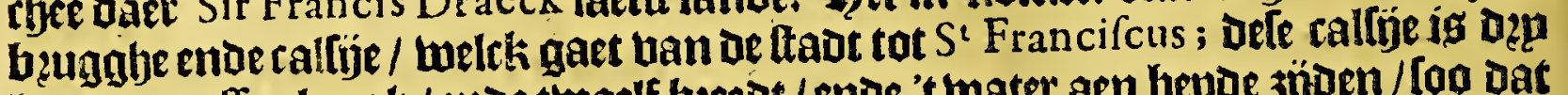
jonoert pallen langly / enoe twaelf bzeedot / enoe 't water aen bepoe jöoen / [oo oat

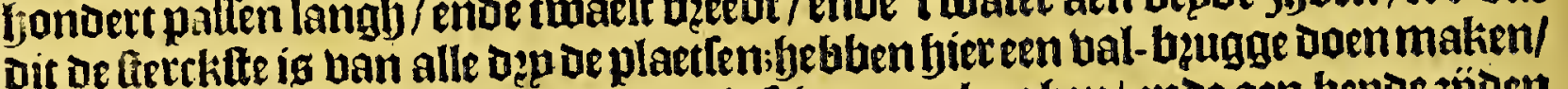
ende ap oen top een platte fozm om ofjefrjut op te leggien/ende aen bepoe zijoen

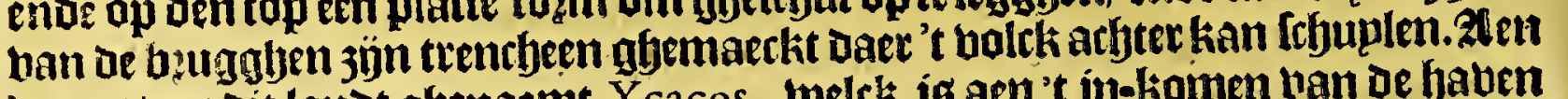
't punt ban oit landt ghenaent Y naer S a Anna toe / jebben bop ecn foet gbemaeckt ban bout/ melck bier-kant is/

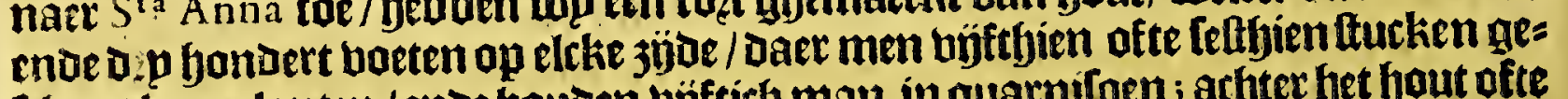
I buts kan planten / enoe bouven vijftich man in guamiloen ; achter bet bout ofte piancken leaht een wal ban aeroe bier boeten dick/enoe baet acfrer lanot; oit foet

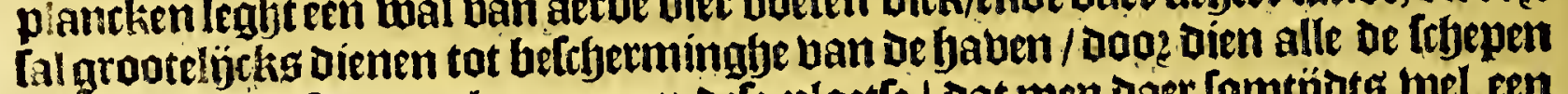

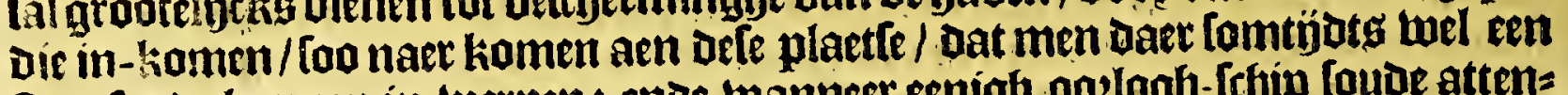

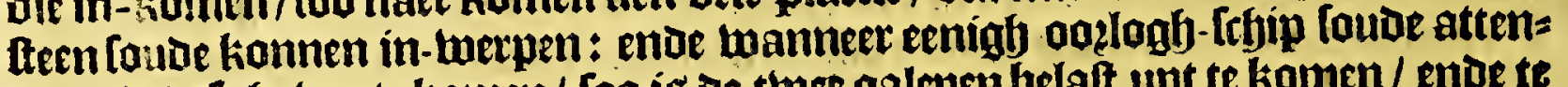

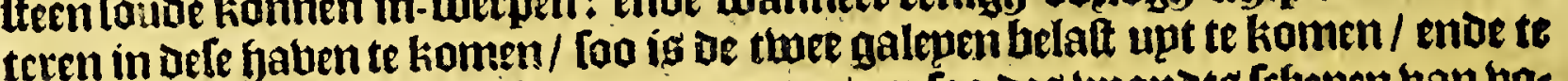

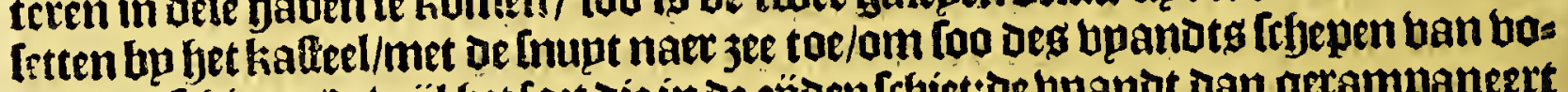
ren in te [efjicten/oewijl bet foet die in oe jüben [chiet:de bpandt dan getampaneert

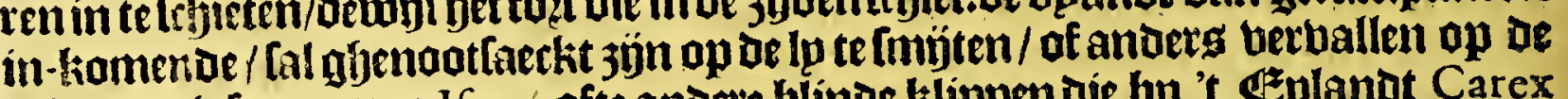

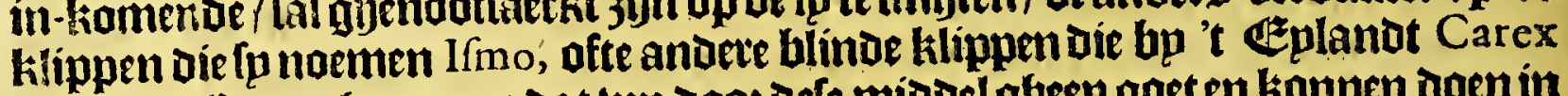
Ieraben. Enoe ghenomen bat wp doos defe midoel glyeen goet en konnen doen in orf plaetr/ende dat oe bpandt foude onoer-ltaen met langfye booten ofte pinalien te tomen doo? de naeube mondt:[oo dient men biet fregatten gbeteet te bebben/ om oe galepen nael't lelbe naeube hanael te roepen/ booz dien de in-komite fou ahebartijcken is / en fal baer gljeen frfip dien toegh in oe bauen komen komen/

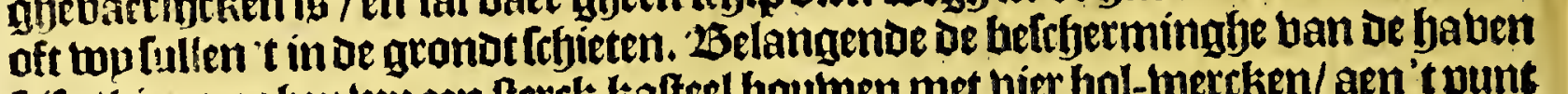
[eifa/ljer mogben wo een lferck kalteel bouben met bier bol-bercken/aen't punt

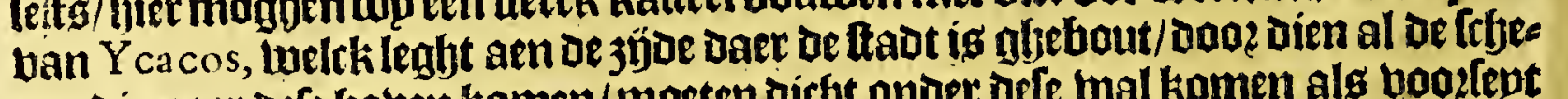

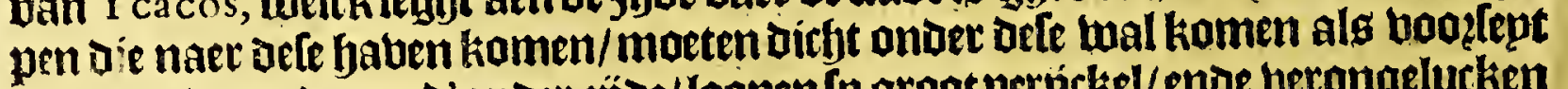

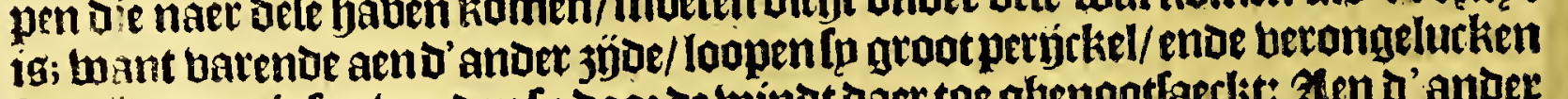

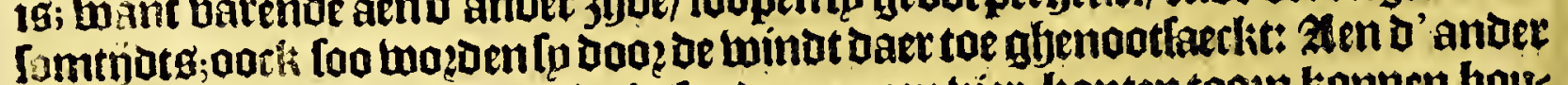
jijoe Laer't Geplanot Carex leght/Loube men een vier-kanten toogn konmen bou= twen / ende bier oft bÿf fucken op legaben/am te berbinderen dat daet gheen kleps. ne [ifepen ofte barckenfier bu nacht mochten in-fuppen om lchade te Doen / ofte-

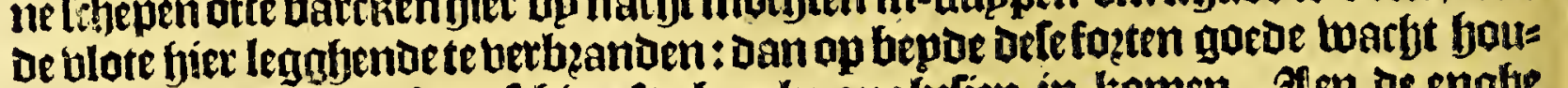
Dente en kan fier gfeen lfjip ofte barcke onghelien in-komen. Zlen be engfye

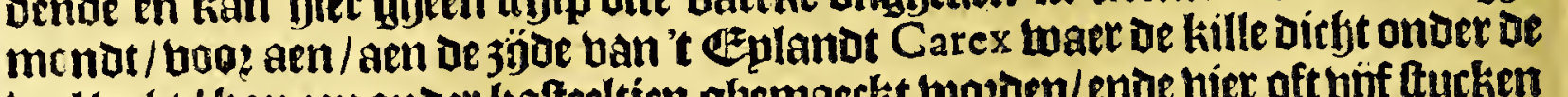

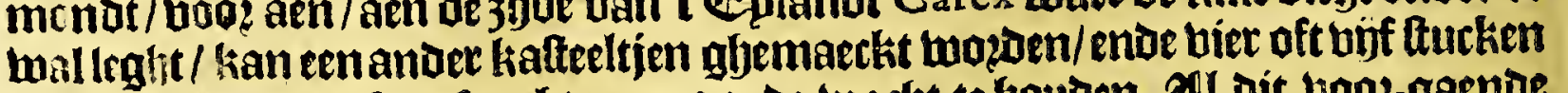
op afjelengt / enoe fes oft atyt man om de wacht te houben. Zll dit booz-gaenoe

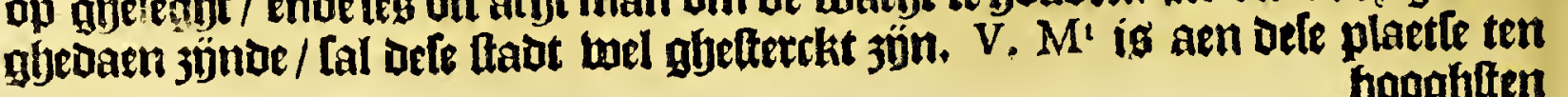
boouffen 


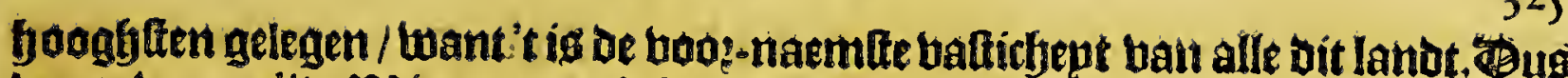
berte Antonelli. Fieng raedt in't foetifieren ban defe ftadt ghebalght ig; want

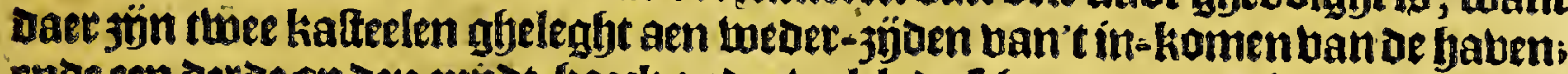
ende een derde op den jupdt-fjoeck onder laelck de fefjepen ten antker moeten kas men; ende een bierde aen de aber-3joe op't balte lanot naer de ftadt toe,

\section{Het Lelfhienoe Capittel. \\ $\checkmark a n$ de andere fteden van defe provincie.}

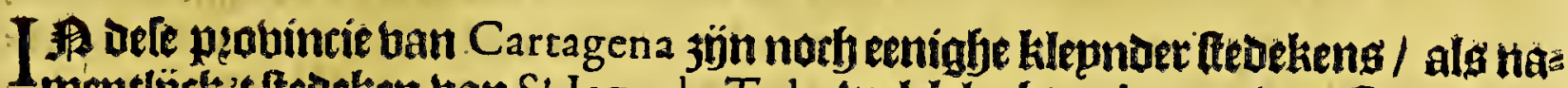

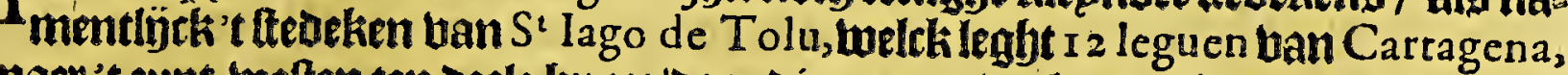

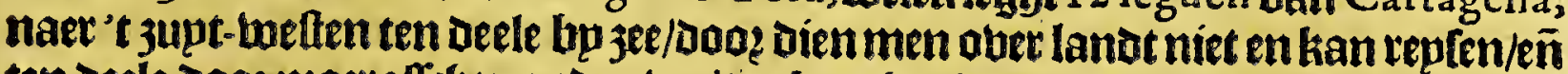

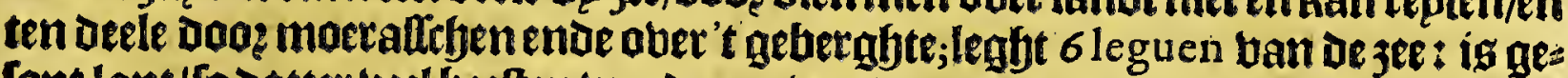

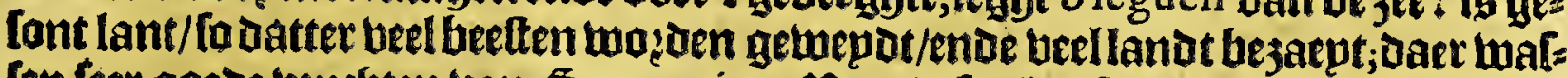
len leet goede beurgten ban Spaegnien: Ban dele plaetfe komt Den koftelijetien ballem/Die [u noemen de Tolu, welcli Monardes beffyeyft in fpn Hiftoria Simplicium Medicamentorum in ro tap, Baer twot nu(fegt bp) upt feker probincie ban t bafte lant / gelegen tuttijen Cartagena ende Nombre de Dios, bp de Jndianen genoemt $T$ ölu, ouet-gebzacht feker liqueur ban ballem/ ban for groote ktacht/eñ tupt-nemenile medicament dat opt upt defe landen is ober-tgeb:arbt; de hoomen

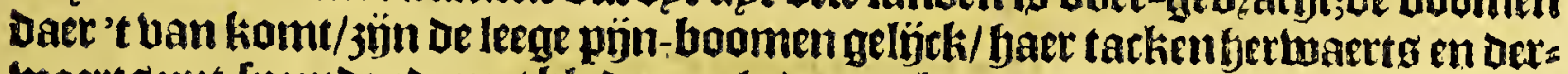

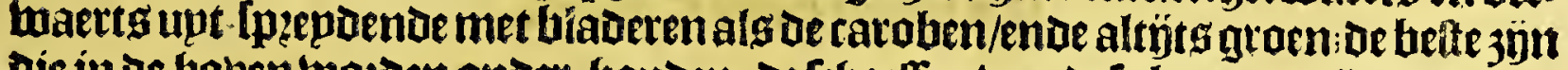

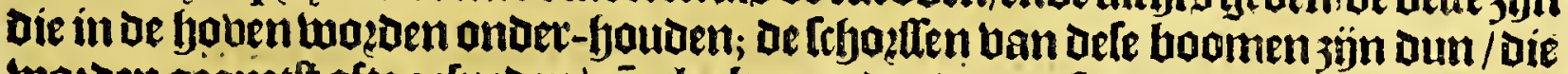
wadoen gequet tofte gelmeden/ eñ platken ander de quetlure eenige Iepeltiens ban

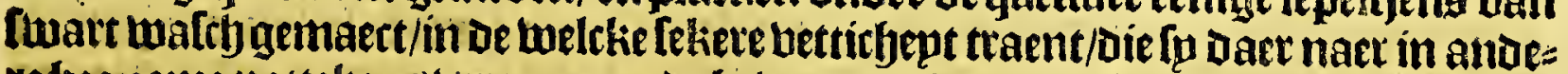
re bequame pottekeng betgaren enue beluaten : Dit moet gelfbieden als de fonne ap

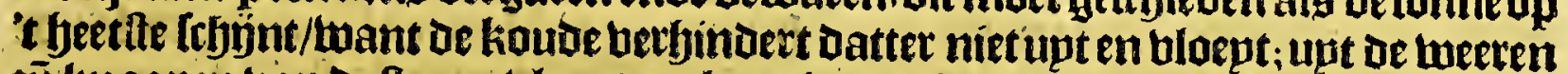
eñ knoopen ban de ftupt bloept oock eenige bochticbept/ Dan die detuppt op o'aer= be/ente gaet berlozen. Bele boethtichept is root ban berwe naer't gaubt treckende/ niet beel dick notf beel dun/ Leer baft-fjoutende / foet eñ aen-genaem ban (maeck/ ende niet walgeligck als anoere ballemen/[eer lieflïck tuan reuck/ende de limoenen bp naer geljeckenoe/ foo doat [p niet verbogen bljft waerfp oock is/maer berbult

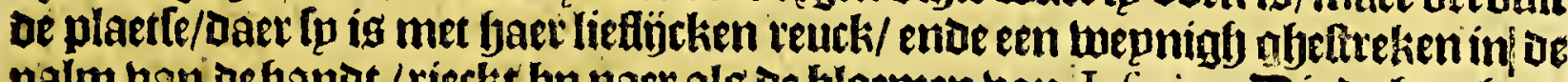

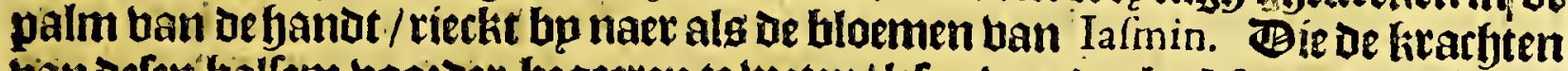
ban delen ballem boozer begeeten te weten/Ifen bopezer bp Monardes; oft in't htuput-boeck ban Dodoneus bp D. Raphelengius uermeerdert.

$\therefore$ Boozts is in dele probintie noch eeri plaetfe die fo noemen la Villa de Maria, thee-eli-oertich leguen uan Cartagena gheleghen naer 't jupoen.

Santa Cruz de Mopox leagt lebentirfy leguen ban oe taad Cartagena, men

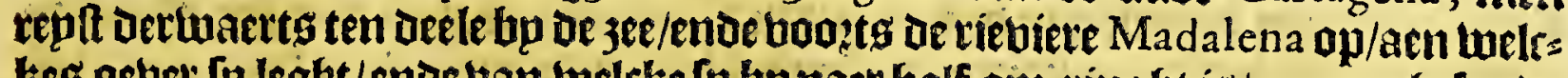
kes oetuer lis leght/ende ban welcke [p bp naer half om-ringht is/een ongfelonde plaetle doos dien lp legbt tuifrtyen moevalleben; is anders mondet tuel gheleghen boog Den koop-handel die op oe groote riebiete wozot gbedzeten; van daet tot

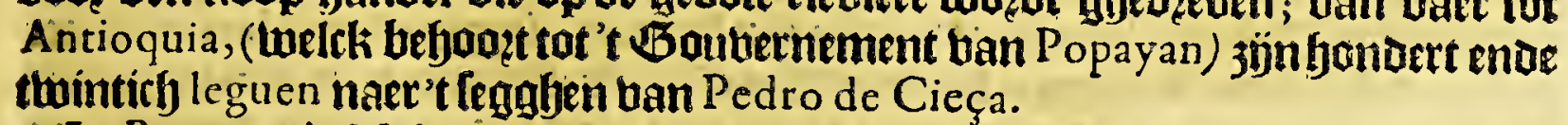

La Baranca de Malambo is een tol-fupg tot de jurifoirtie ban dete probintie be= boozende / jerticfy leguen ban de ftadt / op Den oeber van be riebiere Madalena,

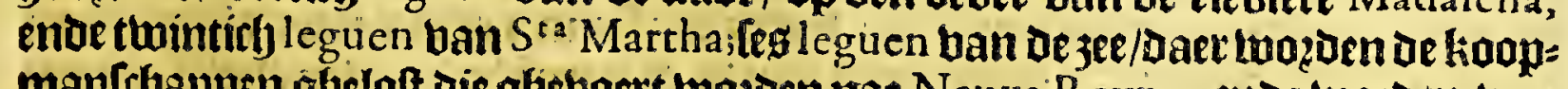
manlrbappen gheloft die afjeboett mazden nae Neuva Reyno, ende toozden tan Gier boozts of riebiere met ranoen op-ghebzoche.

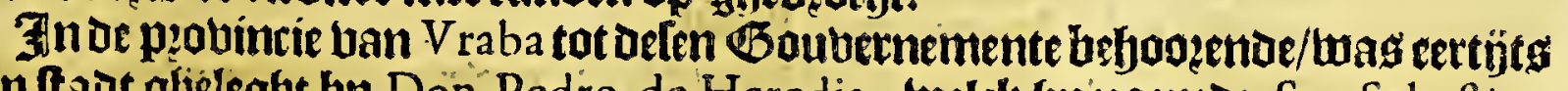

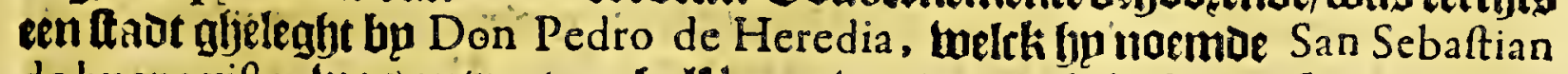
de buena vifta, twas onttent een balf legue bail of $3 e e$ ghelegfen op leecker kilepne

$$
\text { ffi beubeltieng: }
$$


326

Terra Firma.

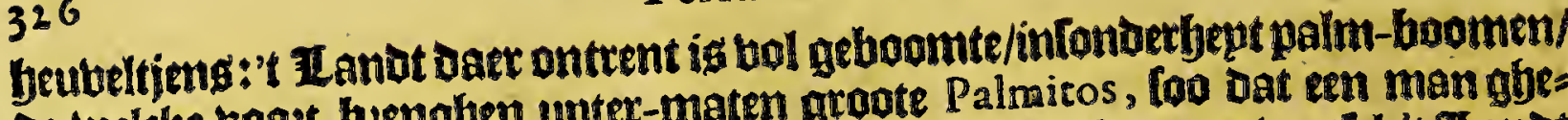
De twelske boozt-bzengfyen uptex-maten groote Palmicos, foo dat een men gbe=

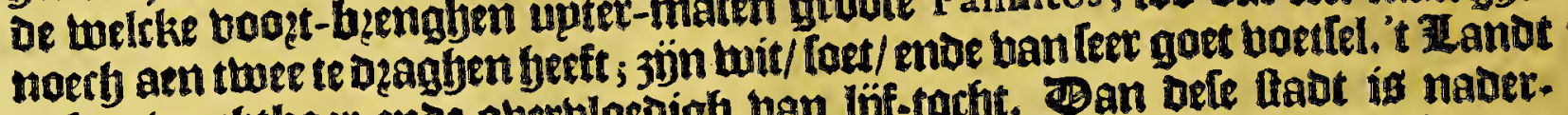
is leer bzurbtbaer ende oherbloedigh ban lỉf-toctyt. Ban defe fadt is nader. gandt beoer berlaten Doo be ontdechinghe ban Peru ende andere rỉcke pegs

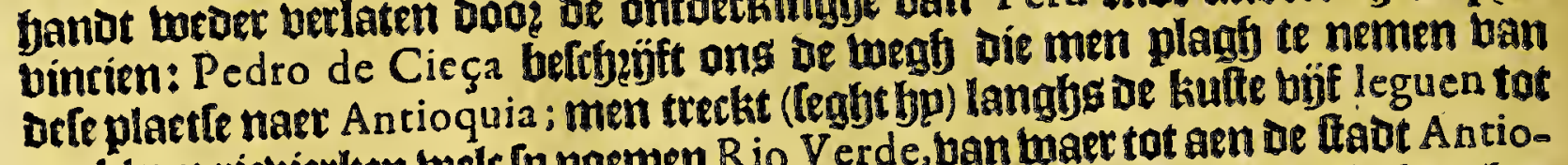
en kilepn riebietken wele Ip noemen $R$ io Verde, ban maer tot aen de ftad Antio-

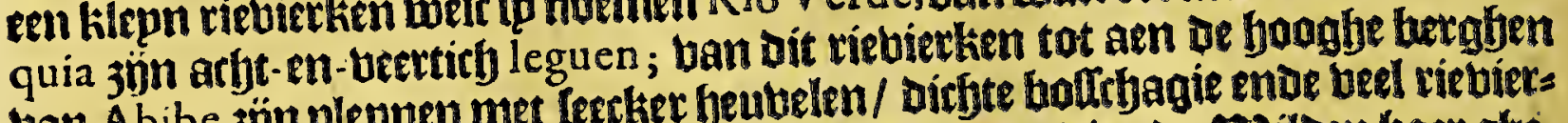

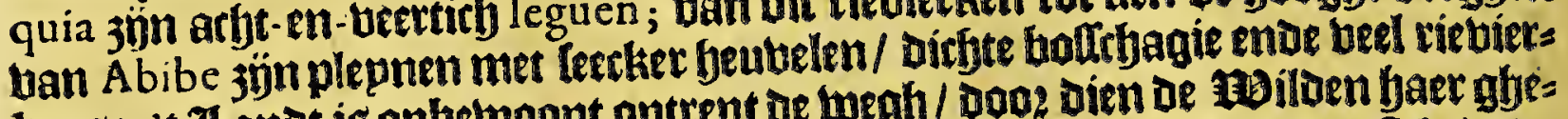

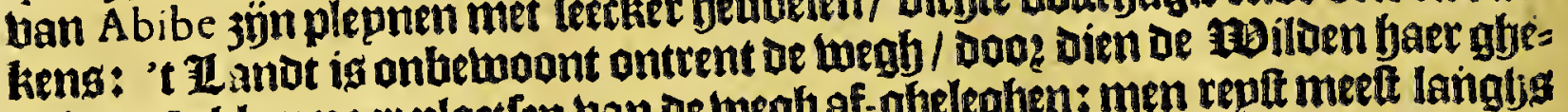
reticeert hebben naer plaetlen ban de begh af-abelegfen: men repit meet langlyg De riebieren / Dooz dien daer gyeen ander twegben en jön ban weghen de dirtte bolltyagie. Om daer [onder ghebaer te replen moet men waet-nemen de maklis Den uan lanuar. Februar. Marr. ende A pril, want daex naer reghent bet feer/ende be rievietert wallen ende loopen fterck. Brfe plepnen gbepalfert zönde / homt men aen 't youghe gbeberghte ban $A$ bibe, vaer wp bier booen ban bebben ghes Ipjaken; ende ober 't gheluergbte komt men aen een fryoane ballepe enoe black lanot / welckfo noemen del Guaca; daec aen bolgben De ballepen ban Nore Daet oe Itadt Antioquia ing geleghenis.

\section{Wet Cobentyiente Capittel.}

Van de rievieren, havenen ende punten van defe provincie.

$\mathrm{O}$

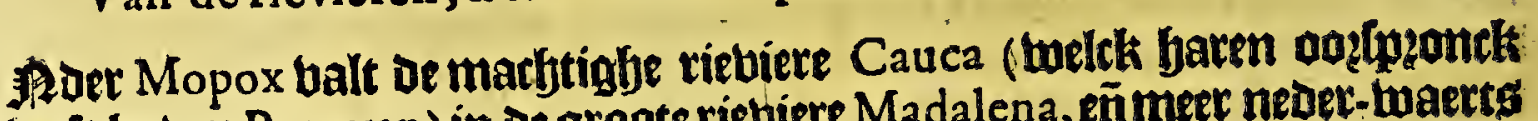
beeft boven Popayan) in oe groote riebiere Madalena, eñmeer neder-waterts

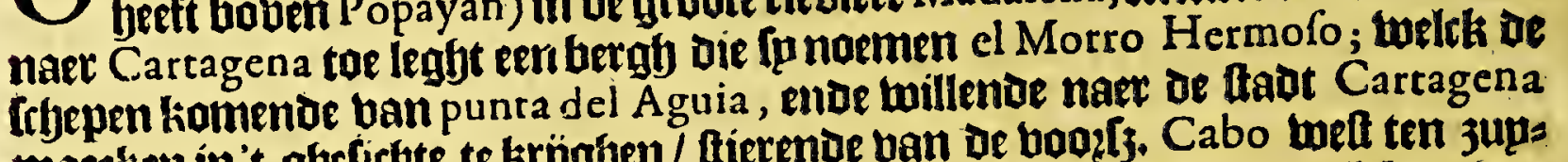
maecken in't ghefichte te kröghen / ttierende van be boos [y. Cabo welt ten jups

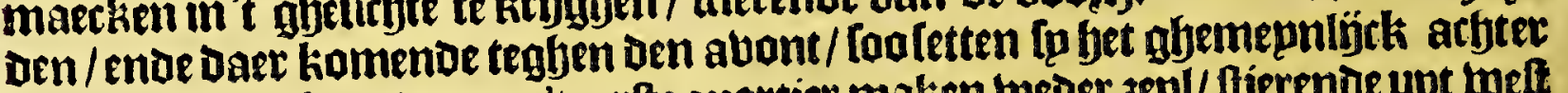
Mor ro Hermofo, ende naer't eertte quartier maken weder jepl/ Gierende upt melt ten noozoen om te mijoen Ifola de A renas, welck Ieght twee leguen t' 3er-waerts recht teahen ober Zamba : De merck-teeckenen ban Mor ro Hermolo jün 't gefietyt. van een ltwart landt niet leer boogh ende ronot. een teetken oe glyeljóckenís ban een gallepe die ghetakelt is: vaet naer bolobt op oe telbe kulte el Buhio del Gato, weitk ighoogh landet met tercker witte kliffen te 3ee-waetts / enoe meer naex 't wetten leght punta de la Canoa, twee leguen ban oe ftadt Cartagena, naer't oolten toe; ig Ietgh lanot legghende ghelïcks be jee/: ente daer epnoet oe kufte / Die onftenoe weft ftreckt. Boogder leght punta de los Ycacos aen't in-komen uan de baben ban Cartagena, tegften ober fet Eplanot Carex daer wo bier bozen vangetpzolien bebben; ende punta de la Nao, aen't bas

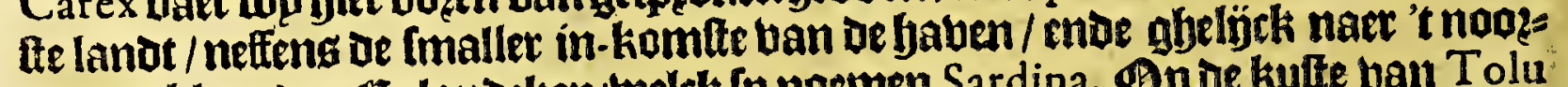
Den een klepnoer Ejplanoeken/buelck [p noemen Sardina. Op be kulte ban Tolu legahen of Eplanoen van Baru, weltke jón leg natr't fegghen van Herrera; maer.

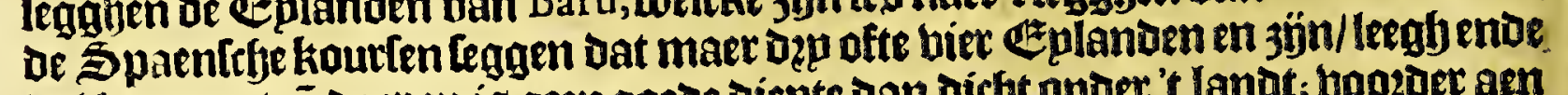
bol boomen/ēn daet en is geen goede diepte dan dicht ander't landt; boozecr aen het begin ban De Golfo de Vraba, De Eulandekeng Diefo noemen de San Bernardo, teghen oucr oe rieviere ban Zenu, welck jön les in 't gfetal naer' t leggen ban Herrera ende bolngens de oblerbatien ban oe 5 paentehe kourlen; bol ban boos. ghe beralyen met feerker 3 andot-bapen naer $3 e e$ toe/ ende bebben gaede diepte twee ofte vep leguen af / melck fp noemen la Bacilla.

Her.d.2. Tor riebiere ban Zenu, ig grootende diep/Daet de p?obintie de naemiban beeft/ l.t.e.6. Iegabende Dertich leguen ban Darien naer bet noften, Doojtg lna Fuerte, een Eplanot 


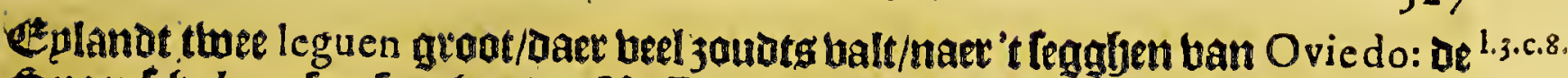

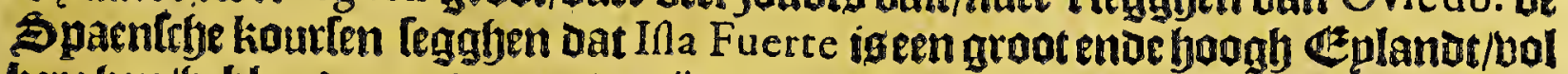

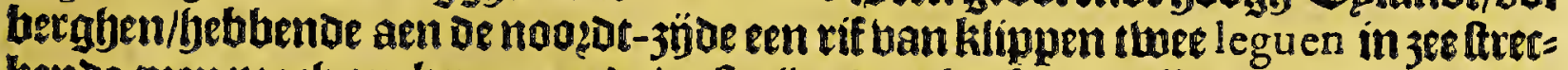

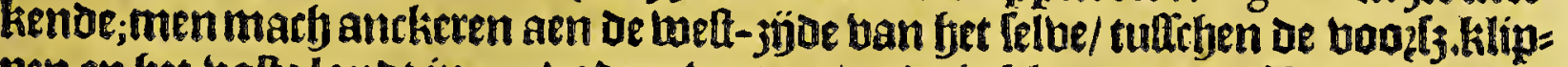
pen en fet balte lanot in 15 badrm twaterg/ enoe ig klep-gronot. Baet lequt me= oe 't Cplandt Tortuga, welck ig klepn ende onbelwoont. Be baben ban Zenu leght bỉf-en-twintity) leguen ban Cartagena, is eft groote bape die baer in-ko= men beeft ban't weffen/igleer [eker/ende daer wajot veel jouts gfemaeckt.

hoe-tuel de ríeviere die fp noemen Rio grande om baer grootbeut/eñ de Madalena, an dat baer mont aen de noosot-3ee op dien dagh ontoectit mirtot/gaet oo:[pzanck jeeft boben Popayan, ende derbaluen daer bp ong beecder daer vanlal ge= fpeken wozoen / fullen even - wel giex een wepnigh ban de Telve aen-roeten/ om

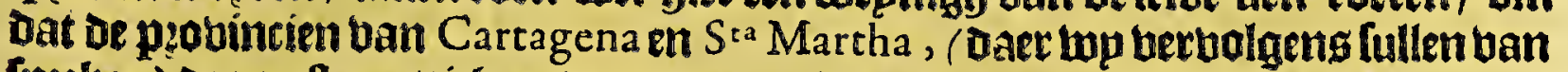
Ipetken) De meefte nuttithept daer bangenieten. Defe rieviete fomt leer beet ende matbtight in jee loopen/ 26 leguen ban of ftadt Cartagen a naer'toofen toe/ op oe

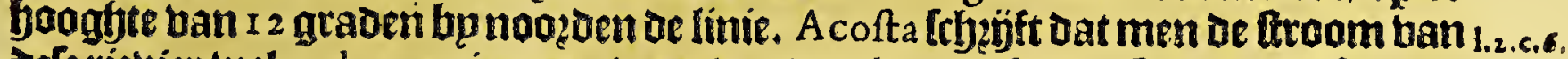

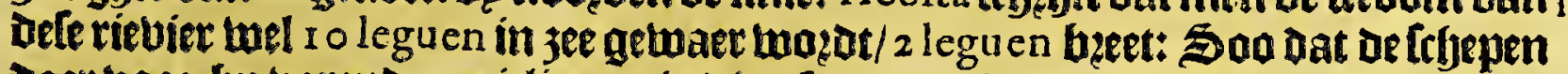
Daer boo-bp barenue pericliteren in dien fp te naer komen/Doo? oe rabelingh van oe froomen. Hefte een Ezplanot in haet mont; wozt meer dan 150 leguen op-ghe=

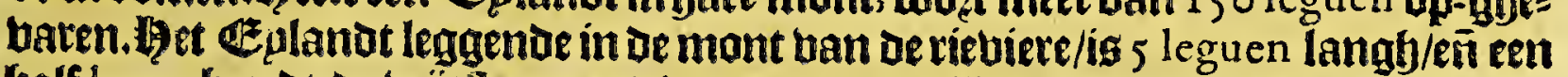

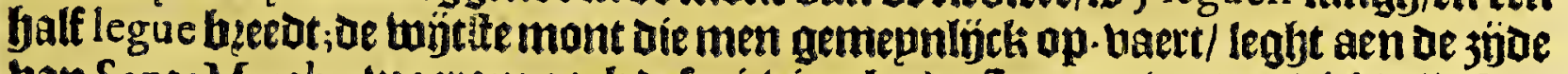

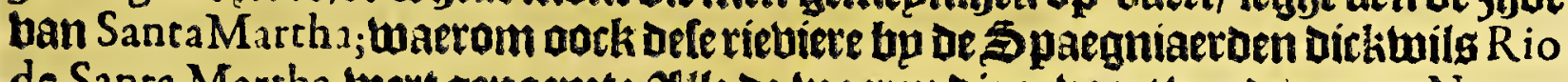
de Santa Martha bert genaemt: 20lle de twaeten die geboett werden naer Neuvo Reyno, twerden dele riebier op-gebzarbt met getwelt van roepen/ende trecken met de lïn/ende men is belirfj om die 150 leguen op te varen ober de 2 maenben;daer-

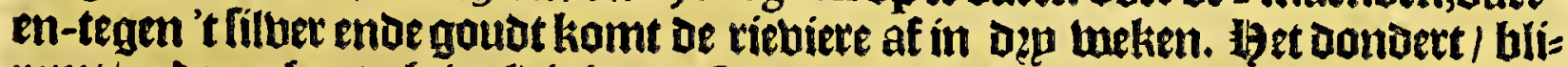

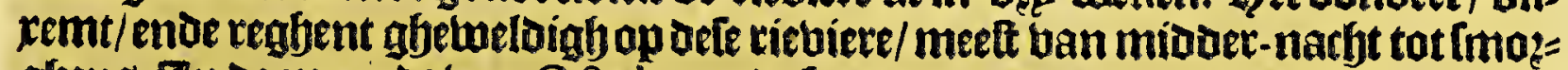
gheng. In de maentet ban Oatober ente foo vooets tot A pril, twalt jet twater bain d.s.l.ro.

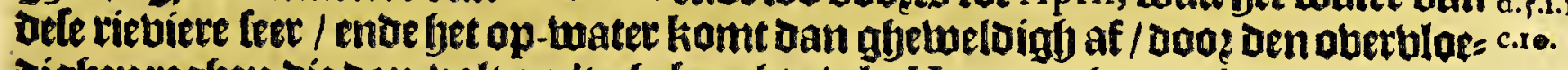
Dighen reghen die dan balt op 't gfeferghte / als Herrera ghetupght.

\section{S A N T A M A R T H A.}

het adfthiende Capittel.

Van de gheleghentheyt van defe provincic.

$\mathrm{D}$ Ez probintie ende't Gaubernement ban Santa Martha legbt betbolgeng op de kulte van Terra Firma, beft in de lenghte tulthen be upterlte palen ban 't Boubernement ban Cartagena aen de wett-jojoe/eñ 't Goubernement uan Rio de la Hacha, aen de oolt-żjoe 7 o leguen ende vack too beel leguen in be beerde.

De gbeltalte Deg lucbts ban Dele płobincie is beet ontrent oe jee-kufte:maer bins Her.d.4.

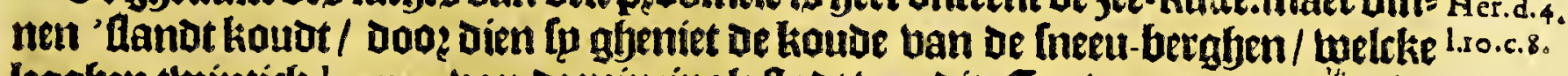
leggben thintich leguen ban oe peincipale ttadt wan Dit Bouterneinent/eride in= Conaerbept gheniet arle koelte de peabintie ban Tairona, welck is bergharytigb

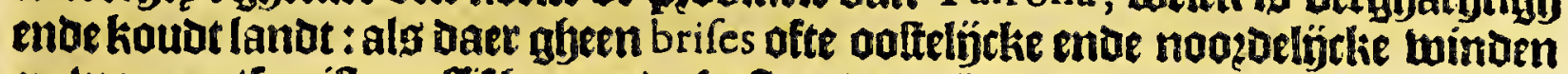
en waepen / foo ifterceflif beet op de kufteenoe oe landen daer aen palende: 't tres ghent daer feer in Demaenden van September ende October, in de andere maen=

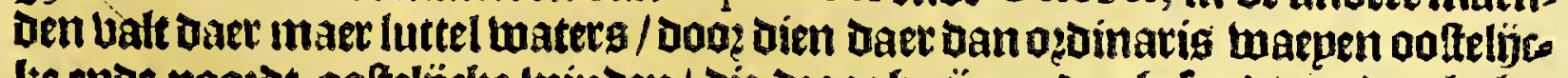
ke ende noozot-ooftelïcke twinden/ bie dzaogh jön ende ghetonot; ende als bet

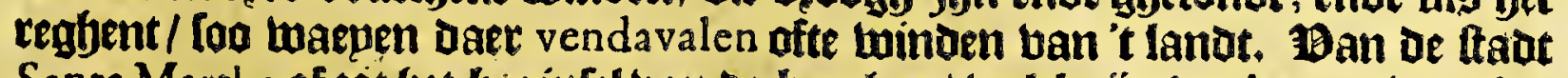
Santa Martha af tot bet beginlel ban de hergben / welck jún dęp legwen tweeghg/ is bet black lanot ; 't abebergfte is leer fteenarbtigh/onbzucbthaer boo mepoen/ conoer beuchten ofte boomen/ende daer ballen veel rievieten ban't gljeberghte af;

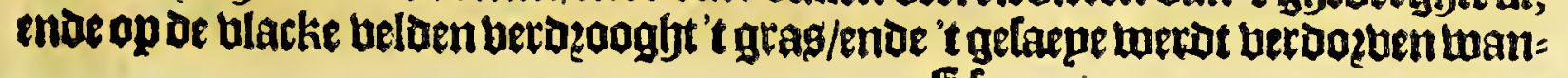
If $\mathbf{f} 2$ near 


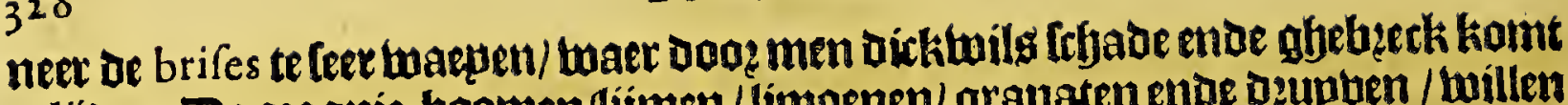
te líben. De ozagnie-boomen/límen/limoenen/granaten ende buguptuen / willen Daer tamelïck wel wallen: Men beft daet Guayavas, Platanos, ende andere

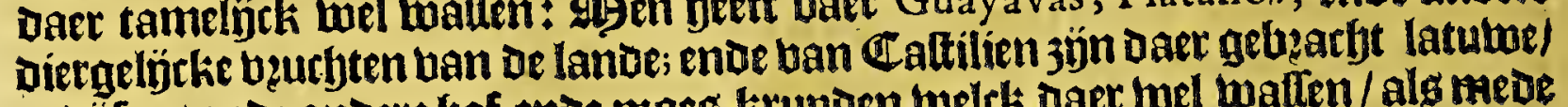
rabjien / ende andere fjof ende moes-krupden welck daer twel walten / als mede meloenen/pompaenenende comeommeren. Daer jün beel boenderen ban Caltí

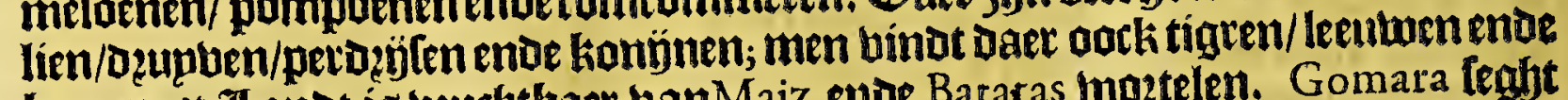
hepzen. 't Ianot is buchthtbaet vanMaiz ende Batatas motelen. Gomara leght Dat be Yuca die bier waft oock raulw mang ghegeten wozoen fonoer gebaer/Daet fe

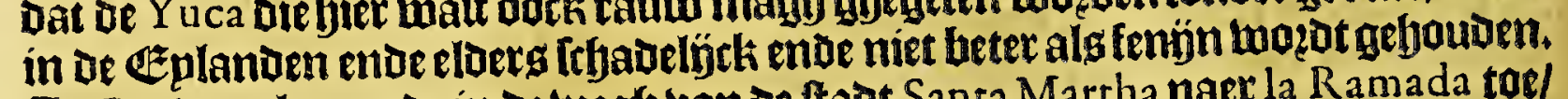
7) 1 B Britaca leggenue in oe twegf ban de ftadt Santa Martha naer la Ramada toe/

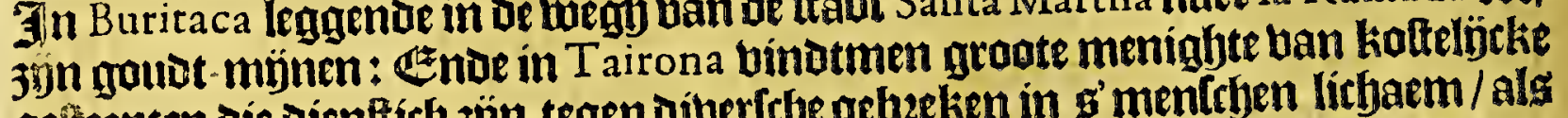

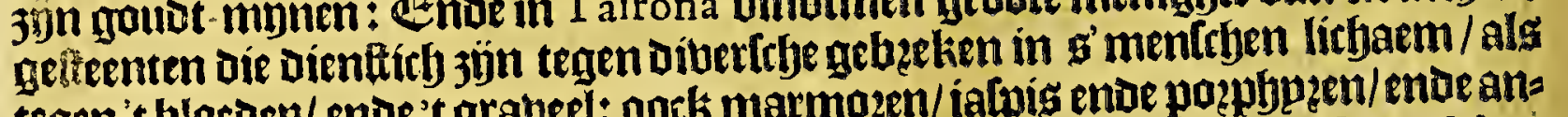

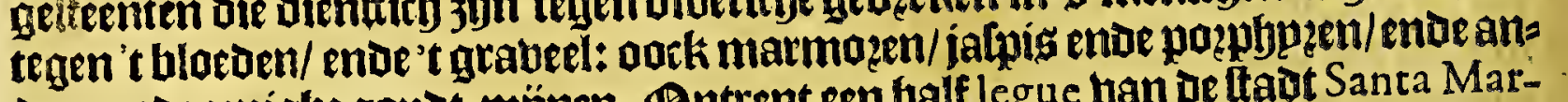
Dere:ende eeníglo goudt-mïnen. Bntrent een half legue ban de ftadt Santa Martha jün veel gemaectite jout - pannen/Daer de Jndianen feer goet jout maken/met

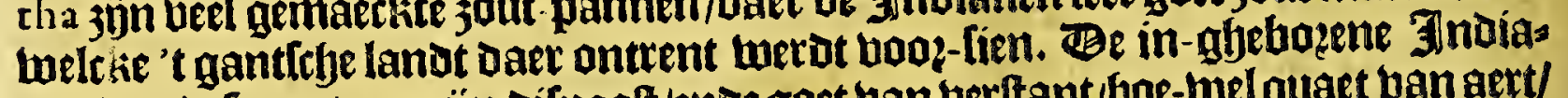

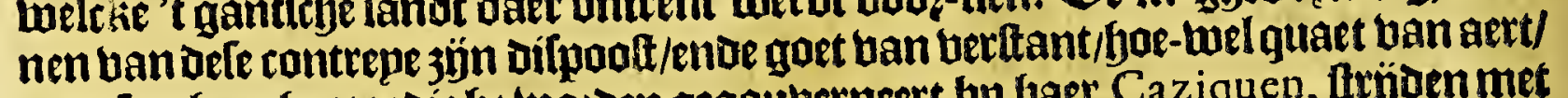
choe [eer fjooth-moedigly: mozoen gegouberneert bp haer Ca,ziquen, frijoen met bogen ende fenijnige pijlen; [p kleeden yaer met mantelg ban cottoen/gelefjildert met dibertebe liouleuren; daer ig noch beel bolcks / ende zint met de Spaegniaers

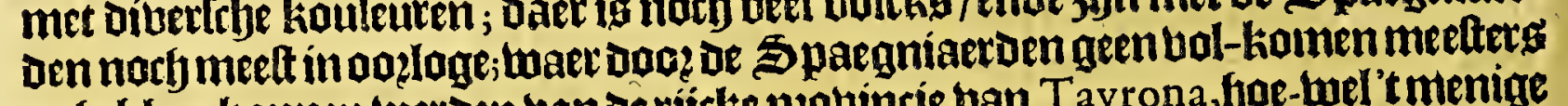
en febben lionnen werden ban de rijcke prouincie ban T ayron, fjoe-wel 'tmenige

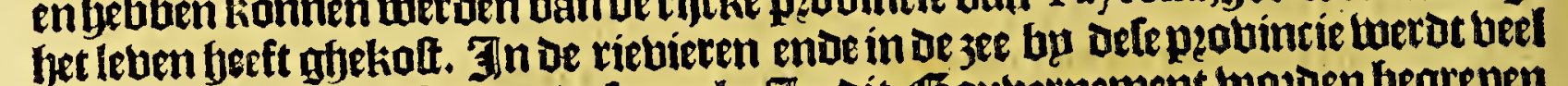

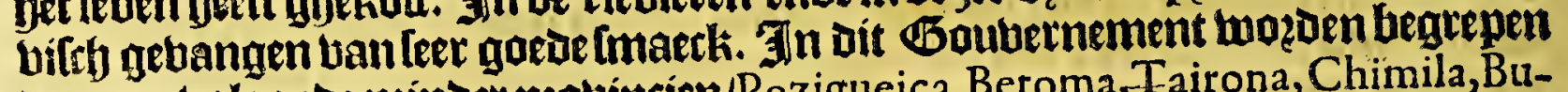
Her.d. 4. ue naer-volgende minuer pzouintrien/Pozigueica,Betoma, Tairona, Chimila, Bu1.5.c.ri. ritaca. De vallepe ban Tairona leght tes oft leven leguen Uan de ftadt ban Santa

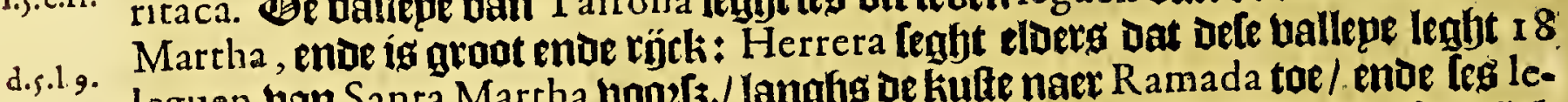

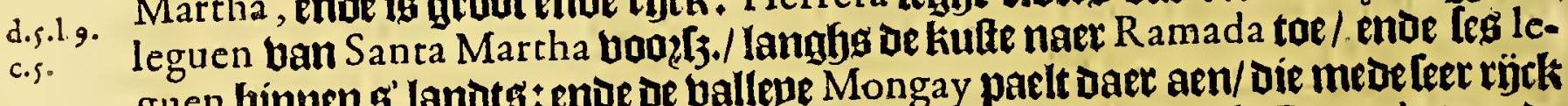
guen binnen $g^{\prime}$ lanotg : ende de ballepe Mongay paelt daer aen/ Die mede leer rück

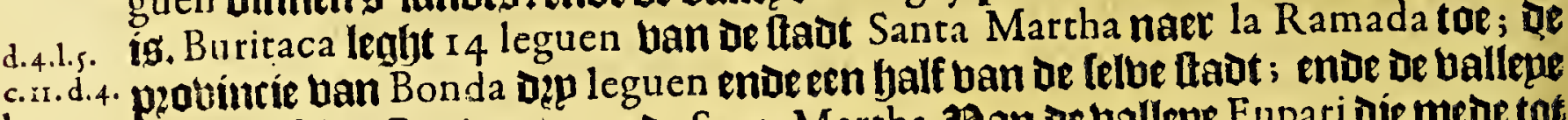
1.7.c.7. Coro tuttrijen Pozigueica ende SantaMartha. 3an ot ballepe Eupari die me be tof iit Gombenement belanght / liet bp De RaDt de los Reyes, in Dit boetl/ rap, 20; Fin of ptovintie ban Chimila is Ieer fraep vequmen-bolck / ende de mans jün

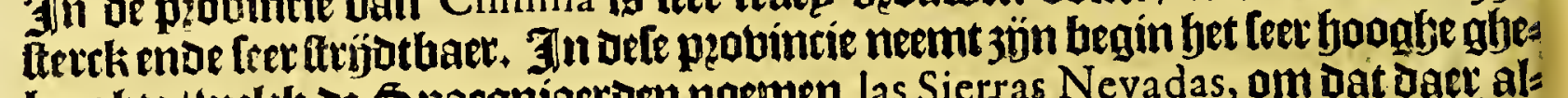
berghte / weltk ae Spaegniaerien noemen las Sierras Nevadas, om Dat daer als

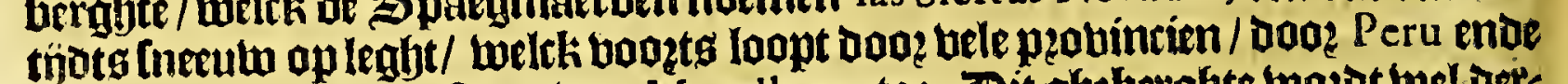
Chili, ende tot aen de ftrate ban Magellanes toe. Dit ghe hetghte wozot wel oet's

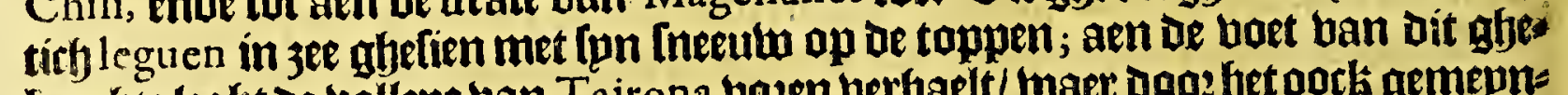
Grrghte leght of ballepe ban Tairona bozen berfyaelt/ waer dooe bet ootk gemepn

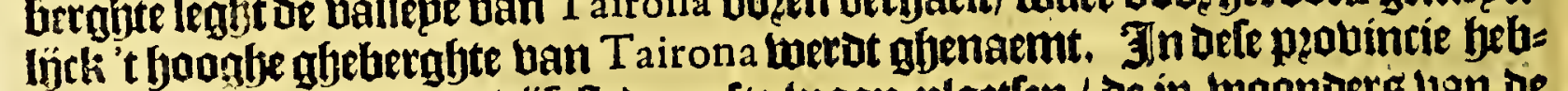

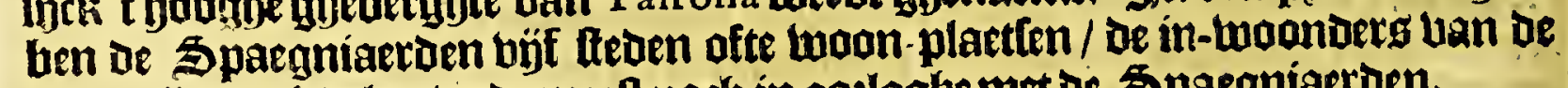
lande $3 \mathfrak{i n}$ noch belen/ende meet noch in oollogbe met oe Spaegniaerden.

Wet neghen-thiende Capittel.

Van de fadt SA T T MART HA.

E voo:-naemfte ftadt/ende Daer dit Goubetnement Den naem ban boert/ is Santa Martha; leght op De hooghte ban thien graden bp noozoen de línie/ende op de lengfte ban bier-en-Lebenticly graden ban Den meridiaen ban Toledo, naet tleggen van Herrera:andere ttellen bie op thiengraden ende een balf; ende Petrus

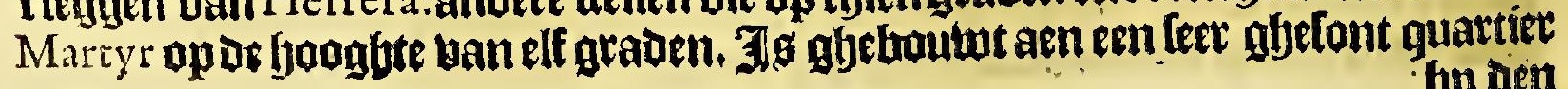
by den 


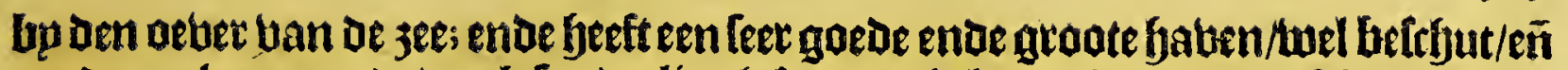
goede ancker-grondt/ oock Tonderlingh fraepe gbelegenthept am de fchepen ouer

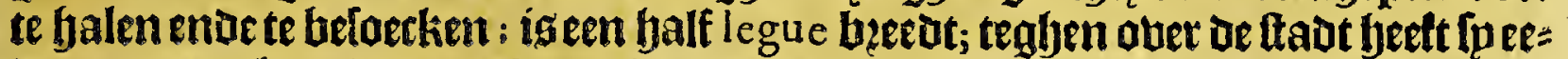

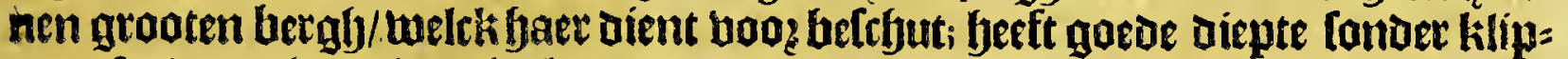

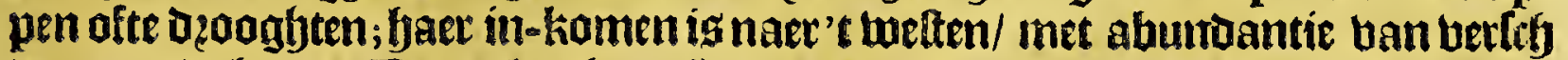
water ende boutor. Baer pleegf eettjots beel bolcks te twoonen/ Dan íg nu leer afgtjenomew/ende bu naer uerlaten/Doos dien oe uloten van Spaegnien daer niet meer aen en liamen ghelijek fupleghen te daen.

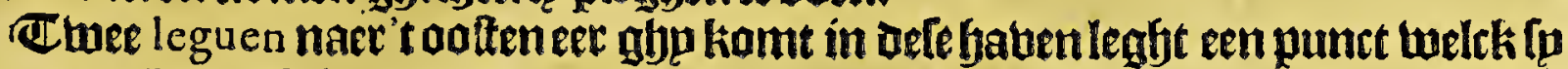
noemen Punta del Aguia, mele Dangeteus ig om te Doubleren: 24 leguen bam Dete ftadt nate't ooften leglyt Salamanca de la Ramada, ende 40 leguen naex' t jupdent

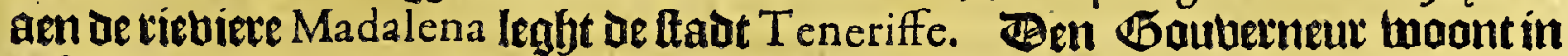

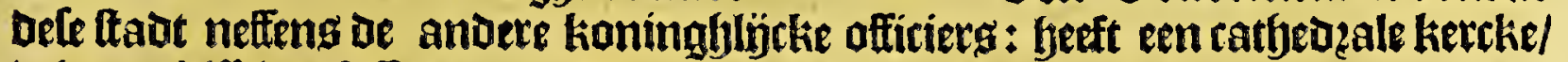
wiens 25ifichop Luffiagaen is van die tuan Neuvo Reyno de Granada.

Ben 7 ngenieur Baptifta Antoneli fryzüft in den jare 1587 , van or ftadt Santa Martha, aen den Honinglj ban Spaegnien aloug:

Santa Martha de pzincipaelte thad ban het bifoom ofte diocefe ban de fiufe ban Terra Firme, leght op thien graden enoe eengalf/oe ftadt ig gfoleght op een

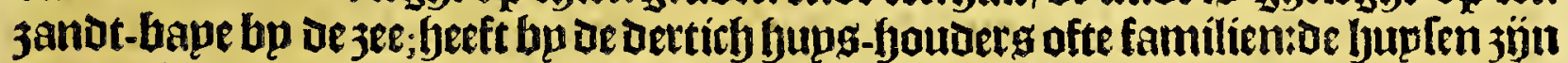
gemaeckt ban rieaen/ende jün abedeckitmet de bladeren uan palmiten/ende fom: mighe oock met tichelen: [p en gebben met niemant bandel/als met oe Indianen ban 't Telbe quartier/weltke in of ftadt te koap bengen aerden potten/ende andere

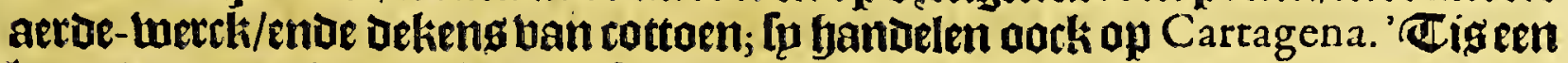

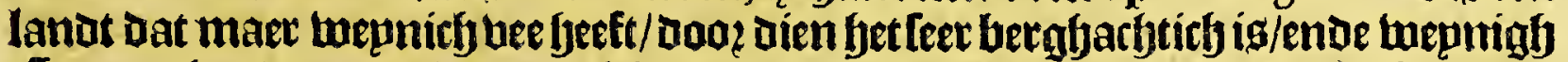
Spaegniaerden Daet moonen. Baet is een goede faben/oun-cingelt met leer fyod: ge bergenende groote klippen/die tot aen de jee-kant komen; Lelck boogl-landot

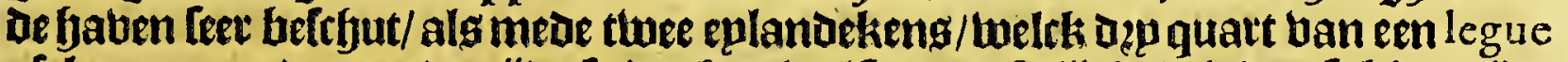

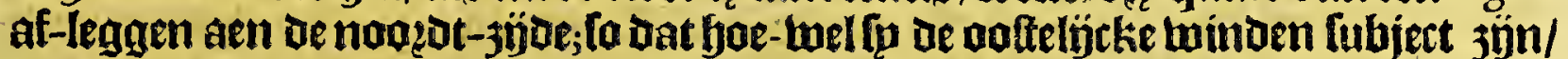
ende dat met fto:m/ oe twinden nochtang geenirljade en doen aen die landen bills Ien. 25 inmen de Ljauen iseen plaets genaemt la Chaldera (Dat is/De ketel;) Daer [q in boo -tijuen getwoon watende fehepen ober te halenenoe te calfaten.

Hat ae haten belanght / het en is niet noodich die te foztificeren / afte daet fon:

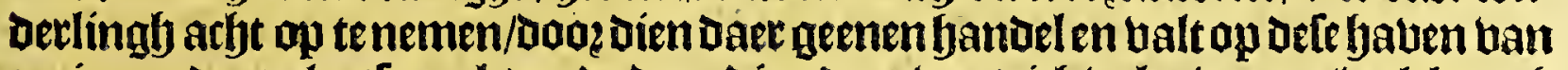
eenige andere plaetlen; als mede Doog dien daet wepnich tralex twaont/welck nordy

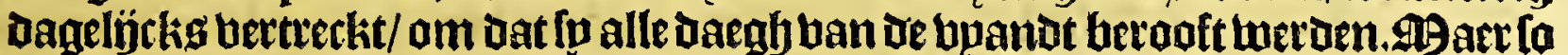
oe lioningh wiloe gebieden dat oe blote gaende naet Nova Hifpania, baer koutg couve nemen ap ocle plaetle/enue bier water eñ berbertehinge falen/(alle de piloten

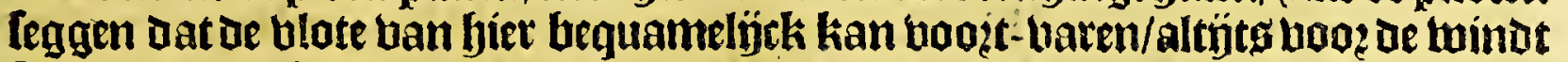
(eplende) ende fo voots waten recht naer de Cabo $S^{\mathfrak{t}}$ Anton, aen fet eulant Cuba, ende bozoer naer Nova Hifpania : [o loube bu deTen midoel de blate niet beboeben

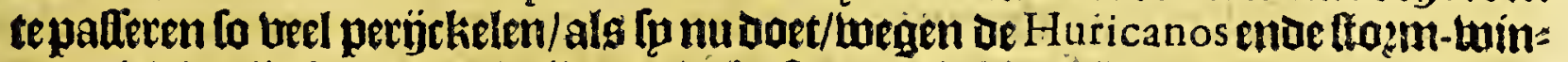
Den die dictwils haer ober-ballen op de kutte ban Hifpaniola ; tuaer dooz de féfepen Dickbils berangelucken/ende fouden langyg dete twegh in gets ghebaer met allet kamen/ende bejue de blaten fauden 't lamen konnen vaten; eñ die naer Nova $\mathrm{H}_{\text {- }}$

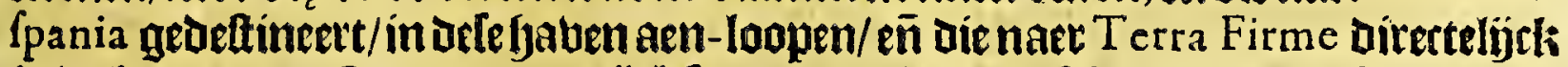

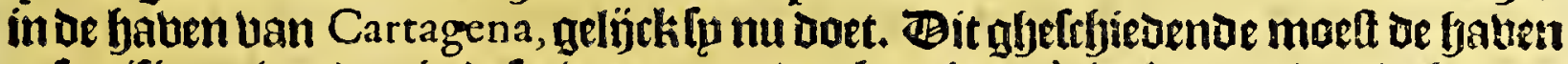
gefoetificest twet den in deler boegen: op den bergls aen't in-komen ban ae haben/

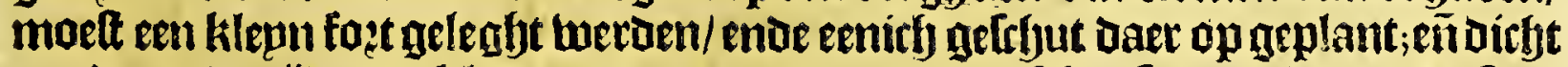

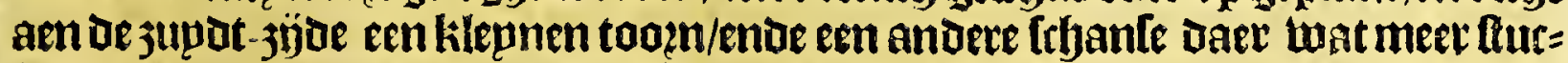

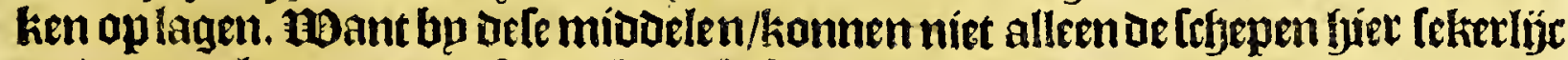
op de teede leggen/maer fal oock een brfherminge jön boo de in-moondets ban

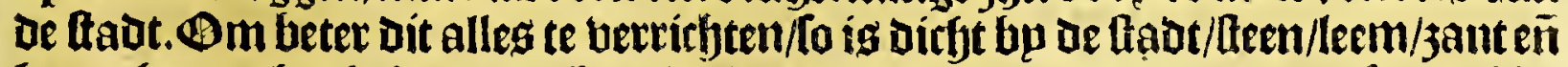
bout gbemoegh te bekamen. Hoe-wel de blote willenae naef Nova Hifpania biev fi $\mathfrak{f}_{3}$ niet 


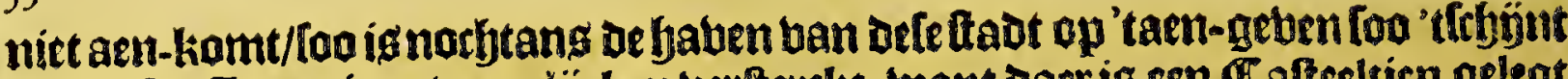
ban oeten Tngenieur taemelïcken berfterckt; want Daer ig een Gafteltien gelegt op een klippe ligghende tuffityen't punt ban'tbalte landt ende een klepn eplanoe: ken Datter boo--leght; ende een ander grooter Calted teglyen ober dit ertee aen frandt ander De ftadt.

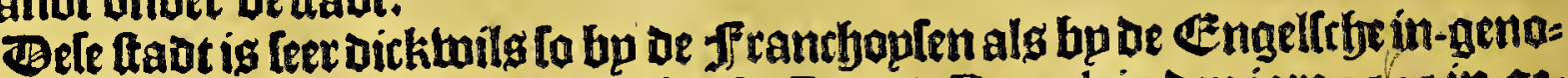
men ende berooft; als namentlïck bip Sir Francis Draeck in Den jare 15.95 in-ge nomen ende meeft verbzandt; eñ wederom yet jaer daer na bp $S^{r}$. Antoni Sherley.

\section{(1)et twintifffte Capittel.}

Vande anderefteden ende placten in deprovincie van SANT A MARTha, by de Spaegniaerden bevvoont.

T Eneriffe igeen ander thad van dit Goubernement gelegen aen ben oeber ban 1 de groote riebier Madalena, 40 leguen ban deftadt Santa Martha naer't 3 upd-

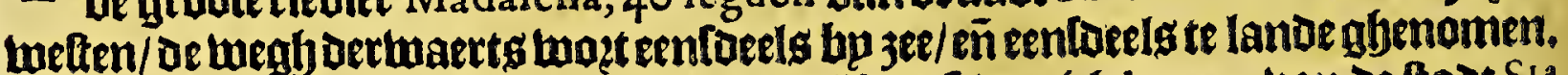
Tamalameque ofte Villa de las Palmas, unf-en-[ebentíty leguen van de ftadt $S^{\text {ta }}$

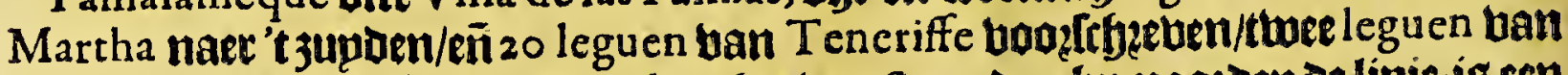
Rio grande ofte Madalena; op de foochte van 8 graben bp noozoen oe linie;ig cen

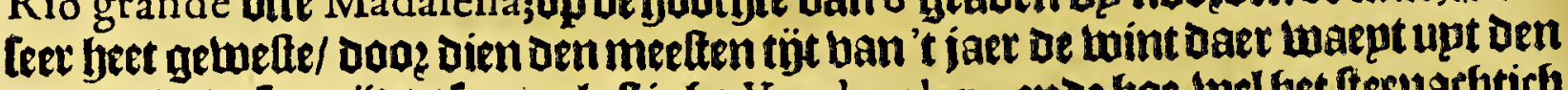
jupaen/ende [omtídts Leer onluthigbe Venda valen; ende boe-Lell fet Iternatytich lanot is ende boogh/[oo jön daet niet te min groote plapnen/endegaede gelegent= hept am beettente wepoen/intonderbept oflen ende koepen; op oe felue plapnen is

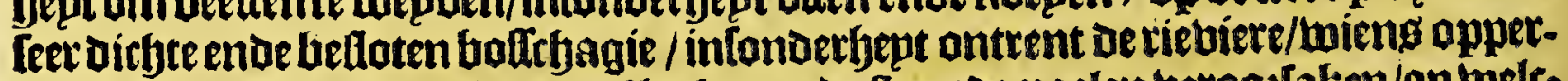
wateren op oe blacke ueloen beel lacken ende ftaende poelen betoo flaken/op telts ker oebers de in-geborene moonen/enoe baren daer op met baer canoen / eñ ban=

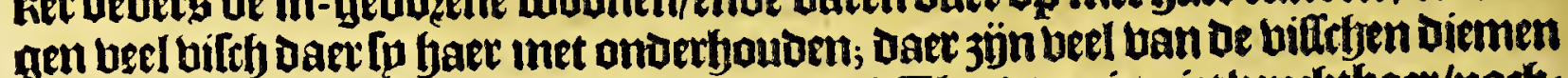

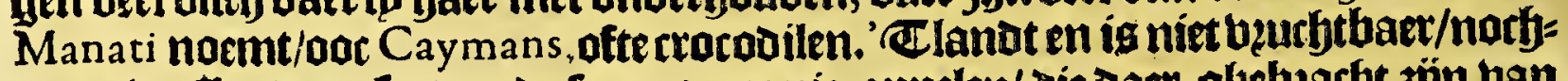
tans baffen daec loete ende fuere ozaegnie-appelen/ die daet glyebzacbt sijn ban

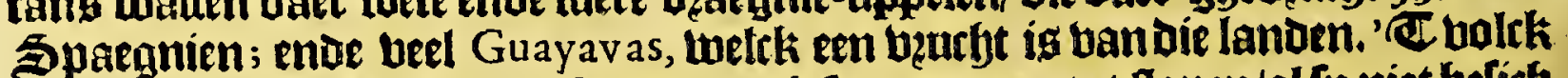
ban or lanoe is klepn ban berttant/ traegh/teet genegen tot dlapen/al [u niet befich

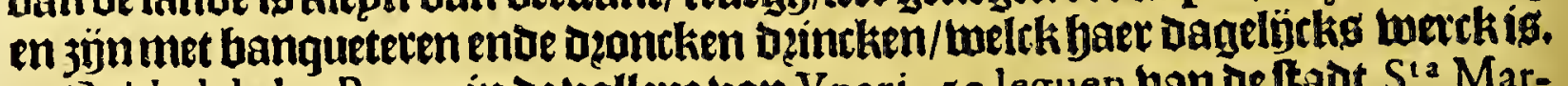

Cuidad de los Reyes in De ballepe ban V pari, 50 leguen ban de ltadt $S^{12}$ Marthanaer't zupot-onften/enoe 30 leguen ban Rio de la Hacha; 180 leguen ban $S^{t a}$ Fe de Bogota; leght bp een groote endemachtige riebiere die fp noemen Guatapori : 'Cl lant biet ontrent en is niet [eet bittich/Doos dien in baren [omer welc ígi in Demaenden van December, Ianuarius, Februarís, Martius, ende A pril, oe brifas ofte oolteligcke winden beel waepen:maer in be winter allt daer betl regent/eñ dop?

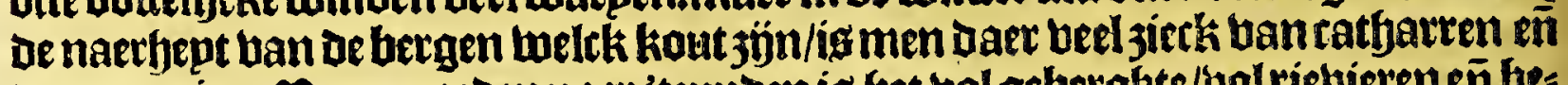

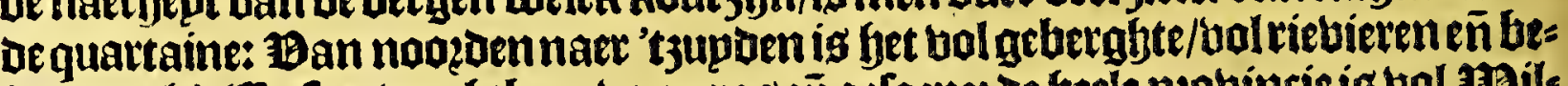

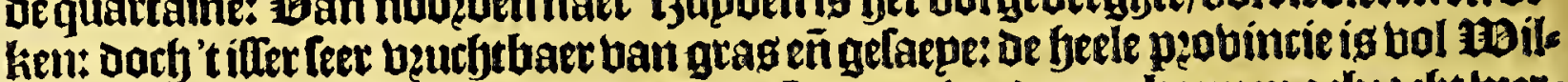
Den / Die tot geengefjoolaemfyept bp de Spaegniaeroen en kannen geb?acht tuet=

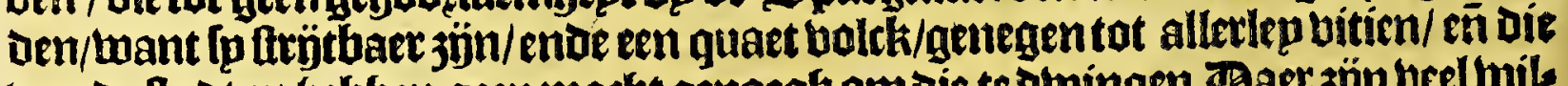
van de thad en febluen geen matht genoegly am die te owingen. Baer jün beel bils oe boomen die buchten dzaghen/ als Platanen, Guayaven ende andere; ende den grooten boom Xagua, welck een yzutyt boatt-bzenght als ken boone / in Lun yaus weeen ander beucht als een $O$,ende beeft de fmaeck ban rajünen; De boonen bouds

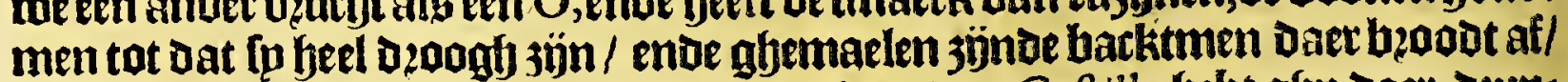

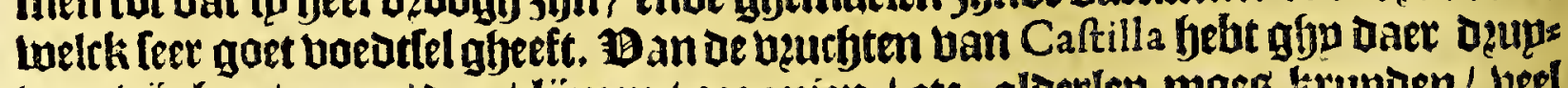
ben / büghen / granaden / lỉmen / ozagnien / etc. alderlep moeg-krupden / beel Maiz enae cottaen; welck oe Jndianen wan ooen bebben tot fare kleedinghe. Bu dienen haer ban de wattel wan Scorzonera, als eenighe langh ofte baghe=

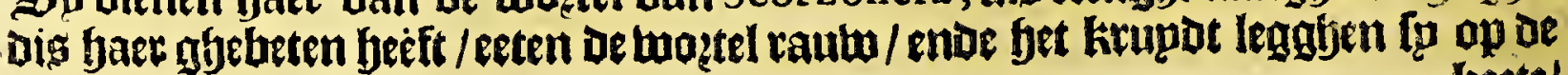

bettel 
bette / entue ghenten iaer ban; 't feltue Doen mede de spargniäetden; ente de

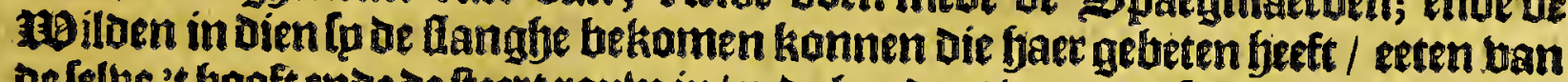
de felbe 't fooft ende de fteett rautw in/ende boudent boos een foutterepne remedie. Gebeupcken beel Tobactegen oe catjarken enoe pinn in t fooft / enoe trecken bet in pulber be neul-gaten in: Deincken oock 't Fap endepurgeten feer daet mebe. In 'tgeberghte ban dit lant jÿn beel mỉnen ban kopet ende loot; oock eenige monite: ren ban filuer/maer werben niet bearbept doog't onbetmogen ban defpargniare:

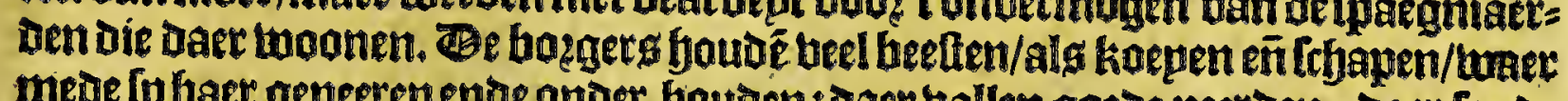
mede [p faet geneerenento onder-fjouden: daer ballen goede peerden; baer foube wel fupeker-riedt wallen/ente alles anters; als daer maer naer getratht twiert.

Ocanna totlck eerfit gbenaemt twiett Santa Ana, is een fedeken ente binnenlanotfffe baben/tot bit goubernement befoogende/paelt aen Tamalameque, top= ber en binde baet gheen berfjeet af.

La Ramada, De welcke certijots thiert genaemt Neuva Salamanca; toag gelegen bertich leguen (naer't feggen ban Herrera) ban de fadt Santa Martha naer't oo: ten/ende acht leguen ban Rio de la Hacha, aen be boet ban de Sierras Nevadas, in be ballepe ban V pari; Daet foo teel koper ig/als tteen; feglt Herrera.

\section{Het en-en-thintidblte Capittel. \\ Van de Rievieren, Caben, Havenen ende Kuften van't Gouvernement van SANTA MART HA.}

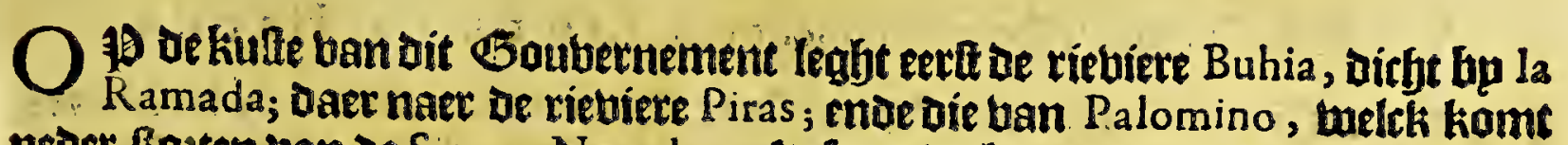
neder-Gatten ban oe Sierras Nevadas, oftelneeutw-betgen; loopt feet fnel/eñ twatt

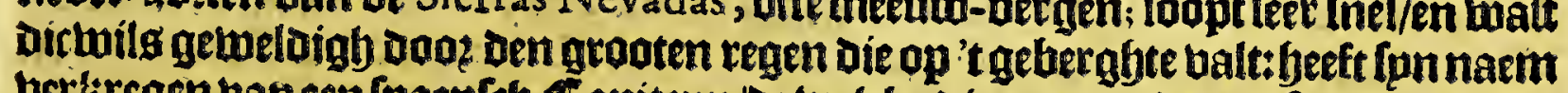
britregen ban een lpaenich Capitepn/De toeleke die mepnente met fpn peero aber

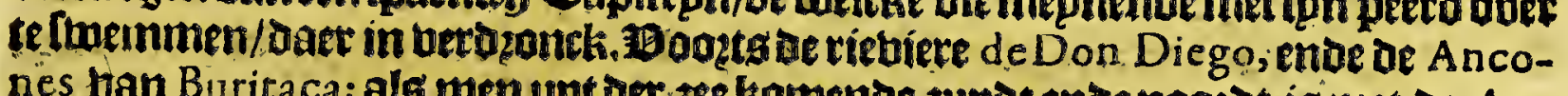
nes toan Buritaca; als men upt der zee komenoe jupde ente noozot is met de Ancones, foo fiet meneen twit jande-frant 3upt-welt ban jem; op de gebele kufte en is gecinmeer dierghelÿck/ende ig aen de lueft-jjoe ban dele baben ofte reede: Daec aen bolght Cabo de Aguia, gelegen op 12 araden bp noozoen Delimie/ofte als ans

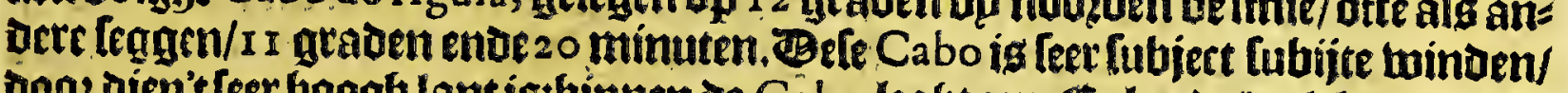
booz dien't leer boogh lant is:binmen de Cabo legljt een Epland//welck op'twett-

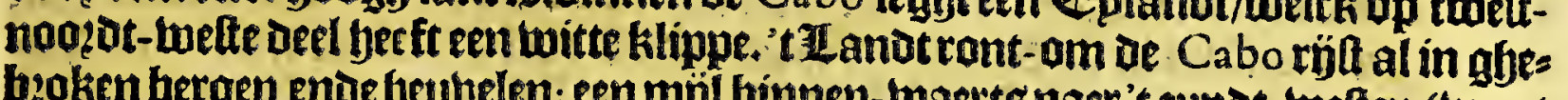
byoken bergen ende frubelen; een mijl binnen-waetts naer't jupot-belten (mant

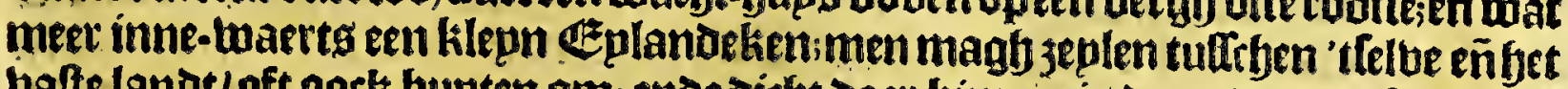
bafte landt/ oft oork bupten om; ende dicht baer binnen is de reede ende ltadt van

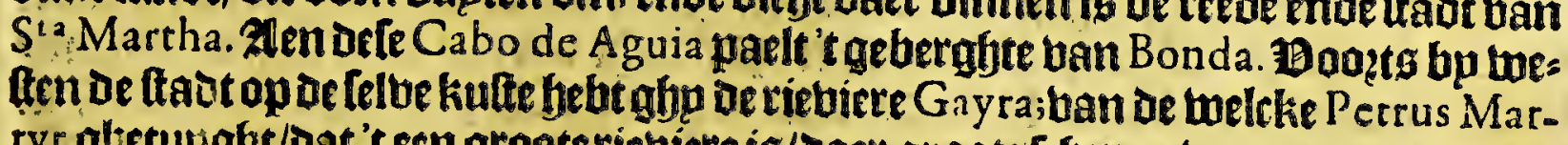
ry gltetupght/Dat't een grooteriebiete ig/Daer groote febepen bermogen te anckes ren; balt ban een leet joogen fneeulu-bergh. Baer ontent ig noch een riebiere ban beter twater/banenaer'tfrggen ban de Eviloe/fo en is' thater ban de riebiere Gay-

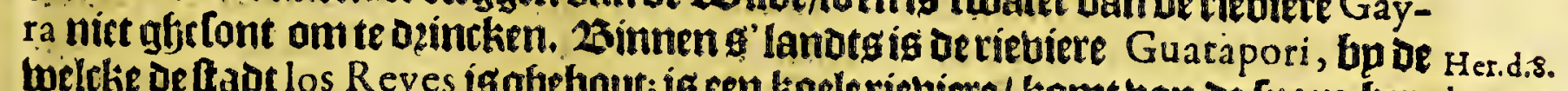

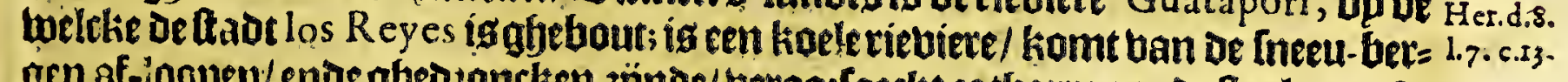

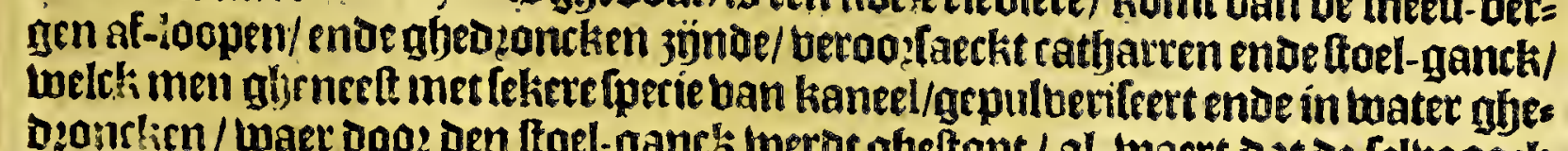

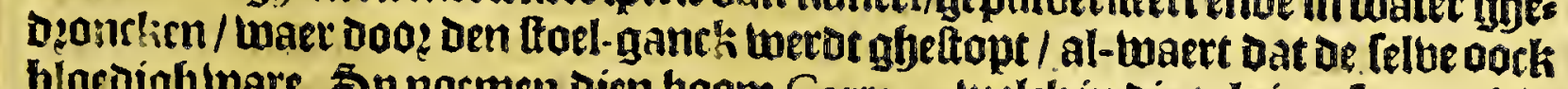
bloedigf tware. Sp noemen dien boom Carrapa, welrkin die tale is teleggen/bit:

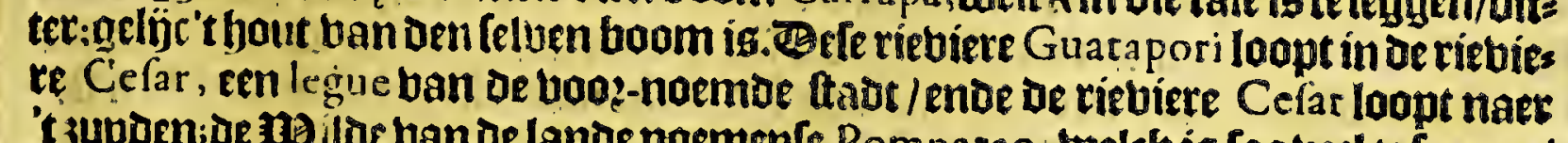
if jupden; de no idoe ban de lande noemente Pompatao, tueleli is loo beel te leggen/ 


\section{2}

Terra Firma.

als pênte van alle riebieren/Dooz dien daer vele riebieten in loopen, eñ intontot:

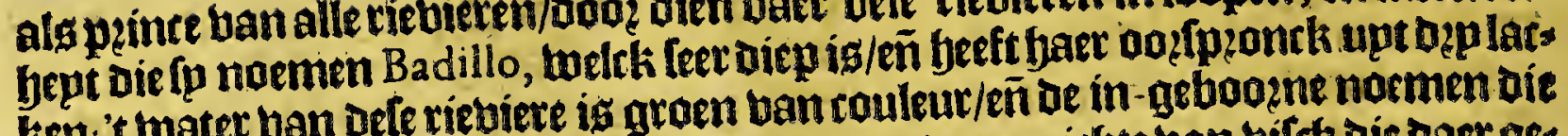
ken;'t water ban Dele riebiere is groen ban couleur/eñ de in-geboozne normen oie Socuigua, welckig te [eggen/aberbloedich/Doaz de menichte ban bilth die daet ges

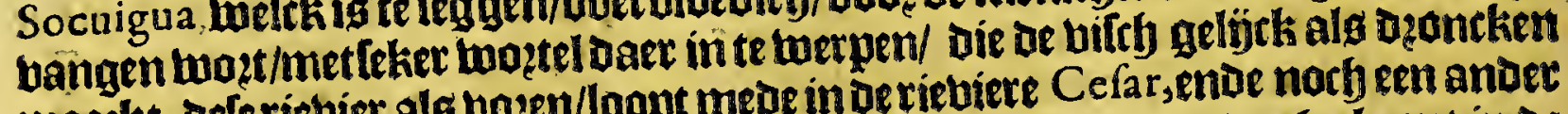
maeckt; dele riebiet als boęen/loopt mede in ae riebiere Cefar, ende nocb een ander

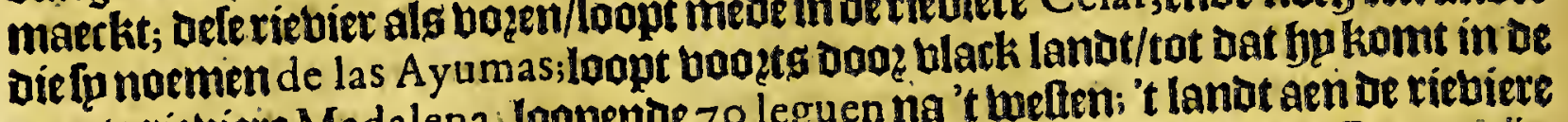
groote riebiere Madalena, loopende 7 o leguen na't welten; 't landt aen ie riebiere

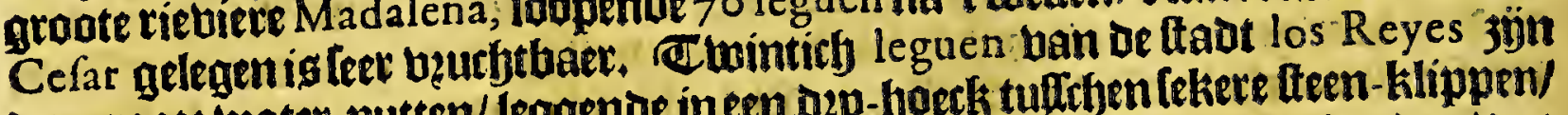
ozp groote water-putten/ leggende in een Dzp-boeck tuferben fekere ffeen-klippen/ al-waer de 3 ndianen boo - feker foutoen/ een groot ferpent fich te onthouden/ Dat beel menfthen feeft betlonden ; ende boe-Lel de [paegniaeroen 't felbe hebben na

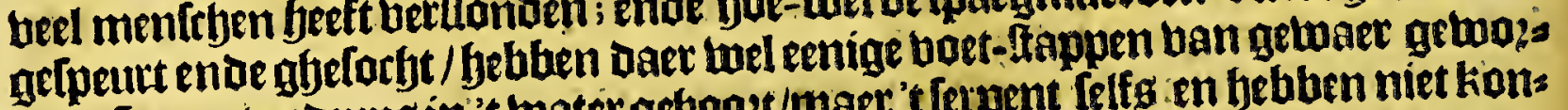

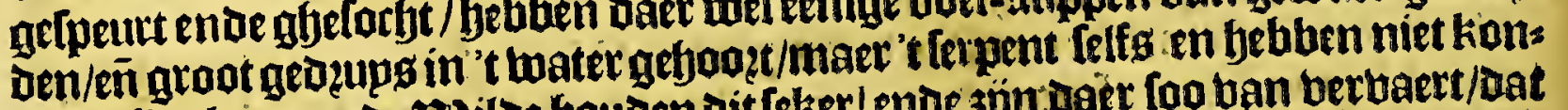

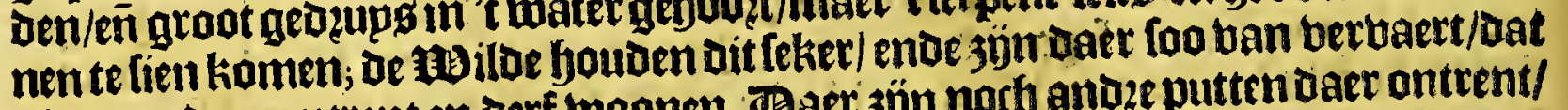
niemant daer ontrent en Derf woonen. Baer 3 jun nory andze putten Daer ontrent/ daer leecker perk ofte tar in wozt gevonoen/ welck [a kleeft/ Dat cenitb gevogeltel

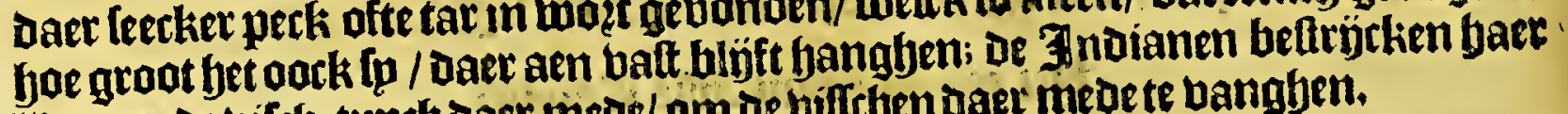
linen ende bilch-tupely daet mede/ o m de billeben daer mede te banghen.

fet thee en-twintichate Capittel.

Van de Stadt ende 't Gouvernement van R R O D E I A H $H_{\text {C }}$ H A.

D.

Et ftad Rio de la Hacha, wiert eetlt genaêmt noftra Sennorâ de las Nieves,

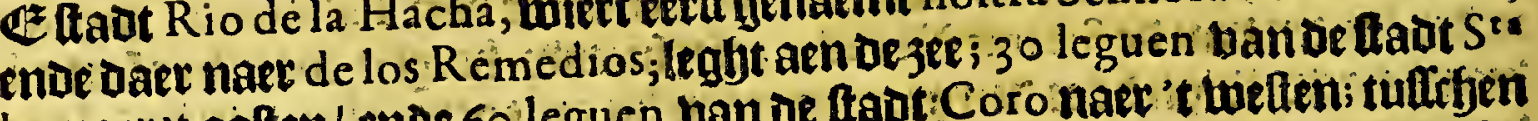

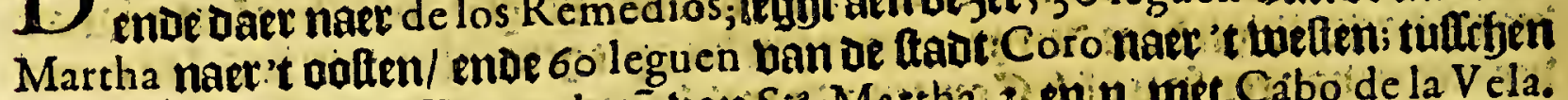
't goubernementuan Vençuela eñ ban St Matthá, 3 en ni mít Cábó de la Vela.

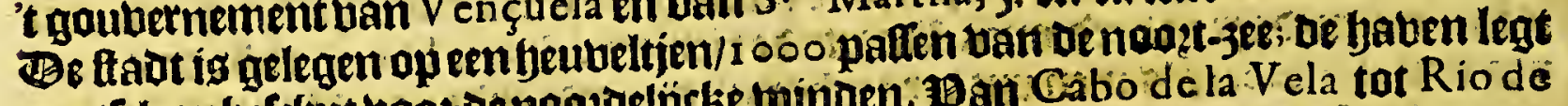

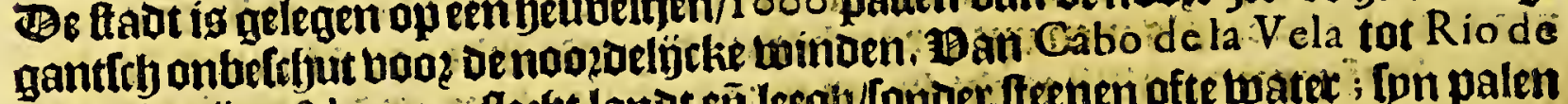

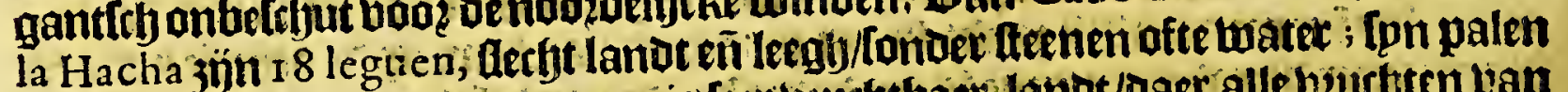

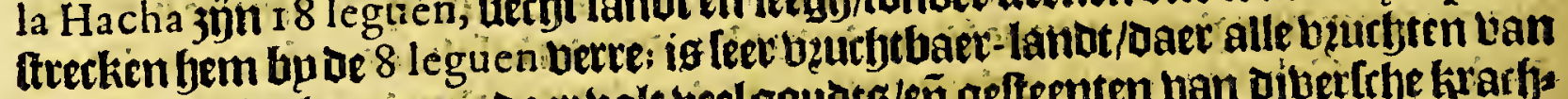
Spagnien twel groepen; daer valt veel gauots/eñ gelteenten ban dibertebe krarfy:

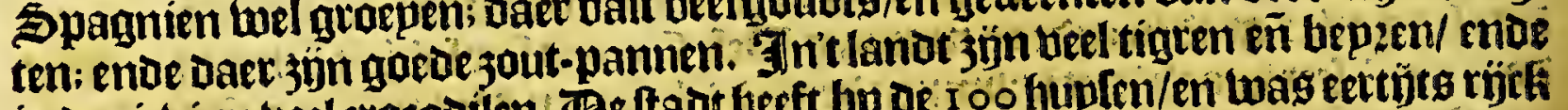

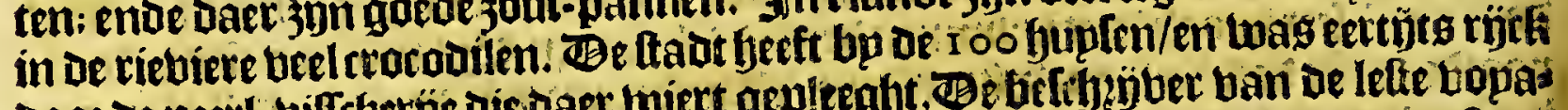

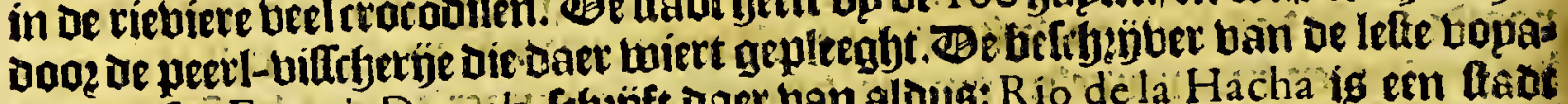
gie ban Sir Francis Draeck, tefyejft Daer ban aldug: Rio de la Hacha is efn tated 2o leguen na "t tueften van Cabo de la Vela, niet feet groot / oan leght in een fret veuththare ende bermaeckelinck getwefte. Ons bolck nament in te Io upeen in den

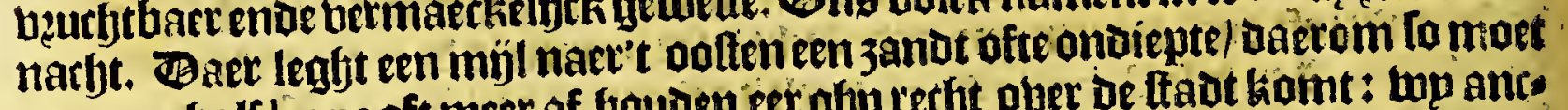

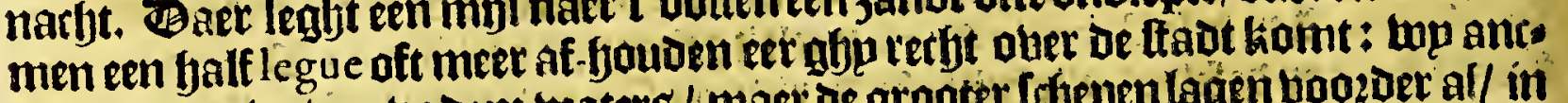
keroen Daer in twee badem waters/ maer de grooter frbepenlagen tioozoer al/ in

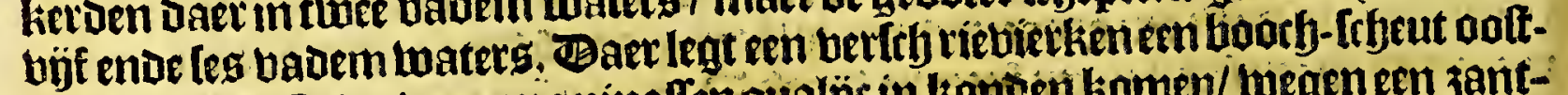
waett ban de ftadt; daet ong pinallen qualÿ in konten komen/ wegen een jantbantlie die refty in de mont ban bet rievietken leght / maec daec binnen is 't nabis gabel troo: bercken uan 20 oft 3 o baten/les oft arljt leguen op-waerts. Seg leg.

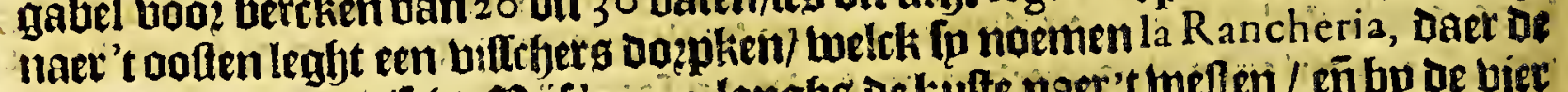

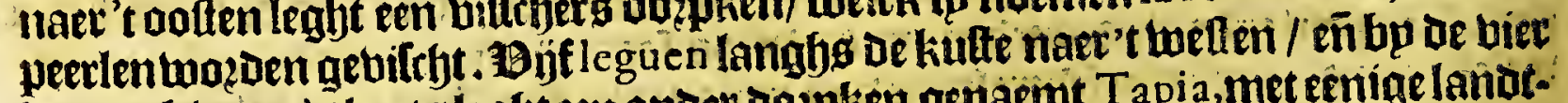

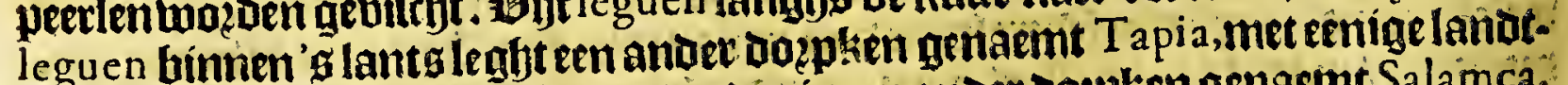

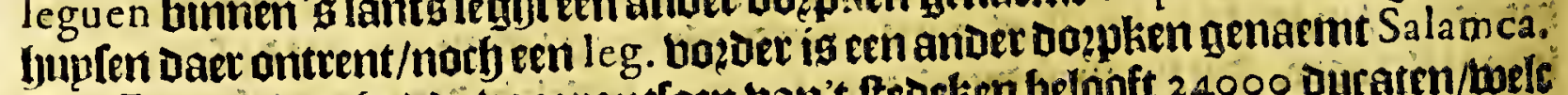
- Be Gouberneur gadDe voo rantloen ban't fredeken belooft 24000 durarm/toelc bp pzelenteerde te betalen met peetlen/tot loo hoogenpzijs/uat de CEnnellthen bie

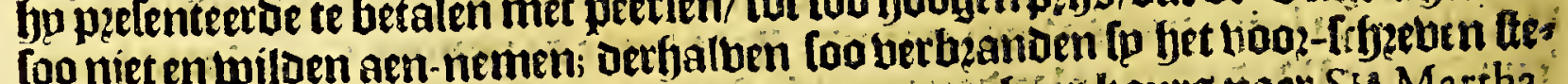
Deken ende alle vooz-noemoe plaeten/endenainen baer kourg naet S a Martha? BESCHRIL 


\section{Uan \\ W E S T-I N D I E N. Net negbende 25oeck. \\ Neuvo Reyno de Granada.}

Get extle Capittel.

Deeerfe ontdeckinghe van NEuvo REYNO DE GRANADA, onderhet beleydt van den Licentiaet Gonzalo Ximenez de

Quefada, in den Iaere 1536 .

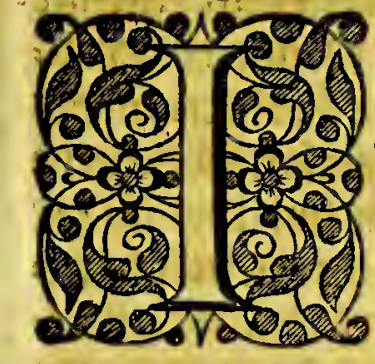

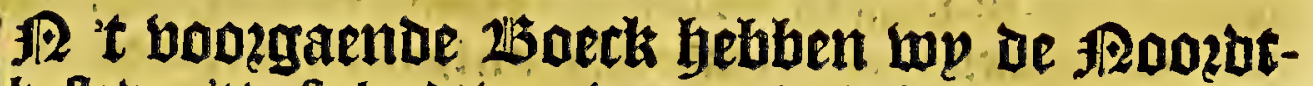
tulte ban't tuafte landot wan A merica berbolght tot aen' $t$ Gous vernement ban Veneçuela, fullen nu doo? de binnen-lanottribe

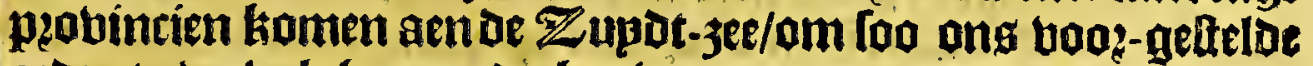
ozdete te betholghen; ende beginnen met de pzovinte die men yedenfaaeglgo noemt Neuvo Reyno de Granada ; Dan eet top

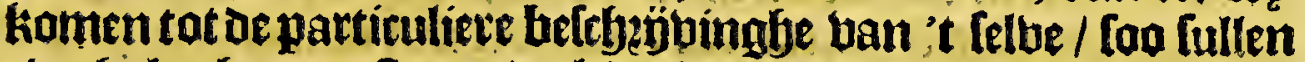

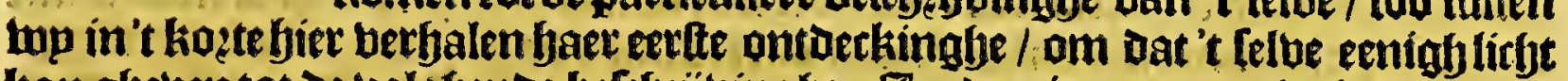

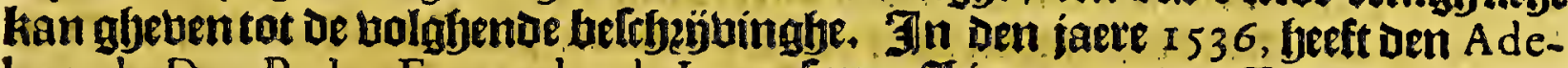
lantado Don Pedro Fernandes de Lugo, [menen ZLieutenant oen al icentiaet Gop- Her. d.s. Grande ofte de la

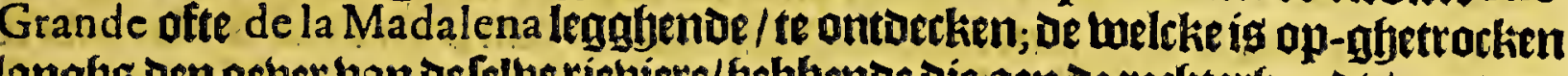

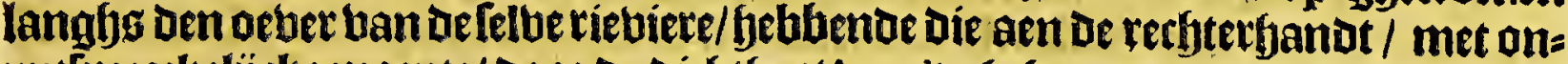

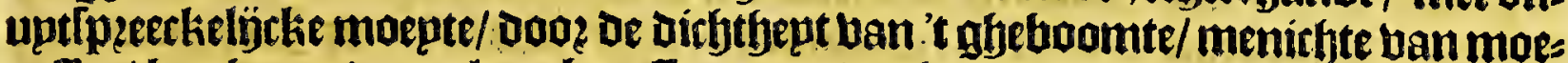

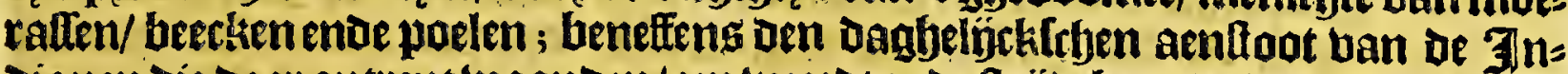

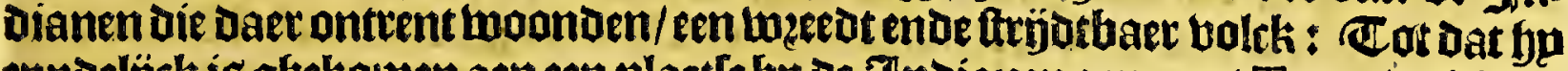

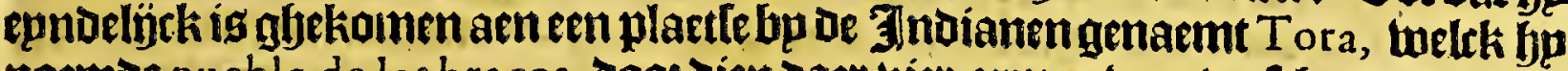
naemoe pueblo de los bracos, booz dien Dare vier armen ban bertibepoen riebies

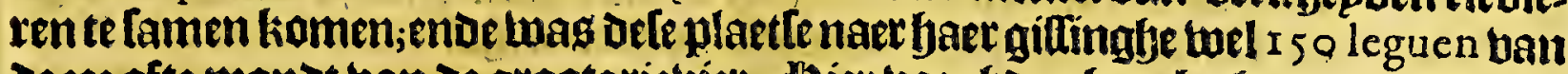

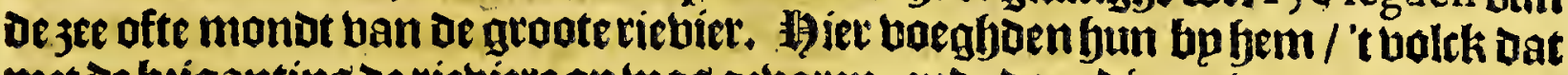
met de baiganting de rietiere op wag gevaren; ende dooe dien't twater ban de ries =

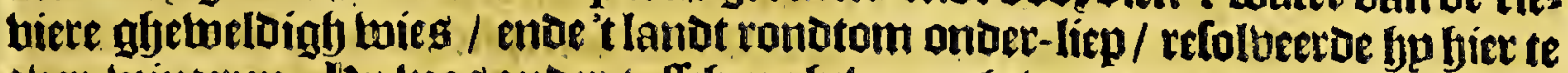

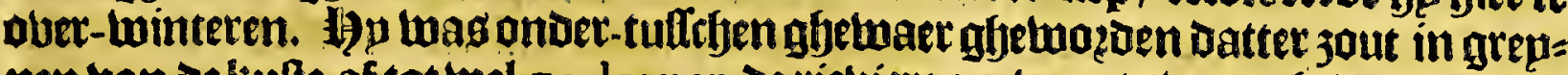

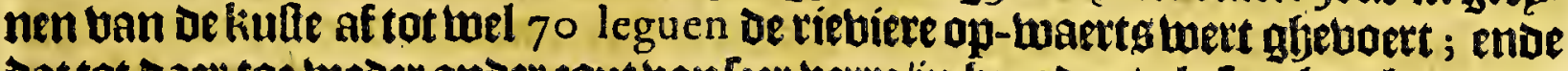

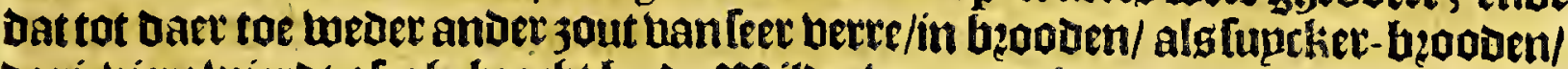

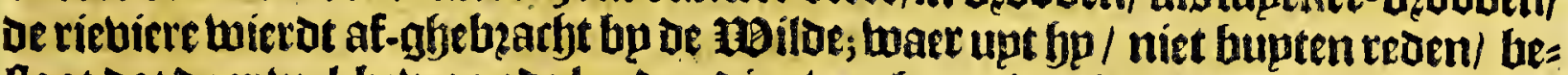

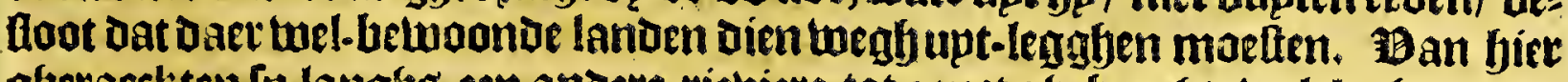

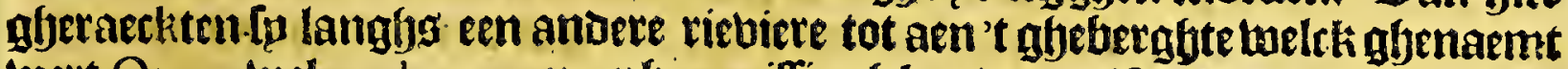

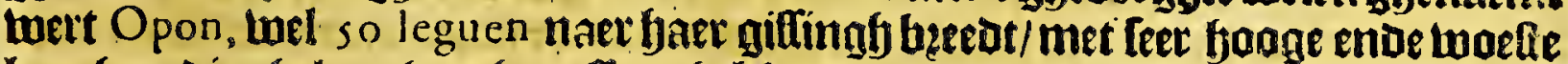

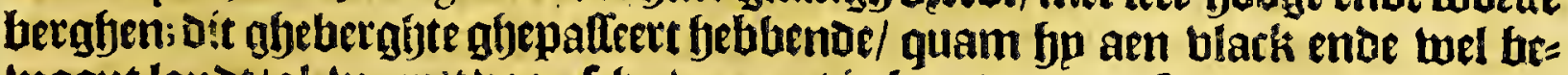

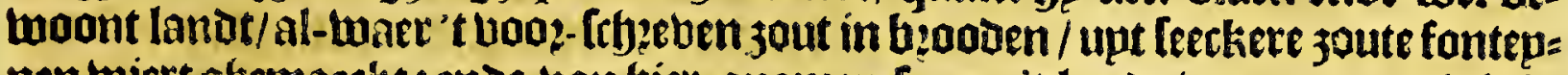
nen wiert ghemasckt: enoe ban bier quamen fo aen't lanot ban een marlytiqbe Cazique, belkkts naem twag Bogota; Đe twelkke te boozen ban de komfre van een

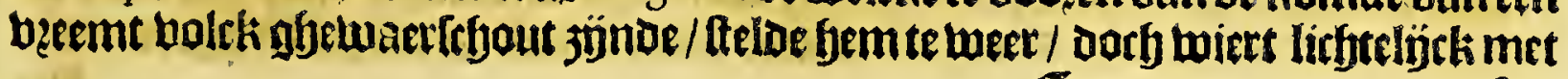




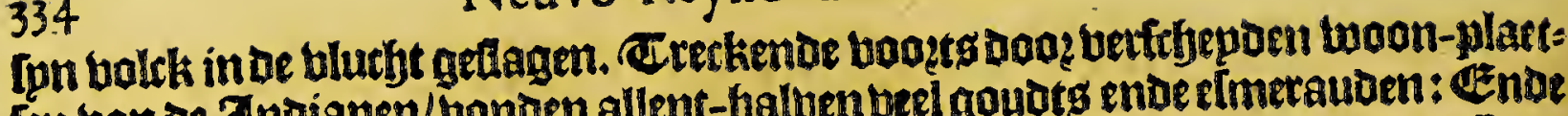

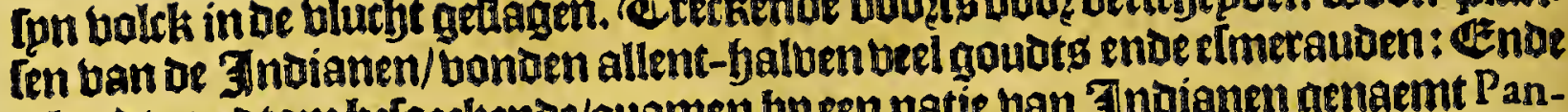
't lanut rondtom befoeckende/quamen bp een natie van Indianen genaemt Pan-

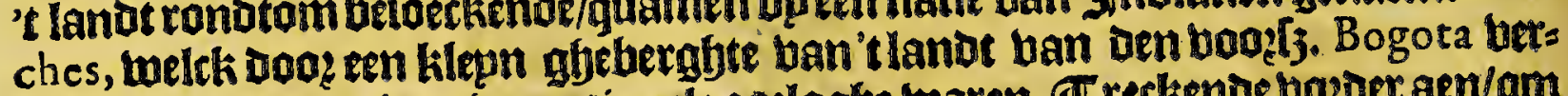

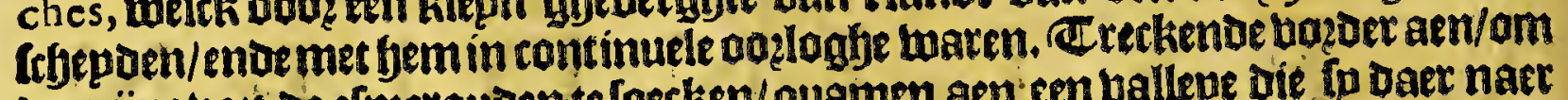
De mijne bari de elmerauden te [oecken/ quamen aen ren ballepe die fo daer naer

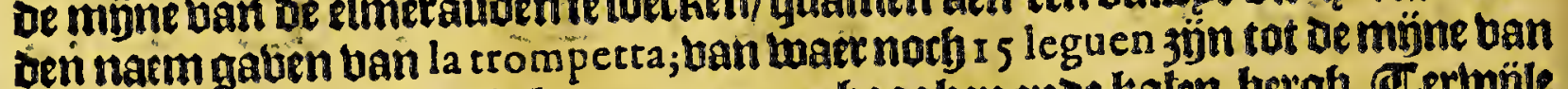
De efmerauden/melck Iegththoben op eenen hoogbenenoe katen tergh. Certwöle Ip in defe ballepe vertaefoen/quamen daer feeckere E Eiloen dis baer pesfenteetden Den lwegh te wojifen omeen ander groot ender rijck Heer ghenaemt Tunia, onber:

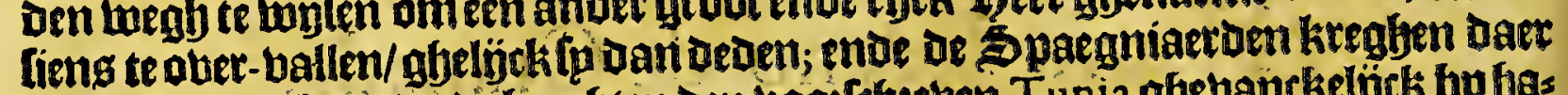

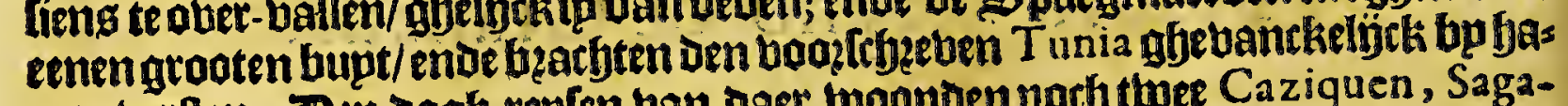

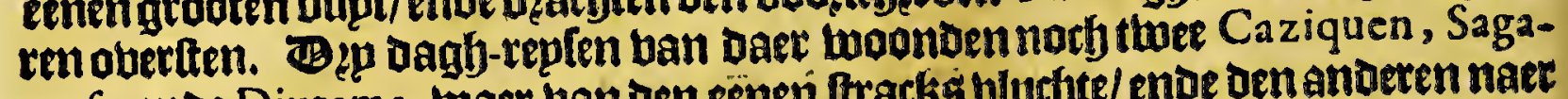
mofa, ende Diutama; waer uan ben eenen Itracks blurfte/ ende den anderten naer wepnigh luederffanots retireeroe bem in een ftercke plaetfe; kreglyen bier mede

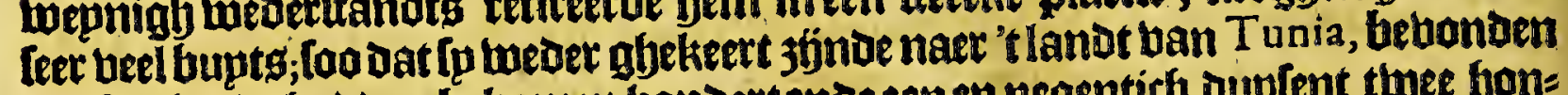

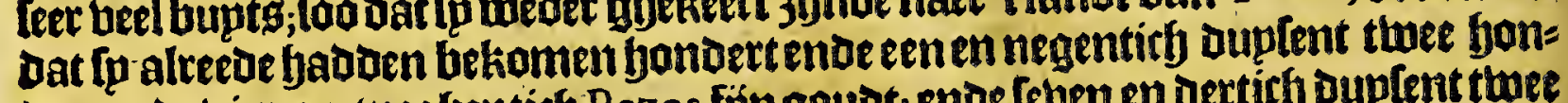

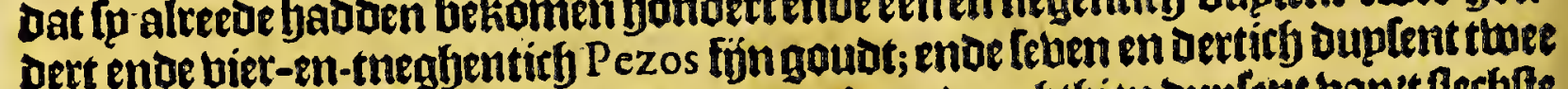

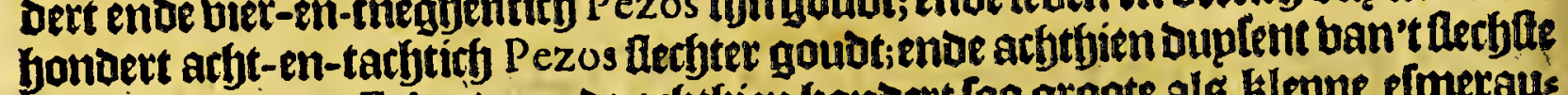

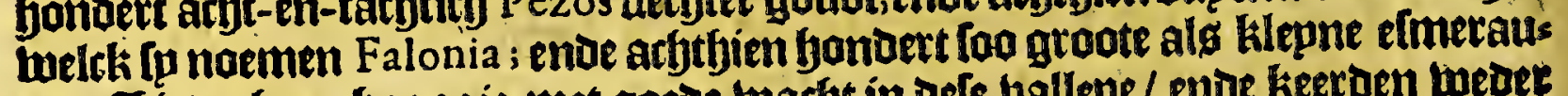
ten. ILieten faet bagagie met goeue hacht in defe vallepe / enot keerben weder

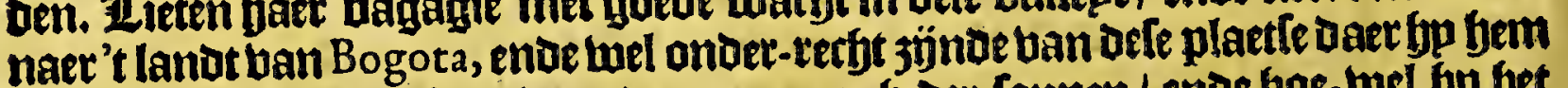
ontbielt / over-bielen Gem vooz den op-gangh der fomen / endoe boe-wel bp bet

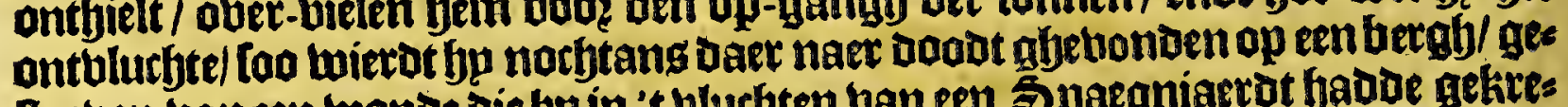

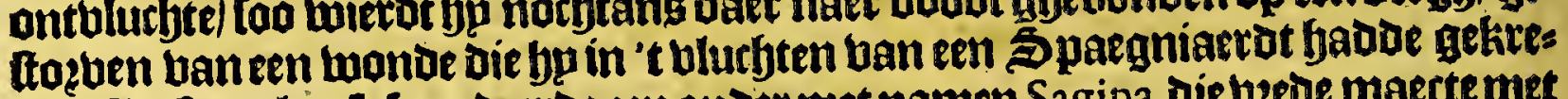

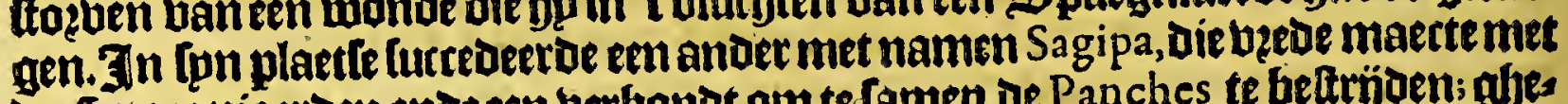
oe Spaegniaerden ende een berthondt om te famen de Panches te beatrijoen; qujes

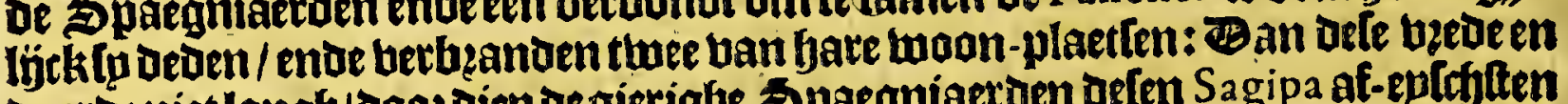

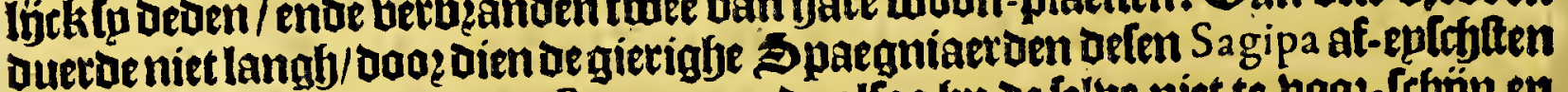
De verbozghen Ichatten van Bogota, ende alloa fop de felue niet te book--ctyjn en

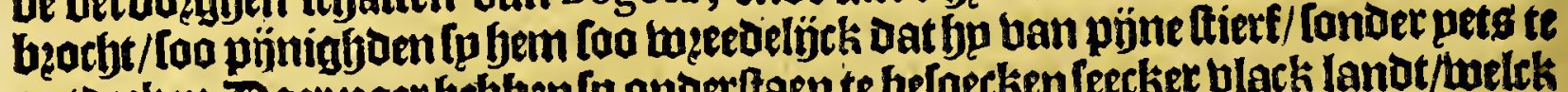

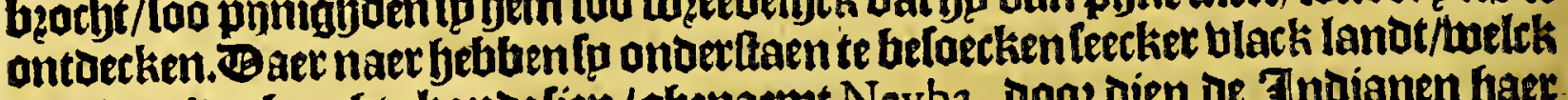
men van 't gebergfjte Kande lien/ghenaemt Neyba, Dooz dien de Thnoianen Gaer. wijs maeckten/ om Defe gaften quj̆t te getaecken / Dat in dat lanot feet grooten

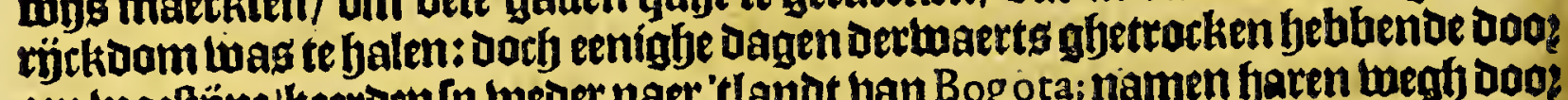

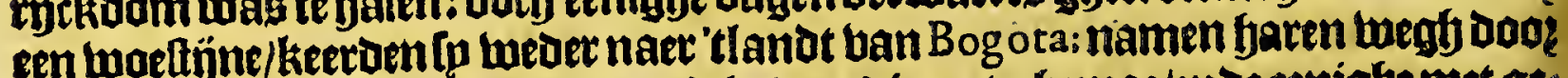
oe Panches, ende beveroighoen eenighe ban diemet ngemae/ende eenigbe met ges welt.X Ximenez 't landt nu genoegh ont beckt fouddende/gaf' $t$ Den naem van Neuvo Reyno dé Granada, Doo: Dien bju ban Granada gethooetich wag/ endoe hoube

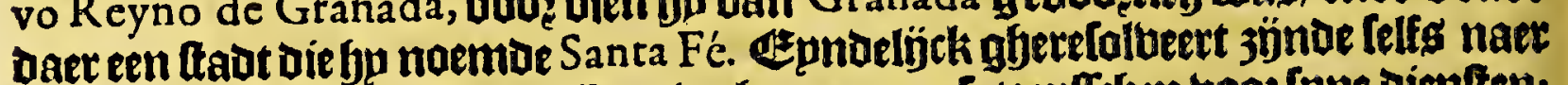

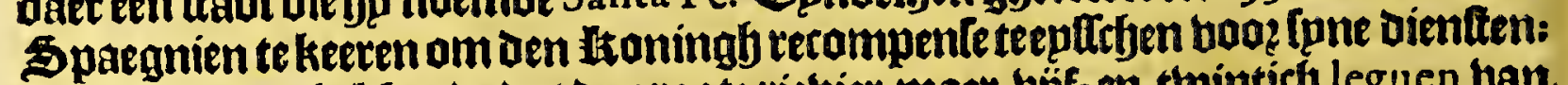
ende bethanden betbende dat oe groote riebier maer bjj-en-twintich leguen baan.

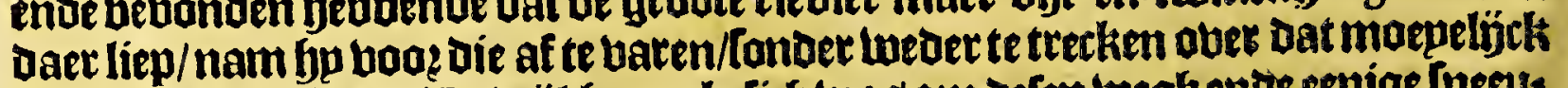

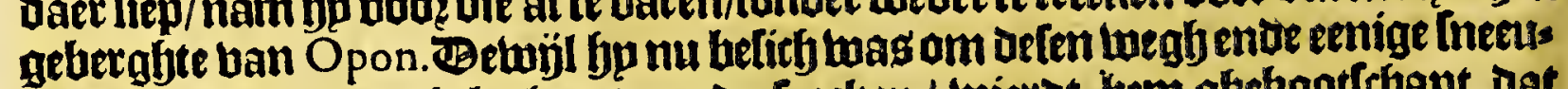

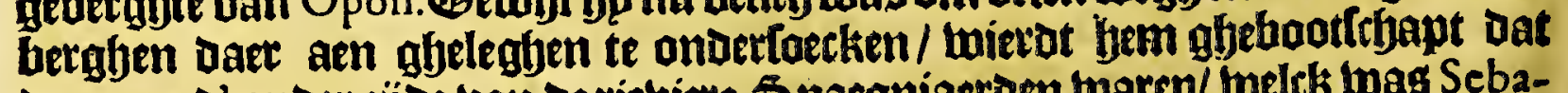

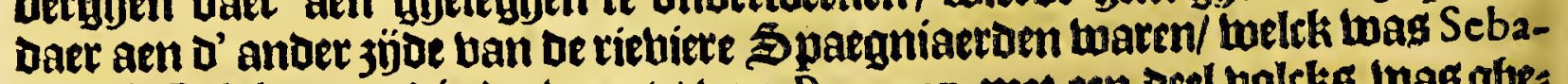
ftian de Belalcazar, Die Detwaterts ban Popayan met een Deel bolcks luas ghtes

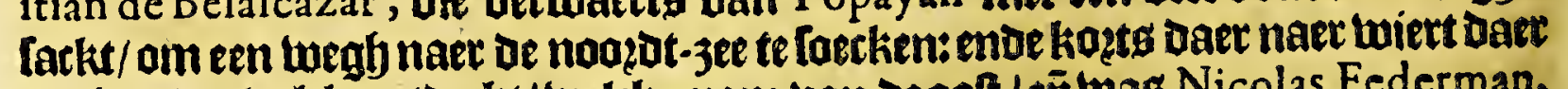

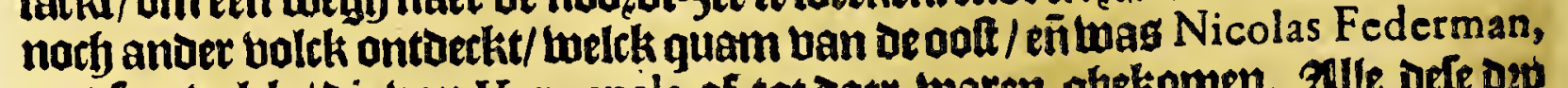

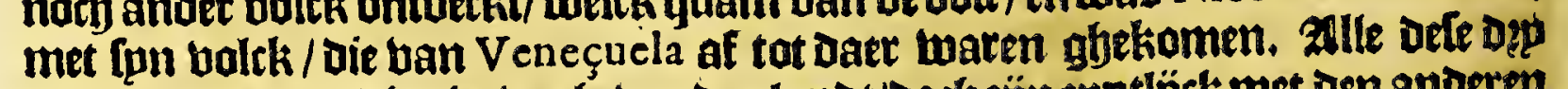

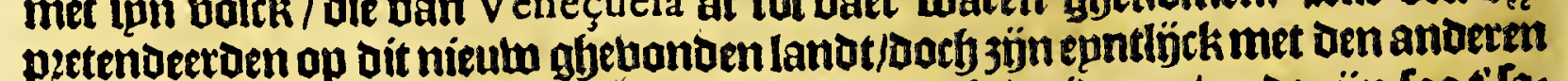

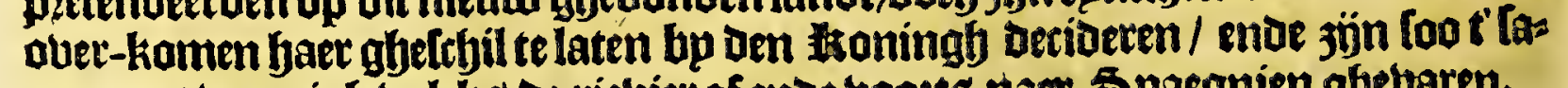
men met we wnigg volck de riebier af enoe boo 
1)et tweede Capittel.

Befchrijvinghe van de gheleghentheyt van defe provincie van $N E$ u v $\odot$ RE Y N O E GRANADA in' $r$ ghemeyn, ende de befondere provincien daer onder begrepen.

H Et nieulwe rïck ban Grana da, neemt fan beginlel bp zupden bet gheberabte Her. d.6

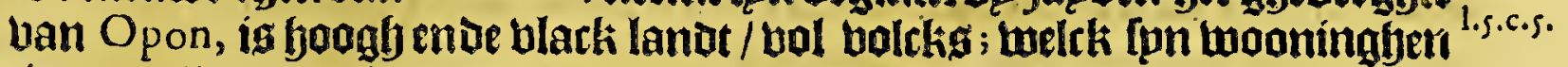
Geeft in oe ballepen; is in't tonde gantefy om-cingelt ban een natie van Jndia= nen die fp noemen Panches, tuelch jün menichen-etets/ welck die van Neuvo Reyno niet en jün. Let lanot van De Panches is heet/ ende dat ban Bogota ig kotior / ofte ten minlfen feer getempert; ende gelíck die faer Panches noemen/ loo noemen die ban Bogota ende Tunia faer felteren Moxas. Dit röth ig langh (naet 't fegghen ban senige) I 3 o leguen wepnigh min ofte meer; enoe bece d 30 leguen,

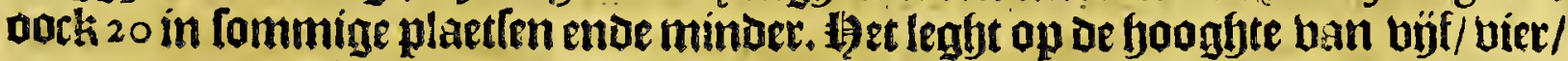

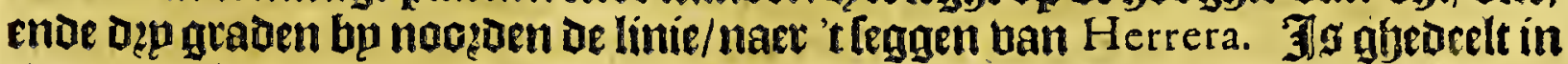
twee principale probintien/ Bogota ende Tunia; welck fjaec berferepden Hecten hadoen van dien naem/ Doen de Spaegniaets daer eerí quamen. Bepzonintie van Tunia ig rïcker ban gout ende efmetauden/als die van Bogota, boe-wel defe

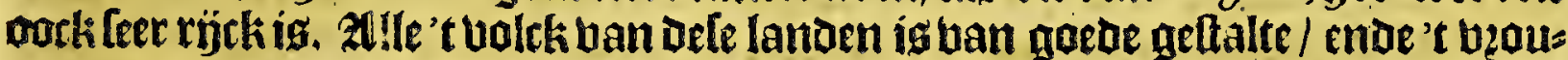
tuen-bolck be[nedener ban aentictyt/ende niet foo buun als in andere quartierent ban defe nieulu gljebonoen landen: Sp kleeden faer met fwarte/ twitte/ende glyes koulcurde mantels om't lijf gegoet/uan oe boelt tot de boeten/ende fommige oork wel ban de fefouderen neder-waerts ; dzaghen op 't booft ktanten ban bloemen ban coftoen ghemaeckt/ban Differente houleuren: ende eenighe puntipale Dzagen bonnetieng ban tottoen/ende [ommigfe oock netjeng. Be touse en gheeft daer geen ongemack/ Loa datmen t bper [oude ban doen geblien/Dan boutot eeneenpa=

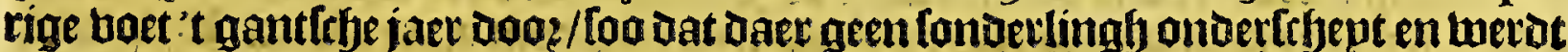

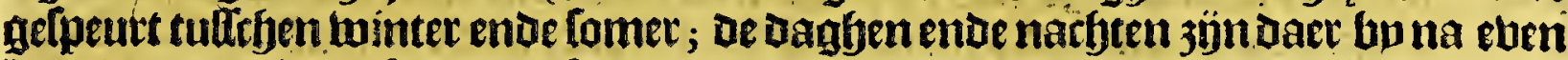
langf: boos Dien defe landen foo na onder de limie equinortiael leggen.' Cl lanot ig

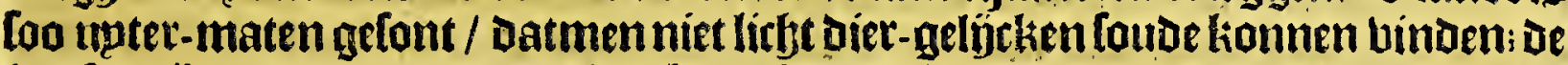
bupfen jïn Dooz-gaeng ban plancken ghemaerkt / ende met langh froo gedeckt. 't Bolck eet daet Maiz,ende ach Caffa vi, alg mede lekete twottelen die fu noemen Yomas, ende [ekere rapen die [p noemen Cubias; daet werotueel jouts gemaecke/

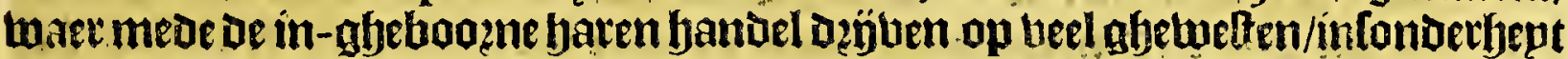

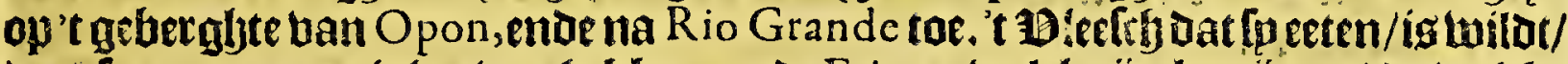
baerfu groote menighte ban jebben; ende Fricos, welek zön koninnen/ De luelcke bie Lan Santa Marcha noemen Curies; Daer is tepniglj afjettogelte/ ennighe toz= eel-bupben; epnot-bogyelen tamelïcken beel/ die in de laclien bzoeden ; in belcke

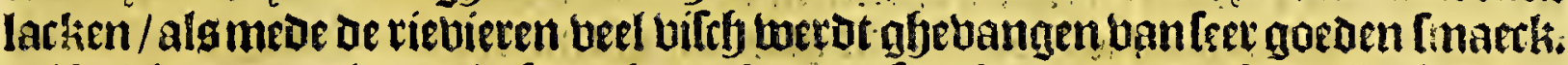
t Bolcli ban de lande ig feer ghenegljen tot limglien ender danfen/3ün fret leu= ghenachtigh als fetmeefte bolck van Indien; hebben tamelibe berftand om di= betfilye hande-wertken ende kontten te leeren. Ban de natie van Panches balt mepnigh te legggen/ aengaende baer maniere ban leven / die feer beeftelight ig.

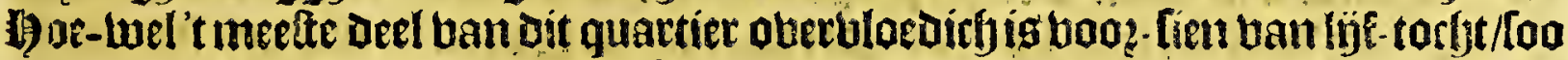
3ijn Jaer voct gfyelweften Daet bet feer armelïch dien aengaende ig gfeitelt; want in eznpzobincie/ neffens die ban Tunia ghelegen/ twierot bebonden dat de Hoiloe

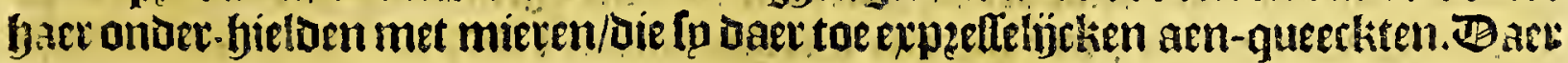

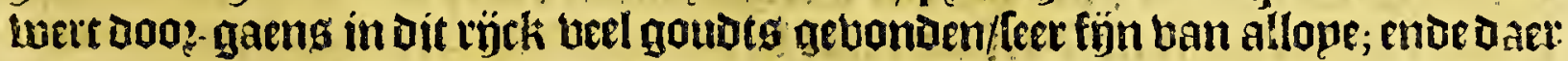

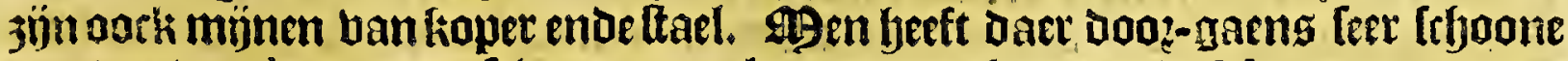
wapden boos't bee; ende feljoolle jaep landen daex koogn ende Maiz, ende andere

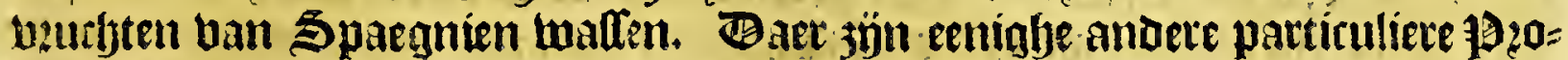
bitrien die onder Neuvo Reyno bejoozen / die fullen wu beferyejuen bp de 


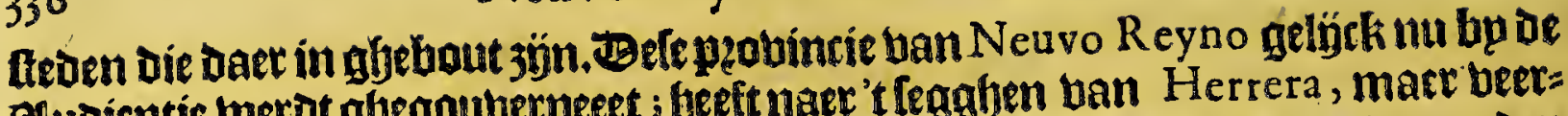
Zludientie werdt gbegouberneet ; heett naer't fegghen uan Herrera, mart beer=

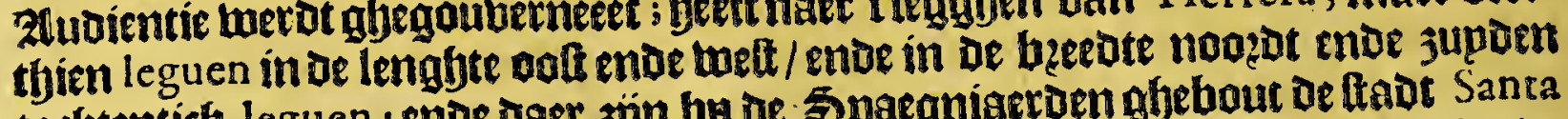
tarbtentirb leguen : ende daer 3 jon be de Spargniartoen ghebout de ftad Santa Fé de Bogota, De blecke ban $S^{2}$ Miguel; aeftoen Tocayma, la Trinidad, Tunia, Pamplona, Merida, Belez, Marquita, Ybague, la Vittoria de los remedios; St Iuan de los Llanos, enoe de blecken tanla Palma, ende San Chriftoval.

\section{Het Derde Capittel.}

Befchrijvinghe van de hooft-ftadt SANTA FE DE Bocota, ende van. de vlecke SI MIGVEI, ende de ftadt TOCAYMA, ende de gheleghentheyt van de landen daer ontrent.

D

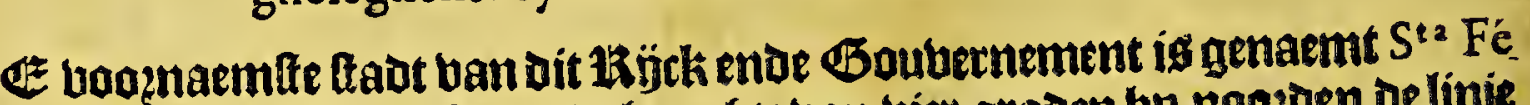
de Bogota, welcke leght op oe fjooghte ban biet graden bp noożen oelinie equinactiael; ende op de lengfte ban twee-en-leventich graden ende een balf ban den 9 eríuiaen ban Toledo, na de rekeninge ban Herrera. Jg gebout bp Gon. çalo Ximenes de Quefada, aen de voet ban' treberghte van Bogota, foo genaemt naer de naem ban de Cazique die de Spaegniaerden daer bonden ten tojoe van

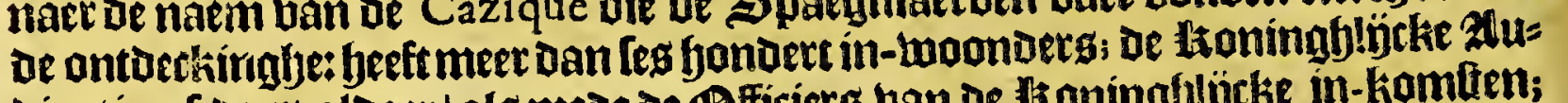

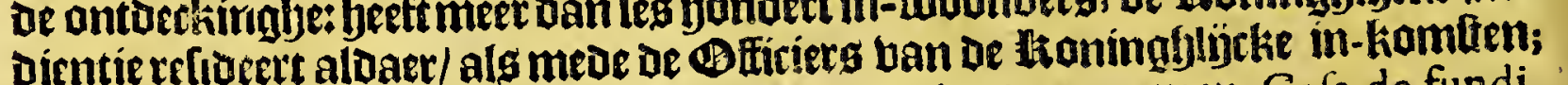

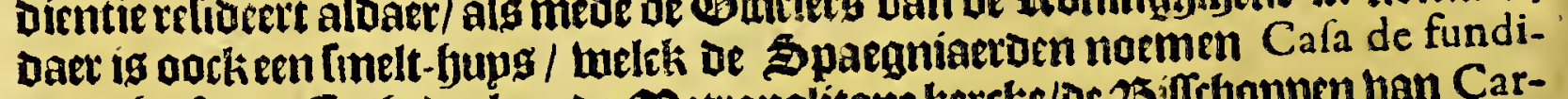
cion ; feft een Catfedzale ende Shetropolitane kercke/De 25illtyoppen ban Cartagena, $S^{\text {ta }}$ Martha ende Popayan, jón luftraganen ban de Lelue / Daet jün thee

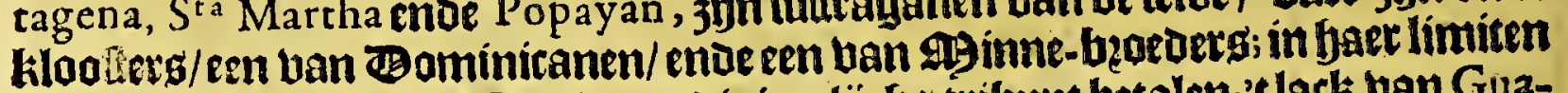
woonen meer dan 5000 Jndianen die jaertibckg tribupt betalen;'t lack ban Guz-

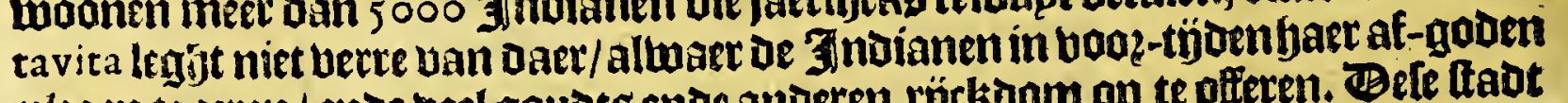

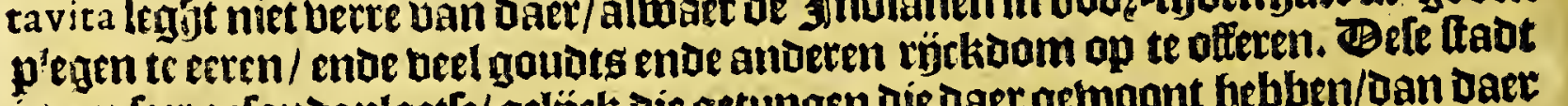
is een feer gefonde plaetle/gelijek die getupgen die daer gewoont beblen/Dan Daer

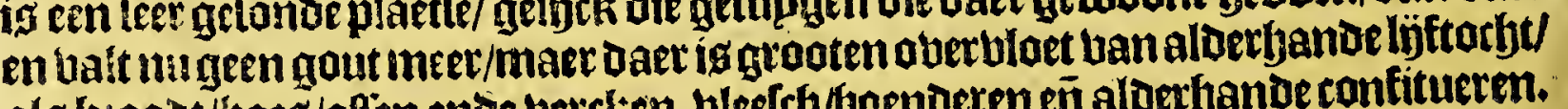

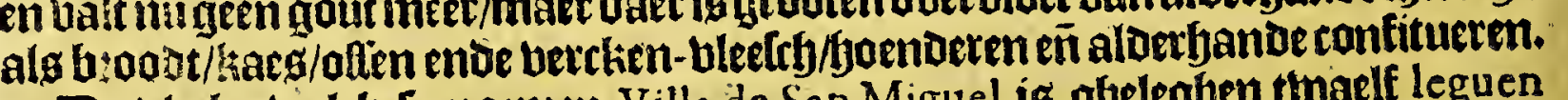

De viectie tweltk in noemen Villa de San Miguel is gloeleghen twaelf leguen ban oe ftaot Santa Fé de Bogota, naer het noożoen toe/ is Daar gheleght om

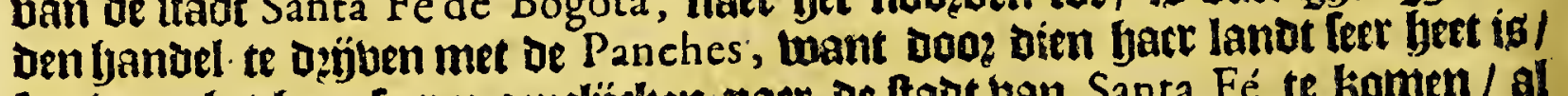
foo mag bet baer feer moepelijcken naer de thadt uan Santa Fé te kamen/al wart kouder ig.

- Be ftaot Tocayma leght bujfthien leguen ban oeftadt Santa Fé naex 't belten/ cen wepnigh declinerende naer' $t$ noagen: is gbebout aen den oever ban de groos Her.d. . te viebicre Pati, Die faren tourg neemt îl oe groote riebiere Madalena : of glteles

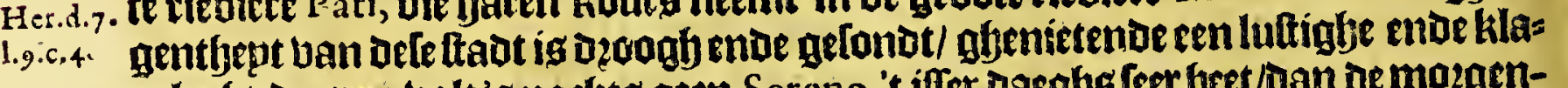

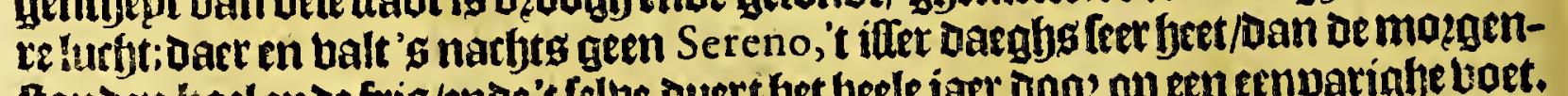

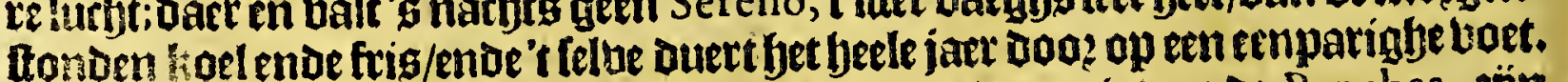

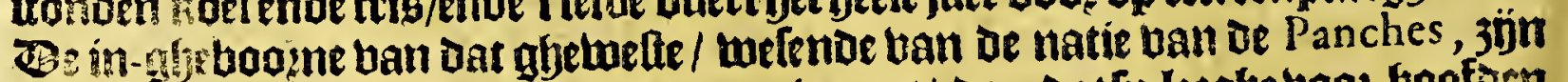

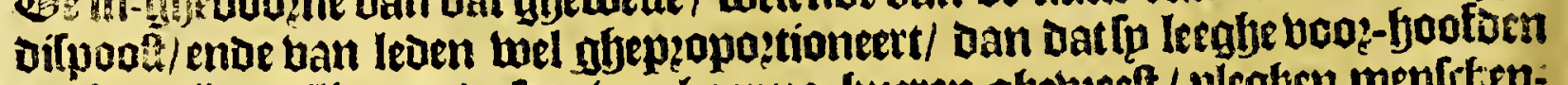

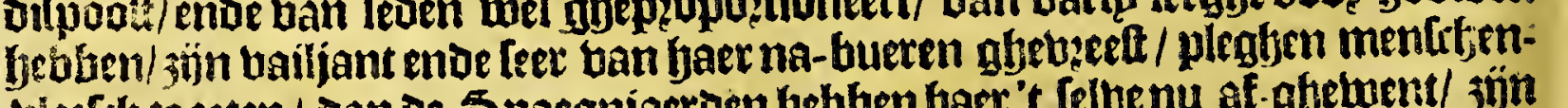

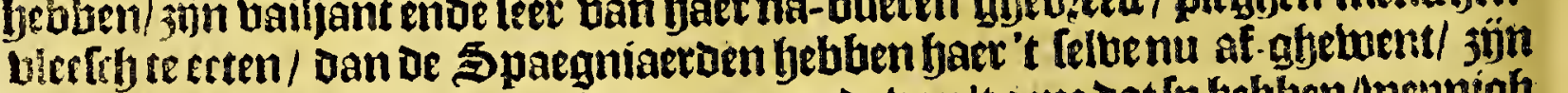
liberael ban conditie/ende deeien naerne mede ban't gene dat lp bebben/wepnigh bzgecrigh naer goust ; Ifer tw2aeck-gierigh/ Inel in't loopen / enoe ghetweldighe

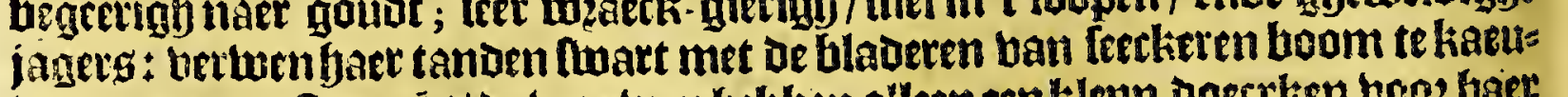

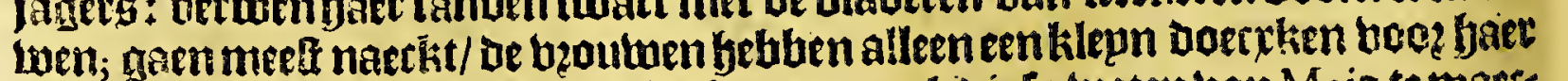

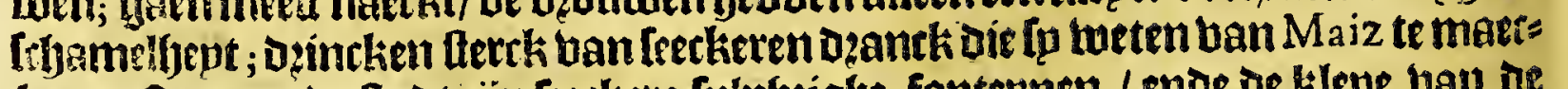

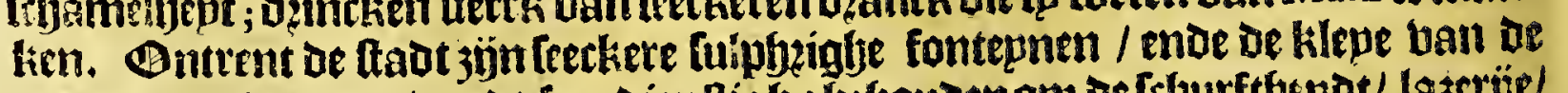

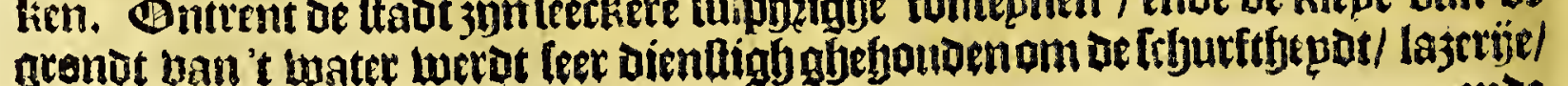
ento: 


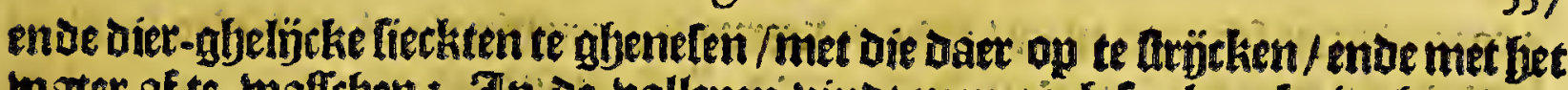
twater at te wafirben: $3 n$ de ballepen bint men oock Leetkere lpinghen ban

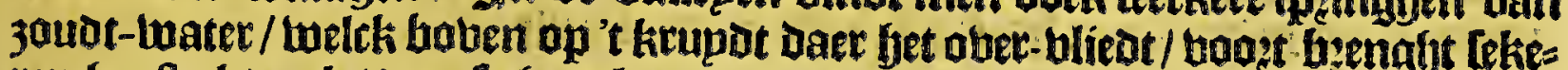
ren bart als peck / daet fp yaer kanoen mede pechen: Daer jön oock leeckere beete baben tuftethen twee koude beken / daer men bele qualen doo kan gljenelen. Op

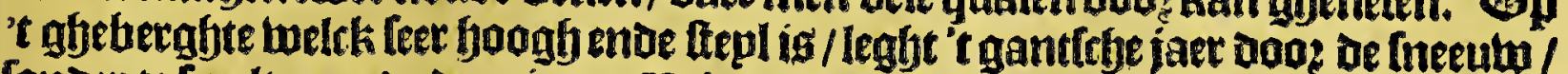

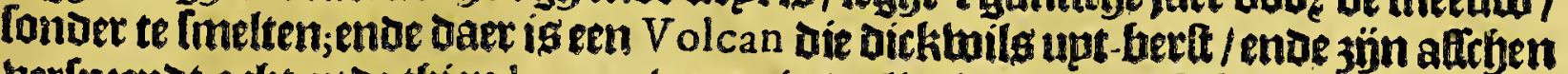
berlplepot act) ende thien leguen verte: in be limiten ban dele ftad 3 jn beel mij= nen van goudt / filber / koper ende looot. (Herrera fegft in fan Defcripcion de las Indias, Dat Defe plaetfe gheen goubt en jeeft.) Men beeft baer goede burbten

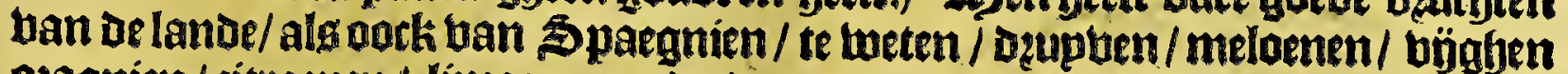
ofagnien/citroenen / limoenen ende dapen; Daer baet beel fupcket-riedt / ente werot oock fupcker gyemaeckt; daer balt kooen op de hooghe ente koele lanoen/

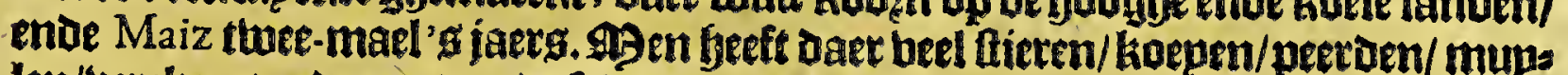
len/betckeng entie gepten; de Cchapen willen Daex niet wel aerden; be tigren//eeus

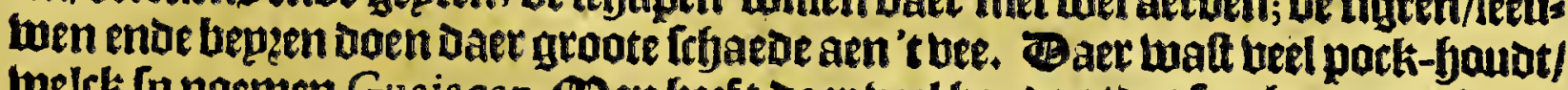
melck fp noemen Guaia can. Agen beeft Daer beel boudtg / bat leer bequaem is am buplenmede te timmeren/ende beel dat onoer 'tmater nopt en bergaet; beel tedat-

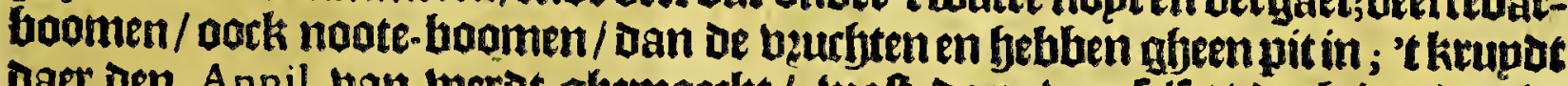

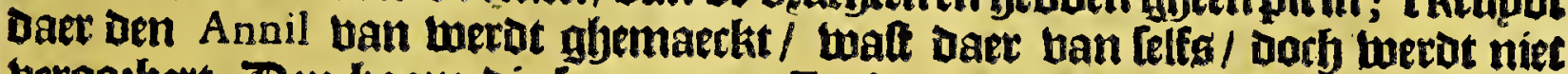
berooefert. Den boom die ip noemen $Z$ eyba, ballen fpn bladeren alle thaelf upzen / ende groepen terltonot wedex-am aen: men binot daer groote varietept

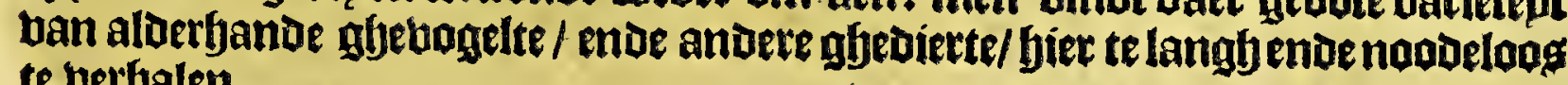
te berfjalen.

\section{Wet bietoe Capittel.}

Byfondere befchrijvinge van de provincien die by de Volckeren bewoont werden diefynoemen MVSo's ende CoI YMas; de gheItalte van ' $t$ land $t$, ende manieren van' $t$ Volck.

A Ez ne probincien ban Bogota ende Tunia, canfineren mede te peobincien ban leecker bolck die ghenaemt werden Mufos entue Colymas; twelck lanto

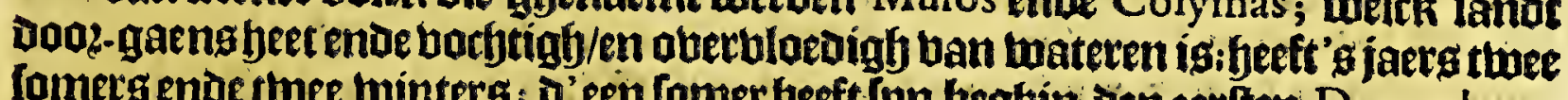
fomers ende thee winters; a' een fomer beft lpn begbin den eerten Decemb. en buert tot 't lefie ban Februar. enue d' eerfle lwinter van Den eerften Martij tot bet lefte ban May; ende dan begint den tweeden fomer/ende duert tot jet epnoe ban September, ende foo booztg den tweeden twinter : niet dat bet d ten tỷ beel beeter

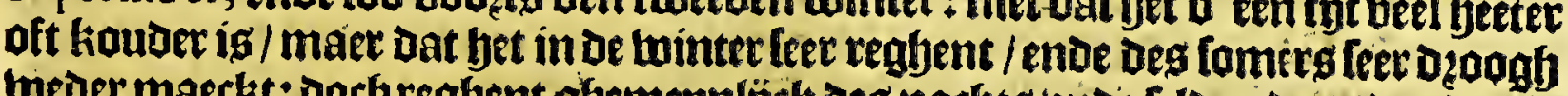

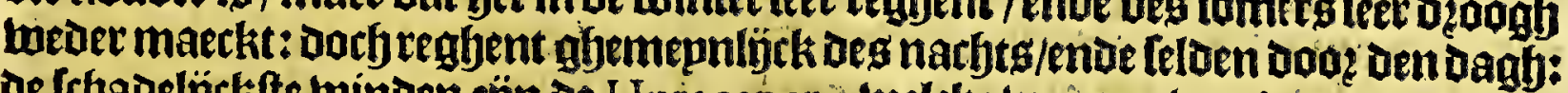
de Ichadelïckfte minden 3 ïn de Huracanen, twelcke twatpen ban 't noozen naer

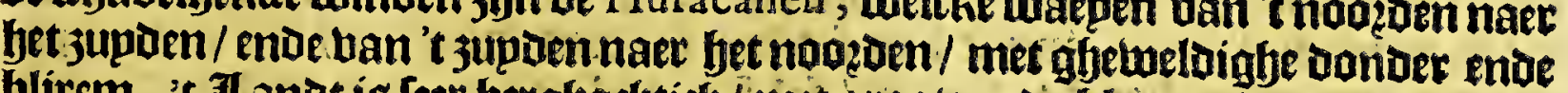

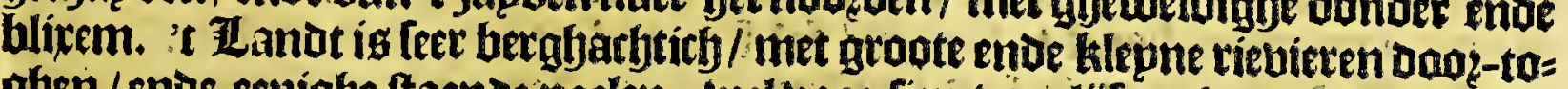

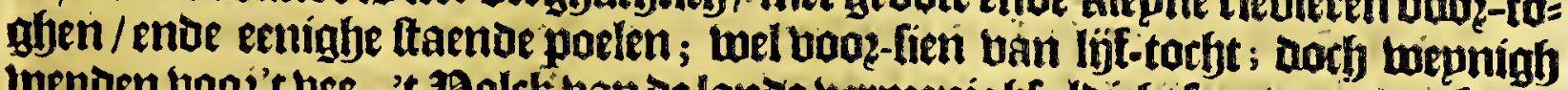
wepden boo't bee. 't Bolck ban de lande bermenighfuldieft feer / naer dat lp af-'

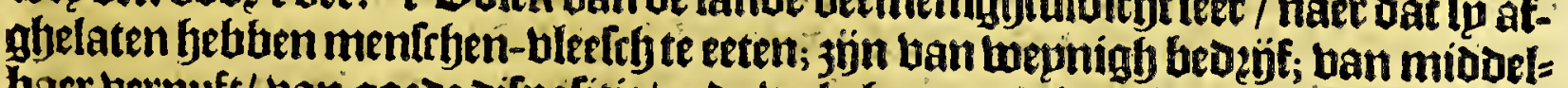

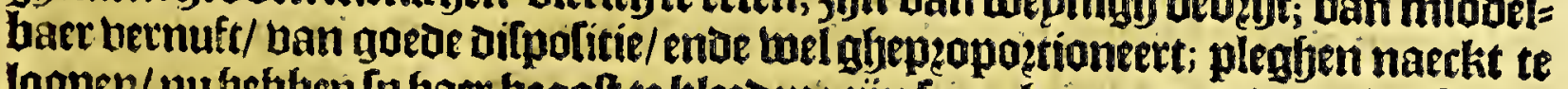
loopen/ nu febtuen [p haer begoft te kleeden: 3 gn feer ghenegen tot ozonckentrgap/

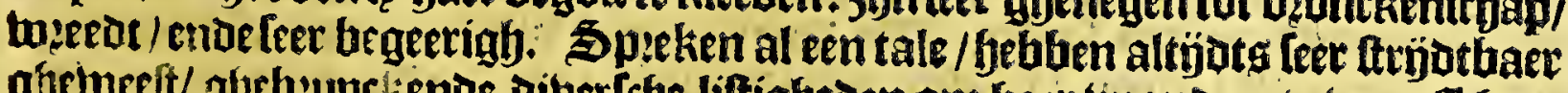

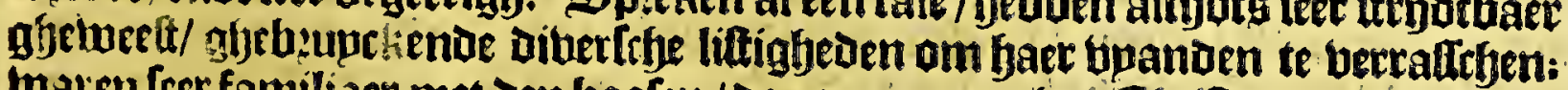
waten fer familiaer met ben boolen/ Dan nemen nu fjet Ggeiftenen gheloof leer bel aen/endenaer d at fu den doop febben ontfanghen/en weten nu ban ben oups

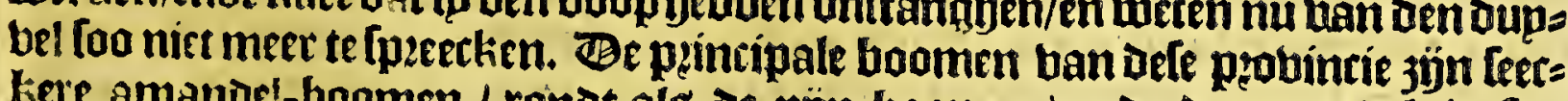
kete amandel-boomen / ronot alg of pün-boomen/ ende de amandel is loa Bg 3 
Neuvo Reyno de Granada:

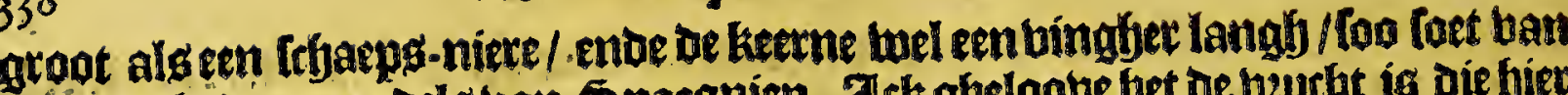

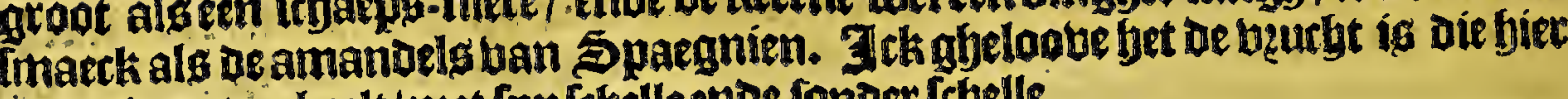
onder is upt-gethelt/met fonichelle ende fonder lchelle.

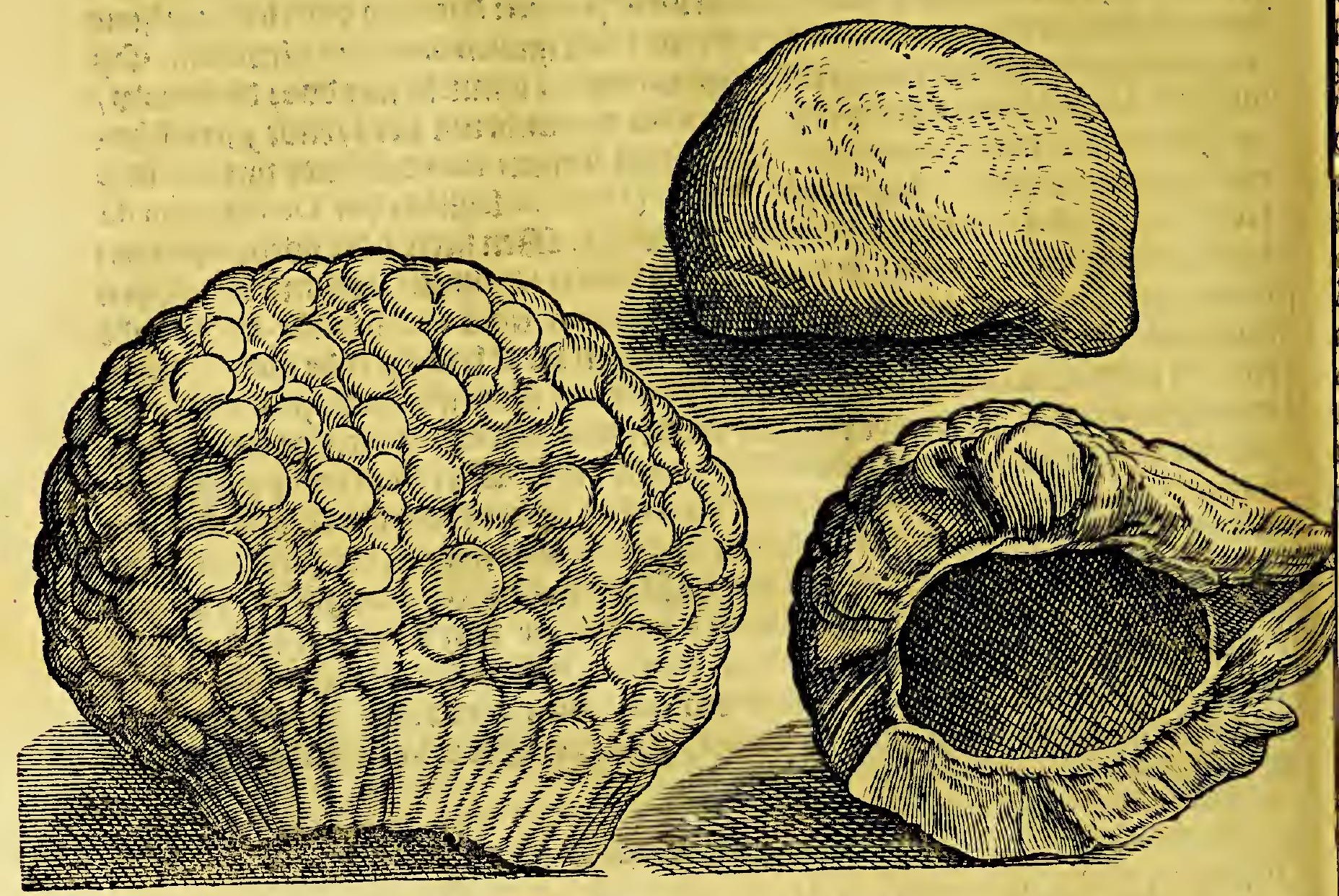

Daer is norben ander boom die [y noenten Q ua que, bengende een eftbare

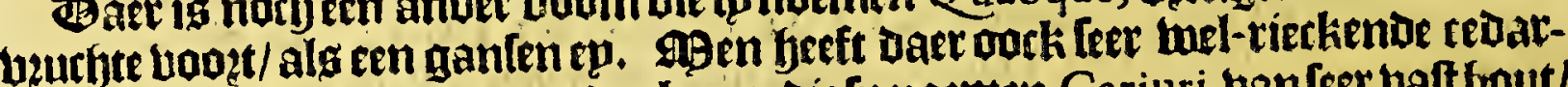
hoomenidaer balt norlyeen ander boom die [p normen Cariuri, wanleer balt fyout)

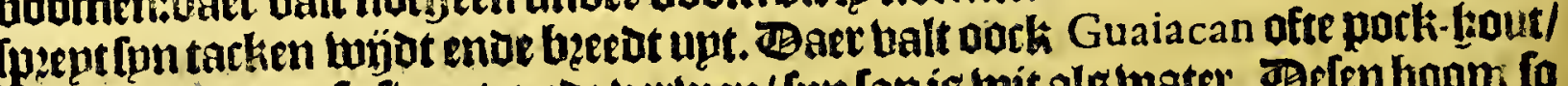

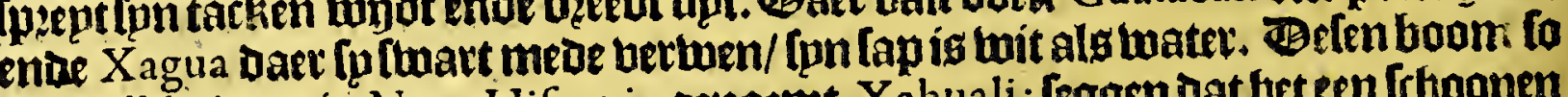
ick giflelje woxt in Nova Hifpania genoemt Xahuali; leggen Dat fret een fryoonen boom is/ende de bladeren bp naer gbelíck on Te ellefyen-boomen; beeft leer lmaer boubt: ende Dzaeght een beurbt bp naer als de man-koppen / Dan dat bet gbeen

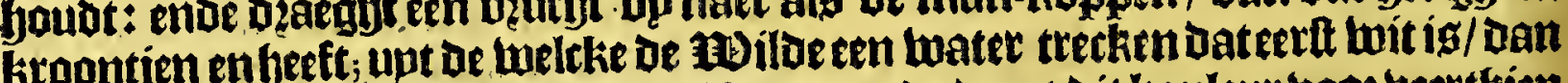

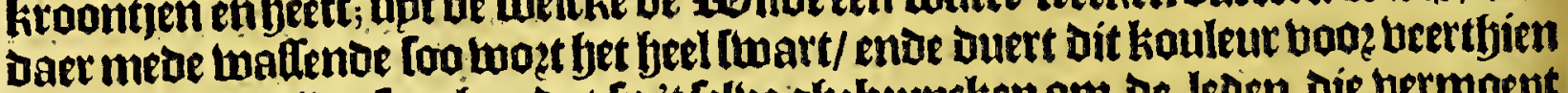

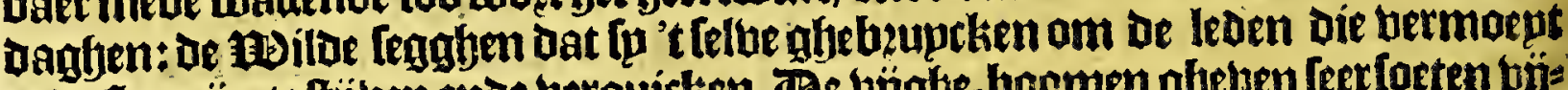

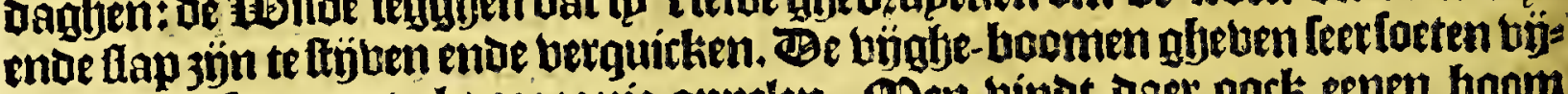
aften/ende loo groot als ozaegnite-appelen. A-en bindt aset oock eenen boum Die fp noemen Aguapa, melck ban fulkten grooten kradjt is / Dat in dien pes manot daet onoer kamt te taepen/ fal feer op-fiuellen; ende in bien bet een

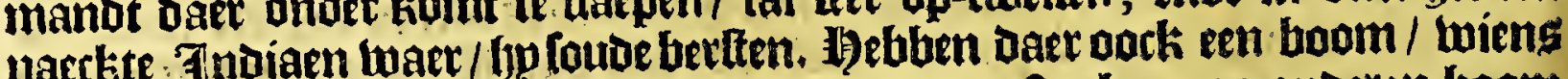
baft dient als hennep om koozon ban te beaepen. Bock eenen anderen boom

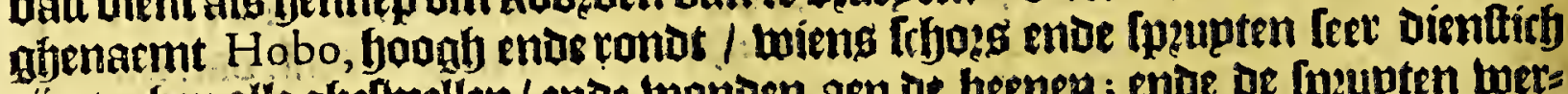
jon teglien alle afefluellen/ende tonoen aen de beenen; ende oe fpeupten mer= wen glyegeten om af -ganck te maecken :ende meer anoere diergbelijeke butchten ende boomen ban den lande. Be boomen ende butben van Spaegnien/ als ozaegnien / limoenen / vijghen ende dzupben / die walten Daet nu ter tỉot

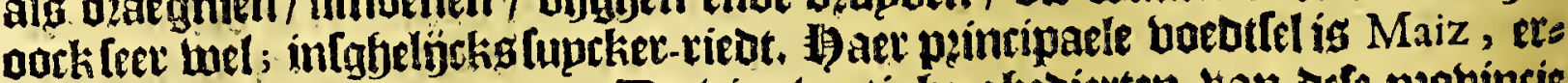
ten/ende Yuca, oock Batatas. De hier-uoetíghe ghedierten dan orfe prabincie

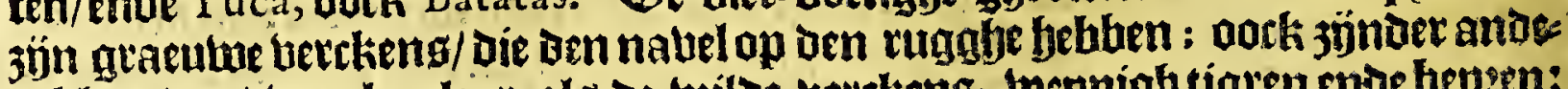

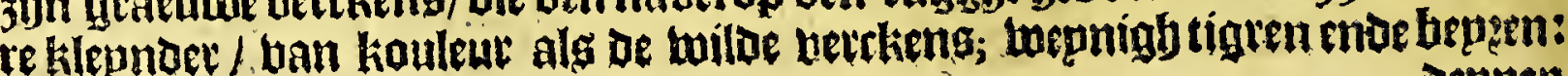
ofpnen 


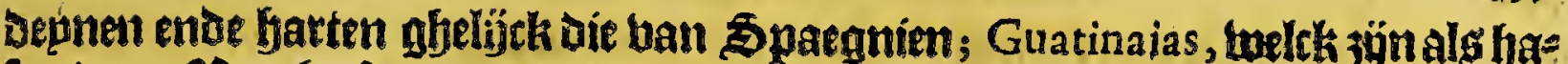

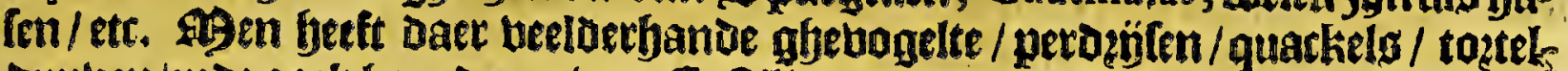

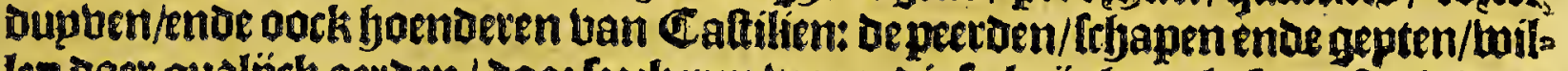

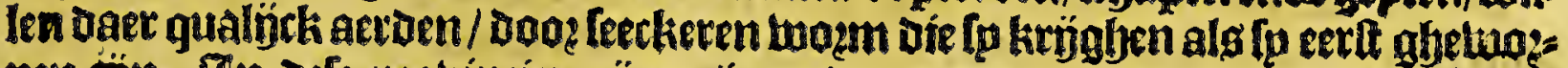

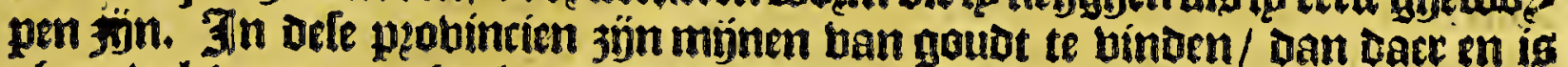
gheen bolcti ontrent glyeplant/om batyet leeghe ende feer ongelonte plaetfen 3 g̈n; t gouot bat Daec upt-ifheljaelt ig / was ban een-en-thintich quilaten; ende men

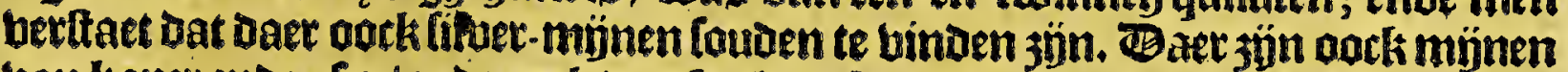
bankopet ende pler / ende dock ban feeckere [watte aerde daer de Indianen baer

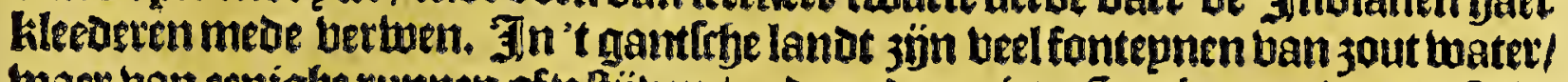
waer ban eenighe rumnen ofte ltijben / ente anderenit. Seg leguen ban ie ftadt Trinidad, is een groote fontepn betck fp noemen de Tupa, Daer beel ende feer gaet jout balt: 't is tenoteten / Dat alle vefe fontepnen ban jout water weroen gheton=

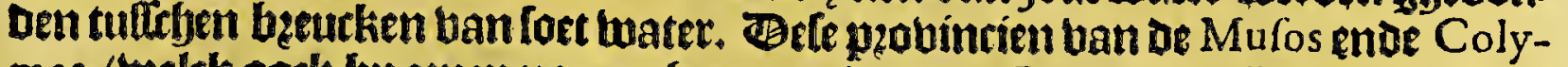

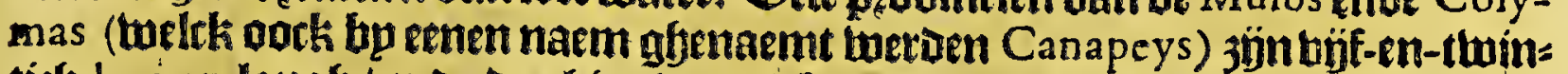
tich leguen langly / ende berthien leguen bzedot / ende legghen ban Bogota naer

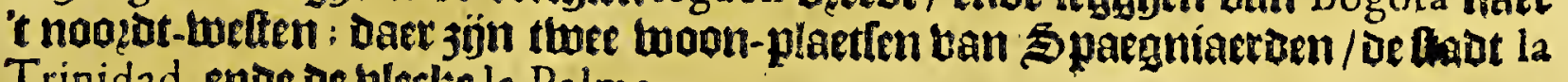
Trinidad, ende de vlecke la Palma.

\section{Yiet bütoe Capittel.}

Gheleghentheyt vandeftadt $L_{A} T R I N$ I D A D, ende $L_{A} P_{A} M_{M A}$; velcke beyde zijn gheleghen in de provincien van

Mvs os, ende Cory a As.

I De probincie than be Mulos ende Colymas, was cetft een moon-platte ban Her. d.8. Spaegniaeroen geleght/ twelck fp noemoen Tudela, bp oe riekiere Zarbi; Dan ${ }^{1.4 . c .5}$. am darfe foo naet aen'tgeberghte lagh/enoe de Spaegniaerden bp de toiloen foa

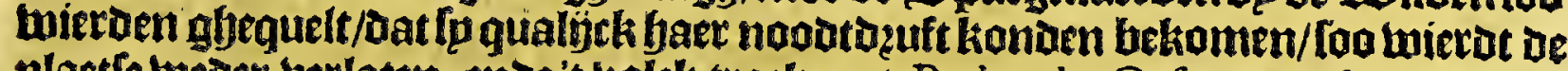
plaeffe tueder berlaten; ende't bolrk trock met Pedro de Orfua om el Dorado te

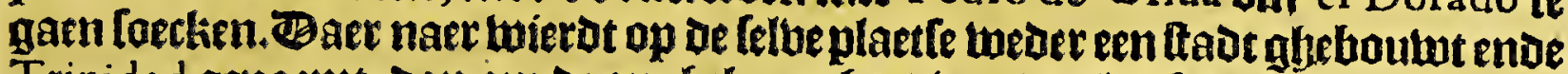
Trinidad genarmt; dan om de onghelegentfoept ban de plaetfe twe derem verleght aen 't ghrtwefie daer fo nu norb leglyt / welck een fjecl goe ae ghelegentlyept is / hoe-

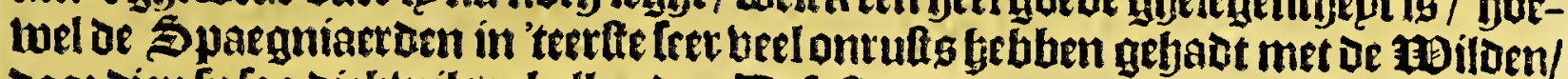
Dook dien fo foo dickitwilg rebelleetoen. Befe fladt 3 oude naer's feggen ban Herrera

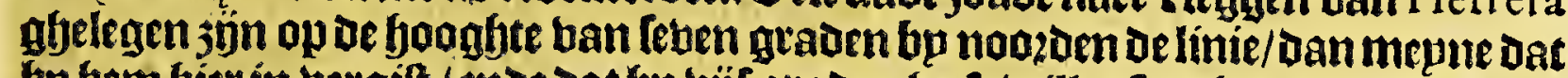

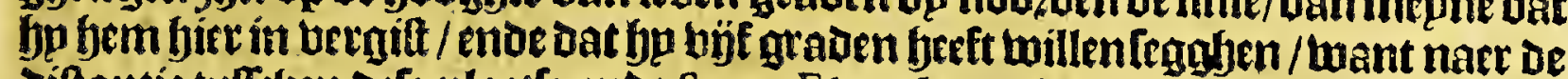

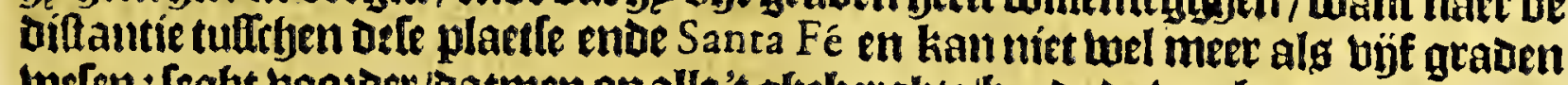
welen: Leght boozorr/batmen op alle't gheberghte/bepte to madyters ban't nooz= Den/ente bet krupgs aen 3 upot-pool kan lien;ende dat men in'tepnde ban A ugufto Santa Fé de Bogota naer't nooźt-weften; fes leguen ban 't koube gbebergbte van Neuvo Reyno, welck qfeferghte men noemt El Paramo, om fpn groote fooghte

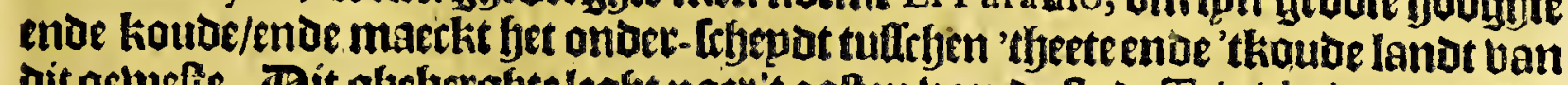

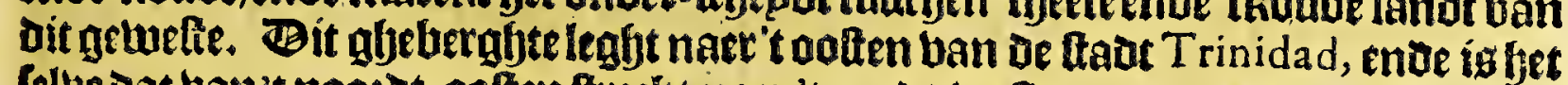
Celue dat ban't noozot-ooften ftreckt naer't jupdt-weifen / ende naer oe gfemepne

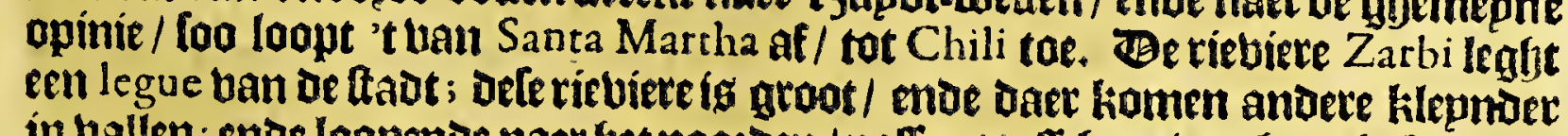

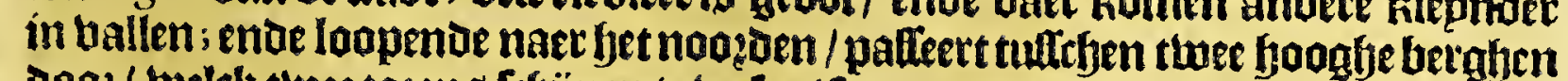

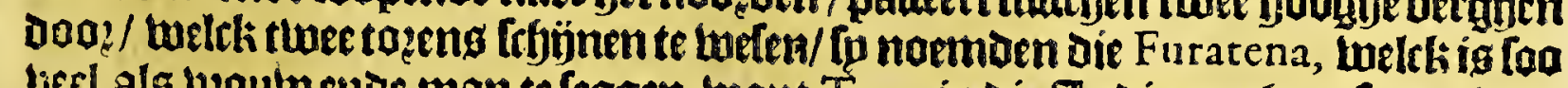
betl als beotu enoe man te feggen; want Tena in die Jndianen bact fpeaectie ig efu man te legghen / enve Fura een bzoulwe. 25innen de palen ban defe fand twetoen efmeraubenghebonden in [eerkete wịnen; daer oock rriftallen in tuet ben glecuonden diamants gbewós ghefoeckt / ende foo bardt alg De efmerauden

$$
\text { Bg } 4 \text { Ielfo; }
$$




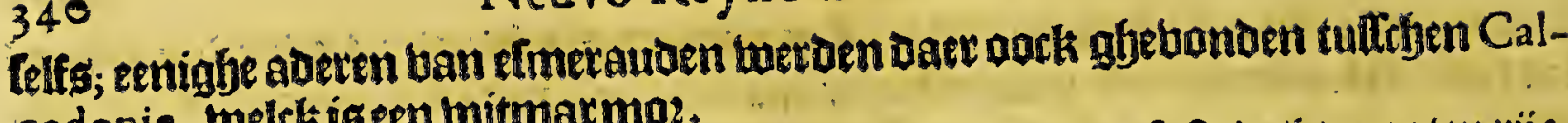
cedonic, welctífeen witmarma?.

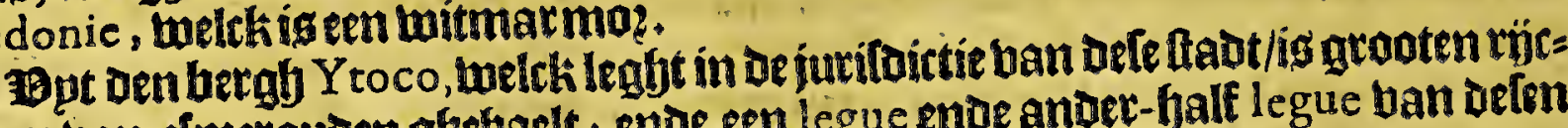
somban efmerauden ghefjaelt; ;nde ent legue enoe ander-balf legue ban delen bergh jijn weder andere mínen ontoeckt: ende dex leguen ban Y to co op een an= Deren bergh/ Die In naemen A bipi: dan oefe mïnen en werden niet ghevalght om bat Daet glyen water ontrent ig. Baer jün oock mïnen ban Beryllus, onder de welcke enighe aroate fucker ban leer dooz-luchtich rriftal wetoen ghebonoen.

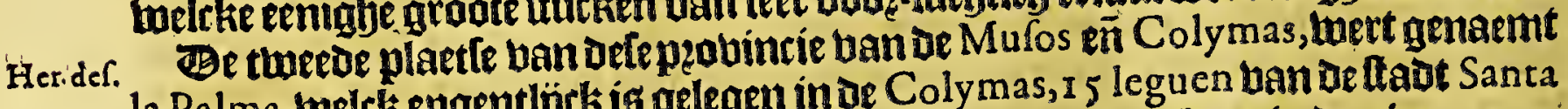
la Palma, welck epgentlïtk ig gelegen in ae Colymas, 15 leguen uan de ftaot Santa Fé, naer' tnoozot-weften'tig daet eer beet als kouot; wag gebout in oen jare 1572 .

\section{9et lefte Capittel.}

Befchrijvinghe van de refterende fteden ende plaetfen van NE U v O REYNo de Granada, te weten, Tvnia, Pamplona, St ChristoVal, Merida, Belez, Mareqvita, YbagVe, ia Vit tokia, ende Si IuAN de los Llanos.

F de prabincie ban Tunia, welck legtht noożen van Bogota, ende is ban eens Der glyeleghentyept ende gljeftalte/ is abetiout oe ftad Tunia, twee-en-twintich leguen ban oe ftaot Santa Fé, bp naex naex.'t noozot-ooften / op eenen booghen

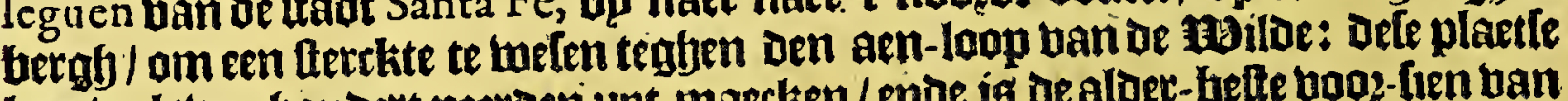

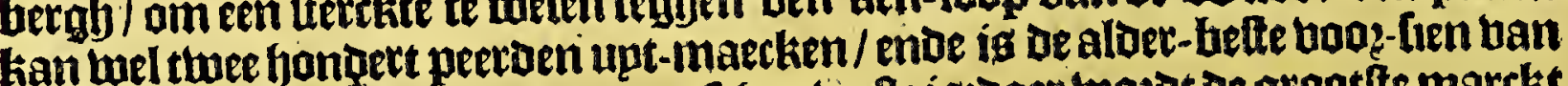
alberfyande liff-torbt/ die in dat gantich getwelte is:Daer bozot de grootife marckt

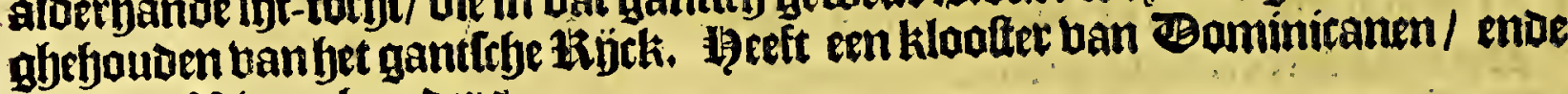
een ban 9 inne-bzoeders.

Deftadt Pamplona legftetfich leguen bain Santa Fé de Bogota naet 'tnoazot: boften toe / Daer wopdt ueel gaubts ghebonden/ende baer is leet beel bee / ende en kloofter ban Bominicanen.

Deblecke $S^{t}$ Chriftoval lengt uerthien leguen ban Pamplona booz-Lefeethen) naev't noozoen toe/ bp de jzobintie die fo noemen Grita, Daer twazot leet weps

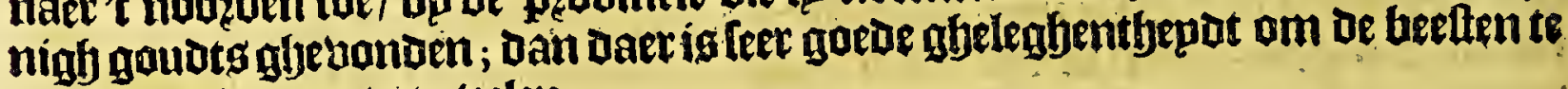
twepuen ende uodzts te teelen.

Be ftadt Merida is afjelegben op de palen ban de peobintie ban Veneçuela, ende Neuvo Reyno, beettich leguen han Pamplona naet't noozot-aoften:'t 'anot beff goudt-mïnen/ende gljeft oberbloedigf ghetwas ban kooen: Jaex't ber=

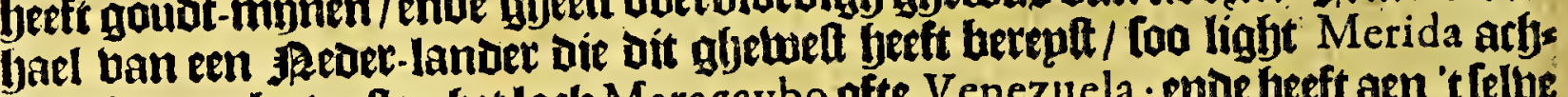
thien leguen bu melten fret lack Maracaybo afte Venezuela; ende beeft aen 't tellee

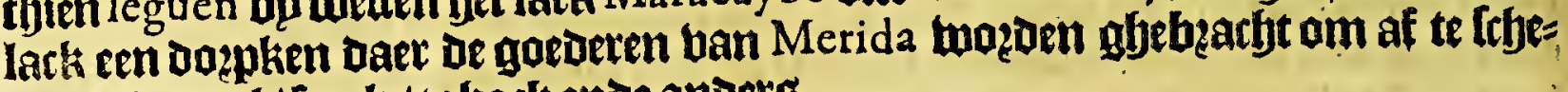
pew/ als meel / lpeck / tobarkende anderg.

De ftadt Belez dertich leguen van Santa Fé de Bogota, naet het noozoen/ enoe bufthien ban Tunia; bet blixemt enue weet-licht dapper in Dat quartiet;

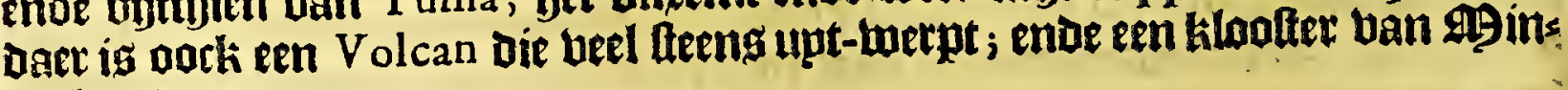
ne-beaederg.

- Be ftadt Marequita, aurf anderg gbenaemt San Sebaftiaen del Oro, legbt beettiry leguen ban Santa Fé de Bogota, naer't noożd-welten/ bolgeng 't fegren ban Herrera; ís ghebout op leftere blacke wepden aen de boet ban't ghebergbte;

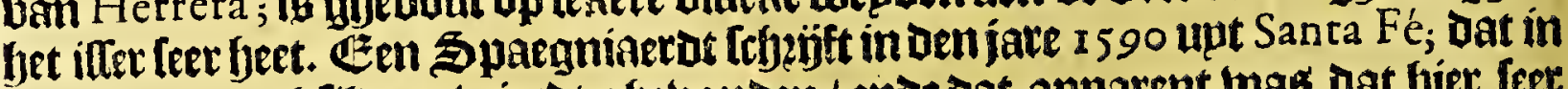
Marequita veel lilbers wierd gfyebonden / ende dat apparent was dat bier feet

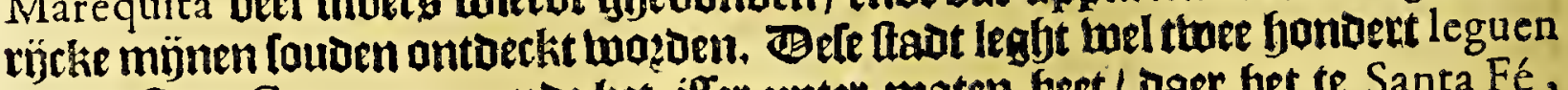
ban de ftadt Cartagena, enoe bet ifler uptek-maten heet / Daer fyet te Santa Fé, welck maer Dertich leguen, naer't leggben uan Delen Spaegniaerot / van Marequica legft / tamelïck kout is. 
De ffabt Y bague leght op't upterlte bp naer ban id limiten ban Neuvo Reyno enoe Popayan, Dettith leguen ban Santa Fé de Bogota naet 'tluellen; Daet is een kloofer ban Bominicamen.

Beftaut la Vitcoria de los remedios, unjfticy leguen ban Santa Fé de Bogotá nacr't nooget-weften / is leet rück ban nünen.

Be ftade $\mathrm{S}^{r}$ Iuan de los Llanos, býftiry leguen ban de fadt Santa Fé naet bet 3upDen / Daer balt mede beel goudts.

Alle de goedertn eñ koopmantrbappen die gebatht wotoen naet alle de ffeden ban Neuvo Reyno de Granada, woeden oe groote rieviere Madalena op- get toett

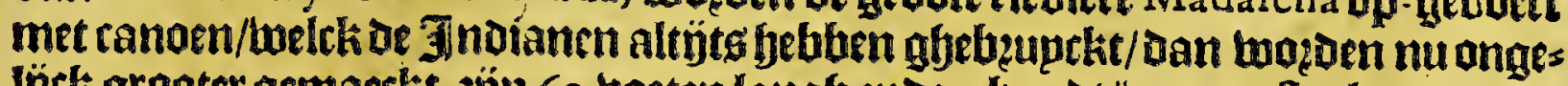
İ̈ck grooter gemaectit; 3 ín 60 boeten langf enoe 4 beerd/ban een ftuck/gentrepn=

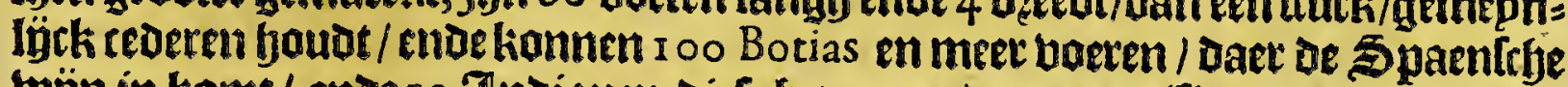
wịn in kamt / ende I 2 3ndianen diefe betoepen / met pqobilie boas 20 Dagben/ welck [p befich jän om ap te lioment tot een leket binnen-lanotlcbe hauen/ welck fp noemen del Angoftura, niet berre ban de taad Marequita gyeleghen/25 leguen ban de ftaut Santa Fé de Bogota : (Too Herrera fryenftt / dan naex hp in ten kaerte af-teeckent/ende be reden van de diftantie tutroen Marequita enoe Santa Fé, fous= be bet ueroer moeten wefen:) Defe plaetfe wagot ghenarmt del Angoft ura, om dat

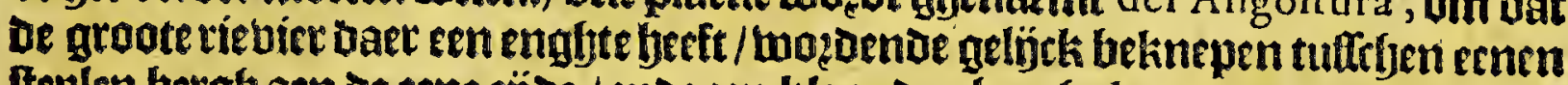
teplen bergh aen oe eene jüoe / ende een klepnoer berghslien aen de anoer jyoe; tot bier toe han men de rievier bequameligeli met tanoen op-baren.

\section{P. O P A Y A N.}

\section{Het lebende Capittel.}

Befchrifvinghe van de gheleghentheyt ende gheftaltenis van defe provincie P O.PAYAN in't ghemeyn, ende de particuliere pro. vincien daer onder begrepen.

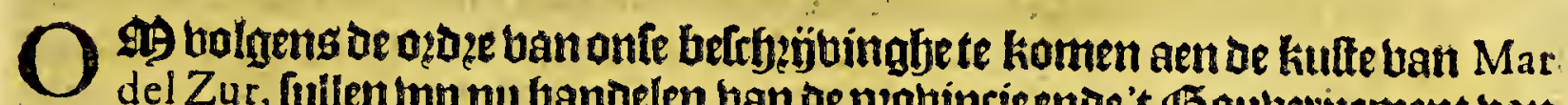
del Zur, fullen lup nu bandelen ban be peabincieende't Goubetinement vall Popayan, melck naelt gelegen ig naer' t welten aen De probincie van Neuvo Reyno de Granada, daer wo nu van febben gelpeoken. Be limiten van defe p:obincie

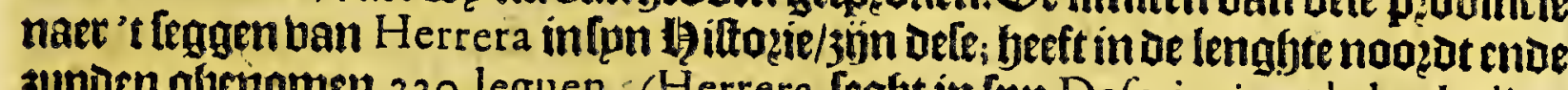
jupDen gheriomen 220 leguen, (Herrera feagt infpn Defcripcion de las Indias, d. s. 1.10.

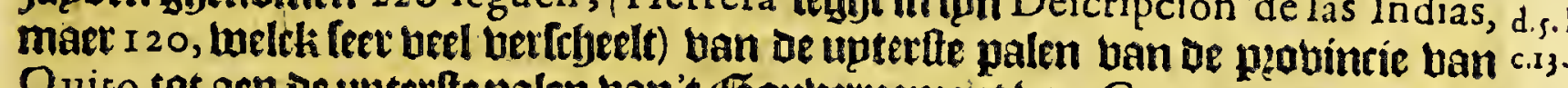
Quito tot aen oe upterfte palen ban't Goubernement ban Cartagena; enoc in be bercte ontrent de roo leguen, ban De palen van Neuvo Reyno de Granada tot aen de 3upat-3ee. Pedro de Cieça die ofle provintie lelfs beft boo--uandelt/ feght in fun Chronica del Peru, oat de peobincie ban lopayan langf is 200 leguen, Lepnigh mert ofte min / ende 3 ofte 4 o leguen berdt; febbende aen oe ene jüoe de jupdot-jee/ende lekere booghe enoe twoefte berghen; enue aende antuer jojde oe Cordillera ban oe Andes; ban bepte welcke gbeberghten feer beel rievirrch af-

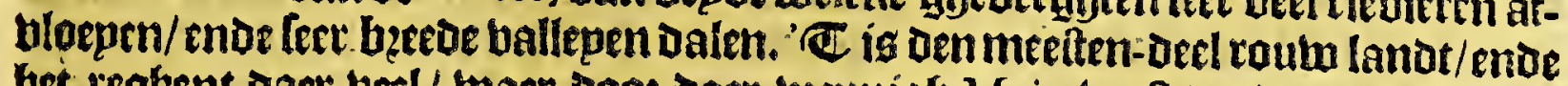

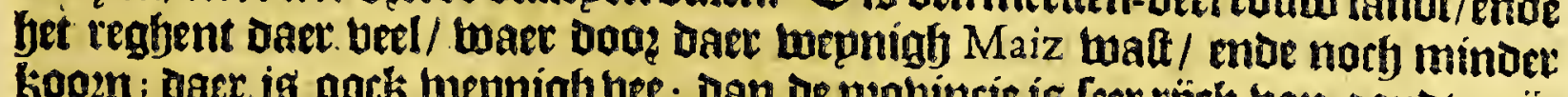

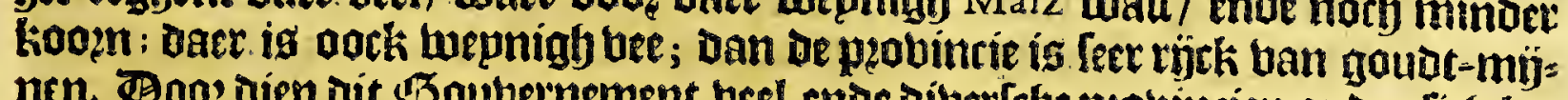
nen. Booe dien dit Goubernement beel ende diuerfebe peabincien ander lief be=

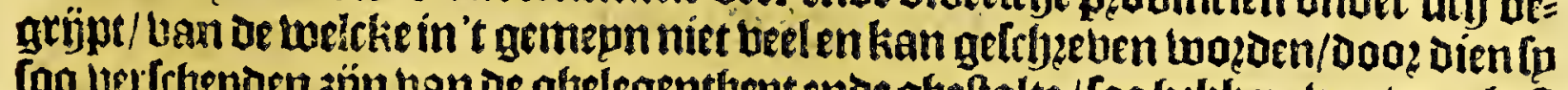

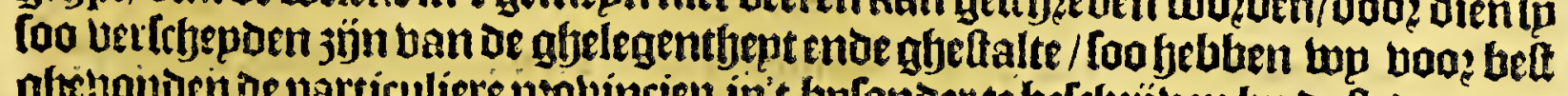

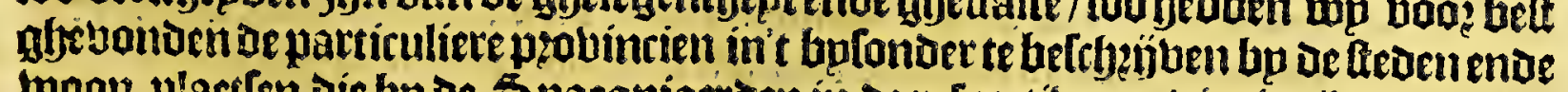

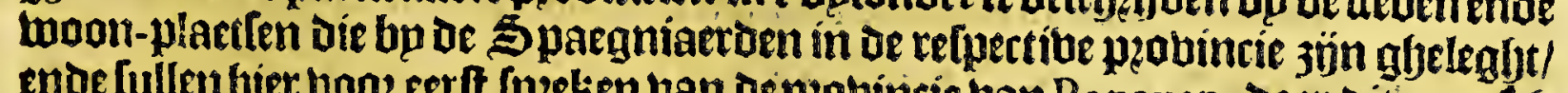

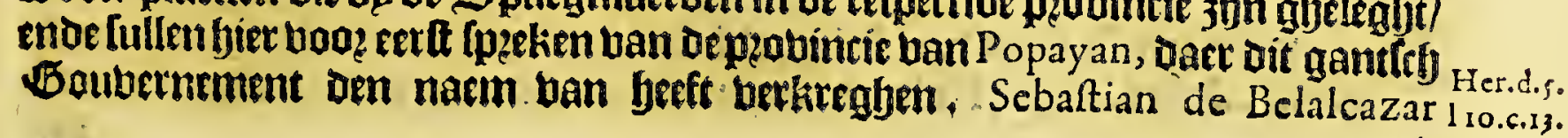
Die 
342

Popayan.

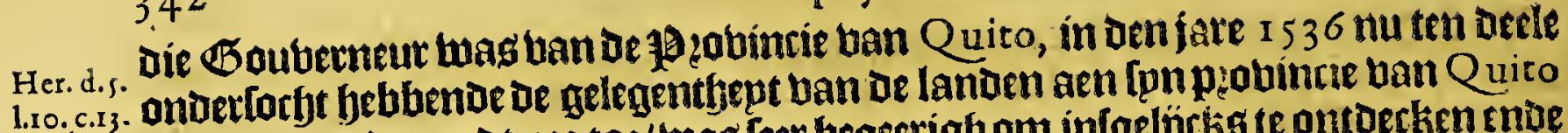
1.ro.c.13. ondexlocts fechendede geleg

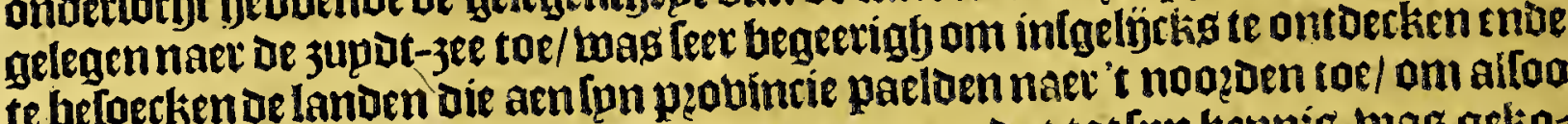
Den wegh te openen naec oe noozot-see; te meer om dat tot [pn kennis was netio

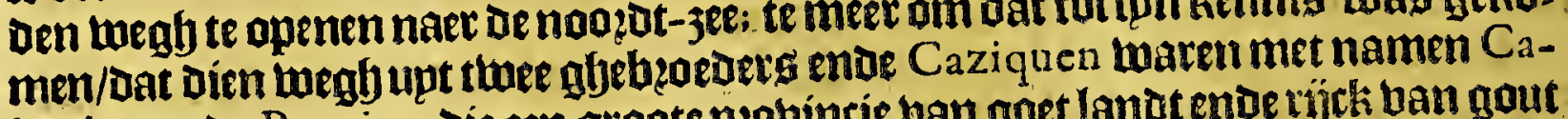
lambaz ende Popaian, die een groote pzobincie van goet landt ende rijct ban gout

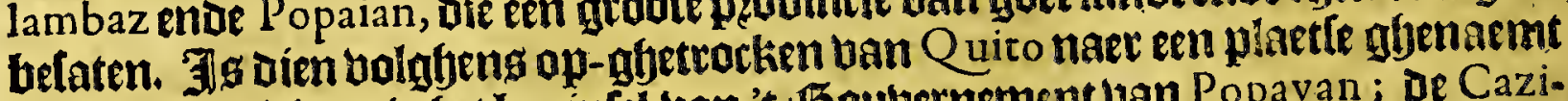
Orabalo, melcti nu ig bet beginfel uan't Baubernement uan Popayan; oe Cazi-

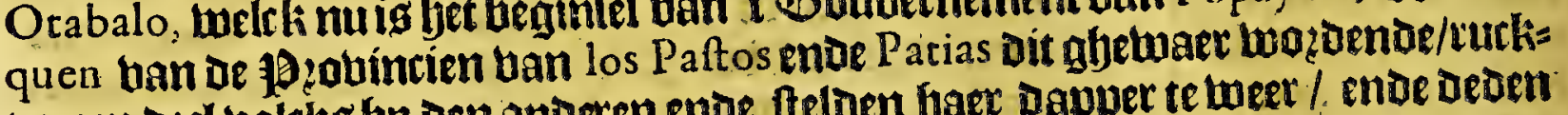
teneen deel bolckg bp oen anderen ende fteloen faer papper te weer / cnde deoen

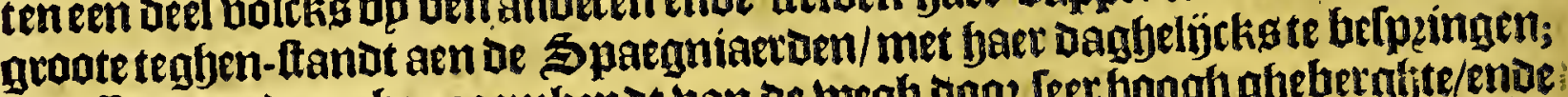

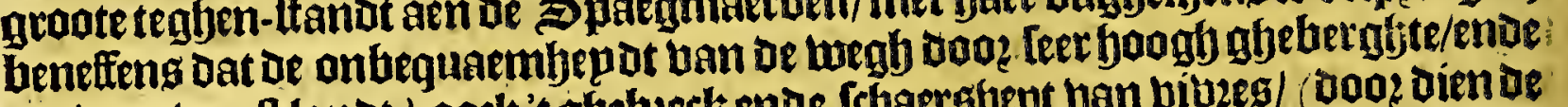

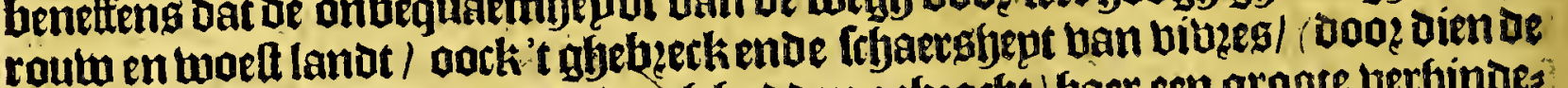

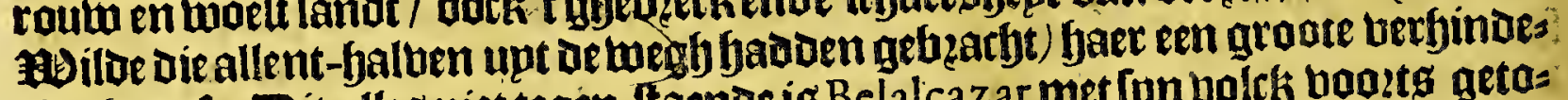
rimgle gaf. TBit alles niet tegen-Ltaende is Belalcazar met Ipn volcli booutg geto:

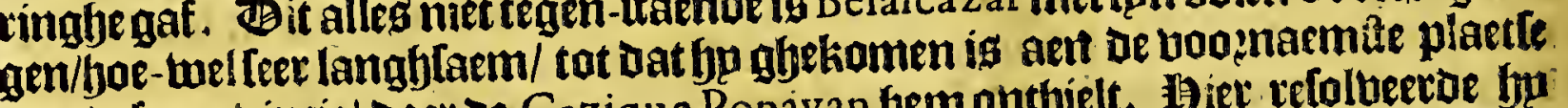
ban oele pzobincie/ oaer of Cazique Popayan fem onthielt. Hiet relolbeeroe bu met fun volck te rulten; allo hp in dit quartier bonot beel blacke beloen/ende daet op veel fraepe houlw-fuplen ban of 3 ndianen (welcli de Spaegniaeroen noement Eftancias) tot aen een arm ban oe groote rieviere/ welenoe bp de is leguen, bol. frfoone beloen/ende belbeplant met aengenamefrupt-boomen han aic lanoen/

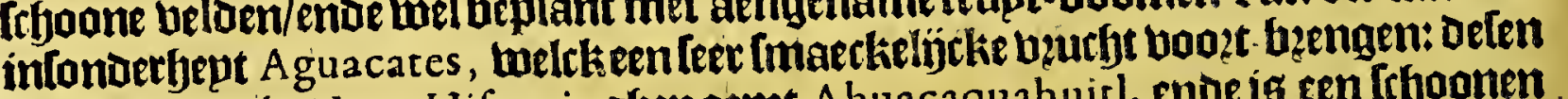
boom tmozot in Nova Hifpania afjenoemt A huacaquahuit, ende is en Trboonen.

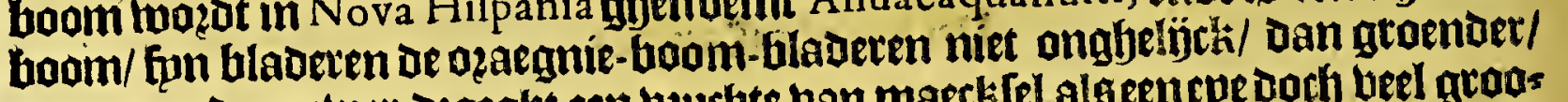
grooter enoe coumer; Dzaeght een beuchte ban maec [el alg eencpe poch teel geous ter; van binten twart ofte feec Doncker groen/ ban binnen upt ben groenen ento [eet bet gelick oft boter bare; ban fmaeck als berlebe noten; met ketnen lo groot als oupben eperen / in tween becoeelt alg oe amanoelen / met een rofte trbelle/ban

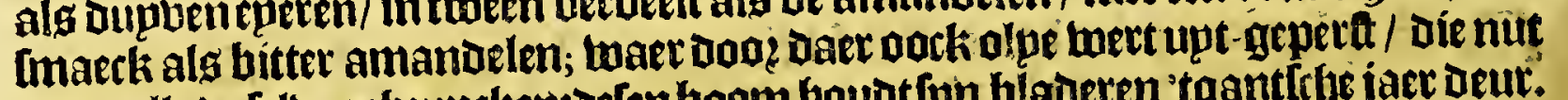

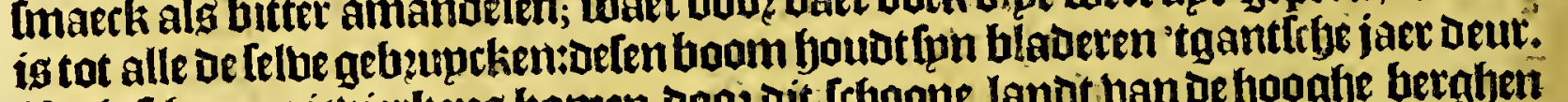
Becle frhoone riebierkeng komen boos dit feboome lant ban be joogfe berghent ban ae Andes af-loopen/han leet gelont ende klaer water/ snoe in fommige ban

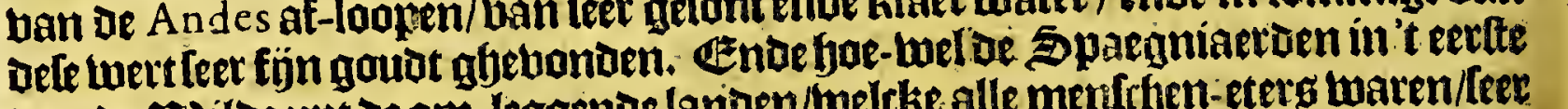

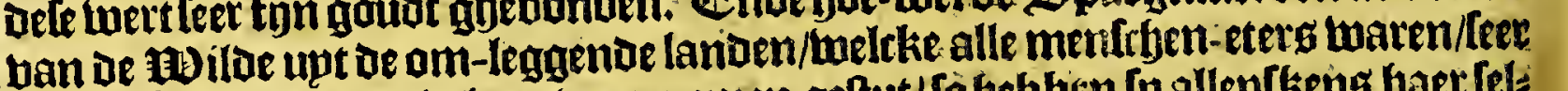

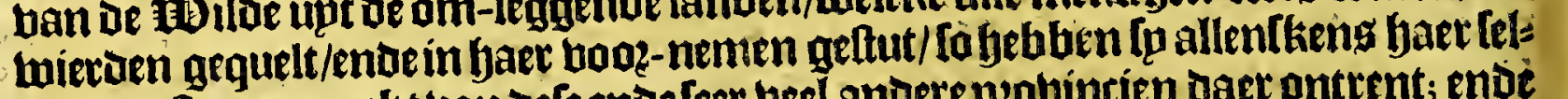
ven meefter gemaeckt ban oele ende feer beel andere probintien daet ontent; ende

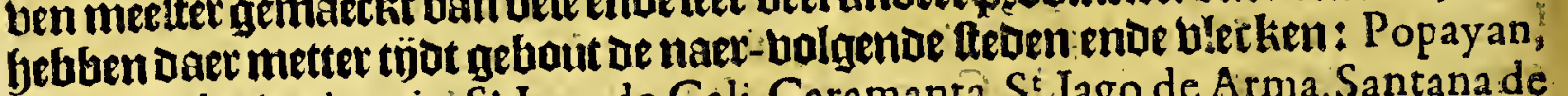
Santa Fé de Antioguia; $S^{t}$ Iago de Cali, Caramanta, $S^{i}$. Iago de Arma, Santana de

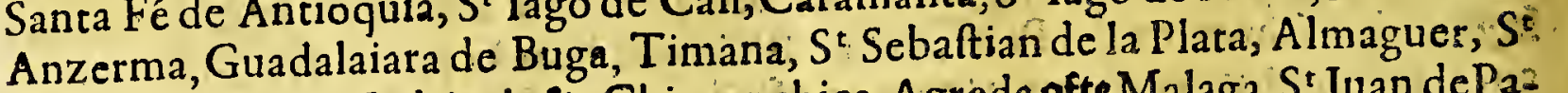
Iuan de Truxillo, Madrigal ofte Chiapanchica, Agreda ofte Malaga, St Iuan dePaz to, St Sebaftian de los Paezes: van oe thelcke entigfe toepnige oaer na weuer jön

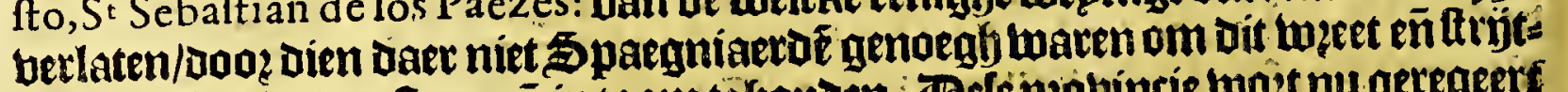
baet bolck te wedet-ftaen eñ in toom tefouden. Dele pgobincie woet nu geregeer bp een Jieutenant gouberneur/Doaz dien eenige ban oe fteoentrfozteren onder be audientie ban $Q$ uito, eñ entige ondert audientie ban Neuvo Reyno de Granada.

Het actjette Gapittel.

Van de Hooft-ftadt van defe Provincie PoPA $\mathrm{Y}$ N, haer gheleghentheyt ende de gheftalte van de Landen daer ontrent ghelegen.

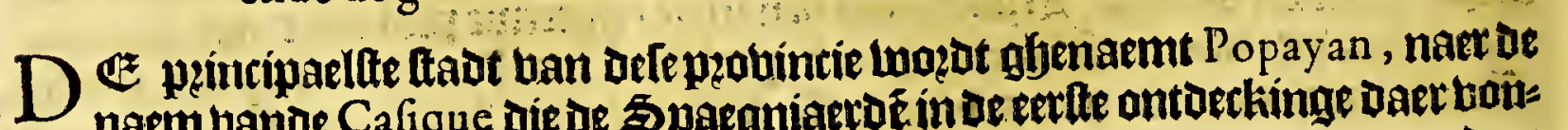

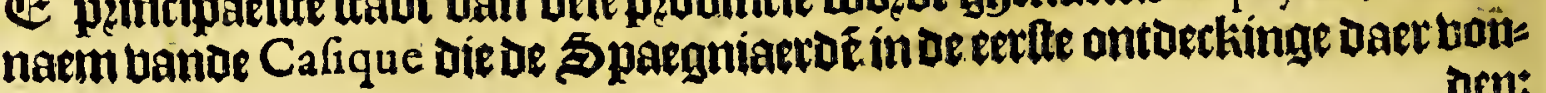


Den: is gelegen op te boaghte ban thee graden ende een balf bu noazoen de linis/ ento op ce lengte ban 78 graden enie een balf ban oen gherioiaen uan Toledo, naer de rekeninge ban Herrera : In een luel-getemper oe ente gbefande rontrepe/ Her. d.s:

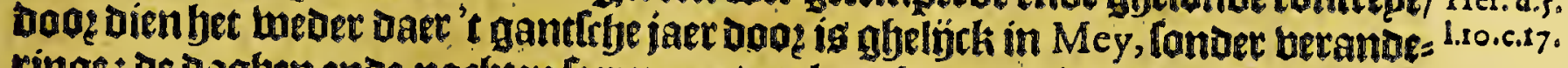
ringe: de Dagben enoe narlyten feer naer eben langh/ dooz dien dat bet foo naer í bp oe linie: oaer pafteett een tiebiete dooz ban goet water: alleen reghent bet fjec wat meer als tol op andere plaet[en / ende donuert ende blixemt Daer feer beel.

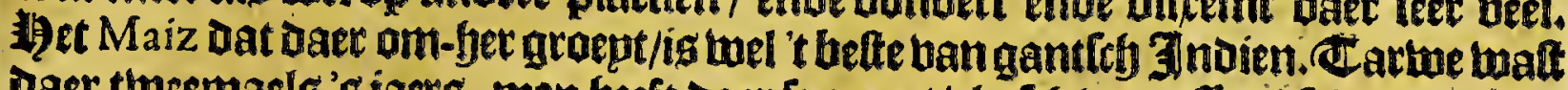
vaer tweemaels'g jaers; men beeft daer feer goet bleefch ban offen/ [chapen/gep= ten ende berckens/ ende ueel beucften ban de lande/ ende ban die upt 3 paegnien Daer gebzacht sün. Be in-geboome ban Dit quartier jün berfhepden ban die van

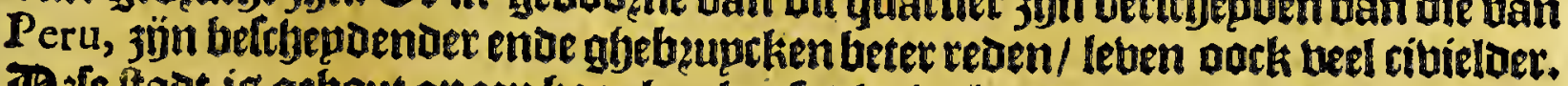

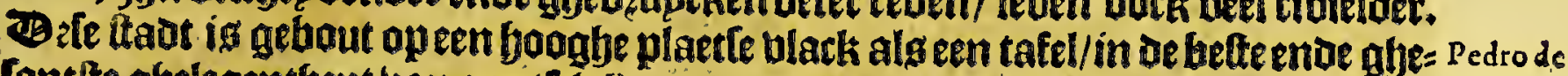

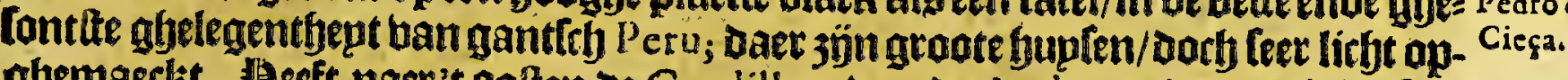
ghemaeckt. Heft naer't volten de Cordillera ban de Andes, enoe naet't weften een ander boogh gfrebergbte/weick langhg de 3updt-jee feenen fteckt, Raer bet

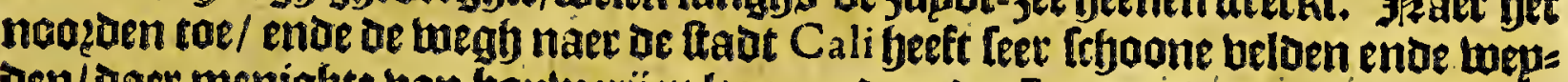
Den/ daec menighte ban boutwerijen leggen : daer de Spaegniaerden faer beeten

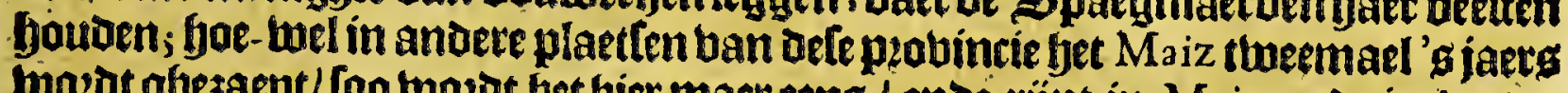
bozot ghesaept/ [oo wozat bet hier maet eeng / enoe typt in Maio ende in lunio; ende de tarme thozat gefneden in Iulio ende Augufto, geligck in Spaegnien. Boo: bele blacke beloen loopen beel riebietkens die tan oe Andes af-liomen/ban leer

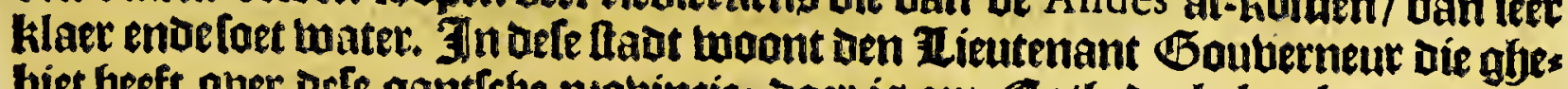
biet beeft ouer oele gantfche ptobintie; Daer is een Catbedzale kercke; ende een kloolter ban 9 onnicken bie fip noemen de la Merced. Be ftadts limiten frecken baer wijt ende bzecot upt / Daer Irer groote dospen legghen; naer't ooften leght ofe peobincie Guambia, bie bol bolcks iś; ende een ander die fu noemen Guança;ente vootts Maluafa, Polindara, Palace, Tembio, Golaça, ente anterte meer die altuel

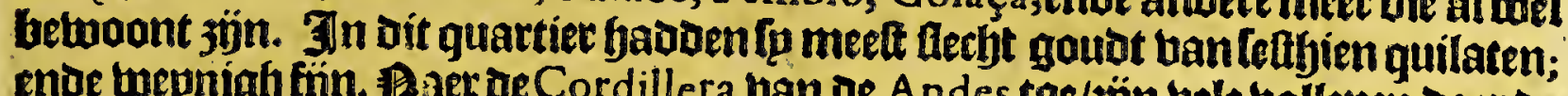

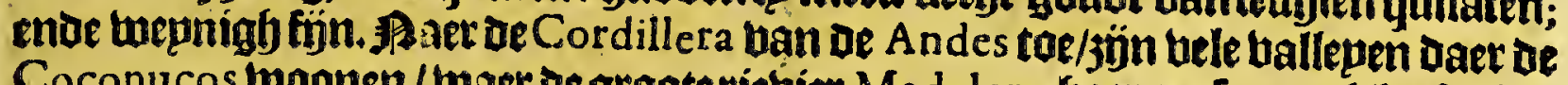
Coconucos twoonen / waer te groote riebier Madelena gaer o oflpzongh beeft ; bo: ben op't gfobergbte jöneenighe Volcanen; ende oock Lpeingben ban heet water/

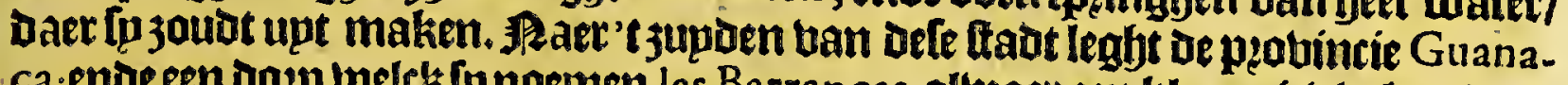
ca;ende een doep tuelekfp noemen las Barrancas, allwaet een klepntiebierken boos loopt ban or felue naem; noch boozder de dozpen twelck fo noemen las luntas, enoe de los Capitanes; ende of groote pzobincie de los Maftelos; ende een thlecke welck ghenaemt wozot Patia, leggende in een fdjoone ballepe baer een riethietken Dooz loopt. Raer't weiten ban uefe fiadt legbt de peobintie ban Bamba, altuart een blecke van Spaegniaerden leght / welck Ip noemen Chapanchita, Jaer twy
bier naer fullen ban fpeecken.

\section{Fit neglyende Capitte!}

Particuliere befchrijvinghe van den oorfprongh van degroote rieviere de MADALENA, ende haren loop door verfcheyden landen.

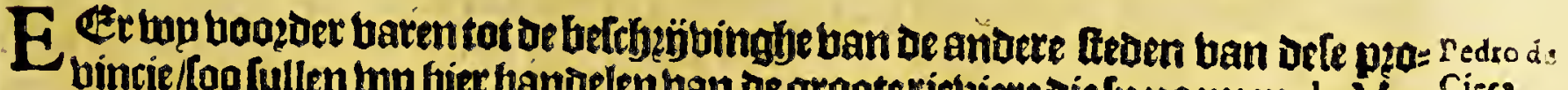
dalena, eñ oock tuel de Santa Martha, bou grooterietiete diefp noemen de Ma- Cieqa. dalena, eñ oock luel de Santa Martha, boog dien lp niet betrs tuan de ltabt Popayan Der-waets bp de Indianen Cauca wozat genaemt/ ende onder Mopox inde an= in een komen/bebben f baer beginlel beeft: twant Dele twee riebierm bie daer naer. in een komen/bebben haer oos \{peongh ban ben anderen bp pe 4 o leg. bertchepden:

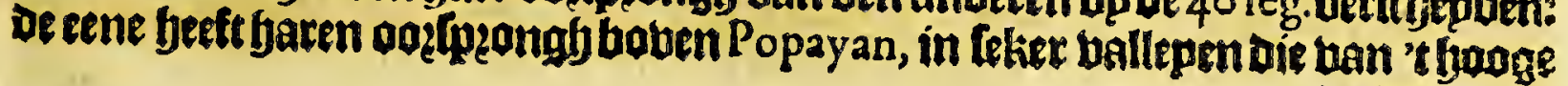
Antuershe 
aebergfte ban be Andes af-ftrecken/betwoont bu Teker natie ban Jonbianen bie fo noemen Coconucos, bpe en blecke ban'telue bolck betwoont/welefp noemen Co.

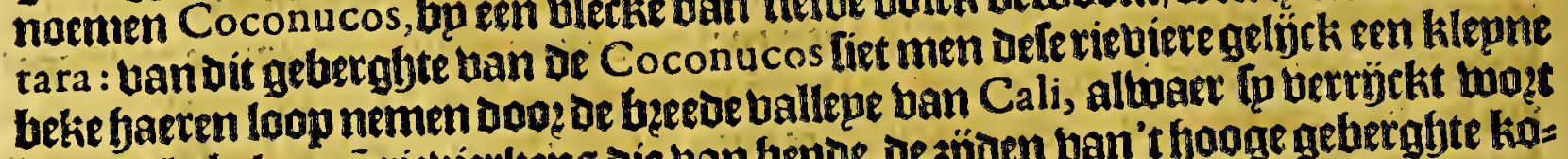
met beele beken eñ riebierkeng die ban bepoe de jojoen ban't booge geherghte ko: men af-loopen/ [oo dat fp ontrent Cali koomentoe/alreede loo groot is gletwozoen alg oe riebiere van Guadalquivir boo Sevilla in Spaegnien:endenaer datie noch boazder ig gbeloopen ende leer beel andere riebieren in-ahelaten/ komenoe bu

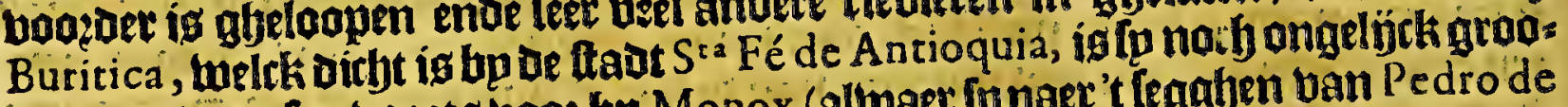
ter/enoe loopt foo booets boos bo Mopox (albaer fo naer't legaben van Pedro de Ciç̧a epgentlightk aennaemban Cauca boert) tot dat de twee tietieten in cen ko:

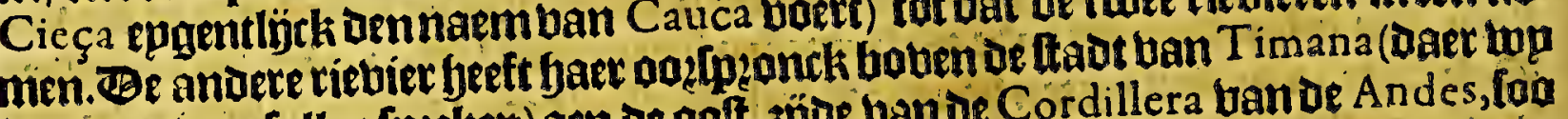
bier naer ban fullen fpyeken) aen de ooft- 3 joe ban de Cordillera ban oe Andes, foo

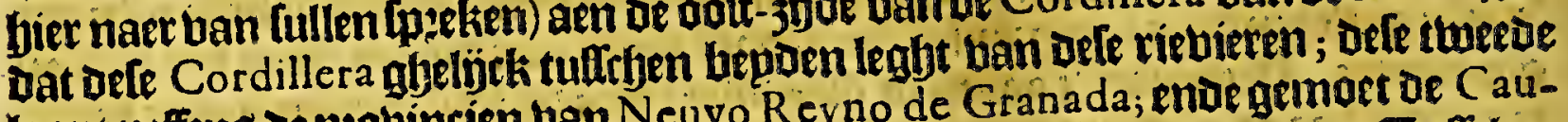
loopt neffeng de probintien uan Neuvo Reyno de Granada; enoe gemoet oe Cauca, alg boyen/negen leguen ander Mopox naer 'tleggen ban Herrera. Euftrben bepden Defe twee riebieren/ eetlp bp Den anderen komen/legghen Ieer groote lan/

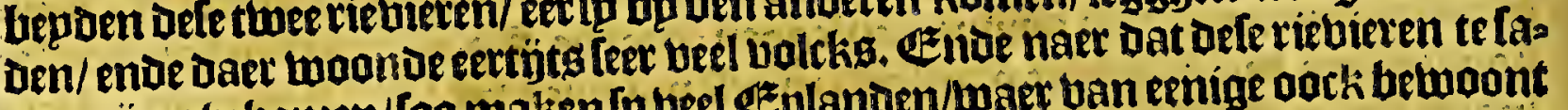
men jün gletiomen/loo makenlp beel Ezplanoen/waer ban ernige oock betwoont jön: ende men beft daer beel trocodilen/ ende ban die vifferen diels Manati noes

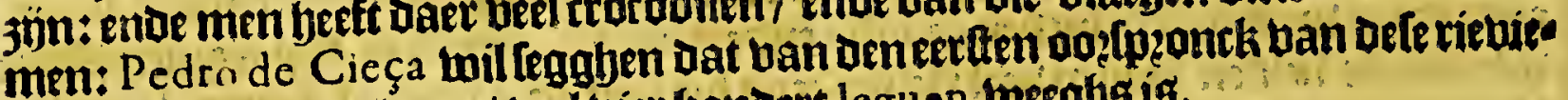
re tot daex fo in zee loope / wel biex fondert leguen beeghs is.

Het thiende Capittel.

Befchrijuinghe van deftade A N T o c H 1 A, ende de gheleghentheden daer ontrent; de wegh van defe ftadt naer $A N Z E R M A$, ende van de ftadr C A R A A A N T.

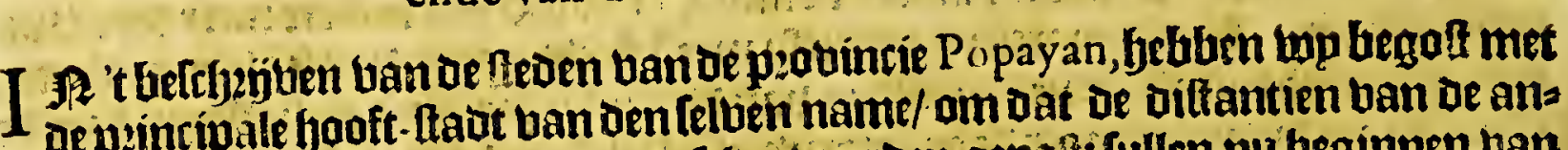
of peincipale hooft-Itadt ban den felberi name/ om dat of diltantien ban de ans Dere ftedenende blecken meelt op de Telve twierden gepalis: Tullen nu beginnen bau oe ftadt Antioquia, welch of upterite is ban oe p'obincie naer 't noozoen/ende te limiten ban't Boubernement ban Carragena naeft ghe!egen/log dat oe Bbouters

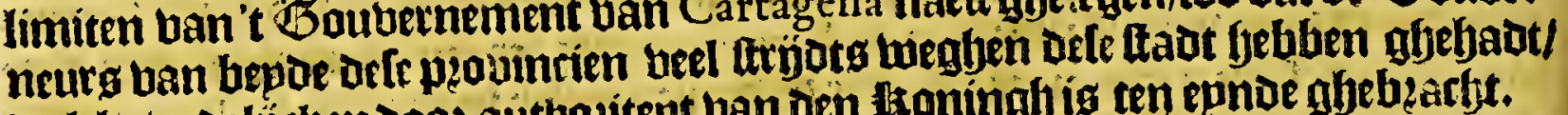

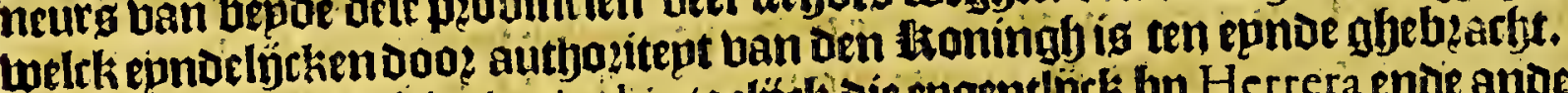

Ped. de De tadt Santa Fé de Antiochia (gelinctio die engentlinck bp Herrera ende anoere

Ciec. wo:t genaem is bp de Spaegniaeroen gebout in een ban oe ballepen die lp noes imen Nore, tulteben twee loo bermaerde ende rubthe riebieten/del Darien entoe S:2 Martha ofte de Madalena;ende tufferjen bepoe de Cordilleras han bergen die daec langhgljenen loopen. Be gelegentheut ban de ftadt is léergort/burlende genomen op fraepe entoe groote plepnen/beneffeng een riebiertien; Dart-en-bouen foo loopen Daer ontrent norb beel riebierkeng ends beflen ban feer goet water/ oe welcke bare

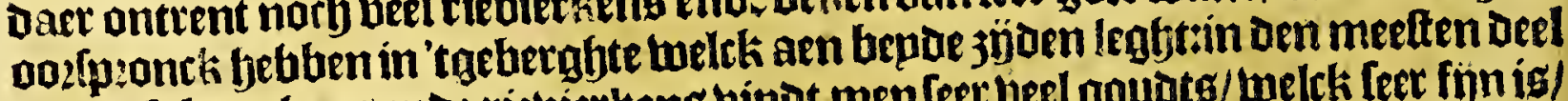
van De[e heetxheng ende riebirekeng binot men [eet beel goudte/ welck [eer finn ig/

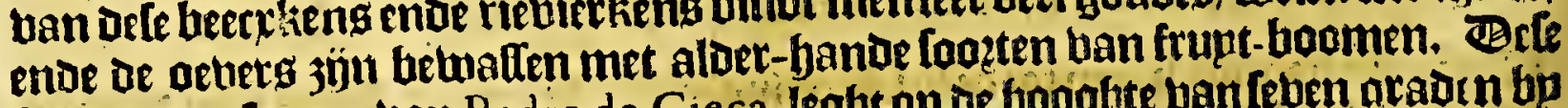

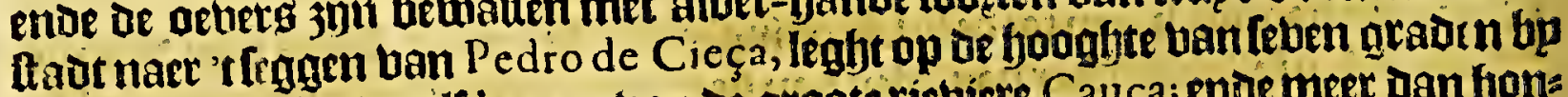
noozden de linie/ twaelf leguen van oe groote rietoiere Cauca; ende meer dan fon: ofrt leguen ban de ftadt Popayan naer t noozot-ooften / too Herrera gfetupght. De melcke lerght dat oe in-abebooune ban oe lande daec antrent fjel goet bolck is/ fraep van lífyaem ende wit: oat de gheltalte ban de licht fulcks is / oat bet bolck

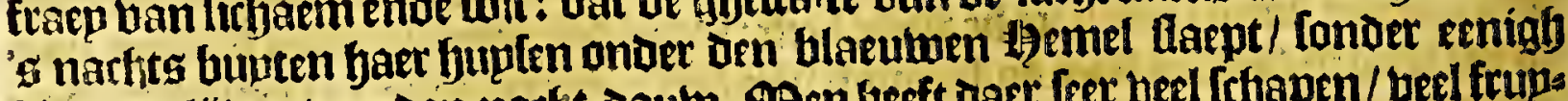

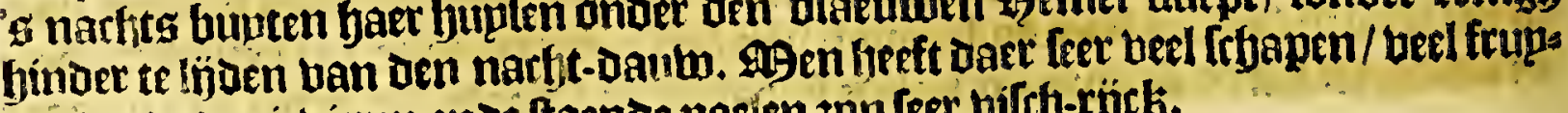
ten/ ende de rievieren ende ftaende poeien jpuleer viletb-rỉck.

Pan 


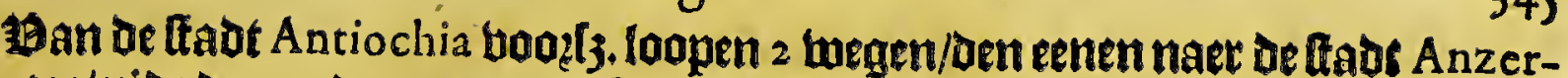
ma toe/entoe den anoeren naer de ltadt van Cartago ende Arma:tup [ullen fier eerf [peken ban Den wegf welck naer A nzerma loopt/om Degelegentfept van tlanot ende plouincien dien wegg upt-gelegen/te berfaen: defen wegh twozot ans bp Pedro de Cieça alous belchzeven in lun Chronica del Peru, in't I 4 Cap. Creckens be ban de ftadt Antiochia de twegf na Anzcrma tae/kamt meneerte telien den bet: maerden ende rijcken bergh ban Buritica, daer fulcken menighte ban goudt in boolledentÿden is upt-gebaelt. Cuffefen de ftadt Antiochia ende de tadat Anzerma jün 7 o leguen, enoeig een feer moepelícken wegh/ meelt ober booge ende kale bergen. Jg meel al betwoont bp Jnoianen/die haer butten ende wooningen ber

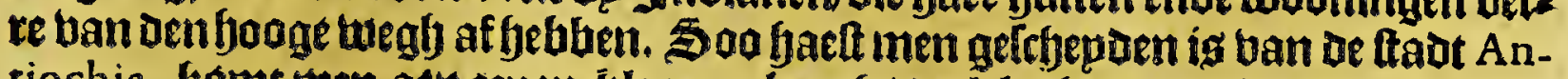
tiochia, komt men aen cenen klephen bergf / welck ghenaemt mozot Corome, (Herrera noemt die Curume) gelegen aen [ekere klepne ballepkeng/baer leet beel bolcks placfjt te boonen/ Dan naer dat de Spaegniaerذen daer gekomen jónom 't landt in te nemen/foo is't tgetal wonderligcli uermindert. Dit doup beeftleet rijes

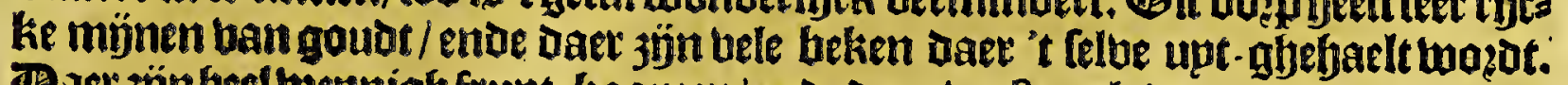
Baer jün beel twepnigf frupt-hoomen/ende daer walt oock wepnigh Maiz. Ban Daer komt men aeneen plaetle ghelegen beneffens een qrootenende boogen bergh/ daer een groote blecke ban beel butten $y$ leegh te leggen; daec beel mineurs plact)=

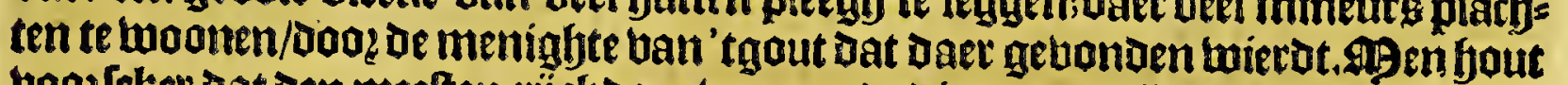
boo? feker dat den meelten rijchdom ban goubt die men eertij dts feeft gljebonden in ae begraefnillen ban Zenu ofte Cenu, al gekomen ig ban dit guartier. 1Ban dit

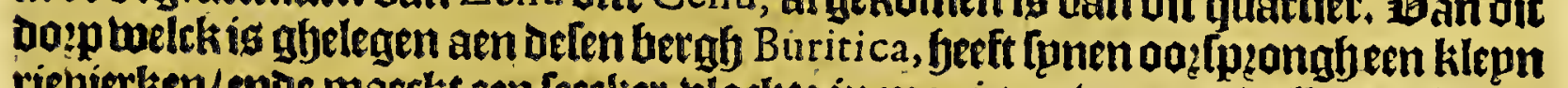
rievierken/enoe maeckt een feectier blackte in manieren ban een vallepe; altwaer een blecke gelengt is/om de mijnen te beneficeren/twelck [p noemen Santa Fé, ende

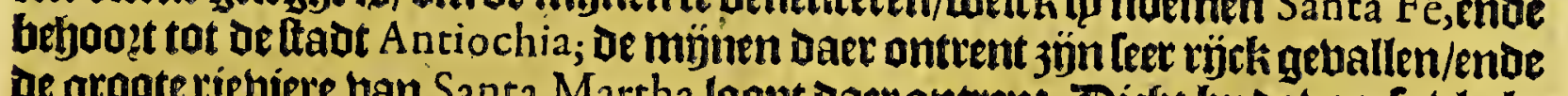
be groote riebiere ban Santa Martha loopt Daer ontrent. Birft bp de boof $\{$, blecke is een ander Doug gheleghen/ welck fo noemen Xundabe, ban be felve natien van beel ben/ende ban gelícke ntanieren als de broz-gaendetbelitten beel ballepen daet beel bolckg twoont/ende dact loopt een Cordiller afte bertuglab van berghenmide

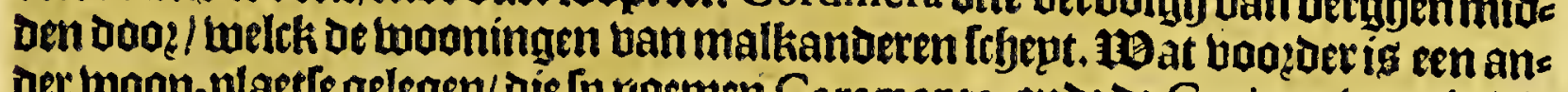
Der woon-plaetle gelegen/ die [j roenten Caramanta, ende de Cazique thas in die tỷden gbenaemt Cauroma. "C volck ban die probincie was wel gelfilt volck ende frijbthaer /peaken een ander tale als de booz-gaende. Bele ballepe beft ronot-om baet feer booge ende woefte bergen/ende daer loopt een grooteriebier doo?'t míd= benneffeng beel andere beken ende fontepnen/wan de thelcke be in-woonders beel 3outs maken/een lake om te bethonderen : ende inlonderficut maken [p [eer twit

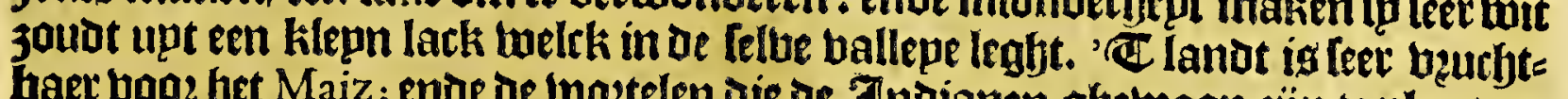
haet booz bet Maiz; ende de twotelen bie de Indianen gfelwoon jịn te planten: ban febben feer luepnigh frupt-boomen. Zlen $\delta^{\prime}$ ander jöbe ban 't geberghte naet 't ooften toe/ legite een ander pyabiutie die fp noemen Cartama; 't bolck ig ban be

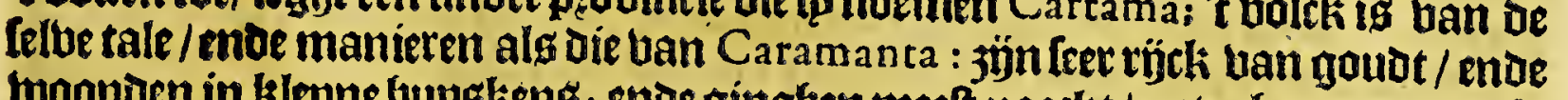
woonden in klepne bupskens; ende ginghen meef naeckt / upt-ghenomen dat la

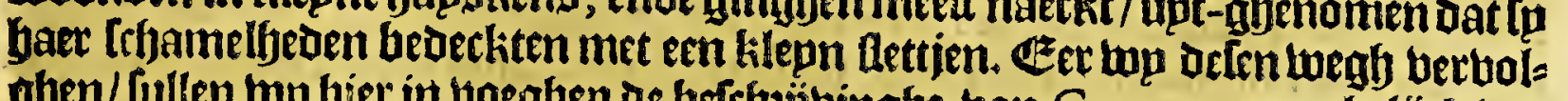

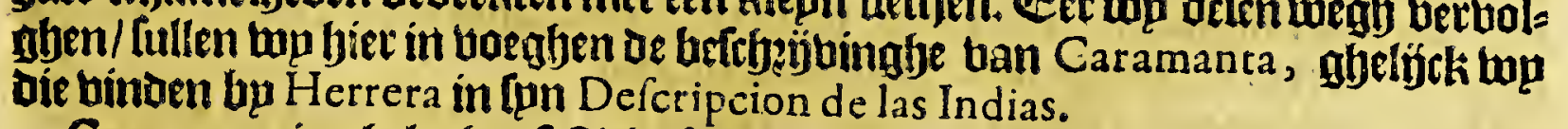

Caramanea is gheleghen fettich oft tebentich leguen ban de thaot Popayan naet 'tnoozot- ooden toe / neffeng de groote rieviere Cauca, befjoopt onder't diftritt van

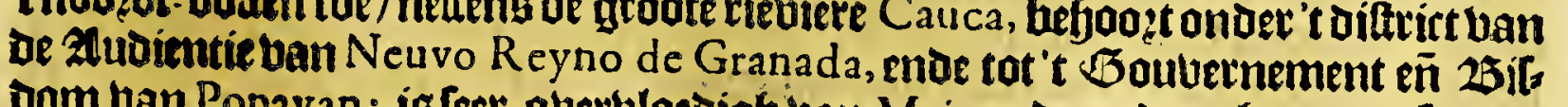
jom ban Popayan; isfeer ouetuloediaf uan Maiz ende ander abezaepe: Conder

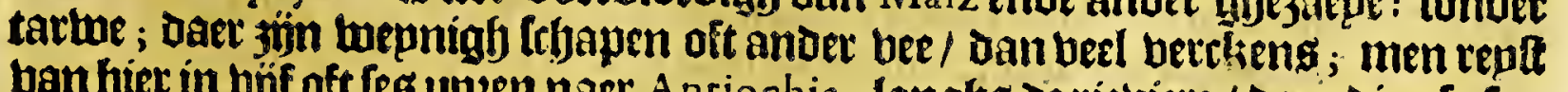
van bier in bj̉f oft leg upeen naer A nciochia, langhs De rietuiete / Doog dien fp foo

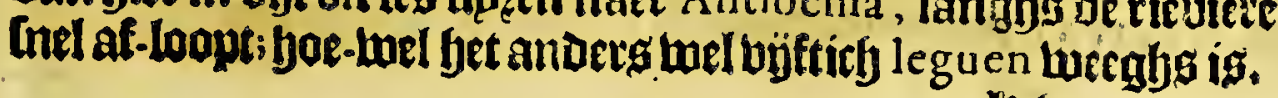




\section{Het elflte Capittex.}

Vervolgh van den wegh van Antrochia naer ANzERMa toe, ende befchrijvinghe van de ftade SANT A ANA DE ANZERMA.

$S$ Oo baelt als men ghepalteert is de pzouincie ban Caramanta, Dart wo in het $S$ booz-gaende Capittel ban bebben gelpzoken/loo kome men aen een leer yoogh geberghte/weldk wel 7 leguen Duert ; is leet Dirbt met boomen betwallen/ fou dat bet upter-maten moeplinck was te palleren/ende doen de Spaegniaerden Daet

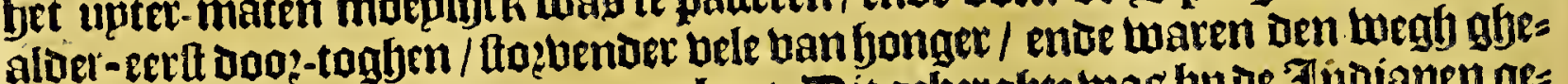
nootlaecht te openen met groaten arbept. Bit geberghte was bp oe 7 hibianen ges naemt Cima; Daer ouer 3 judo/komt men eett aen een klepne blacke ballepe/ baet wrpnigh bolclis moonoe; maex een twepnigh boazoer leght een lchoone eñ groote vallepe/ oe welcke ten tjoen dat oe 3 paegniaeroen daer eerft quamen/bol volcks

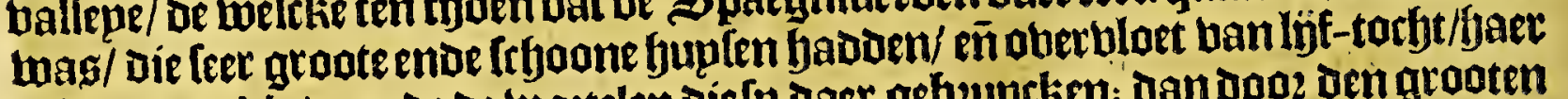
beloen tan Maiz, ende de wotelen Dielp Daer gebeupeken; Dan Dope oen grooten oberlaft enoe tprannüe ban de Spaegniaerden minoerden dit bolck leer yaett/en De relie ontliepent / ende verlieten baet woon-plartlen/ende gingenfjaet buonnín: gen nemen in 'tgeluerghte Cima booz-noemt. Ce wee leguen entoe en yalt boazder is norb een kilepnoer vallepe / welck ftreckt ban de boet ban 't gbebergbte af/ op welck ageberglte de ttade Anzerma gueboumt íg.

Be traot Anzerma miett entt genaemt Santa Ana de los Cavalleros, is gebout tufthen 2 klepne riebieren/opeen black berbeben belot/werciert met feer feboon ge: hoomte/ende menighte ban frupt-boomen/[on mel van oie ban Caftilien als ban 't landt [elfo; ende andere aerot-betthten/ bie daer wanderlïck wel twalten. De

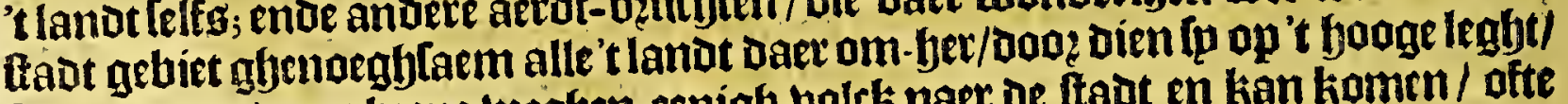
[oo dat baer ban gljeene weaben eenigh bolck naer ofe ftad en kan komen/ afte kan terftonot bu die van oe ftad befpiet wazoen; ronot-am oe ftadt legghen leer

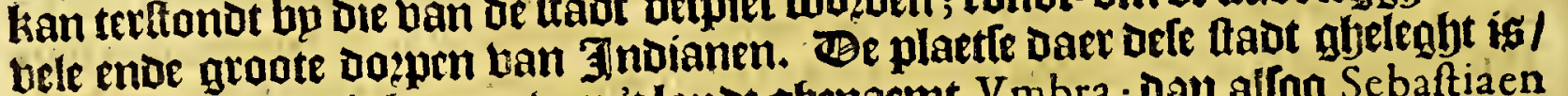
wierdt bp de in-gheboome ban 't landt ghenaemt Vmbra; dall alloo Scbaftiaen de Belalcaçar, Doen bp dit landt eet ontoeckte / gheen tolcken en badoe die dit

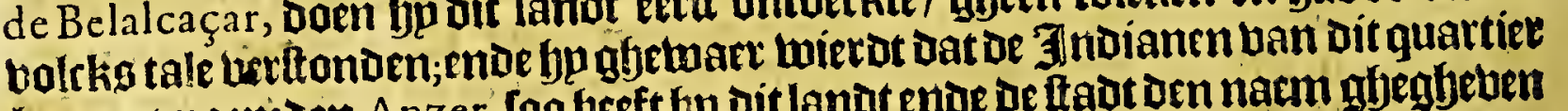

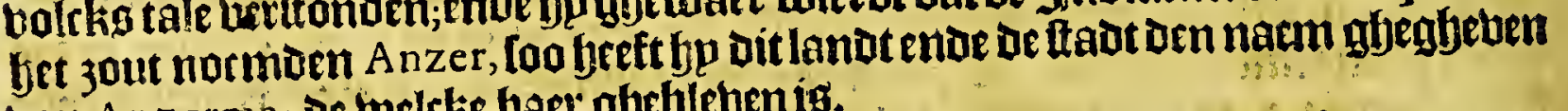
tran Anzerma, oe twelcke baet gheblebenig.

Bier leguen ban offeftadt naer' $t$ wetten legfyt een blecke die niet feet aroot en

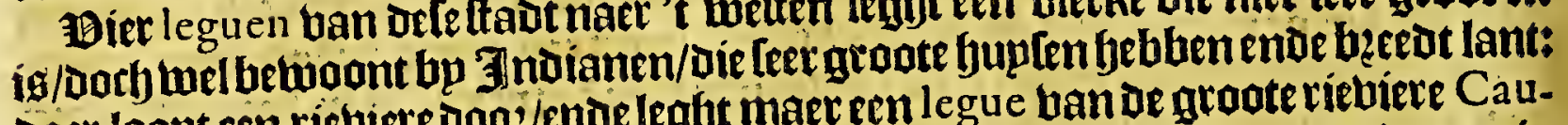
Daer loopt enn riebiete doo /ende leght maer enn legue ban oe groote rieviere Cauca. Bref Indianen lpetien de lelue tale han die van Caramanta, ende haren in

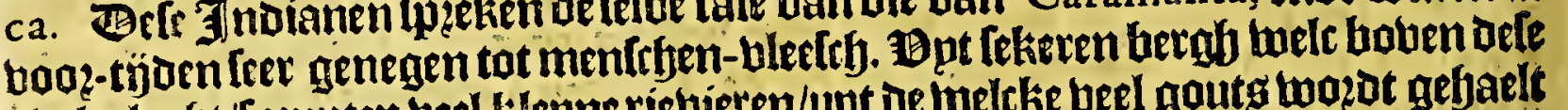

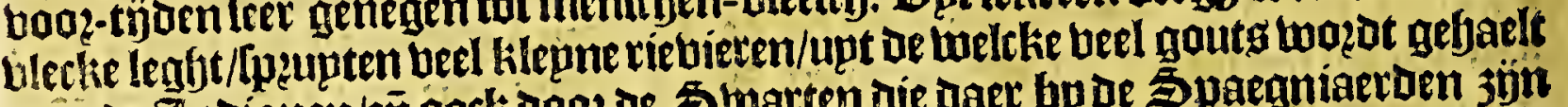

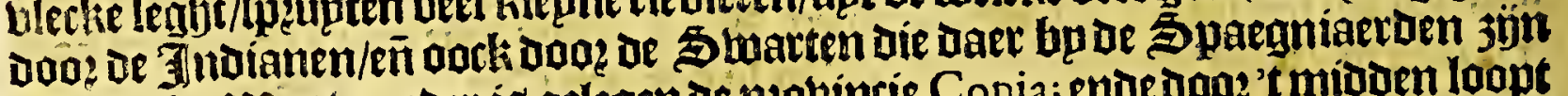

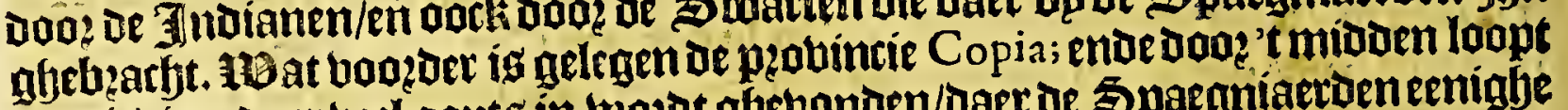
een riebiere daer beel gouts in lugzot ghethonden/Daer de Spargniaerden eenighe landt-fupten bebben ghebout: ronfineert met be płobintie ban Cartama boozen

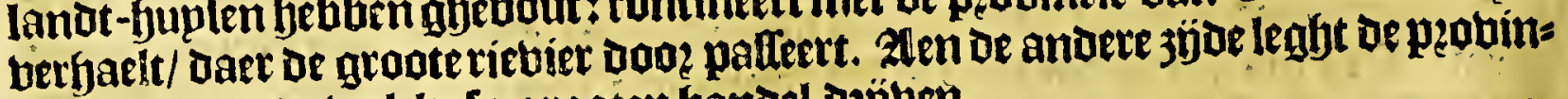
tie Pozo, met oe tuelcke lo grooten yandel azýtien.

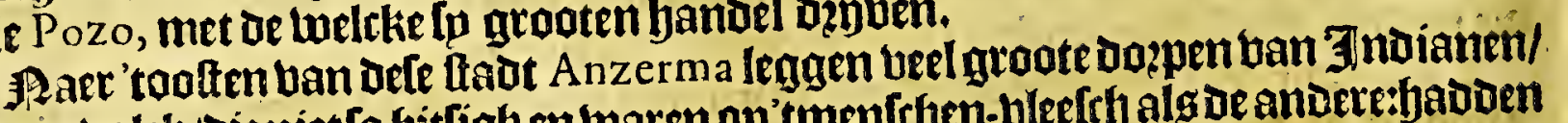

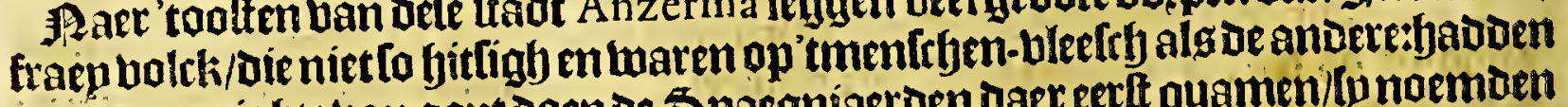
groote menighte ban gout doen de $\$$ paegniaer den daer eerf quamen/lu noemoen

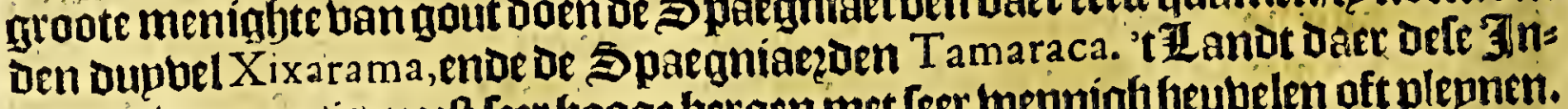
Def.de dianen moonen/ig meet [eer hooge bergen met [eer toepnigh beubelen oft plepnen.

Herrera lenbt dat dele ftadt Santa Ana de Anzerma dias. Gan de ftadt Popayan naer'tnoozot-ooften/op den oeter ban oe riebieet Cauca ten 
Het neghende Boeck.

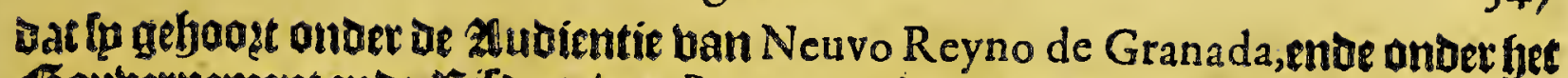
Boubernement ende 25iloam ban Popayan. Ende that de geltalte deg lutgtg aengaet (fegft fp) dat daercen bitligfe lutbt ig/ende feer onderbebigh bet weer-licbten ende blixemen; dat Daer geen bee en is / ende oock geen tarbe en twall : Dan bat in oe limiten ban defe ftadt feer goede mỉnen ban goud wogden ghetonden.

- Gan dele thadrnaer de zupdt-jee toe / feght Pedro de Cieça, woonen feer beel

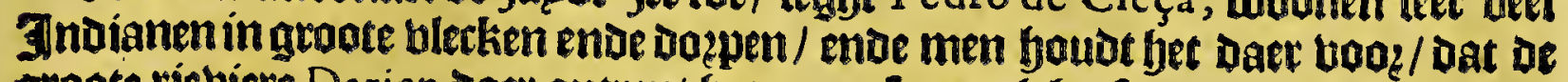
groote tieviere Darien Daet ontrent baten oofprongb beft.

\section{Het thatiffe Capittel.}

De wegh van de ftadt A N TI O CH I na de ftadt ARM A toe; de ghelegentheyt van de provincien tuffchen beyden ghelegen; ende van de ftadt $A R M A$.

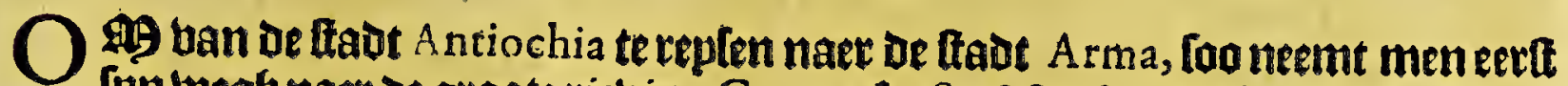
Ipum wegh naer of groote riebiete Cauca ofte $S^{\text {ta }}$ Martha (gelijts als Pedro de Cieça die noemt) belck jón twaelf leguen tweeghs: men pafteetr of rieviere met

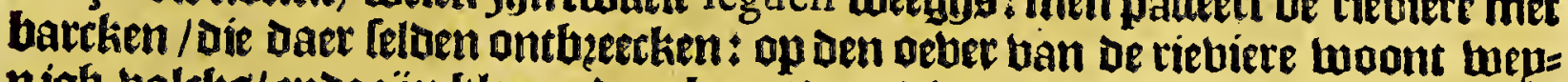
nigh balcks/ ende zijn klepne dozpkeng/ Dooz dien' t volck fen wooningh al vers re ban Den hooghen wegh beeft af-gheleght. ßaer eenighe Dagb-replen komt new aen een Dadp welck eertjots feet groot was: ende wievot genaemt Pueblo Llano:

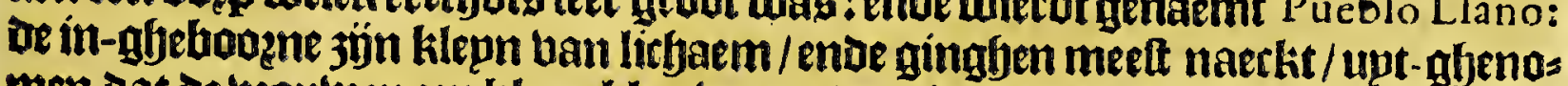
men Dat oe beutweneen klepn kleetjen om de mio oelt Dzoeghen; Gaer peincipalen Gandel is met joudt;joe-wel fp goerot-rỉcke riebierkeng bebben/ende berl gauot:

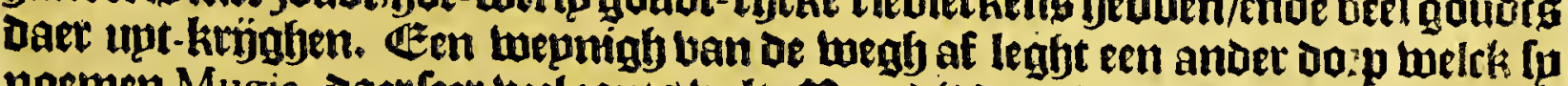
noemen Mugia; daerfeer beel zouts balt. Ban dit op?p voozder aen narr t oolien is ghelegen de ballepe Aburra, ende om Daer te komen/ moetmen ouer oe Andes

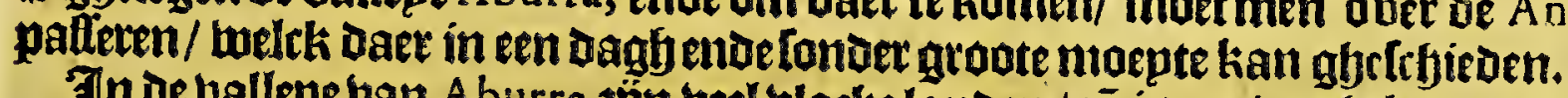

In de ballepe ban A burra jọn beel blacke landen / eñ ig een beuthtbaren grant/

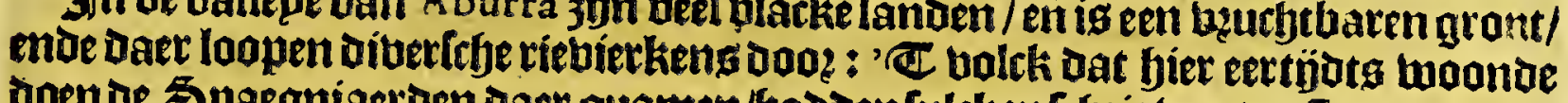
toen be Spaegniaer ben daer quamen/badoenfulckentifyeic ban oe Spargniaer= ben / Dat fp haer felven beel berfinghen / bepoe mans ende brouturn: van ocle ballepe liep een fooghe wegf naer't ooften toe / booz of belcke fa met berffjepoe andere natien gandeloen. Hat voożer van Pueblo Llano boot-normt / fiome men aen een anoer plaete die [p noemen Cenufara; is een tmel-ghelteloe plaet ende men mepnt dat daer leer rỉcke graben te binuen 3 jun. leght een ander doep/welck fin noemen Pueblo Blanco ; óm naek Arma toe te trec ken / laet men de riebier ban $S^{\text {ta }}$ Martha âtn ote rechter-banot legghen.

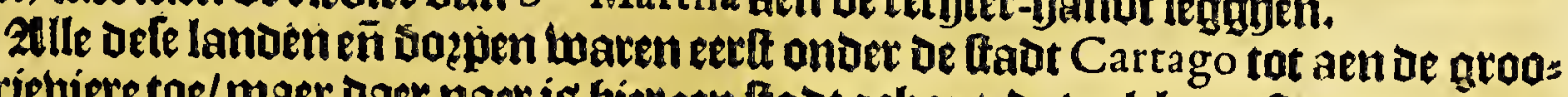
te riebiete toe/ maer daer naer is bier een ftadt gebout; De wellke eecit was afleght

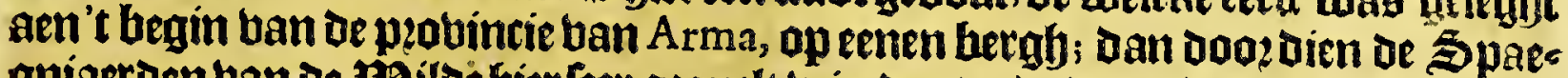

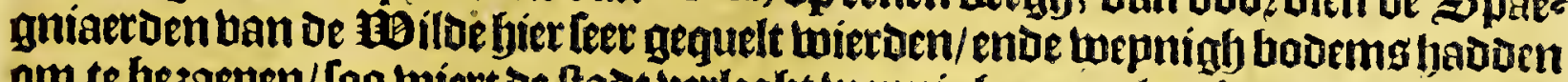
om te bejaepen/ [oo wiert de ftadt herleght twepnigh meer als 2 leg. ban oe groote rielviere: ende is nugelegen 23 leguen ban de ftadt Cartago, ende 12 leguen ban oe faut Anzerma, (endenaer'tleggen ban Herrera soleguen ban de ftaot Popayan, noozot- ooft ten ooften) endeeen legue ban de groote rieviere / op een blackite tur: ffyen twee klepne riebierkens gelegen/om-ringft bat een palm-boffy/daet gorae

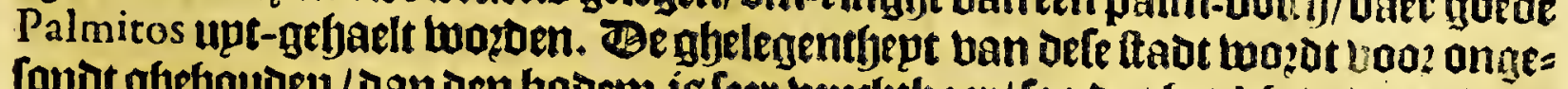

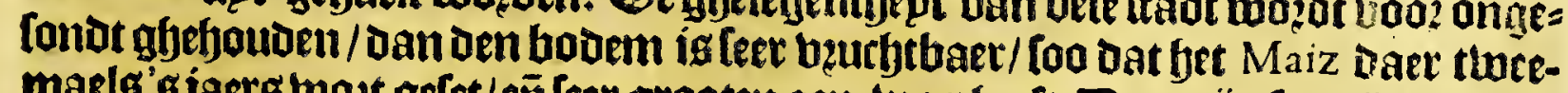

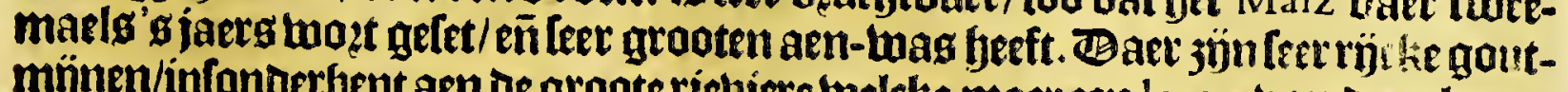
münen/infonderfept aen De groote rieviers belcke maer een le gue ban oaer loopt.

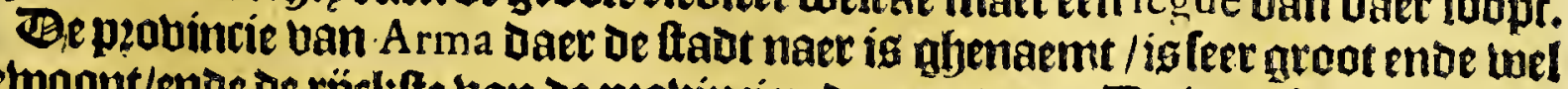
betwoont/ende de rücklte ban de peobincien daer ontrent. Te in-geboo:nen had= oengraateronde buplen/die bobenront toe-Loopen/eñmet frop gedeckt. Deffe:0=

1) 2 vincie 
$34^{8}$

\section{Popayan.}

bincie is turl I o leg.langh/eñ 6 oft 7 beet:mett geberghte/ wol ban albetlep fruptboomen van de lande/infonderlyept han en butucljte dielp noemen Pytahaya. Des Ce lueucht is ban Lultken kracht/ Dat men een daer ban etende / water maeckt als bloet, 19an De[e betgen bloepen eenige riebieren/eñinfonderfjept een die de 5 pae= gniaerden noemen Rio de Arma, welcke lozgelück is te palferen in De twinter-tüt;

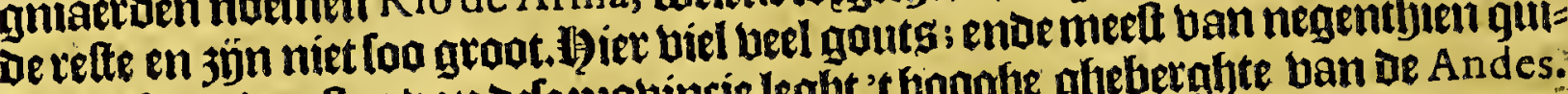
laten. Paer' tooften van defe pzovincie leght 't hooghe ageberghte ban de Andes.

Deftadt Sant Iago de Arma ([eght Herrera) beeft feet veel gaudt-mínen; is

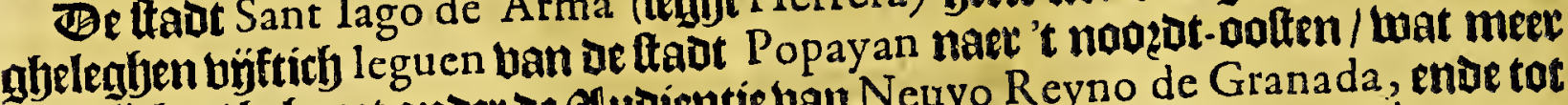
oaltelijeker/ befjopt onder ae Zludientie wan Neuvo Reyno de Granada, ende tot het Boubernement ender 25 ifoom uan Popayan; [onder tartwe ofte ander grain van Caltilien/maet obetbloeding uan't grain ban de lande. De miloen daer

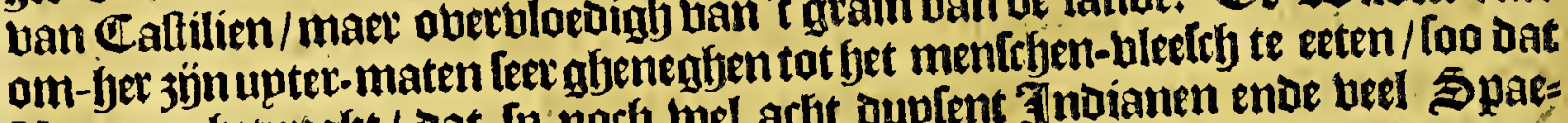

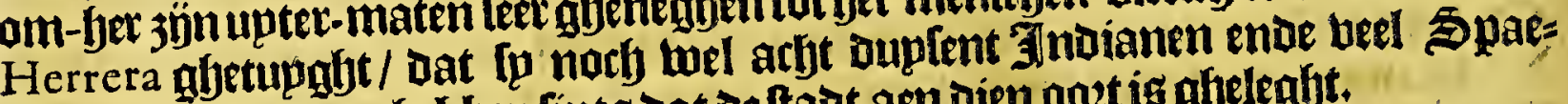
aniaetaen glyegeten bebben lints dat oe ttadt aen dien ooet is abeleght.

De groote pzobincie ban Arma Dooz-netrockenjönde/komtmen fraer aen een ander/welekefp noemen Paucura, welckes bolek een ander tale [ptack als die ban.

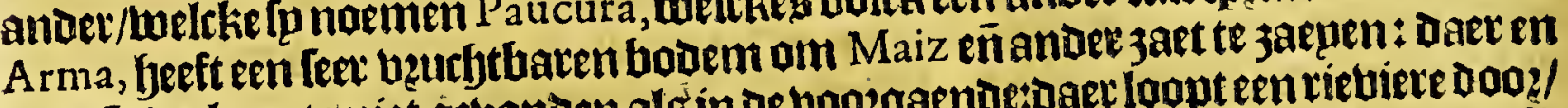

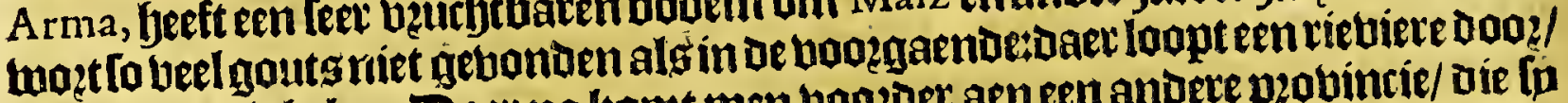
benefteng bele lekten. Baet na komt men boozoer aen een andere pzobincie/ oire ló noemen Pozo, 't uole wag ban de Teltue taleenoe manierenalg die ban Arma. Defe

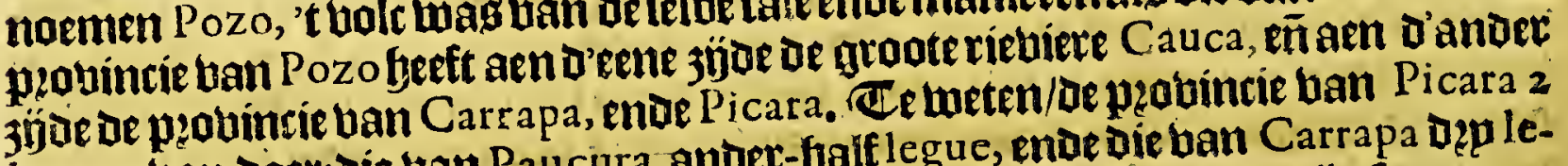
leguen han daet; die uan Paucura ander-fjalt legue, ende die ban Carrapa Dęp le-

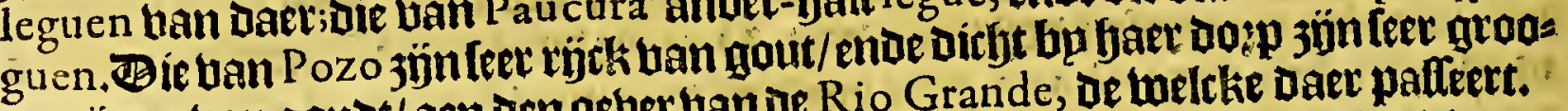
te minnen uan goutot/ aen den oeber ban de Rio Grande; de welcke Daer paffert.

Dan De provintie Po zo naer's ooften toe/ leght oe pzobincie Picara, twelcke een

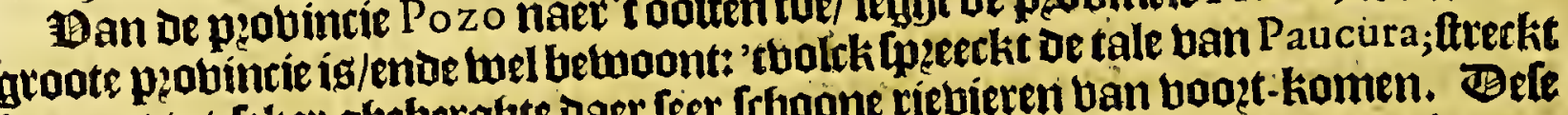
baer upt tot leker ghebergfte daer feer fryoone riebieren ban boott-komen. Bele pzovincie nan Picara befft Get groote ende yoogbe abeberghte nan de Andes nae 't oolten: aber welcli gheberghte de pzobian

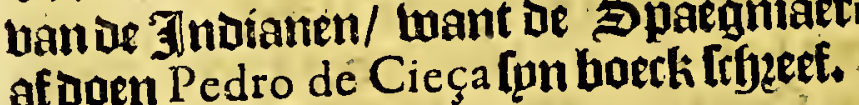

\section{Het aerthienae Capittel.}

Vande provincie van CarRAPA, ende die van QuYMBAIA, tot de ftade CART A G toe, ende van de ftadt CAR T A Go.

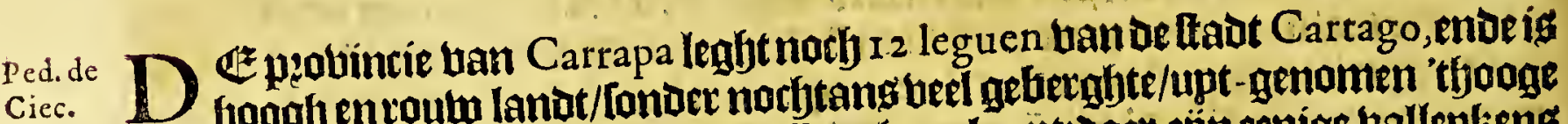
gebetglte ban oe Andes, wele Daer neffens been loopt:Daer 3 jun entige ballepkent

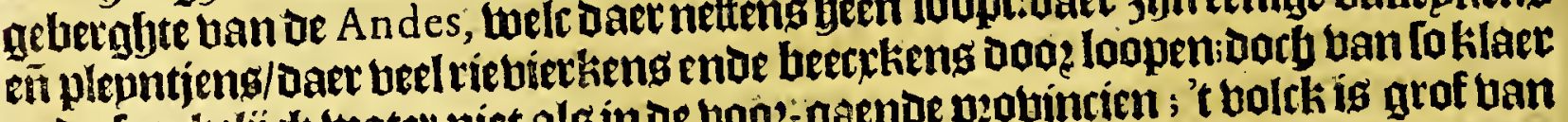

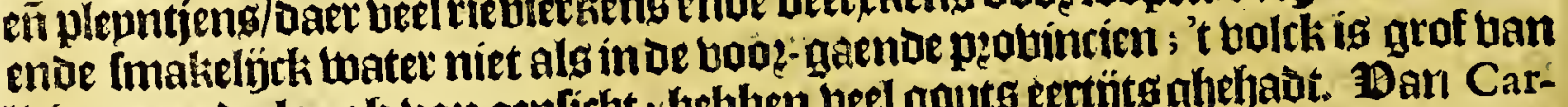

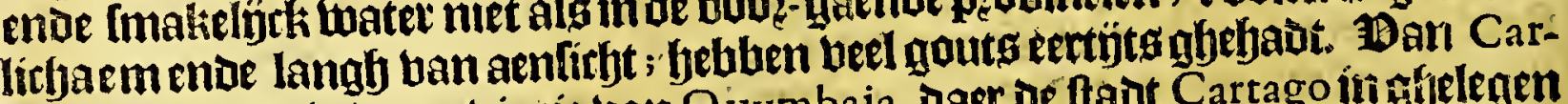
rapa komt men in oe peovincie ban Q uymbaia, daer of ftadt Cartago in effelegen is/ 22 leg. ban De tadat A rma. De pzobintie van Quymbaia ig i o leg.beet enoe is: leguen langh/ bain be groote rieviere af totaen't joogegebergbte ban be Andes; de

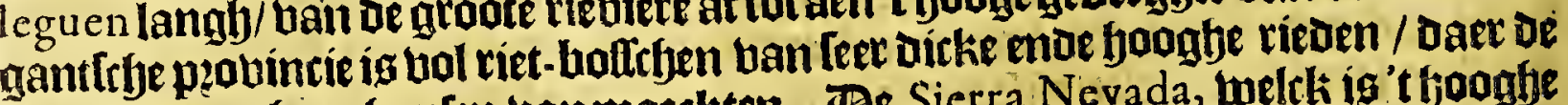
ili-Loonders hate huplen vanmaeckten. De Sierra Nevada, welck is't fjoghbe

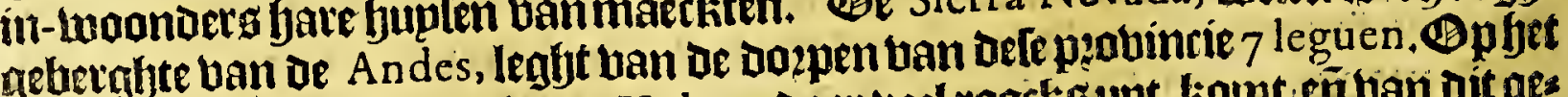

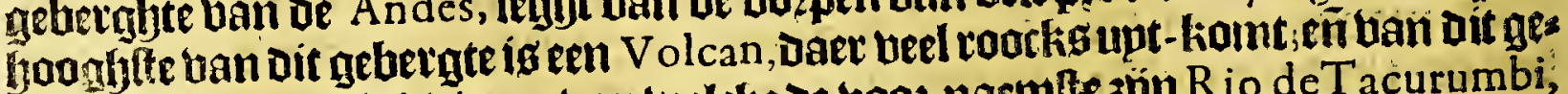

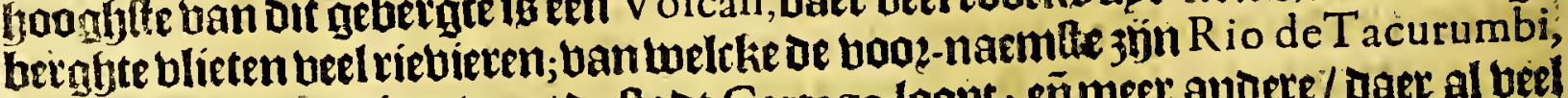
enoe de la Cegue, Die nebeng ae ftadt Cartago loopt; eñmeer andere/ daer al beel gauts 


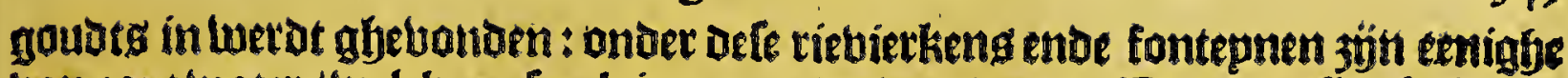

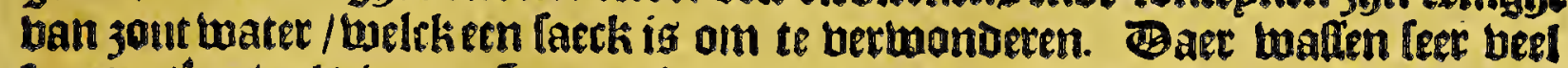
frupten/ioo tuel die ban Spaegnien daer jün gebeacht/als die ban de lande. De gheftalte ban oe lutbt is in dele pyobincie feer gbelonat / niet te beet/ noch te kouat/ Coo dat de Spaegniaerden die daer woonen kepnigh fierk jön/ende lange leben. Den binat in orfe p?obintie beel twilde buen/ vie baer bonigh maetken in de holte ben be groote rieden ende boomen. Baer waft oock feecker veuchte welck fu noes men Caymito, foo groot algeen perfe/ ban binnen fwart / bebbenoe feer klepme kerntiens/ ende leecker fap tuelck foo baft kileeft dattet qualigek is af te toafichen: Datr twatlen mede Aguacates ende Guayanas, eenighe foo fuer als limoenen/ban feer goeden reuck ende fmaeck. Cultefen defe dichte riedt-bofictyen onthouden baet beele dieren; ootk groote leeutuen/ende een anoer bier-boetigh beelfijn/welck fp noemen Chuca, welck fpn jonghen met fem deaeght in een lack; daex jijn beel batten enoe konïnen/ende tueel Gua da quinaies, welek jün gropter ala balen/ende baer bleefry is goet ban fimaeckende geeft goet voetfel: eñ dietgeligcke beelfen meet. De faot Cartago ig gelegen opeen blacte/tutichen thee klepne beken/7 leg. han De riebiere Sa Marcha, bu een ander klepnoer riebierken/Daer de Spaegniaerben

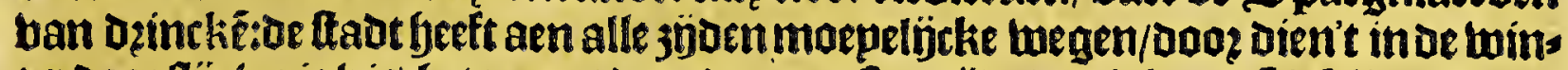
ter daer dujcketigg ig;

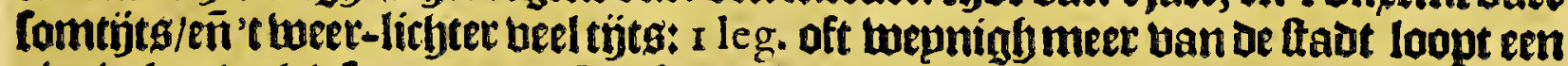
rievierken welck fp noemen Confura, eñ daer bp is gelegen een klepn lack daet be in-moonoerstthoon jout maken upt een joute fontepne die daer is. Be ftadt $C$ artago (legltt Herr.) is gelegen 25 leg. van oe ftadt Popayan na 't $n$. o. befjodat tot de auvientie ban Neuvo Reyno, en 't Goubernement eñ 25: en walt geen tarke oft ander jaet ban Caltilien; isgetempert lanbt/ende gelonot; men bint daer bepnighgouts; Daer en wogden niet Dan koepen ende peeroen aengetelt: Daer is een liloofter vanminnebeaederg. Om tan defe ftadt te replen naer

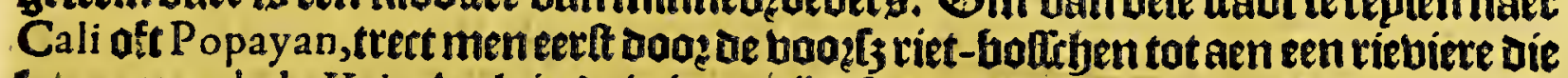
Ipnoemen de la Veja, twele in oe twinter-tijotleer morueligck is te pafteren/is 4 leg.

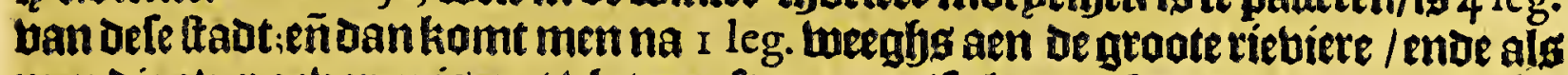
men die ober gebaren is met blotten ofte tanoen/ fo loopen bepoe de wegen in een/ te wóten die van de ftadt Cartago af-komt/eñ Die uan Anzerma af-komt. 廷De

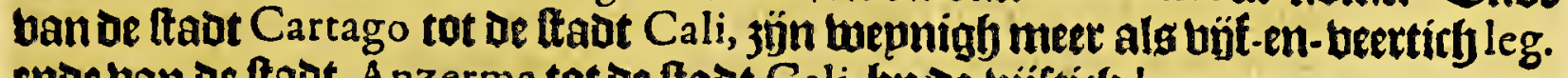
enoe ban de ftadt Anzerma tot de fladt Cali bu de bifftieb leguen.

Met beetthienter Capittel.

Befchrijuinghe van de Stadt $C_{A}$ L 1 , ende de Landen daer ontrent ghe. legen; als mede van de haven BONAVENTVRA.

D Eftadt ban Cali (Tegt Herrera)ifigelegen op oe boggfte ban 4 grad bp noots

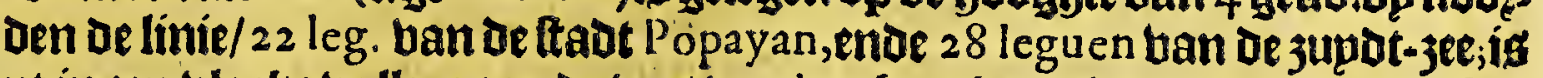
gebout in een blacke ballepe aen de boet wan't gebergbte gelegen; daer is een feec

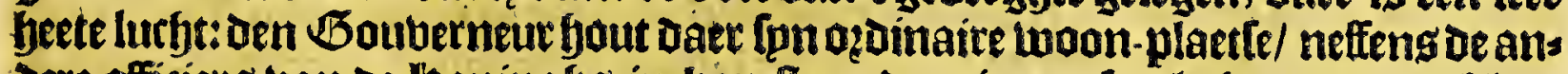

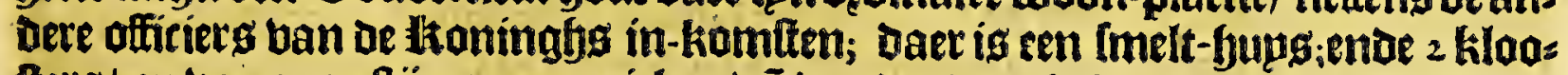

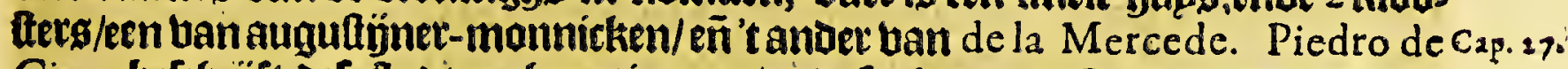

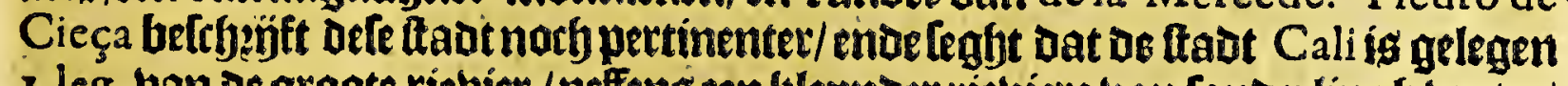
I leg. ban oe groate rievier / neffens een filepnoer riebiere ban Lonuerlingh water/ welck baer oojfp?ongh heett in 't gebergte dat bouen be fade legt. Alen bepoe de $3 \dot{y}=$ den ban Deferievieren leggen beel lchoone boben/Daer beel bututhten ende krup den in toallen. De ftadt is ge bout op eeneffen plepn/eñ ten luare bet daer upter-maten heet waer / foude een ban de bequaemite plaetten jijn ban beel Indien. Befe ftad twaj eertt bp Sebaftiaen de Belalcaçar geleght in een ander quartier onder ecn na= tíe ban Jndianen/ die [p noemden Gorrones; Dooe dien De Spacgniaerden die peobincic eerft antoeckente/ ento de tale ban't bolck niet berftaende / bemerckten

等 3

par 


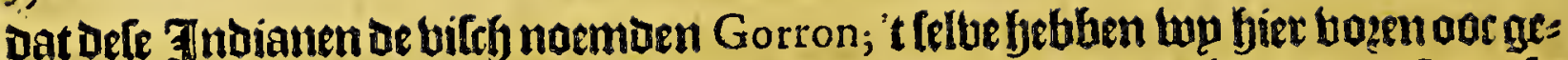
fien in Anzerma. Dm De gelegentfent van defe peobincie noch beter te berltaen/to fullen wo upt Pedro de Cieça de fake van wat booger aen-leggen: Ban oe ftaut Popayan af begint bem tuttryen bepuen de Cordilleras ban'tbooge geberghte eet vallepe te lechten/ oe welcke I 2 leguen beft in de beerote / op Commigbe plaeten

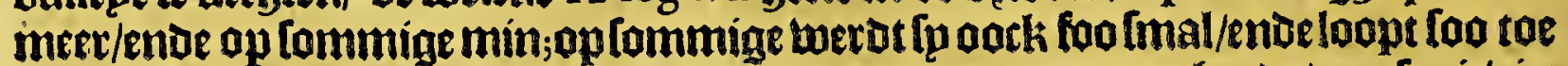
met de rieviete die daer Dooz-loopt/Datmen doo? ae groote enghte de boos[j. riebiere norf met barcken/nody met blotten/norf andere midoelen in dat quartier kan palleren:want beeft daer fo Inellen loap/ende maeckt too ueel hielen ende dzaevin= gen dat Get al te gronoe gaet wat daet op komt. Befe gantlebe vallepe ban oe tads

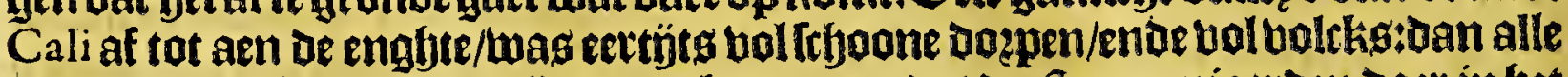

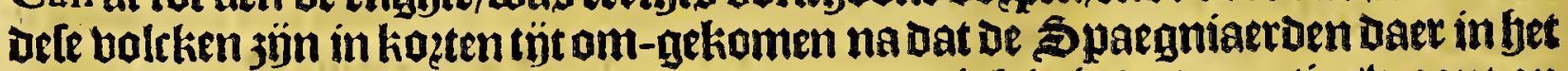

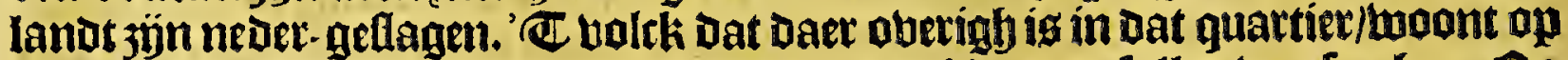

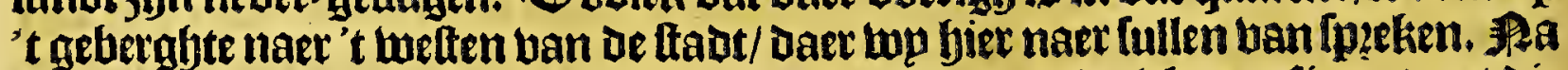
't noozden ban dele ballepe leggt een ander pzobinrie/ oe belcke confineert met die

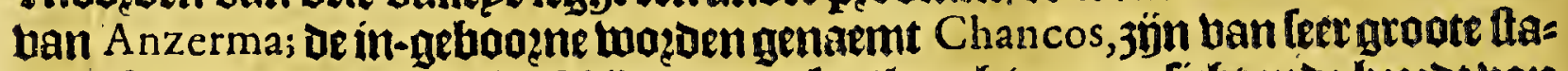
ture / loo datte klepne reulen Ictjónen te welen/ langh van aenticht enue bzeed ban

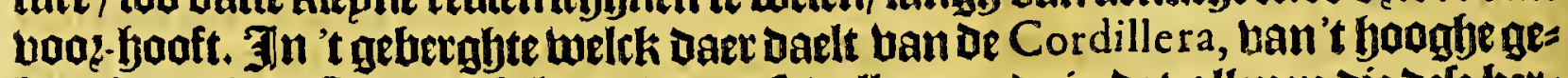
berghte na t welten toe ghelegen ban offe ballepe; ende in be ballepen die dele bet: gen maken/woonde beel balcks welck fo noemben Gorrones, als boazen; de tweles

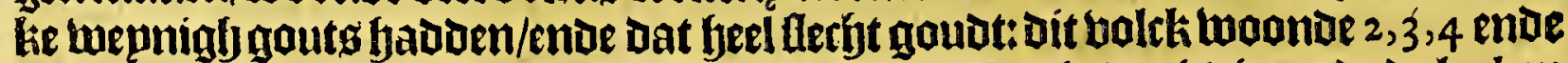
meer leguen uan de ballepe eñ de rievier; ende quamen ín oe riebiet ende de larken

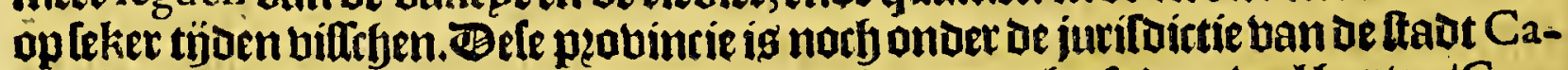
li;is feer bzurhtbaer yan Maiz ēn anoere bzuehten:men beett daer veel harten/Guada quinaies, ende anotet wilt/eñ veel gevogelte. Be groote ballepe han Cali, fjoe-wel

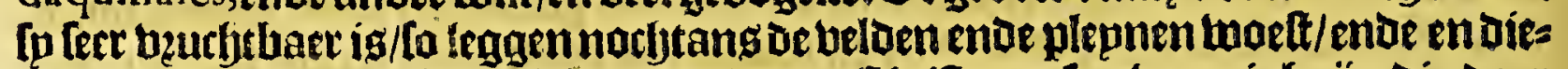

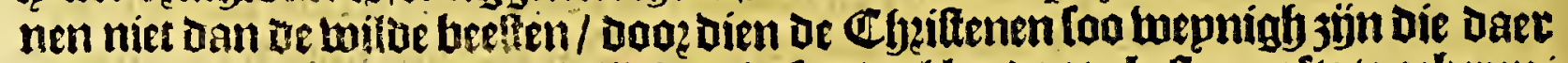

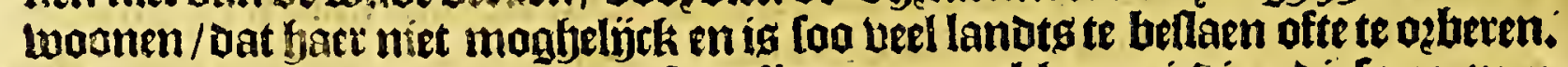
Pedro de Omna de ftaut Cali te komen/[o paflecttmeneenklepne riebiere dielp noemen

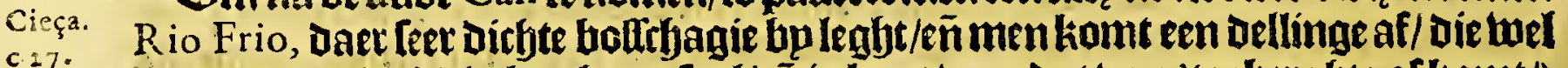

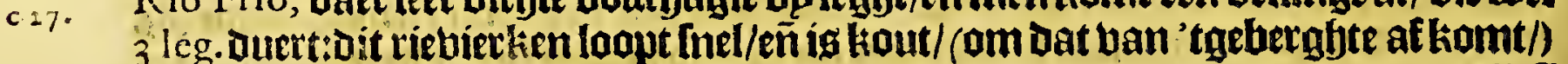
loopt dooz cen ghedeelte ban de ballepe Cali, tot in oe groote riebiere! ende berlieft. Däetfun naem. 2UIs men aber dit riebierken is/Lookamt men op groote blacke bels

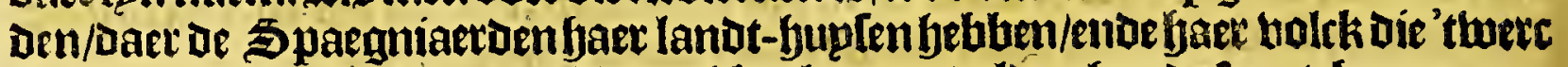
tuaer-nemen; ende'tlanot is bier mel beplantmet aloet-fjande fuupt-boomen.

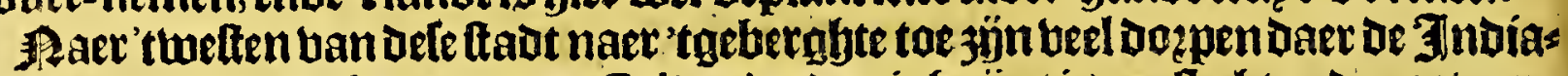

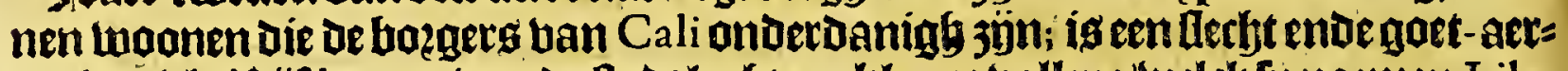
digh balck. Bijf leguen ban oe ftadt leght een klepne ballepe/welcklp noemen Lile, Daer leer beel Maiz groept/ende Y uca; beel frupt-boamen; eñ doos tmidoenloopt een riebiere/langfy de welcke leer gaede benchten wallen/ende onder andere een die

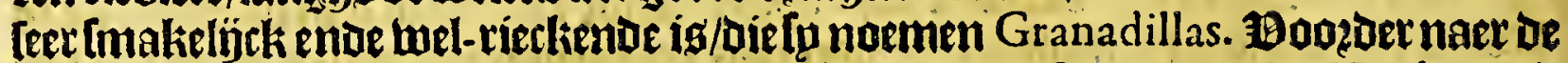
3updt-jee leght een ander peovintie ban volcketen die lu noemen los Timbas; dit

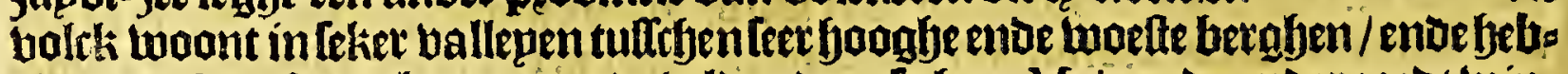

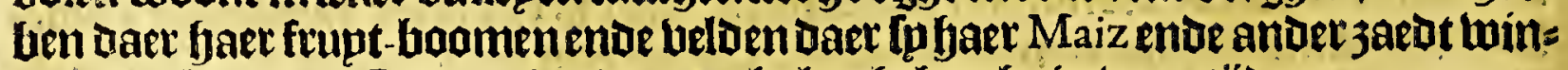
nen: Gebluen beel Spargniaeroen om bals ghebzacht in boaz-tijoen.

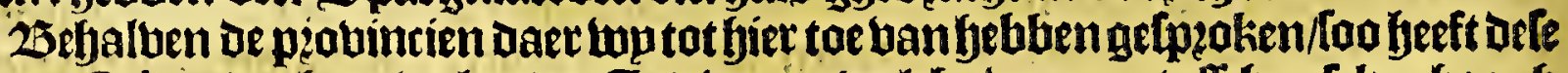

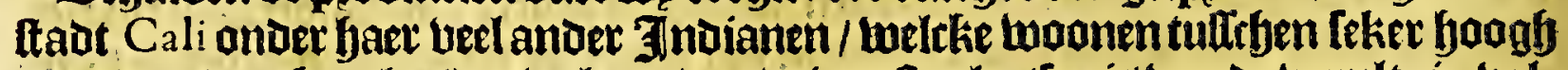

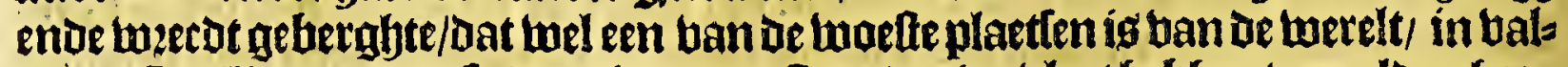

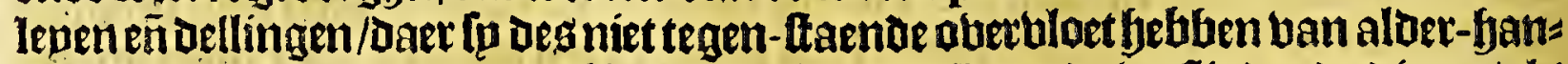
ae liff-torbt:in'tgeberghte ontfouden baer veel wiloe ende bertlindende dieren/als by namen/tugten/Die beel Indianen en oock Spaegniaerden berlínden/als bie van Cali naer oe 3 ee toe treeken / ofte van jet wejer keeren naet Cali. Bep daghreplen boozaet aber [eet hoelte bergen/bol ban palm-hopmenende moeraltrben/ 
legft oe haben die fp noemen Bonaventura, 3 leg. ban de ftadt Cali, ban be tuele= ke fip gantffyelje dependeett. Herrera ftelt de fauen ban Bonaventura op deboog= te uan Dep graden en een balf bp nootoen de linie. Baer twoonen eenighe wepnige familien om de koopmanfryappen die van Nova Hifpania ende ander quartieren

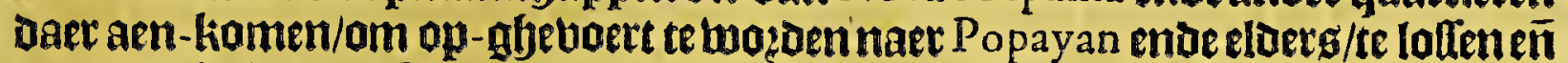

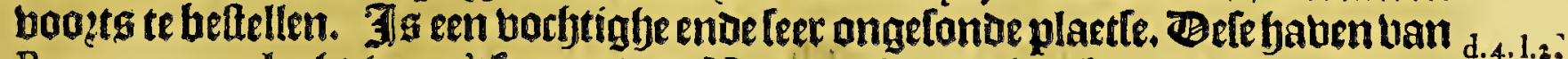
Bonaventura legbt (naer'tteggen nan Herrera) ineen diepe bape/welck genaemt cap.s. mogt Bahia de Bonaventura, enoe foute gólegen jünnaer 't feggen uan Pedro de

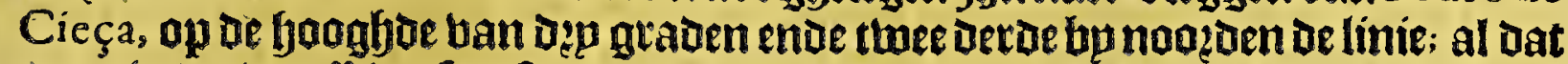

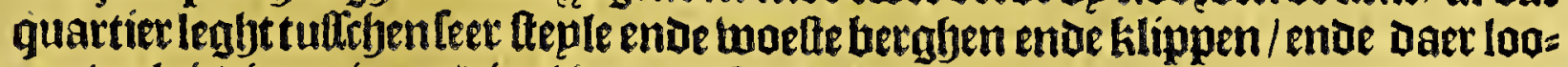
pen beel rievieren in $3 e e / d i e$ al baet oos[pyongh nemen in dit gebergte/ Daex' $t$ meelt

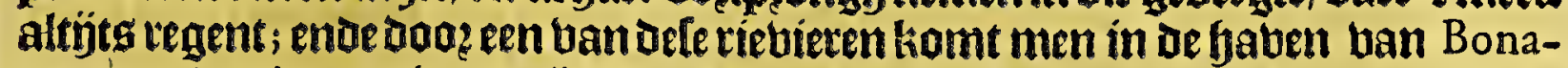

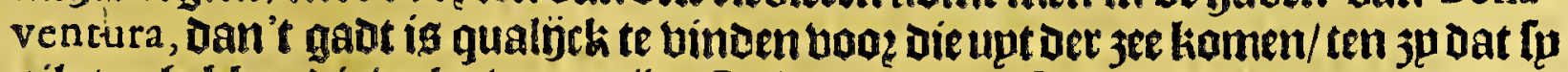
piloten febben die wel erbaren 3 ïn. Pedro de C'ieça Tequt dat den eenighen mido= Del om oe goederendie fier ontladen wozoen/te beenghen naer Cali, ig/oe lelte de Zndianen op den fyals te Doen Dzanden; want dooz de fardiclyept ban't gebetghte en íget niet wel magreljck peerden oft muplen daer te gebupctien: ho:-bel noch= tans daer een twegh is langhs de riebiete Dagua daermen perden lan gbebature ken/Dan toerden foo af-gedlaeft/oat fp bp naer niet weett jin als fp te Cal komen:

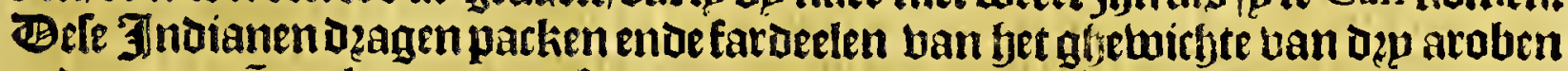
ende meer; eñ aockeen man oft een bzou op een faeltien fíttende / ober bergb oliet

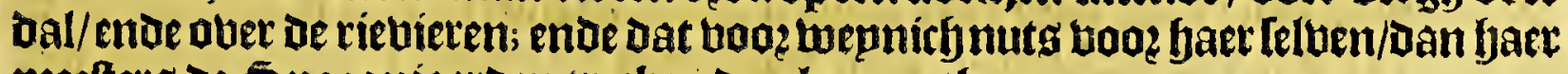
meetters de Spaeguiaerden trecken Den loon na baer.

\section{(9) büftfienoe Capittel;}

De wegh van de Stadt Calrnaer de Stadt Popayan, ende de gelegentheyt van de Landen tuffehen beyden ghelegen.

V'ande tadt Cali (Daex wp in 't booz-grende Capittel ban bebben gelproken) tot de fooft-ftad ban dit Boubernement Popayan, 3jon gelinck wo gefent beb: ben/ 22 leg. al doo: Leer bequame toegen/ober blacke beloen/fonder bergen/foetuel

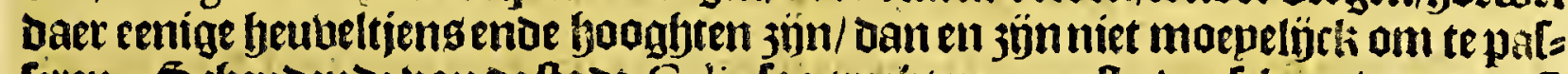

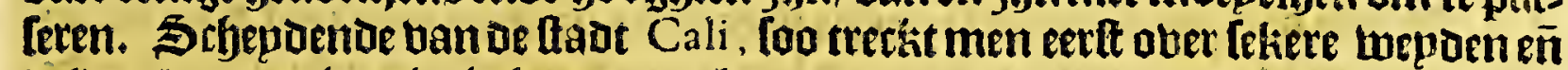
beloen/Daer eenige riebierkens doo?-loopen/tot dat men komt aen een welckinirt

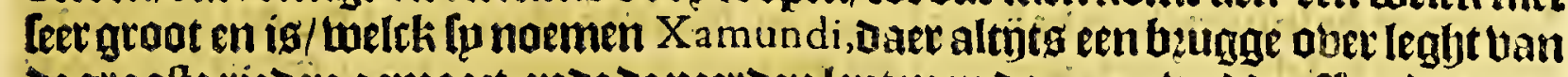

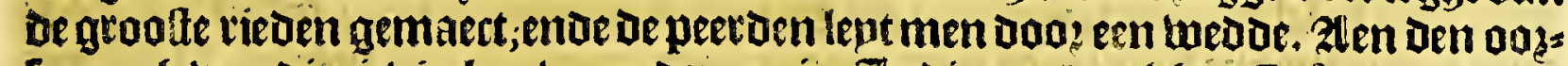
fpzongh ban dit riebierkentwoonden eenige 3 ndianen/weelcker Cafique fiet $X$ a-

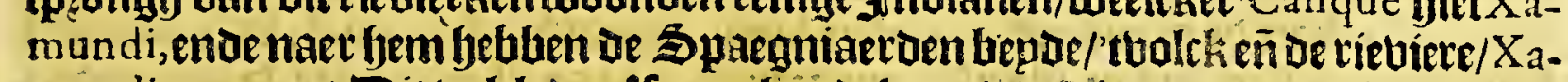
mundi genaemt. Bit bolck Deeffpnen bandel met 't uoick van oe yyobíncie de los Timbas, Daer wp fier voen getwarb van fjeb ben gemaecht; fadoen veel goudtg/ twels haer meelt han de Spaegniaerden is af-genomen/siefy in Enconicnda (als

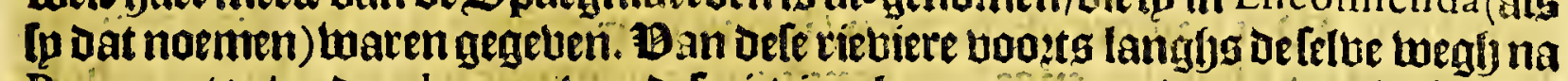
Popayan toe/ ende 5 leguen ban Delerieviere homt men aen ie groote rieviete $S^{\text {ra }}$

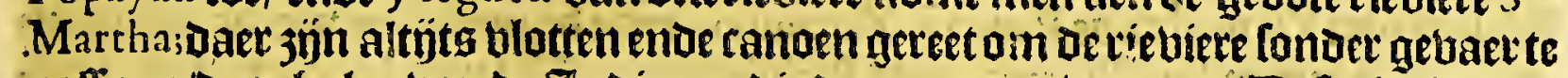

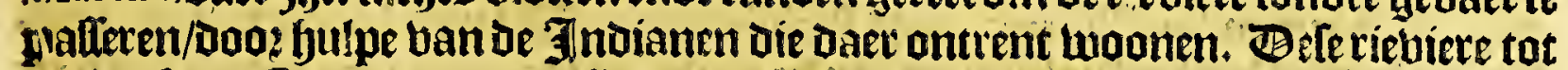

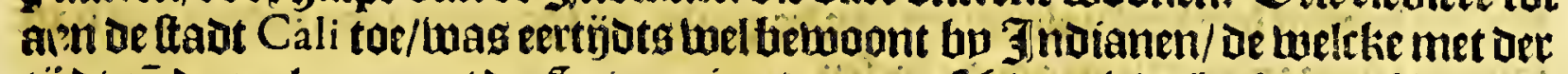

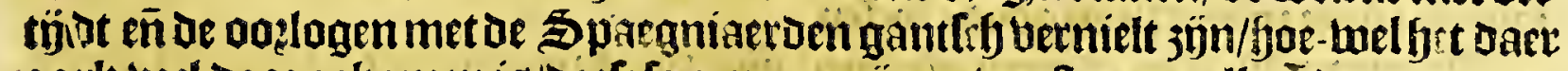
oar k beel doo? gețomen is/Datté fo genegen jün gelueelt ommalkainderen te eten. - Ban Dit bolcl jünnotyeenige wepnige ober-get leven die aen d'en ende d' andere 3 joe ban De rieviere noty twoonen/ende twozoen genaemt los A guales, defe dienen/

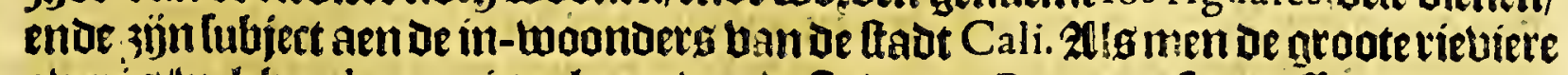
ober is/twelck i 4 leguen is gelegen ban or ftaot van Popayan, [oo paifert men een

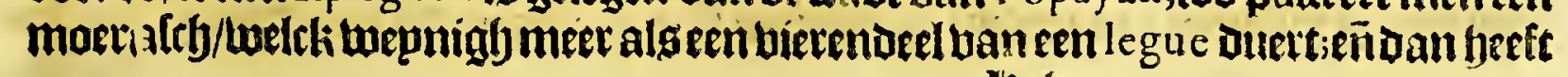
i) ij 4 men 
$3\lceil 4$

Popayan.

men bootoer een feer bequame wegh/tot datmen kamt aen een ander rietuietc bele

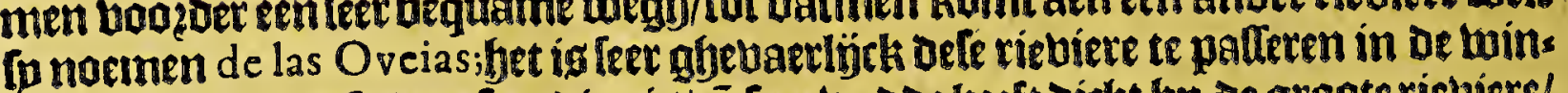

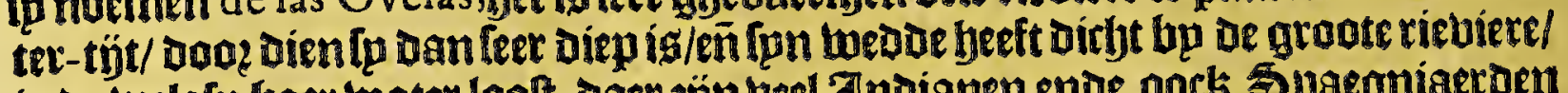

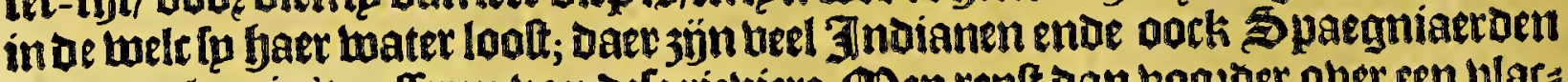
berdzoncken in't pafferen ban Dele rietiece. S9en replt dan boozoer ober een ulat: ke booghte/melck 6 leg. Duert/ ende is leec bequaem om te ghebzupcken; ende aen tepnoe van de fellue palleert men norb een ander riebiere / die fo noemen Pianda. mo. Bntrent Dele rievier heeft eertýts beel bolcks ghetwoont/belck am de redenen

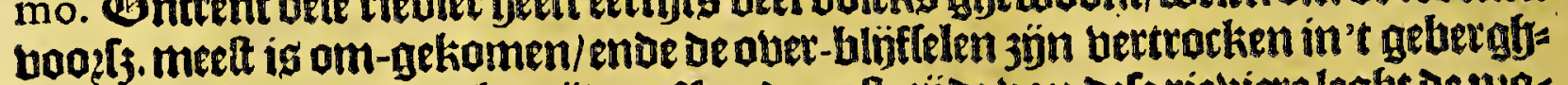

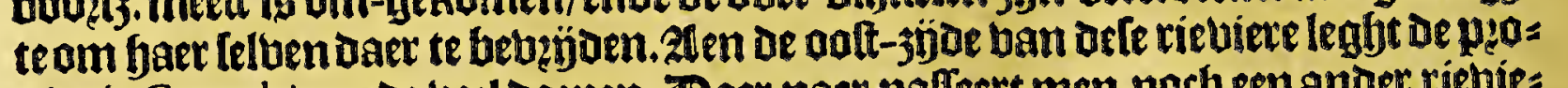
vintie Guambia, ende betl doepen. Daet naer palleet men nech eenander riebie: re die [p noemen Plaça, aen fon begin ende bep̧e jüden luel beluoont: enoe norb boozoer palfeett men lueder de groote riebiere ban Santa Martha, ober een wedoel. Doge dien't daer niet ober een Galt badem diep is. De riebiete gepafleet jünde/[ao is'tgantfche lanot tot De ftadt Popayan toe bal ban feyoone boubuerneneñ landt-

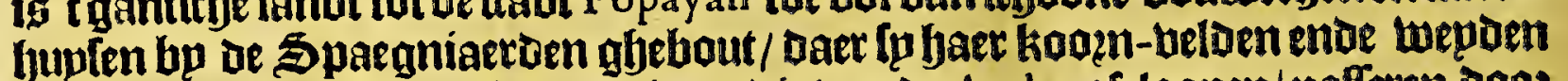
hebben vook de beeften. Bele riebieten die uan de Andes af-loopen/pafleten Dooe dele veloen; ; noe men beett in boot-tijoen Daer eenighgoudt gevonoen. Op dere beloen ende plepnentwoonde pock Ieer beel volekg/die alle fubjert waren oe Cazique ban Popayan, daer dele plouintie ende ftaot de naem beeft ban befouden; dan.

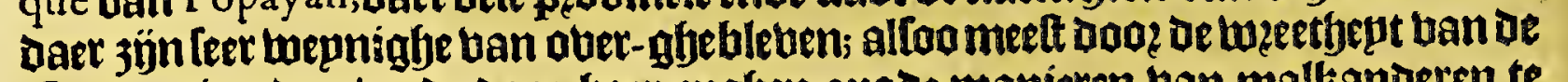
Spaegniaeroen/ ende doos baer epghen quade manieren ban malkanoeren te verflinuen/ jün om-ghekomen. Dele lwegh ban Cali naer Popayan twozot leer beel gheftequenteet / Dooz dien naer 't leggben ban Herrera daer gheen bequamer weghen igom ban Veneçuela, ende alle de kulten ban de noozdt-ję/ ende bant Novo Reyno [elfgtekamen naer Peru ende Chili, Dan Den delen.

Wet teltjiende Capittel.

De wegh van de ftade Popayan naer de ftade Pasto, ende de byfondere gheleghentheyt van de landen ende volckeren daer ontrent gheleghen; ende van de ftadt P A s T O felfs。

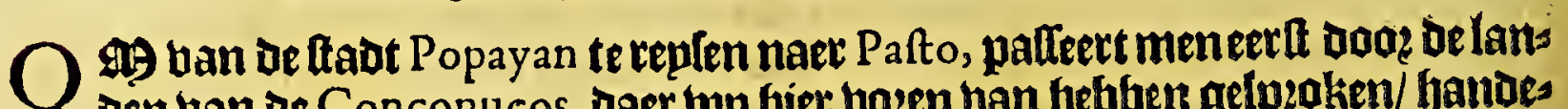
oen ban be Conconu cos, daer wo hier bozen ban bebber gelpzaken/ bandes Iende van de límiten ban de ftadt Popayan. Be Telue ghepalleett jynde / loo komt

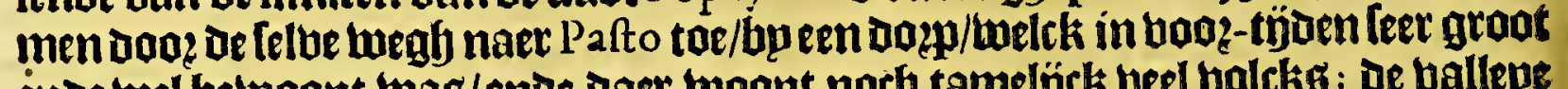

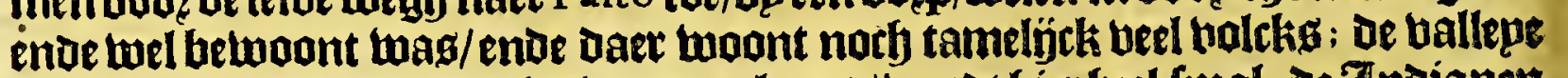

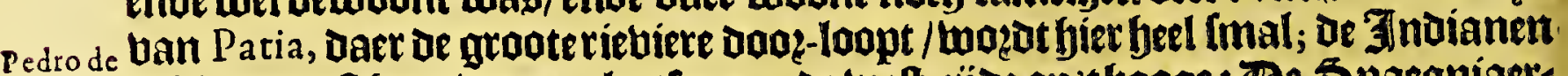

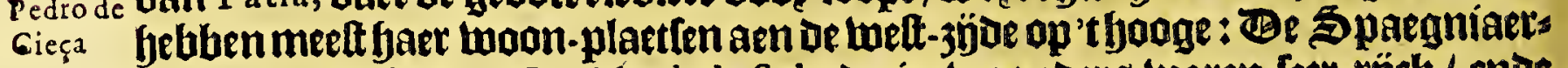
den noemen dit dojp Pueblo de la Sal: de in-woonders waren leer rỷek / ende

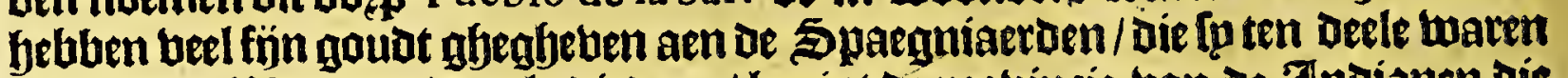

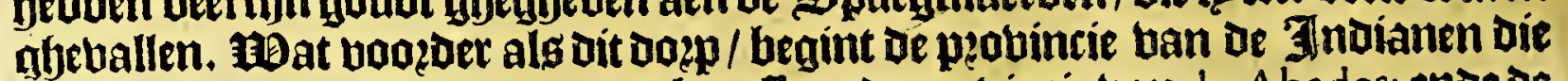
fo noemen los Mafteles; ende daec benefteng De plobintie ban de A bades; ende de Dozpen ban Y fancal ende Pangan, Za campus; ende de pzobincie ban de volckeren

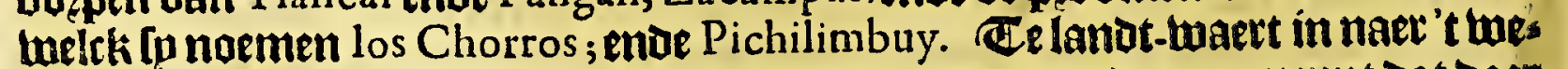
ften toe woont leer veel holcks/ tot aen be 3 undt-jee toe ; ende men mepnt dat daet fouoen rúcke münen ban gou d tuelen.

Te dozpen die daet ontrent ghelegen zijn/ wozton genoemt Afgual, Mallama, Tucurres, Capuys, lles, Gualmatal, Funes, Chapal, Males enue Pyales, Pupiales, Turca ende Cumba. Afl dele doepen/ende de Caziquen uan dele plaeten voenden Den naem van l'attos, ende de faat ban dat quartier feeft den felven naem uerktes aen ende behouden. (Dock foo palen aen de felue dozpen enoe volckeren andere nas tien ban Jndianen / of Lelcke fo noemen Quillacingas; die bare toon-platten

beblent 
hetben naec 't ooften; De namen ban de plincipaelfe doepen wan bit hole jün Mo. condino ende Bexendino, Btyzaco, Graianzangua enor Mocoxonduque, Guaquan quez ende Macaxamata. Enoenoch meer naet' tooften leght norfeen ander

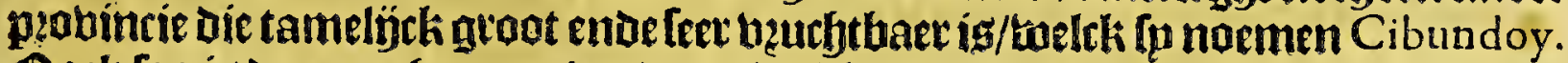

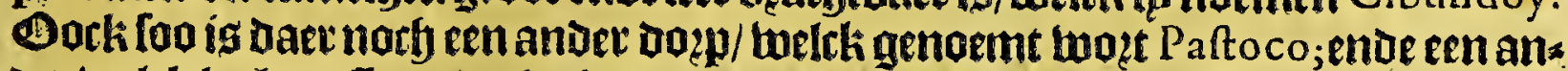
oer welck leght neffens en lack/Dat op een wan de booghtte bergen daer ontrent is gelegen/van feet kout water/foo dat daet gantfrygeen birfh ofte gevogelte in wo?t

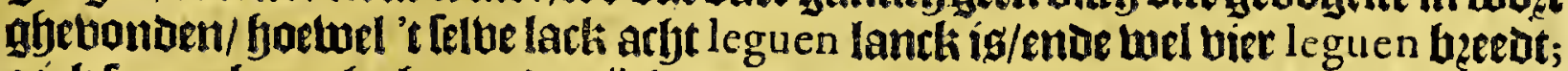

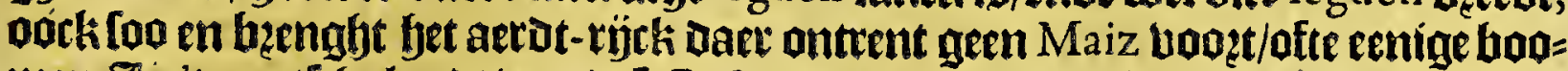

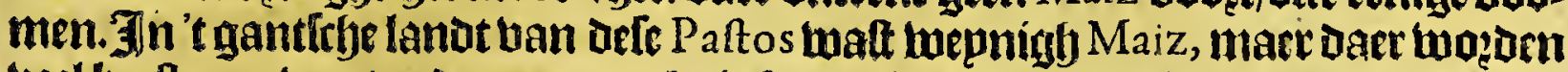
beel beeften getuept ende aen-geteelt/ inlonderfept wertheng bp grootemenichten.

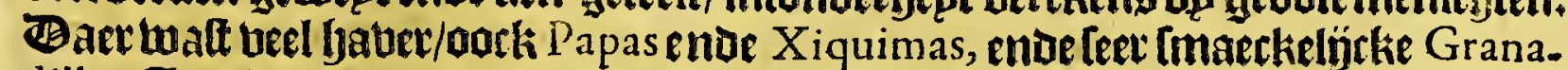

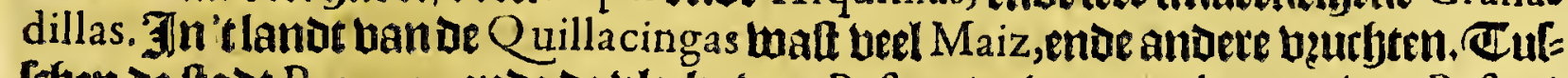
Iffen are ftadt Popayan enoe de bleckie ban Pafto, (te tweten gleguen ban Pafto, ) iseen rieviere gfelegen/welck [p noemen Rio Caliente, welck in de winter-tijot frec moepelijek endengebaerlijck is om te palleten. Heft anders bet belte water

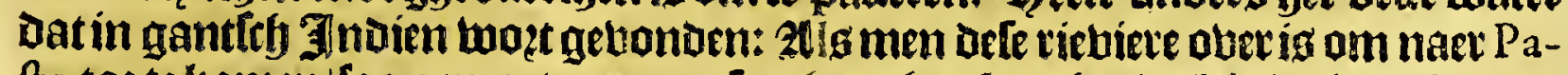

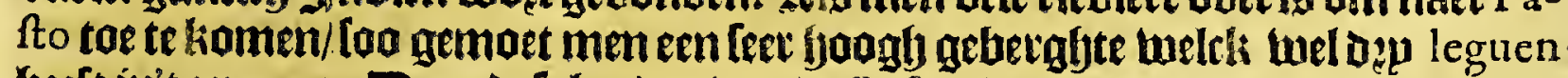
berf in't op-gaen. Doos Defe landen ban oe Paftos loopt noebeenticuiere de welcs ke lp noemen Angafmayo, imelcke riebiere't upterlte was ban't gehiet ban de Yn-

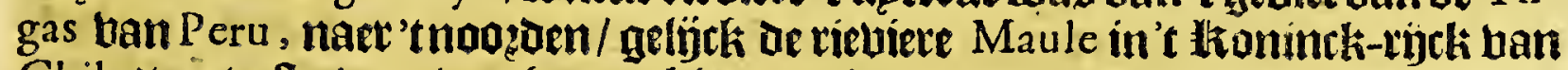
Chile 't upterfte was ban baer gebiet naer bet jupden. Be riebicte die [y noemen Rio Caliente, gepaltert jjnae/ende't geberghte hoo?-noemt/ [oo treekt men ober

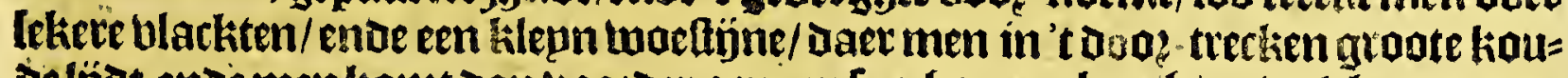
telijot; ende men komt dan boozoer aen en leer boogen beroly/ap welckes top een Volcan ig die Dooz-gaens beel roock komt van Popayan naet Pafto, aen De redjter-bandt legghen.

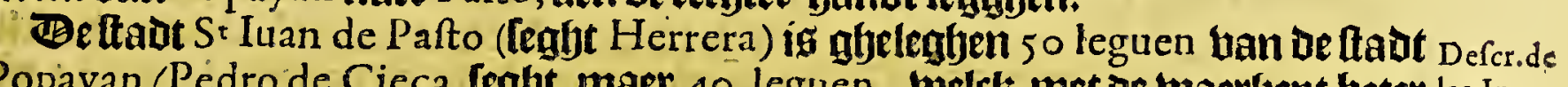
Popayan (Pédro de Cieça leght maet 40 leguen, melck met oe waerljept beter las In-

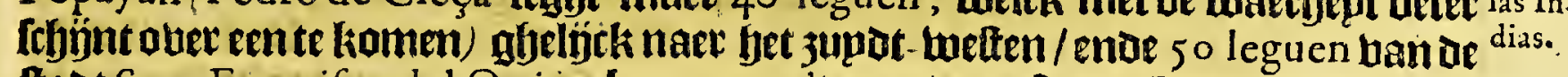
thadt Sant Francifco del Quito, bpnaer na't noogdt-potten/ (Diego Fernandez feglt 40 leguen ban Quito) op deffonghte van een gkaed bp noozoen de línie/ende 4o leguen van de jupdt-jee/naer't tegghen van Her rera. Be fadt ig ghehout in

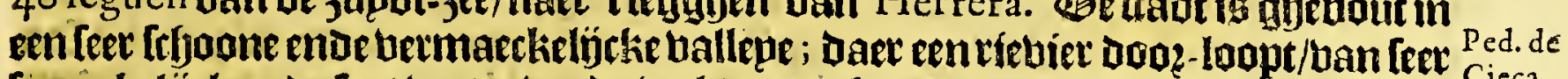
Imaeckelÿck enor [oet water/ enoe beel andere beecken ende fontepnen : Dele val=

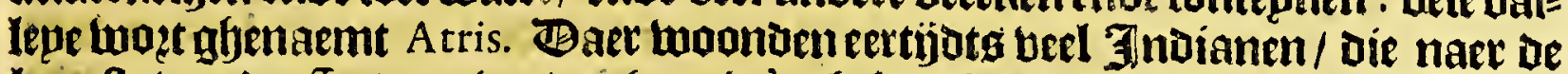

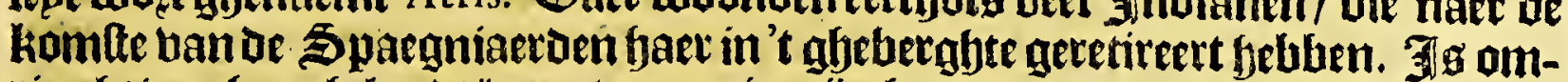

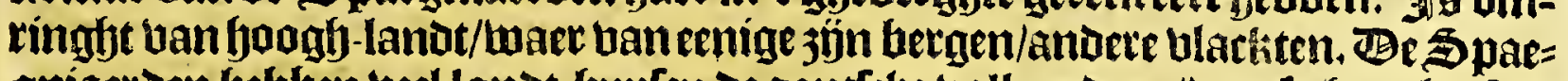

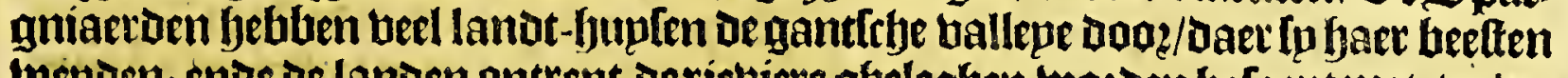

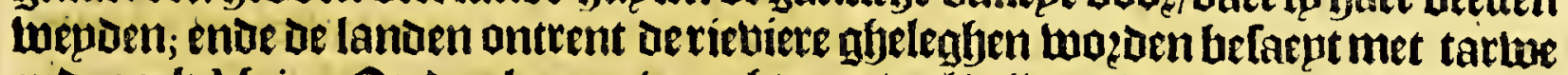
entoe oock Maiz. Op de plepnen banghtmen ved Lilots/ban baiten/Konjuen/

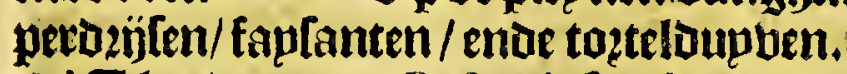

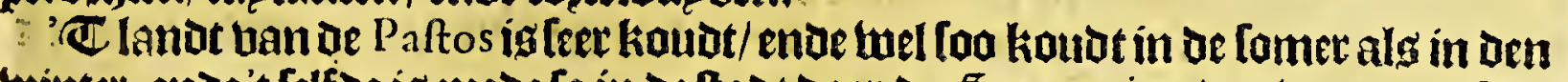
winter; ende't felfoe is mede lo in oe thad daer de Spaegniaerden woonen. Herrera fegift dat jet een feet goet lanot ig/ende tuel ghetemperde luclit/ende dat daet

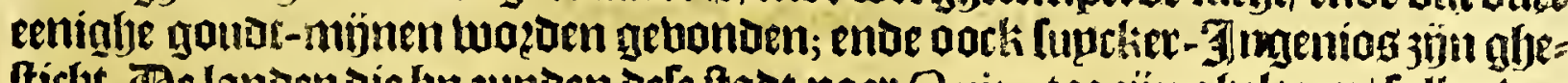

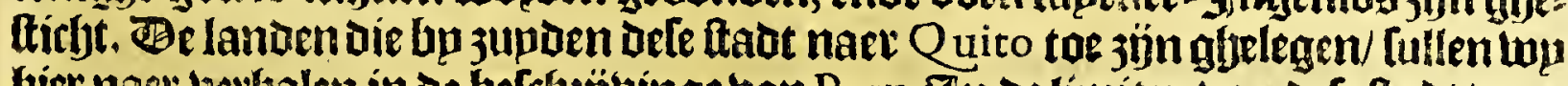
fier naet bethalen in de befegejuinge ban Peru. In oe limiten ban defe fadot/naet t feggen ban Herrera, woonen mel bier-en-twinticf dupfent In nianen/ die den Spaegniaeruen ten dienlte sün ghegeten/ende tribupt betalen; en luaren gheen men[rijen-eeterg gyelijeli als baer ghebueten/ dan mif-maeckt ende bupl bolck/ ende klepn van begripg ofte berftanot. 


\section{Het [eventhiende Capittel.}

Befchrijvinghe van de andere Steden onder het Gouvernement van P OPA Y A N behoorende, ende eerft van de Stadr TIMA N A, ende GuADAIAIARA DE BugA.

Her. de- $\mathbb{E}^{2}$ Stadt uan Timana leght 40 leguen bam de Stadt Popayan, naer bet fcr. D uupdt-aoften toe/ende 60 leguen uan Santa Fé de Bogota : aen't begin ban oe ballepe Ney va, (welcke ballepe leght aen oe ouft-jÿoe ban oe groote Cordillera ban de Andes, die daet ban SantaMartha af-komtende dit gantićne lant booe

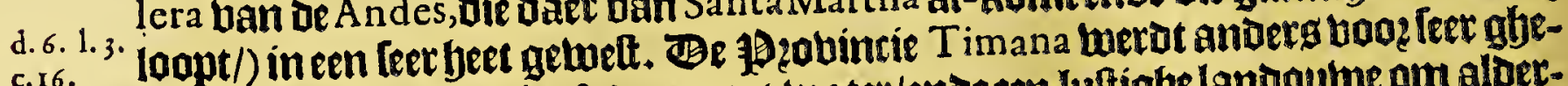
Conot gef jouben; men beft daer gaet water/ende een luttingelanooulwe om aloerbande bee te twepden. Hedens-daeghs ig de meette neeringe ban de in-getoozenen ende in-woonoers ban 't lant Daer om-fyer/ alderfjande conferben te maken; doo? Dien daer grooten oberbloedt van bonirfy in de boamen werot ghebonden/ende de goede frupten die Daer twallen/intondertjept leeckere keernen geljeck als amandes Ien/ oaer lip jupcker-bzopkens ban inaecken; diefp neffens andere confitueten te marckt Dragen/ naer demïnen ban Almaguer enoe eloers. Sp fjebben oark beel bouen daer or Coca groept/welck beeft een bladt wat klepnoer alg oe roolelaers: De Indianen getuen groot gelot booz dit krupot/ endoe kaumen het lelve geltadity

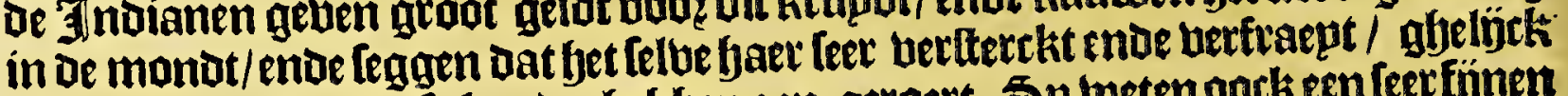
wp op een ander plaetle beetaer beb ben aen-geroert. Sp weten oock een teerfijnent

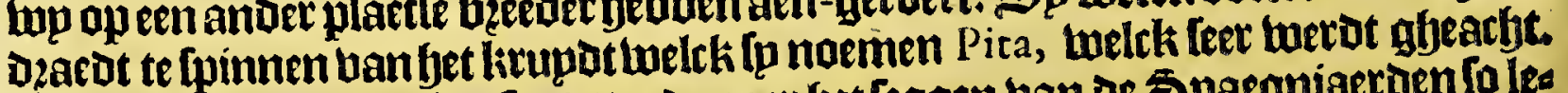

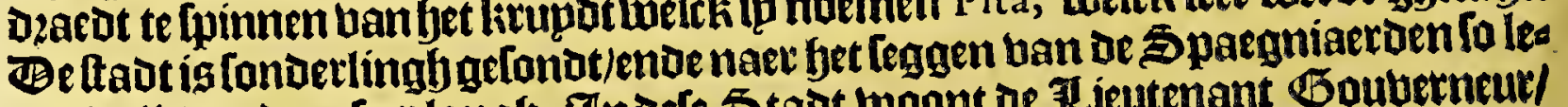

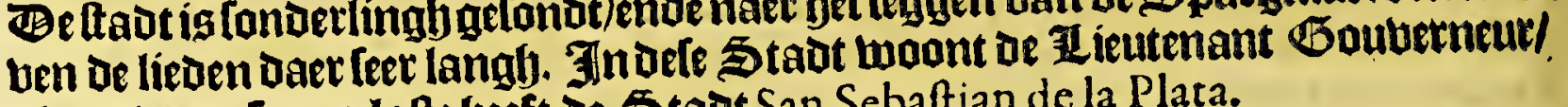
die mede tat funen lafte beeft de 5 tade San Sebaftian de la Plata.

Ontrent dere Stadt leghteenen beroh vaet men 3 epl-fteen bindt: foo Herrera getupght. Zlen defe Bzabincie palen de Jindianen die fpnatmen Yalcones, welck eenttrijothare ende ftoute natie is ; ende onder baec leght of ballepe Aquirga : ễ

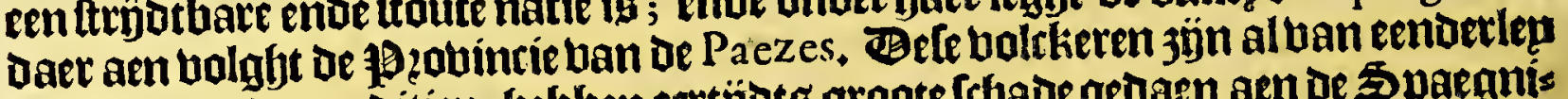

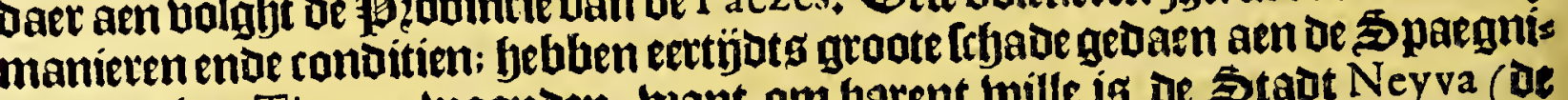
aetoen die te Timana moonden; want am barent bille is ge Stadt Neyva (oe

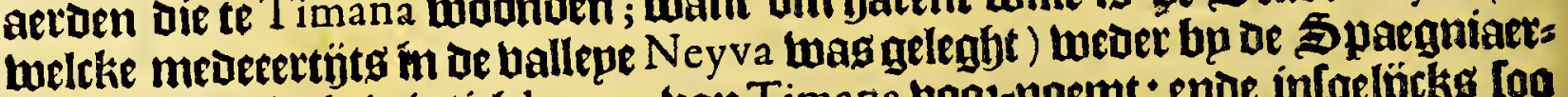

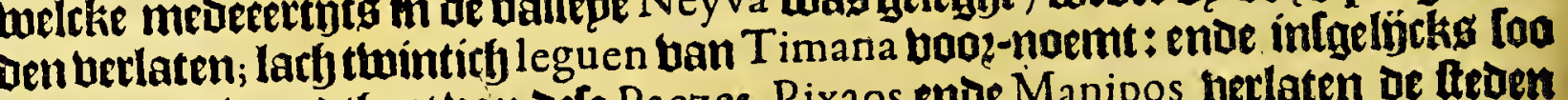

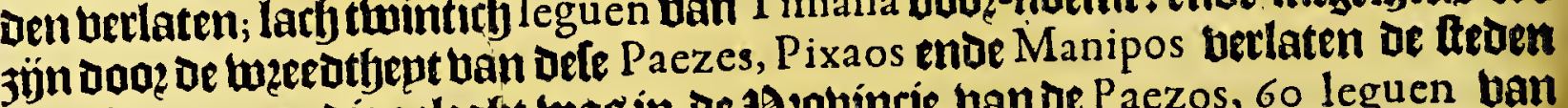
Sant Vincente, die geleght magin de 1 \&abincie bande Paezos, 60 leguen ban Sant luan de los Llanos, ap oe frontieren ban ae jogobintie van Popayan: ende Villa de los Angeles, 9 leguen ban Neyva booz-noemt/ende 22 ban Tocayma.

Te Staot Guadalaiara de Buga, is gelegen is leguen ban de ftadt Popayan naer bet nooet-ooften/ (naerfyet legghen ban Herrera) in be ballepe ghenaems Buga; welck naer't leggen tuan Pedro de Cieça, legt in 't oppertte ban de Cordil-

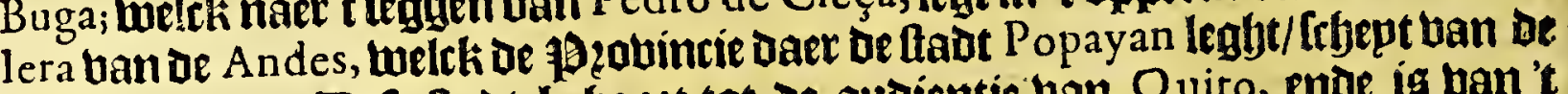
ballepe Neyva: Jefe ftadt befjoozt tot de audientie ban Quito, ende is ban't Bouluernement ende 2 Sifoomban Popayan.

(het achthiende Capittel.

Van de refteerende fteden van defe Provincie S' SEbastian DE La Plata, Almagvez, Trvillio, Madrigal ende Agreda.

D Etaot Sant Sebaftian de la Plata, íg gelegen op de frontieten uan 't $t$ Bout= vetmement van Popayan, bujf-en-Dertich leguen ban be hooft-ltadt / ende 30

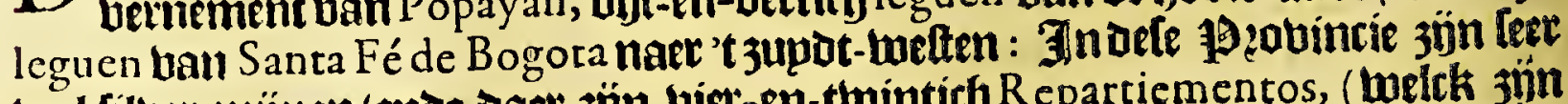

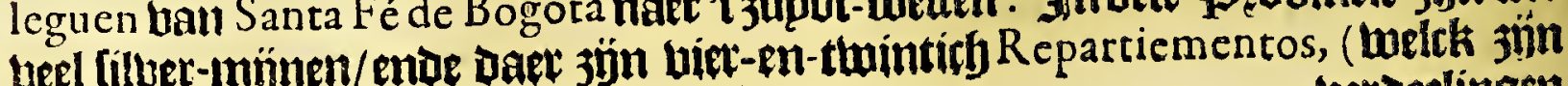
beroedingen 
betbeelingyen ban de in-geboozenen/Die den Spaegniaeroen ten Dientte werden

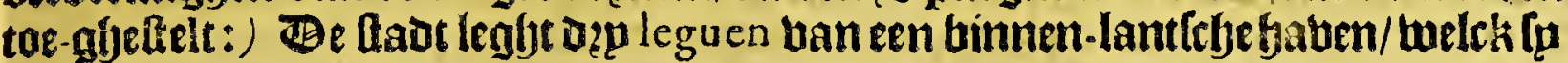
noemen Onda, aen De groote riebiere ban Magdalena; al- -waer be bercken ontla= Den/Die op-komen ban Cartagena eñ $S^{\text {ra }}$ Martha naet dit Goubernement; (naet

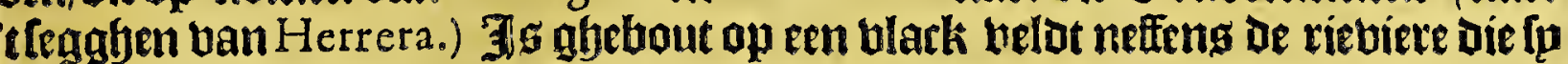
noemen Guali; ig beel aett-bebingen onoer-boepen/ende in be twinter is bet meer

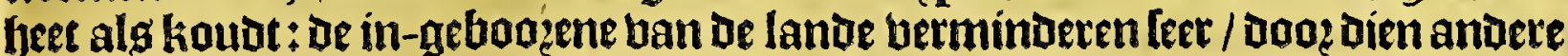
7ndianen daer ontrent woonende/ diefunaemen del Rincon, die berflínden;entue

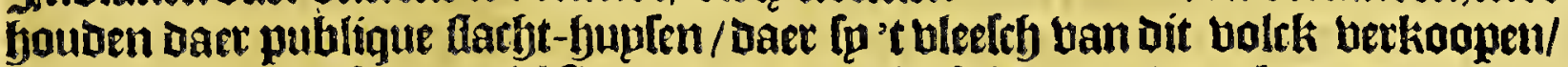

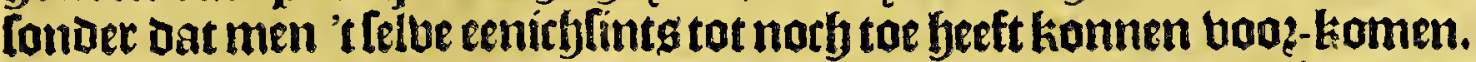

Be ftadt A Imaguer is gfeleglen twintich leguen, ban De hooft-liadt Popayan naer't 3 uubt - ooften toe / op enen ulacken ende woelten bergh; de geftaltenig uan oe lutht is yeel koel endefrifry; de in-ghebooene kleeden yaer in cottoene-líntuat:

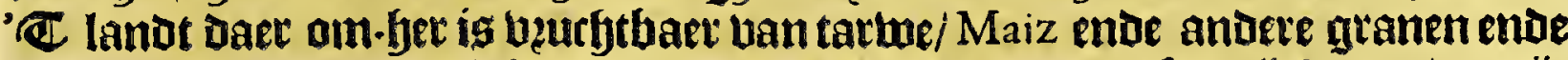
3aden; ende daet is menigfte ban bee; ende men heeft Daer [eer rücke goudt-müs nen gbetonoen in dat quartier / waer bopec daer een grooten toe-loop is ban be plaetlen Daet ontrent.

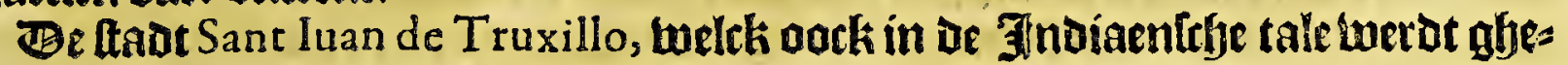

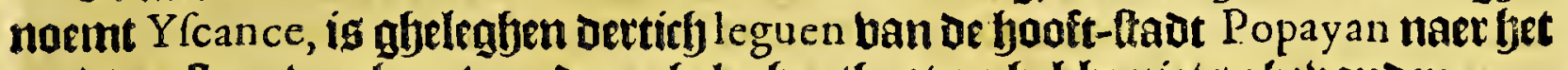
3upot-oolten: ban fyaer voozoere gfeleghentbept en bebbe niets ghe von den.

Be ftadt Madrigal, of welcke in de 3 noiaentebe tale odek twetor genaemi Cha-

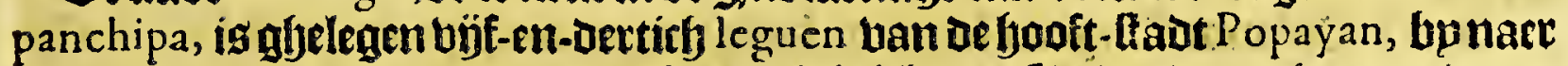

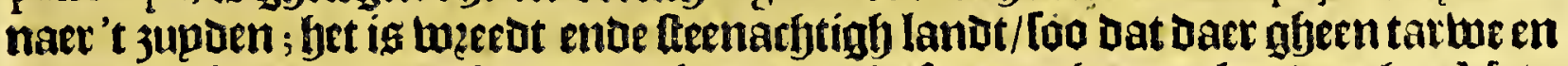
mozot ghelaept / noef gheen bee gfelmepoet / ofte op ghequeeclit: dan bet Maiz

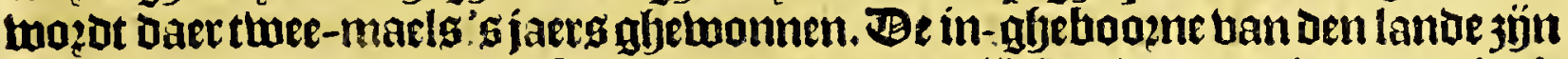
Doo de fardirfyept ende woettyept ban 't landt qualjek te beoluing baet ontrent oock goede mijnen ban goubt ghenonden.

Be ftadt A greda, toelck oock anbers bp De Spaegniaerden taerot ghenaemt Malaga, is gheleghen büf-en-veertich leguen van de houft:-tadt Popayan naet bet zupot-Lelten toe; biex ján aock entighe münen ban goutot.

\section{Het negfjentfiende Capittel.}

Vande havenen, reeden, punten, rievieren, ende Eylanden op de kufte van dit Gouvernement gheleghen aen de zuydr-zee.

13 De kulte ban Dit Goubernement ban Popayan aen be zupDt-jee gfelegen/ van Cabo de Corrientes af / welkk leglyt op ue jooghte ban bijf graden bp noozan de línie / jeeftmen eerlt de riebiere meltk tp noemen Rio de Salinas, tuff téjen de too: [3. Cabo de Corrientes, ente bet $\mathbb{E}^{2}$ planot de las Palnas.

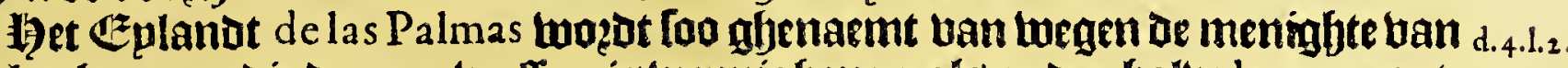
palm-boomen die Daer op wallen; is wepnigh meer ald ander-halbe legue groot; c.8. men feeft daer ennighe rievierkeng ban qoet enoe bertsy water / ende pleceld bp Pedro de Indianen bemoont te 3 în ig gfolegen binf-en-twintith leguen ban Cabo de Corrientes, op oe fooghte van vier graden ende een derde bep nodegdn de linie; oe klls Ite ftreckt hier zupot ten weften tot aen de Bahia de Bonaventura; de welcke torpe nigh meer als dep le guen ban daer is gheleghen: tan defe bape ende de faben uan Bonaventura bebluen wp bier vooken ghelpeoken.

Ban de bape de Bonaventura af / Itreckt oe kulte aolt ten jupden tot aen fyet Eplanot Gorgona, twelck jün büf-en-twinticfy leguen. Be kufte ig fier vlack

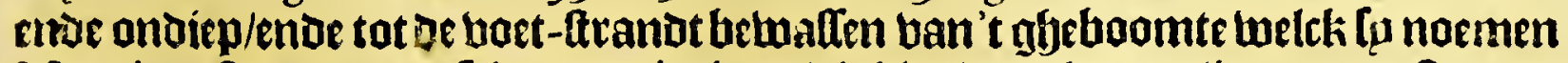
Mangles. Onder de bei Tefjepden riebieren die hier in jee loopen/ig de grootlte ende Inelite die tuelck lu noemen R io de Sane Iuan, met de welctie verre binnen 'llandts refpondeerde de ftadt Pafto; (naer't leggen ban Herrera) Den oever ban Deviebiere 


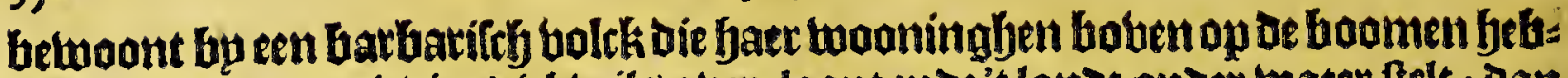

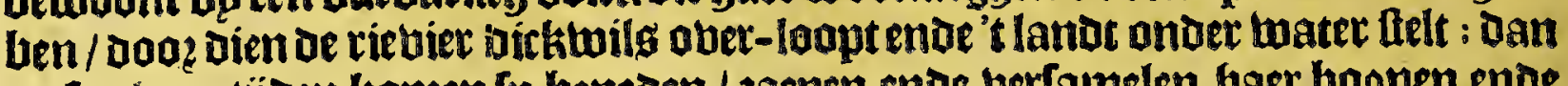
op [eeckete tjoen komen fp beneden / zaepen ende berfamelen gaer boonen enoe

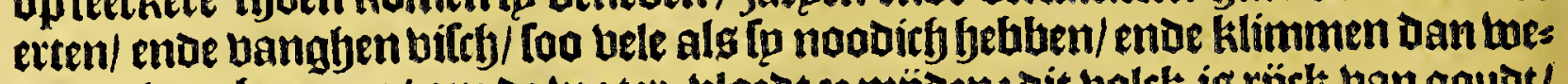
oer op baer boomen/ om de water-bloedt te mijoen: Dit balck is rÿck ban gouat/ welck be rievieren af-beengfsen; ende baer landt is bzuchtbaer/ boe-wel oneffen ende bol thaende poelen.

d.3.1.ro. Ceghen aber de monot vandele riebiere Sant Iuan, leglyt bet Geplanot Gorgo. c.3.Cię̧. na, op de hooghte van dęp graden bp nopzon de línie. Bit Geplanot wozat bp oe

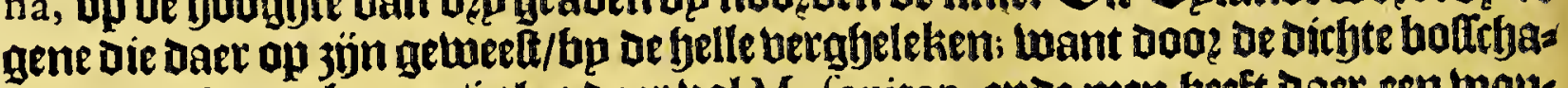
gien ende booge bergen/ig het daer bol Mofquiten, ende men beeft daet een wolls Detlíf he onghetempertbept ban lucht / Doog dien fet nimmermeer af en laet ban reghenen/ loo dat men de Con Daet nimmermeex en jíet. Slgen beeft Daer bele Guadoquinaies, welck jün dieren grooter als barten. Baer walt oock een leeckere

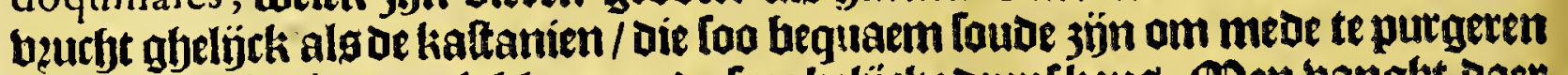

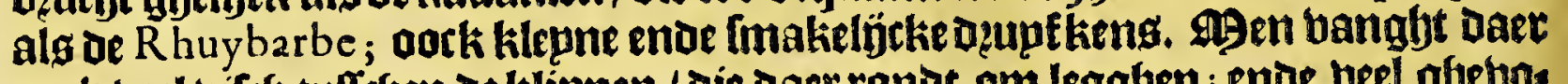

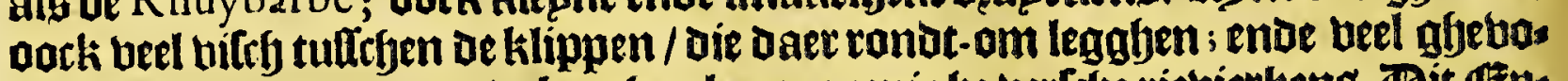
gelte op de boamen: ban de berghen loopen eenigbe berlebe riebierkens. Dit \&epe landt is dęp leguen groot; ende is vermaert Dooz dien Dat Francifco Pizarro, eet gp Peru ontdeckte/ bem fiec met derthien ban fpn bolck een rupmen tijot ants bieldot.

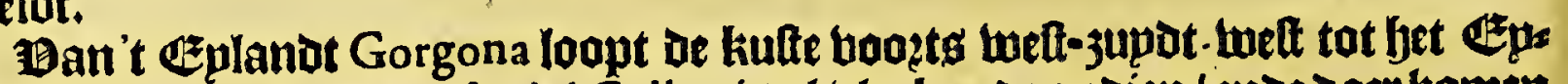
landt / welck fp noemen ina del Gallo ; is al black ende ondiep / ende daerkomen beele rievieren ín jee / alo namentlïck Rio de Sant Lucar, Rio de Nicardo, ende Rio de Zedros: Het Utalanot del Gallo ísen legue in'tronde/ ende legbt op ve booghte ban twee graden bp noozden de linie.

Ba an bet Ezplandt del Gallo, keert baer ae kulte naer 't jupot-lwelten/ tot aen Punta de Manglares, welck leght op twee graden frgaets / top noozoen de limie:

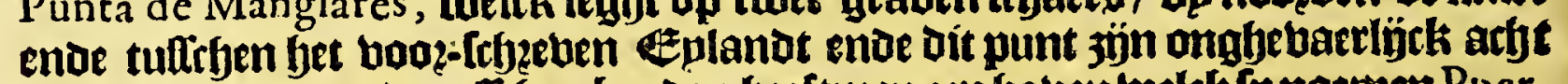
leguen tweghg / ende tulfeben bepoen beeftmen een habentwelek fo naemen Puerto de Cruz : De gantefye kulte ig black/enue binten berghachtigh/ ende daer kos men oock eenighe rievieren injee/ die belwoont jön met de felbe dagh ban bolck abelinck als de righiere Sant luan.

Cot Defe Punta de Manglares toe/werbolght oe kutte fuelcke tot bet Bauberne: ment ban Popayan bebooxt : ende ís bet fefepot tuffyen bet Goubernement bai Popayan ende Q uito, ende van bier voozts begint bet landt welck epghentlí̀tk

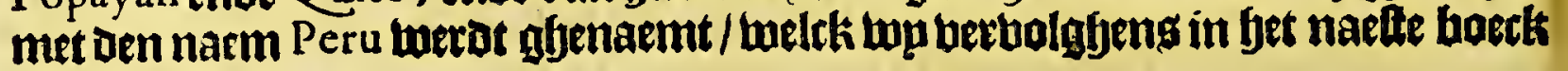
fullen befcbejuen. 


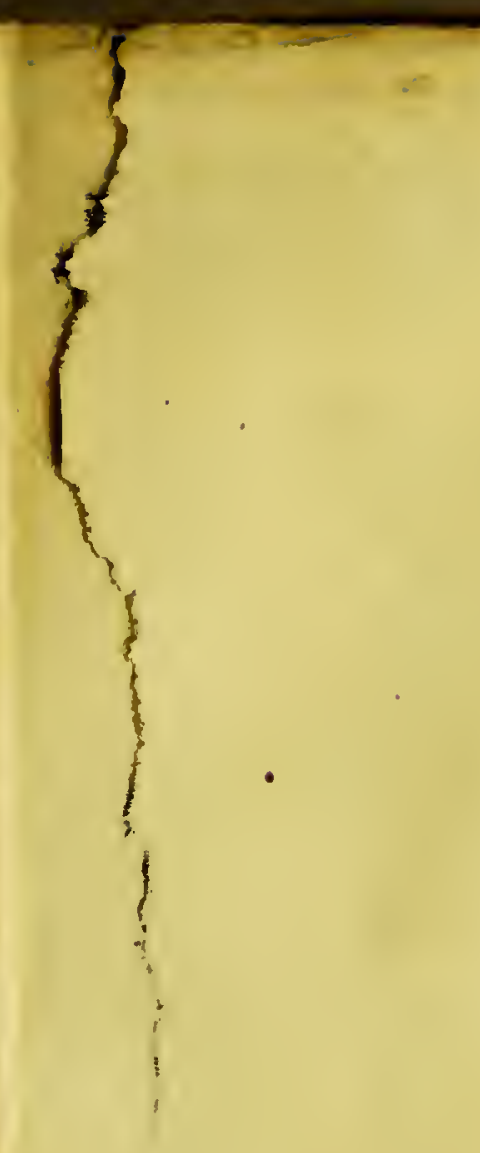

(PPCB

- 


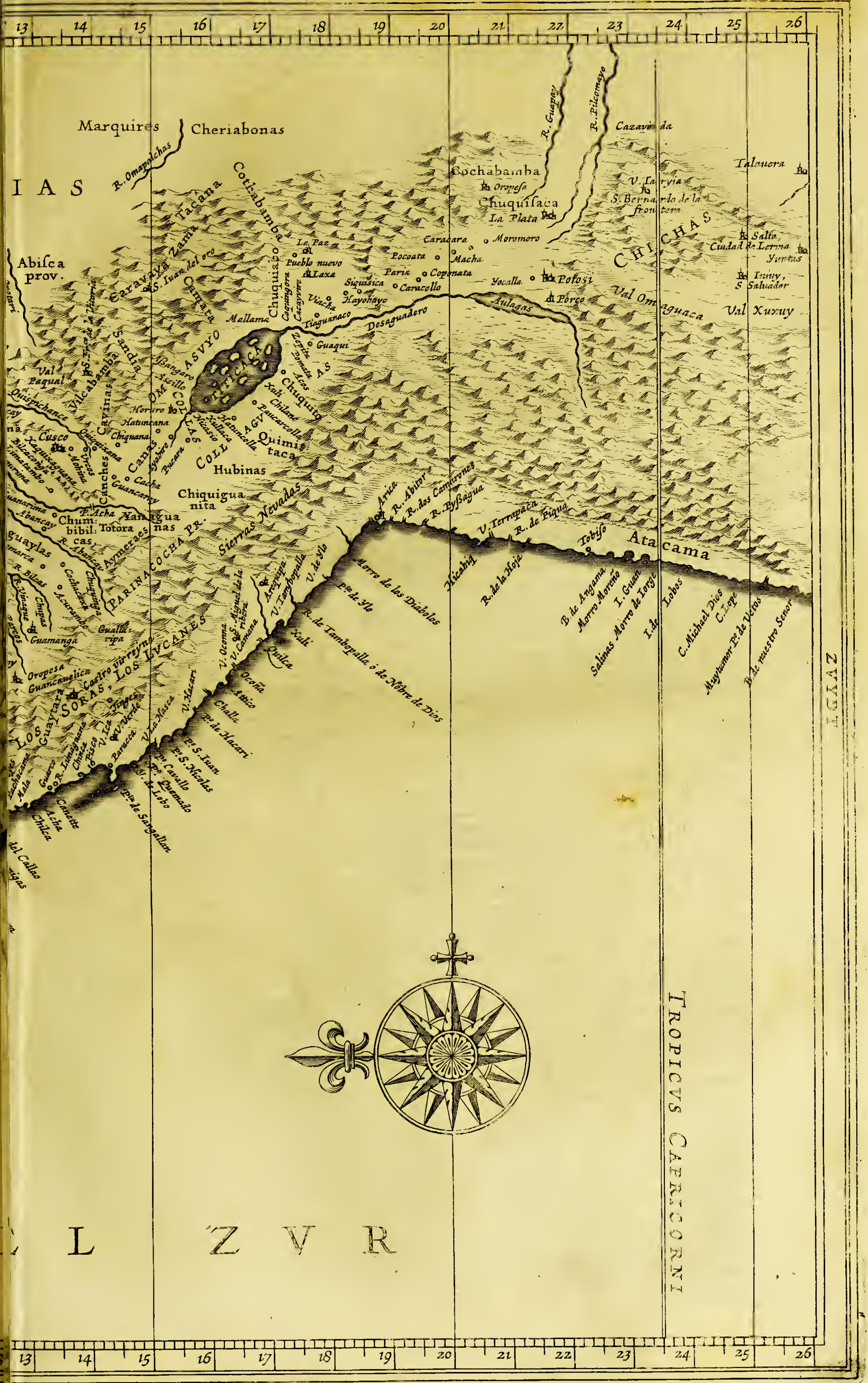


BES CHR I IVINGHE

\section{Uan \\ W E S T - I N D I E N. Wet thtende 25oech. \\ P E R U.}

Get eetfete Capittel.

Generale befchrijvinghe van ' $t$ Koningh-rijck van $\mathrm{PER} u$, zijn gheftalte ende eyghenfchappen in 't ghemeyn; ende de verdeelinghe van dien; als mede de ghemeyne manieren van het volck.

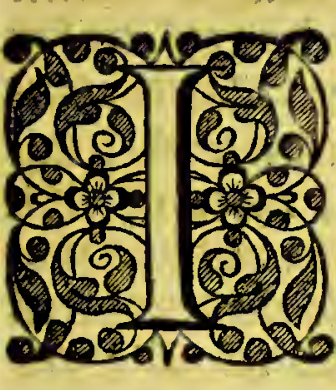

12't booz-gaente thaeck hebben we ghebandelt

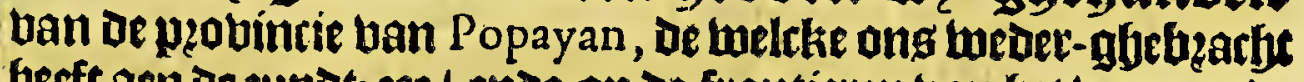
Geeft aen of 3 updt 3 ee / endoe op of frontieren ban yet bermaerbe

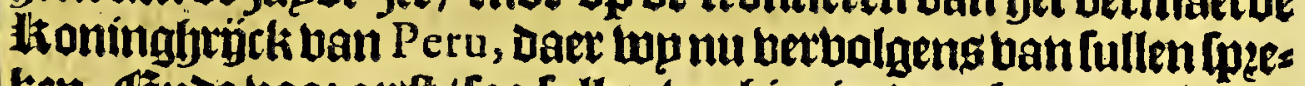

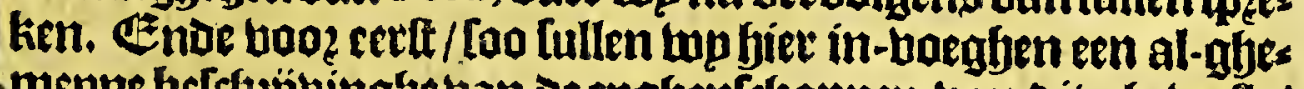

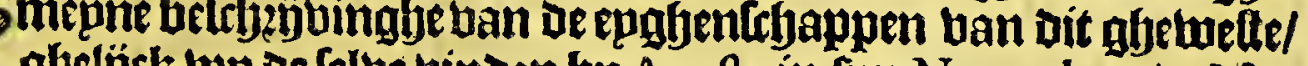

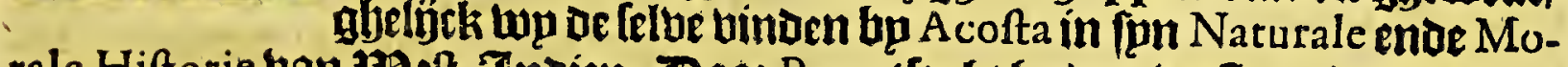

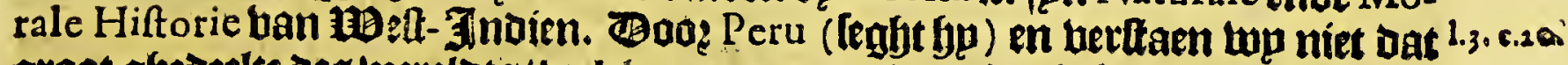

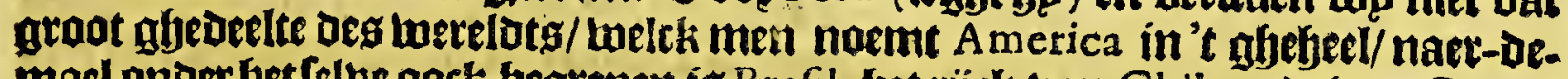
mael onder bet felbe oock begrepen io Brafil, bet rijck ban Chile ende ban Grana.

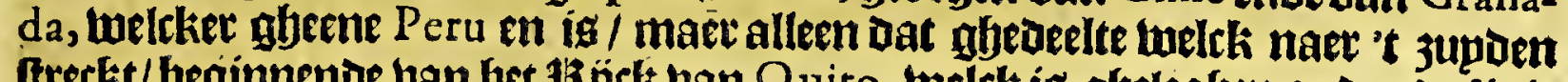

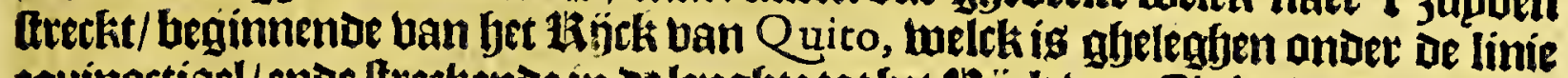
equinoctiael/ender ltreckende in oe lenggte tot bet lajick ban Chile, melck bupten

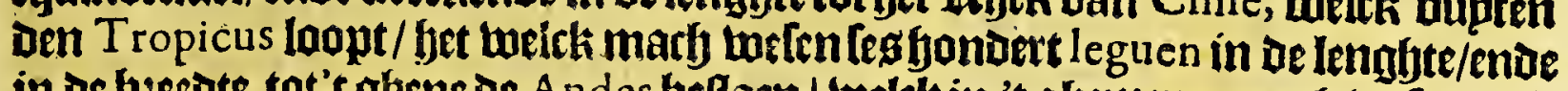

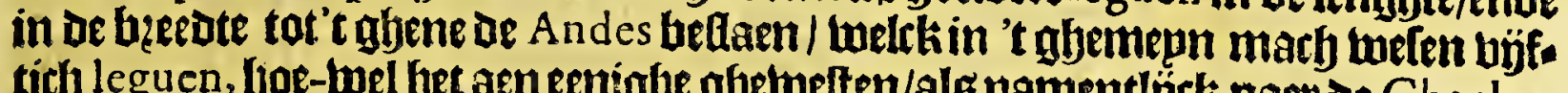

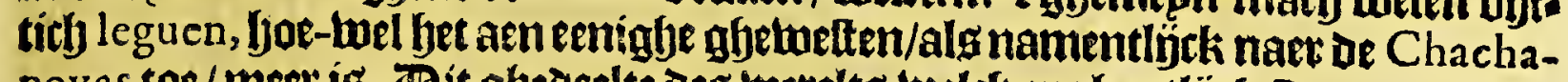

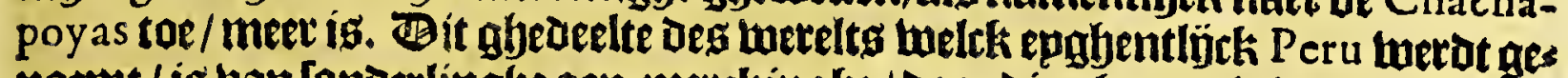

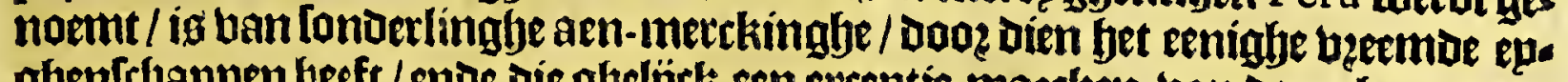
ghenfryappen heeft/ enoe die ghellïck ken erceptie maecken van uen gfomepnen

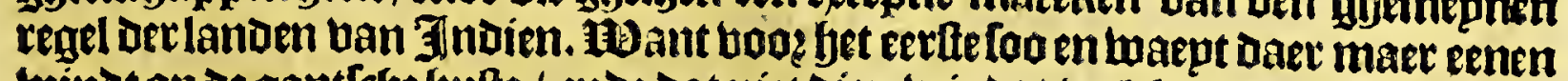

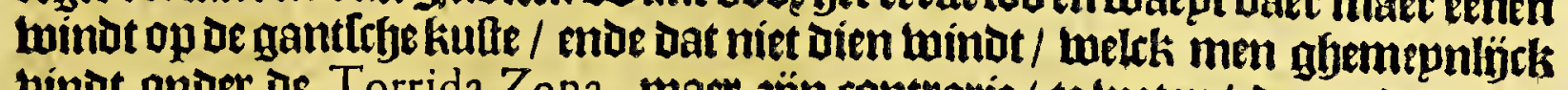

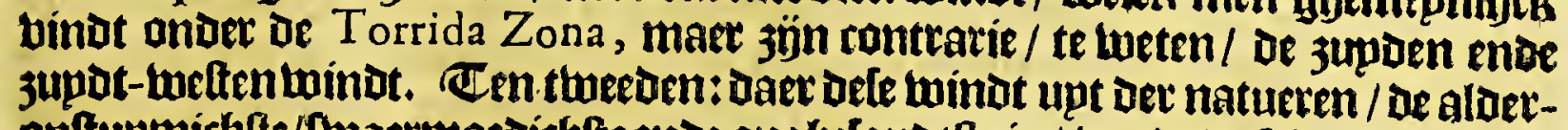

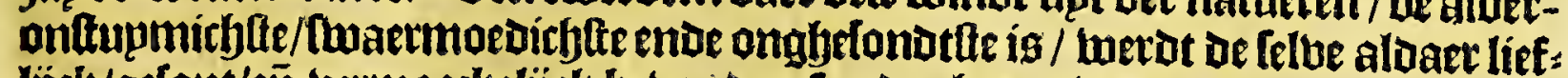

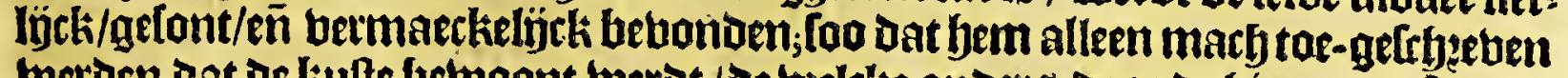

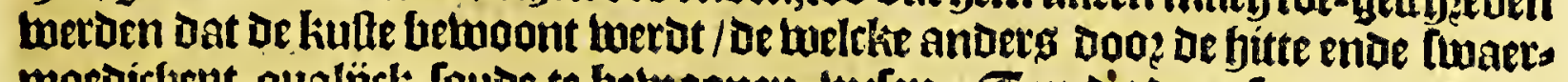

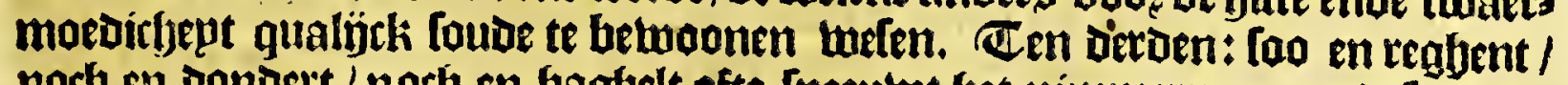

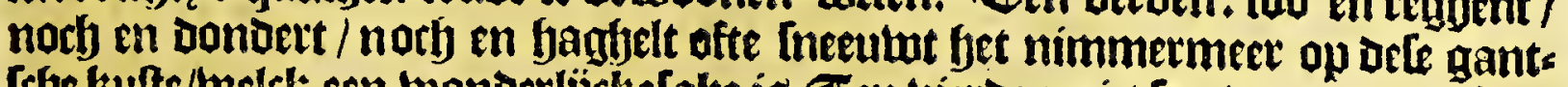

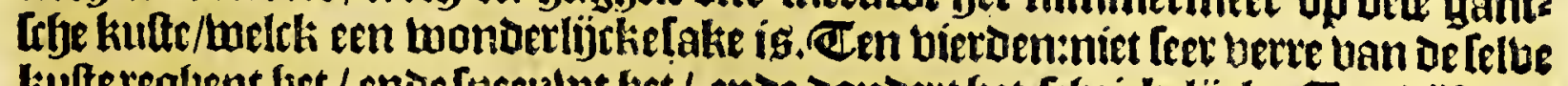

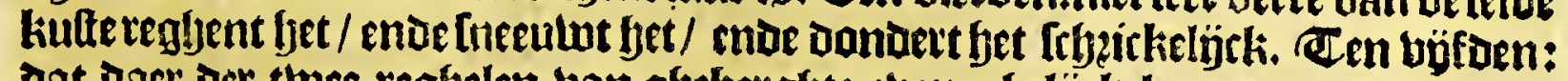
Dat Daer Der twee regfelen van glecherghte eben-ghelijek loopen op een boogls:

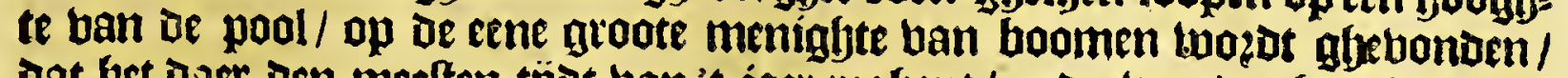
Dat bet Daer den meeffen tyot ban't jaer reghent/ enoe wonder beet is: enoe

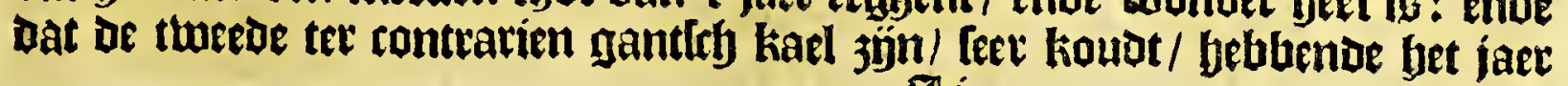
betraelt 
$35^{8}$

Peru.

veroedt in Comet ende winter/reghen ende frhoon weder. Op bat dit alles beter

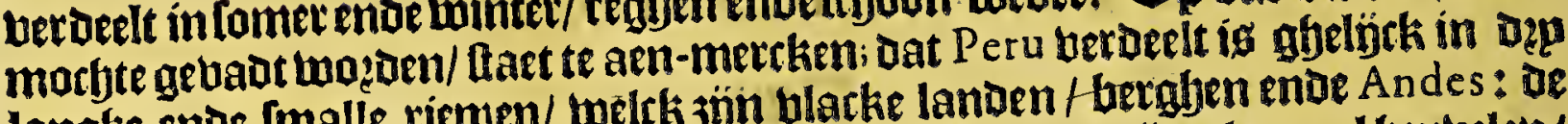

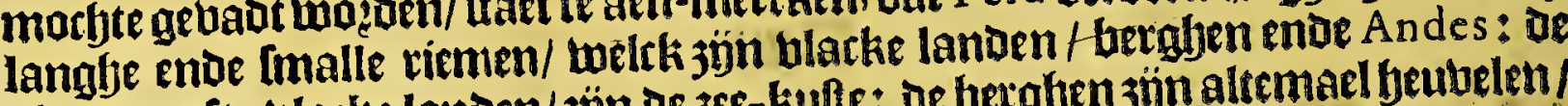

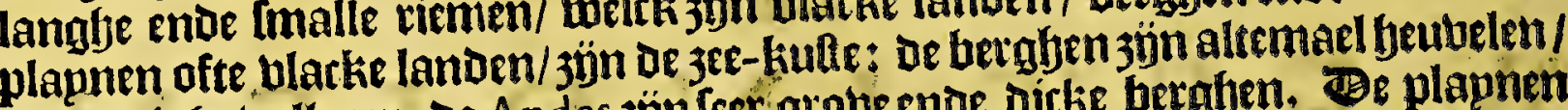
met eenigbe vallepen; de Andes jön Ieer groue ende dicke bergben, De plapnen bebben ontrent thien le guen in oe betote / in fommighe plaeten minder/ snoe in andere oock meerder; De bergfen (welck fo nocmen las Sierras, ende la Sierrania) moghender thintich beblen/ende oe A nd des oock thintich/intammigbe plaetten meet ende Comminge min; locpen in oe lengljoe zupoen ende noozoen/enoe legs

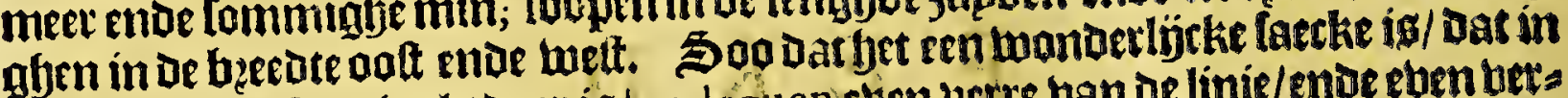

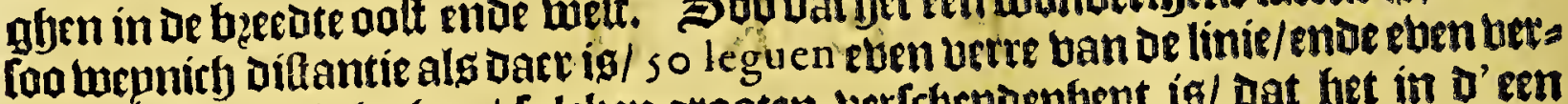
re bande pool gijeleghen / fulcken arooten vertebepdentgent ig/ Dat bet in o' een

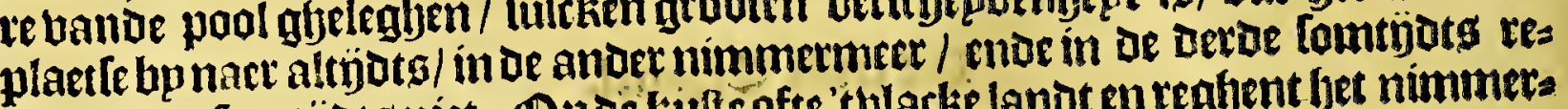
gljent ende [omtjots niet. Op oe kille ofte tulacke lanot en regbent jet nimmers

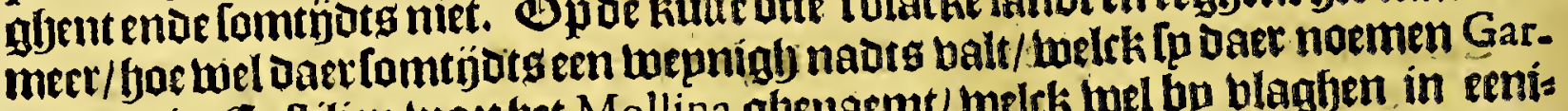
va, ende in Caftilien woit bet Mollina ghenaemt/ melek toel bp blagben in eenis ghe Dzuppeltieng twater berandert/ welche uallen maer men beff in ber daet daet ahecn Daeckenteghen ban Daen. De daerken die fo bebben zün renighe matten

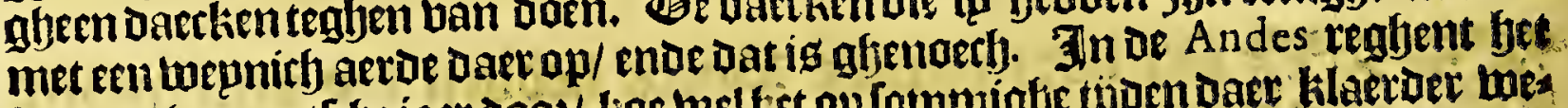

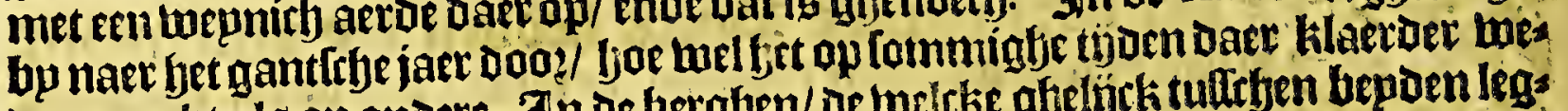
Der marckt als op andere. In oe berghen/ or welcke ghelÿck tufletyen bepoen legs

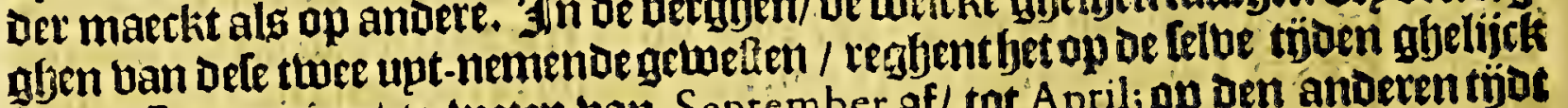
als in Spaegnien/ te weten ban Seprember af/ tot A pril; op Den anterentijot

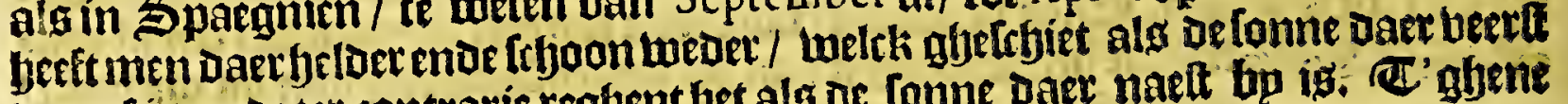

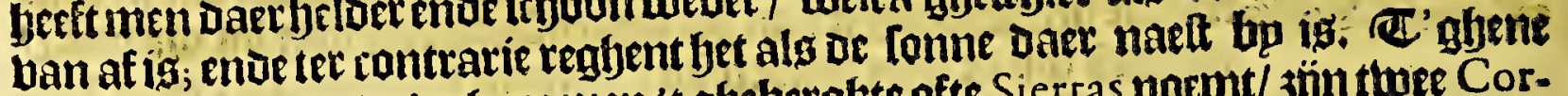
men De Andes, ende't ghene men 't abeberghte ofte Sierras naemt/ jün twee Cordilleras, Dat igregulen/vanleer fooghe berafen/De thelck bp of ouplent leguen uetre moghen loopen/ in't gheficljt o'entuand' ander/ enoe bp naer op een eens parighe diffantie. $31 n$ yet ghebreghte onthouden baer ontelbaer kubden ban Vi-

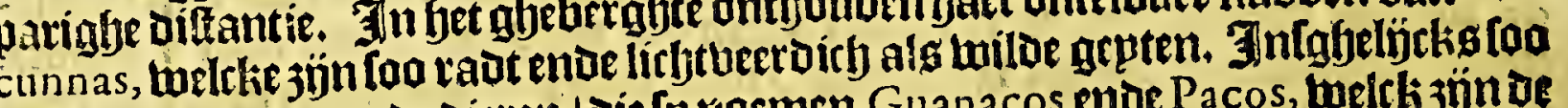
ontfyoubentaer oor de dieten / Die [p roemen Guanacos ende Pacos, welck 3 jun de Icyapen/ende oorli te famen de laft-pertoen ban dit lanot/als top bier naet fullen [erghen. In eñ groote menicfte ban papegaepen. Daet walt mede bet krupot ofte uen boom/

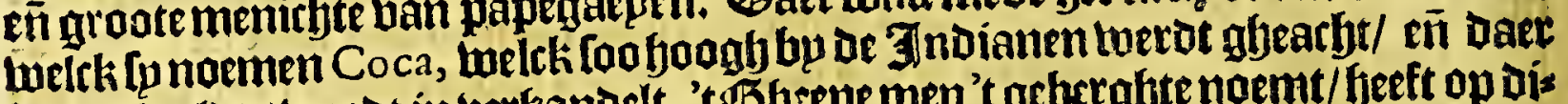

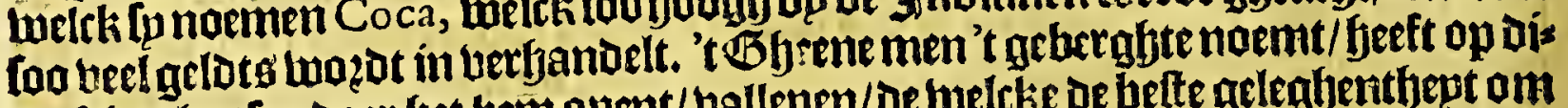

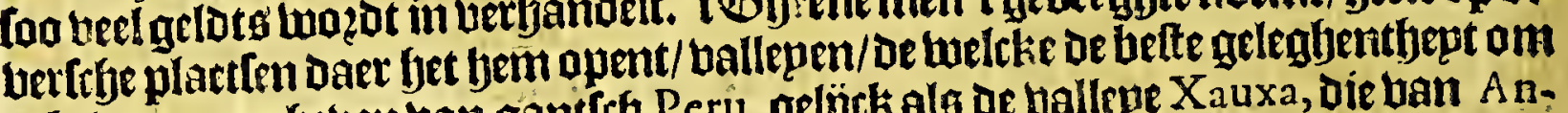
te betwoonen afjeben ban gantlry Peru, geljok als of vallepe Xauxa, die ban Andaguailas, enDe die ban Y ucay. In Drfénto dietgbelÿrke ballepen walt bet Maiz, oe tartwe/ende ander butyte/ in a' ecn meer/en iil d ander min. Booz bp de ftadt wan Cufco (welck in boo thoen was het gof uan oe Heren han defe thonines

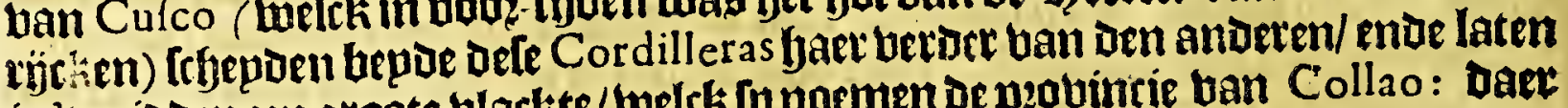
in't mioden een groote blacke/ $/$ welek [p noemen De peovincie ban Collao: Daet mp oplun plaetfe beeroer ban lullen [pekten. Bug berte upt A cofta. Pedro de

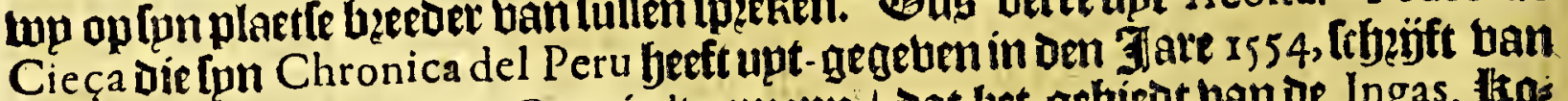

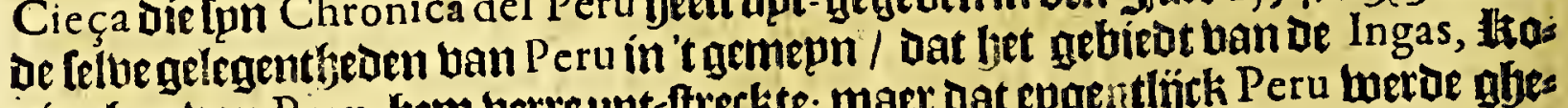
nínglen ban Peru, hem berte upt=ftreckte; maer dat epgentlíck Peru luerde gbes naemt allefhet lanot welck nelegen is tufteben Quito, eñ Villa de la Plata : welck in ue lenahte heeft Teuen yondert leguen, ende inde beecate hondert leguen, ende in fommighe plaet [en meer/ ende in Tommighe oock min. Dat dit land terbeelt is in beyp Cordilleras ofte reghelen van berghen / ende booglbe platten; van melclie het ene zün oe hooghe berghen ban oe Andes, bol ban sirlyte bols fefjagien / ende 't landt fou onghe[ont / Dat dact gheen bolct en kan loonen/ ofte 
ofte opt gelwoont beeft / ten sp ober 'ttellue ahe berghte. Fet theede zón we bergen ofte la Serrania, welck de felfoe lenghoe fieeft met oe Andes baomaemt/ ende $3 \mathrm{jun}$

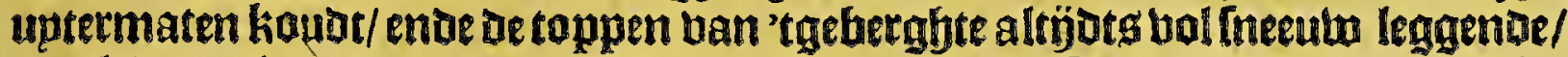
welck daer nimmermeer op-fjoudt te ballen; belcke allo mepnigh bequaem jön om te betwoonen/ joos of groote koude ettoe menighte van fnetulal alg mede Dooz de fcherpe winsen die baer doo?gaens waepen. Be detoe Cordillera noemt bp de jandt-dupnen/tuelcke ban Tu mbe $z$ af/ tot Tarapaca toe Dueren: Daer men

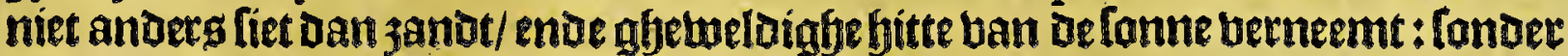

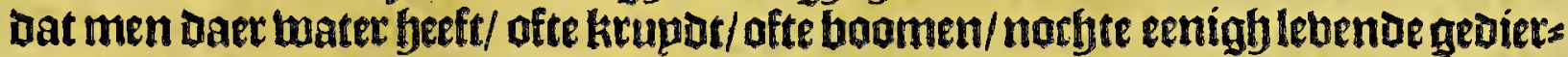

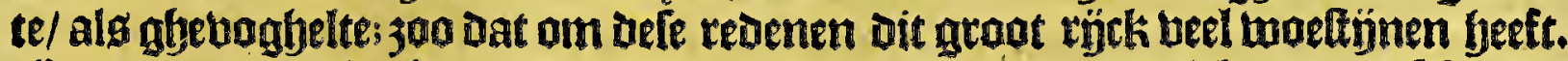

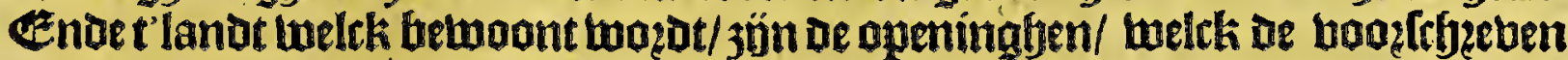

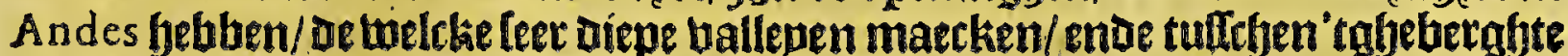

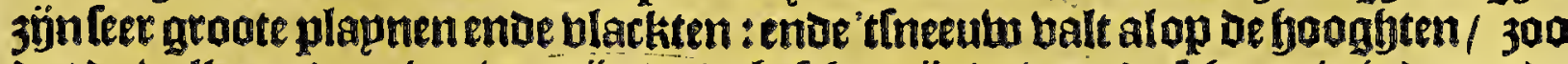

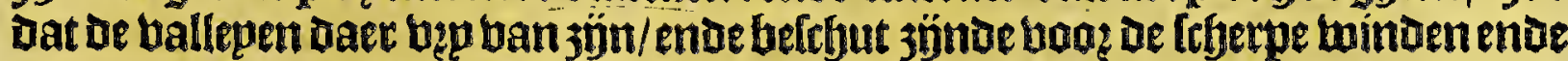
koude/jünteer bquchtbaer/ enoe alles twat men Daer faeut / waft wonderlïcken Lel; ende daer ig beel gheboomte/ beel ghetioghelte/ ende menighte ban Dieren.

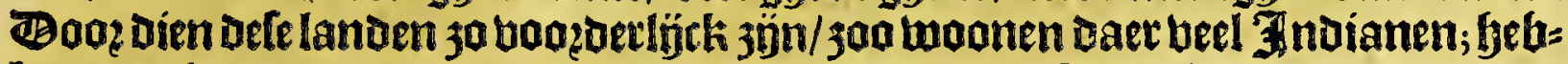
ben daer bare sazpen/ende buplen ban fteen/ende met ftoo ghedeckt; lewen Daer leer ghelontende bermarckelijcken. Be Andes ende de Sierra Nevada in beler boes aben baec openenbe/ ende dibetffye blacke belden maeckende/ joo heeft men Daet feer groote moon-plaetlen/ Daer beel holckig plagh te twoonen/ende norb toondt;

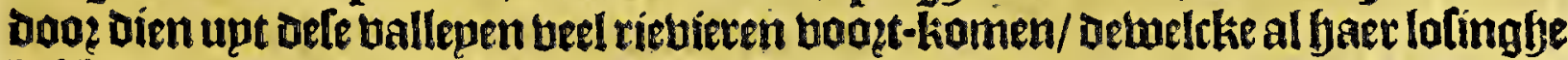
bebluen in de jupdt-jee. Be groote Cordillera ban de Andes, ig ban De jupdt-jee bertchepoen opeenigfe plaetfen beettichleguen, opeenigfe feftict $/$ end ap andere meer oftemin;ende dooz dien 'tgheluerglete 300 hoogh is/ende op Commigbe plaet: Ien 300 naer bp de zee komt/ 300 vallen de riebieren klepn/ joo dien baren loop 300 koet ig. Het tweede ghelerghte twelck fp noemen la Serrania, neemt ż̈nepnos aen de blacke landen/melch fp noemen los Llanos, op eenigfe plaetlen maer ope leguen ban oe jee/ende op eenighe ghetueften oock acht ende thienleguen, meet ofte min.

De ghettalte han de lucbt op defe plapnen ig meet beet als koudt/ doo? dien In 300 leegf legghen ende by naer ghelijcks waters met de $3 e e$. Alsen beeft baet de meefte fitte als de fon ober't hooft ig ghepalfeett/ende tot aen Den Tro. picus Capricorni gyekomen/ende ban Daer weder-keert naer de línie. Ban 'tgeberghte/ boe-wel men baer eenige tuel getemperde landen ende pęobincien beft / magh men tec contracie legghen/ uat bet meer kouot ig als geet. Ende

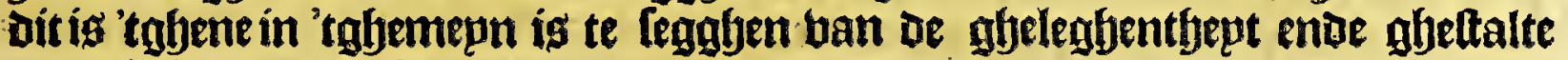
ban dit landt van Peru.

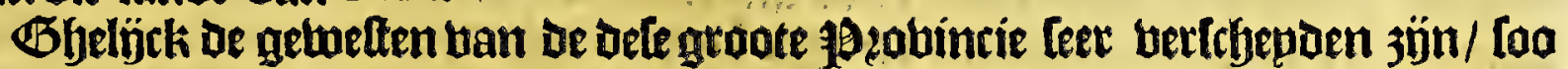

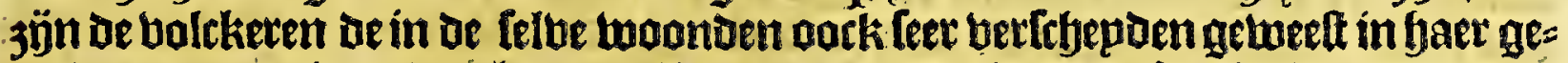
ttalte ende manieren ban leben. Fant die op de plepnen ofte blacke landen aen den aever ban de 3 uput-jee paelenoe woonden/leefoen meeft onder den blaeulwen bemel/ afte anoer ae frbadutwe ban de boomen: bet-manmen-bolck kleeden firf met Leeckete hemoen tot aente knuen neder-bjanghende/ ende een los manteltien ober delchouderen; Der bzoutaen ghetwat bas langher tot op de bielen; bepoe blechten bet bapz op met Ieeckere cattoeme línten ban berfchepden couleuten; baex

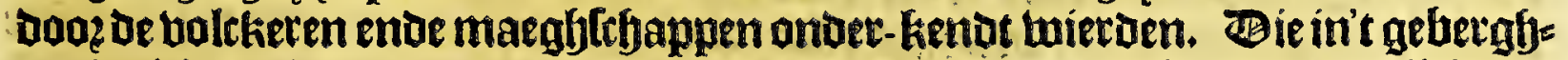
te (welck wo la Serrania noemen) woonden/woaeren veel ftercker ban litbaem ende kloecker ban berltanot als de boozgaenoe; yadoen fjaere fuplen ende gfe= houtwen boben met loden ban aetoe aedeckt; de mans kleeden fich in toolien: laeckenen/ die [p maeckten vande wolle ban baer Ichapen/ Deagfende lofte rote ken; maer der bzoutwen gemaet mas engber ende met leeckete banden inglyeto: ghen esdoefluptende aen bet ligr; meteen manteltien om den bals enoe aber be

Ii 2 lfgouderen


fefjoutoren / welck tooem balt was ende toe-genepen met filteren ofte gouben cpellen/naer een peders midoelen ende gheleghentbept: noemaen Dele [pellen in baer taele Topos: Dit beubuen-bolck wag blanck ende ban goede manieren / leergbedentiechento onderdaen aen yaere mannen; die fo in alle wercken gbe: trouluelj̈ck bu-ftonden; baer bogemaemite geneurbt ende oeffeninge is bet jagen;

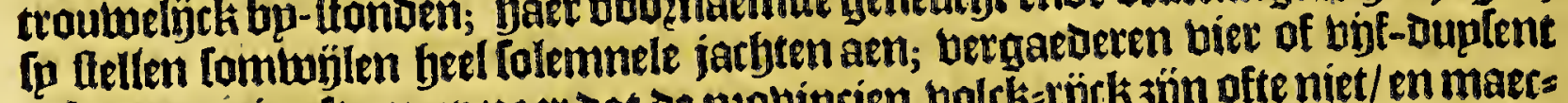

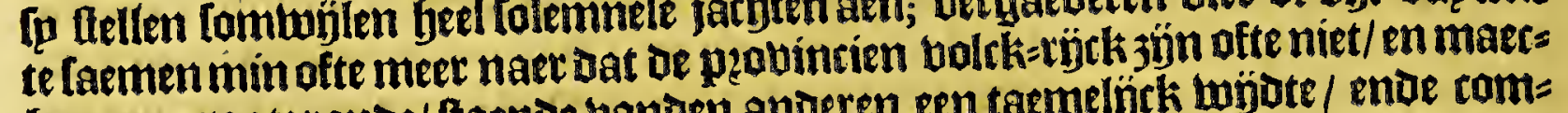

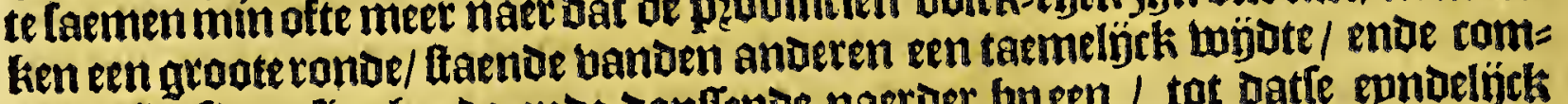

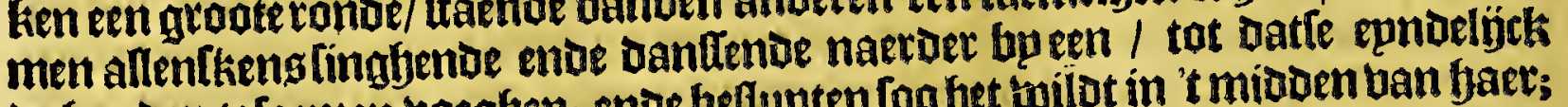
oe handen te [aemen boeghen; ende beflupten foo bet wilot in 't midoen van fraet;

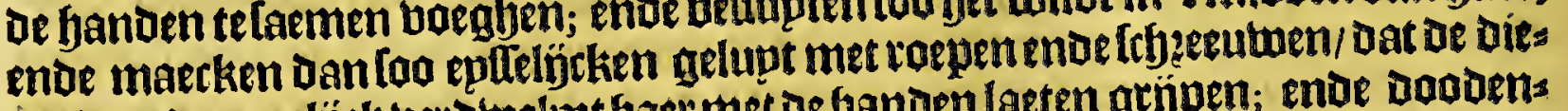
ren Daer Dooz gelíck berdwelint baec met de Ganden laeten gejpen; ende doodens Det loo veel alg faer goeot bunckt. Ip in baer tael noemen Zara: ende yaer ozoinarie kot 't blestef ban't wilbt: ens oe aemepnlte dzanck A rica ofte A zua, twelck [u ban Maiz ende water maecken: beneffeng Dele beblen lu noch een anderen Dzanck die lp noemen Sora, die als bier ban 't tellue Maiz woet ghefoden ende ghebzouluen; orfen is hoofoigh ende maeckt Deontken/ Der-wegen die mede berboden wot beel te gebupcken: ende Den Deroen Dzanck Die ghemaeckt wot upt Den boam Molle, Daer bop bier naec

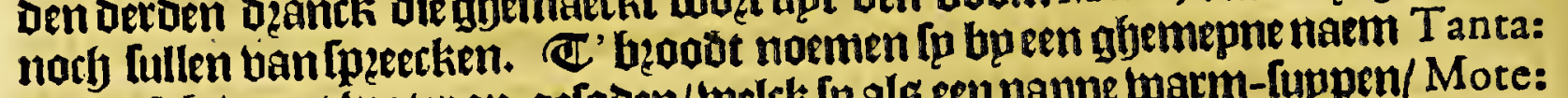
ende 't Maiz met water op-geloden/welck [p alg eenpappe warm-[uppen/ Mote:

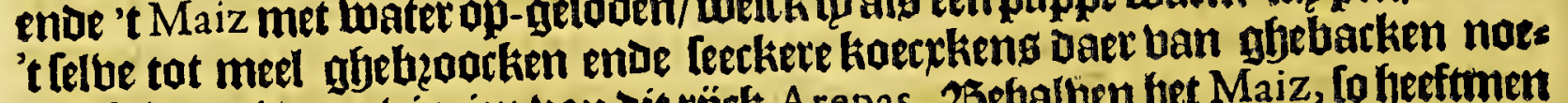
mente in eeniae probincien ban dit rïrk Arepas. 25ebalton bet Maiz, Lo beeftmen bier oock Caffavi twelck ban of Yuca wert gbemaeckt; ende of moetelen diele

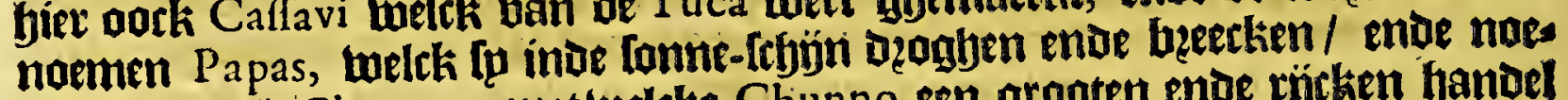
men datmed Chunno: metwelcke Chunno een grooten enoe rürtken bandel mazot ghedzetuen in dele landen/met de telde te berboeren naer oe mijnen ban Potofi ende naer anoere ahewelten die frbaers jün ban liff-tocht. . Dug veele vande manieren enoe gljeftalte des bolckis in't gemepn;'t genefy belonderg gebs.

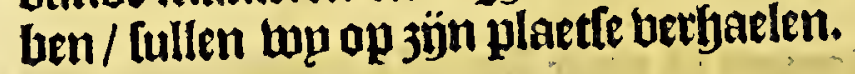

\section{Het thecoe Capittel.}

Van eenighe planten ende vruchten, als mede ghedierten die defe landen van P E R V doorgaens ghelijck cyghen zijn.

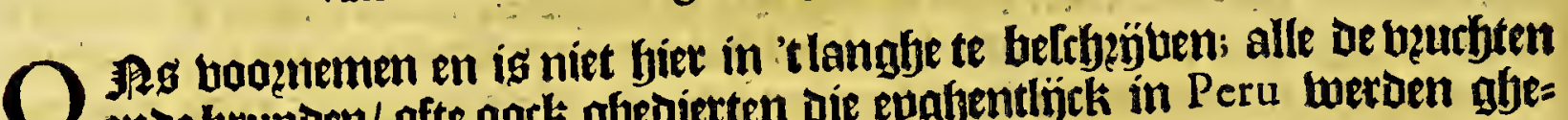
ende krupDen/ ofte oock gfedietten die epglyentlïck in Peru wetden ghe vonoen / 't felve if bp Acofta ende andere oberbloedigh te binden: alleen en konnen wo niet boos-bp gaen eenigbe Conderlinghe beuthten biec aente roeren/ als mede eenighe beetten die ban londerlinghe aen-merckinge ende gebuuptk 3ün in dele landen. Ghelÿck in de landen ban Nova Hifpania bet Cacao een lanis berlingh ghebeupck ende migbupek beeft/ 30 beeft oe Coca mede in dele landen van Peru: Befe Coca twerot ong by A cofta belcheetuen/ in manieren alg bolght:

lib. 4. c. De Coca is een klepn groen bladeken/ welck watt aen boomkens oie on:

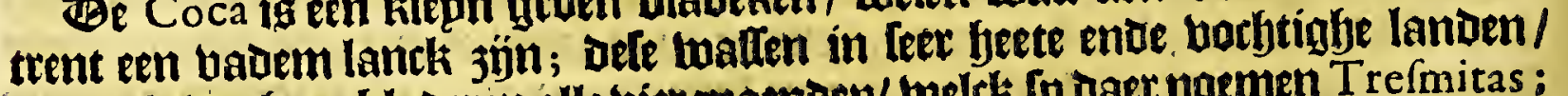
ende gheben baet bladeren alle bier maenoen/ welek fo daer noemen Trefmitas: will in't op-bzenghen wel betozght ende waet-abenamen welen/Doaz dien 't leet

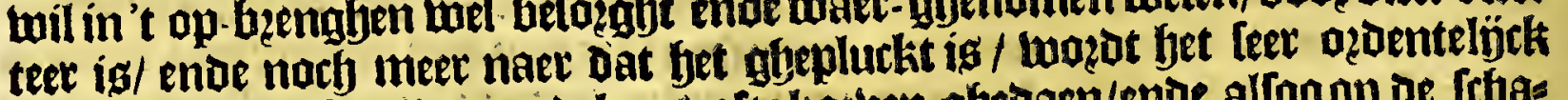
in langhe enoe fmalle mandekeng ofte kozben abeoaen/ende alloo op of Irbas pen van 't lanot affeladen/ Die met dele koopmantehappe over lanot trecken in

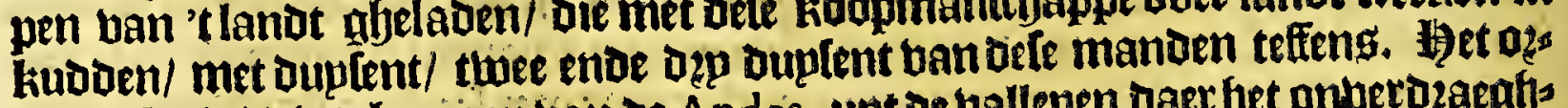
dinarifte ig/ die te beengen ban de Andes, upt De ballepen oart bet onberozaegfys lóch ljeet is/ ende oenmeeften tajot ban 't jaec regent; enoe 's waer-nemen ende beneficecen 
beneficeten ban dele Coca, kaft ie JInoianen niet wepnigh moepte / ende oack wel 't leuen/ Doos dien [p uan 't ghebergfte ende koude rlimaten af-komen/ om bie te plucken ente te halen: Soo dat daec beel ghelpzecks enoe diberlebe opinien

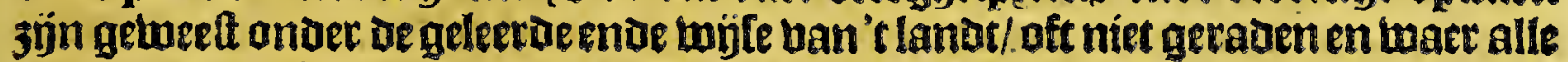

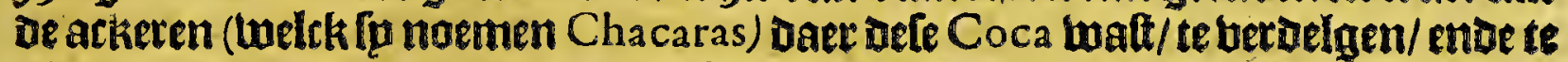

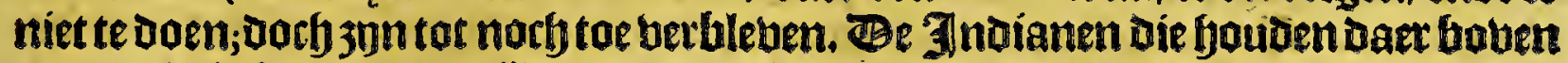
maten beel af / ende in de tjoen ban oe Ingas, thoningen ban Peru, en twas fet oen

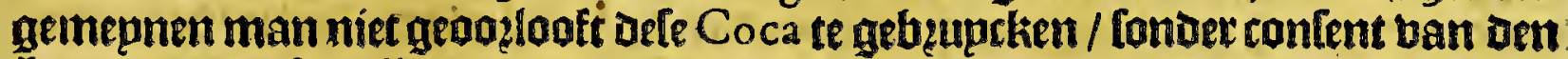

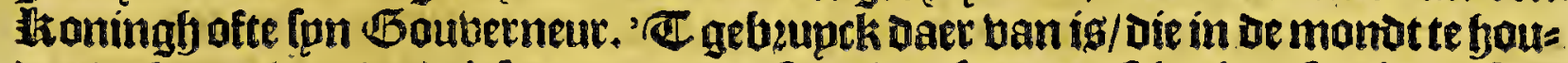
Den/te knacutwen/ende't lap daer upt te Lupghen/[onoer't felbe in teftoelgen: [eg-

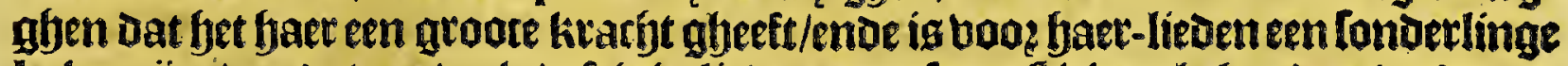
leckernge : twozot ban beele Deftiabe lieden boo? fuperltitien abehouden/ ende cen enckele imaginatie: maer om de waerfepot te fegghen/en kan ict mp niet in-beel= Den bat bet een enclieloe imaginatie foude jün / maer laet mu eer buncken dat bet

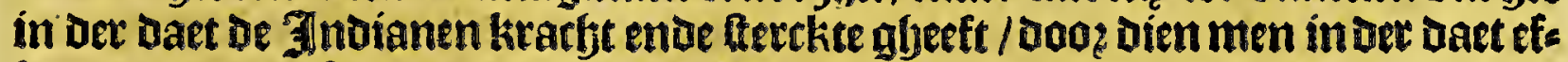

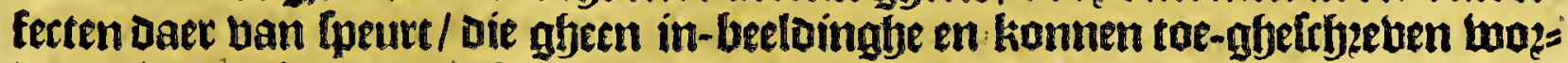
Den; alg Daec is / met een fandt-bo! ban Dit krupd Dubbele dagh-repten te Doen/ Tonoer bu wijlen pets anders te eten/ende dierafjeliftke twercken meer. Be faule

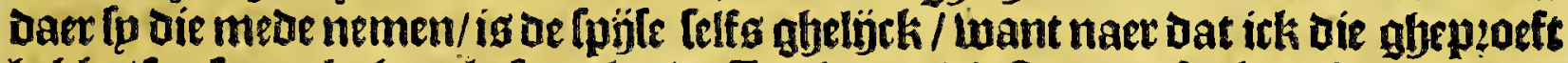
bebbe/ foo lmaeckt bet als fmacke; de 3ndianen die ttooten ofte beetken die met aldben ban gebtanden ende gemalen beenderen/ ofte met kalc/alg andere [eggen.

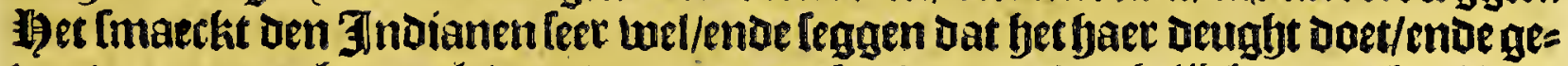
ben Daer geerne haer gelt boo?/enoe mangelen Daer meor ghelötk met gelt/al tuat

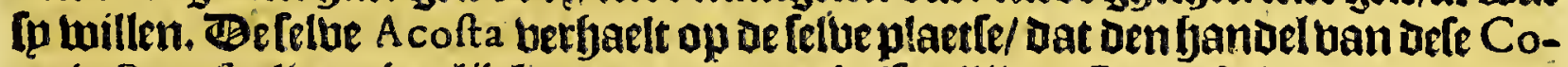
ca in Porofi alleen/ jaetlïrtis meer dan een balf millioen Pezos beloopt; doo: dien

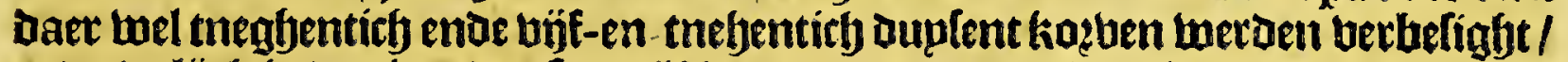
enoe (gellïk in den fare oupfent viff fondert Dap-en-tachtentict) oock twel fondert ouplent. Soo een kolf Coca, is in Cufco meerot/ban twee en een balf tot dep Pe. zos toe: enoe in Potofi bier Pezos ende feg tomines, enae aork unjf geetlapertae Pezos contant gelt :enoe is't gent daet bp naer alle lwidelinghen ofte koapen met gec

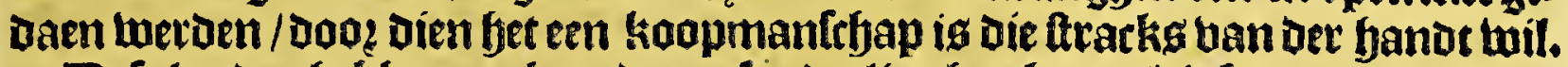

- Bele landen febben oark mede een londerlinghen boom/Die fp noemen Molle, (boe-twel de Celue nu meoe in Nova Hifpania is nbeplanot / ente twozot baer ben boom ban Peru ghenaemt / is een frboonen boom/ fun bladeren de oljf-boom

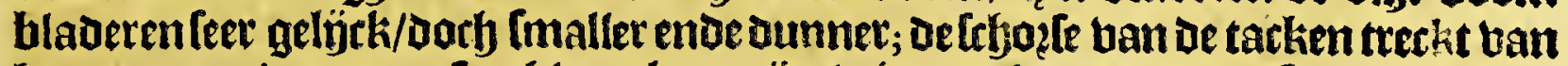
Jet graen op 't purper; fpu bloemlieng jün bit ende bangen in roolkeng; de weles

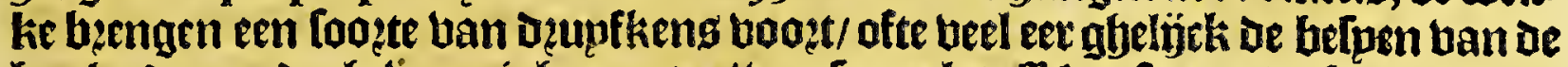

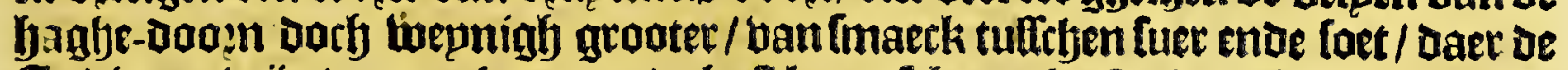
Indianen wijn ban maken: upt de baft kount leketen ferte die wel rieckt bp naet alg de Lentifcus.

In Peru mozat oock enige bier-toetige ghedierten gebonden/ die netafyens els Dersen wozoen getuonien alsalleen daer ende in Chile, twelck Daer aen paelt/Dan

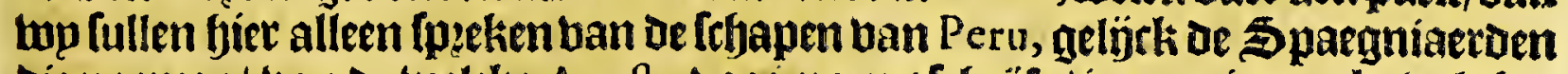
Die noemen/ ban oe welcke A cofta boof-noemt fchejft / im manieren als bolght: Peru en beeft geen dinck ban meerver boo-deel ofte rijchiom / alg't bee ban den lande / welek oe onfe noemen fryapen ban Tndien / ende or Indianen in de ghes

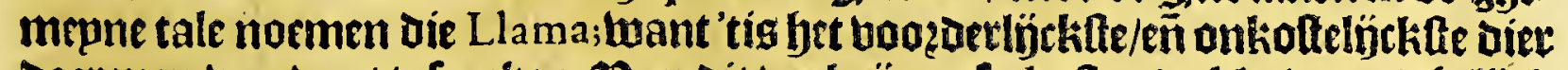
Daer men ban lneet te [peeken. Ban dit bee krïgen [p kaft ende kleederen/ghelörk in Europa ban de fryapen/ende daer beneftens too dienen [p baec daer ban/am alle laften te Jaaghen: ende is niet nodiigh die met pfer te bellaen/ofte te fadelen/ofte toomen; beel minder baber te gfieten: dienen yaer meefters om niet/ende befelpen haet met de kxupden die [p in't belot binden. Bele fryapen 3 jun bain tweedertep lagb/oe eene jịn Pacos ofte wollige fchapen/oe andere jịn kael eñ ban wopnighe

Ii 3 wollel 
$3^{62}$

Peru.

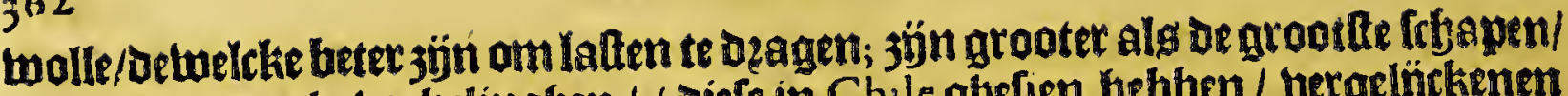
enoeklepnoer als bockelimghen / (Dicte in Chile ghelien bebben / vergelibrkenen

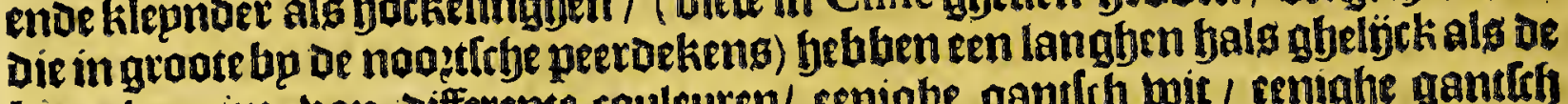
kamelen; 3 in ban siffereme couleuren/ cenigbe gantlib wit / emighe gantrfy [wart/ettelgcke graeuto/ enoe fommighe gemenght ban couleur/ oie [p toemen

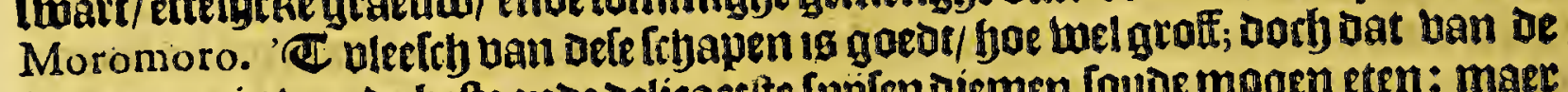
lammeren is ban de bette ende delicartite fpjien diemen Coude mogen etem: maer

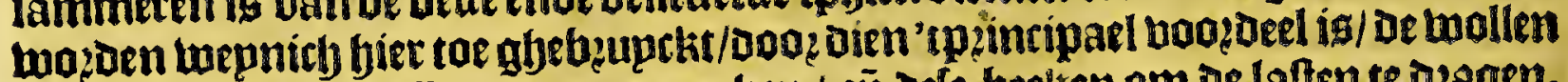
te gebsuprken om ftoften ban te maeclien/ eñ Defe beelten om De latten te Dzagen. De Indianen bereuden ue molle/ende marcken daer laken af daer fo baer inklees. oen; cen foote welcke grof enae gbemepn ig/ welch fp naemen Havalca, enoe een

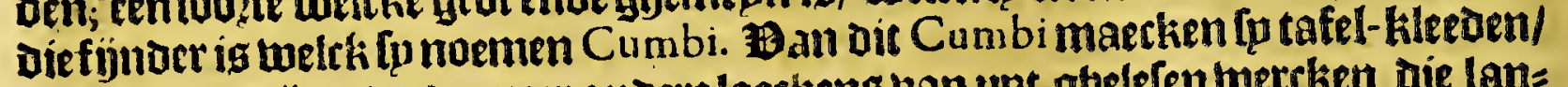

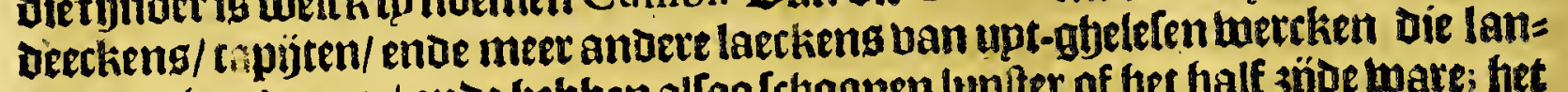

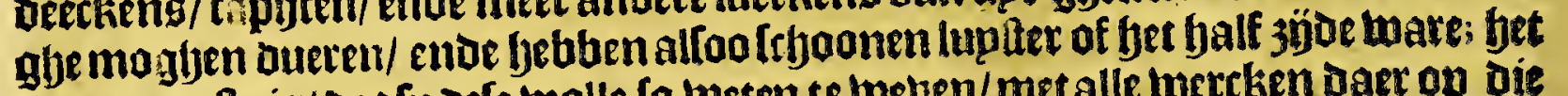
boo naemtte is/ dat fp ocle wolle fo tweten te weben/met alle wercken Daer op die [p.w.llen/ Dat fet aen bepoe jyoeneben frboon is/ Conder Dat inen Den Dzaet ofte het epnoe daer ban ergbens kan lien. De ltoninghen ban Peru onder-bieloen als tüts [eer arootemeriterg ban lueberg/ am uefe Cumbi te wertken/ende de baozs naemae die Loonoente Capachica, bp oe groote Laguna ban Titicaca. Sp vers

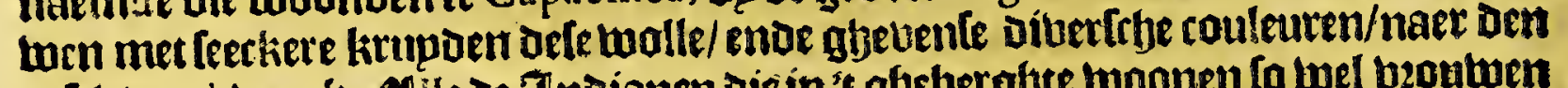
eplety van' twerck. Wile or Jndianen die in't gheber afte woonen fo wel bzoktuen

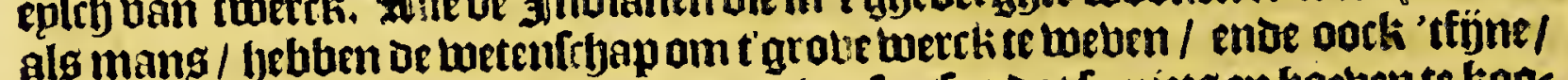
bebuen daer tweef-abetoutwen toe infjaer buplen/Loo bat fu nists en yoebente kade peil baul 'tghenefp deg-twegen in yaer buplen ban noode bebluen. Ban't bleefty

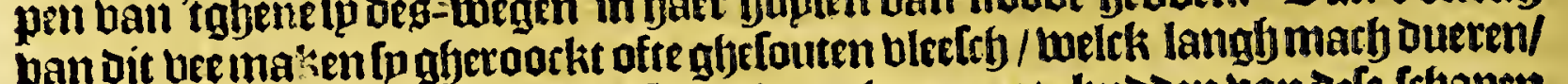
enoe wozt oock veel berb:upckt. Sp gebzupeken groote kuboen ban Defe frjaptn om de laltente Dzagen; ende dikitwils wel dep younoert/ja ouplent ineen traupe I. belck twijn/ Coca, Maz, Chunno, ende quickfilber dzaglben/ende eenige andere

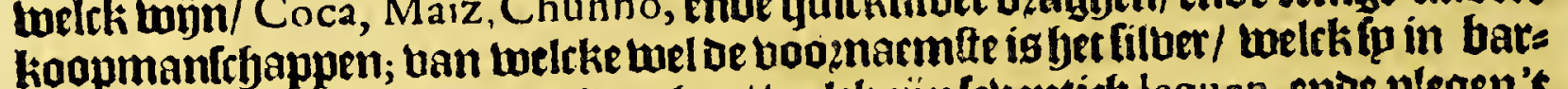
renuan Potofi naec A rica toe dzaghen/ weick jünlethentich leguen, enoe plegen't eertÿots naer A requipa te bzengen/welck jün banoert ende 500 leguen. "e 'beeft mp Dickbils berwonoert te fien Dat oele kudoen ban tebapen ober lanot gins gen met eenenoe twee Duplent barten filberg/ende ooe meer / welcke meet als Degs bonoert duplent outaten bedzaghen/ [onoer ander wadjt ofte beffjut/ als alletn met bepnigh Thoianen/ (am defe fthapen alleen ben wegh te wijfen / eñ te laben eñ ontladen) enoeten yoonten een \$paegniaert; enoe bernartjen alle tÿotg ín't mioden ban fet velot onder oen blaeumen bemel/ conoer ander befefuot als boo ren: EEnde in Dien langhen meaben met too toepnieb wachts/ en nhebzack nopt

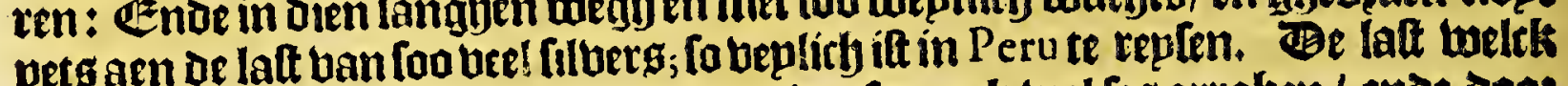

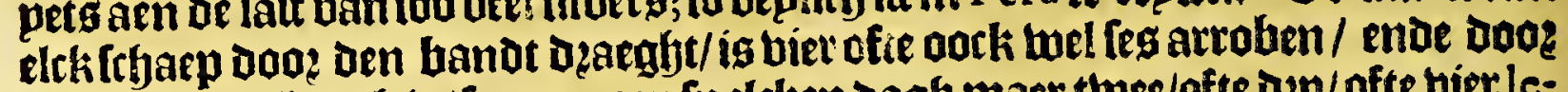

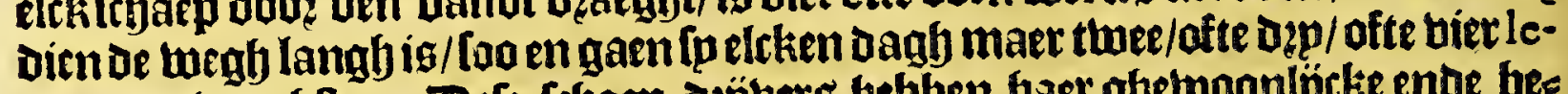

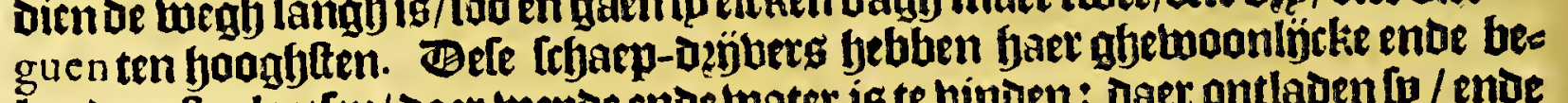
kenderult-p'aeten/ Daer wepoe ende water is te binden: daer ontladen lo / ende flaen baer tentieng op/maecken biet enoe halt ghereeot / enoe en febberit niet

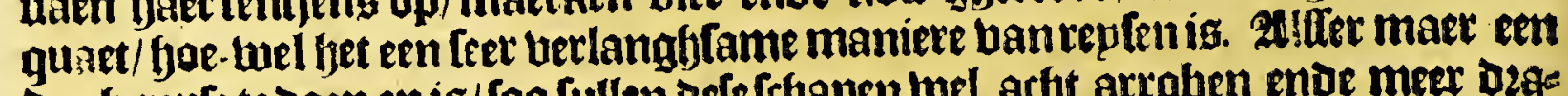

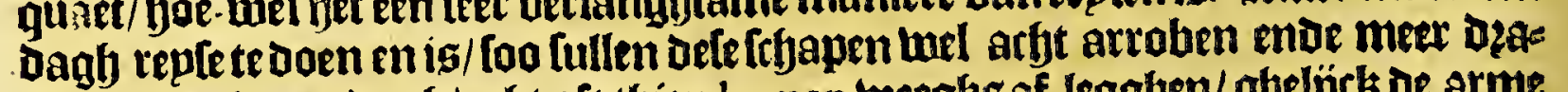
ahen/ende in een Dagh/acht oft thien leguen weegbs af-leggben/ghelörk oe arme foldaten die boaz Peru replen/getwoon jünte doen. Dit bee ig beienot bankoude lurbten/ ende dartom lo feot enoe teelt bet wel hoazt in bet gheberghte / enoe fterft ban of aroote hitte op of ylapnen: bet ahebeurt ooch wel bat dit ghediette

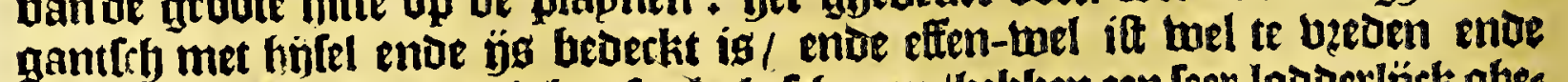

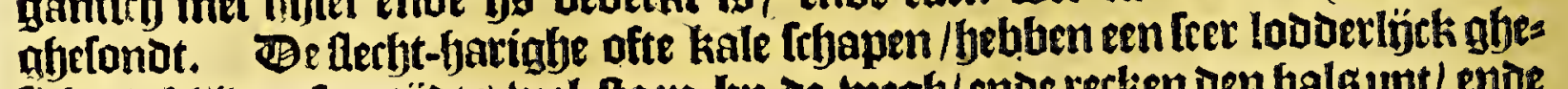
fichte / blinoen fomtijats wel taen bp of wegb/ende rectien den bals upt/ enoe blÿbat 


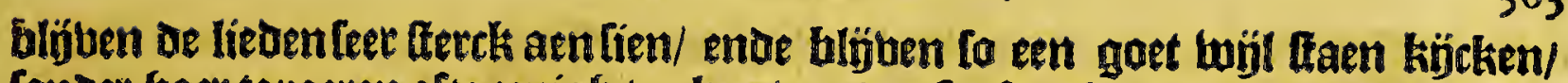
fonder baer te roeren ofte eenigh teeclien ban veefe ofte ghenoegen te thoonen/ foa

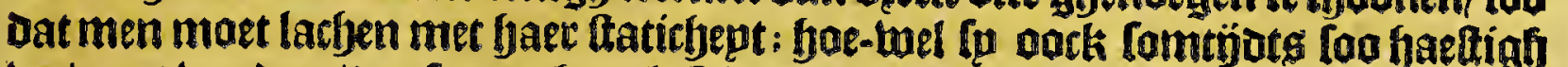

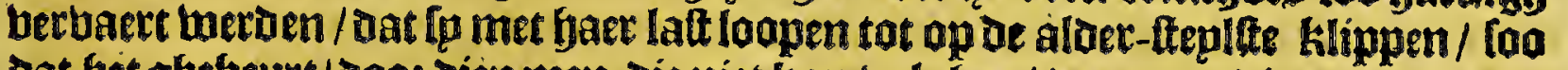
dat fet ghebeure/ Dooz dien men die niet kan bolghen/ bat men die met een roer. Doodt maet fchieten om't filver welck fp dzagbenniet te uerliefen. Be Pacos tuer Den oock fomtijots fos grimmigh ende maepeloog ober De laften/ Dat fp baet met. De felue ter neder-legghen/fonder dat daer midoel is om de feltue weoer op te boen faen/maer fouben baer eer in bupfent ftucken laten foutwen/als faer defe moepz:

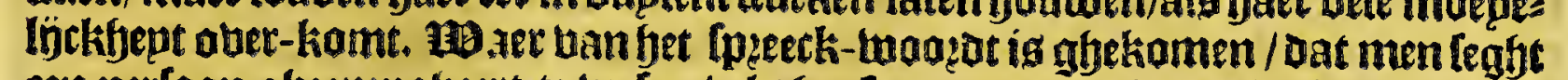
een perfoon gbeempakeert te thelen/als fy foo tergramt is dat by gem niet wil laten ghefegghen/Doog dien de Pacos foo doen / als baer dele grimmighept ouetkomt. Te eenigbe remedie die de Jnaianen dan gbebuuthen is te rulten / ende bem neffend de Pacos neder te fetten / die te freelen ende troetelen / tot dat haer grimmicfepdt ober gaet / ende ban felfs lweder op ftaen; ende bet ggebeurt twel/ Dac fp Daer twee ofte dep upęen naer moeten warbten / eer faer grimmirchept oter

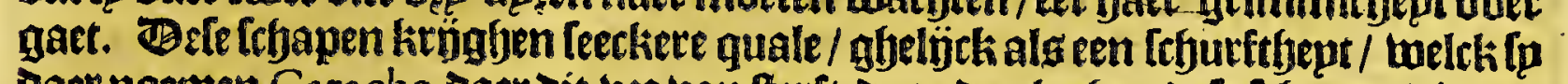
Daet noemen Carache, daer dit bee ban fterft de oude plegfen dele frbapen die met oele Carache beimet waren/ Ievending te begrauten; op dat't feloe die anoete niet

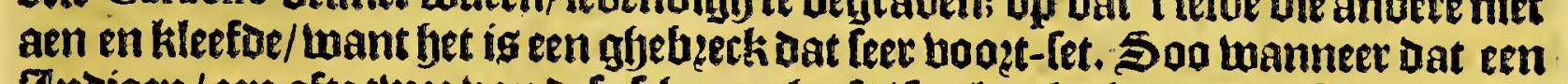

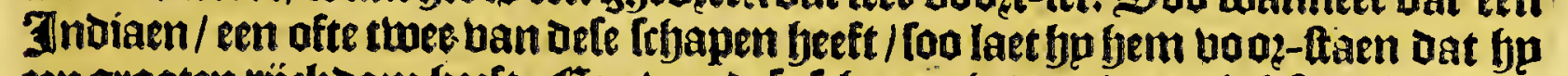
een grooten rịckdom feeft. 送en van defe ffjapen is daer beer Digf fes ofte feven abeellapertoe Pezos, ende oock meer; naer de gheleghentlyept uan de tijoen enoe plaetlen. Bare 3 ïn noth andere dieren/alg de Vicunnas enae Torugas, die defe

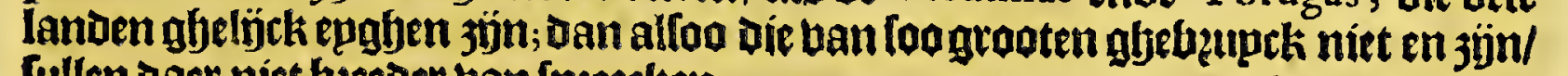
fullen daer niet beeder van lpeecken.

\section{QVITO \\ Wet Deroe Capittel.}

Verdeelinghe van 't landevan PERV in verfcheyden provincien, ende bea fchrijvinghe van Qurro in 't ghemeyn: de gheltalte van de landen, ende manieren van de in-gheboorne van de lande.

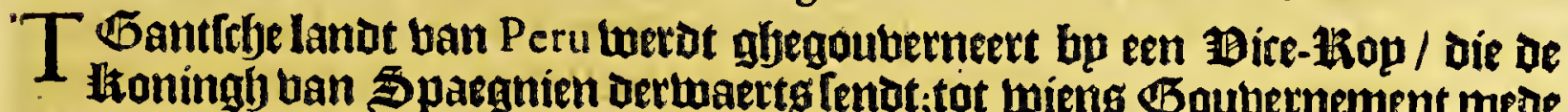
gehoost 't Loninahrick ban Chile, entoe fentr tot wiens Boubernement mede mon; naer't cotten de lanoen enoe probincien ban $R$ io de rijck ban Peru berdt berdeelt in Dep Deelen bp oe Spaegniaerden verbolgeng be

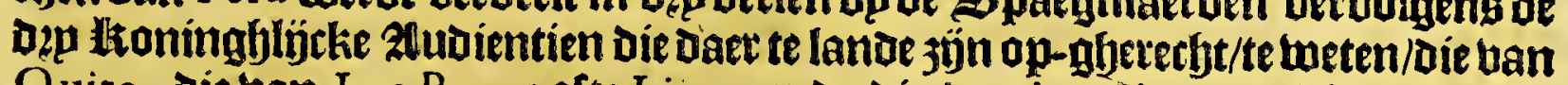
Quito, Die uan Los Reyes ofte Lima, enve die ban los Charcas, Diemen oork

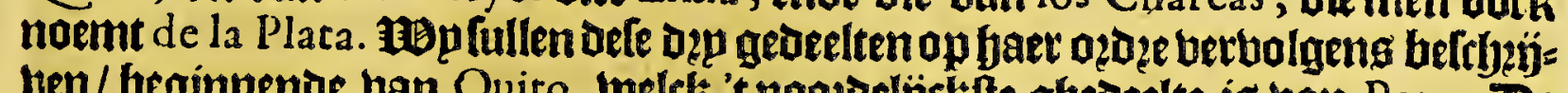
ben/ beginnende ban Quito, welck 't nodęolijckifte ghedeelte is ban Peru. Be Aludientie van Quito begrïpt onderlífy Popayan, los Quixus, Ia Canela, Iuan de Salinas, Pacomoros enue Ygualfongo ; van Popayan bebben twp reede getpet= ken; ende ban de andere lullen wp bier naer lpeetken.

Je pzobintie die epgentlíck den naem ban Quito toe komt/heeft naer 'tleggen banHerrera, in de lengfte van tachtentiff leguen, ban dicht onder de linie equino: rtiael/tot aen de limiten ban be audientie ban Lima:Pedro de Cieça geeft die maer feventit\} leguen in ae lenghte/ente bïf-en-twintich ofte dertich in oe beecate. 25: gint naer'tleggen uan Herrera op de zee-kulte ban Punta de Manglares, bp noo: oen de linie / ende ftreckt tot Punta del A gula, bp jupoen de limie/ enae wat bp noożoen de haben van Paita. Binnen 's landts tegintle ban Carlufama naev bet noazden toe gheleghen/welck beboot tot bet Goubernement van Popayan:

$$
\text { Ti } 4 \text { naer't }
$$


364

Peru.

naex't oolten ftrecktie tot Baeza toe / melch is in't Bouternement ban los Qui. xos; naer't welten tot Puerto Veio, ende twat leeger tot la Montanna, ende't vers Dzencken lanot aen oe jupt-zee; naex't jupden tot of limiten ban ae audientie

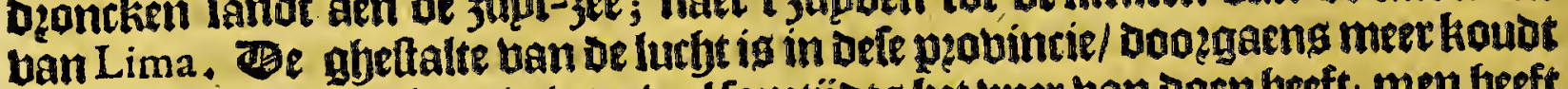
als beet/ 500 datmen in oe winter wel fomtỷots het bper ban Doen beeft; mem beeft Daec een Klave ende beloere lurbt; de Lonne rïlt ende daelt daer [eer luftich/ ende ig feloen met wolcken betogen/ Dan als hetreghent/ ofte bem ftelt tot regenen ; baren uninter begint in October, ende duetr tot in Martio, ende gheduetende vien tübt / regent ber beel/ Danbet fneetbot Daernimmermeer / als alleen op eenige befondere getweften ban oe groote Cordillera ban's gyeberchte; iseen beel gefont getwettel enoe de lieven leven daer veel langer als in Spaegnien. In oen jace 1 558. twas

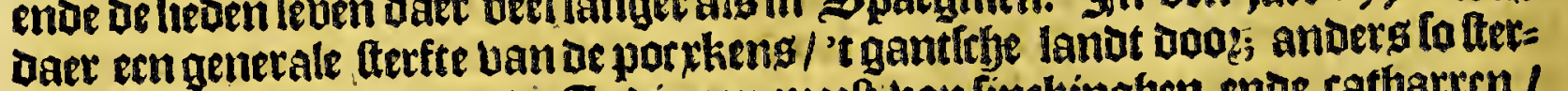

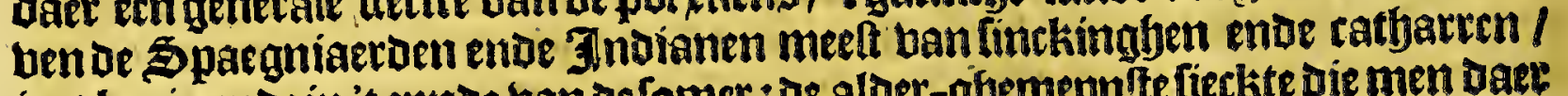
in't begin ende in't epnoe ban defomer: of alder-ghemepnlte fieckte die men daet

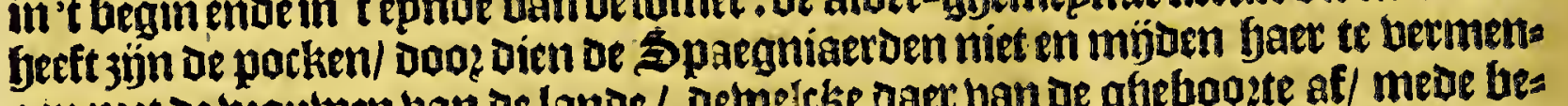
gen met oe vaculwen uan de lande / Detwelcke daer ban de gfoeboozte af / mede be=

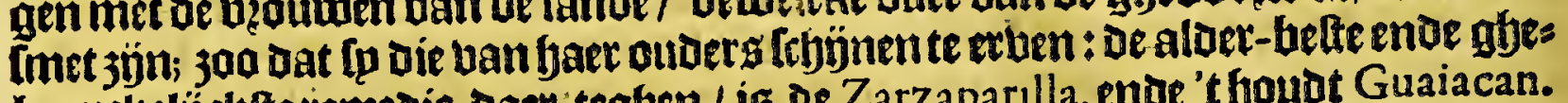
beupckelijeklte remedie Daer teghen / is de Zarzaparilla, enoe 't boudt Guaiacan.

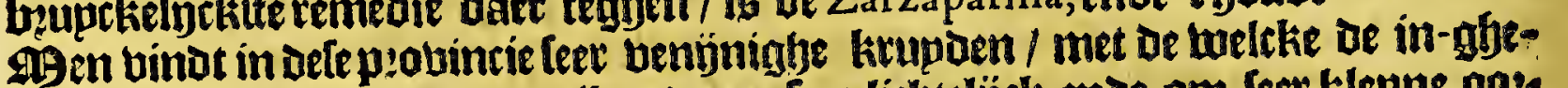
boozene ende in-gljefetene malkanoeren leer lichtelïrk enoe om leer klepne oqe Caecken om yet leven beenghen. In de Cordillera van't gheberghte naer bet wes ften toe gajeleghen/ werot beel goudts upt-ghegraten/ dan is eqgentlijelis onder t Boubernement ban Popayan begrepen. TnIghelijcks in oe rieviere melck [u noemen de $S^{\text {ra }}$ Barbara, pleetht feer beel goudatg betlamelt te twerden/ 't welck nuluoozen tijot feeft op-getyouden/ naet dat bet be oen leoningh berboden ig/ ae Indianen Daer toe te gebuupchen. Doo de groote borbtitbept ban de gronds werot in beele deelen ban dele p'ovintie veel falpeter ghebonoen/ waer ban fe feec gaet bus-poeder maecken. Op't beettle gedeelte ban orfe pzoluincie/ walt een le:

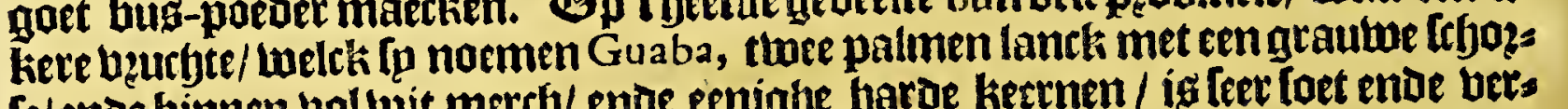

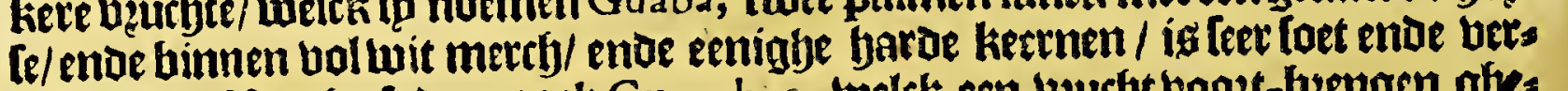

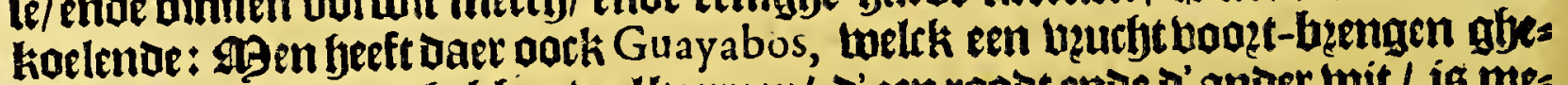
lijethalg appelen/dan Jebtien veel ketenen/ a' een roodende o' ander wit / is me=

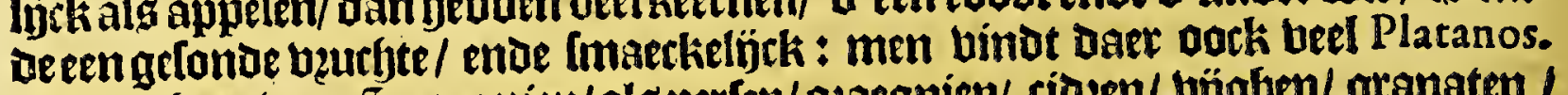
Debzuchten ban Spaegnien/als per/an/ozaegnien/ cidzen/ bỷgben/granaten/ quet-appelenende yeeren/ watten daer wonder wei/ dan de beuchten en fouben

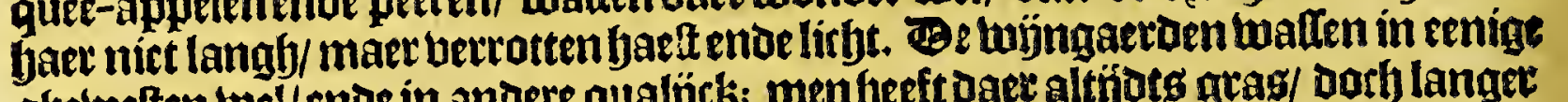
gheluelten wel/ende in andere qualjek; men beeft daec altijots quas/ Dorb langet inde tuatmete als inde koelte. Jer twerde beel tartwe/gertte ende Maiz ghefaept:

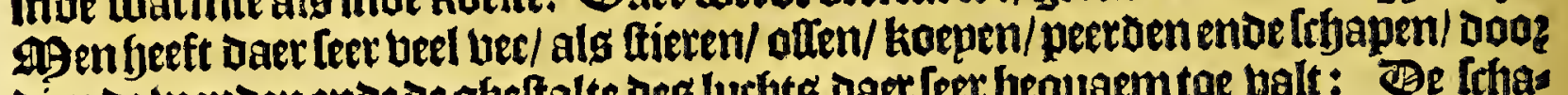

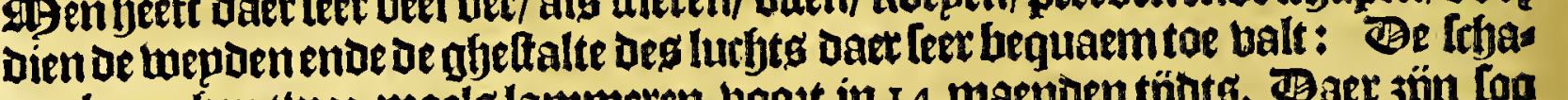

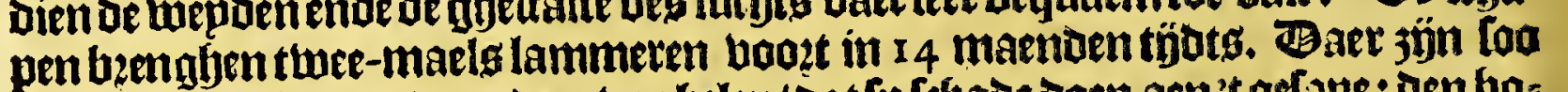

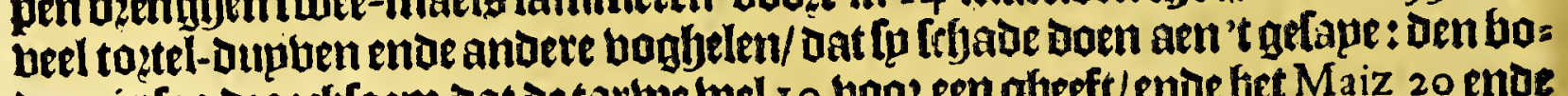
Dem is [oo Dzaedhlaem Dat De tarke wel ro boose en gheeft/enoe bet Maiz 20 ento 40 boozen; de tartwe laet haer wel een jaetende meer betwaren/ Doctj belt in's Itroo. AGen beft daex oock alder-hande aert-beuchten ende moel-krupden ban Spaegnien/ende beelderbande gbevogbelte fou tan' tofene daer ban outs ig ges

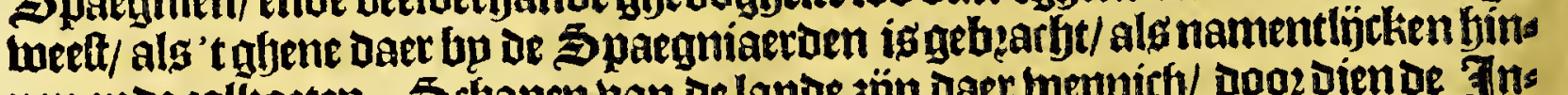

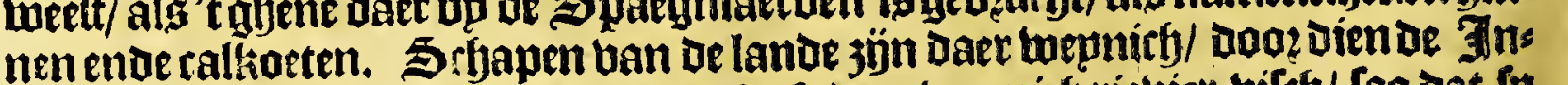

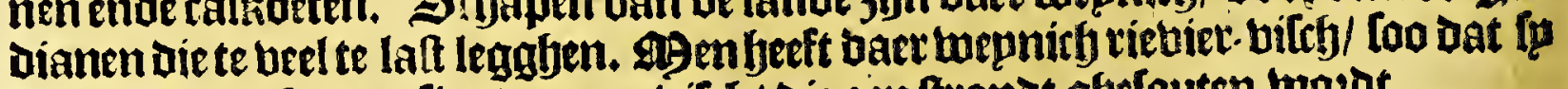

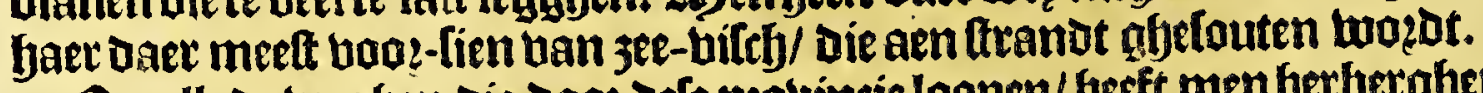

Bp alle de wegfen die Doos dele provincie loopen/ feeft men berbergben welck fo noemen Tambos, alle büf ofte [es leguen weeghs/daer men ban alles bindt tot

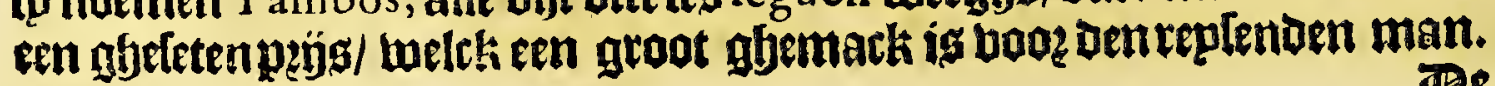

De ingbes 
Dein-gleboozne ban selande leben bertchepuen in bp/ondere gehuetten/ende en berlaten niet licht de plaetle ban baer ghebonten / ten twate ip vaer toe ghe: nootlaeckt woghen / boo: bet quaet thactement ban baet Caziquen: 3 jun ban fraep

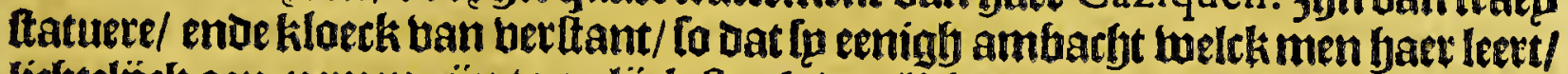

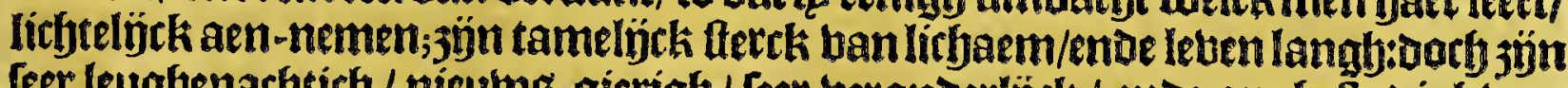

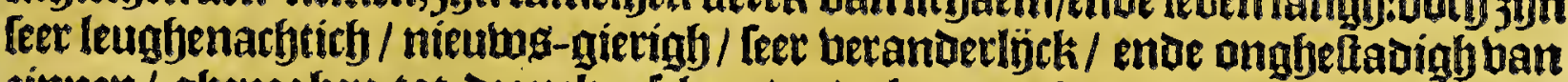

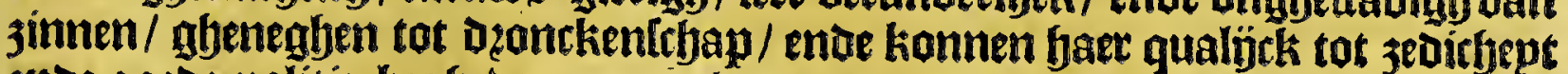
ende gaede politie hegfeben; upt-abenomen eenighe duptenden die ontrent de Itaot Sant Francifco del Quito moonen/ bie nu bat beter glyemaniert jịn: baet ozdinaire kleedingbe is een bemat-rock fonder moulwen / onder ende baben eben wöbt/[oo dat fo met de armen ende beenennaeckt gaen: dzagen langh fjape/melck

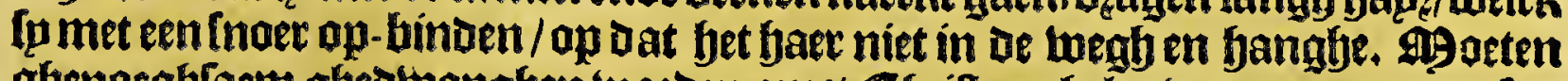

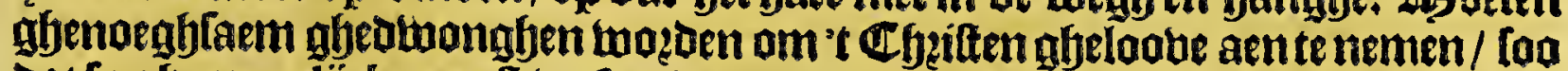

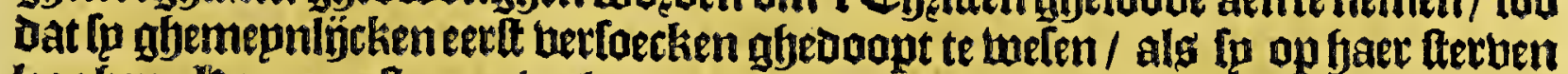
legghen. Haer meelte neetinghe ende fanteeringbe is cottoen te koopen/ ende te berequén / Dake mantels ban te maken: de molien te babenen / te fpinnen / lakes nen ende andere ftoffen baer ban te tweben; welck [p alleg ban de Spaegniaeroen gheleett bebben; betalen baer tribupt aen de \$paegniaerden die โu geentams

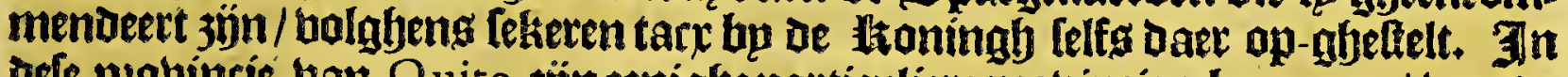
befe peobincie ban Quito jüneenigheparticuliere peobintien begrepen / ban de melcke wo fier naer fullen Lpeken / bp de tteden die daer in ofte onttent ghelegen 3j̈n. Baer 3 ün de naer-bolghende fteden ende blecken / Sant Francifco del Quito, Rhiobamba, Cuenca, Loxa, Zanora, Iaen, Sant Miguel de Piura, Sant Iago de Guayaquil, Puerto Veio. Ban De twelcke wp uerbolabeng fullen fpetken:ende op dat de ghelegenthepot ban de lande te heter macht weroen berttaen / foo fullen

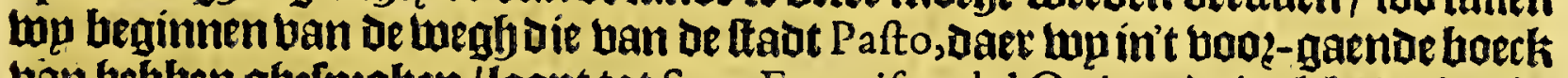
bain bebben ghe[peoken/loopt tot Sant Francifco del Q uito, De weltke De booftEadt is vandele audientie ende peobincie.

\section{(3et bietde Capittel.}

De wegh van deftade PASTo naer St Fr Ancrsco DEL Quiro toe, ende de gheleghentheyt van de landen tuffchen beyden gheleghen.

$S$ Cfepbende vande ftadt Pafto, om naer Quiro tae te Kamen/komt men eetf

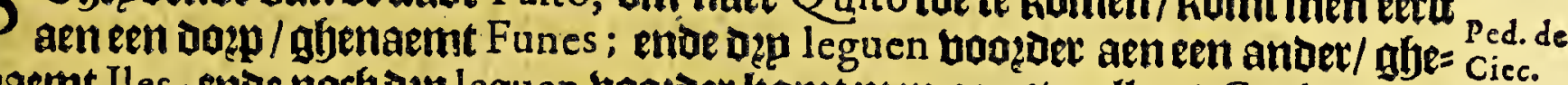
naemt lles; ende naty dę leguen boozer komt men aen 't palleps Gualmatan; ente nocf dup leguen boazder aeneen doup / gloenaemt Ipiales. Diego Fernandes in [pn Hiftoria del Peru, telot Ypiales veertbien leguen van Patto. Tn alle dele boepen waft wepnigh ofte gheen Maiz; boo? dien't lanot leer koubt ig/ / ende't jaet ban bet Maiz teer: Maer daer walt menighte ban Papas ende anoer wotelen/ die be in-gbeboone zaepen. Ban Ipiales komt men aen een klepne probintie/welcke [pnoemen Guaca ; ende eet men daer kamt/ [oo fiet men den fooghen wegh van de Ingas, die foo vermaert is in die landen / alg den wegb die Hannibal maeckte

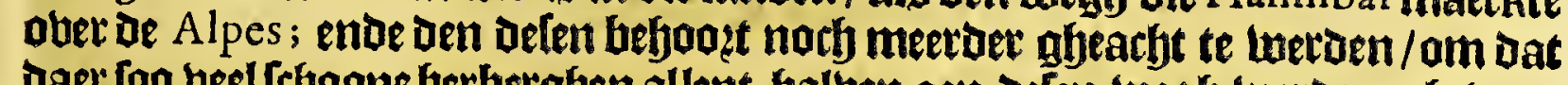
Daex foo beel fejoone herberghen allent-halben aen Delen wegh tweroen gljebon= ben/ende dat delen wegf met foagrooten maepte oberfyarbe ende waelfe bergben is ghetrocken/loa dat het een monber is om lien. Agenkomt aock aen een riebie re daer men be aber-bljffelen liet ban een fterckte die de Ingas eertijots badoen ges maeckt om de Paftos te beltrijben. Ober defe riebiere leght een fteenen hzugghte/ een farde klippe welck onoer aen be gronbt een ronat gat beeft/Daex 't water met groot ghedeupg dooe-loopt / ende houen gaet men baet ober: werdt in te \#ndiaentrbe taele ghenaemt Lumichaca, welck foo beel te legghen is als Atenen- 


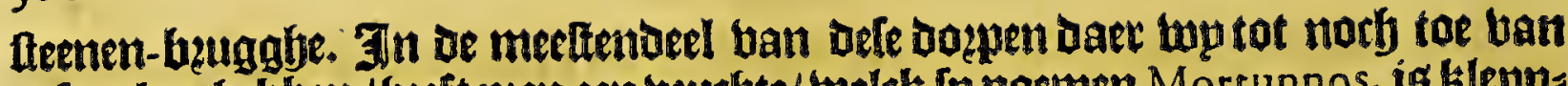
gefproken feblien / heeft men een butthte / welck [p noemen Mortunnos, ig klepn=

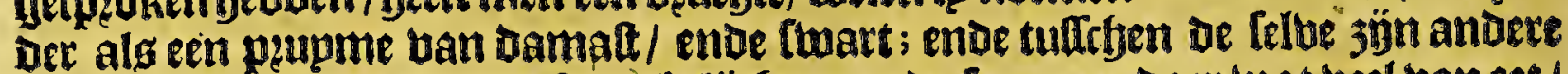
klepne deuptkeng / die baer feet ghelïcken; enoe foo men Daer wat beel ban eet) foo wozot men daer dencken af / ende beroos laecken groute benauthept / foo dat

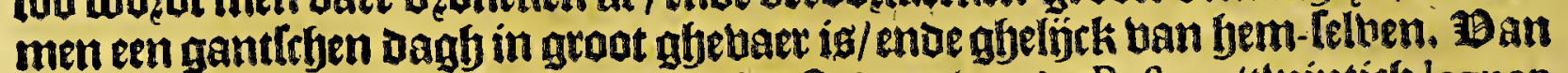
Guaca komt men te Tuça, welck is't laette Joup ban De Paftos; (twintich leguen ban Q uito naer't fegghen ban A uguitin de Zarate;) ende wat boożer aen een

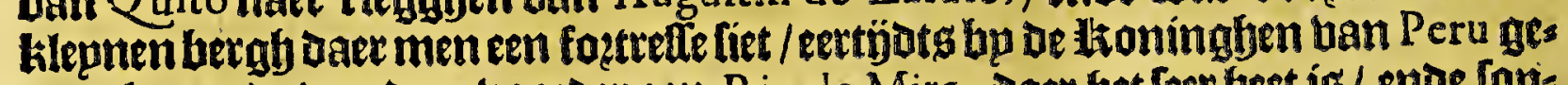
maeckt : ende ban daer boożer aen Rio de Mira, Daer het feer feet is / ende fori:

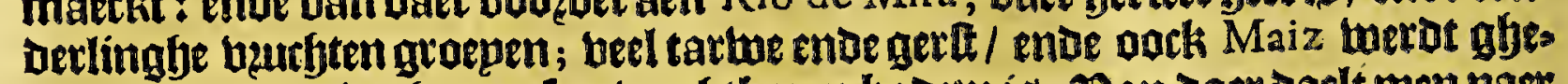
wonnen/ doo? dien bet een leer buthtbaren bodem is. Ban daer Daelt men naet De groote ende koltelijeke palleplen ban Carangue; Dorbeer men uaer bp komt / liet men fet lack welck de Jindianen noemen Yaguarcocha, welck loa beel te feg:ghen is als bloedt-3ek/ Dooz dien een ban de Foninghen ban Peru, met namen Guaynacapa, daet eertijots bel twintich Duplent mentrben die bo basde Doen Doouen/heft in Doen werpen. Tit pallepg ban Carangue, legbt op een klepne

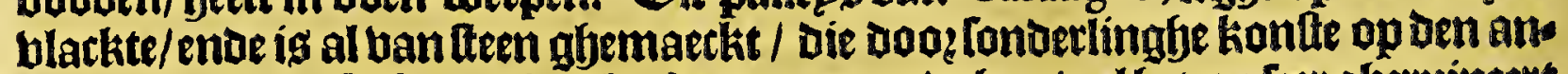
Deren 3 ïn ghepal / conder kalck ofte tement ; enoe boe- -mel bet nu [eer gberuineert is/Loo kan men eben-wel norblien Dat bet en groot ende kaftelijck ftuck berckg is ghetweet. Ban Carangue treckt men langhg te koningflỉcke twegh ban De Ingas tot Otabalo toe/ welckeen anoerpallepg ofte foninghligcke flot twas/ento is norb een voo:-nemen plaetle; (twaelf leguen ban Quito, als Zarate getupgbt;)

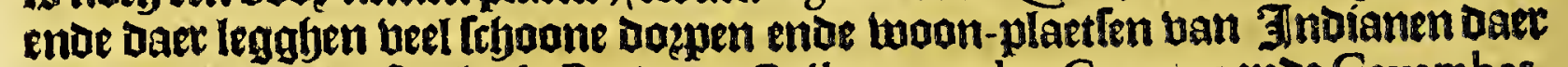
om-lyet. Paer 'tlueftenleght Poritaco, Collaguaço, los Guancas ende Cayambes. 'Paet' toulten Cotocoyambe, inde't ghebergbte han Yumbo, ende andere wounplaetfen meer. De in-ghebouzne ban Otabalo ende Carangue, twerdenghenaemt Guamaraconas. Ban Otabalo komt men te Cochefqui, imelek is een anderpals

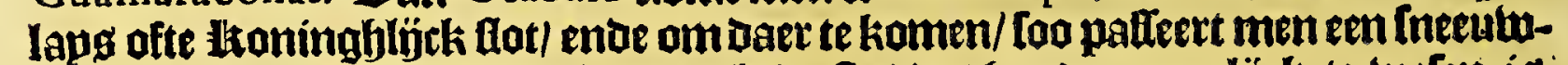

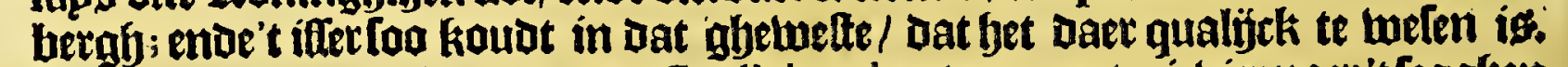
Ban Cochefqui treckt men naer Guallabamba, (een grooteriétier naer 't [egghen uan D. Fernandes) daet't wat fyeet is/om Dat bet leegh lanot is/ ende bp naet recbt onder de linie gheleghen; Joef 't is ewen-wel betwonot/ ende men bindt Daec ban alles oberuloedigh / wat tot onder-fyoud ban's menteben Ieben noos

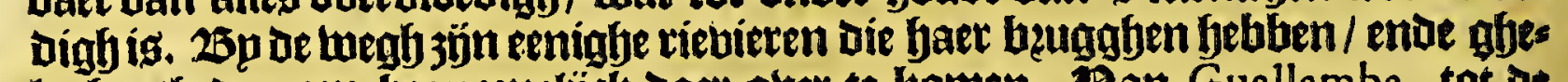
legbentfeden om bequameliek daer ober te homen. Ban Guallamba, tot de ftadt Quito, en jün maer biet leguen; ende tultefen bepoen jün beel lanotbuplenende boulw-huplen die de Spaegniaerden Daer beh ben om bet bee te tweps ben/ tot bat men komt aen bet belot ban Annaquito, baet in Jen jate 1546 ben Bice-Liap ban Peru, Blafco Nunnez Vela, uan Gonçalo Pizarro thierot ghedlagben; ende dan komt men terftondt aen te that Quito, Daet wp um lullen ban lpetken.

\section{Het büfoe Capittel.}

Befchrijvinghe van de hooft-ftadt van defe provincie St FRANCrS CO DEE Qu 1 TO, ende de gheftalte van de landen daer om gheleghen.

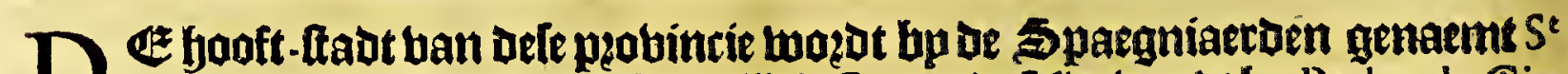

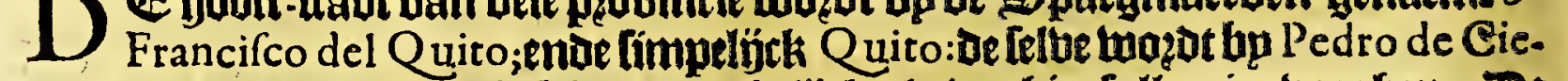

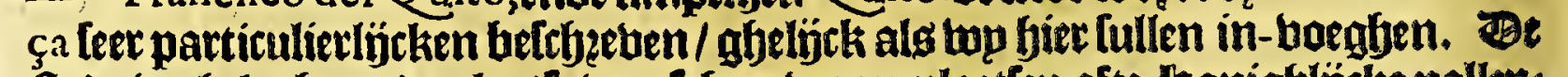

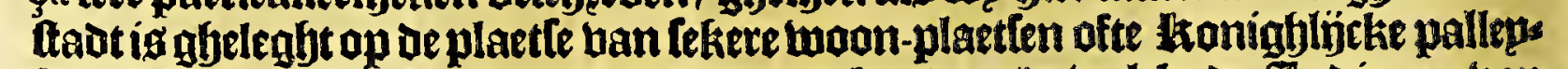
Ten/Die de Ingas daec eertijots badden laten boumen/se toelcke de Tnoianen ban outs noemaen Quito. Beftaot beeft toepnigh glefichtg/booz dien lp geleght is op 
Het thiende Boeck.

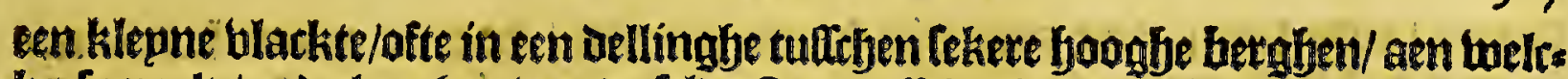

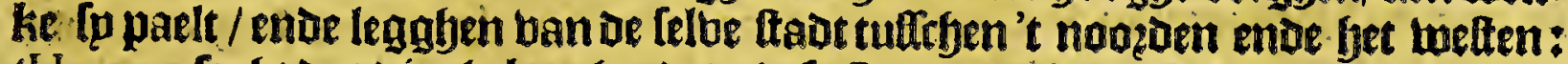
(Herrera leght Dat bit gheberghte Daer Defe ftadt aen gheleghen ig/ eene Cordil- Defcr.de lèra is / luelek fjaer begintel geft bp Puerco Veio, aen be jupht-3ee'/ ende loopt las Ind. tot bp Carcagena, aen oenooght-jee: ig ghelegfen naet 't fegghen ban Herrera op be boagfte baneen fjalbengraedt bp zupDen oe línie/(Pedro de Cieça legft dat Gij foo naer aen oen rquinottiael leght/ Dat maer feben leguen ban oaer paftett) ende ap of lengfte tan ther-en-tathtenticf graden ban ben meridiaen ban To-

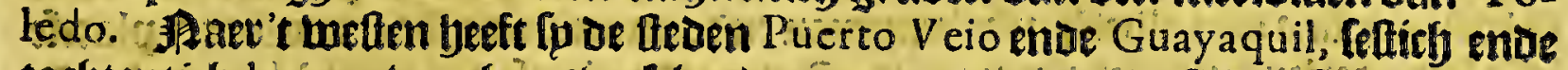

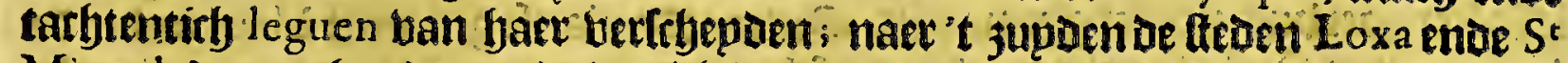

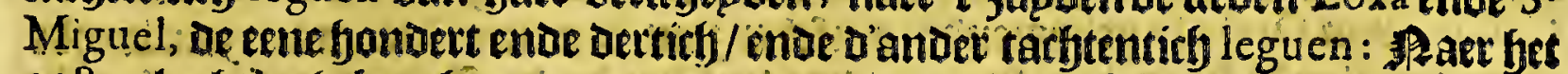
ooten legbt th gheberghte s endenaer bet noozen de peobintie van Popayan. Her-

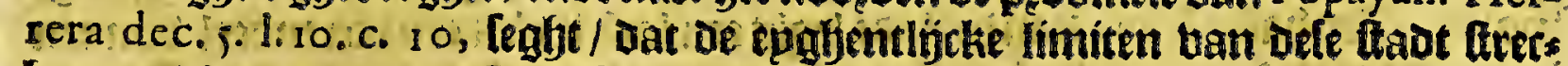
Ken naet tnopgen tot Cartufama, welth tot bet Gouvernement ban Popayan beboozt; noe naer 't 3 uptoen tot Tiquizanbi, naet of frontieren ban Cuenca; naer 't onften tot Baeża in de Quixos s naer t weften tat Puerto Veio, ende

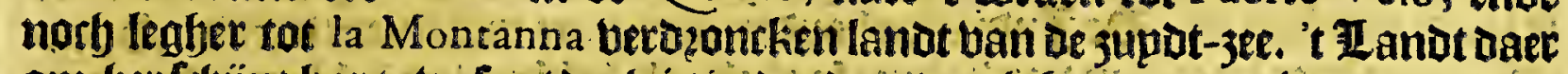

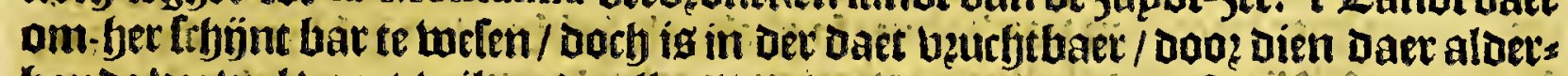

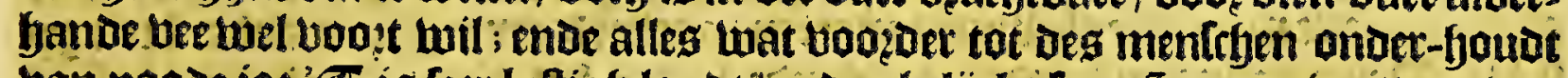

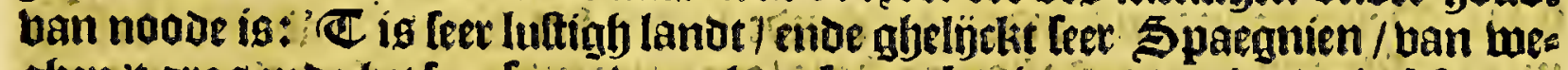
ghen 't gragende feet facploen ; want bater foimet begint in April ende in Martio, ende duert tot November: ende 't iffereer koudt alg feet: De tartwe thil daer leer mel waften. De in-gheboogente ban de lander daer ontrent jyn beel jedigher ende

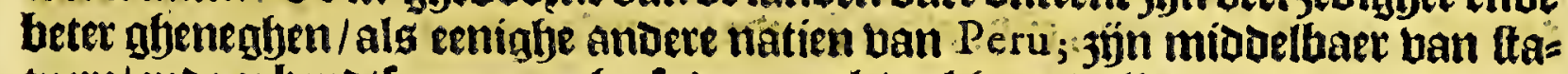
tuere/ende arbepdrfaem: men beeft daer oock beel heete ballepen daet beel frupdtboomen groepen ; ende oock tun̈ngaerden; groote dzagnic enoe limorn-boomen; men leeft baer oorkeen [pecerye welck [p naemen Can ela, die lp ban't gljeberghte balen/welck naet toofen leght van de ttad. lisebben menighte ban rattoen/ Daet Ip laken ban maken om mede te klecoen / ende betaelen gaer tribupt in cottoen: men bondt fiet oock beet uan oe frbapen ban oe lanoe / daer wp fiet hoosen ban

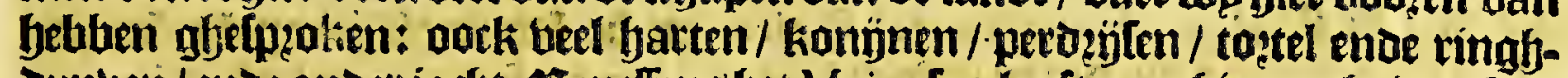

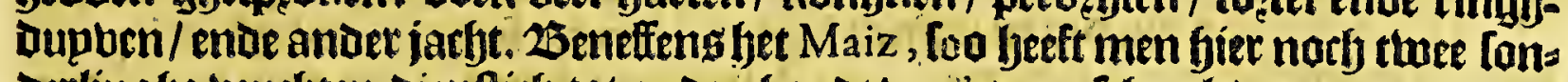
derlinghe beurbten dientich tot onder-houdt ban's menleben leven: de eene noe= men lp Papas, welck jün als aerdt-aetkers / ende naer dat bet ghefoden is / foo ifl foo mals van bimnen als engheloden kaltanie; maft onder d'aetoe/enoe fefict een loof upt / min ofte meer als twiloen beul die ander hoom waft. Be andere normen [p Quimba ofte Quinua, melsk loof beeft als bet ourcks koom/enoe waft een mans lengh be boogh/ ende geefteen beel klepn jadeken/ Lommighe twit/ commighe roout. De Jnoianen maken daer Dzanck af / ende eftent oack in pot-

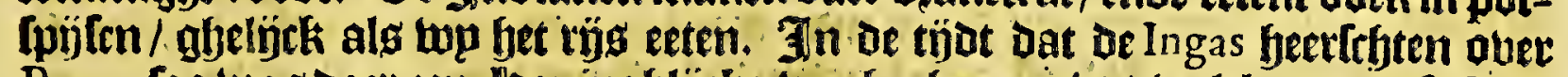
Peru, foo was daet een Jtoningblïtle wegh ghemaeckt / welck ban defe ltadt repelite tot aen be ftadt Cufco; ban waer hieder alloo groote ende trefligt ie luegb liep tot in Chile toe; tweltk van Quito af wel twaelf bondert leguen is. Op

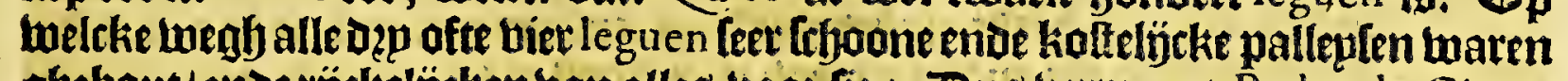

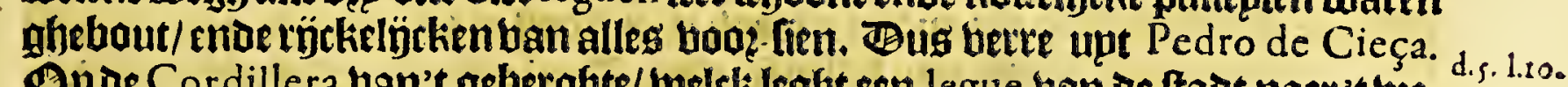

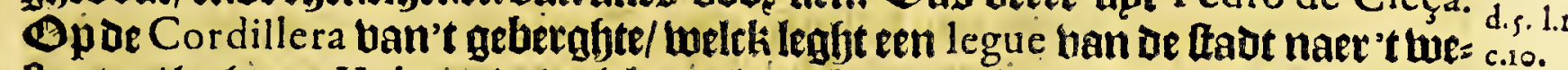
Aten toe / leght een Volcan, De welcke teel roocks upt-gheeft / ende groot ghelupdt maeckt / ghelijck als oft bonoerde / ende pleeghy oock beel aftergen upt te mozpen:

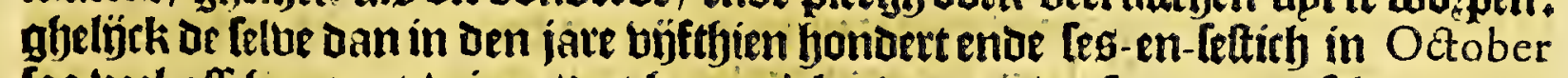
foo beel affitens upt-mierp/ oat bet aen tlanat enoe vee frer groote frbade dedel

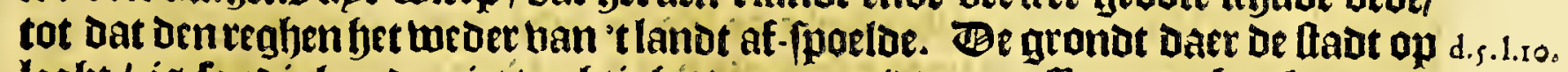

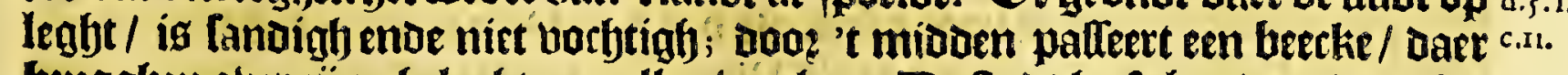
bqugghen ober jön gbeleght aen allen wegben. Be ftadt beft beede ende rectjte

Itraten/ 


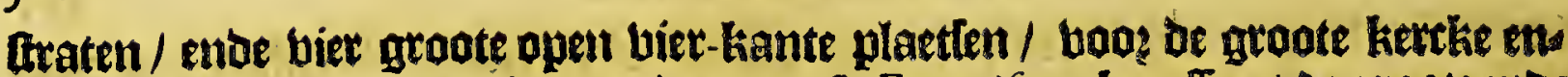
of boo de kloulters ban St Domingo, en St Francifco ; beneffeng of groote ende cathedeale kerche/ jünoer noch twee/ De eene ghenaemt San Sebaftian, ende d' ans

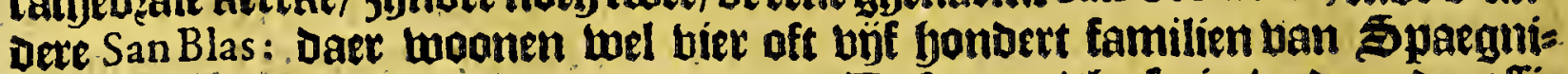
aerden; efnighe jootugelen ende beembe. Defarteur/theelogier/ endor ander affis

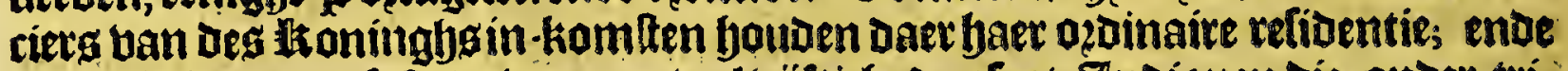
in' $t$ diftict ban defe ftadt woonen wel bjeftich oupfent Indianen die onder tris

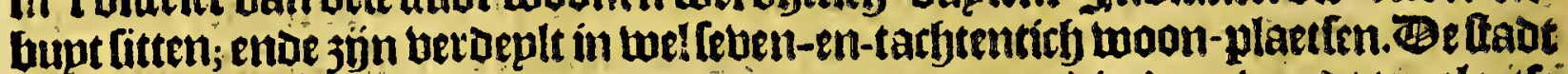

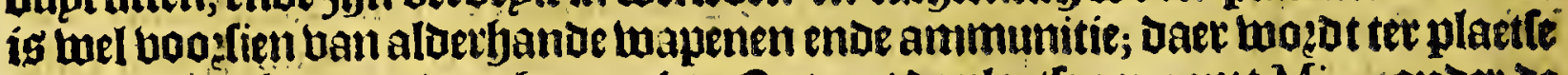
felfo [eer goet bug-poeder gbemaetht. Ontrent de plaetfe genaemt Mira, onder de

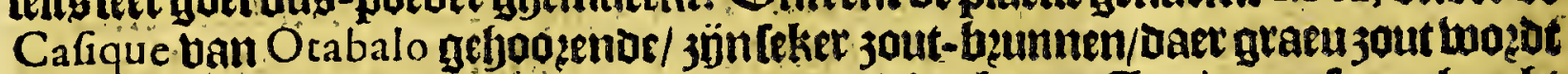

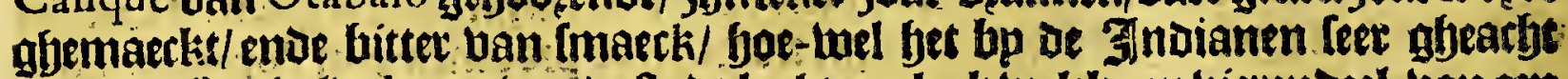
mozot. EEen Galbe legue ban oe fradt legbt een lack welck een vietendeel ban een. legue aroot ig/ Daer bem teelganlen ende ander gjetuogbelte ontfoubt. Be ans

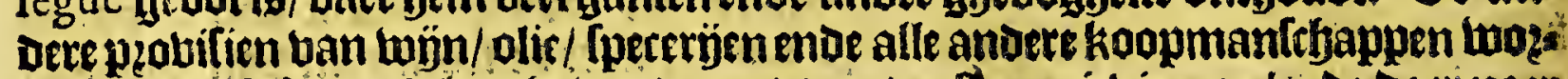

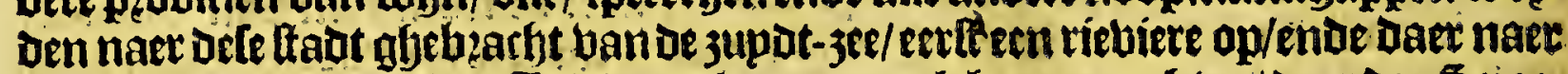
te lande met katren. De Indianen youden oock hate matckten/Daer oe spaes

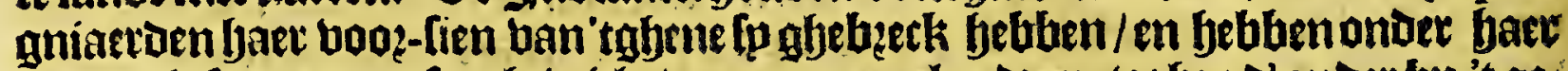
gfeen ghelette mate ofte ghetwicht/ maer mangelen d' een teghen d' ander bp 't ges fichte. Ben peincipalen bandel van 'tlanot bouen bet ghejaep ende bee / beftaet meelt in lebapen-kaes ende lioepen-kaes/ooc vangepten/ kleetkens ban cattoen/

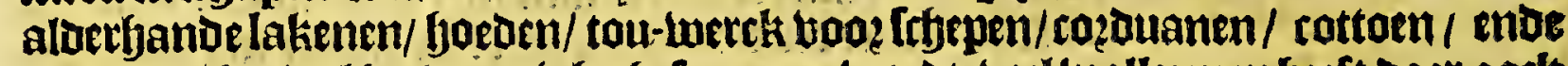
beel blas/ boetwel bet wepuing ghelponnen wogot; veel wolle: men beet daet oock eenigle fupthet-Ingenios, ende aloer-bande manufactueten.

\section{Het lefte Capittel.}
De wegh van Si Francisco del Quito naer RHIOBAMBa toe, ell- de de gheftalte ende gheleghentheyt van de landen ende volckeren tuffchen beyden.

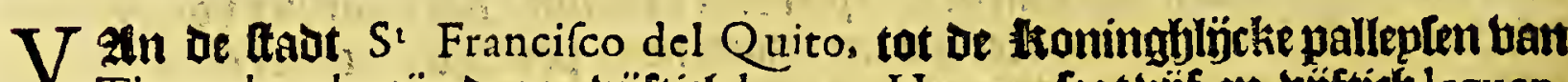
Thomebamba zün Dąp en büftich leguen; Herrera legt vijf-en-büftich leguen, welck wp bolgheth om Dat of reeckeningh beter upt-komt; enoe men treckt booe beel andereplaetfen die top bier terbolgheng upt Pedro de Cieça lullen aen-teers

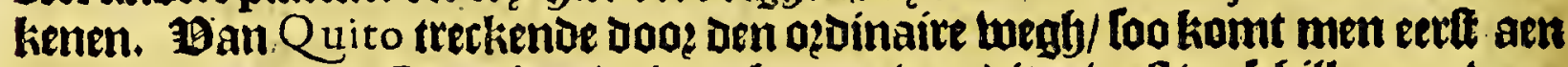
eenplaetfe genaemtP a çaleo; de in-gebooente ban ditgetwett verfefjillen een twęs

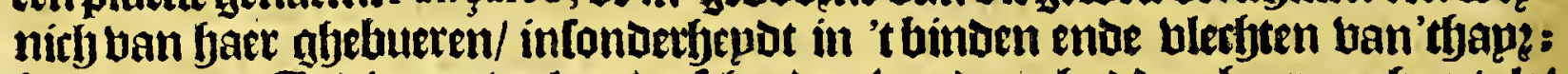

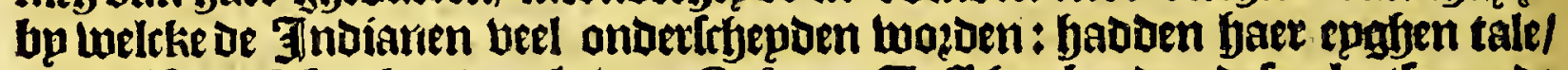

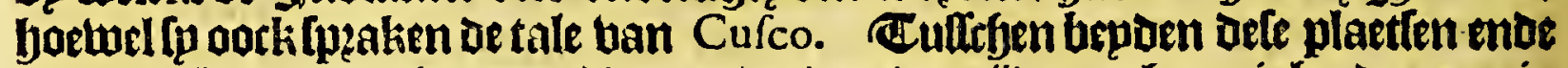

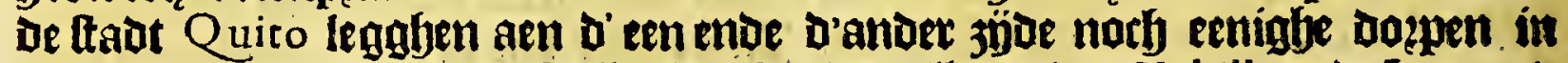

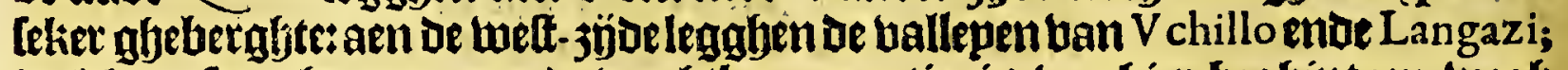
welck een leer glyetempert ende buthtbaer quartier is; banbier beghint een wegb

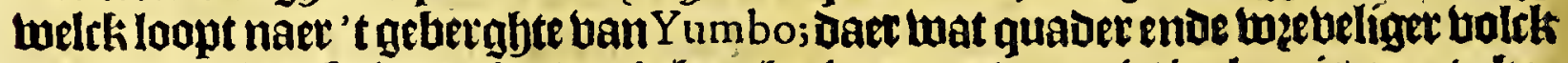
- woont/om Dat [p in een hardt gheberghte woonen daer nirt lwel en is aen te kos men. Baer loopt noef een anderen wegh naer't ooften toe / welck gaet naer oe Quixos, Daer tup hier naer ban fullen [petken. Deppleguen boożer alg Pançaleo, leght de herberghe ende'tboep wan Mulahalo, almaer eertht's goece ferbergen eñ

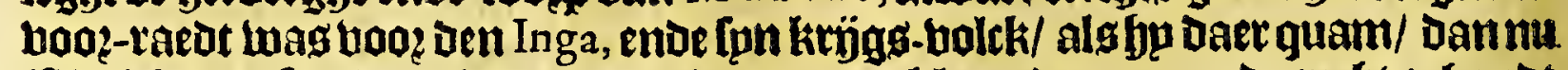
ift bolck Daer Leet berminoert/ende ís maer een klepn boep: aen de rechter yands

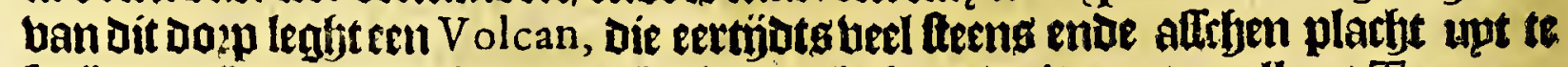
Imöten. Een kepniqgy voozoet legft de blecke ente 'tgroote pallepg Tacunga, welc allo treffelincti was in vooz-tijoen als dat ban $Q$ uico, enot bijfthien leguen Daer ban geleghen naet bet jupuen alg Diego Fernandes getupgbt/ 'twelck notb 
Het thiende Boeck.

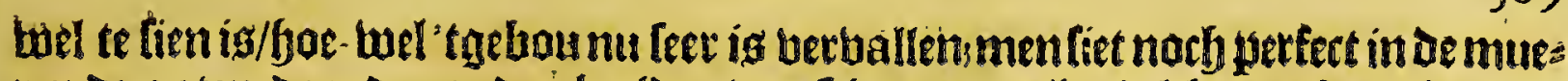
ren de gaten daer ذe gouden beelden ban frhapen eertijts beblen geftaentjadoen Gier een tempel daer fp De fonne aen-baden met faer maegboen toele fo noemDen Mamaconas, om den dienft te doen. Bele plaetle was upter-maten toel voos-fien

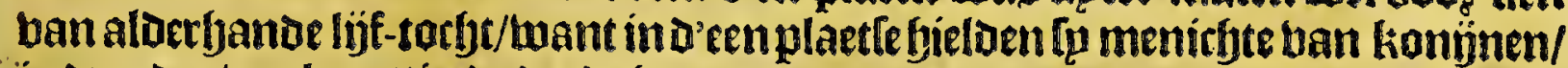

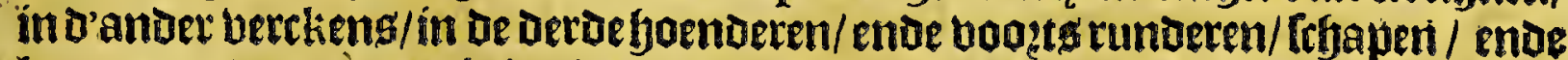
lammeten/ende gaeboghelte. Je hup[en jün al ban feen gemaecktenoe met ftroa

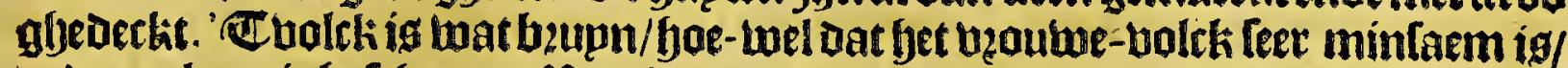
ende oockeenighelfyoon. Ban Tacunga tomt men langhe ben boogbe wegh ban de Ingas te Mulambato, daer oock ferbergben baren/ ende boos-raedt ban liff-torbt ende anderg / ende 't bolct ban oe felbe manieren endeconditien als die van Tacunga. Ban Mulambato kome men aen de rietuiete Ambato, Daet oock enighe ferberghen twaren als de booz-gaende. Bep leguen vooter leggljen de Koftelíek palleplen Mocha, die feer groot waren ende wonder om fien/ hoewel fo nu ghelijtk de andere geboutuen bande Ingas meelt berballen jün:ontrent $\mathrm{Mo}$ cha tuoonen noch eenighe Thuianen/ ban manietenende gheftalte alg de boo? gaende. Raer 'twetten legghen eenighe doepen ban Jindianen luelck fu noemen Sichos; ende naev' toolten die [p noemen los Pillaros; woonen in een bzurthtbaer-

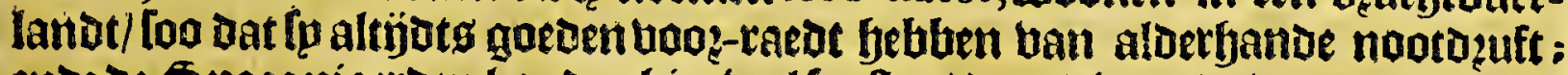
ende de Spaeghiaerden bouden bier beel beetten/ Doo? die goede twepden die men

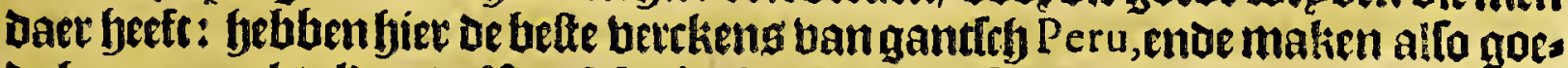
De fammen alg eloers. Dan Mocha komt men te Rhiobamba, Daer alloo kofte=

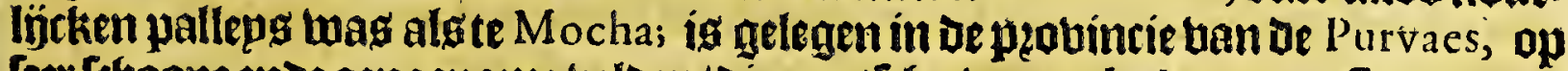
teer frboone ende aengename beloen/ die ganttry abet een kohten met Sparghien in de getempertyept ban de lurbt/krupoen/bloemen/ende anders. De fladt ban

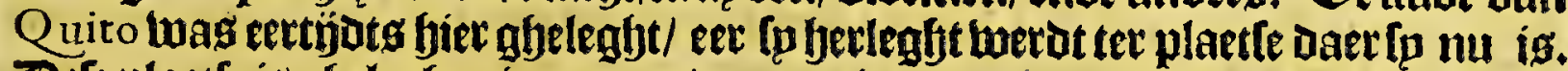
Defe plaete is ghelegfen in een goed quartier: ente tualch is beecotlarm/ ende gaengekleet als die ban Quito : Dzagen feer langh fapz/fraepkens op-gebleght.

Herrera legjt dat R hiobamba leggt bijf-en-twintich leguen ban de fadt $S^{t}$ Francifco del Quito naer 't 3 upot-wetten toe; (Diego Fernandes maer twee-entwintich leguen;) ende dat nu een moon-platte is ban berders / [oo dat daet twel beettich duplent koppen ban bee 3ijn/meeft fegapen.

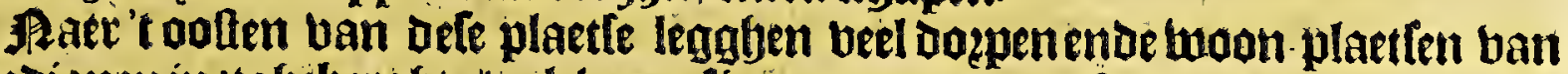
Indianen in 'tgheberghte/welcke contineren met denoo:Lzongh ban se rieviere Marannon, ghelijtk Cieça ende Herrera die normen ende met bet gljeberghte ban Tingaragua, Daer voets teel Doppen om ligghen. ßater't wetten leght een ander fueeu-geluetgfte/ welck fp noemen V rcolaço Daev oock beel boleks twoont / ende ontrent delen bergh leght een twegh die naet Sant Iago de Guay aquil loopt.

Dan Rliobambakomtmen te Cayambi, welck jün andere berberaben: in een black enoe koubt lanot gaelegfen; ente ban daet aen de Tambos ofte palleplen

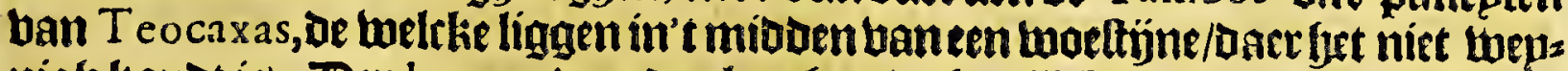

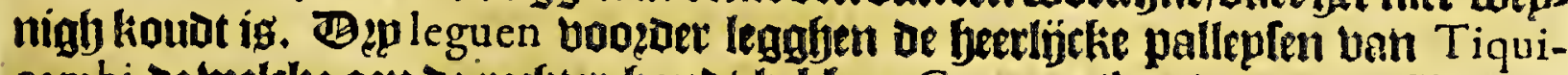

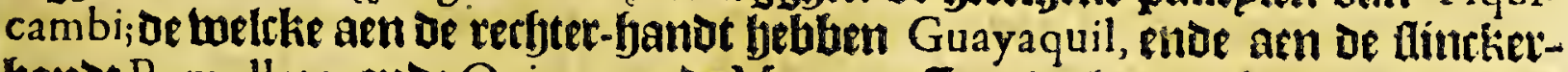
Gande Pomollata, ende Quizna, ende Ma cas, neffeng beel ander landen endep:o: bintien die naer Rio grande toe ftrecken. Pan bier daeltmen naet de bebergbe wan Chanchan; infeet landt/ welck Daetomghelinck alle andere beete ghelueten/ bp de in-ghebozene werden ghenoemt Yungas. Ban bier beeftmen noefj twintich leguen tot de magnifique pallepten ban Thomebamba, ende alle Dele twegl is elcke twee / Dzp / oft vier mijlen booztien ban Tambos ende herbergben/ onder de welcke twee peincipaele 3 ijn / ban twelcke de eterte berot glyenoemt Cannaribamba, ende de andere Hatuncannari : tan tueleke de in-gheboone ben de lande de naem uerkregben bebben ban Cannaris, welck [p noch bebouden. 
Fet lebende Capittel.

Van'tkoftelijck Palleys van Th о ME B MBA; van de CANNARIs, de gheftalte van haer Provincie, ende hare manieren.

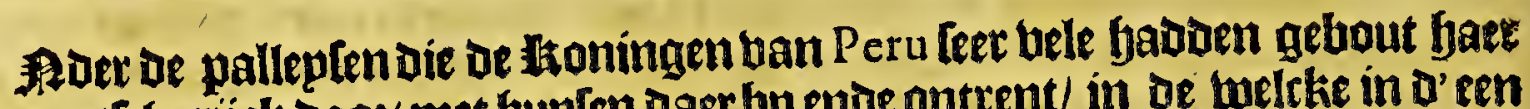

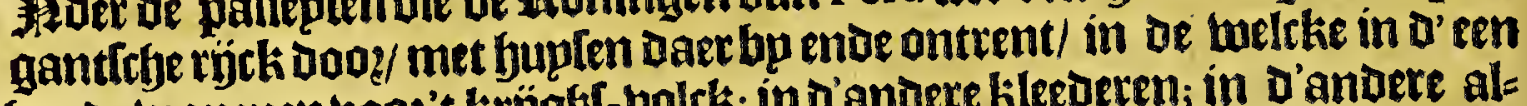

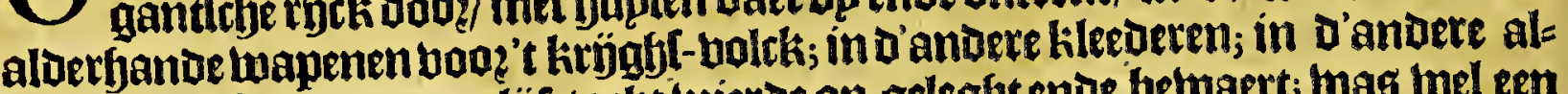
oethanue booz-raedt ban liff-tocht wierde op-geleght ende belwaert; was bel een ban de upt-nemenfte in rỉckdom ende magnificentie fet pallepg ban Thomebamba, gyeleghen in oe ptobincie ban de Cannaris: ban'thelcke De Jndianen wonder wetente verbalen/ Doch niet foo veel/ ofte men kan noch wel Leuren aen

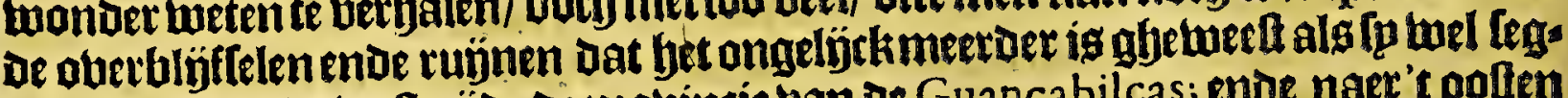

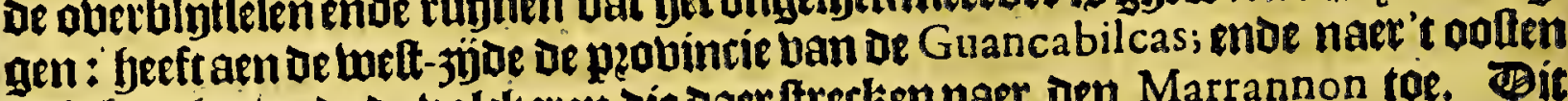
'tabelergfte/ende De volckeren die Daer ftrecken naer Den Marrannon toe. Dit palleps is gljeleglyen aen eenplaetie daer twee riebieren telamen komenop een blacke campagne/ jie wel twaele leguen in 'tronde is. Jo cen koude contrepe/

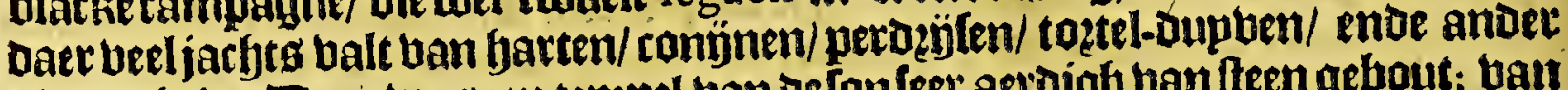

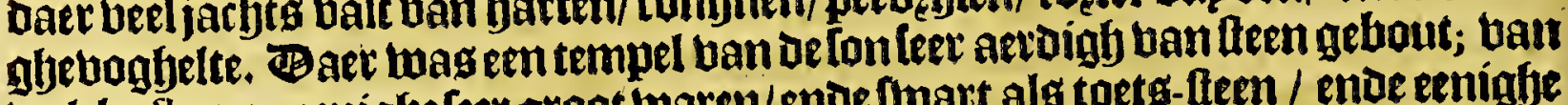
welche tteenen eenighe leer groot waren/ende fmart als toet -fteen / ende eenighe

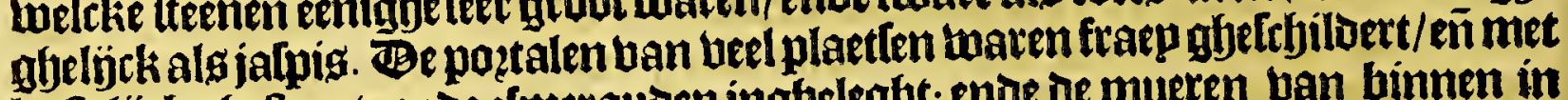
koftelÿck glyelteente ende elmerauben ingheleght; ende de mueren van binnen in

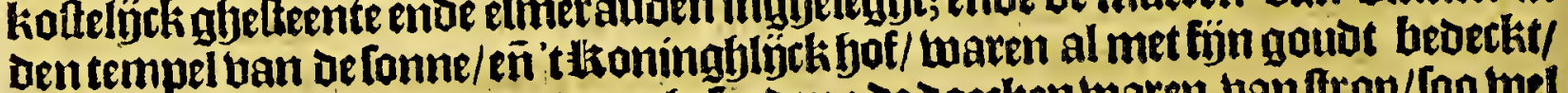

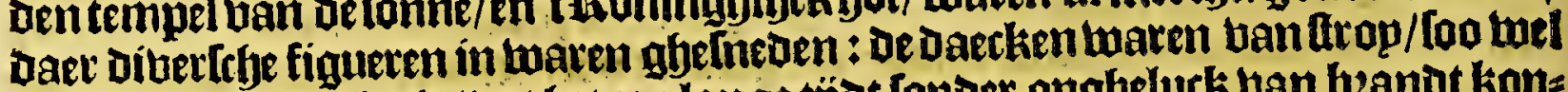
glitwoeglyt ende geleght/Dat bet een lange tijot Conoer ongbeluck ban bzanot kon=

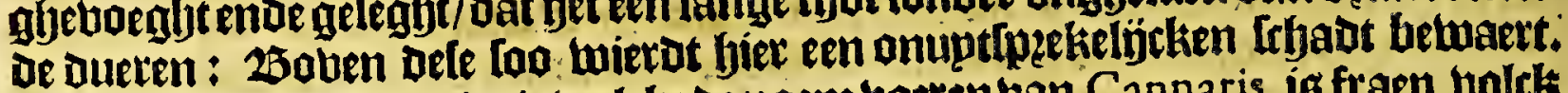
- Cuolck ban dele peguincie welcke denaem boeten ban Cannaris, is fraep volck ban lichaemende aenficht/Dzagen langhyapg / ende 'tellue in lulcket boeghen opgeblecht met een kroontjen op'thooft/ bat [n daet hp van De am-leggende bolckes

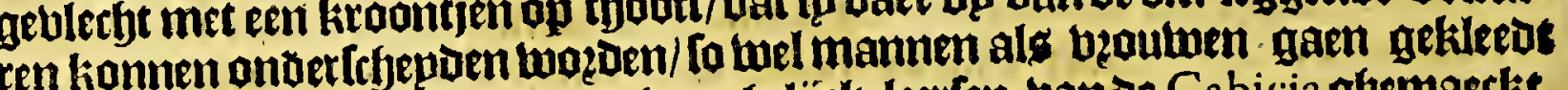
in wolle ende tottoen; ende dzaghen ghelíck leerten van de Cabicia gfjemaeckt.

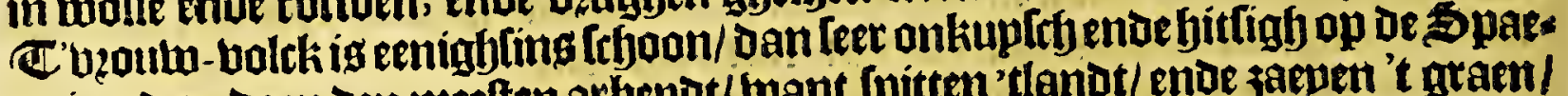
guiaerden; Doen Den meelten arbepdt/ want fpitten'tlandt/ende jaepen' 't graen/

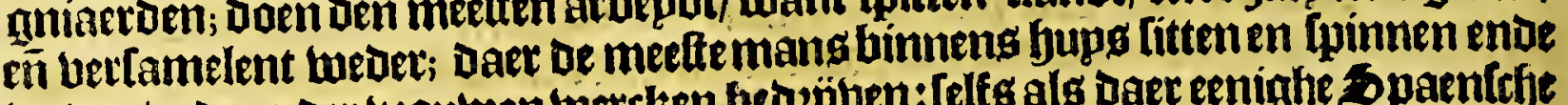
weten/ende ander bzaulwen wetcken bed troupen boge-trecken/verleenen fp fjaer broutwen entoe Dorhters om ve bagagie te Dzeghen enoe [u blïben'thupg/ welck eeninge daer op fteken/Dat daet onghelj̈ck

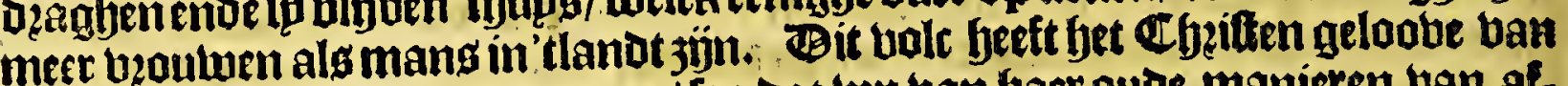
oluer langh beginmen aen te nemen/ Fo dat wp ban haer oude maniexen ban af-

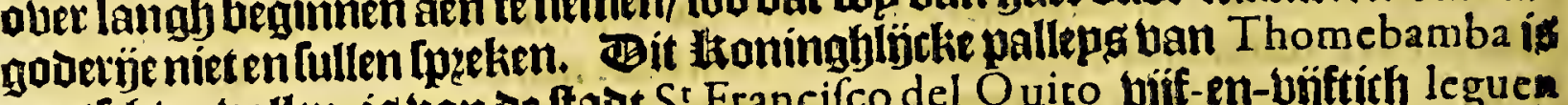

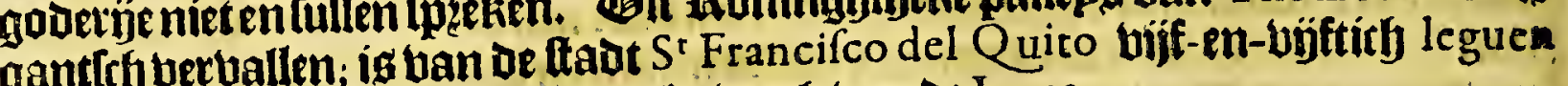
werabs/al langhg de knoninghlijcke twegh ban de Ingas.

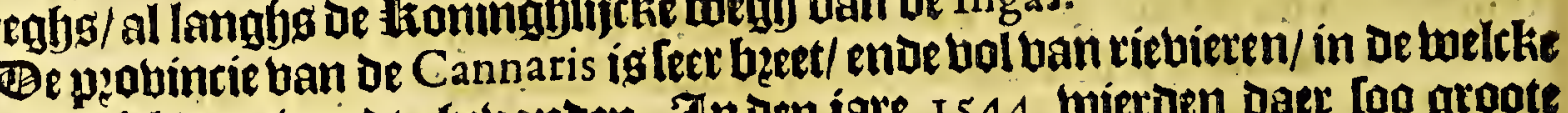
groute rijckiom wozot ghetuonoen. Jn Den jare 1544 wierden daer loo groote enderijcke mijnen ontoecht/ datde burgherg ende' in-moonders ban Q uito, Daet wel arbt ljantort Dupient Pezos goudts upt haeloen/ ende de menichte ban 'tgout wag foo groot/Dat [p bp naer [oo ueel goubts als aec oe teffens upt-haeloen; gelijck 'treltue dan op Teerliere twetentryap bp Pedro de Cieça tozot berfjaelt: In allen

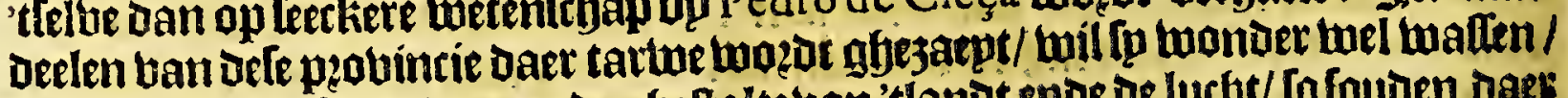

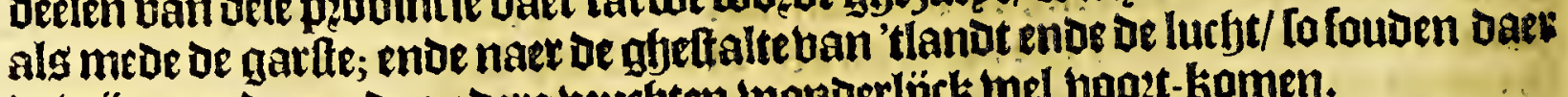
oe wïngaeroen ende anoere beuchten wonderlijek toel boott-komen.

Ban Thomebamba en leght geen gebupckelijeken wegf naec de jee-kulte toel ten ware booz de limiten ban de ftaot San Miguel, daer top bier naev ban fullen apeerchen. 
Het thiende Boeck.

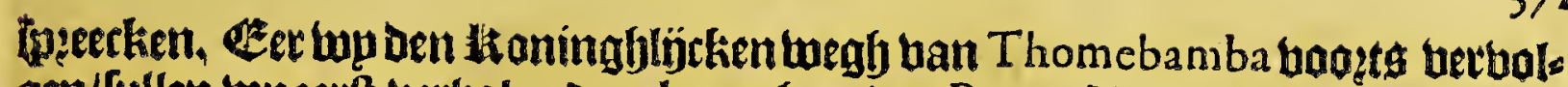
gen/[ullen wpeerft verbalem de gelegenthept ban Puerto Veio, ende de landen daet

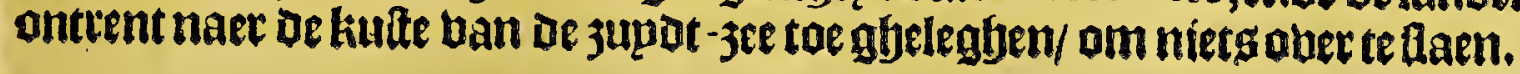

\section{Het achtete Capittel.}

Befchrijvinghe van de wegh van de Provincie van Qurto, naer de kufte van de zuydt-zee, ende de gheleghentheyt van de landen

daer ontrent gheleghen.

1) depalen ban be pentincie ban Quiro, enteniet leer berte ban Rhiobamba, Ieght ae pzobincie Chumbo; Doch eer ghu Daer aen kount / foo feeftmen cię̧x c: norfy beel doupen daer beel ende leet bequaem balck twont/ welck al onderferbeps

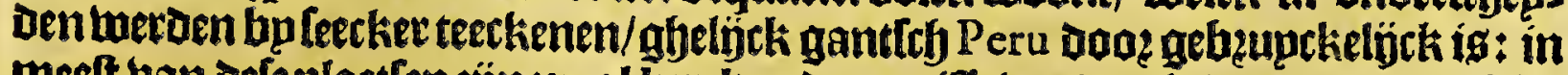
meelt ban defeplaetlen jön nu al ketcken daermilfe werot gbedaen/ende de kin= Deren ban de Indianen de gebedekend geleett. Ban dele prabincie Chumbo treckt men beetthien leguen bogeen moepelincken ende ltwaren wegly/tot aeneenrievier baet de in-ghehoome altzo otg blotten ajereet Gebben om de replende lieden langa de riebiere te boeren/ tot arn een plaetle die lp noemen el paffo de Guaynacapa: Daer twp bier naer nocty fullen ban roeren.

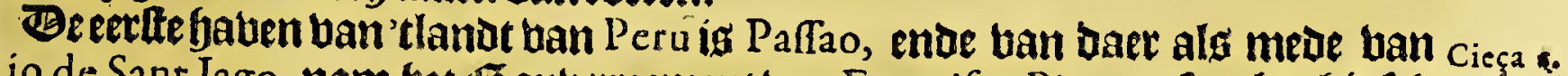
Rio de Sant Iago, nam bet Goubernement ban Francifco Pizarro fon begbinfel; 45.

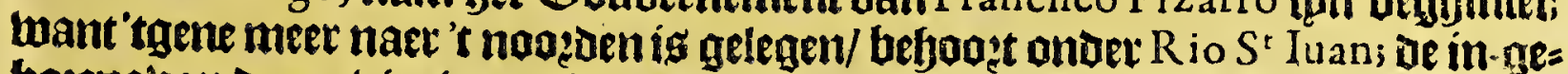
bozene ban de pyabintie uan $S^{t}$ Iago de Puerro Veio, jün uan miduelbare fature ende befitten een leerbutgthaet landt/ Dooz dien daer groute menichte ban Maiz ende luca walt / als oock Batatas, endeanoere woetelen bequaem tot onderthoud van'smenlchen leten : pock beeftmen Daec beel goede Guay a vas ban twee ofte Dẹp footeny Guavas ende Aguacates, Tunas bantwee tooeten; Caymitos, ende een an: Dere beucht dis [p noemen Cerezillas. SGen beeft daer oock bed meloenen eñander beuchten ban Spaegmien: beel betckeng ban de lande die de nabel op oen rugge bebben/ ende bercfiend ban Spaegnien; ende beel lyatten banalloo fonterlinglye

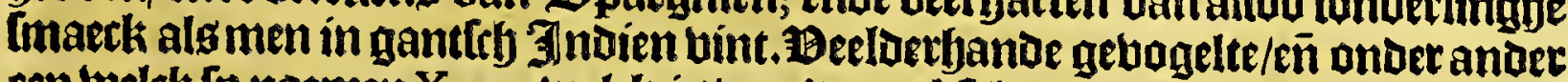

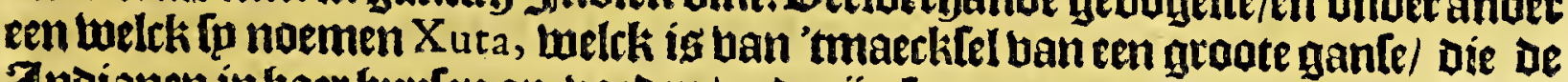
Zndianen in faer huplen op-boeden/ende jün leet tam ende goet om t'eten. Cen= De een ander welckfp noemenMaca, wat minoer als een baen/ende feeft fo ftyoun couleur ban beeten dat bet lwonoer is am fien; jeeft een beck wat grooter als een bingfer/ende ban twee couleuren geel en rooat. Op tobebergljte ende inde dels lingen 3 g̈n groote ende dirfte boamen ban ueetaerlep [oosten / ende bequaem om

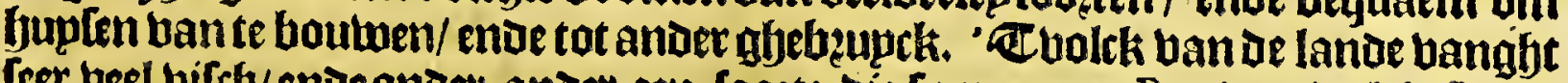
feer beel biffy/enoe onder ander een loozte die fp noemen Bonitos, welck deef)te

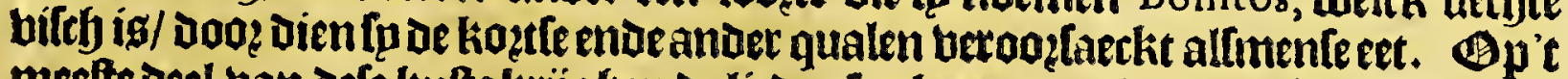

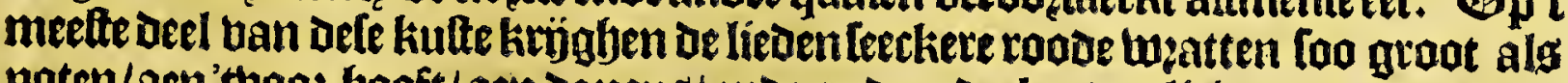
naten/aen'tboos-booft/aen deneug/ende andere deelen deg licharmg; ende men

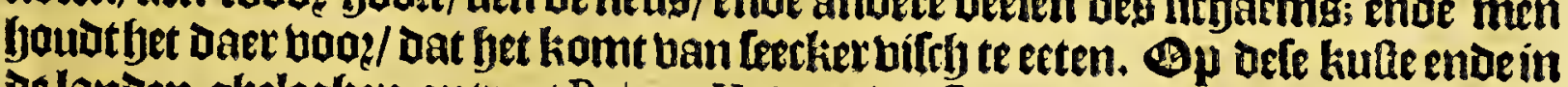
oe landen gbelegfen ontrent Puerto Veio ende Guayaquil bebt gljp tweederlep

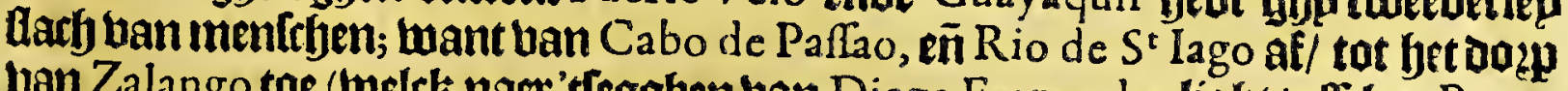
uan Zalango toe (beltk naex'ttegghen ban Diego Fernandes light tullelyen Punca de Sant Helena ende Cabo Sant Laurenzo) jün Loo twel mans alg vzoutwen init aenficht ghepirtkeert/ ende gfjefneden ban 't uptertte bande ooze af tot aenoe finne: bevcieren hacr met diberfefye tlepnodien ban goudt / enoe feeckere klepne kraeltieng die fp noemen Chaquira colorada; welck roodt Chaquira een feer joogh obeacht dimgben is in alle dele quartieten. Be principale doepen daet dit bolkk moandt / jön Paffaos, Xaramicho, Pimpaguace, Peclaufemeque ende de ballepe ban Xagua, Pechonfe, ende die ban Monte Chrifto, At 1 Apechigne, 
372

Peru.

A pechigne, Silos, Canilloha, Manta, Zapil, Manavi, Xaraguaca, ende andere:

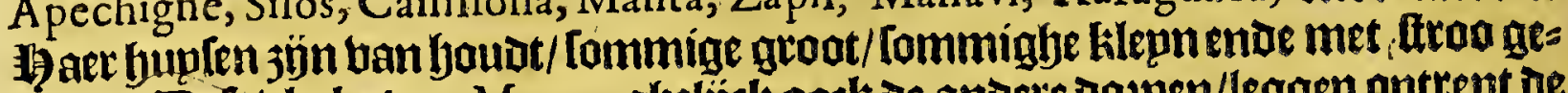
Deckt. Befe blecke van Manta, ghelijck oock De andere Dozpen/leggen antrent de liufte ban De 3 updat-jee/ ende de Jndianen quamen in booz-tjoen bierlaen-bidoer een [eet groote elmeraude / ende baer offerbanden daer vooz doen; entoe men fout booz feecker dat de múnen van de elmerauden daer ontrent te lant- maert ín legs

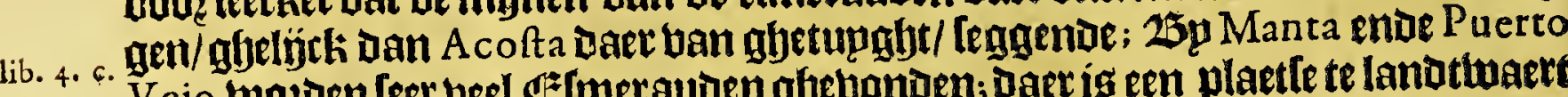

14. Veio wożen leer beel Gefmerauden ghebonden; daer is een plaetle te landtwaert in/ Die [u naemen de las Efmeraldas, Doo de kennifle aie men feeft dat Daer beel

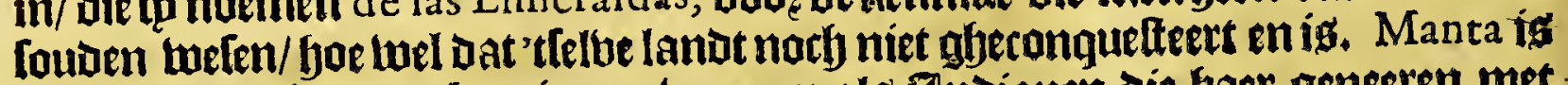
nu eenfabentien daet bp niet en woonen als 3 ndianen die baer geneeren met toutwen ende kabela te maecken.

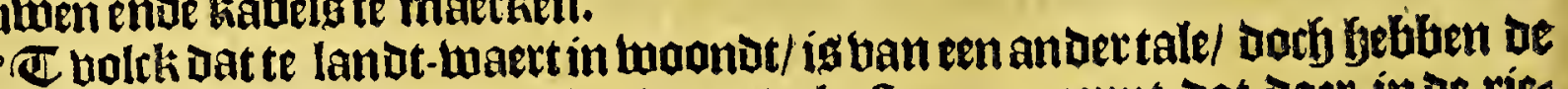

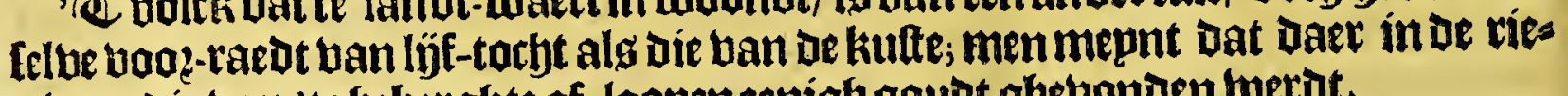
bieren die wan'tabebergbte af-loopeneenigh goudt ghetuanden werdt.

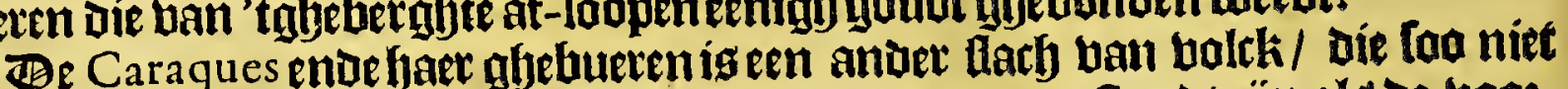

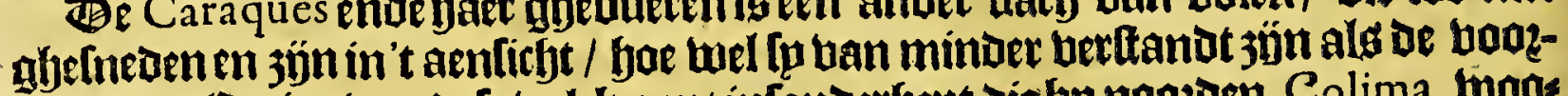

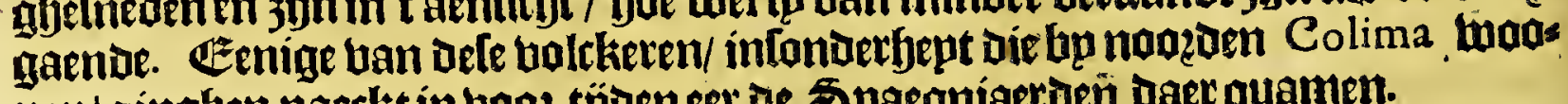

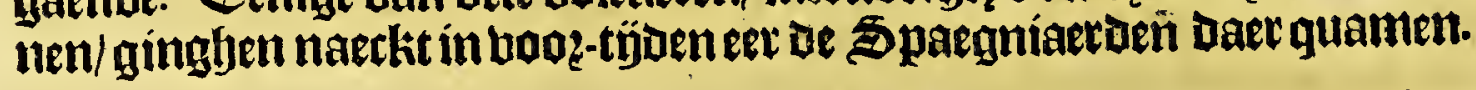

Yet neghende Capittel.

Befchrijvinghe van de Stadt Puerto Vero; ende de Stadt $S^{t}$ Iago de Grayalili: Ende Castro in de Provincievan Bvnigando,

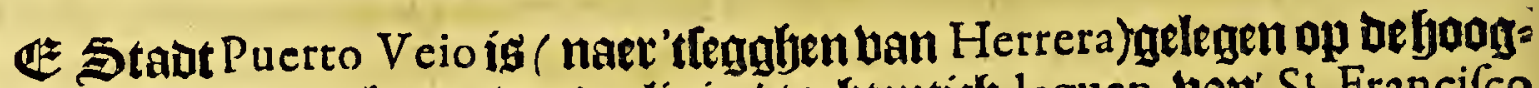
te ban een graeat bu jupden de linie / tachtentich leguen han' $S^{\prime}$ Francifco del Quito naer'twelten/boe twel dooz abeen open ende bequame twegh/ende búf: tíchleguen ban $S^{t}$ Iago de Guayaquil, niet leer betre han de jupdt-łee. (Diego

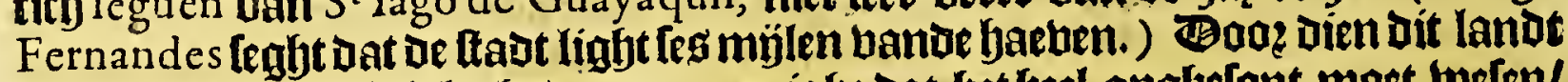

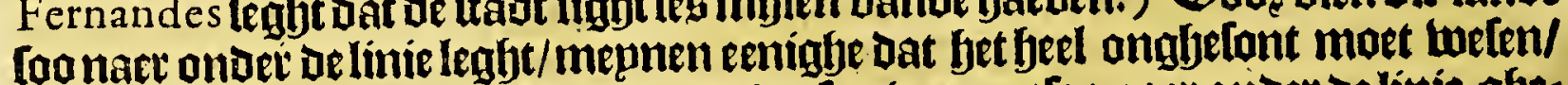

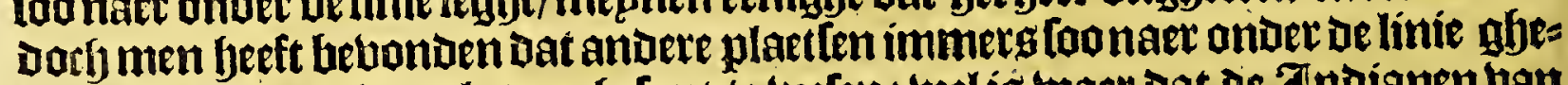

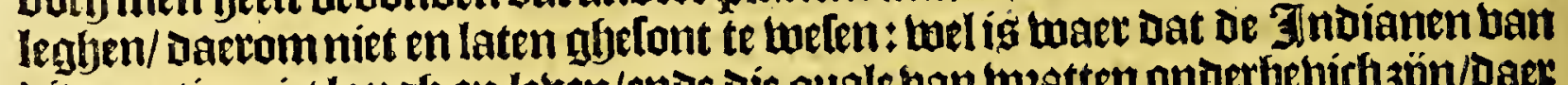

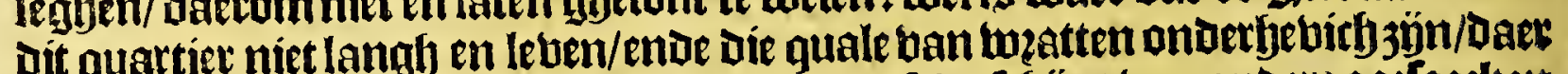

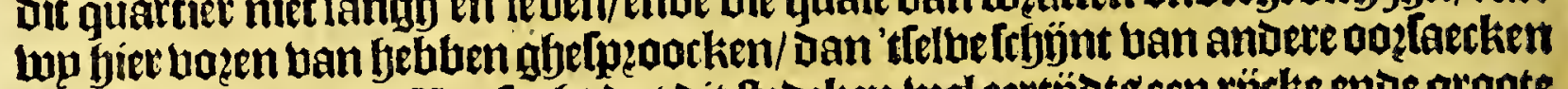

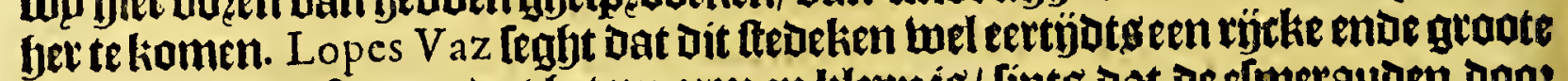

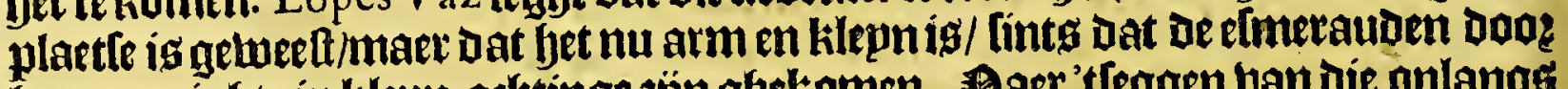
haer meniafte inklepn acljtinge 3 jun ghetsomen. Paer'tleggen ban die onlangs Daer jün ghelueft foo Louden in dit ftedeken ontrent 3 o familien ban Spaegni. aeroen waonen/ welcker rijekjom meer beltaet in beeften/ dan in gellot. Ontrent

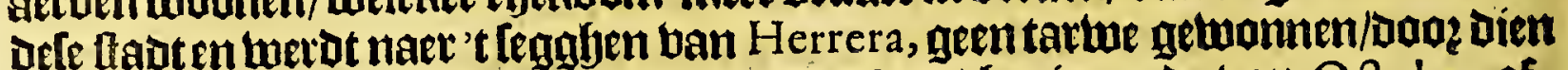
het daer bp naet ar ht maenuen ban'tjaer regfent/ beginmende ban Oetober af; an daet is groote apparentie datter rijcke goubt-mp̈nen fouben te bindert Lerlen.

Her. de- De ftadt $S^{t}$ Iago de Guayaquil, De welcke oack anders nfenaemt wetot la Cu:

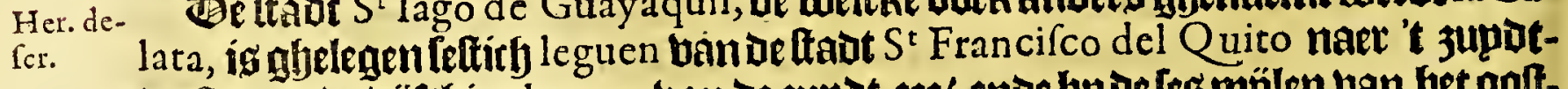

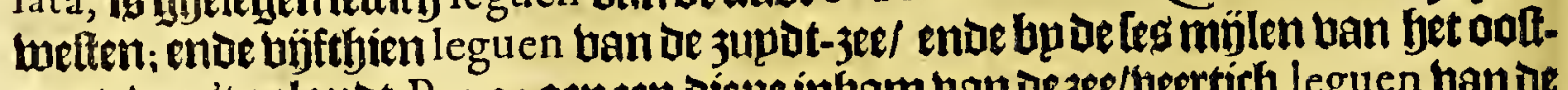
punt van't eplanot Puna : aeneen diepe injam van de zee/weertich leguen ban de haben ban Paita naer bet noozoen; ende aen't begin ban de inbam ofte mond ban De riebiece lsglyt een woon-plaetle ban 3 ndianen/welck [p noemen Tumbez.

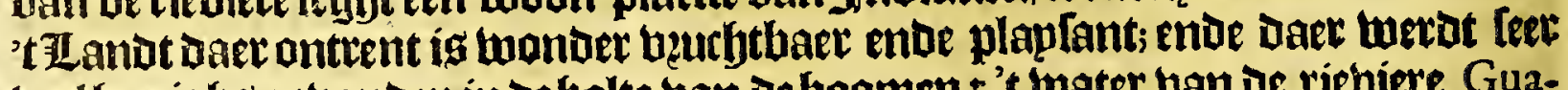

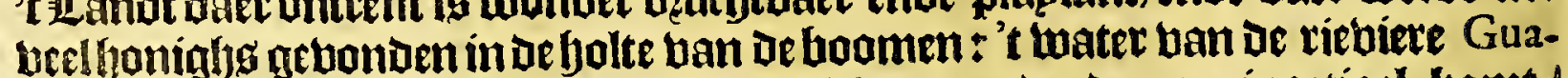
yaquil, Daer de ftadt naet ghenaemt is/welck ban ander Den equinoctiael komt /

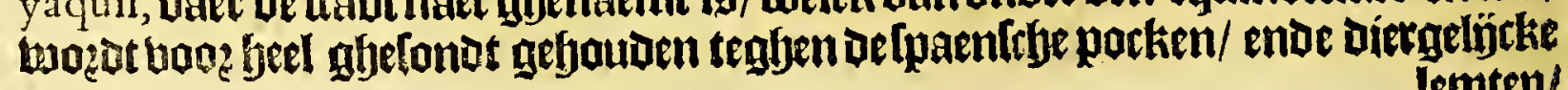
lemten/ 
Het thiende Boeck.

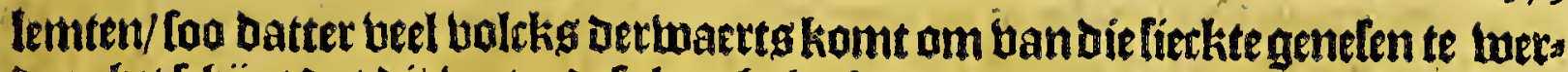
Den : bet [chyjnt dat dit water dele krarft beeft/megen oe groote menichte banZar. zaparilla, die ontrent eñaen Dele riebiere groepet. BDant daer wozot groote quan= titept ban orle Zarzaparilla ban biernaer andere quartieten berboert. \&Gen fjeeft

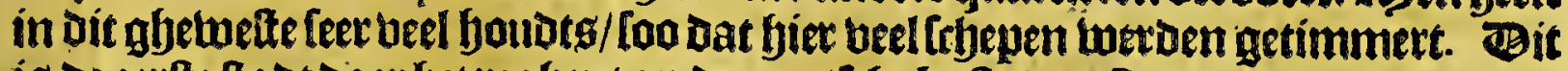
is of ectlte ftadt daet bet reghent op de gantlfye kulte ban Peru, van A tacama af/ belck leght bp Chile. Defe ftadt werbt bp de onfe indenjare 1624 ingenomen / Dan alco fp te fwack ban bolck twaren/enkonden die niet in-ljouden of te den bupt af-bengljen.

De rieviere ( to Herrera legft) en is niet groat/gelijckhp naer gbeene die in de

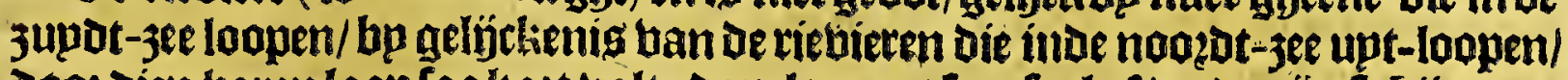

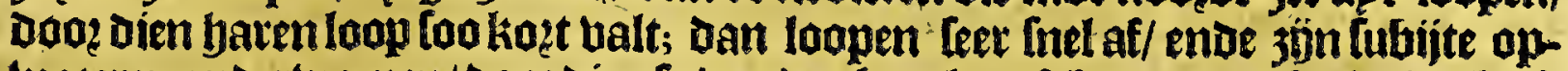
wateren ondertwoepen/ soog dien Lp ban't geberghte af-komen: ocle riebiere beeft Garen oof [p?ongh in de plobintie ban Quito, upt bet booge gebergte/ welcknaet 't ooften leght/enoe ondertwegben komen baer beel andere riebierkeng toeloppen/ foo dat fp (naer't leggben ban Herrera opeen ander plaetfe) wel anderbalf legue d. s.l. se?

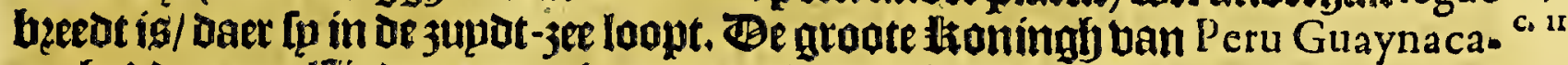

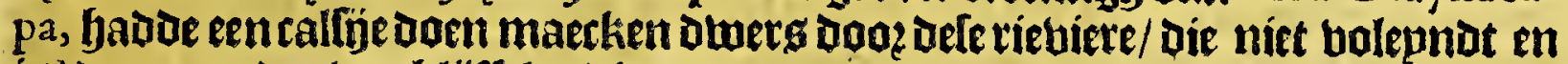
is/ Dan naer de ober-blijffelen diemen baer norfy ban fiet/ loo moet bet een trots werck nelweeft 3 jin; noemen't el paffo de Guaynacapa : welek naer Datte leggen (Eeght Cieça) twaelf leguen is ban' tęulanot Puna. Be koopmantrhappen die upt

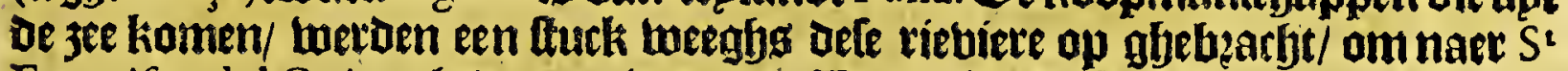
Francifco del Quito ghetioert te wozoen. Be natie ban Jnoianen luelek fp noe men Guancabilcas, $3 \mathfrak{y n}$ de in-moonderen bandefeltabt onderoaen; $\mathfrak{e n}$ beneffeng Defe/ too gffehoozent tot defe ftad of Dozpen uan Yaqual, Colonche, Chinduy, Chongen, Daule ende Chonana, ende andere meer: alle bele volcken moonen in

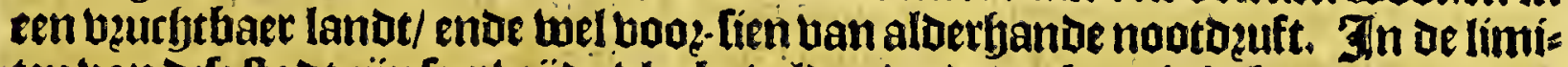

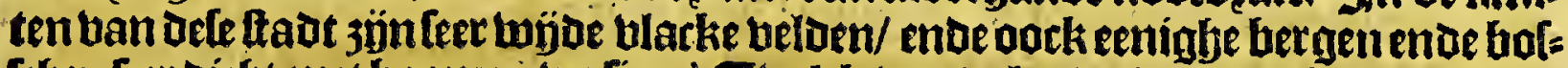

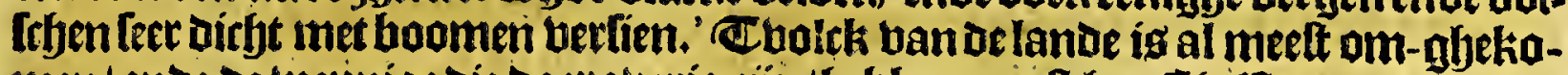

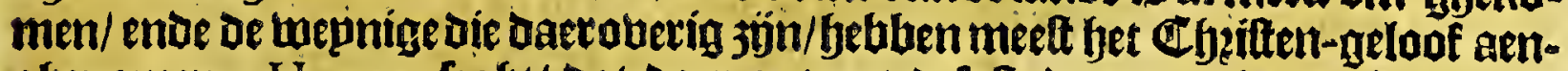
gbenomen. Herrera fegft/ dat daer ontrent defe lfadten natievan Jndianen moont die fp noemen Chonos, langhg De riebiere Daule; Diemet blotten de koops manfryappen Derieviete ap-boeten naer $Q$ uito ende antereplaetfen/ende dat fp anders niet bequaem en jýn om te lande te arbepoen.

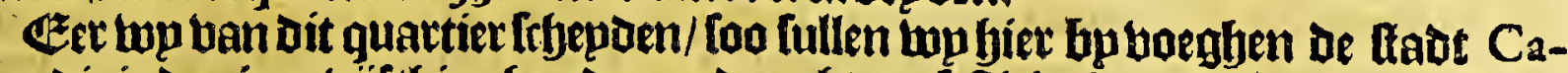

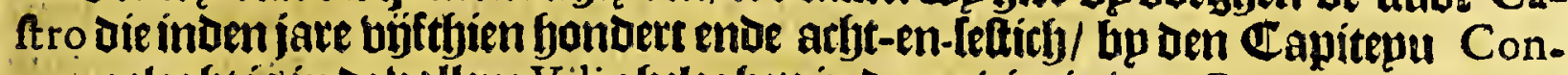
tera geleght tín de ballepe Vili gfeleghen in oe pzobincie ban Bunigando, Imdinono ende Gualapa, welek lp noemen de peobincie ban de efmerauben; fjp nam fun weg oertwaerts ban Guay aquil, ende ont deckte de bozbere plobincien vanPaffao af/tot Deriebiete ban S: Iuan, Daer bug fier boozen ban bebben ghelpzoken.

\section{(1)et thiende Capittel.}

Vervolgh van de Koninghlijcke wegh van Th о ме в а м в A af, tot de ftadt Loxa toe; ende gheleghentheyr vande landen daer ontrent; vande Stadt Loxa en Cuença.

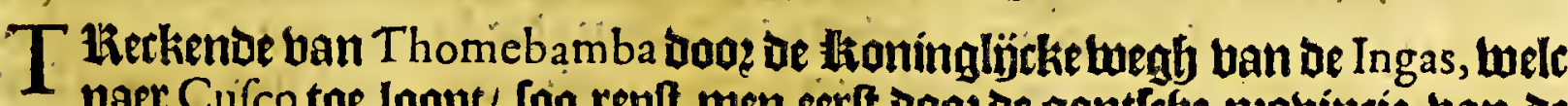

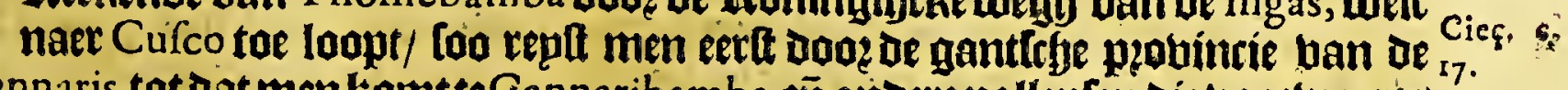
Cannaris tot dat mentiomtte Cannaribamba, eñ anijere palleptén die boo twaett upt-leggen: aen d'een ende d’ander jujoe lietmen beel dozpen ban de felbe peobins rie/enderen boogf geberghte aend ooft-jijde geleghen/ welck bp ooften aock al betwoont is/enoe fteckt bemnaer de riebiere Marannon, als lp die noemen. De peobincie han de Cannaris gepafteert jünue / fo koint menaen die ban de Paltas: 站 3 in of 
374

Peru.

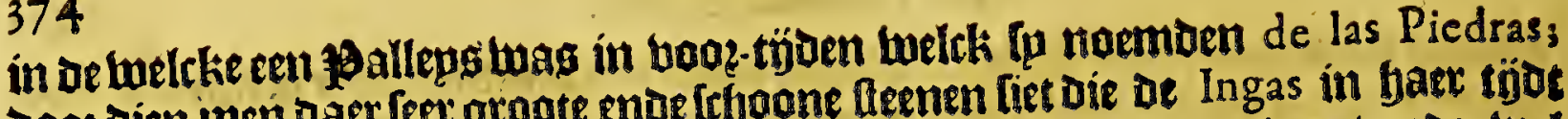
Dooz dien imen oaer leet groote mae fefoone fteenen liet die de Ingas in baex tijot

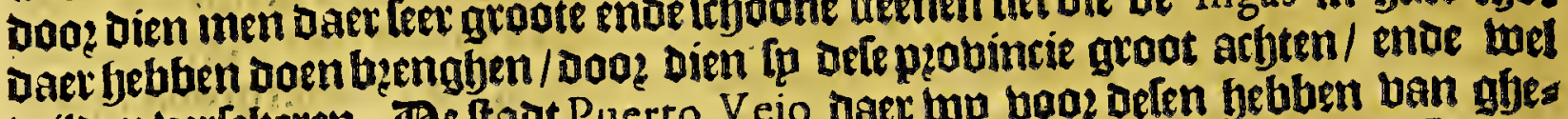
wilden beriekeren. De ftadt Puerto V eio Jaer wp booz deren bebben uan gyes

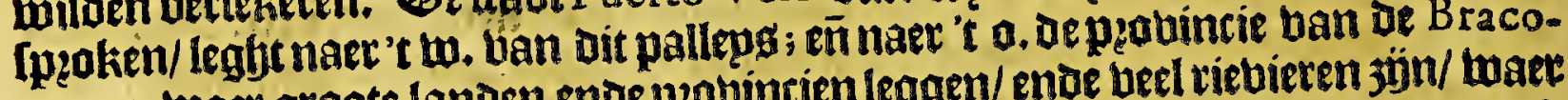
moros; waer groote landen ende pzobincien leggen/ende beel riebieren 3 jin/ waet

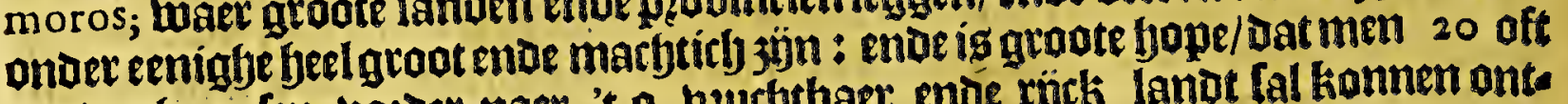
30 Jagh-repten yozoer naer 't 0 . beutbtbaer enoe rück lande fal konnen ont. Declien. Be wiloe ban die quartieren bp a. dit ghebergbte / gaen al naeckt / ende en $3 \mathfrak{g}$ ban toog goeden berltand niet als dieban Perti, en waren oock nopt bp of Ingas onoex fubjectie ghebzarbt. Ban oe pyouincie ban de Cannaris tot de thad Loxa jön 7 leguen, Teer moepelijclien wegh ende cenighe moeraften.

So baeftals men Ictept ban bet palleps de Piedras, to begint Daer een gebergs

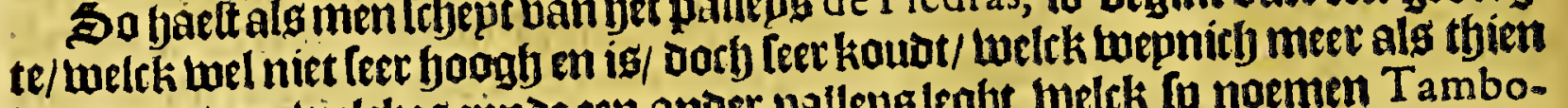
leg. Duert/aen Luelekes epnae een anoer pallepgleght welck fa noemen Tambo. blanco, van waer de Honinghlïrke wegh loopt naer oe riebiere Catamayo. aden

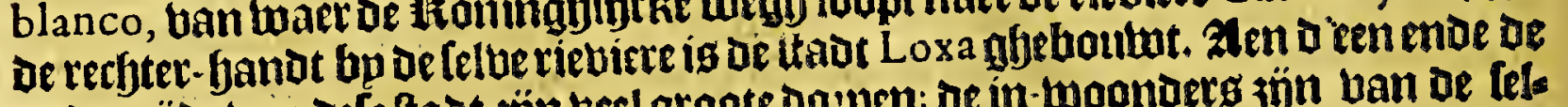
andex joj de ban of be convitie ende manieten als de voozgaenoe. De gfeftalte ban oe lutbt ban ore pzouincien ig goet enoe glyctonot : oe vallepen ende oevershan de rievieten zön

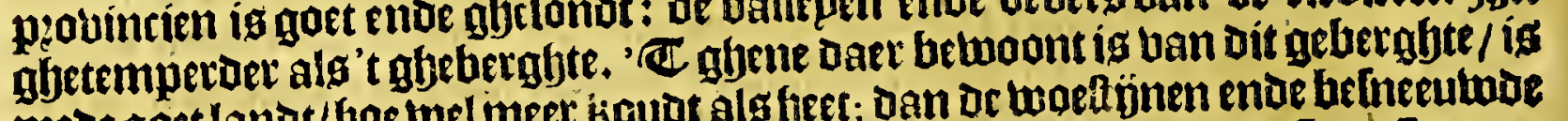

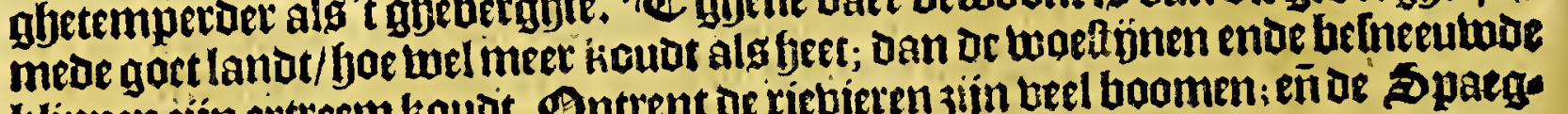
klippen sijn extreem koubt. Ontrent oe riebieren zijn beel boomen: en of Sopaegs niaerden bebben daer fints baer kom(te) beel frupt-boomen uan Spargmien ge: planot/ biefyeel bel toe-neinen. In de limiten lam oe ftadt Loxa, wozben beel uerckeng aen-gequectit/alsmede gepten/ ende ander bee. Ban Tamboblanco komt men aen of peobintien ban Calua trioe A ýavaca, belekna bet o. bebben de

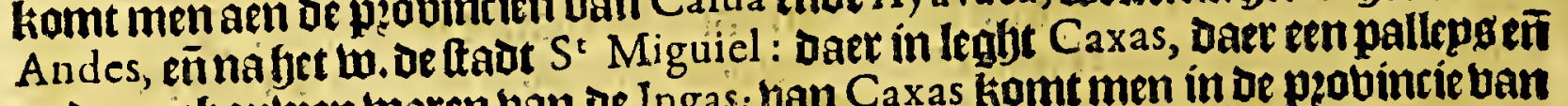
andere gebouwen waren han of Ingas; ban Caxas komt men in oe probintie ban Guancabamba, daer groote geboutwen twaren/als in De peobincie Calua; bagder leggen ander peobincien die ten oeele onoer Loxa befoozen; Daneer; wo boozoet ban defe ftaot [pececken/ [oo moeten wp oeftad Cuença niet booz-bu gaen/ díe naerder $Q$ uito leglyt.

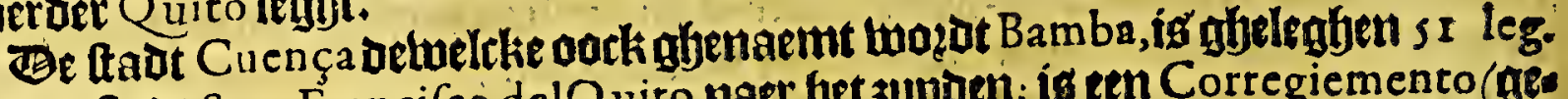
Mer. de - bam oe thadt Sant Francifco delQ uiro naet bet jupoen; io een Corregiemento (ges: Ser.de las linck als oe Spaegniaeroen Dat noemen:) Daer igeen kiloolter van bominicanew/

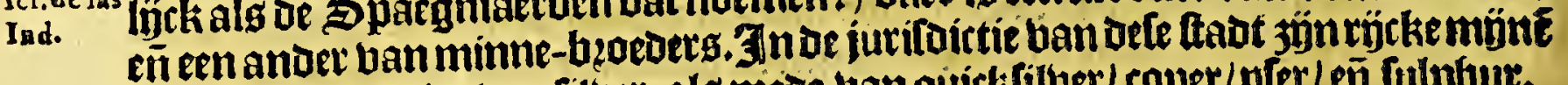

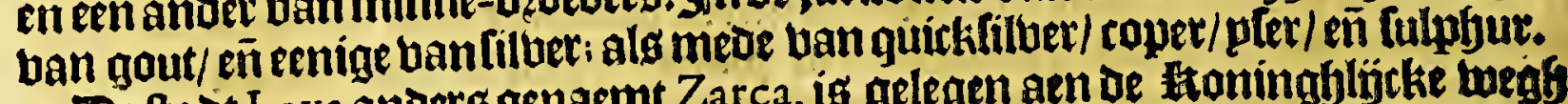

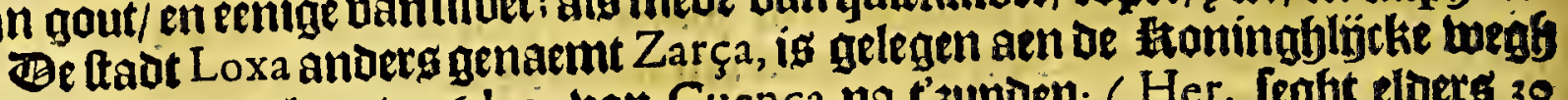
diena Cufco toeloopt; 16 leg. van Cuença na t3upden; ( Her. Reght eloers 30

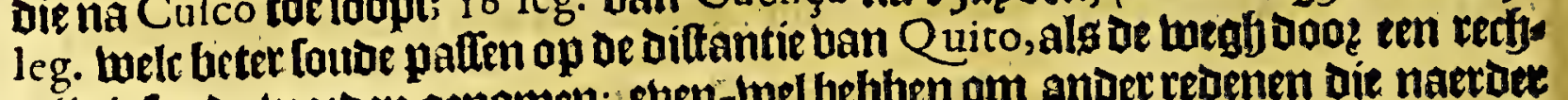
te linie foude wozoen genomen; even-twel bebben om ander redenen die naetaee Guença geleglyt.) 80 leg. van $S^{t}$ Francifco del Quiro na'tzuupoen tonfíneert lä

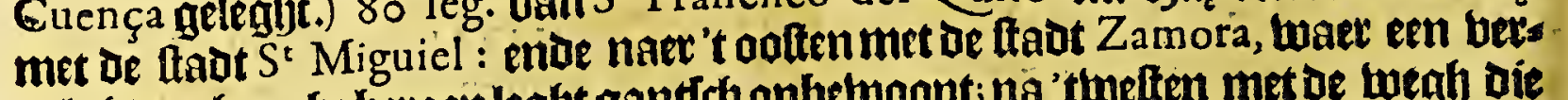
bolagy wan booghe bergenleght gantich onbetwoont; na twelten met de twegh die na de haben van Paita loopt. Beftadt is gelegen tulleben thee riebieten ban leet goet water/ in een leerfthoone enoelultighe vallepe/ die lp noemen Cuxibambs,

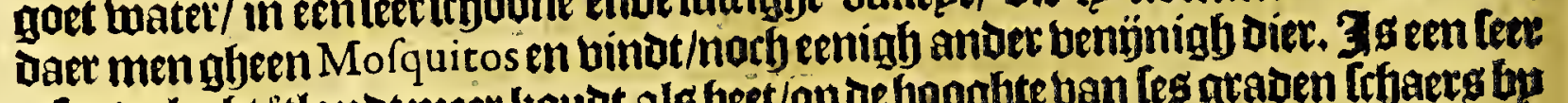

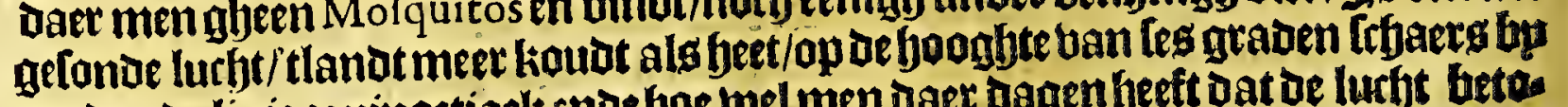
5upden ie linie equinoctiael: rnde hoe wel men Daer dagen heeft dat be lurbt beter

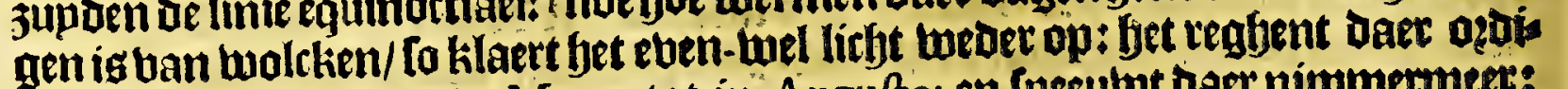
naerlijtk ban oe maenot Maert tot in Augufo; en Cneeutut baet nimmermeet: men bindt in dat gantfeg quartier leet peofitabel boudot als cedzen / ellen / willigen/. 
Het thiende Boeck.

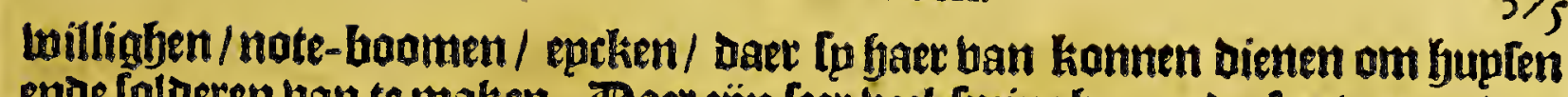

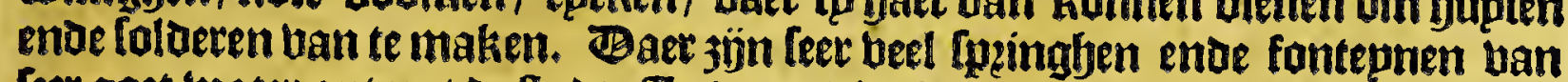

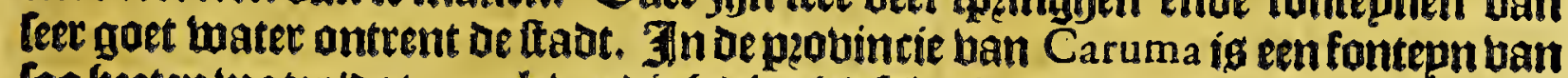

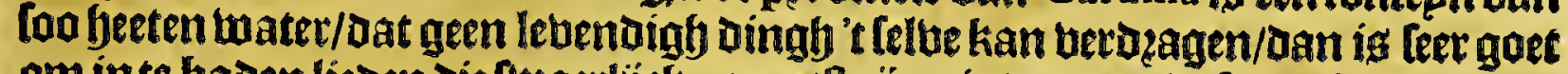

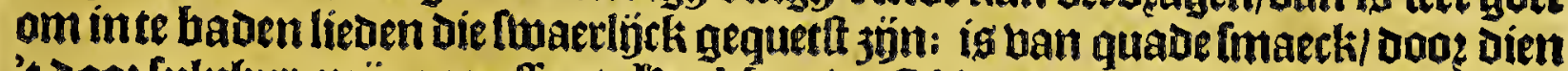

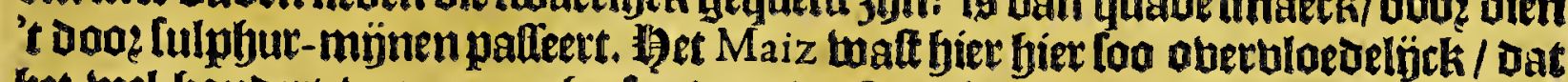

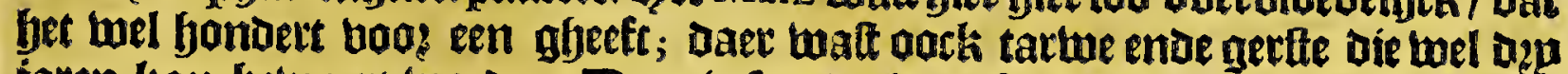
jaren kan betuaert thołoen. Baer is feer beel bee/ loo mel ban dat ban Spae= ghien / al ban Dat ban de lande; veel gebogelte : entue in alle de rievieren beel biffy

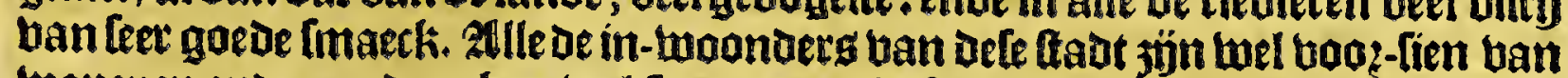

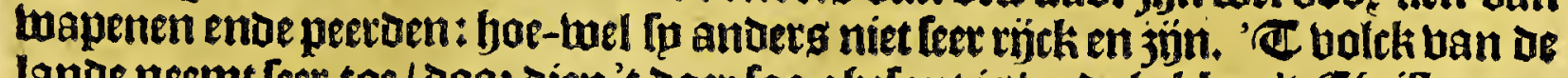

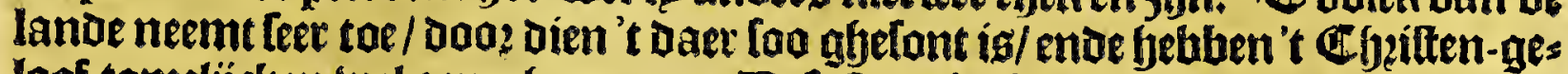
loof tamelÿsken twel aen-ghenomen. Befe thaot jeft fjaer kercke/ende kloofters ban Bominicamenenae ginue-beoederg.

Het elftece Capittel.

Befchrijvinghe van de ftadt ZAMOR A, ende I A EN, ende de gheleghentheyt van de landen daer om-her gheleg hen; ende van CHu QurMaro.

D. Eeftadt Zamora (naer't feggen ban Herrera) ig ghelegen ap be baogfte ban

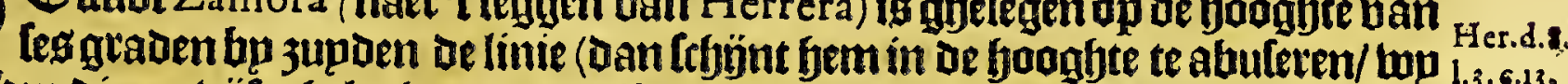
Jehben die op unf gheleglft om de biftantienuan de plaetfen beter te tinder) 90 leguen ban De ftadt $S^{\prime}$ Francifco del Q uito, bpkants naer 't Jupdr-poften toe/aen

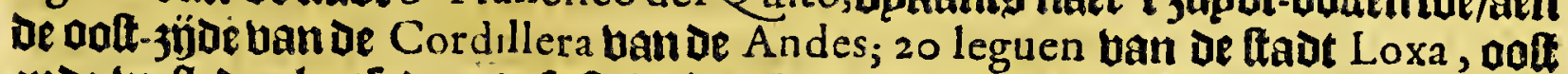

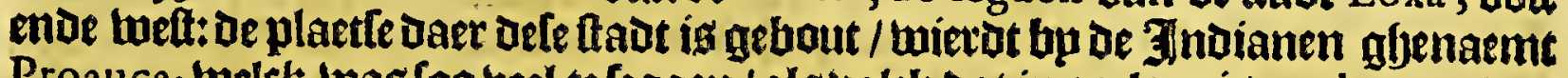

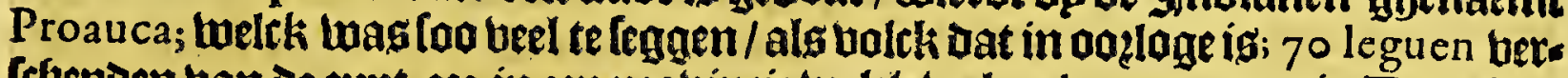

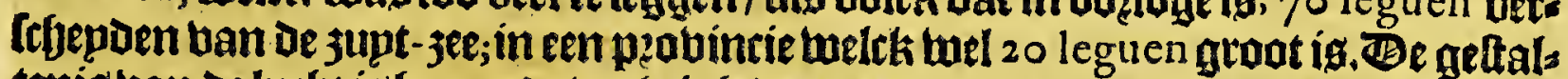

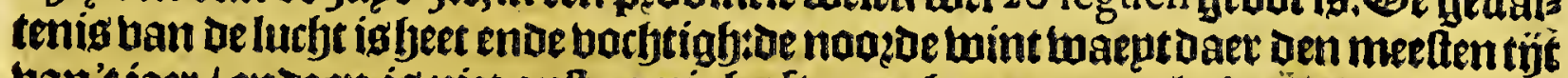
ban't faer / endeen is niet onltupmigg offe onghetempert: als fet Daer reggent!

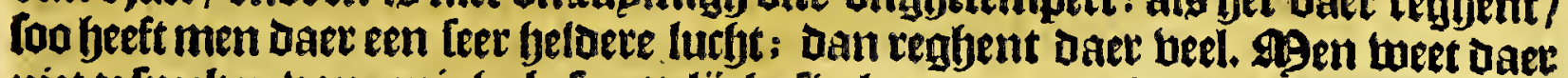

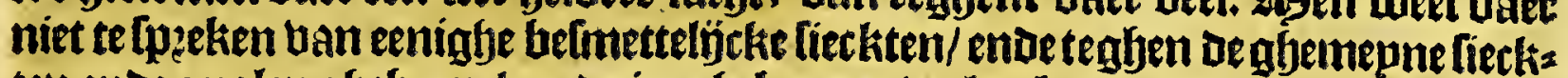
ten enoe qualen gfeblupelien de in-gheboone beel toback; ente noch een ander

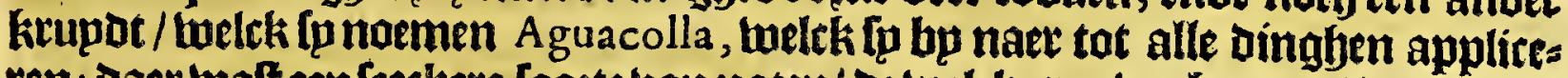

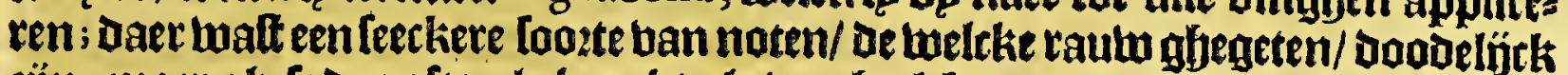

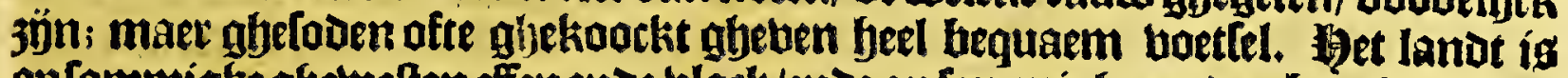

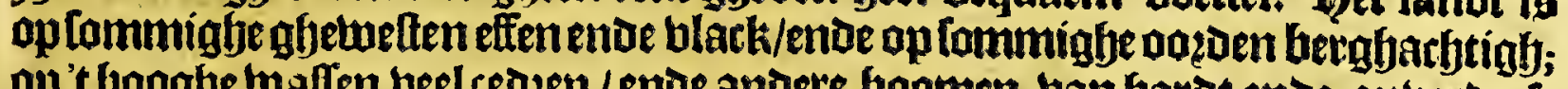
op't boogbe waffen beel cedeen/ende andere boomen ban fardt ende onterverfs

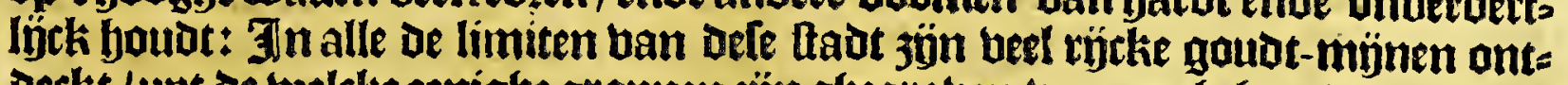
Deckt / upt de twelcke eenighe grapnen jün ghegraben ban ongbeljoozenen groote;

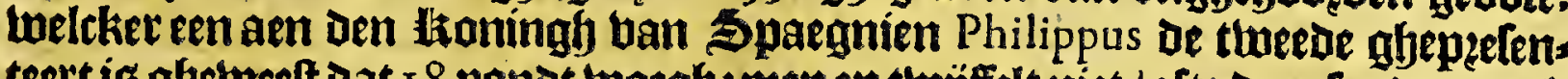

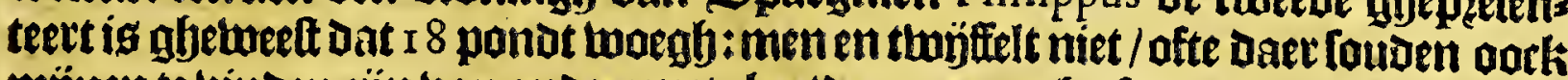

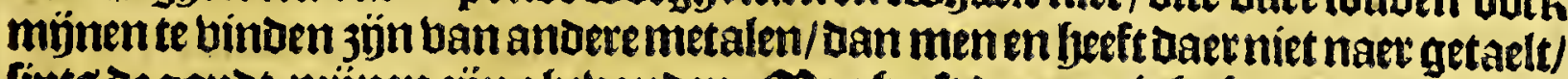

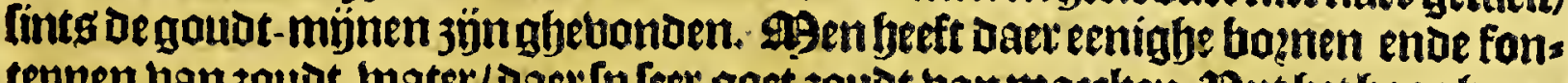

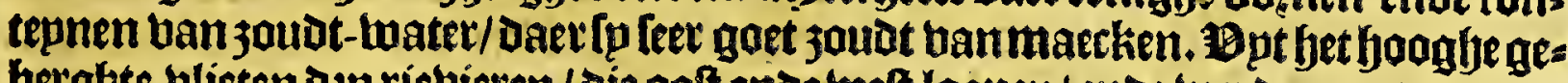

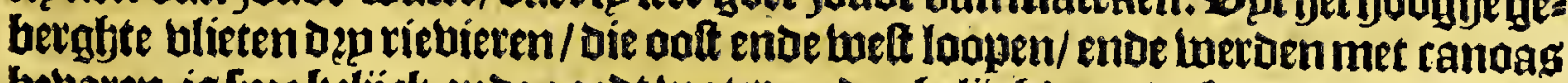

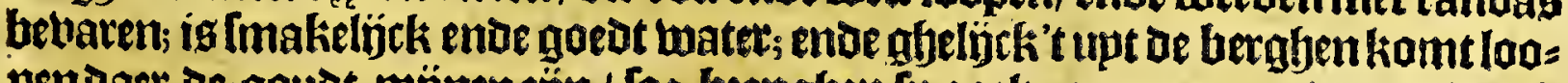
pendaer of gould-mïnen jün / Too beenghen [p oosk grapnen gouots mede af.

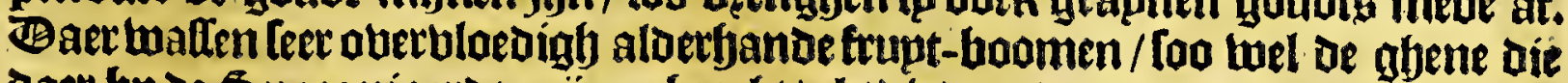

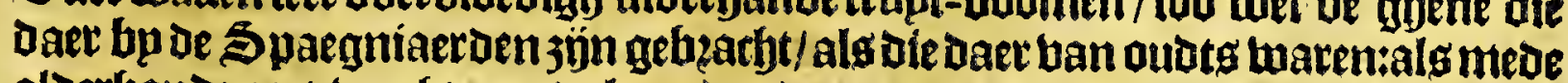

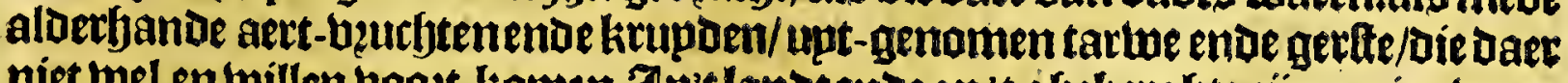

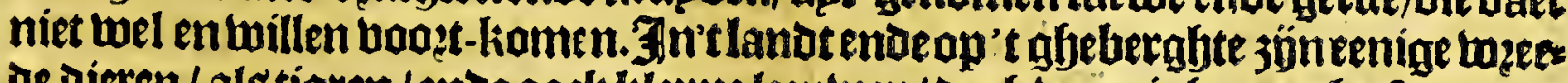

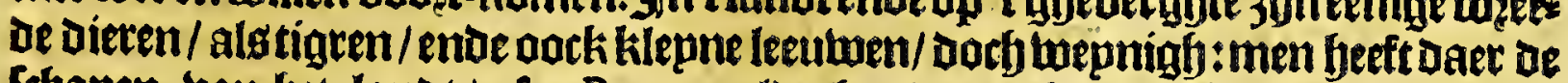

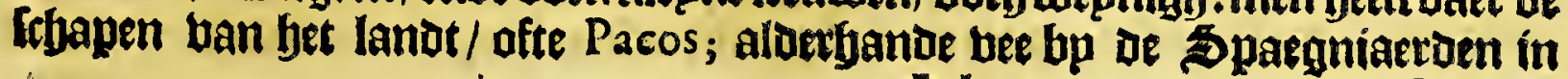


376

Peru.

Indien ghebzadyt / ald thieten / kospen / berckeng ende gepten: In de riebieten werot abundantie uan leer goede vilth gftebanghen: men beft Daer buen ban oe

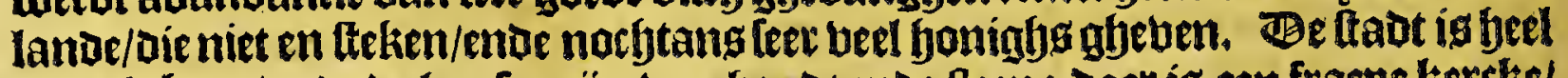
wel abebout/ ende de buplen jón ban boud ende fteen: Daer ís een fraepe kerrke/

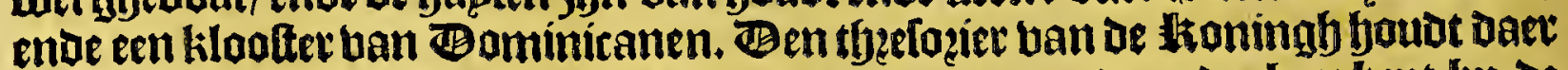

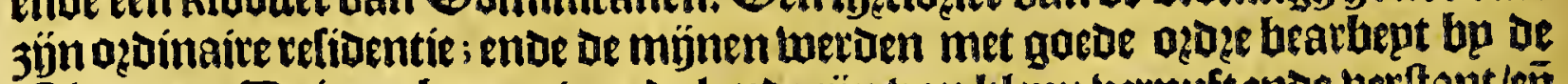
S warten. De in-aeboozne van de lande jün van klequn bernuft ende vertant/eñ gantffy niet gemegen tot arbepden; oen lp meelt op den roof; beltolen malkanderen/ende toegen malkanderen doodt: Dannu febben [p begoll beter manieren aen te nemen/ ende baer te kleeden.

d.8.1.5. De thadt Iaen ig (nacr't tegghen ban Herrera) 55 leguen ban Loxa gheleghen: c.12. 30 leguen van Chachapoyas, in een pzouintie welck ghenaemt woz̨ot Chacaynga, ende is eene banoe peouintien die onoer Chuquimayo werden gherskent; bet is berghactjtigh ende boanh lanot/ente ban gletemperde lucht.

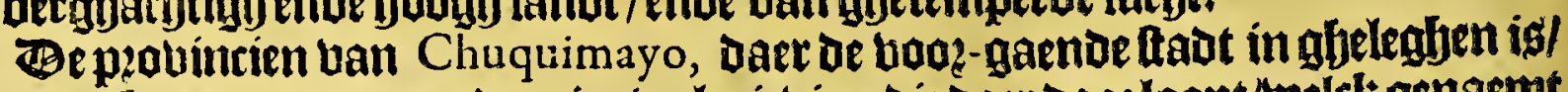

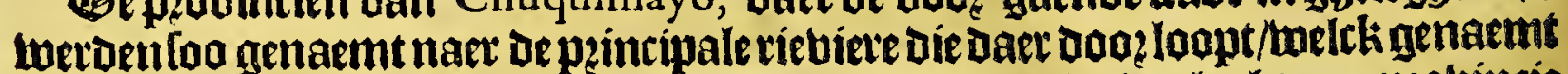

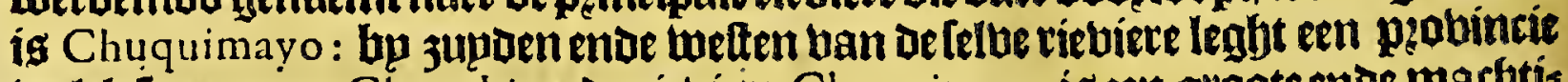
welch Ip noenen Chenchipe:de rieviete Chuquimayo ísen groote ende machtis

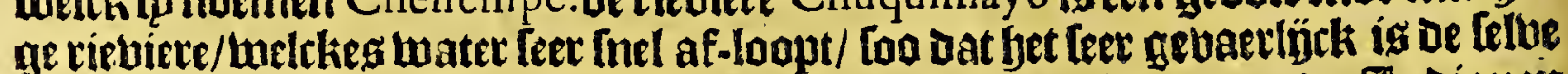
ouer te luemmen booz Spaegniaetoen enoe anoer natien / maer be Tndianen uan Chenchipe die groote twemmers 3 jun/ maken Daer mepnigh werckg af / [oo dat De begutwen felfs met fjaer kimberen die ober-fmemmen. In dit quartier binot men beel Maiz, luelck daer waft enoe rỉp waet wan 4 maenden tot 4 maenoen;

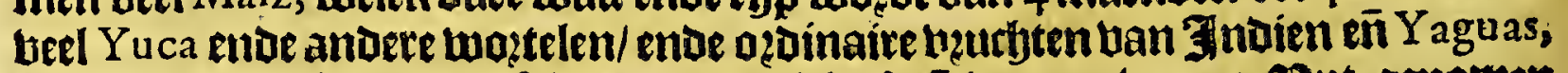

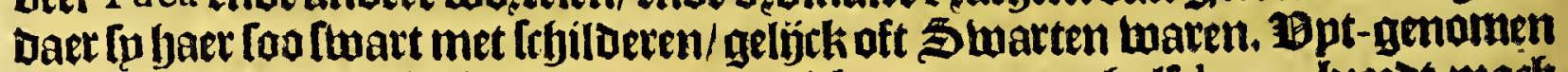
oe ballepe daer ae ríevier doa? loopt / melck ontuent een balf legue beerot mady

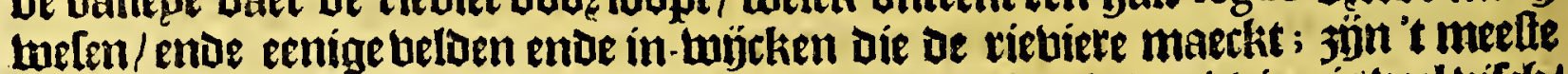

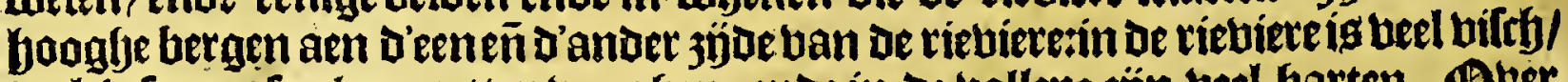

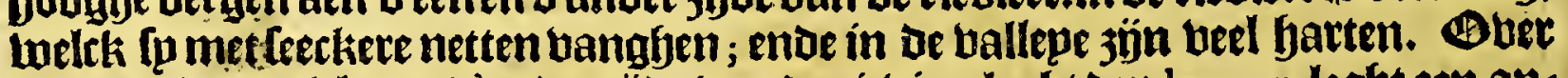

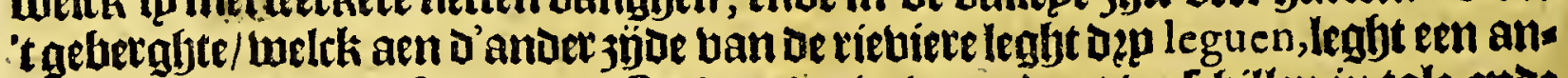
oer plovincie welck fp noemen Perico; de in-woonaets berfebillen in tale ende manieren ban die bp De riebiere woonen: 'Slanot is hel bewoont/wetuchtbaer en

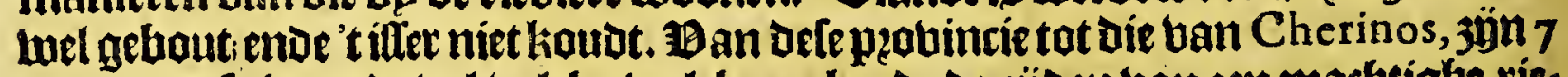
leguen: Defe is mede bal walcks welck aen bepoe de jüoen ban een marbtighe ries biere woont/Den boaem is beuchthaer ende't balck ltröthaer/ende [peetken baer epgen tale: in de rieviete ban Cheri nos werdt veel gaudts gevanden. Ban Cherinos komt nuen in de peabintie ban Silla ende Chacaynga, daer de fladt laen als boagen is aljeleght/is tergighlanot/foe-wel niet Dubbelt/ende ban goede temple. De probintie uan Copallen, is ban defelbe maniere: Gebben veel trbapen. Fet unleti moonende in de probintie uan Llanque ofte Lan ça, leeft naer of felbe wiblel als aock de bolcketen die fu noemen de la Loma del Viento. De bolkketen die fon noemen Tomependas, ende die daet woonen inde ballepe dís fo noemen de $\mathrm{Va}$ -

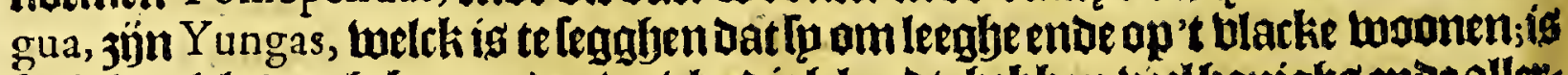

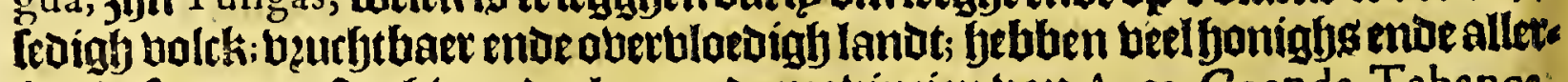
Gande frupten. Raef boozoer leggen de peobintien uan Anta, Coanda, Tabancaras, Palanda, Xaroca, enoe Cobibinbinanama, welck alle op 't gebetgfte leggen/

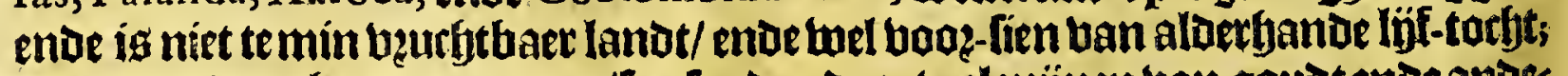
ende naer dengbemepnen roep/loo loutden daer beel mỉnen ban goudot ende andes

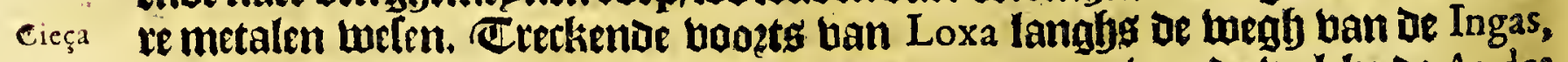
c.57. komt men aen ae probincien ban Calua ende Ayauaca; ban de welcke oe Andes ende de peovincien uan de Bracomoros naer't oolten legghen/ ende de thadt Sar

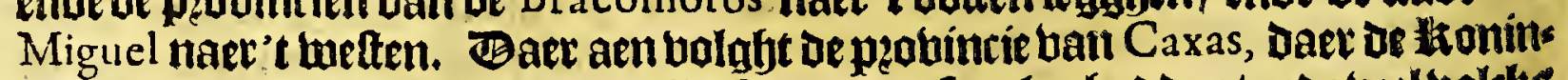
gyen van Peru eertyotg groote pallepienende arlenalen badoen/ende veel bolcks ondor- 
Het thiende Boeck:

ondet-bieloen om ie tribupten te innen ban ae om-legghenue boldketen. (Diego Fernandes rekent tulfeben Canas enoe Chincachara negben leguen,ende tultegen Chincachara ende Piura (eluen.) Ban Caxas hamt men aen de peobuncie ban Guancabamba, Daer nocty grooter geboulwen waren/ende een leer ftercke faetrefle/ vaer men noch eenighe oberblïffelen ban fiet ; want 't is anders ghetuineett ghes libck alle d' ander gheboutwen. Sommighe ban dele plaetlen ghejoozen nu tot de ftadt Loxa, ende eenighe tot St Miguel.

\section{Het twaelffe Capittel,}

Befchrijvinghe van de playnen van Peru, tot de ftadt SAN Migve L toe; Van de valleye van TUMBEZ ende andere: van de ftadt San Migvel, ende haven Paita.

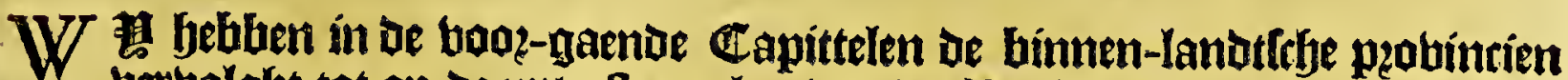
berbolgft tot op de upterfe paelen van de studientie ban Lima: Om nu met goede ofdete te fpeecken ban de plapnen ban Peru, foo fullen wo beginnen. met de ballepe ban Tumbez, Doog te helcke en tiebiete loopt ban de telve naem/

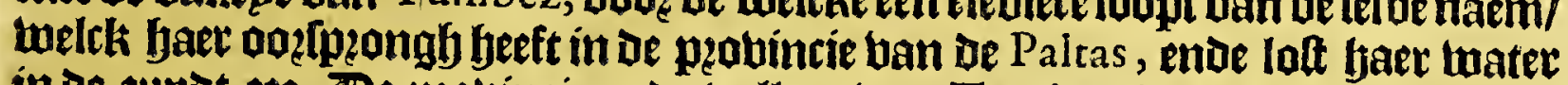

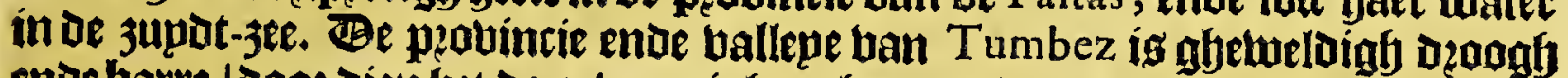
ende barre / opog dien bet daek mepnighreghent / ende dat noch dicht onder't glye= berghte / want dicht bp de jee-kufte en reghent bet nimmermeet. Bele ballepe ban Tumbez pleegh wel bewoont te welen / ende gljecultibert/ bol ban bequame

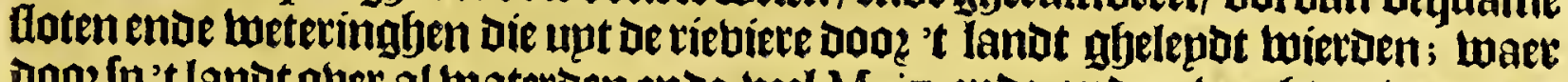
jooz fp't landt ober al waterden ende beel Maiz ende andere batuchten wonnen/ ende booz dien miodel beel booz-raedts ban allethande lijf-torbt verfoegboen. (d. bolck ban oe lande gingh ghekleedt / ende wag arbepotamer ende beter

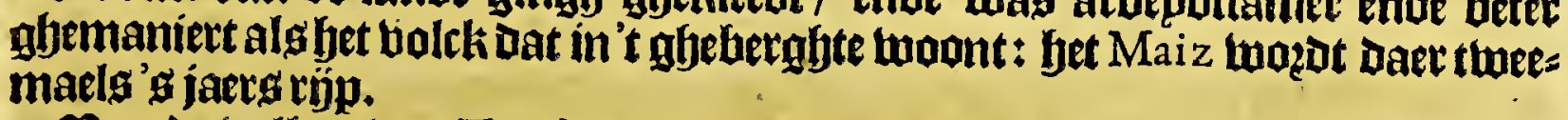

Ban de ballepe van Tumbez, fomtmen in thee bagf-repfeng aen de ballepe Cap.s, Solana, weltkin bope-tjoen leer betwoont was/ende daer waren feer gropte ghe

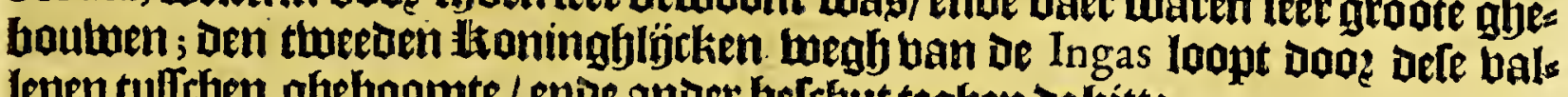
lepen tulderyen ghe boomte / enve ander betrjut teghen de bitte.

Ban Solana komtmen aen ie ballepe ban Pocheos (foo Cieça dienoemt) ofte Poechos (foo Herrera die heet/) welcke ballepe ig gfeleghen aç De riebiere Po e-
chos ofte Pocheos, boe-wel eenighe die oock noemen Maycavilca (ofte [oo Herrera dienoemt Mayabilca) naek oe naem ban de Cazique die de Spaegniaerden daer bonben. (Anguftin de. Carate reetkent ban Tumbez tot Rio de Poechos aertich leguen. Bele vallepe was upter-maten wel betwoont / ende moet een p20 bincie ghetweelt 3 ýn ban grooter weerde / aen-ghelien men Daet foo treffeligcke gheboumen beett / Die nu meett berballen 3 jin.

Chee dagh-repten ban de ballepe ban Pocheos leght Dé hallepe ban Piura, al maer twee ofte Dep riebieren te famen komen / maer dooz de ballepe foo beect is. Be ltadt San Miguel (melcke de eerfte ís ban de afjene die bp de Spaegniaeroen

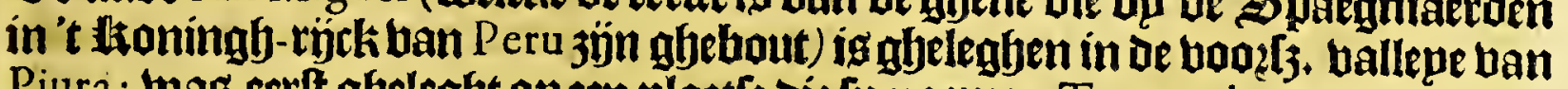
Piura; thas eerf ghelegft op een plaetle die fu noemen Tangarala, dan dog dien bet een ongletonoe plaetle mas / foo is fp nu berleght aen een anoer oquot / melck Herrera noemt Chila : tulforen thee blacke ende frifle ballepen/ vol fefjoone

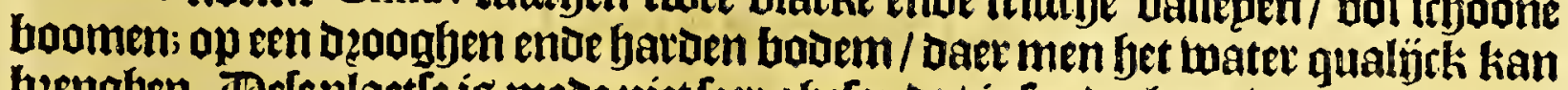

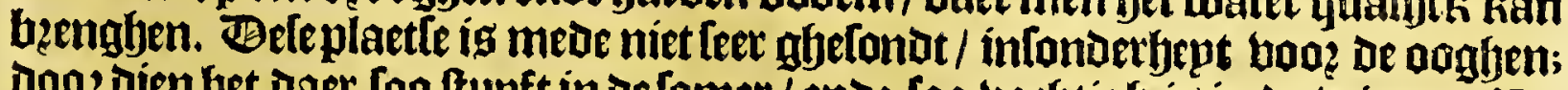
boo zien bet Daer loo ftupft in de lomer/ ende loo borftigh is in ie winter. Be

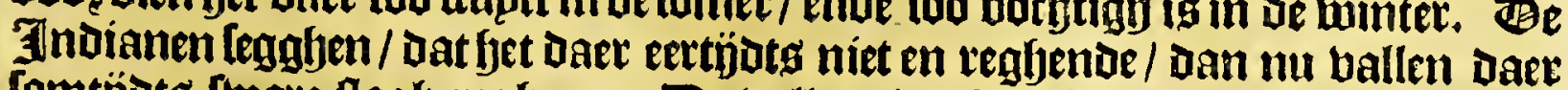
fomtjots lware flagh-reghenen. Be ballepe is gheljek die van Tumbez, ende men beft daer beel wojngaetoen ende bügbe-boomen ende andete frupt-boomen 


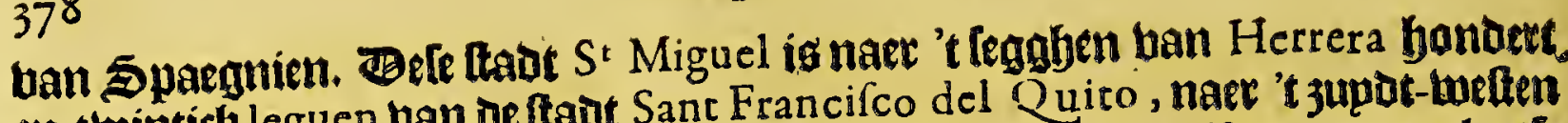
en twintirfy leguen van De ftaot Sant Francifco del Q uito, naer 't zuput-woffen toe. CEnde naer't legghen uan die daet onlanghg waren/ too ift een open plaetle Daer tuepnigh bandels balt.

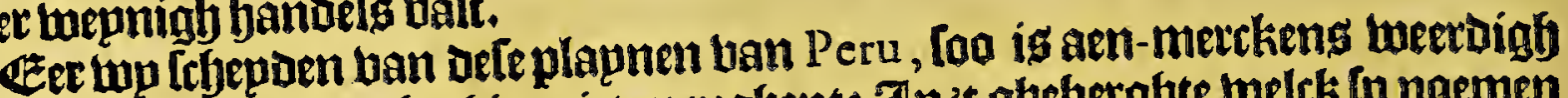

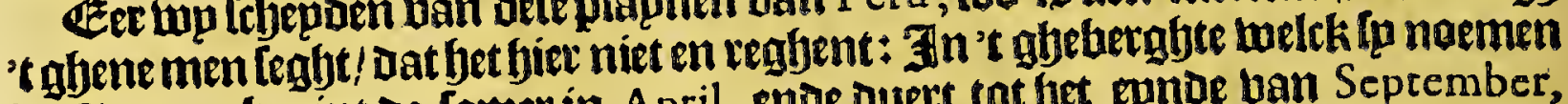

las Sierras, hegint de fomer in April, ende duert tat lyet equne uan September, ende de winter in October, ende vuert tot fet ephoe han Martio : maer op de plaps

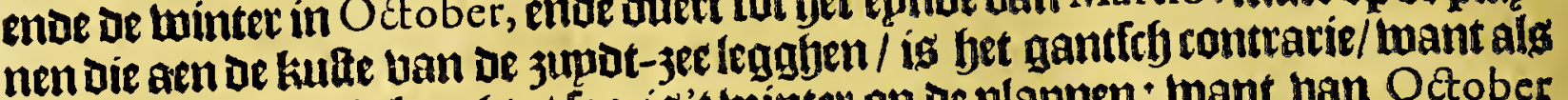
bet Tomer is in 't gheberghte / Tod is't thinter op De plapnen: twant ban October af/en regfent 't gantfry niet op De plapnen/en balt maet alleen mat dautug/belck

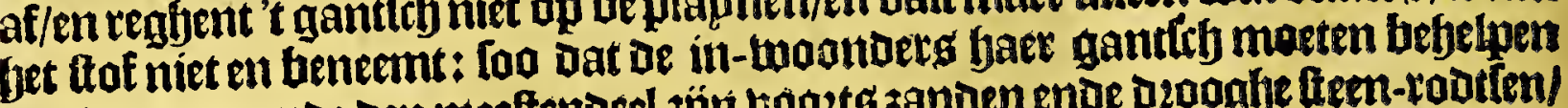

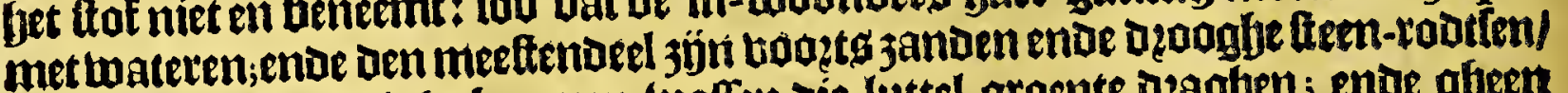
op ae welcke wepnighe boomen wallen die luttel groente dzaghen; enoe gbeen

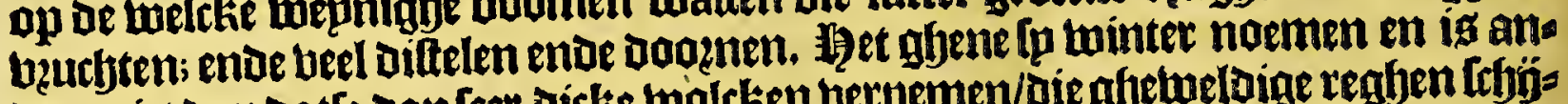

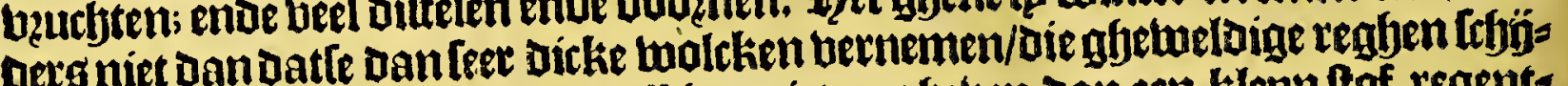
nen te Dępgaten/ende Daet-en-tultefyen niet en gheben Dan een klepn ftof-regent-

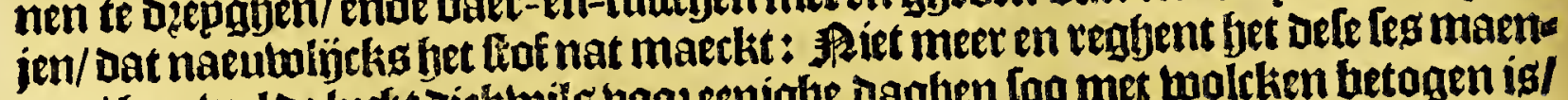

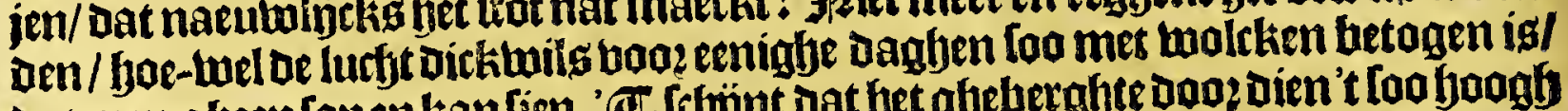

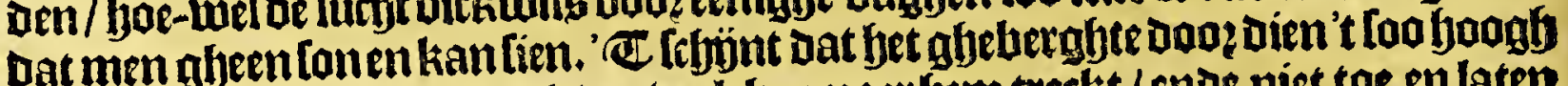

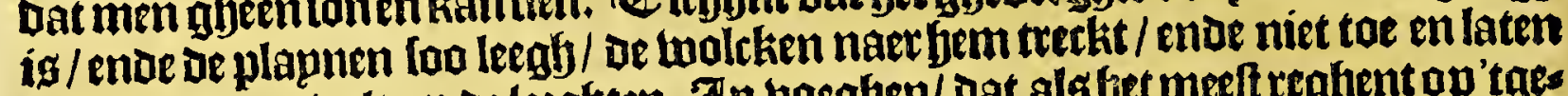
Dat Daer water walt op de leeghten. Jn voeghen/Dat als bet meeft reghent op'tges berghte/ yet aloertyettete ig op oe plapnent ende als Die klepne flof-regbenen ballen op de plapnen/ Dat dan jet aloetheldertte weder is in't ghebergfte.

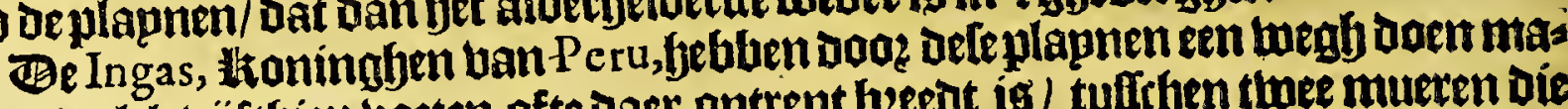
Ken/ welck büfthien baeten ofte Daec ontrent bzedt is / tufteben twee mueten Dic

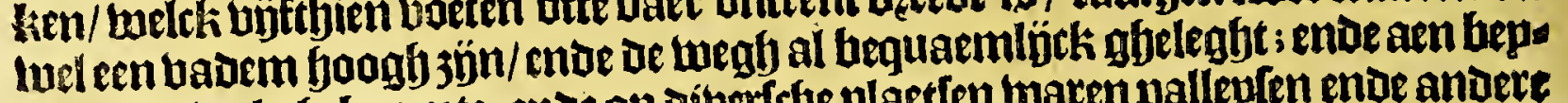

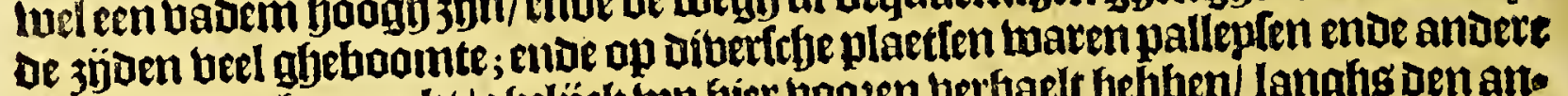

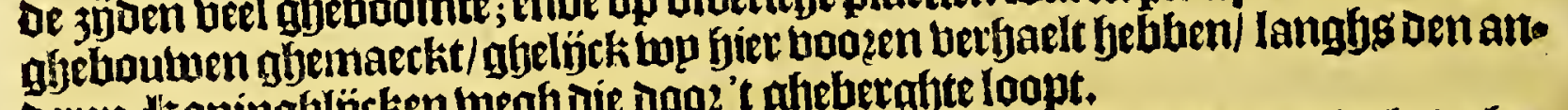

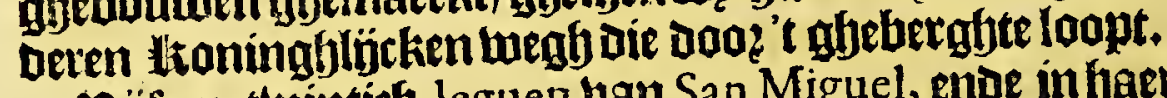

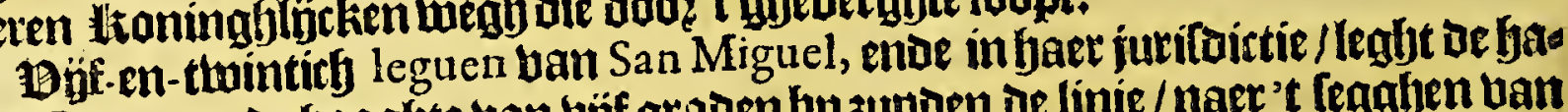

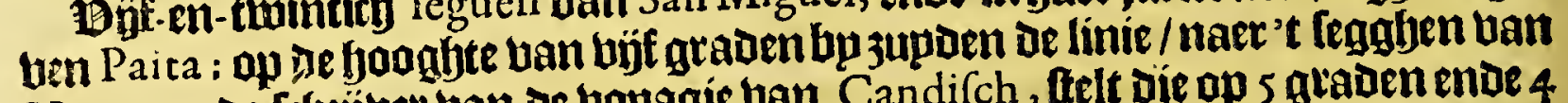

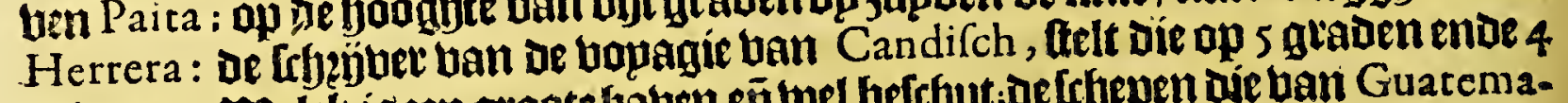
minuten. Aelck igen groote haven eñ wel belegut; defehepen díe ban Guatemala naer Peru kamen/3̈n getwoon in Dele hauen te ontladen. Thomas Candifck quam fjec op de retere in aen jare 1587 ; ende lande met [pn bolck in qujt ban of spaegniacroen; boutot vaer een kilepn ftedeken/ban ontrent 200 buplen met fpn raedt-bups in't midoen; ende een foetrelle welck oe Spaegniartaen hadoen bes

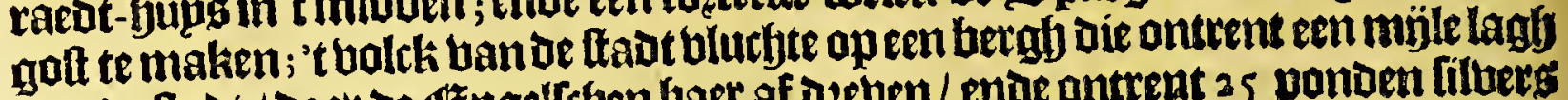

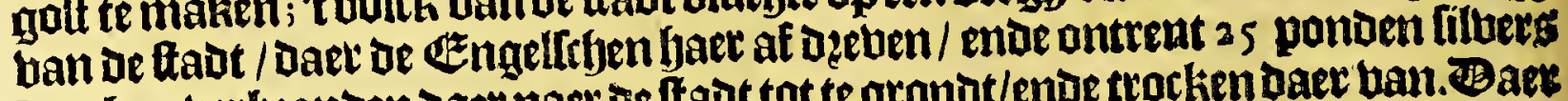
Kreghen:berbeanoen Daet naer ve ftadt tot te gronot/enje trockendaer ban. Baet naer in Den jare 1615 is De Telbe plaetle thederom in-genomen by de onle / onoes 'tbelepot van Den $\mathbb{G}$ enterael loris Spilbergen, naer dat de ím-woonderen daer upt

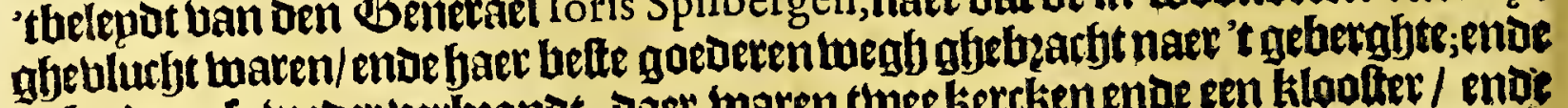
is bp de onle weoer berbzandt; Daer waren twee kercken ende een kloolter/ entos beel andere frboone gheboutwen ende bup [en.

Het Derthiende Capittel.

Van de binnen-landtfche provincie DE LOS Qurxos, ende IA $\mathrm{CA}_{A-}$ NELA; behoorende tot het ghedeelte van Quiro.

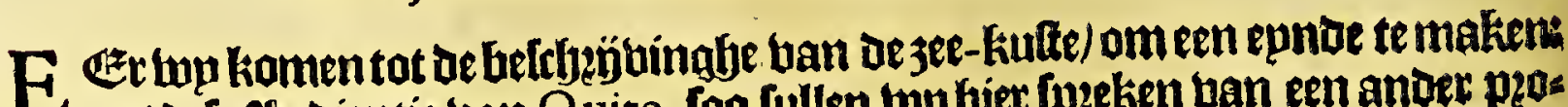
met dele ztubientie ban Quito, foo lullen wo biet fpethen ban een anoer pros bincie 


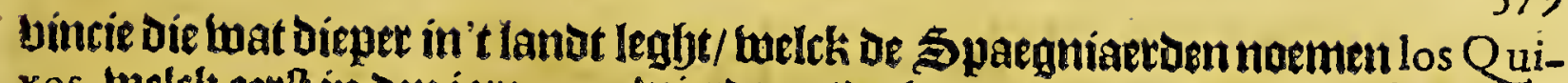
xos, welck eerlf in Den jate 1557 woiertor ontoectit/ naer Dat de ftad Cuença wag

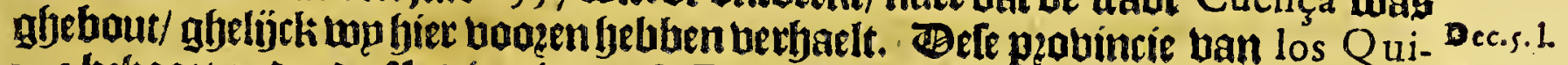
xos befjoot onder de âtudientie van $S^{t}$ Francifco del Quito; ende leght bp ootten ${ }^{10 . c .14}$. van ie ftadt $Q$ uito; feeft naer 't 3 upden bet Boubernement ban Y Yuarfongo, ofte

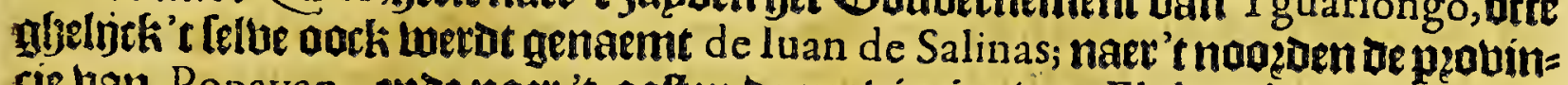
cie ban Popayan; entoe naer 't oulten ur peobintien ban El dorado: haet meette yooglte en komt niet tot een graedt bp 3upden den equimortiael: beeft in be lengby= te luepnigh minier als 40 leguen, ende in beerote minuer als 20 leguen. 'T gant=

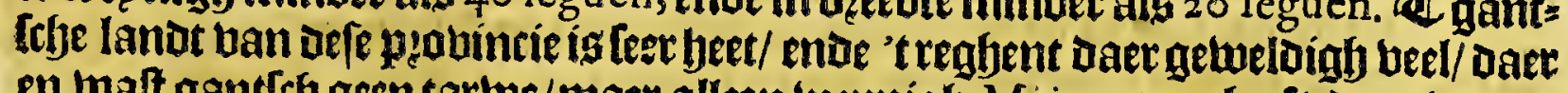
en walt ganttry geen tartwe/maer alleen twepnigh Mäz: men beeft daer ban de boomen die de fpererije boots-benghen/ Diefp noemen Canela, om dat bet geftods ten jünde/eenighe ghelj̈ckenis beeft ban't kaneel : men binat daer aock de oezdi= naile bruclten ban Peru, ende infonderbept loo beeft men bier foo goede Granadillas als in geene andere plaetfen wan dat gantffije rjek : Daec wallen oack nu ozagnien ente límoenen/ ende dibertcbe moer.krupden ban Spaegnien: men

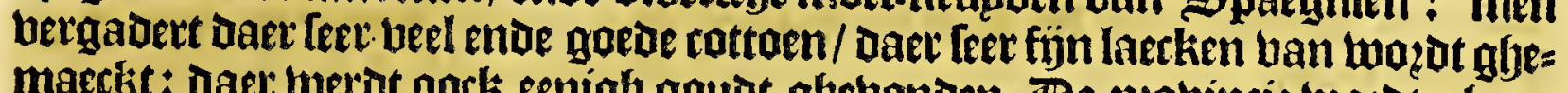

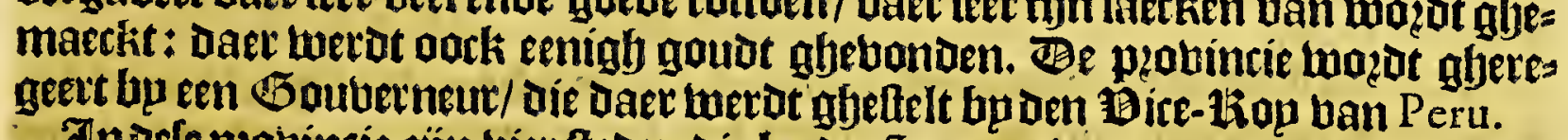

Indefe probincí jön bier fteden die bp de $\$$ paegniaerden twerden betwoont. De eetfe entoe booznaenlte ftadt ban defe yeobintie de los Q uixos lon bet genaemt ghen arfithien leguen ban de ftadt Sant Francifco del Quito, hp naet naex' tyunot-

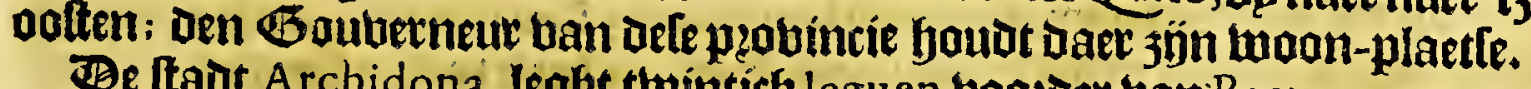

Be ltadt A rchidona, legbt twintich leguen boozer ban Baeza.

De ftadt A vila leght naer 't noozden ban de itadt Archidona booz-noemt.

De vierue faut wozut gfenaemt Sevilla del Oro; helckes gbelegentheptende diffantic ban de andere plaetlen Herrera niet aen en teeckent/nochenttelt die oock

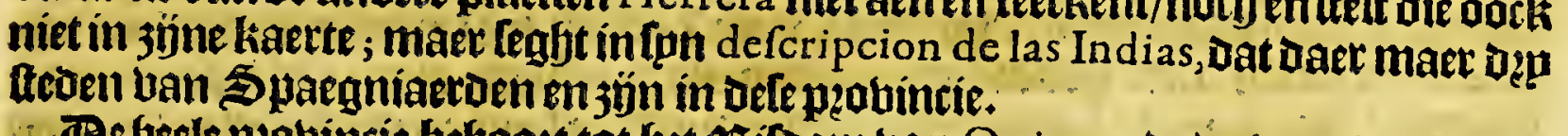

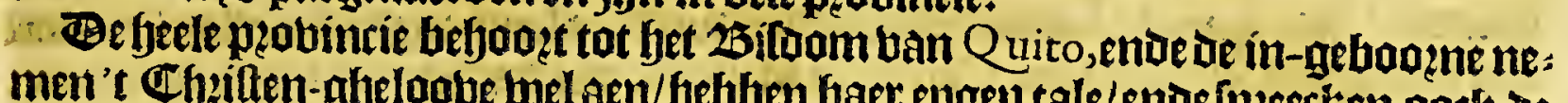
men't Chyiften-gheloobe bel aen/hebben faer epgen tale/enderpyectken oock be ghemepne tale ban Peru; thaten de andere 3 noianen vall dele lanoen gheljekt in kleedinghe/manieren/ende religie: ') bolck ig bęp wat bermindert Dode lieckten ende oork doog den oolloghe; want in't eerlte doende spaegniaerden daer quas grelijet andere bolcketen bie ouer't geberghte woonen; ende rebelleetoen oock al to met/ Dan nugeblen baer tot ftilhept begheben/ende leven in beas.

3Race't ooften ban uele peobintie de los Quixos, leght een ander peotúncie die

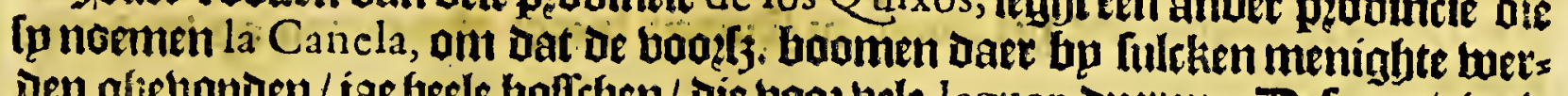

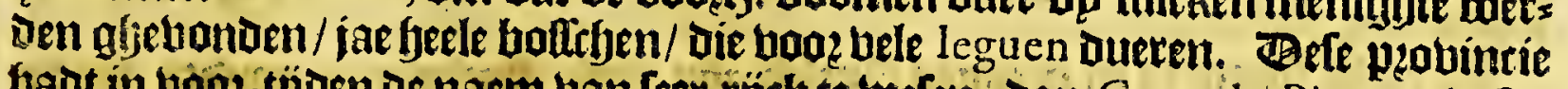

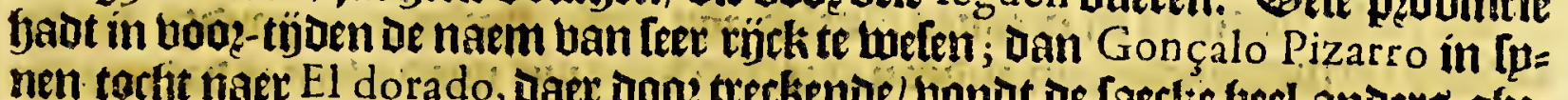

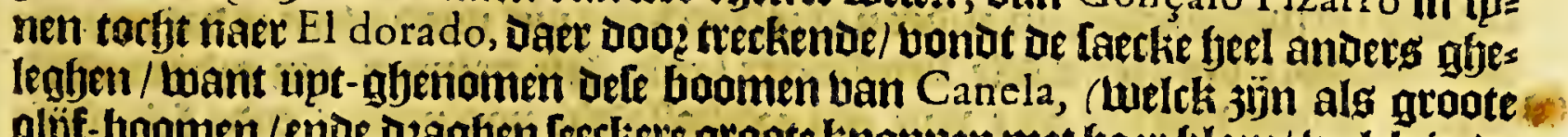
oljif-boomen /ende dzangen feectiere groote knopyen met faer blom/. Luelch is ie Canela, daer de in-ghebooze faren bandel met deefen) die men in ander quate tieren ban Peru niet en bint/ en bondot hier niets daneen arm bolck/ban klepn bermuft; welck woonve in klepne terballen Guttekens : gantleb gheen kennis

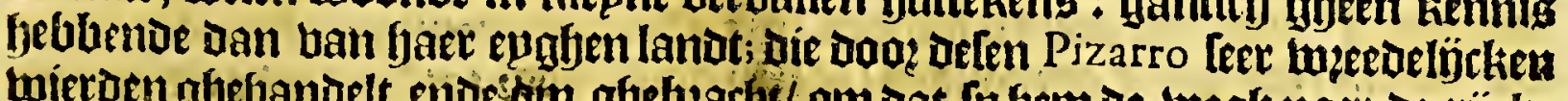

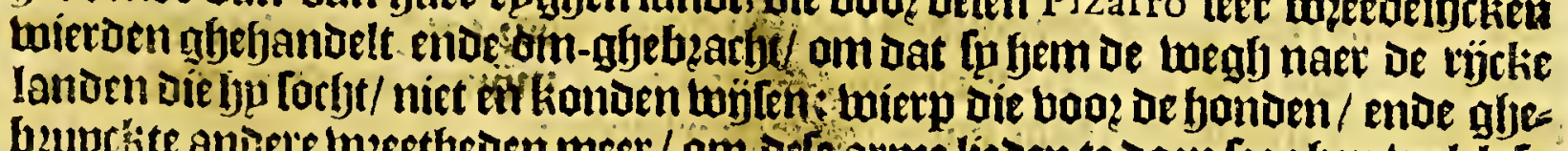

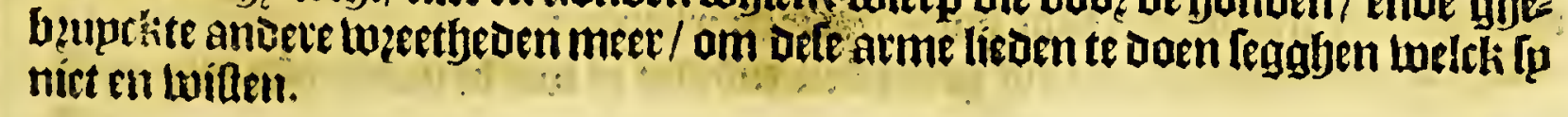


Het berthienue Capittel.

Van de provincie van de $B R A C O M O R O s$, ende de fteden daer in gheleghen; ende van YGVARSONGE, ofte luaN DE Salinas.

Totoe felve 2 fudientie ban San Francifco del Quito, befoogen de pzobincien

1 ban de Bracomores ofte Pacomores; ende Yguarfongo; ofte de plobintí ban Iuan de Salinas; defe probinitien bebben in ae Ienglese ftreckende naer 'toaften/that bonoert leguen, beginmenoe ban oe groote Cordillera ban of Andes, twinticfy leguen bp oolteri ban of thad Zamoras ende belben oock bp naertoo beel leguen

d. s. 1.ro. in de beeedte/ jupden ende noogen/naer't Teggen ban Herrera. 3 g goedt landt/

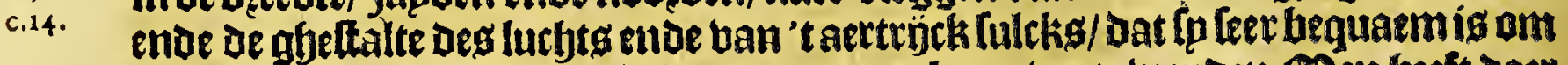

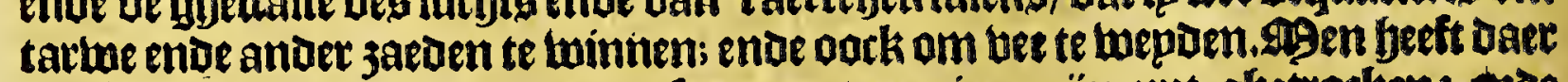
feer rijcke mijnen ban gaubt / Daer leer groote grainen jön upt-ghetrocken: thoe be Spaegniaerden begben graote nutrigbepat upt defe gaubt-mïnen ghenoos ten. Be Spaegniaetuen getuen in Defe peduimeien vier twoon-plaetten / bie

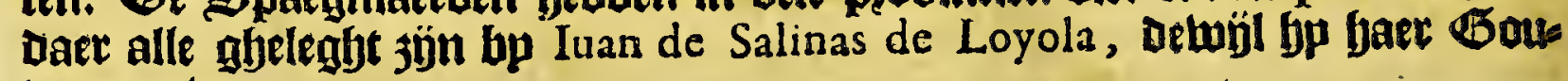
vetneur twas.

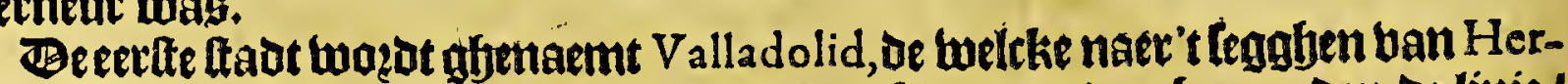

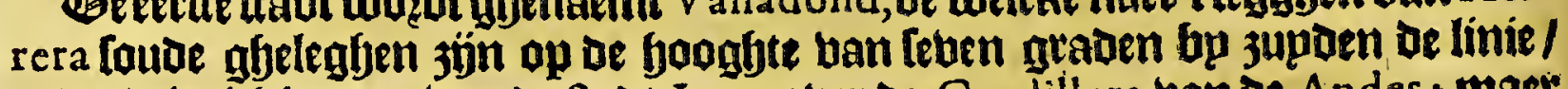
ende twintich leguen ban oe fadt Loxa over de Cordillera ban oe Andes: maet

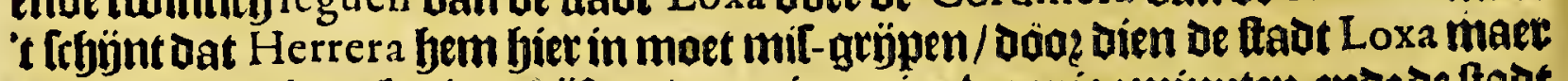
en leght op de hooghte ban uñf graden min eenige twepnigeminuten; ende de ftadt Zamota op lujf graden rupm/ twintich leguen van Loxa, naer't qofted; foo dat ick mp in-beeloe dat bp in ftede ban Loxa, Zamora beeft willen legghen.

Be tweede thad thozot ghenaemt Loyola, ende in oe Indiaentebe tale Cumbinâma, welcke leght twintíf leguen van Valladolid naer bet oolten.

De berde ftadt wozot ghenaemt Sant Iago de las Montannas, welek is gelegent bujfrich leguen van Loyola, bpkants naer 't ooften toe: ende in de límiten ban oefe ttaot werot meet gaubta ghebonden als in eenighe andere plaetlen van dits quartier/ende't goutot Dat fier ghebonden werot is leet foogly ban allop/boe-bel niet loo boogh alg dat ban Carabaya ín Peru, ofte dat van Valdivia in Chile,

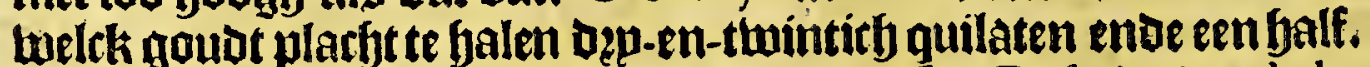

1.4.c.4. Be bierbe plaetle en two tot by Herrera in lpn Defcripcion de las Indias, noth in lpn biftozie niet afyenoemt / Dan A cofta in lpn natuetale ende mozale bittogic ban Hoeft-Indienlpeectit ban de münen ban Cartama, in bet Boubernememt ban Salinas, al-maet bp frbejft gbeliente beblen / teet groote tteenen oie gantich net goubt waren booz-trocken / ente boek eenigbe die balf goubt waten enos half âten; want bet is te tweten (op Dat wo dit bier in't boog bp gaen upt Her. reta aen-teeckenen) dat bet goudt in Fndien werat gbebonden op ogpoetles manieren.

De eerte loote is in grepmen/ welck zön beele fluck kheng goubtg fonbet eenighe bertuengingle ban ander metael/ho dat 't niet noodighen ig dat men bie

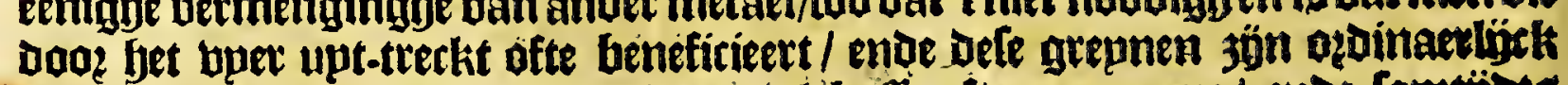

ban de groote ban bet jaet ban een caleballe ofte pampoene/ enoe comtiots oock bel grooter; ban dit goubt wozot daer wepnigh gbebanoen/ in regard banfet anoer.

De tweede foote is in fteen / welch is een ader ban goubt welck in of felloe fiecn groept / ende dele fleenen twazoen in 't Goubernement ban Iuan de Salinas booz-noent / feer gloot ghebanden / al ban gaubt Dog-toghen / ende eenighe bie

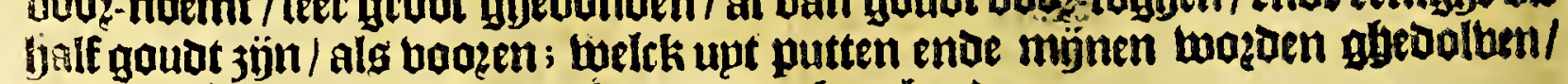
ende zön feer moepelïck ende harbt am te bearbepaen.

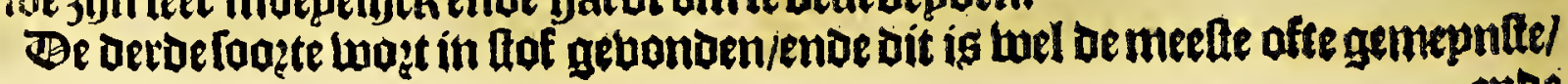

moe 
tnbe werot ghetonden in de riebieren ofte plaetendaer de riebieren bebben ober

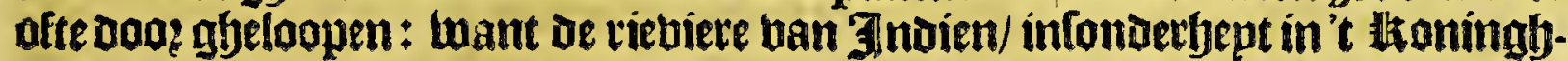
rijck ban Chile, in De pratuintic ban Quito, Daer bup nu ban bandelen/in't nieus toe rỷck ban Granada, febben beel ban dit gouot; ende Doen oe IIndien eetr

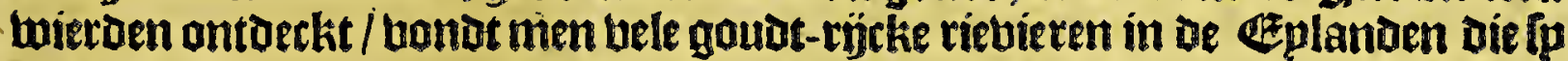
noemen ar Barlovento. 99en kan bzeeder bier ban lefen bp A cofta in Ipn fiftozie booz-naemt / in't bierde 2 seckende vietde Capittel.

Het uñftibenae Capittel.

Aen-teeckeninghe van de gheleghentheyt ende ftreckinghen van de kufte van de provincie van $Q u$ I т o op de zuydt-zee, haer havenen, rievieren ende punten.

19 the kulte tuan dele zludientie tan San Francifco del Quito, jün de naerbolgbende babenen/ pimten/ende riebieren. Ban Punta de Manglares, ఎaer

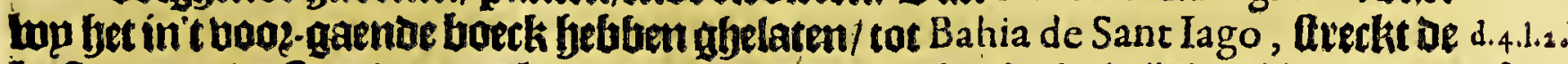

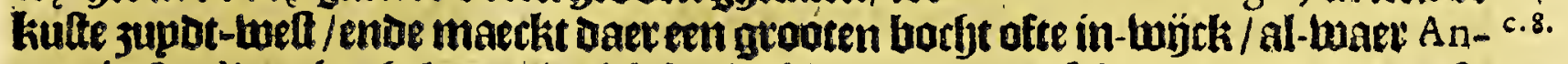

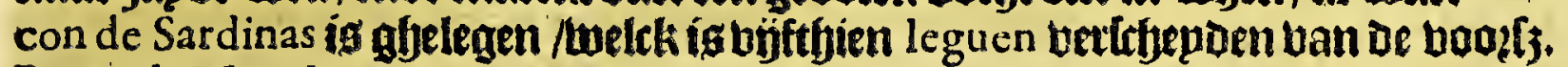
Punta de Manglares, welck ia fet uptettte van Popayan: enoe biet loopt De groote

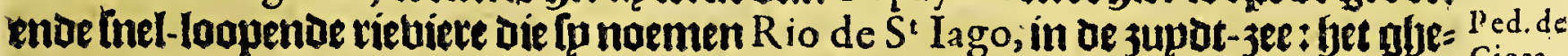
beurt dat in de mont uan defe riebiere de frbepen act)ter valt fullen 3 itten/ende too o tarbtentich badem diepte heblen; ento dat men ban twee badem waters lthacks

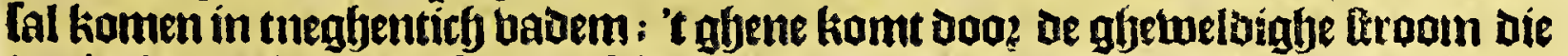

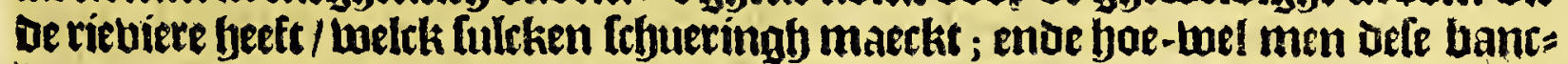
ken bier beeft / loo en jün die ebenwel net ghebaerlijek / nady oe fibepen en laten Daetom niet oe riebiere in ende unt te loopen. Bopozoer aen befo ghp oe Bahia de

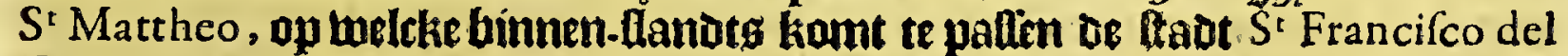
Quito; (naer't leggen ban Herrera) Dele bape leggt op eengraedt rupm bp noof= Den oe linie. \$Raer'tfeggben van Sir Richard Ha wins, Too is dele bape een leet

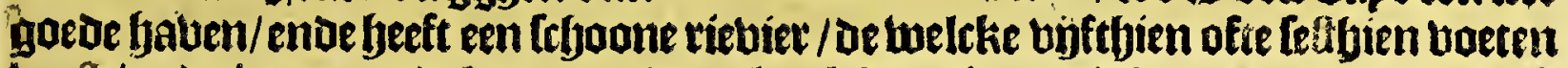
watt / ende is een goedt lanot / ende bal bolckg/ oie menigljte van goubt ende ef: mexauden bebben: De Spaegniaeroen ban Guay aquil yadoen bier eertigy bolck gbeplant / met hil ban oe in-moonoerg ; De welcke daer naet de ongheregeltyept ban de Spaegniaerden niet konnende verdzaegen/aen-Lpanden meteen Mulato, ende doegben alle de Cyeiftenen boodt/ op twee naev/ die met groote moepte ont: quamen naet Quito. 't ILandt Dat aen de [e bape daer ontrent gheleghen is/ia leer bocftigh dooz dien fet daer loo beel reghent. Be booz-noemoe Haw kins, ftelot tulthen ofle bape ende oe Cabo Sant Francifco, noch eetl andere hape/ bie bju noemt Atacames, leven leguen ban be boo:-[rfyeduen Cabo, bebluende aen

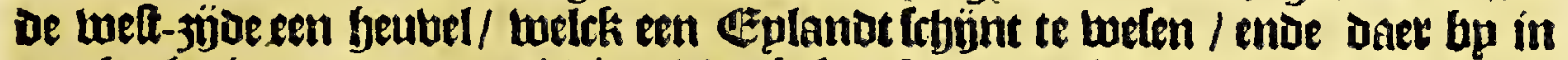
een bocbt is cen groote riebiere / boch bzack / upt-ghenomen met bet leegf water.

Ban Bahia de $S^{t}$ Matheo, loopt men welt-maetty aen naet de Cabo de Sant Francilco : De Diftantie ís thien leguen : oele kape legbt aeneen boagb-lanot/ente bol boomen/ende daer benebeng legghen eenigbe bancken die baer roodt ende lait bertjeanen / ende ís gljelegben op een graeot bp noozoen oe límie. Ban bier loopt

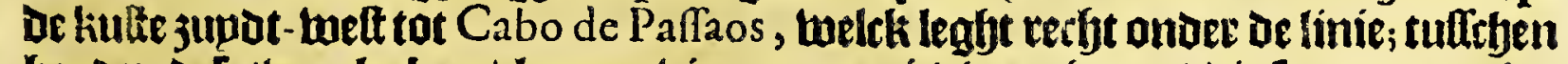
beuoen dele thee kaben/ loopen bier groote riebieren in jee/ die [p noemen los Quiximies. Diego Fernandes legltt dat be Quiximies jijn [eechere kitredken/Die tol thien mïlen te landt-waert in loopen / ende maecken fet loo bocbtigh ende

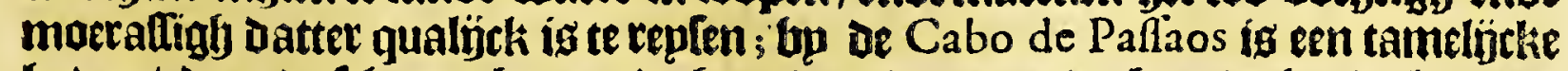
Gaven/Daer oe [chepen bp noodt Gaer ban water ende bzandt-foubt konmen boos-fien/ welek up enighe de naem lwetd gbegbeven ban El Portete. De Cabo 
382

Peru.

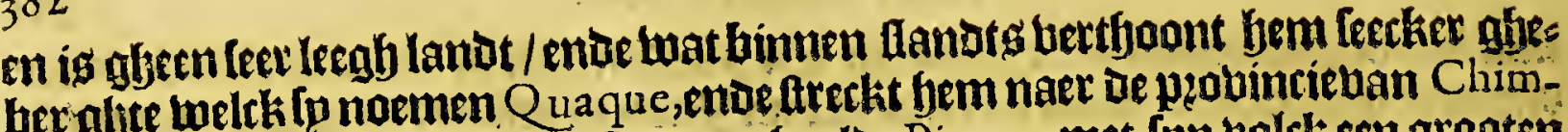

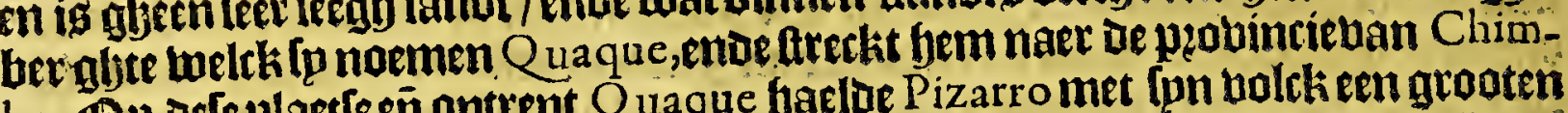
bo. Oy dele plaeteeñ ontent Q uaque baelae Pizarro met lpn uolckeengrooten bupt van goud enoe efmerauben; alloo bp in oe eerte ontoeckinghe van Peru; Defe plaetfe ontuerfieng ouer-biel. $S^{\mathrm{s}} \mathrm{R}$ ichard $\mathrm{Ha}$ w kins leglt dat ontrent 80 leguen

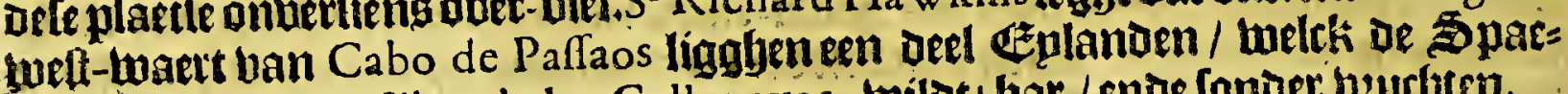
guiaeroen noemen Ithas de los Gallopavos, wilot/ bat / ende fonder bezucljetr.

Ban Cabo de Paflaos, ftreckt De kufte jupdt ten meften tot Puerro Veio tae:

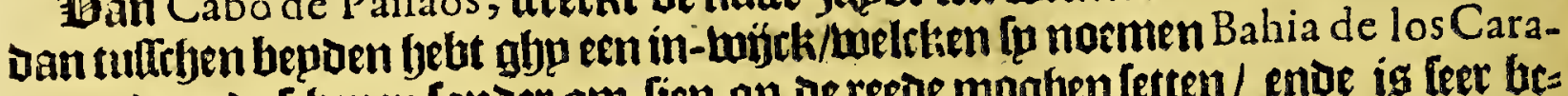
ques, Daer de febepen londer om-lien op De reede moghen fetten/ ende is leer be quaem om de frbrpen om yough te balen ende te uerfoecken/enje calefaten/al was ten't noth Joo groote frjepen; is daer leer litht in ende upt te komen / upt-gheno= men dat Daex een klepn ezplandekenleght van klippen/ Dorly daet en ig geen an= Der Dangier dan Dat men fien kan.

Bijf leguen uan Puerto V eio, op de lellue kours/is gheleghen de Cabo St Lau. renço, op oe fooghte ban mat meer als een graedt bp jupoen be linie; enoe dzy

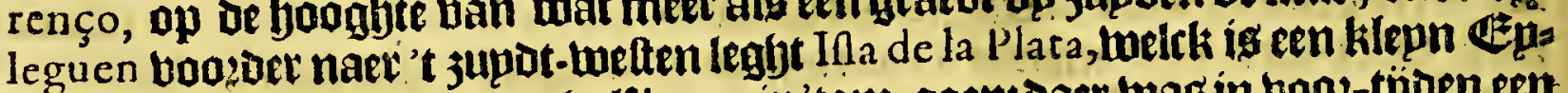
lanbeken/ente ontrent anderyalf legue in tom gaen: Daer was in toot-tijoen een

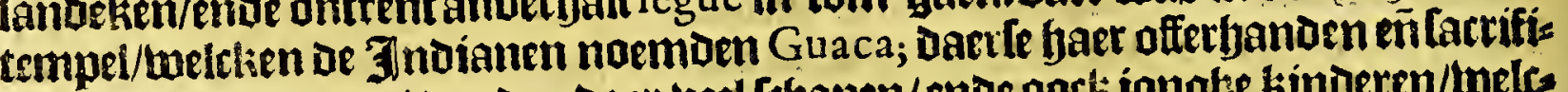

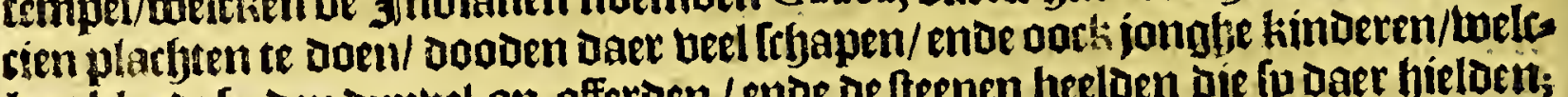

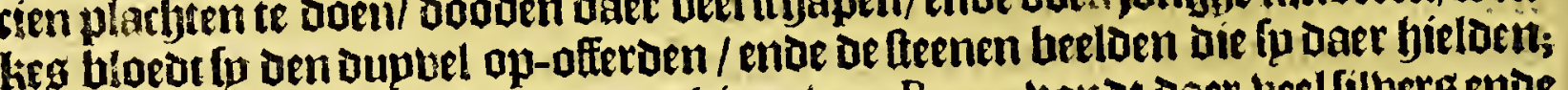
Francifo Pizarro in oe eerfte ontoeclimge ban Peru, tontat daer beelfiluers ende goudta / ende anoere jumeelen; oock beel mantels ende bemoen ban tralle ende

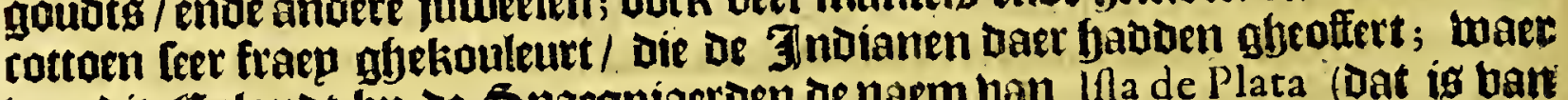
van Dit Éplandt bp of Spaegniaeroen de naem ban Ifla de Plata (Dat is ban fet filber/) feeft bebouden: is anders naer de bebindinghe van de oule die daets waren in den jaete 1599 , een bar Ezplanot Daer niet anders op ftart als een

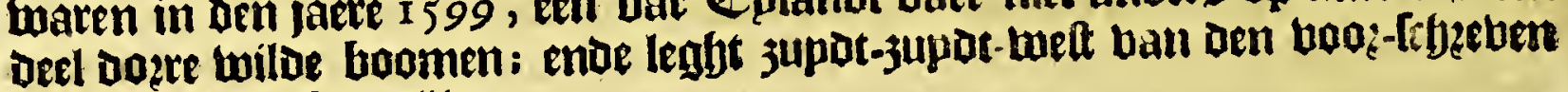
boeck / bijt ofteleg mïlen.

Ban Defe Cabo S Laurenço, verbolght de kulte naer' 3 upden ten tuetten tof een punt landt / welck fu noemen Punta de Santa Helena; dan ect men koms

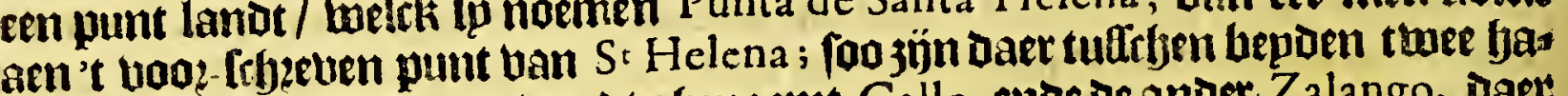
tenen / van tweldte de eene two ed ghenaemt Callo, ende de ander. Zalango, daet

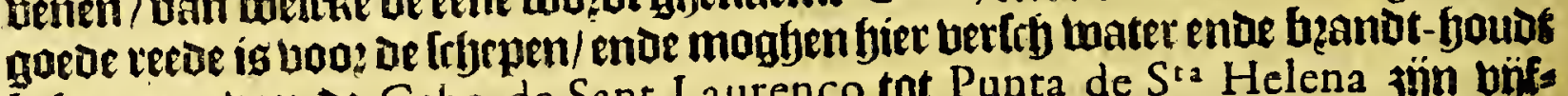
betomen: van oe Cabo de Sant Laurenço tot Punta de Sta Helena jën büf= thien leguen, enoe dít punt ig gheleglien op of booghte ban thee graden rupht bp zupoen oe linie: enje 't telve punt maecke een in-Gam naex 't noozoen toe/al

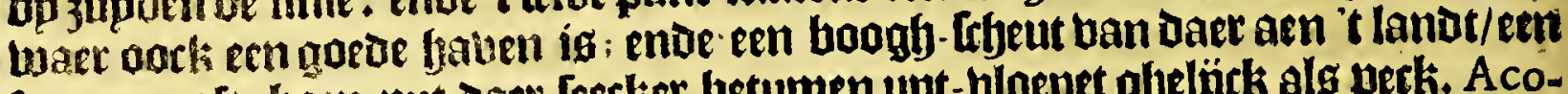
fontepne ofte bon-put Daet leeclker betumen upt-bloepet gljeligek als peck. Aco-

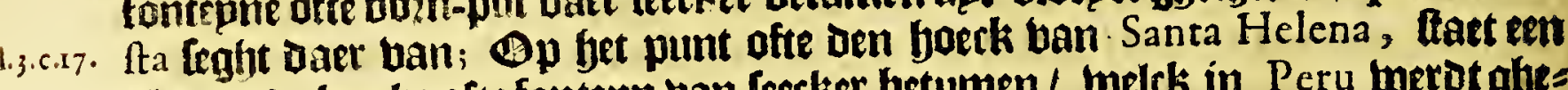
blospende beeclie ofte fontepn uan leecker betumen/ melck in Peru toerot gbes naemt Copey; De zee-lieden ghebeuprken't telbe om haer mandet ende taeckelo' mede te tceren; want bet is alloo dienttigh ende bequarm als bet peck. De in. alyrboane berfyaelen beel wonoers ban eenighe groote keulen die ontrent bit punt Couden gbetwoont beblen ende Doos een jonghelingb van oen bemel af-ghtee Daelt in Lectlete uallepe al són omghebzarbt: A uguftin de Zarate gbetupght dat de Bouberneur ban Porto Veio in Den jaere duplent byjf jondert ende dep-en-

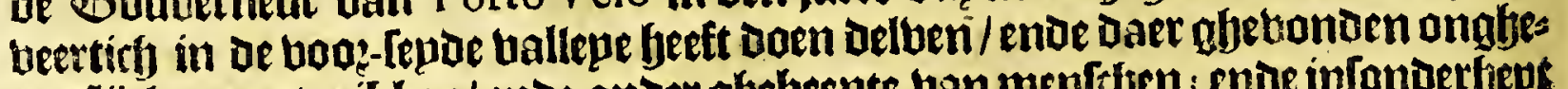

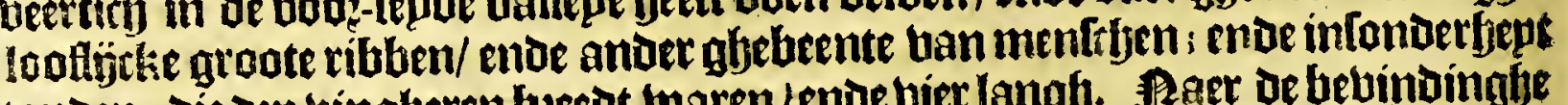
tanden; die azp binglberen beetot waren/ende bier langh. Raer oe bevindinghe ban oe oule / lou leght ban dit pumt te zee-Laertin een klepn ezplandeken bolges boamte / Daer goet ancker-aronot is / thee-en-Dertich bauem teeck-gronot.

Danlfetpunt ban $S^{\imath}$ Helena baet men naet ae rieviere van Tumbez, welck 


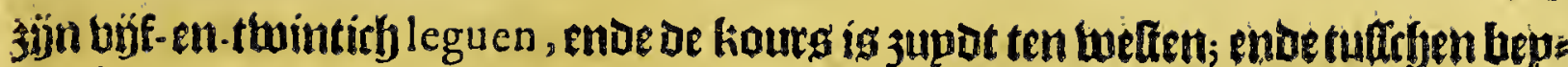

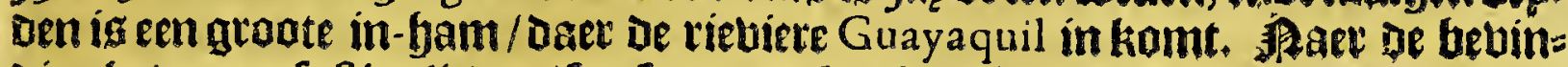

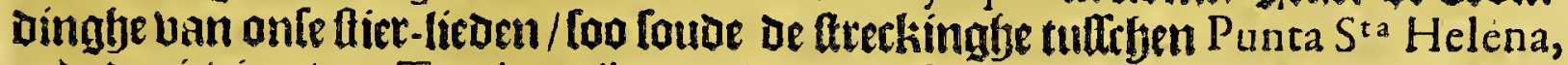
ende oe rieviere ban T umbez 3 ijn/ supot ten oolten; 't welck wp in onte kaerten bebthen gevolght. Herrera fteit de rieviere Tumbez op 4 graden/dan altod't niet

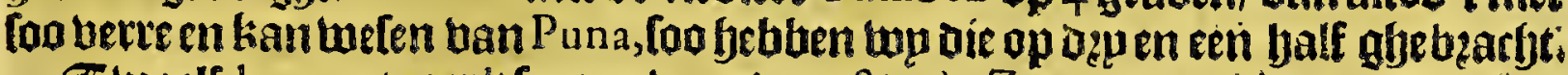

clvalf leguen (naer't feggen ban Auguftio de Zarate, ) naer' t noozot-oafien ban de rietiere ban T umbez, is abeleghen get (Epland Puna, op de hooghte ban twee graden hijftish minuten / (naet dat Thomas Fuller beft atn-gbeteectient op de bopanie van Thomas Candifch :) Bit Ezplanot Puna is naet bet leggben ban Pedro de Cieça meer dan thien leguen in't runde. (Herrera leglje eloerg dat

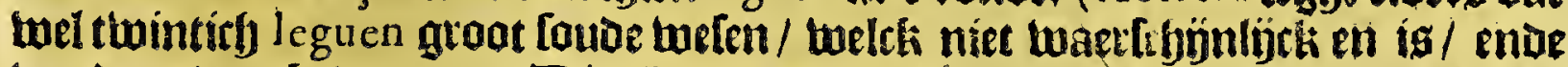

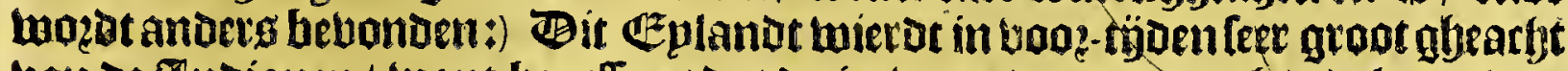
ban de 3noiamen/ want beneffens dat of ín-moonoers gropte banoelaets twa= $\mathfrak{r e n}$ / enoe in baer Eplanot olierbloet badoen vanalles / oat tot onoerfoubt van 'imenfryen leten noodigy is / loo twierden fp bp bare na bueren booe kloeck ende Itrijotbaer ghefouden. Helaben in boos-tijoen met die tan Tumbez enoe ande:

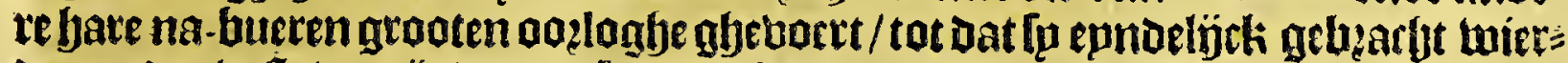

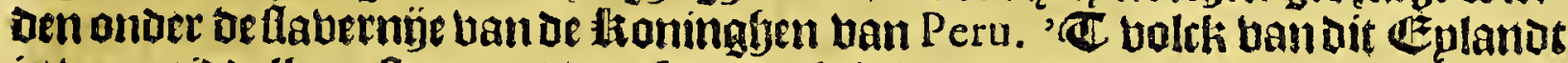
is van mioselbaer ftatuere / wat fwartarbtigh / ginghen ghe hlecot bepoe mand enoe bzoutuen in tottoen lijntuaet/ende verrierden baet met ketenen ban Chaqui-

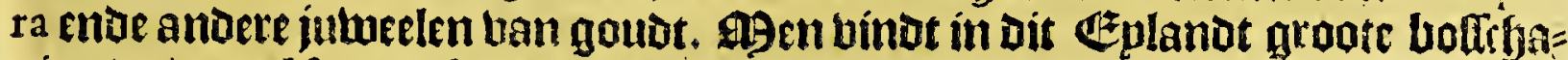

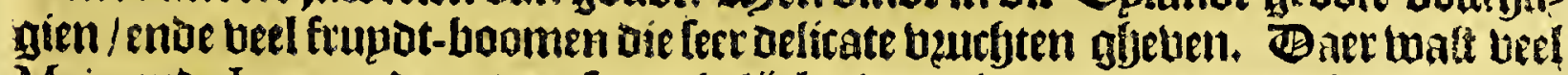
Maiz ende Iuca, ende andere limaeckelóble twoetelen; ende men beft daer beel Derlep loozen ban gljebogljelie/ ueel papegaepen/ende die lp noemen Guaca-

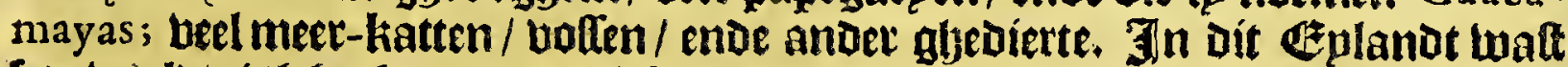

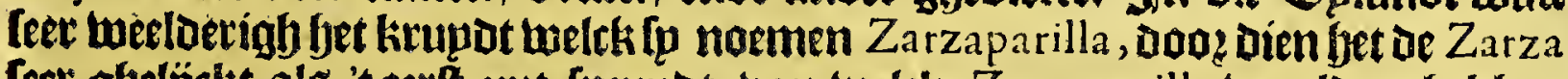

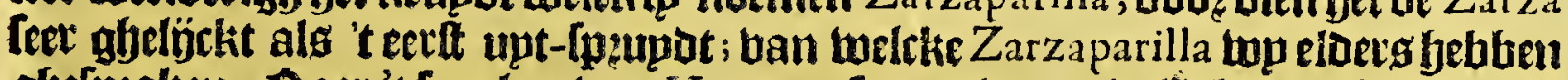

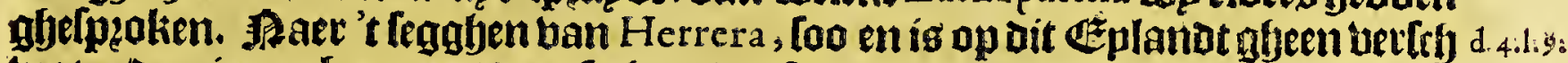
water/oan in een bogn put daer fp faer oes fomets meoe bebelpen/ende Deg twin= c.2.

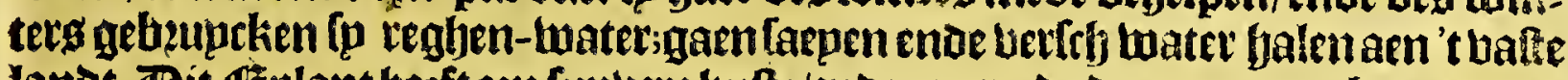

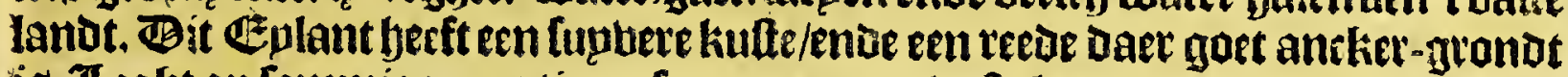
if. I Ieght op lommige quartieren loo naer aen't bafte lanot/Datter maet efnenge Itrate tufthen benden en id; Dan Daer oe bauen oft trede leght/ is twee leguen ban 't batte landt. Bein-geboome bebben nu't Cegeitten-geloobe wel aen-genomen)

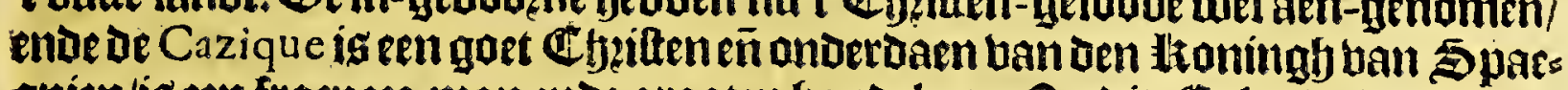
gnien/ís een fraep zee-man ende grooten Jyandelaet: Op dit eplandt togogen de

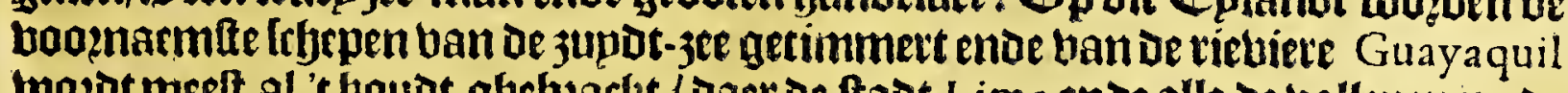
wozotmeelt al 't youdt ghebzaclyt / Daer oe thad Lim a ende alle de ballewen mede

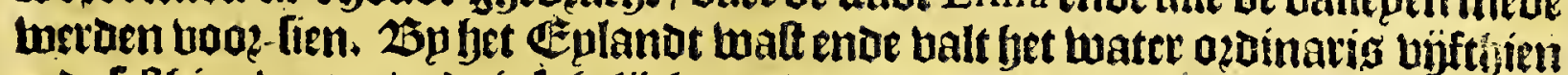
ende leltfien boeten/ende inlghelg̈cks op de boog̨aele kufte naer Panama toe/min= oer oft meer naer dat oe ghetijen loopen.

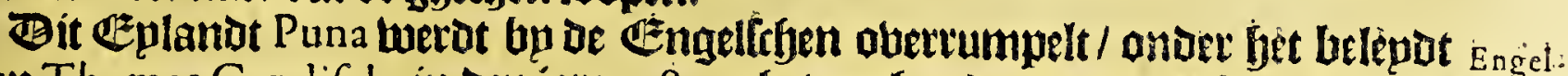
ban Thomas Candifch, in Den jare 158 ; ghetupghen Daer ban Dat fjet een goe or fche vas:

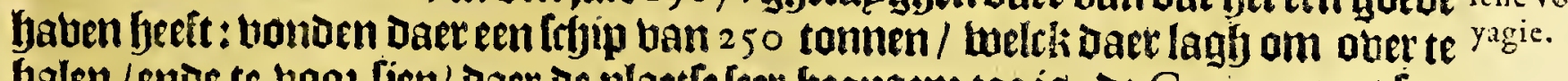
Galen/ente te boo:-fien/ Daer de plaetie terr bequarm toe is: de Cazique met fun

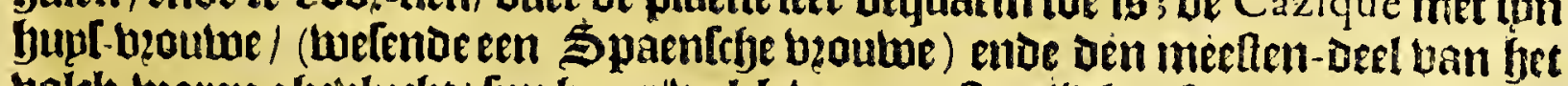

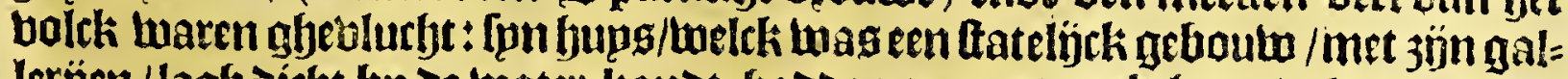

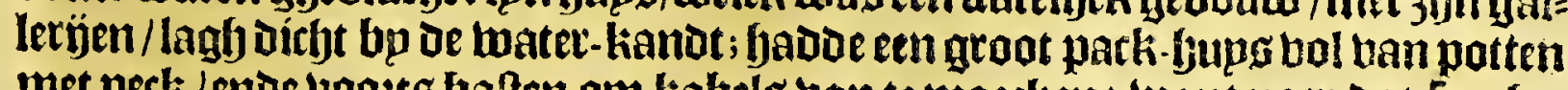
met peck / enoe voozts batten om kabels ban te maerlien: Lant naer dat fp ques= tupghen / foo luevion fjer de befte ente meefte kabels gemaechit ban be gantffye

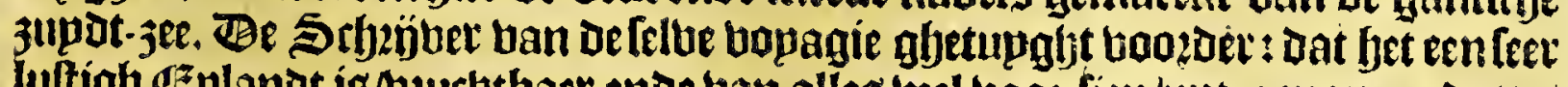

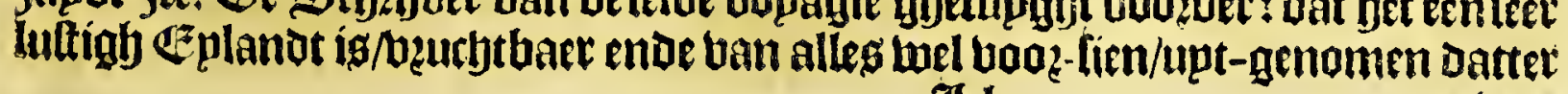

$$
\text { II } 2 \text { gbern }
$$


384

Peru.

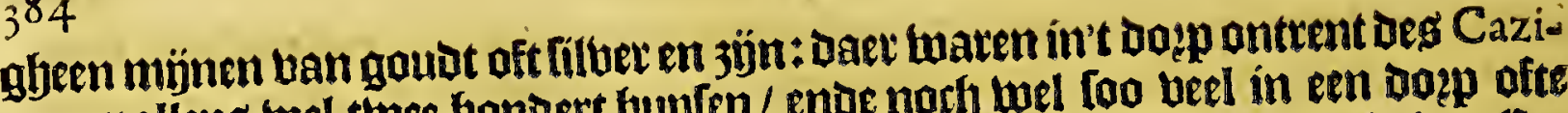
ques pallepg twel thee bondert buplen/ enoe norb well foo veel in een doę ofte

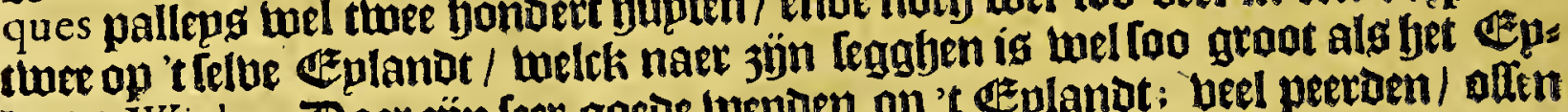
lanot Wight. Baer żjn feer goede luepoen op 't Eplandt; beel peeraen/ offen enoe ftieten/ enoe feer fthoone ende bette fthapen/menighte ban tamme gepten/die ghetwoon jün glyemelckt te wazden:daex íg menighte ban oupben/kalkoeten ende end-bogelen dieleer groot jün. Ontrent het buug ban de Cazique twas een fracpe kerch ghetimmert/ met eenighe klorktens in aen tooen. De Engelfoben ber:

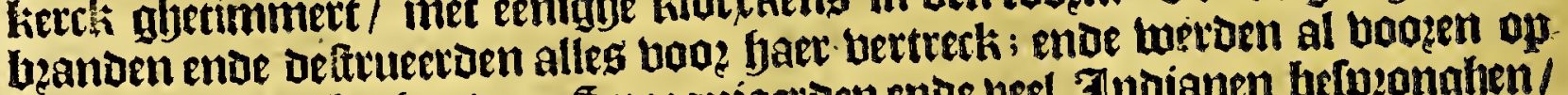

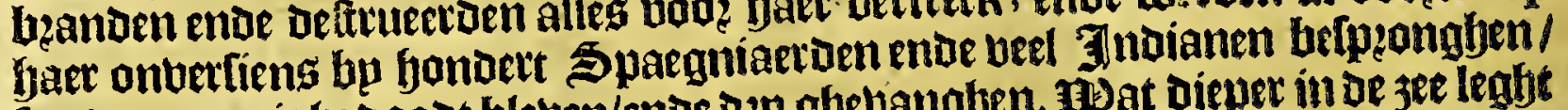

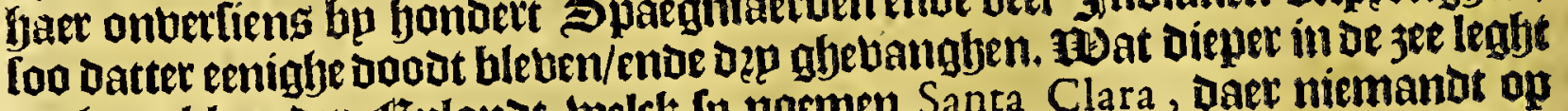
nory een kilepnier E⿺planot welck fy noemen Santa Clara, daet niemandt op

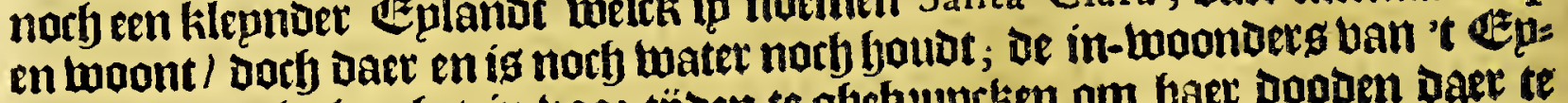
lanot Puna pleghen fet in vooe-tjoen te ghebeuptien am haet booden Daer te begraben.

Be rieviete ban Tumbez is tuel betwoont / ende daet pleeglj een foztrefle te leg ghen ban feer fraep werck / Dí de Ingas, ltominghen van Peru daet fadoen doen Irggen: De mondt ban defe riebiere leght op de hooghte ban dep gradeneneenbalf bp zupDen ae línie. Ban Defe viethiere tot De Cabo Blanco ftreckt of kufte jupdot3upot-ueft / ende ie diftantie ig bifthien leguen : Dete $C_{a}$ bo leabt bp naet op de booghte ban bier graden naet't leggljen uan Herrera ; Dan Pedro de Cieça trelt

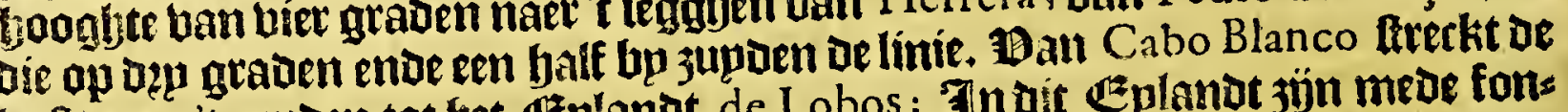

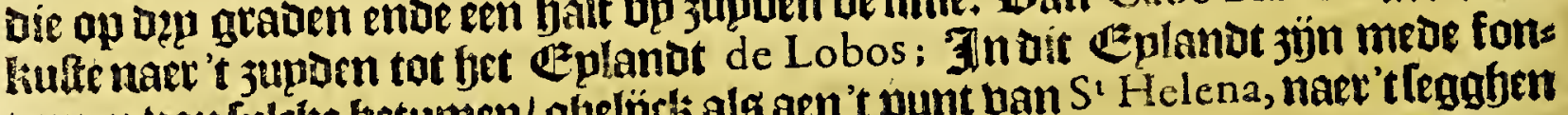
tepnen banfulcke betumen/ gljelincli als aen't punt ban $S^{\prime}$ Helena, naer't legghen uan $A$ cofta. Culftyen Cabo Blanco ende Ifla de Lobos, legbt eell ander punt

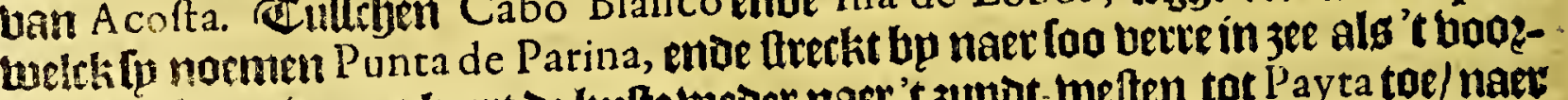

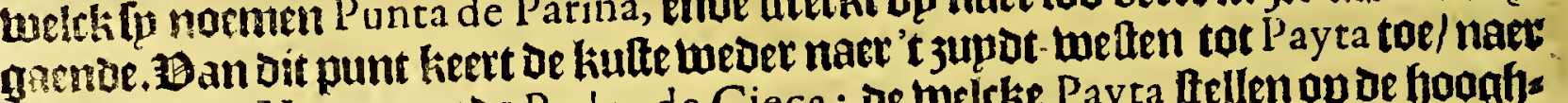

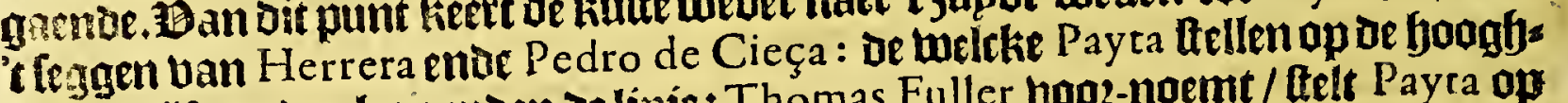
te uan büf graden bp zupden de linie: Thomas Fuller booz-noent / ftelt Payra op büf qraden ende bier milluten; (Sir Richard Ha wkins op büf graden:) enoe leght

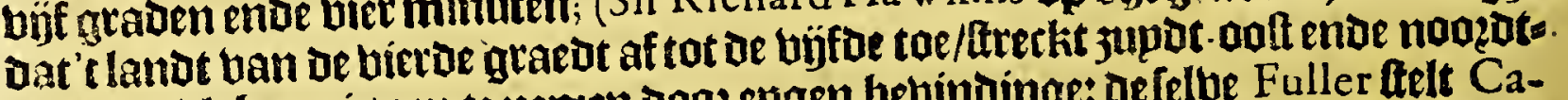
tweft welck beter is aen te nemen soozepgen bebindinge: de felbe Fuller felt Ca-

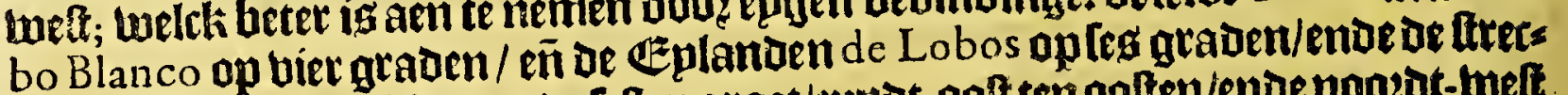

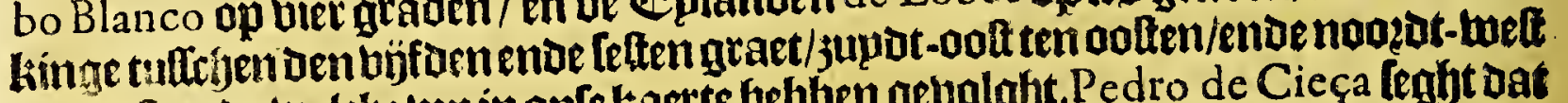

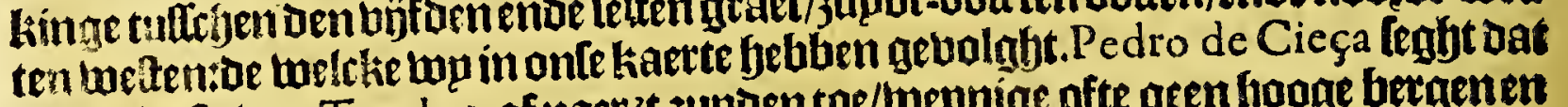
oe jee-kulte van Tumbez af naer't 3 upoen toe/wepnige ofte geen fooge bergenen befft/ Dan alleen eenighe dupnenende rootten/ ende dat daet Teer loepnige riebier:

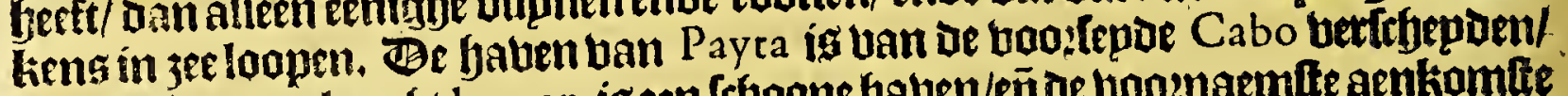

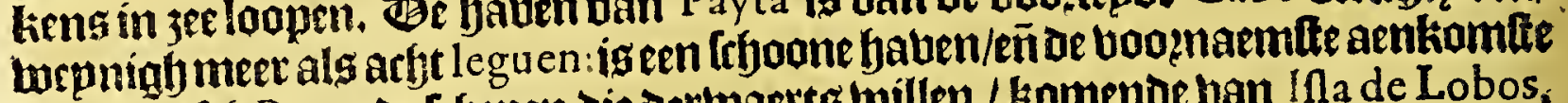
van gantey Peru : De Trhepen die Dertuaerts billen / komende ban Ina de Lobos; loopen aof ende twe ft tot aen Defaben/welck 3 ýn bier leguen:(tulfiben Payta ende $\mathrm{p}^{\text {ta }}$ de Aguia felt Herrera noetytwee habenen/Silla ende T angora.) Bam oaer bex: volght oe tulte naer't jupoen tot punta del Aguia; ende tulterben bepoen is een groote in-ham / daet goede refoe is / belchut boo de twinden ende goede gheles ghenthepot am de fryepen te repareren. Bit punt leght op oe booghte ban fegt

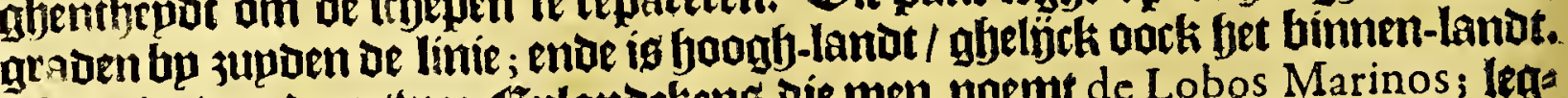
9Aen jiet van Dare twee Ezplandekens die men noemt de Lobos Marinos; leg

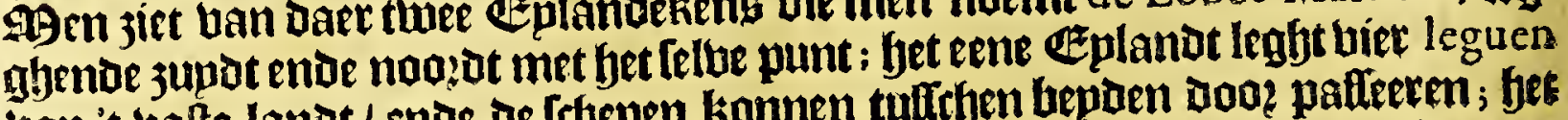

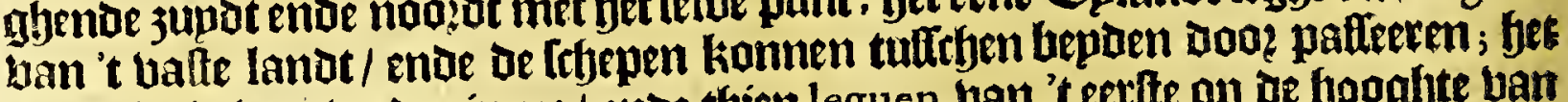
antoer leght wat berder in $3 e$ / endo thien leguen ban't eerite op ae hooghte ban teven grauen Ichaers bp zupoen de línie ; (Sir Richard Ha whins ffelot die op leg graden en een balf: ) op offe Ezlanden en binot men niet dan robben ende Pinguins, enue anoer ghe boghelte / gheen hoomen / notly gras ofte water; aen hes groutle 
Het thiende Boeck.

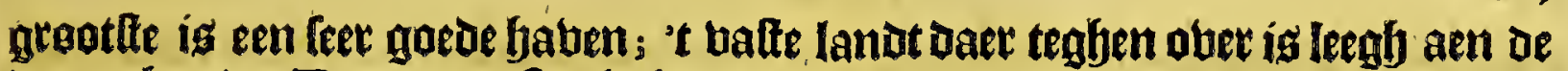
mater-kandt. Bus berre Atreckt fyem de kufte tan de pzouincie ende 2luaientie nan Quito.

\section{I M A ofre L O S R E Y E S.}

Het Leltyienise Capittel.

Groote endegheleghentheyde van de Audientie van Lim A; de vvegh van San Mrgvel naer de ftadt van Trvxillo toe.

De theede Aluoientie Lan Peru tuozat genaemt Lima ofte Los Reyes; ftecki baer noogot ende jupden ban ontrent de fjoogfte ban les graden / tot oe feg: thien ofe [eventyien graden al bu jupoen De linie; treick sijn in de lenghte langhg

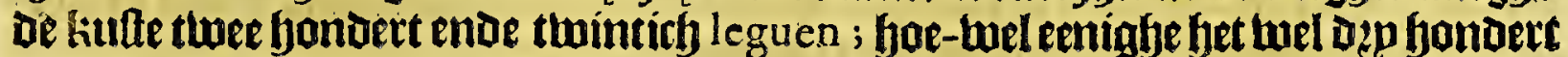
leguen meegho legghen te welen: ban punta del Aguia af aaet be zludientie ban Quito epndicht / tot voot-bp de fladt ende häben van Arequipa Daer be Zludien= tie ban Los Charcos begint: oolt enoe welt beft dele studientie/ boos foo beele fo.

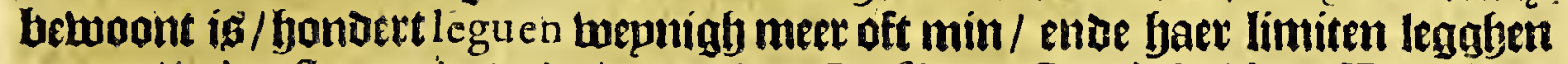
open naer 'tooften toe/ende de lanoen ban Brafilende Rio de la Plata. Ben Bire-

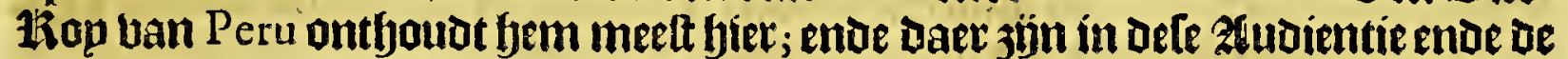

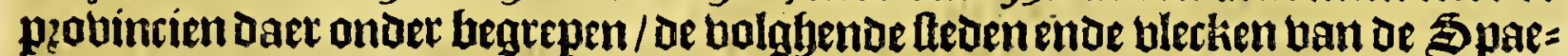
guiaeroen: Cuidad de los Reyes afte Lima, Arnedo, Santa ofte la Parilla, Truxillo, Miraflores, St Iuan de la Frontera, Sant Iago de los Valles, Leon de Guanuco, Guamanga, Cuzco, $S^{t}$ Francifco de la Vittoria, Sant Iuan del Oro, Arequipa, Sant Miguel de la Ribera, Valuerde, Canette ofte Guarco,entie Oconna. Om Je gfelegenthept ban de landen ende pzovincien beter te betfaen/ foo fullen twp oe belefyejuinghe ban dele zludientie beginnen met bet verbolgh ban de blaclie lanoen ofte plapnen/ abelíck ong den tuegy uan de ftadt San Miguel naer de ltade Truxillo, Daer toe fallepden. Auguftin de Zarate fegft Dat De in-moanders ban

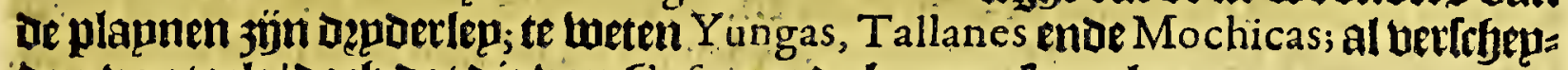
Den vantaele/ boch Dat die ban Cufco meor konnentpeerken.

. Ban de ltadt San Miguel tot de ballepe ban Motupe jijn thee-en-twintich leguen; al landigfe ende feet moepelíclie wegh / inlonberbept Daet die nu gleleght ig; tultijen bepde de oupnen jün eenighe balleplieng; ende boe-twel daer enighe riebieres ban't gbeberghte af-loopen / loo en komen die eluenluel miet tot daer toe/

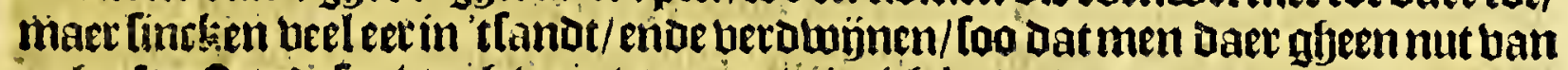

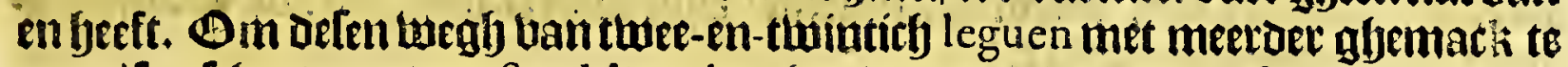
gaen/ loo fryept men uan San Miguel teghen den abonot/ende replt inen gantecben narfyt/om met 't kriecken uan den daghe fe zön aen eenplaetle (Cieça leght unos Xagueyes) Dare den reptenden man te deincken binot; ende van Daer vodets gljes boelt men de fitte ban de Tonme/maet wepnigh. Ez noe die konmen/ Dzagen jaet

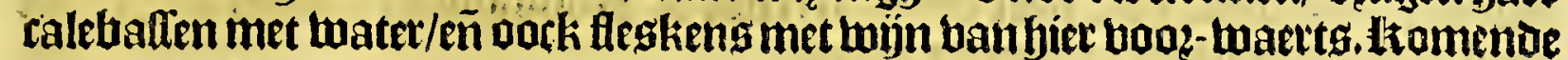
aen de ballepe ban Motupe, foo fiet men terftondt de ltoningblístie wegl daet twp bier boozen bebben ban gbelpzoken. Dit is een bzeede ende beuthtbare vals

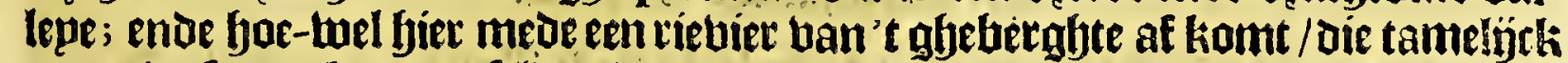

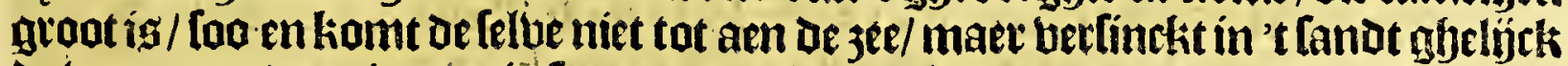
De boo?-gaende : niet te min [oo groepen biet beel boamen/ doo? de bocijticljept dic [y onder in de gront uindentende tholet dat in de doepen in bet leeghete ban de val= lepen woont / ander-bouven baet met fiet twater bietek [p upt putten balen / die [p Daer grtaben: bebben beel cottoen. boomen daet fo faer kleedinghe ban maecken/ ende ljandel met dęüun.

Biet leguen ban Motupe Ieght de ltfjoone ente frittife vallepe ban Xayanca,

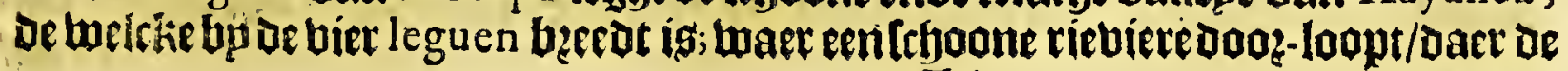
IL 13 ingles 


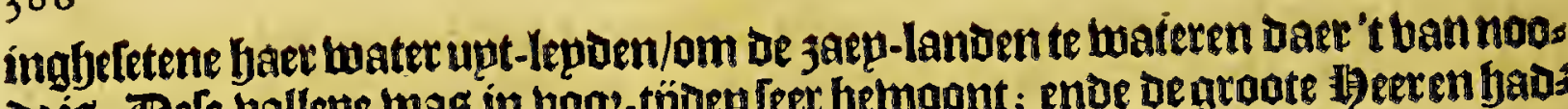

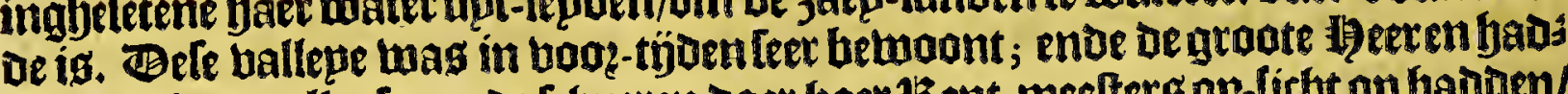
oen fier yaer palleplen ende fryueren daet baer Rent-meefterg op-licht op badoen/

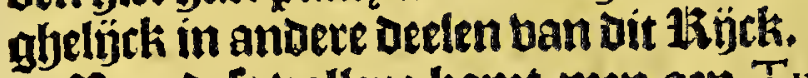

Ban dele vallepe komt men aen Tuqueme, melck ooch groot ento lultigb is/ enoe bol ban boltegagie / ende de berballen hupfen ende looninghen die

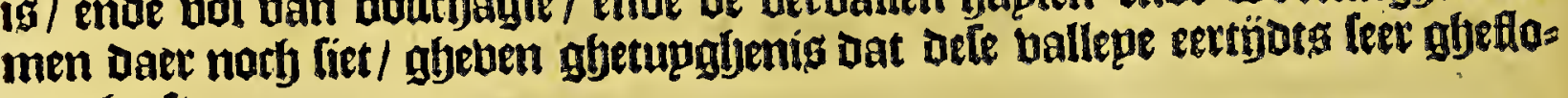
reert beeft.

Eenklepn Dagf-reple voozoer legft De Tryoane ballepe Cinto. De lefer fal gelies

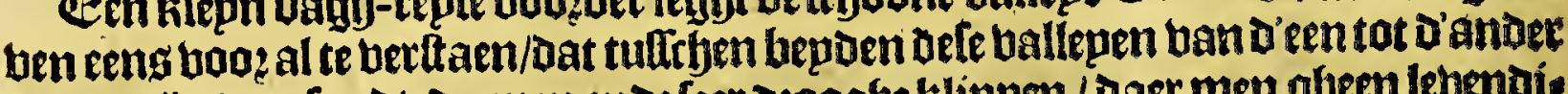

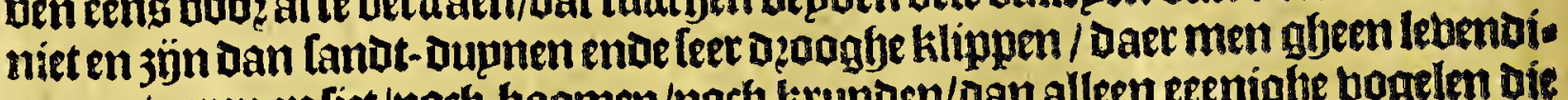

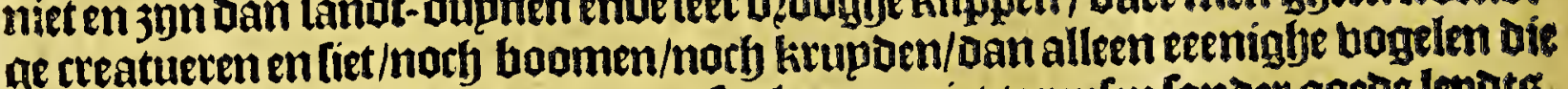
Daer ober bliegen. Ag en dient ouer oele plapnen niet te replenfonder goeds lepotgfieden/ Dieden wegh dode Dele dupnen weten te wälen.

Than de ballepe Cinto tomt men aen Collique, Doos de belcke en riebier loopt

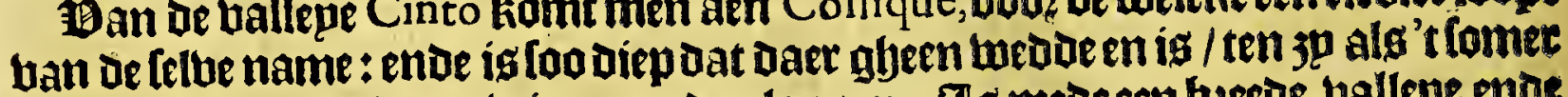
is ap't gheberghte / ende winter op oe plapnen. \$1 mede en bzeede vallepe ende

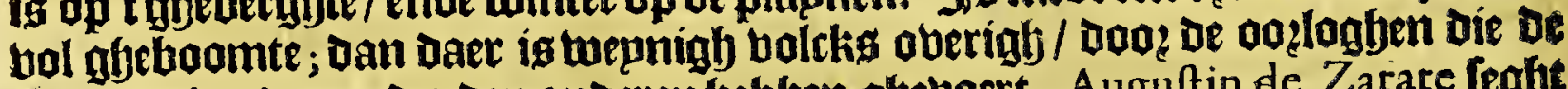
Spaegniaetien onder den anderen bebluen ghebert. Auguftin de Zarate legbt dat Collique ballepe light beetrity leguen ban $S^{r}$ Miguel.

Bande ballepe Collique treclit men naet Zana, uan ghelïcke ghettalte ald te voos-gaende:ende bootg komemen in de ballepe Pafcamayo, De welcke de beuctyts baertte ende volck-ríckile is ban alle oe booz-gaende: De in-gheboogne ban defe

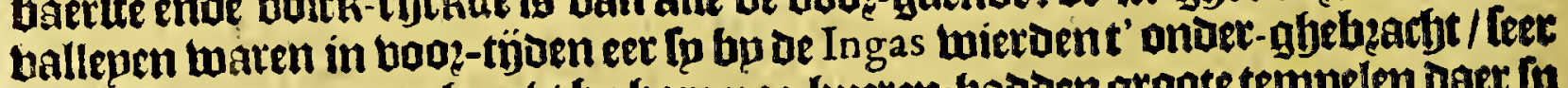
marftígh ende groot gheartht bp bare nae-bueten; badoen groote tempelen Daer ip

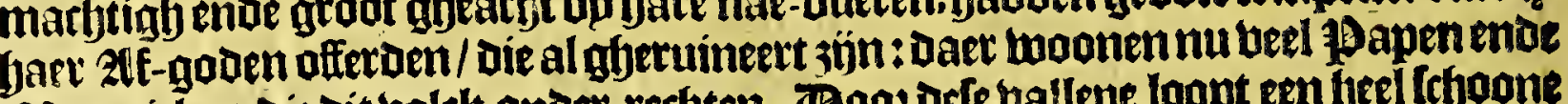
IT omnicken die dit bolck onoer-rechten. Boos Defe ballepe loopt ent beel fchoone rieviete / waet upt de Indianen eenighe footen ende wateringhen trecken om bes

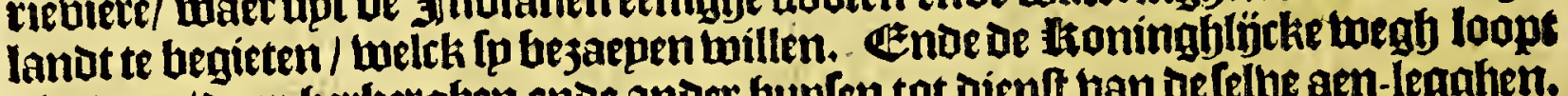
Gier $>002 /$ aer berberghen ende ander buplen tot dient ban oelelbe aen-legghen. 3) II aefe ballepe wozot beel cottoene lịnwaet ghemaectst; ende de koepen willen fier twel tieren / ende nach beter de berckeng ende gepten/ende ander bee / enoe iss cen wel ghetemperde plaetle.

Bpt de ballepe van Pafcamayo kommen aen die van Chacama, bie pmmers [oo groot ende beuththaet is / bebbende boben dien beel fupcker-rieden daet beel ende gopt lupeket van woget ghemaeckt; ende andere buchten: of Dominicas nen hebben bier een kloofter.

Bier leguen boozor legbt de vallepe Chimo, die groot ende wjot is / daet de Itaot Truxillo is ghe'eghen: de ltoninghen uan Peru naet dat [p meelter waren

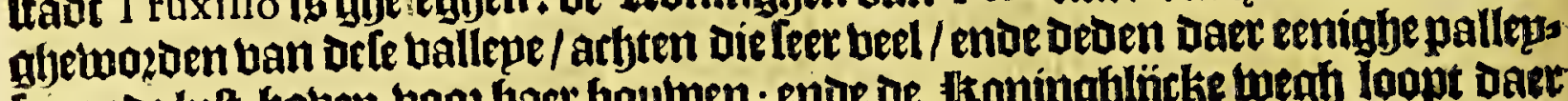

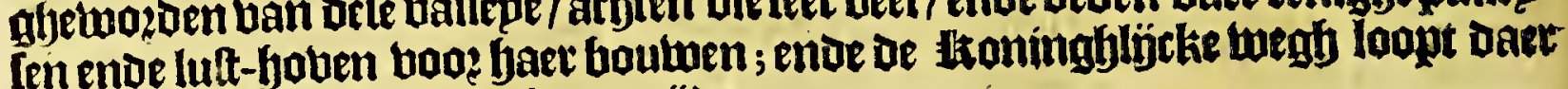
Dop? / met lon mueren aen begoe jögen.

\section{Wet Letuenthiente Crapittel.}

Van de vlecke Mirafiores, ende de ftade Truxilio: ende de vlecke SANTA ofte PARILLA; oock ARNEDO.

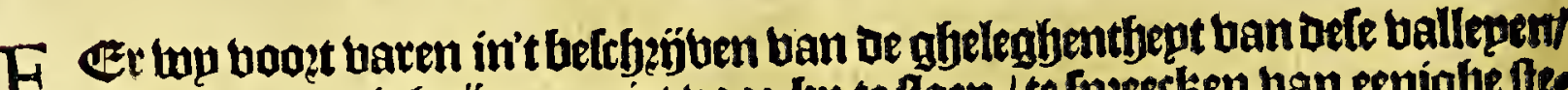

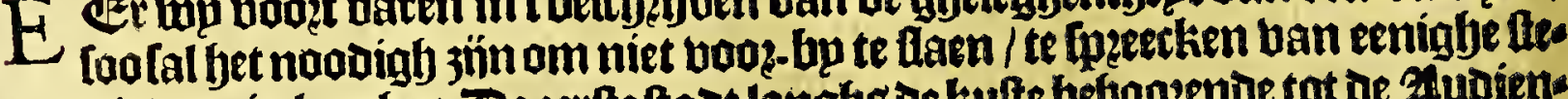
oen die daer in legghen. Be eerlte ftadt langhg de kufte befoozende tot de studien. tie van Lima, wozat ghenaemt Miraflores, is ghelegfen in oe ballepe Zana, büfen-tneghentiry leguen ban Deftadt de los Reyes naex' tnoaz̧oen; büf leguen ban 


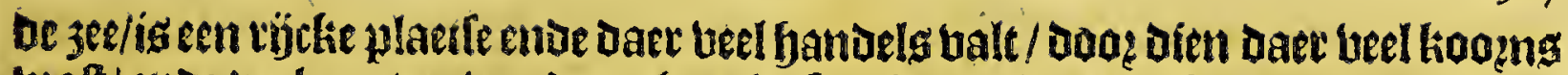
walt/enoe beel gepten buozen abeteelt: fpn baten wozot gbenaemt Cherepe,

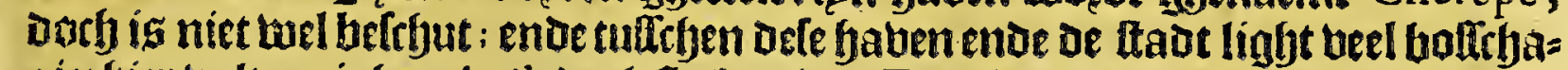

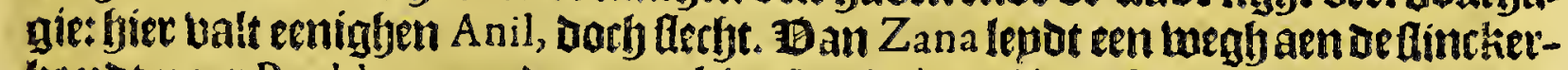
hanot naer Pueblo novo Daex een tiloalter íg ban Alugultiner-mannicken ghe= naemt Guadalupe.

Be fradt Truxillo, ofte Trugillo, is gheleghen in de ballepe Chimo boogen be cieça tcheeben/nebentsen groote ende frboone riebiere / upt de tuelcke de Spaegniaer= c.6 6 . Den diverffye flootenende tweteringben lepden am baer boven enoe boomgaerden te thateren:ende benghen't water in alle be buplen ban de ftadt: 't lanot oaet

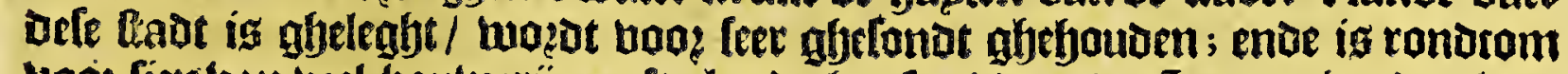
vode-fien ban beel houtueryen ofte lanter-juplen/ Daer of Spaegniaerden baet beeften houben / enoe't lanot bezaepen: enoe allentjalben jön beel wujngaerben

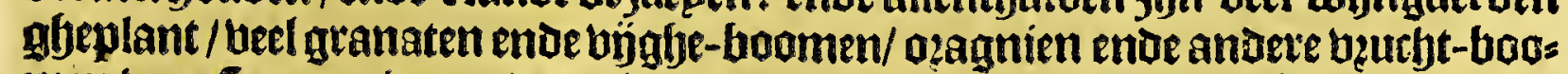
men ban Spaegnien; ende beel tartwe wogot saer ghetwomnen. Soo dat de in-

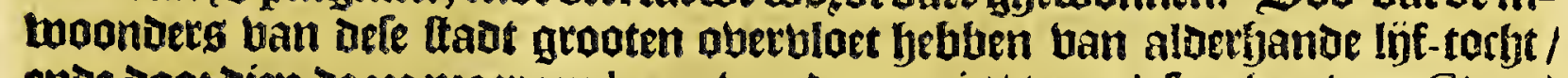
ende Doog dien de jee maer een legue ban daer en is/ (naet t fegghen ban Cieça)

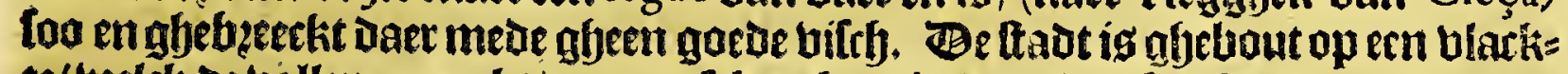
te/ welck be ballepe maeckt/ontrent lekete berghgkeng ban leer barde cube d o ooge

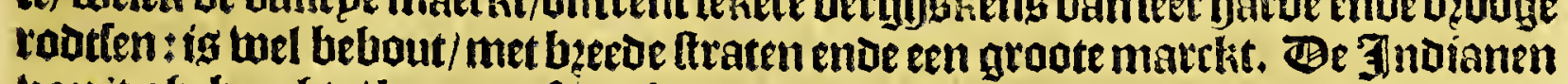
ban t gheberghte/komen af upt hare peobincien / om de Spaegniaerden die in dele ftadt woonen / te dienen; ende boot-lien de ftad ban fulckis als in gaer ghe brefte balt. Befe thaot naer't tegghen ban Herrera, is ghelegben op of booghte ban Ieven graden enoe dertich minuten bu zupden de linie: tarfitentich leguen han de taout los Reyes ofte Lima, enoe twintich leguen ban Zana ofte Miraflores. ' $t$ Supeker dat in dit quartier wozot ghemaecht / wozot meeft ghemaeclit in de

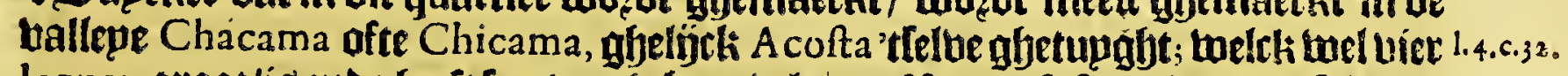

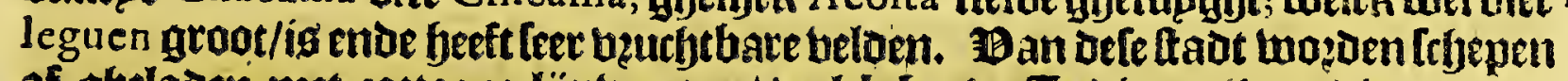
af-afbeladen met cottoene ligntuaten / welck bp de Indianen ban dit quattier

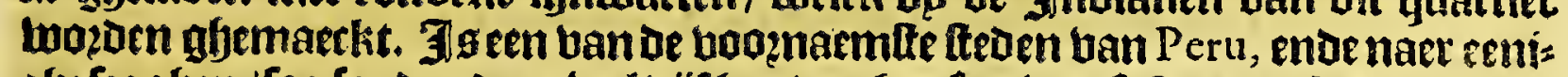

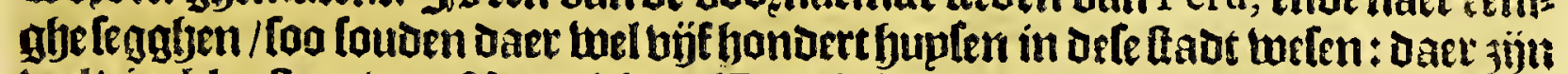

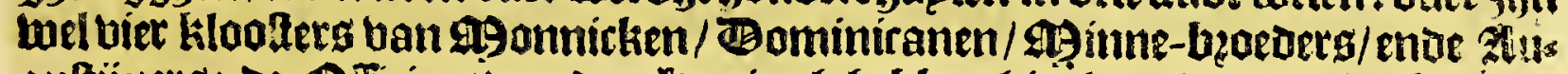

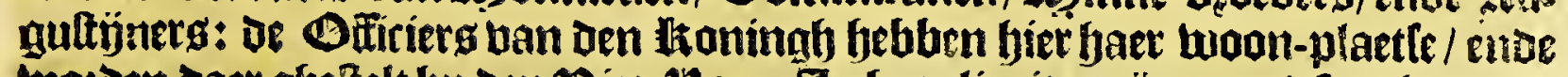
mojoen daer gheltelt bp den B ice-kop. In haer limiten 3 ïn naer $t$ legghen ban Herrera bel uiftich oupient Jndianen die tribupt betalen/ herdelt in twer-enbeertich Repartiementos, ghelỉtk de Spaegniaetden dat noemen. Be baven ban defe ftadt welck ly noemen el Arrecife de Trugillo, leggt twee leguen han Daer/in De bape die qualïck beftyut is tegfjen de twinot/[oo dat fyet een quaede entoe onlectkere refoe ig.

De blecke la Parilla, welck oock anderg mozot gluenaemt Santa, naer oe ballęe Daette in is gatelegfen/íg bijfthien leguen ban Truxillo booz-noemt naex't 3upuen/ ende [ebentich leguen uan Lima naer' tnoogoen: op de booghte ban neghen gra= ben naer't legghen wan Herrera; ig gheleghen bp of jee neffens een fogoone ende

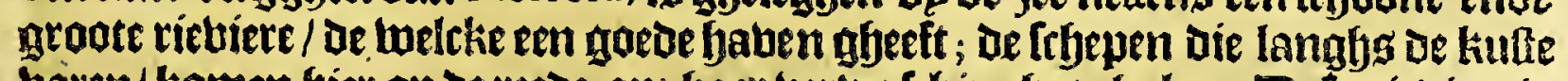

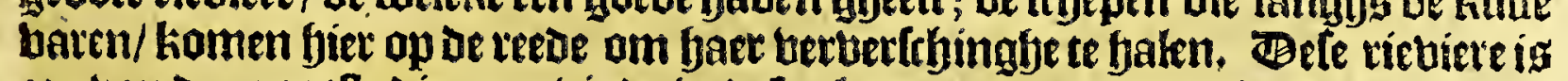

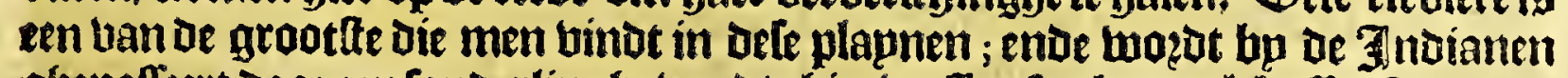
ghepaftert soos een fonderlinghe bonot; hier wallen feeckere calebaflen foogroot

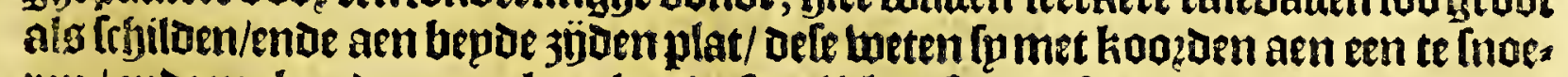
$\mathrm{ren} /$ ende maken daer een langh enoe fimal blot af; Daer fp de goederen enoe ment:-

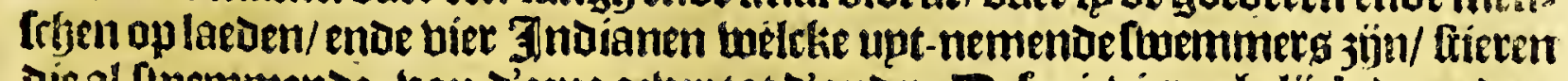

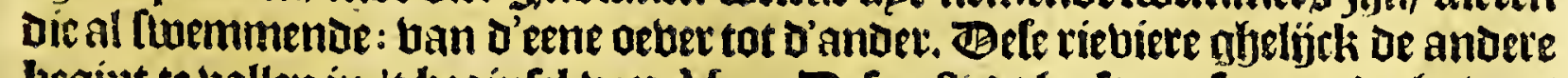
brgint te vallen in ' $t$ beginfel ban May. Belen ftadt beeft een feet goede baten/

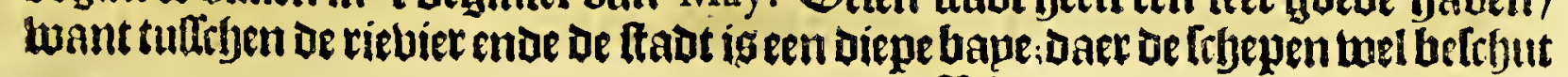
II 4 liggijen. 


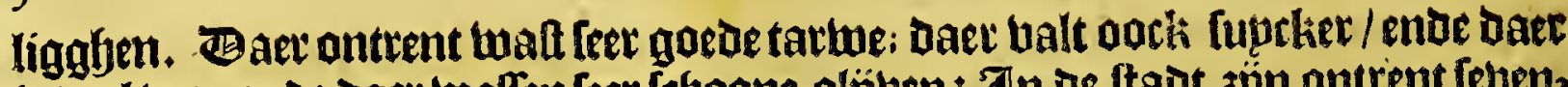
ig veel bee; ende daer tuallen leer fefoone oljuen: Tn of ftadt jyn ontrent feten. tich hupten ban Spaegniaerden.

De blectie Arnedo is abeleghen in de balleqe uan Chancay, thien leguen ban

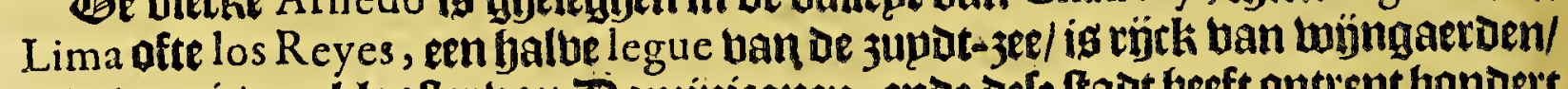
ende daer is een kloofter ban Dominicanen; ende defe ftadt feeft ontrent bondert

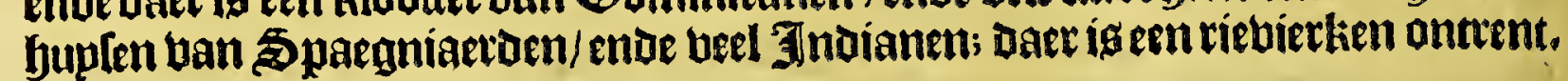

Het achthiende Capittel.

Van de valleyen die voorder zijngheleghen van $T_{R}$ uXiLLO af, tot de. hooft-ltadt $L_{I} M$ A toe : ende haer byfondere gheleghentheden.

V Aln đe ftadt Truxillo tot Lima jön tachtentich leguen / al Doǫ tandt-Dup: nenende ballepen: 1)pt de ballepe Chimo Daer De thadt Truxillo inleght/komt men in die ban Guanape, fevenleguen ban Truxillo nact de ftadt Lima toe; Defe

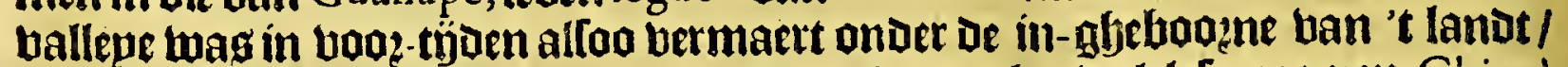
weghen den goeden dęanth die daer wierdt ghemaeckt (weltk [p noemen Chica) als Madrigal oft San Marcin in Caltilien / van weghen de goede twijn; $\mathfrak{e n d e}$ Daet moonde eertijots beel bolck / Dan jün nu feer bermindert. Bele ballepe beeft een

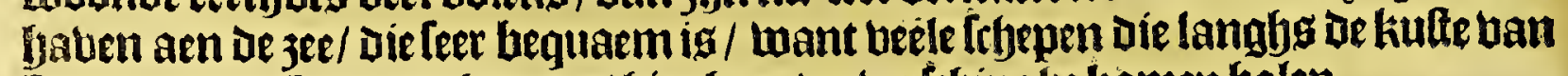
Panama naer Lima toe komen / bier baer bervertflingbe komen balen.

Ban Guanape komt men aen de ballepe ban Santa; Doct tulteben bepoen leght noty een klepn vallepken / Daet gheen rieviere dooz en loopt/ Dan Daer is fenlercker put / Daer de replende lieden upt deinclien. Santa is een ban de groots fte/langblte / ende beestete vallepen ban alle de booz-gaende / ende daet is de fast Santa in gheleagen Daer bu hier boozen bebben ban ghe[y:oacken.

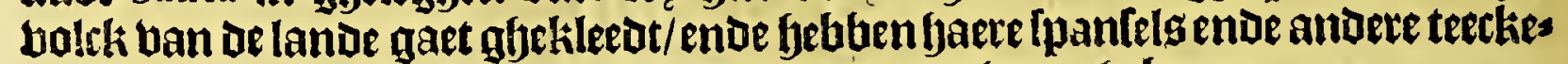

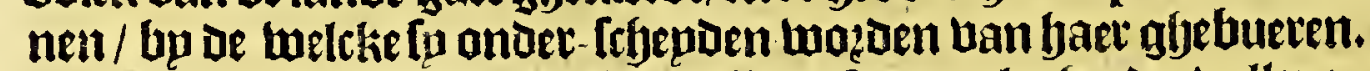

Clate Dagl-teplen van de tallepe Santa, Ieght de ballepe Guambacho, Daer mede een riebiere Doo: loopt/Daer de in-moonderg !yaer meten ban te dienen als in oe booz-gaende vallepen: bier by leght Cazma met een fyaben daer fres gattent liomen laeden: want teuen leguen van Cazma onder't ghebergbte walt berl tuing.

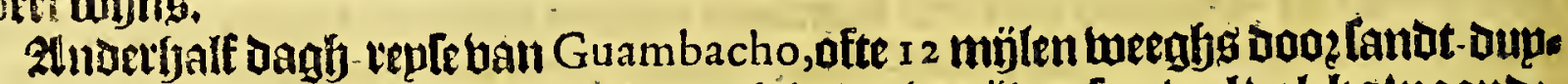
new/legft de ballepe Guarmey, daer aork in bozige tijoen feer beel bolcks twoontoe; ban nu neifen [p Daer beel berckeng / ento boúden Daer beel koepenende peer den.

Ben Generael lor is Spilbergen was̉ hier in Den jare 1615 , naer dat bp de blos

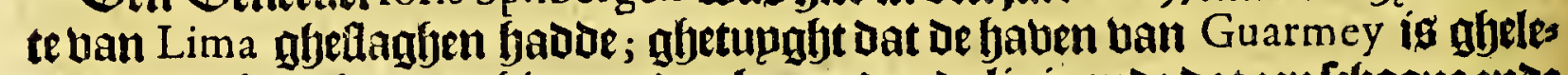
ghen op De hoogfte ban thien graden by jupden de limie;ende dat een [rfjoone ende plaplante plaetle is / met een groote ende wel-ageleghene haten/ Daer men met veel fryepen magh legghen; vonden Daer een ftaende poel ban berfely water / Daer fp baer baut uerfaghen. Wet bolck twas al abevlurbe/ foo dat fp be buplen in bet ltedeken meelt leedigh bonden: daer lagh een ghebzaken ende verballen lianeeltien.

Paeft de ballepe ban Guarmey bolght die ban Parmonga ; in de tuelckel

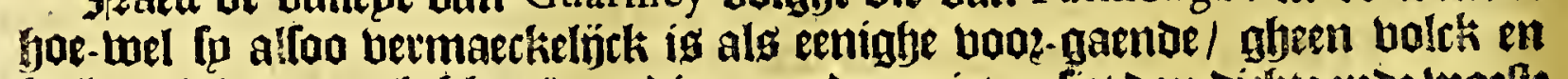

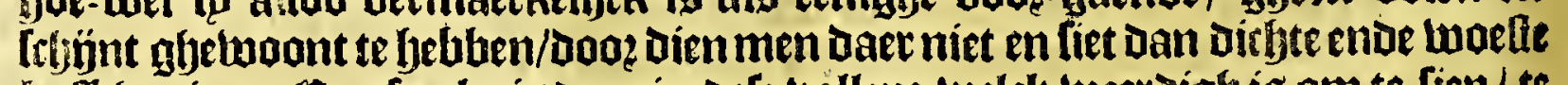
bolichanien. UEen faecke ig Daer in Defe ballepe melck weerdigh is cm te fien/te

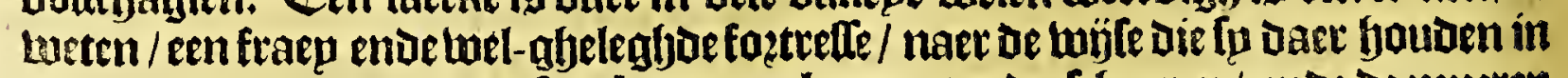
gaer timmeragien: hadoe leet bequame hamers ende frbueren/ ende de mueten taren al ghefrbiloert met aldectyande beelten ende boghelen/ dan is nu mest vet:

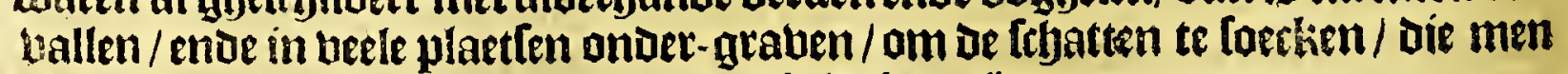
mepnt neffeng de dooden in de graben gheleght te zün.

Itwee. 
Cluee leguen ban De ballepe Parmonga loopt derietuiete Guaman, Melck in de Spaenffye tale foo becl te legebenis/als Rio del Halcon, tietiete ban ae ualcken;

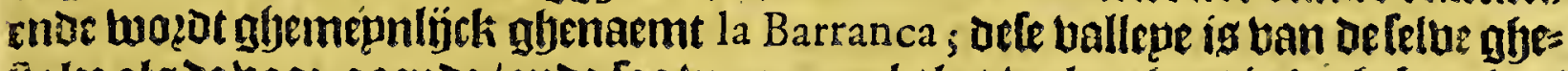

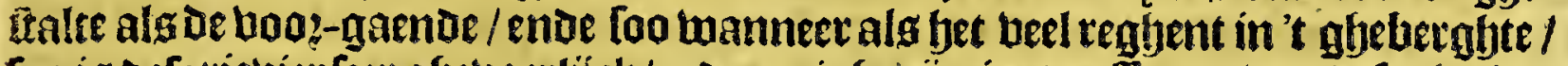

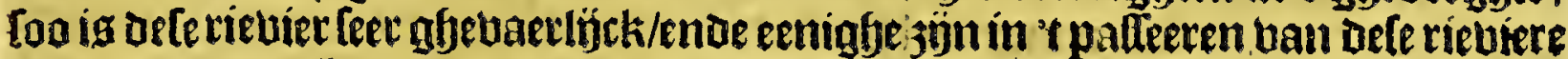
verozoncken. Een dagh-keple boogorer Iegljt de ballepe ban Gaura, daet oock een

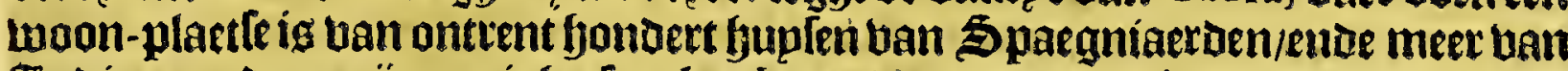
3ndianen; daer jín eenigbe fupcker Ingenios: van daer komt men aen de Sa. linas ban Gaura, twelck een uan de wonoerbaerlïrklte fout pannen zijn ban oe werelt; want daet en liont gheen water ontent / maer ig een rodte die upt-nge= Gouken wogot ende weoer aen-Luat: oit foubt mozot ghebyorht naet de baben ban Gaura, enve booztg in Gatcken naer. Lima; ban daer loopen twee beghen naer Chancay, baet Arnedo in light biet bogen berbaelt: ban baer lomt men aen de riebiete tan Chanciy, daer een fteenen bygghe ober leght: ouer ofle ries viere kame men in be Canot-Dupnen ende gbeberghte/ welch Duett bijf leguen; Dit ghebergfte af-dalende / komt men aen een in-fjam ban of zee daet beel billtherg

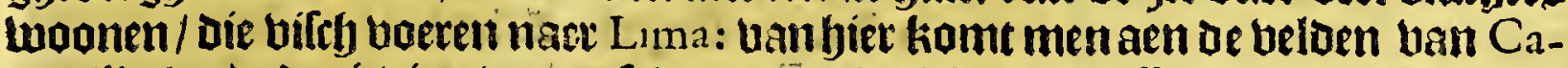

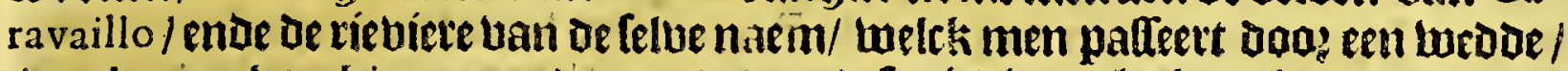
twee leguen ban Lima: aen or monot uan offe rietiere plarfiten laer te ontfou:

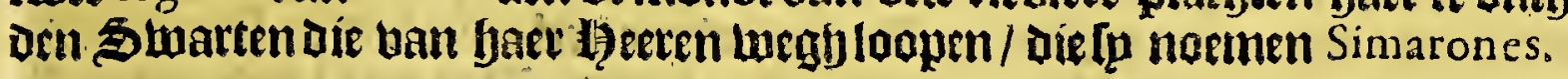

\section{Het neghenthiende Capittel.} De gheleghentheyt van de ftadt IOS REY Es, ofte LIMA: ende de
Wegh van daer over ' 2 gheberghte naer 't volten.

D

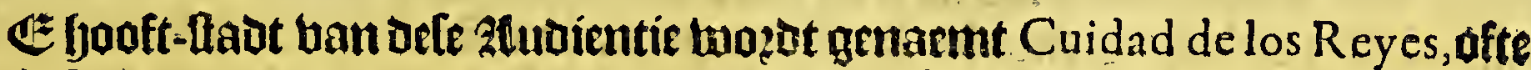
de Lima, naer oen naem ban or ballepe vaerfa in gleleagen ig ; welck wel een ban de grootlte ende beerotlte ballepen ig / van alle de gfene die imen beeft op Defe plaunen uan Peru van Tumbez af; Ieght op de ljooghte van thaelf graden bp 3 upden de linie / op de lenghte ban thee-en-tarhtentich graden uan den meri= Diaen ban Toledo, naet't frgghen ban Herrera. Alnoere fellen die op ae hooghte Engel. bau elf graden ende büfrich minuten; ende aniete op De hooghte ban thaeff

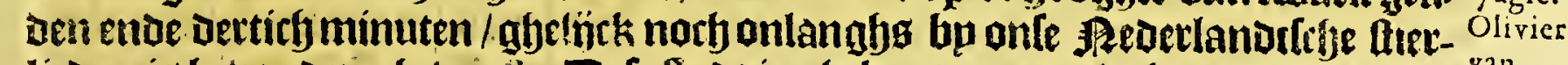

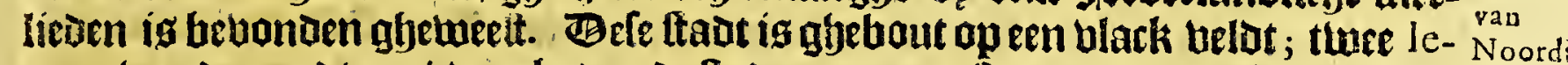

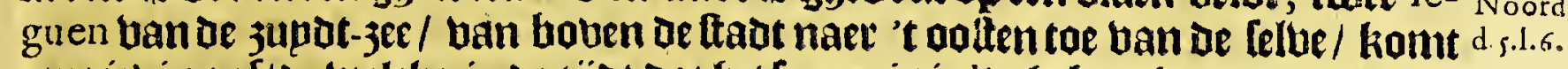
een riebiere af/ oe tuelcke in oe tijot dat het fomer is in't gheberghte/wepnigh wa= ${ }^{\text {c.12. }}$

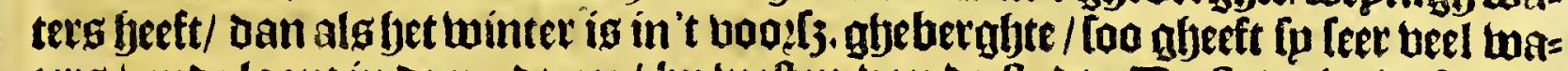
terg / ende loopt ín ue zupot-jee / bu weften ban de ftadt. De ftadt is in fulcket

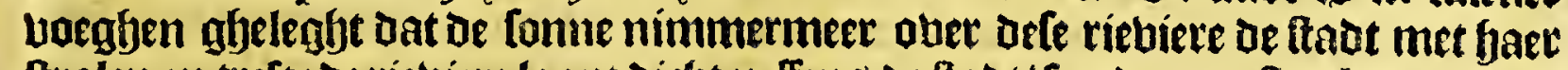
Itralen en treft: of riebiere loopt dicft neffeng de etadt/ fao dateen ferck man ban 't marckt-betat tot aen be riebiere met een Iteen mathtigh is te tuozpen: Raeft

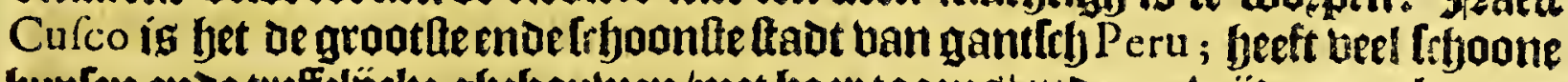

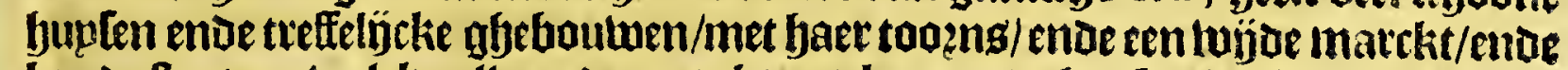

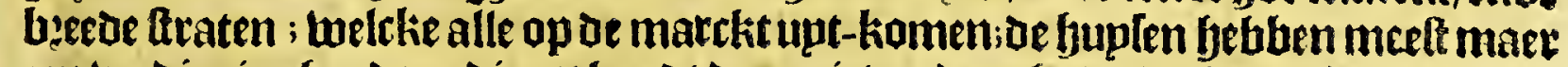

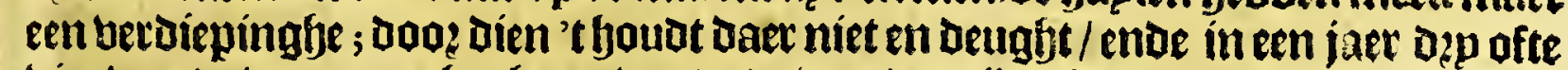
bier ban de woemen ghegheten wozot:de thanden jïn ghemaeckt ban louvt/ende

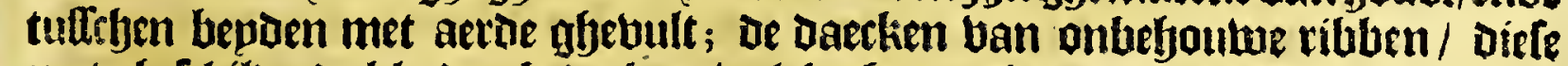

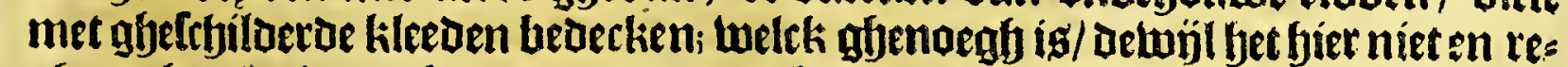
glyent: boe-toel eenighe mepnen dat bet beter is booghe buplen te bebaen/entoe

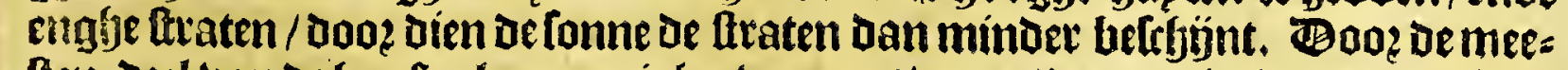
fern-ded ban de bup fen loopen riolen ban goet water/ daer de in-woonoets baet boben mear wateren; want hebben fier beel lefjoone ende luftíghe hoben. Baet:

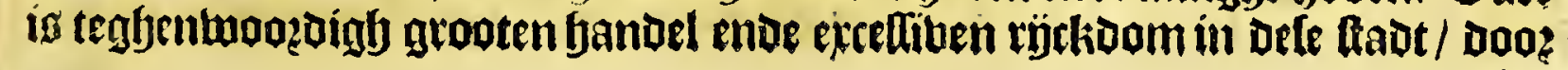

Dín 


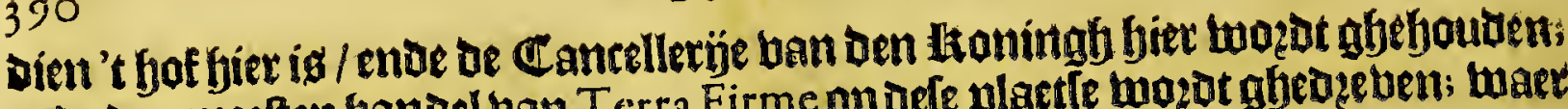
ende den meeften yandel ban Terra Firme op Defe plaetle twozot ghedze ben; waet Doo bier Dooz-naeng grooten toe-loop ban volck ig/ende beel winckels ende tens

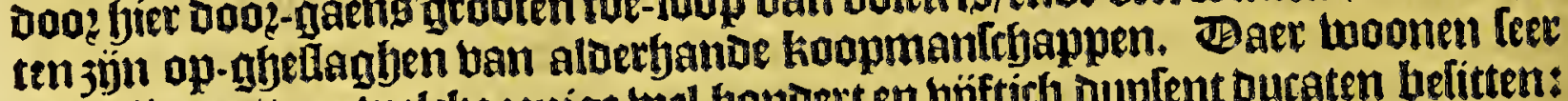
rïrke lieoen / van welckecenige twel bonoert en büftich Duplent oucaten befitten:

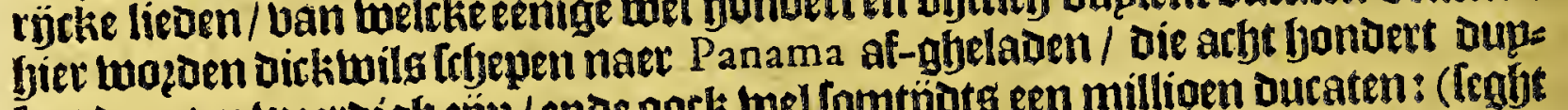

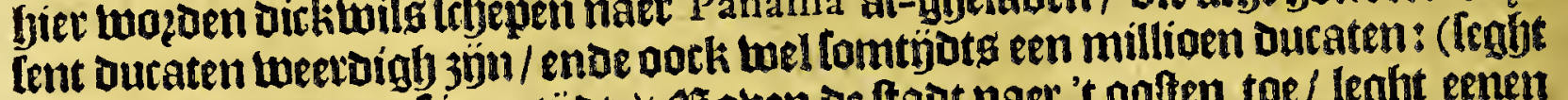

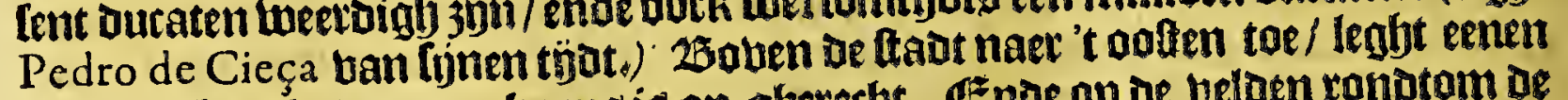
hooglen bergh / Daer een krupg is op-gberecht. Eznoe op oe beloen ranotom ae

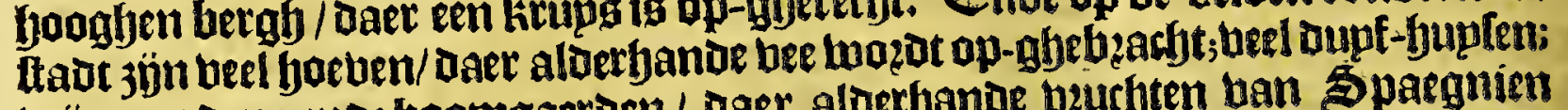
Lüngaetoen; enoe boomgaerden / oaer aloerbanoe vecurbten ban Spaegnien waften / welcke saec pock leer goet enoe fmaeckelỉet ballen: Mgen kan ban oe veurfytbaerfepot van orfe lanooule niet gbenoegh fegghen. Tin fomma/ men

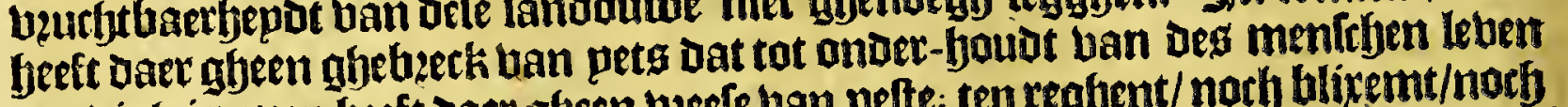
noodigy is; men beeft daec affeen beefe ban pefte: ten reghent/ norb blixemt/noch en weet-lítyt Daer nimmermeer/men beeft Daer Doos-gaens een beloete ende klare

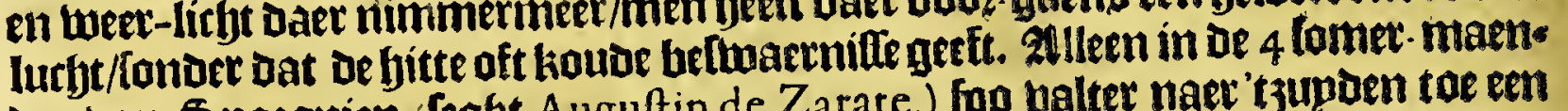
uen ban Spaegnien (erght Auguftin de Zarate,) foo ualter naev't3upoen toe een

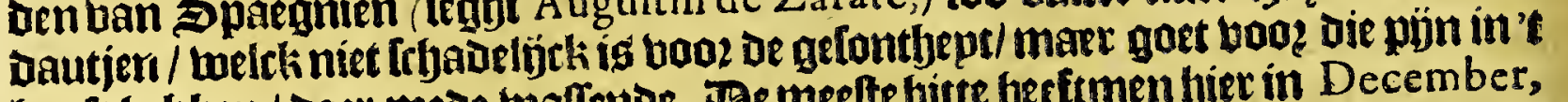
Gooft beluben / daec mede waltento. Be meelte hitte bertimen bier in December, Ianuario, Februario, ende Martio; dits baeren tomer. Ben berfit enoe gbetwas komt hier in de maenden December ende Ianuarits; de Dupuen rupen ende moz Den ahefneden in April. Ban May tot Seprember ift hier winter. Den Bice-12op

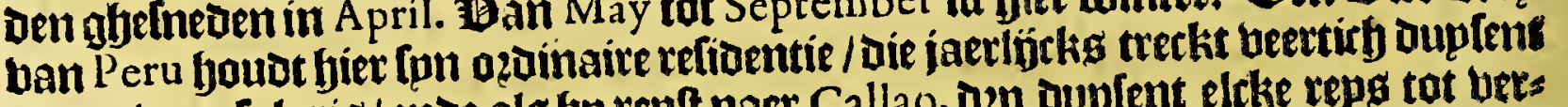

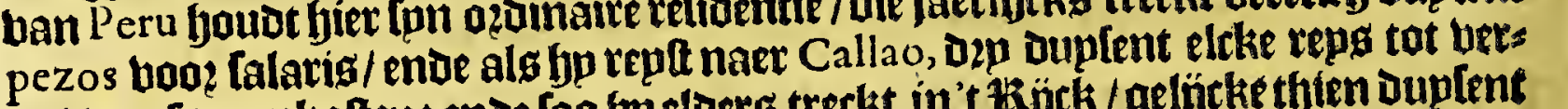

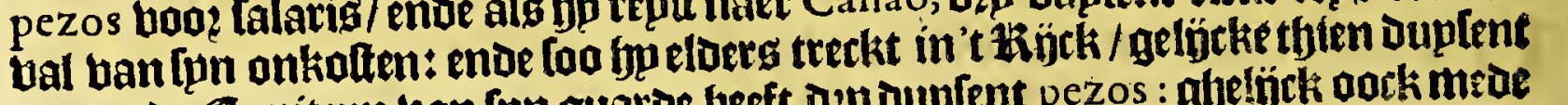
pezos; of Capitepn van Lun guaroe beeft dep ouplent pezos : ghelṕct oock mede

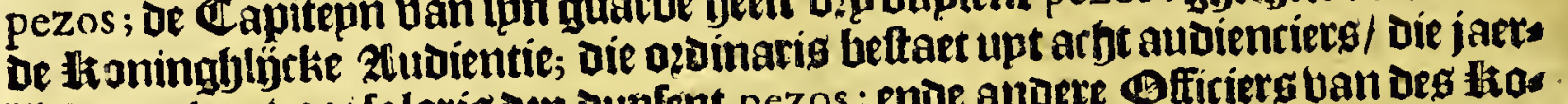

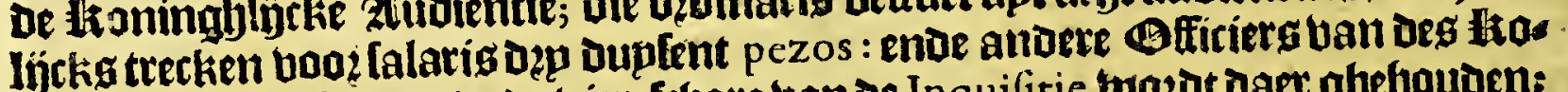

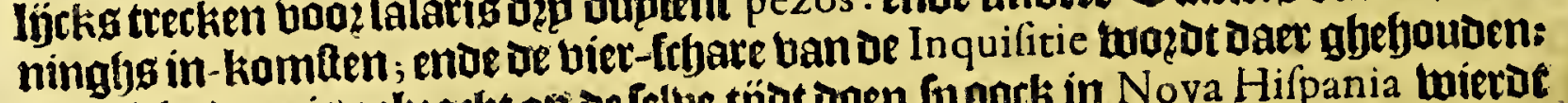

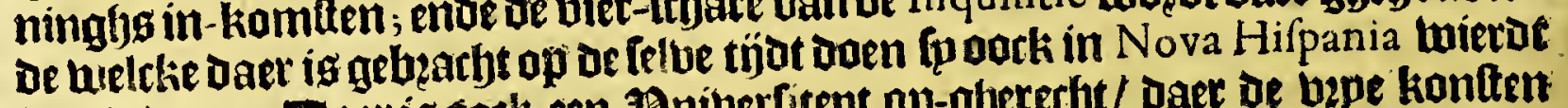
ill-gbetoert. Taer is oock een 19niberfitept op-gyeretbt/ Daer be bepe konften boz oen gheleet /enoe berfrhentan talen van or 3 noianen / welck meelt wozot bes

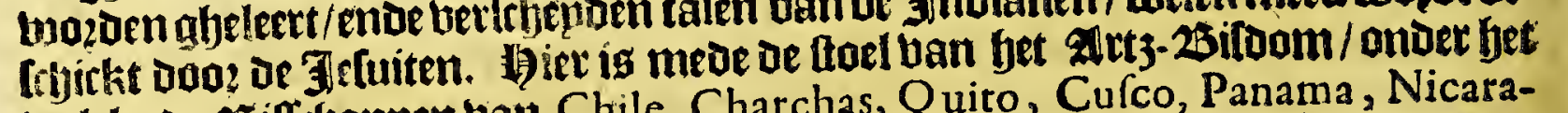
welcke de biflchopren van Chile, Charchas, Quito, Cufco, Panama, Nicaragua enoe Rio de la Plata refotterten: Daer jün dęp paroctbien / ende bíf kloafter

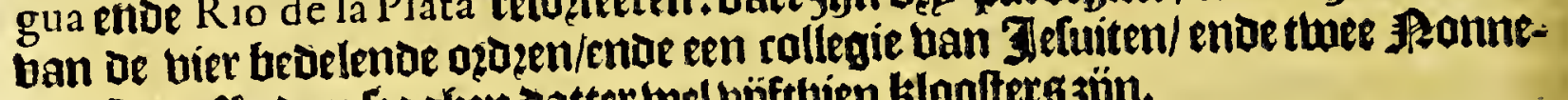
kloofters. An noere legghen Datter wel bÿfthien kloufters zïn.

De haven van defe Stadt wotgenaemt Callao, ig een groote/rupme moe leet

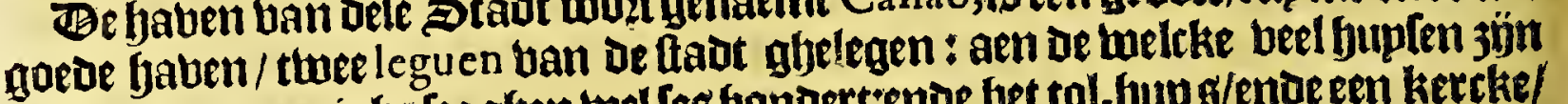

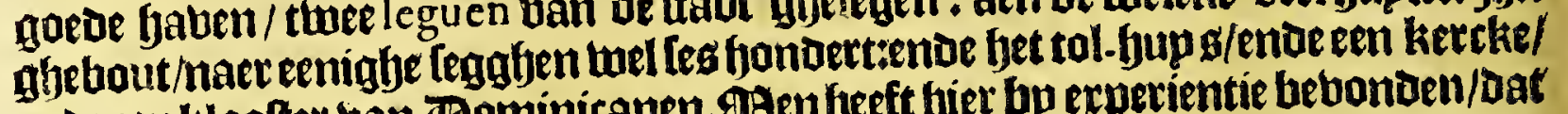

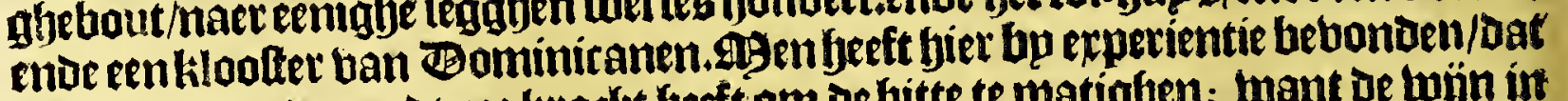
het water van de zunDot-jee kratht beeft om de bitte te matighen; want de wijn int

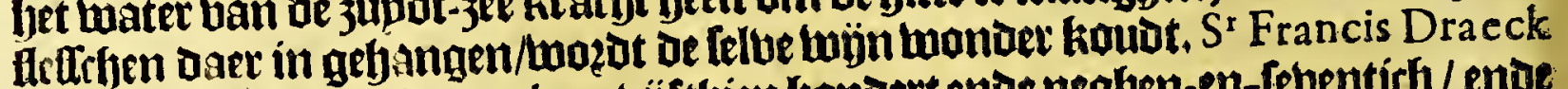
quam in be fe ljaben in den jare unfthien hondert ende neghen-en-\{ebentiefy / ente bontet vaer twaelf (chepen aen ancker legghen; ende in 't cene een tifl met beel fil.

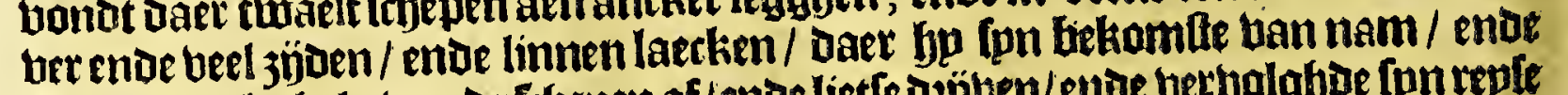

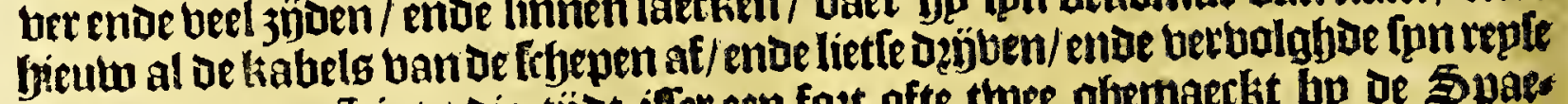
nare Paita toe. Sints die tijot iffer een fout ofte twee abernaerkt bp de 5 par

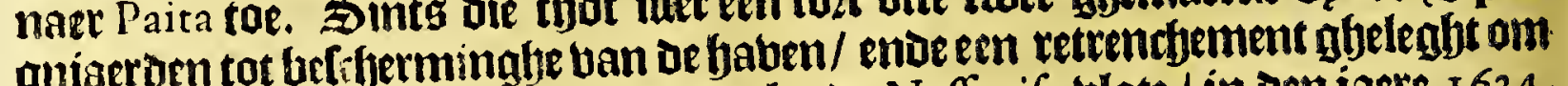

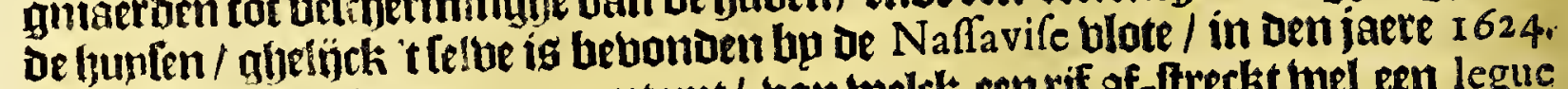
't Landt freckt bier met een punt upt/ ban welck een rif af-ftreckt wel een leguc

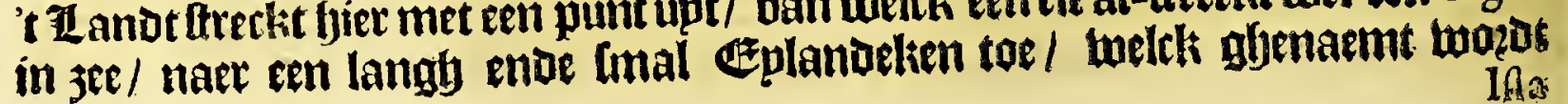


In a de Callao, ofte oocki Ina de Lima, Itreckenoe in be Ienghte noozot-welt ento

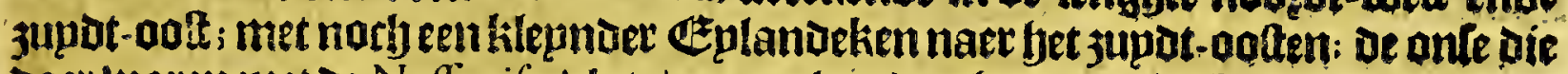

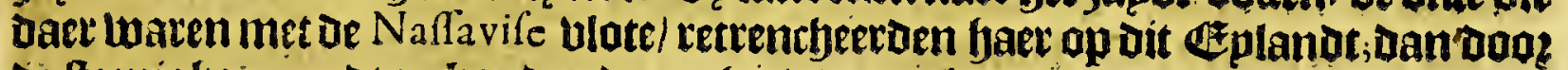
De lteeniglbe gronoten honden daer gheen watei begratien ; alleen tonoen opern bergh menighte ban graen krupdr / belck leer dienltigh twas teghen bet febeurbupck; acn bepoe jgue ban bet boos[3. punt berlielt bem get lanot / ende maeckt twee in-fammen in foume bat een halue mane/ maer ban de eene treckit naex het noozot-meften taan of bauen ban Callao af/ tot aen leecker Eplandelteng ofte klippen/ welck fo noemen Inas de los Pefcadores: ende of ander naer fet jupDt-jupdt-oolten tot ern ander upt-Iteckende boerk; ende aen delen tweeden in-bocht is ite tallepe ban Pachacama gbeleghen / Daet wp nu tan fullen Lpeectien.

- 19an Lima loopt een luegf naex' 't oofen obse het gheberghte; bier leguen ban oe ftadt light de ballepe Seneguilla; ujf leguen toozoer leght Chontajo; $\mathfrak{k e n}$

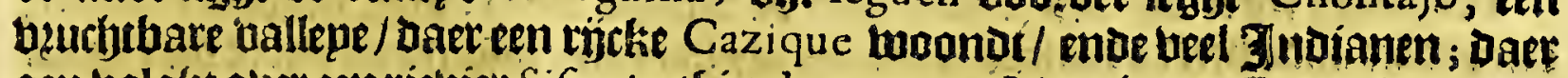
aen bolght ouer een rieuier Sificajo;tfien leguen uan Lima is een Corregiemento, aen de boet ban't gheberghte; van baer hegint mente klimmen naex een dopp van Indianen genaemt Cónillo, Dertbien leguen ban Lima, daer't leet veglent ende tonaett; banfjier liomt men te Guadacheri, een röcke blectie ban Indianen/Dité noemen Chapiy ungas: is getempert lanot/tufterben koudt enoe feet; ban bier Daelt menende flimt weder op naer'tyooge geherghte ban Paviacacia; Daer oen replen= ae-man ghelp̈ch jee-jiecli wozbt; is twee-en twintich leguen ban Lima : Dit abe-

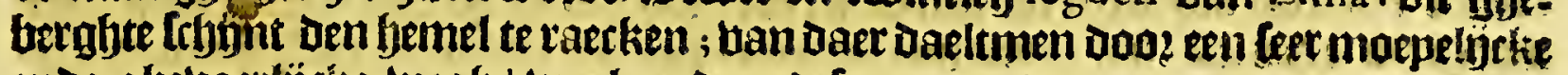
ende ghetuaetlije

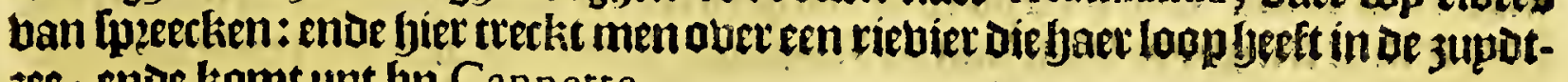
JeE; ender kamt upt bu Cannette.

\section{Het thintichlte Capittel.}

Van de valleye PA CH A CA MA, ende de vervolghende valleyen langhs de kufte van de zuydt-zee, ende haer gheftalte, ende gheleghentheyt tot Guar co toe; ende van de vlecke CanNET T E.

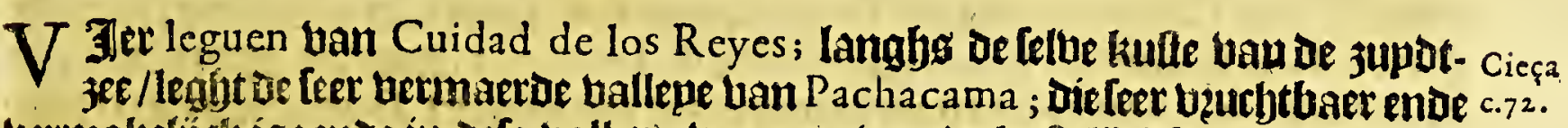

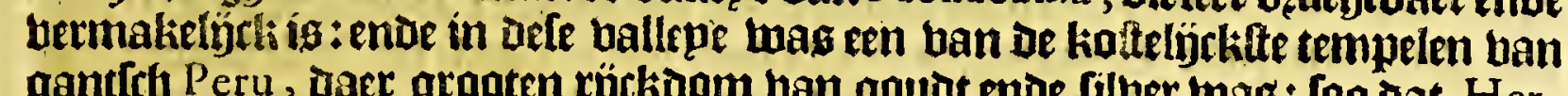

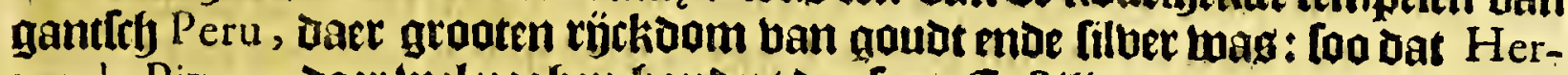
nando Pizarro Daer bel neghen fondert Buplent Caltilianen upt-jaeloe / [onder bet ghene bp de foldaten glyenomen luictot: ende niet te min foo baudet men boos [recker / Dat de Deiefters ende de Tndianen err Pizarro Daer konde komen/ hel

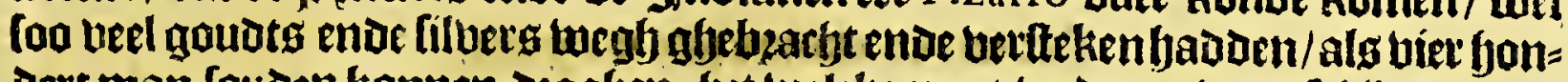

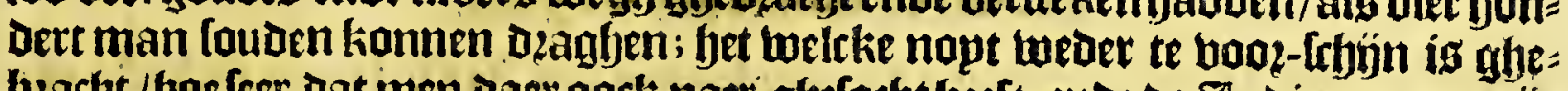

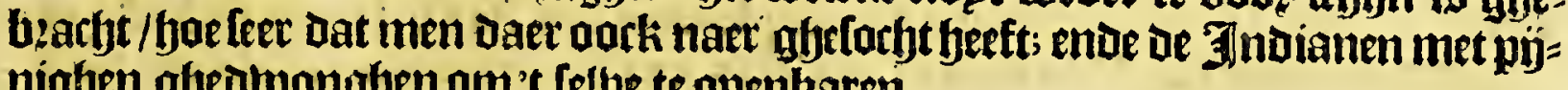
nighen ghestwonghen am't telbe te openbaren.

Ban be ballepe Pachacama komt men aen die ban Chilca; daermeneen bon=

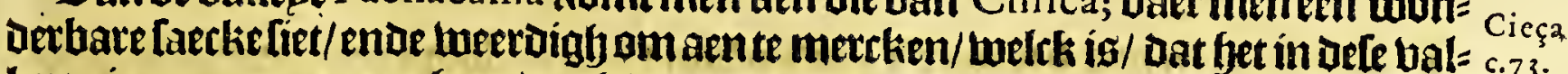
lepenimmermeer en regfent/ noch baex en loopt wark geen rieniere ofte belie doog/ ende narhtans foo is bet meelten-Deel ban De booz-[epde ballepe bejacpt met Maiz ende andere woztelen / ende daer jün oack beel frupt-boomen: ende op dat De $3 a=$ den endeplanten be noadige borbtighept marbten bekomen/ roo maerken fier de

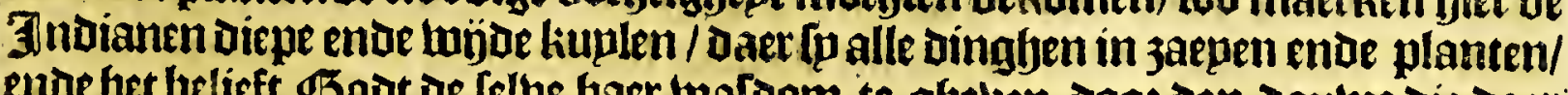

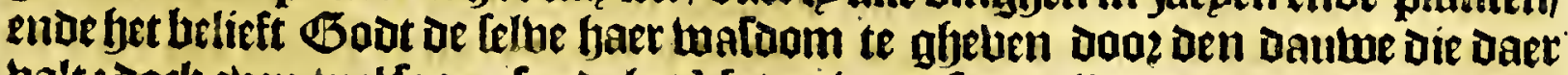
balt :Dorl] eben-we! fooen [ouse fet Maiz niet tot [pn balkamen wafoum kamen' ofte pocti op-kamen/ ten ware fo bp bet jaet een ofte twee loofoen ban farounen 
392

Peru.

Lepoen / ende die te lamen met aetoe bedeckten: toelcke Carob̈nen fo met baet neft

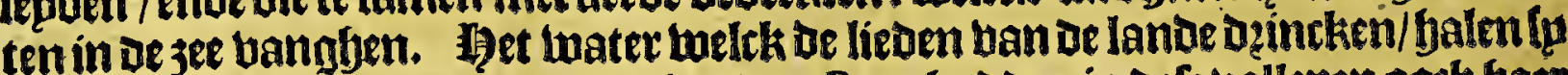

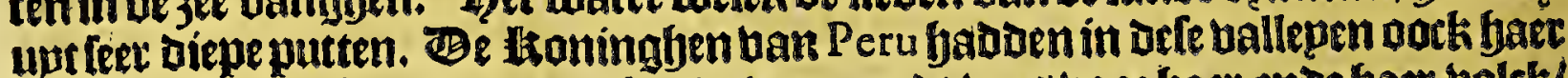

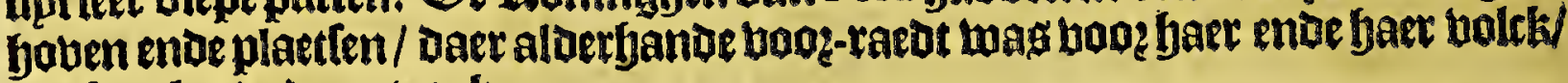
als [p't lanot top?-trocken.

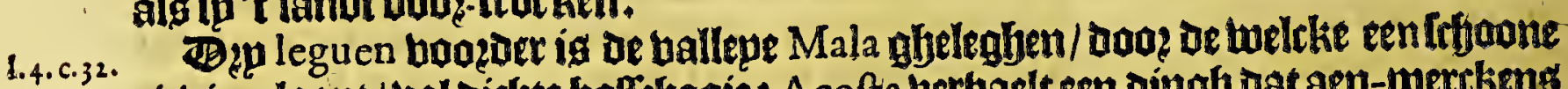
riebiere loopt / bol dichte bollethagie: A cofta berbaelt een oingh dat aen-mercken: teerdigh is ban dete vallepe : Jn Mala, (keght bp) derthien leguen ban de ftaot de los Reyes, ftaet een büghe-hoom / oe welcke aen fon een jyoe naer bet jupoen. toe ende naer't ghebergbte / groen wogdot / ende fon beuchten ghesft wanneet bet comer is in't gheberghte : ende d'ander 3 joe ban den boom welct nate ae plaus nen ende 3 ee-kandt toe ftaet / gheft gaer bladeren ende bzuchten ter conttarie als bet Comer is op de plapnet.

merpnigh meet als büt leguen ban de ballepe Mala, leght die ban Guarco, en groote ende bzec de vallepe / enoe bol gheboomte ; inlonoerbeptot is daer geoos te menighte han wel-rieckento ende maeckelócke Guayavas, ende noct meets aer Gua vas. De tartwe ende 'c Maiz maften Daer wel/gelïck oock meeft alles twat If jaepen ende planten. Be Ingas ban Peru behben biet een leet treffelýcke ende tryoone ftetckte gheboulut / op een bergbgken aen een vallepe gletegben/ op abetroote biec-kante fteenen met wel gheweorbte poetalen / enoe groote kametg.

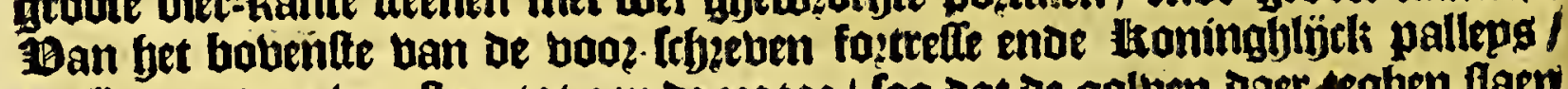
Daeloe een trap van fteen tot aen be $3 e e$ toe / foo dat de golben daet cegben thaen met geod gbetwelt / dat te berwonderen is / boe dit eerfmael beeft konmen ghes

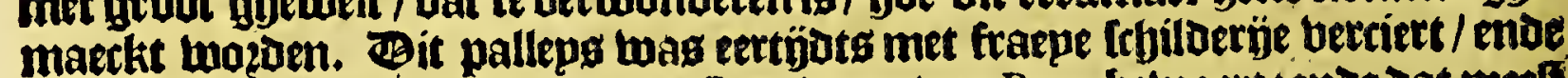
paer wierot een groote frgat ban de stoningen ban Peru bewaert: enve dat meel is te bermonderen/ baer bit loo grooten ende twaren gheboulu is / enoe ban lod groate fteenen gbemaeckt / Dat men daex gbeenkalck ofte erment aen en ziet / jae

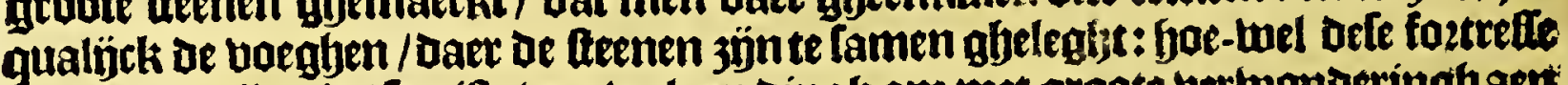

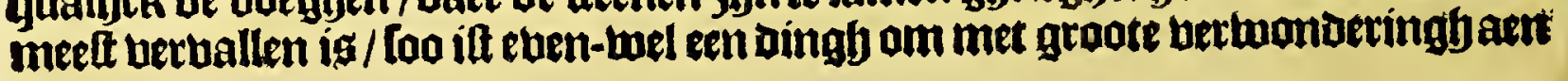
te fíen.

Her.des. In sele ballepe íg nu een blecke bp of spaegniaetoen obehout / welck ip noes men Villa de Cannette, ofte del Guarco, naer den naem van de ballepe ; íg gfteles

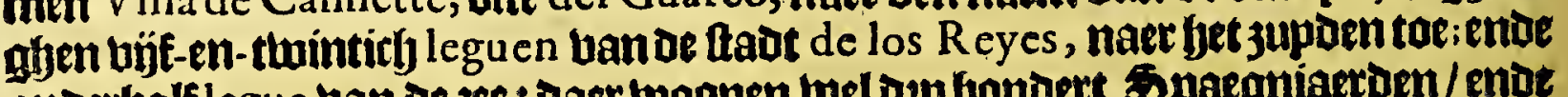

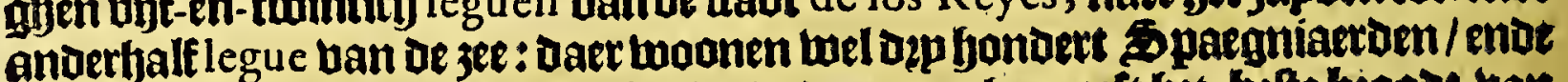
beel Indianenende Swarten: bet land daet om-bee geeft bet bette bzooos ban

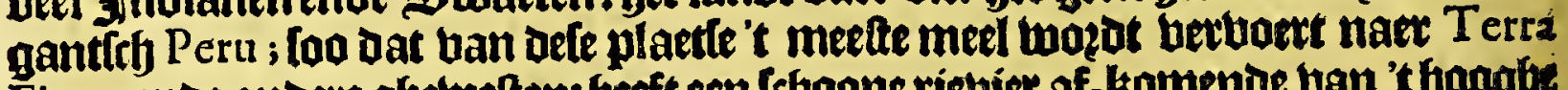

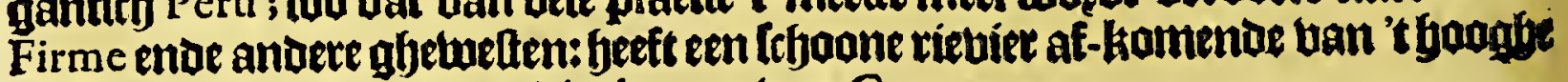
ofjeluergbte ban Pariacaca, bier leguen ban Cannette.

\section{Het en-en-twintichle Capittel.}

Vervolgh van de befchrijvinghe van de playnen van PEku, langhs de kufte var de zuydt-zeevan Gua co af, tot TARA A Ca toe; ende van de vlecko

VALUERDE, Castro VIRREYNA, ende de ftadt AREQViPa.

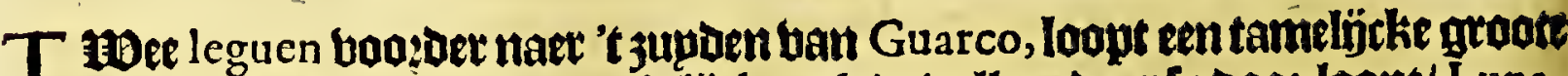

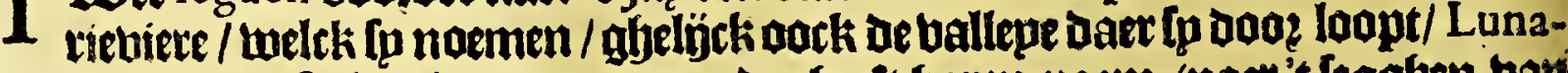

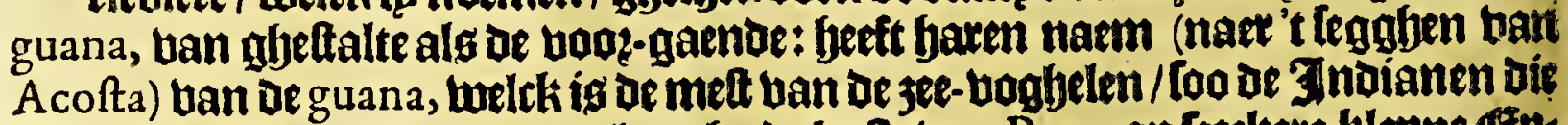
noemen/ welcke men / batende langfys de kulte ban Peru, op leeckere klepne e ps landeliens met boopen als klepne berghen fiet legghen/ oie be Jinvianen wam bes

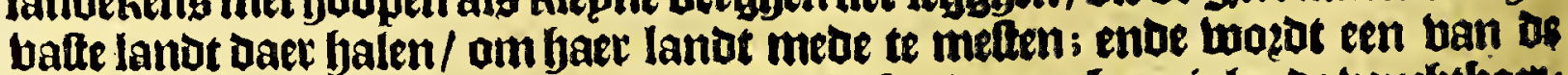
profítabelfe melten betonven die men beeft ; loo dat oock eenigbe be bsuefthaets bept ban die ballepen delemelt jön toe-lefyzóbente. 
Het thiende Boeck.

Sest leguen ban Lusaguana legljt ae groote ente ffyoone ballepe Chincha,

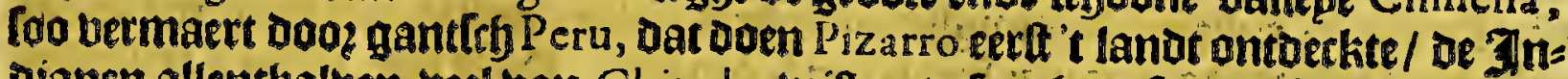
bianen altenthalben beel ban Chincha wilten te fegglien; foo dat Pizarro in fpn contrart met den Honingb/boo? limiten tian fon Goutoenement nam Tempulla ofte Rio de S' lago, naet't noozoen/ rnde Chincha naer't jupden/foe-wel fo foo

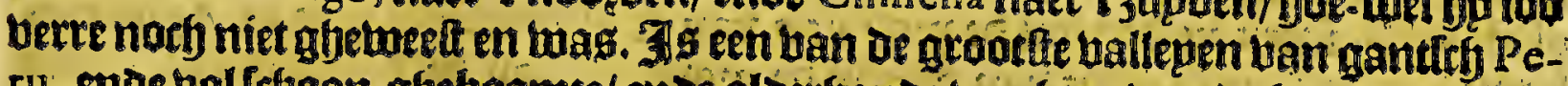
ru, ende bol frjoon gheboomte/ ende aloerfande nzuchten ban oe lande enoe ban

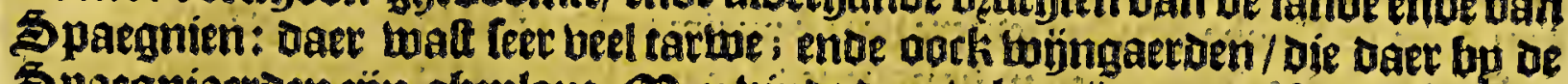
Spacgniarroen jýn gbeplant. OSen binbt baer bele rupren ban feet groote ge: bouben; bel berlaten buplen enoe Lepultueren baer imen de lichanen notb geel in

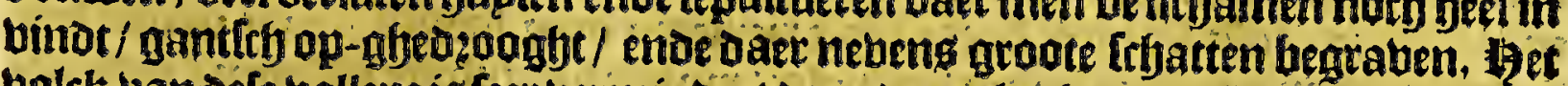

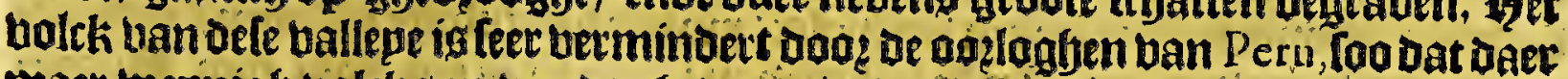
maer toepnigh bolcks en twogat gbebonden. Auguitin de Zarate felot Chincha maer thintich leguen ban Lima.

Ban of ballepe Chincha, replenoe ober be plaphet kome men aen be friftrye ballepe ban Yca: Daer loopteen frape tienier doos/ oan ten tijoe dat het in 't gbe= bergbte niet en regent/ foo feeft fp foa toepnigf water

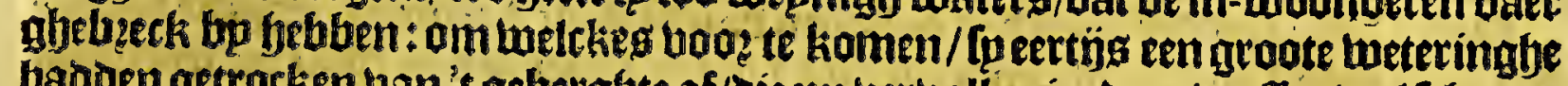
baboen getrocken ban' 't gebergfte af/oie nu bertallen ig: Daer wallen beel frboone

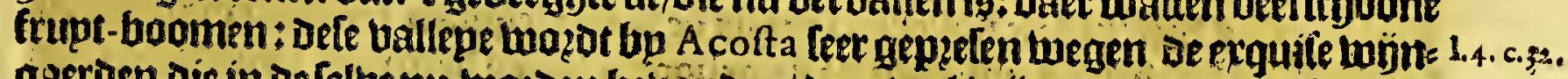

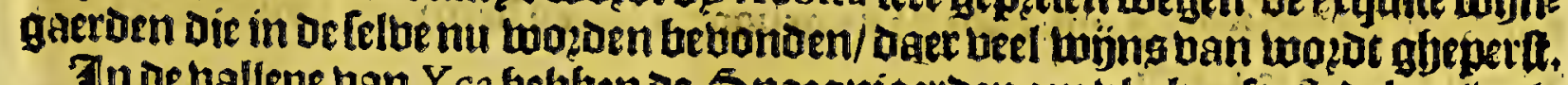

In de ballepe ban Yca geblen oe Spaegniaeroen een blectke ofte itedetien/welc

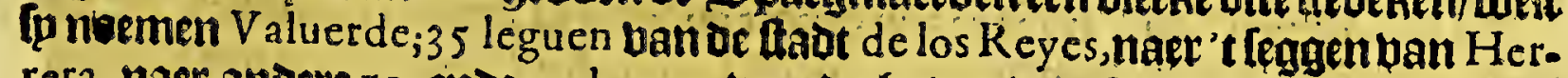
rera, naer andere 50 ; ende to leguen van te faben ban Sangalla; 12 ban Pifco;

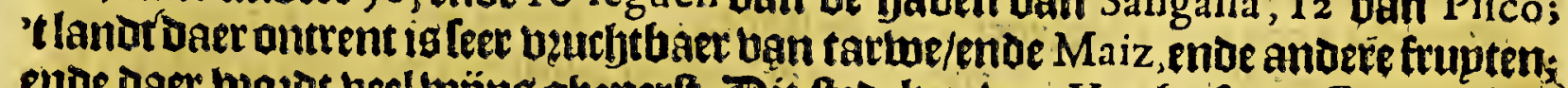

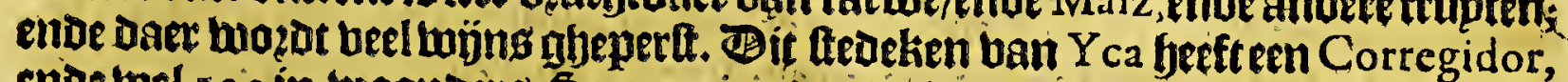

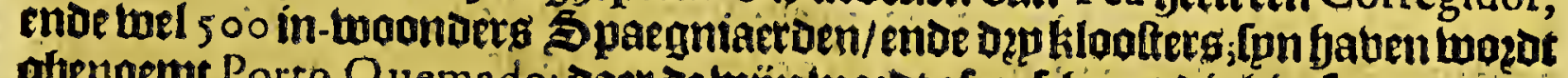

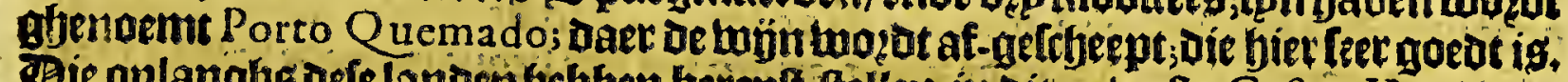

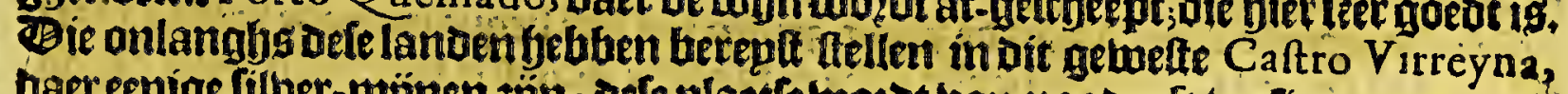

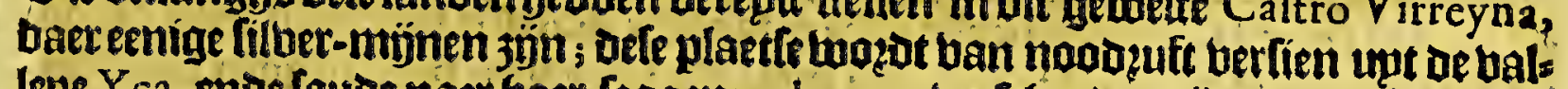
lepe $Y$ ca, moe Loube naer baet feggen 20 leguen berfchepuen jün ban Guancavelica. Eendie onlangfos dete landen beeft beloche / /eght dat Caftro Virreyna ofte foo de 3 Indianendie noemeti Chocolococha, light is leguen ban Guancavelica, naet' jupden/ende 6o leguen ban Lima, ende dat Daer een mine is ban filber/bet fijnfte dat men binot in beel Peru : Daer jaerlỉeks ban komen 900 batren/ Die ge

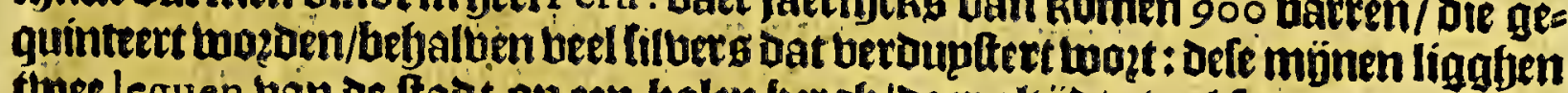

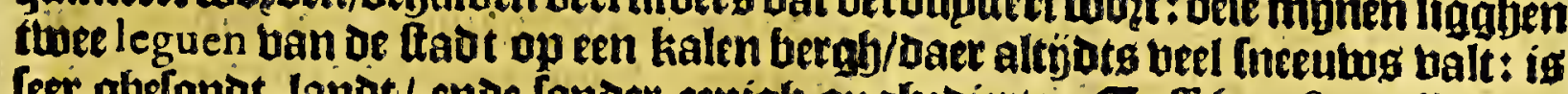
fer ghelondt lanot/ enoe fonder eenigh ongbedierte. Uufteren. Sangalla ende De ftadr Cufco legft bet boogh ghebergfte beltk fp noemen Sierra de Guaytara ; welck naer fet leggfen van Herrera komt tot op biec leguen aen de ballepe d.6.1.4.
ban Lima.

Ban de ballepe ban $Y$ ca komt men aen be fryoone ballepen en be riebieten ban Ia $\mathrm{Nafca}$, weick eertijots oock feer betwoont waren; uan al out arm bolck is meef boos de ooflogben ban ie Spaegniaeroen onder ben anoeren om-gljekamen enoe tot niet ghebzatht: In een ban oe boomaemite ballepen ban la Nafca (welek oocli mierd ghenaemt Caxamalca) badoen de Ingas groote ghebouterilenbe

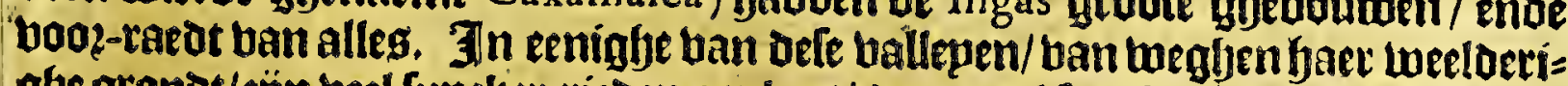

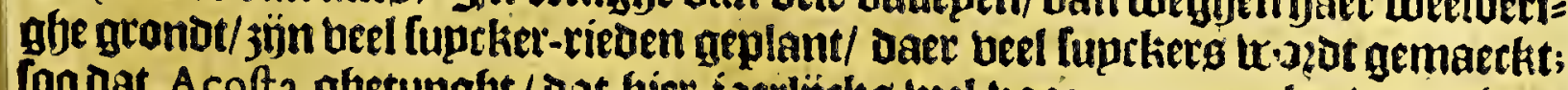

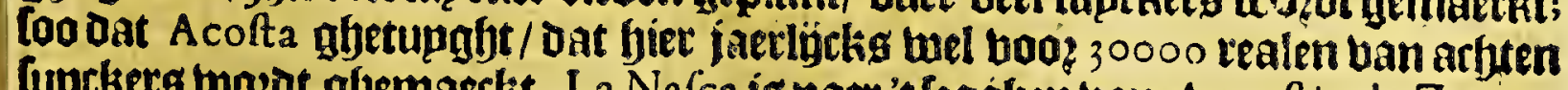
lupckers mozot glemaeckt. La Nafca is naer't legghen van Auguftin de Zarate, 1.4. c.32. bjftict leguen ban Lima. Bierleguen banla Nafca, light de vallepe Villacuri,

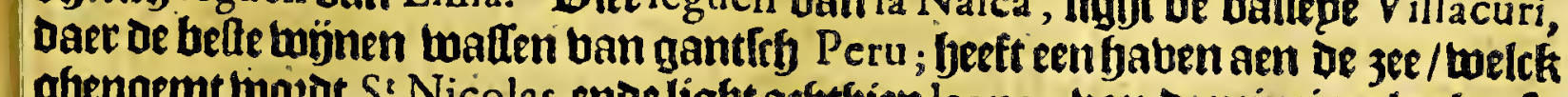
ghenoemt twożt $S^{2}$ Nicolas, ende ligbt acftetjien leguen ban be yzincipaele plaetfe. 
394

Peru.

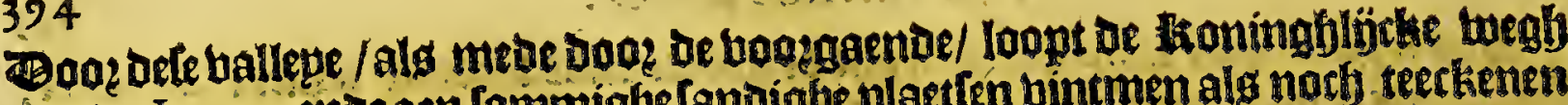
ban de Ingas, ende aen lommighe landighe plaettón bintmen ald norty teeckenen enof aen-wojtinghe om van of begy niet te o walen. Faelt ofle ballepe te lanbits

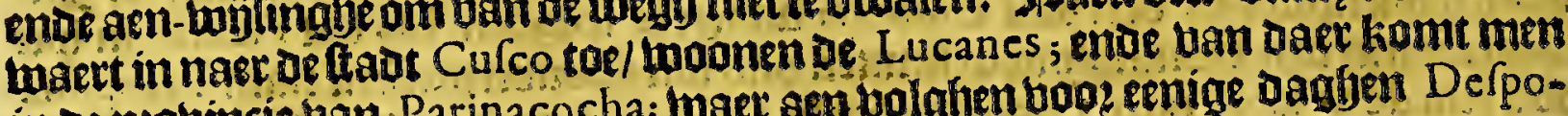
in oe plovimcie ban Parina co cha; waer aen volghen booz eenige daglen Defpo-

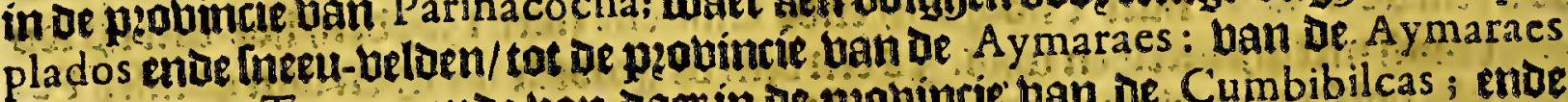
tomt men te Totora, ende ban daer in or peabincie tan oe Cumbibil cas; ende uan Daee te Cacha aen de ticuiete ban A purimá, naet Dat Herrera getupglyt.

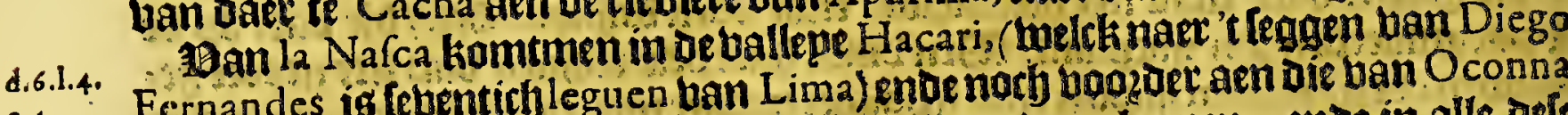

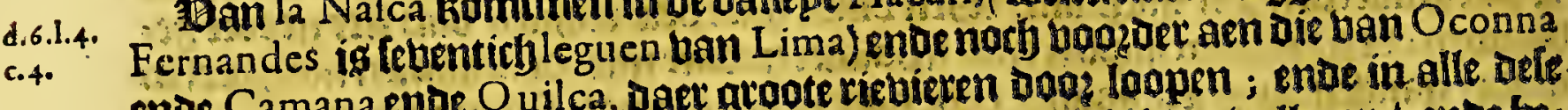

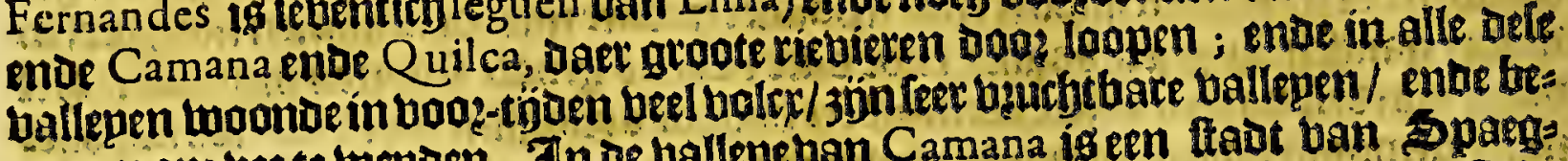
quaem om ber te toepoen. In oe ballepeta niaerden gelegen/welckfp noemen S. Miguel de la Ribera, I 3 leguen ban de Itadt de los Reyes, naer't jupden; ende 22 ban A requipa, naer't noogoen; befooget tot jet 2sitoom ban Cufco. Lopes Vaz legbt oat bet en ftadt is bam ontrent 200 buplen: ende dat oaer wän balt/ ujgen tnoe tofjnen.

Tan Quilca bozoer (welck is oe baben ban de ftadt A requipa) legbt de ballepe de Chuli, enoe Tambopalla, ente díe ban Ylo;ende daer aen de rỉeke ballepen van Tarapaca. Ontrent Defe vallepen langyg de kulte/ legghen senigfe equlandekeng Daer veel zee-robben op jp̈n; ende oe in-getoogne baren dertwaerts op blotten/om t vogbel-meft te balen.

In ve ballepen ban Tarapaca jön groote ende rücke minnen ban filber/teer thit

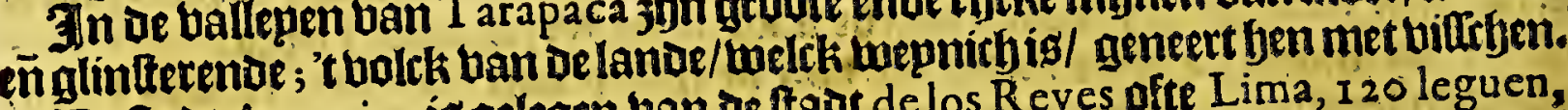

Beftaot A requipa íg aelegen ban de taat de los Reyes ofte Lima, 120 leguen,

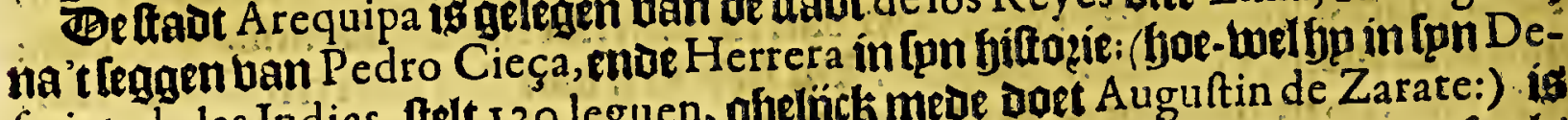
fcript. de las Indias, Itelt 13 o leguen, gbelinct mede baet Augultin de Zarate:) is gebout in be ballepe van Quilca, 60 oft 70 leguen ban de ftadt Cufco, 14 oft als andere leggen I 2 leguen ban oe jup ot- 5 ee/op een leet bequame ende frillobe plarts

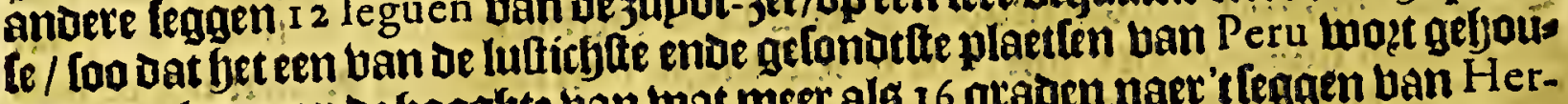
den:is gelegen op de fjooghte than mat meer als 16 graden naer't teggen ban Her-

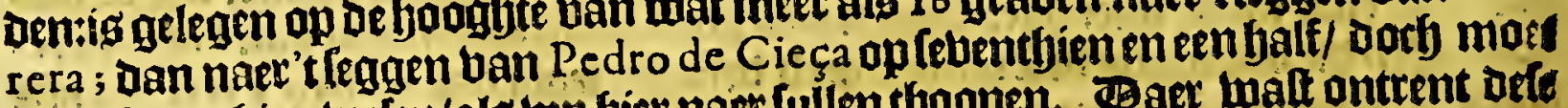
maer febenthien welen/als wp bier naer fullenthoonen. Daet walt ontrent offe

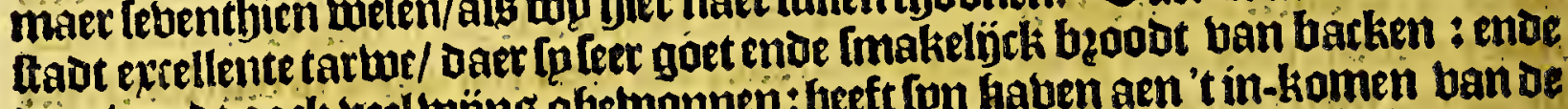
Daer wozot oock weel wöng afjetwonnen: beeft [pn Gaben aen't in-komen ban oe

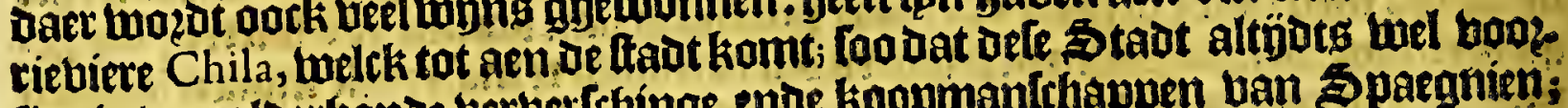
Tien is ban aloerbanoe bertuetrfyinge ende koopmantchappen ban Spaegnien;

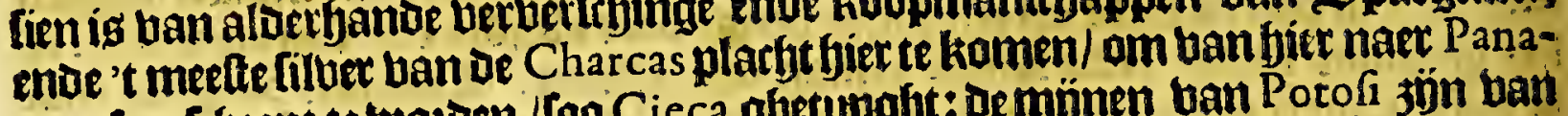

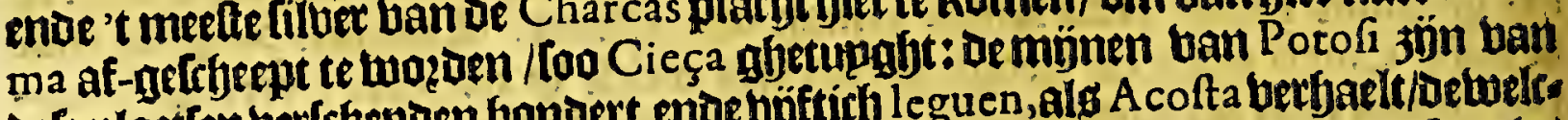

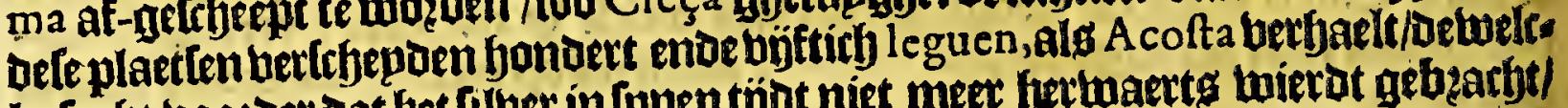

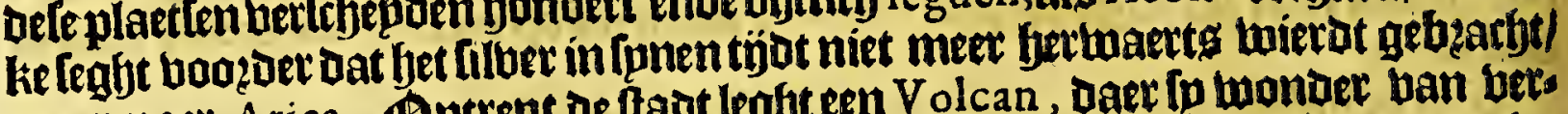
maer naet A rica. Ontrent de ftadt legft een Volcan, daex fp wonder ban bers

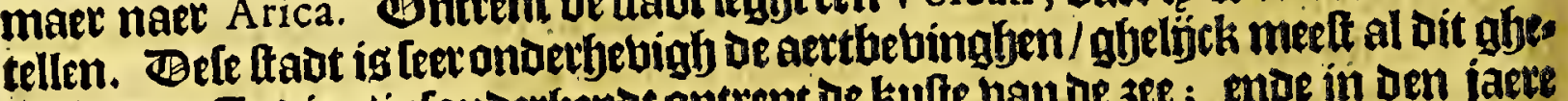
wefte ban 3 ndien/infonderbepot ontrent de kufte van de jee; ende in den jaete 1582, biel defe ftaot bp naet ober-hoop dooz een fryzickelibctie aetot-bebinghe. Es noe weoerom inben jaete i 600 twierp aelen Volcan loo grooten menighte ban

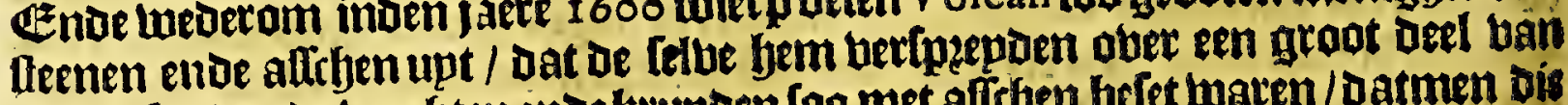
Peru, [oo dat oe byuthtenende kitupden loo met affichen brfet waten / Datmen ois

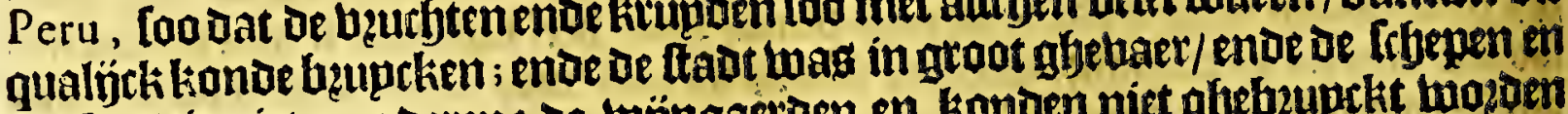

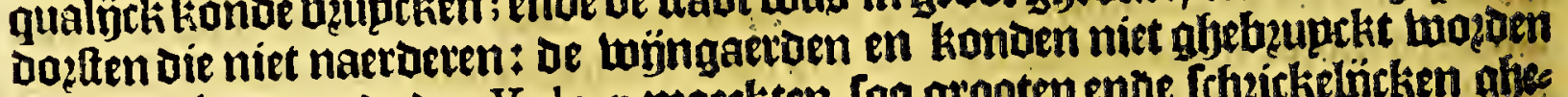
boo bele jaren; ende den Volcan maeckten loo grooten ende frojickelṕcken gfjec Deupg datmen bet booże op alle de plapnen ban Peru ald oft ghezondert badoce. Onder de jurifoictie bau oefe thad gebogen de plepnen ende ballepen ban Hacari 
Het thiende Boeck.

at tot Tarapaca toe; ende te lanot-baett in $/$ in oe plobimtien die fo noemen oe

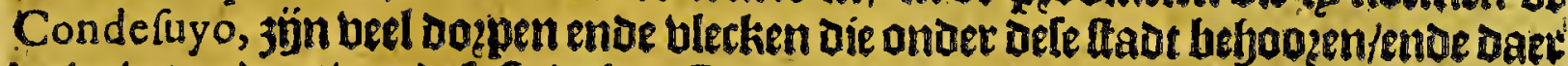
De in-twoonoers ban oefe ftad baer Encomiendas bebuen/gelijek or Spargniaer. oen die noemen; als baer zün los Hubinas, Chiquiguanita, Quinuftaca, enoe los Collaguas, Daet eetrótsts beel bolcks woonde 1 die veel ban de trfapen ban Peru haboen: Dan dit volck is doot de oozloghe van oe Spaegniartoen feer bermin= Dert: joe-wel dat Herrera feght/ Dat daet wel biftich ouplent Indianen Die tris bupt betalen/ondet defeftaotgefoogen. Inde twegh van defe ftadt naer Chuquito toe/ leght De ballege Moquegua, Die feer luttigh moe buththaer is.

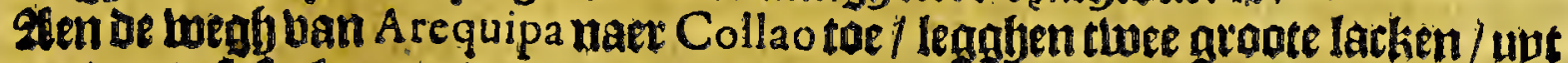
"tene bam dete fegftmen bat de tieviere A purima baer oo!lpgongb foube bebben.

Met twee-en-thintichffe Capittel.

Yervolgh van de binnen-landtfche provincien, langhs de Koninghlijcke Wegh over't gheberghte van GUANCABAMBA; voorts van de CHACHAROY As ende MOYOBAMBA.

W

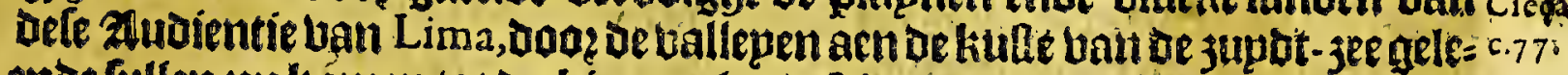

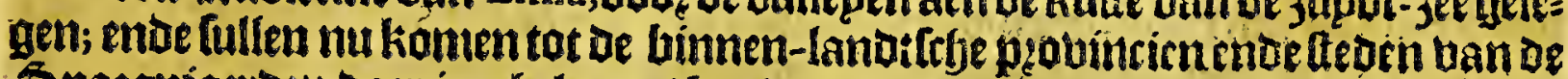
Spaegniaerben daer in ghelegen / heginnende ban Guancaba mba, dact wop bet in'tuoge-gaende bebben ghelaten. 19an Guancabamba tot Caxamalca, telient

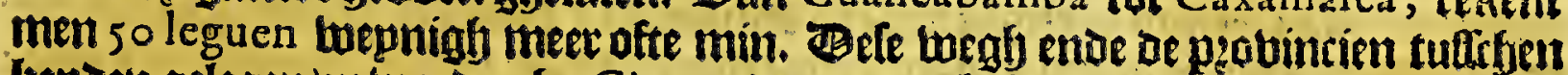

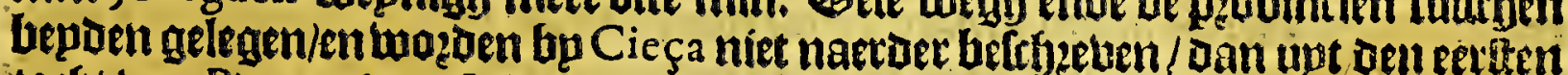
torft ban Pizarro ban $S^{t}$ Miguel naer Caxamalca, konnen tup ten oele oe gfolf: gentfjept af-meten: Herrera fegft dat ban $S^{t}$ Miguél tot Caxamalca jún twaelf groote Dagf-keplen; entoe dat Pizarro treckende bain $S^{2}$ Miguel oble De riebier/ertet quam in't lanot bande Curaca Pavor, weltk waten friftibe balfepen: bat Caxas

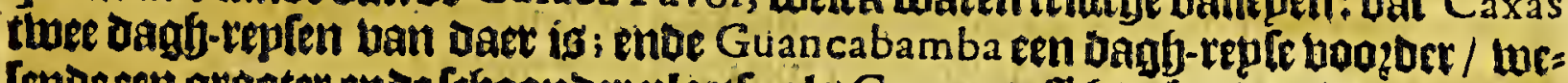

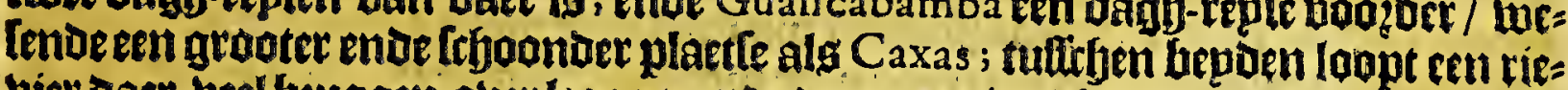
biet daer beel beuggen ober leggent; ente be groote begh ban de lngas loopt Daec

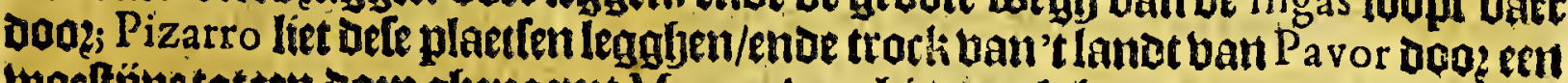
woeltÿne totten Dogp ghenaemt Motux; ban hiet trotk fp twee dagfen boo bal lepen vie wel betwoont waren / die Herrera niet en nocint / enoe tweder een oagl.

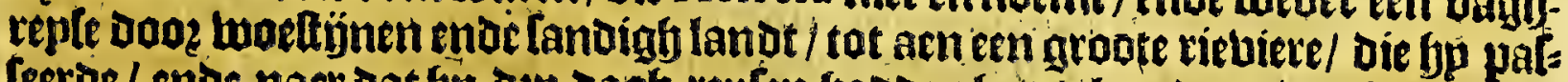

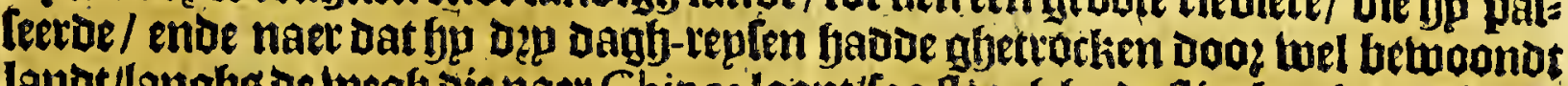
lant//anghg De lwegh Die naer Chinca loopt/foo floegh hp De tlincket-hant af naet

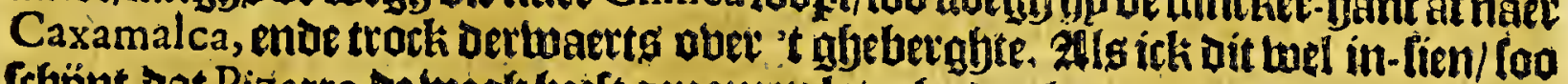
febint dat Pizarro de wegly yeeft genomen langhs oe plapnen lan Peru, finoe dat

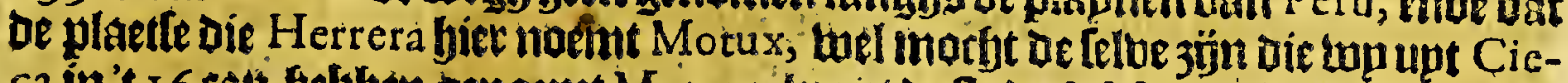
ça in't $16 \mathrm{cap}$. fobben genoemt Motupe, loant ie fadt St Miguel lagfo coe aencen

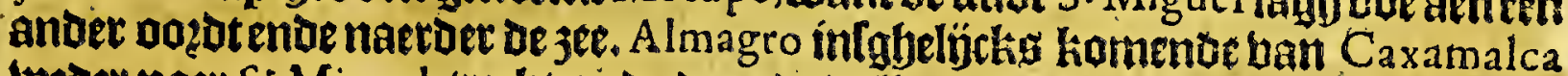

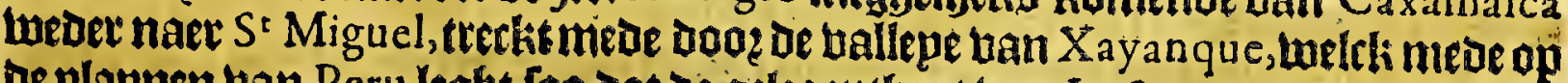
De plapnen uan Peru legbt; foo dat De gelegentljept ban La Serrania moet uerfaen boezon upt de befryejuinge ban Yaen ende Chuquimaio, wele tutarhen de Serraniz ende de Andes in leggen/ende komen te leggen tulterjen Guancabamba eñ Ca-

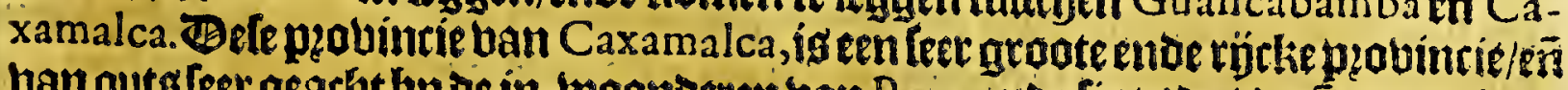

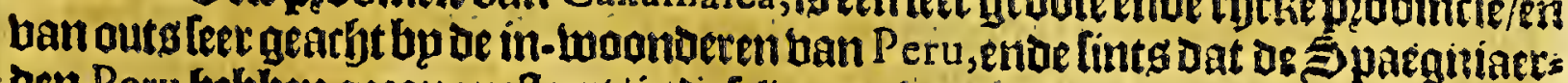

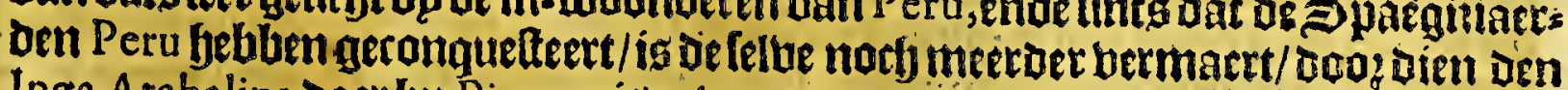
Inga A tabalipa Daer bp Pizarro isgevangenende omgebsacht. Be Honingen van

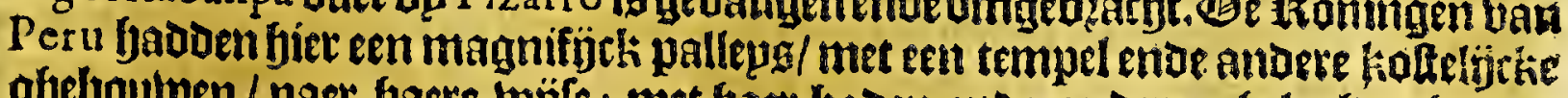

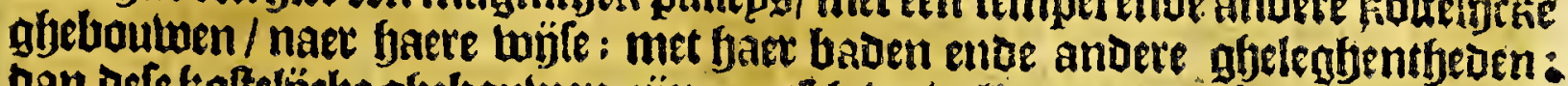

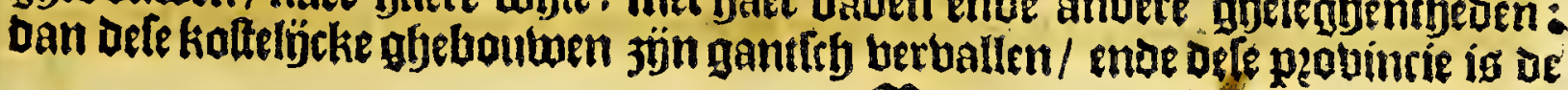


396

Peru.

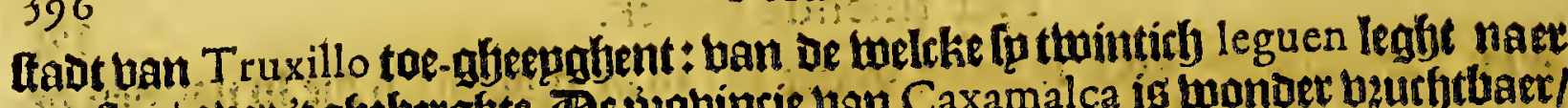
't oolten/ over tgfeberghte. De pzobincie uan Caxamalca is monoer bzurbthaer/

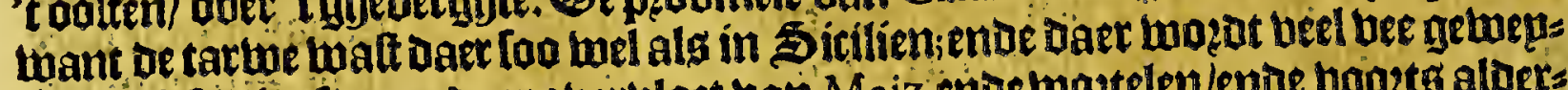
Det oock loo beft men daec oberbloet ban Maiz endoe woetelen/ende bookts aloer:

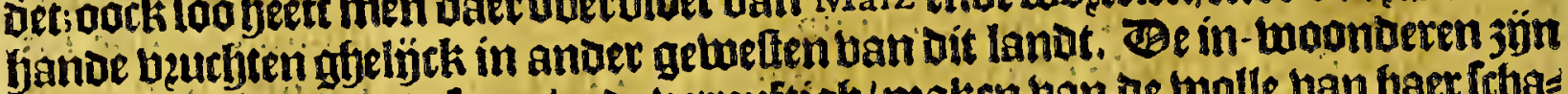
ban goede aerot beecotlaem/entoe bernuftigg/maken ban de twolle van baer icthas

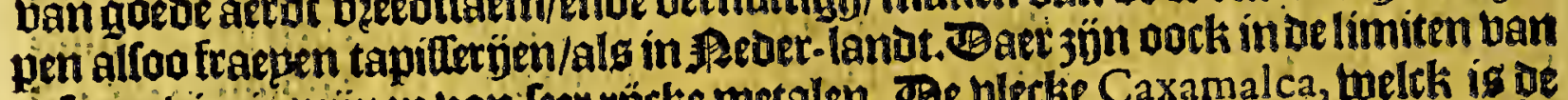

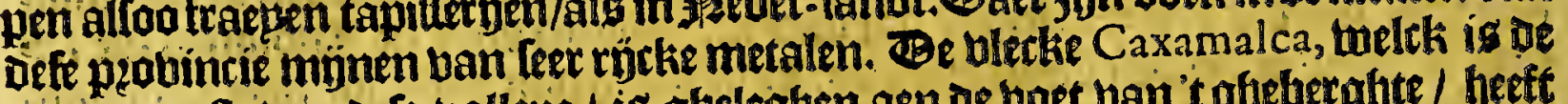

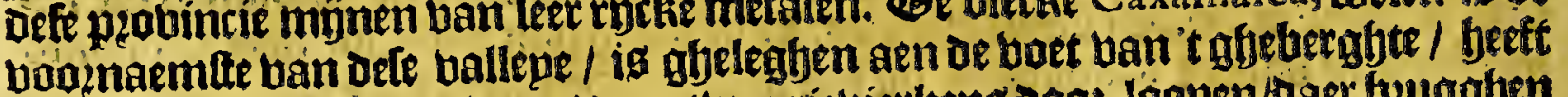
ontrent een legue black land/ Daer twee rievierkeng too - loppen/baer bugaben

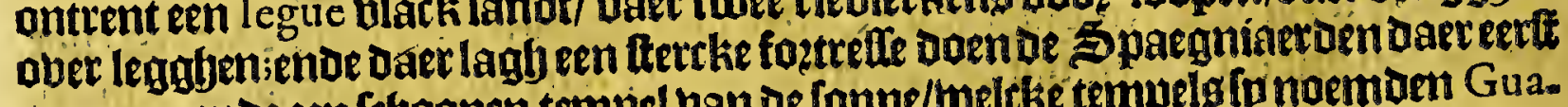
quamen; enoe een fryoonen tempel ban De fonne/weleke tempelg fonoemuen Gua. cas. Stellen dele vallepe ban Caxamalca, 90 leg. van Lima, ende fo veel mede van Truxillo. Ban Caxamalca treckende ober tgeberghtenaer Lima, [ookomt men

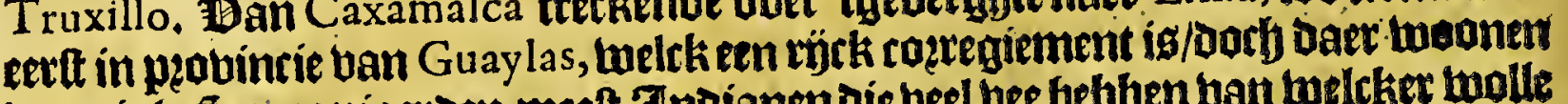
mepnigh Spaegniaerden; meet J noiamen die beel bee bebben ban welcker wolle [p beel bape ende laeckenen maecken.

Cieça Eer menkamt aen de pzovintie ban Caxamalca, legbt daet enten andeten

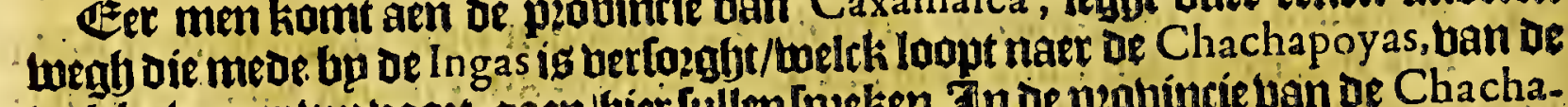

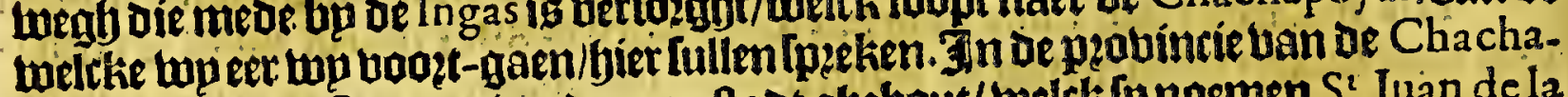
poyas, is bp de Spaegniarcoen een thad gbebout/melck lp noemen $S^{\imath}$ Iuan de la Frontera;íg gelegen I 2 léguen van be ltaut de Los Reyes afte Lima, naex 'tmadzes

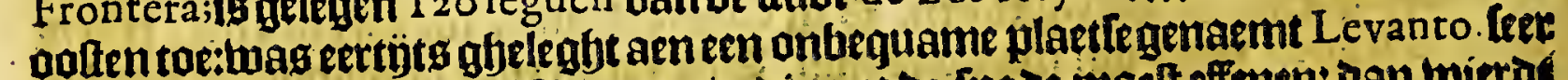

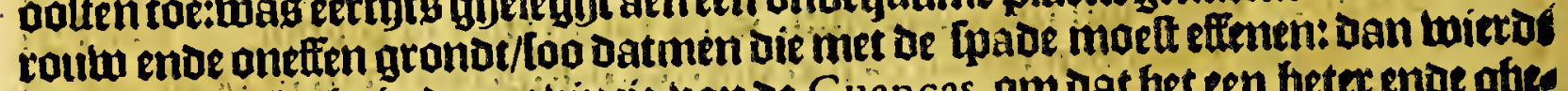
Daer naet berleght in of peobintie vam oe Guancas, om dat bes een betec ende gfes Conoer quartier was/ (oodi Dien Herrera eldergín ftede ban Guancas leght/ Gua-

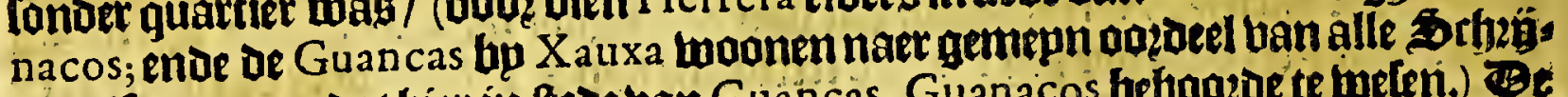

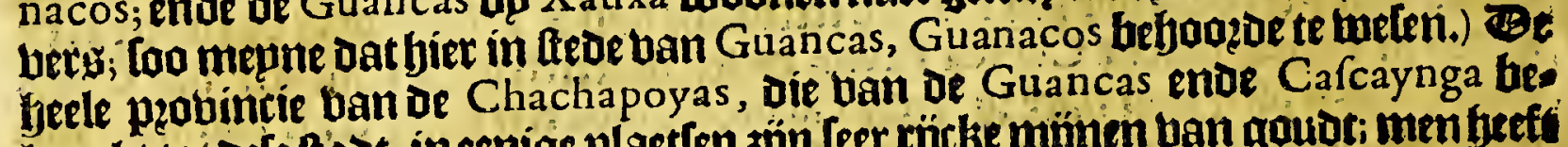

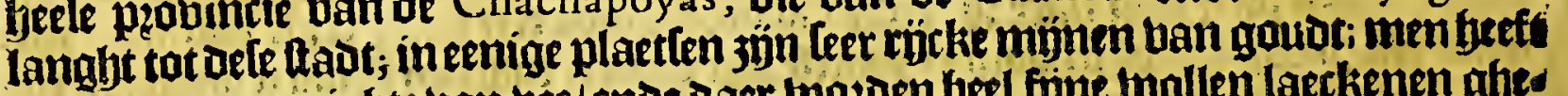
Daet groote menighte ban vee/ende daer twozoen beel fine twallen laeckenen ghes

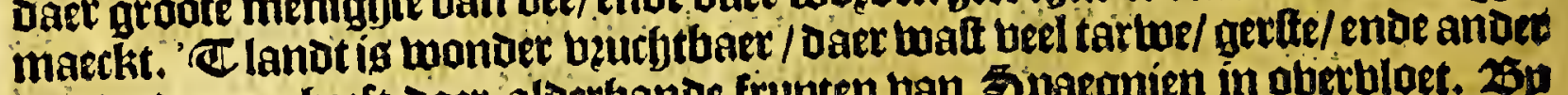
zaet ende men heeft daer aloethande frupten van 5 paegnien in obetbloet. $25 p$ ooften ban oele ftad loopt oe groote Cordillera ban oe Andes, ento ober be lelbe leght de groote riebiere Moyobamba, ende andere ban gljelópke groote; ende daec legahen eenighe doypen ban volck/ welck van klepn bernuft ig/ende naer oe ghes.

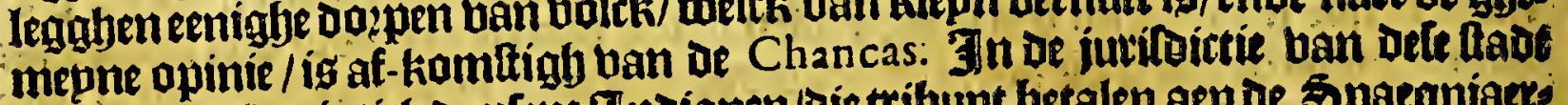
woonen wel twintich Dup[ent Indianen/bie tribupt betalen aen de spaegniaces Den; is witter bolck/ ende ban meerder bernuft enoe aerdigfept als 's ander bolck

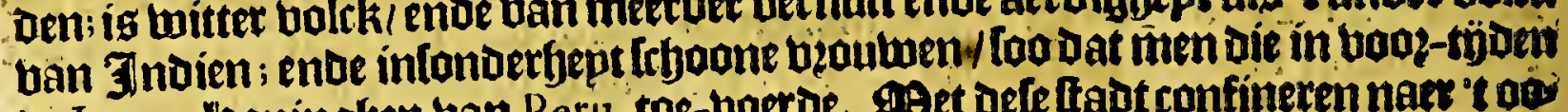

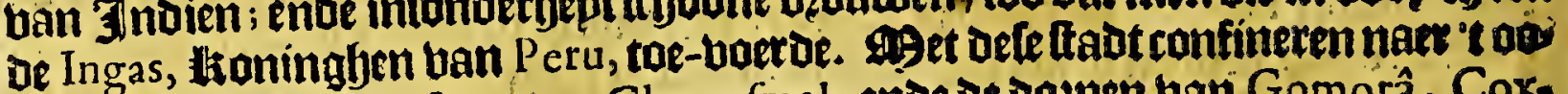
Iten depeobincie uan Longua, Charrafmal, ende de doępen ban Gomorâ, Coxcon; ae probincien Hafallao; Toncho; Chillao.

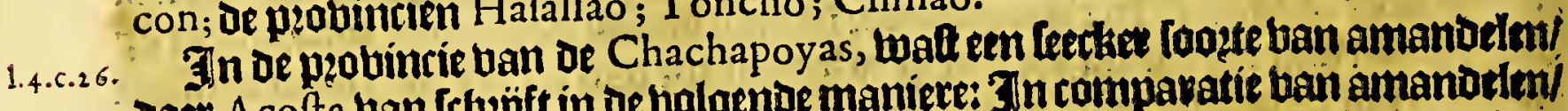

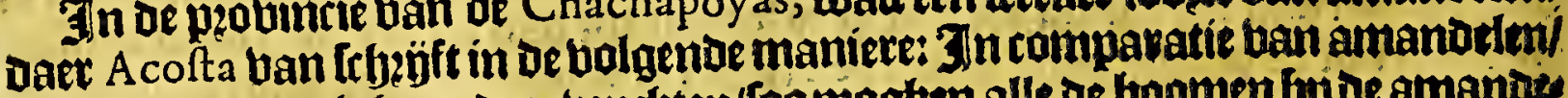
als ooch ban ennighe andere bruchten/Loo mogten alle de boomen bp ofe amanoes Ien uan oe Chachapoy as wel lwághen; noemente amanoelen om datie die ghteti

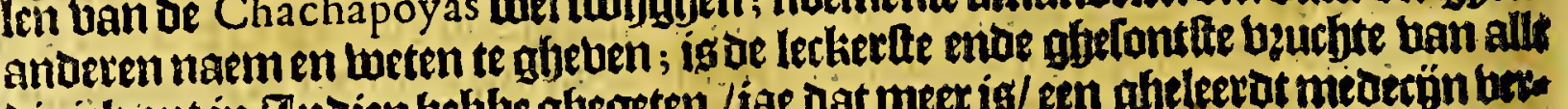

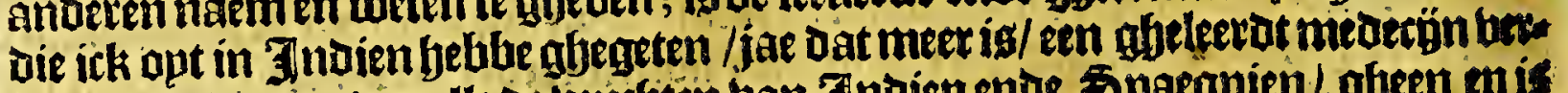

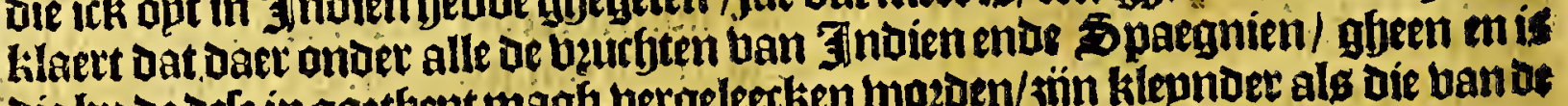

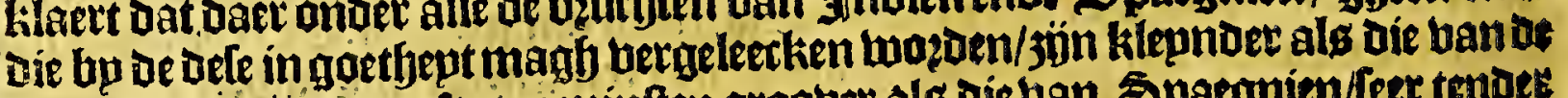
Andes, ende grouter ofte ten minften groduer als die uan Sopatgnien/feer tenoes:

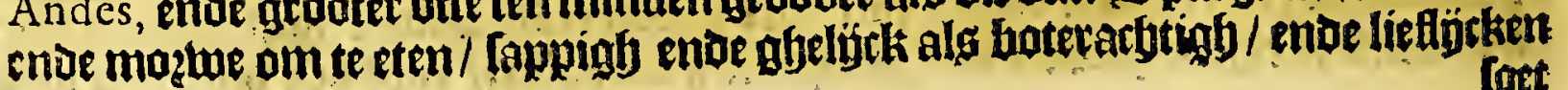




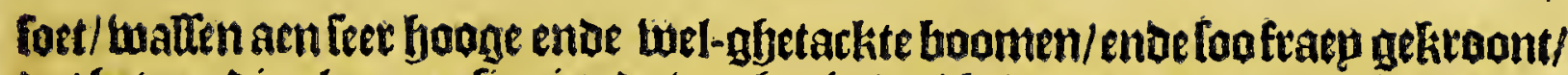
oat bet een dingben omfien is; de beuchte is wel belwaert / groepen in bupgkens ofte doppen/een twepnigh grooter ende fcherper als de fupgkens daer De (C) aftas

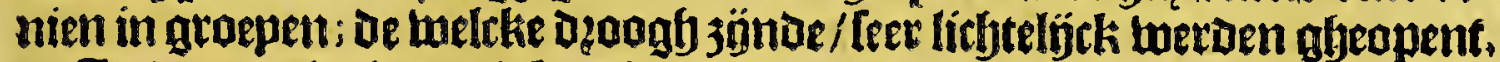

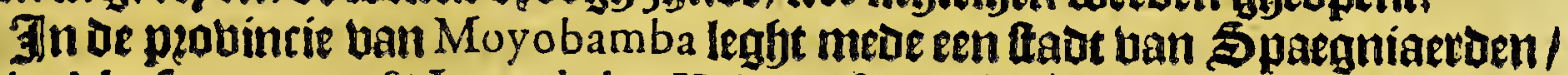

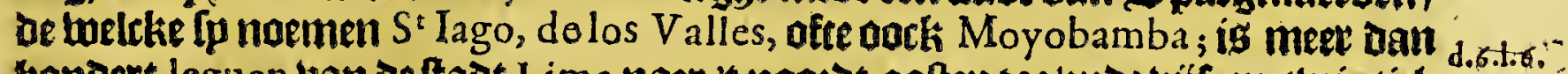

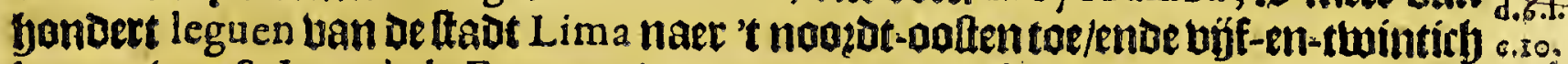
leguen ban St I Lan de la Frontera booz-noemt/imeen feer regenathtigf quattiec/

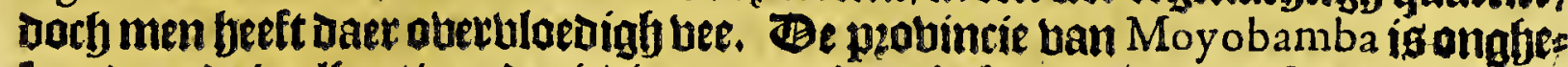

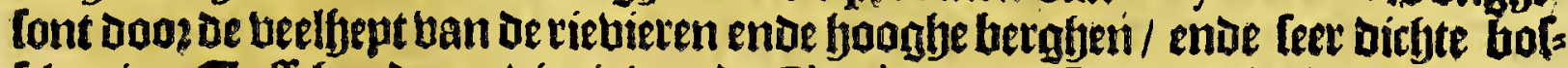
frbagien. Cuftren de pequintie van de Chachapoy as eñ de pzobintie Moyobam. ba, leglyt een ander pequincie toelcke de Sparguiaerden de naem gaben ban los Motilones, daer beel riebieten Doot-Ioopen/ende de pzobincie ig niet bel betwoont/ foo Dat baer ghebzeck is ban lịf-torbt.

\section{(1) $\mathfrak{a t}$ Dequ-en-twintichlte Capittel.}

Vervolgh van de binnen-landtfche provincien van $P_{E R U}$, langhs den hooghen wegh van de INGAS, beginnende van de provincie van $C_{A X A \text { - }}$ MALCA tot Gua nuco;ende vande fadt LEON DE GUa nuco.

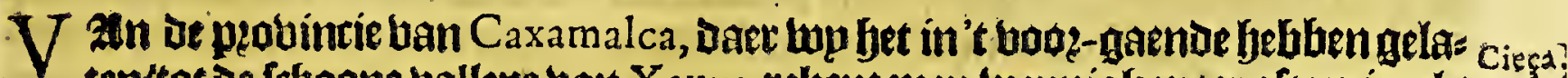
tenftot de fefjoone vallepe ban Xauxa, rekent men luepnigh meer oftemin als c.81.

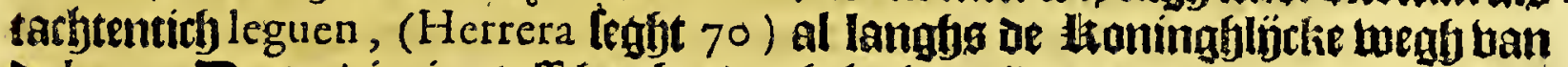

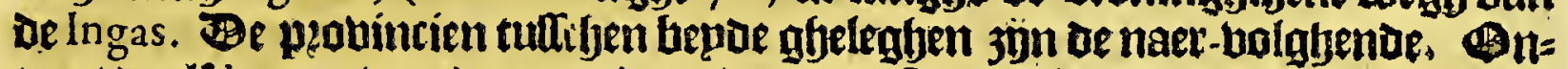
trent de elf leguen uodzoer naev't jupden uan Caxamalca, leglut een ander groote p:abincie Die eertj̄ots feet betwoont was/or twelcke fp noemen Guamachuco: tul=

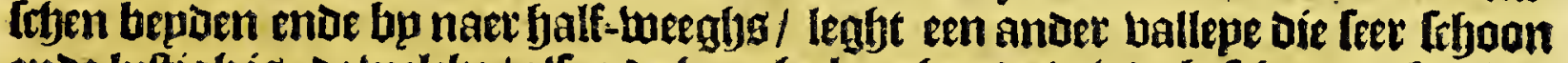

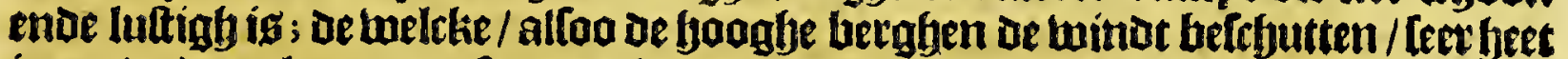

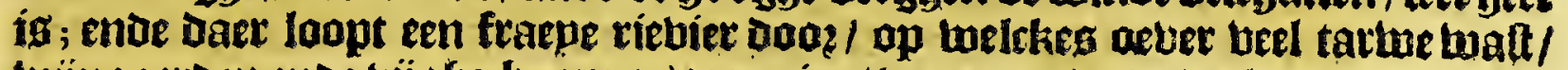
töngaetoen ende büghe-boomen/ozagnien/limaenen/ende beel andew bzuchten

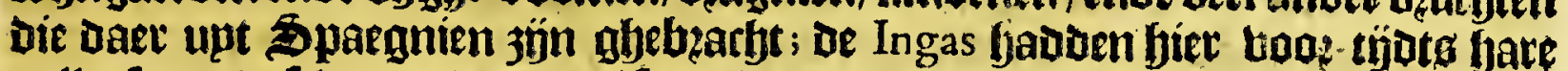
palleplen enoe lobueten/ende beel faep-landen om oe noodigbe book-taet te berfas: gluen. Be pzobincie ban Guamachuco is die van Caxamalca in alles ghelijek/

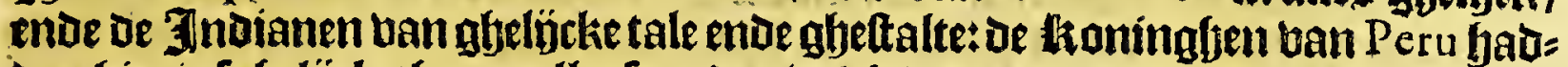

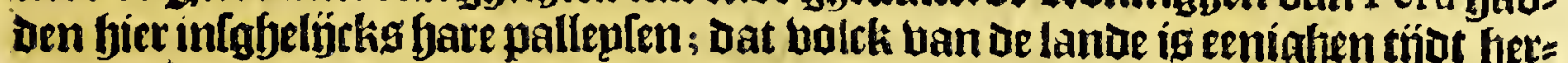

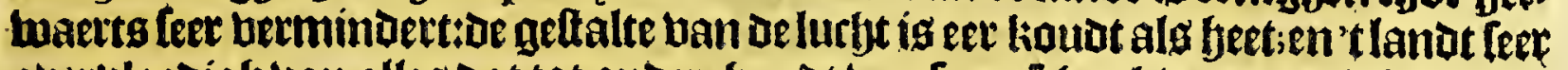

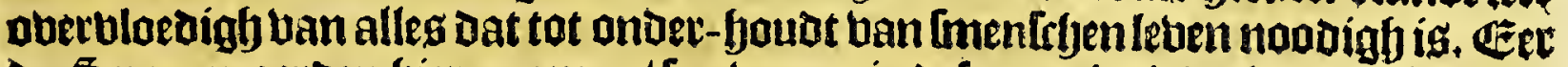
be Spaegnaerden fier quamen/ Loo waten in befe pevuincie beel ban oe fejapen ban de lande/ ende op't gfjefergfte Daer om-her beel Guanacos ende Vicunnas.

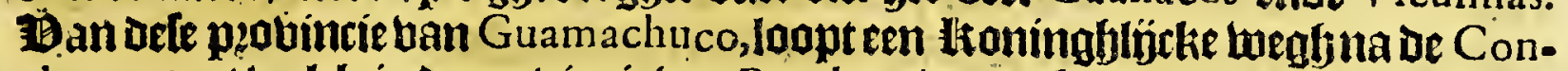
chucos toe / welck in de peglíntie ban Bombon weder-lieetot / en fen boegftemet de boaz-gaende twegh.

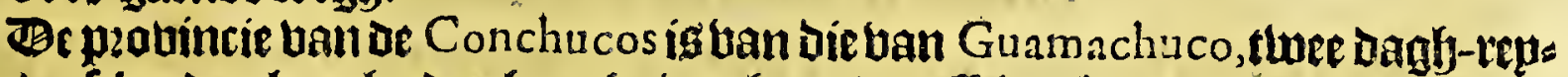

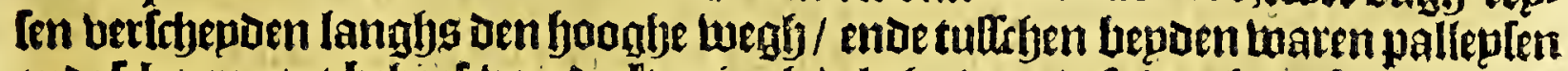

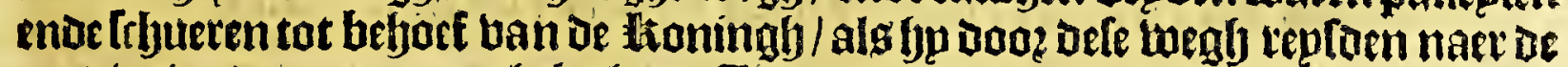
provincien daer ontrent gheleghen. In of yzobintie uan de Conchucos, waten

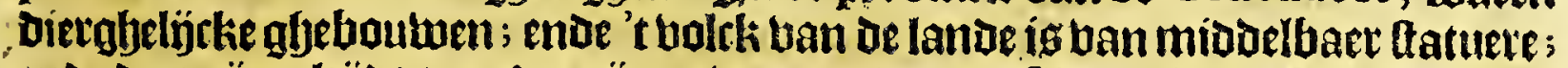

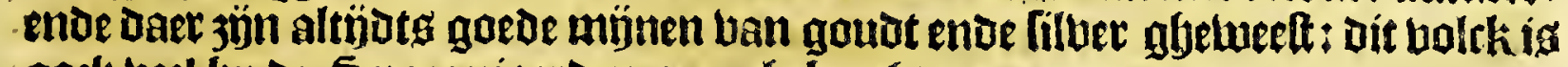
oork beel bu de Spaegniaetoen om-aljebzactjt.

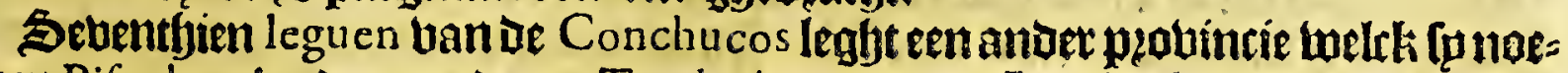
imen Pifcobamba, daer mede een Tambo luas booz oe ktoning ban fteengemaett.

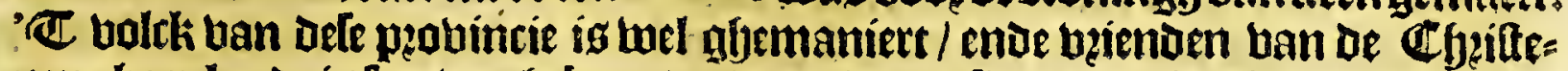

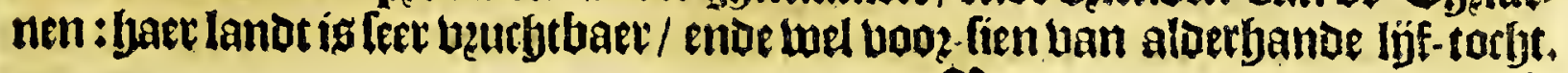
in 3

Atrot 
398

Peru.

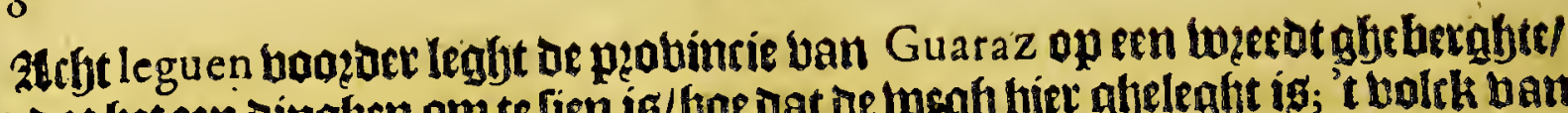

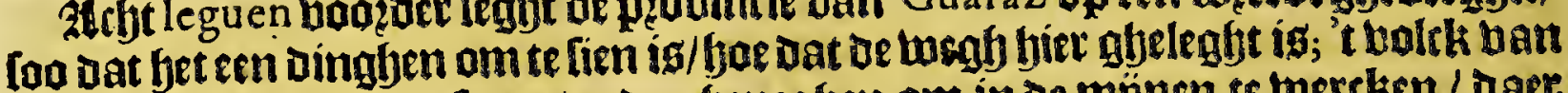
De lanoe is teer arbepottaem/ende ghenegyen om in de minnen te wercken / taec In eettỉts yaer tribupt ban betaeloen aen De thoninghen van Peru : men liet Date een fottefle die Leer fraep in bet bier-kandt ban tteen is gbemaeckt / naer de wijle ban sat landt.

Mat boozezer legyt oe pzobincie ban Pincos, Daer een riebiere bu loopt; ende oe 3 noianen van dit quartier is fraep bolck / ende aenfienligct in baer manieren: tnoe wat boozoer ig gheleglon jet groot ende hoftelïck pallepg van Guanuco, welck toel een ban de voomaemte is gljetweet naeft Caxamalca; hier ig nuen

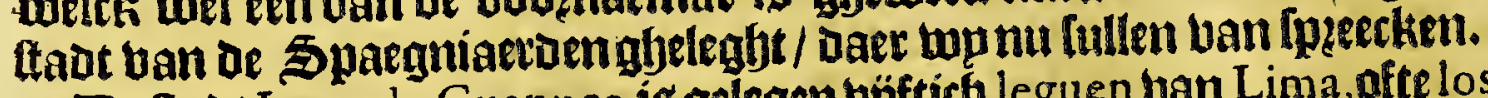

De ftadt Leon de Guanuco íf gelegen unftich leguen ban Lima, afte los Reyes,

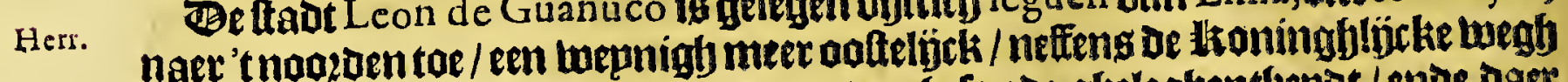
ban de Ingas; is guebout in een goede ende ghefonde gbelegbentlepar / ende daet is groate oberbloed ban aldertyande ligf- tactht / ende beel bee; men beeft daer bock

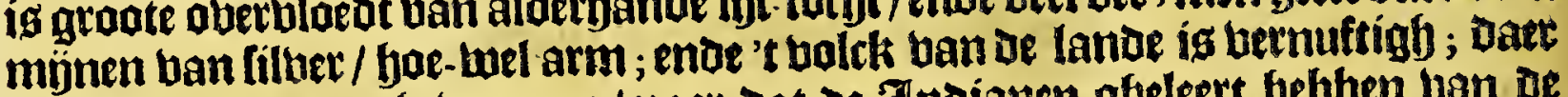
mozot beel tartwe ghetwonnen/naer dat oe Indianen gfjeleett febben uan of Spargniaerden't lanot mel te boulwen / ende frebinden baer beter gljedient ban de tartwe als van Maiz, dope dien bet Maiz (oo goeden voederel nies en ghetit) maer ig grover enoe hitfigher / ende maeckt beel bloedts: Daer waften pock beel wajngatoen / vígfe-boomen/ozagnie-boomen/ende voozts aloerfjanoe frupt-

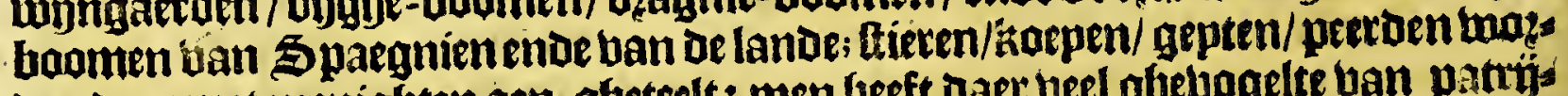

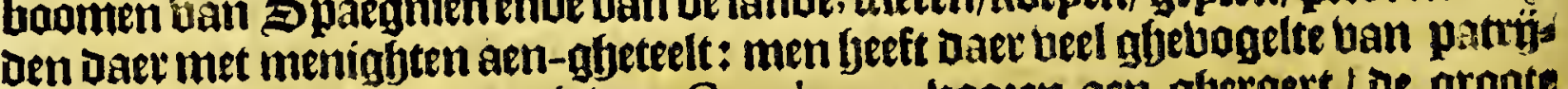

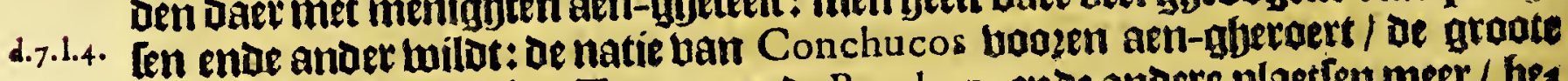

c.4. plabincie tuan Guayalas, Tamara, ende Bombon, enoe andere plaetien meer / bes langhen tot de limiten ban defe thade. In veele quartieten ban defe pzobintim wozaen filber-mínen ghevonaen. Tn Defe ltabt naer't tegghen ban die dare one

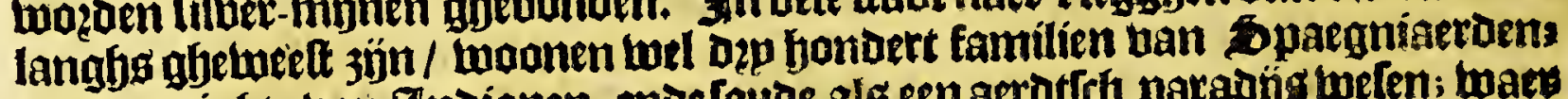
ende menighte ban Indianen; ende foude als een aerottely parading twelen; twaes

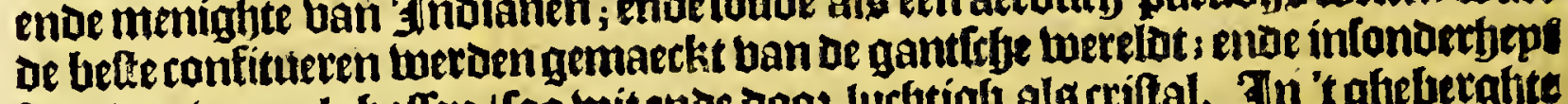

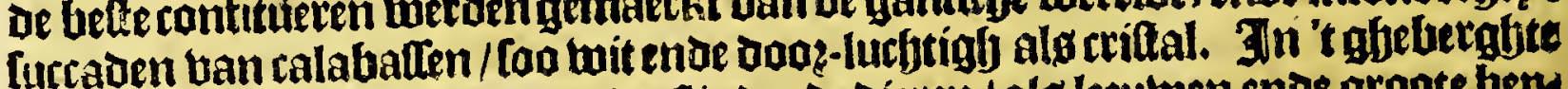

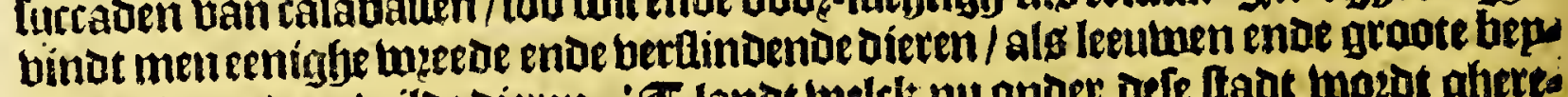

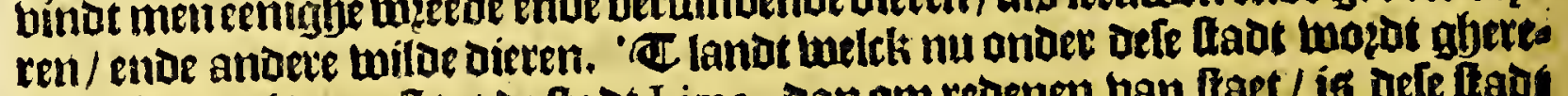

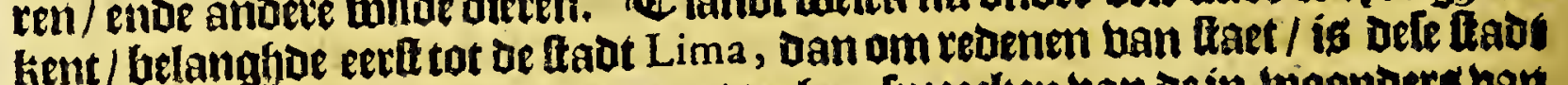

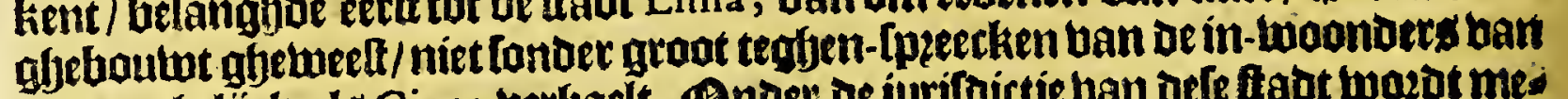

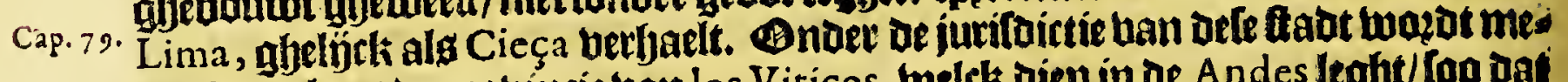
oe gifereeckent de peobincie ban los Viticos, welck diep in ae Andes leght / fon dat ie Inga Mango, naet dat oe Spaegmiaetden Gaer meelters glemaectit hadoen

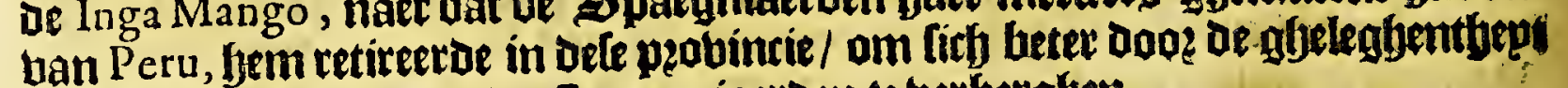
van dele plactle / seglen be Spatgniaeroen te berhergben.

Het bier-en-thintidfle Capittel.

Vervolgh van de binnen-landtfche provineie van die van Gua wico af, tot die van Guamanga, daer de ftade I A Vit TORIA is gheleghen.

Cieça

N Aleft De yzobincie daer Leon de Guanuco in gheleghen is/ balght of probinrie Bombon, twelck feer ftetck ig bannatueren / ende oe gbeleghenthept bart

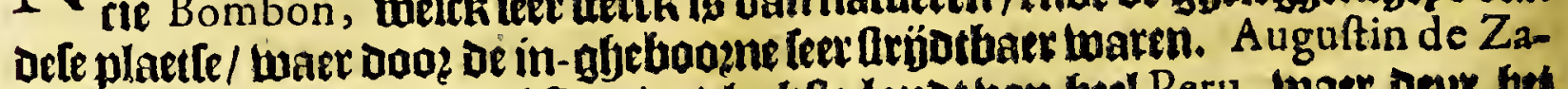

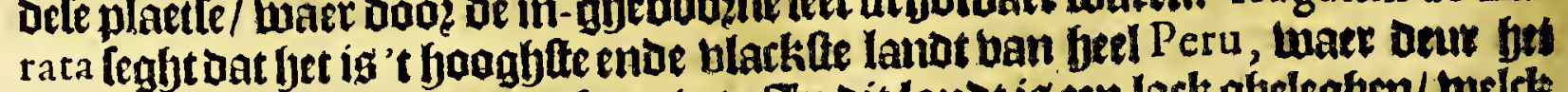
vaer dooe-gaens hageltente ineeutut. In dit lanat is een lack gfeleghen/ trelck wel thien leguen in't ronde feeft; ende 't lande feles ig ulark enoe kouds : ente fot

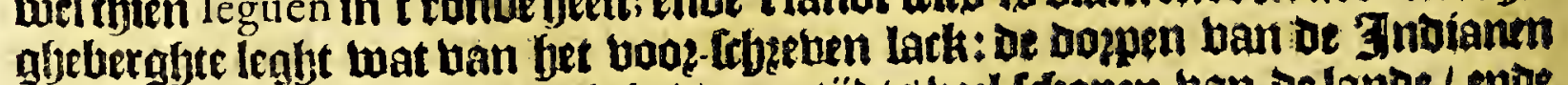

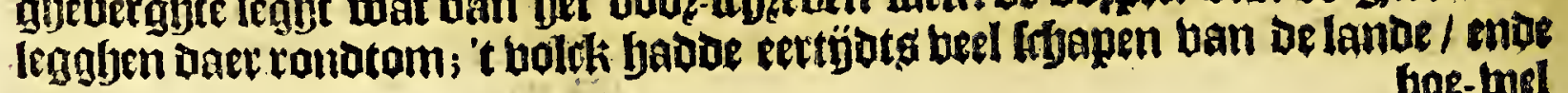

boe- $\mathbf{t a l}$ 


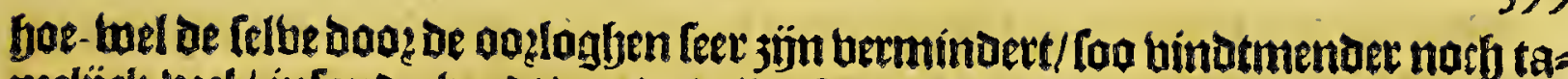

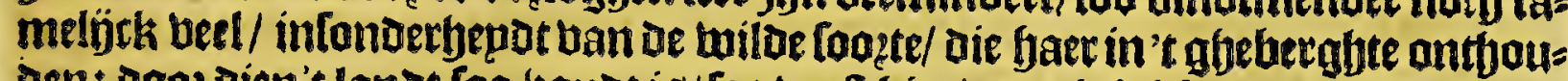
Den: Doo: Dien't lanot foo kouot is/ Too waft bier torepnigh Maiz; dan laten daet. om miet te bebben andere wotelen die bequaem jijn tot onder-houot uan 's men= frhen leven. In oele Laguna leggben eenighe feplandekeng ende klippen ; op oe belcke twalten eenige bielen ende ander krupden daer be Indianen baer bee mede

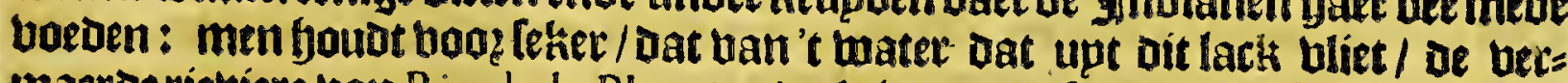
maerde rieviere ban Rio de la Plata ten ueele baren oaspzongh beft; Doo: Dien't boof de vallepe uan Xauxa loopende / al-reede een groote rieviere maeckt / in oe welcke daer naet nodj fomen loopen de rievieten Parcos, Bilcas, A bancay, A purima, ente Y ucay; ende loopende naer't oaften/ kamen baer noch meex riebieren in/tot aen oe Paraguay toe/witcheen uoo?-nemen arm ig van Rio de la Plata. Bombon foude biex-en-twinticf leguen dan Lima ligggen.

Chien leguen boozder legbt de pzobintie ban Tarama, welcke ban heter

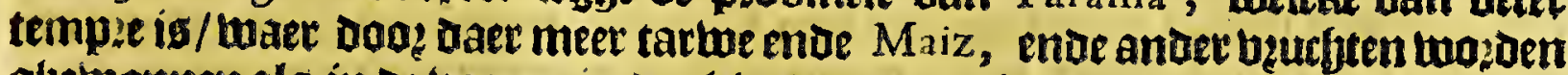
gljewonnen als in of booz-gaende : bier twaren oas i eertijots groote gheboulwen ban ue Ingas.

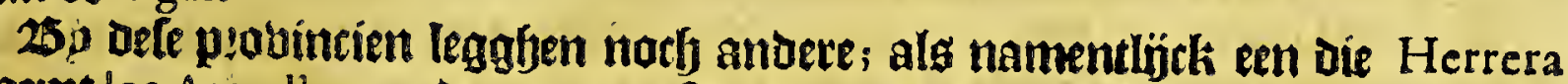
noemt los A tavillos ; entoe naet 't oolten ober / ofte in't gheferdife / De probincie ende riebieren de los Chupachos; langhs oe tuelcke men ooft-waett komt in be

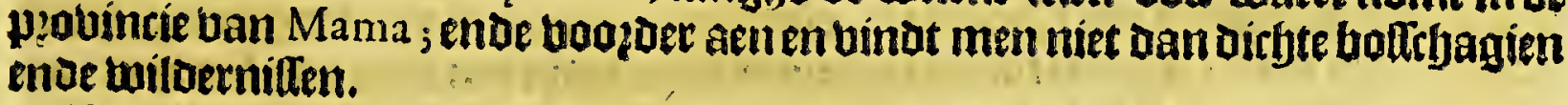

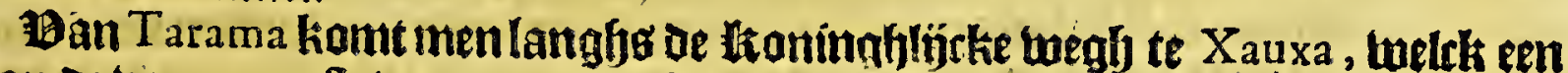

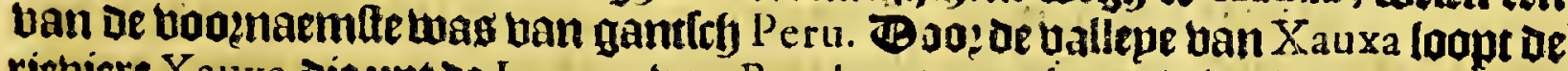
riebiere Xauxa, die upt de Laguna ban Bombon boot-komt/alg fier bozen ig bet:

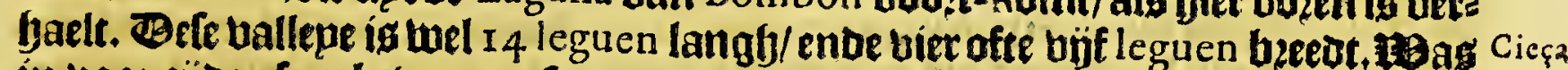

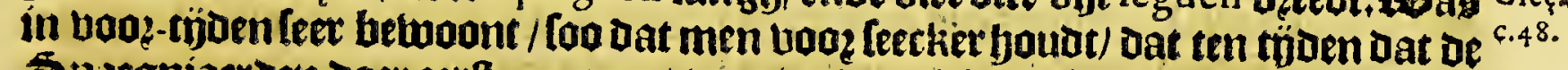
Spaegniaerden daer eert quamen / Daer twel oertich oupfent Indianen twaren; enoe nu (feght Cieça ban (pnen tjot) thujfele ick Datter qualïck thien dupfen two

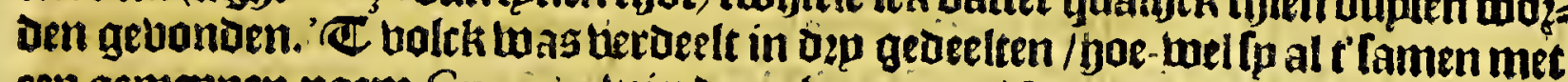
een gemepnen naem Guancas twierden gbenoemt. (Herrera noemtfe oack Yaios.)

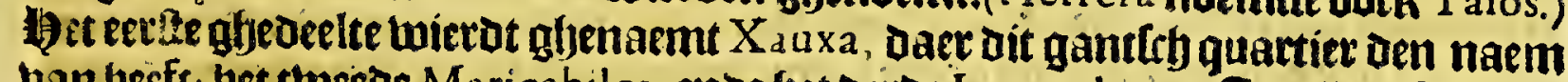
ban berf; bet tweede Maricabilca: ende bet derde Laxapalanga: In alle Defe deelen

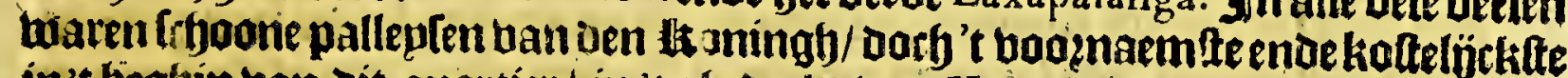
in't beghin uan oit quartier / in 't gheorelte ban Xauxa. Be ballepe ban Xauxa ig om-cinghelt van 't getereghte daer (neeulw op leght. Herrera feght Dat defe val. d.7.1.3.

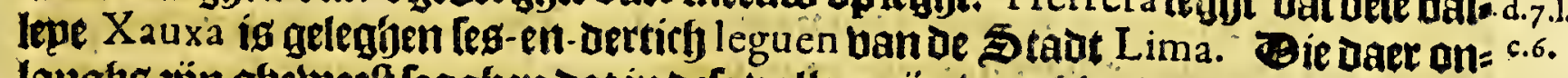

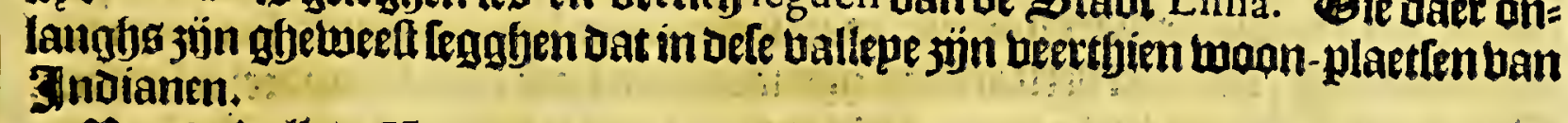

Ban de ballepe Xauxa tot te ftadt la Vittoria de Guamanga, zún zoleguen replende langfes den booghen twegh/komt men aen leecker booghten/welcke leg = Cię̧a gen bouen be ballepe / oaer men feker oude gebouben tiet / Die gantleb beruallen 3ïn ende bodzts treckeride kont men ain fet basp vain Acos, welck neftens cen moerafty legft dat bol rieot-bolletyen leght; de Inoianen ban A cos twoonen wat

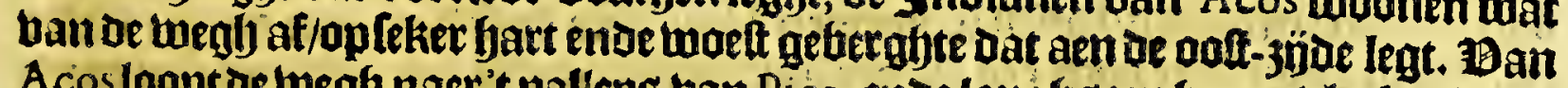

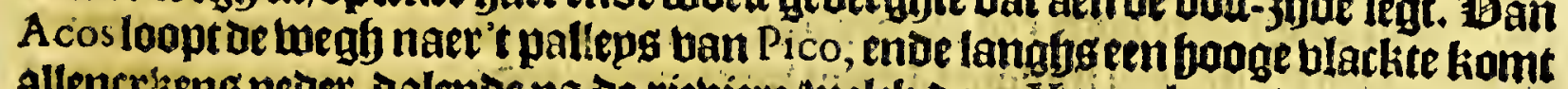

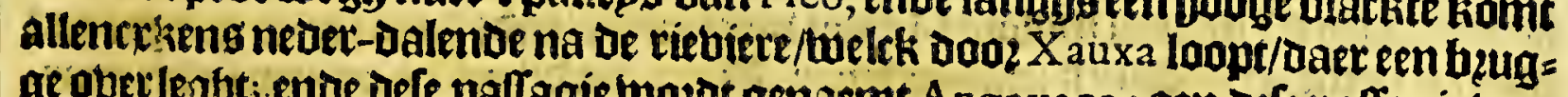
ge ober leaft: ende Defe palfagie wozot genaemt Angoyaco: aen befe paflagie ha: teneenigbe tuooningen booz de Konimgerigebout/met een badt/belck baet ban leecter feetelpzinghen twozatghemaeckt.

19an bier boosts treckende aber een ander klepn tiebiekken/komt men aen bet

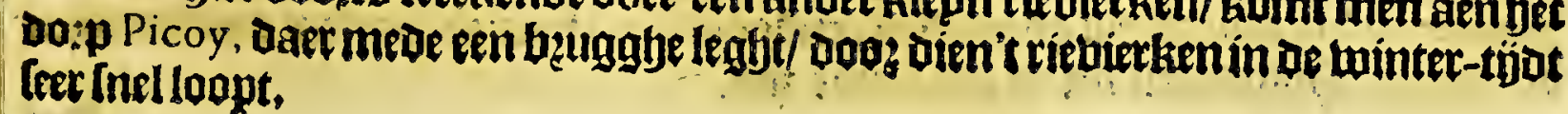

Im 4 
Dan Picoy fomtmen aen be pallepien ban Parcos, welck op ent rop tuan eer

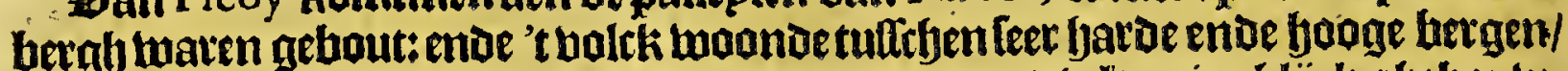

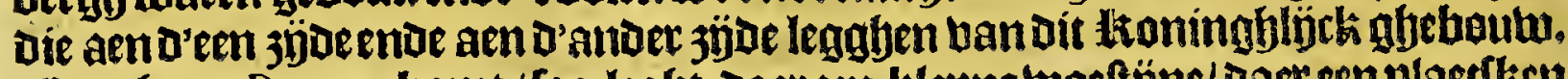

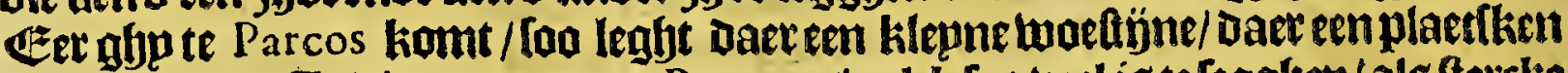
legft/welck of Indianen noemen Pucara, (twelck [oo ucel ig te [egdjen/als ftetcke

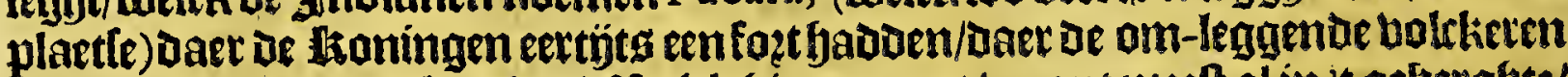
jaer tribupt quamen betalen.' $t$ Bolck fier ontrent woont meelf al in 't gefuerghte/ Daer meeft doo - naens beel fneeus op leght/Doch fo jaepen ende planten in de bals

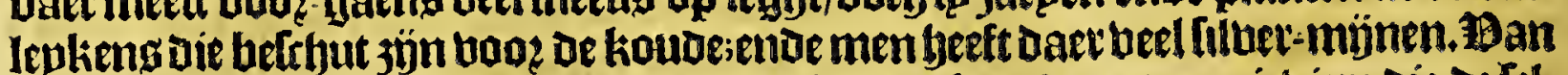

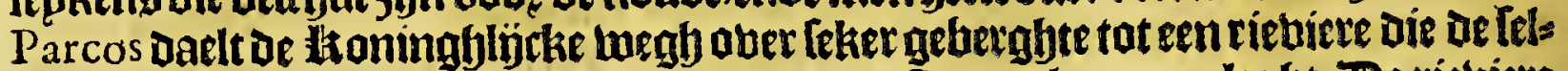
be naem boert/daer een beugge leght/op groote teenen bogen gelegft. Be riebiers ban Parcos ober jónoe/[oo treckt men voots naer't pallepg/tmelck genaemt twote

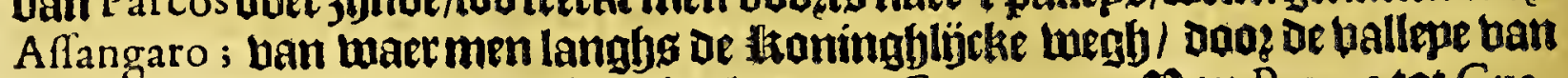
Vinaque, twelck frjoan en luftigh is / komt te Guamanga. 10an Parcos tot Guamanga jün elf leguen, naer't legghen uan Herrera. Auguftin de Zarate feghts dat la Cuefta de Parcos, melck is een quade pallagie/niet ber gheleghen is ban Gua. manga, ente un̈ftity leguen ban Cufco.

Be ltadt Guamanga, ofte St luan de la Vittoria leght op de fyoughte ban i 3 ta Herr. Den bp jupden de limie/ 60 (oft als andere feggen 78) leg. ban ue thad de los Reyes ofte Lima, naer 't jupdt-ooften aen de Haminghlÿcke twegb van de Ingas, op em blacke plapn/ontrent een Cordillera, oftevetuolnh ban klepme betgen/legghende

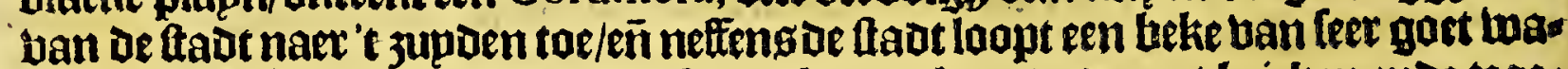
tet: De fupten ban de ftadt 3 wn meef ban teen gebout/ende met beicken ende teges

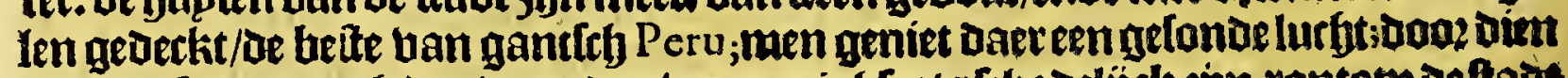

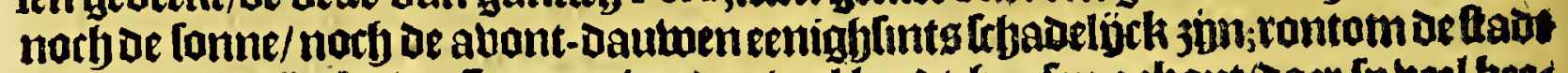
ende in t velt tjin bp de Spaegniaerden beel landt-huplen gehout/daet fp beel bees ften wepdenaen be rievierkens ende in de ballepen. Oe groatle rieviere die fp biet:

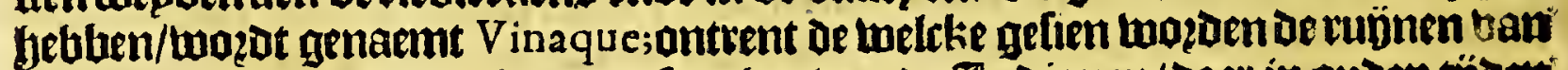

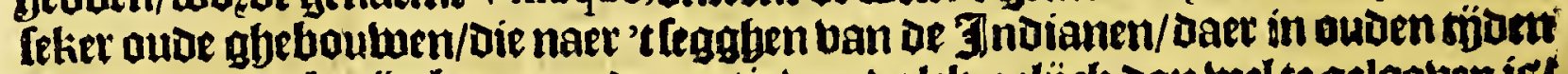
fouven gemaeckt 3 g̈n bp een ander natic ban bolch:

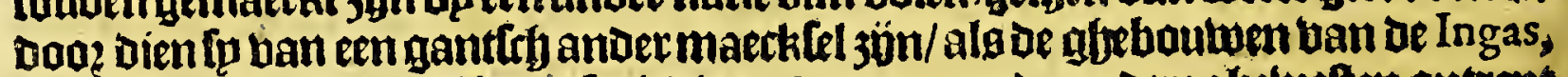
lioningen ban Peru. Zlen dele riebiete Vin a que, ende andere ghelueten ontrens Defe ttad geleaen/wozot alloo goede tartwe getwonnenals in Spaegnien/ vaet for

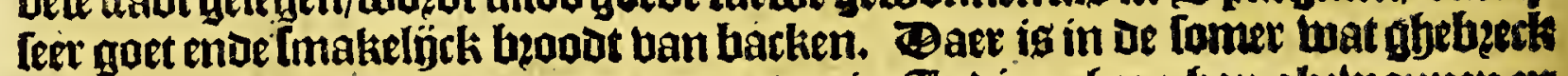
ban grag boo? de peetoen / te meet om dat in Indien gheen bap gbetwammen en wo:ot Dat de beefen willen eeten. Be Cordillera ban de Andes leghtnaer't reggent ban Herrera, I 8 leguen ban de ttad naet' tooften. Be in-gefoome ban defepers

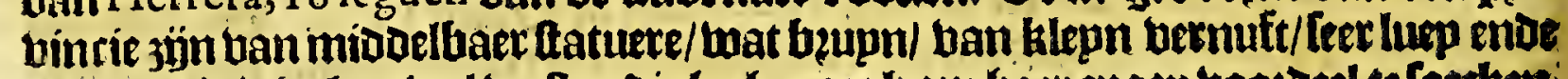

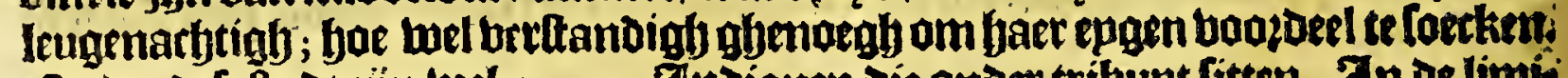
Onder oefe thad jỷn bel 30000 Wndiamen die onder tribupt fitten. In de limi: ten ban defe ftadt woet beel Coca bergadert; Daer valt leer goeden bonigh/ eñmen jeeft daet depnen die foo goet 30 in als kalueten. De riebieckens die ban ar An.

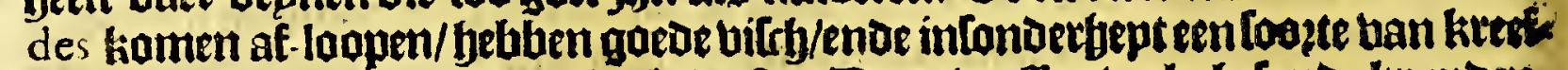

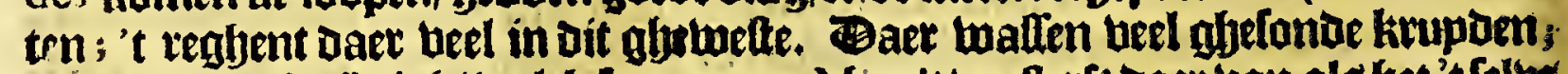

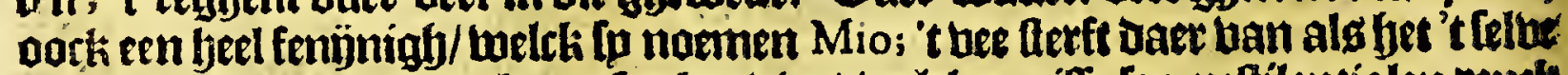

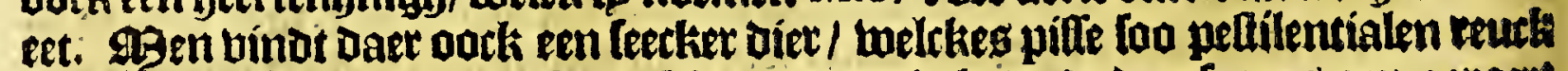
beeft/ a at men 't bel een mufquet-lefjoat berte rieckt/ende daet [e eens aen-getoert

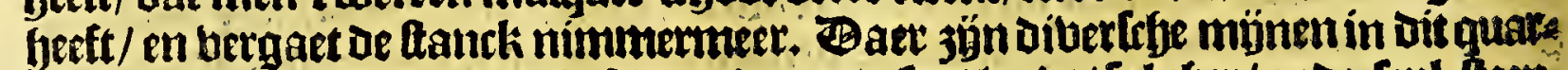

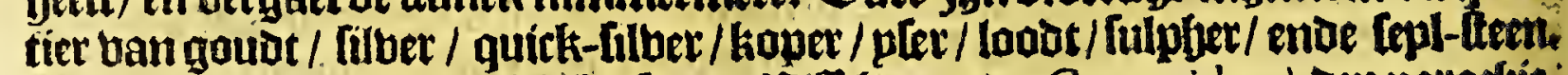

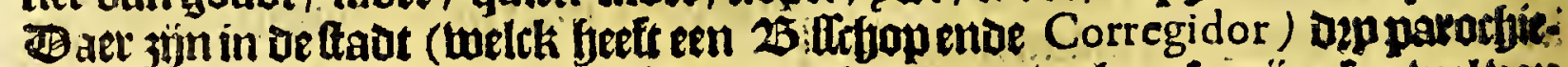

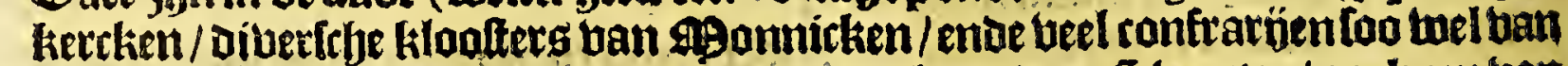
Indianen als ban Spargniactien; enoe oocken van Slwarten/oock en ban be fraeplte Holpitalen die in dat lamot 3 ñn. 
Het thiende Boeck.

(1)et büf-en-thintichlfte $\mathfrak{C}$ anittel,

Vervolgh van de binnen-landefche provincien langhs de wegh van de - Ingas, van GuAMANGA af, tor Ci's co toe.

V

Zln de peobintie ende ltadt ban Guamanga af / tot de groofe ftabt Cufco, tes kent men luepnigh meer oft min als feltich leguen, A uguftin de Zarate fegbt tachtenticlj/ Dooe een barde ende onfequaeme twegh/ wegben 't ghebergbte ende klippen; in befen tuegh legghen oe plapnen ban Chupas: twee leguen ban Guamanga naer 't legghen uan Zarate. EIf leguen ban Guamanga langhig of ta: ningblïcke tregh / legghen oe groote gheboumen ban Bilcas, baer De \$ndianen rekenen de rerbte helft te welen ban $t$ gantefye rück ban de lloningen van Peru, Dope dien dartfoo beel tweeghg ig ban Quiro tor Bilcas, alg van Bilcas, tot Chile; ente eenighe \$paegniaetden die deten wegh bebben ghetepd / mepnen dat bet

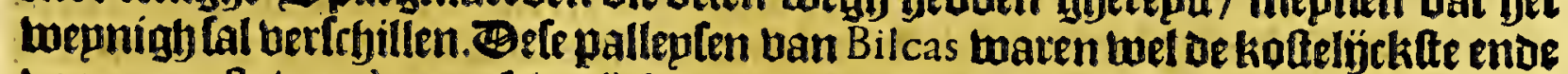
booenaemlte ban 't gantf(je rỉck / Dan jún nu gantrob berballen / foo Dat Daer nier bp naet als de terballen teen-fjonpen van te fien en 3 jon: Bilcas ig nu een Corregiemento, welck beelaen-liggbenue doepen onder fictjyeeft.

Beben leguen ban Bilcas leght V ramarca, ende tultrben bepdenloopt ae wajoe rieviere die fp noemen Bilcas, om datle naer bp dele palleplen gbeleglien is : Daef

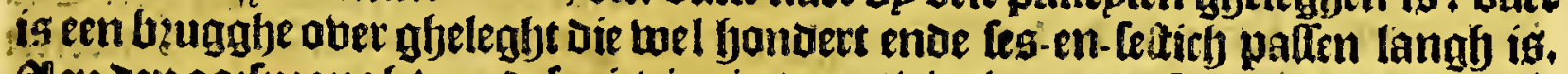

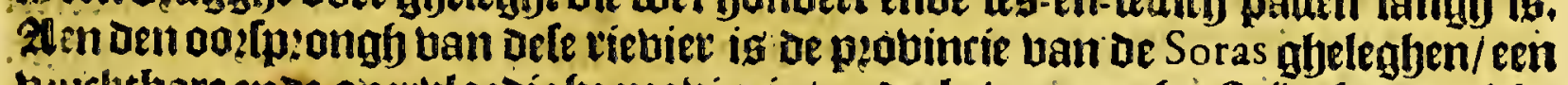

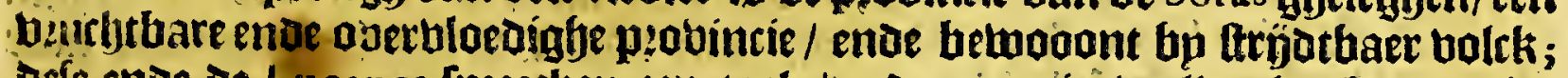
Defe ende de Lucanes [perecken een taele/ende gaen in mollen-laeckenen gbe=

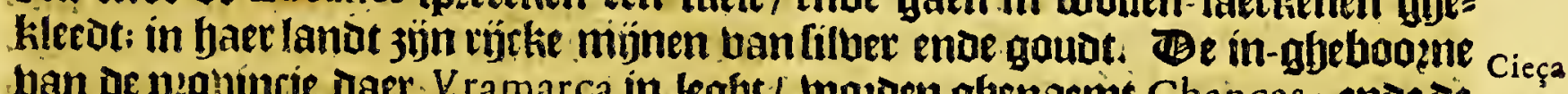

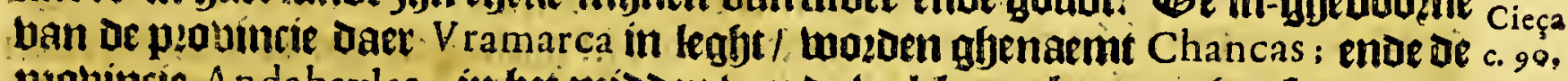
pyobincie Andabaylas, in fet midoen ban de tuelkke dock groote fuplenende de Ifbueren waren tot befjoef ban oe Ingas van Peru. Jge een groote ende langhe peabincie daer ueel tam bee ig; daer watt beel tartwe/ende in ennigje feete vallepen wallen fryoone frupten. 'C bolck is leer vermindert dooz de ooflogben ende tp=

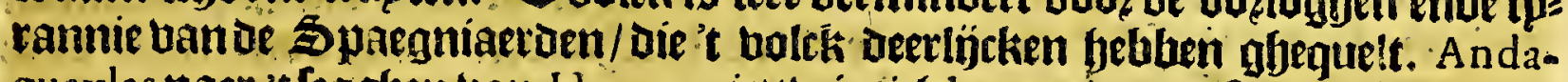
guaylas naer t fegghen tuan Herrera, ig twintich leguen ban oe ftaot Gúamanga: ende ig etn rijet Corregiem ento.

Regen leguen boozor ban Andaguaylas, fiomtmeri aen de rietriere tian A bancay, in luelcke riebiere lterclie fteenen pilaren jịn / vaer een bzugge is ober geleggt

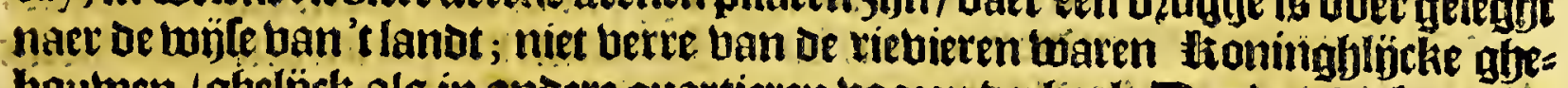
boutwen / gbelijck alg in anoere quartieren boozen berfiaelt. Bap leguen bp noog=

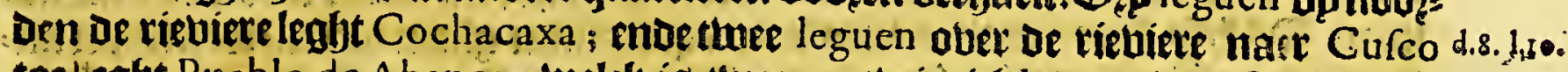

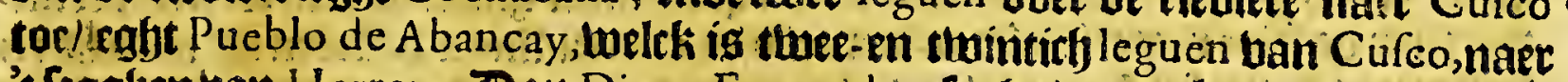
Tegglien uan Herrera. Ban Diego Fernandez light dat de bugagle A bancay maer twintich leguen ig ban Cufco; gheln̈ck mede tebzâft Auguftin de Zarate, be toelcke twaeif leguen boben Puente de Abancay ftelot de vallepe Cotabamba.

alcht leguen ban A bancay loopt of riebiete A purima, thelthe tuel to grootlte is

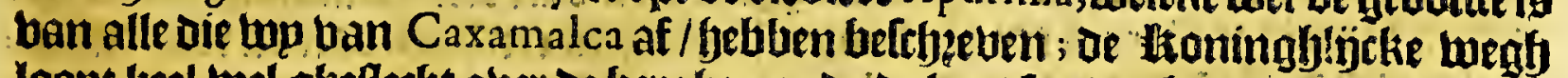
loopt ljeel wel gheteetht ober de berghen ente balen / loo bat het grooten arbepot enoe moepte moet ahelioft bebben die too te ttethten/ infonderthept in 't af-Dalen naer oe riebier/al- waer feer fartot ende weecot qheberghte is: In Deriebiere taen the groobe Ateenen pilaren/ om oe fiugghe ober te leggisen; De welcke daer

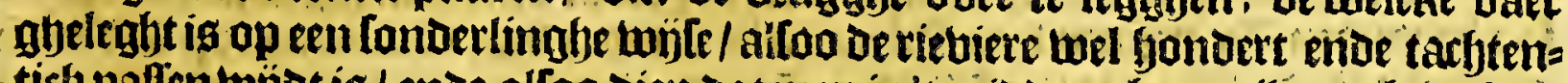
tielj palten wojot is / ende alloo diep datmenin thiosen abeen pilaten kan fons veren; Daet is een A lcalde die de fellue twaer-neemt die jaetljeks vooz falaris heeft Dupfent pezos: enve alle lioopmanfryappen die daer trecken / betalen een balf ten bonocrt / tot feparatie ban de bugghe. 250 ben op Defe riebiere woonen be Ay- 


\section{2}

Peru.

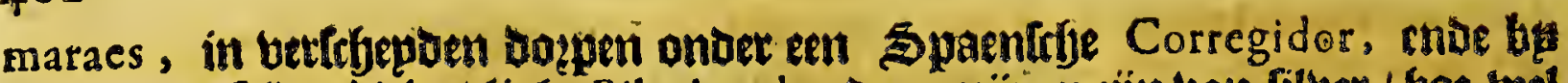
noazoen de Lelue riebiec/ light Bilcabamba, daer münen zün uan filber / gor-Lat arm; niet te min wozdender jaerlīeks 500 barten upt-ghejaelt.

Ban de rietiere A purima (melck is twaelf leguen van Cufco, nart't leggfen van Diego Fernandez ende A uguftin de Zarate) komt men aen of pallapsen ban

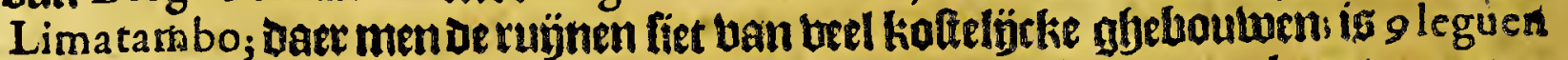
han Cufco; ente treckende ouer 't gbelierghte van Bilcaconga, liomt men aen

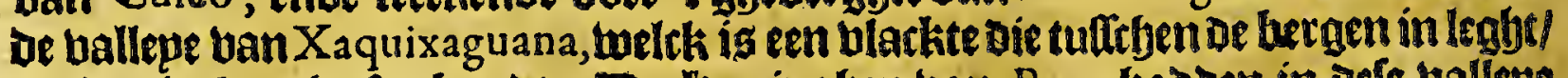
en is niet langy afte biecd: De Honinghen ban Peru babden in aefe vallepe groote frboane luft-joben daer Ip faet quamen becmaectien; ban befe ballepe tot

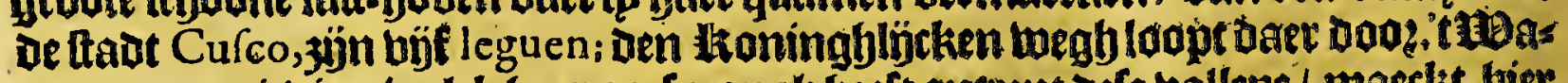
ter ban een riebiere welch faec oos [pzongb beeft ontrent defe ballepe/ maeclit biex

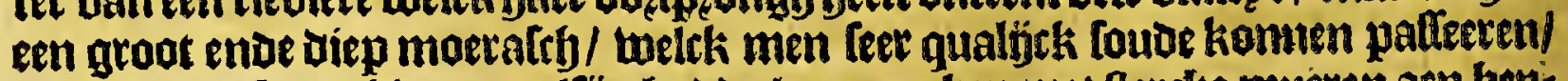
ten ware of Ingas hiet een rallïe badue boen maken met ftereke mueren aen bejis

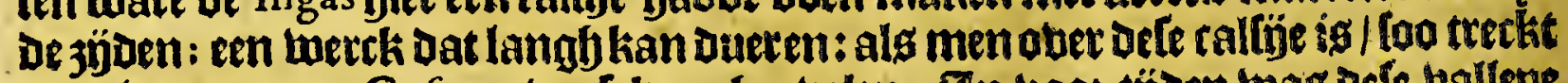
men boots naet Cufco ouse tekere beubelen. In bog-tíjoen twag of fe ballepe ban Xaquixaguana feer belwoont/ende bol zaep-Landen ende ackeren die foe ghes leght ende van Den anderen berfefepoen waren / Dat bet een gheneucht wag on

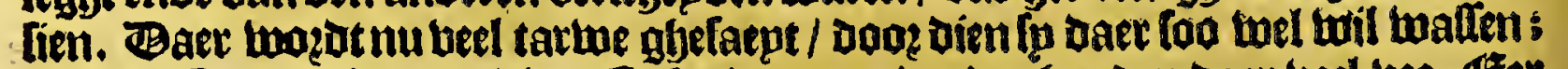
ende de Spaegniaerden die te Cufco twoanen/ onder-youden daet beel hee. [Eee

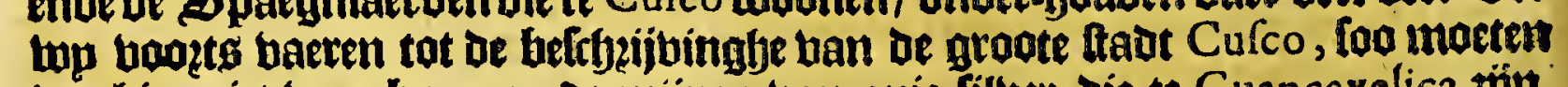
top hier niet booz-bp gaen de mijnen ban quic-filuet die te Guancarclica jojt.

aleht oft thien leguen han Guamanga bier boozen befryethen! bphants naet

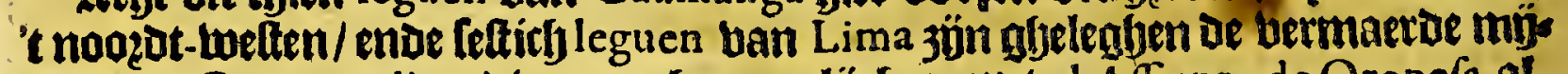
nen ban Guancavelica, Die men gbemepnljork noemt el Affiento de Oropefa, alwaer de monderlïcke mijnen ban quic-filber zijn gbelegben. Be Honingben ban Peru, ende de Jndianen/en bebuen in boo:-tijoen gleen arbt gbenomen op dic metael / ofte eenigbe kennis daer ban gbefjadt/ oan fp gbehyupekten alleen bet. Minium ofte bermillioen/ om baer lichamen mede te beftrijcken enoe bertwen : noemoen dit bermillioen in baer tale Limpi, ente dit bertwen ban baer licbamen

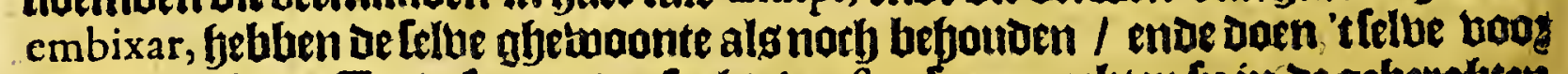

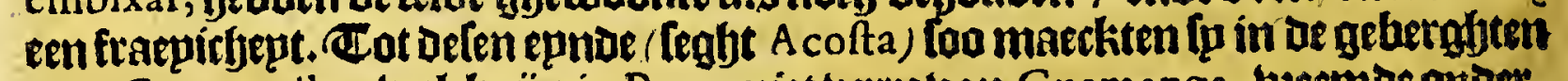
van Guancavilca, welck jün in Peru, niet betre van Guamanga, beetmoe ontoetgrabingben ban mỉnen / al waer fp dit metael upt-trocken / endoe jön in fulckes boegen gemaeckt/Dat fo men noch beoeng daeghg in oe feloe folen ofte Socabones (als de 3 paegniaetoen Die noemen) bp De Indianem voog Deten gemaeckt/kom

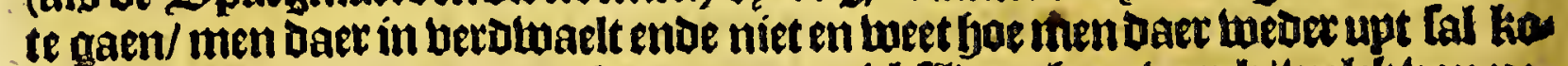

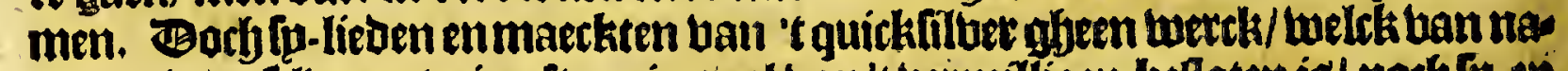

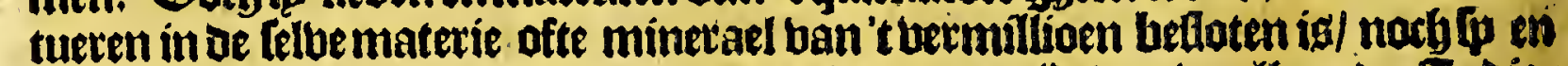

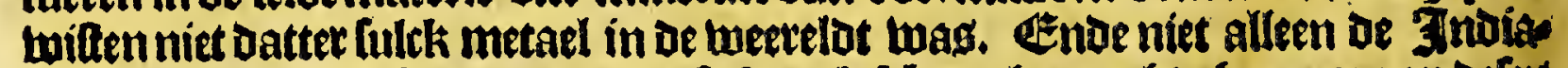
nen/maer oock de Spaegniaerdenfelfs en bebhen gbeen arbt ghenomen op decen rürkiom/ tat inden jare is 66 ende 67 , altooen jün dele mignen ontoeckt op de

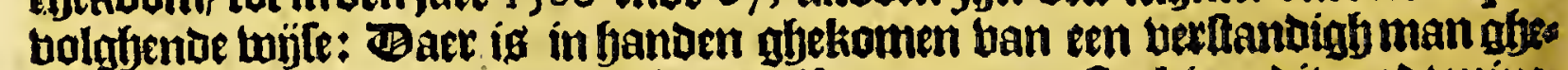

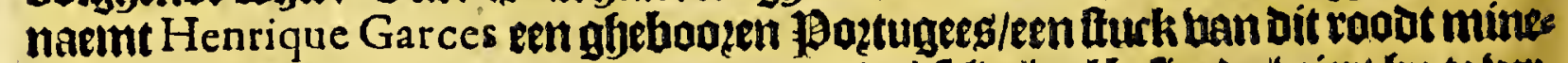
rael/welck of Thuianen noemben Limpi, ende 't telue twel befiende/wiett bp te bots kenuen dat bet 'tfellue minetael was welc men in Spaegnien noemt Vermellion, anoe wetende dat bet quic-filluer ende bermilliaen al upt een minetad wozoe ghes

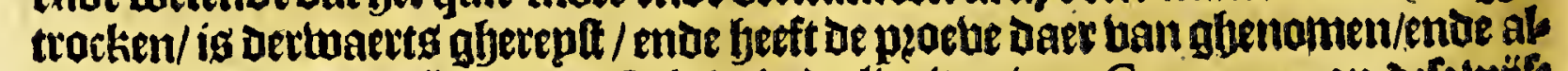
toa betwonden. Be minnen ban Palcas in de limiten uan Guamanga op orle twiffe

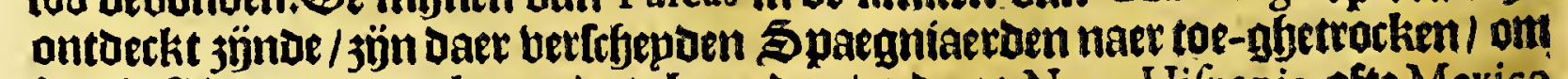
'tquic-filber upt te trectien ende te betepden/ende na Nova Hifpania ofte Mexice

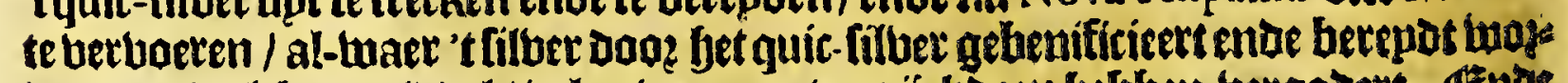

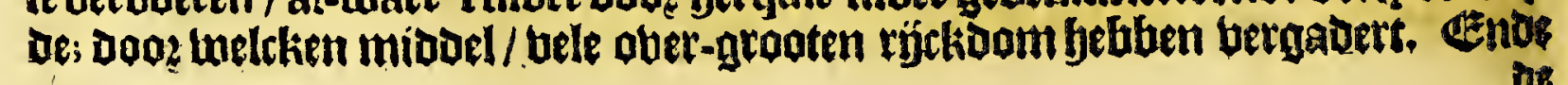


Het thiende Boeck.

be rontrepe baer defe mïnen jün/ twozoen terftonot met bele toogninghen ban

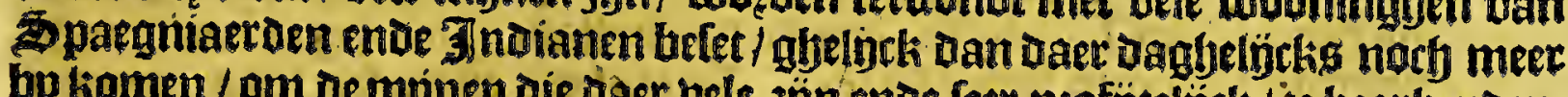

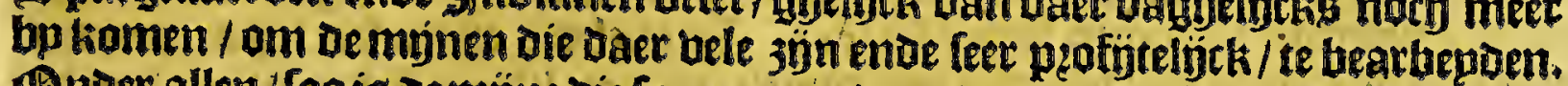
- Bnder allen/ /

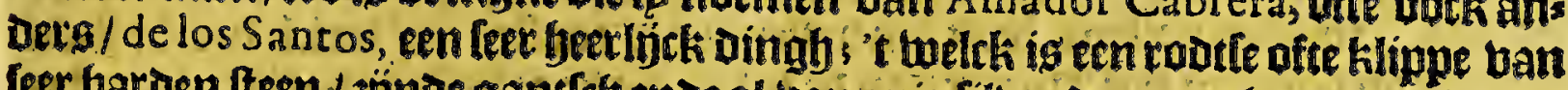

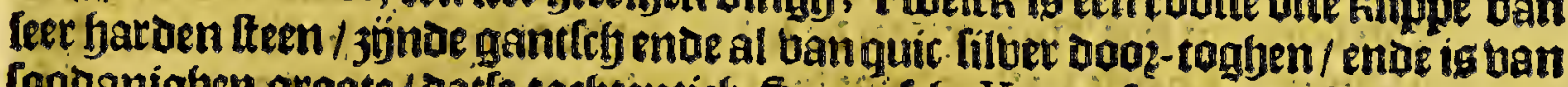

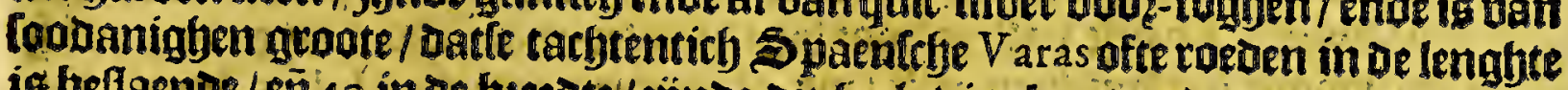

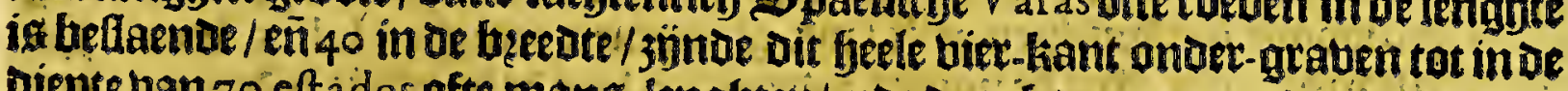
Diepte ban 70 efta dos ofte mang-lenghten/ende daer Konnen meer ban 300 man=

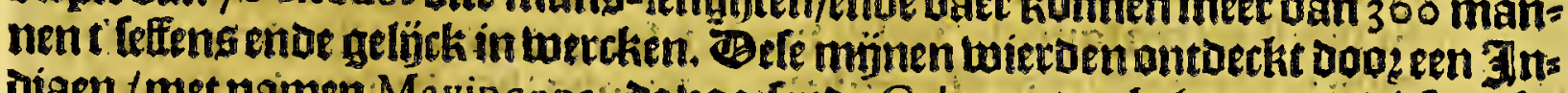

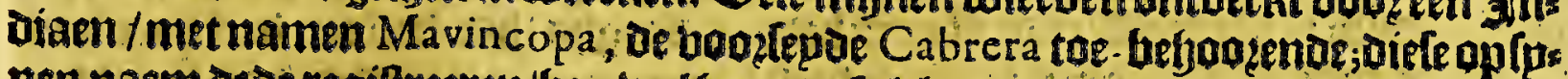

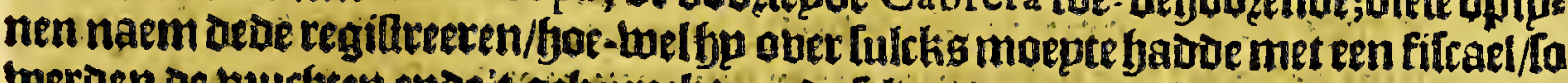

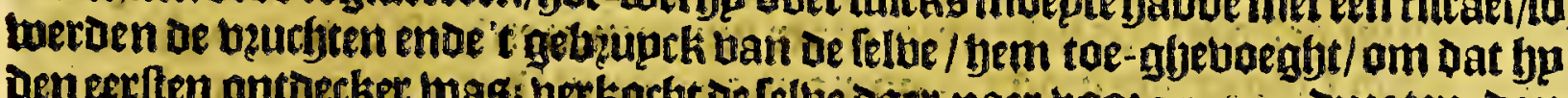

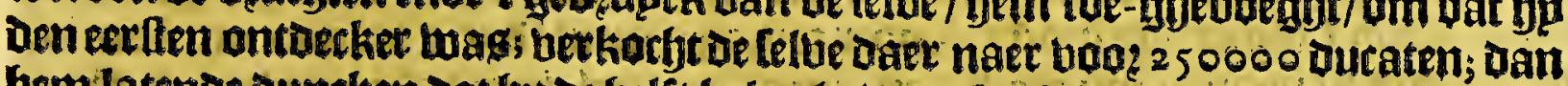

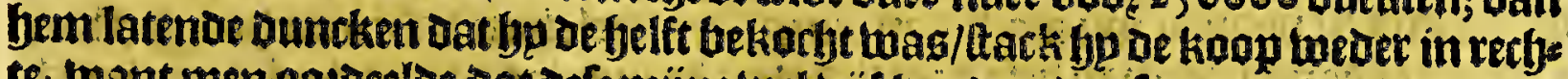

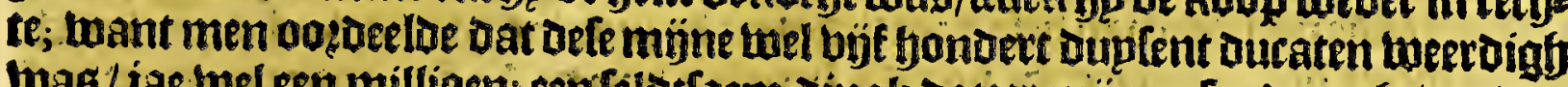

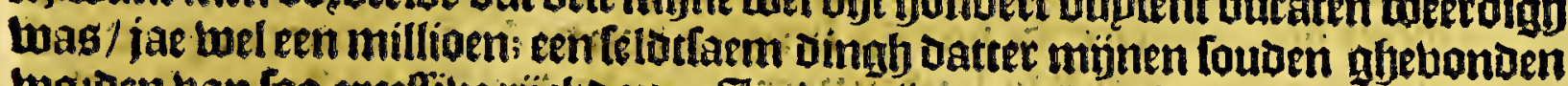

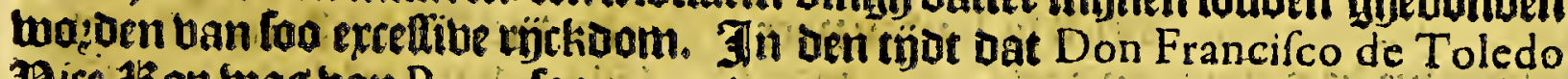
Bice-1iop has ban Peru, foo quam Daer een met namen Pedro Fernandes de

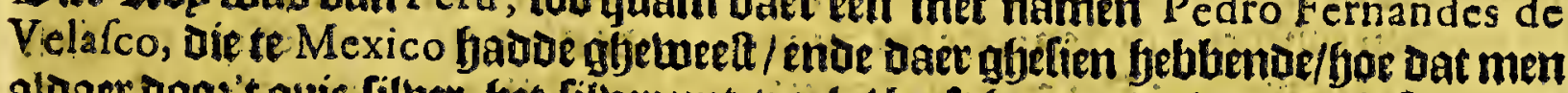

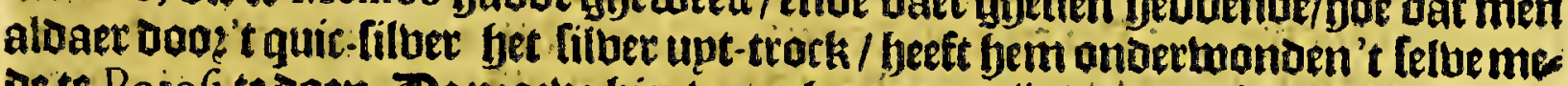

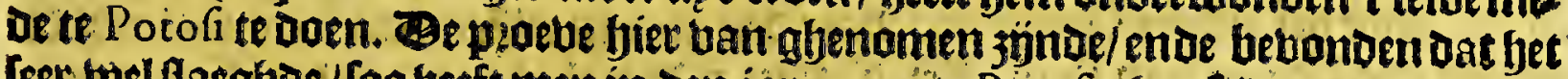

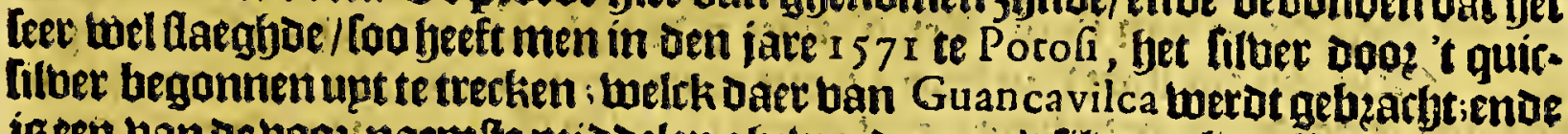

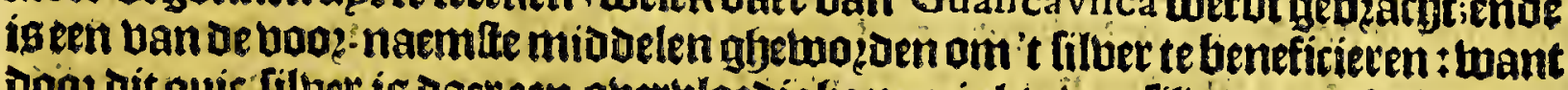

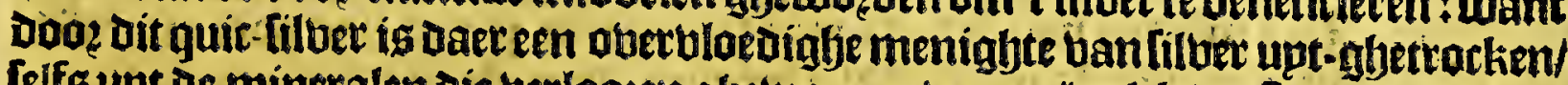

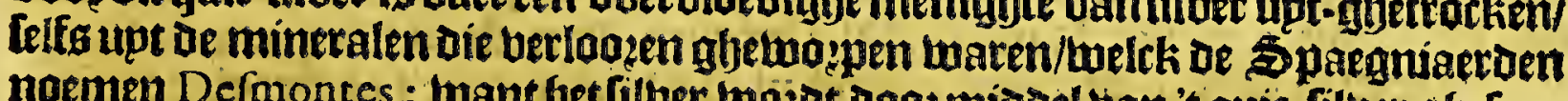

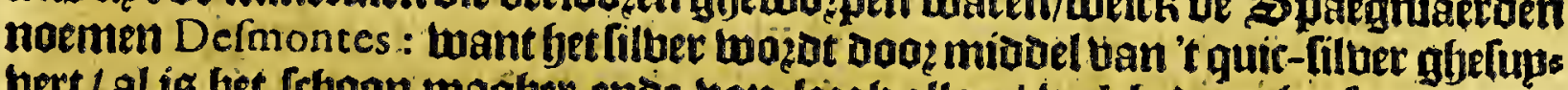

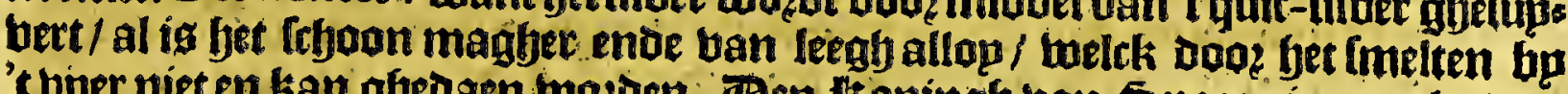

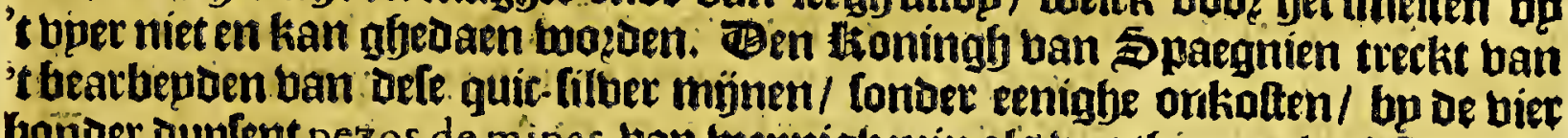

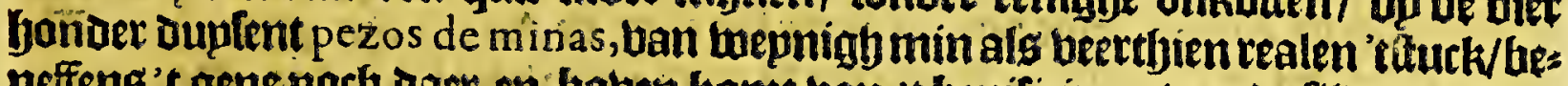
neffeng' $t$ gene nact daet-en - boben komt ban 't benificieren ban de fill ber-münen ban Potofi, welckt horbeenen grooten febat geft. Baer tweroen bet eene faer ono:'t andert/upt oe mijnen ban Guancavilca tertrocken 8000 quintalen quir-filbers $/ \mathrm{enn}$

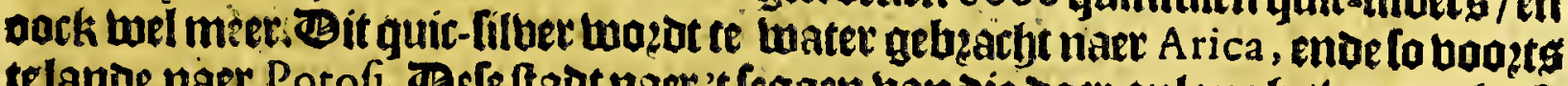

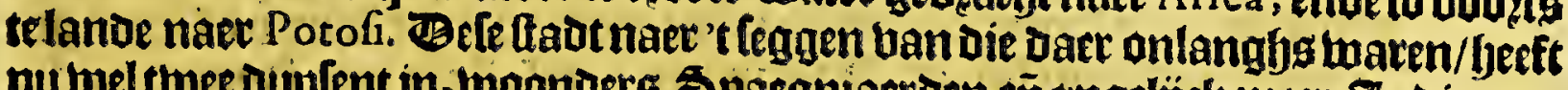

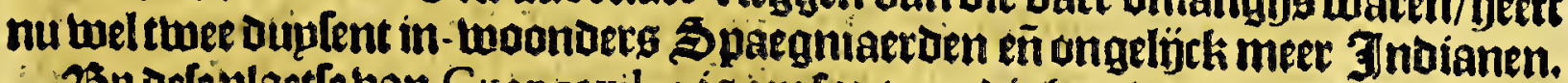

$23 p$ defeplaetle ban Guancavilca is eenfontepn die feet twater upt-ghteeft/ Dat Acofta

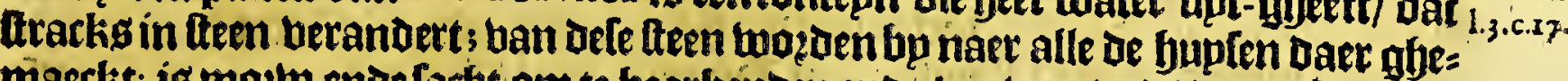

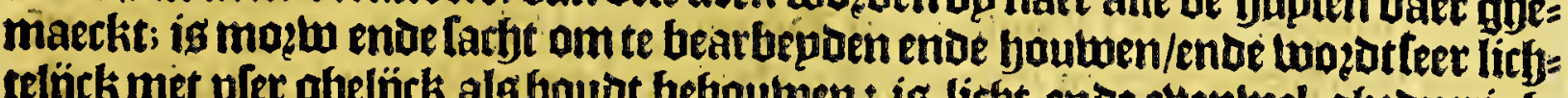

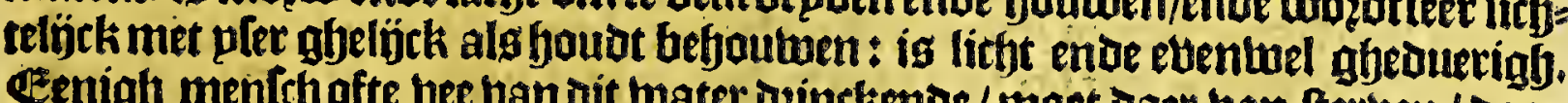

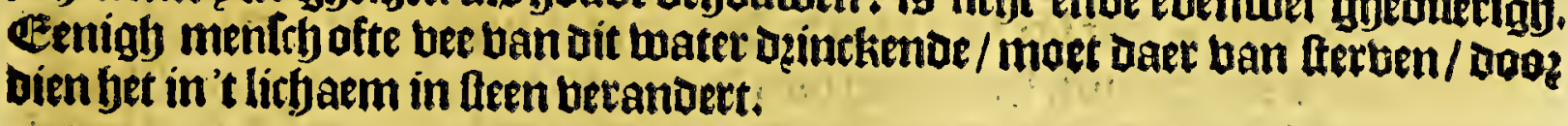

\section{Het [es-en thinticfite Capittel.}

Befchrijvinghe van de groote fadt Cus $\mathrm{CO}$, ende de gheleghentheyt van de landen daer ontrent gheleghen: ende van $S_{A N} F_{R A N C I S-}$ CO DE IA VITTORIA; ende S? IIZA DEL ORO, in de provincie van CARABAYA.

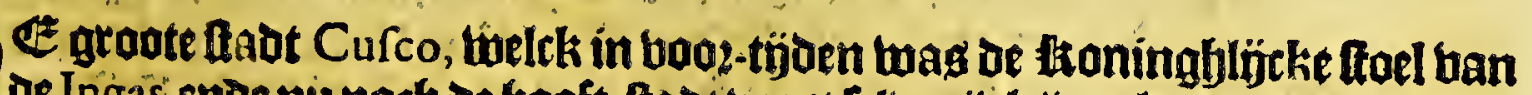

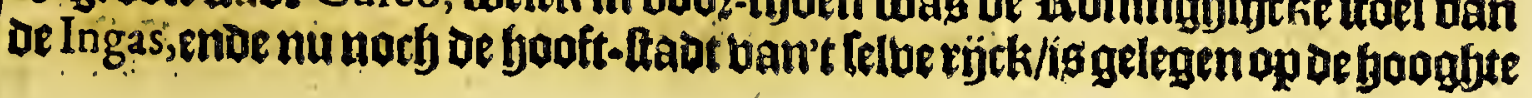


404

Peru.

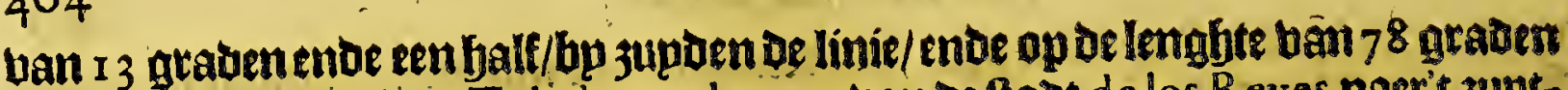
ban oen merioiaen ban Toledo; 25 leguen ban de fladt de los Reyes naer' zuptbalten/ bolgens 't Tegghen ban Herrera. Jo ghebout op ren feer barde gronot/

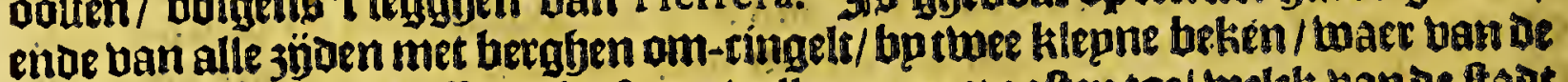
ene doo 't miouen paffert; beeft een ballepe naer' tooften toe/ belch bande ftadt

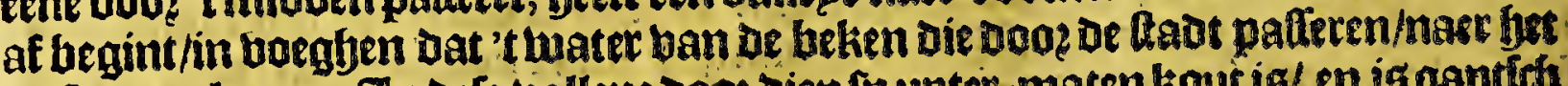
Luelten toe-loopen. In dele ballepe doo bien fp upter-matenkout ig/ en ig gantich gheen gheboomte dat buteften geeft / upt-ghenomen eenigbe Molles, wetck zin

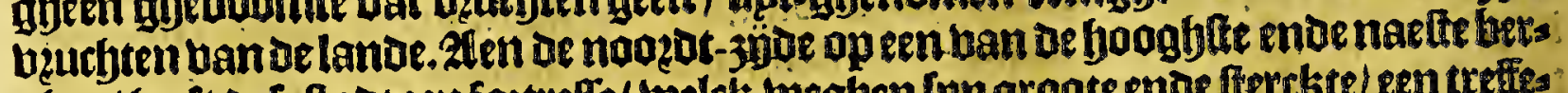

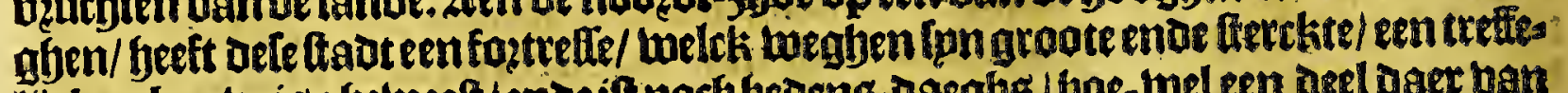

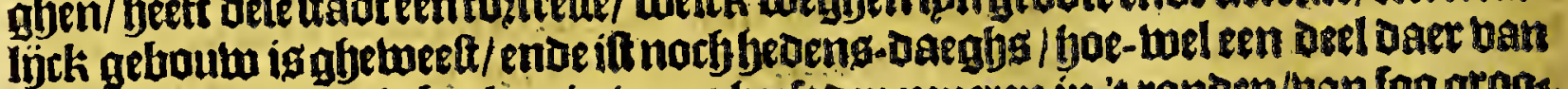
terballen ende af-ghebzoken is; want beeft Deg mueren in 't ronben/wan foo groos. te ftenem op-geleght/ dat elcke muer maer Deg ftecnenen beeft in De boaghte/end:

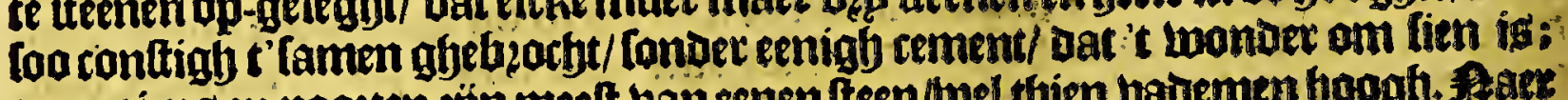
toomtiens en poozten jïn meet ban eenen fteen/wel thien bauemen boogd. Aaes

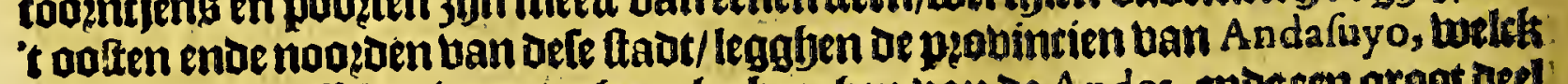
zón De dichte boffchagien ende boogbe berghen van de Andes, enderen gropt deel ban Chincafuy, Dooz welck de landennaer Q uiro toe meroen bethaen: Raer bet Jupuen toe de pzadincien bain Collao enoe Condefuyo; ban tuelcke oie ban Col-

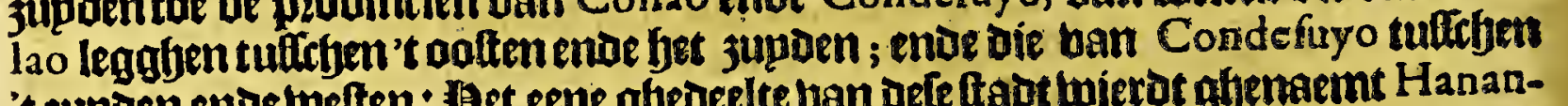

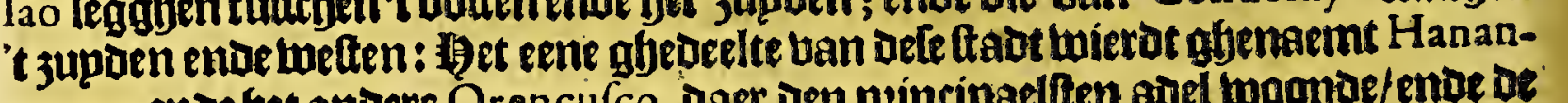
cuzco, ende bet anbere Orencufco, Daer den peincipaelfen aod wontae/ente de

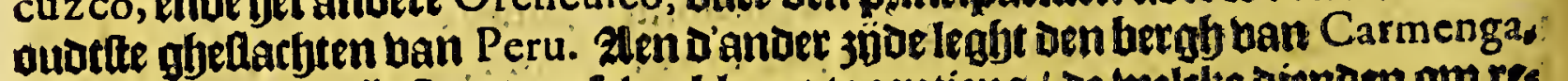

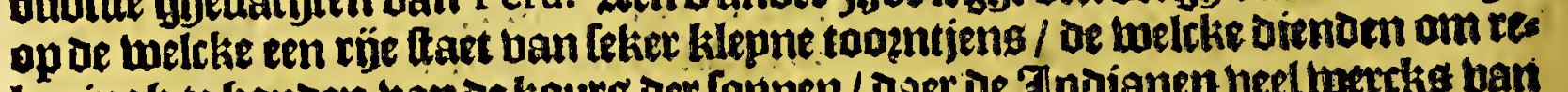
keningf te fouden ban oe kourg der fomen / Daer De 3 noianen beel beecks bat maeckten. In't midoen ban de thad was een marckt- plaetfe han goes maechisl: ban welck unt-gaen vier toninghlïrke weghen; De eerlte wotot gentaent Chin-

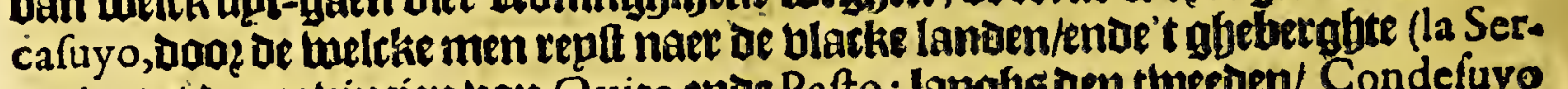
rania) tot de protuimtien ban Quito ende $P$ afto : lamgges den theeden/Condefuyo afebeeten/reptemen naer de pzovincien die onder dele fadtende Die ban Arequipa behoozen: langhg den deruen / Andefuyo, treckt men nat of probintien bie ant ae voet ban de Andes, ende oockeetighe die aber ae Andes jön gheleghen. De vierde ende laette Collafuyo, ftreckt tot oe probincien ban Chile tae. Fe riethiere Die doo? oele ftadt loopt / beett baet byugghen om ouer te gaen: Enocin gheen gee Deelte uan Peru en wierdet een plaetle ghebonden / die toa de ghedaente bados bail

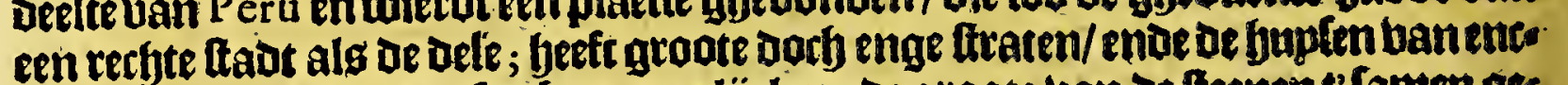
kel fteen gemaeckt/enoe foo bequamelïck na of groote uan be ffeenent' famen ges.

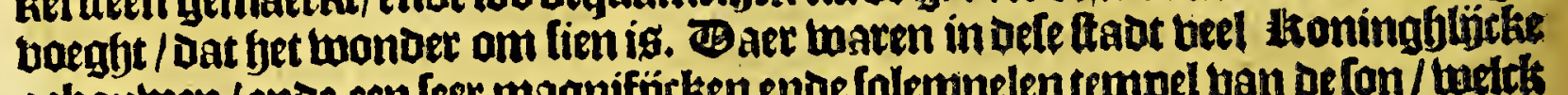

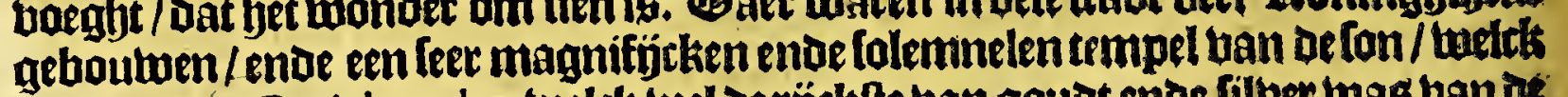
in noemoen Curichanche, welck wel oe rỉcktte ban gouot enoe filbet was ban of:

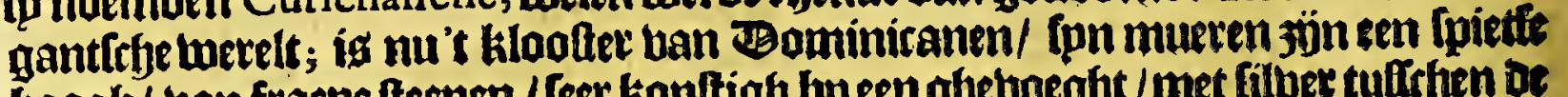
boogh / ban fraepe fteenen / ceec konltigh bpeen gbeboeght / met filuer tulfeben of

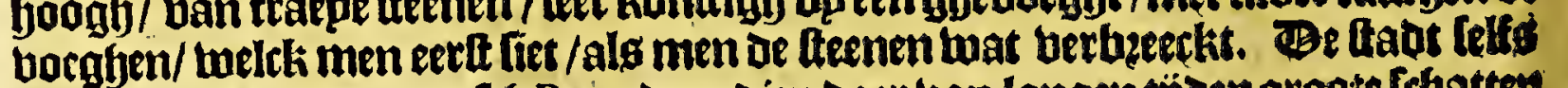

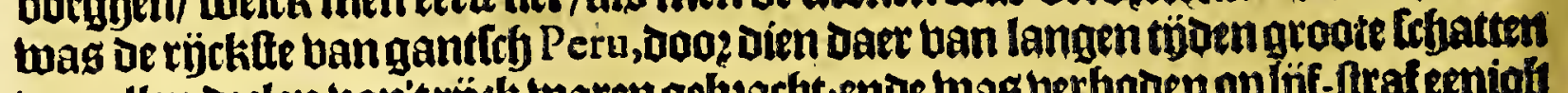

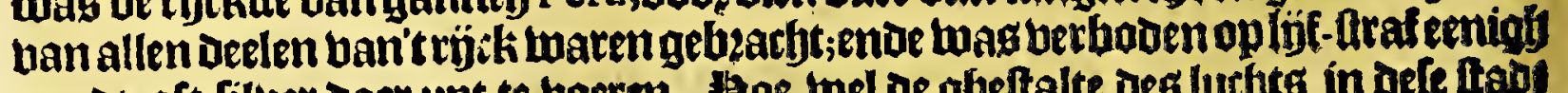
goubt oft filver saer upt te boeren.

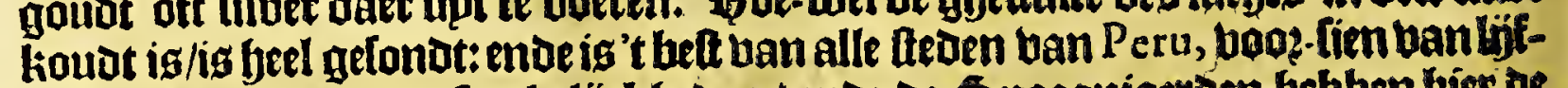
torbe ende andere nootlaeckelíck hejen / ende de Spaegniaerden beb hen bier be meefte en comiendas ober ae Indianen. Heft nu 4 parerbie-ketcken/ende 4 kloos fers ban de bier ozogen/ ende een rollegie han Jefupten. Daer twoonten in oe fad

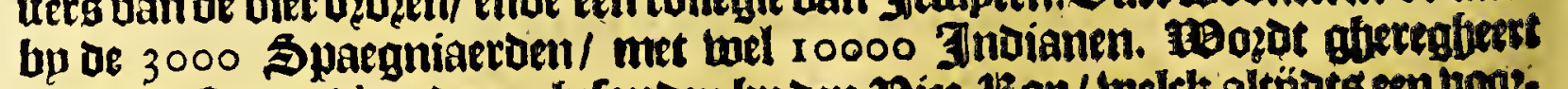

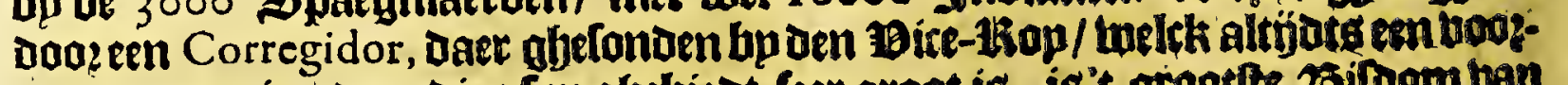

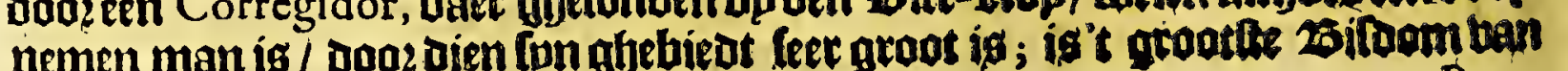
Peru: 
Het thiende Boeck.

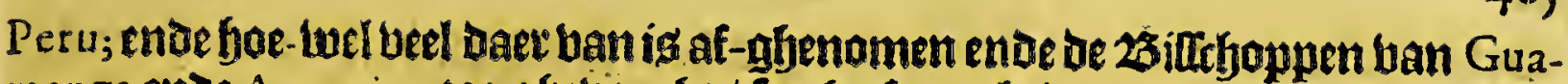

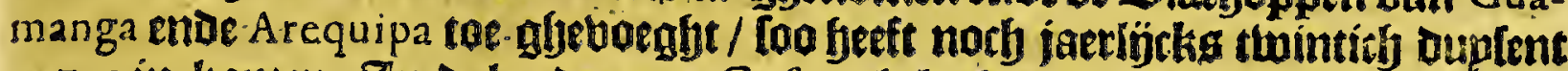

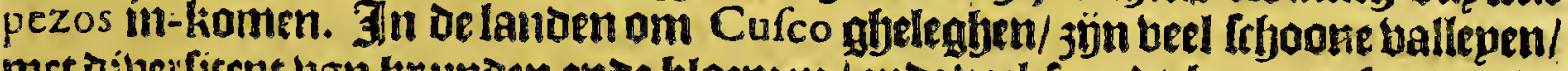

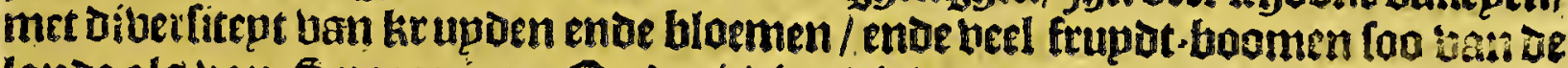

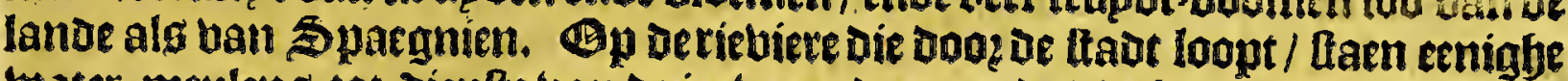
water-meuleng tot Jiente van de in-woonverg: ende vier leguen ban De ftaud/

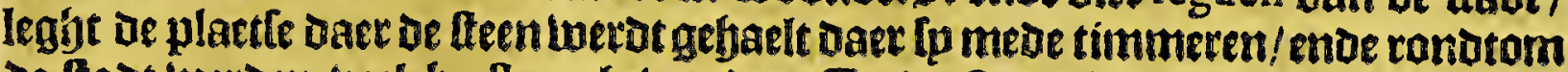

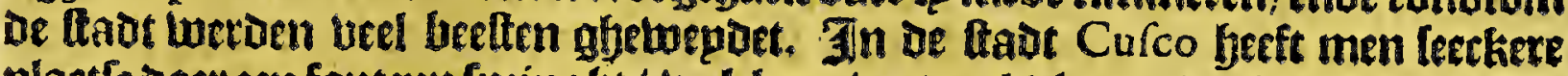

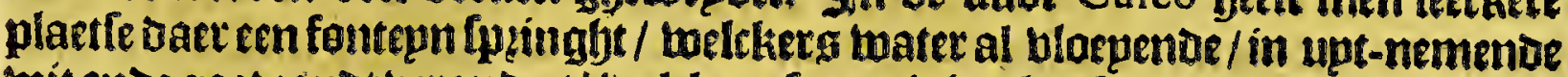

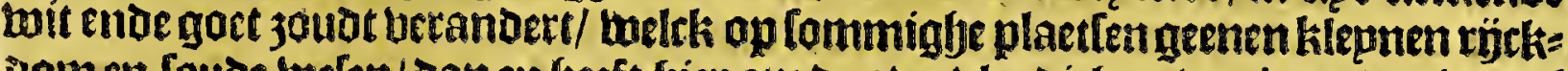

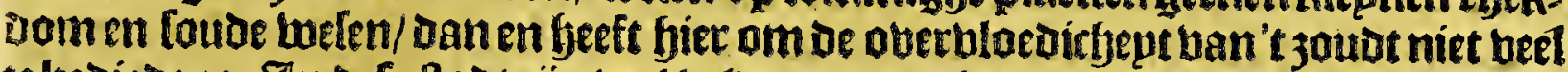

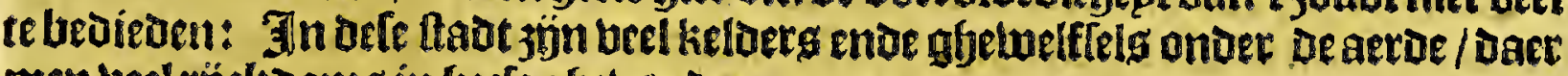
men beel rỉcliooms in beeft aghebonden.

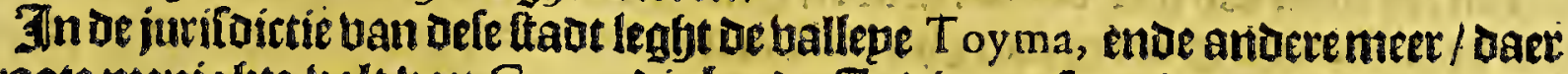

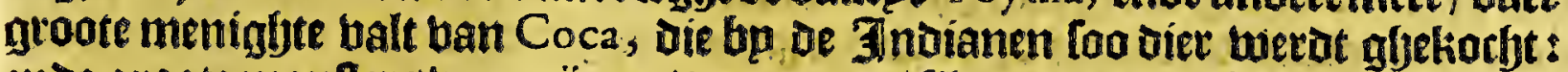
Ende groote monfters ban mijnen / ban gouver / filture ende quic-filber: ende in de

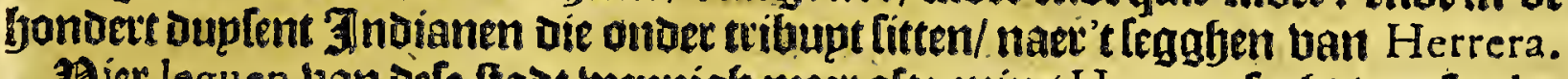

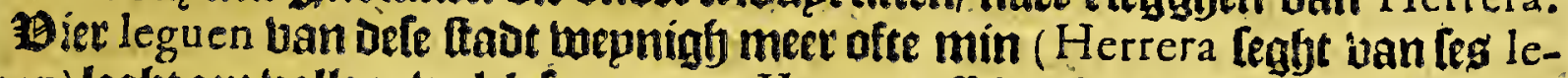

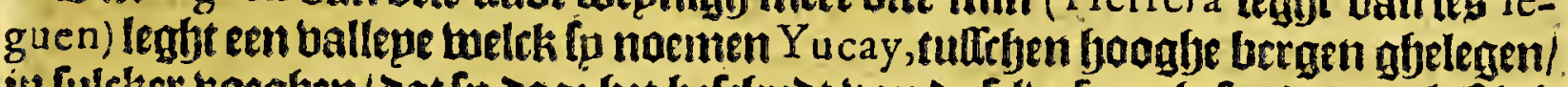

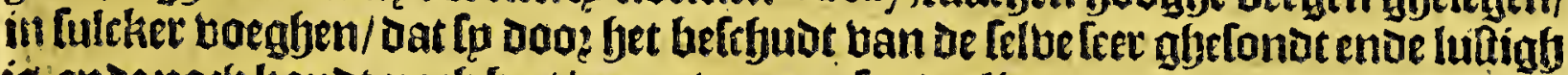

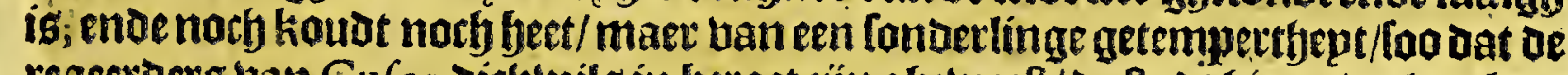

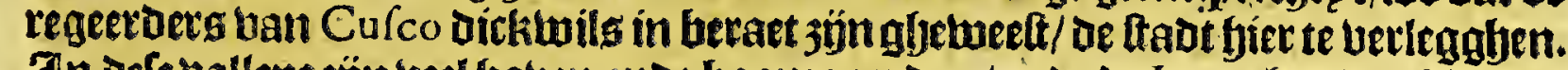
In defe vallept 3 jun ueel l jouen ende boomgaerden / endoe de Ingas hadoen fjer eets

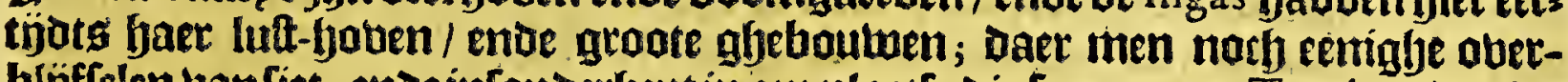

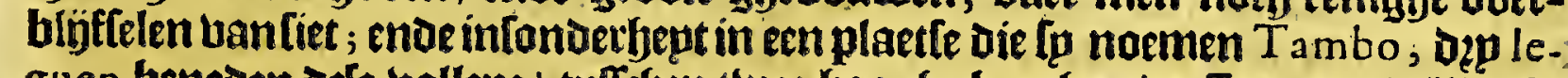
guen beneden Defe vallepe/ tultrben thee booghe berghen/ nefteng ken Dellinglse

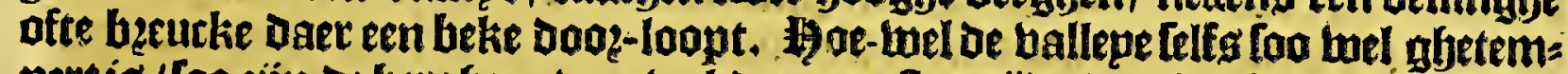

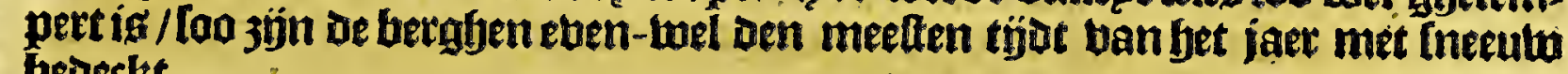
beueckt.

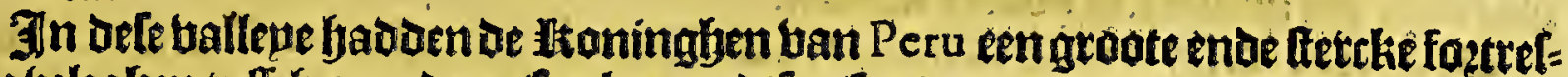

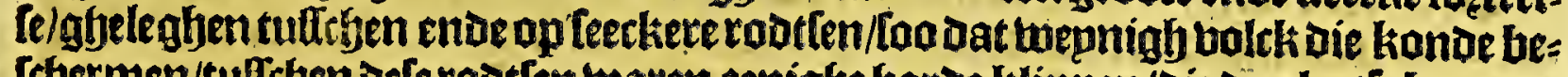

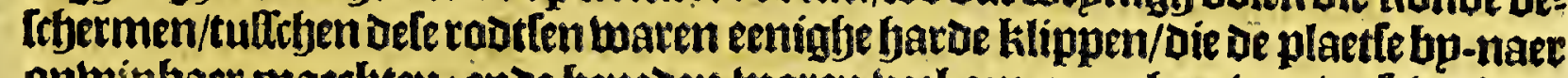

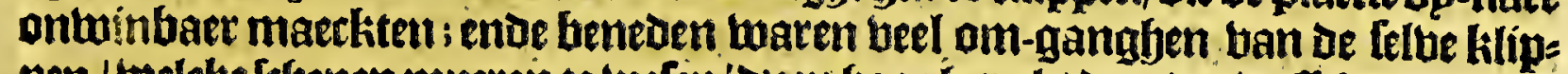

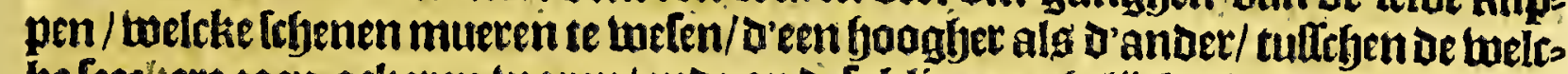

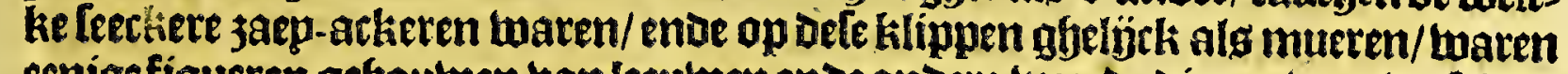

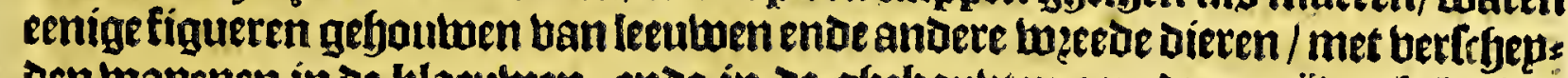

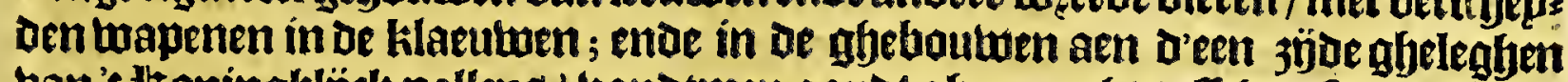

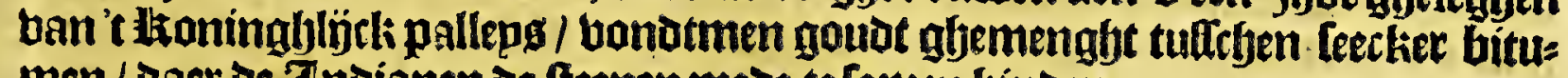
men / daer de Jndianen de fteenen mede te Lamen binden.

Onder de probintien ban Condefuyo, weroen begrepen be tholckeren die men noemt Chumbibilcas, de $V$ binas, enve antere dierghelijeke meer ; ban de wellcke

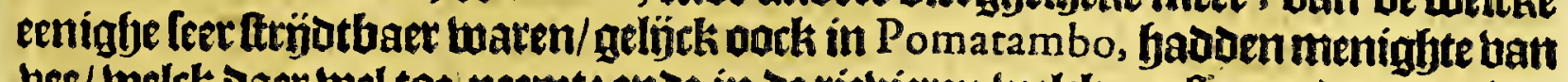

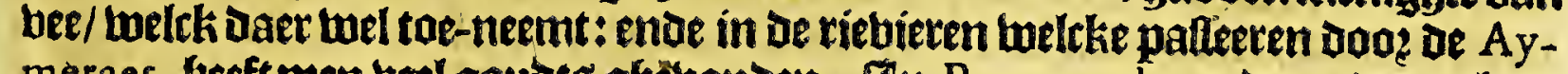
meraes, fjeftmen beel goubts gyetronuen. In Pomatambo ende antuere plaets Ien ban Peru, wozot teer fraepe tapiflerije ghemaeckt / booz of fj̉nbept ban wolle

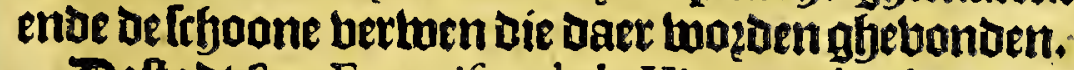

Beftadt San Francifco de la Vittoria, is ghelegen in de ballepe ban Vilcabam$\mathrm{ba}$, in't quartier ban Andefuyo, tulfthen be Cordillera van oe Andes; bp na 20

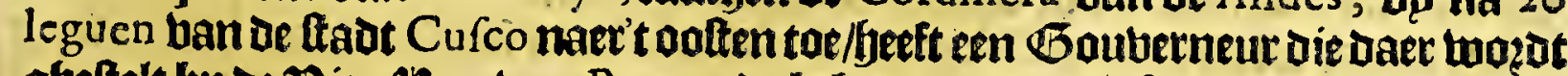

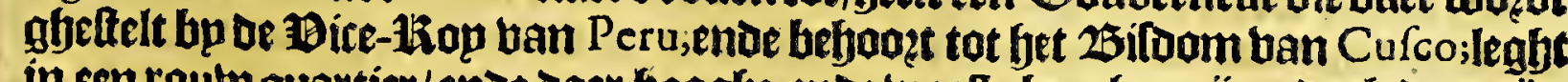

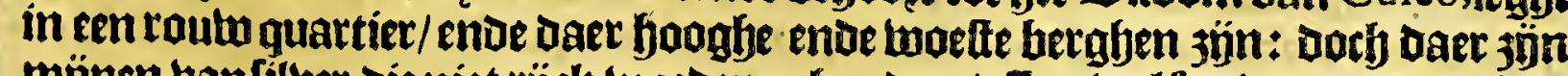

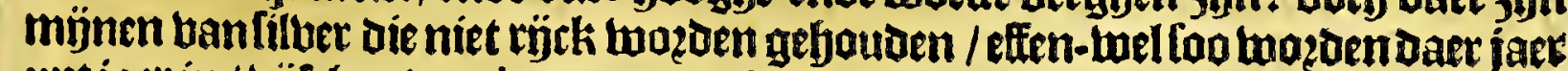
upt jact in / büf fondert barras upt-gfethaelt. 
406.

\section{Peru.}

Deblertie uan Ss Iuan del Oro, ig ghelegen in de probincie ban Carabaya, tartls tenticly leguen (andere fegafyen 40) bam de faot Cufco naer't ool- - zupdt-ooften/ cnoc dertiríleguen naer tooften van de Laguna wan Collao; werot ghenaemt del Oro, doo ae ober-groote menighte han finn gout belck in yaer limiten wozot gebohden. Bit gout ban Carabaya ig uermaert ober fpngroote fúnfyept onder alle

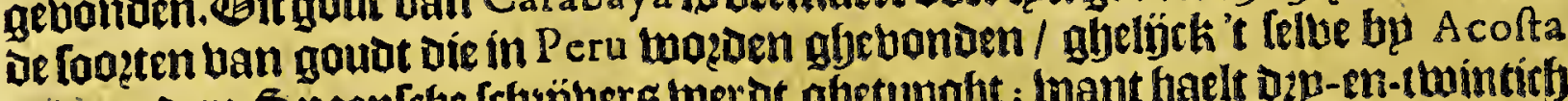

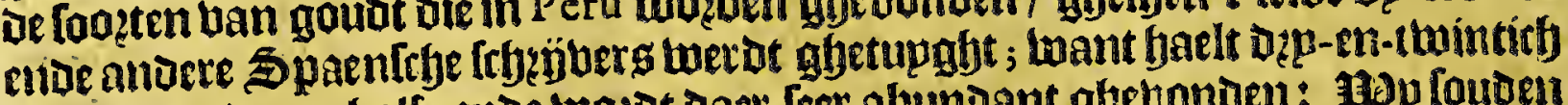

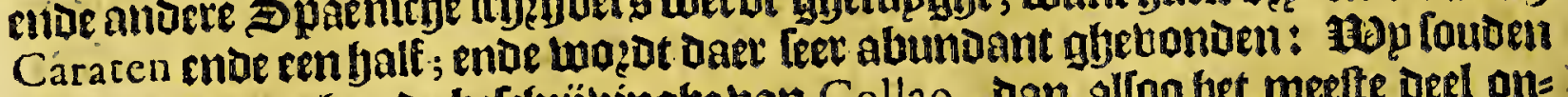
Giet nu bp-voeglen de befrbejuinghe ban Collao, dan alloo het meette deel ons

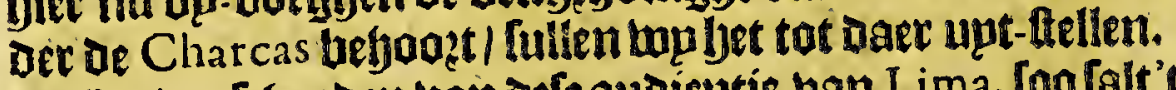

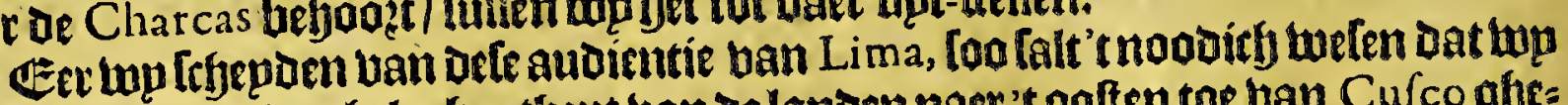

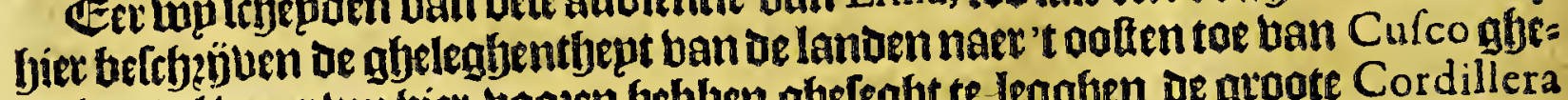

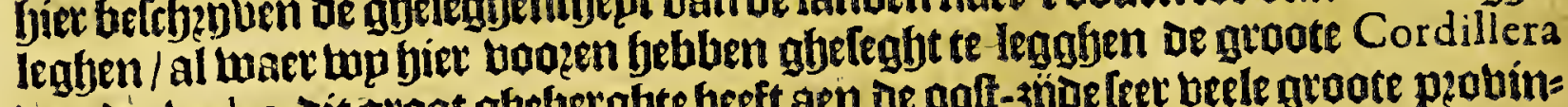
van oe Andes; dit groot ghefuetghte beeft aen oe oolt-3joe leer beele groote probin= cien/ ban de welcke eenighe bp de Spaegniaeraen jun ontarckt; om tot de [elloete liomen/ [oo heeftmenoaoz ae Cordillera ban ae Andes vier bertebepoen begthen d.6.16. gebonoen/gelijck Herrera getupght; de welthe tulicjen Opotari, ende de vallene c... wan Cochabamba begrepen 3 ïn / in de lenghte ban 70 leguen noogen ende zups

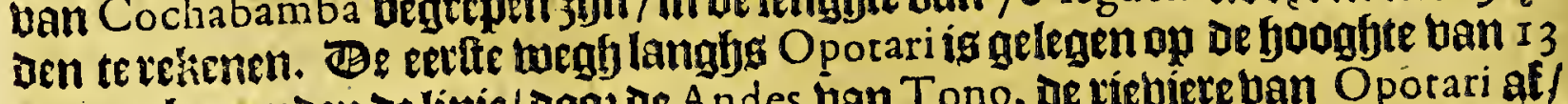
graden bp 3 upoen de linie/ Doo de Andes van Tono, de viebiere ban Oporari af/ ende 30 leguen uan Cufco: Om van Cufco naer Defe plaetfete komen/Loo treckt men Doo oe ballepe ban Paqual, welckig I o leguen ban oe felue ftadt/ende 5 ban ae Andes, ende foo Looets tot een plaetfe in' tgbeberghte welck fo noemen Tono,

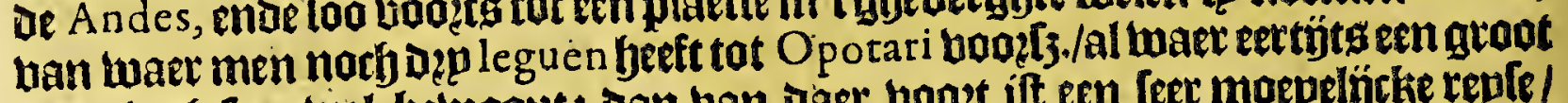

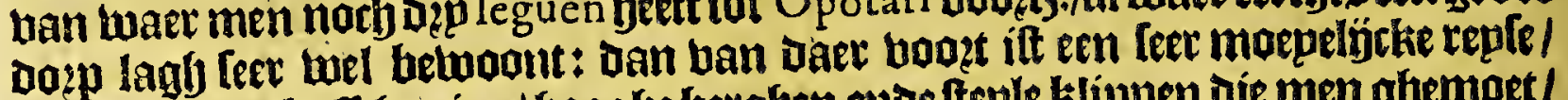

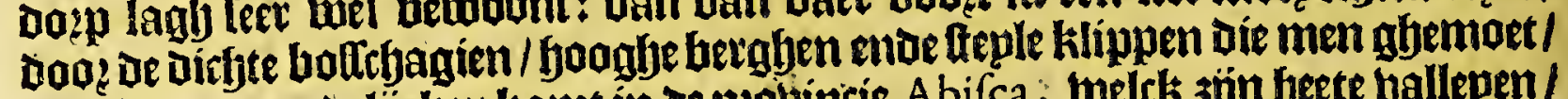

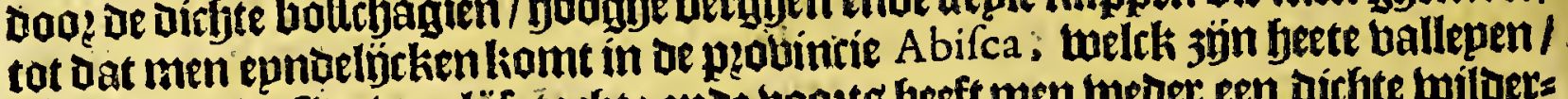

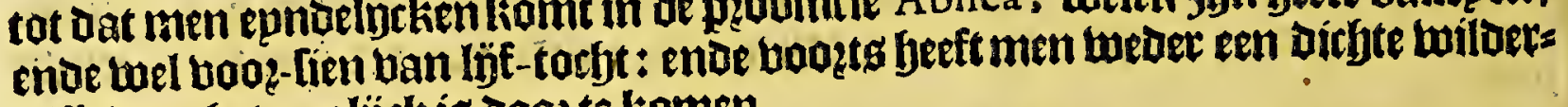
nille daer het qualÿck is dooz te komen.

De theede twegly ig dooz de limiten uan Caravaya; lamghg Sandia enve $S^{t}$ Iuan del Oro, wepnigh meer als dertich leguen meernaer't 3 upuen/ban de eerlte dooztorht in Opotari; dooz Jeten tweeden megh befben de Spaegniaerdenghetracht

d.6.1.s. Anzurez dooz Caravaya gyetrocken jünde met groote moete tot moe plobincie c.2. ban $Z_{2}$ ma, bonot booz-baetts aen een weetot ghebetghte ente leet dichte bor Ichagie enbe twiloernille; doot de tweleke lp quamen in de pzobincie tran Tacâna;

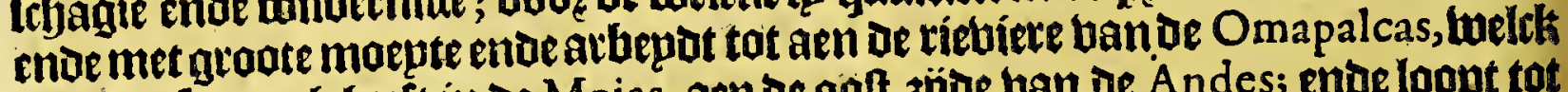

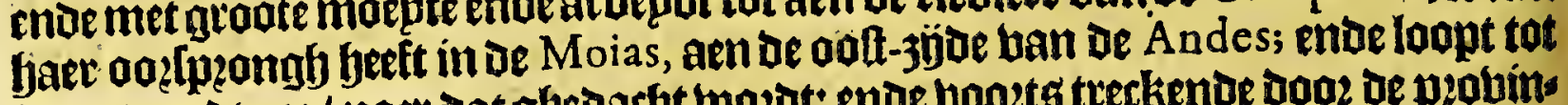

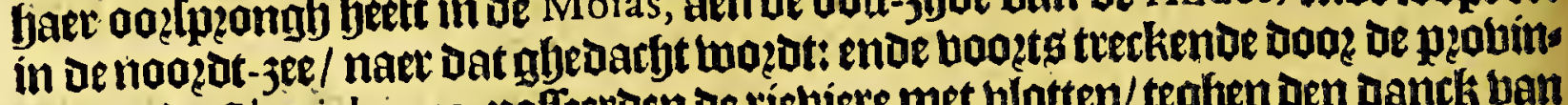
tie uan ae Cheriabonas, pafteerden de riebiere met blotten/tegfen den aanck ban

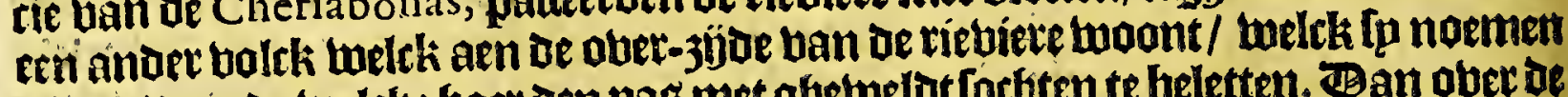

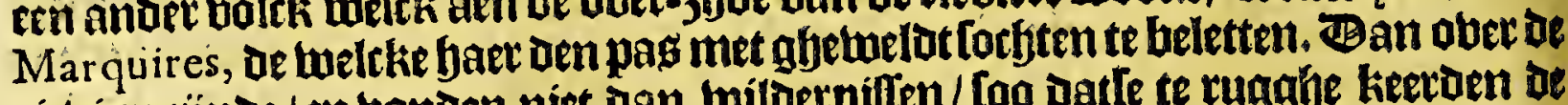

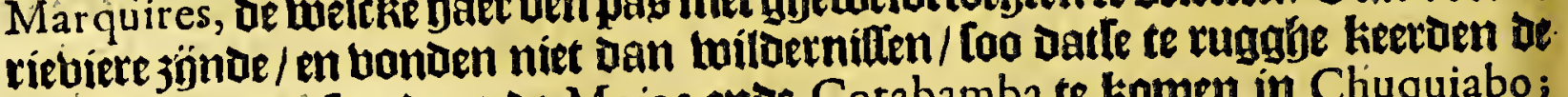
ríetiere op/ om loo Dooz ae Moios ende Cotabamba te komen in Chuquiabo; enoe quamen naer dat daer beel wolcks banbonger enoe onghemark gheftozuen wag/epnoelïck in de plobincie han Tacama, ende foo bootg te Ayavire.

Den deroen lueghis doo: Camäta, arfithien ofte thintich leguen meet naet bet 3upoen / als Sandia daer oe theede twegh Doog-loopt.

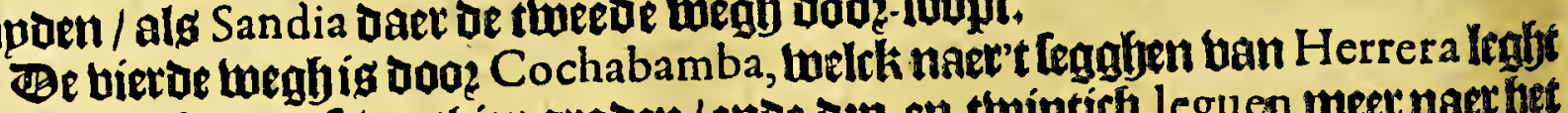
op oeljoogfte ban Lebentyiengraden/ende dęp-en-twintich leguen meet naet bet

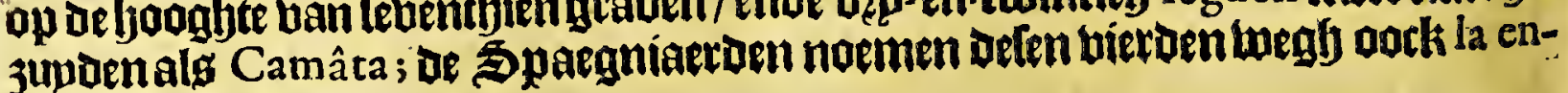
trada de los Moios. 
Het thiende Boeck.

Wet [even-en-twintichlte Capittel.

Van de havenen, kaben, punten ende rievieren, langhs de kufte van PERU, in't begrijp van de audientie van LrMA, ende ftreckinghe van de kufte.

O 19 de kufte ban Peru in't begrüp ban dele audientie/ jün de naer-bolgfiende yabenen/caben ende rievieren/ende oe aen-ghelegen Ufplanden/beginnende ban Punta del Aguia, oaer oele audientie faer f́bept ban oe audientie ban Quito: Eertt de Éplanden de Lobos Marinos, op de joophte van antrent feben graden bp jup oen de línie/ o een bier leguen ban de kutte gheleghen / ende D'an. ber wat boozder af in 3ee. (Fuller ftelotte op de fjooghte ban leg graden.) GEen d.4.L.2.

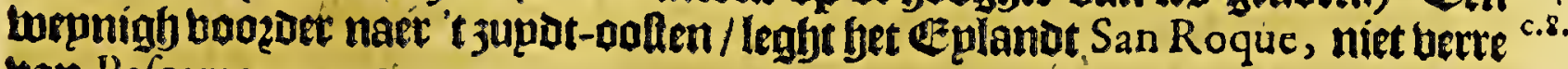
uan l'afcamayo.

Be onte die dele quartieten bebben bebaren ín oen jare 1599 , gfetupgfen dat Ip onttent de fooghte ban les graden ende dertich minuten bu 3 upden oe linie/ een (1Eplanot bonden daet Penguins op Laten / ende ontaliöck anuer gljetuogbelte entue zee-robben; Dode dit बÉplandt loopt een gat / Dan bermaeden dat men daer met gbeen Lebip mocht Daoz-leplen : Daer en tonoen gheen boomen op/ofte eeni= gbe andere groente; is binnen bupns grof jandt / ende bupten ftenighe klippen;

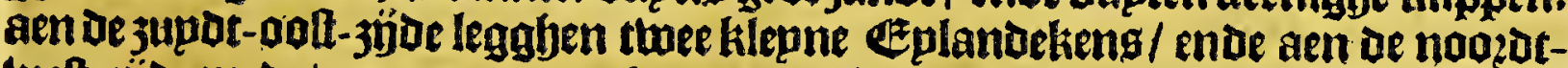

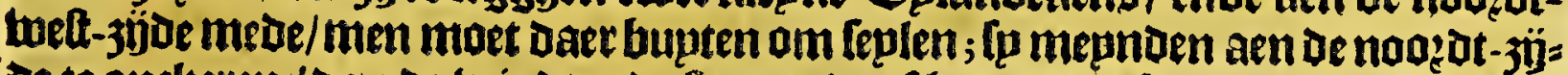
De te anckeren / Dan de windtende froom Deet baer daec af.

Bolght op de kufte tan't bafte land de baben Malabrigo, die qualjotk belcfjut is tegen de binden/ende de frhepen en komen daer niet in/ oan bp calmte. $S^{r} R_{i}-$ chard $\mathrm{H}_{2}$ wkins ftelot die op feuen graden. Ban de Punta del Aguia totbier toe/

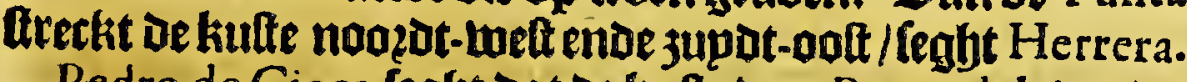

Pedro de Cieça legbt Dat oe liutte ban Punta del Aguia af-keett naer 't juptot-

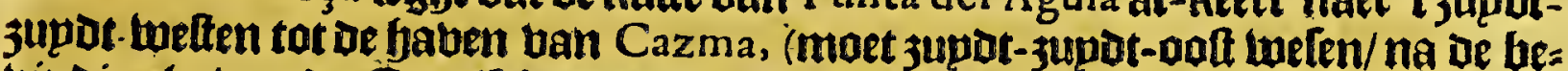

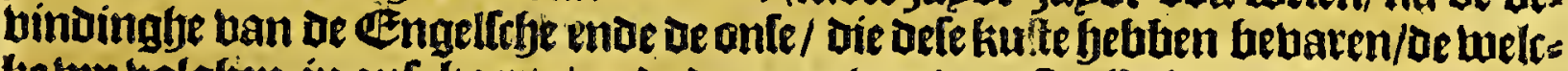
ke tou bolgfien in onfe kaerte) ende datmen ban't eerfte EEplanot de Lobos Ma. rinos, loopt nogezot-welt ende jupot-oolt tot Malabrigo.

Chien leguén boazder leght el Arricife, twelckfu noemen de Truxillo, welck mede eet qualïck befrbutte reede is ; ende twee leguen ban defe bauen te landtwaert in/leght de ftaot Truxillo, op de foogbte ban fearn gladen ende een balfs ofte thee Deroe / bp jupden oe linie.

Seuen leguen voozder leght de bauten ban Guanape, op acht graden ende 20 minuten/ naer't legghen ban Pedro de Cieça : Dan moet fem in De booghte wat abuferen / ofte or diftantie moet grooter jün tuffrben Truxillo en Dele plaete.

\$2 och voozoer naer t 3 upoenleght de gaben van Santa, op de boogfte ban ne; ghen graden bp jup den oe linie / daet oe lebepen jün gbetwoon in te loopen / endé

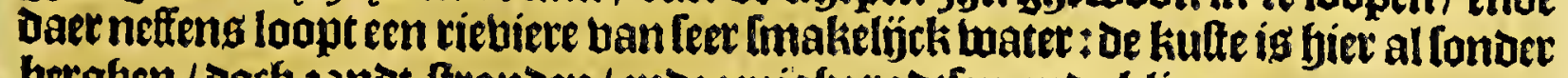
berghen / Doch jandt-atranden / ende eenighe toutten ende klippen.

Bijf leguen ban Santa, legljt debaben ban Ferrol, welck gaedt is / Docfj daet en ig norf water noch youd booz de lefjepen te bekomen.

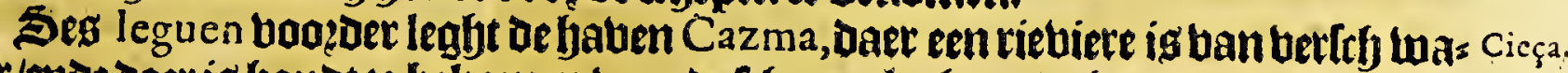
ter/ende daer is fouot te bskomen bog de lebepen/legbtop de fjoogbte ban I o ara:

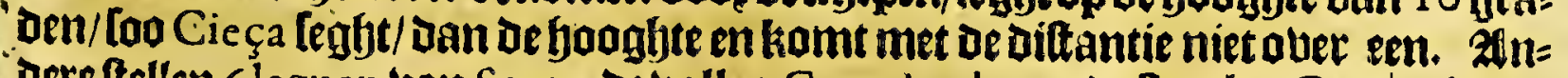
Dereftellen 6 leguen van Santa, de vallę Guambacho, endeftrackx Cazma baxa, ende Cafma la Alta, tuelcke dęp woon-plaetlen 3 tön van Indianen: daet komen

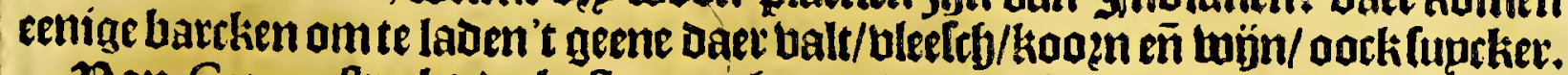

Ban Cazma Areckt de kulte naer bet 3 uppen tot los Farallones, Die fi nae: men de Gaura; that boożer leght Guarmey, atht oft twaelf leguen uan Caz$\mathrm{ma}$, aen de mont ban een rictiere: Fuller infpn memoziael fegbt upt epgben

Rn 2 bevin= 
408

Peru.

bebinbinghe / Dat bet landt ban Den elften graed ende büfticf mínuten / frects

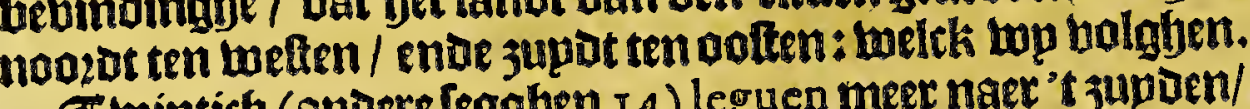

ctmintich (andere lenghen I4) leguen meer naer't jup jen/ is ghelegen la Barranca. De bopagie ban Olivier van Noort, ftelt die op ofe boogfte banelf gradew/

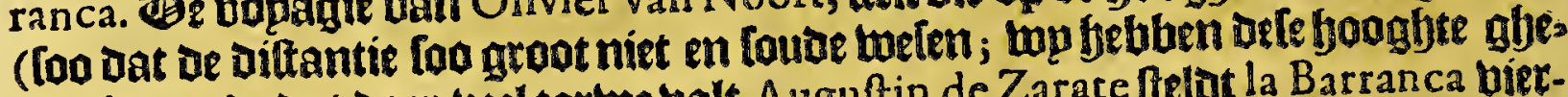
volght:) ende dat zaer veel tartwe balt. Auguftin de Zarace ftelot la Barranca biercn-twintich leguen ban be ftad Lima.

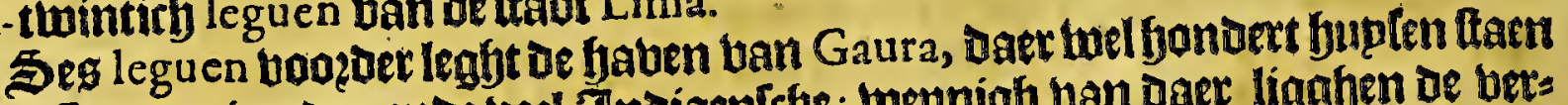
ban Spaegniaeraen ende ueel J noiaentebe ; wepnigh van Daer ligghen de bet: maerie Salinas, in een ballepe daet glbeen water bo en kamt; fet 30 ut wogat daet gljebonden in leer groate ende batde ftucken.

Bier leguen boozor leggende Farallones buanoemt/ban welcke de unterfte 8 leguen in jee leght van't vafte lanit af; ende defe Farallones ttrecken van 't punt

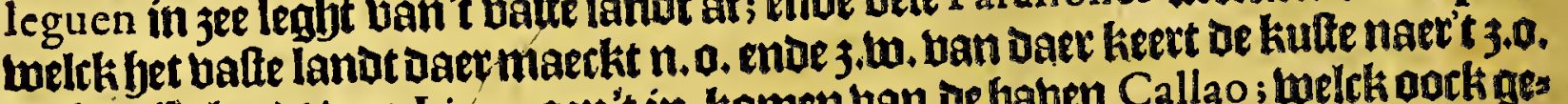

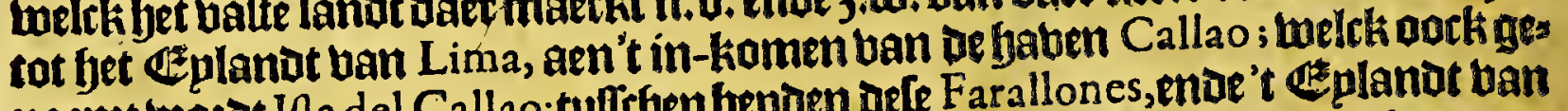

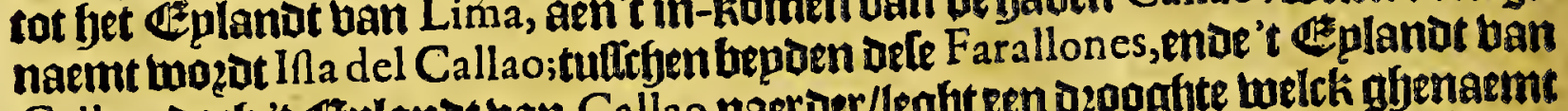
Callao; Doch't \&zlanot ban Callao naerder/leghteen ogoogfte welck ghenaemt mozot Salmerina, 9 ofte ro leguen ban't lanot leggbende : endoe wat meet als bj̈́

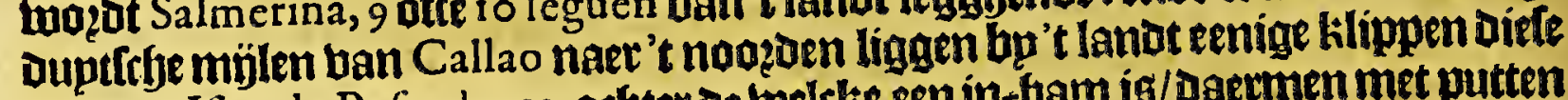
noemen Iflas de Pefcadores; arthter De twelcke en in-ham is/Darcmen met putten tegraben aen tranot wel eenigh berich-water kan bekomen. 't Ezplanot ban Callao befrfut de baben ban Lima, ende legbt op de booghte ban i graden ende een Deroe bp zupDen De linie/ naer't tegghen van Pedro de Cieça; Dan ae onle beluben 't op 1 graden ende een half bebonden/gfelijck top boozen bebben berbaelt.

Feghen leguen ban Lima naer't 3 upoen light bet equ be ban Chilca, naet bet Iegaben van Diego Fernandez.

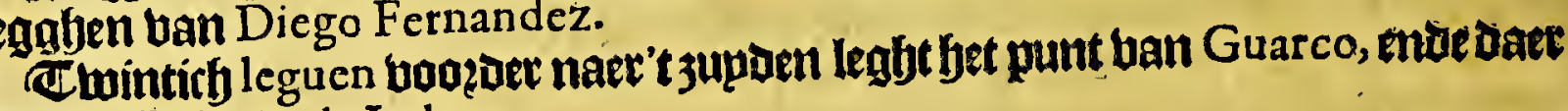
bp een Eplanit de Lobos.

Bojftyien leguen bodzder/ende 25 ban Lima, natt'teggen uan Pedro de Cieça leght Puerto de Sangalla, enoe oe kouts is juphen ban Lima af/naer tpn legghem. - Ban na de bebindinge van Fuller, is de itrethinge ban I 3 graden ende 30 minus

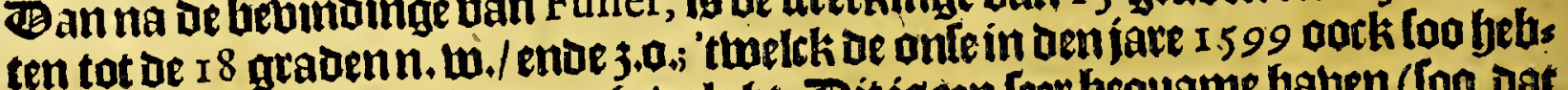
ben bevonden/ende is bp ons ghevolght. Bit is een Teer bequame baven (foo dat

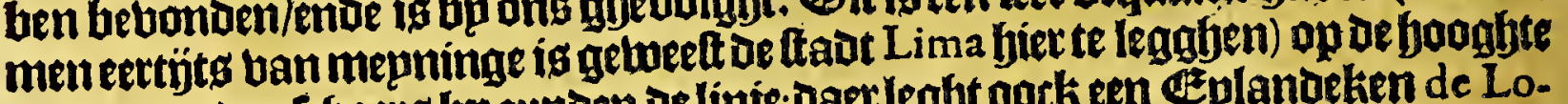

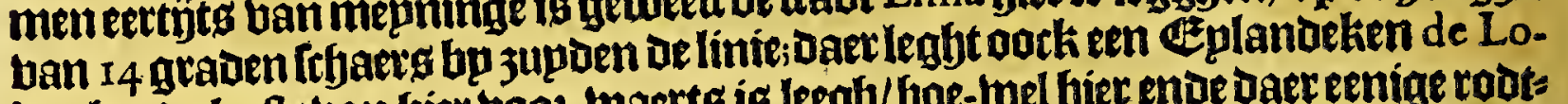
bos bp: de kufte ban bier booz-waetts is leegb/boe-wel bier ende daer eenige rodt:

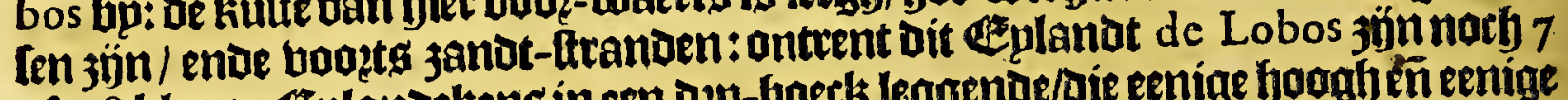
ofte 8 klepne \&plandekens in een Dęp-boeck leggende/Die eenige boogh ên eenige leenh 3 g̈n/al onbetwoont/[onoer water ofte boudt/oftegroente; alleen bouden baer aaer jee-woluen ofte robben; legghen wat meer als bier leguen ban't bafte lands:

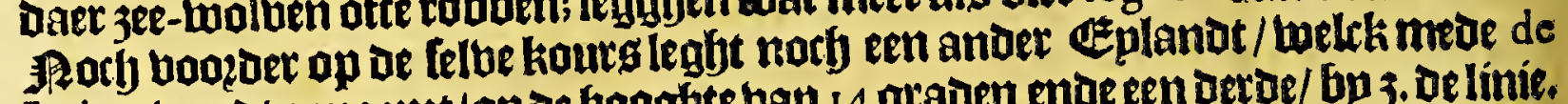
Lobos wozot genaemt/ ap de hooghte ban i 4 graden enoe een oerae/ bp 3. De línie.

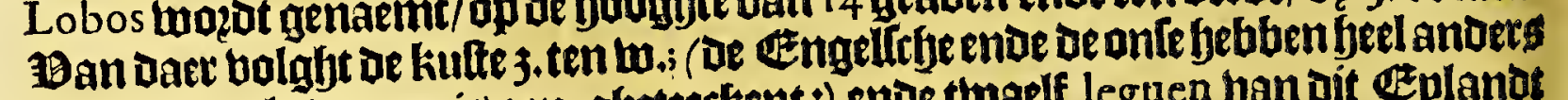

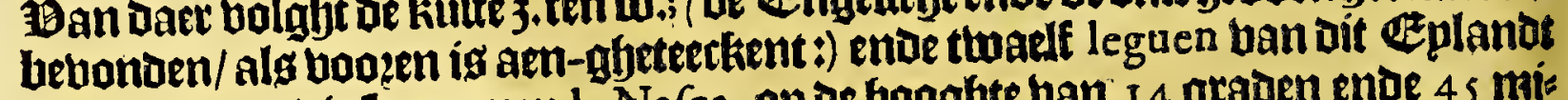
leght een rape die fpnoemen la $\mathrm{Na}$ (ca, op oe booghte ban 14 graden ende 45 mis nuten; daer is goet beféfut boo de frbepen; maer niet goet landen boos lloupen ofte booten. Op delelbe kouts leght een ander Cabo, welek fy noemen de $S^{\prime} \mathrm{Ni}$ colas, op de booglte tan búfthien egraden ende een derde.

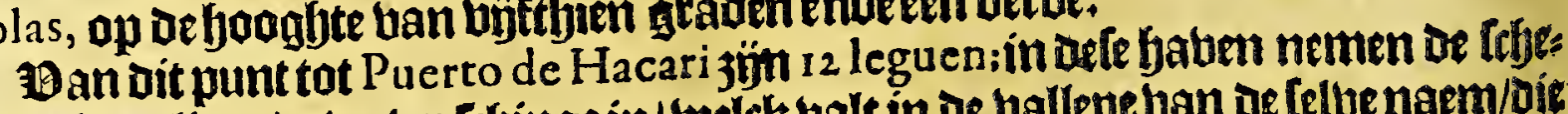
pen bietualie ende berbertebinge in/ welck balt in De ballepe ban ae felbenaem/oir

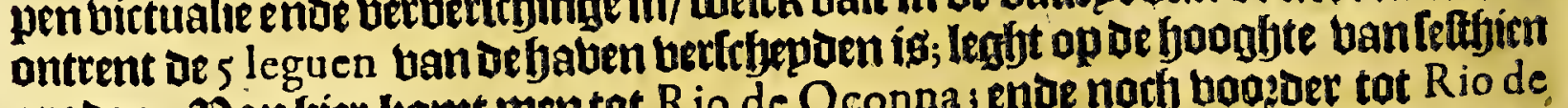
graden. Ban bier komt mentot Rio de Oconna ; enoe natf boajoer tot Rio de Camana; ende foo te Quilca; ghelíck Pedro de Cieça defe kulte betuolght. Herrera 
Hetrera felt Punta de Chincha op oe fooghte van büfthiengraden bp zupten de limie / ende Daer bu Punta.de la Nafca. Olivier van Noorde fegft Dat la Nafca leglt bu Puerto $S^{t}$ Nicolas, 't twelck een gaede Gaben foube $3 \mathrm{un} /$ betwoont bp Spaegniaerden/ende dat vaer de belte bujnen ballen ban gantích Peru.

Bopap der leght get punt ban $S^{t}$ La urenço in De vallepe ban Quilca, ende benef= fens de riebierevan Arequipa. Olivier van Noortfeght dat de haben ban Arequipa, is een ferr naeuln kílleken in't in-Komen/tutteben boogfe berghen:ende leght naer 't legg Jen ban Pedro de Cieça, op Leventbien en een balf graden bu zupaen De linie: Dan't fobjnt maet [ebentbiente moeten jün; alloo de felbe/Chuli ende Tambopalla op febenthien en een balf ftelt/ oie norbtang twaelf leguen meer naex 't jumaen legghen / na jỉn eyghen rekeninghe.

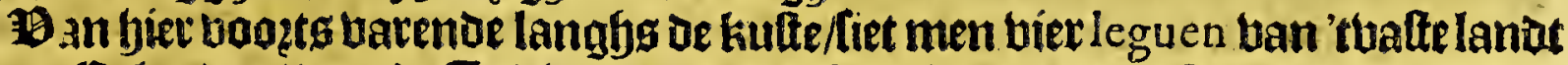

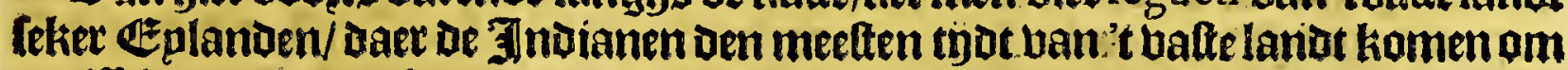

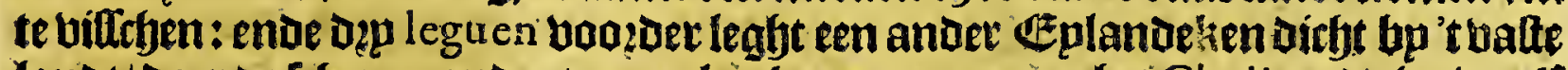
landt/ oaer of febepen onoer ten ancker komen; noemen bet Chuli; ente is twaelf leguen bp jupoen Quilca : ban hiet tot de riebiere Nombrede Dios, ofte Tam-

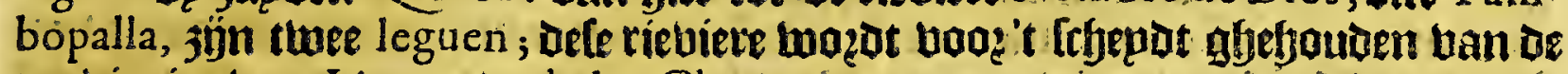
peouincien uan Lima enoe de los Charcas.

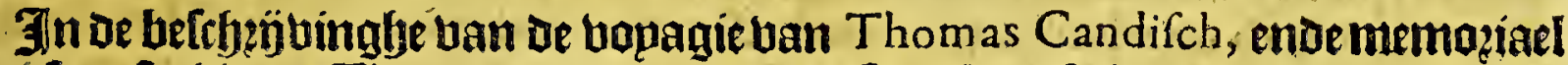

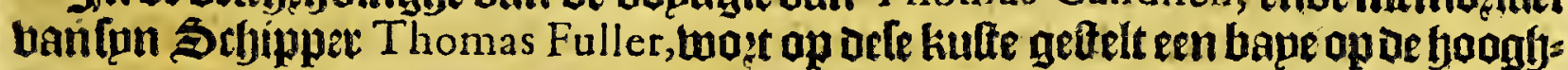
te van I 3 graden ende 30 minuten/ Daer dep klepne poepen fouben legghen / $\mathrm{Pa}$ racca, Chinca ende Pifca ; van de welcke Herrera gfjeen mentie en maeckt.

Olivier van Noort leaft/ / dat Paracca ende Pifca jon thee baueng bp den ande= ren/ op defyooghte ban I 3 graden ende 20 minuten / enoe dat 8 mijlen te landtwaert in/Yca is gelegen; daer de meelte tunn balt van gantfry Peru. 99 aet Sir Richard Ha wkins leght dat Pifca leght op de booghte ban is graden ento is minu=

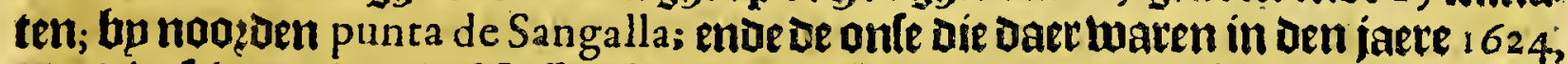
imet bier frbepen ban de Naffa vife blote/ghetupgen dat be plaetle numet een mupe

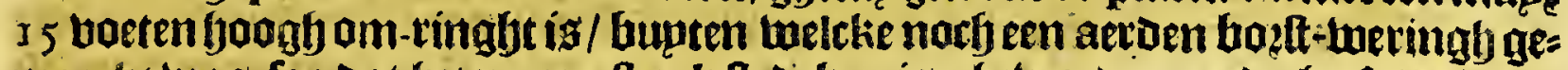
maeckt was; foo dat bet nu een ferck ftedeken is afjetwozoen; ende beeft wel 400 in-twoonters; íg ghelegen 4 leguen van Valuerde, ende beeft een baten die berteer: kert is boo? fto:men; De Ithepen liggen ontrenteen yalf mijl ban of tmal;alleenlijek foo ballen bier (ombujlen oes abondts ftertke landi-binoen/ oie fo noemen $\mathrm{Pa}$ raccas. Ban Pifca tot Caftro Virreyna 3ín 26 leguen:

Epmoelinck loo ig bp onle Stier-lieden in Den jaere 1599 , in haer fournael aen-ghemerckt / dat het lanot ban Peru, uan A rica af / tot op De fooghte ban nes

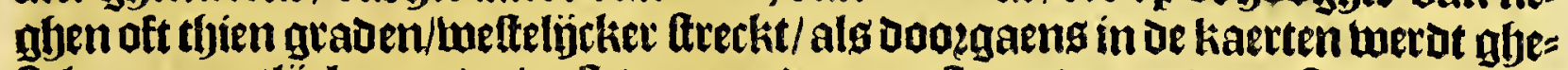
ftelt; namentlÿck noozot-welt ten nopzoen naett / ende zupot-ooft ten zunden naelt: welck Lup ten naeften-bp hebbengbetulght.

\section{O S C H A R C A S.}

\section{Wet acht-en-twintichlte capittel.}

Befchrijvinghe van de derde audientie van PERU, welck fy noemen Los CHAR CAS in't ghemeyn; te weten, haer palen, ende anders.

H et derde deel uan Peru, ende de audientie die daer in hu de \$paegniaerden Hig op-getecht / wozot gemepnlÿrken genaemt de los Charcas, ende oock wel de la Plata, naet oe boomaemite ftadt ban Defe p?obincien: dele andientie ban los Charcas lefjept faer uan oe audientie ban Lima, op oe kulte ban oe zupot-3ee/ met be riebiere Tambopalla ofte Nombre de Dios, op De hooghte ban I 7 graden enas 30 mimuten / bp zupden de linie; ende binnen's landtg methet begin ofte noase Delijette deel han Collao; beeft in de lenghte ban de bootly. Limiten endefrontieren $\mathfrak{R} \mathfrak{n} 3$ van 
410

Peru.

van ie audientie ban los Reyes tot de halleue tan Copiapo toe/ welclis itet bes gintel ban thoninglength ban Chili, op oe hooghte uan lugpuigh meer ofte unin als 27 graden/300 leguen; for hel men naet oe wegen te rekenen/ wel bp de 400

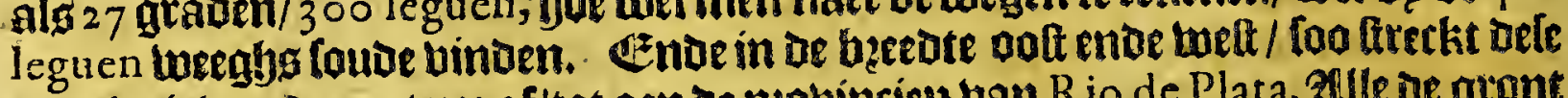
peobincie ban ae zupt-3ee af/tot aen be plobincien ban Rio de Plata. Zllle ae gront

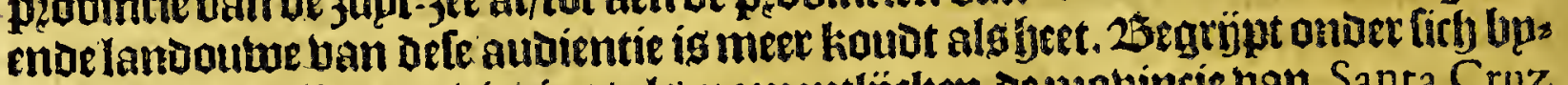
Condere particuliere peovincien/alg namentlïtken de pzobincie van Santa Cruz de la Sierra deptobintien uan Tucuman; los Iurias, ende Dyagutas, ende teel an:

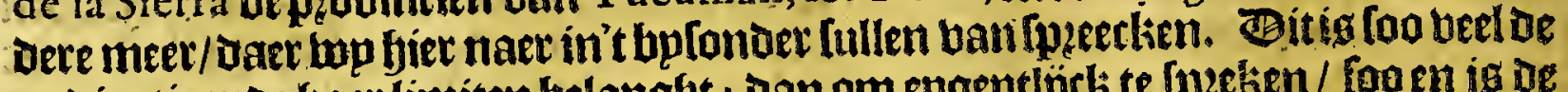
audientie enoe faer limiten belanght : Dan om epgentlijth te [pethen / foo en is oe pzobincie van los Charcas niet langher als honoett en uijftich leguen ofte Daec ontrent/beginnenide bande aptertte palen ban de audientie van Lima, ofte los Reyes,

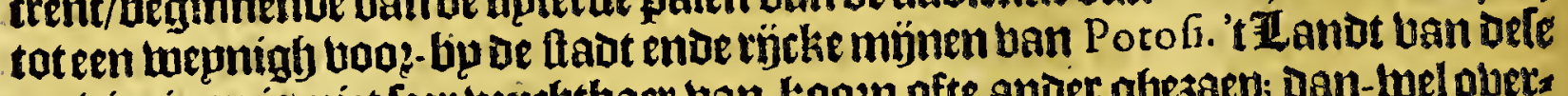

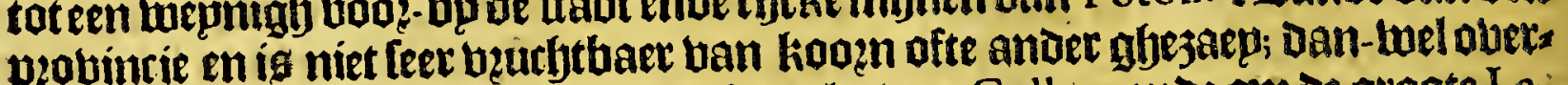
bloeviah han vee/ infonoerlyept in't ghedeelte ball Collao, ende am be groote Laguna Tirica ca, die daer midoen in leglbt. De fomer ende de lwinter is lier bp naes contrarie als in Europa; men beft in befe pzobincie obet-ateote meniclte ban

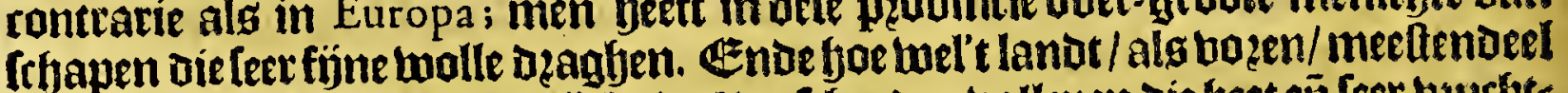

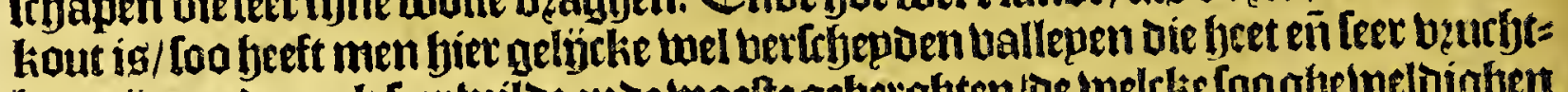

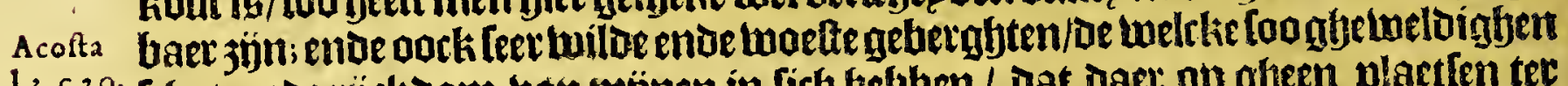

1.3. c.20. Tohat enoe rn̈rtidom ban mïnen in fich hebben / dat daer op gheen placten ter

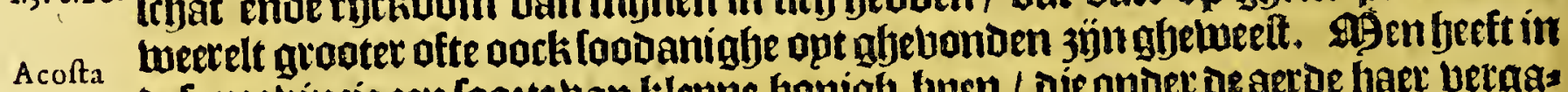

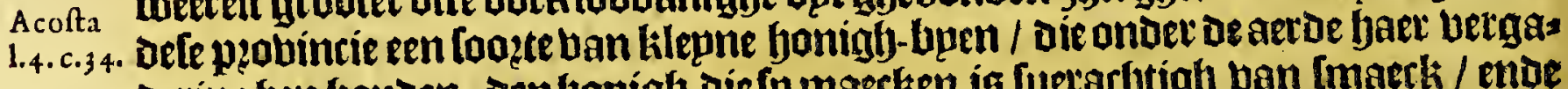

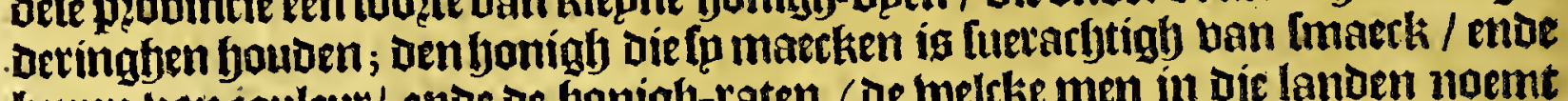
bzupn van couleur/ ende de bonigh-raten (de welcke men in die landen noemt

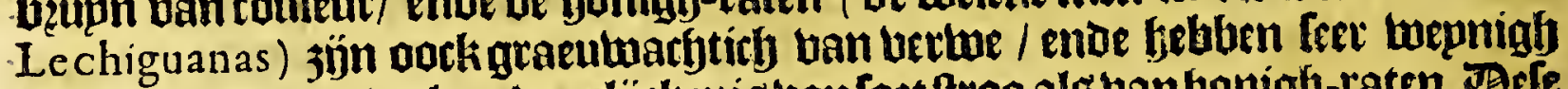

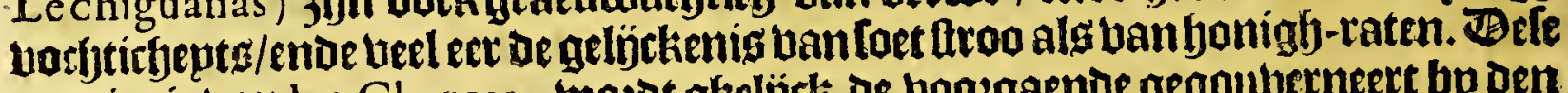
pzovincie van los Charcas, wozot ahelijek de boozgaende gegouberneert bp oen Bice-1iop van Peru; beft in [un begrijp thee 25 ifoommen/ende thee butondere

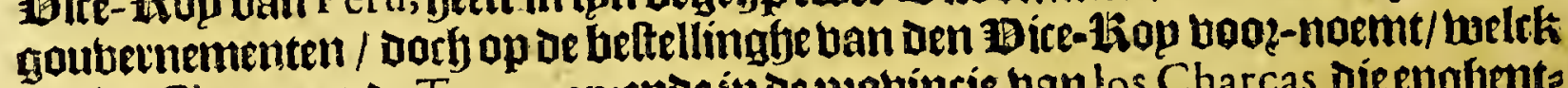

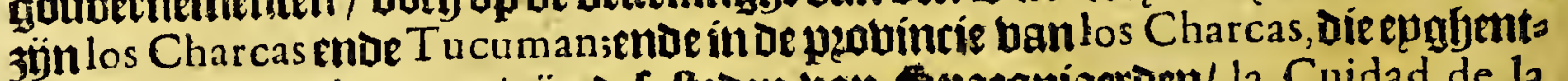

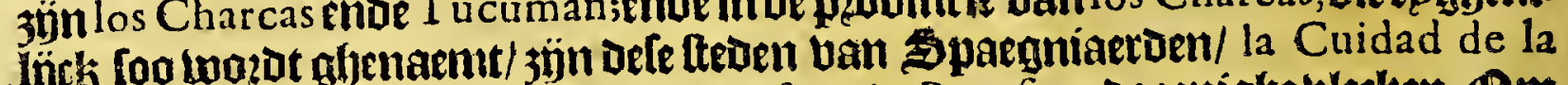
Plata, neuftra Sennora de la Paz, Oropefa, ende Porofi; ende eeniglje ulecken. Om

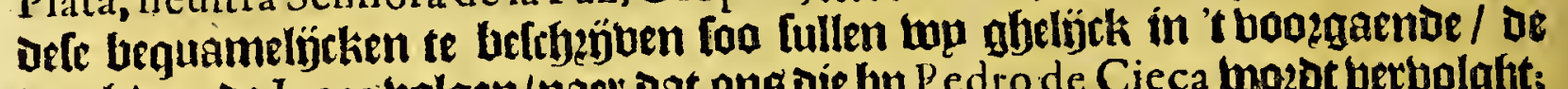
wegh han de Ingas bolgen/naer dat ong die bp P edro de Cieça boz̨ot berbolgft;

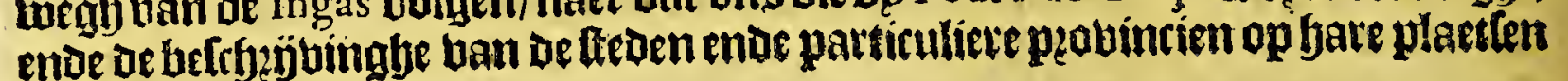
in-uoeaben.

\section{Iiget neaben-en-tibinticflte Capittel.}

De wegh endegheleghentheyt van de provincie gheleghen tuffchen beyden de feadt Cúsco ende de ftadt de la Paz. Van Coliao.

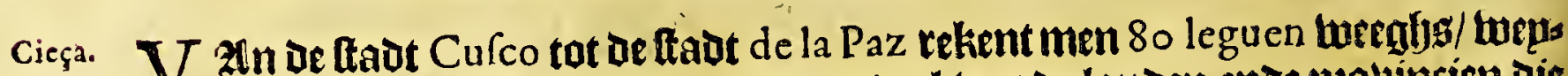

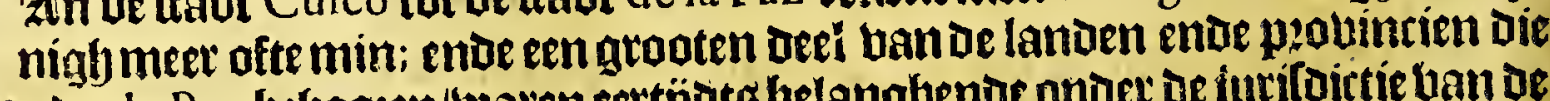
nu onder la Paz behoozen/waten ertijuts belanghenoe onder de furifoictie ban oe Itaot Cufco. Treckende van Cufco langlga oen fooghe tuegl ban Collafuyo, repet men eerlt tot aen een plaetle die fu noemen las Angofturas de Mohina; laten=

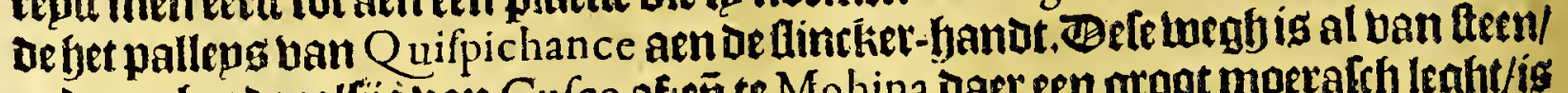
enoe een bardecallíe ban Cufco af;eñ te Mohina daer een groot moeralch leght/igs De felbe ban feer aloote fteenen ende rement glyemaeckt: bier waren in boos-tij=

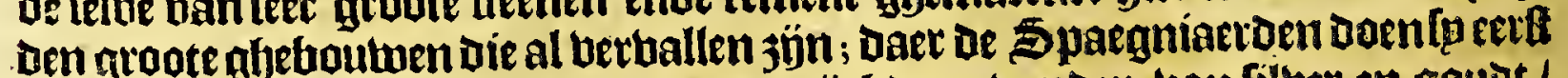
in Cufco quamen met Pizarro, grooten rijekoom bonden ban filber en goubt/

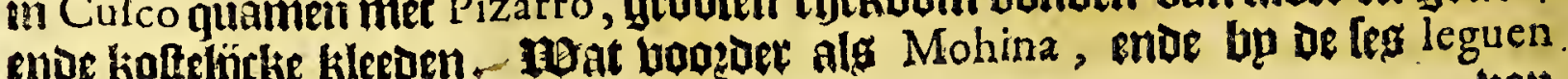


Het thiende Boeck.

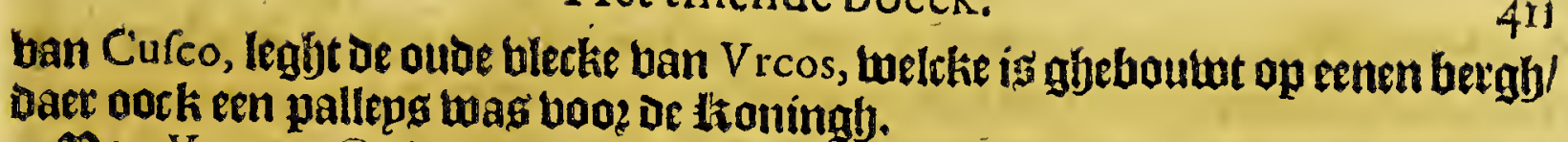

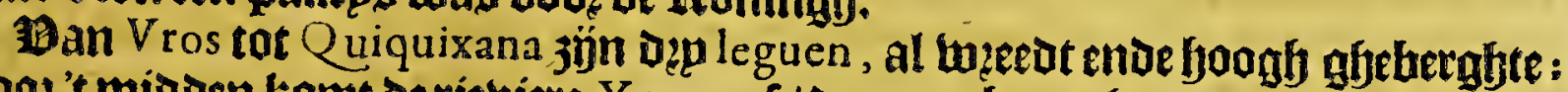
boge 't midoen kamt be rieviere Y u cay af / Daet een beugobe ober leght. Ontrent

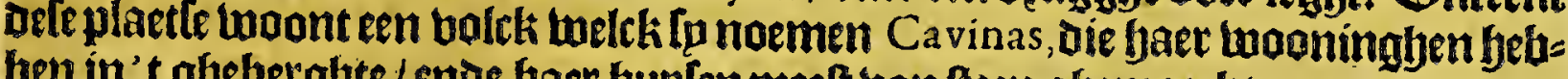
ben in' $t$ gljebergbte / ende baer buplen meelt wan tteen ghemaerkt.

De Canches, uolgyen bier aen: twelck igen natie ban Jndianen ban goet bet:

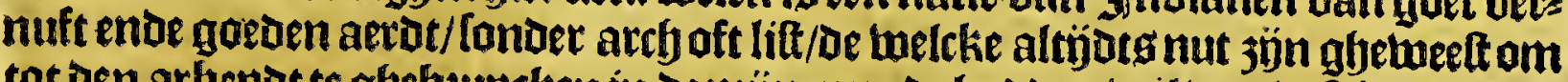
tot den arbeptst te ghebqupcken in oe mínen:enoe badoen beel ban de frfjapen van of lande. In 't gantlrbe lanot ban ofle Canches waft beel tatme enoe Maiz; men heeft daer beel patrïfen/ende de \$ndianen bouden beel goenderen/ende banghen Daer beel bilth in be riebieren.

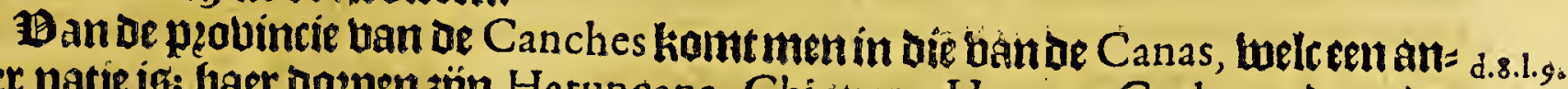
ber natie ig: baet boepen jün Hatuncana, Chiquana, Horuro, Cacha, ende andis= c.r.19.

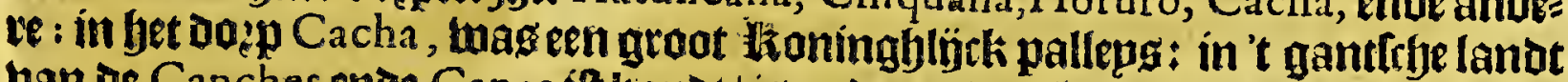

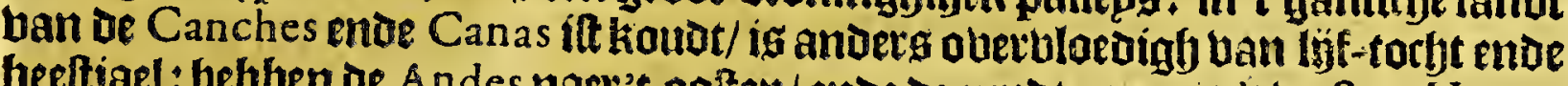
beeltiael: bebben de Andes naev't onften/ ende de jupdt jee naet't wedten. Herre-

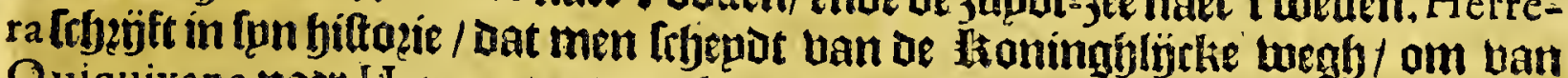
Quiquixana naer Hatuncana te tterken; ende bat Hatuncana ig thee leguen ban Ayavire. Ban Chiquana tot Ayavire reeckent inten ujeftbien leguen, enoe tult= Icten bepoen leggben noch eenighe doepen ban oe Canas. A yavire twag in vooz-

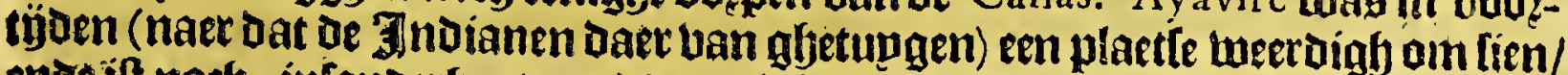

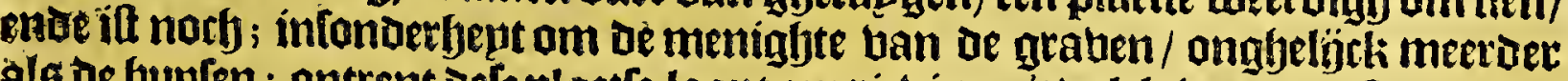
als be buplen; ontrent oefe plaetle loopt een riebiere: tuolcli is numeft om-ghe komen dooz de bolloglsen ban de Spaegniaerden.

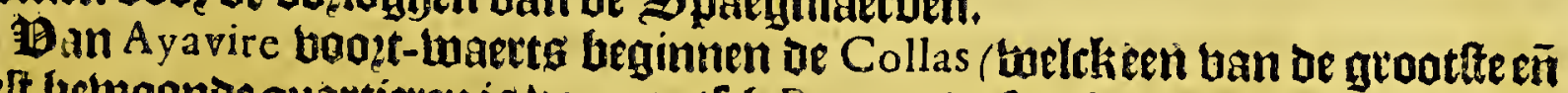
belt bethoonde quartieren ig ban gantfof Peru) ende frecken fien upt tot Caracol.

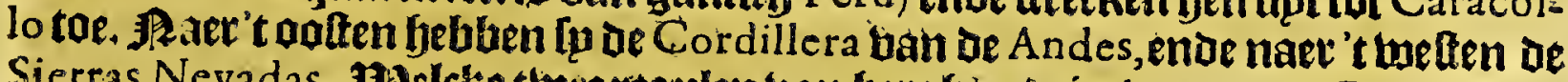
Sierras Nevadas. Abelcke theer tegulen ban betghen / niet berte nan $\mathrm{Cu} \mathrm{CO}_{3}$ baer

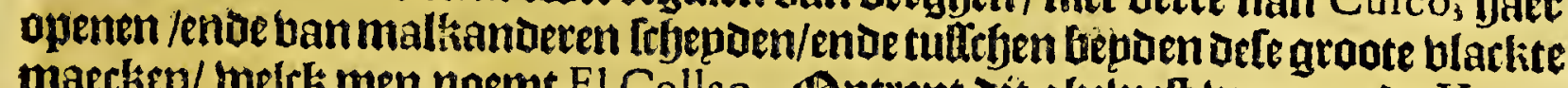
maecken/ melck men noemt El Collao. Bntrent dit gbeluelt moonen de Yanaguanas; ende Chumbibilcas. 25enefteng 't landt luelck bet bolkt bellat met baet bo:pen enoe jaep-ackeren/ too jïn Daet aroote budeltïnen/welcli bol twilde dieten 30̈n. Cuffryen Ayavire rnde de plapnen ban Peru, op oe kulde ban de jupdt-3ee gljeleghen/ig een groote iwoeftine/ welet ta noemen Parinacocha, twel 32 leguen

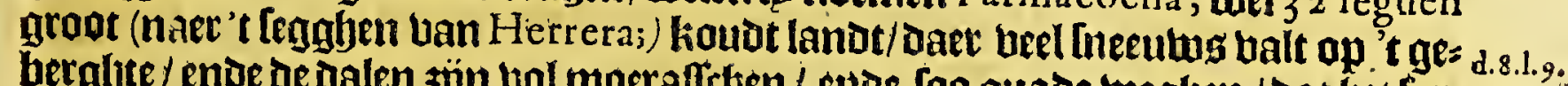

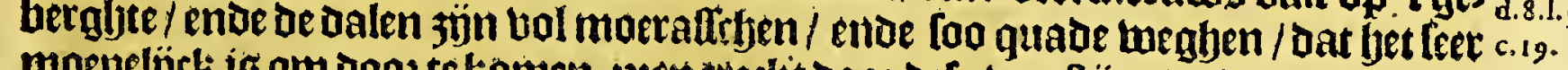

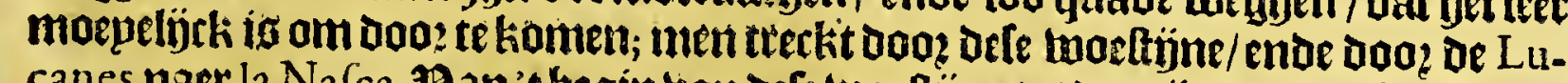
canes naer la $\mathrm{Nafca}$. Ban't begin ban defe twoettỷne tot de mijnen ban Guallaripa jÿnleltjien leguen, ende ban daer tot Chuquinga bier leguen, welth is een ban be

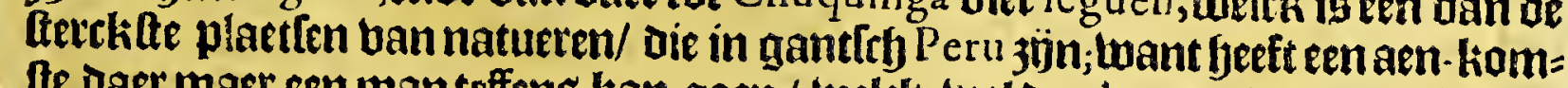
the daer maet een manteffeng kan gaen / welck thel dęp leguen buert; ende dan een boong gljeberghte aen de een jujde / ende de riebiete $A$ bancay aen de andere / met norbernighe booglye beraben. Bm nu weder te keerennate de fioninghlinc= ke turgly. 'T gantrebe landt van Collao is blatk / ende dooz beele deelen loopen berf(yepden riebieren ban goet mater/ende tulfben bepden feboone ende wijoe

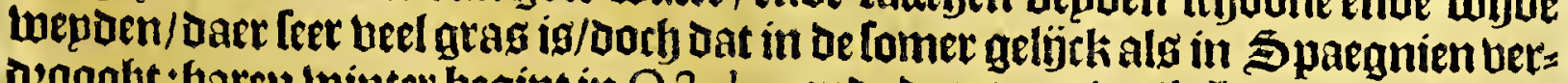
Dzoongt: haren Linter begint in October enoe duert tot A pril. Het is hier kouner alg ineening getwefte ban l'eru, upt-ghenomen in't Ineeu-abeberghte; toelck daet

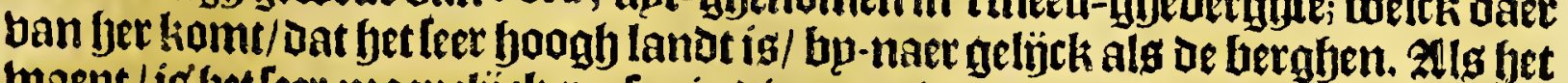
waept / ís het leer moepelijck replen in dit quartier; dan als fyet atil is / ende dat De confrbÿnt/is het een ghenurbte de frjoone ende wel belwoonde beloente fien; dan oooe dien bet too koubt lanot ig / foo en waft daer gheen Maiz ofte gheboomte. 舟 4 Tags 
412

Peru.

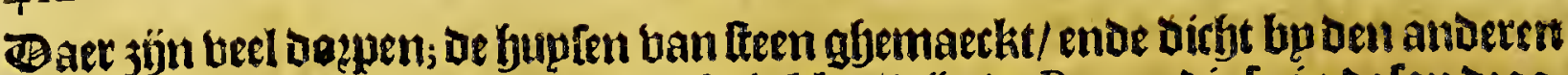

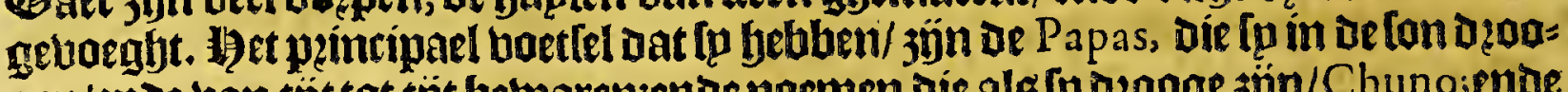
gen/ende ban thit tot tijt betwaren:ende noemen die als [p dzooge jún/Chuno; ende

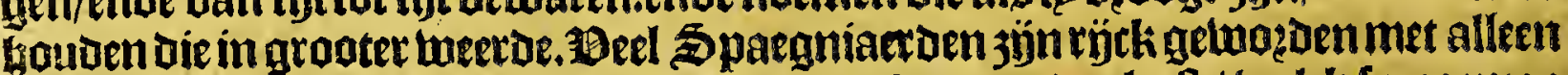
Dit Chuno te boerennaer Potofi. Oca: ende een telier zaet/welck [p noemen Quinua, bp naer als het rÿg: ende two sen boozts ban ander quattieren voo-tien ban Maiz, ende andere dingen: infon: Dethept ban fonigh die wonder encellent valt in de Charcas. Be Collas, ig volck ban goet verltandt / Die naer beel dinghengheluzaeght zönde / tamelÿrk goet on=

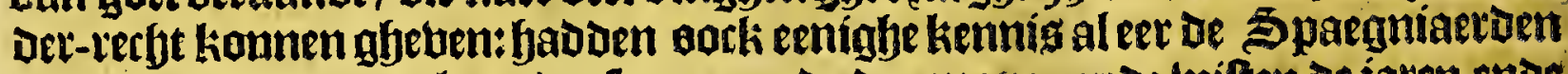
Daer quamen / van de loop der Connen ende der mane; ende wiften de jaren ende maenden te reeckenen; bet jart noemben lp Mari, ende de mane Alespaquexe, ende ien Dagh Auro.

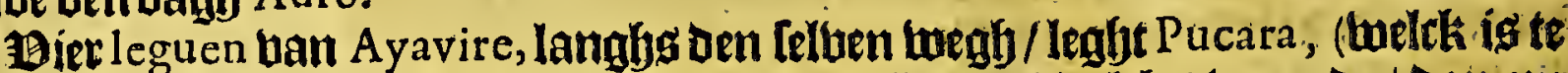

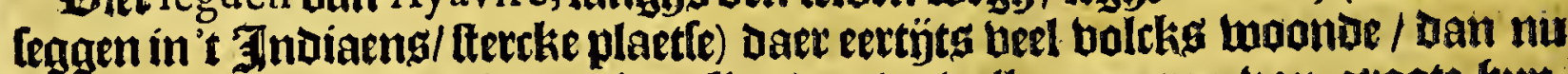
fehiet geen: ende daer en is nuniet te fien dan berballen mueren ban groate bups: fen/ende eenighe fteenen beeloen ban menteben.

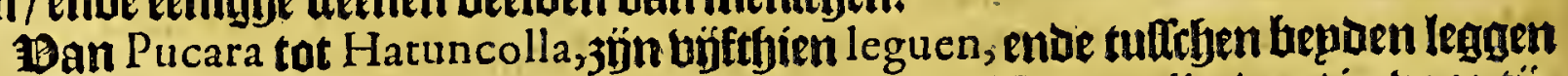
enígbe doepen/alg Nicafio, Xullaca, ende anoere. Hatuncolla luag in booz-tý=

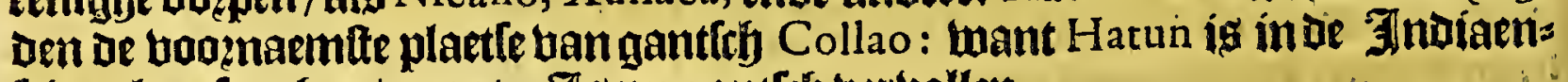

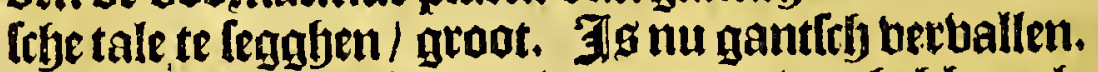

Ban Ayavire af (daer wo booken ban bebben ghelpzolien) komt een andere megh/ aenaemt Omafuyo, welck loopt langhg de eene jübe van't lack / Daer wu

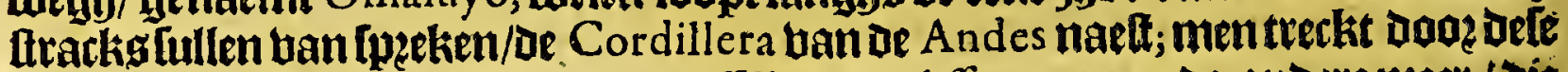
weaf naer de doepen ban Horuro, Affillo ende Affangaro, ende attoere meer / vie

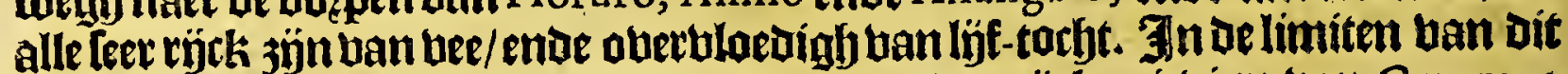
gheluefte in't getrerghte ig de bermaetue ende ober-rijcke riebieke han Caravaya

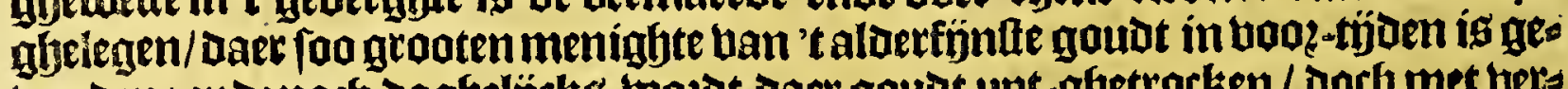

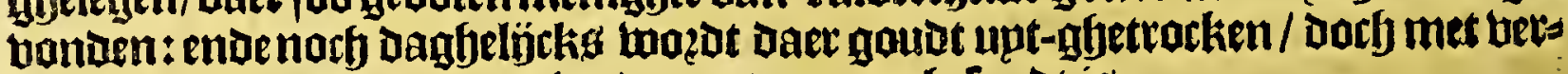
lies ban beel bolcks / Daoz dien de contrepe onghelonot is

\section{Wet Dertichtec Capittel.}

Befchrijvinghe van't groote Meyr Titica CA, welck leght in't midden van de provincie van B I C O L L A $O$.

Cieça

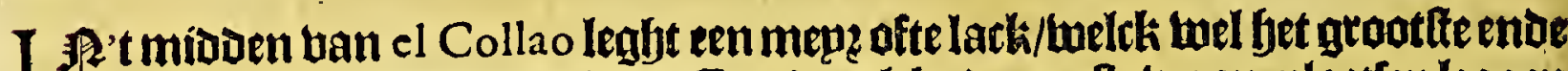

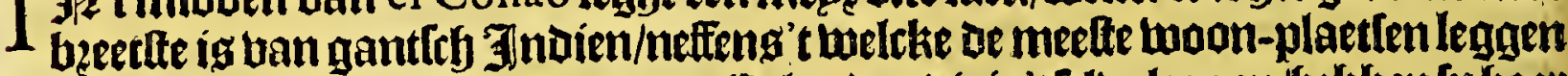

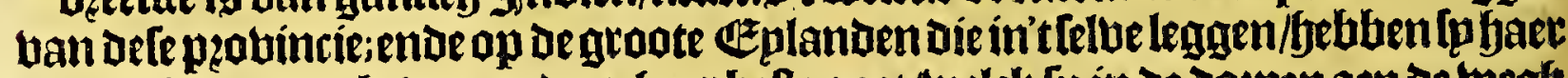
3aep-ackers/ende beluaren daee baet belte goet/welck [p in de doupen aen be wegh aelegen/ niet en Do:ben bertroulwen. In de bieg-boffeben ban dit lack foudt bem

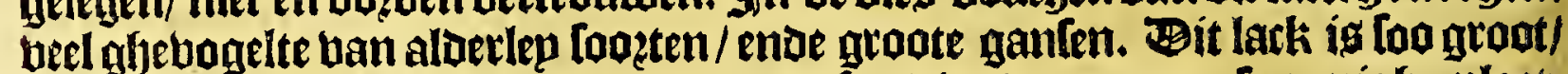
dat fer 8 o leguen Jeeft in't am-gaen /ende loo diep dat men op lommighe plaets

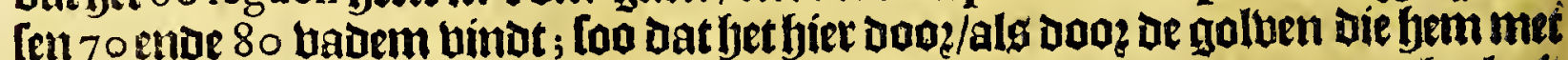

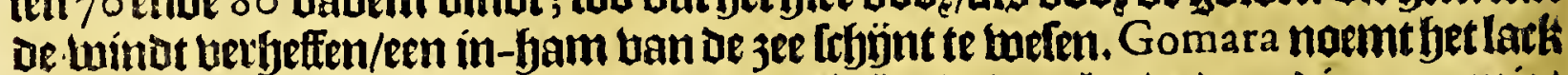

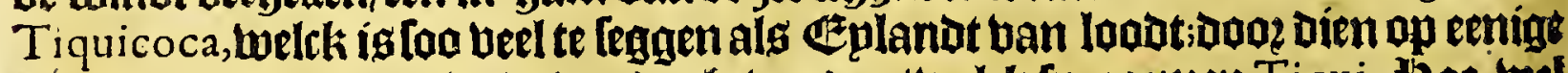
ban de Geplandekeng loodt woedt ghebonden/melck tp noemen Tiqui.

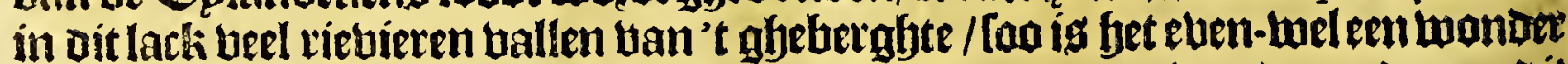
waer dit groote water ban komt; want is wel leltichleguen ban de jup Dt-jes; wit

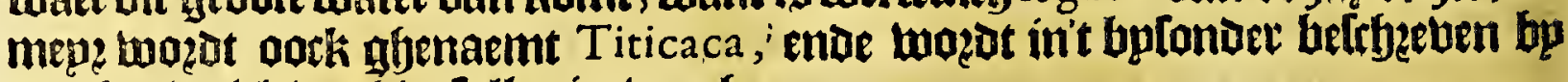
1.2.c.6. A cofta, inelch tun fiet Lullen in-boegljen.

Th bit larl: ([eabt ljp) Loopen meet aan thien bolkomen riebieren upt/heeft alleen

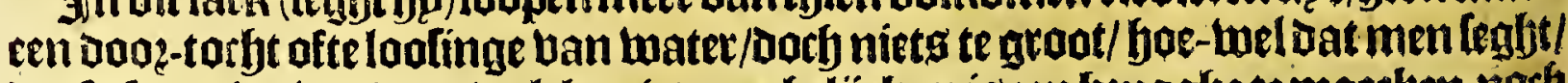

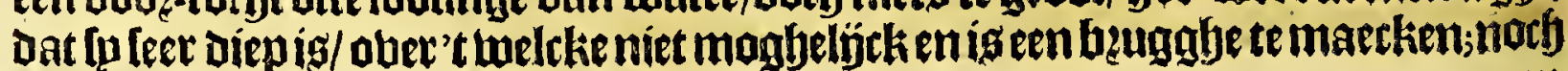


Het thiende Boeck.

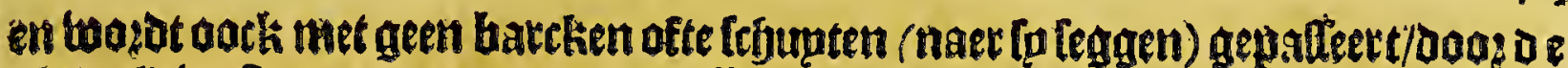

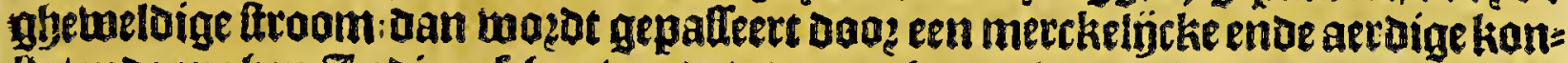

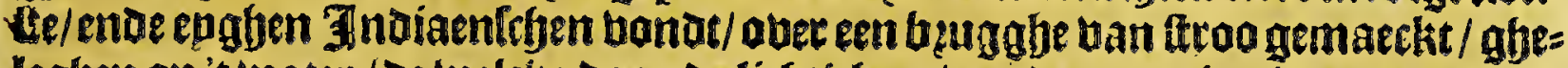
Legben ap 't water / oe welcke doos de licftichept ban de materie niet te grande en gaet/ende geefteen licfte ende fekere paftagie. Defe Laguna magh 35 leguen langb

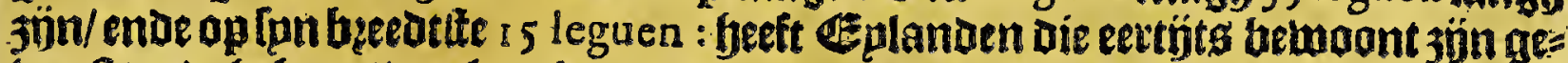

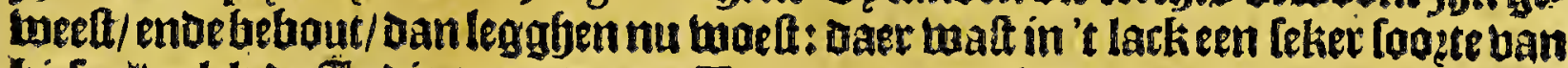

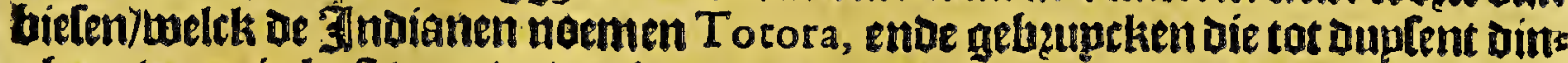
ghen; want is kof voo? de berckens ende peerden/ ende boos de menfrben felfs; maken daer futten ban/ende bercken/bzanden die/ enve de $V$ ros maken daer bal

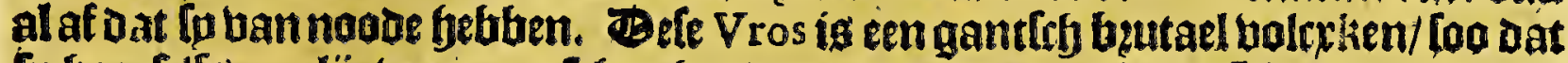

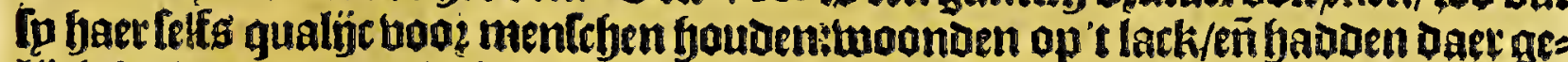
ligck beele oozpen op boftchen ende blotten ban defe T otora gemaeckt ende bp den anderen gbeboeght; met de weleke fo tan plaetg tot plaetle Deduen / enoe foo baet booningen berandetsen.' $t$ Bater ban bit lack en is niet feel bitter ofte b2ack/g $\varepsilon=A$ cofta

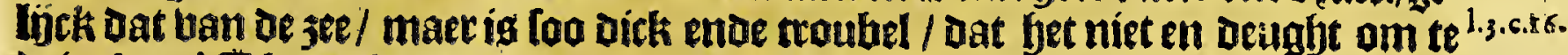

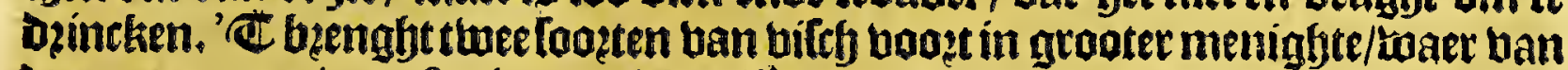

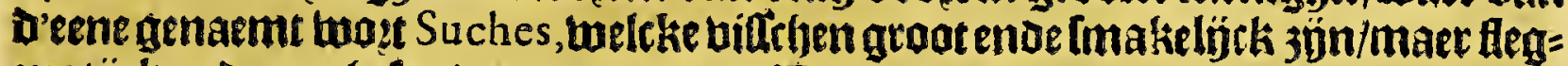
matÿck ende anghetonot om te eeten. D' andere wozen glyenaemt Bogas, die

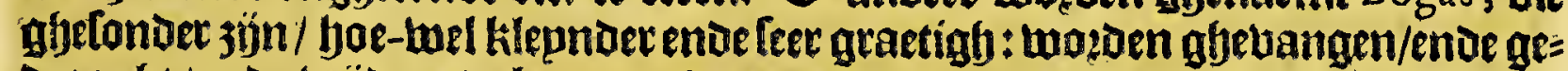

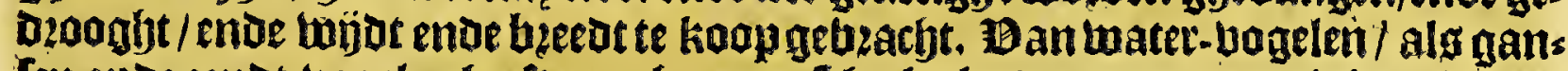
Ien ende eenot-bogelen beeft men bet gantefe lack aber groote menighte. than: neer de $\exists$ ndianen cenighe feelte ofte onthael twillen ghe ben aen De ghene die sao: Chucuito ofte O mafuyo (welck be twee aeveren van 't lack $j$ jun) baet pallagienes men / loo betgaderen fo een groote menighte ban blotten / vie fo noemen Balfas, ende flaen een ringh in't rande/ enoe beflupten enoe berbolghen loa de ganlen ende endot-vogelen/tot dat fp diemet der banot grijpen/ende [oo beele bangen als

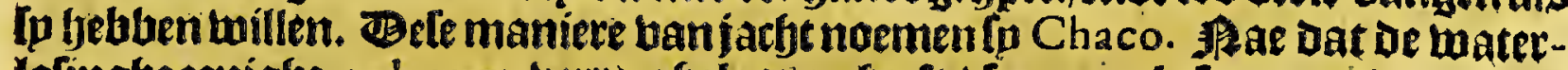
lofinghe eanighe 5 o leguen berke gfjeloopen beeft / foo maecktte cen minder lack

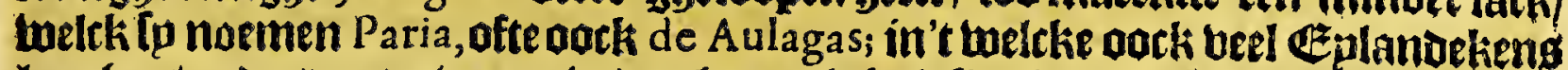
legghen/ende men en tweet niet dat bet eenighe lofinglje beeft; foo dat bele ban ge=

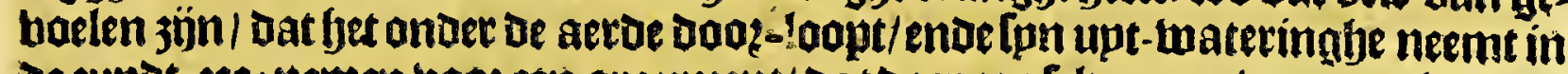
De 3uppt-jee; nemen booz een argument/ dat daer een feter arm ban een rievier in

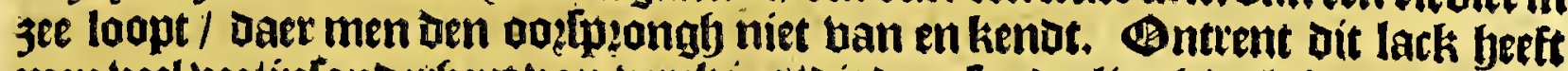

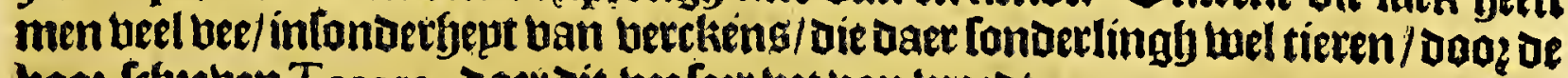

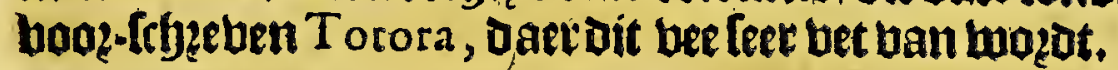

\section{Het en-en-bertichlte Capittel.}

Voorder befchrijvinghe van de landen ende volckeren gheleghen langhs den hooghen wegh van Cusco aftot de ftade I A PAz. Van Chrovito ende deftadt Nuestra SEN NOR DE La PAZ in Chuquiabo.

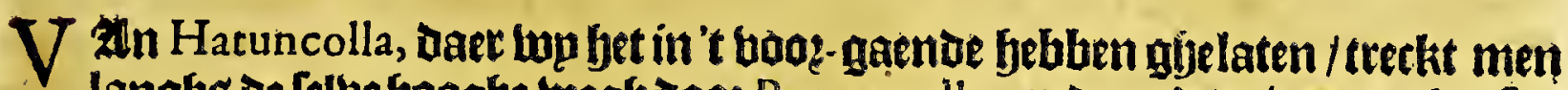

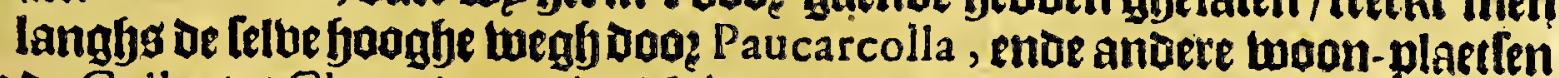
ban de Collas tot Chuquito toe; welck ígen ban de peincipaelfte ende bolkoment= te woon-plaettendie in dit groote getwelt twazden getanden:eñis de booff-plactle ban alle de Indianen die den Spaeghiaert beefe in dit quartiex; De doppen ban aefep:obincie topęon genaemt Xuli, daetfe teggen wel 30000 Intoianen moonen/Cię̧

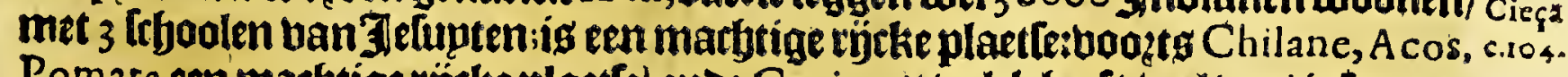
Pomata een mathtige rijcke plaetfel ende Cepita; 't valck beeft treel bee / inlonder= bepot Iefapen/ende aberbloet banlijf-tocht / gbelỉek men in oie landen beft: in oe meetten- deel ban oefe plaetten jỷn nukercken bp oe \$paegniaeroen gbebout: ende't bolck zön nu beel Cyziltenen gbetwozeden/intonderbept de Heerent. 


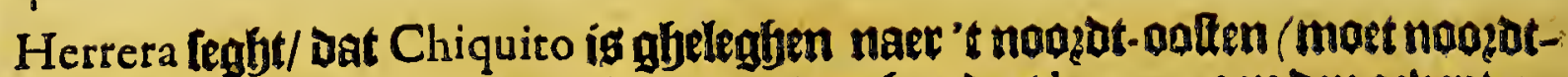
welten wefen ) ban de ftadt la Plata meer dan fondert leguen, aen Den oeber van t groote lack Titicaca, ende Dat het een wooningbe ig ban Jndiamen onder eenen Spaentelyen ILieutenant Gouberneur/ ofte Corregidor, alibith fo dienoemen:

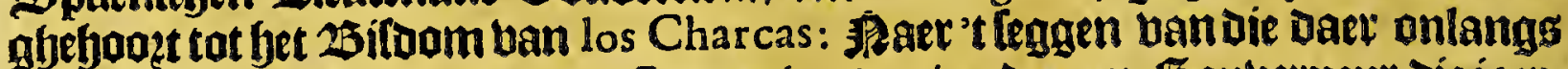

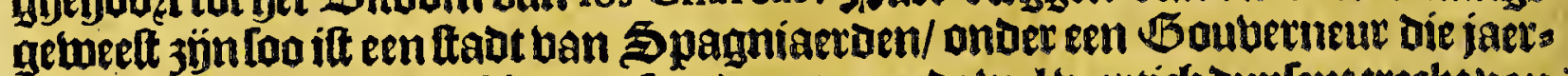

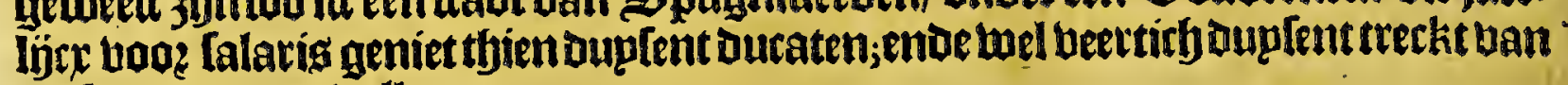
verthepden toe-ballen.

ß2effens bet Doep Cepita Joopt oe Deffaguadero ofte hater-loofinge ban't nroote lark; de Ingas badoen in tooz-tīDen bier yaer officiers die tribupt ontfinghen ban 't bolck welck ouer de bugghe palteeraen/ bie bier was geleght/ in boegen als bog

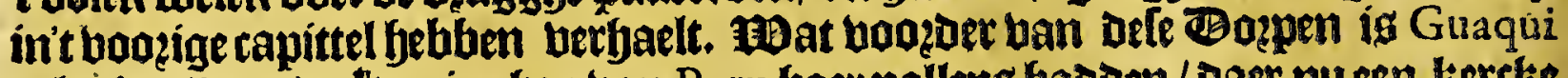
geleghen/ Daer oe thoninghen ban Peru baer pallepg hadoen/ Daer nu een kercke is getticht/ Daer be jonge lieden in't Clyefiten-gelooue wozoen onder-belen.

Tiaguanaco enig gheen groote blecke/ Dorbig bermaertwegen De groote gebous

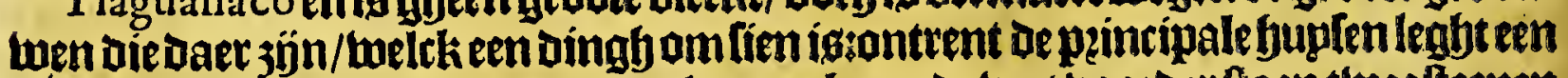
beubel/welck op fercke mueren is ghemaeckt; ende wat boozoer ftaen theelternen beelden ban bet maeckfel ban menleben / loo fraep gfyefjoudon ende ghefatloeneert

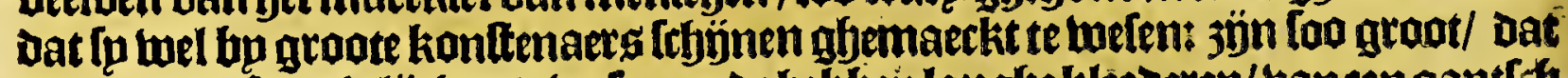

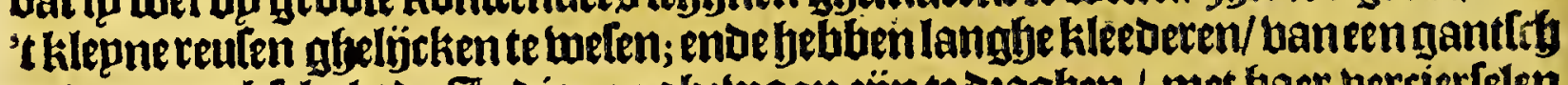

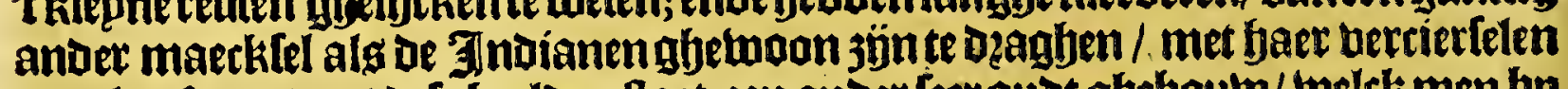
op 't booft; ontrent dele beelden flaet een ander leer oubt ghehoula/ / welck men bp

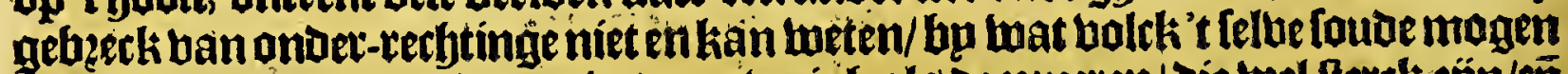

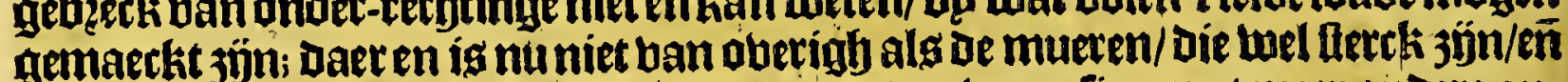
van fo groote fteenen op-gelegft/dat bet wonder is om lien; met meer anoere ans tiquitepiten die bier in defe plaetle te fien $3 \mathfrak{g} n$ / foo dat bet een van de booznaemle ende aubtlte ghellichten is bangantteb Peru,

Seben leguen ban Tiaguanaco, langhs defelbe megh leght bet dozp uan Viacha, ende men l. " aen De flincker-bande legghen de doepen genaemt Cacayavire, Caquingora, Mallama, ễ ander viet-geliptket entoe daet ontrent leght een plapn melck fpnoemen Guarina, bermaert doos een tagh die in Spaeguiaerden daer onoer Den anderenbebben ghellaghen. Bmban bier te trecken naer Cuidad de la $\mathrm{Paz}$, foo laet men de Honinghlícke wegh van de Ingas legghen/ enoe gaet,

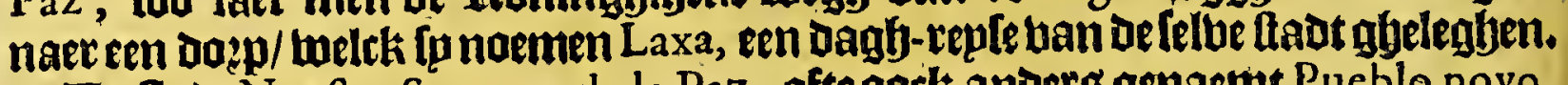

De ltadt Nueftra Sennora de la Paz, ofte dock anoerg genaemt Pueblo novo, ende Chuquiabo, naer depzobincie/ig gfeleghen int midoen ban Collao, Gonbere leguen ban be ftaot Cufco, naer't teggen uan Herrera, dan Cieça ftelt maer węp: nigh meer ofte min als tachtentich; ende tactetentich leguen ban de ftadt la Plata; Cieça Iegft tneghjentich; twee fondert ende twintidy leguen van oe ftad de los Reyes naer'tleggen wan Herrera;enoe tachtentich leguen ban Potofi, ende 5 o leg. ban Oropefa, inde ballepe ban Cochebamba. De thaot legft tultithen't geberghte ineenklepne ballepe/ baer goet water ende beel boutgig te bekomen; de ballepe

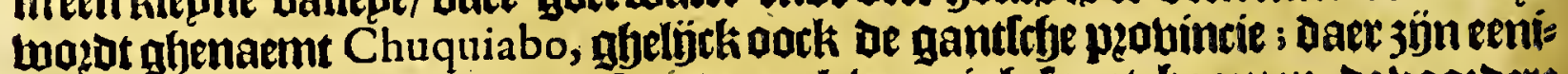
gloe 3 aep-landen daer Maiz wait / ende oock torephigh frupt-foomen; be boozoere befjoeften ban líf-tocht ende anders/mazden toe-geboert upt de twarme trallepen ende andere pzobincien Daer ontrent. Baer loopt een kilepn riebierken bp oe flad ban feer goet water. Depzodincie van Chuquiabo (kegbt Herrera) welck in de

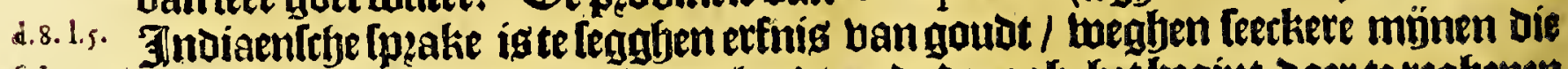
c.3. Daer wozoen gebonden/ ig koutat landt ende bzoogh; bet begint daer te regbenen in December, ende Duert tot in Martio; tan A pril tot in Augufto ifl daer feer kouds ende bzaftigh/ Loa dat de boamen ende krupden berdzaoghen; de maenden ban Seprember, October ende November, jün leer getempert/entoe de boamen botten

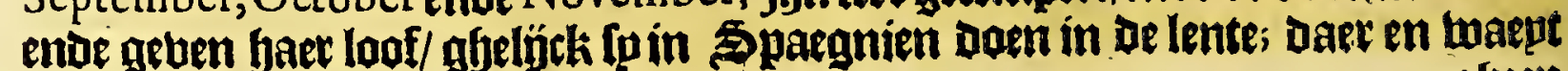
oljeen 


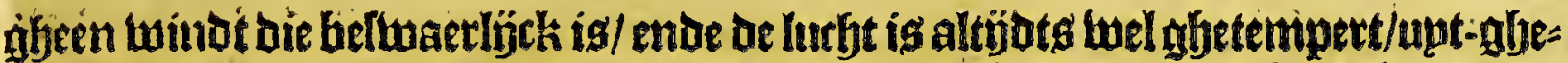

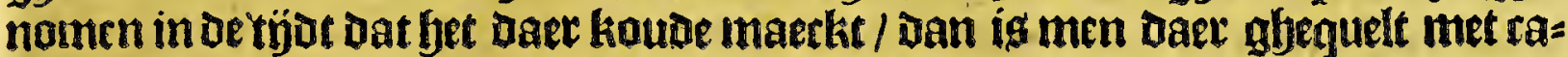
tharrm ende pijn in de jijoc. Beftadt ig ghethoutut in een diepe ballepe / een balf leguc in't om-gaen / black landt conder freubelen/ Doch aen de boet ban bet ghe: brtgljte om 't befefhut ban de twinden; beft beel fontepnen ban goet water; beel

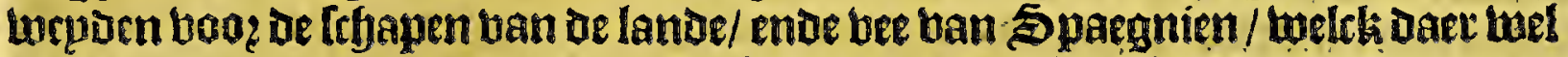
toe-neemt: beel wijngaetoen/ böghe-hoomen/ ozagnien/limoenen/queen/pers

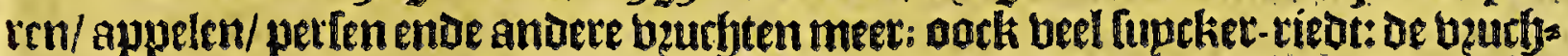

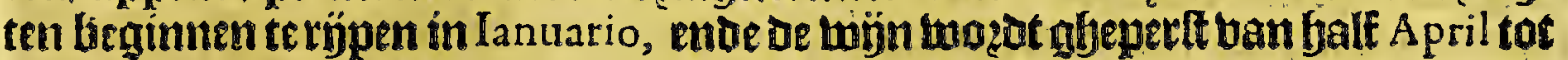

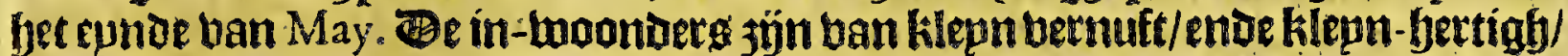

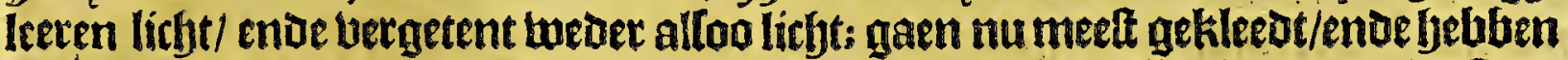

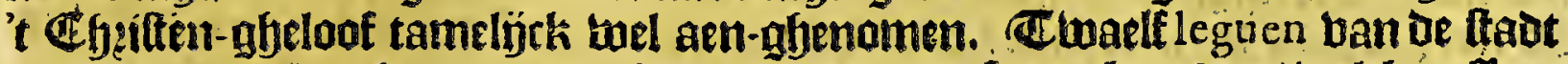
naer't noogen Ieght De gronte Cordillera han de fneeu-berghen / wielck pafteet boo't betle rỉck ban l'eru, ban Cartagena af / tot de Itrate ban Magellanes toe.

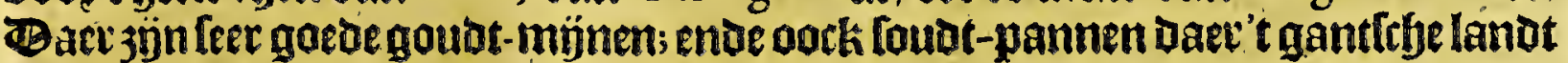
baet onttent mede ghedient twozot.

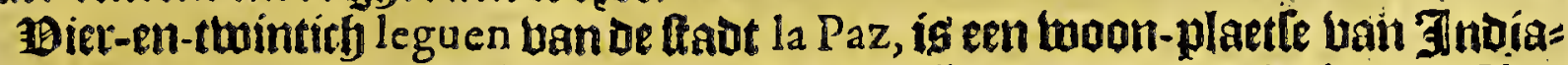

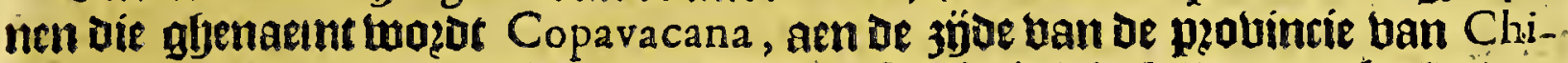
quito, op ecrnpunt ban bet lanot / welck bem ftreckt in 't lack / Daet een beelot ban onfe liete beutwe is in een kererken; welkk mirakel boet / naer fet feggen ban oe Spaegniaeroen. In de ballepe ban Caracato, weltk is in Defe peouintie ban Chuquiabo, twatlen onoer anoere be belfe wijn-ftorken ban dit gantlebe quar: tier ban Inoien.

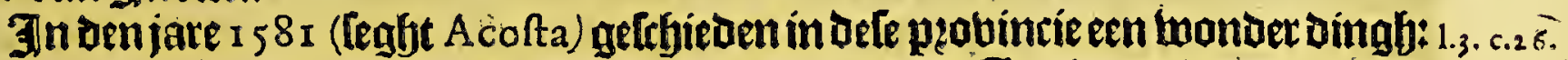
een groot decl baneen dowp gheriaent Angoango, daer Indianen twoonden die booz toobenaers uermaert waren/ ftozte ober hoop/ foo dat daer beel bolcks on=

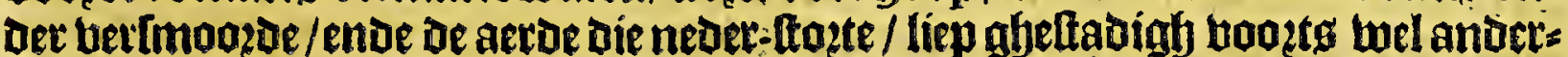

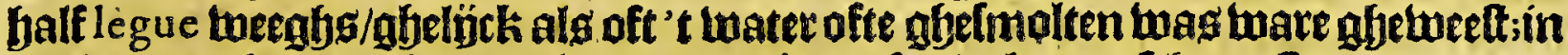
fulcker boeglen bat bet een klepn mrpeken ofte lack gantfey toe-ltopte / ende de

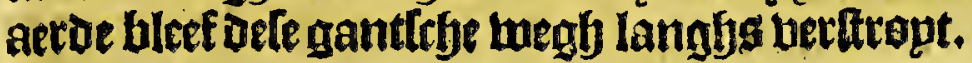

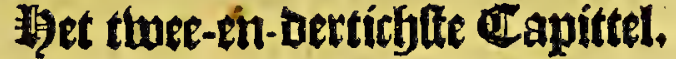

Vervolgh van de Koninghlijcke wegh tot de ftadt I A PLA T A; de gheleghentheden van de felve ftadt.

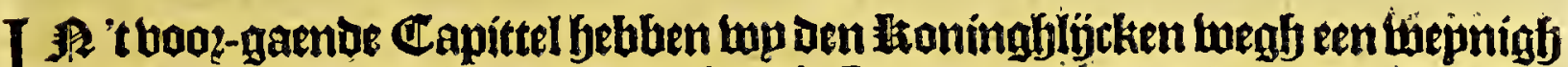
Iaten legghen/omte kamen tat deftadt la $\mathrm{Paz}$, om nu beder de begh te bethol= ghen tot de ftabt la Plata toe / Cullen wo bet hetuatten aen be plaetfe Viacha, Daet twp fet ghelaten bebben.

Dan Viacha kome men te Hayohayo, Daer te Ingas engroot pallepg hadoen.

Dan Hayohayo home men te Siquifica, welck isifet uptertte ban de Collas.

Ban Siquifica komt men aen bet doep ban Caracollo, welck jön elf leguen weegfy : ented dit doẹp Caracollo light op fekete gloote blacke beloen onttent de

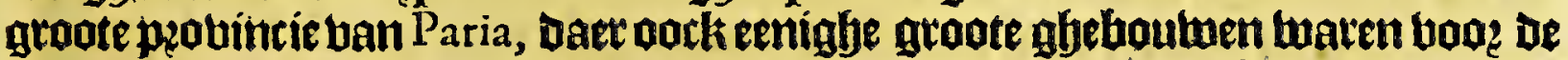
Ingas, Honingfen van Peru. De Dozpen ban Paria legghen meet ontrent de was terloolingbe uan bet lack / ende eenighe een mepnigh daec ban berfefepoen/alg Coponata, ende andere meer. Mlat boogoer als Paria, Iegghen de doypen ban Pocoata, Macha, Caracara, Moromoro;enoe onttent de Andes nach andere pya: bincien ende balckeren.

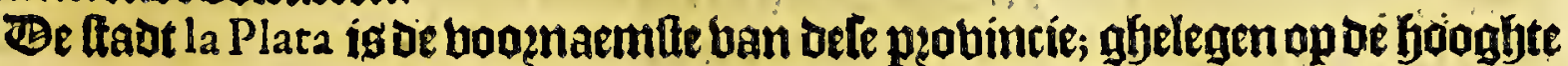
ban negbentfien graden bu zupDen de linie / naer't legghen van Herrera; Doth alloo A cofta ende Herrera bepoe elders getupgen/Dat la Placa entóe Potofi op een

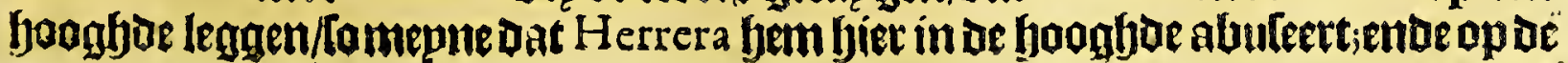


404

Peru.

Irrigte ban thee-sn-Fetuenticly graden ban Den meridiaen ban Toledo, honbert

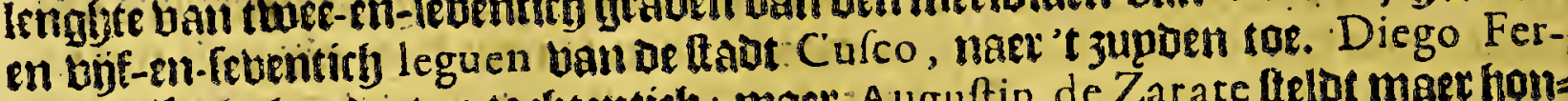
nandés teght bondert en tarbtentich ; maer Auguftin de Zar ate felot maet bon=

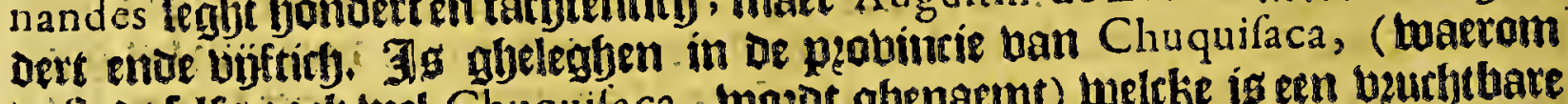

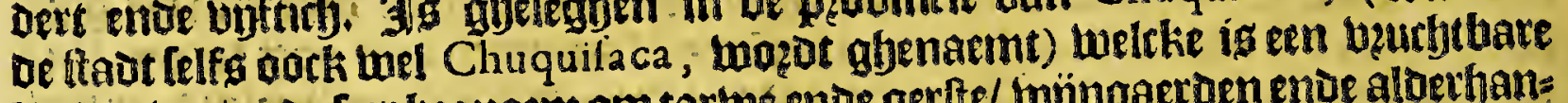
fandoule / eñe feer bequaem om tartwé enoe gerte/ wöngaerden enoe alderthan: De buthtente winnen: Daer is een gbetemperde lucht/ naer dat Herrera upt Cie-

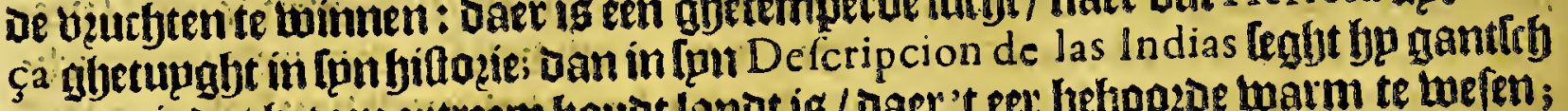

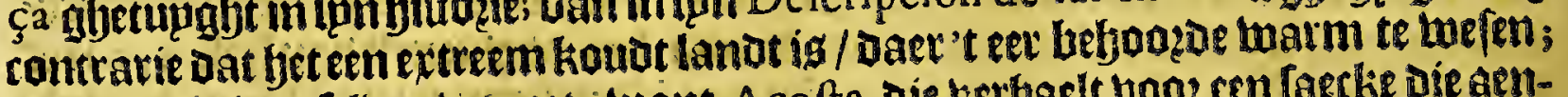
waer in by bem felben betgeet ; want A cofta die bethaelt boo? cen laeclie die aenmetckeng tweetiogh ig; bat/waer defe ftad maer 18 leguen en leght uan Potofi, eñ

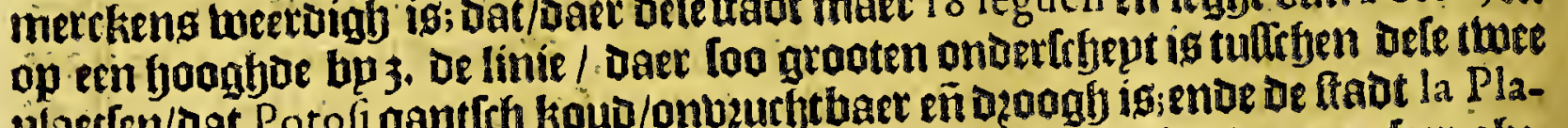

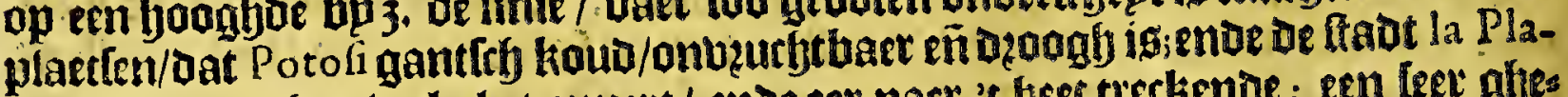
ra daet-en-teglyen wel ghetempert / ende eer naer 't beet treckende; een leet glyes

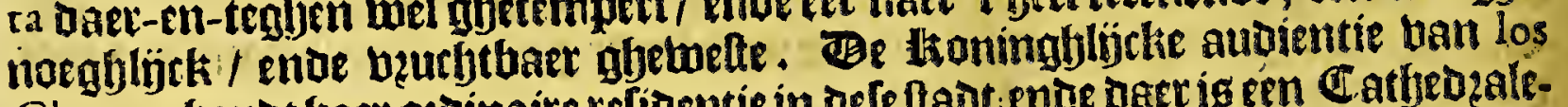

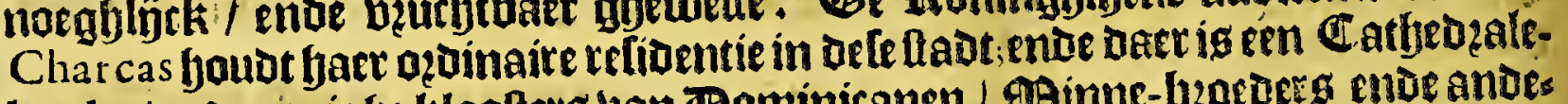

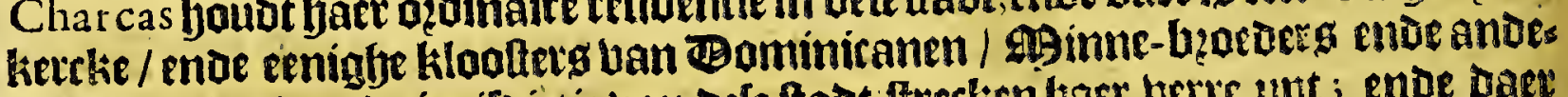
te. Be palen ban de jurifoirtic ban dele ftadt ftrechen baer berte unt; ende daex

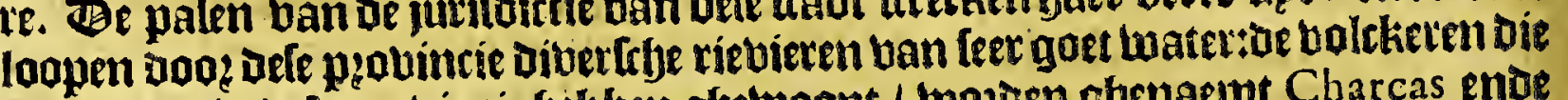
van oubts in Dele pzobincie fyebben ghetwoont / bozorn ghenaemt Charcas ende Carangues, ende maren ftrijorbaere lieden. Oe thoninglien ban Peru bebben bier ban ouden tijoen beel bolchis beligly ghelyouden om de filuet-mïnente ondergraben infonderhept upt den bergly Parco ofte Por co; upt welcke mỉnen mengljes

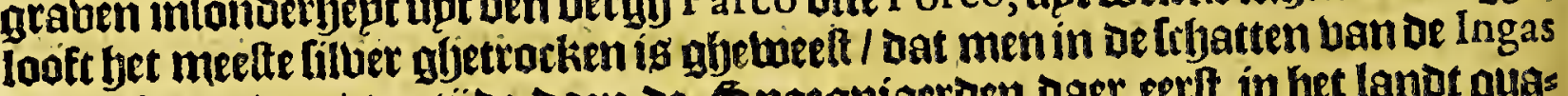
jeeft ghebonden / ten tijoe doen de Spaegniaerden daex eerlt in bet lanot quas men. 23 enefteng dien jünder nach andere mïnen ontoeckt ontrent de le ftadt; ende men houot dat dit gantlfy quartier bol minnen ig/ ende niet dan minerael than filver / waer ban Dele ftadt oock Den naem beeft befouden: want de mïnen ban Porco haren ban groote apparentie; ende Hernando Pizarro yadoe een mijne

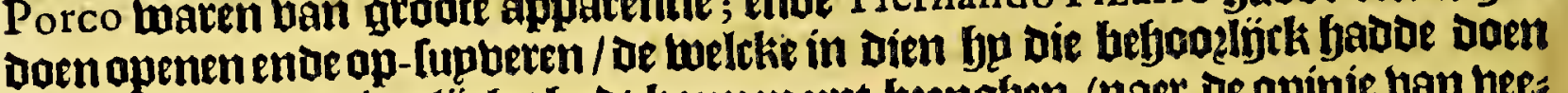
verbolgljen/ bem jaetlijcks badt konmen upt-beenghen (naet de opinie ban bee:

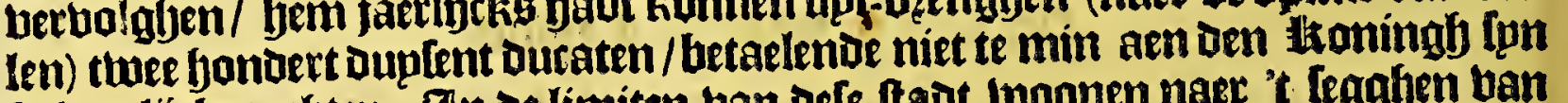
befool lijtke rechten. Fin de limiten ban defe ftadt moonen naer 't legghen ban Herrera, wel arbt banoert Spaegniaerden op haer lanot-buplen ende boutwes rijen/weltk [p Daer telande noemen Chacaras; ende twel rettirb oup[ent Indianen die tribupt betaelen / betoeelt ín -neglyen-en-thintich Repartiementos; gfelïck de Spaegniarcoen Dat noemen. Adlle jaden van Spaegnien twillen baer tael boazt-komen / ende men binot daer leat beel filuer-münen ban feer rück metael;

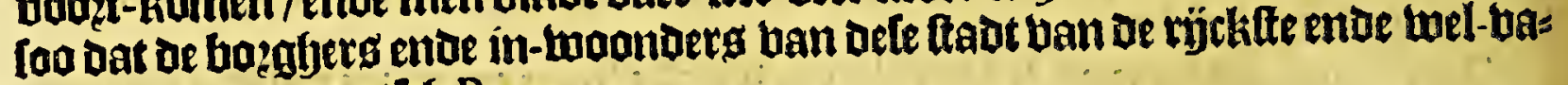
rentte zön van gantity Peru.

25oben oe doepen ende plaeten in fret begin ban dit Capittel verbaelt / foo be: hoozen noch tot dele ftadt de dozpen uan Totora, Tapacari; Sipifipe, Cochabam. ba, los Carangues, Quillanca, Chayanta, Chaqui, ende los Chicas, ende andere meer/oe welcke alle leex rück jün; ende eenighe/ als namentliök Cochabamba, feer beurthtbaer ende bequaem om tartwe ende Maiz te zaepen/ ente alderbande

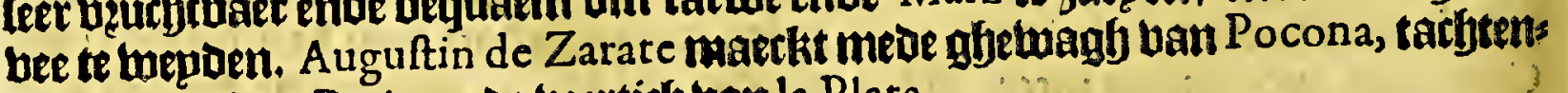
tích leguen uan Paria, ende beertich van la Plata.

In be vallepe van Coch abamba is een ftadt gheboumt bp den Bice-Liop ban Peru, Don Francifco de Toledo, weltk tunaemen Oropefa; ig gbeleghen tuan be ftadt la Plata twinticy leguen; de in-moanderg gheneeren baer met tarke ende Maizte jaeqen; ende met bee te baeden. 
Het thiende Boeck.

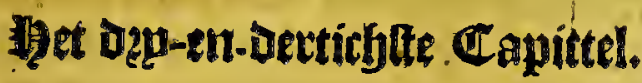

Befchri, vinghe van de ftadr $\mathrm{P}$ o $\mathrm{x}$ o s I, ende de rijcke filver-mijnen die in den bergh van Po T OS I wierden ghevonden.

D E fteplerlïtke ftadt (als de Spaegniaerden bie noemen) van Potofi is gbe:

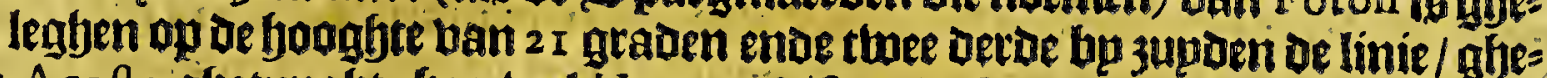

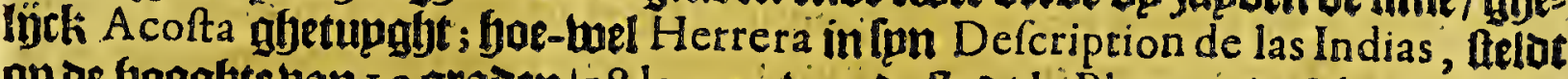

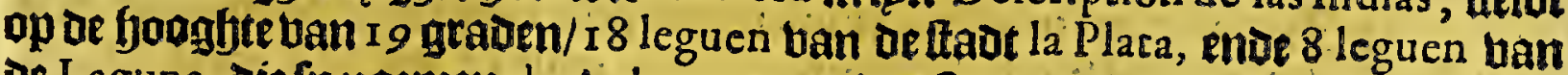
oe Laguna, die fp noemen de Aulagas, naer 't noten/aen de boet than 't geberabre

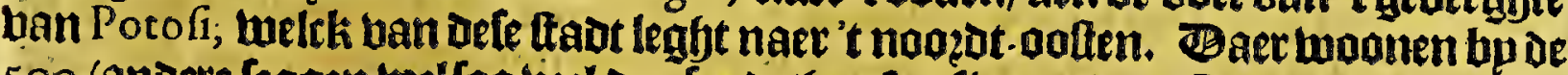

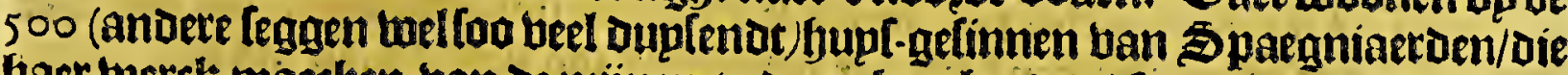
baer twerck maecken ban de minen te doen bearbegden/ fonder de koop.licden Die gaen en fomen om't filber te berfjandelen; ende bel bp de 50000 Jndianen

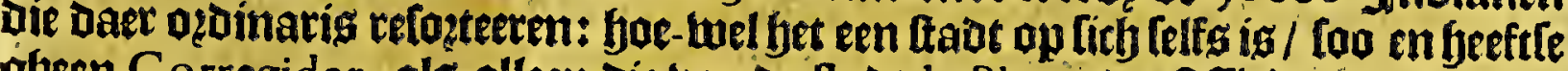
gheen Corregidor, als alleen die ban ue tabt la Placa ; de Officiers ban ue Ha

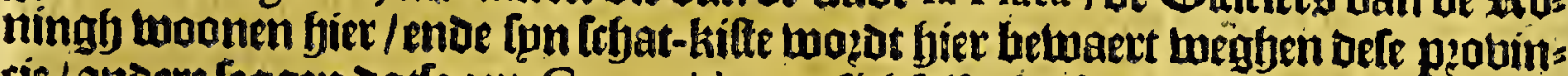
tie/ andere feggen Datfe een Corregidor op fich leffs beft wellkg in-tiomen jarts lïrks loude beten tbien duptent pezos.

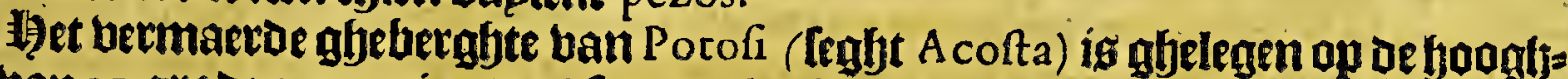
te ban 2 I graden 40 minuten / foo dat bet komt te legghen tuffitjen de Tropicos aen 'tupterlfe ban be Torrida Zona; ende des niet tegtyen-ftaenoe / foo ift boten

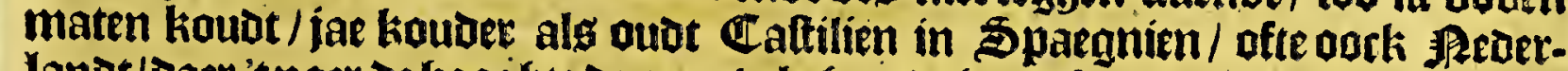

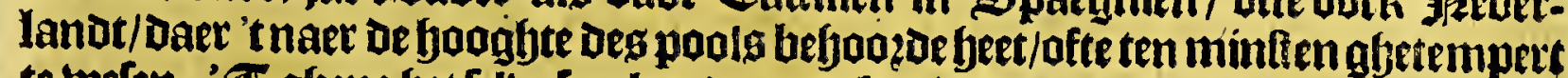

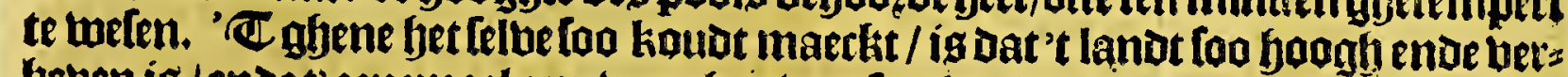

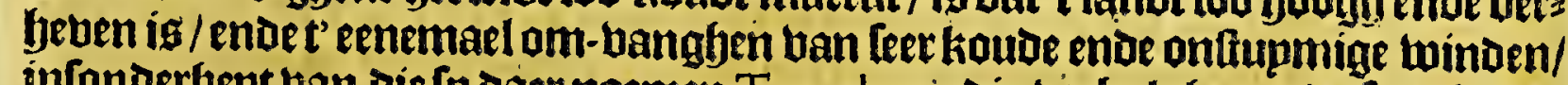
infonderbept tan die fp daer noemen Tomahavi, die vertholghen enue feev koudot balt/ende daer regmeerdet in May, lun, lul, ende Auguft. Ben bodem Daer ontrent

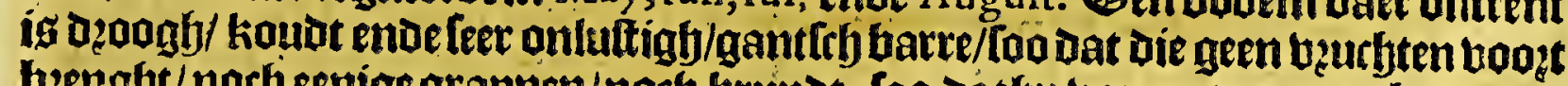

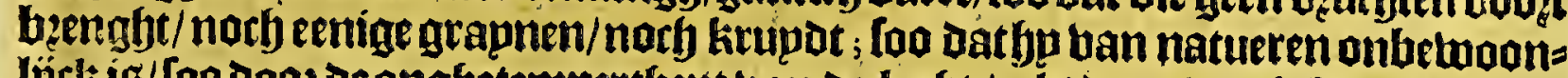

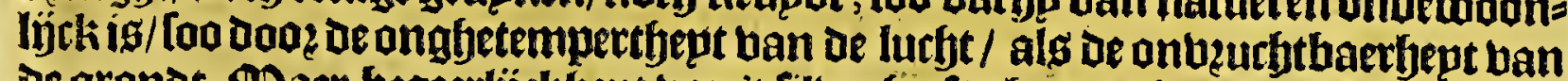

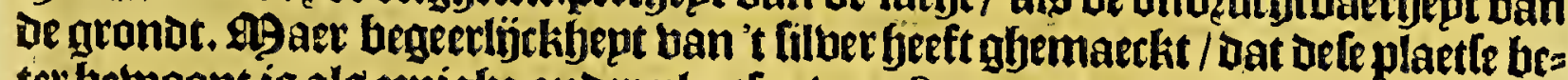
terbetwoont is als eenighe ander plaeten ban Peru, enae aoet be feltue too aber: bloepen van alderfjande nootopuft ende leckernjen/Dat men niets en foude kions nen wenfthen/ofte men falt Daer binden; ende foe-wel dart alles ban bupten

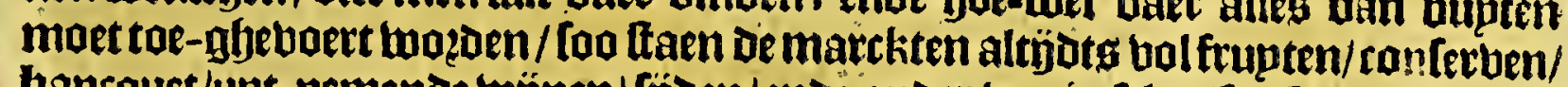

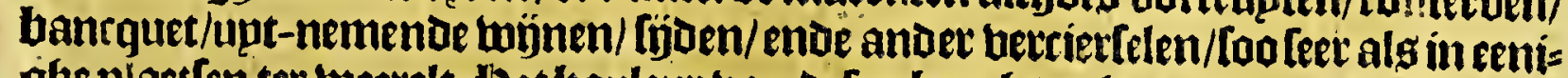

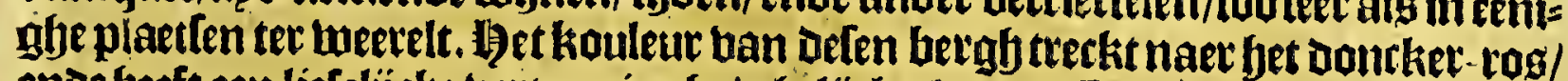

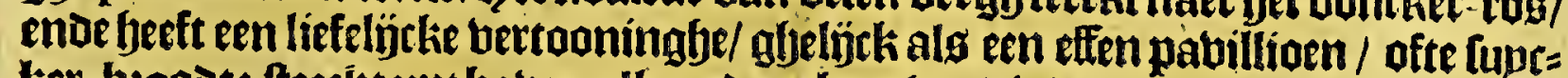
ker-b2oost: Ateetkt upt boben alle anuere berghen die daer ontrent legglien. IJs moepelincken om op te klimmen/al joe-tuel men die te peerde kan op-rỷoen/kome

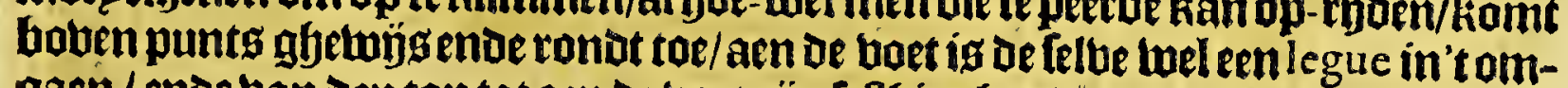
gaen / ende ban Dentop tot aen be boet 3 jun felthien fondertende bier-en-twintich ghemegne roeden / De wellke gheredureert naer de mate ban de $\$$ paentrfbe mij: Ien / fuilen een quart ban een legue upt-bzenghen; aen de boet ban aeten bergh

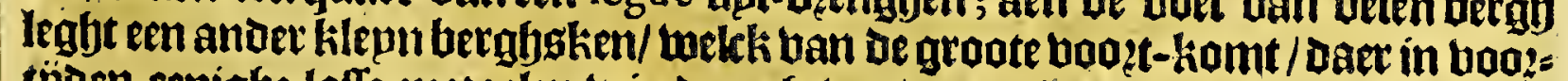

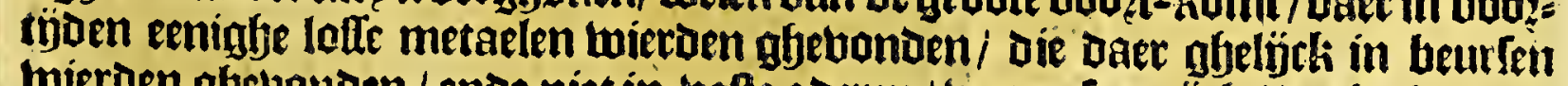

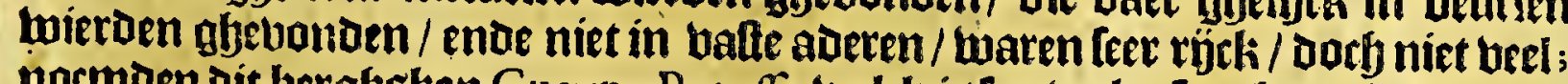
noemden dit berghsken Guayna Potofi, welck is foo ueel te fegghen/als De jonge Potoffi. Zlen be boet ban oren klepuen bergh begimnen be tuooninghen ban de Spaegniartuen ende Indianen / diegbekomen jün om den rijtkdom ban Potofi te bearbepden ende upt te treeken. Bele bleste magh bp de twee leguen in

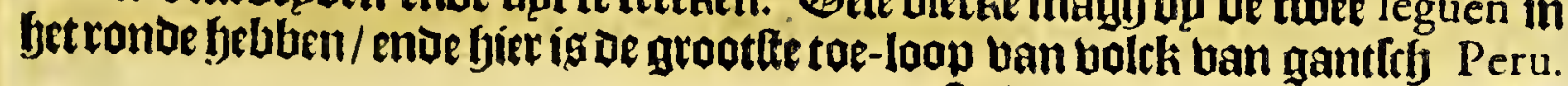


418

Peru.

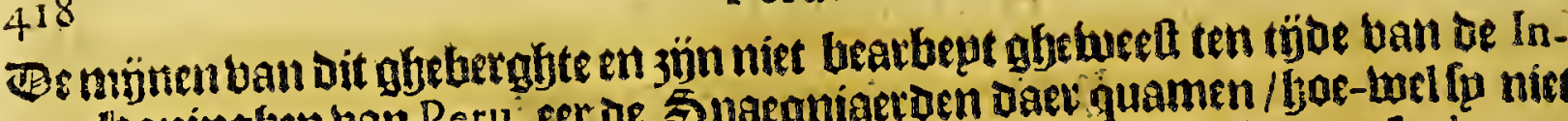

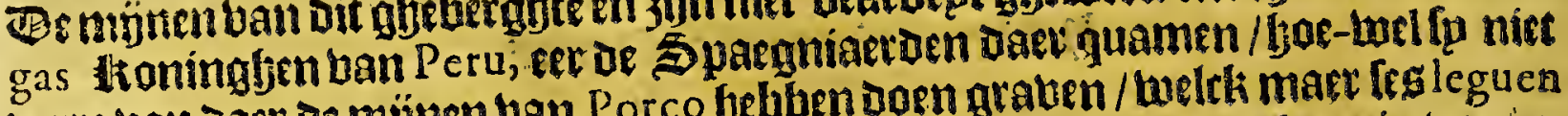
berre van dact oe mijnen ban Porco bebben Doen graben/twelch maer fegleguen ban Potoffi legaben: D' oplalie moeft weten/ Dat fp Daec gheen kennig ban en hadoen: norbte naer dat de \$ \$argmiaerden oare gyetom

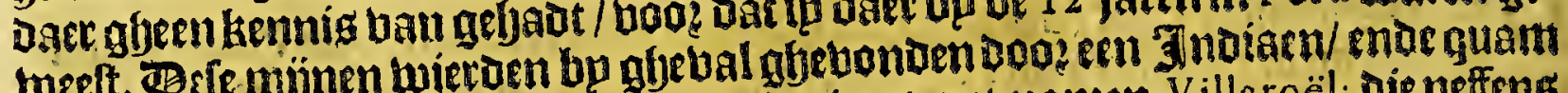

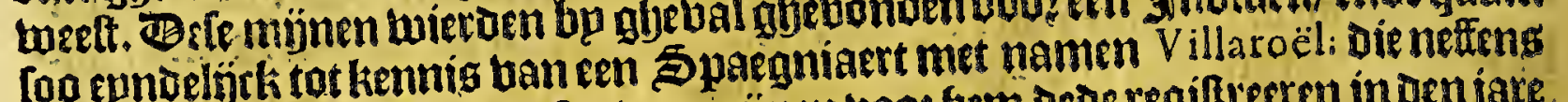

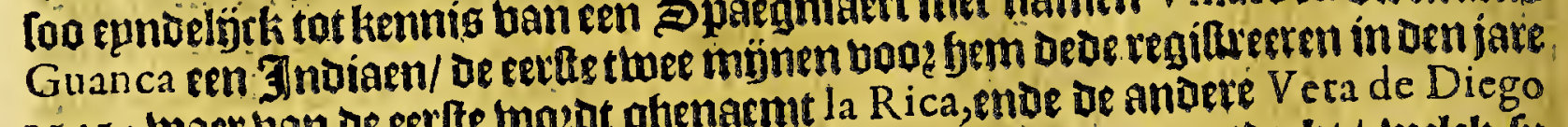

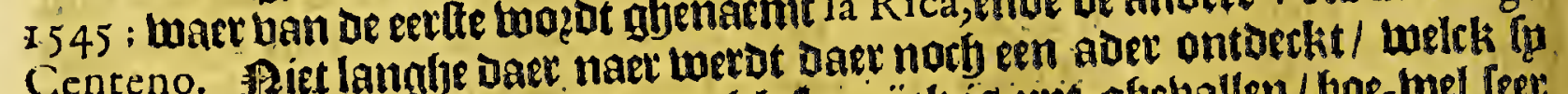

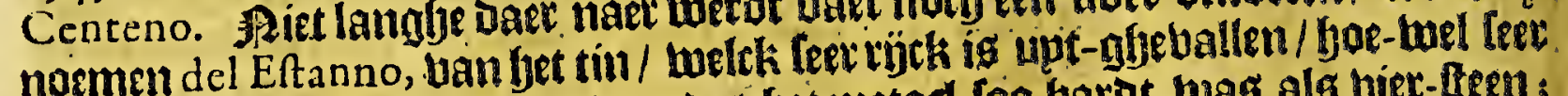
noemend del Etan bearbepten/om Dat bet netad too barat was alg bier-Reen;

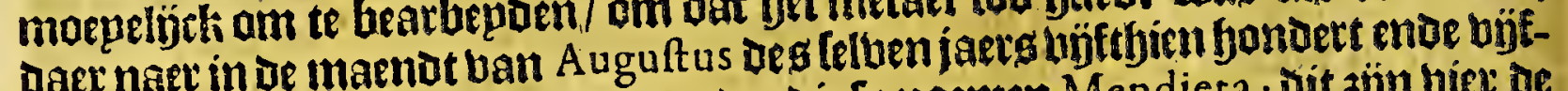
en-beettich wierdt aberegifteert oe ader die [p noemen Mendieta ; Dit jön biev de

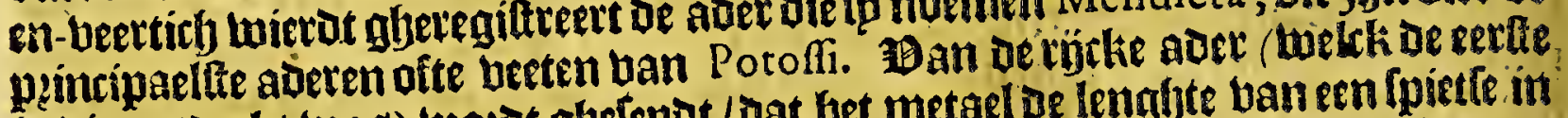

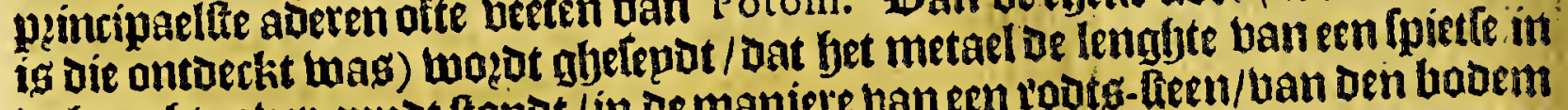

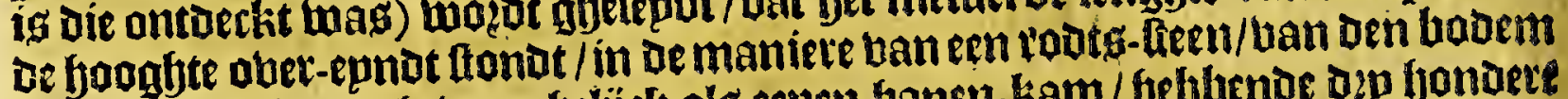

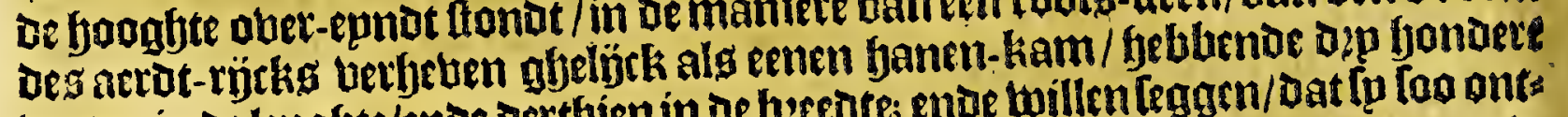

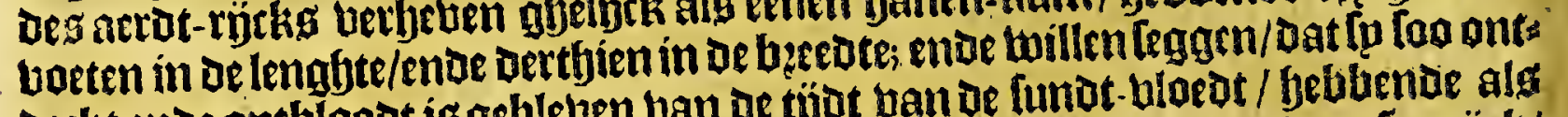
oeclit ende ontbloodt is gebleben ban de tijot ban oe funot-bloedt / beblende als

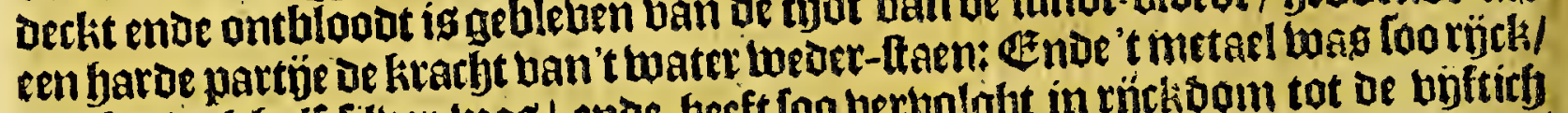

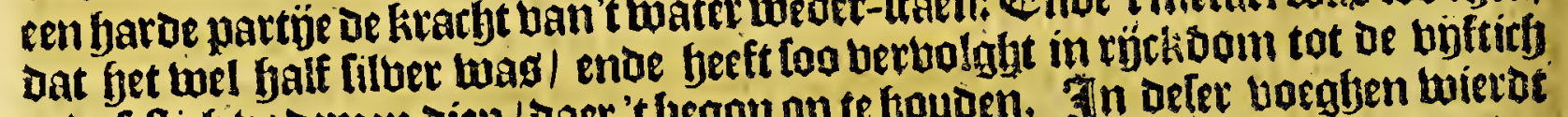
ende feftich bademen diep/ Daer thegon op te fouden. In deter boeglyen wier ot

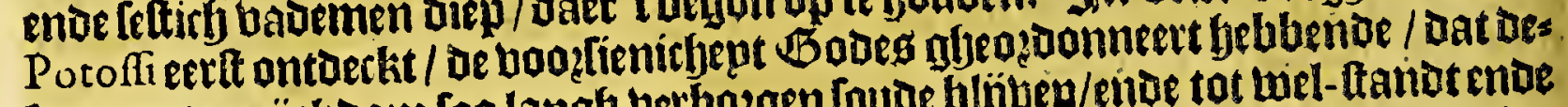

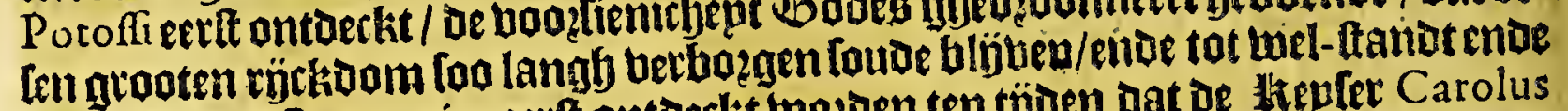

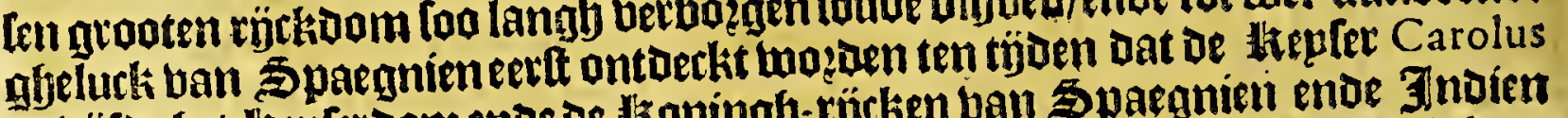

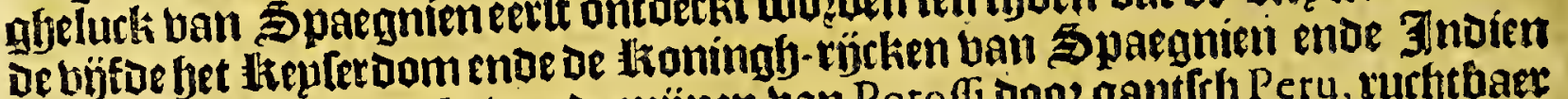
belat. De ontoechingye uan de mijnen uan Potoffi dooz gantfry Peru, surththaer

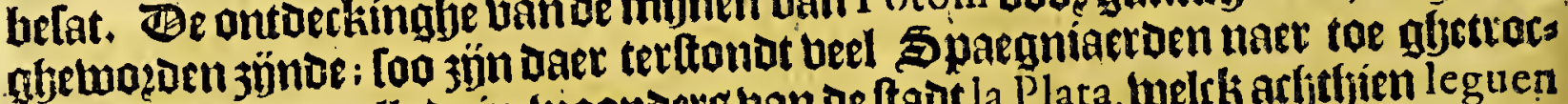

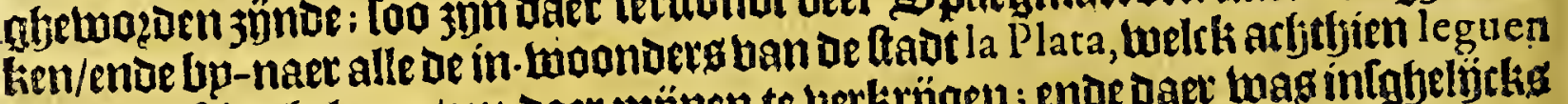

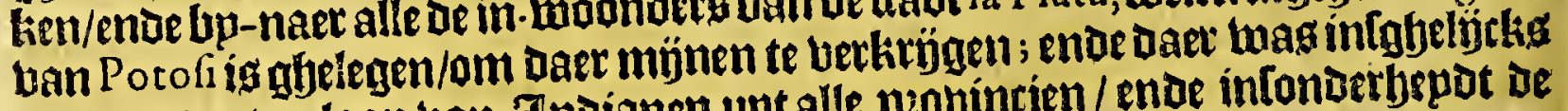
cen grooten tor-loop ban 3 noianen upt alle pzovintien/enoe inlonderbepdet ise Guairadores tan Porco, too dat het in koten tijot de betwoonfte plaetfe twietat

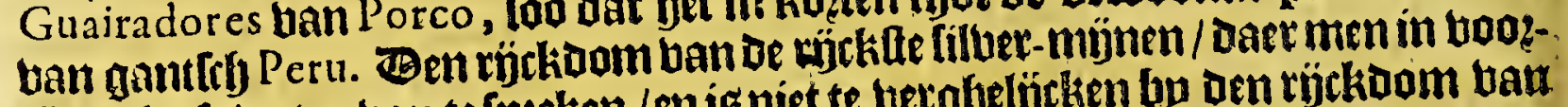
tijoen feeft weten ban te [p:eken/en isniet te betghelijelien bp den rijckbom bau Dele münen uan Potofi; want naer dat blïckt bp des lionimglys boecken ende re: giffers ban't contractie- ljuus ouer die plaette/ende naer Dat oude gheloof-meerdis,

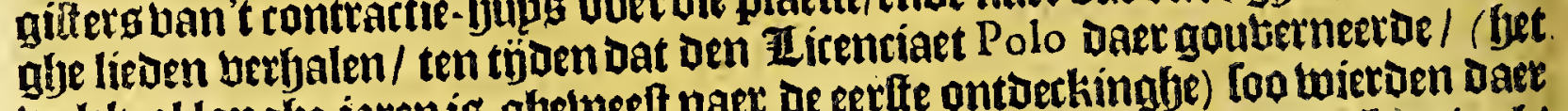

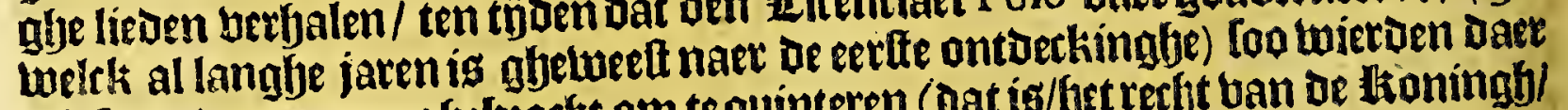

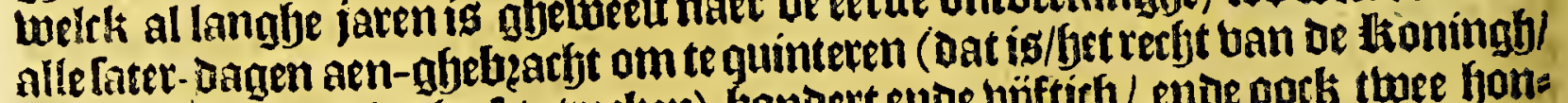

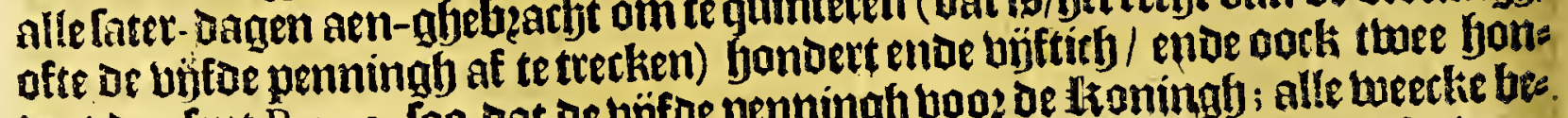
Dert buufent Pezos, foo dat de uñfoe penningh vooz de lioningfy; alle weeclie bee.

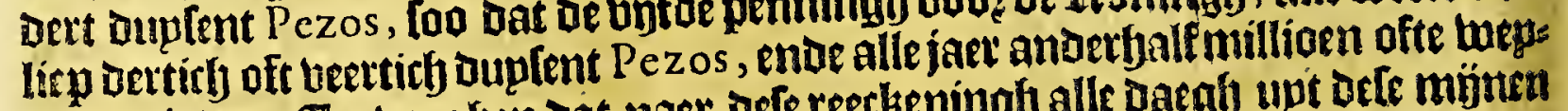

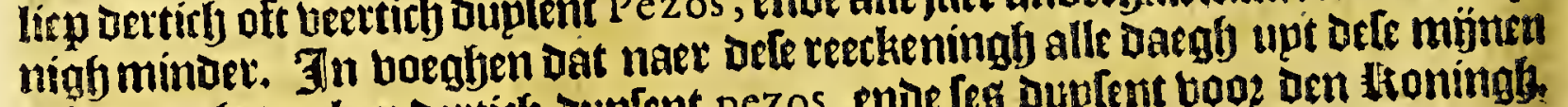

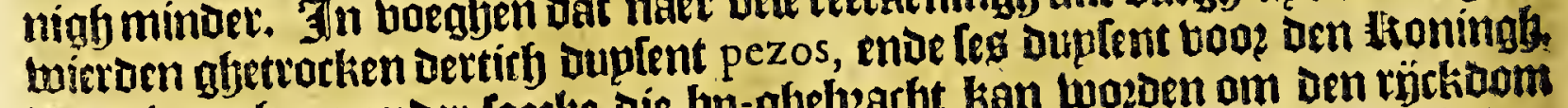

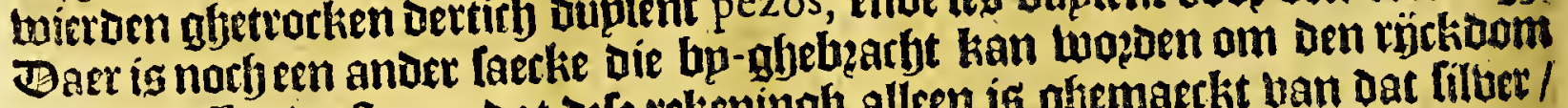
ban Porofli te bertaen; Dat orfe rekeningly alleen is gfemaeckt ban dat filber/

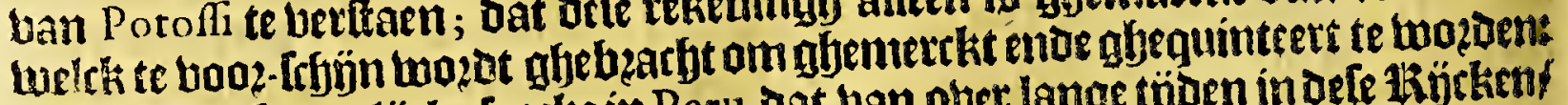
mefenoe een kennelijeke faecke in Peru, dat ban ober lange tijoen in defe liöcken

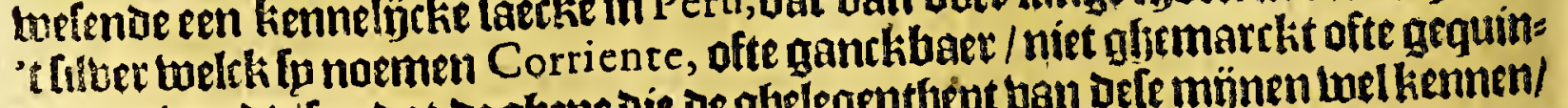

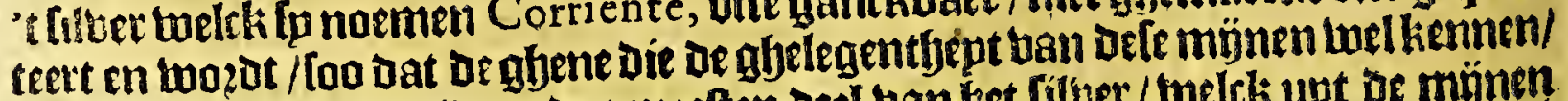

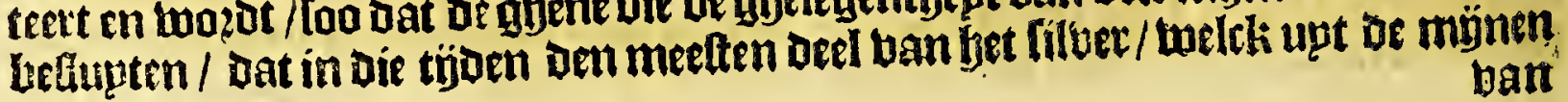




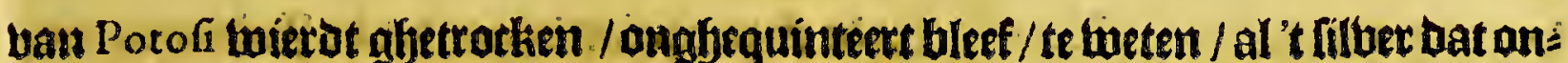

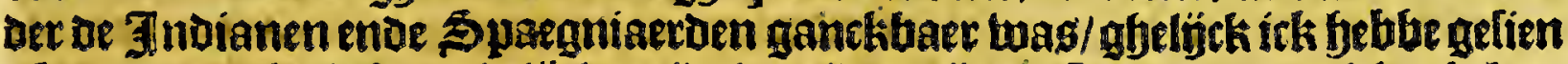

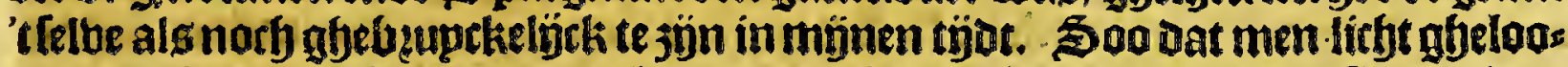
uen magh/Dat wel een deroe ieel / enoemoghelíck toel de helft ban't filuer niet te Loo:-Srginn en loozot ghebzarbt ofte gbequinteert.

Jaer is nocly een amber aen merckinghe/ Dat Plinius betbaelt ban de mÿne van

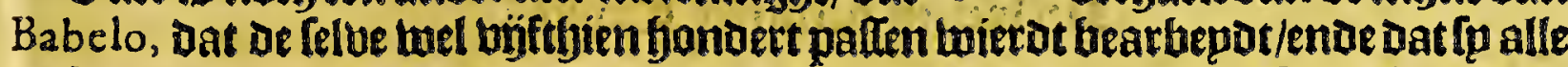

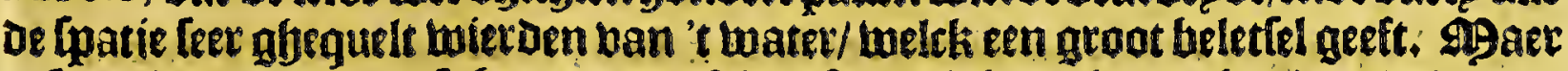

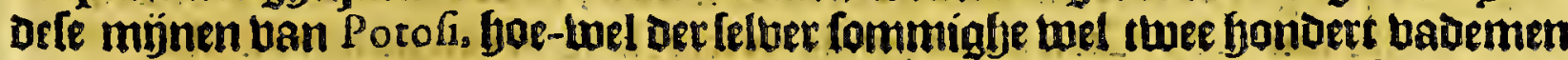
diep fomen te gaen/ en feuben nopt water berriomen / welck bet grootlte gheluck

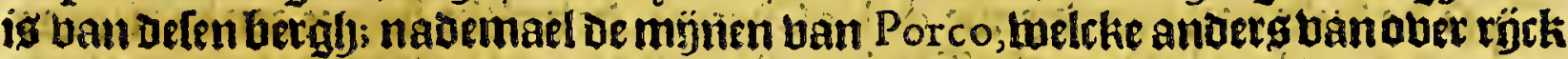
metael jün / geden-daeggg twogenn naer-ghelaten te graben / oogę Get ongemack

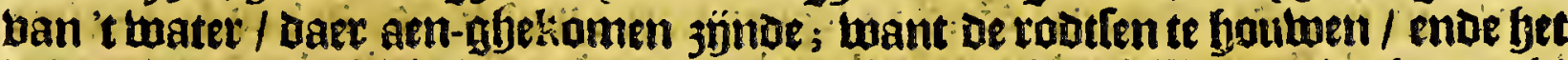

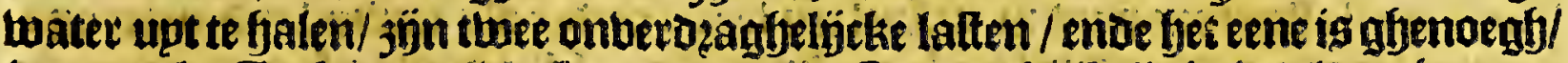

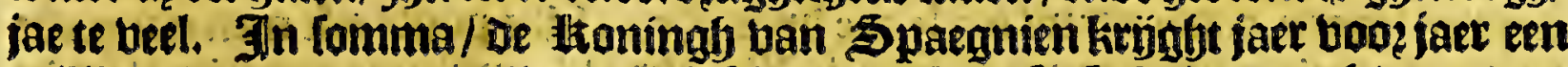
millioen ban de quintos alleen ban't filber van Potofi, befalben noth oe andere rijckbommen ban fet quic-filber/ende andere in-komlen ban bes lentughs tollen/twelek neoe een grooten rijetioom is. Soo dat de teeckeninghe ghemaeckt

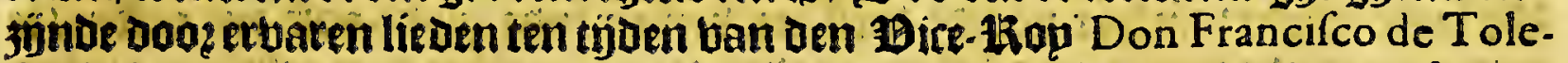
do, is betonden bat tot den jare 1574 Daer te Potofi twaren ghequinteert feg-enfeventicf millioenen; ende fints die týd tot in deviare 1585 inclups/mozot be deg

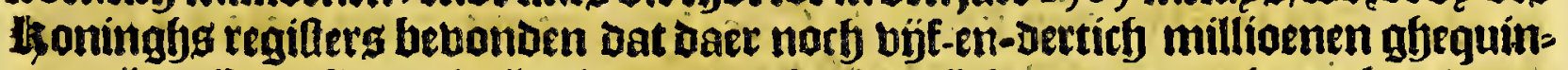

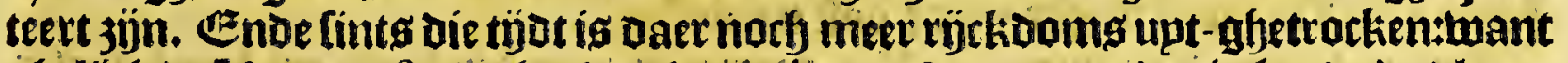
glyelijck de telue A cofta berbaelot / índenfare 1587 quamender in bepoe de bloten ban Peru entie Mexico elf millioenen/ waer ban bu-naer oe fyelft den lioningh toe-quam/ enae be twee deroen waren bel upt Peru gbetiomen. Bap fouden biex upt A cofta bp-boeghen de maniere ban t filbet te gearbepoen / Dan om niet te loopen bupten of limiten ban ons pyopoolt / foo fullen wp den le fer bercenden Acofta tot Acofta felfs.

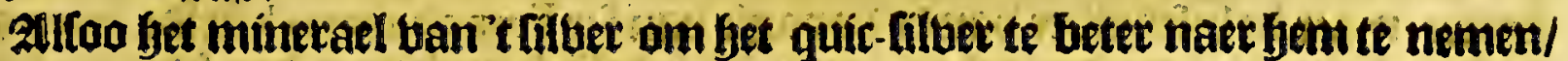

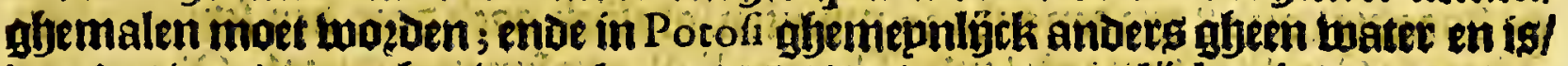

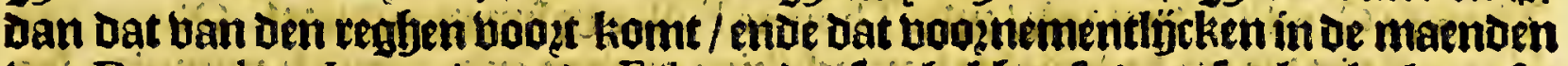
van December, Ianuarius ende Februarius, too behben Ip daer feecker lacken ofte

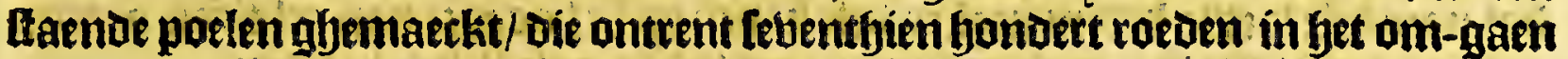

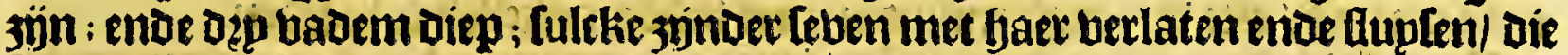

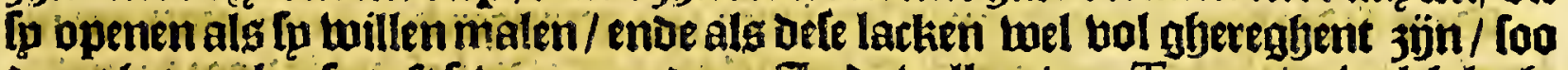

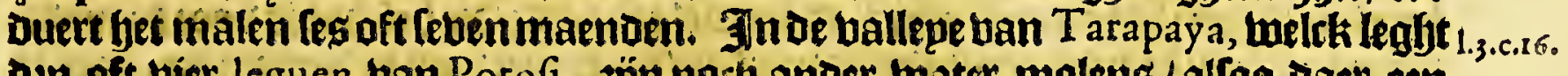
bep oft vier léguen ban Potof, jün nortj ander twater-molens / alfoo daer een riebiete Dode-1oopt. 2len't epnoe ban defe ballepe feeft men eenlack/ foo rondt oft

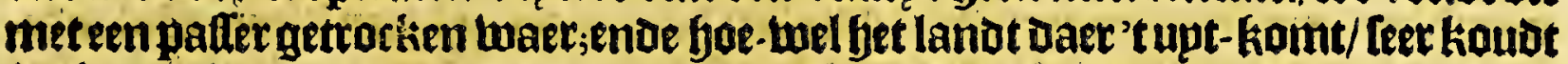

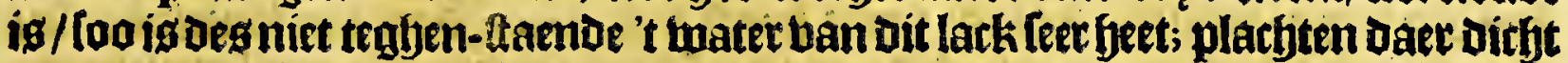
aen bekanten te baden / want komende wat meer naer't midoen toe is de bitte

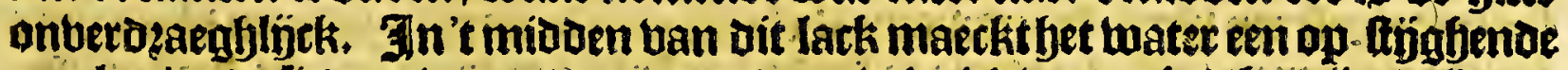
meulen/enoe fiedent twatec / ban meer ban thintich boeten in't begejp / allibaet ben oozlpzonafjende op-komite ban't lelbe lack is ente fjoe-twel fpn op-komite too groot is / foo en fiet men nochtands't lelbe lack nimmermer bermeetoeren/ ofte berminoeten / joe-wel men daet een ranael beeft upt-gbetrocken/om leecker wa: ter-moleng tot Get ftampen ban't filber te boen gaen.

Ses leguen ban de taatende mijnen vai Potof, op den twegb naer be faben ban A rica toe/ is ghelegen Den bergh Porco met oe vermaerdefilver-mijnen/twee leguen ban 't klepne lack / welck fonoemen des Aulagas ofte Paria, twelkk is een oude ghelegentthept van lilver-mijnen die bp de thoninghen ban Peru ban ouden tjoen jijn onder-graben/ ende upt de lélbe boude men booz leker gejaelt te toeten 
420

Peru.

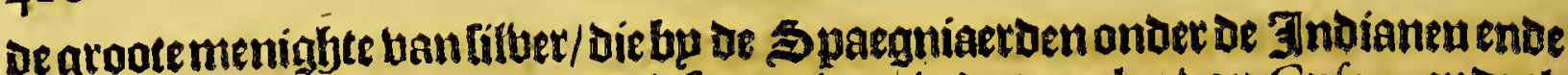
in oe fegatten ban de Ingas, ende inlonoerbept in oe templen ban Curco, ende ele

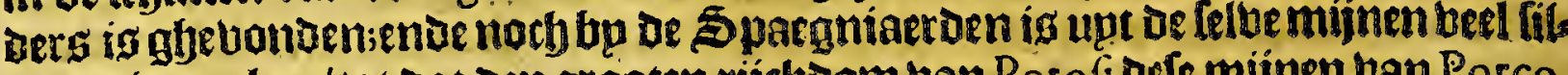
bers ghenrorken/tot dat oen grooten rijckidom van Potofi Defe mijnen ban Porco, ghelijch betouplett feefe / ende minder Doen achtem.

\section{(3et vier-en-Dertichlte Capittel.}

Befchrijvinghe van de havenen, reeden, kaben, ende rievieren op de zeekuftevan IOS CHÁRCAS, ende deftréckinghe van de felve kufte.

$\mathrm{O}^{\mathrm{s}}$ De liulte ban de audientie de los Charcas, de welcke begint aen oe riebiete.

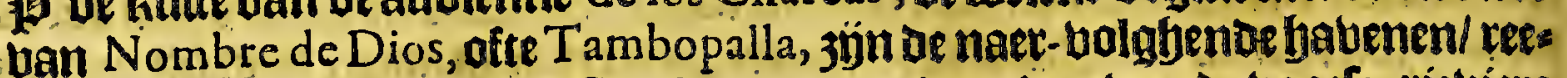
oen/ punten enae riebieren: Eertt I l leguen naer't jupden ban de boos [3. riebiere Tambopall a teett eenpunt in jee/wel een le gue beroer alg tander land; waer op 3 Llippen leggen; ende ontrent etn legue by zupaen't felloe punt beeft inen een goede baben/ oe melcke men noemt l'uerto de Y lo, ofte Hilo, neffeng een riebiere/ op ae boogfte van 8 graden ende 3 o minuten; ofte 20 mimuten/ghelíck als Pedro de Cieça die Relt dan bolobeng [pn epgben reeckeningh/kan maet i 8 graden balen.

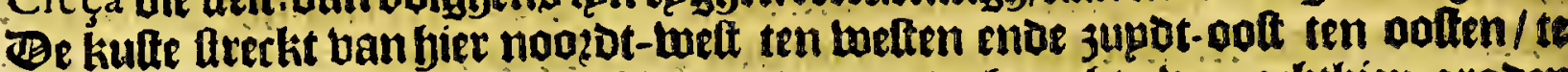

Jagic. Leten van de booghte ban arbtfien graden tot we boogbte van atjtbien graden ende oertich minuten bp jupden de linie/ naer 't fegagen enoe bevindinghe ban

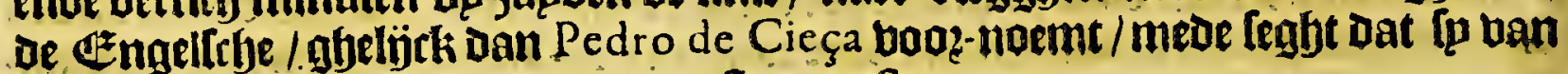
Puerto de Ylo boazt Atreckt 3upat-onft ten ooften.

Seben leguen van Puerto de Ylo, meer naer 't jupuen leght een berab toelck De Spaegniaeroen noemen El Morro de los Diabolos; welck is een ronden feus

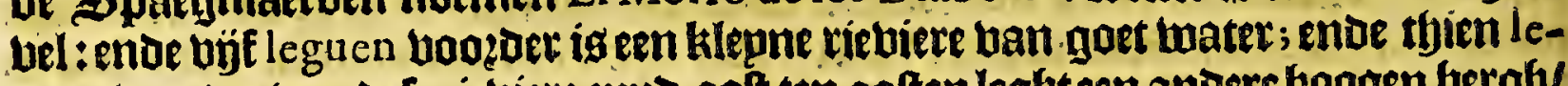
guen boozaer ban Deleriebiere 3upa-oaft ten ooften legbteen andere boogen bergb/ ende daer tegen obereen eplanot; entoe daer bu leght de baben ban Arica op de fooghte ban I a araden ende 20 minuten/alg Herrera endoe Pedro de Cieça jie Itellen; maer of betchejuer ban de vopagie ban Sir Francis Draeck ftelot Arica op

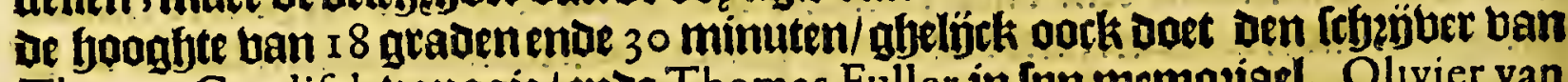
Thomas Candifeh uopagie/ mae Thomas Fuller in Ipn memoziael. Olivier van Noore telot die op de boogbte van aththien graden ende beettich minuten; fou Dat naer oele laette bebindingfyen oele baben op oe fooghte ban achthien graden

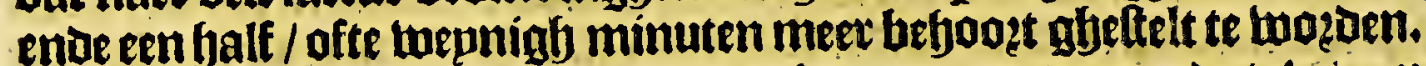

Be onle die daer gelweef jün in denjare I 599 getupgen dat A rica maer een int

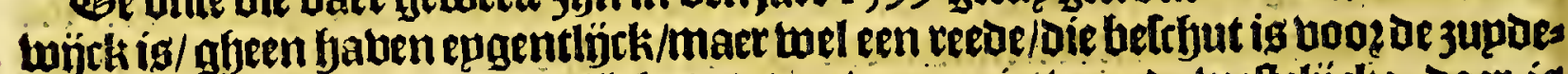

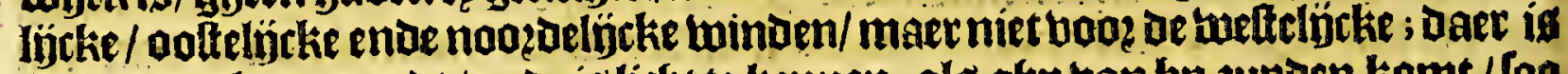

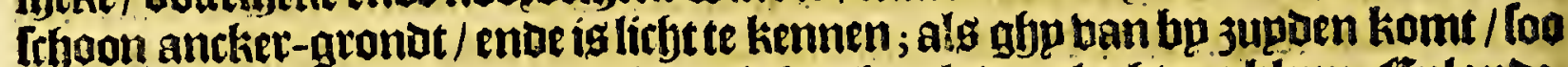
openbaet bem eenen boogen witactjtigben foectidaer leght een klepn Geplande ken ofte klippe oirgt bp : dit ig de zupot boect ban Arica, daer om-komende / liek

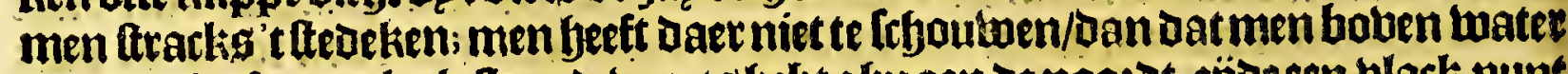

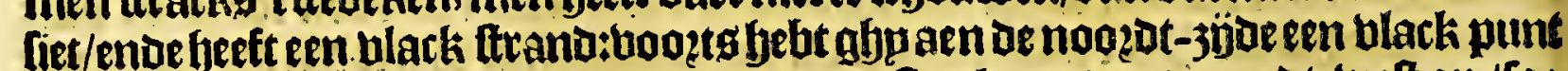

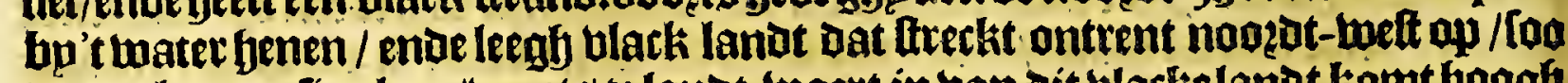
uerte als men fien kan/vooets te landot-waett in ban dit blackelandt komt boanf lanot/enae is feer kennelíck: [p waren met de lloep dicht onder A rica, ende fagen

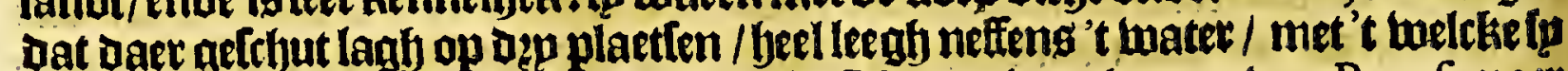
leet betre konden toe-keptken. Be plaetfe eñ haben is 70 leguen van Potofi, naet Dat Acofta ghetupght. Sir Francis Draeck tuelende in De jupdot-jee/quammet lpn

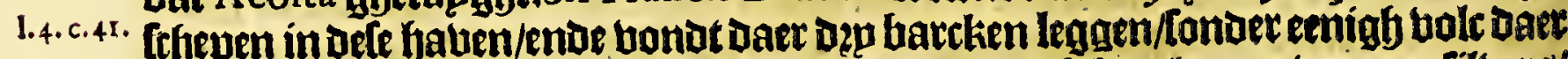

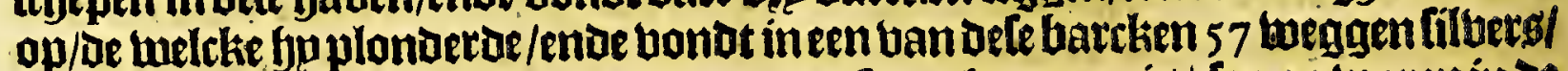
die elck ontrent of 20 ponot woegfen; naer lpn gffetupgenis / Loo en twaren in be Itadt maer twintich buplen; Dan andere leggfen dat daec bel bondert buplen 


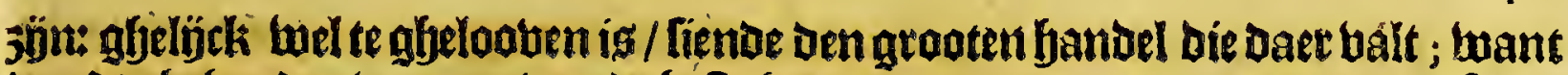

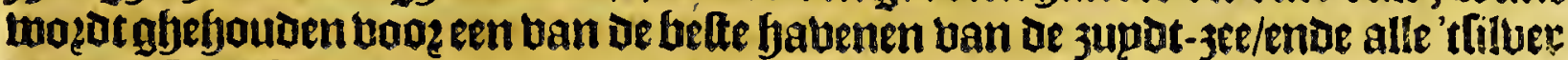

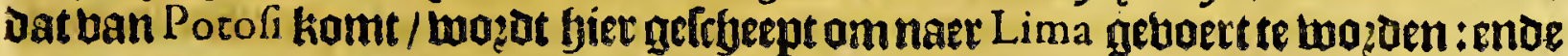
alle ae koopmanfryappen toogden fier ontladen om aber lande naer Potofi, ende die abetwelten aljebzacht te wozon.

1Ban Arica logpt de kulte (naer'tleggen ban Pedro de Cieça) 3upt-3upt-wedt g leguen, alwaet een riebiere in zee loopt/ die fo noemen Pizagua. De onfe die fiet

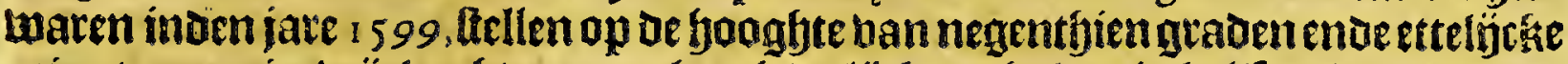

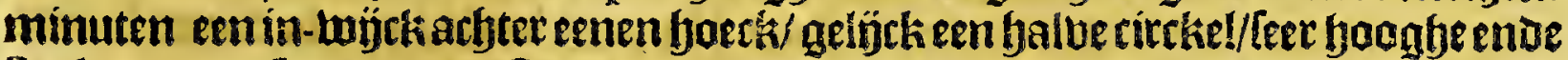
Ateple grandt/[onoer boet-ftrandtense ontrent de thintich graden/een daepken welck ly noemen Hickahick; twaer al do? lamot ontrent is met toepnigh groente; ende foo voosts op de thinticf graden ende uertyien minuten/al [eer hoogh lanot

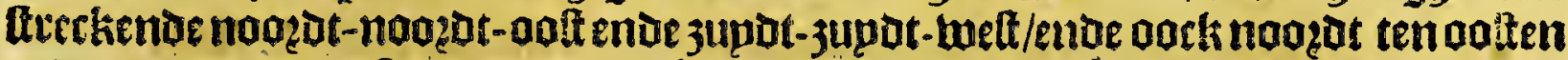

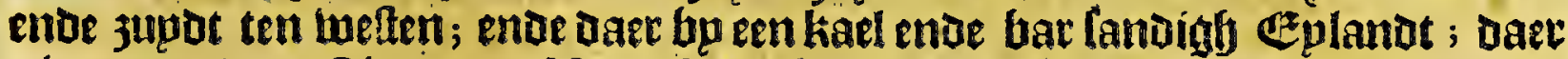
niets open twas. Olivier van Noort Itelt Pizagua op thintichgraden. 19an Pizagua rekent inen tot de faben ban Tarapaca, op de felve kaurs/bijf-en-thinticfy leguen; ontrent Defebabenleght een efpland ontrenten legue groot / ander-balf legue uan'tuafte lantot/ weick een bapemaeckt baer be haben is ghelegen/op de googfte ban een-en-twinticf graden bp zupben ae línie.

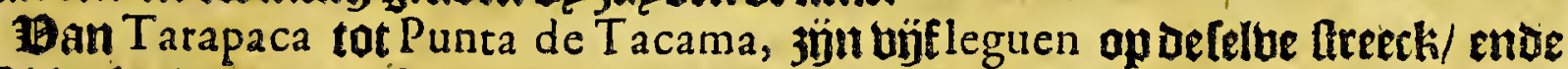
reatbien leguen bozoer Puerto de los Moxillones, op de fooghte uan twee-en-twin=

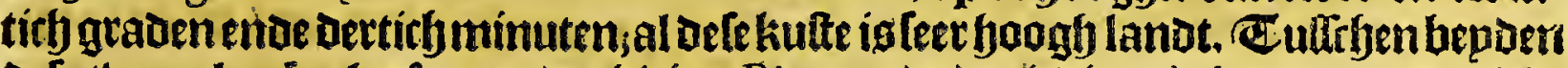
dele thee plaetlen beeft men de riebiere Pica; ende de riebiete. de la Hoy a; de weicke Olivier van Noort, noemt Rio de Loa, ende feltre op de hooghte luan twee-en-

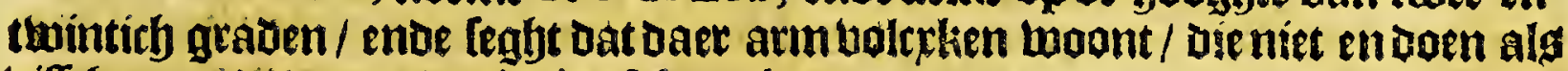
vifletjen; ende boottg de rieviere Montelo.

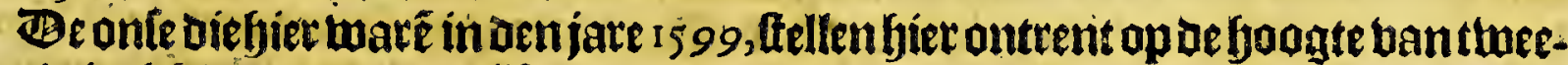

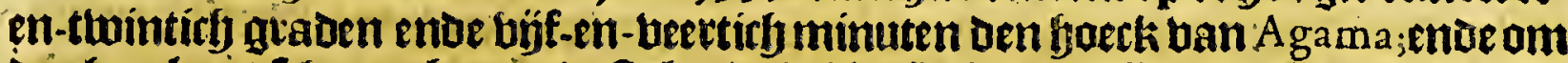

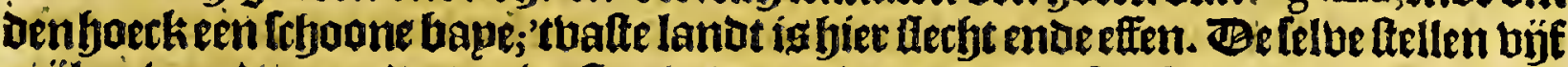
mỉlen boozoer jupdt ten welten ende jupdt-jupdt-melt Morro Moreno, daet

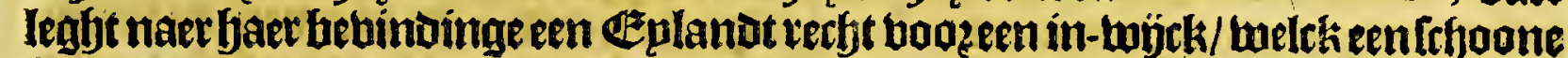
baben maeckt/belloten ente befehut boof alle toinden/ende is diep in't in-komen ban bp zupden büf-en-thintich vadem gaede gront; daer tuel ro fifhepen mogen in leggen;ende is goet om in te jeplen/Doos dien Daer niet te mïهen en ig/als'tgene menliet; dan daer en is noch bertch water norbyout te bekomen/ want't igeen bar ende onbzucfthaet lanot. De [e Morro Moreno twozot oock ghenaemt Punta dc los Farallones: Candich in [pin topagie/enoe Fuller in fonmemogiael/als oock Olivier van Noort, ftellen die op de booghte van dęu-en-twintich graden ende Dertich minuten/enoe legghen dat fet een goede baben ig; daer Ieght een Eplanot

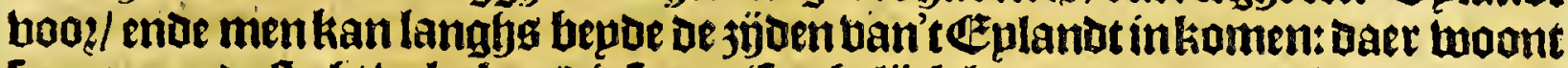

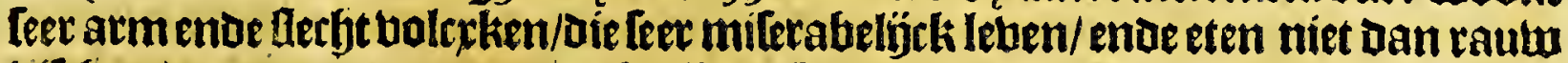
bileffende mosten baer ban nocf tribupt betalen aen oe Spaegniaerden/boos de

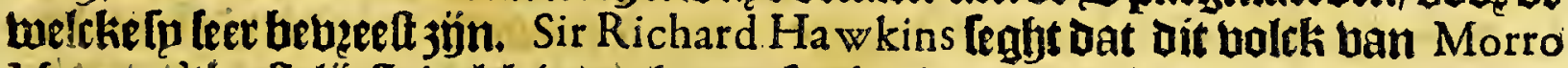

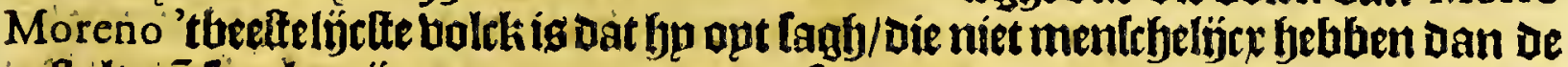

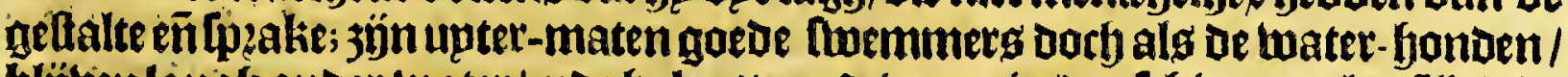

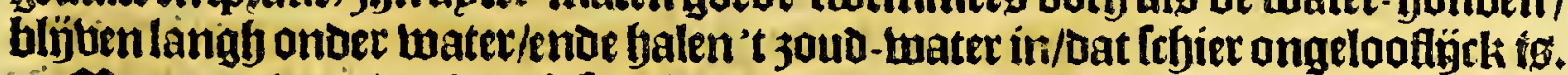

OSeer naer't zupden/naer't legghen ban Herrera, Ieght la $Q$ uebrada, ende Punta Blanca ende Quebrada Honda; ende de riebiete Santa Clara, wellt is oertich leguen ban Copiapo, daer ofle kulte epnoigft/ende die ban Chile begint.

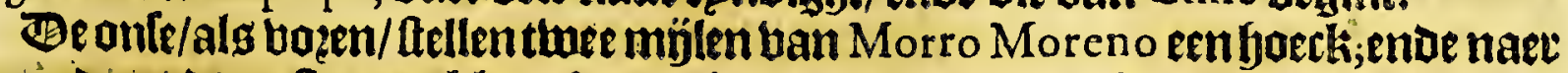
't slipb-jupdt- ooften een klepn babentien daer dęp ofte bier frbepen fouden kamen

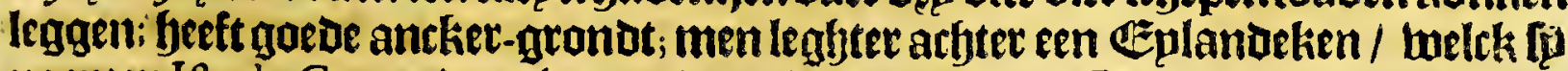
noemen Ina de Guana; daer is I 5 ende 16 ladem diepte/ cñ Daet legt jout foogh in

$$
\text { (1) } 3 \text { 'tlands }
$$




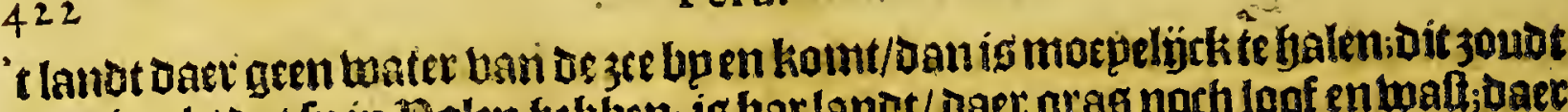

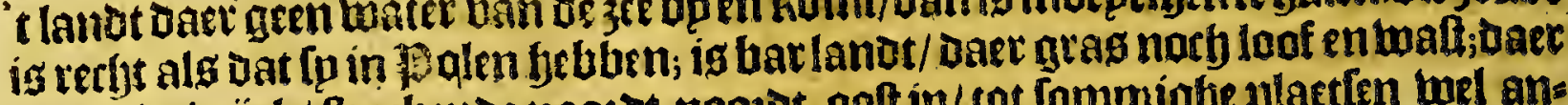

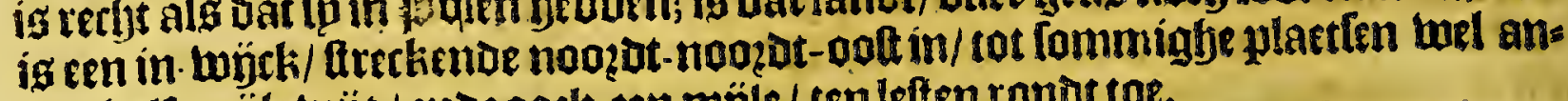
Der- $\mathfrak{y}$ alf mỉle wö́t / ende oock een müle / cenleften rondt roe.

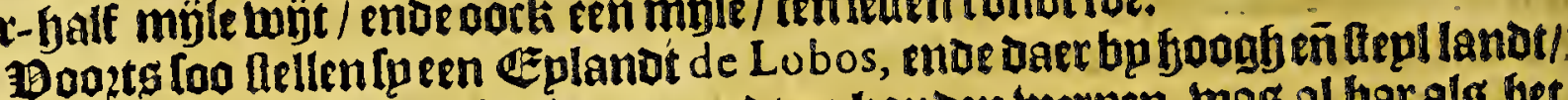
fonoer boet-arandt/ Dakr fo gheen gronot en konden tuerpen; was al bar als bet vooz-gaende; noemenbier een boerk tan Michel Diaz, ende dęp leguen boozoer Cabo de Lopez: ende ghedenthen Dat 't landt boots tot Chile toe/ een barre ron:

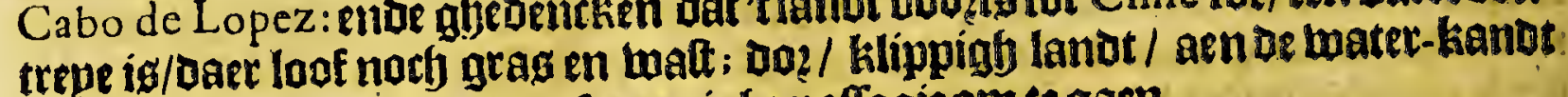
tepl/ / fonder boedt-thandt / ofte eenighe paftagie om te gaen.

Het büf-en-Dertichte Capittel.

Befchrijvinghe van de binnen-landefche provincie, cnde de ftade SA T A CRUZ DE LA SIER RA.

$\mathrm{O}$

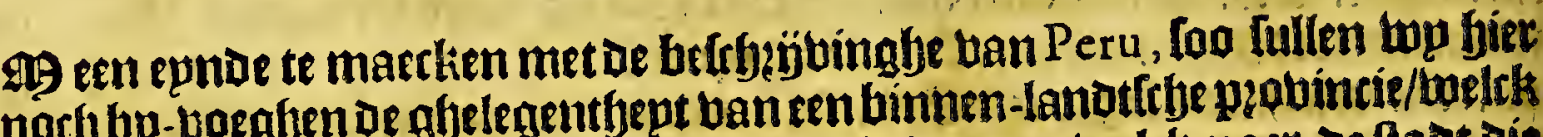
noch bp- voeghen de glyelegenthept ban een binnen-Lanottelye pzobincie/belcts aen ofle landen ban Peru bozot ghereeckent te befjoozen; welck naer de thad die

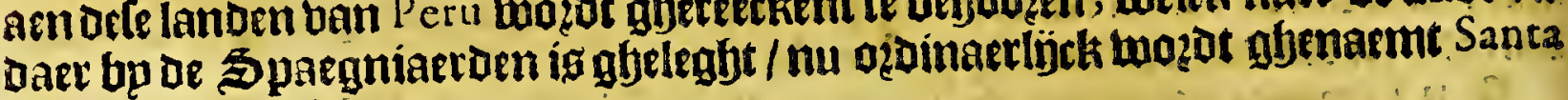
Cruz de la Sierra.

Defe ftaot Santa Cruz de la Sierra isgheleghen/ naer 't tegghen ban Herrera, yomoert leguen van de probincie de los Charcas, nae't oaften toe / in de wegb welck men neemt ban de Charcas, naer de fadt Affumcion, in de płobincie ban Rio de la Plata ; tultryen Luelcke men reeckent / naer Dess felfs Tegghjen 300 leguen

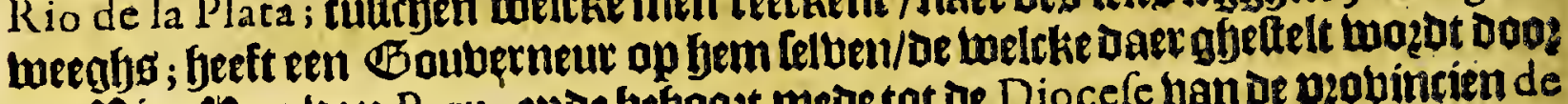
aen Bice-1hop van Peru, ende befjoot mede tot de Diocefe yan de pzobincien de

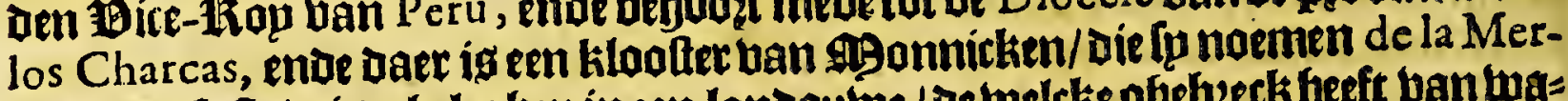

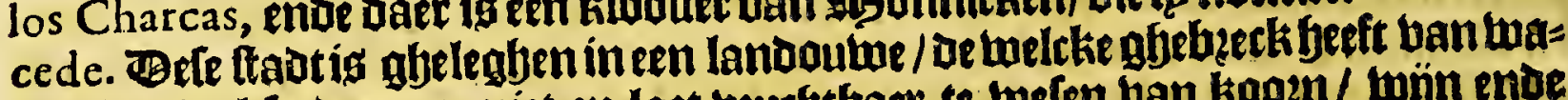
tev/ boe-bel fo daerom niet en laet beuchtbaex te toelen ban koodn/ wän ente Maiz. Be ftadt ís ghetrout aen de boed ban 't gbebergbte / op een black belot: ende ban daer bogztg beginnen de bergharltighe ende dzogbe plapnen ; de bupten zön ten Deele ghedeckt met bladeren uan be palm-boomen. Heft een beke/ welck boot-komt unt [eeckere rodten / ende loopt ineen lark / welck bier leguen ban

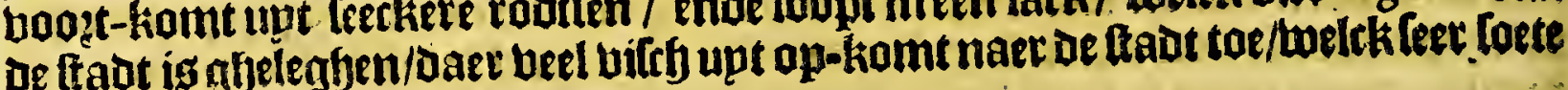
enoe Imaeckelỉetke bilfb is.

- Bart baften veel buthten wan die landen/gelijtk Daer jön Plazanos, Guayabas Pinnas ende Granadillas; A mbabayas, Luiumas, Tucumay, welcke alle feer goedel

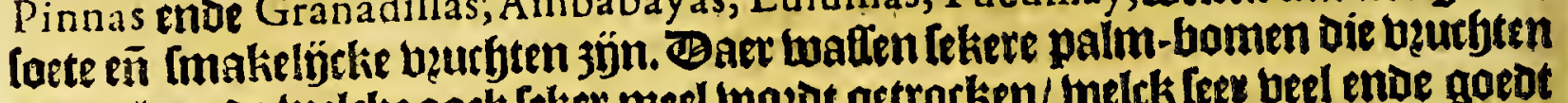
geuen/Lan de welcke oockleker meel wozbt getrotken/ belck leet beel ende goedt

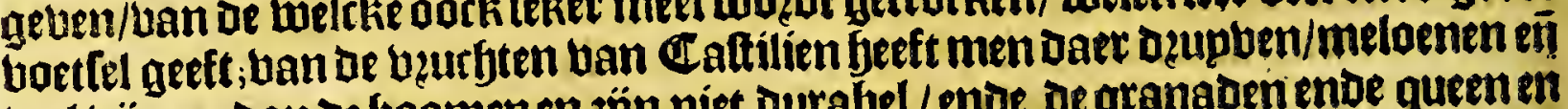
beel búgen; dan de boomenen zún niet durabel / enoe de granaden ende queen en willen daer niet wel mafien; norf oock 't koozn/yor-wol men gelooft dat bet beter foube tuallen in'tlandt ban de Chiquitos, (welck een geveelte is ban defe plobins

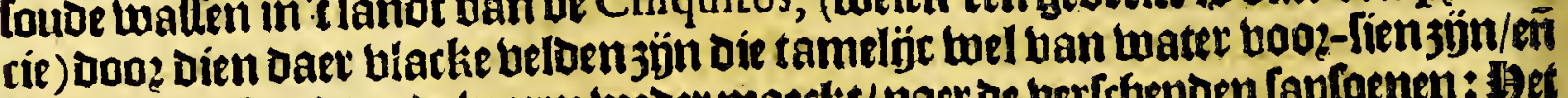

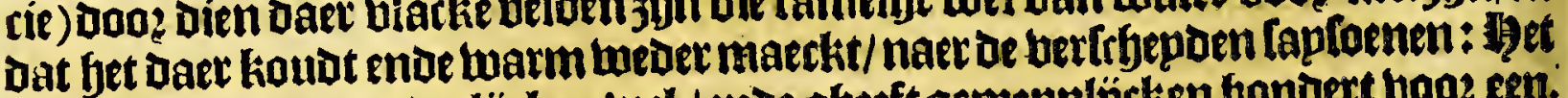

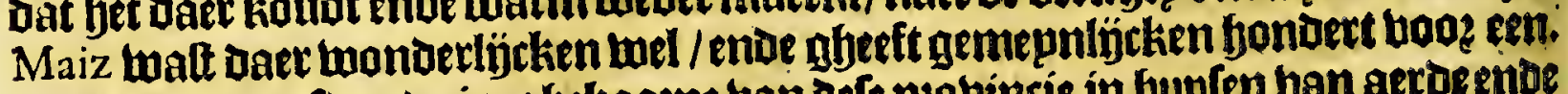

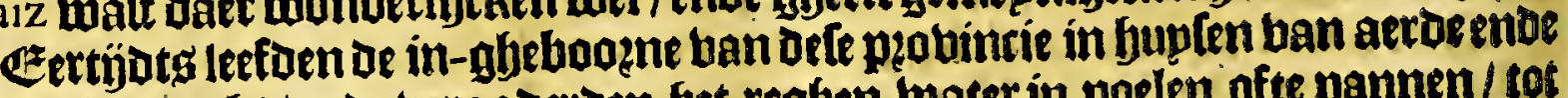
flück gbemaeckt /endo bergaderoen fet reghen-water ín poelen ofte pammen/ tos

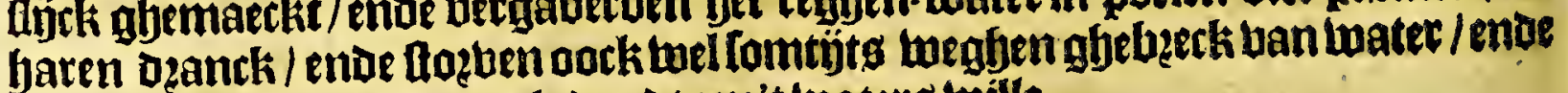
loeghen malkanderen oock Doodt om't waters wille.

Bete 3ndianen wierden feet gyequelt ende berbolght ban een ander natie ban Indianeu / welck lp noemen Cheriguanaes, twelcke baet gúebueren toaren; ghes

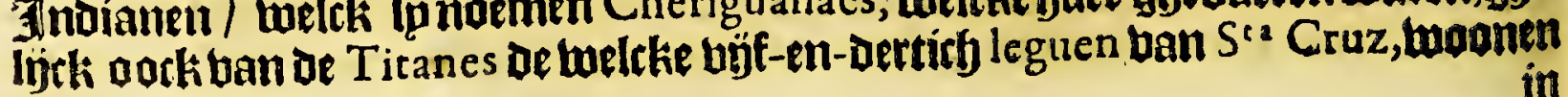




$$
\text { Het thiende Boeck. }
$$

in em goede enue butlotbare lansoulue. Fn dit lanot ban de Titanes binot men mïnen van koper / loot enoe ooch filluet.

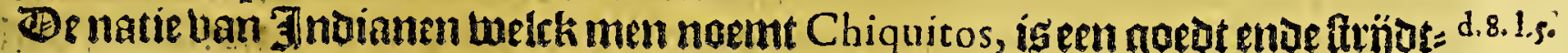
Laer bolck / endae arbeuotraem ; fp bergaderen beel Maiz, boontjens ende andere e.ro.r. Diregfelijtke beutbten/ende berlamelen oock beel cottoen; baer bequtuen gaen ge=

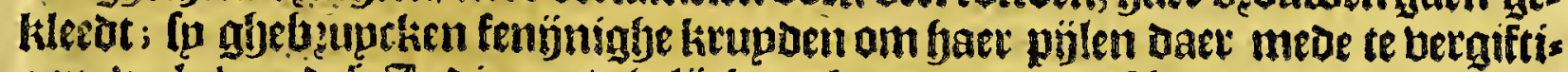
gen; beele ban ofle 3 ndianen/ghelïcti oock mede ban oe Cheriguanaes, zün met goetbept daet toe gebarfjt/ Datfe ontrent oe ftadt Santa Cruz haec bebben komen

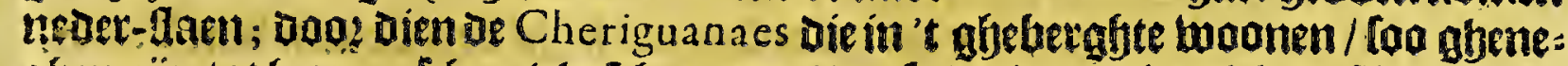

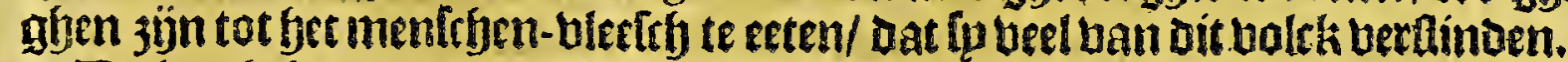

Be in-gjehooene van de lantoen ontrent Santa Cruz,en beblaen niet alleen beel cottoens/maet febben oocli beel bertwen Daer fu de cottoen meis bertwen/als

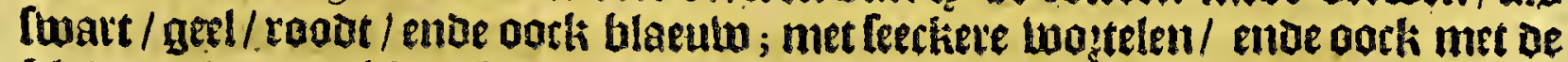
bladeren ban een klepn boomken/ welch th tweten te lieden ende te berepden/ende

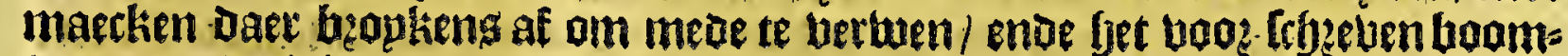
kell Duert veele jaeren.

A cofta in fun bieroe boecli banfon Hiftorie Naturael ende Morael, in 't dertoe

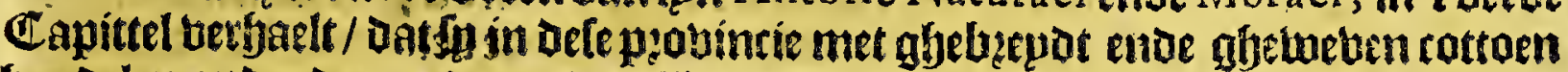
Gandelen onder den anderen / ahelijsk men elders doet met geluet.

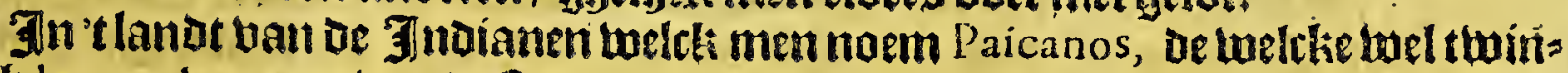
tith leguen twoonen ban de ftadt Santa Cruz de la Sierra, twallen fertierte calebat=

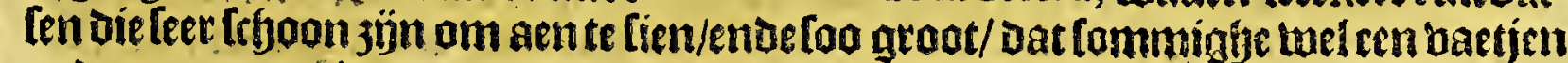
ende meer nats konnen bouden; In ghebupcken die voo kiften ofte kalten om

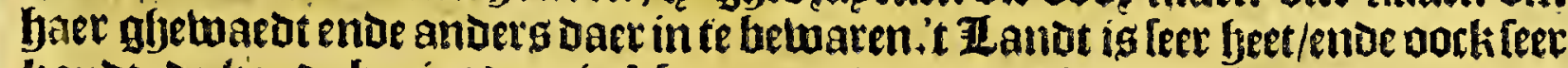
koubt; de foude begint daer in Mayo, ende duett tot't begin ban Auguftus, ende

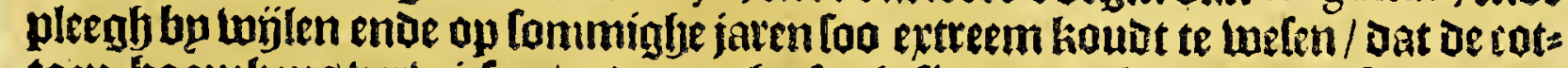
toen-boomkeng verugiefen / ende men beeft gbefien dat de boomen die fu noemen

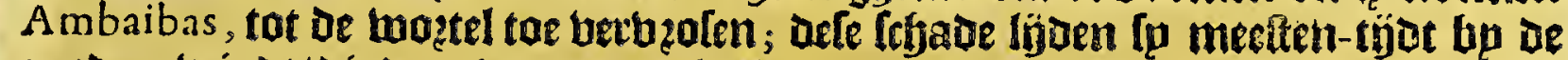
3!tuden-Luinot/ die daer twaept ban bale Iunius, tot let epnoe ban Iulius; De meefte bitte bebuen fo ontrent Kerfmis, 't 25 sgint daer feer te regbenen antrent $S^{2}$ Francifcus-Dagb; -yaeren peimcipalen jaep-tgot is ontrent alloer-beplighen / ende

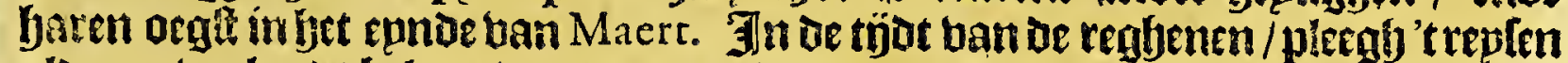
aldaer ohev lanot belet te twogen dos? bet op-wateten ban de richieren; ende $\mathrm{Dov}$

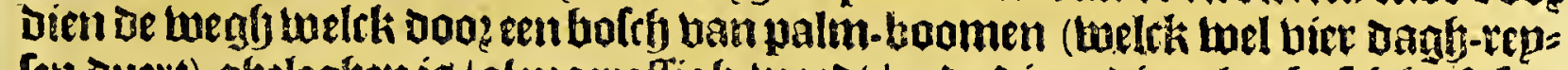

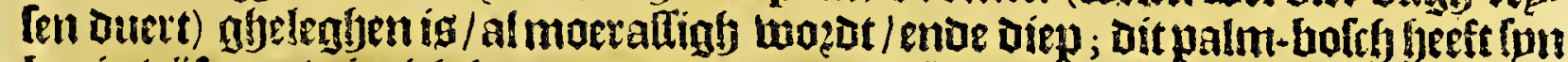
begin büf-en-thintiry leguen eet men aen de ltade Santa Cruz komt; ende ter contratie/ foo en luoget Dit lanot niet fiequamelïcken berept in oe maenot than

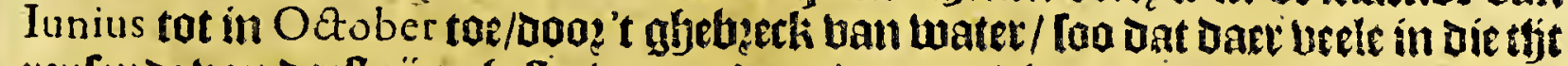

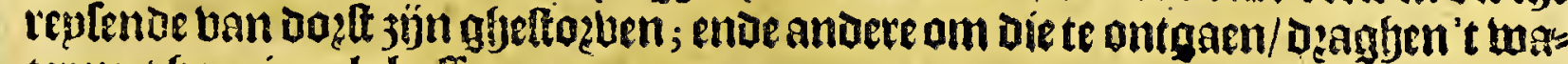
teimet fyart incalabaften.

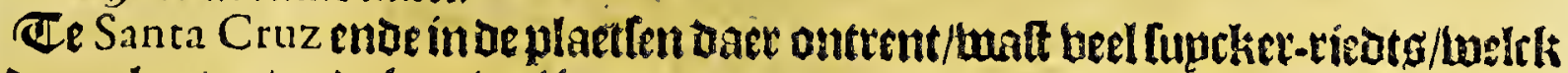
Ip Daet planten/ ende lian beel jaten Dueten; maecken daet goede [p?çe ban/ende bock uptet-maten goet tupetier. Jin cen dellinghe niet berre ban be ftadt/ is me= nighte ban filepn wilot; beel hoepen / twilbe berckeng; menighte bail peroginten/ parutuen / faifanten / papegaepen / ende ander albevogelte: daer jön beel frjilot-

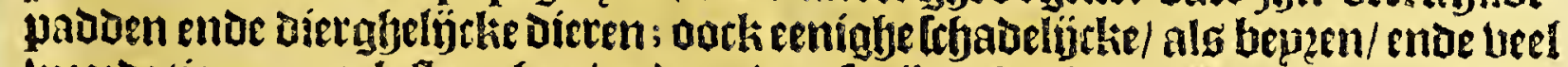

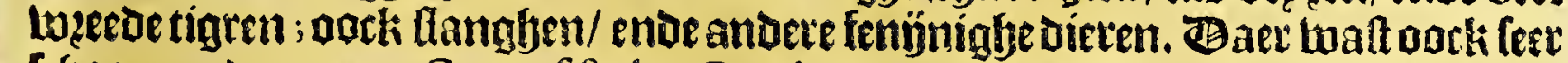
Iryoone ende groote Cannafiftola: Caroben in abumdantie; Guaiacan ende an: Dere nedicinate boomen.

Zllle't bolts han dele contrepen 3 j̈n nederigh ende dom/ende gantfif niet loog:

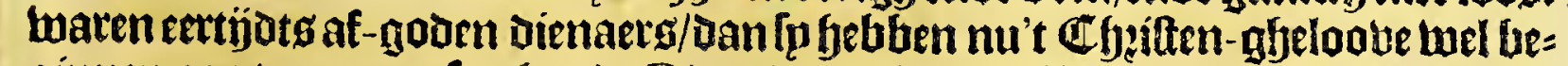
ginnen aen te nemen: [pleken de Diaguicen tale/ De tuelcke ghemepn onder haerlieden is/boe-wel funacb uier bulonoere epaben talen onoer baer-licorn belben: 
424

Peru.

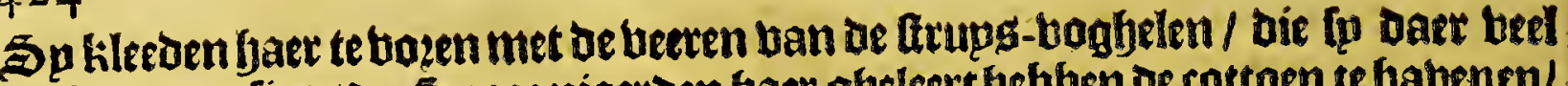
bebben; dan fints de Spaegniaeroen faet gheleert jebben de cottoen te babenen/

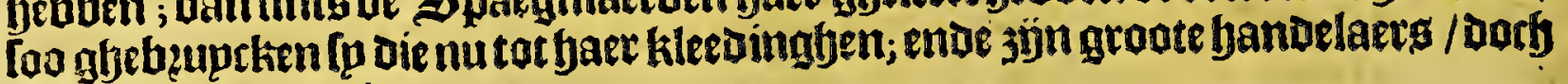
al bp manghelinghe.

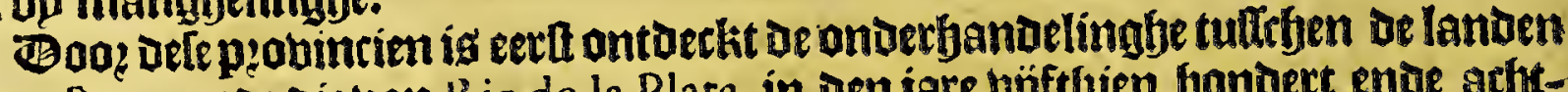
van Peru, enoe die van Rio de la Plata, in Den jare büfttjen bondert enoe achten-beertich / Doo? een Spatgniaetat met namen Nuflo de Chaves; 't bolck van die contrepen merat bp bem ghenaemt Taguamacis.

Bertity le guen yan oele ftadt naer bet ooften toe/ leght de peobincie ban Y tatin, daer beelmünen wazjen abebonoen bar divertebe metalen.

Dntrent Santa Cruz jün notb ennige andere plobincien ende balckeren glyelles ghen/ghelī̌rk alg uaer $3 \mathfrak{j n}$ de Chivichicocis, los Moxos, Cheriguanaes, Tipiones:

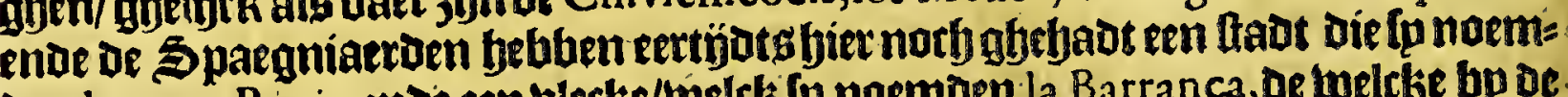
Den la nova Rivia,enoe een blecke/welck fu noemaen la Barranca, de toelcke bp oe. Fibilde van dat quartier/ende namentlinck de Cheriguanaes, gantich gbedeftrueers

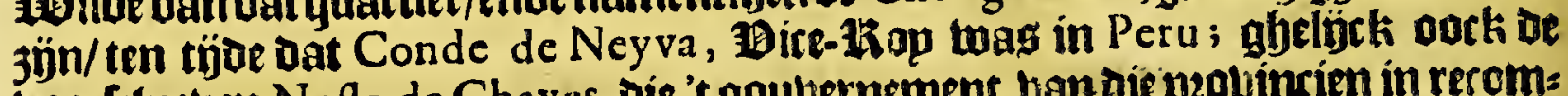
boo, frbeben Nuflo de Chaves, oie 't goubernement ban bif pzouincien in resom: pente vanfpnen dientt in't binden ban oelen wegh/gadot tiktamen; baneen Che-

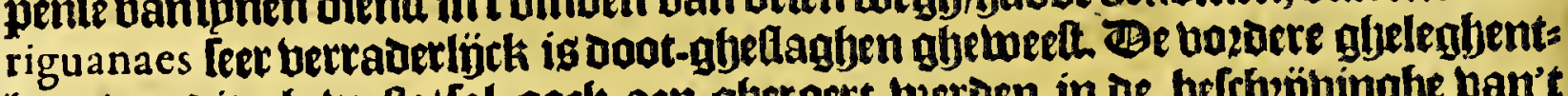
bept bandit ghetwelte/ Tal oock aen-gheroert werden in oe befrbejbinghe ban't goubernement ban Rio de la Plata, allo dele landen met oen anderen rontineten/ ende oe peonintien ban Santa Cruz de la Sierra een Doos-torft gljeben/ aen oe gbene die upt de peobintien aen oe Paraguay ende Parana gheleghen / willen naee Potofi ofte eenighe andere guartieten ban los Charcas.

BES CRHII-

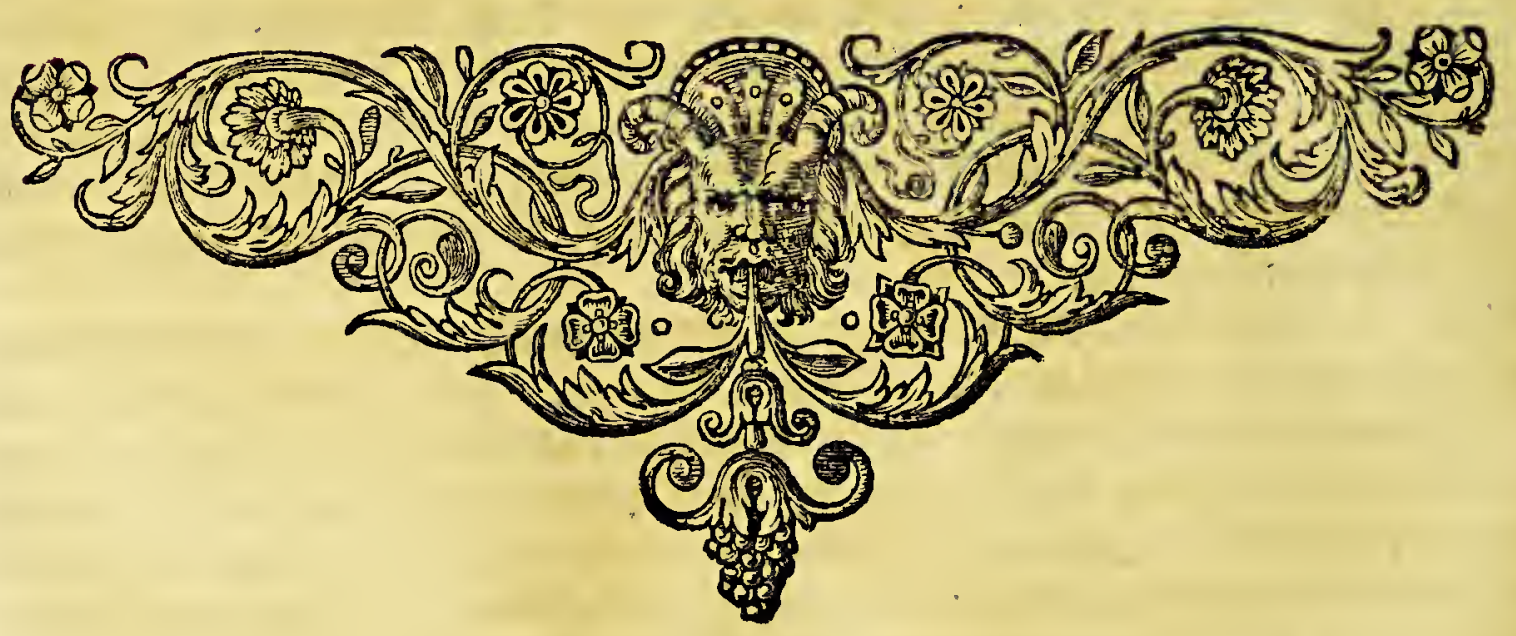


(10ax) 


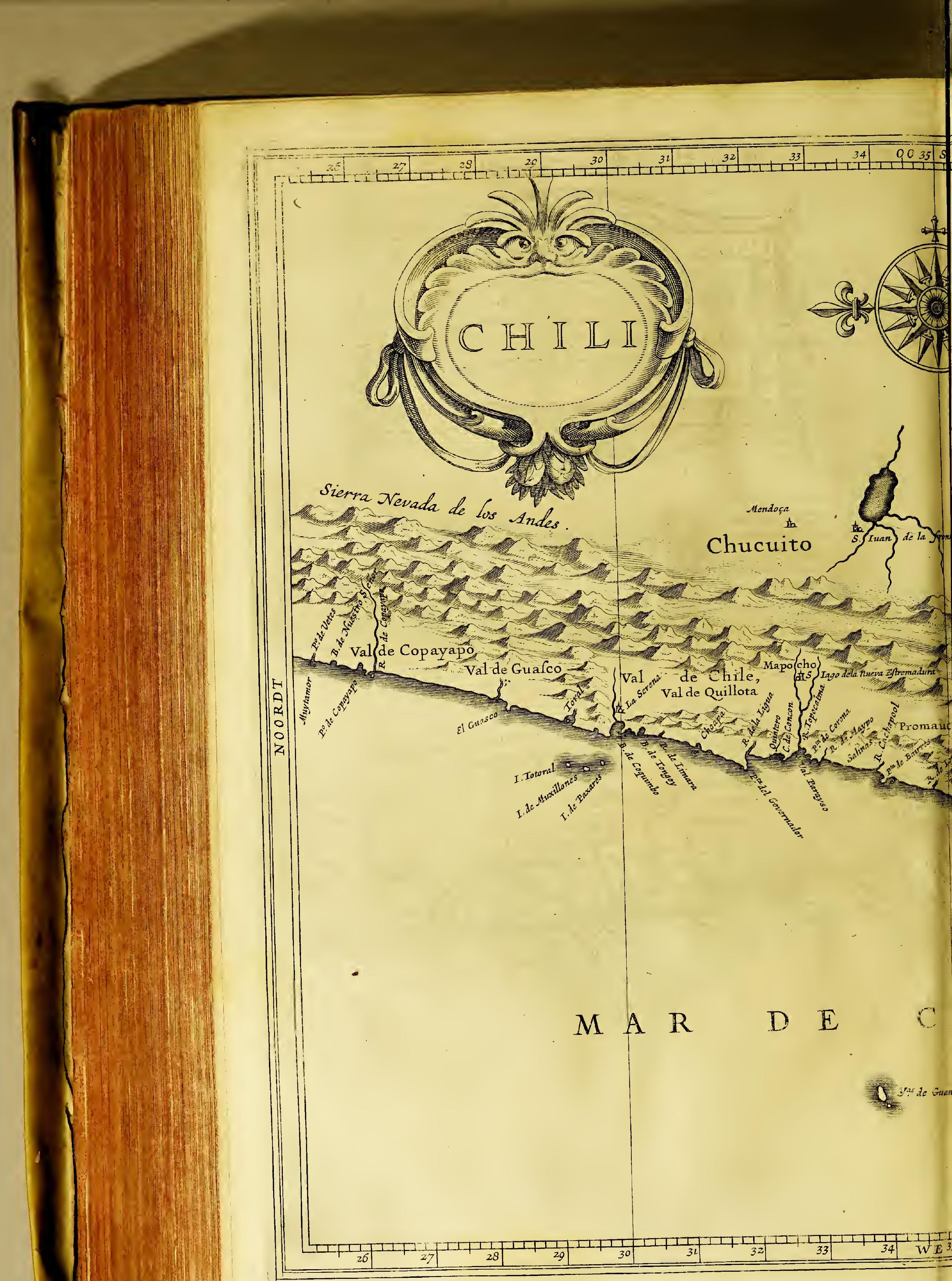




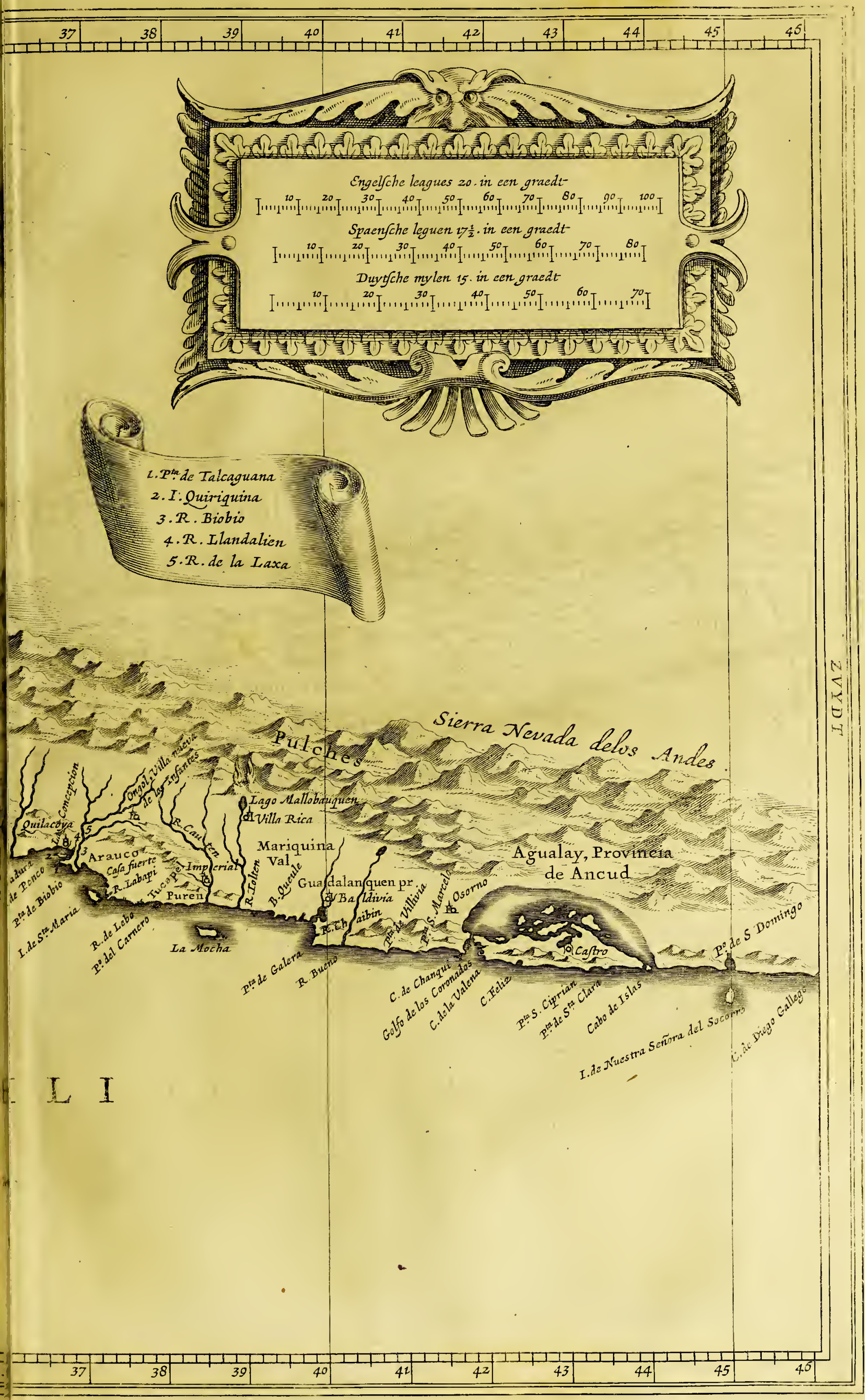


BES.CHR IIVINGHE

\section{alan}

\section{W E S T I N D I E N.}

Fet elfute Boech.

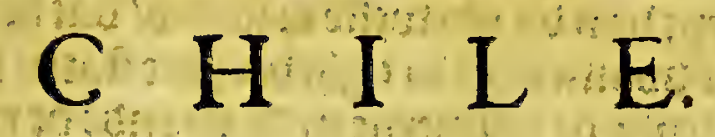

19et eetfe Capittel.

De generale befchrij vinghe van de provincie van $C_{H} I I E$.

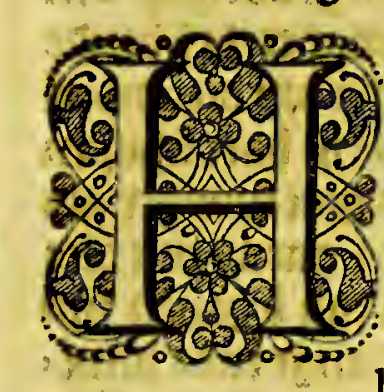

Et Goubernement van Chile, abtolutelijck glye: nomen/ftreckt fich (naer't leggen van Herrera) ban be upterfte

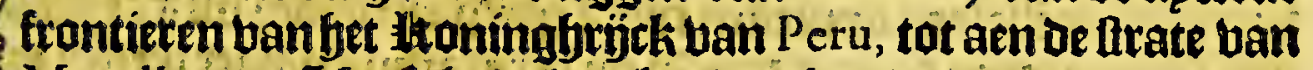
Magallanes, erif beeft in oe lengbte ban betnoozoen tot' $t$ 3upoen/ beginnende tan de ballepe ban Copiapo, twelck Iegbt op de fjooghoe van 26 graden bp jupden te línie equimartiael / 500

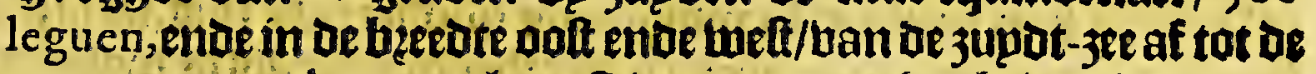
noozot $3 \mathrm{ke}$ toe/ ban 400 tot 500 leguen, almeelt lanot dat noth te bebetoigen ende

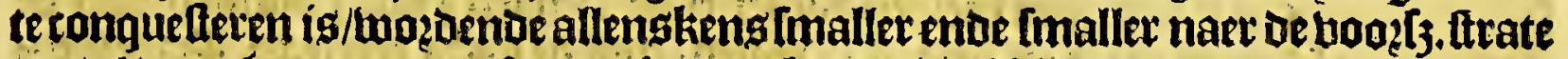

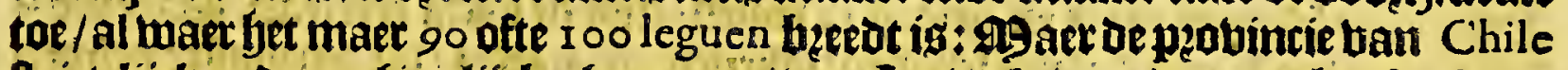

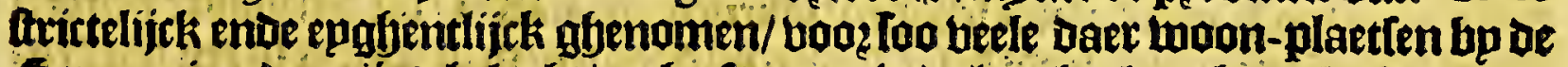

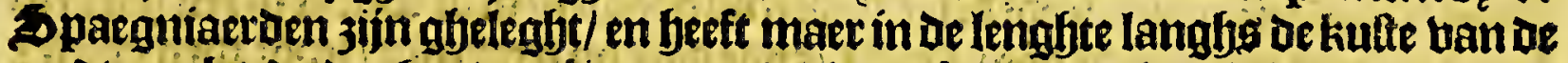

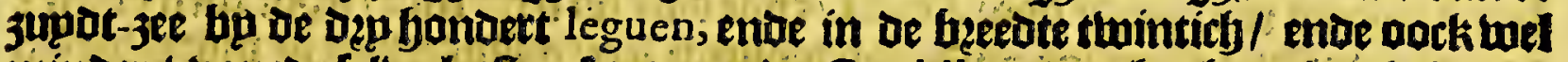
minoex / ban de feltue liufte af tot aen oe Cordillera ban bet fooghe ghebergb:

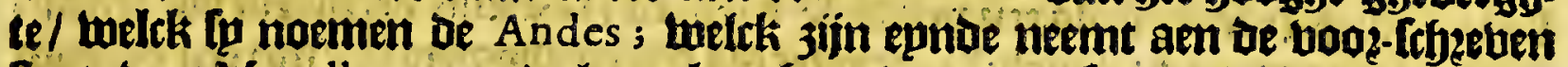
trate ban Magallanes, enoe loopt langfós ende oooz defe pyobincie ban Chile, leet hoogh/ende bp-naer altijots met beel fneeutus beoeckt. Auguftin de Za-

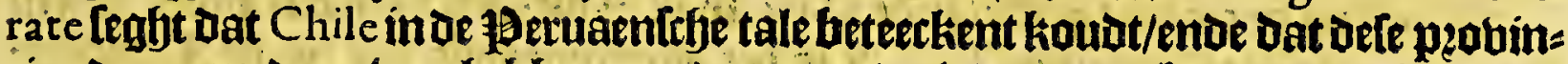
rien oe naem Daer ban beblen om dat men berwaerts treckt booz een feer kous of twegf.

Tet lanot ban Chile if meelt black / iminers [onder merckelijcke fjooghte/ uptobenamen daer't gebergfte van Peru af-komenoe/ welck [p noemen la Serrania, Dooz palleert; twelcli bier maer 2 ende 3 leguen ban be jee-kufte en loopt:eñ op Lom: mige plaetlen oock tuel tot aen de 3 er toe. De temperatuere ban De lutht/ooog dien dit lanot gelegen is bupten den Tropicus Capricorni, is that berfefepden/naer oe verlchepder fjoughten ban ben Polus Antarcticus; ende alloo 't gelegenis bu naet op oe telbe fjooghte van oen zupot-pool/gbelijek als Spaegnien ghelegen is van

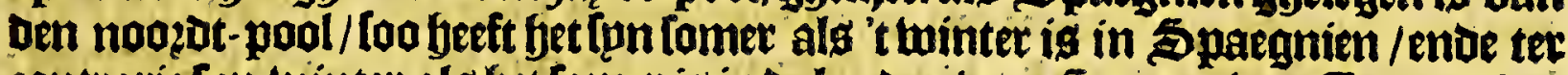
rontracie tun minter als het tomer is in de lanteri ban Spaegnien: In boeghen

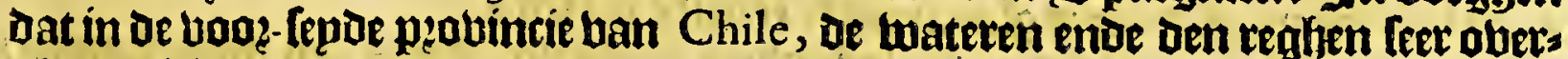
bloedelijchen met de koude aen-komen/ ten tijoe dat de fon ban dele quartieren hegint af te twijclien/'t twelck gljelthiest ban bet errlte ban A pril, tot upt-gaenoe September; ente de warmte ende deoghten komen lweore / waineer of tonne baet Leder homt te genaecken. Bpt welcke ooslaecke' t telue lanot / foo wel in be

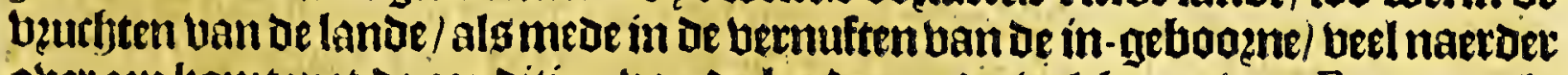
ober cen fiom inet de ronditien ban de landen ende bolekeren ban Europa, ald

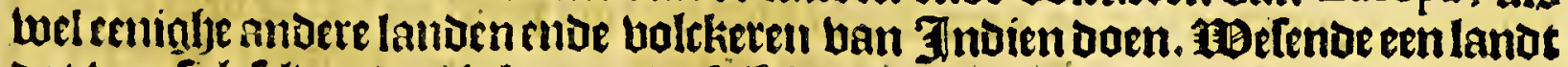

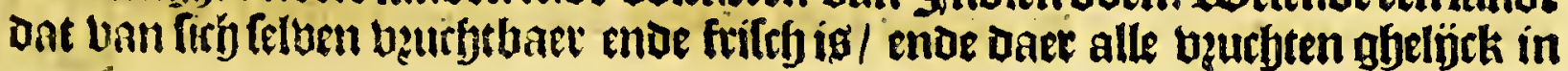


426

Chile.

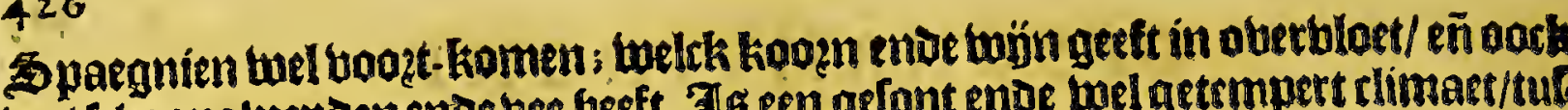

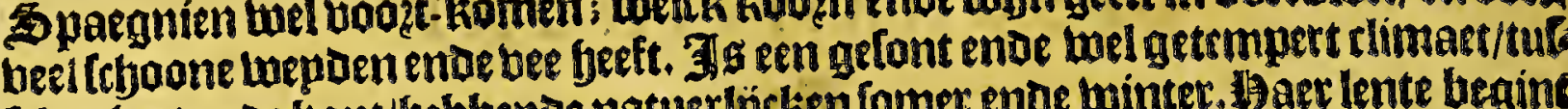
Ifyenlyet enDe kaus/bebbenoe natuerlýcken fomer ende winter, aer lente begint in September, yaer tomer in December, Den berhet in Martio, ente de twinter in

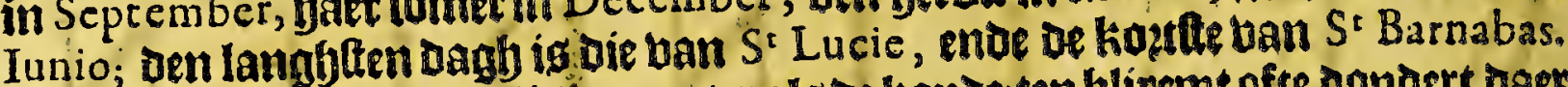

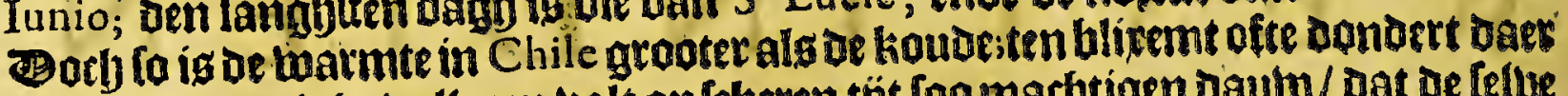
niet beel; in eenighe ballepen balt op fekecen töt foo machtigen Dautw/ Dat de fellue

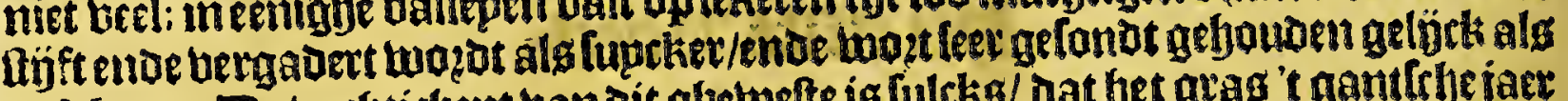

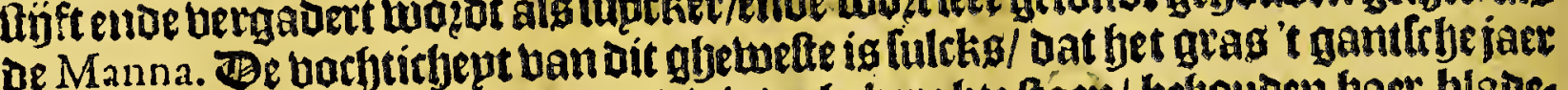

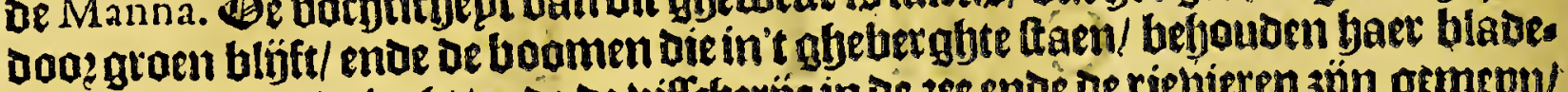
ren: oe Lepoen/ Dejarbt/ende de bifteberne in oe jee enoe de rievierenjön gemepn/

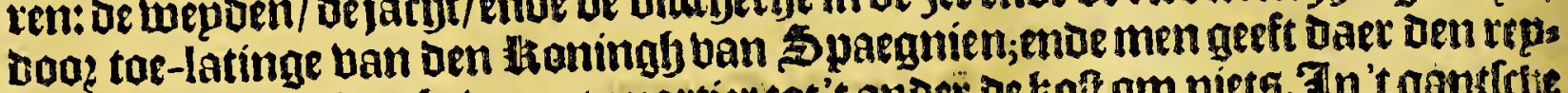

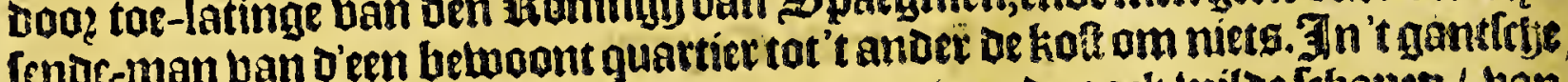
rinck uan Chile vinot men een foote ban tamaie ende oocli wiloe frhayen / ban maecklel bp-naet als de camelen/ upt-aenomen datfe geen bult en beb ben op oen rugge/ueel grooter als de Lchapen van Spaegnien/ende oock joogber/beblente

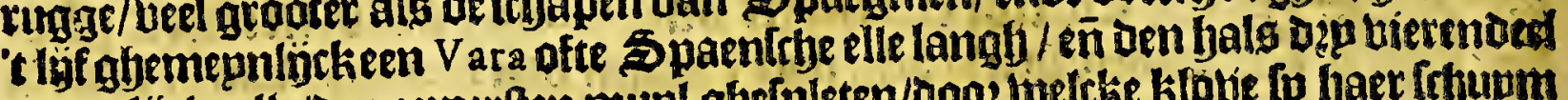

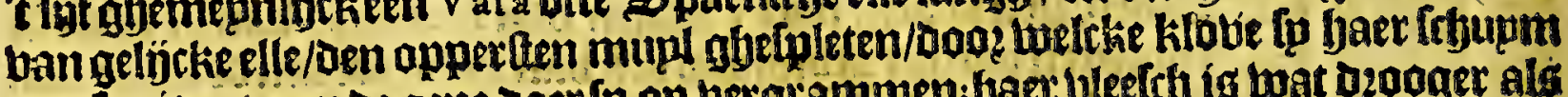

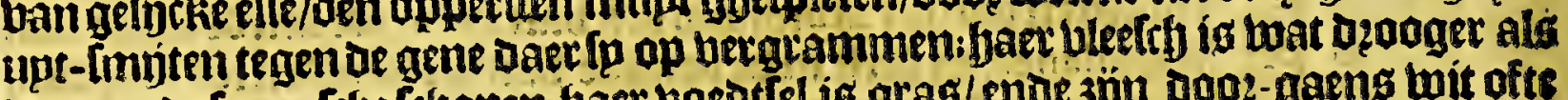

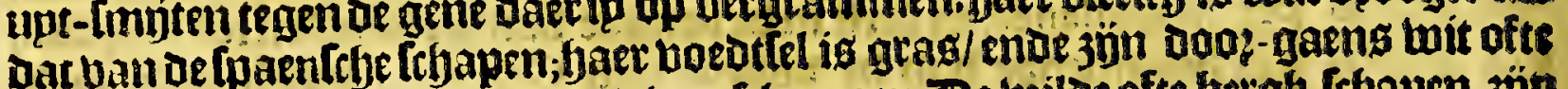

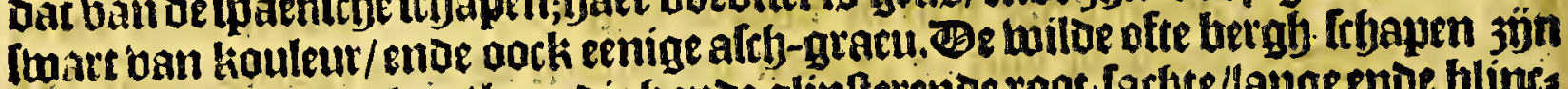

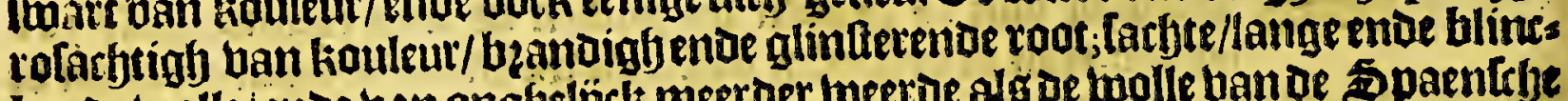

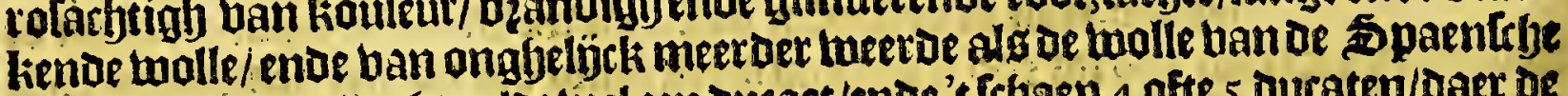

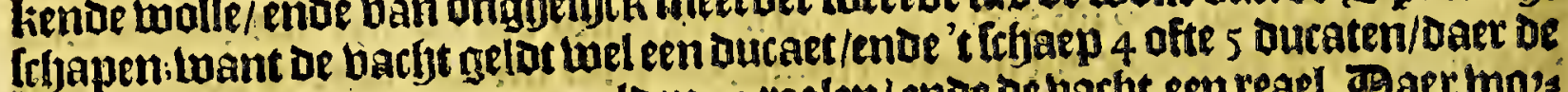

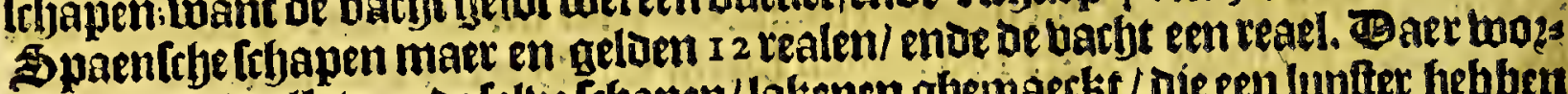

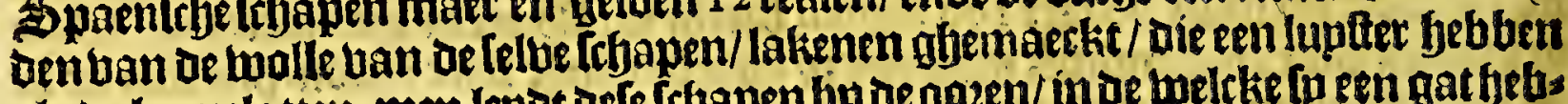

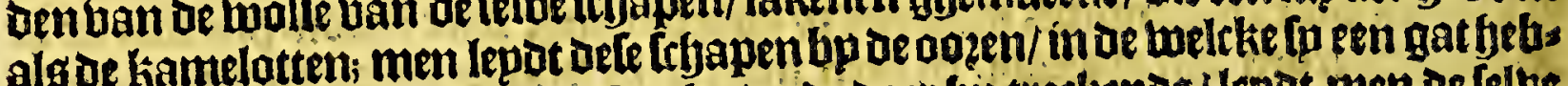

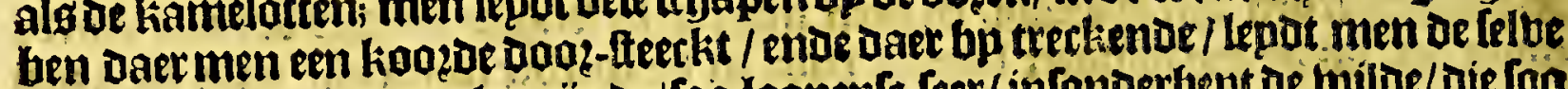

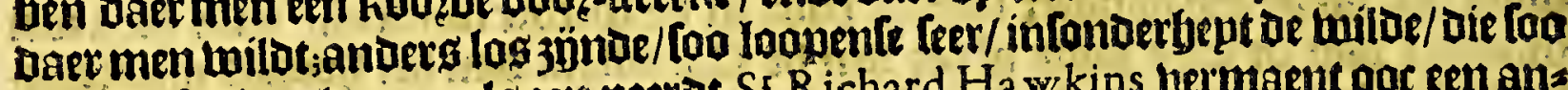

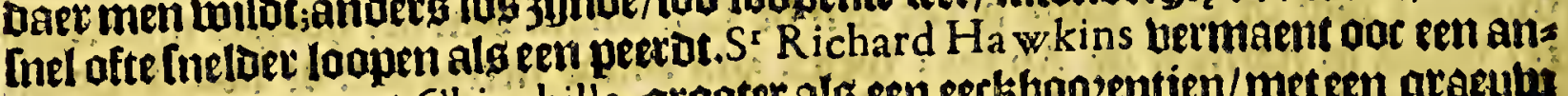
Der diecken aenaemt Chinchilla, groder als een eeckbogentjen/meteen graeuba belletien; ende foo larbt ban gap? oat fot al ander bondt te boben gaet.

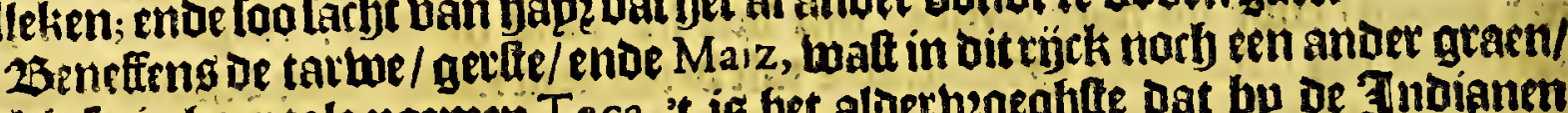
melts In in faer tale noemen Teca, 't is bet alderbzoengte dat by of Indianen moet relaept/want fplaepen dat in Februario ende Martio,ende tooet in Novem.

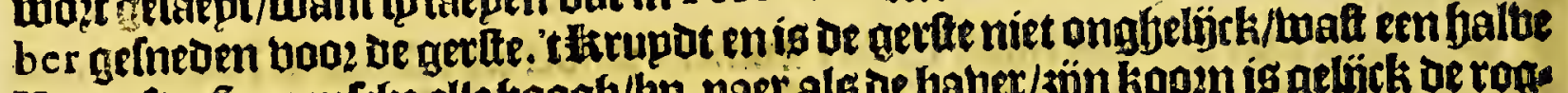
Vara ofte \$paenfrbe elle foogh/bp-naet als de bauex/3ÿn koom is gelörck oe rogs

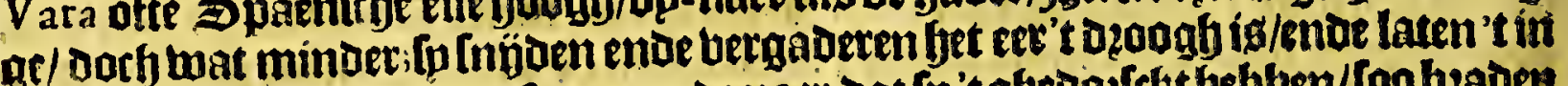

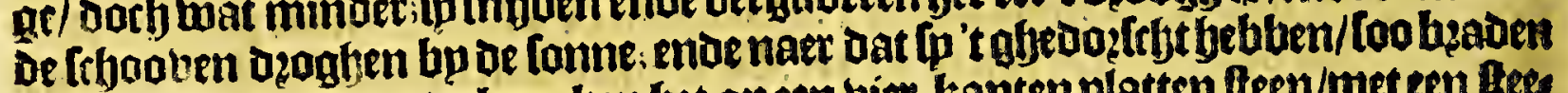
Ip bet in beet jandot/endo beecken bet op een bier-kanten platten fteen/met een lees nen rolle ban oe lenghte en be dickte ban een mang arm; waet medefp't in kostent tït beecken ; ende baesen bet meel met baer als fu ergents replen; ende een mubos ken ban dit meel is bequaem am een mante boeden boos acht dagben ; bet bien: laer boo koft ende dzanck ; want fp dzincken bet met beel waters bermenglots enoe met wepniah waters gibetempert / eeten [p bet felue.

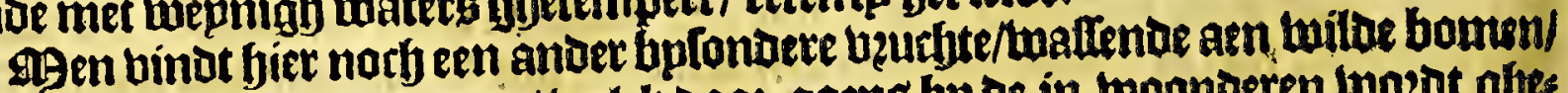

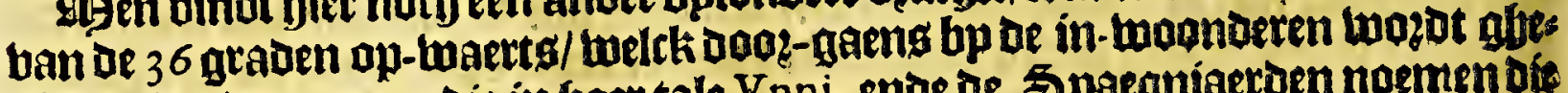
abeten / entue noemendie in faer tale Vnni, ente de Spaegniaeroen noemen ofe

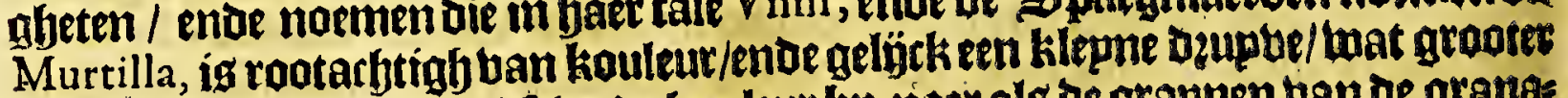
als een etwete/ ban maeclicel ende kouleur bp-naec als be grapnen tan de grantas

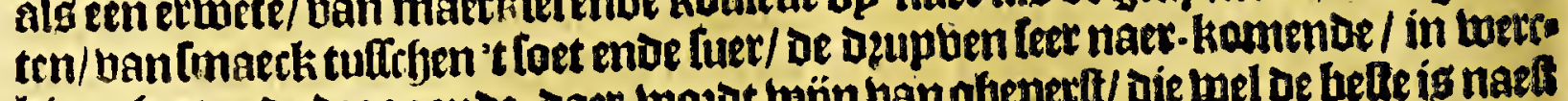

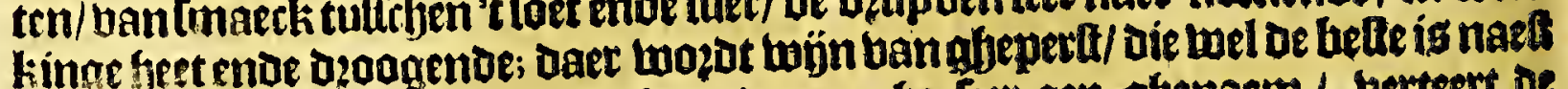

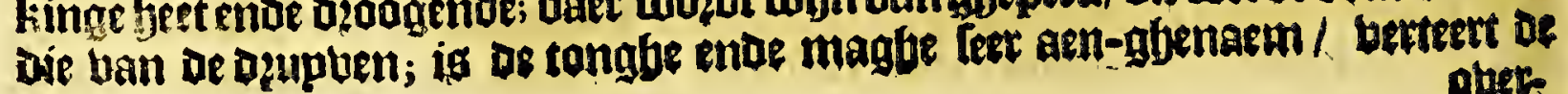
atup 
Het elfite Boeck.

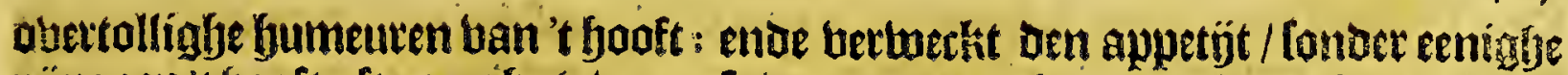

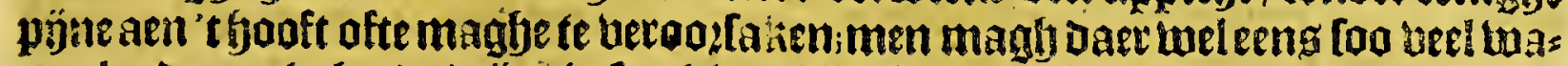

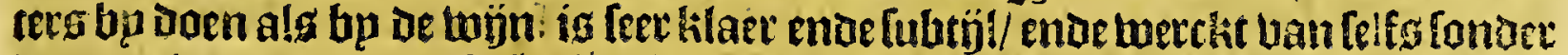

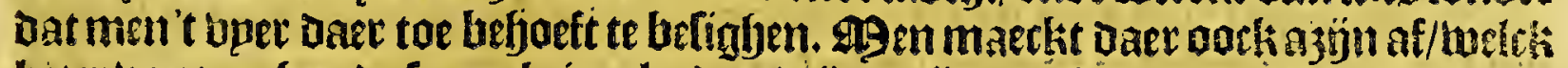

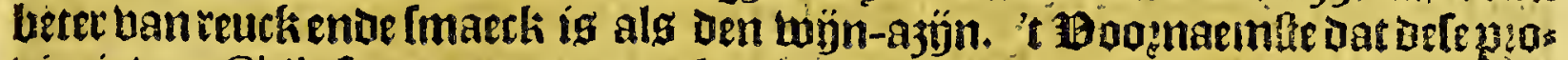

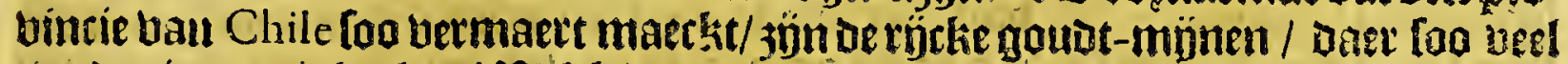

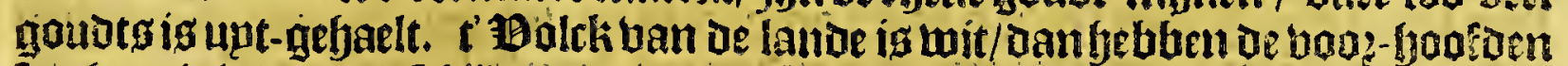

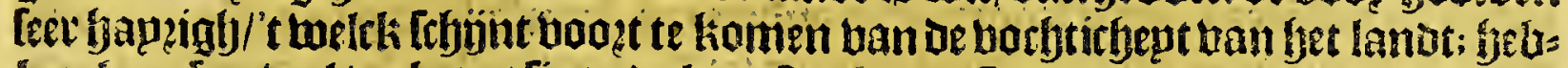
ben faer [eer ueel berbetert lints de liomte ban de \$paegniaetien/ende ginghen

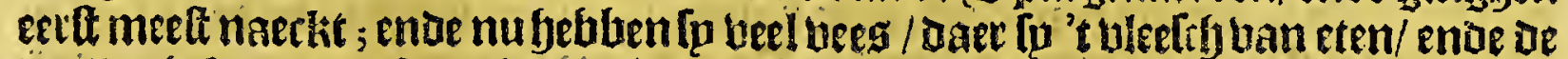

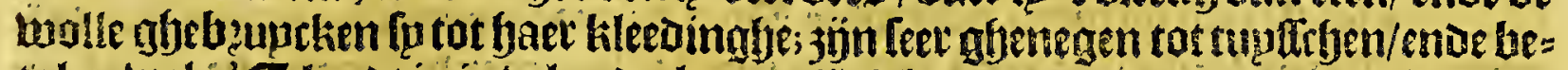

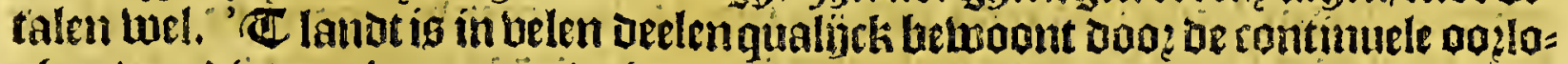
gyen uan die vall Arauco, ende gaer aeconfedetretoe tegfen de Spaegniaetoen:

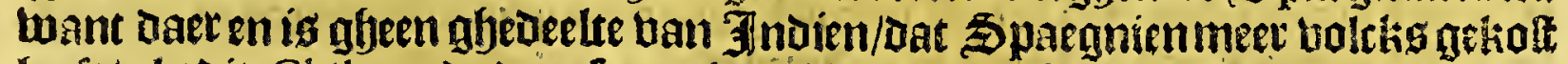

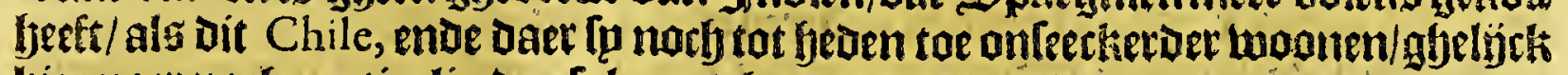
ljiet naer norb particulier der lal aen-gberoert moedon.

\section{Het tweerie Capittel.}

Van de Woeftijne van A T A C A MA, ende de wegen over lande van't Koninghrijck van PER v naer de Provincien van CHIL toe.

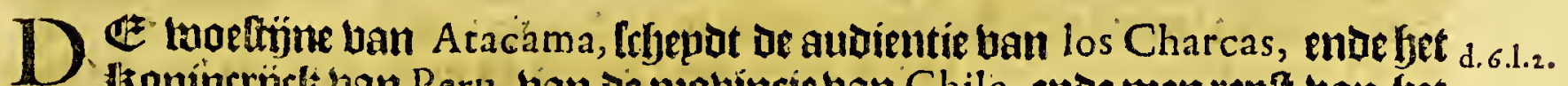

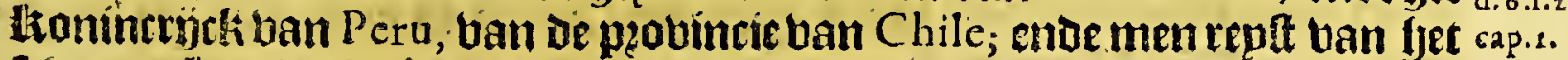

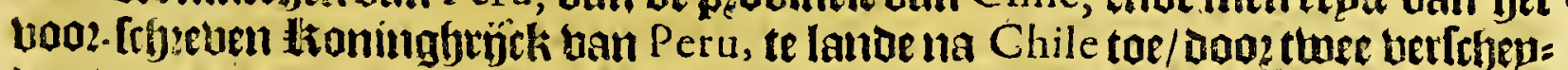

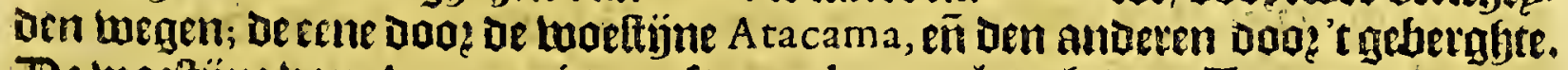
- Be woeltýne ban A tacama ig 90 ofte roo leguen langh / Den T ropicus tan Ca.

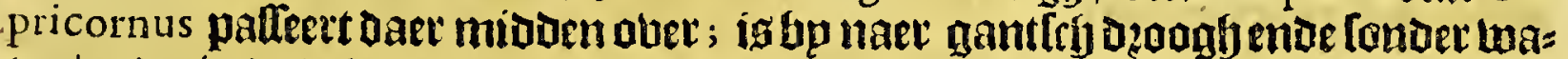

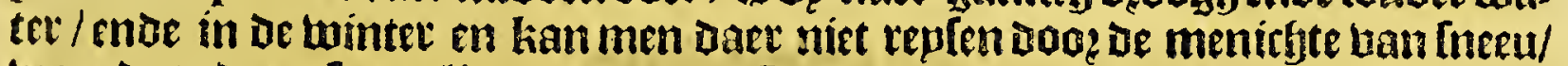

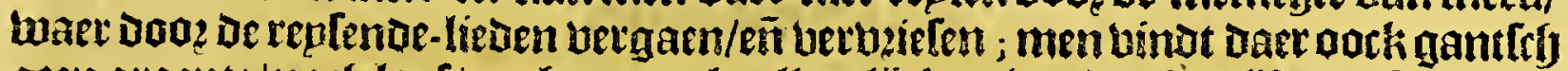
geen groente/noeb loof/norb gras; als alleenlincken ín bier ofte unff plaetfen/ aaer

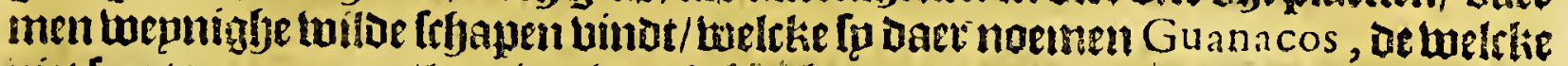

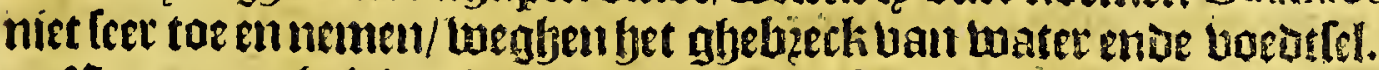

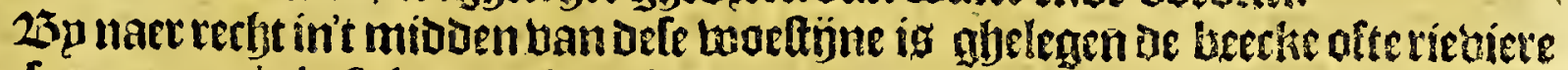
die fp noemen de la Sal, op oe joogfjoe ban 23 gladen ende 45 minuten/:iomt upt

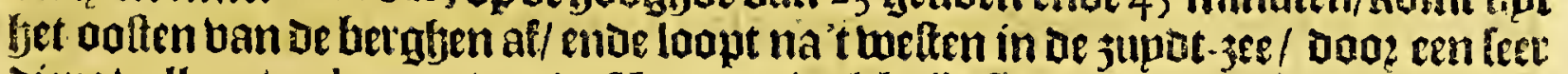
Diepe vallepe / 22 leguen ban oe Xaguy es, tueldk jön fekere boen-putten ban berfer water/ want in die 22 leg. weeghs en heeft men geev ander berfoh water als orie putten. Drfe belie ofte rieviete / is ban alloe fouten twater/ dat bet in be Ganden ofte in ecnigf uadt fracts in joudt betandert/ende de aeverg leggfen bol vanfer voastryeten jouts.

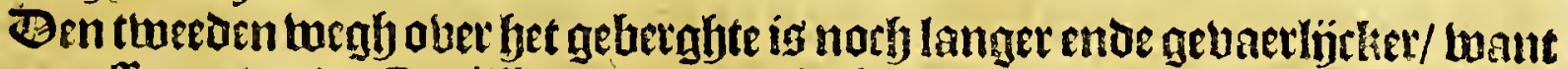

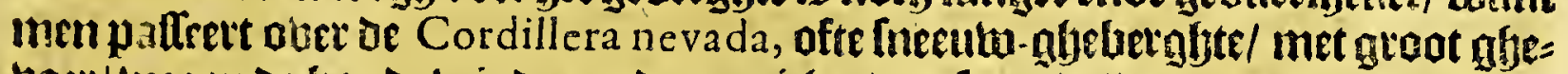

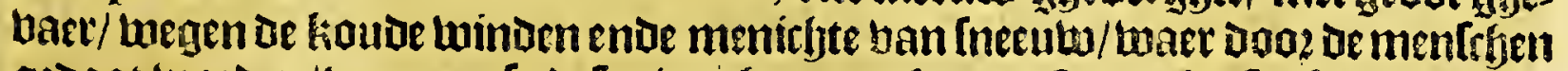

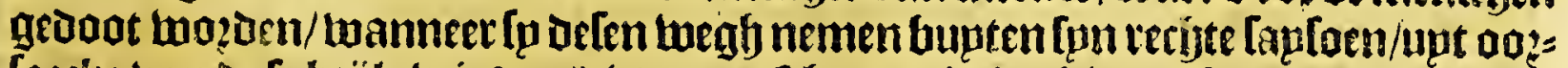

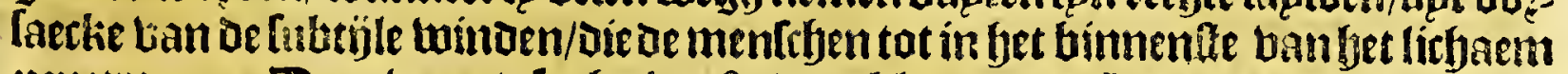

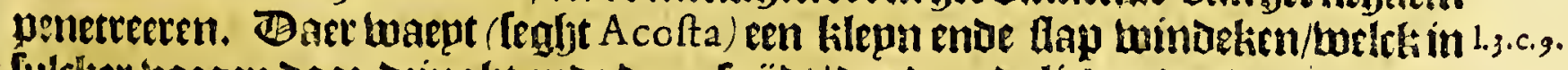

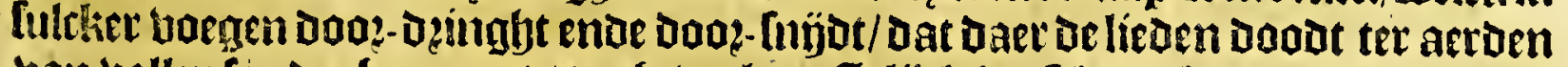
ban ballen fonder bp napeta te ghevoelen. Belijek bet telue gebeurt is in ie eetfe ontorthinge uan Chile, bp defpargmiacrden Dod defen wegh boos-genomen/als

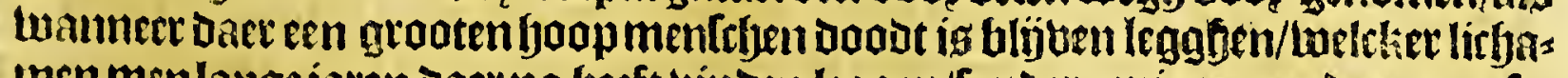
men men lange faten Daet na heft binden leggen/Londer eenigen guadenteuc ofte

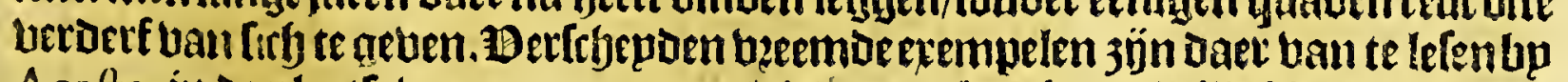
A cofta, in De plaetfe wozen aen-geroert/die hup om koetbeptg wille bier oter-flaen. 
428

Chilc.

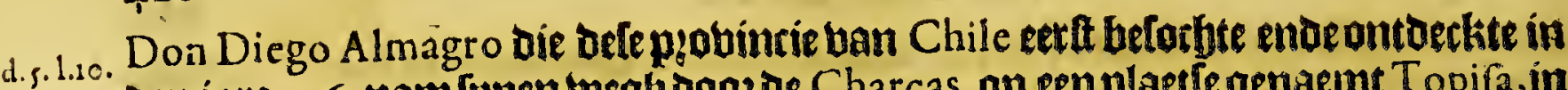

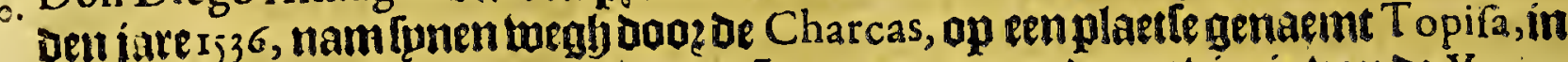
ae peovincie ban de Chicas nelegen / eñ ban daer naef oe pzobincie ban de Xuxu-

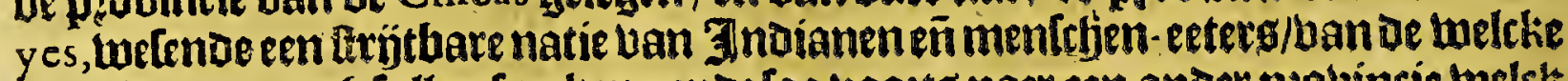
wo fyicr naer norfy fullen Ipzeken : ende loo vopts naer een ander pzobincie toelck fp noemen Cha quana;enoe bandaer bootg dope een luaelt ende moepelÿek land

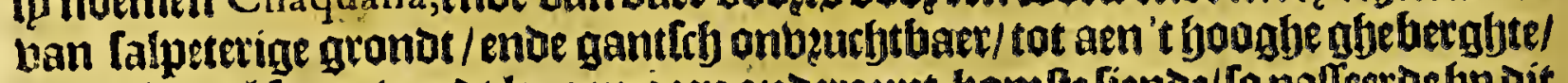
belck lyp vol fneea bonot leggen;geen andere upt-komfte fiende/ Ta palleerde bp dit gebergbtemet onuptlpeectielintke moepte/ ende grout berlies ban mentchen ende

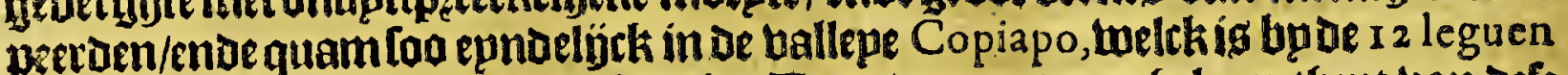

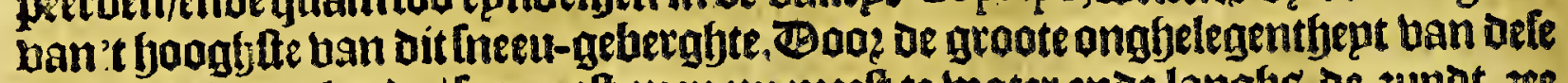
twee twegljente lande / foo repet men nu meeft te twater ende langlg de jupht-jee

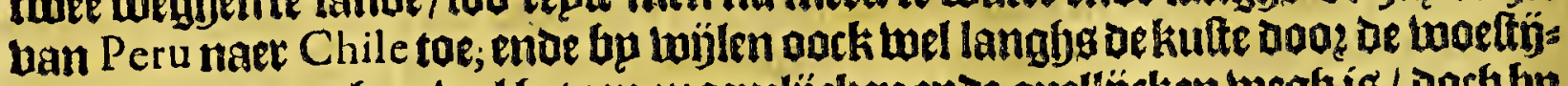
ne uan A tacama, hoe-bel bet een moepelícken ende quellícken wegb is / Doch bp berre too ghevaerlïcis niet als den anderen aber't ghebergbte.

De Spaegniaerden remarqueeten dat ban oe fjooghte ban dep-en-thintich araden by 3 upoen oe linie of te baer ontrent / tot aen be firate ban Magallanes toe / meelt waepen depderlep twinden / te weten den jupden-Linat in de lente ende las mer/ ende eenighe anoere dagben dat get klaer weder maeckt; dennoogen-winde

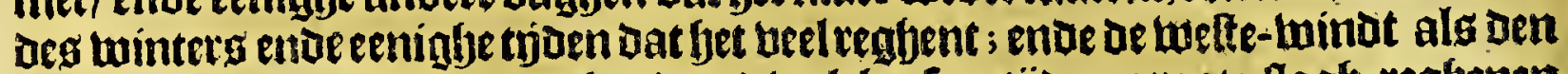

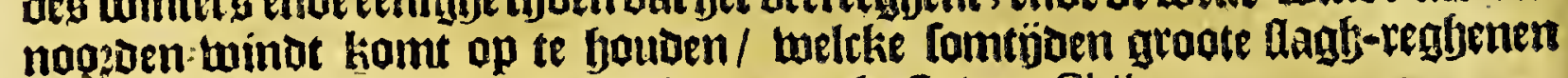
beraosfactht/ enoe is contrarie luind ap de kulte ban Chile.

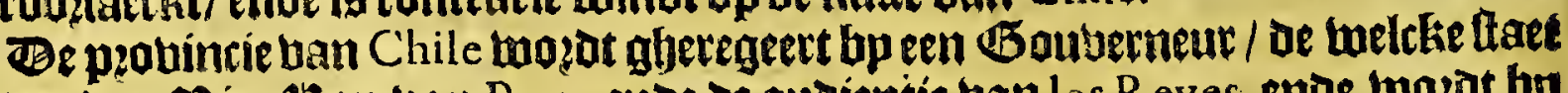

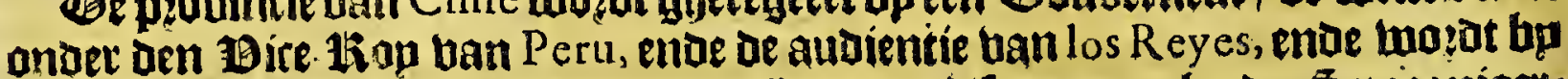

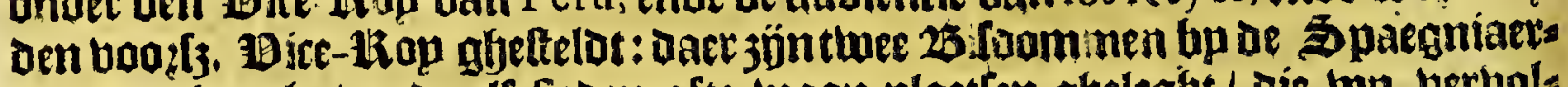
den op-gheresht/ ende elf fieden ofte woon-plartlen gheleght/ Die wo berbol: gijens tullen befrgzỉuen.

\section{Het beróde Capittel.}

Van de valleyen Copiapo, Guasco, ende Chile.

A En ber.d.7. begin ende eetle aen-komen ban Chile naer Peru toe / is gheleghen

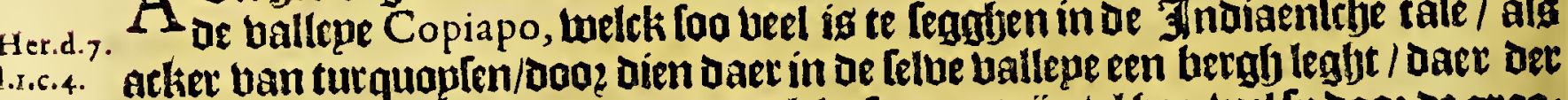

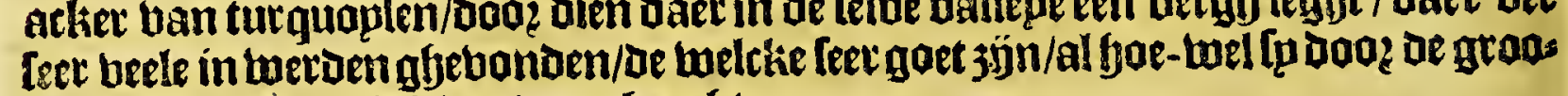
se menighte twepnigh weraen gbeact.

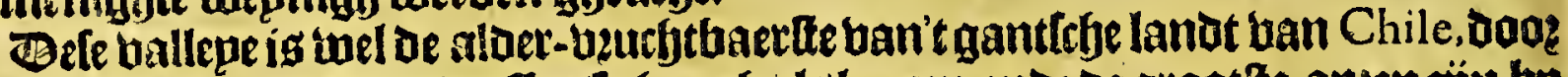
Dien Datr Maiz-fyalmen waften/[o hoogh alglancen;ende ae grootite apyen jün bp naet een balve elle/ ende de klepn te een bierendeel langh//oo datlp gemepnljeken

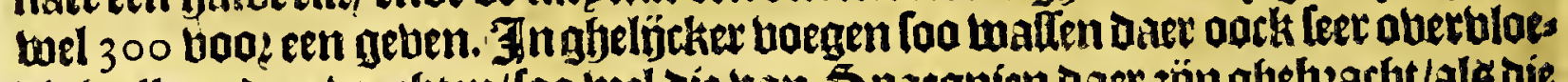

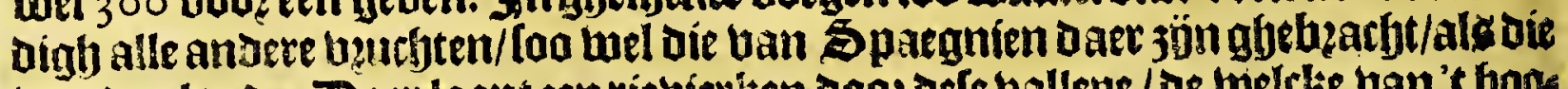

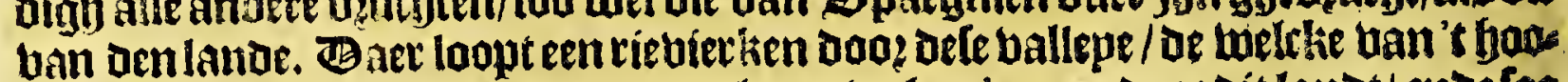

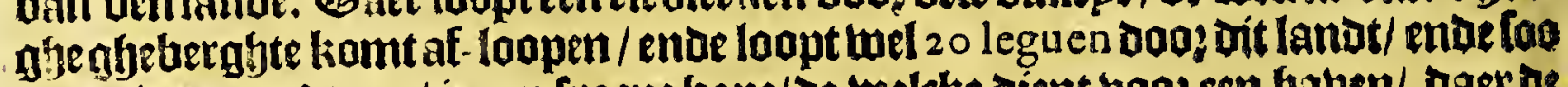

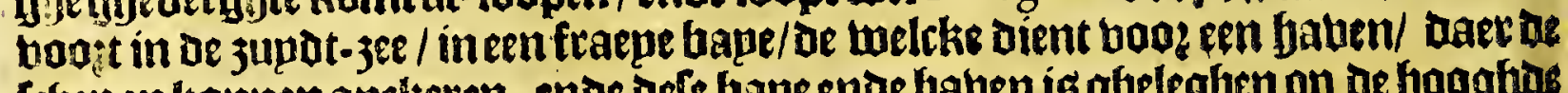
fchepen kanmen anclieren; ende defe bape ende haben is gheleghen op de boogbos ban 26 grainen bp 3 upden den equinottiael / naer't legghen uan Herrera.

Ban dele ballepe ende faben ban Copiapo, reectient men naet des lelfgi lege ghen/35 leguen tot be ballepe ende baben wan Guafco, twelthe foube ghelegen 3 g̈n

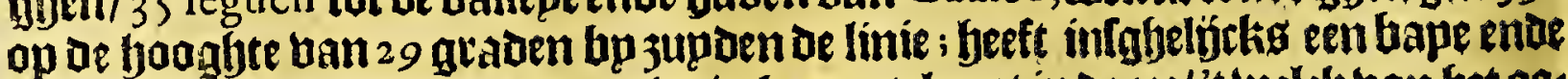

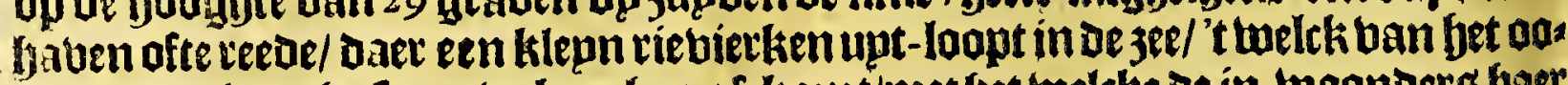

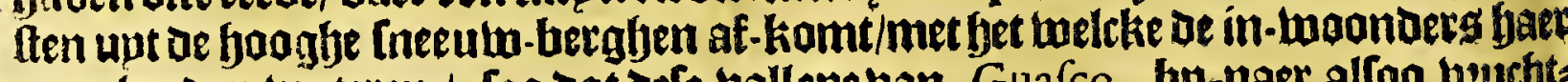
jaep-lanjen wateren / Coo dat orfe ballepe han Guafco, bp-naer alloo buchts baret is als as upop-gaenoe ballepe ghenaemt Copiapo. In defe ballepe entae andere 


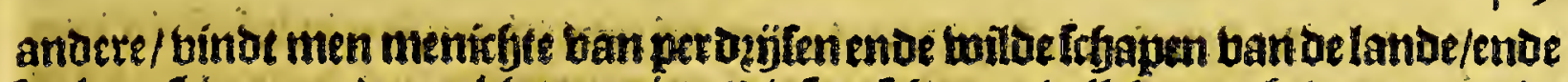

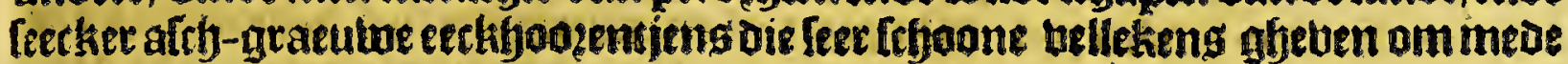
te botperen. Centijoe dar dele plobintientuan Chile eertt wietoen ontoeckt bp de Spaegniattoen / onder't belept ban Valdivia, fo was in ofle baltepe ban Guafco

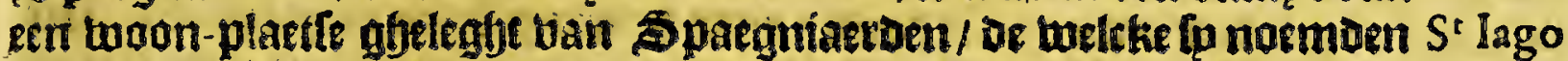
de la neuva Eftremadura, opeenplaetle ende gfelegentfept die fíp of in-luoonoe: ren toierot glyenaemt Mapocho, beettbien leguen berfbepoen ban oe jupot-jeel

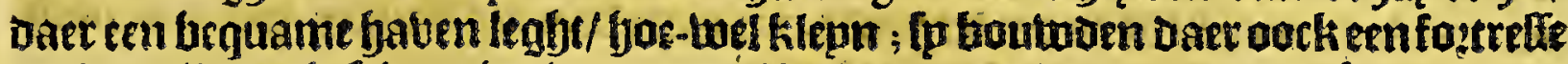
tot jaet-lieden befryerminghe trgen de moilde ban be lande. Ban defe ftadt ande

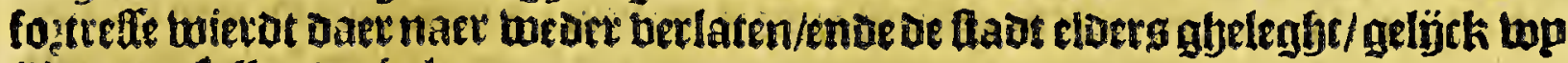
biet naet fullen terbalen.

Olivier van Noort Itelt de fyaben ban Guafco op de fjooglyte vanatht-en-thin= titf graden ende derticty minuten/ende feght dat let een gorde teede is boa? fehepen atfret eenigfe klippen die bupten aen legghen; ende daet komt retriebierken van

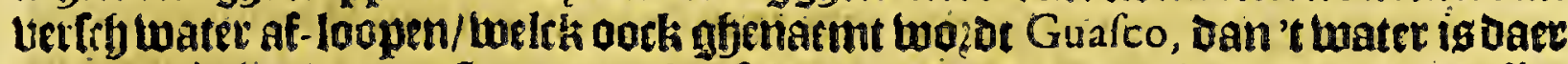
quacb te jalen:Daer en faen geen bupfen Dan te landtwaett in; ende Daer balten

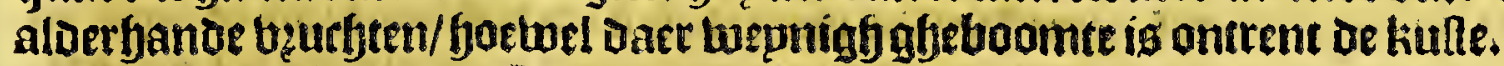

F aeft of valleve ban Guafco, tolght de vallepe Chile, welck twel een uande

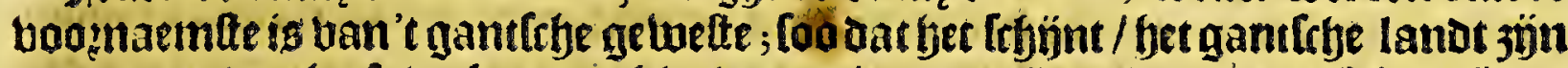
nacm daer vanyeeft vertivegen; fyier twaren in boo? tijuen de gowot-rijeke münen Dielp noemben de Quillota: upt De tuelcke Vald

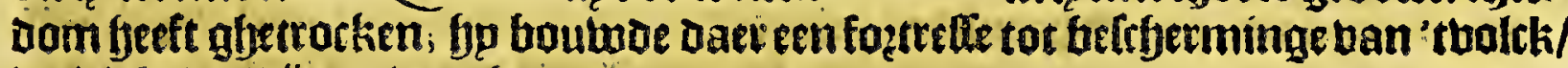
twelek in oe mỉnen watorte.

Lopez Vaz gfetupght Dat aen of fauen han Copiapo leght een klepn Gaben/ welekt is betwoont bp Indianen bie ten dienlte fraen ban de Spaegniaerden/cn's

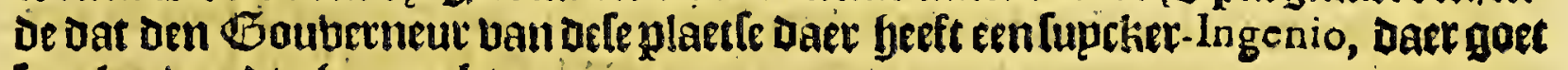
lupcket mog̨ot ghrmaeckt.

\section{Met vieroe Capittel.}

Befchrijvinghe van de Stedén I A SERENA, ende St IA GO.

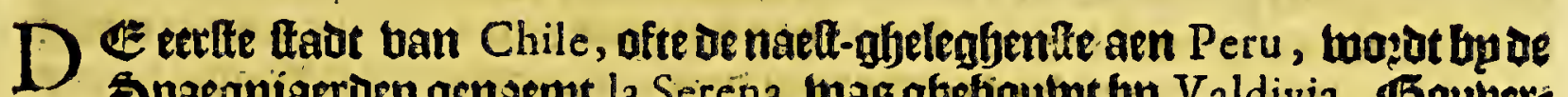
Spaegniaerden genaemt la Serena, thas gheboutot bp Valdivia, Baubers neur ban Chle, in oenjaete i5 44, niet berre ban be juput- jee / in De ballepe ban Coquimbo; twaer dod oteftad aor bp tujlen Coquimbo hp oe Spargniactoen wiert gfenarmt: is glyelegen naer 't feggben ban Herrera, op oe booghte ban 30 gitaden upp 3 upden oe linie; oen langhttendagh is daer ban is upten/aen elften Jecember; enoe den langhtennatbt ben elften Iunius : boe-wel dat Herrera in fpn Deferipcion de las Indias feght dat oe gaben uan Coquimbo legft op de boogfbe van 32 graden/waer infph bemabuleert; thant oe bopagie ban Olivier van Noort lett die op 30 gladen/entee die ban. Thomas Candifch op 29 graden 30 mikuten/ foo dat fin rectyte hoogljoe moet weleri onttent de $29 \mathrm{en} \mathrm{een} \mathrm{balf/} \mathrm{ofte}$ 30 graden by jupden be limie. ILeght 60 leguen ban oe ftadt $S^{\prime}$ Iago naer'tnookt-

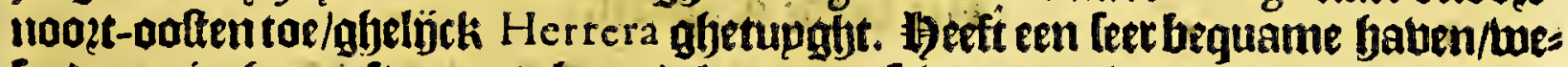
Ienoeen in-Gam ofte groote bape / al - waer de frbepen ontladentwogoen thee leg. ban oe boo?. [r ferben fradt: beeft eenlilepne rietiere/ waer mede alle de blackelan=

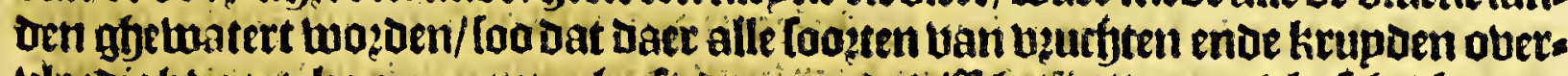

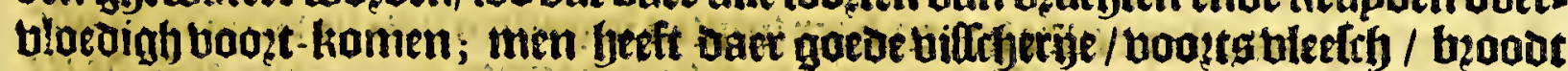

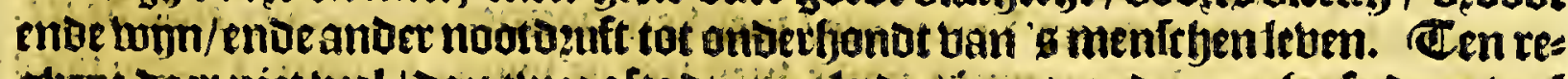
gbent daer niet betl / Dant twee ofte ospinacls deg jaets ; ende men feeft Daer beel fitjoane zaep-lanoen. In oe limiten bait bele labet wozbe veel goubots betgadert;

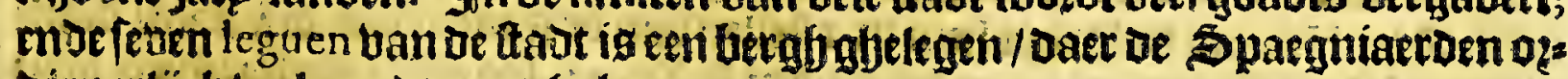
ctaacrlijck bat gouotgupt fjakn.

鼠 3 Lopes。 


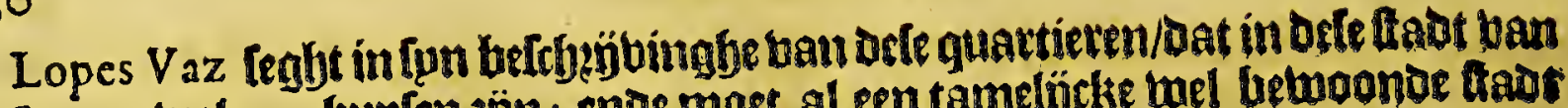

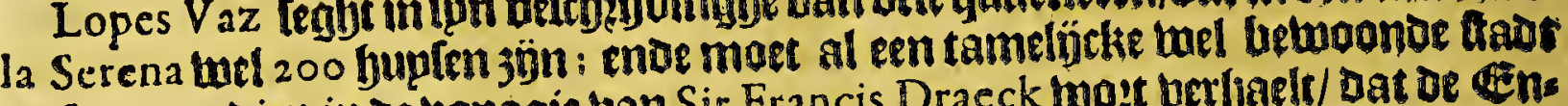

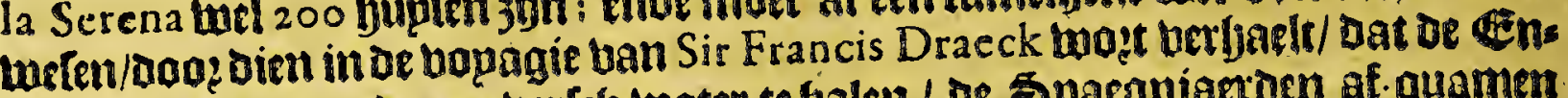

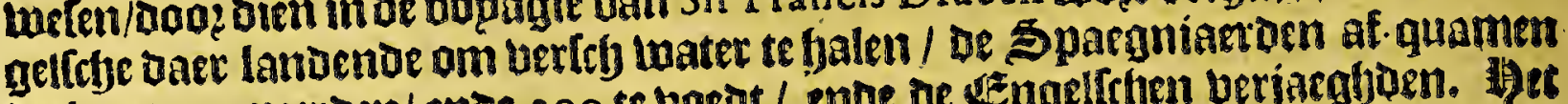

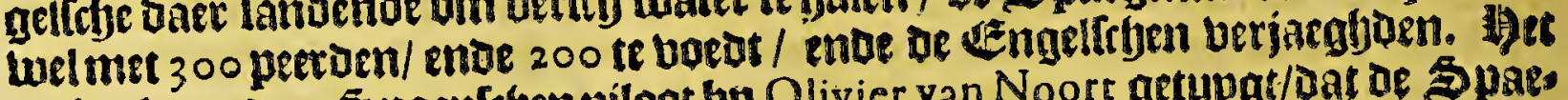

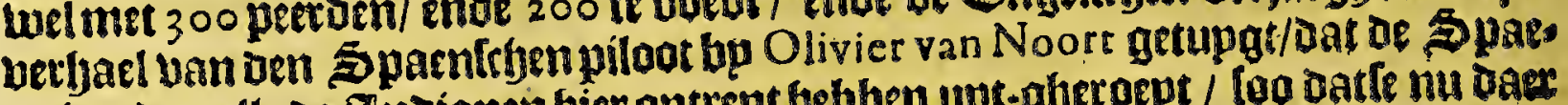
sniaet oem alle oe 3 ndianen bier ontrent heblen upt-gher oept / too oatle nu daex geen bolck meer en yeblien om de goudt-mínen te bearbepoen/boe-loel Daer norb feer rö́cke mínenjôn van goudr ende koper.

De ftadt S'Iago, welck is de pyincipaelfe tradt van't gantlche lanot ban Chile, is aelegen op or foogbte uam 34 graden bp 3 upden oe linis/ cube op oe lenghte ban 77 graden ban den meribiaen ban Toledo, naer 't teggen ban Herrera: 5 leguen van de jupot-jee/ende ro leguen ban de ballepe Chile boo;-noemt, Den bous berneur van 't gantfrbe koningrück wan Chile, youdt brm ogoinaris in arle ftadt; enoe daer is een katjed? ale kercke/ ende eenigbe hloofterg van ogmicken ban

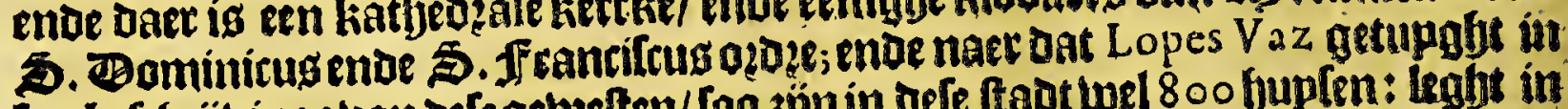

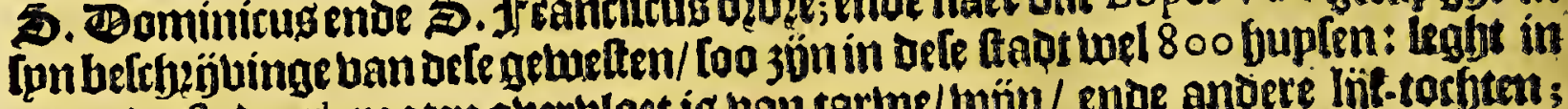
een aetwelle daer'groonen oberbloet is bau tartwe/ wän/ ende andere lije-torften; ettoemen beft oaer ontrent (eec rỏcke gout-münen; enoe in haer jurifoictic woos nen wel tachtenticf oup[enc Indianen/die berdeelt jönin 26 Reparciementos, gt: lijk de Spaegniaerden die noemen.

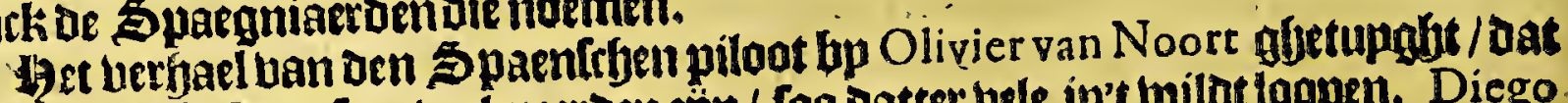
ontrent Defe ftadt feet beel peeroen $3 \mathrm{phn} /$ foo Datter bele in't wilot toopen. Diego

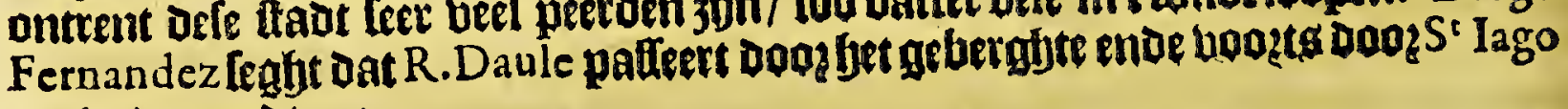
tot in of jupdt-jet.

Defe ttadtwozotgedient ban be faben Valparay fo, aen de monat ban de ries biere Topocalma, welc vooz-bp de tadt $S^{\prime}$ lago loopt. Defébatí ban Valparay fo is ghelegen op de booghte ban 33 araden ende 40 minuten bp 3 upoen de linie/naet 'tfeggen van de bopagien ban Sir Francis Draeck ende Candifch. In oele yaven wozoen de goederen komende van Lima, ontlaoen; ende't gout dat hier ontren balt/ mederom gefrheevt. Sir Fr. Draeck homende in dele haven/berralte daet een Icljip/in 'twelck hp bonot 25000 Pezos ban fän gout ban Valdivia, enoe beel wịn ban Chile; was mede aenlanot/ende bout daer een kapelleken/ entoe 9 oft 10 bups Ien/twelck [on bolck beroofoen enoe berbzanden. Den Bemerael Spilbergen was

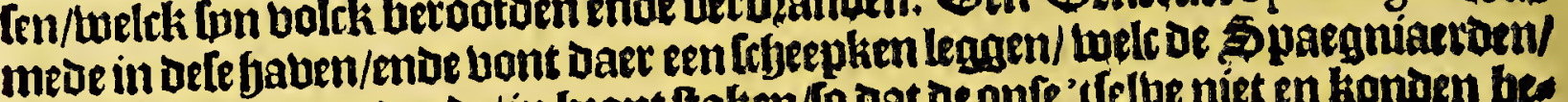

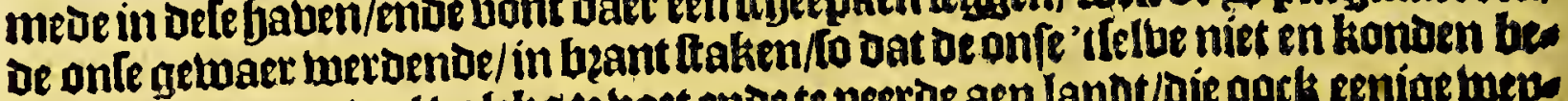
komen; Daer was beel bolkk te boet ende te peerde aen landt/oie oock eenige bepe

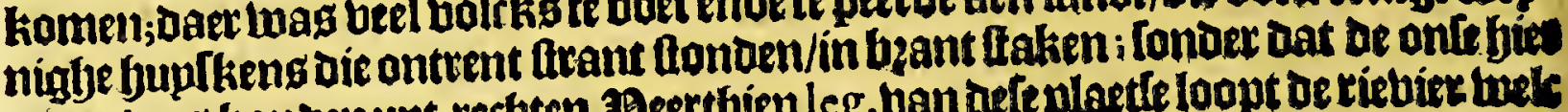

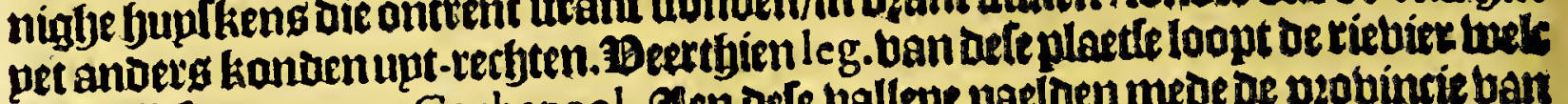
te Cfjileten nosmen Gachapool. Aten oele vallepe paeloen mede de protuincie bant De Parmacanes, ban welcke mencomt aen be riehiere Maule ende aen de boypen ban Guelec ende Tata, ende foo boogts te Quilacura.

\section{Fet unfor Capittel.}

Van de Stade Concepcion, endevan't Eylande Sra Maria.

D

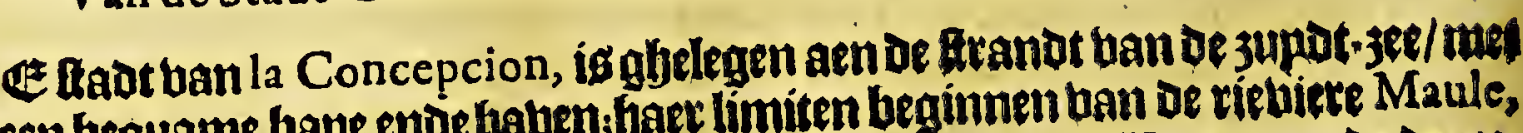
een beguame bape ende bauen; Gaer limiten beginnen ban de riebiere Maule, ende Itrecken tot de rieviere Y taten toe / welcke fp noemen oe Y tasaya, ende de jee-

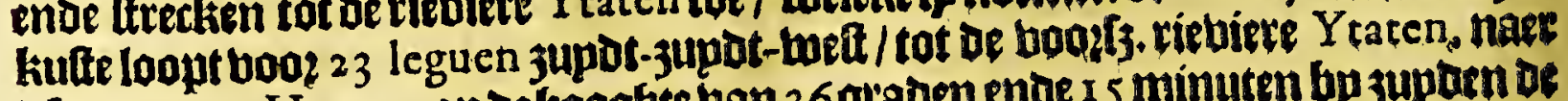
d. 8. 1. 6. 'tleggen van Herrera op de boogfte ban 36 graden ende I 5 mimuten bp 3 upuen de

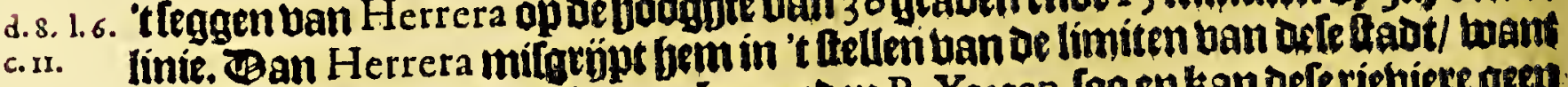

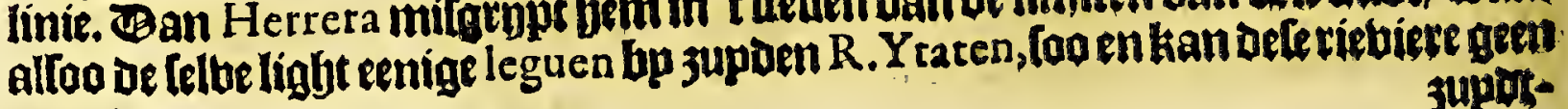
3upto- 
3upot-limit 3ön boo? Defe plaetfe/maer hal R. Biobio. Ban de riebiete Ytaten

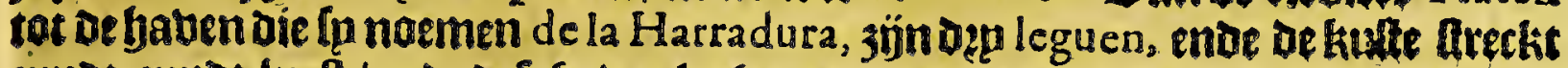

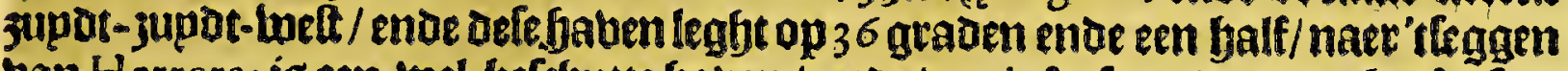
ban Herrera; ig een toel-beffoute baben/ enpe ban't fatfoen ban een foef-plex/ Dare fp de naem ban jeeft berktegben: uan gier tot oe bape uan Penco 3 in 4 le. guen, ende de liufte loopt jupden / ende hier legbt de booffj. Itadt la Concepcion, op de looghte ban 36 graoen eñ 45 mimuten bp 3 upoen oe linie: (Herrera ffelot die op 37 graden in (pn Defcripcion de las Indias:) 3 oc bape liomen twee tilepne ric。

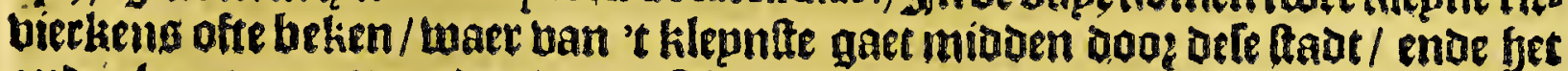
anoer loope naer 't 3uporn ban oe Telbe / welrk twozot gbenarnt Rio de Llanda. lien, naet oen naemban de ballepe / welch glenaemt topọt Andalien. Ban bet

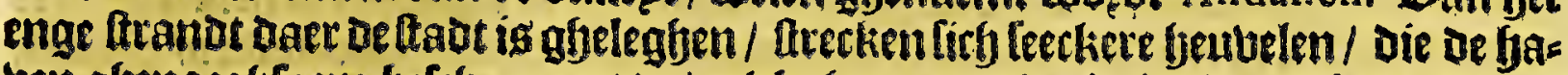
ben glenoegbfaem befteermen / oe welche faer openingbe beefe naer't nopgen/ ende de ffade legft nacr bet jupden in't binmente ban oe boo, [5. bape. Defe beu= belen ende hooger glbettalte ban't lande en is niet Teer aen-gljenaem/ boe-wel bet baer nuloo bol bobenenoe frupot- hoomen is / oat fee een lult ig om te fien. Fn

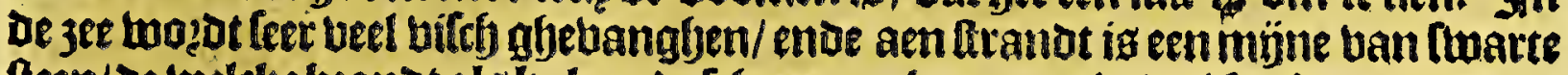

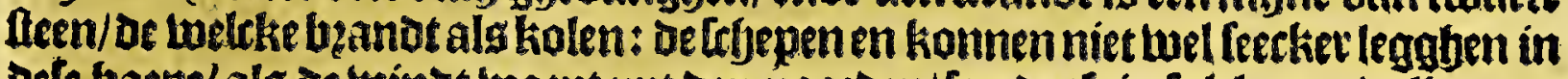
Dele baepe/als de winot waept upt oen noozoen/ [oo date in fulcken geballe gaen

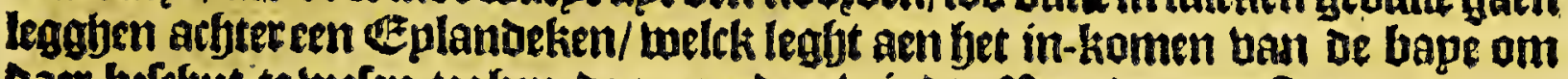
Daer beichut te welen teglen Den noogoen-wintr. Ban De upterlfe monot uan bele bape tot bet ezplanot wekt fp noemen de Santa Maria, jön naet bet leg= ghen van Herrera dertfien leguen. Ban defe fradt de la Concepcion tot De rietiere Biobio reeckentmen thee leguen; de tuelckefeer breed is ende diep/6oo bat men baer gheen lwedoeen beeft/ende wozot oock niet bevaren. Ban defe rie hiere Biobio tot oe riebiere Labapi jön büfthien leguen, ende de fiufte loopt naet bet jupt-wellen/ enoe in 't midoen is een groote in-bam! / alwaef de peobincie van A rauco ig gfelegben.

- Befe tadt de la Concepcion, Ieght feventirb leguen ban de ftad ban S' Iago,

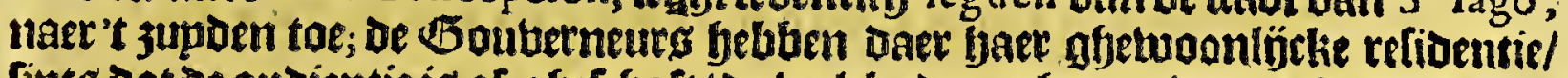

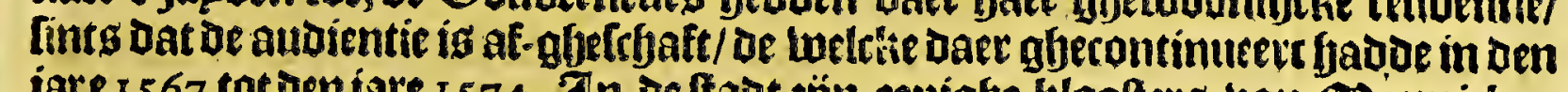
jare 1567 tot Denjare I 574 . In de ftaot jün eenigbe kloofters ban gyomiclien van 8 . Domimicus ende S. Jf rantifrug ogzdęe.

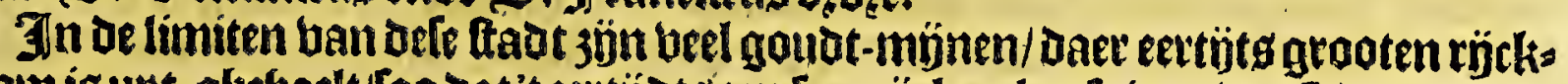

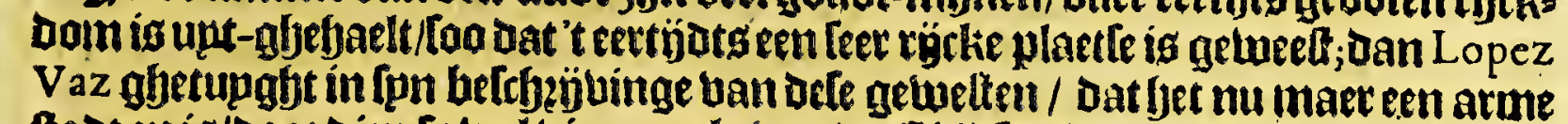
fadt en is/Dooe dien fp wel bier-maels ban de C Gilefen is berralt ende af-gebzant'

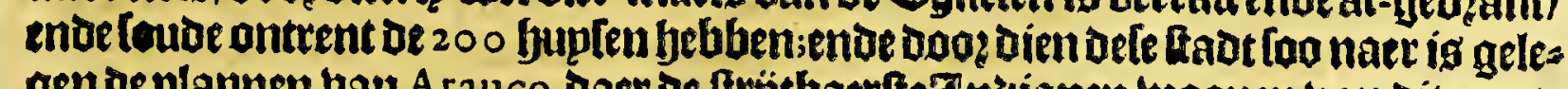
gen de plapuen ball A rauco, daer oe ftrijtbaetfe Induianen woonen ban dit gants

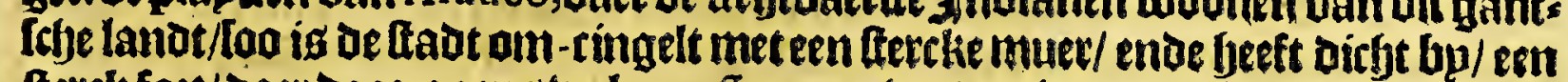

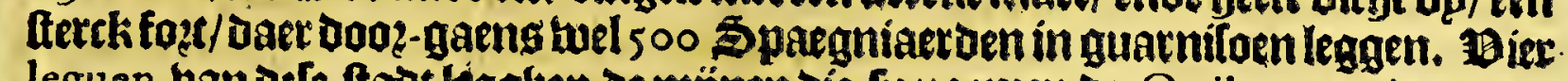
leguen ban Defe tadot kgglen de múnen die fp noemen oe Quilacoya, daer den.

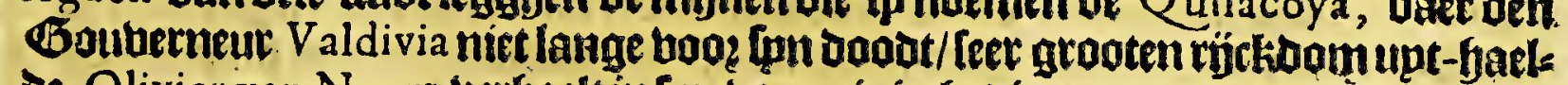
De. Olivier van Noort berfaelt in Lpn bopagie in het jaet 1600 . Dat daetbel 700

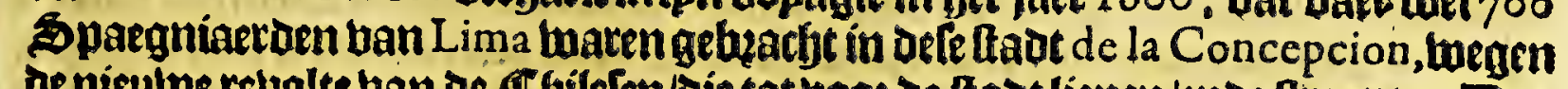

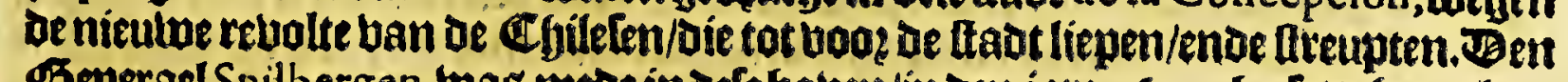
Benerael Spilbergen was mede in defe bauen/in oen jare I 6 I 5 ; bp lettefjet acjter t Eplandeken welck leglit aen oe manot ban be bape / welcke fjp oe naem gbeeft ban Q uiriquina: enoe am dat oe hinde niet en bienoe/ en quam bp oe flade nies naetder/ boch berftonot ban of gbebanghens bat daet in offe ftadt wel twee bon: bete Spaenffye foloaten laglen/ enoe oock beel Tnoianen.

Iset Eplandt Sanca Maria is gelegen op de boogbte ban 37 graden ende 20 mis nuten bp 3 updon De linie/ naer't feggen ban Herrera : De bopagie ban Candifch

$$
\text { op } 4 \text { atos }
$$


$432^{\circ}$

Chile.

ftelt 't lelfoe op de felbe fooghte; enda Olivier van Noort bijf minuten minder: is gbelegfen rectjt ouer De pzotincie ban Arauco, Daer't lamat een grooten in-hami

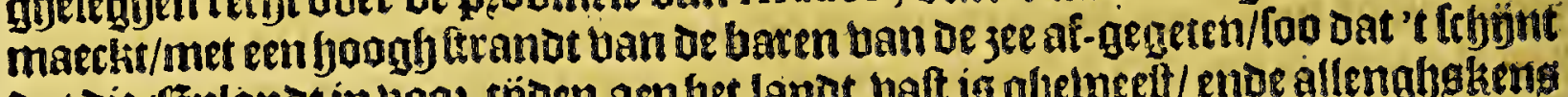

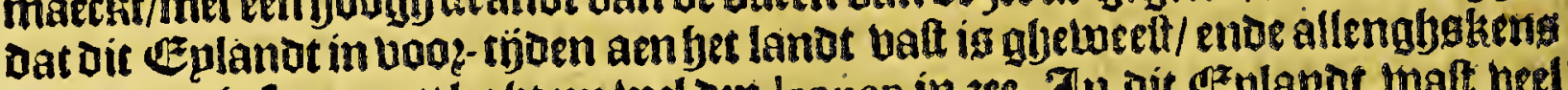

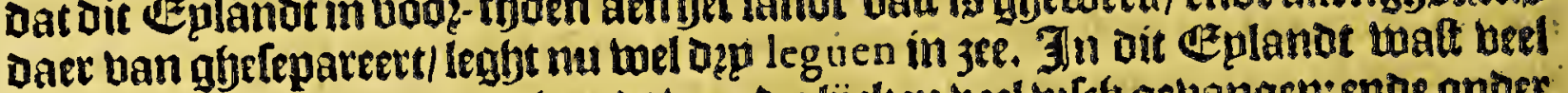

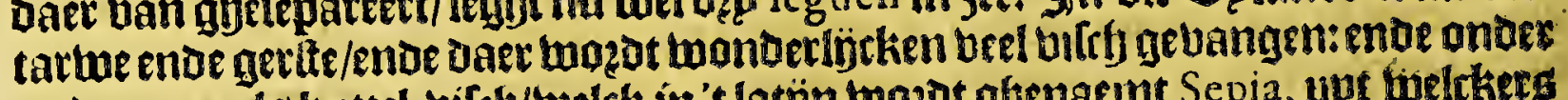

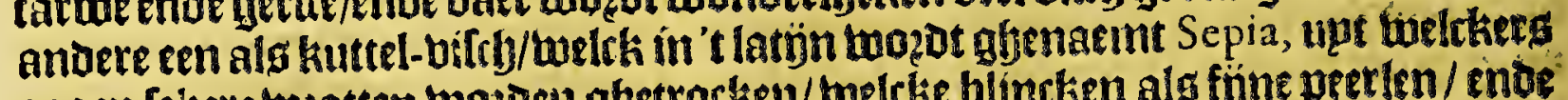
oogen lekece waatten wozoen ghetrocken/ welcke blincken alg füne peerlen/ende

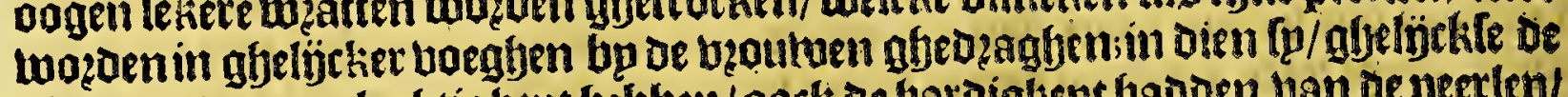
glants ende ooos. Iuchtigbept bebben/oork de bardigljept badoen ban oe peerlen/

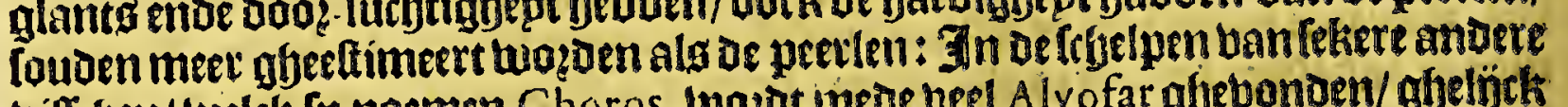

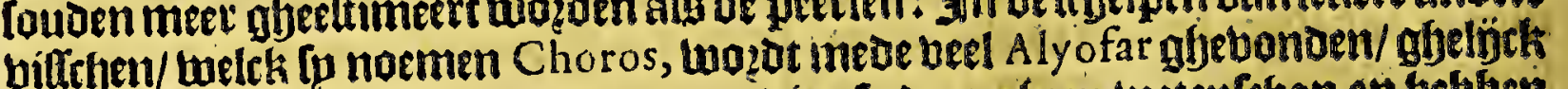

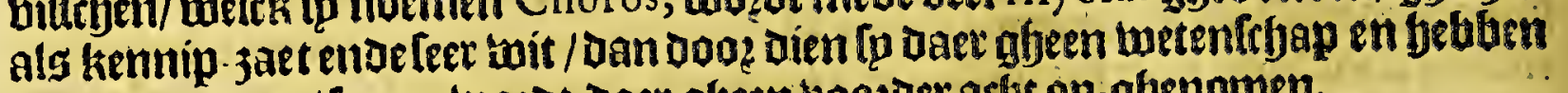
oin die te gaten / foa en thazot daer gheen boozder arft op-abenomen.

Sir Thomas Candilch luasaen Dit EEplanot/enoe anckerde met lpntrbepenaen

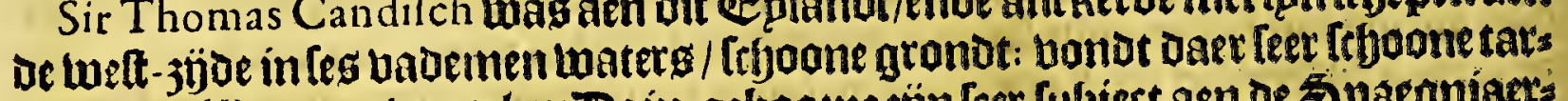

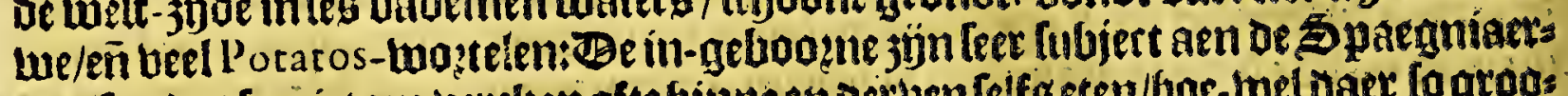

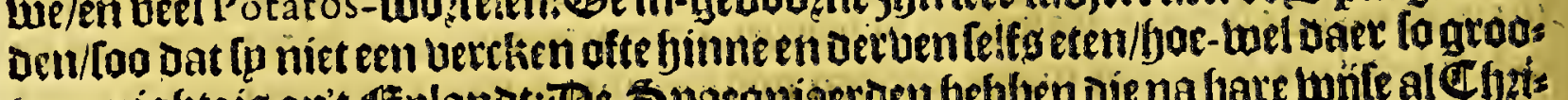

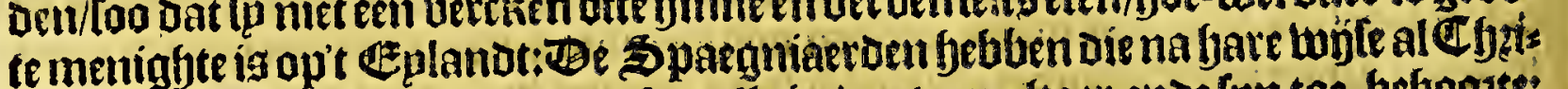
fenen gemactkt/ [oo Dat Daer een kapelle is / met een altaer ende fpn toe-befoogte: Daer walt oork Maiz, ende ueelderbande hoede frupten; foo dat men bem baet ban alorefjande beruerlebinghe ghenoegh fian booz-lien/als men baer meelfer ig.

- Den Jenerael Ioris Spilberghen wà gier mede in och jare I 6 I 5 ende nam't Teloe in met ghelwelot/ brquamen baer turl 500 Itfapert/ boots hoenderen / ende

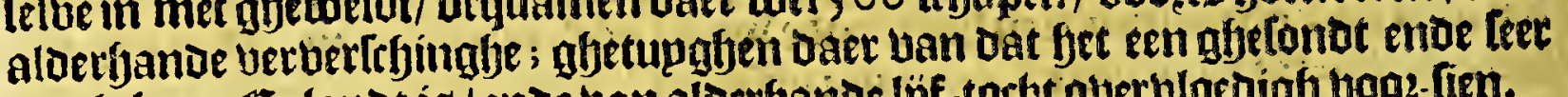

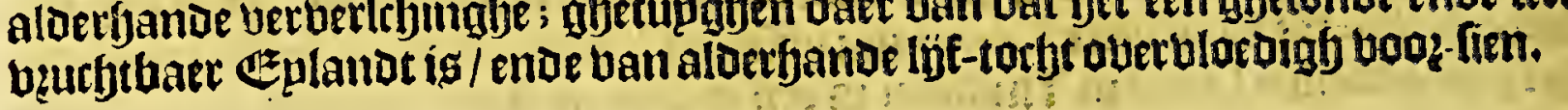

\section{Het Lelte Capittel.}

Van de provincien van $A_{K A}$ U C O, T U CA PE L ende PUREN.

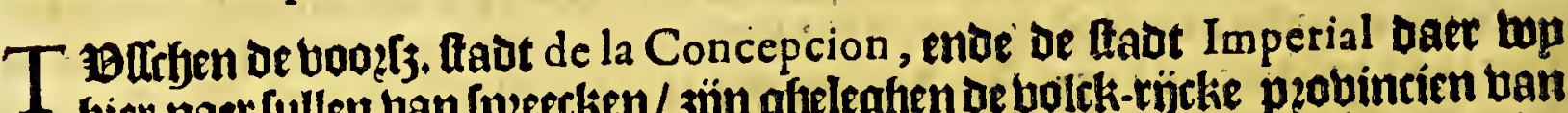

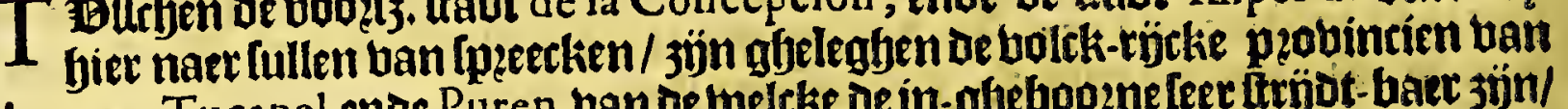

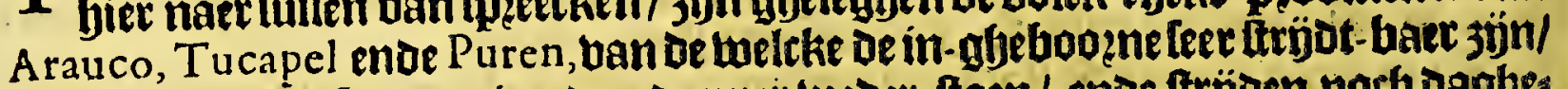
ende bebben de Spaegniaerden dapper weder-ttaen/ ende ftrjoen norb Daghes

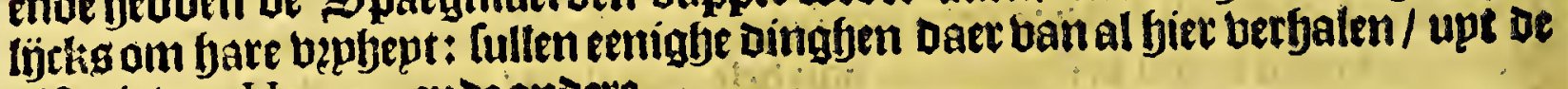
bittouiz van Herrera enoeanuere.

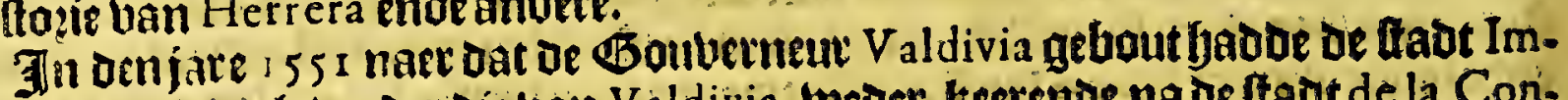
perial, ente noety vazder die ban Valdivia, weuer-keerende na de ftad de la Concepcion, bont gorot in delé lanoen boos-noemt/teleggen 3 fosten/ontrent 8 leguen elck ban oeriatioeren/ectn in de pzobincie ban Tucapel, een ander in bie ban Puren,

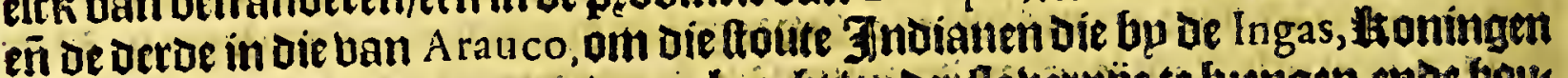

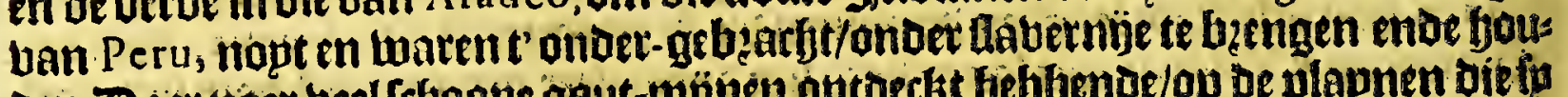
Den. Daet nare beel lefjoone gout-mïnen ontoeckt febbende/op be plapnen diefo noemen de Orgol, [oo bouse bp baer noch) een ftaot belck fo de naem gat ban los Confines, die Daer naer weder is op-gebzodken/ente aen een ander oogt berleght.

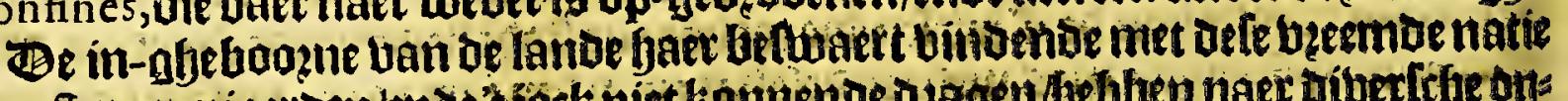

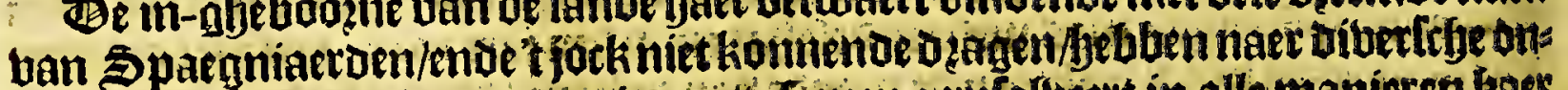
derlinge ende fecrete bp-een rottingev//te Tamen getefolueett in alle manieren baes

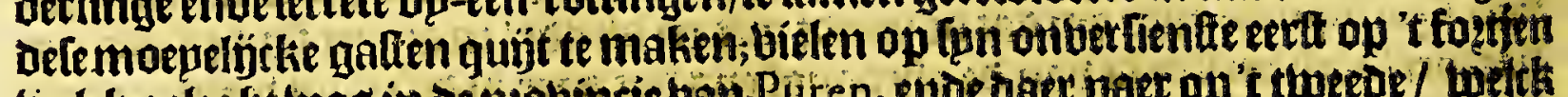

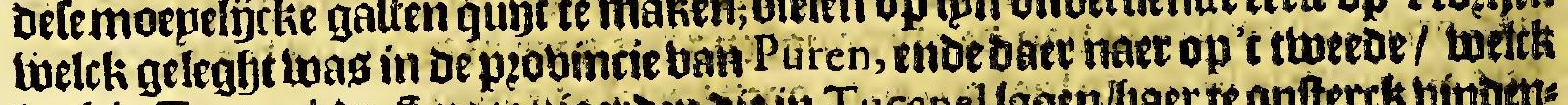
lagf iil Tucapel; de Spaegniaetoen bie in Tucapel lagen/faer te oniterck bindom

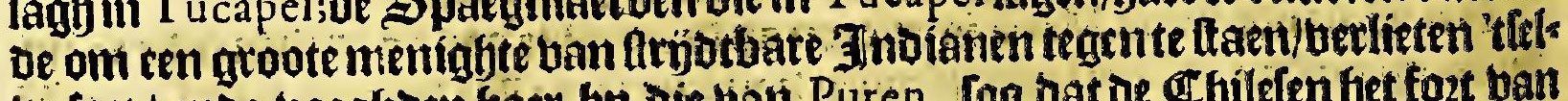

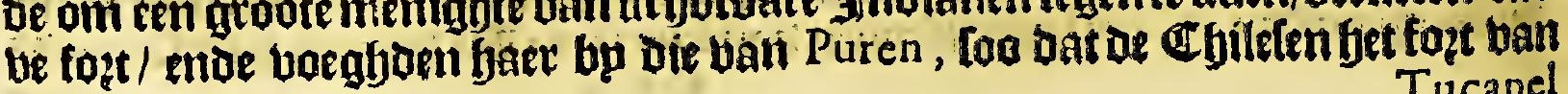
Tucapel 


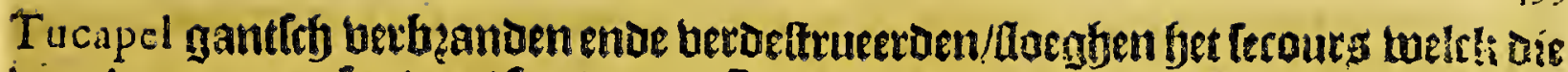

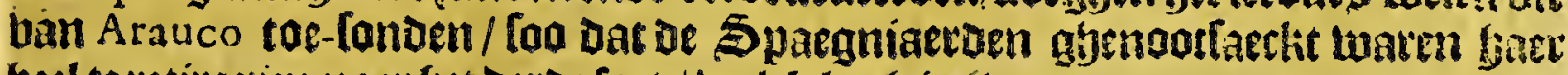
becl te retirceren waec bet oerde foet / welch lagh in A rauco.

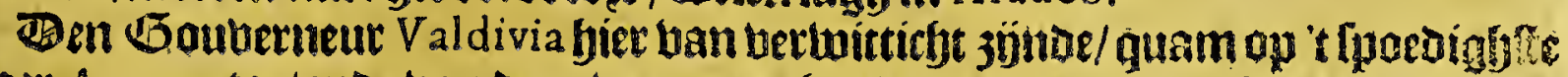

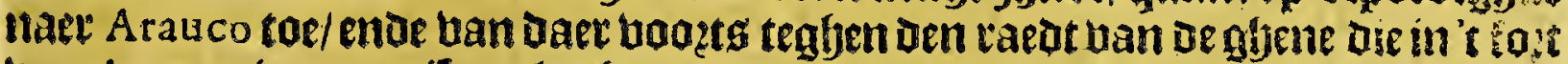
ban Arauco in guarnifoen lagfen / met 53 man naer 't fott ban Tucapel, endse

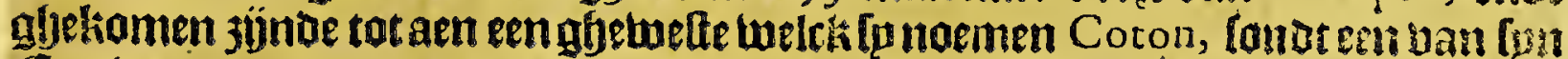

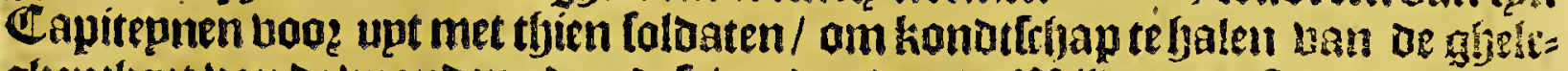

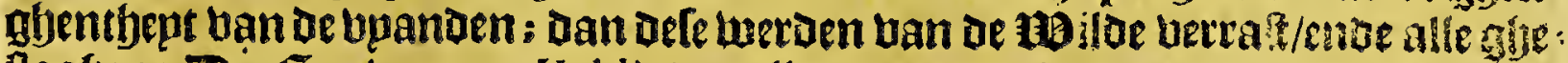

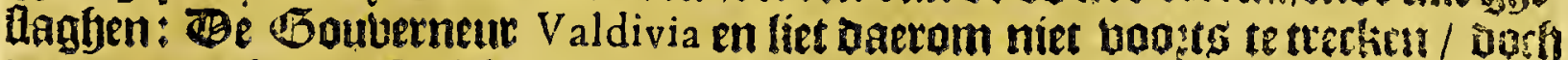

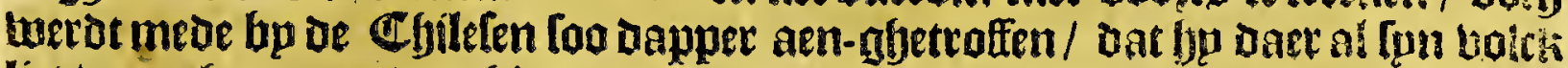

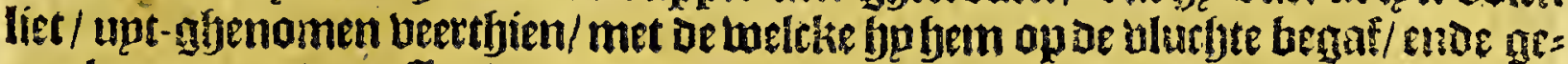

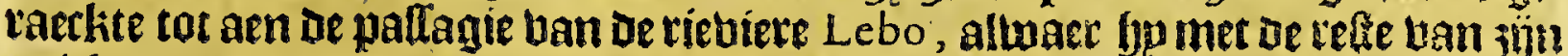

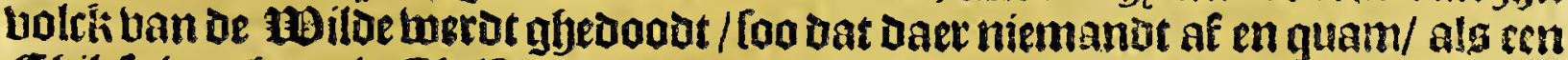

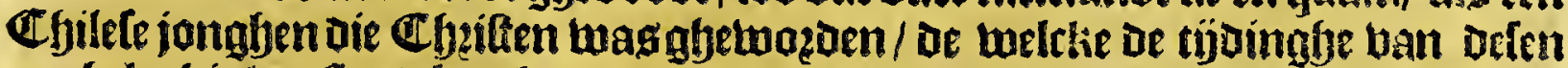
ongbeluckinben thagb bzotbt/aen die ban't fort Arauco. (Genigfe berbalen/ende ander andere Lopez $V a z$, Dat de Bouberneur $V$ aldivia lenendigh in handen biel

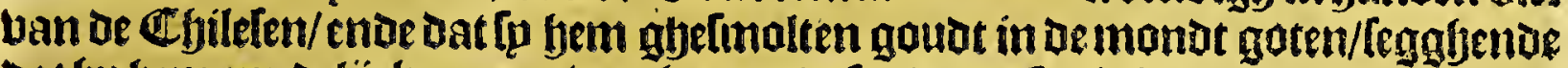
dat bp yem epndelýthen eeng van het goubt toude bertadigben.)

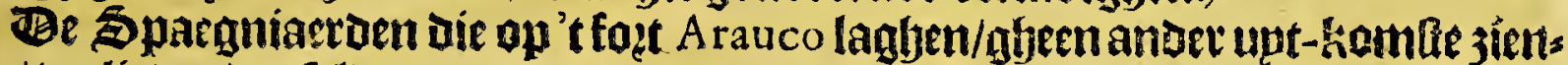
ae / Letíften bat Ielue / ende bertroclien naer de ftad Concepcion; ende die bat 't foit Puren, naer berlies baneen Deel bolckg/naec de thad Imperial. Be Iieute nant uan Valdivia gljenaemt Francifco de Villagra, troc's daet naet op met bouts

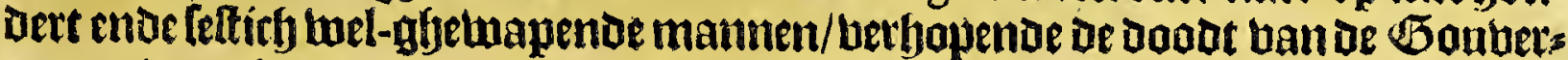

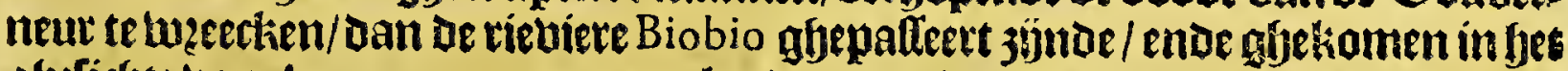

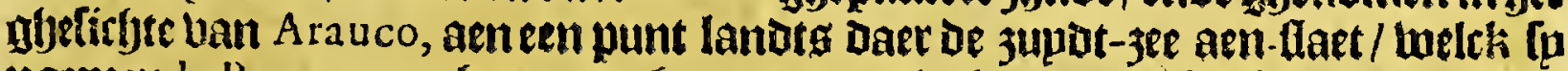
naemen la Raquetta, gljemoeten fp fen groot legher ban Ghilsten die hem leer

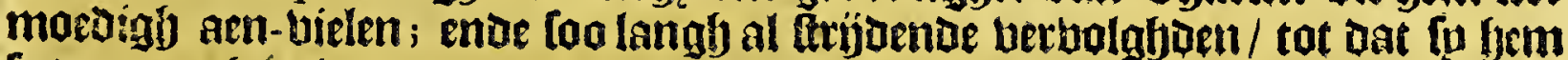

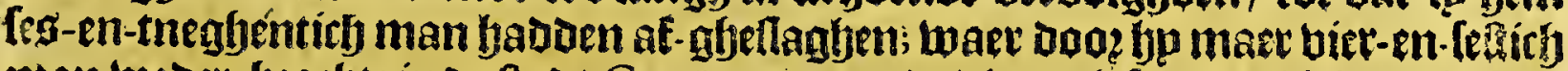

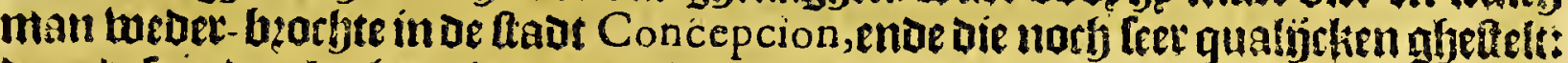

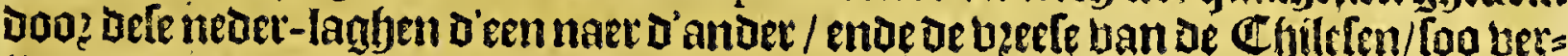

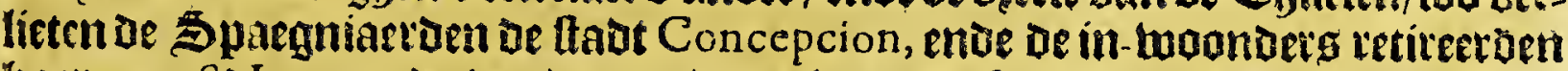
jaet naet $S^{t}$ Iago ; enoe tmerden mede vetlaten de ftadt Rica, entae de los Confines, enoe locijten alleen oe ftaot Imperial te befyouben.

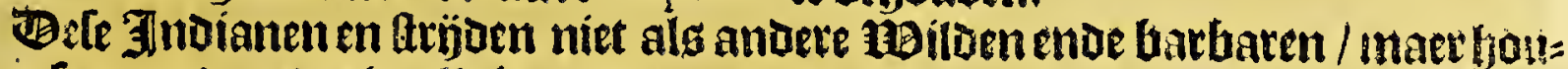
Den ferr garue agde in alle baet booz-nemen / werpen foten op/ Daer [p upt eñ in

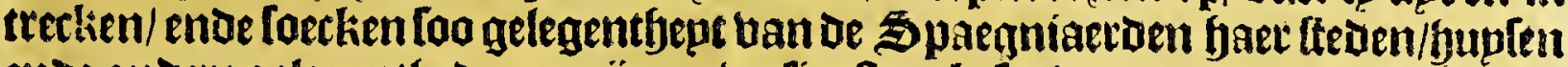
enoe andere gelegentljeden op 3 ïn onverlientte te befpeingen/ ende te terb?anden; bebluen oock geleert oe twapenen die fpertt ban de $\$$ paegniaetoen beblen geno:

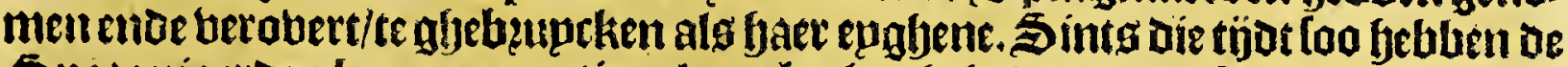
\$paegniaerden bp-naet tontinuele oosloglje ghefadt met of Gileten/ende beel

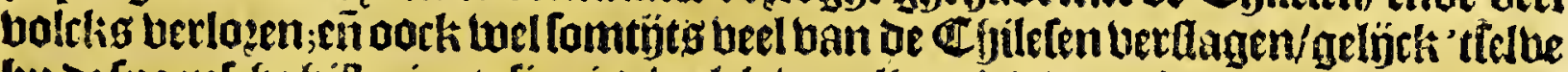

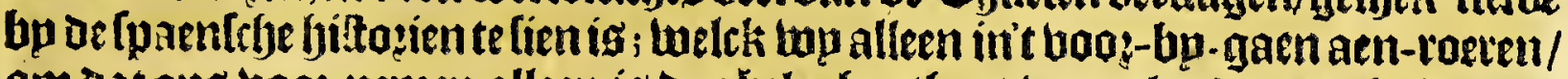
om dat ons booz-nemen alleen is de gheleghentijept ban 't lanot te berfjalen.

Don A lonfo de Erzilla infpn Araucana, Leght Dat aepzouincie welth funoemen el Eftado de Arauco, maer een klepne pgobintie en is ban begríp/ontrent 20 mï̈=

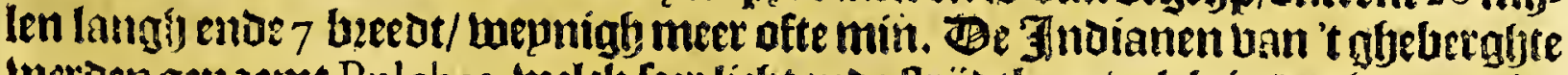
weroen genaemt Pulches, walck [eer licht enve ftrijotbaer volck is/Dorlj van min= Der Lerfant/als die op de plapnen woonen. De twapenen die de A caucanen gbe=

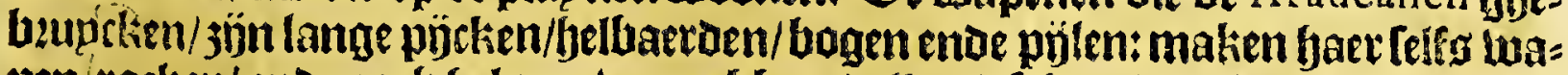
pen-rosken/enoe aock gelmen ban robben-bellen;'t leberp ban baer pücken baag

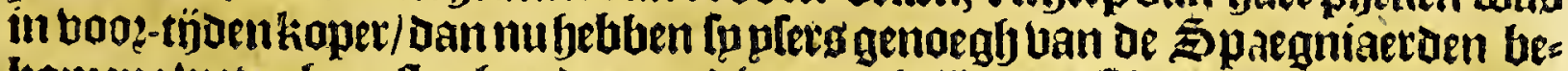

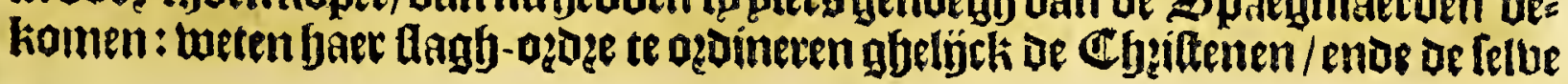


$+34$

Chile.

aen te boeten enbe te beleusen/met mannelÿrlie couragie enbe dappethept; foo dat

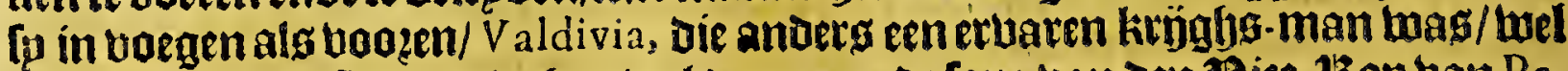

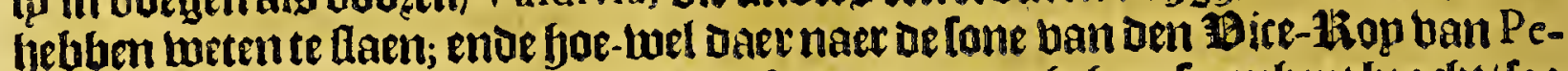

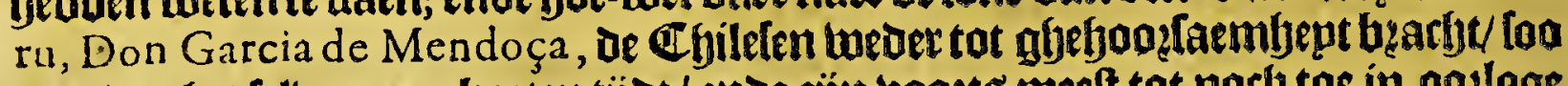

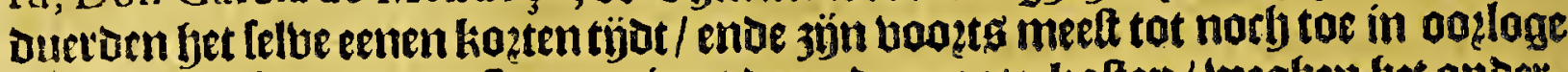

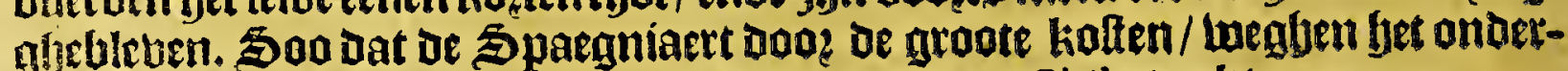
jouben ban de Toldaten/ Leertwepnigh boozedels upt Chile treckt.

De topagie ban Candifch, feglyt Dat oe pzouincie ban A raucofeet ríckig/ente

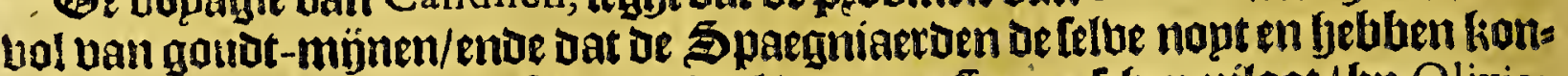
nen bermeefteren: ende upt feker berbael ban een Spaenleben piloot / bp Olivier van Noort gljebangen enbe geeramineett/ blückit dat oe Spaegniaeroen wel een fottien faodenaen't begin ban Arauco, daer 80 Coldaten op laglben / Dain dat fu

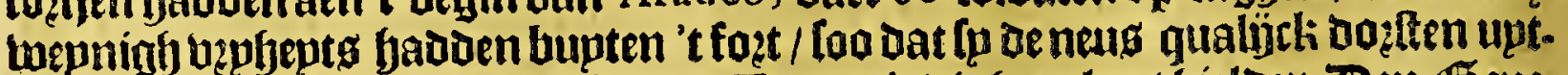

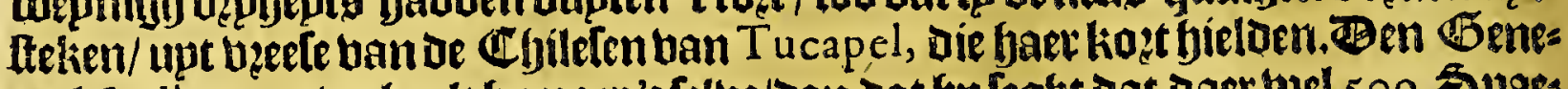

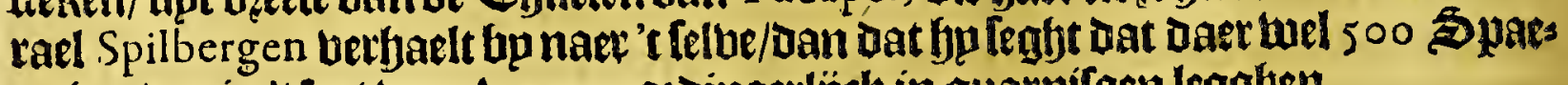
gniaeroen in 't fort uan A rauco, ozoinaerlïck in guarnítoen legghen.

De vyouincie van A rauco en beft gbeen ander bauen ofte reede als ae bloote liulte / aaer men ghenoeglj mach ancketen Lonoer cenigh gyebaer; oit glyeluelte bes

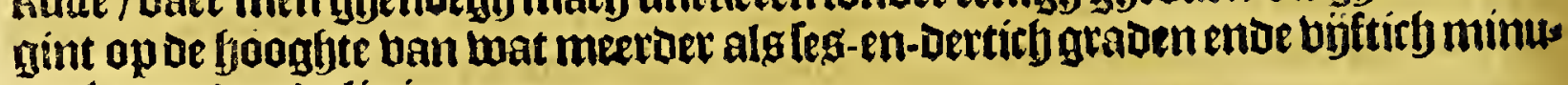
ten bp jupoen ae línie.

\section{Het levende Capittel.}

Van het Eylandr L a Mocha, ende de Eylanden die fy noemen DE IUAN FERNANDES.

$T$ Dt de baliepe han A rauco ghehonet 't Eplanot belcli fp noemen la Mocha,

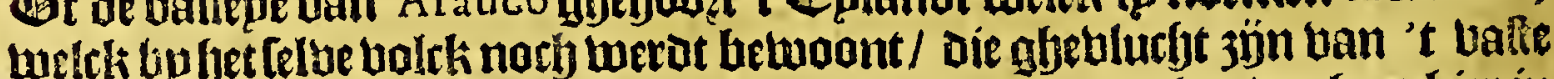

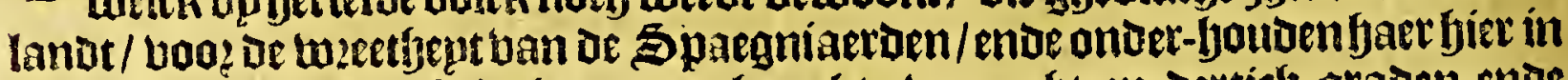

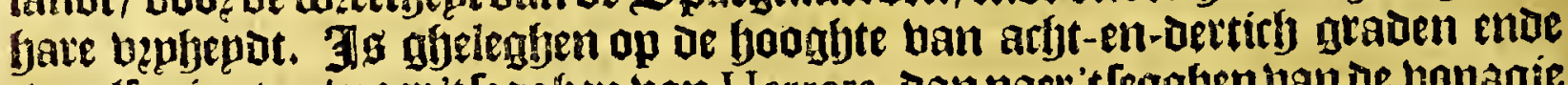

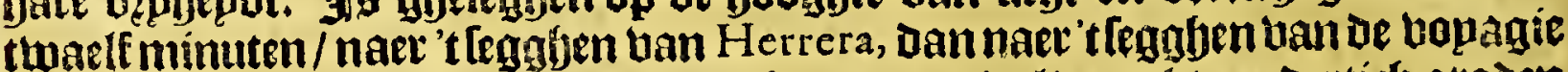
uan Sir Francis Draeck, ende Fuller in [un memoziael/op arbt-ent-oettich graden ende derticfymimuten; ende naer 't leggen van de hapagie dan Olivier van Noort, op actht-en-Derticly; welch alles twel kan twelen/ naer oe abetuelten daer De boogljte

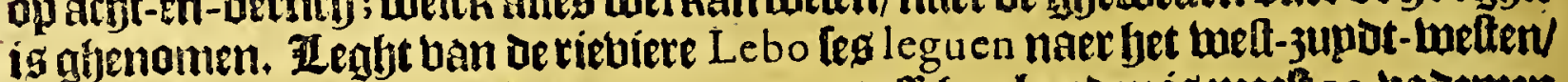

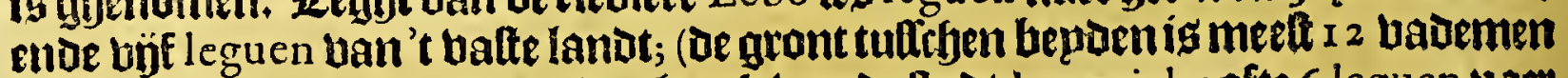
Diep/ eñ feel black: ende ban den boeck ban de ltaot Imperial 5 ofte 6 leguen naet

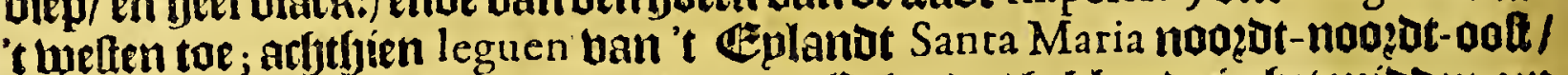

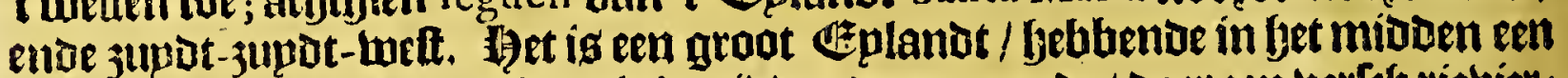

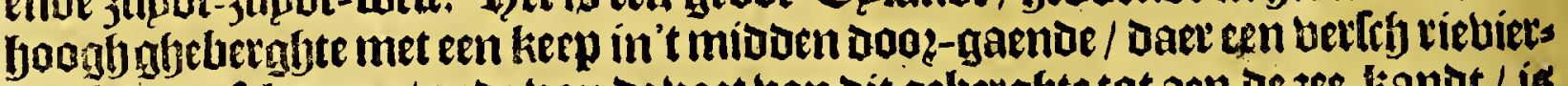
lien lomt af-loopen / ende ban De hoet ban dit geluerghte tot aen De jee-kandot / is

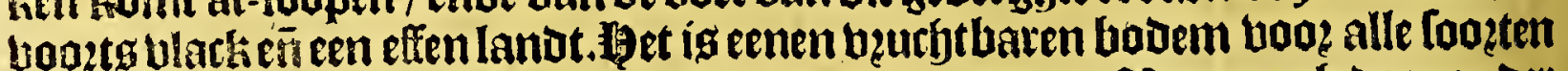

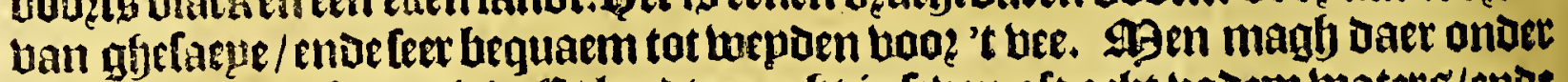

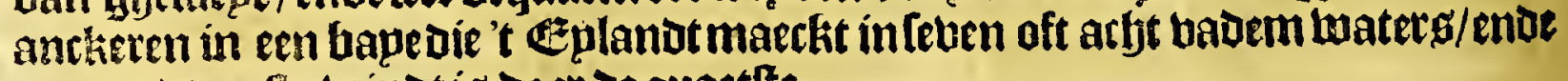
Denoded-oofte windt ís daet de quaetlte.

Sir Francis Draeck mas aen oit Geplanot / ende kreegf uan de in-woonderen

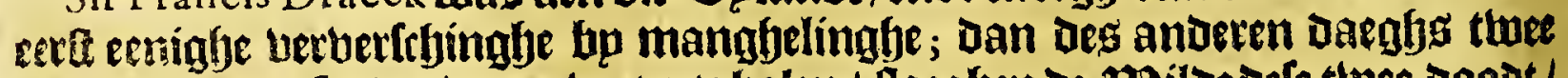

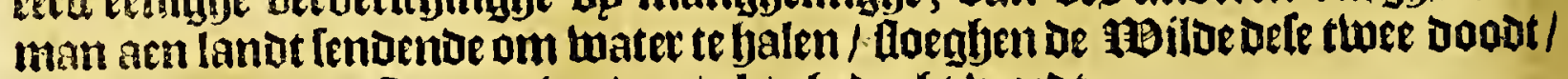
nemende die boos Spaegniaerden/als gfjedarft twog̨at.

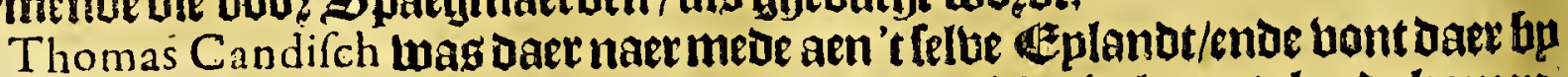
nacr alyelïctie bejeginghe / want fp en lwilden lpn balcti niet laten te lande komen.

De onfe hebluen't daer beter aebonden/mant Olivier van Noor hag Jaer aen/ enue handelde begolijeken met de ín-woonderen / ruplende bülen eñ metten tegen frbapen ende andere bictualie; kregben booz elcke bọle een frbaep / enoe boog een 
Het elflte Boeck.

mes een boen/ende fomtïts cock tuel twee; eñ boottsiz, Batatas, poutpoenen

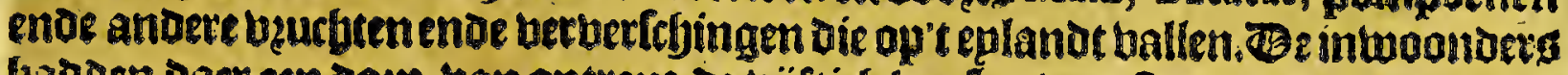

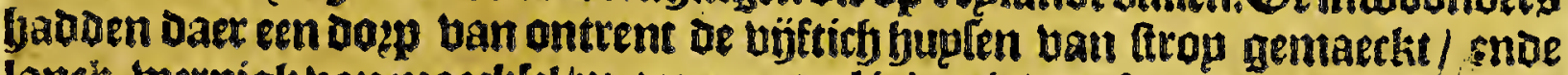

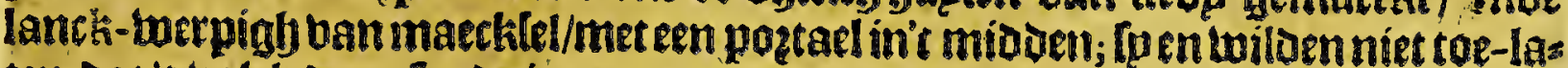

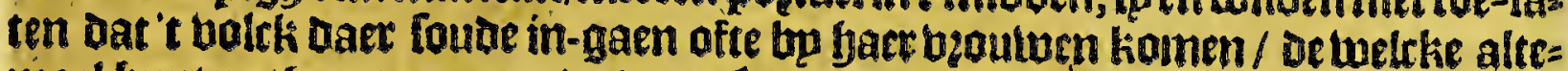
mael bupteltg bupg quamen/enoe op leecker oberocy dat De mang maecliten / op baer knien ginghen fitten in ogp ofte bier jooyen. Befe J noianen nenten aljoo vee!

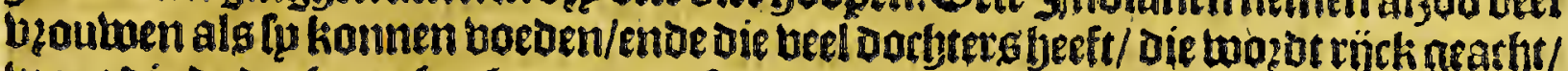

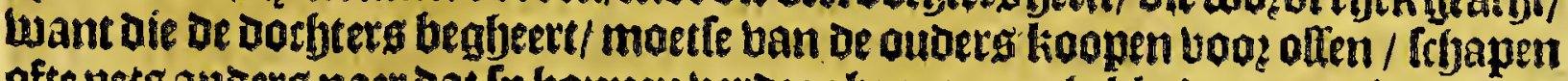
ofte pets anders naer dat fp komen berozaghen; gaen gbetileedt met rocken onoer

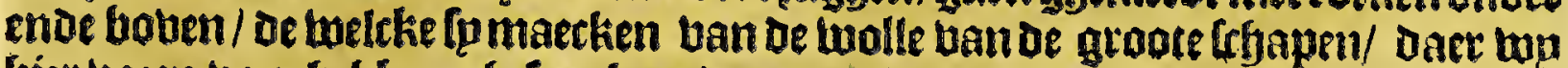

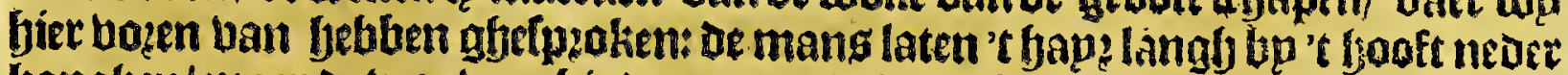
banglen/maer de byouwen binden ende blectern'tfelbe op achter in oen necke.

Den Generael Spilbergen was mede fier aen in Den fate $16: 5$ eñ brguam inct goe gemoepe alle berverthinge van't volch: De betchzijure ban fpn bopagic ghes

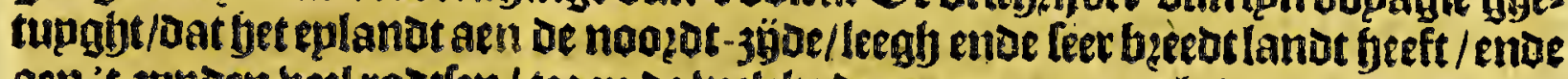
aen't 3 mpoen beel rodten / tegen be trelcke or 3 ee met groot gbed?ung op loopr.

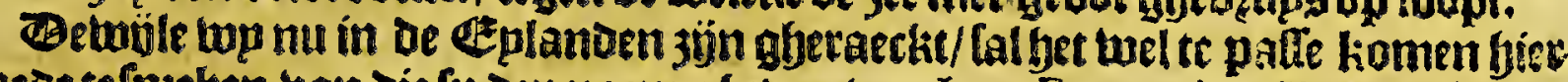

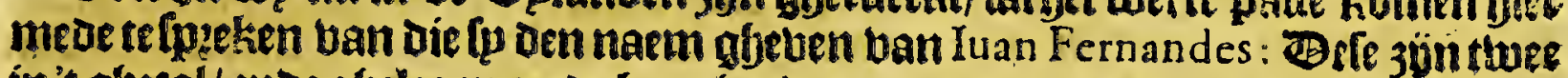
in't gheral/enoe gfelegen op de hooghte ban 33 graden cnoe 48 minuten bp zupe den be linie / naet de bebindingbe ban Le Mairo; bepoe herl boogy lanot/ Doch

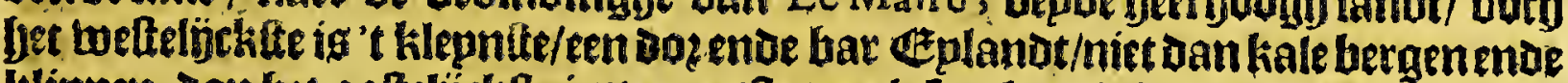

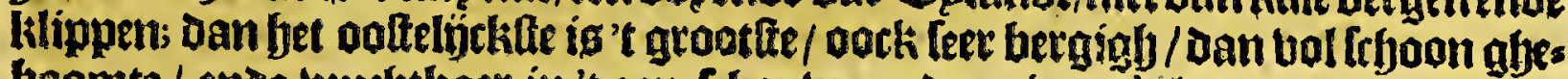
boomte / ente buthtbaer in 't aen-frboutuen; Daer is op't lant menighte van bocken ende vetchens/ ente aen De kufte in 3 ee onuptfperckeligctie menighte van

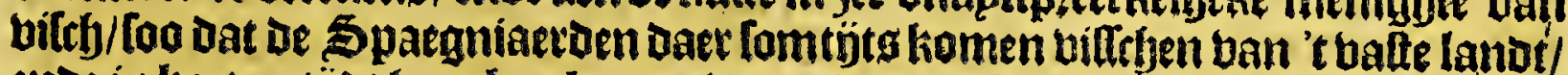
ende inkazten tjot jaer bercken bol bangben/die fu naer 't lanot ban Peru bos: ren. De reede leglt bp den ooffen boeck / foo datmen daet bp poften moet aen- Ho:

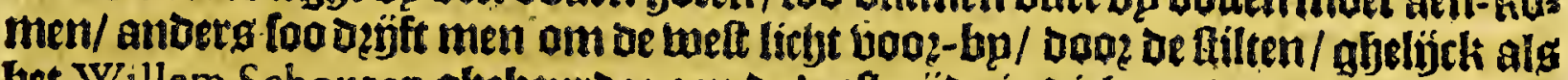

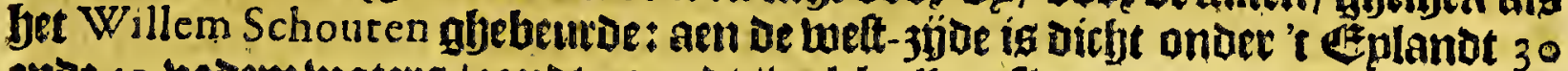

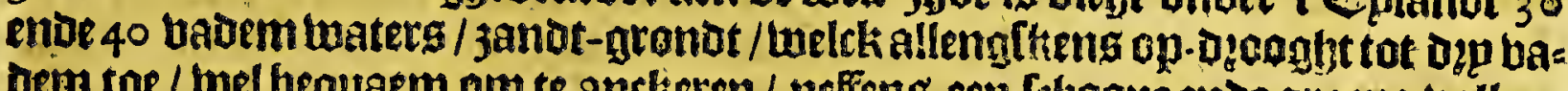
bem toe / wel bequaem om te anclieren/ neffeng en frboone cnae grosne ballepe Die bol aroene boomen ftaet / Ieet liefligthen om aente fien.

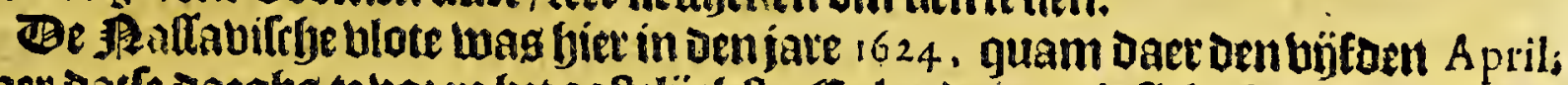

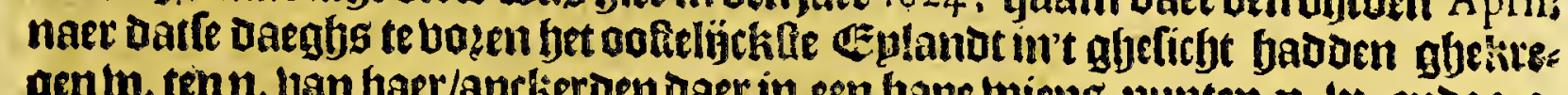
gentw. tenn. Lan baer/anclierden daer in een bape tuieng punten n. W. ende 3.0 . ban oen anoeren liggen; daer is een groene ballepe.' $t$ Journael fefyéft daet ban

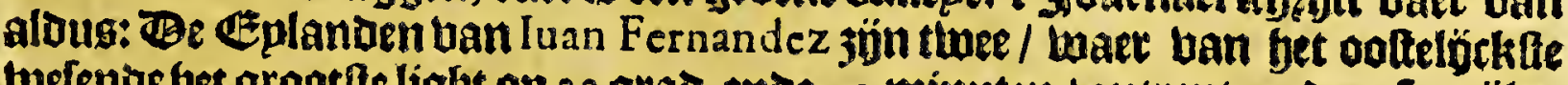
wefende get grootife light op 33 grad. ende 40 minuten / ontrent 70 oupte mijlen ban't valte landt Chili; bet ander volgeng 'tfeggen ban oe fpaenfe piloten w.tenn.

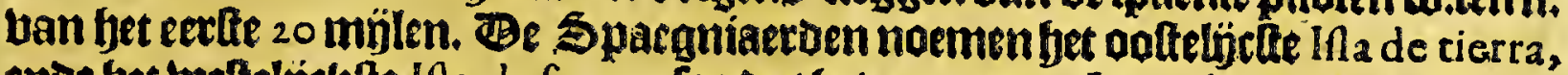
moe bet weltelýckite Ina de fuera, coo dat bet een groot abupg is/be klippe die na

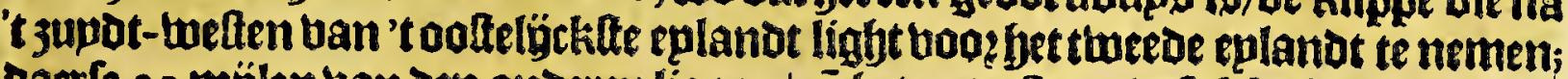
Daerfe 20 mólen ban Den anderen liggen/ eñ bet upterfte medefulcke klippen beff.

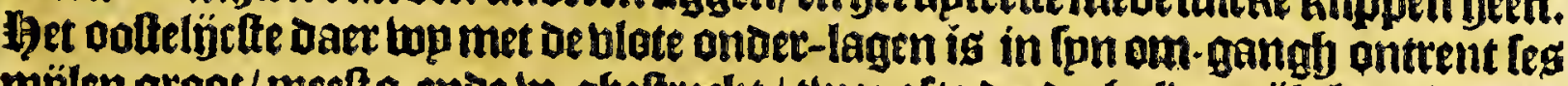

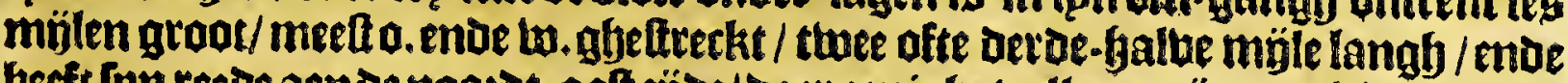

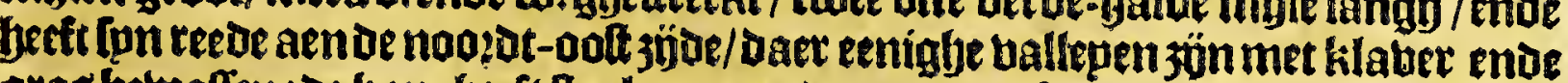
gras betwaften: de bape beeft fteplop gaenoe gront enfoeels ruoligh en tupl/eent= beels lwart fand: men beeft om oe groote diepte beel moepte eermen op $34 \mathrm{eñ} 40$ bauem/en balf mulquet fryeut wan lanot ten ancker kan komen. Sait Eplanot

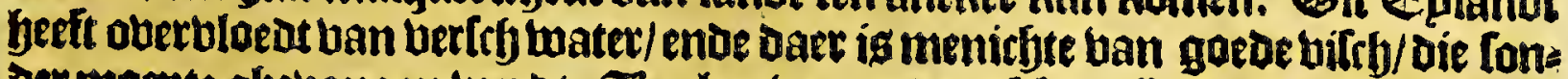
bex moepte ghebangen werbt. ZRe- leeutwen ende robuen jündet met Duplenden:

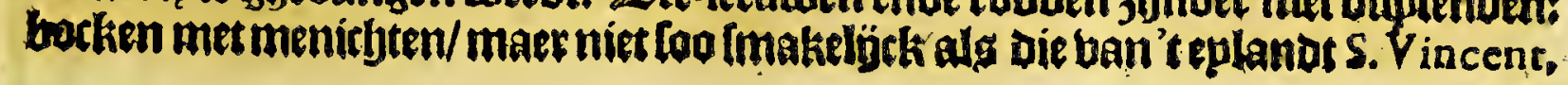

enos 


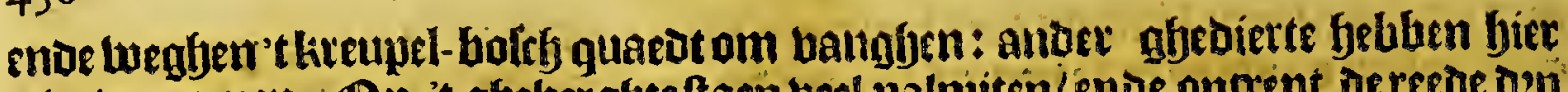
tuiet betnomen. Op 't gbebergbeftaen beel palmiten/ ende onnent be reede oye

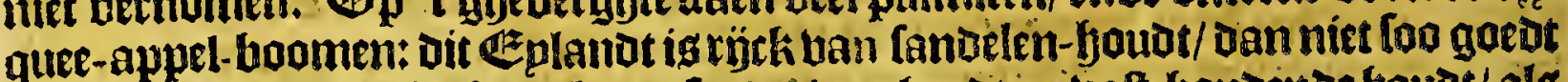

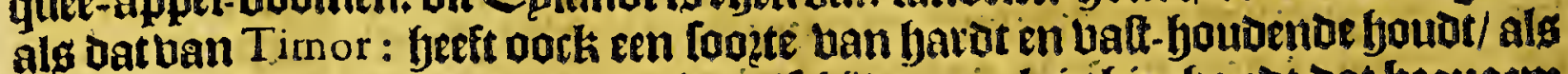
ipen-bout; bequaem tot güen/blocks en frbjuen: oock is bier boudt dat bequaem ig om te bertuercken: Dan booghe boomen tot maften/ en behben bier niet berno= men. Eertỷots plachten fiec thien oft thaelf Indianen haet te onthouden om traen te maecken ban zee-robben / Dan nu moonter niemanot. Alen dit Eplano

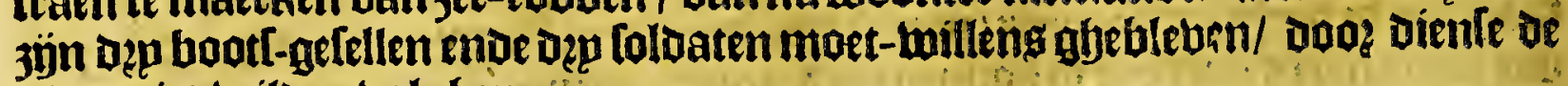
blote niet lwitoen bolghen.

\section{Tet adjutte Capittel.}

Van de Stadt de ios Confines, ofte Vili a Neuva pe ros INFANTES, ende van de Stadt IMPERIAI.

D. Et ftadt de los Confines ígerlt-mael to genaemt doo den Gouberneur Vil. lagran, enDe Daet naer Dooz Garcia de Meridoça bex-naemt Villa neuva de los Infantes; is gelegen bimen' glandtg/ende ontrent of I 8 leguen ban De $3 \mathrm{ee} /$ op de fooghoe ban 37 graden ende 3 o minuten bu zupuen oe limie/naer't leggen ban Herrera, op deplapnen/ twelcke fp noenien de Ongol, moe de rieviere die van de Sierras Nevadas, welck oock jún de Andes, af-komt/looptneffeng deleftadt/ende

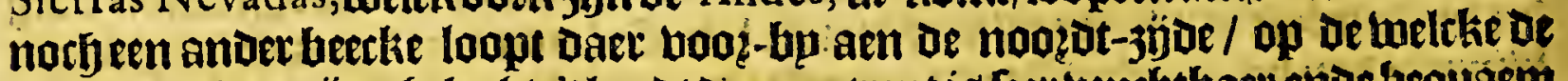

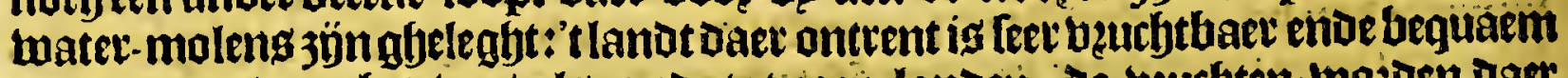
tot wevoen booz het bee / als mede tot zaep-landen; de beurbten mozoen daet

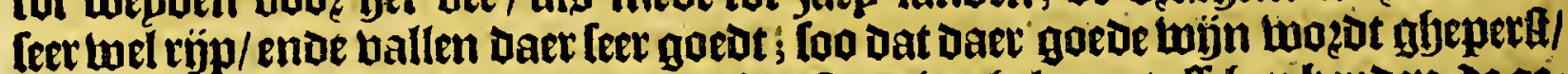

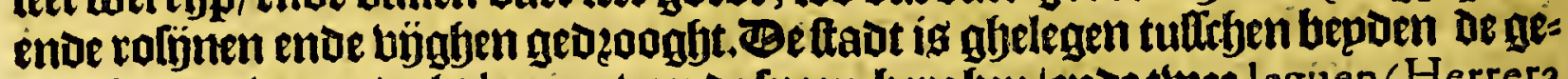
berglften/te Leten/acht leguen van De [neeu-berghen/entoe twee leguen/Herrera Ieght oock elderg bier) ban't gheberghte dat naelt de 3ee-kulte loopt / ende dit jön oe palen ban oere ftaot ooft enoe welt: baer palen ftresken faer noożt ente 3 ups oen upt achthien leguen, de arbt leguen tot aen oe riebiere/ welck in noemen de la Laxa, Doo dien bet water op een plaetfe wel twintich hademen neder ftoet: De ans Dere tbien leguen, ttreckende naer 't jupten laugbg Den boogben wegb/ welck loopt naer be flaot Imperial. S9en binbt daer groote menighte ban ripets-boos men/ Daer men lwel-rieckenot hout ban kokt/ende men mepht dat ban dien boom

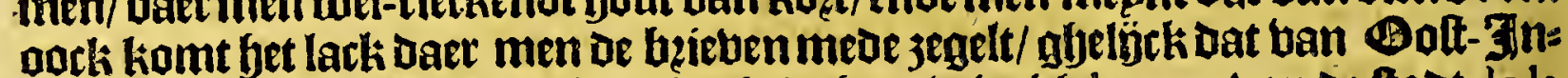

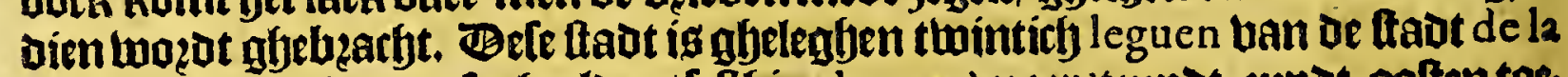
Conception, (Herrera fegbt eloetg feltbien leguen) naer't3upot-jupot-oolten to:;

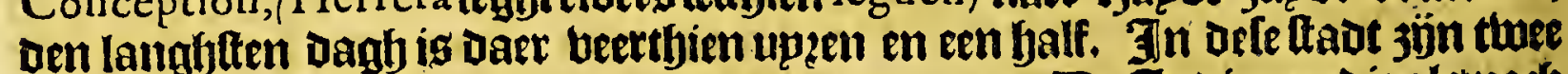

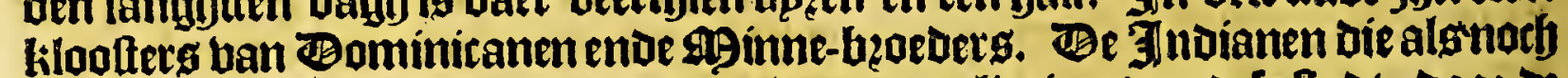
oosloglen met de Spaegniaerden / palen aen oe limiten ban oele ftadt : Dooz ne welcke de riebiere Biobio pafleert nettens andere die ím be [elue komen; als mede een andere riebiere die fonoemen Nivequeten. 't Berbael wan Den 5 paenlefien Biloot bp Olivier van Noort noemt ఎele ftadt Ongol, ende Ieght Dat Daer tuel twee

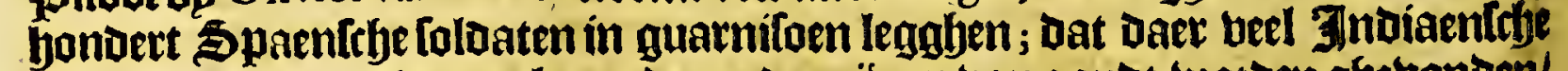

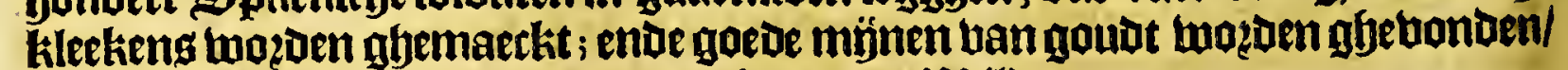
Dorly niet abemineert oooz den do:loghe met de milden.

Deltaot Imperial is gheleghen op oe booglte ban acht-en-dettich graden ende veertich mimuten bp zupoen oe línie (Herrera legbt etoers op neghen-en-dertich)

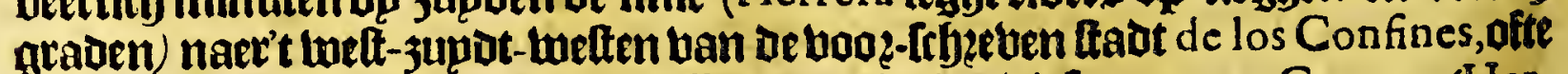
Infantes, vier leguen ban de jee/neffens eentieluiete die lu noemen Cauten, (Herrera noemtle oock Vten) oe welcke ban't Ineellw-nbeberghte fiomt af-loopen/

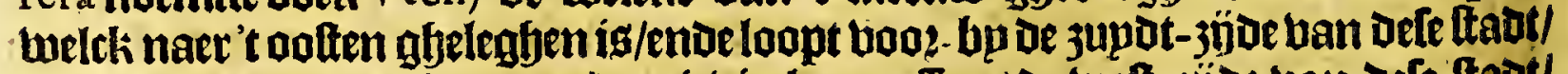

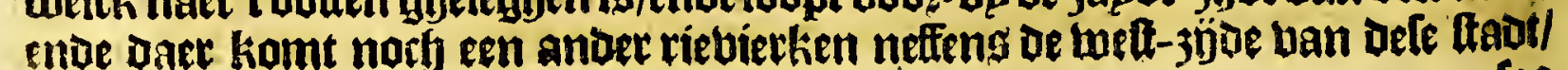




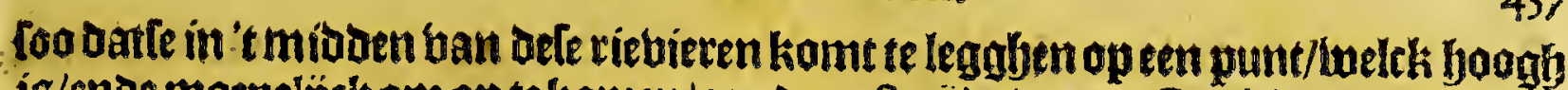
is/ende moepelíck om op te fiomen/aen de volt-jybe van oe Cordillera ban't que: bergbte dat langbs de kufe benen loopt. Defe ttadt is de booft-ftad wan 't loesde 25 ifoom/ luelck is int thoningh-rücis ban Chile;fate palen arecken tjien leguen naet ' noozoen/ ende naet't jupoen tot en riebiere die lp noemen $Q$ ueule, weick leggt op of booghte uan negen-en- dertich gradenende ecu balf/maer't Ieggen van Herrera; foo dat de límiten ban defe fraor jün noqut ende jupten arbthien le-

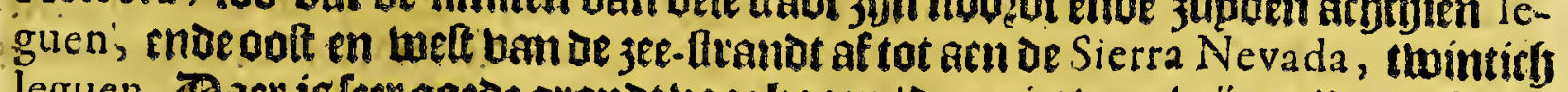

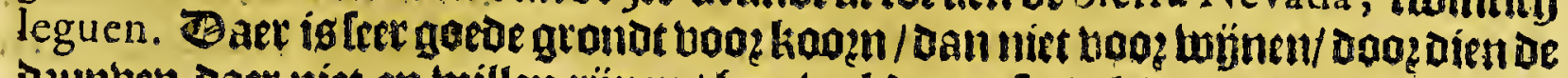

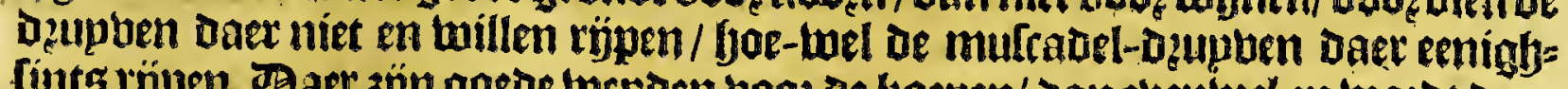

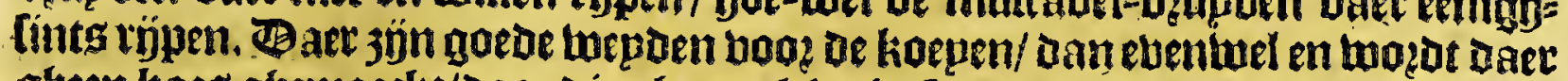

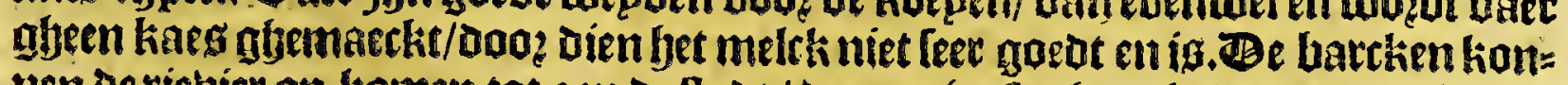
nen De riebier op. Homen tot aen oe thadt/ dan en beeft gbeen baben/ Dooz dien bet een black frandt ís met fandt-bancken ban dep badenten tot en baif badem toe,

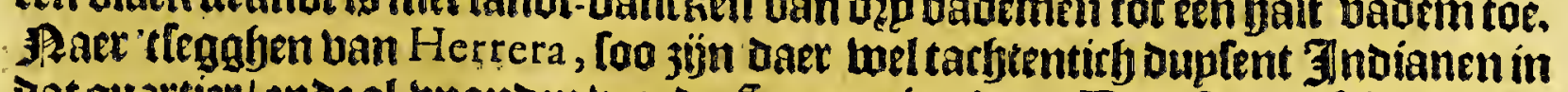
ilat quartiet/ende al bpanden ban oe Spaegniaerden. Ben Spaenlefien pilooc

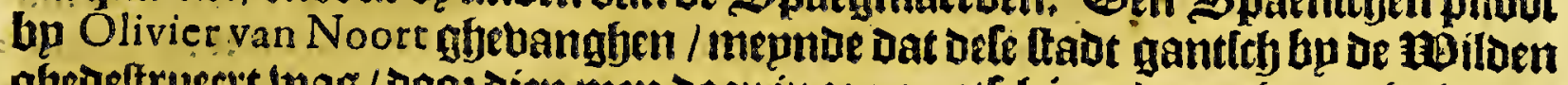

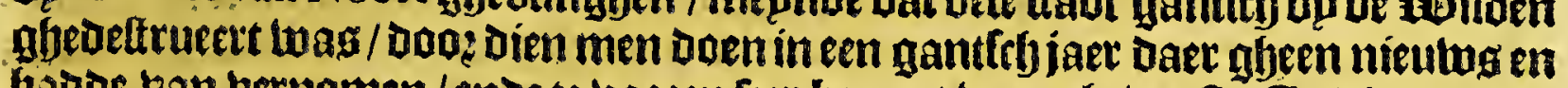
baude tan bernomen/ende te boasen leer benout was gljetueft. In dit quartiet

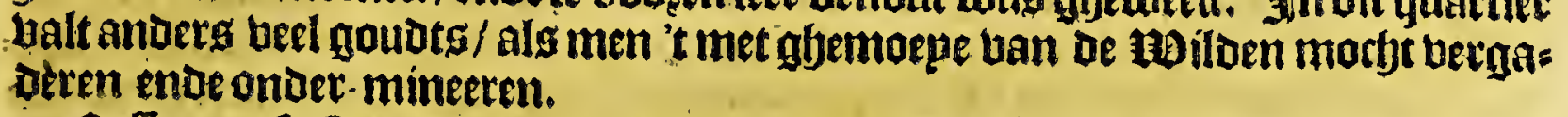

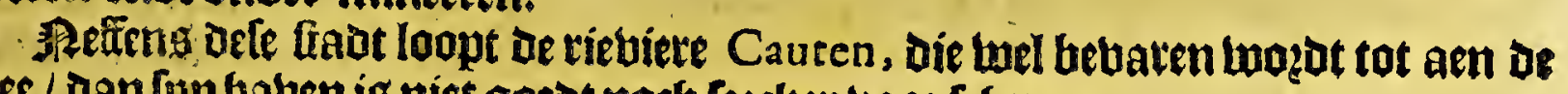
zec / Dan fun baben is niet goeot nocb leecker boo? frbepen.

Het neglende $\mathbb{C}_{\text {apittel. }}$

Van de ftadt welck fy noemen VIL a Rica, ende defadt V A L DIVIA, ende de gheleghentheden daer ontrent.

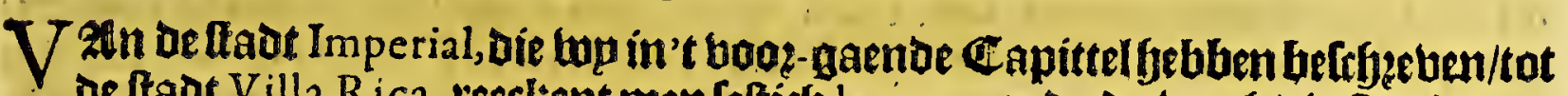
De thad Villa Rica, veeckent men leltith leguen, ende oe wegf die freckt dets

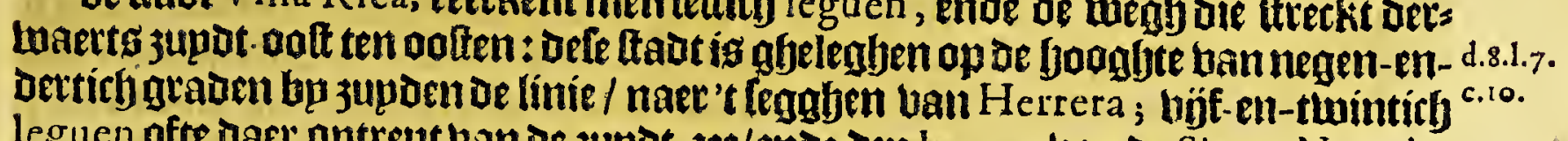
leguen ofte daev ontrent ban De jupわt-jee/ende bye leguen ban be Sierra Nevada, ofte [necu-glyehe'ghte naer 't tweften; saer leght een groot lack ontrent/Lelcli feeft in oe lengite ooft ende twelt deg leguen, ende in be bzeedte jlupden ente noogoen bandit lack is defe ftadt gyjebout / neffeng de water-Loofinghe ban bet felbe lack /

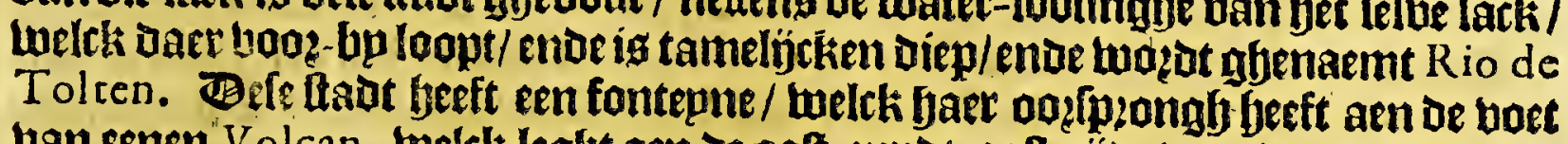

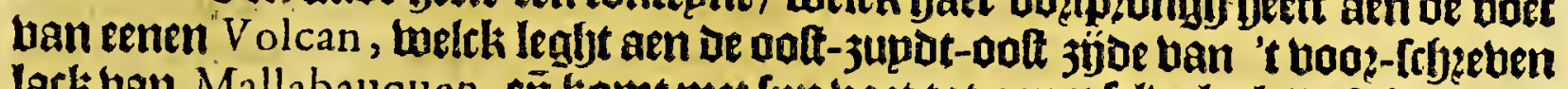
lack ban Mallabauquen, en komt met fpn boet tot aen 't lelue lack/ Defe fontepne

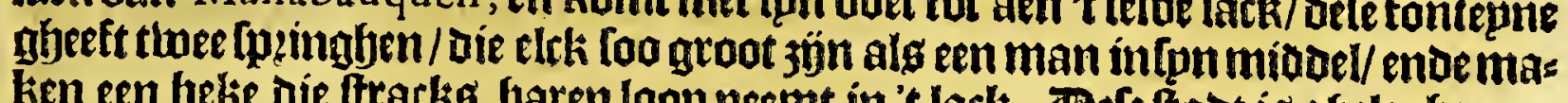
ken een beke die ftracks baren loop neemt in 't lack. Befe fatot is gfollegfen op bxicken wozaen ghebacken; feeft bequigh blacke gronot / oe welcke beurjts

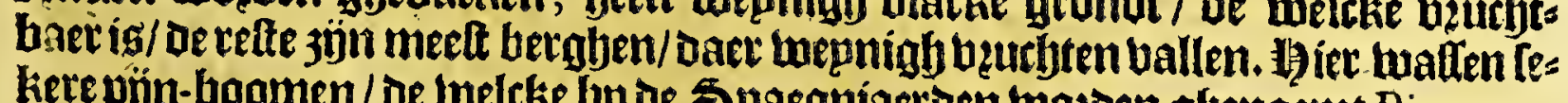

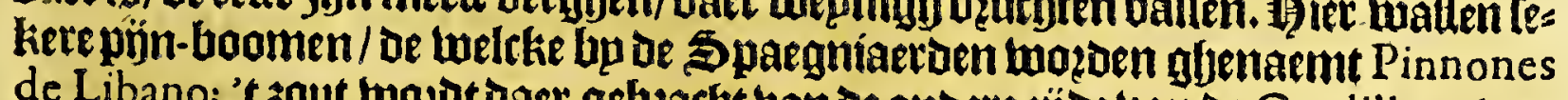
de Libano; 't jout wozot daer gelzacht ban de andere jöje ban be Cordillera, ban be finetu-bergen: aen de boet ban't telue geberghte woont een bilot eñ arm bolck) welck [p noemen Pulches, welck Gaer felben ander-boudenmet de jarbt/welck [p boen met baer bogben en pjilen. zulle be relte ban't lanot welelt men liet bp ooften

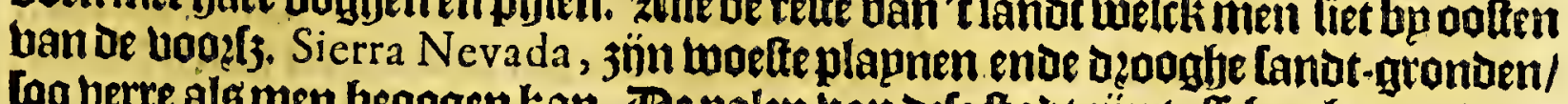
too berre als men beoogenkan. Depalen ban defe ftaot jün tuacben baer ende de Q $\mathfrak{q}$ Raot 
438

Chile.

Itaot Imperial; aen de pallagie uan de riebiere Tolten, acfl leguen ban befe fadt; enve tuflefen dele teadt eñ de thadt Valdivia tot de ballepe/diefp noemen Mariquina,andere arft leguen;ende nae' tooften tot aen de Sierra Nevada Dąu leguen, date

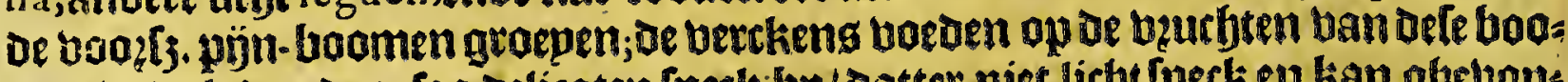

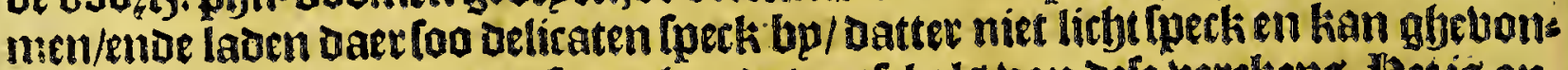
Jen twozoen van [oo goeden lmaect ende voetfel als ban defe verckeng. Ders tamelijek koudt landt/ende gbebeckigh van kooun ende lün. Ben Spaens frljen piloot bp Olivier van Noort ghetupght/ Dat in dele taot teer beel Ijuntuatts

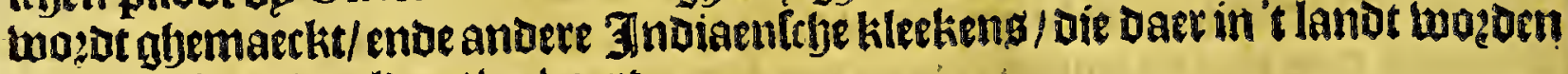
berfandelt / ende eloers bettuert.

d.7.1.6. Je bermaerde thad Valdivia leght bp-naet in't midoen/tufteyen't begin [el ban 1.7. De landen ban Chile ende de Itrate ban Magallanes, in een plobincie/welck fo noes men Guadalanquen, twee leguen ofte daer antrent van oe kutte ban de jupot-3ee/ enoe op de booghte ban veerticly graden frjaers by jupoen de línie/naer't fegghen ban Herrera, de welcke leght oat't berlfbil tuflehen den meridiaen ban Sevilla in Spaegnien/ende den meridiaen ban Defe ftadt Valdivia fulcks ig/ oat als 't mios Dagh is in Sevilla, foo ift te: $V$ :aldivia les upzen enoe thee deroe ban ern upe fmogs aheng/ loo datter norby üf upenende een derde agfebelken/om midoagh te torlen te Valdivia ; Den langhtten Dagb is Daer van wat meer als beertbien upen.

d.8.1.7. Deftadt $V$ aldivia beeft naer $D e s$ felfgleggben een goede baben/welck faer opes

c.10. ninghe ferftnaer't noazoen/De frbepen kamen Daer in/ende baren Den grodtten

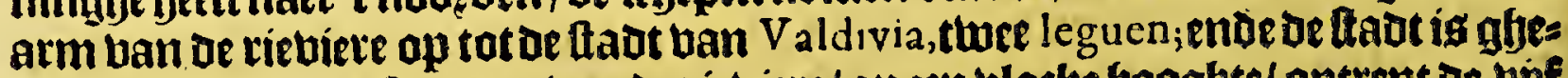
bout aen den kilepntten arm ban or riebiere/ opeen blacke boughte/ ontrent de byf bademen fooger als gemepne boogbte ban oe rietuiere; theltk is een filie enoe klas re riebiere/ende't aljetije fiamt ban Der $3 e e$ af op / tot aen een plapn met beubelen om-ringelt / twelek fp normen Guadalanquen. De palen van oefe ftadt ftrecken Gaer upt naer't noozoen/ afte naer de ftedell Imperial ende Villa Rica, atfot leguen tot Marequina booz-naemt ; ende thien leguen naev't 3 upuen / [oo dat lu noozden ende jupoen begrüpen adythien leguen; naer't aolten tot de Sierra Ne vada toe/3ýn

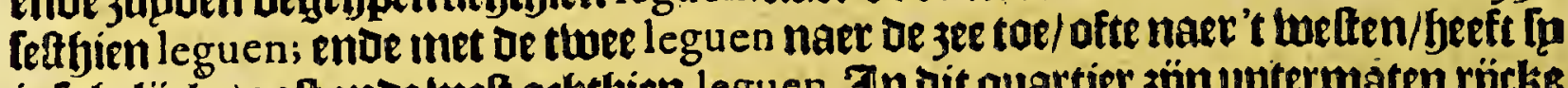

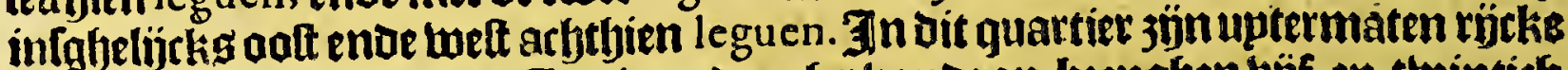

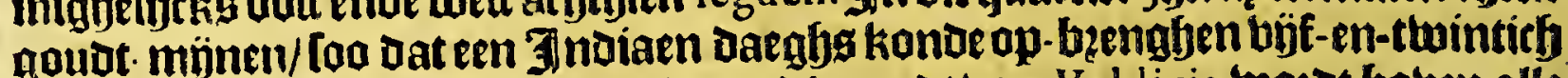
ende oork dertich Pezos fín gout; want dit goust ban Valdivia hozot hoben alle

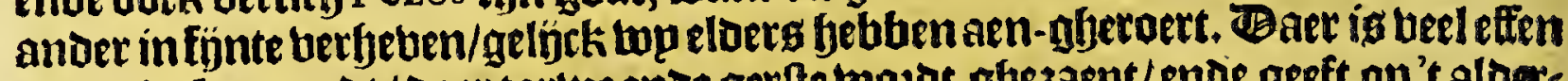
enoe blacke arandt / Daer tartwe enoe gertte twozot ghejaept/ende geeft op't alders minfte twintich boozeen/enoe beel-trjots wel dertich ende beertich; Daer twallen beelDerbande gaede beurbten ; dan de deupben en twillen daet niet wel rúpen.

Jen Spaentryenpiloot bp Olivier van Noorc berbaelt / Dat de le thad in oen jare 1599 in November bp of Cfilelen toas oberballen/ende alle oe Spaegniaer: Den die daer woonuen/ Dooot-ghellaghen ; dan dat oe Spaegniaer ben daer twes oet waren ghetomen/ende daer woonden unet baer twee bonderden/onder'tgyes hiet ban een Goubernett.

\section{Wet thiende Capittel.}

Van de ftadt Os orno ende $C_{\text {hilue ofe }} \mathrm{C}_{\text {astro, }}$ ende de gheleghenthe den van de landen daer ontrent; ende de provincie van Crucus 0 .

$\mathrm{D}$ EE ftadt Oforno (legfte Herrera) is gelegen 60 leguen eñmet ban de ftadt la Concepcion, naer't 3 updon/ende of ftrate ban Magallanes toe/ 7 leguen bam

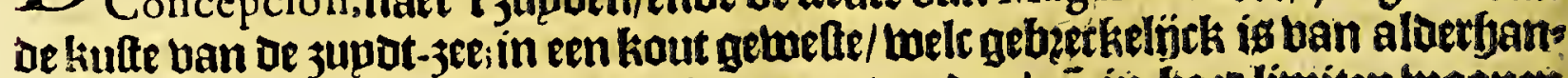
de ljyf-torbt: Dan oaer wott. [eer beel gouts gevonden/ eñ in baet limiten twoonen wel 200000 Jndianen die onder de Spagniardoen jün berdeelt tot baren diente. Den Spaenffien piloot bp Olivier van Noort gjetupght / Dat Oforno esn grooter 
grootec flabt ig als Valdivia, te landt-matt in gfelegben op de booghte ban 43

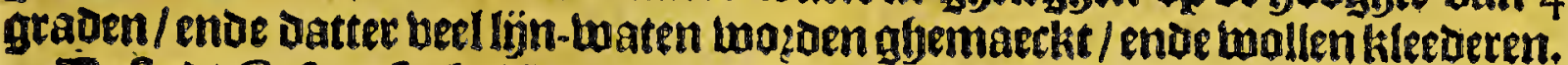

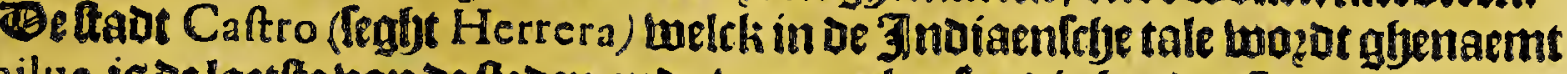
Chilue, ig de laette ban de fteden ende woon-plaeten die bp de Spaegniarroen

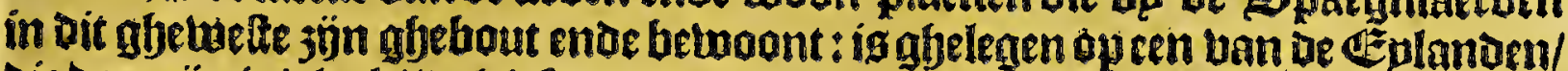
bie daer zönin't lack/ welek lp noemen Ancud afte Chilue, (be Archipelago van Defe Etplanten leght op oe booglte van 43 graden bp 3 upDen de limie) 42 le guen

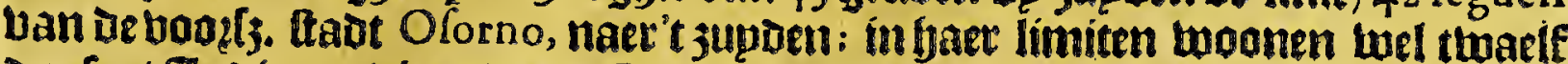

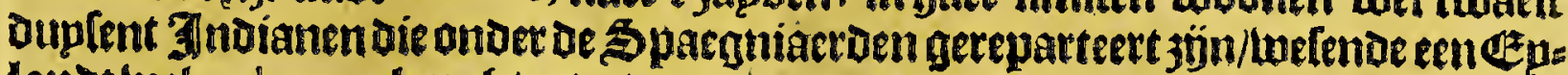
lamot wel soleguen langh/enoe ban twee tot negfen leguen beeedt/ welcke oe jee

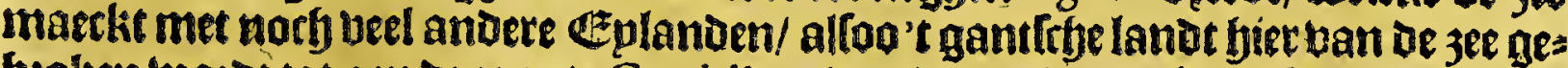
begken twozot tot aen oe groote Cordillera tuan be Andes tae; fet is berghachtigbe

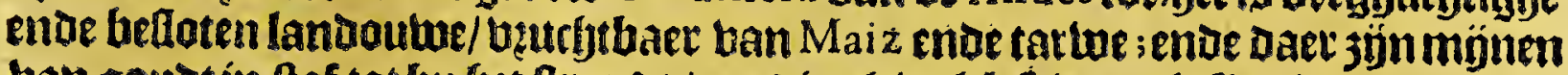

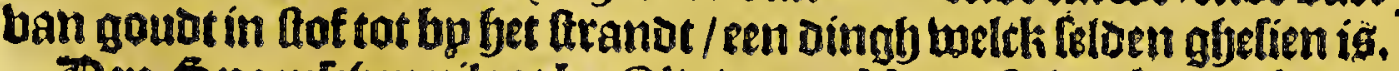

Den Spaenitgen piloot bp Olivier van Noore ftelt oefe platte ojuler-en-bers

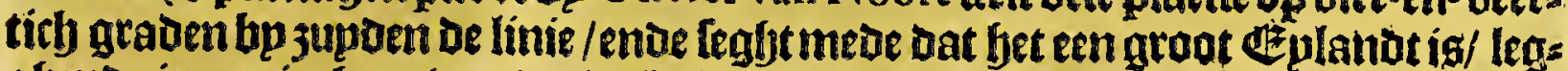
ghende in een in. Gam ban beele eplanden/ Dat rontom is belwoont bp de $3 p a p=$ gniaer Den/Die Daet een Bouberneur febben : Dat Daer beel twolle balt uan De fryas

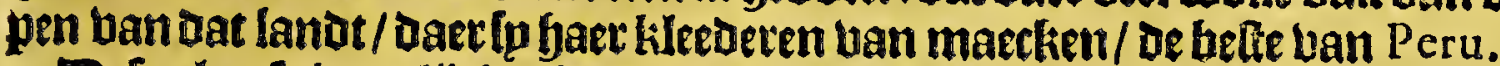

Dele placte is (geljick 't lelue bp de vopagie van Ioris Spilberghen mozot aengheroett) bp De onfe in-genomen ghetweeft onder'tuelept wan Theun is Theunifz.

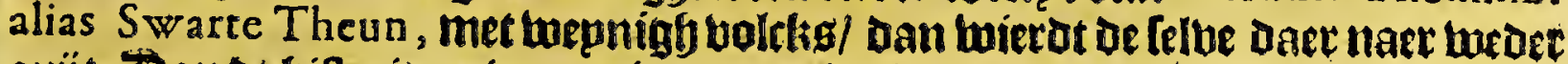
quït. Dan be biltogie en is mp niet ten bollen bekent: alleen lod bebbe íck ghefien leker af-tceckeninge ban oefe plaetle bp Den feltuen Theunis Theunifz. berbogert:

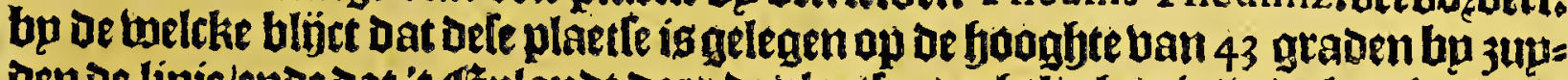

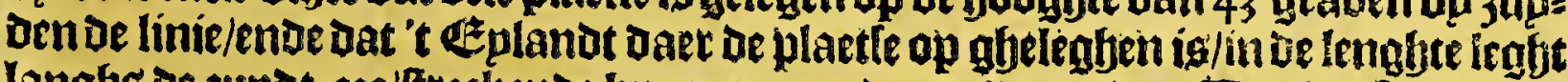

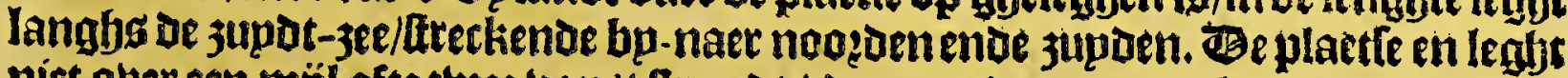
niet ober een möl ofte thee ban't frandt / Dan om daer aen te fomen moet men

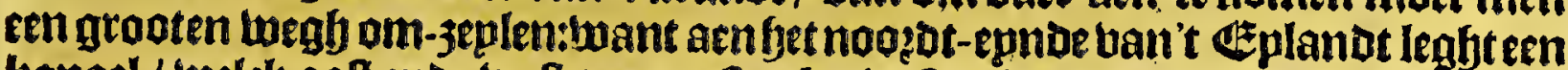
kanael / welck ooftende welt ten naelfen bp in-ftreckt/ende is in be monot hp oe twee mïlen enoe een balf beecot / enoe loopt binnen rondt toe / al waer maet eet

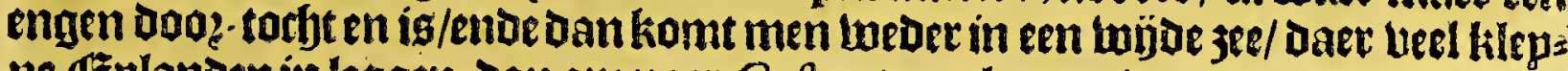
ne Eplanden in leggen; Dan amu naer Caftro toe te loopen/ moet men oe ooll-wal

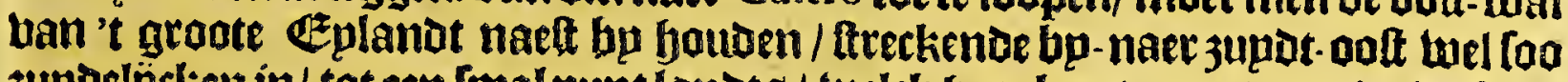

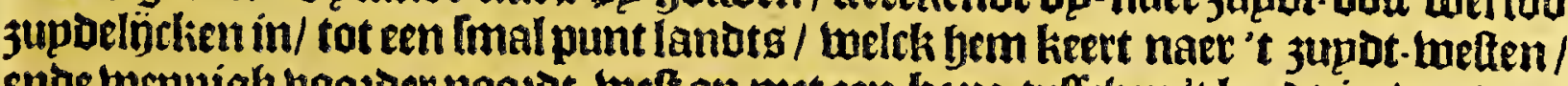

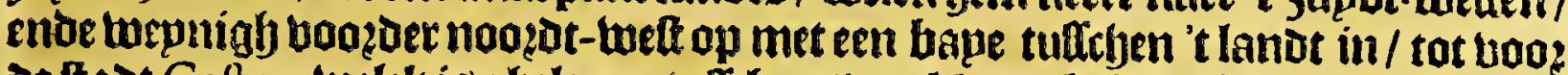
De ttaut Caftro, weIck is ghelegen tuffiben twee kilepne beken ofte kreken/met eet

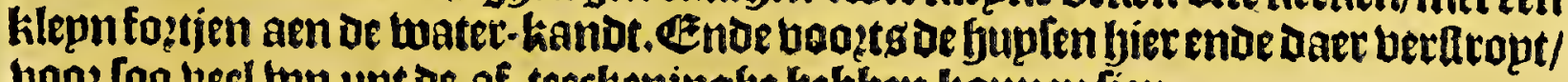
boo: foo beel top upt ofe at-teeckeningbe bebben honnen lien.

25eneffens defefteden ban Chile, [oo jünoer norb twee die mede tot het Bbu=

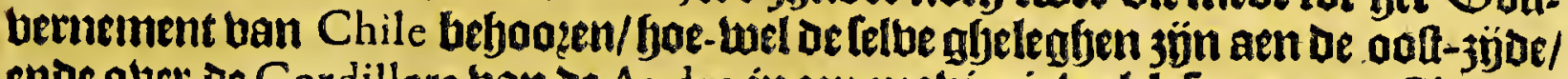
ende ober oe Cordillera ban oe Andes, ineen peabincie buelek funoemen Chucui-

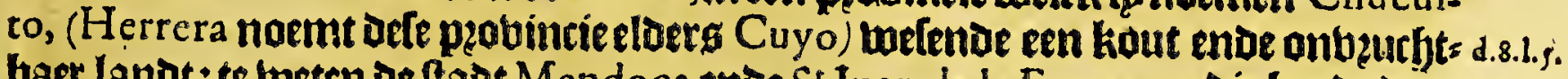
baet landt: te tweten De faadt Mendoça ende S' luan de la Frontera; Die bepde daer c.9. guebout jïn by Don Garcia de Mendoça.

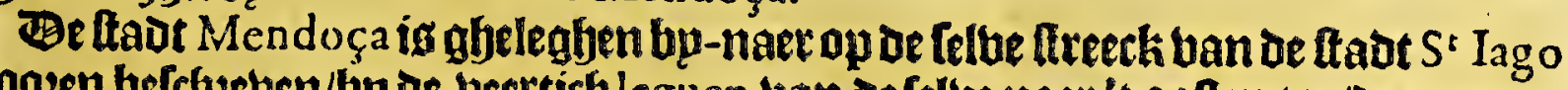
boozen befeletuen/bp oe beertichleguen ban defeltue naet' ooften toe/Dope eenen leer moepelintken wegh begben de menighte ban 't fneeu/ welck baer leght in oc Andes pfte Cordillera van be fnetu-berghen die men pafferen moet.

Be andete ftadt is genaemt $S^{t}$ Iuan de la Fronter a; leght notj twat boogerder naet 't jupoen als de ftadt Mendoça: naer banetnneder-lander ben ondet-ritht die in Rio de la Plara ende Peru íg ghetweelt; loo caude S' Iuan de la Frontera maer i Io mïlen leggen ban Buenos Ayres, Dooz centechten docblect eenlamen wegb; Lo Dat Rq 2

men 


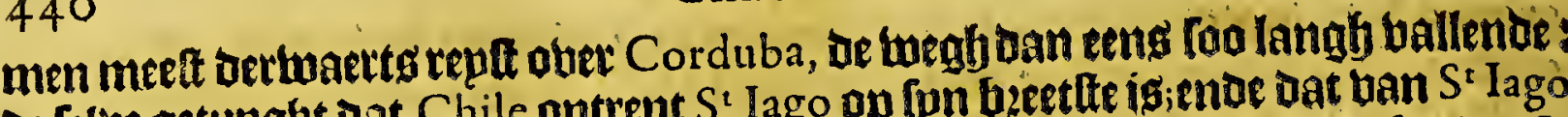
ae celue getupght Dat Chile ontrent $S^{t}$ Iago op fon beetlte is;enoe dat uan $S^{t}$ Iago tot aen be bugge in't geberghte over en rieviere gelegen jün 60 mijlen; foo dat S I De voozacre abeleabenthept ende booghte van defe ftedenen beb irk tot noth tae

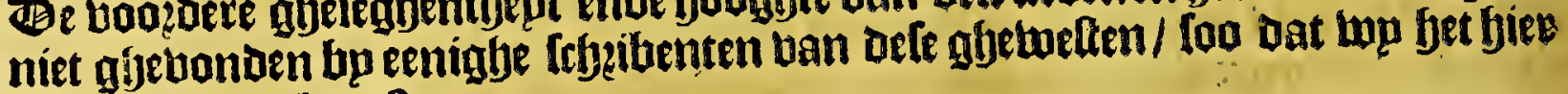
bu fullen laten berulten.

Het elftece Capittel.

Befchrijvinge van de zee-kufte van $\mathrm{CH}_{\mathrm{L}} \mathrm{L}$, havenen, reeden, kaben, bayen ende rievieren, van de fes-en-twintich graden af, tot de dry-en-dertich toe.

D E kufte ban Chile neemt baet beginfel ban de baepe ente ballepe ban Co:

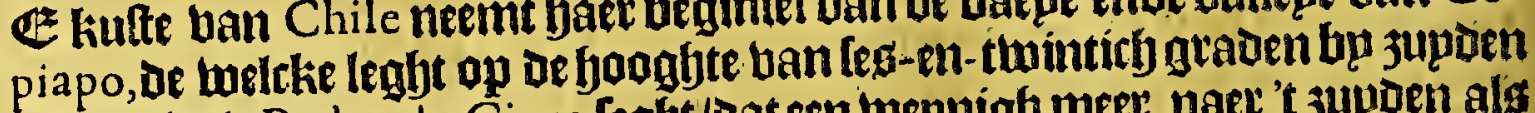

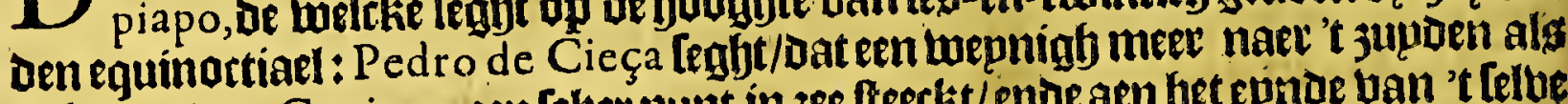
de bauen ban Copiapo, ecen Leker punt in 3 ee fteeckt/ende aen bet equnde van 't lelve een bape / Daer twee kilepne Farallones op-ftaen/ende aen'tepntoe ban de bape een riebier van feer goedt water/welckes naem is Guafco: dit bood fy. punt leght naes

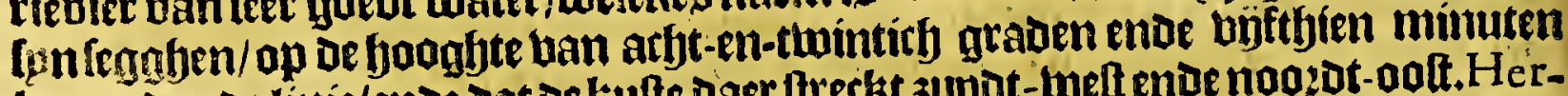

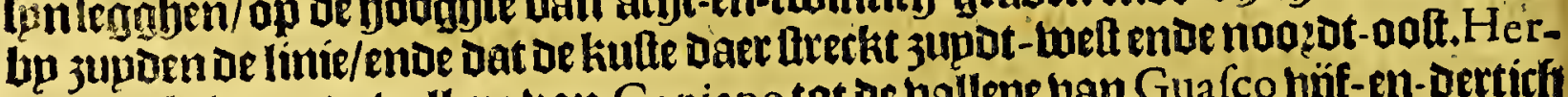
rera die telt van de ballepe van Copiapo tot de ballepe van Guafco büf-en-Derticfy

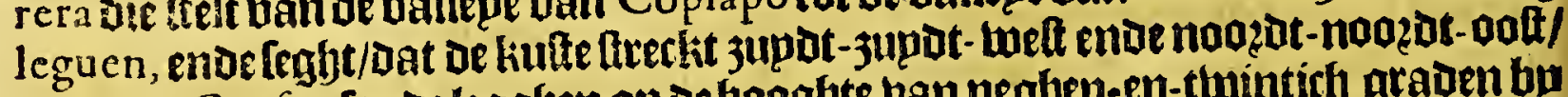
enoe Dat Guafco loude legglen op oe boongte ban neghen-en-twintich graden bu jupoen de límie. Olivier van Noort ftelot Die op de booghte ban atht-en-twintich

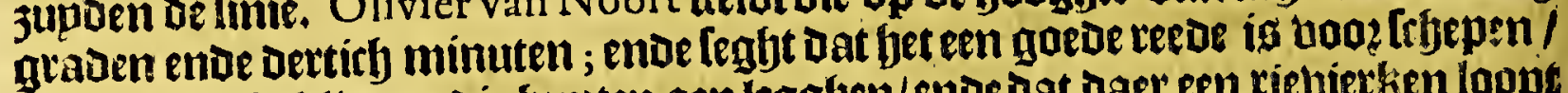

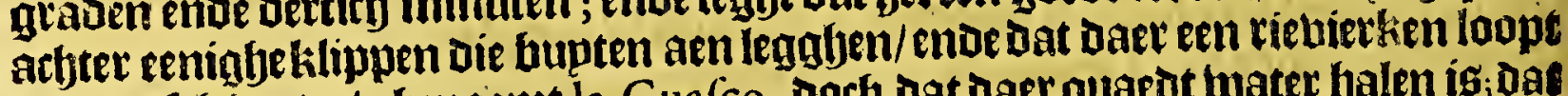

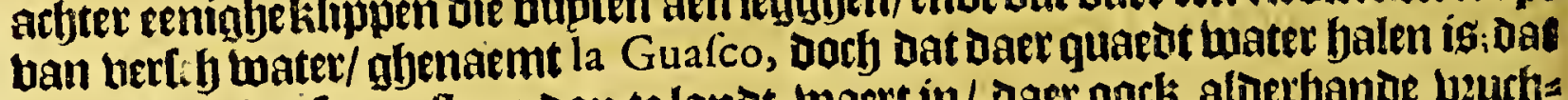

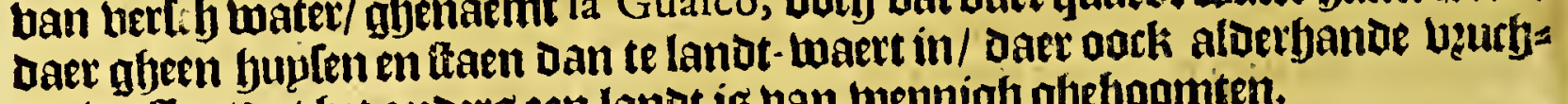
ten walten/Dat fet anders een lanot is ban twepnigh gheboomten.

10 an Daer loopt de kulte naer't jup den tot de baben ban Coquimbo, tuelck leghe op de booghte ban Derticly gladen naer 'tlegghen ban Herrera, ende behindingh van Sir Richard Ha w kins; $\mathbf{D a n}$ Pedro de Cieça [eglyt / Dat thien leguen ban ljte

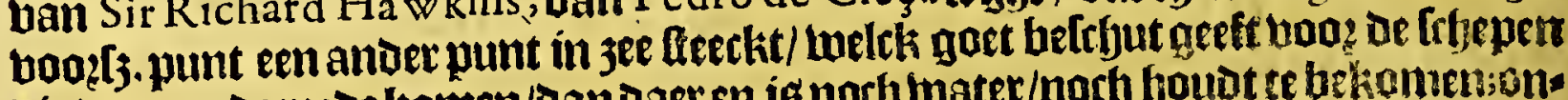

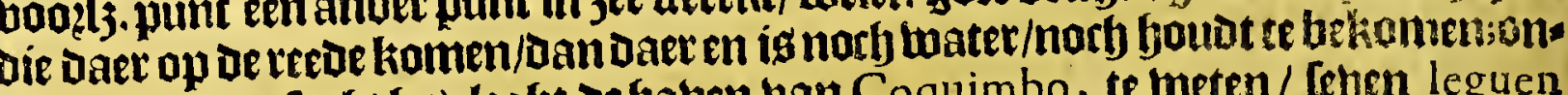
trent dit punt ( leght fjp) leght de fauten uan Coquimbo, te weten / fetuen leguen daer ban uerfrbepden/ende de [e haben [oude legglyen op neghen-en-twintiog gras

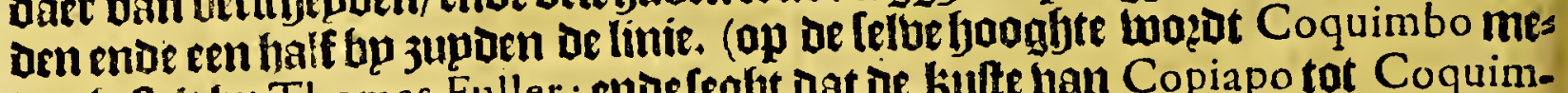
De ahefteit bu Thomas Fuller ; endeleght dat de kulte uan Copiapo tot Coquim-

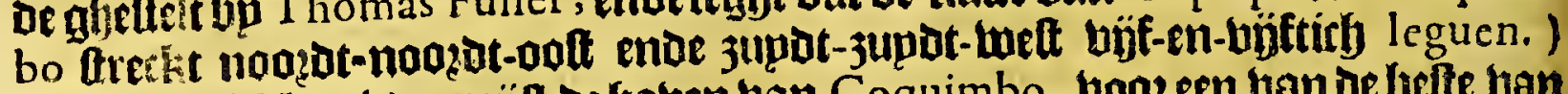
Sir Richard Ha w kins yejplt de fyauen uan Coquimbo, hoozen uan de belte ban

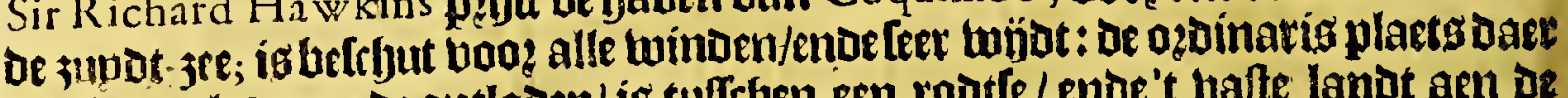
or fibepen laumende ontladen/ig tuffehen een rodtle / ende't balte lanot aen de

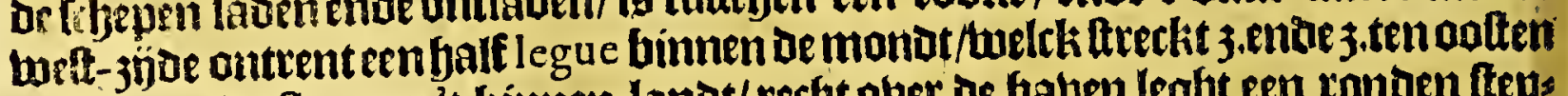

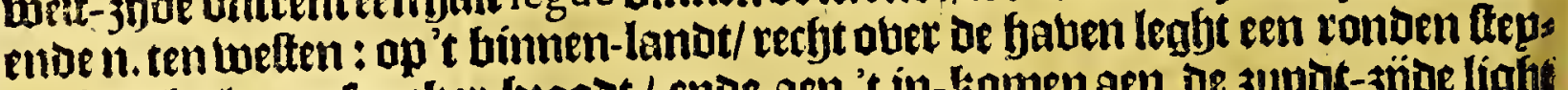

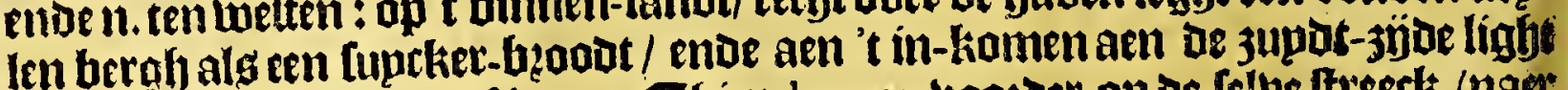
een rootle een wepnigh af ín jee. Cljien leguen boogder op de lelbe lfreeck (naen

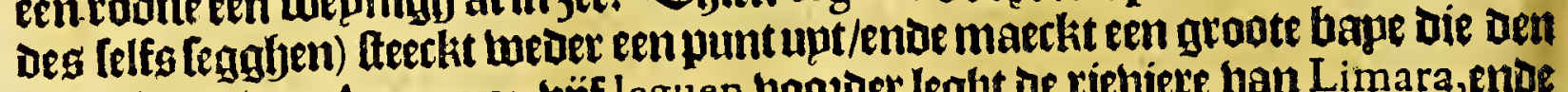
naem boert van Atongayo; büf leguen boozoer leght be riebiere ban Limara, ento

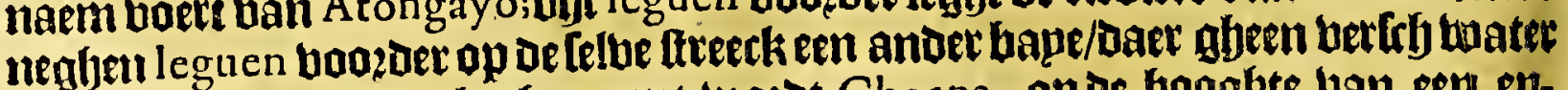
cn ig te bekomen/ melck ghenaemt wozot Choapa, op of booghte ban een-endertich araden by jupden de linie/ende noch een-en-twintiry leguen boazdet op

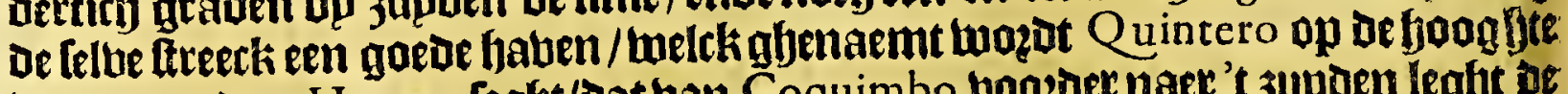
d.7.1.7. van 32 graden. Herrera leght/bat ban Coquimbo boozoer naer't 3unden leght of baten ban Cigua, in de riebiece; ende dat de haben Quintero is gheleghen a in 
Het elffte Boeck.

De monot van de riebiere Concagua. Be vopagie ban Thomas Candifch fielot

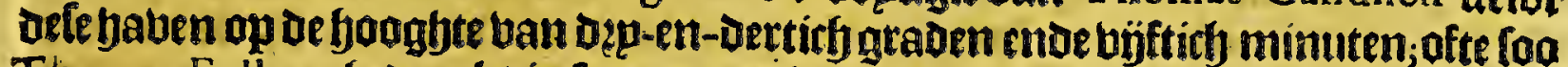
Tho mas Fuller gheoenckt in [pn mentoziael / twintich minuten; in De bape legtit cen klepn Gzplandeken Daer Penguins ende andere uogbelen baet op ontbouben.

Ben Jemerael loris Spilbergen mass met fon blote in Defe baten ban Quintero, ende anckerden daex op 20 bademen waterg; qhetupght daer ban dat bet isem fchoone enoe plaplante bape/ bebbende ene twe!-gheleghene teede/in oe taelcke de tobepen in fulcken berfekertbent legghen / Dat gfeenighe wimoen ter wereit baer eenighe legade foude konnen aen-doen/ende daer en hoben foude men geen betev gbelegentbept konnen febben om twater te halen/yj̈noe'tfelbe feec klaet ende foet ban fmake; fp wierpen baer een halbe mane op/tot beftberming be ban bet bolck

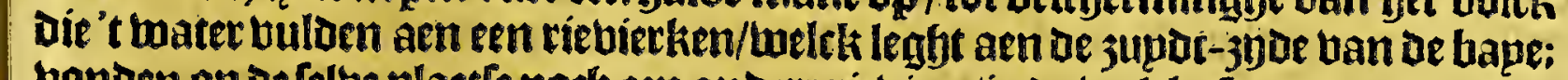
bonden op oe felve plaetle norfy cen andere riebiete/in oe tueleke fu groote menigf

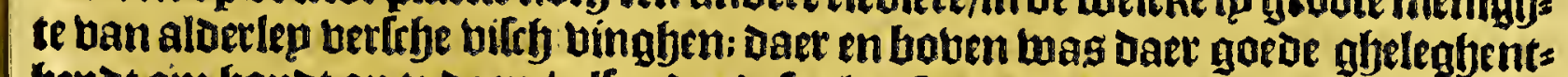

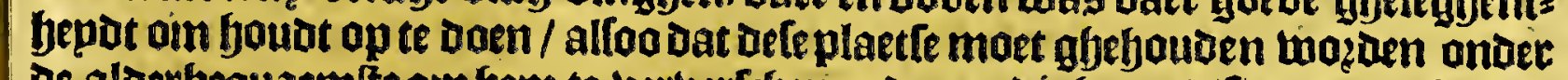

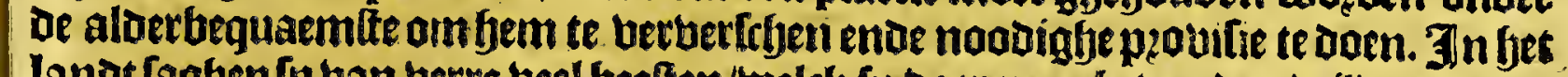
landt fagbenfp ban berte veel beeften/welck fo haer naer bevonden wiloe pertoen te befen/;amende aldaer deineken upt een klepn riebierken/ waet in't bertery was ter liep upt of fooghte tan bet gbeberabte. Bele peerden en fjadoen ons boick foa baef niet betnomen/ofte namen de blucft met grootefnellicheqt/[onoer opt tueder te komen loo langbe fp Daer laghen. De Spargniaerden bettjoonden fun twel ban berre met cenighe peetden/ dan en doeften ong bolck niet aen-taiten/oanbiel: Den haec ftil in een ballepe/ aen Den foeck ban een bofrbken dat daer leght.

De onle die daer twarenin den jare 1600 met Olivier van Noort, te tueten met bet fépip ban den Pice-2ldmitael / gbetupghen neffeng de boongte vall 33 gras:

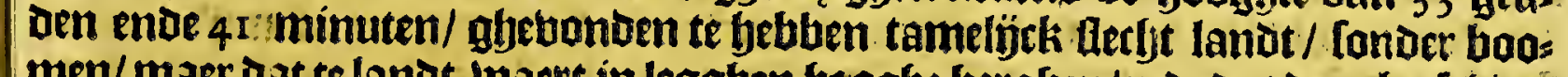
$\mathrm{men} / \mathrm{maer}$ dat te landt-Laert in legghen booghe berghen/ende dat daer bp lchinns een rievietken te welen met een bauen oftereede/ende dat feteen grooten in-wijtk is; ende dat de kufte daer ftreckt ban punt tot punt noogot ten ooften enaenoo?drnoazot ool / ende batter diberffbe in-jjammen liomen / ae welcke foo men twiloe

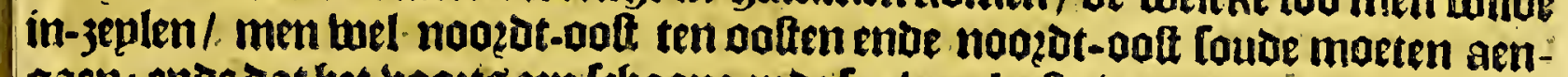
gaen; ende dat bet boots een lefoone enoe fupbere kufteis.

Bam Quintero tat de jaben uan Valparay fo, zön leben leguen, naex 't fegatjen uan Herrera, ¿an Pedro de Cieça legfot I o geljokt oock Sir Richard Ha wkins, op de fooghte ban 32 graden ende twee derde; Dorb leght op de hoogte ban 33 graben ende 40 minuten naet de bebindinge ban. Thomas Fuller, eñ de kouts is naer fpn fegghen noozot-aoft ten noazden ende zupot-welt ten 3 upden. Olivier van Noore Aflot die maer op 33 graden / waer in gp Lefinnt te mitten. Fuller in Lon memos riael ftelot mede tufichen: Quintero ende Valparay fo feben leguen, gbelijtk Herrera. Ben Jenerael loris Spilberghen bas meue in Defe bauen / ende phetupght

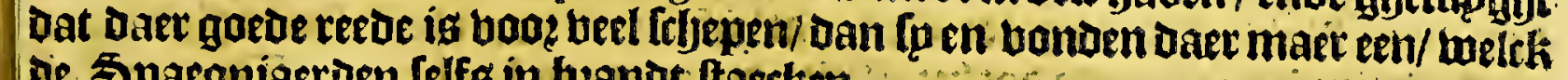
oe Spaegniaerden Lelfs in bzanor taecken.'

: Bntrenteen leg ue bp 3 upden de bape/liggt een Klepn Eplandefen ofte Klippe

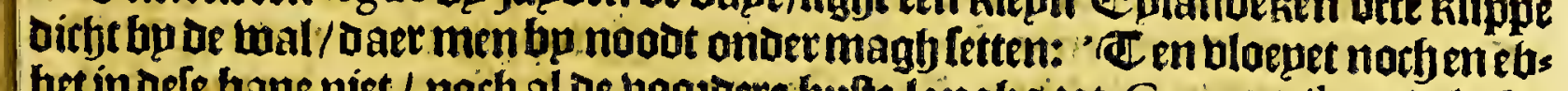
bet in bele bape niet / noch al oe boozore fulte langhg tot Guay aquil toe / als bp Sir Richard Ha wkins tuerot aen-gheterelkent.

\section{Het twaelffe Capittel.}

Vervolghi van de Chilefe kufte van VAIPARAYso_af, tot op de hooghte van wat meer als twee-en-veertich graden.

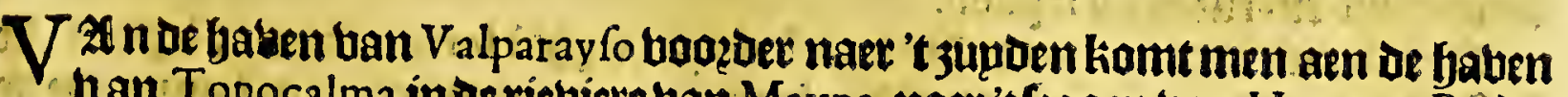
b an Topocalma inae rieviete ban Maypa, naer'tleggen ban Herrera: Pedro 
442

Chile.

de Cieça feglft dat tuan Valparayfo tot Topocalma zijn viet-en-thuintiff leguen , enoe een-en-twintich leguen boozoex een punt lanots / enoe baex bp be riebiets Maule. (Jetwíl de riebiere Topocalma famt in de baben ban Valparay fo, gelïrts. top cap. 4 bebben aen-ghetuefen; (oo moet hier in de aen-toj̈lingle ban Herrera choe Cieça cenigh mir-uerttandt jön.) Ban defe rietbiere Maule begínnen de lis

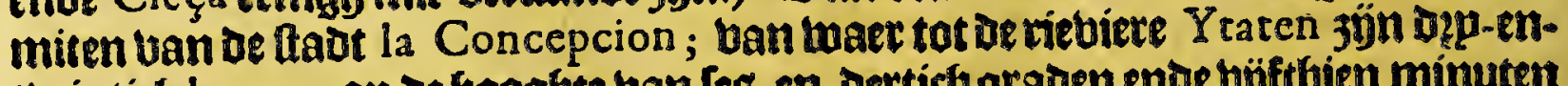
twinticly leguen, op de hooghte ban leg-en-derticf graden ende büfthien minuten naer'tfeggen ban Herrera:Dan Pedro de Cieça en reeckent van de rietuíere Maule tot $Y$ raten, maer beertbien leguen, ende ban daer jupdot ten weften oe riebiere.

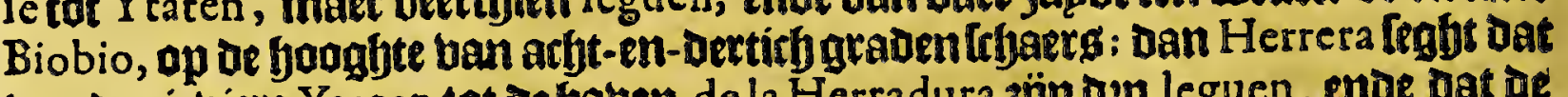
ban oe riebiece Yraten tot de bauen de la Herradura jïn bęp leguen, enoe Dat ie kufte loopt 3updt-3upot-wett/ende van daet tot de baven van Penco vier leguen; ende dat de kulte ftreckt 3upoen;alwaer de ftadt Concepcion legbt/ende van daec tot oe riebiete Biobio twee leguen. Thomas Fuller, als mede de toppagie van dett Benerael Spilberghen ftellen oe bape van Concepcion op de booghte vanfeg-enderticly graden enoe beertich minuten. De [elbe waerlfyout/ dat men in dele bape magh ancketen atbter een klepn ezplanot in neghen badem waterg ; ende Dat of noordt-noozot-wefte windt De llímlte is in die bape.

Ban de onle die daer waren in den jare 1600 betfaen/Dat aen'tin-komen ban oe bape is dertich badem twaters/ en binmen beel leegblandt / ende dat bp jupoen Den foeck leght ae riebiere Biobio, ende dat neffend aen boeck leght een groot rit/ welck olwers af in jee ftreckt/ende bupten bat een thlippe ontrent een balf mỉle ban land / welck klepn ig / ende boogh baben water / Daer men boven om moet loos. pen; dat voozoer dele faben ban Concepcion goet is om in te 3 eqlen/ ende datter niet te fehoulwen ig/Dan dat menliet bp oen yoeck een klepn Eplandeken vat men aen thier-boozot laet leggen; is ontrent een müle langb/enoe geen balf müle bgeeot!

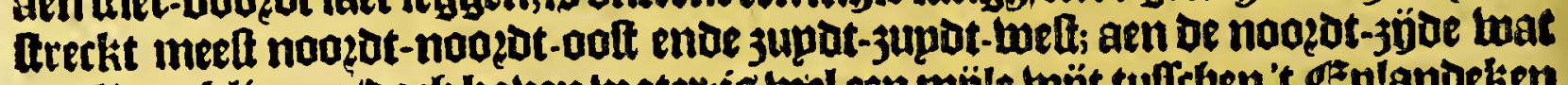
bupl ban klippen/Doch boben water;ig wiel een mijle toüt tufében't Eplandeken ende het bafte lanot: men magf achtex't Eplande 3eplen dat men geen zee en fiet) op oit đeplanot is water gbenoegh/enoe gbemackelíck am te falen; vonton daet: beel gerlt ende boonen / ende erten / oack beel Potatos, boenderen ende menighs

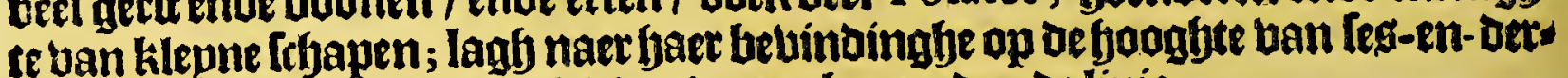
tich graden ende twee-en-büftich minuten bp jupden de linie.

De lelbe bonden neffeng be hooghte van bier-en-Dertich graden ende acht-enDetticty minuten/ dę aubbelt lanot; bet binnentte't booghfie / met [neeu bedeckit?

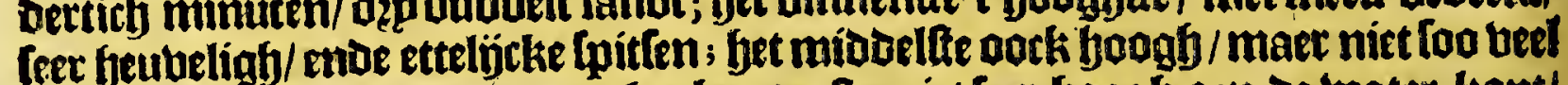

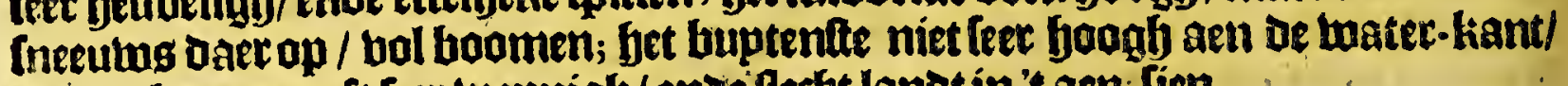
foriber boomen oft leer-wepnigh/ enoe lectet lanot in't aen-líen.

Ban De bape ban de ftadt Concepcion tot aen't $\mathbb{E}^{2}$ plant ban $S^{i a}$ Maria, retent Herrera $1_{3}$ leguen naer' $t 3$ upot-meften ten 3 upuen: Dan Cieça Crojejft dat ban De riebiere Biobio, tot eengroot etplanot bujf leguen ban't battelandt ghelegben/ jujn ujífthien leguen, ende dat bet Géplanots naem is Luchengo. Thomas Ful-

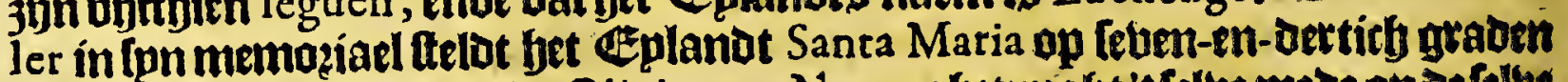
enoe biftejien minnten/ende Olivier van Noore ghetupght 't lelbe mede op ae felloe booghte givebonden te febluen. Ben Genetael loris Spilberghen bermaend bat

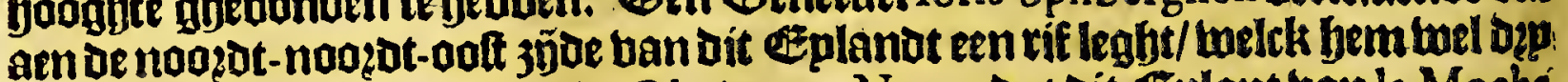
mijlen Lamgh in jee ttreckt ;ende. Olivier van Noort, Dat dit Eplant ban la Mocha bertefyepaen is arfthien leguen, ende ue kours noozot-noazot-doft ente jupto-

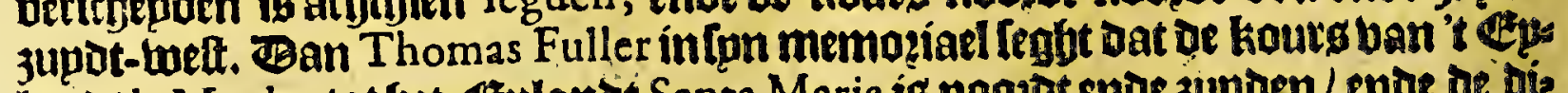
lanat la Mocha tot fet Eplandt Santa Maria is nooget ende 3 upden/ende de di. tantie bÿf-en-thintich leguen.

d. 8.1.7. Bande riebiete Biobio tot die ban Labapi (Tegft Herrera) jän Is leguen, te

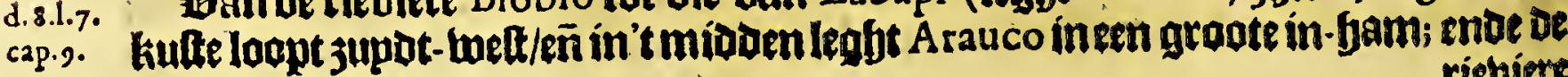
riebiets 
riebrere Labapi foube naer tun legghen legghen op oe boogbte ban leben-en-dets tich graden ende een balf/ himmen in den in-bam ban A rau co, aen de tueft-jupdt-

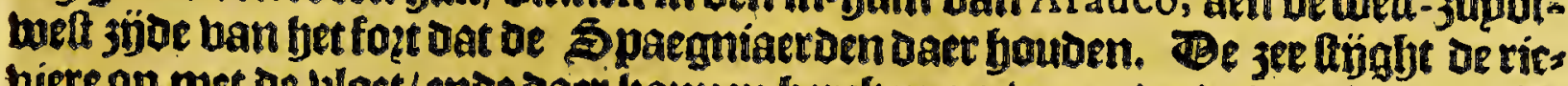
biere op met de uloet/ende dare konnen bercken op-baren/ende bart is ueel bifeb te bekomen / ende oock joubt / welck bem daer fet ban't joubt water.

Ban't punt ban Labapi tot be rieviere ban Lebo stín les leguen, ente de kutte ftreckt jupdennaet't legghen ban Herrera : de riebiere Lebo, loude ghelegben jün

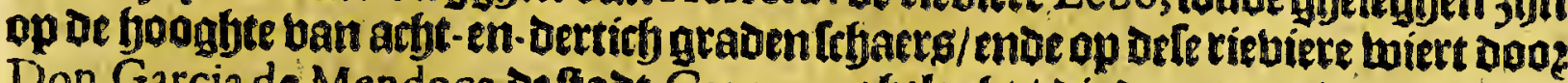
Don Garcia de Mendoça deftaot Cannete gheleght / Die daer naer ban toegben Den ooglogfmet de Cgileiten/ tweder is berlaten.

Ban de riebiere Lebo tot't Eeplanot la Mocha, $300 n$ Lea leguen, natr 't tegngen ban Herrera; ende legft ban oefe riebiere buelt-3updt-loet; op de foogfte bau arbt-en-dertich gradenende een balf / naer bet feggben uan Thomas Fuller infpn memosiael.

Raelt de riebiere Lebo bolght be baten / theld If noemen del Carnero, ban wart men te landt-twaert in treckt naer be ftadt de los Confines.

Daer aen volafte Cabo de Cauten, tran weicke Cabo totaen be riebiere Cau. ten, welck oe javen maeckt booz oe lfabt Imperial, rekent Herrera bier leguen, ende foude ghelegten sijn op oe booghte ban acht-en-berticf graden ende beetich

19an de riebiete Cauten tot de riebtere Tolten reeckent bp bp-naer leg leguen, de tweicke foude legghen op de boogfte ban neghen-en-Dertich graden bp jupDen

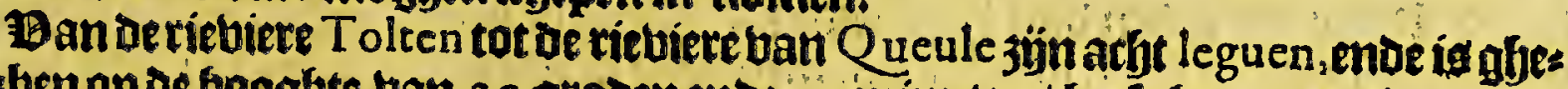
leghen op de googhte ban 39 graden enve 30 minuten / beeft baer openingh ofte monot naer' t noopen/ende daer konmen barcken in-konten/boe-lwel lp kilepnis.

Ban ie rietiere $Q$ ueule tot die ban Valdivia $39 n$ negjen leguen, ende de kufte loopt supben nate't tegghen ban Herrera, ende is gljeleghen op oe boogfte ban bertich graden fryaerg/ embe ban $Q$ ueule tot Valdivia loopt of Cordillera ban

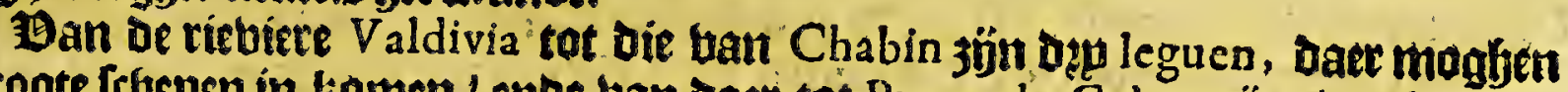
groote frfepen in-komen / enbe ban Daer tot Punta de Galera jün twee leguen; filde van dit punt tot tentiebiere die [p ntoemen Rio Bueno jïn feten leguen; in des

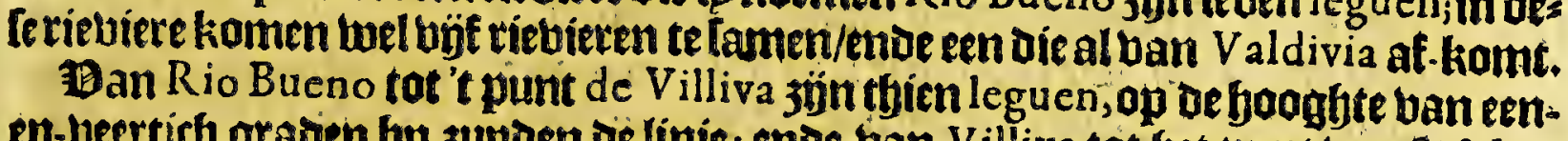
en-beertirh gradien bp jupoen de linit; endoe ban Villiva tot Get punt uan $S^{2}$ Marcelo jün feuen leguen. Ban een tuepnigh onder oe rifuiere Valdivia; treekt de Cordillera ban bet gheberghte dicht langhg oe 3 ee / ende de kulte íd diep/ sndefup:

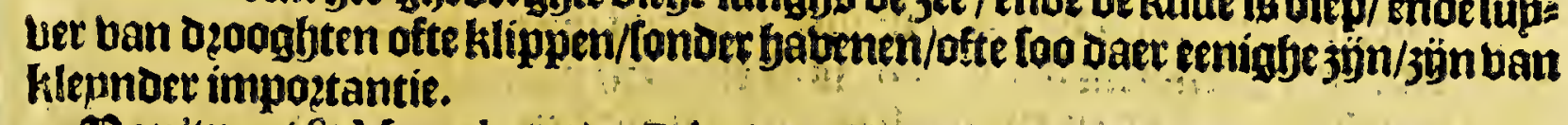

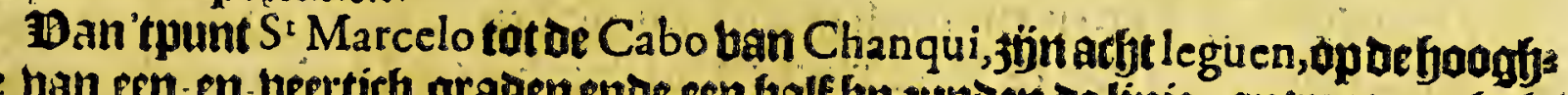
te ban een -en beertich gradenende een balf bp jupsent de linie; ontrent ken bals be legue aen oe noozot-jijoe ban bele kape leght een bebout efeplant/ ende baet

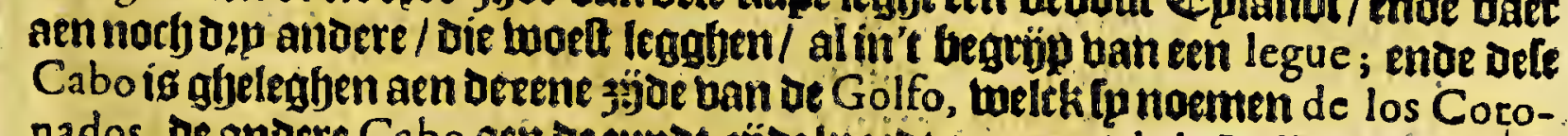

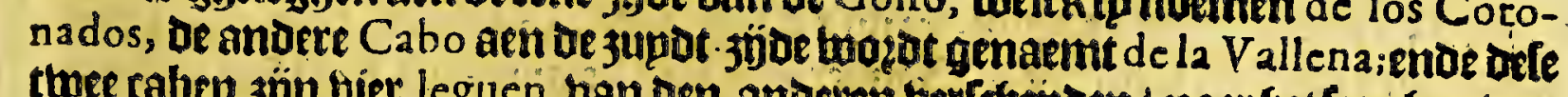

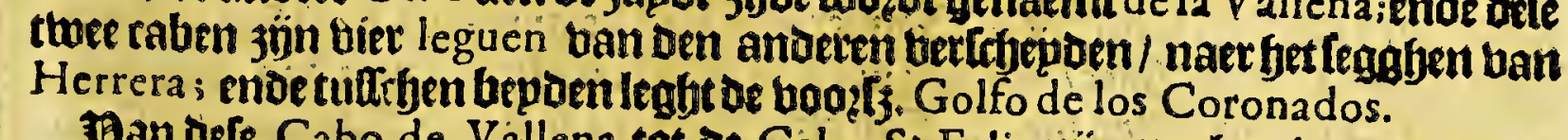

19an defe Cabo de Vallena tot de Cabo Si Felix zón negben leguen, op oe booghte tan beg-en-beettich graben ende thien minuten bp jupden oe linie; de

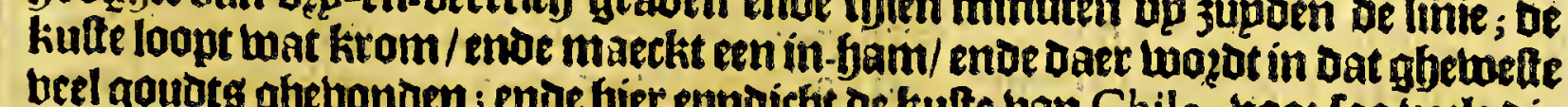
betl goutots ghevonden; ende fiet epnoicht oe kulte ban Chile, troos foo begle die tot noty toe bp de Spaegniactoen is hetwoont.

$$
\text { Qq } 4 \text { TVCY. }
$$



444
Chile.

\section{T V C V M A N}

\section{Fet Detthiende Capittel.}

Befchrijvinghe van de binnen-landefche provincie Tu cum a w j ende de principaelite ftadi S: IAGO DEI ESTERO.

$\mathrm{D}$

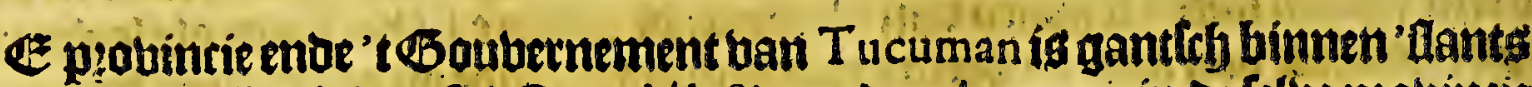
gelegen/gelịe die ban $S^{\text {ta }}$ Cruz dé laSierra; Daer tuoonen in de telof pzobincie Dep natien van 3 noianen/Tucumans, Iuries, ende Diaguitas, ban welcker boo?naemite de provincie den naem boert ban Tucuman. Peemt faet begin aen bet epnoe van de p2obincie der volekeren die men noemi Chicas, toelc is een natie van

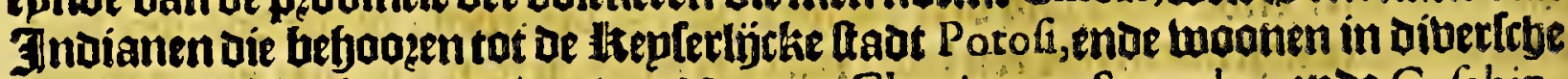
blecken / welck ghenaemt wozden Moreta, Chocinoca, Sococha, ende Cafabin.

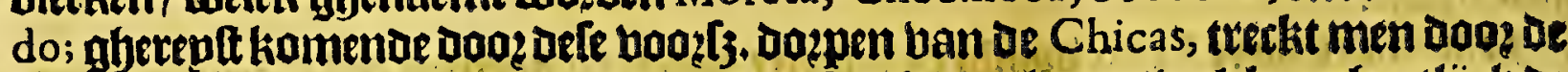
tooeltíne die I 5 ofte 20 leguen ouett / ban leer kouot lanot / welck equgentlijeti De Cordillera woest ggenaemt / Dan Daelt men ftracks naer warmes enoe gbetem: pert lanot/ Daer den twegh boop-loopt die naer Tucuman lepdot / een twepnigh bet:

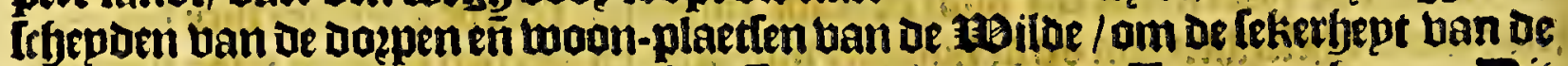
reptende-lieden die naec ende ban bet Boubernement bain Tucuman komen. Bis Bouternementenoe probintie ban Tucuman, paelt aen doen jöjo mer bet Gous: bernement van Chile, ende daet doo met de 3 updot-zee/ende aen o' ander 3 jotemet De probincien ban Rio de la Plata, ende loa met oe nogedt-jee, aen de derde zjoe

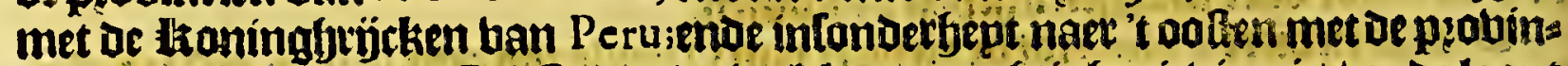
cien Die In noemen del Rio Bernio, toelch een machtighe riebiete is / ende loopt in de riebiere la Plata, (welck beel groote enoe machtiglje riebieten ontfanget) leett baer oofprongh in de ballepe diefu noemen luiuy, ende oe Indianen normen die in Gaer tale Xibixibé, ende van een anoer rietuiere tuelct loopt neffeng oe Cordillera die fij noemen de Efteco, ende nu werot oe felbe ghenaemt de Ciancas, Done

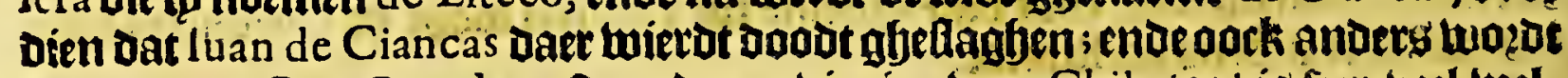
[o gfenaemt Rio Grande. Raer oe peouincien ban Chile toe / is feer veel twe!bemoont lanot; ende oock beel dat noch te ontoecken ís naer oe ftrate ban Magallanes toe/oaer men groote kumbetrfop van beft in de ltadt ban S' Iago del Eftero, tnoe twozot bp de spaegniaetden aloaet ghenaemt la. Trapalanda, enoe die bau Chile noemente la Sal. Beptobincie ban Tucuman is een tuel-gbetempert lantot/ ende tamelijeken buchtbaer: Dotb Daer en 3 g̈n tot noch toe ( Ieght. Herrera) geen

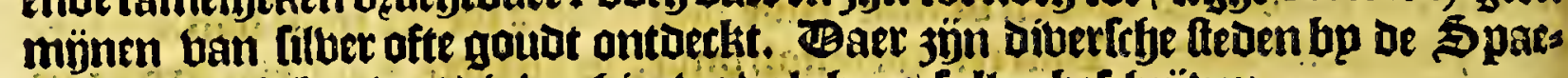
gniacroengheboutot / Die top fier berbolghens fullen berebejuen.

Be voomaemite ltaot ban Dele probincie wozot ghenaemt Sant Iago del Eftero, wierdot rert gheneemt del Varco; is gheleghen/ naer 't legghen van Herrera, op de hoonbte ban arbt-en-twintirb graden bp jupaen oe linie/ bondert en bijfen-tarbtentich leguen tan of Keptertícke ittadt Porofi, naer tjupoen/een twepnigh af- wnrkente naer 't oollen: ende naer bat beel piloten legghen (legbt Herrera). ban ae bauen van Buenes Ayres op Rio de la Plata bonoert en tactgtentich leSiet hies guen, ende cenígfe legghen oock minoer; enoe ban Rio de la Plata, op fet naefte chaens 80 leguen; ban be jupot-3ee op't aldernaette 120 leguen, op oe hufte ban't

in Rio de toningh-rjick ban Chile: Be Souberneur ban De probincie beeft fpn getwont

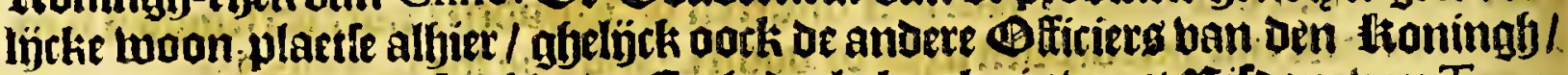

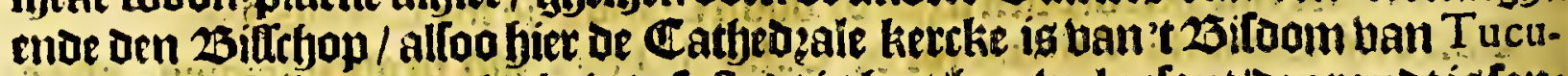

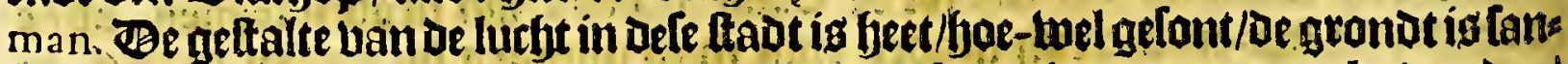

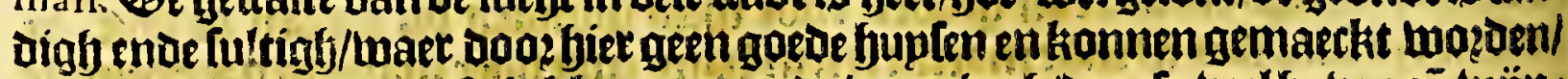

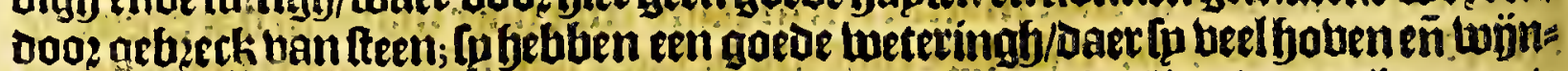

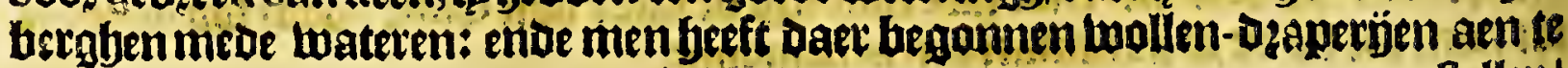

atellen! 
tellen/ant be wolle te albeten/entoe men maeckt daer fwarte ento gekouleut de las henen/Lapen/bapen ende frifaden; ende men berepot daet oock leder/endemaeckt Daet goeve cozouanen; Dan Daer en jün geen tilber ofte goubr-minnen/als boozen.

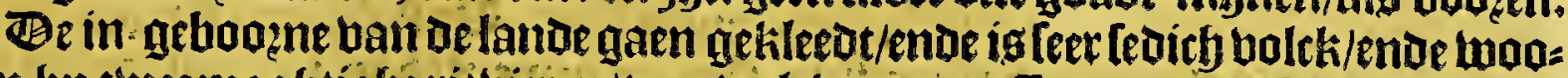

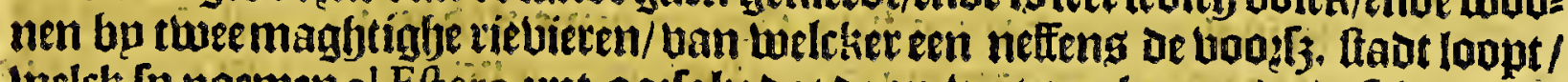
welck [u noemen el Eftero, upt-ao fake dat de op-Lateren komenoe/oe Lelbe aberloopt/enoe haer berdeelt in beel armenende torbten/ende delwÿl't teer black lanot

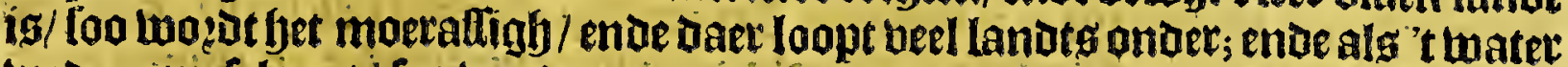
wederom af-loopt / foo lwozden op 't natte lanot groote acheren bejaept met tar:

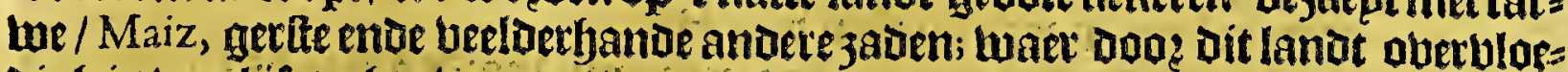

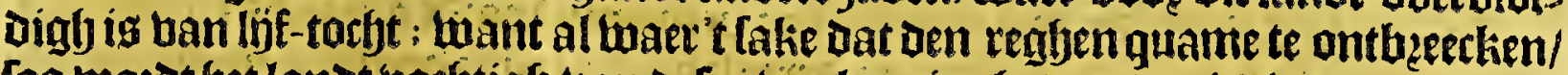

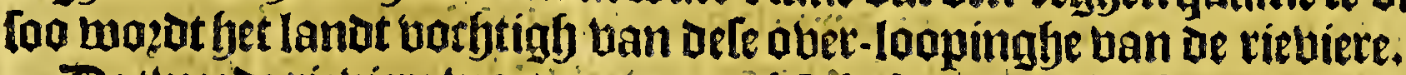

De thecoe riebiere toot genaemt el Sala do, doo dien fon water brack is; loo= pen bepoe ban bet welfen naer't oolteri booz feel black lanot/ende ontrent I o ofte

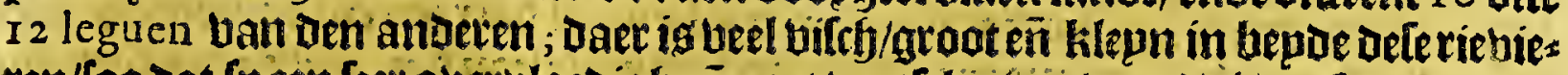

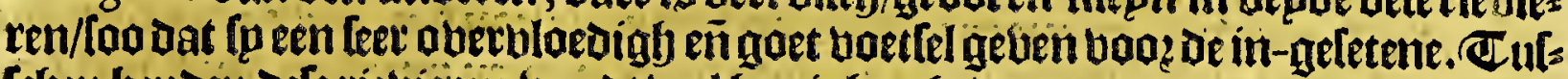

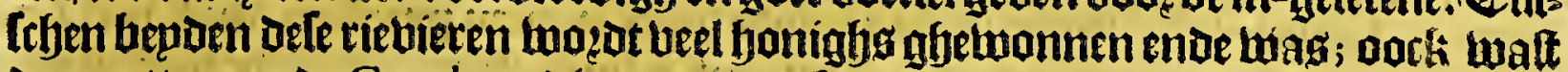
vaer cottoen ende Caroben, die goet boedtel gheben/ente' gantffye jaer bueren; men beft daet oock Cochenilla ende Anñil om de wolle mede te bertuen: $D_{e}$ bo: gers feblon leer beel bee / groot ende klepn; daer is feer goede jactjt ban batten/

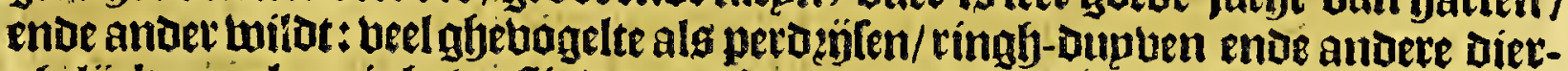

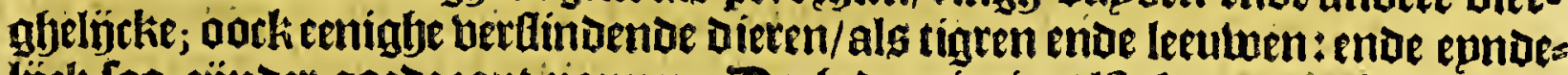

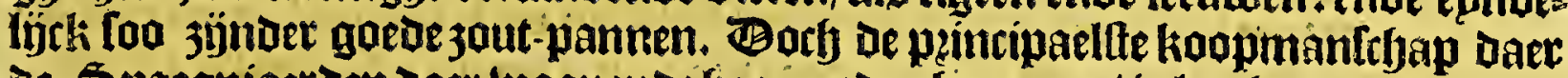
De Spaegniaerden daer luoonende fhaer meoe gheneeten/ig laecken ende rottoe ne-ljnwaet / weldk [p Daer gbeluzupcken in ftede van ghemuint gelt / ende de Vara

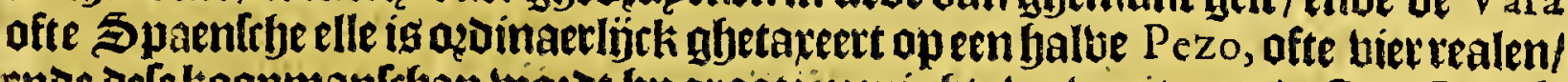

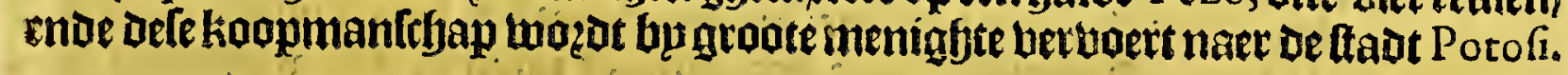

et veertfiende Capittel.

Vandefteden. San Miguel de Tucuman, Nuestra Sennora DE Talavera, ende Cordoua.

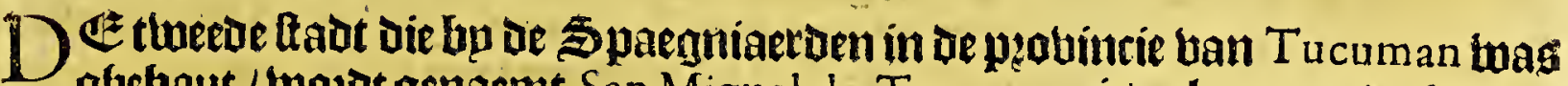
ghebout / wozot genaemt San Miguel de Tucuman; íg gelegen op De hooug=

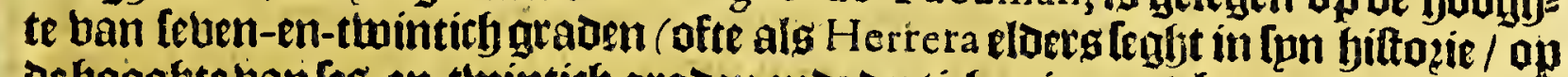
befoonfte ban (eg-en-thintich graden ende dertich minuten) bp jupden de líne: loopt naer de audientie ban los Charcas; isgbelegben aen ie boet ban een tweret elloe lwoelt gheberngte/ op een bequame gheleghentljept/ ende lyeff een beteringh daer de houen / wijn-bergljen/ende zaep landen met gbewatert togeden : nefteng - aefne jöbe loopt daer een riebiete melck komt ban la Quebrada de Calchaqui, ende daer ontrent 3 jün notb meer andere tievieten die ban twee tot fes leguen ban Defe hadt loopen; de welcke ban't ghe betgbte af-komen / enoe maken epnaelöth de rievier die Daos $S^{t}$ lago del Eftero loopt. 't Zlanot antrent Dele ftadt is over= bloedigh ban tartwe / Maiz ende gevlte ; Daer wozot wijn ghepert ; fn fyelaben daer menighte ban aloerfande vee / ende frboone jarft. Baer wagat beel cottoen ber=

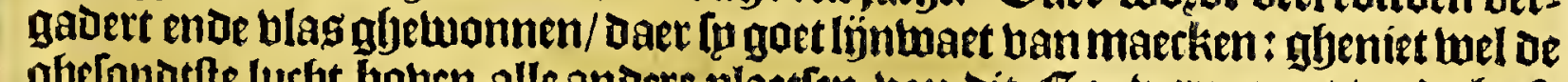

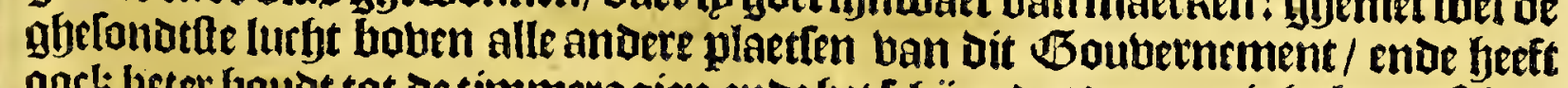

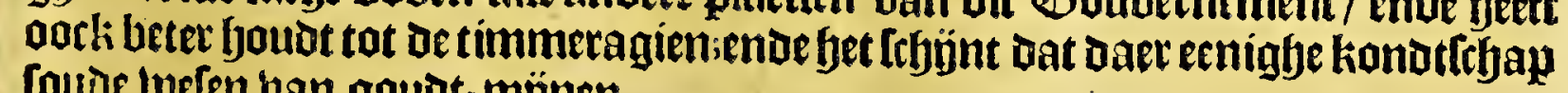
colide tuefen ban goudt-mïnen.

Te derde ladat die daet lup de Spaegniaerden is gebout/ mozot bp faet-lieden genaemt Nueftra Sennora de Talavera,ende in de tale ban't landtwott to epgent=

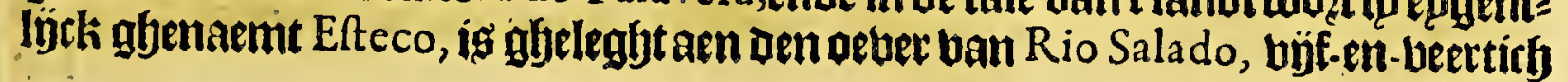


leguen uan Sant lago del Eftero naer bet noozben toe/ ende beettich leguen ban be aade Potofi (waet in bem Herrera yondert leguen moet mil-grijpen/ Detuỉl aa Sant lago del Eftero hondert ende bỹ -en-tatbtentith leguen is ban Potofi, gelijels algin (pn Defcripcion de las Indias gheductit ftaet.) Be lladt bett een ban be als

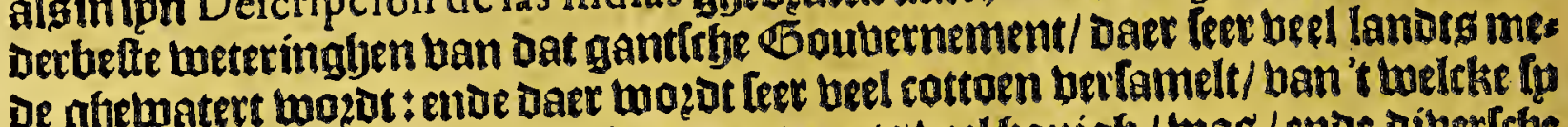

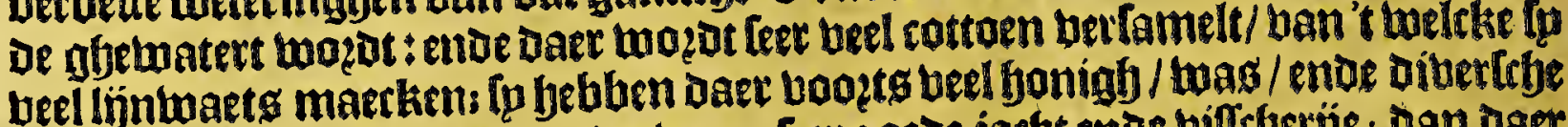

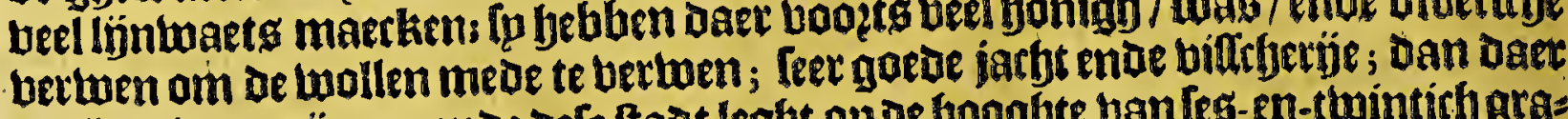

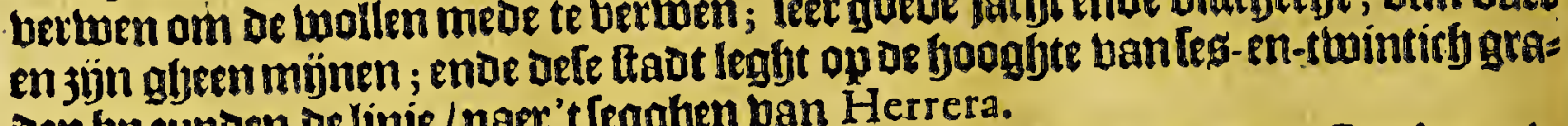
Den bp jupoen De linie / naex't leggben ban Herrera.

De vierde faot bp De Spaegniaerden betwoont/ wo dot genaemt Cordoua, is abelegen op de booghte ban twee-en - Dettirb graden enoe aertity minuten bu 3uus

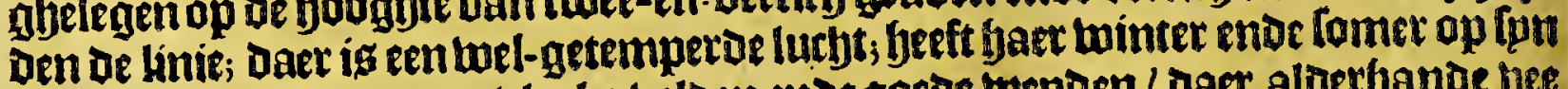
töt; daer jün feer groate blathe beloen endoe goede mepden/ daet aloerbanoe bee

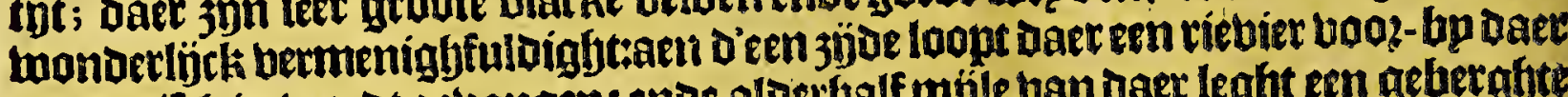
gaede biffy in wozot gebangen: ende aldertjalf múle ban daer leght een gebergfte met beel batwoonoe vallepen/ waer eenigbe filber-münen zön: Daer watt beel tars

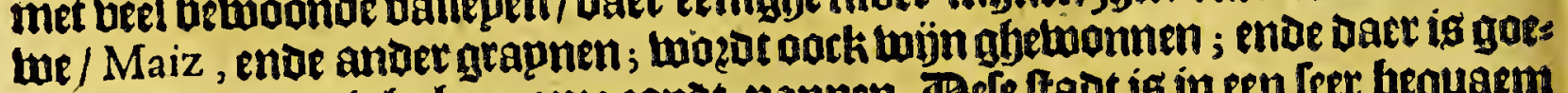
De jacbt / enoe eenigbe bequame zonot-pannen. Dele ftadt is in een Teer bequaem

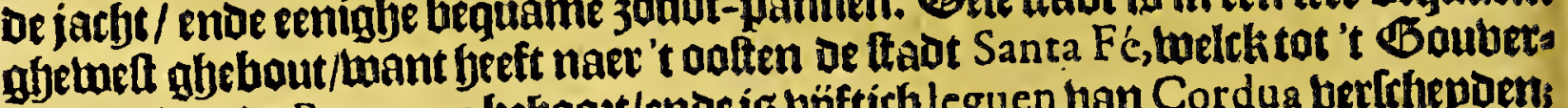
nement van oe Paraguay bejoott/ende ig väftich leguen ban Cordua terfchepden; ende naer 't welten beeft In de ftadt $S^{t}$ Iuan de la Frontera in oe probintie ban Cuyo, entae van bet Gouturnement ban Chile, die oack bijftich leguen ban defe

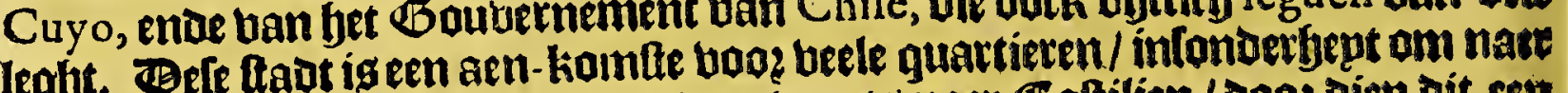

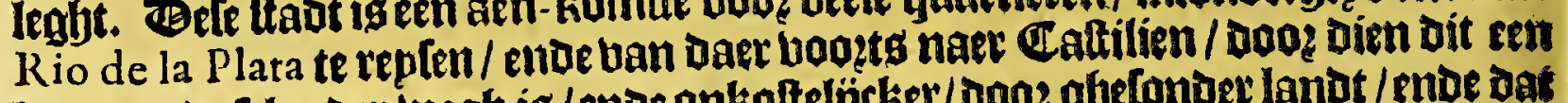

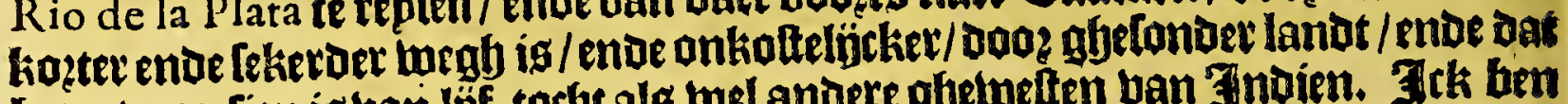

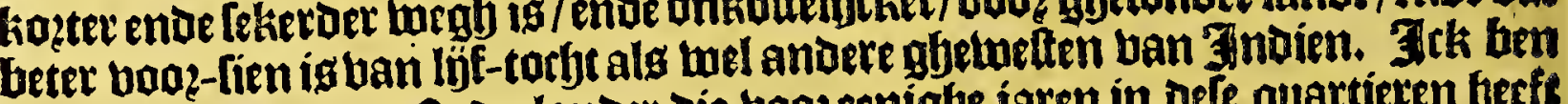
onder-recht ban een Pederlander die boozenighe jaren in defe quartieten beeft getweelt / Dat Dele ftadt bp De zoo in- woonders beeft/ die baex meeft geneeren met

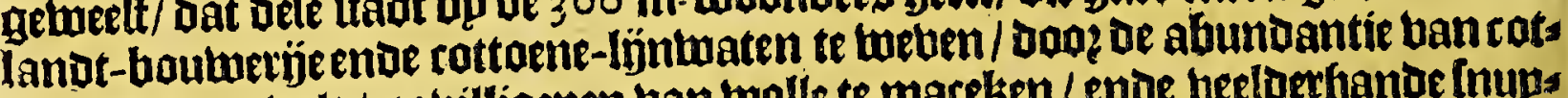
toen Die Daer balc / pebillioenen ban wolle te mareken/ende beeloerbande fnups fterije / welck al naet Potofi wozot ghelonden; foo dat dit wel de belte betwoonde Anst is van 't gantleffe Goubernement ban Tucuman. In dit Goubernement (Leght Herrera in Inn Defcripcion de las Indias) maren ten tijoen Dat Don Garcia de Mendoça bembier onthielt (melenoefpn bader oe Marquis ban Canette, ce. Thop ban Peru) norb dood oe Spargniaerden gebout eenftadt/welck [p noems oen Neuva Londres; ende een ander ftadt ín Calchaqui, welck fp normaen Neuva Cordura,im De plabintie van de Iurias ende Diaguicas, oe belcke naer wepnigfy jaren weoer berlaten wierden. 'S bolck ban of lande gart ghekleedt in molle /

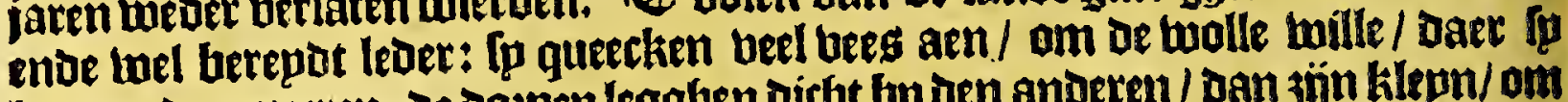
haer mede aeneeren; De Doepen legghen dicht by Den anderen/ Dan jïn klepn/ om Dat in elck Doep bp-naer maer een gbellarbt en woont / legghen in't ronoe / entes sün met bopenen-boomen am-ringht booz oe oologgen die fi met ben anderen boeren; is arbepotlaem bolck / ende dat fem loo niet dzontken en byinckx ald wal

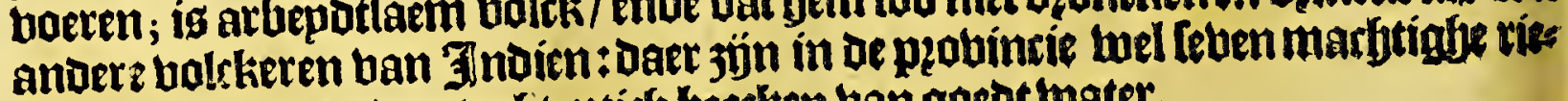
bieren / ende meer dan tarfentich beetken ban goedtwater.

\section{Het bíftbiende Capittel.}

Van noch eenighe andere fteden, ende gheleghentheden van defe provincie van T u c u $\mathrm{M}$ A .N. ftaen/Loo lullen wp bier bogts in-Loegen't gleene Herrera daet ban Leghtin 
Bar jön Teer wegpnigh Spaegniaerden in dit Boutuernement van Tucuman,

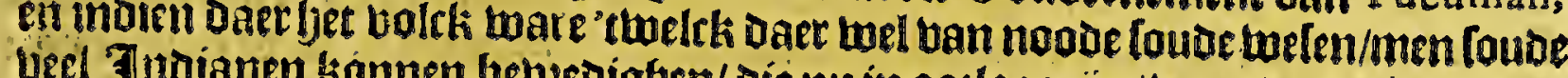

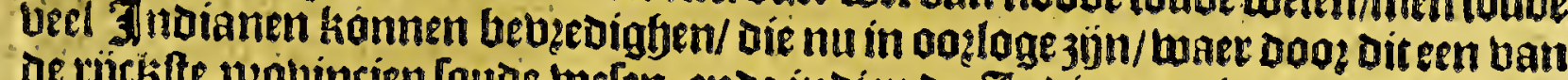

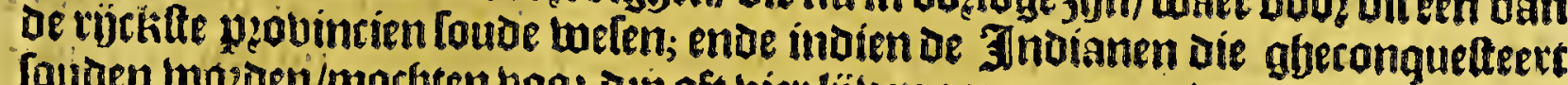

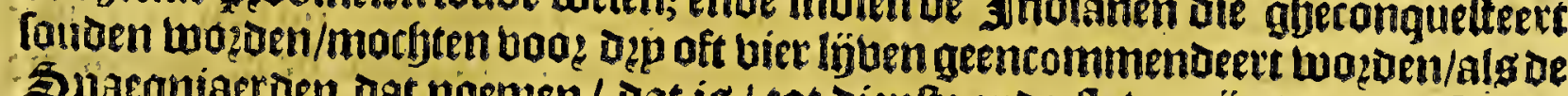
Spaegniaerden dat noemen / dat is / tot dienfte ende daternije van de Spafs

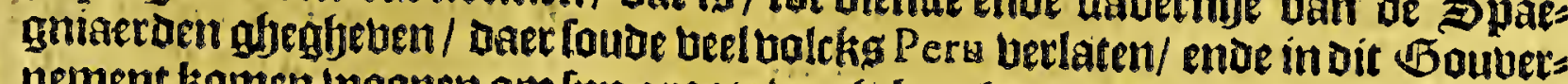
nement komen lwaonen om lpn groate bzucbtbaerbept; ende men foude noch twee

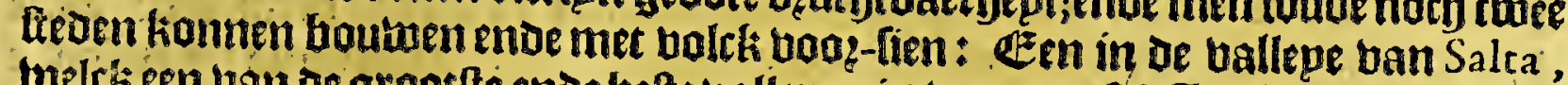

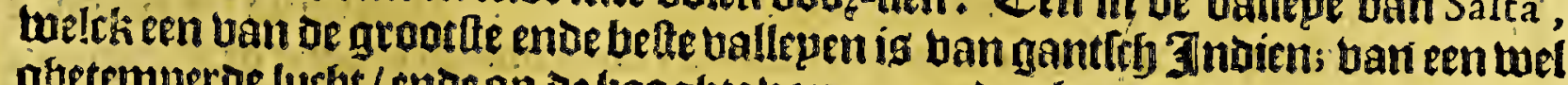
ghetemperde lucht / ende op de ljopgbte ban 25 graden bu 3 upoen De linie/ beb ben= of feer bequame landoutue/ente gaede twejaen voag't bee/ frjoone riebieten ende beel beecken ende weteringhen uooe't agezaepe ; dele taot foude in't misoen leg:

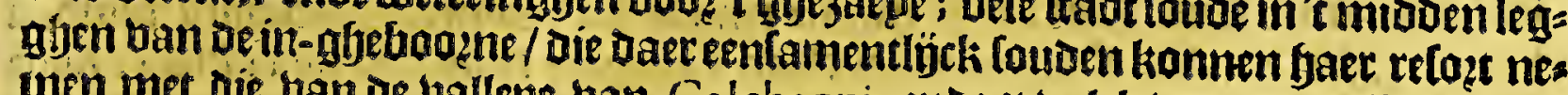
inen thet die ban de vallepe ban Calchaqui, ende 't uosck ban de ballepen ban Iainy, ende Omaguaça, enbe alle of andere die daer twoonen tot aen den pas boer de tiebier Efteco; enve de doepen uan Cafabindo, Sococha; Cochinca, Moreta, ente de Indianen diefo noemen A patamas; ende met bet legaben ban bele ftadt twaer bet lanot tuffefen Peru ende Tucuman foo terleeckert/ dat een man alleen loube tionnen replen uan Peru naer Tucuman, Rio de la Plata, enoe tot aen de noozot-3ee. Dele vallepe leggt antrent yondert leguen han Villa lmperial de Poroli, enoefeftich leguen ban $S^{t}$ Bernardo de la Frontera, in de ballepe ban Tarya gheleghen/ende ujftich leguen ban de ftad Nueftra Sennora de

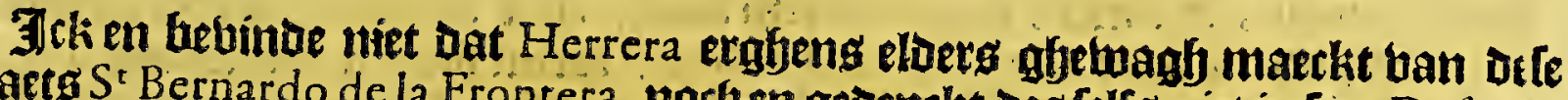
plaets $S^{\imath}$ Bernardo de la Frontera, norben genenckt deg telfs niet in [pn Defrjp. cion de las Indias; nocjtang frfjunt defe plactle mede te befjoqzen tot fet Goubers nement ban Tucuman, ofte buel tot de audientie de los. Charcas: ende naer bpeen

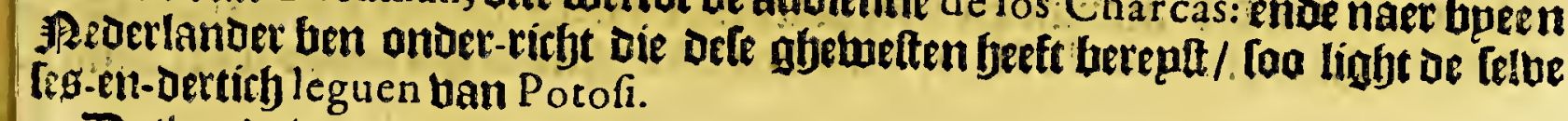

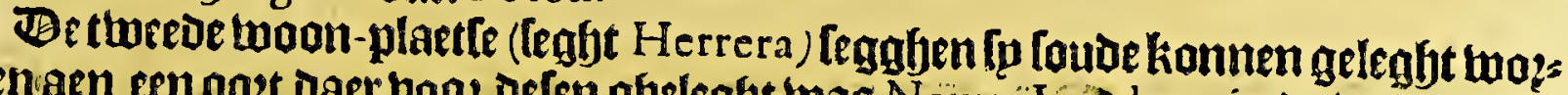
Denaen een oogt daet boo? defen gheleght was Neuva Lotdres, in de twegl ban't Boubernement ban Tucuman, nare't Goubernement ban Chile, Lele's weder

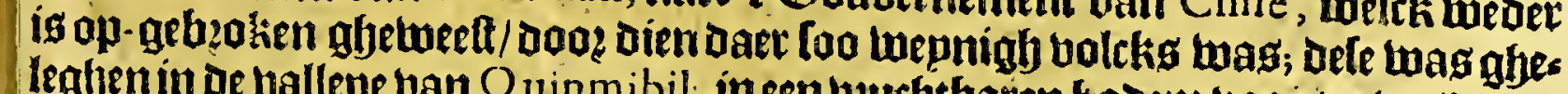
legben in de ballepe ban Quinmibil, in een betuththaten badem veo? tartwe/Maiz, ende andere graphen / in een twel-ghetemperde lurbt/ oaer twíngaerden wieften/

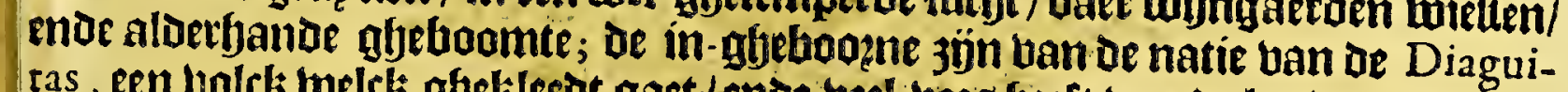
tas, een bolkk tuelck gfekleedt gaet/enoe beel bees fjeeft ban de lande/ ende beel minnen ban filver ende goubt inde hp dete miadel foude defe probintie enoe fjet

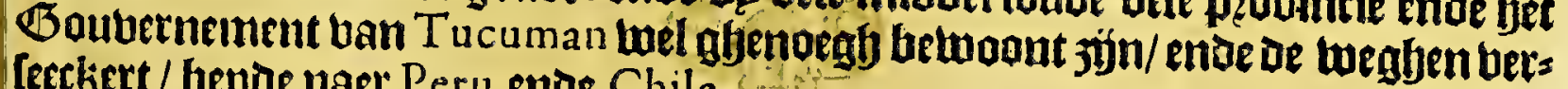
Ieeckert / bepde naer Peru ende Chile.

Raer dat ictionber-rectit ben ban een ban onle Pederlanders/ too ig al voos eenighe jaren een twoon-plaetle ban \$paegniaeroengfeleght in be boo ban Salta, De welcke lu den naem febhen ghegfeben van Cuidad de Lerma; enoe notheen anoer ín De vallepe van Iuiuy, die fp noemen Cuidad del Salvador; toa bat ghenoenflarm ba'-trorken is bet gbene biet bp Herrera by manieve ban een boo:-flagh wozor booz-gljegheten.

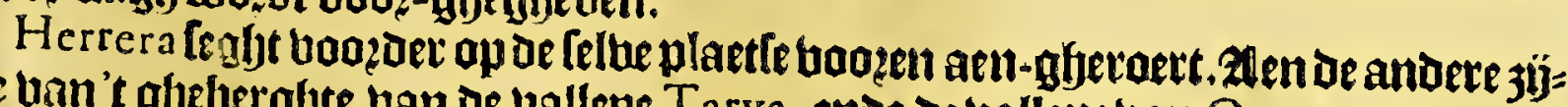
de ban't gheluerglyte ban ie uallepe Tarya, ende de vallepe ban Omaguaza, op de plapnen dis daer neoer. Dalen naer de riebiere Paraguay, neffeng de riebiere die la noeinen Rio Bermeio, loube nocb inel cen luopn-plaetle ban Spaeguiaerden dienen 
$44^{8}$

Chile.

Ditenen te legghen/oe welcke foube ghenieten bepde blacke lanton ente gebetghte; ig een beucbtbaer lanooube enoe twel-ghetemperde lurbt; daer woonot beel bolekg dat gbehleet gaet / ende daer ig beel bees; ende liomt te legghen in bet mits den tufferjen oe prabincien ban Peru ende die ban Rio de la Plata; ende dele ftade

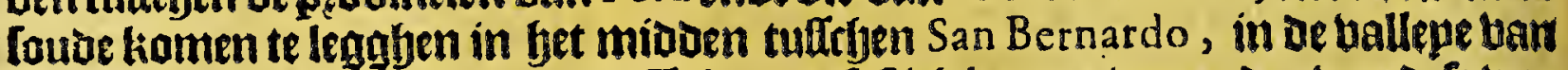
Tary a ende Nueftra Sennora de Talavera, fettich leguen ban peoer ban offe bets

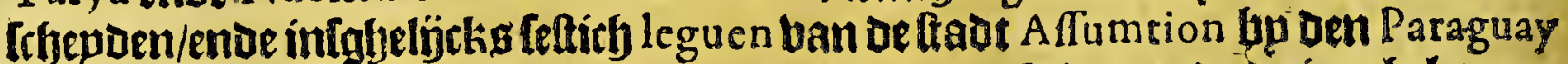
ghelegten; ende byftich leguen van de ballepe ban Salta, ende de in-gheboume

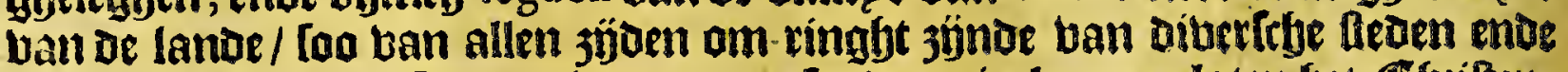
woon plaet ten van Spaegniaerden / en Louden niet konnen laten bet Cysilfengbeloobe aen te nemen / ende met gyerultyept onder de felbe te berkeeren: Defe plaetle faude meise leggljen bondert leguen van Potof. In fomma / men loude kannen replen te twater oe riebiere Bermeio af/ ende boozts langfgs de Paraguay, ende de riebiete de la Plara, tot in Spaegnien tae; welck een leeckeren ende ka?

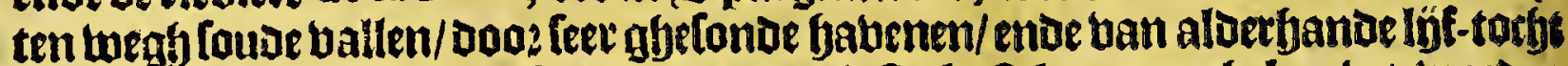

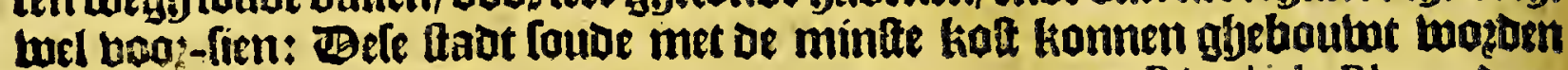
van in 3 tho ben bet Goutertiement uan Paraguay enoe Rio de la Plata, Doog bien daer beter booz-raedt ís ban uolck/ peerden ende twapenen/ om dat bet een

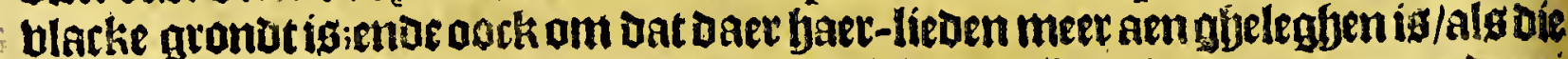
ban Tucuman, een gaven te openen booz die ban Peru dooz eenen naetoeren begh/ Conoer verte om te trecken Dooz bet Boubernement han Tucuman, offe Get Gauvetnement ban Santa Cruz de la Sierra; booz bet turleli men andets gfelwoan is de onder-bandelingbe met 't Honingfrijet ban Peru te onderhouben.

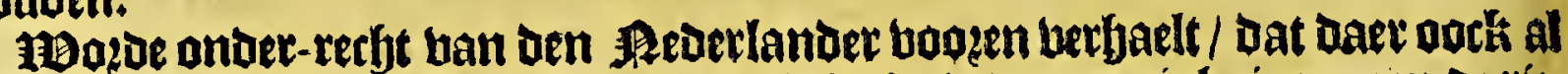
een luoon-plaette ban Spaegniaerden gbeleght is boos eenigbe faren aen de ris tiere Bermeio, de belcke de [elue naemuoert/ ende dat men ban Daer eluentwel fpn wegh neemt naer Sane Iago del Eftero, welck louden tadfetitich leguen

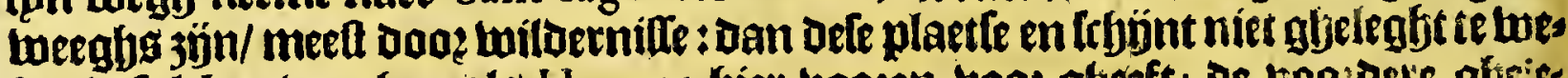

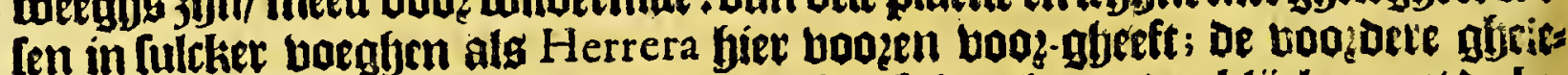

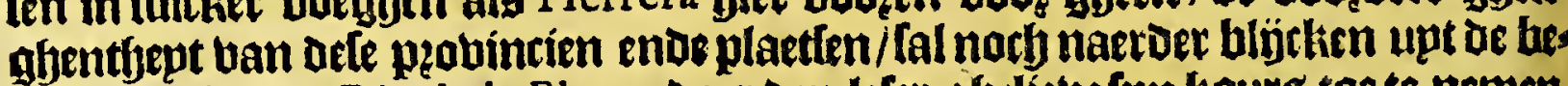
frbejuingbe van Rio de la Plata, baes uen leter gljelieve fan kours toe te nemen.

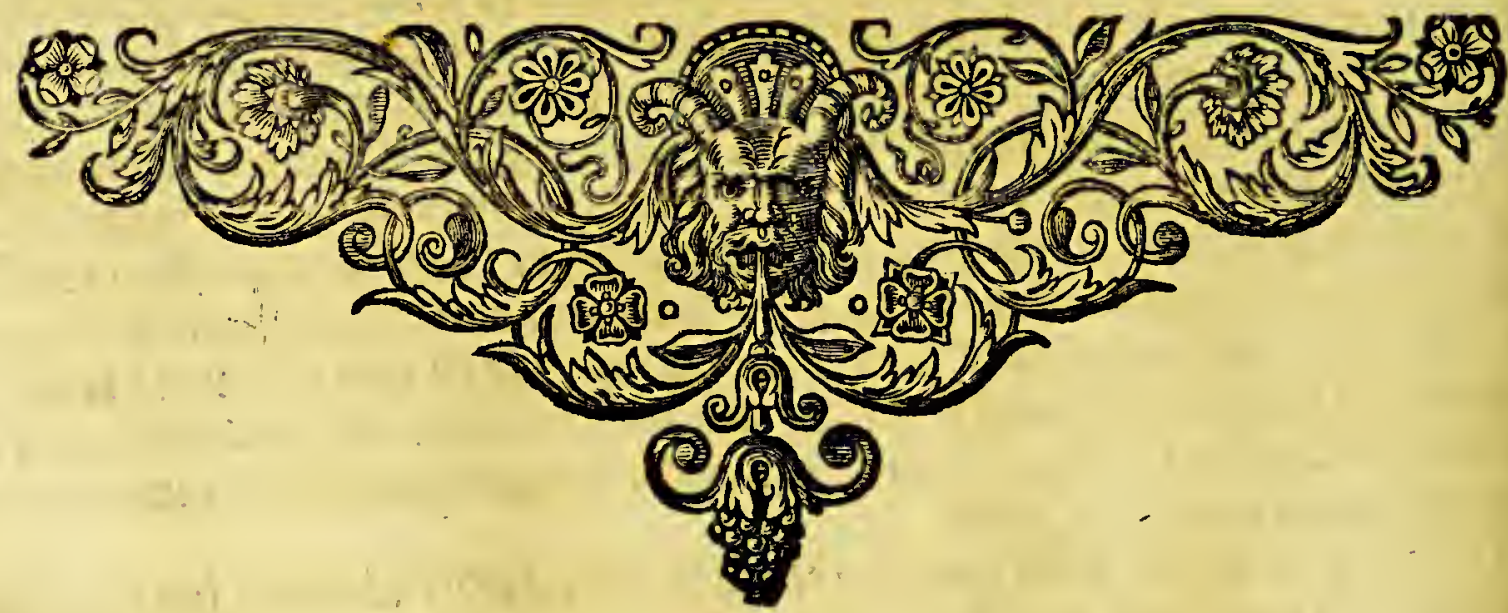

BESCR HIL. 
Casers 


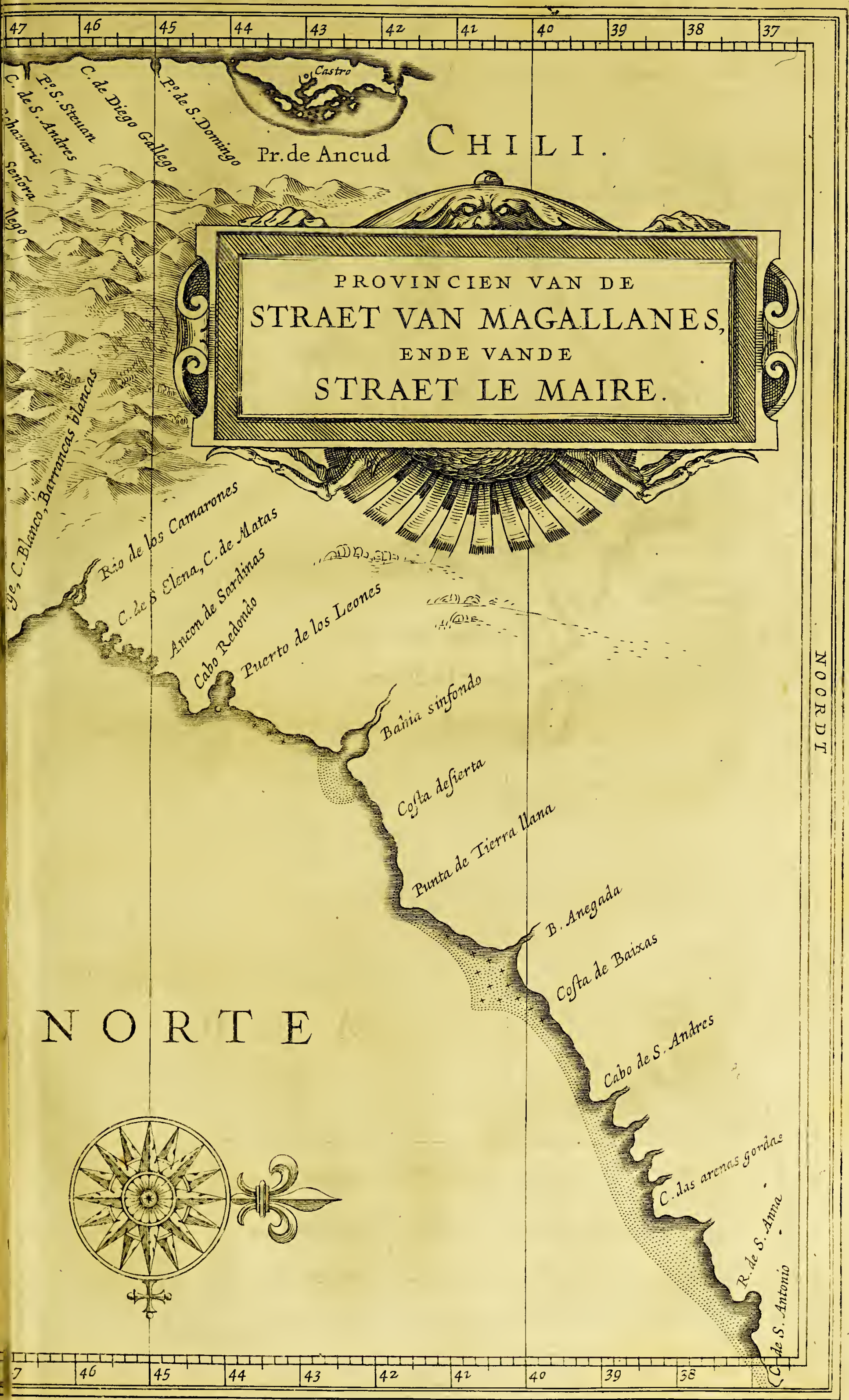




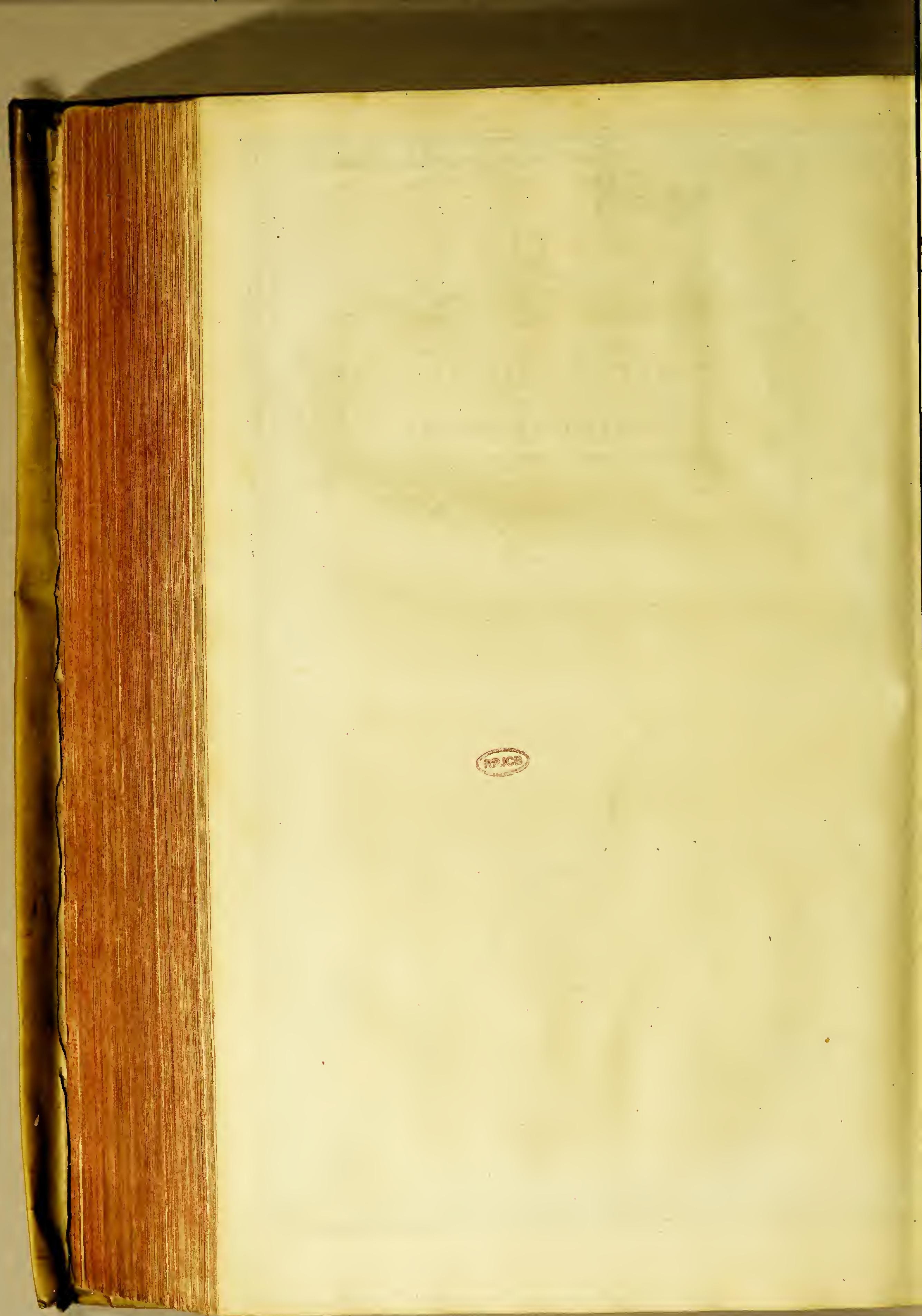




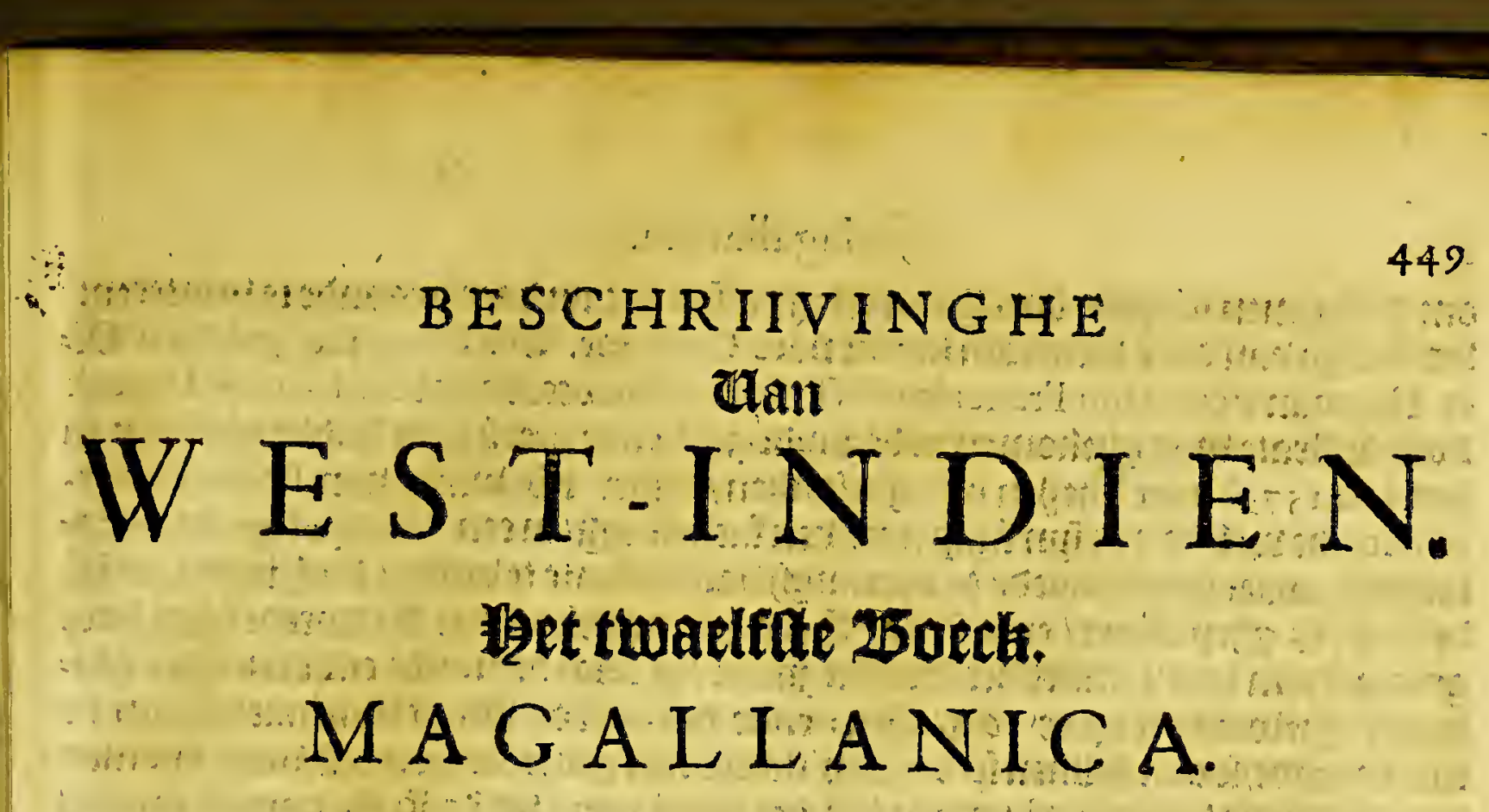

Het eetite Capittel.

Befchrijvinghe van de Provincien van de Strate van Magalianes in't ghemeyn, ende haer limiten.

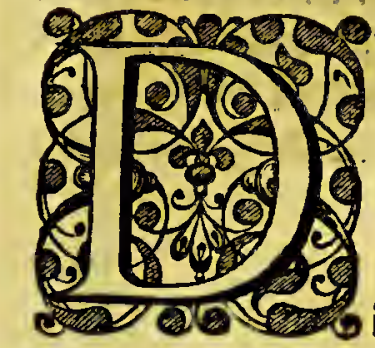

\#povincien van de Strate van Magallanes (leght Herrera) werden genaemt alle de lanoen welcke daecleg: gfen booz-lup de riebiere Rio de la Plata, aen ae noozat-jee tot aen ve 5 trate;ende in oe jupdt-jee van bet uptertte uan Chile tot De boolfcyeetuen ftrate/ welck 3 ün bu de twee bondert leguen ban

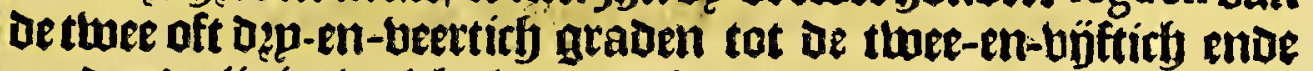
meer graden bp jupden de linie; welcke landen / bor-wel men daer vertehepden replen langhg bepde de jeen boo - bu beeft gbebaren in't geticlyte ban de kulte/ende

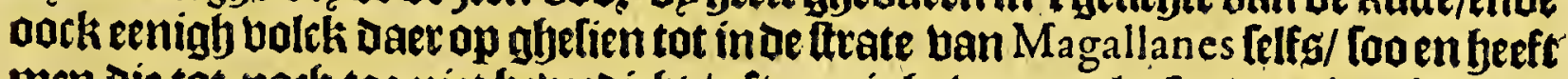
men die tot noch toe niet beveedicht / ofte eenighe woon-platten daer in ghelegbt/ upt-ghenomen vie bp Diego Flores in de frate lelfs twag ghelegly / Daee wp bier naer ban fullen ipgeken.

Dm tot Loikomen kennillete komer ban dit quartiev / booz foobele betnube:

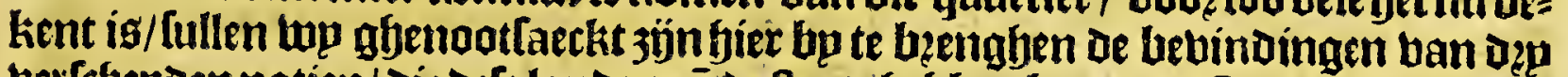

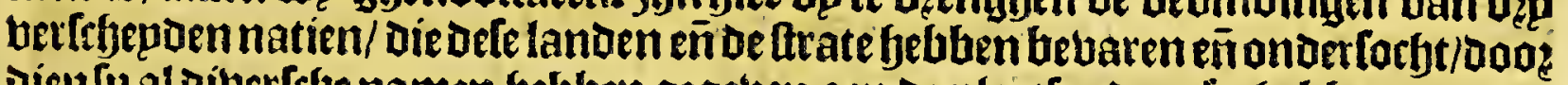
Dien fu al diverfeye namen bebluen gegeben aen de plaetfen daet fp bebben aen-ge: weet, want boe-wel betfhijnt by ang [ouden konnen bergenoeghen met de aen.

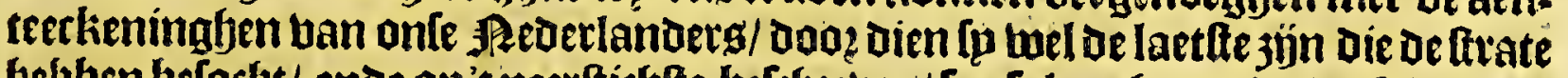

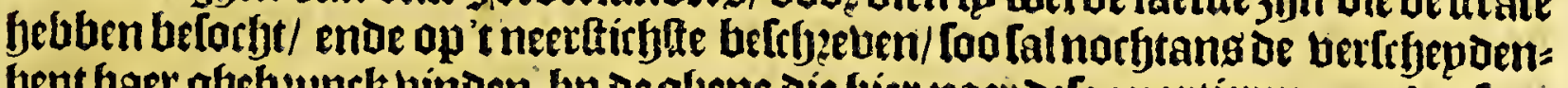
bept baer gbebeupck binden bp degljene die bier naet defe quartieten naerdet fous: Den Luillen ondertoectien.

Alop fullen ong oogly - mercli nemen op dep dingfen; eerft oplt lanot ende de kuffe Die daer legft tufthen Chile ende de frate: ten tweeden op de ftrate van Magallanes felfs met bet ghene daer aen-kleeft / als namentlibth De nieutu-gfiebondene

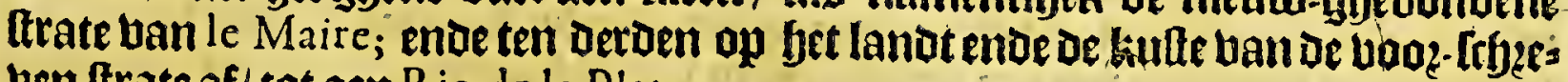
ben ftrate af/ tot aen Rio de la Plata.

Hat belanght de glyeleghentfepd ban de lanten ende kute ban Chile

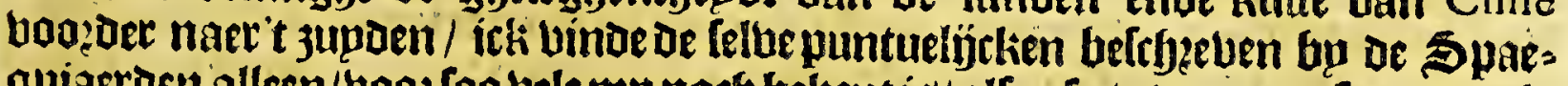

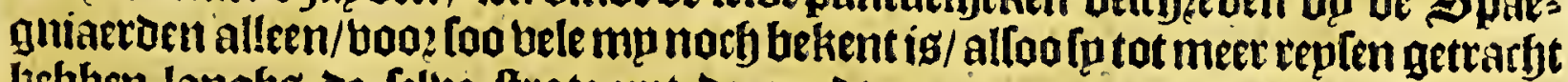
Jebben langhs of felde frate upt de jupdt-jee naet oe noobot-jee te komen;

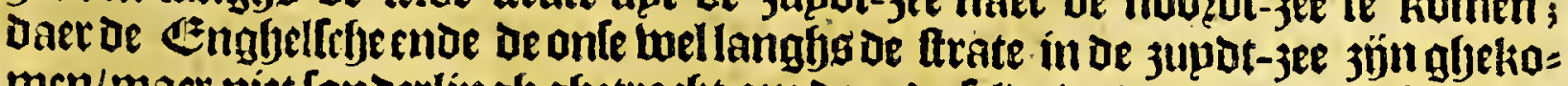

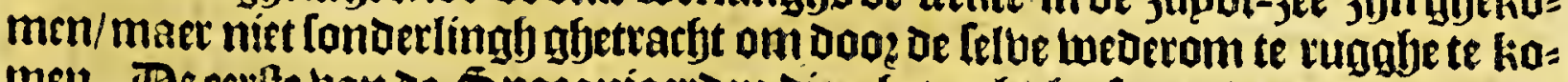
mell. Te eetlte bande Spaegniaerden die gbetracht beeft upt de jupdt-3ee naet De noozot-3ee te komen doo? of Strate ban Magallanes, is quetweet Capitspn Ladrillero, doos laft ende bevel banden BGouberneur van Chile, Don Garcia de Mendoça; de welcke wel van de supdt-jee Doo? de Strate ban Magallanes

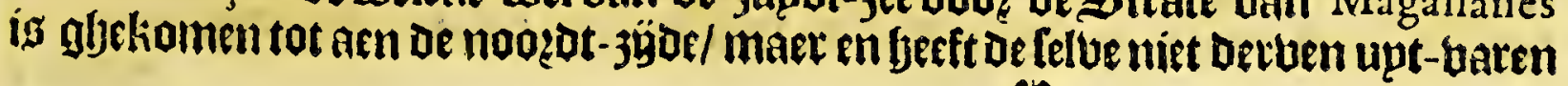


om de ftoemen die bem daet ghemoeten / alloo bet nu daet begonde te twinteren:

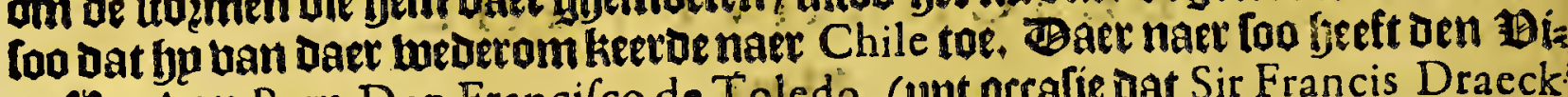
te-1Rop ban Peru,Don Francifco de Toledo, (upt orcalie dat Sir Francis Draeck booz de frate was ghekomen in de zupdt-jec/ ente beel fchade baude ghedaen in Den jare 1 579) thee tegepen upt-glyefonden / onder 't betwinot ban Pedro de Sar.

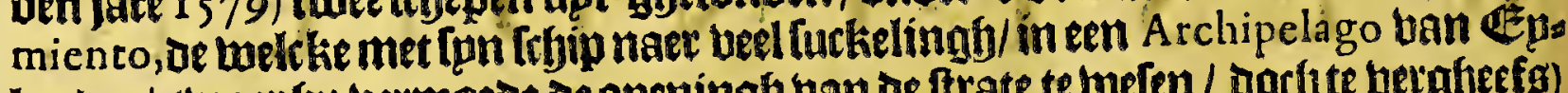

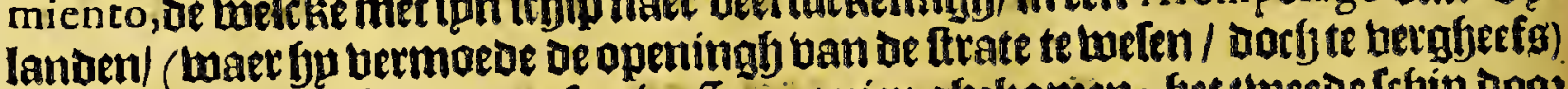

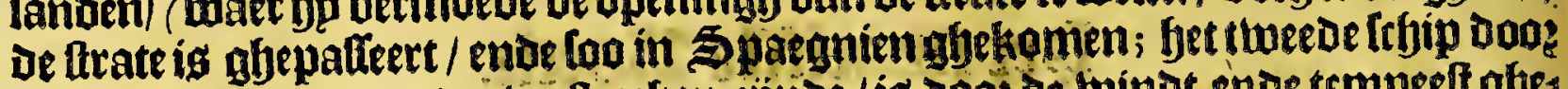

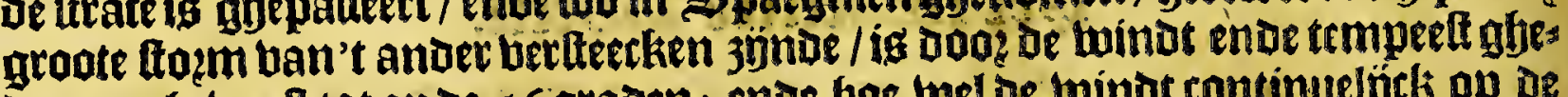

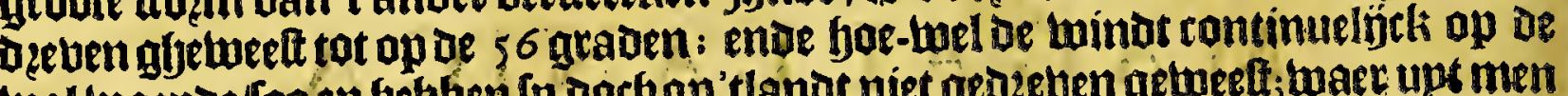

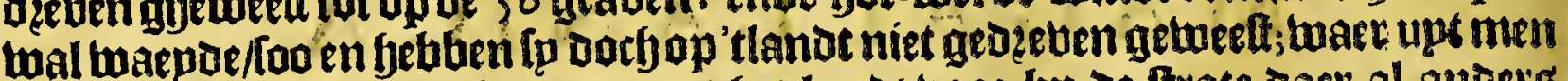
dan wel beeft konnen af-nemen dat bet lanot boos-bp ae frate oaer al anoets moeft ftrecken/als men twel bermoede;ende daer naer wel bevonoen is getweelt by ons bolek/in De ontoeckitugfe han Den niculaen Dopz-gangf / die men noemt de

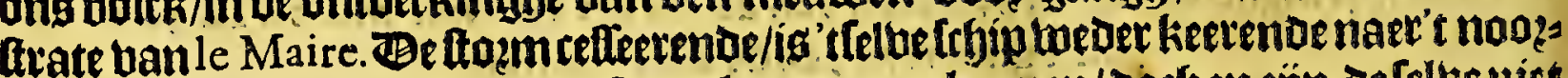

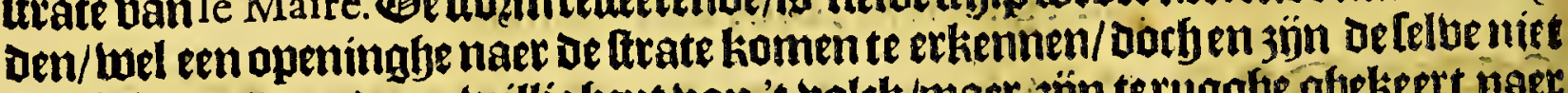

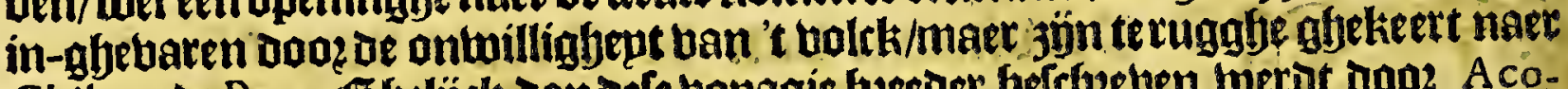
Chile ende Peru. Gbelíck dandele bopagie bzedoer berefgeten tuerdt dooz A coftam in fon aerde boeck endeelffte Capittel / ende bu Leonardo de Argenfola, in boeghen alg fier in't kozte bolght.

\section{Wet tweede Capittel.}

Kort verhael van de voyagie uyt Pedro Sarmiento, van de zuydt-zee door de ftrate van MÁ ALLANES naer Spaegnien, wyt Conevista DE IAS MOLVCCAs, van Leonardo de Uargenfola.

W Zler bat Sir Francis Draeck De Itrate ban Magallanes tuad dooz-ghekomen/ beft dert Bicr-1Rop uan Peru, Don Francifco de Toledo twee Ténepen Doen gfereet maecken / ende daet ober als Commandeur offeltelt Pedro Sarmiento, met lalt om Sir Francis Draeck te beruolghten. Pedro Sarmiento is met uele twee fryepen vam Callao de Lima gfeeffyepton ben I I. October oes jaet 579 : quamen

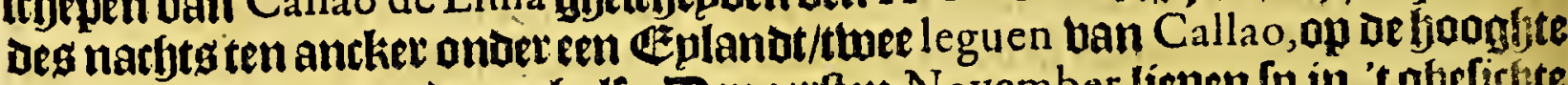
ban thaelf araden endeen falf. Jen eetten November liepen fo in 't ghelifgte booz-bp Teecker Eplanton die oe Spaegniaerdennoemen Defventuradas, op ve boogfte ban uj̈f-en-twintich graden ende een derae / bp zupden or linie : tuelche in den jare 1574 ban ben piloot Iuan Fernandes, varenoe naer Chili, bp quebal maren ontbectit; ende wożen nughenaemt San Felix ende San Ambor. Op de cerfe onbekende plaetle daet fyp daer naer aen-quam/ yadoe fy oe fooghte ban neghen-en-beetticf gradenende een balf:bondt daet afjeen bolck/dan wel eenigfe teeckenen van bolck datter ghetweef mas / alg boet-Itappen / pijlen / viemen ende nettjens: klaberoen met groote moente op berghen die beel twee leguen twaren op te klímmen; ende ban den top ontoeckten [p diberfefe groote kanalen/in-fam: men/ riebieren ende fjabenen; ende alle't landot dat fp konden lien/ frbeen al gbes broken lanot / Too dat [p fjet een A rchipelago cozdeeloen te tweten/ende hereeckens

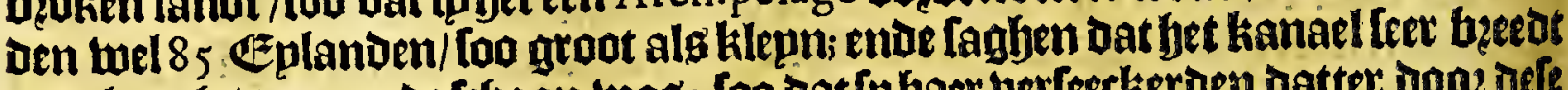

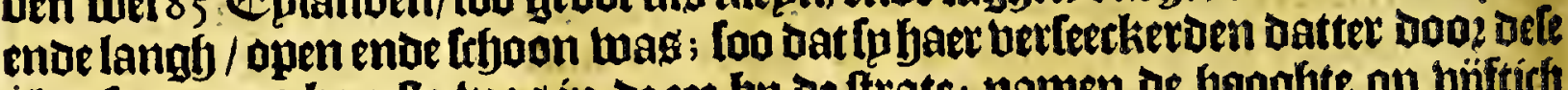
plaetfe een upt-komfte has in of zee bu de ftrate; namen de boogfte op bjftich graden bp zupden de línie. \$2uembe oe baben Nueftra Sennora del Rofario, enae het Eplanot la Sanctiffima Trinidad; ende nampofteflie ball dit lanot den 22 November des booz-fryeeben jaetg; boer ban daer met oe floupe om de kanalen

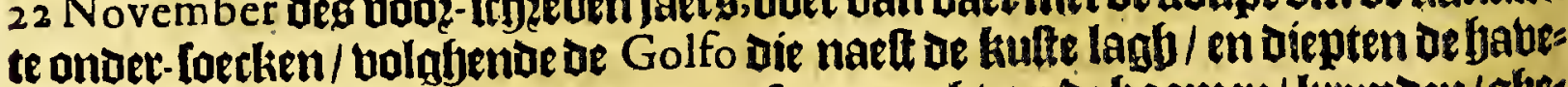
nen/ be belcke fjp hplonoere namengaf; nam arft op de hoomen/krupDen/ghes bogelte; ende bonot aen Leecket ftrand boet-ltappen banmentchen:quam bpeen riebiets 
Het twaelffte Boeck.

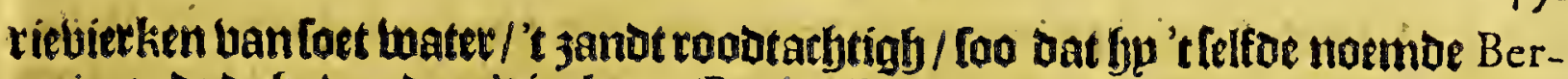
meio, endue de faben daer' tin-kiomt/Puerto Bermeio: (agagen menighte van vifcy)

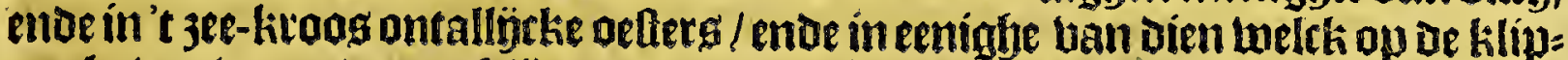

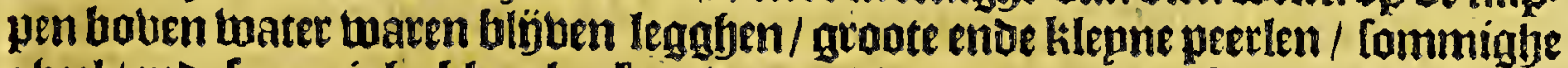

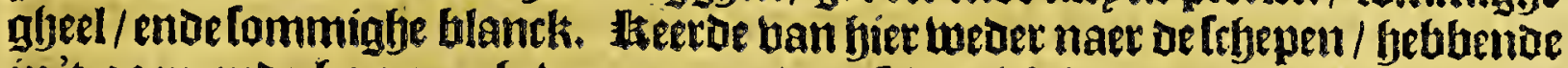
in't gaen ende kamen ghyebaren meer Dan febentich leguen, ende bafortht treel

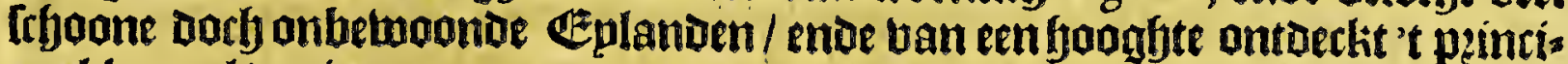
pael kanael Dat in zee gaet ; entue andere treele entoe dituerffye kanalen entoe ontel=

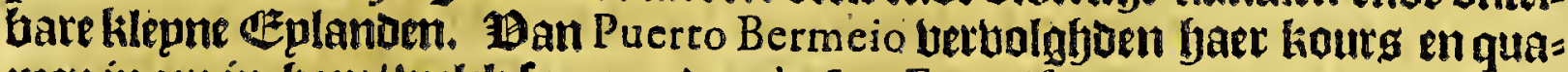

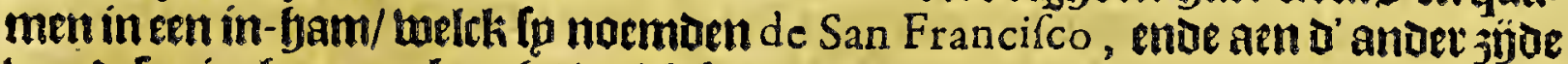

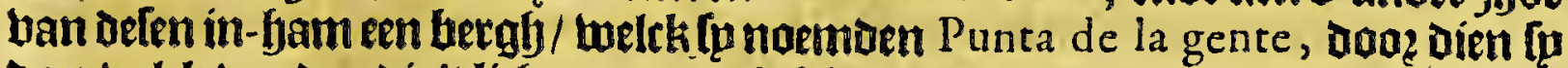

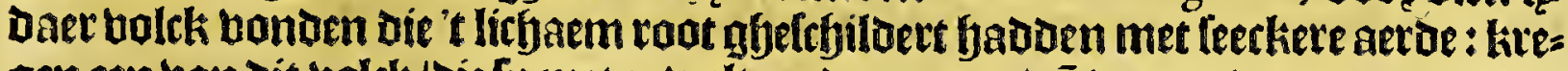

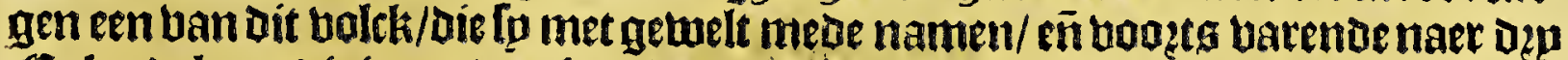

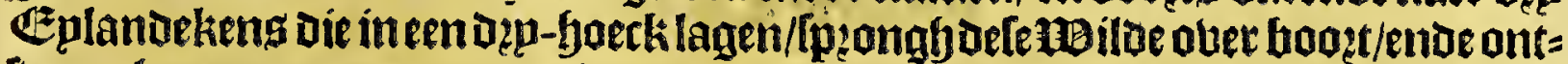
twom baet: guamen aen menigfte van Explanoen al onbelmoont / upt-genomen

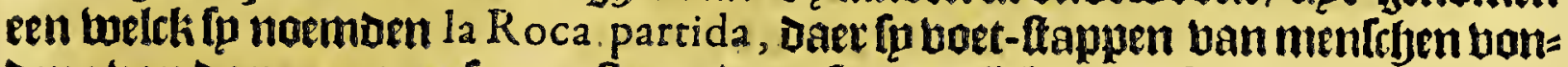
Den: ban daet quamen fy met ftozm dooz feer cenlijckie plaetfen / in cen in-fjam twelck tp noemden Nueftra Sennora de Guadalupe: bandaer gekomen yojnde aen

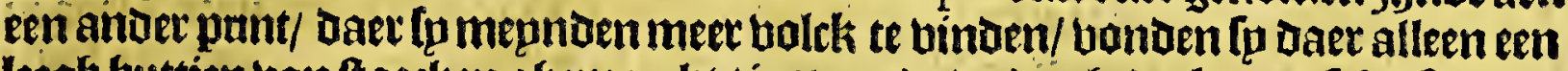

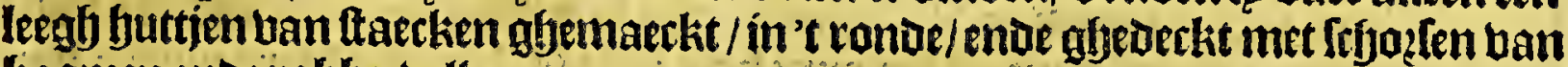
Goomen ende tobbe-bellen.

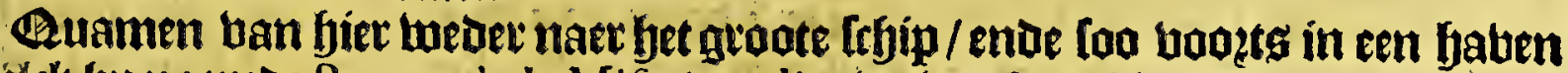
twelck bp noembe Puerto de la Mifericordia : Letwachten bier / endoe in een ander baten melck fop noemoe Nueftra Sennorä de la Candelaria, dęp leguen boozoer/ 't frbip dat oaer ontbaack / weltck al weder-ghekeert was naev Lima. Ban bier

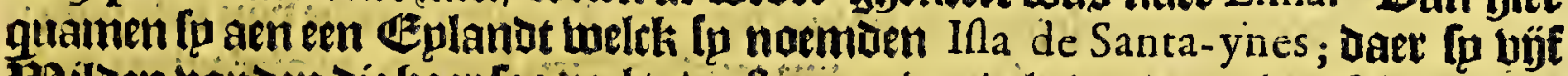

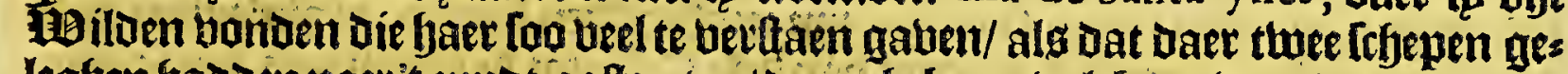

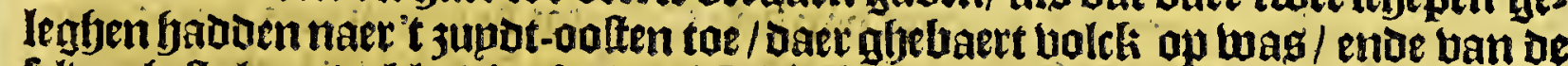

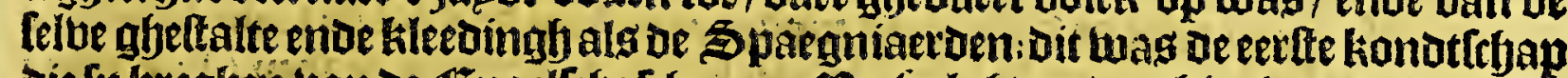

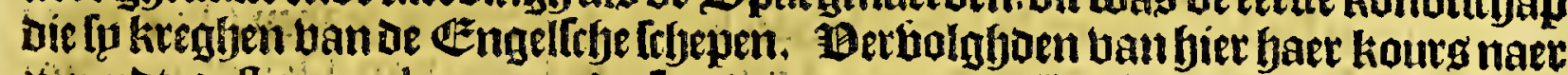

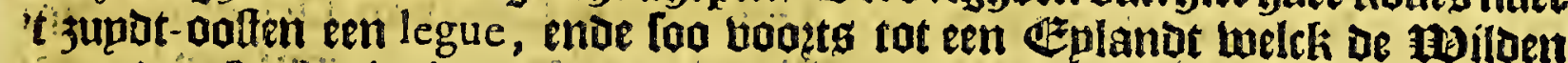
noemden Puchachailgua; tnde een anoer beelck fp noemaen Cayrayxaxylgua; ender werben t thanall gethaer/melck begint tian de monot gbenaemt Xaultegua,

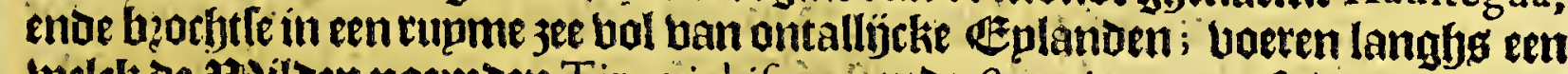
tuelck oe abilden noemben Tinquichifgua, enoe Sarmiento, gaft de naem van

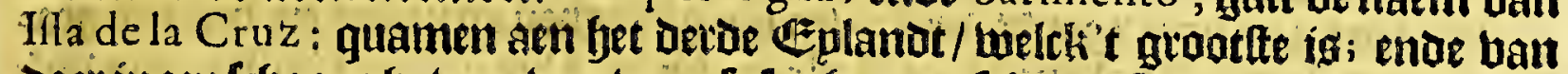

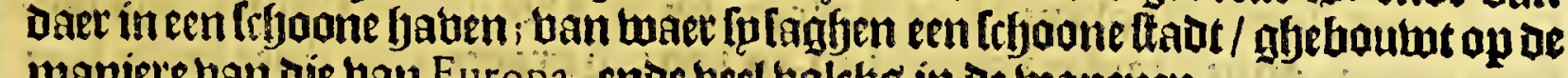
imaniete ban die ban Europa, ende theel holcks in de wapenen.

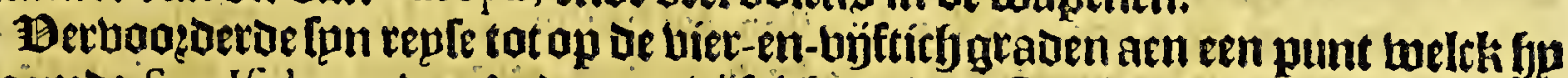

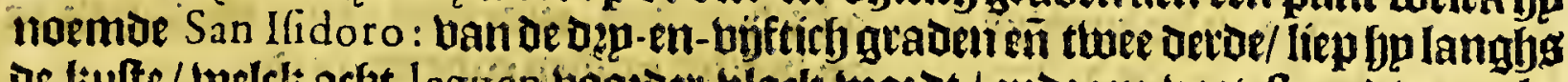

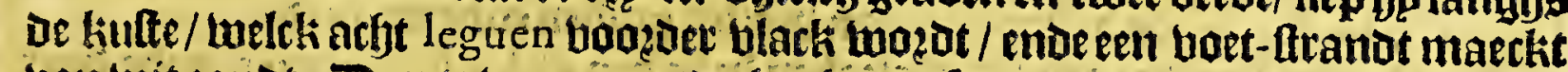

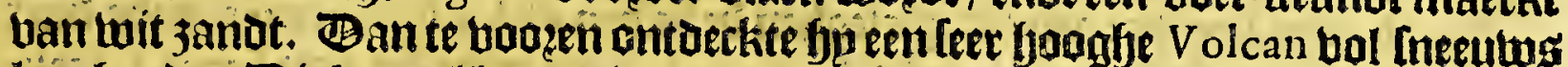

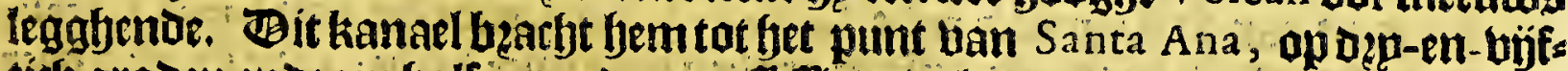

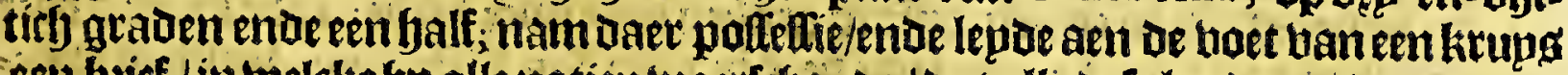

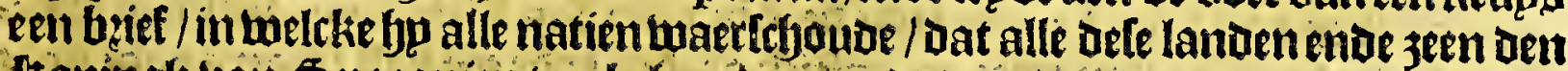

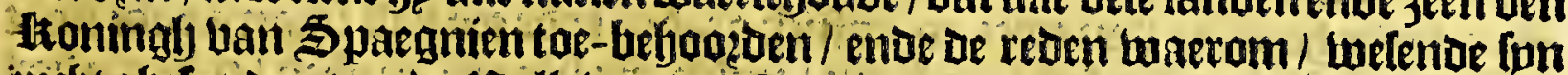

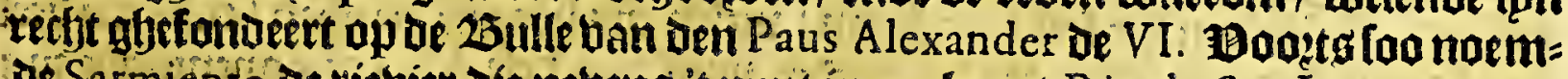
Dé Sarmiento ae riebier die nebens 't punt ín jee kamt Rio de San Iuan; ende ae

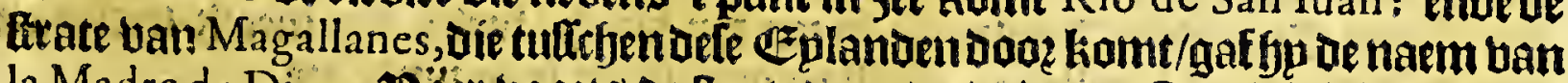

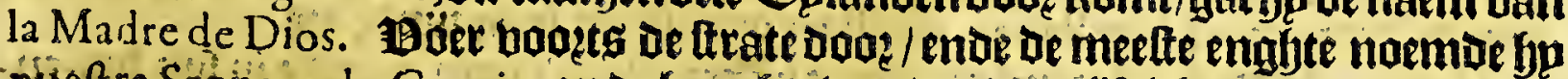
ntieftra Sentiora de Gracia, ap de boogbte uan Dep-en-böftich gradenten een falf.

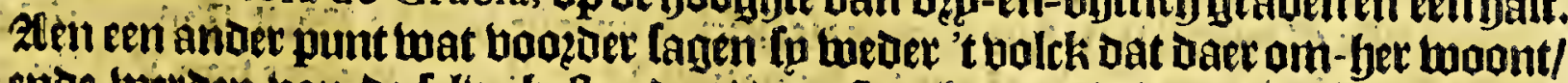

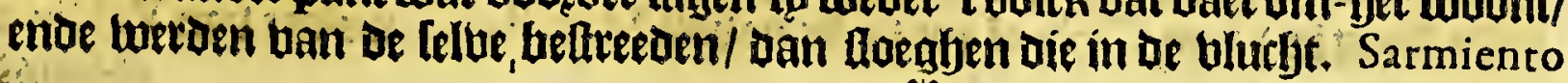

kik 2

gingf 
$45^{2}$

Mágallanica.

gingh 't lanot befitftighen/ ente gaft Jen naem ban nueftra Sennòra del Valle;

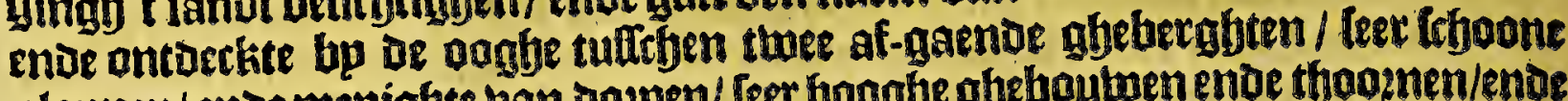
plapnen/ende menighte ban doepen/ Ieer jooghe gbebauluen ende thooenen/ende nartbem Dorbte/koftelícke tempelen/ende van fulcken exceflibe aen-fienlijckbept) Dat bp [pn ooghen qualp̈ck lelfs gbeloof gaf / ende opzeceloe bet eet een fadt in of lurbt te welen: (ghelijck andere wel licht fullen ghelooben die maet een tuepnigh)

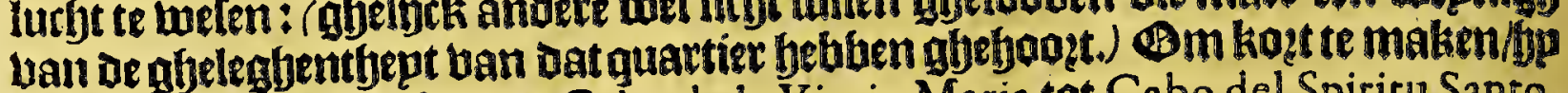
palleerde de trrate die bp uan Cabo de la Virgin Maria tot Cabo del Spiritu Santo,

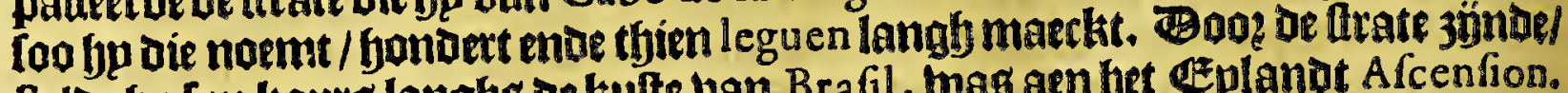
Ateloe bp fon kours langhg de kufte uan Brafil, thas am bet e eplanot Afcenfion. enoemaetkte daer naer [pn befteck too / Dat als bj mepnde feltity leguen ooft ente toelt ban Pernambucte twelen / loo berbiel bp op Sierra Liona, \&c.

Het Decoe Capittel.

Befchrijvinghe van defe kufte van $C_{H I L}$ af, tot aen de ftrate van $M A G A I L A N E S$.

I De vooz-gaentue Capittelen elf enve twaele/bebben wo be kuilte ban Chile

c.st. ban gaens berbolght tot de Cape ban San Felix. Ban dele kape/ naet 't teggen Greckt jupoen; ban dit punt tot bet punt ban Santa Clara jỏn biet. leguen; ban Santa Clara tot Cabo de las Inas (Dat ís 't booft ban de Eplanden) jün thien le. guen; ban defe Cabo tot aen bet \&planot ban noftra Sennora del Socorra, jón achthien leguen, enee de kufte ftreckt 3upot-3upot-welt; Dit Eeplanot leght bp-naer abefjecht aen 't valte lanot; ban dit E Elandt ban noftra Sennora, legle. guen naer't ooften/is gheleghen de baben ban San Domingo, enue ban oefe faben tot aen de Cabo ban Diego Gallego, jün neghentbien leguen, ig abeleghen op te Goonfte ban leg-en-ueettich graden: ban dele $C_{2}$ bo tot de baben han San Stevan, jijn thaelf leguen, ende de kulte loopt 3 upden;ende ban daet tot de Cabo ban Sant Her.der. Andres, $3 \mathfrak{g} n$ leg leguen, op oe hooghte ban Leven-en-beettich graden/ van tuaec be kulte recht jupoen loopt: ban Sant Andres tat de Cabo ban Ochavario, $303 n$ d.8.1.7. actjt leguen; ban Ochavario tot De ballepe ban Nueftra Sennora, yön thien leguen; c.11. ende igeen bape die tuftegen twee heubelen ofte berglien inleght / op de booghte uan acjt-en-beettich graden lefjaers. Ban dele ballepe ban Nuefra Sennora, tot

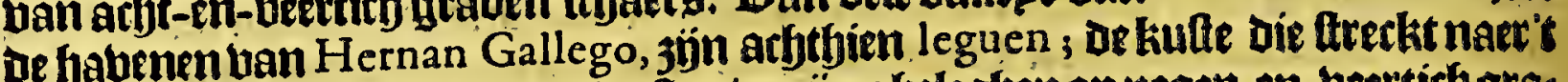

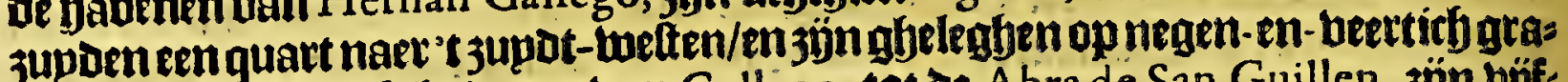
Den fryaers: ban defe habenen ban Gallego, tot de Abra de San Guillen, jön bj̉: thien leguen, op de boogfte bannegben-en-beertich graden ende twee derde ban een qraedt: uan oe A bra van San Guillen, tot de Punta del Gada, zjün leg leguen, en is gheleghen op oe fooghte ban bÿftich graden; ende daec aen is gfelegben of baben de los Reyes, op de hooghte van bjftith gradentende een oetoe.

Seg leguen boozoer aen / ís gfeleghen oe jaben de los Innocentes, ente daet aen bet punt ban $S^{t}$ Auguftijn ende Cabo de la Roia, enoe díe van Santa Catalina, op de hoonhte van een-en-böfticf graden ende thee betoe; enoe ftratkg daes aen de yaben ban Sant Amaro, ende de Abra van San Victoriano, weltk ís gbele: ahen op oe hooghte ban twee-en-bijttich gea ben ende een balf febaets/enoe leght

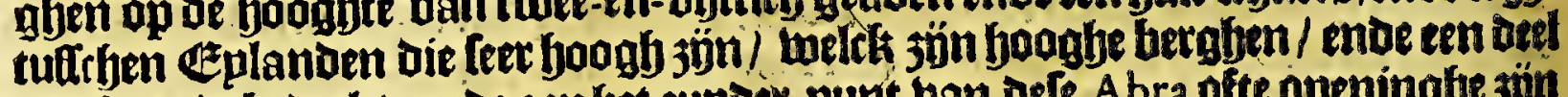
met Ineeulw bedeckt; ende aen fet 3upder-punt ban dele Abra ofte openingbe jün

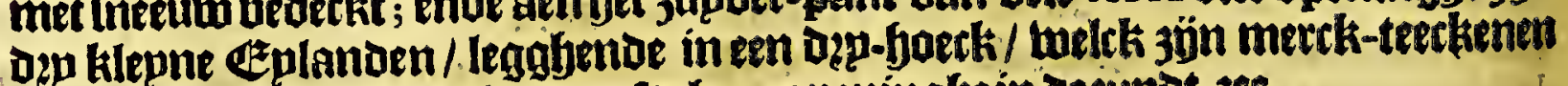
ban oe ftrate ban Magallanes, ofte baex openingfe in De jupot-3ee.

Her.der. Herrera Itelt dele gelegentbeoen twat wifferent ban'tbooz-gaende in fon ogn-en-

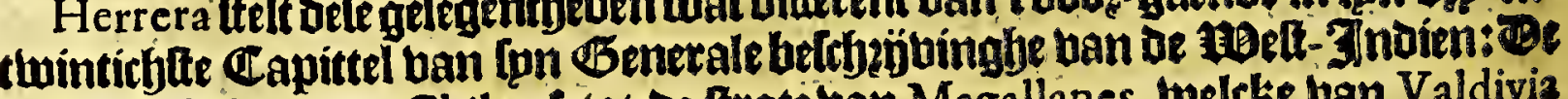
kuthe (leabthp) ban Chile af tot of Itrate ban Magallanes, welcke ban Valdivia af-Joopt 
af-loopt bu ve fondert leguen luelt-3uptot-welt / beeft oe Cabo van Sant Andres, op de booghte ban feben-en-beertich graden / waet be kutte baer loend naer het 3upden/ rectit naer ot frate/ boos-bu de Cabo ban San Roman, op de yoonbte vant arbt-en-beertich graden; ;ende daer neffeng 't \&eplande ban Santa Catalina, nef= fens de groote bape die fu noemen del A lcarchofada, ende Daer binnen de bape vannoltra Sennora, enoe 't Éplandt ban Santa Barbara, ende boozder ofhauent Uan Hernan Gallego, op actj-en-veettich graden anoe the deroe; ende of baue uan los Reyes, acheffien leguen ban de boaefy. Jabend ban Hernan Gallego, ende oe bape ban San luan, op ujftith graden en een derde: De Cabo ban San Francil: co op de fooghte ban een-en-ujftich graden / ban waer renigfe tanalen te landetmaert in-ftrerken; ende fet eta planot la Campana, elf leguen ban San Francifco, mede met eenighe kanaien te landt-twaert in / die niet bevaren en 3 ijn; (A cofta l.3. c.r.

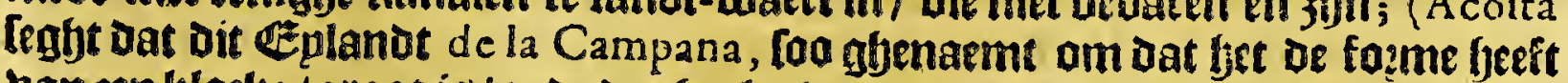
ban een klocke / groot is/ enoe dat fret leggt voos de monot ban ae itrate.) (Enoe

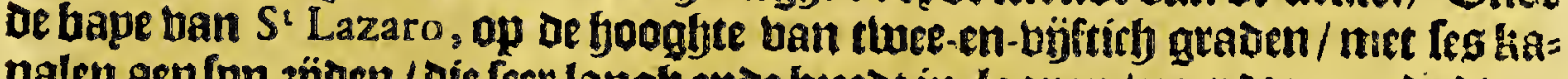
nalen aen lpn 3 jodon / die feer langh ende beedo in-loopen / naet d' een ende d'all=

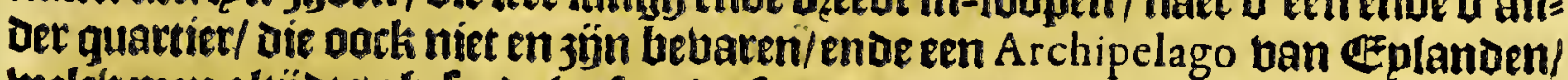

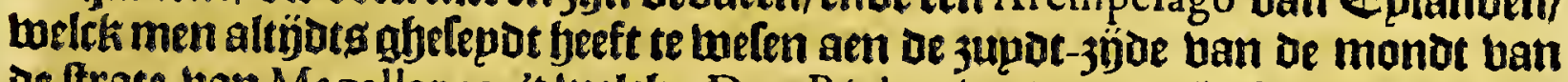
oe ftrate uan Magallanes; 't welcke Don Richardo A quines lachent/ Dooe dien be legbt/ dat bp aen oele monot ban de frate naer de jupot-jyjoe toe / maex en uanot bier [eplanoekeng en een in't midoen / ban oe ghedaente als een fupckerbeoodt/en datfe ten minften fes leguen verfefepden jön ban de monot ban de fira: te / ende dat de A rchipelago aen een 3 bue leght / ende boubt boos leecker dat bet ig 't gbene andere noemen 't valte lanot aen oe juptot-jöbe ban oe frate/ ente dat

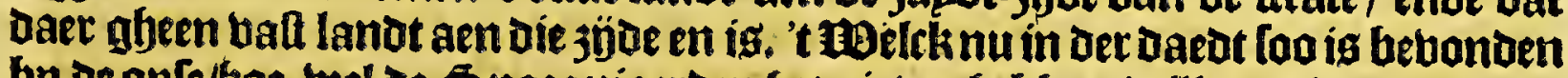
bp de onle/gor-twel de Spaegniaerden bet niet en febben twillen gelonben/ maex

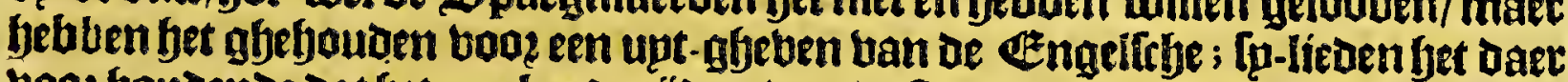
booz boudenoe dat het aen begae 3 jo oen tan de ftate balt lanot wag/ alg A colta berfjaelt in be plaetle fier booren aen-ceroert : Doch oit fal fier naer klaerder blÿc=

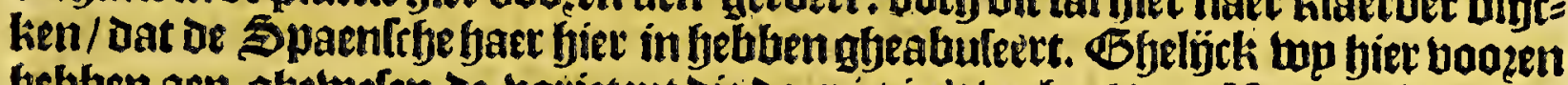
bebben aen-abetwefen de batietrpt Die Datr ig in't betfoel van Herrera Felfs / be= langhende de namen ende fjoogjten ban plaetlen ban dit getwelte ban Chile af / cot aen de frate ban Magallanes; foo bebinden top norb andere namen bp een baertien tuelck in Spaegnien ig upt-ghegheben/ wegfen feecliet ontockimgte bp de Spaegniaerden boos-ghenomenin denjare 16 I 8 , daet bo bier naer op (pn plaete norb Lullen ban Ipeectien; in bet weltke wp bevinden op oe jooghte ban wat meer alg bjif en-beertich graden / ende aen't eqnoe ban los Coronados, een riebiere die fp noemen $R$ io de los Barbudos, enoe op de les-en-beettich graden ende een yalf (thaers Rio fin Fundio; ende tultchen oe feuen enoe acht-en-beetífy graoen eenighe in-wöcken met oe aen-teeckeningh Aqui fe perdio Diego Gallegos, dat is / Diego Gallegos, is fiet ghebleben; ende op oe hooghee ban negben-

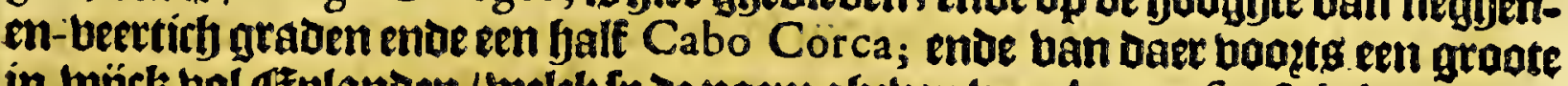
in-wöck bol Ezlanden/welck fp de naem gheben ban Ancon fin Salida.

Het bierde Capittel.

De gheleghentheyt van de ftrate van MAGALIANES felfs, naer de befchrijvinghe van de Spaegniaerden.

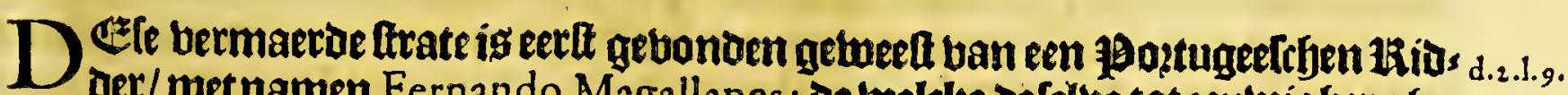

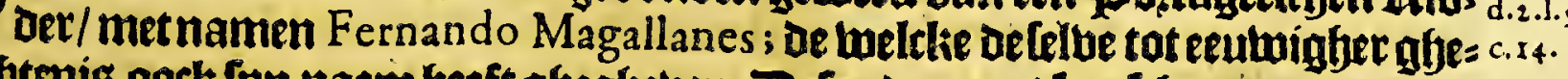
Dachtmis oock fpn naem beeft gfjegheben. Befen ban met fpn thepen ober- -win= tert bebbenoe in de bape ban San Iulian; op de jooghte ban negben-en-beettich graten en feben-en-veertich mimuten $/$ ig ban daer ' 'seplgbegaen oen bier-en.

$\operatorname{lar}_{3}$ twin= 
454

Magallanica.

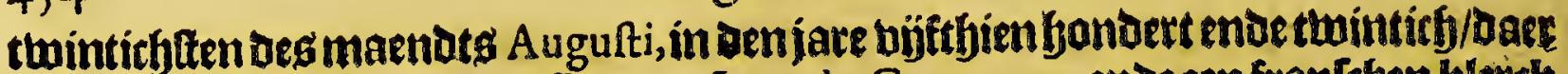
aen landet latende tot een traffe eenen Iuan de Cartagena, ende efn franlchenklextk ofte geeltelïck pertoon:ễ boer ban Daer naer de riebiere ban Santa Cruz, al-baer ljp bertoefoe de maenden ban September ende Odtober, bangende groote quan:

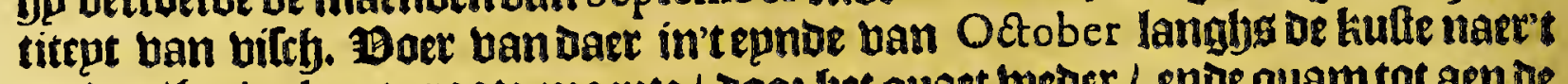
3upden/yoebel met groote moepte / Dooz ljet quaet weder / ende guam tot aen De

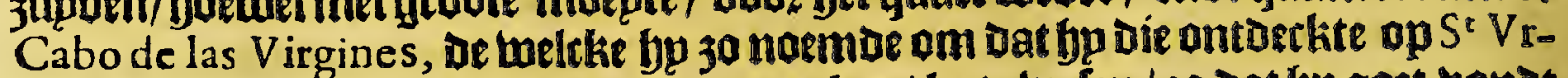

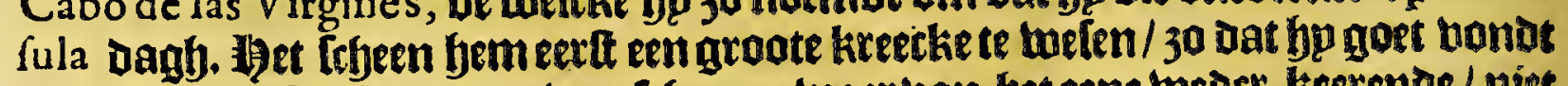
Die te Doen beloecken dooe twee fchepen; waer ban bet eene torder-keerende/ niet beel befcheetg en bacht; maer bet thees leer groote apparentie/ Dat fier een doo?s

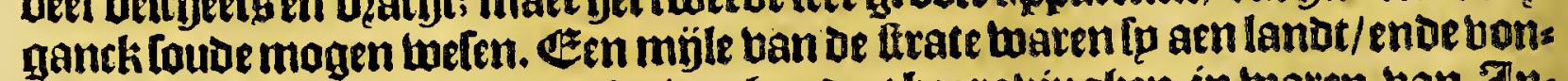
den baer een futte / Daer meer als twee bonoert begrabinglyen in waren ban $3 / n=$

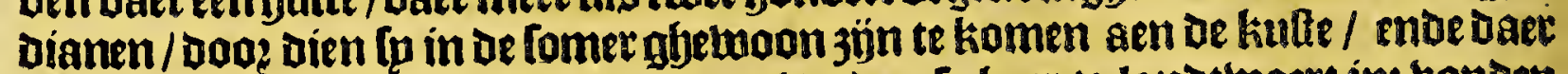
baer Dooden te begraben; en g'winters bouden [p yaer te lanotwaert in: bonden oock een groote walbitty boodt / ende beel gebeente ban de [elbe; 300 dat toel was

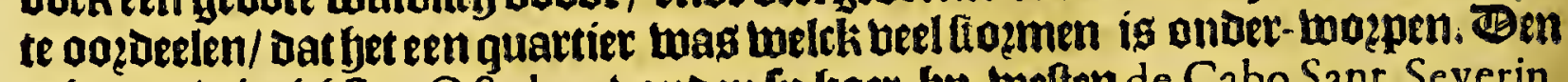
acht-en twintichften October bonden [u yaer by teeften de Cabo Sant Severin, leg leguen op de booghte ban twee-en-bifftich gradenende bäf-en-büftich minu: ten: om dat lp bp nacljt beel bueren Lagen noemoen fo dít landt Terra del Fuego.

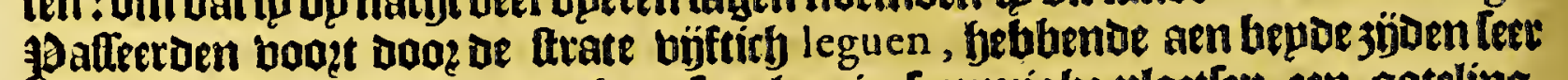
If foon lanot/ende was naer baex feggben in Commighe plaet fen een goteling. frjoot beedt / enoe op Commigfe plaetten Itboane baepen. De büftith leguen ghepalleert jände / quamentuftchen bepden boagbe berghen met fmetulu beoeckt/ enve befet met boomen ban beelderlep looten; berlaghen baet ban water ende

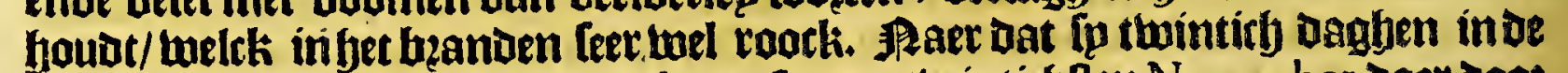

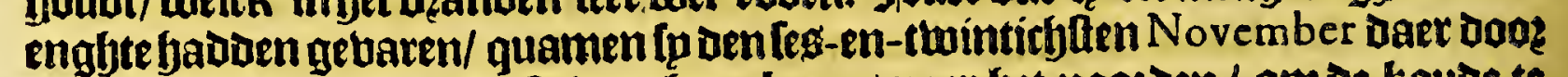
tot in de tujoe 3 ee; ende fteloen baer kours naet bet noogen/ om de koube te. ontuaen.

Daer naer wiert in den jare 525 de tweede reple booz-genomen bp den Coms

c. 4. mandeur Garçia de Loayfa, melcke aen de Cabo de las Virgines quam/ende de

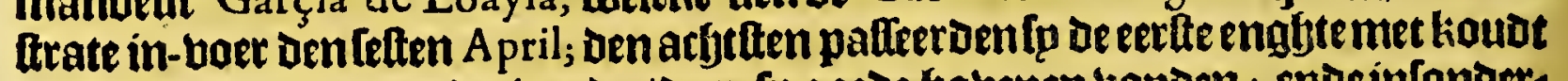
weder; ende daer naer de tweede / baer fp goede habenen uonden; : ente infonders gept een welck [p noemDen Sa Iorge, Daer fp groencaneel bonoen/ welck [p aeten/ boe-wel bet wilot is; aen be zupat-jijoe bonden fp eenigbebauenen/Daer defrbes. pen Conder toubu feker moghen legghen:Den twee-en-twintithften kreghen fo twee Canoas met milden ontrent bet ftyip / De twelcke baer ltbenente deepghen; Leet groot ban líchaem / too Dat eenigbe die noemoen Gigantes, dat is theulen / antoete Patagones.

Ben bier-en-twinticflten May, waren in een ander baben diefp noemoen Puerto Frio, obermidtg de groote koude die Lop vernamen/daer oock eenich bolck ban ttiett.

Den büf-en-twintichlfen palteerden lo de trate/ en quamen in be jupt-jee: Jaer bet relaes ban degene die weder-quamenín Spaegnien/onder erdegedaen/. 30o Toude de trate langh welenbondert endetbien leguen, van de Cabo de las

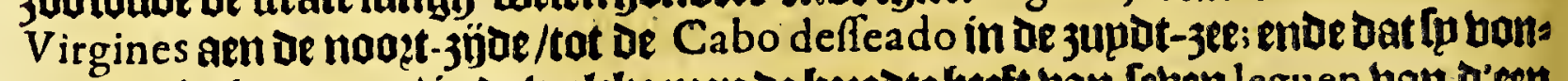
Den dep in-bammen / in de welcke men de becedte beeft ban Ieben leguen ban d'cent landet tot bet ander/wepnich min ofte meer: ende in oe engbten een balbe legue, oft Daer ontrent; ende Dat De eerte enghte eenlegue, oe therde ther leguen langhis/

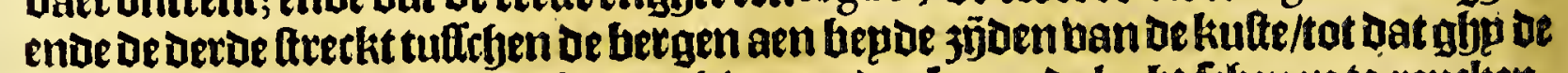
frate upt-komt/ende dat die fo boogb twaren Dat Ip aen ae lurbt Ichenente repcken;

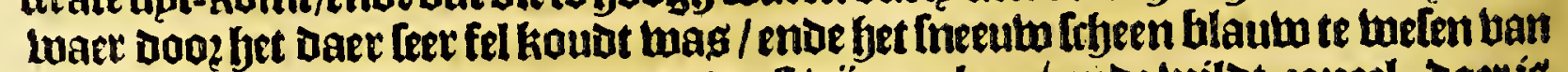

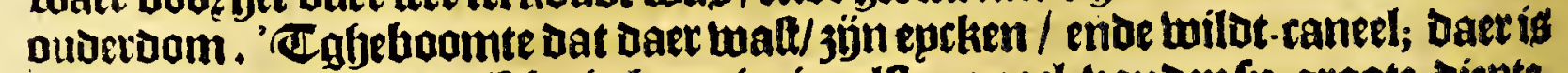
goet water. / ende beel bilety: inget prineipaelfte canael bondenfg groote biepte. 
Her twaelffte Boeck.

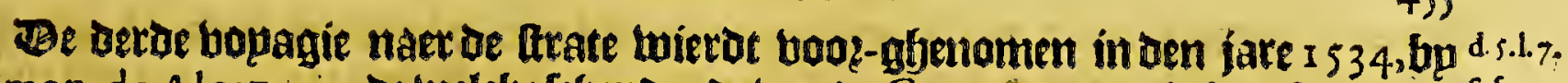

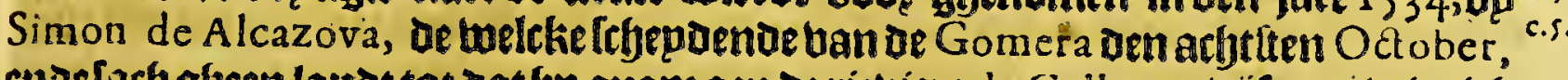
enoefarb giject lanot tot dat fjp quam aen oe rieviere de Gallegos, bijf-en-twintich leguen banoe frate/als alleen Cabo de Abreoios allwaer bp atriberoe aen I 7 Ia. nuar. I 535 , bielent in de ftrate al aen de teeffer-fyanot / om dat fet lanot aen oe

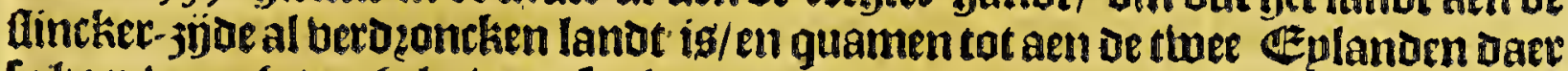

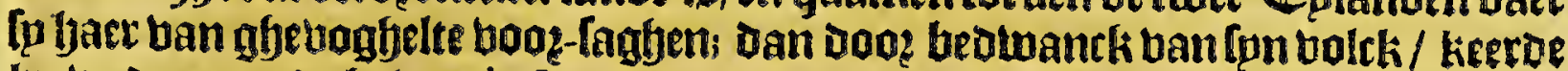
bp taeoer naer de haben de Leones, ente quamen daer Deerljictien om.

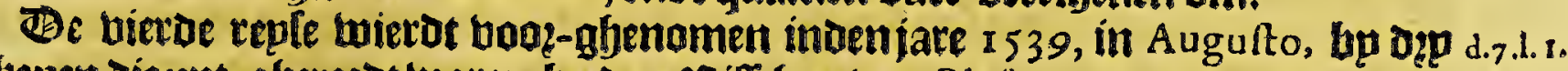

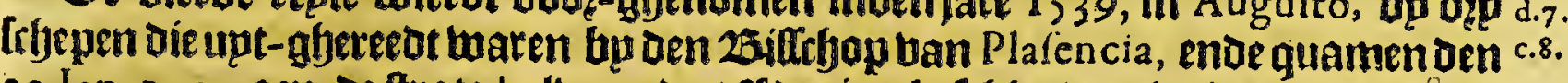

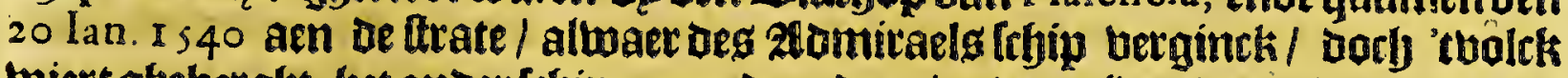
miert gbeberght; fyet ander fehip quam daer doos/ ende arribertoe te Arequipa; bet Det de naer datfet betwintert yadoe in een baben binnen de firate (die In noemoen de las Zorras, om dat fp Daer beel boden uonden:) keeroen boder naer jupg.

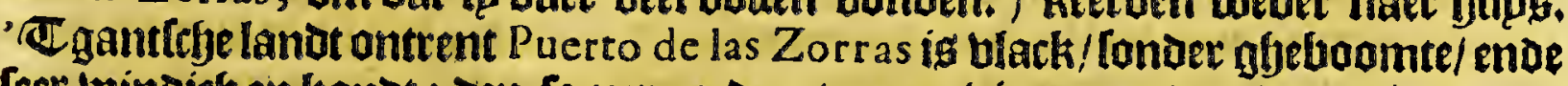
feer twinaich en koudt : Den fomer en suet maer vier maenden / enoe in Mayo begint de fouce van den winter/ende bet fneeut daer tot fet eqnoe van December.

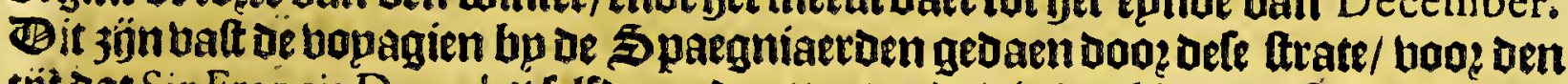
tijt dat Sir Francis Draeck't felfoe mede attenteerde/als wp bier naer fullen yoozen.

Cot een bellupt fullen wo biec bp voegen de beicfyejbingbe ban de ttrate/gelijel Acofta die beeft gbeftelt in fin derde $250 e c k$ / aen bet I 3 Capittel. Deftrate (feght bp) ig gheleghen op de booghte wan 52 gcaden frfaers aen't Jupden / beeft in de lengte ban D'een 3 ee tot D'ander 90 afte x oo leguen, jünoe op haer fmalte wepnich

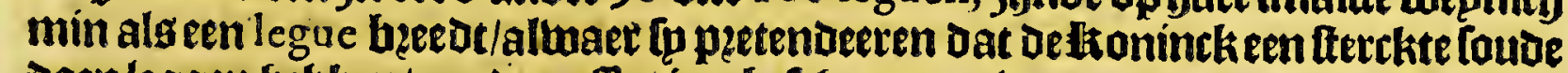
aon leggen fjebben/ am de paftagie te befrbermen/ is openigbe plaetten loo diep Dat men daer niet kan gronoen/ende op ander oozoen beft mengrantr/ jönde op Commigbe plaetlen maer 18 ende 15 badem diep. Ban de 100 minlen die fp in de

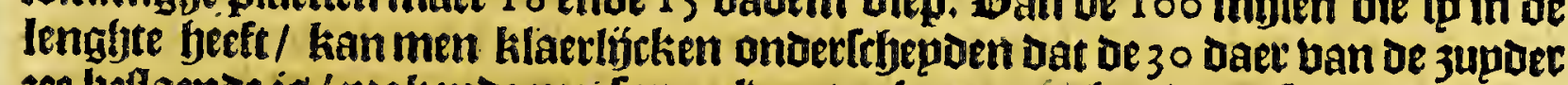
see bellaende is/makende met fan golben teectienen tot boe berte fo in-loopende

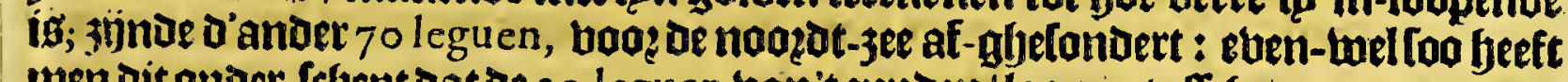

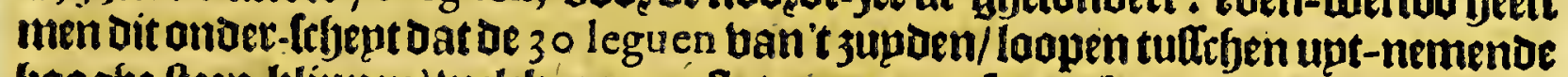
boogbe (teen-klippen/ welcker oppertte toppen met Ineru bedeckt jün / tegünende boog ae groote joogfte aen malkanderen baft te komen/matrom de ftrate aen de jijoe ban de 3 upot-jee foo qualísken te kennen ig. TI $n$ offe 30 leguen is uptnemenoe diepte / conver dat men daer anckeren kan: niet teghen-ttaende mach men de lfyepen daer wel op't lanot halen doos de bequaembept oer oebeen die daex is. In d'ander 7 leguen die de noordt-jee in-loopt/binot men gronat/ hebbende aen bepoe 3 joen groote blacke beloen/enoe daep-laeckeng/gbeligck men die noemt. - Ber komen in of ftrate beel en groote riebieren van ercellent bater upt-loopen/

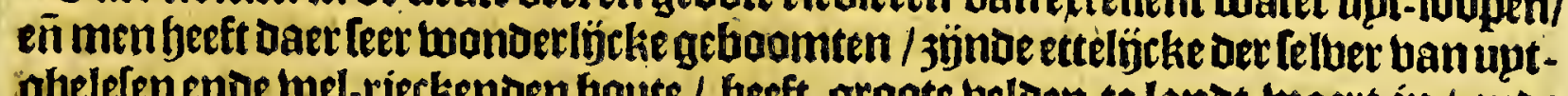
gbelelenenoe twel-rieckenoen youte / geeft graote beloen te lanot-waett in / enoe midoen in de ftrate legghen bettebepden Geplanden. DTndianen die aen oe zujoe

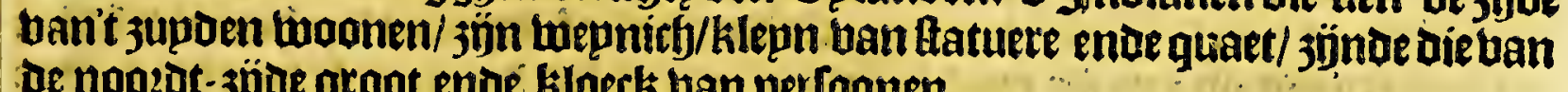
ae noożot-3jö groot ende kloeck ban pertoonen.

\section{Het vijtoe capittel.}

Voorder befchrijpinghe van de Strate, felfs by de Spaegniaerden.

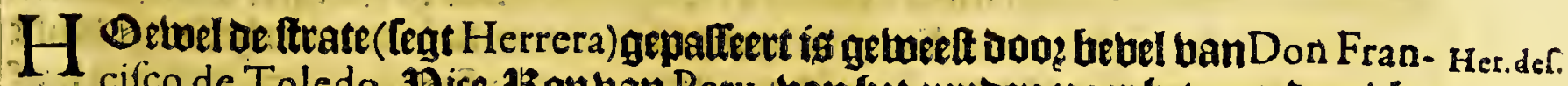
cifco de Toledo, Bice-1Ropuan Peru, ban bet jupben naer bet noozen / bp Pedro Sarmiento, $\mathfrak{e n}$ Antonio Paulo Corfo, eñ Datmen meet datlp leght ban oe 52 tot de 53 graden / daer fp meelt naer bet 3 upden ftreckt / ende dat men baer lengbte ende baecote oock ten naeften bp tweet/ loo en heeft men nist verbolght de $2 \mathfrak{1} 4$ 
$45 G$

Magallanica.

Lelbe te bebaren uan de zupot-zee naer de noozot-3ee toe / nocfy te oock be andere

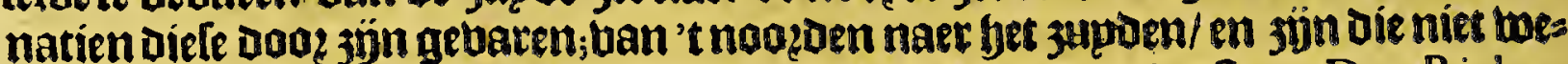
ber te rugge sooz gekomen/Loa beel men nody beeft konnen berftaen. Don Richar-

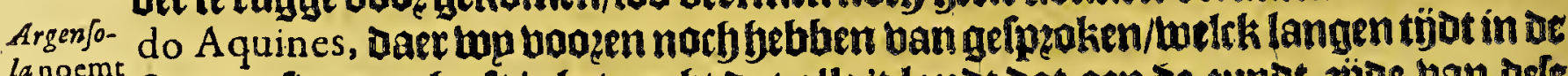
Sir Iobn frate geltwarmt beeft/ghetupgbt Dat alle't lanot Dat aen de supdt-jigoe ban oele Havv. Itrate leght / gheen valt lanot en is / maer veel Eplanoen/ welche kepeken tot de kins, Luan hoogfoe ban 56 graden toe; t tuelck bp konoe tweten/Doo? dien yo liep tot op fulcs Aquines; Ken booghte Doo?'t midoen uan Defe [eplanden/ende liende Dat be niet Dan zee en

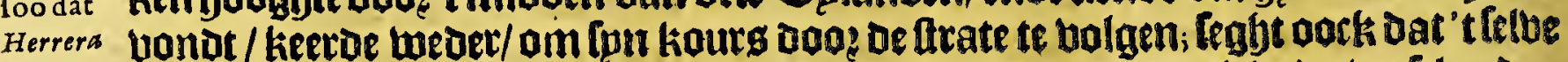

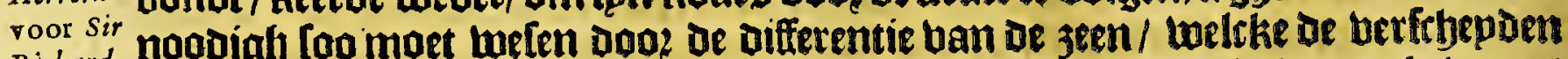

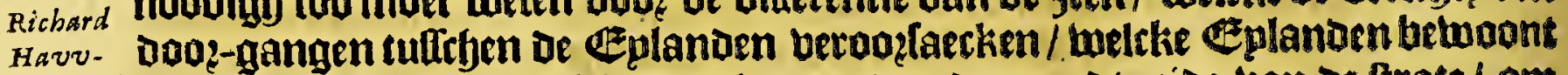
kins vel mozoen ban bolkk De tuelcke Daerkamen van De nodzot-3joe ban de ftrate/ om

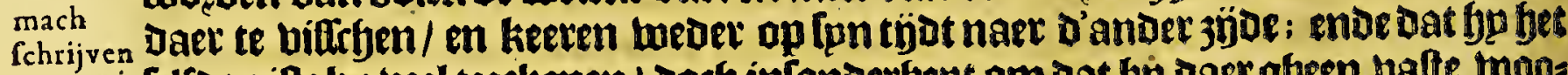

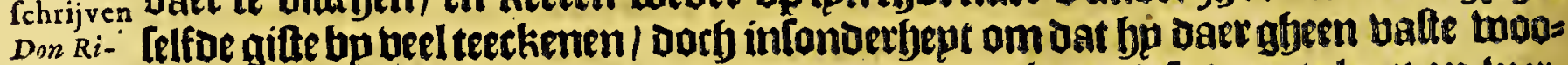
chardo ningen gevonoen en badode/ Dan alleen eenige buttieng die fp daer te loop op- wors: Aquines. pen. (foe anoere dit ghebonoen bebben / lullen up bier naer legghen/ upt "twelck [al blijeken / dat dit aen-gheben ban A quines waratjtigb is.)

Cot naetoer betifanot ban't abene bier bp Herrera wozot gbefeght ban Don Richardo Aquines, foo is te terten Dat in Den jaere 1594 Dode? de trate van Ma. gallanes, in oe jupot-jee quam een eEngelfth frbip Daer boos Generael op bort Sir Richard Hawkins; ende merot bp Don Beltran de la Conna ghenomen/ naer dat wel dep Dagen yaer mannelïcken badoen gbetweert/tegen cen Spaenlet galioen met twee-en-Derticy metaelen lepel-ftucken baer wel bier bonoertman op was / enoe een ander frbipken met arbt oft thien metaele flucken; Daec bit Uens

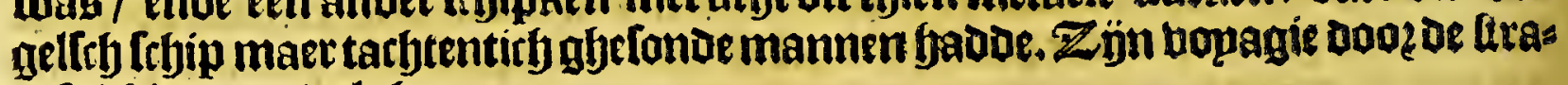
te Cal hier naet bolghen.

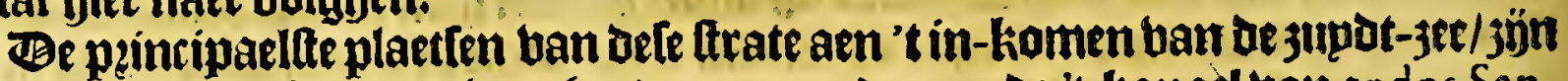
De Cabo Deffeado, op defyooghte uan 53 graden ; ende't kanad uan todos Santos 22 leguen ban oemonot / feer beerot ende langb/ende daet boot-bp de baven die \{p noemen oe Traycion; ende daer naer een anoer groot en langh hanael) welck loopt naer fet noozot-wellen/enoe la Campana de Roldan, welck ig een groote klippe in't mioden ban bet begintel baneen ander kanael. Bet punt ban Poffeffion vier leguen ban Cabo de las Virgines, aen bet in-komen uan de frate aen oe noozot-3ee / op de fooghte van twee-en-büftich gradenende een balf.

Doen Pedro Sarmiento (als booken berbaelt ig) De trate ban bet jupden naet

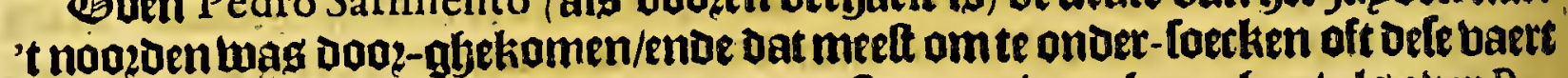
gbereeder wag om 't riluer enoe gouot naer \$ paegnien te beengben/als ouer $\mathrm{Pa}$ nama enoe Nombre de Dios, foo namen Ip meett acht op twee engften / welcke

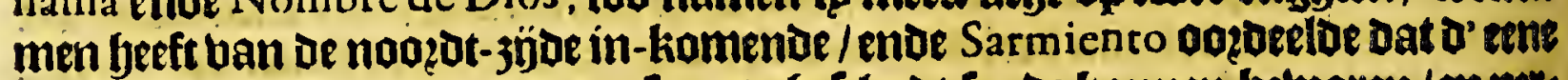
enghte foo naeutw lwas / datmenle met gfelchuot foube konnen betwaren / en pets

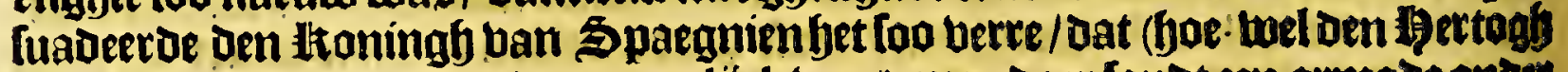
ban Alva altÿts lepde Dat 't onmogelíck was) men oaer fonot een ammade ontuse t belepot ban Diego Flores; dic onventbrbaerligek af-liep/ (als twp bier naet lullen berfalen:) ende op tepnoe bonotmen oat bet een leet dangereufe baetot f́; moe dat oe blocot ban bepoe oe zeen/melck op een plaetle te famenkomen/baer twetee retireeren met fulcken furiel (bet lwater op fomminge plaetlen ballenoe meer dan feltich hademen/) Dat/ al waert Dat oe frbepen niet Danmet kabels ghelaoen was. $\mathfrak{r e n} /$ om te hou

Zllomen de Cabo de las Virgines ghepaffeert ig/ ende komt aen bet leege lanot in thien ofte twaelf badems / too jüt ghp recht ober la Purification, ende een balf legue binnen 'tanots was een ftaot gheleght ghenaeme Nombre de lefus, walt

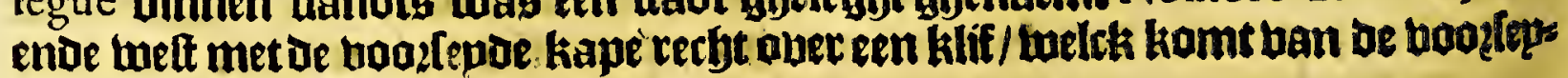
Dekape / enoe loopt binmen be frate. 
Het lefte Capittel.

Voordere befchrijvinghe van de frate van MA GAL L ANES, ghelijck die by de Engelfche is ondervonden.

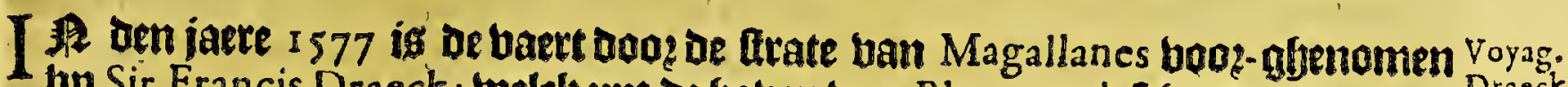

1 up Sir Francis Draeck; tuelck upt de gaben ban P leymouth frgepoen den Det: thienden Decemb. ende quamen den viftoen A pril i 578 op de kulte van Brafil op

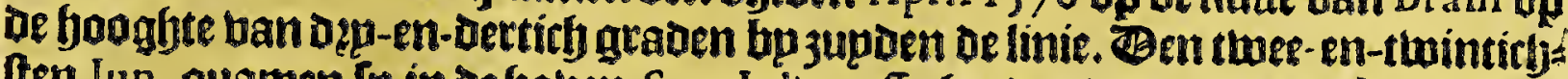
Iten Iun. quamen Ip in de faben Sant Iulian. Schepden ban daex Den feventijien: Den ban A uguf. enoe Den twinticheten dito quamen fp aen de frate. Ben renen-tmintichften boeren fp Daer in/ ende vonden datfe fadde diber[fhe keeten/ende gbelijck als op-[chnttinghen / ghelïck alg ofter abeen Doos-gangh en lwaer ghe

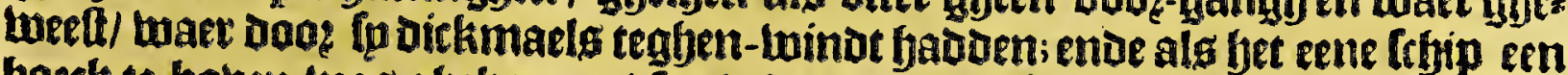
boeck te boben wag ghetiomen/ fon wierd bet ander wel te rugghe gbeopeten /

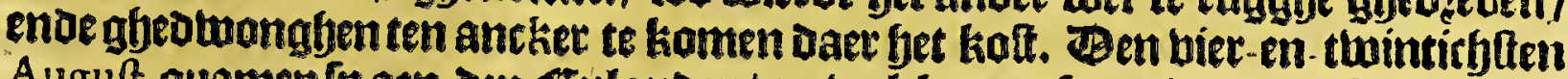
Auguft.quamen lp aen dapp Eplamben/ op weicket eenlp toel ołp ouplent bagelg

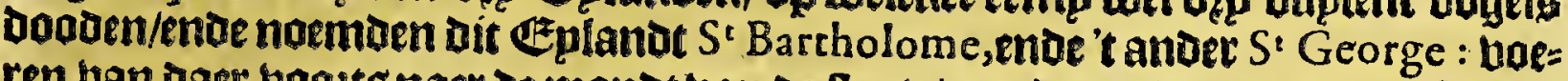
ren ban daer boots naer be monot ban de ftrate/ aen de jupbt-jee/ altwaerfp anc:

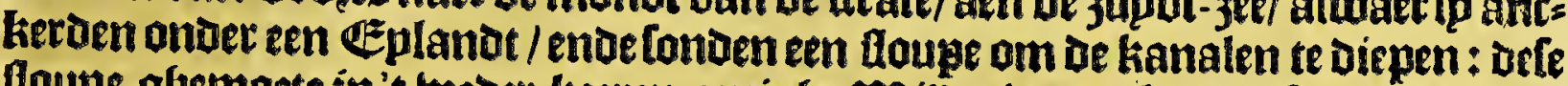
loupe ghemoete in't weder-keeren eenighe miloe in een kanoe feer fraep ghes maeckt ban balten ban boomen / ende te faemen ghenaept met neftelg ban robs ben-bellen / booz en arjter op gaende met een kromme atben: Dit bolck bas

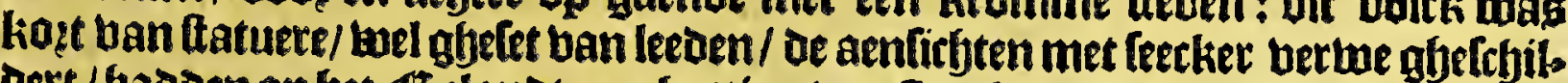

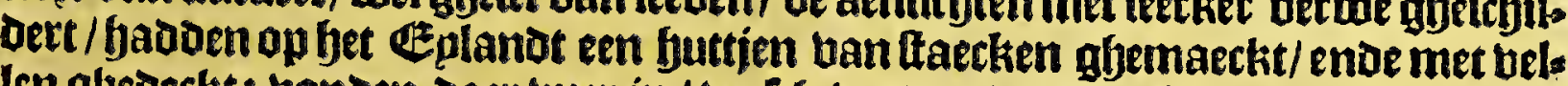
Ien glyedeckt: bonden baer bper in / verlef watec / ooode robben / mofielen ende

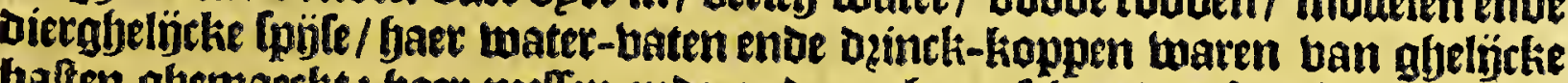
baften ghemaeckt: baet mellen enve andere gfereetfchap daete defe baten met maecken/ twaren groote moffel-frbelpen/oirfe op leecker tteenen foo weten teftber pen datfe daer mede niet alleen jatot goud maet pock been mede befnjoen. Den 6 September quamen [p in be zupot-jee neffeng De kape. Den levenften buieroenfp booz cen groote ftoem ban de monot van be ftate gbedzetben wel twee bonders mijlen in de lengljte / en cen graed jupoelïrker als de fooghte ban de frate; in toelcke fooghte li oen eclipe ban oe mane faoben den bijfthienten September cen leg upeen deg nachts. Defen ltozm buptoe bel twee-en. víftich Daaben / loo batfe in groot ghethaek twaten om alle te bergaen/ende een ban be frjepen bet=

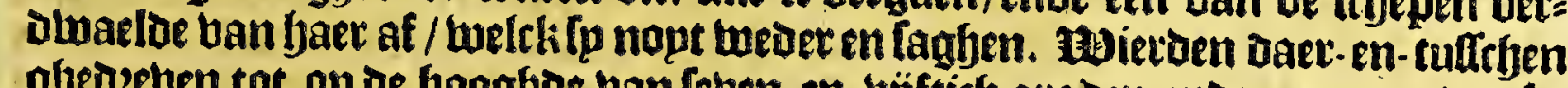
gljedecben tot op de booghoe ban feben-en-ujftich graden ende quamen den les uenden Oetober op die boogboe tell antker in een bape: dan wierden dooz de hinde weder ban baer antker gbedzeben/ ende den Bice-zlomirael gberaeckte bier van yaer. Ban defe bape/toelck fa noemoen The baye of fevering

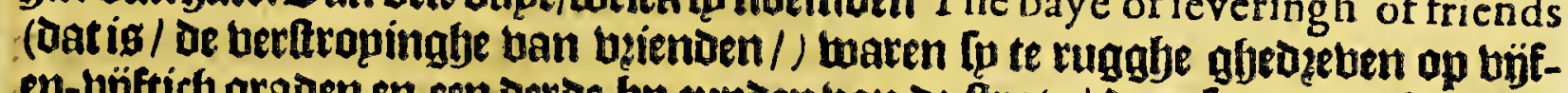
en-ujftich graden en een oeroe bp jupden ban oe frate / baer fp aen ancker quas

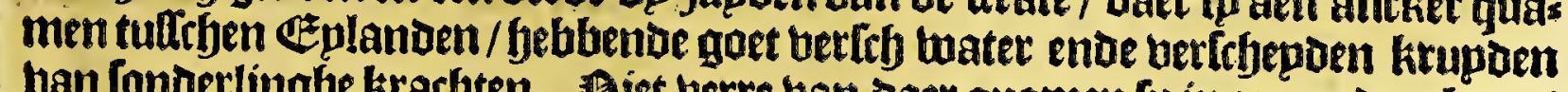
ban fonderlinghe kracbten. Piet berte ban Daer quamen fp in een andere bape/ baer fp bolck bonden bepde mans ende veouben / littende in baer kanoas beel naeckt ende barende ban fet eene Eplande tot't andet om baren koft te foecken; fu bandeloen met dit bolch / enoe berkeghen ban baer fulcke dingfen ald fp bads Den. Ban daer keerende naer bet noozden toe / bonoen Ip Den berden October Dep Eplanden/ in tueltker eenlp fulcken menighte ban bogbelen bonden/ oat

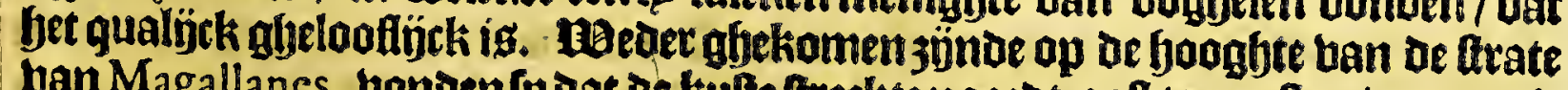
ban Magallanes, bondenfp dat de kulfe freckte noozot-ooft ten oolten/ contracie als boog defen in oe kaerten was ghelfelot ghetueet / bet 3 p ontwilleng booz mig-

berftant 


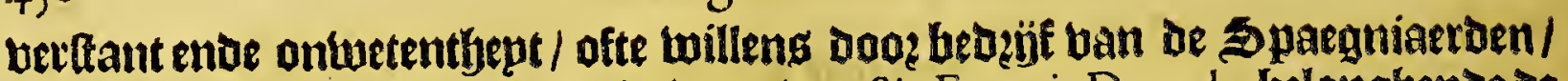
om te bedieghen: Dug beel ban oe baett ban Sir Francis Draeck, belanghende of

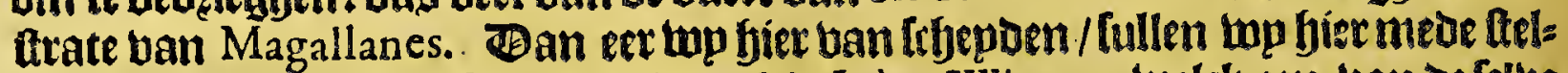

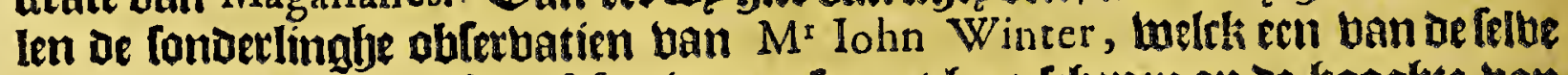
vlote was. Den twaelfoen May waren Ix met baer fefiep on op of fooghte ban [eben-en-beetity graden/ tutlck lambt den Generael Draeck noemoe Cape de Hope. Daet naer in Port Sant Iuliaen als boosen berfaelot/ daet fpernighe Filden bonden/ Dorb by berre loogrooten volck niet (naer Get legaben ban be (Engelfeyen) als de Spaegniaerden mel gebben upt-abegbetent. De kape aen den manot uan de ftrate abeleghen noemoen fp Cape de Victorie, ende bevon: oen die te legaben op oe foogbte ban twee-en-bjftich graden en eew hall bp sup: den de limie.

Tn de ftrate leffs en bonden [u gbeen current / als Commigbe imagineeren/ welck loube bolghen get primum mobile, ban oolten naer bet waetten; maet een

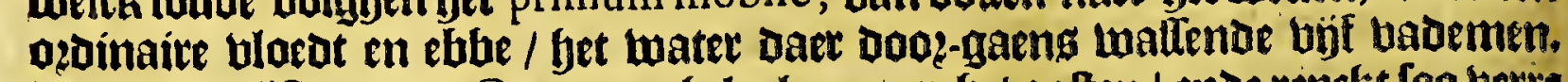
De bloed rijlt upt den Oceaen, gheleghen naer bet oolten/ ende repectit foo berre

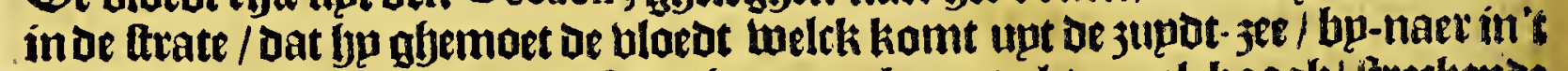
midoen ban de ftrate/ daet of frate haer om-kromt als een el-boogh/ itreckende

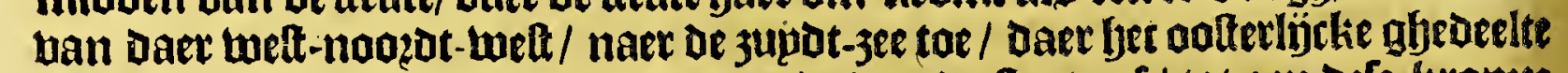
ban delen el-boogh ban de noozoer-monot ban oe trate af / tot aen bele tromse

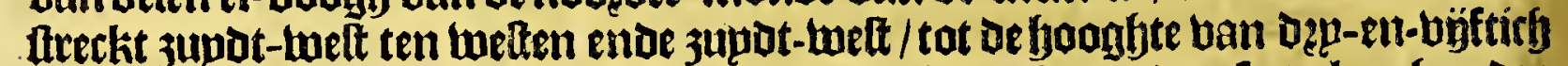
graden en een balf. Betticy múlen binmen de frate bevonden fo te legaben Dą explanden/ waer vanlp bet een noemoen Elizabeth, lyet anoer Sant Bartholo. me, ende fyet derde Sant Georges. Ben fetten September pafleerden lp bp te Cape Deffeado, in de jupot-3ee / enoe líepen noozot-melt bu de lebentiry mólen;

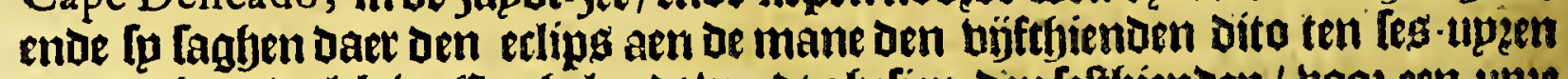

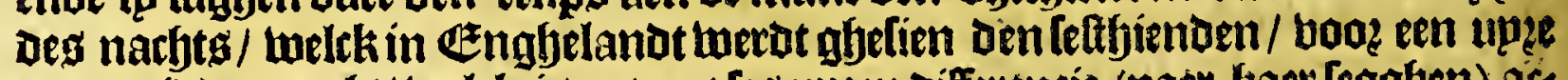

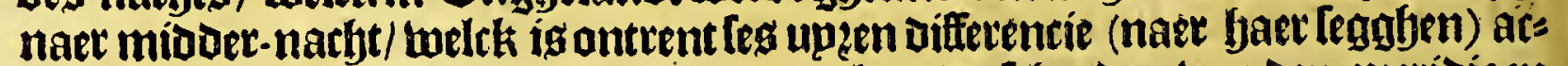
cozoerende op een bierde-part ban be wetelot/berfebepoen ban den merioiaen

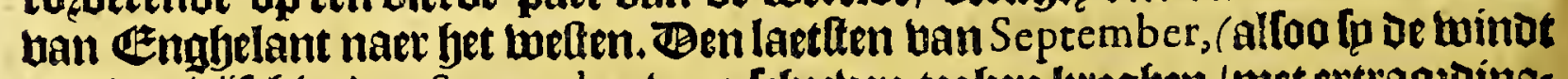

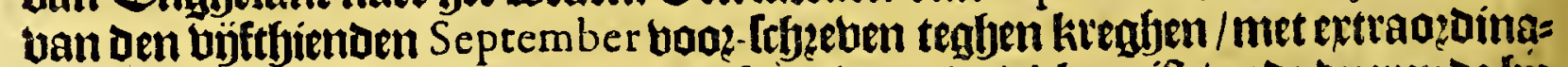
ris bupl toeder ban regben/baghel / fneeula / ende dicke mift / ende duerende bu De dep weecken / foo dat fp gljeen jepl kanden boeven / ende waren gljedzeben tot op de [even-en-ubftich graden bp zupoen de linie;) Is (teloen baer hours tweder oof naer de wal toe/ende kreghen bet landet in't ghefiefte/Den Leuenden Odtober, berballende in een leer dangereule bape / bol ban Hlippen / entoe twierden daer ban De compagnie van Draeck berfteecken. Ben Dagh daer aen quamen fp beder in De ltrate van Magallanes, Itwaerlÿck baer ubereodert bebbende unt de klippen/ ende anckerden daer in een open bape / boo twee dagfen; ban daex quamen fis op een ander reede/ daer fu dęp tweecken bertoefoen / ende noemoenle of baten of Health, doot dien't bolek daer meder gbefonot twietot.

Sp gaben oe reple ouer / ende keerden boen han bier toederom naer bups den elfoen November; bp of Cape Victorie, af ftrate van Magallanes wederom uut-Ioopende.

\section{Het Lebende Capittel.}

Voorder befchrijvinghe van de frate van MA GA I I A ES by de Engellche, volghens de voyagie van Thomas Candifch.

IR den jaete 1586 thierot de theede repte naex ofe ftrate booz-gbenomen bu $1 \mathrm{M}^{\mathrm{r}}$ Thomas Candifch, of welcke met dep frbepen febegue ban Plimmouth oen een-en-twinticjten Iulii; ende Den thienden September fefepton fp tarn of 


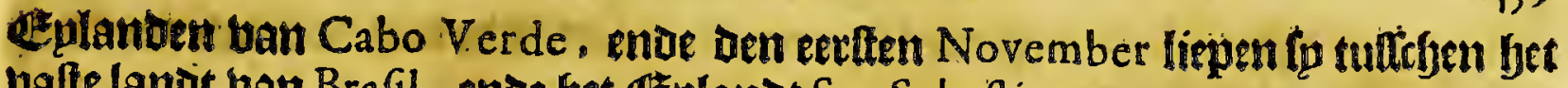
valte landit ban Brafil, ende het $\mathbb{E}$ tulandr San Sebaftiaen.

Ben feven-en-twintichlten uan December quamen lp op de hoonfte uan arfyen-beetich graden bp jupden oe límie / ende liepen in een jaben die fu noemoen Port defiré. Sefjepoen twederom van taet den acfit-en-twintiffeten Decem. ber, ende boeten aen een eplanot bel Dep mịlem baet af-gheleghen naer brt
supoen.

Ben iecoen Ianuar. 158 , quamen [p aen een groote witte kape gfyeleghen on De booghte van ttuee-en-bjftich graden ende bijf-en. beertich mimuten.

Ben felten deg feluen maendto boeren fp de ftrate uan Magallanes in.

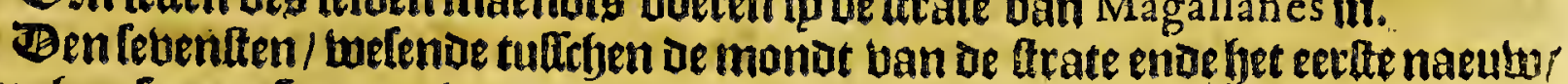
kreghen fpeen Spaegniaert ghetanghen/ bie baer was met norb bep-en-twin: tich andere alleen obet-ghebleben ban biet fondert/ welch Daer gyelaten labar

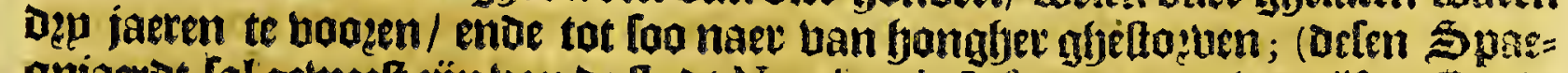

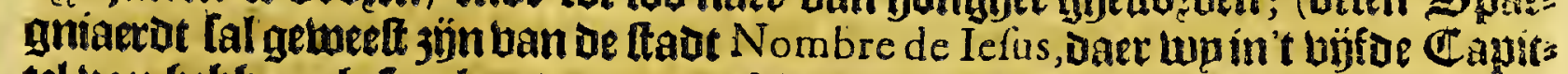

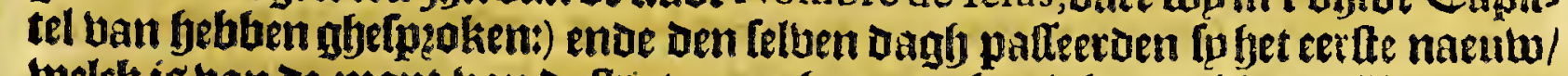
welck ig ban de mont ban de ftrate naer baer reeckenigh beertbien mülen/enoe

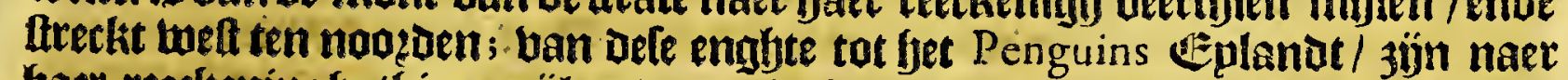
Gaer reeckeningh thien mijlen / ende leght welt-jupat-melt wat jupdelïclier; Dit Eplandt beft fpu naem bekomen yan bet gbetuogbelte welck men noemt

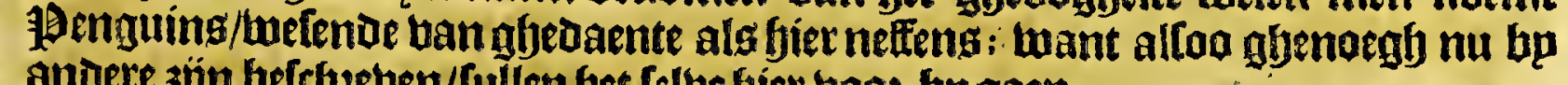
anvere 3 jön befrlgethen/fullen bet feloe fier boos-bp gaen.

Zeplende han daer zupot-3updt-wett na de fadt die de thoningb uan Spaegnien Philips de II daet hadde doen legghen. Melche ltadt badoe vier foeten/ende op elck fout baode gheleghen een fuck gberchuts/twelck ooen waren begraben/ende [p groeben die beder upt : De ftadt toas gheleght aen de bequaemiten oogot ban de ftrate om toa= tet en boud te belomen: (De Spaenlefe ditectie tan fourfen leght Dat punta de Santa Anna leght op te boughte than oze-en-bujftich graden en pen balf / ende vat naet het noozot-weften daet af / in een boeck was ghelegljt la Cuidad de Don Philippe, enoe bat imen moet tem ancker komen noogd-waet daer van/als ghp 't hafteel gfoepalteert 3 ÿt/enoe een grooten foom die baer that tot cen licteecken.) Bele Spaegniaeroen waten bier ghebzarbt (als boozen oork is aen-ghetoert) om oe

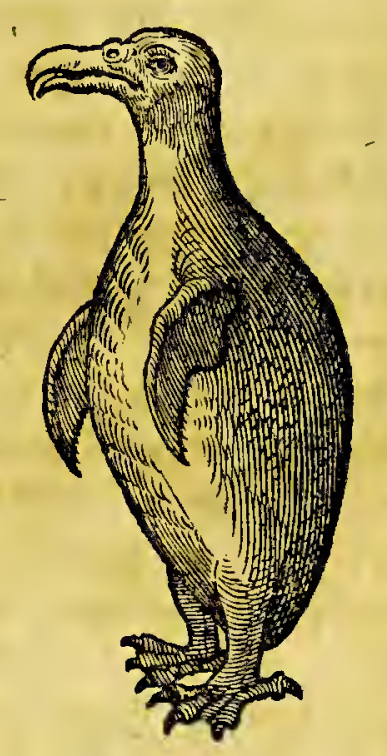
frate te bebpyon ende te be!etten dat daer gbeen ander natien booe en fouden maghen palteeren ; dan bet fchyjnt dat Goot fulcks niet en beeft glbelieft / want

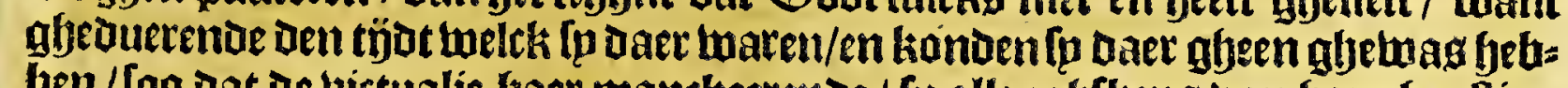
ben / foo dat oe bictualie baer mankkertende / fp allenghfteng ban jongher flier:

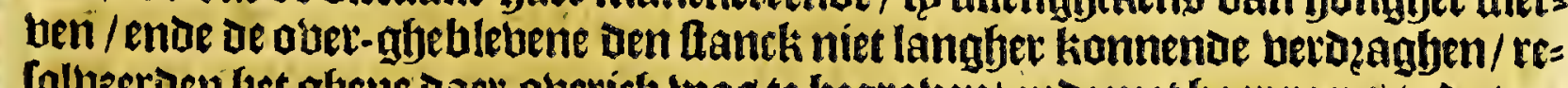

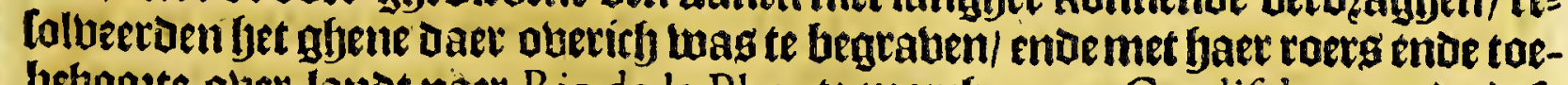
bebooete auer lanbt naer $R$ io de la Plata te marcheeren. Candifch noemoe bere Engelplaetle Port Famine, ig glyeleghen op dep-en-ujftich graden. (naer bat men ber= = che

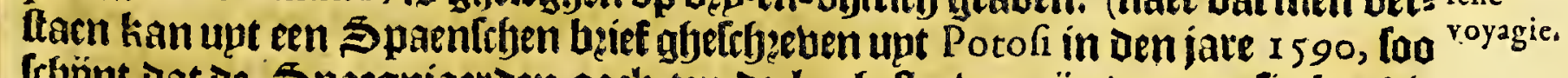

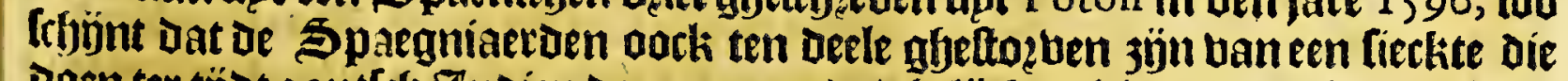

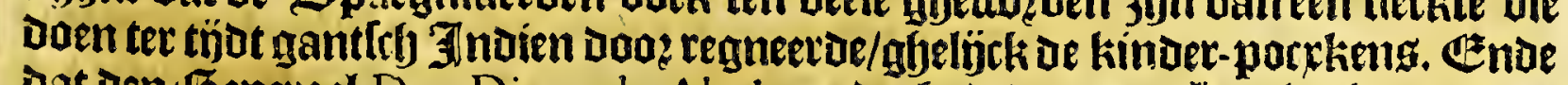

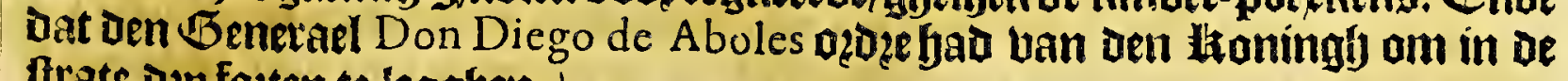
Arate \ęp foetten te legghen.)

Den beetthienden lanuar. Irbegðen[p ban Porto Famine, ende boeren jupdt-

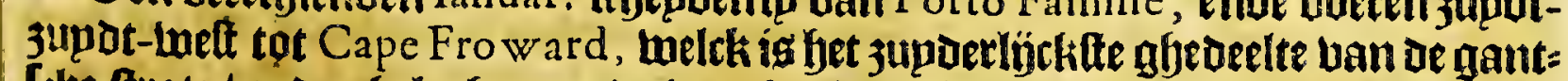

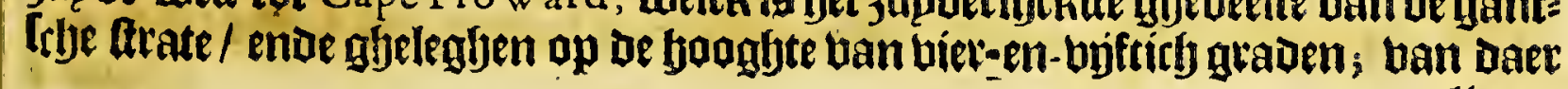

liepen 
460

Magallanica.

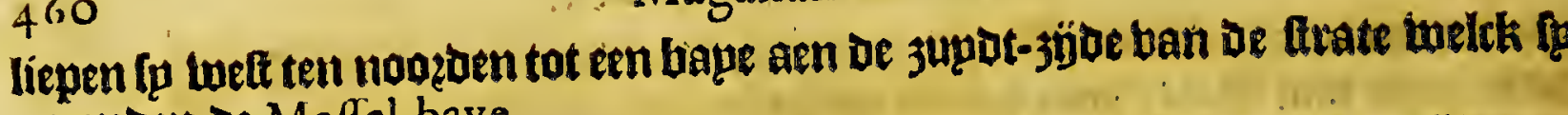
noemoen ae Moffel-baye.

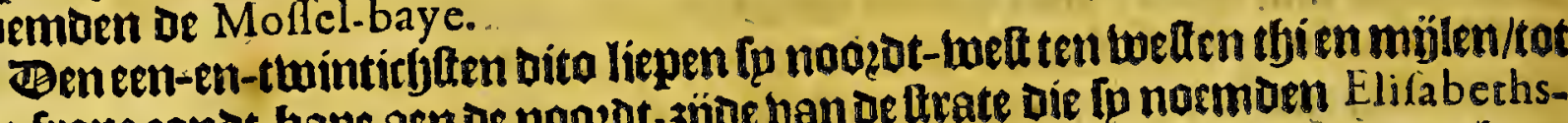

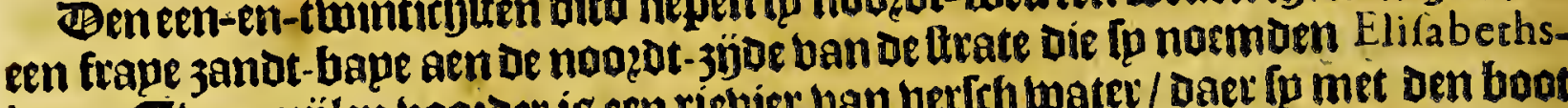

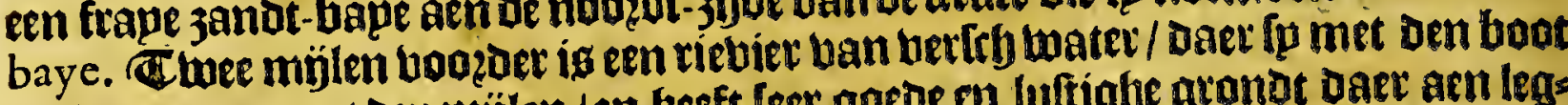
op-voeren ontrent Dę mijlen /en beeft leer gaede en luftighe grand oaer aen leg ghenoe / leegh lanot en beldigh als daer gheen en is in oe ganttrbe etrate / weltck voots klippigh ende bergharbtigh boogh-landt ig. Op defe vieviere woonden beel toildoen / menffyen-esterg / enoe op raeutu. Uleefry voedende / ende andere buple Dingfen: welck oock eenigbe ban de Spaegniaerion badoen ternielt/

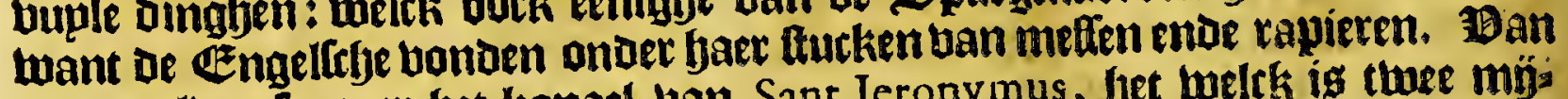

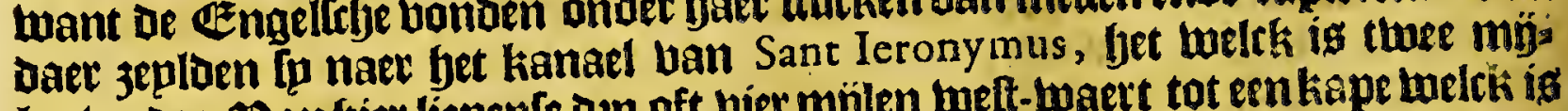

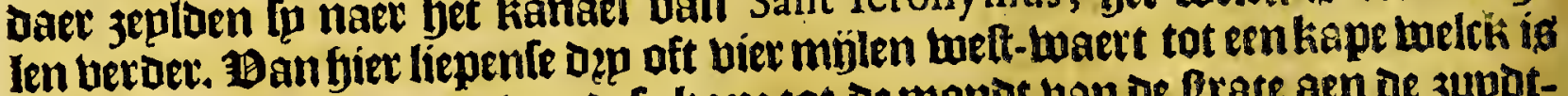

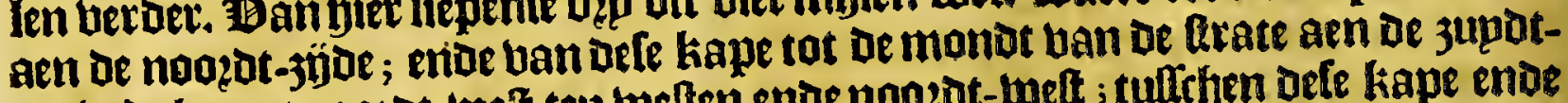

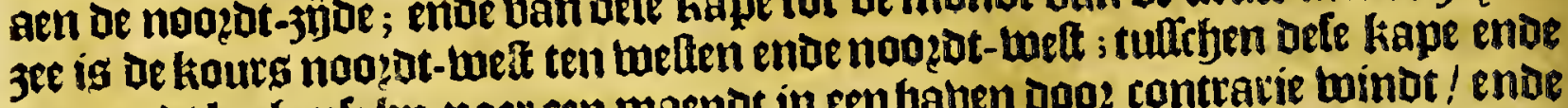

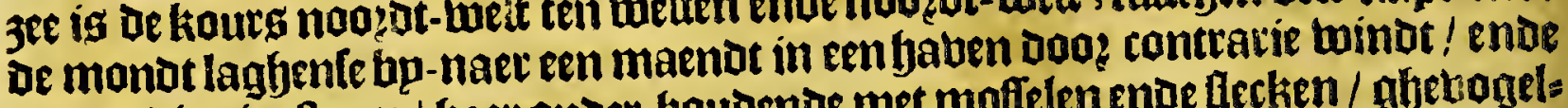

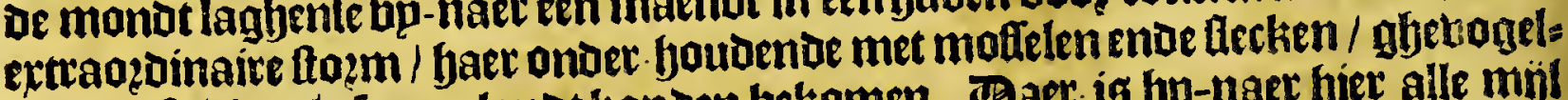
te/enoe fulcks alsfpaen lanot konden bekamen. Baer is bp-naer bier alle mü! ofte twee miglen / een yauen aen hepde 3 juden ban de ftrate. Eende ban de riebiere

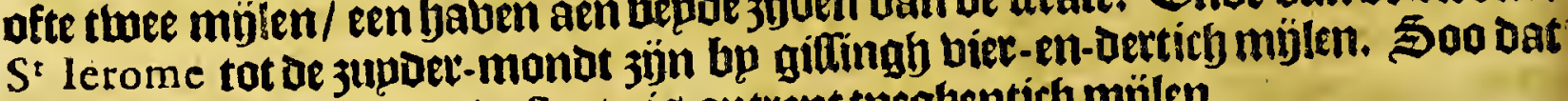

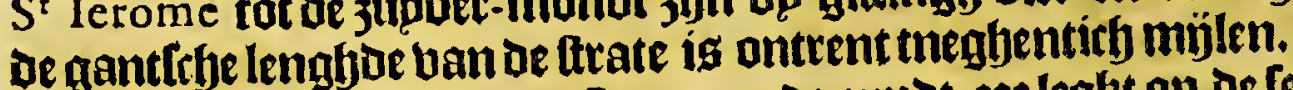

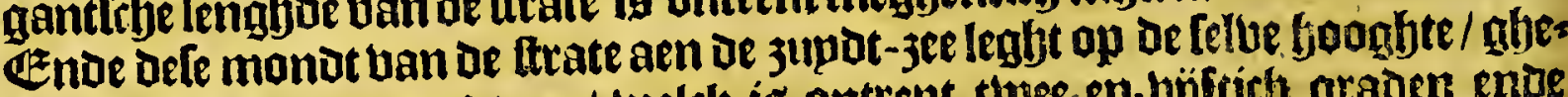

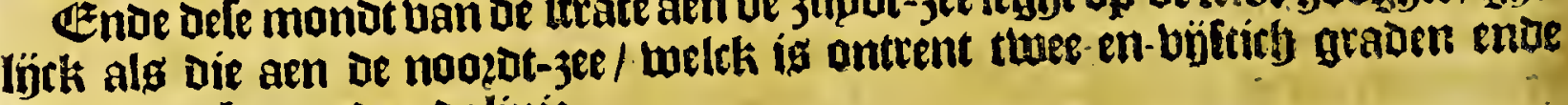
thee deroe bu zupaen oe linie.

Ben bier-en-twointidflten Februarius quamen In in te 3upot-3et; aen bet upt-komen aen de 3 updt-zjoe ig een lehoone hoonhe kape imet ees leegi punt

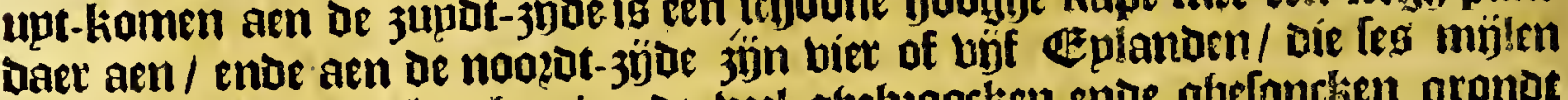
wan fjet bafte landt legghen/ enve ueel gafebzoocken ende ghefoncken gronot Daer om-her.

woat oe lenghte ban of ftrate is belanghenoe/ Thomas Fuller een ban be Schippers uan Candifch blote / telot in jọn Memoriael De lenglise bam fondert

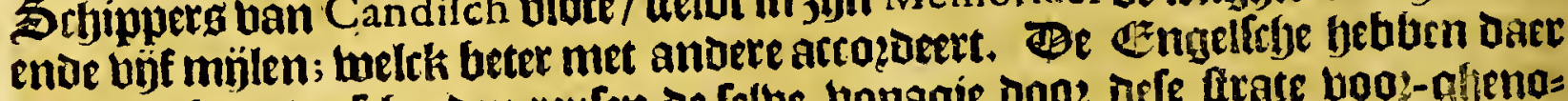

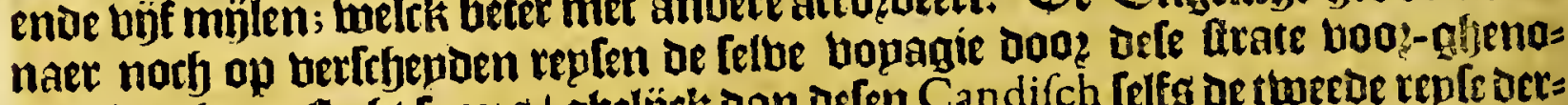

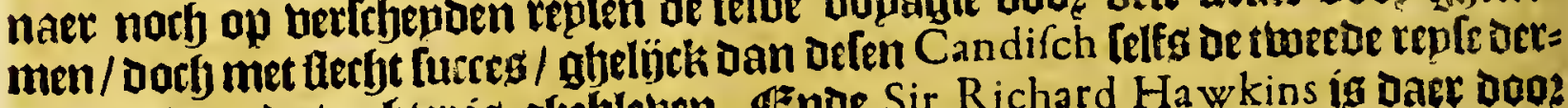

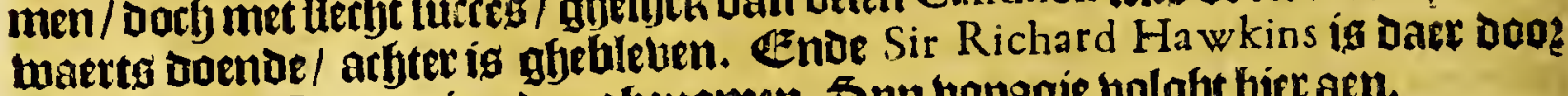

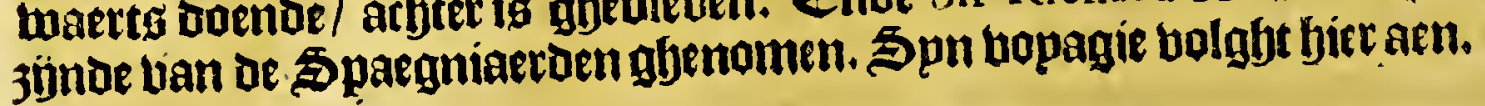

Wet artbttet Capittel.

De voyagie van Sir Richard Hawkins door de Strate van MA GALI ANES.

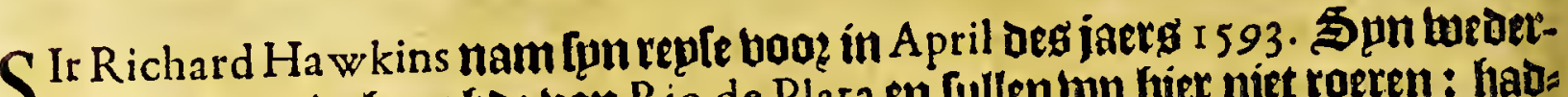
baeren tot op oe fooghboe ban Rio de Plata en fullen tou bier niet roeren: bad:

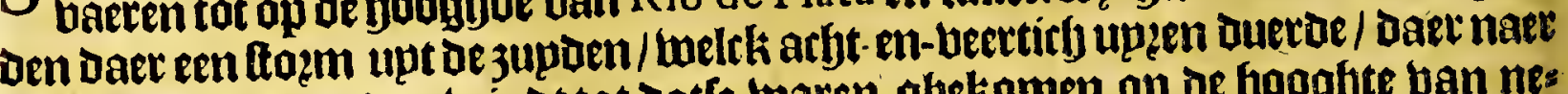
kreghen twe der goeden twindot tot datle twaren ghekamen op oe fooghte ban nes

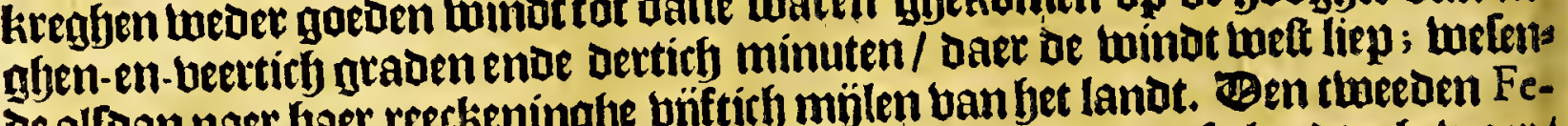

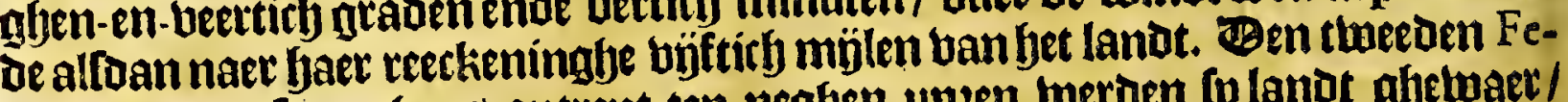
bruarij 1594 (mozgheng ontrent ten neghen upeen twerden (p landot ghetwaer)

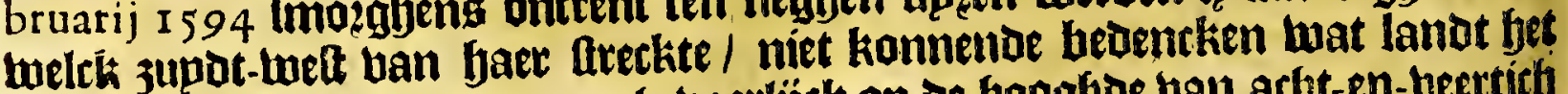

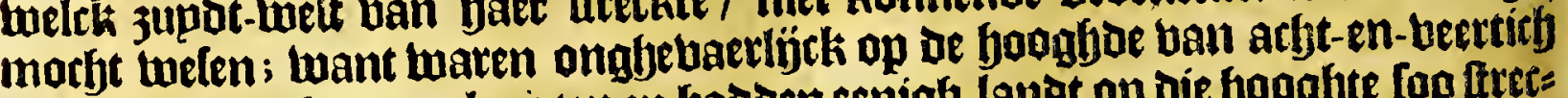
graden / ende gheen jee-kaerten en badoen eenigh lanet op die fooghte loa freces

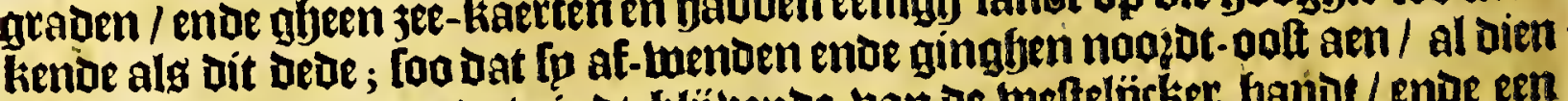

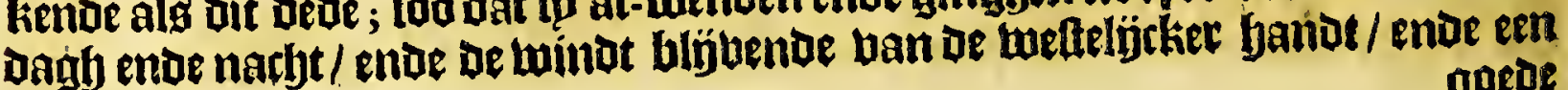
goede 
Het twaelffte Boeck.

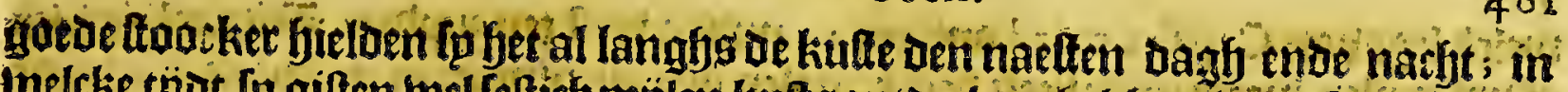

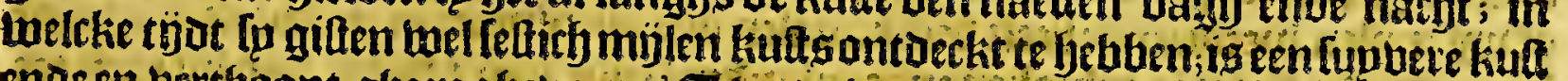

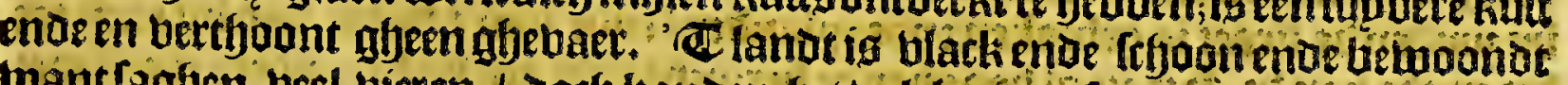

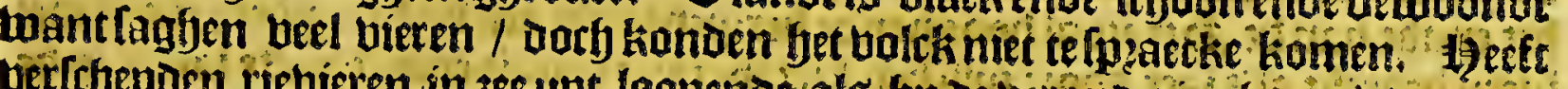

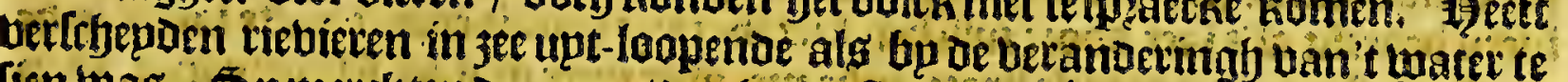
lien was. Spmerckten daer aen/ bat fetluefter-punt daet fp eert op bervielent

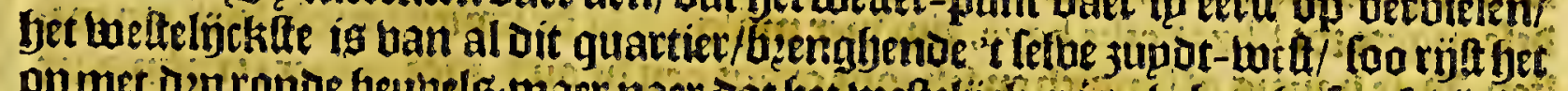

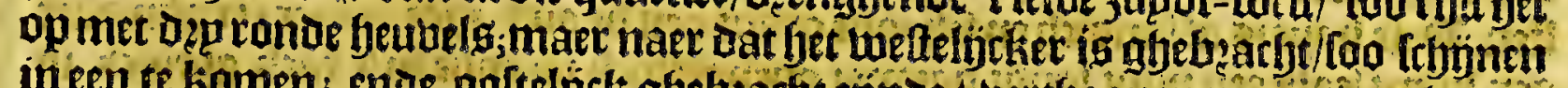

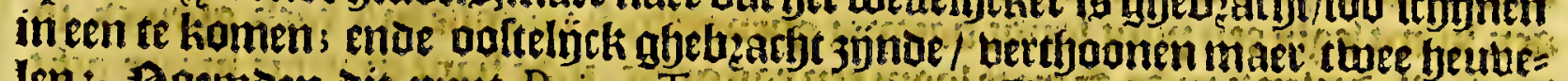
Ien: Paemoen dit punt Point Trenountaine. Thaelf oft beetbien nimlen

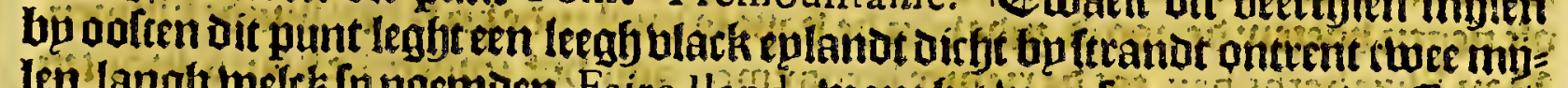

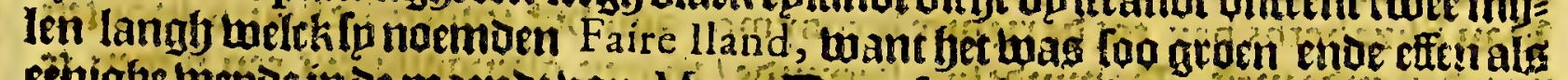

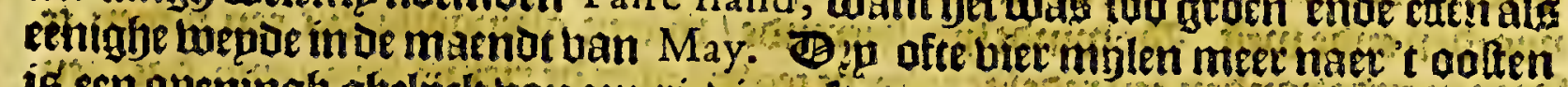
is en opening ghelích tan een riebier ofte arm ban oe 3 ee / met frjoon lanot

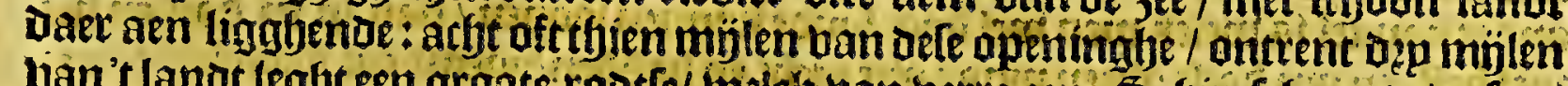

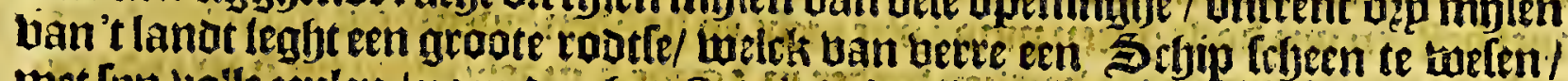

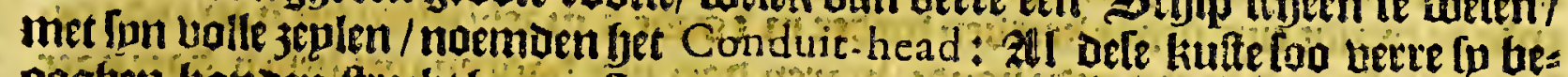

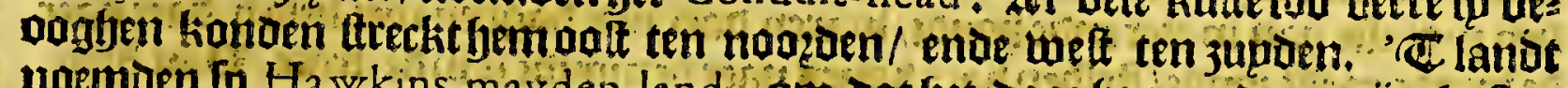

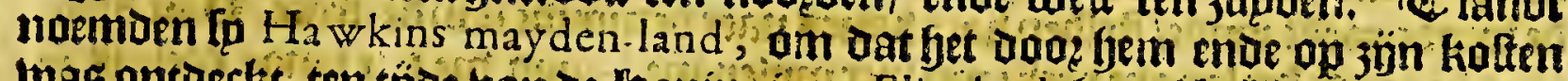

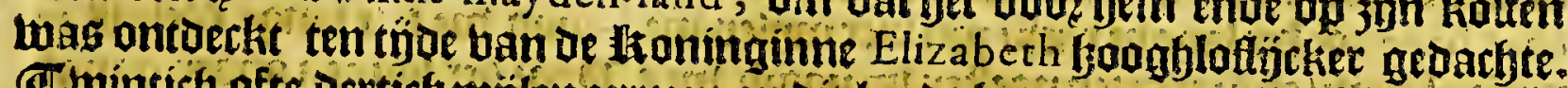
Chintich ofte dertich milen eermen op oit land fomt te verballen fon gemoet

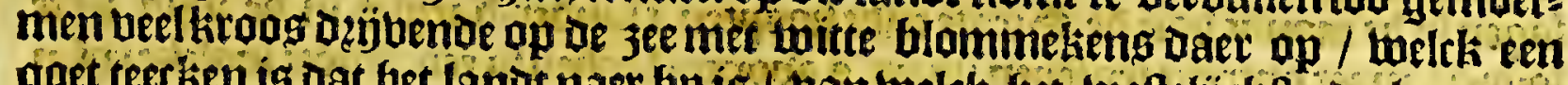

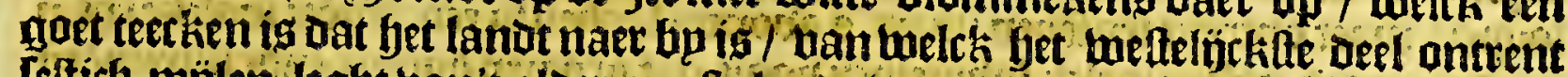
Íftich mülen leght ban't aloet-naelte lanot ban A merica. De tainot goet toos Jenoe um dooe oe Itrate ban Magallanes te looperien oedengeen boo der onder-

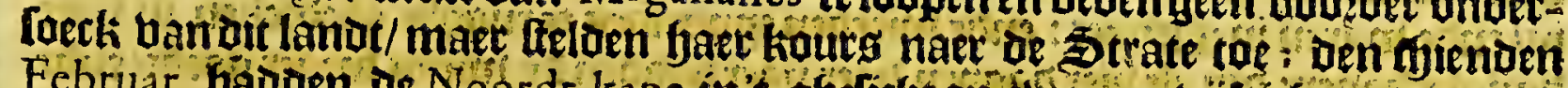

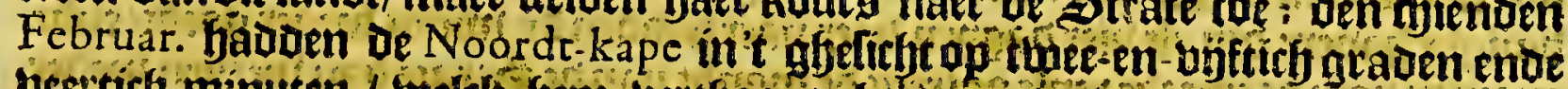

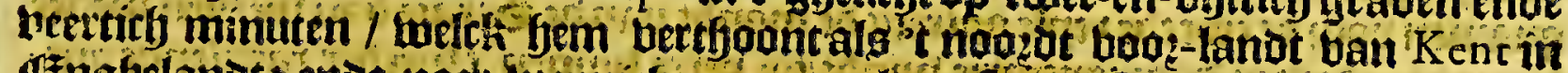
Cinablande ende napt thephich upen 3 eploen of of strate in welck in of

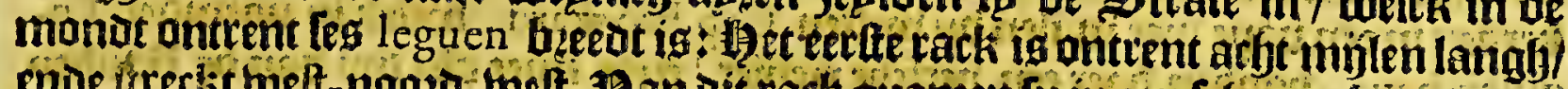

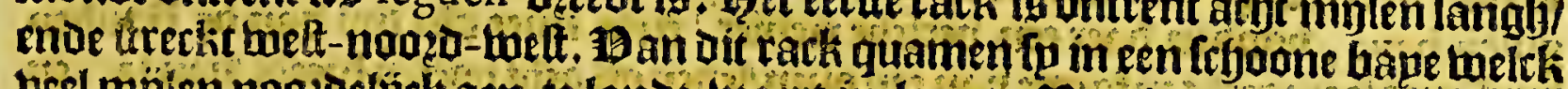

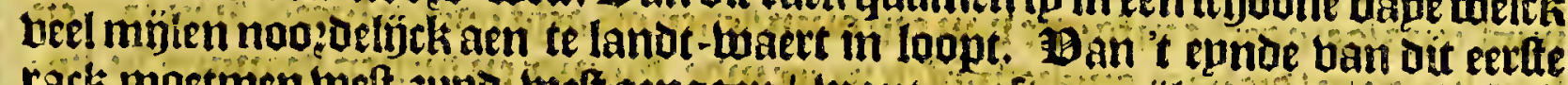
rack moetmen weft 3 up a weft aengaen/ want 4 oft is mijen bogeder leght oe

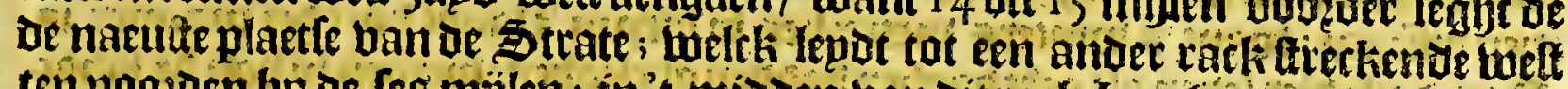

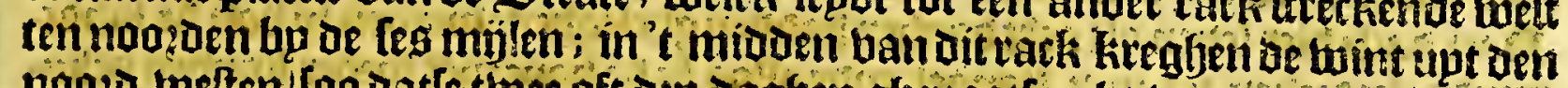

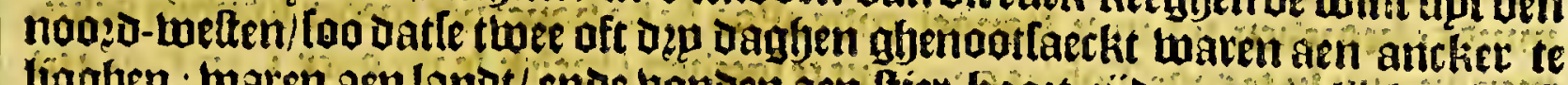

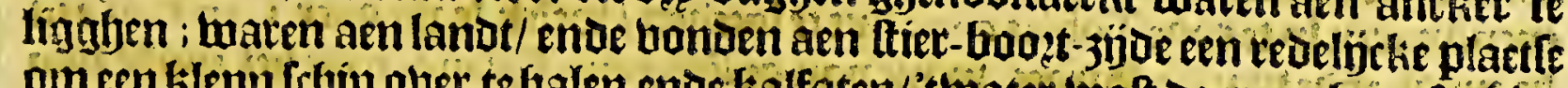

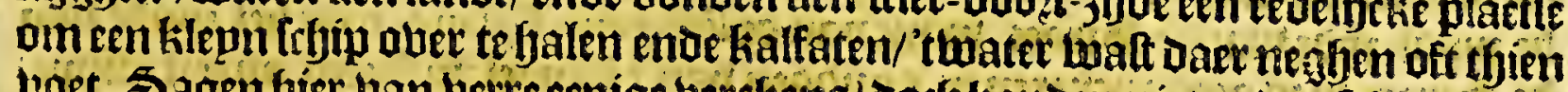

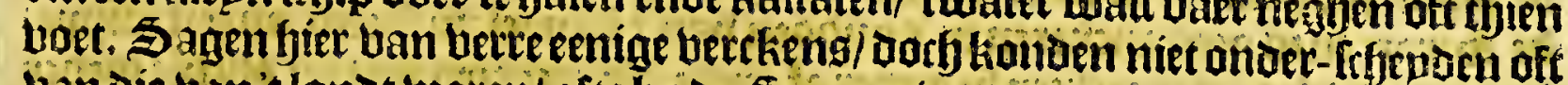

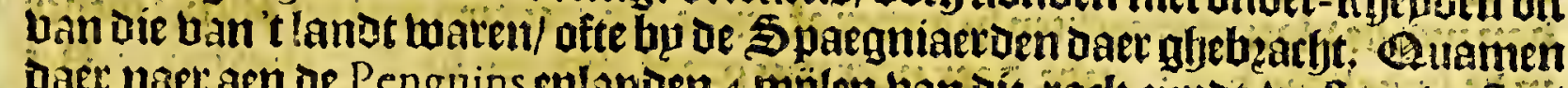
daer naer aen oe Penguins eplanuen 4 mülen ban dít rack jupde-twelt ten twefteri:

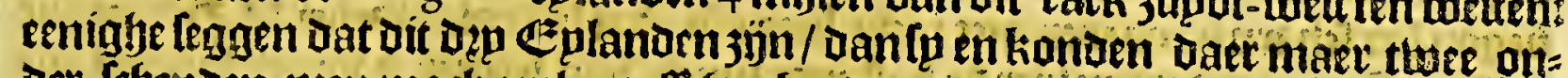

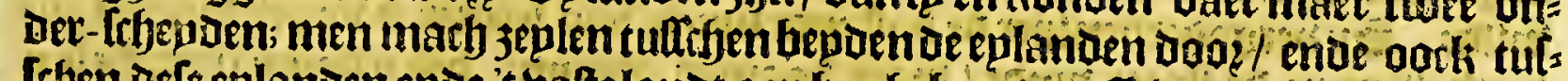

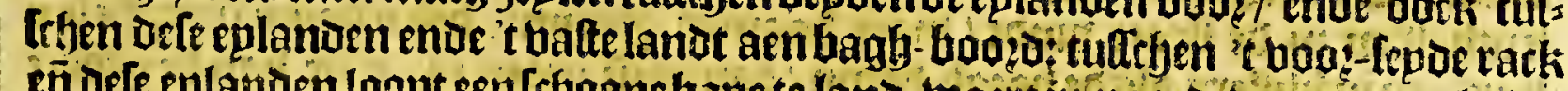

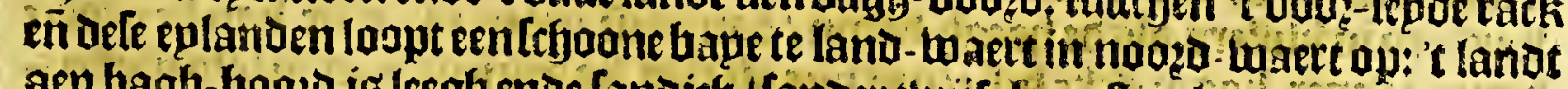

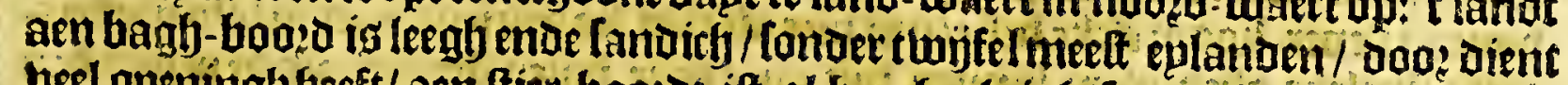

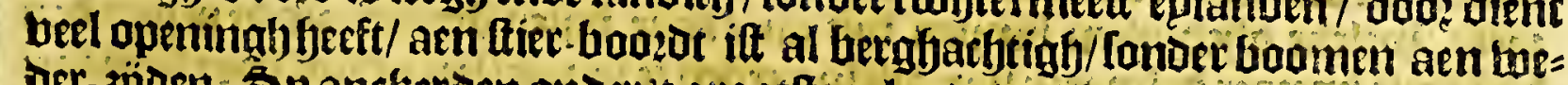

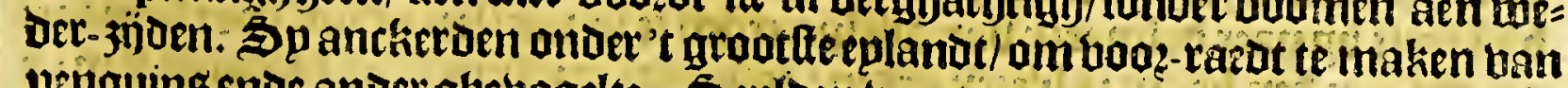

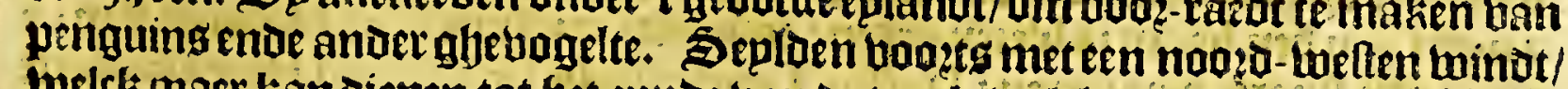
welck maer kan dienen tot fee epnoe van bat rack twelck ontrent 2 mijlen langh is/ende dip oft bier beet/ende firectit tor be Cap Agreda: jupd-heft banorfe kape

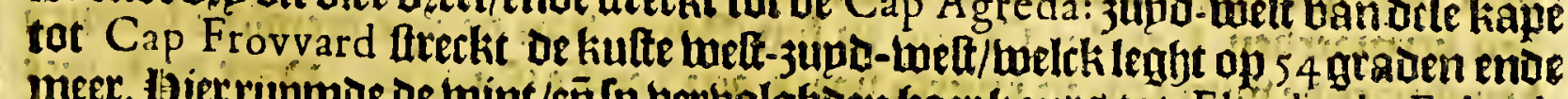

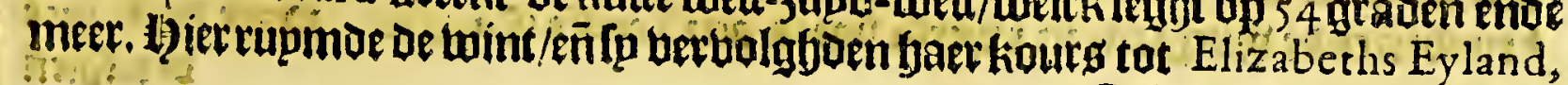


462

Magallanica.

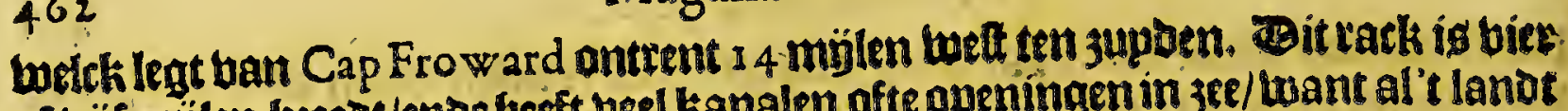
of böf miglen beedot/enoe beeft beel kanalen ofte openingen in jee/ want al t lanot up zupoen de ftraet is gebzaken ende eulanden/ enoe ban't begin ban dit rack tot bet epnoe van oe Strate al booghenoe bergichlanot aen weder. jöoen/meelt met Ineeu bedectit al t iaet dooz: tuiffben Elizabeths Eylandt ende't valte lamot is of

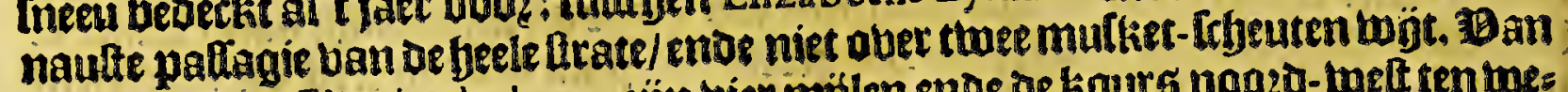

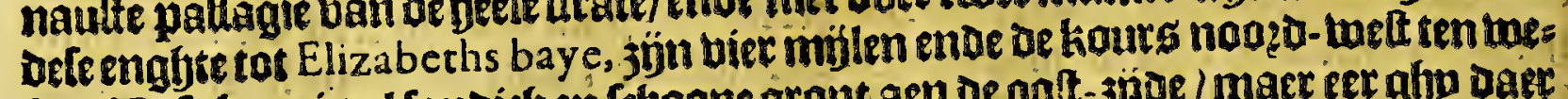

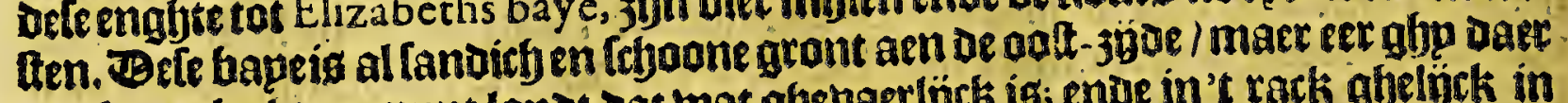
aen komt legbt een punt lanot dat wat gbebaetlg̈ck ig; enoe in't rack gbeligek in meelt alle deelen ban oe Strate loopt een ras getpe ; inje bape watt fyet water acht

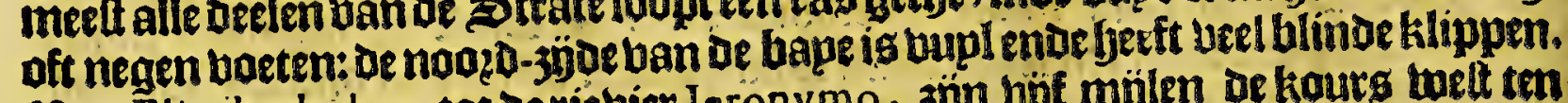

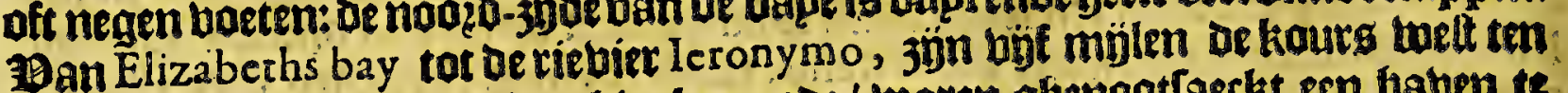
noozen enoe welt. Be windt bier keerende / waren gbenoatlaeckt een yaben to Coecken ende bonden een redelícks/ techt tegfen ober de rievier Leronymo, Daet een ander kanael is toelck men wel Doo? foude konnen looper / Dan fo en boyeften bet niet beltaen om Datie gbeen pinas ofte jacht en fadoen/noemoent Blanches baye, ende de twint rupmende keerden wieder in t oudoe kanael / fetten bet daet ende des. Den p:ovilie ban water ende boubt/ waren daex biat dagben met beficb; Daer naer

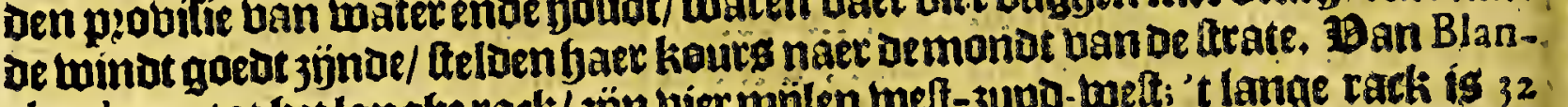
ches baye tot bet langhe rack/ jän viec mólen welt-3upo-taelt; 't lange rack is 32 injlen langh/en trectit tennaelten bp naoza- welt. Booz der fonnen onder-gangh

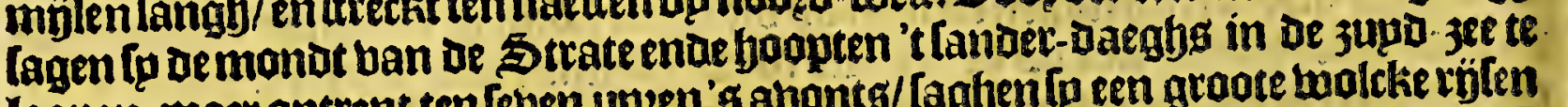
loopen; maer ontrent ten leven upzen's abonts/ lagbenfo een groote bolcke rbjlen

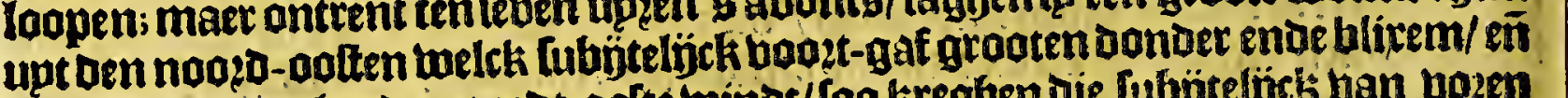

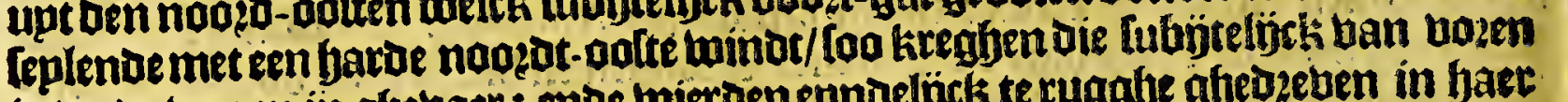

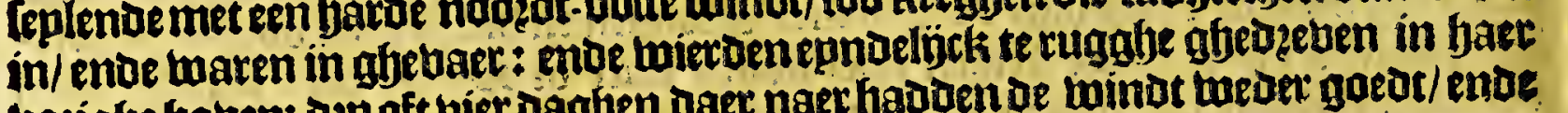

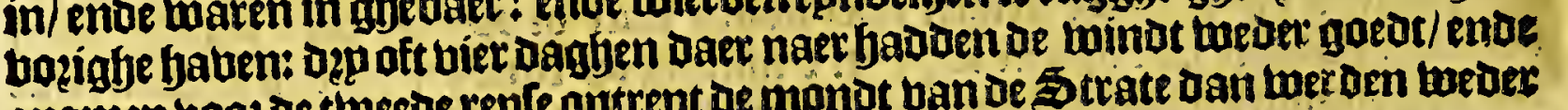
quamen voo? de tweede repfe anterent de monot ban oe Strate dan wer ben weder

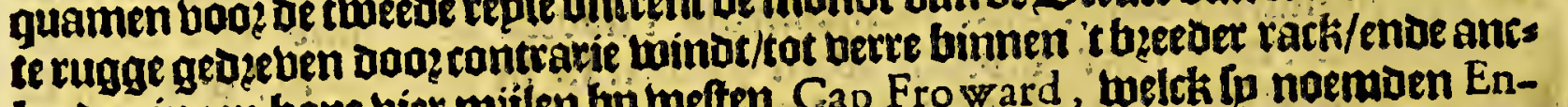
ketoen ineen bape vier misilen bu metten Cap Fro ward, welck fp noemoen Englifch baye, vonden daer een bertefe rievier / ende thee ofte dep ban de Hilben buptiens/gemaeckt infoeme ban een oben/[even aft act boeten bzecot/van tacken

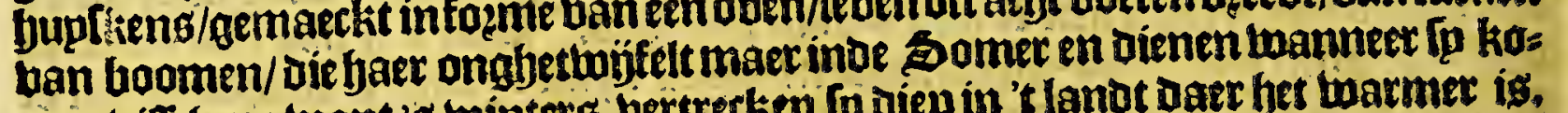
men bifthen : want 's winter berterken fp diep in 't land daer bes twarmer is. Faer Datle bier feben oft acht Dagfen badoen gbeleghen/werben fp ban be lanot-

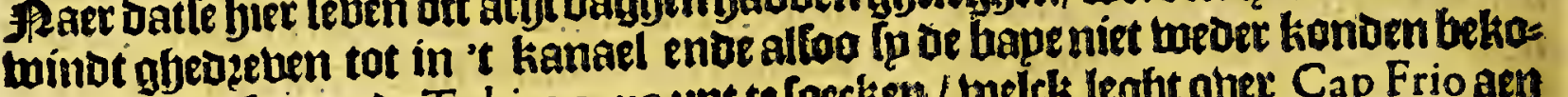
men/waren fp te rade Tobias coue upt te foeckrw / welck leght ober Cap Frio aen

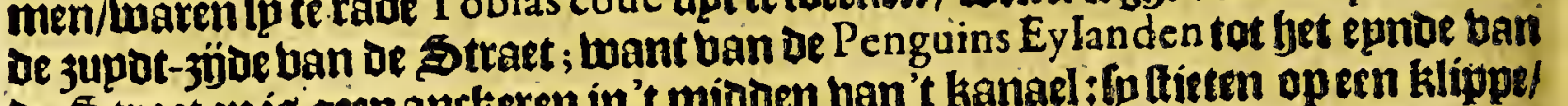
de Straet en is geen anckeren in't mioden ban't kanad : fu ftieten opeen klippel Danmet oe bloet gheraeckiten [p weder af / enoe gheraeckten met bet ghetije beber in oe Engelfche baye: ende oaer naer met groot ghetaer in Blanches baye:

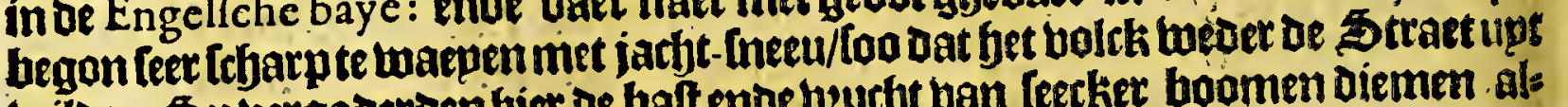
wiloe. Sp vergaderoen bier be baft enoe beuct) ban leecket boomen diemen als lenthalben in Je frate binot / waer boomen grospen; Delen boom osaeght fpr

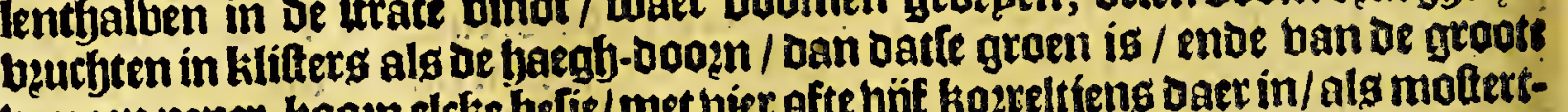

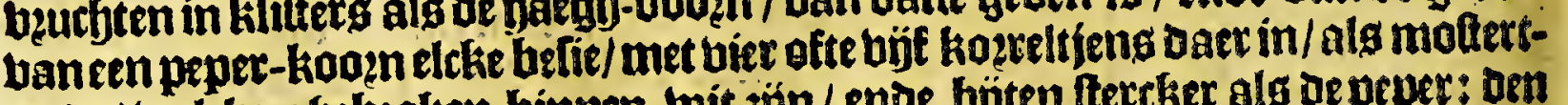

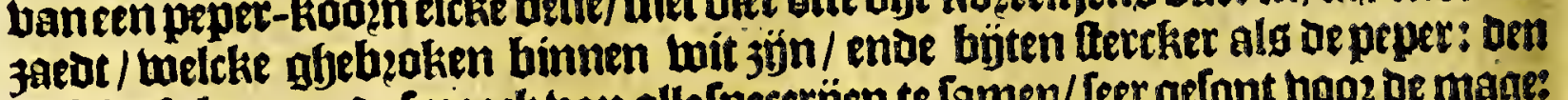
balt beeft bp naer de (maeck ban allefpecerïen te famen/ leer gefont vooz be mage?

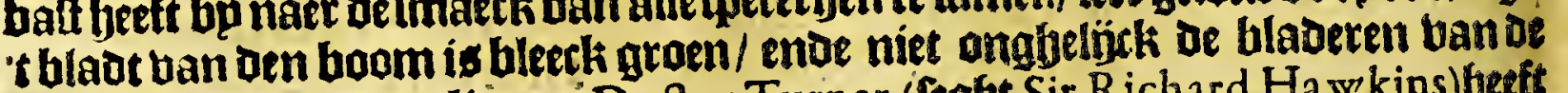
afpen ofte (marte populieren: Doctor Turner (Fegft Sir Richard Ha wins) betft Daer ban abrtrbeteen onoer of natm ban Cortex Winteranus; ghelijck aock oen bermaetoen Carolus Clufius in lon 23oect ban oe upt.heemlebe boomen

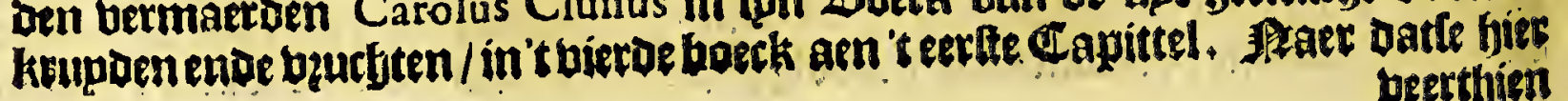
verethien 


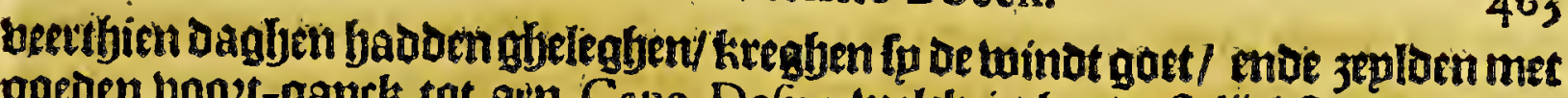
goeden vooet-ganck tot aen Cape Defire twelck is bet weffelijothere epnot van

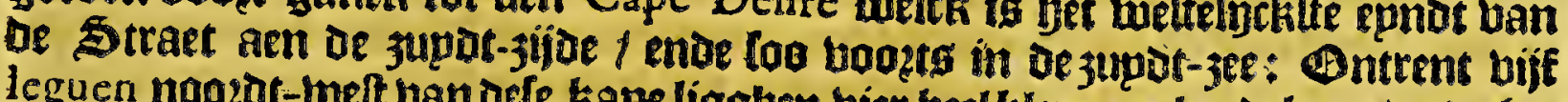

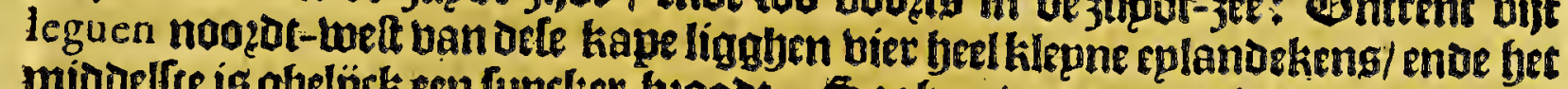

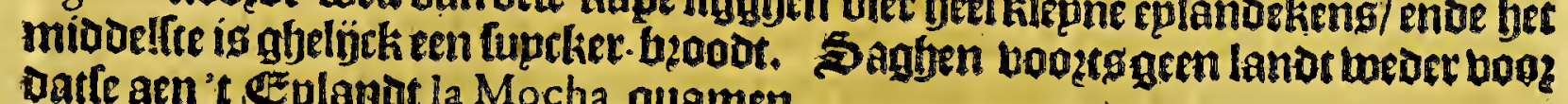
vaffe aen't Eplandt la Mocha quamen.

\section{Het negbende Capittel.}

\section{Befchrijpinge van de Strate van Ma gatla NES, ghelijck die by de} Nederlanders is bevonden in den Iare 1598 .

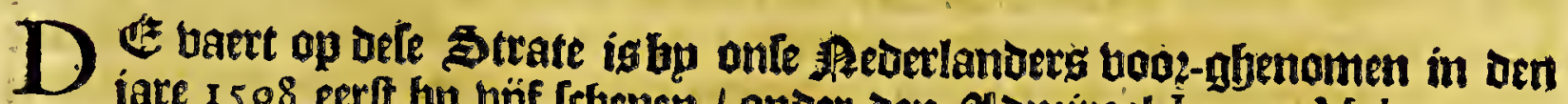
jare 1598 eerf bp büf crtgepen / onder den aldonitrael laques Mahu, ende

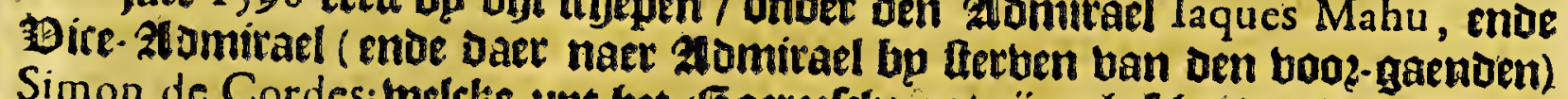

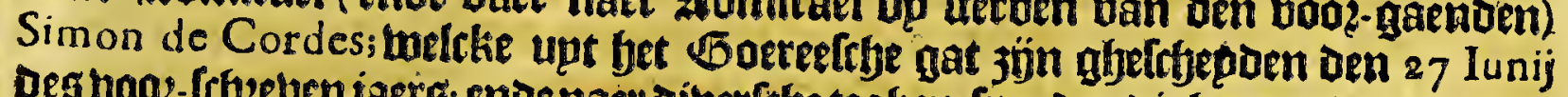

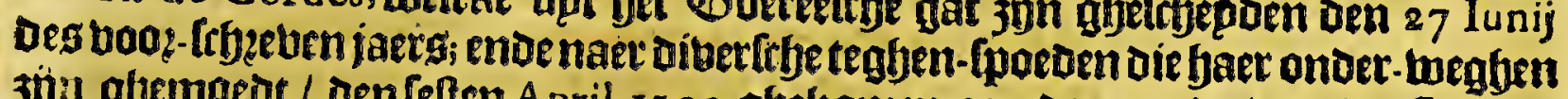

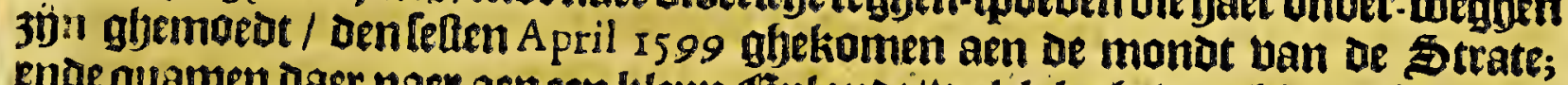

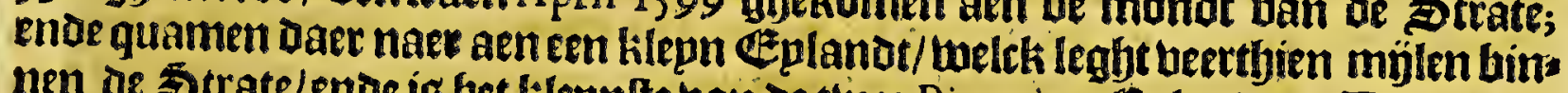

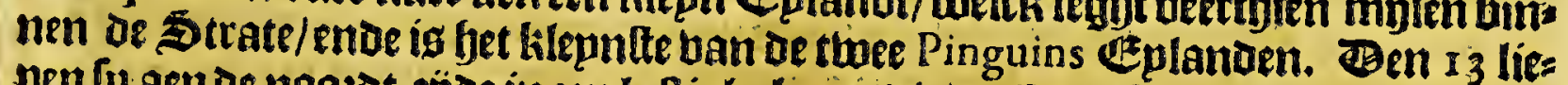

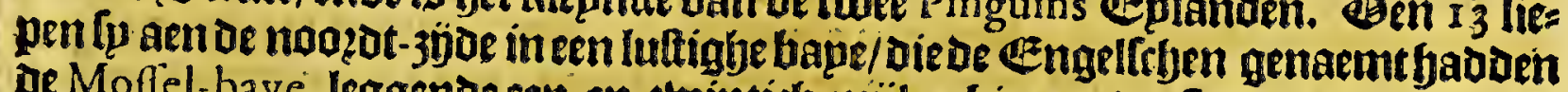

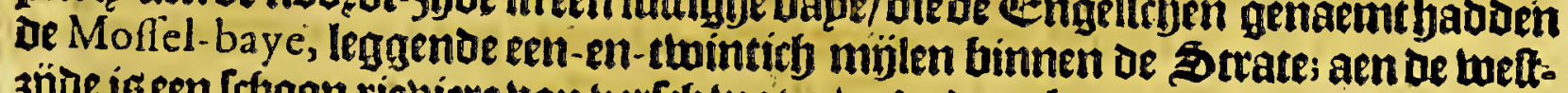
3 jue iscen Irfjoon rieviere van vertef water/ende daer bp menichte ban moffelen

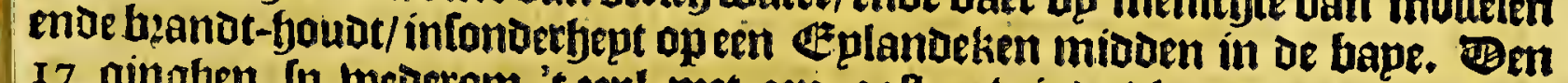
17 ginghen in twederom 't zepl met een ooften minot / loopendes 3 upart-wet

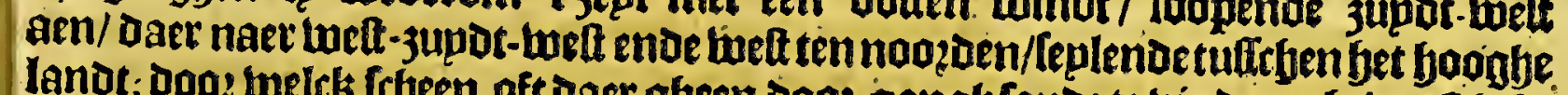

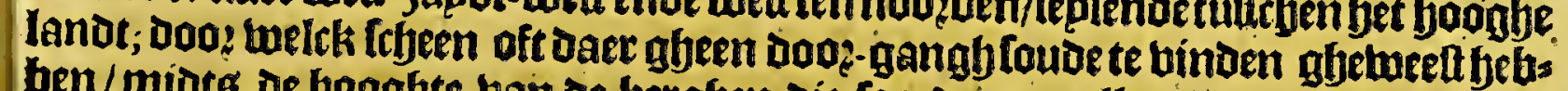
ben/miots de jooghte ban de bergfen oie foo ovoz malkanderen liepen / endoe

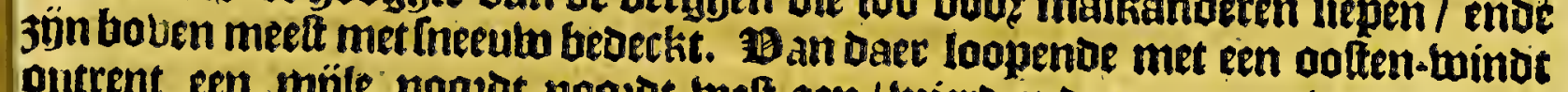

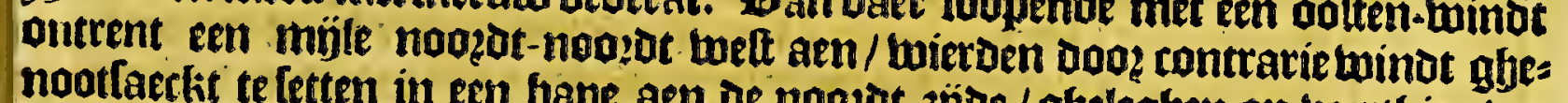

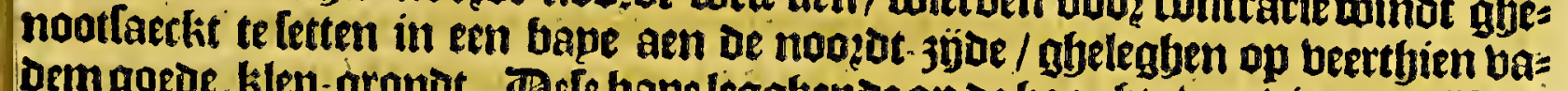
Dem goede klep-gronot. Befe bape leggbende op oe boogfte ban biex-en - bjiftich graden/ig glyenaemt de groene baye, ftreckt faeer met een kromte om den nooz=

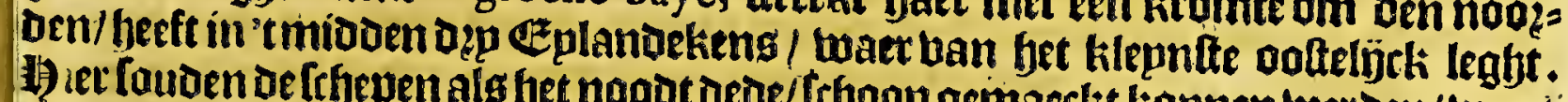

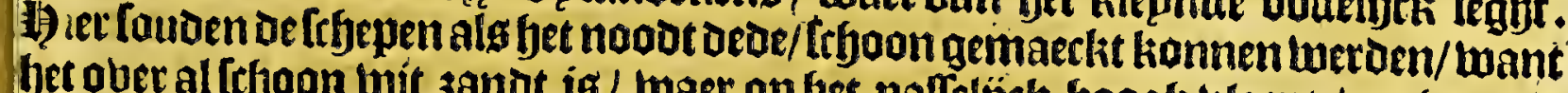

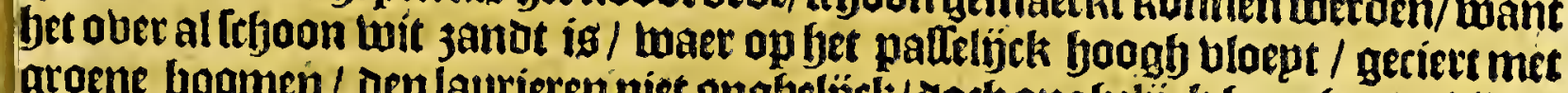
groene boomen / oen laurieren niet onghelijth/ Docb ongheibck boonger/ altijota

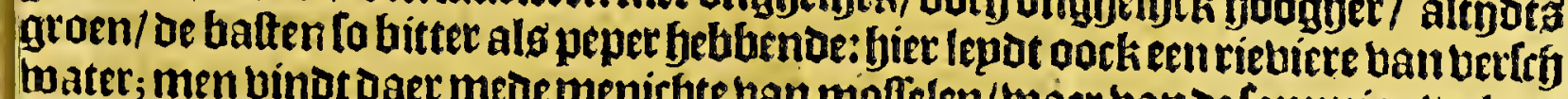

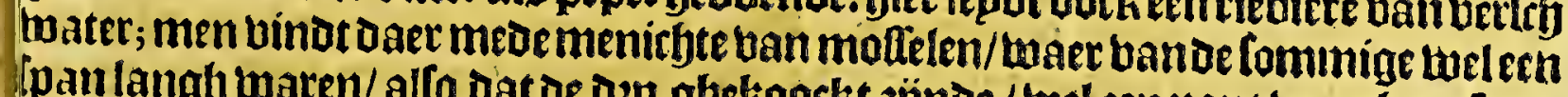
panlangh waren/ allo dat oe dap gbekoockt 3 ïnde / wel een pont woegben ; fom

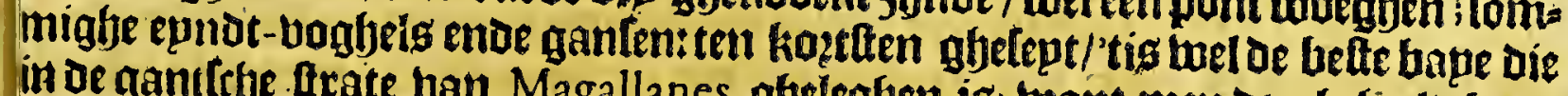
in oe ganitfbe ftrate ban Magallanes gfotleghen ifi wait men oe abefjeele bape booz op $12,15,20,3$ ender 45 baben anckeren magh. 1) ier lagben (p/ midets den

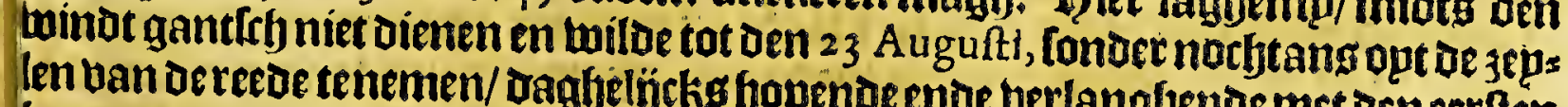

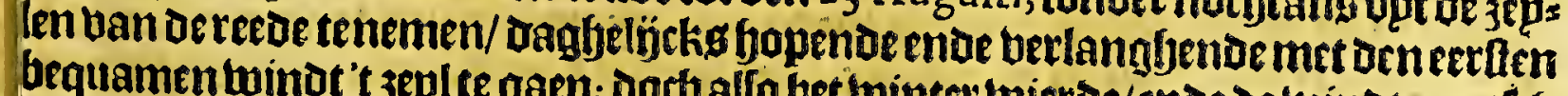

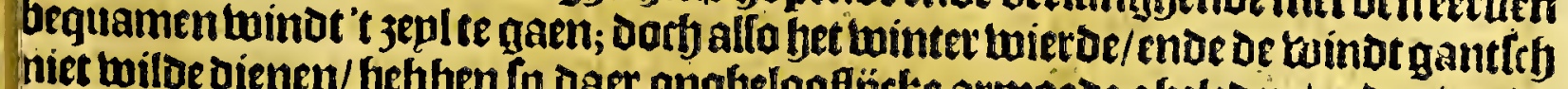

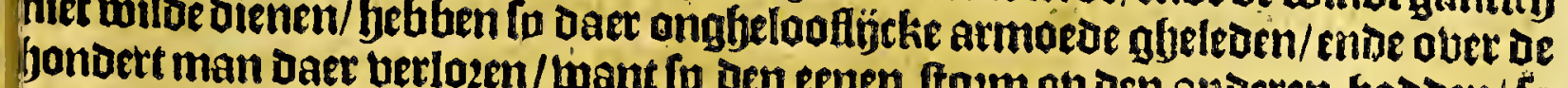

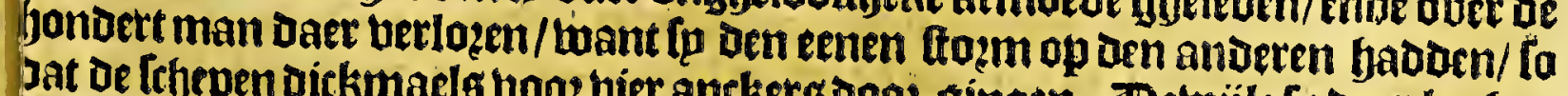
Jat De frhepen dickmaels hooz bier anckers doog gingen. Detuijle fu daer laghen

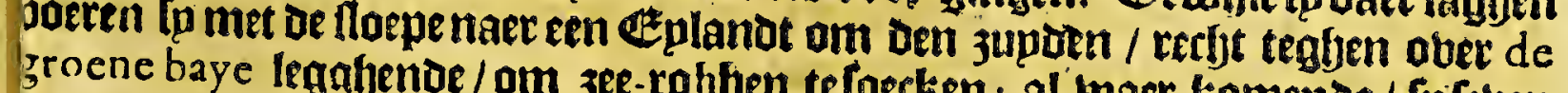

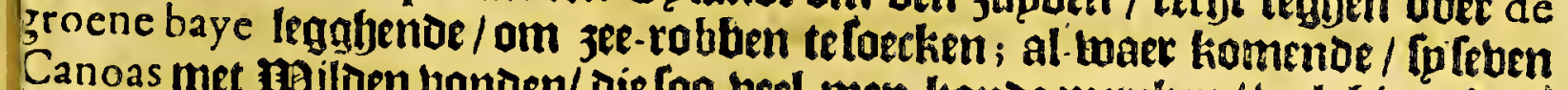
Canoas met maiben bonden/ die foo beel men kionoe metrken/ wel thien oft elf

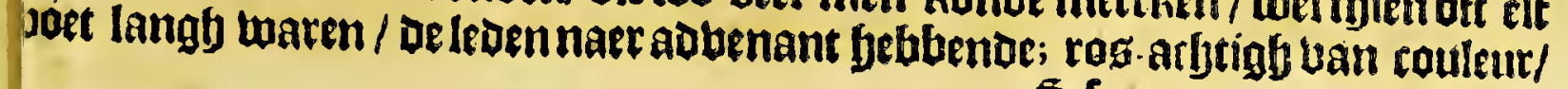
SI 2 ende 
enoe het hooft lanck ofjebapt ; welck ofle tlospe fiende / met grooter baet naer' lanot liepen; waet ban [p [oo gbetweloigh met leenen leierpen/ Dat de

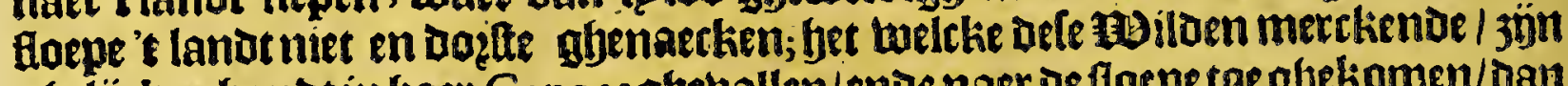
ghelïcker-bandt in baer Canoas gheballen/enoe naer de floepe toe gletiomen/Dan

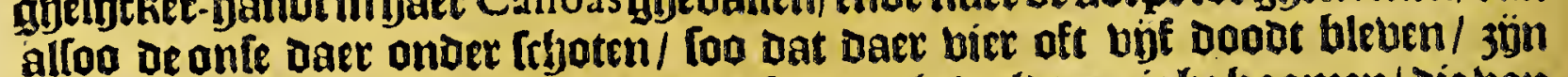
Ip tweder aenlanot gbeloopen; al-waerfp met ghetwelot eenighe boomen/ die ban berte twel cen Ipan dick Itbenente twelen / upt der aerden trocken/ ombaer te be: fchanten; dorbong volck ftyepden daer ban. Dit volcti was al naecht / upt-ghes nomen dat den eenen een ouot Kobben-bel om den belo badoe: jaer gletuepe

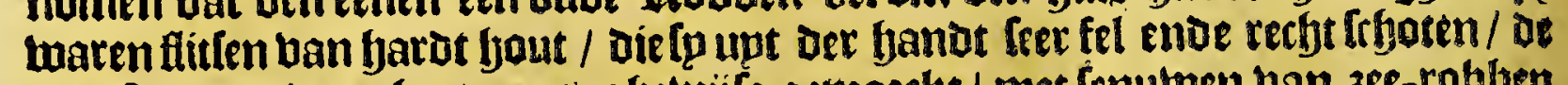
booefte punt was harpoens gyetwijle gemaeckt / met fenutuen ban 3ee-robben aen de lange flitlen gljebonden: Sp ober-bielen eenige Dagben Daer naet eenigh bolck/ende dobdender dęp/ende quettender twee/ Die genefen bierden met groote moepte / Dooe dien de ljarpoenen to diep in't lijf faecken; waren aen den eenen

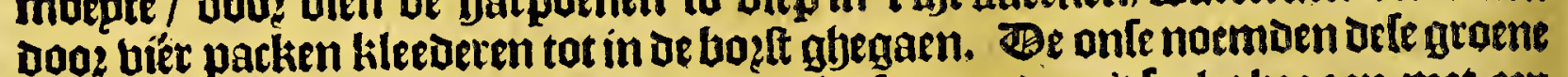

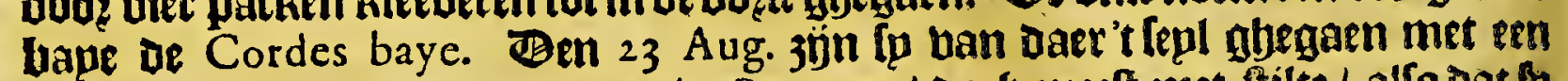
noozot-ooften winot / noozotten welten aen / Dotly meeft met ftilte / alfo dat to Daeglys daer aen in oe mo:ghen-tronot / ae feplen aen de maft bangende / wedes fettenmoeften/ende anckerien op 28 vadem/aen oe zupdt-3ÿues Dorb Des abonts helabenfp oe anclierg tueder abelirbt/ende met de boos-eble laten Deguen tot oen thien upeen Des natbts/ dat fu in efn groote bape / aen't 3upden legghende / gua:

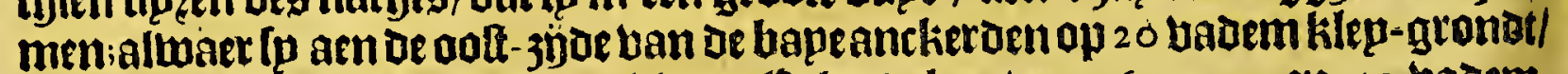

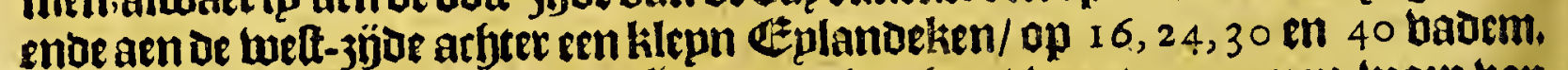
Fier ift beel brquamer boos be frbepen te legghen / want men cenen bo:p ban 'tlanot beengbenoe/ban bier met alle winoen't tepl kan gaen/luelck men ban te oult-jübe niet boen en kan. Foemoen dele bape De Ridders baye, boo? Dien lp - lier een forietept ofte broederfrjap ban den ontbonden leculw / met ridoertiös lie cetemanien aen-ftelden. Den 28 ginghen Ip uan bier twe Jer't 3 epl meteen 3upot ten ooften winat welt-noazot-meft aen/ ontrent een groote balf müle

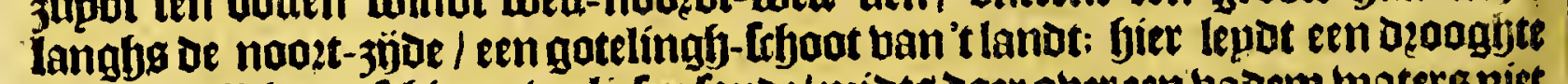
bart men licht een febip op berliefen loude/ miots daer ober een badem waters niet en is; alloo Dat betlthip't Gheloove bier bp naer opj-komende / in groot ghebaet was/ bocty kregen bet Daer bouen op beertich badem klippige gronot anckerende;

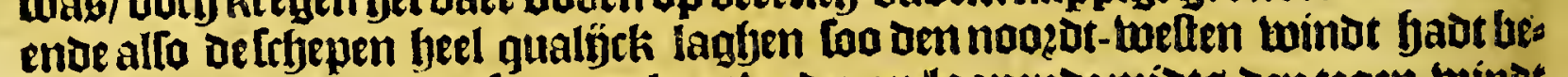

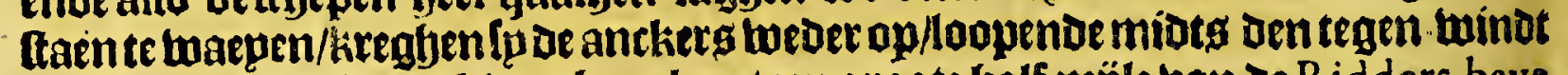
oin Den 3upDen/ in een kitepn baeptien / een groote balf mïle ban oe Ridders baye

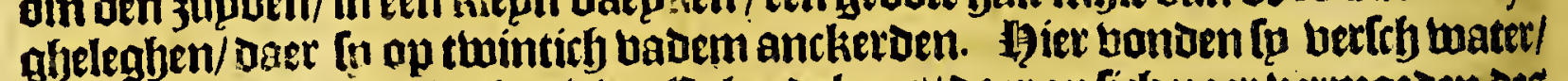
ende aen de oalt-3joe laghen bier Eplandekens/ daer op líth naer bermoeden bes

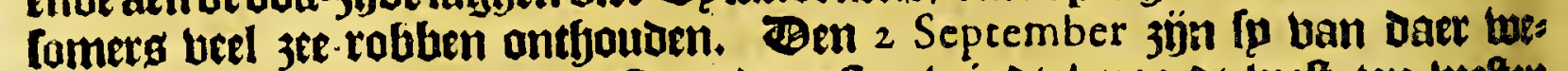
ber te fepl gfyegaen met een ooft-zupot oolten winot / noozot-wett ten betten aen: Ẽnde Den 3 met een noozot-onften lwinot ende meerder koelte/ enoe 3 jn in oe boos-nacht de frate ban Magallanes ten epnoe gljeleplt / komenoe met leet

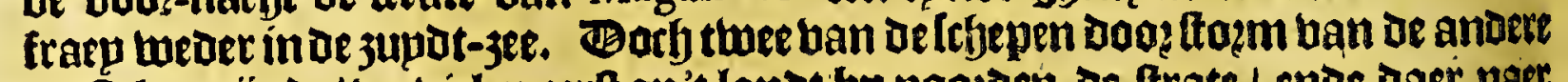
berfteken 3 j̇noe/ berbielen eerft op't lanot bp noozoen be ftrate / enoe daer naer meoer in oe ftrate; alwaer bet eene weder ooo? quam/als in't langhe te lien is by het journael Daer ban in Deturk upt-ghegheben / oaer top oen begbecrighenleter

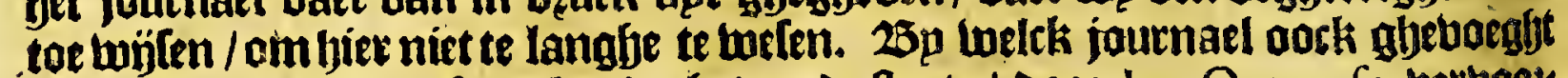
is een leer pertinente af-teeckeninghe vande ftrate / Doo lan Outgerfz. verboos Dett/ Die wel de exactle is han alle de ghene die tot noty toe 3 jun boot-ghekomen; fo dat onfe natie de balkomen kennig ban dele larate doos de induftrie ban defen inan betiomen beeft/ ende anderen mede guedett. 
I.

Voorder befehrijuinghe van de Strate van MAGALIANES, naer dat die by de Nederlandersis bevonden:

I bet leltue jaet 1598 jün andere vier fefrepen onder uen Grinerael Olivier Oliv.tan

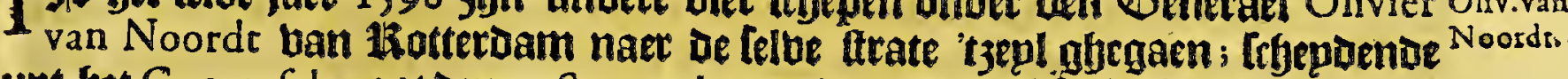
upt bet Goereefche gat den 13 September: ende naer beel fuclielimglen guamen fo Den 20 Septemb. 599 in Porto Defire; ende frbepden tuederom uan daet Det 29 October, ende ben 4 Novemb. quamen fin in de frate / ende boge ftozm upt

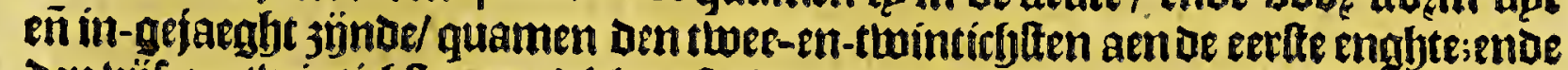

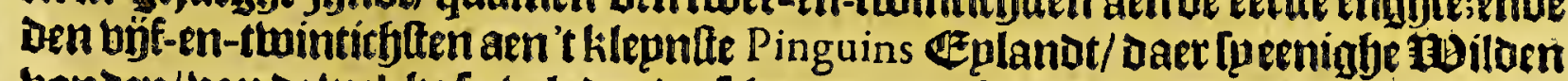
bonoen/van de twelcke [p vele Doodt-frboten/ende kxegben Daer eenighe jongljers gletuangben. Berftonden degbeleghentbeut ban baec-lieden lanot / welsk Lags in de bolghenoe mantiere.

Bit ghellacht ban bolck is ghentatmt Enoo, betwoonente een lanot welck la noemoen Cofli; maer dit Eplandt is ghenaemt Talcke. Het andete loelck bet grootte ig/gfjenaemt Caltemme, al-waer ueel Pinguins op jụ̈ / Daerfp baer/meet medegeneeten. Ban de bellen maken [p baer mantels/ die [p om't 'jy beblen] ende sún boots naeckt/ woonende in bolen in de aetDe ghemaeckt.

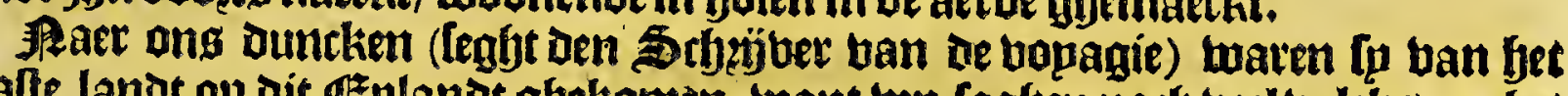

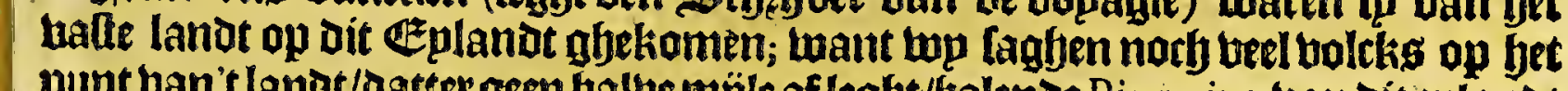
punt ban't lanbe/dattergeen balue müle af leght/balende Ping uins ban dit tplande vooz baer eeten. Oock jjo doaer noch ander ghedierten die [p noemen Cafoni, wp

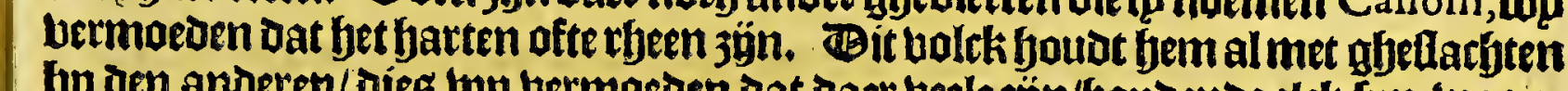
bp den anderen/ dies wap bermoeden dat daer beele jün/foubende elck fan woonplatte apart:twant fp badoen kennig van norb bier geflathten; Kemenetes bewo. nende en plaetle gfenaemt Karray: Kennekas twoonende in eenplaette gbenaem Karamay : Karaike moonenue in een plaetle ghenaemt Morine. Bit is al volck ban thatuere geligek die ban Enoo, die wo betiomen badoen; van be groote als een man ban ons landt/ Dan jín feer bzecot ende boogh ban boefte / frbiloeten baet in't aenficht en booz-Gooft met eenighe bertwen. Demang baoden haet frbamels

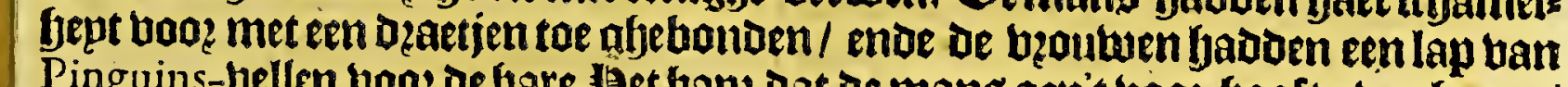

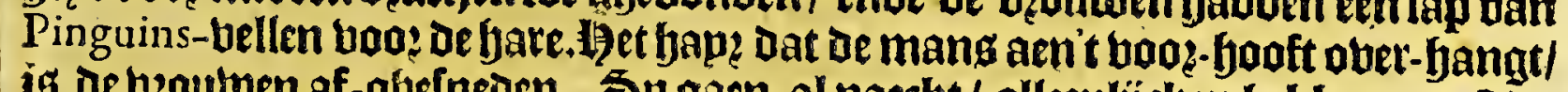
is oe bzoutuen af-ghefneden. Spgaen al naeckt / alleenlijelien beblen een Pin-

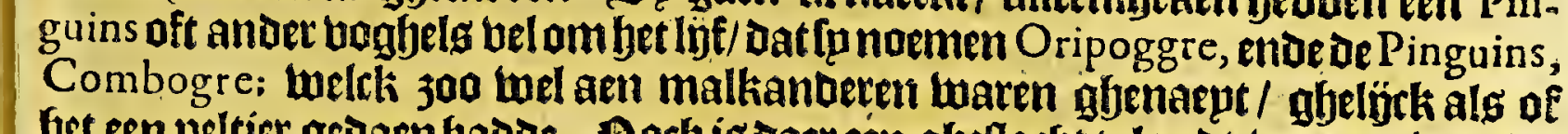
fet een peltier gedaen yadoe. Joct istoer een gbedlacht te landt-waetot in / ghes naemt Tirimenen, de belcke een lanbt betwoonen/ghenaemt Coin. Bit 3 jü groote mentchen als reulen/3jónde thien oft elf boeten lauck / ende liomen tegfent

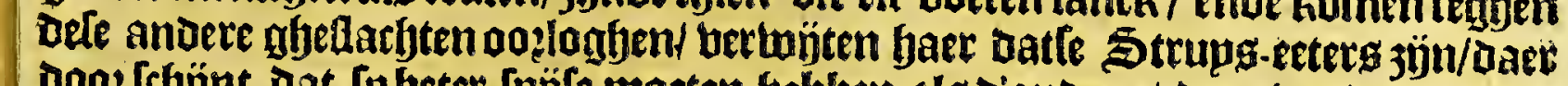

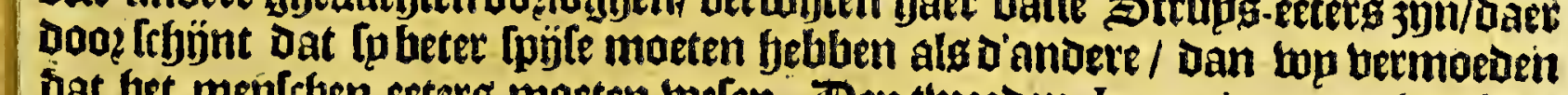

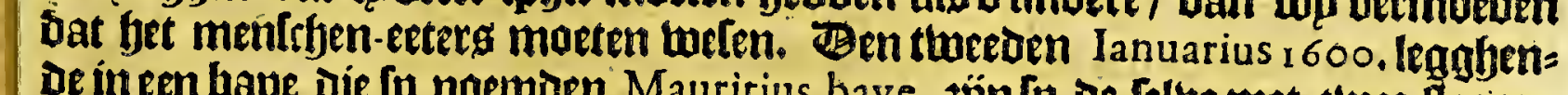

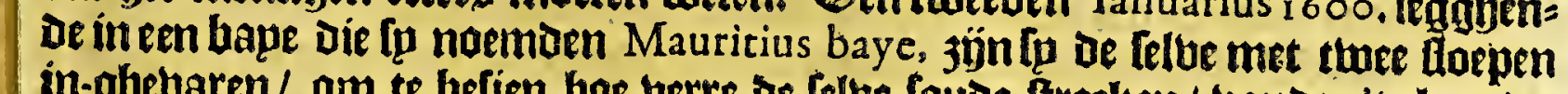
in-ghetuaren/ om te befien boe berte be lelbe foude frecken/ bonden't al 3upotoof op loopen met diterffbe canalen ende groote mepeen ban berfeb twater / daec fp upter-maten beel pg bonden/ welck naer baer buncken daer altijotsleglyt want menmet eenlïn ban ro badem niet en konde gronden/feet twas numidoen in de fomer; en jün met de loepen daet boots dooe-gekomen / tot weber in de trate/upt-gaende teghens Cape Galanti, entoe de Éplanden die daer gelegen jün; 30 datfp te reelyt bermoeden bat dit al gehzolten-lanot moet welen. Ben I 4 dito qua: imenlp aen een hape die aen be nookd-sjode leabt/genaemt Capo Boluto, ban daec

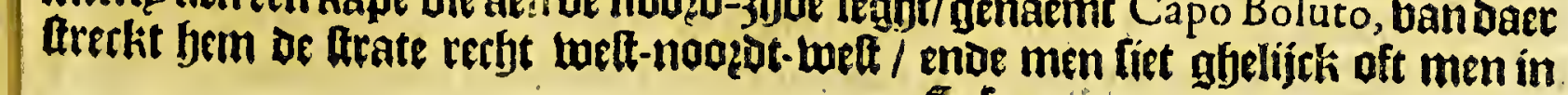




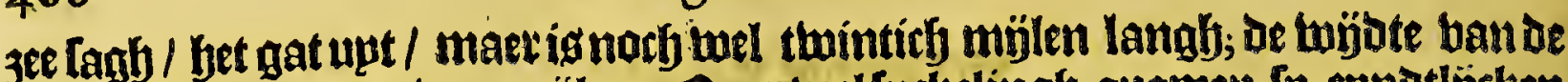
Itrate ig hier ontrent twee mölen. Paec beel luckelingh quamen lp cpnotlÿtken

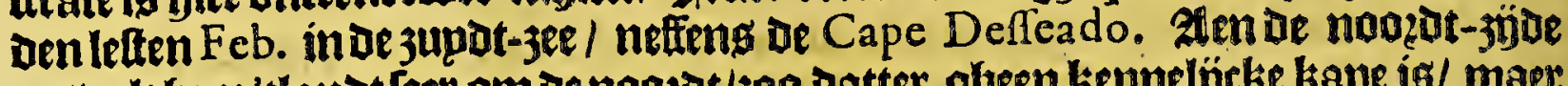

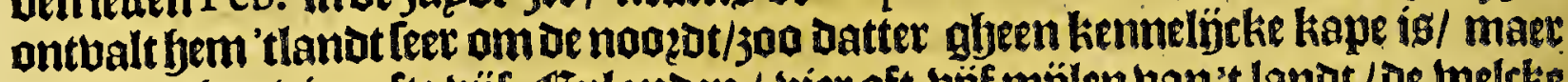

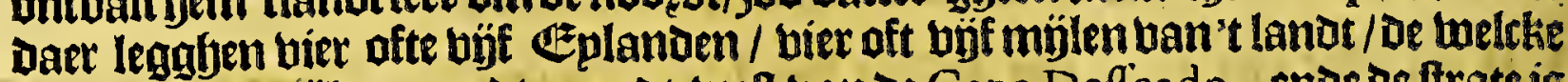
legghen adyt mílen noożt-noozot-wett ban be Cape Defleado, ende be frate is biet wel leven mÿlen wijot. Die meetoer particulatitept ban dele vopagie be= geett te weten/kan bet journael Daer ban upt-ngeghetuen lefen.

In Den jare 1614 , ig aen Generael Spilberghen upt Texel gherchepoen oen achitfen Auguftus, ende den tweeden Martij 1615, aen de trate abekomen met groote perÿckel/ want dicklwils dín-komfte ban De ftrate hem belet tuier dt Doo? bele ftamem / quaet meder / ende tontrarie winden/ aortj3ijn den Derden A pril be eerlte enghte ghepalfeert/ende den Lettjiende in de Cordes baye geltomen/Daet If Gaer van water/ joubt/ ende anders berfagen; ende jín loo met groote mospte

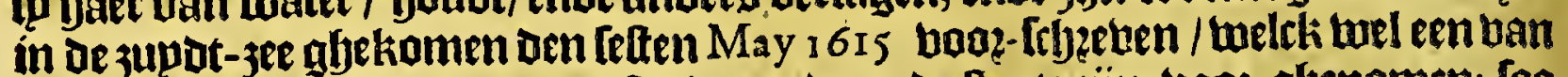

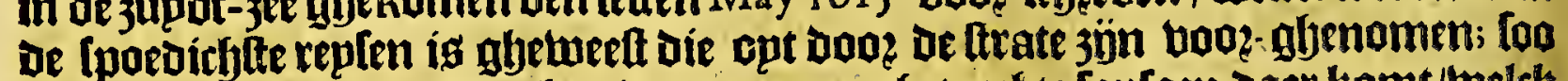
wat bet bele daer aen ghelegljen is/Dat men op bet reethe fap[oen Daer komt/welck bp belentwetot gheacht te welen in lanuario enoe Februario, alloo bet dan daet fomes is.

\section{Met elfte Capittel.}

\section{Befchrijvinghe van de nieuwe Strate van LE MAIR.}

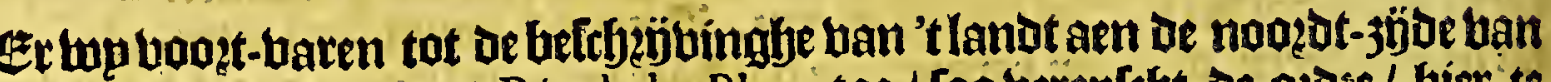

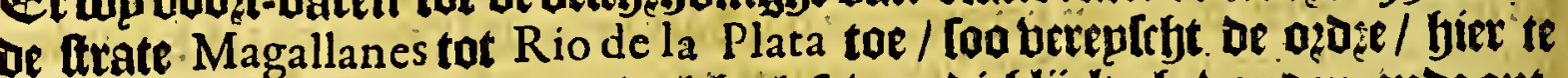
Ipeecken van de nieube trate de welcke lef-lweerdicflïck gljebonoen ende ont=

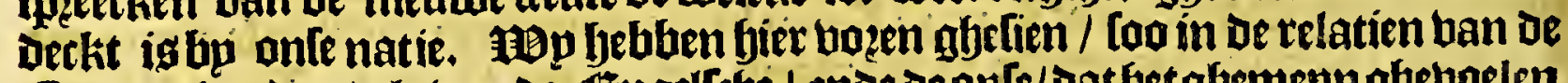

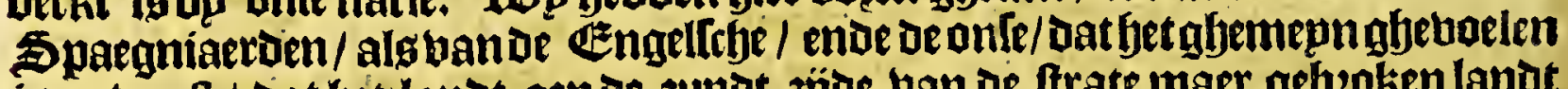

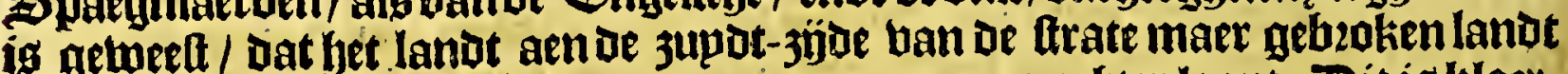

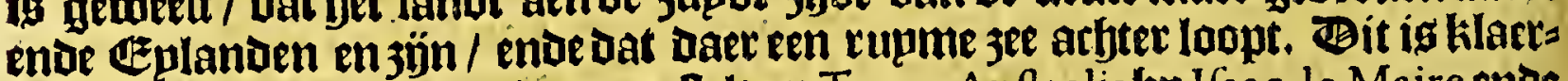
lö́ bebonden bo de vopagie aen-geltelt op T erra Auftralis bp lfaac le Maire ende Willem Cornelifz Schouten van Hoorn; oe weIcke een lebipende eenjactyt tot Dien epnoe bebben upt-gfjemaeckt: welck ban elerel jün't jepl ghegaen den beetfjienden Iun. 1615, welende apper-Irjipper ban defe twee frbepen Willem Cornelifz. Schouten, eñ opper-koopman I a cob le Maire Tone tan Ifaac le Maire

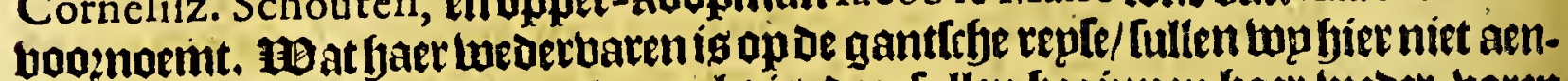
roeten / alfoo haer journael gheopuckt ig; Dan fullen beginnen baet beoer-baren te vergalen ban Porto Defire af / altwaer lp den fevenden Decemb. atribeerden/ ende berlozen daet fyaer jacht bp ongfehtuch ban den bzandt. Den is Ianuarius i 6 I 6 3eploen In weder upt Porto Defire, ende Tagen Den i8 Seboldts Eylanden, opde boongte van een-en-büfticf graben. Jen 20 betuonden yaer op dep-en-bÿts tirfy axaven/ entoe giften baer thintich mülen ban lanot bp zupoen of ftrate ban Magallanes. Ben 23 dito boeren [p met een noogoelïcken windt in bleeck watet supden ten weften aen : ende ontrent Depuren naer De midoagh fagen fp lanot in 'twelten ende jup o-welten/enoe openbaerdefyem oock koets daer naer in' 3 uptoen fofjadoen' gabonts een noozolíscke wimot/ende ginnfen ooft-jupot-ooft aen/om bouen 't lanot te blíben. Jen viet-en-twintich ten des maegheng beoegh taers - oen [u fyet lanot aen ftier-hoozot ghelwaer/en lagh nietmeer als een groote míl uan fjaet; fyadoen gronot op beertich badem/ ende een welfelïcke winot; bet lanot Atreckte hier oolt ten jupDen/met Leer hoogf geberghte/Dat al twit met [neeu bedeckt lanf. Zeploen al bu Dat lanat langs/en ontrent de midoagh quamen dat tea ephs oe/enae Lagben ecn ander landt daer bpoofen/Dat oock Teer boughende backeligh 
Het trvaclfite Boeck.

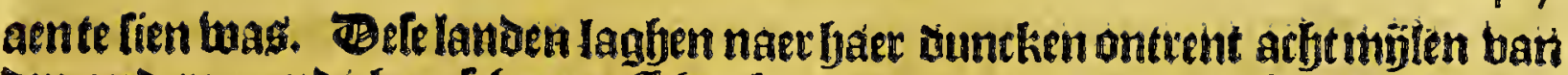

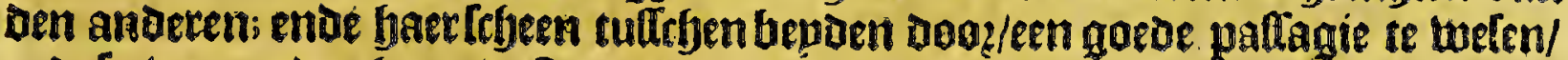

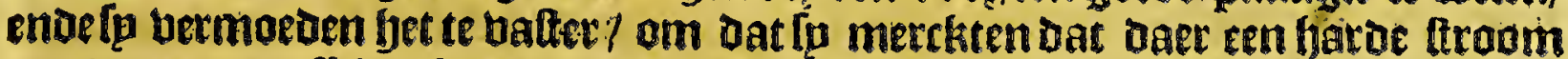

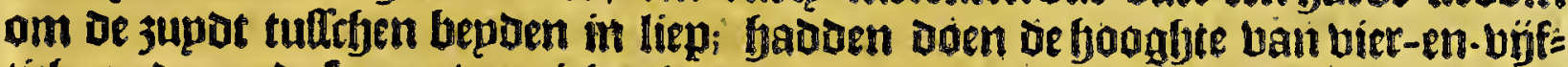

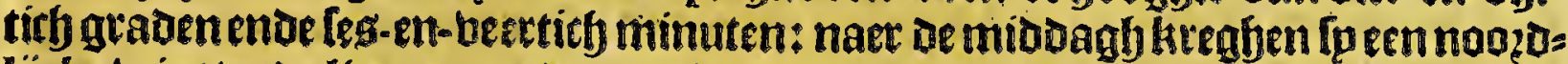

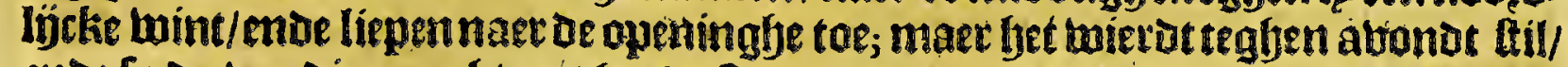

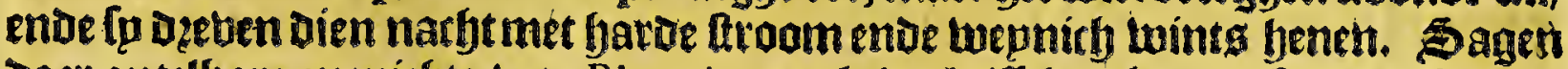

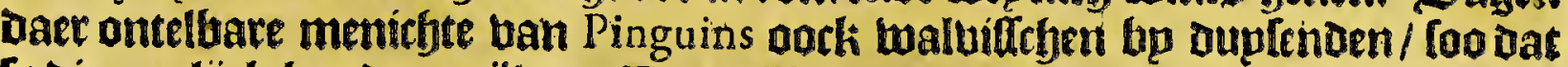

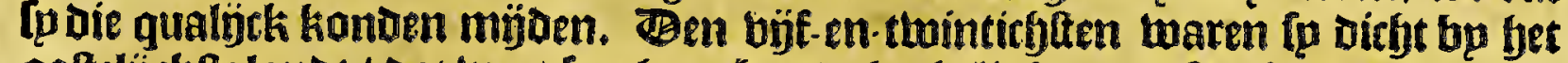

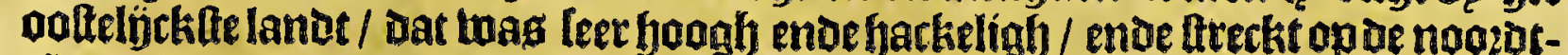

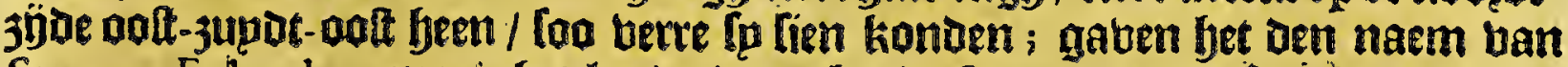
Staecen Eylandt : maet bet lanot daet by weften noemben fri Mauritius de

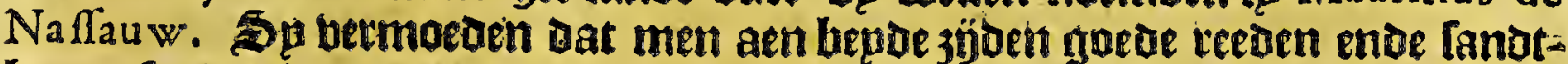
bapen fouve binden / twant t twas aen bepoe 3 phen met frjoone fahot-frandent

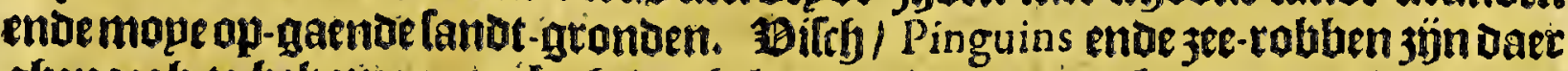
ghenoegh te bekomen; dockghebogfelte ende thatel; dan boomen en konoen fa

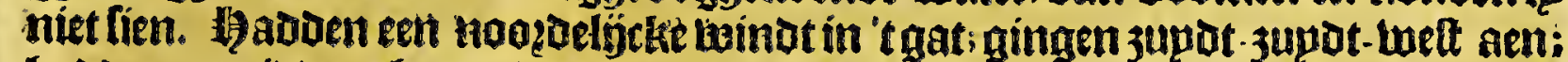

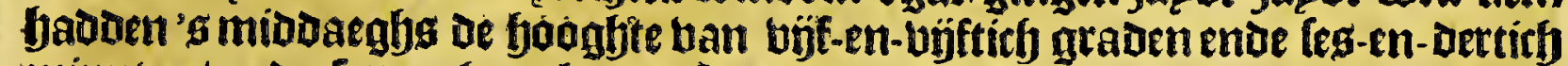

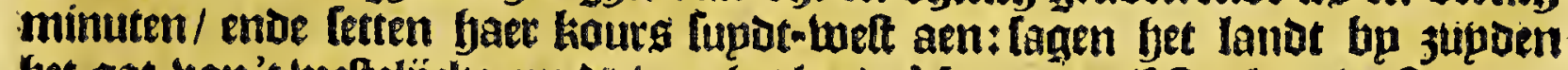

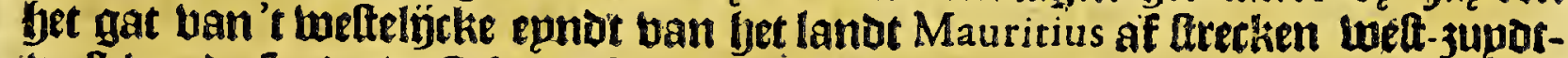

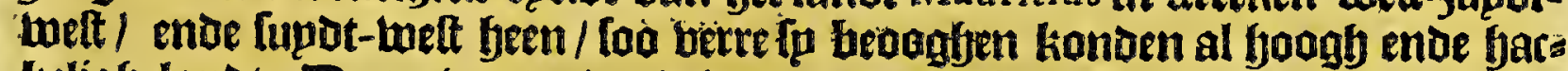

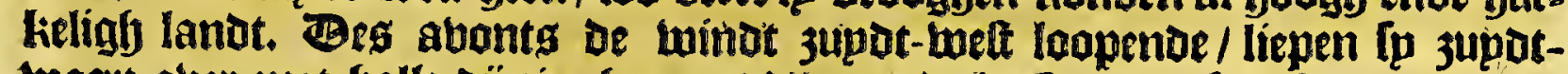

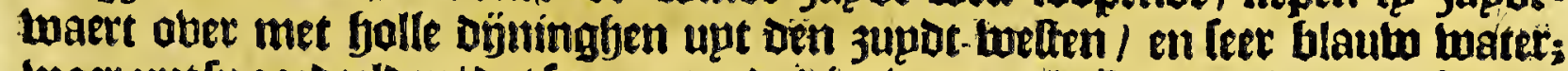

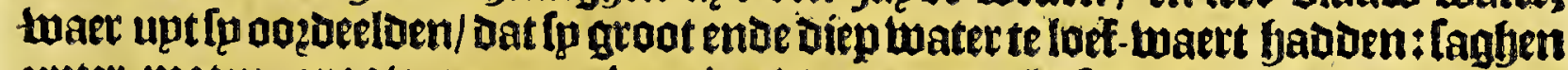
upter-maten groote Jee-merutwen/ ende grooter als ftwanen; die doog de ons getwoonte ban mentchen te lien / op's frchip quamen fitten / en lieten faeer ban'

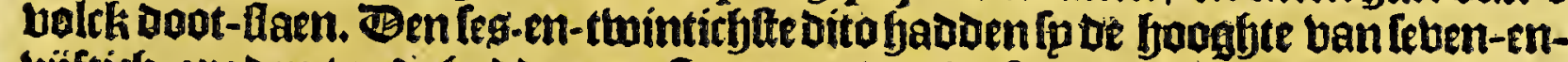

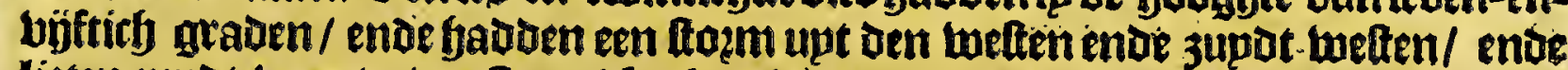
lieten jupot-woart ober-ftaen / fagben in't noozt-Leeften norb boogh land/ ende

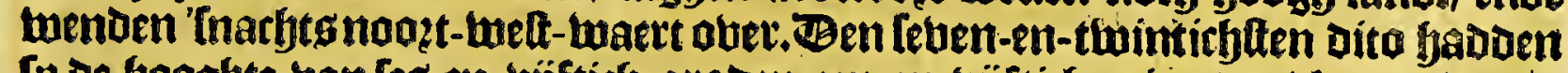

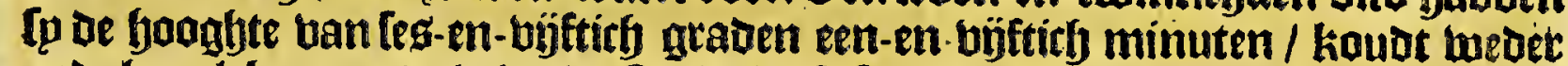

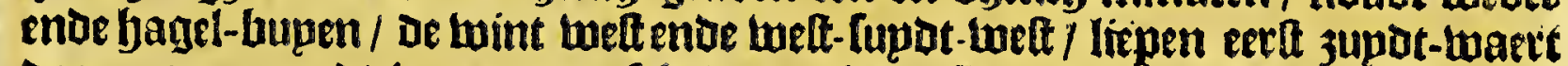

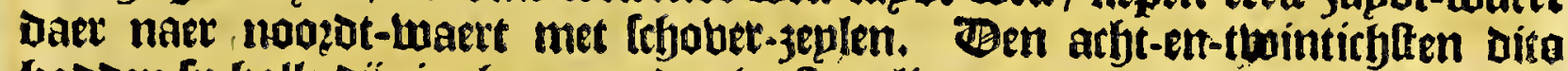

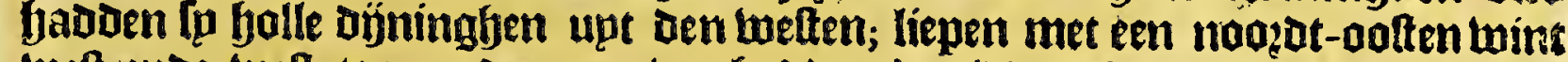

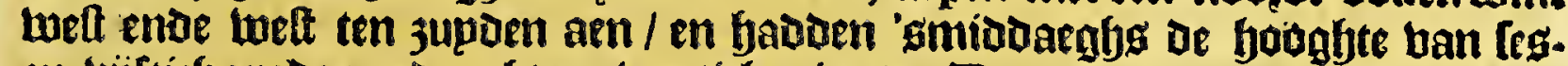

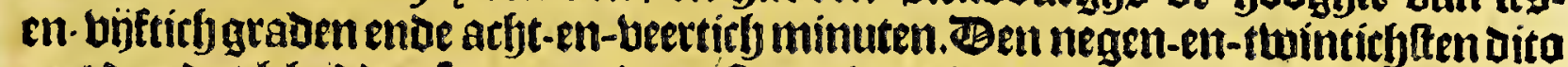

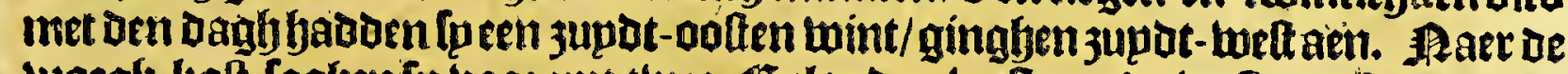

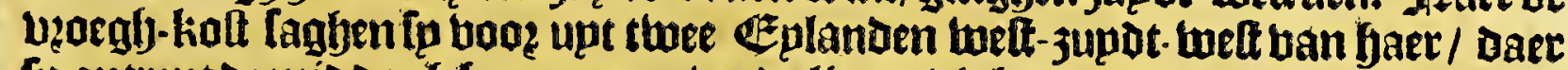
[p ontrent De mis Dagh th quamen / enoe liepen Die bp noozoen om / waren Dore

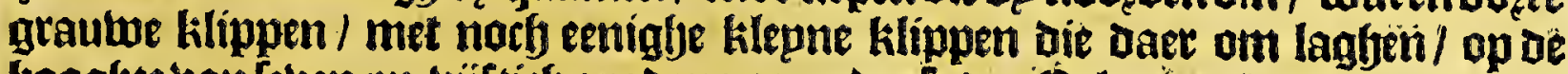

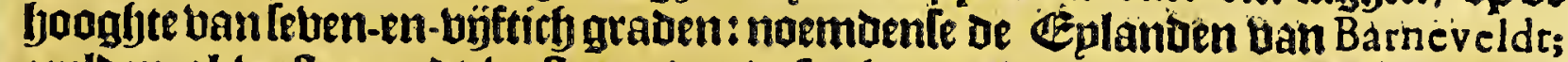

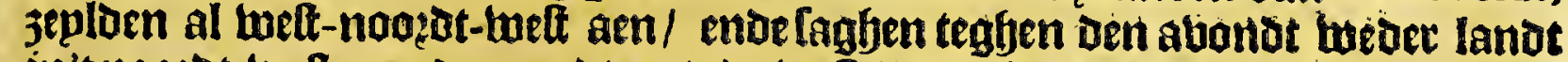
in't noozdot-keften ender noozot-noozot-weeften van yaer / oat was fet lande bo

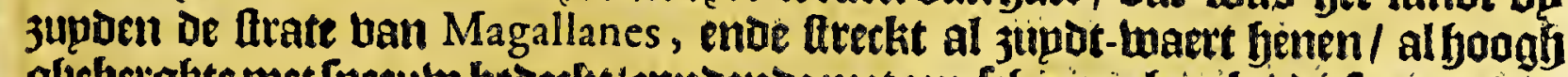

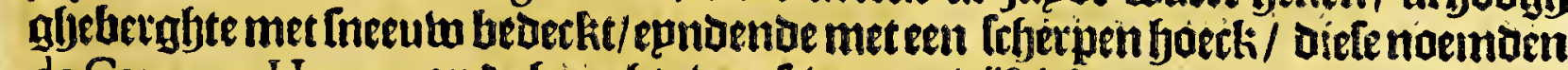
de Cape van Hoorn, op be fjoughte ban fewen-en-bijftich gladen acth-en-beettitf

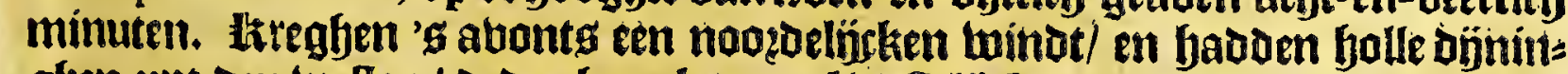
ghen upt Den twelten / Deden yaer kours al heffelijek aen/ en bevonden dat Daer

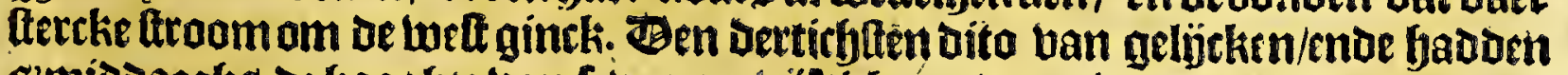

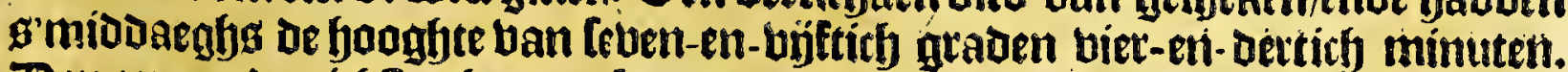

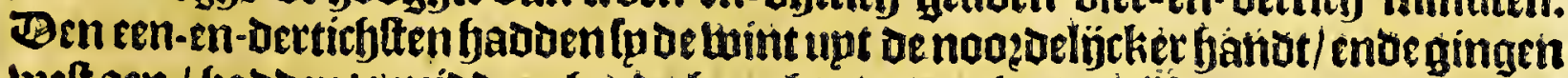

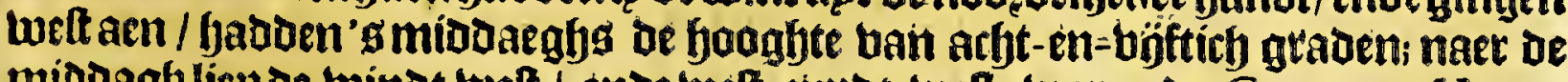
midoagb liep be windt tued / ende weft-juptet-weft; waren de Cape van Hootn 
Joenghepalteetr/ende en kandengljeen land meex fien/maet hadoen bolle bignirts

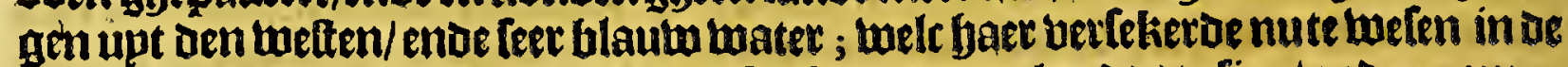
3upot-3ee. Boeren faa diberlefe kourlen Londer meer landts te lien/ ende guamen op de booghte ban neghen-en-büftiry graden / tot Dat [p Den thaelfaen Februar.

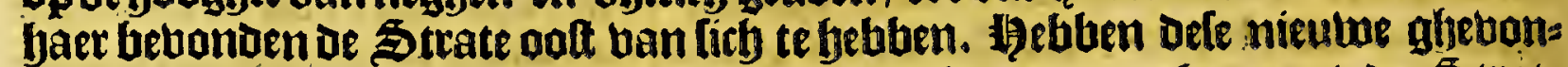

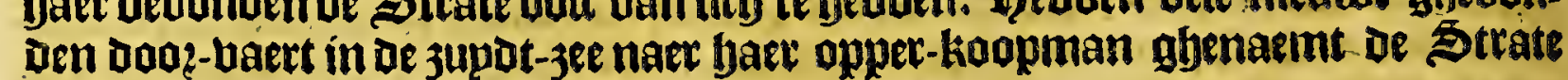
vanle Maire.

\section{Wet tivalfoe Capittel.}

Voyagie vande Spaegniaerden door de Strate van LE MAIRE.

$D$ EE toningh ban Spaegnien naetoer-banot ban dele nieulwe frate affes boot hehbende / heet in Den jare 1518 thee karbeelen af boen beeroighen am befe frate naerder te anderfoecken; dele jojn oen feven-en-twintiebten ban September 't jeplghegaen van Lisbona, onoer' t belept ban Barrolome Garcia de Nodal,

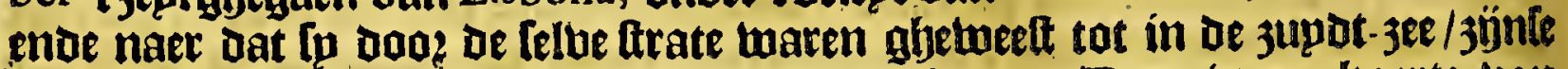
weder-ghekeert te $S^{t}$ Lucar Den neghenoen lul.16 19. Taer ig een liaerte van upt-gheltomen / ghemaectit Dooz den Cofmographus van oen thoningh van \$paegnien/Pedro Texerra Ealbernas, in oe belike de zupoelijeke hape ban of noozoelïrke monot ban de ltrate ban Magallanes mott genaemt $C$. del Spiritu Santo; ende op deftreeck naer denieutwe ftrate toe/Punta de A renas, opde foogfte ban ontrent de bier-en-biftich graden/ neffeng een oooe-toclyt die in we oude ftrate ban Magallanes upt-komt/ melck [p noemen Entrade de $S^{\mathbf{r}}$ Sebaftiaen, ende eqn

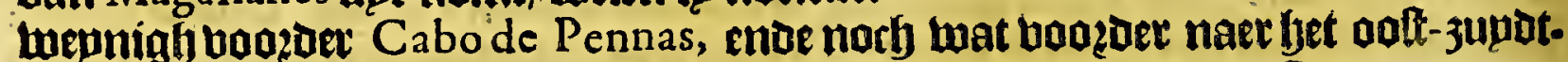

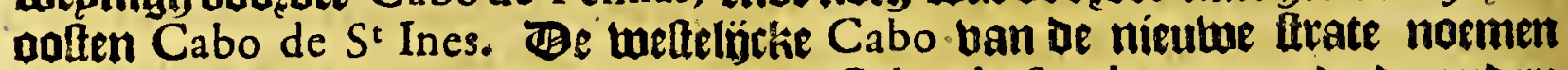
ip Cabo $S^{t}$ Vincente, ende ae aoltelícke Cabo de Setabence, enoe oe andere Cabo St Bartholome, bepde aen Staten Eylande gheleghen. $25 \mu$ jupden de Cabo St Vincente aen't lanot melck confíneet met de frate ban Magallanes, ftellen fuerti Puerto del buen fucceffo, ende narb voager Monte Gordo, ende daer bu

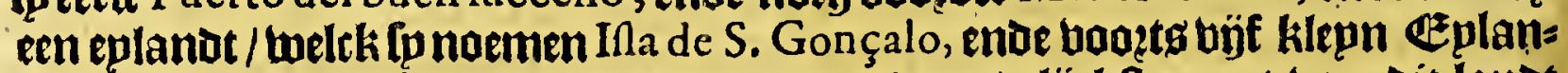
oekeng de $S^{t}$ llefonfo; enve twat boozder ban't jupdelijeklte punt ban dit landt Ille de Diego Ramires.

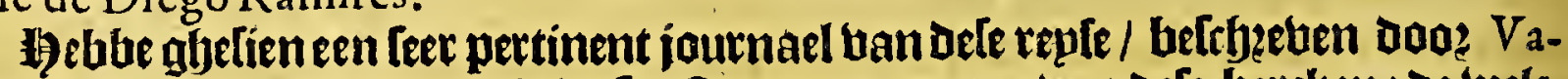
lentijn Ianfz. van Statijn, abetwelen ftupe-man apeen bau dele bercken: de tuele=

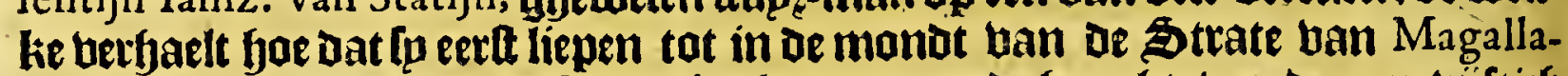
nes enoe uan daer $j$ updt-woft aen ginghen ende op be googlte ban bep-en-ujiftity graden ende bier-en-twintich minuten quamen booz een groote openinghe die meer als Dęp mijlen bande noazot tot oe jupdt-sjoe twijot is/ende open [oo berte men beooghen kan conder landt; de jupot-oafte gangh lepde bast binnen een

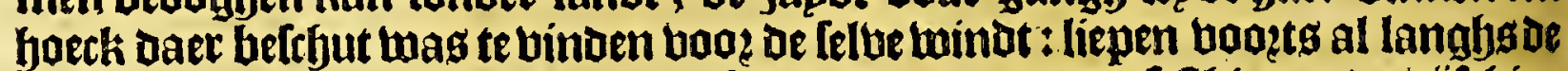
wal jupot-3upat-aolt ende jupot-ooft ten jupoen aen / op Tefthien ende bíftbien badem/banden faer ineen baetht die feel lcharpe granot feeft; 't lanot in de batbe

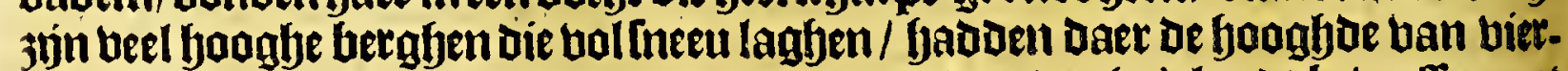
en-bỷftich graden enoe bỷf minuten / ende wat voozoer is 't lanot betwallen met boomen; ende op oe hooghoe ban bier-en-büftich graden ende büftljien minuten betthoont fem 't lanot metbeel foec fen / enoe daer jün beel bapen daer menmet Ifbeepen [oude kanmen ligghen/ de wal fteecht bem bier jupot-3upot-ooft wel loo

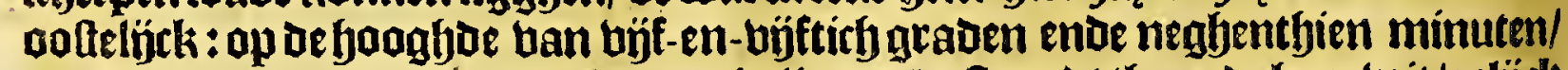
honden een bape daex twee eplanden in liggen/De ftranot thoonde hem wit/gelÿch

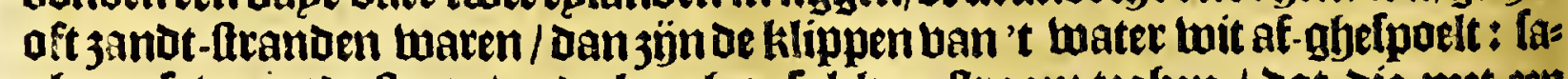
abent' labonts de ftrate / ende kreghen lulcken ftroom teghen / Dat die met een

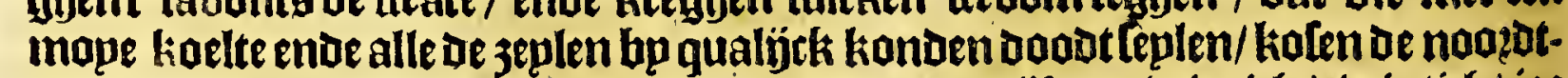
twal ende liepen daet bp in op feben-en-twintich / böf-en-twintich / twintich/ jae [eftuien/ 
Het tvvaelfite Boeck.

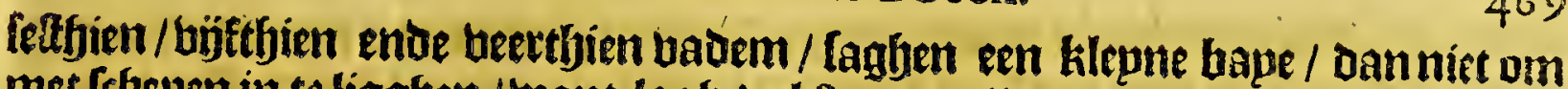
met fegepen in te liggben / twant lagb bol feenen: liepen een mjle binmen / uast banden fpeen Irboane. fanot-bape/ ende fetten daer op veertbien badem lwarte lanot-gronot met frbelpkeng ghemenght; ' $t$ belte ligghen is miooen in of bape ofte aen de noojot-jyoe: fet is daec in de Strate bolpinguing ende ander gyelio: ghelt / loa groot alg epnot-bogbelg / enoe oork beel groote meutuen; waren aen landt am boubr / ende bonden daef een berthy riebiertien ende boudts ghenoegh:

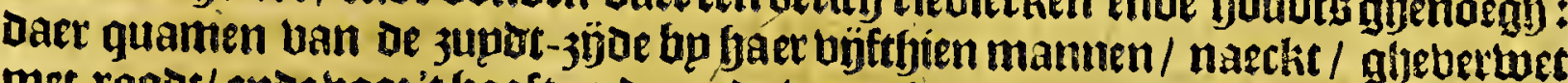
met roobt/ enoe boos 't boaft ende op de wanghen met wit : een Deel fadoen ban baer fchapen bellen om 't lïf met defelbe bertue gbeverbert; ende onder baer ba= ren twee aude / welcke ombadoen beflen ban andere beelen feer fijn van graetha yapg/ enoe badoen op 't hooft bellen ban groote cogmeulwen/de beeten upt-ghes pluckt/ ende den dong daet op ghelaten/ gadoen bogisen die niet langh en waren/

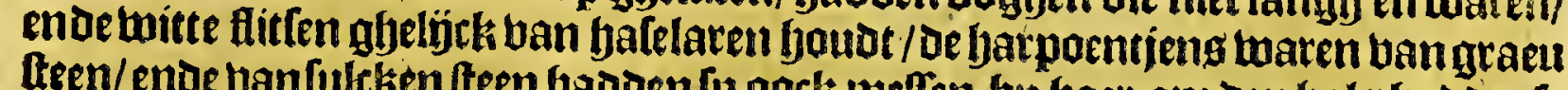
feen/ende vanfukcken lteen badoenlu oock meflen bu baer; am den bals badoenfe [noeten ban klepne bitte ende blinckente foozentieng/fraep ap een riemken uait gemarckt/ente am't lijf een riem ban leeder/ende badoen bp baer wit garen ban Irljapen twalle gbefponnen / en konden baer niet berftaen; als fppet fegghen twils den afte pets begheerden / en lepoen niet dan $\mathrm{H}_{0}$, ho, hoo; en wilden met baet nict eten ofte deincken / Dan pluckten ende aten krupdt ban' tuelot / welck maren geele boter-blommen die daer met heel groot loof waflen//maeckt wat bitteract= tigf : Ip hielpen twater en fouot laden/ende als lp bp't volcl' quamen/[oolepoenle baer baghenende knodren neder/ leerden bet Pater nofter ende Bader onfenaet fegghen: aen d'ander 3 joe ban De baue laghen bel böftich perfoonen / ende leegbe buttjeng ban rieden enoe ghebogben ftaecken ghemaeckt / ende met grag gedectst/ dan poele moltel-frbelpen. Bpt oele bape toeder't 3 epl gaende / mierden weel viet

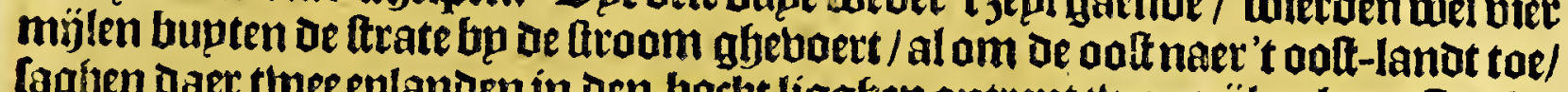
lagigen daer twee eplanoen in oen borbt liggtjen ontrent twee mỉlen bp oolten bet gat : De ftroam keetende/ Deef faer weder naer't gadt: Lagijen daer meoe een ofte twee fryoone bapen/Dan was daer diep/ern falf mịl bupten de twal geen gronot; quamen tweder in 't gat dirft bp de ooft-wal/ daer liepen mede baepen in/ infon= oerbepot dirft bp de jupdt-punt / Dan was dicht aen landt meer als bijf-en-beer=

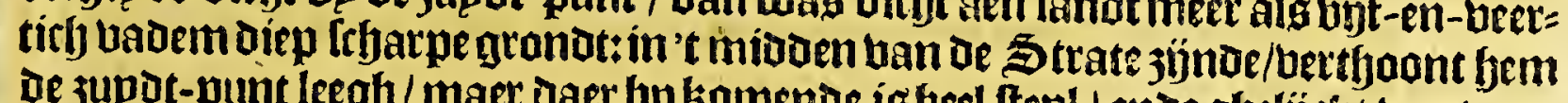
of zupot-punt leegh/ maer daer bp komende isgeel ftepl / enae abeligckt van berre

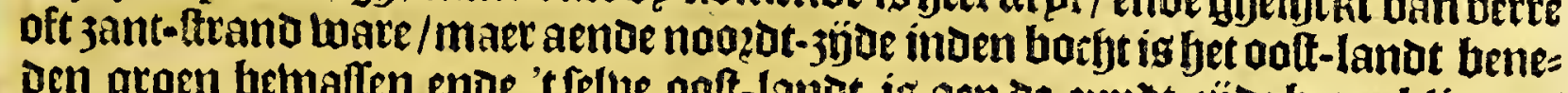
Den groen bewallen ende 't felue oote-lantit is aen oe jupdt-3joe barte hlippen/

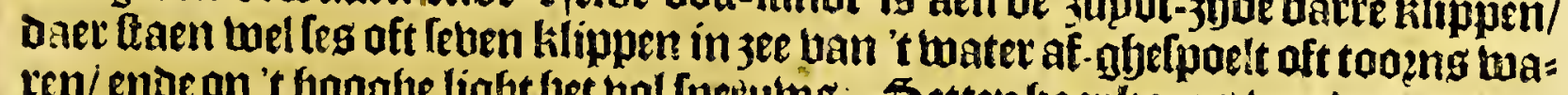

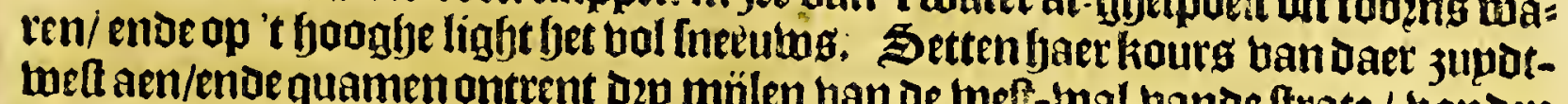
meft aen/ende quamenontrent dęp mïlen ban oe twef-twal bande frate / bonden gheen gronot / ende daet loopt een groute boetde welt-noozat-weft in bet landat

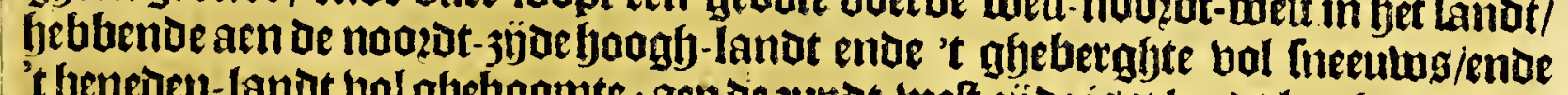

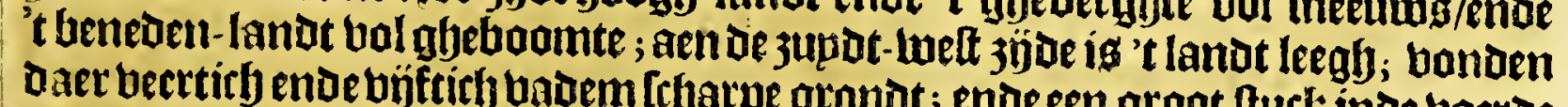
baer beertich ende byjfticly uadem lcharpe grandt; ende een grout ltuck inde boerde light een eplandt: ginghen daer naer tweder jupdt-jupdt- ooft aen/ ende deeten daer naer dooz de ghetweldighe twinat ende fneeulw oolt enoe ooft ten jupdenaen; Dír luas den lactlen Ianuar. Jen tweeden Februar. Getuonden faer ap bỷ.enbinfticly graden ende acht-en-beettich minuten / ende met den welt-naozd-twelen gangh kreegfen bet ooft-landtuan de Strate weder in't ghelfeft noo?dt-ooft ten

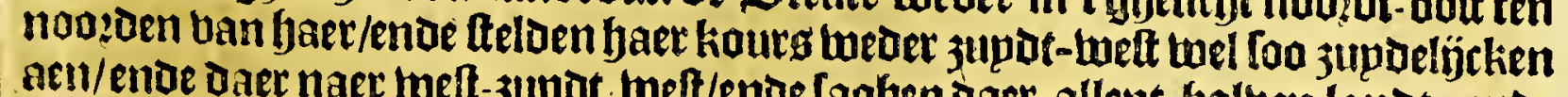
aen/ende daer naer twell-zupdr melt/ende laghen daer allent-baltuen landt ; ende

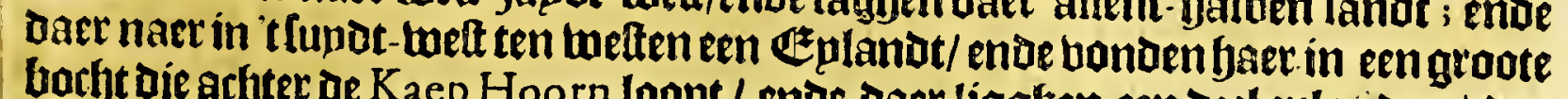
borbt die achter oe Kaep Hoorn loopt / ende daer ligghen sen det eplatiden / Da?

$$
\text { Sis land: }
$$




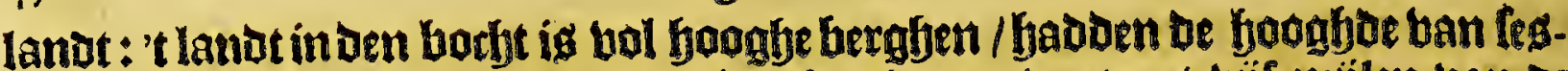
en-ujfticly graden ende twee-en-thintich mimuten/ontrent bj̉ mijlen ban de

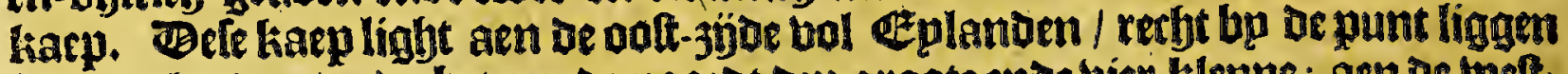

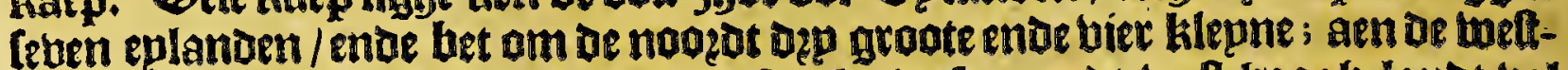

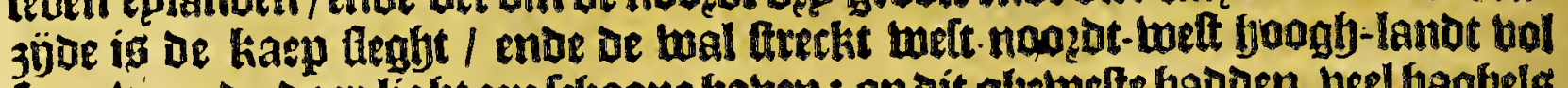

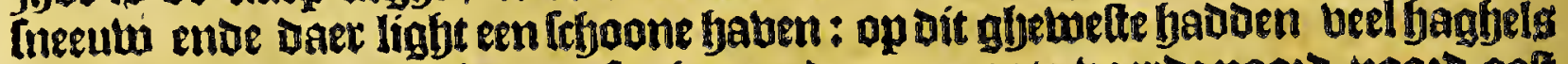
ende fneeu met groate koude: Lagben mede een groote boerde nooza-noozo-ooft

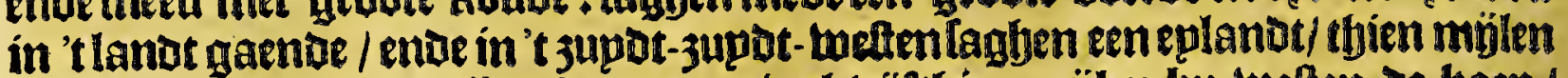
bupten be wal naer giffingh/ waren twel bífthien mülen bo welten de haep / oan wieroen alle weder te ruggbe gbedzeten/ coo datie of kaep wederomlagben

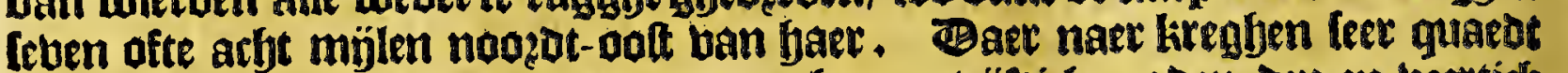

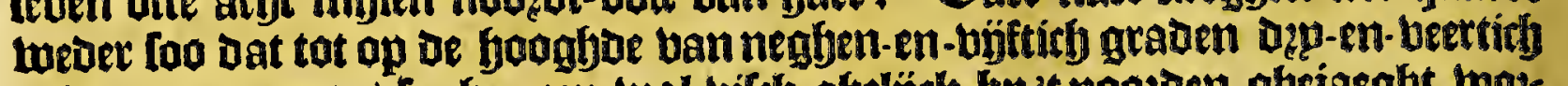

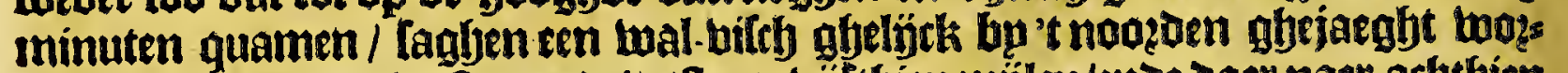
Den : ningen tweder twelt-nooz-twett aen bỷlthien mỉlen/ende Daer naer arbthien

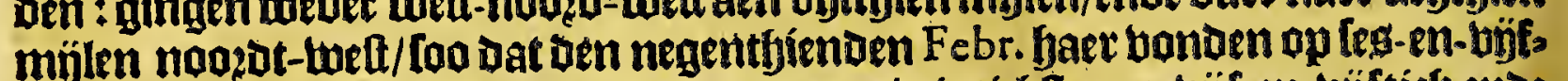

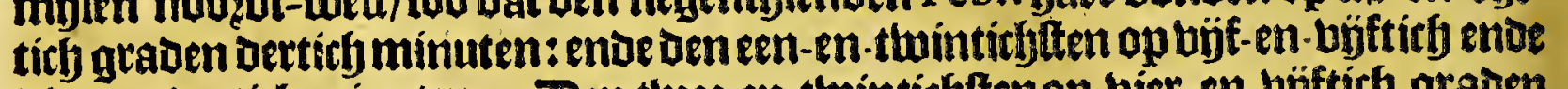
vier-en-Dertich minuten. Ben twee-en-twintichttenop bier-en-büftich araden felthien minuten. Bendap-en-twintichften op dep en-bỷftich grad. bies minuten/

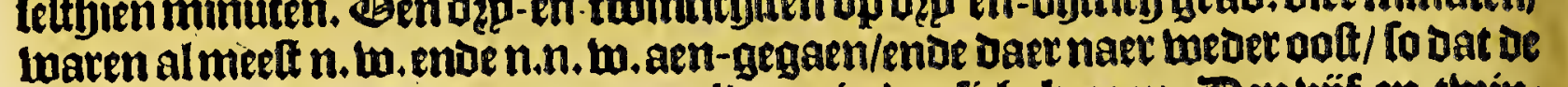

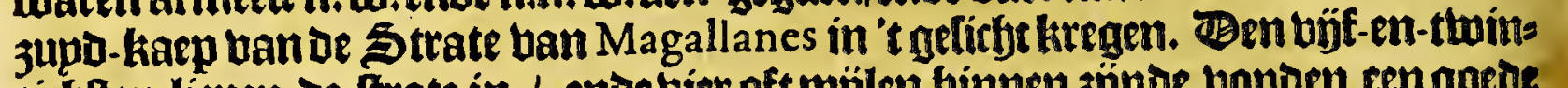
tichten liepen ie ltrate in / ende bier oft mílen binnen jünde vonden fen goede baben/lettent op leben vadem janto-gronot. Zïn fo oe Strate van Magallanes weder beur gbetomen naer Spaegnien / te Pernambuc aen-loopente om to verberlfben.

\section{Tet detthiende capittel:}

De voyagie van den Heer Admirael laques L'Hermite door de Strate van LE MAIRE.

I Pen jaete 1623 , in 'tlefte ban April bertrock be Naffaufe Vlote, belfaente 1 upt elf '́chepen; onder aen zamirael Iaques L'Hermite, upt bet Goereefche gaot ; enoe naer beel fuckelíngly die wo hier boos-bu gaen als beecier te leleut

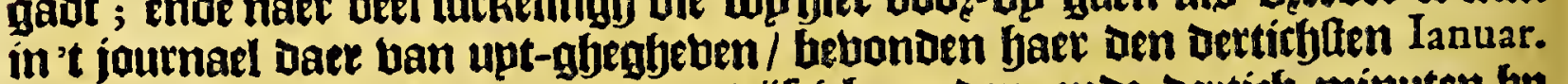
1624, op of boagboe van twee-en-vỉftich araden ende oerticly minuten bp 3updon de linie.

Den een-en-Dertichlten eenluackete oolt-noozdt-ooften wint ghekreghen bebbende.

Den eerten Februar. lagfen lanot jupot-3upot-welt ban bast / ligghende ontrent bujf mijlen/welck was de Cabo de Pennas, bemberthoonende met yoos

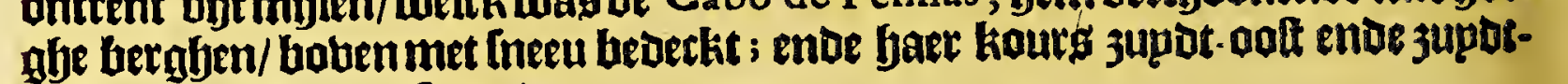
ooft ten jupoen aen-[ettende.

Den theeden met den Dagbe betbielentode de mont ban de Strate le Maire be welcke bp Valentijn Ianfz. Ater-man op bet lthip de Eendracht, (oe welcke vaet in jare 1619 , met de Spaentche Carabellen/ala boosen berbaelt gfetweef (was) berkent jünde bp oe bergfen die aen oe tuelt-3joe ban de monat ligghew

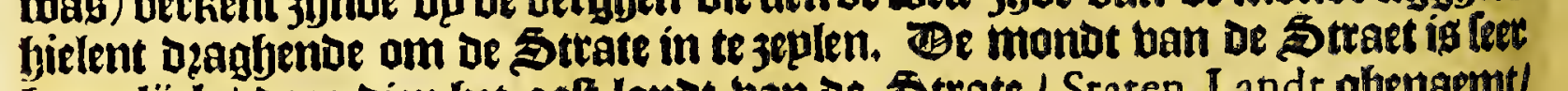

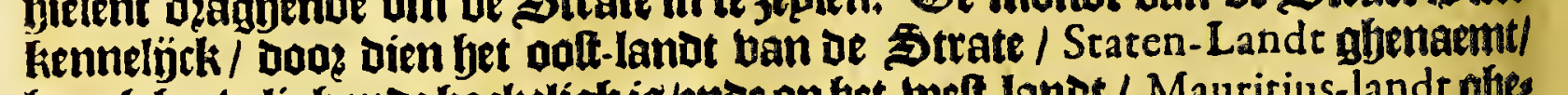
foogh feubelighende fackeligf is/enoe op fyet melt-lanot / Mauritius-lande ghes

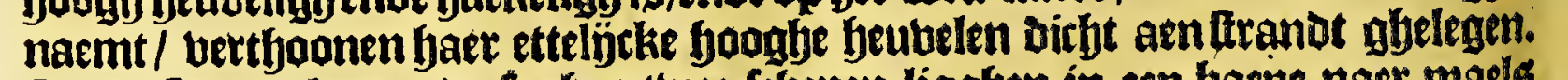
Tnoe Straet kamenoe fagfen twee fejepen ligghen in een baepe naet-maels Verfchoors-baye ghenoemt / ente alloo be winot feet aoltelÿtk liep/ marenin twujfel oft in Valencijns-baye (Die ban bp noożoen af te reeckenen tulftben Den

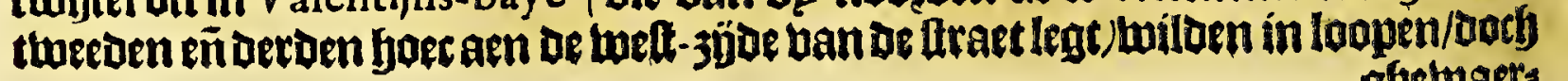
gueltualts 
Het twaelfite Boeck.

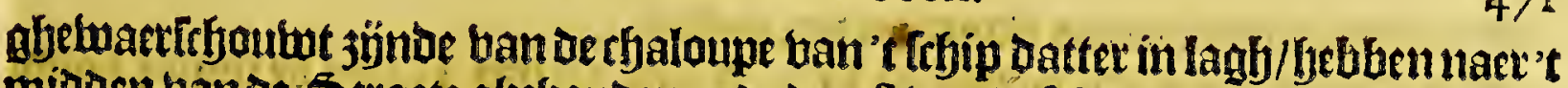

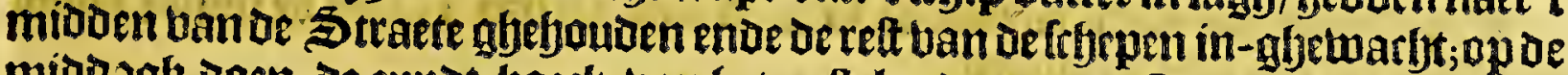
midoagb ooen De jupot-boeck ban fet ooll-lanot van oe Straet oolt ban baet

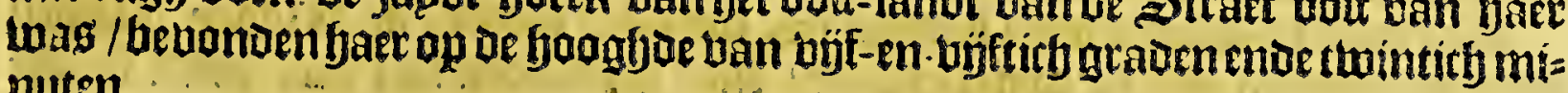
nuten.

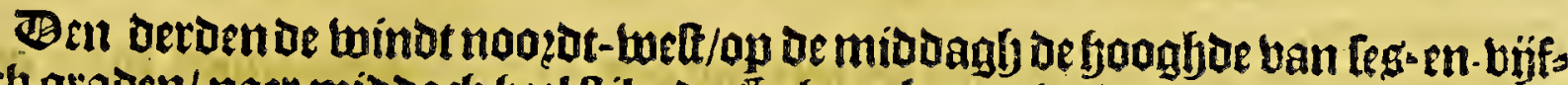

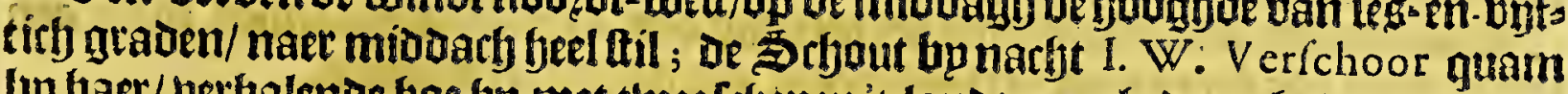

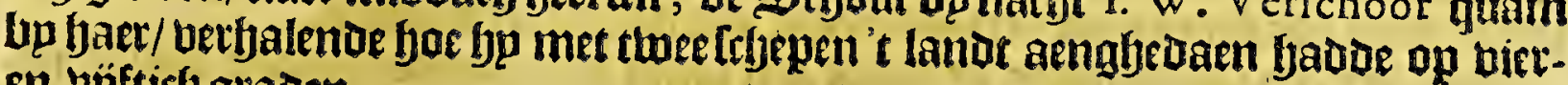
en-ujffticl graden.

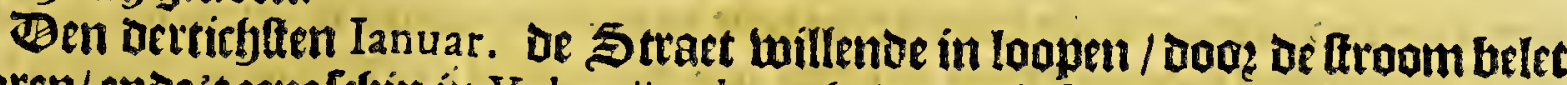
Luaren/ende't teene Ifhip in Valentijn s bay e badoen ghetonoen/endefelfo in Ver-

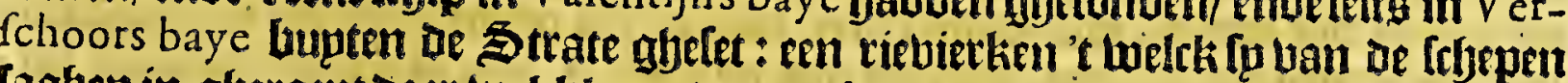
lagben in-gferoept daev wel klepne/maec gheen groate frfepen booz alle winden befcjut honden ligghen; hadoen met oe in-maonders gbebandelt / entabe rob: ben-Uellengleruplt/ maet gheen betberffinglie ofte beften konnen beliommen; binghen beel bileg ban ghedaente ende fmaeck als frgel - big.

Den feften met den dange faghen Caep de Hoorn, dip mijlen noopdt- nooget-

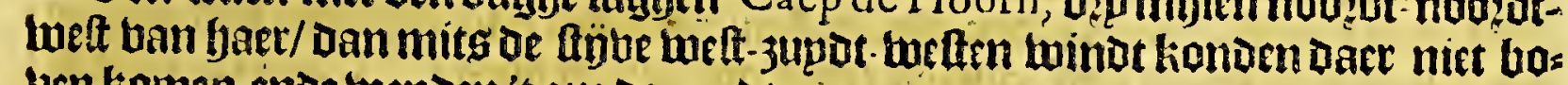
ven komen enoe tuenden't om de jupdt.

Den arbetten badoen norb alle barde ftom upt den wetern / enoe beboneen

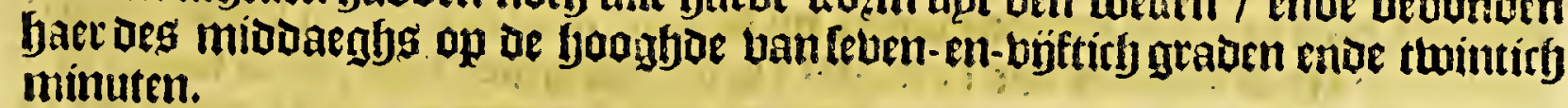

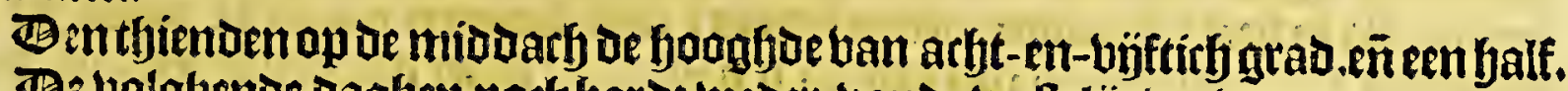

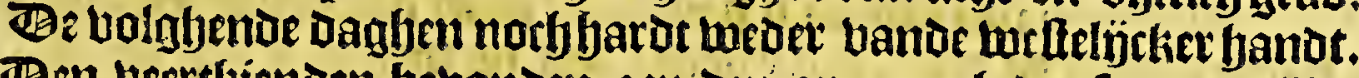

Ben veertjienden bebonden aen oen op-gangh der connen uǵf-en-twintich graden noozot-oolteringh/andere badoen maer dzp-en-twintich enoe eenighe

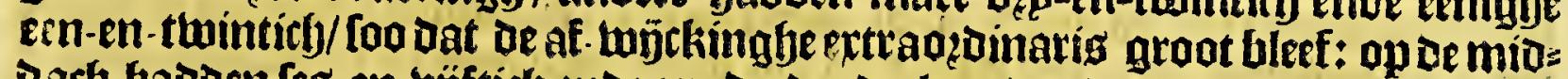
dach badoen [é-en-vöfticl] ende een Derdendeel graden/ende faghen tweder Caep de Hoorn feben mijlen twelt-noozot-welt ban baer / maer upt betonden dar be

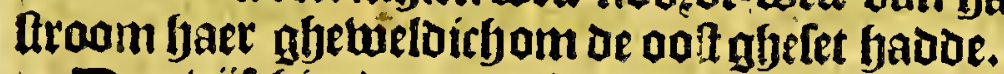

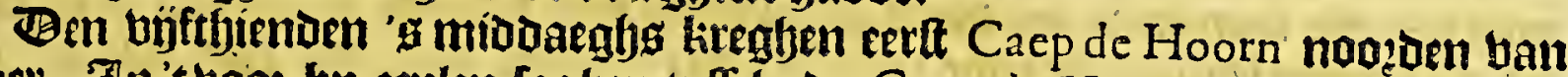
bart. In 't boos bu 3 eplen lagben tuffrbe de Caep de Hoorn, ende ae naefte bu wefen / een groote in - winkk die bem foo verte te lande in ftrerkte allmen beoogen liond: / too datmen bethoopte dare eenighe goede hapen te binten / ente om dat

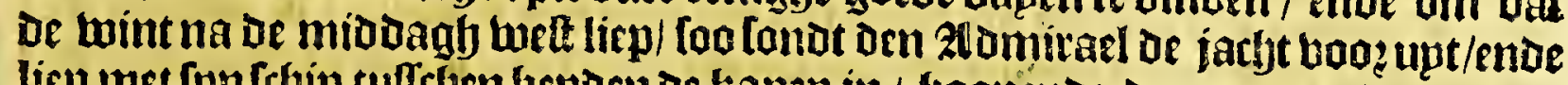

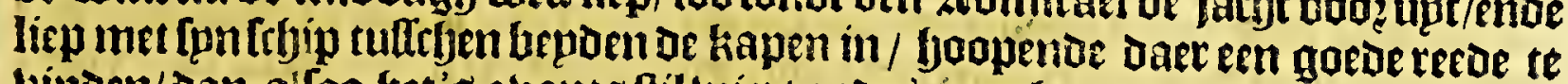

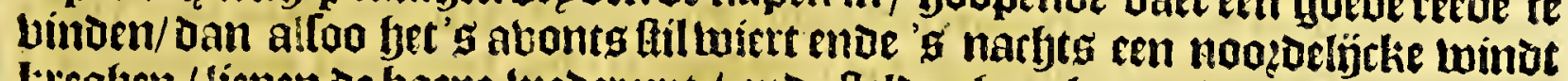
litealien / lípen de baepe weder upt / ende ftelden haer hours langhs de toal.

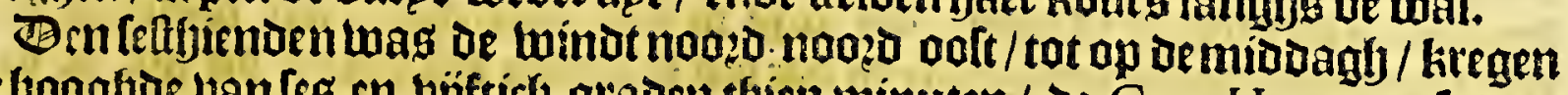

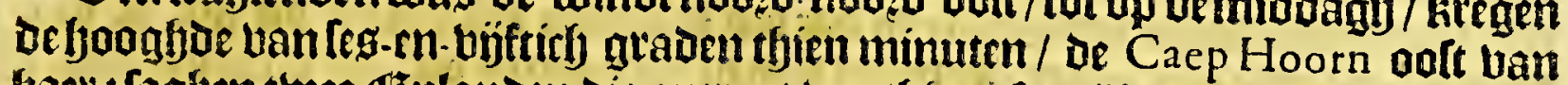

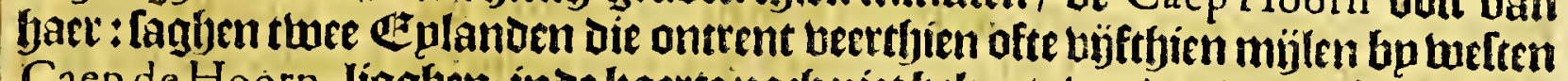
Caep de Hoorn, ligghen; inde kaerte norlj niet belient: tonoen dat de fironm am

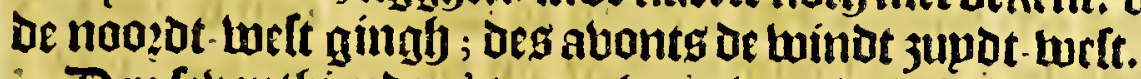

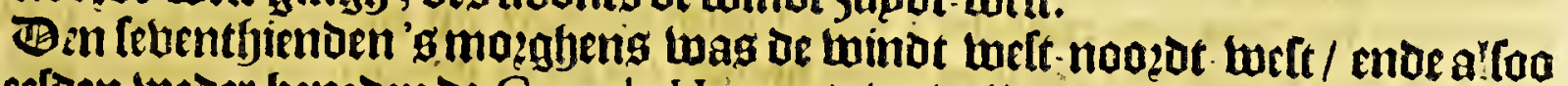
beeloen lueder beneuren oe Caep de Hoorn te berballen / namen faer liours de beerde in die daer naer de Naffaufe voerde ghenoemt hebben/ende beblient daer afferet op bÿf-en-twintich a dertich badem lialrk gronot:

Den achthienden toeten aen lanot ende bonden bequaembent om bimmen ic

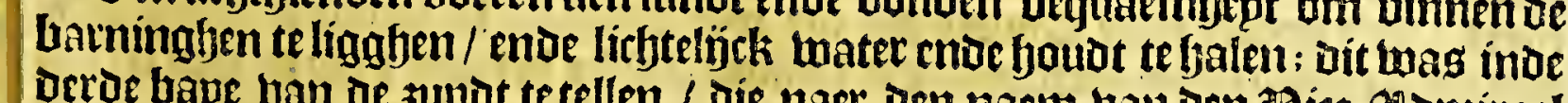

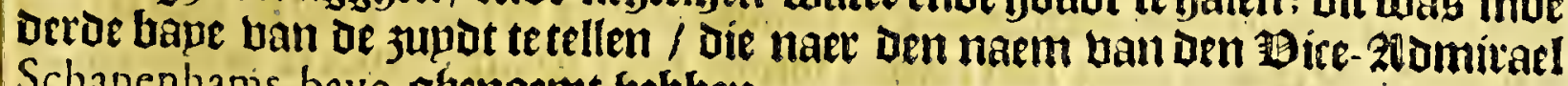
Schapenhanis-baye ghenoemt hebben.

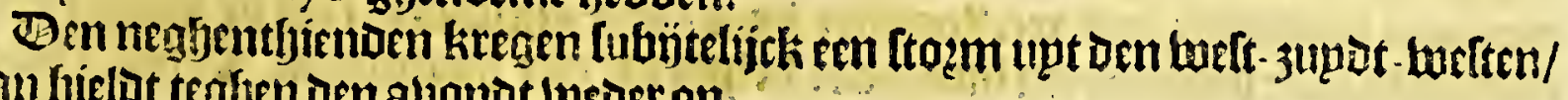
onn Gielot tegryen den aljonde lueder op. 
Dentwintithften bedaet frozm wot aen beften.

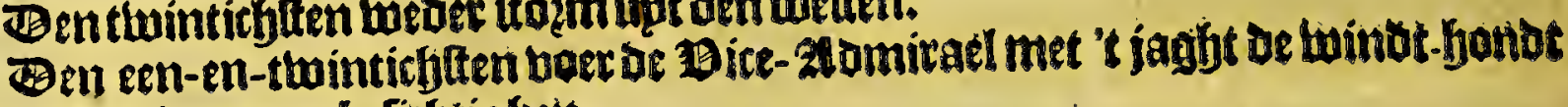
de boeroe in/ om te belicbtighen.

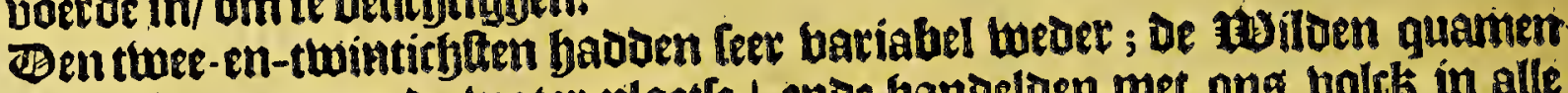
Gaee bertboonen aen of twatex-plaetfe / ende bendeloen met ong bolet in alle beiendtchap.

Danoen deg en-twintichlen lietbet teghip Den A rende negbentbien man aen lanot ftaen / De fozm baet berbinderende aen boozat te kommen.

Den biec-en-twintithfen de boots aen landt kotrmende bonden bande ne:

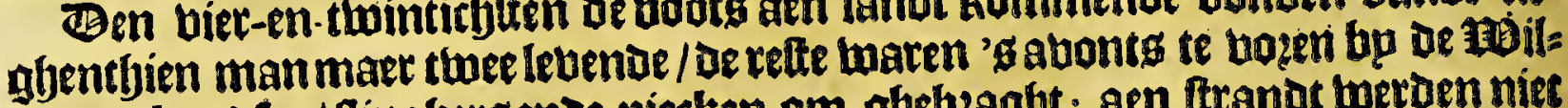

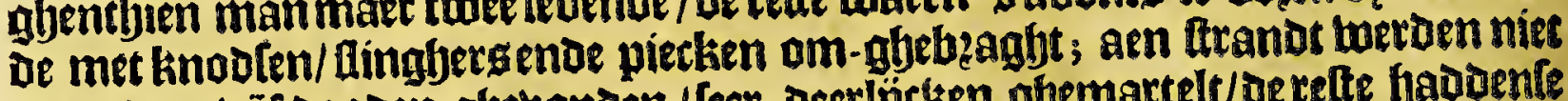
meer ban bÿf booden gbebanden/leet deetlpeken gbemartele/ De relte badoenfe met ghenomenom te eeten; naer die tyjot en bebben daer gheen Hailoe meet bet: nomen.

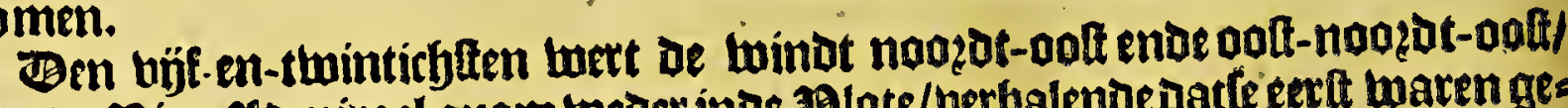
ende de Bice-zomirael quam toeder índe Blote/berbalende Datfe eer le waren ges loopen retyt naer een bape de Winde-hondes baey gbenaemt/Daec berfétepoen Guttekens ban toilden yadoen gbebonden/ ende mer baet minnelijikerigbebam

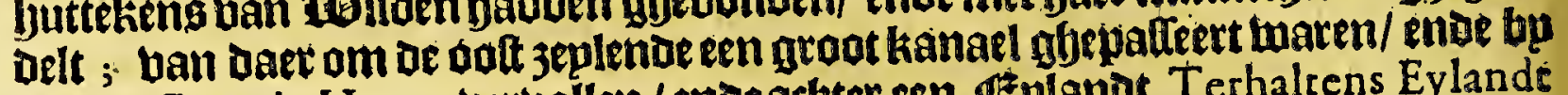
oofen Caep de Hoorn veruallen / envearbter een Eeplanot Terhaltens Eylande genaemt gelet gelegen/ tot datfe tweder bp be blote dooe den oulten hiinot waren ghebzacht. bettjoont) in beel Eplanden verdeelt was / enoe datmen om in de zupdt-3ee te geraecken Caep de Hoorn niet beboeft te palteeren / maer oatmen de Lelve bu zup: oen latende ligatgen/ oooz de Naffaufe Voerde wel bp weiten Caep de Hoorn weder in jee kan upt-kommen / moe alloo lich ouer al beel borbten ende in-yam: men bertbonen die foo wät te landat-maert in freckenallmen brooghen kan/ dat wel te perfumeeten is/ Datter paltagien jún waet Doog men in of Magallaen/cho frate kan gheraecken.

Terra del Fuego is meel betgharbtirb/ Dan feeft abex al lchoone ballepen ende luftighe beemoen / die bebloept lwozen met fegoone af-materinghen upe bet gheberghte Lpeuptende ende verthiert met fcboone krupoen; beeft tulfichen de Eplanden verlchepden Lchoone reeden daermen een blote Ldjepen met Leeckerbept Toude kanmen berghen/metoberbloet banbertch-water/boubt ende fteen tat bals

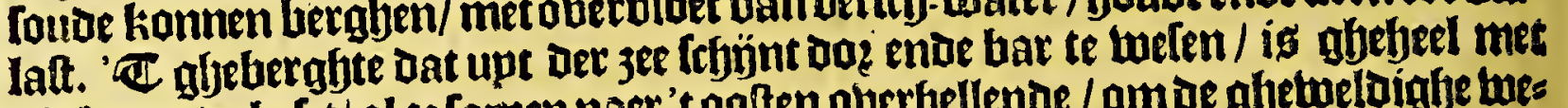
ghrboomte befet/al te [amennaer' tooften oberbellende / om de ghetwelaighe tues Reinclie winoen die in defe contrepen ozainarig domineeren. De aeroe ban't ghes berghte daer deféboomenin waften is veenarhtich / bol ende niet voer twee ofte

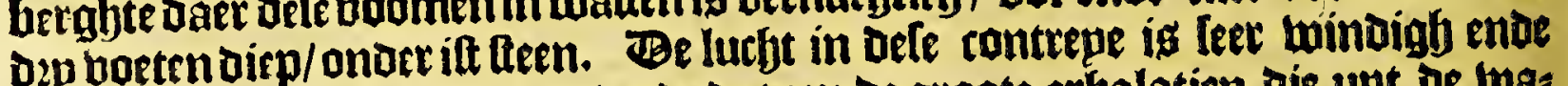
beel tempeelten onoer-mozpen/ende dat om de groote exbalatien die upt de was

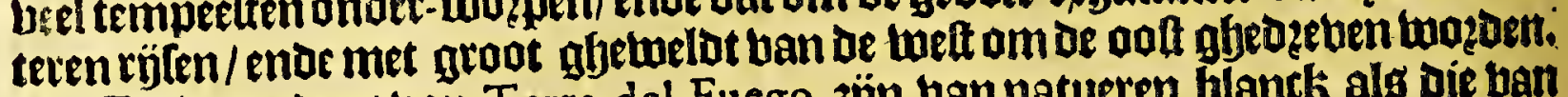
De 7 n-woonders ban Terra del Fuego jün bannatueren blanck als die ban

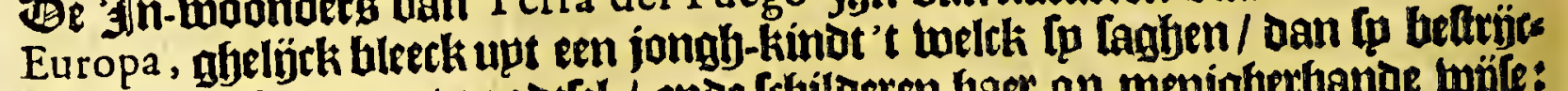

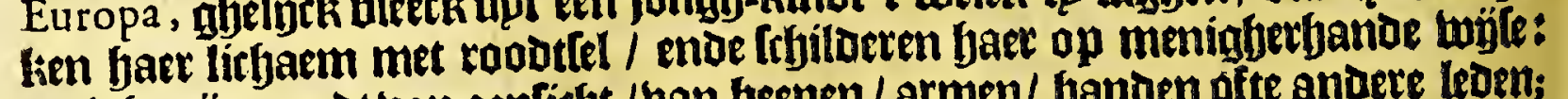
cenighe jÿn roodt ban aenticlyt / ban beenen/armen/ banden ofte andere leoen; De relte ban't lichaem wit / plackerich / betchiloert oft belteecken; daet 3önder

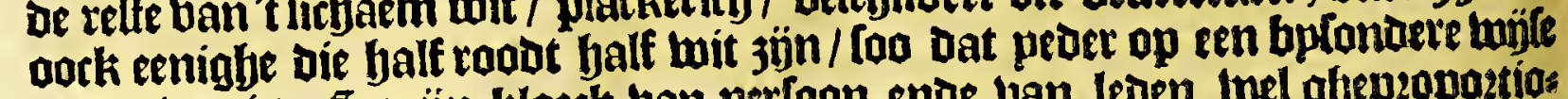
ghevertuet ig. Spjön kloeck ban pertoan ende ban lejen tuel abepzopoztio: neert / van groote ente ftature als die tan Europa ; Ip Dzagben langh ende oick twart bape/om te beeteligcker te lthïnen / ende bebben frbarpe tanoen als een mes; de mang gaen beel naeckt fonder baet frhamellyepot te bederken/De bzoumen bedeckent met een turcken leers / jujn ghefrbíldert als de mang / ende

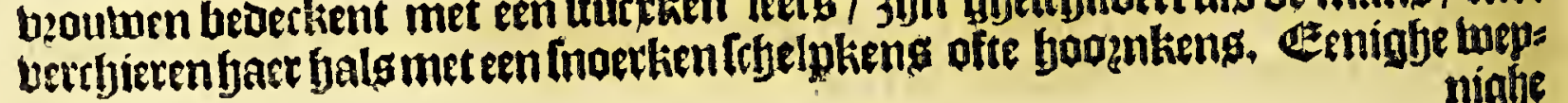
nigbe 


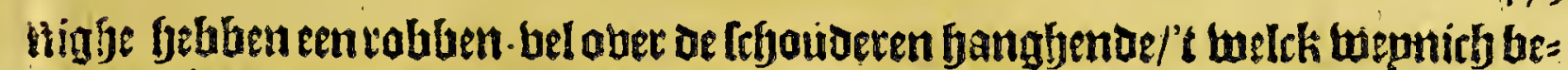

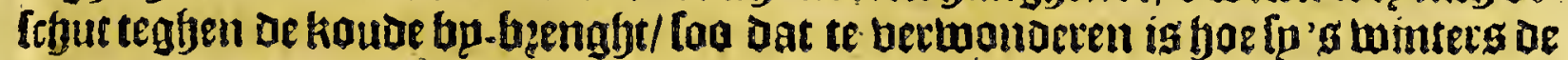
liaude deur-[taen. Here buttekeng jün uan eeniglse boamen te famen glefet/

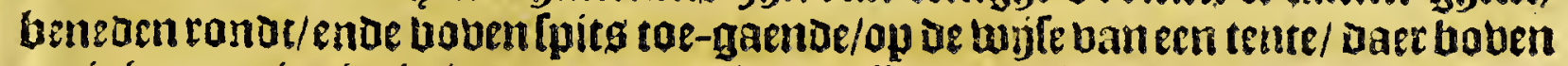

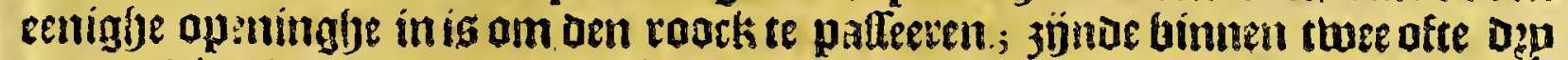
boetell diep in ae aetoe upt-gljefjoolt / ende bupten met acroe befiot. Tn haete

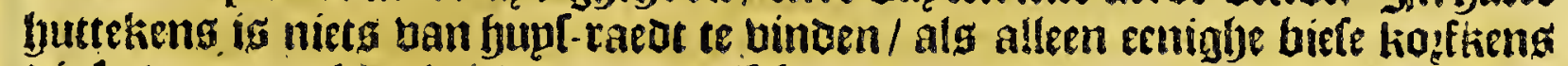

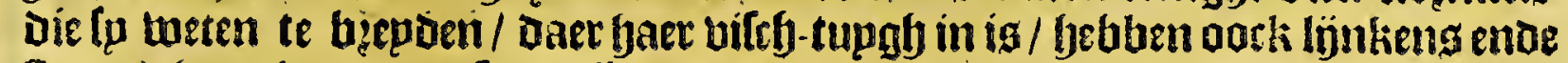

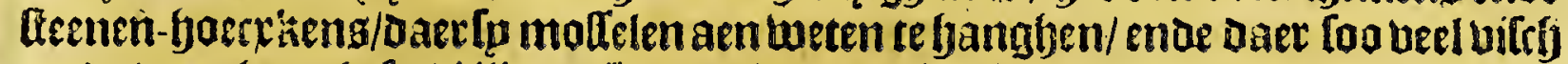
meac bangljen ald fo billen. Iteenen barpoentijens feer kon!tigg gbemaeckt ; langbe laieften / met een feberp

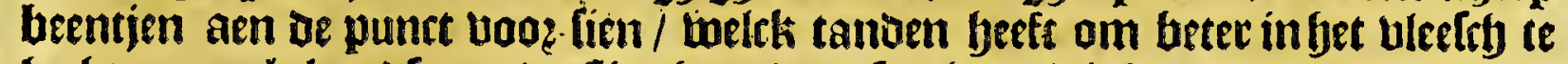

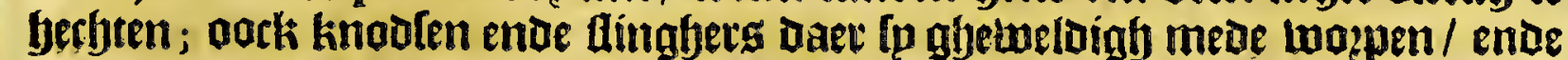

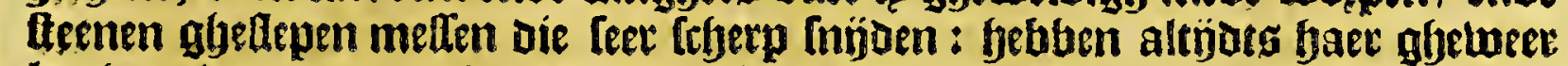

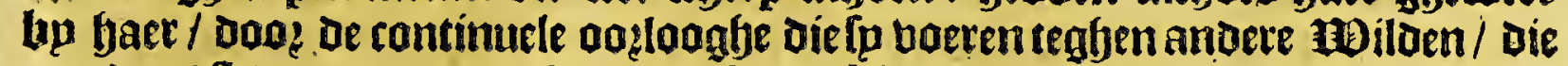

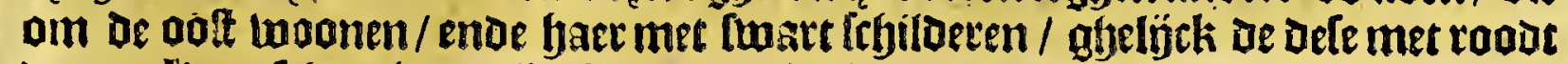

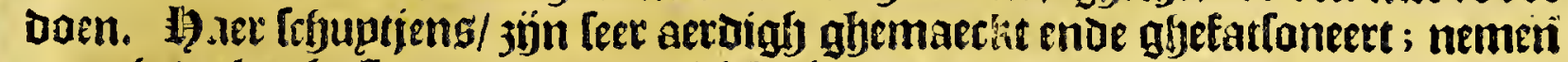
een njeijedlen baft ban oe aloer-bickite boomen/ die fu loo Lueten te bupghen/ Commiglje riemen daec upt.inpdende/ende dan die toeder te lamen naepende dat

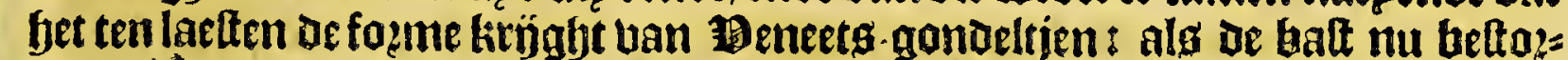
benig/ loo ober-legghen fa Den bodem ban bogzen tat achteren met goutjeng

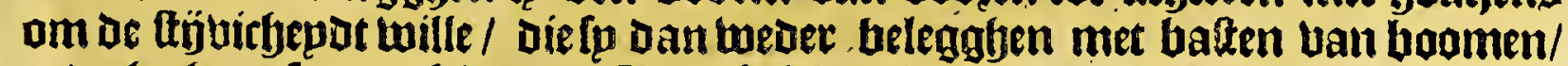

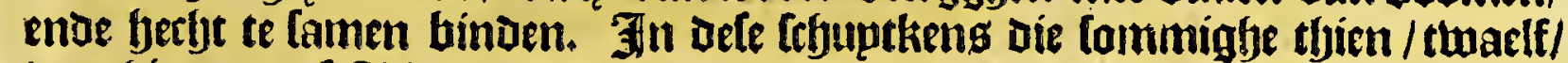

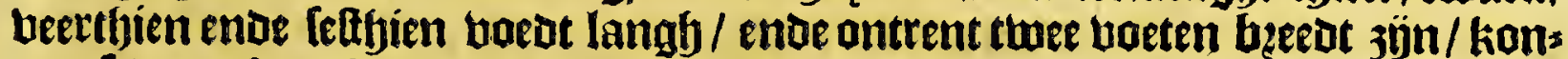
nen leven ofte acht man bequaemincken fitten/ roepen baer meoe loo fterck als met een rlgaloupe. Bit volck is anders den beeten meer ghelïct als oe men= leben / twant beneffeng datle vautw mentehen- bleetef eeten / ende in 'tmintte nies

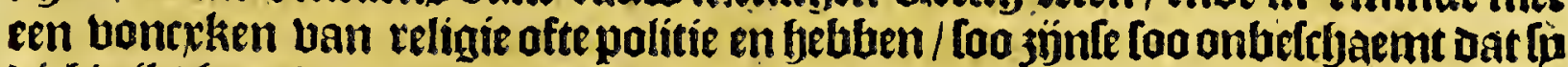

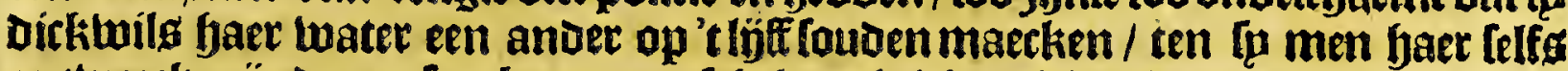
ontweeck; jönde een feec boogenoe fryeimarbtirf bolek; thoonende met deneer: ftende beende niet dan veienotfeyap / ander-tuftejen nieutuers meer op benc= liende als om de felve op get onvertienfte te ober-ballen.

(Dntrent of bape ban Schapen-ham en ig gbeen bilch te binten/ als mottelen

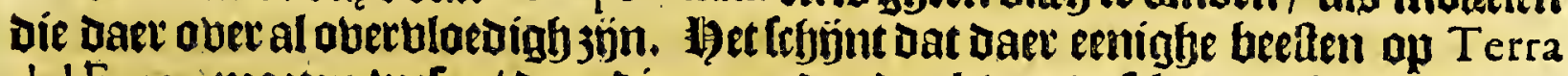

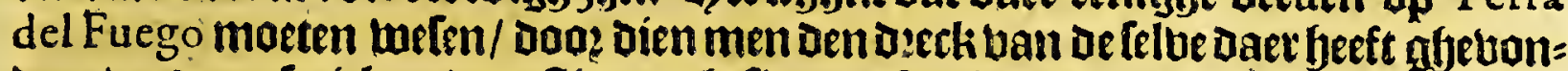
Den / ende yelericken tan fteren gljefien. Oack is oe Bice-zudomirael onder Goeree (een bape bp Terhaltens Eylandt) ten ancket ligghembe ban een Sol=

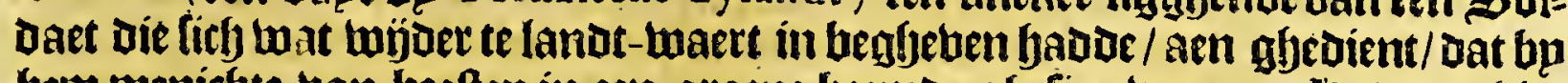
hein menichte ban beeften in een groene beemoe ghefien waren. Gadoen biev

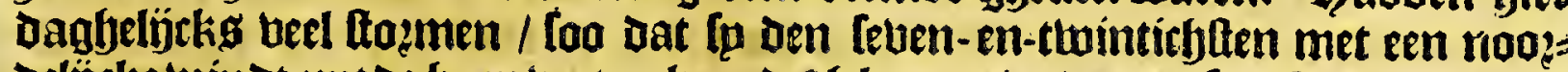

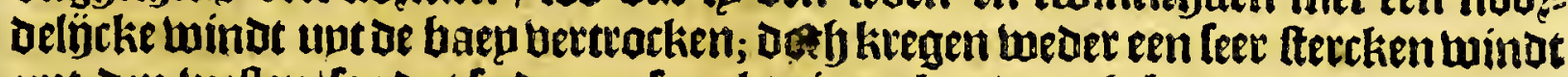
upt den wetten/foodat fp de marl-3epls niet en kanden ghebzupcken.

Den eerften Martij noazdelÿckte be twinte/ ende fin maeckten de marf-sepls

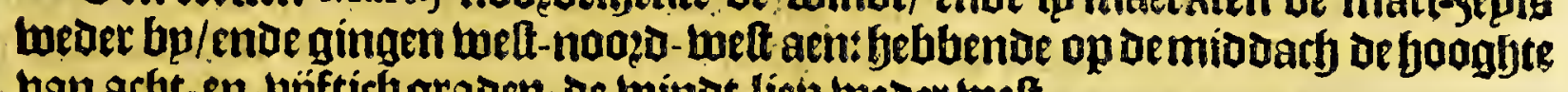
ban acht-en-vijftich graden; oe twittut liep tweder wett.

Dentiuecaen badoen debooghte ban neguen-en-biftich graden. Fen berden Martij badoen negfen-en-bujftich graden ende bijf-en-beertict
minuten.

Den bierden taag oe trinot welt- zupot- weft.

Ben bủfoen kreggen Defoogbae ban acbt-en-büftich graden ende beertich mis nuten.

Den levenden of booghte ban fetrity graden bÿftbienminuten. 
Den acheftem een-en-leftich graden.

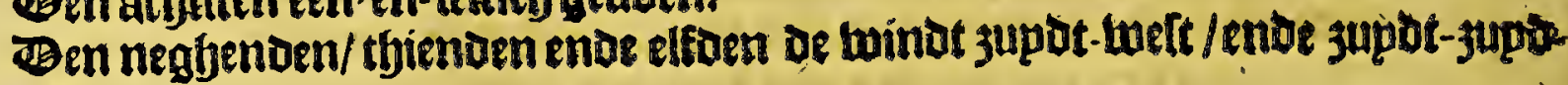
twett.

Den twaelften ende derthienten de wimbt noozdelijek.

Den veettbienden de booghte van acht-en- bijftich graden.

- Ben viffthienden/Lettjienden ende feventbienden Den wind 3 updt-weft:

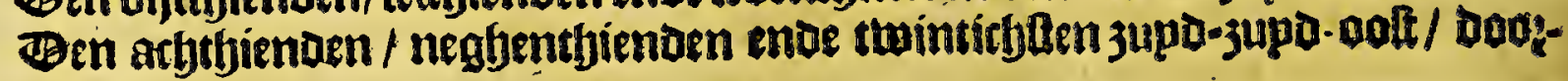
gaenoe koelte.

Ben een ende twee-en-twintichlfen neazd-nodzot oolt.

Den ołp-en-twinticy teen frozm upt Den 3 upot-welten.

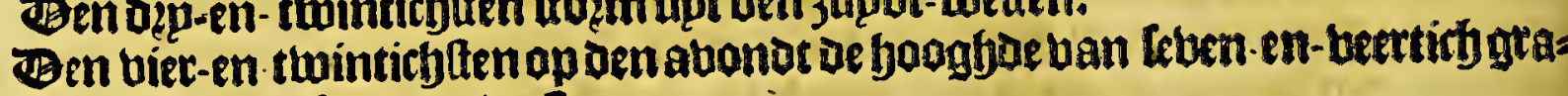
aen/ae twinat wett-jupot-bert.

Ben ujif en twintichtich ten de boogboe uan böf-en-beetich graoen enoe een

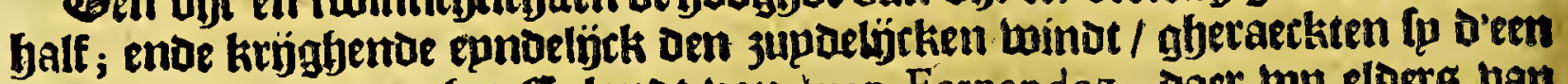
voos d’ander naet aen fot Gepland ban luan Fernandez, Daet wp elorrg ban Ipeecken.

\section{站et beettbienoe Capittel.}

Verhael ende befchrijvinghe van de voyagie van Diego Flores, ende hee bouwen van de Steden in de $S$ I R A T E

Van MAGAIIANES.

$\mathrm{E}$

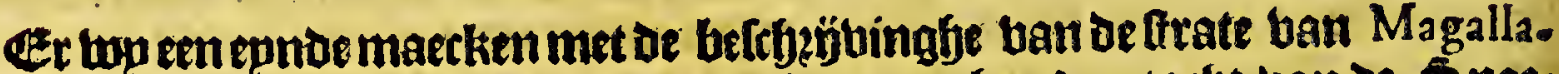
nes, foo fal t de pjune tweerot jünhier in te voegben oen tacbt ban de Spats gniaetoen onder 't belepot ban Diego Flores, upt de beffyejtingbe ban 1 opez $\mathrm{Vaz}$; Defe thietot van oen koningh ban Spaegnien ghrfonden om in of litate eenighe Colonias te planten onder bet Goubernement ban Pedro. Sarmiento:

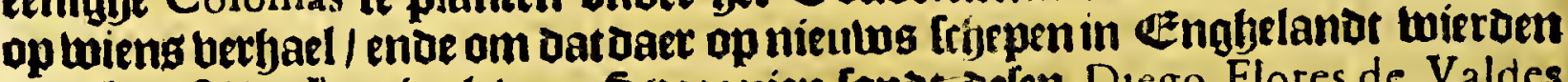
toe-abecult / de ltoningh van Spaegnien [onot Delen Diego Flores de Valdes met dap-en thintich fejepen / ende dep dupfent ende büf fondert man / ence een nieuwen Bauberneur naer Chili met vinf fondert ouoe foldaten/ Die nieubigirls upt Peoerlanot maren aljekamen.

Jele ftbepen hadoen leer quaedt ghelucks / want eer fp konoen gbetaecken bai

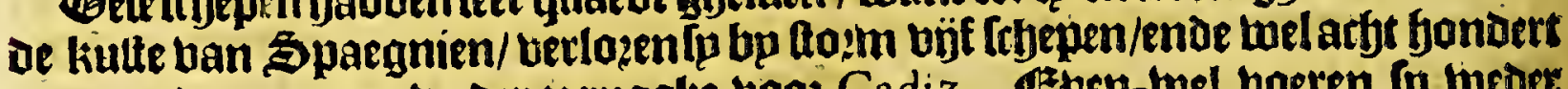
$\operatorname{man} /$ ende quemen meder te rugghe booz Cadiz. Eeten-bel boeren fo meder ooo beuel deg tzoninghg af / met alleen fettyienlebepen ; bp oe twelcke Pedro Sarmiento bierar ghefonden om Gouberneur te twelen in de thrate ban Magallanes;

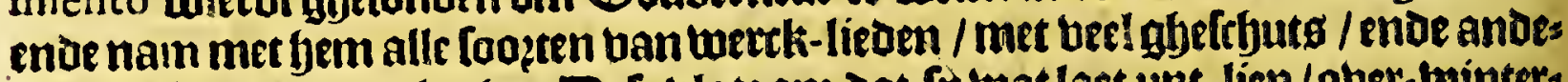
re bejoeften ban oo!laghe. Befe blote om dat eplwat laet upt-liep/ober-twinters de aen de fulte ban Brafil, in oe bauen ban Rio de Ienero. Ban daet boots zeplende / kreghenfp op de googhoe ban thee-en-beertich graden fulcken fto:m/ dat fp wel twee-en-twintich daghen ghedwonghen waren aen en af te fouten/ ende ber!oozen cen uan faer befte lrbepen / met dep bondert man ende twinticf veouluen die in De ftrate foude gaen woonen/ en eengroot orel ban de ammunis tie die dertwaetts ghedeltineett was: too dat fp gheolwonghen waren tweder te keeren naer't Eplanot Santa Catalina. Daer hoozoen'fp ban tmee groate $\mathbb{E}^{2} n=$ ghelfrbefrfepen (dele twaren ban de blate ban $\mathrm{M}^{\mathrm{r}}$ Fenton) ende bermoedende

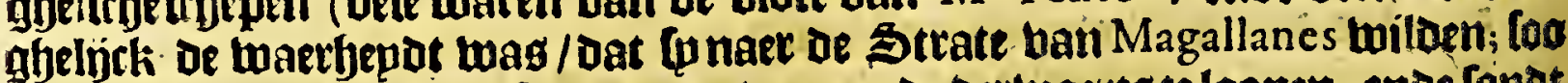
koos Diego Flor es thien frjepen om daer mede detwaerts te loopen; ende lonot Dep te rugghe met het onbequaemfte valck enoe de begubern/ naer Rio de lene. so; ende twee af-gbevaken febepen liet bp baer. De deg lrbepen bielen in ban- 
476

Magallanica:

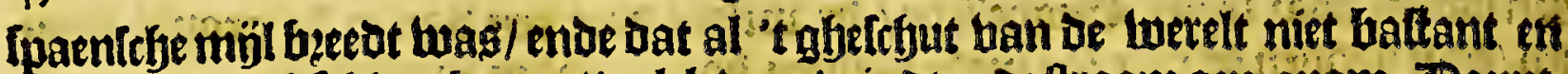
was een eenigh frbipte keeten/ welck boo? twinot ende Aroom aen-quam. Be upts komite ban oit milerabel bolck in de Itrate tan Magallanes gheplantet/ beblem Cap. 7. wop fier nooeen berfyelt upt bet relaes ban of vopagie van Sir Thomas Can.

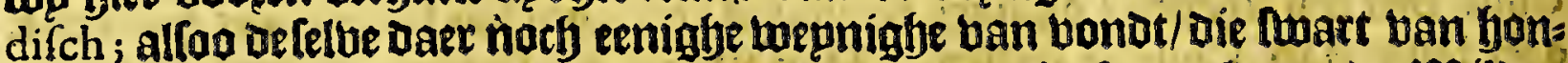
gher waren/ oe refte al vergaen zojnde van gbetzeck ofte oock ban oe wilden

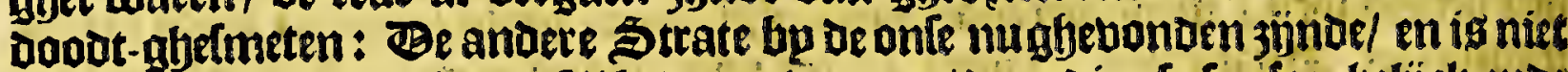

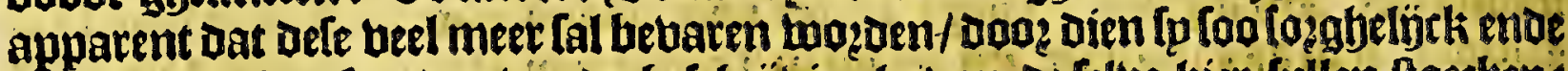

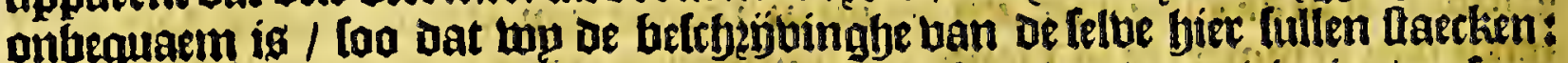
ende boots baren tot de bertfegejuinge tain De naeft-bolgende yeobincien/canfoem de ougde glec bogen by ong beraent.

BESCHR If:

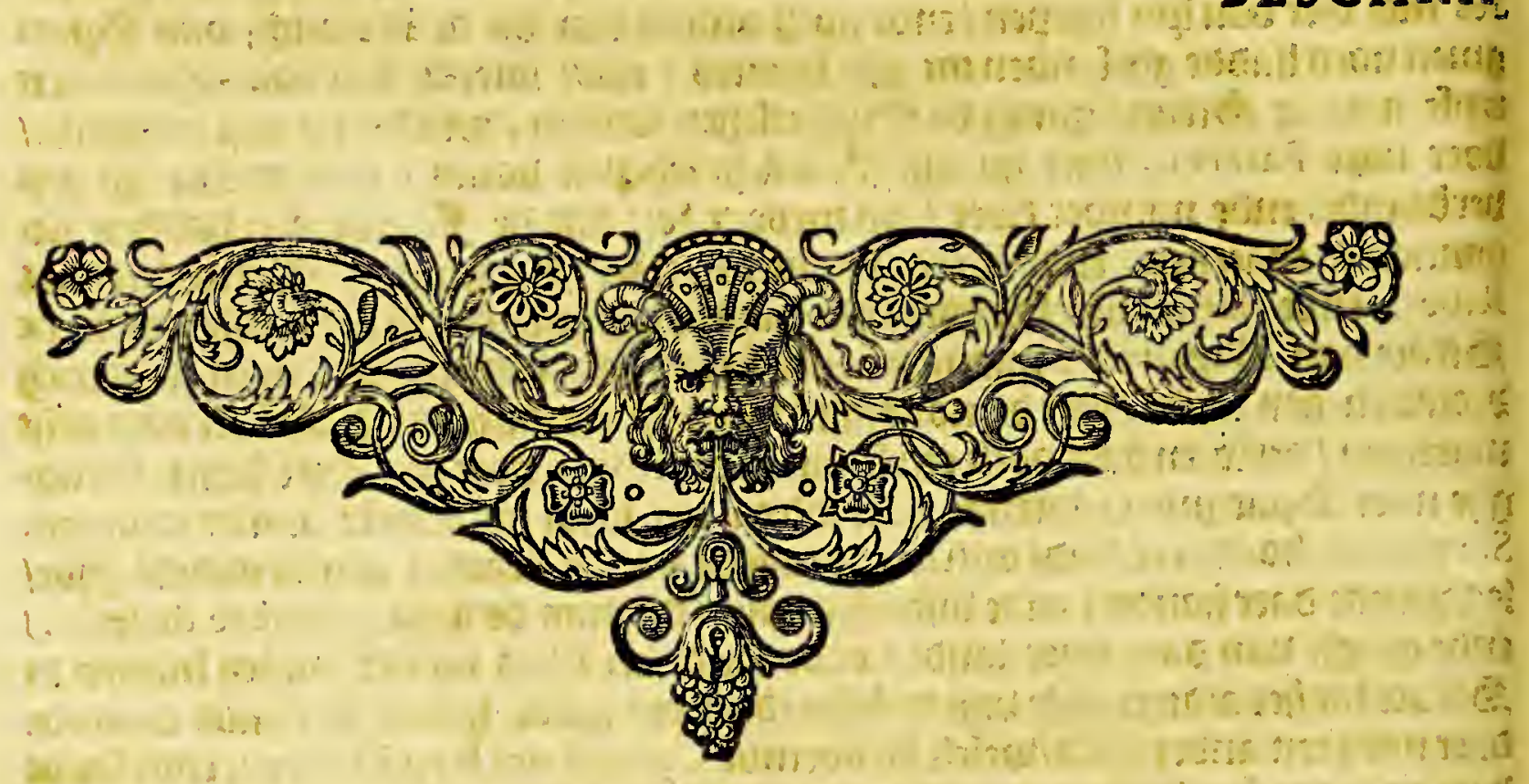


(APJCB) 


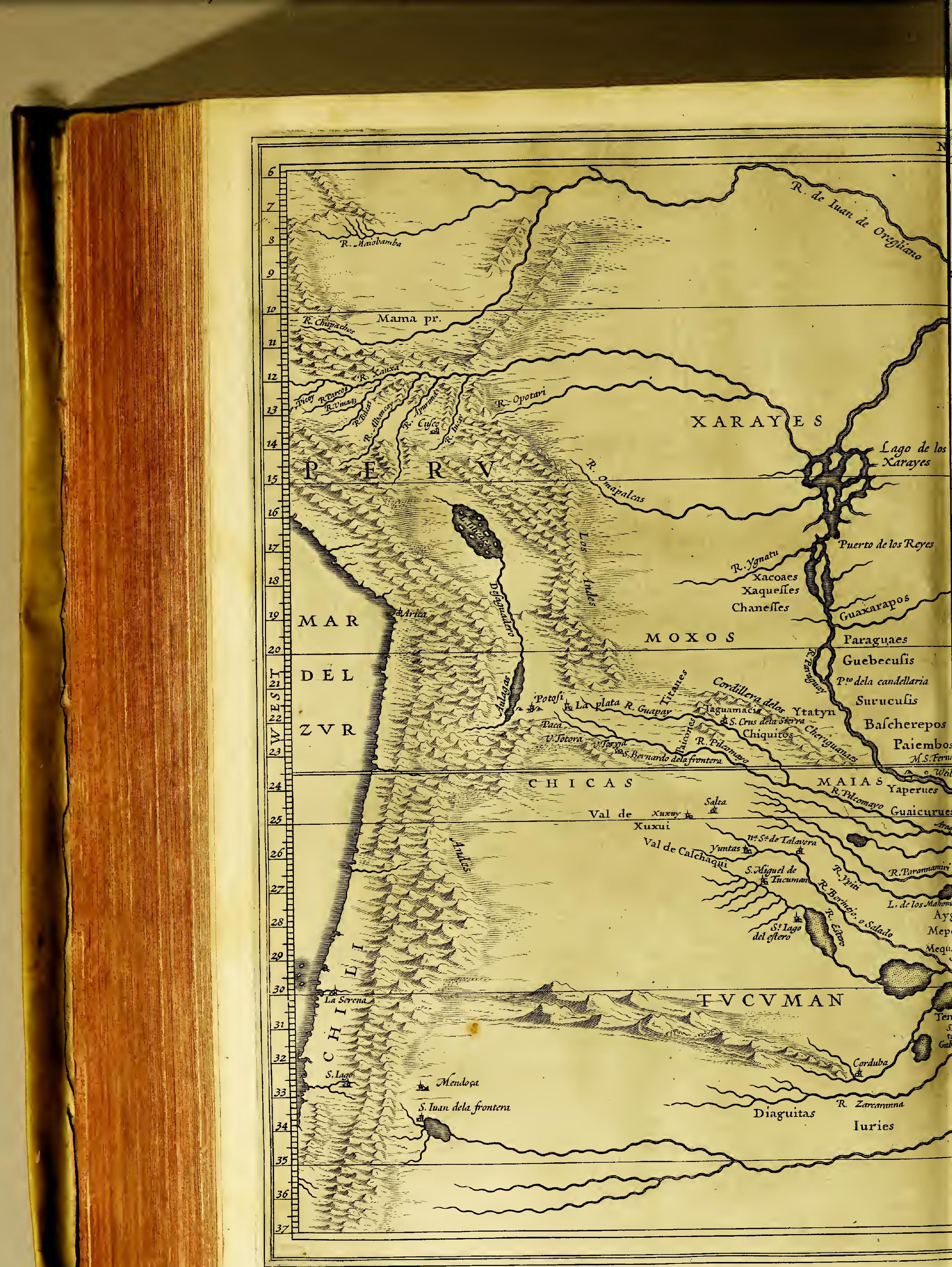




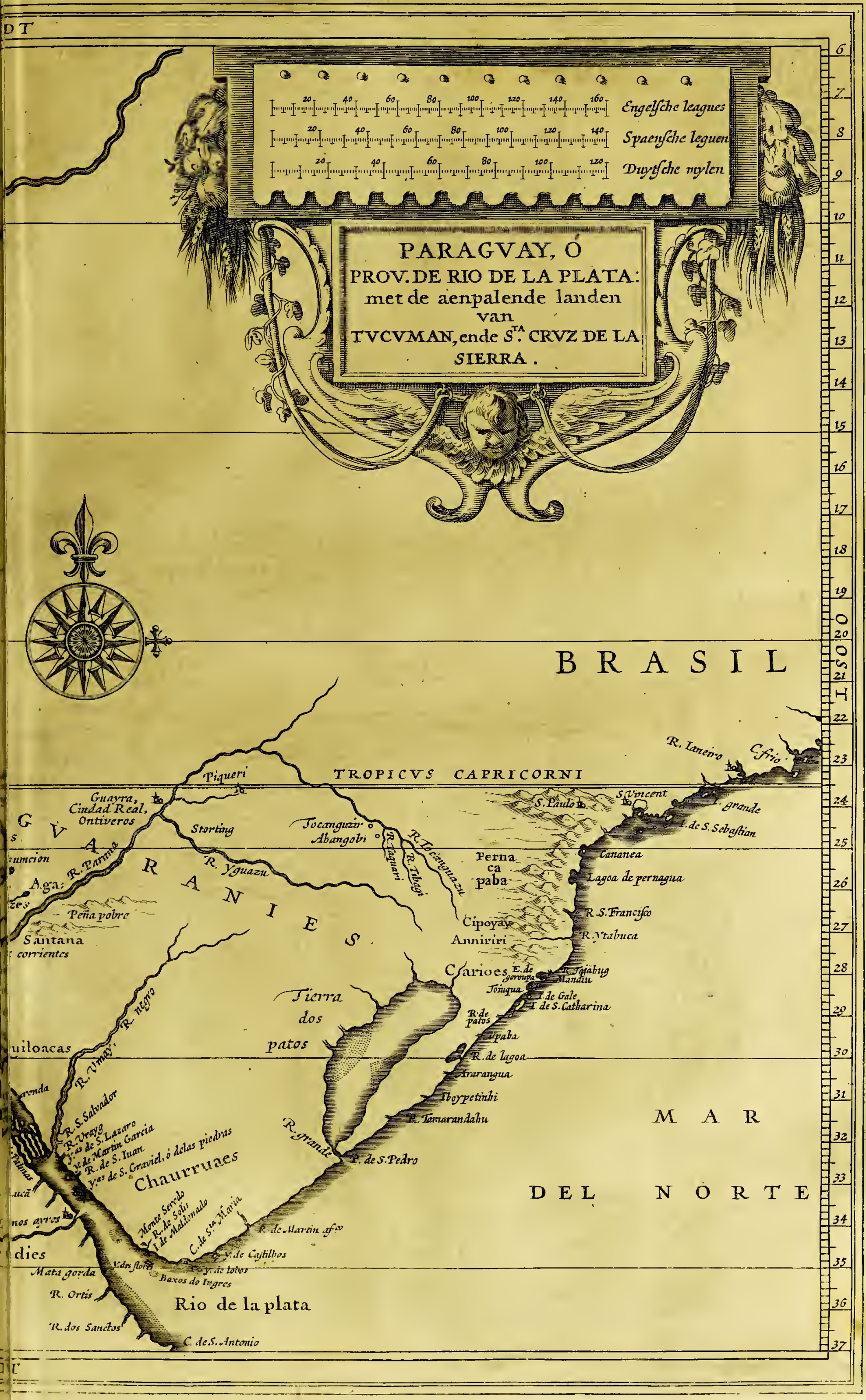




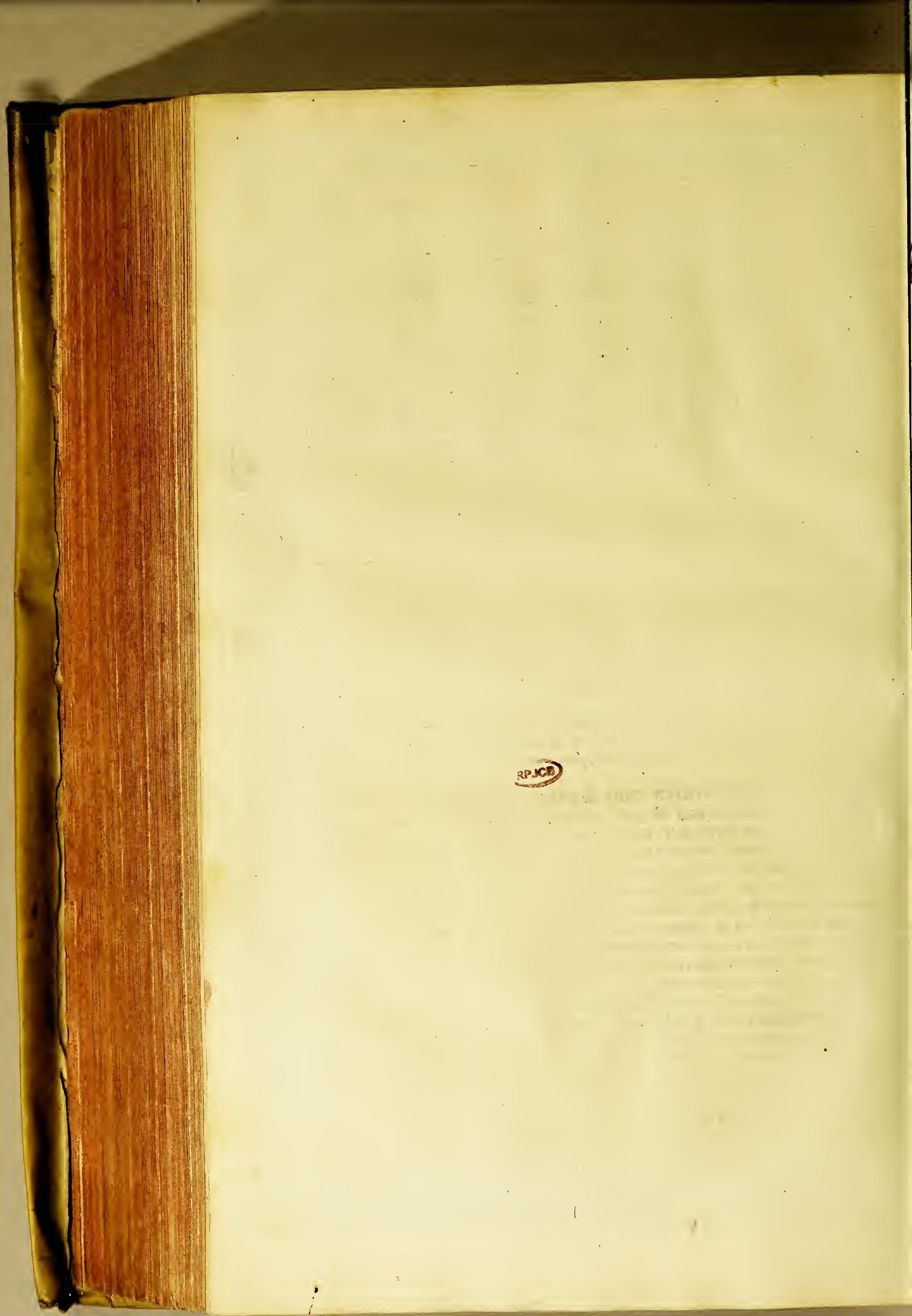


BES CHR IIV IN G HE

\section{đan \\ W E S T - I N D I E N. Net Detthtentite 25oeck. RIO DE LA PLATA.}

\section{Inlepuinghe.}

Olghens de verdeylinghe in 't voorgaende Boeck gemaeckt, foo badden 5. e. legghen by noorden de Strate van Magallanes, tot aen Rio de la Plata, alfoo de felpe ghemeynlïck onder Magallanica pvorden ghereeckent, ende oock daer toe bebooren, doch ons beefi bequaemer ghedocht, de befchrijpingbe van de felve Landen te bechten aen de befchrÿpinghe van Rio de la Plata, om dat $f y$ eenigh liche den anderen konnen gheven, ende de ordre van de Xavigatien vanionfe Landen naer die quartieren daer door te beter fal verfacen voorden.

\section{Wet exte Capittel.}

Befchrijvinghe van de $L$ anden ende Zee.kufte ghelegen tuffchen de Strate van $M A G A I I A N E S$ ende RIO DE I P P A T A, volgens de obfervatien van de Spaegniaerden.

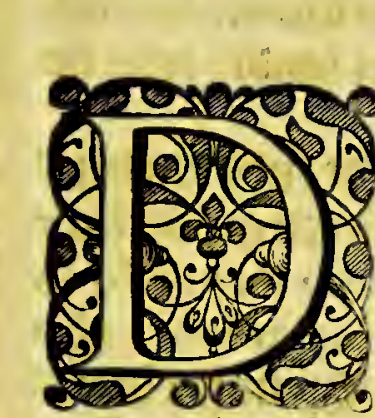

1) 2ovincien ende zanden glyeleghen tuatben oe Sirate tan Magallanes enve Rio de la Plata, weltk een groote freech is/te tweten/ ban de 36 graden ende een balf/tot of 52 graden ende een balf bp jupaen oe limie/jïn tot noch toe twep= nich bekent/alg alleen langhs de kufte ; ende de bekende plaetlen natien die de felve kufte beblon bebaeren ende be achegeben ban de berfebepden boozgaende oruze die wo in' be

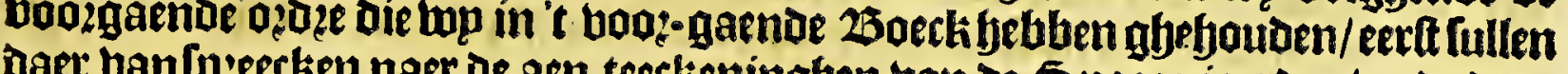
naer banfpreecken naer de aen teecheninghen ban be Spaegniaerden/ende daer

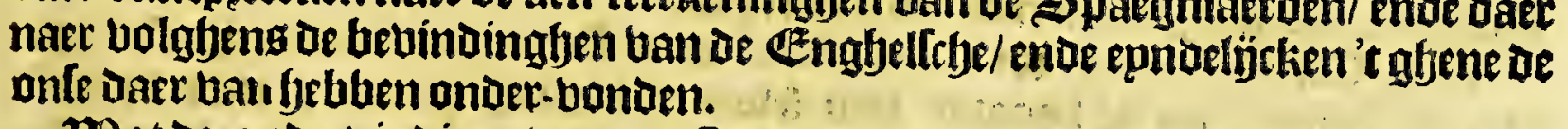

Pat of onderbindingeban de Spaegniaerben belanght/be felbe binoen wh

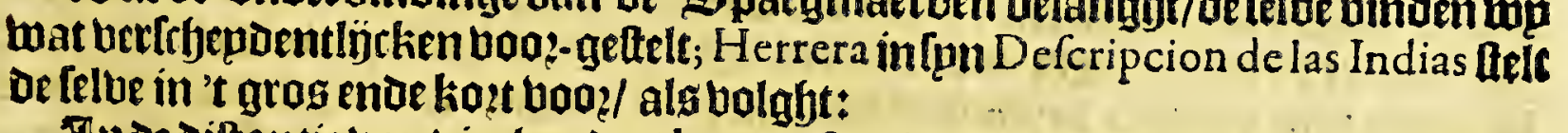

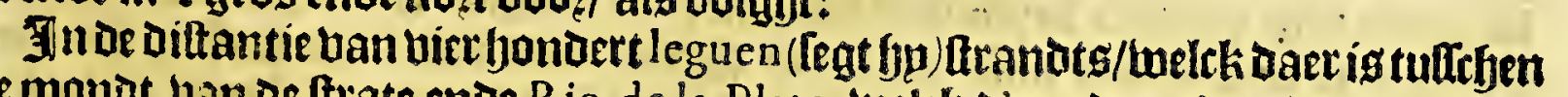
De monot ban de ftrate enoe Rio de la Plata, weick deen Doos d'anoer te reecke nen/arteckt noozot-oolt ente jupDt-meit; feeft men R io de S. Ilefonfo, twaelf leguen han Cabu de las Virgines; boots Rio Gallego, eñ Bahia de $S^{t}$ lago, 14 leg.

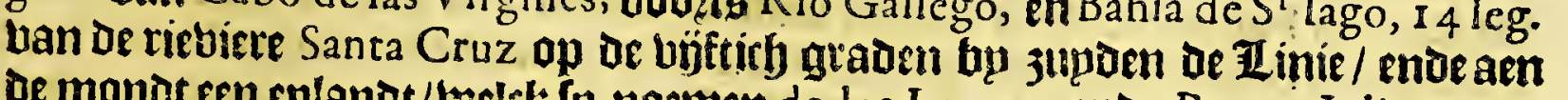
be monot efn eplandt/welth fu noemen de los Leones; ende Puerto Iulian op de त. $t$ booghte 


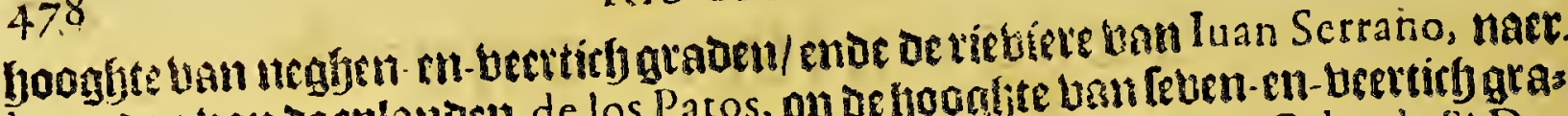

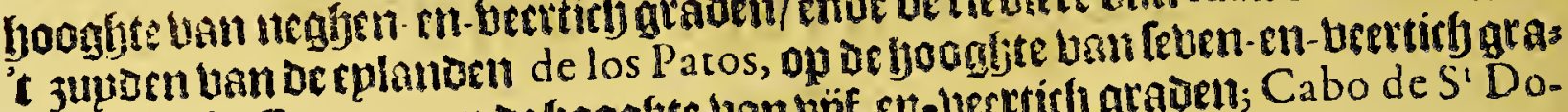

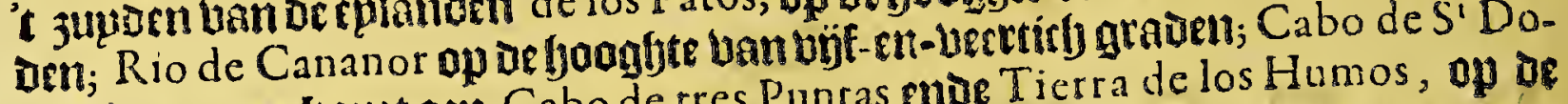
mingo efmen liomt aen Cabo de tres Puncas ende Tierra de los booglete ban 38 graden; bet punt $S^{\prime}$ Elena ende ban Santa van Rio de la Plata.

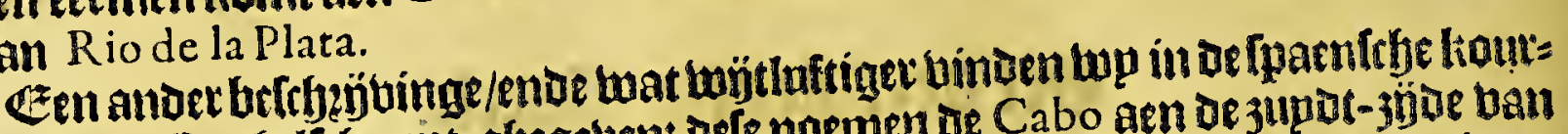
ten bp of Englellthe upt-ghegeven: Defe noemen de Cabo aen oe jupot-jüve bau De monot van Rio de la Plata, Cabo ds 2 Antonio, ende leggen Dat van ie liape Sc Antonio tot de Cabo de Arenas Gordas, 3 ijn 48 leguen, ende oe fiulte ftreckt

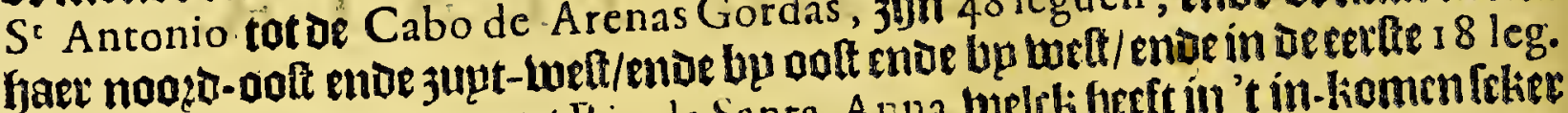

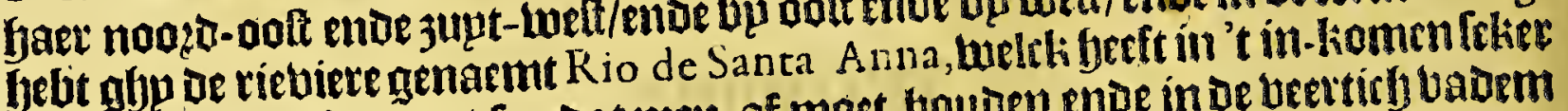
ondiepten ende Landen / foo dat men af moet bouben ende in de bettich vadem Laterg bljuen omleket te gaen. Ban de Cabo de Arenas Gordas tor De Cabo de St Andres 3 ijn een-en-Dertich leguen; ende ftretken nogędt-oolt ten oolten/ moe

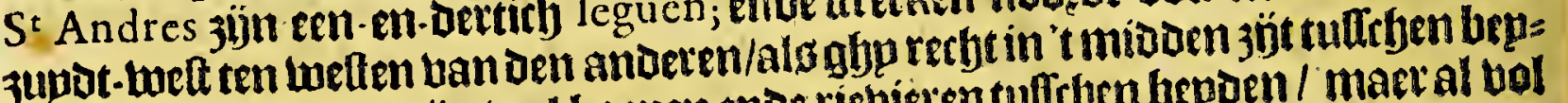

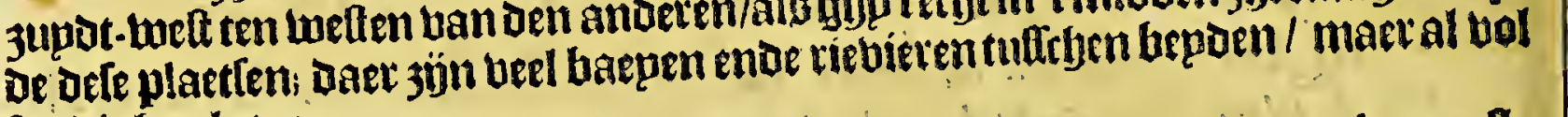
landigbe platen.

Ban de Cabo Sant Andres tot de baue Diefunoemen Anega da jön 30 leg. oottnoozot-oolt ende weft-jupot-welt; op oe hooghte ban ueetticy graden/eer min als meer. Bam Anegada tat Punta de Tierra Llana $3 \mathfrak{m} n 25$ leguen noozot-noozotoolt ende 3updt-3updt-wedt; dit punt leght op oe 4 I graden ende an yalf, Ban dit

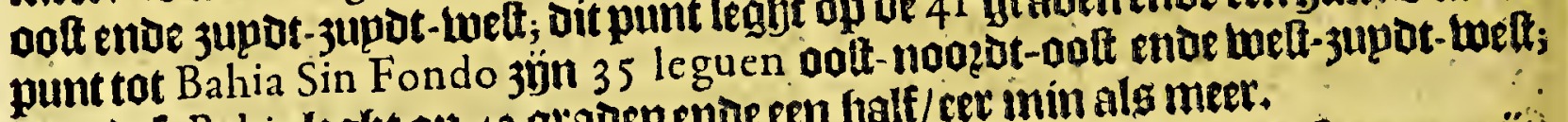
ende dele Bahia legft op 42 gladenenoe een ljalf/eer min als meer.

Ban Bahia Sin Fondo tot Cabo Redondo ende Puerto de los Leones, jón feveri-en-oertich leguen noozzt-noozot-ooft ende 3updt-3upot-1net / wepnich naev't noozoen enoe zupoen. Ban Rio de la Plata af tot fire toe / $\mathrm{kn}$ ig niet een goede hauen boos groote frhepen: De kulte ban oele plaetfe tot Puerto de Leones is luptuer / ende men magh bet lanot mel ghenaken; is leegb landt met witte kilifg. Puerto de Leones leght op viet-en-ueettich graden; die oertwaerts loopt most boo: ljem lien/ achter dat gp op oe booglje ban wat meet als dep-en-beertich graden koint / want daer legghen leer klepune rud [en dirft bu bet lanot / enoe bp noozen oefe haben.

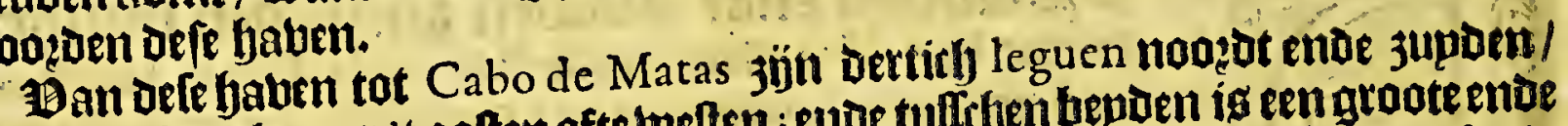

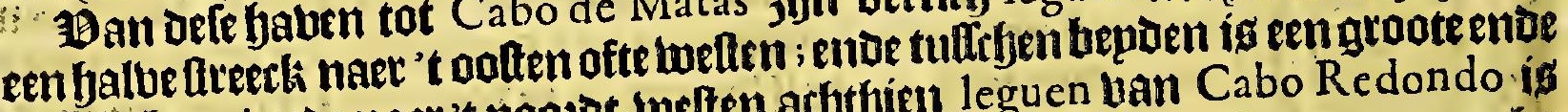
langhe bape/ enoe naer't nowzot-welten arhtyien leguen ban Cabo Redondo is en riebier / ftreckende ooftende welt/welck fp noemen Rio de Cafo in het water

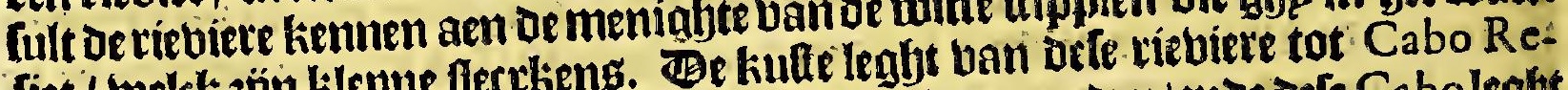
fiet / welck 3 jom kilepue tleckteng. dondo noogzt-Left ten noozerenchoe

- Ban Cabo Redondo tot Cabo Blancombe Barrancas Blancas jün twete-tr.

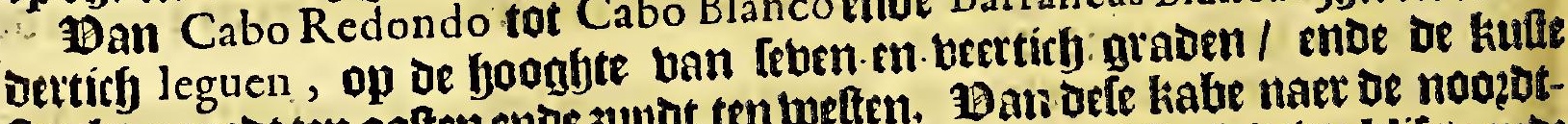
freckt noozot ten ooften ende 3 upot ten weften. Bat orfe habe naet oe noozot-

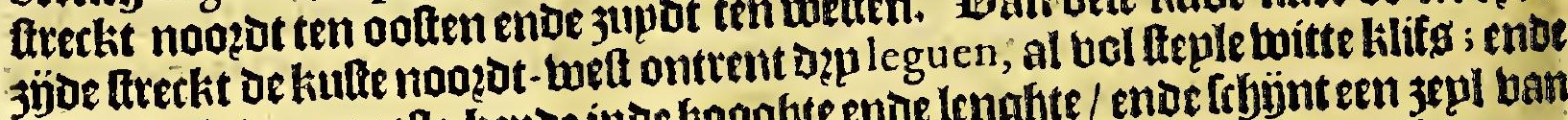

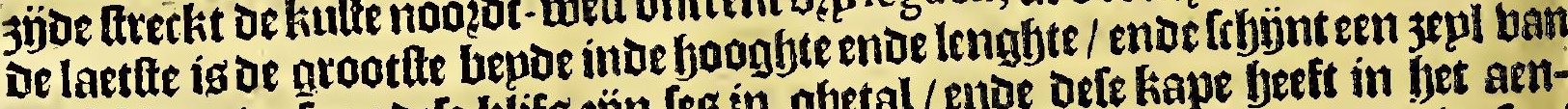

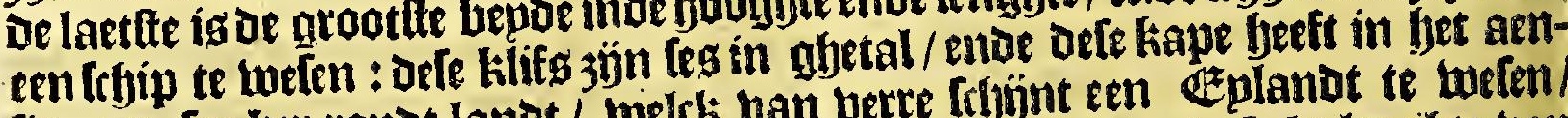

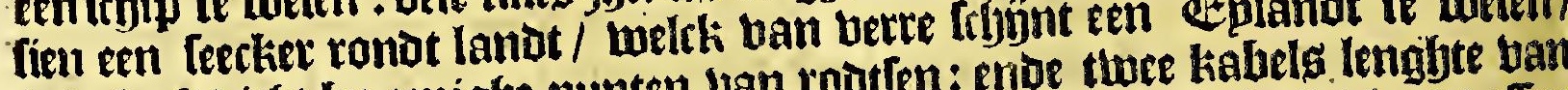

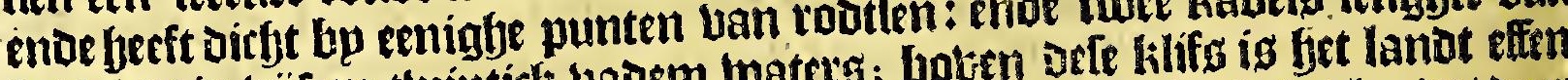

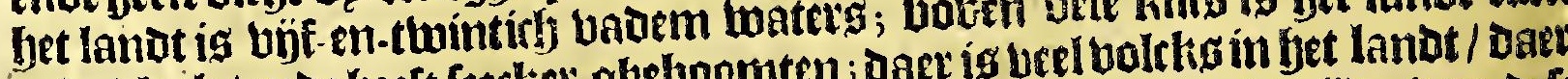

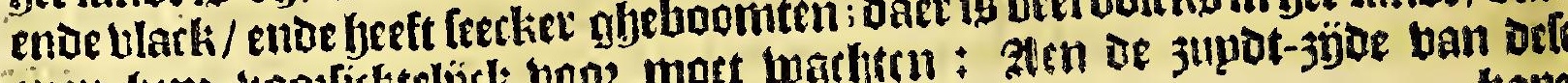

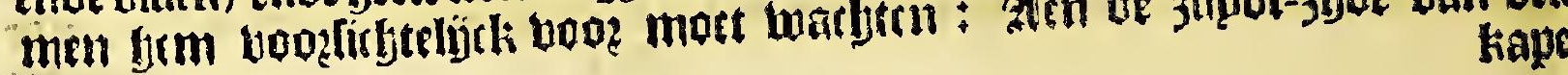


Het derthienfte Boeck.

kape ig een goede haben ende teede / ende een bape in het midoen. (be bopagie ban Magallanes felt biet ontrent een fraepe bape / mal in fet in-komen/ente d.2.1.

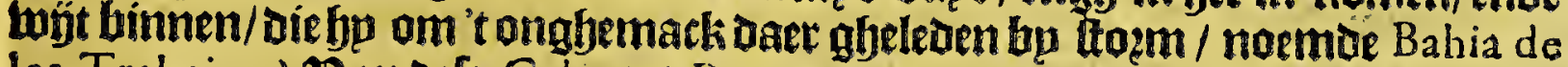
los Trabaios.) Ban defe Cabo tot Puerto de San Iulian ún feben-en-Dertityle. guen op de booghte ban neglyen-en-beettich graden. Be kulte legfje noopt ten

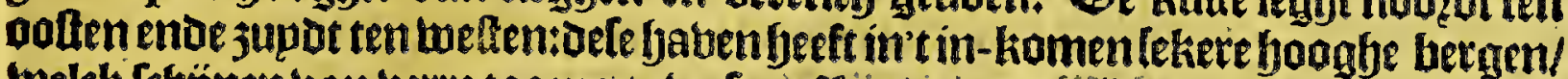

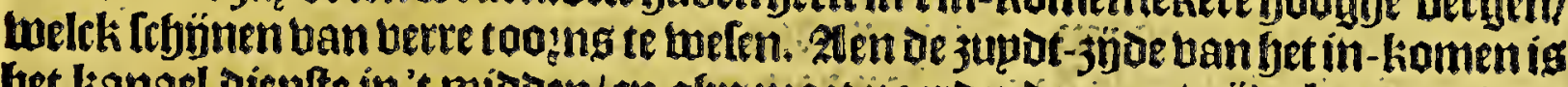

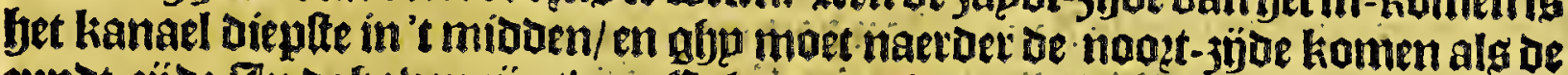

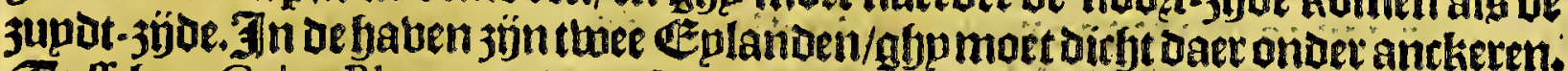
Cultehen Cabo Blanco ende dele haveri legghent de Geplanden ban Afcenfion, buelck 3 ïn arfjt. Magallanes oberwinterte in de baben ban San Iulian; enoe dede erecutie obet eenigbe gemuptineerde : enoe bevont die op de fooghte ban ne= d.2.1.9. gen-en-beeticfgradenenfeben-en-beertichminuten.) Ban Defe habentot Morro cap.ra.

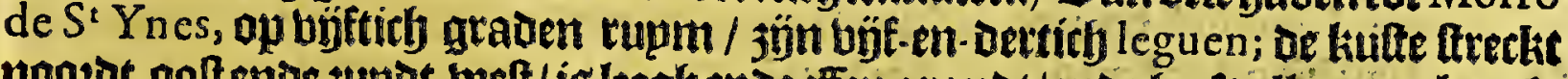

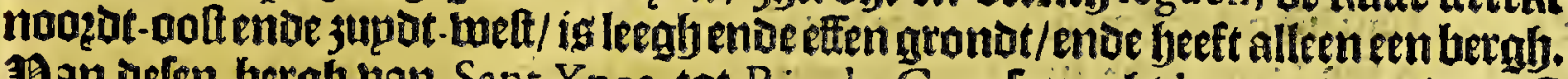

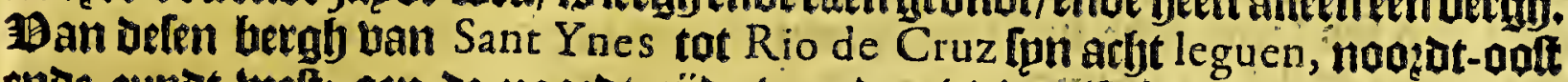
ende jupdt-weft; aen oe noazot-3joe ban de riebiere if leer joogh lanot / ent op oen top itt effen / twee leguen beede / noopt en jupdt / enoe infet Dalen aen

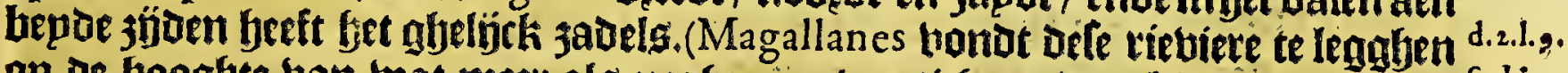

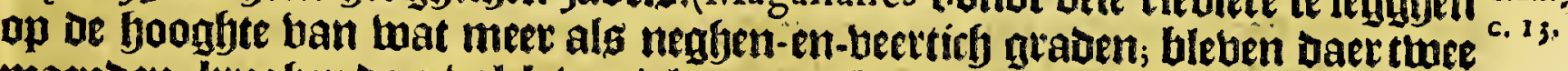
maenden; liteglyen daer bolck ban't landt aen boozot/ Daer ban be klepnte lan=

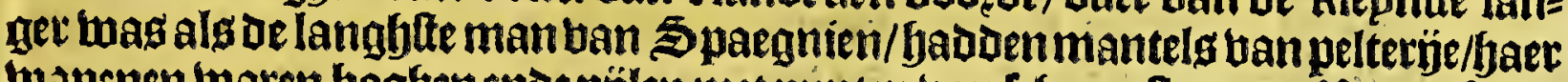
wapenen waren bogfjen ende pólen met punten ban féferpe teenen.)19andefe ric=

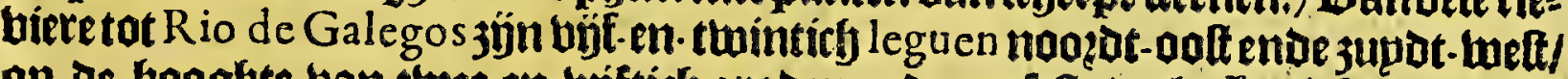
op de boogfte ban twee-en-býftich graden ende eenlefte deel. Heeft leker boogl landt/en 't hooghfte is effen landt / en aen't noozot-oolten is Daer ern pyjcke op met feker twitte kliften/ ente op den topen nederwaerts ifl fwart; aen de boet ban't boogh landt naer't oolten beeft get ceket treden als een leete/eñ na de jee beeft bet een fryerp punt/ welck leght ban Defe hape bu naer een half móle. AR aer't 3 upoen ban bele kape ígen klepne bape/ welck is bet in-komen van dele riebiere de Galegos, bloept enoe eblet twaelf badem. Ban oefe riebier tot de ftrate freckt ie kulte noozot-noozot-1welt ende 3upot-3upot-oolt / adjt leguen tot Cabo de las Virgines, welck is de monot wan de ftrate.

\section{Het therde Capittel. \\ Befchrijvinghe van't voorfchreven Landt, ghelijck'telve by de Engheliche is bevonden.}

$S$ Ir Francis Draeck Die De eerfte is ghelueelt van fpn natie/de tuelcke bele quars tieren heeft beuaren ende beforbt / beeft wel op defe kulte aen gheweet / botb

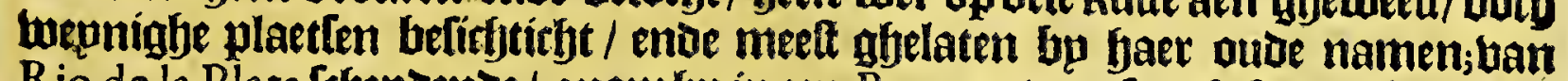
Rio de la Plata frefepdende / quam by in een Baye ontrent feg oft fetuen leguen by 3upden de boozlepde ríebiet onder eell kape die bp noembe Cape loye, ende daet naet thaelf legu en botber in een ander bape op 36 graden 20 minuten bp 3 upden de linie / Daerfe een bequamen baben bonden / en feploen een rievier op tot datfe maer dę badem luater's en bonden: ban baer bookt-barende en konden gljeen bequame haluen binden booz de frhepen; ende antkerden op de booghoe van Defpen-beertich graden/ende noemben die plaetfe Cape de Hope, ende voeren daet in een bape die redelijcken goedt was: [agen daet eenigh bolck met betwelcke[p oork bandeloen; waren fraepende ftertli ban lichaem/rap te baet/endeffbenen feer actif

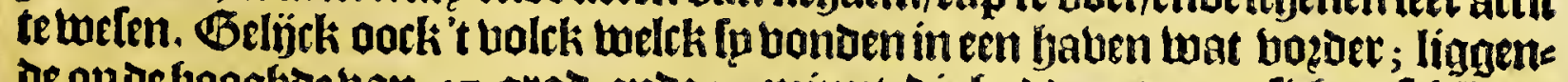

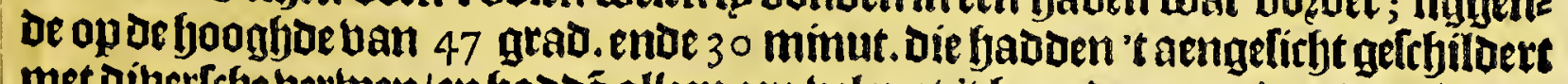
met diberlebe bertuen/en jad dé alleen een bel met 't hap? daet aen/om de midoelt.

$$
\text { C } 2 \text { Bif }
$$




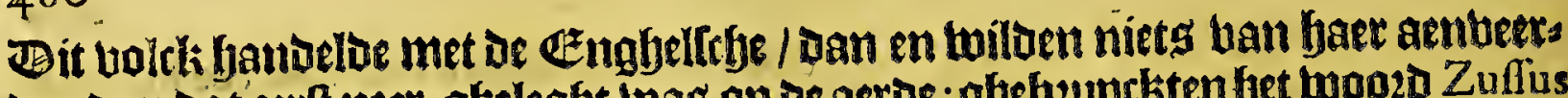

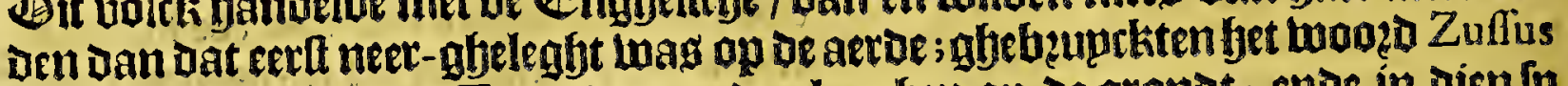
uno manghelen / ende Toytt boo? neser-legghen op oe grond ; ende in dien le

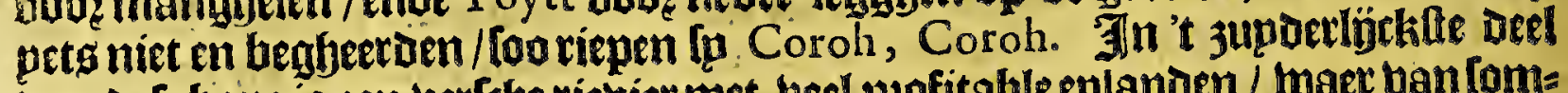
uan ofle bape ig een berfche rievier met beel profitable eplanoen / waer van [om: mighe tonouer veel rabben bebben / anders jün ober-goten met menichte ban bo: abelen ban allerlep looeten. Sp noemien ofle bape om de menichte ban robben Die fu daer tuonden/Seale Baye. Ban daer quamenfy aen Port Sant Iulian, op of hooghde ban 49 graden 3 minuten; oe E $\mathbb{E}^{z}$ gyellthe ghetupghen dat Magallanes niet al beozogen was dit bolck reulen te naemen/ ooo? Dienfe deur-gaeng beel lans ger/grober ende ftercker fon ban leden alg de glemepne fopte ban menleyen; Dorth niet loo oft men uinot Telfa in Enghelande die alfo langhjön als eenine ban dete; ende loo boorts in de ltrate.

Thomas Candifch Doende de Celloe bopagie enighen tijot Daet naer/quam aen

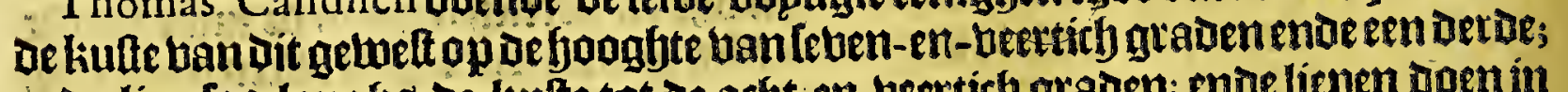
ende liep loo langhs de kulte tot de acht-en-beetich graden: ende liepen doen in cen hauen heick fo noemiden Port Defire, in de welcke een Eplanot ofte twet wag / Daer menighte ban robben op was/enoe bogbelen op een ander $\mathbb{E}^{z}$ plandt.

Bele Robben jỉn wonder groot ende monftreus ban ghedaente/ende twat

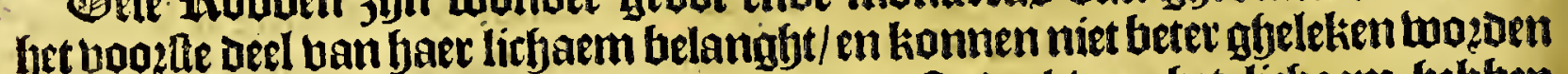
Jan bu leeuluen; yaer booft / neck / ende boofte deel ban bet lirfaem bebben langh fjap; baet pooten jün als binmen / eñe niet onghelÿck een mentchen banda / [u beopen alle maenden/ende boeden fare jonghen met melck/balende niet te min al haer boetlel upt de jee: De jonghen jon feer geet oum te eeten / ghes

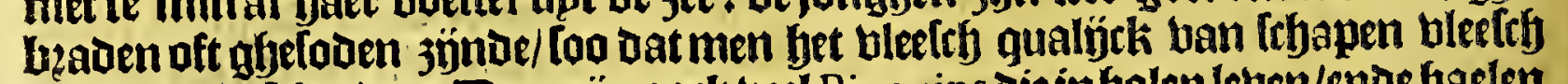

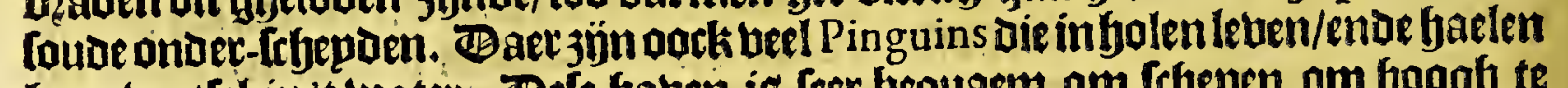
yaer boetlel in't water. Bele baten is leec bequaem om fryepen om boogh te benafien ende frboon te maken / want t bloept ende ebt Daer leer. Sp lagben

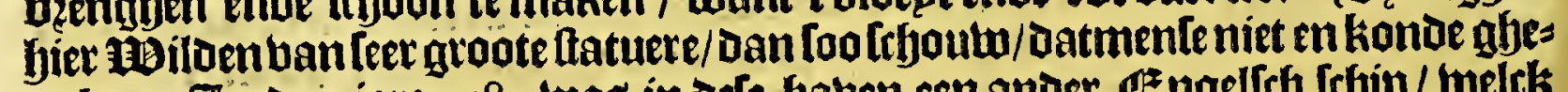
nalien. Thi den jare 1589 was ín Dele baben een ander E bonot daer thee klepne fpeinghen ban berfey water op 't nopgat- wett deel ban 't landt. Op de fjooghte ban acht-en-beertich gradenende een balf lept een klippe binffmijlen van't landt/miet ongheliftk Edifto on bp oe hauen ban Plimmouth. Op be fooghte van neghen-en-beertich gradenendeeen yalf iseen kileun plat Et planot

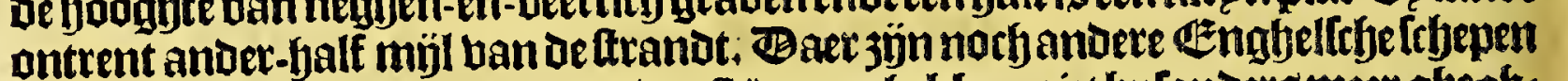
naer der bandt in bat quartier getweeft/Danen beboen nietbplonders meer gheobs lerbert.

Thomas Fuller diemet Candifch was in [pneetfte bopagie/ getupht dat Porto Defire boomoemt/leglyt op 47 graden ende 50 minuten/oft oock op 48 graden; ende dat daet aen de noo zed- jojoe een rif leafjt ban klippen ontrent een legue ban Get ftranot:enoe aen de nogt-jyjoe ban De mont ban de haven twee hlippen die met

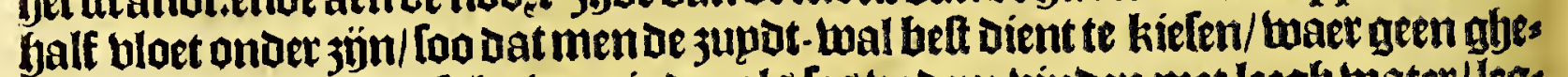
baer en is; ende men fal niet minder als leg badem binden met leegf water/legs

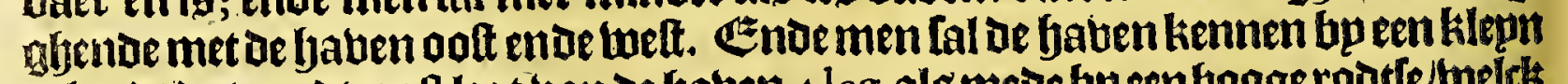

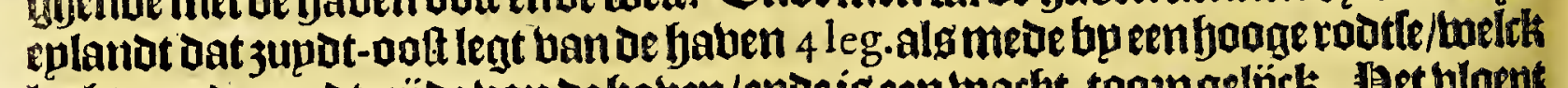

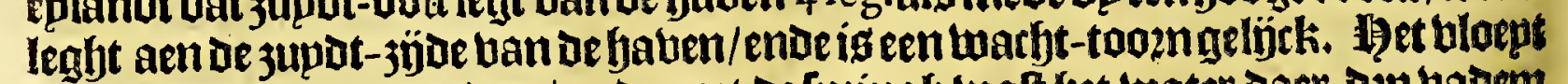

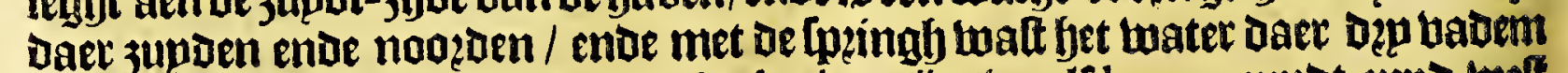
ende een half: taan Porto Defire tot Seales bay 3 jon twaelf leguen juptot-jupd--me ende ozp leguen merr naer't 3 upden igheel leegh landt; ende teben leguen ban Seales bay, op de fjoongte ban actit-en-beetich graden ende treettich minuten/ bet landot ftreckende jupdt-welt ten jupden/fult ghp een klippe fien büf leguen ban tranot:eñ op de fjooghte van negen-en-beettich guadenende een balf fulop een plat

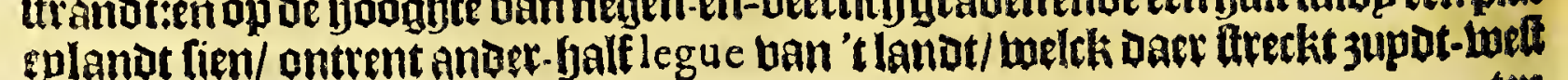


Het derthienfte Boeck.

ten 3upden/ento ban hier tot op de fooghte ban bjiftich araden fireckt flet lanot 3upot ten meften/ enis hoogd landr. Ban de 50 grad. tot 50 graden ende 40 minu= ten/ Itreckt bet landt jupd - wett ten jupDen; enoe ban daer tot de 52 graden en

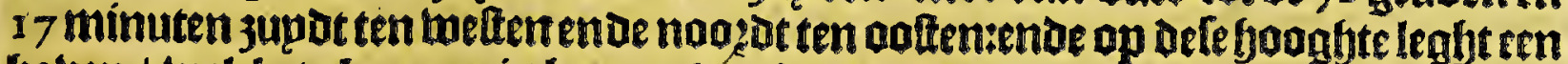
baben / weick te kennen is by een lanck rif/welck legft aen oe jupot-jnoe ban be baben; ban bele baben tot Cap loy ap twee-en-bjftich graden enoe beertiry

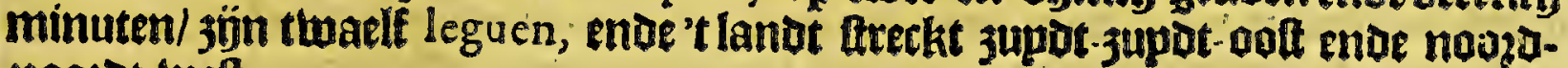
noozot-melt.

\section{Wet Deride Capittel.}

De befchrijvinghe van't felve landt by Suyden Rio DE LA PL ATA, naer de bevindinghe van onfe Nederlanders.

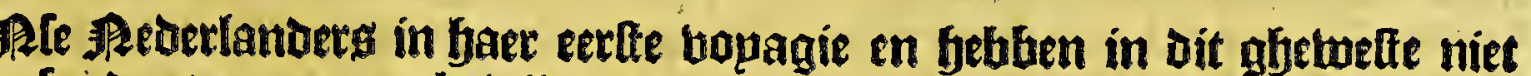
bplondergaen-gemerckt/alleen Dat Sebalde de Weertin't tweder-keeten upt oe trate/ Dep efplandekens getwaer is gewozoen/ die in oe kaette bon? defenniet belient en jojn getweelt / ende derbaluen Sebalds Ezplanden jijn ghenaemt; lagben

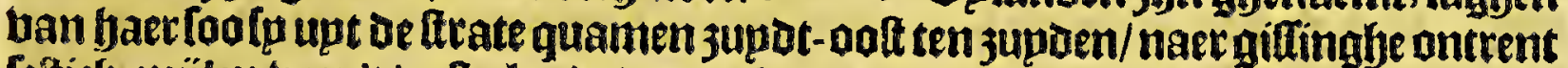

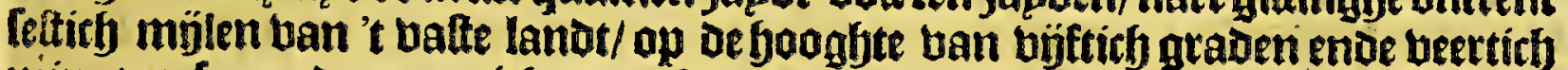
minuten; (agen Daer menicfte ban Pinguins op/ dan bp gbebeck tan een boot ofte. fegupte enkondenfp daer niet aen lanotgheraken. Olivier van Noort in fun repfe

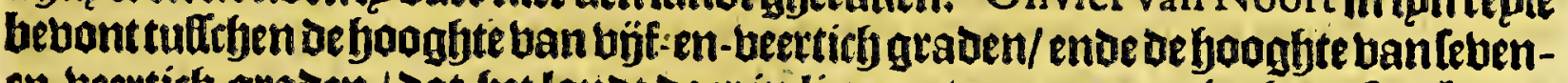
en-beettich graden / Dat bet landt daet in liep met een groaten in-bam treckende onft-zuport-bolf ende tweft-noogd- welt; tis een feer leegf effen lande / witachtigf

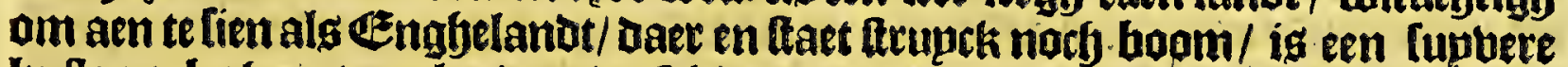
kufte om bpheente jeplen/met berlrbęuen boecken ende in-fjammien. Quamen taer naer in Porto Defire; Dan vonden Daer gfeen bolck/maer wel graben Daes Ip faer Dooden in leggben / welck ttonden op boogbe beutelen banklippen / alwaer fp ueel fleenen op bet graf leggen/Die al root ghe berbet 3 inn/ bebbenoe baet graben met eenigh cietaet befteecken / alg pjilen/ beeten/ ende andere beem= Dirbeden. Sp lagben daet fommigfje bilbe buffel'sende Garten/met beel ftrupsboghelen ; welckers eperen lp toel tot neghenthien toe / in eeneri net bonden.

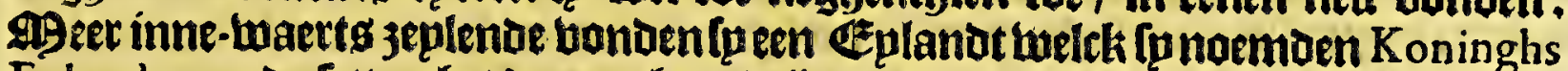
Eylande, ende [etten bet baer athter / jünoe een goede klep-gronot; ende Daes

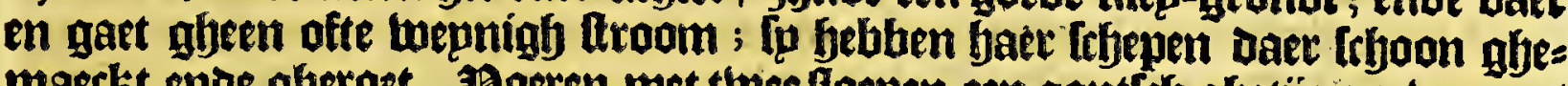

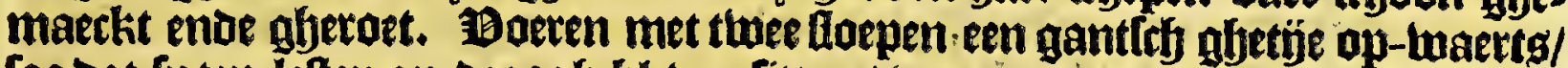

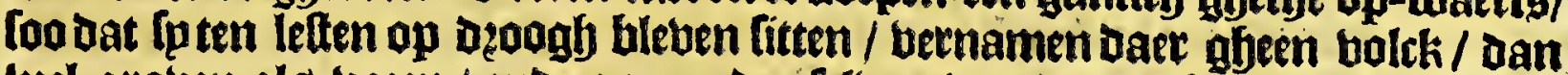
wel graben als boen / ente op een der feluer twee groote faben plets/twelck Spaenfch plet fcheente jön: Sagfen daer naer aen oe noozot-jóbebolck/boeten oaer naer tor/ende detwijl [p daet komende abeen bolcken bonden / tracken [p te landt-waet in/ midoeler-tjot bierden de loepen ban de twiloen belpzonghen/ ende dzep ban't bolck boot ghedlaghen/endecen ghequetit. Be wiloen waren ons trent oerticf) fterck/ Leer groot van gheltalte/ bebbende lanck bapg/ ende't aengbes

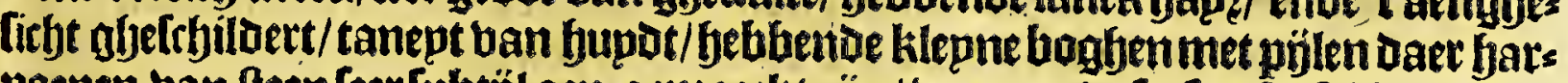

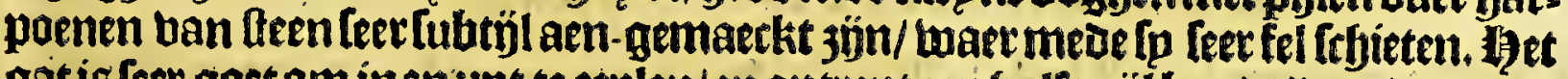
nat is feer goet om inen upt te 3 eplen/en ontrent een falfmïl bzeedt/ aan boo? aen bp-naer in't mitoen ban't baer-water liggen twee blinoe klipperi/ oie men met boogh water niet fien en kan. alen de jupot-sjobe leggben oock eenige ఏzoogh: ten die zupdt-ooft in zee Arecken. Sp bonden Porto Defire op de booghte wan leven-en-beettirfy graden min bijf minuten. Willem Cornelif Schouten quam mede in Porto Defire, welck hp ttelt op feven-en-beettirh graden thoe veettirh minuten: Bmte mijoen de klippen baer Olivier ban ffjeifft/Die dooz

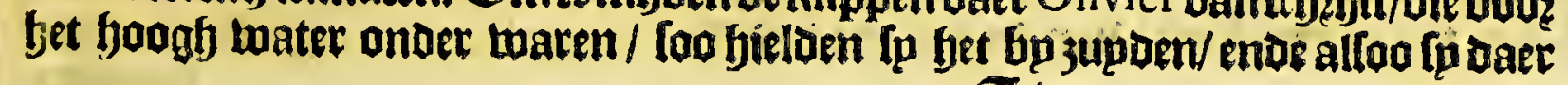

$$
\text { It } 3 \text { eenigbe }
$$


482

Rio de la Plata.

eeniglye klippen laglyen/boeren daer bp jupben bouen/ enbe bp jupben bet rectjte

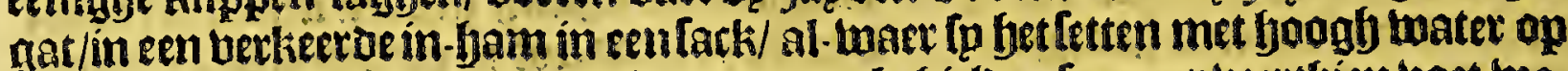
bije-thalf vaiem; dan met lecgh water en belieloenfo maer beetthien boet wa=

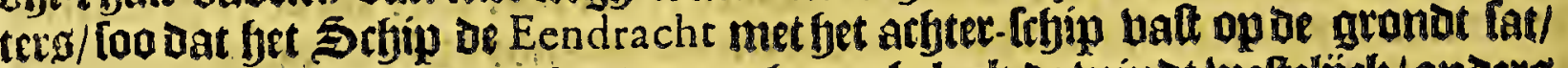

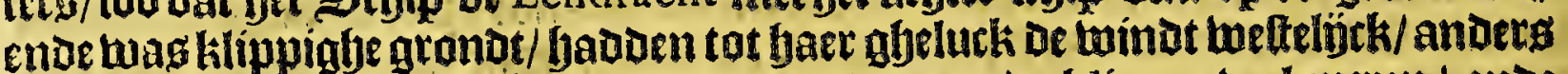
fajoen gropt perńckel gbeloppen: bonoen Daex op de klippen beel eperen/ ende binglen fefjoone molelen ente bifch / onoer andere fpieringen ban leffien oup: menlanck/Daec ober [p bet De Spieringh-baye noemoen. Ouamen daet naet bp 't Koninghs Eylandr, welck bp-naerbeel met eueren beoerkt was. Jonoen in't

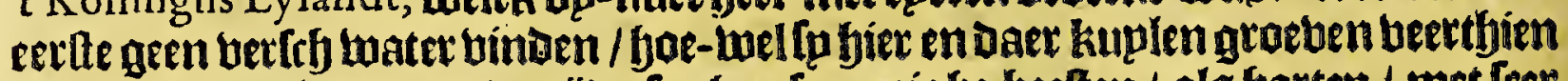

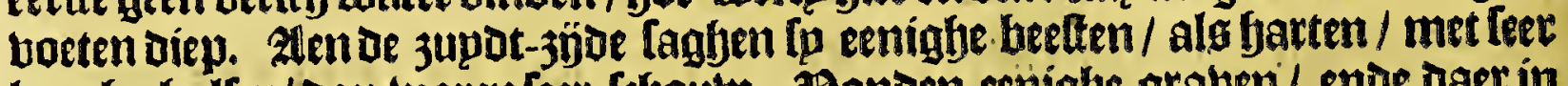
langhe halfen/Dan baren feet Ifboulw. Bonoen eenighe graben/ ende daer in abebeenten banmenichen thel thien oft elf boeten langh. Jaer naet bondente aen

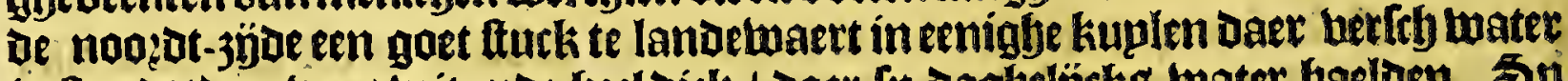

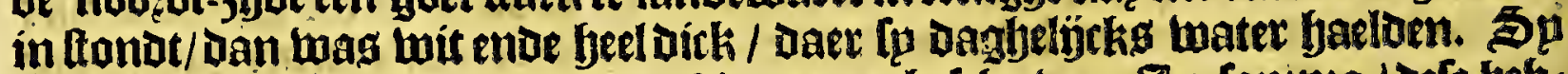

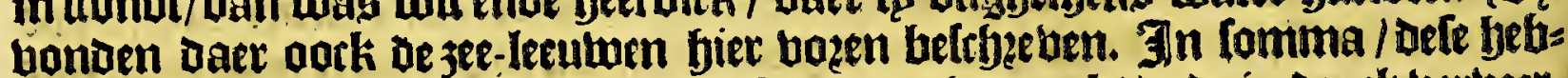
ben een perfecte af-teeckenimghe ban defe baben ghemaeckt/ende in puck berber: Dicht. Gen Peoerlander die gebaren beeft met De twee bercken ban Lisbona om oe nieulu nfebonoen Straet te gaen belichtighen / ghetupght bu zupoen Porto Defire op of booghte ban feten-en-bertigh graden twee-en-biftich minuten/ge:

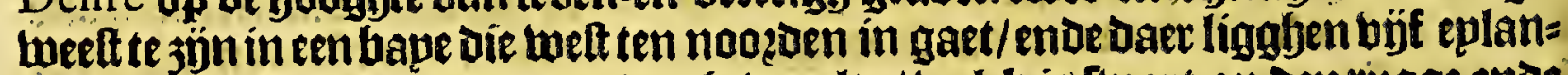

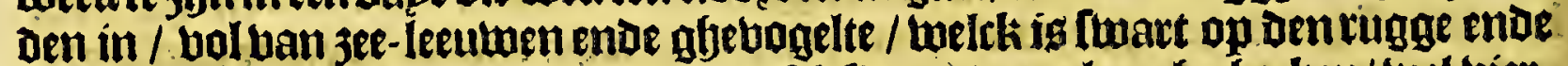

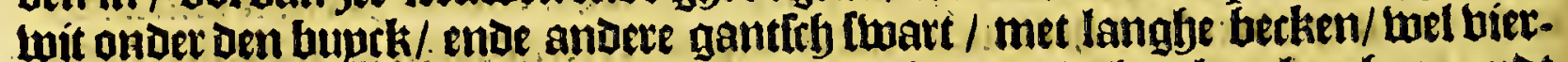
macl foo groot als rauen : de bape is büt enve bzedt / De boecken legggen jupot ten belten ende noozot ten oofen ban malkanderen/: Daer is goet ligghen op bij

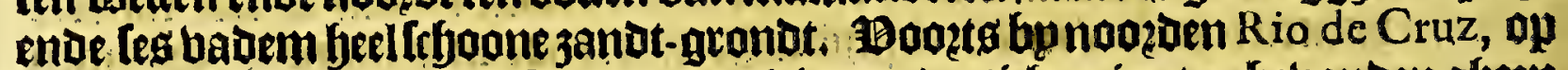
befooghto ban een-en-bjfticf graben bier-en-Dertich minuten bebonbengheen

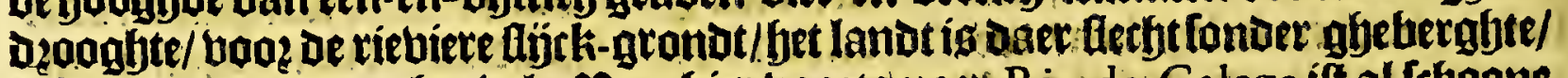
hiet en daermaer een beubel. Ban fier boots naer Rio de Galego ift al feboone.

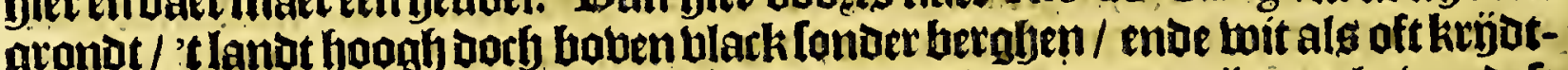
bergen waten; ende als gjp komt aen ben boeck die be noozot-jÿmaeckt ban Defe

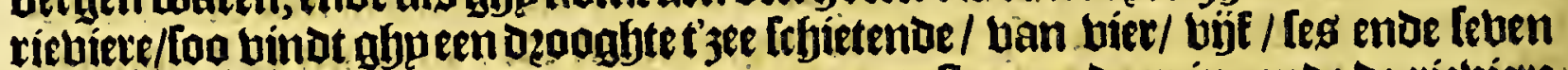

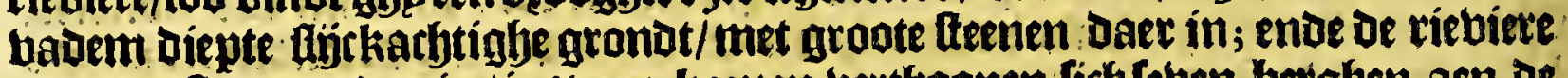
loopt welt ten 3upden in / in't aen-komen bertfoonen fich leben batghen aen de

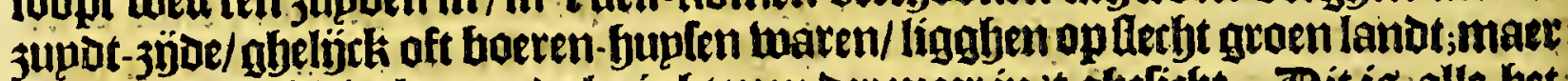

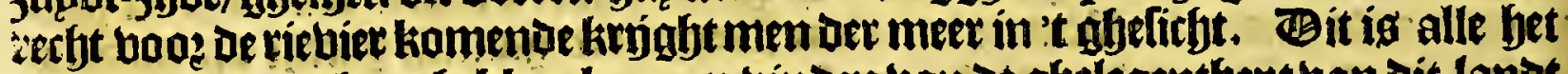
abene top tot noth toe febben kommen binden ban oe gfelegenthept ban dit lanos tullefien de frate ban Magallanes ende Rio de la Plata.

\section{RIO DE IA PLATA.}

Het tierde Capittel.

Generale befchrijvinghe van de gheleghentheden van de Provincien die onder RIO DE L A P I T A wordengherekent.

D E pzobincien Lan Rio de la Plata bebhen Garen naem ban de vermaetoe ries

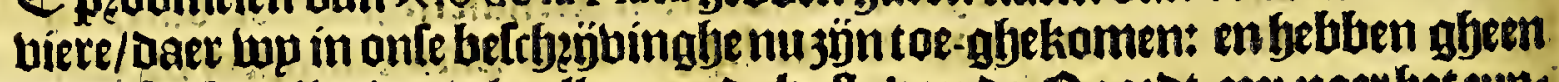

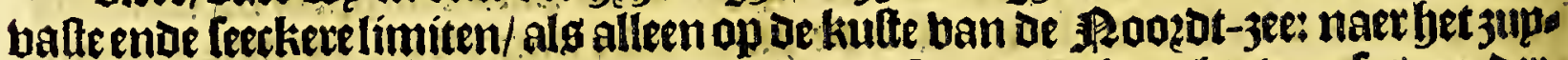

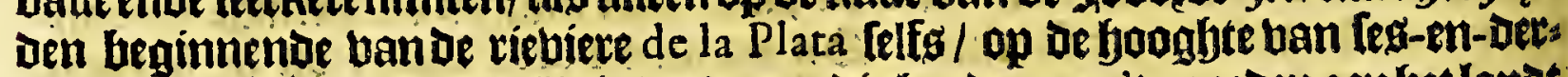

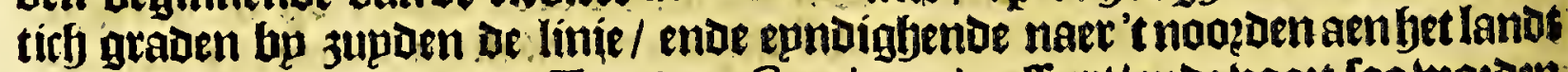
uan Brafil, ontrent daetaen Tropicus Capricorni paffert/ende boot foo wozden Ij aen de ooft-jöbe by de limie baen de landen de ktoone han Caftilien ente Leon toe-abeepgbent / ban de landen ban de kroone ban Portugael mede bet: frfjepont 
Her derthienfte Boeck.

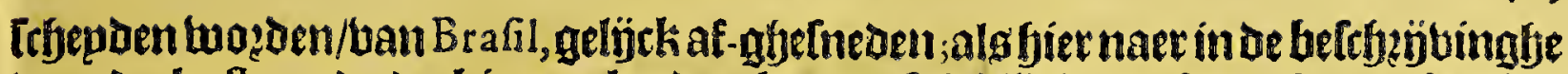

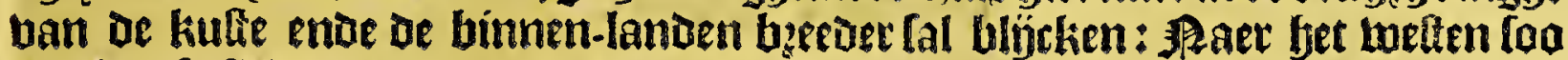
ftrecken [u [icbupt totaen de plobimtie van Tucuman, choe op anderequartieren tot aen $\mathrm{P}$ eru toe/ende de lanoen die nach ten deele niet belocht en jün/gheligck oock 3upden ende noozoen bimens landts fp baer wjot ende beedot unt-ftrectien fon:

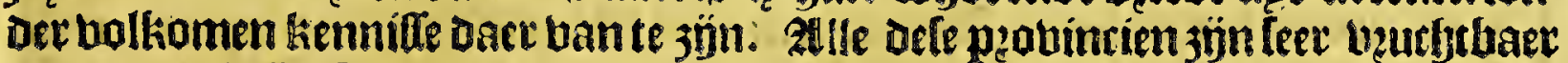

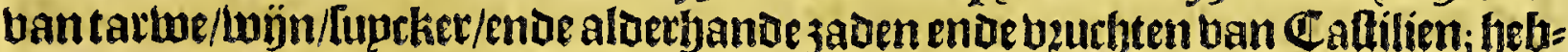
ben groote toepden booz alderfjande bee/ Die feerbermenichfuldotht 3 ïn/ende in= Conoerfepdot de peetden; (Lopes Vaz bethaelt oat de Spaegniaetden betlatende De plaetle ban Buenos Ayres; Daet lieten baer meeren enoe benghlten/ De welcke te weten dettich meeten ende leben benghfen / in be tijat ban beertich jaren loo vermenichbuldichoe/ bat bet landt twintich mülen int ronde/ ban de felbe gantfrh

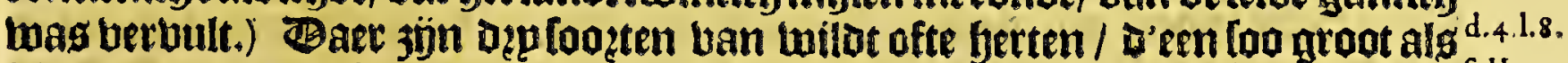
klepne koepen met feet aroote hoomen/welcke fjaer fjouden ín Demoeralien ende rieat-lanoen:andere wat grooter alg groote bocken/Die baer op be beloem onthou=

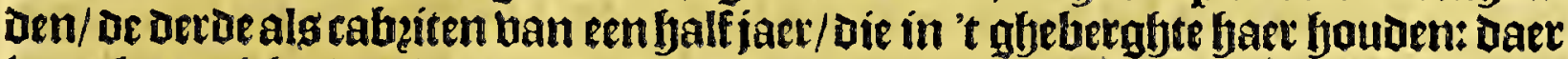
igoeck menichte ban depnen/beel twiloe bercheng met den nabel op oen rugghe/

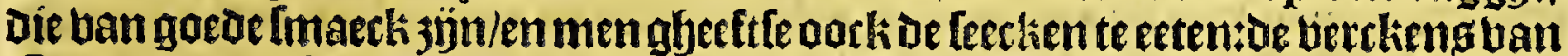
Spaegnien jünder aock feer vermenirbuuldirgt/en ballender feer groot: menbeeft Daet meet-katten met grodte fteetten/ende gebaert/ van be groote ban een menfey/

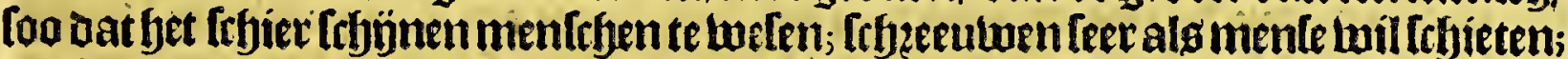
trecken De pjilen upt lyet lïf enoe wetpen die naet de ghene dielegelchoten bebben;

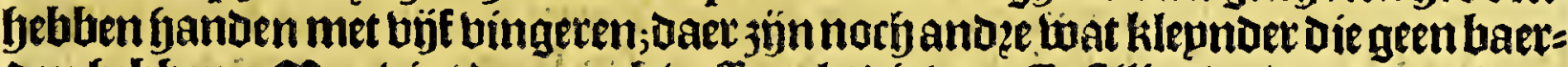
Den febben. Agen bint daeroock boften als die ban Caftilien/ende ander dieren foo groot als rabeiten ban twee maenden/Diefoo lilepnen mupltien febben bat fu niet meer algecn miete konnen ín faelen/en Doen qbeen quaet. 99en beeft baer

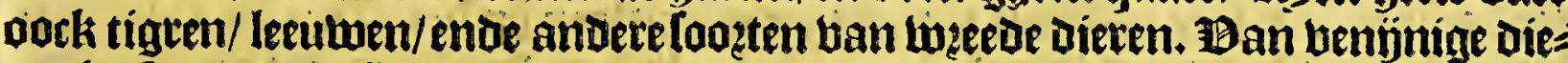
ren beeftmen daet flangen die vier vademen langb 3jón/oe welcke men beele harten met booener en al int löf binot/en boen andersigbeen quaet; ende diberlche Looten

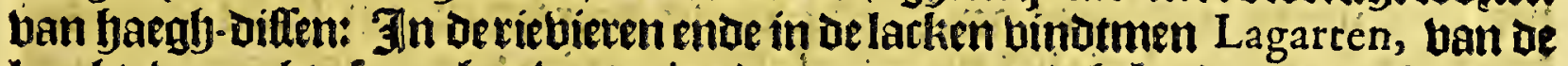
lengbte ban acht oft neghen boeten/en boan geen quart/ghebeaden enoe gbegeten/ jün vet en fmaeckelíck. Agen bindt baer ltameloeng / foa groot alsmidoel:

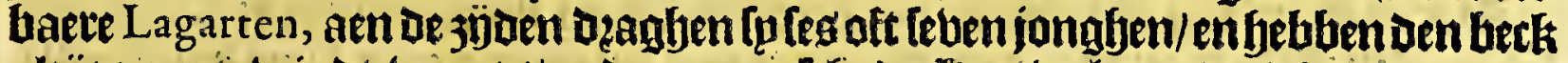

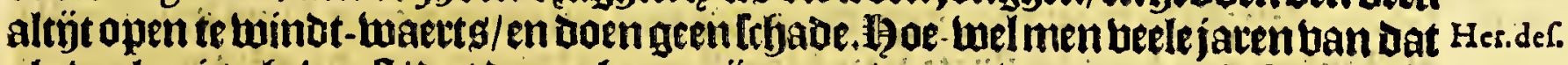
gbeboelen is ghetweelt/ bat daer gbeen mínen en waren ban goubt oft filber / foo beeftmen muleet goedo monlters daer van ontoeckt/als mede bankoper enoep[er/

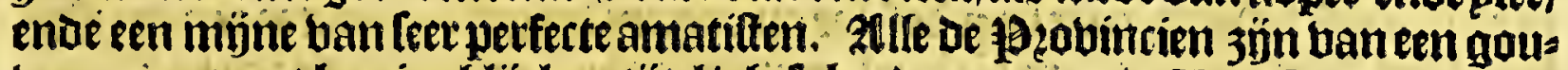

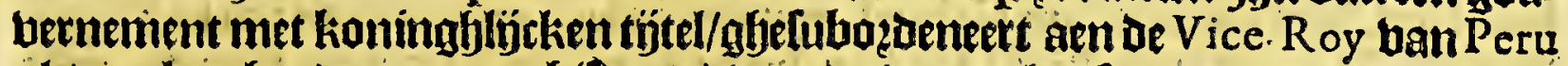
als aenlegafienot; met een hitbom/ daer de hoonplaetten ban oe Spaenniaer= Den onoer reloteeren/en groote menichte ban in-ghebozenen ban groote licha:

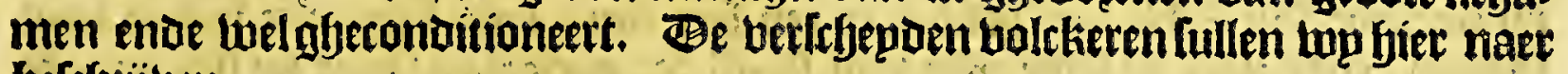
berriyüben.

- Bienaer aele riebiete boostpoedelijek begheert te baten/ ent magh niet ban de d.s.l.g.

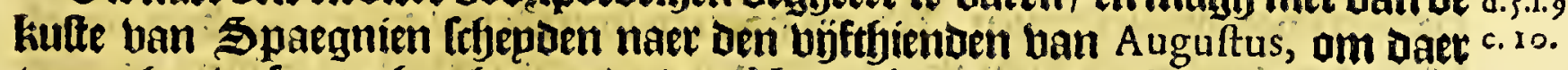
te moghen luelen tegfen fet epnoe ban November, twanneer't tomet is in dat lanot / ende de Brifas regneeren / welck 3 n̈n noozot ende noozot-bofte binaen; wantloofulater ban Spaegnien baren/ foo jün folecker aeriebiere niet te kon= nen beliomen boog Martio boogt-waerts / als manneer de Vendavalen maepen/ welck zún zupoen ende jupot-oolte twinoen / welck groote alteratie cauleeren in orle $3 \mathrm{ee} /$ loo dat men infulcken ghebal abenootfaetkt is te gaen betwinteren aen bet ezulantat Santa Catalina oft eloers. 
Wet búfoe Capittel.

Befchrijvinghe van de Rieviere I a PI A $\mathrm{x}$ A in het gros; met haer eerfte ontdeckinghe.

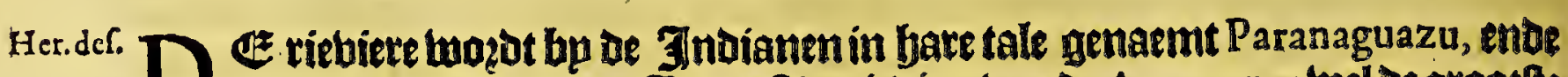

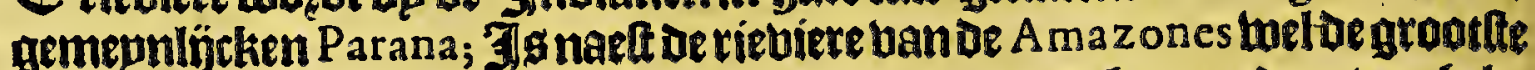
ban de weerelt; beeft baer monot aen oe noozot-3ee/ naer bet jupoen toe gheles

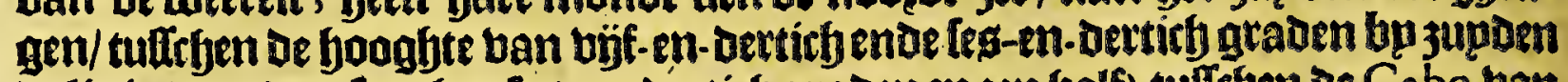

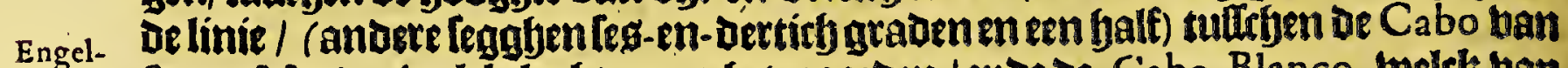
fche vo. Santa Maria, welck legbt naer bet noozoen/ende te Cabo Blanco, welck ban yagie. andere oock ghenaemt mogat Cabo de Sant Antonio; naet bet jupden ban d'een Cabo tot oe anuere 3 j̈n Dettirf Spaentrbe mülen; en leggen ban malkanoeren

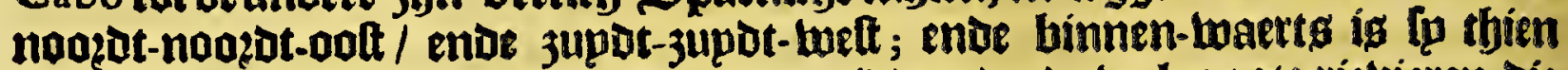
leguen beetot/met beel Gélanoenin bet mioden / ende beel araote rievieren die Dare in komen ban get oolten ende bet welten tot be baben de los Reyes toel welck is een groot lack welck lp noemen de los Xarays, toepnigh min als Dłp hondert leguen ban de monot ban oele riebiere; in welck lack beel rievieren

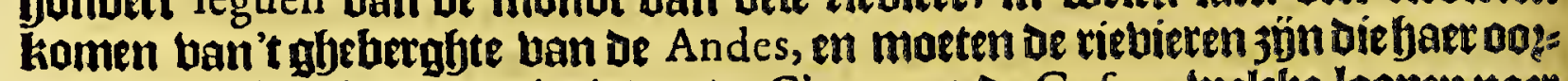
fpeongly bebben in de peobincie ban de Charcas ende Cufco, welcke loopen naet het noozoen; aen oe noozot-3ÿbe ban dit lark kamt een anoer riebiere / welrk

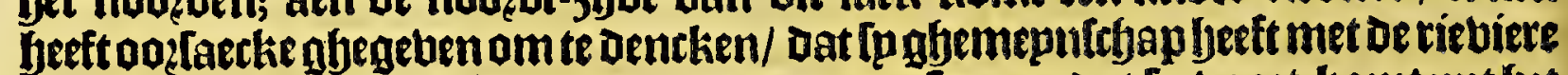
ban Sant luan de las Amazones; ende andere leggen dat fo boot-komt upt fiet lack ban El Dorado, melck bÿftbien dagfj-ceplen loube welen ban bat de los Xarayes; hot-wel Datter zijn ban Dat ghetuelen dat Daet gleen Dorado $\mathrm{mn}$ ig.

d.2.1.r. Bete riebiete die nu ghenaemt moęot Dooz-gaeng Rio de la Plata, was eerf cap.7. ontbeckt in ben jare bijttjien bondert enoe tojftbien bu Iuan Dias de Solis, ban melck ip oock Den naem kreegh Rio de Solis: Gp boer de felbe op tot aeneen ezp= landt/op oe booghte ban bier-en-dertich graden ende twee Deroe. Saghendaer beel futten ban \$ndianen aen'tland; 'tuolck baer lieden aen lanot lockenoe!

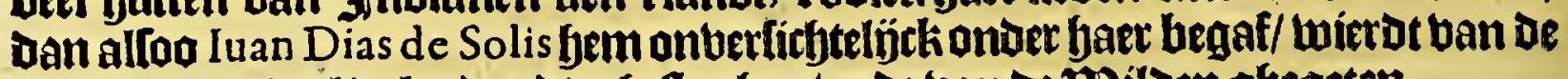
felbe met een Deel bolcx Doodt-gheflagben/ende ban de abilden gbegeten.

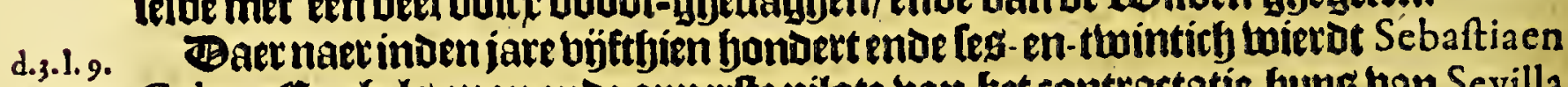

cap.3. Gabot $\mathbb{E}^{z}$ ngfels-man ende oppertte pilote ban bet contractatie-bupg ban Sevilla gfelonoen om Dooe de trate ban Magallanes te loopen naer de Eplanden ban

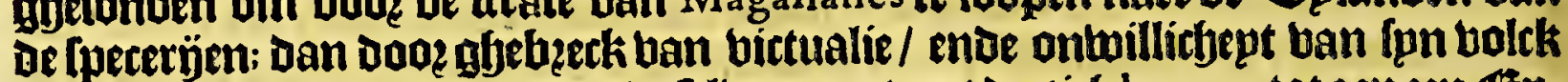

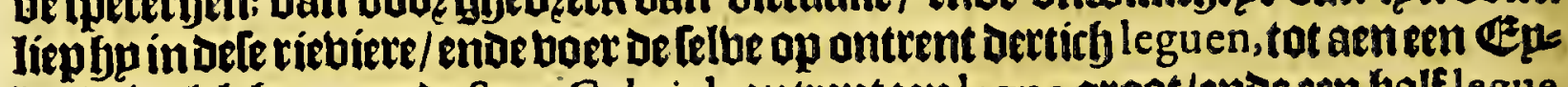
landt welck fjp noembe Sant Gabriel, ontrenteen legue groot/ende een balf legue ban 't bafte lanot naet Brafil toe / ancketde Daer met oe groote fryepen; ento met de bouten feben leguen boozoer barenoe / ontoeckte bpeen riebiere/ welch Gp noemide San Salvador, behbende een leer diepe ende bequame baben boos

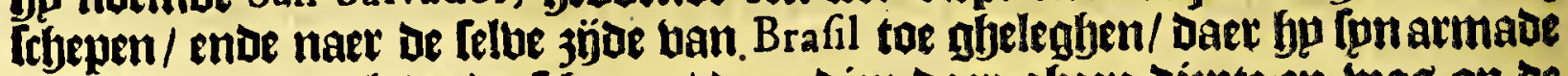

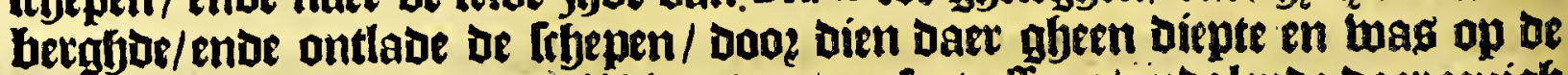
riebiere booz groote febepen. Heierp Daer een foetrefte op/ ende lepde Daet eenigh bolck op/ ende nam booz met de lloepen ende een cartued of riebiere boozert te onder-[oecken.

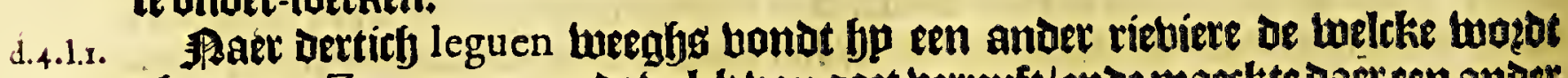
cap. I. ffjenaemt $Z$ arcaranna, ende bolck bangoet bernuft/ ende maeckte daer een ander foet/ helck bp noembe Santi Spiritus, ende oock anders fyet fott ban Gaboto; van Daer boet fph boots de riebiere Parana op/Daet bp beel Eplandenende rietuieren inontbeckte / ende bolgbende het meefte canael/naer Dat bp bp de twee fondert leguen op twas ghebaren / quam aeneenander riebiere die lp noemen Pa raguay, liet de groote riebiere doen aen Derecter-bandt leggben/bem in-beeldende dat de 
Celbe te feer Declineerde naev't quattier ban Brafil toe; D'anDer riebiete Dan an= trent viet-en-Detriclj leguen op-ghebaren zönde / bonot fo bolck Dat fem met de

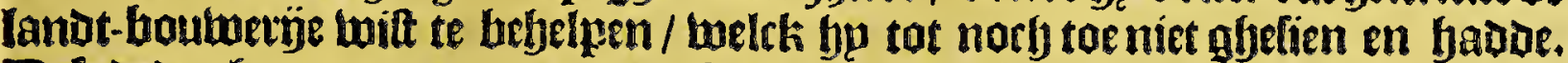

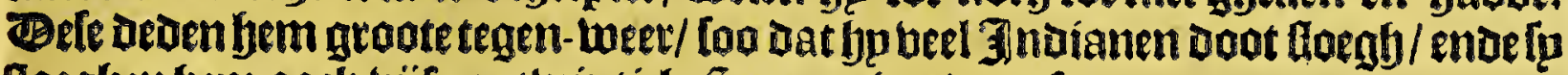
loeghen bem oock bijf-en-twintich Spaegniaerden af.

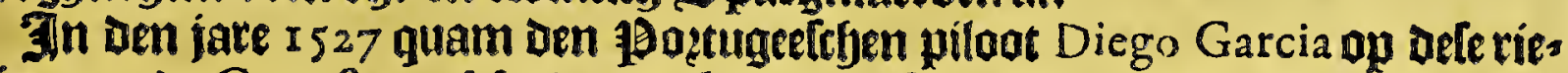

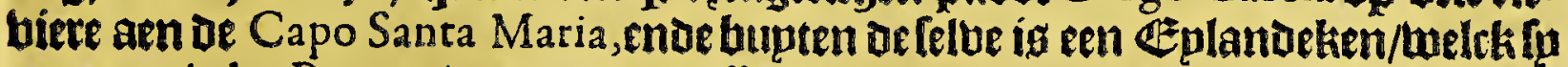
noemen de los Pargos, Daet goede vilteberije is; bimmen oe Cabo legbt bet $\mathbb{E}^{2}$ lant de las Palmas, is een goede haven/ enoe tuel ghelegyen booe de gbene die naex de ftrate ban Magallanes twillen/goe-twel dat daer aen be kape / nothoock aen be kulte hem gfjeen bolck en bertoont: Dan een tuepnigh meer inneloaerts/igs een natie ban bolck twelck men noemt los Chaurruaes, die bp de vifleberye enoe

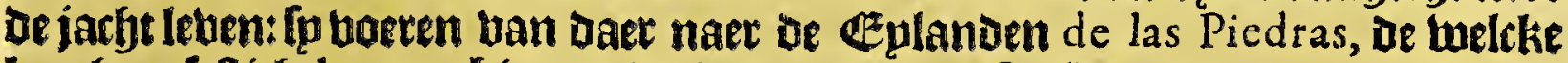
Iegghen leftich leguen binnen be kape. Zlen Dele Éplanuen de las Piedras maeckten lu een byigantín op/ de twelcke [p in ftucken badoen medeghebzactyt/

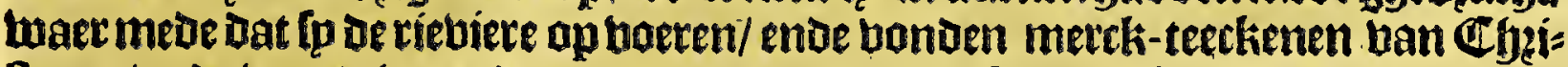
fenen/ende boots batenoe nookd ende noozot-ooft aen büf-en-tbintichleguen, bonden twee frfepen ban Gaboto. Ban daet nam Diego Garcia funlwegh de Parana op/welck ftreckt noagat-weft tennoogden:ende ontrent tachtentichleguen gheduaren bebbenoe / bondenfp een fterckte bp Gaboro gbelout / enoe gljenaemt

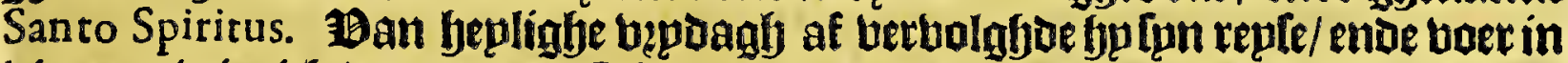
bier-en-thintich dagen daer Gaboto beel maenden hademet befigh getweelt/ento quamen aen oe Paraguay; ende bootts aen fet fat Santana, Daet hy Gaboto wondt/ende guamen't tamen te rugghe tot daet de foljepen twaten blïben legghen. Dooe dien lo eenigh fílber ban de Jndiamen badoen bekomen / tolck t terfte

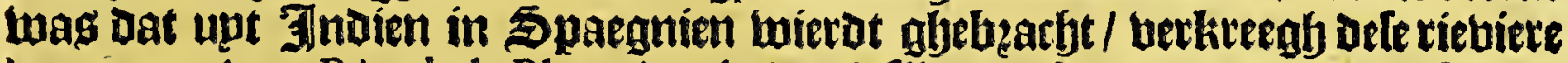
ben naem van Rio de la Plata, Dat is van't filuer. Raer De weder-komfte ban d.5. 1.9. Gaboto bleff de ontoeckingfye ban defe tiebiere acfjter tot in oen jare 1535 , Doen c. ro. boet Dertwaerts met elf fchepen ende actjt fontertman/ Don Pedro de Mendoça;

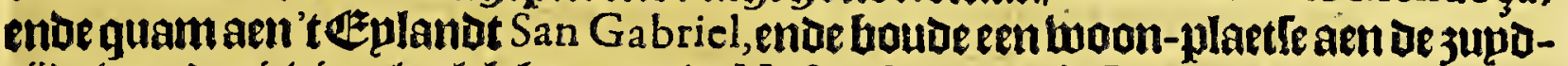
3 jud uan de rieviere/welck be noembe Noftra Sennora de Buenos A yres; ende bet: looz daec beel bolck bp gebeck ban bictualie. Derbalben [ondt bp Iuan de Ayolas om birtualie te gaen foecken / Die de [elbe vonot bp een lark/ Daer bpenigh balck liet / ende keerbe naer Buenos Ayres; bolghoen daet naet weder gaer ontoes kinghen te landt-luaet in / boch met groote moepte / ende twepnigh voozdeel:

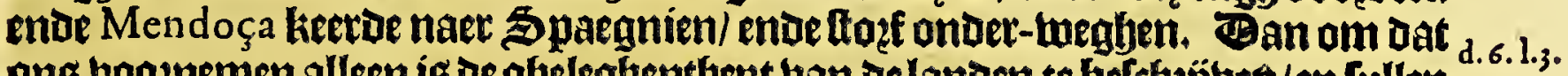
ong boomemen alleen is de gheleghenthept ban oe landen te beftyzijten/en [ullen top de ghelchiedeniften niet voożoer berbolghen. Jan alleen fier bp boeghen dat in oen jare büftyien yondert en beetticf Dertwaertg boer Alvar Nunnez Cabeça de Vaca, enoe dat lints bele pqubintien eetf ban oegbe jön begaft te ontoecken/ endemet bolck te betaen.

Het lelte Capittel.

$$
\begin{gathered}
\text { Befchrijvinghe, van de Rieviere by Martin del Barco in fy } \\
\text { Lrgentina Canto, I I. }
\end{gathered}
$$

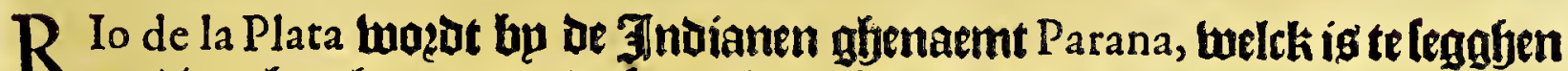

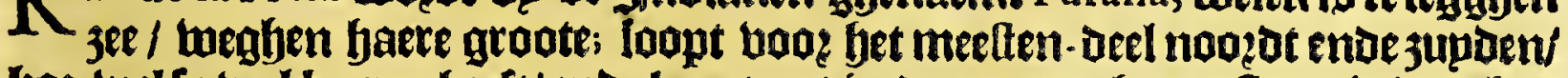
boe-twel fp beel keeren beeft/ ende komt upt in ae zee naer bet ooften / in boegfen Dat de jupoen laind komt ouer 't lanot ban Buenos Ayres, ende be noozoen twinot ban de jübe ban Brafil;komt met een frelle ftroom af:ende beeft in de monot meer als Dertich leguen ban de Cabo de Santa Maria, twelcli is aen de jü be ban Brafil, op of booghteban bier-en-dertich graden en een Galf/ tot oe Cabo aen be 
jübe van Buenos Ayres op de booghte ban feten-en-bertich graiden; bepot

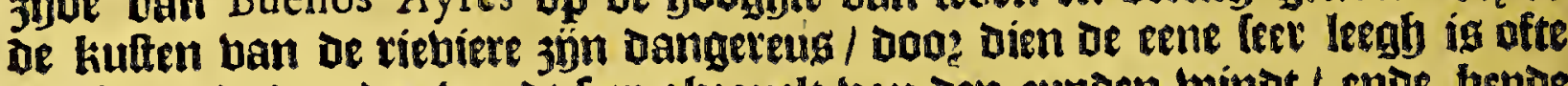
black / enoe D'ander wozbe feer glyequelt ban oen zupden twindt / ende bepde

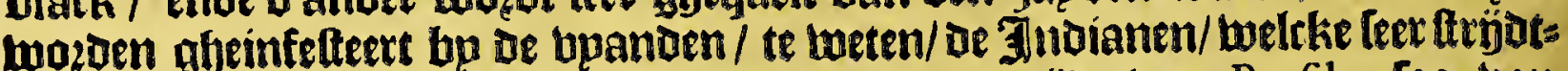

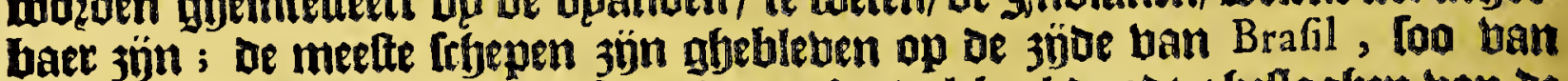
Spargniaerden als Engbelfiben/ ende bet bolck al ooodt-gheflaghen ban de abillon.

De Cabo naer't noozen ig gfenaemt Santa Maria, niet berte ban de Eeplan. oen de Caftillos; d'anoer Cabo wozat ghenaemt Cabo Blanco, welcli reefter ín jee loopt / ente ondieper ig / loo dat men meel baent aen de ander zjode. Suen de Cabo Santa Maria jön twee Eplanden/ die men noemt de Lobos; endoe luat berder in/twee EEplandekeng Die men noemt de las Flores, ende Derfich leguen ban Daer de Puerto San Gabriel, melck jön Ieuen fraepe Eplanden Daer De Icthe= pen geladen ban Spaegnien abozoeren; ende teghen ober naer' 3 upden leght De ftadt Buenos A yres. Be riebiere ig fier negen leguen oft wepnigh meer beedr; ente tot fier toe diep ghenoegh/ upt-ghenomen Dat Daet twee oft Dęp ondiepten

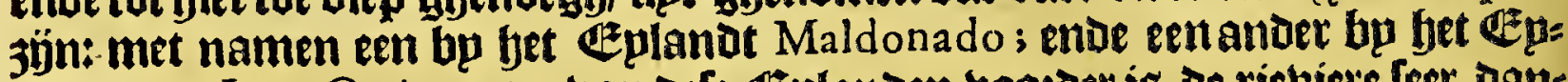
lanot ban Itan Ortiz: Maer ban offe Ezplanden boozder ig de riebiete leer Dans aereug van ondiepten: Defe (Eplanden ban $S^{t}$ Gabriel legghen ban de nooz ot - jübe ander-balf legue, enue eeniglye minder; ende meelt arbt leguen van Buenos

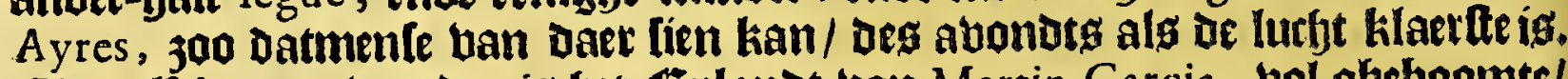
Clualf leguen boozer is bet GEplanot !an Martin Garcia, bol gheboomte/ ander-half míle langh enoe een balue beedot; daer is goed jaep-lanot:'t bolck ban Don Pedro de Mendoça baode bier een twoon plaette/ ende daer naet' toolck ban Iuan Ortiz de Carate.

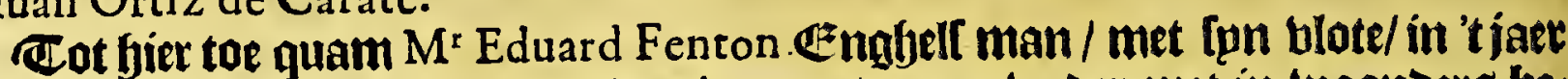
1582, ende Buenos Ayres wast twee jaren te voo?en weder met in-woonders bes fet / loo dat bp daer groote febade hadoe konnen Doen / indien bp daet gbeko= men badoe.

Nota. Be gantflye bloodt ban Fenton en quam op de riebiexe niet/maet alleen lohn Draeck met [pn Ithip melck bp daer berloo:/ ende Ieefoe wel büftbien maenden onder de MBilden.)

Bier leguen berder jón de Ge Glanden ban $S^{\imath}$ Lazaro een half müle ban't bafte lanot; een balf míle van daer leght De uermaerde riebiere $V$ rayg, welck een half míle bzetot is in de monat; daer komt een ander riebiete in/ die Gaboto noembe Sant Salvador:twee leguen bopecoer legt De riebiere Hum ofte Rio negro, Dooz dien [p [wart water heeft/komenoe upt moeralten / loopt loetjeng ende is biep / heeft

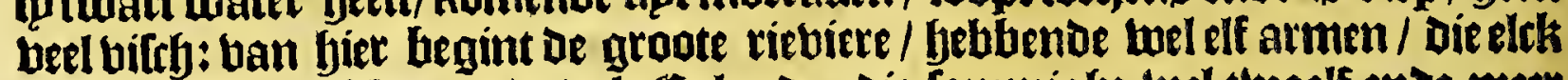
groote twỉdte bebben; ende bol Eplanoen die fommighe wel twaelf ende meet leguen groot $\mathfrak{j \mathfrak { j } n}$ / bol fraepe krupoen ende bloemen/ende alleen betwoont bp de natit ban de Guaranys. Bandele Eplanden keert Deviebiere tot yaer boozgaende groote/ welende aen bepoe 3 joen wel betwoont ban bolck. Ban Gier bondert en twintich leguen oe riebiere op-maertg / jün noch anoere Eplanden mel bes moont/in[onocrbept bp of Cherandyes; ende in oe twintich leguen is ghelegen ie ftadt Santa Fé. Carftentity leguen boożor komt oe rieviere Paraguay in de Parana, welcke van daer fpn kourg wendet naer fyet oolten; ende de Paraguay Areckit naer lyet noozoen/ ontfangljende de riebieren die ban 't gheluergfte ban Peru af-komen.

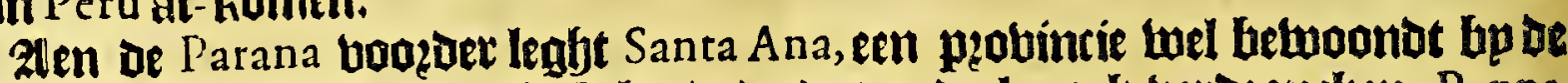
Guaranys, feer goedt ende black lande/ende ten deele oock betizoncken. Penna

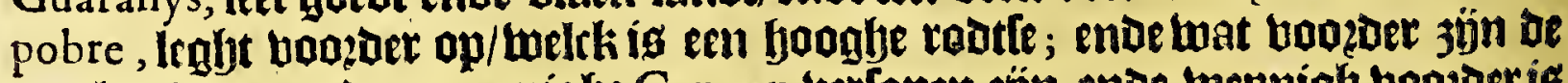
meulen- wateren daer meenighe Canoen berlopen jön; ende lepenigh booz̨or is Dact oe rieviere met groot ghedęug en gbetwelot balt ban jooghe klipgen; ende 
Het detthienfe Boeck.

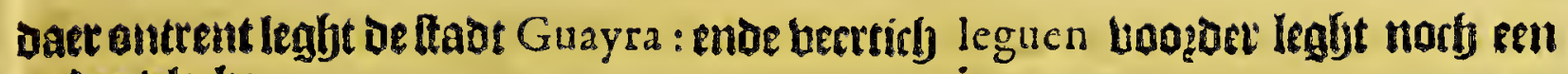
ander blecthe.

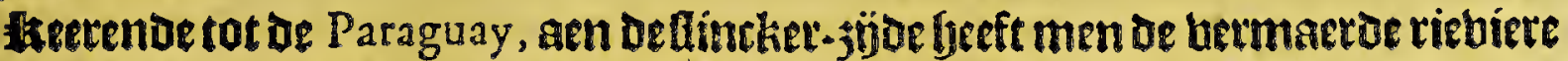

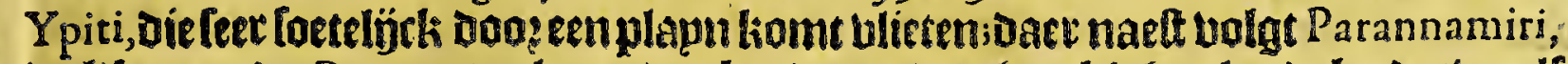
welck naer De Parana toe loopt/makende een Dap-joertigh eplanot bo Det twatif leguen groot. 25p Ypiti is een lack twelck fp noemen de los Mahomas, Dop? Dien be feltue natic op be hozaeren twoont/ wellch kamt in Rio Vermeio, altwaer perts len ballen. Be viethiere matckt een enghte eer gyp komt aen de ftadt Aflumcion, ende fier komt de riebiere Pilco mayo in de Paraguay, tomende uan de Charca's

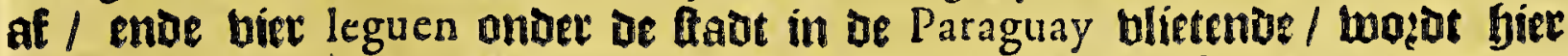

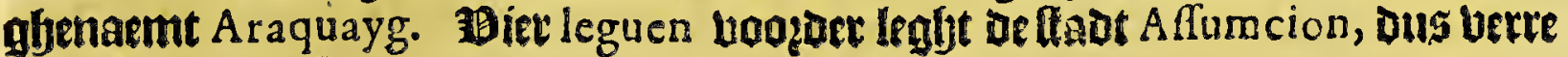
upt Martin del Barco.

Met Cevende Capittel.

Particuliere befchrijvinghe van de Rieviere I A P A T A, ghelijck die by de Spaegniaerden vverd

D \& Spaentchekourfen fpeecken feer betftegton ban de abelegentbent han Defe viebier / ofte baec eact in-kommen tot Buenos Ayres, ofte de Eplanden van $S^{\mathfrak{r}}$ Graviel toe; twant het Ruttier twelch $M^{r}$ Hackluyde in fon of ngbeltrye bopagien beeft in-ghetueght/ende welck mede wozot ghebonjer int Roteiro van Figueredo, fegft dat de kape ban Santa Maria Kan bekent wozden bp enn Eplant

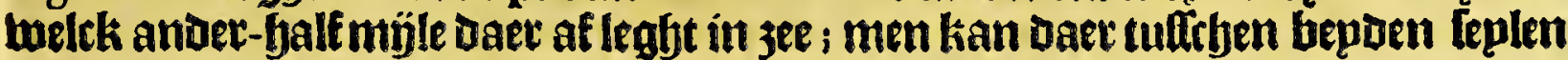
Doos dien Daer actet tot neghen badem twaterg is. De kape heeft op 't punt eenen kileenen bergh welck leght ober bet Eplandt ina de Lubos. 1 an defe hape moet

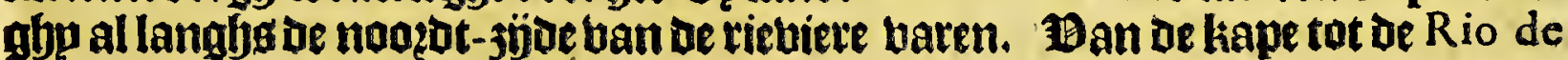
Solis, jün tfien leguen, of kulfe ftreckt oolt ende tweft. Ban baet tot los tres

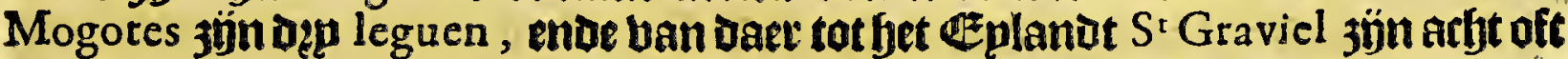

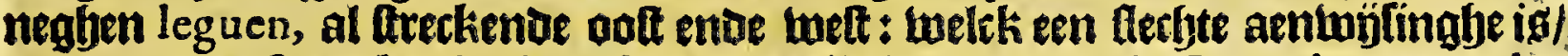

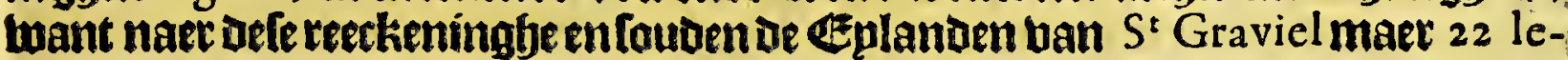
guen ligghen van be mont ban de riebiere : both Figueredo in't felbe Roteiro op

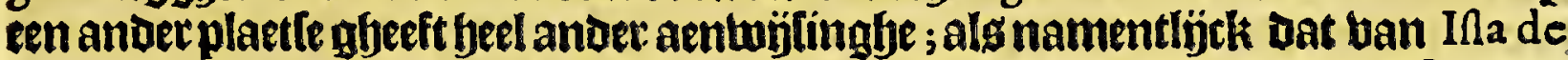
Lobos tot Ifla de Maldonado fun bier leguen noogot. weft ende zupot-ooft/ ende bat de kulte ban daer ftreckt oof ende weif biet leguen tot ken punt lanots; ende boozts meft-zupot-welt thien leguen tot Ina de Flores. Ban Dit Geplanot tot

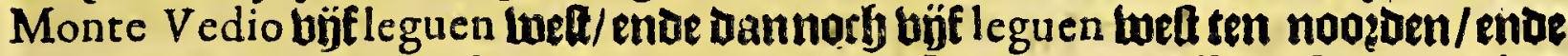
boozts belt-nodedt-welt tot llhas $S^{t}$ Graviel. Stelt mede tufteben Ina de Lobos

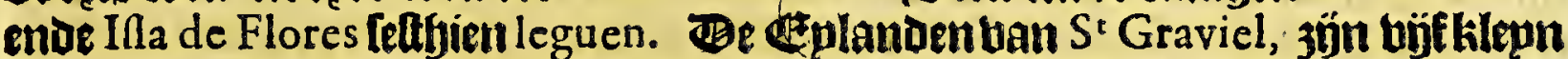

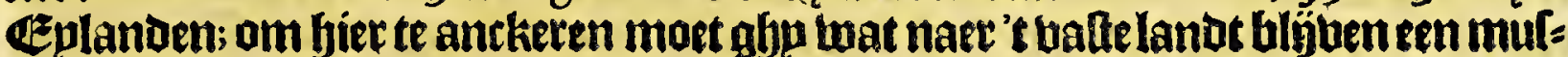

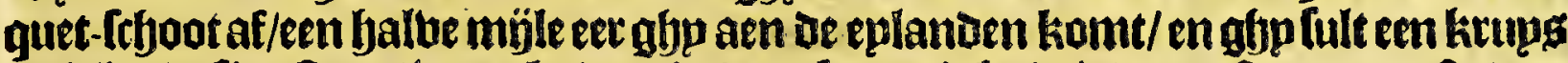

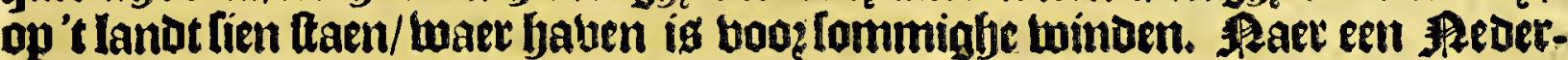
lander ghetupght die in defe abewellen langh beeft verkeert/ [oo moetmen in't opbaken ban ueriebiere naer Buenos Ayres toe/ be Gelanden ban $S^{*}$ Graviel aen De

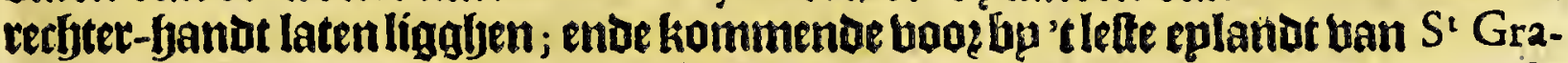
viel, [oo legft aen't vaite lanot een bekenoen bergh/ twelck fo noemen Monte de $S^{r}$ lfidio; ban melcke men fon kours let naer Buenos Ayres. Ban dele eplanden

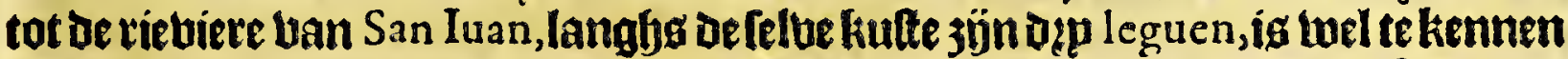

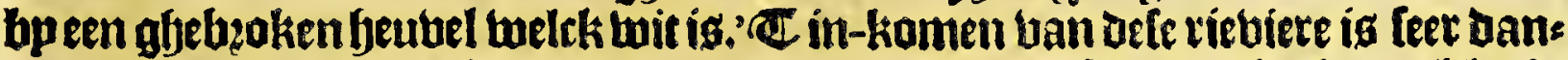

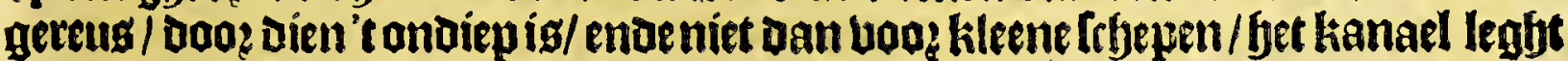
aen de luelt-züde onoer bet landet.

Ban dele riebier tot het \&Eplanot ban Martin Garça, (welch ghenaemt molt

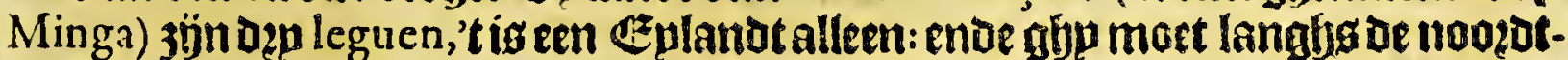

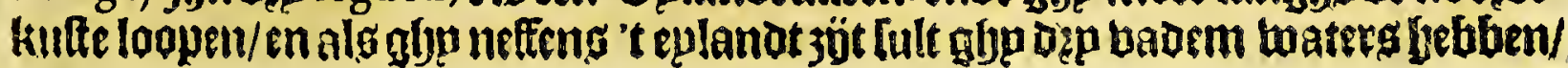




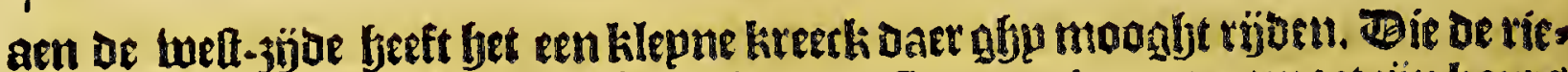

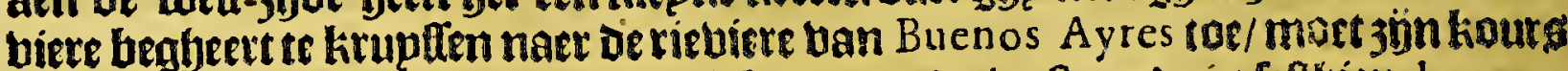
ban de UEplanden uan San Graviel Ietten juptot-med : ender is fefthien leguen,

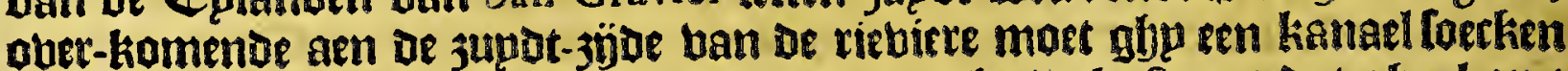
ban dep badem waters/ ende ban loopen langhs de kulte tot Dat ghj komt

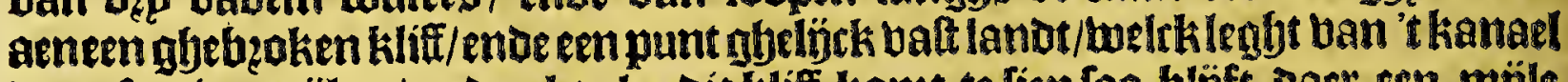

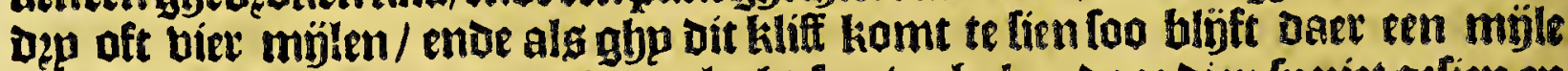
af. Be riebiere ban Buenos Ay res leght feer berholen; Doo? dien foniet gefien en

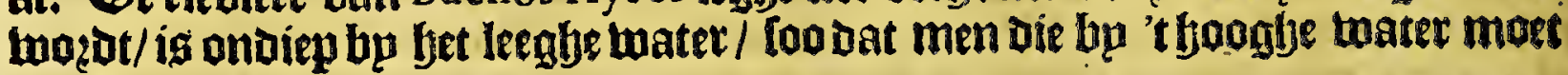
aen Doen.

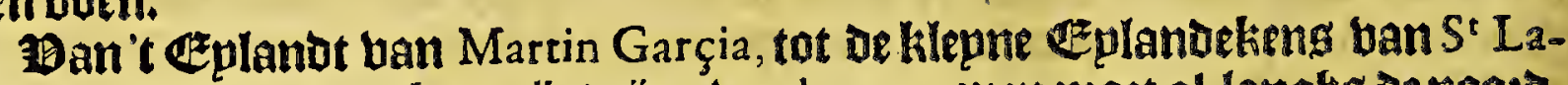

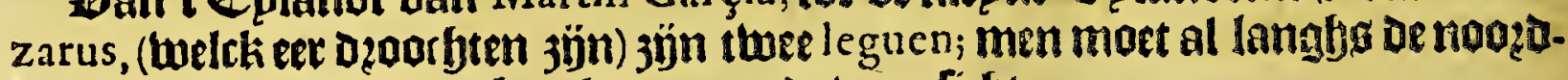
kufte bouben met lilepne barcken en goede booz. Iirfyt.

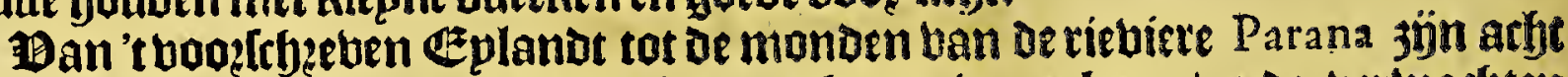
leguen: Agaer ghp befjoeft wel erth te antkeren in ten bape/ ende bertwathten

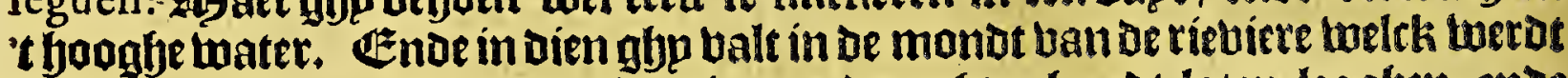
ghenaemt Vruay, foo moet ghp die aen de rerfjer-bantot laten Iegaben; ende

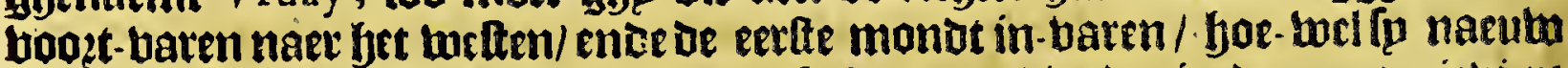
fthönt; ofte eenich van de monden/ want [p kamen al toedet in de groote riebiere Parana.

Diebanfyet Etplanot Martin Garçia begheert te tarten aen de ríetirre de Palmas, welck oe befte monot ig ban allen / moet beft aen-loopen choekomende aen

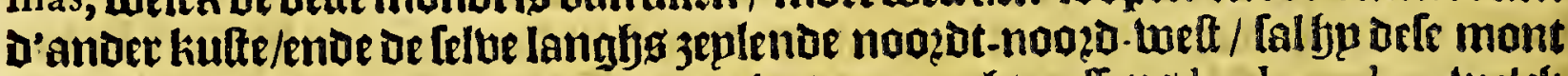
ban de ríeviere ontmaeten; ende moet in-baren reetyt neffens los luncales, tuelcki leggen aen be jupt-jojde; binmen is goede oiepte; alle binf of monoen jön bol ban ondieptennaer't oolten toe/ defpacie ban twee mülen: foo dat men voosfirlftich moet baren.

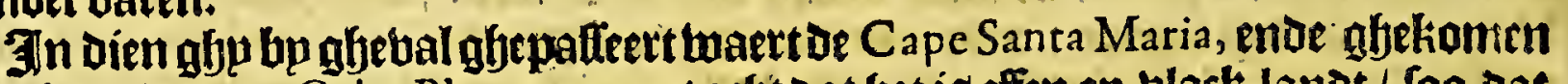
tegljen ouer aen Cabo Blanco, neemt arbt dat bet is effen en black lande / foo bat

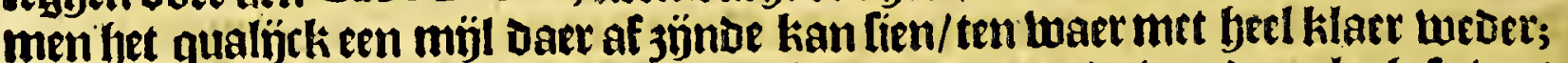
ende defe kufte legbt foo al leegh tot by Buenos Ayres, ende han daer leghtle wat boogh tot aen'tin komen ban Rio de Palmas. Clmaklf leguen bp oolten Buenos

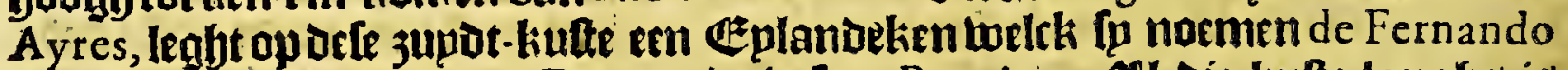
Ortiz, nate t tegghen ban Figueredo in fpn Roteiro. 2fl die hulte langhg is feet quaedt-bolek / die eeten de gheene die [p komnen krÿghen/ ende daet 3 j̈n pock veel tigren. Ban bet Eplanut ban Martin Garçia, tot San Salvador

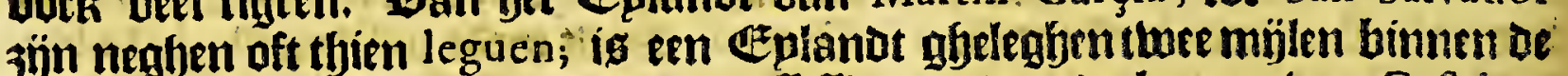
eetfte monot/ baet Sebaftian Gabota poftefle nam boo? de kroone ban Caftlien ende Leon, ende dit lanot is wel bewoont bp entiolck ghenacmt Carios; dan men moet daet fem ban hachten/ want ly jÿn doodt-vpanden ban de Spaes miaerden; de zupotlijekfte monot bam Parana genatmt $R$ io de Palmas,isfeftion Jeguen langh/en herft beel keeten/en beel palm boomen daet aen groeprnoe/ ende ten epnoe ban or feltbien leguen komt lp in Parana. all de ander atmen

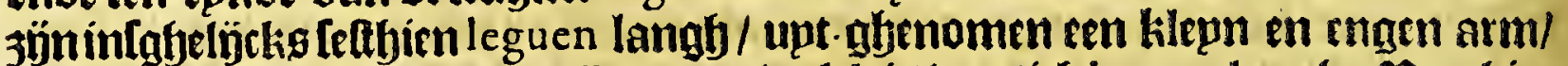
welrk ig abenaemt R io de los Beguaes; walch ig ueetricly leguen Jangh. Ban biet

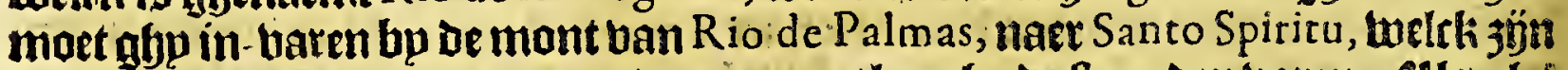

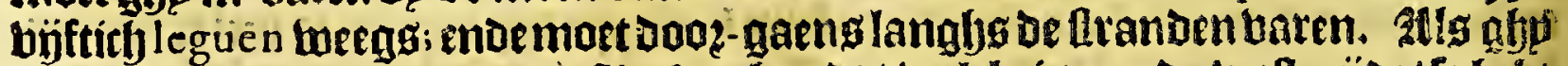

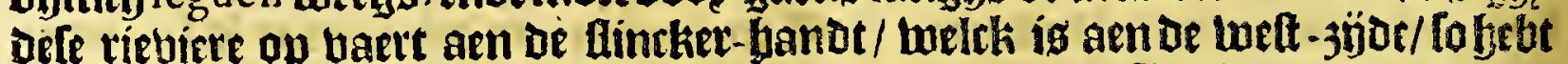
gfjp ueel Eplanoen larkenenoe klepn riebierkeng/ tn utel Jndianen die u bpan= aen jún. Ban Santo Spiritu tot een bolck torltk genaemt wozot los Tenbuis, jïn

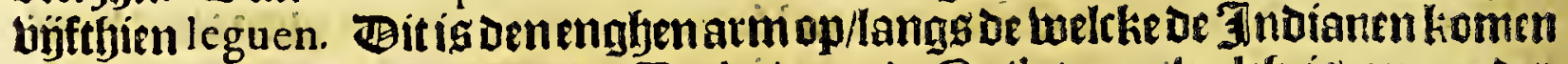
aen de rieviere Parana: ban de Tenbuis tot de Quiloacas, welct ígen ander natie / 3ýn twintich leguen; ende alle oele rieuiere langys ig trel bolcks. Ban 
Het derthienfte Boeck.

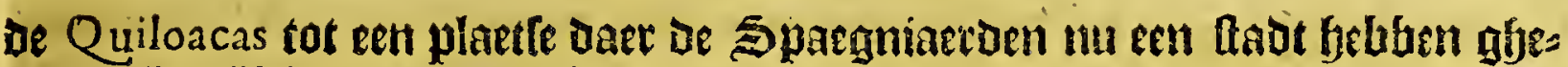

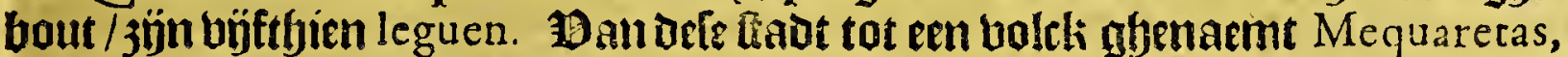

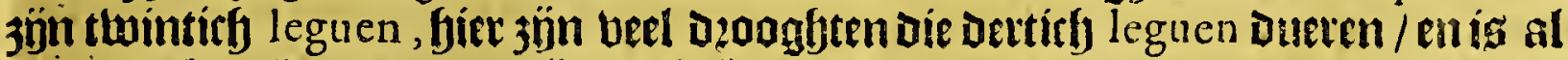

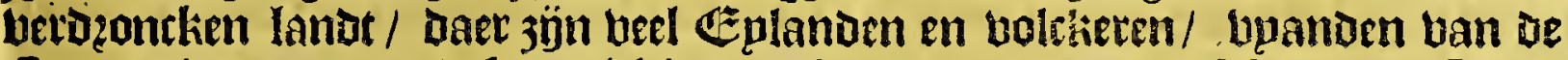

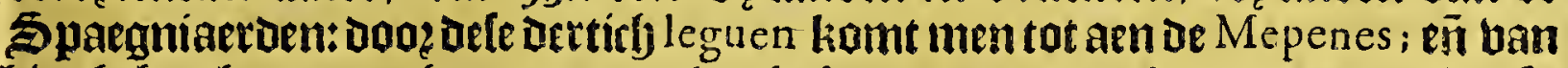

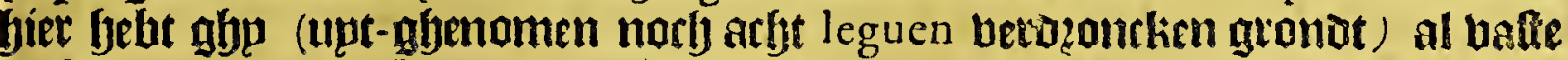
kufte tot of rieviere Paraguay toe; ende dain de Mepenes tot oe monot van $\mathrm{Pa}-$

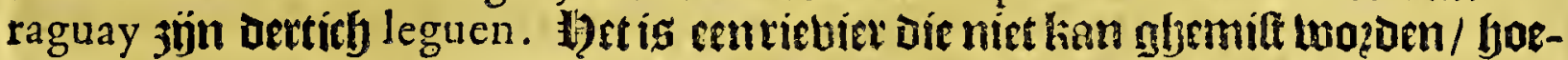
wel to tueel armen beeft / Cplamden ende dangieren; fyeft ern marck twee lę-

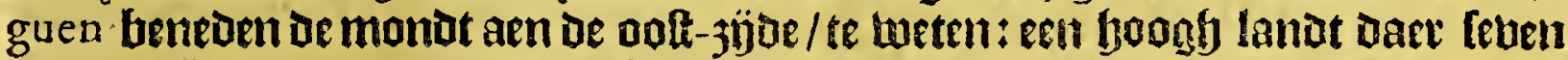

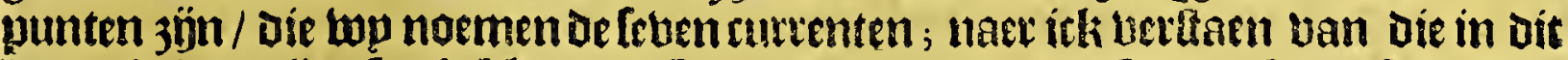
lanot belient jün/loo febben oe Spaenniaerden aen oele placte een ftaot afye Iegfit die [a noemen los Siere Corrientes; enoe recijt baben Drferurrenten ig een

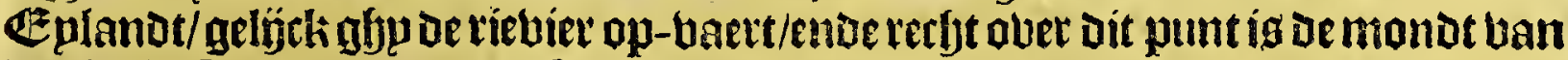
be rievier Paraguay ; ban oefe monor is oe riebiete Parana betueelt/ welck ig een

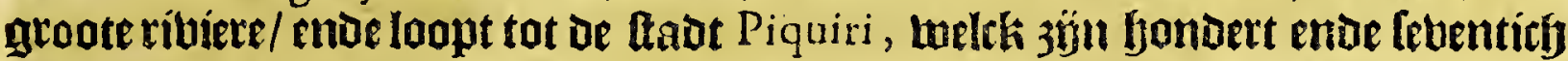

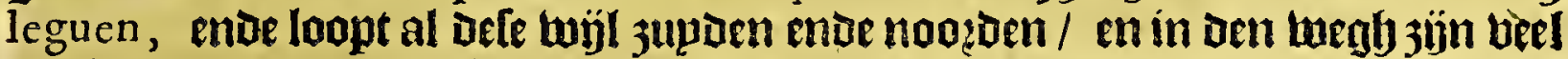
ondiepten; en beel boleks / welck een quade tace is / yae-twel betoeelt. Ban de

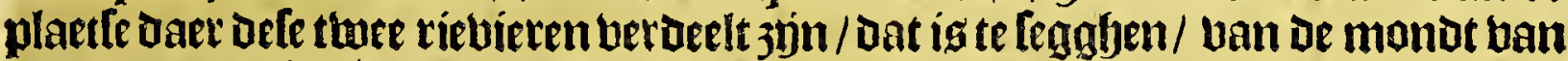
Paraguay $3 \mathfrak{j} n$ [eftich leguen tot de ftadt Aflumtion; Dit igen goede riebiere ende beter op te 3 eplen dan alle de refte. Ban dele ftadt tot los Xarayes jön twee bon= bert leguen, feer twel betwoont ban bolch die oe Spaegniaerden dienen/ende onderdaen jün.

(3et achtte Capittel.

Befchrijvinghe van de rieviere I A P I A T A, ghelijck die by de Nederlanders is onder-focht.

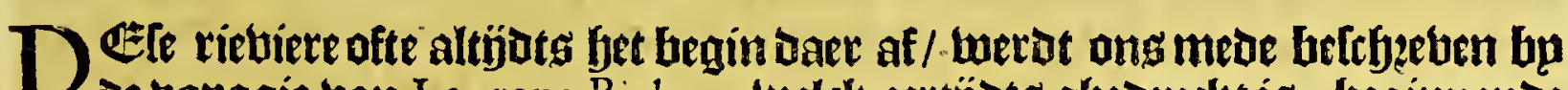
de bopagie ban Laurens Bicker, twelck eevtijotg abeduckt is; benimnente

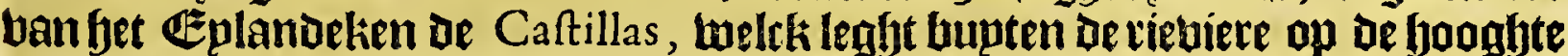
ban biex-en-derticly graden ende een fyalt bp jupoen oe limie; is in bet aen-fien

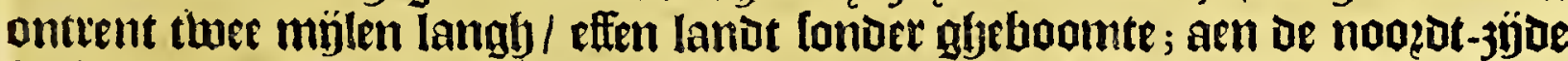

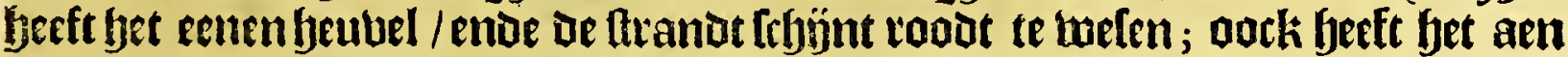

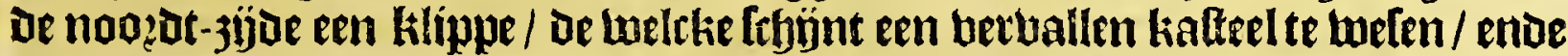
aen oe jupot-jübe jün noch twee andere klippen/ enoe bp 't weften legft bet valte lanot / ober ljet Geplanot beenente líen. Het balte lanot legbt thee mijs

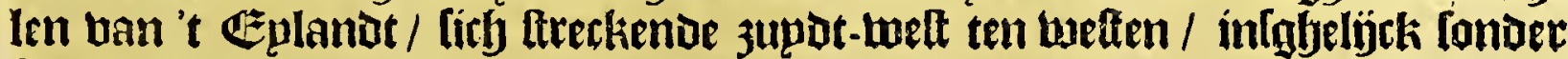
boomen.

Ifla de Lobos Yeglyt booz aen in Rio de Plata, op de fooglyte van un̈f-en-dert= tirb graden / en is anderg niet Dan een gheduerigfye fteen-grondr/ Daet niet an=

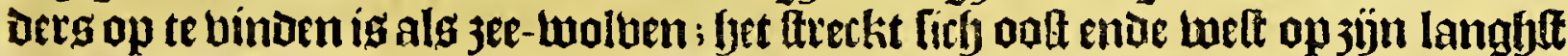

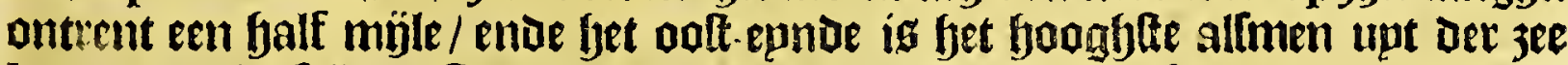
komt / ban fet felbe ooft-epnie loopt aock een rif ban fteen af / ontent een roergfrbeut in jee / Die men ghenoegly marf tien rabelen al ift thil; norb leght daet

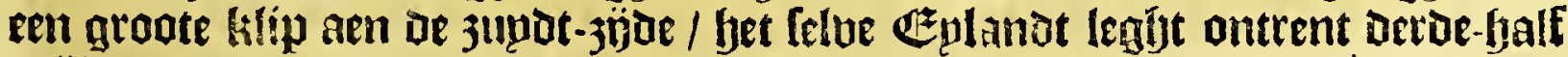

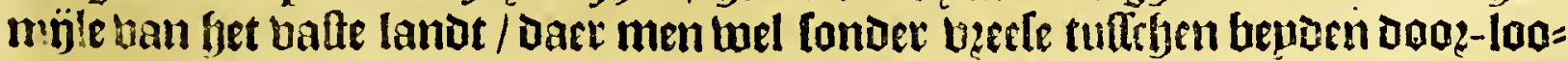

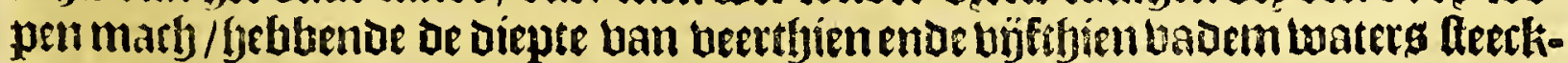
arondt.

Dit Explanot leglt neffeng de Cabe wan Santa Maria, welth is ten blacken

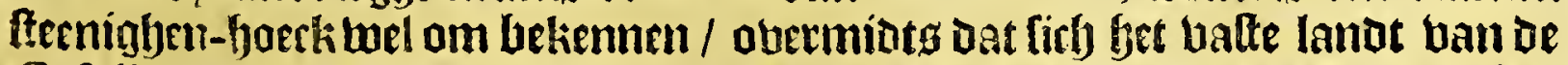
Caftillas af / tot de kaep toe jupdr-weit ten twelten ende nogęst-ooft ten ooften

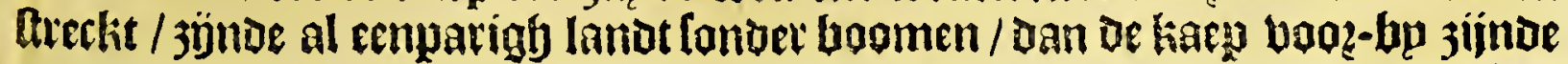

ob bolghter


volohtet foogh lanot / bet melck lirb van de kape íme-waerts aen / ontrent büf

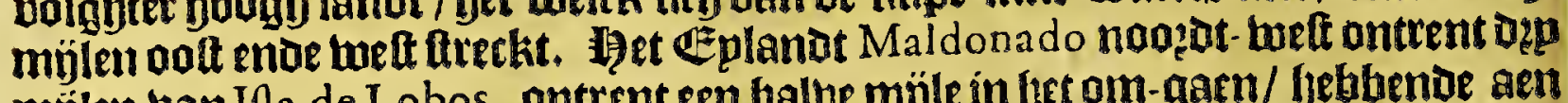
mülen banlla de Lobos, ontrsnt een balbe müle ín frec om-garn/ bebbende aen

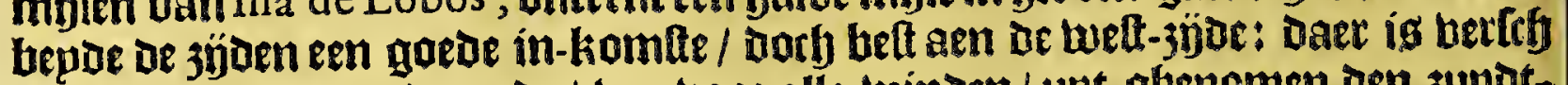
Lwater/ ende een goede reede / bap booz alle winoen/ upt-qbenomen den jupot-

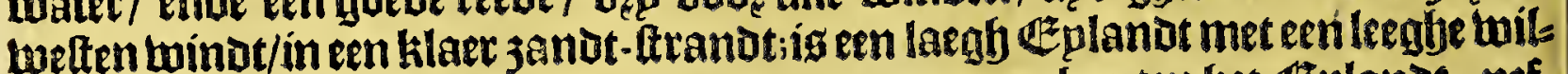
Dernig/t loet water legbt tulltyen of klippen/ rontom bupten lyet Geplanot; net, feng 't Eplandeken freckt fem het bafte lanot met een ronden borft/ een gotelinahfcheut berfétepoen van 't Eulandeken.

Zlen bet balte lanot noozot-noozot-wett ban't Ceplanot is efn bzaeck ban berfeh water ontrent een vierendeel van cen müllangly / ende een fteen-wozp ban

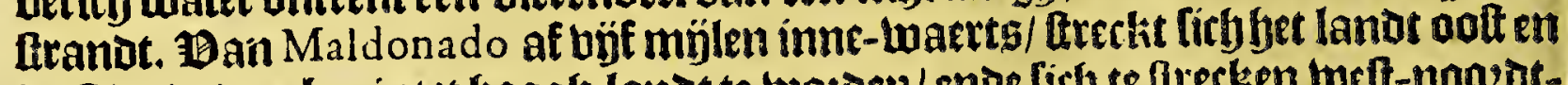

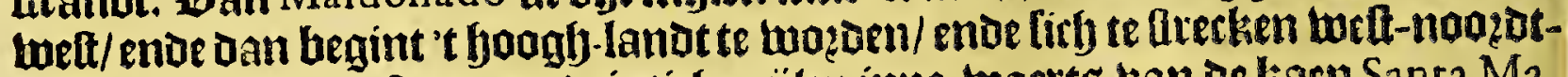

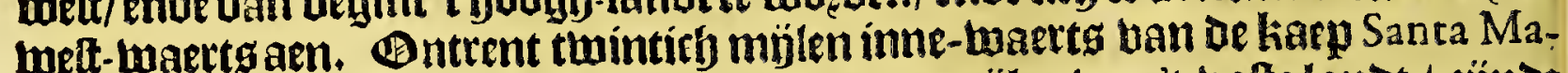

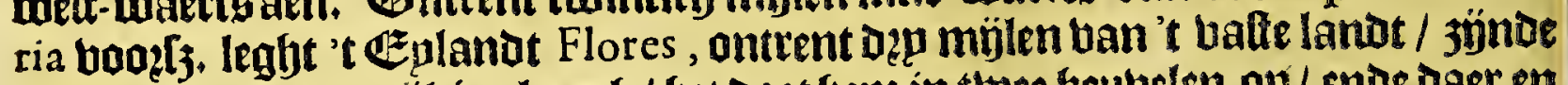
ontrent een filepn mijltien langh/, Get Doet fem in thee beubelen op/ ende daet en walt niets op het Eplanot.

Ban Daer jeult men naer Monte Seredo, welchiseenen fyooghen bergh. Dn

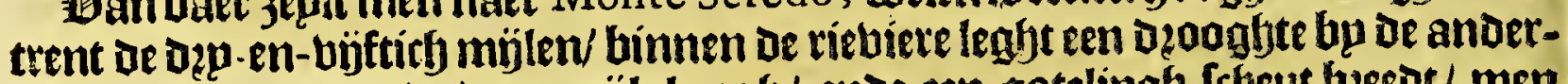
balf ingile ban 't lanot / een mijle langh/ ende een gotelingh - frheut beesot/ men

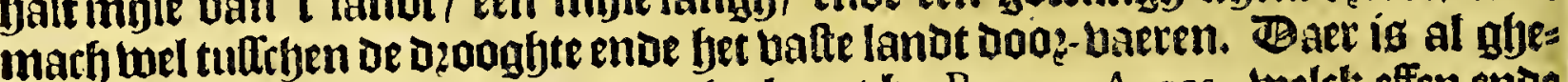

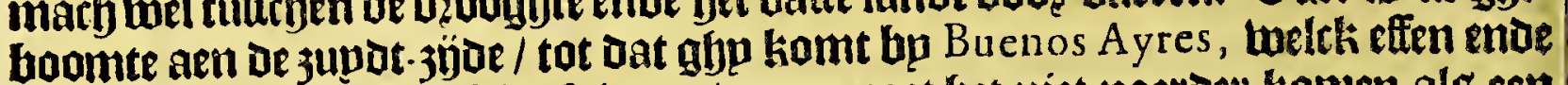
aecft lanot ig al oft ghelefyaeft ware / men moet bet niet naerder komen als een anoet-falf mijle / tot dat ae buplen jupoen ban u jün / dan marf men recfjt op

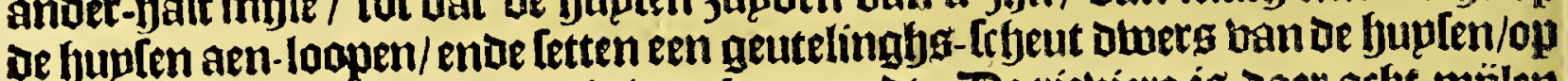
ae deg vademen diepte; daer is weecke gronot. De riebiere is daer arbt mijlen beedot/ende aen de noozot-wal ontrent twee mijlen af / leght bet eplanot Sant Gabriel. Gen ander \$Rederlander Die hier berkeert heeft feght mede Dat fjet landt

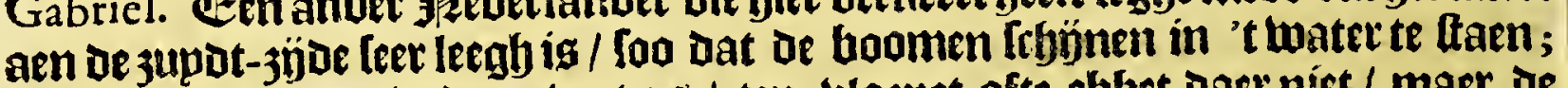
Daer ís maer twee bavem maters / ten bloenet ofte ebbet Daer nict / maer ide

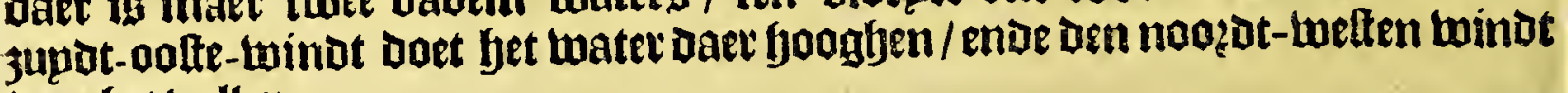
boet bet vallen.

\section{Heglyende Capittel.}

Befchrijvinghe van diverfche Natien van Wilden, die ontrent defe rieviere woonen.

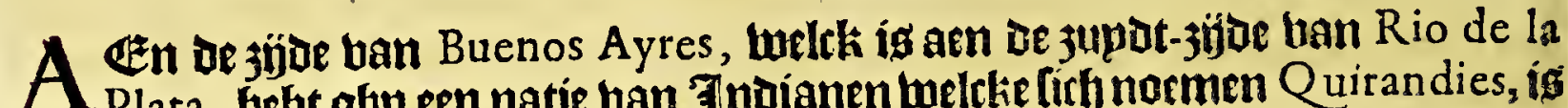

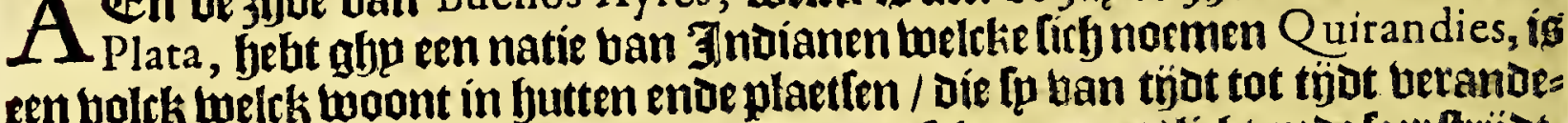

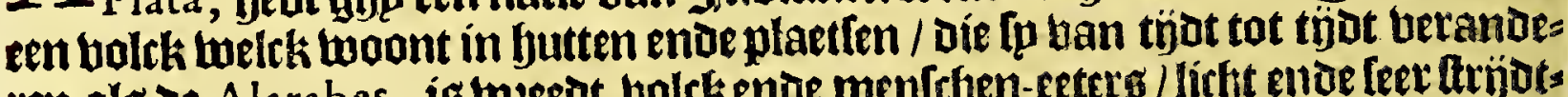

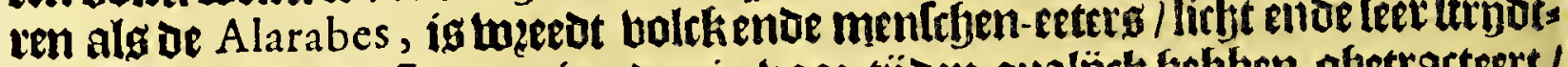

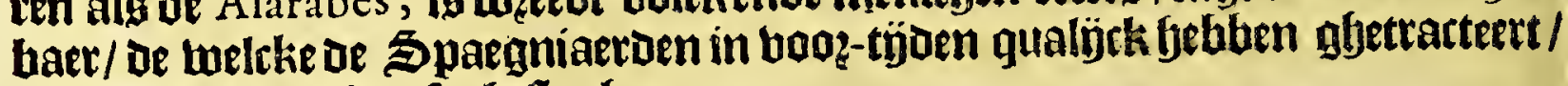
ende een beel boltkg af -ghellagljen.

d.s.liro.

De riebiere op-waetts aen een lack/ /beht ghp Leecker natie ban Indianen dis jaer met bilfefyen glyeneeren: ban de natien die men noemt Timbues ende Carcares, dark de Spargniarroen goet onthael bonoen in De tÿorn ban Pedro de Mendoça; ende bouden Daer ontrent een boon-plaetle die f́p noemoen de Buena Efperança.

Alen De riebiere helck men noemt Paraguay, hebt gljp be natie ban de Ame-

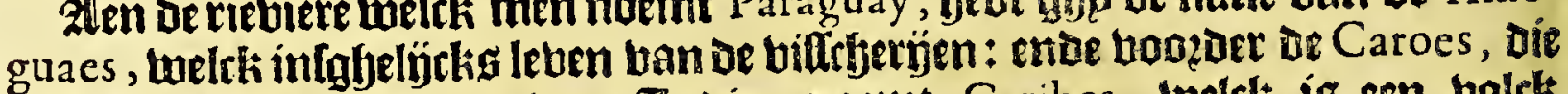
men in andere contrepen ban 3 moien noemt Caribes, thelck is een balck

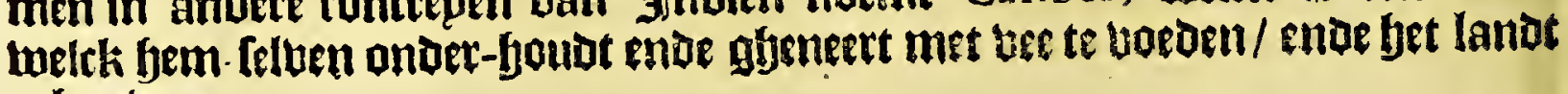
te bouluen. 
Enbe norb boożer twoonen of bolckeren die men naemt Payaguaes, welck jön bp de fondert leguen.

Ban baer boozoer te landt-twaert in/ woonen de bolclieren die fich noemen d. 6.1 .7 . Chanes, ende die men noemt Chemeneos entoe Carcaraes, bp de welcke ueel c.5. goubtg ende filuers twetot afjebonden: Iuan de Ayolas weder-keerenoe uan be Chanes, twierot ban 》e Milden (Die beienden waten ban de Payagoaes) met alle fon bolck aoodt-ngeflagben. Defe natien wierden uan oe Spaegniaerden ontoeckt in ben tocht ban Ayola, onder't ghebiet ofte Goubernement ban Pedro de Mendoça.

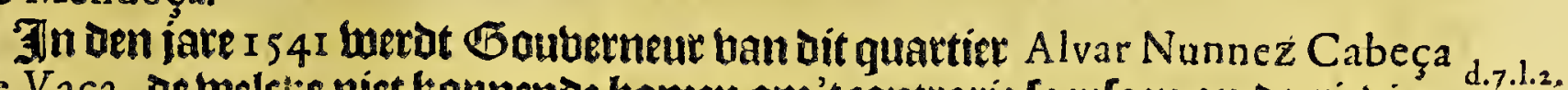
de Vaca, de meleke niet konnende komen om't cantrarie laeploen op de riebiere c.7. 8 \& de la Plata, nam fun luegf ouer landt / beginnende aen ae rieviete Ita bucu, twim=. Regq. tiry leguen van bet Eplandt Santa Catalina. Ban twaer by trock ober beogfe

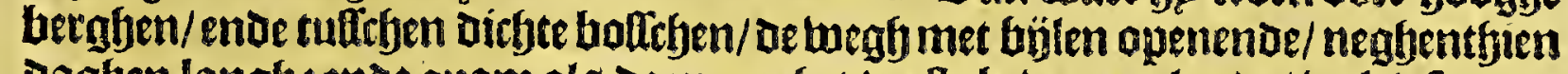
Dagben langl : ende quam als doen aen fet berlte betwoont lanbt/ welek [p naes men del Campo: al waer fa bonuen get ghebiet ban be A rmiriri; ende end daghreple voogeder de beerffljapyije ban Cipoyay, ende ftracks daev aen die van Tocanguazu. Bat bolsk mazden ghenoemit Guaranies, fp jaepen ento bergaren Maiz thee-maelg's jaets/ende altijots Cazabi; jebluen beendeten ende ganfen)

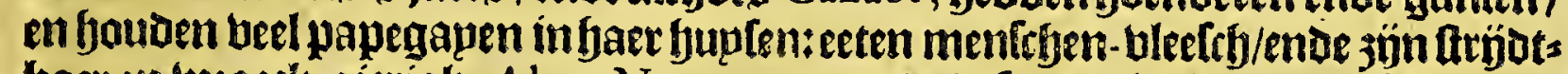
baer en twzaech gierigh. Alvar Nunnez noembe defe peovincie Vera. Hp quan Daer naer aen de rieviere Y guazu, ende's anbet-daegbs palleerden lu met groote maepte de rieviere Tibagi.

Dentelten December quamen fp aen De riebiere Taquari, op welckets kant leght een blecke ghenaemt A bangobi; Daer naer quamen [p aen een ander blecke ghenaemt Tocangu zir, twelck fphetuonden te legghen op de hooghte uan biet-enthaintich graden en een falf bu jupden de linie; al oat land is Teer veurbthaex ende fris / met groote blacke beloen / rievieren endegbeboomte. Baer aen volght een Lueftÿne van bergben / maeraflen/ riedt-ueloen/ende uichte bofthagien. Belcke gyepaleert jynde / homt men meder in' t landt bande Guaranies, daer Maizende

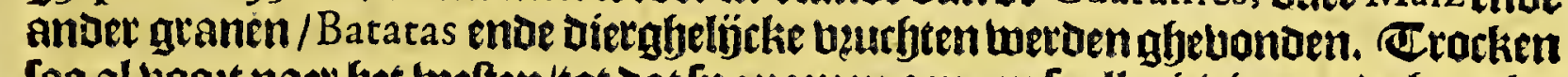

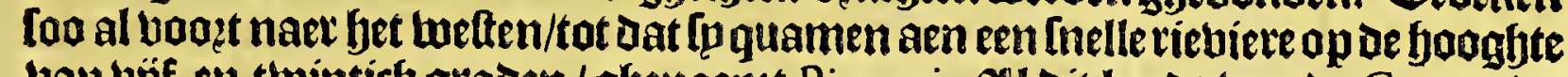
van byjf-en-twinticf graden / ghenaemt Piqueri. All dit landt uan de Guaranies is fert betthtbaet en aen-ghenaem / ende bequaen om fuptker-Ingenios te maets ken; ende Daer ig groote apparentie ban liluet-mïnen / Dan't bolck ig feer twilot enoe eeten menlchen-bleeleb. Baer naer arlythien dagben langber ghereplt bebben=

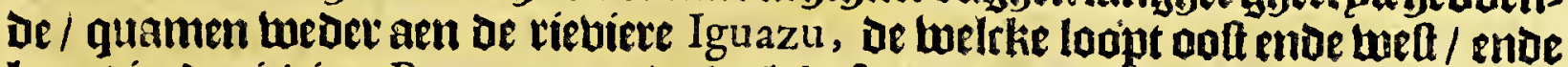
liamt ín de riebiete Parana, aen de belke fo vaer nack quamen op de fooghte ban bier-en-twintich graden; ende ban bier 3 jon negben aagh-replen tot de fradt
Afumcion.

Zlen de riebiere Paraguay woonde ecn natie ghenaemt Agazes; die groot ban líchaem jün/ en fretck ; baten op den roof langbs ae rieviete londer te jaepen ofte d.7.1.4. te mazpen. Martin del Barco legft infpn Argentina, Dat Defe Agazes loo jijn bers nielt bp de Spaegniaetoen/ Datter bu-naer gheen ban jün ober-ghebleben. Ëen ander natie ig Daer ontrent Die fo noemen Guaycuraes, ig groot bolch/ fhijot= baer / cnoe rap te been.

De felue rieviere Paraguay op/legghen of Cacones, Die bet lanot bouluen d.7.1.7.

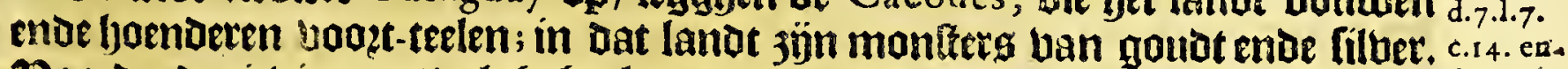
Boosoet de riebiere op/ bolght het lanot ban De Guaxarapos, weicke legghen aen de ver: een rieviere tollck loopt naer 't oolten/ op de boogfte ben neghentbien geaden volgens, ende een oerde / en kome loo in den Paraguay : 'r volcti bandit lande / als't twater

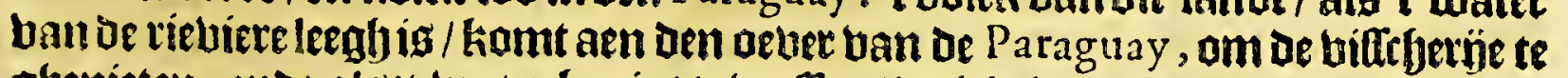
gyenieten; ende als't water begint te twaffen/ helck is in Ianuario, treethenfe te B b 2 lanot- 
492

Rio de la Plata.

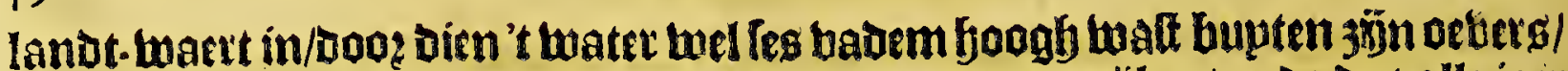
en vertpetpt fem ober 't blaclie lanot meer als bondert mülem / ende dat alle jaer. wanner de fonne van den Tropicus Capricorni af-frbept om naer den Tropicus Can cri te keeren. Baet naer koms men aen een lark Daer be riebiete Paraguay, hacr in berlieft / ende daer komen ander riebieren upt ifelbe lark / ende bp namen Yguatu, op welthe rieviete ote Xacoaes, Xaqueffes moe Chaneffes woonen: ende

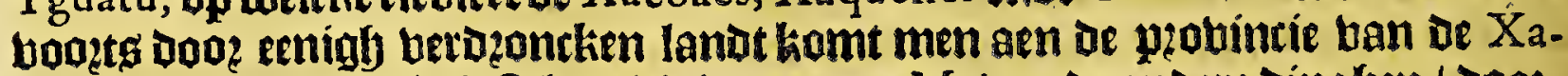
ray es, welck een wel ghettelt bolck is / zaepen Maiz ende andere dinghen / Dootbooeen Gaer lippen / oe mans jaepenente bearbepoen 't landt / ende de beoumen maepen ende berfamelent; jün groote [pinfters ban kottoen. Daer aen holght cen feer dirfte wiloernis/ tot dat men homt aen een platefe ghenatmt T a puaguaz û, Daer de wacninghen weder beginmen; ende' tholct daet ontrent wetoen ghenaemt Tarapecocies, Daer beel birtualie/fjinnenende ganten tuerden gheton:

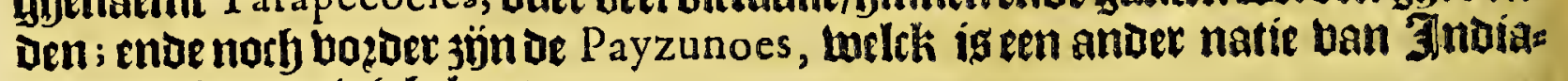
nen / noty texpnigh belient.

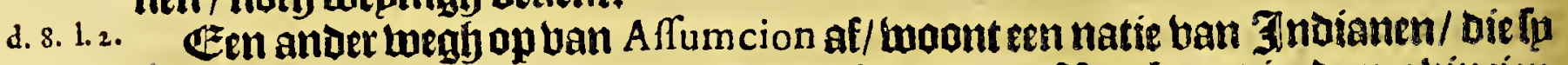
cap. 17. normen Mayas, en is op de tweghnaer Peru toe. Agen komt in de plobintien d. 8. 1. gljepalleert zönde / kamt men dooe divertche lanoen ende natien / al-waet groote appatentie is ban fíber-mïnen/ tot de plobintie ban of Tamacoas; enue fou boots homt men tot de plovintien de los Charcas. De eerlte die aelen wegh doog ig glyetracken/is gbetueet Nufle de Chaves, ter tijot dat oe Zicentiaet de la Gafca in Peru perfioceroe: in lpnen torft mozon bolckeren ghenaemt Taguamacis,

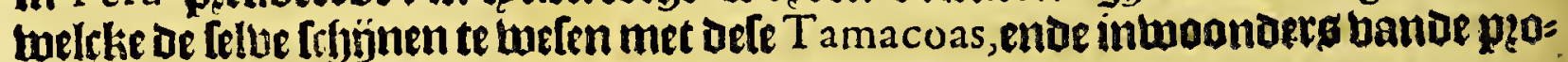
bincie $S^{t a}$ Cruz de la Sierra ; fiet boeck I 0 rap. 35.

Yet thiende Capittel.

Befchrijvinghe van de fteden in defe provincie gheleghen, ende eerft van de ftadt B U E N OS A Y R E. c. 1o.

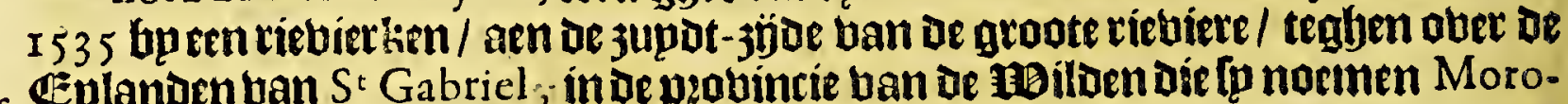
Her.def Cplanden ban $S^{t}$ Gabriel, in De provincie ban de mbilden de fp noemen Morocotes. 't Lanot ig doo den banot beel black/ upt-ghenomen eenighe twepnighe beubeltiens/entoe ae Cordillera ban 't gheberghte belck loopt langfys of kulte:

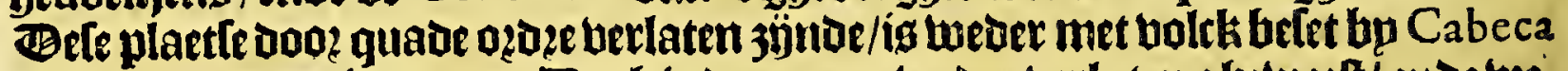
de Vaoca, indenjake 1 542, Dorbigdaer naer weder verlaten ghetweelt / ende twe: bet op nieutwg met bolck befet ontrent het jaet 1582 . De bopagie ban Laurens

I opez Bicker leght dat dele plaetle leght ontrent leatith mojlen binnen de rieviere / op een

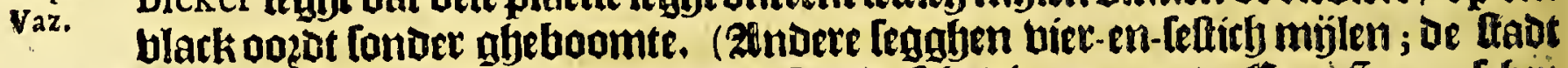
leght opeen fooghe Barranca als de Spaenletye die noemen.) Een Spaentrben-

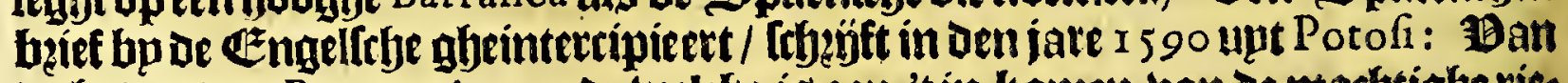
De haven uan Buenos Ayres, oe welcke ís aen 'tim-komen ban ae marbtighe ries viere la Plata, wozoen aloerbande \$paenirbe ende \$ooztugaelfrye koopmans Ifyappen geboert raer deIe ftadt ban Potofi met kareen ende pertden/ want ten ís

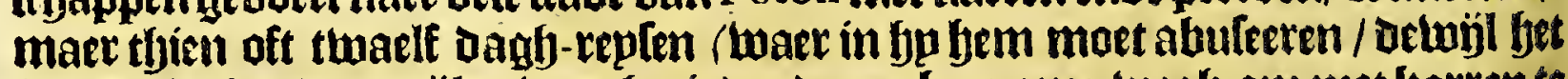

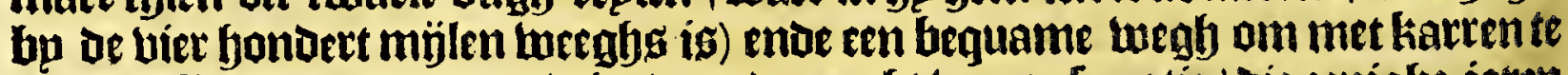

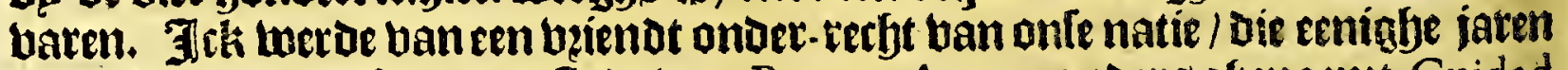
Daer ghemoont beeft / Dat de ftaot ban Buenos Ayres, anoersogfenaemt Cuidad de la Trinidad, is uan wepnigh confideratie / gebbenoe twee bonoert in - woons

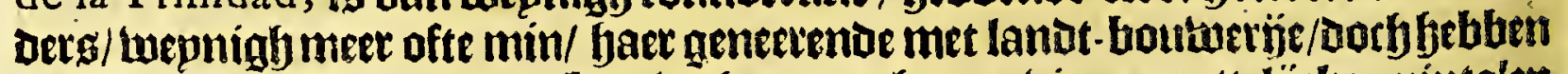
al te met permiftie van den foningh te mogben navigeten ettelp̈cke quintalen bitlicupt/ 
Het derthienfte Boeck.

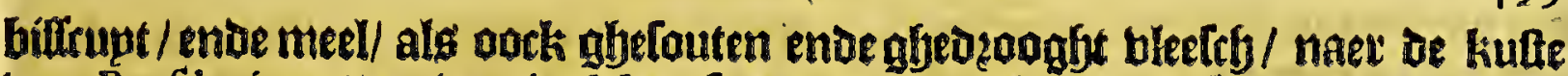
ban Brafil, in retour ban torlckes fo tweoer eenighe koopmantryapyen been=

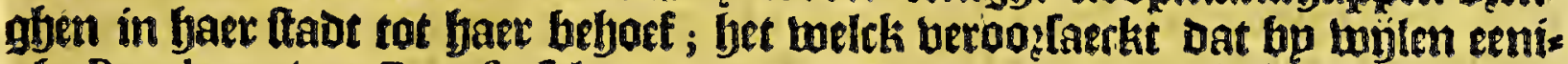
ghe Peruleros ban Porofi af-homen met realen van arften/om oie aaer te em= ploperen/ borf met perïckel; Dooz dien de Honingh niet en wil toe. Itaen datter

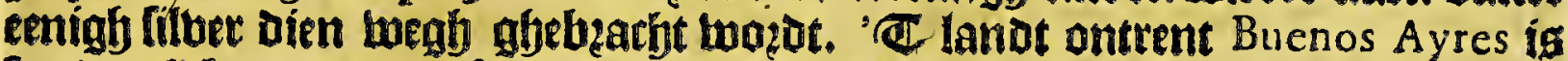

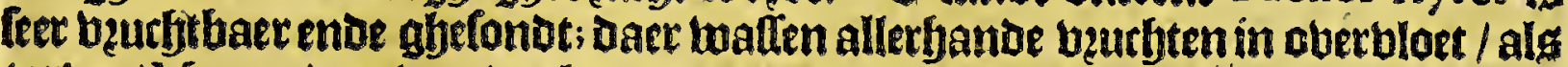
tartwe / Mayz, Dęuphen / meloenen / pompoenem / komkommers / etc, te lanot-

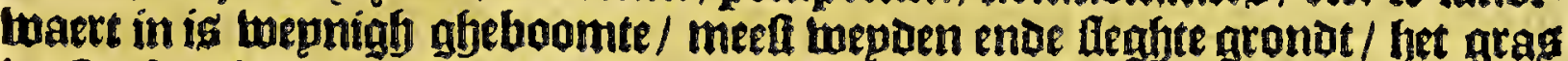

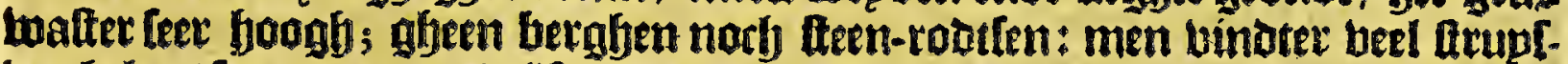

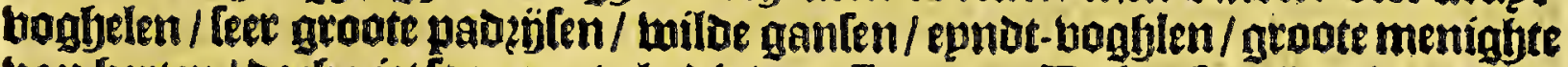
ban ferten/ Dotf niet too groot als die ban Europa. De buplen jün al ban aet:

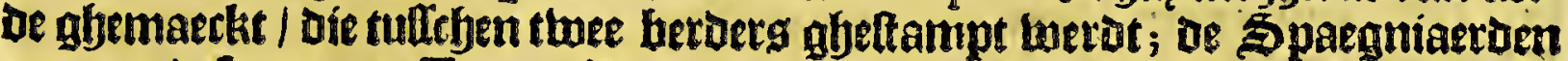
noemen befe mueren Tapias. Te riebiere beeft beel bifrb. Be Hailoen gaen meef naeckt / ofte met bier-kante mantelg ban ofterf-bellen / Diebier tuel mozden ghe bangben; maecken hutten ban rieot met matten bedeckt; onver-fouben haer meelf bp oe jacht ende billeberye; maecken teel toercks ban be fonoen; is boots fraep bolck / wel ghemaeckt ende tamelïck langf. Dit ledeken is bed onterck/ alleen bet bups ban de Goubetneur liggbende op 't water / beft een tooen baex

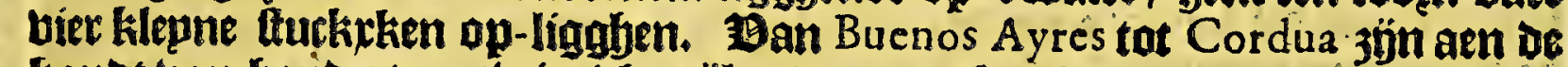
Fanot ban bontert en twintich mölen/ (andere tegoben twee bondert:) is een willoetnille ofte Defpoplado, Daer onder-twegen bups notb hof en that / Ionber boftchagie/ban een fehoon en effen landt/feer bequaem am bee te boeven/waet haes menigf fonoert buptent peerden gheneeten / die in bet wilde loopen; ander-twes

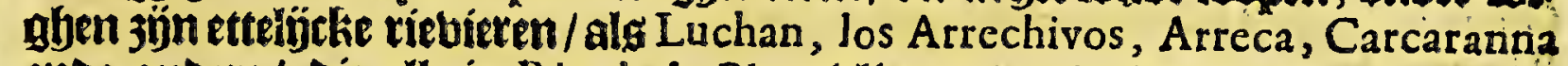
ente andere / Díe alle in Rio de la Plata blieten; oe riebiete Carcaranna (naer

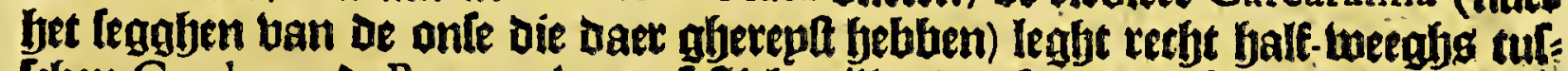
Thben Cordua ende Buenos Ayres, fettich mülen ban bepoe berthenoen. Defe rie: biex feeft deg fomets lootwepnigh water Dat men Daer met een karre magh Dooz-

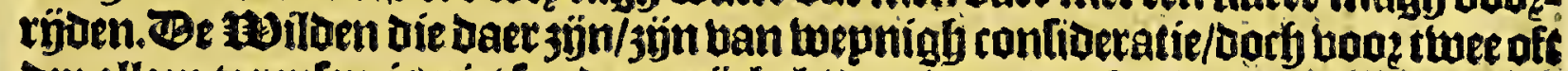

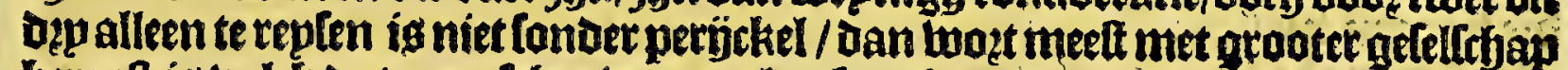
berepet;ís bolck bat geen leker looun-plaetle en boutot / ban bertrecken nu bier nu

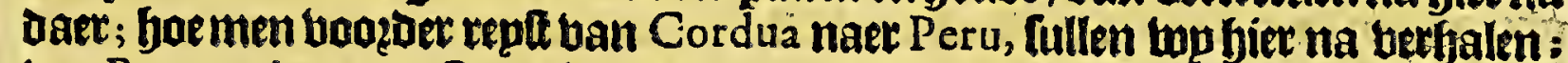
ban Buenos Ayres tot Peru, is ober oe 400 mỉlen weeghs / naet eenighe tegghen.

\section{Set elffe Capittel.}

Van deftadt Assv MCioN, welck de voornaemfe is van dat ghewefte, ende de gheleghenthoden daer ontrent.

D选 boomaemfle ftadt ban dit lantot is Neuftra Sennora del Affumcion, Herr.de

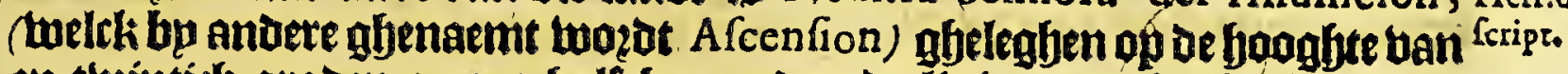

bijf-en-twintich graden en een balf bp zupoen oe limie / naet bet feggben ban Herrera.

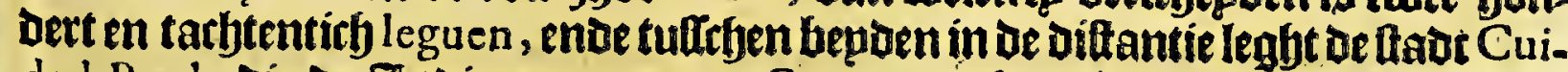
dad Real, Díe oe Indianen noemen Guaira, tarbtentich leguen ban de that Affumcion : aen oe twelt-3igoe naer Peru toe / is [u glyelegben deg fondert en tacb)= tentich leguen ban be faat la Plata, ende twet fondertentarftenticf leguen ban Santa Cruz de la Sierra; (Herrera leght eldets ghelijet wo in bet thiende boeck aen bet bijf-en-dertichlte capittel bebben gbeallegbeett maer oze bondert leguen ban de Charcas ente twee fontoert van Santa Cruz de la Sierra; twelcke diftantie beter frbjüt te accozoeeren met of beede ban bet lanot) naer het 3typoen/ melch is naet of ftrate ban Magallanes toe / fieefite feet groote enoe rïrke landen/ ende is gbelegben dęp fondert leguen ofte foo Herrera eloerg feght

19 3 
Dęu hondert en böftith leguen ban de mond uan De rietiere de la Plata; is gebout neffeng oe riebiere. Paraguay aen oe ooft-jijoe; daer jón tuel bier yonoent burs getg Spaegniaeroen/enoe noef toel ozp ouplent die Daer in bet lanot jïn

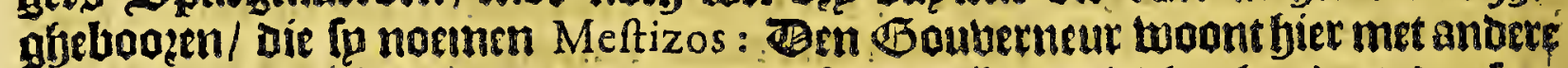

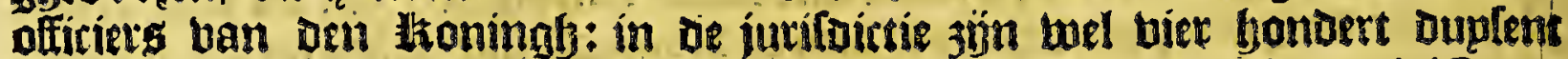

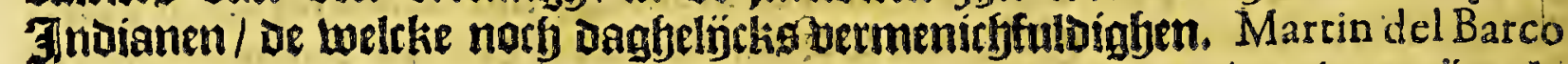
Legft in fpn Argentina, Dat in be aad Affumcion beel meet byoutuen zön als mans / Joo, dien de continuele oologen of mans Teer confumeeren. Daet is

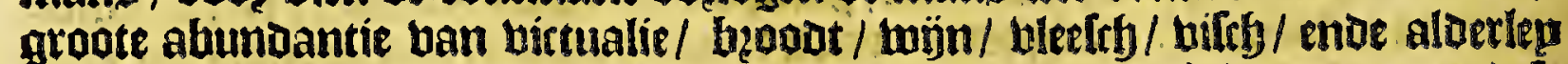
beucften uan 't lanot enoe van Spargnien. De temper ban't lanot ontrent ofle

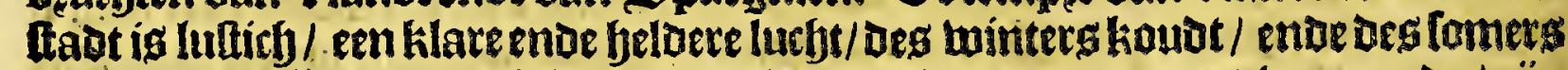
beet / ende't ifler meelt altóts groen. De natien Daer ontrent boonende / zün beel enoe berfeffepden / Dach boomamentlijet de Cheriguanes, be wetcke de

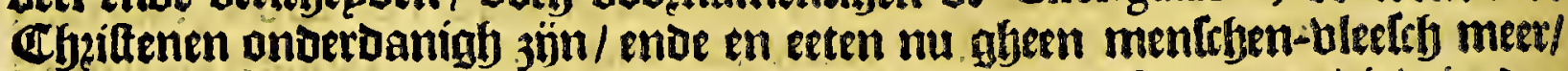
ban bp lonoerlinghgebal. Higer ontrent woonen oork de Guatataes, die bejenden 3jin ban of Spaegmiaeroen; als mede oe Mogolaes ende Connanequaes, die allenaelt-gheleghene jün ban be ltadt Afumcion, endekomen diente boen aen die ban de ltadt / boe twel lp niet ghereparteert en zinn. Ontrent of ftadt Affumcion leght een bermaerden berab/ghenaemt Lambare, be booghtte van alle de berghen van Dit lantot / ende de riebiete op-twaerts is een bermaert lack / helch of Jnoianen noemen Y rapua; in toelchers midoen is een rootre ban een batoe

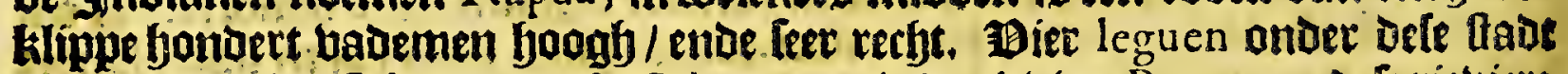
komt oe riebiete Pilcamayo ofte Bilcamayo, in de riebiete Paraguay; defe viebiere Pilcamayo homt af ban oe Charcas in Peru; ende toogt fyer onder ghenaemt Guapayg, endepafleert twaelf leguen van Chuquifaca, enoe wot daer gljenaemt Rio grande.

De ftadt Cuidad Real, anters aluenaemt Ontiveros is gfeleghen fontert leguen ban Affumcion, naer bet noozot-oolten/ enoe naer Braflien toe/ neffeng De riebiete Parana. Jlg gbeleghen in een goed quartiev/ ende oberblopdigh ban bictualie; saer jön bunngaeruen / ende feer goedt hoper / ende beel Tnuianen

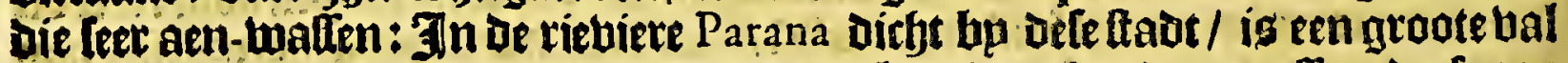
ofte fortingbe ban water / Daer nirmant bp twee gondert paten beif aen

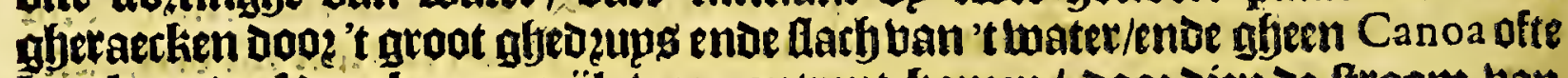
batcke en oert saer bpeen mijle berre ontrent komen/ Doog dien oe froom ban

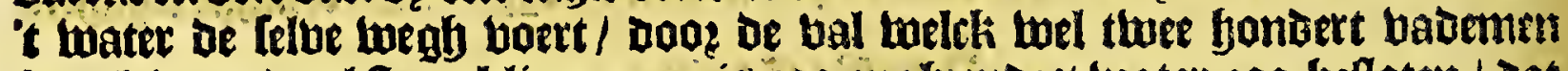
booglj ís / enoe al fteen-klippen; enis joo engh ende't water 300 belloten / Dat 't Ithint men die met een boogh loude ober Irhieten. Martin del Barco leght in \{pn-Argentina, Dat beertich leguen of riebiere op-Laetts noch een ander laot is ghebout / bie bp niet en noemt:entoe dat of itabt Cuidad Real oiefye noemt Guayra, en fruacke ofte ongbelonoe plaetle is / ende continuelj́chen booz de oollogyen met de Cheriguanas in onxuft.

\section{Tet thadfoe Capittel.}

Befchrijvinghe van de andere Steden ende plaetfen van defe Provincie, te Weten, SANTA FE, SAN SAIVADOR, ende andere.

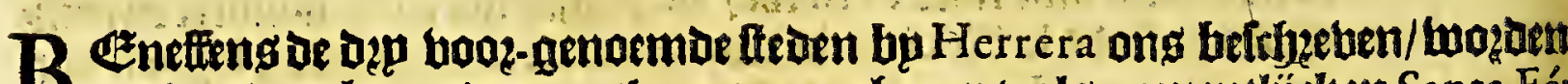
noch andere bp enoere autbeurg aen-gheroert: als namentlíthen Santa Fé; helck is gbelegben naer't zupoen ban Aflumicion. (bonberten tüftrich leguen

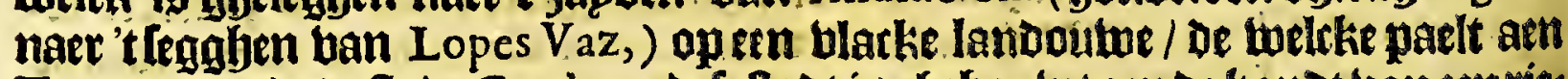

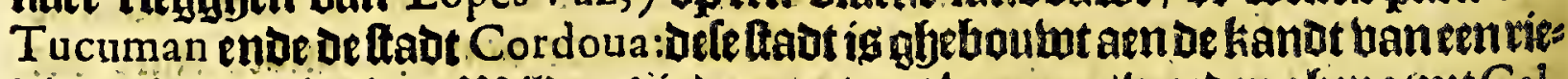
viere. De natien ban moiloen die daet ontrent woonen/wog̨on gfyenatmt $\mathrm{Cal}$ chinos, Mepenes ende Chiloacas. 
Het derthienfte Boeck.

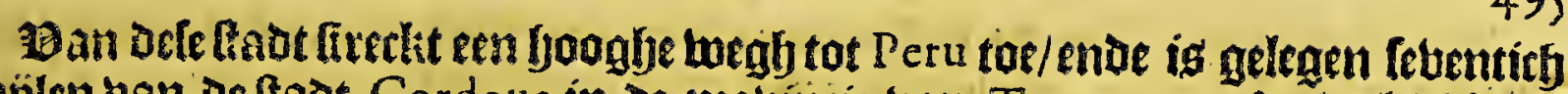

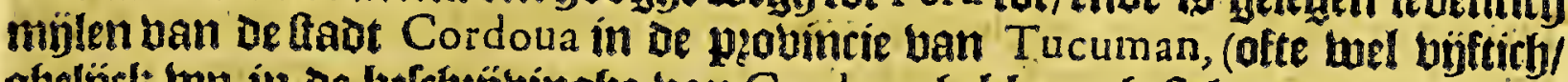

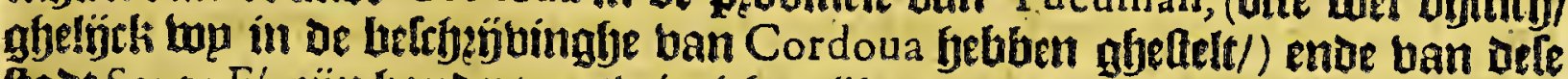
ftadt Santa Fé jïn ljonuert en twintich mïlen (naer bet fegathen ban eenigbe) tot De ftaot Buenos Ayres, of eerte aen'tin Komen ban Rio de la Plata. Befche= pen ban Den Wrabe van Cumberlande kregbeneeniglege gevanghen op oe riebiere

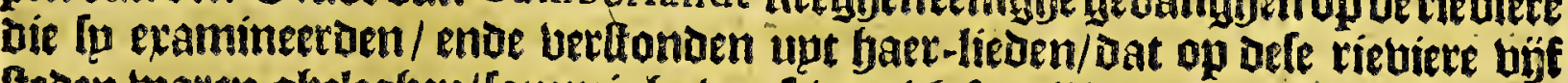
fteden waten ghelegfen/[ommighe banteluenticly familien/ende foinmighe ban meer. Bat de eerite taut byenaemt Buenos A y res wag ujittich mïlen oe riebiere op/ ende d'andere betricl en bjftich mijlen ban oen anoeren/ 300 vat of laette

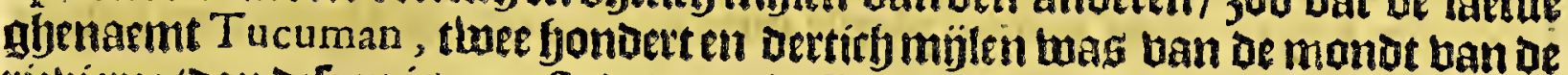
rieviere: (Dan dereen ig geen ftadt van oit Gुoubernement/maer een peobincie op bem (elven/als vozen berfaelt) Dat in defe fteden gtoote alumbantie ig ban kozen/

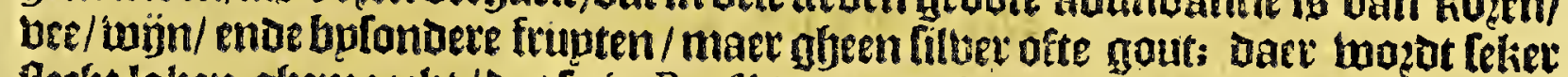

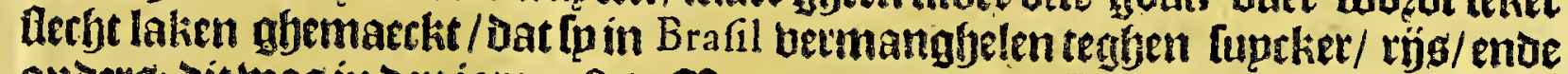
anderg; dit was in denjare 1 586. Agaer een paetuges Francis Suares frigejft aen jijn broeder twoonente tot Lißbona, upt Rio de Ienero in Brafil, in uen fate I 596 ;

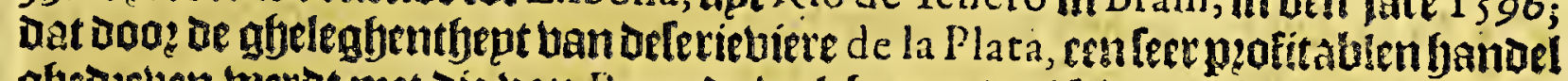

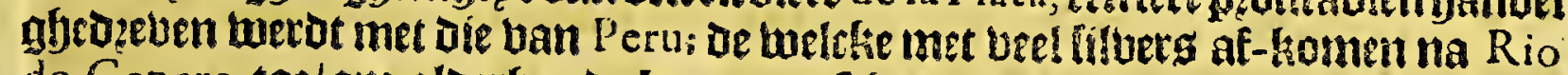
de Genero toe/om aloethande koopmanfryappen to koopen; ende bat bet bel een ban de naefte ento bequaemte tweghen fig on met die ban Peru te fandelen/ Doo? Dien men booz defen wegh kan treckeri te larde naer de rÿrtie nijnen ban

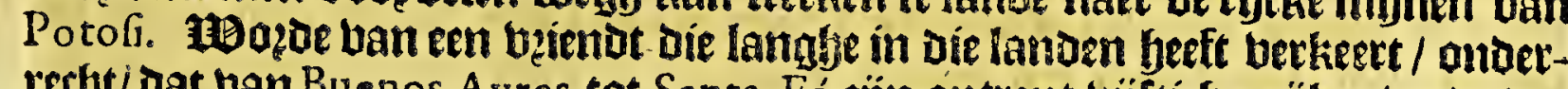
rectyt dat ban Buenos Ayres tot Santa Fé jön ontrent büftich mülen / ende dat men daer te thater enoe te lande naet toe kan replen; ende dat bet een ftadt ig bp na ban oe felbe tonditie endegroate alg Buenos Ayres: Bie ban Santa Fé naer Peru repten willen/komen ban daet ootli op Cordoua, welck legbt op een

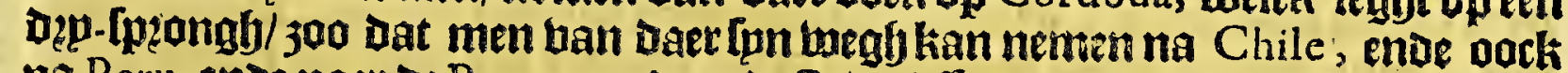
na Peru, ende naet de Paraguay, daet deftaut Afumcion aen gbelegben is. Om naet Peru te replen neeme men oe wegh naer Sant Iago del Eftero, bier-en-tatfls tentiry ( ofte loo andere legghen tarftentich) mijlett bouen Cordoua gbeles ghen ; fnde ban daer naer een ftadt gljenaemt noftra Sennora de Talavera,

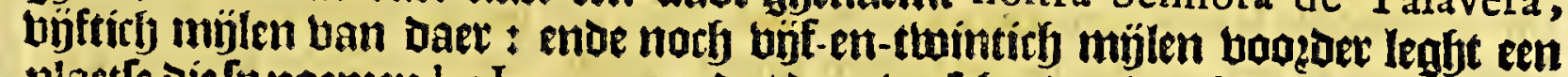
platte die fp noemen las Inntas, om dat daer bertejepoen wegben in een komen; want men replt wock ban Sant Iago del Eftero Doo: een anderen wegf / naet

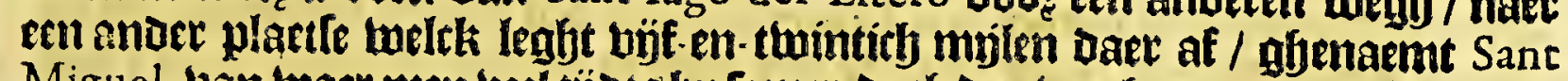
Miguel, tan waet men beel tijots bp (omex-daef den weghneemt naer las I untas

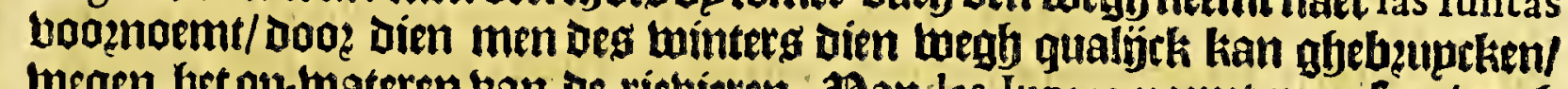
wegen het op-wateren ban be riebieren. Ban las luntas neeme men fun tuegh naer Salta, een ander ftadt / ofte oock naer een anoer ter jjoen af ghelegben/ gljenaemt luyu ofte Cuidad de Sant Salvador, beertbien mijlen af / melet is te upterftefladt uan Tucuman, ende is ban las Iuntas ontrent dettich mijlen / ente ban Potofi fjondert mijlen:enoe ig te noteeren dat onder wegen beel riebieren

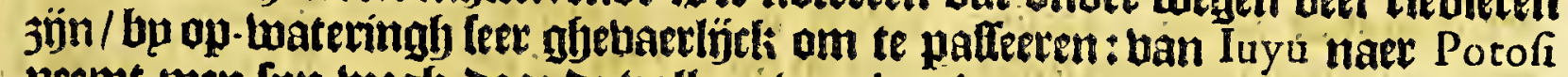

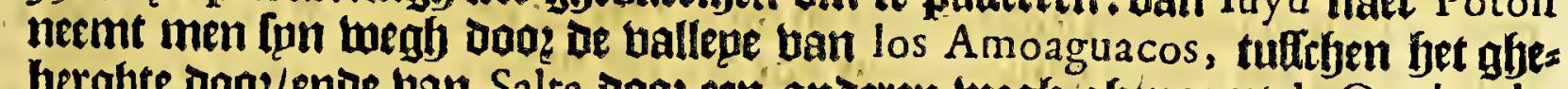
berghte Dope/ende ban Salta Dooz eent anoeren tuegh ghenaemt la Quebrada; Doch dele twee tweglien berfamelen weder oertichnülen onder Potofi.

Anvere reeckenen oelen twegf alous: tan Buenos Ayres tot Corduba there bondert leguen; ban Corduba tot Sant Iago del Eftero feltity leguen: ban Daet tot Efteco tachtenticy leguen, ende ban fier tot Potof fondertendeleftich leguen;

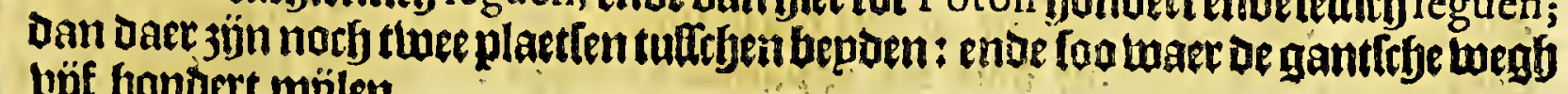
büf bonbert mílen.

10 4 Martin 
Martin del Barcolpectit in [yn Argentina uan norly een anter platte / Die Jp noemt San Salvador, gheleghen arn oe riebiere met een goede baben. Eende noch than een ander plaetfe / gheleghen bp de monot ban of riebiete Paranas

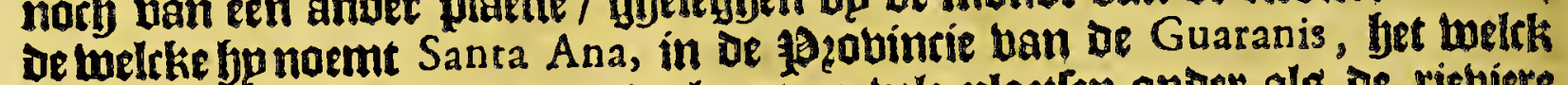
is goedt enoe black lanot / ende loopt op bele plaet ten onder als de cieviete komt te wallen. Ban De fadt Affumcion of riebiere op-Laerts/ is ghelegfen

3.7. cap. Puerto de la Candelaria, op de booghte ban een-en-thintich graden min een

14. DerDen-Deel/ Daer eertijotg Iuan de Ayola met tarbtity man berradelijck ban

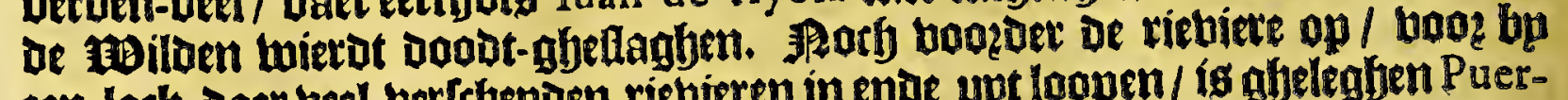
een lack Daer beel bertchepuen rievieren in ende upt loopen/ íg ghelegfen Puer-

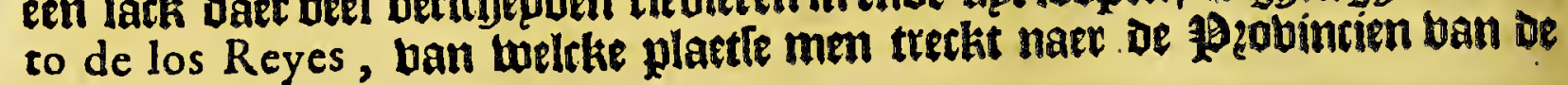
Xarayes.

$$
\begin{aligned}
& \text { Van de Havenen, Eylanden ende punten, op de kufte van } \\
& \text { defe Provincien. }
\end{aligned}
$$
Her.der. 13 be kutte han defe pzobincien uan't landt ban Brafil af/ tot aen Rio de ban Sant Vincent teghen ober Buenabrigo, daet of linie ban bet telyeptle! tulftyen oe kroome tuan Caftilien en Portugacl ober palfert: Ies leguen bozoer naer het jupoen is de rietriete Vbay. UEnoe veertich leguen tan Sant Vincent

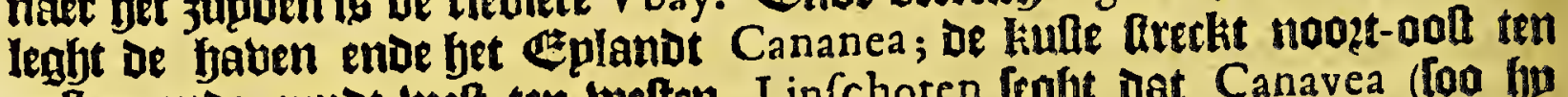
Enghel- oolten ende jupdt-welt ten welten. Linfchoren fogbt Dat Canavea (Foo by fche vo- bet noemt ) ís een Geplanot twelck een goede baben beeft / en ghelegfjen is op

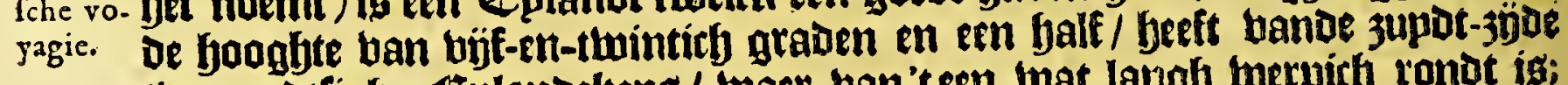

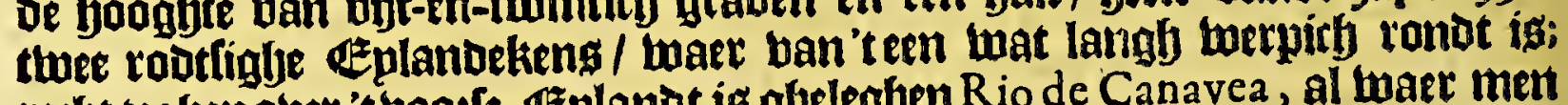
recht teghenouer 't wook $[3$. Eplantot is alyeleghen Rio de Canavea, al waer mett met klepne fryepen marb in-loopen. mat hoozoex bebt ghp de riebier de la Barca; Ban Deriebiere Canavea tot oe riebier ende haben ban Sant Francifco

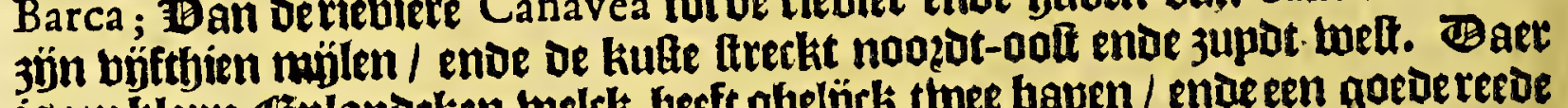

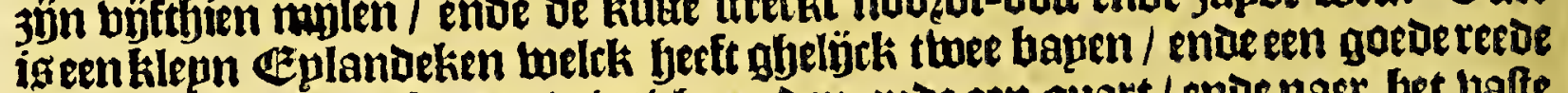
op De booghte ban lesten-twintity graden ende een quatt / ende naet bet bafte Her.def. landt toe / is lyet boogh $\mathfrak{m}$ backeliry lanot. Ban San Francifco tot Boca do

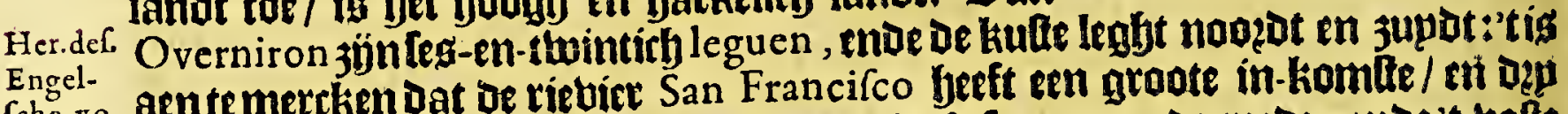

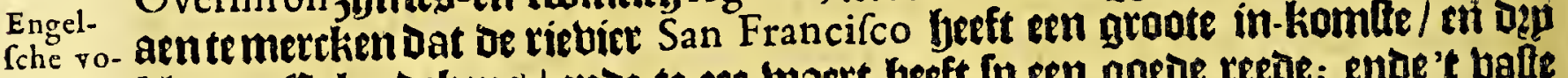
yagie.En klepne Eplandekeng ! ende te 3ee-waett beett fp een goede reede; ente't bafte Lincho- lanot is hooghende hackelieff. Ban Boca de Overniron tot liha de Arvoredo,

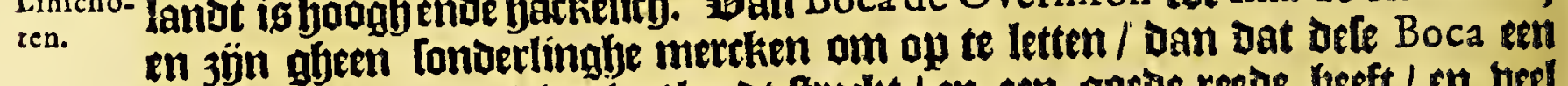
groote bape is / en Diep in'tlanot freckis / en een goedo reede beeft / en beel Eplandekeng/ en is obelegfen op De boogljte han arft-en-twinticf graden

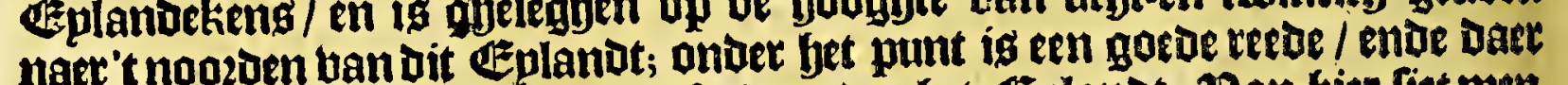
is abeen ander biet ontrent / ende lo is onder bet Geplandt. Ban bier fiet men

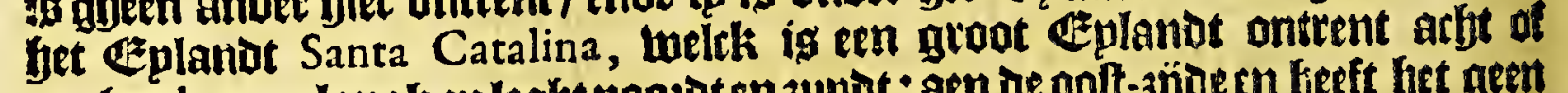

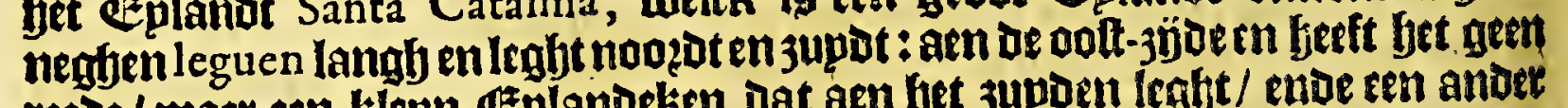
reede/ maer een klepn efeplandeken Dat aen bet jupoen legbt/ ende een anoet

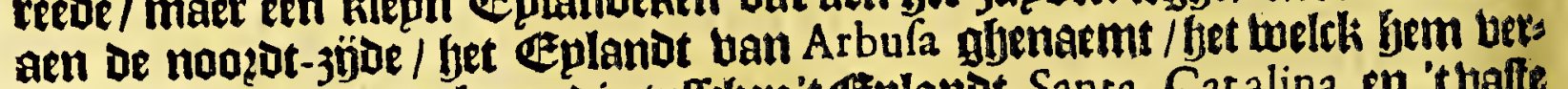
toont als een groote bape Die tulfeljen't efplanot Santa Cat alina en 't bafte lanot leght / in welche bape abp meught anckeren: aen de juptot-jyjoe beft bet een ondicp ban klippen / Die verbozghen legefen dirft bp be punt ban't

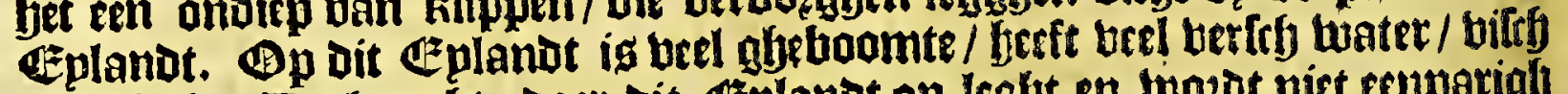

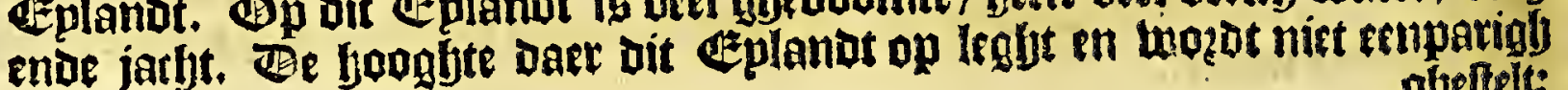
abeltelt: 
gheltelt: Herrera ftelot bet op meer als neglyen-pn-twintirly graden; Linfchoten op arfe-en-twintich ende een half; ende de befrbejuinghe ban- Diftantien der plaeten acfter de vopagie uan Candifch gheboeght / ftelot fuet noosd-point

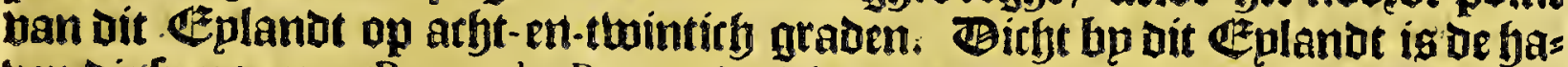
ben die fu noemen Porto de Patos, welks leght op de hooghte van negben-entwintict graden/thintich leguen ban Santa Caralina als Herrera betuphlyt / sngelenve thien ofte elf leguen ban Porto de Patos, als oe kourlen legghen/. is gujes fche roleghen Porto de Don Rodrigo, enter ar kulfe ig ftrertiente noogot en 3 uput. yagie.

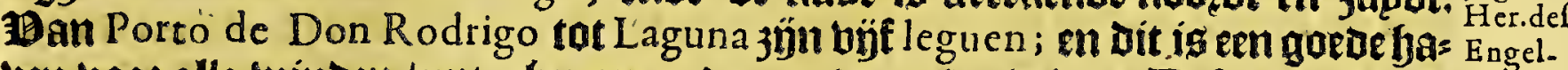
ben boot alle winden / upt-ghenomen be noozot-poiten twindt. Befe wozbt oock fche voghenarme Biaça, nten moet biet niet in-komen dan met booglj-water/ om yagie. eenighe Deooghten twil / die in de monot legghen/ enoe fet bojot betiendt bu een Eplanot / twelck legft een müle af in $3 \mathfrak{c e} /$ ghenaemt If a de Reparo, Daet men ontrent andieren moet / om het kanael te loedken; Herrera ttelot bijf leguen van Porto de Don Rodrigo, De haven van Porto Cerrado, melck ô felfue moet welen. Ban bele plaetle af / tot aen de rieuiete la Plata, en is niet efn fas ben om met een groot lfbip in te loopen. Ende Rio Grande lyeeft beel doongly= ten aen De monot/ [oo dat baer niet Danfmalle barcken in konnen komen; Defe rieuiere Ifyepot de voltketen gljenaemt Carios ban die Guanaes: ende ban Giec af is bet al leeglyen ulack landt / tot Rio de la Plata toe / melck jön tacthten= tirb leguen, ende men moet al twee of dep mijlen ban de kulte feplen / tot dat

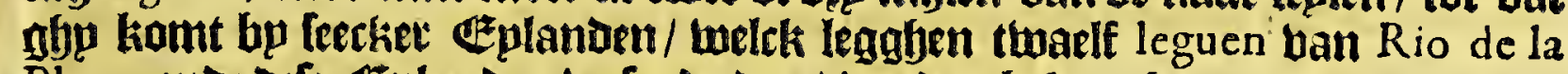

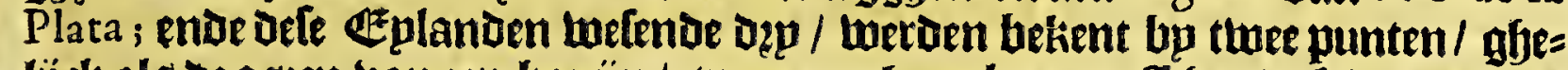

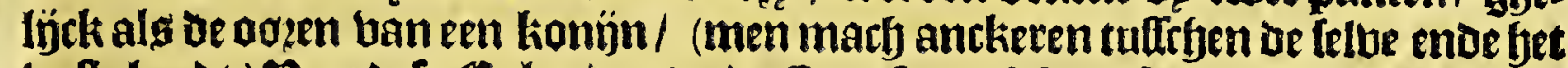

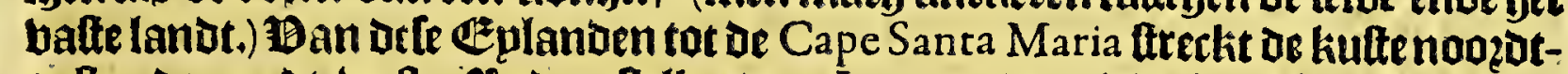

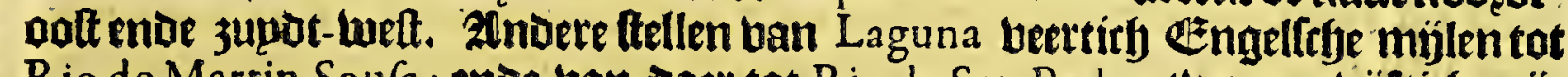
Rio de Martin Soufa ; ende ban Daet tot Rio de San Pedro twee-en-büfticy mij= Voyagie Ien :ende ban Daer tot Cabo Santa Maria twee-en-beerticf glelïcke mịlen. Her- Canrera ftelot ban Santa Catalina tot Porto Cerrado uj́t leguen, tot Rio Poblado büfthien/ende ban daer nocf uöftthien tot Bahiahonda; ende de riebiere Tiraqueu, Her.der. op de houghte ban thee-en- Dettich gradenende een falt: ende Cabo de Santa Maria op vïf-en-Dertichgraden.

Wet bertbiende Gapittel.

Befchrijvinghe van de felve kufte ghelijck die by Figueredo in fyn Roteiro, ende by Dirck Ruyters is uyt-ghegheven in fyn

Toorte van de zee-vaert.

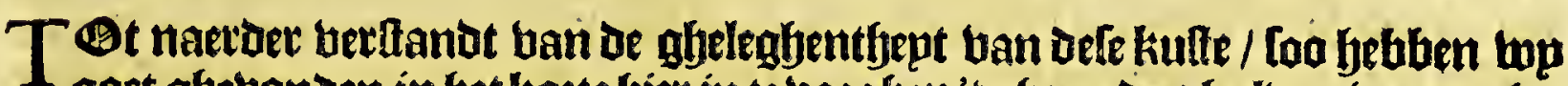
gart ghebonden in fet kozte biet in te boeghen't ghene ves-fyalben is upt-afjes affeben bp Figueredo in lpn Roteiro, enDe Dirck Ruyters. Figueredo reetkende van Cabo Santa Maria tot Porto de Sant Pedro [eventity leguen, ende en noemt gheen ander plaetlen tuffrben bepden; maer Dirck Ruyters ftelot ban Cabo de Santa Maria tot eenen boeck welck bp noemt Spaegniaerts punt; thien mïlen/ Daer twee Ceplaniekeng legghen / Die faer berthoonen als twee konïns ooken: een van dele Eeplanden luozut oock ghenoemt llha des Caftilhos, ende is naex fon legghen ghelegfen op de hooghte van viet-en-dertich graden ende beettich minuten, Ban liha de Caftilhos jün leg-en-twintirly mijlen tot mar Manfe. ende de ftreckinglje is noazot-ooft enoe zupot-twelt: ban mar Manfe tot Rio Grande, huelck oocli anders twożt ghenaemt Porto de Sant Pedro, ż̉n mede feg-en-twintich mïlen / ende de ftreckimghe noozdt-oof ten noazoen ende jupotwelt ten jupden; fet ifler ober al black ende effen grondt / De kulte bol bugnen

ento 
enoe betgh bp betglj; foo dat $D$. Ruyters bier maerenreetlent 62 mülen: ente

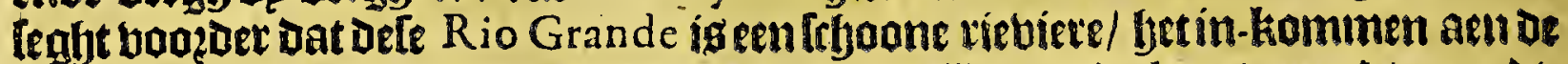

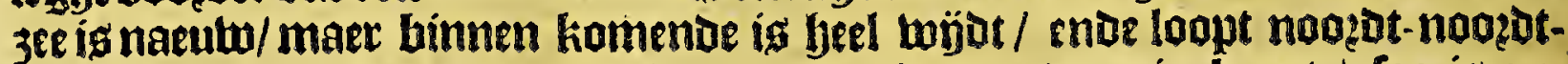
welt op tot bet land ban de Patos toe; als men base in-komt / foo is aent bagl-boozot goede reede. The lutte ig bupten oluer al fethoon/ foo dat men

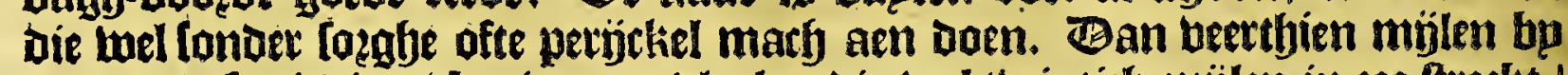
3upoen Defe riebiere / begint een blackte die wel thintith mijlen in $3 e$ efrectit ! ende bu het landt langhs / oe kulte if ober of vífthien mülen beedot; begint met de oep-en-bertich graden / enoe buert tot de bier-en-derticly aen bet land:

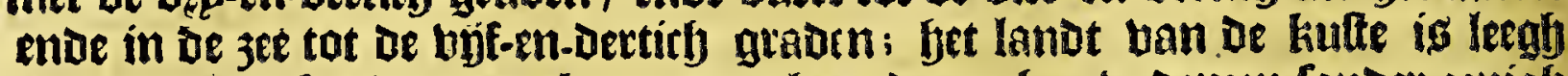
bupn-lanbt / loo dat men komt ap arbe ende negben bademen Conoer eenigd lanot te konnen lien; Dep mülen ban de wal is fet thien bademen diep/enve thaelf ofte dertljien mijlen van fet lanot büf-en-twintity vademen; mar Man-

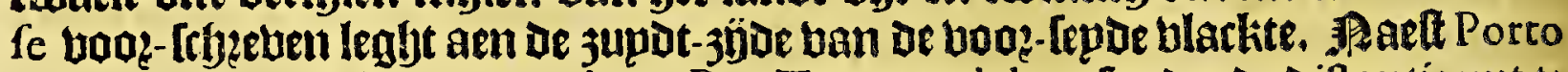
de Sant Pedroltelot Figueredo ie R 10 Tamarandahu, Conoer de diftantie upt te Dutken / ende dertfien leguen ende een half tropzoer Rio Iboipetinhi, ende thien leguen boożoer Ararangua, ente vóf leguen boożoer Rio de Lagoa:- maet Dirck Ruyters leglyt Dat van Porto de Sant Pedro ofte Rio Grande tot Taramandahu, jün thien mülen; ende uan Daer tot Ararangua, Daer Iboipetinhy lealyt / beerthien mijlen / entue van daer tot Rio de Lagoa neghen mülen: Defé rietuere bozot oock ghenaemt Porto de Biaça, is alleen boos kilepne lebepen;

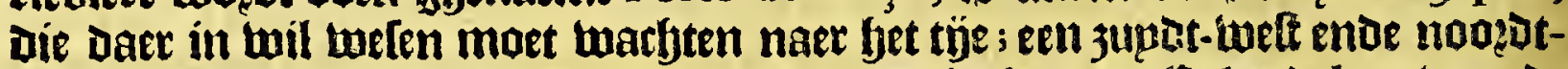
oofte maen/ maeckt Daer hoogh water; Daer leght een Eeplantokten booz de riebiere aell de 3 upDt-jijoe/ ghenoemt Reparo, Daet men bet onder moet letten in een bape/ want boozder gljeen goede antker-gronot en is: Jet Eplanot leght op neghen-en-twintich graden ende beertich minuten. Figueredo reec= kent han Rio de Lagoa tot bet lanot luan V paba adyt leguen, ende bat men maex een badem diepte en beft in bet in-komen/ ende glenoemt wożot Barra de Ibnafup, ende bier epnoirfyt bet lanot ban de Patos; alle dele booz-[rbzetuen riebieren bebben quade reeden ende foonh hetgijactjtigh lanot. A9aec Dirck Ruyters legft bat ban Rio de Lagoa tot Rio Vpaba jün leg mijlen/ melck maer les boeten diep is in bet in-komen / Dan binnen ig bet een fraepe riebiere. Figueredo legbt: thien leguen boozder langhs de luufte leght llha de Santa Cathatina, ende de kulte ftreckt Dele thien leguen noozoen ende 3 upden/entoe aen bet landt leght Rio dos Patos op neghen-en-tminticl graden: Dirck Ruyters. feght dat ban Vpaba tot Rio dos Patos jujn Ieben mílen / juppen enue noozden langhg de kulte: ende dat defe riebiere redyt open lingt met bet jupotepnoe ban Ilha de Santa Catharina. A9en moet bem twathten boo? De neilden

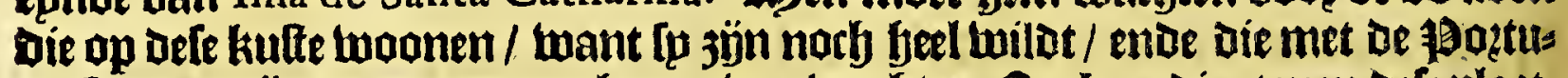
geelen eens jön/moetmen norb naeulwer warbten. Bork en Dientmen trele plaets feniet aen te Doen / Dan bp noodt ban Maert tot Auguft, Dooz dien't aldaertuins ter ig in die tijot/ ende beel ongheltadíglj weder maeckt ban winot/lkoude ende res ghen. 't \& $\mathbb{E}^{z}$ lanot Santa Carharina is actjt mijlen langh jupoen ende noozoen/

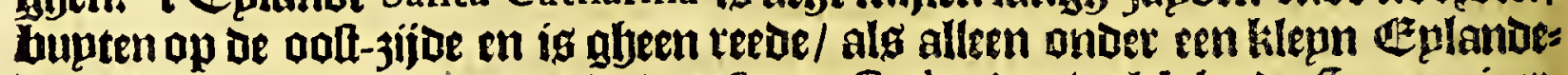
ken/ghelegen aen't 3 upbt-epnio ban Santa Catharina, we!ch bp oe Spaegniaet: Den trogot ghenaent llha de Arvoredo; Dooz Dien bet bol gfelbomte ftaet enoe thoont Derfyaluen grooter als het ignaer't teggen ban Figueredo. Ban Santa Ca-

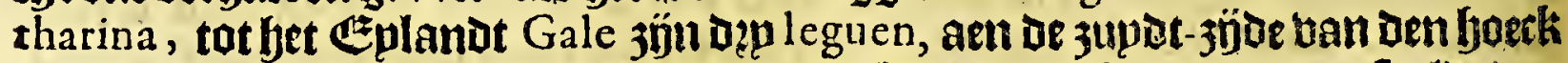
Mandivi, aen't balte lanot ig gheleghen den bocht ban Tojuqua, men leplot vers tuaerts langhg de nodztt-jijbe uan Santa Catharina, latende Gale ende Mandivi noozden af-legghen; Delen borbt leght bol Eplanden/ foo Datmen ouer al teede

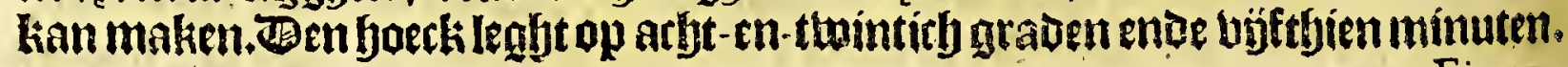


Het derthienfte Boeck.

Figueredo leght: Danghg fet punt van Mandivi loopente matr bet noozd-

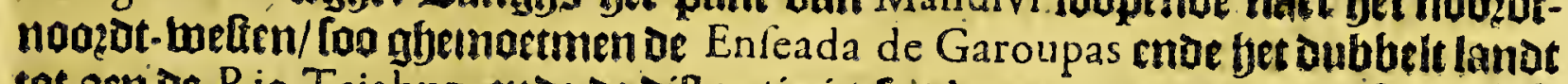
tot aenio Rio Tajahug, moe de diftantie is tes leguen: enoe ban befe rieturere

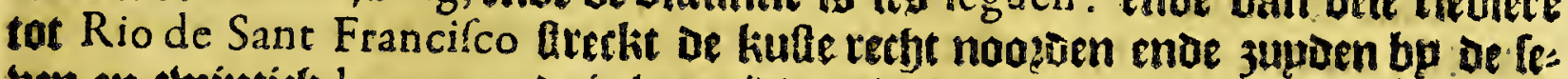
ben-en-twintity leguen, ende in bet midoen legft de rietiere T apuca ghenaemt. Dirck Ruyters feght Dat ban Mandivi tot de riebicre Tajahug, $30 ̈ n$ uof leguen

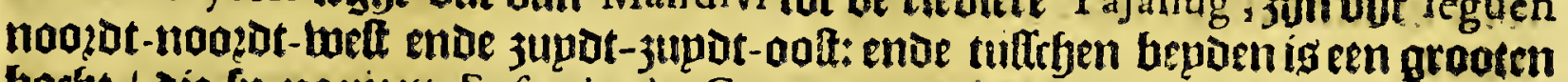
borft / die fe noemen Enfeada de Garoupas : be Rio de Tajahug Ieaht op of arbt-en-twintich graden. Alen Tajahug bolgbe de riebiere' Tapuca, ote noch twepnigh befocht is : de kulte tufferen bepden gheleghen is rectht ende frboon/ende Atelt gljeen diftantie.

Ban Tapuca tot Rio San Francifco, jün thaelf leguen noozot ten twelten ende juput ten oolen: De riebiere Sant Francifco beft thee in-homlen/ende ig

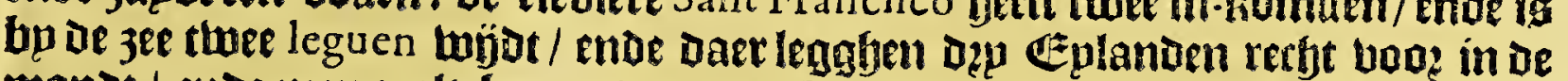
monat / ende men jeplt bp zupden enoe bp noosern de lelbe in de riebiete; het lanael bp jupden ie ezplanden gheleghen / wo;ot ghenaemt Aracari, ende bet noozdelÿckite kanael Bopitanga ; defe riebiete en wotot niet beele betaren ofte abeacht. Figueredo leght dat Rio Sant Francifco eent groate monot beeft/ aree=

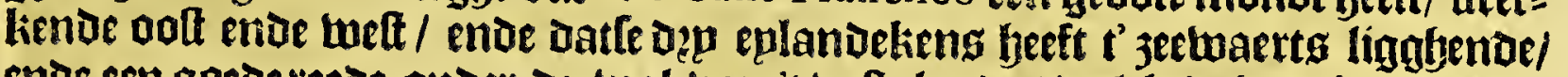
ende een goede teese onder de thal ban 't balte lanot / meick ig boogh enoe hat=

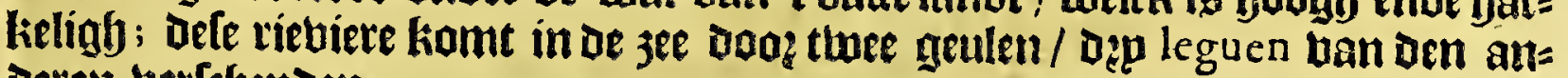
Deren betrfbepoen.

Ban Rio Sant Francifco tot Lagoa de Parnagua jün thaelf mölen / (ofte naet bet legghen ban Figueredo bÿfthien leguen) op de boogdte ban bỷf-en-twins tich graden ende thien minuten/ (naer't fegghen ban Figuere do bjef-en.twin= tich graden ende beertich minuten) is gheleghen in 't gheberghte van Parnapiacaba, ende is viff groate mülen (Figueredo leght feg leguen) wijot langhg de kulte/ende heeft dẹp bplondere in-komlten; de jupdelijeklte wat ghenaemt Ibopupetuba, is feg badem diep in't in-komen/ende een müle binnen ig een goede reede; thee groote mịlen (Figuere do leght ren legue) boozder naer 't noazden ist bet midoel-diep / welck [p noemen Bayfagafuy, ende beeft büf badem waters in't in liomen: enae norb ontrent thee kilepne mïlen (Figueredo leght een balbe

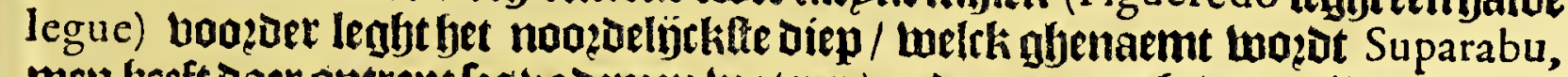
men beff daer ontrent les bademen waters / ende men marf daet allent-haluen

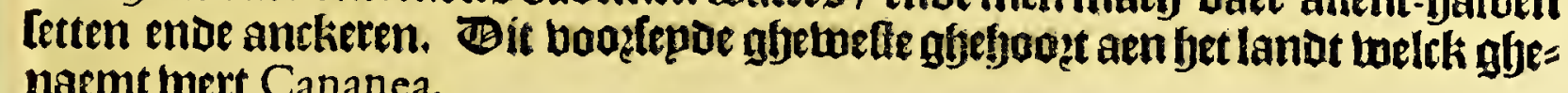
naemt wert Cananea.

1)an Lagoa de Parnagua tot Ararapira 3ijn büf mijlen/ (Figueredo ftelt fegs leguen) is een rietiere die men math in-komen op tiet bademen waters. $\mathfrak{O p}$ Dit lande is beel berberfebingbe ban frupten/meniclje ban boenders/ende was ter: ende de milden ban dit quartier jün doodt-bpanten ban de \$oztugeten/ foo dat men bem moet warbten ban daer booz upt te gheten / maer beel eer te thoonen buanden te 3 j̈n ban de Spaegniaerden ende 190 ctugeefen / om alleg ban faer te lirjaben wat men ban doen fjeft. Befe riebiere leght aen de jupDt-

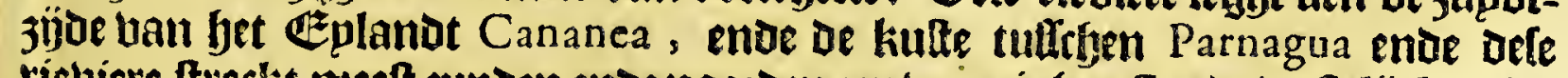

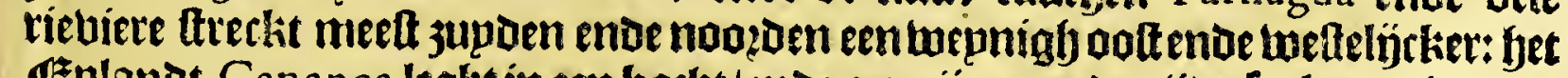
Eplandt Cananea leght in een boebt/ende aen 3 ifin nogyt-jijor lepltmen in naec De ríthiere Itacuatiara, welck ig deptincipaelfte reede ban Cananea, daer is biff bademen waters in fet in-komen. Figueredo reetkent tutteben Ararapira ende Itacuatiára there leguen ende een falf/welck is dercede uan de hoon platte die de 19 oetugerlen bier hebben aen Cananea.

Ban Iracuatiára ltreckit de kulte noozed-ooft ten ooften ende jupot-mett ten

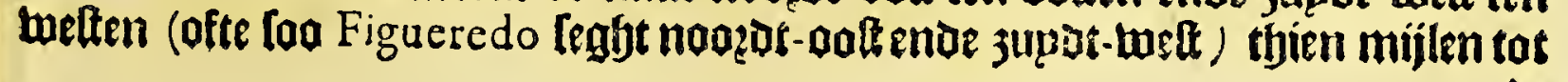


500

Rio de la Plata.

De riebiete Vguaa, Daet men op bijf vademen in-loopt / ende daet loopt een bliet 3upuen op in't landt.

Ban de riebiere Vguaa, tot Capiuarii jijn thien mijlen (Figueredo legbt

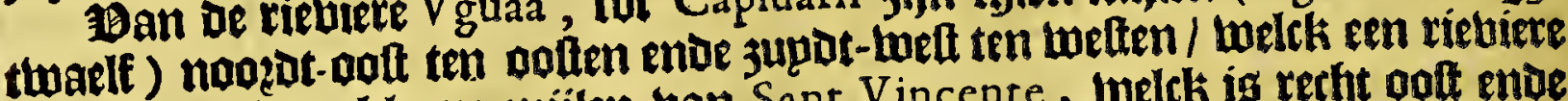
ig ontrent twee kilephe mijlen ban Sant Vincente, welck is rectht ooft enive tweft in-ftreckende / enae beeft booz in of monot en Dozpel ban Dęp vademen Diepte.

Figueredo leett ons oat bp Rio Capiuarii enn nikutwe twoon-platte legbt

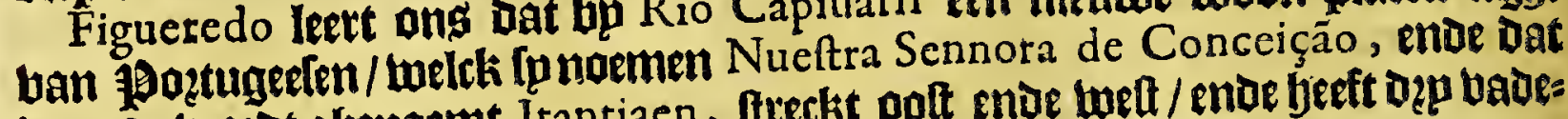

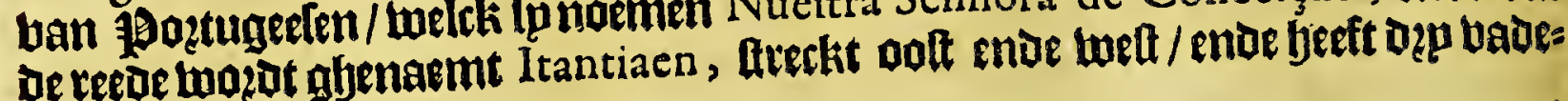
men Díepte.

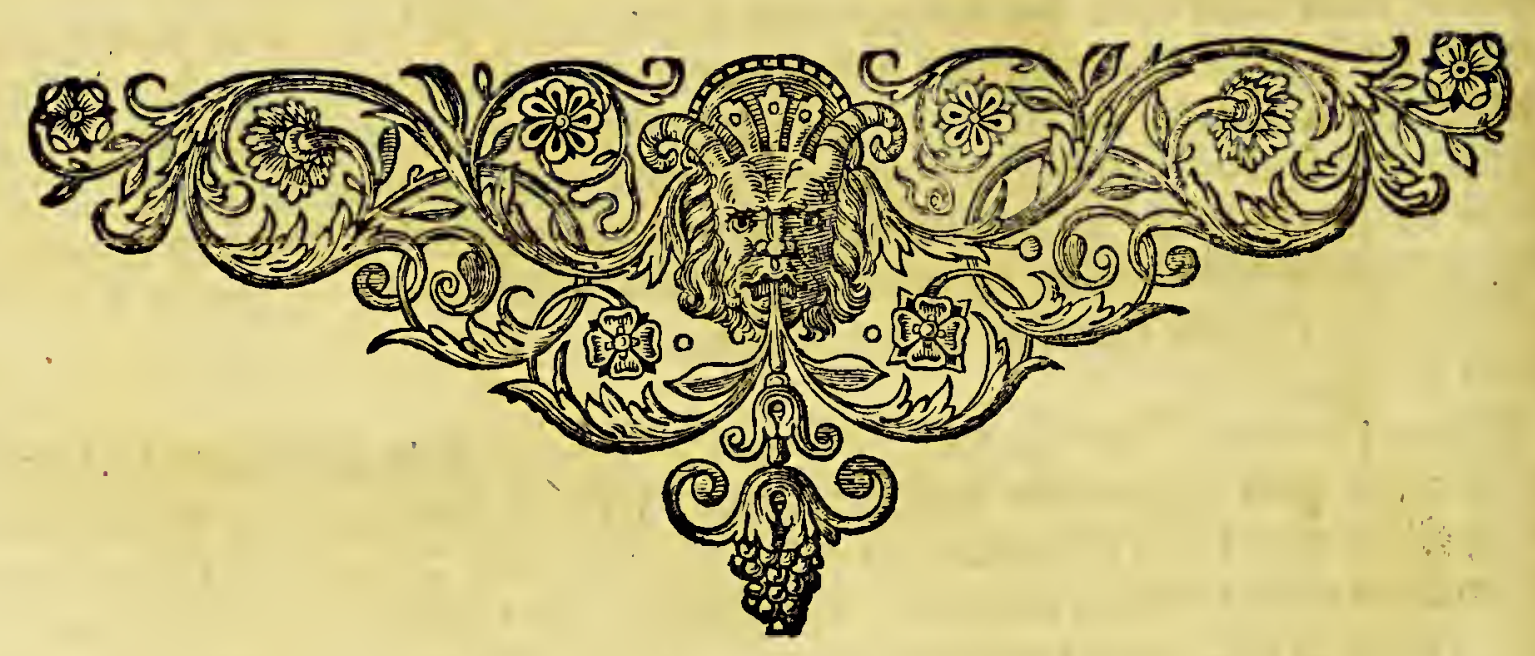

FESCHRII- 
(APICB) 


\section{BESCHR IIVINGHE \\ Jaan \\ W E S T - I N D I E N.}

Wet bethtento Daeck.

B $R$ A $S$ I L.

(1)et eetfe Capittel:

Generale befchrijvinghe van 't Landt van B R A S I L, fyn eerfte ontdeckinghe, ende andere ghelegentheden.

Yle de Zanden van de 1híeviere. La Plata voozoer

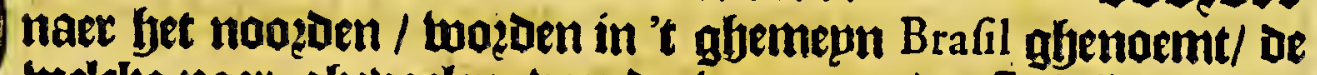

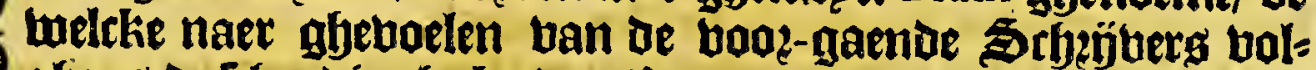

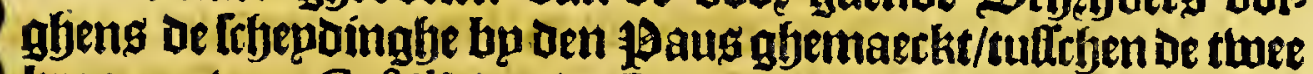
kroonen tuan Caftilien ende Portugael, beginnende tan den neghen-en-thintichften graedt/ Eenghte ban den meribiaen ban Toledo, ende epundigfien aen den neghen-en- Dettichfen qraedt; ende in de bzeedte noozot ende juppen ban Cabo de Humos tot fyet Eeplandi

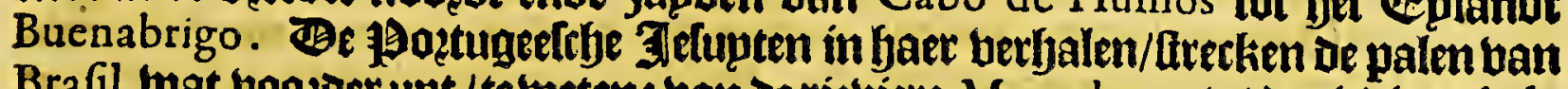
Brafil twat voozoer upt/te weten: ban De riethiere Maranhon, tot De riebiere de la

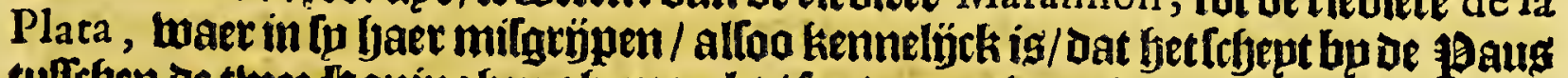
tultrben de thee Hioningben ghemaeckt / Loo berte niet en komt.

Bit lanat waseert (naet's tegghen ban Herrera) ontoerkt tooz laft ban be Cattjoliǰkte lloningen bp Vincent Iannez Pinçon, enve daet naet bp Diego de Lepe; in't jaer 1500 : entue les maenden daer naer quam aen dit lande bp ghethal

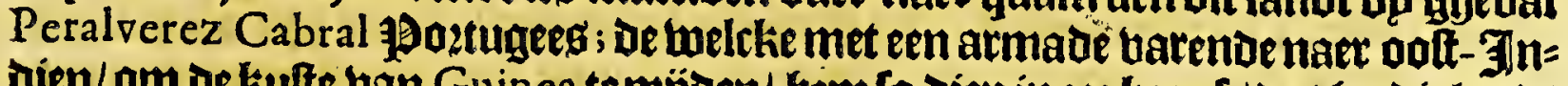

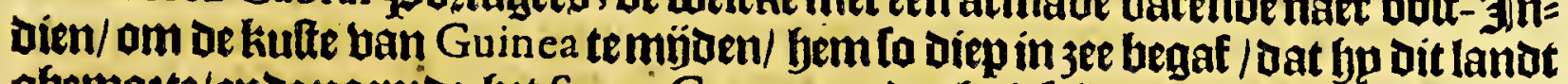

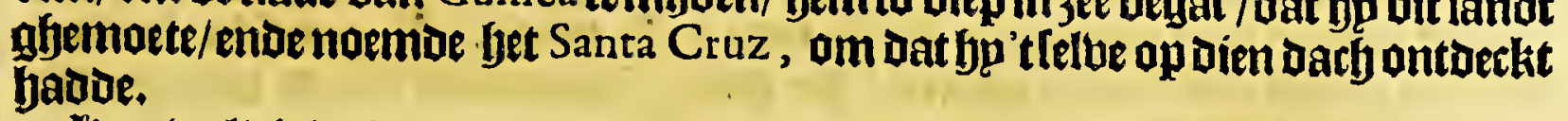

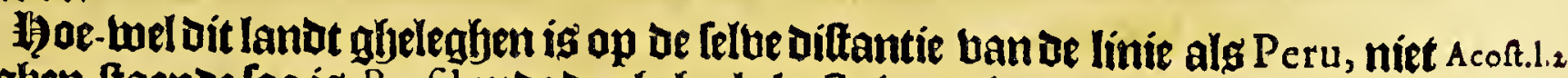
teghen-ftaenoe foa ig Brafil ende de gheljeele kufte ban dien een upt-nement beet ${ }^{\text {cII. }}$

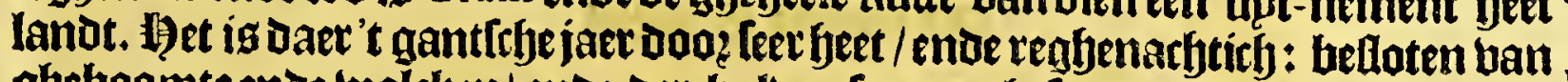

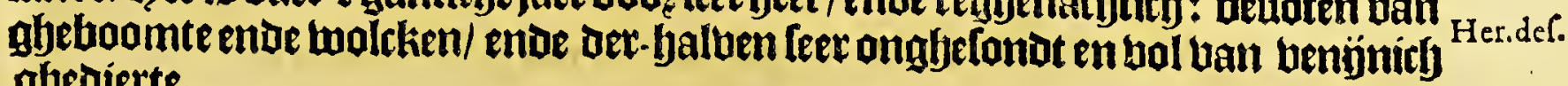
qubeierte.

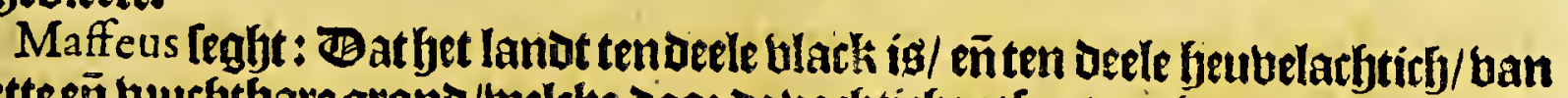

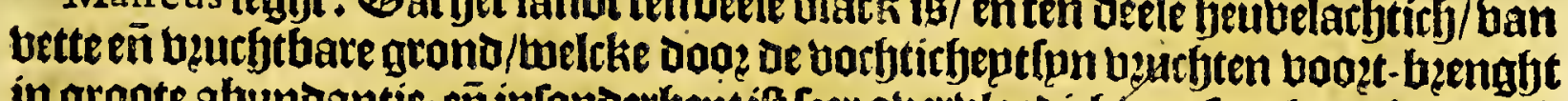

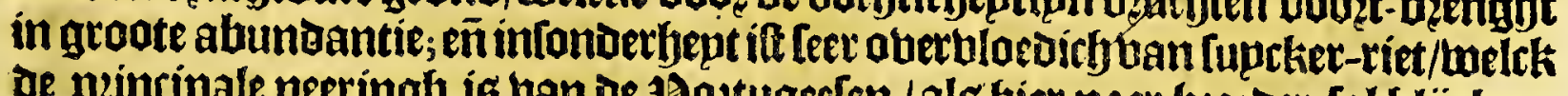

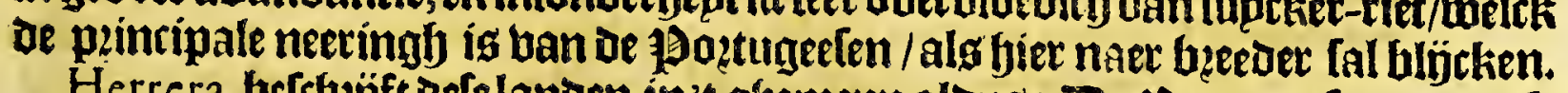

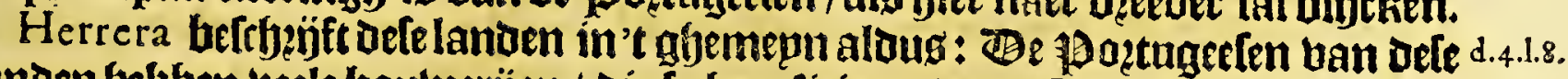

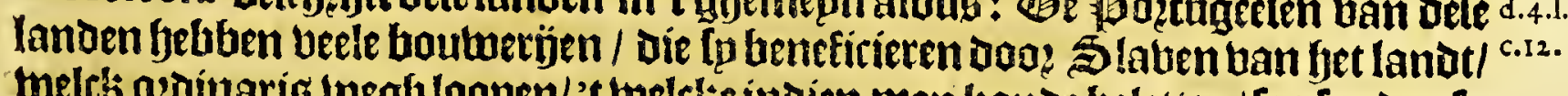

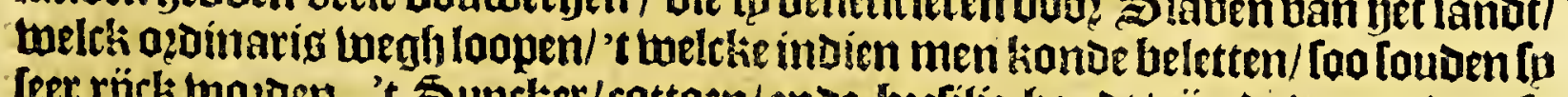

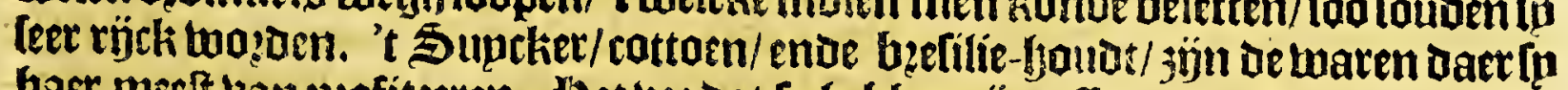

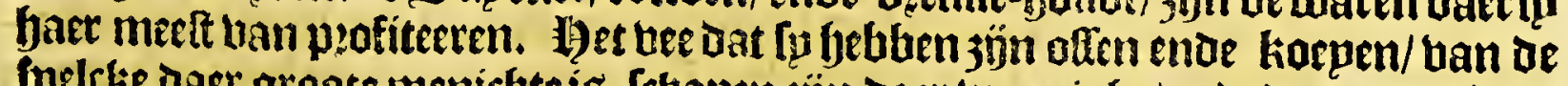

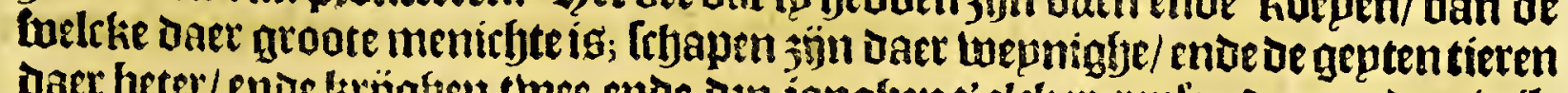

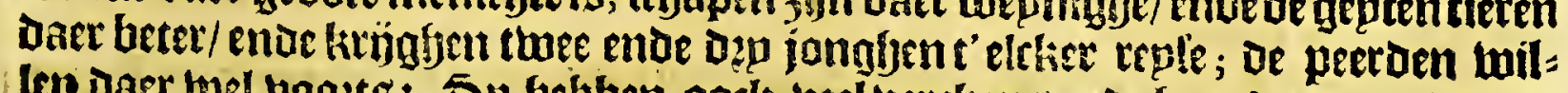

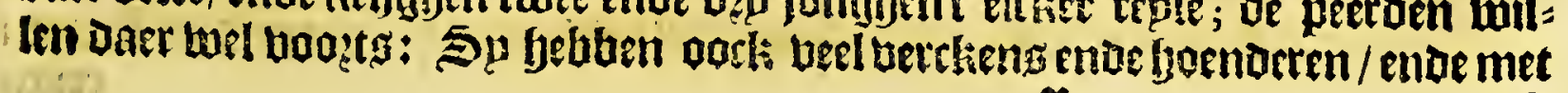


502

Brafil.

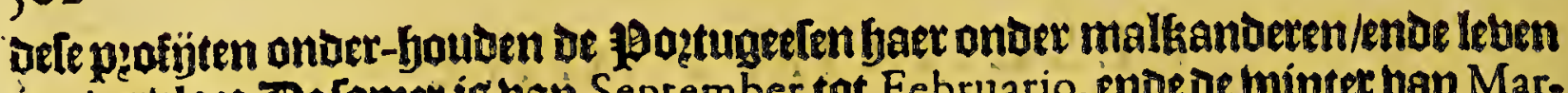
in ouerbloet. Be Comer is ban September tot Februario, ende de winter ban Mar-

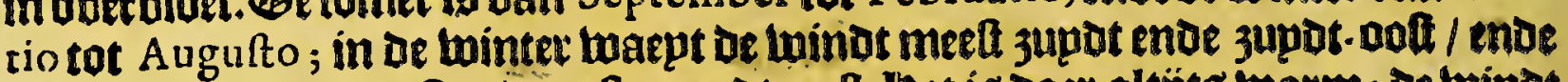

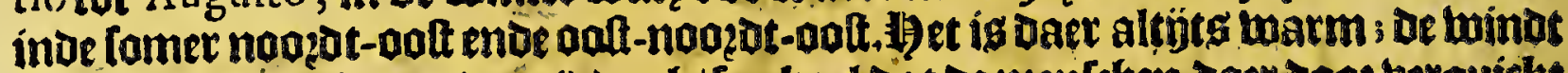

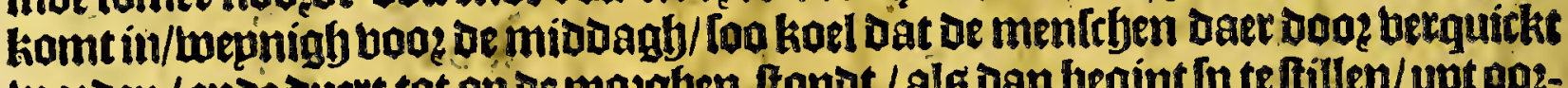

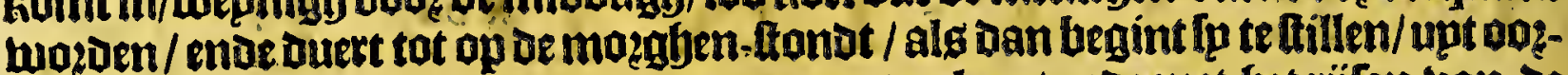
laecke bande Dampen Die upt Der aetoen op-trecken/ende met bet rỉfen ban oe

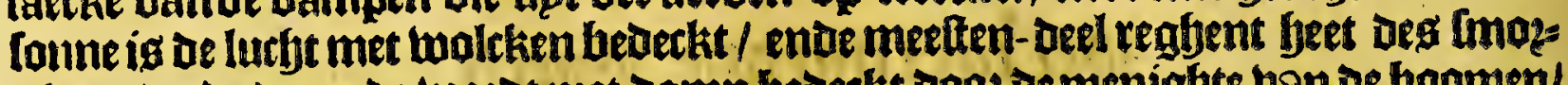
gheng/ ende oe aerde wozat met damp bedeckt dop: de menighte ban de boomen/ Die de bochtichept naer baet trecken; enoe ban t lanot waept sen loet twimoeken sot dat oe warmte ban de conne fet Telbe confumeert/ moe oe lucbt klaet moe fupber blÿft tot 's miboachs / wanneer de ghetwoonlícke buinot aen-komt. SBe

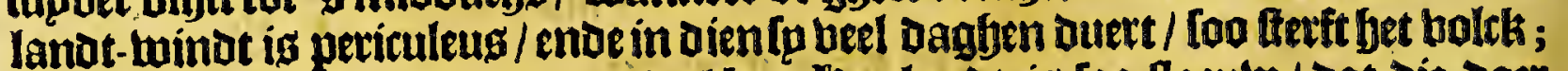

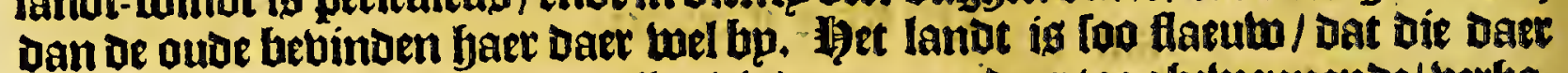
eerlt komen/ Gaer gantich berballen bimoen; maer daec toe ghetwenmenoe/berfa= len yaer voougbe krachten / gbelijck oft [p daer gbeboogen waren. Gbeben aen de

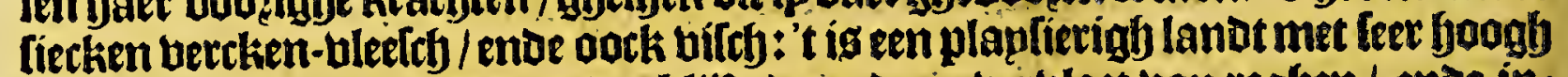

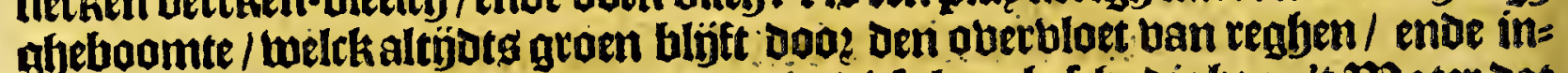
fonderfept om Dat Daer gbeen koude en is diele han belchadigben. 't Hater Dat Daer ohedzoncken mozet / is leet [makelïck.

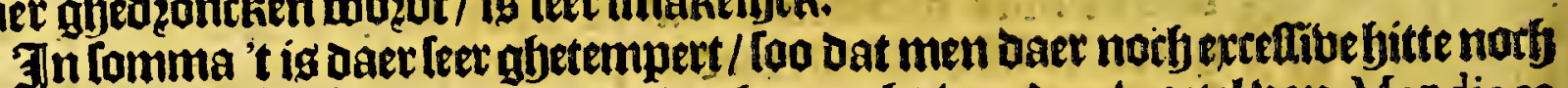
hoube en gbeboelt. Het bzoot toozot gbemaeckt ban uen motel ban Mandioca

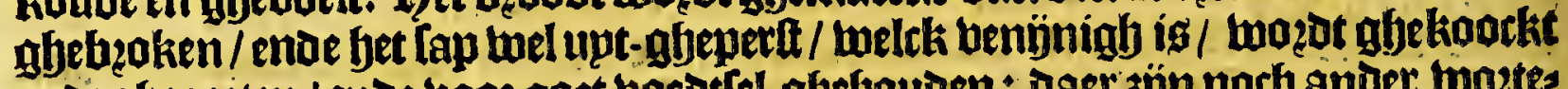
ende gfegeten / ende booz goet boedtel ghefjouden: Daer jün noefy ander boztes

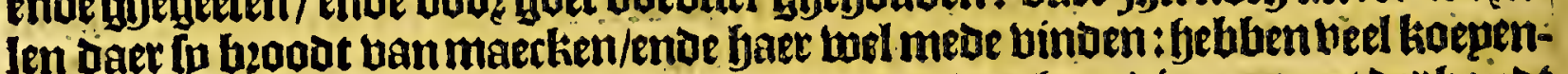
melck / rijg / boonen / etten / hatatas / enoe ander buchten die men met der banot leef : ende beel bifth op deganteche kulte.

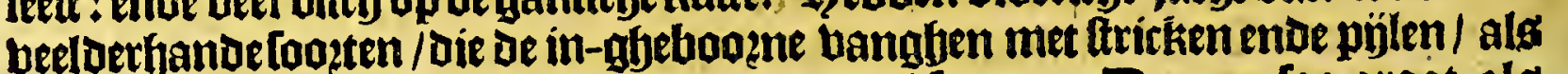
Daer jün barten enoe wiloe berekens ban beel fookten. Bepnen loo groot als koepen enae ban gbelijoke (maeck / met dicke bupaen en fterck: De konjinen bebs ben klepne ento ronde oozkens: Pacas een ghedierte grooter als balen/ die fmakte In̈tk bleetry hebluen : daer 3 jün klepne meer-kattiens die men eet / [oo groot als lios

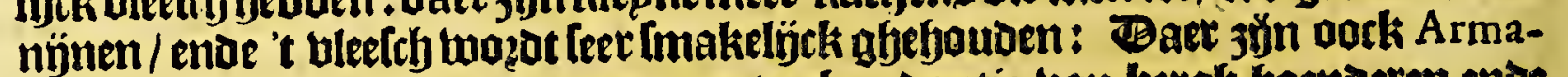
dillos, die [p gaeme eeten; ende groote abundantie ban bergb-boenderen ente

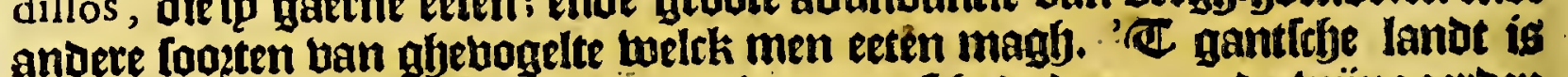
bol ban groote ende klepne mieten / Die groote febade doen aen de wïngaeroen ende ozagnie-hoomen.

\section{Wet theede Capittel.}

Van de vier-voetighe ghedierten van defe provincic.

D

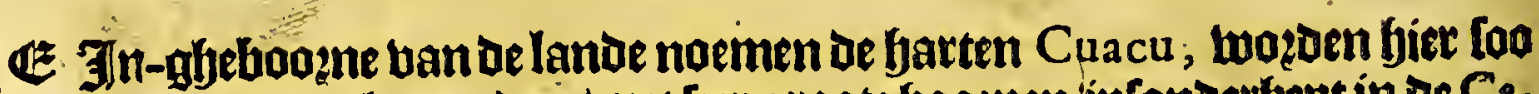
groot gebonden als peerden / met leet groote hoo enen/infondertiept in de Ca.

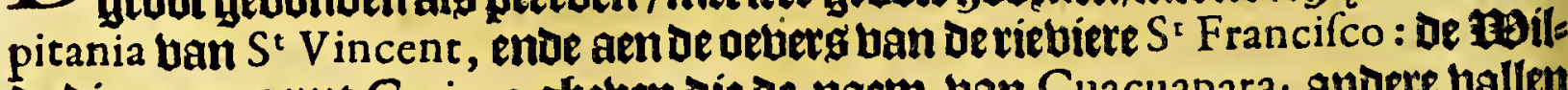
De die mennoemt Carioes gbeben die de naem van Cuacuapara; andere vallen

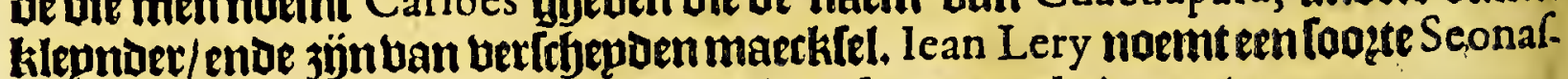
fou, dieklepnoer fooenen feeft/ ende't bap? bp- naet als be gepten.

Tapyrete ofte Tapyroffou, ig een dier de muplen niet onghelÿk/met een lange

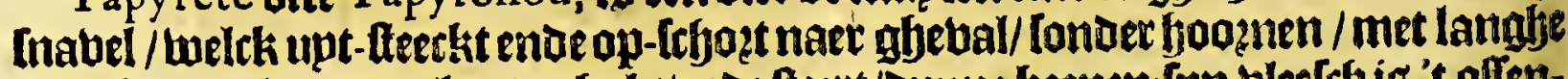
cnde bangende oozen/kozten bals/ende feert/Dume beenen; fun bleelch is 't oflen-

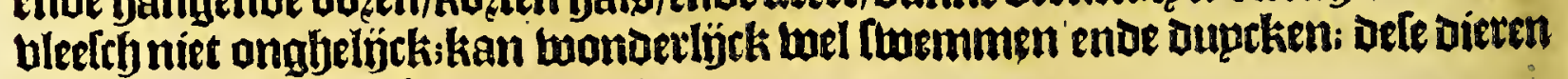
jön bier met menighte.

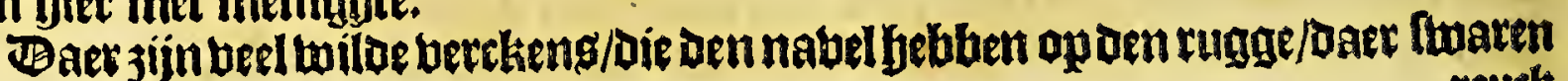
reuck 
Het veerthienfte Boeck.

reuck upt fomt bu-naer als wan boffen ; too Dat de fondon die licht ap dentreuth ontoechen : de Elbildoen eeten baer bleffrb [eer gaerne.

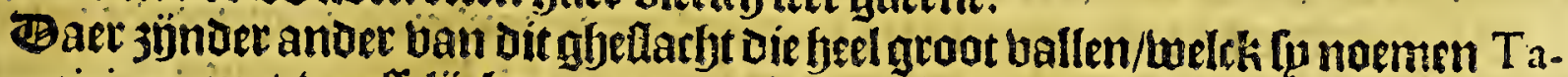

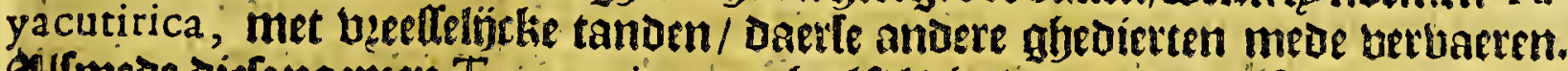
Xifmede diefenoemen Tay acupitas, een feel fel dier/ende dat menffefen ende ljon=

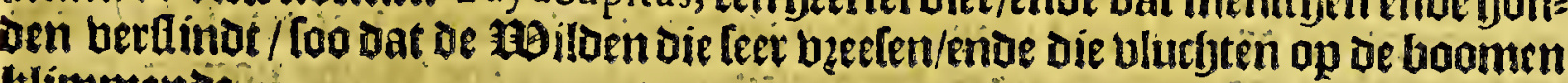
klimmende.

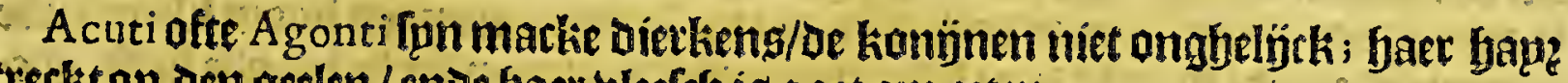
treckt op Den geelen / enoe baer bleeffy is goet om eeten.

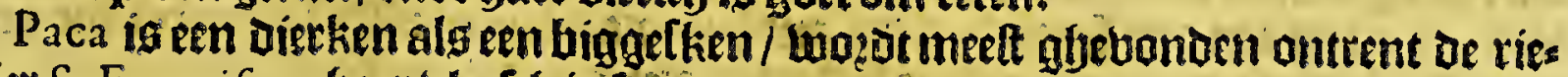
bier S. Francifco, lyaer bleefth is thaer om verteeren.

Pág ofte Pague if ban maeckfel ende fooglfoe alseen twindt-fyonot / met ken

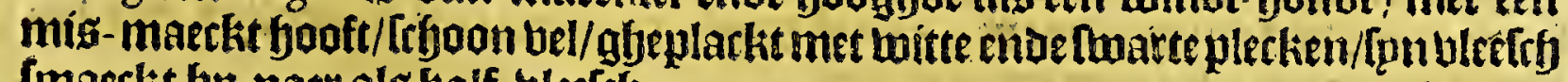
(maectht bp-naer als kalf-bleeffy.

$\mathfrak{A g e n t}$ binter mede beel luppaertg/imfonderthept in oe Capitania ban $\mathrm{S}^{\mathrm{t}}$ Vincent, Leer frgoon ghepleckt / een weecot ense berdindende dier; niet te min foo bindts

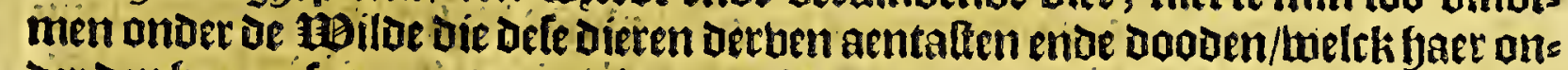
uer Den bacren loo grooten eere is / als offle een bpandt in den flagb badden ber=
meeftert.

Canigua ofte Sarigoy is een dierken alseen bog/ ooch twat klepnder enoe ban

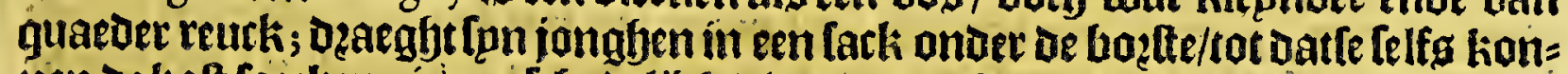

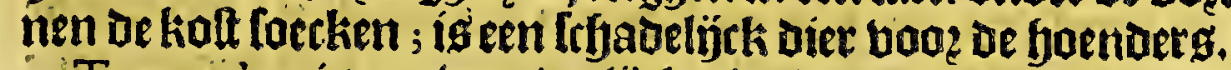

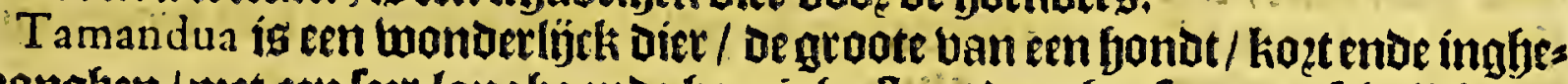

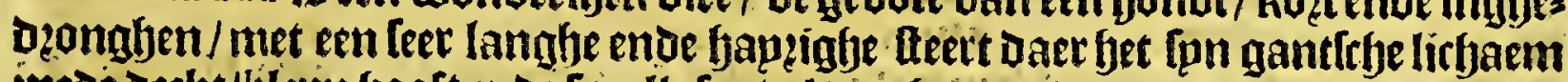

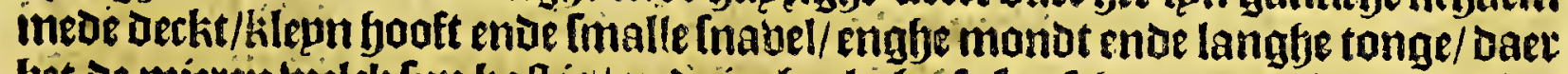

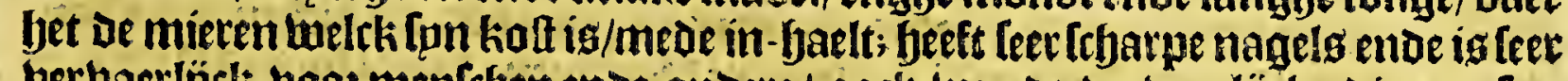

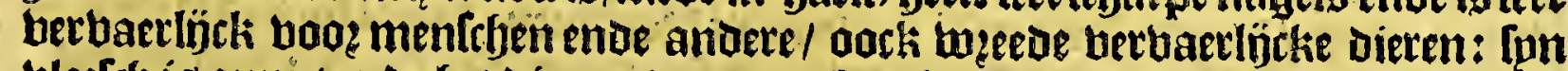
bleefch is onnut ende fet dier en doet gantefy glyeen goed / Dan Dat feet oe mieren neften verftoots.

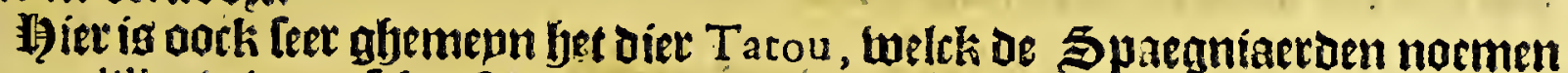
Armadillo, twiens at beelfel bup freer in- boegen/ig ban groote als een biggegken/

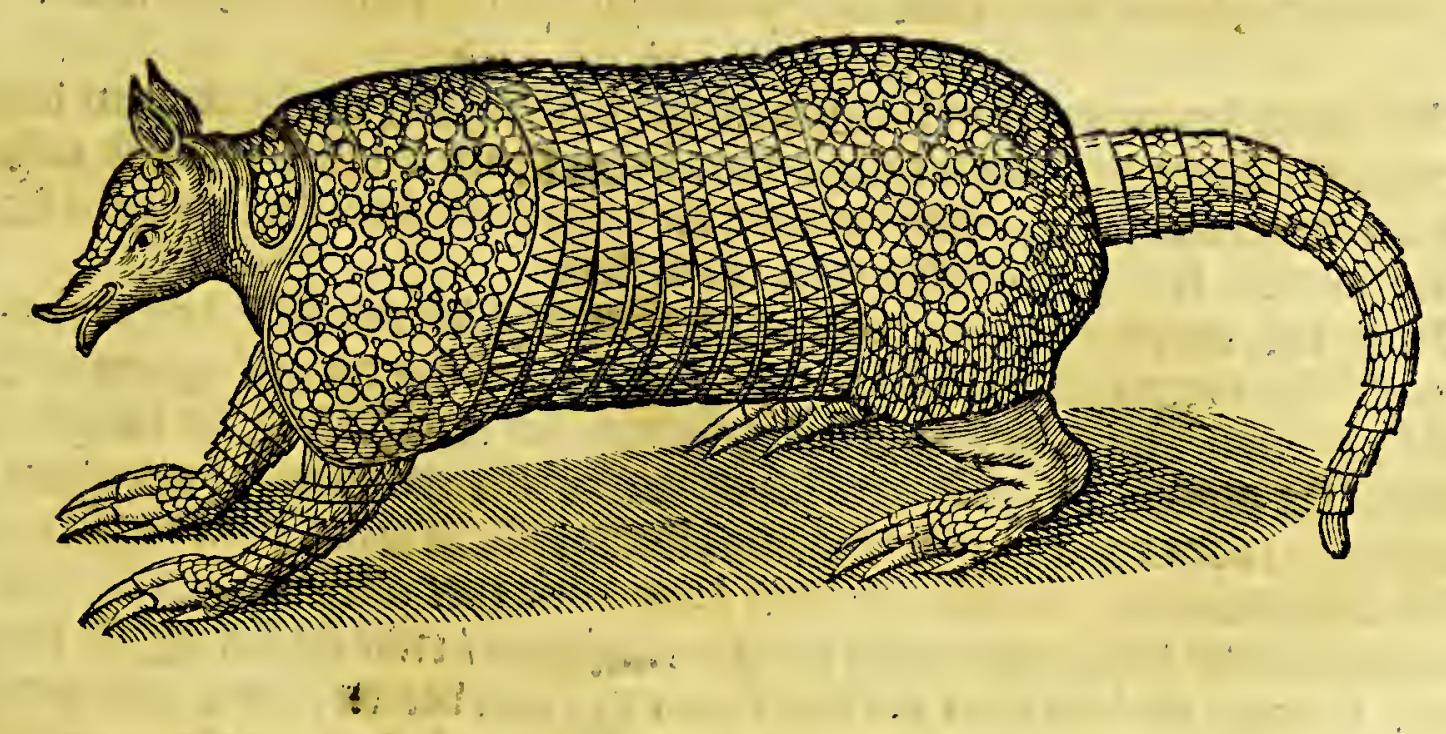

ende yet gantlrbe lijf met barde frobben bedeckt / bph-nate als een Rhinoceros;

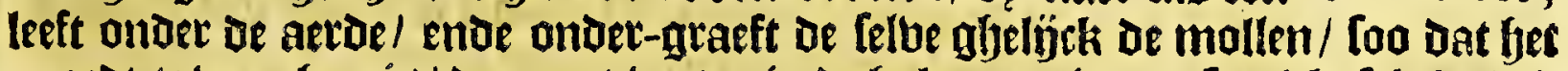
quaed te banghen ig/ / Dan met water in De folen te gieten: fen bleefey is buit

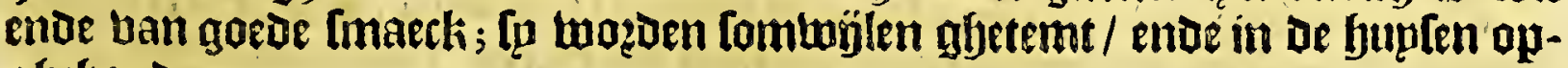
aghetrouorn.

Gebben Daer mede beel pfet-herckeng / noemen de groote Canduacu, ende de

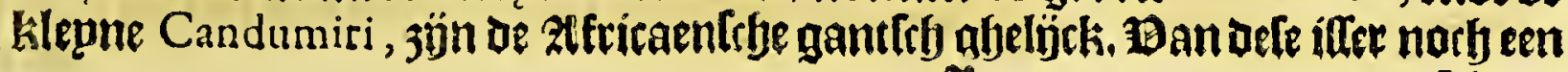
F $x^{2}$ klẹn? 


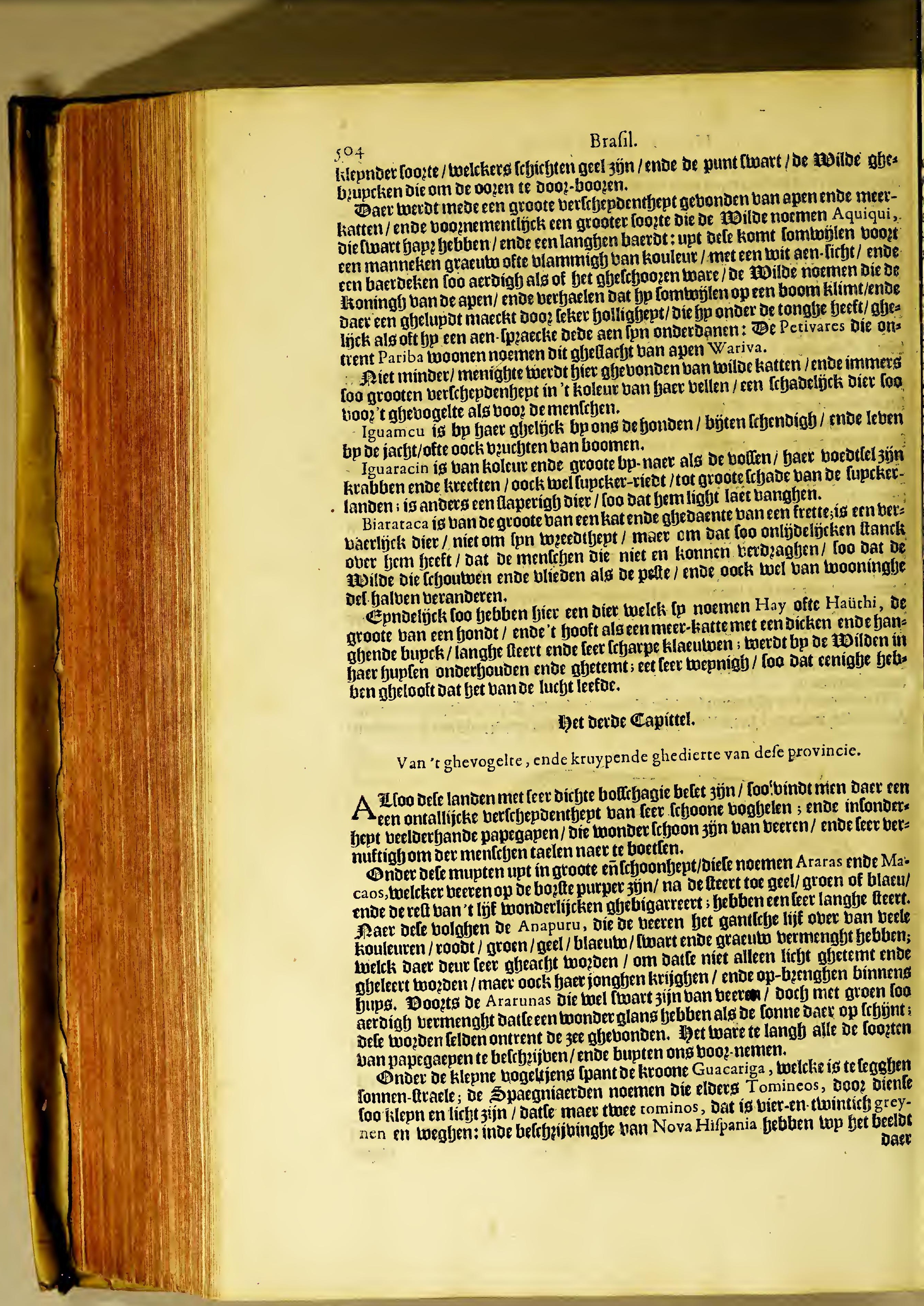


Het veerthienfte Boeck.

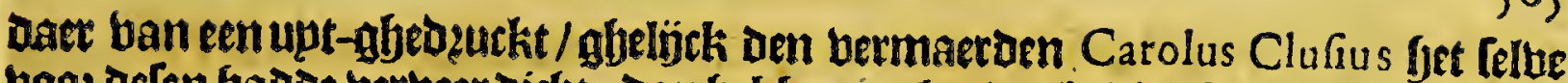

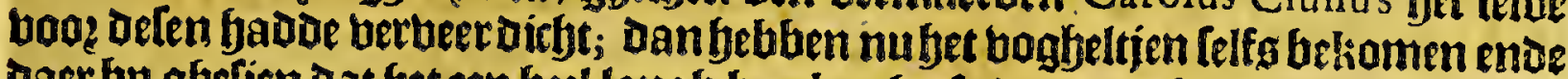
Daer bp gfefien Dat feet een beel langb becrken fyeft / ende recht upt-gaende / Daer Dat heelot een krom ende koter beerken beeff; De glants ende terfffbepoentlyept

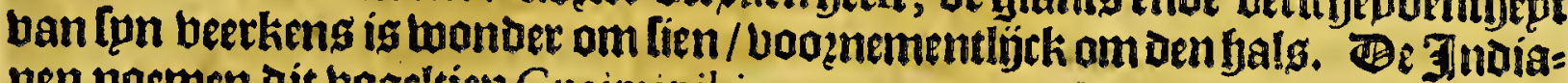
nen noemen dit bogeltijen Guaiminibique.

Tangara is ban De groate als een mus / / wat ban beeren / upt-níentomen aen bet booft/ twelck geele plupmen beeft/ende en lingbt niet; ue wilben en eeten die niet / om datfe megnen dat dit togbeltien de ballende-liechte onder-be= bighig.

De Wilben maecken groot tuerch ban't bogeltien Quereiva, welck Teer frthoo=

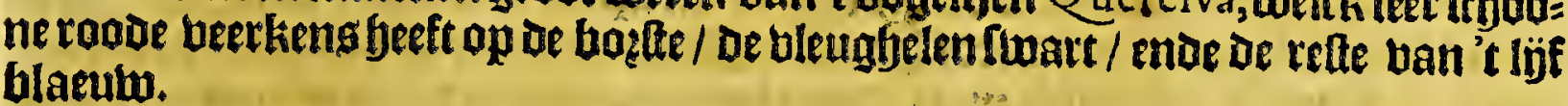

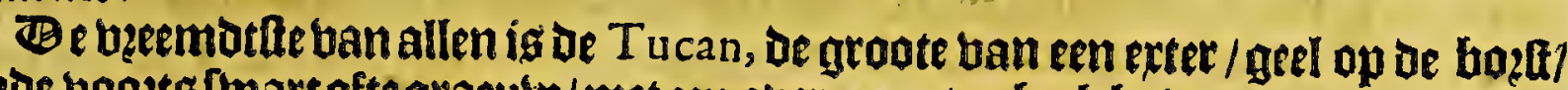
ende boozts ftwart ofte graeutw/met een aber-gragten beck hoben oe propoztie ban tlichaen/ die buyten geel is / ende ban binnen lírft-roodt.

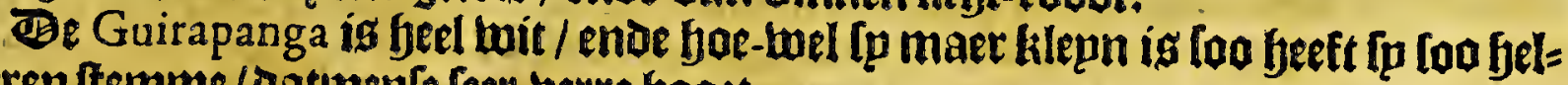
Deren ftemme / Datmenfe feet berre boa zt.

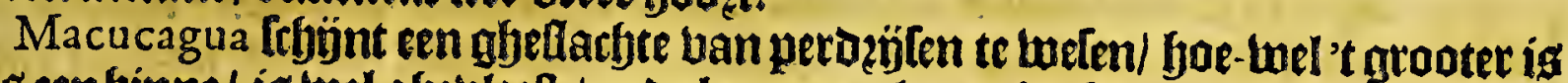

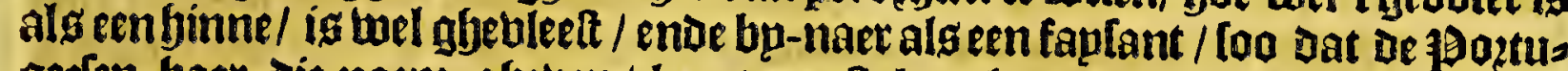

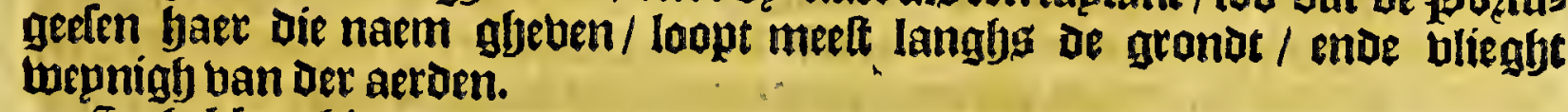

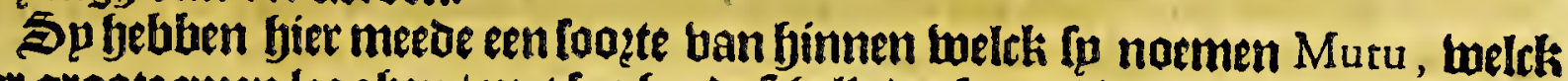

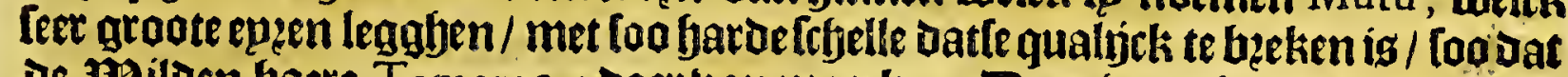
De E⿱ milden baere Tamara cas Daer ban maecken. Baer is oock groote menighte

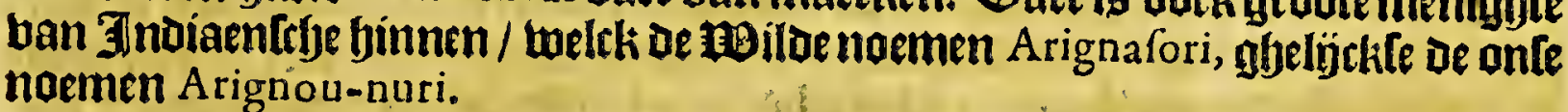

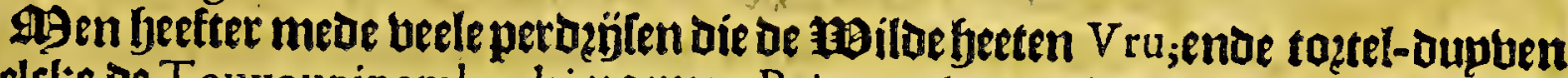

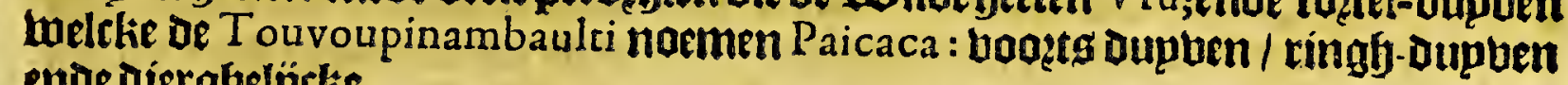
ende diergbelíctke.

In oe misdel-lanottche probintien Geft men beel frupg-boghelen; by baer $\mathfrak{a t y e n a e m t ~ A n d u g o a c u . ~}$

Onder de roof-boghelen munt upt be Anima, welck is een (teer aroote bogfbel!

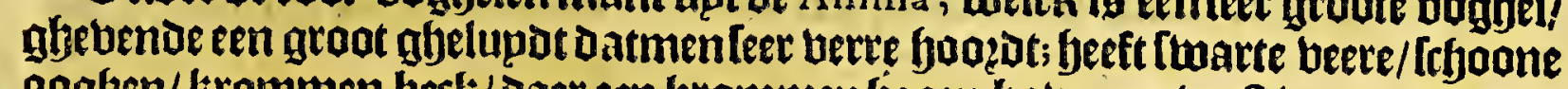
ooghen/krommen berk/ Daer een krommen fjooen Lroten op walt twonder groot;

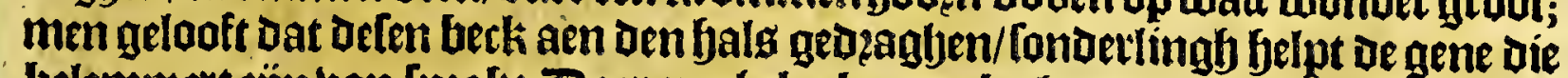

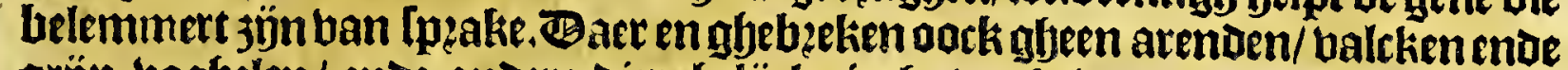

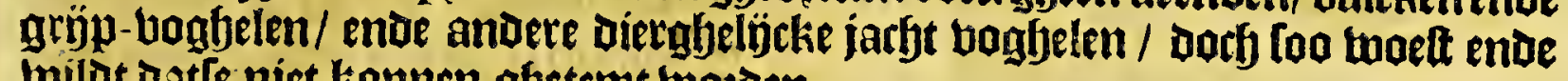
Lwilot Datte niet konnen ghetemt twozden.

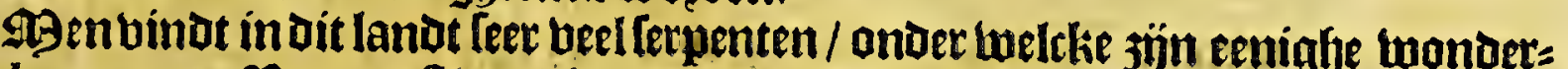

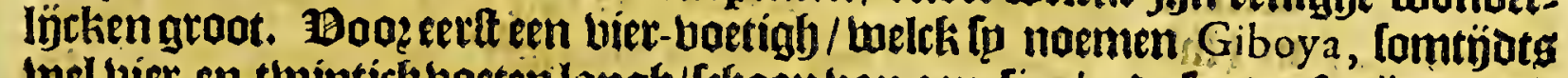

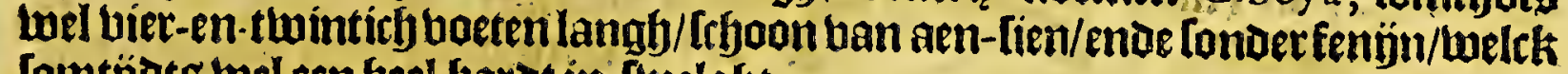
Comtỉ bts wel een heel barot in-fluelght.

Baer naer de Guiraupiaguará, langh / op den rugy (twart/ ende geel aen den

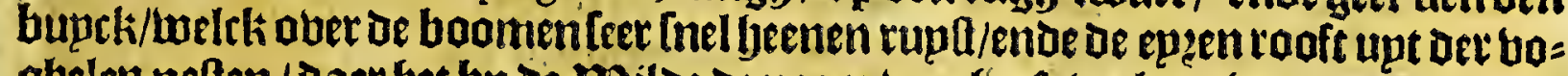
abelen netten/ Daer fet bp de wailoe de nasm uan fjeeft verkreghen.

Canina een langfe ende dicke laangbe groen uan uertue ende fraep.

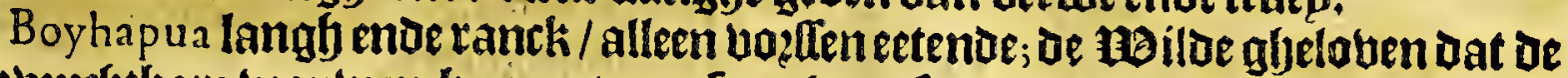

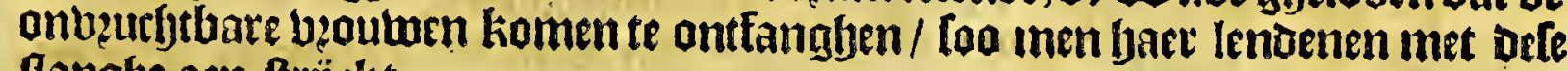
Ganghe aen-Rrỉcht.

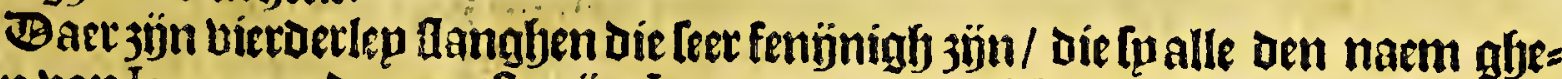
ben ban Tararaca; De grootfe 3 ün lararacucu, Die Dicktuils thien voeten langh

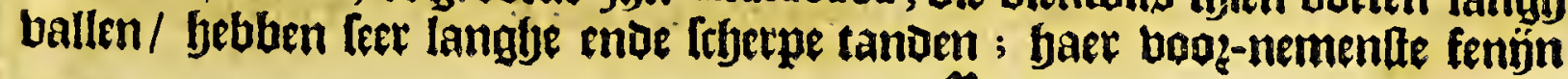

$$
x_{3} x_{\text {isin }}
$$


506

$$
\text { Brafil. }
$$

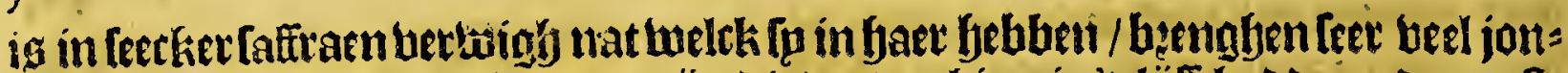

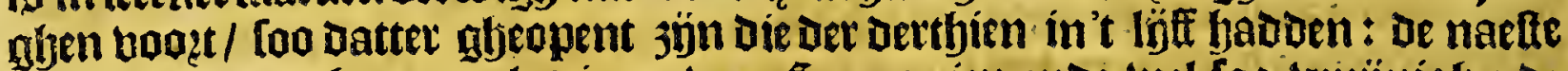
laracoaypitiuga be naet alg bipen ban Spaegnien ende bel too tuentonigh : de Derde la rarae peba graeulw ban betwe met een roode limie ím maniere ban een $\mathrm{ke}=$, tentien bem aber ben rugh ende bupck loopende. Be minte ballen feloen groo: ter alseen bingber enoe 3 jn than een aetdt kouleur met upt-puplende aederg aen 't booft als de adoers dirfe ghelÿck 3 j̈n.

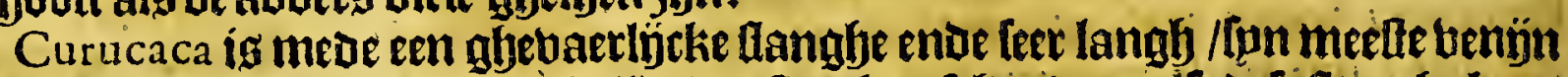

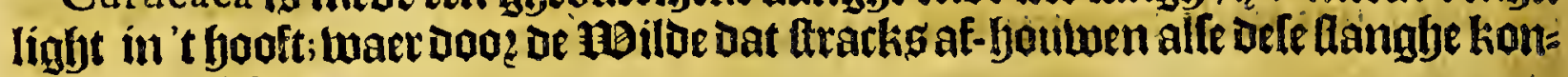
nen berrafferen.

De wondethaetijekte han allen is de Boycininga die atn't uptetfe luan ie

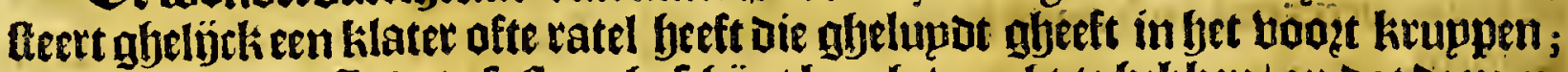

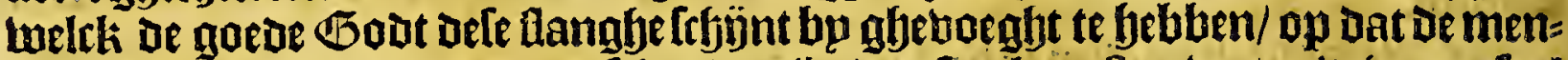

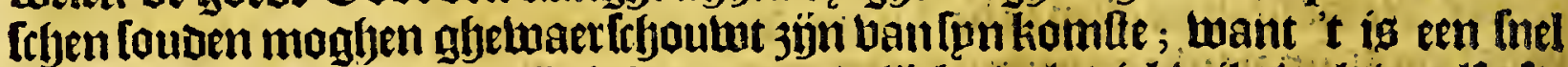

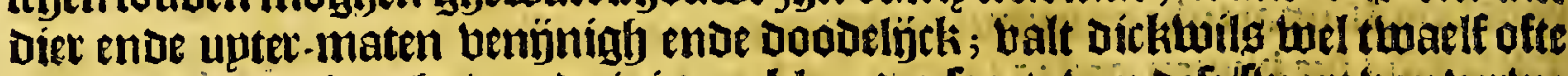

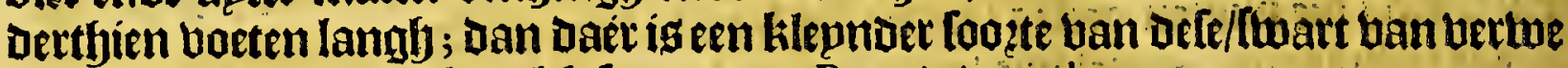
ande Lonoer benjuigh twelck fp noemen Boy ciningpeba.

De Ibiracua is foo benijnigh / Dat foo fo pemant komt te büten / Atrackg bet bloest upt alle Deelen des lírbaems / cogben / oozen/ neule/ ert. upt-jäeght / ende

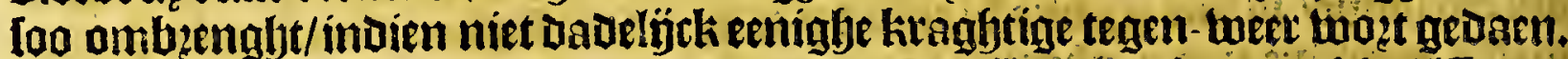

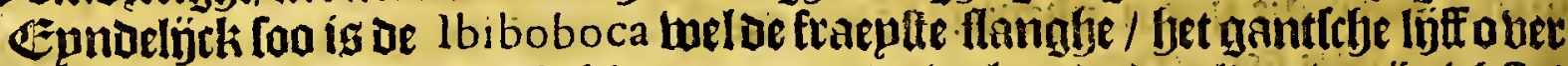

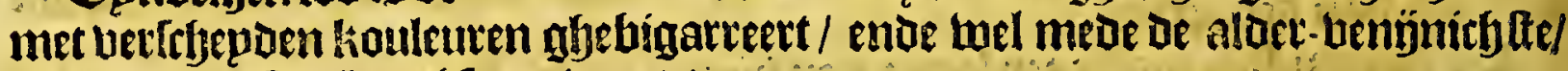
cock licuppt teer langftaein tuodets.

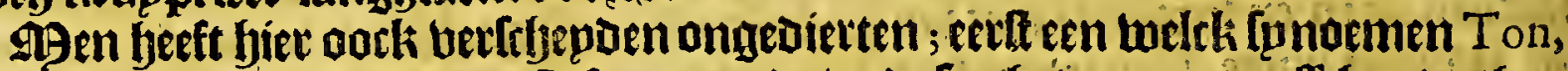

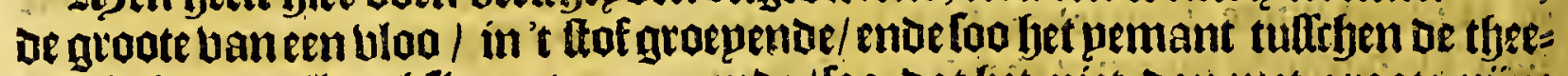

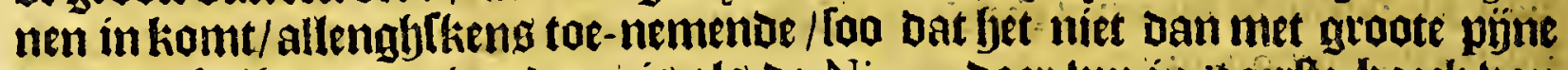

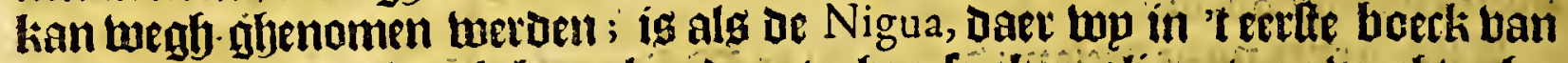

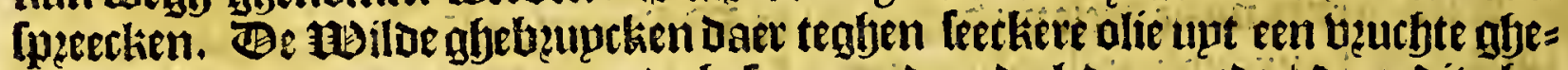
perft dicle noemen Courocq : ende befmeeren daer de leden mede / Daer bit glye= Dierte aen ueeten. Cen anoeren een lpecie van mugghen (noemente Yetin,) die

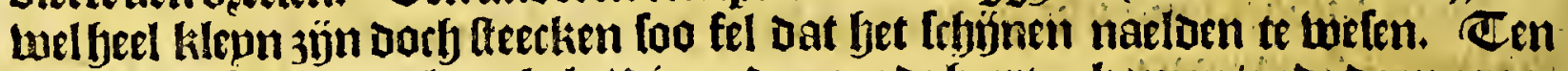

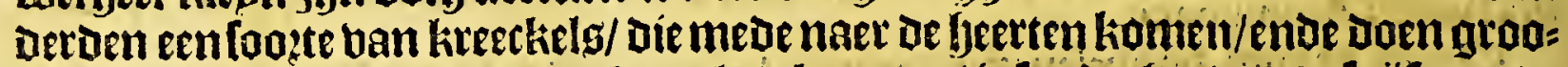

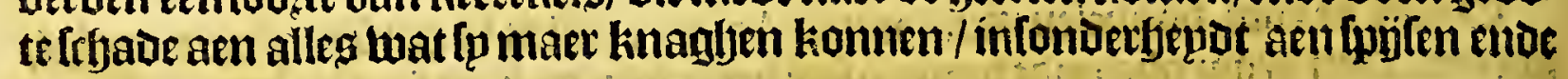
leeder.

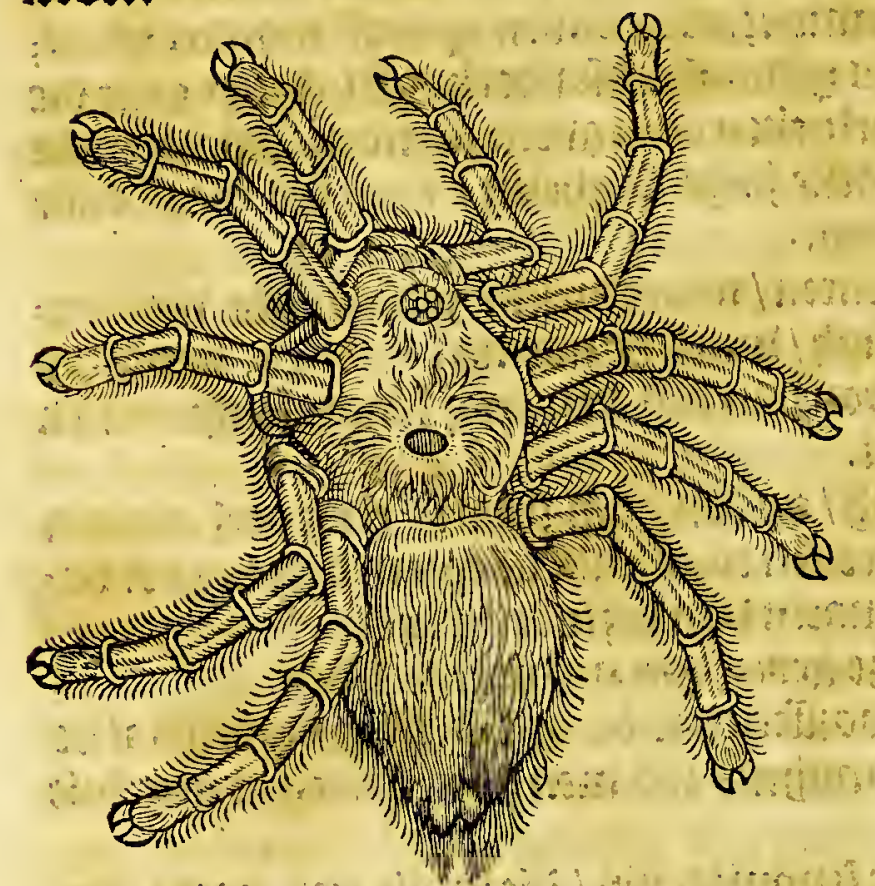

Épnoelinck een looete ban Spin: nen die lér groot ende berbaerljich is/ Def-toeghen wo bet af-beelfel upt De (chyeften van den bermaerden l)eet Carolus Clufius bier beblen bp abe= boegft: Dele Lad ghetien in de Bahia; enoe tuas tel Dip oupmen langh / en: De wel ecnoupm beted / gantteb baps righ ; bebbenoe aen elche zijoe bije beenen in beel abeleden betoeelt/ende infogelijcks bapzigf ; op oen rugghe beeft bet een meirkelijel gat als een nabel: troet Teer frbadeljochenoe benij: niahghefjoutben.

¥n Comma dit ghteluele is teer ons Der-bebigh ban benijuighe eribe oock frhaedelijcke ofyedietten / loo dat Jent

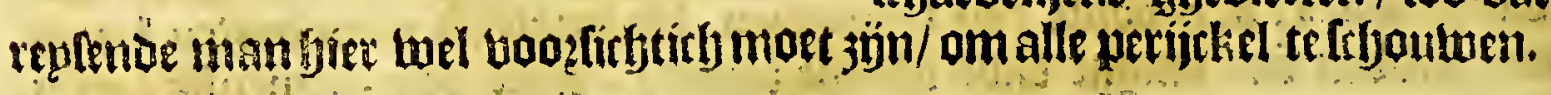


Het bieroc Capittel.

Van de boomen, vruchten, ende ghe waffen van defe Provincie.

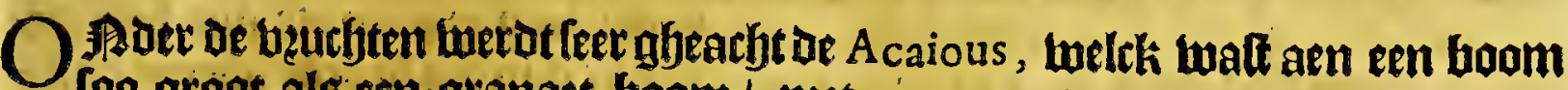
foo groot als een granaet- boom/ met bleeclie graene bolligbighe bladeren / mitte Gloemkens als ozagnie-bloemen / Docf van meetoer blaederen eñ ban geenen reurli; upt thelcke bloeme boot-komt / eerlt een groote boone / welck top hier nevens beblen boen af-beeloen; tultefjen de twelcke ende de treel een antoer berutht upt-gioept ban De gedaen= te ban een appel ofte peere / oe groote van
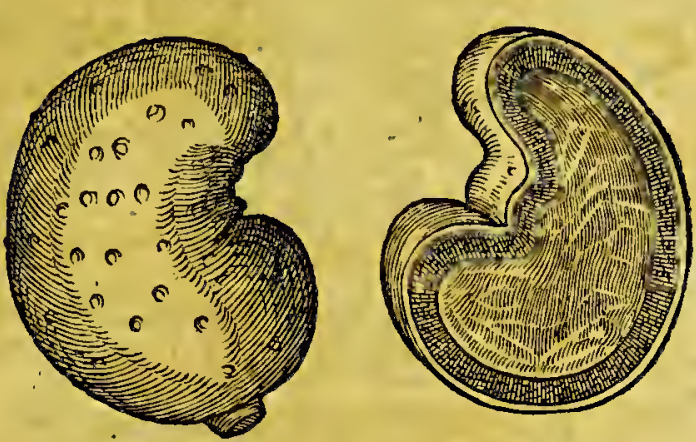
een gantenepe/ende oock twel grouter; welck

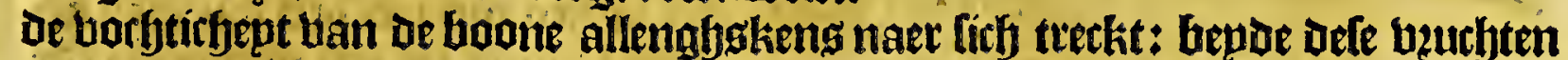
werden Caious ofte A ccajous ghenaeme / ende is de ronto bzucht / bol lappighmergh als een citroen / boog enoe fpongieug / Conoer Laet / loetachtigg Doch wat toe-treckende / is goet boos de maeghe. Be boone die onder aen de butht bljyft

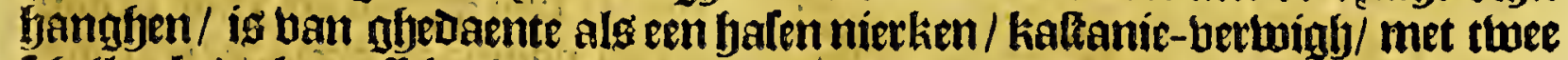

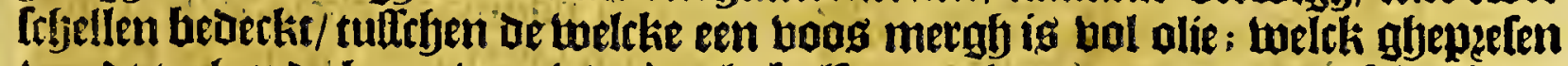

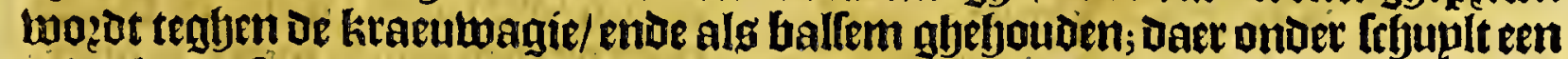
witte lieern loo goet om eeten als be Piftacien, te weten als bet bliegken Daer af ig/

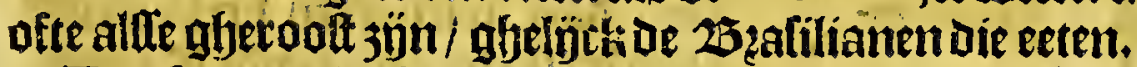

Den boom Manhaba, welck meelt werat getuonoen in de Capitania ban de $\mathrm{Ba}$ hia de todos los Sanctos, feeteen baft ende bladeren als de efletben/igaltỉt groen;

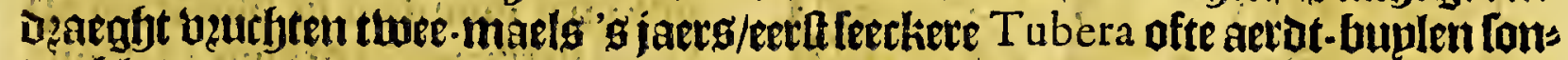
Der bloemen; daet naer bloemen die feet wel riecken als de Iafmin, upt twelcke cen bzuctyt boogt-komt als A pricocs, ban bupten geel met fwarte ftippen/ van

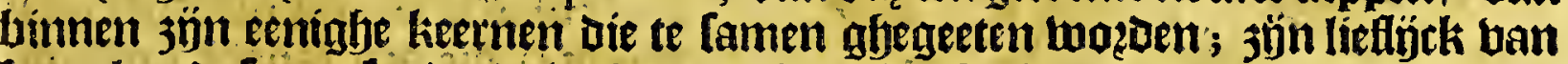

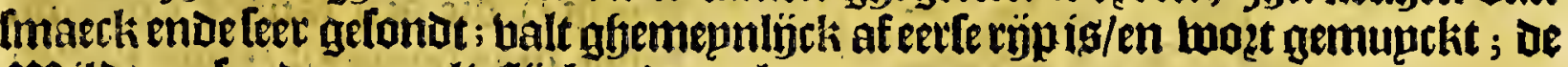
SHilde perlen Daer een lieflótken Dzanck upt.

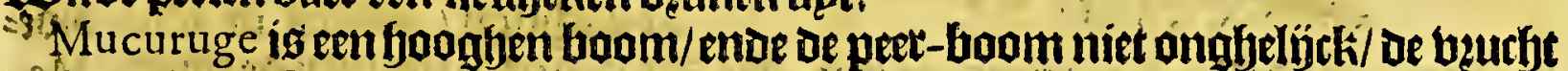
beeft een lange fteel/ente alde rinp werot is fer goedt ban Imaerk/enoe twert book gfetonot gbefouiden.

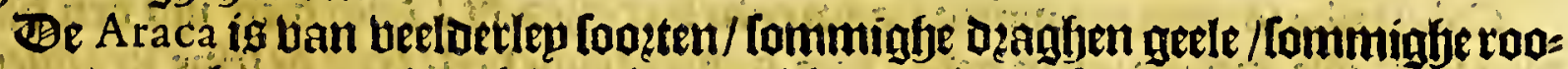
de / ende oock groene tyurbten als appeltjens/ die en lupen enoe leer aen-nge= namen fimaed heblen.

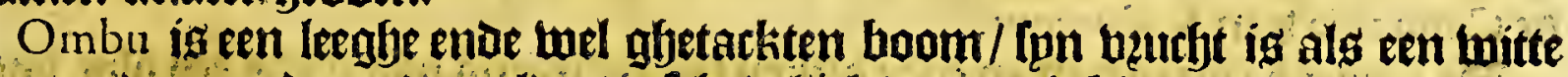

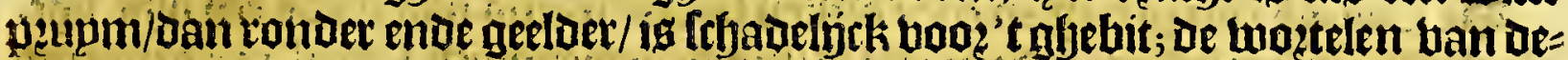

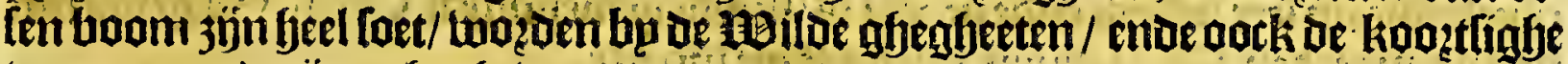
vooge enmederijne ghegdeben.

Iacapucaya is een leet fooghen boom / Dzaeght fpn vequfyt in feckere kelcken

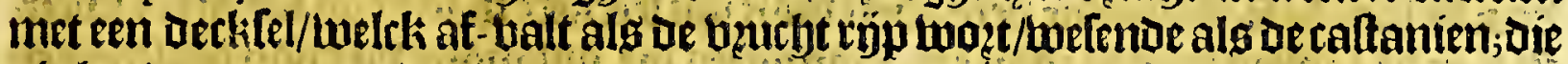

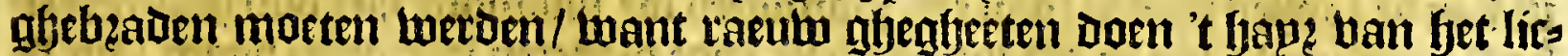

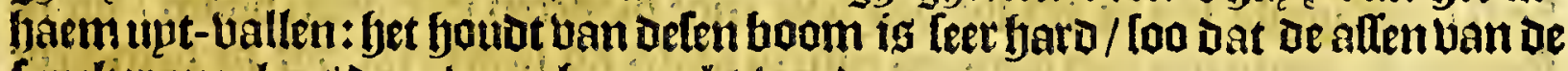
fupeker-meulens daer ban gljemaeck wozoen.

Araticu ig ban groote als den ozagnie-thoom/ beeft Lladercin als de citroen-

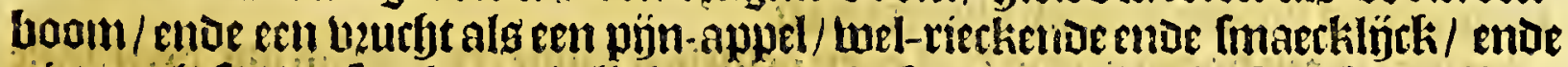

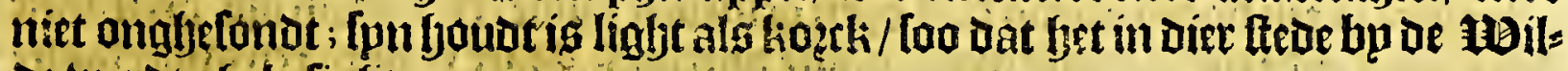
De inetor glucterfiglit.

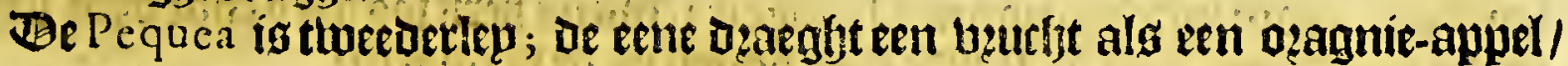
met ecm farde bald / tun Tap igmelckarbtigh ende feet fort / met eenighe keernen $\mathfrak{F} \times 4$ bermenght; 
508

Brafil.

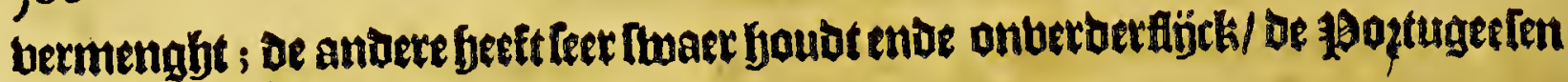
noemen bet Setim.

Den bermaerden Carol. Clufus belthenft ong thee boomen upt de onderbin:

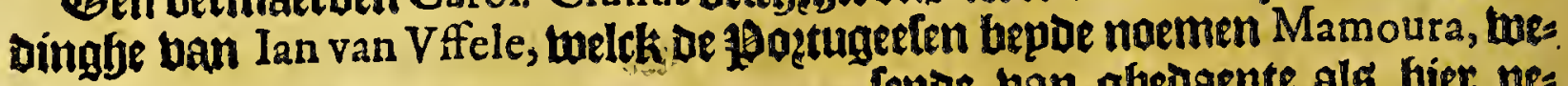

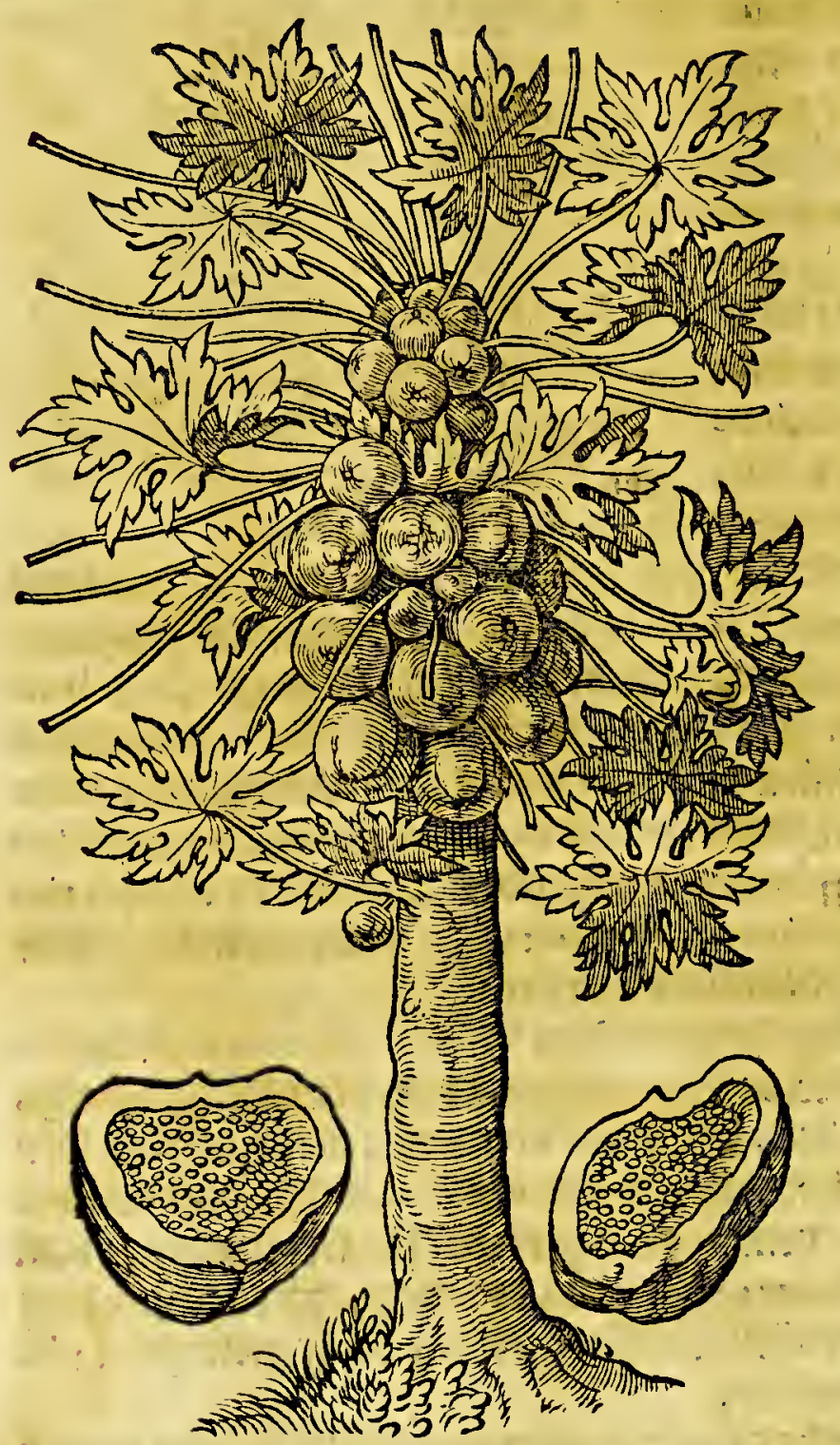
fente van abedaente als bier ne: beng / Dan dat de eene gheen beucly: tew en Dzaeght / wef-halten bp ae eene noemt giganneken ende d'an= Der möntken : bet wijfken ig alleen bzuchtbaer Dan en jeeft gheen bloes men / ende en krijgft oock gheen beurften / foo Lonneer het manne: ken daec te berte ban is. Be frupth is bp oe twee boeten dick / ende nes gen hoogf: [oo groot jónae / larỉgly= tet tacken met feer beel butbten ge: laden/ Dirbt bp een gljetuoeght / De lelve nory wel negfen haet boggh om-cingelenoe: Brete beucht is balrondt/ ban afjedaente ende groote hlepn pomyoen gheljek/ / imet ged bleetcy/alle rijp is/ welcli de toildo keten am den bupek meeck te maer= ken; Daer in Trhuplen beel keernen als etwetkeng fwart ente blintken: De / netghens tae nut. Fuffrben oe beuctenten kommen de blaederen op lange Aleelkeng/De gtoolte Platanus blaederen ghelötk. Jet ander glyes dactit Dzaecht bloemkens(cnoe gekn beurft /). Die aen langhe tteclkeng Defupf-Lño hanguen / upten Litten geelartigh / anders of vliet-blote men gelijckende/ Dodb netgeng toe nut. De 1 pogtugeren noemen de beucht Mar maon, dele hoomen wozoen meelt gebonden ontrent de Bahia de todos los Santos.

Cabueriba is eenen fryoonen boomende feer gheacht / Dooz Dien upt den balt bliet feker olie diele de naem geben ban ballem/ende feeft oock De Telbe lirachten;

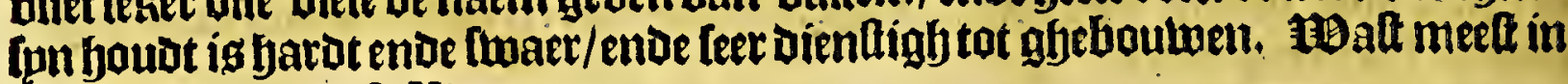
de Capitania ban S. Vincent.

De Cupayba igeen reetyten ende dicken hoom/ wieng balt mede een olpe uptgheef/ / die nu feer bekent enve geacht is/wogot gemepnlïtk Copal-yva genaemt; aen bermaerden Car. Clufus beftheñft die bzeeder.

Ambaigtinga geeft medeleecketen ballem upt/ Die bu Monardes werot belehyet= ben; De welcke feght Dat die bergadert wot upt leeckere blarflens die arn't upter=

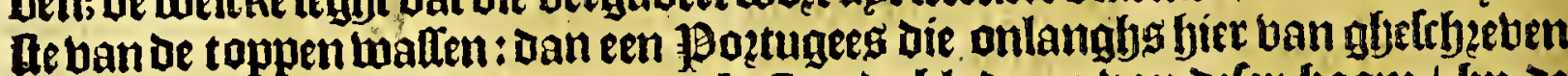

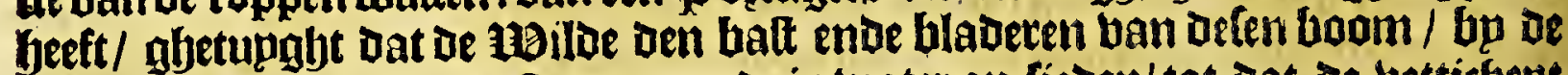
fonne dequghen/ende dan ttampen ende in watet op líeden/tot dat de bettirfept

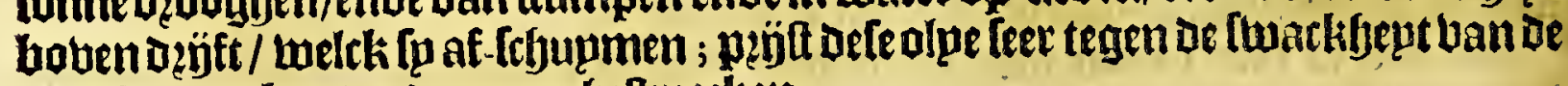
magfe/ban bupten daer opoleftreecken.

Igcigca is een boom luiens balt open ge[neden 3ïnoe cen tuit [ap upt-geeft/melc haro wot ense wel riett als maltick/ofte wierooct. Baer is noch een andertoozte

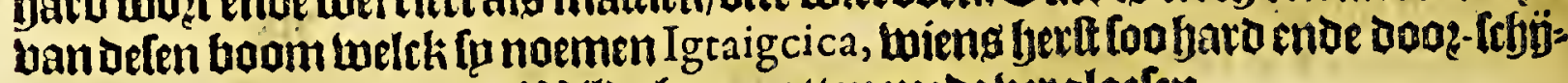
nende is alg glas; daer de thiloe baet potten mede berglaten. 
Het veerthienfte Boeck.

Iequintinguacu bratgbt een butbt als een aerot-befie met een ronje teen / die

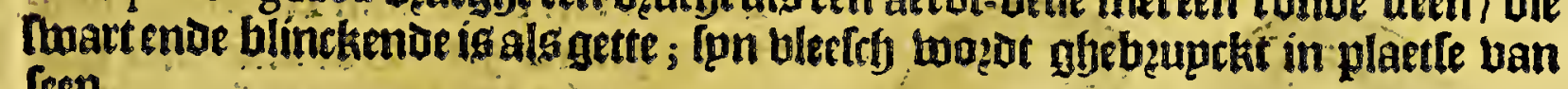
[ẹp.

Daer zijn notb meer buthtbaere boomen fiet te langf om te berfjalen / veel cocos-boamen / beel pign-boomen enoe dietglbelijche.

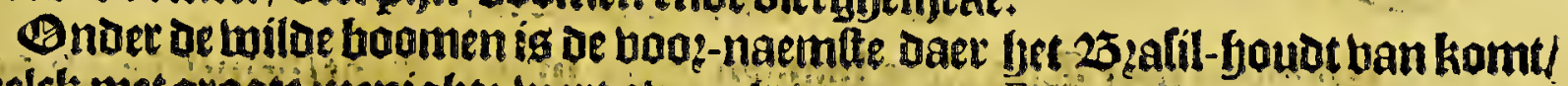
toelct met groote inenighte bert ober-gbetioert naer Europa.

1)et vïfae Capittel.

Van de Kruyden, Wortelen, ende andere ghewaffen.

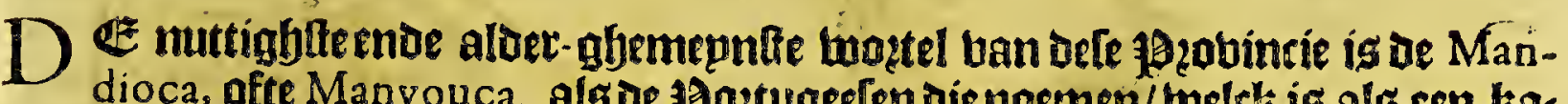
dioca, ofte Manyouca, als de 1pottugeefen Die noemen/ belck is als een ka=

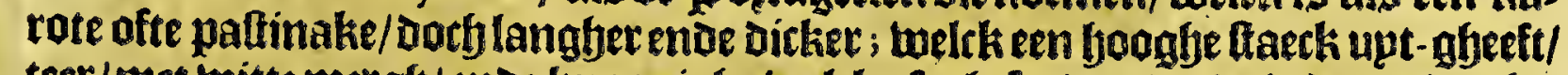
terc/met bittemergh/enoe knoopigh; thelck af-ghefneden / enoe in be aerae ghe = fteecken weder wotelt/ende infeg oft neghen maenden tifots weder bequaem is om tegbebzupeken. Ban defe twoztel maecken lp baer meel/entoe backen daet

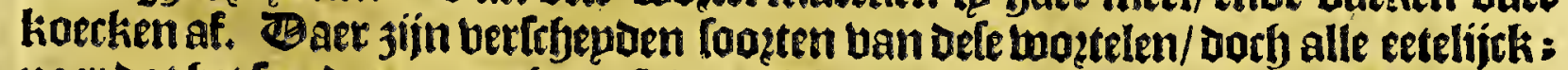
nart bat fet fap oaer upt-nfbeperft is/melck luttel beter is alg benijn. Ban defels be woetelen maecken fo mede berfebenden dzantien diefe Mingaes noemen / leet

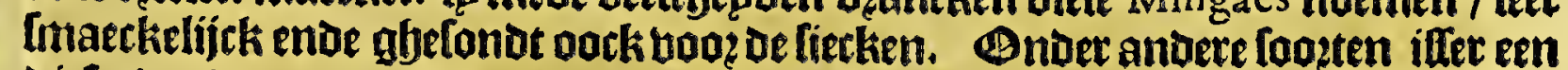

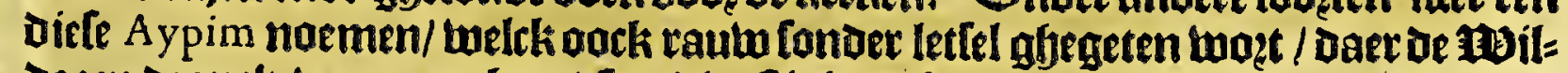
Decen Dzanck ban maecken / feer dientligh teghen de beete leber / foo datte daer

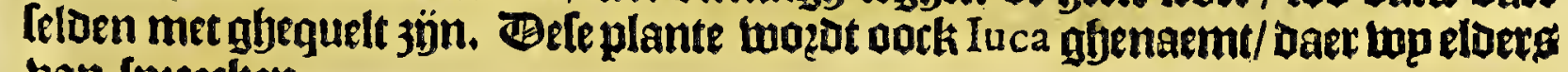
ban lpeeccken.

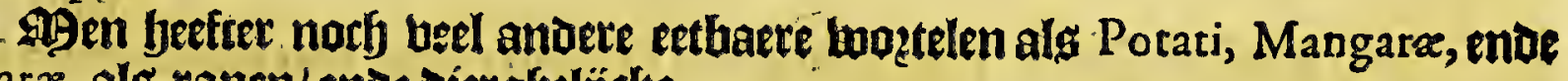
Car $x$, als rapen/enoe dierghelícke.

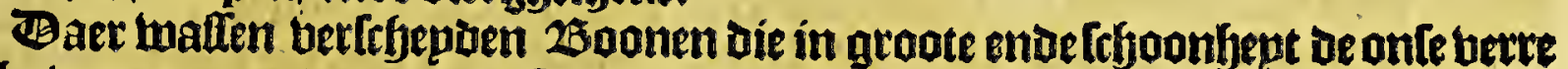
te bouen gaen; ende booe eeclt een flagh ban Curcriche boontjeng / bp Den ber: maerden Carolus Clufius upt-gheozuckt alg bier onder; De toelcke bp beftyegft in oeler boeghen:

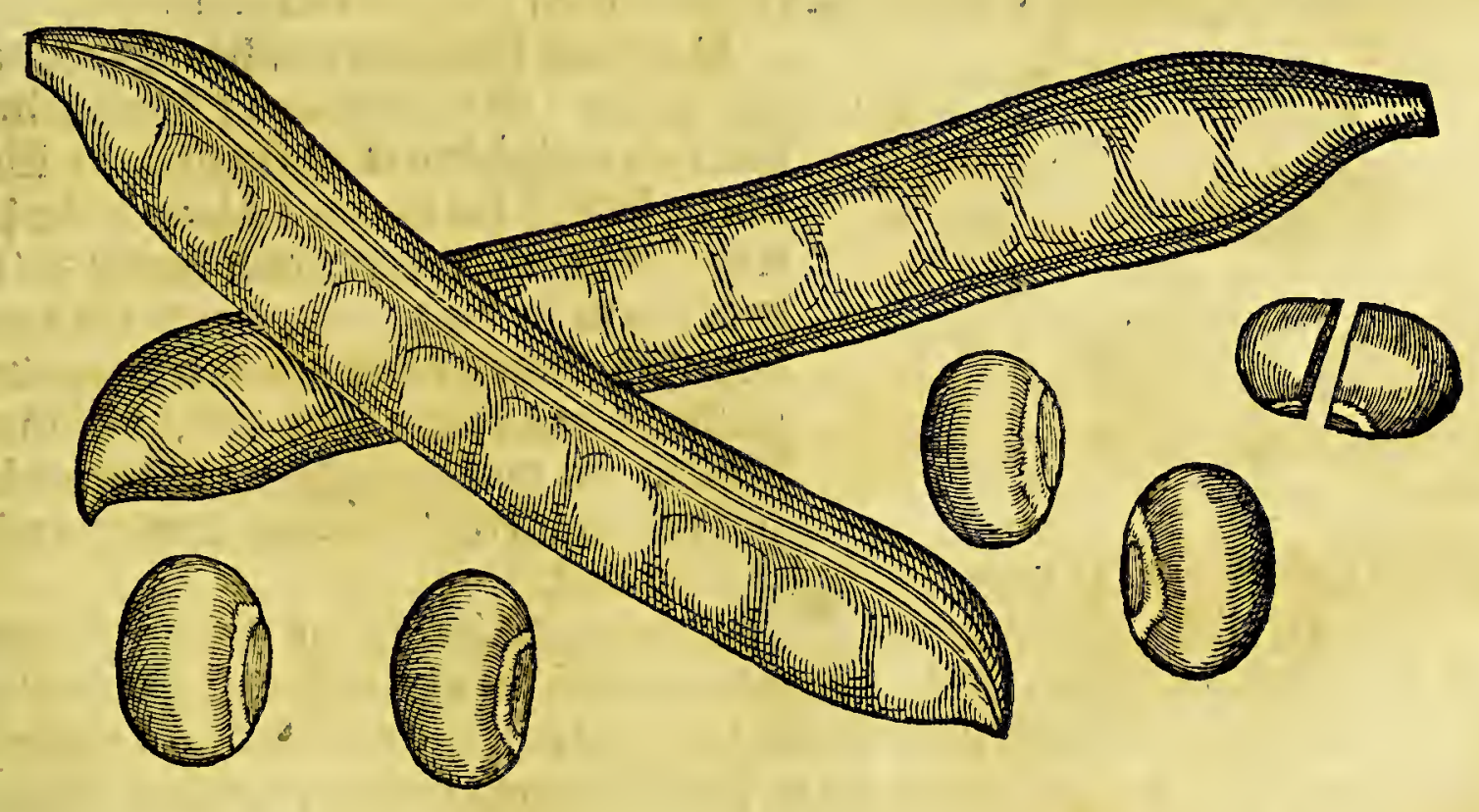

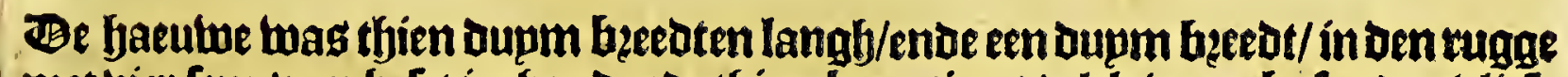
met biex [enumen belet in-fjoudende thien boontiens / eltkin een bp fonoer bliel= ken bettoten / een oupm beedte langf / enoe balf foo bzerat / beupn / met een tritte plack. 

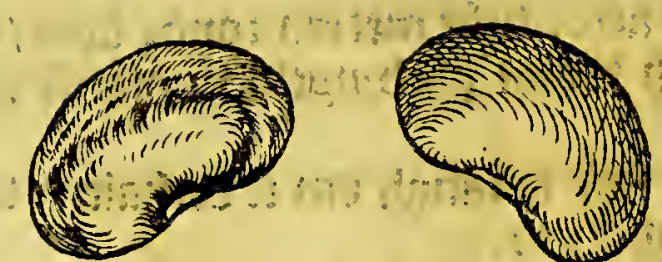

Doots en lootre ban troomithe boo neti / die platter jun alg oe onle/ende twit/ met fommigfye geele trerpen feet aeroigh

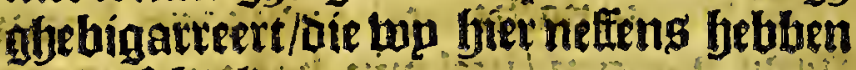
boen at-bettern:

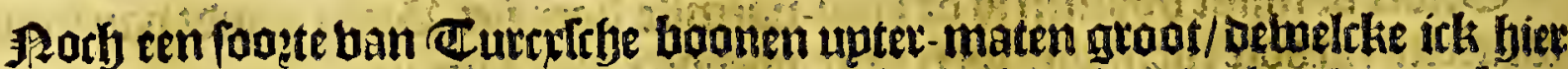

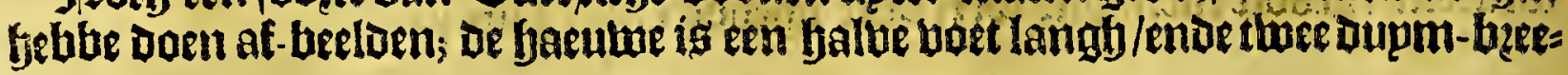

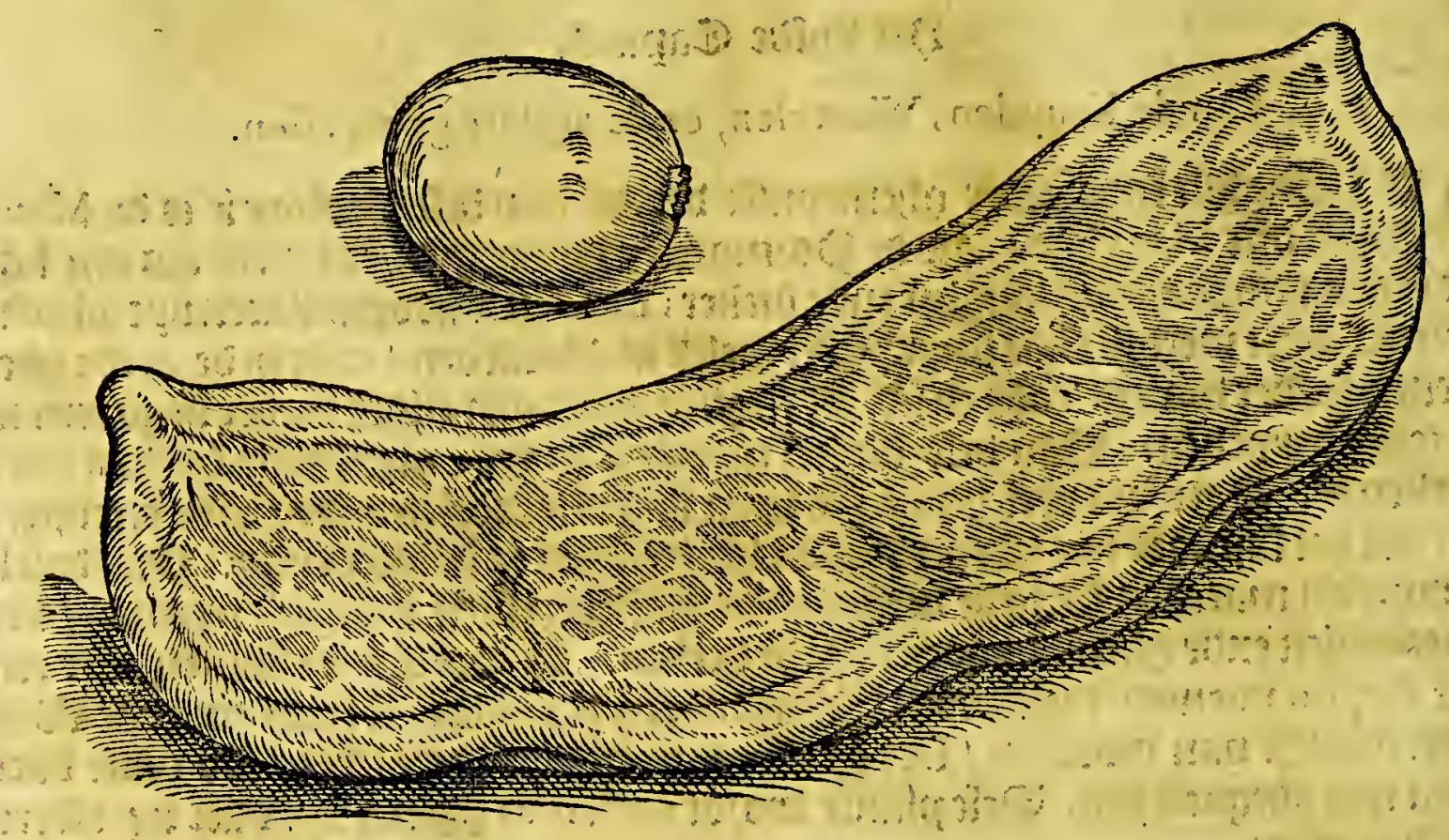

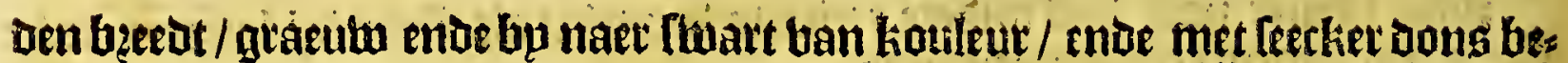

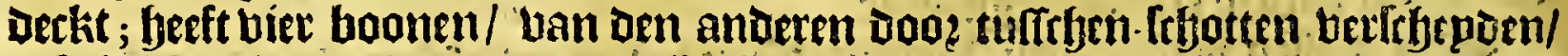

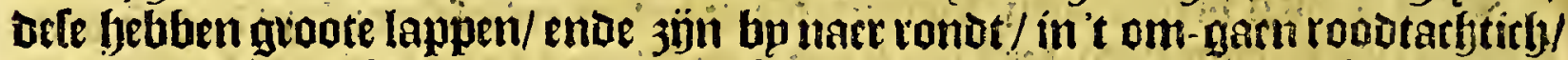

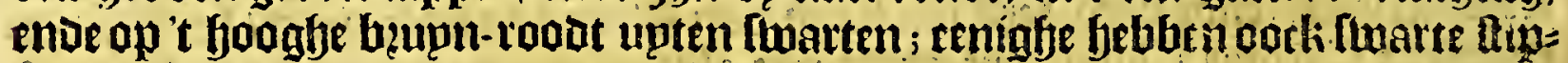

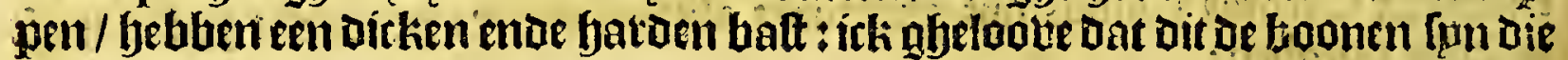

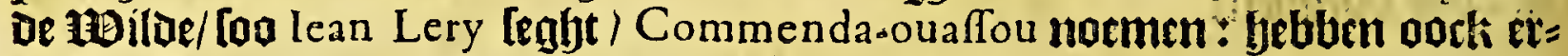

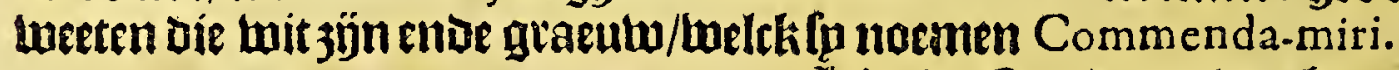

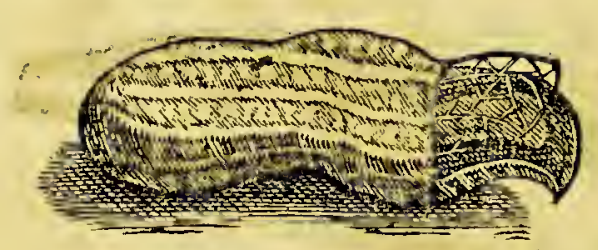

Jier thall mede een bzucht onter te aetoe glyeligtk de Tubera ofte aerdt- buplen/welth biec nebens bebluen af-abebeelt; Lery frbejtth

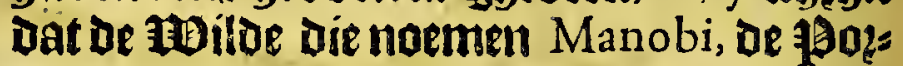
tugeelen maeclien dart groot twetck af/Dan

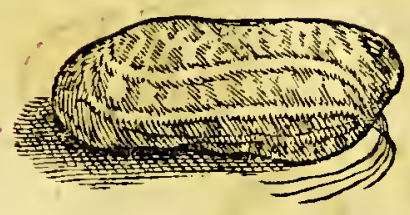
wat naem fp die gljeben is mp noch onbes kent: Defe aerot-buplen jijn aenden andeten ghefeetye met dunte ende langhe lenutwen/ bebben eon ag-uertwighen battrompelarf: ticljende antterck/enoe ban fímnen eenkeel als een bate-note / bp naer han be telbe maetk.

lean Lery befrbeyft norbeen anderen woetel/ Die fpp Hetigh noemt / gbemepns

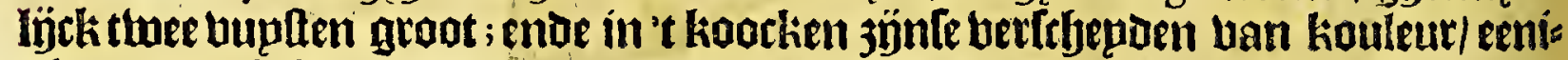

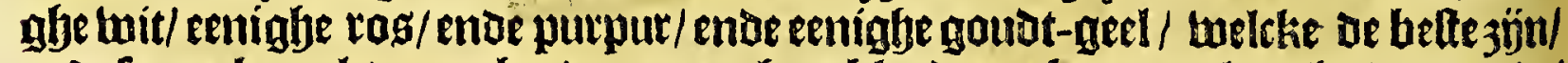
ende fmaeclien als een gebzaden peeve; faerblaederen kruspen langfis of gronat/

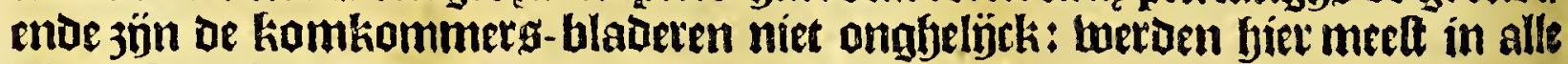
gbetaetten alyeb onoen: wozern vootts gyeseelt als oe Yuca.

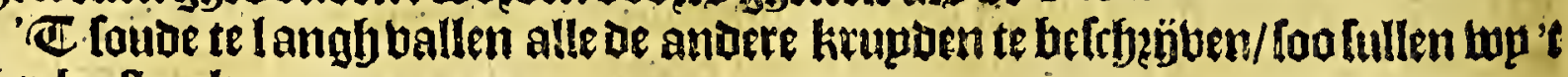
bier bu ftaecken. 
Wet [elte Capittel.

Gheleghentheyt van de volckeren endelih-gheboorne van 'tlandt van BRASIL in't ghemeyn:

DE menighte uan 't bolck ban Brafil ig twontor groot / (feght Herrera) foo Her.d.4.

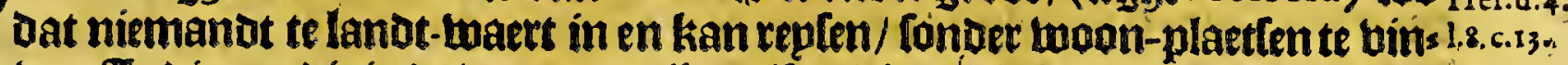
Den van 3 indianen die in of wapenen sijn / altoo dit bold in groote oneenichept

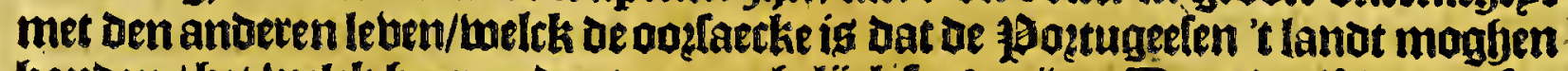

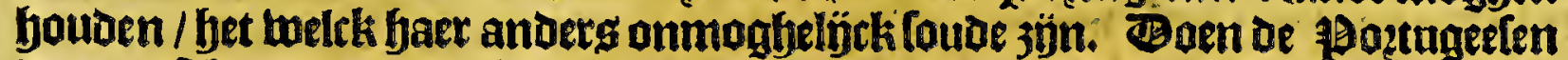
baer erext begonden te neffelen / vonden [p groote teghen-ftant / Dotb berjaeghoen 't bolck allengfgkeng ban de kulte; oe lpzaecke was eenparich de gantlthe kufte langys. 't Bolck gingh naeckt / hepbe de mangende de beouben / fonder entigh

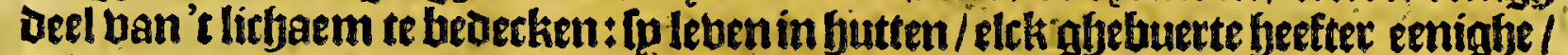
adbt ofte neghen/vol ban bolck; met faer netten ente Hamacas, twelch jón baec bangljende bedoen daex Ip in tapen. Spen bebben gleen laningb/alleen een

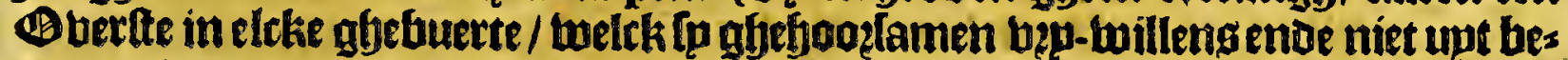

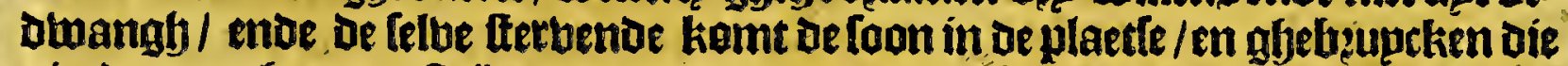
niet dan om fyaer ten ftrijoe te boeren/ ende te raden boe fo bechten fullen; fo en Atrafteniet / nothen ghebiedt baer niet tegben baer wil : beeft dep ofte vier bijoen/ maer ban oe eerfe meelt gheeltimeert twer ot : en bioden gheen oingt aen/norf en glelooben niet Dat Daer een ander lebenis naer bet befe/ maer dat bet al ferft met

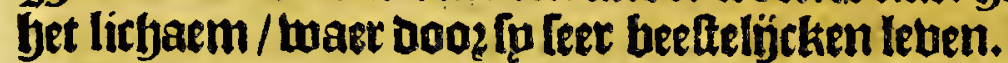

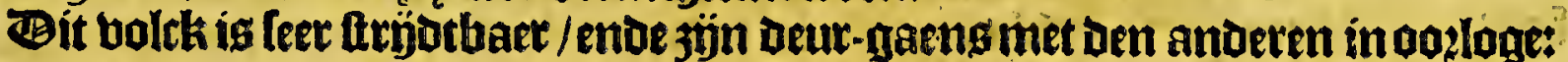

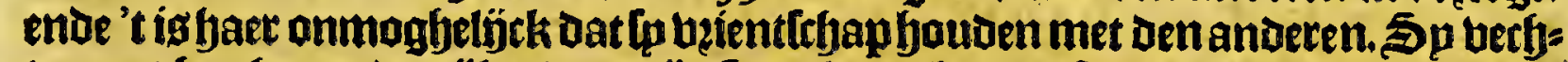

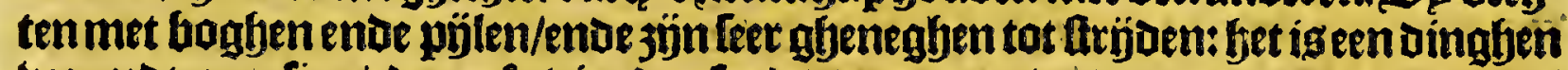
beemat om fien/ dęp oft bíer duplentot man van de een enoe de ander jỷof

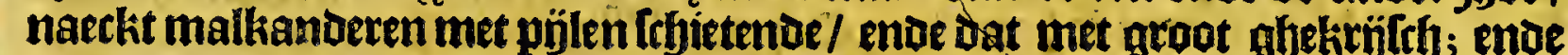

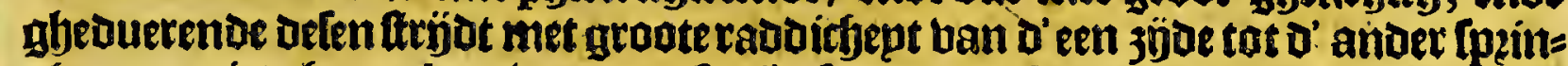

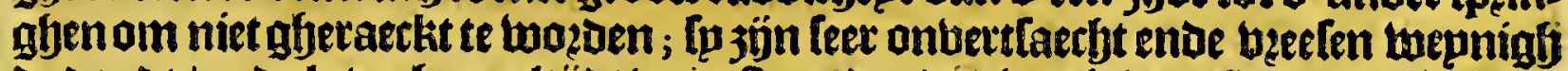
be dood / ende laten baer altjot booz-ftaen dat de tictojie booz faet is : en nemen gheen ghebanghens / maer flaen al doobt ende eetenle; ende die ober-blïben/nes menle met baet; doen de ghebanghen een grooten balt om den fals/ op dat bp niet twegh en loope; ghe ben femeen Hamaca om in te thapen/ ende eenjonghe oorftet ban de feyoontte om bp te legghen/ die bem belwaert ende te eten gheeft / ende

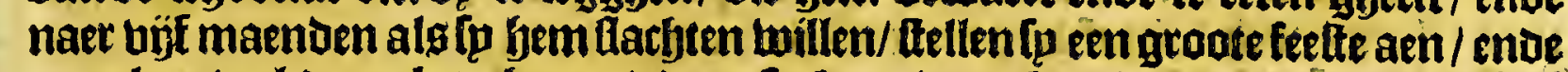
maecken beel dzancks gbereet / baer [p baer beoncken in dzincken/ende boo Den fem boots in manieten als bp Leri enoe andere in bet langhe is beitgese

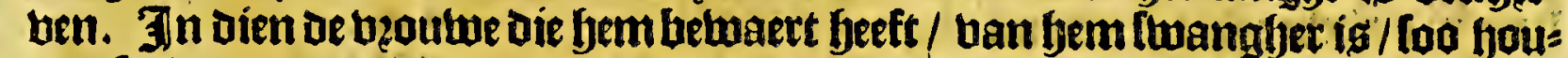
oen Ip het boozen ban oe grootite wzaecken ober faer bpanot/ ljet nieutm-ghes boozen kindt mede te ecten: Doth fet ghebeurt dat oefe bzoutuen foo gjeaffectio: neert luozoen op de gheluanghen / dat [p die log laten enoe met frem luegh loopen/

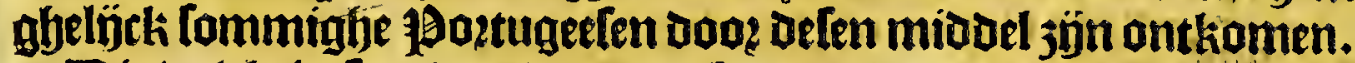

Bit bolck is leer wzecot/ oneerbaer ende gheneghen tot bleelofelijcke lulten/

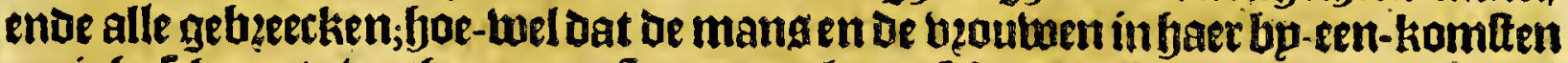
eenighe lchaemte bertfoonen. Speeten al menfefen-bleelch ban haer bpanden; enve twat fp oock eetrn/noodighen alle de om-ttanoets daer toe/ welck is al baer liefoe diefu thoonen. Be mans bebben de onderfte lippe dooe-boot / ende daer een gfyelteente in om de fraepictept: ander fyebben't aenficht bol gaten/ende vaer

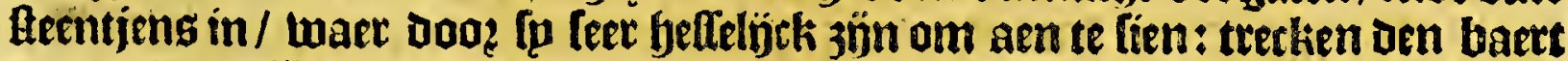
upt/ ende en lijoen gbeen bap: aen't gantffye liehaem/ als alleen bet booft. Be bzoutuen febben groote pearbt in baer hapg / en otagben get feer langf: eenighe 


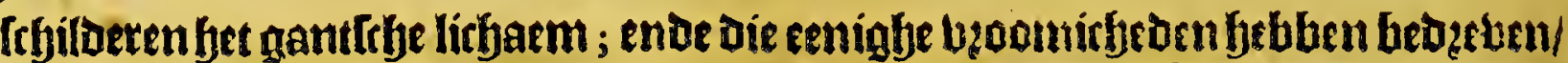
Dzaghen daer feeckere teeckenen af. Be bertwe is fet fap ban freckicr beurbte / wals fende aen den boom Ianipaba; welck is ban gheftalte als ozagnie-appel/ende

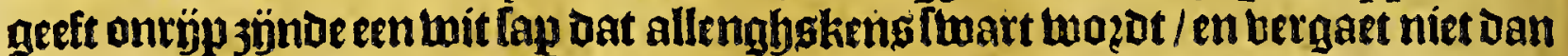
naer ben negenlen bagh. De bzoulenen jün baer mang getrou / snoe konnen gern

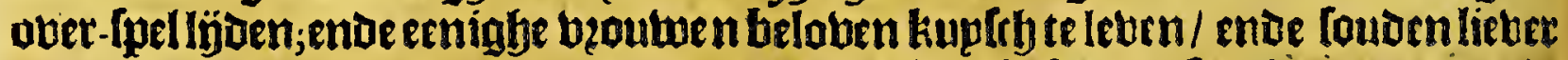

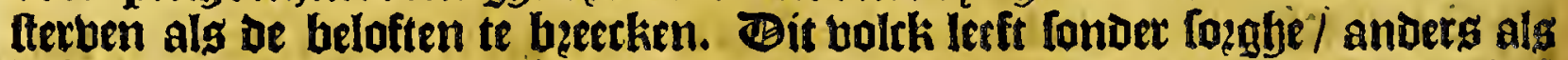

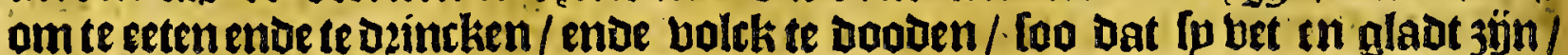
Dorb tozoen waneen klepn onluft bertaghen enoe ter neder gbtbzarft: De bzou= wen alg lp obebaert bebben / walten baer en gaen Daer benen/ knde de mang gaen

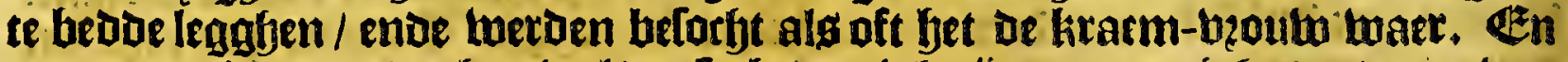
vergaten gheen goedt; boe-wel dat in begeetigh zün naet enighe goederen ban Spaegnien / als fyemien ende plec- werck / weltk fp groot acfiten: in manghe:

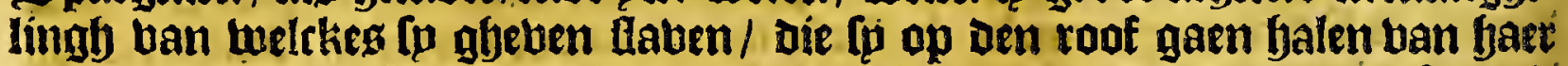

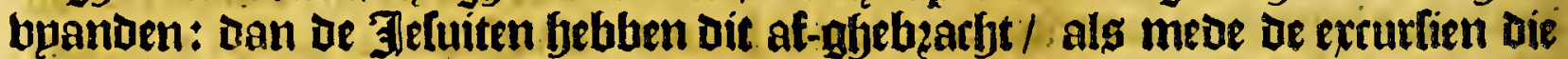
ie ploztugeelen abetwoon waren op dit boick te Doen/gheen flaben toe-latende/

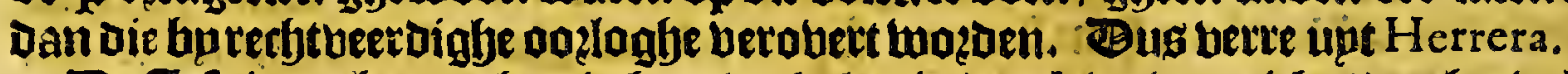

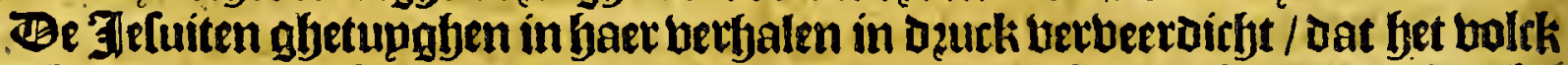

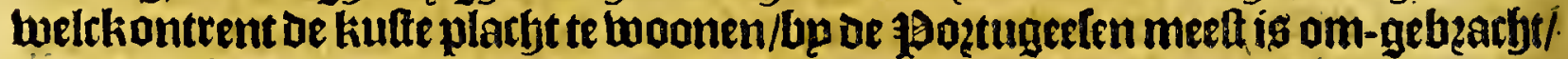
enoe de relt berjaeght binnen's landts.

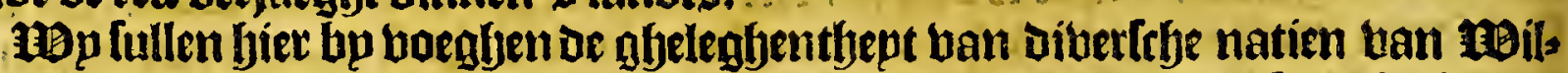

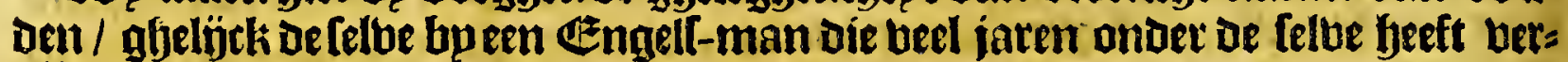
thert / ende meelt alle De contrepen beeft dooz ghelwermt / 3 j̈n aen-gbeteeckent.

Purchas Be Petivares en 3 jun loo barbaris niet als de andere/ haer litbamen jijn met Pilgri- fijn lwerek ghepickeert; hebluen gaten in oe lippen/ende daer een fteentien in/als mag. oock andere 25 efikanen: bebben gheen teligie / gouben ueel beuben / maer oe

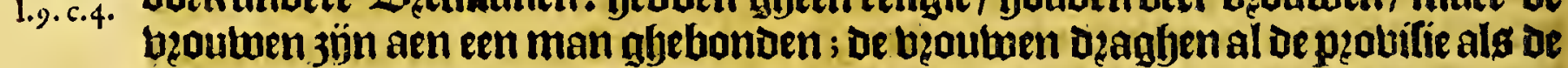
mang ten krüghe gaen/ voeten beel Tobac met baet / en hebben gfjemepnlÿck

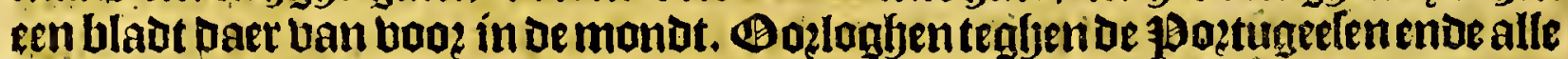
andere: eeten ratenfrjen-bleelch/ ende fouden dat fet telbe baer robult en fterck mackkt. Bgoonen ontrent Parayba.

De Maraguites twoonen tufthen Pernambuc ente de Bahia, andere 7 noia: nen noemente Tapoyes, Dat is twiloemenfchen te fegalien/ welcke naem alle ander

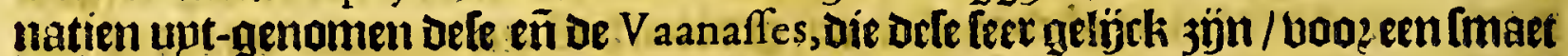

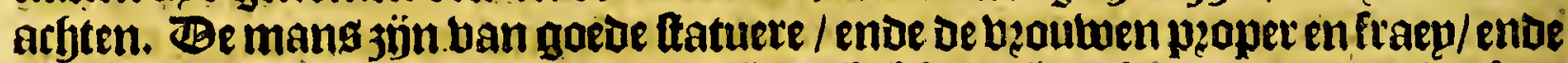

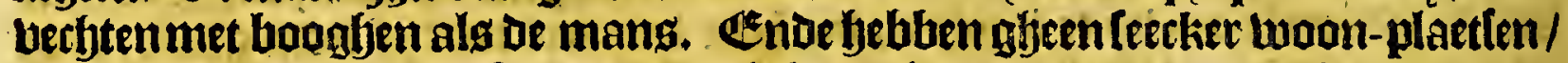
noctjeligie/ noeth beientfryap met eenighe natien; dan luaren boen in vecede met

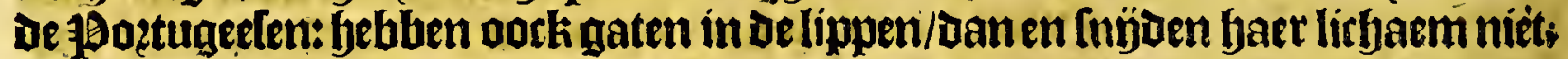
3 ju [nel / ende komen nimmermeer op't blacke betot om te berften / maer bouden Gaer in't gyjeberabte; etten mentrben-bleefry.

Be Topimanbazes twonen ban Rio de San Francifco tot Bahia de todos. los

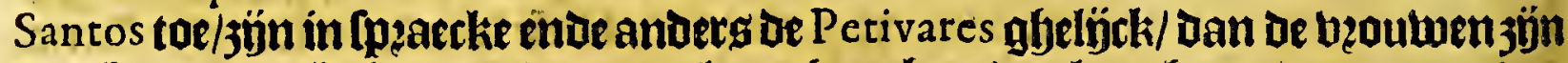
uan beter complexie / enoe de mang laten faer baeroen langh groepen.

Be Waymoores (beellitht Gaymures, Jaer bo boozen van hebben ghe[pzoken) woonen wan $B$ ahia tot Ifleos toe/groote liedenuan ftature/ende [nel algeen peetat) bỷf ofte les ban fyaer Derben een lupcker-bupg aen-ballen vaer bonorrt man in is:

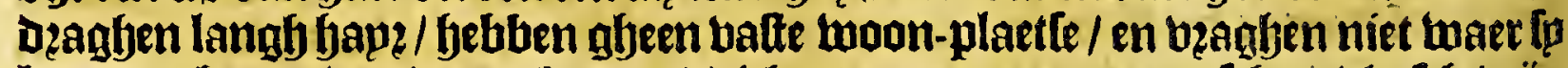
komen / betroumende op baer rabdichept : eeten geerne mentrben-bleefry/ zïn

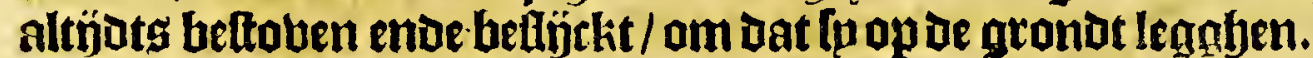

De Tomonymenos twoonen ontrent Spirito Santo; felbben bafte twoon-platt(en/ met groote leenen daer am ghelet / tamelïtk foogh / en van bimmen wallen banklep ofte fteen: entue baet fuplen bebben ronde gaten om doo? te frbieten; bes

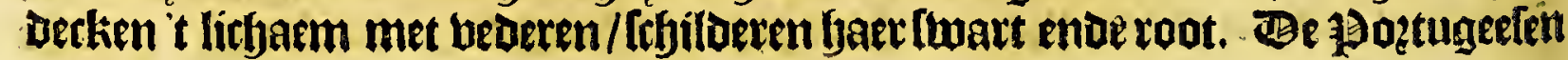
namens 
namenter bel I 6000 ghebangen/ende floegen tbiende-ded taet bandoodt/ende

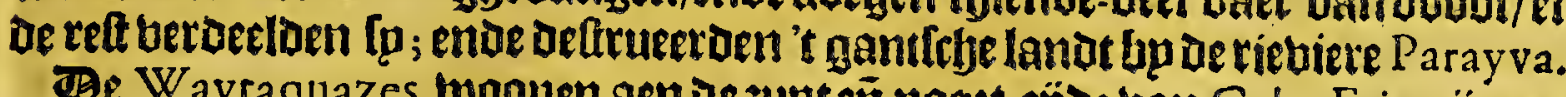

De Wayta quazes twoonen aen De jupteñ noogt-jjoe ban Cabo Frio;júngroo: ter ban frature als of Waymores; baer byoutwen berbten mede met bonfjen;leggen op oe gronot als verckeng/een bier in 'tmidoen/Gouden merniemant veecoe/ban

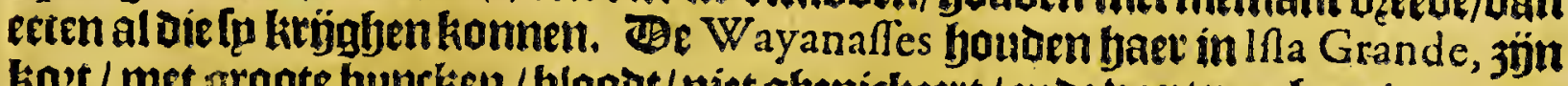
kozt / met groote bupcken / bloodt/ miet ghepickeert / ende banteren baet ban geen

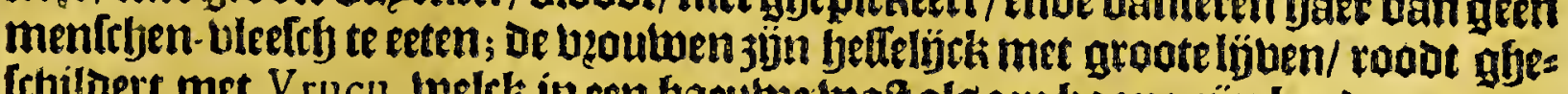
Icbildert met $V$ rucu, belck in een faeubre twat als een boone; 3 in bepde mannen

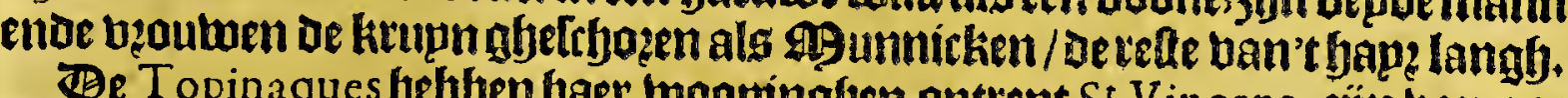

De Topin aques beltien haer boomingben ontrent $S^{t} V$ incent, jinn ban goede Catuete ende romplexie : de bzouben ghelrbildert met Diberfébe kouleuren: eeten menfthen-bleeleb / biosen niets aen: alleen alg fp een man darljten / foo bertwen Ip yaer met een veuchte ghenaemt Ianipano, en met beeders op 't gooft/groate letes

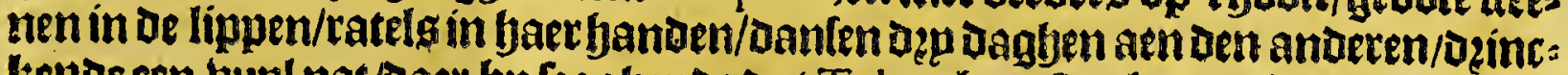

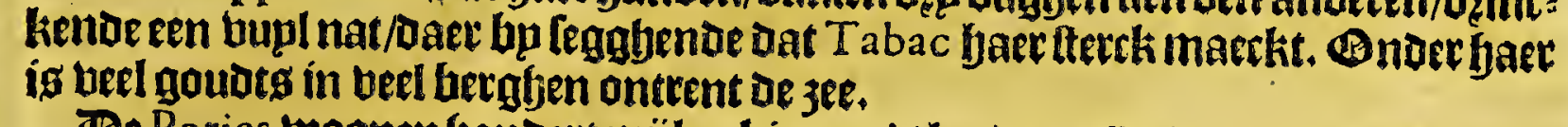

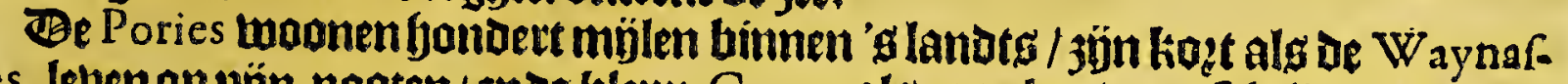
fes, leuen op pün-nooten/ende klepn Cocos als appelen / met fthellen als walnoaten / maer harder; noemen die Ey rires : Ltríden met niemant/ keten geen mens buplen / als twee oft Dap tacken ban boomen te lamen gfoluonden / ende bedeckt

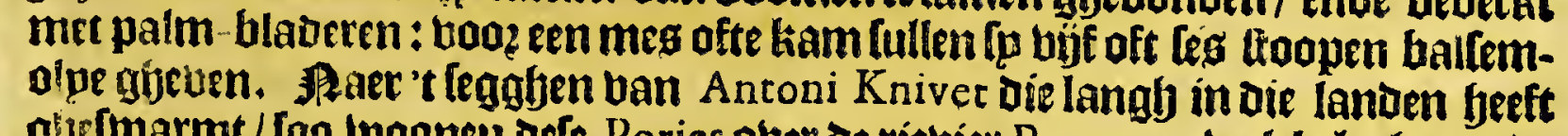
gljerwarmt / loo toonen defe Pories ober de rieuier Pareyva, welck leght op de een en-twintich graden thee derde bp 3 upden de línie.

De Molopaques moonen bp de viebiere Paradiva, jijntoo gloot als Dupts

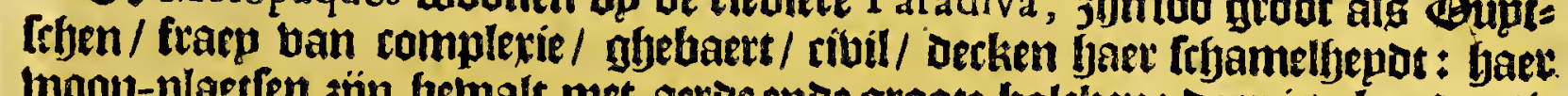
woan-plaetlen jün betwalt met aerue ende groote balcken: daec is abundantie ban qailot / melck [p niet en achten nocf en ghebzupcken / Dan om aen baet net ten te hangfen; ditg de riebiete Paradiva, tarbtentity mijlen toozoer als Paraeyva ; uergaderen gheen oan bet gbene den regfen uan'

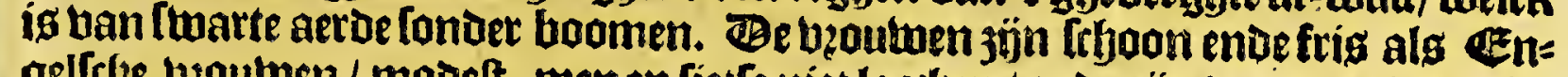

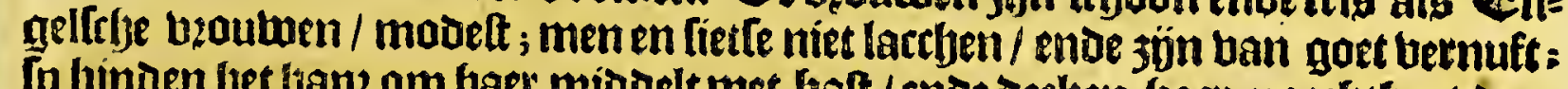
ip binden ljet ljaps om baer midoelt met balt / ende decken Gaet naeckttjept baet

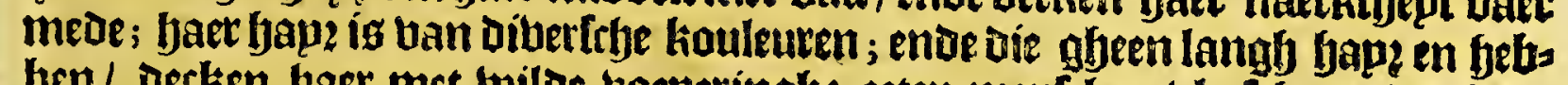
ben/ Decken baer met bilde boeperingh: eeten menftyen-bleefty; onder-fous Den Deg midoaeglys ende's aboutts te eeten; (

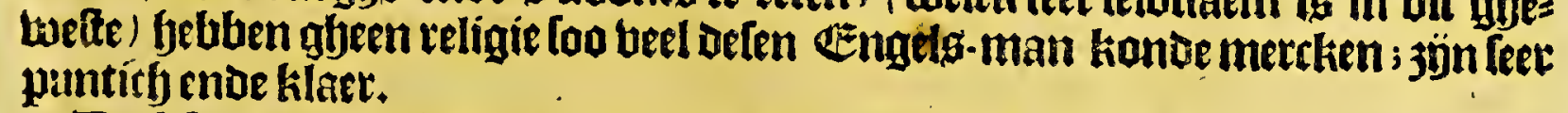

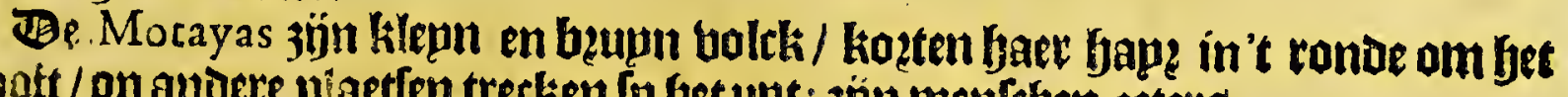
boatt / op andere plaetfen trectien fa bet upt; zin menfthen-eeters.

Be Lopos ofte Biheros, als de Hoztugeeten die noemen/ fousen fraet in bet

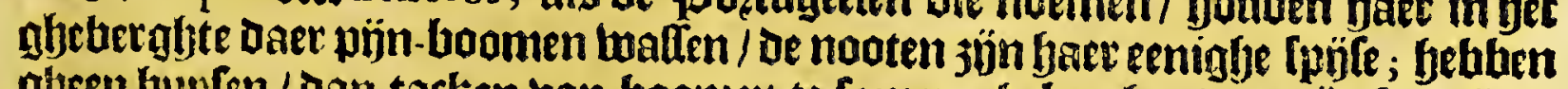

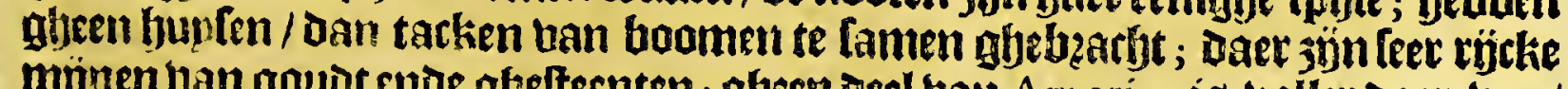
mijnen than goute ende gljelteenten; gheen deel ban A merica is boller aaer ban/

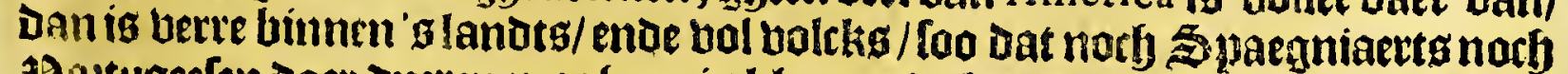

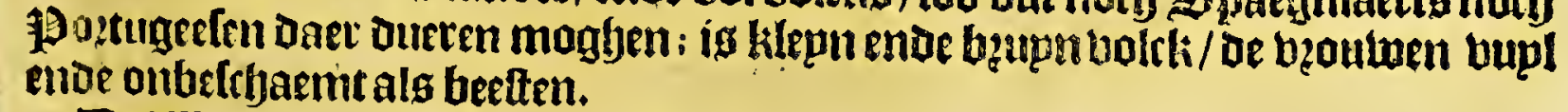

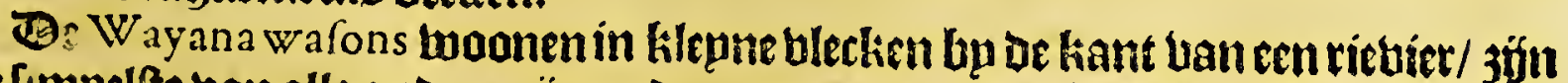
of [impelfte ban alle andere; 3 in anders groot ende lanck/ wol gljemaeckt. Jen

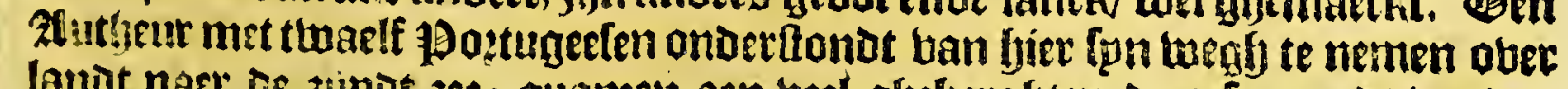

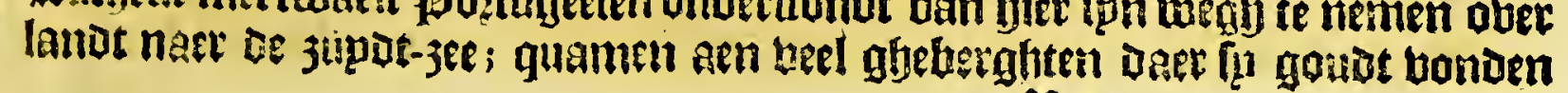




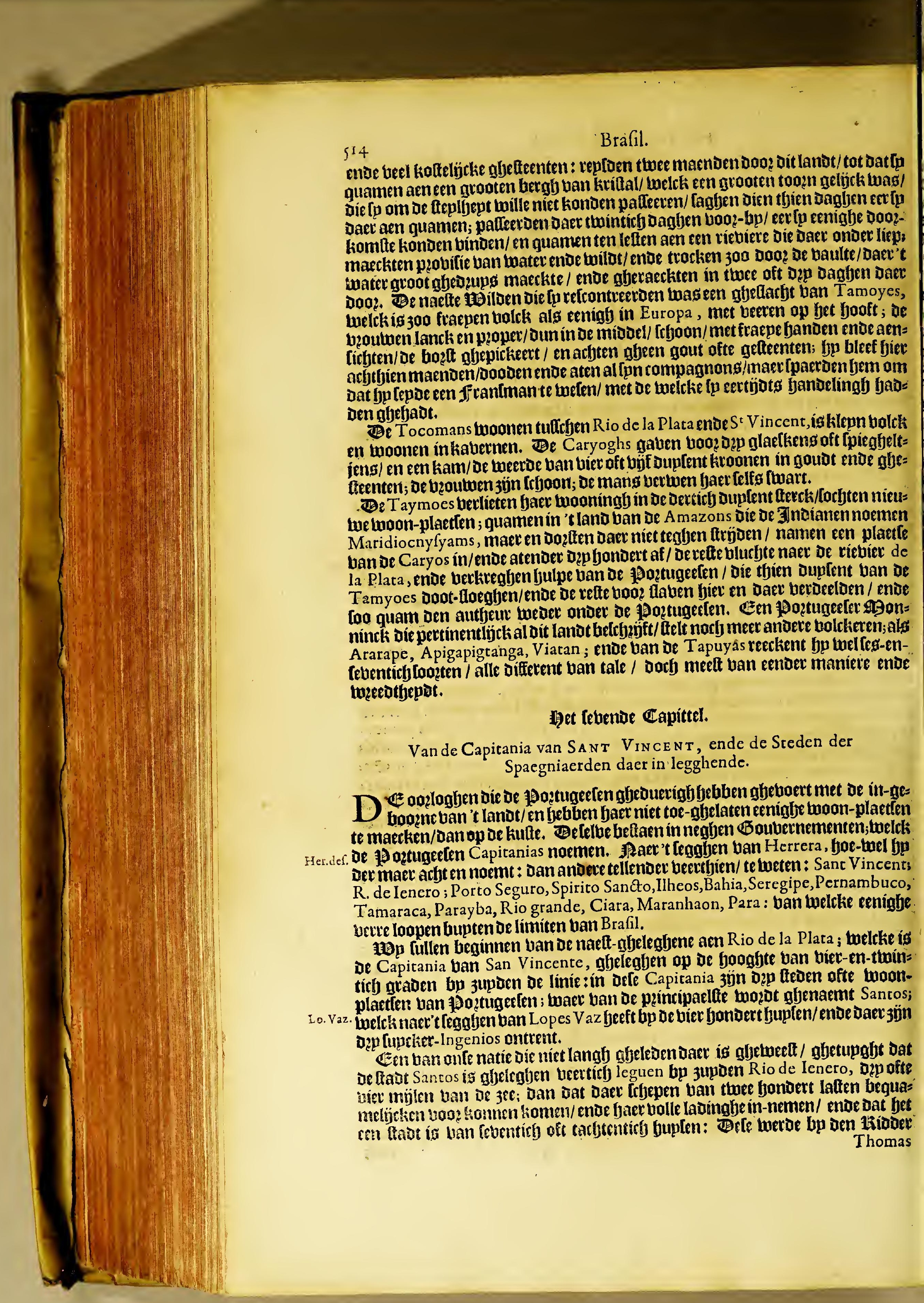


Thomas Candifch in -gfenomen / ende twel tweemaenten in-ghetfouten in den

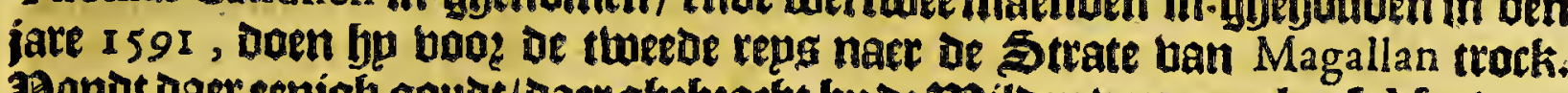
Bondt Daet eenigh goudt/ Daerghebzactht bpue moiloen van een plaetfe Mutinga,

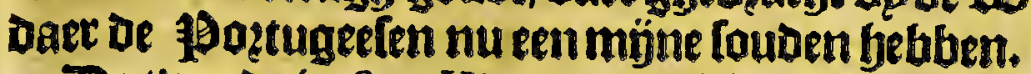

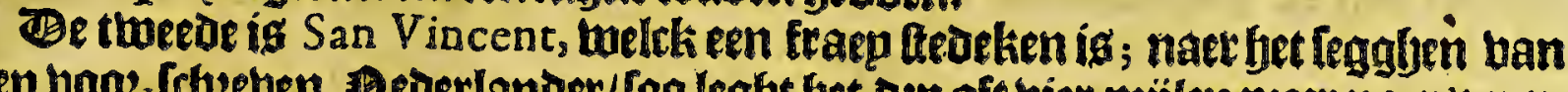

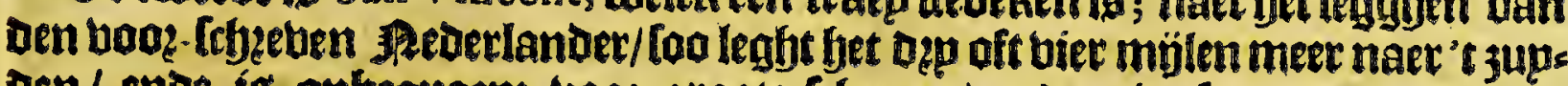
oen/ ente is onliequaem boaz groote lchepen/ ende niet too groot ofte mel betwoont als Santos.

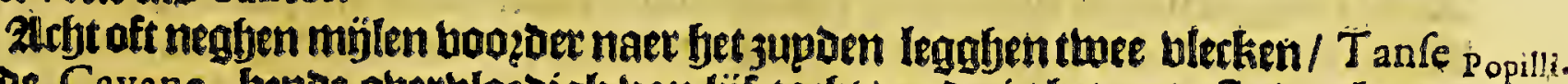

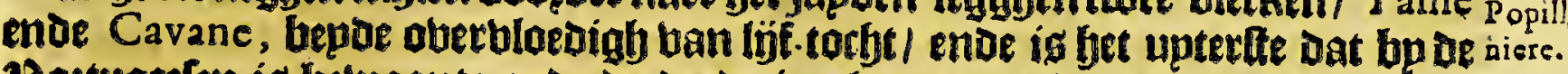
29oztugefen is betwoont: ende be dertoe is gfenaemt Hitauhacin, ujif leguen

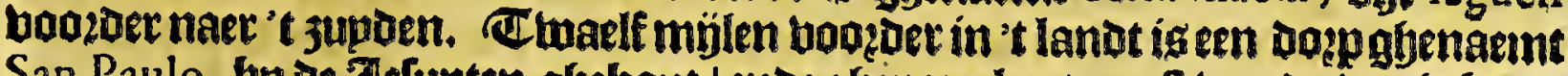

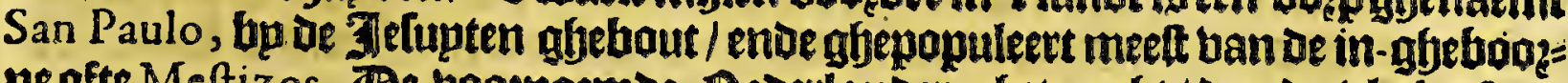

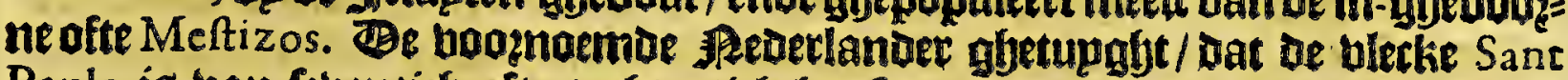
Paulo is ban fewentich ofte tacbtentich gupfen / ende Dat men daer benen repit

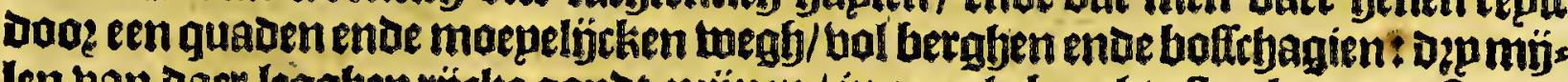

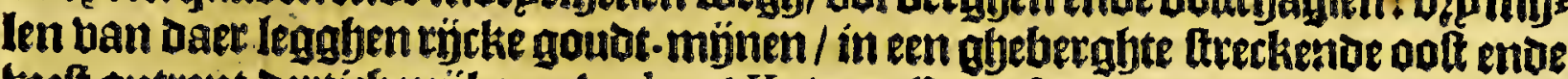
tweft ontrent derticf mijlen. Anthoni Kniver eEngellman/ langh in bit ghetweft

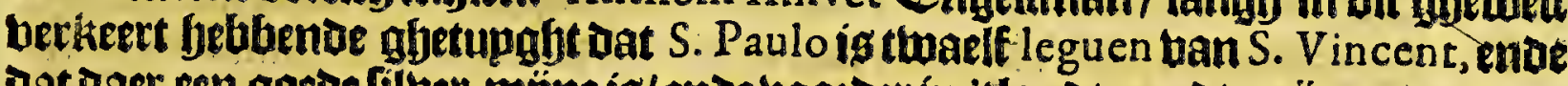

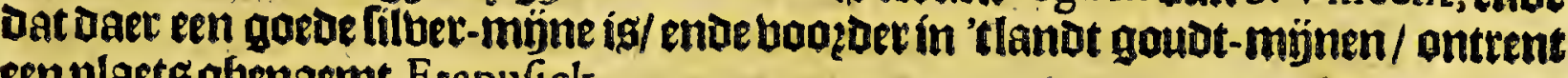
eenplaetsg ghenaemt Etapufick.

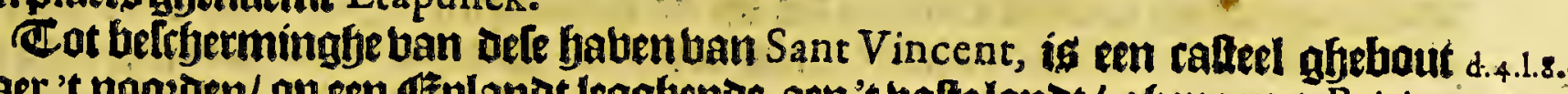

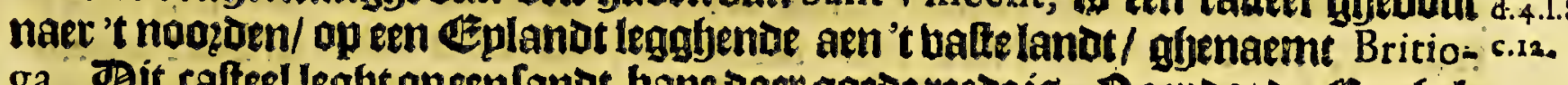

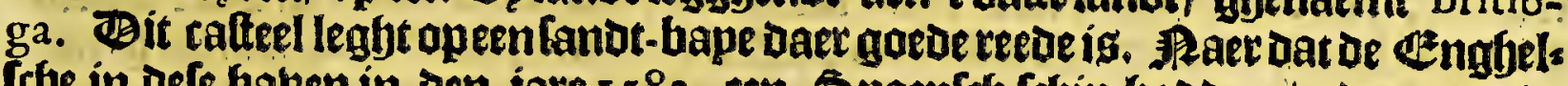

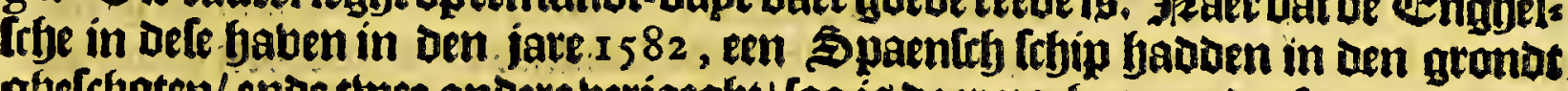

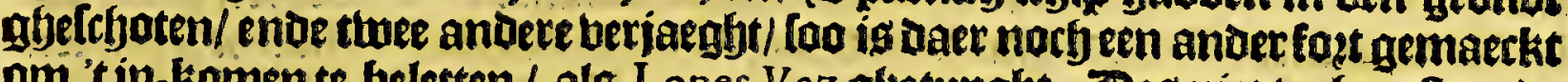

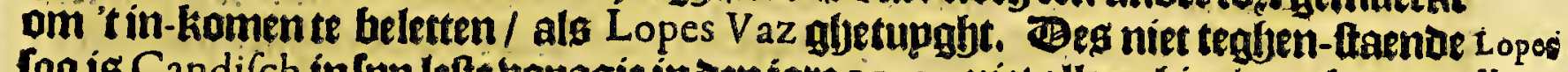

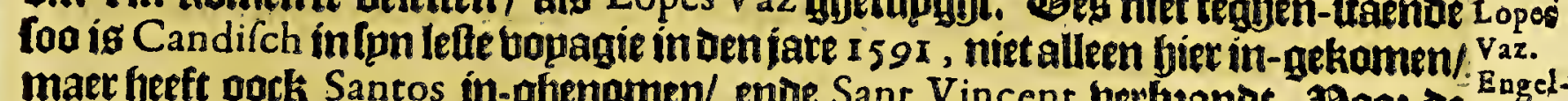

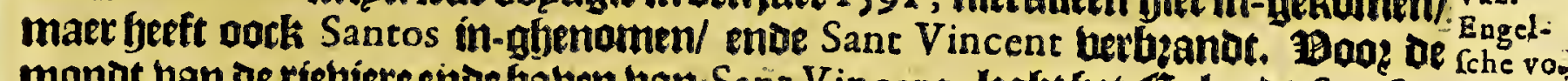

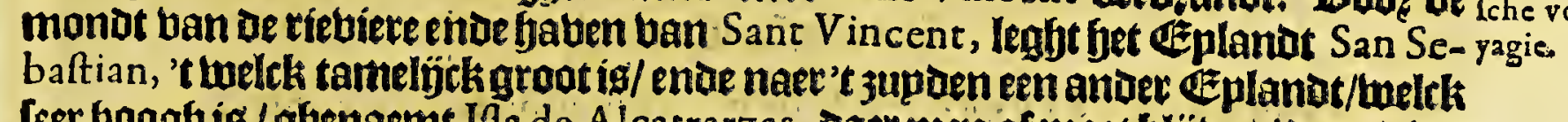

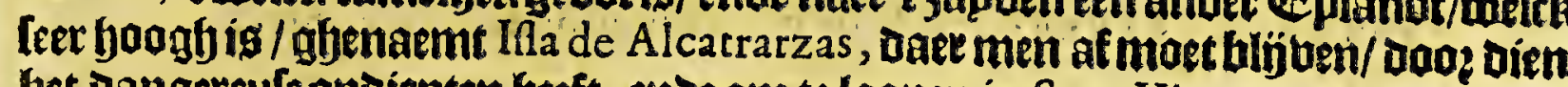

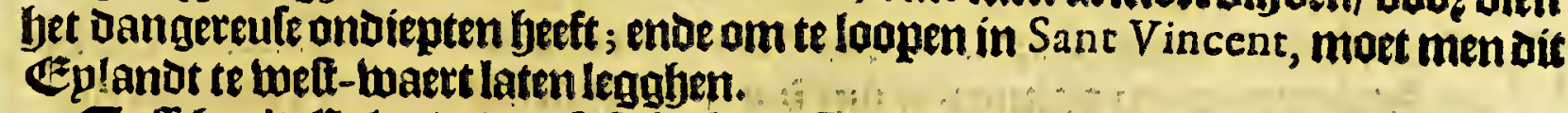

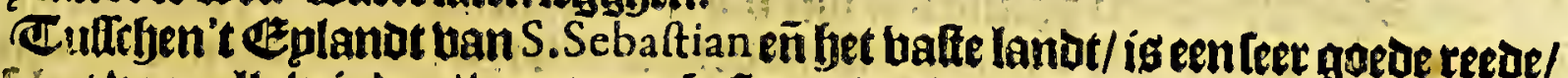

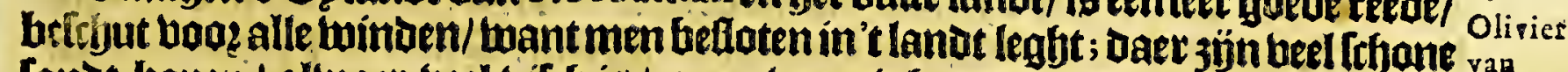
Canot. bapen / allwaer beel bifty is / maer wepnigh anver bertuertchinghe / want Noords: 't $\mathbb{E}^{*}$ planot ís bol huilot gbehoomte/ Dat men niet magh in-waett gaen; water is

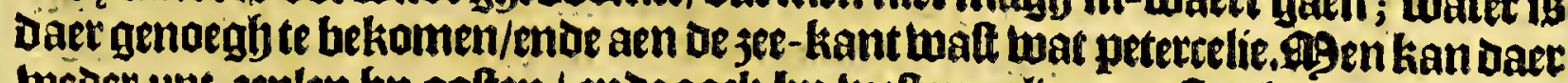

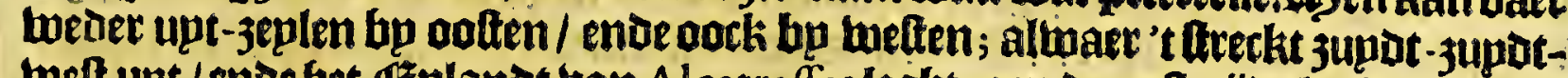

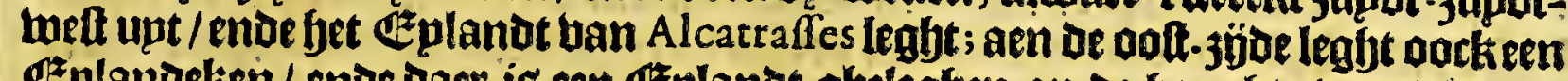

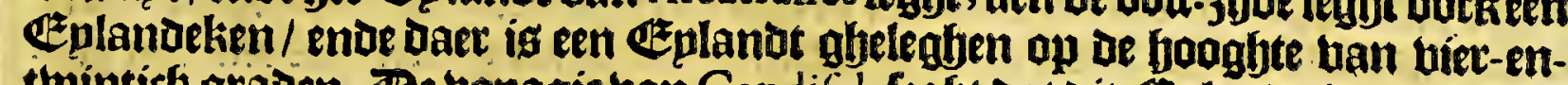

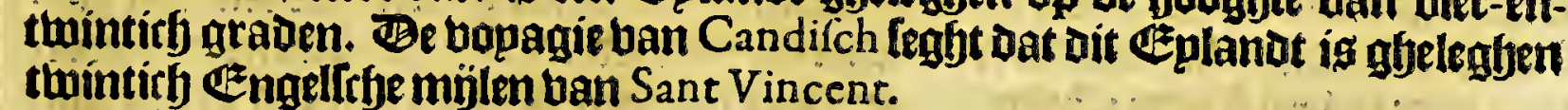

Een EEngeltrb-man ghetrout in Santos met namen Iohn Withal frgeg̈ft in Engel. Den jare 1578 aen fpn beientente London aloug:

Ick heb defe daghen fprekende met de Capiteyn, van hem verftaen, dar daer yagie. feker mijnen van filver ende goudt ontdeckt zijn, ende darfy daghelijcks werck. lieden verwachren om de felve mijnen te openen. 99 aer be efengelftrbe die daer

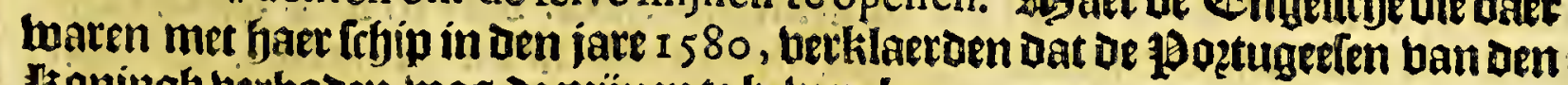
Itaningh verboden was de mỉnen te betwercken.

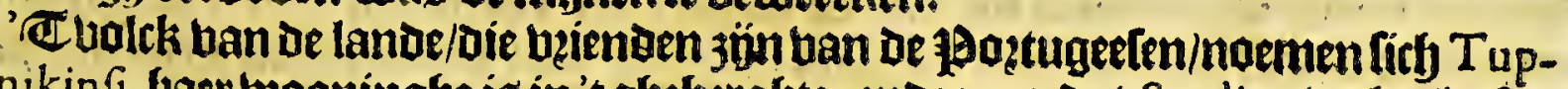

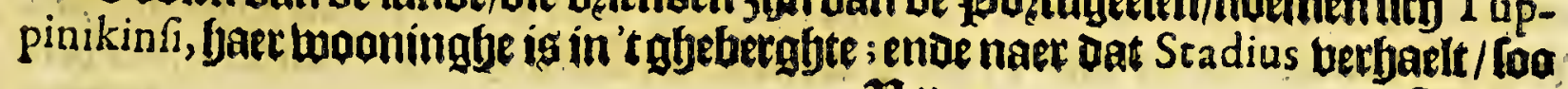
翼 frecken 
$5^{16}$

Brafil.

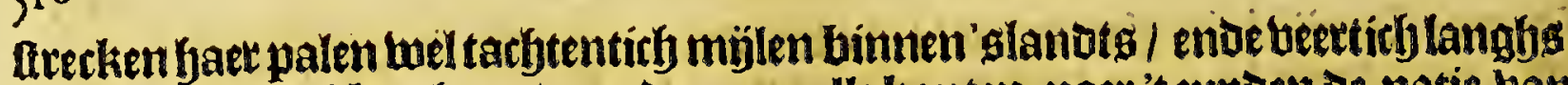
De kulte; Defe ljebben baer vpanoen aen alle kanten; naer 't 3 upoen de natie ban oe Carioes, ende naex't noozonende Tupin Imbas, welcke lelte beel fryade bebben

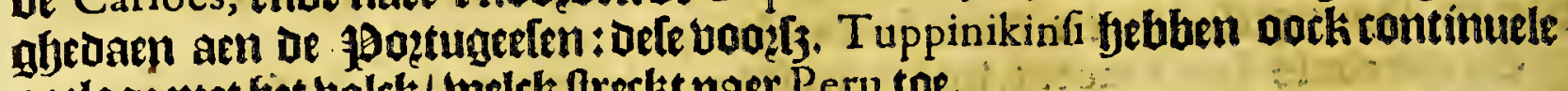
oolloge met fiet bolck/ welck freckt naer Peru toe.

De Jelupten gljetupgen in baer berfialen dat ontrent Sant. Vincent woont een natie van Jndianen die [o noemen Miramumins, een wilot ende batbarifry

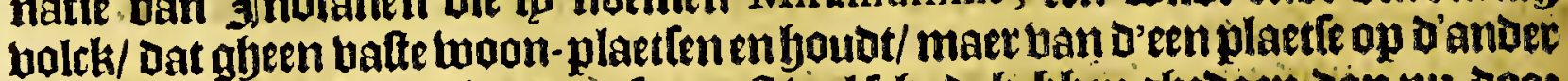

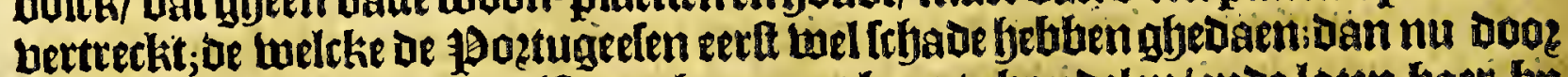

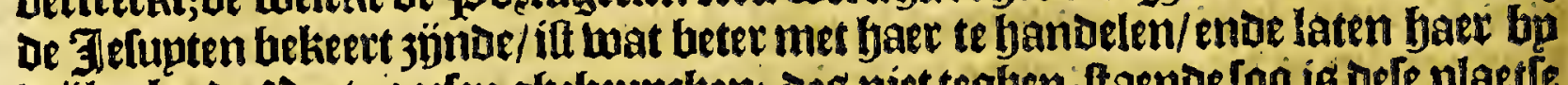

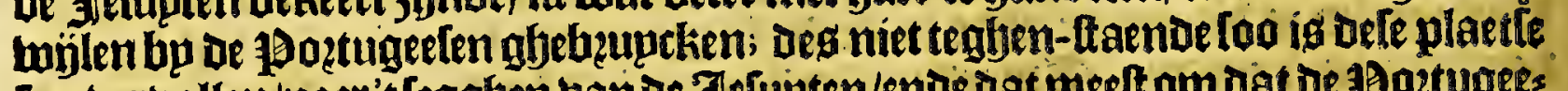

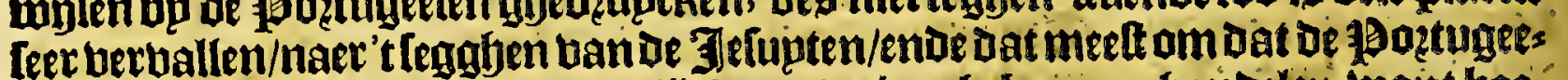
Cen loo ontroulwelïck ende wzeedelinck met de in-gbebogene bandelen; want boe -

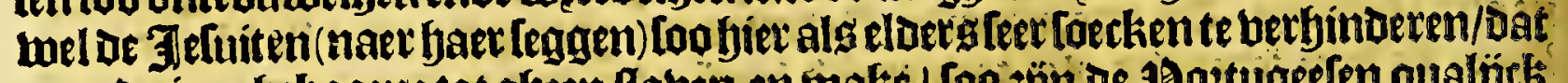

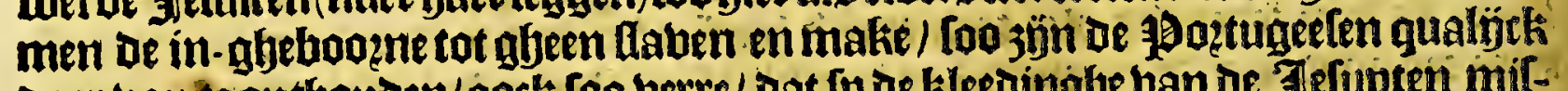

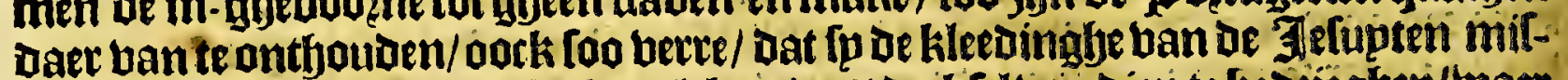

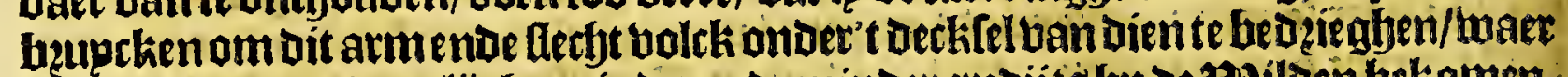

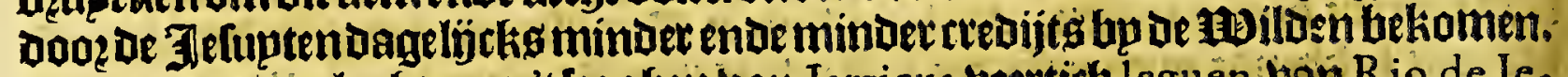

Sant Vincent leght naec'tleggfen ban Iarricus beettich leguen ban R io de Ienero; de Jelupten die fier woonen/Doen diberfbe torftente lande- waert in/ende uoomamentlibck naer of Carioes die bp De tachtentity leguen ban baer naet' zupden woonen/langhys de kulte tot bp de mondot ban R io de la Plata toe; ende is en fraep ende bequaem bolck / meer aligenigh anber oat in o it getwelte tooont wit/ende kleeden baer met bellen ban beelten : Loconen óm de Laguna diefp noe

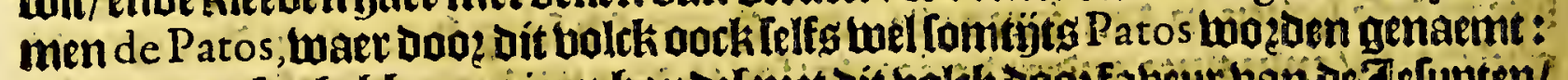

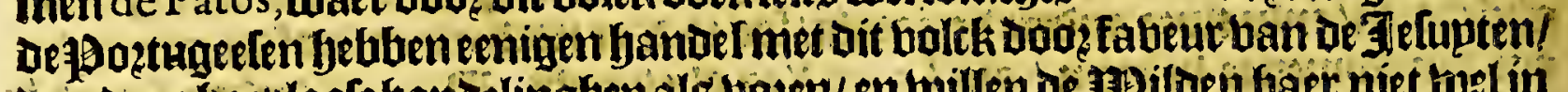
Dan booz haer loofe hantelinghen als vozen/en willen de tebiloen Gaer niet wel in baer landot laten komen.

Wet aubtte Capittel:

VARRIODE IA NERO, cnde de gheleghentheden daer ontrent.

D EE naett-abeleghene Capitania aen Sant-Vincent is Rio de Ianero, loo bp De Spaenniaerden ghenaemt/ om Dat in die maend tontieckt wag bp Iuan

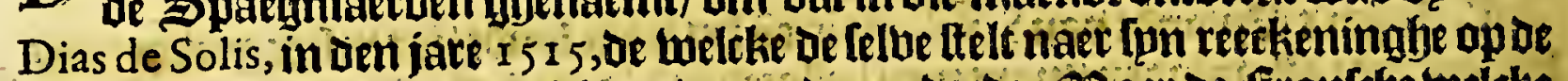

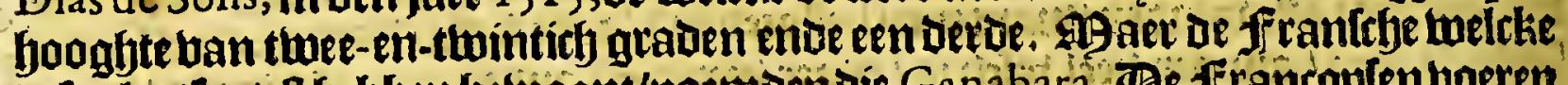

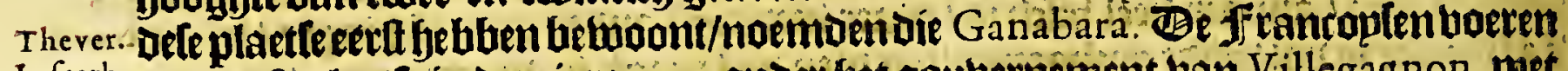
Lefcarb. naec dele plaetfe in den jare i 55 onder bet goubernement ban Villegagnon, met

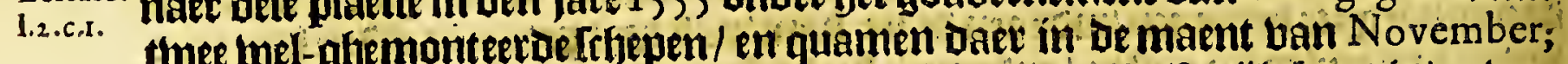

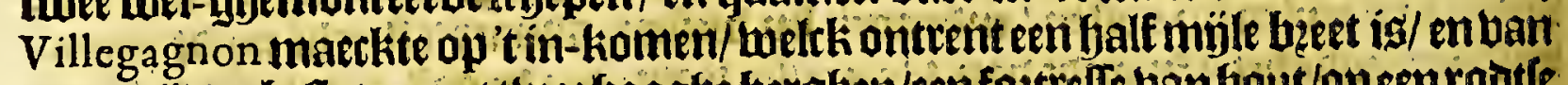
bepae jy den betloten metthee fjoogbe berghen/een foetrelte banfjout/opeenrobtle welcke fiondert boeten lanck ig/ enoe teltirth bzeedt / Daer fjp een Deel ban fun ghte fibut plante/om de in-komite te berfekeren. Beriebiete is ban bínen [eet begedt

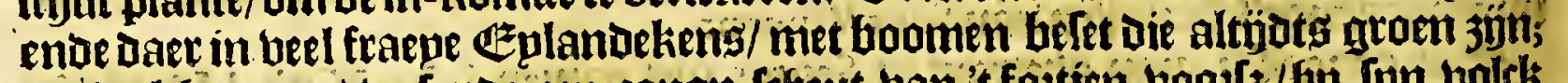

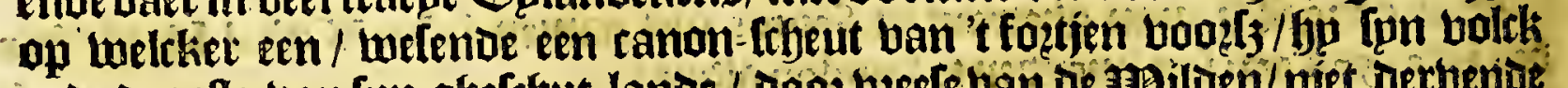

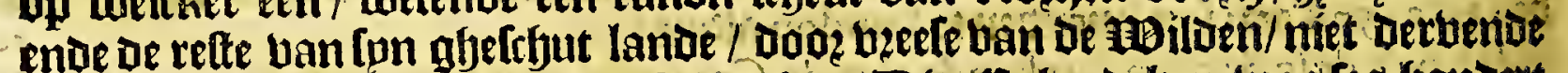
aen 'tualte laindt fon woon plaetle legghen. Bit Eplandeken twasteg hontoert paften lanigf entjondert pafen bzeed / legghende bertebepden ban't bafte lanot

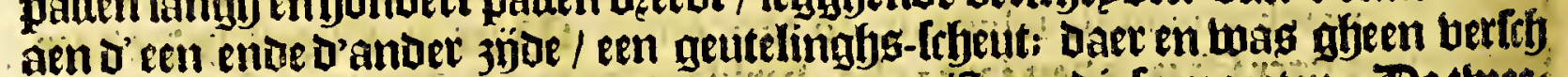

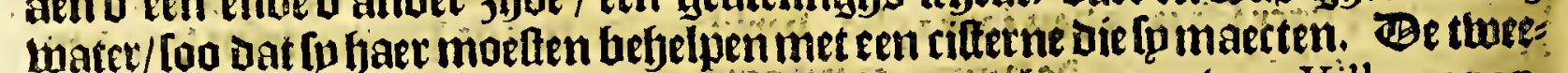

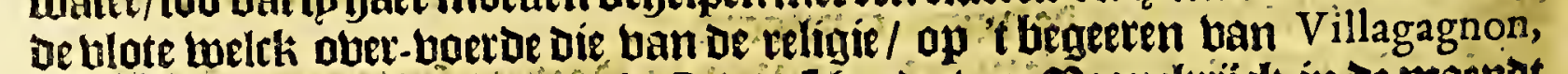

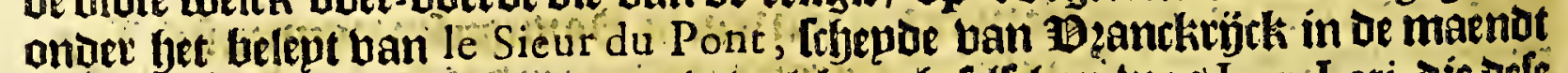
van November in fret jaet 1556 , in wellker ghefellchap toas Iean Leri, die vefe thered 
Het vecrthienfte Bocck.

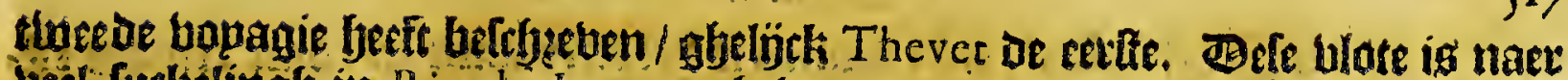
beel fuckelingh in Rio de Jenero glbetomen in Martio 1557 , enoe bet bolkt

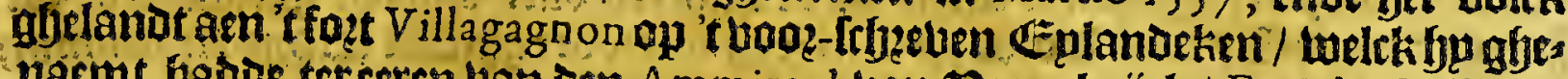

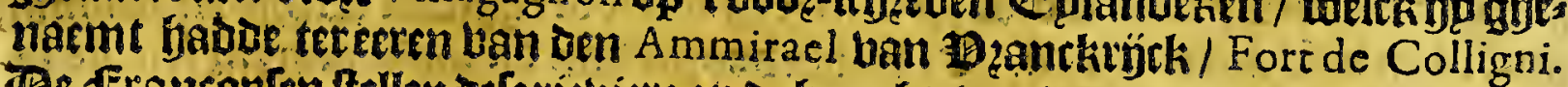

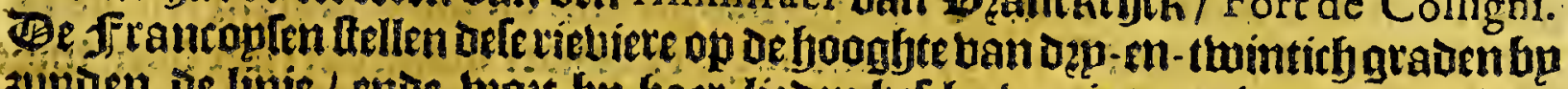

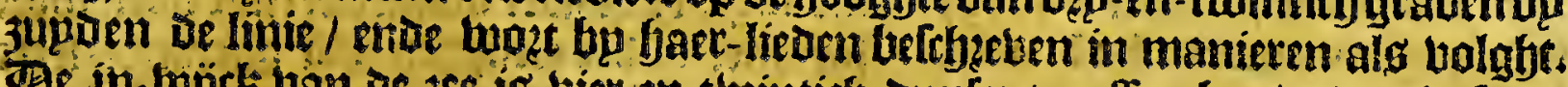

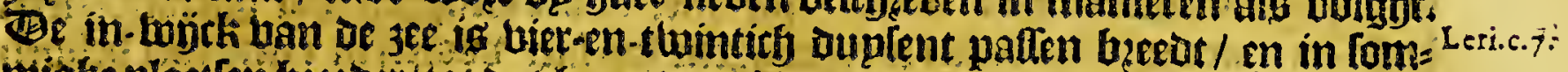

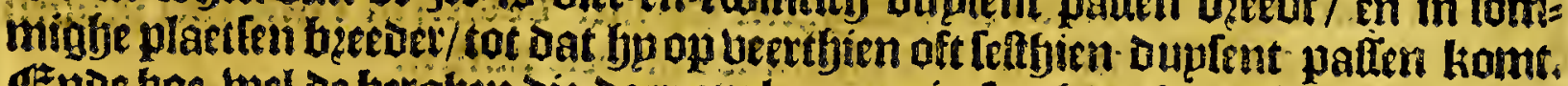

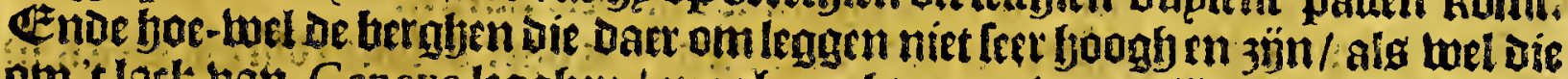

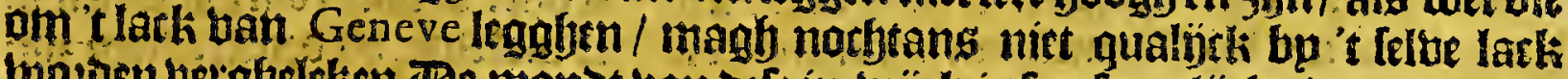

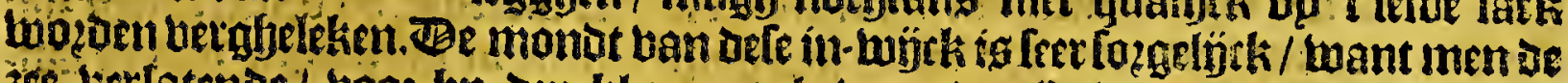

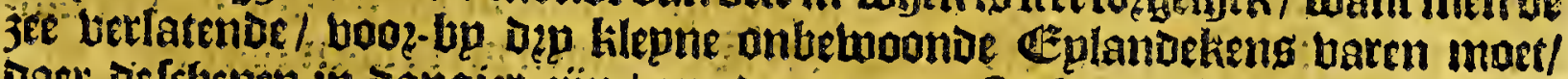

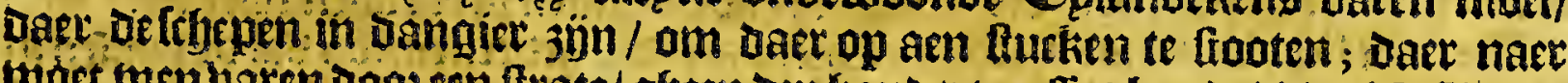

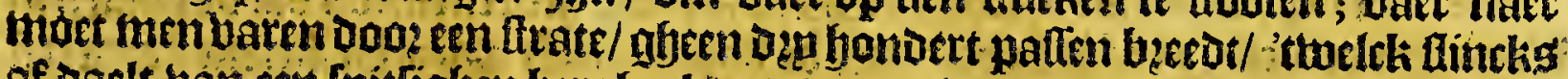
af paelt ban een fpittighen betgh als en ppramioe / bie niet alleen feet groot ig/

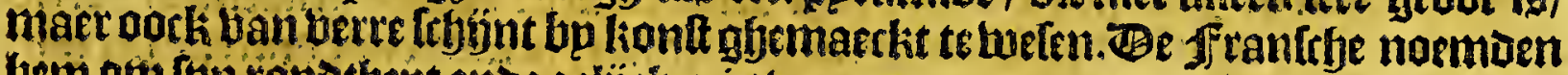
bem on fon rondthent entae gelijtkenis ban een groote toom le Pot de Beure, bat

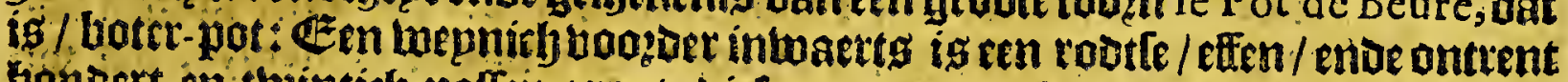

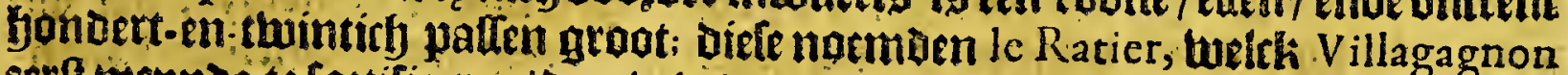

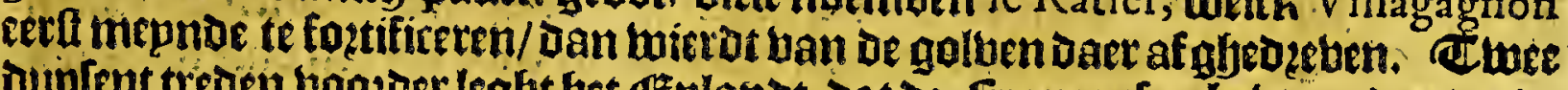
Duplent treden boozaecleght bet Eplanot Dat de francoplen beteonden/ente

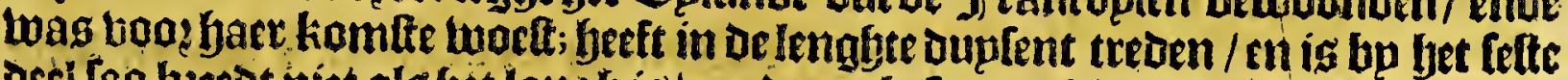
ocel loo beedot niet als bet langh is/ronotom befetmet klippen glyelïrkg bet toa= ter legahende / foo dat de trljepen be een gotelingf-frbrut daer af moeten blij=

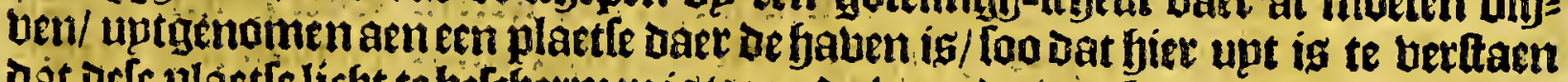

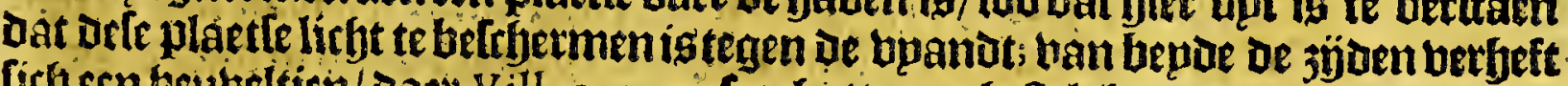

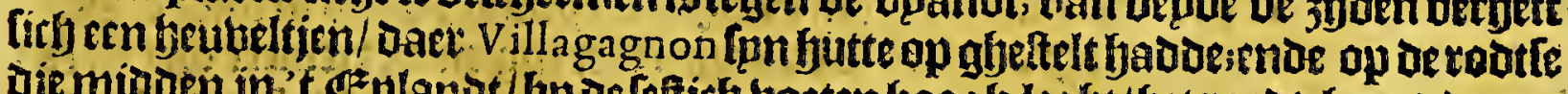

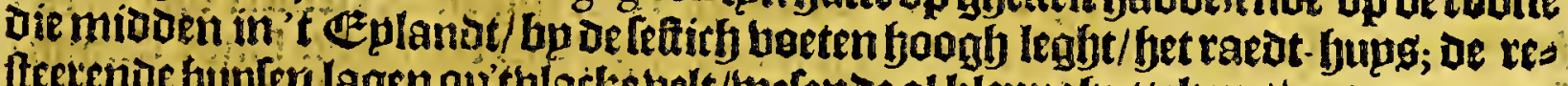
ftereno f buptri lagen op tblacke belt/werende al klepne huttekent/upt-genomen

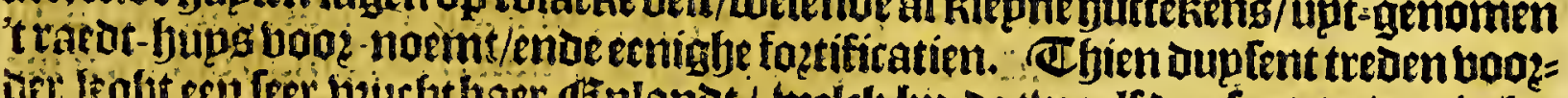

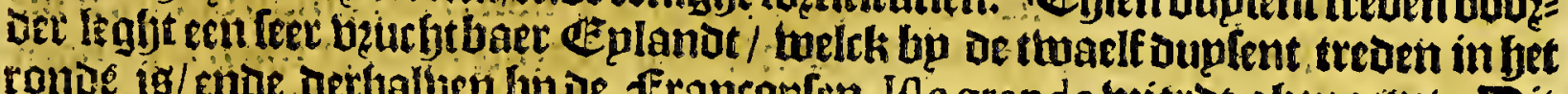

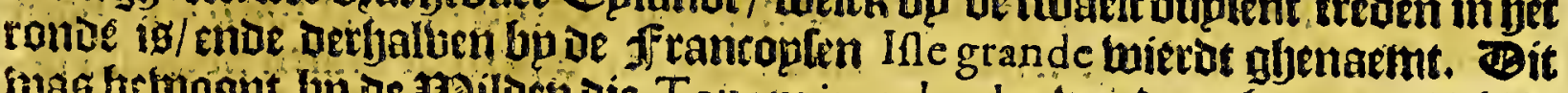

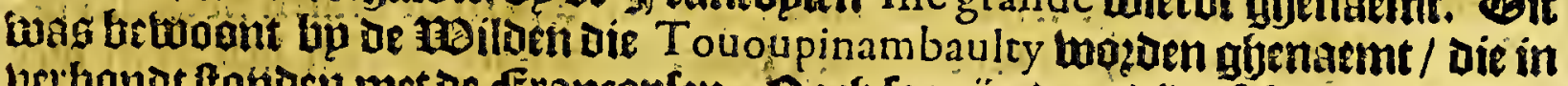

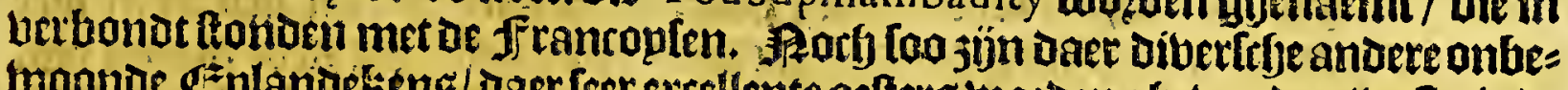

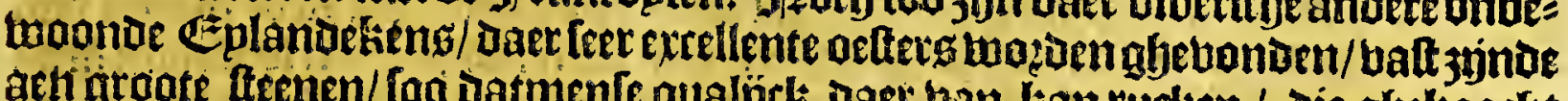

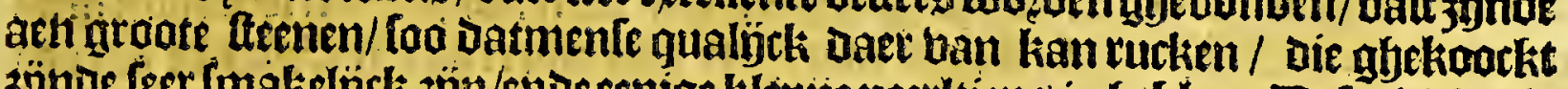

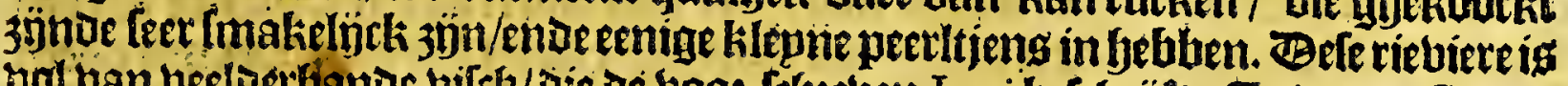

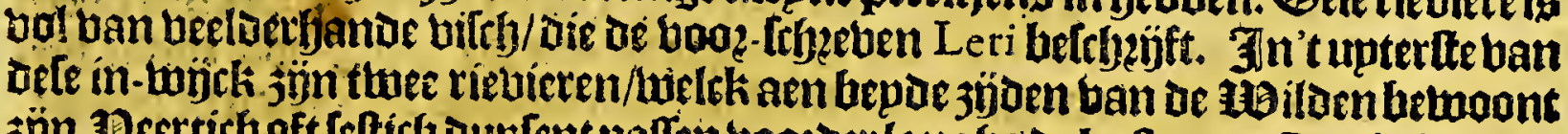

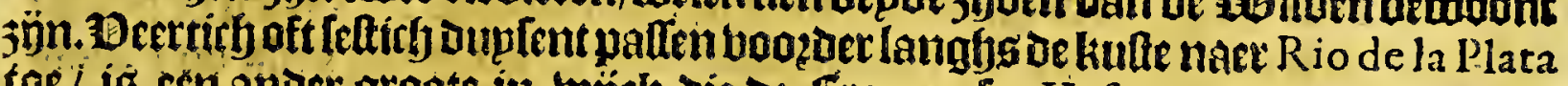
toe / ig efrn anver aroote in-minck die de Jfrancoplen Vafarum noemen/ Daer oe

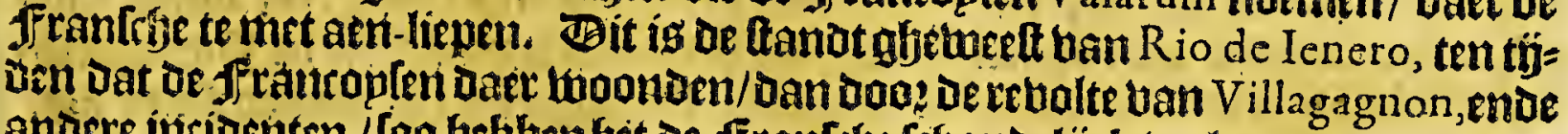

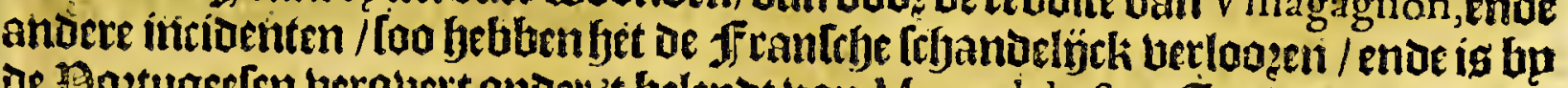

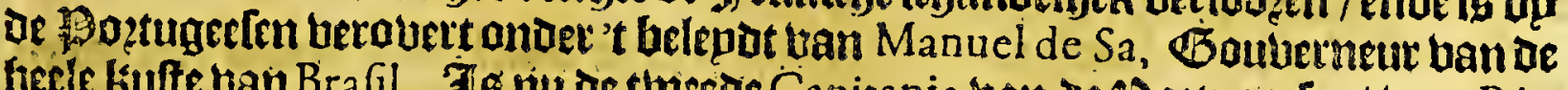
Jecle kufte tain Brafil. To nu de theede Capitania ban oe 1 goftugerfen/ van Rio de la Plata af-retienenus ; ofte de achtefe beginmende ban baten; Je thadt is ghe=

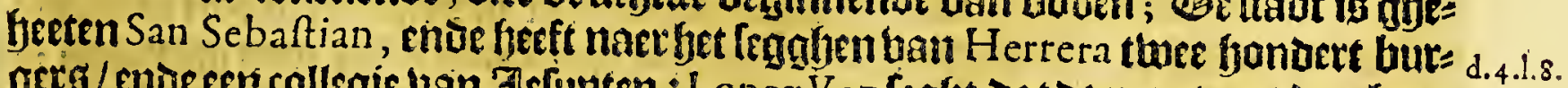

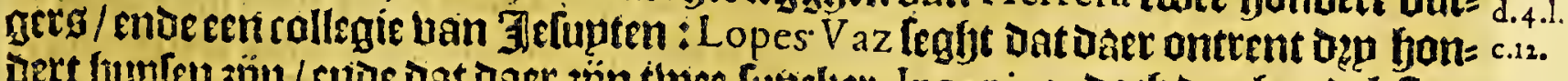

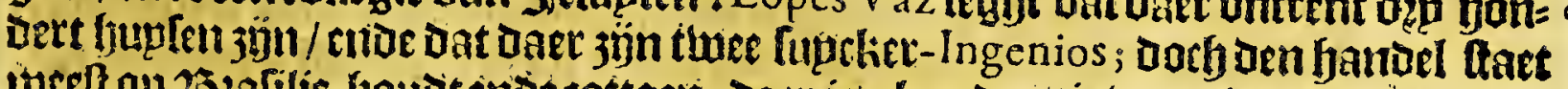
itrelt op 23 safilie-lyoudt enbe cottarn; baer is abundantie ban bictualie. Je ftaot

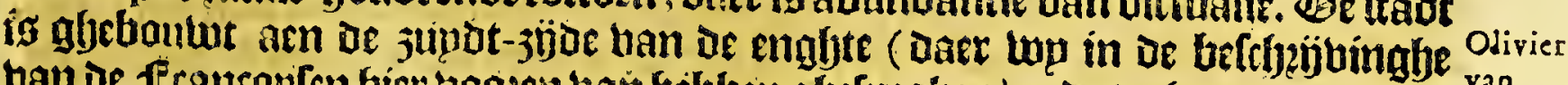

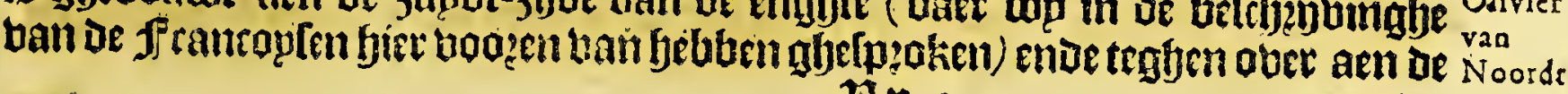

$$
\text { 琵 } 3 \text { moget- }
$$




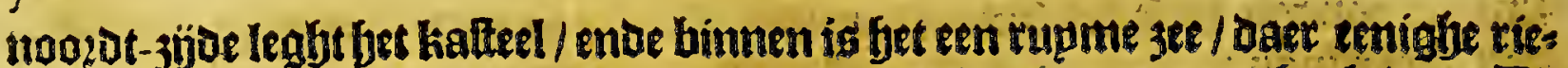
bieren in loopen; abelijtk te fien is bp be figueren daer van upt gbegbeben. Te boogbte ban Defeplaetfe wožt bp Olivier van Noori gbeltelt op ozp-en-twintich. graden en bỷfthien minuten. Be in-gheboozne ban dit landt ontrent $R$ io de Ienero twozen ghenaemt Touou pinam bauty, ende faer manieren ente boen twozt

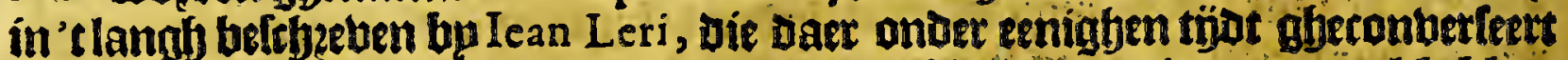
beeft ;en tomt meeft ober een met bet gfene wp biet boozen in't generael beblien aengheroert ban oemanieren enoe gheftalte ban befe natien.

De Jefunten ghetupghen in yaer verlyalen / Dat Daet in baet collegie toelts is

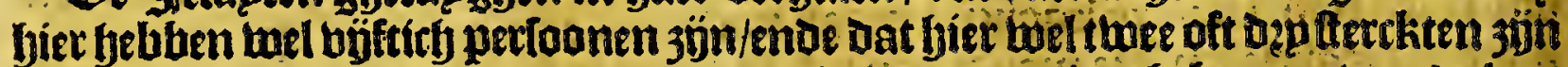

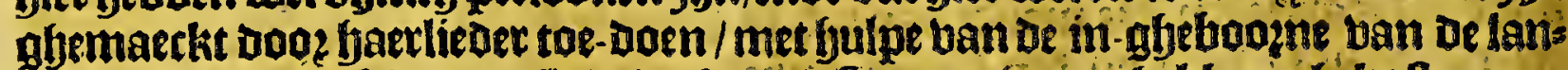

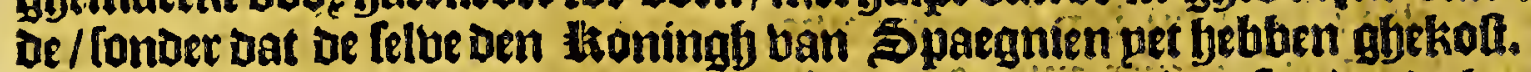

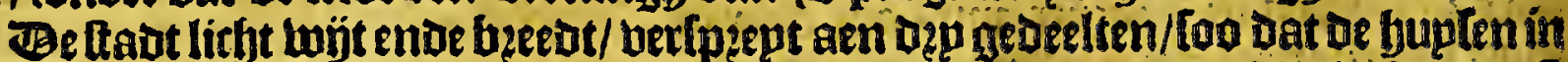

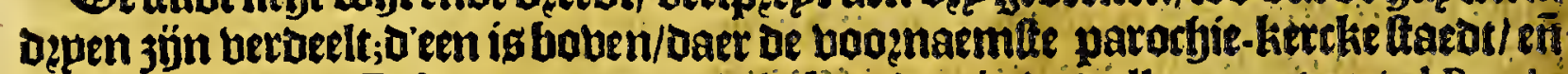
't kloofter ban oe Jelupten; D'ander litht beneden in be uallepe genaemt el Barrio de St Antonio; ende De Derde langgg de jee-Itrandt / beginnende ontrent bet bin=

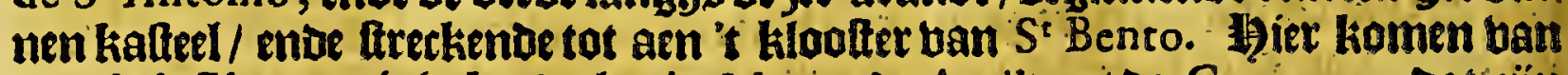
Rio de la Plata eeniglje katueelen in May ende April met oe Generays, Dat jǘn zupot enve zupit-welte winden/ende beengen beel tartwe/meel/kaelen gbeloutenbletefy / frjaeps-twalle ende beel ftucken ban achten/ ende komen Daer mede goes Deren entue taeuen koopen.

Iarricus ghtupght Dat Rio de Ienero tacthtentith leguen naet 't jupoen leght ban de Bahia de todos los Santos, eñ dat de Jef(upten daer een callegie bebben daet

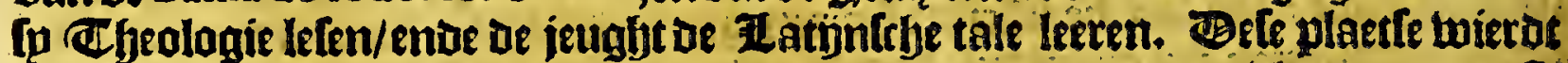
bp of ff rancoplen in den jare i 58 , foo larricus berbaelt/met een blote aen-getall;

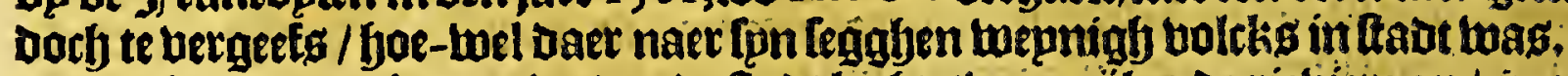

Dirck Ruyter ghetupght / Dat be ftaut:leght twee miblen of riebiere op/ in een

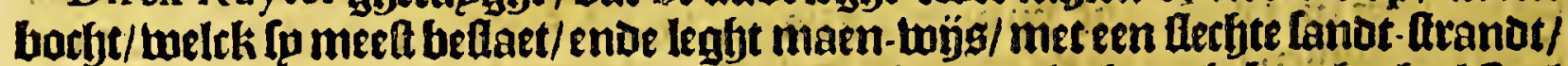
conder bergben ofte beubelen/Dan op bepoe de epnoen legbt 't ghe fiergbte beel fepl op-gaende / boty ue beele ftadt legbt flectht langhs 't water/ foo langh dat men die qualïc in een balf upee kan ten epnoe gaen/Dan oe beecte ig maer thien oft thaelf buplen. Jn Denjare feltjien bondert en atbthien en waren de fraten notb niet gee calfít / en baot oock dbeen mallen noch pooeten: al baer fterckte beftaet in biec katteelen/waer ban bet peincipaelfe is gljelegen op de oolt-zÿue in de montot ban ae riebiete op oen oeber ban eenen booghen rodt-fteen / Daet notb loof noch gras op en walt : bet tweede kalteel leght wat meer innetwaert opeen \&plante dat aen oe wedt-kanot van De riebiere legft / [oo Dicht aen't landt Dat men oaer met gheen

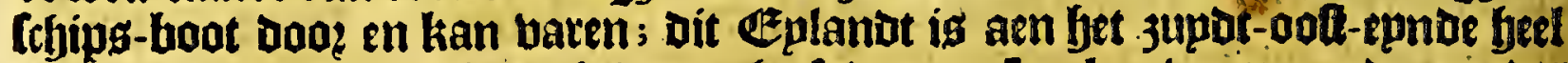

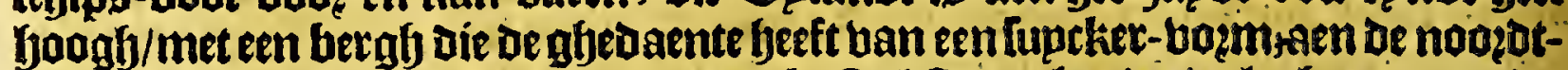

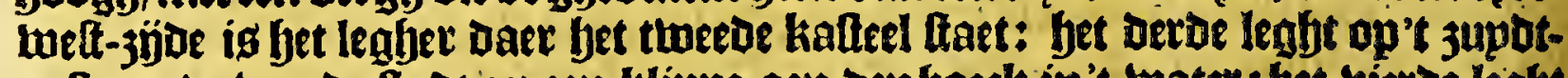
aof-epnoe ban oe thau op een klippe aen ten boeck in't watex: bet bieroe legbt

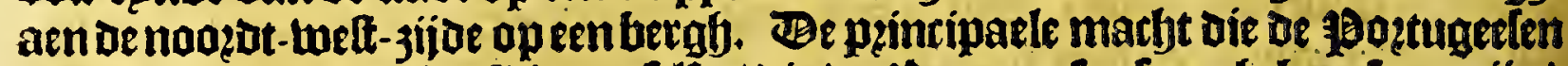
baer bebben jijn de 2 ? oat fp boo: faer doozeen uper fouben loopen

Tndefe Capitania liomt Cabo Frio, ont rent de twelcke feex gropte crocadilen

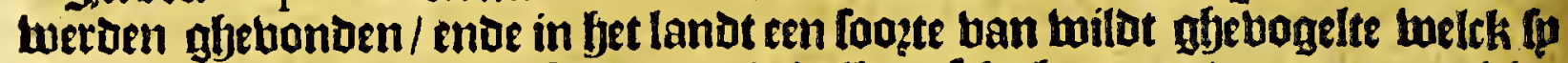
noemen Mutas ofte Mudas, [oo groot als kalkoenlebe-hanen enoe grootemenichte ban wiloe [mijnen. 'C glyeberghte is daer bol plat-luplen/ Dat men gfenoegf te

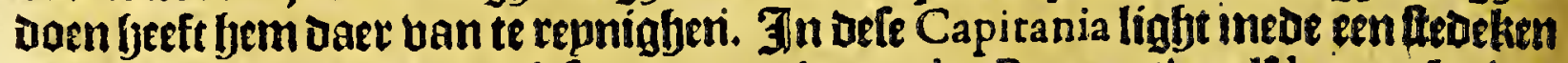
onlanghs gfeboutut / welck fu noemen Angra dos Reyes, twaelf leguen bp twes fen $R$ io de Ienero, teghen ober Ifla Grande, enoe andertyalf legue ban een klepnt ort Eplandi Y poia ghenaemt/ naer fet noogot-oolten/alg Figueredo gbetupglt. 


\section{Iget neghende Capittel.}

Befchrijvinghe van de Capitania dic by de Portugeefen worde ghenaemt SPIRITO SA N T O, ende haer gheleghentheden.

$\mathrm{D}$ et naelt-giveleghene Capitania is bie ban Spirito Santo, tolch is te febente

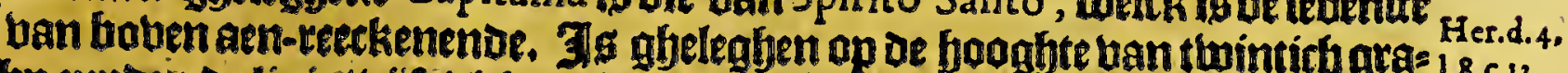

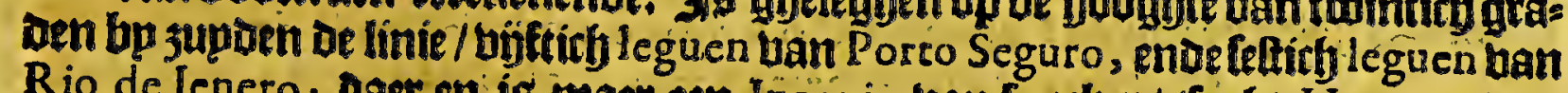
Rio de Ienero; Daet en is maer een Ingénio ban luptler / (feght Herrera) Dan

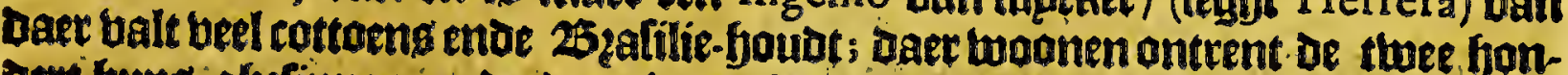
oert bups-ghefinmen; ente baer is eet bupg ban Jefupten; enoe aen bet in-ko=

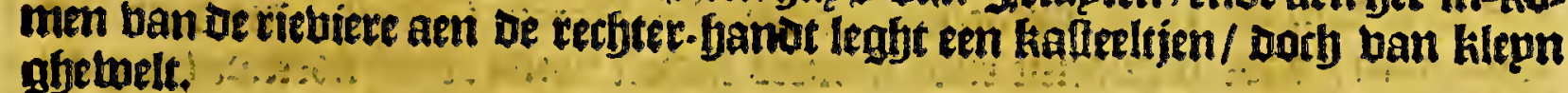

Lopes Vaz betfaelt dat dele Capicania beltaet upt thee feden/ enbe bat fo te popelfamen ontrent Jep fondert gupten Gebben. Befe Capitania is oe buchtbaerfe/ lin.

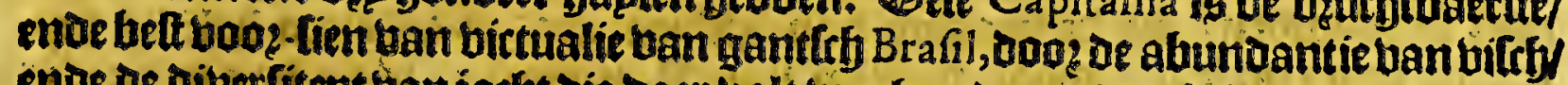

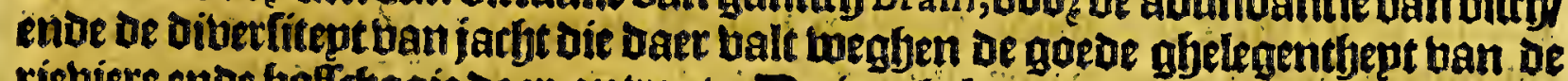

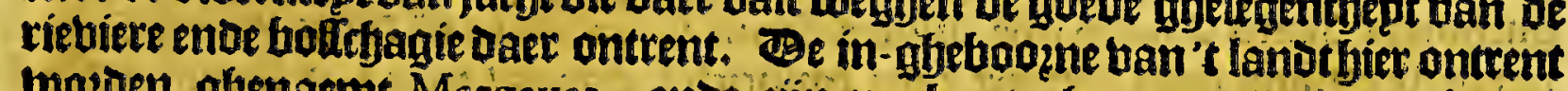
wozoen ghenaemt Margayas, ende zint nu bont-ghenooten ban de gootu= aeflen; of gheltalte ende manieren ban bit bolck twozot bp lean Leri befrbetuen

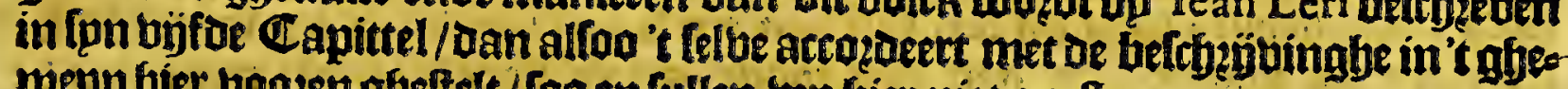
mepn fier boozengheftelt / foo en fullen wp fier niet op-Ataen.

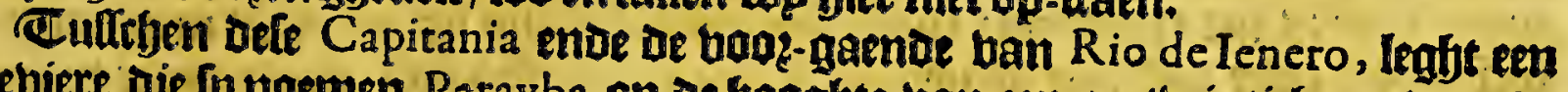
riebiere oie fu noemen Parayba op be booghte ban een-en-twintich graven (oe kourlen ftellen die op een-en-thintich graden ende beertich minuten) toelck is cen lcbone chos groate riebiere / enoe leer bilch. róck.

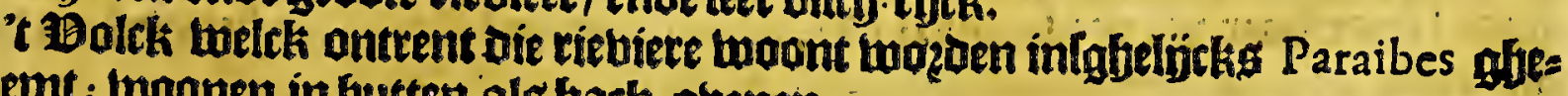
naemt; touanen in butten alg back-obenen.

Befchrijvinghe van de kufte van Brafil acfter oe uopagie ban Candifch gfee boegft / feght bat bet noogot-oolt punt ban Spirito Santo beeft een rỉe ban root= fen; van den punt ontrent twee mijlen te lanot-waetts in/fiet men eenen boogben

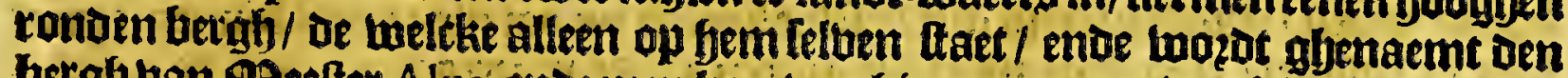
betgh ban gseetter Alve, ende men kan ban hier een groote wegb in jee fien. Bat Spirito Sancto een groote bape is / ende beel klepne Éplandekeng in het miboen

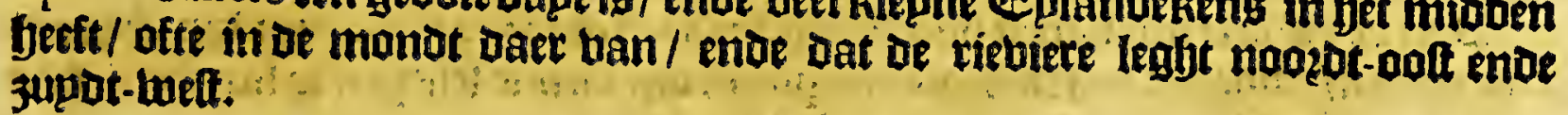

Iarricus [eght / a at Santi Spiritus ig gheleghen febenticf leguen ban Rio de Ie-

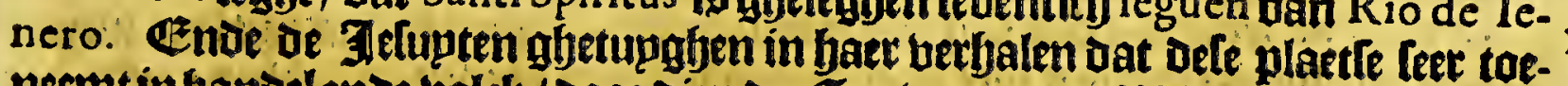

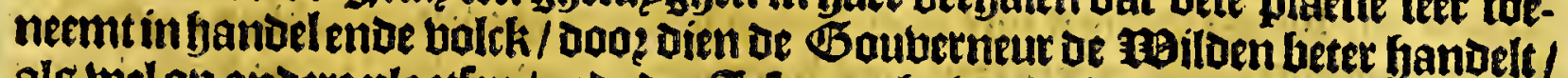

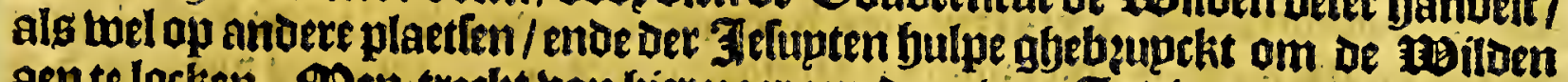
aen te locken. Ifen theckt ban bier naer een Dopp ban Indianen thelck Ip noes men dos Rey es Magos, Daer De Jelupten naer baer Regghen beel MBiloen gles Doopt / ende tot het effeitten-gheloobe bebben ghebzactj; dan om dertwaerts te baren/ repef men dooz bet lanot ban feeckere B Bilden / die [p noemen Tapuyas, ente baer ghebueren de A piapetangas, die noch beel twilot 3 g̈n/ende buanden ban

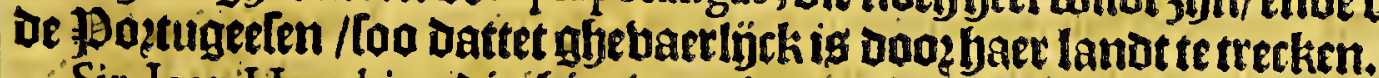

Sir Iean Hawkins die bier was in den jaere 1593 , Teght dat de faben ban Spirito Santo, toel is te Fennen bp eeneri graoten joogben bergb/ligabende op oe haten die bem bertboonot als eenklocke/ ende wat naerder aen landt komenoe lietmen een witten thoazw/ghelegben op een foaghen bergh dicht bp de zee; on.

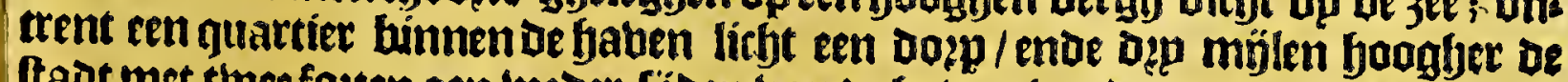
ftad met thee foten aen lueoer-löben ban oe haben in 't boep ende in Den mitten tboozuliggben ozoinaris bondert toloaten. Be bare ban oe baben en beeft met 


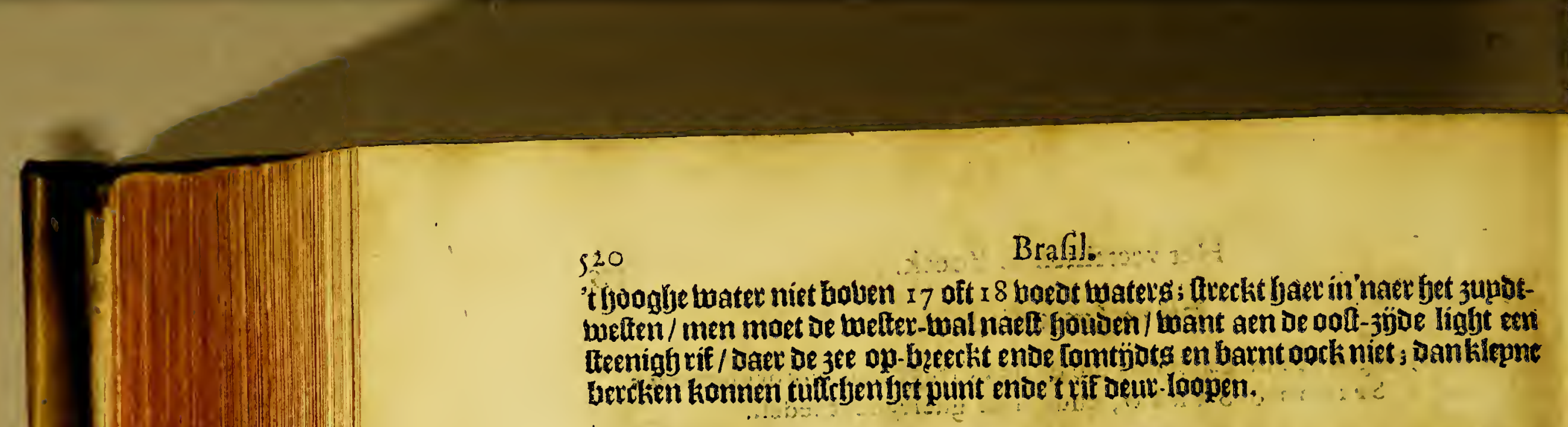

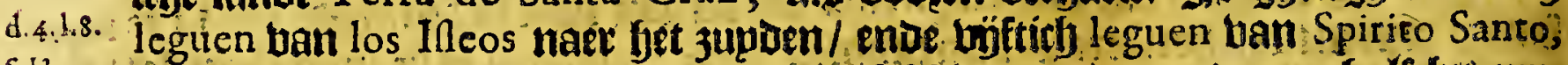

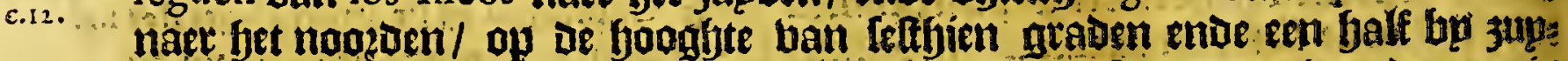

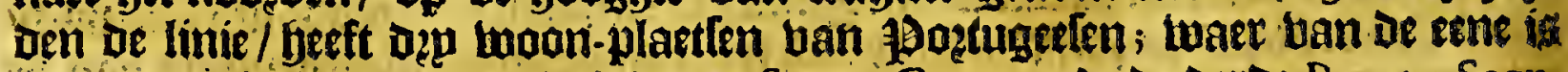
ghenaemt Santo Amaro; de andere Santa Cruz, ende de oerde Puerto Segu-

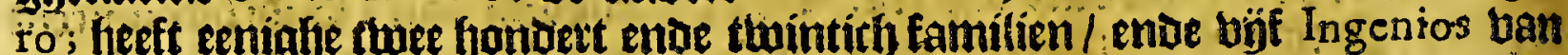

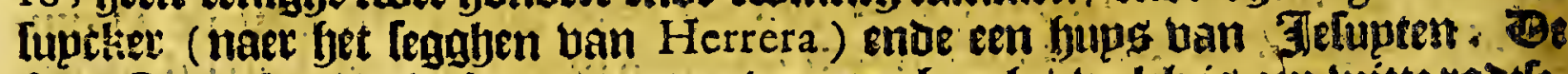

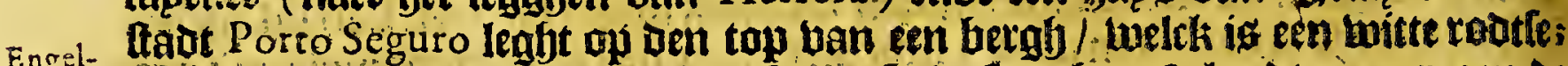

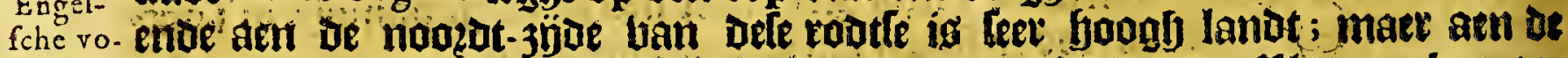

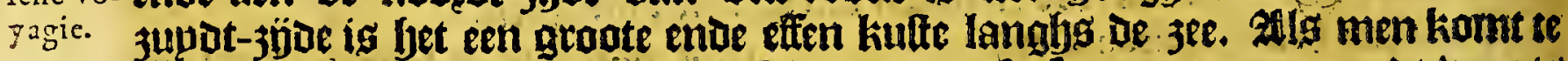

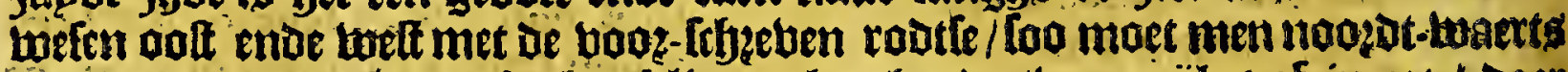

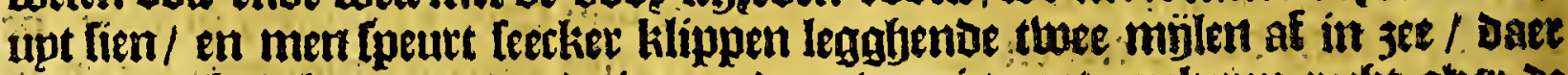

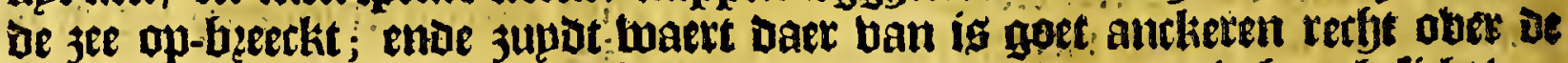

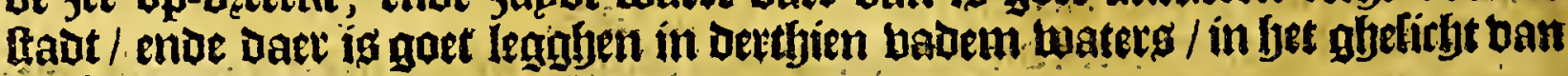
tie latat.

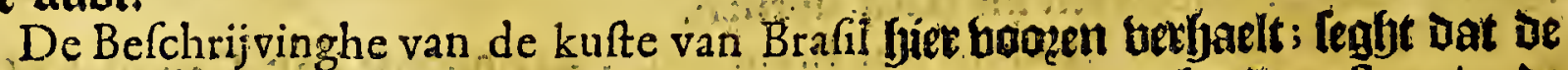
jaber Seguro beft groote roobe kliffen/ die aen be boet ban fet boy thaen/enos

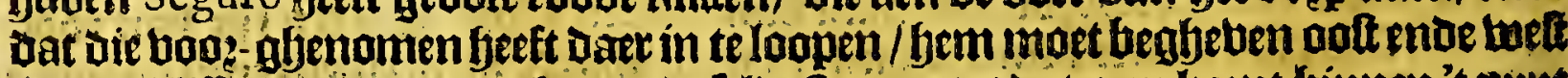

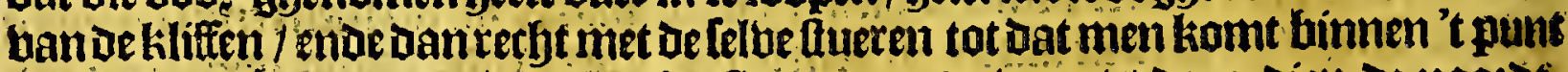

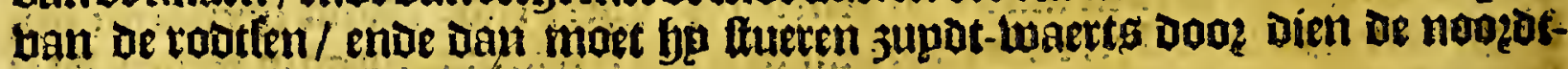

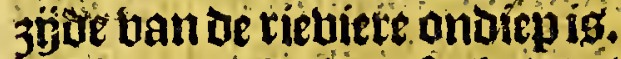

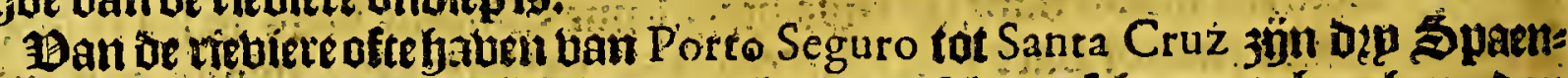

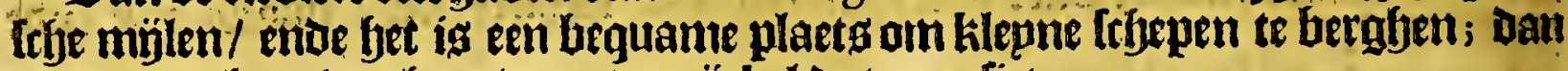

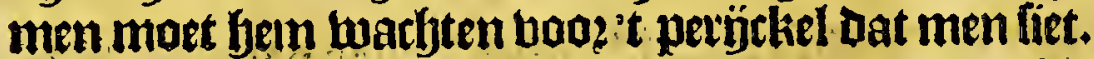

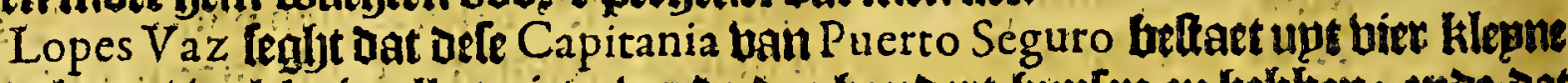
ftedekeng/ welcke in alles niet ober be spe bonoert buplen en bebben; ente Dat

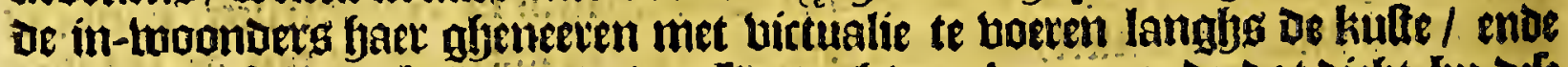

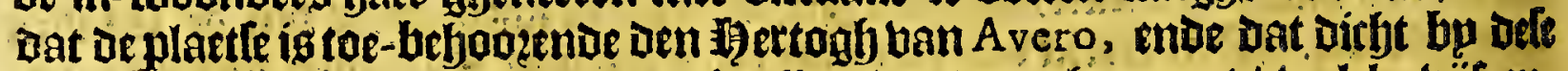

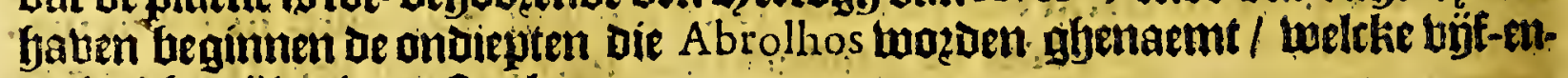
thintief mïlen in jee ftecken.

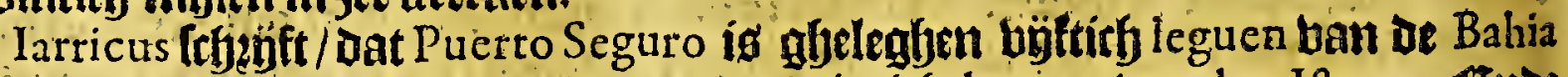

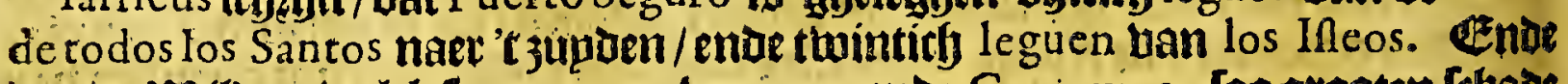

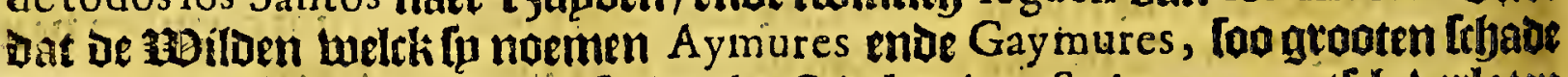

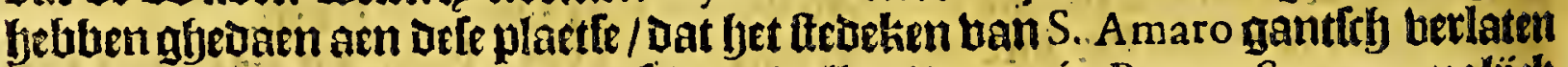
is/ enue arfegantiffe Capitania foo bertuallen/ batter in Puerco Seguro qualóth

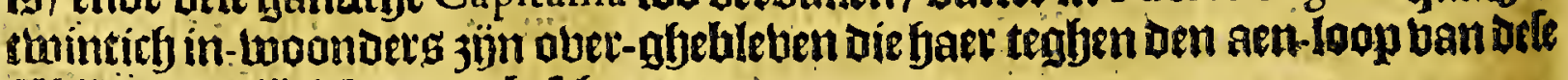

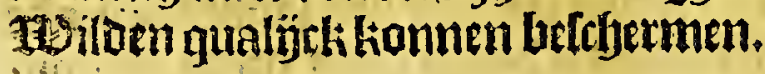


Het elfute Capittel.

Befchrijvinghe van de Capitania van I os Is I e os, ende de ghe-

leghentheden van dien.

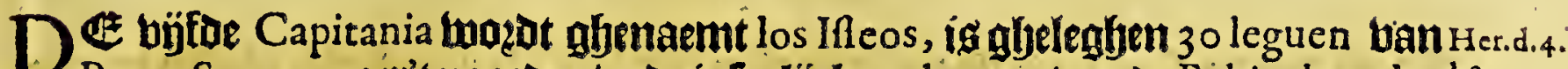

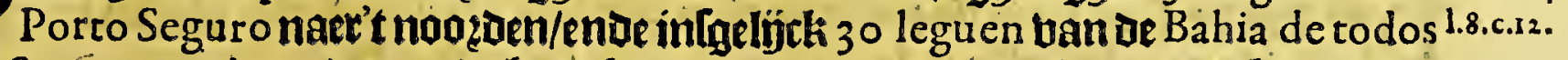
los Santos naec't 3upden op of boogfte ban 40 graden ende twee derde bp jupden De linie/naer't teggen ban Herrera, die hier in bariegt ban larricus, alsjwp in fet boo-gandoe Cap.bebben aen-gheraet. Heeft 200 hupg-nelinnen met een riebiere loopende nefferig de ftadt; daet 3in 8 lupcher-Ingenios, ende de Tlefupten bebben Daer een bups. Lopes V a leght dat dit maer een klepn ltedeken en is/ente niet $L_{\text {opes }}$ ober 15 o buplen en beeft/ende maet dep luptker-Ingenios, ente dat de in-twoon=Vaz. Dexs faer meell geneeren met landt-bouben / ende bittualie te boeren in klepne batcken naet Fernambuc, enoe dat de plaet Te toe-befjoat Lucas Giraldo.

Seben leguen ban Defe plaetfe te lanutwaet in is een lack tan foet twatet/we= d.4.1.8:

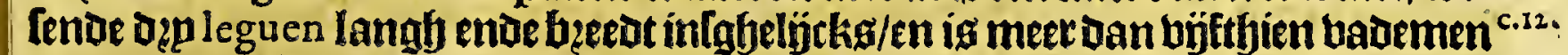
Diep; daer komt een riebiere upt-blieten/ ooch Dop [ foo engenmontot dat Daer quas

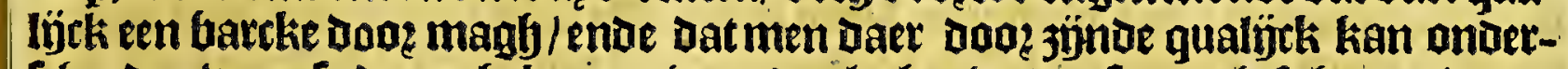

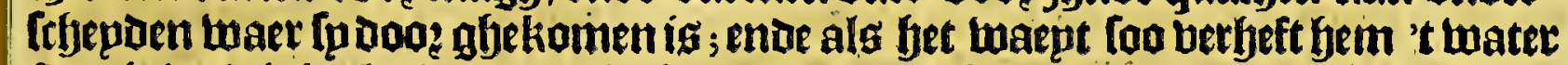
foogfetweldigh als in de zee; feeft beel viffy / infonderfept ban die men Manati noemt/Die foo geoot 3 g̈n/ Dat Commighe beertity A rroben wegfen / ende jün leet

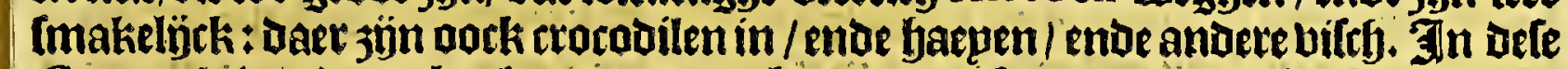
Capitania toozot oock ghewonden een boom/oaer fert excellenten ballem bange= trocken twozot ban leer loeten reuck/ende groote krarbt; [njoende eenighe [neden in den boom/ too diltilleert Dit liqueut allengkeng daer upt. Fn dele Capitania ig

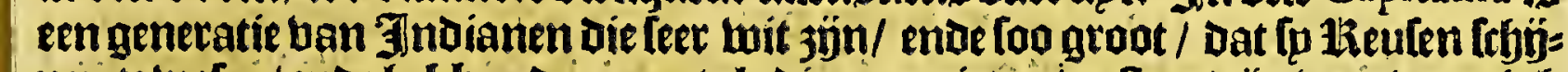
nen te lwelen/ende bebben daer een tale die men niet en berltaet/jün booz toepnigh

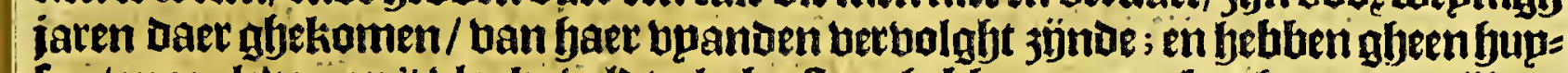
fer / maer leben op 't blacke belat als beeften; febben groote bogfen enae pylen/

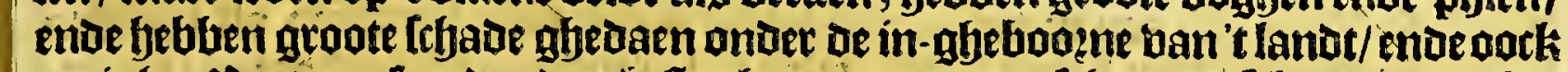

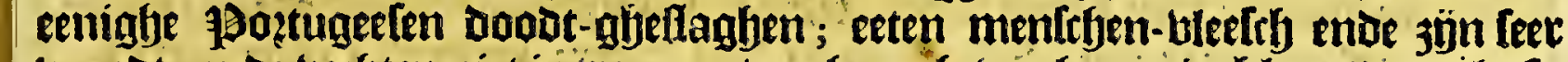

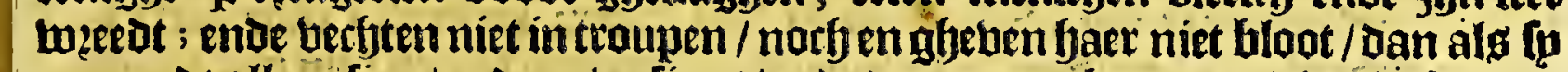
pemanot alleen lien / ende anberlieng / ende daetom en kan men die niet bettap= yen dan mét groote moepte endae perÿckel.

- Deluptket-Ingenios legghen aen ae troet ban een boogly landt bp naet in bet Linfch: midoen ban de bape/ Yegghende twelt-3upbt-melt ban u als ghp om't noozoen lomt aen de hape daer vele plaele in leght.

Iarricus gljetupght mede dat ineos is ghelegfen 3 o leguen ban ie Bahia naet t 3 upden ende dat niet verre van daer te landt-waert de Aymures booken verfjaelt

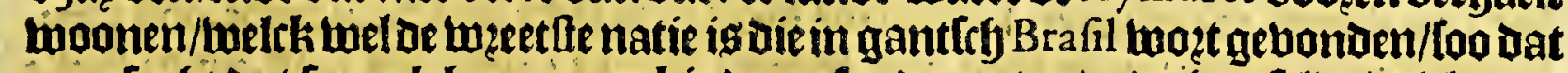

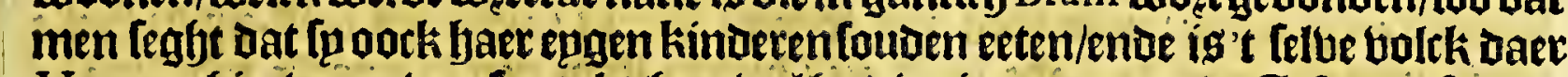

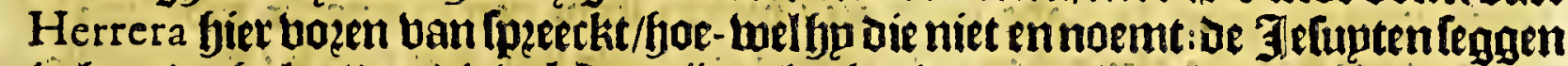
in yaer berfalen/Dat dit bolck eertíts plaghte woonen langfe oe jee-kulte ban Rio de Sane Francifco af tot Cabo Frio toe; dan dat fp ban daet jún verjaengt by De Tupinambas ente Tupina chins, ento gedwongen laer dieper in t landt te be=

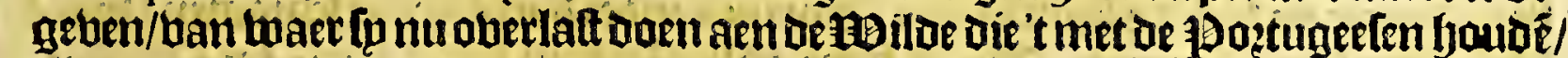

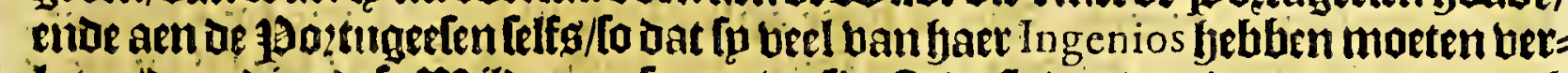

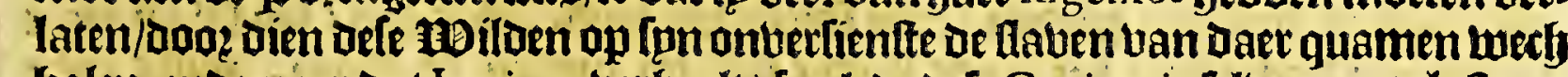
Jalent ende naer dat Iarricus verfhaelt/ loo lede defe Capitania felte grootelaft om ganterly berlaten te wozoen / ten ware baet ghebzarfit twaren de reliquien ban S.

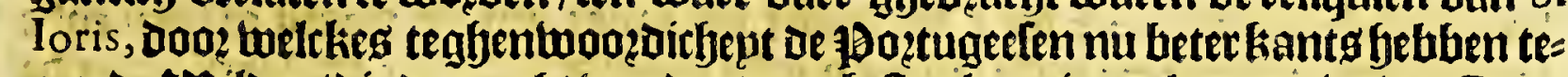

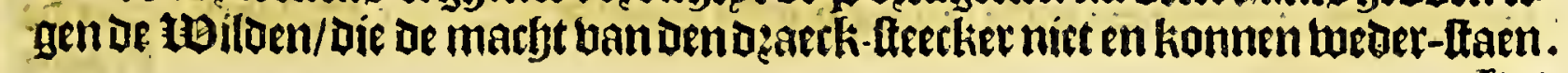

Het 
Fet thatifore Capittel.

Befchrijvinghe van DE BAHIA DE TODOS LOS SANTOS; welck is de voornaemfte wel van dit gant-

fche quartier.

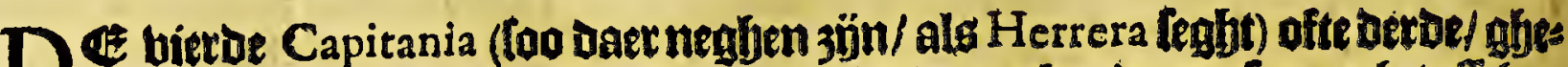

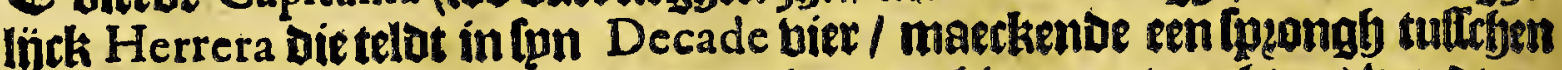
d.4.1.8. Defe / ende los lineos; (mp fullen poogben dit erreur bier naer te rechten;) mozot ges 6.r2. naemt Bahia de todos los Santos; ig gheleghen ban los Ifleos Dertich leguen naen

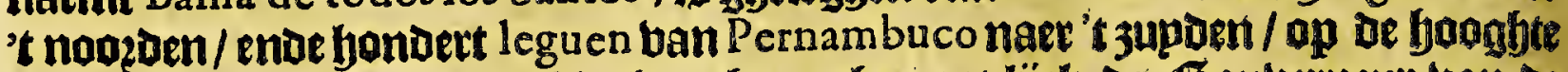
ban dertbien graden; enoe biet bout fem ghemepnljeth oe Gauberneur ban oe gantlche kulte ban Brafil; poog dien als Lopes Vaz enoe andere betupgben / dels

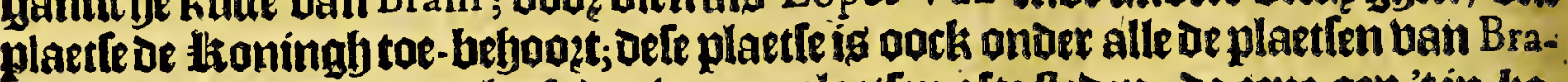
fil alDermeet betwoont; heeft Dęp woon-plaetten ofte fteden; De eene aen 'tin-kes menban de bape ofte by het kanad / die fu noemen Villa Veia, enoe hag de eerle gheboutin dele Capitania ; ie anoere San Salvador gbehout bp Thome de Soufa; De Derde / viec leguen te lanot-waet in/ghenaemt Paripe; in holdke dexp wel Dups fent oft elf Gonoett bups-ghefinmen fullen welen. Be ftads $S$. Salvador liggt op een

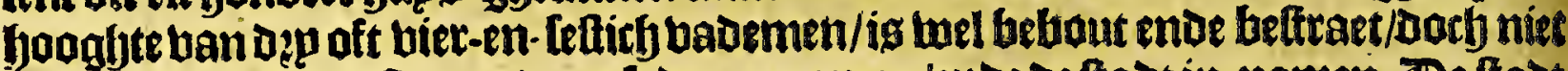
mel bewalt ghelueelt doen oe onle daer quamen/ende de ftadt in-namen. De ttadt is berfien met dęp kafteelen ende dęp fozten / onder langhs bet ftranot. Het eerlfe Kafteel genaeme S. Antonio op een bexgh aen het in-komen ban de bape; fet twees ie onlanghigfjebout ontoer te that in 't water; fet derde S. Philippe een groos

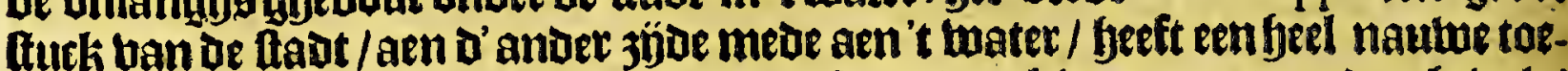

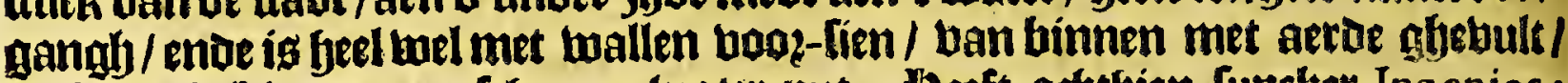
beeft pock bimnen een lchoone water put. Beeft arbthien fupcker-Ingenios; hoe-twel het bolck fem meet gheneert met tottoen: in be thad jün büf ketcken/ ende een collegis bam Jelupten. Lopes Vaz legbt bat daer bel beertich fupes

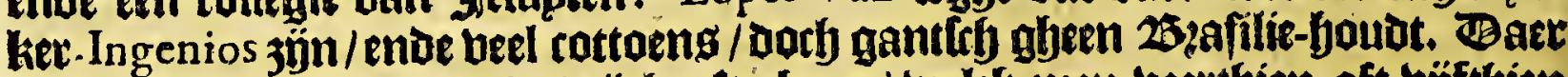
is in dele Capitania een in-wütk ofte bape / welth men beertbien oft büfthien leguen in-waerts kan baren / ende beeft beel feer lubtighe Geplandekens / die one tallijek beel rottoens upt-abeben; is in beel Deelen berDeplt / ente beeft beel armen enoe in-wöcken/Daet oe in-woondets haer ban Dienen/om met barcken

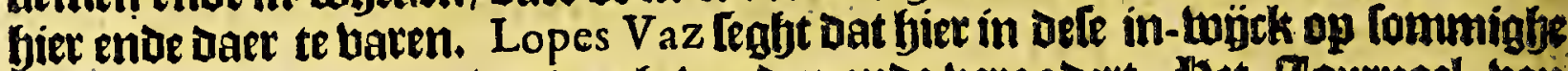
faeten beel Ambregris wozot ghebonden ende bergadert. 3 journael bau

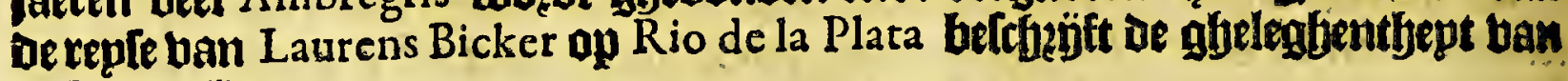
ae Bahia altus.

Je Bahia ban Todos los Santos íg gfeleghen op betthien graden bp jupben be

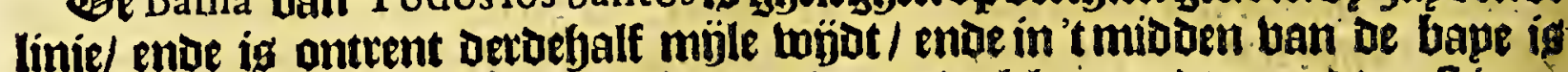
het ban twaelf tot achthien badem toe diep/ De twelcke noogot-nootot-oof ime lwaerts ende jupot-zupdt-welt upt-waerts Itretkt / ende een welt-3upbt-weffe maen maeckt boo de ftaot bolle $3 \mathrm{ee} /$ twelcke ftadt aen of noojot-3y de ban be hape op het booghe gheleghen is / ontrent en müle ban oen boeck / daes bet kas Aeel Sant Antonio ghenaemt / is gljeboulut; ban oen feloen foeck loopt een

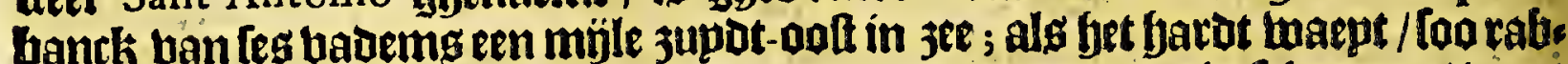

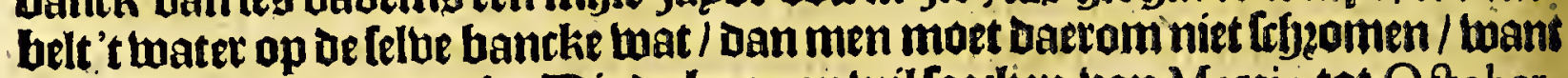
bet ig daet diepghenoegh. Die of bape op will Coerkent ban Martio tot Oetober, die loope op oerthien grauen / ende loecke bet landt alloo aen/ foo lal fop rectje op het gat verballen/ het lanot atreckt lich bp jupoen oe Bahia, jupdet ente noozot / enoe is een buple kufte: Dan loo pemant of Bahia aen-foecten twil han Oetober tot Maert toe'/ Die loectie bet lands aen op twaelf graden ende een half om deg ftrooms twille / want ban de maendt Oatober tot Martio gaet be Iroam 


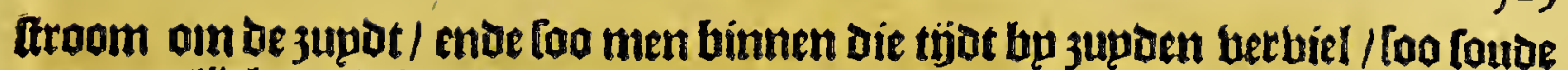
men qualÿck oe Bahia konnen kitýghen; bet lanot treckt frem bp noozoen de Bahia jupdt-boelt ende noozot-boft. Ilet is een teboone kufte om de Bahia aen te loecken/ enoe pock leer liennelÿck; ban berre bertfjoont fet bem als ofte Daer en deel bebben op den blepck laghen / loo twit ift ; ende leg maenoenloopt De ftroom om of 3updot / ende fes maenden om de noozot / als de fon mede baet.

De 3 elupten ghetupgben in yaer verfalen dat fu in fet callegie / welck fo fyeb= ben in dele ftaot ende eenighe andere huplen daer ontrent / wel tarbtentich per [oo:

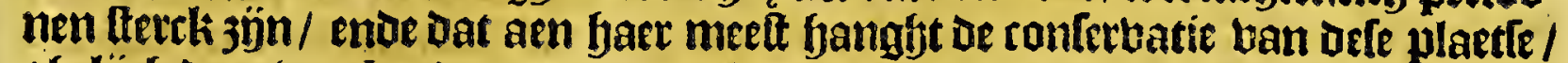
ghelijck daer ban Iarricus eenerempel berbaelt in den jare ujfttjen hondert arbt-

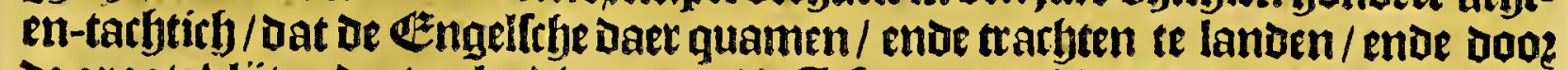
De groote blint ende aen-lepdinge ban be Jefupten berfindert twierden/[oo dat de Engelftbe onverrictyter faecken moelten bertrecken. Je felbe berfjalen mede dat thien oft thaelf leguen ban be Bahia naer' $t$ jupbeneen plaetfe leght abenaemt $\mathrm{Ca}$ choeira, een rÿrke 13 oztugees toe-befjoozende / wefende frontiete met de Aymures, ende dat Doge funtae-doen ende bulpe bande Jeflupten ucel ban de milde tot

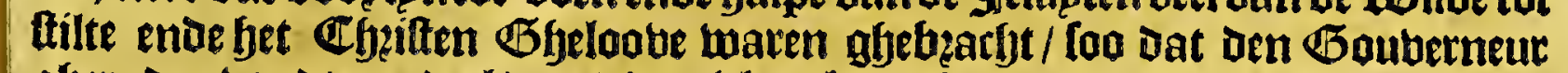
gheraden bonot een Deel ban dit bolck te beenghen op fet Eplandt Tapira ; om naerder bp der fandt te lueren ende minder quaedt te konnen doen; Dan dat fyet [elbe niet bel beeft willen ghelucken doo? oe onghefontbent ban de plaetle / waet

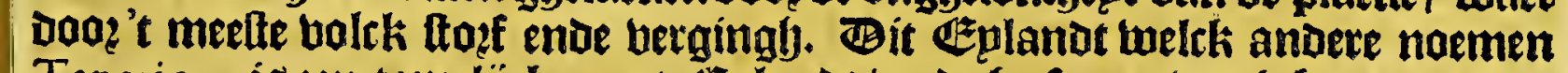
Taperico; is een tamelÿck groot eaplandt / ende beft een beuchtbare grandt / Daer waft veel tabac/ ende daec is beel beeftiaels/ ente cen fupctiex-malen / Doch wozot ban elderg ban fupcker-riedt vooz--ien; daer wozt beel traeng ghemaeckt

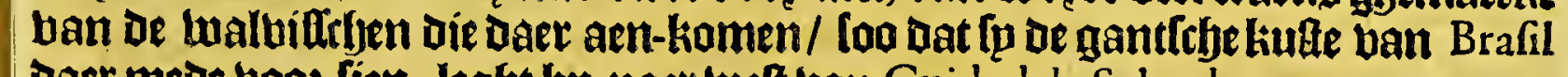
Daer mede booz-fien; leggt bp-naer treft tan Cuidad de Salvador.

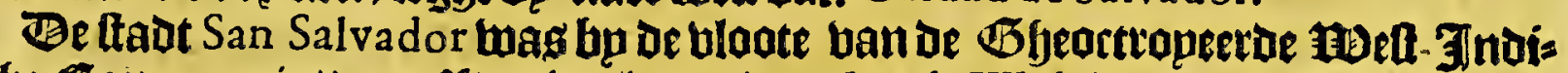

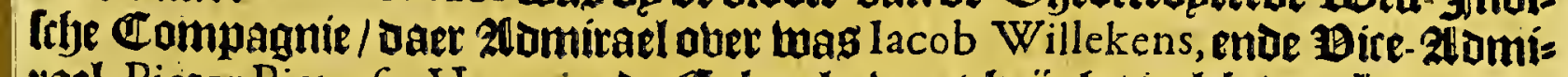

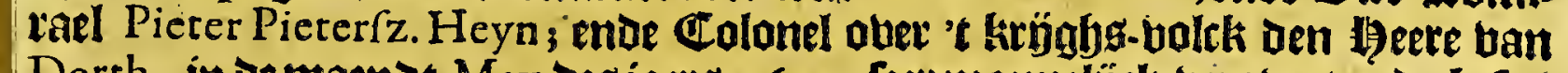
Dorth, in De maendt May Deg jaets I 624, feet mannelïck berobent ende befet;

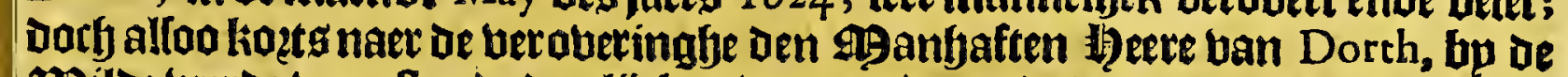
Milde herde bertaftenoe deerlijcken bermoozot; enoe daer naer des Janinghg ban Spacgnien magftige bloote/ontor 't belepot ban Don Frederico de Toledo Daer quamende de ftadt helegerde / too ig be felbe ftad bu bet Guarnifoen feer frbandelírti tueder in't lelt ban A pril i 625, bp apointement obergbegbeben; Cons oer eenighe noodt; als beeter in be hiftodien fal wertan berfaelt.

(yet Dettbiende Caxittel.

Befchrijvinghe van de Capitania van PERNA n B v co, ende de ghe. leghentheden dacr ontrent.

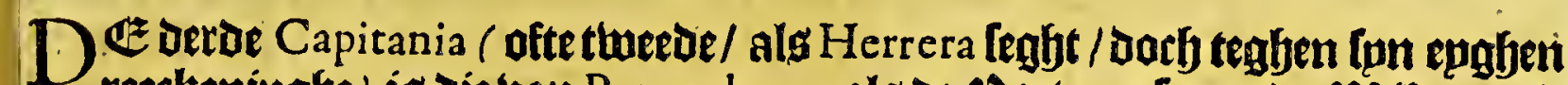

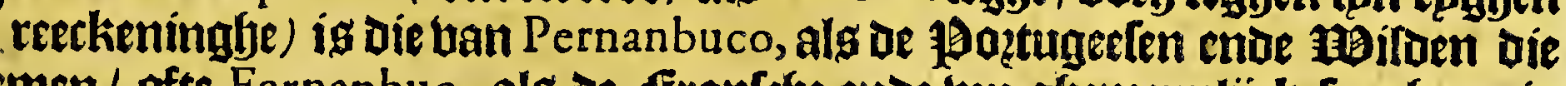
noemen/ ofte Fernanbuc, als de franlebe ende wo abemepulijek leggfien; is gheleghen un̈f leguen ban Tamaraca naex't zupoen/ende honoert leguen van De Bahia de todos los Santos naec't nopzoen/op de foogyte han arfit graden bp 3upden de linie. Jn dele Capitania 3 jón (naer 't legghen uan Herrera) thee ftes d.4.1.8.

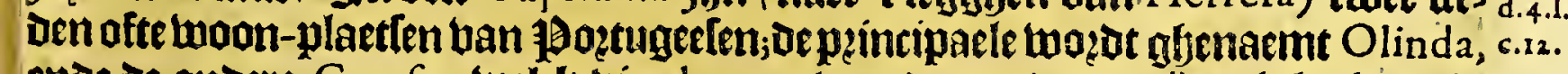
ende de andere Garafu, twelck bier leguen ban Den anderen jün ofbelegfien; in

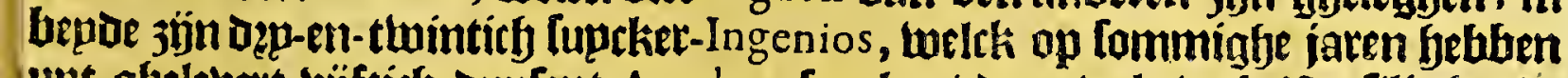

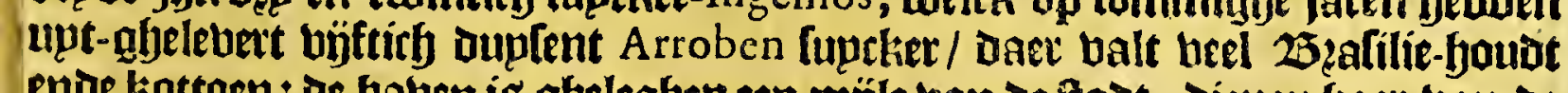
ende kottoen: de haben is ghelegben een míle tran de fadt; disnen yaer van de aranot ende en kilepn riebierken.

Lopes. 


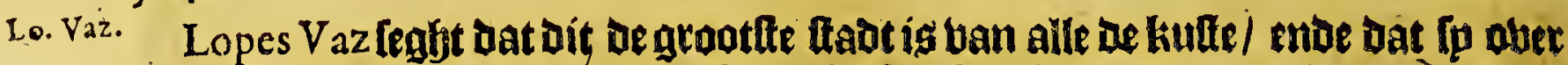
Dedep Duplent buplen beeft/ende leventichfupeker-Ingenios; maet dat daet groot gebzeck is ban vittualie/ alfoo fo die al moeten krÿghen oft ban postugael ofte ban ander plaetien op oe kute. Bat oe haven een beiloten baben íg/ende alleen bequaem vop? klepne barcken. De lupcker-moleng leggfen fier en Daer/foms mighe twee mijlen/[ommighe vier ban de ftadt berifbepden; te Popitango, ende aen Rio de Eftremo.

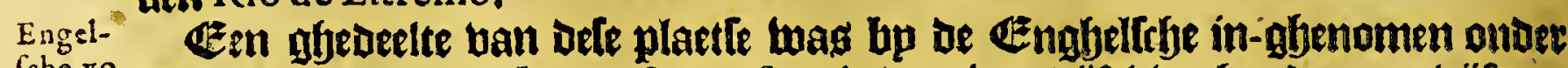
yagie. Get beleput van $\mathrm{M}^{\mathrm{r}}$ Iames Lancafter in Den jare bjufthien banoert en büf-enyagie. tmegljentich/upt twieng bopagie defe naer-Lolghenoepointren/ Defe platre aetgaenoe/ te bemetcken jön.

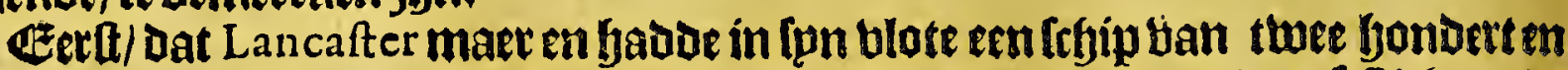

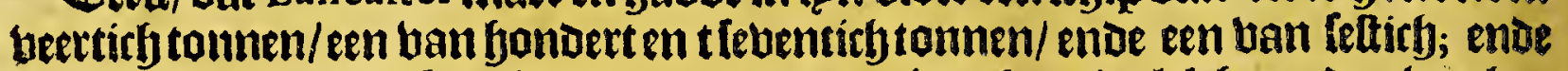
twee hondert ende bïf-en. [eventich mang ende jonghers; welch by onder-loeghen

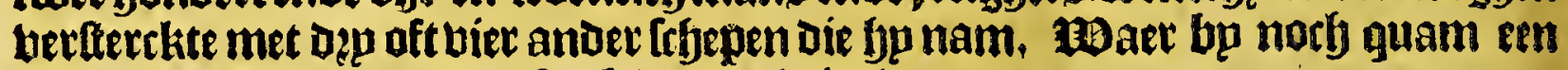
Capitepn $V$ enner met vier [oo lcbepen als jarbten.

Jen tweeden/Dat daer een foet leght op de imonot han de baten/ op t twelcts alfooen lagben feven metalen ftucken/ welck foet de Cenghelfche eevil in-namen/ recht daet op aen-vallenoe/ enoe haet gallepe ende bootg al teghen bet ftranot in flucken loapenos / om dat't volck gheen upt-komlte liende / te touragieulet fouden aen-ballen/ boe-wel daer twel Les honbert man gheltomen mas ban de

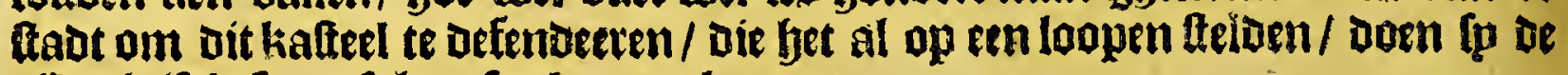
Enabelltye foo refolupt Laghen aenkomen.

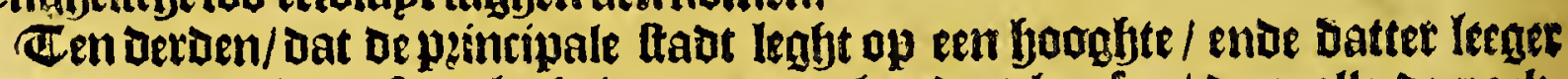
aen't water een booz-ftadt leght ban ontrent lyonoert bupfen/ daer alle de park-

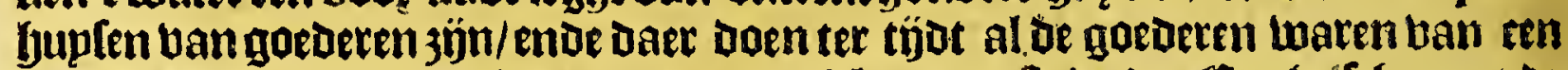

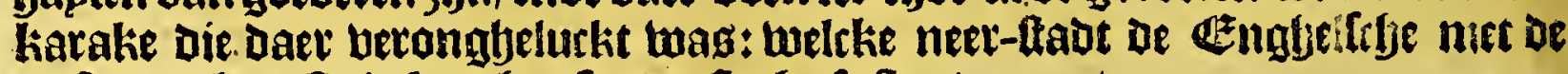
eerte aen-kounlte in kreghen fonoer flarb oft ftoot.

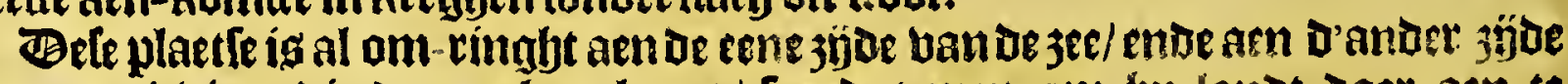
hy een rieviere die Daer achter loopt/ los dat men on bp lanot Daer aen te fomen moet palteeren een enge toegh/ melck bp bet boonh water gheen beettif

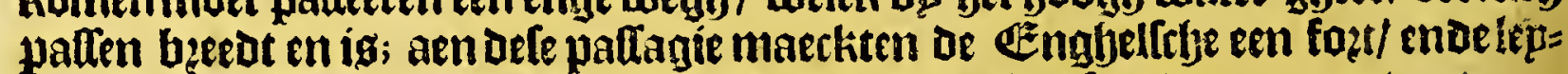
Den daer bijf ffucken op ban aie [p berobere badoen in' 't folt booz-noemt.

Cen bietden/Dat ae booger ftadt is dan defe leegle gheleghen by de vier ezngels Ithe mijlen/op een bergh.

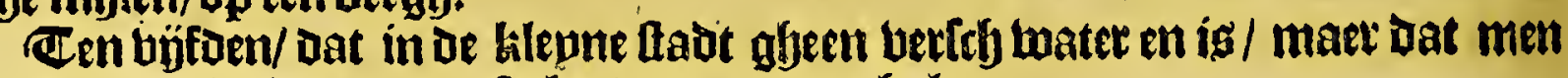
bet ober de rievier aen' $t$ yatte lanot moet gaen balen.

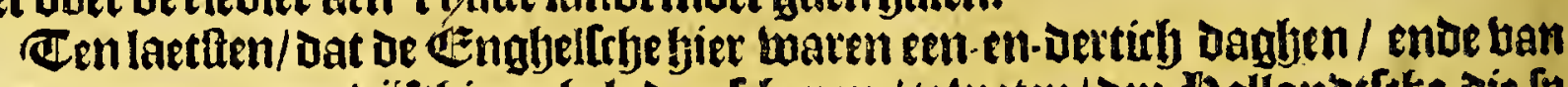

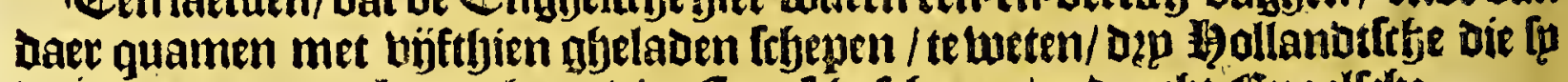

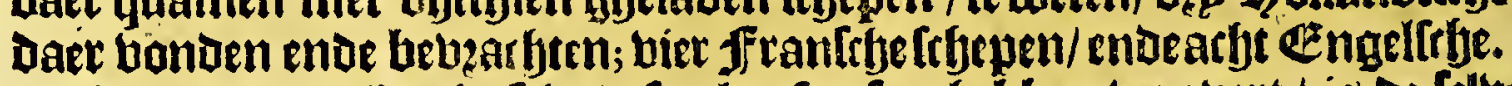

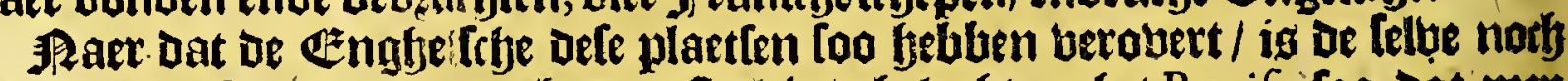
meerder gheltercht/ende noch een ralteeltienglyeleght op bet Recif, foo bat men nu om in defe haben te komen / tufflyen thee calteeltiens moet book-loopen/ lwelch al twat abewaerlijet is / te meet om iat bet in-komen lelfs weglyen de

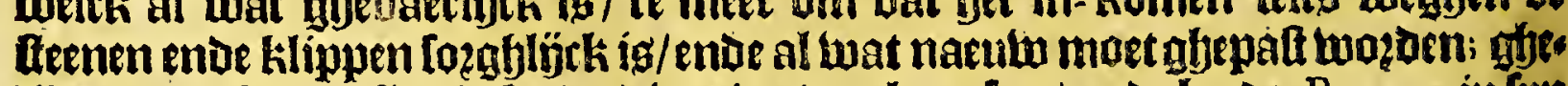

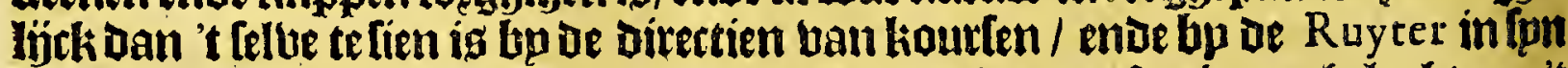
Toortfe der Zee-vaert. Baer naer jijnoer norb ture fortjeng gfeleght op 't felue reliff / ende een trenchement abetrocken lamalys Den oeber. Be lebepen ontladen aen't Dow welcs legbt op't epnoe van'trecifi/ ende wozot gemepnighth

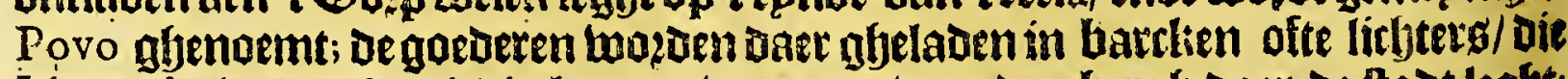
binnen's landts hetrievierken op-baren tat booe ben bergb daer de ltaot leght;

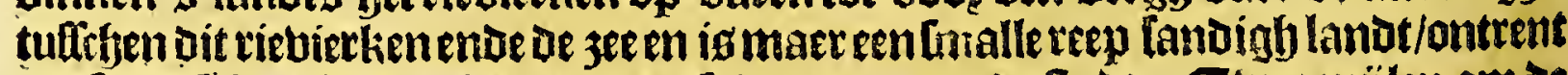

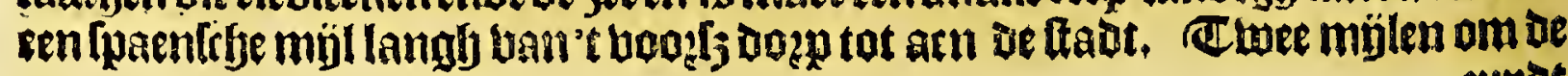


3upot is een klepn tiebietken booz barken / gbenaemt Popitango, altwacr bee!

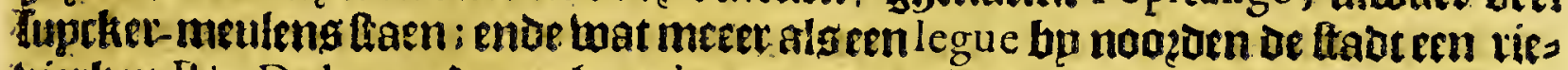
bierken Rio Dolce; ende norbeen legue boazder Rio de Pao Amorello.

Cuffeben bepden oefe Capitania ende de Bahia, is ghelegben Sergippo del Rey,

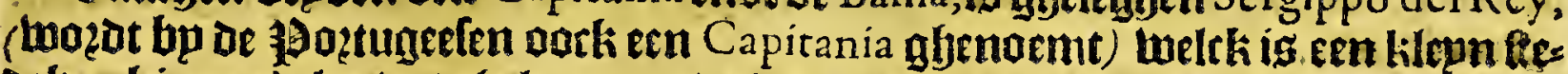
deken binmen's lanotg gbelegen/ende beeft een klepn riebiere die in oe jee loopt/ daet met bet fpezingh dertfien ende beetthien boet waters is. Bele plaetfe is ban

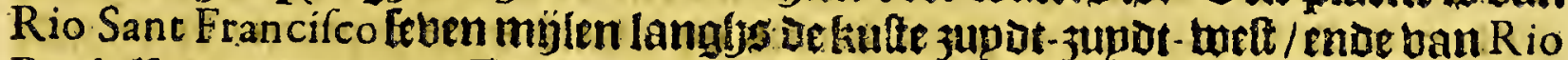
Real elf groote mülen. Tot Sergippo del Rey is ueel vee van treren ende koepen/

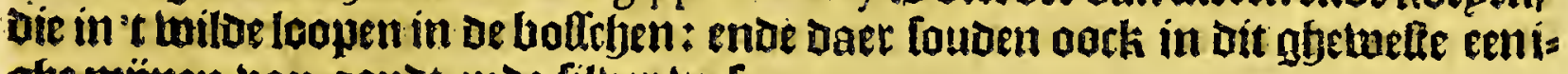
gfe mïnen ban goubt ende filber tmelen.

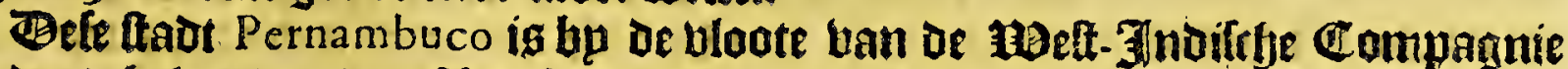

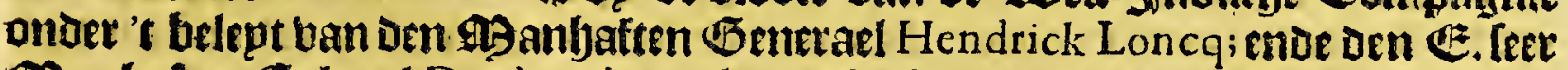
29 anbaften Colonet Diederich van Waerdenburgh, in-ngenomen den tureden Martij deles jaers 1630 . Den Eenerael bertrock Den 27 I unij 1 620, met arljt frbes =

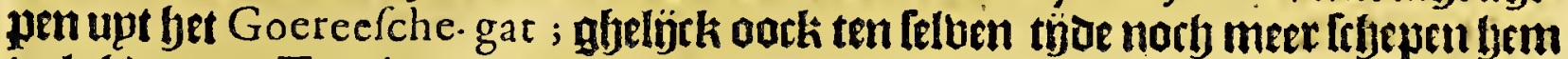
bolgboen upt Texel, de Maefe ende Zeelandt; hp aberaetkte met fan arft frje= pen Den 23 Augufti ontrent Teneriffe ontertiens ander de bloote ban Don Frederico de Tol edo, beltaenoe in ontrent beertity felyepen/ende bejegbende eenigfe

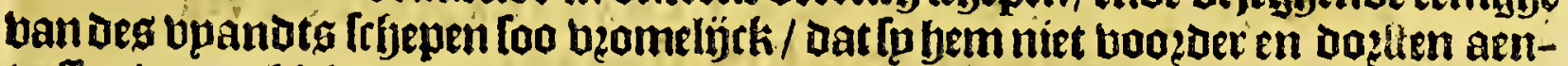
treffen/maer bielen baer kours ende lieten bem vaeren / in dit treften alleen bers loozen febberide twee mannen: yp quam met fun bu-fjeblende frbepen den biet: den September in de bape ban $S^{\circ}$ Vincent een ban de Caboverdife Eplanoen; altwate de relteerende frbepen beruolghens bp bem quamen/ enoe epnoelijek Den negben-en-tmintirbften November uen Colonel Waerdenburgh, upt Texel te fepl ghegaen jïnoe den twintichften Oetober: foo Datfe Doen fterck lwaeren 54 loo frbepen als jachten/ twee berabetide lefrepen ende dertbien groote chaloupen; feven bupfent twee fondert ende tarbtentich man; waer onder twaeren bęp Duplent

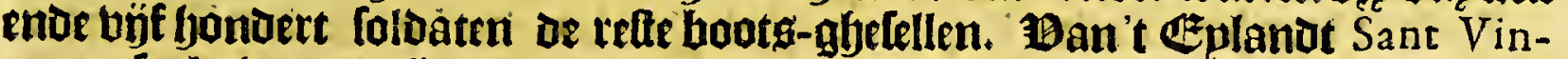
cent $t$ ' fepl ghe gaen jünoe / kreghen 't lanot ban Brafil in't ghefirgt den tweeden Februarij 1630 , op oe hooghoe han Eeben graden enoe bier minuten bu supoen de línie / endor den derthienden der felber maende de Cabo $S^{t}$ A uguftin aen glyedaen Jebbenue/ig aldaet gerefolbert dat Den Colonel met felthien foo [rfjepen als jaths: ten/ fouben loopen naer Pao Amorello, twee mijlen bp noozoen Pernambuco; ende aldaer landen met 2 I 00 folbaten ende ontrent de 700 matrolen; ende dat de Generael met de refterende febepen/ ende boldk foude loopen naer't recif. Zz ïn

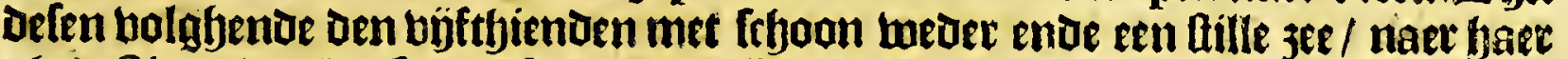
alje deftineeroe plactlen berfeplt. Ben Heere Benerael boo: de Barra gbekomen

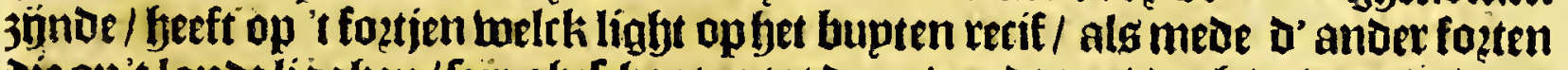

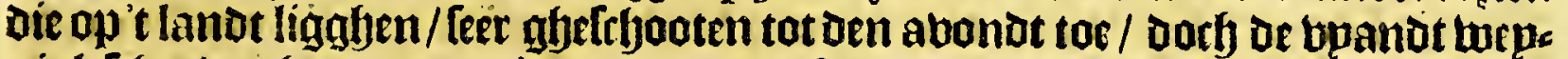

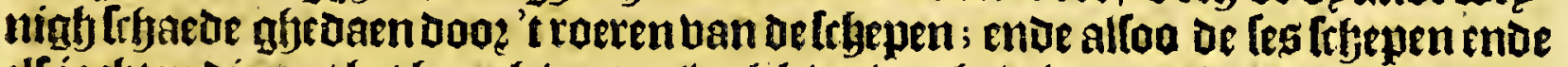

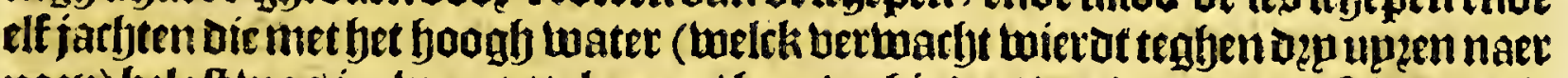
noen) belaft twag in-Laerts te loopen/ baer berbindert bonden dooe defrbepen die De bpandt te boosen in 't gat yadoe doen fintken/loo in de Poco als oe Barettino; 3 üu Lepde genootfaeckt gemeelt des atonts af te koeten. Onder-tuftefyen lande de Colonel met fpn bolcti ende twee klepte ftuctiens die dip ponot ufer fryoten/ in

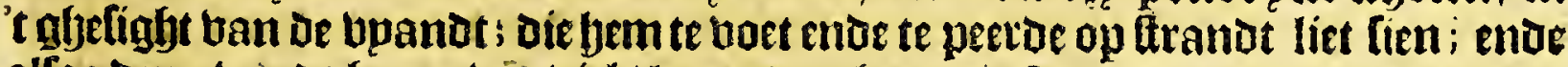
alfeo den abondt baet ober-biel / logeerden yact op ftrandat: enoe baer berbeplt bebbente in dap regimenten/ende een troupe viex-roerg/ Laaer vante abant-gat-

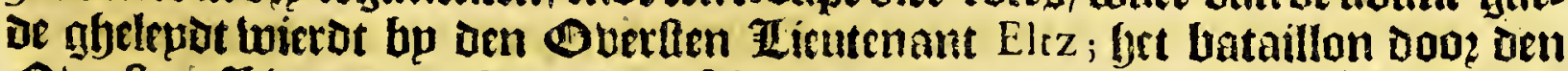

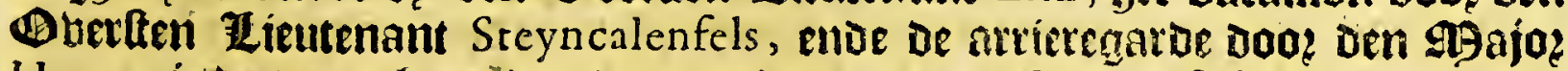

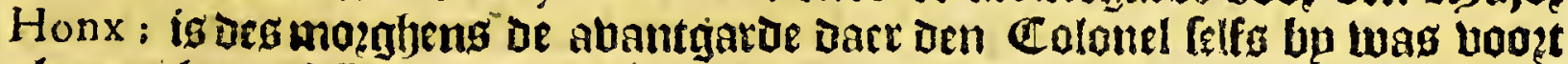

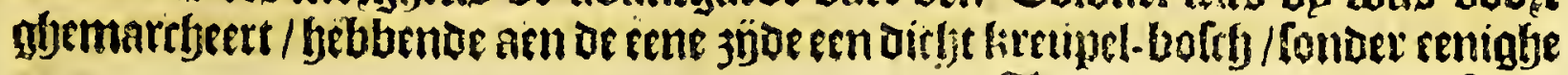

$$
\text { S aen-ltoot! }
$$


526

Brafil.

aen-lloot/ tot baffe quamen aen Rio Dolce, Daet be bpandet ontrent bupfert noe acht foutert man fterch bem abetrentbeert badoe; alwaer een barde fchers muttingbe onttonot / enae boe-twel ons bolck tot aen oe midoel boo? bes mater mole/ bebben ae buanot manneligek terugghe gbedegeben/met twepnigh dooden aen onle ż̉̆e.

Ban Daer is ben Colonel Condex rulten bogts abemartbert naer be ftad! heeft bet kloafter ban oe Jelupten beklommen/ be poozte met gheluelot gheos pent / enoe aen bpandet met groot berlies die plaetie Doen rupmen: De bpand die in De rettenthementen onder oe tradt lagh Dit ghetwaer wozoende / enve liende Dat de atriere-garde op haer aen-quam/ is Daer upt-afjeblurbt: mos naer dat be Benerael twee compagnien Toloaten enoe enigh boobts-bolck

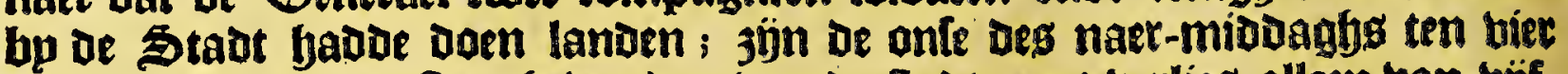
upeen bolkomen meetter gyetwozoen van oe ftadt; met berlieg alleen ban bijftich ofte leftich foldaten. Baer naer bebben oen tweeden Martij De foeten op bet lande enoe jee-reciff bp appointement in-bekomen / als bzecoer te leelen is in De biltogie.

\section{9et beettjiente Capittel.}

\section{Befchrijvinghe van de Capitania TAMARACA, ende die van} Pariba ende Rio Grande.

$N^{2}$

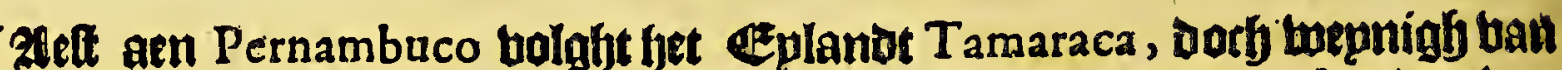
t bafte landt berfebepoen/beblende in oe lenghoe oųe enos in oe beecote truse mïlen; welck toel een ig ban be outotte Capitanias, ende eertijotg bp of frans coplen belet / tot dat de \$oztugelen baer Daer ban bebben gbedzetwen: Daer 3 jü eenighe tupeker-molens / enve daec balt beel 25 atilie-houbt ende cottoen; vorth mozat beden-daegfg bepnigh gheacht/onog dien Pernambuco baer foo naer líght aen d' een/ende Pariba aen d' ander-3ÿde.

Pariba ig een beel nieulue Capi tania, gbelegfen boozer bp̣ noozen Tatnaraca, ende ontrent 20 mijlen van Pernambuc, op de riebiere Pariba, (welck oock anders abenoemt wojot S. Domingo) in een wäbe ooth ondiepe bape; bet tteoeken light wat inne-waerts / ende beeft tuffrben oe 5 enve 60 o buplen; daer light een foettrefle die fo noemen Cabo Delo, niet berre van't ín-komen ban be riebier aen De 3 upDtjujoe/melck oele boolleden jaren op nieug gefoettificeert is/ eñ meer ftucken Daer op ghebzarljt/foo Datter nu in alles Is fouben op ligghen; oock foo is bet ftedcken Das te boozen open lagb/met een trencbee oft muer om-rimght tegen ben aen-loop;entoe en bol-wertk op trants ahemaeckt daer feben tutken op-liggben. Baer 3 g̈n berfrbepoen fupcker-Ingenios, Die tot Dele plaetle beyoogen.

Bolght op de kulte die naer't noozoen fiet de Capitania uan Rio Grande, op-

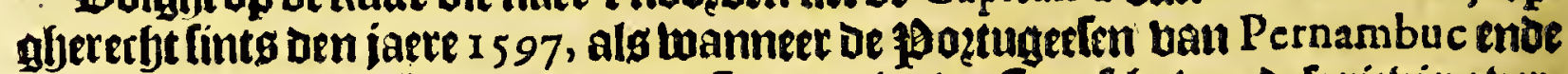

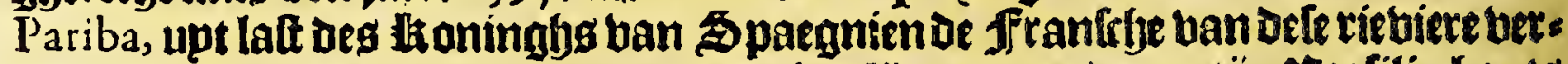

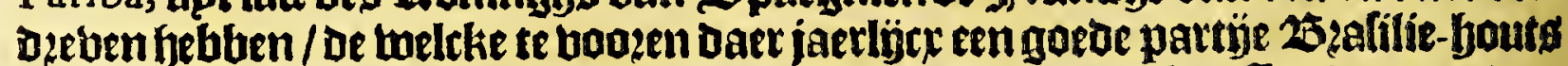
hadoen gbeljaelt; ende naer dat Feliciano Cieça de Carvalasho Bouberneur ban Pariba uerbaelt/[oo hadoen de ffrantrhemet bulpe van of Pecivares een filbet-mije ne ontoeckt in een plaetfe gljenoemt. Copaoba, die feet rïck bierdt bebonoen.

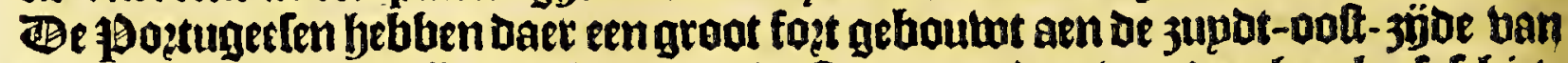
de rieviere op en reciff / weltk noozd-wett ten noozoen ban oer boeck af-fefiet: tnoe norbeen ofte meet eloers/booz dien niet alleen be ffranfebe ban bupten/mate

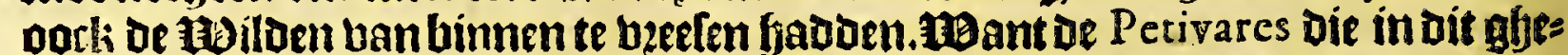
belt twanen mect genegen jünoe tot de francoplen/quamen norb in Den jare 1601 be 1) oztugetien met een groot legher beflooten / foo oat ot Gouberneur Feliciano Cuello genootfackt was hulpe te berfoeckert aen den Gouberneur ban Pernam-

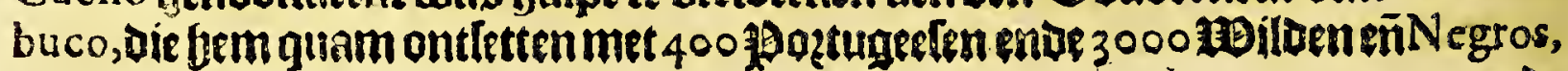


Het veerthienfte Boeck.

ende floegl) den obetiten ban oe Petivares met naemen Piraiu wath (twelck is bin ban een viffy te (eggfen) [o datter twel böf duplent Hoilde doodt blewen; uaser op den o berften van ae Petivares beede maeckte met ae joptugeefen/ende fem

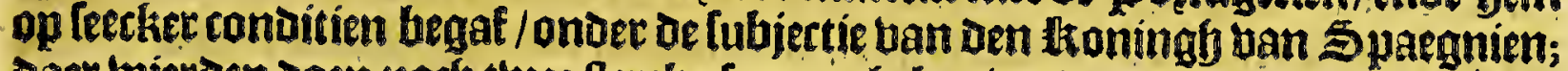

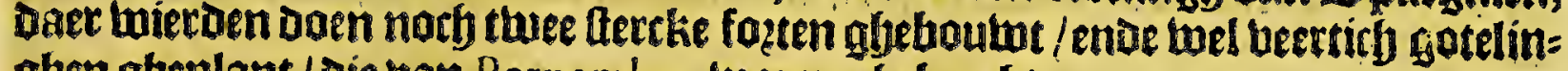
gben gbeplant / die van Pernambu c loaren gljebzacht.

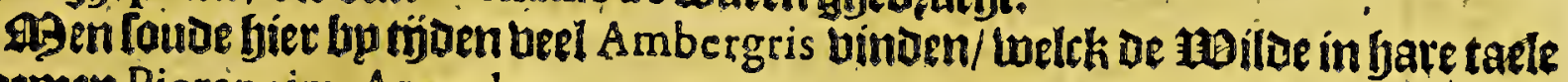
noemen Pierapoim-Arepoly.

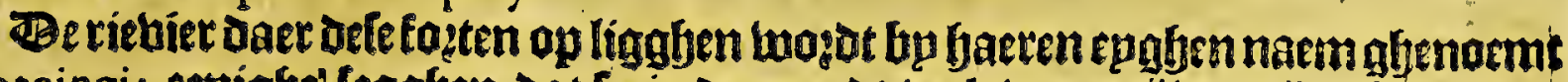

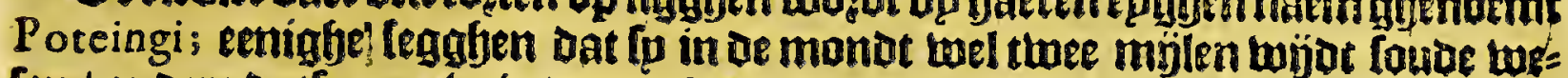
fen/ anuere datfe naeulu is/ enve gfelijcli t gat van Vianen in Portugal.

(2et ujiftbiende Capittel.

Befchrijvinghe van de kufte van't lande van $B$ R A S I I, van $S A N T$ VINCENT TOT DE BAHIA DE TODOS LOS SANTOS.

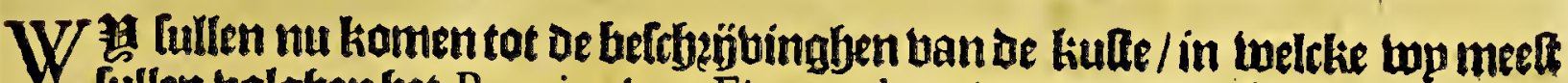
fullen bolghen fyet Roteiro ban Figueredo ende de anlangbte bebindingfen ban be onle / beginnende ban de Capitania ban Sant Vincent.

19ier leguen bp jupoen Britioca, melck is 't noozodijcktte gat ban $S^{r}$ Vincent, litht bet Eplanueken Muella loo Figueredo Dat noemt/Lelck is klepn/ende ligbt en legue ban't batte landt.

Ban Britioca boomormt tot fiet Eplantit Monte de Trigo,is anderffalf legue weit-naozot-meft ende aoll-jupdt-polt / ende ban Monte de Trigo tot Ina de Al-

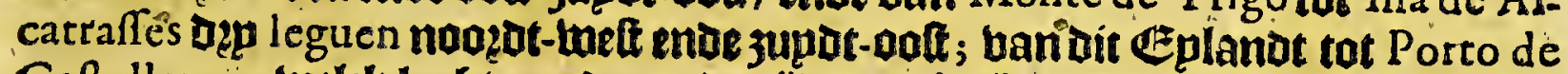
Caftellanos, welck legfit aen oe jupbt-jnoe van't 造planot S. Sebaftian, vier le-

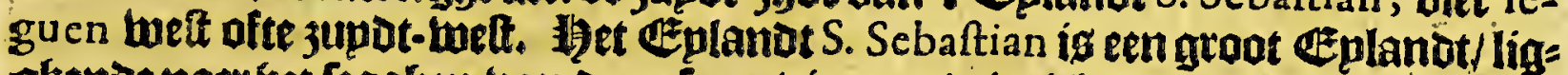
glbende naerbet feggben ban de onfe op biet-en twintichgraben bp jupoen oe lif

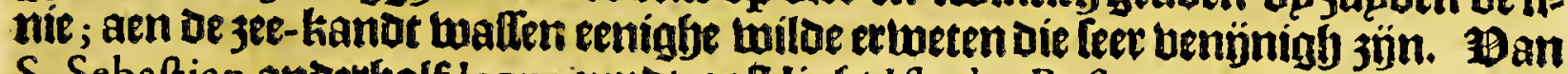

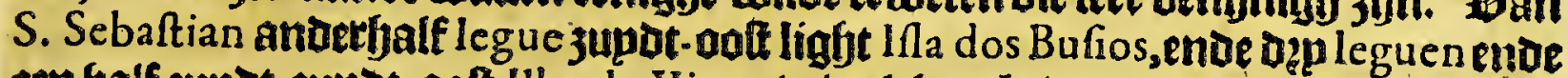

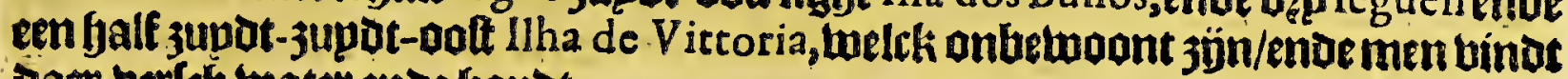
saet berteb watet ende bouver.

Ban llha S. Sebaftian tot Il ha dos Porcos jün biet leguen ooft ente tueft / Daer igen leet goede reede tulftyen 't Eplande ende het valte landt. Ban Ilha dos Porcós tot fet well-epnoe ban llha Grande jün acht leguen. Zlen 't uafte lanot bo

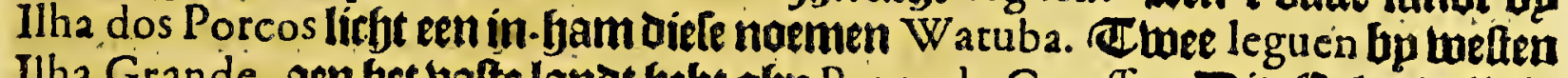
Ilha Grande, aen bet valte lanot gebt gbp Punta de Caroffu. Bit Eplantet lingt

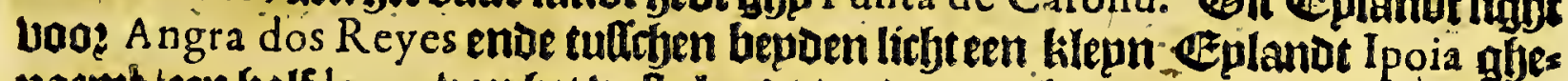
naembken fjalf le gue ban fet balte lanot / ende naer jet noozot-oolten leght de woon plarté ban Angra dos Reyes, ende bp 3 upden Ilha Grande, een quart van eenlegue af light Ilha de George Grego. Bpp ooten tha Grande light Moren-

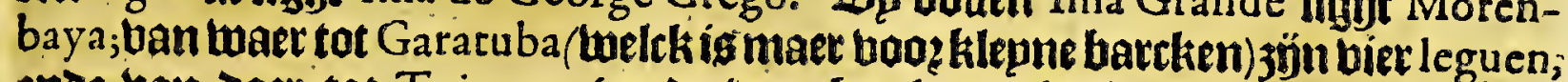
moe ban Daer tot Toiuqua (mede booz bercken) gbeliṕcke vier leguen. Ban Toiuqua tot de Gauea, welck is een fooghen bergb met een af-ghefoulwen fpits/ thee leguen ende ban daet tot bet in-komen ban $R$. de Ienero notb twee leguen; Soa dat van Morenbaya tot $R$. de lenero jün thaelf leguen, ende ban Sane Vincent tot $R$. de lenero twee-en-bertich leguen naer eenigljereeckenen.

Ban R. de Ienero tot Cabo Frio teeckent met arththien leguen. Ce weten naerbet leggfien ban Antoni Knever Ezngelg-man dic langfe in dit getuelte beffit berkeert / ban R. de Ienero tot Pirateninga dep leguen, is een bape tuffrben twee

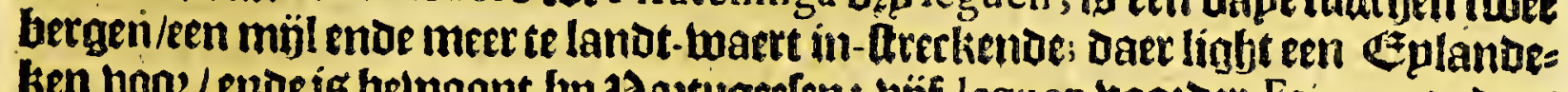

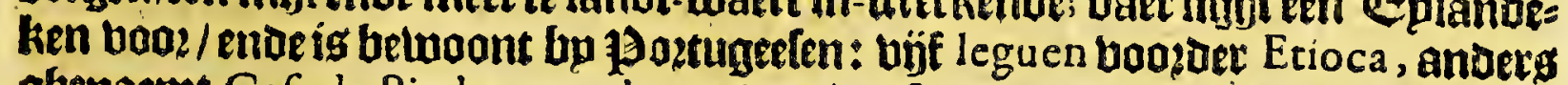
gbenaemt Cafa de Piedras; enn legue bopłoet Saquarema, belck en ríebierken 
528

Brafil.

ig dart of fr ranche fchepen pleafyen te bandelen met oe Tamyoes; aen oe jupotzjoe ban 'triebierken light eeenen yooggen berab / die de toiloe noemen Boipcra. Cabo Frio light op dep.en-thintitb graden bp zupden de linie/bertjoont bemi als een rodtre / met beele witte ftepen/men marb anckeren Conoer losgbe aen of Luelt-zijoe.

Ban Cabu Frio tot de bape ban S. Salvador, reeckent men neghen ofte meer

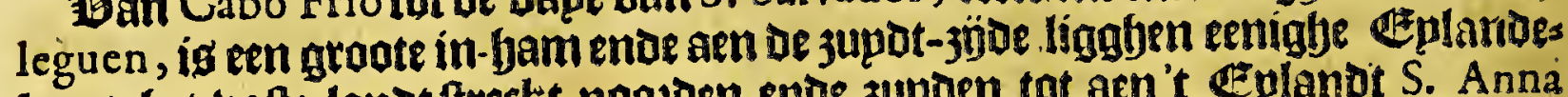
keng: bet batte lanot ftreckt noozoen entoe zupoen tot aen't Epland S. Anna (welek eenigbe oork noemen $S^{r}$ lago) twaelf mülen bu noozoen oe voo!noemoe Cabo ; ende twee mölen ban 'tuafte landt; beft twee Eplandekens dirfyt aen lig:

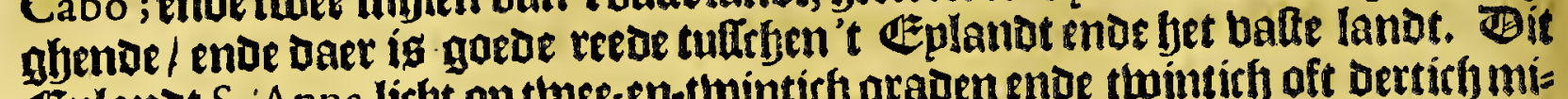
Ezplanot $S$. Anna litht op thee-en-twintirfy graden ende twintirb oft Dertirb mi= nuten bp zupden de línie; is een goede toe- vlurbt om onoer te anckeren als men Cabo Frio doo? contrarie twindenniet kan bekomen; men binot daec berfchepden frupten/eñ onder andere een loozte ban ketlen/wallende aen boomen alg peupm-

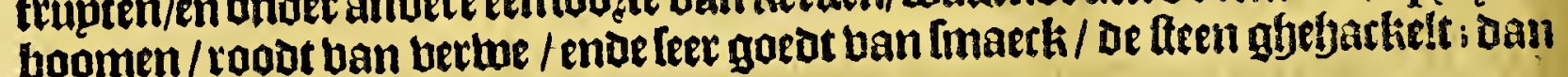
Daeren is afieen goed toater.

Ban't Éplanot Santa Anna tot de Cabo S. Thome zín arbt leguen, be kufte Areckt noozot-oolt ende zupot-weft / oe Cabo lígyt op twee-en-twinticf graden Itjaers.

(J)e Engeltrbe maecken ghemagh ontrent bit ghetwelt tuan Cábo Blanco, welck is leegb/ende landigh / bebbende annigtye fanden ente bantkien bier mij: len afin zee/ Daer men bem ban moet warben.)

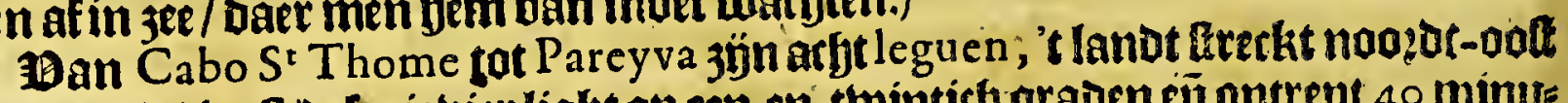
ende zupdt-welt/oele rie bier light op een-en-twintichgraden eĭ ontrent 40 minus ten. Ban datr tot Manage jün uýt leguen, op oe booghte ban een-en-twintir graden. Be onle ftellen op een-en-twintich graden ltyaere Rio Dolce, daer beel

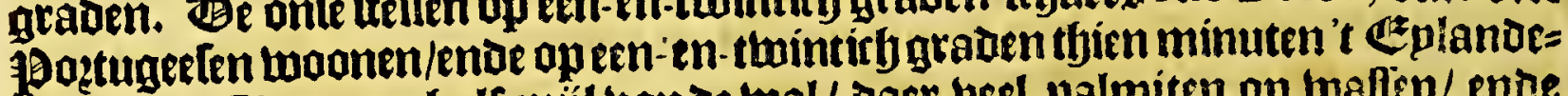
ken Santa Clara, eenbalf mül ban de wal / daer bee! palmiter op twaften/ ente

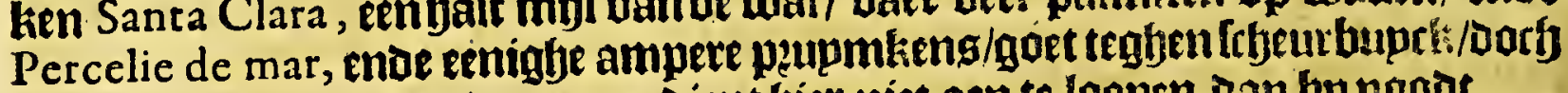
twepnigh bertry water ; dan men dient bier niet aen te loopen dan bp nood.

Ban Manage tot Itapemerim jün bủt leguen, ende baul baet tot Glenetebe bier oft vijf; dit punt beeft een rije van rodtten anderfyalt möl in 3es / ende light op thintich graden 45 minuten. Ban baer tot Guarrapare oft Sierra do Gariparim 3ỉn Teben leguen, daet lighteen EEplandt voo ghenaemt In a Saluage, anderbalf myl ban de wal / ende op thintich graden dertich minuten. Baer aen bolghen uep Eeplandekeng/ ban welcke tot Spirito Santo ggeteetkent wozoen twaelf leguen.

Ober 't nooztot-polt punt ban de Bahia ban Spirito Santo, ontrent twee leguen te lanot-waett in betthoont bem la Sierra de Meftre Alvaro, welck is een renion booglen bergh / alleen op bem felben ftaende; enje is't metrk-teecken boo die ban bp noozen kamen naer bele plaetle. Ban Spirito Santo'tot Rio des Reyes Magos jünfeg leguen, op de hooghjo van neghenthien graden ende teertich mi= nuten. Ban Daer tot Rio Dolce feten ofte arbt leguen, op negbenthien graden enoe twintich minuten; 't landt ig aen Den aeber blark/enoe timnen' 'glandets legfit eenen boogfen bergb. Ban bier tot Cratere ofte Criquare op arbthien graden ende 45 minuten / jän Leven leguen; dele rieliere berthoont lirb met bier opes ninghen / welcker twee foonb ende thee leegh lanot berthoonen/ ende jün den

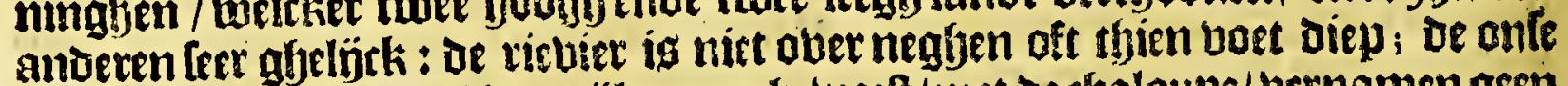
bebben daer wel fetentfien mílen op gheterelt / met be rbaloupe/ bernamen geen bolck / maer wel eenighe futtekeng met bladeren gbedecht. Ban daet tot Mara. nepe ofte Mocuripe op arbthien graden ende büfthien minutsn/zp̈n thien mujlen;

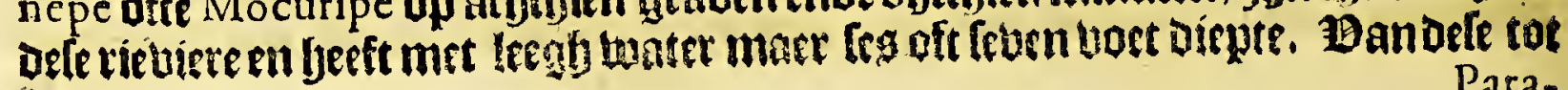
Para- 
Het veerthienfte Boeck.

Parawepe ofte Perteripe, jön bujf leguen, men liet ban bict oe onditpten ban oe Abrolhos, ende ig bier ontrent mede black. Ban defe tot Rio das Caravelas, jojn Deg leguen; is ondieg/ende beeft entige fandt-platen't 3 ee-Luaktt.

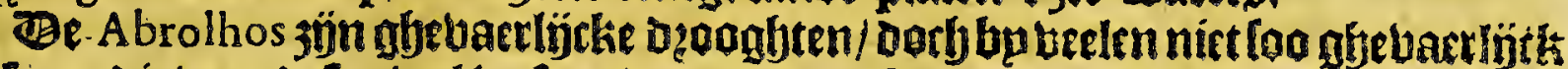

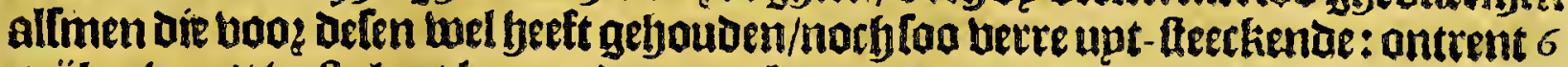
mülen ban't bafte lant loopen daer Dupp kanalen doos/diemen met kilepne frbepen mach befeplen; daec liggen bier eplanorlieng Monte de Pedras, llha Seca, Il ha dos

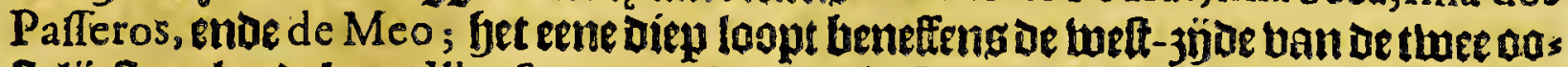
Aelijelte eplandekeng llha Seca tnue Monte de Pedras: bet tweede lamghg De ooft-

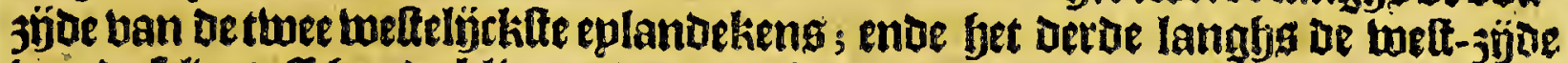

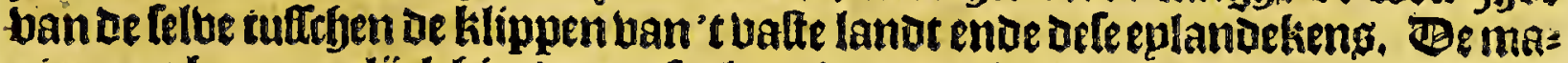
niere om bequaemlïck bier dooztefeplen bindtmen bu Dirck Ruyters.

10an Rio das Caravelas tot Barreiras Vermeilbas júnujú oft les mülen; ende ban't eunde bandele Barreiras tot Corebabo thee leguen, op De boogljoe ban i $T$. grao.eneen falf; men moet fier niet ober anderbalf mijle bande tual bousen. Ba an

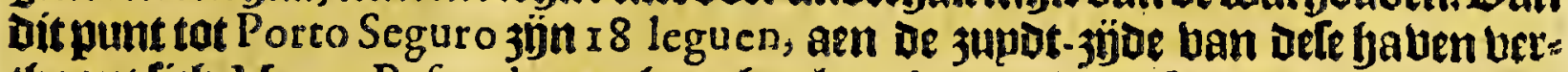
thoont fief Monte Pafqual eenen boogfen langh-werpigben bergly; de rievier van Porco Seguro light op tettien tradenende een half.

Ban Porro Seguro tot Santa Cruz, Daer de Stadt eertt was ghelegft/3g̈n Dzp leguen: is een bequame baben booz klepne frbepen. Ban daet tot Rio gtande $3 \mathfrak{j i n}$ 9. oft 10 mílen/op is graden ende 30 minuten; men moet de wal niet naerderen

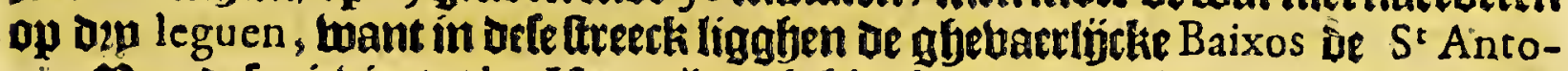
nio. Ban dele rievier tot los Ifleos 3 jun achthien leguen, Dan bu zup den dele plartfe líggfjen las Sierras de Aymores, welck jün leer booghe bergen repckende tot aen De wolcken; ve kufte ban fier tot Ithe os is fupber; ende naer't jupat-welten ban Ilheos light of in-wijek Tambepe; ente een legue van Ilheos naer't noopden Barra de Tepe.

3an Ilheos tot Rio de Contas, 3ijm atht oft negfen leguen op betthien gras Den tijef-ent-twintirb mínuten; Deferiebier feeft een naeutu gajt /ende met leegfmater en is op oe Decppel maet elf oft twaelf voedt diepte; is met lecgb-water berlfy tot aen de monot; binnen if dieper: de 19oztugefen bebben bimen de riebier een luprket-Ingenio.

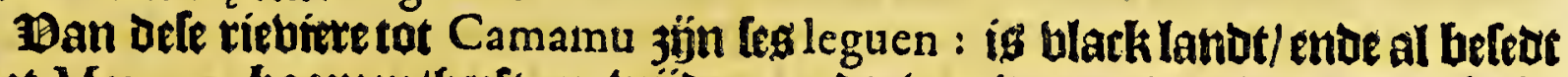
met Mangues hoomen/beft een luijoe monot; ban't punt ban de noogdt-kufte lít ghj't explandt Cayepe, twelck verl blackiten feeft; bandaet tot Quepena oft Boypena, zijn dep leguen; ende ban Quepena tot Tinhare bier/ op de boogfjae

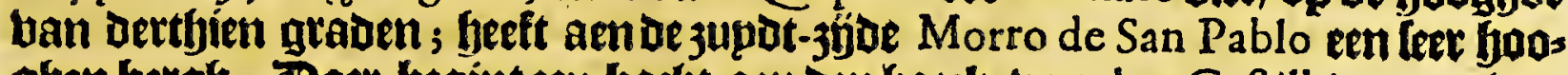
gben bergh. Jaer begint een botht aen Den foeck ban dos Caftilhianos, thee mijlen bp jupden Boypena, ende bp offe Morro de Sant Pablo is fn op jet

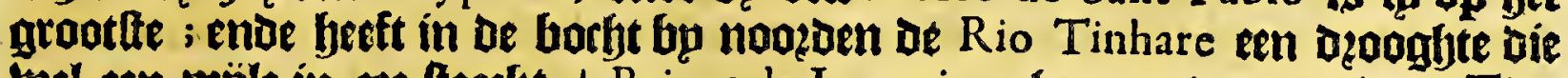
well een müle in Jee fteeckt / Baixos de Iaguaripe ghenaemt; maet tooe Tinhare ende Morro Sant Pablo is goedt ancker-gronot; Rio Tinhare loopt bp oen boeck ban Morro in / aen de noozat welt-3jobe ; enoe beeft in bemondt fes tot feben badem diepte/ binnenilt norf dieper. Brfe borbt epndigft aen den baeck ban Taperico.

\section{Wet feltjiende Capittel.}

Vervolgh van de kufte van Brafil, van de BAHIA DE TODOS LOS SANTOS tot RIO GRANDE ofte POTEINGI.

V Aln de Bahia de todos los Santos, tot Rio Real,jün Teg-en-twintich leguen;

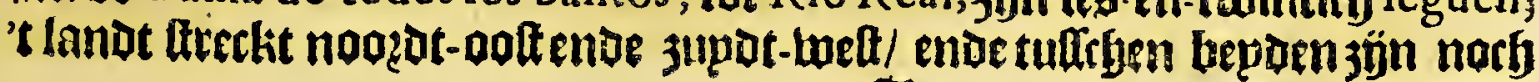

$$
\text { 空 } 33 \text { eniabe }
$$


eeninhe riebieten ente plaetlen daer wepnigh gheluagh wogot ban ghemaeckt:

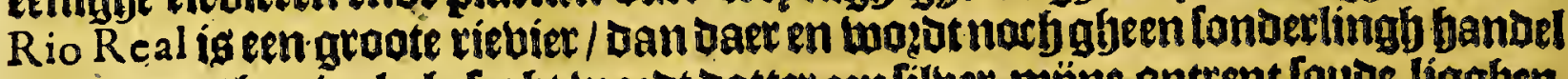

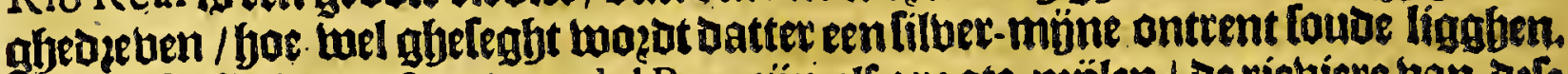
Pan dele riebier tat Sergippo del Rey jún elf groate mälen / De ríeviere ban defe plaette is klepn/ ende tuffecten bepoen ligbt een groote in-wöck; Enfeada de Vafabaris gfenoemt / op de boaghte ban elf grauen enbe bäfttjien minuten /als bp de onle is ondet-bonden / welckeen gbebaeclijcke plaetle is / wegben de klippenende omoiepten; endue om dat t'allen tijoen 'twater met groot gbeluelot naer fightecekt ende inlonoerbept als oe windt teghen is. Ban Seregippo tot Rio de San Fran-

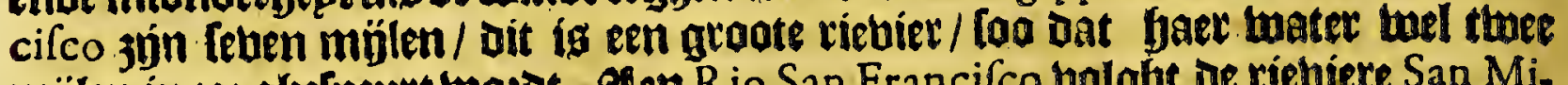
mijlen in zee ghelpeurt wagdt. 2ten Rio San Francifco bolght de riebiere San Miguel, ende tualigen bepaen jón narh eenigfye klepnder/als Cafuays, bíer leguen bu zupaen Sant Miguel ende V panafou, een legue bu jupden Cafuays, daer goet berich water te betomen if.

Raeft Sant Miguel volght de riebiere Sant Antonio, op neglyen graden ende büf-en-beetticly minuten / foo Figue re do fchejift ; is maar boo bercken: onttent dele riebier woonen de Carayas, een tweeroe natic baer men bem twel boaz moet wachten: De rieluier is diep/maer naeulw/ ende loopt berre te land-twaett in. Ban Delerieviere tot Rio Camarigibi 3 ỹn Dz̨ leguen, ende tot Porto Caluo negben; De

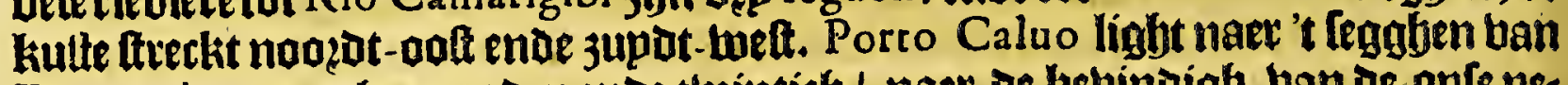
Figueredo op neghen aladenende thintich/ naer oe bebinoing ban of onte ne: gben-en-beettity minuten; Daex en magben maer frljegen in ban ontrent tnegben= tich lalten.

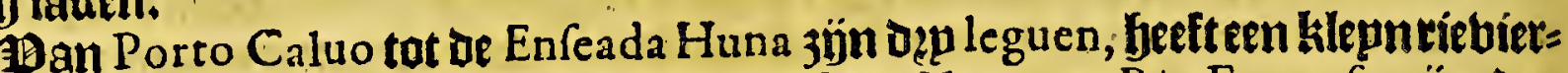
hen/ende maet bequaem boaz betrken. Ban Huna tot Rio Fermofo zỉn Dap leguen, ende daet en komen gheen frbepen in komen. Ban Porto Caluo tot

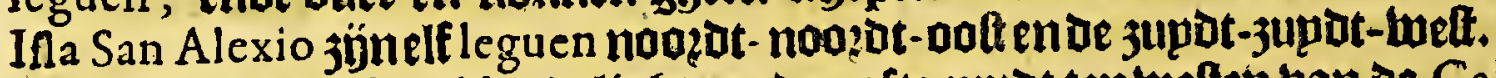

19et Eplanot San Alexio lingt jupden ofte jupdt tenueften ban de CaboSant Auguftin bujf ofte Les mülenisgen fratp eplanot omlebepen te Letten endelfboon te maethen: 't jupber-gat is goedt om in te homen dirbt bp 't recif in/ beeft les/ [es.

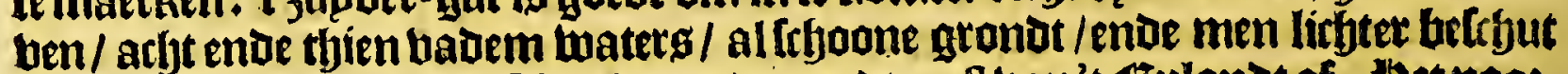

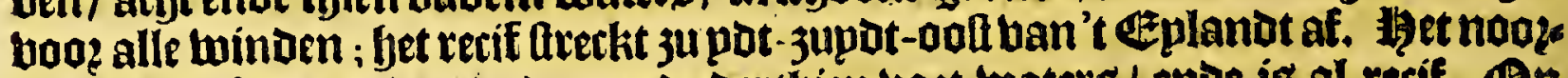
Dex-gat heeft maer twee badem ende Dertbien boet baterg/.enoe is al recif. Op

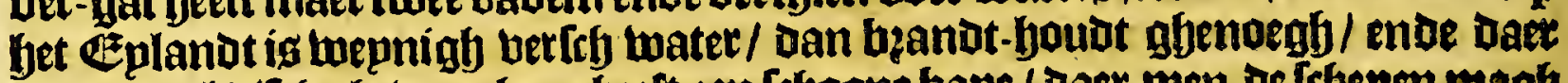

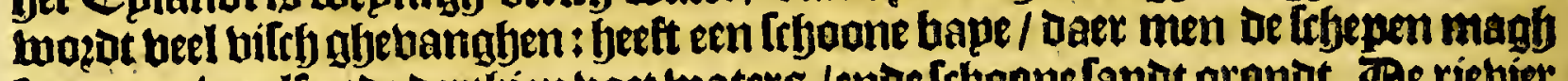
Cetten op thaelfende Dertbien boet waterg / ende frboone fanot gronot. Be riebiet Macaripe light recht tweft ban't Eplanot een biet-en-Deel mỉls / enoe Rio Fermofo anoerfjalf migl ban 't juput-punt ban bet Gplanot / men maet die langfg oe noozot- wal in-loopen / is kenneligek bu eenen teplen boeck / ende op de jup ofboeck ftaen booghe boomen. Een jupot-melt ten wetten-maen maeckter joogh water.

De Cabo Sant Auguftin ligft op de fooghjo ban arbt graden enoe dettich mi nuten / bertfoont ligh als een leegh balf ronot Eplanot/ waer van noth twee

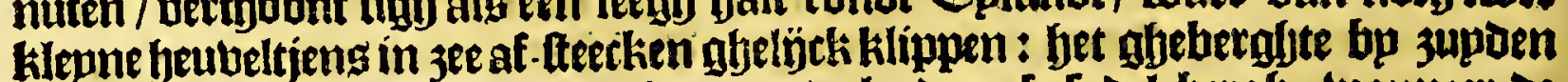
oe Caep wozot gfenaemt Mercahipe, ende bu de onle Tadel-bergh; manneer oe Cabo welt-3upot-welt wan uig / loo komt den ladel-berabrecht teghen't upterte

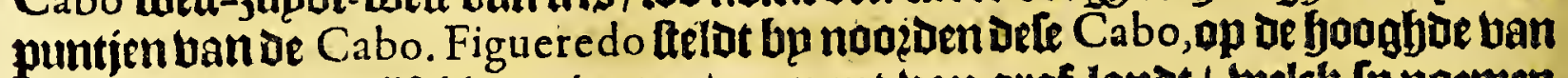
acht nraden ende büftyien minuten / een punt ban grof lanot/ welck [p naemen Cabo de Pero Cabarigo, enue bp jupoen Dit punt ontrenteen legue Rio de Eftre. mo, die niet enigdan boo? Klepne bercken. Ban dit punt begint een groote inwijck/melck freckt tot Punta de Marim, Daer de ftaut Olynda bp leght; entoe ment reeckent ban de hoo:-noemoe Cabo Sant Augultin tot of baben ban dele fad negyenleguen. 
Het veerthienfte Boeck.

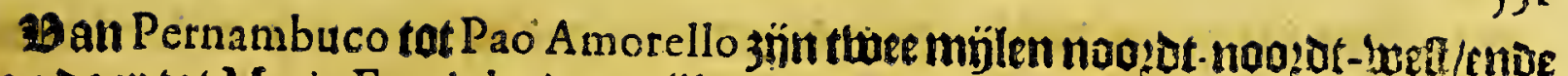
ban daer tot Maria Fuerinha dęp mülen; of liutte is bol riffen ende kifippen. Daer aen bolght fet eplanot Tamaraca, twelckes in-komen bp ecnigle van of cure wozot abeftelot op Teven araden ende bỉtthien minuten.

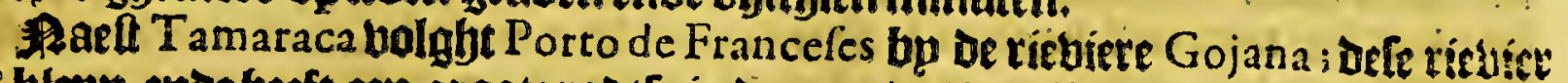
ig klepn ende beft een groote rodte in de mondt / Daer bem Doos-gaeng berl see-

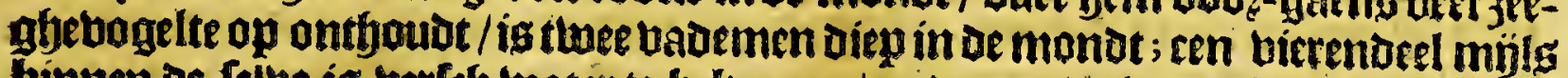

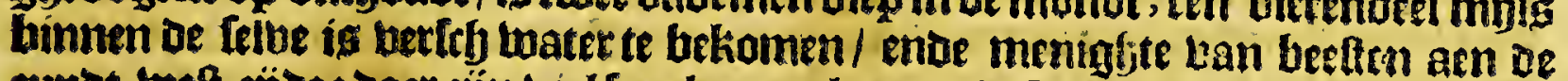

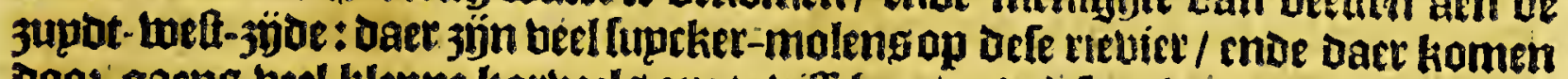
boo-gaens beel klepne katbeels om te vilfeben / enoe' t lupther naer Pernambuc te boeren; men bint daer oock 25 talitie-fjoubt/gemuev/cottoen ende 3 noiaenlrbenooten; de Petivares woonen daet om-lyet, Hoatmeernaer 't nopedon light Pedra Furada ; enoe daec aen Cabo Blanco op oe joogboe ban fra graden enoe vijf-snveerticf minuten; ende vier leguen meet naex 't noogden Rio Pariba; defe ligft bol bancken / ente heeft op t diepte met leegh twater maet dep baurm luaters; ende is binnen de Deooghten naeulw; ende bet hanael loopt reetyt op't fottien aen/

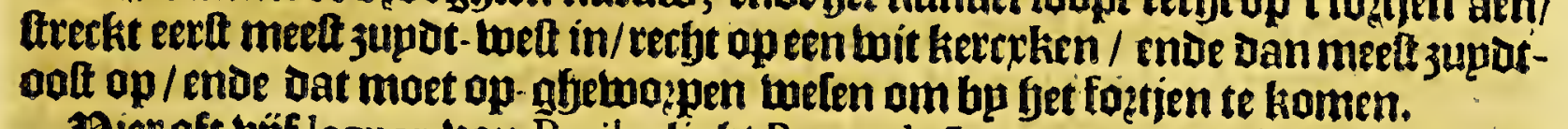

Bier oft búf leguen ban Pariba ligbt Punta de Lucena, ende 2 leguen boopor Mongoangapi, welck ig een klepne rievier/met een grootemono/bol bancken/ente

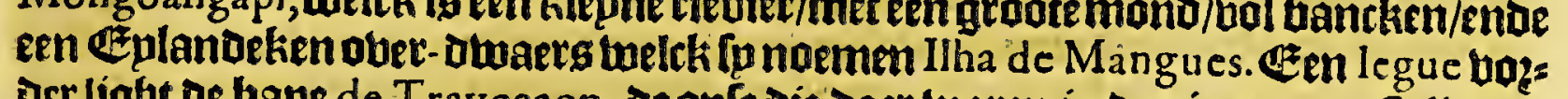
drr light be bape de Trayceaon; de onfe die daet waren in ben jare 1625 , frellen be lébe leben mülen bp noozden Pariba op les graden ende een derde; beeft een les= gyen boect: altwaer een retif af-teeckit/ belck be bape bethut/light met leegh toa=

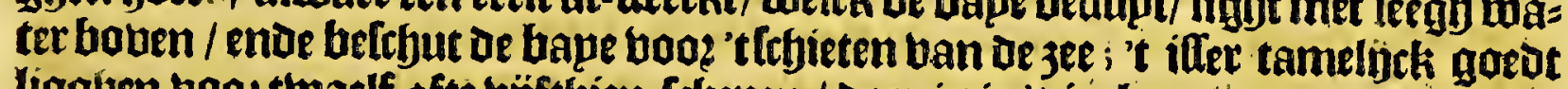
ligglen hoo: twaelf ofte bijfthien ftbepen / Daer is in't in. Kamen ban ozp tot fes badem thaters ; binnenis ae gronbt modberighenoe fteenigh / foo dat de habels

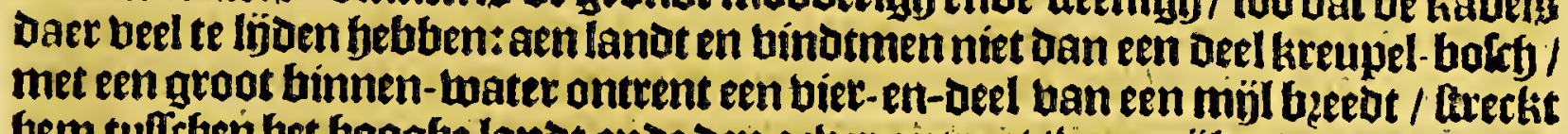

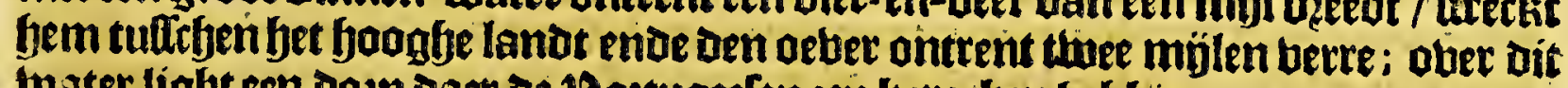
water light een doep daec be 19 oetugeefeneen kercrken beblien.

Raer offe bape een legue boozoer bebt ghp Gromataim, eenklepn riebiecken; Daer aen bolght een punt lanbts / belck de 13ottugeelen noemen Punta de Pipa,

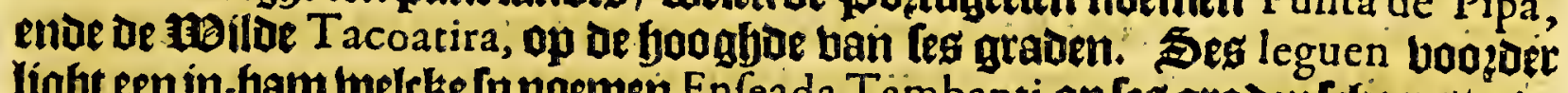
lígt een in-bam welkke fonoemen Enfea da Tambanti, op leg gradenldfiaers/ente bier leguen boazder. Porto dos Bufios, ende twat boozaer Porto dos. Touros op

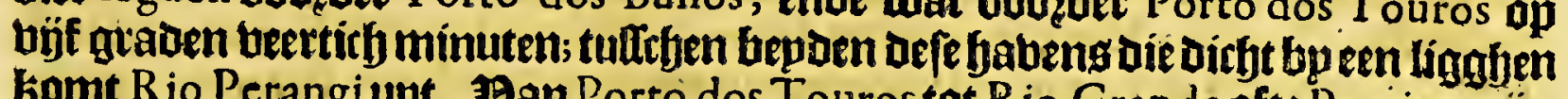
komt Rio Perangi upt. Ban Porto dos Touros tot Rio Grande ofte Poteing jỷ feg leguen, op bijf graden ende oettich minuten/als Figuere do gbetupgbt.

\section{Iet [ebenthiende Capittel. \\ Vervolgh van de kufte van Brafil van $R_{\text {I }}$ G $G_{A N}$ D tot de MARA N N ON.}

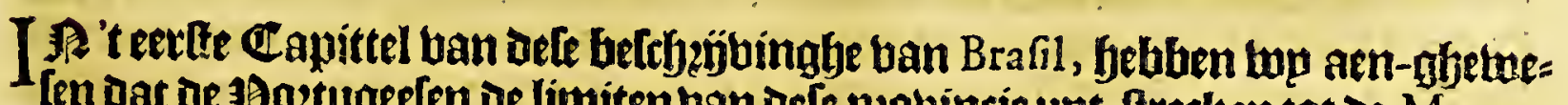
fen dat De 19 oetugeelen De limiten ban Dele pzobincie upt-frecken tot de Marannon toe; Be onfe noemen dit gantleg ghewelt welck bolnfit aen Pariba, ende hem

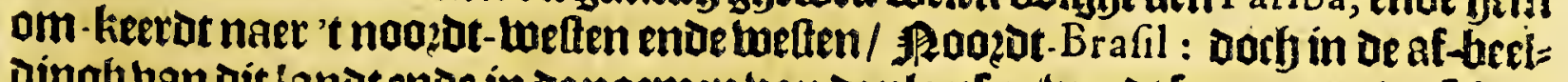

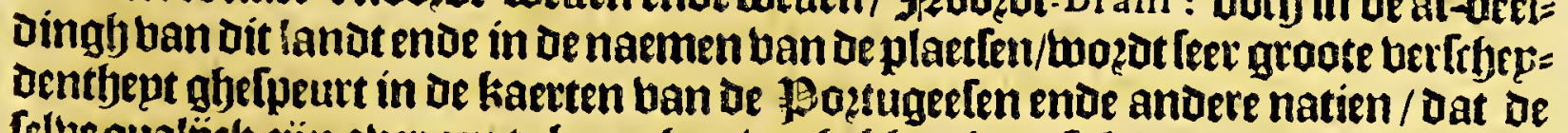

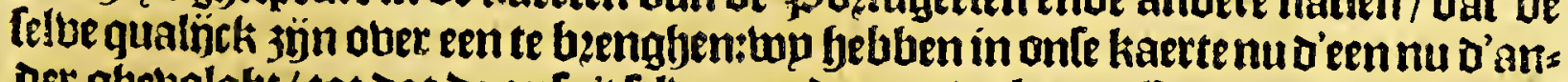

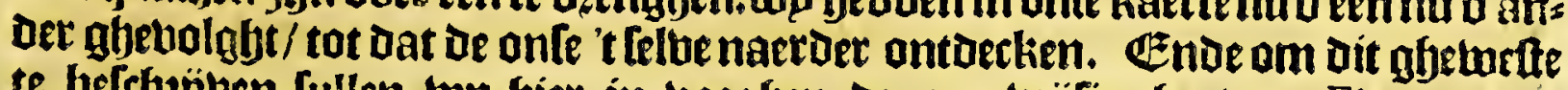
te belfbejben fullen wp fier in-boeghen de aen-wojlinghe ban Figueredo,

$$
\text { I3 millga: }
$$


$93^{2}$

Brafil.

mitfgabers fet gheme bat by be onfe ente by antere nation is ontort-bontom gfolueet.

De Baixos ban Sant Roque feght fyp te lignbenop unf graben bp juptom de lie

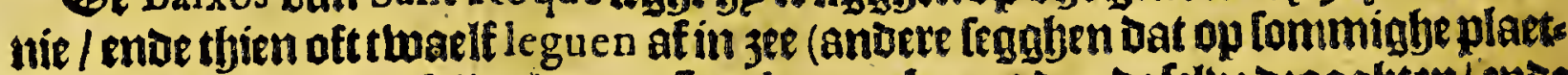

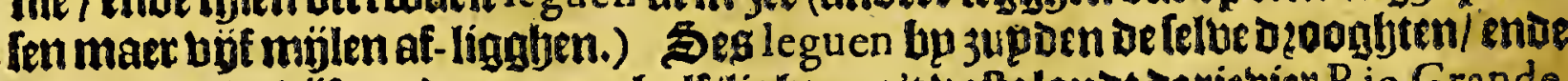
ontrent op de bojt graden en ern half/light aen't valteland oe riebiet R io Grande, ende bp epuben naem Potengi, (ick gheloobe dat dit oe riebiete is die de betryejuect ban Lancafters hopagie normt Potajou, daer of f rancoulen baer een loịl beb ben

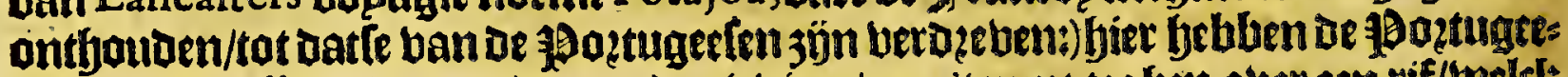

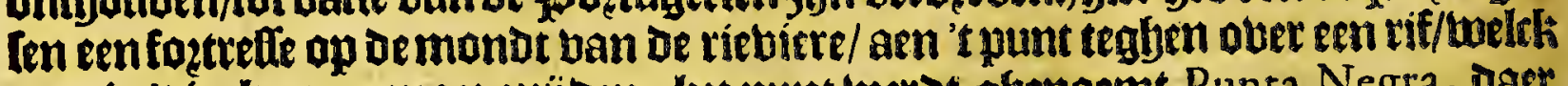
menin 't in-komen moet mäoen; bet punt toerot gbendemt Punta Negra, Daet light een Dzooghte recht booz oe barre.

Ban Rio Grande tot Punta de Siara jün thete leguen nogot-noozot-hertt ende van daer tot Enfeada de Petitigua neghen oft thien leguen, fis ken groote bape

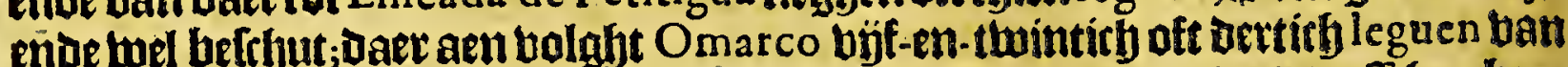

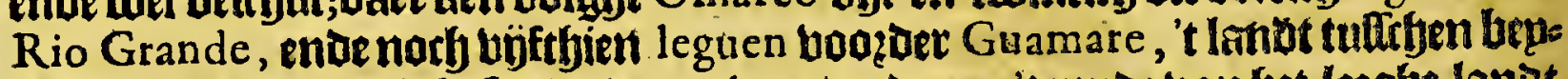
Den ig blark met eenighe lanot - oupntjeng / ende aen'tepnoe ban bet leeghe lanot te lanot-waett in / fiet men bet boogbe gheberghte ban Buturuna, wat toos:

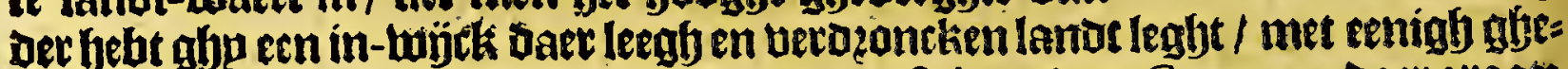
hoomte uam Mangues, hier ontrent liggfjen de Salinas ban Guamare, Daer groote

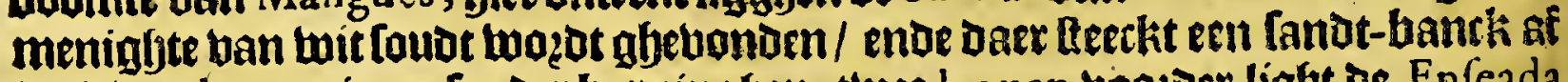
wel twee leguen in zee Ionoer barninghen; twee leguen toozaer light of Enfeada Maretuba ; melck bier manoen beetr; uan bier is de kufte foogjer met leeghe bof fchagie befet tot een punt landto ghenarmt Punta do Mel, waer een laute kteecke upt-komt/agenaemt Geararahu: twee leguen boożor lingt Rio Vquaiguara; ente arbt leguen bopzer Rio Hupanema; ban bier beruolght een blacke hille metpalm-boomen/ aen welckeg epnoe beginnen tenighe roode klifen ende de Enfeada van Vbarana; van waer tot laguaribe jün tljien leguen, bier begint meder foogh landt/ hol boomen tot Iguape toe thintich leguen, welck is eft

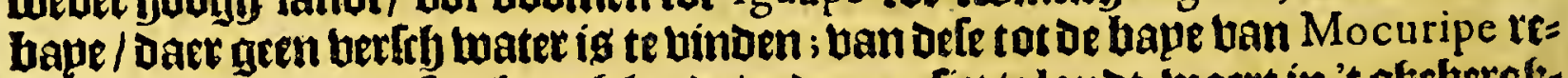
kenen fp acht le guen, (eer boogh landt/ende men fiet te landt-waert in 't gffeliergly: te ban Aquimume ofte Camume; ende byjf leguen ban Iguape komt eenrieviete upt/afyenaemt Ypocaru, die gheen baben beeft ofte befrbut; enoe twee leguen boozer Rio Coco. Be hape van Mocuripe light op Dep graden ende beertity minuten bp jupoun oe línie. Ban fier loopt men naet de Barra ban Siara, Daet

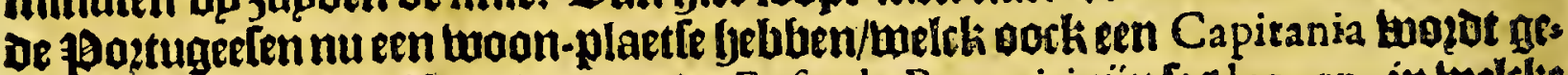
noemt bp Olyveira. Ban Siara tot oe Enfea da Paramiri zünfes leguen, in torlelte enigge riebieten upt-komen / ende boghraemlijek of riebier Paramiri, die feet gaet water heeft/ende aen de oetuerg wallen beele Carous; de Moiltoe die Daer wogs nen zün Tapujas, Daer men fem moet booz warhten. Ban 't leatelícklte- punt ban Defen barbt tot een punt lanotg / welck de miloen noemen Tatajuba ofte Itajuba jijn arfyt leguen. In't midoen ban dele diffantíe ligft Rio. Tiraira, die ahen Barra en beft. Bier leguen boozoet wan Ta a juba bebt nhpoe riebiere Mon. dahug ligghende atjter cen punt landets. Baer aen lolght Satahuba, moe boats be bape ban leruquacuara, Daregaed mater te beliomen is/ Dan men mart biet

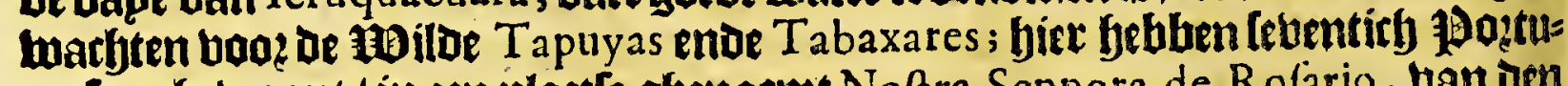
geeten gftelwoont / in een platte gfetaent Noft ra Sennora de Rofario, than Den

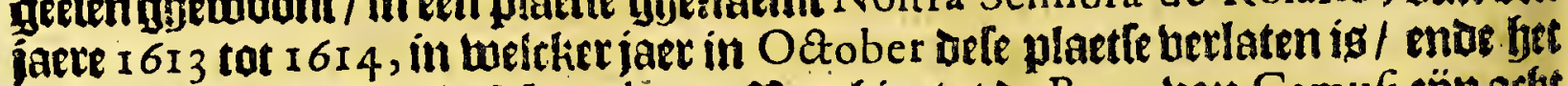
bolck gljebaeren naet de Maranhaon, Dan bier tot ie Barra ban Camufi ż̈n arft leguen. Ban hier tot Rio Guafipuira ujuf leguen, ente boapderg tot Rio Iofara Dap leguen. Baec aen volght enn in-borbt verre in-freckende naer't jupoen $/$ in welcke de marftighe rievict Para upt-komt / Dorb onoicp in de monot. BBan dele vievier tot de Maranhaon jön biff-en-tuintich leguen, meeft leegb lanot lonaec boamen: 
Goomen: ente aen fet epnoe ban 't leeghe lanot fomt oe riétere Maripe upt; van toelck't landt boo? wir fandt/ende aen 't epnde bebt abp een feer frboone riebier Perca ghenoemt/me!

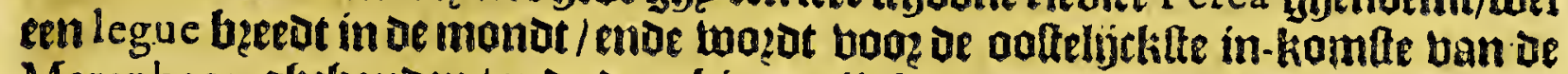
Maranhaon glefouden/ende daer binuen light S. Iago, d' ertte plaetfe daec de 19o:tugeeten baer neder-floeghen inden jaere I 6 I 4 .

He maeckt oock toers abetwagh ban Ototoy, twinticb leguen hp ooften $\mathrm{Mia}$ ranhaon, op de booghte ban twee graden enoe betrticl minuten/ Leick is etn groote bape met ued Ẽlanden in De nonor.

De boozdere kuffe tot aen Rio das Amazonas, ig blackende vol fanclien/ende Teet ghebaerligck. Dus uetre upt Figueredo.

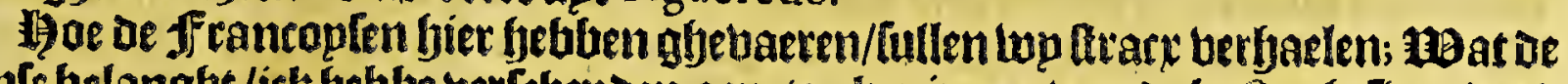

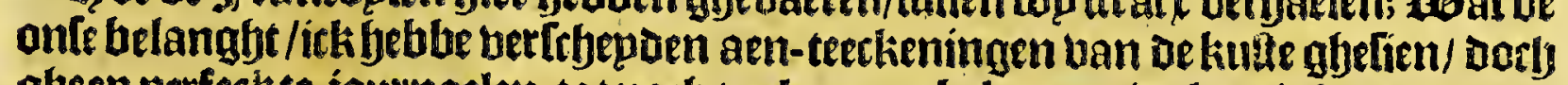
gheen perfeckte journaelen tot norb toe homen bekomen; bel eenighe aet:-merc= hinghen / Dorb foo wat ban oen anderen bertebillende; fal bier in-upegben upt twee / t ghene Dient tot kennis ban oit ghetwelfe. EFenfer pertinente ael -teeclie= ningt van of op-Doeningbe van of kulte / fegft date't retle lanot laghen op of fooghoe ban bier gladen bu zupden de limie/ enoe't lanot ftreckte aldaer med-

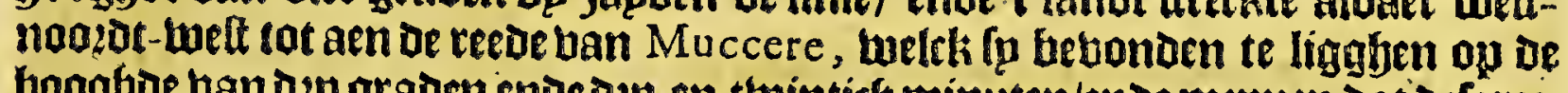

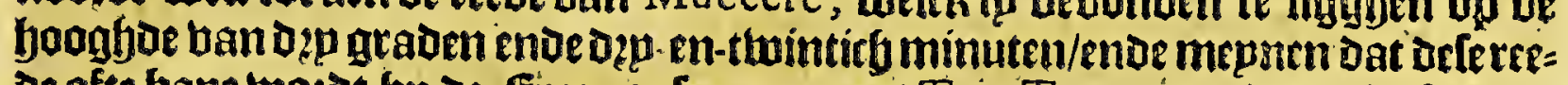
De ofte bape woetot bp of ffincoplen genoent Tres Tortugas, ware in tp hare

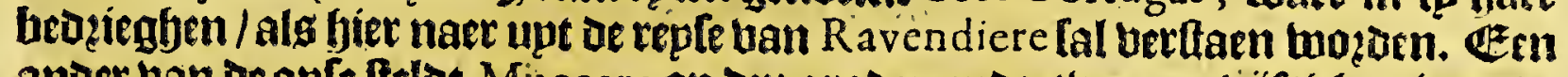
anoer ban oe onfe ftelot Müccero op Dep graden ende twee-en-bjuftich minuten; ban den eertien telot twasle leguen meer om de weft / norb een ander bape) welck de andere booz Muccere febünt ghenomente bebben/want ftelot ban Muccere tot Cabo Blanco bier-en-twintich mijlen/ende foo beel mölen fteld of eerffe mede tufthen de theede bape ende ae booz-Lepoe Cabo, ende tuffljen Muccero

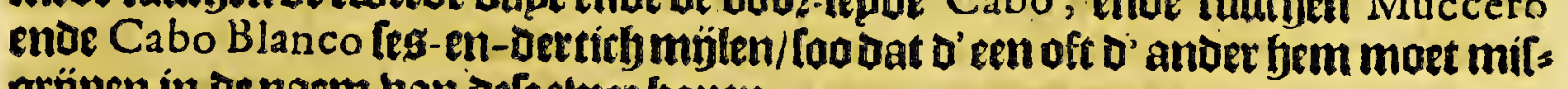
geñpen in de naem ban orfertwee hapen.

Ben eertenffelot Cabo Blanco op ttuee gradenende acht-en-bertich minuten/ belcli bu-naet de jooghoe ix han Cabo de la Tortue ofte Tres tortugas, foo bip be ffrantebe ghenoent/ loo dat mp in-beelde dat de onfe van de lelbe Cabo lpeer. ken/boe- -wel fp dieeen ander naem gheben.

Ban Cabo Blanco reetientaen eetfen feben ende den anderen les mülen tot Rio de Camboltip ofte Campocip; ide f trantoplennoemen nael Cabo de laTortue deribiete Camufi. Be theede leght die hebonden te feblon op de foogboe vain twee graden ende twee-ch-ujftich minuten / ofte uptetlijck ozp graden bp jupaen De limie. Raer ons den theeden aen-lugita / [oo badoe een f/rang-man te diet tỹor cenl klepn fostien op de monot van oe rievier Camboftip, ende efn febip daet on: oer liggbenje; maecken bepde ghewagh ban een roooen foeck aen oe welt-jyoe/

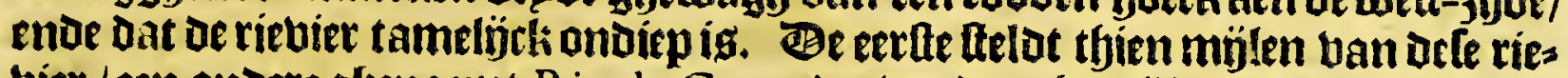
vier / een andere ghenaemt Rio de Cruz; de tweede arbtmijlenente een balf van

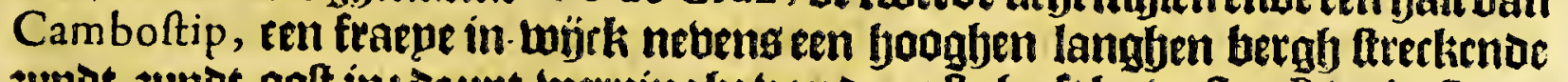
jupdt-jupot-ooft in: De upt-Luerpingbe ban oe eetlfe beeft bp welten R io de Cruz, rerbt op of monot ban oe rievier een lanaben booghen bergh; foo datfe ban ceil

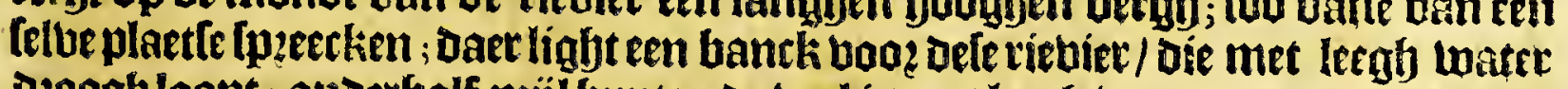
Dzoogbloopt ; antorbalf mijl bupten oe twal is met leegh twater maer o sp baorm/

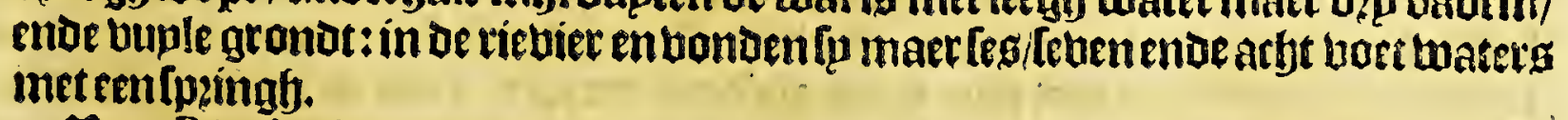

Ban Rio de Cruz tot Rio Grande ftelot oen cerfen neglyen mijlen: orfe ries: bier is quaet in te komen/ Dooz de barninghen ote aen ae monot ligghen/ biex

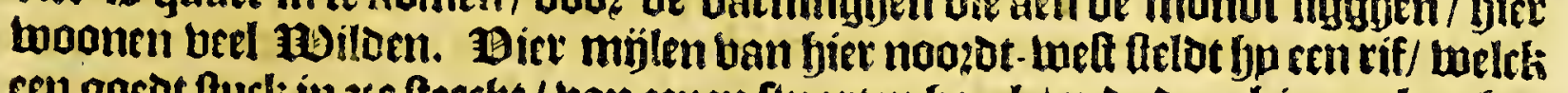

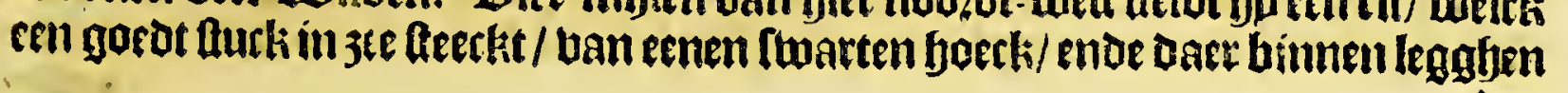


334

Brafil.

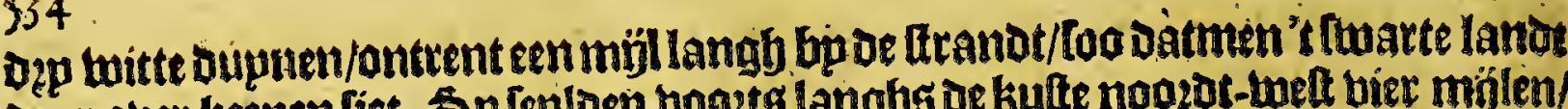
Daer ober beenen fiet. Sp Ieploen bopgtg langhs oe kufte noożt-Lelt vier mílen/ ende weft ten noo ecoen deg mijlen/ende faghen een openinghe als ban een.riebier/ Dan barnoe foo gljetweloigh owarg boge $t$ gat / Datfe de felbe niet boeften gfe: naecken; twee minlen boozoer welt ende weft ten zupden / fagben een arider ops: ninghe/ met cen fanot boben water olwarg boo?'t gat/ ende ghetwelaigbe bancken

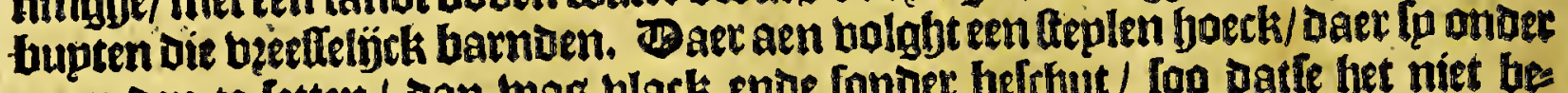
mepnoen te letten/ Dan twas black ende fonoer beftyut / loo date het miet be ftanden; 19an bier bopets freckt de wal belf ende welt ten nopzoen/ fop ber alfe fien konoen / Dan uonoen foo oneffen gronden/Datle jet niet langher bp de wal

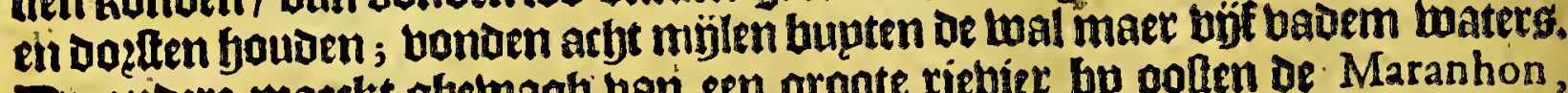
De antere maeckt abemagh ban een groote riebiet bo oofen de Maranhon, welck oe frantoplen noemen de Baye van Alderheylighen. Bits loo beel als wp tot berklaximgle ban Defe kutte upt be onte bebben konnen metcken.

\section{MARANNON ofte MARAGNAN.}

in

\section{(zet actutbiende Capittel.}

15. Eenighe generale aen-merckinghen op de Provincien van den MARAGNON; ende de rechte gheleghent-

heyt der felver.

\footnotetext{
G
}

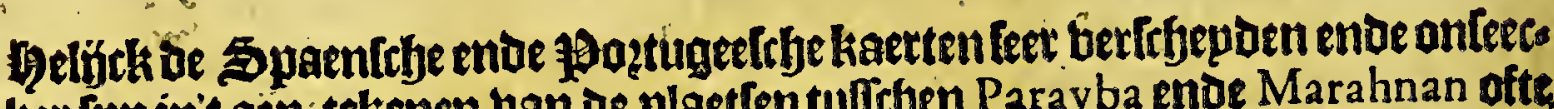
ker Len int aen-tekenen ban de plaetfen tultetyen Parayba enoe Marahnan ofte

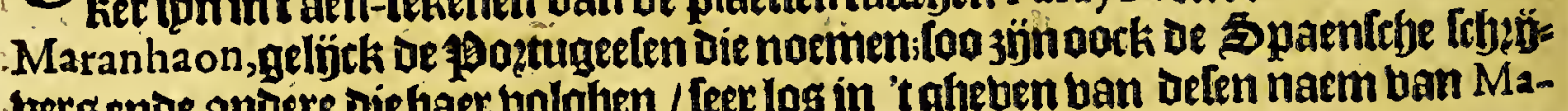
bers ende andere dief faer bolghen / feer los in 't ghe ben ban defen naem ban Marannon, aen rietieren die gantfeb berre ban den anderen berichepden zïn: twane geven Den naem uat Marannon niet alleen aen De riebiere $S^{t}$ luan de las Amazones ufte Orellana, maecoock aen Den Orenoque; ghelíck 't telbe (op Dat tup beel anoere exempelen booz-bpgaen) klaetlijeken is te lien bp A cofta in [pn tweede

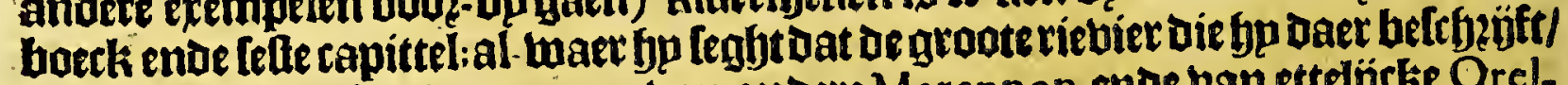
vaneeniglje Rio des Ama zonas, van andere Marannon,ende ban ettelícke Orel. Jana twerot ghenaemt; enoe datle bp-naer recht teghen ober 't Geplandt Trinidad in see loopt. Die maer een wepnigh kennig en beeft wan oe gljeleghentbedit tan

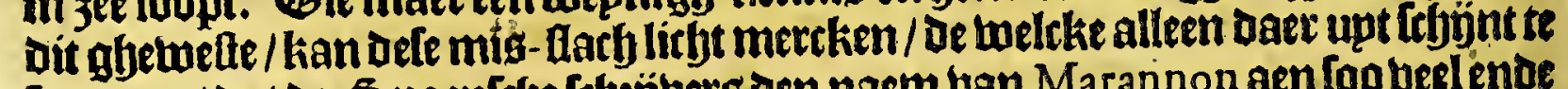
Ipupten/Dat oe Spaenfche fcheñbers den naem ban Marannon aen foo beslente

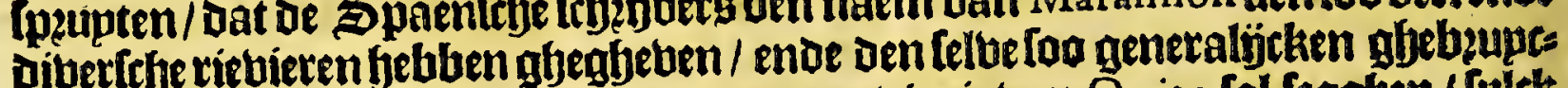
Ken / Dat Herrera [elfg Lpzeckenoe ban de peouincie ban Quito Lal legghen / Tulck ofte fulcke pzodincie Atreckt naer oen Marannon toe/ Daetnochtand fulckengtoote

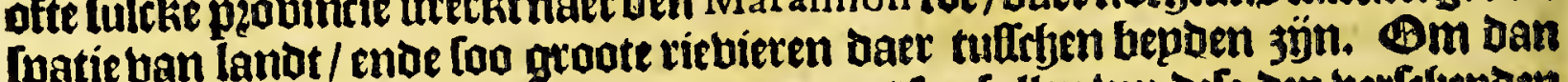

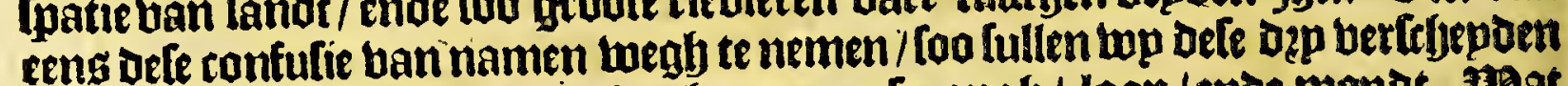

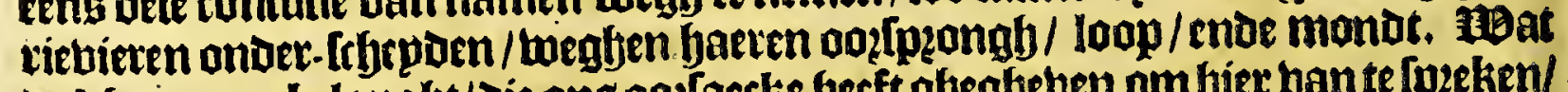
De Marannon belanght/Die ong oo:[aecke becft gljegljeben om bier ban te [peeken/

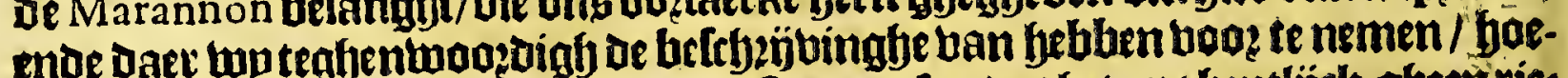

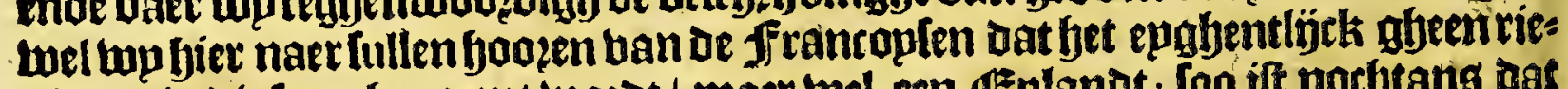
bier en ig die Loo ghenaemt mogst / maer bel een Eplanot; foo ift nochtans dat De riebieren die ontrent Dit Eplandt upt-Lateren/ende infonderbeut de mitodelfte

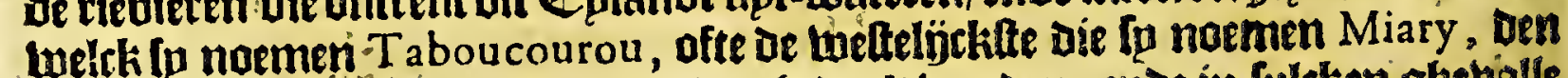
naem ban Maranto tuel kan mede gheoeplt wozoen; ende in lulcken ghetialle

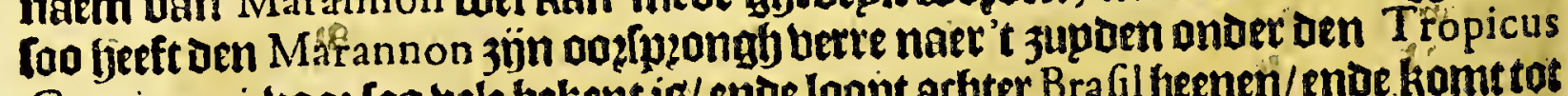
Ca pricorni, voo? too bele bekent is/ ende loopt atbter Bra fil beenen/enoe homt tot

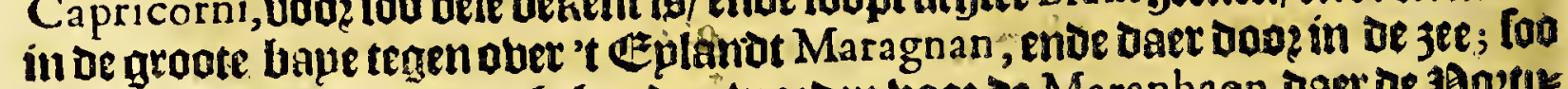

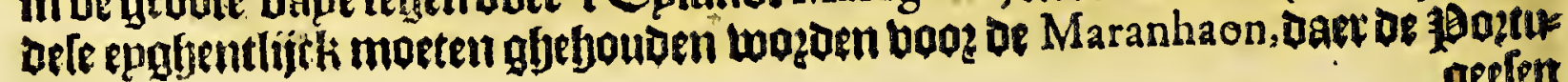
getion 
Het veerthienfte Boeck.

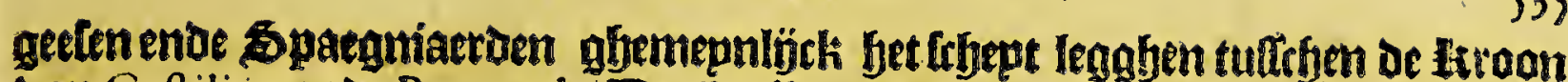
ban Caftilien ende Portugal. Be Orellana ofte Rio des Amazonas ig cen tgatt

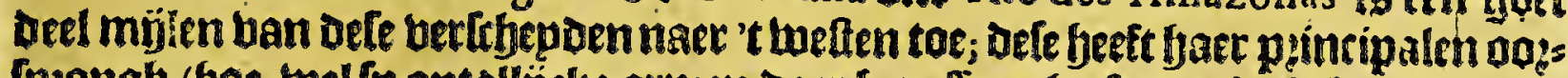

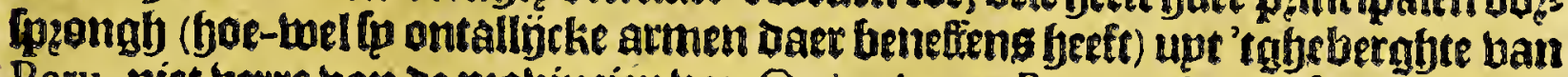
Peru, niet betre van de peobincien van Q uito, want Pizarro begon Inn torft tan

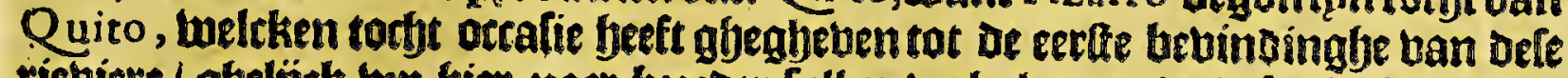

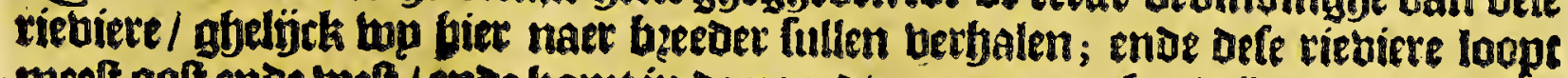

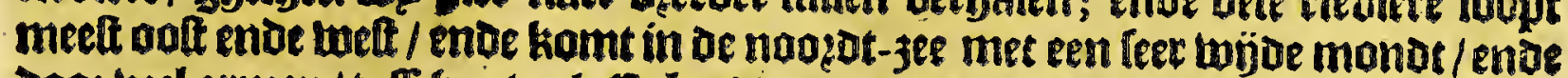

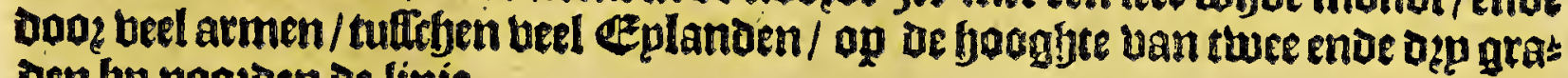
Den bp noazden De limie.

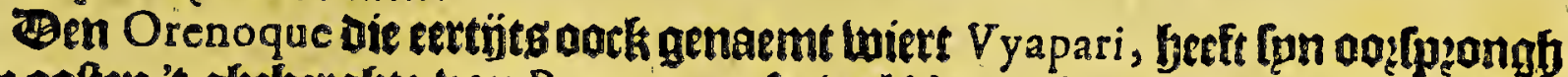
by ooften 't ghetberglbte ban Popayan, offe wel Neuvo Reyho de Granada, mog loopt in $3 e$ teghen aber de Trinidad, ende langlyg den hoeck ban Paria. Soo Dat

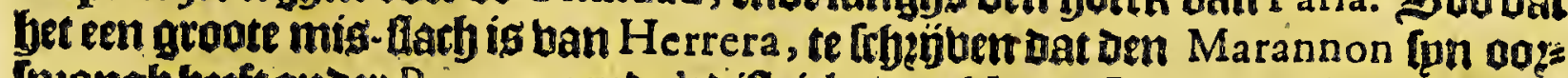
Itenghbeeftonder Popayan; ende'taiftrickt uan Neuvo Reyno de Granada, gés

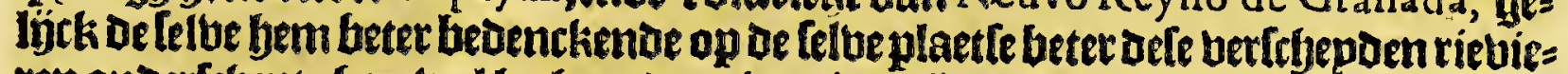

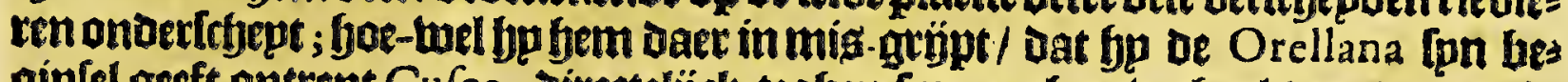

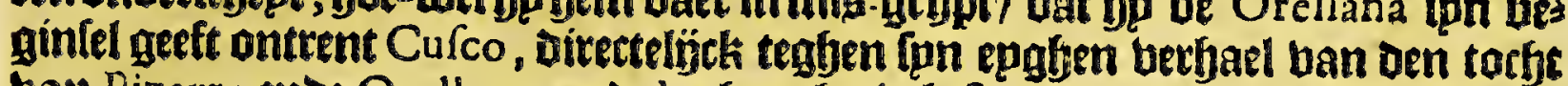

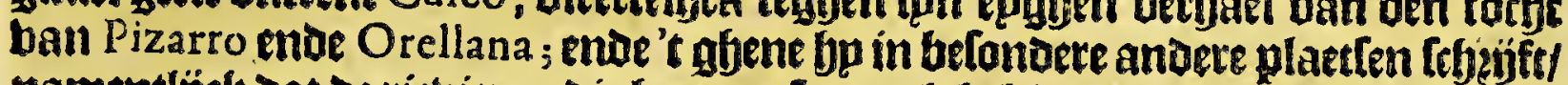

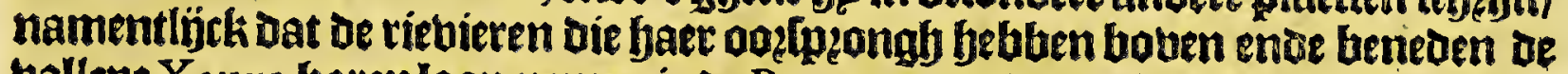
ballepe $X$ auxa baren loop nemen in de $P$ araguay, ende doot Rio de la Plata fyert upt-watering be bebben in be noodot-3ee. Om dan defe tonfulfie tan namen

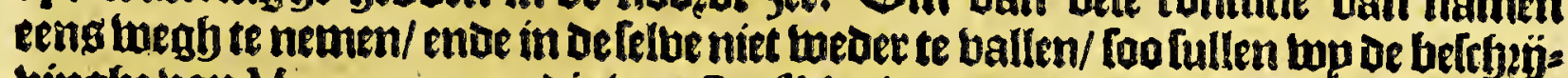
binghe ban Marannon aen die ban Brafil becthen / als een ghedeelte ban de lefte probintie (Detwïl de joptugeefen die befitten/ende oock booz een Capitania twoxt

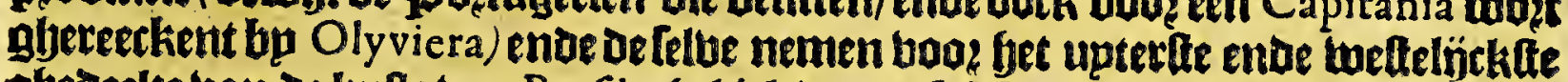

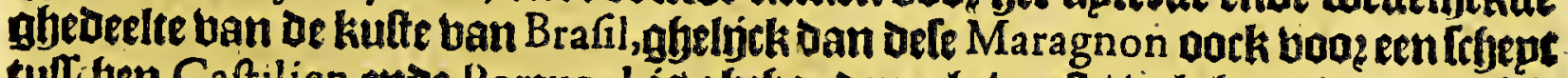

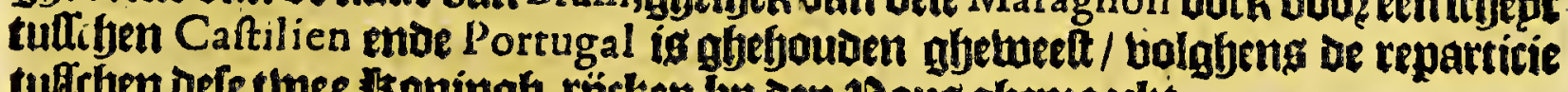

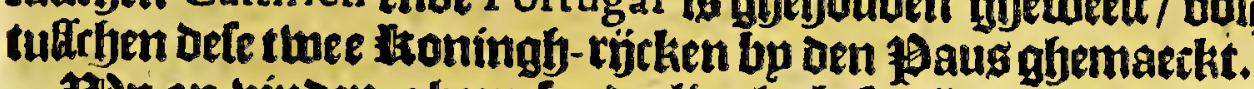

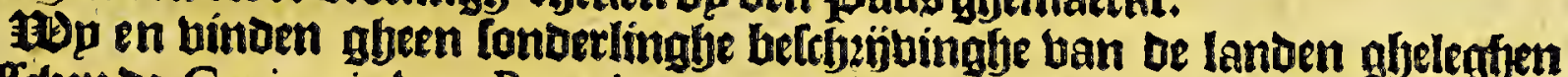
tuffrben be Capitania ban Parayba ente' $t$ UEplanat Maragnan, als allem van een deel ban be kufe / enoe eenighe twepnigfe plaeten binnen 's lanots bp de

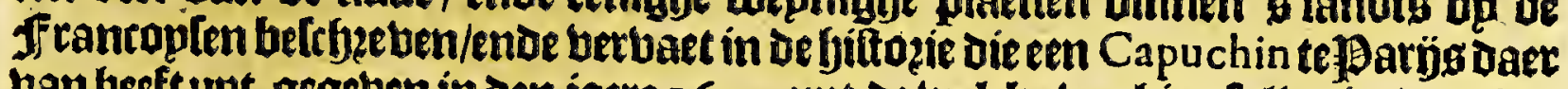
van beeft upt-gegeben in den jaere 1614 , upt be twelcke top bier fullen in-boegben

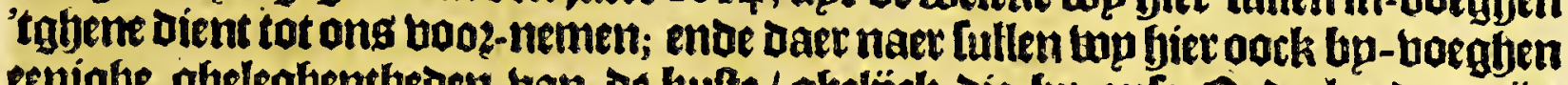

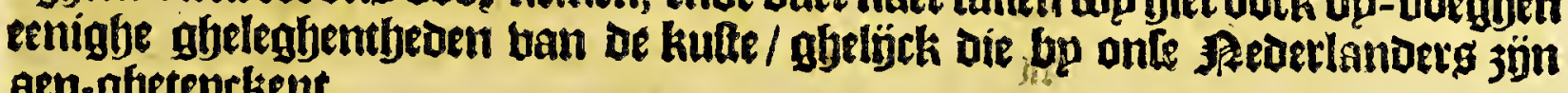
aen-gfetepctient.

\section{3et negbentbiende Capittel.} Befchrijvinghe van de Eylanden van FER NAND DE NOROHNA,
ghelijck die by de Françoyfen worden befchreven. .

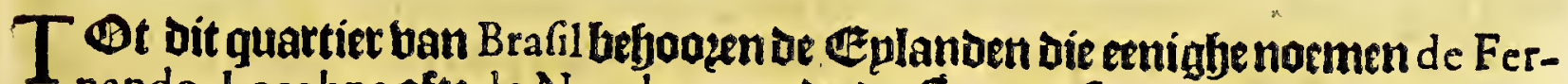
1 nando Lorohna ofte de Norohna, ende de framtoplen noemen oie Fernand

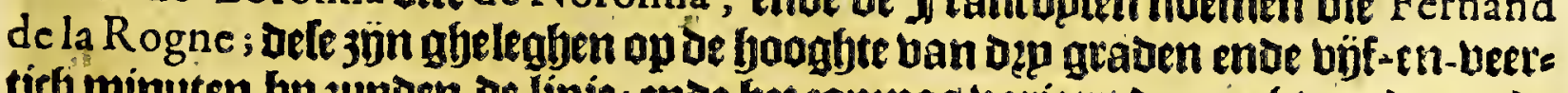
tirfy minuten be 3 upden de linie; ende bet compas barieert taer actht graden ende

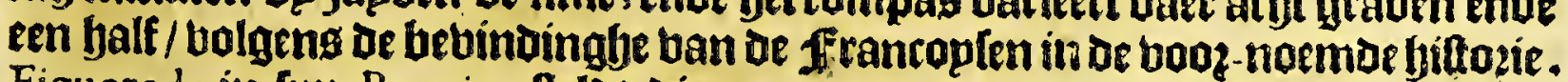
Figueredo in fpn Roteiro ffelot die op Dzp graden ende dertich minuten. Bit

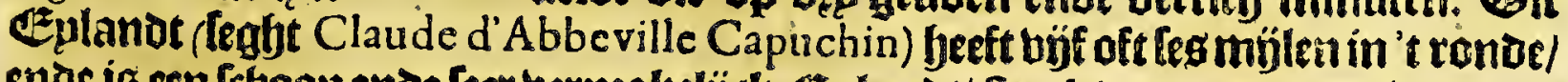

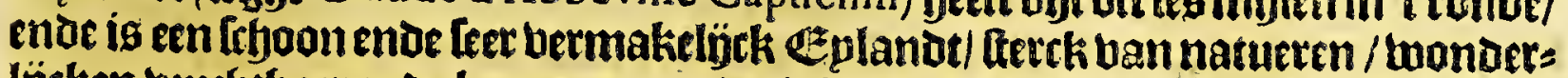

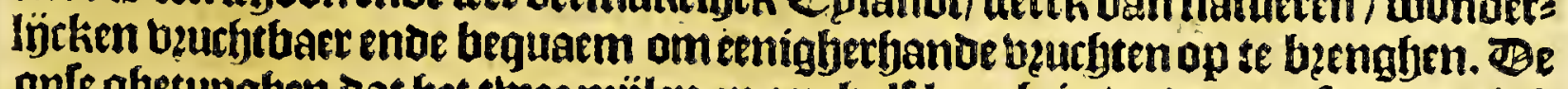
onfe ghetupghen dat bet twee mijlen en een balf langh is / ende een ofte torgning.

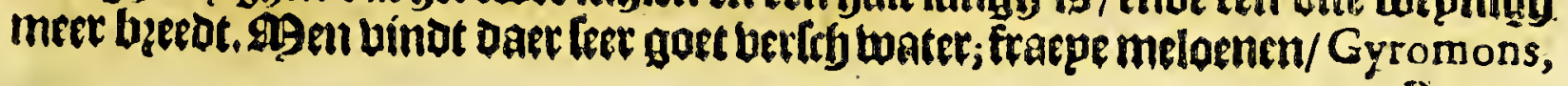




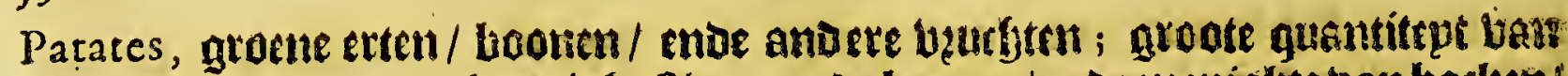
Mai z ende cottoen; oock eeniabe theren ende hoepen/ cnie meniglte ban bocken/ mis wiloen gepten/Doch fect quacat om krügben teegfen ljet krrupel-bofth ende

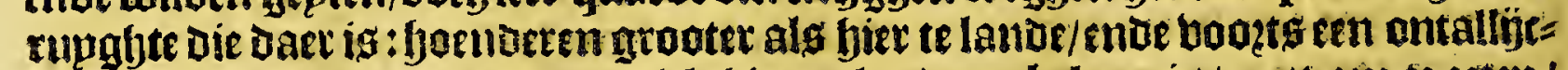
ke menighte ban gljebogelte / welch biet te lantue onbelitut is / gott om te teten/ ende leet litgt oin banglien / want laten baet in baer nefien met be banot grijpen.

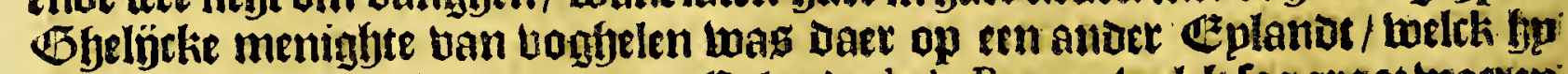
noemt Ine de Feu, niet berte han't Eplanot de la Rogne, welck log groot toatren

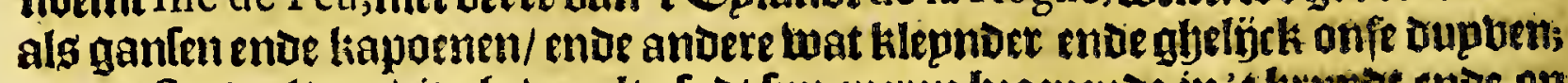

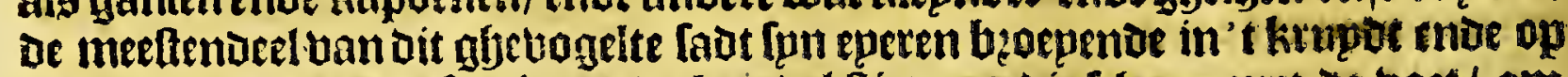

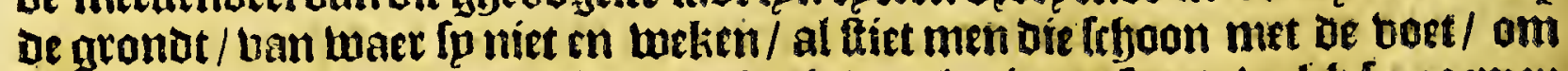

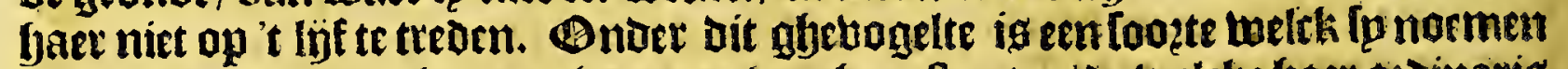
Fourcades, ban weglen ue glyedaente ban baer fterten/be welcke gaer bejoinaris

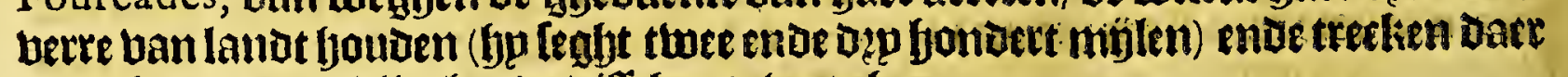
ap oe jacht om ae blieghende viften te banghen.

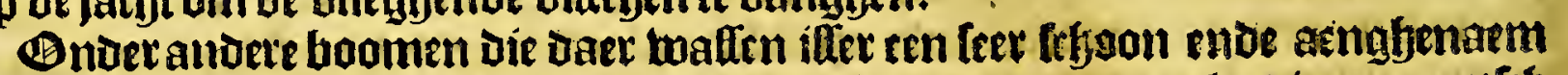

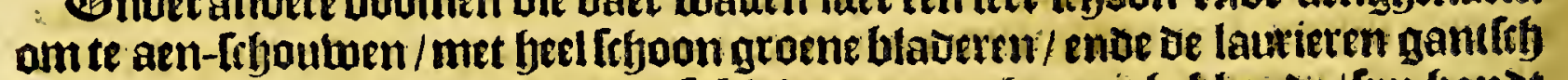
naer komende ; Dan in dien men dele bladerenaen-aberoet bebbende / fun banot

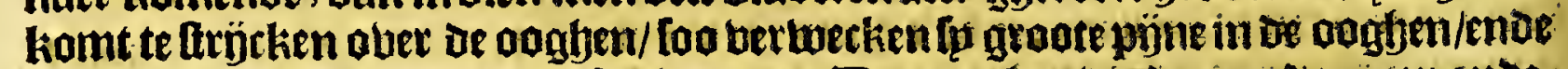

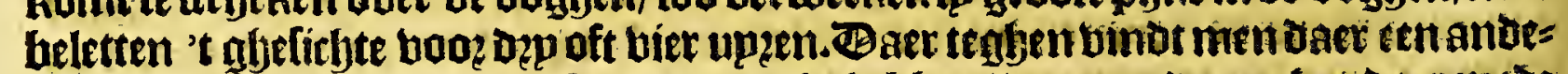
ren boom belckes bladeren fulcken krachthebben/ bat men de oegljem daer mede

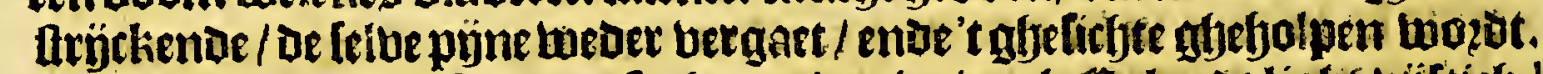

Figueredo in fpn Roteiro leght dat 't peintipael Esplanot light bijftity leguen ban bet balte landt van Brafil, ftreckenoenoozot ende juyot/eñis bep leguen langh

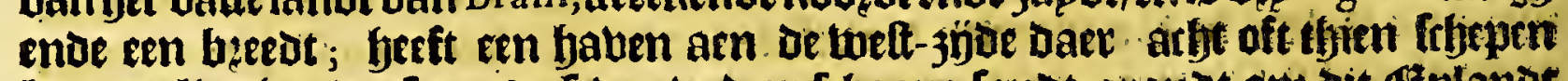

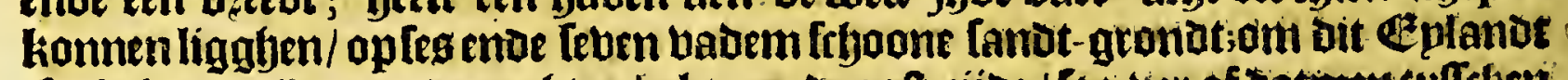

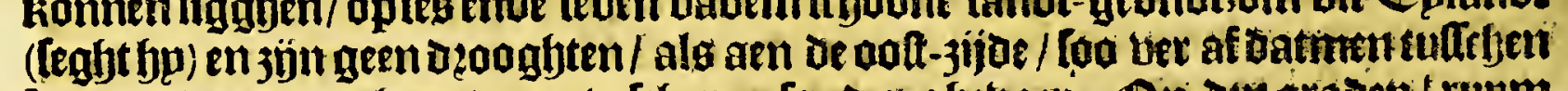
bepuen ieur magb met groote Irbepen Tonoer glyetraer. Bp Dep gradew/ rupm twaelf leguen ban Dit Eplanot naert noozot- welten leght efn begoghte banlanot

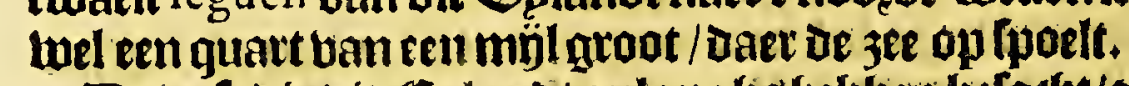

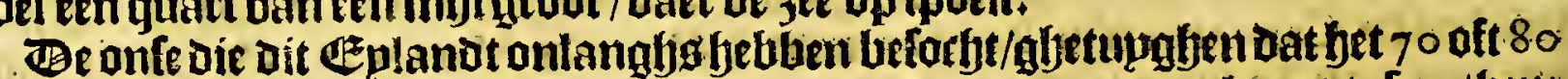
mijlen fouden legghen ban Brafil, ende alfmen bet eerît uptev 3ee homt te fien/hem

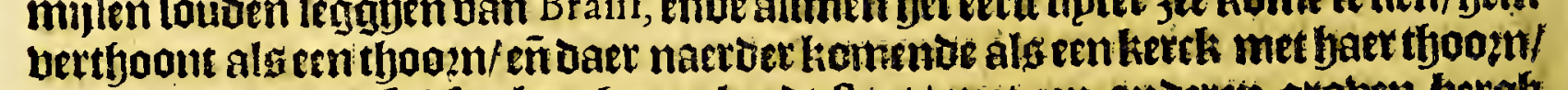

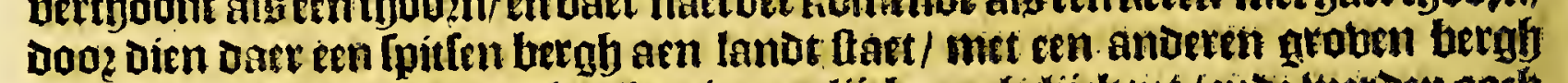

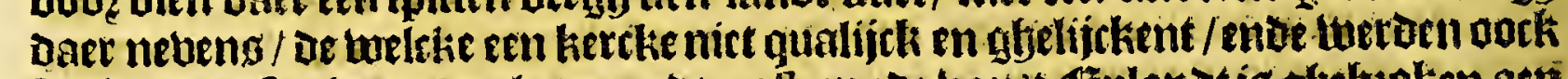

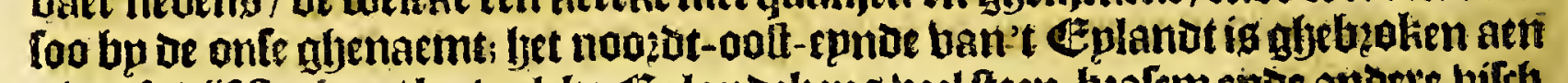

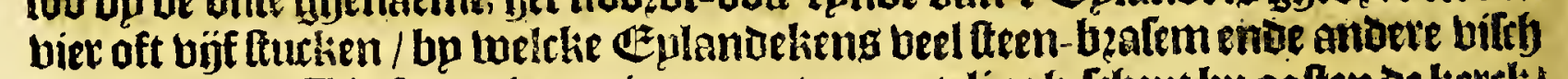
is te vangen.' (c) befte anckeren ig ontrent een gotelingh- frbeut bu ooften be ketrli/ enve oock foo betre ban is wal in i 6 tot 17 bavem luaters landr-ntont. 2ten lanot olwars ban oe reede is gort berfeb twater/loopenoe infonoechept in of re:

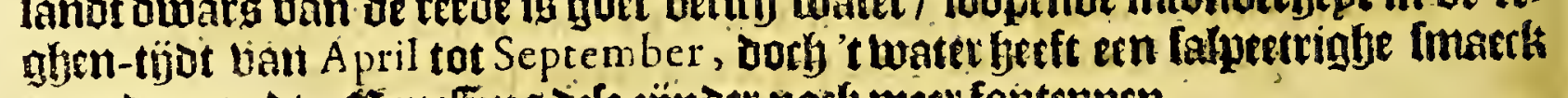
vaer or arondt. SBeneffeng vele zünorr norly meer fontepnen.

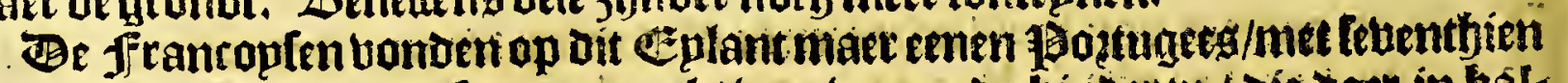
oft achthien Indianen / coo mang als bzouwen ende kinderen / vie daer in bals

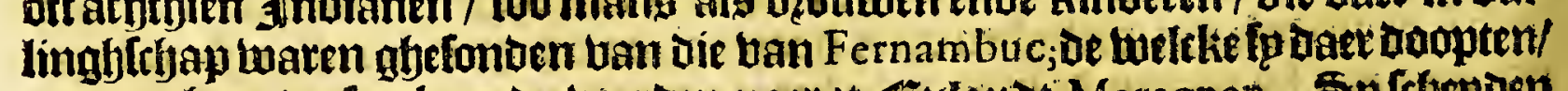

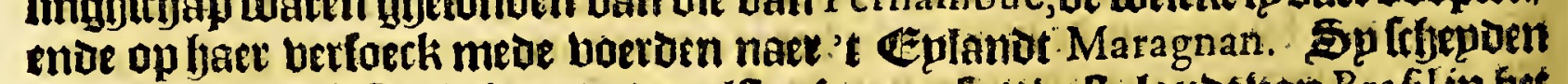

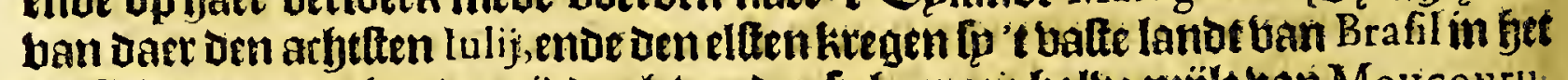

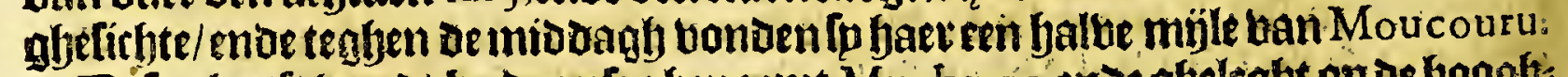

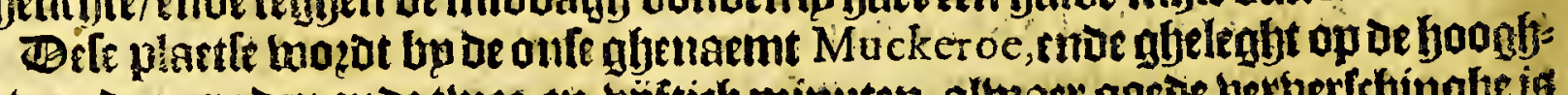

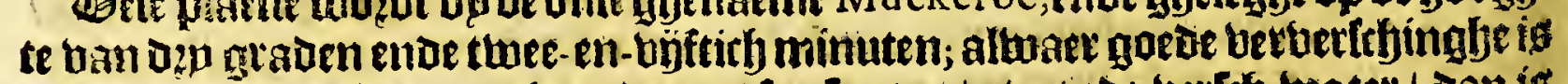
te bekomen toan. Patates, hoenderen / faplanten / etc. ende berldy bater / oan is

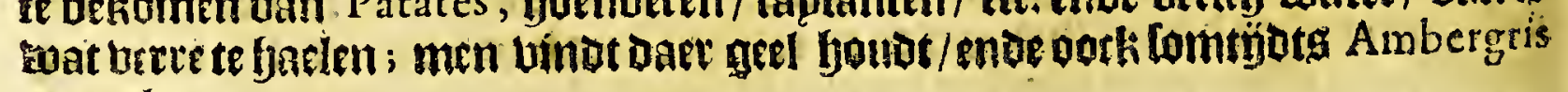
se ruplen. 
Het veerthienfte Boeck.

(-) thintichle Capittel.

Berchrijvinghe van 't Eylandt MAR A GNAN, ghelijck de felve by de Françoyfen is uyt-ghegheven.

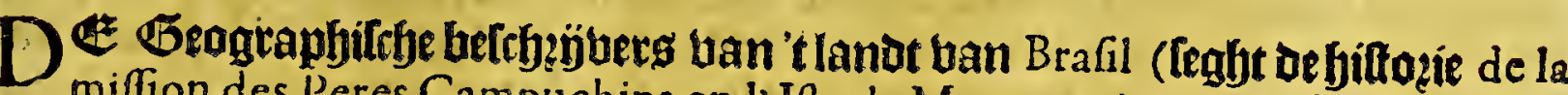
miffion des l'eres Campuchins en l'Ine de Maragnan) en maecken geen bers maen ban dit Eplandt Maragnan; Dan lpecken alleen baneen riebiere dielp noes men Maragnon, be welche in Dat gantche quartier niet en wozot ghebonden / ten

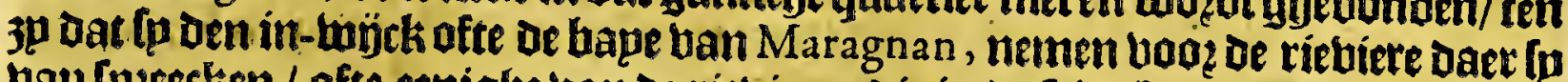
ban fpecectien / ofte eenighe van De riebieren die in de felve bape upt- wateren; bet welck nothtang wepnigh belcheet g beeft/ oooz dien elcke riebiere haer epgen naem

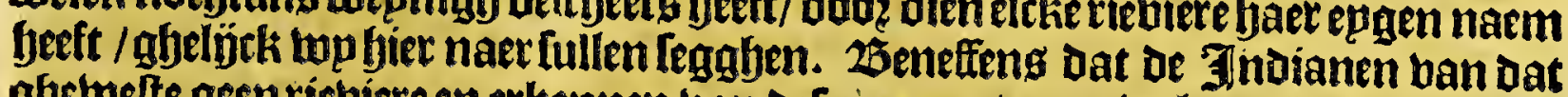
ghetwelte geen riebiere en erkenmen ban defen name/ maer wel bet Eplandt tolck fp noemen't groote (E)planot ban Maragnan tot een onoerlchept ban andere klep: ne Uzplanden die daer ontrent wozoen ghetuonden. Bele in-wivk fjeft meer dan

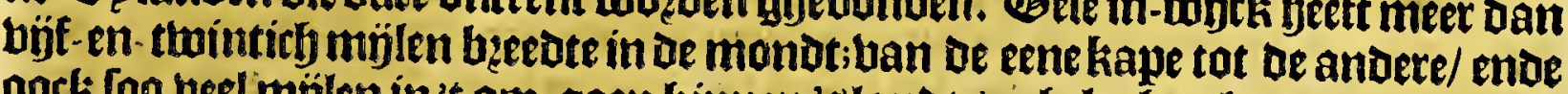
oock foo beel mjjlen in't om-gaen binnen'slanots; gheleghen bp-naer in't mito.

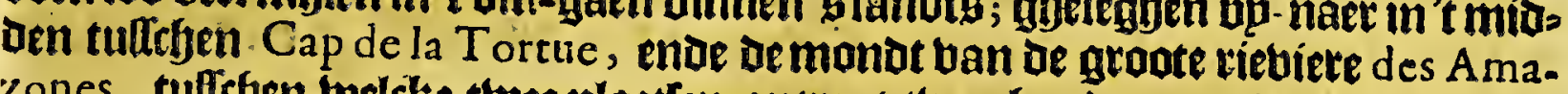
zones, tultefen welcke thee plaetten ontrent twee bondert en twintich leguen

Alen 't in-komen ban dele groote bapenaer 't ooftentoe/ende bueen trape die fu noemen Cap des Arbres Secs leght een kilepn Eplanot / welck de ffrantoplen

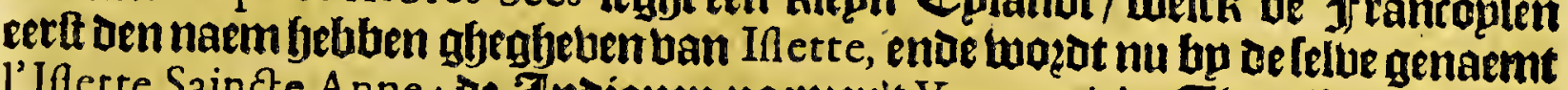
1'Iflette Saincte Anne : De Indianen noemen't Vpaonmiri. Cetuaelf mülen van dit Eplanoelien binmen de bape / leght een groot Eplanot belck men noemt Maragnan, welck wel byj-en-beerticf mijlen is in't om-gaen: op de booghte ban thee graden ende dertich minuten bp zupoen de linie equinortiael.

In 't binmenlte ban de bape sijn dep Ichoone riebieken /, oe tuelcke in Dete bape

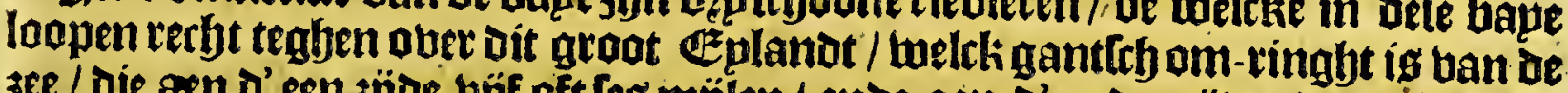

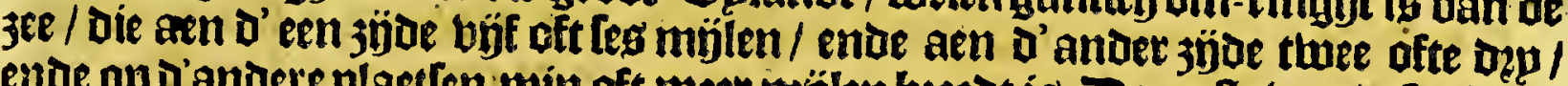
ende op d andere plaetlen min of meet nijlen breedt is. Be eerte ban dele riebie rennaer 't ooften toe wozot ghenaemt Mounin, welck ontrent een half quart ban

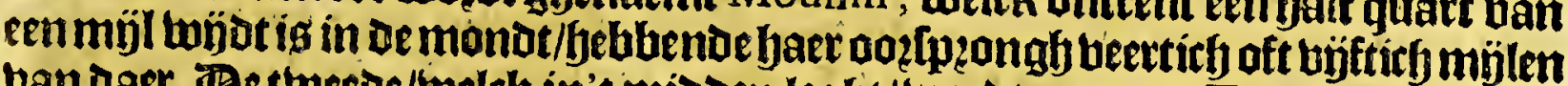

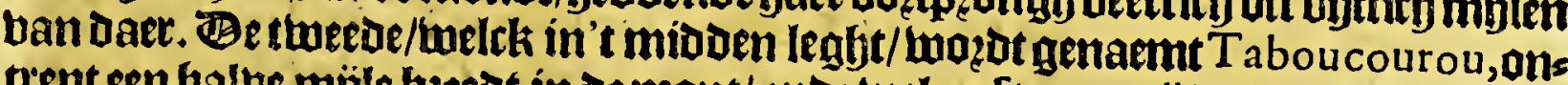
trent een yalue mijle breed in de mont/ enoe wel 4 oft 500 mïlen betre af-komen= de. Be derde die naer't tweltenlegft / wazot gyenaemt Miary, ende is buel biff oft les mülen beerat in de mondt/ende feeft baet beginlel onder den Tropicus $\mathrm{Ca}$ pricorni, ban waer weleenighe dele rieviere zjon af-gjelioment thier toe.

Baer is noth een ander riebiere gbenaemt Mara cou, die baer berlief in die ban Pinaré; ende die ban Pinaré balt in die ban Miary eenighe lebentirly oft tarbtene

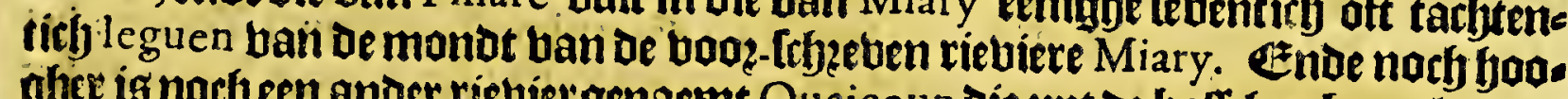

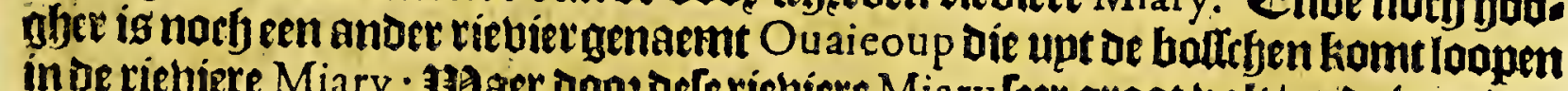
in be riebiere Miary : Haer doo dele riebiere Miary leer groot balt/ende tuonder= lijck fnel loopt in de mont; geljigk oock die ban Tabou courou, de tuelcke engh is in be inont/wegen twee rotlen die daer leggen/ende faer beelenger maken alg fu twel binine-waerts is/ [oo oat de bloest op enoe af lomt met groot getwelot/ welck dit

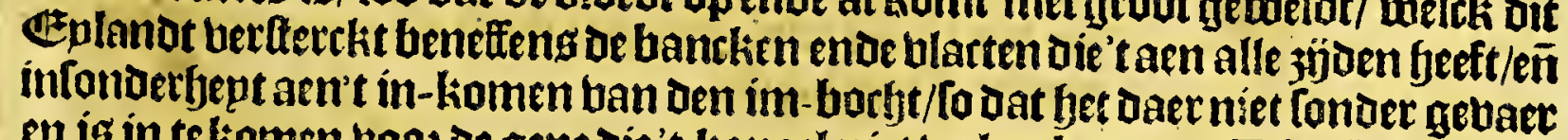
en is in teliomen booz de gene die't hamael niet tuel en kemmen. Bit Eplanot is

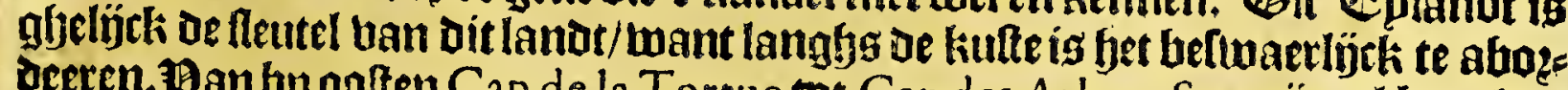
aceren. Ban bp oolten Cap de la Tortue tot Cap des Arbres Secs jün al bancken

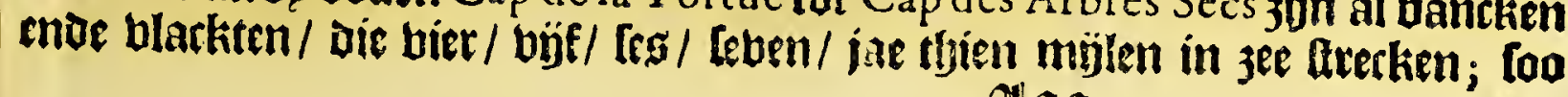

2ป aล




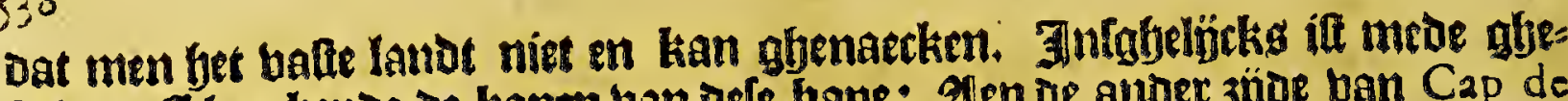
frelot tufthen bepoe oe kapen ban dele bape: Alen oe alloer 3 joe ban Cap de Tapouytapere af birbt bp Maragnan tot Rio des Amazones, legghen loo bed Eplanden langhg de kutte/ oat het onmogbelphch ig Daer aen te kamen aen bet

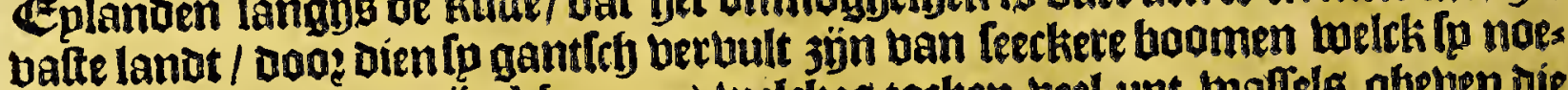
men Apparituriers, (jijn Mangues) weickes tacken beel upt-baflels ghehen vie weder ter aeroe komende / woetelen/ ende fon boots-[etten; waer doos [p loo dicht in een gheblectjt ende ghelwalten zön/ bat men foude legefen Dat bet maet een boom en ware/ enoe maerken dat bet bu na onmoghelíck is Daer oooz te komen;

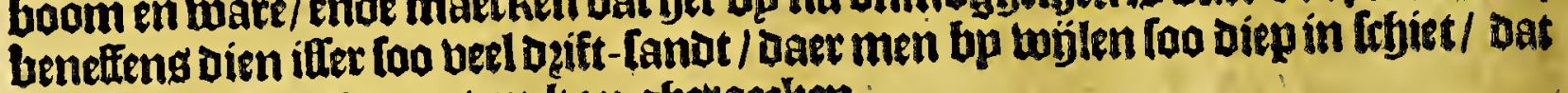
men daet niet weder upt en kan gbetaecken.

Baet en jün maer twee aen-kameten am aen dit aroot Eulanot te hamen:

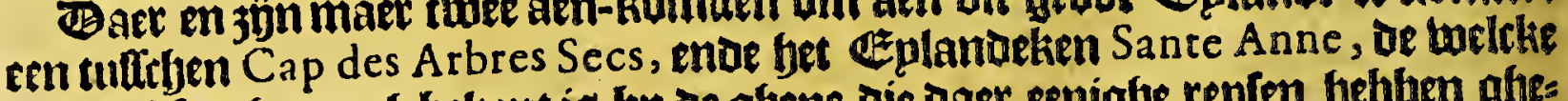
bor-wel la ghenoegb bekent is bp of ghene die daec eenighe replen bebben ghes weett/ [oo jün eben-wel eenighe berfyecumt een lchip Daer in te bzengen; oorls too en fanmen niet veroer met de [chepen komen dan aen't booz-[thetuen Geplambes ken /enoe om aen't groot te varen moet men klepne barcken gbebupeken. De

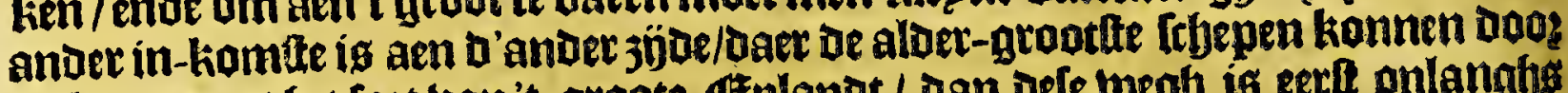
in-komen tot bet fout van't groote Eplanot / Dan dele wegh is eerle onlangho ghebanden / ende is wat lmaer te binden.

De in-moonders ban dit efplande noemen baer dozpen Oc afte. Tave, welct 3ín maer vier logien/ gfuemaeckt ban groote boomen ofte tacken han boomen/ die uan bouen tot beneden ghedeckt zön met blaederen ban palm hoomen/ melck fo noemen Pindo, ban welcke boomen naer beel wallen op het efplanot/ coa dat de bollefjen daec gantcef bol ban jün; Defe bladeren gbeben een goet bes

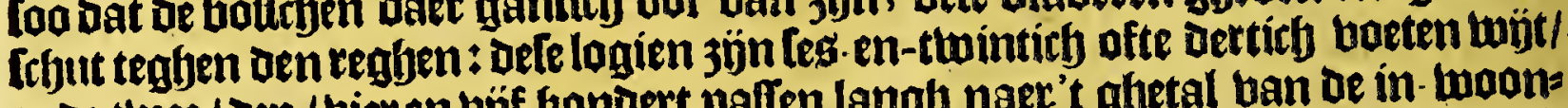
enoe twee / opp / bieren unf gondett palten langh naer't ghetal ban oe in - woons iets / enoe in 't viet-kant gheleght als een klooftec / foo oatter een fraepe plaetfe

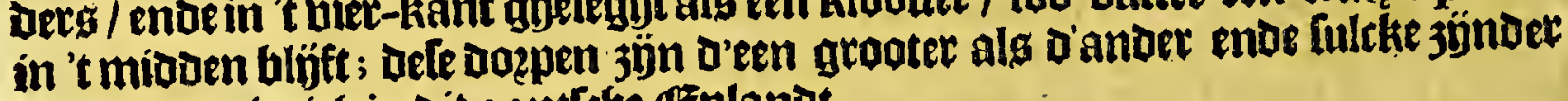

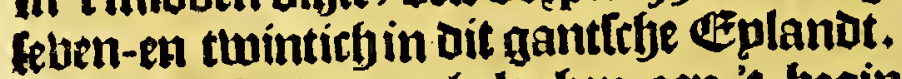

Yet cerfte Doup gheleghen aen 't begin van bet explantot / foo men Daex aen-komt ban het Ceplanokken Sante Anne, wozot gljenaemt Timbohu : bet tweede moeot ghenaemt Itapary, welck is te leggben bet parck ofte villibec

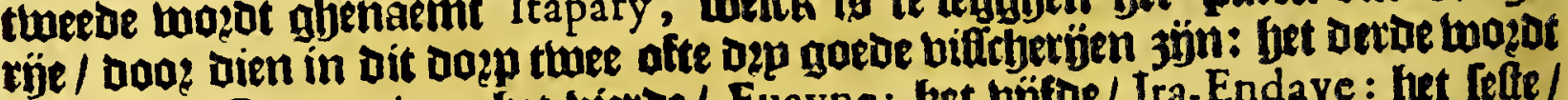
ghenaemt Carnaupiop: bet bierde / Euayne: bet bjotoe / Ira-Endave : bet lefte / Arofouy-leuve: bet [ebende/ Pindotune: bet acbette/ Oua-timbooup: bet nes gbende ende fret grootte ban allen Iuniparan: het tbiende/ Toroiepeep : bet ellue/ Ianöuărem : Get tmaelftte / Ouarapiran : bet Derthiente / Coyeup : Get beetthient

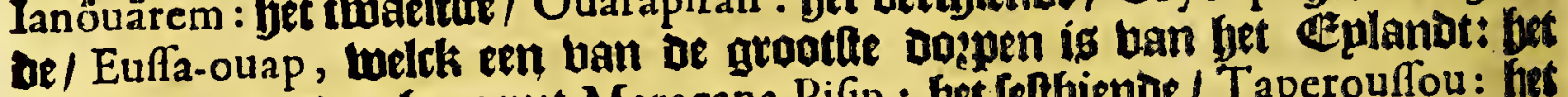
byjfthiende wozot ghenaemt Maracana Pifip : Get Lelfyiende / Taperouffou: het Lebenthiende / Torooupe : bet atjthiende / A keteuve: bet neghentfiende / $\mathrm{Ca}_{2}$. rana-uve: het twintichlte / Ieviree, welck of framthoplen noemen Yueret: bet een-en-twintichfte/ Eucaton: Get twee-en-thintichlte / bet klepne Ieviree: bet bep-en-twintichlte / Oury-Ouaffueupé: Get biex-en-thintichlte/ Mayone: bet büf-en-thintichfte / Pacoury-Euve : bet fes-en-twintichlte / Euapar: bet feven-

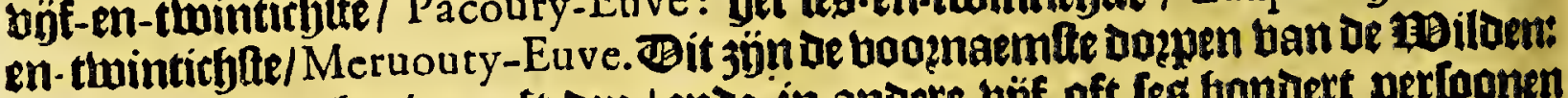

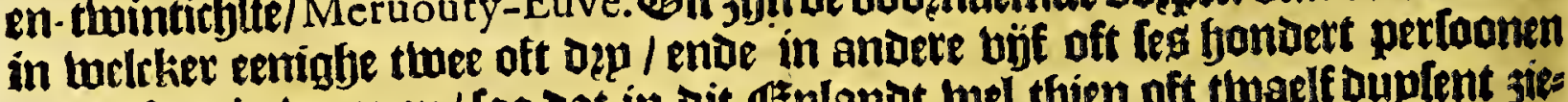

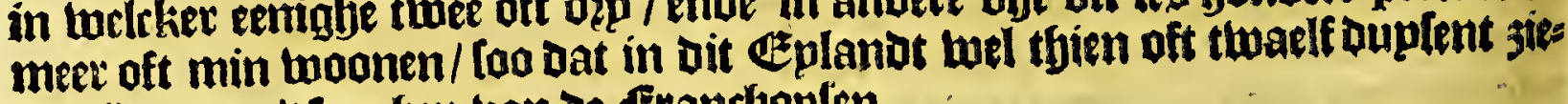
Ien ż̉n/ naer't legghen ban de franclyaplen. 
Het veerthienfte Boeck.

Set een-en-twint infofte Capittel.

Gheftalte van de lucht in ' $t$ Eylandt MARAGN'AN : ende vruchtbaerheyt van den bodem.

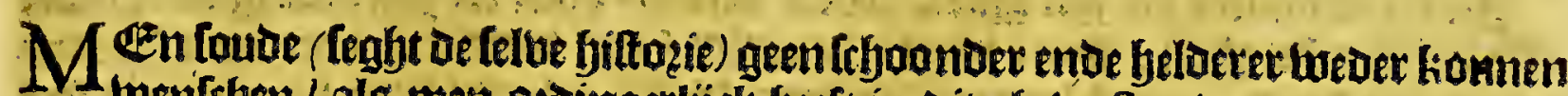
werifrben/als men vezoinaetlibek beeft in dit ghetwelte; want men en beft nimmermeet eenighe groote koube ofte dzooghte; geene miften ofte Ctyadeligethe bampen; geen tempeeften ofte exceflibe winden; abeen [neeulw ofte baglisl; ende

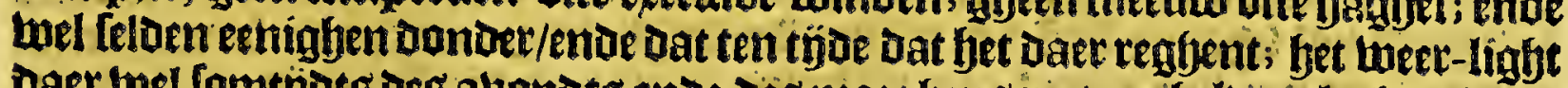
baer wel fomtjots des auonots enoe des moeghens met eeribeliere lucht.

De conne keerende uan den Tropicus Capricorni naer Den Tropicus Cancri toe/teiert ghemepnlísk in alle defe ghewelten Den reghen bog? Gaer upt/ongebaet:

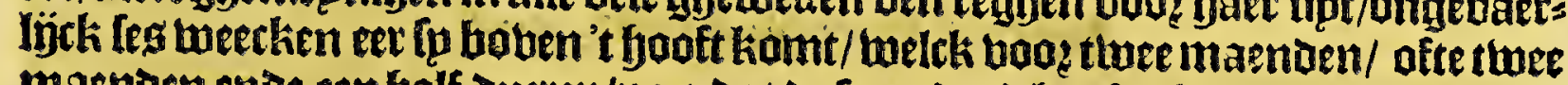

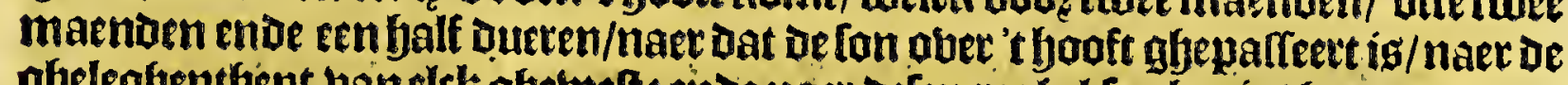

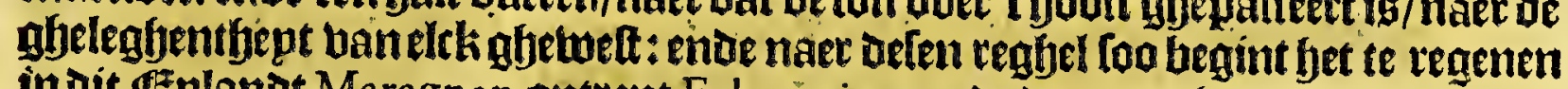
in Dit Eplandt Maragnan onttent Februarius, ende buet tot bet epnoe ban May ofte balf lun : enbe ter contrarie / als de fonne weaer bertreckt naet oen Tropicus Capricorni, foo berbeckt to de windert die fp noemen Brifes, de twelcke röfen met oe conne ofte met de hitte ontrent ten feven oft arft upeen des moegens; ende foe de

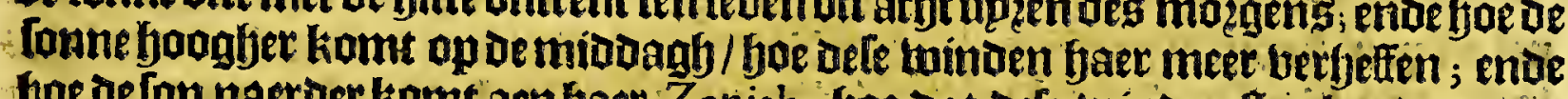
joe defon naeroer komt aen baer Zenith, joe tat Defe winten fercker waepen! ende foe dat de fonne herder betteckt ban baet Zenith foe fy flaeituer wozoen;

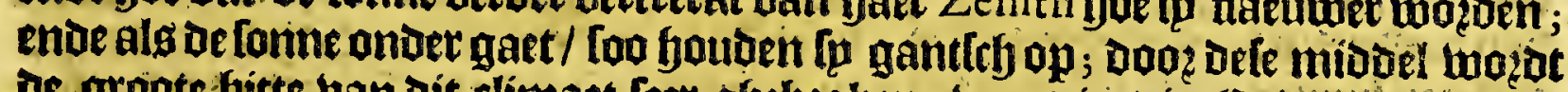
De groote bitte ban dit climate feet ghebeaken: toant in dit Eplantot ende be aen-afteleghen landen entwaept gheen anderen twindt als Den oolten-windt/

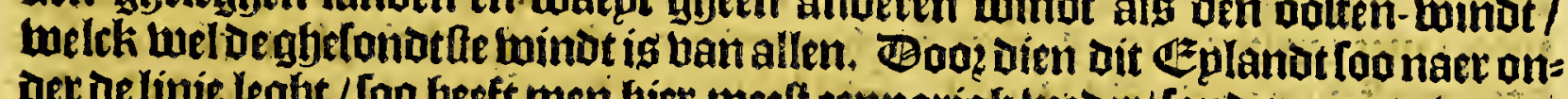
ber de linie leght / foo beeft mer fjer meeft enparigh theder/ conoer groote berans

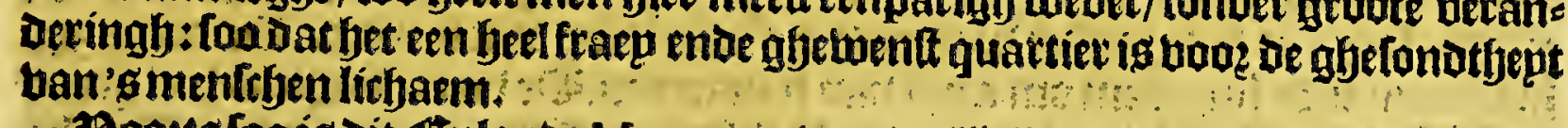

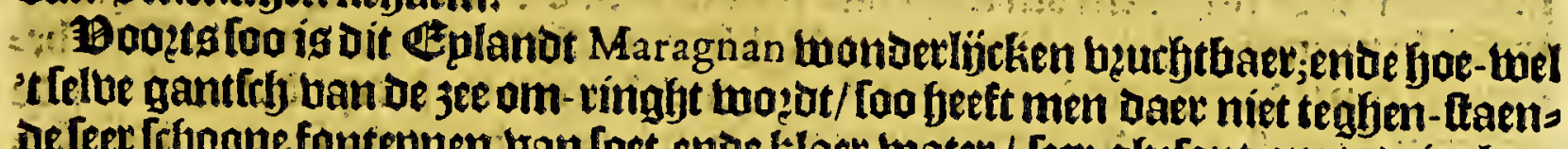

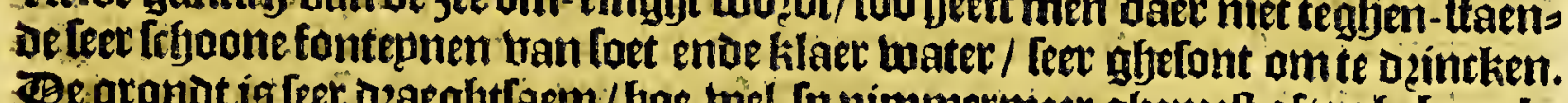
Degrondt is feet Deaeghtfaem/ boe- bel lp nimmermeer ghemelt ofte gbebzaeckt wożt:naer dat men bet Maiz jeeft objesaept ( welck fp Daer noemen A vattyy) foo bergadert men het weder ten langhften in dep maenden met een wonderfijtken

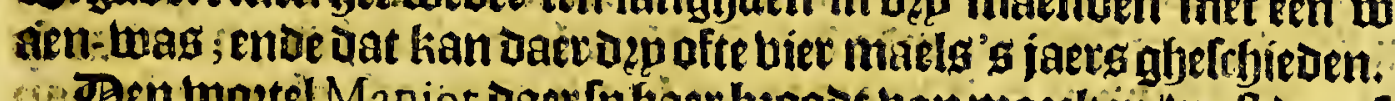

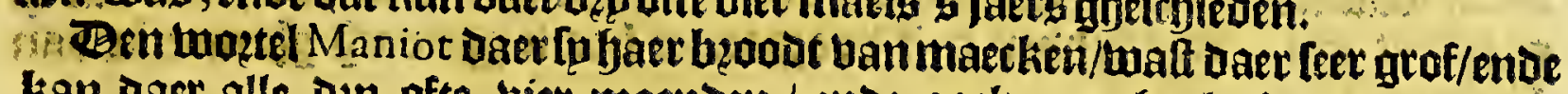
kan daet alle Dap ofte bier maenden / ende oock eet gljenlurkt woedon : be

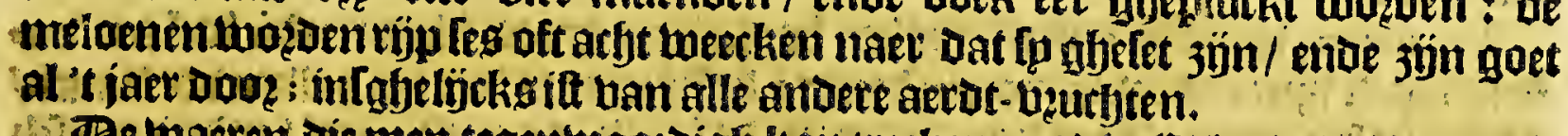

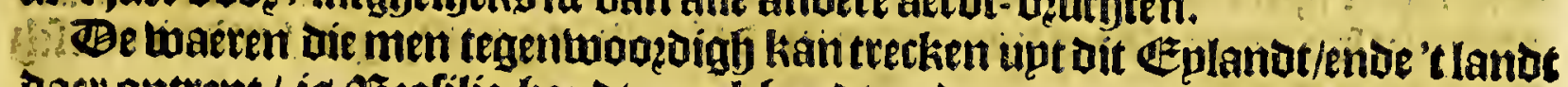

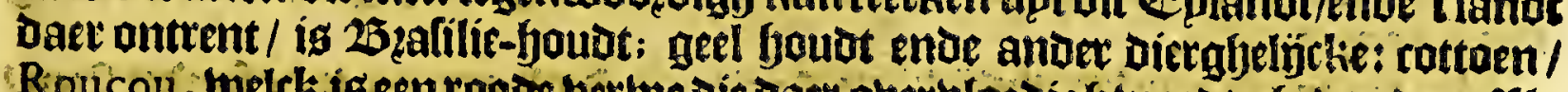

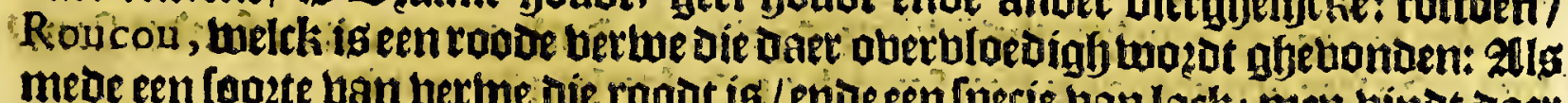
mebe cen foote bain bertue die roodt ig/ende een fpecie ban lact ; men bind daet oork foa goeden Balfem als die van Arabièn : daer walf pock feer goeden Tobac, ende peper/ende diergfjelícke.

Jie aen bodem ban't lanot ban Maragnan bebben onder-[oefht / verklaren be

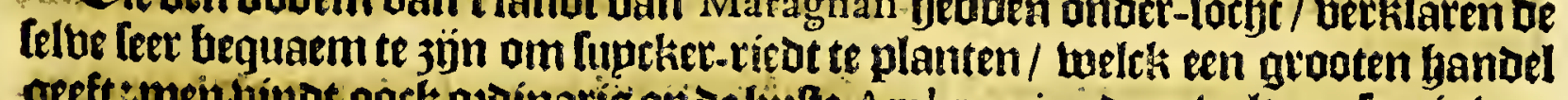
geft:men limot oock ozoinaris op oe hulte A mbregris; oaer balt een lpetie ban Iafpis; daet fo de gevene deentjeng uan maecken diefp in baer lipjpen Dzagen; onck

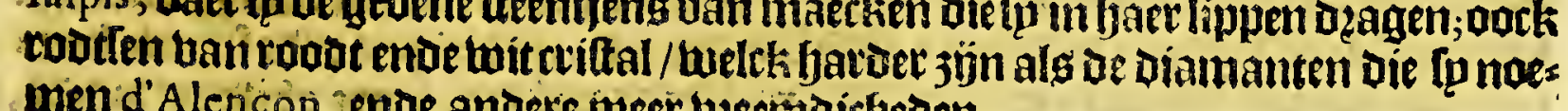
men'd'Aletiçon; ende andere meer veetmoitbeden.

Atas 2 Dacr 
540

Brafil.

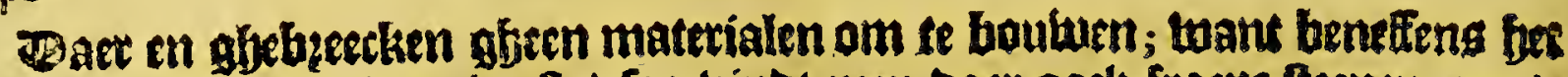

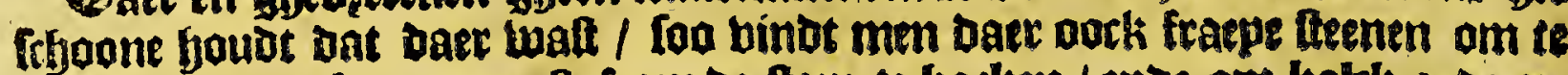
betigfien; ende bequaeme frof om de fteen te backen/ snoe om kalck enoe ces ment te martken.

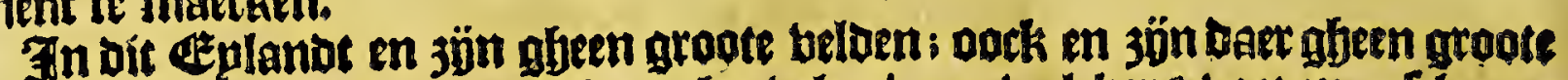
ofte hoogle betohen / maer klepne beubelen/ aen twelckers boet men frboone

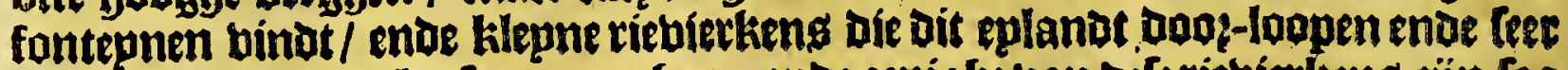
aenghenaem enbe plaplant maecken; ende eenighe ban dele riebietkeng jün fon

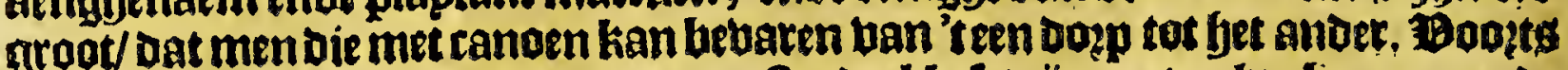

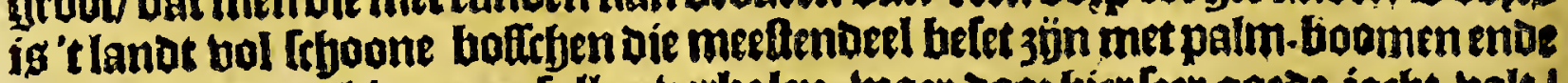

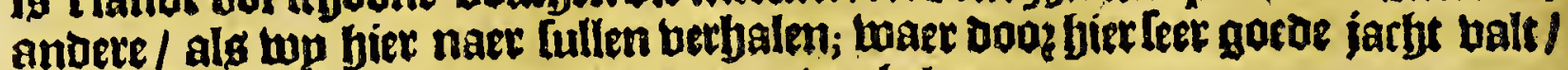
bepdeban biec-boetigbe dieren ende van bogbelen.

\section{2et twee-en-thintichle Capittel.}

\section{Befchrijvinghe wan diverfche Fruyt-boomen die in dit Fylande} MARAGNA N Fafien.

In $D$ oft. Is dies pel oft peet-heomen van Europa ; fpn bladeren jun bie tan be note-boomen ghes

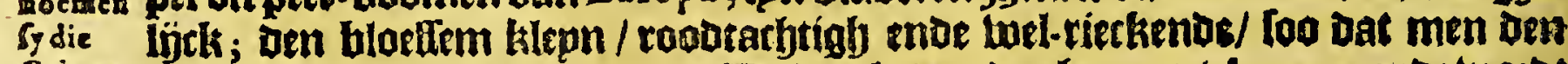

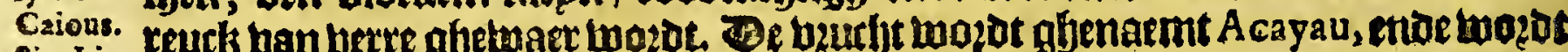

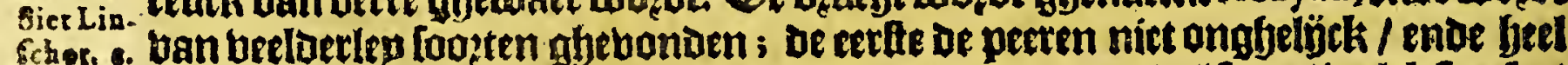

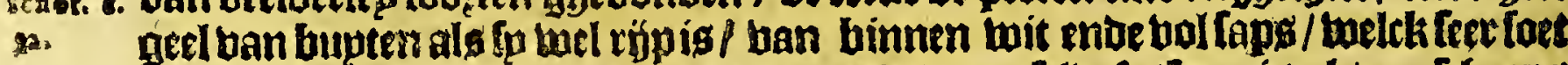

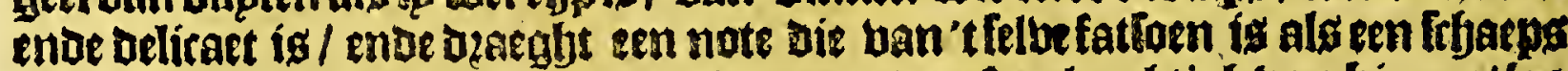

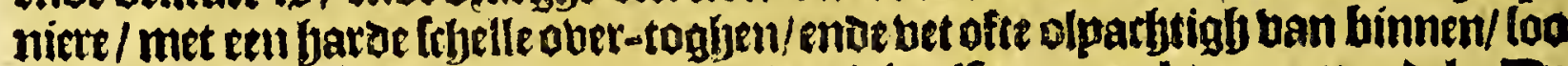
batte ontlteken zjinde lícht beant; ende de pit if alloo goet als een amanoel. Pe

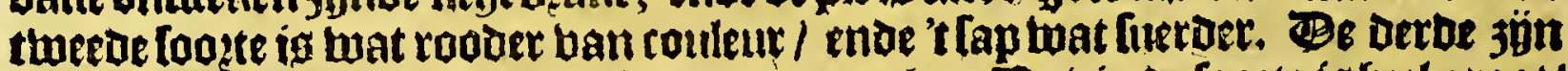
Jeel klepn ento bequaem om ajün ban te maecken. Ge bietbe laozte is foel groot/ welck in noemen Acaiou Ouafion, ente ig feet aenghenaem om teeten: Dele bes ginnen rijp te twozbenin Mart ende A pril, enoe bueren tot get epnoe ban Iun; te ender in Auguft, ende dueten tot jet ennde ban December ende Ianuar. Be 3 ins dianen perfien daet een deandk upt/ welek [p noemen Accaion Caoum, is thit ene oe Teer lecket om deintket; men peete upt een butht wel foo beel nats als upt eft

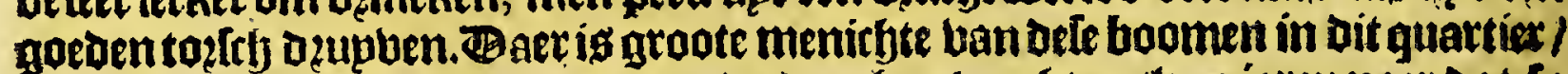

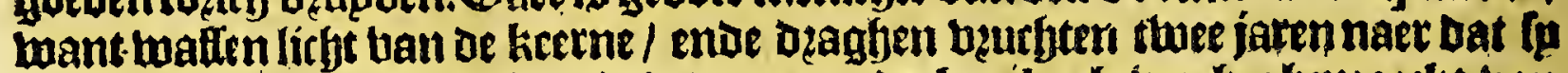

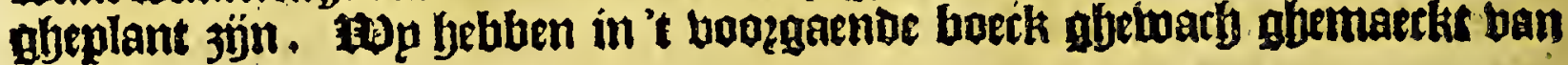
Cayoux.

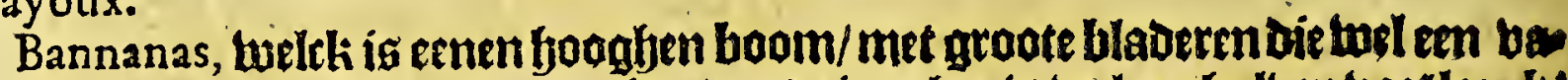

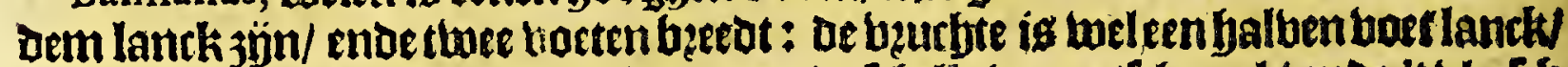

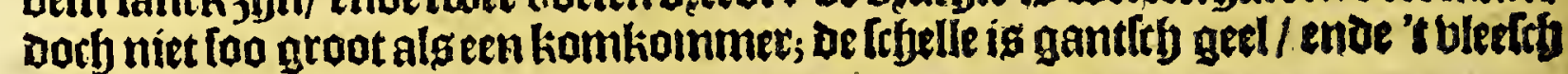
wit alseen appel.

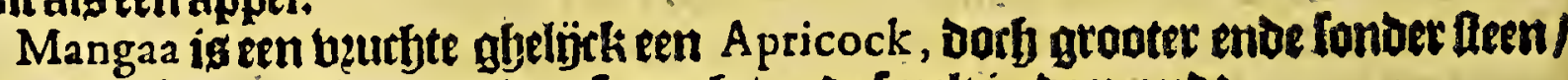
coet ente feet aenghenaem ban fmaet / ende fmelt in oe monot.

Iaracaha is en boom die leer beerot van liroone is / bebbenoe bp nage blabes

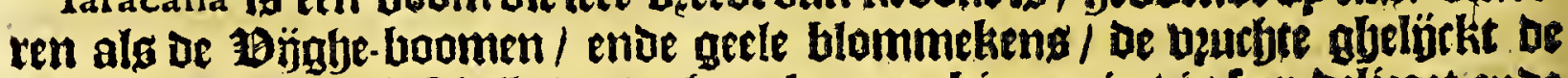
pecten met een geele frbelle / ende baet ketrnen binnen in/ is leer belicaet ende bottaem.

Ouäier ruä is een groaten eñ hooghen boom/bebben de bladeten als be eptkenbomen/Doty groater; ien bloeflem bletek-geel; De beutjteen boet langh/ende alg oe grootte meloenen: van binnen ende bupten geel; met klepne ende thatte keers.

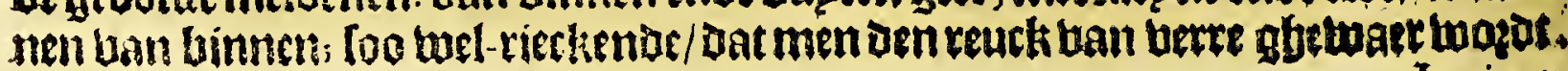


Het veerchienfte Bòck.

Tunipap is tmede sen arooten eñ joos ghen boom/:uan fattoen als oe $\mathbb{C}^{2}$ prkenbladeren / Dorb twee-mael grooter/ wit= ten bloeflem / ronae butfe gfelïrl de groattte appelen; loldker beclot top gort getuonden beblon biex in te voegbrenupt den bermaerden Car. Clufius. Groroen

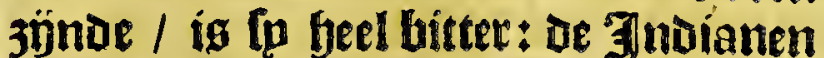
harutwen die om't lap vaer upt te treck melck feboon ende klaer is/eñnorhtang too ment lpn aenfirft ofte banden daes mede beftrït / [o cullen die in minder als bier upen alfo liwart woęen/geligck alg oft gljp diemet inckt beftrekenyadt ; $\mathbf{n}$ gaet oock niet af met wafleryen/Dan naet acht oft thien Dagben. De zailoen afre= beupckent om baer lichamen meoe te Ichilioeren: als oe beurbt rijp is/Loo tooet Iq ban binmen ente ban bupten geel/ $\mathrm{en}=$ te is teer aenghenaem om'teeten / ende Imelt in de mondt.

Agoutitréva iseen grooten boom/feeft bladeren alg den oqaegnie-boom/eñ [eet bered/rootachtigen bloeflem/oe bęuchte twoe buptten dick/met een groenatbtige febelle/ende ban binnen bol grainen als eengranaet-appel/oet enoe aengenaen ban Imaeck.

A raticou ig banbladeren ende blote fem De boot-gaende feet gljelījek / Dan

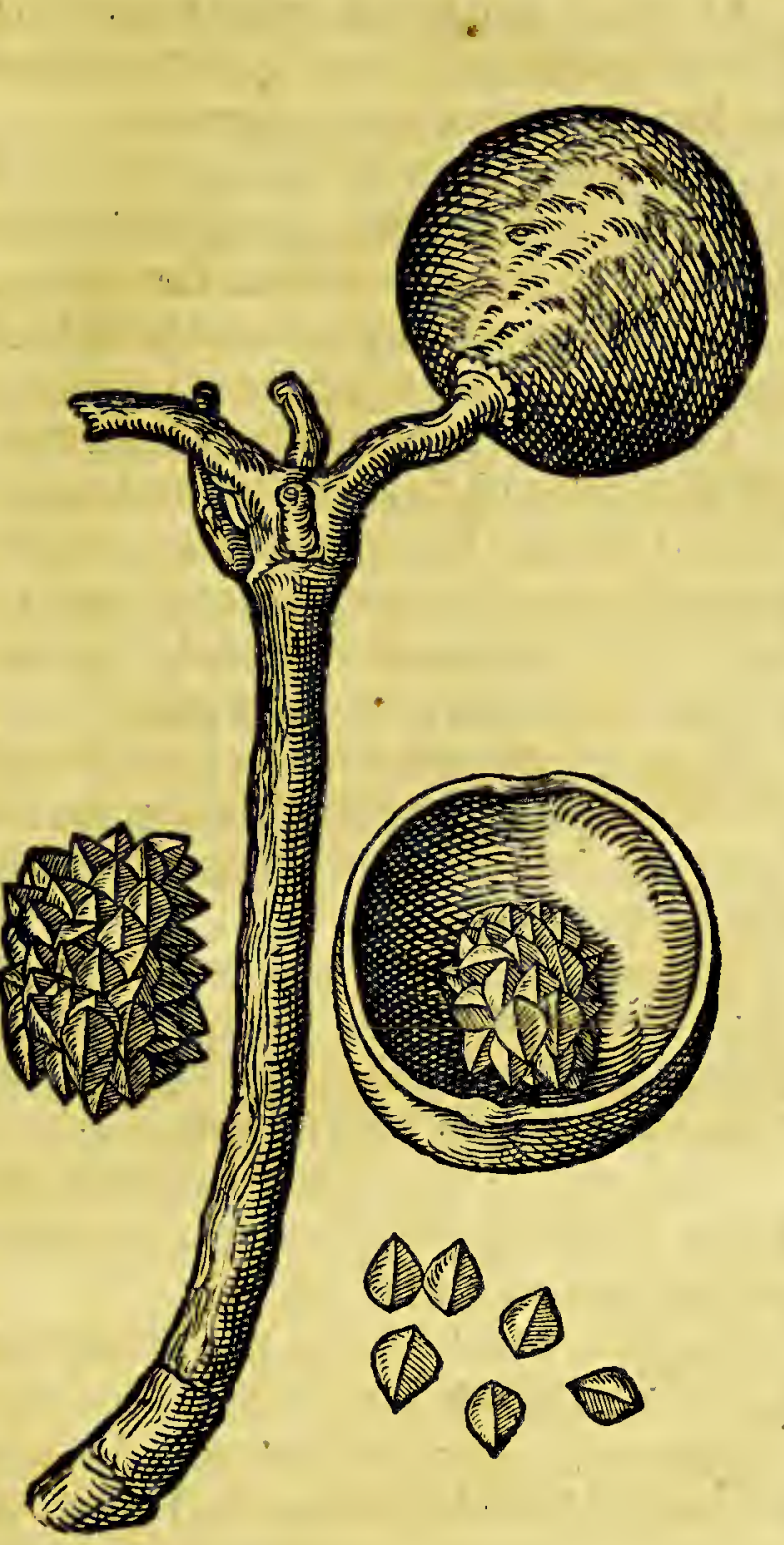
be becuchte balt twel wat grooter / enoe ig leet goedt ban [maeck / ende bel-rices kende.

Caoup iseenappel-boom leer ghelīch ban blaberen/Dan dat [une wat bzeder

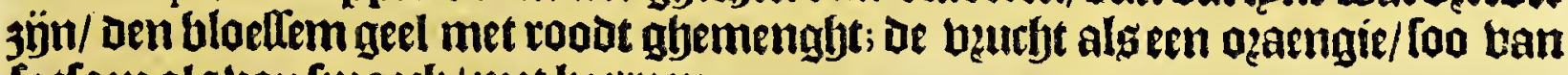
fat foen alg ban (maeck/ met keenen.

Euuauirap en grootenende foogen boom / bebtende klepne bladerkengende roodtarbtige bloemkens/ande een klepne bzuchte wat grooter alg ftekel-befpen/ ende uan 't Telue maecthel.

A ma-uve ig den bỉghe-hoomin betriten ende bladeren leet gheljek.

Goyaue ofte Morgoya is een loogte ban beelter / welck bem om be boomen winot/hebbendo bladeren ban ghedaente alg de thlocxiteng/een leboone bloeme/ fo groot als depaim vaneen yanot/ bebbende veel fpitte bladerkeng alseenlecte/

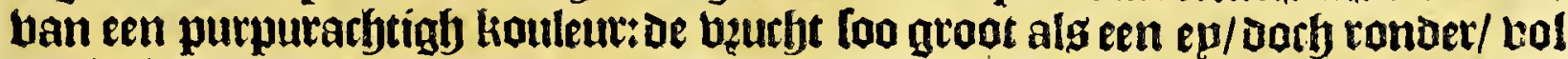
graintieng/ende bupten geel metgroenghemenght; is goet om te eten alg fu gles koockt is/ende Ieer bequaem om te confyten.

Bampalm-boomen binot men in dit quattier bÿf tooten; de cette gljenaemt Ouacoury, welck is den rechten palm-boom daet de Pindo ban kamt/ baer be

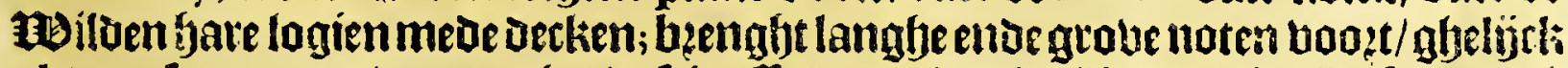

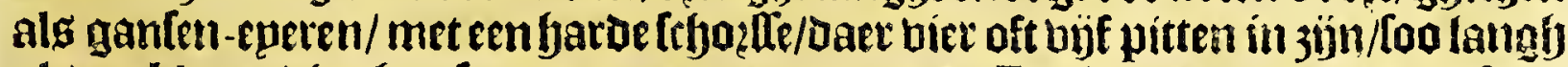
alseen kैlepne bingher/leer goet om teeten/ende ar 3 Indianen maecken daer forte ende goede olpe ban. Winnen de tham ban den boom binot men cen twit merab/

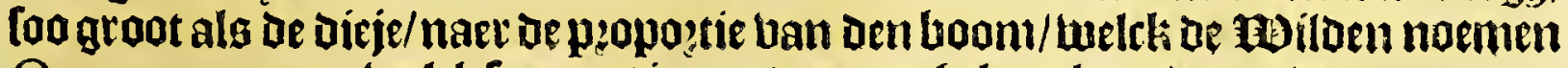
Ouacoury-rovan; butck [eer goet ig om te eden gbetiootht ende raulw.

$$
\text { ม a } 3 \text { Meu. }
$$




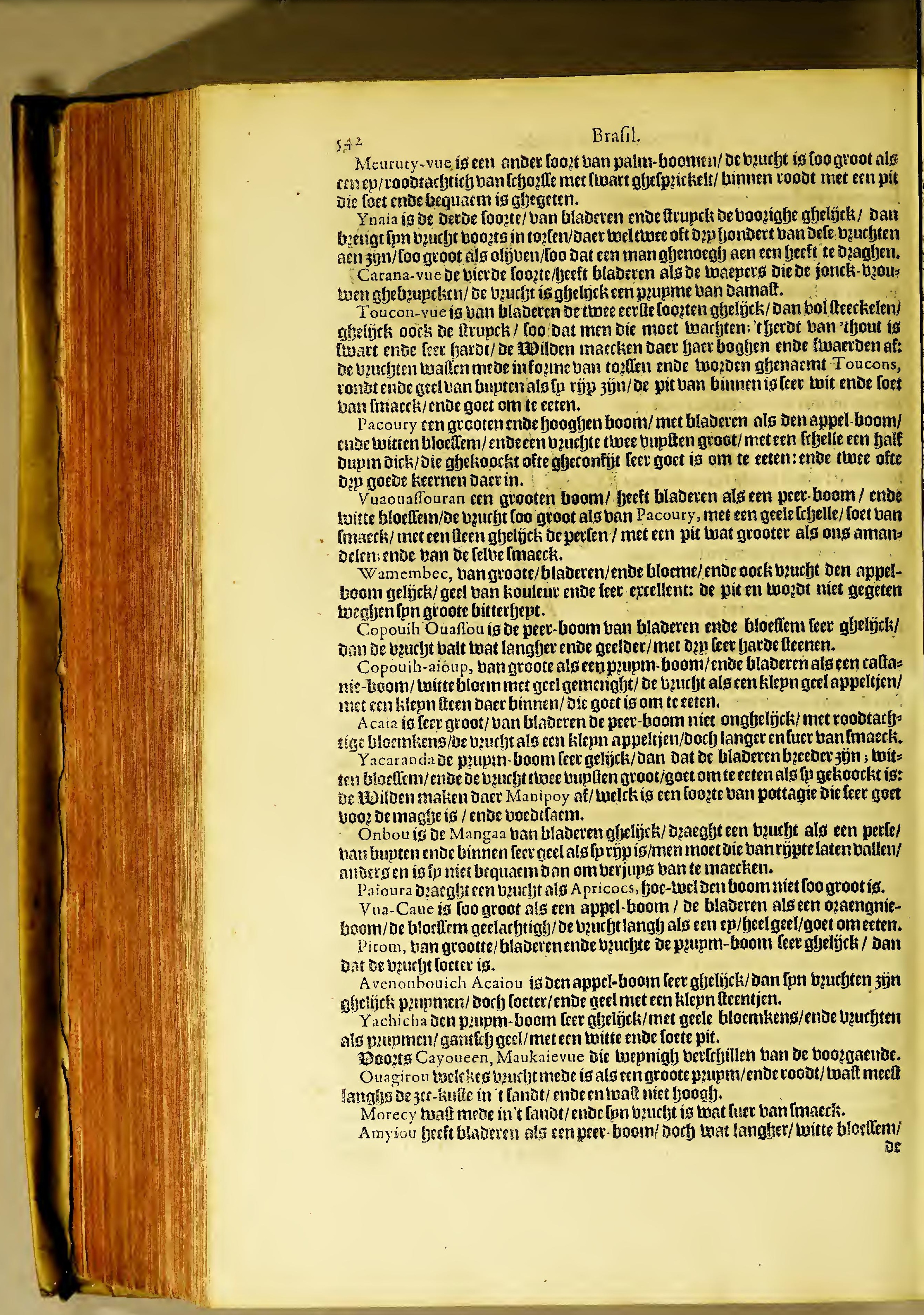


oe butuft als groote appel\$ / ghelïck komkommers gfebult / is ban Imaeck a!g Deperten.

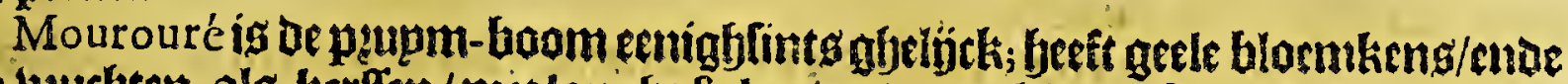

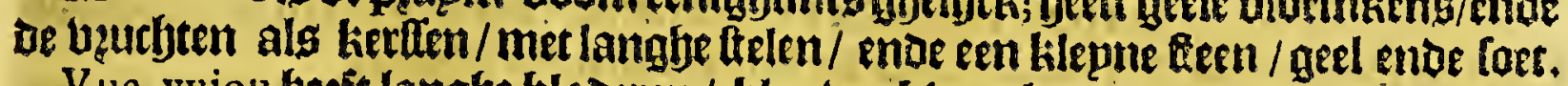

Vua-vyiou beeft langbe bladeren / blaulue bloemkeng / enoe en beurbt gljes Ij̈ckeen ozagnie-appel / Dan foetes ban fmaeck,

Vua Pirup igeen tteeckenoen boom/Geft blaberen als oe note-boomen/ ben

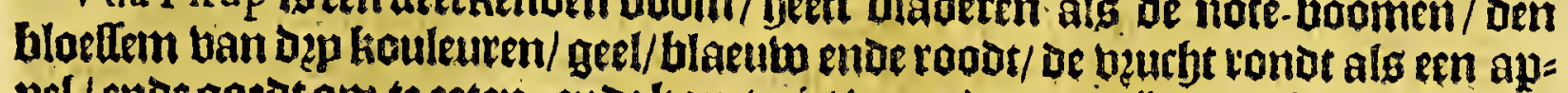
pel / ende goetit on te eeten; ende homt niet bogt dan ten tijoe dat get tegfent.

Onmery beefteen beurft algeen groote peete: A rafa alseen klepuen appel/ $\mathrm{cen}$ uan be befte beutlten als ip röp is.

Pekey is loo grof bat twee oft dpp mans die qualïck konnen om-batten / [pu

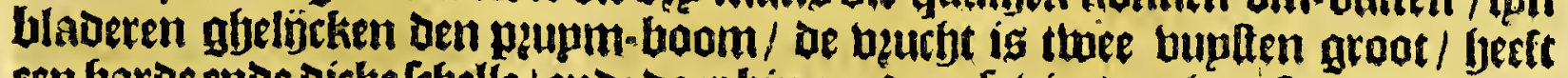

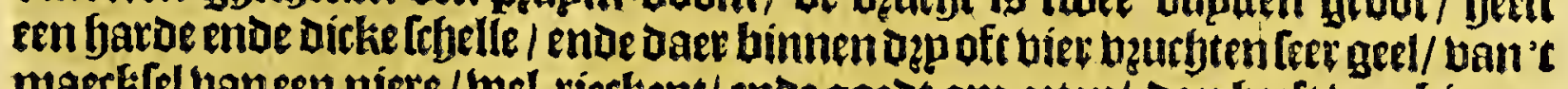
maerklel baneen niete / wel. rieckent/ ende goedo on eeten/ Dan beeft ban binnen een lteen die [eer fleeckende is/ foo dat men bem mort warbten in 'teeten.

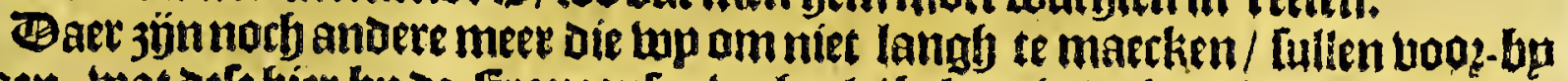

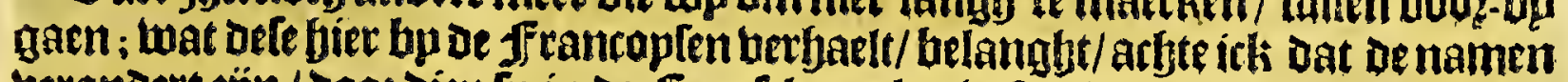

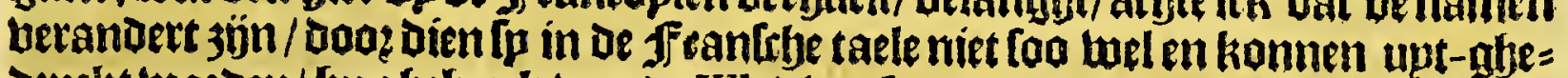

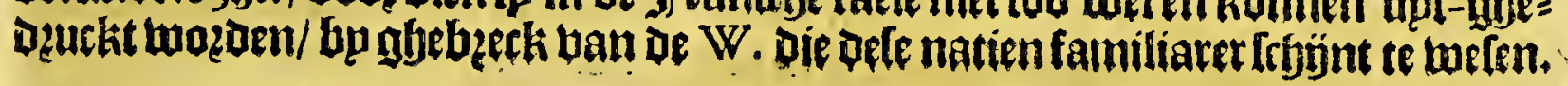

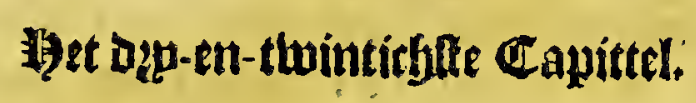

Befchrijvinghe van eenighe fonderlinghe kruyden ende aerdt-vruchten die op dit Eylandr groeyen; ende van't ghevogelte.

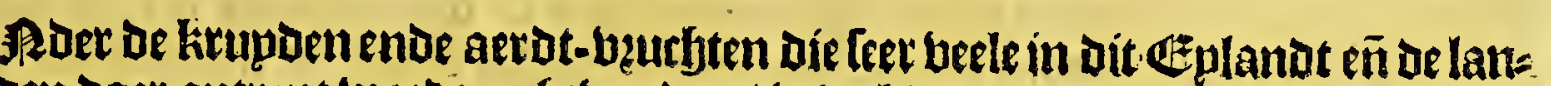
den baet ontrent bozoen gfetionden / ig tuel de booknaemle be Ananas, of welcke bp anderen gbenoegfy is befefeben. De Karouata ig de Ananas genoegf: faem glvelÿrk / beeft bladeren die tuel een elle langh zönende twee dupmen bzeat/ Ieer dick ende ojfteligh aen bepde 3 joent; in 't mioden van de plante/ontent twee

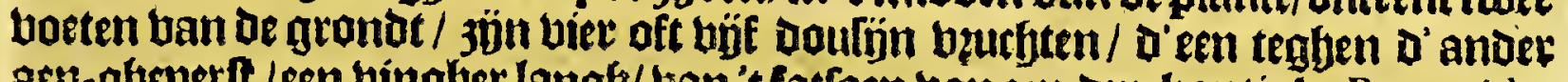

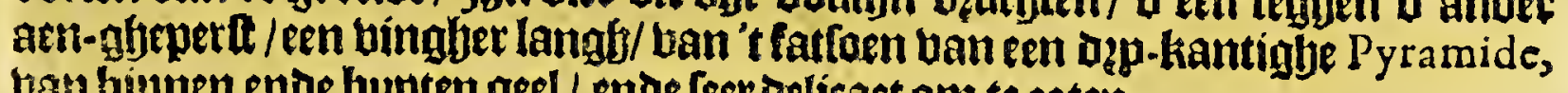
tam bimmen ende buptem geel / ende leet delicaet on te eeten.

Yarammacarou is en leer beembe ende manfiteule plante/ Dicker als de dirie/

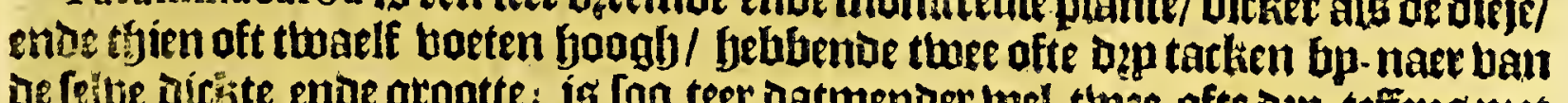

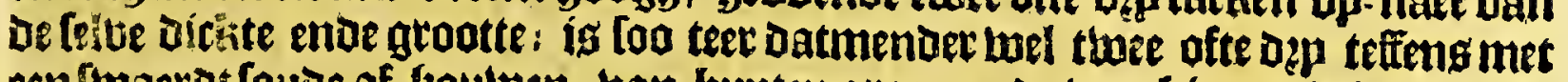
eenfwaerot foude af-Jjoulwen; ban bupten groen ende ban binnen witt/en feft gfeen bladeren dan o oozenen loa langh als eenvinger; de bloem ig tarmalÿr-root

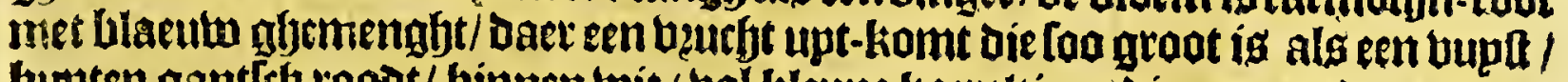
buten gantlty rooot/ binnen twit / bol klephe kojeltieng die men mede eet/enos is feer loet ende aenghenaem/bebbende bp-naer de fmaeck ban be aerdt-beluen
van ons land.

Gyromon is eenplante die 'tbladtende de blaem beeft gbelïck de ritullen; de beutbt is twat plat in 't ronbe / en groot ; De lfyelle is feer tender ende delicaet/ ende is een gaede kaft als lu ghelioock $\mathfrak{j y n}$.

Taker ofte Kaker is bp-naer alg de booz-gaende plante/ Dan dat de butbtlan= gher ígente grooter / enoe de tefelle garder.

Vua-éen iseen faotte ban meloenen grootec als een booft / gantfhy groen ban

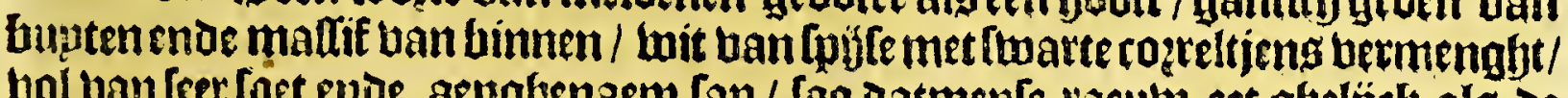
bol ban feer loet ende aengleenaem lap / loo datmenfe vaeutu eet ghelijek als de

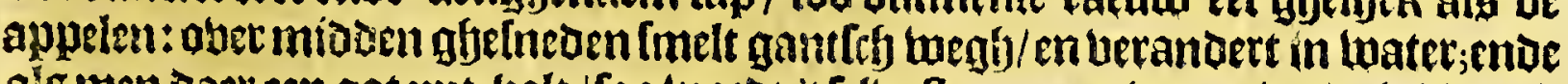

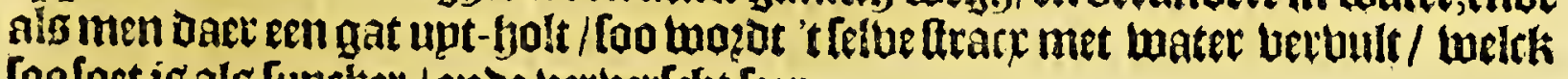
fooloct igals fiughther / ende bertuertebt leer.

Xa 4 Com. 


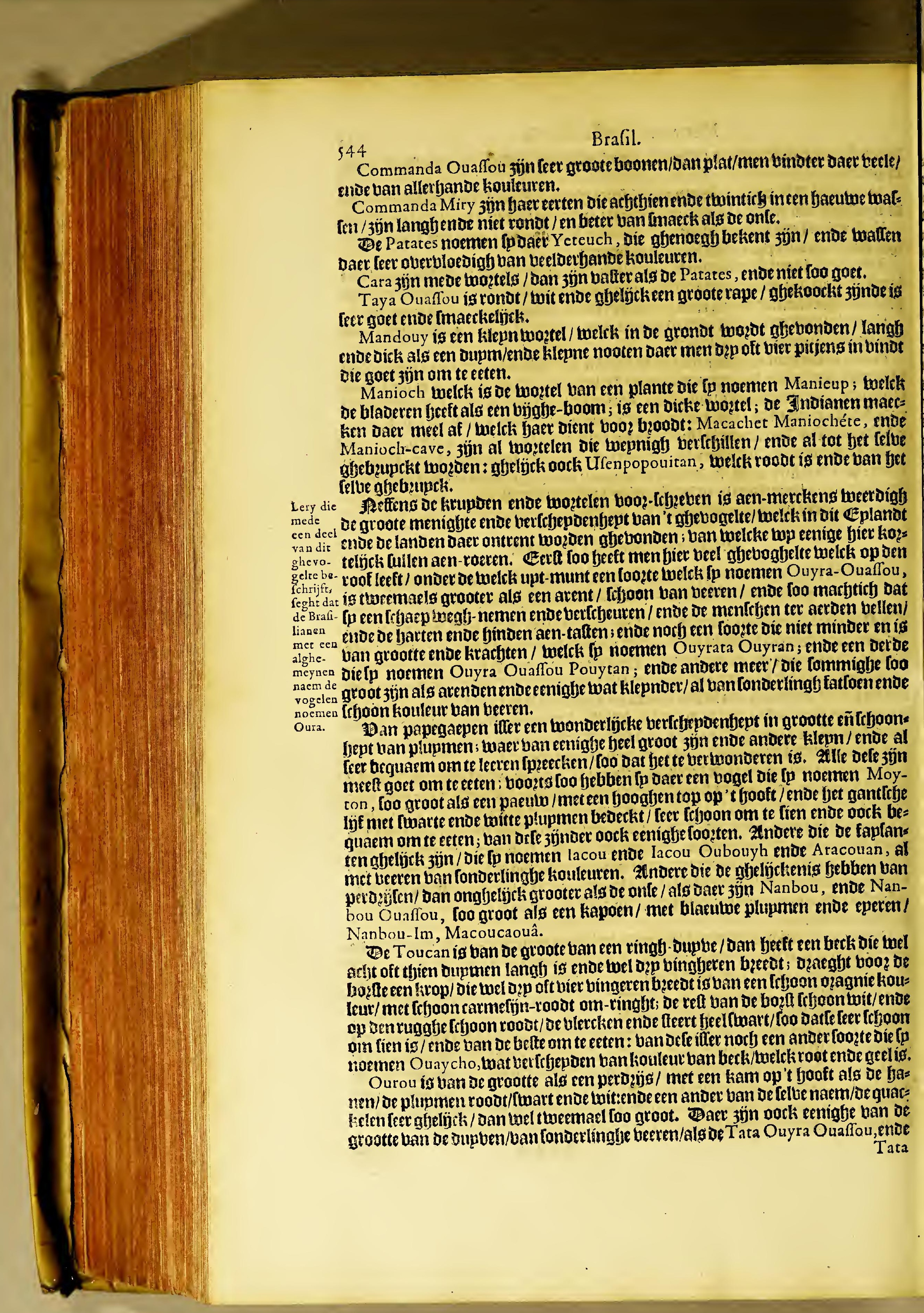


Tata Ouyra Miry, ende A roumara ende Diergelijoke. Agent bind toaer oock eenige die ganttry klepn 3 j̈n ende niet beel grooter als oe pepels/welck [u noemen lapyy enae Ouenonbouyh, oie Conjerlingh jön ban beeten ende bectk. Eenighe nacthtbogelen / ende onder andere Andheura, toelck jijn bleer-mupfen/aan grooter als

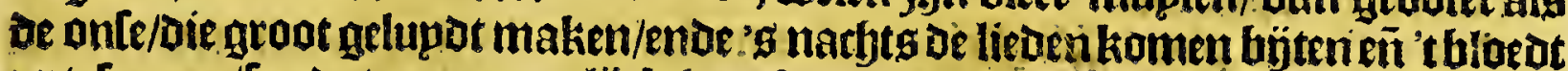
upt-[upgen/[oo dat men' 't qualijck kan Itelpen. 19an lwarer-bogels beeftmen Daer vock veeloerbanoe; Ouara, Tamatian ende Ouacara- on, die al de geoaente beblen bart tuindt-bagels / bie de ffrancopten noemen Corlieu, dan datte van Letffyep=

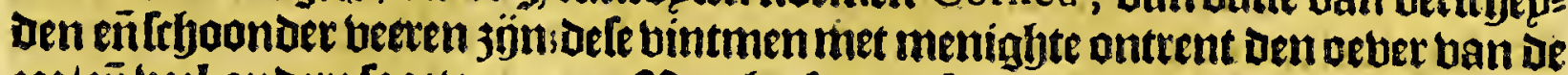

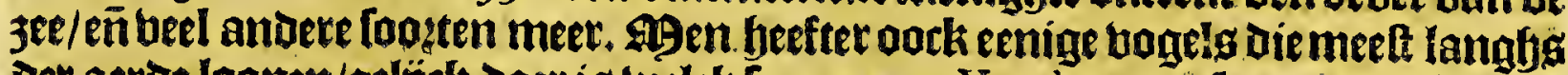

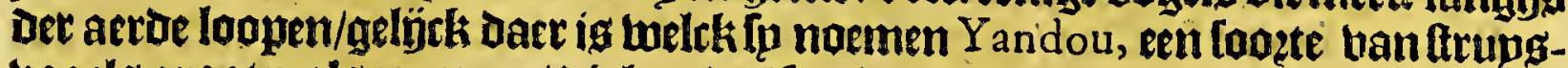

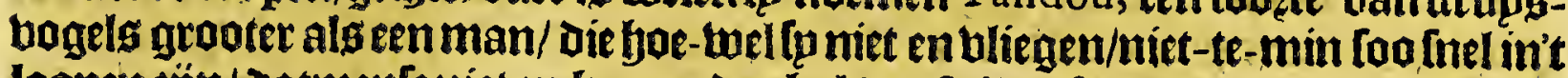

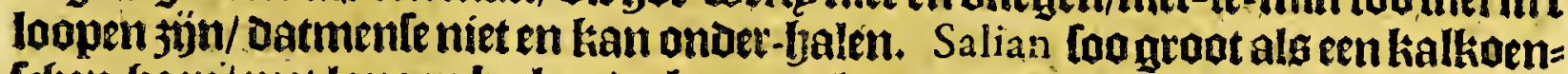
fogen-fyaen/ met langen beck ende heencn algeen openaer / bie niet oter i 2 oft is

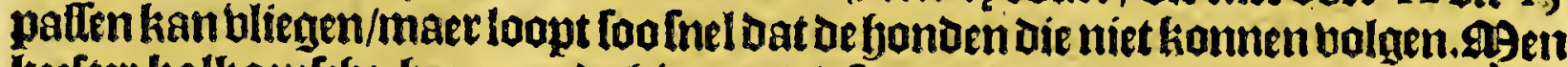
Jeefter kalkoenlfbe-tyanen ente biunen die fo noemen A raignan; ende menighte

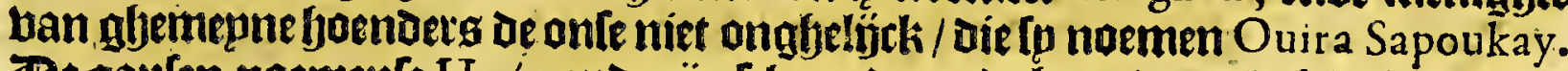

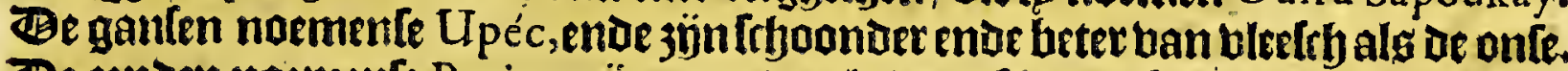
Be eenden nuemenfe Potiry, 3 j̈n grooter als de onfé/ende ctljoonder ban ureeren. Be ringb-duguen noemente Picaffou, ende de gfemeque Picafoutin.

Wet vier-en-ttointichete capittel.

Befchrijvinghe van de viffchen die in de zee ende rievieren worden ghe vonden by 't Eylandr MA $R A G N A$ N ende daer ontrent.

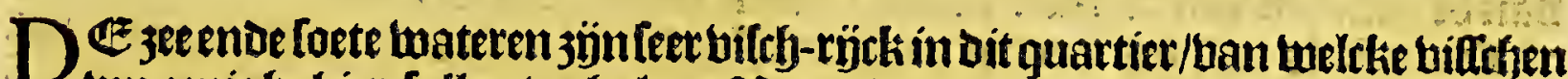
wopenighe fjer cullen verhalen. 29 en binot daer frer groote jee-kalberen die

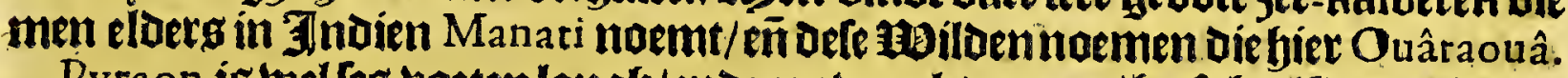

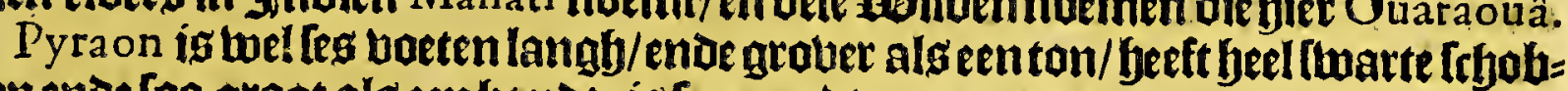
ben ende loo groot als een banot; is feer goetot om te ceten.

Pirapem ofte Camouroupouy is ban gfelighthe groatte enoe maeck fer/ ban fun

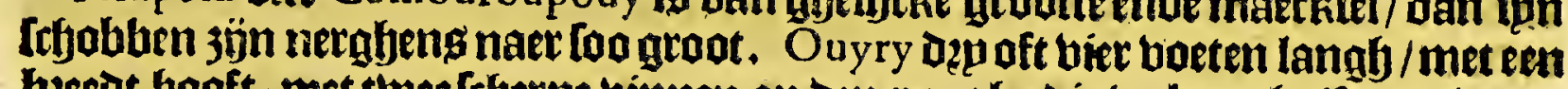

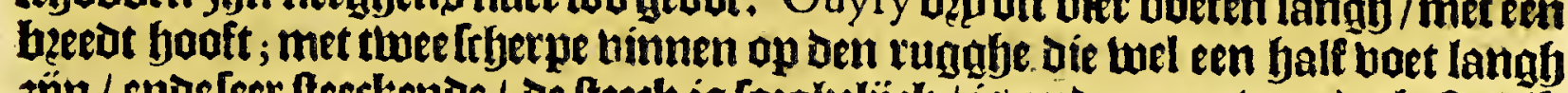

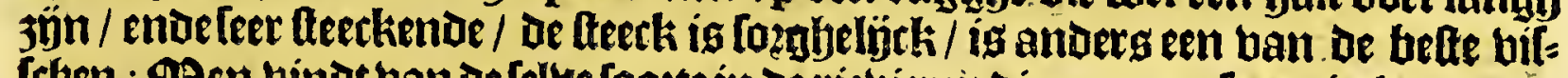

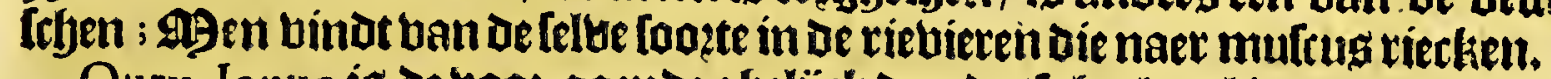

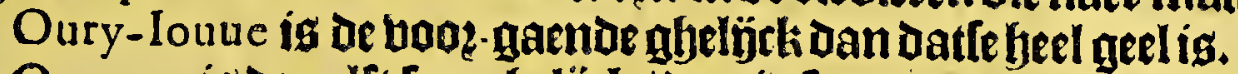

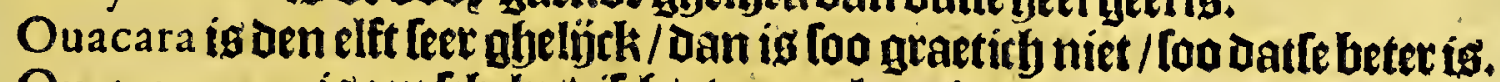

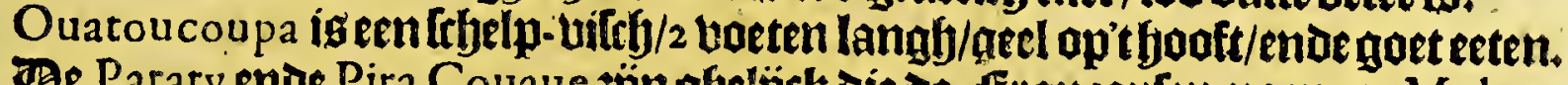

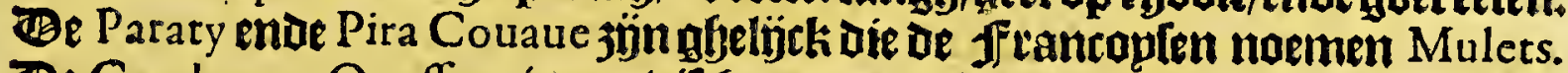

Be Camboury Ouaffou is een bifty ontrent bier boeten langy/ende't fjooft algeen wercken / met een geele fteert enbe bol trhobben.

Yauebouyre isen plat-viffy/'tfattoen ban een roch/ / an heel grooter/ is twel thee bademen langhenue beeest/ ende twel een boet Dick/ met ten teert wel ans Dethalf vadem langh / $m$ et een ftherpe pinne infet midoen meer als een tingher

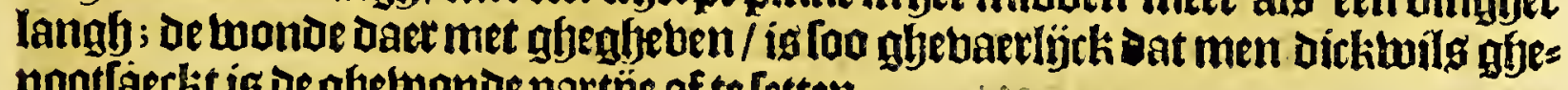
nootlaeckt is de ngetwonde partye af te [etten.

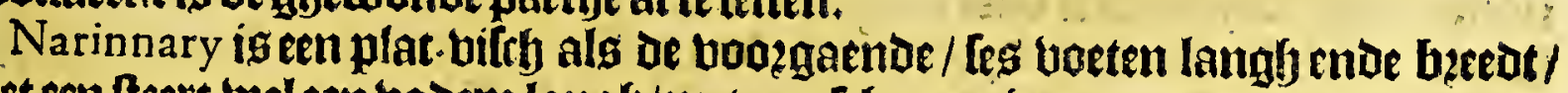
met ten ftert tweleen badem langly/met een frberpe pinne eengroutte boet langy/

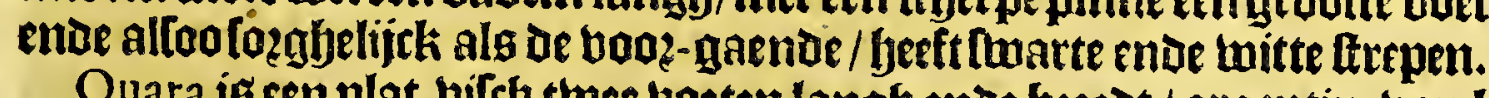

Ouara is en plat-biffb twee tueten langh enbe beerot / argentin han koulfur met geele binmen.

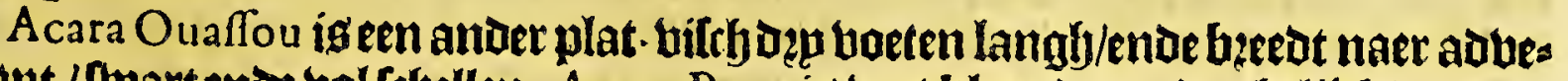

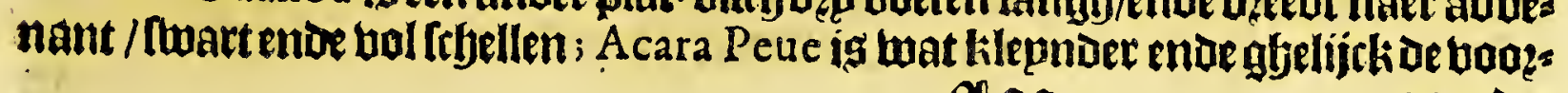
2l aล 5 gaenio: 
gaende:ende Acara Poytan afyelijch oe bool-gaende/dan met roode ende bitte

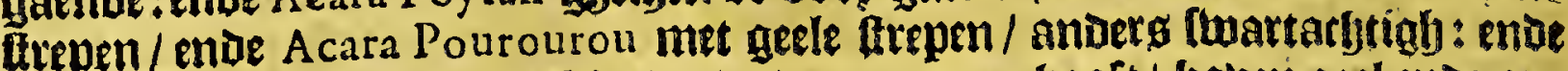
A caraiou een tootlangh bol frbellen/ende een groen booft / bouen geel ende on: Det aen Den bupek loit.

A ramaffa eeti plat-bitef ghelj̈ck een tongbe/ thee boeten langh / moe beteot naes abbenant / Dęu bingberen Dick / Den bupck twit ende Den rugghe (twart) goeot eeten.

A raouaoua is twel acht boeten langh/ met een harde fupde ende een twaet aen

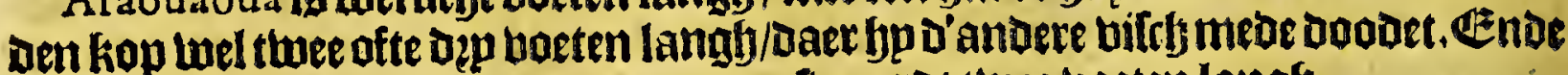
Panapan ghelÿck de boozgaende met een fwaetot thee toeten langf.

Pacamo londer febellen / gejpg van kouleur / twee boeten langh/ met een fees

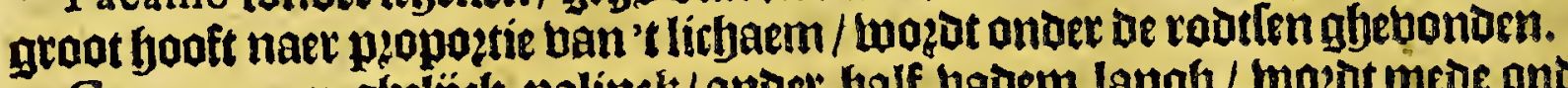

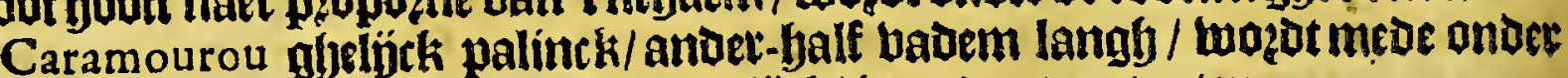
De rootlen afjevonden; Ipn beet is [ozglelíck/ is anders goet eeten.

Tinmocou Ouaffou ghfelýck een palinck/ Dan luit ende wel twee badem lanck/ ende dich naer abtuenant/met een beck alg Defnoetk een bort lanck.

Panyanaiou ghelörk de boozgaende / Dan dat fun bovenfe ban fon booft langher is alg't onoertete.

Onoer de rievier-bifty is aen-merckens tweetoigy de Pourake, melck ther

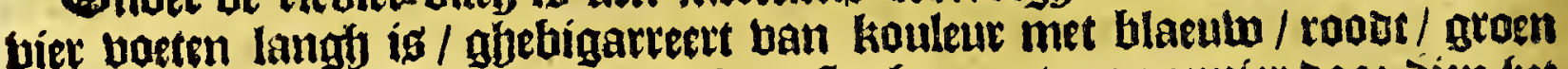

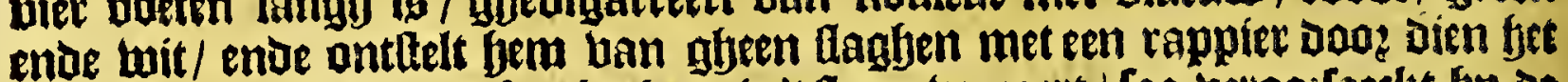

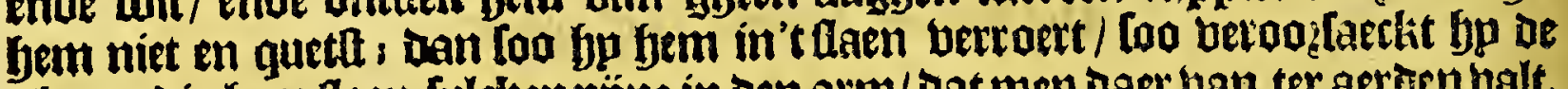
gheene die bem flaen fulcken püne in Den arm/Dat men daet ban ter aeturn balt.

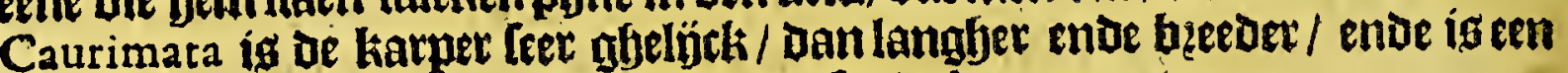
ban de belte billetjendie men in orfe landen foudo konnen seten.

Yaconda is wel Dep boeten langh/uol frbelpen / ende met geele / roode ende

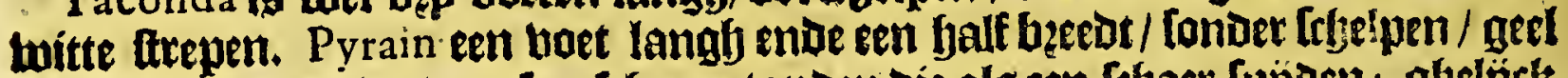

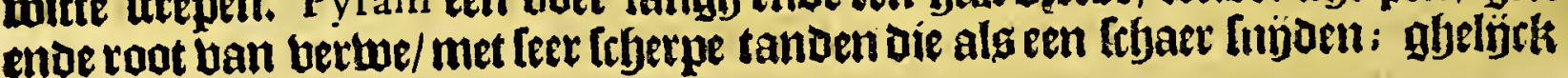
ondk Opean.

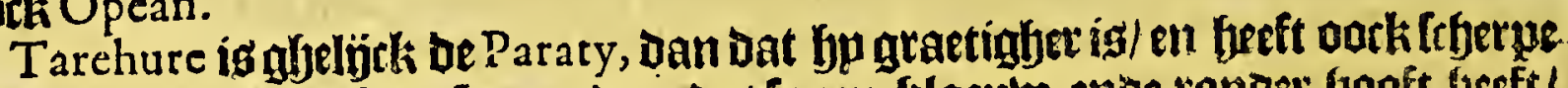

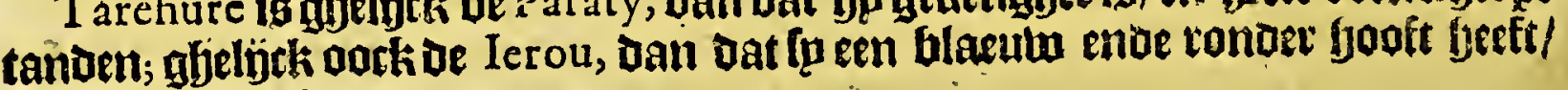
ende een rodod ltert.

Tamoata is maet cen balbe toet langh//bol fefelpen; geel ban biffy/enoe ban goedermaeck. : inupt.

Sarabo ig de lampeepen niet onghelïck / van is twat beecoer en langher ban

ISen binit daet oock Diberlebe krabben ende Kreften/naemen die Ouegnonioin, die heel blatutw 3 jun/met langlye frberrent andere noemen fp Ouffa, met rupghe beenen/ende roodt/men bindtfe aen de woetel ban de A pparitures.

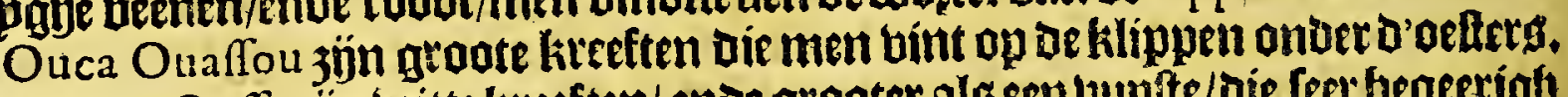

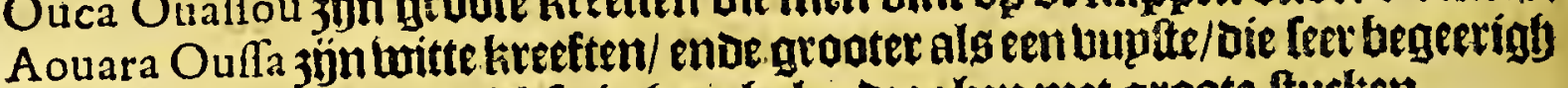

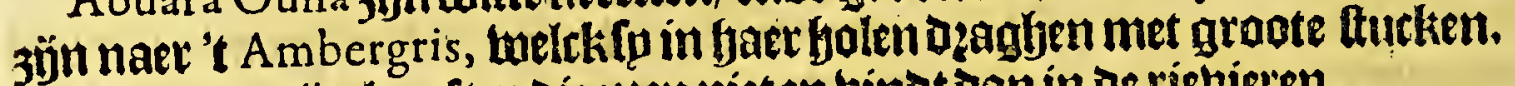

Ouraraup jön kreeften die men nieten bindt dan ín de riebieten.

- De trocodilen noemen de milde Yacare, ende men binder beel groute.

IO noemen die Rery; wallen daec oock aen de tacken van of hoomen/ die aen franat Itaen/ welth In noemen Apparitures: de moflelen noemen [p Xerourou, jän grooter alg be onte / enoe een azoinaire boetfel van de Hidoen.

Jen tỉ de dat fyet Daer beel reglyent/loo komen Dact beel taente poelen ban reglyen-water / Daet Leckere bifthlkeng in groepen/ontrent een boet langl / die

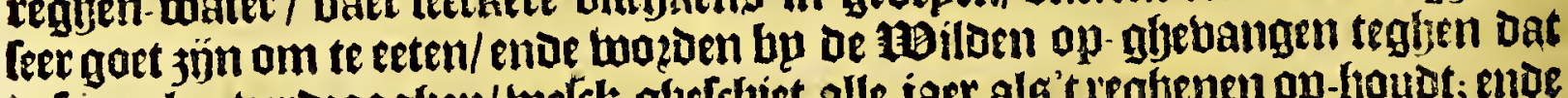

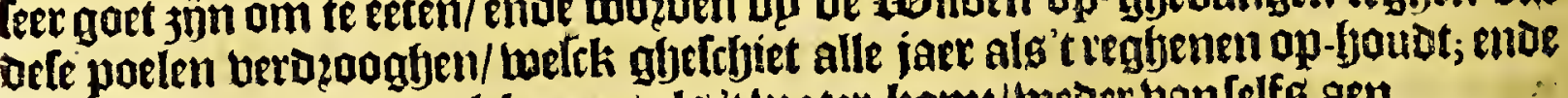

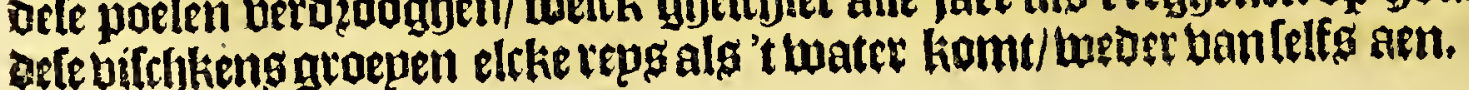


Het veerthienfte Boeck.

Wet bijf-en-twintichlte Capittel.

Befchrijvinghe van de vier-voetighe Dieren die op' $t$ Eylandt MAR A GNA A ende' $t$ vafte Land $t$ worden ghevonden.

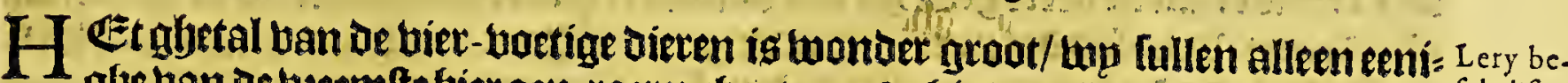

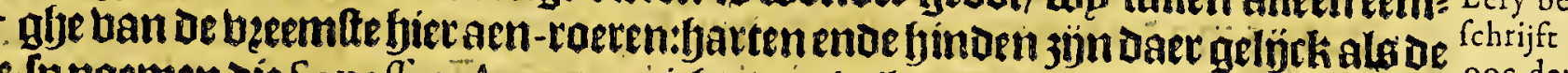

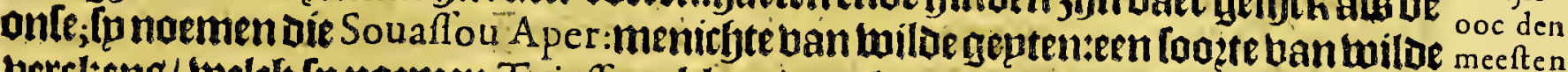

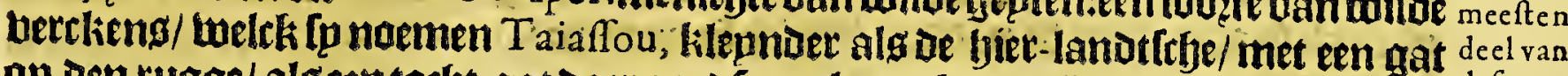
op Den rugge/ als eetrtorbt-gat Daer goeo re reucliupt-komt jün Daet bu menichten.

Daer tjönoer oock grooter als oe onfe/ die [p noemen T ay allou-ete.

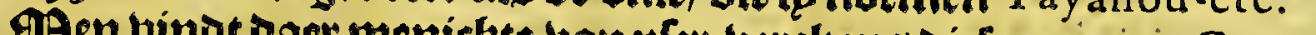
Agen binot daer menichte ban plet-bertkeng diefe noemien Coendou, met lan= 10 cap, gbe tchichten/ende groot ban líf / be naer als een wildt-lwïn.

-Tamandova ig een dier loo groot als een peerot/met een booft alg een betcken/

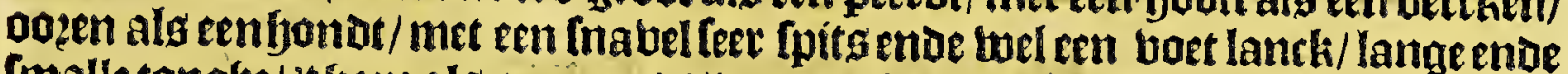
fmalle tonghe/ 't bap? als een peetot/ boeten als een osis left op mieren die't weet

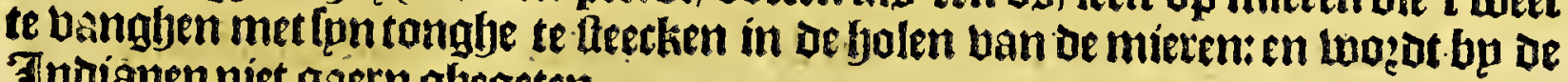
Indiamen niet gaern ghegeten.

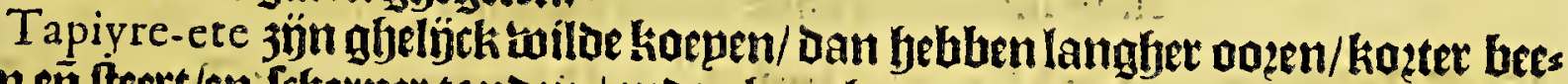
nen eñ fteett/en frferper tanden / ende gljeen boaenen: men bindt daer Bezar in.

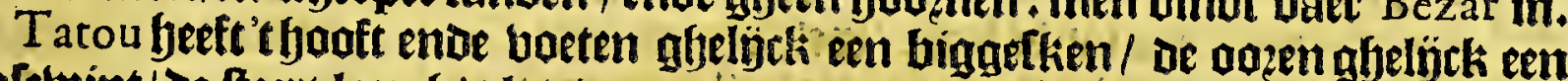
bafetwint/ de fteert langf/al getwapent met groofe frfelpen ban wit ende thart kouleur: ban defe zúnoer vibertebe tookten/alg Ta tou Ouafiou, welek foo graot

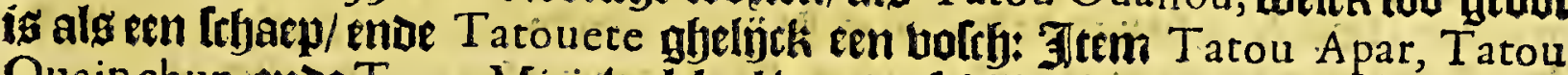
Ouain chun ende Tatou Miri, welck al wat berfehillen in groote ende in baroir: Jept van frfellen.

Couaty ig gelp̈cli onle bolten/ oan battet loo grooten enoe Dicften ftaert niet en heeft.

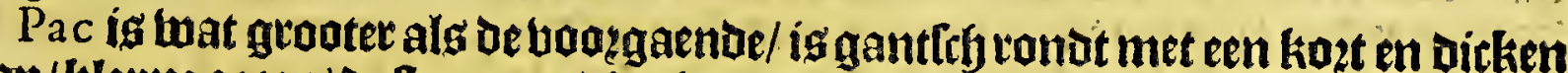

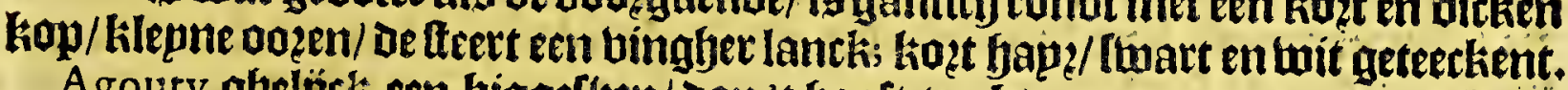
Agouty gbelijek een biggefken/ aan't hooft treckt meet naer een radt / kotete Iteert/ende feet bicht fjap: ban rolacljtich kouleur.

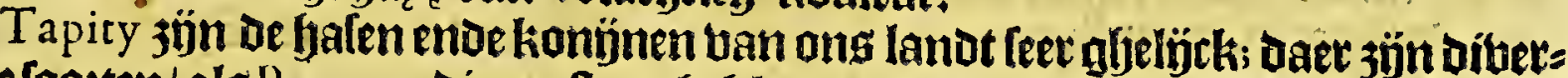

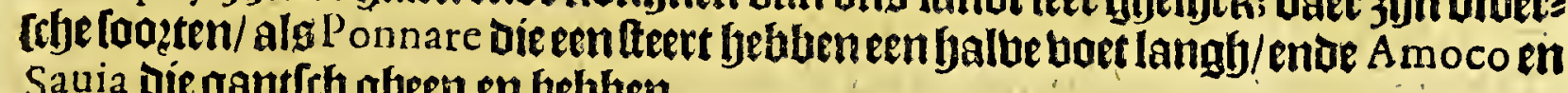
Sauia die gantleb gheen en bebben.

- Onder de tweetde dieren munt de Ianouare upt/ welch een loozte ban loflen is foo groot als een Ẽnghelfijen Dogh/met ken Iffoon bel elloe fraep geteeckent: Sou affovaran een footte ban luparos ban de felue groote enoe fraep gheteeckent) ende Margaia, welck ísen foatte ban wilbe katten/ die eenfeerfefjoun vel bebben.

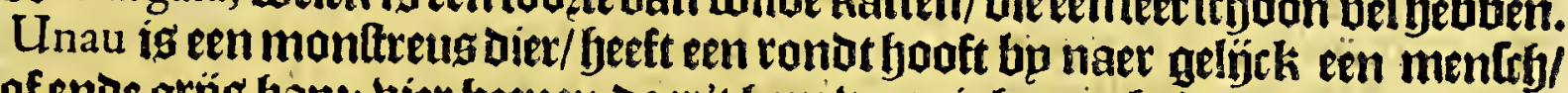
grof ende grĭg bapz; bier beenen daer't bem wepnigh met bebslpt/ bep klautwen aen elcke boet een binger lanck / oirbt bu een/ Daer 't mede klabert: anders kruppt bet ober be aerde/endeet oock aerde; als het op een boom is gheklabert en komt Daer niet af booz dat bet al 't loof beeft af -abegeten: is too traegh in fin kruppen ende hlaberen/ datmen ljet daerom de naem ban lupirlyept feeft gbegeben.

SHen befter beel loo:ten ban apen ende met-katten / groot eñ klepn / van berfebepoen kouleuren / ende eenighe (eer aerdigf); noemen die Ouarive; Cay Ouafou; Cayon diefluart 3 ijm/ende een langhen witten baeth hebben. Cay-miry ende Sapaiou, die lect aeraigh zún. Ta mary beel klepn rnde aeraigh: Marikina; loupara; ende Sagovy baneen argentin loultcur/ be klepnile ende aerdinglte ban
alle de refte.

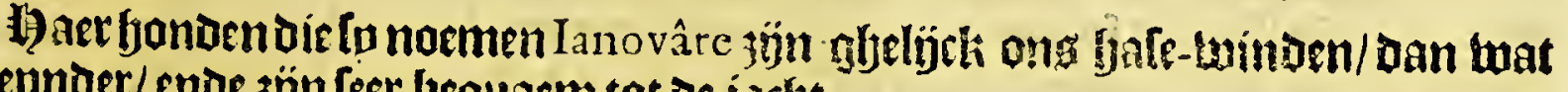
Gleunder/ ende zün feer bequaemi tot de irrbt.

Onder 
Onder de ktuppende dieten bebt gbjuat Boy-ete, welck toel thee badem langh is/[onder beenen/met een fraep ghelchiloerde bund; beeft maer vier tanden/ Dan wel fefjery/met twee píltieng aen de tonghe / aaer't ghetweloigh mede fleecks/

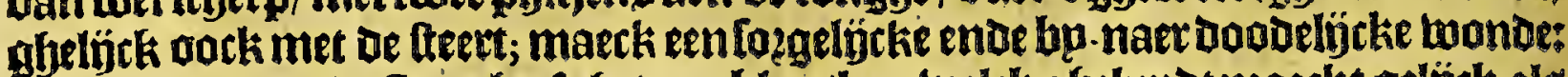
aen' tepnoe ban de tteert feeft bet een blaegken twelck ghelupot maeckt gelíck als oft bolecten wag/[oo Dat men Daer doo gelwaerftyout mozot om fyem te wathten.

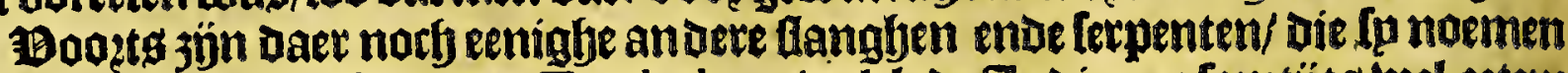
Iouboy, T ara-gouyboy enoe Tarehuboy, welck de Jndianen fomtýts wel eeten:

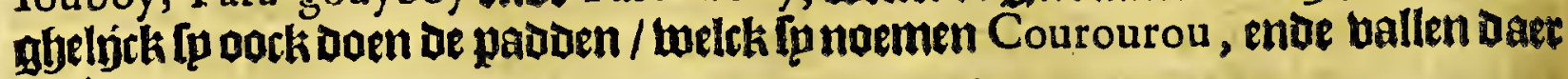
jeel gropt.

भîn beft fier aock die loozten uan blopen die fu in Hifpaniola noemen $\mathrm{Ni}$ gua, ende bier noemen de Beiloen die Ton; Dele baen de mentryen graote quels linghe aen/als mentie niet bp tijotg bem quät en maeckt; De moilden gebupcken aaer den olpe ban den palm-boam tegben/ende Roucou ende Ouroucou berthe.

\section{(1)et [es-en-thintichlte Capittel.}

-Befchrijvinghe van't volck van de lande, haer af-komfte, gheftalte ende manieren ende andere qualiteyten.

D I Indianenban de Maragnan berfalen bat daet ontrent oen Tropicus $\mathrm{C}_{2}$ pricorni enn fraep lanot leght / welck Ip noemen Cayeté, welck is te legghen groot foeft / Doo dien daex een groote boftyagie if ban leer fooghe enoe groote boomen/ arer [p eertijots felbben gbetwoont; ende boerden den naem ban Toupinambas, Dooz Dien [p van De frijobaerle bolcketen waren ban Dat feel ghetwel

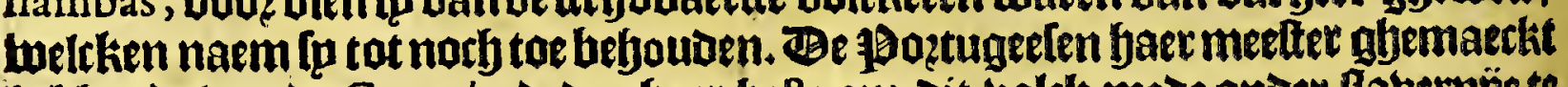
Gebbende van de Cayeté, Deven baer belte om dit bolck mede onder flatuetnöe te benghen/ dan defe Toupinambas 't felve niet konmende berdzagben / retireerden Gaer boos eert in de holferen; Dan yaer felben daer mede bervolght bindende by haer bpanden / zijn loo berte boot gljetrocken tot dat lp ghekomen jün tot aen oe jee / alwaer eenighe baer bebluen neder-ghedlagben langhg ben oeber ban de 3 ee;

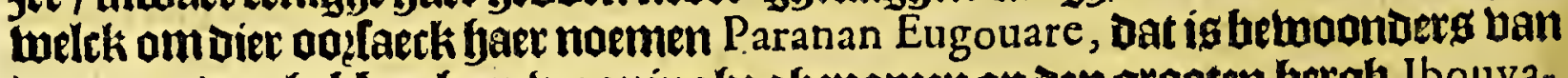

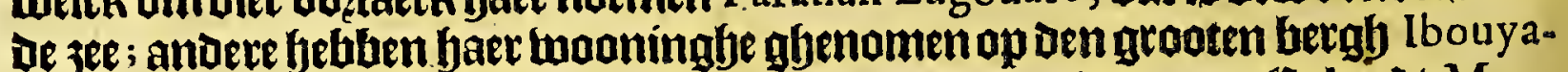
pap, Die faer noemen Ibouyapap Eugovare; andere in't groote Eplandt Maragnan, weltk Maragnan Eugovare wozen ghenaemt : andere langhts de riebiete Taboucourou, weltk faer noemen T aboucourou Eugovare; ghelg̈kt die langlys de rieviere Miary woonen/Miary Eugovare, ende loo bootte eenighe te Para naet 'toolten toe / ende te Para naer't weften toe / ende te Cayeté aen den oeber ban de 3ee; behoudenoe niet te min alt famen de naem uan Toupinamba. Genighe ban be oubtte ghedencken norly / datte naer baer komite in dit landt een groote frefte aen-kethten / welck fonoemen Caoven, allwaer oe booznarmlte bergabert jijnde/

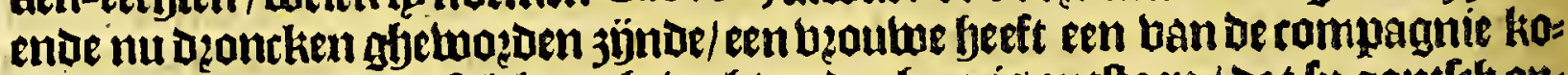

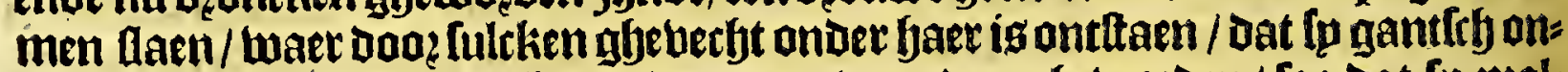

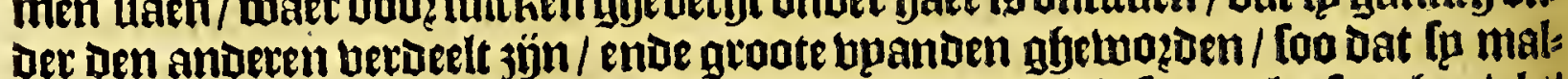
handeten daer naer ghenaemt bebben To baiares, welck is fou beel telegghen/als/

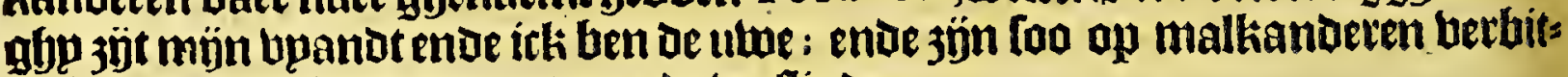
tert / dat fu malkanderen eeten ende bertlinden.

Dele Toupinambas jijn dooegaeng ban midoelbare ftatuere/foe-twel men det oock tindt diefieel langh enoe becoom jün : jün meelt Camuz ban neufe / welck

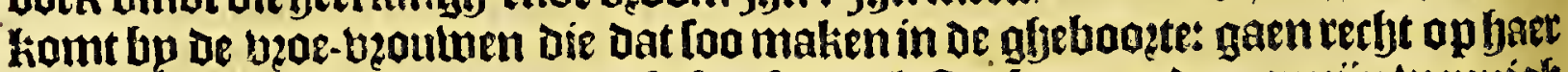

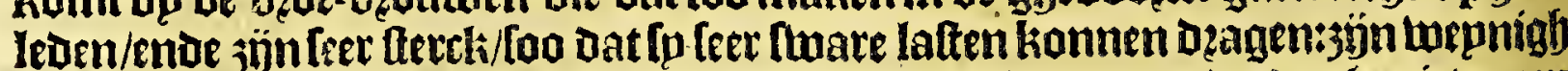

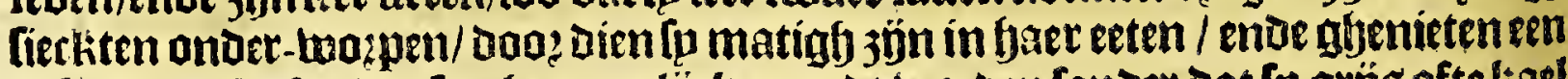

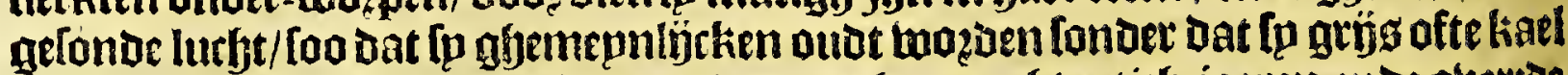
wozoen: ende de beutwen kinderen daer tot baer tarbtentirb jaeten ende aber:de 
Het veerthienfte Boeck.

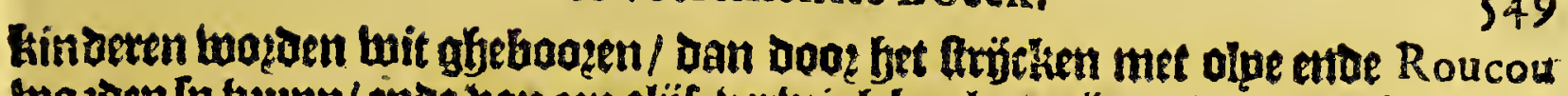

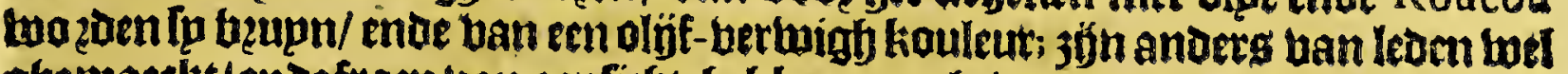
ngemaeckt/ endefraep ban aenficft; beb ben een gfetwoonte ban' ' bap. allentfals ben upt te trecken / upt-gfienomen op 't booft ; welek alaot is / ende niet ofekrult

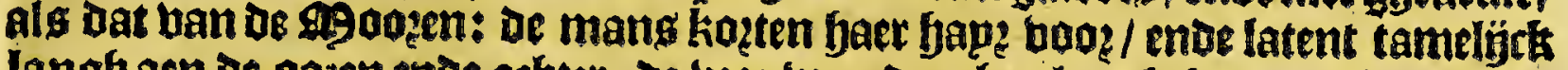

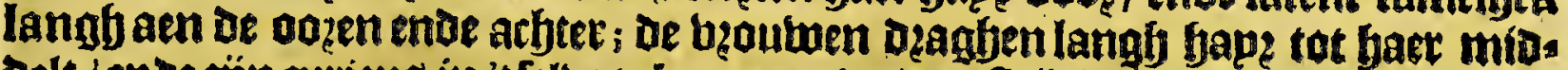
belt / enbe zün rurieug in 't felve te liemmen/ende te ftrijetenmet Roucou, welck f $p$ teder boaffen met Ouapacari twater / welcli een twogtel io die een Irfjupm ban bem geeft glyelígrli de zerpe. Sebben ecn beemoe maniere ban of on oerRe lippe

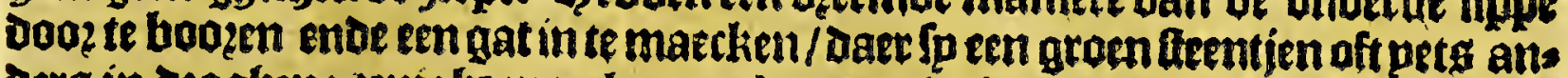
Ders in bzaghen: tenighe maecken oock gaten in gaet neus / enoe dzagben Daer

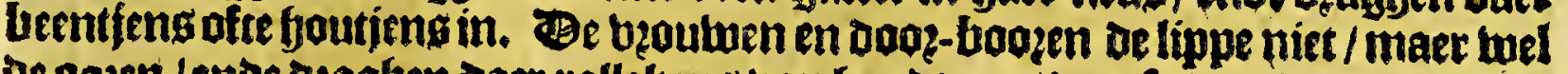
de oazen / ente dzaghen daer rollekeng ban boutot aen/Daerfp wonder mop mede 3ín: Be Toupinambas gaen gantrfy naeckt / fander eenigbe frbaemte te bethen:

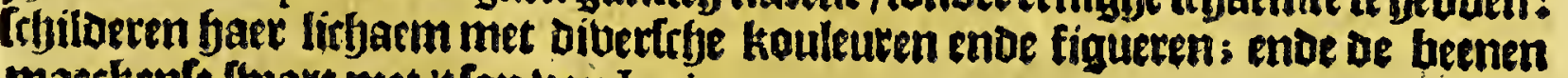
martkente twate met 't lap ban Iunipap.

exenigbe mang grabeeren baer bupot met pet Itberps / enoe toeten vaer bat in te ftrijcken / foo Dat jet grabertel nimmermeer en bergaet / endeis onder baec een teectien ban gropte rouragie.

Op baet feeften tercieten [p baet met plupm-tretck ban dibertrhe kouleuten/

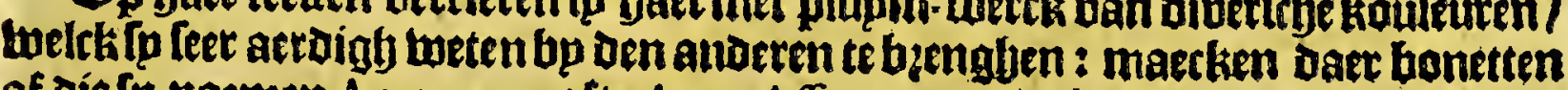
af die fp noemen A cangoap, ofte A can A foyave; mbe kroontieng diefp noemen Akan getar; ende kragen die fp noemen Aiouacara: ende beele mantels dielp noe men Affoyaue; ende koutfe-banoen diefe noemen Ta a a coura: mareken bic park ban rottoene gaetn/ende fjangen Daer Leerker notent aen/ Daet fo fteentiens ofte pet anderg in boen welck ghelupdetgeft / ende noemen Defe banden Aovay, maecken oock arm-ringhen van plupmen die fp noemen Ma pouygh Couay Chovare, ende groote plupmagien op t booft / welck fp noemen Yandou-ave.

Je ghetroude mans/ ende inlonderbept de oude lieden decken oock fjaet tchas melfyept met een lapken roobt oft blaeula laecken / welckfn om baet miobelt bins Den met een cottoenen bzart / naemen dat Caraiove.

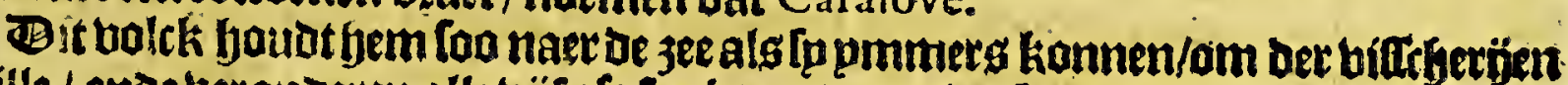

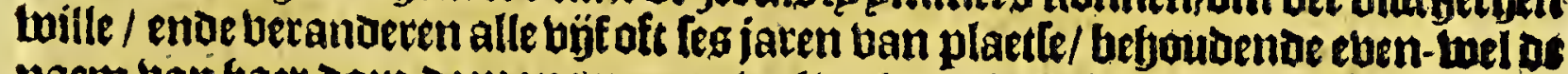
naem ban faet Dozp; Demans magen wel beel bzoutwen bebben/ ban be bzoutwen

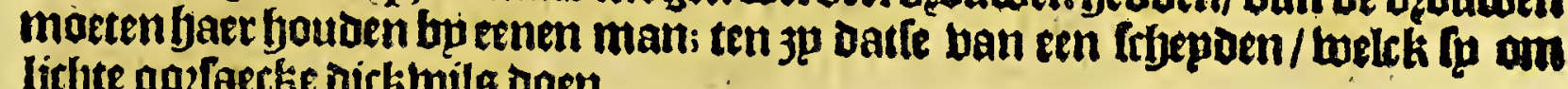
liflyte oolaecke dicklwilg toen.

Sp bebben yaer bedoen ban cottoen/twelck fpnoemen Yni, enoe wopoen ture

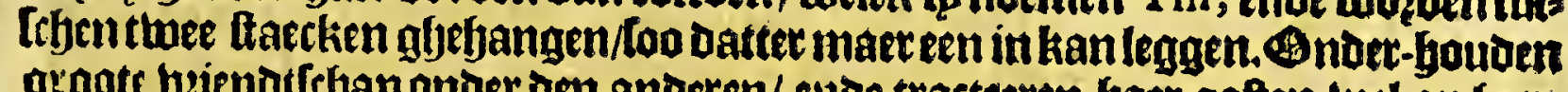
groots beiendtfhap onder den anderen/ ende tracteeren yaer gaften wel op base

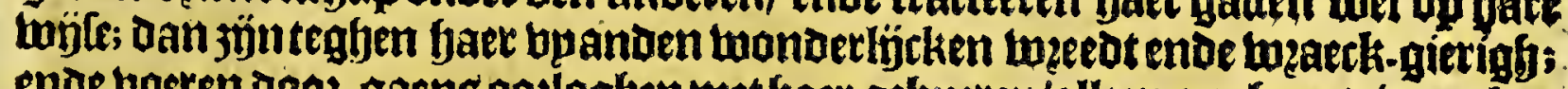
ende boeten dool-gaens ootlogfen met baet gebueten/alleen om baet te tweecken

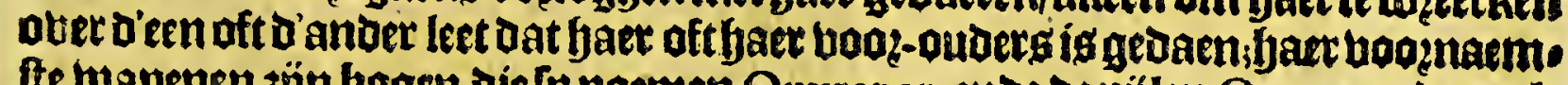
te wapenen sün bogen diefu noemen Ouyrapar; ende de púlen Oouue,ende bock

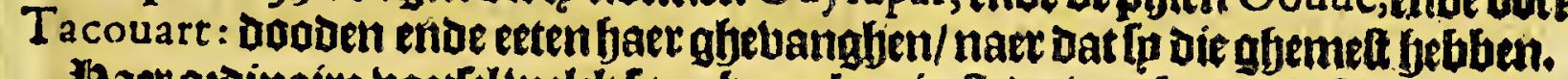

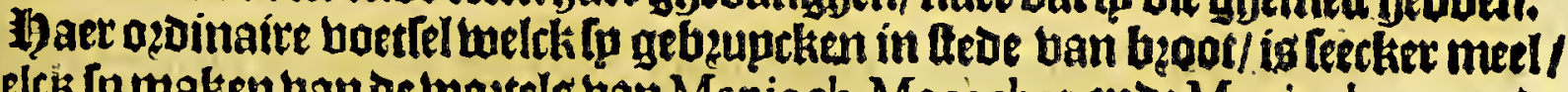
Lelck [p maken tran de twoztels ban Manioch, Macachet,ende Manioch-ete,ende noemen'tfelbe Ouy;ban't fap maken fpeen potagie/ belckfp noemen Manipoy; ende uan't gronot - cop leeckere koecken bie fp noemen Caflave: maecken ban be

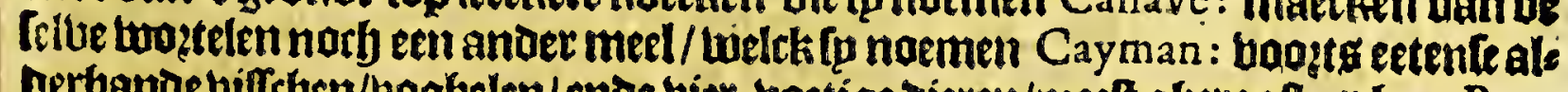
berbanoe billoben/wogbelen/ende bier-boetige dieren/meelt gberoget ap baer Boucans, ende beincken mater. Haet boosbere manicren ente doen kan men lefen bp

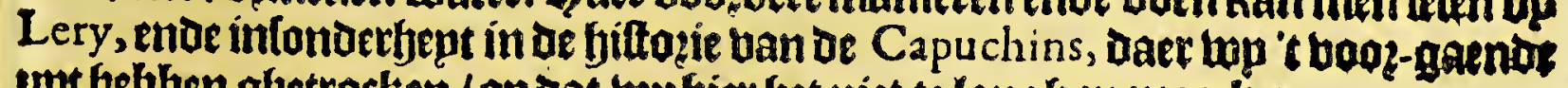
upt bebben ghetrocken / op dat wubiet bet niet te langfen maecken.

7at 


\section{Het leven en thuintitylte ctapittel.}

Deghelegentheyt van TAPOY Y TAPER ende COMMA, welck zijn aen't vafte Landt gheleghen:

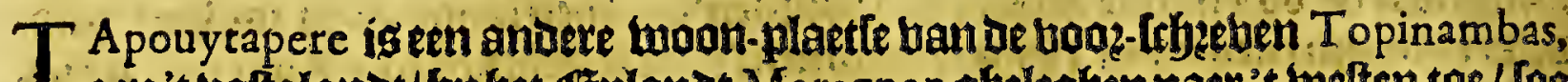

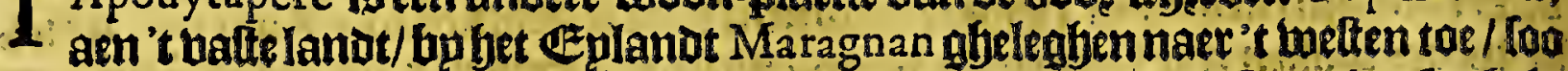

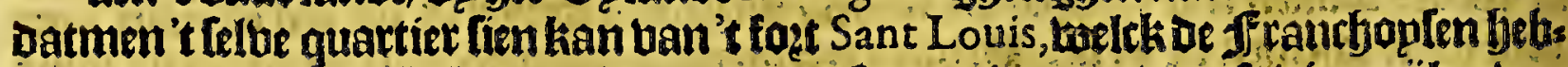

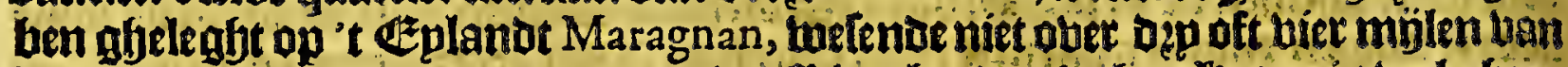

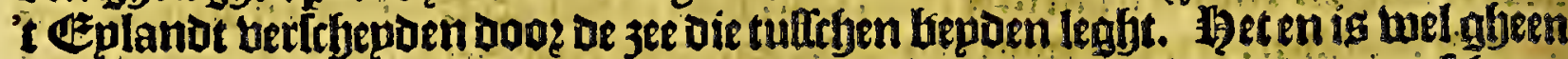

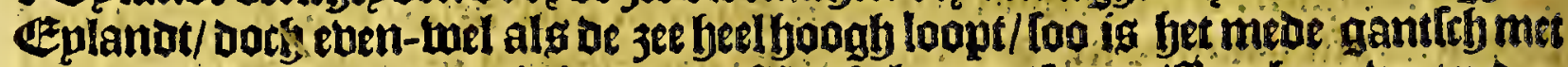

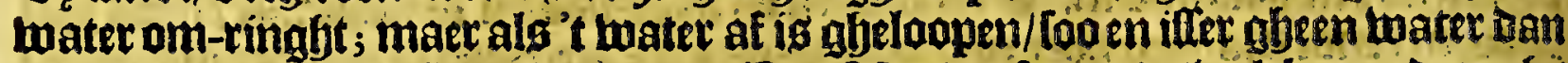

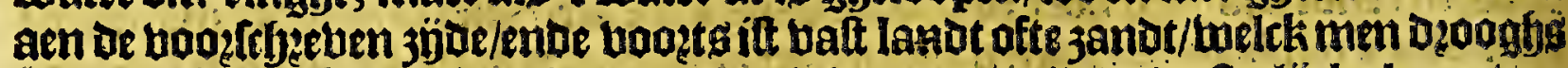
boet kan ober gaen. Den foeck ban jit lanot maeckt oe welterlyethe hape tan

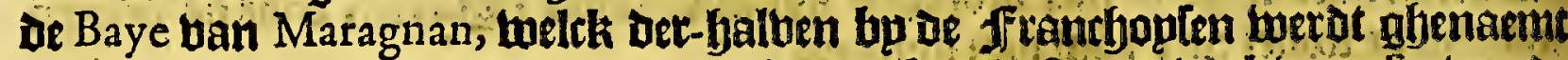
Cap de Tapouytapere, ente becbolabt met Inn kufte tot in timnenite ban de hape ban Maragnan. Bit lanot en ig luel too fterck niet als 't eplanot / maer ig lus

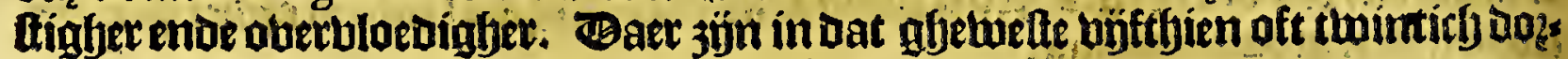
pen/ ban belcke wo de boosnaemite fier fullen noemen.

- Be bermaetle enoe eerfe blecke bogot ghenaemt Tapouytapere naer te

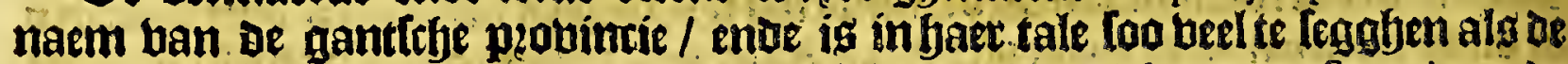
oude twoon-platte ban oe Tapouys. Be theede toert ghenaemt Sery-ieu: de

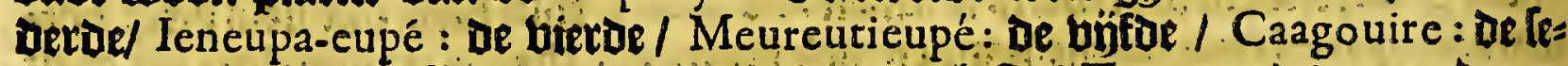
Ite/ Pindotuve : of tebente / Aroueupe : of attitte / Tapouy-tiningue : de ne= - abente/ Eügareté quitave : te thienoe / Oroboutin eugouave. Cende in alle Defe Dozpen woont meet bolcks als bol in de ooepen op bet Cepland Maragnan:

Wat boozder ban Tapouytapere naet bet welten toe is en riebiere ghelegen die fu noemen Comma ; tet land baer ontrent ig leet frboon enoe aen-ghe:

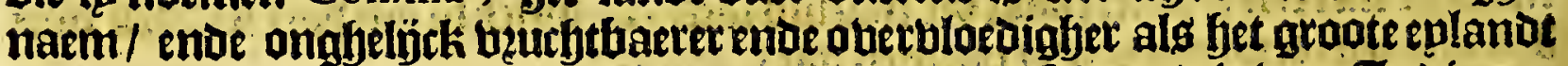
ban Maragnan: enoe is oock beter betuont ban oe Ielue natie ban Jnoianen

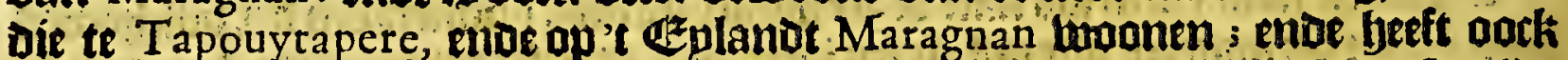

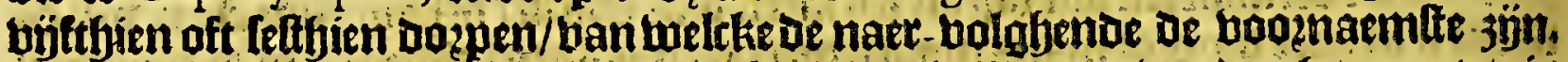

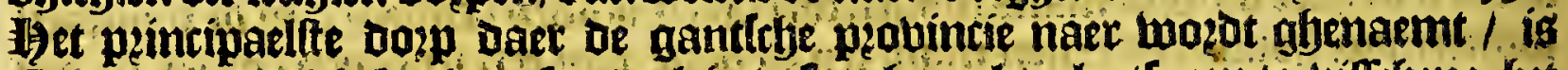

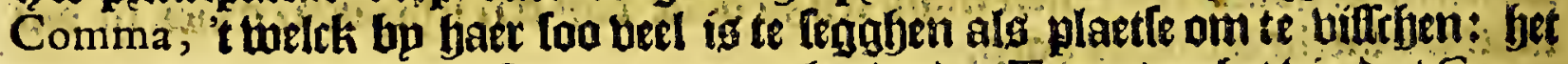
theede wozot abenaemt Ianovacovare: bet deros, Tauapiap: het bierbe/ Couy-

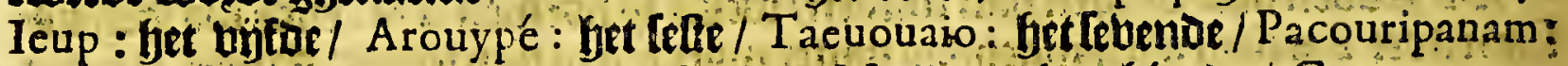
let actitlte / Aouayeuve - fet negljende / Maecan - bet thiende / Couremaeta;

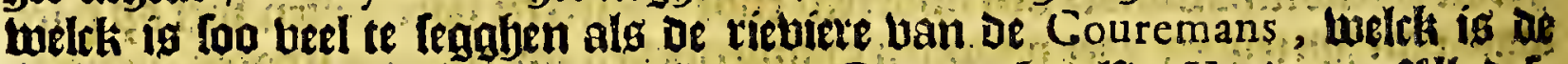
naem ban t in-komen ban be riebiere tan Comma: bet elfoe, Y apieuve. toepen 3 jon beel beter betwoont alg oie ban't Ezplanot Maragnan; ende alle defe tolcketen uan dele dey pzobintien Maragnan, Tapouytepere ende Comma, jọn bzienden ende bonot-afjenooten tegfen alle anoere natien die baet byane ôn jủn.

DBai Comma tot Cayete toe (melek leght dicht bu de groote rietiete Para, ontrent de tachtelitich minlen ofte meet uan bet Geplanot Maragnan / legghen noth beel dozpen ban dele Indianen Topinambas, die op t valfe lante woonen

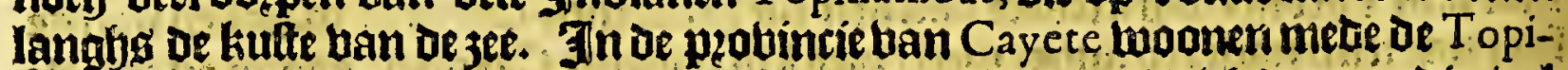

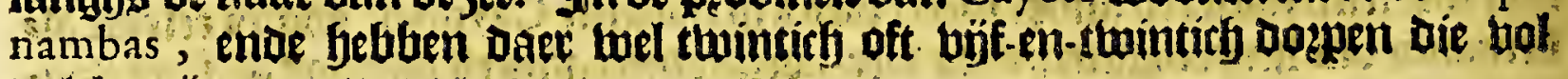
tiblikg $3 \mathfrak{i n}$. 
I itht-en-twintichlfe Capittel.

Kort verhael van't ghene eenighejaren gheduerende by de Françoyfen is voor-ghenomen in dit quartier; ende van den bergh IBOUY AP A P.

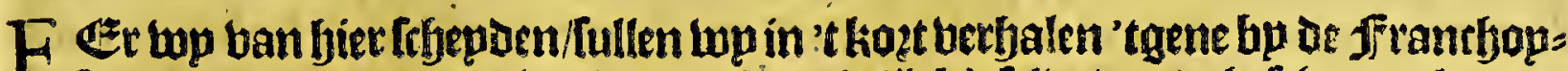

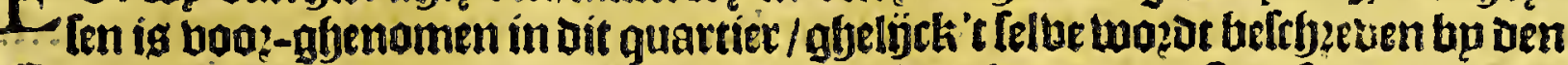
Capuchin Claude d'Abbeville. In oen jare 1594 badde en fitanfinan met na=

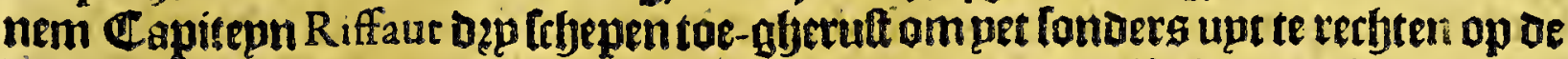

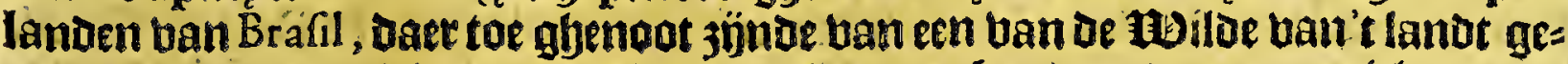
naemt Ouyrapive, Die Daer in 't lanot beel bermoefft; tan Dobe oneenichept van

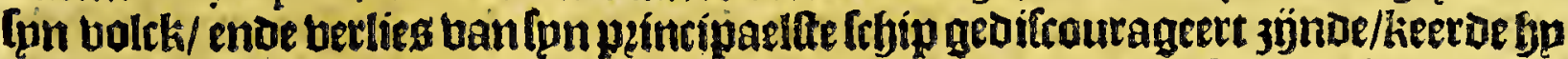
weoer naer b sanckrp̈rk/ enoe was glyenootfaeckt eenigb ban fon uolck Daer aen lanot te laten/eñ onoet andere een jongh etedel-man Monfieur de Vaux, De tweles

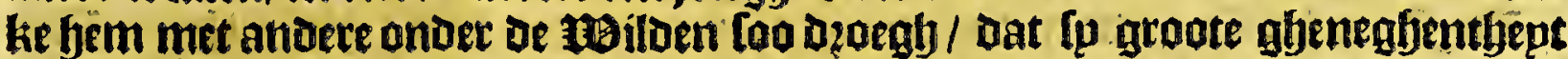
kregben tot of f rantfioplen/ende berlocften Dat een perfoon van qualitept upt

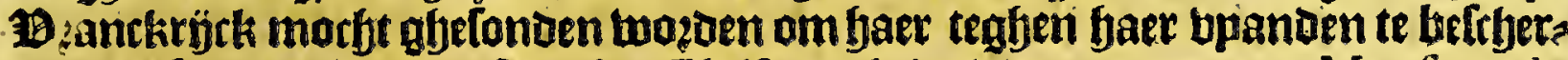

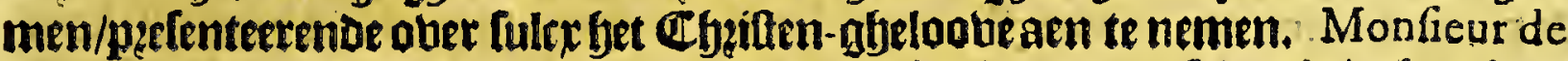

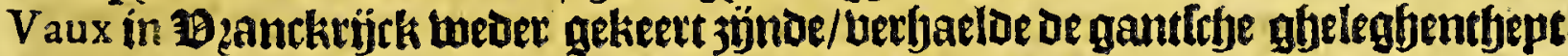
aen oen ltoningf Hendrick de Groote, De tuelcke om Letier vanalleg onoer-recht

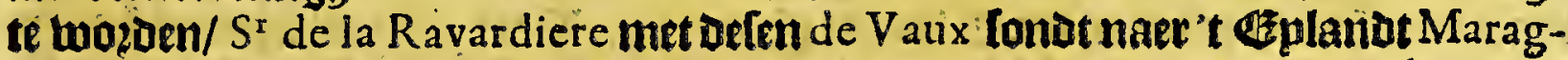
nan, met belofte op [pne koden be laetke boogtenemen/ingeballe de geleghentbept

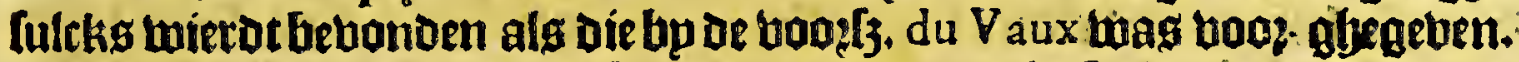

La Ravardiere nam be reple aen/enoe naex datbples maenden badoe bertoeff op't Eeplandt Maragnan ende de landen Daer ontrent/ende alles neerftich onder-

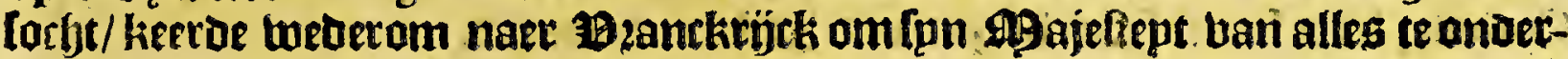

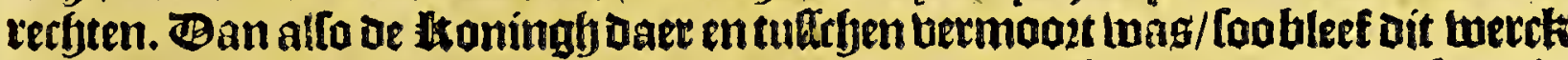
Atertien tot in Den jaete I 6 I I. Ravardiere nam eevt in Compagnie Monfieur de Rafilly, ende daer naer mede den Baron van Sanfi, ende verlothten uan de lionin= ginne glgoeder eenighe Capuchinen om die te ghebeupeken tot bet beketen uan De Hiben; ghelijck Gaer dan bier wierden bp den 19zobinciael ban Pariis totgheftelot/ oaer oefen Claude d'A Abeville een nan twag.

Su vertrocken van Cancale eenfjaben van 25 titaignien ben 19 Mart 1612, met Dep Irbepen; Dan dooz extraoţoinaite ontweder waten abenootlaeckt in Eengbes lanot aen te loopen; frbepoen tweder ban Pley mouth oen 23 A pril; pafteerden tul= frljen Fortaventura ende groot Canarien denleutenden May; ende den elfetenqua= menlp aen Rio del Oro onder Den Tropicus van Cancer, ende liepen lov hootts langhs de liufte ban A frica tot onder De linie; Den Keventhienden Iunius waren lp op de booghte ban biet graden by jupoen de linie: ende den bap-en-twintichaten

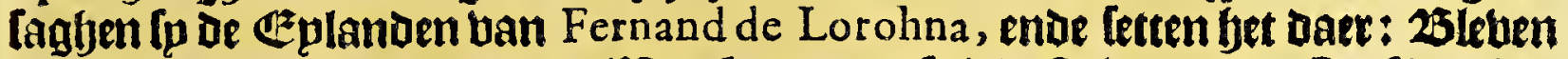
Daer tot Den arbften Iulij; Den elften begannen fp't bafte landt ban Brafil te lien/ ende quamen op oe midoagh ontrent oenin borbt ban Moucouru, ende loopende langys oe kulte/[agljen den tmaelfoen [mo:ghens een fooghen fteplen bergy/ende loopenoe langijs't lant quamen lp aen Cap de la Tortue, Luelch ban oelen bergh

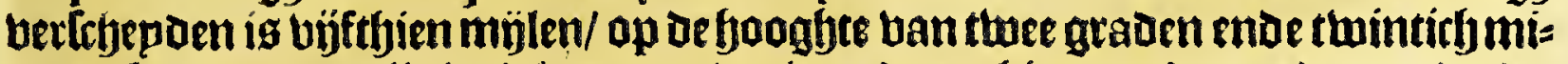
nuten bp jupden de linie: 't hompas varieert daer thien graden ende een oerde. iLagfen dact tot den bier-en-twintichtten lulii, enoe quamen den feg-en-twin=

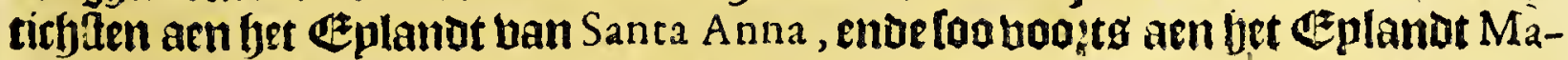
ragnan, al waer fu om anoere oinglen boos bp te gaen/ een fozt maetliten aen een feet bequaeme plaetle / op een hooghen bergh ende bp of peincipaelfe batien taan

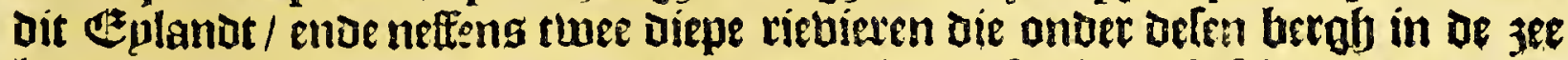

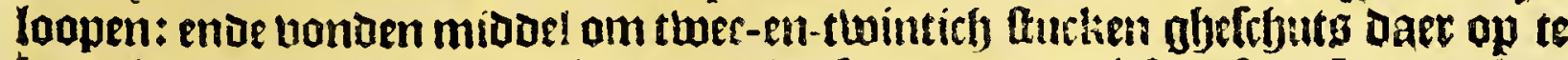
bzenghen tot de befebermingf uan or p!aetle : nocmben uit faęt Sant Louys. 


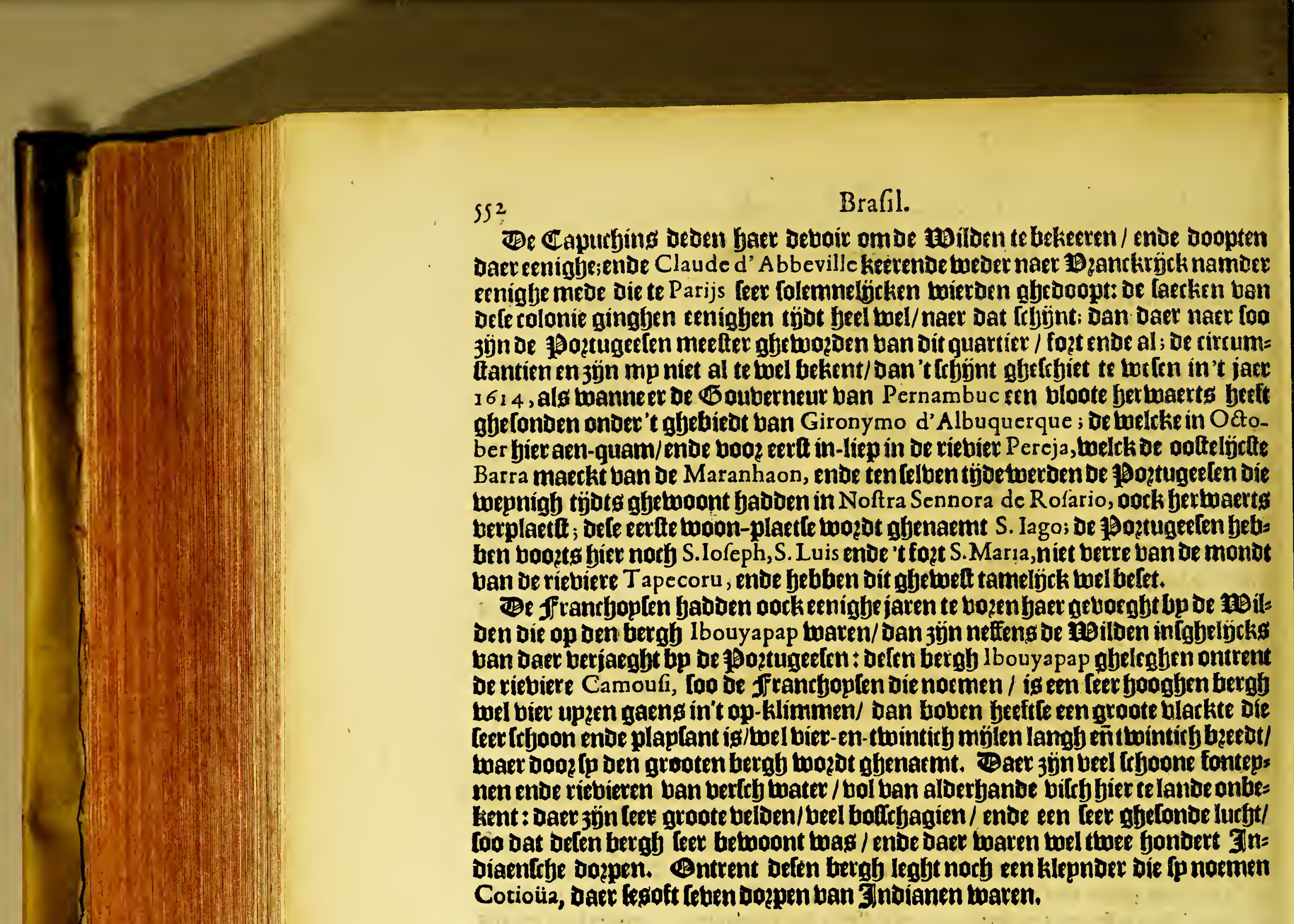

BESCHRII. 



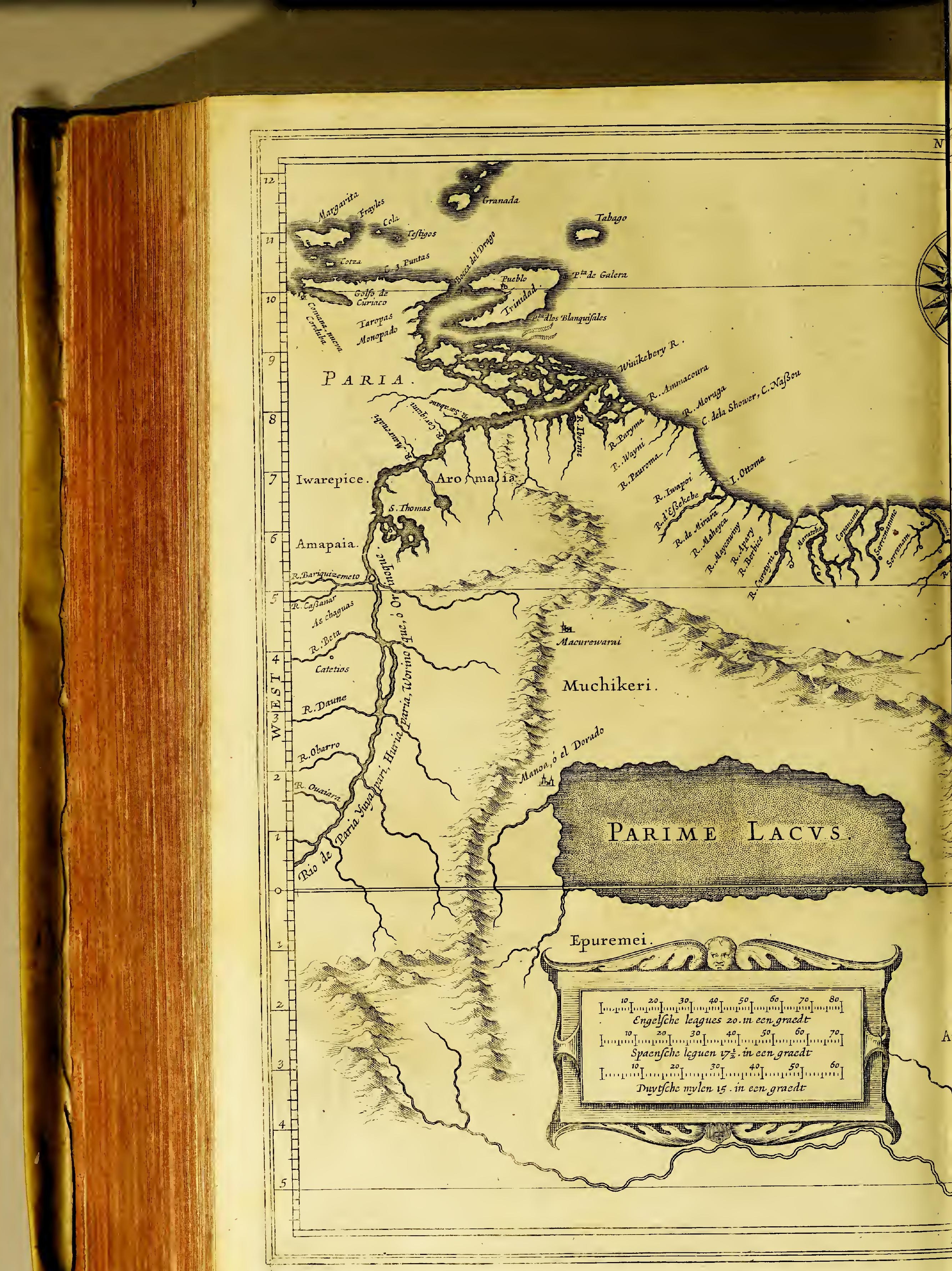




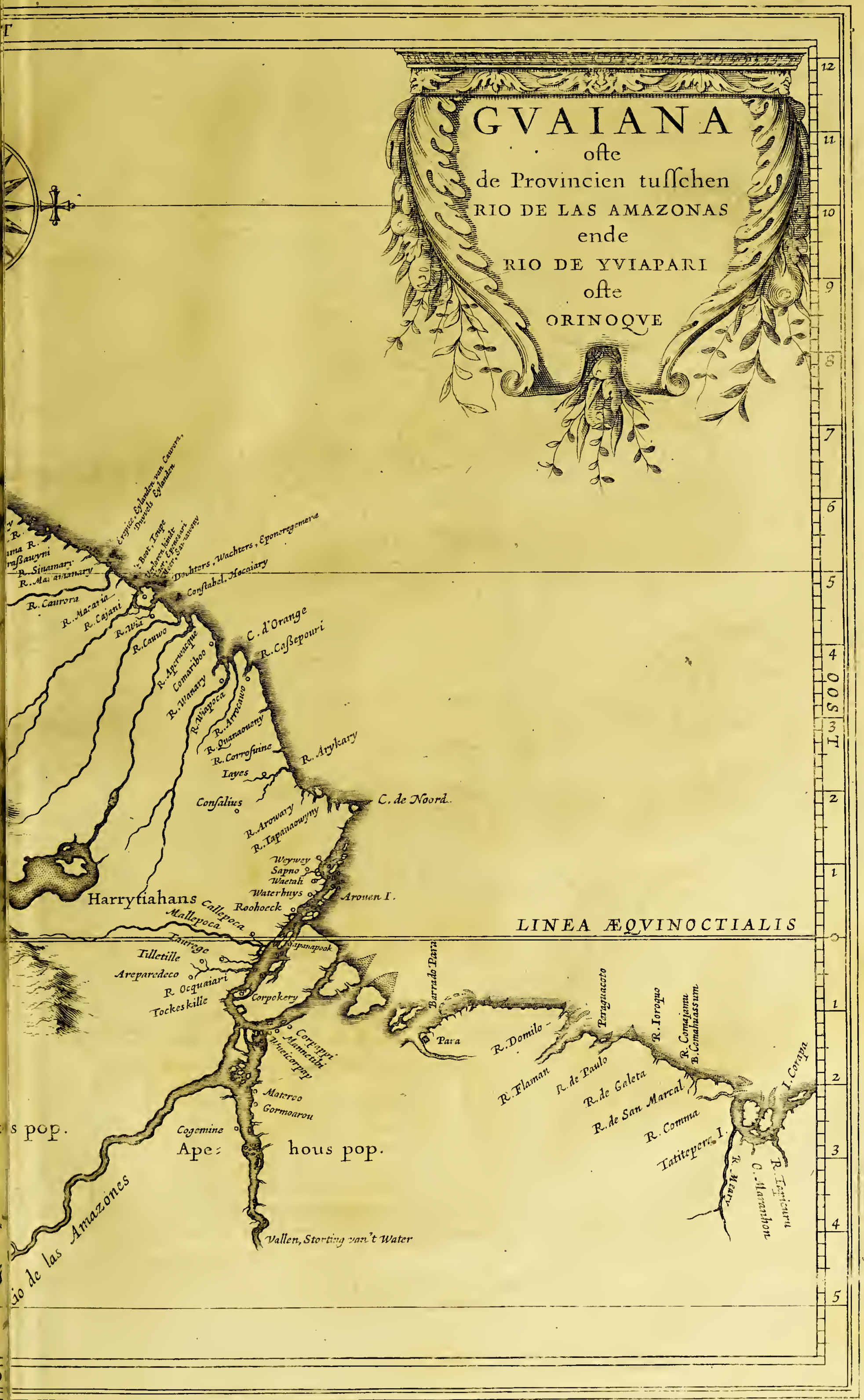




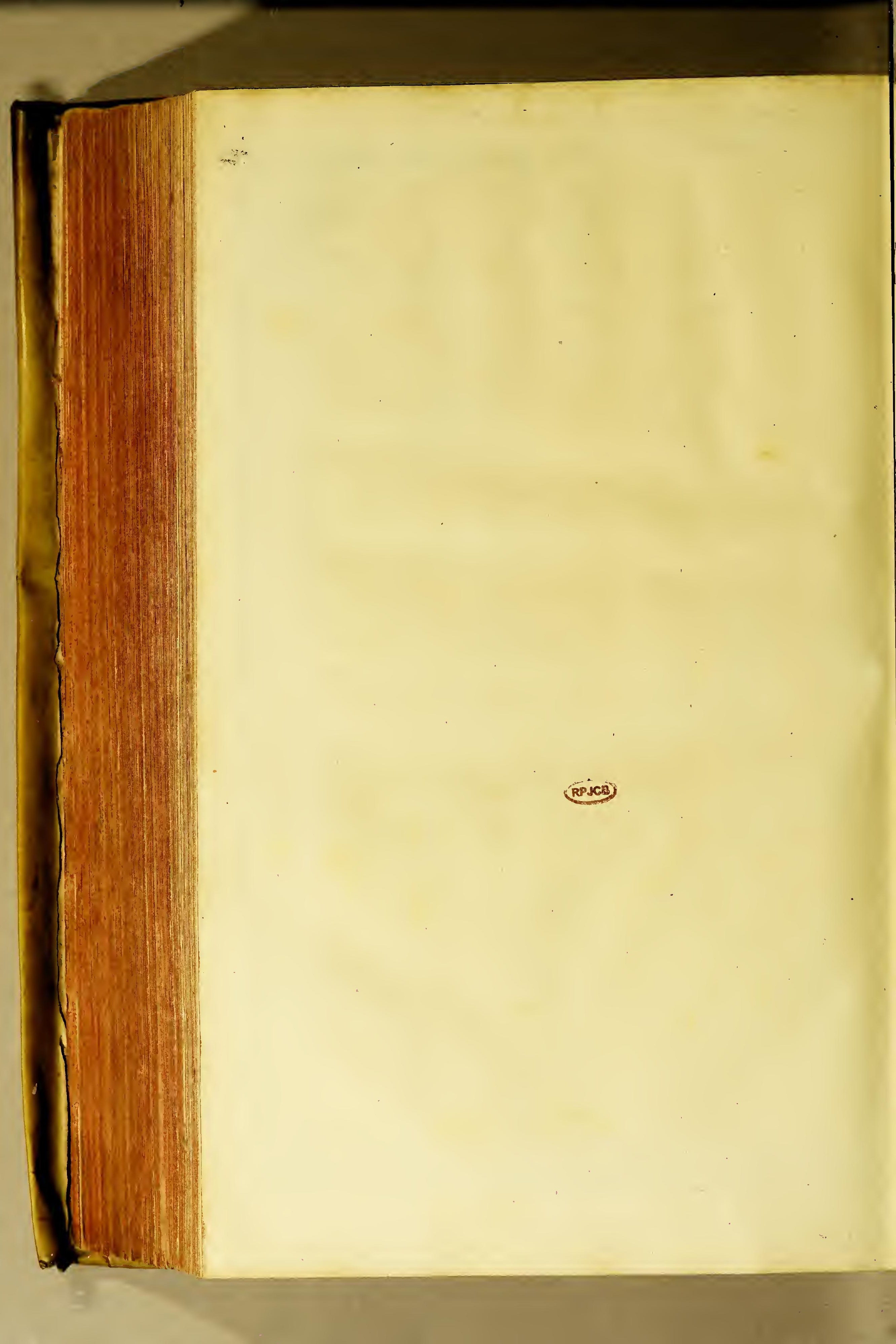




\section{BE S C HR IIV IN G HE}

\section{Uan}

\section{W E S T - I N D I E N.}

Det befthtentoe 25oech:

\section{Wilde Cufte, ofte Guaiana.}

\section{Inlepsingte.}

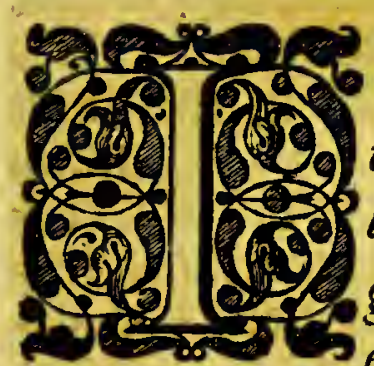

X 't voorgaende boeck zijn wvy met onfe befchrÿpinge gekomein tot het uyterfe eynde van Brafil, ende de rieviere ofie' $t E y=$ lande Maragnan daer in begrepen, ende bebben nu tz reeroolghen een grooteftreecklandes, woelck roveynigh op de kuste, ende by naer gant fch niet binnen s'andes bekent ende ont decket is: Soo dat rovy ons befchrivinghe meeft fullen nemen op dekufte alvpaer fich oock gheen kleyne fvvaricheyt en vertboont, door de groote verycheydenheyt van namen die foo in't ghemeen als in't particulier aen defe landen rovorden ghozgeven, by diverfche natien die de felve bebben ontdeckt ofte befocht; rvelcke verfcheydenheye voy zoo veel ons mogelijcken is fullen fen over een te brengen. VV at den alghemeynen naem van dit ghevpefte belangbt, vinde by Herrera dat by 't gantsche ghedeelte van't vafel landt. van America fende naer 't noorden, van't Eylandt Margarita af, ende nocb voorder by wvefen' 't felve Eylandt, tot aen de rieviere Marannon (die by 't fcheyt maeckt tuffchen de landen de Kroone van Portugal by den $P$ ans toe-gheegghent, ende de landen van de Caftilianen) begrüpt onder den naem van Nova Andaluzia offe' $t$ Gouvernement van Serpa; vvelck by feght in de Indiaenfche tale te vvefen Guaiana; begrïpende in de lengbte dry bondert leguen: In voelck refort (Jeght by) ä̈n begrepen de volckeren die men noemt Omagues ende Omigas met de provincie El Dorado binnen s' landts. Andere noemen een groot deel van dit ghevvefte de Wilde Cuftes andere Guiana ende Wiana, endefoo voorts. Hiet $\sqrt{y}$ met denal-ghemeynen naem foo bet vvil; om dit ghevvefte met goeds ordre te befchrijven, foo fullen rov 't felve verdeelen in dry deelen, ende onder het eerste deel begrïjpen de groote rieviere das Amazonas, met de rievierers ende provincien by ooften de felve vieviere gheleghen; onder bet tpveede de vercheyden rievieren tuffchen Rio das Amazonas ende den Oronoque gheleghen; ende in ${ }^{2} t$ derde den Oronoque felfs. 
Wilde Cufte, ofte Guaiana.

TOBO ofte RIO DE LAS AMAZONAS.

\author{
Het eetfe Capittel.
}

Cheleghentheyt van de kufte van de MARAN groote rieviere DES AMAZONAS.

A Degbeleghentleptuan dere landen beter te bet= ftaenenoe oe kufte beter aen te bengen/ foo fullen bo rontratie 't gbene wp ín oe booz-gaende boecken bebben gbeoaen/ bier bes gimnen met fet berbolgh van de kutte ban bet eElandt Maragnan af / tot de groote rieviere.

In het booz-gaende baeck behben tup ghetracht te tweeren be confulie tan of namen die top bp De Spaegniaeroen bebintons infonbetfept in Den name ban Marannon, Die bop nu naet ong geboelen jịn recte plaetle bebben ghegeben: Herrera in fpn Deferipcion de las Indias etkent de feltie faulte in andere / boe-Lelyp die felts dicklwilg begaet in fpn biltopie; ende ftelot tuffifyen be riebiete Marannon entae Rio Sant Iuan de las Amazonas tachtenticf

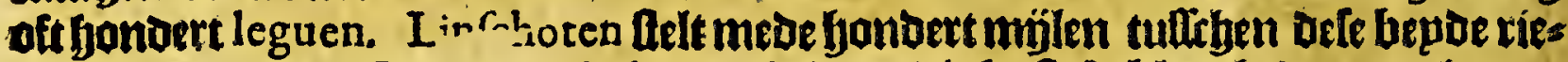

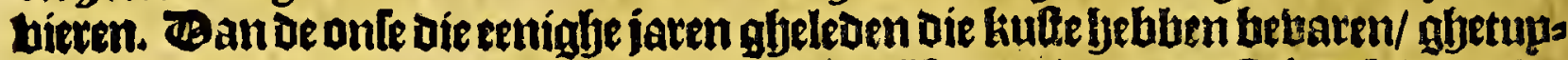

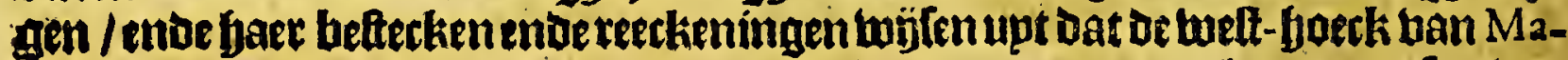
ragnan ban den ood-foeck ban oe riebiere des A mazonas nergheng naet foo vers

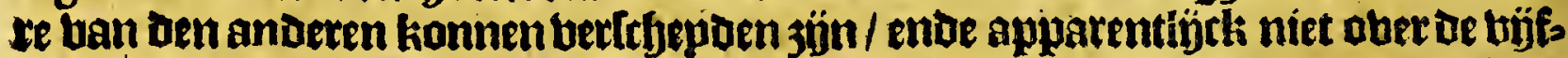

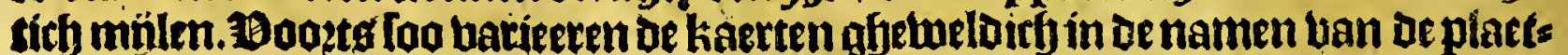
Ien tuttrben bepoen oele thee riebieren; welcker eenigbe wp biex fullen in-boegen/ te weten: upt de Spaenfebe kaette die wu binden in Defcriptionis Ptolemaica augmento ; ende die twp jebben in de kaerte bn Linfchoten, ende die tup binden inde Utugellebe liaerte ba $\mathrm{M}^{\mathrm{x}}$ Hackluydt:

\begin{tabular}{|c|c|c|}
\hline spaenf. & Linfchot. & Engels. \\
\hline acel & $\begin{array}{l}\text { P. de Pracel } \\
\text { R. de Sant Marcal }\end{array}$ & R. delos Éclavos \\
\hline Sabo de Baixos & $\begin{array}{l}\text { ne Paulo } \\
\text { ixos }\end{array}$ & \\
\hline & $\begin{array}{l}\text { R. Dounulho } \\
\text { R. de Ilheo }\end{array}$ & \\
\hline & int Ituan & C. Blanco. \\
\hline
\end{tabular}

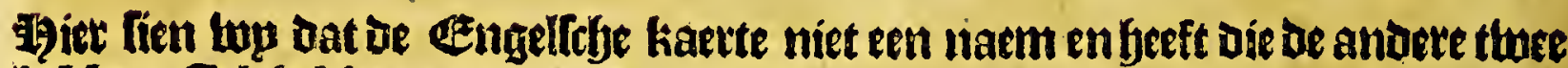

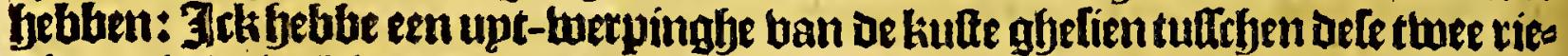
bieten; in be welcke dsp riebieten niet berte ban oen anderen berfebepoen/ waren upt-gelurozpen/te weten:Rio de Sant Paulo, ente Rio de Flaman, eñ Rio Doulho; ban wellke Rio de Sant Paulo lweft-jupht-Lueft in Atreckt / met beel janton in be

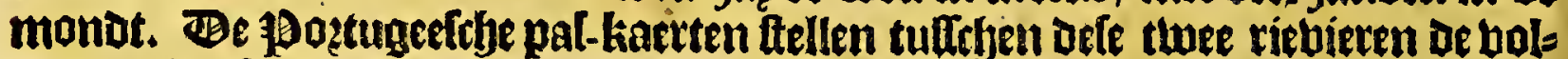
genoe plaetten van Marannahaon af:

Tapitafera

Bit flaet op Tapouytaperé, loo de ff trandjoutenhet noenten; ende de onlenoemen't Tippattepera, ende bouben't een $\mathbb{E}$ p landet te teten/heblente roodtactitighe botcken.

Cuma - Bit is Comma ghelijet of ffrancloplen enoe de once bet noes. men/welck wp in thooz-naende boeck bebben betrfyeten.

B. Coma Huafum Befe bape naev't upt-twin Ten ban de kaerte gaet barte te landtmaert in / banig feet nnoiep.

R. Coma Ianiu Ẽndedaer aen uolgyemde Cofta Alagada. 
Het vijfthiende Boeck.

R. Ioroquo Delceen groote viebietelchïnt te tweten/Dodb ondiep aen De mont: twaer aen bolght Cofta Baixa, ghelijeli dan alle defe kufte bat
black is.

Paraouacoto EEen ander riebiete niet tíep te lantr-watert in fireckende; ende Daer naer Surianame metre een riebiere; ende R. Suramu; R. Itata; $R$. Nama, al booz black ente vol fanden.

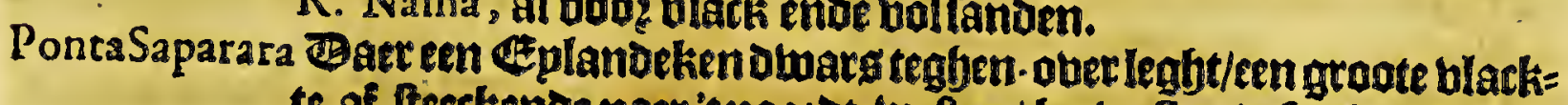

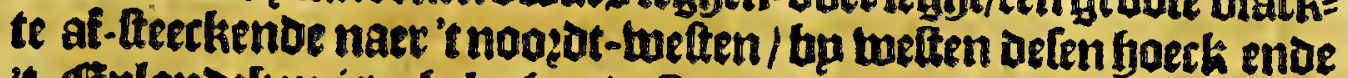
't Eplanoeken is gheleghen de Barra van Para, ofte oofeelijekiften' arm ban R. des Amazones, op twelcken arm of Dopetugefén nu een foet hebben/gbenaemt Para, welckes in- moonoers nu ettelijos ke replem ong bolk op be groote rietier des Amazones berftooer behben/ ende bergindert Datfe gaee colonien met rufte niet kon= nen legghen.

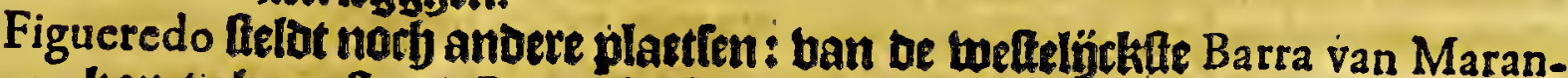
haon, komt gbjeterft aen Punta de Cuma; ban buelcke' 'tlandt boozoer black is enve bol ghelioamite tof Porto de Aippe; Daer aen volght Illa da Cumara ; van melcket tot llha Suputuva jijn there leguen, enoe ban dele tot llha Bianca, wetck

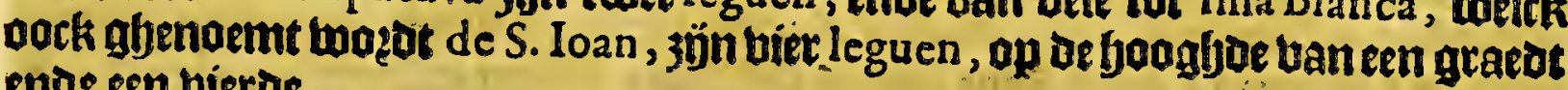
ende een vierde.

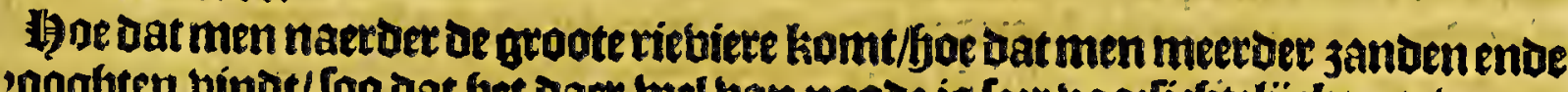

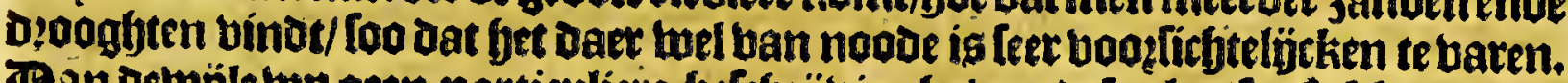

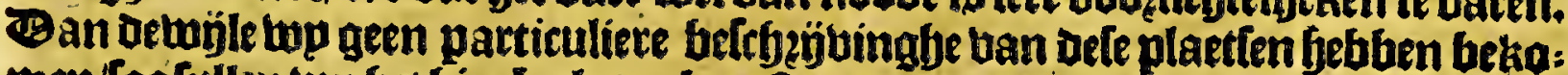

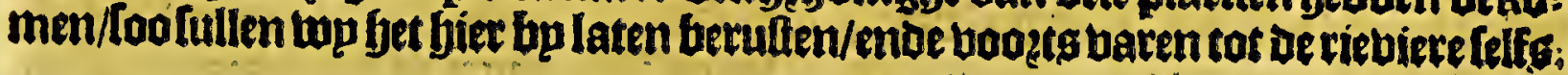

Het tweede Capittel.

Befchrijwinghe van de rieviere $D E$ I S A MAZON A , ende haer eerite onedeckinghe.

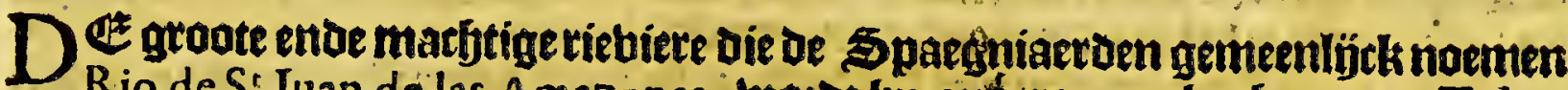

Rio de S' Iuan de las A mazonas, trozot bp antoren oork gbenaemt Tobo, ende Topoi Tapera; ende ban de Spaegniaerden oock Para ende Orellana, Goe- wel Ip Defen letten naem oock gheuen aen den Orono que, confondeerende dé Ten naem in ghelijcker boeghen alg dien uan Marannon, gheligek by A cofta ende

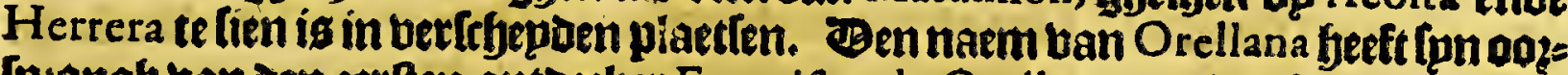

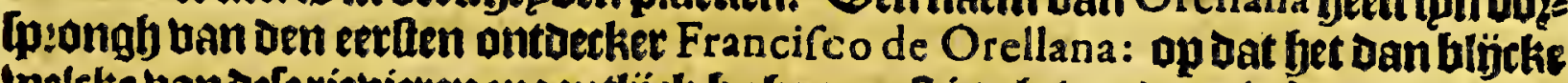

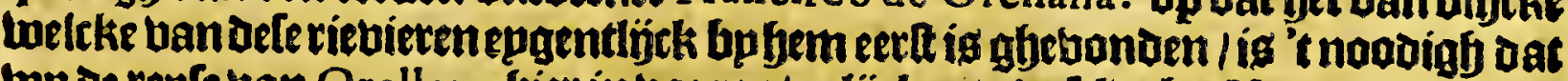

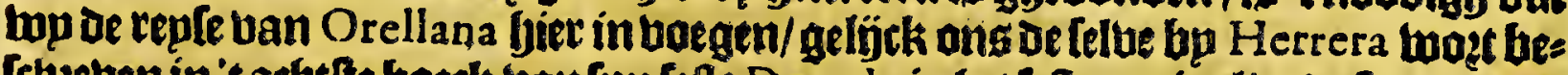

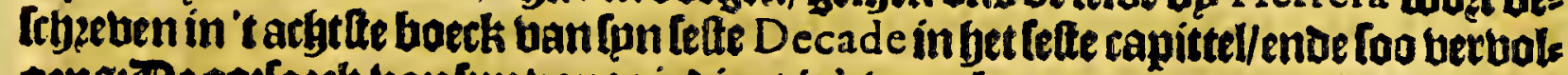

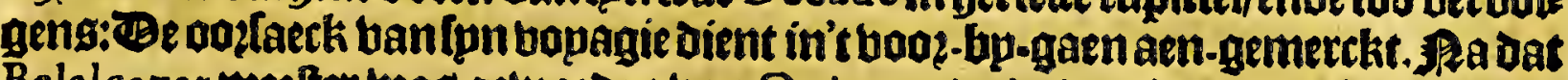

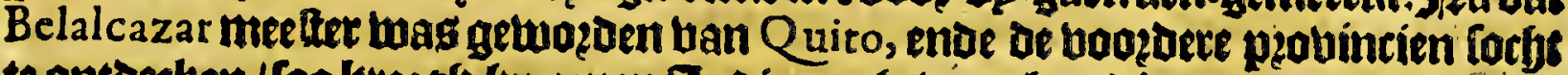

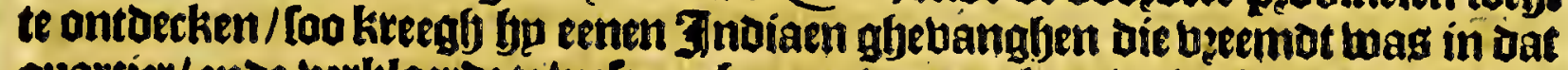
quartier/ ende berklaerde te twelen geformen ban een lant twelck bp noembe Cundirumarca, Daer grooten rijckdom twas te binden / foo Dat de liecen gantffíghes

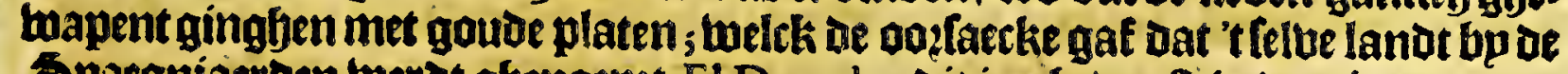
3pargniaerben twerat gfenaent EI Dorado; oit is gbelweeft in Den jaere 1535 . Gon zalo Pizarro Daer naer in denjare 1540, fjet Gouvernement tan Q uito ban Ipn bzoeber berkregen fiebbende/ is begeerigb getween dit Dorado te gaenloecken: Ipn ILieutenant twas Francifco de Orellana. Sp trocken met fyaer volck in De

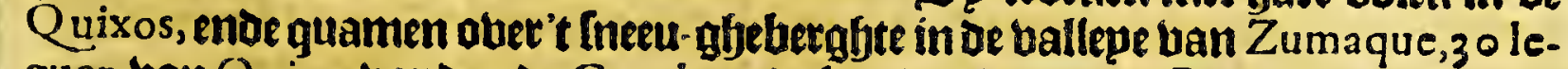
guen ban Quiro; tonden de Canela, ende keerden tweder na Zumaque, ende Ampua; quamen daer naer otere een rievier aen een blecke Varco, Deer fpeen bercke timumerden/ ende Orellana tuetot met de felue ende eenighe tanoen de vieviere af $23 \mathrm{bb}=2$ gferon: 


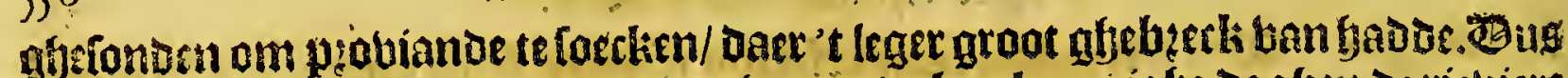

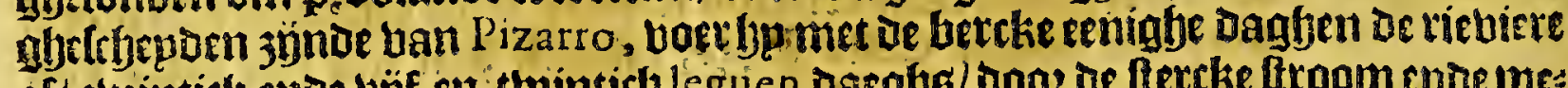

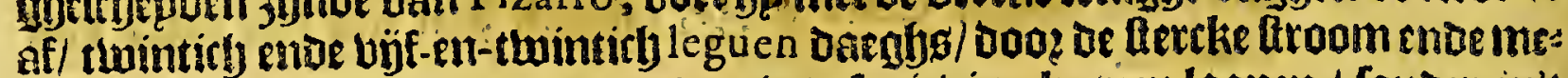
nighte uan riebieten die tan' $t 3$ upoen in Defe riebiere liomen loopen / fonder in't

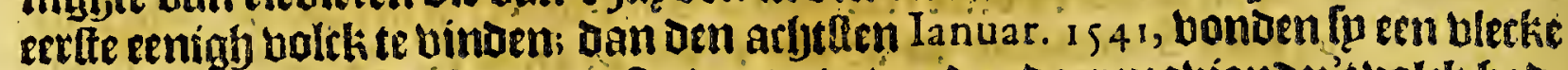

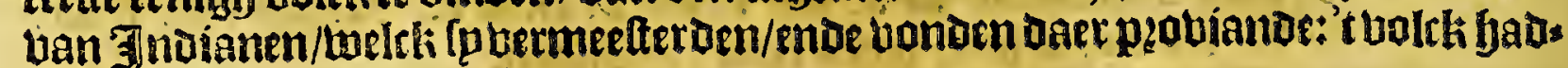
de bier goud ende andere jubeelen.

Orcllana niet konnende oft niet willende tweder-keeren naer't legher van $\mathrm{Pi}_{\text {o }}$ zarro, welck bp in grooten moodt hadoe gelaten (gelïrk dan't felve met groot ber: lies ban balck weoer- seerde naer $Q$ uito) maeckte bier norb een bercke/endenam boos de rieviere boots af te baren. Bertrock ban bieri op V rouwen-Lichtmis, enoe naer 20 leguen bonden fu een anoer rievier die ban de recter-fant af-guam/ ende met fulcken ghetwelot biel in de Dete / Dat fo Daer groot ghebaet upt-thonden. Dan daer boeren fo wel 200 leguen af / Conder eenighe woon-platfen te binden: Daer naer bonbenfo berfrhepden woon-plaetfen / ende volck diebaerfebilot-pad= Den/papegaepen/, perdoeten/ende beel bilth bereerden: quamen aen een dozy wieng Catique was ohenaemt A paria, Die haer twaerfthouoe boo de A mazonas"

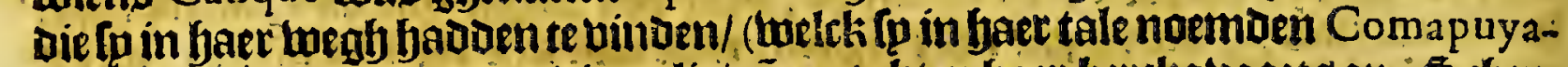

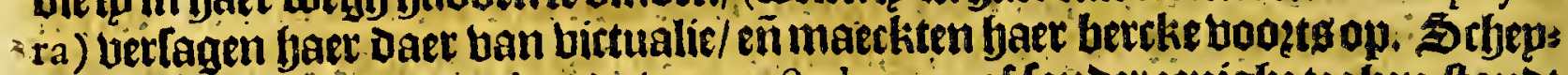
den ban daer den 24 A pril, ente voeren 80 leguen af fonder enighe teghen-ftande te bimben; Doen quamen [p weder aen logel en onbelwoont landt/ende de riebiere Gadoe aen bejoe joben foo tteple ende baroe bergen/Dat fo gbeen gbelegentbepten

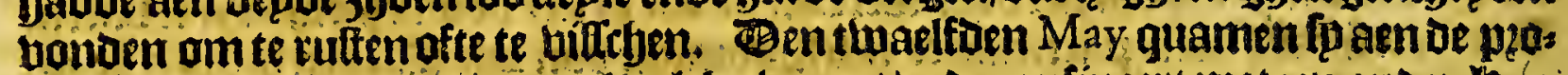
bincie ban Machiparo Daer beel bolcks boont/enoe confineert met een ander feer abenaemt A omagua : werden daer naer bp de 3 noianen in yaer canoen befticly beltreden/ende langh te water berbolght/lonoer rulte te febben twee nacbten ende twee Daghen; tot darfe quamen aen een blecke welck fp met ghetwelt in-namen i ende bonden Daer beel uictualie: ban befe plaete liepen beel boogleende gebaen: de weghen te landt-waett in; enoe fp maeckentectiening ban A paria af tot biec toe/ abebaeren te bebben dep hondert en beetich leguen.

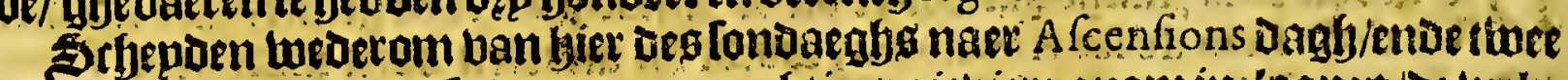

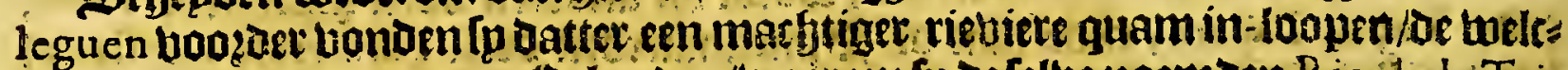

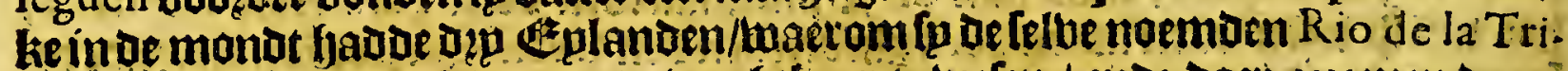

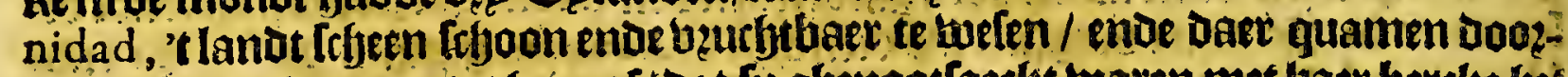
gaens foo beel canoen tot yaer af / Dat fp gljenoutfaeclit waren met baer bercke bet midoen ban de riebiere te bouden. Bes anderen daeghs bonden fu cen klepi

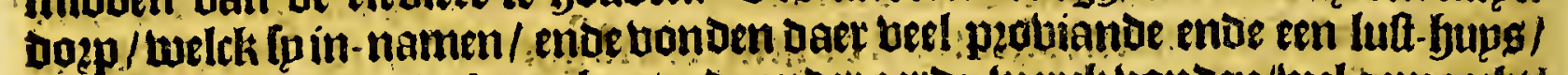

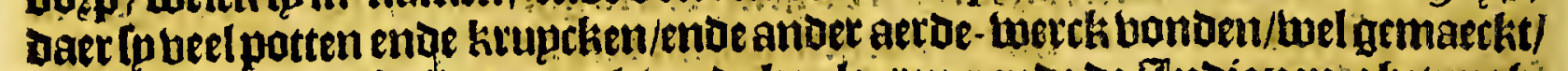

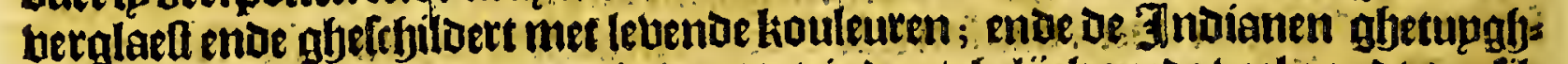

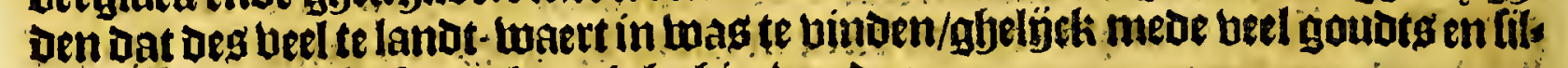
bers / ban weltkeg fp oock eeninge fier bonden.

Baer liepen ban oefe plaetle twee gebaende beghen te lanot-waert in; tan om bat fet lanot allentfjalven foo bolvolckg wag/vonoenfogberaden bootg te ba:

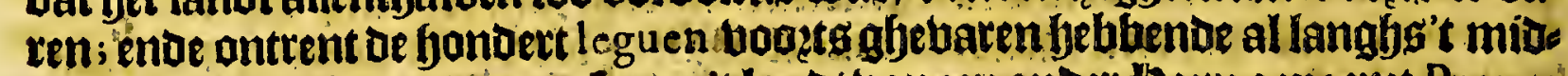
jen ban oe riebiere/ quamen fuaen t lanot ban een anber Leege genaemt Pagua:

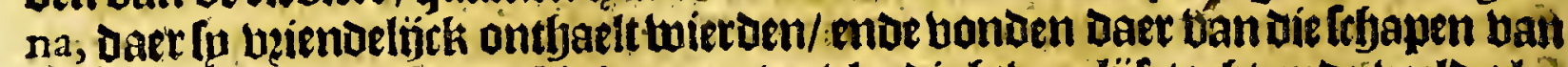
Peru, ende t lanot leet luftigh ende oterbloedigh ban liff-tocht enoe beelderlep buchten. Boeten boots lamghs sen ander groote blecke / en bonden allentfals.

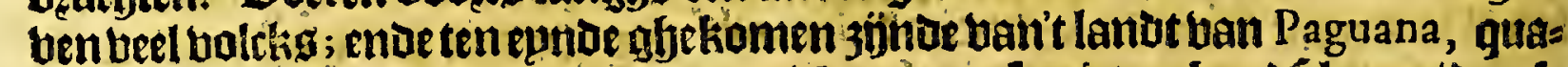

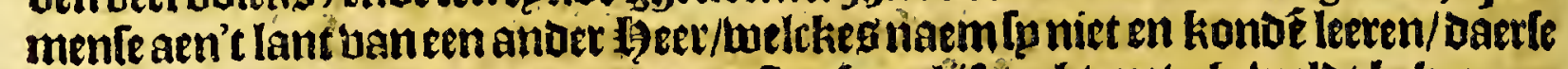

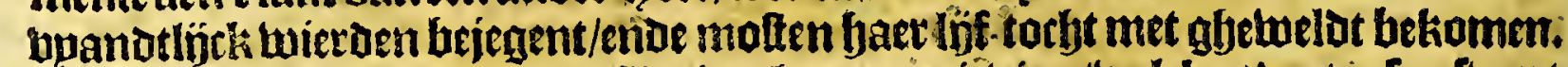

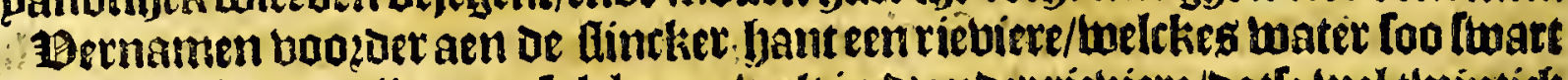

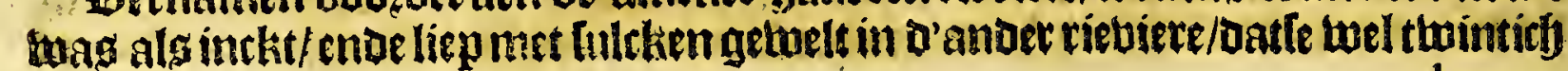
leguen 


$$
\text { Het vijfthiende Bock. }
$$

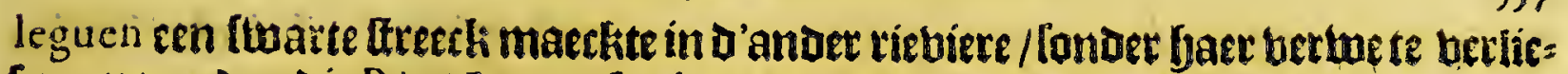
fen; noemien die Rio Negro: lagben veele dołpen/ boe-welniet groot /enoe na= meneen in met gbeweldt / daet [p beel biffy bonden; enoe boeren foo al boosts Dooz veel toepen ende pzouincien/ baer ban noodigbe pzabilie boos-tiende; de rie: viere twas bier foo beerot / Dat als fa de ecne sjöoe fieloen/ oe andere niet en kon: Den ghefien.

Quamen aen een blecke Daex Ipeen Jndiaen glebanghen kregben/ die baet fepde datie nu twaten in't gbebied ban de Amazones, snoe boeren bookts langbs beele doepen tot den fevenden I unij; landen doen/ ende namen een doep in fonder

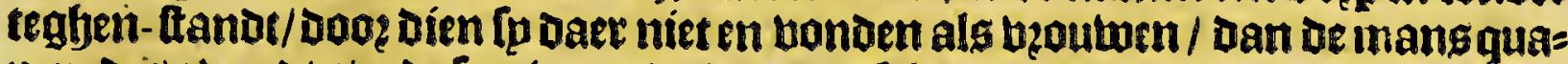
men Des abondts/ende fp gingen wederomt' frbeep/ende boeren al vooets neffeng thel betwoont lanot/ tot aen een groote blecke daer fo feben foofoen op ftaecken fa=

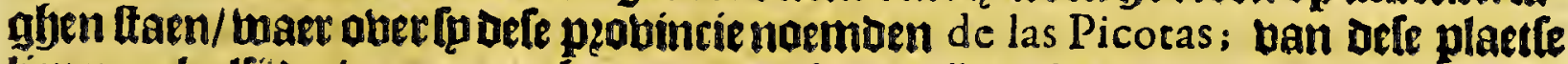
liepen gekalfigoe twegen met boomen aen bepde 3 joen beplant/ te landt-waert in; landen oaer naer aen een anoer diergbelïcke/ende betlagben foer ban bibzes met gfeltuelot / bonden Daer Maiz, frjuilot-padoen / ganfen ende papegaepen: bertoef=

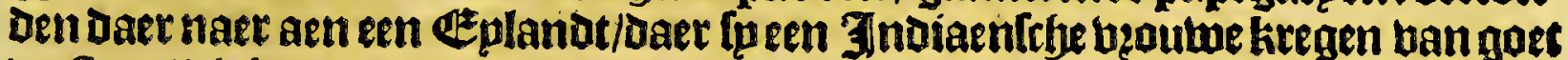
verftant/ die baer verbaelde datter te landt-waert in beel bolckg wag alg De Spae= gniaerden / ende twee witte beutwen bpen en leer die de felbe ban beneden de ries Liete fadoe gbebzacht / too dat [p baer in-beelden Dat bet Diego de Ordas ofte

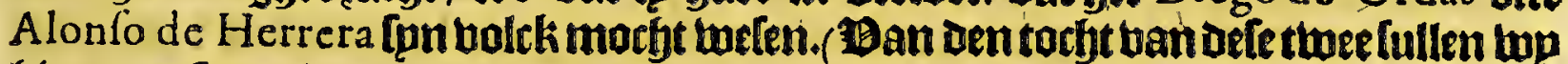
bier naer (pzeecken.) Boeren al boozts booz bp beel bozpen / fonder Daer aen te gaen / tot batte naet eenighe oagben quamen aen een blecke/ ban waer be Tins

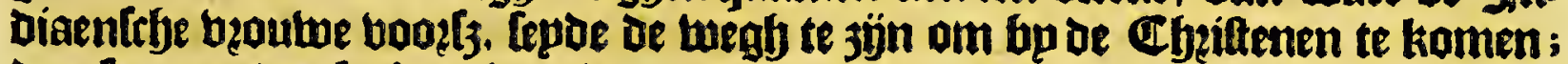
Dan lp en onder-Locften bet niet/maer boeren al boozts tot een bleckie ban Jndia: nen / Daer fu londer tegfen-Leer landen/ enoe bonden Daer Maiz ende bauer alg Die ban Spaegnien; daer de Eiloen Dzanck ban maeckten alg bier; veel tottoes ne löntwaeten / entoe een kerckken daer baer waepenen in bongben/ enoe twee

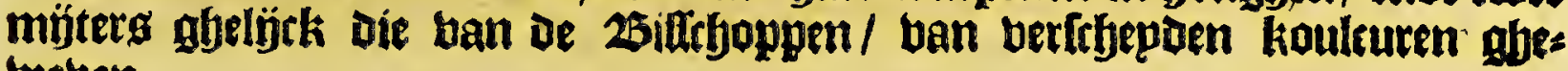
toeven.

- Ben thee-en-twintichetten Iunij ontbeckten [p tuele doupen aen de flinckex-bant] Dan konden daer niet bp komen twegben Den ferctien aroom ban de riebiere; ende in 't Dubbeleeten bat een punt lanot/ ontoeckten fo Leer beele enoe groote twoonin: gfen / daer't bolck al op fun foede was teghen baer komite / ende baet berfin = Derden te landen. Gier laghen fp eenigbe bzoulwen die de mang met groote moe=

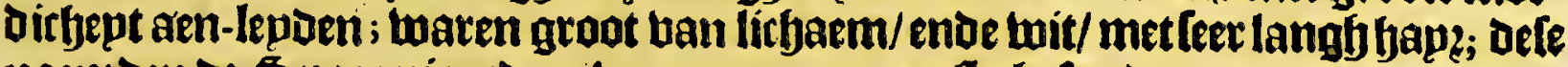
noemoen de Spaegniaerden A maz onas, opeen flecht fondament naer dat Herrera Lelfs ootoeelt / ooo dien 't niet beeemt noctj nieuen is in die quartieren ban

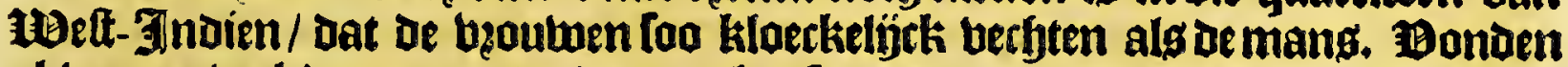
al boots beel doepen ende boon-plaetien aen oe jupot-zjoe ban de riebies

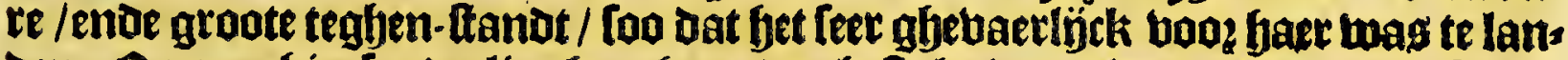
Den. Pamen fier fonderlingfe acft op de gbeftalte ban't landt / bet welcke tebeen feet ghetempert ende beuchtbaer te tweten/ noemden 't lelbe Provincie de Sán luan, om datie opfonen Dagh daer eetf aen quamen; ie bergljen waren beballen met epcken ban beeldetlep footen/ende t landetjoogh/met beel blacke lowefte belden/ ende [eboone jadbt / ende duerde wel fonbert en bijftich leguen, al wel bewoons langhg den oeber ban de riebiere.

- Gielen boots al't midoen ban de riebiere/ tot aen beel Eplanden/ aie boogh/ betuchthaer ende luftigh waren/ende boluolcks/die fjact met baer frbuptjeng (diefp noemen Piraguas) quamen beluetbten: 't groattfe Eplanat was tuel biffricly leguen

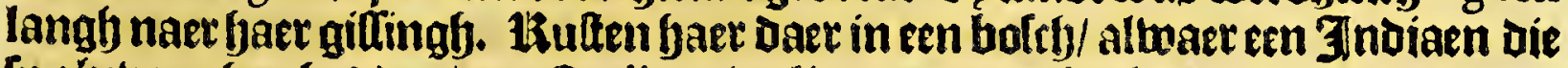
Ip ghebanghen fadoen/aen Orellana beel wondecs berfaelde ban de Ama zonas, boe dat oele bzoubuen leer marbtigg moe rỉch twaren ban gaubt ende filber/ 23 b 3

Dat 
558

Wilde Cufte, ofre Guaiana.

Dat fo bier fempelen baoden ban De fonne/ al met goude plamtien beleglt/ bupfet ban teen / ende bemuerde fteden/ enoe meer ongheloofljétie aingten die Orella-

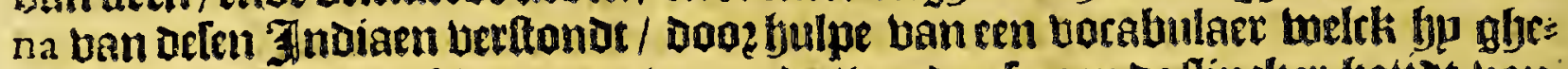

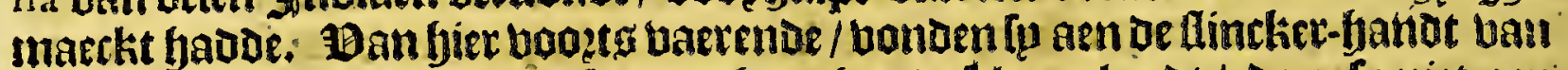
ae rieviet noch al maon-plaetfen / op boong ende felyoon lanot / daet fo niet aen

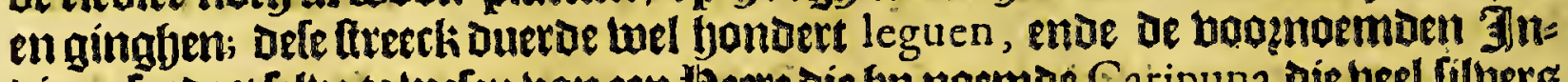

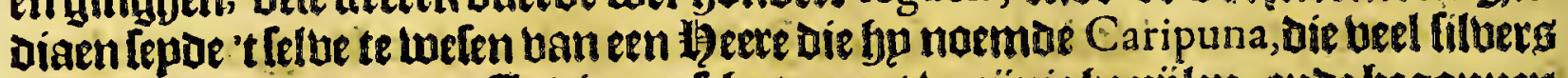

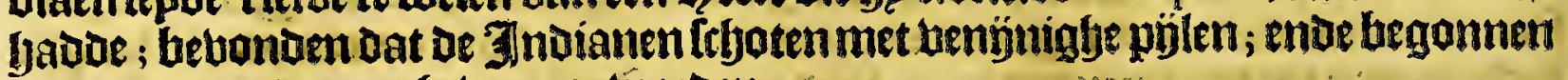
De bloest van ae 3 ee ghetwaer te twozen.

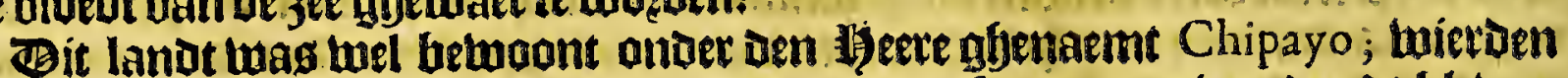

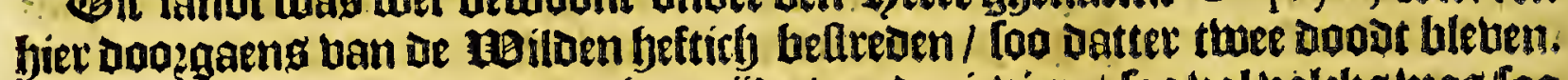

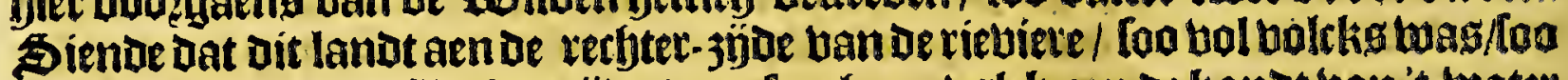

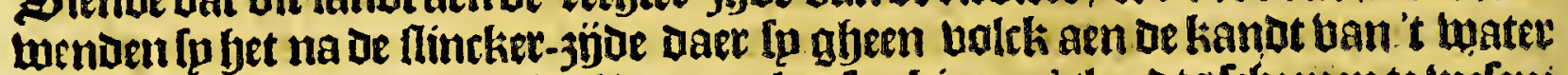
entuernamen/Joe-twel Daer beel woon-plaetten binmen'glanotg frtjeenente wefen:

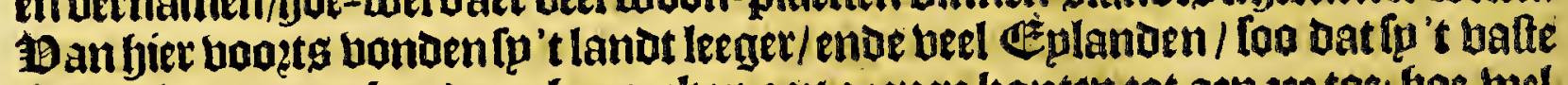
lande niet meer en kanden ghenaecken aen geenen kanten tot aen 3 ee toe; yoe-bue!

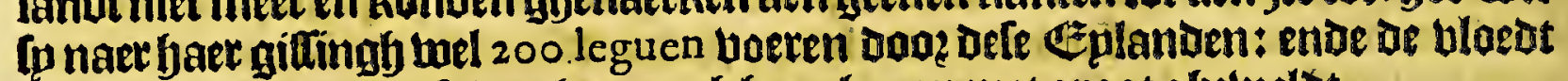
ban be zee quam al dele wegh en nocly boogher op met groot gbelwelot.

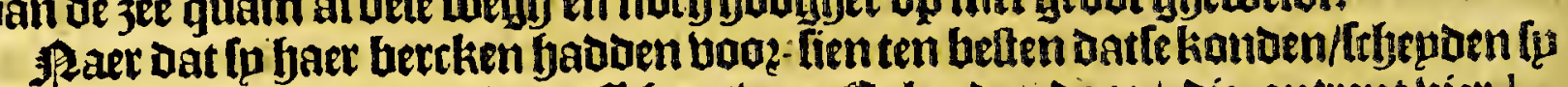

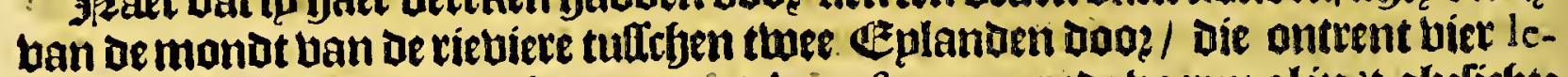
guen van oen anderen laghen/ oen 26 A uguft $154 \mathrm{I}$, ende boeren al in 't gheficfte ban bet landt /ende quamen den neghenten dagb in oe Golfo van Paria, ende

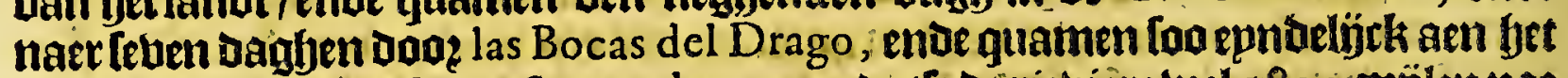

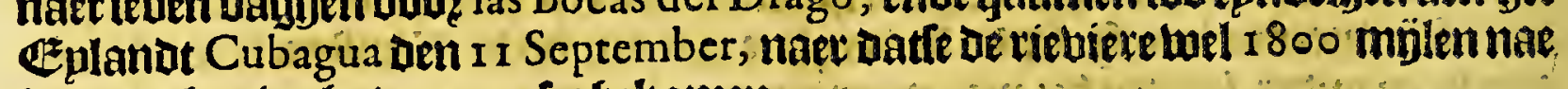
yaer reeckeninghe waren af-abeltomen.

\section{Het Devde Capittel.}

De tweede voyagie van orellana, ende de voorder gheleghent-

heyt van defe rieviere.

FRaneifcus del Orellana Dele groote riebiere ontDedlt febbenue in troeghen fiec Foozen uerfjaelt/ig naet Spaegnien afetiomen am aen oen ttepler te bertjalen

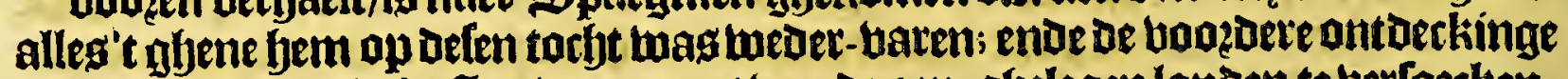
ban de rieviere ende't Goubernement bam de aen-ghelegen landen te berloecken;

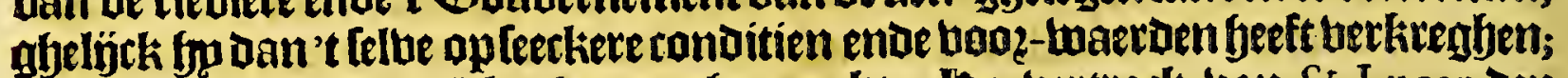
en vier frbepen ende bolck glbereet ghemaeckt: elften May 1549 , ende was aen't É planot Teneriffe, Daet bp Dęp marnden ber: toefae / enve aen Cabo Verde twee: bem ftierben mel arbt-en-tnegentich perfog: nen af / enoe víftich moelt by achter laten om datte onbequaem twaten oe keple te

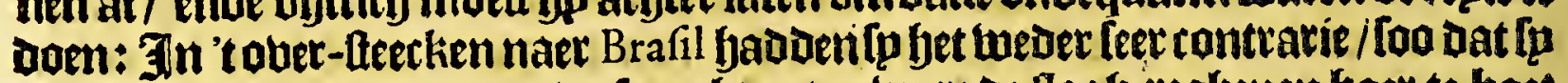

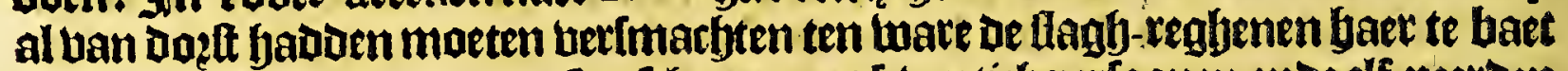
badoen ghekomen ; een ban Ipn Icbepen met febentirly perfoonen ende elf peerden Uleet onder-weghen / foo dat men daer nopt meet van ghefoozt fjeeft; de theere= aeerende fryepen quamente lande ontrent Los Baxos de $S^{t}$ Roque, ento boudende langlyg de kufte/palfeerden in 't gheficlyte ban de Marannon, ende ontrent fondert

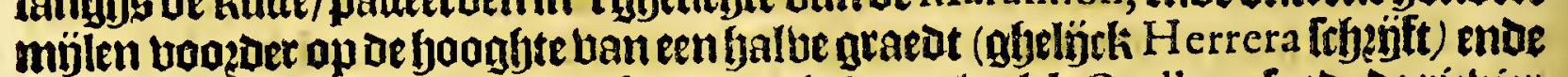

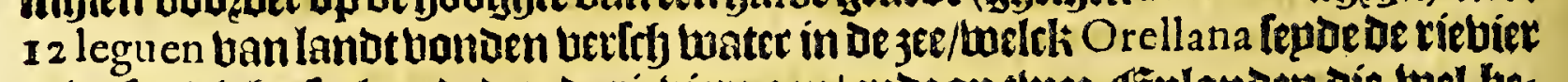
te Lefen die fo forljte: deden de riebiete aen/ende op twee Eplanden die toel be:

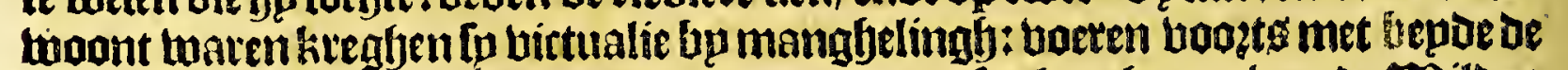
Ichepen be rieviere op tad I o leguen;ende ontrent feecliere butten ban de miloen

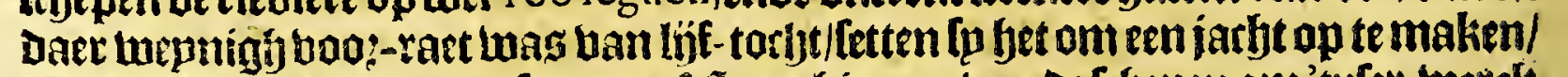

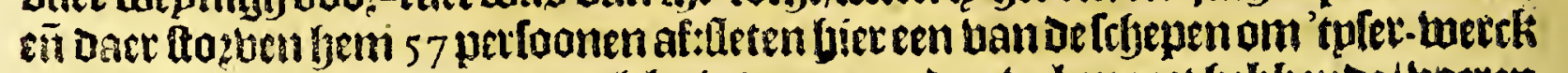

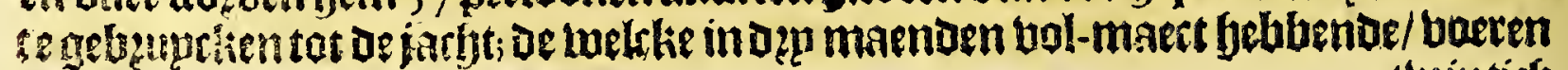
thintict 


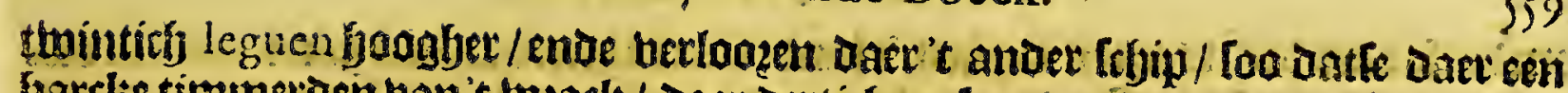
Garcke timmetien ban't twack / Daer dertich perfonen thee macnoen enoe een balf met befigl waren. Bnder tudefen boer Orellana met de jacht om den prine ripalen arm ban de rietiere te foeclien / ende de felue niet febbende gijebonden in

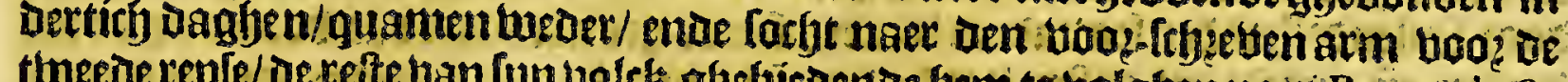

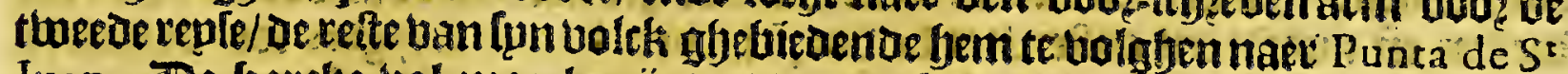

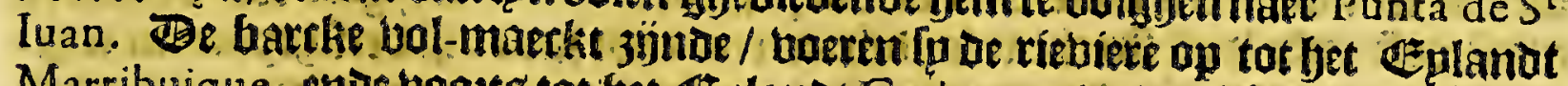

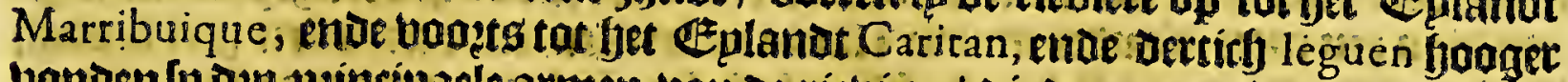
yonden [u dep plintipaele armen van de rietiete / Die daer naer it ęn quamen] foo dat de rieviere daer thaelf leguen beent was; Dan binomoe faer te luact

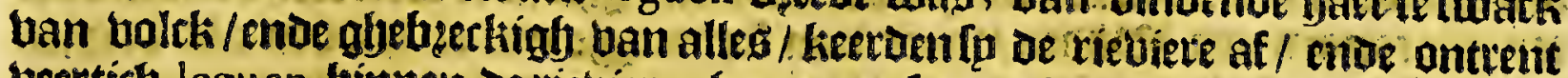

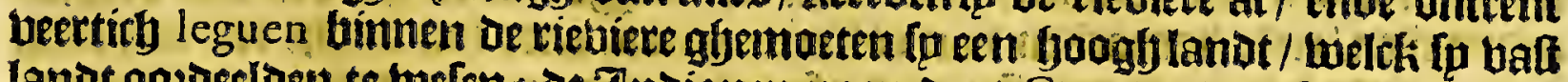

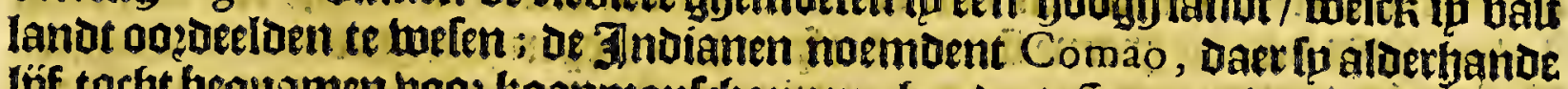

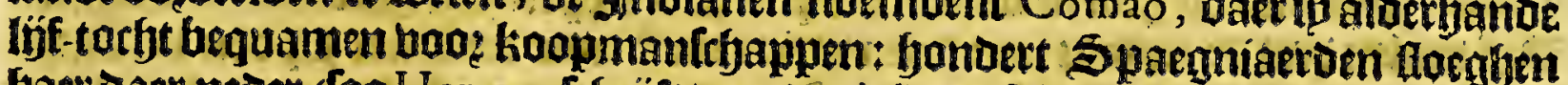

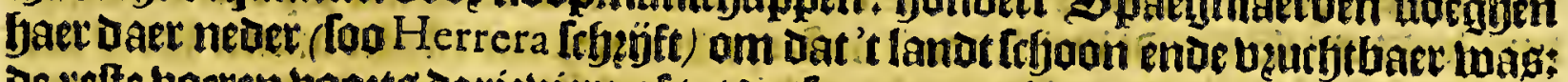
de velfe boeten boozts de rieuiere af tot datfe quamen in de Margarita, daer [p oe Gupf-bzoutwe ban Orellana bonoen / die baer berfaelde boe dat baer man in oe rieviete gheftoguen twas ban fieckte ende roulw dat hp dentechten arm ban oe rie= bier nieten hadoe konmen biman. Bit is oe upt-komlte gljetuedt ban bephe of torfiten ban Orellana, upt thechael ban welcke leet wepnigb bercheets is te rapen.

Jick en bevinde bp geen filtozien die ick tot noch toe beb be gefien/Dat pemant ban of $\$$ paegniaerben oe ontaeckingbe ban defe riebiete nader-hant beft ver: bolight met tchepen de rieviere van onder op barende; alleen fefyejft Lópes Vaz dat

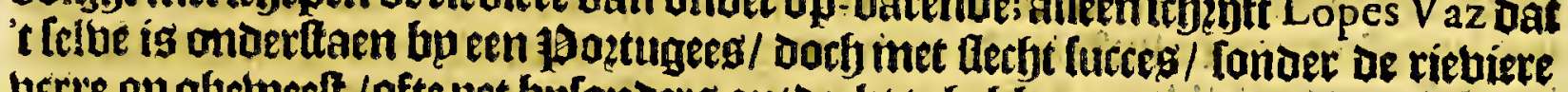
berre op gbetweelt / ofte pet bulanders antoeckt te beliben.

\section{Het vietoe Capittel.}

Ontdeckinghe van de rieviere TOBO ofte DE L AS AMAZONAS by onfe Nederlanders, ende ecrft de gheleghentheyt van de ooft-zijde.

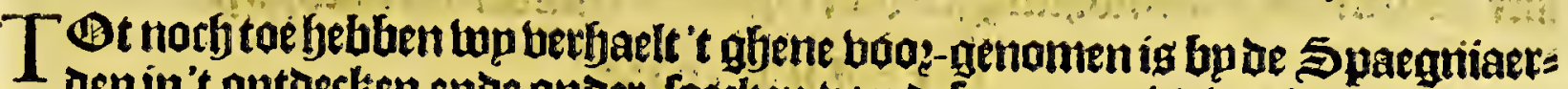
Denin't ontbecken ende onder-foecken uan dele groote riebiete de las Amazo-

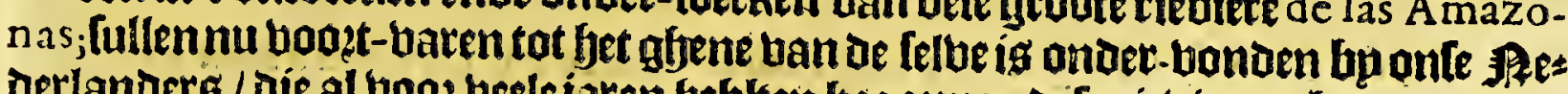
derlanders / die al boo? beelejaken bebleen begonnen Defe riebiere te bebaren; ups

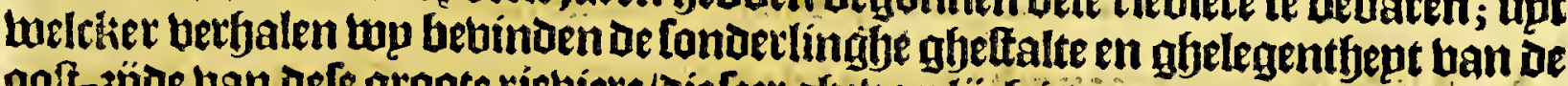

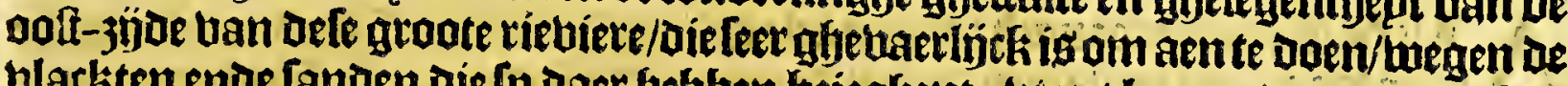
blatkten ende fanden die fp daer bebben bejeghent; want kamende ban't ooffen

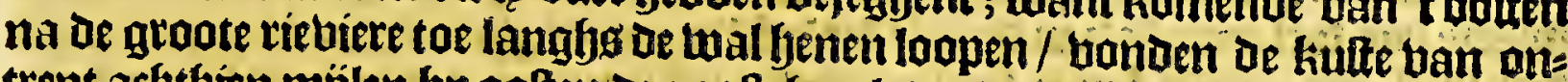
trent achthín mílen bp ooften den oolt-hoeck ban de groote rieviere / meelt fter kende beft ten naopaen ende dede bem op met diberlefe boecken ende in-bochter/ ende meeftenyarigh feel leegh landt/ende ober al harningen tenen fet landt aen; tot datle quamen ontrent leg oft feuen mijlen bp oolfen den boo: [5. boeck/almaerfe baer ronot-om befet uonden met rabelinghen ende fanden ofte platen; ban weles ker eenighe met leegly mater op een lpeingh gant tey ozoogh legghen/rnbe enighe

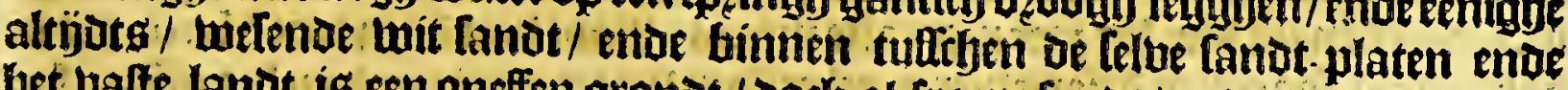

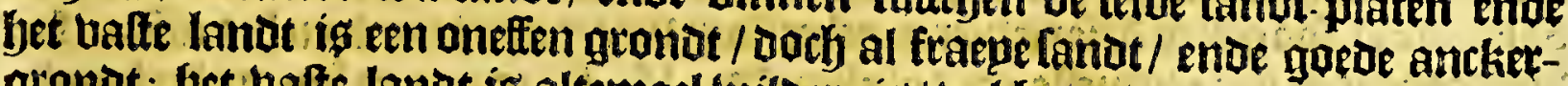

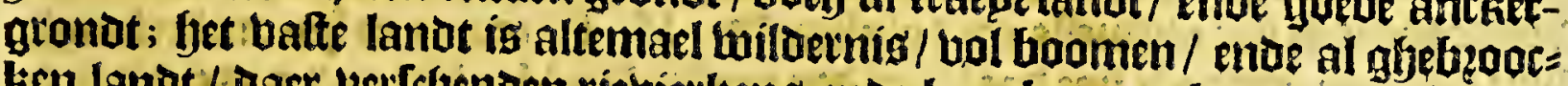
ken lanot / daer verteljępen rieuterkeng ende kreecken upt-komen; de jongbe

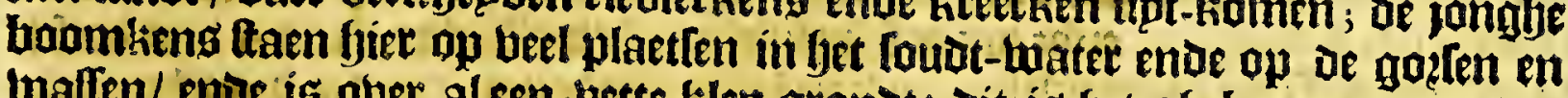
inalten/enoe is ober al cen bette klep-gronot: Dit is bet gheboomte Daet wo

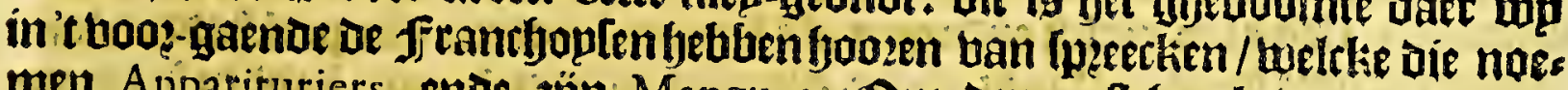
men Apparituriers, ende jün Mangues, $0 m$ den ooft-joeck lan de riebies te tronden de onle met lyaer jatyt een vieviere die fp noemom Rio de Reygers, $23 \mathrm{bb}_{4}$ 
560

VVilde Cufte, ofte Guaiana.

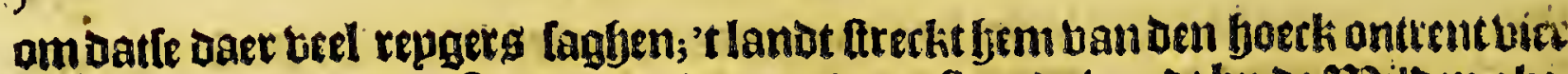

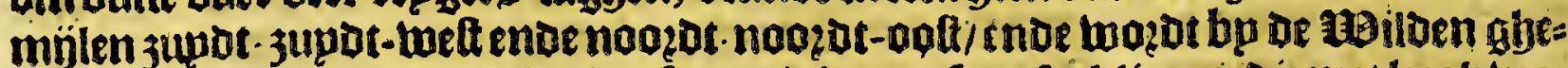
naemt Marapa; (ende daer lagben fommigbe rudtien of fe klippen diemet leegh twa= ter boven 3 win/welck de onle noemoen ie Swarte Verckens, ende tultrben bepden

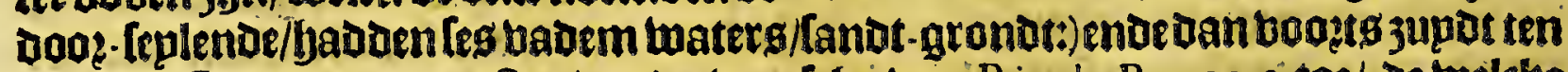
wetten eñ noozot tell oolten/tot oe vooztrbecten Rio de Reygers toe/ De welcke

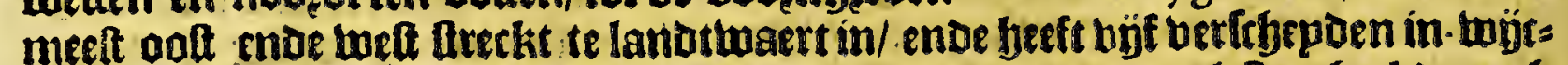
hen die d'een meet d'ander min in 't lanot in Arecken/ende ten letten beel deoogh

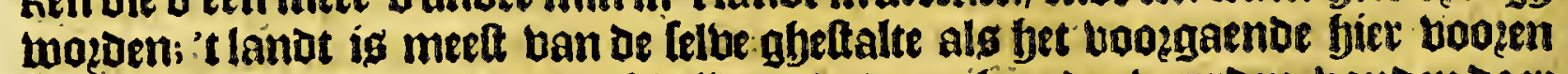

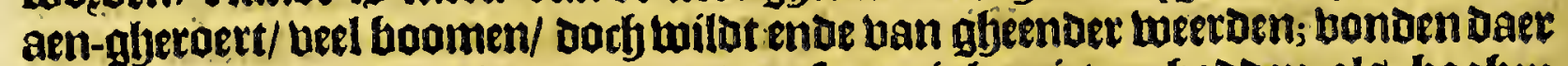
eemige canoen met emilden/ waet ban fommighe niet en fadoen alg boghen ende pälen/ende bamatken ban tottoene garen; ende fommigbe efn laepnigh Tabac, ende van die groene fteenen die fu in faer lippen zijn obetwoon te Dzanben.

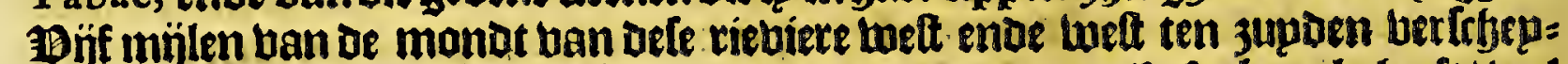
den/ legbt een Éplandt welck áen't ooft-epnoe een groot rif ofte banck beft/ wet

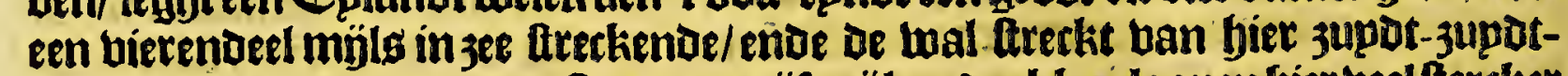
welt enoe noozot-noozot-ooit antrent büf mïlen; De ebben loopen bier beel fercker af alg de bloeden op-loopen. Op de felbe kaurg ende freeck botot men een rieviet ofte kille ghelwaer arbter een boeck lanot ts ende wat boozoer leggben berfrbenden Eplanden bol gheboomte/ oory bangheender toertoen; ende is al vol blarkten ende Dzoogbten aen Die 3 joe ban oe rievier/ 300 Datmen daer feer boosfichteljiclien

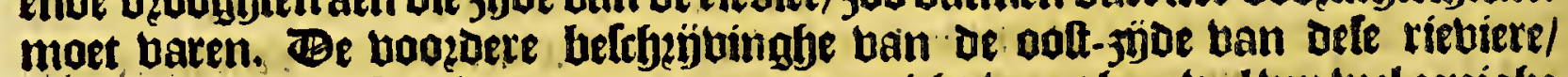
fillen top moeten ftaecken tot naer der onder-richt; want foe-twel wop thel eenighe upt-werplels ban de kufte/ende oock eenighe oblerbatien ban oe gbelegbentbeden

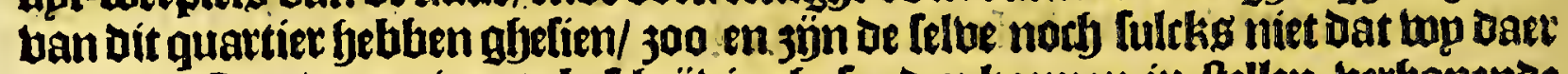
opeen valte ende pertinente be[chejbinghe fouben konmen in-Itellen; berbopende

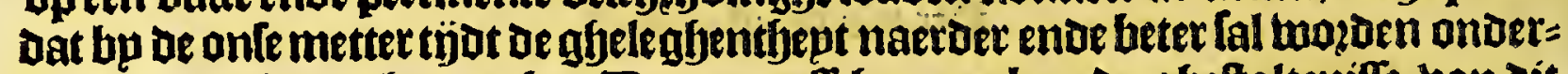
forbtenoe bekent gbemaeckt. Baer en tuffeben 300 kan de gbeftaltenifle ban dit quartier ten deele berltaen wozoen upt bet gheene wp in 't voozgaende 25 oeck ende

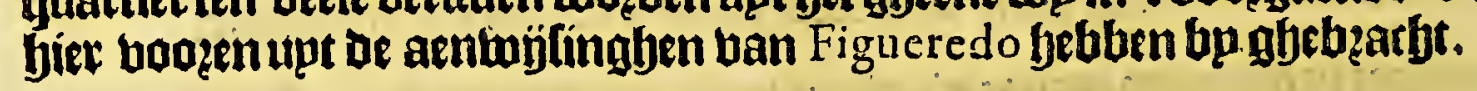

Wet bütae Capittel.

Vordere befchrijvinghe van de groote rieviere DE IAS AMAZONAS, ende de ghéleghentheyt var de felve.

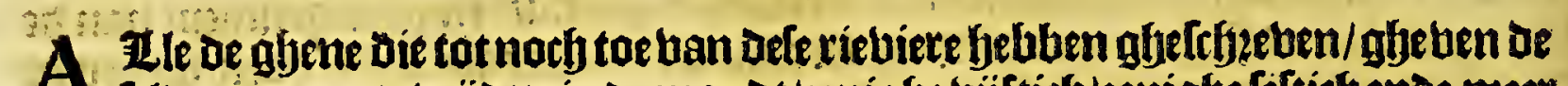

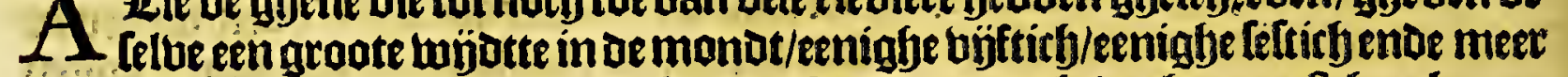

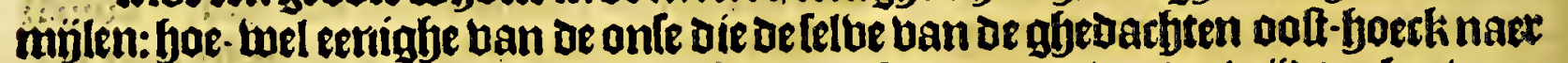
ben twelt ofte noozot-hoek beblen ghekruple / mepnen dat be wijotte bp berce joo groot niet en is/ oe Telue nemenoe op een reethe linie; dan alloo bepde de boes

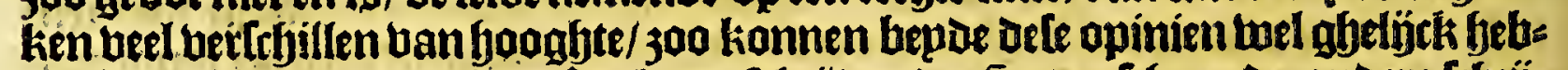

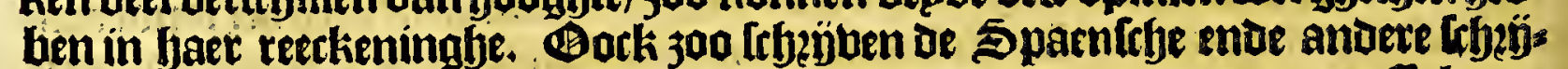
bers twonber bain oe macthtighe ftroom ban defe riebiete/ waer boos te paffe komt

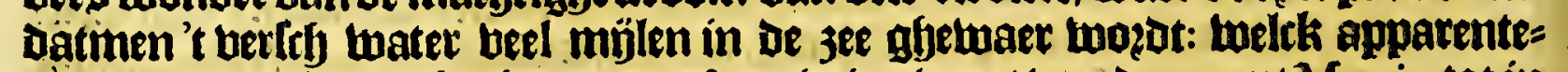
lijek naer den tijt ban bet jaer meer ofte min ig: want van de maent Martio tot in

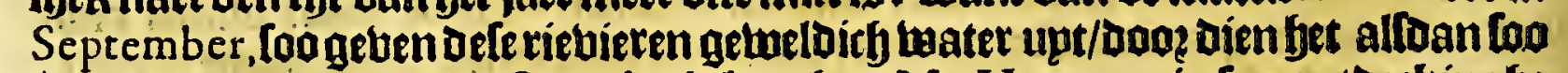
beel reghent in sat ghethelte op't ghebergfte. $M^{r}$ Harcourc in fpnontaeckingbe ban Guaiana, lerthaelt foe dat bp op den neghenden May biel op't current ban be riebiere des A mazonas, ende Dat De leibelulckenghelweloighen froom ban betth

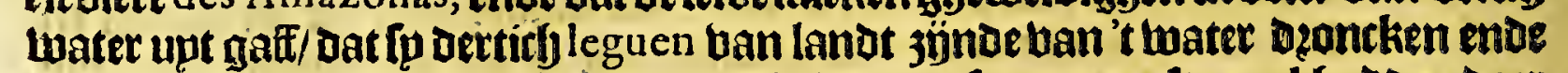
hetonden 't felbe loo berlefj enoe goet als ban een fontepne ofte poel:yadoen daet beerticl) uadem diepte/ al landt-gront; ende deg anderendaegba bad den [p beram:

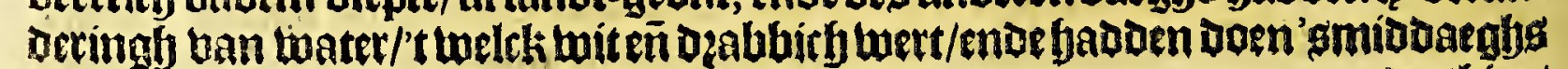
aertfien/
\end{abstract}


Het vijfthiende Boeck.

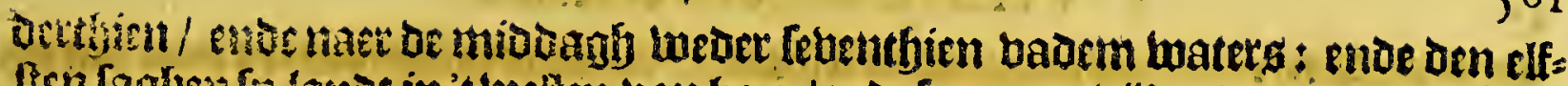

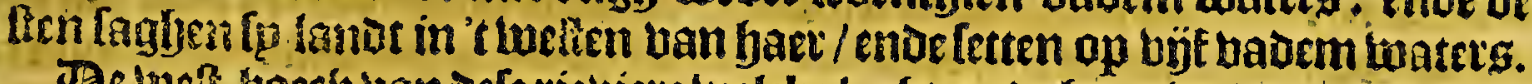

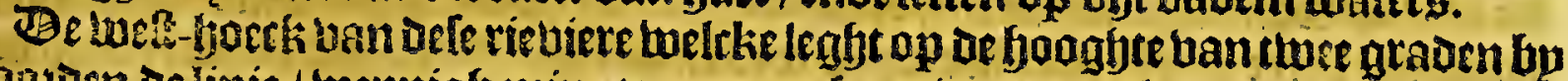

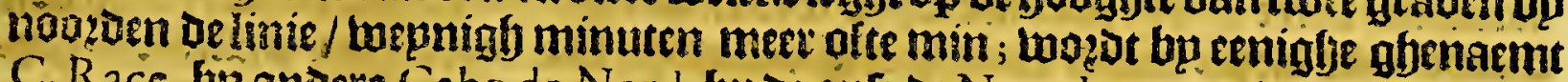
C. Race, fu andere Cabo de Nord, bp ac onte oe Noord-caep, ende oock oe beft-

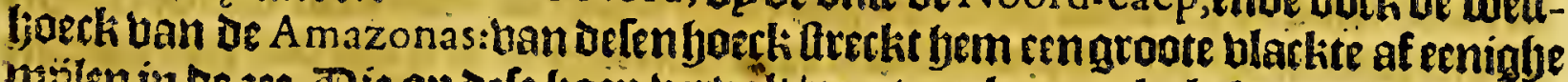

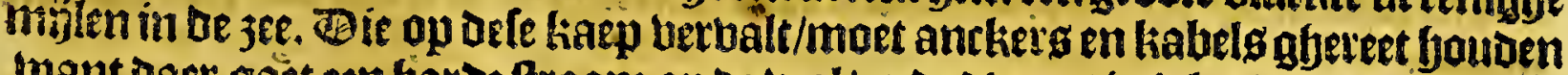
want daer gact ech fjarde froom op oe tual/ ende owat in 't lanot:

Than de noozot-thaep de rietiere op/tot aen een riebiere die in bere grooteloopt/

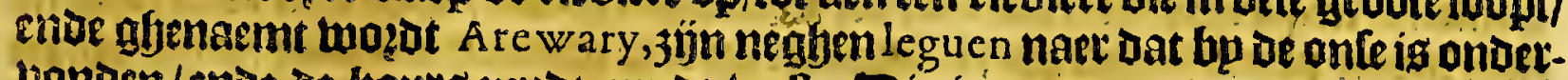

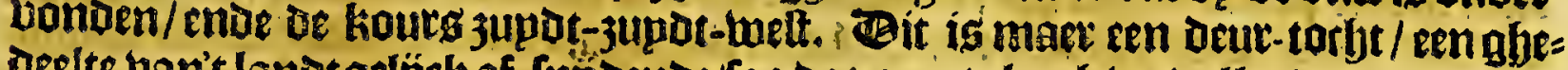

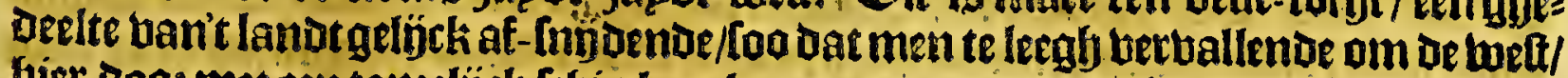

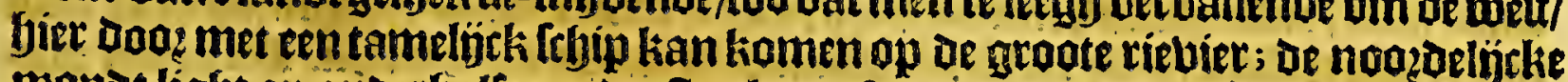
monot light op anoerfialf graedt / ftectit eerlt 3 upot in; Daer naet 3 upot-oof ten aoften/enoe homt weder ooft-nooget-ooft upt. Bic hier dooz naet oe Amazonas

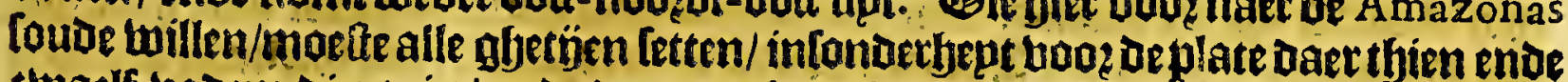
twaelf badem diepte is / ende dan met boogly water ober oe plate fteecken / fouJenoe de lpde ban bagh-boozot. Culliben Arrowary enter Arrepoco, fpn

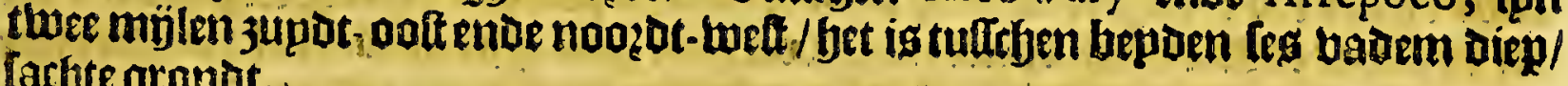
tartite gronot.

Ban Arra wary tot bet eerte ofte noozoelijhtife efpland in of gropte riebiere/

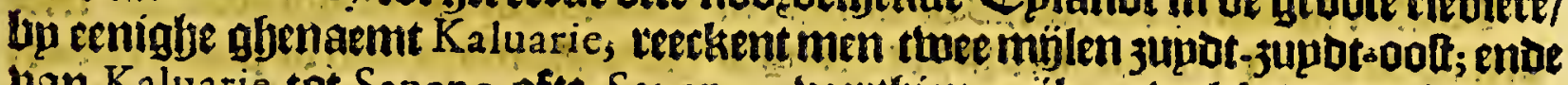
van Kaluarie tọt Sapeno ofte Sapenou beetthien mijlen: toelck ae pertinentte haerte ofte antwerpingbe ban bele riebiete die wo als norb bebben konnen fien/

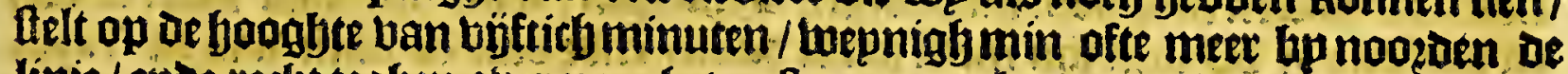

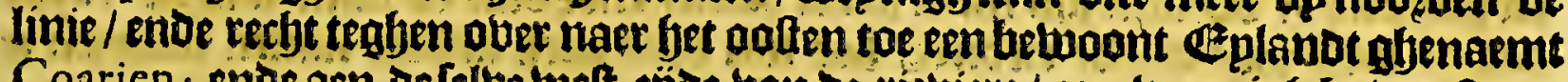
Coarien; ente aen de lelue tuelt-3ÿbe ban be riebiere/ een tuepnigh boben Sapenou, een klepurieuiecken ofte in - let daee bp noozen gbeleghen $/$ is A rro was, ente bp jupden Paricores, twee plaetskens daer De MBiloen jaer onthouben en be tegen

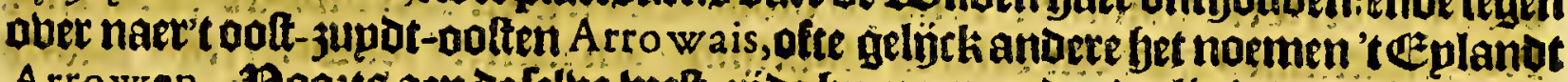

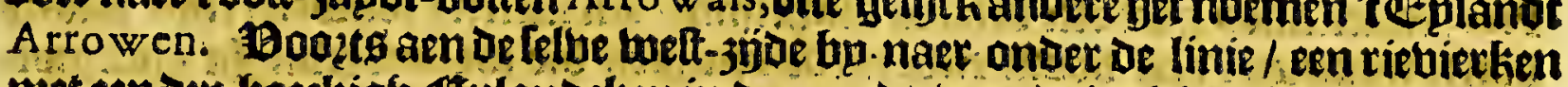

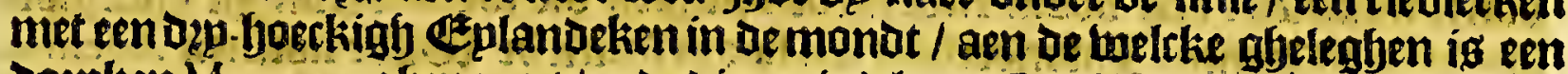
oozken Macarem gbenaemt / ende dicper in't lanot Roakery enoe Anarcaprock;

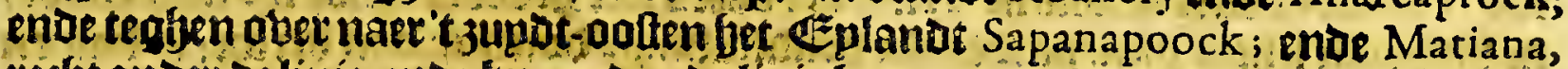
recljt ander oe linies ende bp jupden be limie bp-naer en balbe graed bet oeplands ende dolp Corropokery, thelck aritoete noemen Corpecari; die daetouer aen de noozot- we $-3 j$ de ban oe riebiere teeckenen. Tockes Kille.

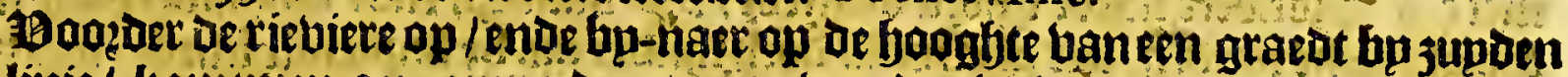

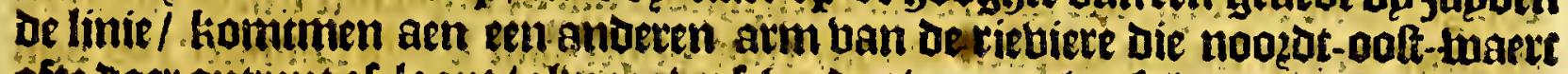

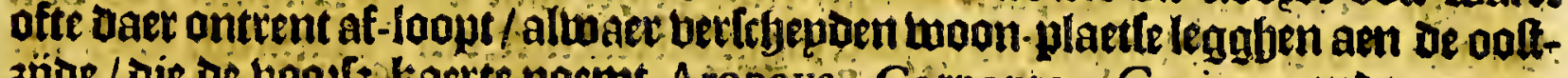
3 be / die de bool[5 kaerte noemt A ropoya, Corpoppy, Capitan iente een an aere kaerte noent tie Wayecorpap Mannetibi, Corpappi. Baer naet op oe

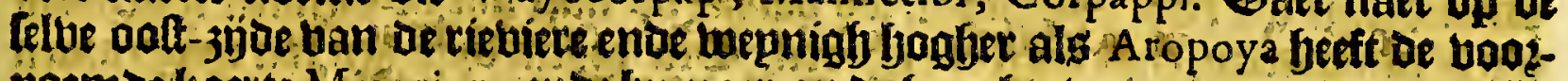
noemoe kaette Matorion, entel lup-naet op oe hoogbte ban een graeot ende bije=

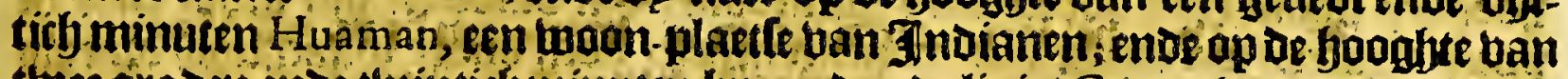
thee graden enoe thintieb minuten bp 3 unden de linie/ Córopkery een dozp ban

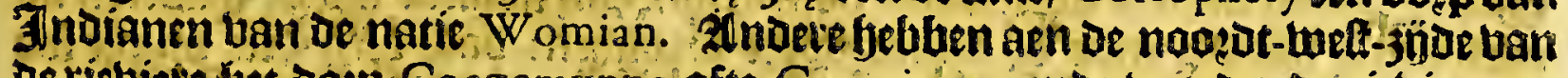
De riebiete lyet doup Coegemynne ofte Coyminne enoe boogar ae rieviere ap

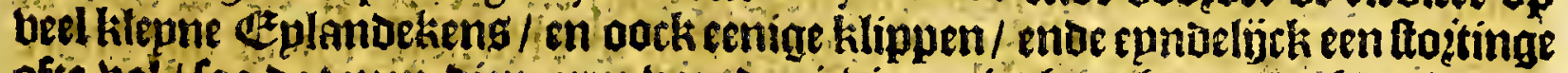
ofte bal / coo dat men bien arm ban de riebiere niet boogbet op en kan bacen/ ende ober fulchit wel te yeflumeeren is/ wat dit de pgincipale viebier niet en moet melen.

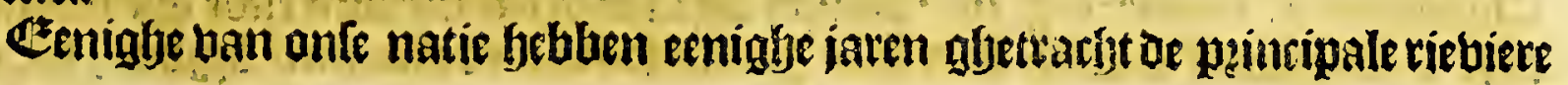
upt 
$\int_{62}$

VVilde Cufte, ofre Guaiana.

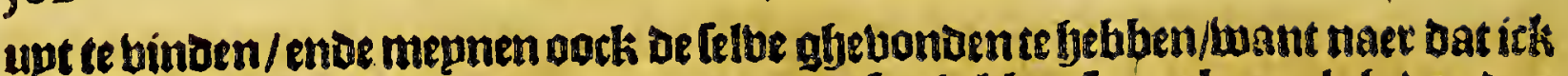

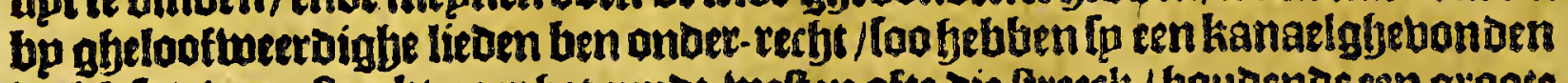
welck feet berre freckt naer bet 3updt-weften ofte die ftreech / boudonde een groote beecoteenue diepte fonder eenighe berbinderingh ban fogtinghen ofte vallen; fels

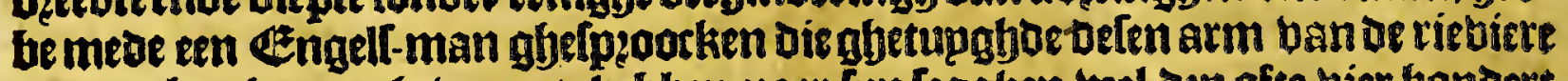
met een bercke op-ghebarente bebben naer fpn Iegghen torl Dep ofre bier bondert mülen.

Onle Reoerlambers bebben eenighe jaren bertwaerts dele groate riebiere bes ginmen te frequenteren/ende die van Bliflingen bebben op oe felbe twee fortieng enoe twoon-plaetfengbelegbt; banluelck bet eene gbenaemt Naffau, is gbelegben op Coyminne, welck gelijck een \&plant ig / arjthien oft twintity milen langh/ maer imal / ende gbelijck meteen kreerke ban't uatte landt af-gfefrbequen; ende werot ghereeckent bp de tarftentity mülen oe rieviec op te toelen. 1 set andor ghes naemt Oragnien, leght [eben mijlen neder-waerts / dan dele 3 j̉n booz eenigbe

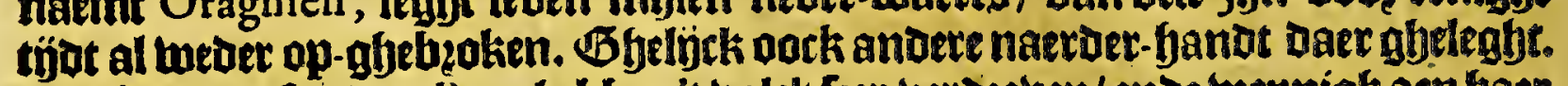
De Boztugeten ban Para beblaen't bolck Ieer berdzeben/ende bepnigh aen baer 3joe gfelockt; (oo dat de onfe in oen jaere I 629 de rieviere foo berandert bonden/ ente 't volek too verlopen datle op oe boomeemlte platten Ithier geen buplen meer en bonden / enve 't volck Datter noety was badt bem gheretireert in kreecken ende moerafien / ber ban de riebiere af / daer menfe qualyck tian binien.

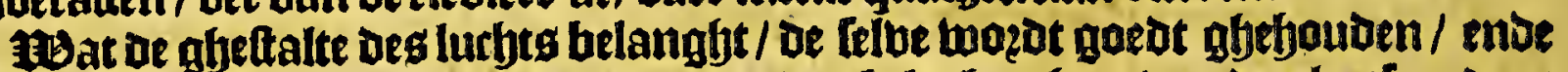

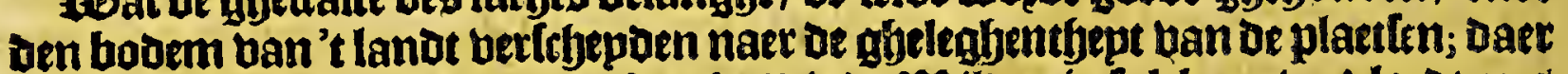
is aberbloedt wan aloerfande liff-torbe / aie de milden in fulcken oberbloed ans bolck toe-boeren ende boos fnupternen berkoopen / Datfe dicktwils maer te bee! en bebben: oe zoiloen jón meelt goede bolck / ende ban de natie ban de Yayos aen be belt-jijoe ban of riebiere/ boe wel Daet noch antere natien woonen te lanot-waert in/als de Cockettuway ende Pattecu, Tockyanen ende Arytiaen, Comoes ende Arwaccas, ende Wackehans. Baer ballen beel nutbare jouten/ Diberlefbe berben / gommen / cottoen / taback ; men beeft daer liupcker-riedt; ende Pita, welck alloo goet ofte beter is als bennip/om netten/toumen/enoe kabels bante maetken: beel boom ende aerot - ozurbten die tot conderlinghe ghebeupe: kenkennen dienen; Inlonoerhept een boom tuelck de thiloe noemen Ademo. nie Totocke; ende de butht Totocke, welck feet groot is / ende bp-naer ronot /

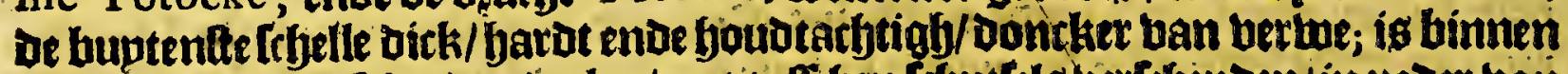

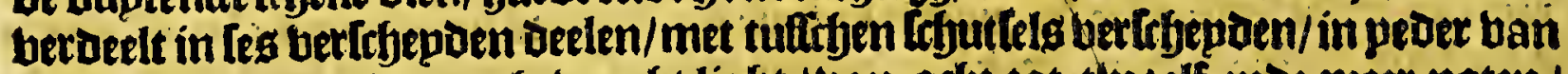
colkke opmalkanoeren gheboegft líght / van acht tot twaelf ende meer noten/ met een butonoere baroe frbofe bekleedt / ogp-kantigh enoe langhtyerpigh met

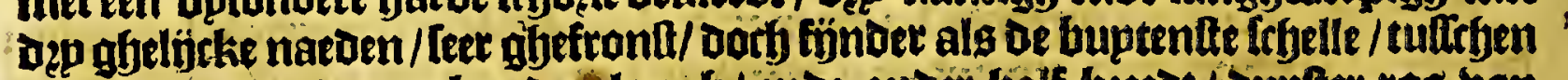

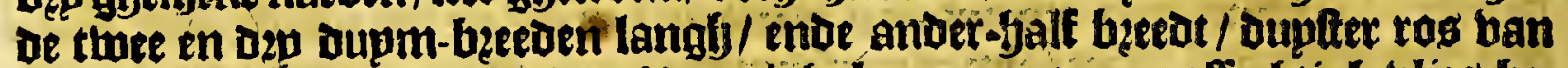
berwe; in befe is een groate langhtererpighe keetne met een rollarbting blies be: Eleedt; valt ban fubftantie / of bale-noten tuan fmaeck naerber komenoe als be amandelen/ wit ende betachtigh/loo dat het bo naec alle de dienlten kan ooen/ als be amanoelen/ende dock olie gfeben. Brfe beucht biat aen een uptermaten Googhen boom ende boben fraep ghekroont/ Ipn bladeren 3ỉn groot ende de ppen-blaberen niet ongbelp̈ck / Doncker groen / Dach onoer tuitarbtigh/Dzaeght pheen bloeftem anders als feeckere bottelieng / van foulcur als ve blaberen die allengkeng fwellen ende de beucht boozt-bzenghen; booz dien oefe beucht foo

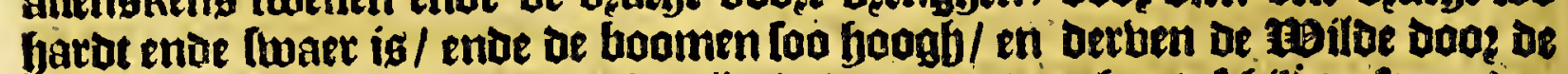
bolichen nirs gaen alg of buchte rijp is / ban met een foute lebilit ofte ander tchuttel op bet hooft / want anoers foube bele burtt baer ap 't booft ballenoe / haer licht berpletten. Be binnente note binos ghjp beftyeeben by Carolus Clufius lib. 2. exotic. cap. 18. Booets berlefeptenmineralen ende gfeletenten/

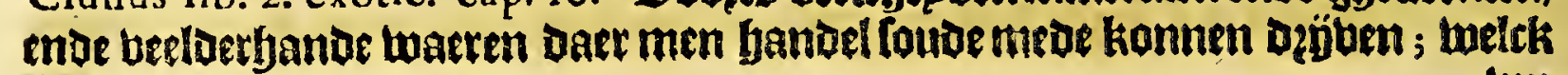
bop 


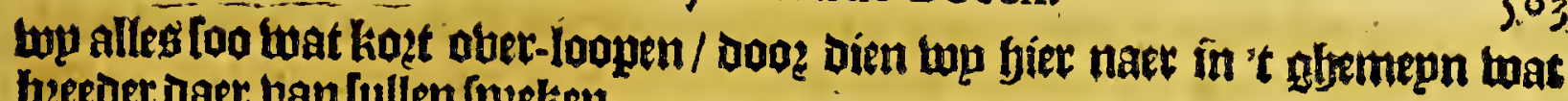
begecter daet ban Lullen fegtken.

\section{Het lefte Capittel.}
Vervolgh van de rievieren ende de lan̆den van R iO DE I A AMASONAS, tot den hoeck van de Baye van WI A P O CO.

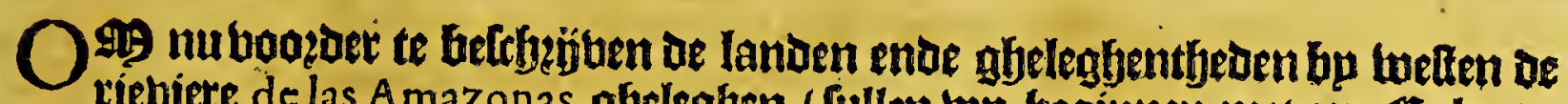
riebiete de las A mazonas gbelegien / fullen wh beginnen met een Geplando

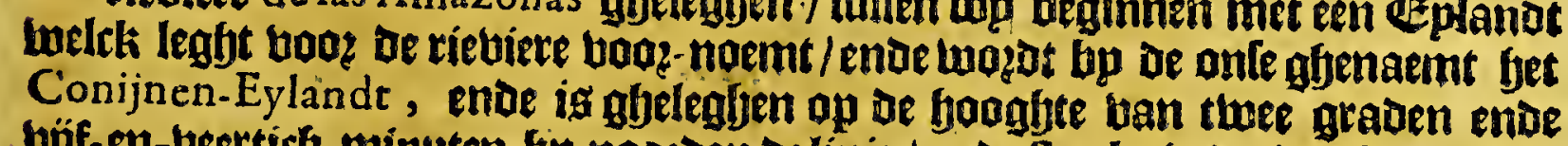
büf-en-beertich minuten bp noopoen de linie / ende ftreckt in be lengbte 3 upden

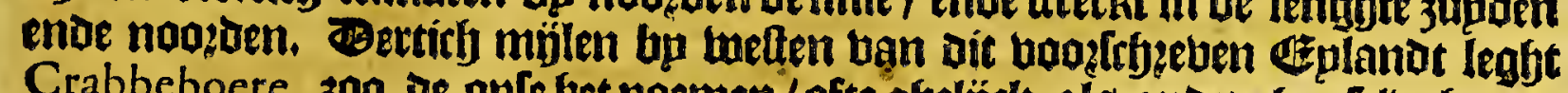

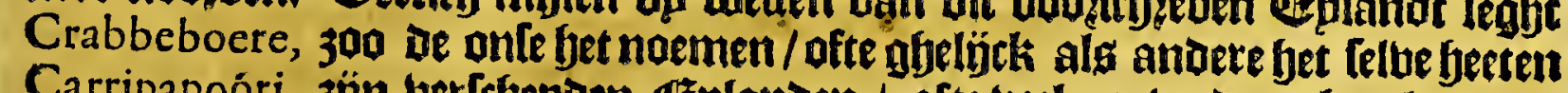

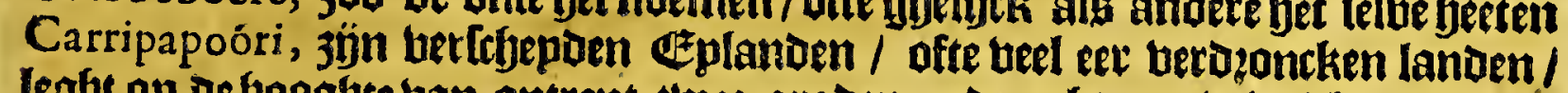
legfe op oe joogbte ban ontrent twee graden ende arbt-en-twintidb minuten; be eerle tijien miglen atrecken recft nooguen ende 3upaen/ ende de andere twintich

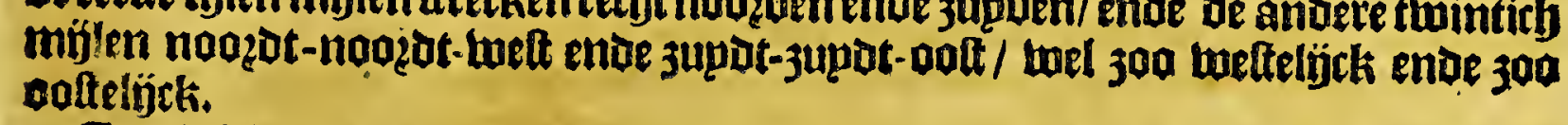

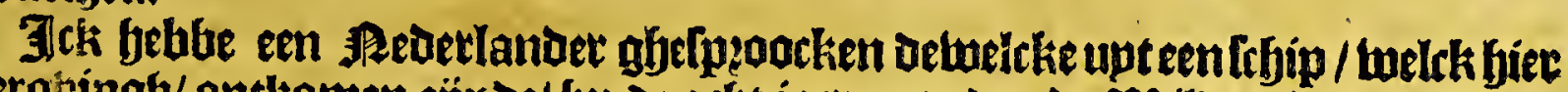

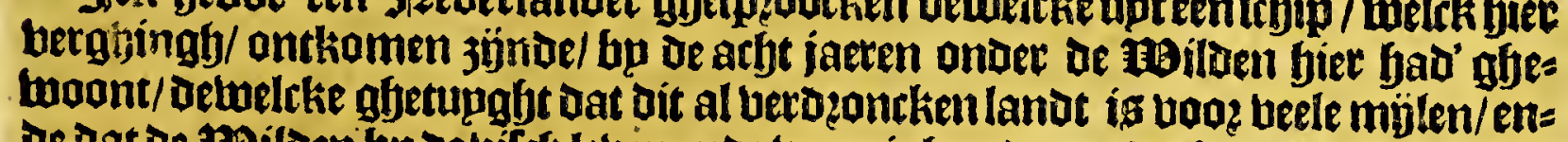

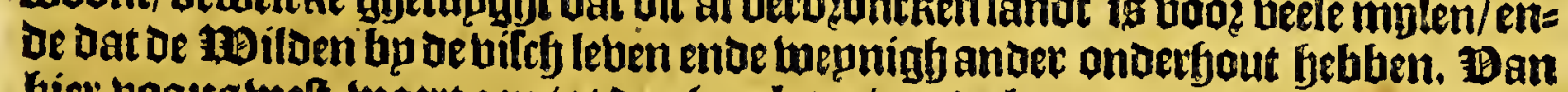
bier boots welt-waert aen tot den boeck toe ban de bape ende riebiere ban Wia-

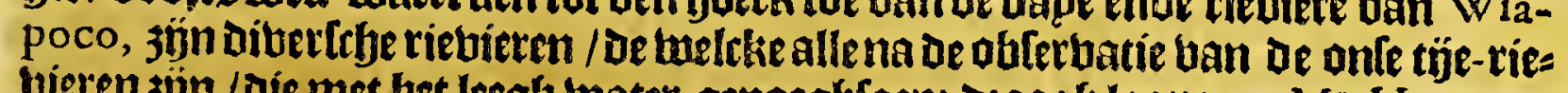

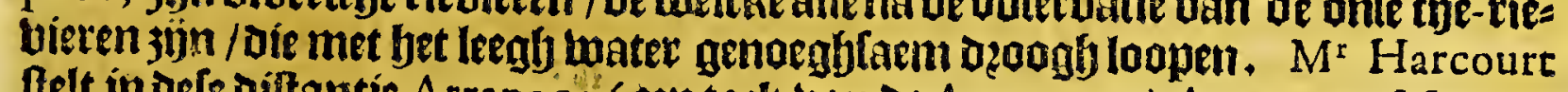
Ielt in dele oiftantie Arrapoco (eeli tacli ban de Amazonas) Arravvary, Micary, Cora vvini, tnde Caflipurogh. Laurens Keymis noemt defe riebiere A rrovvary, lichiere is / Iegaljenoe op de fooghte ban een graed enoe beettich minuten; bebs

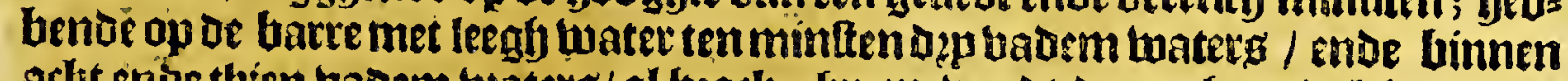
actje ento tbien badem waters/al bzack ; bp en bont daer glben bolth ontrent

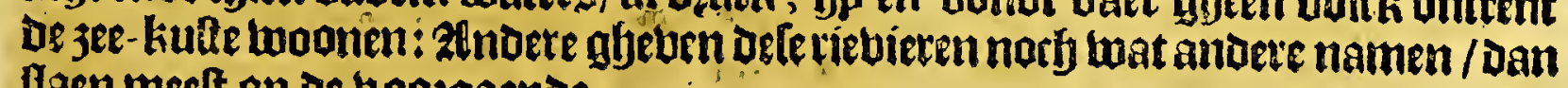
laen meelt op de boozgaende.

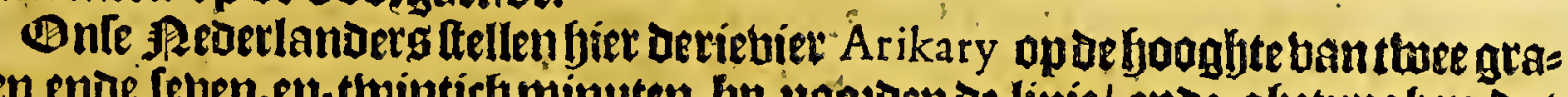

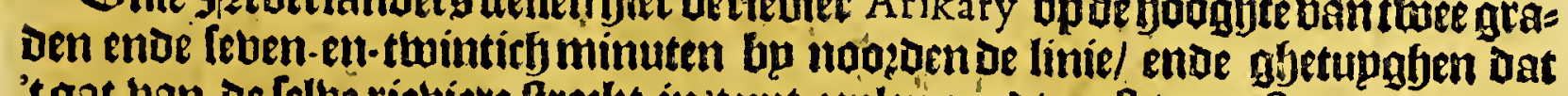

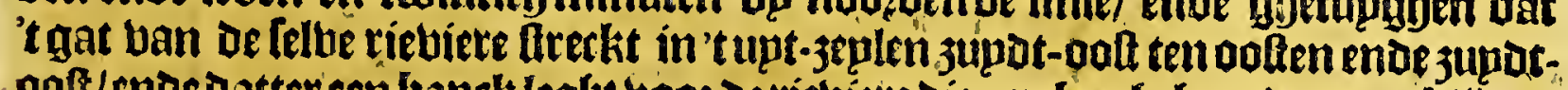
ood/enoe datter een banck leglyt voo? de riebiete die aen bagly-boozot moet bijuen legghen in 't upt-jeplen/ende dat het lande aen ftier-boopt ftreclit jupdt-3uprot-

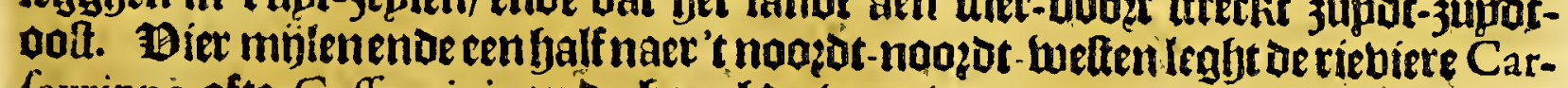
fewinne ofte Caffewini, op of Googhoe ban twee graden ende biet-en-oertich minuten; 't gat ban de felove riebiere loopt ooft ende colt ten noogen in / tultren twee bancken boo/ al waer op tondieple leben boet waterg ig; de tietriere in-lio=

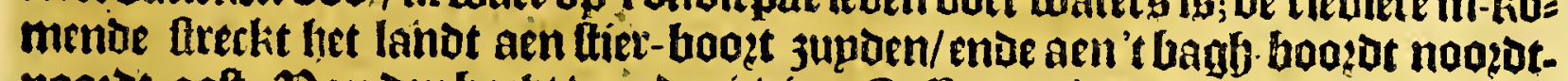

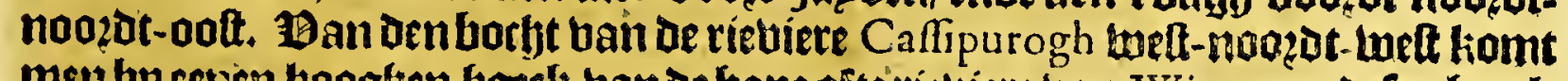
men bp eetien yoogfen foeth ban de bape ofte rietuiere ban Wiapoco, tefen boeck

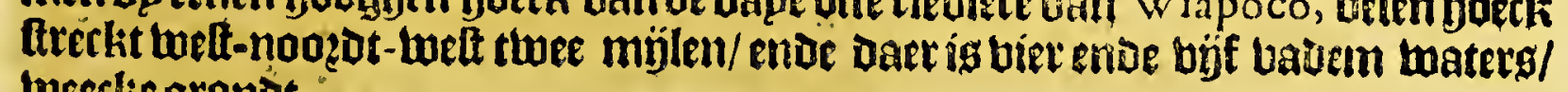
Lueerlie aronot.

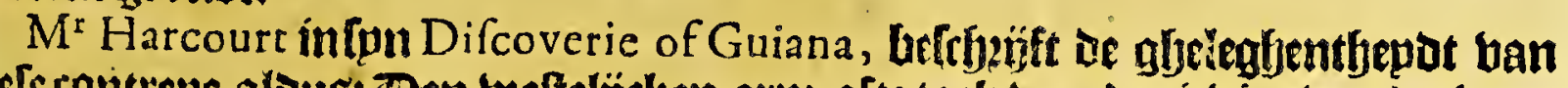
oefe contrepe albus: Ben toeltelijcken arm ofte tack ban oe riebier han de Amazonas, twelck in De 3 ee balt/ig gljenaemt Arrapoco, Daef berl ende bericlyepoen 
564

Wilde Cufte, ofre Guaiana.

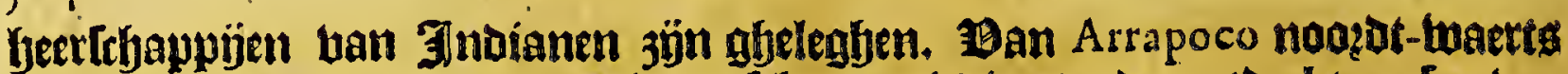
ig derieviev Arra wary, welck is etn lefpone riebiere/ende ontoeckt een leer ber: makelinck landt. Ban Arra wary tot oe rieviere Caffiopurogh Itreckt bem unt oe p2obincie Arricary, welck onder Tirb begrïpt de beertrbappyien ban Arrawary, Maicary ende Cooshebery, daet Anakyury bet booft van is/ een Yaio van ghes boote / ende gheblucht ban de lanion ghelegben ontrent ben Orenoque, upt

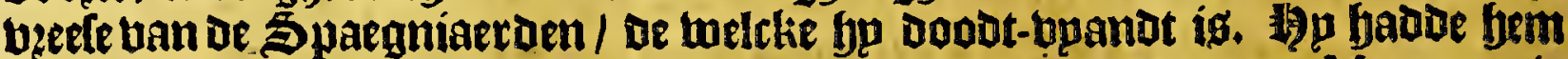
ueder-gbelladben in oepzobintie ban Arricary, ende boont nute Morooga in Deberlthappye van Maicary. Ban Dele plaetle naet 't noozzt-melten loopt de

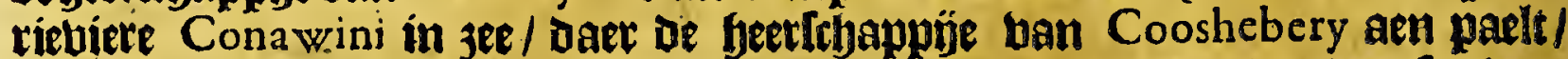

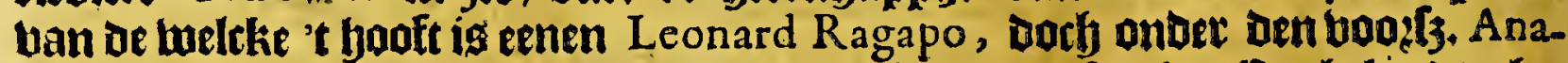
kyary: Defen Leonard is abedoopt entue beeft boo? oefen in Enghelanot abes weelt met $S^{r}$ Walther Ralegh, foo dat fy bemenoe onfe natie norb een feer goeds

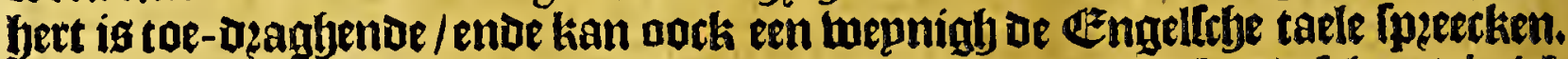
Gheduerende de tijot dat ick te Wiapoco bertoefoe / Doo? de kandtrbap die ick

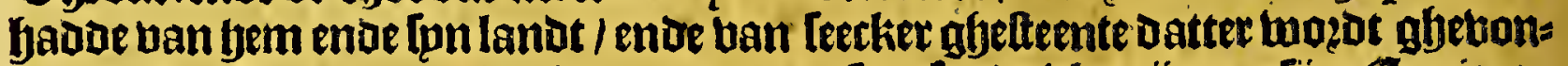
Den / welck men uermoede diamanten te welen: fonot ick mön coulän Capitspn Fisher om dit te onDer-foecken/ enoe eenigbe ban Dele fteenen te balen; Defrn Leonard ontbaeloe mỉn coufín beel twel/ enoe gaf bem lepdts. lícoen om bem te bzen=

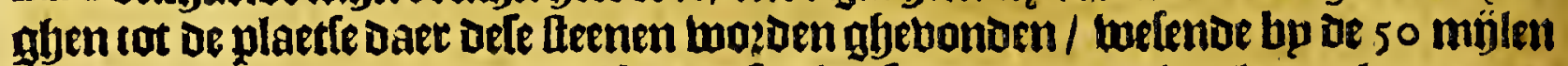
3upot-maert binnen's landts. Ban offe plaetle yoozmaerts betthoont bem eenen booghen bergib/genaemt Cowob, op melckes top (naer 'tleggen ban de thiloen) een aroote poel is/Daer feer Delicate bifery in wozot ghebonden. De lanooulae twas foo feboon enoe bermakelíck als men foute konnen líen; tan de feenen gheen

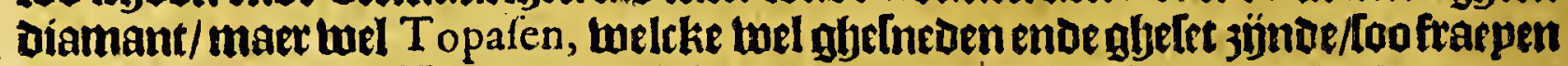
luplter (feght bp) bebben als cenighe diamanten; enos gheten goeve lyope/ Dat men bier naer daer noch beter ghelteente loude moghen binden; want dact ín Ooft--7ndien Defe Topafen wozden ghebonden / baer bind men oock de meefte

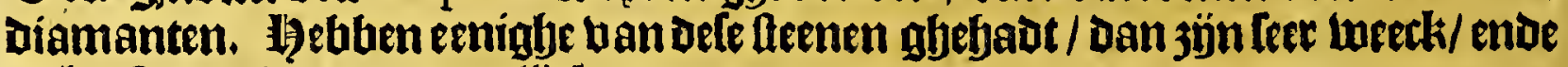
De lupfter en is maet matelỉek.

De felbe Harcourt berhaelt noogdoer dat fpp de peobintie ban Cooshebery bads

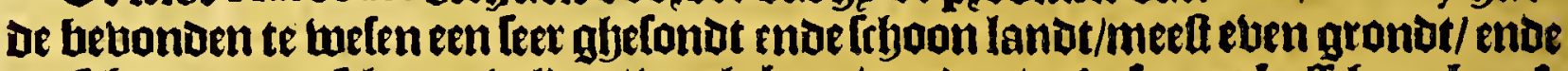
ber[chepoen met frboone beloen/beuchtbare wepden/ende fraepe bofichen; benefs feng eenighe feubelen ende dalen die een Teer lultigb y2olpert gaben.

Dan de rieviere Caffipurogh nooet- welt-waert tot be tictiere ban Arracouw,

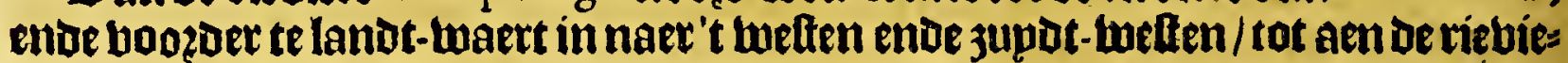
re Arwy (welck in Wiapoco komt toben oe ballen) Arecken baer upt de peouin= tien ban Arracoory ende Morownia ; tueltk al mede jün ban de telbe ghelfalte ende bermakelïrkhept ald't landt han Coos-hebery. Het landt ban Arracoory is twel betwoont / ende baren oppertten Capitrpnig ghenarmt Ipero, EEnDe boe-

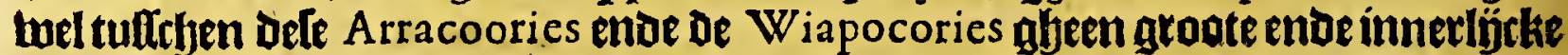

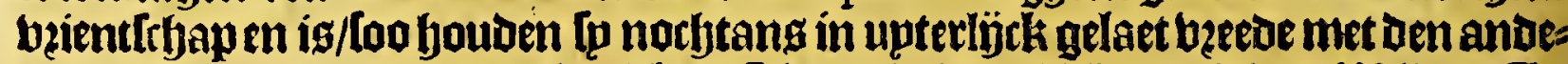

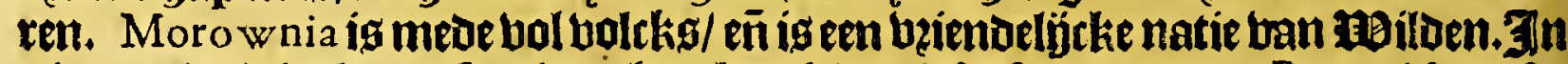
Die pzobincie leght een leer booghen bergh ban t fatloen ban een Pyramide, ofte

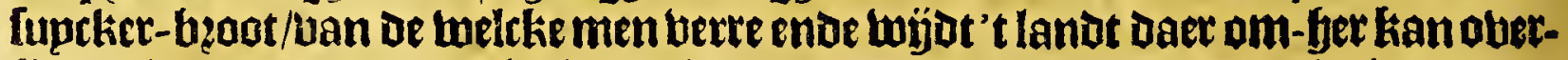
fien. 25y jupoen of pzovincie ban Morownia, op de palen ban deriebiere Arwy

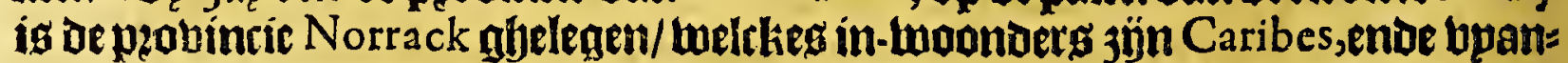
Den ban de in-Lwoonders ban Morow wia ende Wiapoco; thelck al mede thaen ons Der' tafjebic ot ban A nakyury, de grootfte 1 )eer ofte Cafique ban alle de Yaos tíe

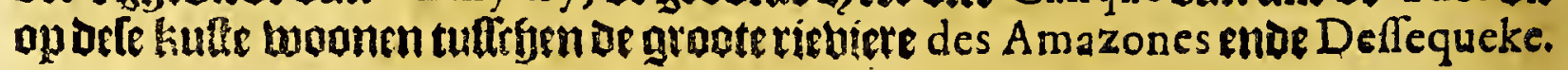

WIA- 
Het vijfthiende Boeck.

\section{W $I$ A}

3et levenoe Capittel.

Befchrijvinghe van de Baye ende Rievieren van Wiapoco, ende
andere daer ontrent gheleghen.

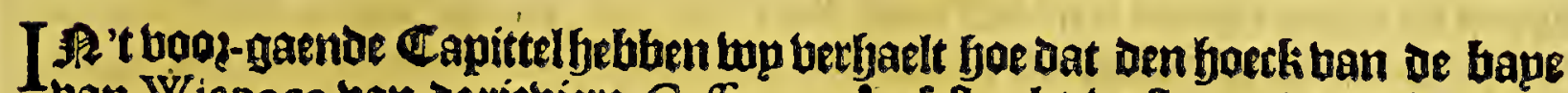
ban Wiapoco ban de riebiere Caffipurogh af-tererkt tweft-noogot-welt; Deten boeck twoetot bu eenighe genaemt Cabo de Norc; bu anoere Cabo de Conde in oe kaerte ban Sir Walter Ralegh; Laurens Keymis noemoe de Telve Cabe Cecil; ende de onte noemen bie gemepnligetken Cape d'Orange. Be bapenaer 't legghen ban Keymis ftreckt baet dertich mijlennaerbet lueften.25innen de bape ban Wia. poco, aen de oolt-3joe loopt de rietiete Arracouw, ontrent een balf mijle naer bat de onle gbetupgen / ende in Arracou w balt binnen' $g$ landts be riebiere Wats, Coo Harcourt gfetupght; dan im eene haette binde ick Datter thee andere riebieren himnen's landotg in A rracou w komen/R io Arrocavile ende Ycoripi. Be riebier Arcovile thierdt bp De onfe belotht in den jare 1600 , twee mijlen binnen de [elbe/ noemen de felbe $Y$ coripe,ende noth dęp mílen boozeer $R$. Tamyne, feec diep/maer niet beetot/ende bp-naec atil-ftaende watev/ende bier mïlen de riebier op't opez Sapyte, enoe boots doos een bolch ende moeraliagen twegf 't doep $A$ warapata. Ghetupgen meoe dat be riebier Arecos in de monot wojot is een fjalbemïle/ende bat de feloe berte op in 't berdzontken lanot moonen be Arrecooffen, beienden ban de laos; bebbende tot bpanden de Mayos. De riebiere ban Wiapoco felfs (als Thomas Masham ghetupght/ die daer was in den jate 1596,) ig gfeleghen bp-naer op de yooghte ban vier graden bp noozoen oe linie; dan eenigbe ban oe onle fellen die op oe fooghte ban biex graden ende een balf. Defelbe Masham ges tupght boges der datfe in de monot beeft thee badem maters/enoe on dieper ig bin= nen de batre / allow daer niet boben leg ente feben boet waters en ig/ ende oock minder in beele plaetten; is in de monot bp een mijle beedot/ Dan binnenniet obet

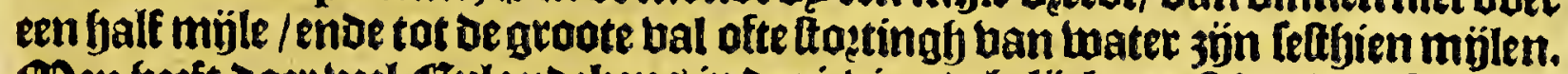

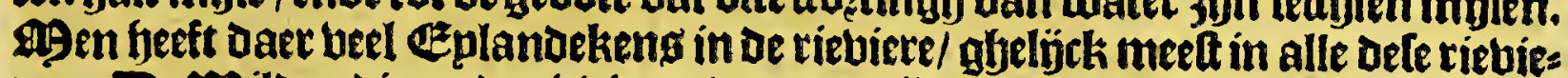

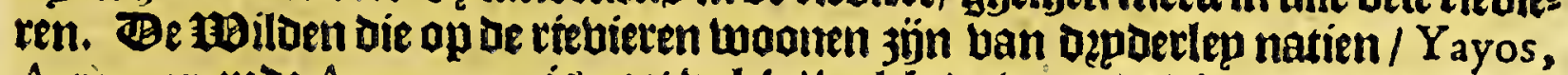
Arrowan ende Arwaccas ; fig get bolck / melck de beemoe die daet komen tod

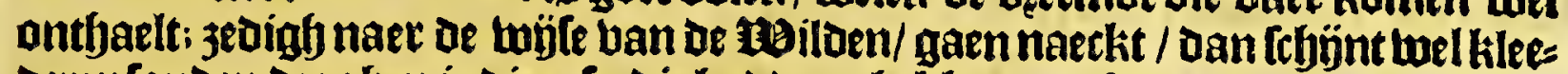
derenlouden dzagben indien fp die badoen: bebben een fonderlinghe bondt om

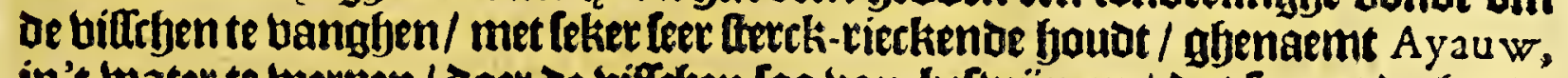

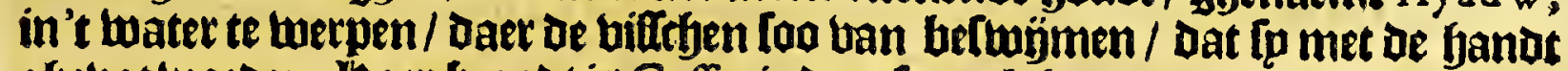
glyebat wozoen. Haer bzoodtig Caffavi, daerfp oock faeten dzanck ban maken/

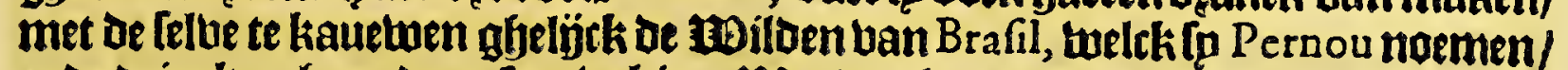
ende dzintken baer daer feet bol in. Hozot gbemaeckt ban Cafta vi beel fwart

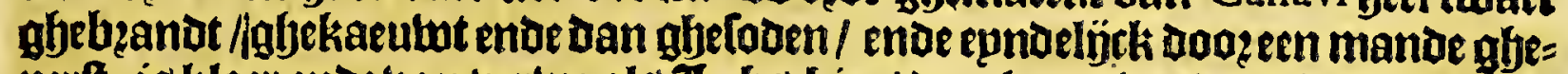

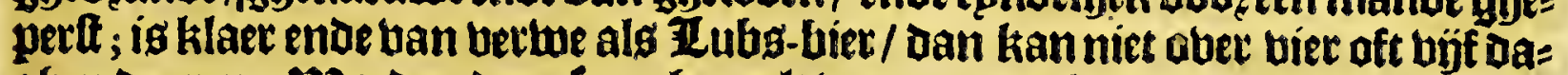
ghen oueren. Hozden daet (eer ghequelt ban een onghedierte abelijck een blop (welck [u Niguas noemen) dat tuffethen de naghelen ende' 't bleefty int-kituppt/ende groote pije ende berderf berooslaetkt. Be gyeleghentyept ban't lanot ontrent

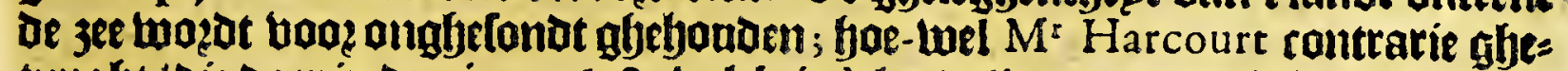
tupght / die daer in den jate 1608 , bolck in't lanot liet/ onder 't gyebied ban fon begeder / Die daer neder-Gaeghen in een doep bp of twilden ghenaemt Caripo, op eenklippighen bergb daet niet wel aen te komenen is/ upt adelake ban oe ditfte boffebagic enoe fteple klippen/ als alleen bu fommigfe wegben die naeum ende Itepl siin/ loo dat bet op-komen lityt kan belet wazoen. Ban oettich die oaec

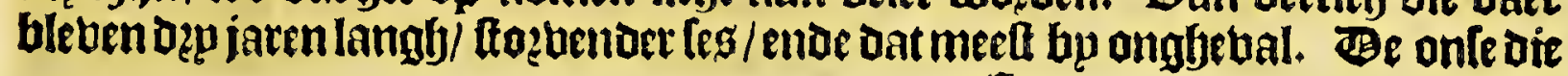
$\mathfrak{C} \mathfrak{i f}$ nocb 


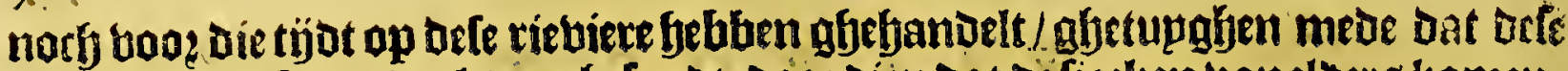

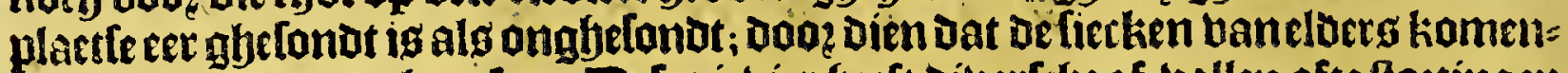
de hier baefl weder ghenelen. Dele rievier heeft diberldye af-ballen ofte froztingen ban water / Deen boogber als d'anoer / welck men lwaetligck kan op-komen/ ende niet als met groote moepte in de maenot ban A uguftus : een loepnigh boben De eerfte bal komt oe riebiere Arwy in Wiapoco loopen/ende ernigfe dagh-replen boben de vallen moont een leker natie than Caribes, welcke loo groote oo?en lou:

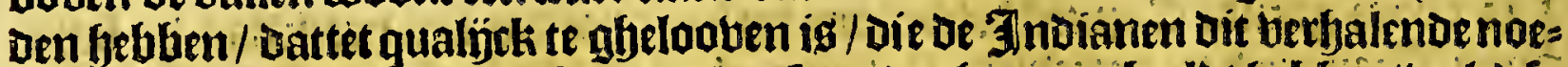

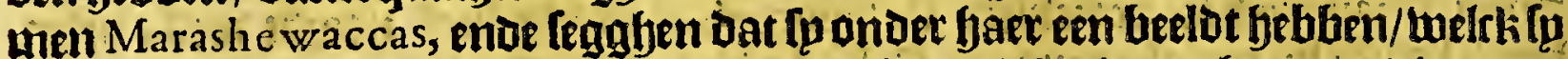

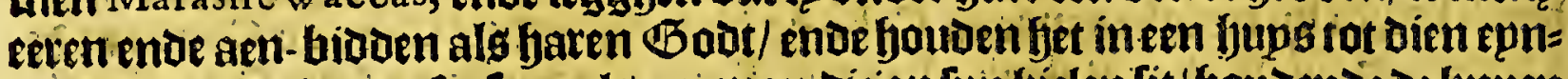

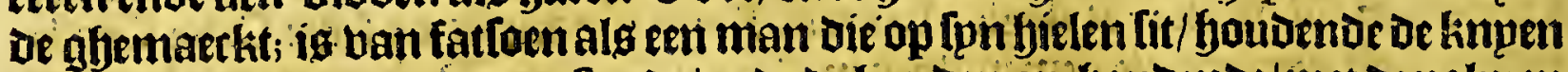
open/De ellehigen daer ap rultende/ ende de ban den op-boudende/met ue palnen

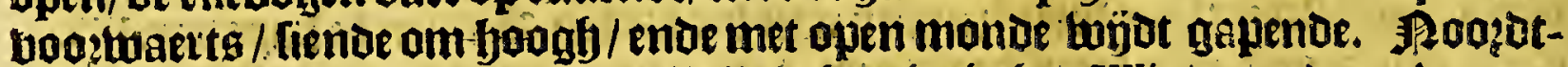
noozat-wett van W ia po co enn müle light fet rievierken Winipoco dact Ar wac-

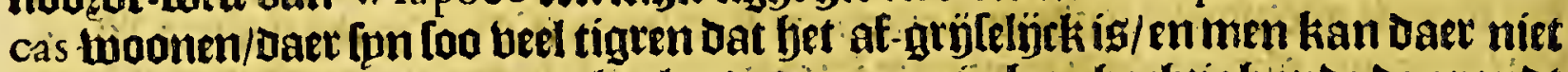
ghedueten ban de Mofquitos, bet lanot daer om is betgharlyting ende de gronot farbe roobe aerde. Ften be noozot-meft-3joe ban Wia poco ontrent bierde-half mỉlen op tupterte punt van't lanot leght een bergh oie Ip noemen Gomeribo, ofte Commaribo, welckes grontit Ieer excellent is om teplanten Tabacco, Maiz, rottoen-boomen/Annoto hoomen/twing gaeroen enoe enighe andere plantagie. Zlen De felve 3 joe is mede een klepne kiteecke/ welck ghenaemt wozot Wainary,

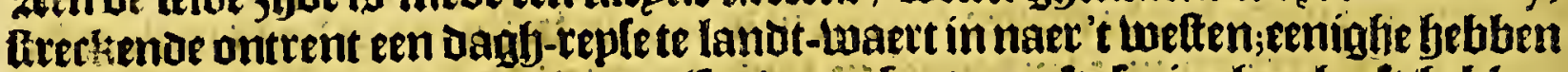
fiet voozen riebier aeboudoen/Dan alloo' tgecti fontepn oftelpzingljen fjeft/beb ben

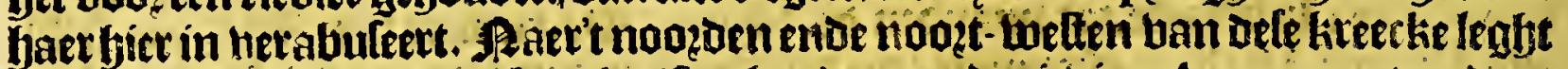
en rije ban feer fjoogh gheberghte/ftreckende naer de riebiere A pur w aca toe (tiaet: wp ftracks fullen ban (pekken) weltkeg gronot is goed ende veurbtbaet am Ta-

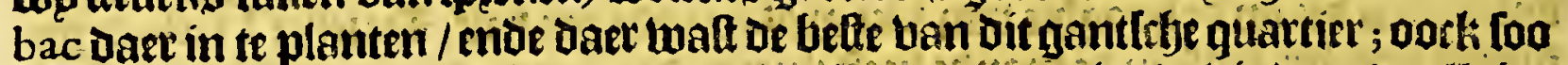

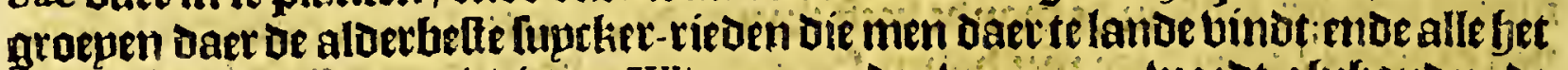

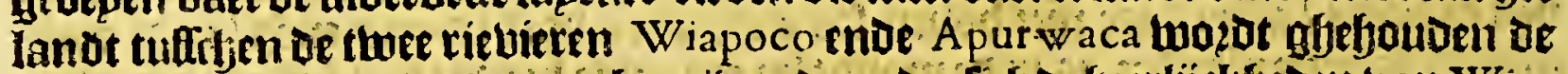
probincie ban de Wiapocories, begrijpende onder fict oe feerlijtk beden ban Wiapoco ende Waynary. Jet in-"somen ban Wainary is klippigfende ondiep/gbe=

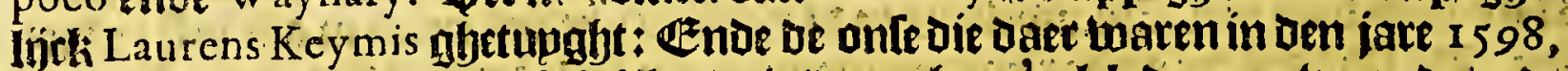

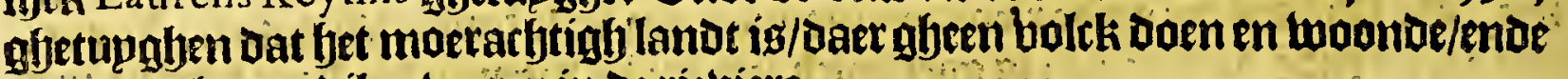
Datter beel crorodilen twaken in de rieviere.

\section{Het arhttte Capittel.}

Voordere aen-merckinghe op de rieviere WIAPOCO, uyt de ondervindinghen van onfe Nederlanders.

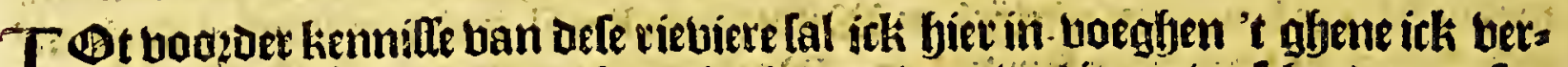

1 t taen bebbe ban een ban onfe natie die taer boo beel jaren berfhepden replen heeft ghe weet: oe Telve getupght; Dat men in 't in-koment ban de riebiere bint beers

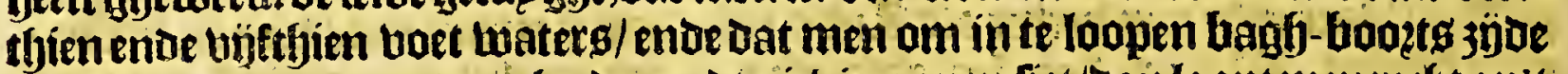
naeft moet fouden tot dat ghp oe jupdt-riebiere apen liet/oan loopt menterfyt op't

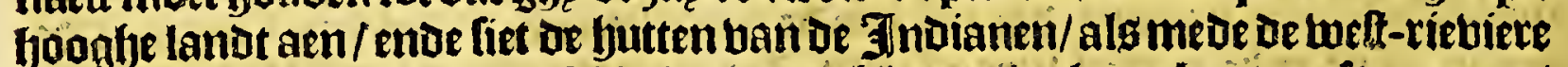
open/ daer men met gbeen [rbip in en magh/ maer wel met booten ofte ranoen/. enloopt oock niet beroe te lanot-waet in : aen ftier-boozot legghen dop bozpen baet A r wacas twoonen / die baer geneeren met Caffavi te maecken/cottoen ende berwe te bergaderen / goet Gagh ban bolck / houden beel fjoenueren / [oo Dat daet goede liff-torbt is te betiomen: om met lebip ten ancket te komen/ moet men de fanot-bape ban 't hooghe landt booz-bp loopen/entoe fetten om oenfjoerti op ope badern enoe een half; ende men kan oork met het frbip op 't läjck loopen:

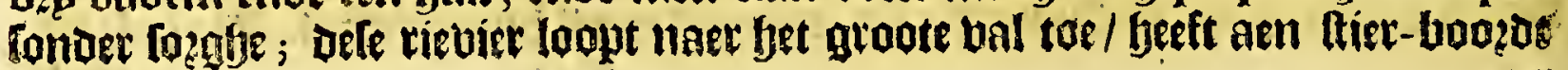


Een boep in zen kreecke / daex jandel balt / ende men feeft aen de felbe jijde norb

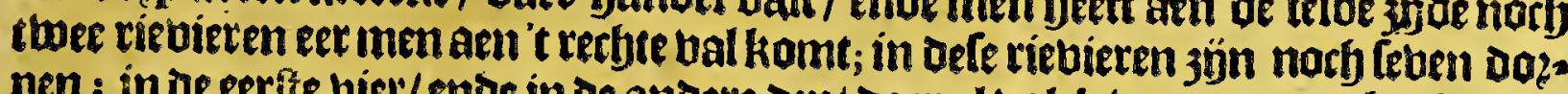
pen; in de eerfite biec/smde in de andere Depp/ Daer al bolck woont; ende bp bet bal aen dier-boozot legghen noch Dep Doppen / in bet op-vaeren; ende aen bagh-

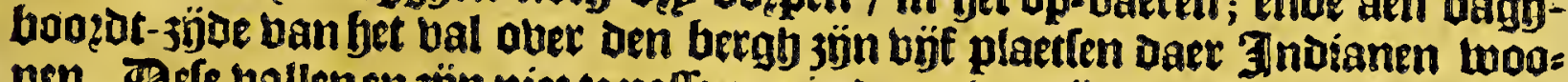
nen. Befe vallenen 3 ÿn niet te palteeren in oe reglen-tỹot/maer opander tijoen varen de Eilden die op met canoen.

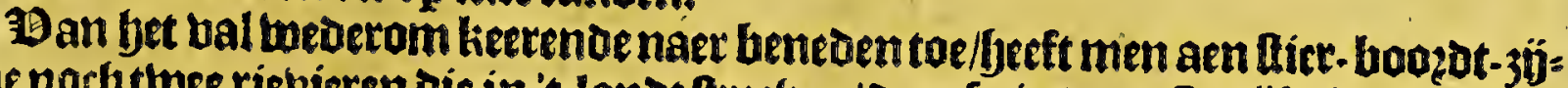

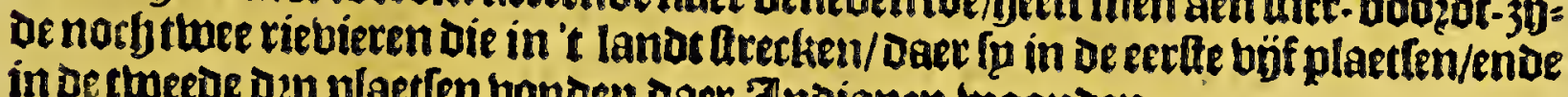

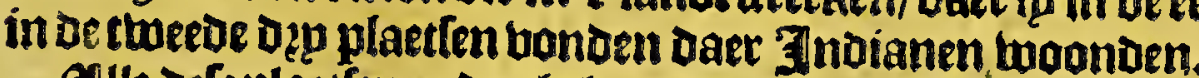

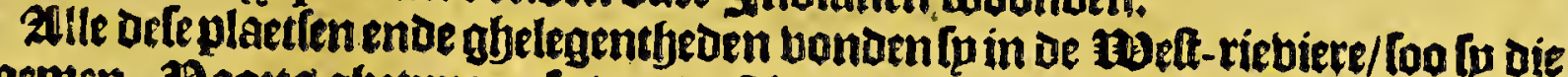

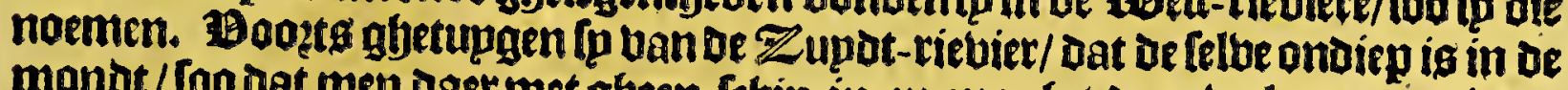
monbt / [oo dat men daer met gffeen Ifbip in en magy / Dan twel met een jacht

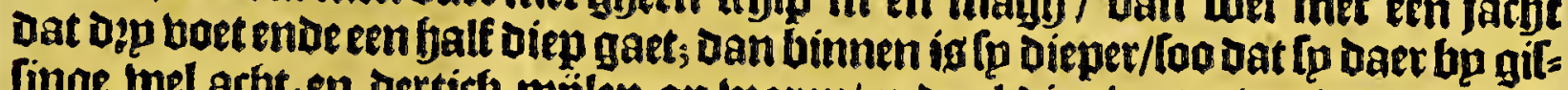

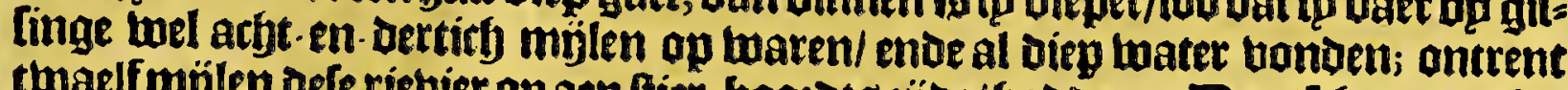

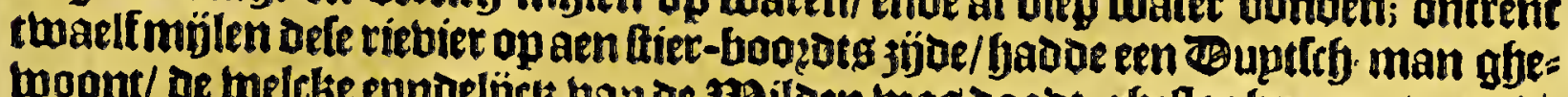

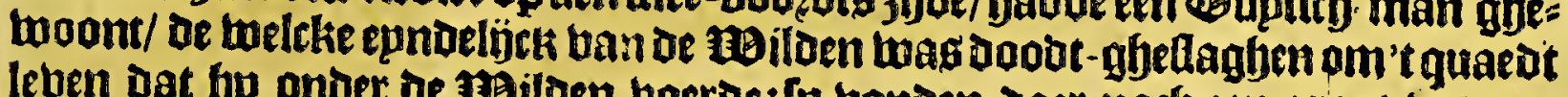
leven dat gp onder de milben boerde: [1 bonden daer noch een groot bat met

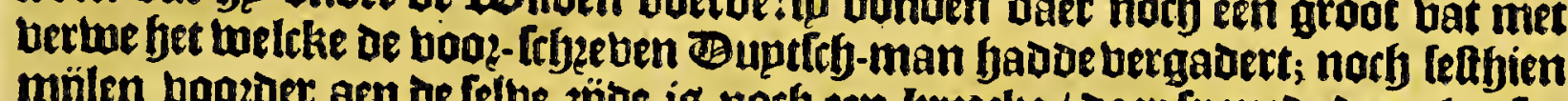

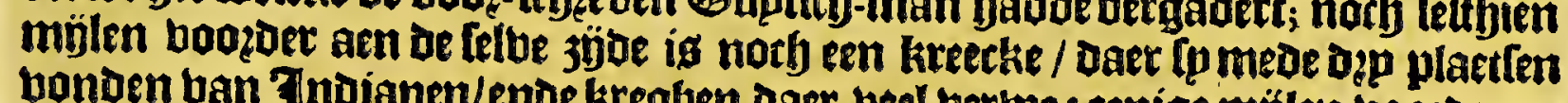
bonden ban In

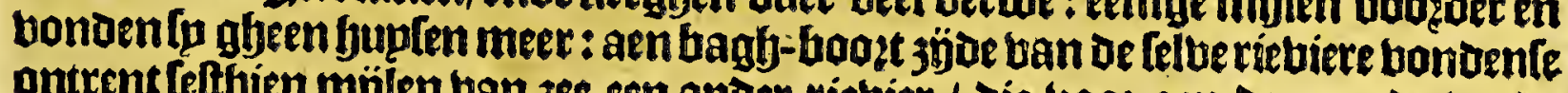
ontrent feetbien mijlen ban jee een ander riebier / die toot aen de monot / enae

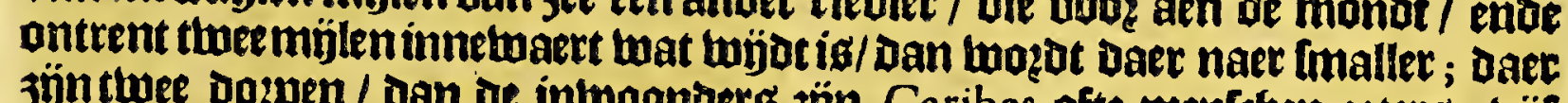

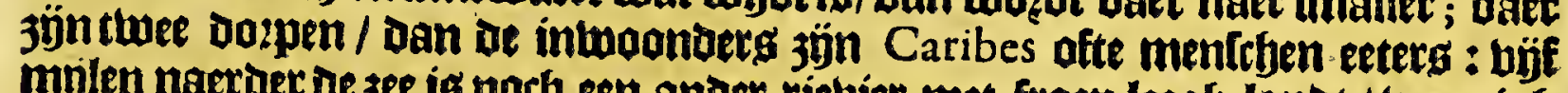
mplen naerder ae 3 ee is noch een ander riebier met fraep leegh lante / wepnigh

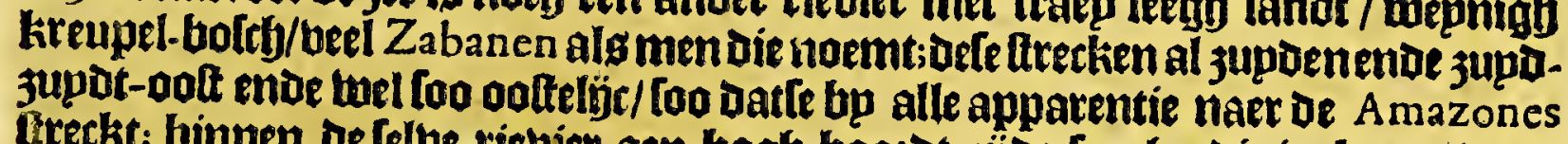

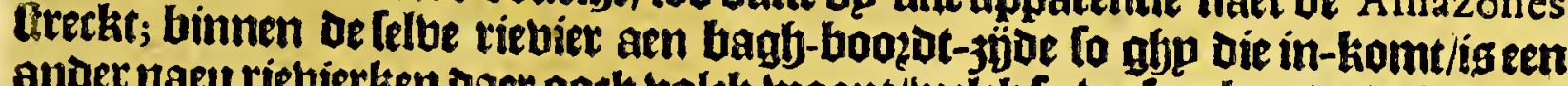
ander naeur riebiertlen daer oock bolck woont/melck [p bertp aken / ende werben

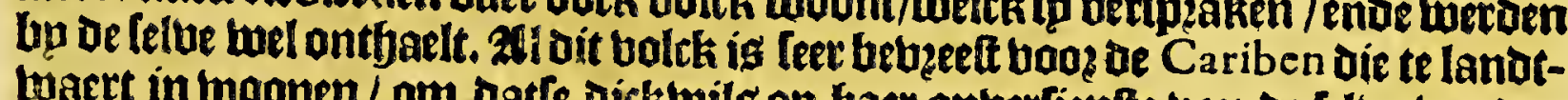
twaert in woonen / om datfe dicktwils op gaec onberfienfte ban te feltue wozoen

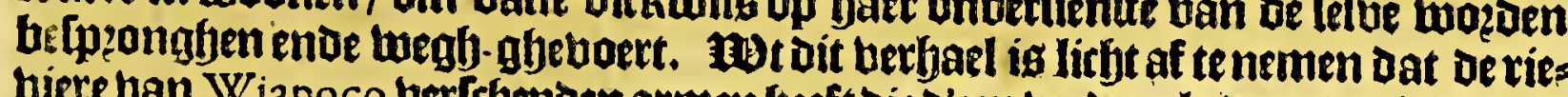
biere ban Wiapoco bertefhepoen armen beeft die deen berder als de ander in't lanter in-loopen; endoe dat bet bolck Dat bier tooont twel meae te Jjandelen is booe fulcks als fp daer bebben; met ncerthigh onderfoecken foude gier wet toat meet te thin. Den luelen.

\section{Wet negbende Capittel.}

$$
\begin{aligned}
& \text { Befchrijvinghe van de Rievieren APUR W A KA, Couwo ende Wia, by } \\
& \text { Weften WI A O O CO gheleghen. }
\end{aligned}
$$

$N^{2 A e r}$ 'tnoozot-welten ban de bape ende viethiere ban Wiapoco komt booz

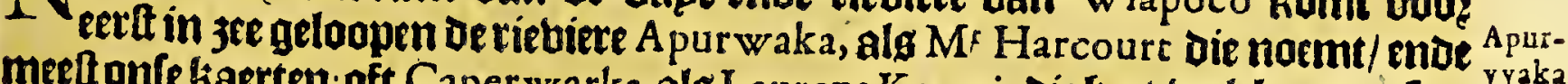

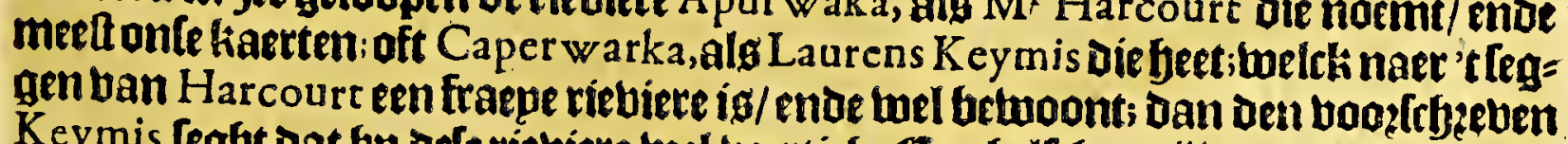

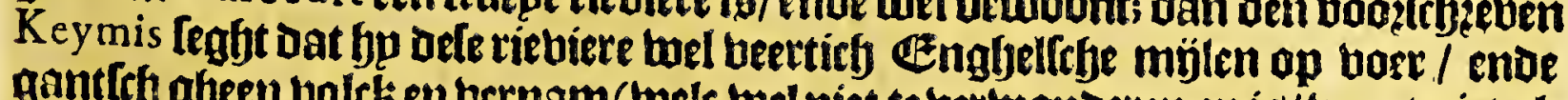
gantlch gheen volck en bernam (welt bel niet te bertwonoeren tn ig/twant niet als Ieen aen deferiebiere maer voc anoere getwefen ban dit quartier bintmen o'een tọt

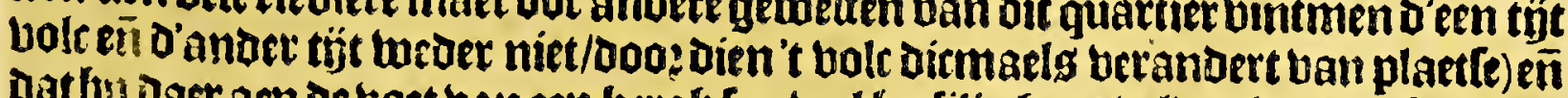

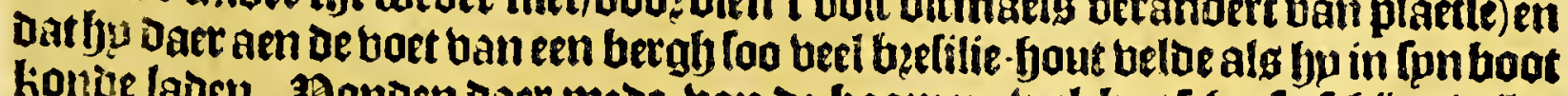

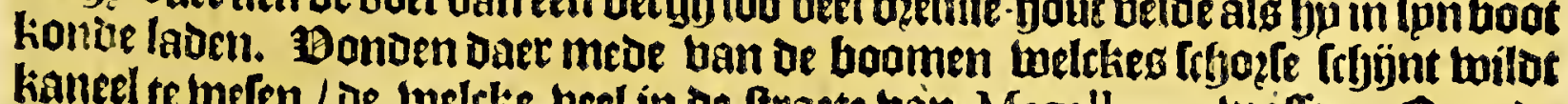

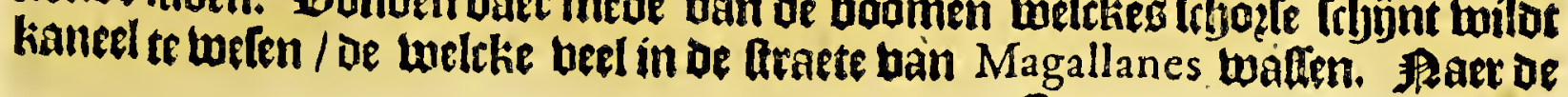

$$
C_{2}{ }_{2} \text { af-tate }
$$


af-teeckeningben die ick gbefien bebbe ban oete rieviex / coo moetfe al tamelijt:

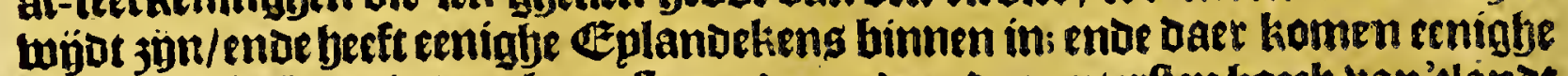
klepnder riebieten in ban bp oolfen ende jupden; Den upterfen boeck van'tland

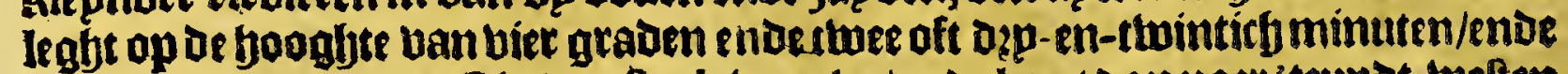

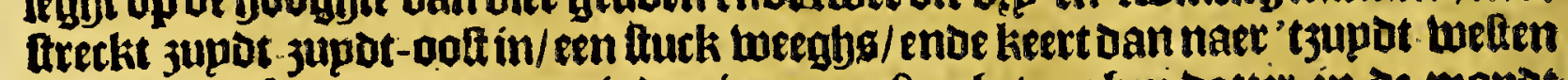
om. Je onle die daer twaten inoen jaete 1598 , gbetupghen datter in de monot

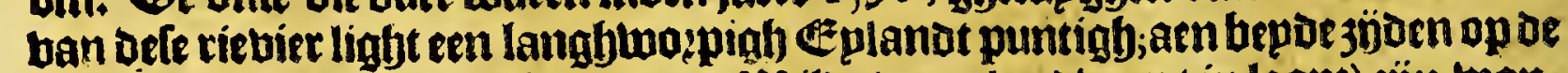

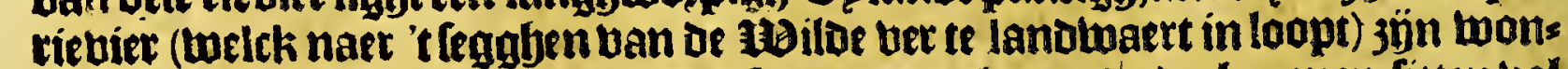
berligck beel papegapen ende anoare fthoon togelen; ende de boomen fitten bol klepne methatijeng ; waer waften beel palmenue Co cos-boomen; ligljt ban Comaribo bijt mijien.

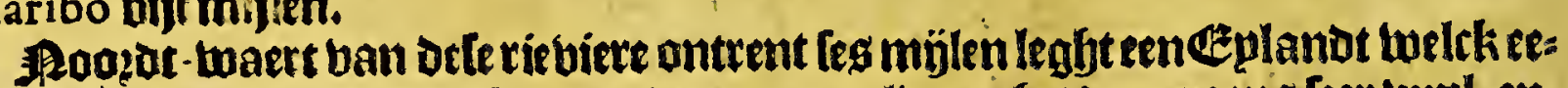
nighe Oncaiarie, andere Ho cayari noemen; altwaer bet boozgacns Ifer bupl en= oe regbenarftifh weder maecki/upt-genomen in Solftitio hy emali, ende ontrent Die tifot/ nacruat bp rmighe is betonoen.

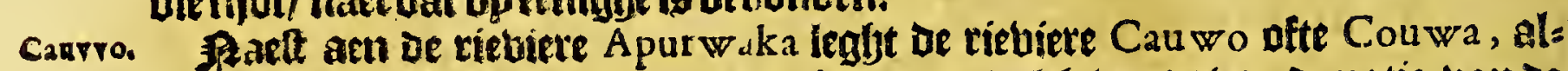
maer of vooz-Itheeben Keymis in Denjare 1596 bolck bondt ban oe natie ban de

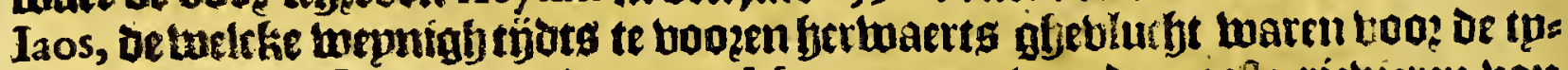
rannie ban de Spargniaerden ban Moruga, een ban de uaefe riebieren ban Orenoque, ende badoen baer evglyen lanot ten befien gljegbeten tooz de Arwaccas, weick een bagabunoe natie ig; meet bolghende oe Spargniactorn.

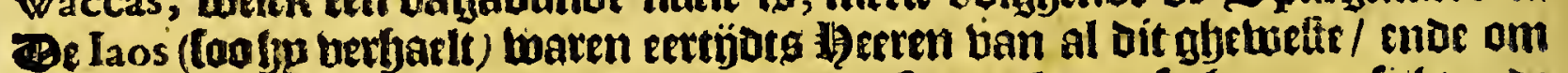

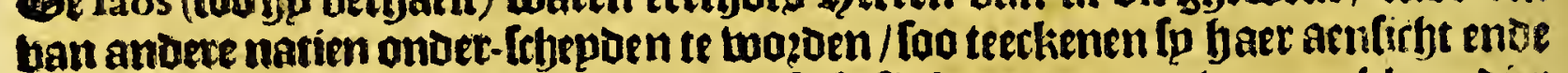
lichaem met diberiege figueren/maer toefp befighen of tanden ban een kilepn dier als een rat/oaet fp frbeabben mede maken/ gbelipck oft met een [pel gedaen ware/ bie nimmermeer unt en gaen. \$2 aer't teggben ban Harcourt loo is dit botrk al beder ban bier bertrorken / enue gier en woont gheen bolck meer; te rieviete en is niet feet groot; yaer monot leght ontrent op lier graden endo thintirly minus

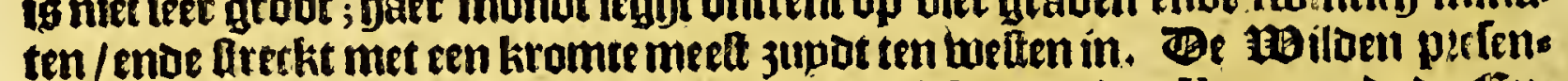

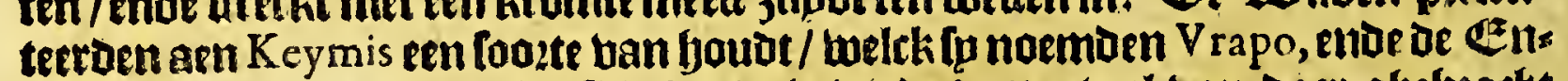

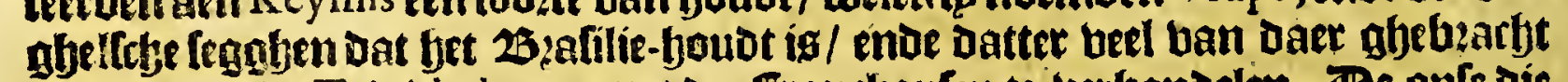
mazot naer oe Trinidad, om met de ffranchoptente berbandelen. Be onfe die bier warrn in ben jaere 1598 , abetupghen Dat op dele ricbier feer beel Mofquitos

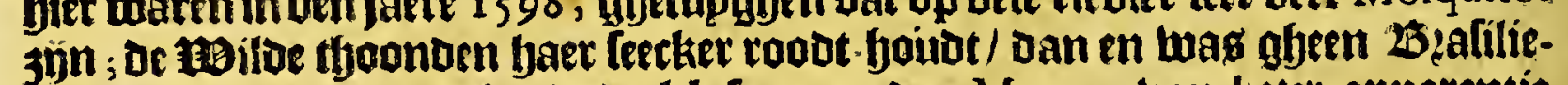
houd; pork een anoer bouot welek fp noemoen Moura, ban heter apparentie. Iight ban A pur waca twee mijlen nooket - welt; aen de welt-jüde tan't in-komen

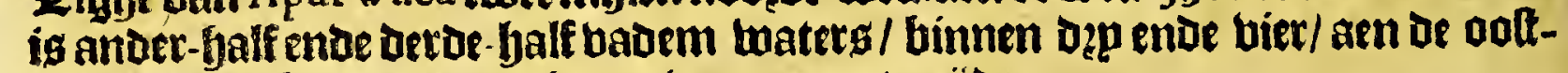
jijoe ligghen feeckere bzaoghten die men moet mijoen.

Wia. Denaell-ghelegheneriebier wozot ghenaemt Wia, welck is naer't fegdjen uan $\dot{M}^{3}$ Harcourt een fraepe riebiere / enoe loopt fert diep in 't boaghe lanot / ende onts

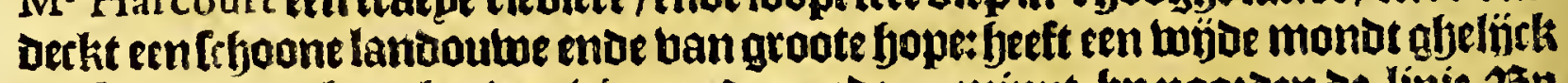
een bape / op oe booghte ban bier gtaden enoe 40 minut. bp noozden de linie. 25p twetten van dele bape (naer't feggen ban Keymis) feefe men leergoede reeden on: ber klepne Eplandekeng / ban welcke bet groote gljenatmt Gowateri, ig bes woont bp Shebaios; ende beneffens den ouerblort ban qbebogelte/bilig/burljten/ milbe berckeng/ende ander bilot die men daer kan behomen/ loo geft bet daet de rieviere Caiana in zee balt (want dit eplanot leght tufterten bepoen de mon: Den ban Wia ende Caiana, naer (pn legghen) een goede fjaben op bier ente büf

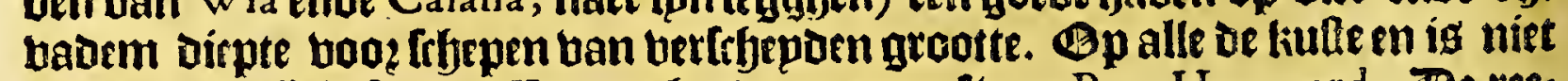

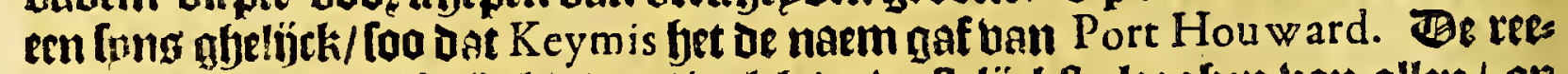

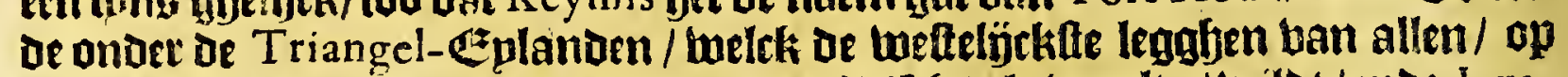
be hoonhoe ban binf araden / waer oock beel bilch/gljebogelte / wilot / ende I wanas jünte beliomen/ig mede goedt/ pach bu of boo?-gaende niet te bergbligchen/ Daet 
Het vijfthiende Boeck.

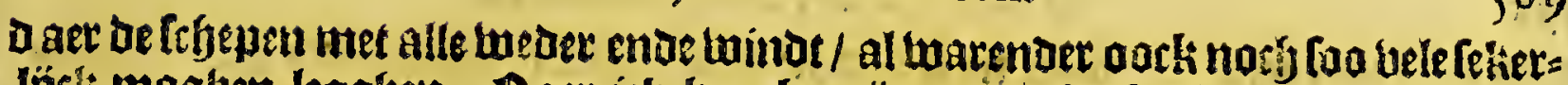

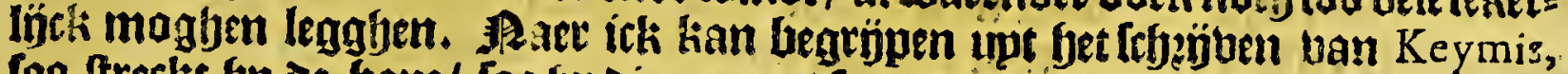
foo ltreckt fo de hape/ foo bp bie noemt / foo betre upt / dat de riebirten A purwaka, Cauwo, Wia ende Caiana daer in begrepen jijn; want bp fegbt dat oe bape aen bepoe 3 joen bipaelt ig met boogh lanot / enoe datmen onlt- waert

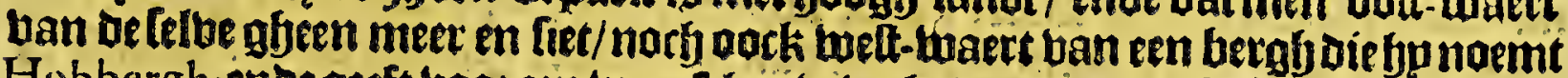

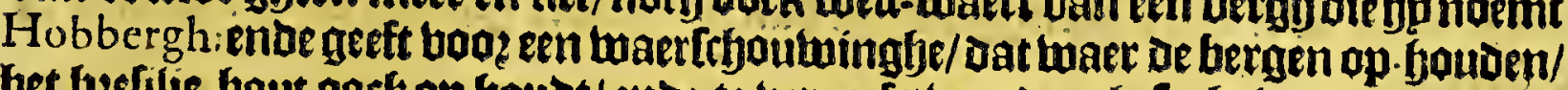

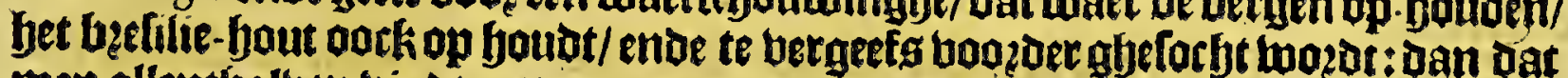
men allentbalben binot cottoen/peper/ jpoe ente ballem/ende menichte vantoos telen ban jet krupdt wiapafa, weith oefmaerk bebben bangember/ende jg̈n ban

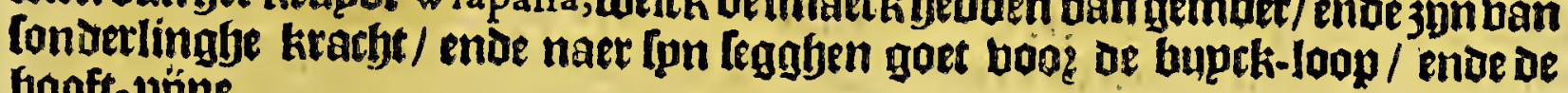
Gooft-píne.

Het Uf elandt welek legbt tullefen Wia ende Caiana, wozot bp $\mathrm{M}^{\mathrm{r}}$ Harcoure ghenaemt Mattoory, is leet foogb lanot/enoe bp de leffjien mojlen groot; ende degfelegfentfyepdot ban dit \&planot is londerlingh bequaem tot befebermingbe ban oe haven ban Caiana, gebende ban natueren twee leer brguame gfeleghent: beden om gfeetchut op te planten/ dat men die niet betet bp kanlt en loude kon: nen maken.

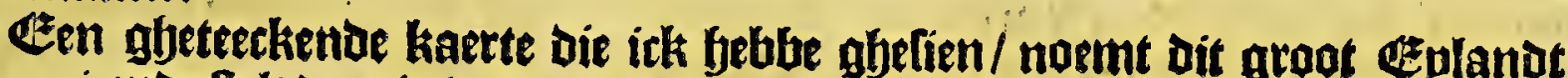
Mayeri,ende telt daet in boo aen' 't in-komen van de bape die na be riebiere Wia toe-loopteen boogb gfebergbte op de kufte met namen Moriori; ende bp naet in 't misoen van't éplanot ober ubars een ander gebergbte met namen Mator ' $w$ i, ende een doep han Indianen booz op't trandt: be Geplandekens die bp ooften

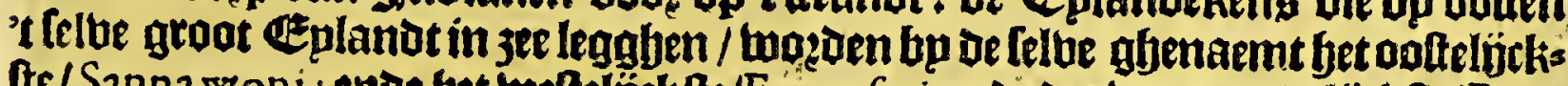

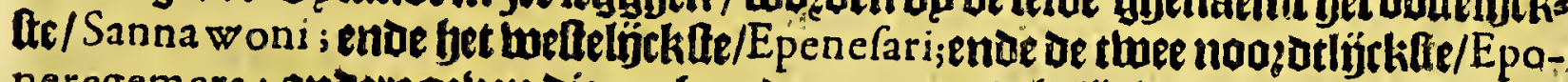
ner egemera : andere getuen dienoch andete namen/gbelÿck een yeder natie daet foncurieuffęt ingbe bzuprkt.

\section{A I A N E.}

\section{跑 thiende Capittel.}

Befchrijvinghe van de Rieviere C A I A N E, ende de gheleghentheden van de Landen ende volckeren die daer woonen.

Nateft de riebiere Wia, folght De riebiere Caiana, of luelcke gheleghen is op of boogfte ban viex graden enoe atht-en-veertich oft bier-en-bijfich minuten/

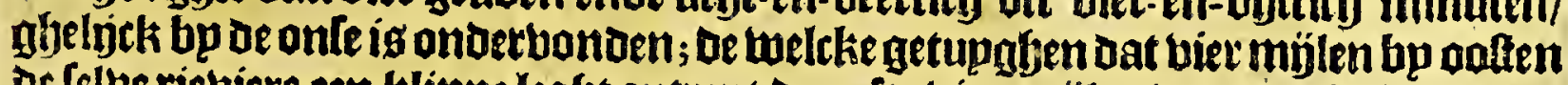
of felbe rieviere een klippe leglot ontrent dep ofte bier mïlen ban't valte lanot/ oie de Bildennoemen Hocaiar, ende de onle noemen die Conftapel, welcke notjeen klepnoer klippe feeft onttent eenbalf mỉle van baer gelegben naer' 't zupden; men

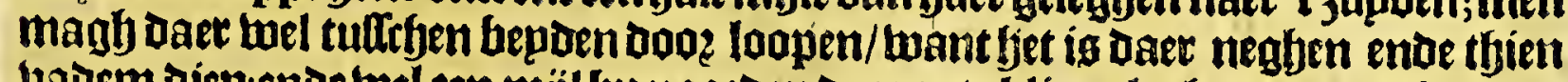
bauem diep:ende toel een mijl bp noo zoen oe groote klippe leght een Deooghte daer 't leet op barnt als 't water bol gaet. Culfeben oe Conftapel ende't kilepne klip. ken doaz-komente/ maet noely al noozot-wett terinoozen beftebent bojoen om

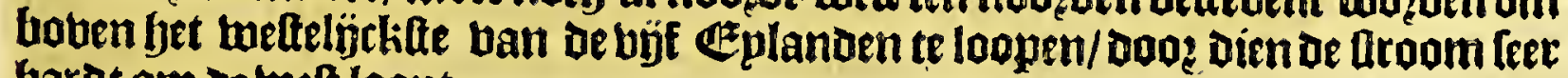
hardt om or twelt loopt.

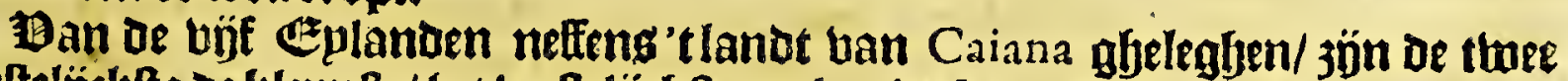

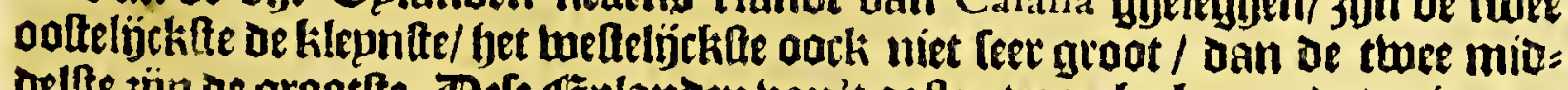

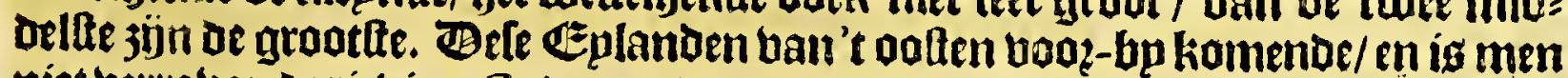
niet berte banderiebiere Ca iana;ende om oe riebiere inte loopen/mort men oe flarb

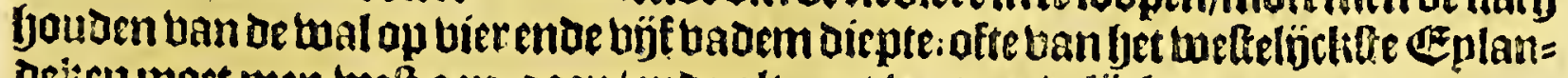

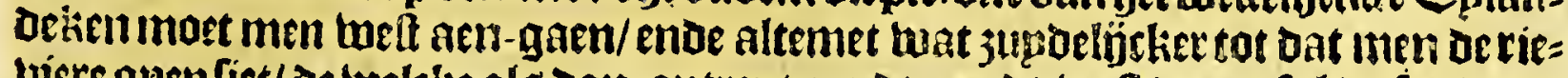

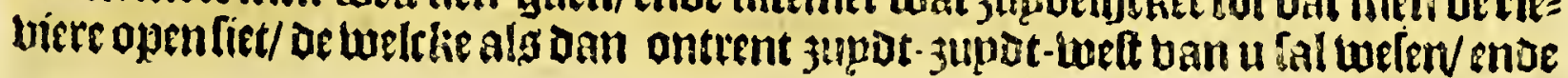

Cra 3

Daet 
$57^{\circ}$

Wilde Cufte, ofte Guaiana.

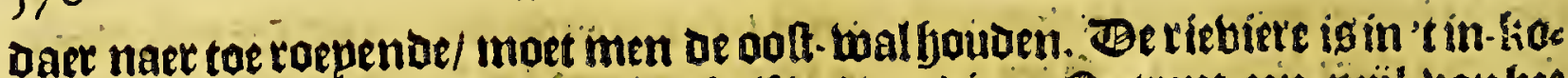

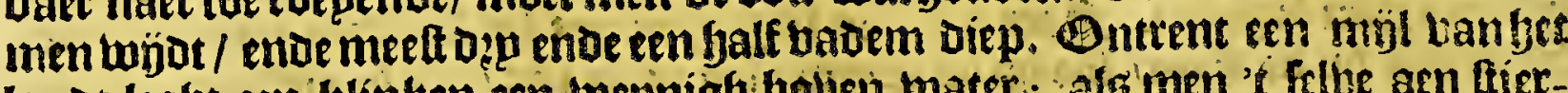
lanot leglut een klípken een wepnigh bolien water; alg'men 'f feloe aen ftier-

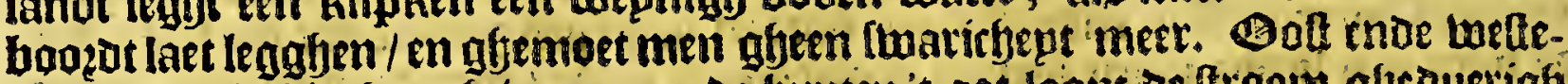
maen maeckt bier boogh water; ende bupten't gat loopt de froom glyeouerigh

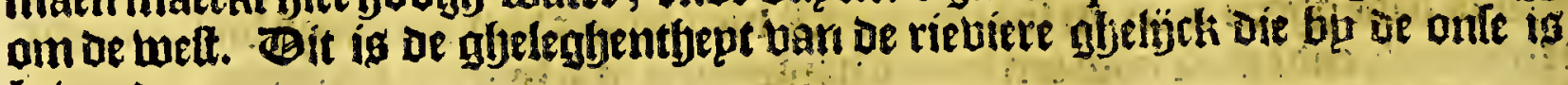
bebonden.

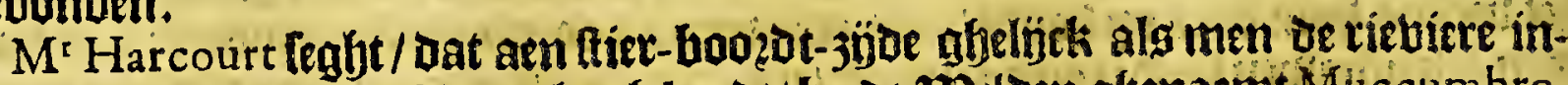

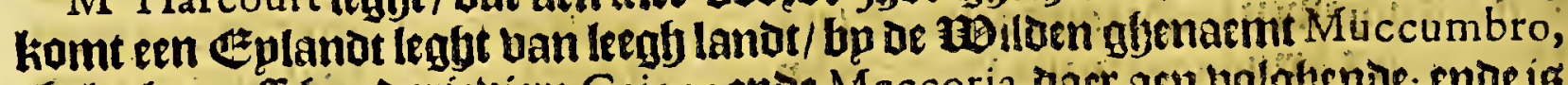
gbelegben tuftefen deriebiete Caiana ende Meccoria dace acn volghende; ende is

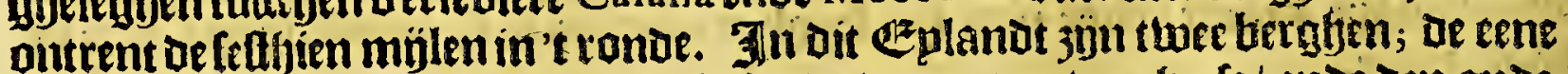
gbenaemt Muccumbro, Dare fet Cepland oen narm uan betf / ender den andes ren Cillicedemo; ban Defe berghen her bet meeftrn-ded ban dit Ėplandr ober-

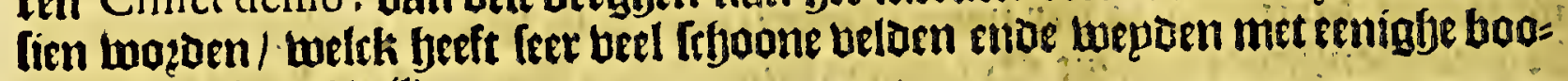
$\mathrm{men} / \mathrm{enar}$ is thol wilotg.

Be in-moonders van de peobincie ban Caiana (legft fju) zyjn Caribes, baet boomaemlte Overtte was ahenarmt Arra wicary; Lelcli woonde te Cillicede-

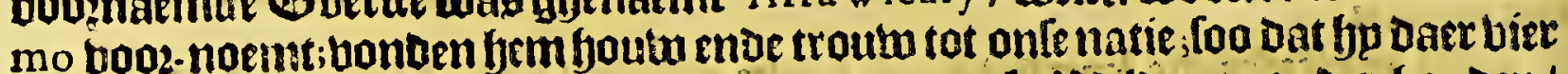

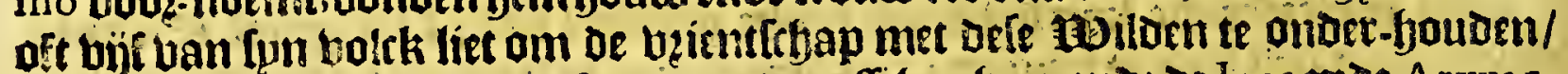
enor fyaer tale te leeren / ende lien de vectue tuffiljen fjact enoe de laos moe Arwac-

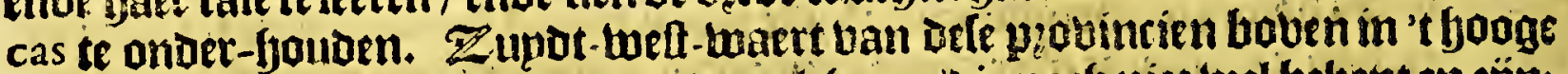
lanot 3 ijn noch beel ander natien ende botckeren/bie noch niet twel betient en jün;

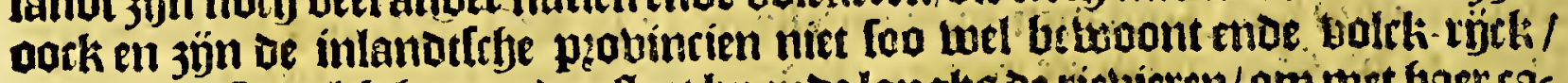

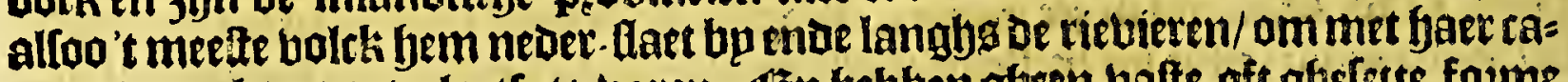

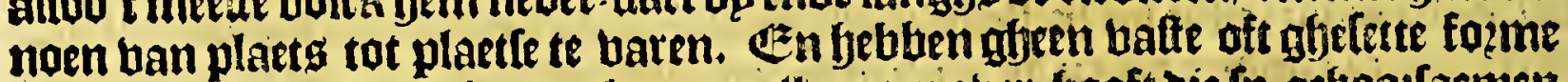
ban regietinghe onder yaer/ erkennen allect en ouer-hooft die fo gejootlaemen foo ter ende langh als het baer luett; enoe foo ljebben lp in elcke probintie ende beerlchappye en Cafique die alleg gouterneert / cmoe bp- mae in elthe blecke ofte

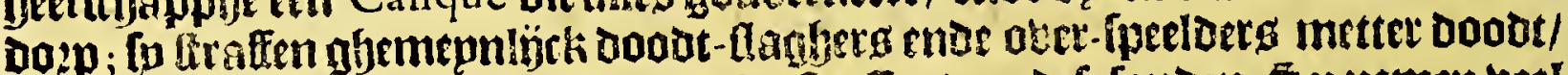

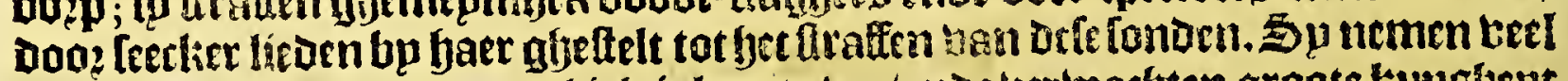

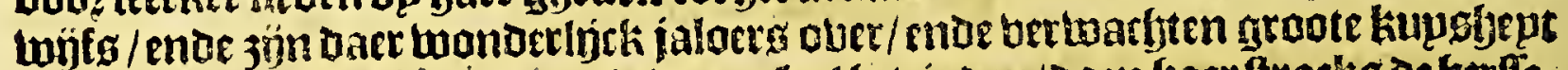

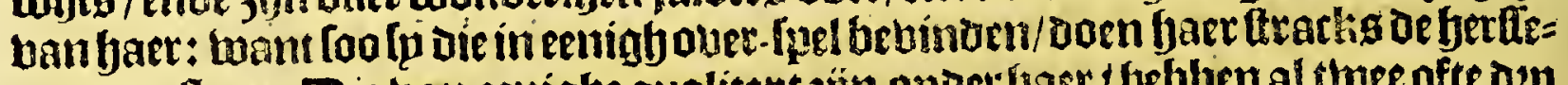

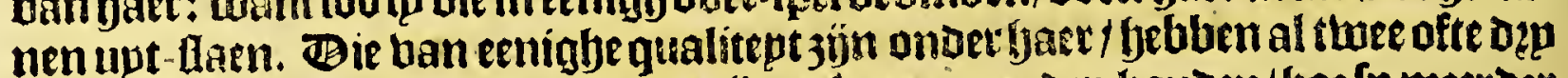

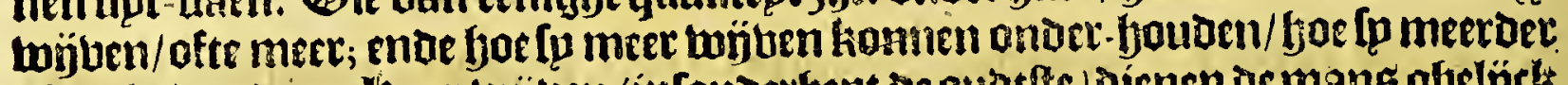

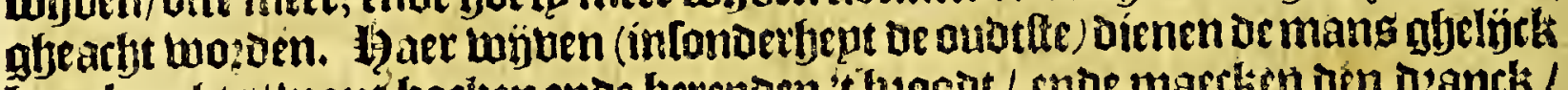

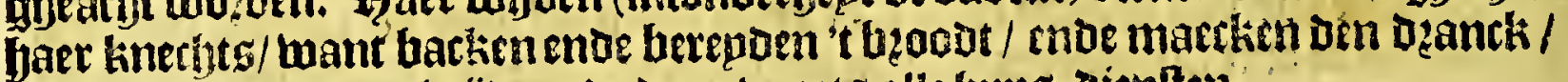
jienen hart ober mael-tijot ende doen boots alle fupg - dienlten.

Be Caribes, naer't feggfien ban Harcourt, 3 jn Đe oudte itt-woenoers ban Dit afhemefe; or Yaos, Sappaios, Arwaccas, Paragotos, jun ofte ban den Trinidad, ofte van aen Or enoque hertwaerts gbebluege voo or Spaegniakroen; Too bat tuffityen de Caribes die op arkulte twoonen / enoe dete andere natien maer ern ghetequfoe pepg; ende tufthen de Caribes die op't hooghe landt moonen/ con= timuele oolloze is; want liomen op [pn onberlieng af/ende boeren een deel ban't bolck weglj/ enoe daen een deel doodt/verbzanten ende beffueeren fjaer buplen/ enoe doen baer alle ouer-laft dis [p Konnen; danfints dat onlenatien daer hebben begonnen te tiomen/ Too hebben Ip twat Lapenen beliomen / waer mede fp baet nutwat beter tegfien de Caribes fiannen bertuceren; ende fouben twel twentshen bat de Clyeifenen daer quamen woonen om haer beter te befobermen teglen baer buanden.

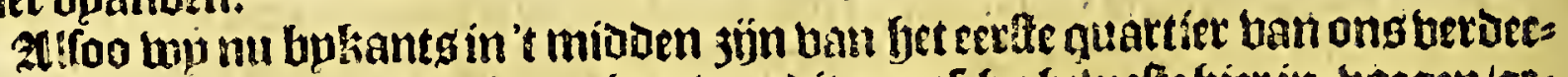

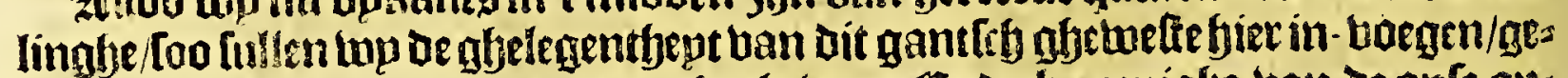

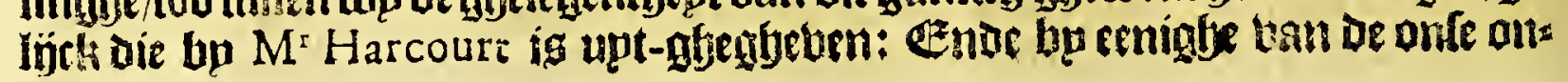
wer-bonien. 
Het vijfthiende Boeck.

Get elfoe Capittel.

Van de gheftalte des luchts ende wreder, ende vooider gheleghentheden van het volck van de lande.

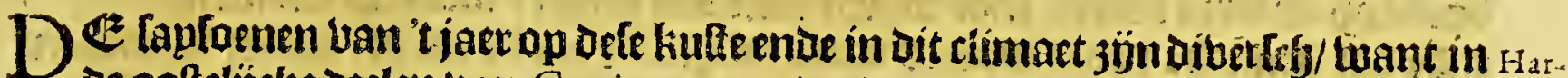

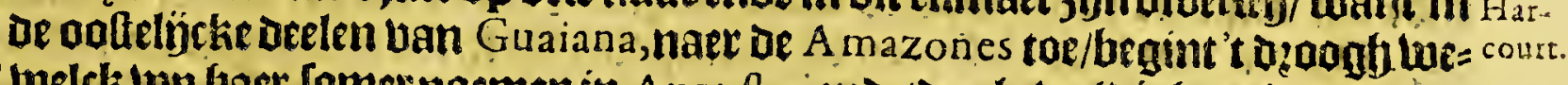

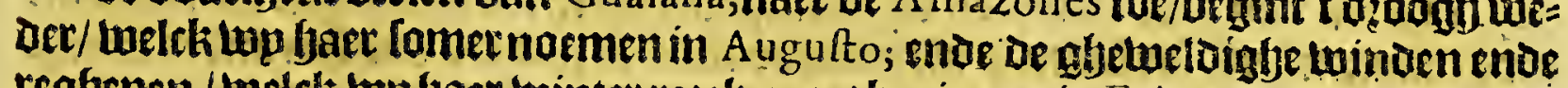
$\mathfrak{r e g f e n e n}$ / welck bue jaer tainter reectienen / beginnen in Februario. Pa aer in De

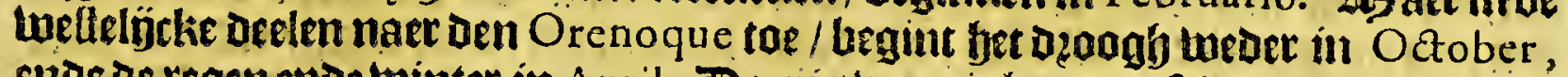

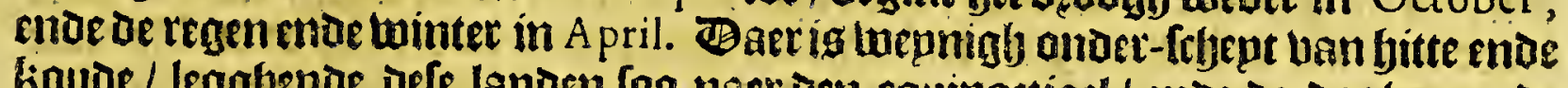
faude / legghenoe Defe landen foo naer Den equinoctiael / enoe de daghen enoe

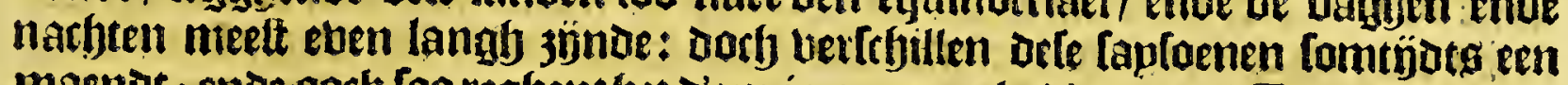
maenot; thote oork foo reghent fet d'een jaer meer als dander. 'C trolck en beeft

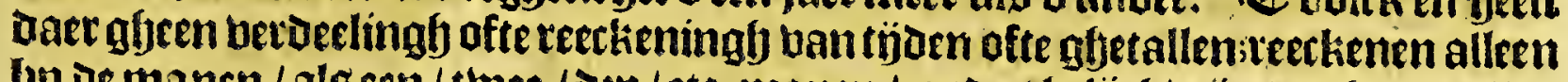

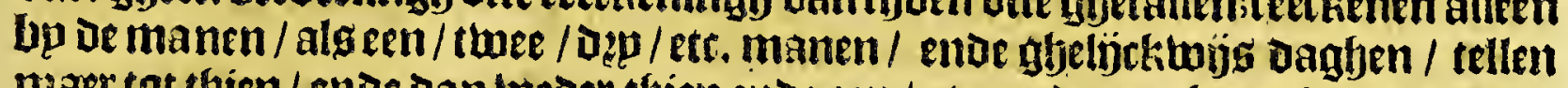
miaer tot thien / ende dan tweder tbien ende een / etc. ende om beter baer mepnin=

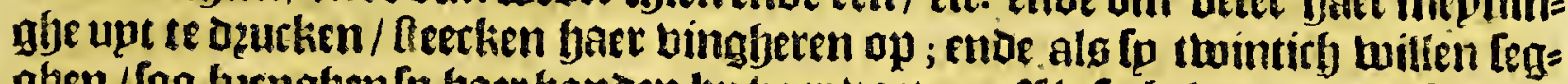

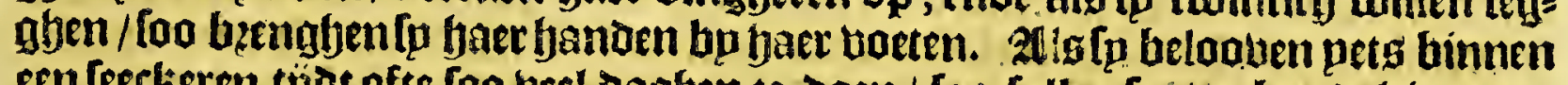

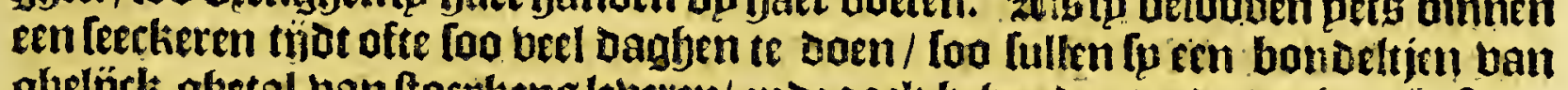

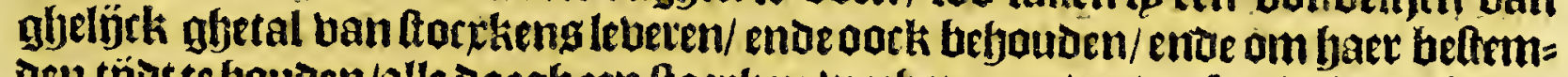

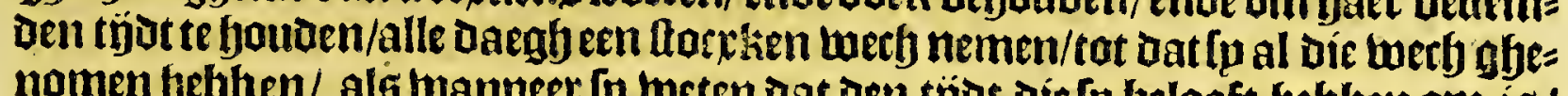
nomen febten/ als twanneer [o tweten dat den tjot derfy belooft betben om is/ enter twillen dan yaer belofte youden.

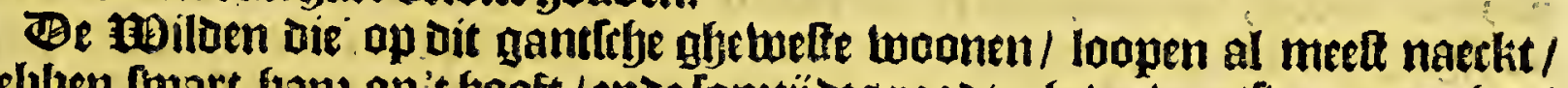

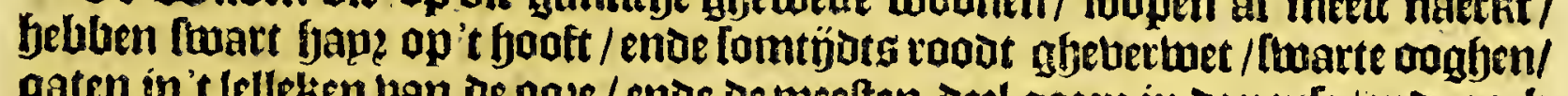
gaten in't telletien uan de ooze / ende de meeften-otel gaten in De neule/ende oock

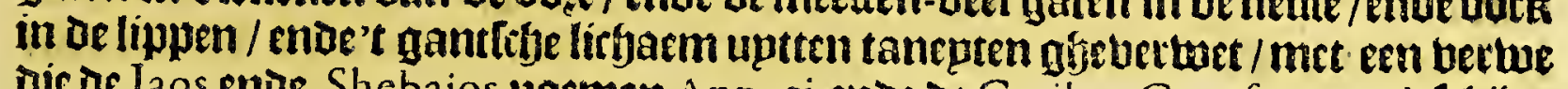

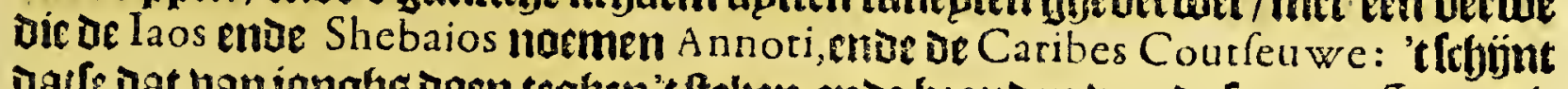

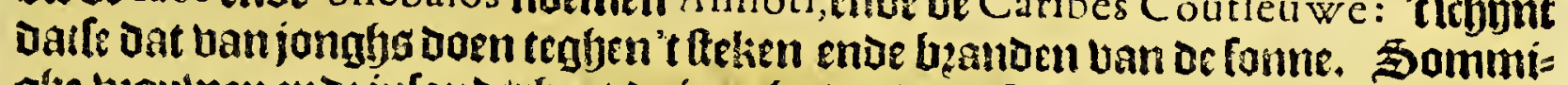

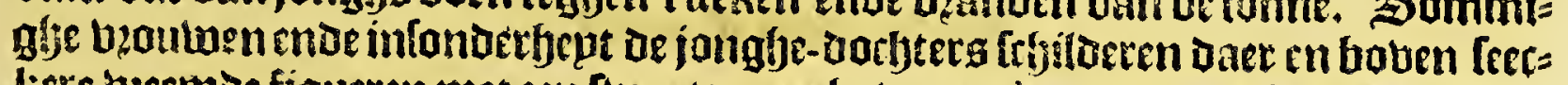

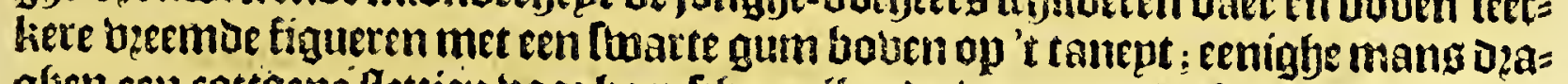

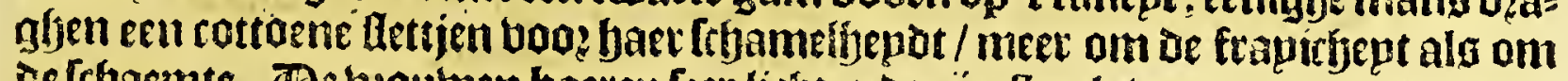

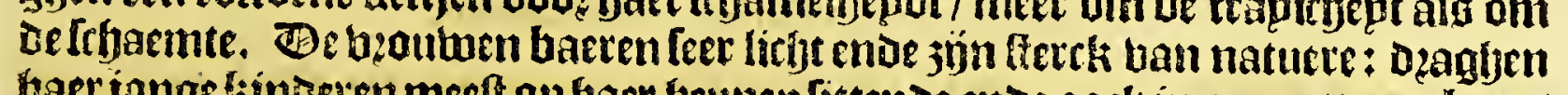

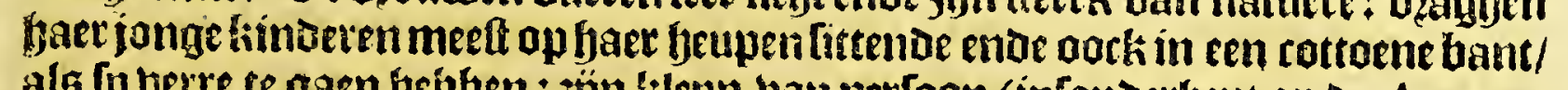

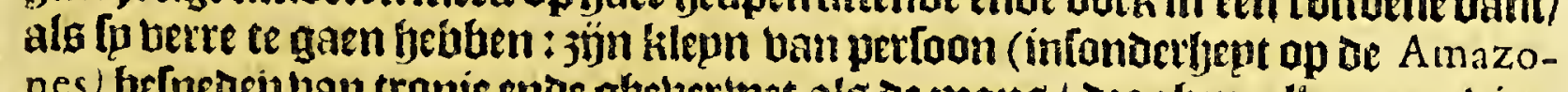

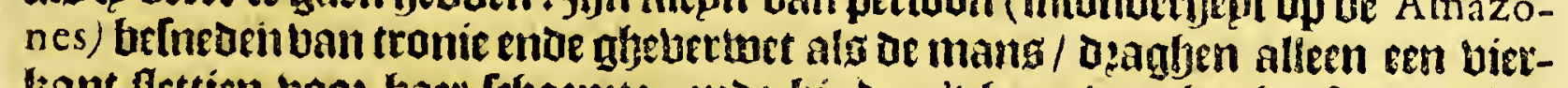

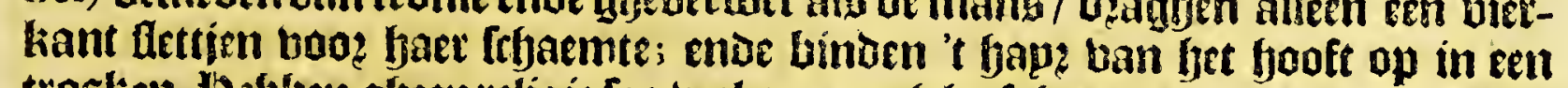
trasthen. Hiabren gbeen religie foo teel men noch beeft tommen mercken/als alleen

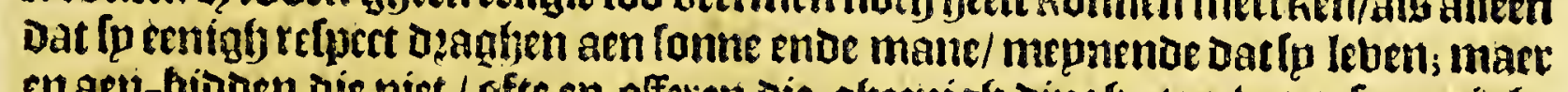

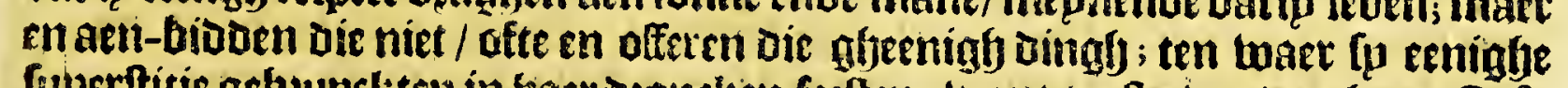

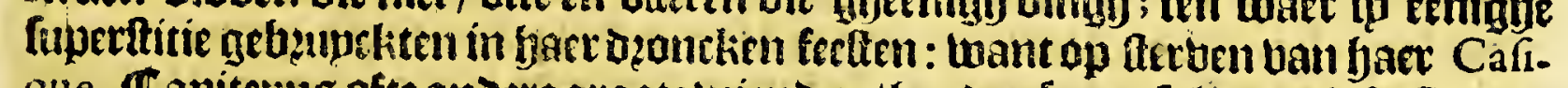

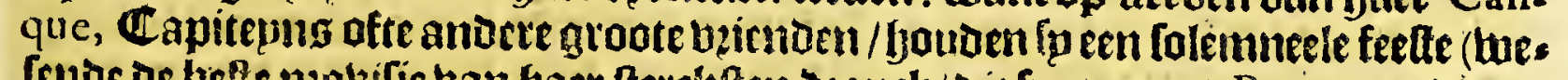

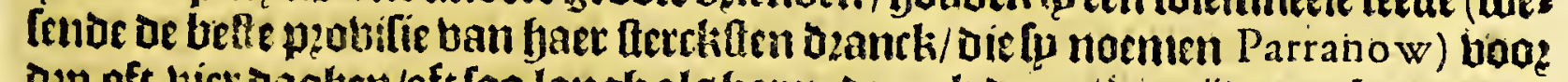

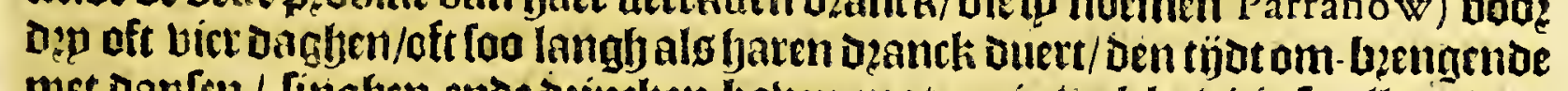

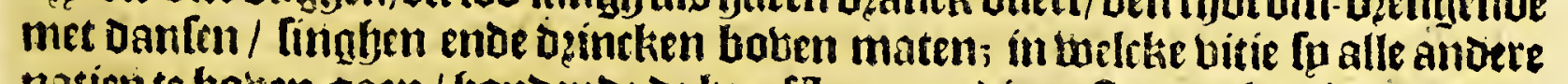

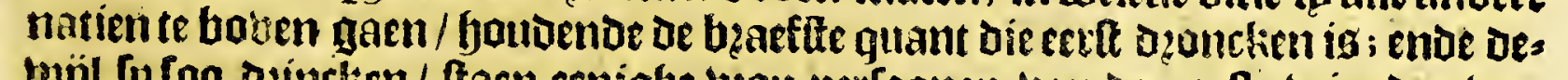

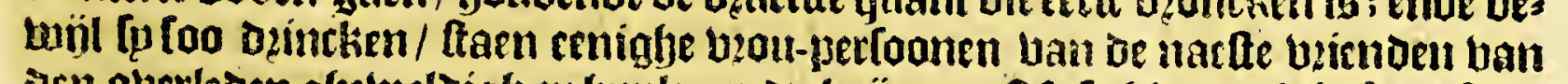

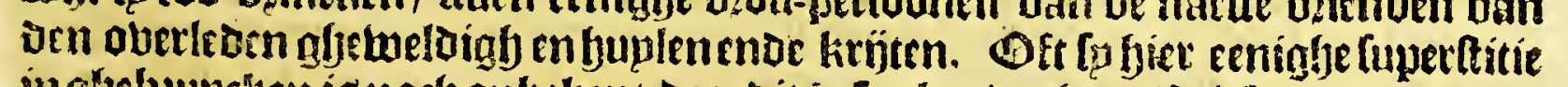

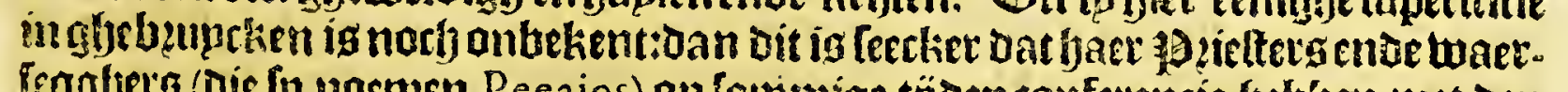

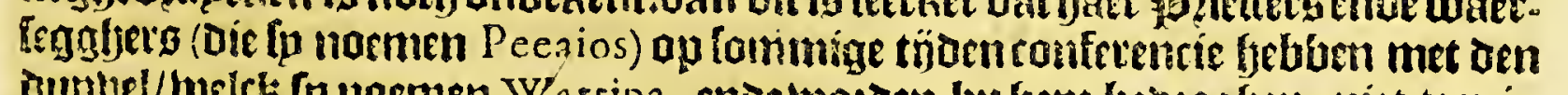

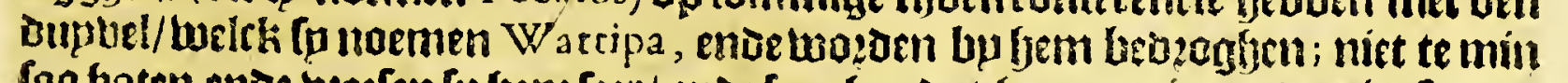

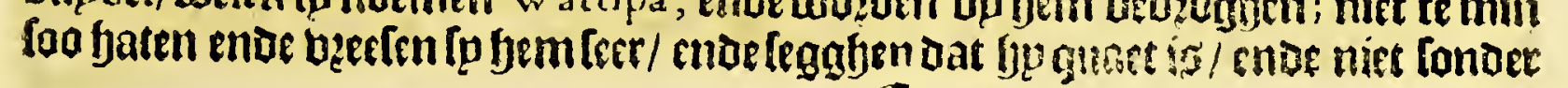
$\mathbb{C}_{\mathfrak{t}} \mathrm{s}_{\mathrm{s}}$ aroote 
572

VVilde Cufte, ofte Guaiana.

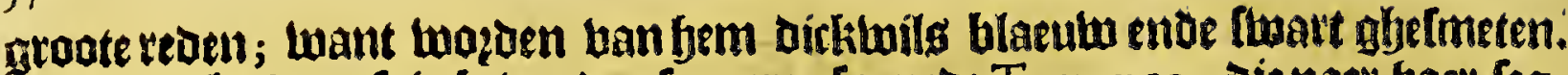
Raer Dat bp te onfe is betuonoen loa eerenf ghen boben moonder ende alles tegeert : be Iaos bibden Delen Tamouco bp-naet alle moegbeng ende abonots aen. Sp ghelooben dat de gaeoe Indianen na baet

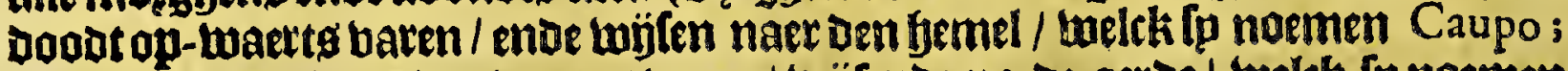

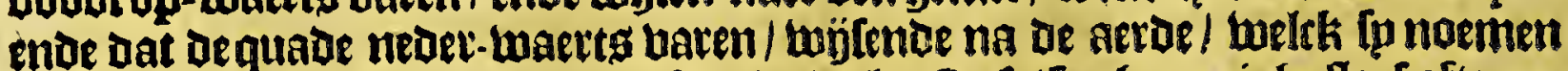

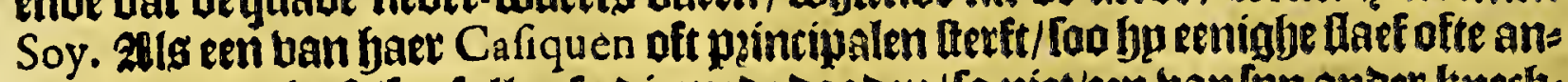
Der gevangen heeft/[oo fullen [p Diemede Dooden/[o niet/een ban[pn ander knecl]=

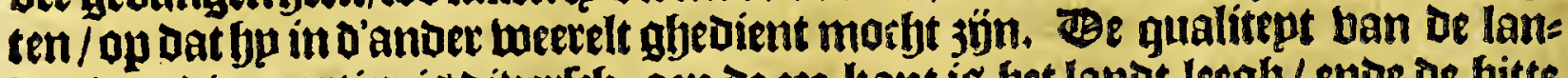

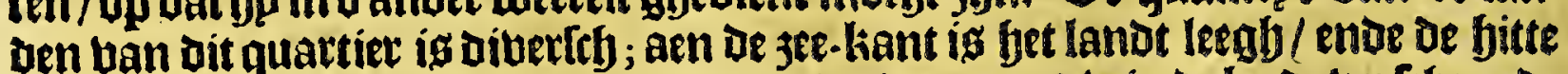

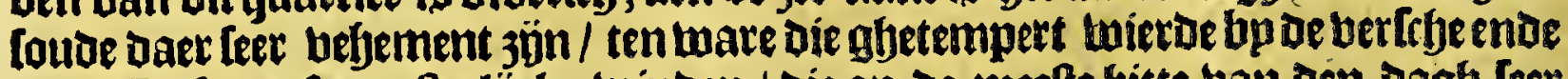
koele Brifen, ofte oolterljicke twimben / die op de meefte hitte ban den Dagh leer

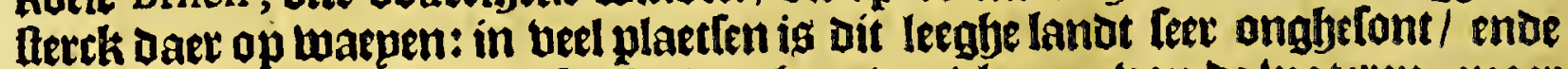
wepnigh betwoont / upt ooęaecte ban bet ober-bloepen van oe wateren; maer

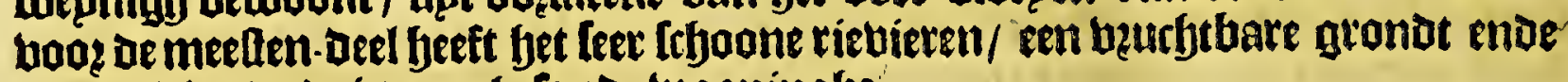
beel bolcks /ende is een ghe fonde wooningbe.

Op 't the berabte is of lucht koubt / ende't lanot in fonmighe plact fen beurbt: baer/ende in fommigbe plaetfen oock niet: maer oo0?-gaens is fet bol mineralen/ ende münen van Divertche metalen/ende geeft Der felben fao beel als eenige plaet:

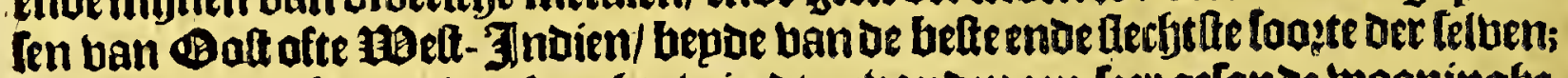
enda aphes meefte ban't geberghte wierot gevanden een leer getande twooninghe.

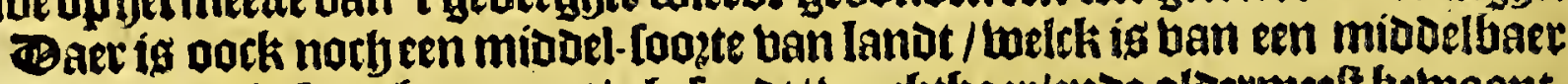

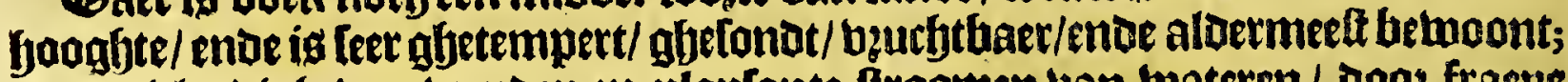

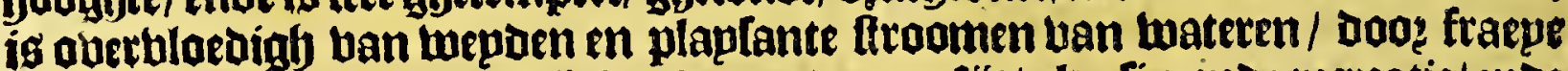

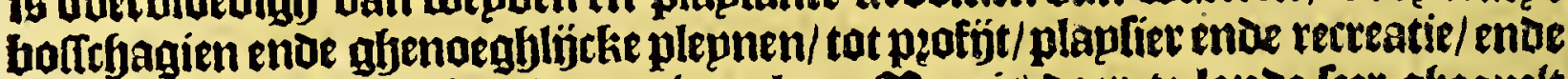

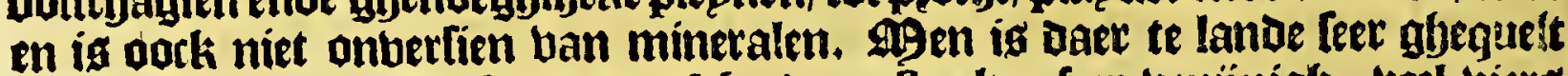
van De Mofquitos, Die [p noemen Mapiery, teeesken feer tenijnigh ; veel biers te troocken is een goede remedie; fyethen baer pock Niguas die lp noemen Sico.

\section{Het twatffte $\mathfrak{C}_{\text {apittel. }}$}

Van de lijf-tocht van' $t$ lande ende andere dinghen die tor onderhoudt van's menfchen leven dienen.

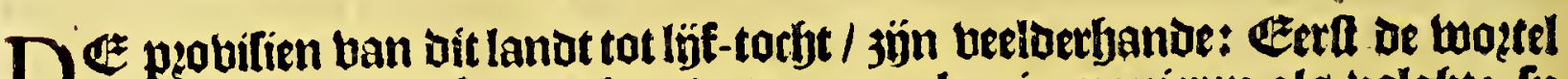
ban Caffavi, daer fo haet bzoout ban maecken in manieren als tolght: [p

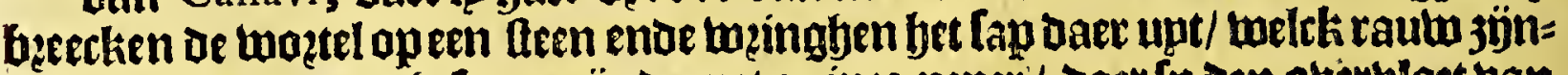

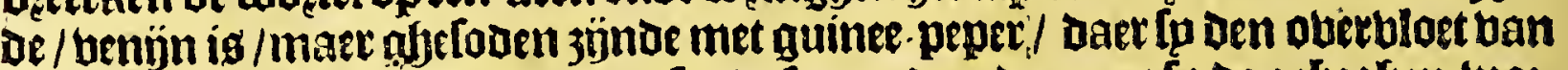
hebben/ageft een ercellente ender gefonde laute; dan dzoogentp de gebzoken woz tel/ ende hackenfe ap een (teen/als men De faber-koecken Doet; dit bzoot is extels Ient/ [eer Gelljijk dorf beel beter alshaver-koecken / ende een bingber Dick: Paet is een [oote van aroote tartwe gfjenaemt Maiz, ente bp [ommighe guinee-koozh/

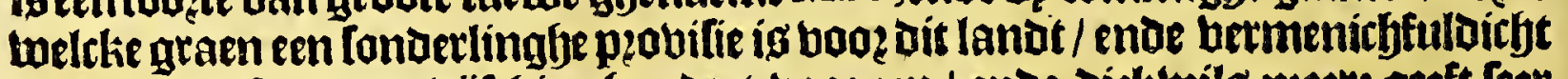

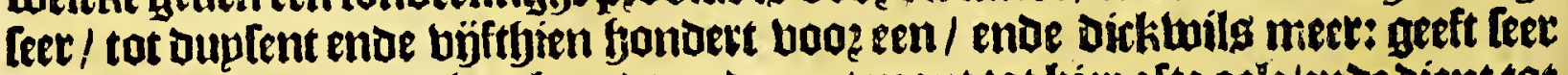
quede bloeme ende meel tot bzoodt; endee gost mout tot bier ofte aele/snde dient tot

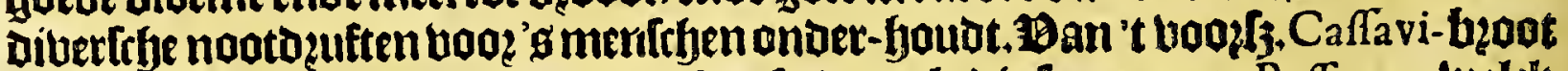

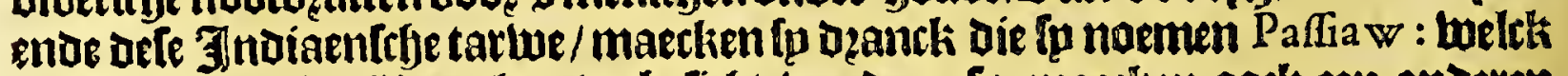

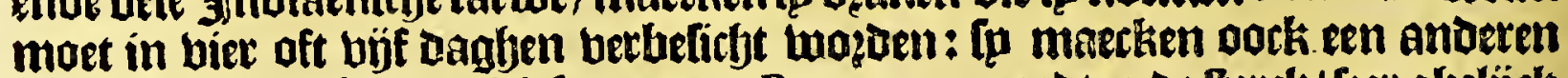

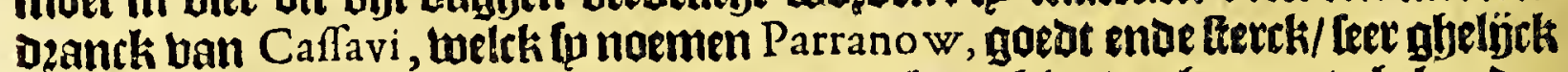
jeet befte maerts.bier in EEnghelanot/ende dat kan tbien Dagben goet ghejoutoen

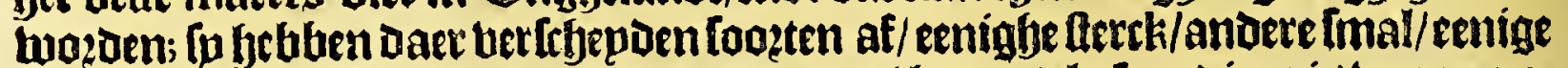

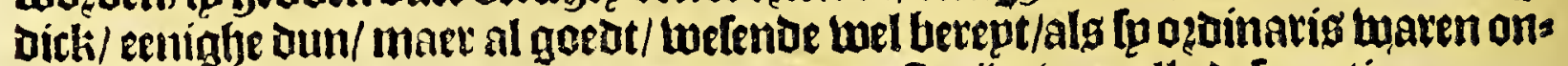

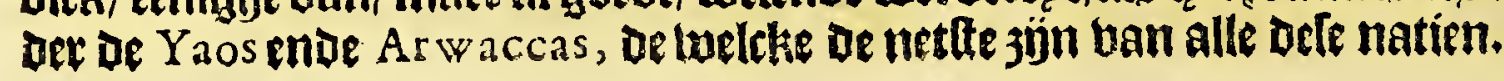


Het vijfthiende Boeck.

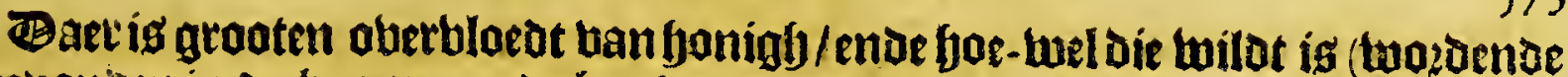
ghetonoen in de boomen ende kuplen onder oe aerde) is too goet als eenigl ter werelt ; Daer goede meede ban ghemaeclit fan twoloell. Bfeen wïngaetoen en binit men datr/maet alloo of gronot bęuchtbaet en bet ig/enoet' climaet matm/ fouben daer twel toalten indien [p daet geplant waten/ende gbeben goede twinnen/ welck boo? dit quartier feet ghefont 3 inn.

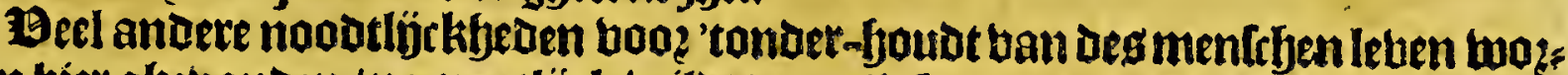
ben bier gbebonden / namentlïck milot ban alle [ootten / wilbe berckeng in groot

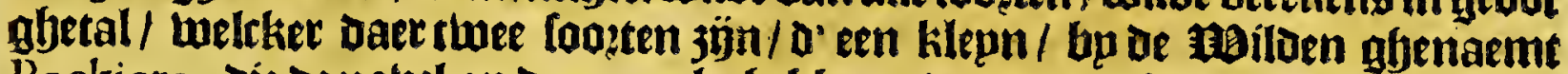
Pockiero, die de nabel op den rugghe bebben: o andere gbenaemt Panigo, toa ffyoan ende groot als eenighe in Ëngljelanot. Baer is menirfte ban baten ende Kanjunen / Dan different van de onfe: Daer jün tigren / /uppaerben / anten / arma= Dillen/Maipuries, die ban Imaeck jän als often-vleeleb / en willen jout bouden; Baremoes, weltk fmarken alg fryapen snoe andere klepne beellen ban or felte (maeck / ban kouleut als de dainen; apen ende meet-katten ban viber'che foozen)

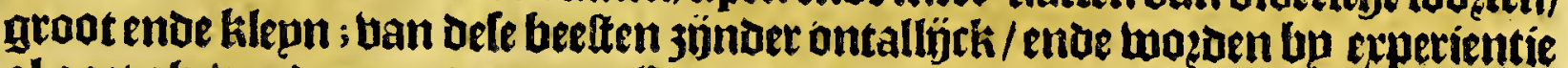
al goet ghebonden om te eeten. EEnde beel anderebzembe beelen meer. Jeonfe

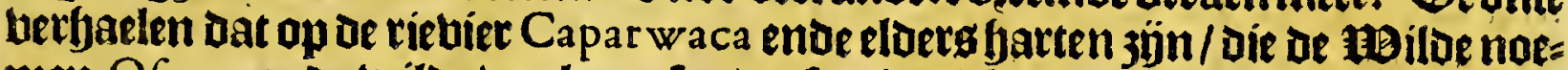
men Ofary; ende willde tuetkens londer tpeck/ diele noemen A bihera; oock illet van die leupe beefieng / (Waricory) roulu van bap? / de boo zfe beenen cotter als

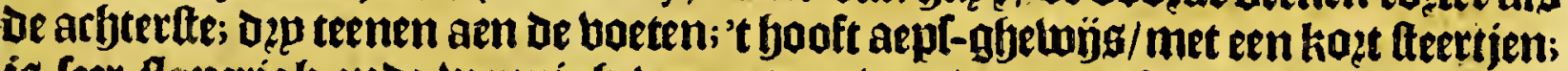
is leer daperigh ende bepnigh ban eeten; monoer traegb in bet berletten ofte klimmen.

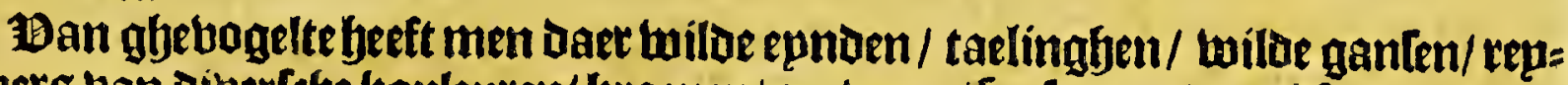
thets ban aiberffye kouleuren/ kraenen/ opebaerg/faplanten/patrylen/aupten/

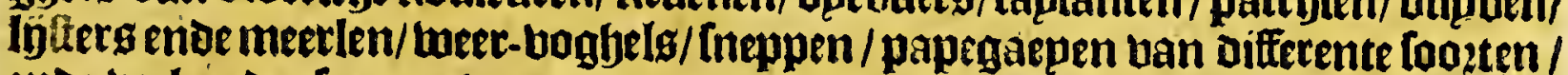
ende beel ander loozten ban groote ende klepne bogelg ban exquife kouleuren; be= neffens groote verllinoende boggels / ende balcken wan alle footten.

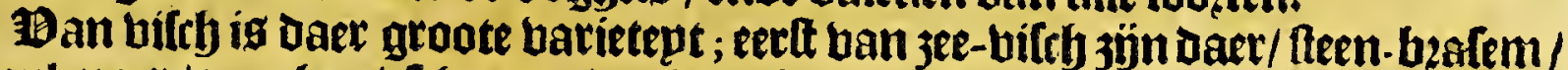

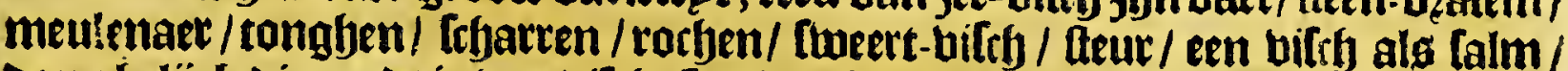

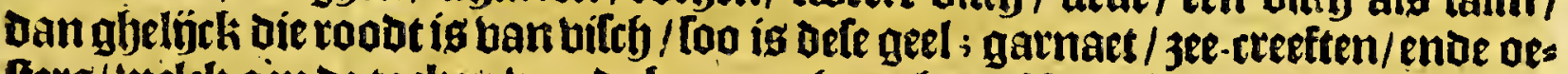
Iterg/ welck aen de tacken ban de boomen yangljen. Baer is ooclieen rare bifcly/ ghenaemt Caffoor wa, die in elcke ooghe twee gbelichten ljeft / ende ftuemmenoe bout bet o'een boben / o' ander onder't bater; of ribben ende den rugh jón ors menfchen rugb en ribben ghelïck/ bebben de eene rande ende d' ander black met een rugh-been baec in; is twat grooter als een fpieringl/ maet berte beter ban Imaeck: ende beel andere leer goede biftefen. Be onfe noemen defe Accare, welck De rrocodilen nifet onghelijek en ig / Dorb dumer / langher ende ghedzonghender uan fooft/komt op't landt/ ooch boedt op biffy/ is goeat om eeten / boch quaed om bauglen / geeft goeden reuck / waee dooz men bie ghetwaer bozot: O wanna

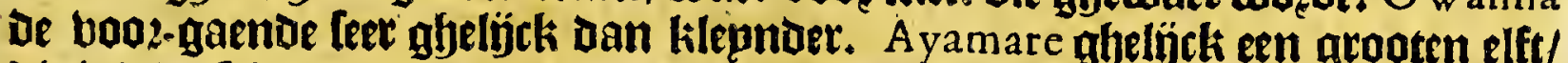

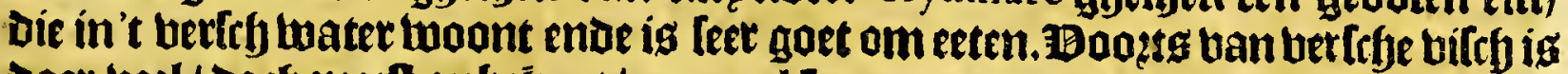
Daer beel / porfy meelt onbekent/ maer al leer goedt ende Delicaet: Soo Dat men onbeltwaett magly legghen dat dit landt magh teraljeleket twozoen met eenigly

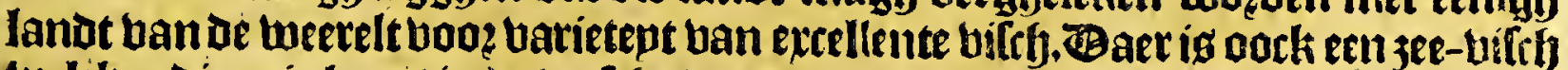

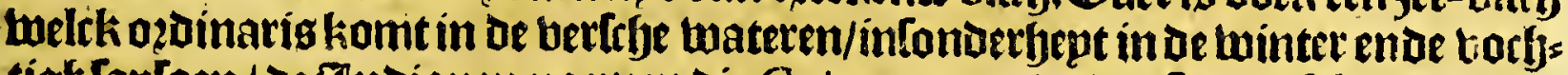
tigh Tartoen/ de Jndianen noemen die Coiumero, ende de Spaenflye Manati, endelup noemen't een $3 e$-koe/ baer tup booz oclen banfyebben gefpeocken; ban oele bilth kan een extellente olpe glemaetkt woiden tot beel gheboupcken: het Imeer ig goet o in bifth oft bleetely mede te fríten: de bupat wil goest buffels maec= ken; ende toctende in de Con gfjedzooght / ende ban 't had betwaert / ig goet booz Trbiloen teolhen oe pijlen ban de Indianen.

De ueturteten jün menigerlep/ De Pinna; Plantana, Potato; mifpelen/p?upmen 
van diberffye foozten/ noten ban beermoe fatloenen. Be sxcellenthept ban be Pinna is groot / waint men loube gbeen beter veurft konmen binden; is ban fmaerk als aerot-befpen met wỉn moe fuptker ghemenght. De Plantasa Imaeckt als een oude puppingh. De Pota to is twel belient. Bemilpelen 3 g̈n feet groot. Je

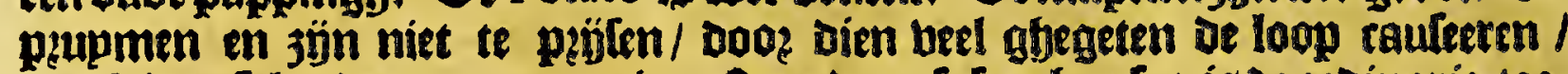
welck in dete landen dangereus is. Paer oe onfe legghen foo is de vedoinarie toe-

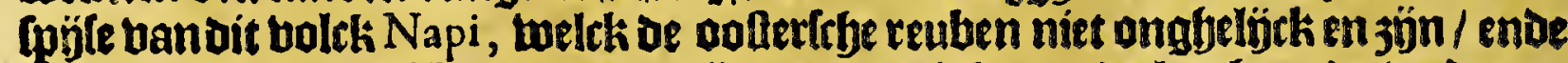
Coa, welck jönkrablien die daer jün met menigyte op de leegbe ende berdzonts kengramoen / enoe of gantlctje kufte langbg.

Wet Derthiento Capitrel.

Van de koopmanfchappen die in het landt worden ghevonden, ofte ghemaecke konnen worden.

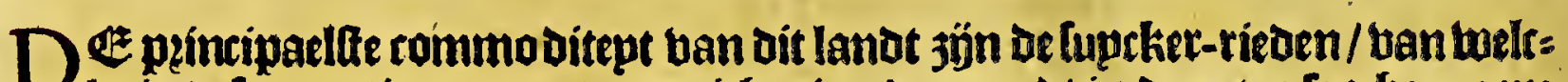
ke in dele quartieren gropte menichte is ; ae grondt is dafr toe foo bequaem als in eenigh anoer beel oes tweerelts ; watien daet in koęten töot leer groot ; by plariten enoe op-boutwen van bequaeme plaetten om 't jupcker daer upt te trers ken (welek in bet begin beel foude kaften). kande men daer grooten rijckdom upt

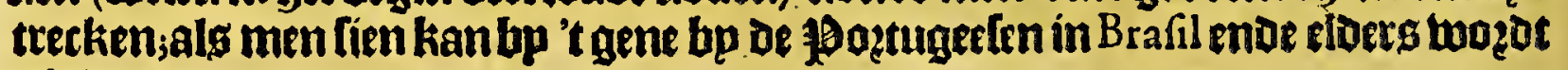
ghedaen.

De cottaen is eengenerale koopmanlefap / feer nut boog de koop-lieden / ende boos ong lanot/om fultepnen/bombalpnen ende anoers datc ban te maken;ende tot anoer gheb?upcken/als Hamaccas ban te maecken/ welck 3 jon dex 3noianen bedoen / leer noodigh in bele quartieren; enoe fijn cottoene lïntoaten.

Baer is oock een foote ban bennip ofte blas / ban groot gbebzupck / bp-naer

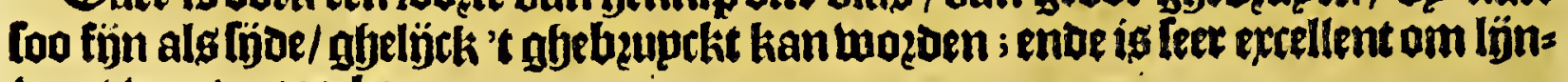
waet bante maecken.

Agen beeft Daet fonderlinge bertwen; ban welcket een is ghenaemt Annoto,een toode be[pe / welck wel ghepeepareert 3 junoe bp oe Jnoianen / bertuet een perfect

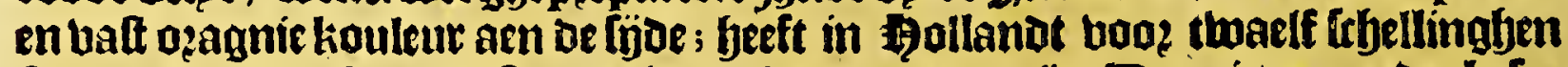

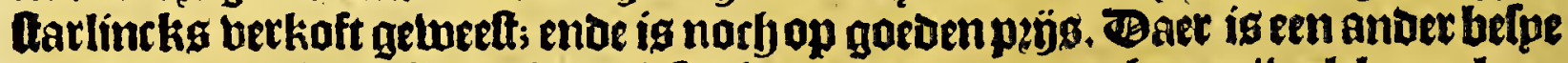
bie blaeub bertuet. Baer ig oork feecker gumme ban een boom/welck aen laet: ken een perfert enoe balt geel kouleur bermet. Baer jän bladeren ban boomen/ wetcke tael berept jünde / een boogh rooot kouleut gheben. Baer is oock bouter

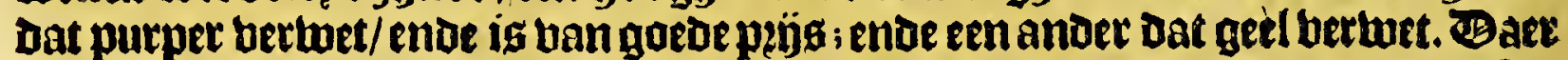
isnoeb een anoer houdt welckes lap purper bertwet als fet beet ig/ ende rarmolpn als bet koube is ; ender merr anoer binghen jöndaer (onghetwijfelt) die nocb niet

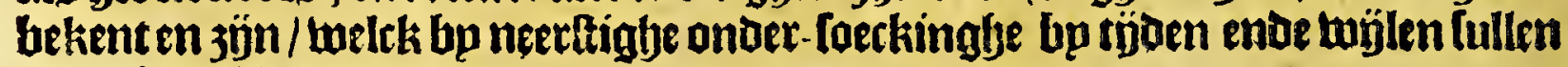
uut-ghevonoen toogaen.

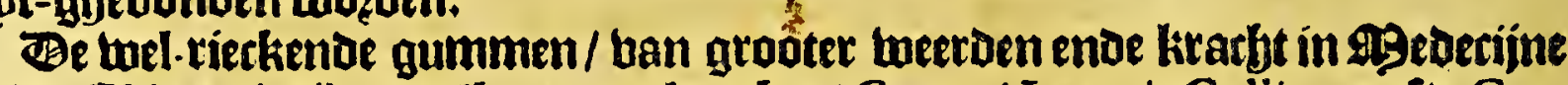
ende Ç birurgie jün ontelbaex; geel amber / Gummi Lemni, Colliman ofte Carriman Baratta, ente andere meer. Colliman if een gumme thart ende byockes lighy/leet ghelijck in't aen-lien fet glyemepn peck; ;een wepuigh oaer ban op kolen ghelegft/lal oe plaetle berbullen met feet toeten endoe aengenamen reurk. $\mathrm{M}^{\mathrm{r}} \mathrm{W}$ alther Cary, eenman die goet berltanot beeft en ooe deel ban gedecing faken/teght

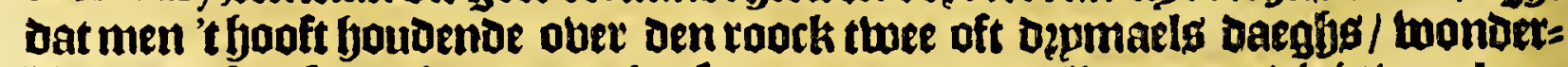
lijck geneett of fwareljept ban 't booft / ende dat een excellente reme oie is booz̨ kous

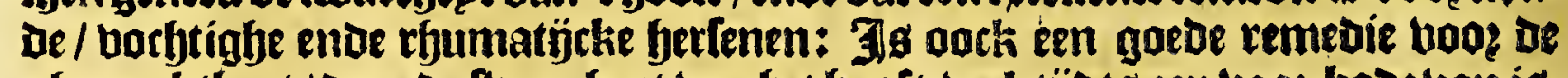

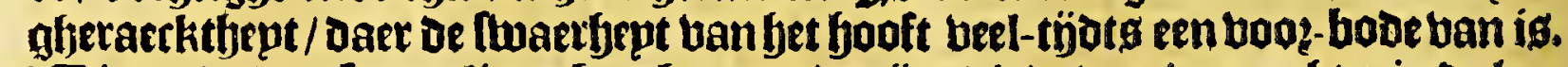

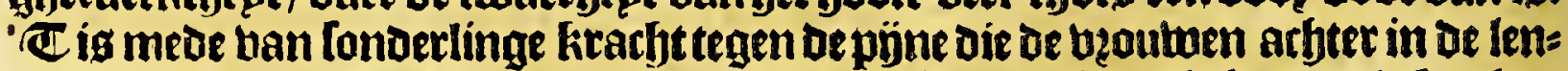
Denen bebben / intonoerbept oe ghene die kimberen beblen ghebad; glefmolen jünoe op eenklepun uperken / wozas met een mes gheimeetr op een fuck leoers/ 


$$
\text { Het vijfthiend Boeck. }
$$

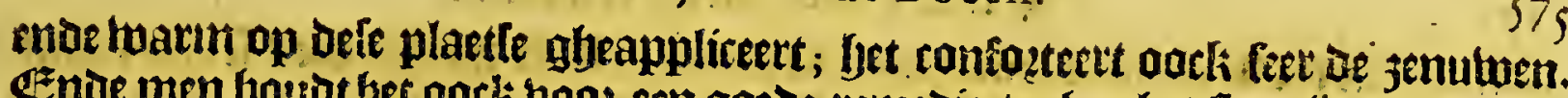

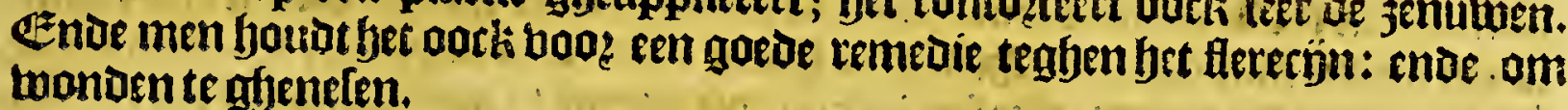

Be Baratta is een leer frellaem hallem/ berre alle andere obettreffende; welch

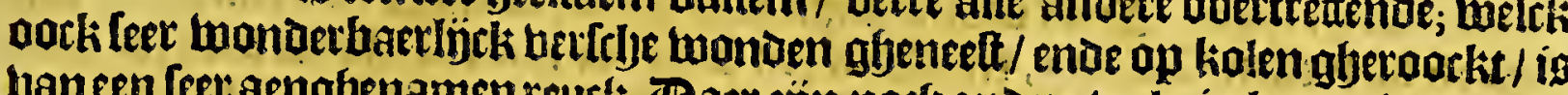
ban een [eer aenghenamen reurk. Baer jön norfj andere thel-tieckende bertten wie feer bequaem jön tot parfumen; infonderfept een belek een leer aengfenamen

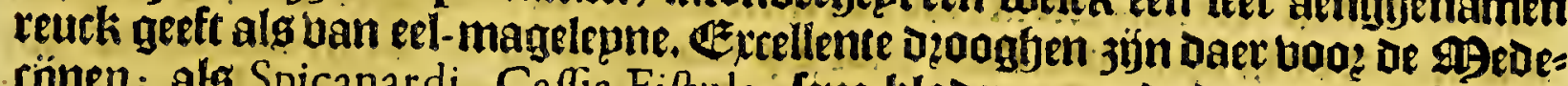
rönen; ald Spicanardi, Caffia Fiftula, fent-bladeren; ende de aetde geeft oock Bolum Armenum enve Terram Lemniam. Baer 3 inn norb ander dzogfen in onfe quartieren onbekent / ende ban fonderlinghe kraclyt: ban belcker een is een

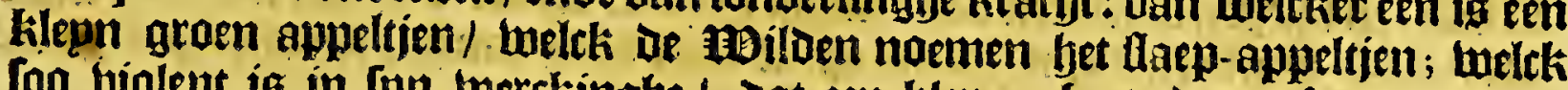
foo biolent is in lpn toerckingbe / Dat een klepne beete Daer af den DoodtHaep berodfaetkt; ende de mintren dzop ban't lap daer af purgeert [eer excellitue=

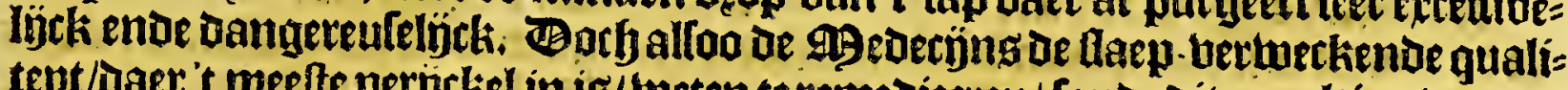
tept/Daer't meelte perijckel in ig/ weten te remedieeten/ Coube dit appeltien bange=

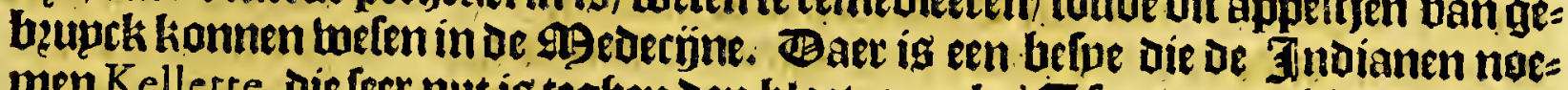
men Kellette, die feer nut is tegfen den bloet-ganck: (c) fap ban of bladerengfe= naemt Uppee, gheneel de twonde ban de benínde pijlen. "Clap van bet bladt ghenaemt Icari, is goet tegben de pýn in't booft; ende diexgbelÿche Dzoghen ende Simplicia meer/alte langh om te verfalen.

Ben boam daer [p faet bift] mede bangfen is ban fonderlinglje ronfideratie: watt abemepnlÿck ontrent Gaer woonimghen; als [p willen gaen billeben nemen fo cenighe tacklieng daet ban/ende barende in De kreecken/ welek met boogh wa= ter meet bol jön bangoede bilch/nemende ftecx'seng/eerft gbemo felt op een lteen/

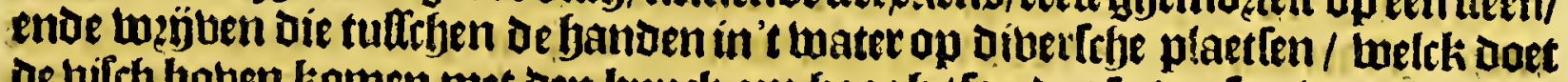

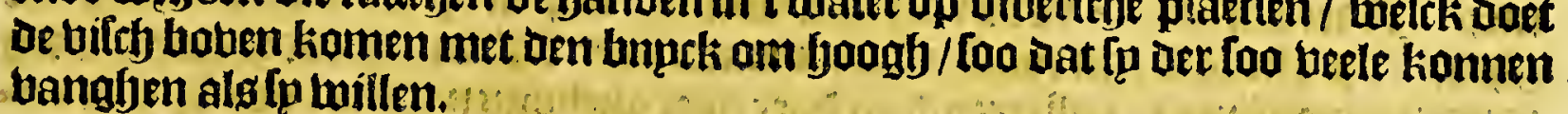

Baer is mede een roobt glelpzickelt bout/belck die ban oe lañe noemen Pira Timinere, (in : Rederlanot beet men bet letter-boutot) tuelck is luetoigh oetticf oft beertity panot fterlince de tonne ofte laft; enae leer excellent tot alderhanoe

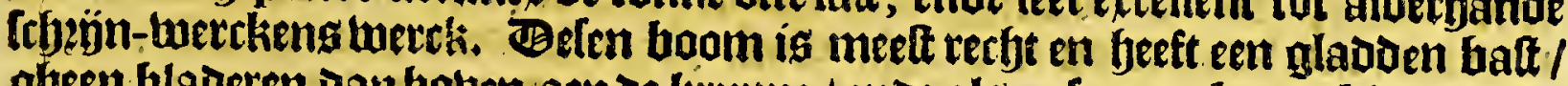
gloen bladeren Dan boben aen de krupne / ende ais onfe peet-boom bladeren.

Baer vallen mede beel kaftelijetie ende pzofitabele ftentn/alg Iafpis, Porphyr, \&c. Epnoelÿck [oo is fier noch een pzofitabele koop-manfchap/te weten Tobacco, welck nu in meeft alle lanoen feet begert wozbt; unt tuelekes plantingh in kaztentÿot leer groote pzofÿten konnen ghelamelt wozaen. Be apparentie ban

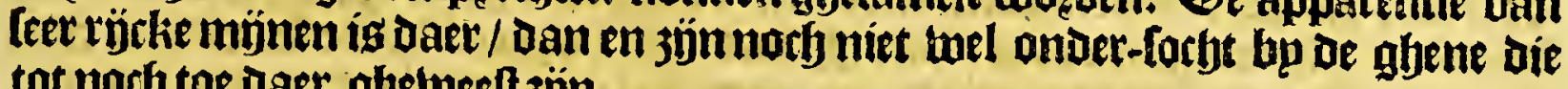
tot noch toe daet ghetweelt 3 jún.

\section{Wet beethithoe Capittel. \\ Vervolgh van de kufte ende diverfche rievieren.}

V Exbolghende de kulte ban de riebiere Caiana naer 't tueften / feeft men eett de riebiere Meccooria, ofte loo ander de noemen Macuria. Baer na de rievierte Courwo, [oo Harcourt bie noemt/ ofte lop ander die naemen Ca wroora, atht miglen bp tweften. Caiane loo de anle gljetupghen; welcli beeft een naeulue body

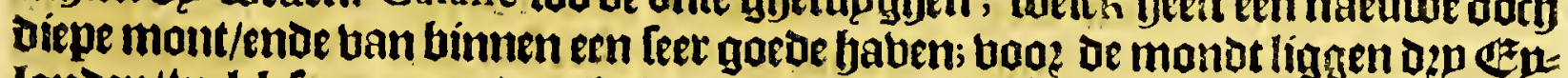
landen/welck fo noemen de. Ëplanden ban Caurara; je gronto ontrent de vic:

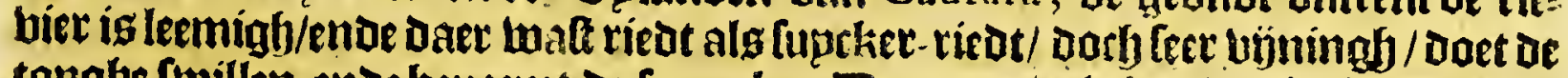
tonghe fwillen ende beneeme de [p:aeclie. Taer aen volghen de rietieren Man-

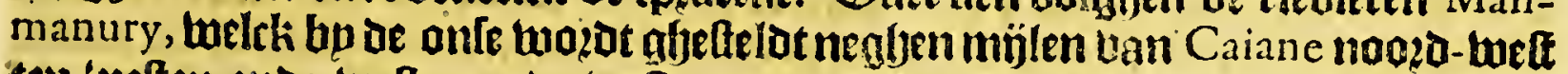

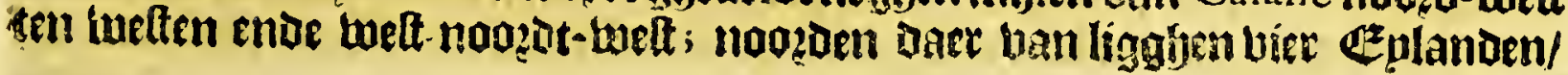


$s^{2} 76$

Wilde Culte, ofte Guaiana.

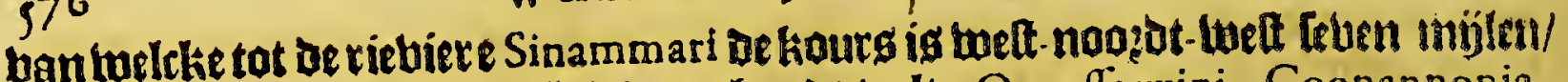
is een klepne kille daer redelÿck letter-houd balt. Oorafla wini, Coonannonia, foo Harcourt die noemt; ofte foo Keymis die noemt / Cunanamma, V racco, Mawari, Ma warparo. Raer bebindingbe ban de onfe loa ligbt $R$. Synnamary arbt leguen bp weften Caurora, endebeeft een bape / ae lufte ltreckt tot Daer toe twelt-

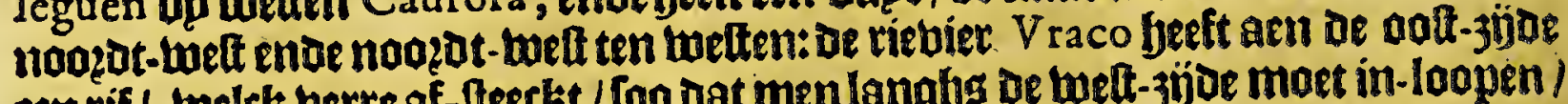
cen rie/ welck berte af-Iteeckt / foo dat men langhg de welt-3joe maet in-loopen/ altwaer fet dirft bp of wal twee ende dęp vadem diep is; oe in-twoonders jün bpanden van de laos. Raelt is glyeleghen deriebier Amonna, tuelck naec't leg gen uan Keym is beeft een wijut enoe diep hanael / en loopt foo fnel oat geen barte

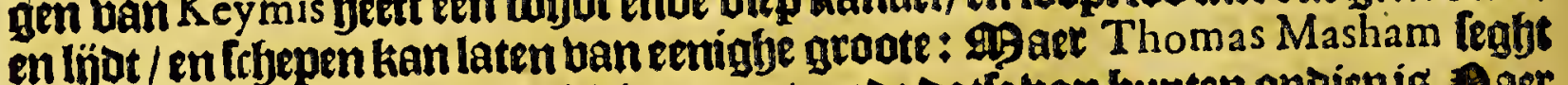
Dat Amano maer een klepn rietiere opent; ende datte van bupten ondiep ig. \$aec bebindingh vande onfe loo light fett op les grasen.

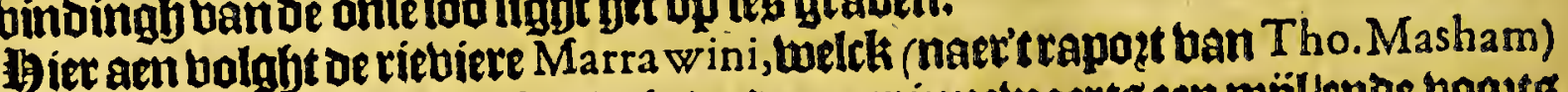
in oe monot wel bier mỉlen bzeedt ig/ente meer innetwaerts een mül/ende bookt\$

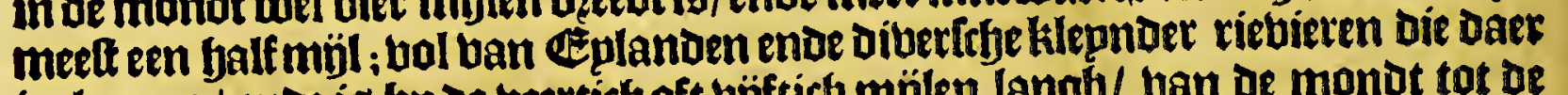
in-loapen / ende is bp de beertich oft büftich mülen langh/ uan de monot tot of vallen / ende ftreckt meeflen- deel jupdt-jupDt-welt op/ beranderende dep freecken by-naer beel recht. Spnkanael heeft dęp/ vier enoe vïf badem waters/ ende thee mijlen binnen de mondt / komt de riebiere Cuffewinne daer ín. $M^{r}$ Harcourt leght ban dele riebier/Dat feteen frboone rievier is/ oan ondiep op oe harte/wele: ke twee ofte dep mỉlen at in $3 e e$ leght / gebbende maer twee badem twaters/ Dan bimen is bet kanael dep / vier ende bijf badem diep. Bjóf mp̈len binnen de rie= bier legghenteker \&planden die nyenaent wozoen Cure w apory, niet betwoont/ booz dien fp met bet ober-Loopen ban de wateren onder-loopen / als beel andere meet. Paer dat men be riebier antent thintich mijlen op is / foo binot men die

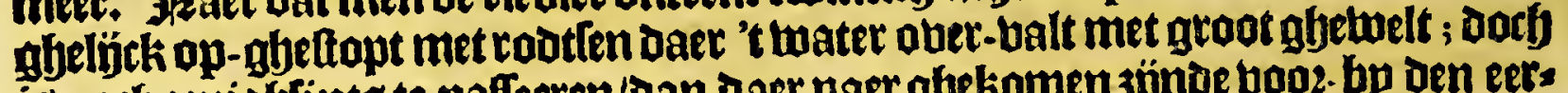

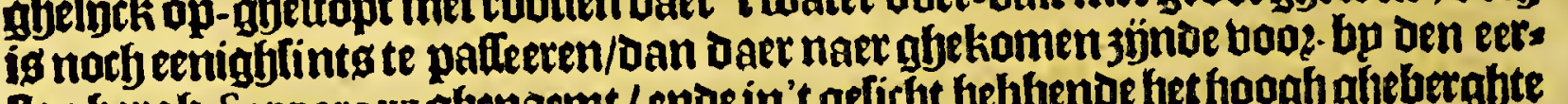
fen beraf Sapparow gbenaemt / enoe in't geficht belabende fet hoogh ghe betghte Mata were Moupanana, bp-naer beettich mijlen de riebiere op/too balt de rievies re loo ondiep/ ende de ftoztingle ban 't water ober de klippen foo befiement/ Dat men daer niet voazder op en magh. Onfe Pederlanders noemen dele riebiere Marwyn, ende ftellen die op de booghte ban ug̉f graden ende lea-en-beertich mi=

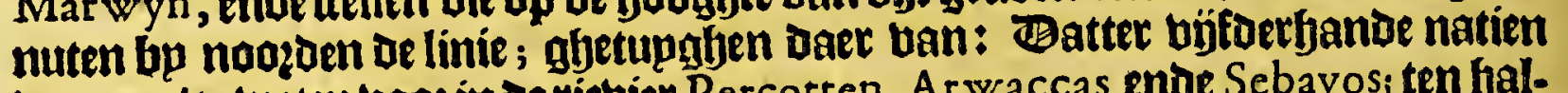
moonen/te meten booz in oe riebier Percotten, Arwaccas ende Sebayos; ten balbenin de riebier Caribes, die fterck 3 g̈n ban bolck / wilot ende niet te betroutwen/ oe mang jän groot van lichaem ende vet/ 't japz op't booft gbeichozen met een

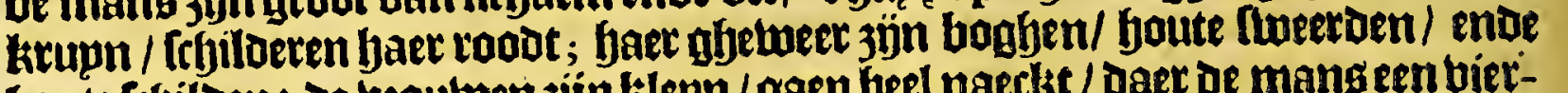
houte fehiloen: De bzoulwen zijn klepn / gaen beel naeckt / Daer de manseen biet-

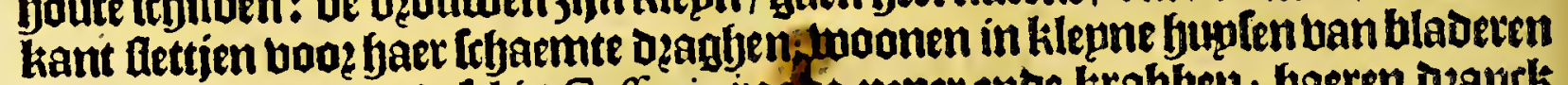
ghemaectit: haer voedtel is Caflavi, touo peper ente krabben; baeren ozanck

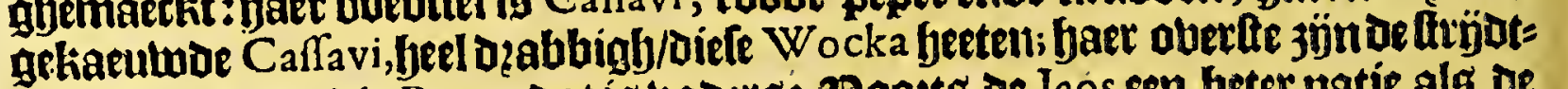
baerfe/ noemen die Pave, dat íg baders: Boots de laos fen beter natie alg de Caribes. Be laos ende Sebayos woonen meelt bp den anderen/ berlebillende alleen ban [pzaecke / haer bzanck is Pernou ; gljelýck mede de Arwaccas ende Percotten:op A mana welck booz aen dete riebier komt/ woonenal Caribes. Hit

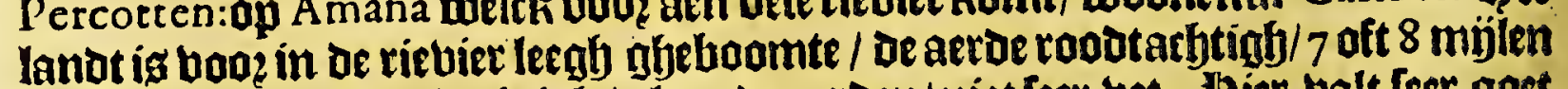
boogb werot het bergharftigh / al roode aetuen/ niet leer bet. Jier balt leet goet letter-fjout. Ben regen.tñt begint in Decemb. ende in Ianuar. Februar. Mart. res gent lyet abetwelaigh. Bntrent deferiebier vond Har court een leker klepn boom=

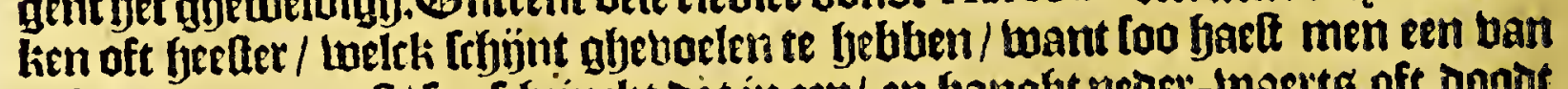

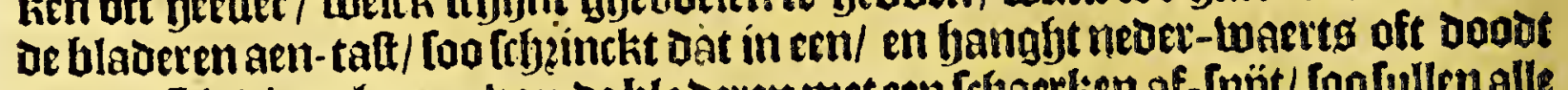

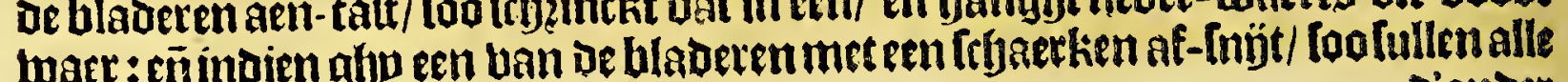
Donder 
Het wijfthiende Boeck.

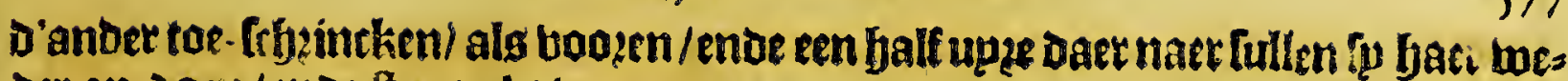
Der ap $\mathrm{t}$ ocn/ende ftaen alg boojen.

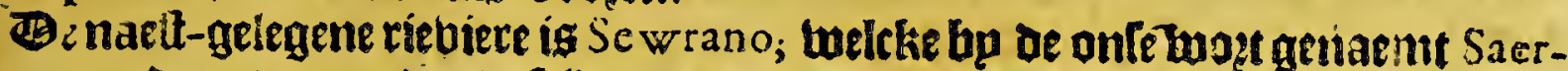

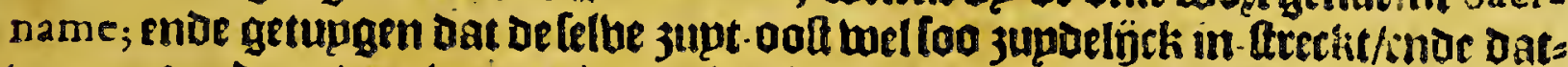

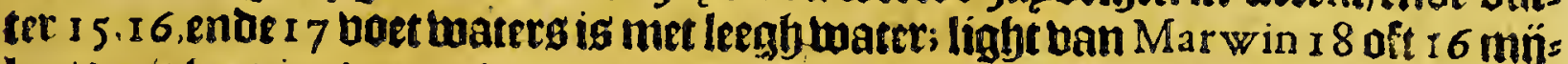

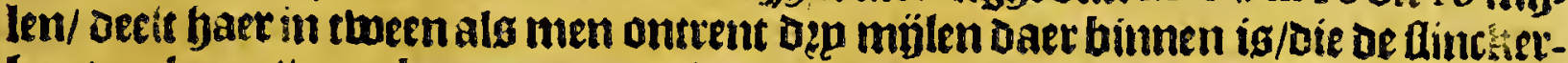
Gant op loopt/ wost lcoteca,ente die de rechter/Serna me geneemt. Tn deferietier

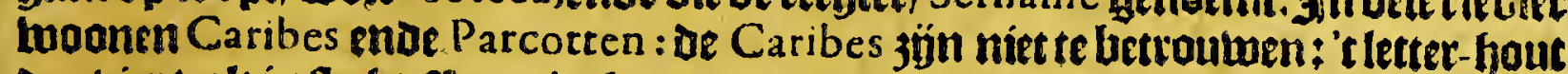

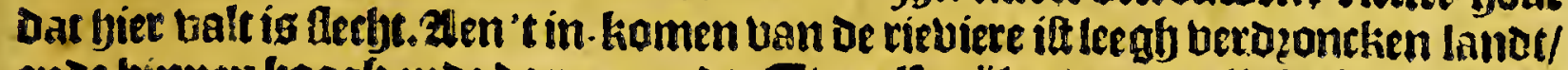

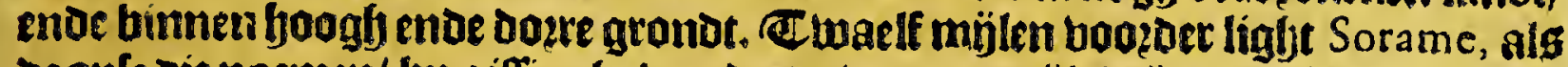

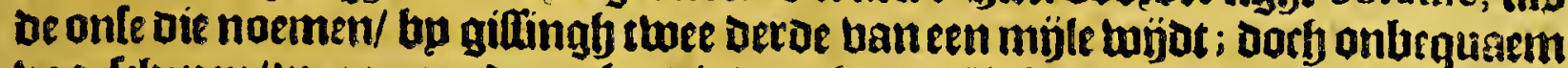

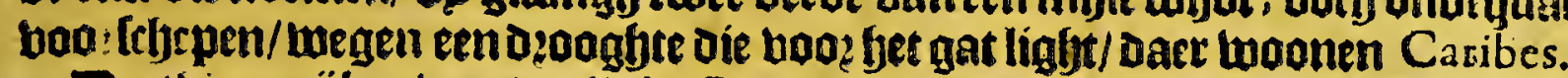

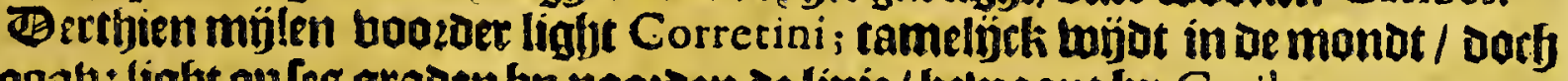
Dzoo alt: light oules graden bp noazden de linie / betwoont bp Caribes.

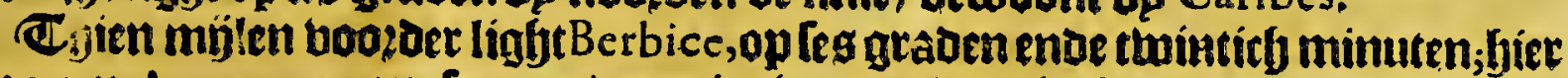
woenen Ar waccas, een Leer goeoe natie; is maer boo jarbten.

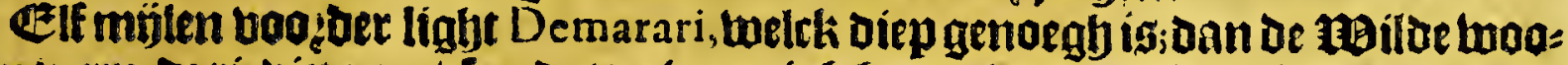

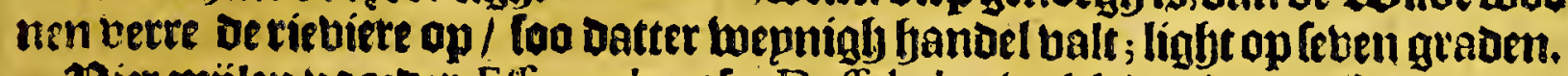

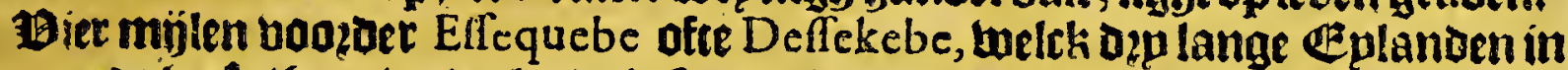
to mantrt beeft / gaer beroeelende in foo ueele kanalen; ae frbepen loopen by 't ouft

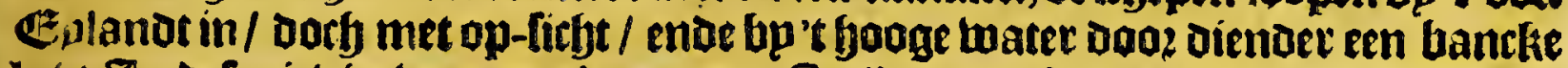
lirjut. In defe riebier twoonen Ar waccas, Caribes ende W acce wayen: De Arwac-

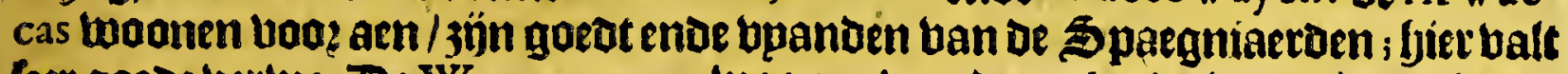
teer goecoe bertue. Be Wacce w ay en twoonen boozder te lanot-twaert in/oozlogen Deurgaeng met de Caribes, eñfyouden fyeer veeemt van de $\mathbb{C}$ heiftenentae Caribes moonen meeit looven de ballen Daer Derietier een epnoe neemt. Be reebier is benes

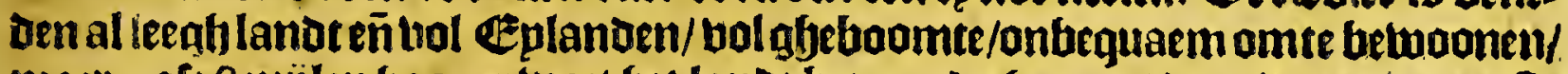
mare 7 oft 8 mijlen fooger woat fet lanot beter ende fjoager/ Daer twoont 't meefte

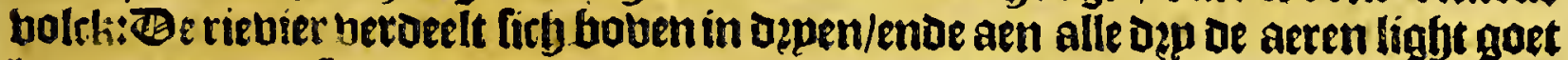

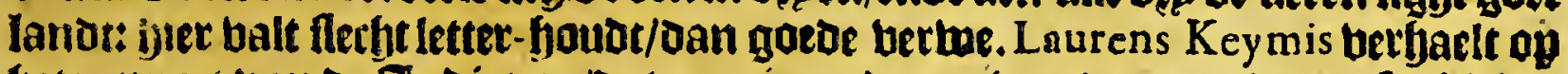
bet rappo?t ban de Indianen/Dat men in 20 dagen ban de mont ban defe riebiere baert tor bet booft oft begin Des felbeg/enoe bat van baereen dagh--reuleng getegen is t groot lack ; welck de laos noemen Roponowini; ende de Chariben, Parime; welck foo groot ís als een jee:ende twozt geturpiceert dat de ftaot Manoa op de kant

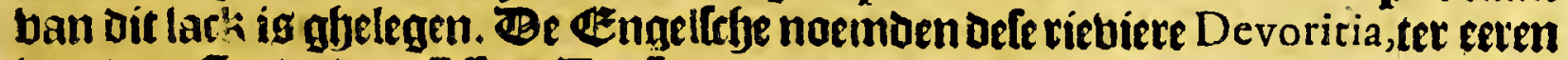
van den Graue ban Efex. Be Spaenniaetoen fadden bier eenigb valkk in Den f tre 1591 , naer'tuertjalen ban Thomas Masham, Dan 3 jun tueder tot niet gekomen.

Ruer Defe riebiere Deffekebe bolgen De riebieren ban Caopici, Pa w rooma, ende Moruga, oft fo de anfe feggen Ammegore, daer de Bpaegniaetoen ban de Margarita eñ Caraceas de Hilloen berdegetenin 'tiare 1596 met bulpeban de Ar waccas.

$$
\text { O R E N O Q U E. }
$$

\section{Wet vöftthiendo Capittel.}

Befchrijvinghe van defe rieviere in 't ghemeyn, volghens't ghene de Spaegniaerden daer van hebben uyt-ghegheven.

W

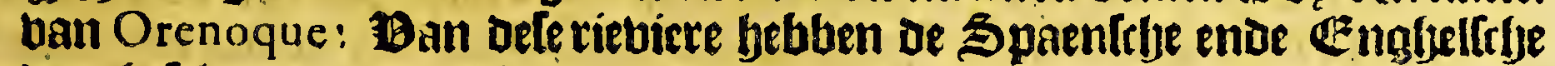

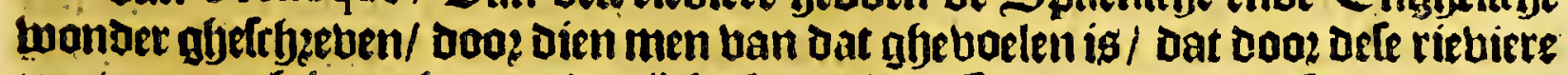

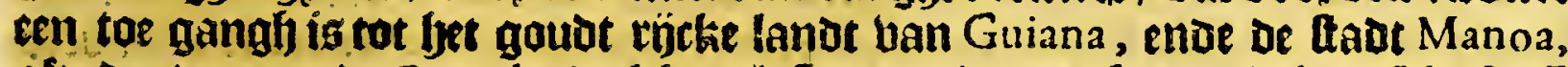
ofte dat vermaet be Dorado Inelck veel Sparegniaeroen foo beel ghektoft beeft/eñ

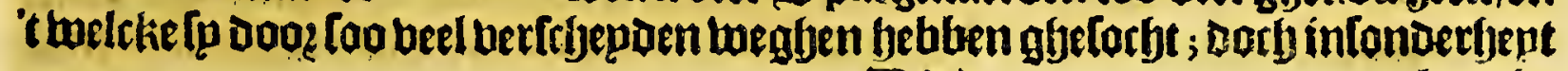
TBDD langhis 


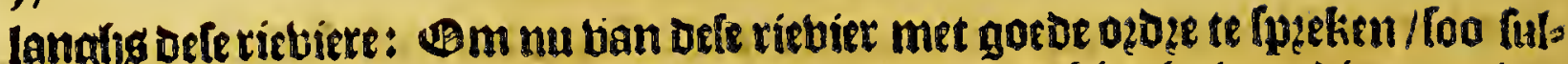

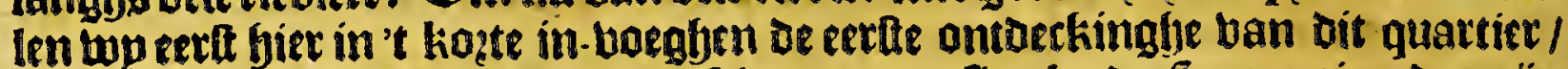
ende oe bptondere torbten die op uertchepden occalien bp de Spargniaerden jün

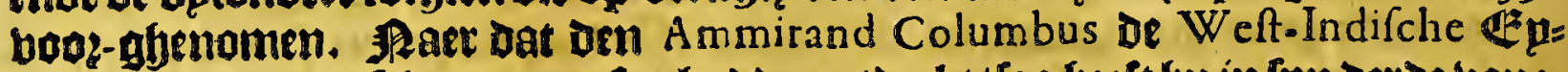

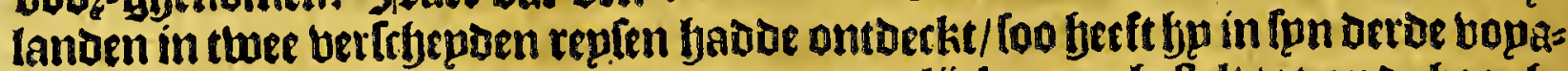
gie in den jare I 498 , [pn kours twat metr zupdelÿth aen. ghelelt tot op oe boogh:

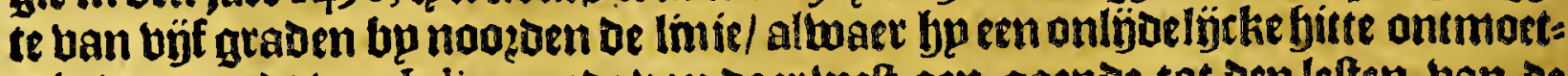
te in demaendt ban Iulius; ende ban darc beft aen-gaende tot den leften ban de

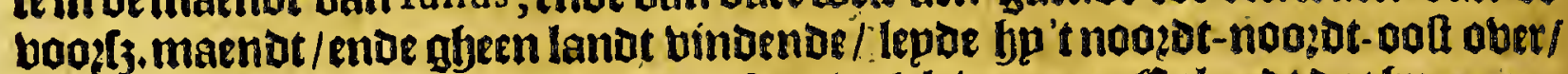

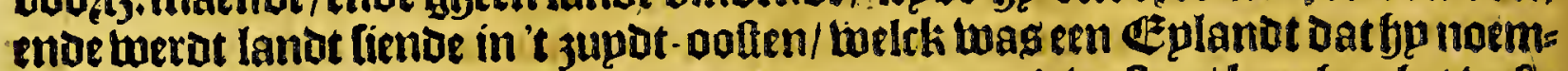
De Trinidad; ente Daer bp jupoen am-loopenoe naer't telten/ krengen bet bafte

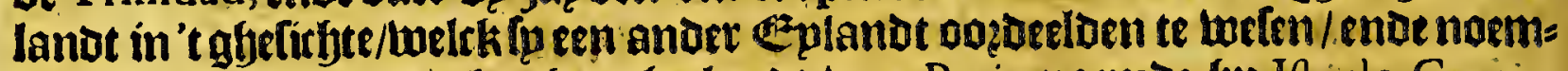
bent Ifla Santa, ende get booghe lanot van Paria noemoe bj Jna de Gracia. Be Trhepen waren bier in groot abebaer weghen defubijte berthettinge ban 't toa ter enoe ravelingh uan of froom; Daer 't water welck upt oe riebiere Yuyapari met groot ghetwelot af-komt / De blocd ban oe 3 ee ghtmoedt; waetom he befe plaette noemoe Boca del Drago ; ende is glyeleglen tufifren't efplanot Trinidad, d.1.1.3. ende den yoeck ban Paria. . Bele riebiere (Eegltt Herrera) twelck loopt in de Golfo c.10. de la Vallena, komt ban meer als bier hondert leguen af; ende voo? oirn daet foo grooten water met fulclien gfelwelot af liomt / infonderfendot in oe maenoen dat= tet in 't gheberabte ende daer reglyent/.ende de. Golfo daev Ip in komt belloten is/

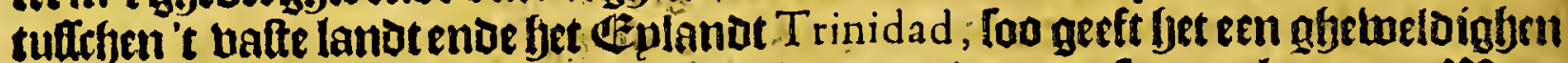
ftrjot wanneer de materen ban de ríetiere ende oe zee te famen komen. Ha aer

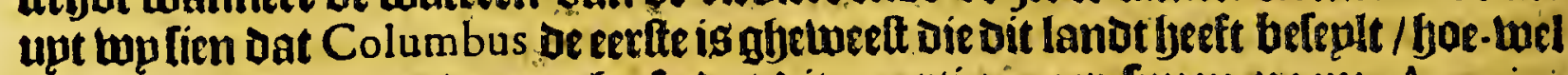
Americus. Vefpucius oe eete beft oat Dit quartiet naer fpnen naem America wozot ghenaemt. Bele beleploe dit lanot in ben jaete 1499 , in het gbelelftyap van

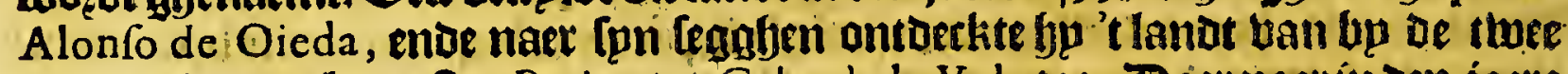
bondert leguen bp ooffen Paria, tot Cabo de la Vela toe. Baet naer in Den jaete 1500 nam Vincente lannes Pinzon, De Celbe ontoerkingbe tooz tie fun kouts

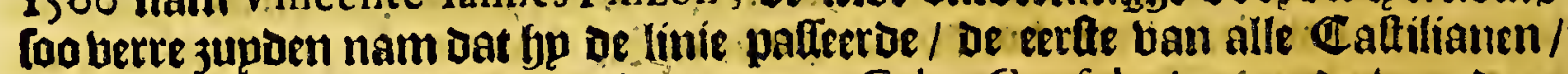
ente ontaerkte eell Cabo die ju noemae Cabo Confolacion's sende ban daet langbs de kulte loopende naer 't welten leetrich leguen, bonden foet water liet

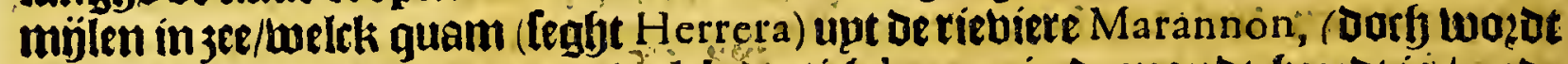
nu des Amazones gbenoemt) luelrt Dertich leguen in oe monot beetot is / enve

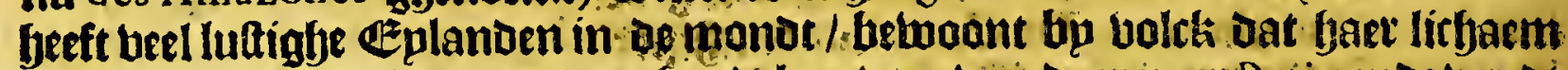

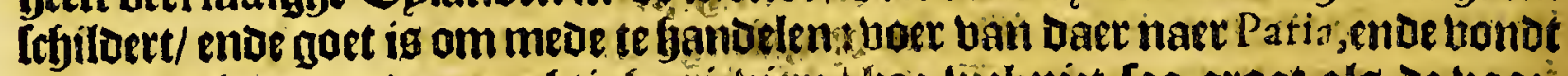
in oe wegly een ander matbtiglje tiebieke hoe hel niet foo groot als of boozgaende/ die fpp noemoe Rio Dulce, om oatte veel mijlen in zee foet thater upt-

af: men beft daer gjeoozoeelt (leght Herrera) Dat Jet een arm toag ban De rié

c.6. biere Yuyapari, welck de Golfo Dulce maeckt tuffifjen't land ban Paria ende Trinidad. Bpt dit berbael fien lop oát oen recften narm bañ dele riebiere Daet mp nuban bandelen/ eetryotg is gleturelt Yuyapari ofte Viapari : gljelijek dan

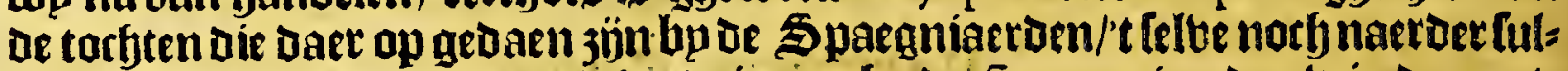
Ien aetl - wojlen. 24 lloo in oe volghende jaeten bp of 5 paegniaetoen wierden ont= Deckt de peetle-bifftyern̈en ban't Eplanot Cubagua ende Margarita, ende too?: Dere kuffe ban fet balte landt / foo en ig naer dele rieviete ende 't lanot daet aen gheleghen niet booper ghetaelt / voos in oen jaere I 531 , boen beeft Diego de Ordas ban den liepler berkregbrin de conquelte van be landen tail Cábojde la Vela af / twee bonoert leguen langhg de kulte naer bet ooften toe / ende tóa berre vootwaetts als bp foude konnen ontoeclien / fonter te toeren't ghene tes yoozoe aen de kroome ban Portugal, met Den titel ban Gouterneut ende antoere.

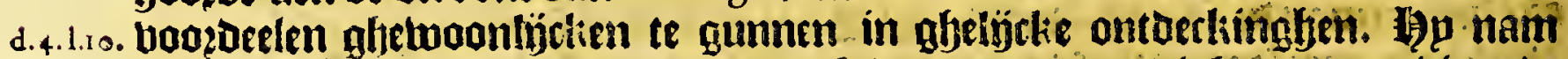
c.ro. met bem op fon frbepen biet bonocrt loldaten met noodigfe emmunitie ende andere. 
andere ghetetichap; ende quam eetlf aeti de Marannon, Daer fp fon ontoeckimge

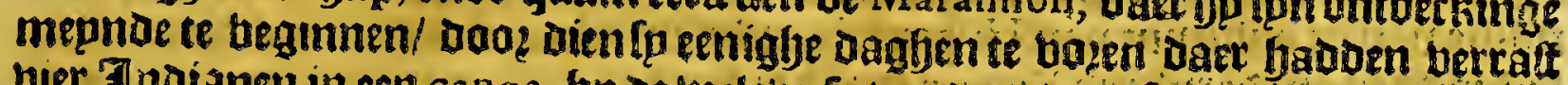

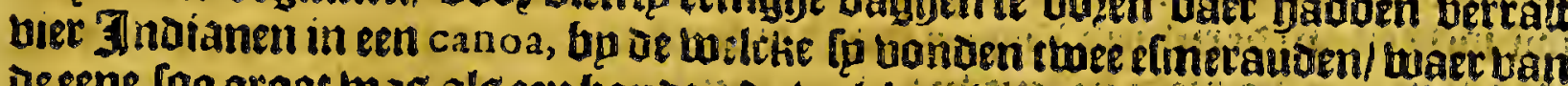

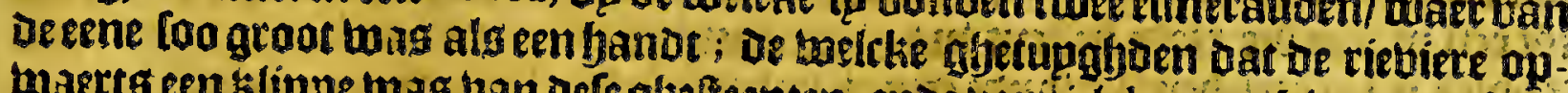
waerts een klippe wag ban oefe gbefeenten; ende veertich leg ten binnen oe reloe riebiere een bergh die bol booge boomen thanat oaer bieroock aen groepde: ooch De blackiten enoe calmten/ enoe ferchen ftroom van oe riebier en ligten Otdàs niet toe defe plaetfe te gyenaecken; bp berloo daer een van fon sctjepen met ten Deel bolcks; ;nde toenoefpn cours langhs de culte naer $P$ a ria toe; ende vonot daer een fortelfe oie Antonio Sedenno, (Bouberneur ban't feplanot Trinidad, Oaer baode ghelegljt int land ban de Calique Yuripari ende met bolek boo?tien onder

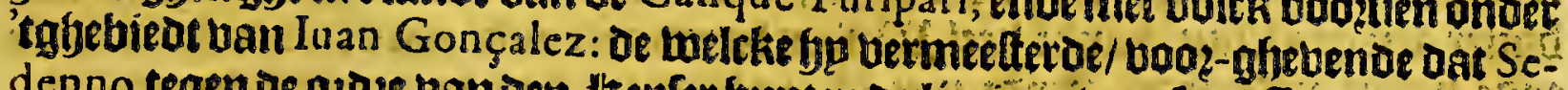
denno tegen De azoze ban Den Hepler bupten ae límiten ban fon Baubernement

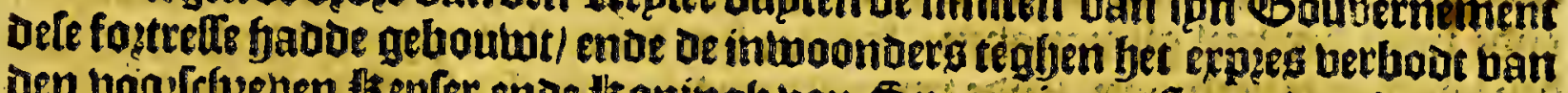

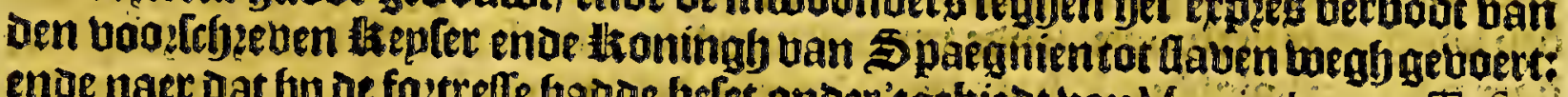
enoe naer dat go de fostrefte fadoe belet onder'tgebied tanMartin lannez $T$ afur, berbozoerse bo fpne ontoeckinghe op de rieviere Viapari, mec groot gbebect ban

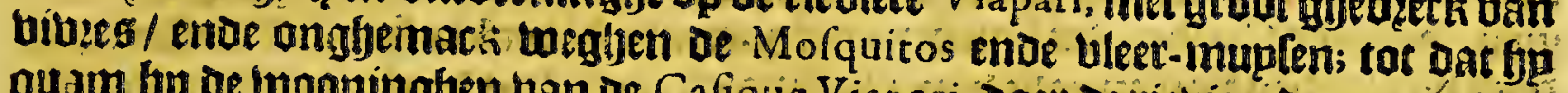
quam bp de wooninghen van de Cafique Viapari, baer de riebiere den naem taan boetde; al-waer fjp mel ontbaelt wierot/ ende aber-binterse teghen bet berfoert van den meeitendeel ban [pn wolck/ die liever ghefien baaden dat jp te landtwaett

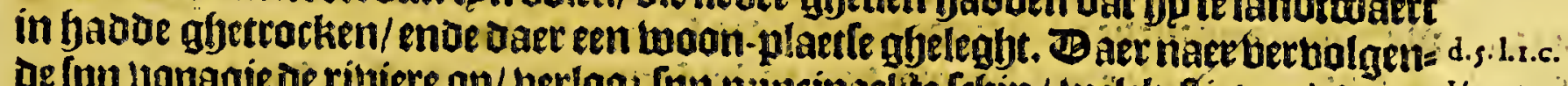

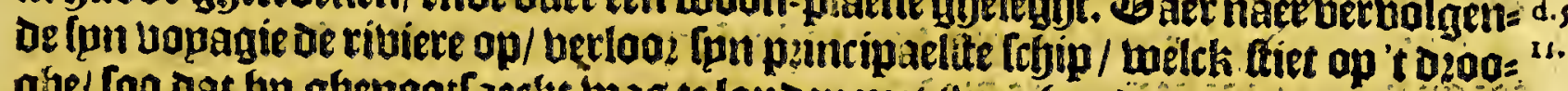
ghe/ foo oat bp gfendorlaeckt was te landen met thee bondertman te boet croto: beertich peerden; track foa vootts langhs den oever ban de rieviete/ fonoer in beel

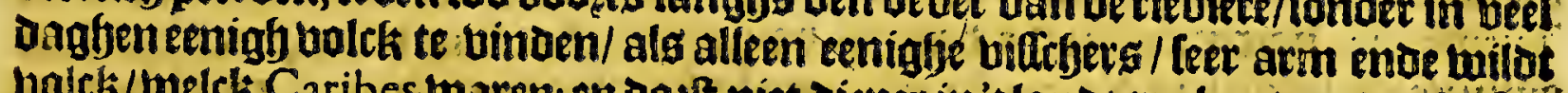

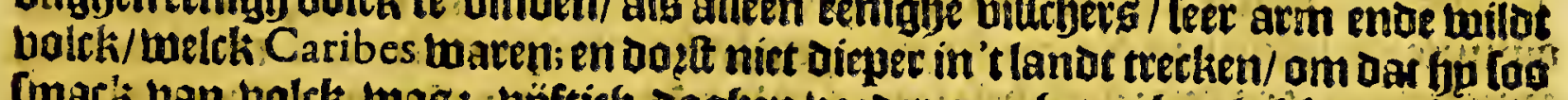

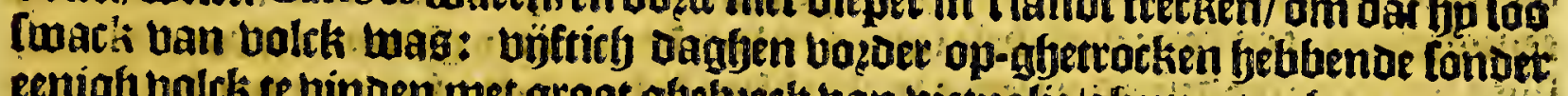

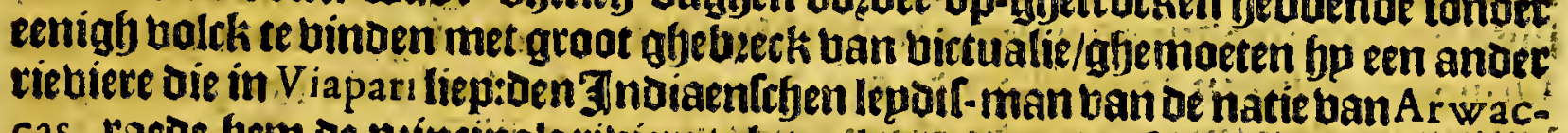
cas, raede bem oe p:incipale vibiere te laten legegen ende defe op te trecken / bem

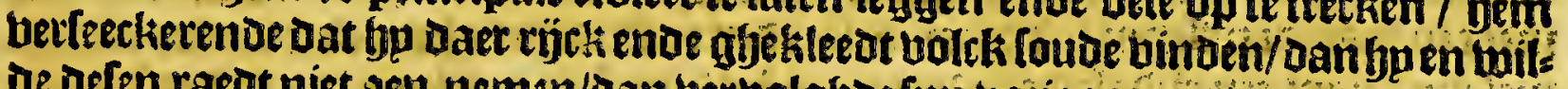
oe defen raedt niet aen nemen/aan vertiolghoe fpn vojige cours tot éen groote bal

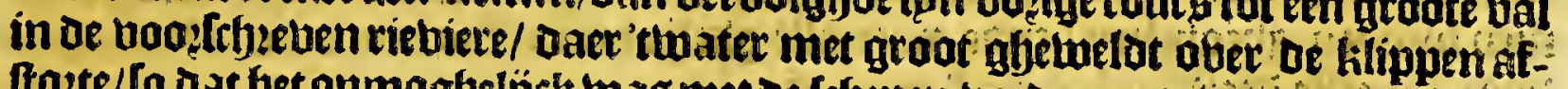
ftotte/ [o dat fet onmagbelibch was met de frbepen voetoer op te baren; enoe fieerde weder de riebiere af / naer uat bp die bugillinge wel twee bontert leguen twas op-

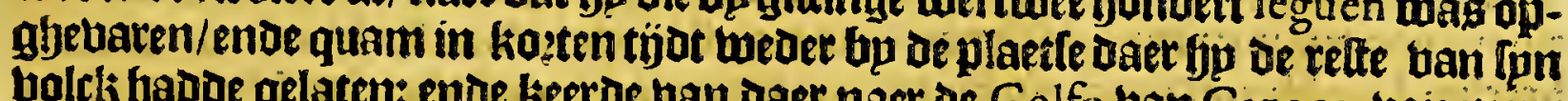
bolcli bajoe gelaten: ende keerbe van daee naet de Golfo ban Canaco, van inep=

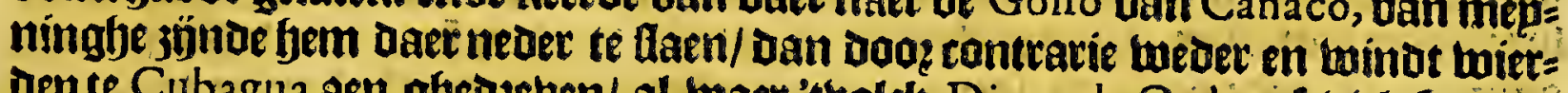
Dente Cubagua aen-gfjedetten/ al-waet 'tualck Diego de. Ordas af-biel/ foo dat bp naer Hifpaniola trock/ ende voozts naer Spaegnien/entue bleef onder begen ofte ftat in 5paegmien/ naer bat eenighe legghen. Bit is deneerten tocht gbe: weelt op defe rieviere; ban de weltke Sir Walther Ralegh bem ueel beutelinghen beeft laten wög-inaecken bu de Spaegniaeroen / Daer gantefy gbeen blïct van

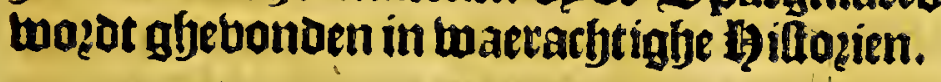

\section{Het Celtyiende Capittel.} Voorder ontdeckinghe van de Rieviere VI A P A R I by Geronymo dé
Ortal, ende andere.

N Ater de boout uan Diego de Ordas, mierot fyet Guubernement ban Paria d.s.l. s.c. ghegheben bp oen feplet aen Geronymo de Ortal, in benjare 1533 , De thelcke. ${ }^{6}$ ede 7.

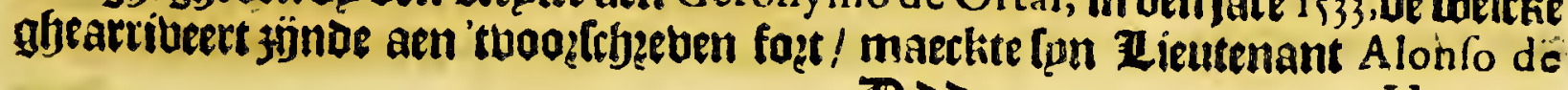

$$
\text { DDI } 2 \text { Herrera, }
$$




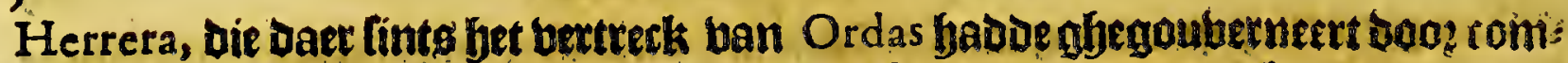
miflie ban De audientie ban Hifpaniola; ende fondt brm met thet hondet man in vijf farbten om de rieusere Viapari te onder-Loechen. Herrera boer be tieluere op tot een plaet fe die reede bekent was/gbemaemt Caroa, ende bertoefoen baft om

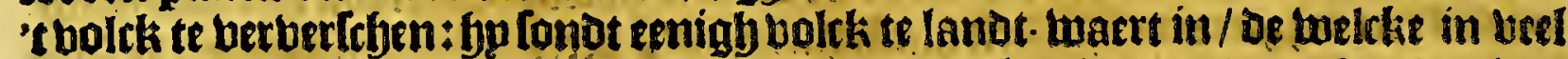

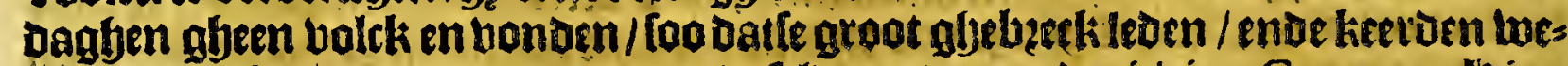
ber naer de frbepen;enoe boerenmet de felbe op tot aen deriebiere Caranaca.

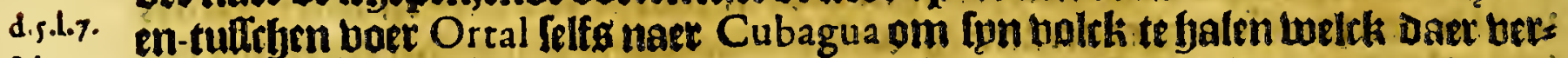

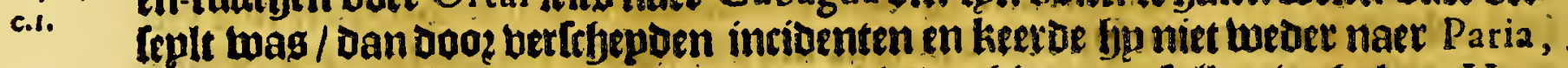
Dan nam fpn ontoerkinghe eloerg book/ als wo bier naer lullen verijalen. Her-

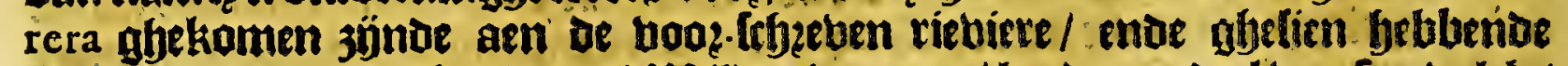

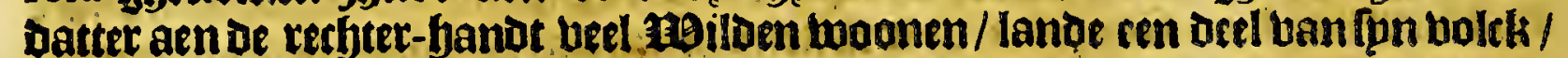
ende fadoe een barden trijot met oe Indianen/ borb verjoeng die epnorljéts/ enoe nam der beel ghevangben; coo Dat Ipn bolck bier ygobiande kretgli om

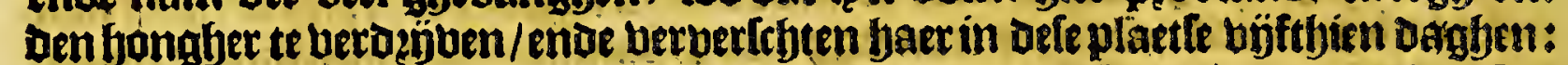

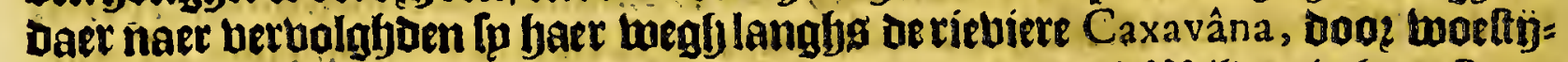

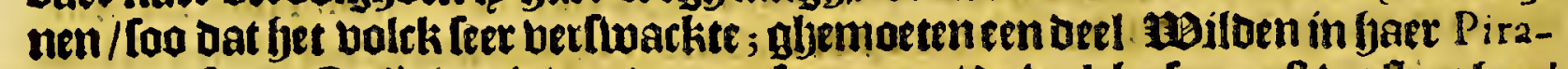
guas, twelende Caribes, die ban den roof quamen/ oe loklcke fomeeft uettlorgben/ aoch met berlieg tan eenighe ban 't befte bolck ; ende werden bp oe gljebangbens ghetwartchoutut/ Dat Guaiana achter af lagb/ende de pzotincie Meta boozen upt / oaer alle 't volck [eer rỉck was enoe gbekleedt ginck. Rameneenityte uan de ds.1.9. ghebanghens mede vooz lepots-liedentot Caburuto toe.

c.6. Antonio de Herrera boeght bier in bu fome ban digrellie: Beele gbeloouen tot op beden / Dat de riebiere die dooz oe pzobincie ban Meta palfeett / de felue is

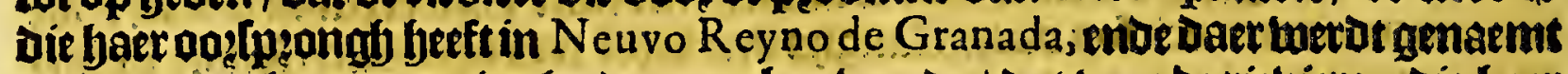
Turmeque, baet mepninghe daer op bouluende / Dat ban be riebieten die baex oofpzangh bebben in Neuvo Reyno,eenigbe baet loap nemen naer 't betten/enos eenighe naer toolten: Dorb dele opinie en wozot niet aen-ghenomen bog? feecker; lints oe ghene die dele quartieren beel bebben belwandelt / fegghen bat bet is den Orino co, thiterjen de meltke ende den Marannon, foo beel enoe foo groote plos bintien legghen / weltke zön de ghene die men noemt El Dorado. Tan om biet

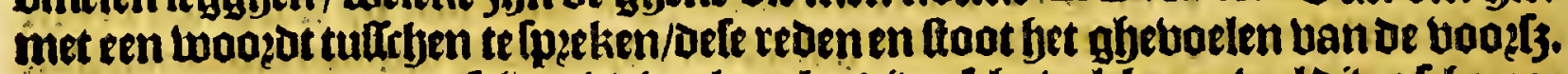
niet om/tmant een ende lelbe riebiere kan bp diberlebe bolckerentwel diberfbe na= men twozden ghegbeven/ ende naet alle gbelïtkenis/ foo komt den Orenoque boos 't meelte deel ban Neuvo Reyno af.

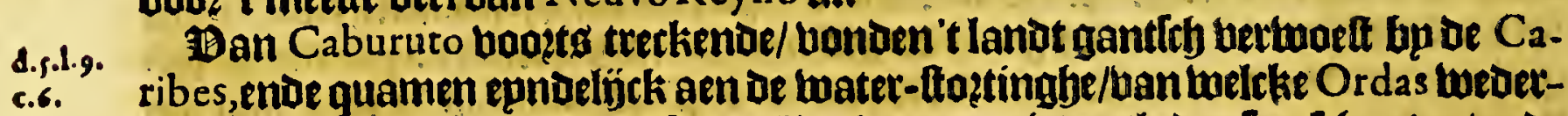

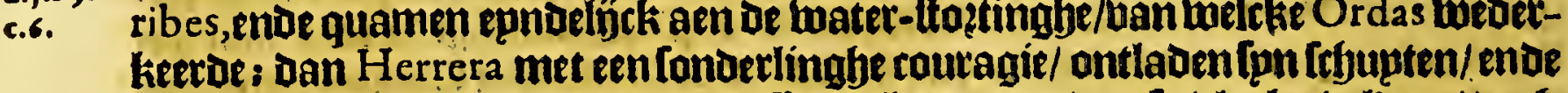
kreegh die daex ober; dele bal gbepalfeett jünoe / vonoen fp blacke beloen / oocty onbetwoont; enoe quamen naer eenigge daghen aen de monot ban de blied die Doos Meta komt / alluaer Ip baer Ichupten verbergboen/ende trocken te lanotwaert in met groote moepte doo? moeralleben enoe poelen/tot dat lp quamen aen De twooninghen ende zaep-aclieren ban de Xaguas, welck jún mentében-eeters

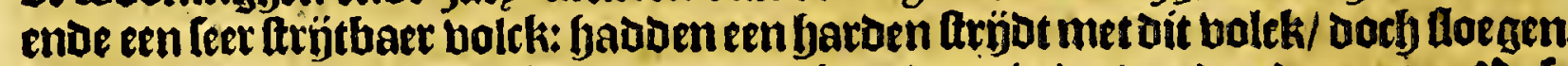

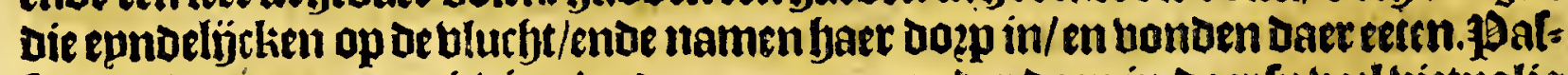
leetoen daer naer een rieviere/ ende nameneen anoer doup in daerfp beel vietualie bonden/ ende onder andere eenighe ftomme bonoen die te Bbiloen noemen Ma-

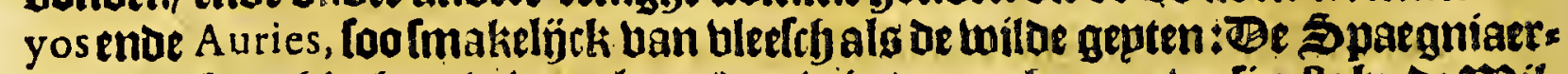
den maetkten fierfaer winter-leger/dan wierden ophaer onberfienlte bp de mail=

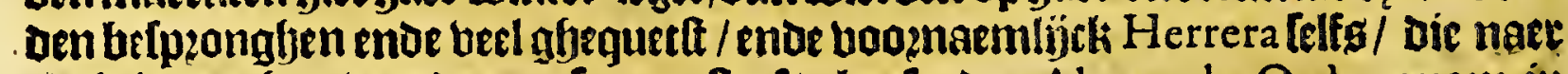
eenighe daghen uan ae quetueren thof/al ralende: Alvaro de Ordas quam in Inn plaetle / die met bet ober-ghebleven bolck lueder-keerde naer be frbupten/ ende vooztg weder naer Paria, altwaer fy de foztcelle op-igbetboocken bonden/ 
Het vijfrhiende Boeck.

Dop tien Ortal ban vooenemen laas berandert / ente trocken foo eenen anjeren megf. Dit wag de upt-homfte ban den theeden toift op De rieviete Viapari bp Ortal, de welcke compagnie fadde gfentaeckt met Sedenno, enoe weder terlaten naer Dat fop ban bog-nemen bas verandert/enoe twijoer limiten ban Ifn Gous

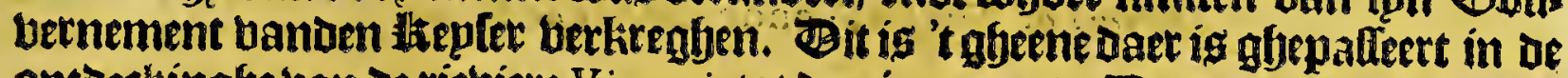
ontoethinghe van de riebiere Viapari, tot den jare 1536 . Baet naer 3 jnoer norb tiberfebe tochten booz-ghenomen bp betrfiepoen spaegniaerden langhg oele rieviere/om de Guaian a ende El Dorado te foectien/welclier lueres top niet parti:

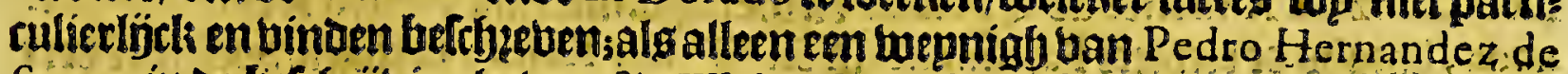
Serpa, in De tietchż̈bingbe ban Sir Walter Ralegh : Delen Pedro Hernandez de Serpa lande aen Cumana, ende trock te lanoe met dep bendert Saloaten enoe beet

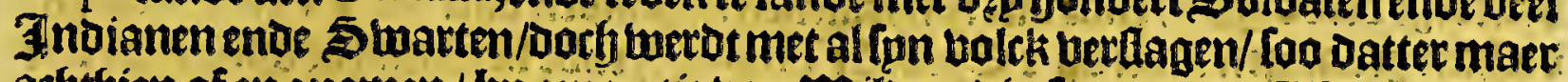
achthien af enquamen / bp een natie ban Eilaen die fo noemen Wikiri, eer bp

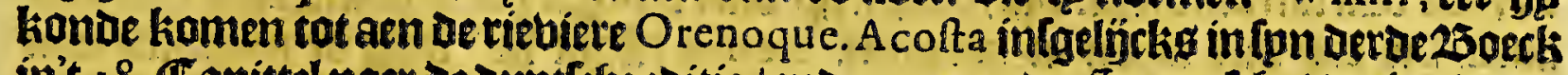

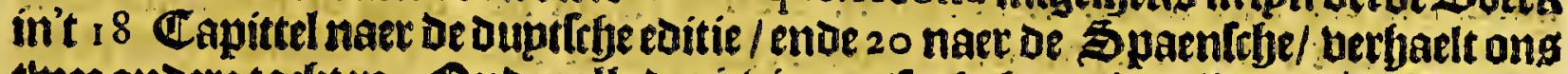
twee anoere tofften. Onoeralle de rievieren (Eegbt bp) niet alleen ban Jnoien/ maer oock ban be gantffye weerelt/beeft oe riebiere Marannon ofte de las Amazo. nas (De mig-neminge ban delenamen booe den Orcnoque beblien wp boen aen-

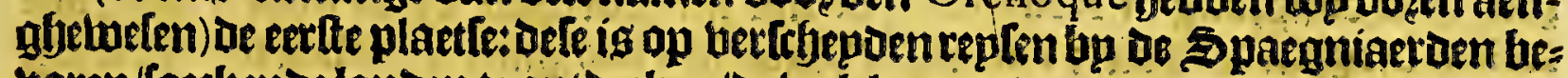
varen/Loeckenbe lanoen te ontoecken/oe twelcke naet den gemeqnen roep feer rijck louden weten / infonderfendot die fu noemen El Dorado ende El Paytiri. Ben Adelantado Iuan de Salinas, oederenmerckeligeken tocfit op Deferiebiere/ aie tot wepnigh effect quam: beeft een pallagie die [p noemen El Pongo, welck tol een

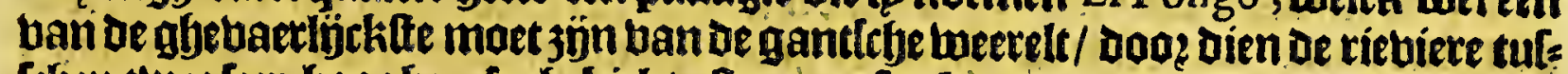

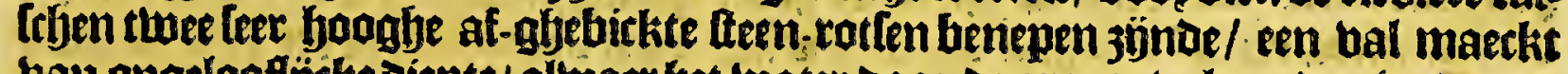
bal ongeloofligcke Diepte/ albaer bet water Doos de groote val zoodanige dzaep: malens ente mael-ftroamen maeckt / Dat bet onmogelj̈ck frbjnt daet te konnen af-komen / Conter te gronde te gaen entoe te berdeincken: Doth des alleg niet

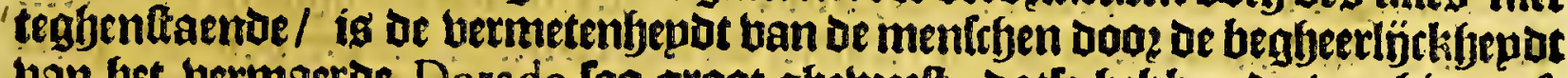
ban bet bermarede Dorado too groot gbetweeft; Date bethen dertuen biet pals feren : lieten bun ban boten af neaer ballen / 3önoe ooo? de furie ban or riebiete gledzeven / ende baet baft goudende aen baet Canoen ende bercken die fp bp Gaer badoen / entoe boe-wel de Celue in 't af-ballen om-floegben/enoemethet bolck te gronde gingfen / quamen weder boben/enoe epndelïcken met lift ende kracfic

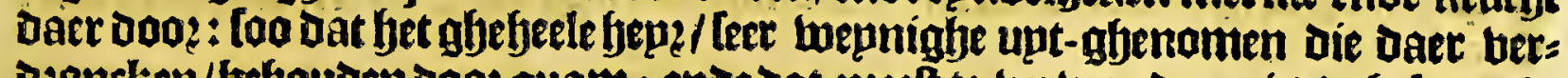

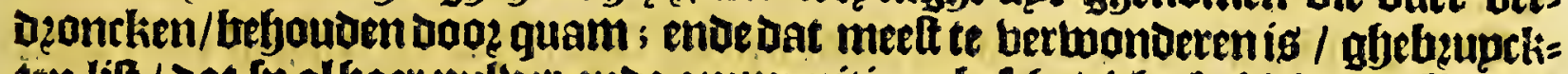
ten lift / dat lp albaer pulber ende ammunitic onbefbadirbt befielaen. In bet weder-ketren (want naer groote moepte ende ghebaer moeften Daer wederom Doo? ) Klaueroen [n ober een ban de boughe tteenrodten/baer bebelpende met.

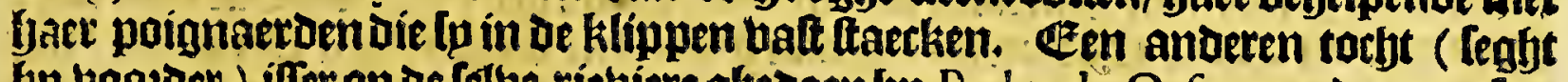

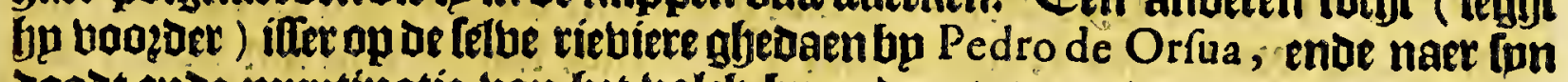
voodt ento muptinatie ban bet bolck bp andere tot aen oe noozot-3ee. Befen

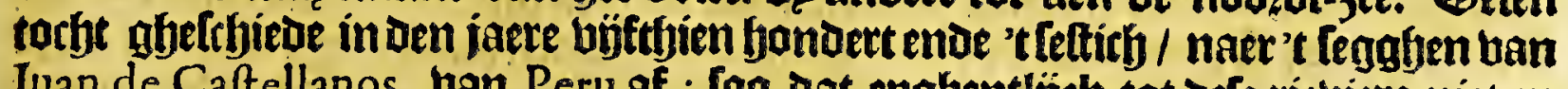
Iuan de Caftellanos, ban Peru af ; too Dat epgbentlight tot Dete riebiere niet en beboget/maer eet tot de riebiere de las Amazonas.

Sir VValcer Ralegh berbaelt eenighe particulatitepten ban ocleritocht in fon belcheñuinglje ban Guaiana, die men daer kan lelen: als mede Lopez $V a z$, die Daer een langh berfael ban maeckt / hoe dat cenen Lopes de Agira deten Pedro de Orfua dede bermoozen/endenach beel andere tozeetlyeden bedzef loo op oe rítuitre de las Amazonas, algmeoe op 't $\mathbb{E}^{\ddagger}$ planot Margarita Daer fjp felfg am:quam.

Do 3 而et 
Het feventbiente Capittel.

Vervolgh van de ontdeckinghe van ditghe wefte by Don Gonzalo Ximenes de 2uefada j ende Antonio de Berreo.

G.

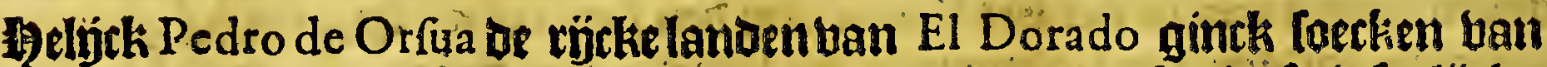

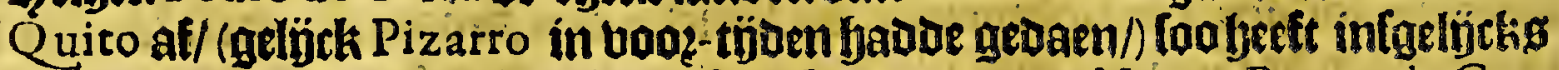
Don Gonzalo Ximenes de Quefada t telue begonnenupt Neuvo R yno de Gra. nada, langbg de riétiete Papamene, fo Sir Walter Ralegh vetfaelt/ oortj met bets Jooen moepte ende kolt. Hp belteeoe [pn Doeftec aen Anronio de Berreo; Die aentocbt becbolgboe/enoe viel epnoeligtken in banoen uan Sir VValter Ralegh, viebem gebangen nam op 't \& eplanat T rinidad, ende berftonot de ozoze ende upt komite ban [pn ontoeckingfe/geljick fo daer eenigge particularitepten ban bet: haelt/ die wo hier fullen in-voeghen. Berreo (Teght bj) Corft be inkamite ban Guaiana upt Novo Reyno de Granada, langhg oe riebiere Caflanar, teleltclie loopt ín een ander groote riebiere ghenaemt Paro;ende Pato loopt in Meta, fnde Meta in Barraquan, welcke oork genaemt wotot. Orenoque. De riebiete Caffanar beeft baet oos (peong in Neuvo Reyno upt bet gebergbte bp de ftaot Tunia, upt

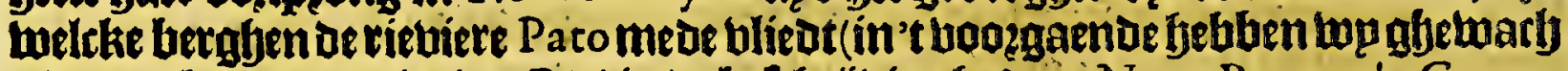

gljemaeckt ban de riebiere Pati in oe beftyejbingfye tan Novo Reyno de Granada) enoe vallen bepde in oe grooterietuiere Meta (Hetrera legbt dat Pati loopt in be Madalen a) welck baet ood(pzongh feeft bp Pamplona in'tlelue rigck ban Granada. Bele/als mede Guaiare, welcke vliedt tipt ljet ghebergljte bp Timana, $100=$ pen al in Barraquan, ende en jïn maer fjooft-lpqunghen van de felue; want bog:= aer komenoe/betlielen Ip baet naem/ghelijck oock Barraquan neder-waerts bert betnảemt/en๖e Orenoque ghenaemt. Berreo quain met fun bolck de riétiere Caffanar af/tot in Meta, ende lo voozts in de rieviére Barraquan, teplende met[pn bolck langfg den oever/ enoe fomtijts met bercken eñ canoenlanggg de rievieren: Dan aekomen zijnde in de groote rieviere/ betloo: hp nu eñ danfpn bolc enoe peets

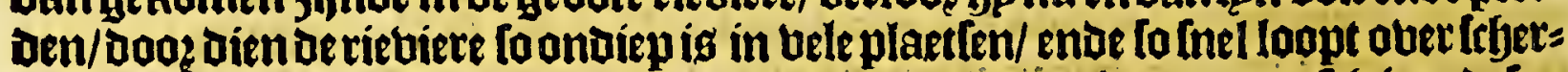

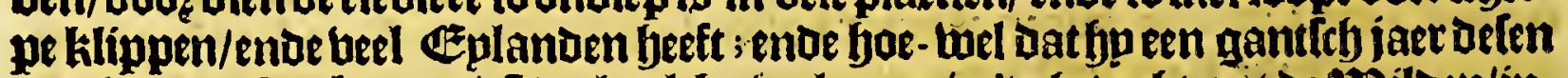
megh was af-gekomen/eñ veel volcks berloogen in 't gyebechtmet de abiloen/infonderbept die ban A mapaia, enkonoe fy niet Teeckers yoozen van Guiana, tot dat

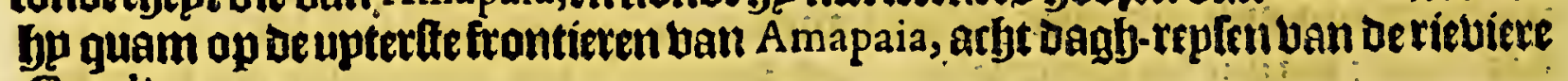
Caroli.

Delepgobincie ban Amapaia ismede op onen Orenoque gbeleaben/ende rỉcik bangoudot (naer't feggben uan Berreo, ende de Moilden ban Guiana.) Berreo bertoefoe daer les maenden/ende berloog daer leltich banlpu befte foldaten/ende meet al de peetoen die bem noch waren ober-agebleten: Dan maeckte daer naer bede met dit balck / ende berkreegb ban baet thien beelden ban fín goud / coo konltigh ghetwechtnaer't legghen ban Berreo ende andere ban Ipn bolks/ als men fier te lanoe foube konnen maecken; die bp bem gbt Tonden wietoen aen den

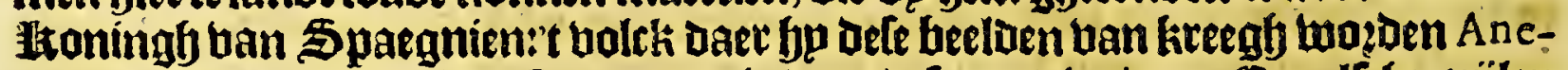

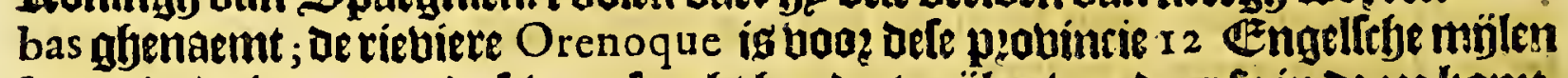
beeedt/ende is ontrent de [eben oft arbt bonoett mijlen van daex fp in oe zee komt. Befe peobincie ban Amapaia is aen den oeber van ue riebiete leeghenoe moerals fichlanot/ende't toater dat boo? de beenighe ende modoeriglye gronot met beele

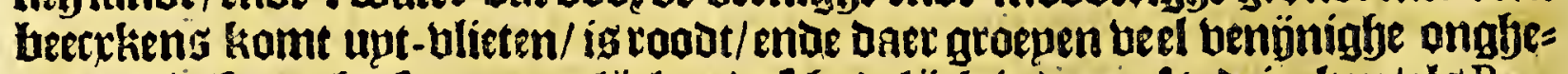

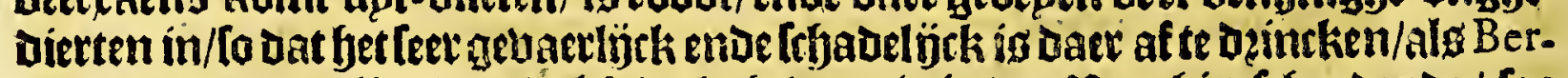
reo met groot vetlieg ban boldt bel ghetwaer twiert. Ban biec frbepdende / foo forft bu langhs of 3 undt-kulte vall be riebiere ecn in-ganck maer Guiana, ban en tonoe daer gheen binten lueghen het fooghe ende tteple ghelarghte dat fem daet langhg fenen Itectit; bp ghemaste oock beel groote riebieren die bepue 
Het vijfthiende Boeck.

ban't zupben ende noozoen in den Orenoque quamen blieten/tan bu en badoe de namen uan de lelue niet gbeleert ofte onthouden/als allecn tuan de vieviere Caroli, Dooz dien bp naer'tleggfen van Sir Walter Ralegh foc ontwetende twag) dat fpp bet ooften ban't tweffen qualijet konde onder-frjepoen. 'Berreo begon te Defpereeren ban 't lutceg ban fpn vopagie/ tot dat gp quam aen de plouintie van

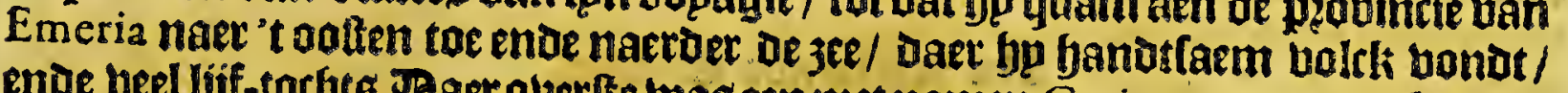
enoe beel lijf-tachts. Baet oluetfe twag een met namen Caripana, een man bunaer bondert jaer outot/ Die eettijots ín oe Trinidad enoe Margarita ende elders twag

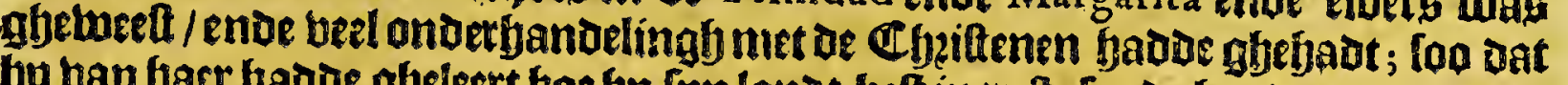

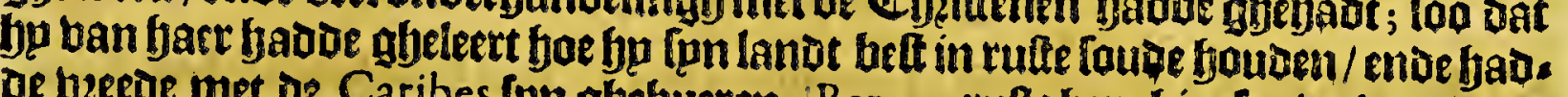

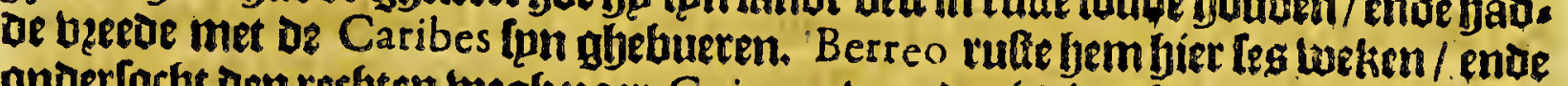
onderlocbt Den refften beglynaer Guiana; boer be rievier af naer Trinidad, ende foo boottg naer Margarita, daer bp büftich foldaten aen-nam / ende quamen met

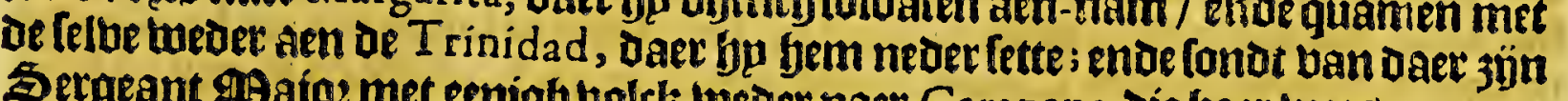
Sergeant g9 ajos met eenigb volcl tweder naer Ca ra pana; die baer wees naer een ander Honingh ghenaemt Morequito, die haet belt konue onder-rerbern ban of pallagie naer Guiana, alloo bp maer bje bagh-replen en tooonde bain Macureguaras, of eetle ftadt ban Guiana. Ban dele Morequito badoe dęp oft bier ja: ren te voojen met beel gaudts gheweet te Cumana ende aen de Margarita, ende een Spaegniaerde met namen Vides foo beel tujg-ghemaectit ban Guiana: Dat dele $V$ d des octrop berforft ban den lianingly van Spacgnien om die landen te gaen ontoecken; ende is te pzefumeeren dat bp in fpn phetenlie book-ghetionicn.

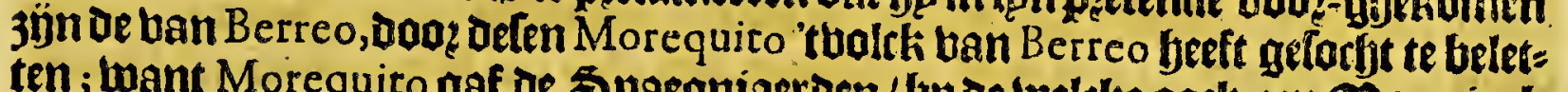
ten; want Morequito gaf oe Spaegniaerden / bp of welclie bock fen gSonminck twag) gbelepot dooz [pn landt; Coo dat fp in elf bagen/naer't tegghen van Berreo, te Manoa quamen / enoe daer veel goubes berkregen/ (joe wel//eght $R$ alegh; of

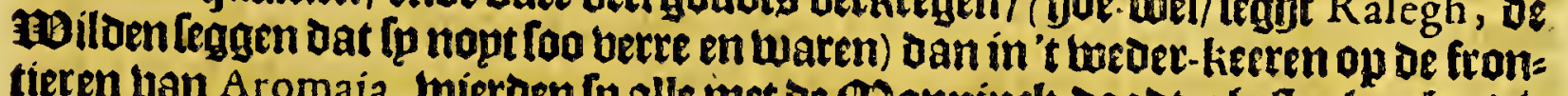
tieren uan A romaia, mierden fp alle met de 9 sanninck boodt-qbelaghen bp die ban Morequito, een alleen upt-ghenomen / oie fet ontbluefter / enve de tỷdinghe aen Berreo bzachte: Be twelcke foo beel bolckg lonbt als by morbte om dit te wege ken; foa vat Morequito fulckg mel breftende/blooot ober den Orenoque, boos be peobintien ban Saima eñ W.ikiri naer Cumana toe/mepnende daer beupet te jün bp den Gouberneur Vides. Ban Berreo lont Darr on frem in de narm van of lha

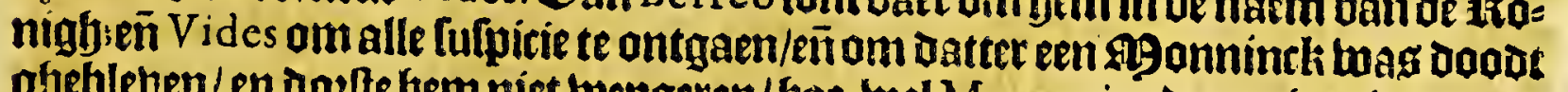

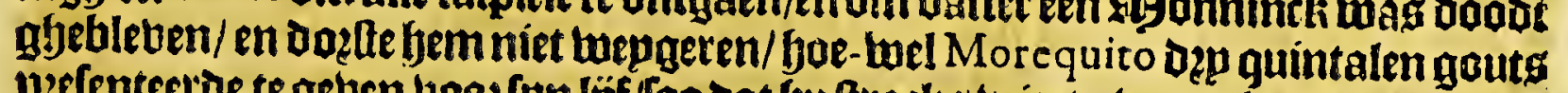
perfentectoe te geben udoz (pn Ijf/hoo dat bp ftracks thiert ober-geletert in banden ban Berreos getanten/ende datelg̈ck gedoot. 'C trolck van Berreo beroofoen jün ganttrye landt/ende namen fpn oum gfyenaemt Topia wari gbebangfjen; die ben felben daer naer ranloeneerden boa? I o platen gouds / ende eenigh ghelteente twelck of Spaegniaerten naemen pied ras Hyadas, entoe tuiert baer naer oberle Lan A romaia. Berreo maetkte bem felfs fer ftinclitrioe bp alle't volcti die aen ben Orenoque twoonen/ ood? fpn groate hzeethept tegen deten Mor equito, ende o'an=

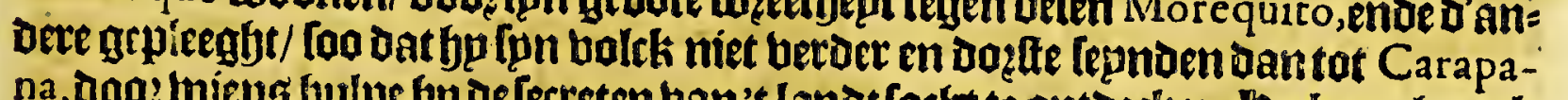

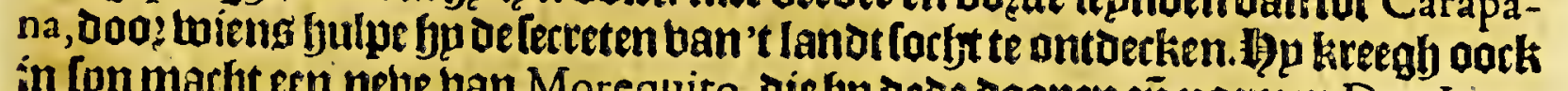
in Lpn matbt efr nelue ban Morequito, die gp dede boopen eñ noemen Don Iuan, ende forfte te fleflen in de peguincie ban Morequito. Onder anvere bandelen die

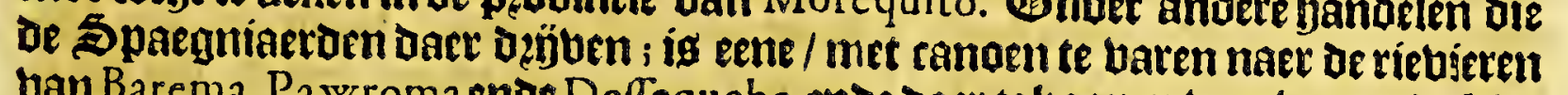
ban $B$ arema, $\mathrm{Pa}$ wroma ende Deffequebe, ende daer te tioopen bzoutuen ende hin deren tande Caribes, ente de felbe met groot peofït tueder te uerkoopen in of Margarica. Berreu fonot oock beel goudes na Spaegnien/om foldatente betga: arren; endenarr Neuvo Reyno ende ander quartieten tot den leluet ppnde: dan werot bp Sir Walter Ralegh betraf in't Eplanot Trinidad, enoe ghevangen ges

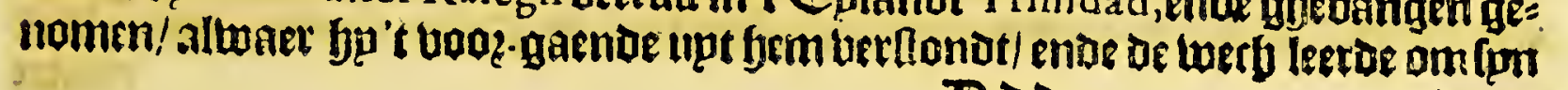
उDo 4 . boots 
boanemen op Guaiana te berbozderen; Daer wp bier nate fullen ban fpectken.

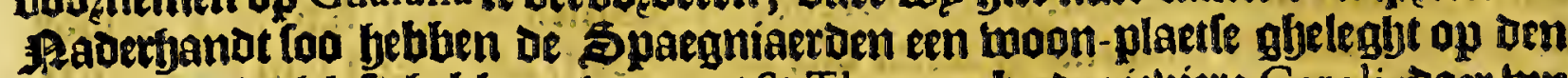
Orenoque, twelck Lp Jebben gbenaemt St Thomas, bp de rieviere Caroli, taer top bu gheleghentbept noch fullen vanlpeectken / ende fiec sertt in-boeghen den torbt uan Sir Walter Ralegh.

\section{1) act athiente Capittel.}

De cerfte voyagie van Sir vValter Raleigh, op de sieviere OR E.NO-

$$
\text { ov. in den jare } 1595 \text {. }
$$

Nater dat Sir Walter Ralegh in manieren boozfy. Jan Lgn gbebangben Anconio de Berreo badoe bertaen Den ftandt ban de lanoen ontrent den Oreno, que ghelegben / too nam bp uoos [pn torbt naer Guiana te verbozoeten: Ipn Bite-2lomirael Capitepn George Gifford, met een jactst ende een betrtie naex oe mondt ban de riebiete Capuri, welck gp al boozen badoedoen diepen en baes= ken/ende bebonden datter met leegb water büf ende met fjoggh water ontrent nes gljen boet waters wag; dan deden bier betlooecn moepte / want konden qualj̈ck foo berte doett-waetts kamen/ende't water ontbiel baer eer [n konden de fanden

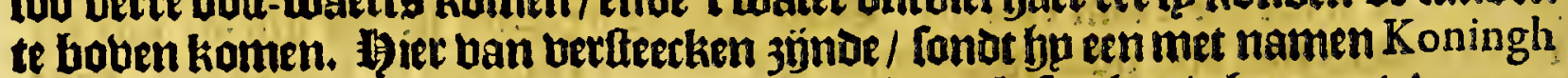
in een boot / om een anderen arm ban de riebiere te belorckín/ghenaemt Amana, glyeleggen in't binnenlte uan de hape ban Guanipa, dan bonde de felbe ondiep als de booz-gaenoe: Dorbeenen Ian Dowglas die Sir VValter Ralegh naer fonot/ bonot bier ander armen ban de riebiere die elek leer tujot waren/ Dan be bape om Dertwaerts te komen / niet ober oe les boet diep; foo oat fo abenotlaeckt waren met den bodem ban een oude galealle enoe andere klepue booten oe reple te book

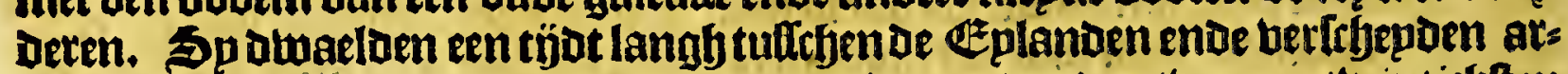
mentuan riebieren/Die Daer d'een in D'ander loopen/tot Den twer-en-thintich fen May; Doen qfjemoeten baet een canoa met HBilden op een riebiere/ die fp de naem gheben wan Red Croffe (Dat is 't Roode Kruys) enbe ber(pzaken of milde die aen landt waren; ende kregben Daer een ouden Jndiaen gbebanglyen/ die baex

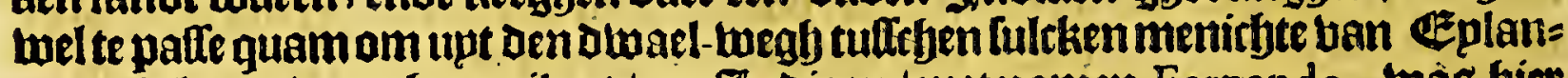
Den te belpen ; want baer piloot / een 3 indiaen/ met namen Fernando, was biex gantfrb onbedzeten. 't Bolck ([eglyt Sir V Valter Ralegh) welck woont op defe ghebzoocken Eplanden ende berdzoncken landen / wozoen in 't ghemepn ghes naemt Tivitivas, ende jün uan twee looeten; de eene ghenaemt Cai wani, ende ot andere VV arra weere. Be groote rietuiere Orenoque ofte Barraguan beeft nes gen armen die aen De noozot - jujde ban fpnpeincipael canael upt-loopen/ende aen

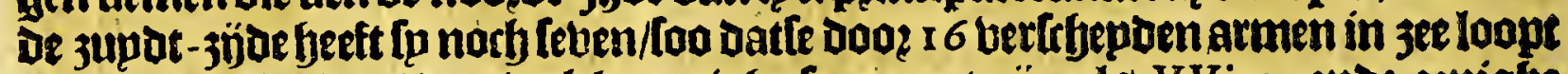

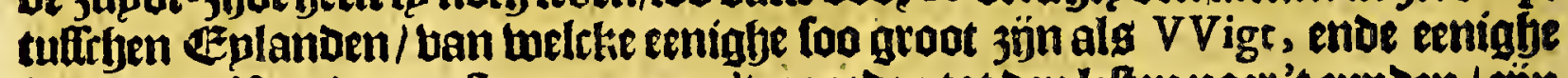

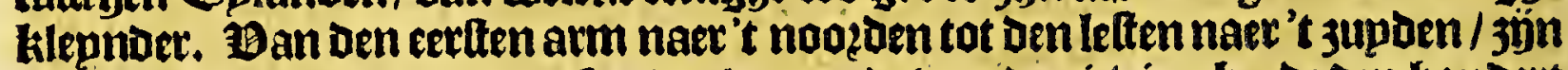
ten minten jondert leguen, foo dat de monot ban de riebiere by de Dep bondert

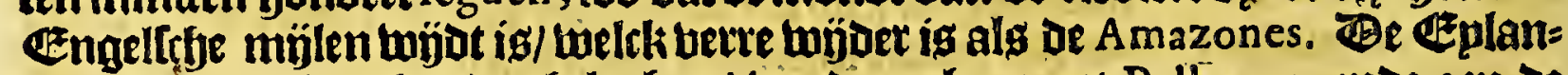
oen aen oe rechter-bande ghelenfen/ wozden ghenaemt Pallamos, ende aen de lincket Horotomaka, ende de riebiete die binnen's lanotg ban Amana tot $\mathrm{Ca}$ puri ftreckt / Macuri. Be Tinitivas is een fraep ende mannelïtl bolck / hebben oe manneljiklte tale die men loube konnen boozen. Somers bebben lp baet wooninghen op de grondt/enoe 's winters op De boomen; twant tufferen May ende September wait de rieliete Orenoque twel dertirb voeten yoogh; foo dat de Etplanden / upt-ghenomen eenighe boogbe placten / wel thintirb hoet dan ons oer water legghen; [p Ieben bp de toppen ban de l'almiros ende andere beucften/ ende bp oe jarbt/[onber eeniabe moepte te willen nemen met laepen ofte planten. Sir VValter Ralegh ban iffe placter ban de Ciawanas boott-barende / quam naer birt dagben in een groote rietiere / ghenaemt of groote Amana, welcli wat rerbter 


$$
\text { Het vijfthiende Boeck. }
$$

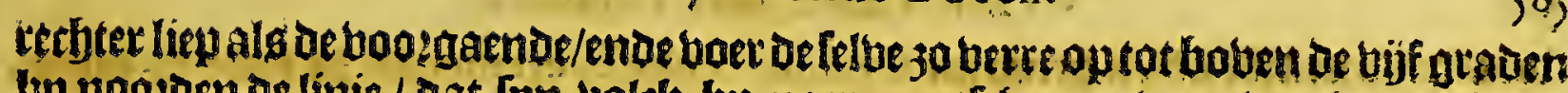
up nootoen be limie / Dat Ipn volch bp naer gantich mat luag toeglen oe fitte/ enoe den arbepd ban op-roepen tegen froam/enoe fun bietualie bp naer ten epnide/

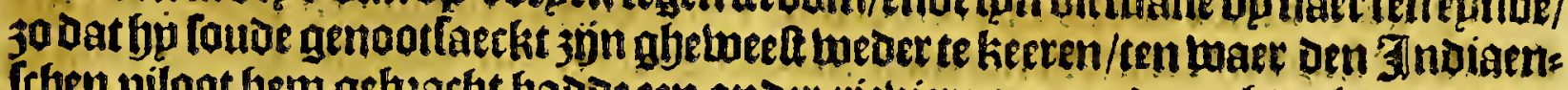
fchen piloot bem gebearbt badoe een anoer riebiere op aen oe refbter-janot/ daer to naer groote moete een deel bictualie kreghen in een oow van Jnuianen;

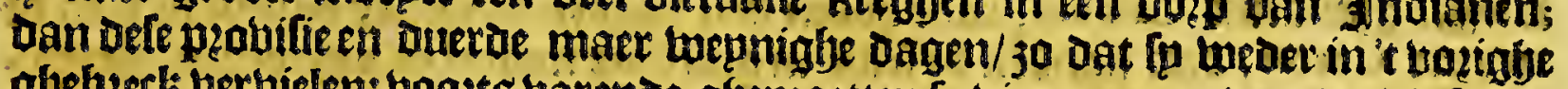

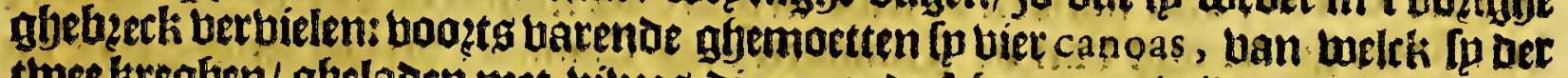
thee ktegfen/gheladen met bibess die naet oe Margarita biloent; in oe ander twee Canoen uaren ogp Spaegniaerden/30 [p uertonorn/ welcket cen buas een

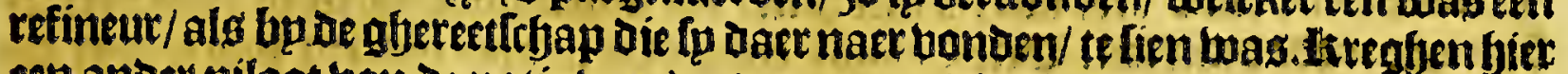
een ander piloat ban oe natie ban de Ar waccas, die gbeoopt toas ende Martin ghenaemt; die haer in vjeftjien daghen bzacht in oen Orenoque felfs/ende in't gbelichte ban'thooghe gbebergfte ban Guiana. Sp anckeroen aen een plaete Daer dep riebieren te famen komen/enbe lanben opeen Leboon [ande-bancke/ Daen menichte ball. Torrugas te banghen waren: Baet quam bu baet oen geete bait Dat gheluelte/gbenaemt Toparimaca, enoe bzactit baet aloerbande bettertebin: ghe/enoe ghelepoe fjaer aen fun dozp; twelck luas ghelegben op een klepn bergbs ken met fraepe bouen ente fejoon lanot baer om:'t oosp tuozot obenaemt Arowocay, ende 't bolck íg van de natie ban ue Nepoios. Dele Cafique gat baer een ander piloot die op defe riebierefyel wel erbaren wag; badoen goet bejulp ban oen ooffen-windt/ want de riebiere ftreckt banfier boozts meet oolt ente bet: 300 dat fp de rieviere op-leploen/hebbende aen de flincker-bandt een Etplanot/ belck [p noemen Aflapana, welende ontrent 25 mülen langh/ende les bzesot; oe

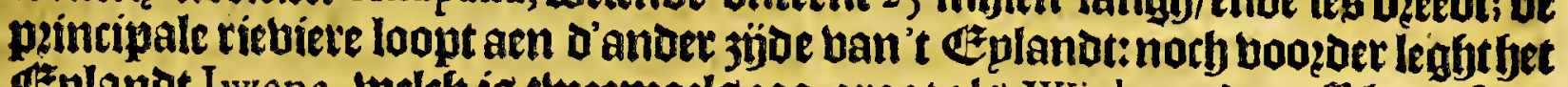

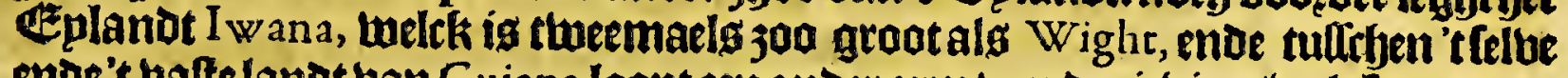
enoe't bafte lanot ban Guiana loupt een ander arm van oe riebiere/wele lp noemen

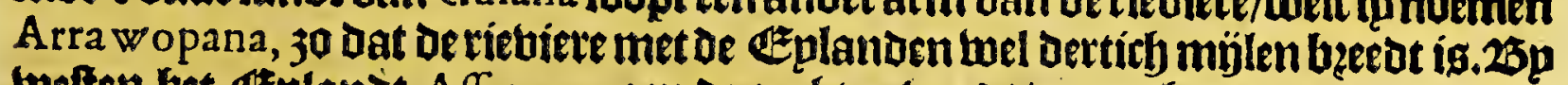
weften bet \&eplandt Affapana aen de rechter-banot/opent bem een tiebiete die ban't noozden komt/genaemt Europa: boos- bp ofle rieviere antkerdentp bp een

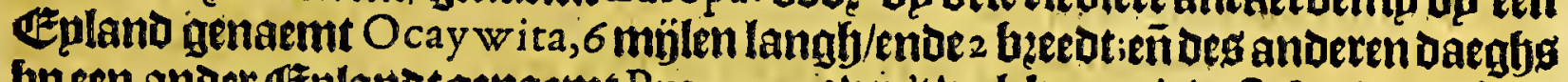

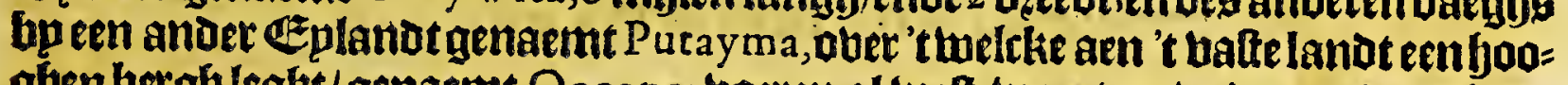
ghen betgh leght/genaemt Oecope: boeren al welt-watet op/ende aen be retjter-

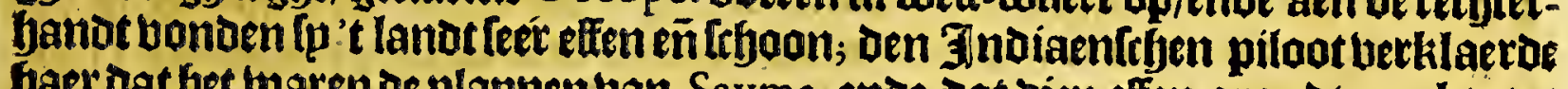
Gaer dat bet twaren de plapnen ban Sayma, ende jat dien effen gronot reptkte tat Cumana ende Caracas, 20 leguen naer 't noagen $/ \mathbf{e n}$ dat daer bierderlep natien twoonden; eerte die ban Sayma; denaelte Affa way; be derde enae grootte Wikiri, daet Serpa bertaglyen wag; de bieroe Aroras, joo flwart als 99 gozen/Dan met

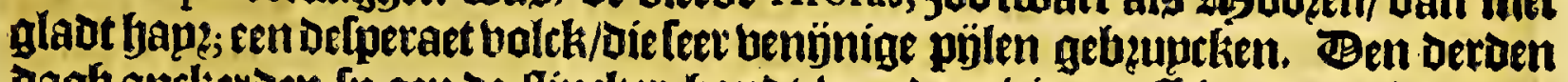

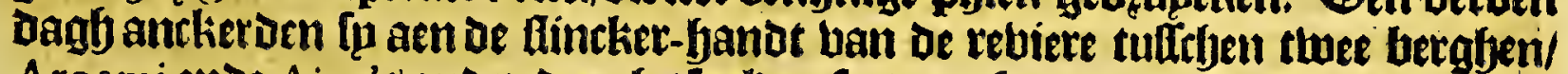

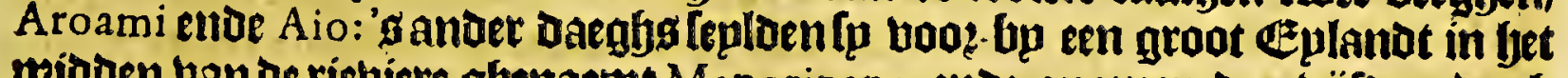
midoen ban de riebiete glbenaemt Manoripano; enoe quamen den bijfoen bagh aen de peobincie ban A romaia, enoe anckerden aen'twef epnoe ban een $\mathbb{E}^{\mid} \mathrm{p}_{\text {. }}$ lanpt tbien mijlen langh ento büf begedt/genaemt Murrecolima; ende'ganoer baeghs im de haten ban Morequito, ende conden om den oomban Morequito;

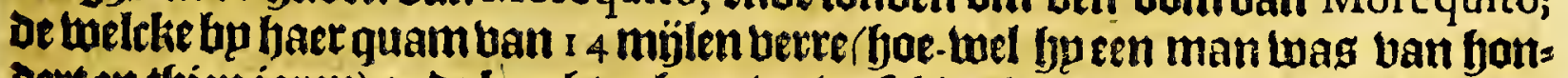
oett en thien jaren) ende bzacten fyaer beruerfebingbe ban frupten/finnen/ende ander ghebogfelte/ende bilfb: Dele betjaeloe haer de ghelegentbept ban Guiana; te weten/Dat dit gantfeb getwette tot Emeria toe/ boos Guiana tuerd gbereeckent; Dan dat [p faer [éluen noemben Orenoque Poni, tot aen't abeberabte toe welck men ban berre daec fiet / enoe ghenaemt twetot Wacarima: dat ober'tfelte gfyé bergbte een ander plapn mas/ welck lp noemoen de ballepe ban Amariocapana,

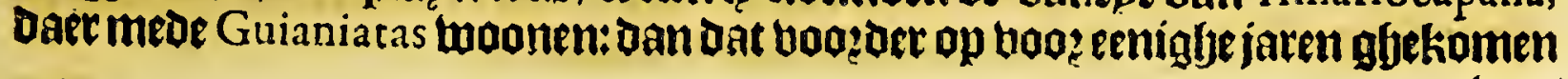


wag een lzemot bolck genaemt Oreiones ente Epuremei, dic de oube in-woone Derg meeft berjaeght ende bernielt badoen/upt-nenomen de $A$ wara wa queri tnde Caffipagotos; ende dat de Epuremei Datr entugrodte fradt badoen glyeboulut met

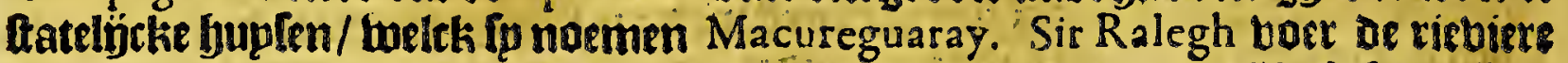
boozder op/ende anckerde Den eerten nacht aen een eplanot väf oft lex miblen langf / glienaemt Caiama; ende quam den maefien deng aen de mont ban of riebiere Caroli, Dan konden de felbe in gueender manieren op-rocpen; Derbals ben fonot bp eenighe ban de Jndianen naer Canuria, berfoeckende dat fp bp bem wilden komen: des anderen daeqhs quam daer een Cafique af met namen. Wanuretona, ende beel bolrkg met bem/ die alderbande läf-todft ende bertier: fchingbe mede bzarteten: Dere Cafique ende 't bolck baer ontrent toaren niet ale leen bpandt ban de Spaegniaerden/maer oock ban de Epuremei; yp verbaeloe aen Sir Walther Ralegh bat be rieviere Caroli op / bpen groot lark / altwaet orle

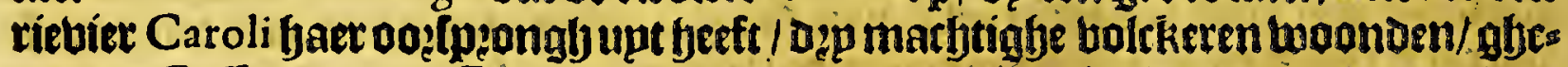
naemt Caffiapagotos, Eparagotos ende A ra wagotos, die al vpanden tuaren ban de Spaegniaerden. Het lack wierdot ghenaent Caffipa: Sir Walther Ralegh Conot eenigfy bolck te lande om dit gbetwelte te onder-Loerlien/ende berbaelt boon= Der ban oe apparentie ban oe rijcke minetalen. aten te dituker-fyandr ban de rieviere Caroli moonen de I warawakerı booz-noemt. Hat boozder is norb een Ichoone riebiere ghenaemt Aroi, toelcli mede unt bet booz-Ictgettan lack

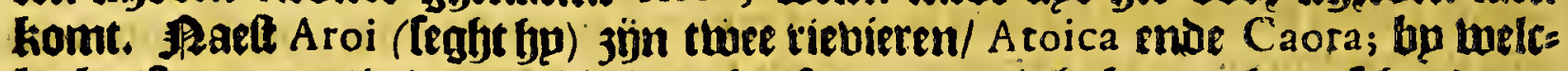
ke laette een natie moont / wens boofoen mepnigh boben baer Irfouderen upt-fteecken / die fp noemen Ewaipanoma; foo dat men legbt dat bark oos

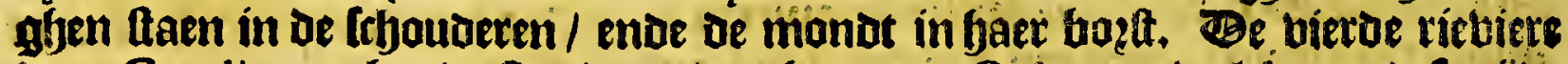
ban Caroli naer bet welten/ wozot ghenaemi Calnero, melck aen defe jjoe ban Amapaia in oen Orenoque komt vlieten/ende is loo graot alg eenighe rie= biere ban Europa.

\section{Wet negbentbiende Capittel.}

Voorder verhael van den tocht van SirVValther Raiegh, ende de gheleghentheden van de rieviere $O_{R}$ E.NO Q V E.

Deterte riebiere (teght Sir Walther Ralegh) die aen De noozot-zinte in den Orenoque balt/ is Cari ; ende bp twelten aen de felbe jübe de riebiere Limo; tulteben defe thee woont een groote natie ban Canibalis, tweIcker peincipaelfe

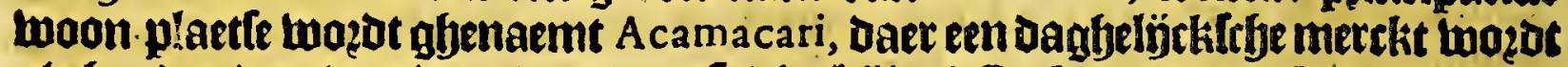

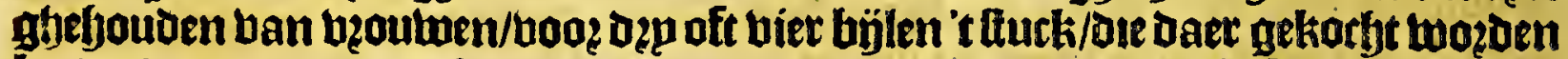

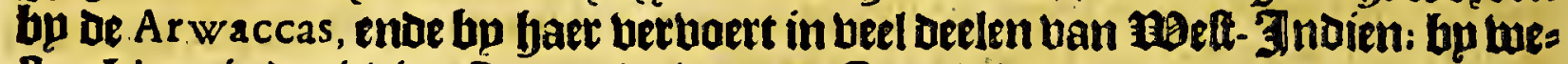
Iten Limo is deriebiere $\mathrm{PaO}$, ende boozoer Caturi, daer aen Voari ende Capuri, thelck komt upt De groote riebiete Meta, die Berreo af-quam uan Neuvo Reyno de Granada. 25p tueften Capuri leght de peobintie ban Amapaia, Daer Berreo

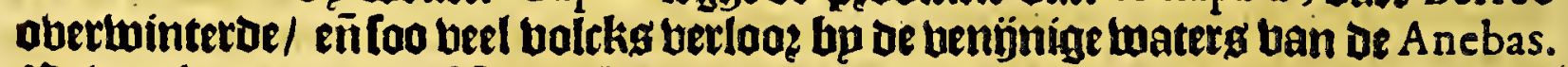
$25 a b e n$ Amapaia naer Neuvo Reyno toe/ ballen in Meta de riebieten Pato ente Caffanar. 2Bp teelten defe rievieren naer de probintien ban De Ashaguas ende Catetios toe/ jün de riebieren Beta, Da wney enoe Ubarro, ende op of frantieten ban Peru legghen de peobincien van Tomebamba ente Caxamalca. (1Ban defe

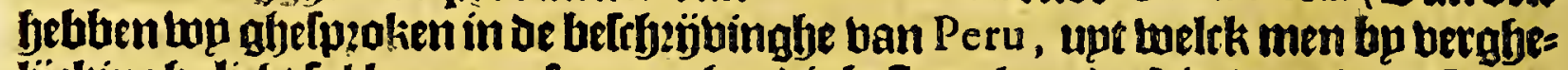
lịckingbe licfjt tal konnen af-meten boe dit beltaen kan.) \$Riet berre ban 2 uito in de noozot - zjöd ban Peru, beeftmen de riebieren Guiacar ende Goavar: enoe aend ander jijde ban't ghebergljte ae riebiere Pa pamene, welck loapt in de Marannon ofte Amazonas, dooz de pzouintie ban de Mutylones, twaer Pedro de Orfua die bp Den berraoer A giri wierdt om-ghebzacht/[un bercken maeckte Doen bp naec Guiana forbt / bu de twegl langhg de Amazonas.

culs 
Het vijfthiende Boeck.

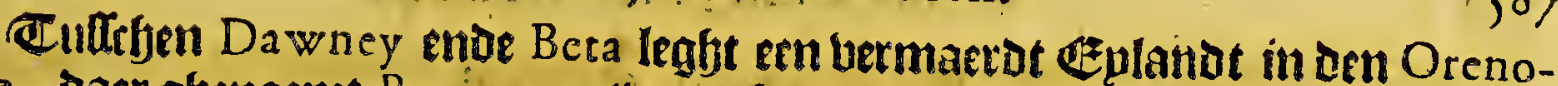
que, Dacr ghenaemt Barraquan (bant boten Meta en is den naem ban Ore-

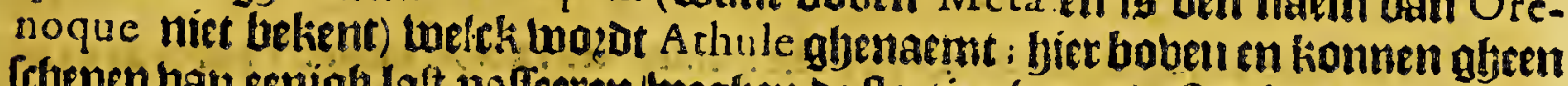

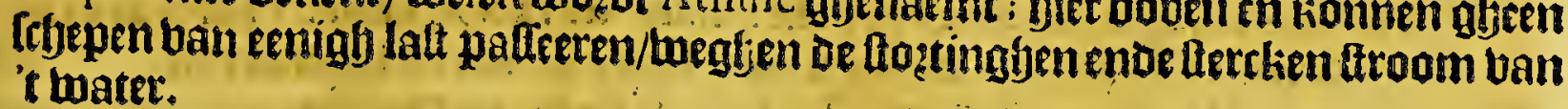

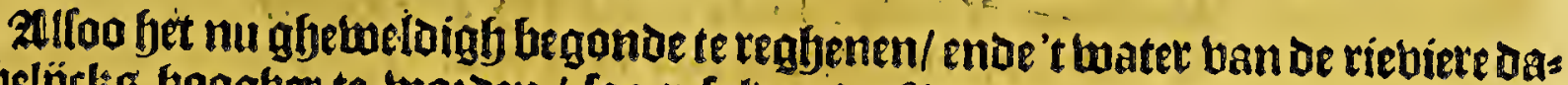

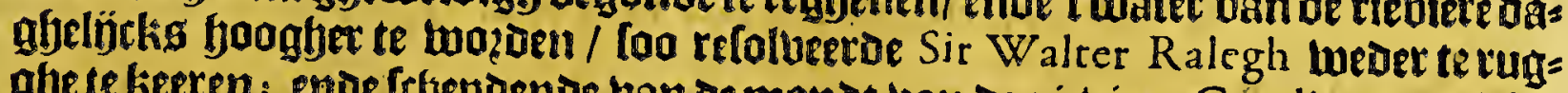
gbe te ketren; ende frjepdende ban oe monot van de riebiete Caroli, quam dien

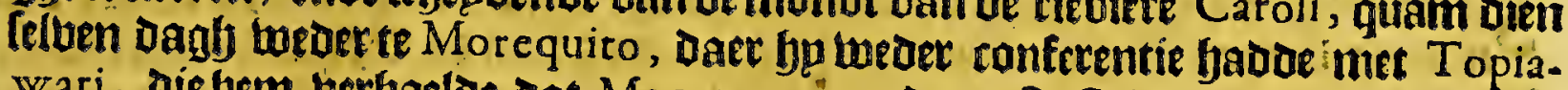
Wari, die bem berbaelde dat Macureguaray oe eerfe ftad ban oe Epuremei, maer bier Dagf-repten en twas ban fpn bleck: bp gaf fpn fone asn Ralegh om mede te boeren/ ender Ralegh liet daer oock twee van finn ualck/ beloobende bet naele jaer weder te komen met meetoer marbt.

I9et bem quam af of Cafique ban Warapana, genaemt Putima, dief faer aen

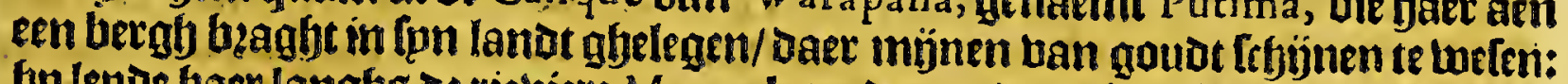
Gp lepue baer langhg de riebiere Mana ; latende aen de rectjter-banot legiben een

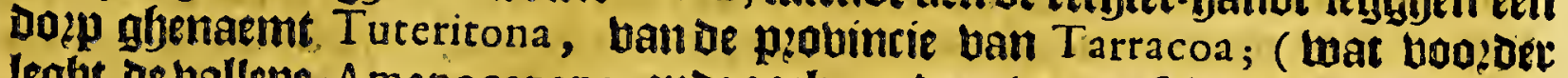

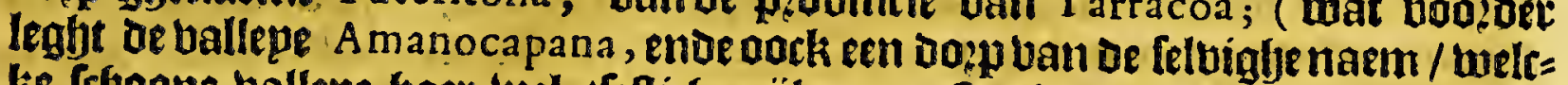

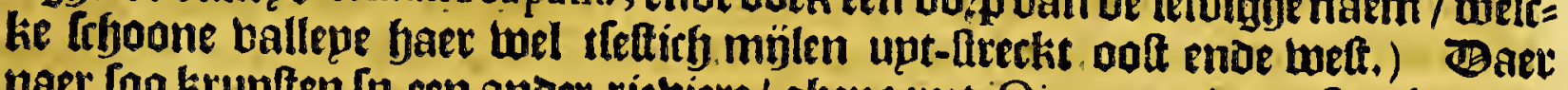
naer foo krupften Ip een ander ricbiere/ gbenaemt Oiana, enoe rufteri gaer bp

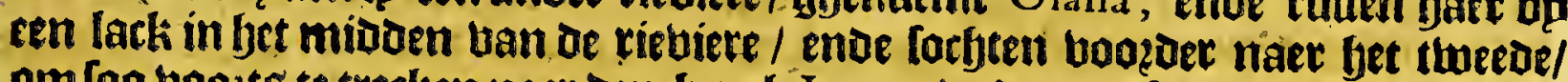

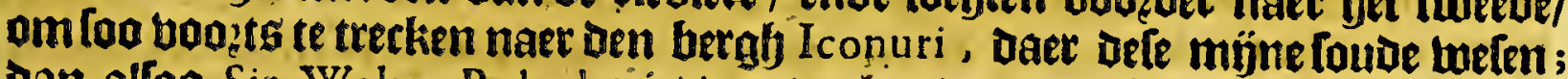
dan alloo Sir Walcer Ralegh niet voozoer konDe gaen / foo lonot bp Capietun Keymis Der-Larts / met oedae oe ballepe dooe te trecken tot cen riebiere gbte naemt Cumaca, daer fop bem foube in warbten: Boeren troots de rieviere af langhg of plobintie Parino, tot Ariacoa toe / Daer oen Orenoque fem berbeelt

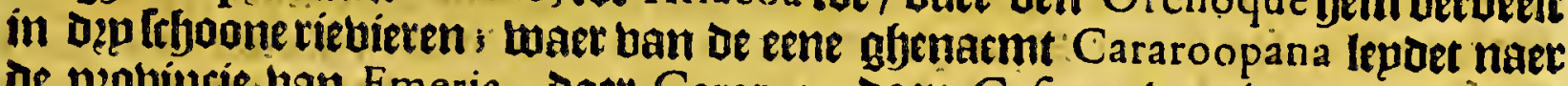
oe pzovintie ban Emeria, Daet Carapana doen Cafique ban was / ende naet of oof-3ee; meltke Sir Walter Ralegh felfs af-uoer om Keymis te ghemoeten. In defe rietuiere leggfen oock beel Eeplanden/ entigfe les / eenigfte thien/ende onck twel twintich mijlen langf; th boeten ren anoere viebiere in/ Die mede in Orenoque balt/ghenaemt Winicapora, Daev een kriftal-bergh Toube legghen/ gbenaemt W acarina, daer fo niet bp en quamen; Dan bethaenoe Dat Carra-

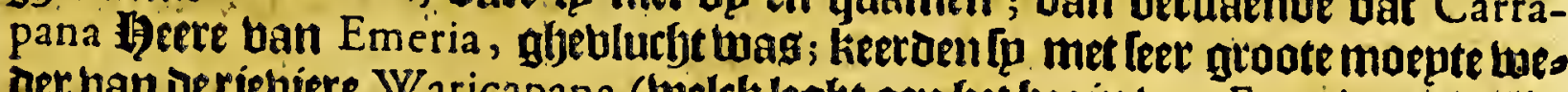
der ban Deriétiere Waricapana (tuelck leght aen fet begin ban Emeria , ende lis= ten bp ooffen legghen vier tiebieren / twelckeal upt 't gfebergljte tan Emeria afkomen/te toeten/ W Waracayari, Coirama, Akaniri ende Iparoma : entemeer ne-

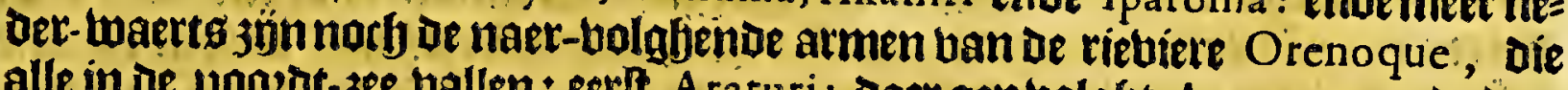
alle in De noozot-jee vallen: eett A raturi ; Daer aentolght Amacura; ende dan Barima; Uootts Wana; ten ujffoen / Morooca; ten letten / Paroma; ende eqn.

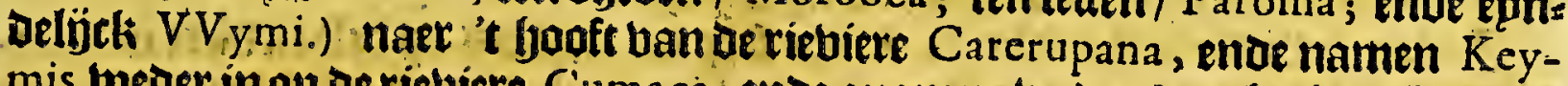
mis tweder in op de riebiers Cumaca, ende quamen tueder langlys feet Éplando Aflapan, in ue faben ban Toparimaca: ende uan daer buoted de riebiere glbe naemt Capuri af / tolltkes monot twel ontrent foo berte by oofen ban baer graote trbepen lagb / als Grevelingen ban Doevers is ligghende ; weltke obi=

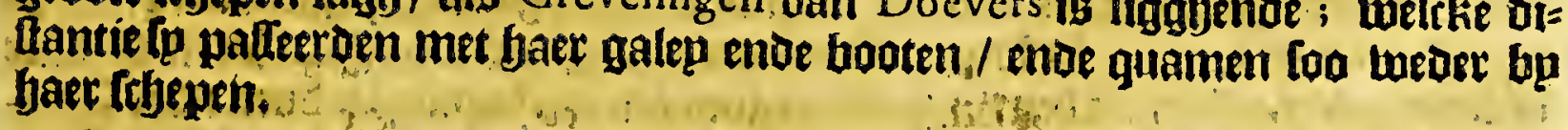


3) thintirtble capittel.

Detweede voyagie van de Engelfchen naer Gura n A, onder'r beleydrvan Laurens Keymis, in den jare 1596. Ende de derde befchreven by Thomes Masham: Ende de lefte by Sirrvalther Raleghfelfs, in den jare 1616 ende 17 .

Str Walther Ralegh 't bupg gfekemen zj̈noe / fonot in 't jaer I 596 meder tertwaerts Laurens Keymis, de welcke fpn kours van of efplanorn ban Cabo, Verde, wat 3upoeligeker aen-tteloe/foo dat fjp quam aen de monot ban oe riebiete A rrowari, ende liep to voots langhg oe kufte/ enoe be forbt De riebieren die daer leggben tulftyen de Amazonas enoe den Orenoque; bp frbepde den leg-en.tmin= tiefflen lanuar, van Portlandr, enoe arribeeroen oen leften A pril aen oe monot ban de rieviere Orenoque, bie hp noemt Raleana. Seght dat bet kamael ban oefe

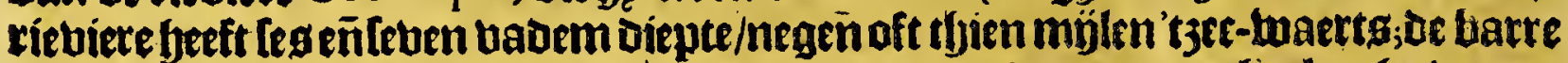
legft beroer upt/enoe en beeft niet ober thee Ladem waterg met fet leeghe toater:

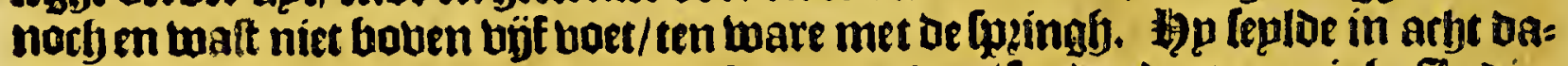
gben De riebiere op tor of haben ban Topia wari toe/ fonber battex entigbe Indias nen ban kennifte aen baer boozot quamen. Alen dele plaetfe baboen of \$paes gniaeroen efn Rancheria ([oo fu bet noemen) ban thintich oft oetritb guplsn;

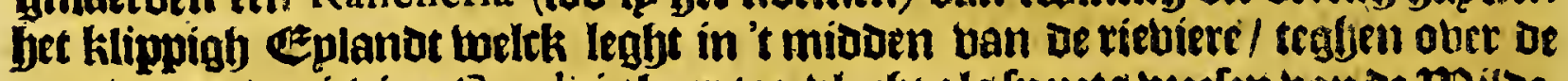
monot ban oe rieviere Caroli,is baet toe-ulueft als fp pets beefen ban oe mbilde.

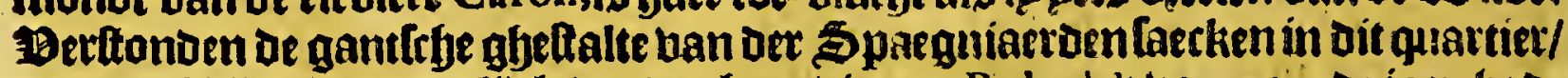
upteen 1 Biloe / namentlioth dat oe ghene die met Ralegh't voo:garnoe jaet gad= Den aen-gbelpannen tegben oe Spaegniaerden/ al gheblurbt waren too? de Spaegniaeraen/ oode dien Ralegh gbeen bolck en badae gbelonoen op oen bes

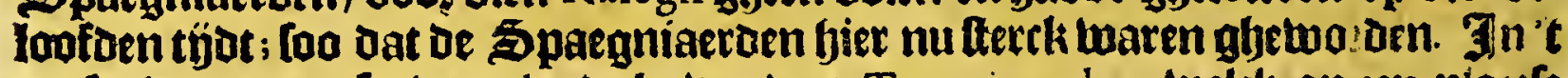

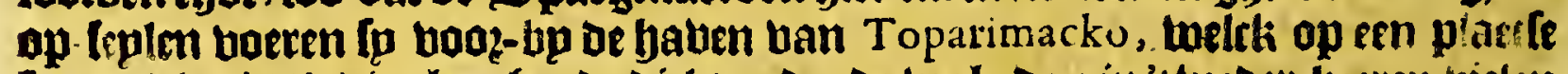

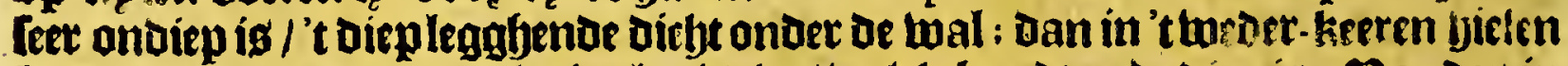

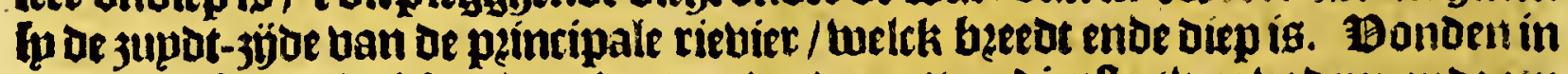
beel plaetlen twintich vadem twaters / ende op't ondieptte thee badein ender een balf/ende dat maer in een oft twee plaetlen. Quam boots tweber naer bups [on= ber pets upt te techten/ Dan Dat bp oe rechte in-komlie ban befe groote rieviete ontoeckte / ende was maer bujf maenoen upt.

Sir Walther Ralegh [onot noty een pinafle in't eprote ban fettelte jaet/ waet op boer een $\mathrm{M}^{\mathrm{r}}$ Thomas Masham, Die De bopagie leeft beldyeeten; Dan[p Deden get lanot aen to Cap Cecil, op de booghte ban dep graden enoe een balf / enoe boeren in berthbepoen riebieren / alg W iapoco entoe andere/ bier boogen bp ons belcheeben; Daty en quamen riet boozoer om de welf als be riebiere Corretini, ende keerden ban daer weder naer Gingljelandt.

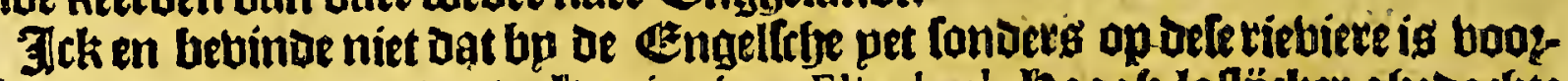

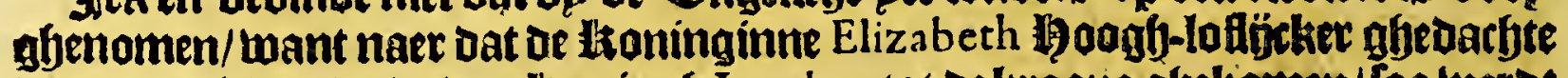
mas obet-leden/ende den ltoningf I cobus tot oe kroone glyekomen/fos tuetat Sir Walter Ralegh van betraedt befdyuloitgt / ende beroazdeelt ter boodt; Dorb

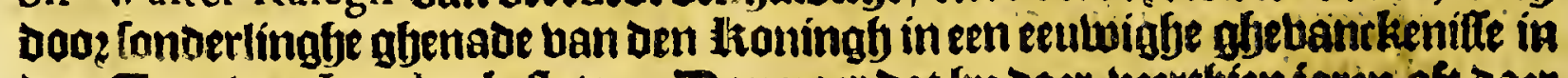
den Cour van Londen belloten. Bannaer dat ljp Daer beertben faten oft Daer ontrent lyadoe geleten/is fem bephept bergunt om een bopagie te boen naer Guiana. Mat unt-komfte defe bopagie beeft ghefjadt / kommen wp aloerbet verftaen upt Ralegs beief aen Sir Ralph Win wood, Die gemmetel heljulpightwag gljetweet

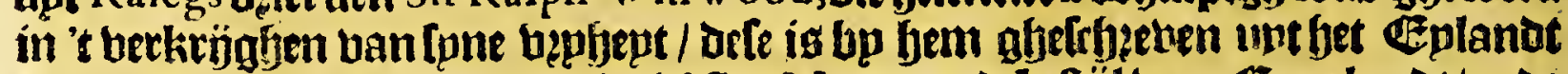
$\mathrm{S}^{\mathrm{t}}$ Chrift oforo, deneen en-twintichiten May naet oen tujl ban engelanot/snae

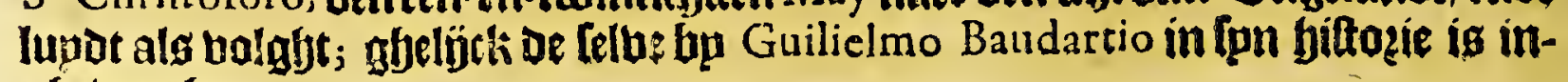
glietroeglyt: 
Het vijfthiende Boeck.

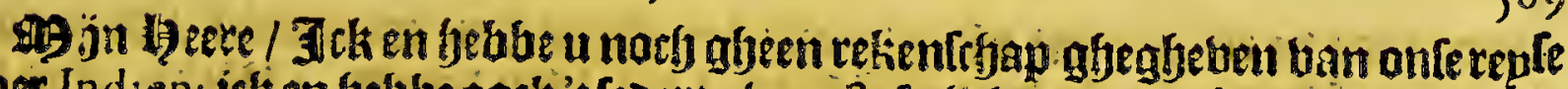

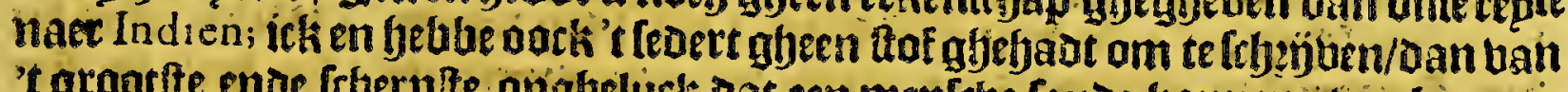
't groatte ende frberple onghbelusk dat een mentche foude fonmen ober-komeri.

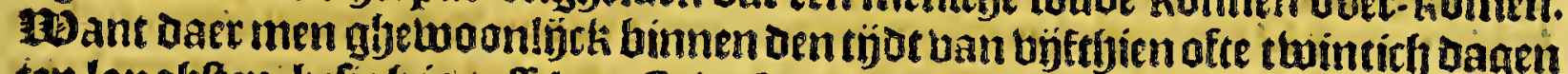
ten langlfern befigh is tuftrben Cabo Vefide ende Ametica; ; foo bebten top of

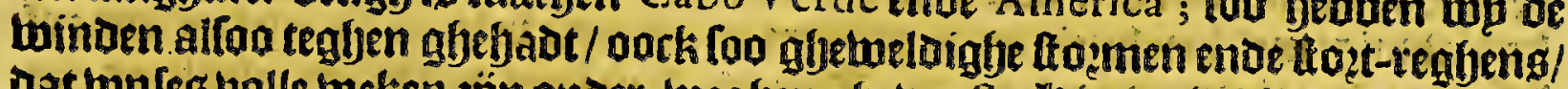

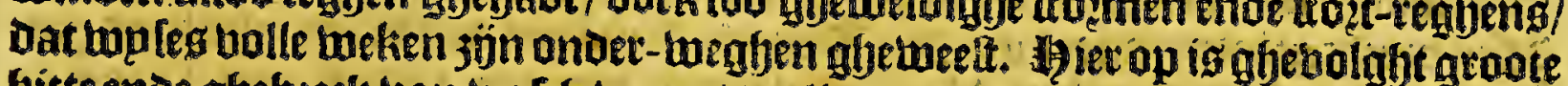

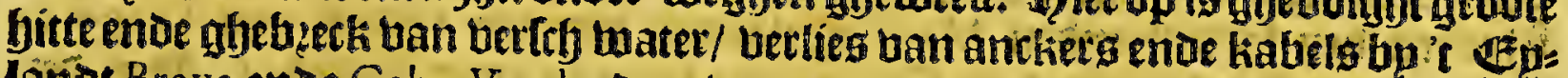
Jaños Brava ende Cabo Verdc, Daer toup mepnoen alle te uetgaen. Ong ouer-bies

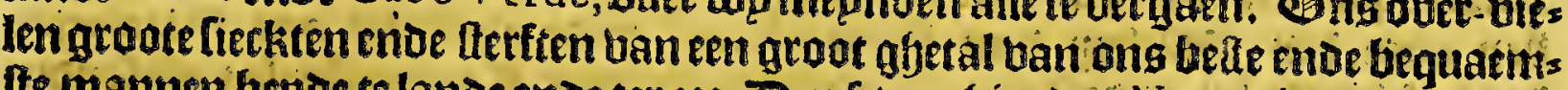

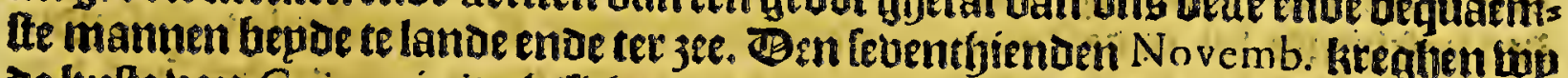

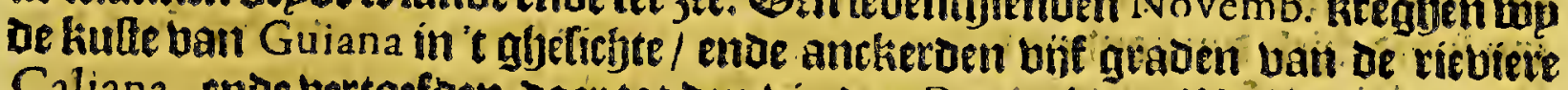
Caliana, enoe bertoffoen daer tot Den bierden Decembris. Wop bratgten baer onfe krantkent aen landt/ende fetten onfe barquen ende flocpen op/die tup upt $\mathbb{E}^{2} n=$

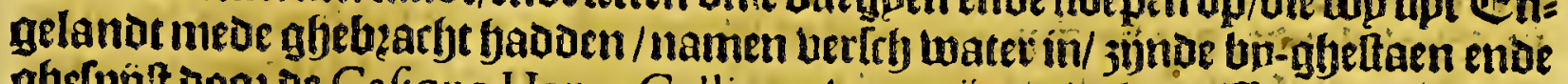

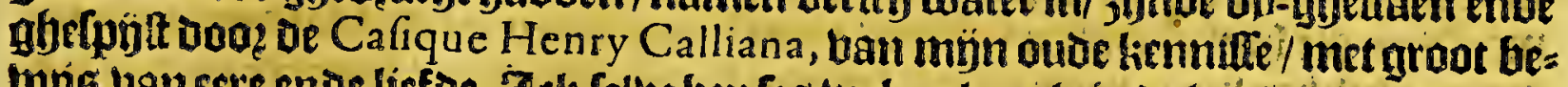

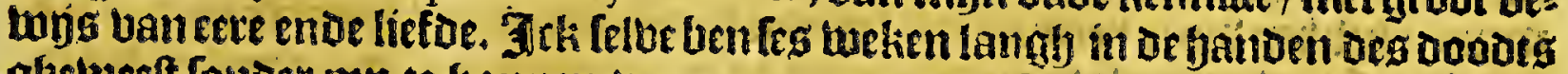

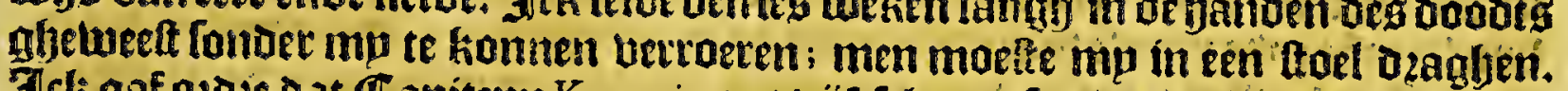

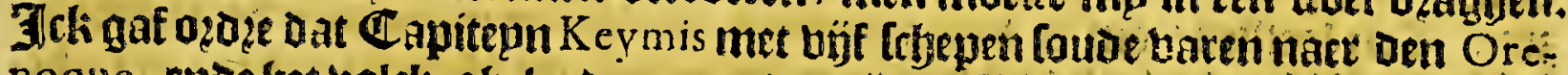

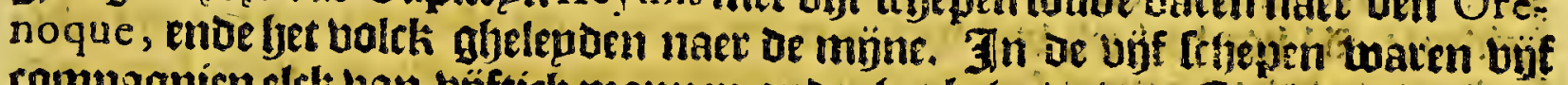
rompagnien elck ban bojftich mammen ender foet beleuot ban Capitepn Parker; Capitrpn Noorth (bzoever van Milord Montaigle, ente Milord Noorth) brabe

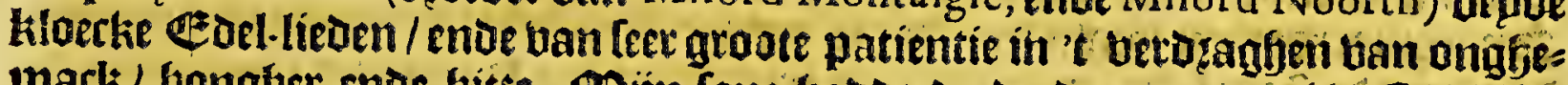
mark/ yongjer ende bitte. Agijn fone faboe oe derde rompagnie, Capitepn

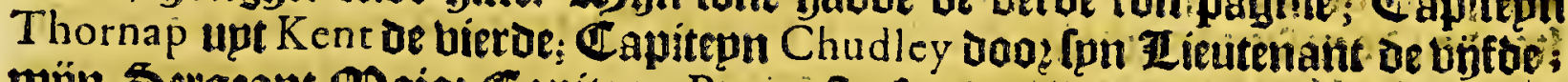

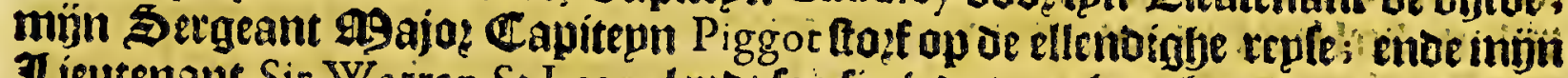
Lieutenant Sir Warran St Leger lepot fuo fiect $k$ Datter gbeen boope uan leven en ig:ende den latt gfegheten aen mïn nebe George Raleigh (Die met grooten lof

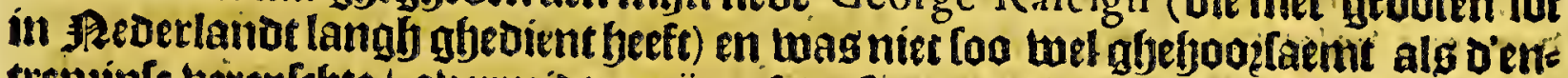

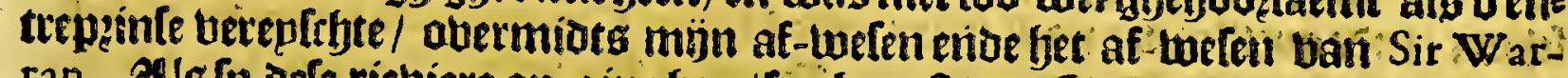

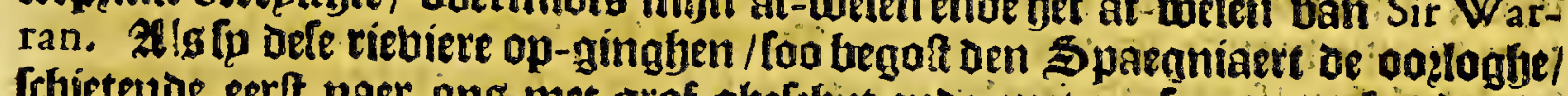
frgietentoe eerft naer ons met grof gbelifjut ende met mulguetten/ loo dat be

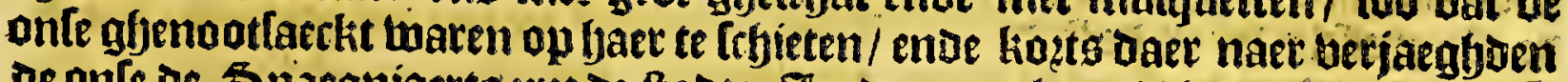

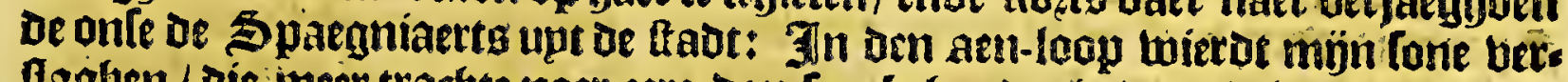

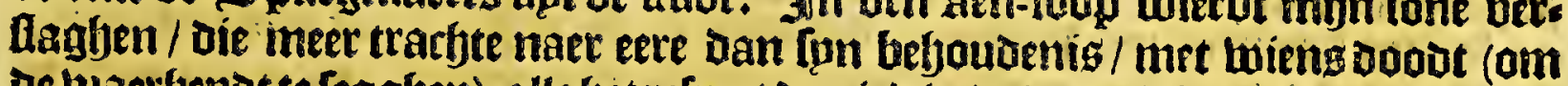

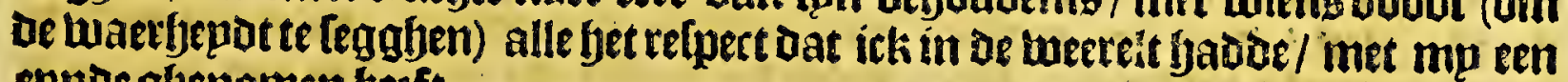
epnoe ghenomen beft.

De ander vijf frbepen bleten te Trinidad, gheen bequamer fatuen bindente bu Guiana. Het tweede Iffip twierot gfecommanoeert bp minnen Bice-2tos mirael Capitepn lohn Pemington, ban tuien ick met de waerbepot moet bes kennen/ Dat jp een ban de bequarmite mamnen ter jee is die efenglelanot

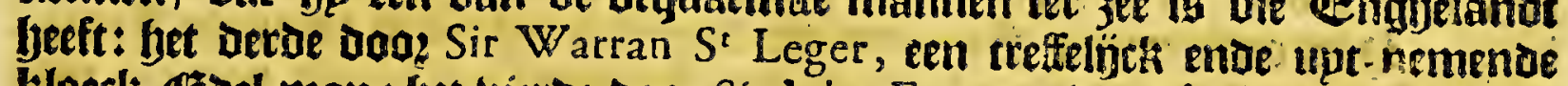

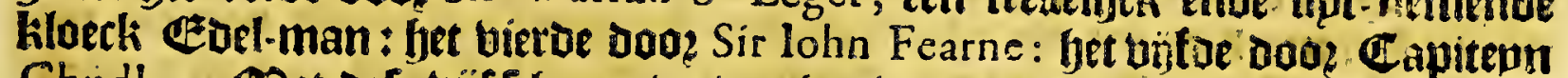

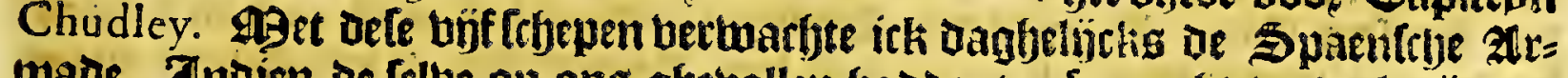

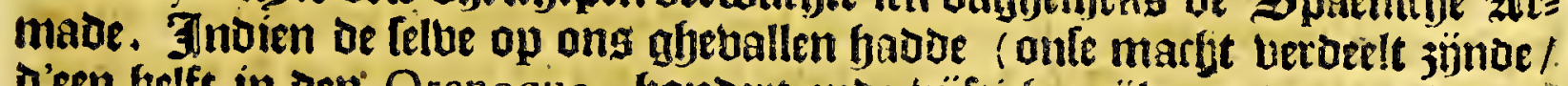

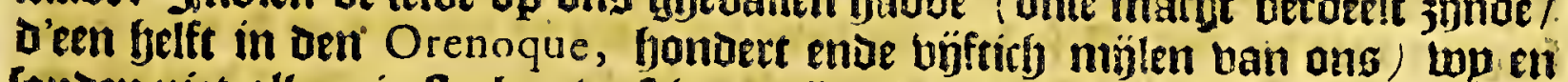

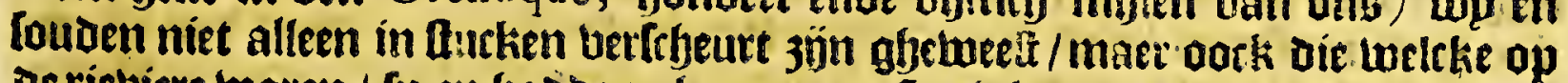

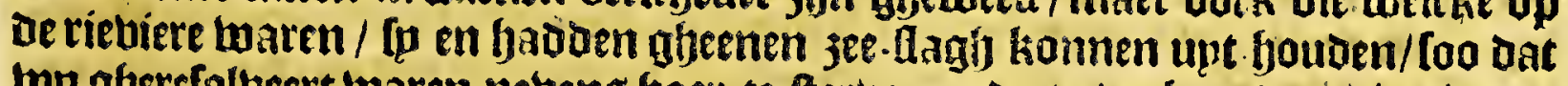
top gferefoltueert waren nebens gaer te feetuen ende te verbeandern/ indien oe.

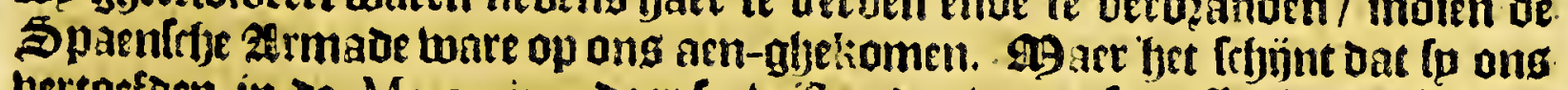
betroefoen in oe Margarita, daer fo milten bat bup onfe pafa agie moelten ne:

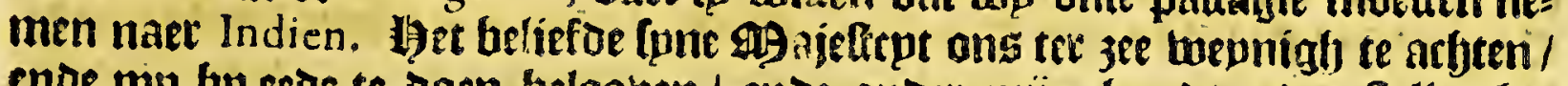
enoe min be erde te doen beloaben / ende onder minn bande neder feellen fiet 


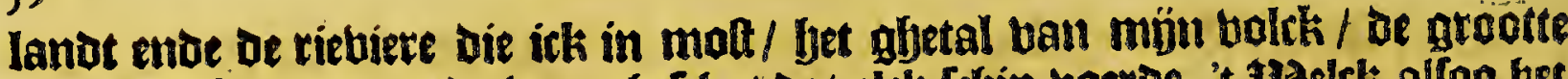

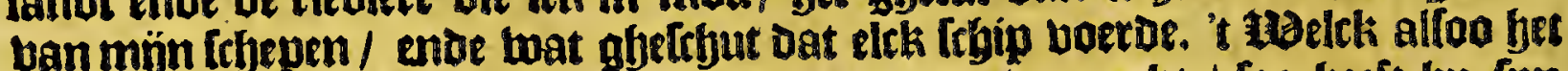

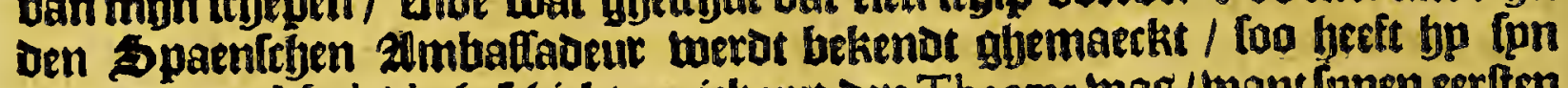
beieben naer Madrid ghelchickt eer ick upt Den Thaems mas/ mant fonen rerffen beief toag ghedateert oen beertfienden Martij 1617 , ober-gbefonoen bp sen bere:

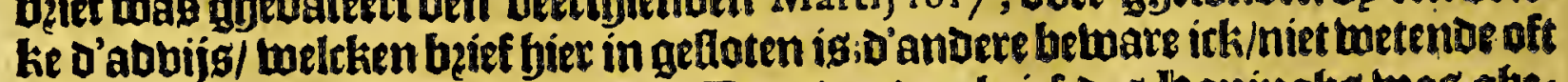

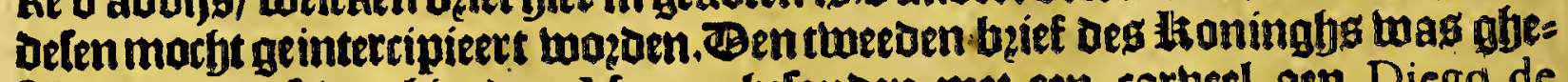
fefjetuen oen lebentbienden May, ghelonden met een tarbeel aen Diego de Palameque Bauberneur ban Guiana, El Dorado ende Trinidad. Ben Detu ben booz den 2Bifthop ban Puerto Rico, ende ghelebert aen Palameque jen uýftbiende Iul. in oe T rinidad; Daer baren opck Commiflariten gfjefonden om Ipoedelöek Dep bandert foldaten te lichten / ende thien ftucken gbelctjuts ban Puerto Rico te Iepnoennaer Guiana, \&c. \$2u/Aerce/aebüle bet alleen Den geenen kennelïtk is die in oe Indien gebandelt bebben/ fints onles ktoninghs regieringe in eznghelanot / Dat oe Spaegniaeroen lebenoigh gbebilt bebben alle die arme

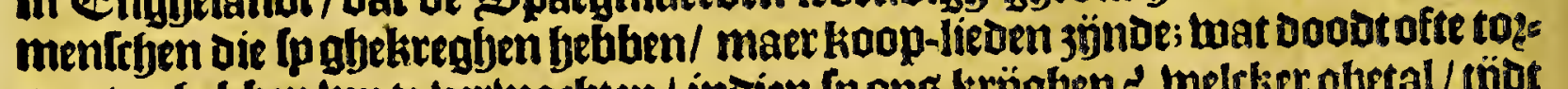
menten bebben top te berwatben / indien fp ong krijgben ? belcker abetal / ijot ban komite enbe platte maer benen inp gaen / alreedtg den Spacgniaert belient zín. Gen laetten/ om te beantwoozoen Dat wp de mïne niet bearbeuot en Gebben: ad boe-wel ick tuel weet oat ick niemandot ([pne Majefteyt upt-ghes Conoett) en befoebe meer (atisfactien te gheben dan mp Telben / mün loon bre

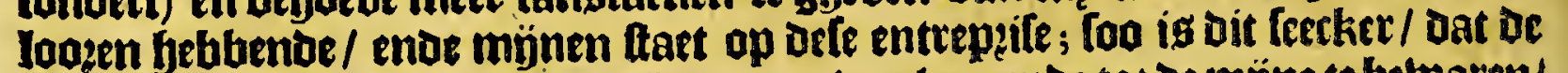
Spaegniaerdtmeer fozghe Dzoegh om Den luegh gaende tot oe mijne te belwaren/

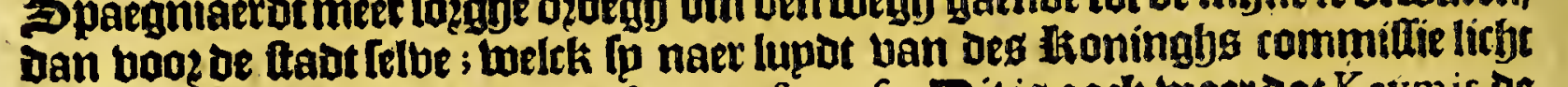
tonoen Doen/Den wegbjúnde afpera \& fragofa. Jit is oock waer Dat Keym is be riebiere heel leeghbonot / ende niet wel aen ben oeber en konoe gyerarcken/maex moelt tol een müle ban baex blijben/ ban tweghen beele bancken die jp daec bonot; altwaer als bpen plaetle abevonien badoe om te lanoen/ loo quam Daer een bolee mulquetten upt oe bollibagie / bie twee ban onfe roepers boo?Itboot / enoe quettender noct fefte / ende lcboten Capiteyn Thornap in 't yooft / ban twelkke wonde bp noch queelt. Boozoer too wilde Keymis fpn epghen hooft bolghen / fegghende dat fet te bergheefs mas de mijne te betratbetn/ om dat De eEnghellebe die in de ftadt Sant Thome bleben/ teghen bet ghe welot dat de 5 paegniaerden Dach enoe narbt aen-menoen met gheduetiab ftozmen/ niet en louben konnen upt-houben; Dat men tot be migne dooe dirfte bolifjen moette gaen / baex leer qualïck was boo? te gyeraecken; ente dat men be mijne ontoeckt bebbenbel gheen volck bp ber banot en baste om baer in te wercken/ foo liet by bet daer om al beel berbljben. OAaer bet is leetker bat be Spaegniactot twee goudt-mïnen beeft bu be fadt ban Sant Thome, De eenen jónde in be befittingbe ban Pedro Rodrigo de Parama; De antere bau Herviano Frontino : De Deroe ig ban filluer in be belittinghe ban Francifco Fof. hardo. Faet ontbeetken Swarten om Daer inte arbepoen / want of India nen en konnen baex toe niet ajedwonghen woroen / upt ktacht ban een bet des fepplets Caroli V. ende den Spaegniaerot en wil norb en kan dien ars bepot niet berdzagfen; Praggadocia bell Spaenlefen zimbaltadeur magh regghen wat by wil. Tht wil bet betwölen dooz oe hanot ban oen Propriador, Doo 't coftupm-boeck / ende Doos's zoninghs Quinto (waec ban ick een

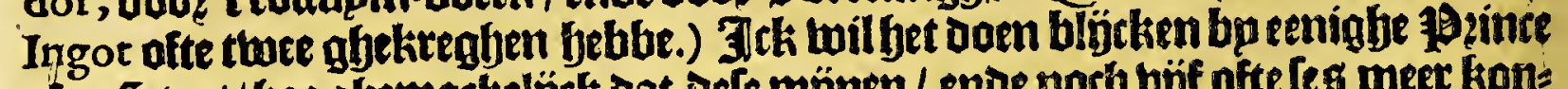

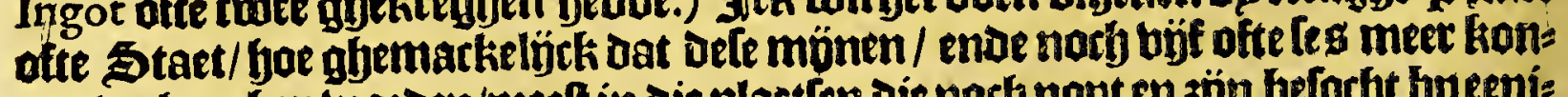
nen berkeghen wozoen/meet in die plaetlen die narb nopt en 3 p̈n beforbt bpeenie afie banat / tot of belcke oock nopt patiagie is gfyevonden ghelueet/ noch ooos

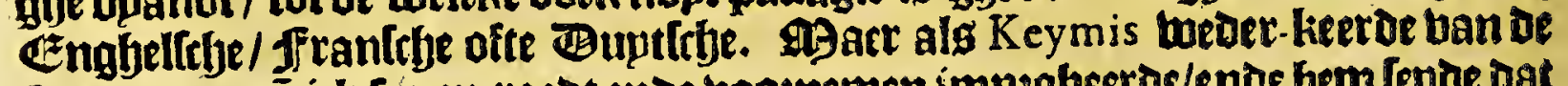
Orenoque, eñick [pnen raed ende booznemen imp?oberde/ende bem Iepde dat 


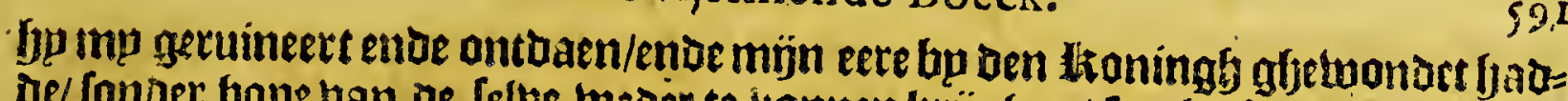

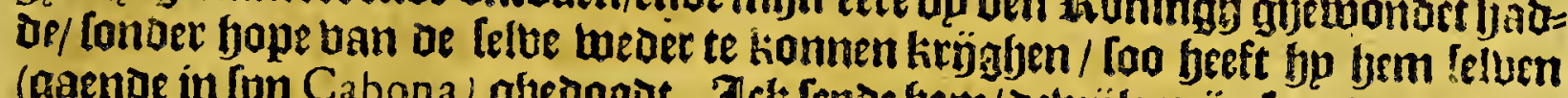
(gaende in fpn Cabona) ghedoodt. 3]ck fepde fern/Debajle minn lone was doodt gfjedleuen/fa en bzaeghoe ich daer niet naer after narbyondert gebleben badoen/ miuts dat de myne ware ontoeckt gbe weel / ende ick allo mpin tredit badoe mo:

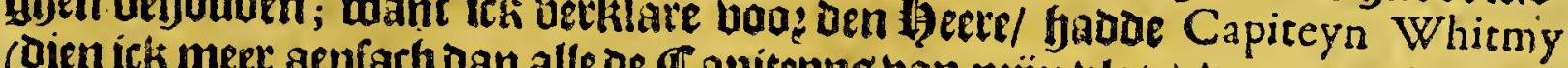
(dien ict meet aenfarf dan alle of Capitepng ban mïn blate) ban mp niet loegh gbelaopen tot de Granada, met bem nocb nemende'tffjip ban Capiceyn Wallahcon, itl foude mín litbaem met mín loong litbaem te $S^{2}$ Thome ghelaten bets ben/Dat de ltoningh tel foude bevonden beblen Dat ick gfern poele laecke en

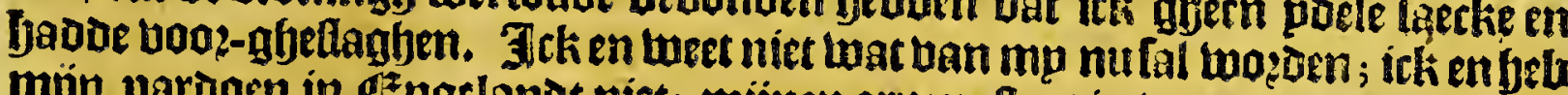
mijn pardoen in Ezentlanot niet; mijnen armen faet is berteett/ende en beet

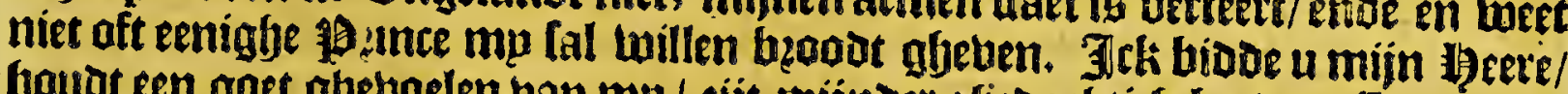

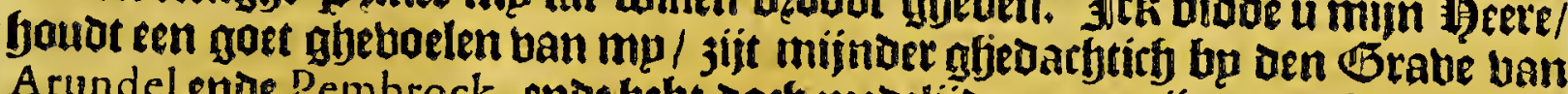
Arundel ende Pembrock, enoe beht ooth medelijoen met mijn arme bupg-beot= the/ aen de twelcke ick niet en Derf frbejuen/ om niet te bernieulwen de Dzaeffenile ban baer loong boodt. Jck bidoe u/ wilt Milord Carewe dit meoe Deelen; twant bet is een berbzolen fette/lwack liebaem ende teedere oaghen/een quellin-

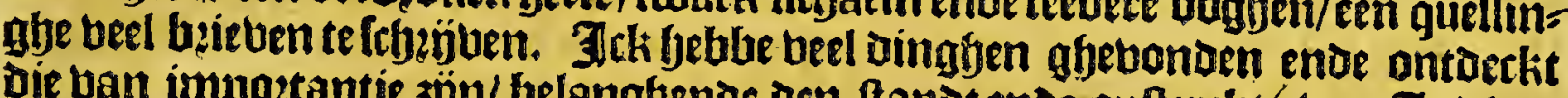
Die van impoztantie $3 \mathfrak{j n}$ /belangfende den ftamatende onfterckte van Indien:

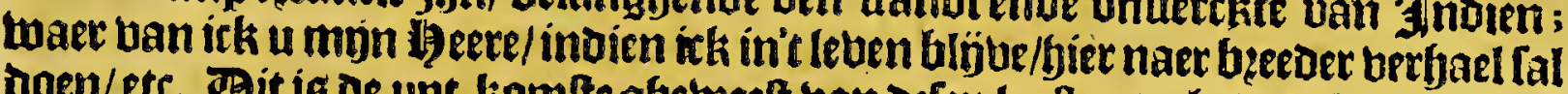
boen/etr. Dit is oe upt komate ghetueeft vam delen laeften tarbt ban Sir Walcher

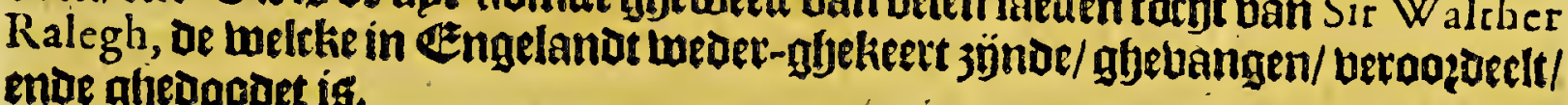
ende gjedocdet is.

\section{Het een-en-tbinticflete Capittel.}

\section{Gheleghentheyt van de rieviere OREN O Q $V E$, nacr de bevindinghe}

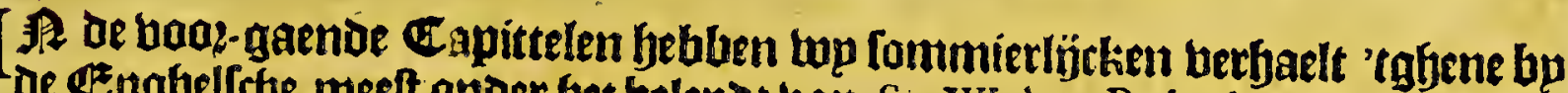

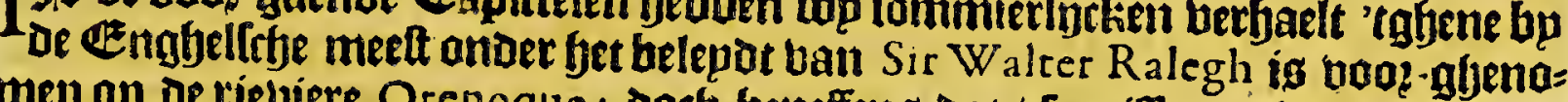
men op de vieviere Orenoque; boch beneffeng dat / loo iller eninge jaren bets. waerts groaten bandel ghedzeluen in Tobac, ende anders op defe rieuiere / foo

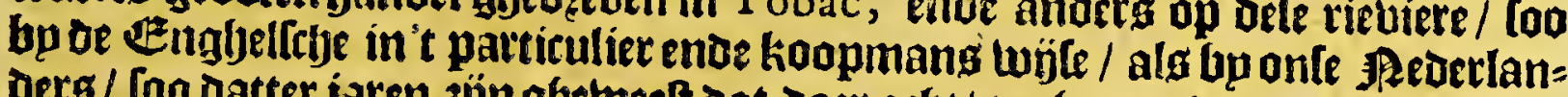
Ders / [oo datter jaren jün ghetweelt dat Daer arbt/ neghen/ende meer frbepen op

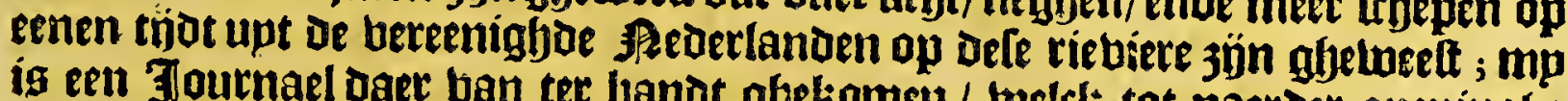
is een Journael daer ban ter lyandt gbeliamen/ twelch tot naerder openingbe

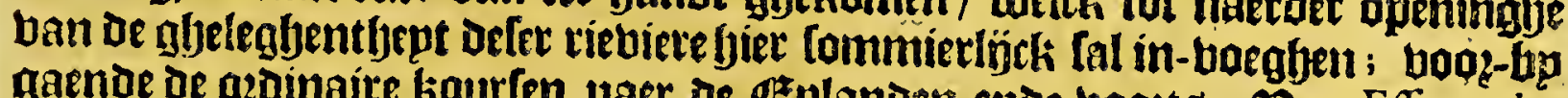
gaende de azdinaite hourten naer oe explanden ende boazts. Ban Efequebe

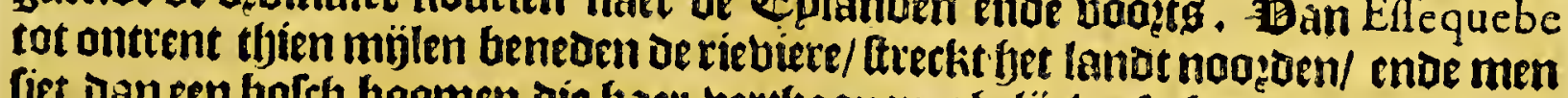
fiet daneen bofry baamen die haer bertjaonen ghelj́ch oft boeten-buplen taa= ren: Bopets boudende langhg de twal op oup ende een falf badem tuaters/liet

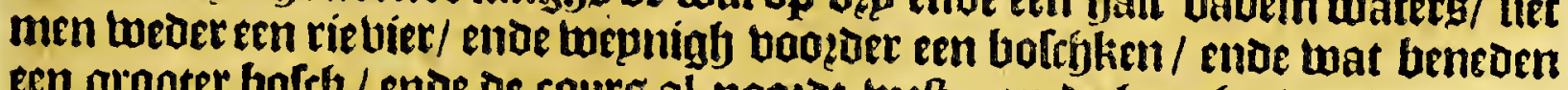
een grooter bofeb / ende de couts al noozot-weft; op te joogfte ban twat meer

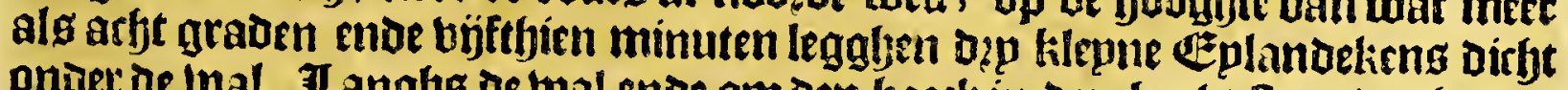

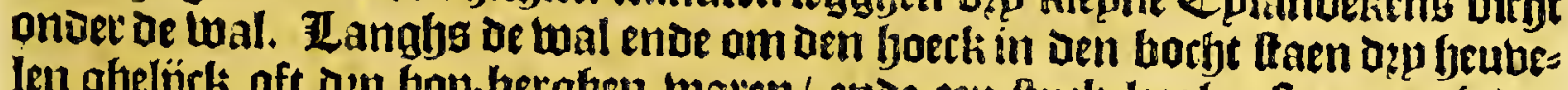

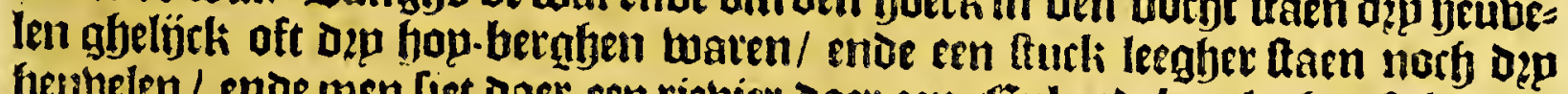
hetibelen / ende men liet daer een riebier Daer een (Eplandelien leght oft fyet efll

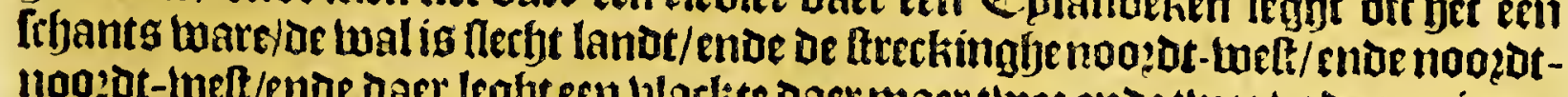
noo:dt-Leet/ende daet Ieghteen blackite daet maer twe ende tbee badem min een

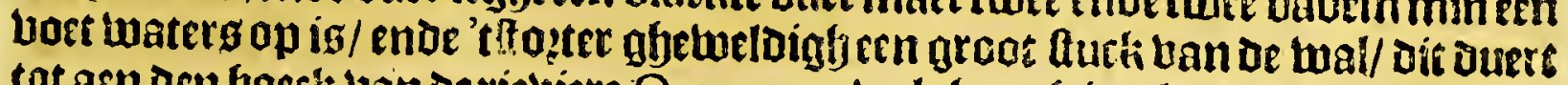

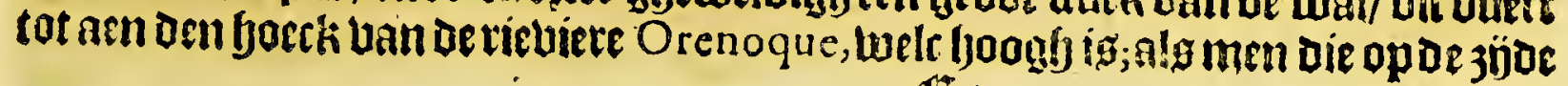

$$
\mathfrak{C E E}^{2} 2
$$




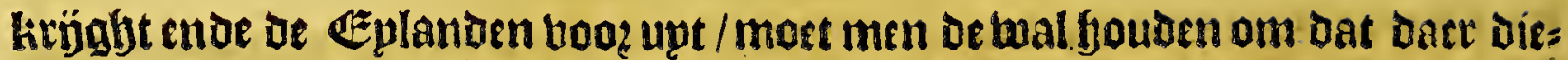
per water ig/enoe de Eplanoen't 3 ee- waert ban u laten leggben / want ale men

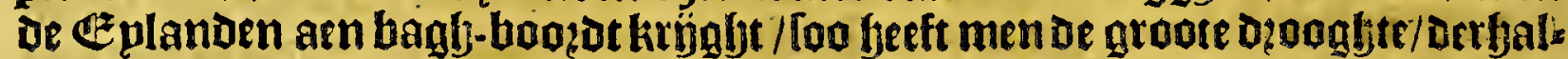

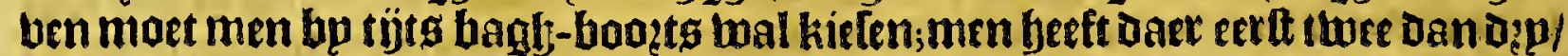

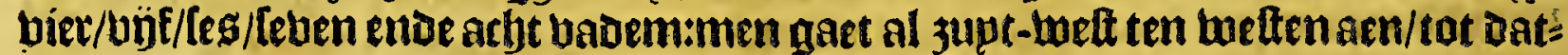

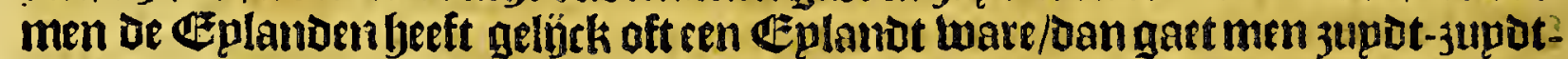
welt in / enoe men kan bet bp abonot letten onoer een teplen yoeck die aen baghboozot leght. De monot van de riebiere Orenoque leght op de booghte tan artht graben enoe büftich minuten. Soen gaet boots al jupot ende zupot ten beften in langhg de bagh-boazotg-mal / tot dat men eenrondt Eplandetien liet / dan moetmen ftier-boozot-kal kielen/ende 't Ezplandeken aen bang-boozot laten legalenmet cen mett-noazdt-weften gangh; ende nen laet boozder een kisun ronot \&eplandeken bol booghe boomen aen ttier-boazot leggben/ende aen bagy-

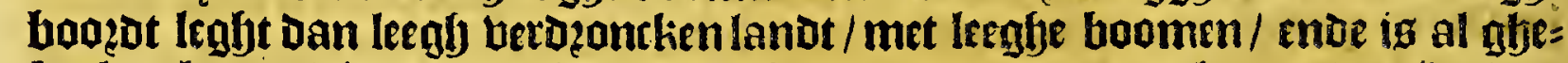
beaken lanot; Diep water dicht aen't [eplandt; Wat boazer komenoe/ jintwere gaten aen bagh-boozot; Dan' theede is naculu daet men pleeglj dooz te loopen; wat boozoer is nocb een gat aen ttier-boozot / maer men moet al tweft in gaen / [oo kamtmen tegljen een Eplandt aen / Daer fteckt aen bepoe jijoen ren gat'। men maet bet flier-boozots gat in / welt-noozdt-weft / eer men bu dit Ezland kamt / beeft men anoer-ljalf babem water; Daer nare gljemoet men ren $\mathbb{E} p=$ lanoelien aen ftier-boozotg-mal / ende tegfen ober hamt een get upt/ enoe men loopt ban fier zupdt-wett aen;ende zupot-wett ten bueften; men liet noch een gat aen bagb-boozat / ende hamt daet naex aen een ronot Cplandelien met thore blacke punten aen bepde epnoen / welcs men aen thier. boo zot moet laten legghen ende dirlyt langhg loopen / ig daet diep ghenaegh ; Dan feeft men een wojot gat / welek men aen bagh-boozot laet / enoe moet reche nooget- Left ende noozot-belt ten welten in-gaen: bp Dit groote gat liet gfjp norb een gat / Dat neex-baerto af

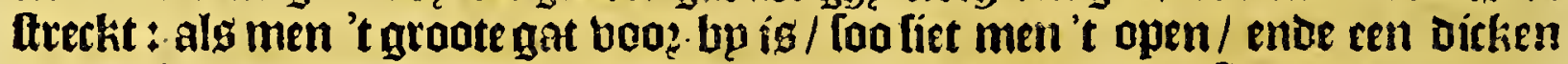
witten boom die Den baft af is / Die laet men aen bagh-boozot ftaen/enoe gat al

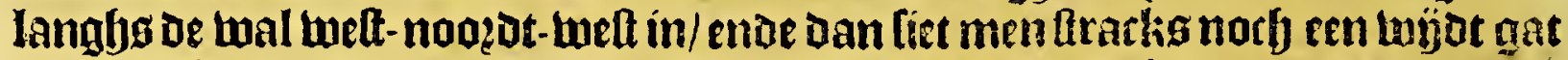

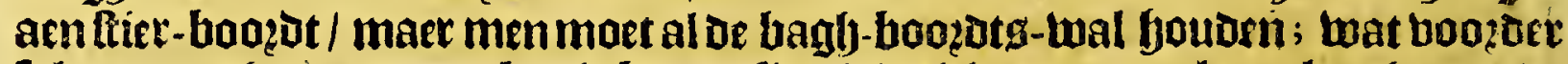
fal mennoch een gat aen bagh-boogot lien/'t twelck men moet laten legghen choc recht Doo?-gaen: hooets liet men noeh dep oft viex gaten aen thier-boozt/ Dan gaet

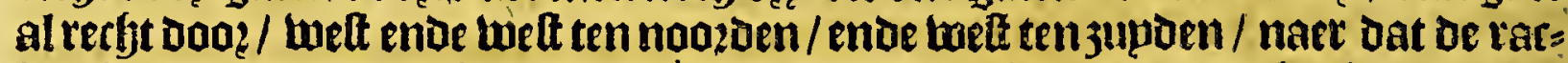

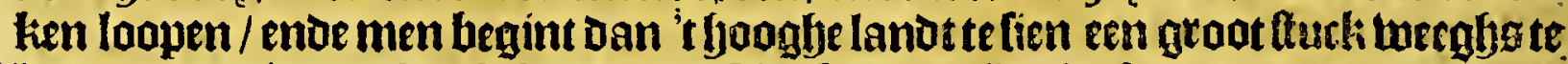

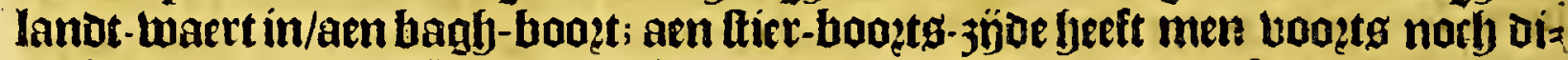
berfche gaten welck Eplanoen 3 jün;men gatt al welt-noazot-wett aen/en gentoet een Eplanot aen bagh-hoozot/als mede een groot gat oat men laet legghen/ende terftont liet men aen ltier-booteen langh [mal Eplandeken/en twat boozoer een engly gaetjen dicht aen de toal aen bagb-boost/ enoe men moet alreelyt upt loopen

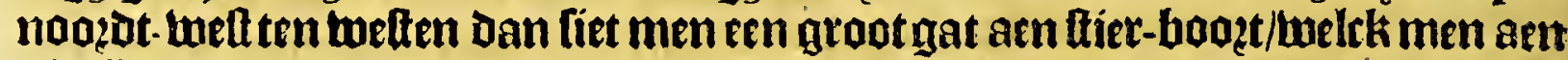

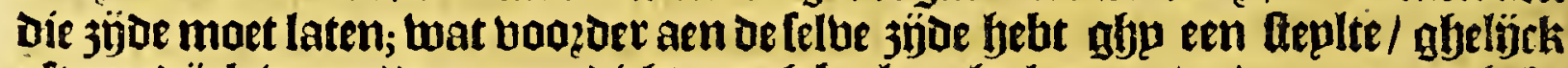
oft een oück twaer / oaer men oicht magh bp langhs loopen / ente ten epnoe bebt abpe een fanot- bape; boots bebt ghpeen gat aen ftier-boozot/ enoe dat glfepat=

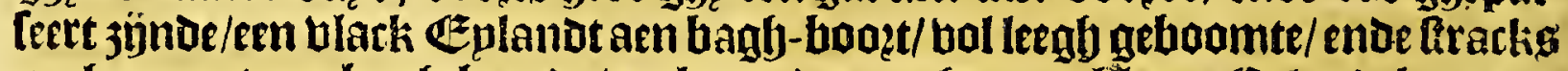
notheen gat aen baglj-boozot / en kamt Dan teghen een kilepn ezplandeken aen/ welck men aen bagh-boozot laet leggfien / ende tertondt fiet men fet gat sooz twelck men naer de Trinidad loopt / glbenaemt Mapure, men laet bet aen ltierboozd Iegghen : wat boozder liet men norly een gat aen bagh-boozst/ weick men

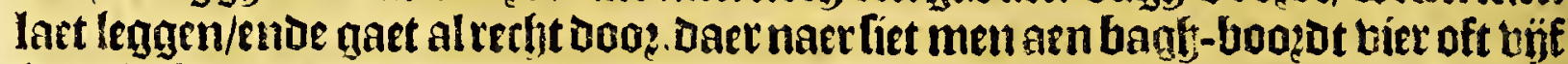
hooglje berghen/ is nody fes oft teben mülen tein Sant Thome, enve paffeett norbeen gat aen ftier-boot / ende homt aen een CElandelien ban toaermen te Sant Thome lomt. 


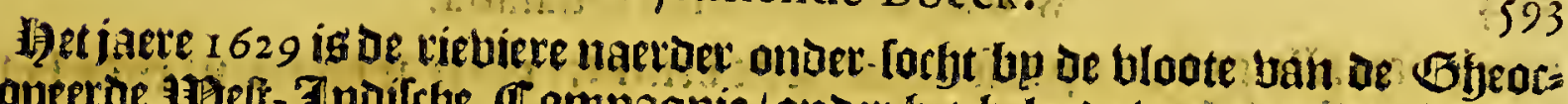

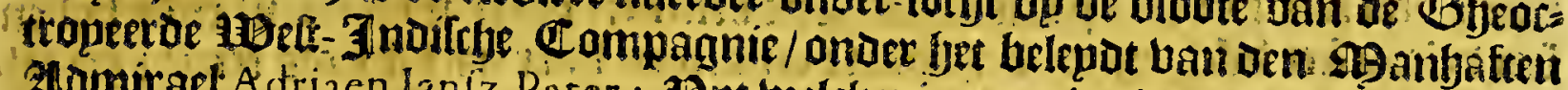

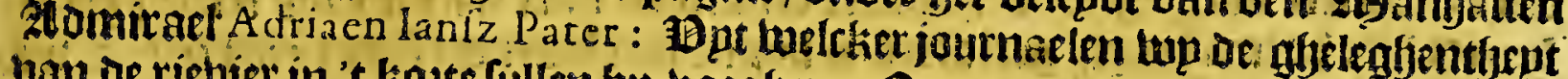

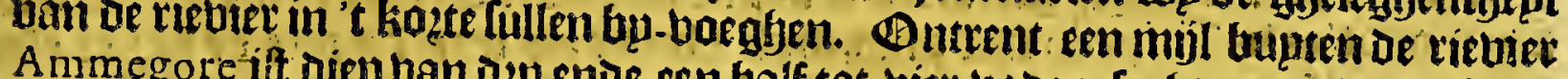

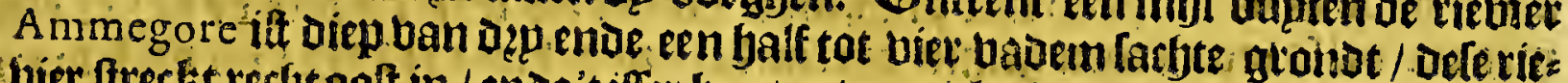

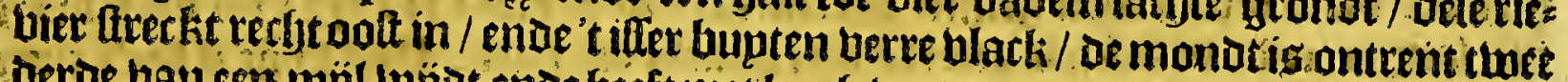

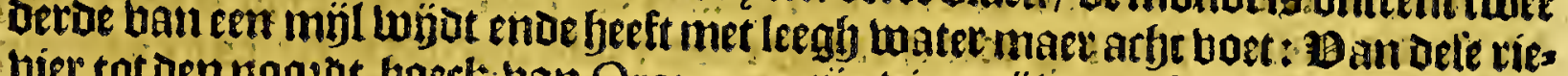

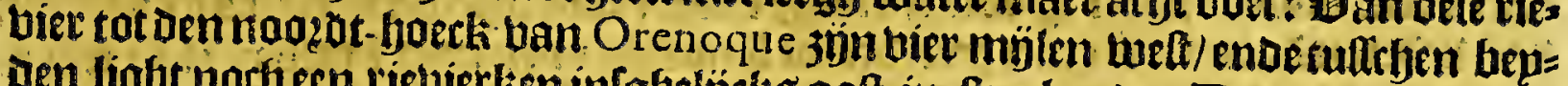

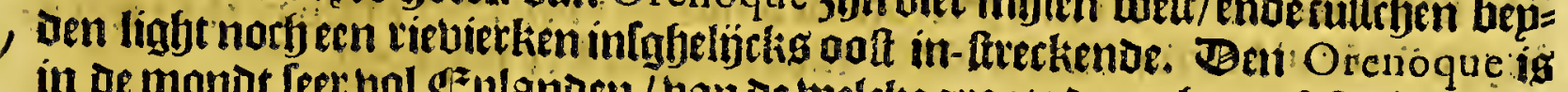
in de monot feet bol GEplanden / ban oe welcke groote dęooghten af-ftecken vier ende bier ende een balf mïle in 3 ee ooft tennoozden / ende oolt-noozot-ooft. Ber: Jaluen de gbeene die op Dele riebier billew/moet die butijdtsende een goedt atuck

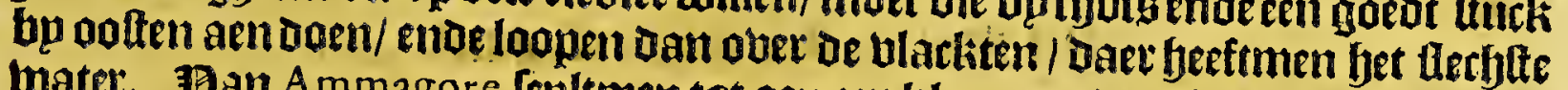
water. Ban A mmagore fepltmen tor aen een kilepn ronot eplandeken/'twelcke aen 't cynde ban een grodter $\mathbb{E}^{z}$ plandt leght/recht op de monot bande riebiere alf=

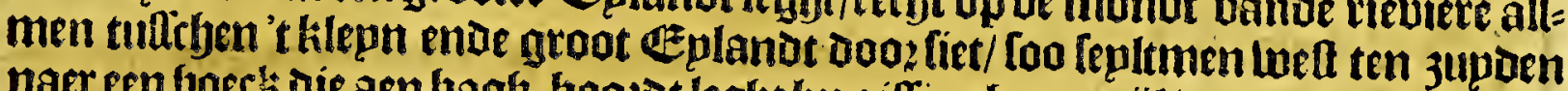

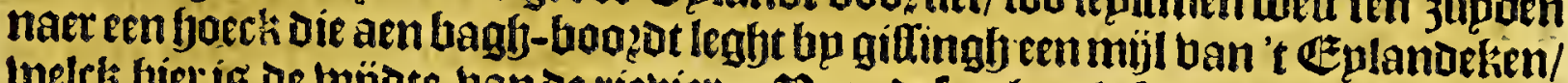

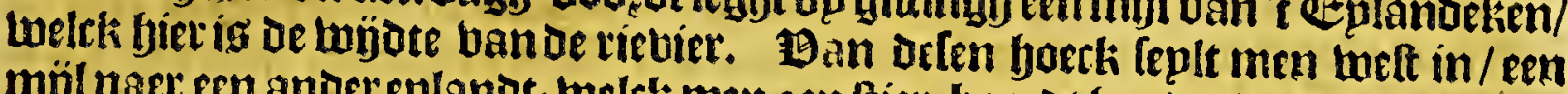

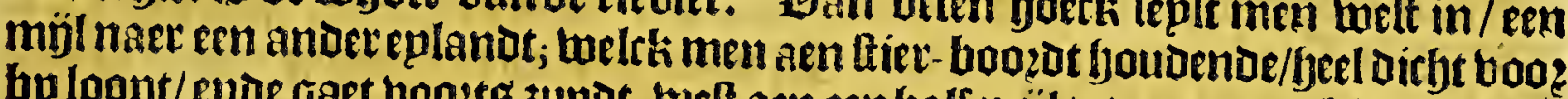
bp loopt/ende gaet bootts jupot-buef aen een balf mijl tot een anoer kilepn eplan= oeken tuelck men aen bagb-boozot laet liggfen / enoe aenltier-boozot een anoer/ neffeng uefl gbebzohen landts; ban defe eplandekens fepltmen jupdt-welt ten twe= ften thee dertoe parten ban een mïl/ Daer bert oe riebiete beel naeuto op Commige jlaetlen een quart ban een mijl tojjot/ met beel kromme racken/ ende gaten/ooef De ineete freeckimgle is theft ten 3 upden ende tueft-jupdt-twed / tot $S^{t}$ Thome toe;

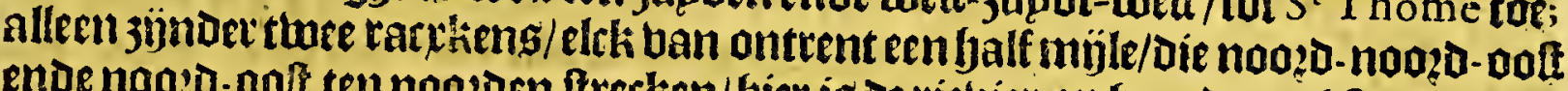

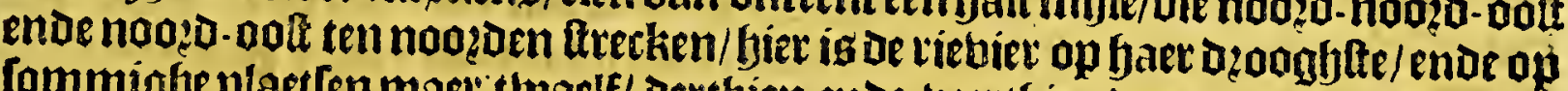
fommighe plaetlen mael thaelf/ dertbien ende ueetthien uoeten diep/ ende men

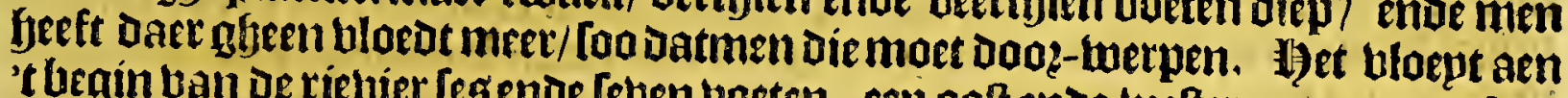

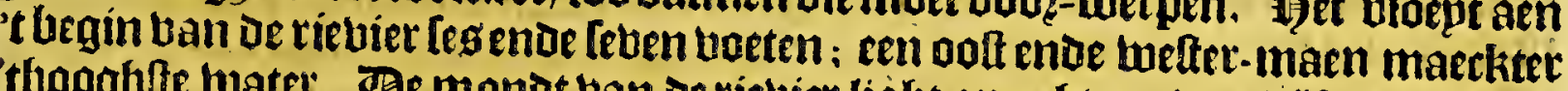

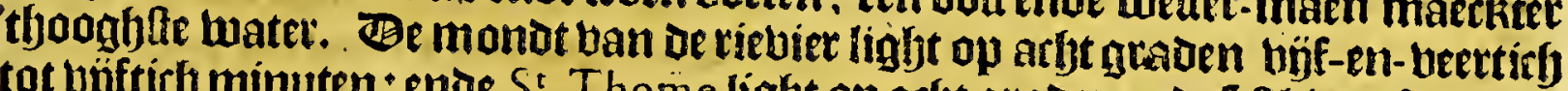
tot unftich minuten : ende $S^{t}$ Thome light op acht graden ende letthien ofte twin= tirly minuten. Om leegh aen De riebiel twoonen oe Tivitives en arm bolerken/Die mecl bp bifry leben endeleecker noten ban paimint-boomen / de groote ban een epe bijftigb tot leftigh aeneen bos groenende / bebben ffyarpe febellen / ende jün binnen als de cocoki-noten. Baer bliegben oock op oe rievier feetket ghediertjens als groote gfeltreepte mieten / bebbende bier bleugeltieng biele af-fchutioden loo

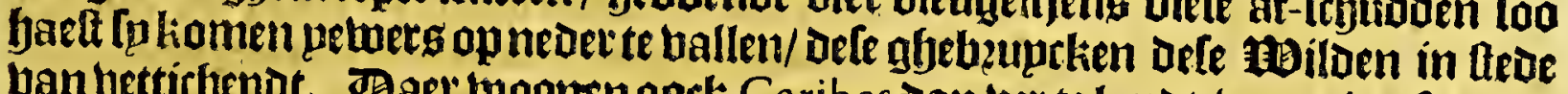
ban bettichepdr. Baer twoonen oock Caribes dan ber te lanot - waert in / loo dat De riebier fier [eer dooot is ban bolck. Cot bp naer tbinticl oft vijf-en-twintirfy mijlen oe ricuier op is al leegl-landt dat in de reghen-tijot beel onoer-loopt. Ban bandart begint' tyooge-lanot dat wel twee badem upt of luater leght: enoe alt= men ontrent dettigh mijlen boogbis / [ookomtmen cerf uut of Eplanden / ende in den recbeten Orenoque, dic daer een mijl bujdt ia / met frboon / Goonh-lantet weder-3jots; enve dan besftmennorf thaelf oft beertfien mij!en tot $S^{2}$ Thome,

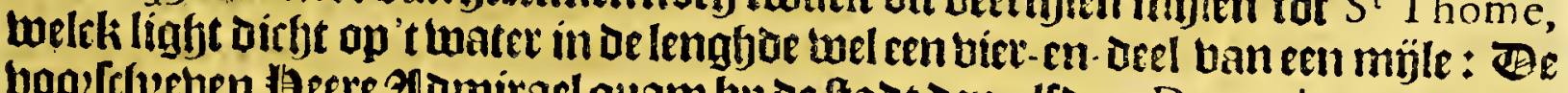

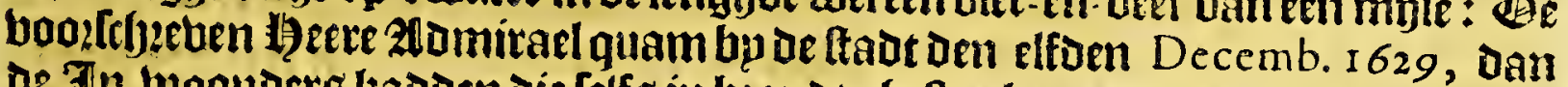
of Jn-woonders hadden die [elfar in bzanotghetterken/ende waren ghedught:

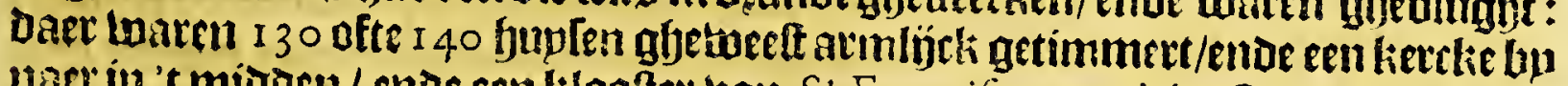
nact in 't mionen/ ende een lilaofer van $S^{2}$ Francifcus aen't weft epnde. In urfe

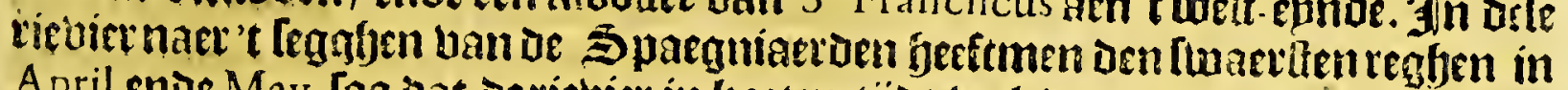
A pril enie May, [oo bat oe riebier in lioten tijot wel oep badem toalt: beneden

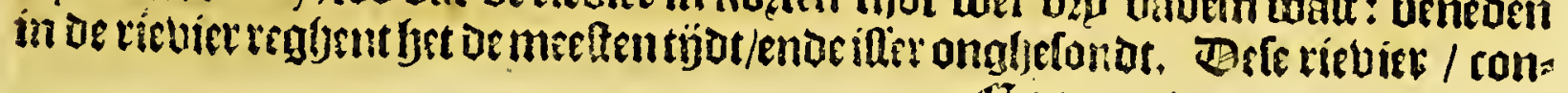

$$
\text { GEe } 3 \text { trarie }
$$




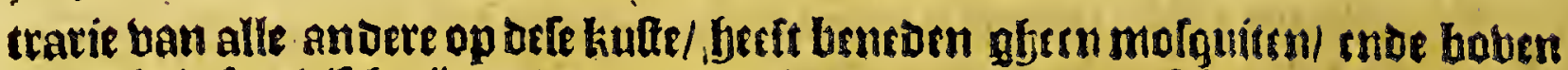

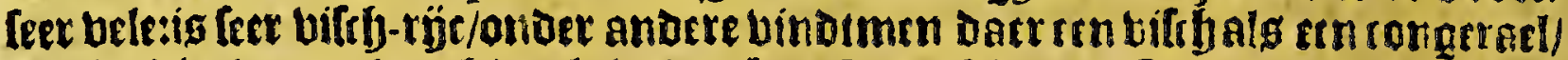

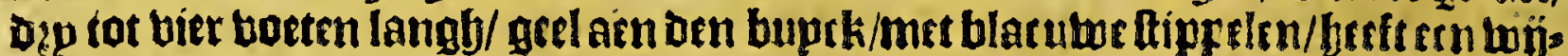
Den niondt/is de Torpedo nitt ongbelp̈ck / want ale men Die met te bandt ofte

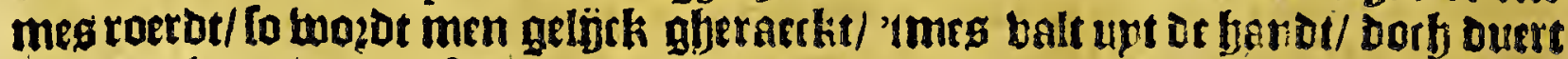
niet langhe/ ente de bifth ig anders niet guatot om etten. Ban togelg berf men baet beele/ onder andere groote menighte ban roode Ispelaets/ die loo Irhoon jün ban bederen datmen diemet geen berbe foude konnen naer toeten; ende te lart: De jün mede al de felbe dieten/alleen'tholek ig bier Tere toepnigh.

\section{$\begin{array}{lllllllllll} & A & T & R & I & N & I & D & A & D\end{array}$}

(1) twee-en-twintichle Capittel,

Befchrijvinghe van't Eylande I A $T_{R I N I D A}$; als'meder'Eylandt TABAGO.

H Et Geplanot la Trinidad is bet grootle bande Ëplanoen die de 5 pargniaer= Hen ghemepnlícken noemen de Soravento, regaro nemende op de courfen ban fare bloten varende naer Terra Firma, ofte Nova Hifpania, ende ban die lp

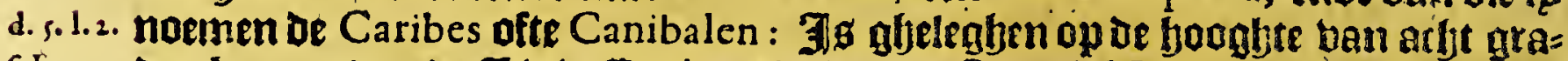

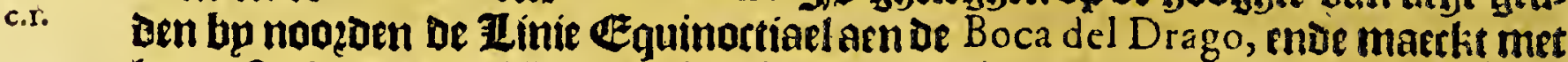
bet balte landet ban Nova Andalufra ofte Guiana een Golfo itueftl fp normen Lib.3.c. Paria, naet'tegghen ban Herrera, die fem in oe boonlyoe fier bergitt: maer Ouie-

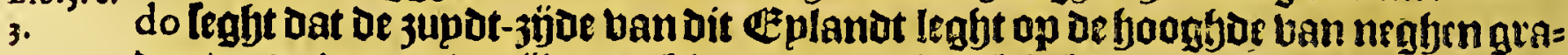

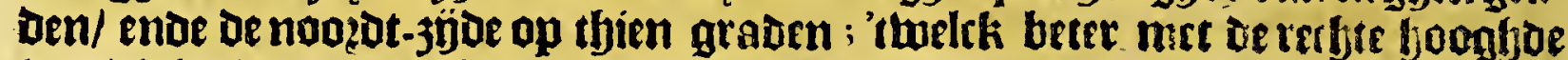
ban oit lanot ouet eenkomt: boe - mel Sir Walther Ralegh feght oat Punta del Gallo ofte Curiapan gbelegten ig op adjt graden ofte Darr ontrent: Onfe Pc:

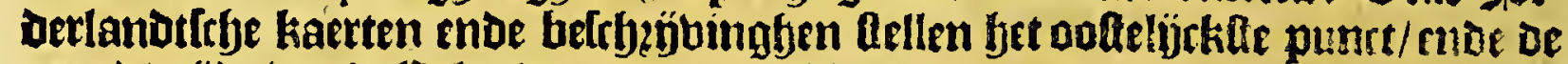

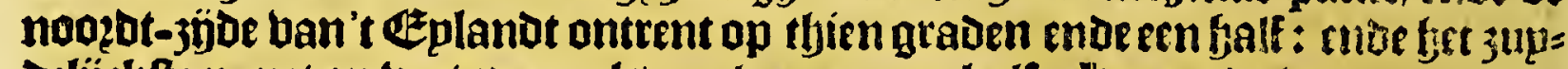
Deligckefte punct op taat meev als neglen en cen balf. liomende ban A nagore berbalt men met een noozot ten welten touts op een punct genaeme punta blanca,

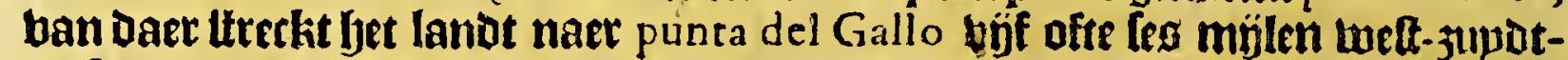
weft; men moet diebt langhs de twal fenen feplen; punta del Gallo is een leegfen

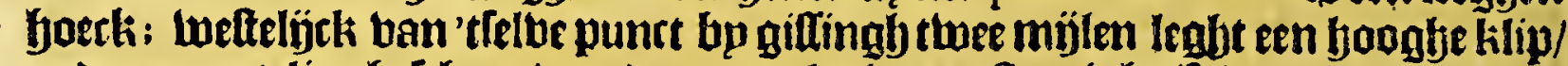

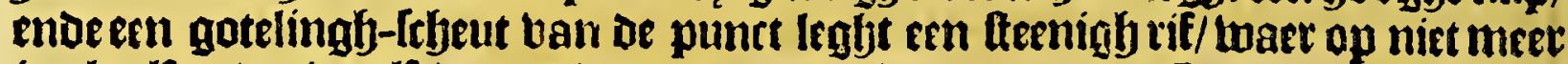
is als elf enoe twaelf boeten twaters; ban dit puntt tot be Bocas lpn betthien

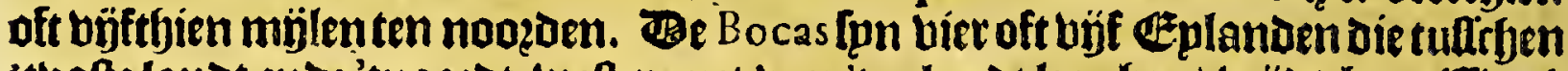

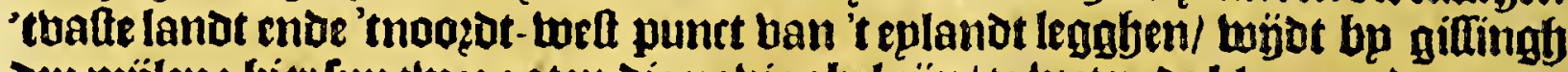
Dequ mïlen: bier [pn twee gaten die nabigabel 3 b̆n/ te lueten oe klepne enoe groote Bocas, dan beeft bet noch twer gaten die niet bebaren wozoen; de flepne Boca is een gotelingh fcheut twïdt/ ende gfjengtonot.

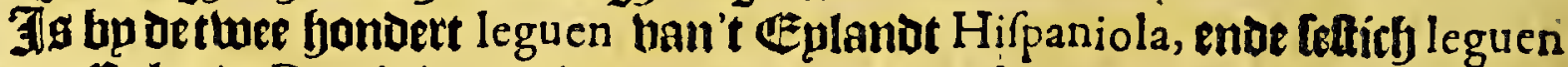
van't Eplanot. Dominica zupden ende noozoen; 40 leguen ban't Eplanot Margarita ende Cubagua. Heft in De lenglte ooft ende mel 50 leguen naer'tegaffen uan Herrera, (de twelcke oork fegltt 35 leguen ofte meer/) enoe bp oe 30 leguen in of beetote/ alg Herrera getuphbt maer Ouiedo [rbyg̈ft dat bet maet 25 leguen langh is/ende i 8 ofte 20 beest; welck beel betrfyilt/Dan komt beter met oe rechte

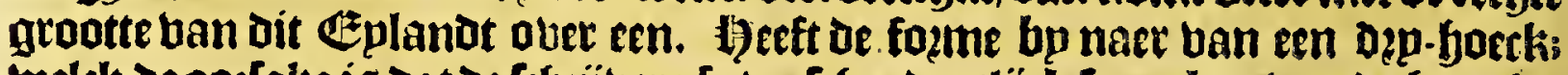

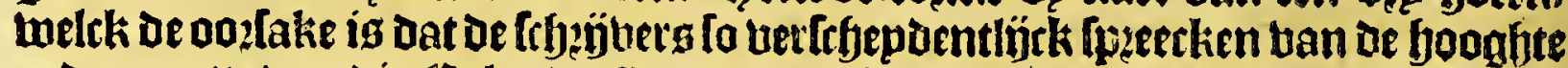

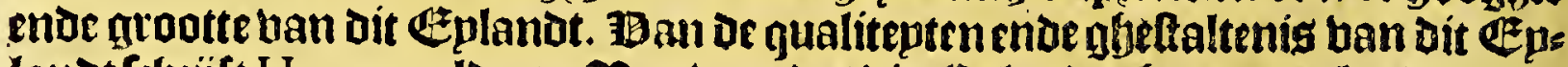

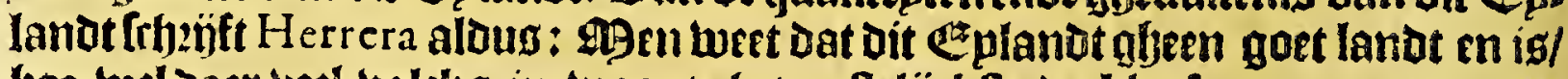

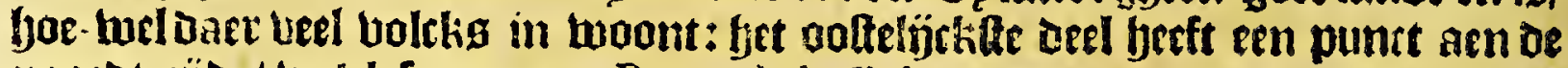
noozot-3ÿor/ weltk lp noemen Punta de la Galera, enoe naer t noozoen datr af ten Eplande methlepne Eplantefirns om-ringelt / weirl men noemt Tabago; 
moe oy de kulte naet 'tzupden een Cabo, loelck fp noemen Punta Redonda, asn be oolt-kant; ende Punca de Anguilla aen de tarfl-fiant in de Golfo ban l'aria,

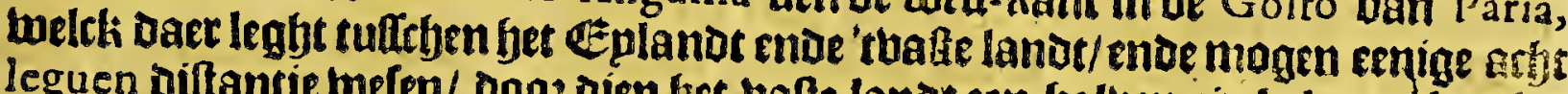
leguen diftantie beten/ dooz dien bet balte lande cen baluen circkel maeckt ofe= Ijckals een kroone; ende dele diffantie is te bertaen als ghp ban bp aoften in

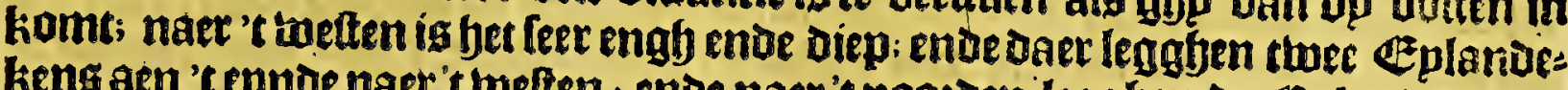
keng aen 't epnde naer' twetten; ende natr' noogeden legghen De Eplanoen ban
San Vincent ende Granada.

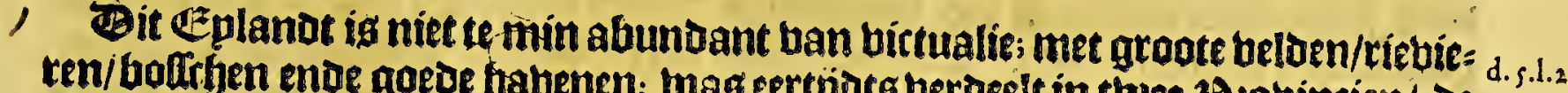

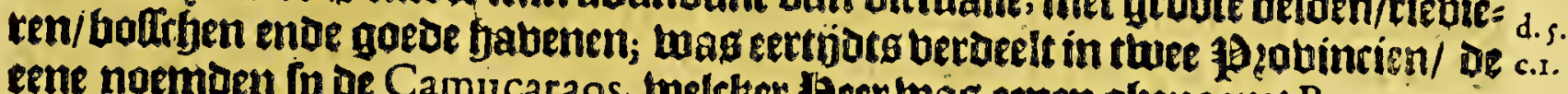
eene noemben [p de Camucaraos, welcker lieer lwas eemen ghenaemt Baucumar; ende de andere los Chacomares, mieng Đuerlte tuas Marûan.

Sir Walther Ralegh Die Daer was in den jare 1595 , frbetift Daer ban'tnaer-bol= gbende.

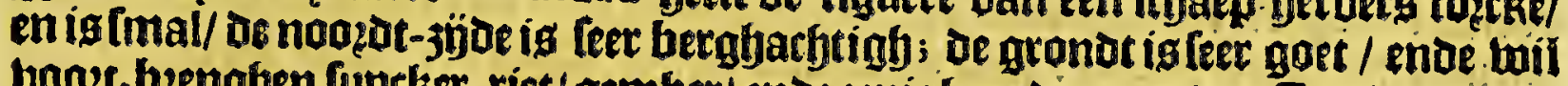
boozt-bangben fuptker-riet/gember/ ende eenigh ander goet dat Tndien boat-

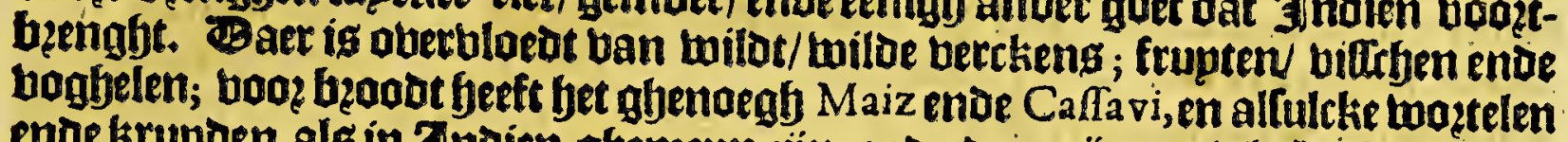
enoe krupden als in Tnoien ghemepn 3 ijn; ende Daer 3 j̈n eenigbe beeten die el Dets in Jndien niet en twazoen gbebanden: de Spaegniaetoen bekenoen dat Ip in commige ban de riebieren badoen gbebonden grainen ban goudt/ maer doos dien [p thooft badoen naet Guiana (welck bet magalin ig ban alle rỷcke metas Ien) Ioo en twag fet baer niet de püne weerd ghebeeft bozoer daer naer te foecken. '(d) Lolck ban be lande noemt bet Eplanot Cairi; ende daer in 3 ün bifterente na= tien; ontrent Parico jün ghenaemt laio; die bu Punta de Carao jọn ban ae Arua-

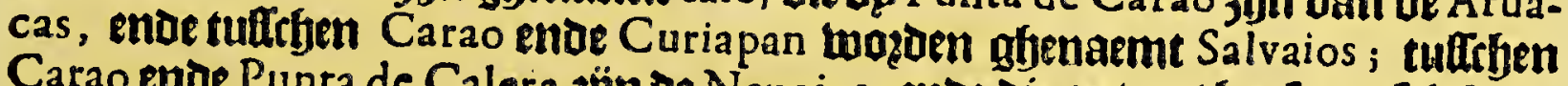
Carao ende Punta de Calera jön de Nepoios; ende die antrent bet lpaentrh ftedes ken noemen baer Carinepagotes. Be Spaegniacroen baer feoeken leght bp een riebierken afjenaemt Carone, moe mozot ghenarmt $S^{2}$ Iofeph; welth Sir Walther Ralegh furpetneerde ende berbzande/ nemende be Gouberneur Antonio de Berreo ghebangben: baer jün in bit fedeken nu bp de beetrich juplen. In Dit

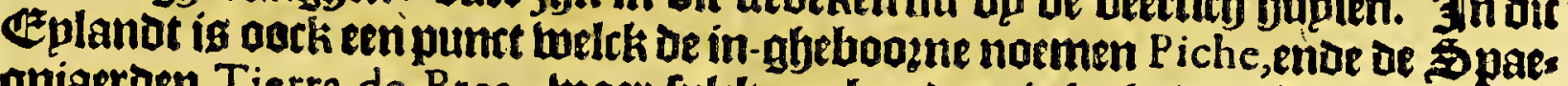
gniaerden Tierra de Brea, twaer fulcken abundantie leght ban ften-peck / Dat men daer ontalighckelchepen mede [oube konnen laden / Dan en is niet leer goet

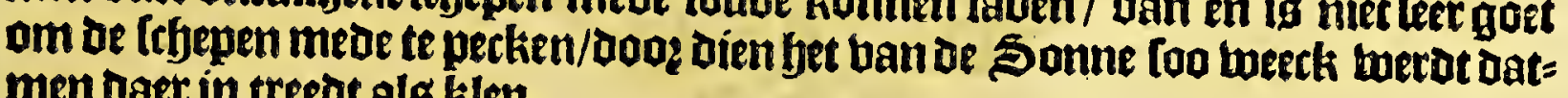
men baet in treet ald klep.

Sir Robert Dudley tuelek toepnigfj vooe Sir Walther Ralegh wag ap offe kulte/ EngelIeght; bphet punt ban Curiapan legbt een bape welck is bol ban Alcatrazzes oftec frhe vo-

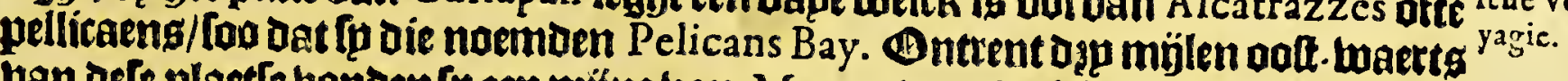

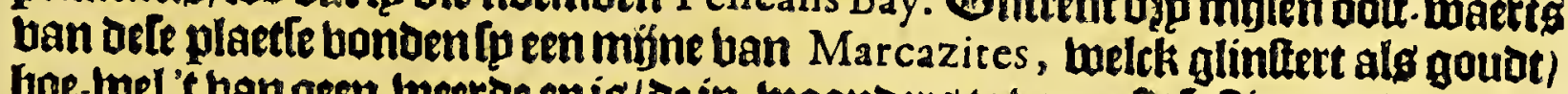

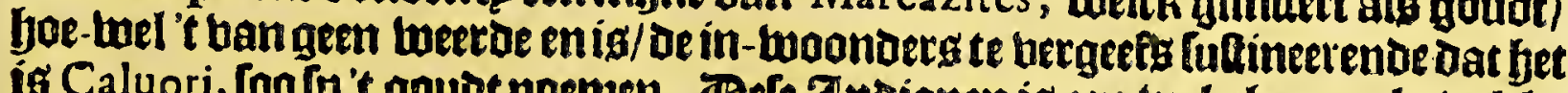
is Caluori, foofy't gouot noenten. Dele Znoianen is een mel ghemaeckt bolck/ loopente al naeckt ende roodt gbebertwet; baer Commandeurs bercieten baet met plupmen. 25tochten aen de (thepen bennen/berckens/plantang/ Potatos, $\mathrm{Pi}_{\text {- }}$ nos, tabac ellde andere waren/ welck [p mangeloen tegljen bijlen/mellen/angelg/ bellekens ende glalen knoopen. Ban Daer komt men ntoer-waerts toteen plaetg ghenaemt Paracoa, daet een bequaeme plaetle is oem loater in te nemen ende de ftbepen te talfaten. Set Eplanot is meelt belet met een Teer dichte bofthagie.

Een ban onfe ßederlanders metnamen Ifaac du Verne, beeft dit Eplantit in Den jare 1606 aldus belefgeben. De Trinidad gheleghen op de boogbte van stjien graden endeeen balf/ is fjoogh ende bergfachtiah/ende nict ban al te goedentem: perature; doog dien bet meel met damp bederlit ja de Spaegniaerts bebten

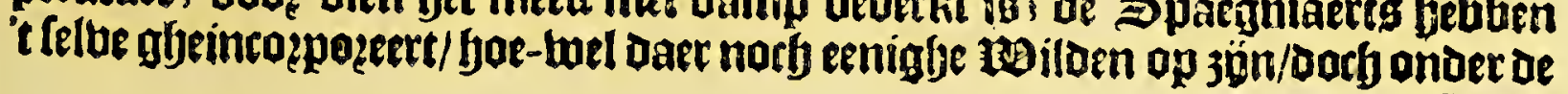

Rabet: 
596

Wilde Cufte, ofte Guaiana.

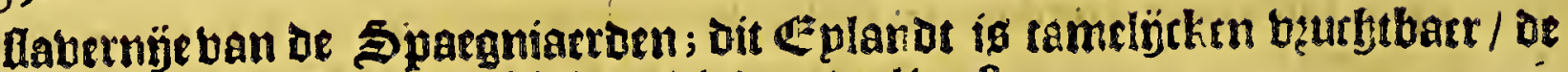
meelfe hantecringhe is in Tobac, Die Darr beel watt.

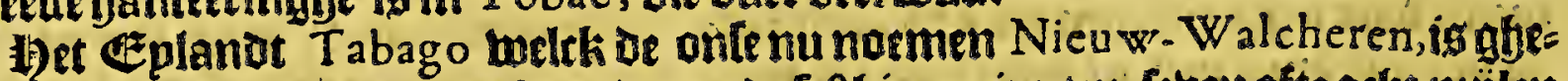
legben op de foogboe van eff gradenende Teabien minuten; [eben ofte actje mplen

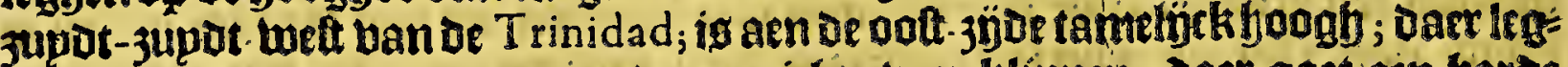
gben twee Eplandelieng aen/ende menirbte ban klippen; Daet gatt een barde

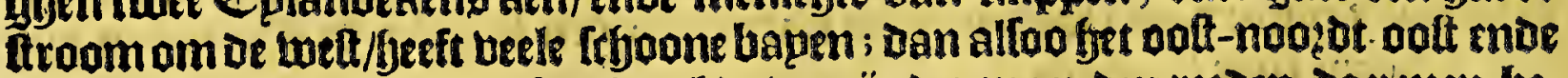

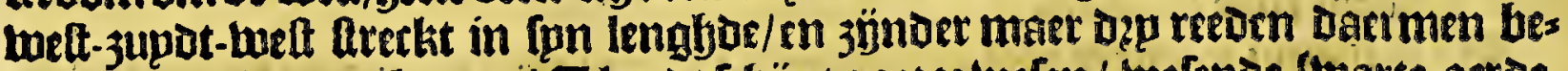

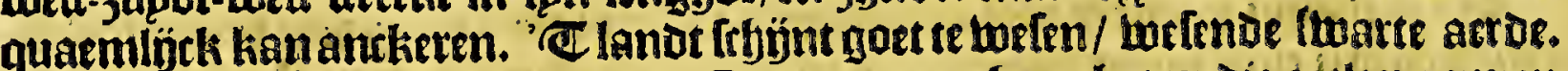

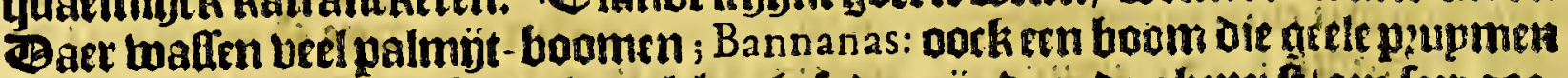

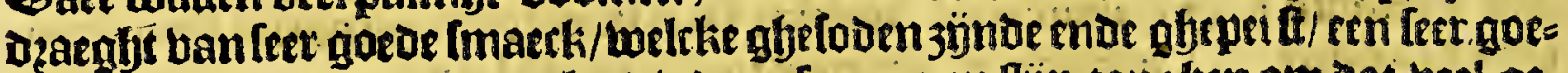
Den dzanck gyeben : een bzuther die de on fe normen täp tonglyen om dat beel ges

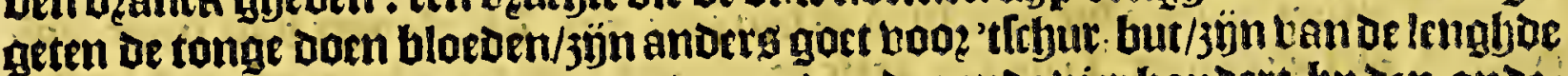
Lan een bíngher/ende groepen op der aeroen dęe ende bier fondert bp orn andé ren in foeme van een roole : ende epndelïtl: Papas. A9en beff dart terl berckeng Elepnen poel ban boltels/met de nabel op den rughbe; be bilde nocmentie P.ackieres, ballen leet vet. Beele koninnen: Y guanen ende armadillen dirfe normen

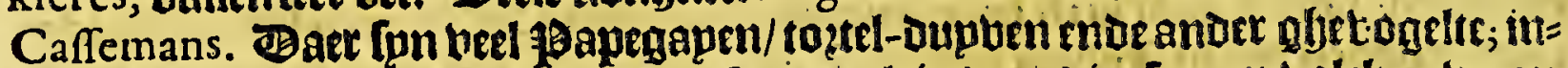
Conberfyept jee-ghetogelte welck bier feer mack is;Doo: Dienle geen bolck getwoon jün. De zee om-ber ig leet bilth-rỷek ; ende deftbilbt-padoen kommen biet ban A pril tot September met menighten aenlanot/ende jịn licht te vangfen.

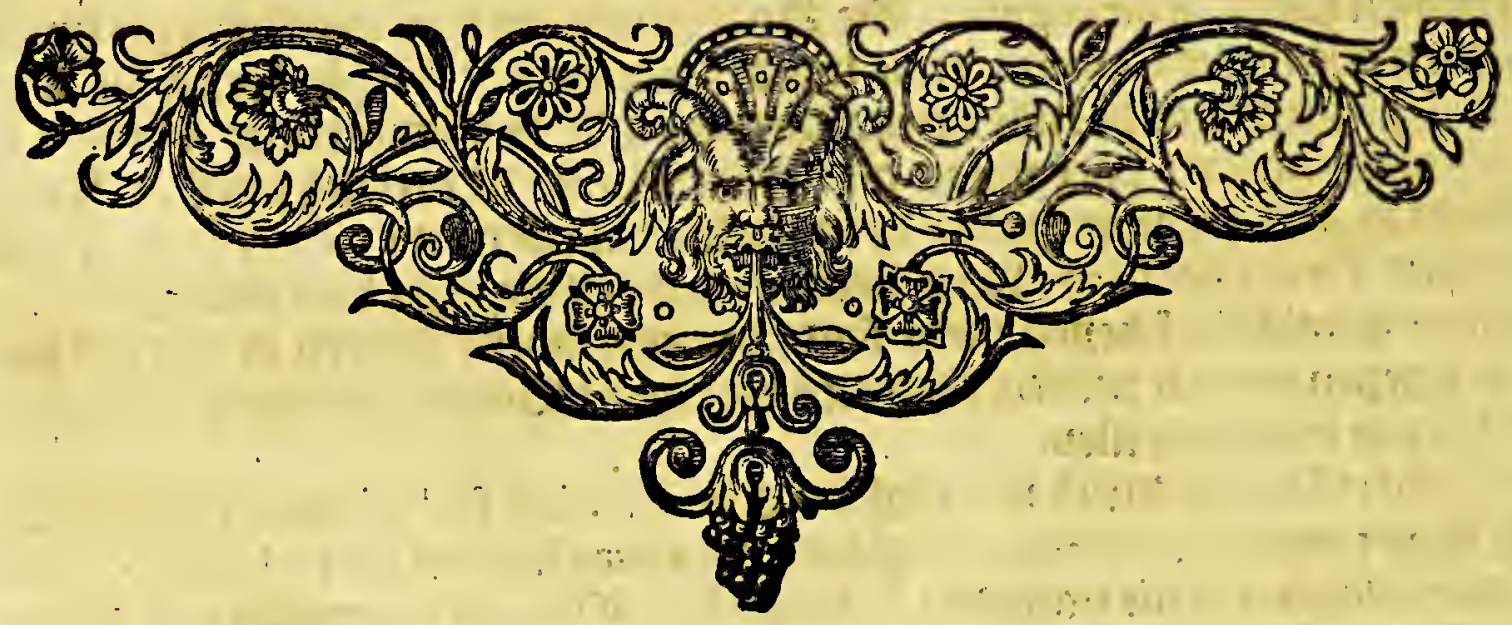

BESCHR II- 



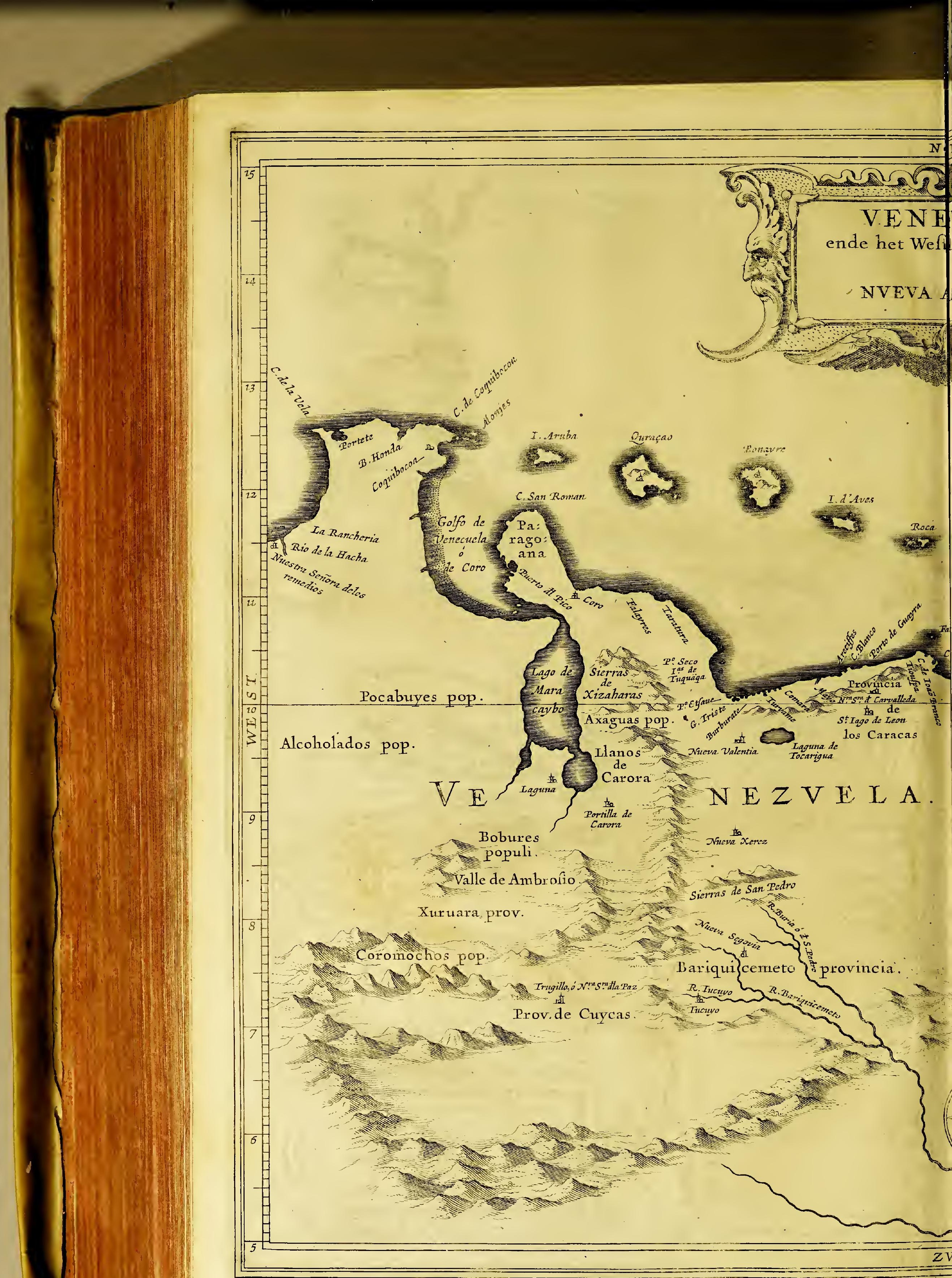




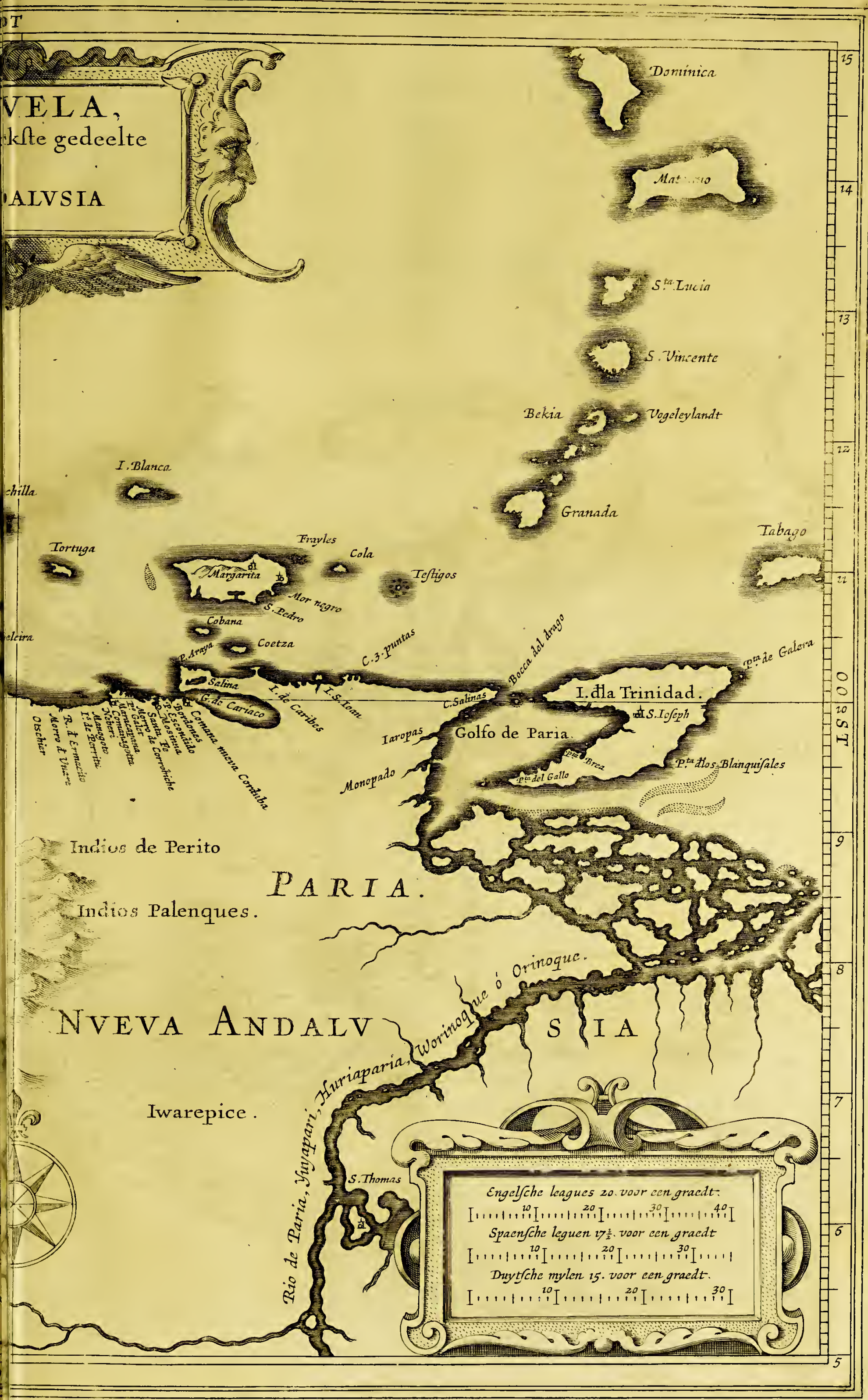




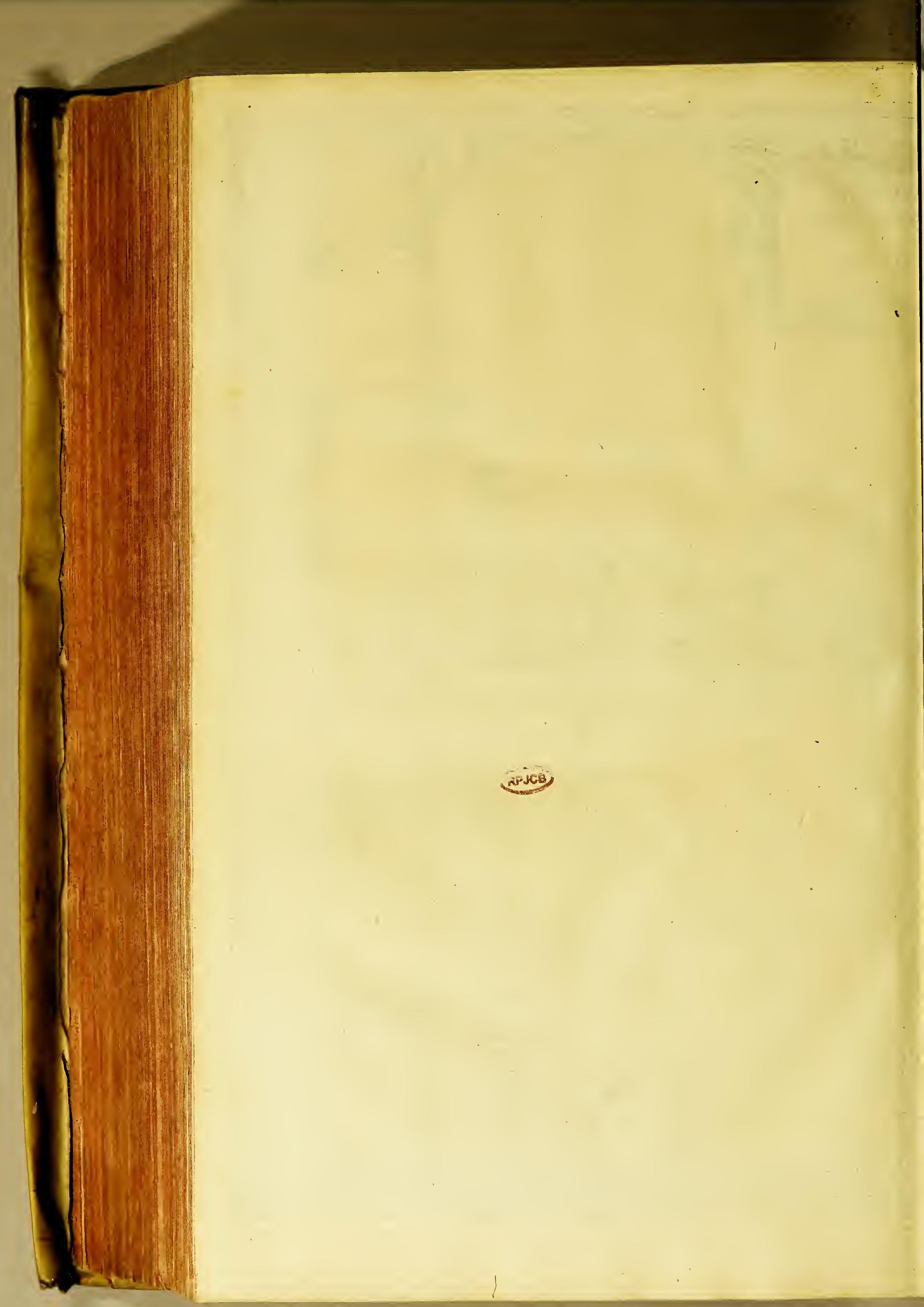


BES CHR IIVING HE

\section{dan \\ W E S T - I N D I E N.} net retutende 25oeck.

\section{NOVA ANDALUZIA.}

\section{Inlepoingbe.}

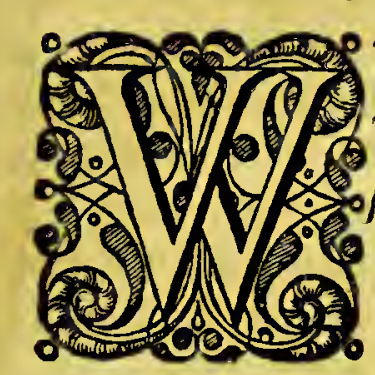

$Y$ zijn nuin onfe befchrÿpingbe ghekomen tot bet refteerende deel van't zuyder ghedeelte pan America, wan bet prelcke't ooAelijckfte ghedeelte paelt aen de rieviere Orenoque, ende de Golfo die daer woordt ghemaeckt tuffchen bet Eylandt Trinidad, ende de verfcheyden Eylanden ende ghebroken landers die daer leggen voor de mondt van den Oreno que;ende fteeckt met een punt uyt teghen over den noordt-pveftelijcksten boeck van Trinidad voor-noemt; vvelck beyde daer een engbe maecken, vvelck $f y$ noemen al Boca del Drago; dit ghedeelte beeft in voor-tijden ghevoert den naem van Nova Andaluzia, ghelück voy in 't voor gaende boeck bebben aen-gberoert, vvelck eenen ghemeynen naem is gbevveest; dan begrïpt onder fich veel par. ticuliere propincien, voaer pan Cumana voel de voornaemfte is, ende daer legghen eenighe vermaerde Eylandes voor, als de Margarita, Cubagua, ende andere: dit quartier is eertijdts feer vermaerdt ghevveest door de rïcke peerlepiffcherïje die daer legghen van Punta de Ayara. Het poeftelÿckste ghedeelte is begrepen onder't Gownernement aen Veneçuela: foo dat voy dit refteerende quartier in tvvee deelen fullen verdeelen, ende bet eirste befchrijpen onder den naem van Neuva Andaluzia, ende bet andere onder den naem van Veneçuela. Hoe-vvel dit ghedeelte poor foo veele jaren ont deckt ende befocht is pan verfcheyden natien, foo vinden voy nochtans' $t$ felve voel op bet flordighfe by de Spaegniaerden befchreven, ende andere bebben daer oock voeynigh pan aen den dagh ghegheven: fullen ons beste doen om foo veel by te brenghen als ons mogbeliyck is, tot verklaringhe van de gheleghentheyt vas dit ghervepte. 
'T EYLANDT MARGARITA.

Het ente Capittel.

Befchrijvinghe van 't vermaerde Eylandr Marg'arita.

d. 5.1.3.

e.11.

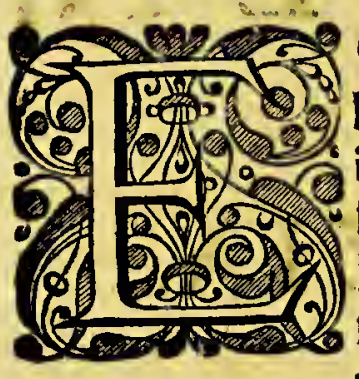

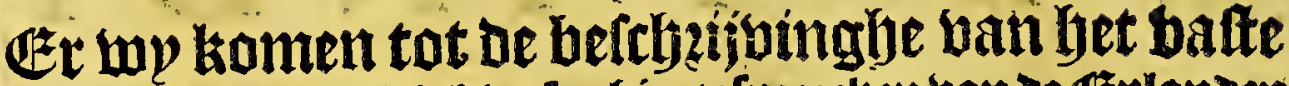

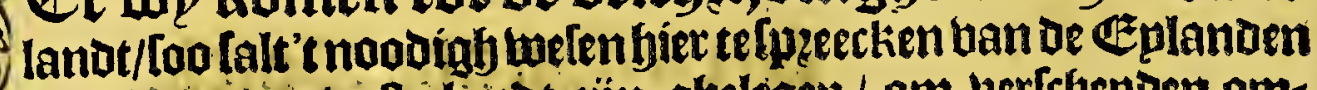
die hier bod? t valte lanot 3 jun ghelegen / om verfchepden om=' Atanoitheden beter te konnen bertaen/ die bem aen bet balte lanot veel tot dele Eplanien rapopteeren; Welcker booznaemite is la Margarita. Dit (E)plandt wierot eerft ontoeckt bp oen eertten Ammirand Don Chrifophor Colon in Den jaere 1498. Homende upt Golfo Dulce, foo bje die noemoe/booz la Boca del Drago, bonde

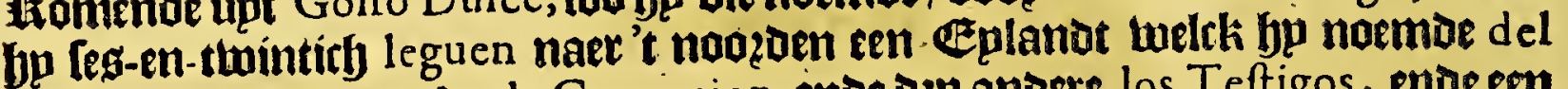
A funcion, ende eenander la Concecion, ende dep anoere los Teftigos, ende em ander daer aen ahelegljen el Romero, entoe andere klepunder las Guardas, ende

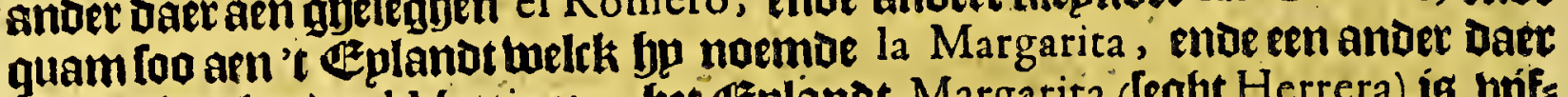

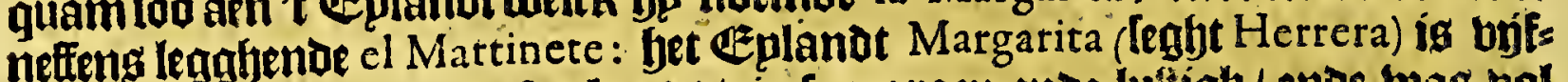

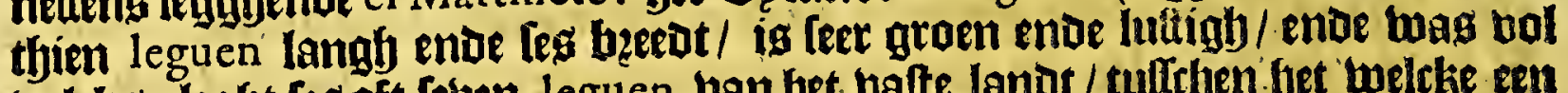
bolcks; leght les oft feben leguen van bet bafte lanot / tulliben fyet welcke een klenne Golfo is abeleghen / ende in het midoen thee Éplandekents naer 't ooltjupot-oolten/ bepoe lu den anderen legahende: bet eerfte is ghenaemt Cubagua, Daer lón beel peetlen jün ghebilfht / ende bet ander Coche; Dele namen jön

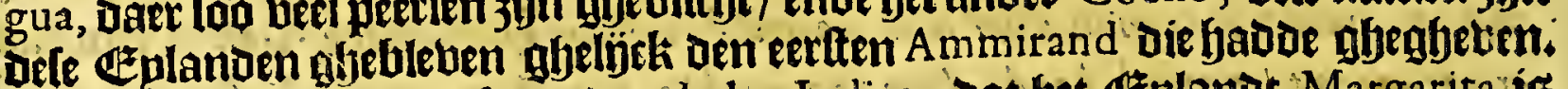
Herrera fétbt inlpn Defcripcion de las: Indiás, bat bet Eplanot Margarita ís abelegben twintich leguen,' vande. Trinidad, naer't taeften/ (naer bat bp de onfe

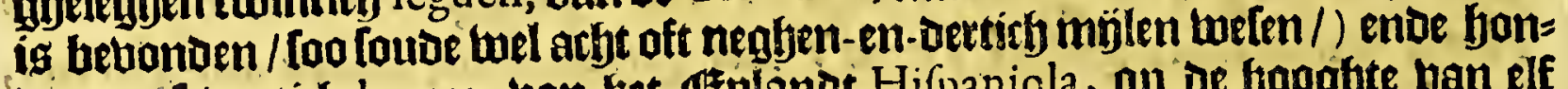
Enel- Dert en Tebentich leguen ban het Eplanot Hifpaniola, op oe boogfte ban elf fche vo- graden bp noozaen de línie. Heeft in of lenghte aoft entoe welt leltjien leguen yagie. ende een half/ende oock too beel in de bzeede; foo oat het in "t om-gaen beeft bp de vijf-en-Dettich leguen naex Dat Ouiedo gljetupght. Baer is groat gbes

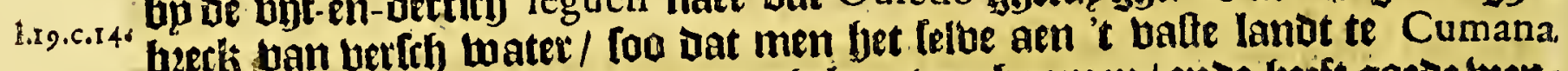

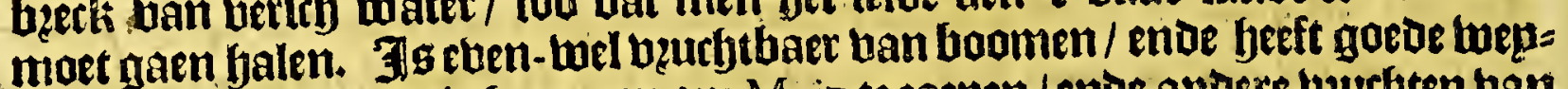

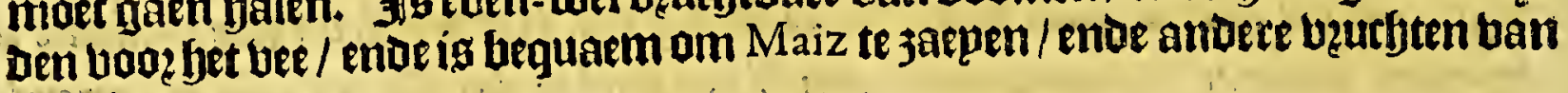
Tndien.

-Baex jÿnnaer't legghen van Herrera thee woon-plaetten ban Spaeginiael'

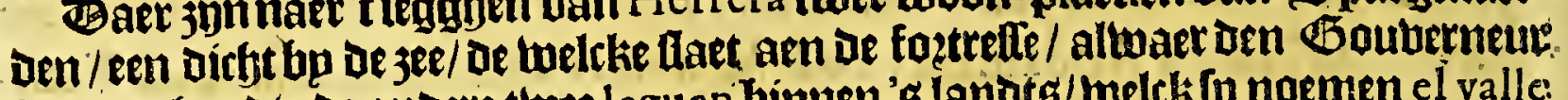
lem onthoubt; de andere thee leguen himmen's landts/melck [n noemen el valle:

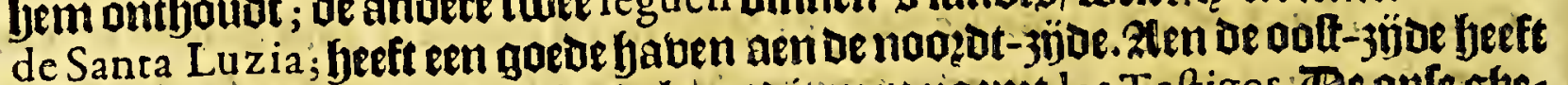
Get eenighe klippen ende Eeplandekeng die men noent los Teftigos: De onte ghe

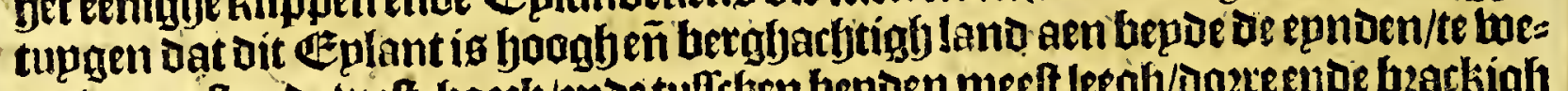

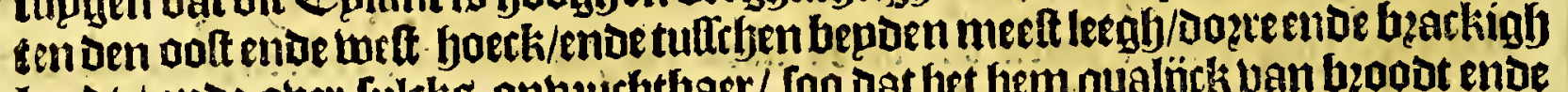

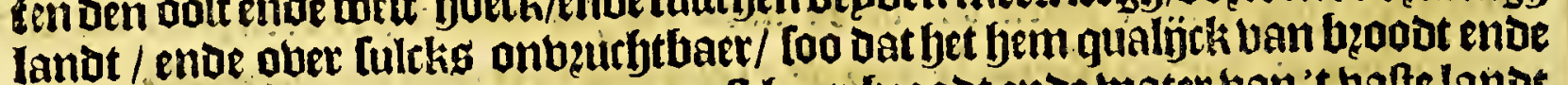
Dzanck lian boeden / Dan moeten meet baer bzoodtende bater ban't batte landt balen: ronotom't Eplandt is meninfte ban goede bilty te basughen / welch bet

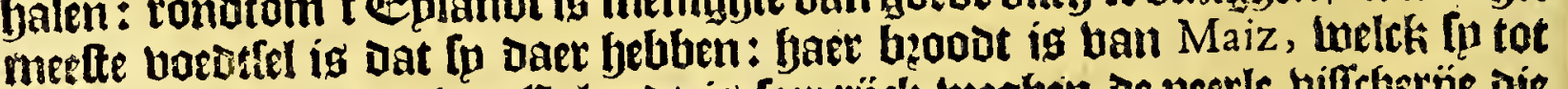

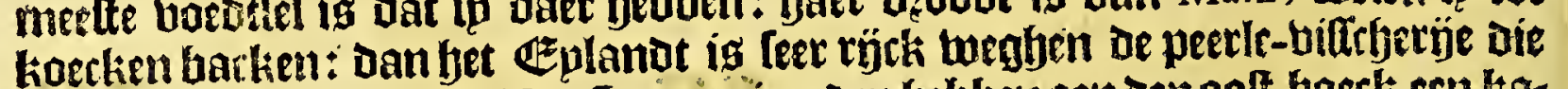

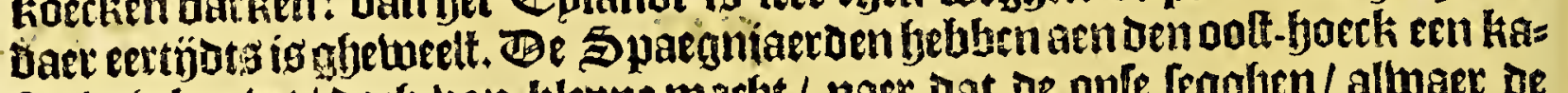
lect gleboulut/ Doch ban klepne macht / naer dat ae onfe fegglien/allwaer ise Syacnlfhe frhepen haer reede nemen; dit kafteltien biert in ten jaere 1626 ,

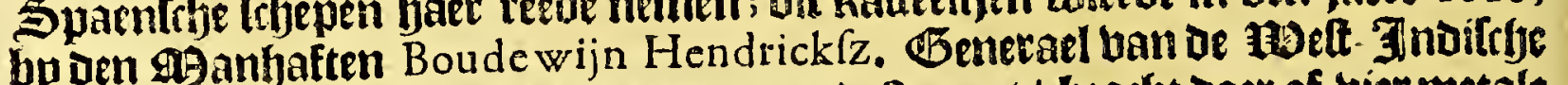

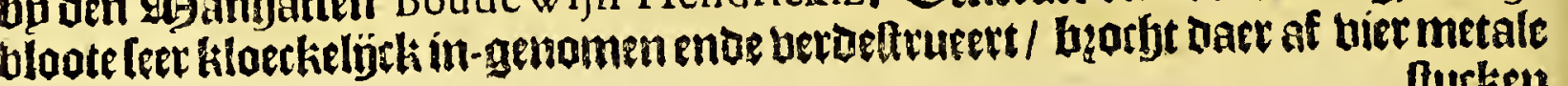
Aurken 
Het felthiende Boeck.

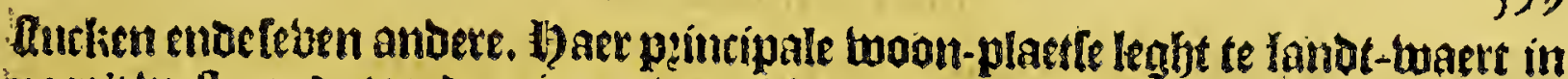

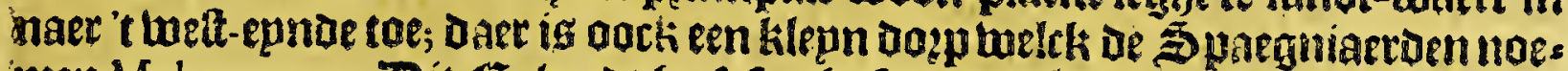
men Makanau w. Bit (Ẽ

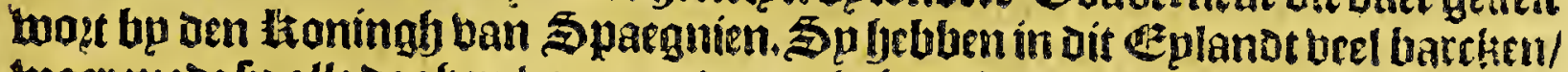
waer mede lp alle daggen varen op oe peetle-banclien om te tillíhen/ boser toe fo gyebzupctien Stwarten / Die daer ghebzacht wozoen ban Cabo Verde, Guinea ende Angola, welcke fp lieden koopen/ende too?den alloo van de Sparaniaecoen bet dupclien gleleert/ende dat met groot ghetwelt van fminten/ente antere to:ment= ten van eenighe beete fubltantie bzandende op 't igft te laten duupen / oorli mct

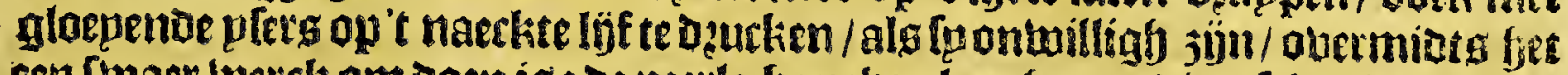

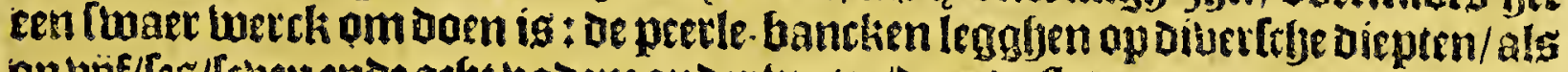

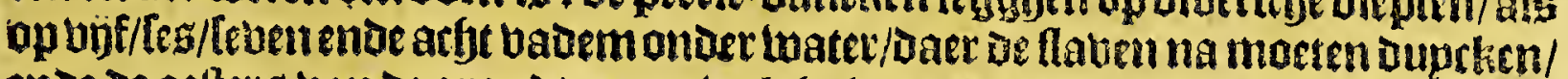
enoe de aellers ban de grondt met getwelt balen:ende tweder boten fomende/poos

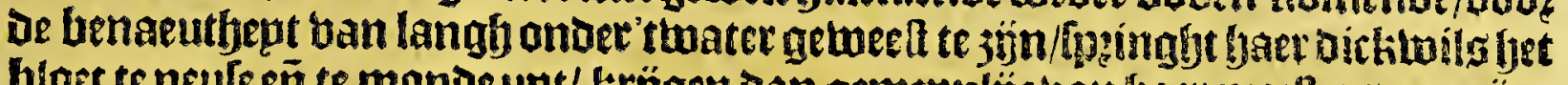

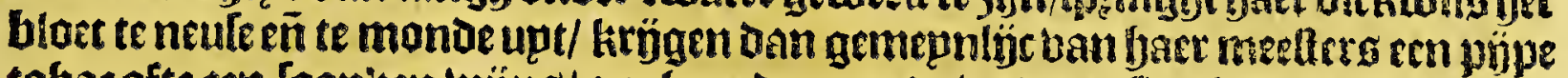

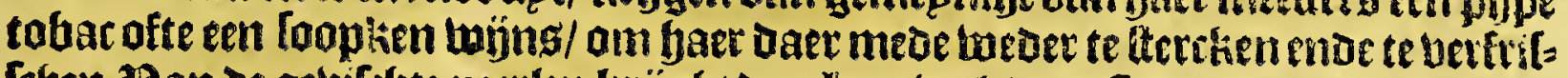
Ichen. Ban ae gevifrfte peetlen krjght oen lioningly ban \$pargnien fum $Q$ uinto upe de grootlfe ende befte peerlen. Soo dat De Margarita niet bufonders enis lone

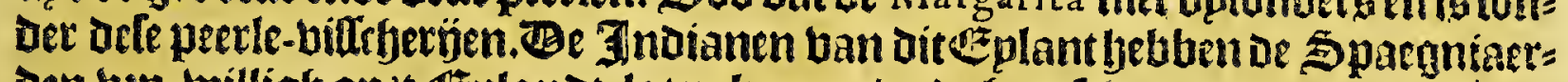

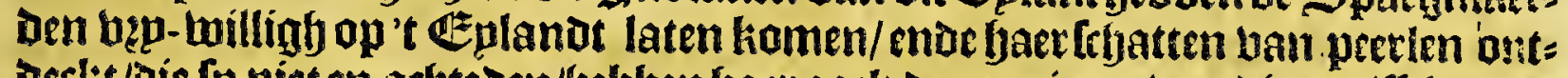

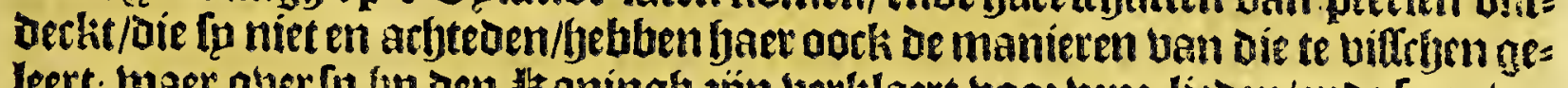

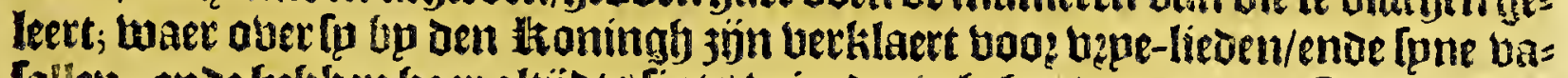

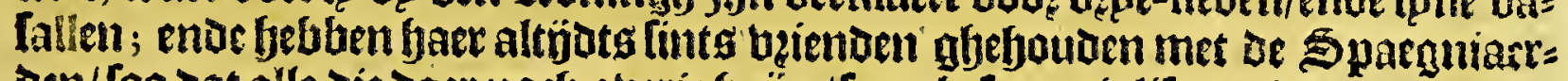

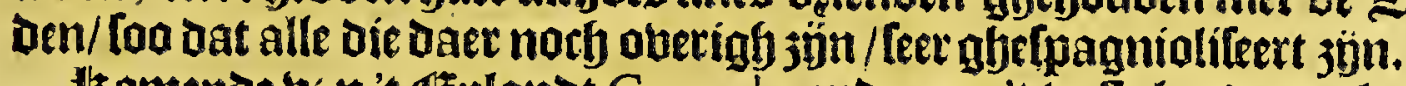

Homentoe bin' 't $\mathbb{E}$ Eplanot Granada, ende naer't balte landt tae-loopenoe met een tuelt ten 3upden gangh / loo loopt men bp 3upden oe Eplandekens afte klip=

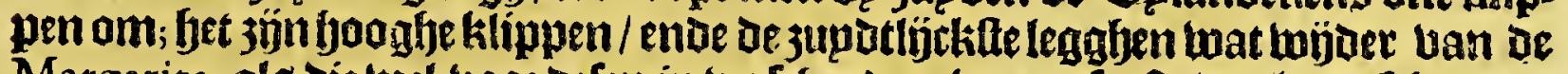

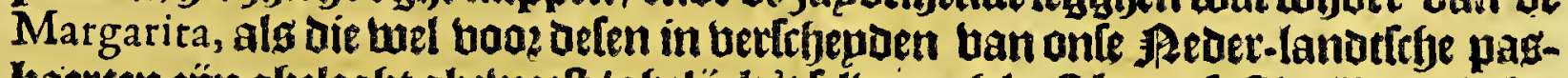

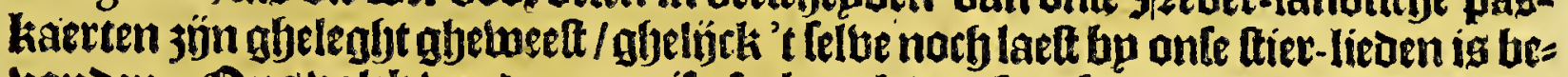
bonoen. Bns bolck bonden een rif afre banck banfes / feben/ ache/ neghen/thien ende thaelf vadem waters / ontrent dæp mijlen bp colten ofte jupat- ouften oe

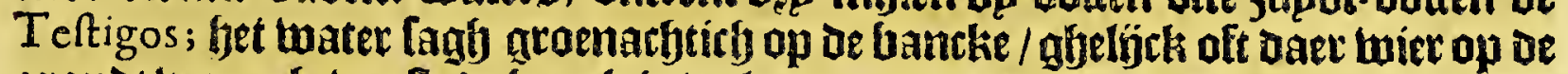
gronut waer ghetweet: de banck is bel ten groote mijl langh/ ende magb ontrent Loo lwijJt ban't bafte land legghen als de Margarita ; Daer naer en badoen fp twe=

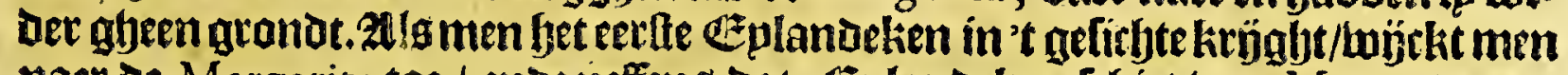
naer de Margarita toe / ende neffeng Dat Eplandeken fr fiet var Margarita efn

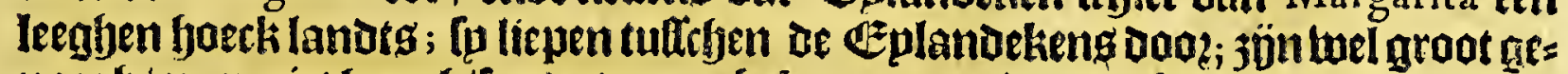
noegb/maer niet boogh/[oo dateen onbelfent man niet raedtlaem is daer bp narbt naer toe te loopen. Dirck R uyters legljt dat de Teftigos leggen 2 mölen ;.lu. uan Granada, enve dat fet 7 Eplanoeliens jön / maec van de 2 miodelte be grootte jön/ Doch datle alle 7 leggen in't begrijp ban 4 mílen/ op de fooghte ban I I grad.

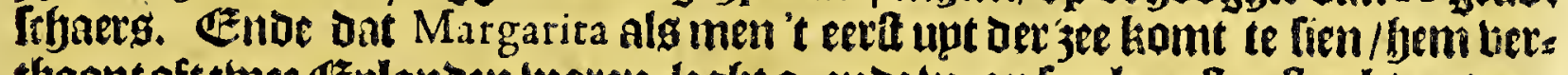

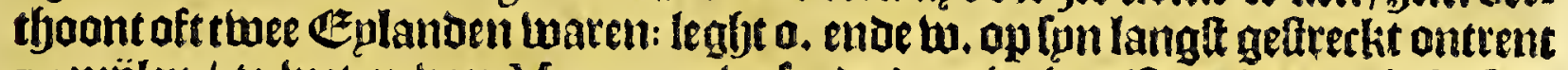
$15 \mathrm{myjlen}$ / te tweten ban Monpater luefende de peimeipael(te reede daer't katfel

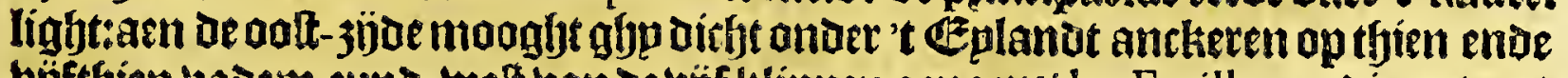

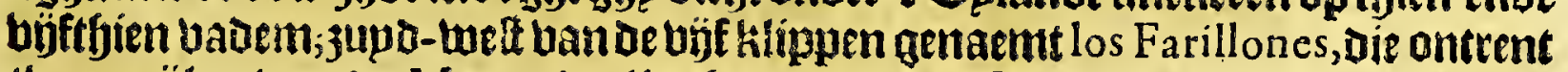

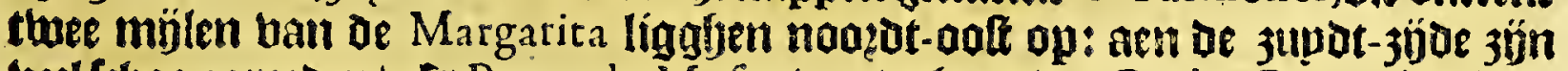
beel (thoone reeuew/ata Punta de Mofquitos teglen ouet Coche; Punta de Man-

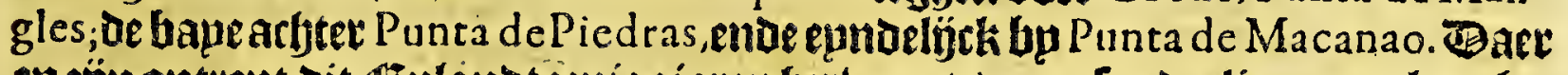

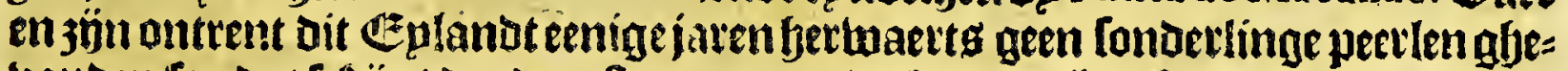

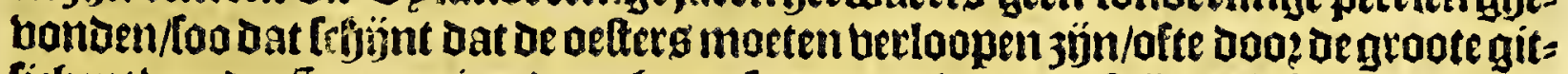

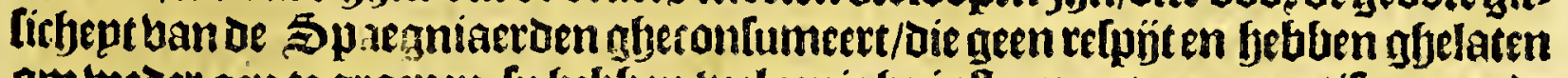

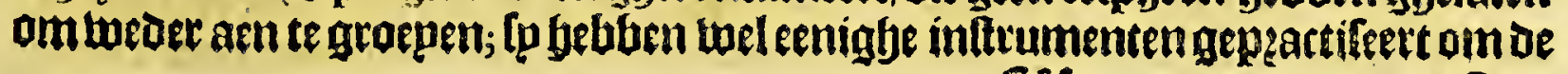
ff 2 2 ofters 
aefers in meetaer biepte op balen/Dochenyeeft tot noety toe niet willen gelucken/ cnoe is tuel te gelooben dat daer in't diepe gheen oqfetes en jün te binoen: waet

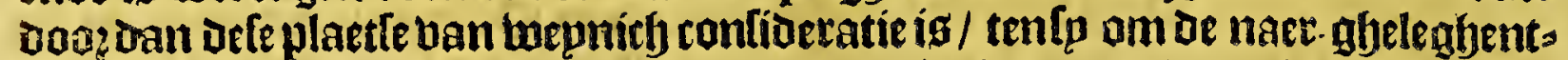
bequ bu ue bermaerde jout-panmen ban Punta de A raya, daer lop biet naerfullen van Ip:seeclien.

\section{Het tweede Capittel.}

Vande Eylanden Cuв a gua ende Coche.

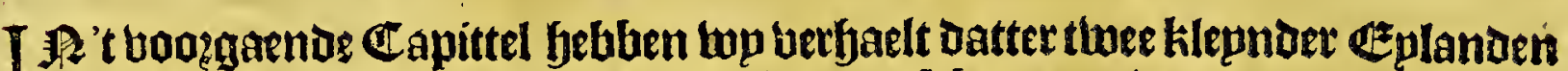

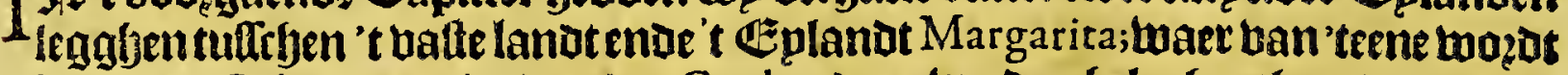
gefenaemt Cubagua, ente 't anoer Coche, Daer tup de glelegfentyepr toat naet:

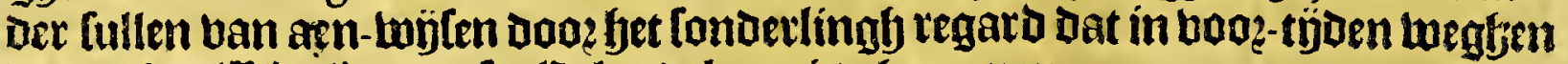
oe pertle-biflecherye op Defe Eplandekens is ghenomen.

Het Eplanot Cubagua ís naer 't fegghen van Ouiedo 160 leguen ban bet Eplandt Hifpaniola ofte daev antrent/ende büftictleguen naer twelten ban Punta de Salinas bu de Boca del Drago aen't balte lande gelegen; fyefte Dep mülenin't ronde/ende leght Jp naer op de booghte ban thien graden naer't teggen wan Herrera, maer naer't frgghen ban Oui ed o ende Benzo, op oe boogbte van tfien graden

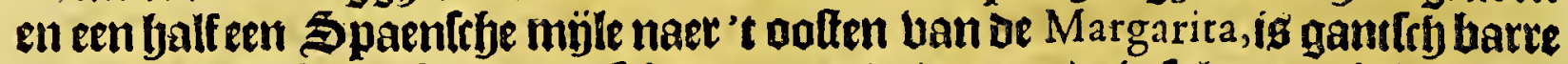

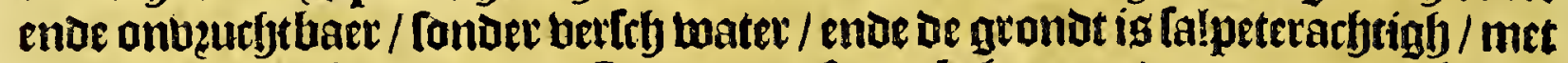
enige bepnige boomen van Guaiacan, ofte peck-fout; entoe een dooenen boleb/ Conder gras ofte krupt/ende fonder gebogelte / upt-nemamen 3ee-bogels / gantlff

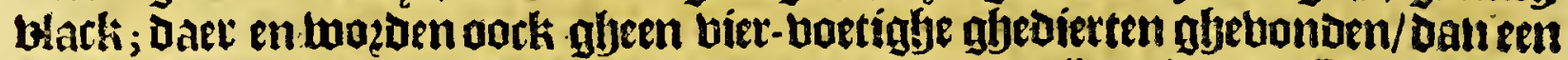
toepuigh konjnen; de Milden die Daer moonden ten tijuen Dat de Spaegniaer: ben daer eeclt quamen/ badoen' $t$ lichaem Ieer glyefrbilbert/ ende onoer-bielen baet met De peetle-oefters/baeloen faer berfey twater aen 't balfe lanot ban Cumana, welck feumleguen daer ban bericbepden ig/ende mangelden't twater bet welck Gaer bandaer gbebzacbt wierot tegben peetlen/ baeloen faer fout ban oe Margarita, welckeen mül uan daex legft/ ende dit Eplandeken om-ringft ban't ooften

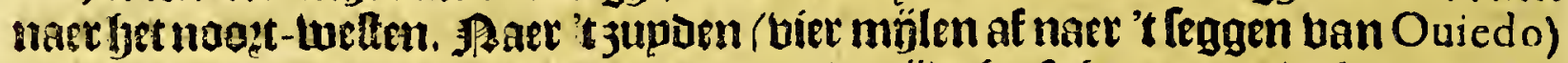

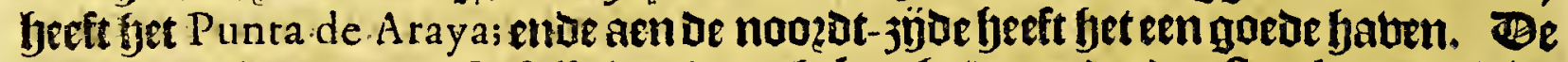
berckens oie oaer uan Caftilla wozoen ghebzacht/beranderden frackg/booz bín

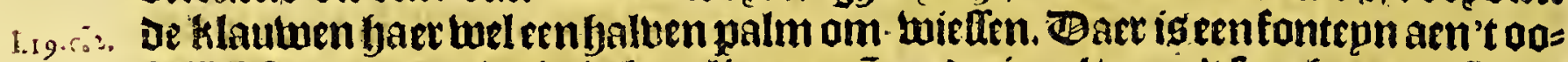

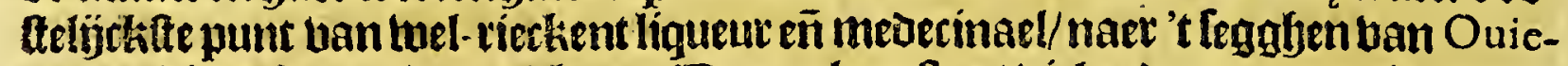
do, twelch op bet 3 ee - water Hottet. De peerle- oeflers bielen baer ontrent in groote quantitept/ in tuelcke de peevlen wozoen ghetonden; Gebben in't eerfe maer een

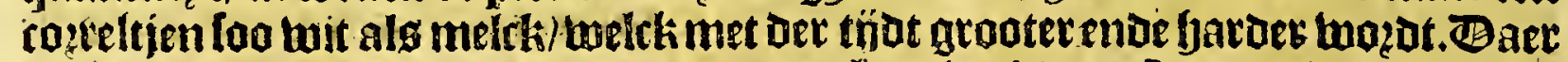

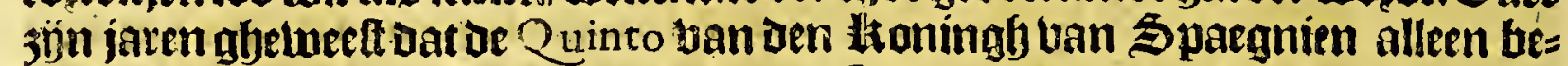

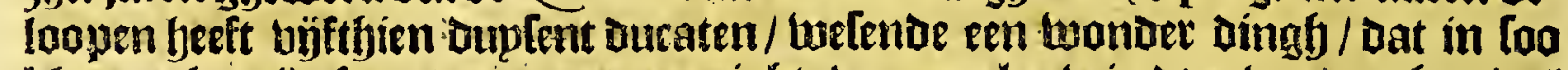

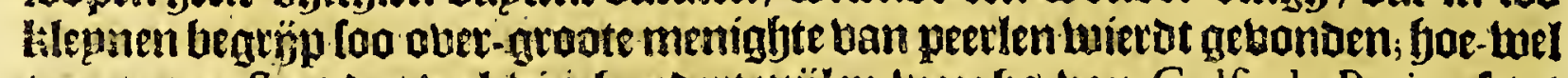
te noteren faet aat wel biet Gondert mỉlen tweeghy ban Golfo de Paria af tot

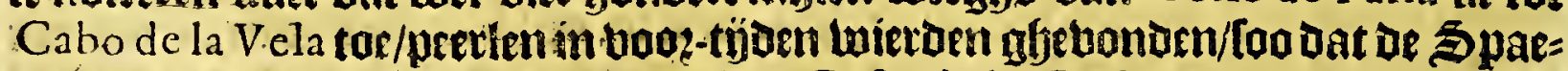
gríarden orle nantfofe ftreeck noemoen Cofta de las Perlas.

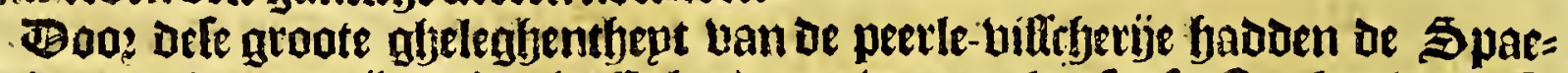

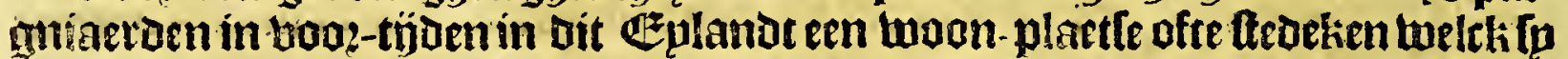
noemoen Nova Cadiz. Th Denjare 152 I Doen de wilben ban't bafte landt bet

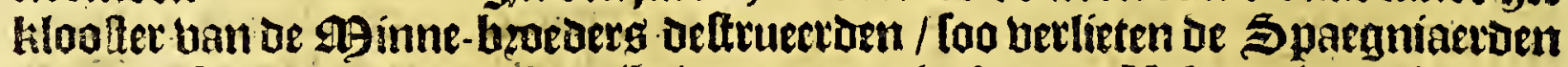

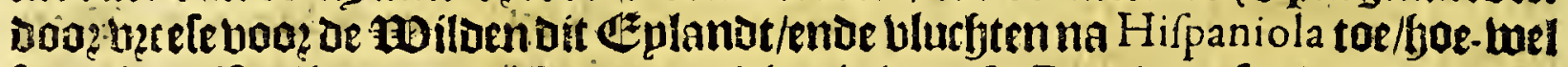
fu wil 300 fretck twaren. Tan be audientie ban $S^{t}$ Domingo Conot meder bijf figepen oetwaerts onder 't belende ban lacome de Caftellon, twelcke de tabe Nova Cadiz luederom op bouden/ ende maeckten daet nírutue fteenen buplen;

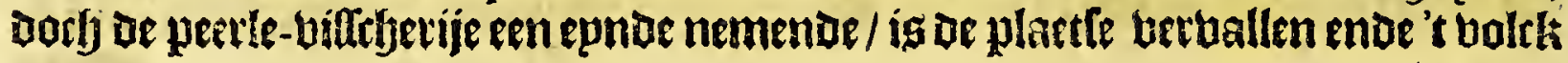
bertrots 
Gertracken; foo dat btt nu gantley berkten is/ Conder dat baev entigf tegard

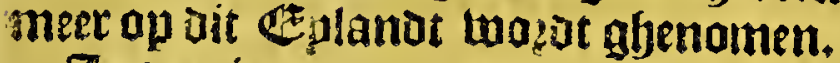

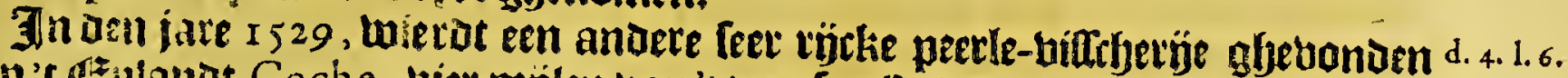

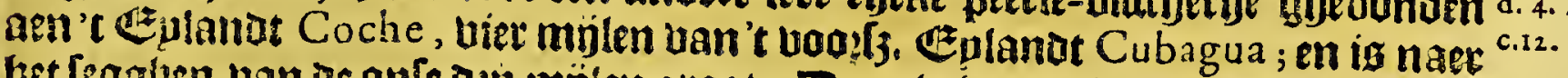
bet fegglyen van oe anfe dep mien graot. Baer bierden in twepnigh neer als

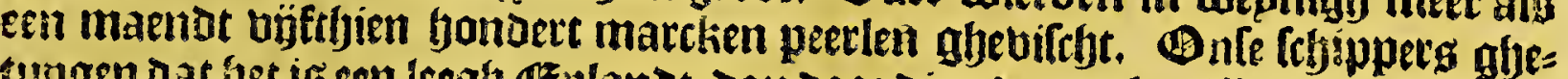

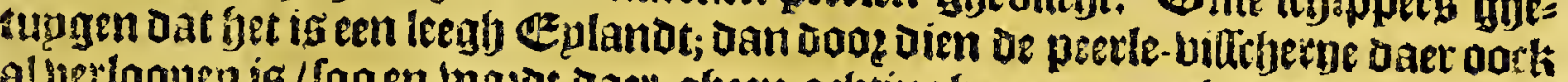
aluetloojen is / foo en thazot daet gheen actinghe meet op ghenomen/ Jan Dat bet in oe tatgh leggt ban de glgene die naer't punt logpen oin jout te balen.

$$
\text { P UI N T A D E A R A Y A. }
$$

\section{Wet Deroe Capitte!.} Van Punta de Araya daer de vermaerde zout-pannen zijn, ende
degheleghentheyt van't $t$ lande daer ontrent.

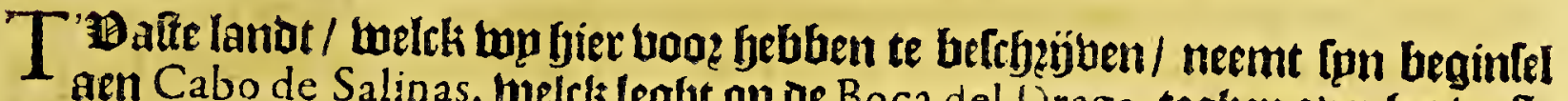
aen Cabo de Salinas, welcli legbt op de Boca del Drago, tegben ouer bet weltepnde van't Eplanot Trinidad, ende threckt tot aen de. Punta de Araya, oaer De

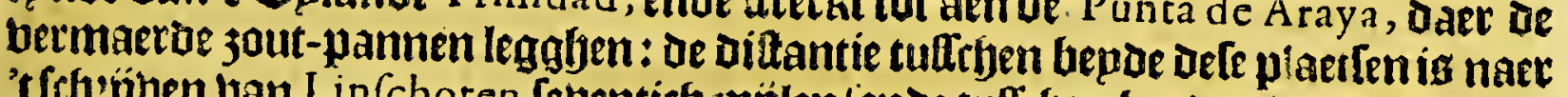

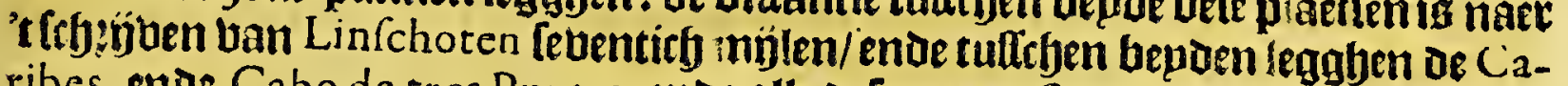
ribes, ende Cabo de tres Puntas; ende alle dele groote ftreeck landetg en ig niet leer bethent ofte belurft/nocf en binden daet niet bplonders ban aen-gljetepcient by De Spaenlefye Schajuets/die tup tot noch toe betben konnen lien. Be Cabo de tres Puntas Lozot gljefjouden te legghen balf wegb tulictben $t$ Ezplanbt la Trinidad enve lyet $\mathbb{C E}_{\text {planot Margarita. }}$

Punta de Araya, twelck onle Sebippers ghemepnlÿcken abulibelÿck noemen Punta del Rey, is een ghedeelte uan' $t$ valte lande/'eggende bp-naer rectbt noozden

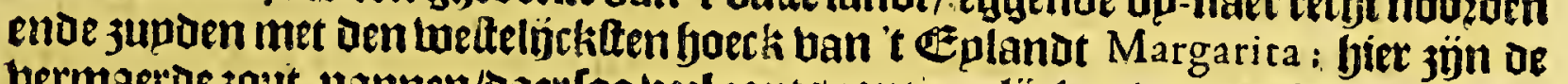
bermaetde joutt-pannen/baerfoo beel jouts continuelïeken mozot ghebaet; want acfter 't felve punt is een lack niet berre ban den oever vani de jee / gantfry jout ende altídts bol joutg onder' t water/ende oock bouen 't twatev/ wanneer bet niet en is in den reglen-tijot afte winter van dat gbewelte. Eenigbe hebben gbemeqnt tat de twinden fet jee-mater daer in o zjuen om dat bet foo naer aen jee ghelegen. is / woéb bet tomt dooz dien daer twellen jön / ende gaten daer bet jee-twater dooz

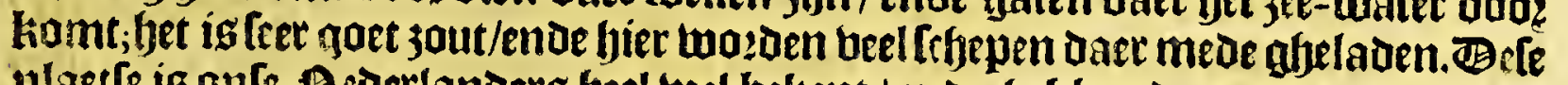
plaetle is onle pederlanderg beel twel bekent / ende betben daet grooten bandel met bet jour te balen gftedzeten : een uan onle $\mathbb{R}$ :aetlanders / met namen Ifaac du Verne, Geeft defelue aldus belcheeben: Punta de A raya iseen boeck aen t valte tanjt/legghende ontrent jupden ban den med- boeck ban M.rgarita ; ontrent byf mijlen uan oen fjoeck af ftrectit een rif in jee / ende bp weden den foect is een inbotgt altwaer oe jout-panne is / ende oren bocbt is oe reeve daer de tobepen legs ghen om gaet ladinglye in te nemen: Ce lanot-maet in ban ae zee- ftranot on:

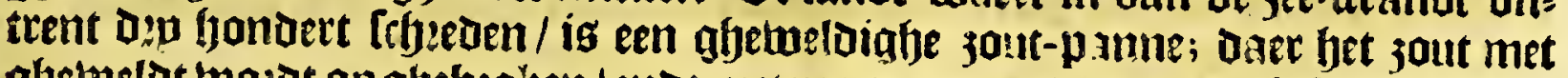
ghebueldt wozot opghebza'ien / enise met pzamen naer aen oeber offebzacht/ ende

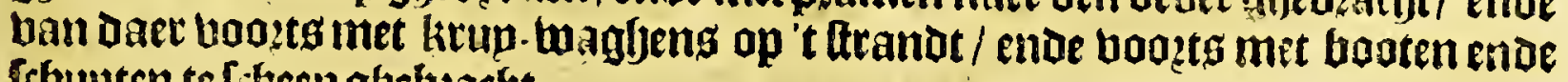
(chuuten te [ityeep ghebzatht.

Buttent defe jout-panne is fyet altemael bergigh / enoe feer do: ende b!ackigh lant/[oo dat daergeen berberlehinge ofte berleb twater en igte beliomen/maer men

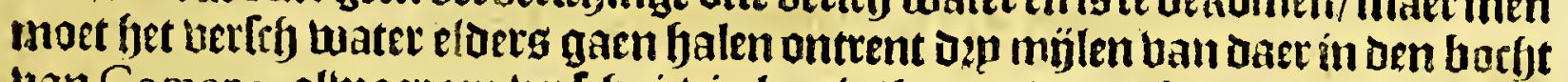
uan Comena, alwaer een bert'b riebierken is/ komende ban't agberghte tolck [p Earmen Bordones, ende de verberlefinge ban frupten enoe anders moet men fití: ghen uan topen oft ftedetien Comena. Op dit lanat ontrent de zout panne ís ffft 3 beel 
602

Nova Andaluzia.

beel wildts/als harten en binden/baten ende konünen met neet ander beemdt

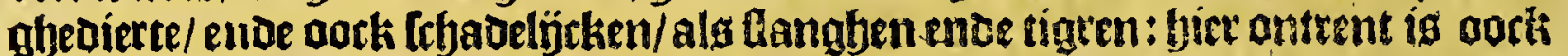

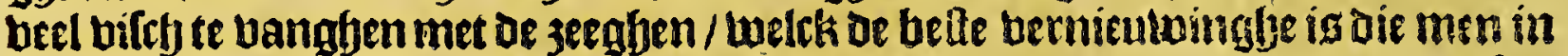
Dit quartier binot. 1 et lanot ig ontrent bet trande meelt ouer-grospt met leer

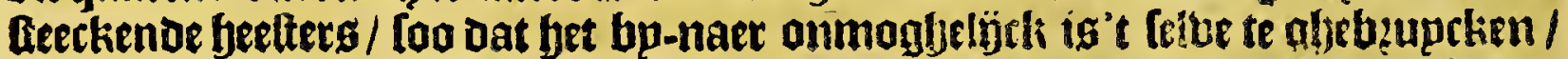

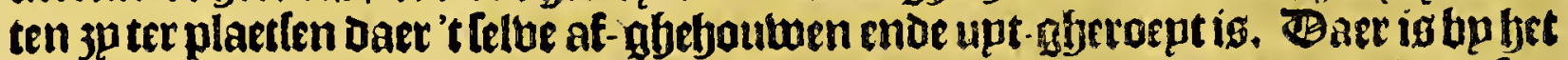
rif aen't felbe punt noctsen klepnoer panne / dan men en vinot daet aftijots foo.

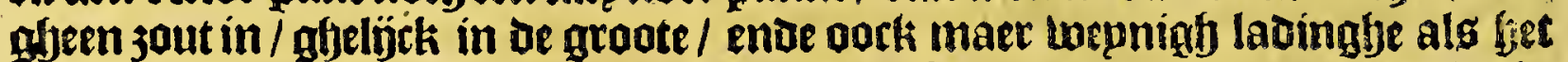

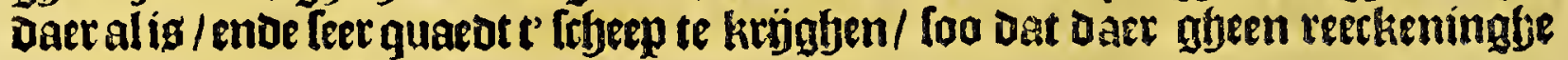
open is te maecken.

Onfe Rederlanotfefje fthepen beblen oefe batrt om jout te balen beele jaeren ghebeupckt / meeft onberhinoert oftemet klepn om-lien tot ín urn jaere I 605 , Doen beft den ltaningly van Spargnien oerbaerts glecenten arbthien wel gbemons teerde Iffepen / Loo galleong als andere/ de twelctie daex zún ghetomen in Novem-

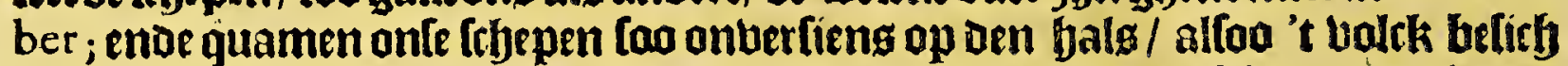
mas met jout te balen om yaer fcbepen te laden / legghente de fetepen angbereos Dert / een deel ban bet bolck aen la ot / een deel met de booten op de bart: foo dat

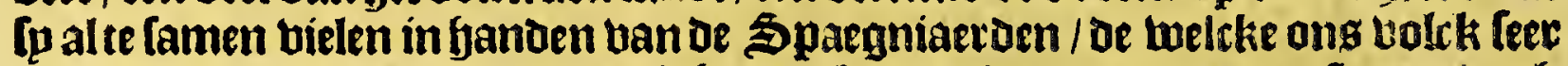

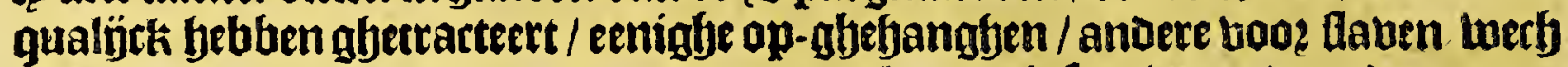
ghetuert naer Cartagena, ende daet op de galepen ghelet; twaer ban daet naet eenighe mepnighe nocb zijn ont-komen.

Daer naer is de felve baet bp oe onfe tweder fer-bat naer't maecken ban oen trebeg met den ltoningh van Spaeguien/ oocb met meetaer om-fieft als te toos

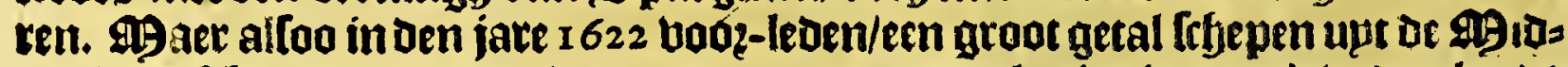
bel-lanotlebe zee dertwaerts boeren ommet een jout-ladingbe naer't bader-lanot te keeten (enoe oock andere upt \$oozotbaren gebaren) Daer komenoe den (eben-en -twintichften November, tonden fu Dat Den Haningb ban Spaegmien daet een fterclikafteel bador Doen legghen met guarnifoenen daet op / om oe onfe het jout-balen te beletten: De onfe beden een aen-bal op't Ielve kalteel / dan booe de ontwillichept van 't meeffe oeel ban jet

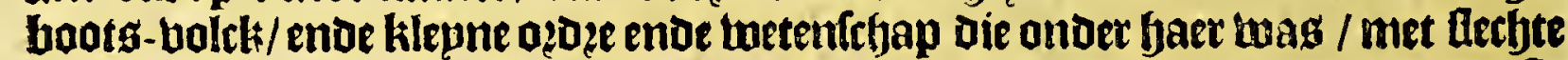
upt-kompe / want eenighe ban be kloecklte bleben aen lanbe booot / ende be refte moelten $t$ ' frbeep keeren. Soo dat alle defe febepen fonder ladingbe moellent bupg keeren.

Dit kafted ig foo gheleght / Dat bet den toe-gangh tot be panme commanteert / too dat het niet mogbelïrk ig datbet bolck't jout kan aen-balen/(onder ban't ghes Ichut ban bet thatteel betchadicht te wozoen; de Spaegniaeroen fobluen fet de naem ghegheben van S' lago; de berhalen: weghen de ghedaente ban 't [elbe kafteel/het

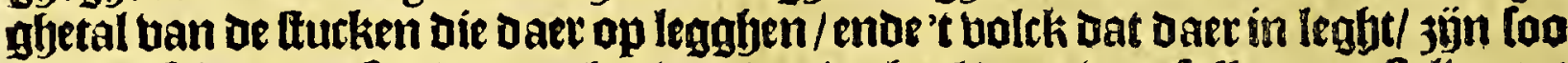
wat betflyrpoen / too oat wp bet boozoer verbael daec ban fullen upt-Rellen tot

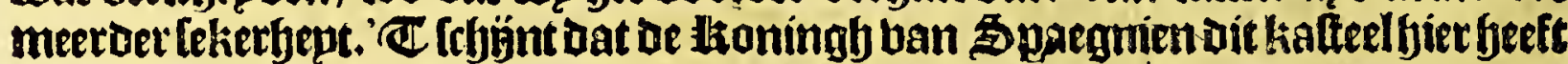

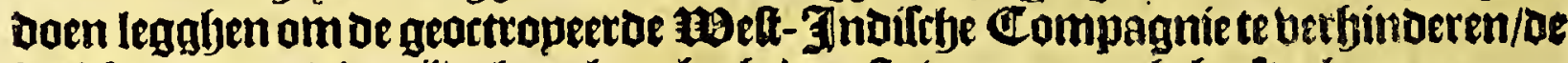
belcke ontrent dien tyot baet langh gfetwente boot-gangh beff ghenomen.

\section{U M A N A.}

Tet biertue Capittel.

Befchrijvinghe van deprovincie van Cumana, ende de gheleghentheden van het landt ende volckeren.

DEzpobintie ban Cumana is gftelegben aen't bafte lanot ban America,tegen ouer het Eplandt Margarita, (eben leguen daet ban berfryepoen ; Daer kome on groote rieviere in 3 ee loopen/ in de melche menichte is ban dat gledierte/ 
Het fefthiende Boeck.

Inelcli de Tndianen Caimanes, ende oe Spaegniaeroen Lagartos, noemmon/cnue jign de recgten reacosilen/ghelighth die ban den Nilus in Africa. 2Jaben Cumana

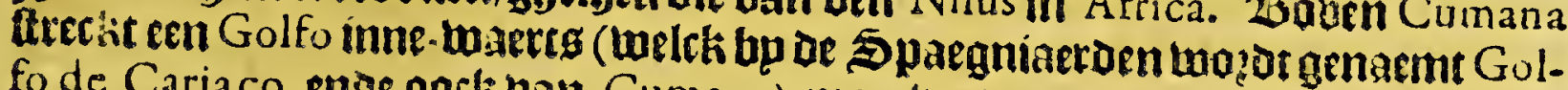

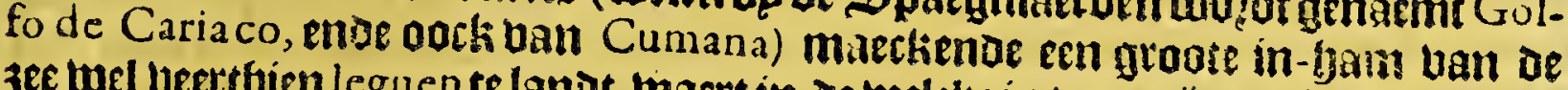

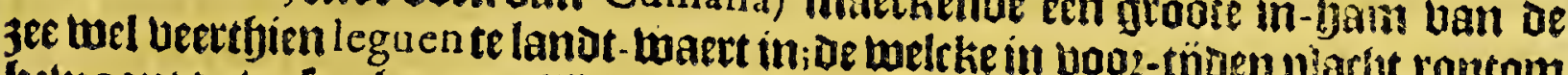

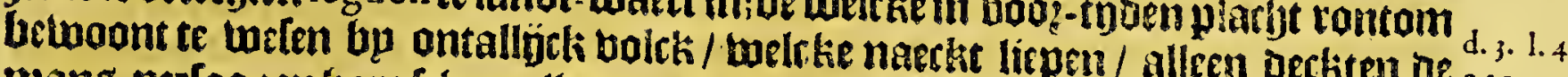
mans-per[oonen bare frbamellyeden met den foals van oecautwoerden ofte cala

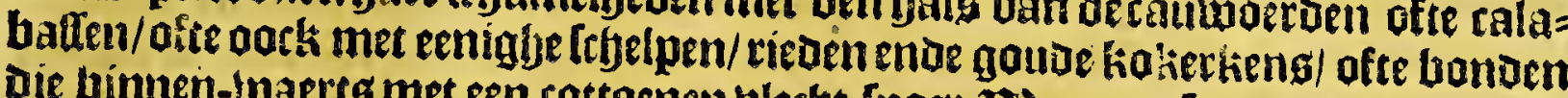

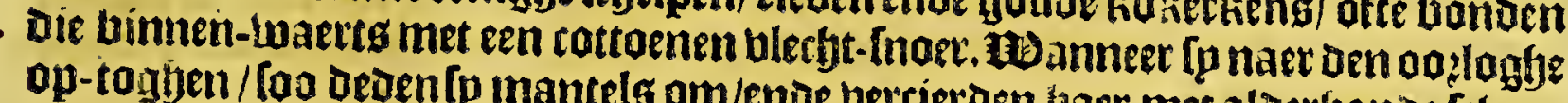

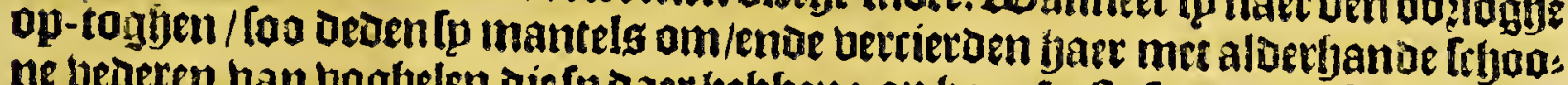

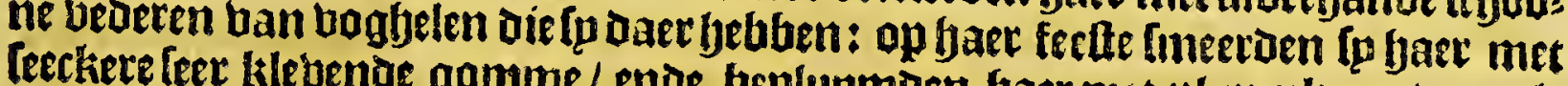
Derhande kouleuren. gamme / ende beplupmoen Gaer met plupmlens tait als

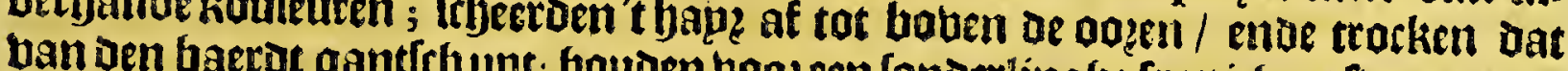

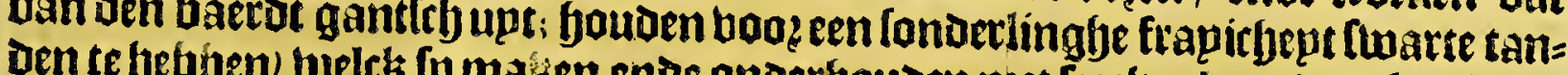

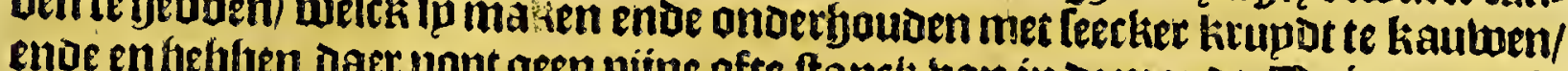

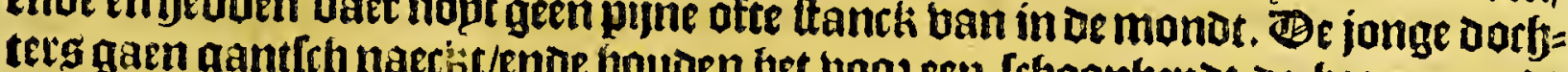

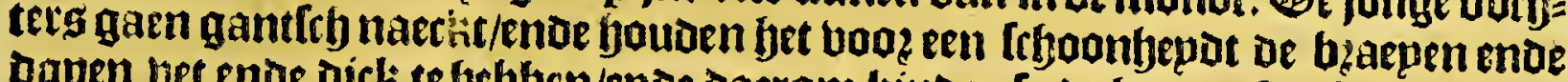

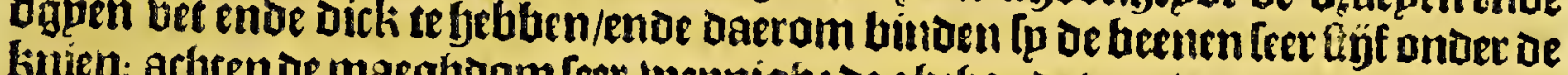

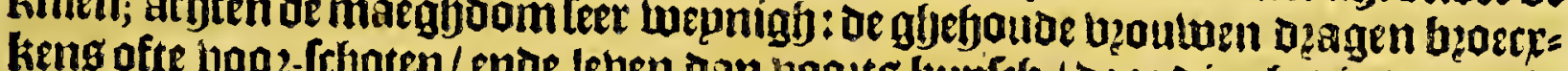

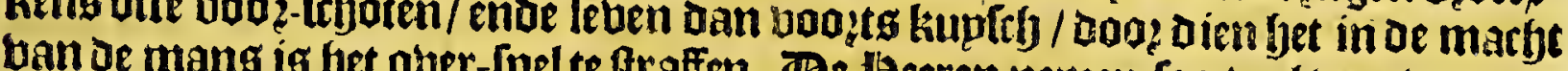
van de mang is bet ouer-[pel te Graften. Be Heeren nemen too beel beoulwen als

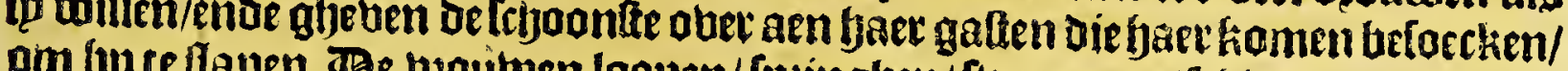

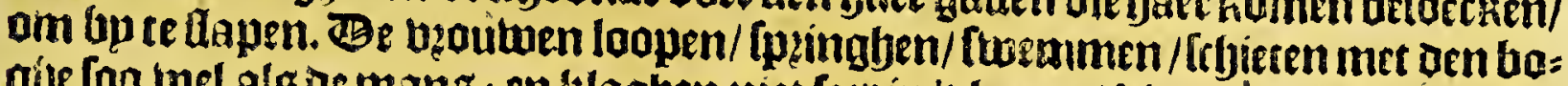

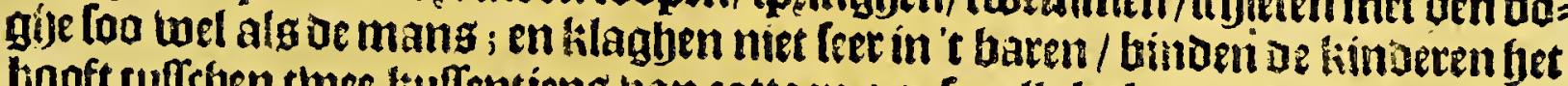

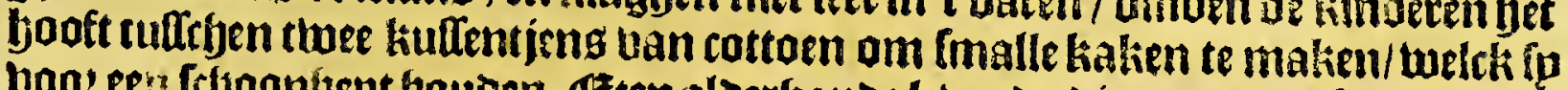

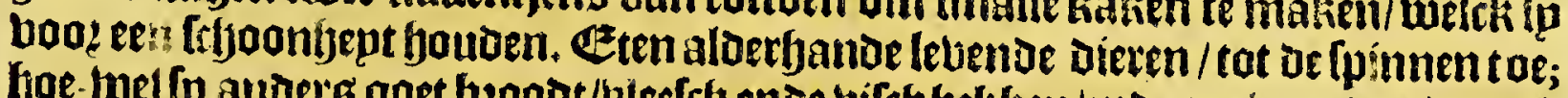

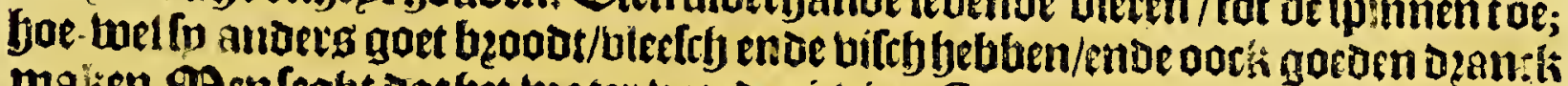

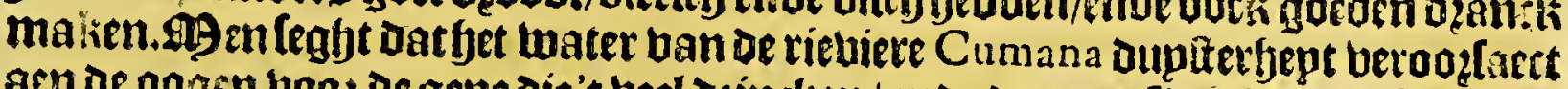

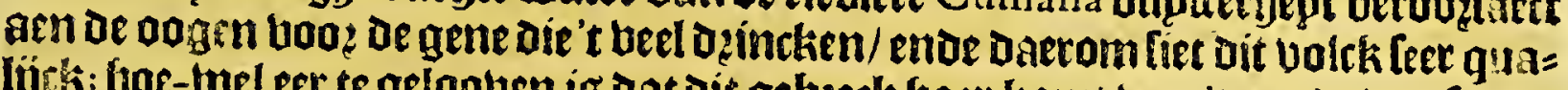

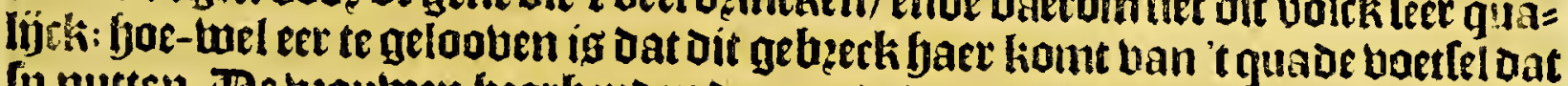

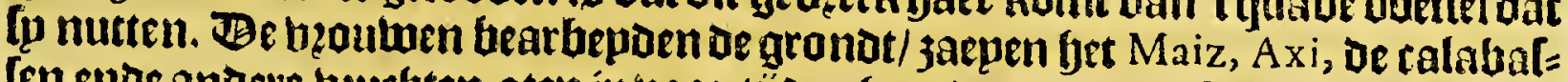

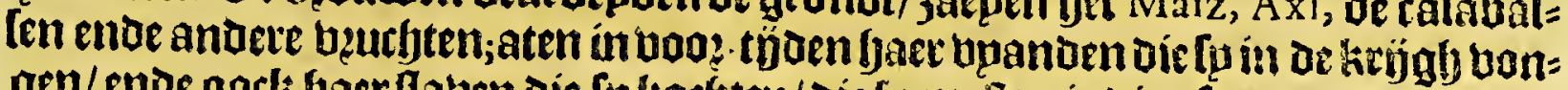

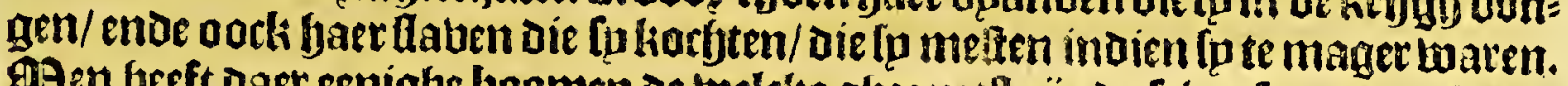

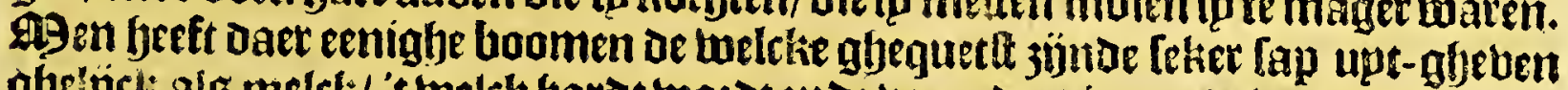

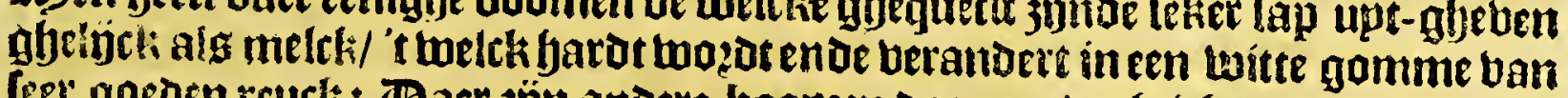
leer goeden reuck: Baer 3 in andere boomen daer ken boctjtichept upt bloept als

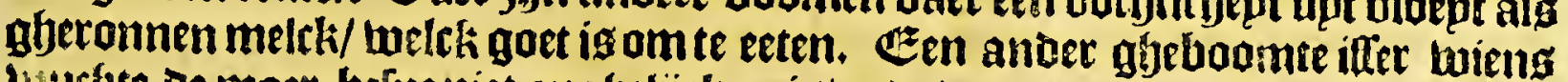

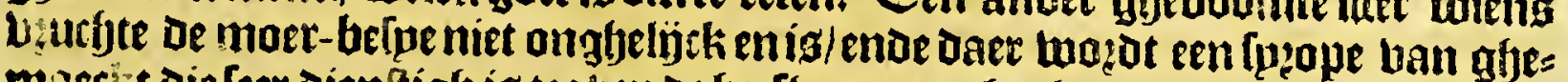

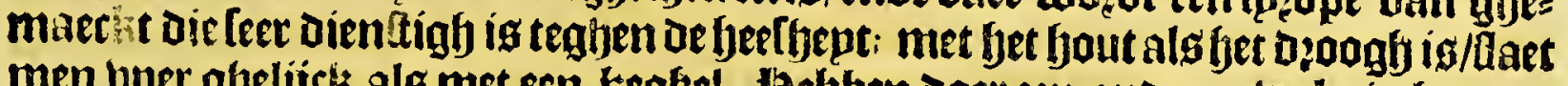

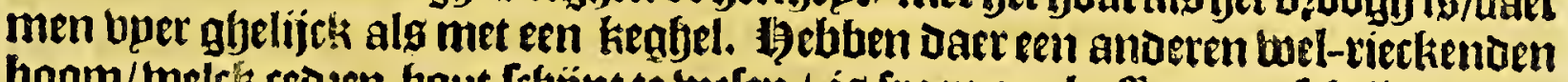

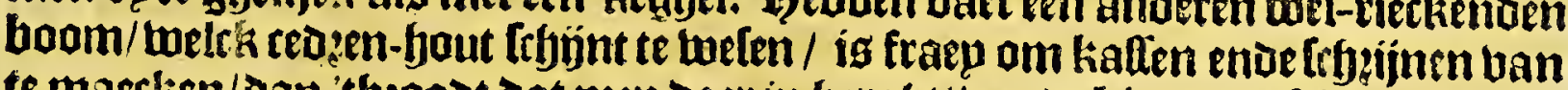

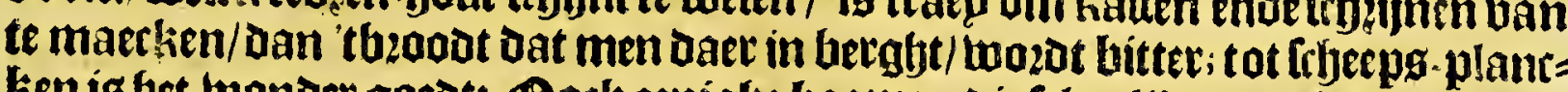

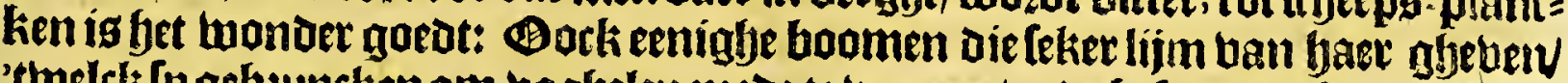

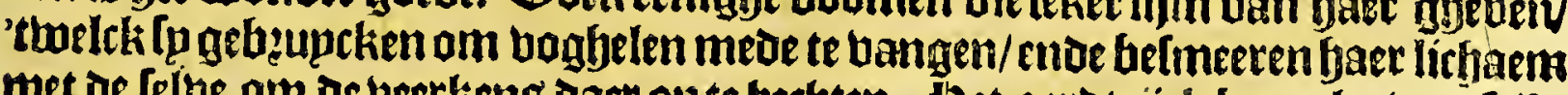

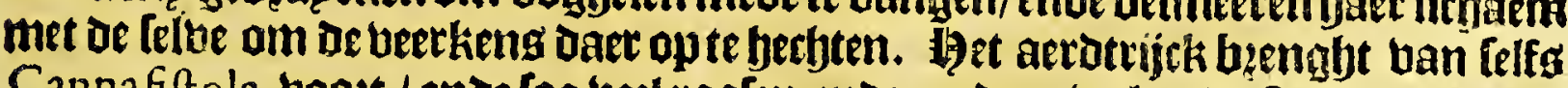

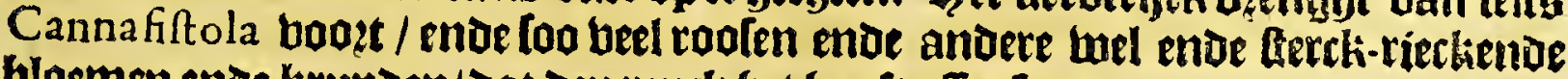
bloemen ende krupden/Dat Den reurk get booft offenfeert.

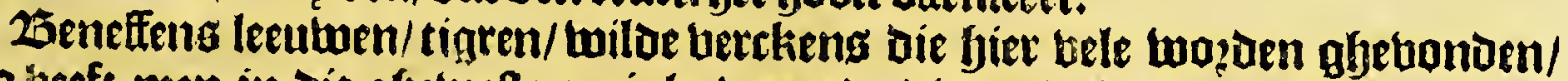

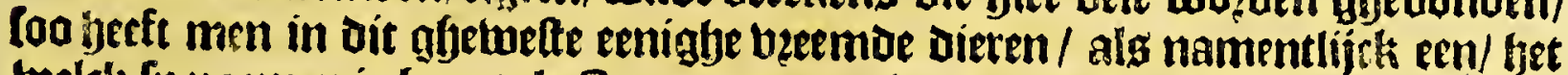

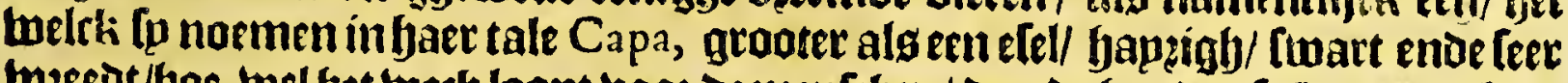

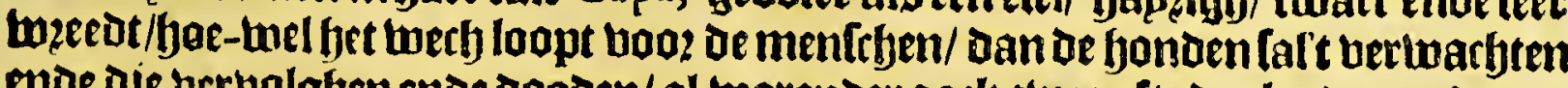
ende die bertuolghen ende dooden/al warenoer oock twoe ofte dep bp den anderen.

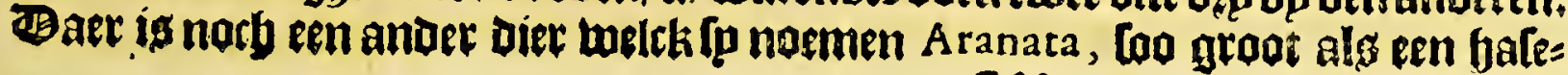
fff 4 winot) 
604

Nova Andaluzia.

winot / beeft een baett ald ecn bock / enoe buplt leer berbaerlïck ; ban en eet geen bleelty/klimt op de boomen; Dit gbedierte gaet meelt met troupen. Agen banght

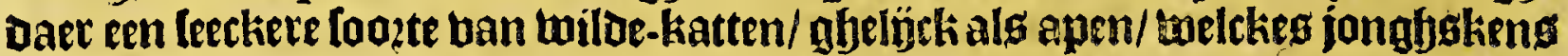

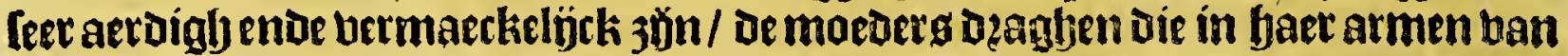
Deneenen boom op den anderern: Daer is noch eell ander weet diet / weltk ie Indianen leer besten / ende Dzaghen daerom Des nathts beandende bouten in ae banot als fp bupten 's bupg gaen/ mant daeghe en luozot bet niet ghelien;

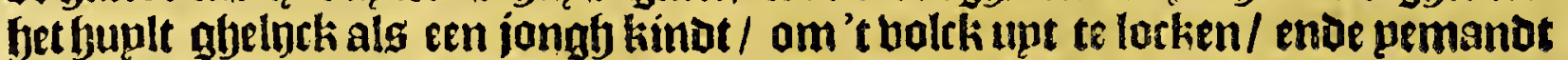
boot-komenoe om te lien twie daer fuplt / foo berthinat fet dien; en is niet grooter alg een ljate winot.

Doo zts Loo beeft men bier alderfyande fraepe ghebogelte/ als papegaepen ende anvere. De bleet-muplen jün Daer beel groot enae büten Dapper/ ende lupgen ueel bloets upt/كoo men bem daer vooz niet en boedt. A9en beeft daer diberfrbe [ooteten

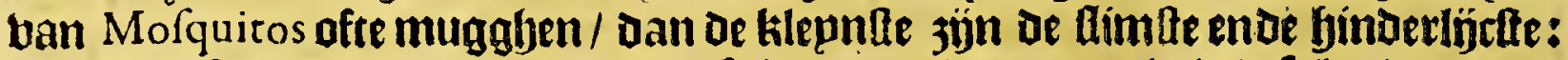
oepoerlep footen ban bonigb-bpen; [pinnen beel grooter als in defe landen/ende

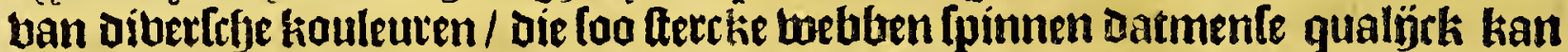

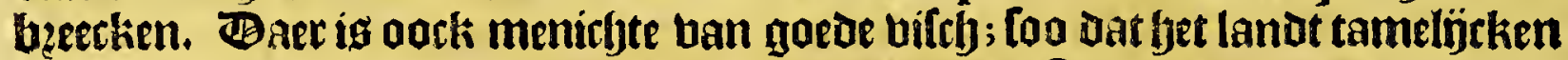
wel ban lijf-tacht vooz líen is. Benzo berfaelt dat oe Spargniaerden al in [pnen

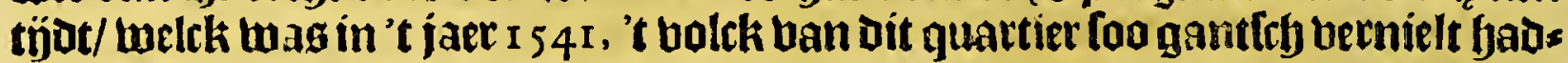
Den/Dat daer maer wepninge arme Cafiquen twaren aber-gebleben/ die de Spae= gniaetion ljadoen gbelpaet om in yaren oienlte ald faben te gbebupecken.

\section{Het vijfoe Capittel.}

Kort verhael van 't ghene by de Spaegniaerden in dit quartier van CúM A A in voor-tijden is aen-gherecht; ende van de ftadt CuMaNa.

d.1.1.9. I Ren jare 15 I 3 verfortyten eenige Keligieulen ban de azde van Sant Domini-

c.14. Lus, omallesn oe miloen uan Terra Firma te mogben gaen bekeeten; bet welc= lie haer welende bergunt/ wierden daer twee $\mathfrak{A}$ gonnicken aen t balte lanot aen-

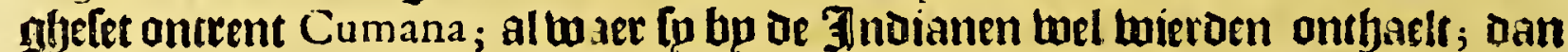

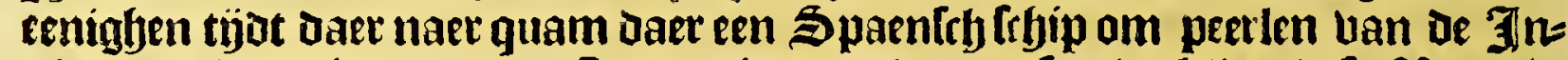

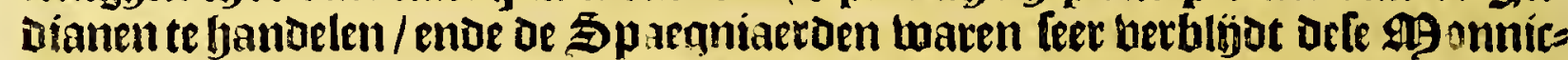
fien bier te binden: Dorf allos de Eilden op't thoozdende bertroutuen ban dele SHonnicken met de Spaegniaerden fonder acjter-Dentken converfeetden/ [oo febluen oe Spaegniaetoen aen heere ban die plaetle op baer fthip ghenoodicht /

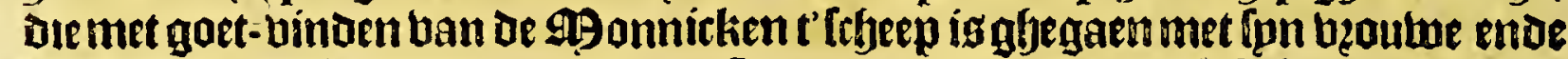
fetuentyien uan [pn bolck: maer de Spaegniaeroen dit bolck tcfjeep bebbende/ trocken baer andiers op/enoe boeren met bele ploiloen boo; twaet aber't bolck

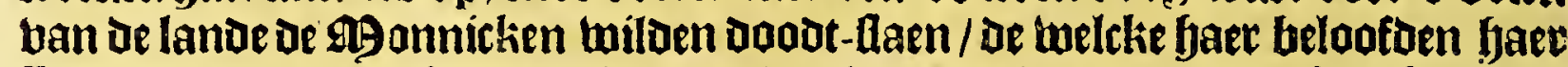
Heere ende de ander binnen bier maenden tweder te leberen; dan alloo'tlelve niet

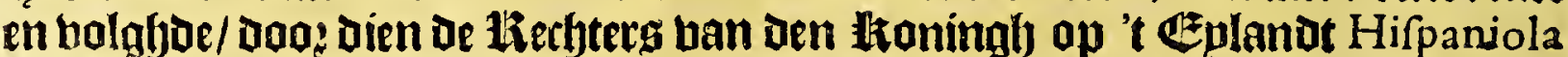

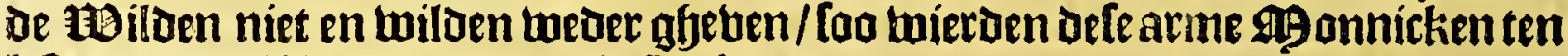
Ielten ban de miloen Doout-gheflaghen.

EEen andere notabele tweedotyepot wietot bp de Spaegniaeroen gfepleeght in

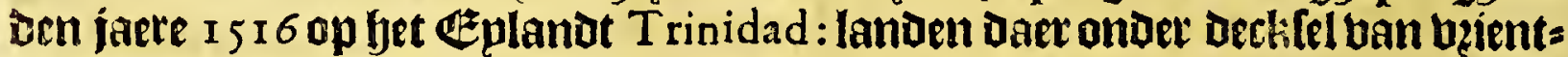

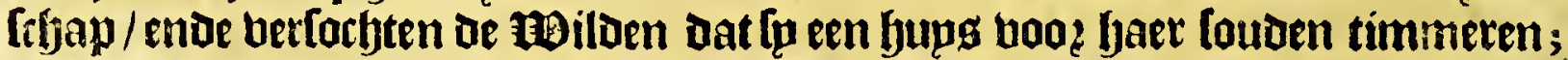
't welch ghedaen jujnoe / riepen [p beel bolcks ban oe lande te famen/ghelïck oft fp die hat wonores hadoen willen thoonen/Dan ín't gupgs gbekomen jünde twel tot bier fyonoert toe / Goten lp 't bolck met ghelweldt in bet bups / enoe namender

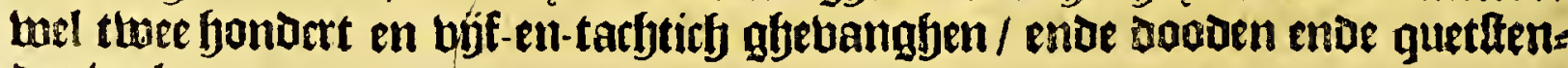
Der toele.

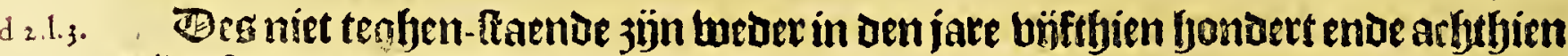
Diberfere 9 gonnicken ban Sant Dominicus ende Sane Francifcus ogde in dit 


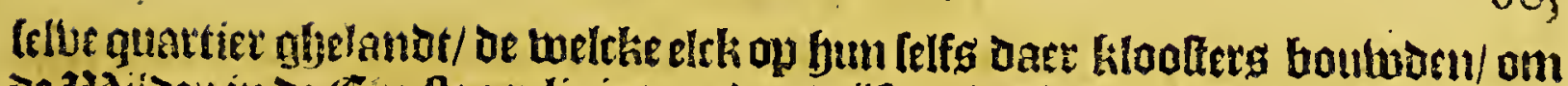

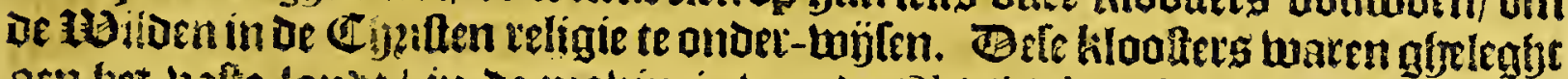

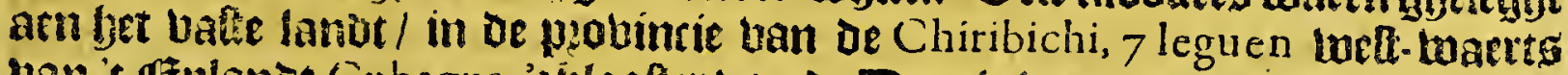

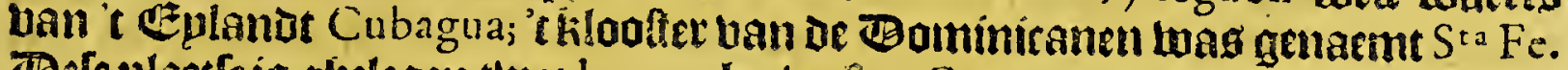

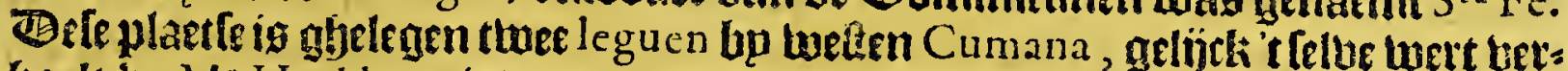
haelt bp $\mathrm{M}^{\mathrm{r}}$ Hackluye, inoe uopagie ban Sir Iohn $\mathrm{Ha}$ wkins, of leelctie dooz aen=

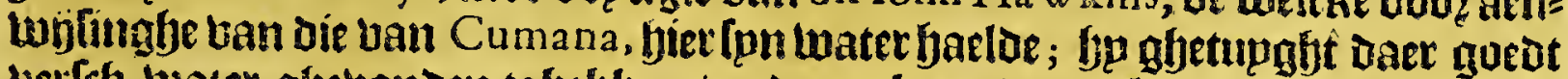

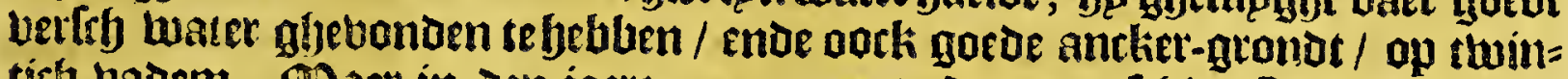
tiry uadem. Agaer in Den jaere 1520 , quam Daer een lebip Spaegniaetion onder bet glyebieor ban A lonio de Oieda, 't twelck ae 3 Indianen ban oat guattier feer altetcerde: ie Spaegniaerden boeren met baer frbip bier leguen booz̨oer naet Maracapana; boos-gfeluende dat fp daer waren ghetiomen om Maiz te man= gljelen lan oe Tagarez, Luelcli wag een bolck oat iep mijlen in't landot op 't abe= berghte woonde aan oe Tangare $z$ af-komente met bjifticl Cargas Maiz, (dat is foo beel als bijfich man Dzanljen kan) die men haer belooft badoe aen ben oeber te betalen/loobebben oe 5 paegniaerden [es en-dertich daer ban batt ghe

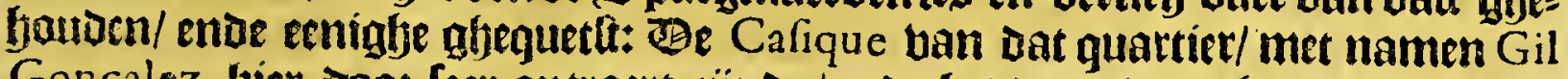

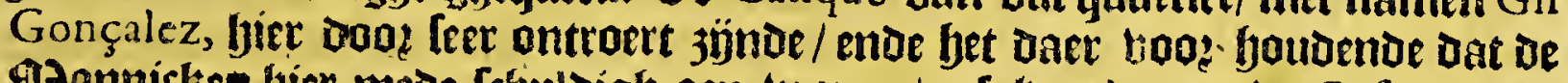
Atonnicken bier mede feljuldigh aen twaren/ refolvertde met de Cafique ban bet gbetwelte baet bet hloolter lagh / gbenatme Maraguey, dat bp met oe lune

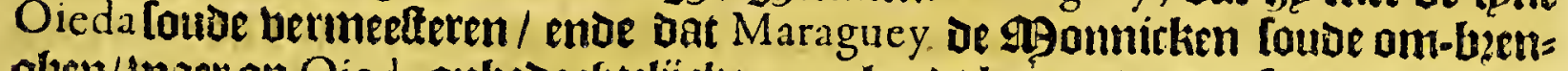
glyew/ La aet op Oieda onbedacftelijeken aen lanot komenoe met les ban oe fine

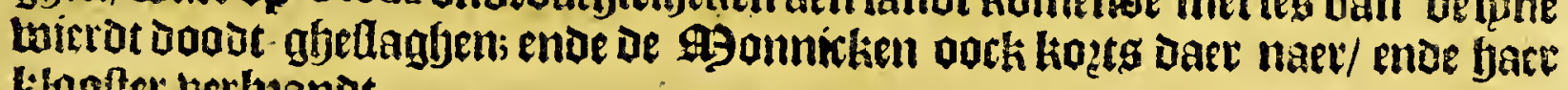
kitoofler berbzanot.

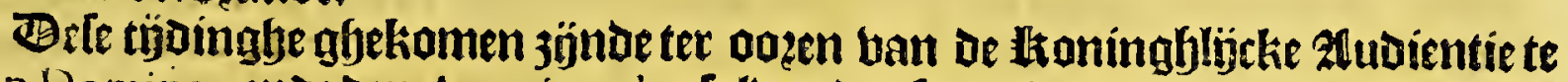
San Doming ende den Ammirand, refolverdenfpeen weerde rebenge dare ober te nemen/enoe t lanot ontrent Cumana te Depopuleeren / ende't bolck boos datuen oberte beenghen naer San Domingo; maeckten tot dien epnoe Dęp frlyepen beer= Digh/ endelonoen daer mede azp bondert man onder 't belept van Gonçalo de Ocampo : ot ghrfthiede in het jare 1520 naer' $t$ feggen ban Ouiedo.

Debujloit Dug in Jnoien palteet De/ was ien Licenciaet Bartholome de las

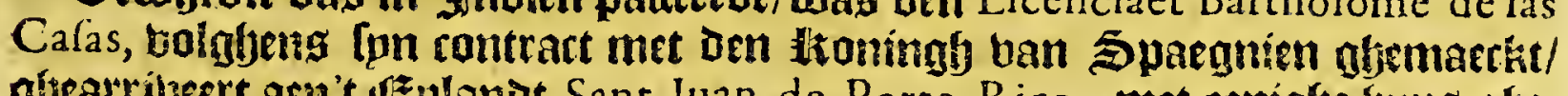

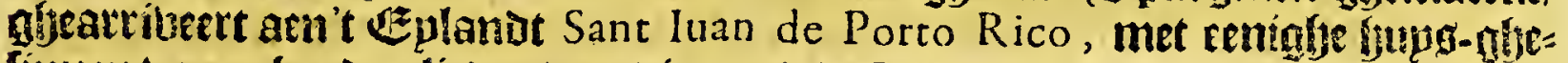

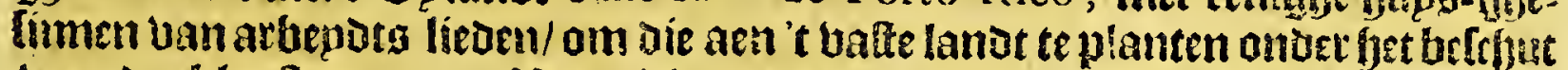

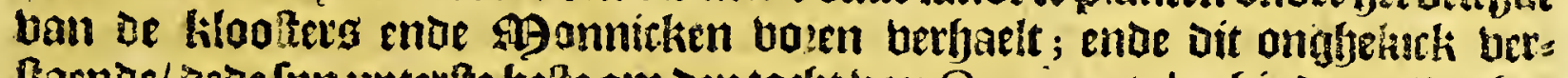

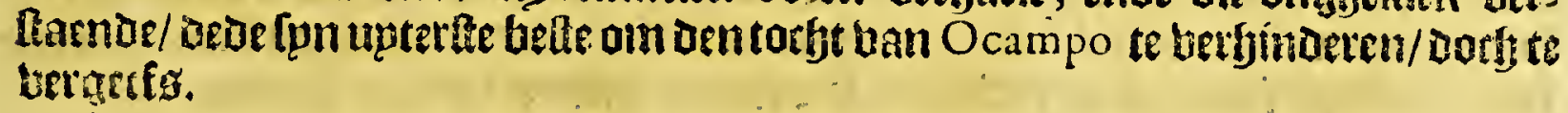

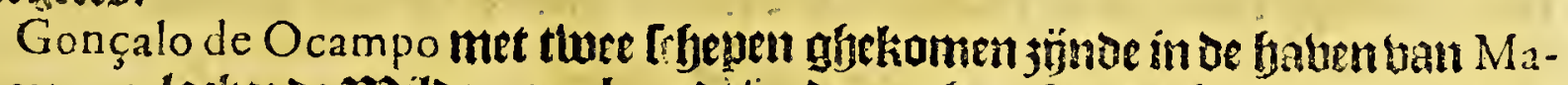

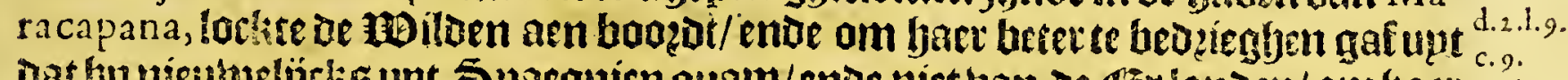

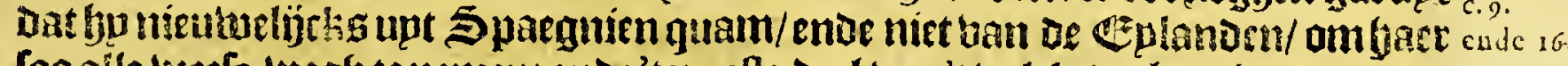
foo alle beefe wegh te nemen: ende't meelfe deel ban't volch betberofiende onder

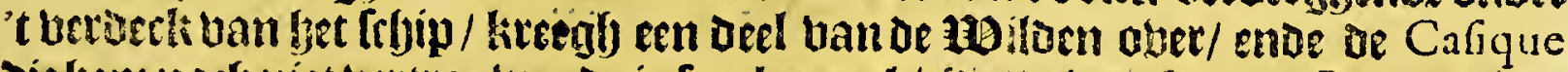

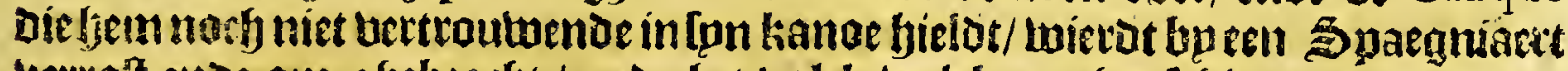

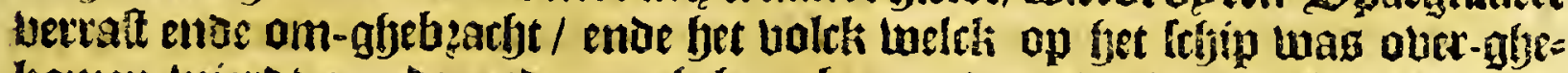
homen twietot aen be reede op-ghefanghen; enoe nam toozts haer oo:p in ende defirueerdefget/ende lepoe een twooninghe ban Spaegniaerden een balue mije or rie biere op/tuelct bp Tole do namae.

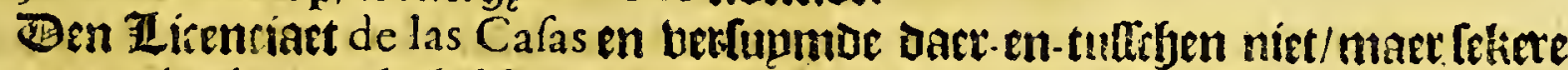
rompagnie ghemaetlit fyeblente met Den A mmirand ende de Ofiriers van oen Laming op 1 Eplanot Hifpaniola, bervozoerden lpn reple naet. Terra Firma,

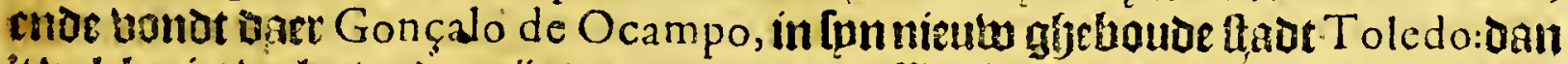
"t bolck niet turl te becaen jünde met de cominilie die den Licenciaet de las Cafas

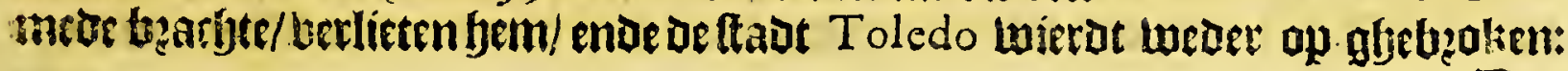


Den Licenciaet de las Cafas met eenighe wepnighe ban (un bęienten) ende eenís

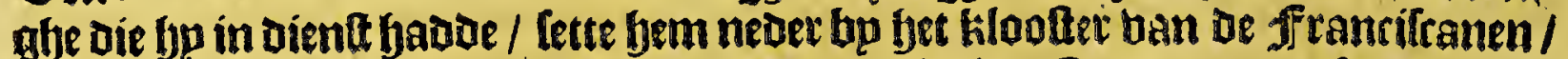
welck lagb dictst op den eeter ban de jee by de riebiere Cumana; ende begonin de monot ban de felve riebier een foęten te houtwen/ Dan alloo de in-Loonoeren van

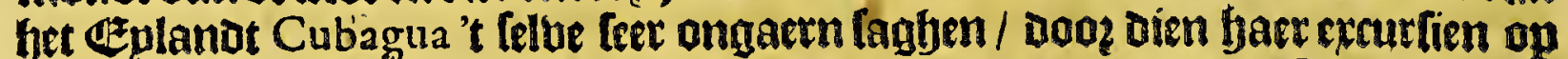
de arme tbildoen ban't valte lanot daer doos werden berhinoert / Coo ontrocken Ip bem lpn werch-meefter / entoe den boutw blef achter. Albaer ober den Licenciaet relolbertoe Inn klachte te oen ober te Spatgniaeroen van Cubagua aen te audientie ban $S^{t}$ Domingo, enve voer naer Hifpaniola, latenoe fon bolck on= Der bet glyehieat ban Francifco de Soto :De Lelcke teghen ex azoze ban oen Licenciaet de las Cafas ae twee fryepen (die by bem badoe gelaten omin bal des noodts hem ban te dienen/enoe bem (êlben met bet bolck daer in te falbeeten) fonot langb̆ de kulte om te handelentoe wailoen defe orealie waer-nemende/ober-bielen Fran-

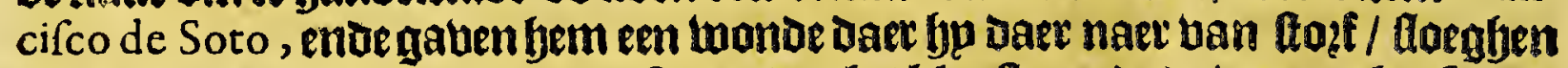
een Deel ban't bolck Doot/ende Deftrueerdenfet kloolter enoe oe woon-plaetfe ban be Spaegniaeroen; [oo dat Daer maer neghentbien perfoonen en ontquamen/ De belcke baer felben falbeerden met een ranoe aen Punta de Aray. Bon Licenciaet de las Cafas oit bernemende/ende fiende dat bet bem alles qualÿck gheluckte toat

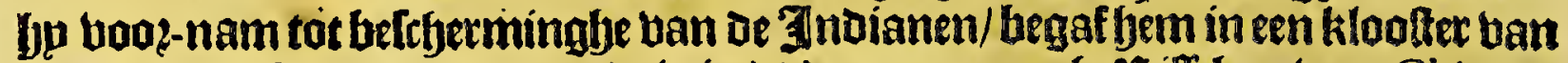

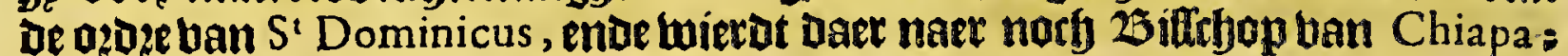
enoe is oe Telve die alle de weeedtheden ban oe Spaegniaerden in't ooouen ende mig-Jjanielen wan de arme Jnoianen aen den dagg beft gyebzacht in [pn boeck] welckin fonoen is ban alle oe teerelt.

Den Ammirand Do Diego Colon afte Columbus, ende de laninaflijctie audientie uan Hifpaniola, fonden in den jare 1522 eenen lacome de Caftellon, om

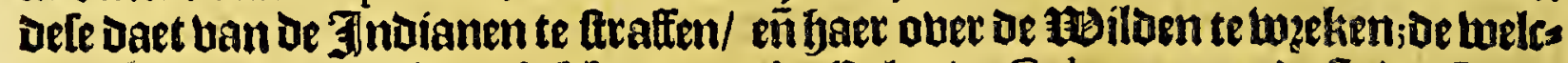
ke enigh volkh ghelaten behbenoe op't Eplandt Cubagua om ie ftavt Cadiz weoer te betwoonen/ voer naer Cumana, enoe nam Daer fpu refidentie/entoe fonot fpen bolck bp troupen te landet-baet in om de Jnoianen te banghen en be te toos Den/ende deae eennotable feraffe ober be mirooenders: boutwoe een ferckte aen ae monot ban de riebiere Cumana, om de wateringh tooe die ban Cubagua te bertekeren: Sints twelcke tijot daer altijots een twoon-plaetle ban Spaegniaete Den is ghebleven. Dit ftede äen Cumana ofte Comena ligbt thiee mijlen binnen 'slandts/ende men kanget niet lien twegben de boomen die bet bedecken/alleen fiet men't Gouberneurs bung dat wat hoogh light / beeft een goede reede in een boeft/baben twee roode beuluels / ligghende in een balbemane/ men fettet ontrent een gotelingly-f(heut af opt twaelf ende detthien badem Irboone gronot.

\section{Get Celfe Capittel.}

Voorder verhael van't ghene by Ortal ende Sedenno is voor-ghe. nomen in dit quartier.

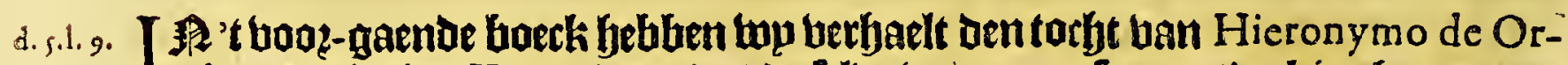
tal op de riebiere Viapari, tot dat de felte tooz-nam Ipn ontoselinghe aen een ander pozt te lieginnen; 't melck alloo gfyefthiet ig aen dit quartier baer wop nus

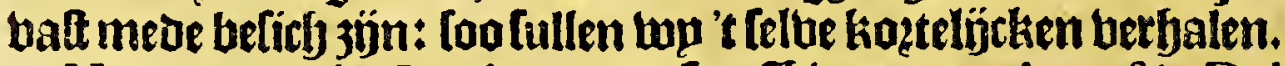

Hieronymo de Ortal nam tot lpn Lieutenant Auguftin Delgado, ende fonot hem met fet bolcli de vietuiere Neveri op/theemúlen ban Maracapana, ende belafte

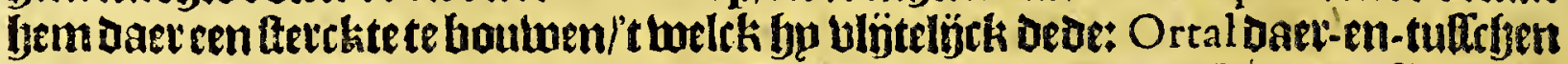
mede daet bu gfotiomen jünoe met norb fonoert man / openbaerden líty the groote [waricheden ; oe eene / Dat die ban Cubagua tegheng Ortal peteteftecoen/ als getreisen ॐn Dat de loldaten ban den booz-gaenden tocfe leet naecht ende blopot waten! 
Het felthiende Boeck.

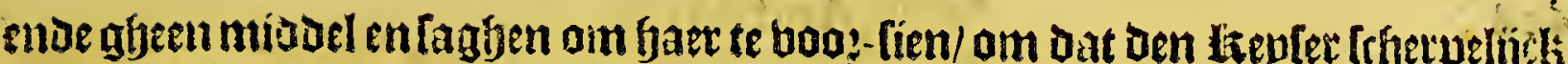

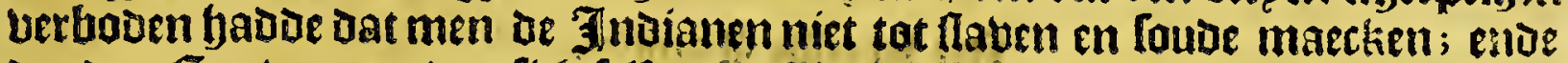
Dat den Gouberneur banfich felfs gantch gheen midodelen en hadoe am oe noot=

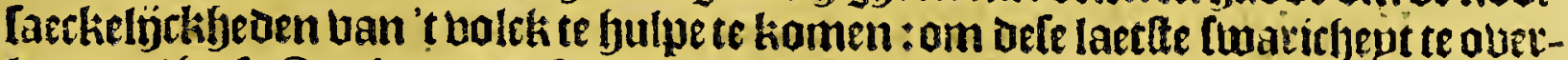

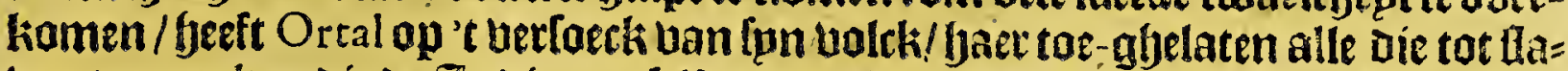

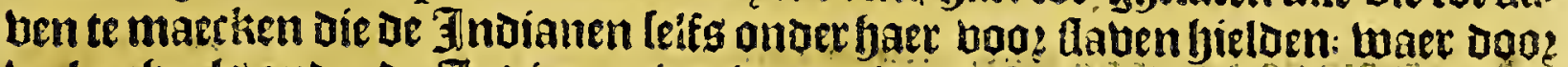

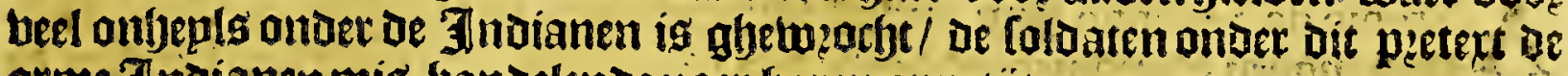
arme J noianen mig--jandelende naer haren appetiot.

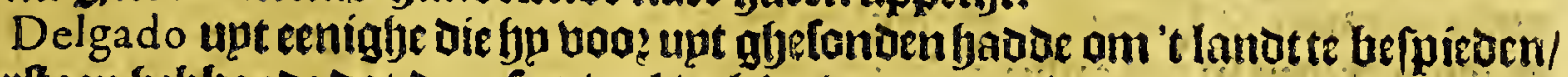
berttaen yelubende dat daer feet beel bolcks twoonde te landt- waert in / en bonot niet goet langher tijot te berliefen / maer trock op met býfticly mannen ofte daet:

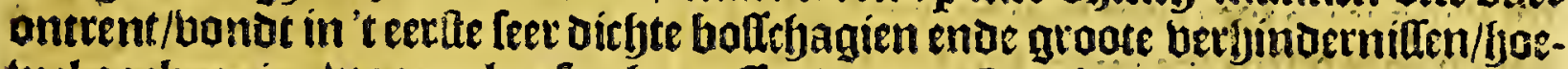

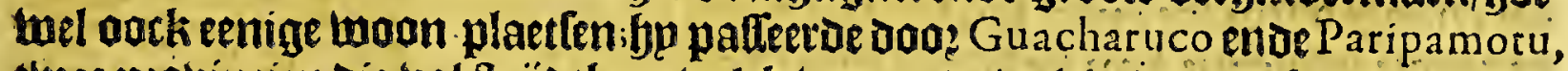

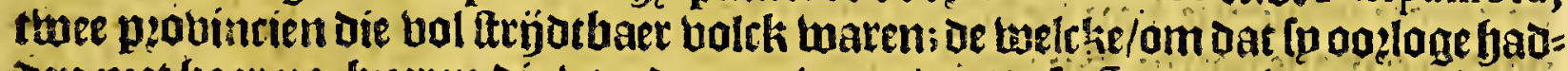
oen met baer na-bueren dé boazoer aen moonden/oele Spaegniaerden beiende. Ijeken ontyaeloen/[oo dat fp vooets trocken met gaede lepts-lieden/enoequamen

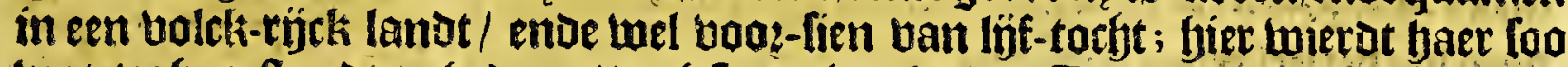

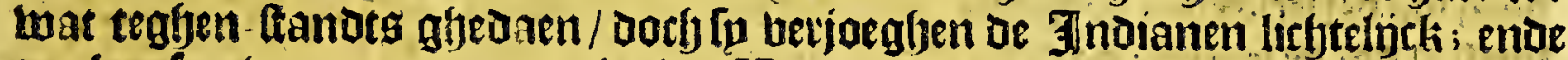
trocken foo boazts tot aen de riéuiere Un are, ende patteerden die naer ecnigh ge: uecht met de Tndianen/ dic yaer oe pas mepnden te beletten/ende bonden dace

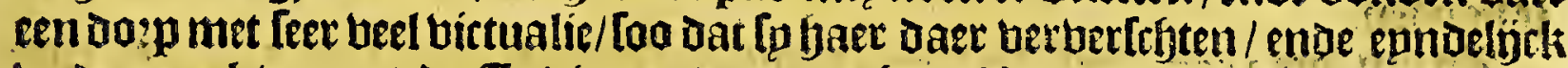
beede maeckten met de Indianen daer om-ber. SAen mepnt dat Ortal leer wel [ouve gevaen bebben fier een ftadt te boubuen/dan't booft fingh berm naer Mera; enve Delgado naer oat gpeeníghe gheftyencken ban oe Cafiquen ladoe ontfangljen / Keerde tweder naer de plaete daer fjp den Gouberneur gbelaten badoe.

In't book-gaenoe boeck bebuen top mede aen gheraert goe dat Antonio Sedenno mede pyetendeerde op dele ontoeckingfjen/ende Dat Ortal compagnie met Sedenno maeckte / ende meder berbzack: Sedenno Dan hoe-wel ban Ortal ver: Jaten jönoe/foozende 't goet lutces ban Ortal, ende de mare die daec liep ban den rijekiom van dele lanoen / vertmeckte die bau $S^{\mathrm{I}}$ Iuan de Porto Rico tot fun bul= pe/ endoe fonot fpn tralck twee leguen binmen't Goubemement ban Veneçuela.

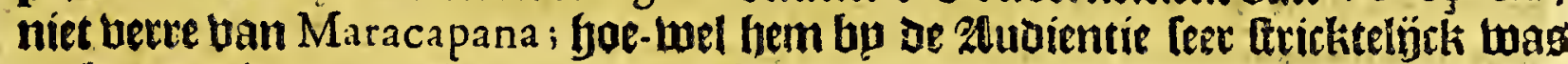

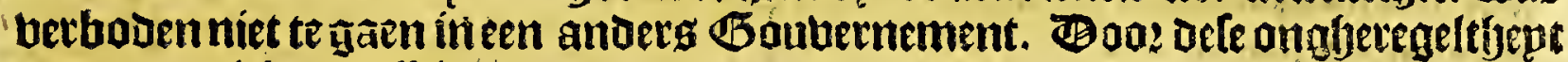
ende oneeniefyept tuffefyen Ortal ende Sedenno, quan te pafle dat lp malkanderen

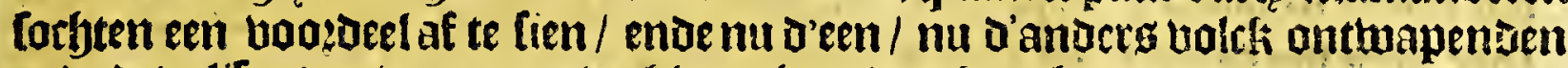
enve debaliteetoen/tat groote berjinderinge ban haer bepder booz-nemen. Bacten-tuffeben betuolghoe Ortal fun reple tot dat bo quam in 't lanot uan een Cafi-

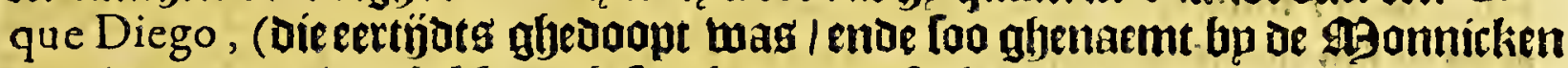

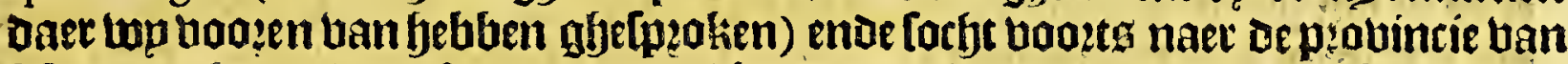
Meta, treckende boo: fraep ende wel betwoonot landt / welck gp gantffy betoof ende ruineetue / om te uerbinderen dat Sedenno bem niet en loube boiglyen : gis

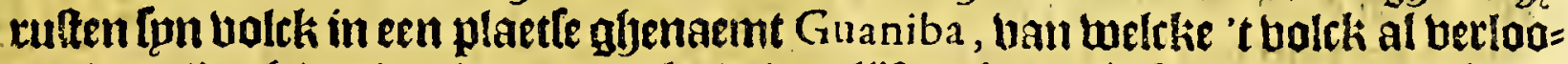

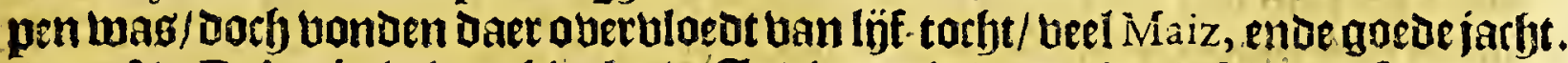

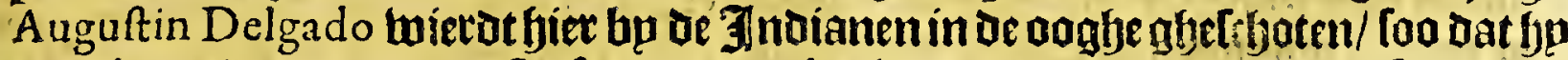
Daer kayts Daer naer ban ftoef: ende Ortal wierot doo? muptenatie banfpn Lolch berlaten/welck fiem meeft uaeghae bu Nicolaes. Federman, die ban Coro tuas op-ghetrocken om 't landet te ontbecken; [oo dat ljp met thien Caloaten alleen te rugghe quam naer [pn foxt/uelck fph \}adoe/ghenaemt $S^{t}$ Miguel de Neveri, Dan bernemenoe dat Sedenno terck op ie kufte twas/ en Doulte bu bet fier niet bout= oen/ maer bloot naer Cubagua, ende wan daer uod?tg naet Si Domingo. 
Het Cebente Capittel.

Vervolgh van den tocht van Antoxio Sedenno in dit ghewefte van

TERRA: FIRMA:

A Ntonio de Sedenno hem ontlaff hínoende ban Hieronymo de Ortal, énoe abebaitghen gbenomen bebbenoe den Licenciaet Frias, Dit ban tueghen oe: a.s.l.ro. audientie ban $S^{t}$ Domingo ghelonden luas/om Sedenno te berbieden dat bp niet .

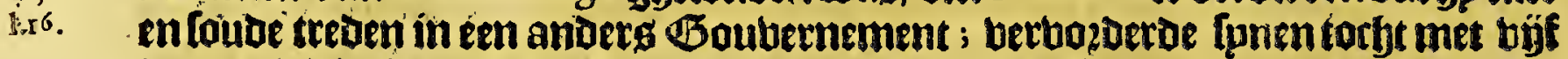
bondett main foo te vaet als te peerae / ende nam eeref fonen twegb langhg de kufte tot Patigutaro toe / ende ban daex te landt-maett in met leer groote difozoze / tons

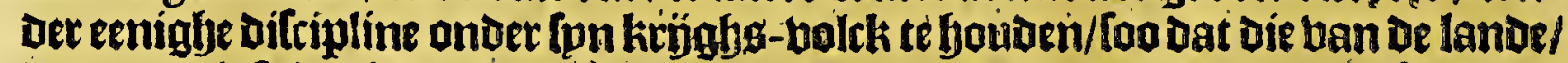

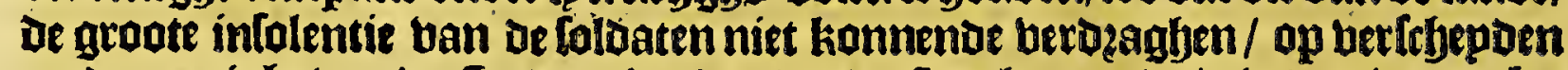
opzen eenighe ban de Spaegniaerden bopdt-loegben; ende twietoen tweoer by

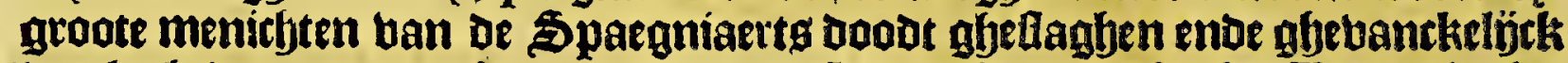
megh ghevoert naer Cubagua, ende booz taben aloaer verkorbt. Boos git ghe: boen foo berleckerden de tigen (die daer Ieer beele waren) loo op bet menteben-

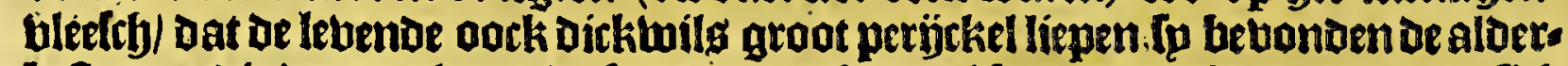
befte remedie daer teghen te mefen/ Deg nacbtg beel bzandende bouten ontrent fich te bouden.

Jn ben jare 1537 , trock Sedenno boozts tot de probincien ban Ana puya ento Orocomay, daer bp twel anthaelt wierot; palleetende ban daer na 't lanot van Gotoguaney, bonbt 't felbe inde twapenen/ende aen't in-komen eenfoettien ban bout ghemaeckt / ende bol bolcks om't lelbe te beffyermen: Be Spaegníaerden

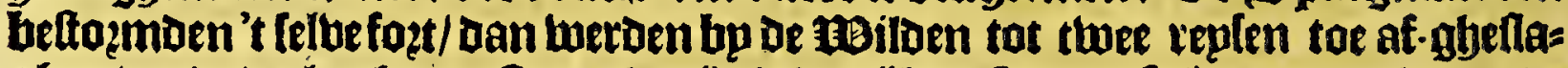
ghen/ ende beele ghequet ti met benjunighe pülen / foo dat fp ljaer met gloepende pletg't venün moetten laten upt-bzanden; dan de zeilden vermetrkende dat Ip beel ban baer bolck berloozen/ ende ephoeligek louden ballen in defanden ban oe Spaegniaerden/ verlieten de plaetle bp narbt/ ende falbeer Den baer met bzoutuen enae kinoeren op't gbelaerabte een legue ban Daer / welck leer dirft met boomen was bebalten. \$aer dat of 5 pargniaerden baer in defe plaetle cenige dagen bad:

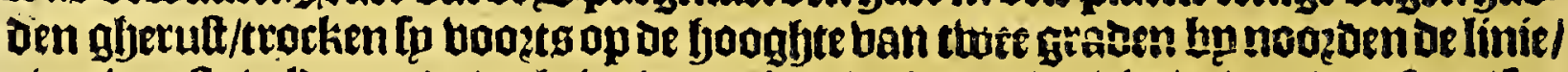
ober buefte beloen ende beel riebieren / hoe- wel met oberbloedt ban beneloen/Loo Dat 'tuolck begonde te muptineren: Dorb Sedenno trafte ernige ban ie peincipale/ ende dilloe loo de relte. Quamen epnidelÿck in de pzobincie Catapararo, gbeles

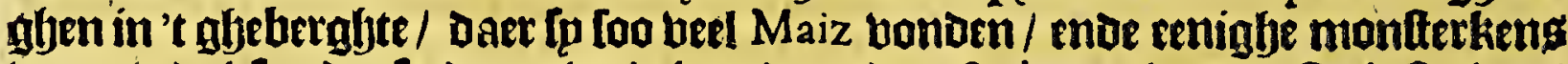

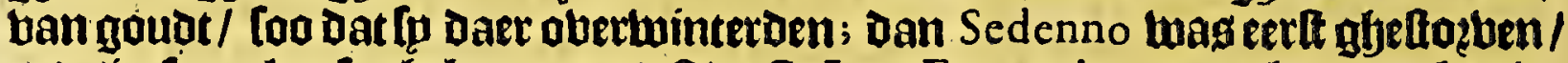
ende in fpn plattfe ghekooen tot Overfte Iuan Fernandez: naeckten reeckenin: gbe dat fa tot bier toe bondert en byjtich leguen gbetrocken waren. Een wep=

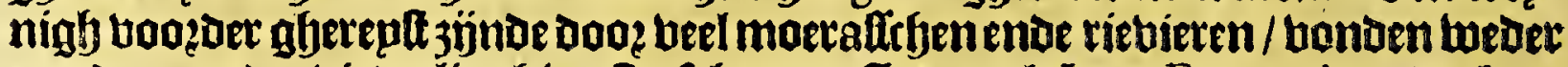
ten dozp enoe bictualie; bier troff haren $\overline{G e n e r a e l ~ l u a n ~ F e r n a n d e z: ~ D o r b ~ e n ~}$ fieten daerom niet baer reple te berbolghen doo? wijoe ende twoette belden; de pis

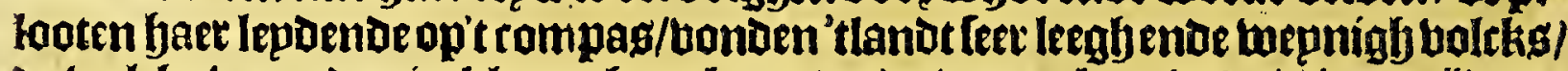
oe welcke woonden in klepne buttekeng / ente bettrocken in ae binter-tjot op 't booghe / als twanneer dele landen gantffy onoer. Ioopen: Be Spaegniaerden

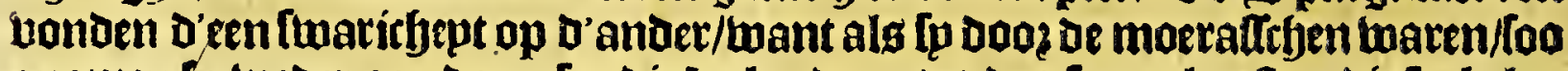
quamen fp tueder aen boate fandigbe landen; tot dat fp ten laetien dit fuckelen moede jünde / ende oneenighgfetwozen jünde onder den anderen / hedoer-keet= den met berfebepden troepen ende dooz dibertebe tweghen/ ende cen deel naer Veneçuela toe / enoe een deel naer Maracapana, ende foo booţts naer Cubaguas tnde foo nam den torft ban Antonio Sedenno eencunoe.

top fyebliten alreede diberfebe tachten belcheeten/ende daet in niets getien ban conoerlinghe confideratie : thaer upt men dan met resen foutoe mogen oozacelen 
Dat in oit lanot niet te binden en ig te moepte twetroigb; maet die wel let ou de maniete ban doen Det S paegniaetoen op bare torben/ [al bem Daer aen niet footen/ bant fp twaren glactwoon't goudot ende bet filuer foo ghercet te binoen/Dat fo foct matr ban be Indianen en befjoefoen te memen; cirde baerfo bet foo gfereat niet en bonoen / daet en locjten fp niet feer/ als meel in hare tarbten te fien is.

$$
V \quad E \quad N \quad E \cdot Z \text { I I E } L \text { A. }
$$

Get actitte Capittel.

Berchrijvinghe van 't Gouvernement ende de provincie van VENEZUE $\mathrm{L} A$ in ' $\mathrm{tghemeyn}$, ende de verdeelinghe van dien.

D e pyobintie ende 't Goubernement ban Venezuela op ie jee-kufte ban Terra Firma ghelegen/confineert naer' touften met fet Boubernement ban Nova Andaluzia, welch oock anders ghenaemt werot Serpa ende Guiana ; ende naet tultrben tuelcke bepoe Gaubernementen bondert ende bertich leguen lowozben gbereeckent / enoe tarftentich leguen te landt-waert in tot Neuro Reyno de Granada. Herrera frgiöft eloers in lpn Hiftoria de las Indias Oscidentales, oat d.8.1.2,

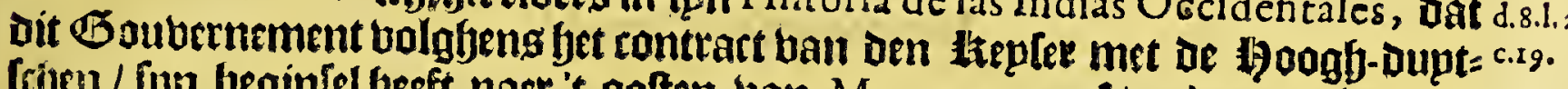

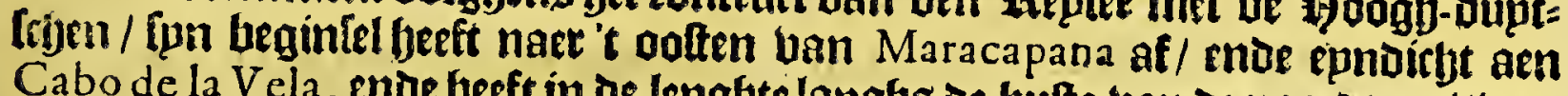
Cabo de la Vela, enoe beeft in de lengfte langhg de kufte ban oe nooget-jee/twee
bondert leguen.

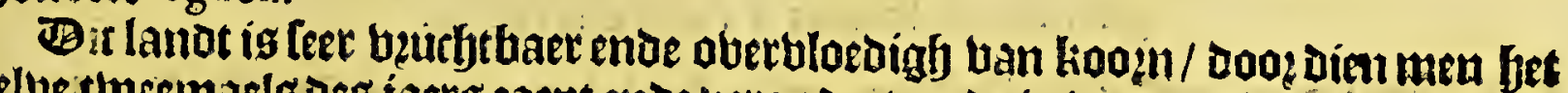
felue theemaels des faers jaept ende bergauert; ende is wanderlöckst bel booes fien van bee van aloerlep loopten/ foo grof als klepn. Bpt oefe probincie wogdo pock groote menichte van tottoene lijntwaeot : ende in Defjaben ban Guayra, in De probincie ban oe Caracas twozden beel fupden gbeladen/ ende Sarzaparilla. Agen beeft in dit land leet goede jact) van alderbande bilot; ende De riebiere

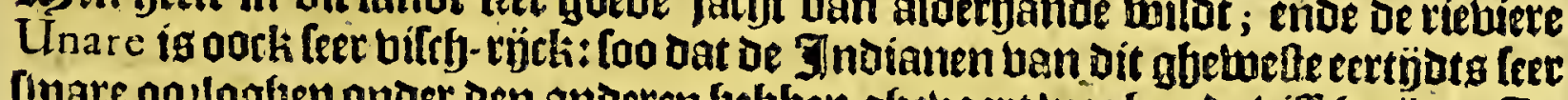

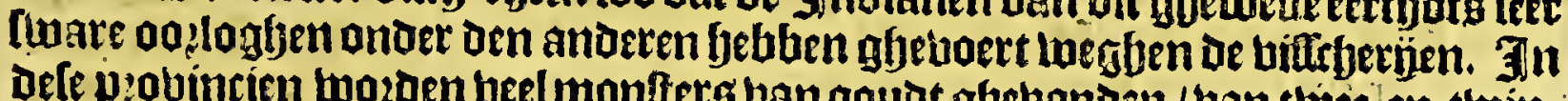
dele p:obincien mozoen beel monfers bangoud ghebondew / ban thete-en-thin= tich quilatenenoe een balt op-twaetts.

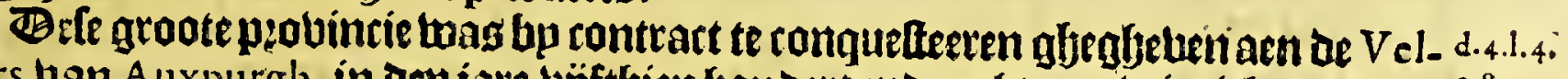

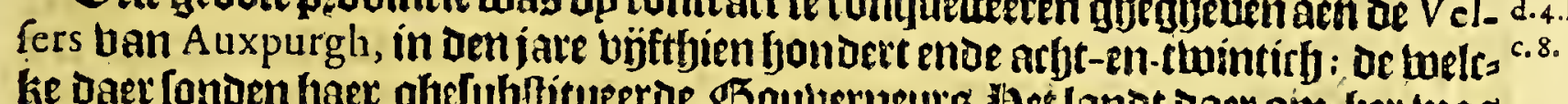

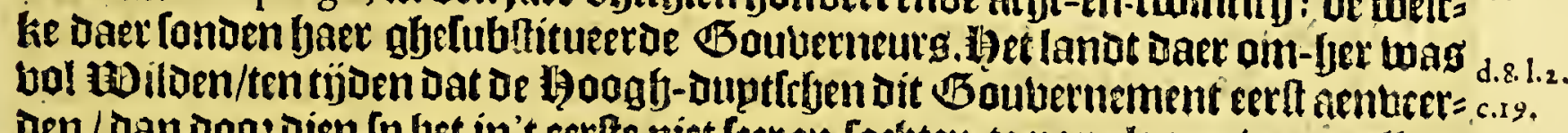
oen / dan doog dien fp bet in't eerte niet fere en forbten te populceren/ maer alleen een roof van daet te balen / foo is dit landt feet ban fpn in-Loanders ontbloodt; haer toe de Spaegniaerden / infonderfept die van Cubagua, niet haepnigh en
bebben gheljoipen.

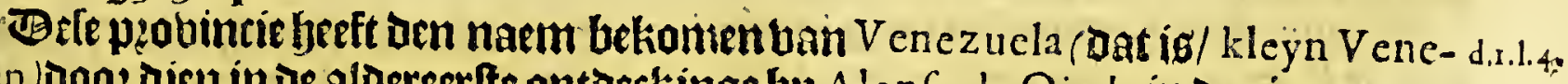
tien) Dooe dien in je aldereerfte ontoeckinge bu A lonfo de Oie da in denjare 1499 , c.2. fp daet bonden een woon-plaetfe tan Tindianen/ oe welcher buplen in't water gleboutut waren op palen/ ente men gincli oles bouten bygggen ban 't cen bupg tot fet ander /ende aen't balte lanot.

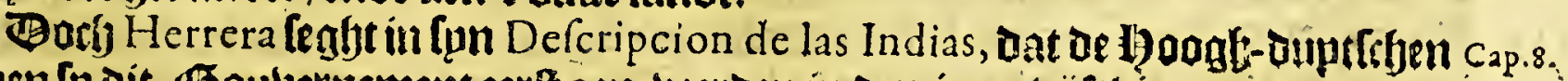

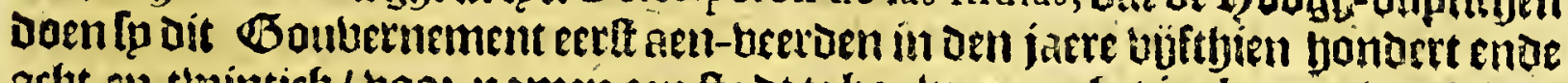
adjt-en thintich / hoo - namen een ftadt te bontuen aen bet in-tiomen ban t lack

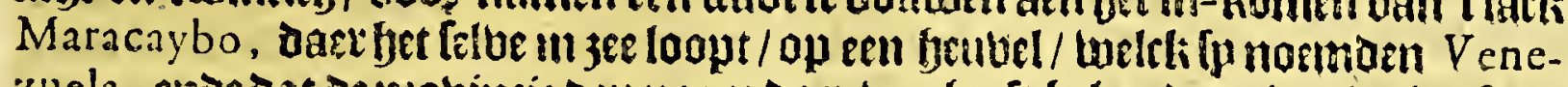

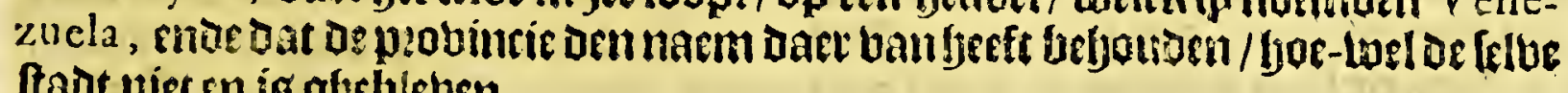
ftad niec en is gubluleben. 
Het (Boubernement ban delepzobincie ban Venezucla ig feer groot / enoe bes

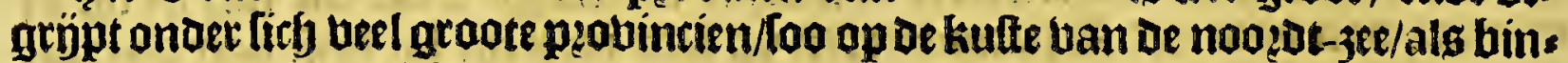
nen's landtg/de toelcke top twel fier berbolgeng Louden befcheñuen/alg Curiana, Cuicas, Caracas, Bariquicemeto, Tucuyo, ende dietghelïstie; Dan doo dién boj Daer ganttry geen pertinent betefept banen binden/Loo lutlen bop oe Lelbe aen-roes ren bp de tteoen die daer in ghelegben 3 ïn/onder oe twelcke die reforteeren/'thelck meer lichts fal kanmengheben aen den aenoachtighen lefer.

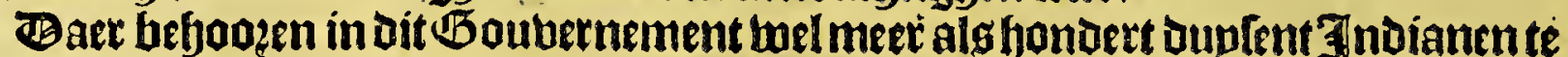
twelen are onder tribute titten (Daet onder niet en moęen begrepenalle die onder *

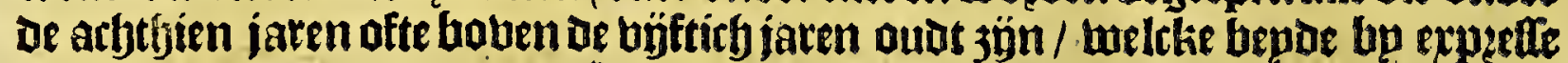
berklaringlje ban ocn oppertten liaed ban Indien, exempt jün ban tribupt

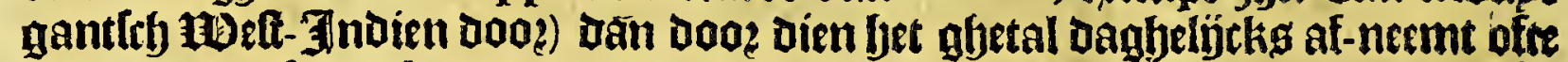
bermeetdert / loo en kan men gbeen leecker ghetal feggfen.

- Baer woyan in dit Goubernement ghe bonden atbt fteden ofte woon-plaetten

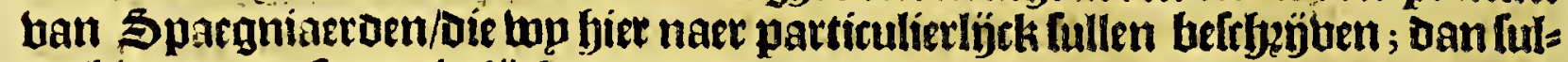
Ien fjert boozen fommietln̈ck aen-roeten eenighe tochten die Dooz oit quartier/ foo

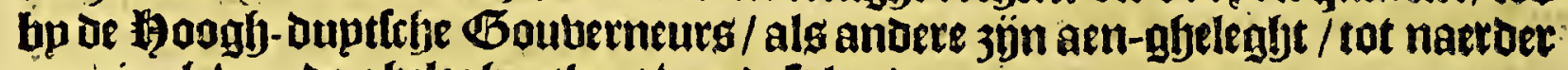
opening ban ae ghelegljentlept ban dere landen.

\section{Het neglyende Capittel.}

Van de eerfe ontdeckinghe vän't lande van' VENEZUE a , by de Hoogh-duytfchen; ende't gheene eenighe jaren gheduerende daer is voor-ghevallen.

I t boo gaenibe Capittel Gebben wo berhaelt / hae Dat ben leplex Karel de

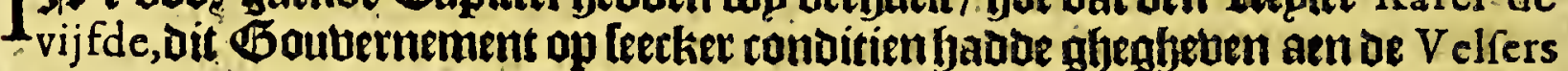
ban A uxpurgh, doo: onderffandelimgfemet Ambrofius Alfinger, . Hieronymus Sayller, enoe Ioris Euiger ín boo: 5 . Velfers naem / niet teghen-ftaende dat luan d.4.1. 6. de Ampues doo laft ban de ltoninghlä́cke Zluaientie uan $S^{t}$ Domingo, De onts c.x. Deckinghe ban dit landt fadde begonnen in denjare 1527 , enbe ghelanot te Coro

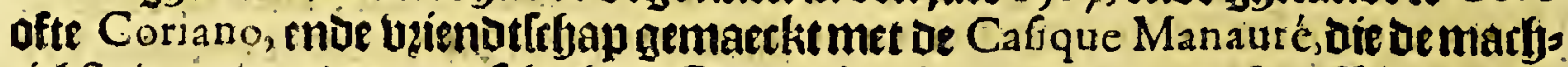
tirbfte was ban oat gantrob gheluefte. Ambrofius Alfinger met fon Zitutenant Bartholomeus Sayller bzacteten Daer in aen jaete 1529 bier fondett man/ende meer dan tatfenticf pertorn/enoe deden oen boot[3. Iuan de Ampues rummen/

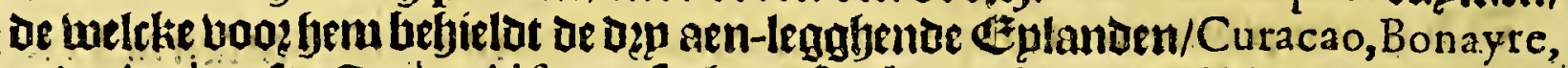

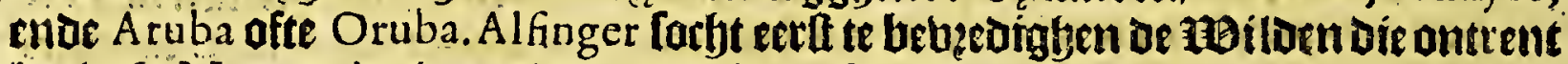
bet lack Maracaybo moonoen / melit de Spaegniartoen noentoen de nueftra Sennora, ende forbt meeft naer goudt-mg̈nen/ enae debe enigfe torftente lanot-

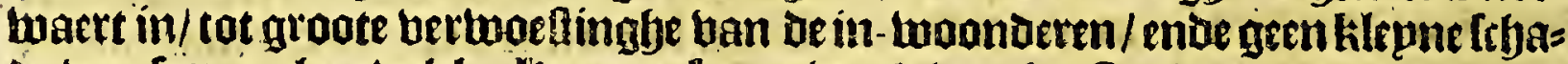
of ban fpu epghen bolck. Ha nam fonen twegh langhg Cupiare, ende quam tot in de ballepe ban Eupary, onatnghefien de feloe ban een andoex Goubernement toag/te tueten/ ban Santa Martha.

Alfinger dede boozer Spn torbt ín den jare 1530 , nam fun luegh naer 't lanot ban de locabuy es, die beel goudts berhanoeloen; quam tot de natie ban de Al-

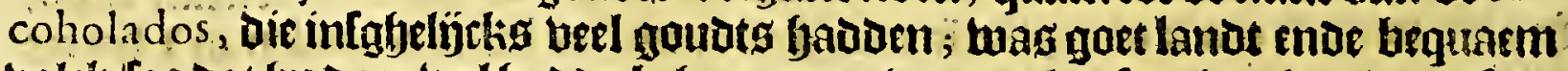

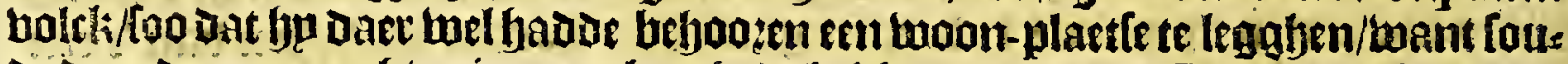
De daat dooz ern rethten in-ganck gefjadt fjebben naex No vo Reyno de Granada.

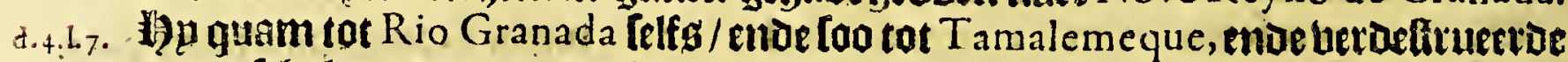

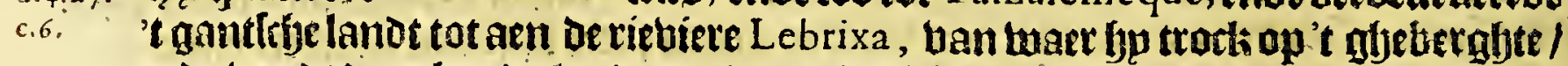
enoe bonot baer kouot lanot / ende beel bolcks / baer hy qualíck ban ontbaelt

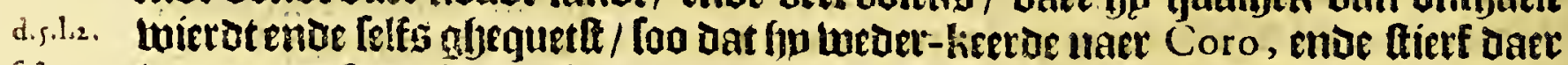

c.3. ban de quetluere in oen jare 1532 . De Velfers fonoen in fpuplatte Ian A leman, die gleen to:bten te lande en aede / ende quam aot! baeft te oluexínoen. In lun plactle 
platte fuccedeetbe lorgo de Efpira, met lón Zieutenant Nicolaes Fecierman, in d.s.l.g. oen faete 1535 , De twelche ban Coro op-rrock in oe maendt ban May, met depp c.s.

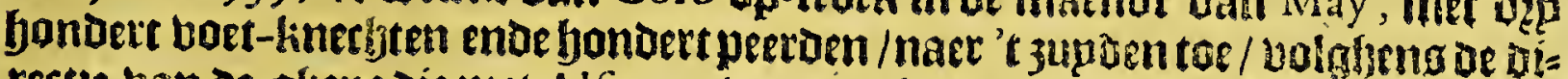

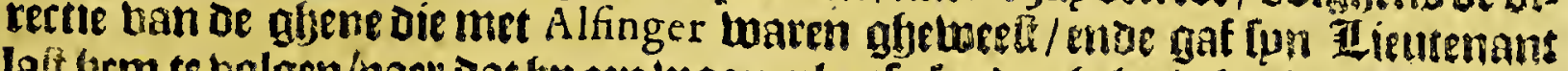
lait brm te bolgen/naet Dat bp een twoon plaete foude gleleght geblun aen Cabo

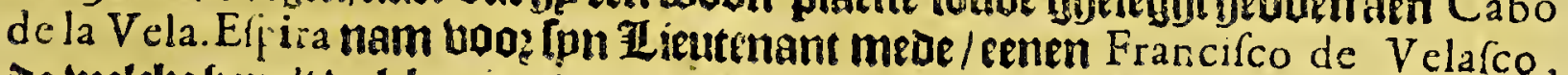
De welcke fem 't bolck mepnoe te muptimeeten/ naer dat fo bp oe twe bonoert leguen twarenghetrocken/Dan Efpira twietot het gljetwaer/ Die defe Velafco daet liet conder andere freafte. Federman bolghens de rommillie ban den Gauter= neur / boer nact Cabo de la Vela om Daer een ftaot te bouluen / Doff liet't felve

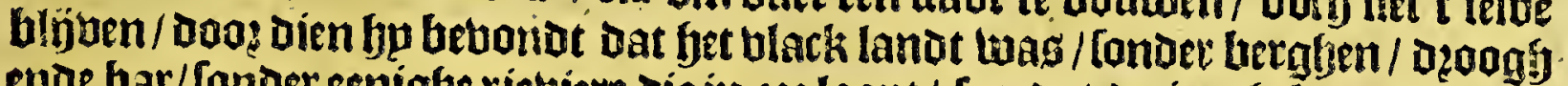
ende bar/ Conder eenighe rietriere die in jee foopt /. foo dat be in-ghebooze ghern

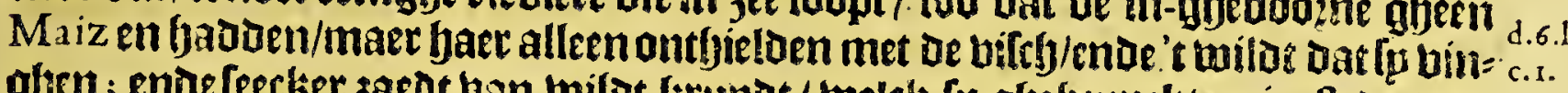

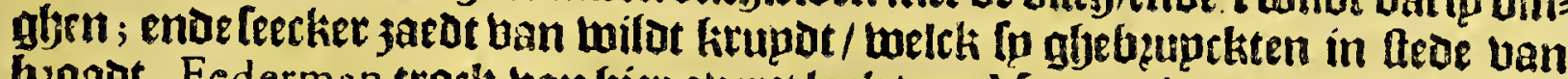
b20odt. Federman trock ban fier ouer'tlack ban Maracaybo, ende quam in De ballepe ban Tucuyo, welckeen legue langh is / noazot ende jupot/ enoe een balf

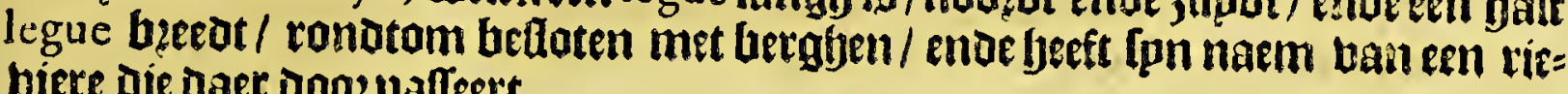
biere die daet doo? palleetr.

Cen feluen tijoe twetot mede bpy bem ontoeclit Bariquizemeto, neffens enn ries biere loo ggenaemt / om datfe't houleur beeft van affbew/ wantwer 't water trou: bel ig. Federman ober-wintert bebbenoe in Tucuyo, frbepoe van daer in December, ende liet daer boog Goubernsur in fun plaetfe Francifco Vanegas, ende

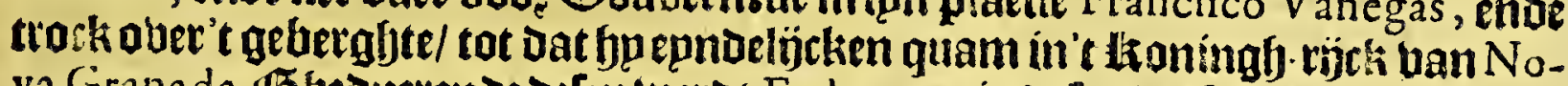
va Granada. G beduerende detentwerot Federman in defe plaetle ban Efpira Gou= d. 6.1 .5 .

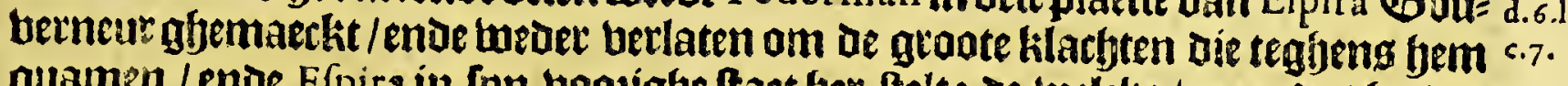
quamen / enoe Efpira in fpn boozighe ltaet ber-ftelt : oe taelcke / maer oat bp oup jaren badoe uut ghetureft op Den torbt / weder-keeroe te Coro in den jace 1538 ,

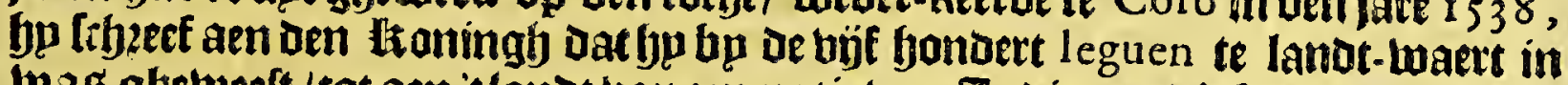
was gleweeft / tot aen tlandt baneen natie van Jnoianen diefo noemen Choques, enoe boe-toel Ijp niet ober de byj-en-twintictjle guen en twas ban oe plaetle die bp corfte/ oar fp niet te min ghenootfaecht twag ghetweel tweder te keeren om bem Telurn ban allew op't nieukg te booz-fien: Ban loef fonder pets bpfonders meet upt te rechten. Be audientie ban $S^{t}$ Domingo felae d'een ende D'ander om d.7.1.ro: Venezucla te gouberneeren tot Dat De Velfers pemande fouben fellen/ han twelctie c.16.17.

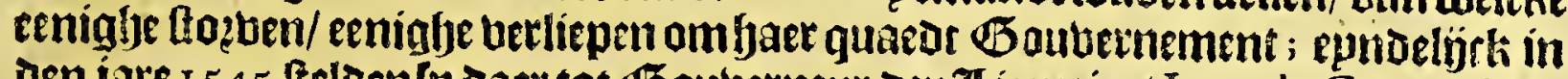
den jare 1545 fteloenlp daet tot Gauberneur den 2 Liemciaet Iu an de Caruaial, die het daer immers foo flecht maechte/ trock op ban Coro ende nam meth al bet be= fiael mede ban die ban De Raor: Crock ober De p'epnen/ latende't getergljte aen

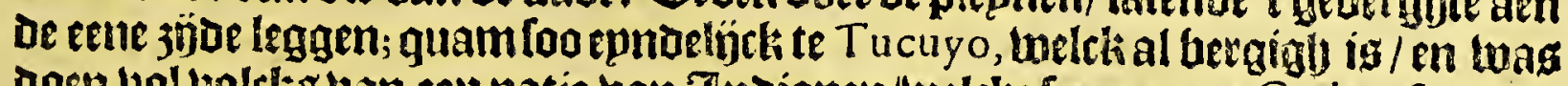

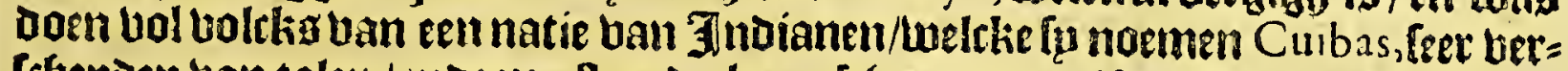

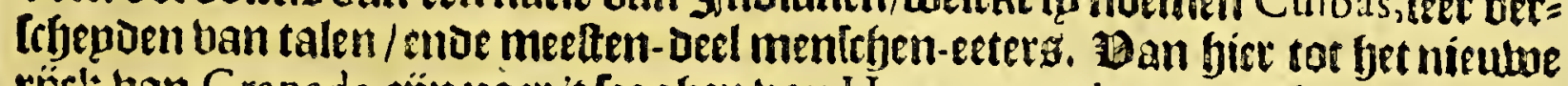
rijeck ban Granada, jijn naer 't legghen van Herrera I 50 leguen, De bondert vlack

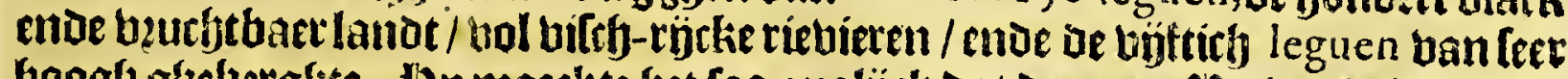

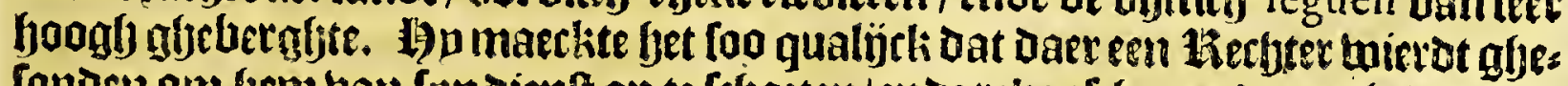

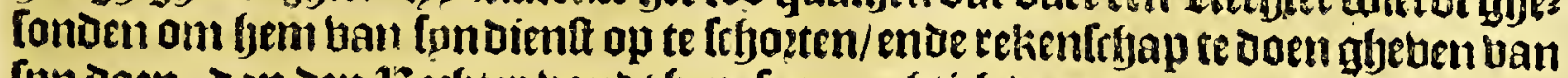
fpn doen, dan den lierfter bonot fem foo mastyticy boos ae groote licentie die ljp 't volck fyadoe gljegheben/ dat bp bem niet en doeffe aen-talten; Caruaial daer-en-

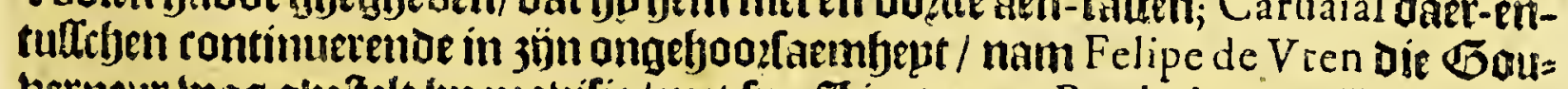
berneır toas glefelt bp p!ovifie / met fpn DLieutenant Bartholomeus Velfer ghes

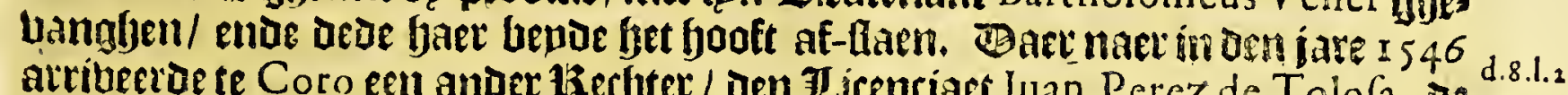

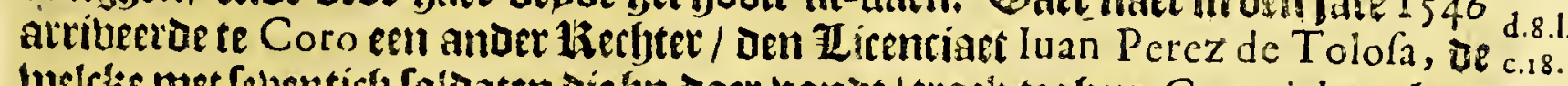

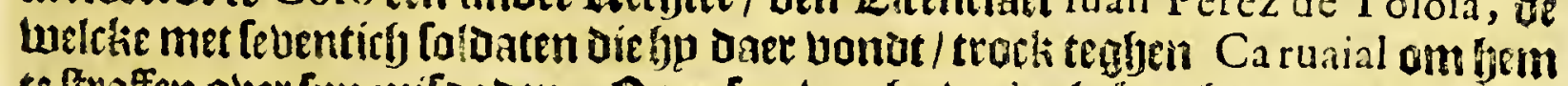
te fraffen ouer fun mifoaden. Ram fan wegljober't gbetergbte / ona te belecten

$$
\mathfrak{G}_{\mathfrak{B g}} 2 \text { Dat }
$$


Dat Caruaial niet en Uluefte naer Neuvo Reyno de Granada; pafrertot de plap:

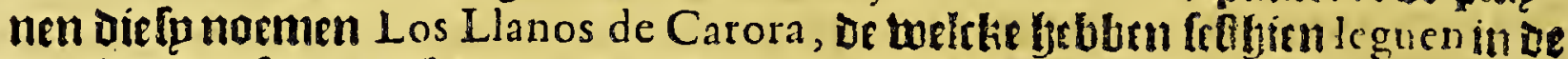

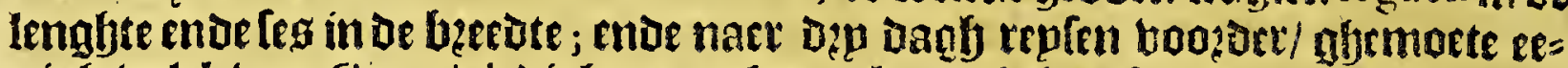

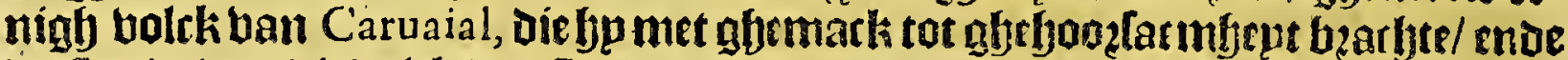
bethonot ban dit voleli dat Caruaial ban Tucuio mas op-gfterorken / enoe fem bielt te Quibore, vijf leguen ban Tucuyo toomormt: foo dat bp hattich boot. trock / en berrafte Caruaial met [pn bolets / ende nam bem gbebantkelpick mede naer Tucuio, ende thafte bem naer [pn gloote milanden.

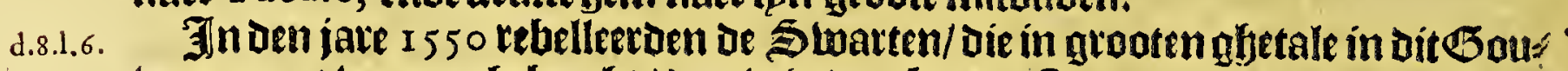
c.s2. bernement waren gbebzacht / Dan microen bu de Spargniaeroen ober-ballen/ enoe alle oat mannelijck taas / om-glyebzarbt.

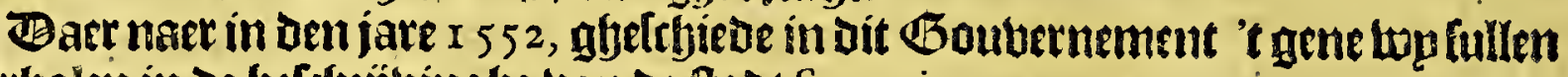
verbalen in de befryęutuinghe ban de tadt Segovia.

\section{Het thiende Capittel.}

Befchrijvinghe van de fadt COR $O$, ende de gheleghentheyt daer ontrent; nostra Sennora de Caruelieda; Si Iago de Leon; Nova Valencia ende Nova Xerez. (E) erfte fladt ban dele pzobincie í Coro, die de Jndianennoemen Corana,

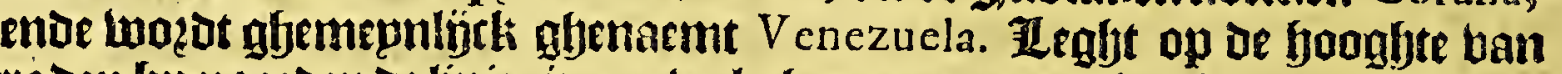
elf graiden bp noozoen oe linie; in een twel ghetempert quartier / boe- bet oaer glye= beeck is ban twater/ han riebieren ende fontepnen; is glueboulut op etn plapn/ tlanot is anuets bergharlytigh / saec is goede enoe ghefonde lurbt / foo bat men gheen medeịng uan doen en jeeft / oft andere medecinalen als be krtutorn van 't lanot / Daer bepde de Spargniaetoen ende in-glbebooentn yaer mede purness

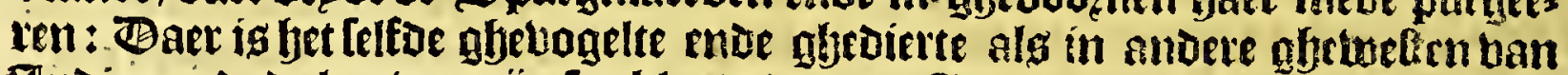
Indien;ende de leeulwen jün [oo bloode dat een Tndiaen met een lyout Die doodet;

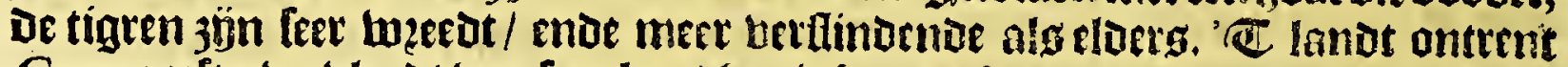
Coro geeft oberbloeot ban lupelier/ jonigh/ gember ende pecli; daer waft lere

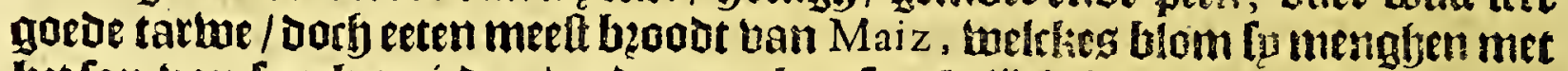
bet fap ban fupcker-rieden/ ende maecken Imakelijek bzooot daer van/ welck langh Duert als twee-bark. SYaecken baren dzancli ban Maiz moe Potaces,

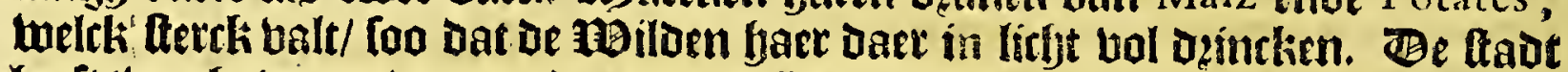

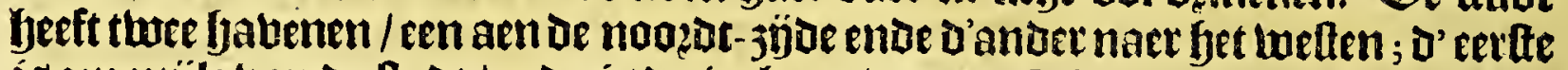
is een mịle ban de ftadt/ende is de in-ljam uan de Cabo San Roman, ende ie

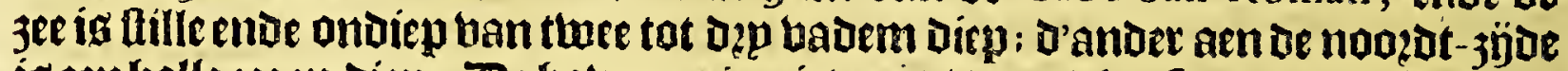
d.8.1.2. igeenfyolle $3 e c e n$ diep. De bauen en ig niet gaet / dooe dien fp wepnigh berthut= tingh feefr/cnde ae ftadt leght twee leguen ende een falf van be faben;

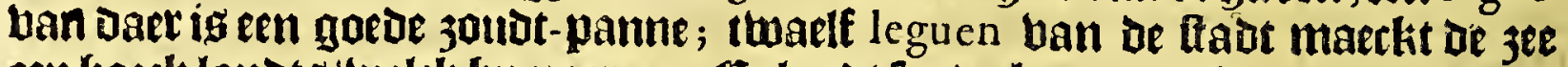

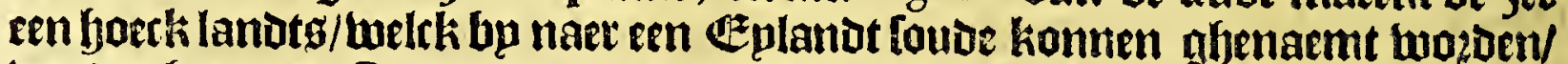
logedt aljenaemt Paragoana, ende de trbippers noemen't Cabo de San Roman;

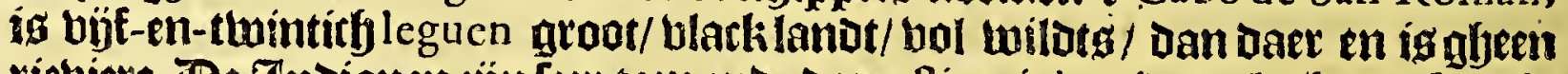
riebiete. De 3 ndiamen 3 jun [eet tam ende domeltirg; int mioden leght een berab! tuelth men liet injee. Daer is een Jouberneur in Coro, ende de Cathedzale-kere:

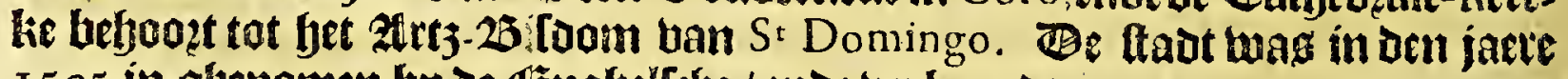
I 595 in-ghenomen bp de Eengfellebe / ende betbanot.

d.8.1.2. Ontrent Coro in de wegh naer bet glfeherglyte legalyen Los Llanos de Carora,

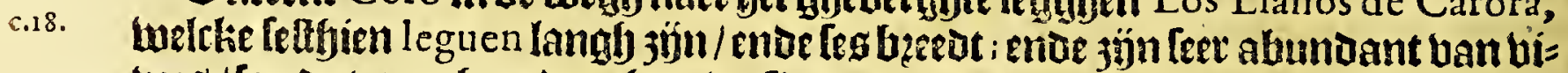
bets / foo dat men Gem dacr han berfien van Maiz ende twildt-beaedr. Fan Coro tepft men naet Bariquizimito, ouer Xizaharas, naeft-gheleaben by Coro, enoe sïn alle woefe beloen / meteenighe berghen / op twellke de Axaguas woonen Die menlifen etell; ende men han met baer ghen bęede jouden. 
Het fefthiende Boeck.

Betluecoe platte bandit Goubentement ig Nofta Sennora de Carvalleda in oe plobincie ban Caracas, ontrent de jee-kulte / tachtentich leguen waer 't aoften Her.der. ban Coro; beeft een berballen ende quade yaben. Op de zee-kufe jebben de

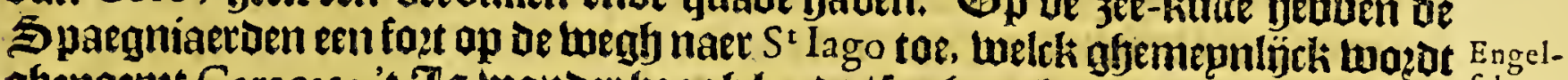

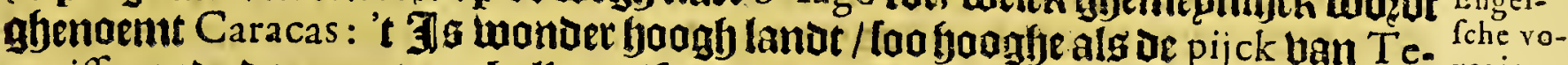
neriffe; enoe daer gaet een balle $3 e e /$ loo datter quaeot is te landen / alo alleen in yagie. een kilepne kireecke retgt boos't fazt.

Be derde plaetle van dit Goubernement is de fiad Sant Iago de Leon, in de Her.def. Kelue probincie ban Caracas, Teben leguen binnen's lanots / oft loo andere feg= gyen bujf ban oe kufte; ende dęp leguen ban Carvalle da naer bet jupoen/ende fes uentief leguen ban Coro, ende mede foo beel ban. Tucujo; de Gouberneur ban

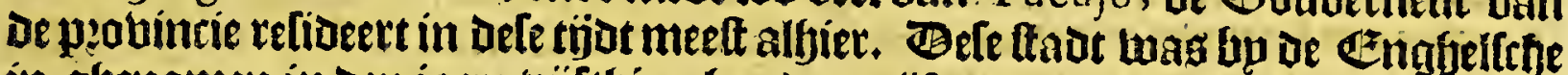

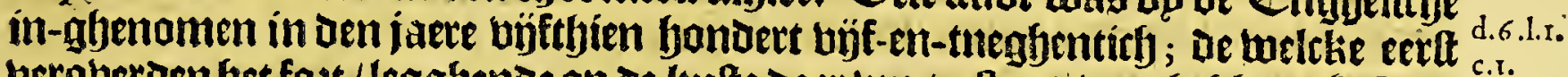
beroberden fet fozt / leggbende op oe kulte daer top terlfant ban bebben gheluza= Engel. ken; ente bevonden datter twee weghen twaten om than ftranot naer de ftade bin = fche voIten's landts te martheeren/een azjinaire twegh twelek feer lícht ís te toppen enoe yagie. te befcheemen/ boas dien in fet misoen ban de wegh een boaglen bergh leght/ ende de paftagie daer maer bijf-en-twinticf oft dertich boeten beecot ig / ende aen bepoe zjoen fteple berghen / ende de bollinagien foo dicjt dat daet niet en ig ioo?

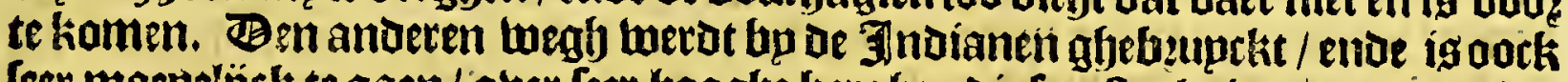
feer maepelijek te gaen/aber feer boaghe berghen aie feer ftepl znj aim op te klim: men. Bie gljepalleert jünde kamt men in een effen black belot/ baer de ftadt ghelegben ig.

De bierde ltadt ig Nova Valencia, feltich) leguen ban Coro, (en kanniet ouet Her.der. büf-en-beertich wefen) ende büf-en-twintich leguen bain Sant Iago de Leon, ende feben leguen ban de faben van Burburata.

De vijfoe plaetle íg de thad Nova Xerez, büftbien leguen bp-naev 3 updot- Her.der. twaetta ban Valencia boat. [theetuen/en thintíty leguen uan Neuva Segovia; en feltich leguen naer bet jupdt-oolten ban Coro igenn nieube ltadt/ende on: langhs gheboutut.

\section{Wet elfoe Capittel.}

Befchrijvinghe van de ftade NIE U SE G OV I A, ende de gheleghencheden daer om her.

I Den jaete 1552 bertrack uen Gauberneur Iuan de Villegas upt De plabiucie d.8.1.8. 1 uan Tucuio, ende ontoeckte mínen ban gaudot neffeng een Cordillera ofte tuer $=$ c.r. balgh van glebergfte / lwelck fp naemen de San Pedro, bp De rieviexe Buria, tie

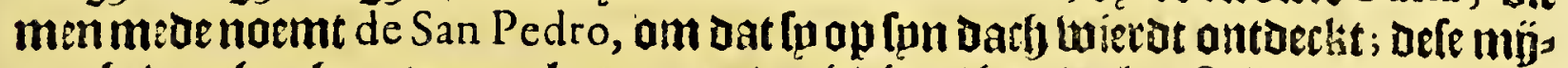
nen betwoghen bem te populeeten aen oe rietiere / goe-terel oe ftad miet langh en

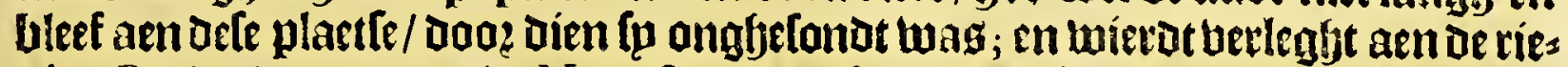
viete Bariquicemeto, ende Nova Segovia gljenoemt. Let tlima enoe de gfjeltalte

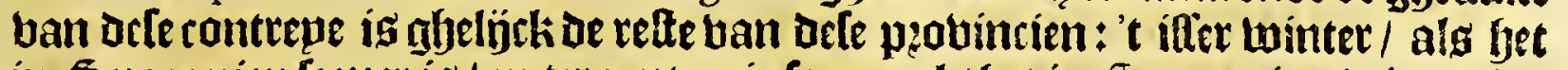
ill \$pargnien fomer is / en ter cantrarie fomer als fet in \$paegnien twinter is; oe ulacke landen jön fjeet / ende ban de gheberghten toaepen hoele winden die ae lieden berquicken/ want leght tuftefen twee ghebergften/ it maniere ban een

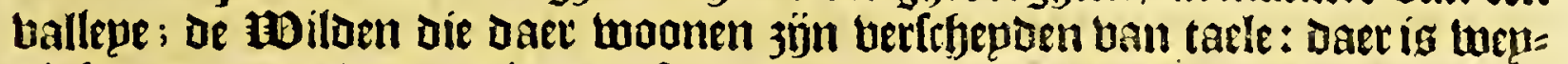

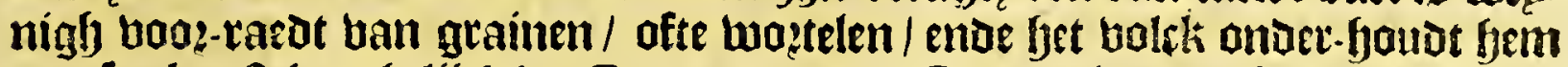
met leecker ftelen ghelífli de Carbaenen van Spaegnien/ die fp noemen Co-

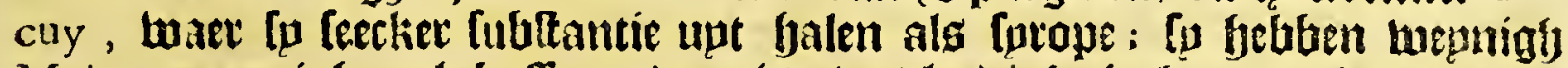
Maiz, en eenighe calabalten; daer ís aberbloesinge jacht ban barten enoe kavijnen: in't ander berbolgh ban berghen aen oe jupdt-jijoe/valt beel Maizent

$\mathbb{G}_{\mathfrak{g} \mathfrak{3}} \quad$ Yuca,


Yuca, Doog toien 't lantot daet bochtigher is / ende in de riebieren Hacarigua ente Borauté, $\mathfrak{e n}$ in ander beken bangbente beel bifty/met ren twoztel die fp norment

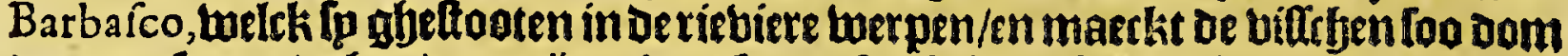

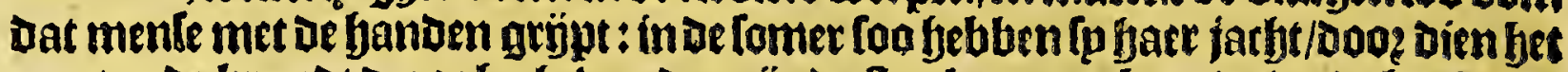

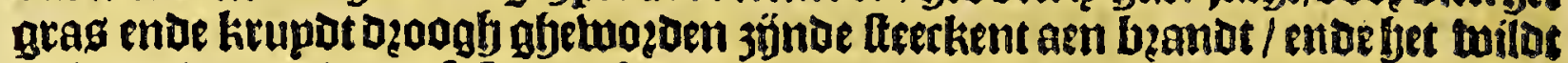

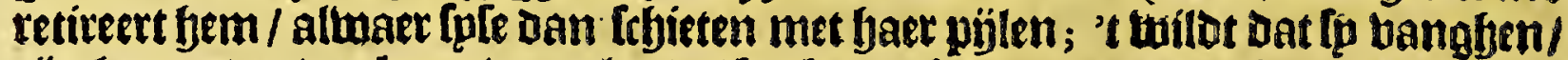
jön barten/en berckeng ban't lanot / bocken/ ofre otpnen / konpinen / Langben/ Bobas, (welck jün lectkete groote tanghen) tigren en armabillen/ enoe op die

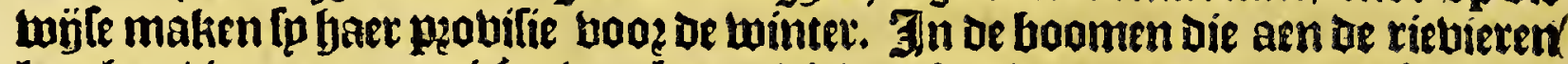
Ieggben/ ig groote menitgte ban bpen/ die beel bonings gheten: alle defe rievies ren ende beken loopen tuel bandert leguen ban Defe plaetle / met meet andere vie

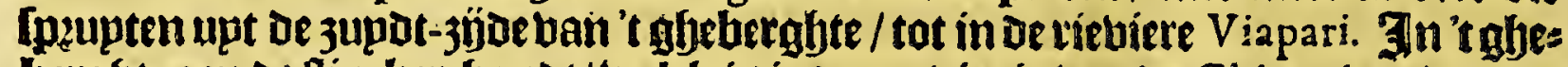
bergbte aen de dincker-bands/melck is in oe pzobincie bande Chicas, wozbt gout ghegrauen/entoe indien de in-moonders ban defe that midoel hadoen/ couden feer beel goubtg konnen berfamelen. Baer twas beel bolkks ban de in-ghebooz= ne) maer de pockkens en andere dífozozen bebben die bermindert. "Ce is bolck ban klepn bertanot en kilepn couragie / gheneghen tot beel ghebeetien/ inlonuers bept tot Deincken/en Dzencken jönde bermoozoen fp malkanberen; Jeben fon:

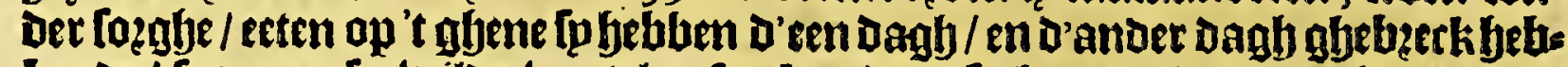
benae / foo gaen Ip twilloe woztelen foecken daer lp baer mede onoer-bouben tot

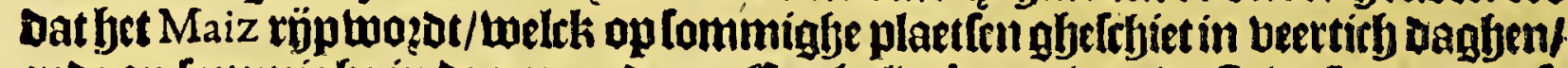
enoe op fommigfe in dep maenden. $\mathbb{E}^{z} e n$ balto legue ban de taot Segovia pafs

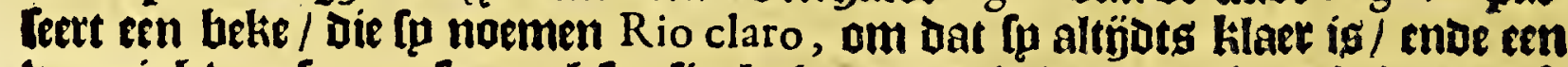

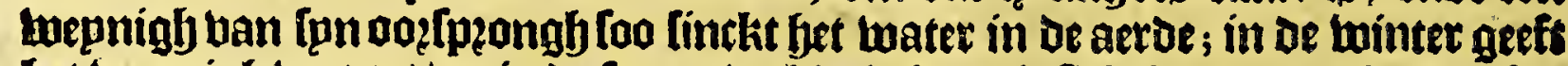

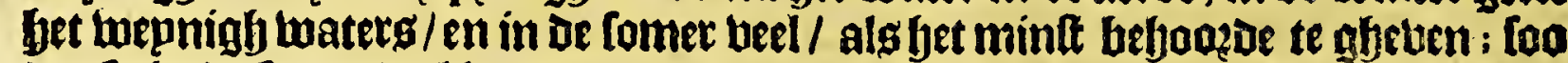

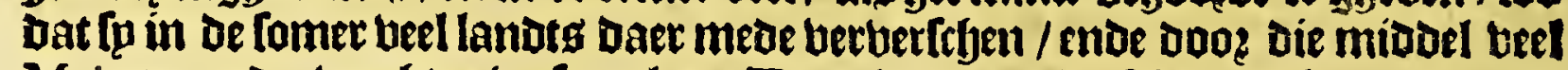
Maiz en ander beutften berfamelen. Taer is groote berfrhepoentbept han gbes bogbelte / als quackelen en ringh-dupben; De peersen / booen-beeften / frbapen/ gepten en berckens bermenighfulbigfen feer; too dat bet bee de meetten bandel ig ban dele ftaot; welck lp te lioop hęengfen naex Novo Reyno de Granada:

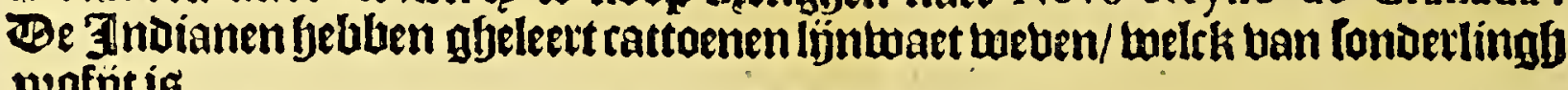
peofút ig.

Her.der. Defeftadt Dan leght thintity leguen ban Xerez naex fet 3upoen / en tbien le. guen ban Tucuyo, en tarbtentith leguen ban Coro naer fet 3 upot-ooften. rept ban Segovia naet Tucuyo boog en ballege/ weltk is twaelf leguen langh.

\section{Het thatlffe Capittel.}

Befchrijvinghe van deftadt Tucuyo, Truxil LO, LA cuna, ende de gheleghentheden daer ontrent.

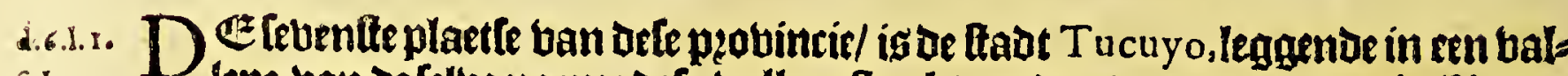
Iepe ban oe felbe naem: defe ballepe ftreckt jupdenen noosoen/een balf legue langfen beetot/ronotom omeingelt ban bergen; ende beff [pn naem ban een rie: biere die daer dooz-loopt:'t íseen feet gefondt landt/ende aen'tin-homen ban beele bergljen / oberbloedigh ban peobiande / foo trel toog de Spaegniaecoen alg book

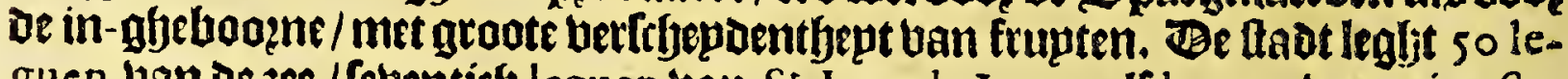
guen ban de 3 ee / Gebentich leguen uan $S^{t}$ Iago de Leon, flf leguen ban nieu Se.

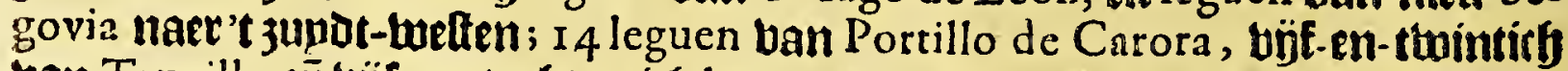

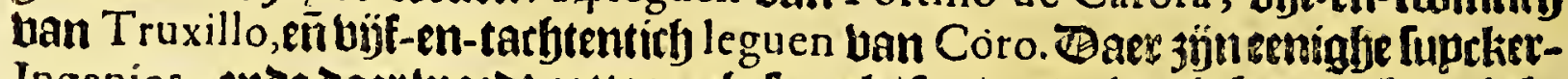

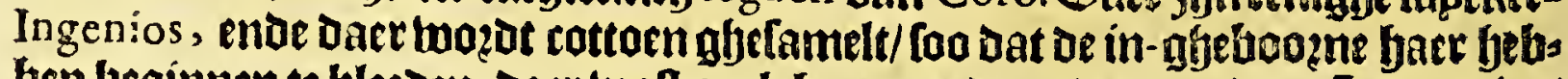

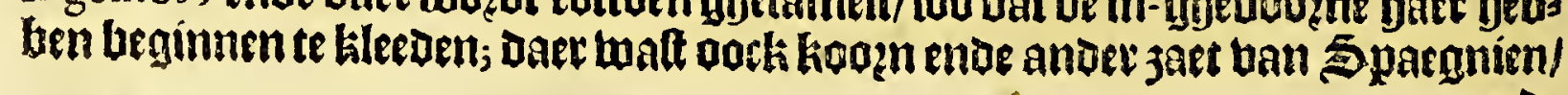


Het felthiende Boeck.

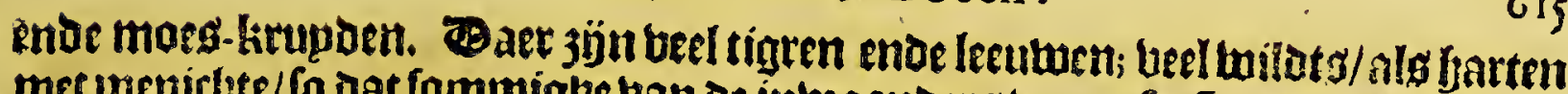

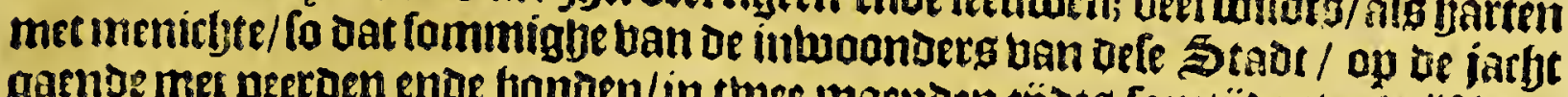

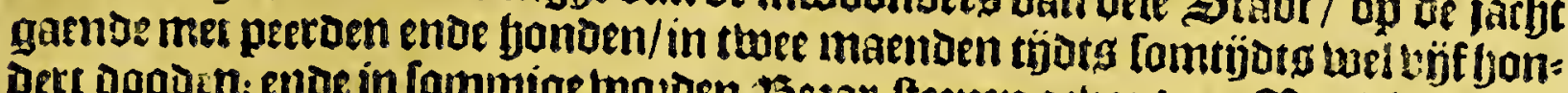

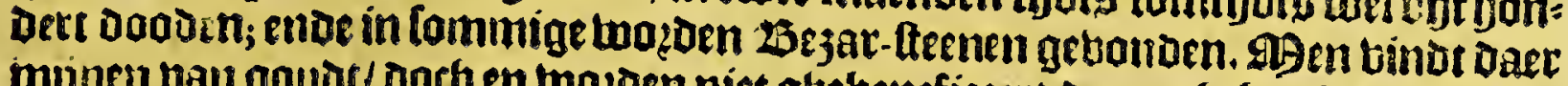

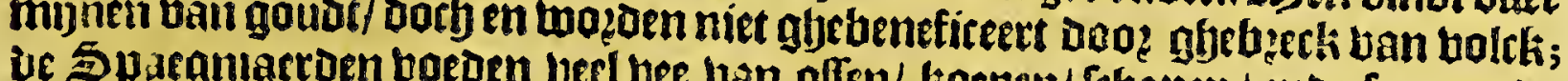

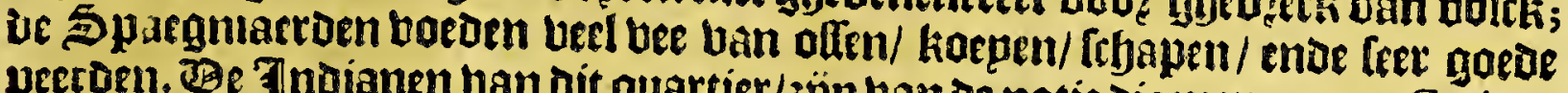
peetben. Be Indianen ban dit quartier/3ynn ban de natie die men noemet Cuibas, d. 7 -1.ro.

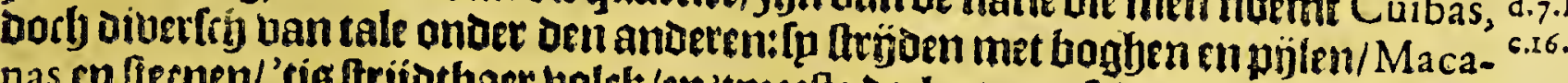

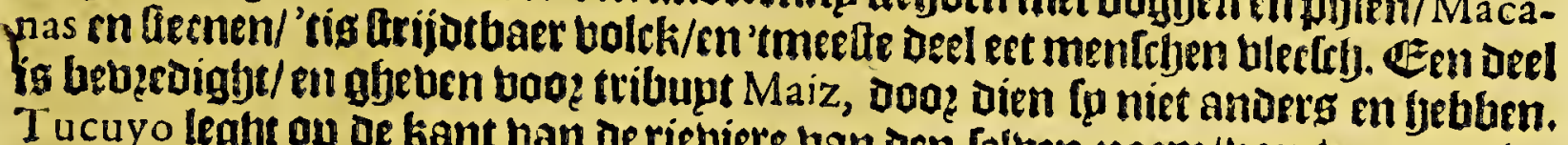
Tucuyo legbt op oe fant ban de riebiere ban oen felben naem/ban baer tot fet

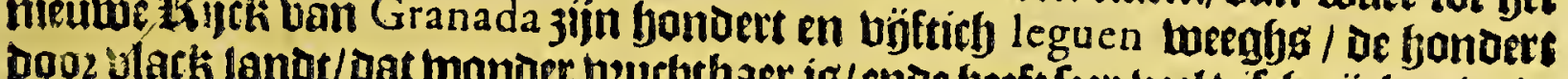

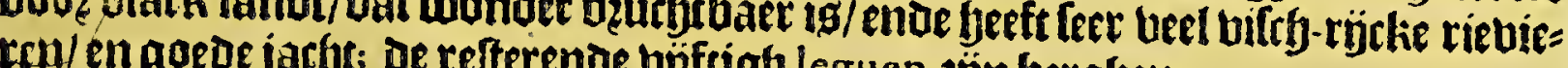

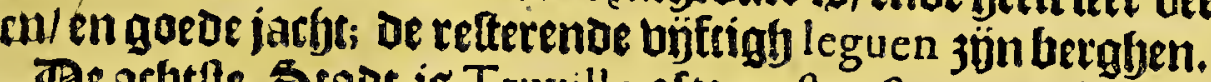

Beacbtte Stadt is Truxillo ofte noftra Sennora de la Paz, in De 1920hintie Her.der. ban de Cuicas, tp naer tarbtentitb leguen recht 3 updr-twaerts ban Coro, eentwep=

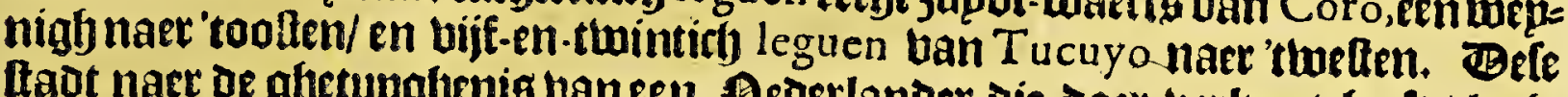

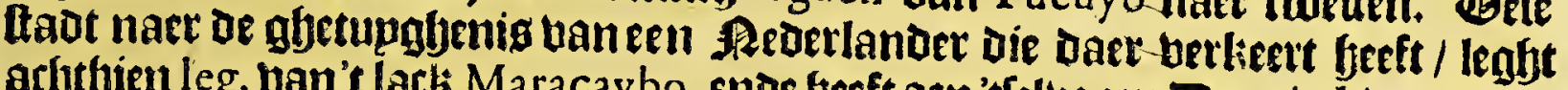

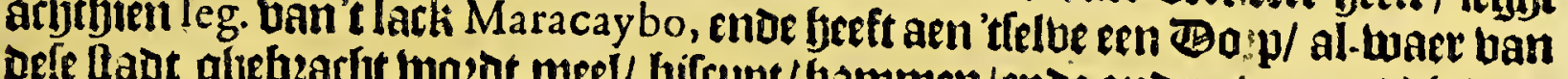

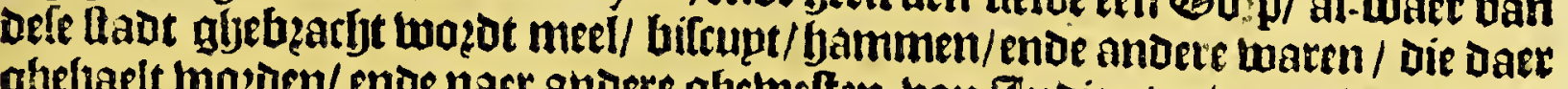

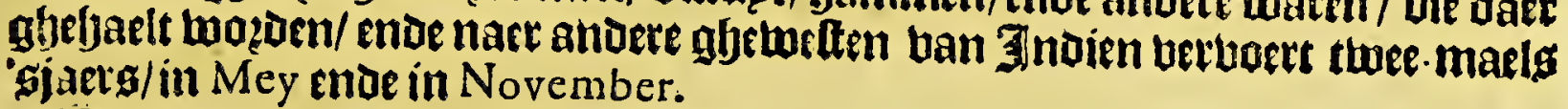

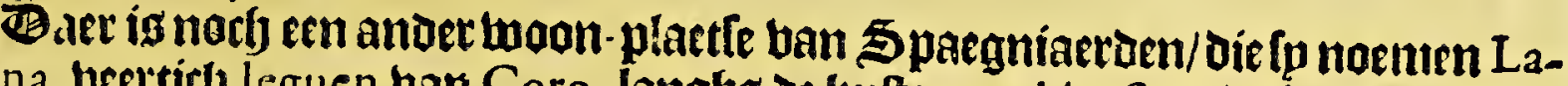

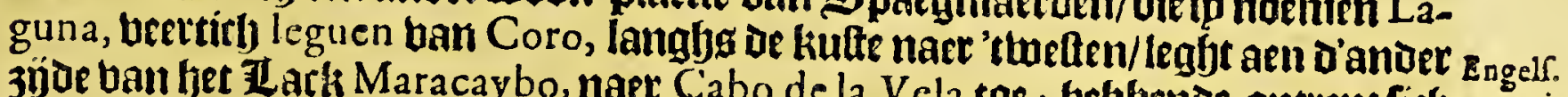

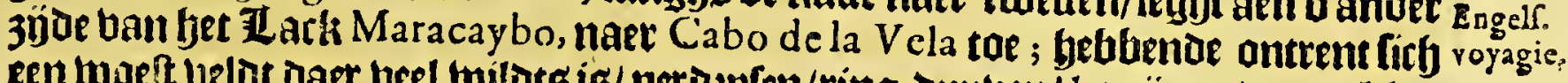

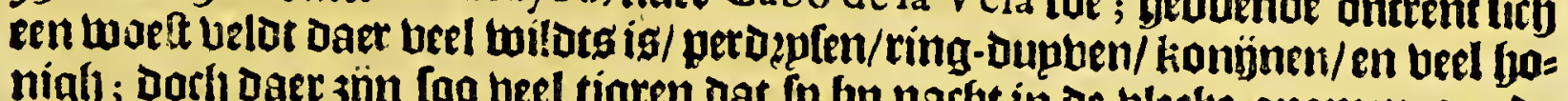

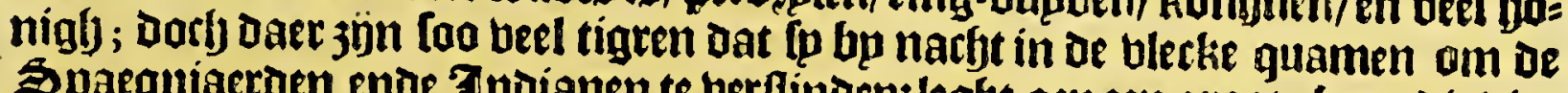
Spaegmiacrden ende Indianen te berdinden:Legft aen een groote bape die diep in't landt loopt/en bal ontiepten en Dzooghten is.

\section{Wet Dertbiende Capittel.}

Befchrijvinghe van't grootelack Mar a CAYBo; ende van MAR ACAPANA op de uyterfte limiten van dit Gouvernement naer' $c$ ooften.

H

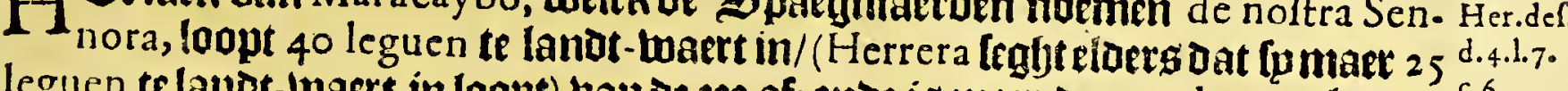

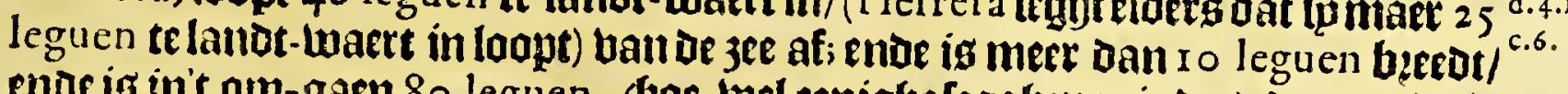

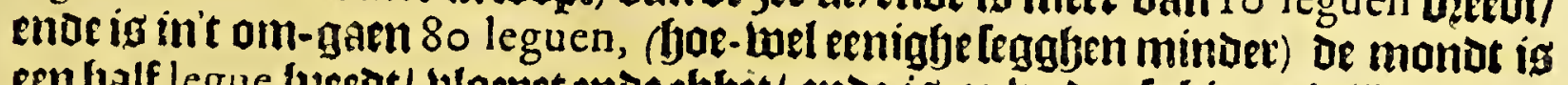

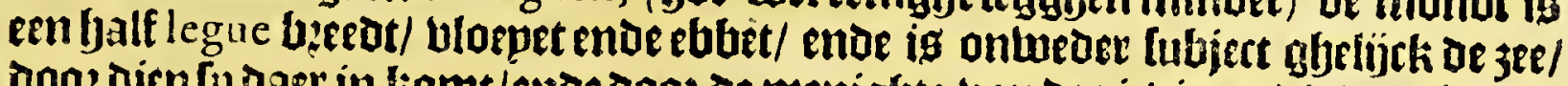
doaz dirn ty daer in liamt/ende doog de menighte ban de riebieven oie daer in ual

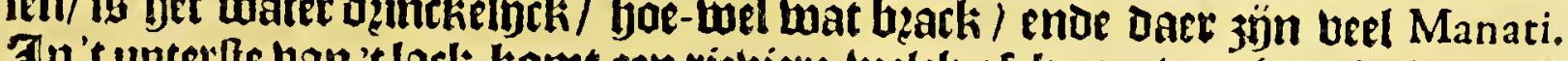

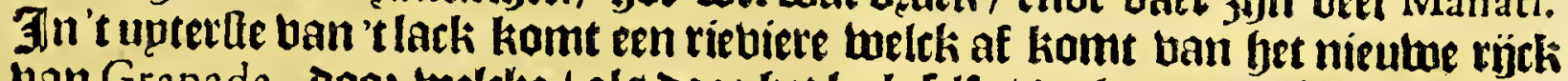

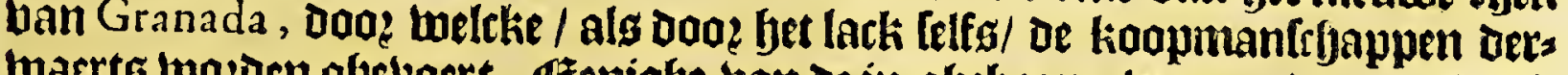

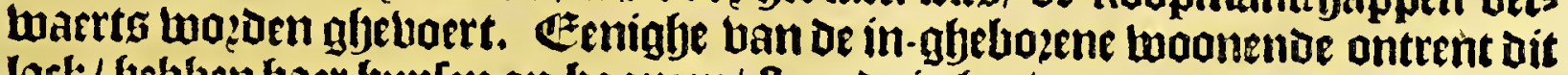

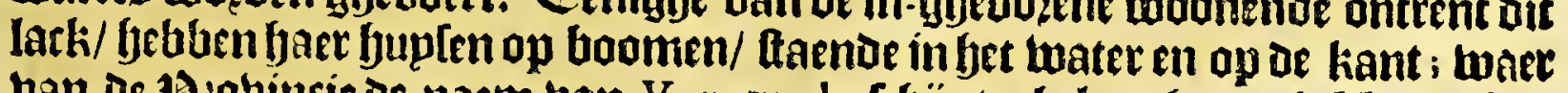

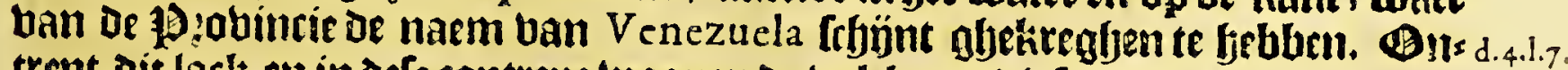
trent dit lack en in defe contrepe twoonen de holckeren die Ipnoemen Pocabucys, c.6. Die beel gaudeg Lethandeldern/ ghelÿtk aock of Alcoholados ren ander natie Daet ontrent/ Die mede beel goubts hadoen; twoonen in een leer gocot lantot/ an

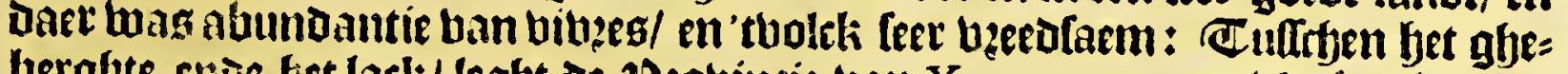

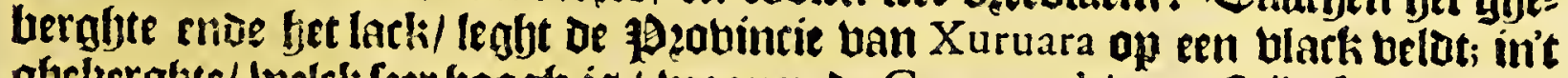

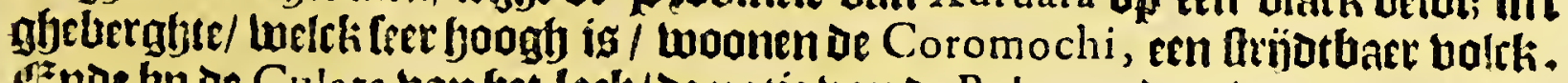
Ende bp de Culata ban bet lack/ De natie ban oe Bobures; dan Doo ze menichte $\mathfrak{G} \mathfrak{g} 4^{2}$ ban 


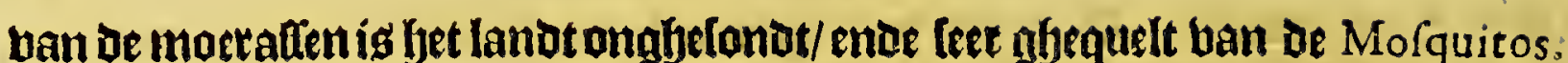
Ban Xuruara tot Coro tae jün tactjentich leguen, met wepunigh boleks / ende Dat nocljniet bebzoigft/ arm bolck.

Maracapana op fyet upterfte van defe 13 zobincie naer bet oolten is een leeckere haben/ De befte ban alle dele kulte; de Thoianen moonoen Daer ontrent op thee/ feg/ente thien mïlen van daer/ die men noemt Chiugotos, eníseen tale/ moo:

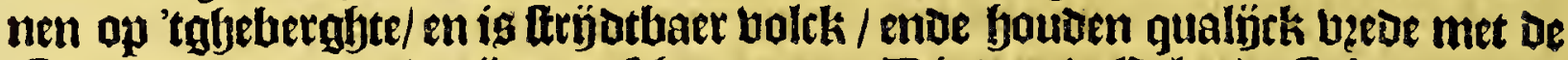

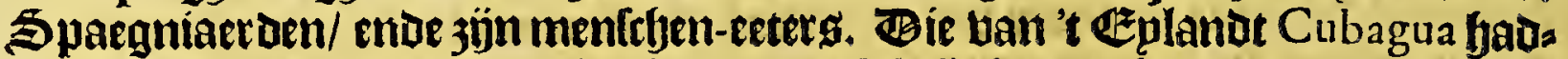

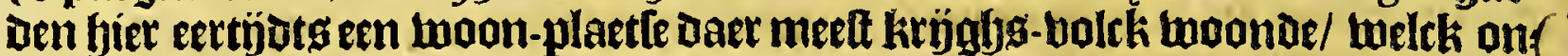
Der deck kel ban het Eplandt te befebermen/ haer tochten Deden in't lanot / ende

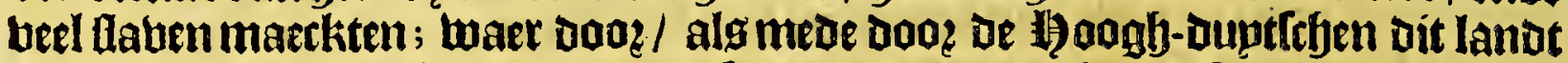
feec van bolck is ontbloodt. Benzo feght / Dat bet een klepn ttedeken tuag ban uettich buplen oft daet ontrent. Ban Maracapana tot Bariquifimito jün bons Dert mijlen ober black landt/ daec goede jacljt ig ende bifleferp/ Dan alles ig gbe: Depopuleett/ en Daet jÿn nu beel tigen.

Het beetbiende Capittel.

Befchrijvinghe van de Eylanden die voor defe kufte legghen, te vveten, I. Bianca, TORTuga, OrGHilla,

Rocca, I. de Aves.

$\mathrm{O}^{\mathrm{s}}$

Poer de bozoere Geplanden die aen Dele kulte legghen lpu aenmetckeng weerdigfy; eerlt Ifla Blanca, abelegljen op de booghoe van thaelf graden/ (oft lod anoere legghen) elf graden ende atbt-en-beertigh minuten) ontrent beet= tigf mülen ban Granada belt ten jupden / ende feftbien mülen van Margarita noogst-welt ten noozoen/ wel loo noazoelightk: ontrent les mülen in't ronoe; ende

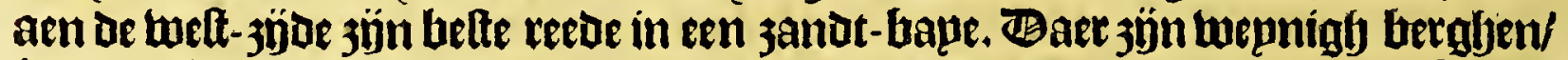

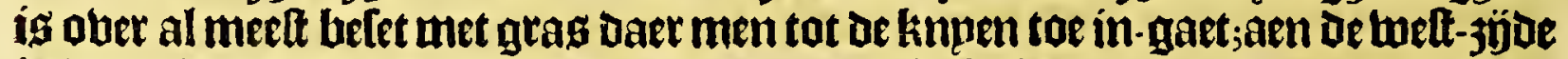

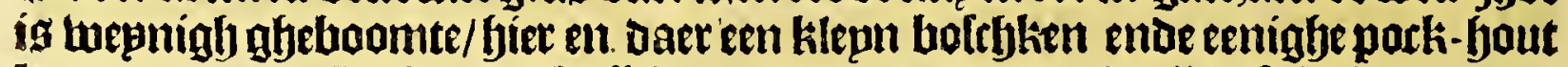

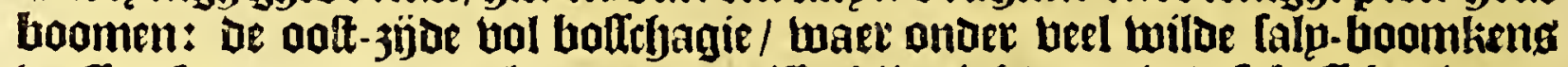

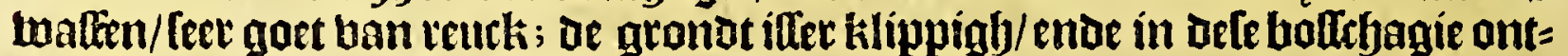
houden fyaer oe meete bocken; enoe aber al daer eenigh gheboomte faet is bet

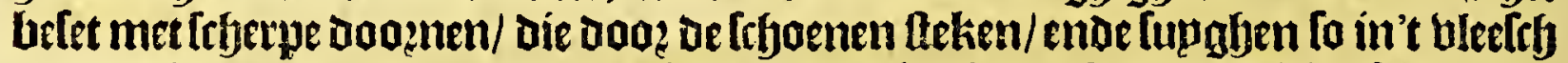
Datmenle met ghelwelot maet upt-jalen; daet is gheen oft-mepnigh berfeb water/ Dan als bet reghent ! De gronot ig doz en dzoogh als turf-mul / [oo dat bet leet

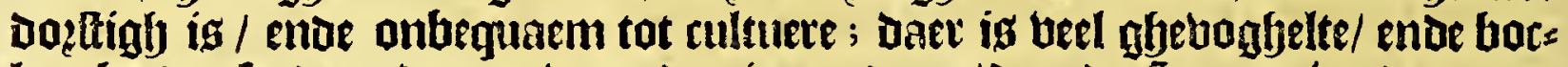
ken bu dupfenoen: Daer en lwoonot niemanot op/dan de Spargniaeroen ende De onle loopen daet aen om bocken te vanghen. Daer jün oock eenigbe joutpammen.

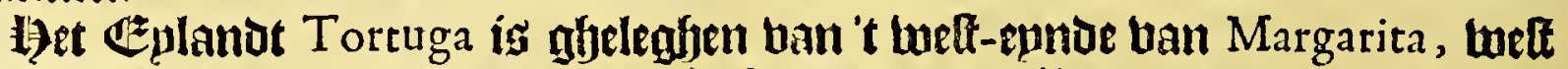
chae tuelt ten zupden ontrent twaelf oft betthien mijlen/ ende ban I. Blanca

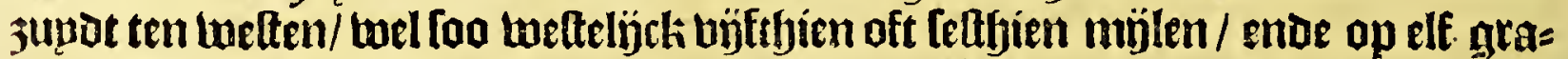

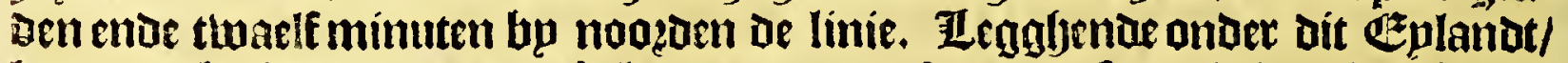
tan men lup klaer beder 'tuafte lanot ende de Margarita fien; is langl ooft ende lueft ban dep tot bier mijlen/ende beecot ander-balf mijle. let oolt-epnoe ende

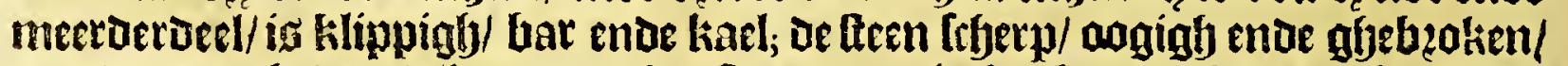
ginaedt om te betwanoelen; naer ljet ftrandt toe ig fet boomigf / ende bp oe $3 e e$

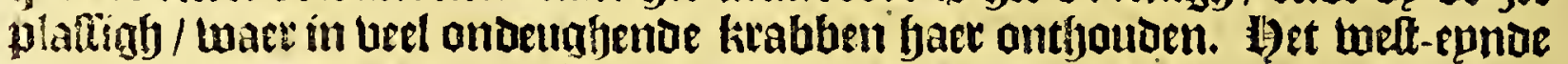
tot bp naev'tmioben ban't EEplandt ftaet bol gljetoomte/waet onder beel pock-

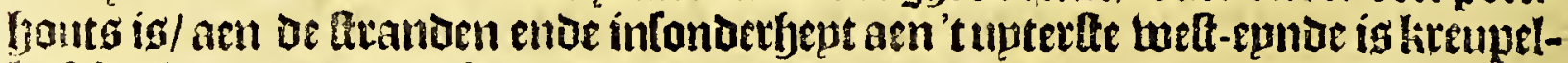

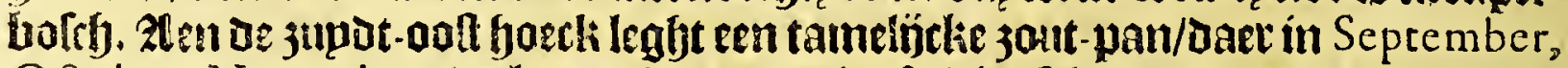
Oasober, November, wel jout is hooz deit oft biet frljepen/ dan de reede en igs

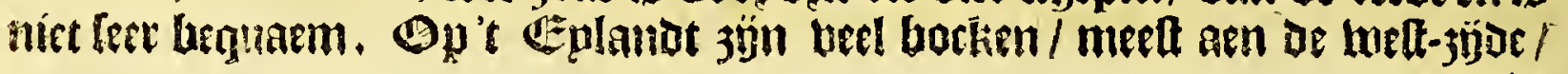




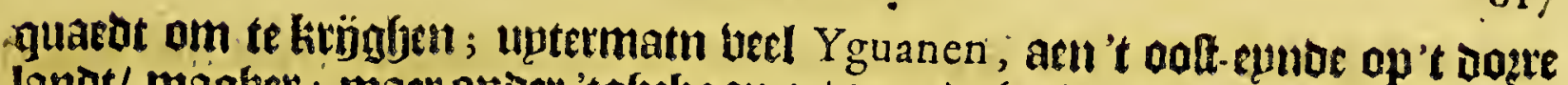

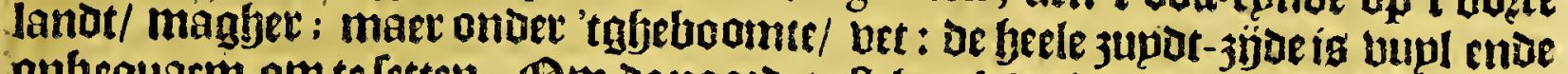

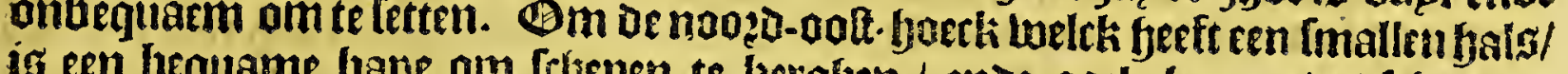
ig een bequame bape om feffepen te bergiben / ende oock by noodt / ffjoon te maecken.

Orchilla ligft ban Tortuga nooget-luefl ten noożon antrent büfthíen mülen/

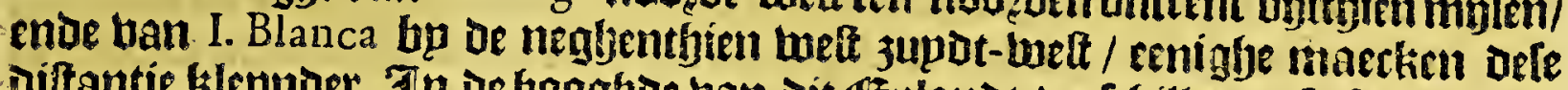

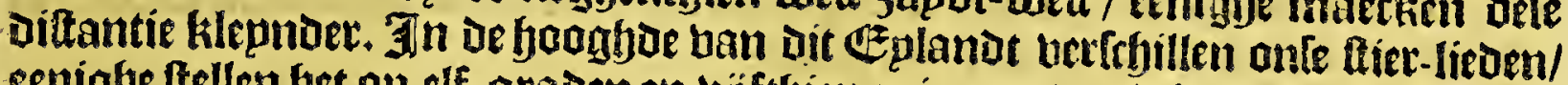
eenigbe fellen fet op elf graden en bífthien mimuten/ecniglje op oerticly minu=

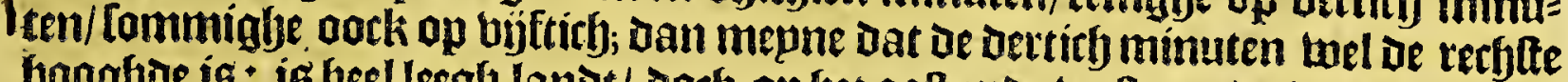

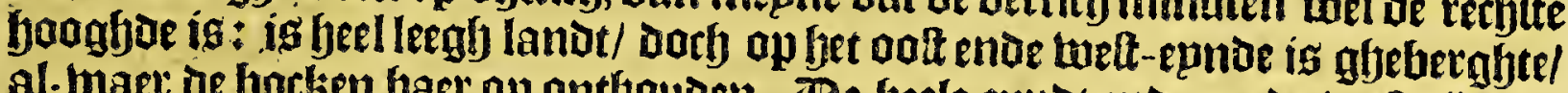

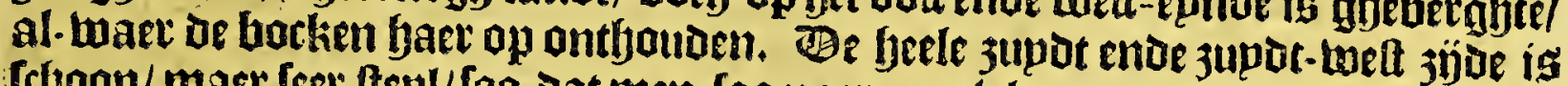
fcljoon/maer fert Atepl/foo dat men loo naet matb loopen als men twil; aen de

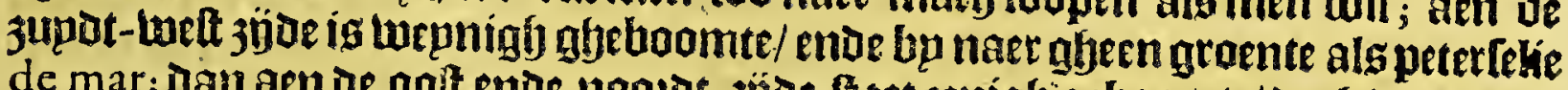

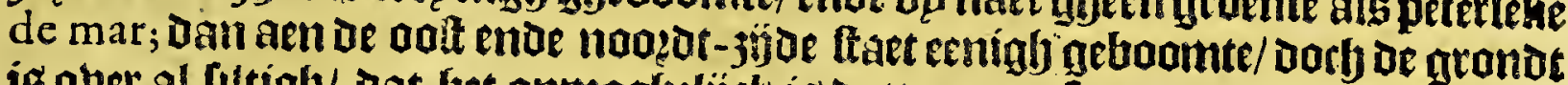

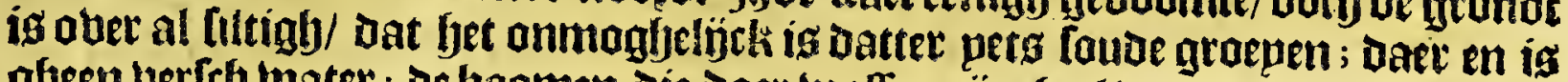

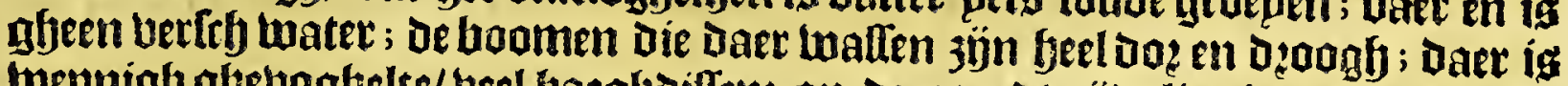

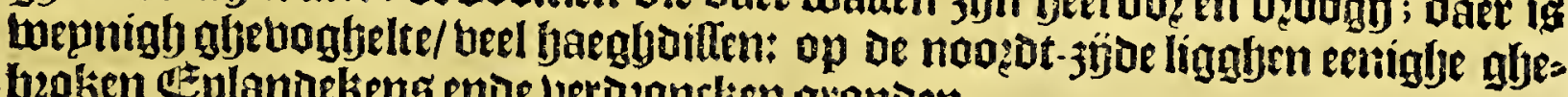
bratien EE Elandekeng ende Uerdzanclien gronden.

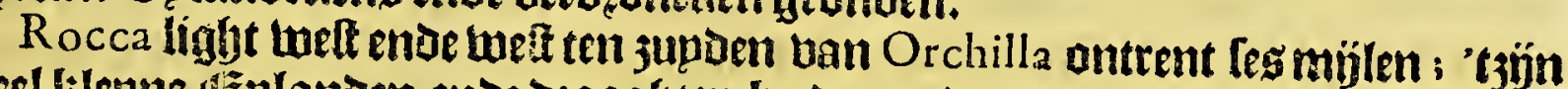
beel klepne diplanden ende dzooghten bp oen anderen / met boomen befet; aen ite nonjat-jijoe leghte een Geplandeken dat een hooglen witten berng heeft / Die

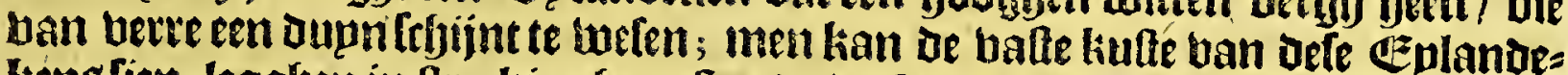

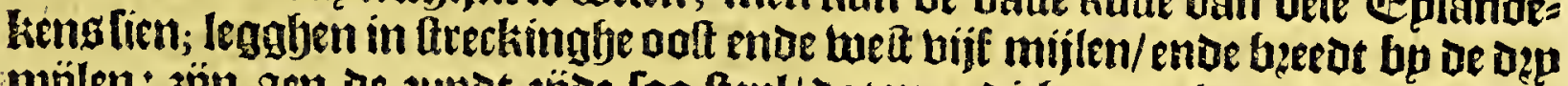

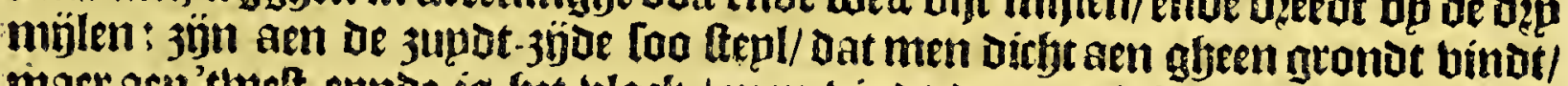
maec aen'theft-epnoe is het black / men bindt daer aenigh jout in oe deaghe maenden: daet ig gheen ghediette op; twepnigh traghelen: eenigbe diefp noemen Flamencos, fyeblen langle beenen bu naet als de opeuaevs/mer roode beeten upt Den ozagnien/ met groote kromme becken: t'lanot is fteening enoe meelt laegh. I. de a ves leglyt ban Rocca buelt ten noozuen thien mijien / op oe booghoe van

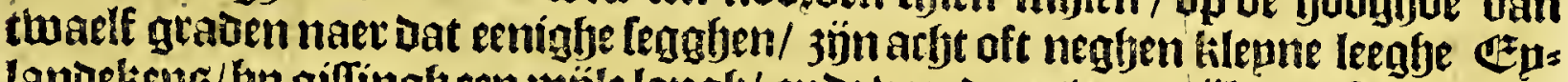
landeliens/bp gillingljecn mijle langb/ ende ban dater twee mijlen ooft ten noos=

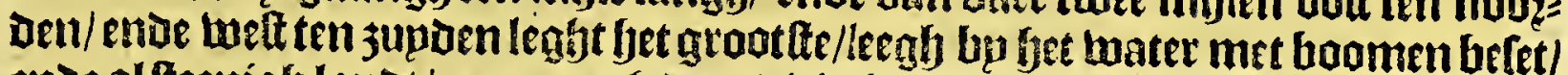

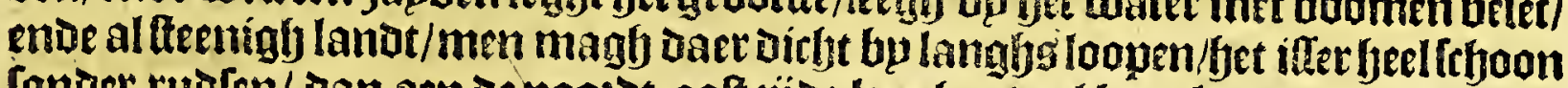

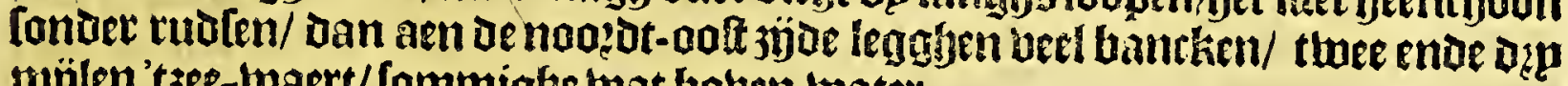
mïlen' 'jet-Laett/ Commighe twat bouen mater.

\section{Het viffthiende Capittel.}

Befchrijvinghe van de Eylanden Bonaire, Cur a ca o ende Aruba.

B Onaire light van $I$. de A ves weft ten noogoen ende lweft noozot-wedt/tulthen

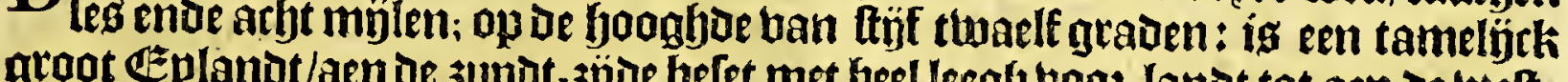
get beel legh boos-lanot tot aen de buefnoozot-Lelt jijoe toe / Daer 'tboollanot een epnoe neemt / ende aldaet Jeeft men De bequaemfte reede / Dorb ifer ffepl/ Dat men met een toutw aen lanot moet leg=

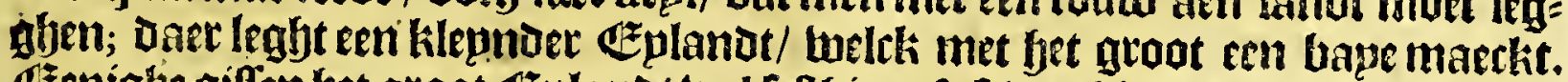

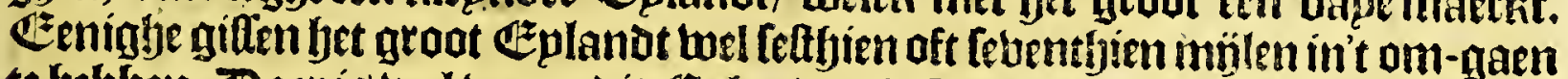
te hebben. Baet ig Leel bee op dit Eplanot/als tieren/ Koepen//rbapsn ende gep:

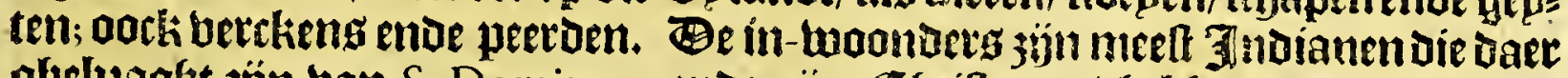

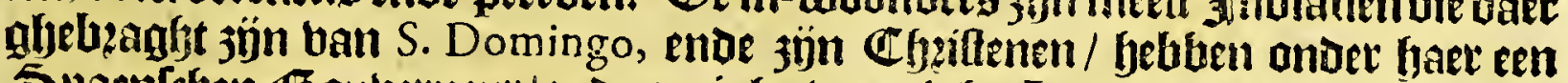
Spaentchen Gauberneut/ende eenighe wepnighe Spaequiaerden; dete taoo:

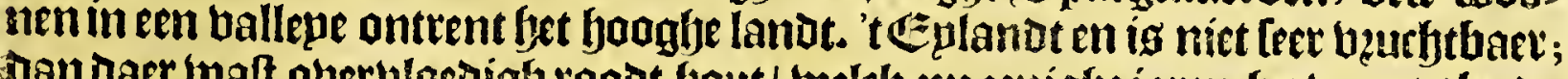

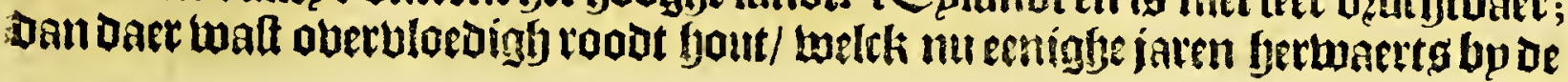

onfe. 
onle met groote menighte is ghefaelt / [oo tat nu ontrent te reete niet beel ie

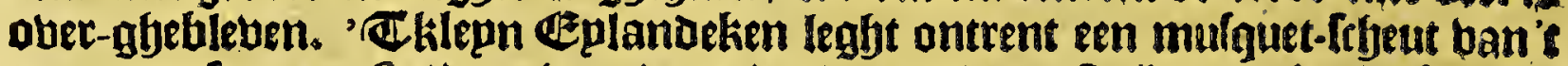

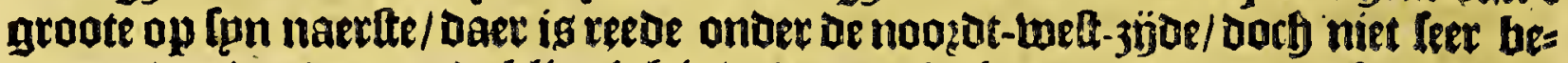
quaem/om dat oe gronot klippighis/ende men leght op 60 badem een feen-wozp ban lanot; daet is mede rocot foutot op/ ooch verie te ljalen; oock potk-fjout ende eenighe cottoen-boamkens: de grand is meelt auer al klippigh/ende op fommige

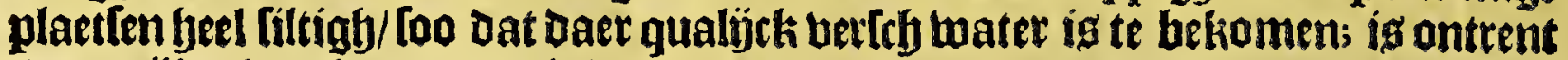
twee mijlen langh; ende dęp in't om-gaen.

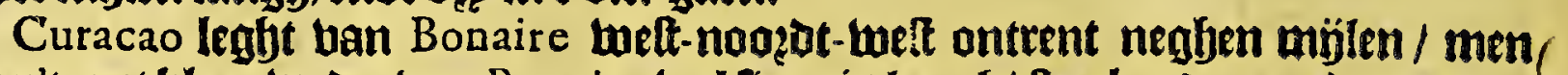
kan't met klaer weder ban Bonaire wel lien: is langy/ Atreckende noozot-noozotweft ende jupdt-jupdt-poft büf múlen; leght op oe boogfjoe van twaelf graden en oe beertighminuten; beeft bel neghen oft thien mülen in ben om-ganng; is

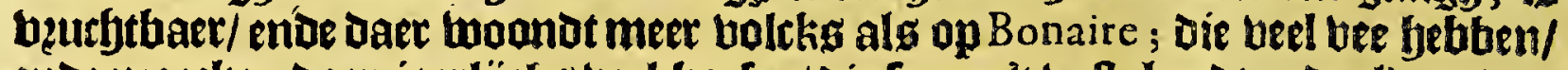
ende maecken daer jaerlÿcks beel kaeten/ die [p aen't balte landt ende el bers bers boeren; Daet groepet mese roobt bout ; heeft aen oe noozot ofte noozot-oolt-jjoe een grooten borft/ Dan baet en is gheen bequame reede/ boog dien bet daet foo Eepl is.

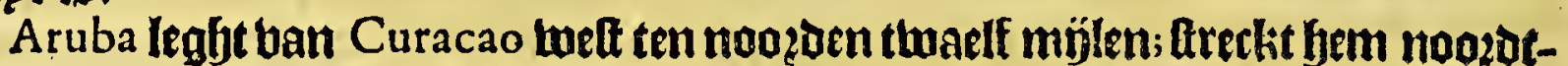

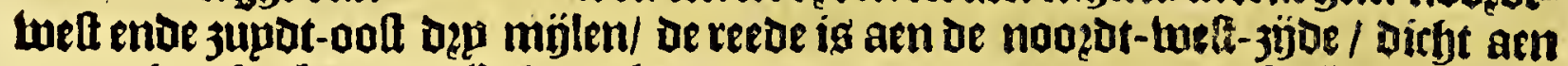
eenen boeck / bp een Eplandeken dat men aen be noozot-wett-zjoe laet legs ghen/men leght op bíf badem landt-grondt; boozts en beft men rondtom bet

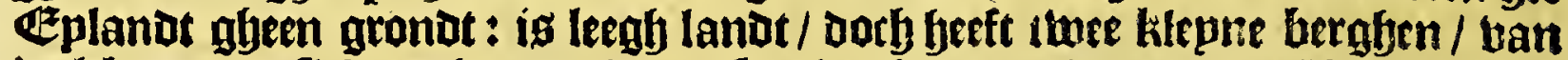
twelcke de eene fieb bertboont als een fupcker-bzood; is ontrent binf mijlen in't

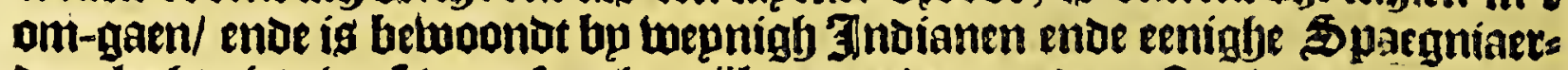

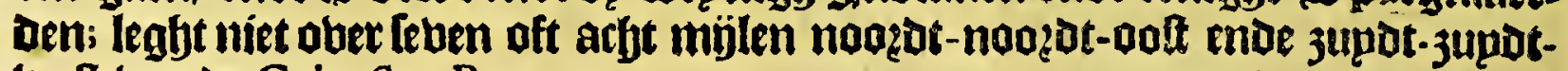
weit ban oe Cabo San Roman.

Onle Srbepen die in den jare I 623 aen Punta de Araya hebben gbelweelf/ alloo [p daer bonden een foetrelle met Spaegniaerden befet/ welch baer bet jouot Galen beletteden/ghenootlaeckt zünde londer ladingbe ban Daer te [rbepden/zün eenigbe wepnighe ban oe felue 5 efjepen ban daer weit-waerts op-gheleplt naes

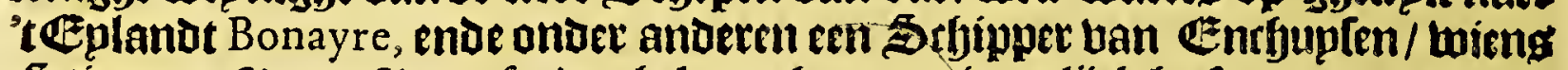
Stietman Simon Simonfz. De gbelegentbept pertinentljekt beeft aen-getertkent/ die lup goet gbevonden bebben bier in te boeghen. Seplende van punta de Araya

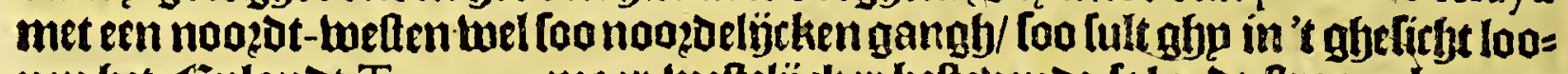
pen bet Ceplandt Tortuga, maer tueftelïrtier beftebende fal u de froom bu 3 upe

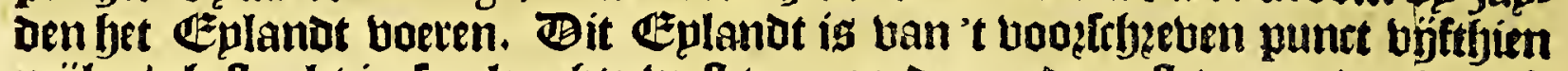
mijlen/abeftreckt in lpn lengfte weft ten nooeden ande ooft ten jupden Dęp oft vier mijlen.

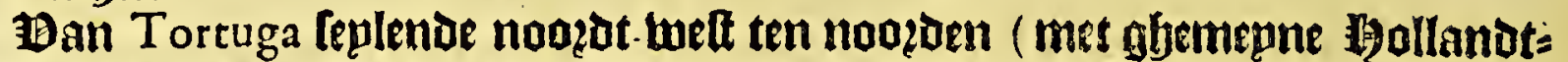

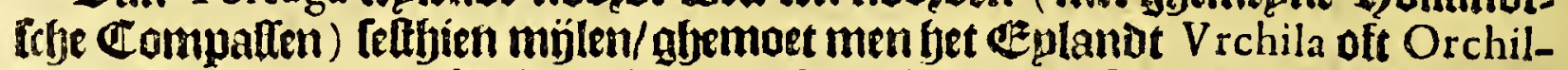

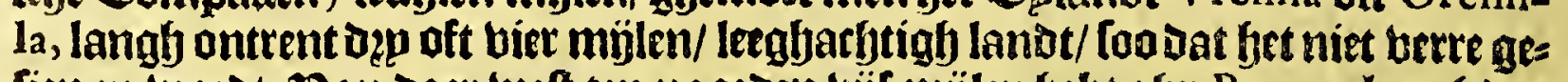
fien en wo: ot. Ban Daer tweft ten noogenen büf mülen bebt ghp Rocca, langfołp mülen/ leegl en [mal/gheen falf müle beecot / aen de zupot-3ÿbe fţoon fonoer ancker-grondt / maer aen de noozot-3ijoe bol dzooge platen/ende tufirben bepoen

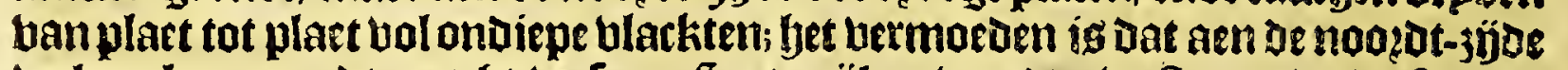

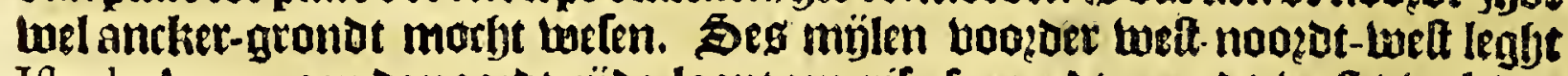

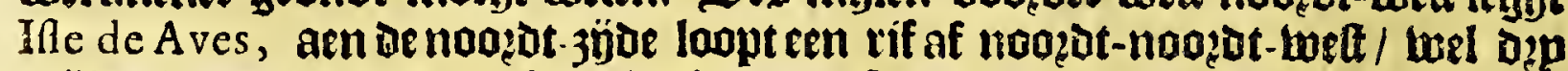
mülen in $3 e e /$ aace men de barninghen ban fet/fo men bp noozoen baer boo? bp

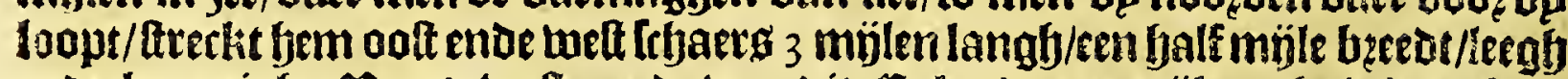

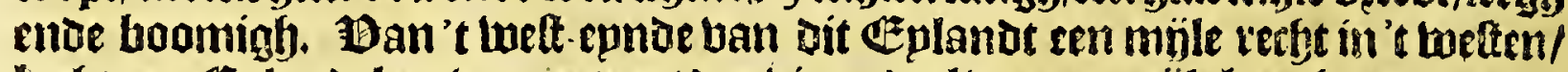

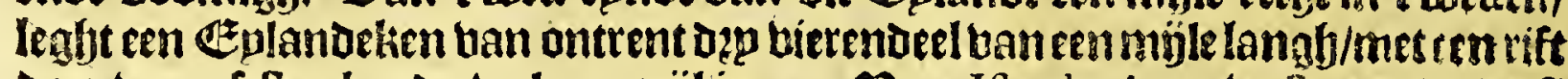

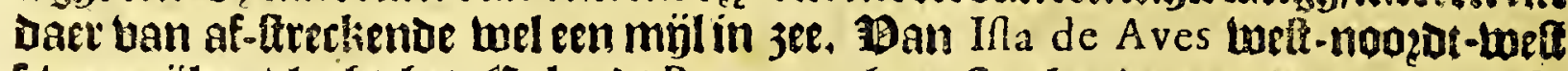

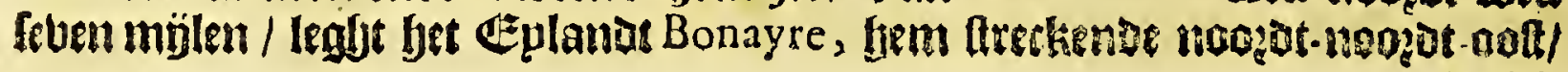


- Het fefthiende Boeck.

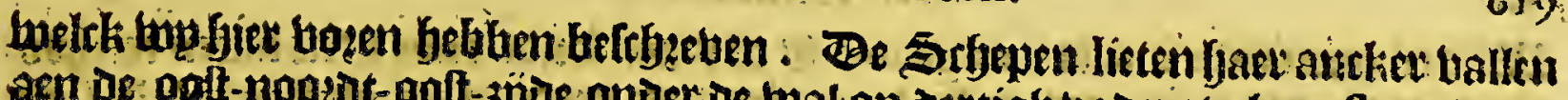

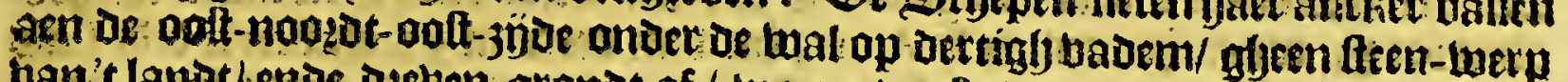
ban t lanat/ende ozeben gronot of / waet ober fp or wal aen latteroen/moe

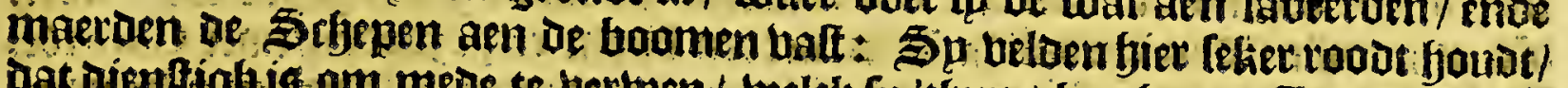

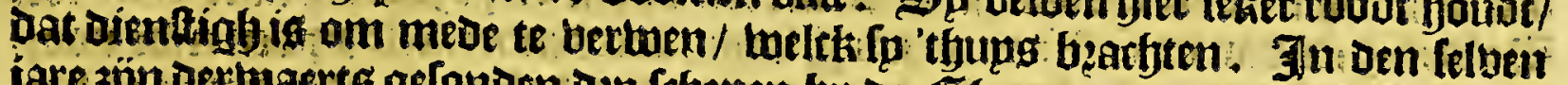

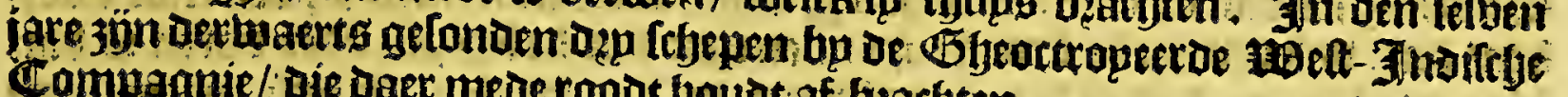
Compagnie/: Die daer mede roobt boubt af bzacten.

Fet Celthiende Capittel.

$$
\begin{aligned}
& \text { Befchrijuinghe van de kufte van'trafte landt van CuMANA } \\
& \text { ende VENEZUELA. }
\end{aligned}
$$

Umana ofte Comena leglt uertefepden ban punta de Araya daer te zout-

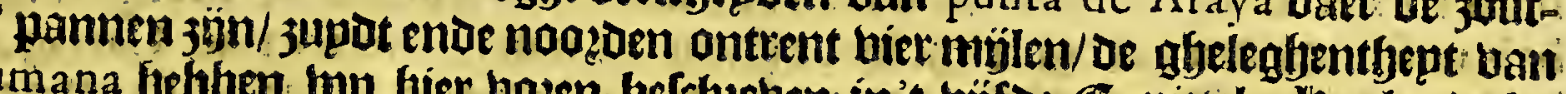

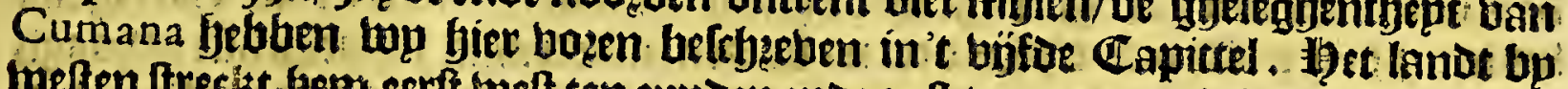

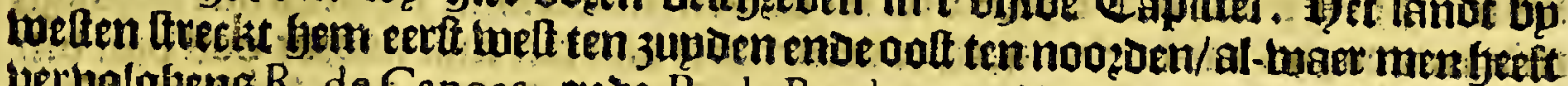
verbolgheng $R$. de Canoas, enoe $R$. de Bordones : Daev aen en betloten batuen.

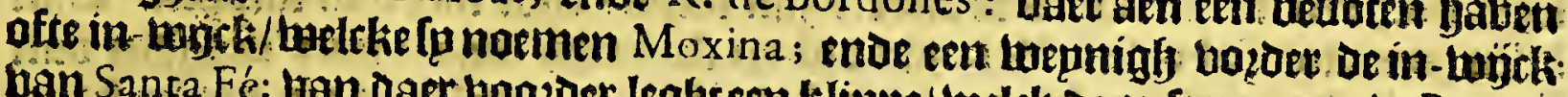
bain Santa Fé: ban Daet boozoer leghteen klippe/ belck de on [e noemen oe Borats; aen ben ood foeck ban de bape ban Commenagod, men Leplet tufliben be felte ende 'tbaite lanot beur: aen t balte land leght en grouen fteplen bergb/ helek

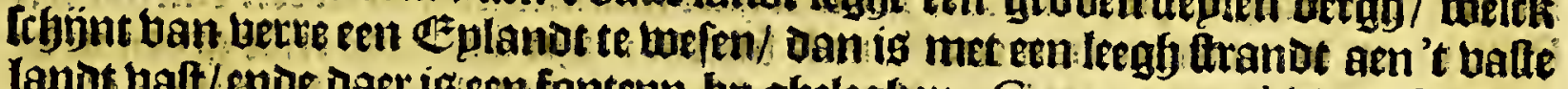
lanot balt/enoe daer igeen fontepn by gbelegben. Commenagod is een tcjouné

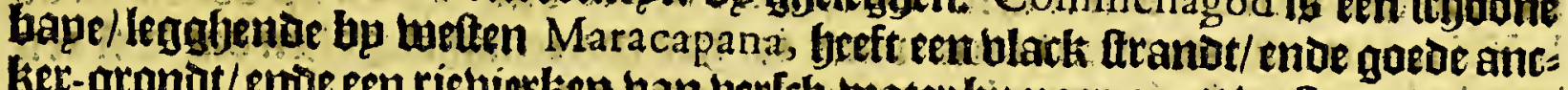

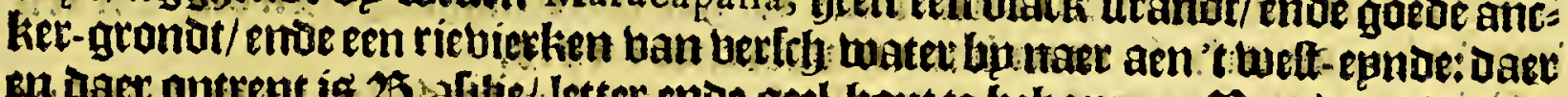
en. dact ontrent is 25 afitie/ letter enoe get- hout te bekomen. Ban de teede tran

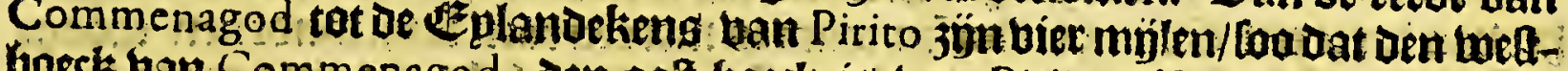

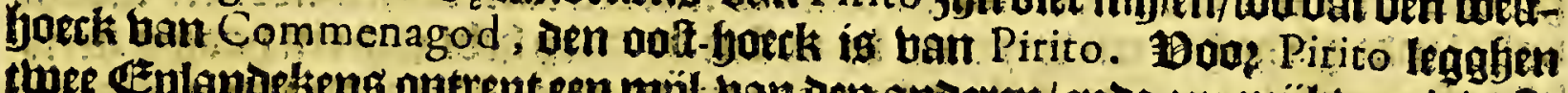
thee Geplandettens ontrent een mijl ban oen andeten/ende een múl ban ' $t$ balte landt/ ban belek efn blatkte-af-loopt/ ban aen defe Eplandekeng is bet diepglies

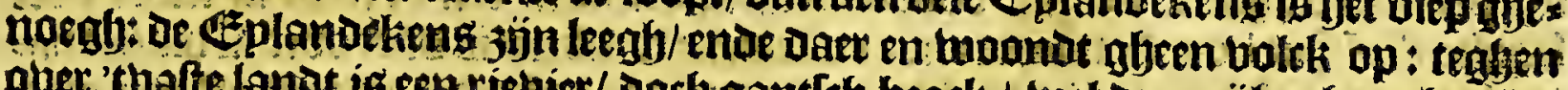

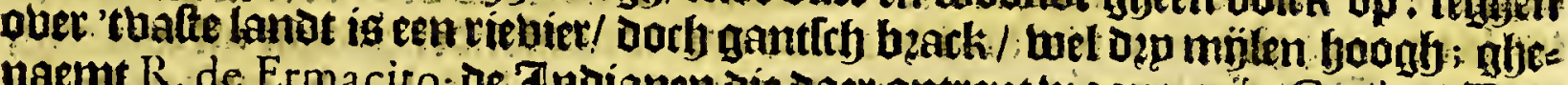
naemt $R$. de Ermacito; of Jnbianen bie daer ontrent wooneri jin Caribes. Bat

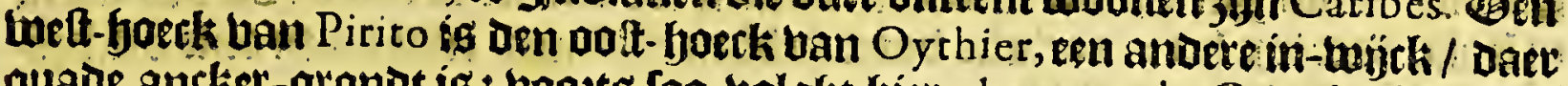
quade ancket-gronot is: bootts foo bolght bier el morro de. Correbicho, lego

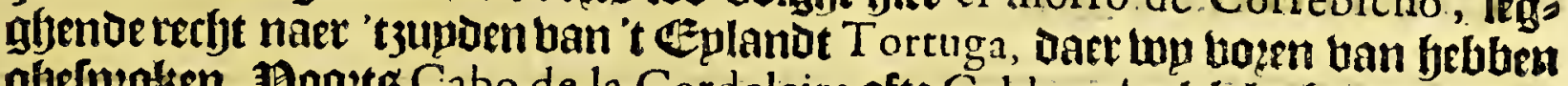
ghefpeoten. Boozts Cabo de la Cordeleira ofte Caldera, tnelch leght jupbt-welt ten zupoen ban Tortuga ontrent büfthien mỉlen; ende ocle late ig leegh/ aorb

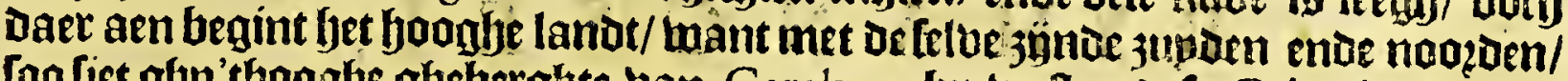
foo lict gljp'thooghe ghebergljte ban Carakas; bp welten urfe Cabo is bet gaet anckeren op twaeif badem waters/ ende baer is trel pocl-bout aen lanot te bes komen; legft op thien graden naer'tleggijen ban Figueredo, andere vorgben baer nocbeenighe minuten boben. Ontrent bifthien mijlen bu wellen dete Cabo leght

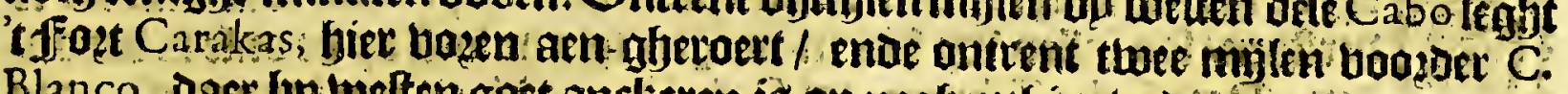
Blanco, oace bp welten gost anckeren is op neglientfien badem een gatelingt.

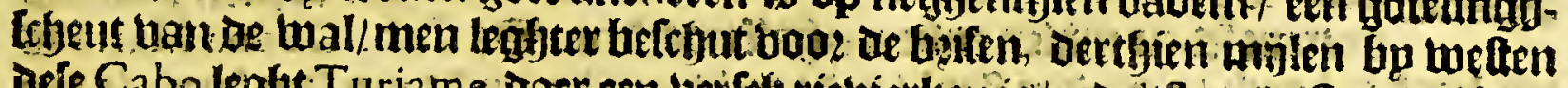

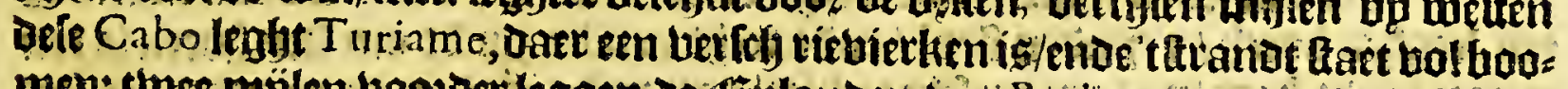

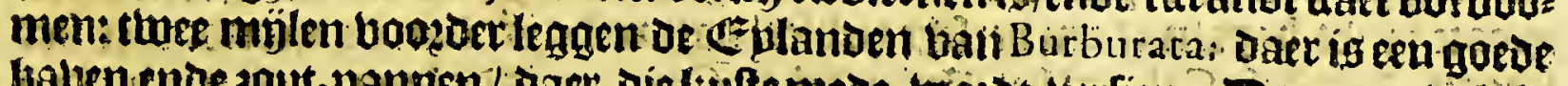

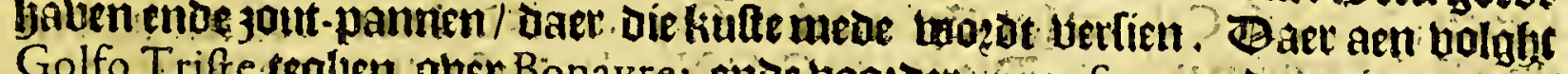
Golfo Trife tegljen aber Bonayre enoe toozoer puata Seca, enoe entige andere

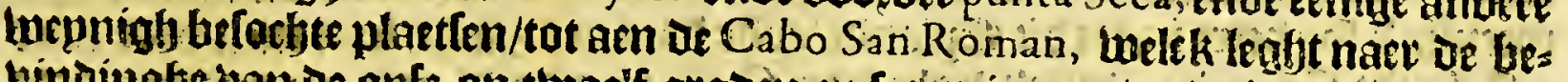

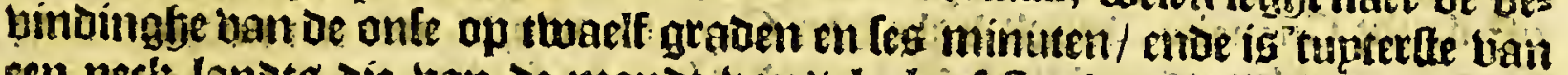

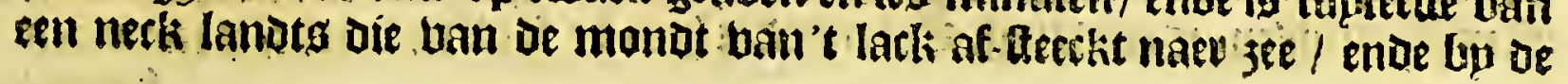
pioiloen 
Hoiloen dunaeme thozot Paraguana; is al vlack landt/ende feeft alleen een boo:

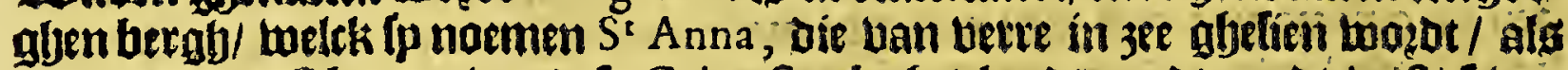
men om de oolt komt: ban defe Cabo freckt get land jupat-3upot-wett/ feven

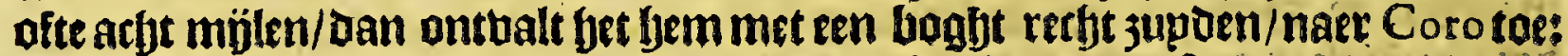

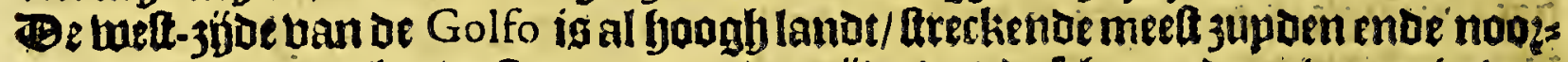
oen/ Daer balt een yaroe ftroom upt; oen tijor Dat De Irfyepen oaer baren is ban May tot Oetober, Dan iff de teeftete tijpt ban de Vendavalen; De brife tuaepet ban

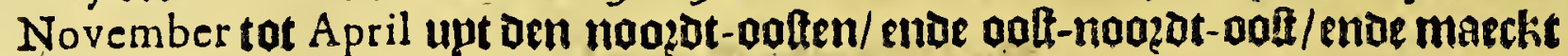

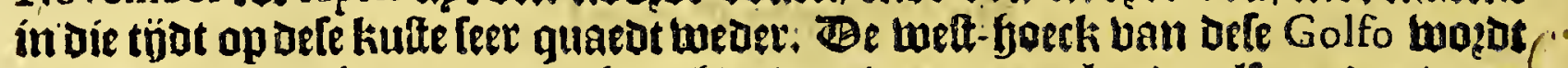
ghenaemt Coquibocoa, op oe houghoe ban wat meer als thaelf graben/ naec 'tleggfen ban de \$paenlclje kourten/ia leegly/ende Areckt met een blackte af; bin= nen'slandes legbt een hoogh gefarkelt gheluekghte / welck oe Spaegniaeroen noemen Sierras de Azieyte: bp oaten bain Defe Cabo legghen of Monges, Daet De liouten wozoen naer ghericht bp de ghene die ban Dominica naec Cartagena

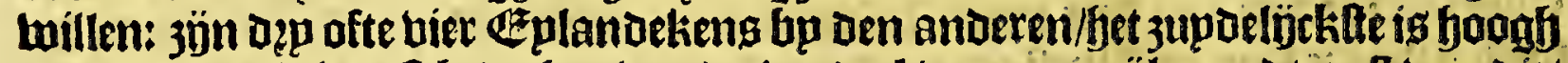

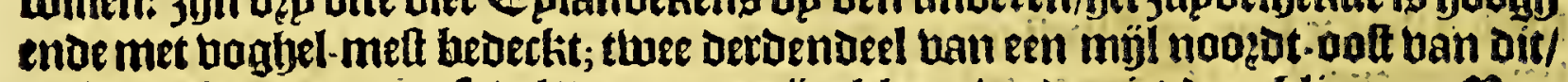

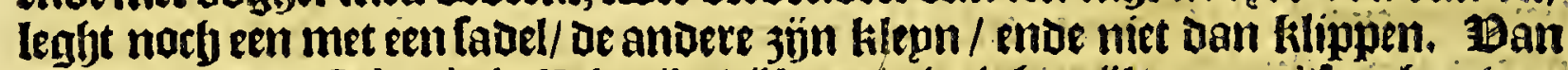

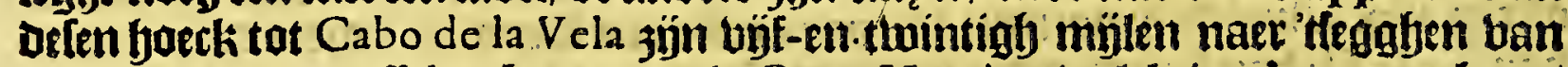
Figueredo, dan tulfegen bepoen leght Baya "Honda, welch ig ein groote bapel ober al black/, oock is 'tlanot bol bimmen-wateren; bet bolck Datter boonot is

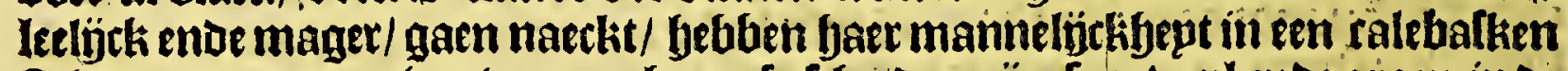
Iteken/ op de maniere ban een fooznfe frbeede; $3 \mathfrak{y ̈ n}$ feer bupl entae groen in de

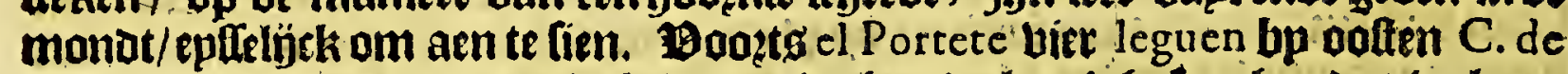
12 Vela, dart allentyalben black water ig/ boe-wel eenighe legghen bat twel een narulw in-liomen beete / maer binuen wöot ende diep is.

Cabo de la Vela is een yoagen yoeck/eñ als men ban bp ositten kount/ fo febïn bet ban berre een Eeplanot te weten/want is met een elien linal lanot aen thooge bafte lanot gheberbt: een twepnigh bp odten oe haep hebt ghp een fooghe Iteenklip ofteboeck / bp welten De welcke mede een baep is/ Daet mon met gbemeene Ifbepen kan legghen / belefut voo woftelijcke twindent on de kape if mede goes

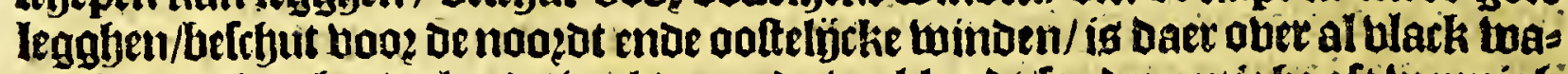

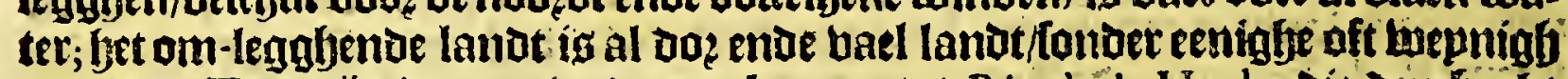
proente. Bug jón tup nu mederom komen tot Rio de la Hacha die ben forbt

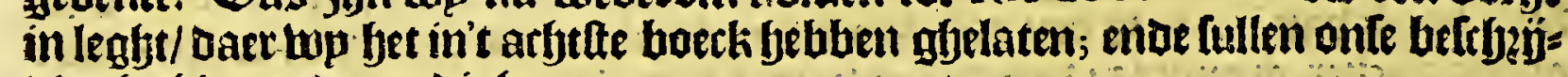
vingbe hiet mede epndighen.

\section{B YH A N G S E L,}

By te voeghen in't eerfte Boeck, 10 Capittel, pag: 16.

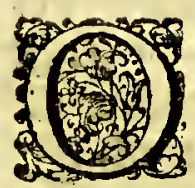

IS de aljelegfenthept ban't toeftepnde ban Hifpaniola twat nast ber te

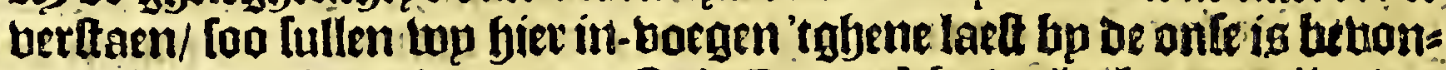
Den. Ban Cabo Tiburon; tot $C$.de Donna Maria jijn hupten slanutg ontrent leten mölen enoe een yalfnoogoen. Be Cab. Donna Maria is

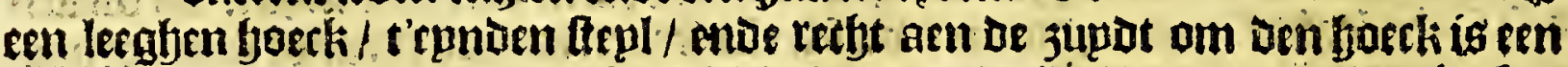

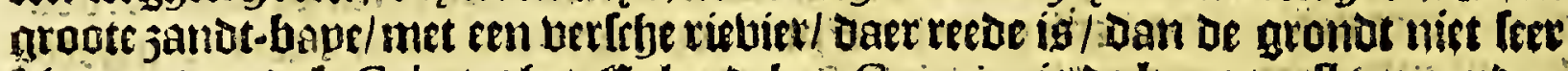
frjoon; van oefe Cab. tot fet efplanoelien Caymito is de lourg oofl ten jupoen thaelf of oettijien mijlen. Bie aen De $C$. S Nicolas twelen twil / Die labert gfes

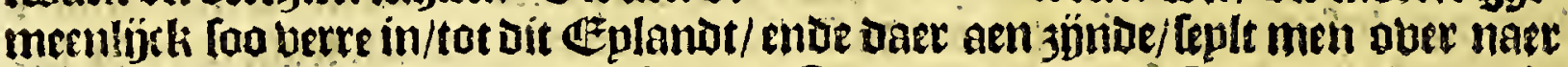
replanot Guanabo, Lelch leght van Caymito noget-ooft ten noogoen erht

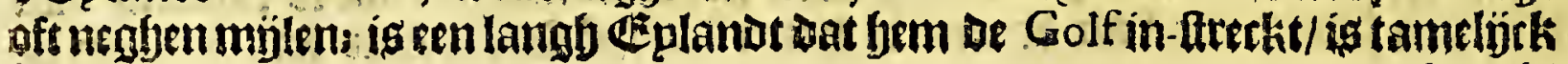
boody! 
foogh/ment imagh aen 't twelt-epnoeluel dicht aen-loopen / want bet ifer fifjoon;

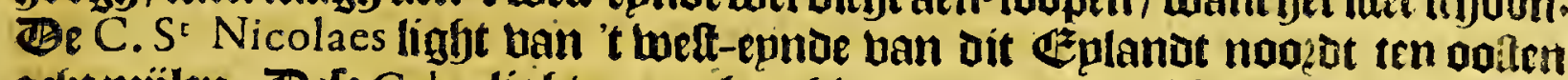

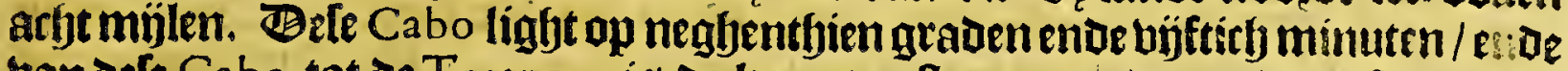
ban dele Cabo tot de Tortuga, is De kours ooft ten noozen ende oolt-noo:st-

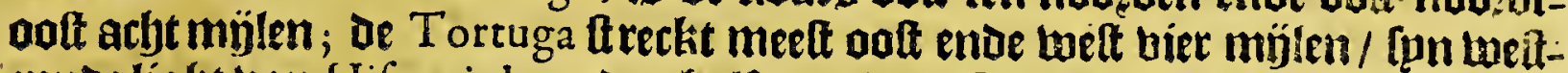
epnoe lígft dan Hifpaniola ander-balf / ende't ooft-ęnde een mịle.

$$
\text { In't felve boeck cap. 19. pag. } 34 \text {. }
$$

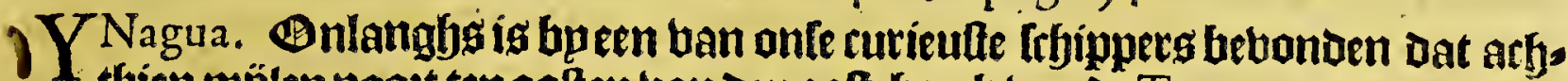
thien mülen novet ten oolten ban den ooff-boetk taan de Torcuga, op de noa ot-

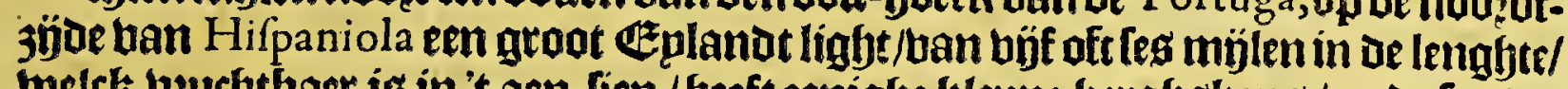
welck beuthtbaer is in't aen-fien / beeft cenighe klepne bergbgkens / ende landthapen / ban den oolt-boeck ligghen eenighe klippen af ; dit lchint Y

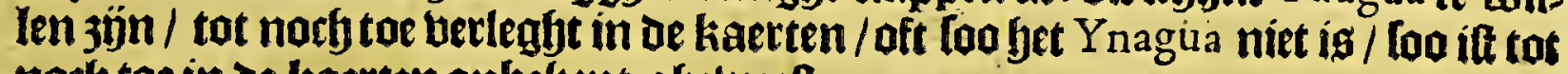
noch toe in de kaetten onbekent ghetweet.

By te voeghen in ' $t$ tvveede Boeck aen het eynde van ' $t$ vierde Capittel. L etere nu upt fet boeck Traicté de la Navigation, \& des voyages de Defcou-

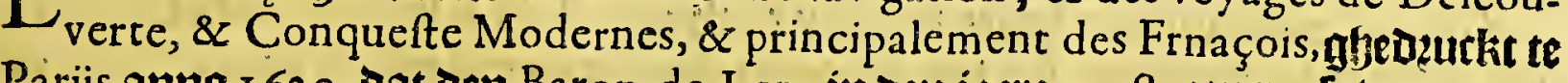
Parijs anno 1629 , Dat den Baron de Lery in oen jaere 1518 , ent reple tooz-nam naer Ifle de Sable ende Campfeau omeen wooninghe aldaer te planten / oan dat

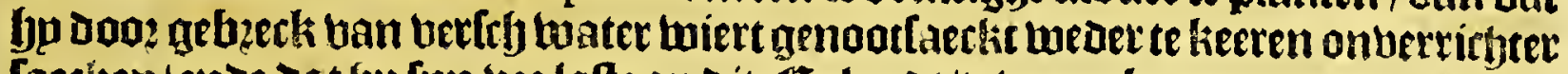

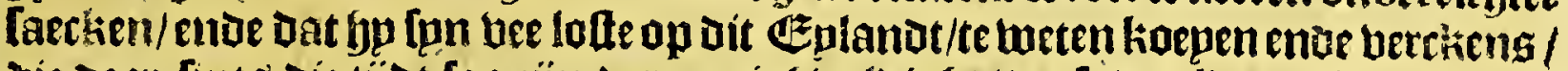
Die daer lints die tijot loo $3 \mathfrak{n}$ bermenigguuldight / Datte oen Baron de la Roche bolct twel te palle quamen.

$$
\text { In't felve op het eynde van het } 25 \text { Capittel. }
$$

$\mathrm{V}$

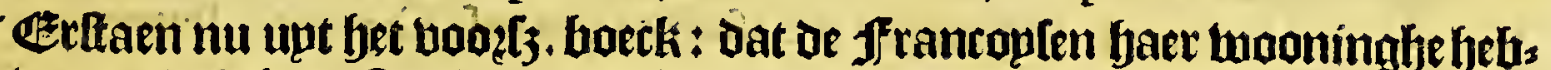
ben berbolgbt te Quebec, ghelýck naerder blyckt upt een bzief ban Charles

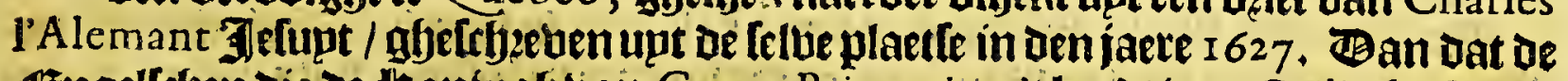
engelleben die de ltontingh taan Groot-Britannicn 'tlandt ban Cadie beeft ber: gunt onder de naem ban Nova Scotia, faer de plaetle begonden te difputeeten;

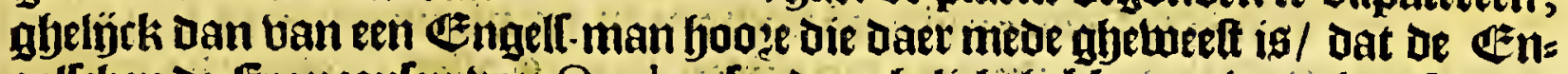

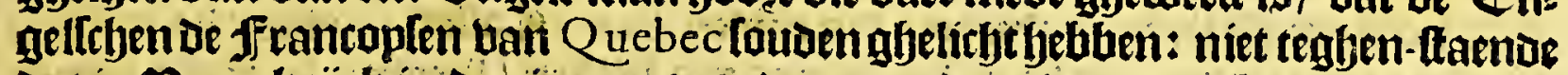
Dat in Bpancktyotk in oen faete 1626 , boo toe- Doen ban den Cardinael de Richelieu een kompagnie is op -gberecht ban bondert ghealforieetue / welck baet Kamerfouden bouden te Morbihan in Britannien, pe meleke betgunt ig Nova Francia enoé Can a da : bu bervolgh van melckes maetje is qbegheben in oen jaere 1627 ende 1628 , aen de liere de Roquemont, Honel ende andere / aldarr marfy= tighe rolonien te planten; ende daex ís een kompagnie ghemaectit ban bondert perloomen boge bỉftbien jaeren / in De welcke Lp haer verbinden ouer te benghen

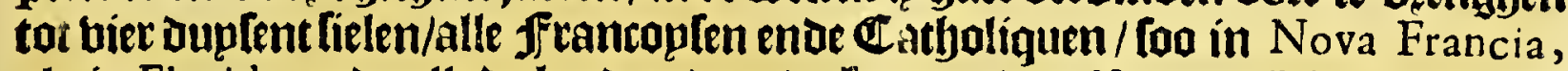
als in Florida, ende alle de landen daer de throone ban Beantkröclieenigy rectyt ban oubts mepnt op te bebloen.

By te voeghen in't veerthiende Boeck aen het eynde van het derchiende Capittel.

DÉturitoictie ban Pernambuc ftreckt lich upt ontrent beerticf mülen naer bet jupoen / te tweten tot Rio S. Francifco, alwaex eeninge Hoetugefern tweonen die faet alleengeneeren met beelten te wepden/ ende Farinha te maecken/ welck Ip benghen te Pernambuc; daer valt mede 25zalitie-hout. Ban daer komende naer't noozen oftenaex Pernambuc toe/beeftmen eerlt Alagoa, Daet bÿf oft lea

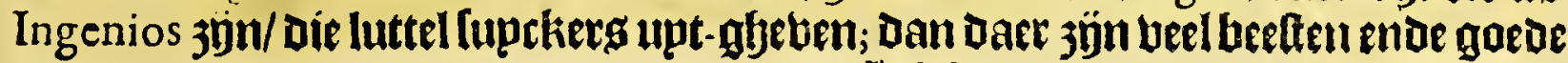
(2) $\mathfrak{y} \mathfrak{b}$ Itif-torbt. 


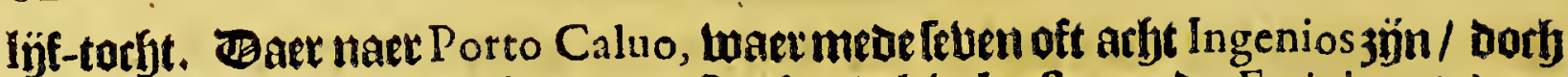
luttel in-Loonders; ende lyaren meelten bandel ig beeften ende Farinha: 't bosp

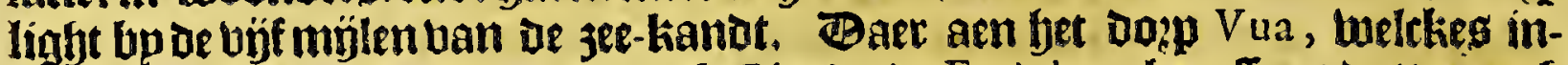
woonders baer mede geneeren met lueltiael ande Farinha; beneffens datter oock

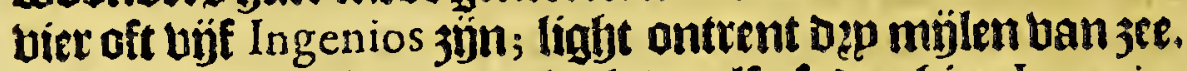

Bootg Serinhan, Daer wel twaelf oft Derthien Ingenios jün/Die't befte fuptker marcken ban Dit beel getwefte;'t Dosplight tluee mülen ban $3 e$ / neffeng een riebiet

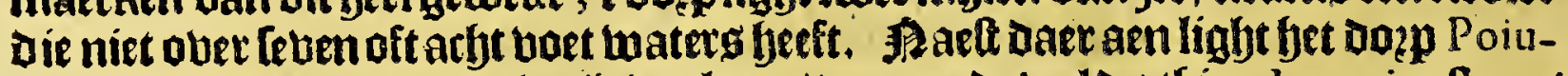
car, een lthoone ende balck rürlie plaets/ Daer mede bel dertbien lngenios ftaen/. Die groote quantitept luptkeren ghetent líglyt aen een rietietken bain de feltut naem/ welck niet ober acht boeten waters jeeft. Daer aen bolght oe Cabo Sant A ugultin, ende't Doup Sant Antonio do Cabo, liggende thee mỵlen ban liranot;

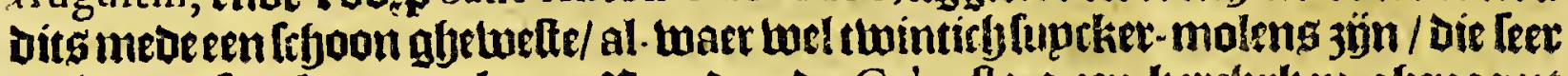

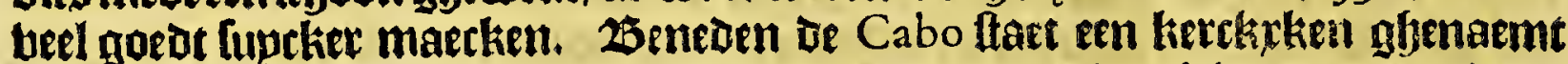
NoItra Sennora de la Candelaria, ban melcke ent open toegh loopt naer oe twep= aen oie Le noemen as Curcuranas, Daer meenighte ban beelten wo?ton gheturpt: is büf mijlen ban Pernambuc; tnde in dat begrijp faen toel thee-en-thintity Ingenios, die veellupcker maecken.

Garafu welek wp bier boen legghen de tweed thatt te tuelen bandefe Capica-

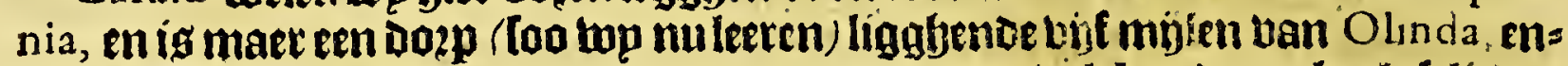

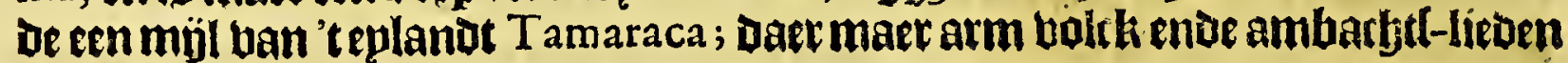
woanen.

In't felve Boeck in het veerthiende Capittel.

I Dejuxituittie van Tamaraca jün ontrent thintity Ingenios, entae demeelte

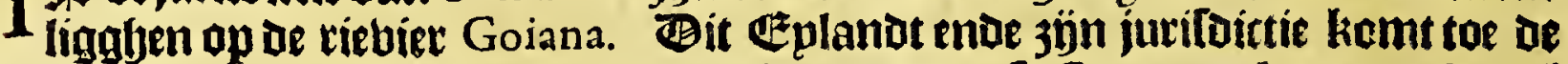
Conde de Monfanto, tmoanentie te Lifbona : upt Dele Capitania kamt oock beel bzalil-houtot.

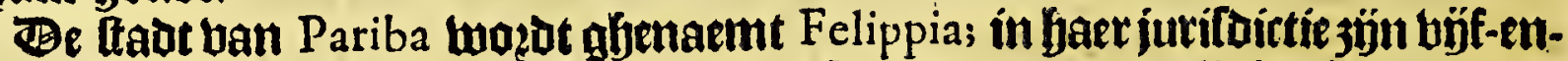
thintich Ingenios die jaerläckg beel goedr lupeker maecken; lígbt bj̣-en-thin= tich mijlen han Olinda. Ban Pariba tot Rio grande zün ouer de Derticly mülen; saet is een Ingenio te Camaratuba; eñnotheen in eenplaetegenaemt Cunhaon; ende norf een oft twee die thee oft Dep mijlen han't Calteel ligghen: De meeften ríckdom niet te min ban de in-lwoonoers 3 j̈n beeften / torghen be goede luepde Die daer is : 't Calteel genaemt de dry Koninghen, ig 't bette ban De gantlebe kulte;

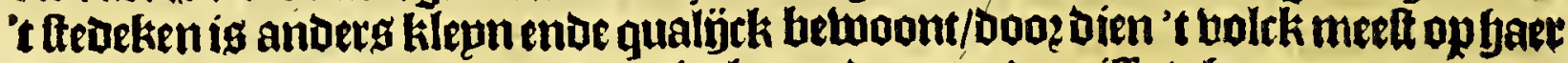
lanot-buplen boonot/ende Daer niet komt dan om de mide te boozen. 


\section{$R$ E G I S T E R.}

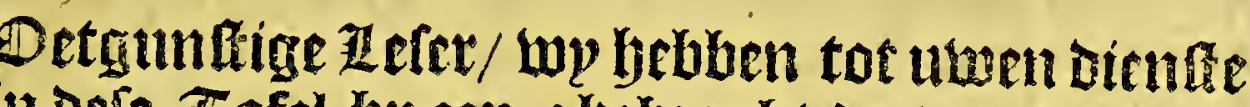
in Dere Tafel byen gljebaght ine boomacmete

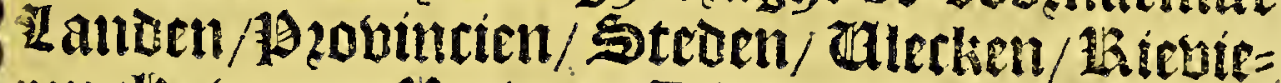
ren/labenen/4aecden/ Dieten ende azuchten; In oien wpie alle hadoen aengheteeckent/ foo Coude de Tafel te groot ghevallen yebben. De namen die beginmen met $S^{t}$ ofte $S^{\text {ta }}$ hebben we ghebraclit ops oe naefte booft-letteren/Daer at. (iz. in' t naex foecken fult ghe = lieven op teletten; tnoe verdacht siin dat oe Spagniaeroen de B ende V D'een vooz D’ander ghebeupeken / foo dat gly in bepde die zetters wel dient te foetken eretgp der af frbept.

A. Bacoa Eulanot ban oe Lu-
caios.
S Abad baten in California.
239. Abancay rievier ín Peru. Abaque eplatat bp Hifpaniola. Abibe ghebergbte.

Abipi bergh van UETmerauden. Abifca probintie Peru. Abrolhos Depoghten bu Brafil. Aburra ballep in Popaian. Acaid boomin N. Brafil. Acaious beuthte Brafil. Acales Itchuptiens Mexico. Acapulco bauen N. Hifp. Acaxutla Gauen Sonfonate. Accadie ofte Cadie N. Franc. Accomack batuen N. Engl. Accominticus batuen N. England. 94 Achalaqui in Florida.

Achecambey enlandt Lucaios. Achufi haven in Florida.

Acla in Terra Firma.

Acos in Peru.

Acuti ghesierte.

Adhothuys bilty N. Franc.

Adives twilde fjonden. A Agoutitreva boom N Brafil. Agredieva boom N. Brafil. Agreda ttadt Popajan. Aguacates goede beucht, Aguacolla krupbt.
Aguada faben Porto Rico. Aguada Segura Californ. 3 Aguapa tenỉnigben boaminde Mufos. 268

Ahuquahurl boom in N. Hifpan. 342 Albion nova in California. 255 Is St Alexio eplandt bp Brafil. · 530 321 Alezay eplandt bp Terreneuf. $\quad$ \$8 340 Alkermes befienin Virginia. 93 406 Almouchiquois bolck N. Franc. 79 .529 Almaguer ftadt in Popajan. 354 347 Altovelo eplandt bu Hifpaniola. 19 542 Amaguajo eplanot Lucaios. 32 507.540 Amana eplande Lucaios. ibid. ${ }_{178} 8$ riebiet Guaiana. $\quad 584$ 181 Almandelen bande Chachapojas. 396 286 Amapaia pyabincie Orenoque. $\quad 582$ 70 S. Amaro in Brafil. 520

94 Amatique in de Honduras. $\quad 290$ Ambaigtinga baam Brafil. 508 Ameguaes uolcli $R$. dela Plata. 490 Ammegore rievier Guaiana. $\quad 593$ Amonna rietrier Guiana. $\quad 57^{6}$ Anapuia plobintie Guiana. . 608 Ancon de Luis Hifpaniola. $\quad 17$ de Sardinas Peru. $38 \mathrm{r}$ Anckerbaye N. Nederlandr. $\quad 102$ Andabaylas prouincie Peru. $\quad 40 \mathrm{r}$ Andalien ballepe Chil. $43 \mathrm{r}$ Andaluzia nova belcheguinghe, 597 Andes glebergfte Peru. 359 Andrefa pumt Hifpaniol. 18 Anebas troldh Guajana. $\quad 582$ Anegada eplandat Canibal. (1) 2 Angaf- 


\section{$R$ E G I S T E R.}

Angafmayo riebiet Popajan.

Angoam baben N. Engl.

Angoyaco pallagie Peru.

Angoango Doyp Peru.

Angra dos Reyes Brafil.

Anguilla epland Canibal.

Annoto bettue Guaiana.

Antequera ftadt Guaxaca.

Antigua eplandt Canibal.

Antiochia ltadt Popaian.

Anzerma lladt Popaian.

Apalache in Florida.

A palatcy herghen in Florida 141.144

A pamatuck rieuier Virgin.

A purima vievier ín Peru.

A purwaca riebier Guaiana.

A quamachuque halcli N. Nederl.

Aquiqui aepen in Brafil.

Araca boom Brafil.

A ranives ftadt Cọta Rica.

Araras oft Macaos bogbelg.

Ararapira rievier.

Araticu hanm Brafil.

Arauco peobintie Chil.

Archidona tadt Peru.

Arequipa flaot ende JjauenPeru. 394. 409.

Arezibo ricbier Porto Rico. fadr in'treltbe Eplanot,

Arica in Peru.

Arikary riebiet.

Arikary liebier. $\quad 5^{6} 3$

Armadillo bettion.

Arnedo bilectie Peru.

Aroi vievier Guajana.

Aromaia, probintie Guiana.

Arougcun beelte Virgin.

Arrapoco Amazonas.

Arrowari rítbiter Guiana.

Arrowen eplandt A mazonas.

Aruba eplanot Venezuela.

Arwy riebiet.

Affapana epland Orenoque.

Affapanic diet Virgin.

Affentamens boontieng Virgin.

Affumcion ltadot Rio de la Plata.

Atacama maeftüne Chile.

Athule eplantat Orenoque.

Aveto olpe N. Hifpan.

$S$. Auguftin in Florida.

Avila llavt imte $Q$ uixos:

A vinno litbei-mïn Zacatecas.

Aulagas oft't larti ban Paria. 4I3.417
353

94

399

415

$5 \div 7$

34

574

200

34

344

346

157.162 .

III

$40 \mathrm{I}$

567

105

504

507

297

504

499

507.541

432

379

4

420

503

388

586

583

II 7

563

$56 \mathrm{x}$

ibid.

618

566

585

II7

116

493

427

587

174

165

379

230

17
Auras bogfeld N. Hifp.

Aute in Florida.

Axi loozte van peper.

Axin bett in N. Hifpan.

Ayamare bifry Guaiana.

A y a vire plaetfe in Peru.

Aymaraes bolch Peru.

Aymures bolck Brafil.

Azua taad Hifpaniola.

B.

$\mathrm{B}_{\mathrm{B}}$ Ahama eplanot Lucaios. Bacoa in Hifpaniola.

Baeza ftadt in de Quixos.

Bahia de todos los Santos.

de $S^{\text {ta }}$ Cruz Florid.

del efpiritu Santo Florid. de Carlos Florid.

de Tampa Florid.

de Meruelo Florid. de Fonfeca Guatemal. de S. Iago Peru.

Bahia $<$ de S. Mathé Peru. de los Caraques Peru. de S. Iulian Magallan. de S. Iago Magallan. de Trayciaon Brafil. de Pinos Californ. de Cartago Honduras. de Carabaco Veragua.

ibid.

ibid. 286 $35 \mathbf{r}$ ibid. $3^{82}$ 453 477

Bajamon rífbier Porto Rico. de Trinité ibid.

Baje de Trepafer ibid.

de Placencia ibid. de Sant George ibid. de Chateaux ibid.

Erancoife N. Franc.

Baixos de S. Roque Brafil.

25 allem ban Tolu.

Bamba peouíncie Popaian.

Cado Peru.

Bambyaias voggels.

Bancli ban Terreneuf.

Baracoa ftaot in Cuba.

la Barranca in Peru.

Baranca de Malambo. 


\section{$R$ E G I S T E R.}

Barbudos equlanot Canibal.

Bariquicemeto riebier ende probincie.

$$
613.611 \text {. }
$$

S. Bartolome eplanut Canibal.

Barraquan ríetier Orenoque 882.58

Baru eplanden Vraba.

Bayamo pevoine. Cuba.

\section{ltadt in't felue eplandst.}

Beata eulandeken bu Hifpaniol.

Beauport in N. Francia.

299

Bell" Ifle N. Franc.

340

Berbice riebier Guiana. : : $\quad 577$

Bermudes culanden. $\quad 40.41 .8 \mathrm{c}$.

S. Bernardo Tucuman. $\quad 447$

Beta rictier Guaiana. $\quad 587$

Biarataca dier Brafil. _... 504

Bilcabamba Peru: $\quad$... 402

Bilcas riejier en palepg Peru. $\quad 40 \dot{1}$

Bilcaconga glubergljte Peru. $\quad 402$

Bimini eplanot Lucaios. $\quad 32$

Biobio rievier Chile. $43 \mathrm{r}$

Blanc Sablon Terreneuf. $\quad 57$

Blocks eplandt N. Nederl. $\quad 102$

Boca del Drago bu Trinidad. $\quad 594$

Bogota prouincie N. Reyno: $\quad 334$

Bombon pzobincie Peru. $\quad 397.398$

Bonaventura bauen Popaian. $\quad 35 \mathrm{I}$

Bonayre eplandt. $\quad 617.618$

Borriquen eplandt $S^{t}$ Iuan. I

Boycininga langh Brafil. $\quad 506$

Boy-ete tangh Brafil. $\quad 548$

Bracemoros pyaduincíe Peru. $\quad 380$

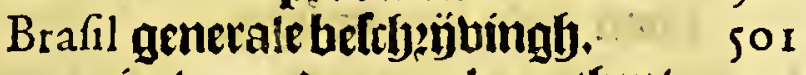
in-moonaeren gelegentfept. 5 II biecboetigle dierell. $\quad 502$ ghetuogelte en Lerpenten. $\quad 504$ hoomen/butbten/etc. $\quad 507$ krupden/ waptelen/etc. 509

Brion eplandt N. Franc. $\quad 54$

Britioga eplandt Brafil. $\quad 527$

Bucnos Ayres Itadt la Plata. $\quad 492$

Burburata baben Venezuela. $\quad 619$

Buritaca pequincie S. Martha. $\quad 328$

Buritica goubt-ríck pęolumie Popajan.

C.

\section{CAb de RaTe in Terreneuf. d' Efpere ibidem.} Sant Francois ibidem. (de Grat ibid.

de Saincte Marie ibid.

de Raye ibid.

de anguille ibid.

du chapt ibid.

Sant Liaurenscap Breton.

du prat N. Franc.

Saint Louis $N$. Franc.

Tiennot $N$ Franc.

Pointu N. Franc.

Royal N.Franc.

Saint Louis N. Franc.

$C a b$

Blanc N. Franc.

Malebarre.

Daupbin N. Franc.

de Rabaft. N. Franc.

de Honguedo N. Franc.

de la Heve 2 . Franc.

Forcbu N. Franc.

de Poutrincourt $N$. Franc.

aux Ifles 2 . Franc.

Francois in Florida.

Lucerne in Florida.

de la Tortue N. Brafil.

des arbres fecsibid.

del Enganno Hifpaniola.

del Cabron ibid.

Tiburon ibid.

Sant Nicolas ibid. . . ibid.

Francesibid. $\quad 18$

de Cruz in Cuba. . 25

de Corrientes ibid. $\quad 27$

Sant Antónibid. ibid.

delgadoIucatan. $\quad 216$

de Cotocheibid. : 217

de Corrientes N. Hifp.254.267

de Sant Lucar Californ. $\quad 253$

de Fortunas ibid. ' 252

Cabo $\{$ Mendocinoibid. $\quad 253$

dela Cruz ibid. . 25

de Nieve ibid. $\quad 252$

de Martin ibid. $\quad 252$

de tres puntas Honduras. 291

de Honduras. $\quad 292$

de Camerón Hond. ibid.

de gracias a Diosibid. ibid.

Blanco Nicaragua. $\quad 296.300$

de Aguia S. Martha: $33 \mathbf{1}$

de la Vela Terr.Firm. $\quad 333$

de Corrienres Popaian. $\quad 355$

De S.Francifco Peru: $\quad 38 I$

de Paffaosibid. ibid.

(de S. Laurenzo ibid. $\quad 382$

a $\mathfrak{y} \mathbf{y}$ Cabo




\section{R E G I S T E R.}

Blanco ibid. de Cauten Chile. de Chanquin ibid. de la Vallena ibid. Sant Feliz ibid. 384 443 ibid.

ibid. Camoufi riebier Brafil. Campeche in lucatan. Campfeau baven N. Franc. de las Virgines Magallan. 454 deffeado ibid.

454.456 de Sant Antonio la Plata. 478 Santa Maria ibid.

Cabo $\{$ Blanco ibid.

Frio in Brafil.

Sant Thome ihid.

Sant Auguftin ibid. Blanco N.Brafil. de Nord. de tres puntas. San Roman Venezul. de la Cordera. de la Vela.

Caburuto plobintí Guaiana.

Cabueriba hoom Brafil.

Cacao beutyt N. Hifpan.

Cadie pyobintie N. Franc. d'oragnie Guiana. Cod in Virginia. Sineamis N.Nederl. Ackibid. May ibid.

Caep Cornelis ibid. Hinlopen ibid. Henry Virgin. Charles ibid. Frovvard Magall. (ban Horn Magall.

Caiama eplantot Orenoque.

Caiana riebier Guianä.

Caimanes eplanden.

Caio Romano atn Cuba. de Nicolas ibid. de Cruzibid.

Caiouz veutfyte Brafil.

Cairabon riebier Porto rico.

Canada in N. Franc.

Cananea bp la Plata.

Canas volckeren Peru.

Canches tolrkeren Peru.

Cannaris bolckeren Peru.

70.71

62.65

496.499

Cannaris bolcketen Pera.

484

518.527

Canela provincie Peru.

Canneta fadat Peru.

528

530

Canuria pabintiq Guiana.

Caoup boom N. Brafil.

Capaha provincie Florid.

Capuri rietier Guiana.

Caracas in Venezuela.

Caramanta ftadt in Popaian.

ibid.

Caranna bexti N. Hifp.

Carangue in Peru.

Caravaia ballepe Peru.

Carauaro in Veragua.

\section{Carex eplanot bp Cartagena.}

Cariari in Veragua.

Cari rievier Guiana.

Carioes bolck bp la Plata.

Carlos ttadt in Verag.

Caroli riebier in Guian.

Carpunt baben Terreneuf.

Carrapa hoom.

345

174

366

406

298

324

298

586

490

300

331

Carrapa peobincie Popaian.

Carripapoori eplanden. booft-ftad ban be felbe.

Cartago ftadt in Popaian. $\quad 347.349$

Calchaqui ballepe Tucaman.446.447

Cali ftadt in Popaian.

Caffew ine riebier ibid.

Cafline dzantk in Florida.

Caffipagotos tolction Gaiana.

California probintie.

Caffipa lack ibid.

Callao baben ban Lima.

Callo haben Peru.

Calongia punt Hifpaniola.

Camaguey peouintic Cuba.

Camamu in Brafil.

Caffipurogh riebier ibid.

Caffoorwa bifty ibid.

Camana vallep Peru.

Camarco ondiepten Cuba. 
$R$ E G I S T E R.

Cattiva eplantot up Terr. Firm. 316.318

Cavannas fauen Cuba.

Cauca rieuiet Popajan.

Cavinas boituren Peru.

Cauren riebitr in Chile.

Cauro riebrer in Cuba.

Caw o rietuer in Guaian.

Cau wrora tictuiet Guaian.

- Caxas pzobiucie Peru.

- Caxamalca in Peru.

Caycos eplanden Lucaios.

Cayete up Maragnan.

Caymito eplaniot Hifpaniol. bsurftín Popajan.

Cazma javen Peru.

Cefar rievict S. Martha.

Chabin rietriex Chile.

Chalcala N. Galicia.

Chacama ballep Peru.

Chachapoyas pzouinc. Peru.

Chagre rietier bp Panama.

Champoton in Iucatan.

Chancas in Peru.

Chancos uolckeren.

Chancay ballep Peru.

Charcas ppotincie Peru.

Charles Fort in Florida.

Chaufarou bilch N. Franc.

Chechinquamins bquryt Virgin.

Cheriguanaes volek Peru.

Cherinos probinc. Perta.

Chefapeac baep Virgin.

Chefchedeck rietiet N. Franc,

Chianchinoltepec N. Hifp.

Chiametla pzotrintie.

Chiapa peobincie.

Chicacolla in Florid.

Chicoza in Florid.

Chichimecas 1 Bíloen Nov. Hifp. 208. 231

Chiepo riebiec bp Panama.

Chilca ballepe Peru.

Chile beitheyuingfye generael. ballepe in bat rijck.

Chimo balleviu Peru.

Chinca ballep in Peru.

Chin cilla dierken.

Chiquitos waon-plaetsin Pcru. 413 bolek in Peru.

Chiribichi pyouincie.

Chocolate bzanck N. Hifp.

Chocolococha Aabt Peru.

Chontales uolck Nicaragua.

326.343

4 II

436.443

22

568

575

377.395

395.396

32

550

349

388.407

$33 \mathrm{I}$

443

268

386.387

396

312

216

401

350

388

409 .

154.

67

II)

422

376

118

61

184

225

270

148

148
Chovacoet riebies N. Franc.

5. Chriftoval equandt Canibal.

Chucuito peptuincie.
Chuli vallepe Peru.

Chulula bp Mexico.

Chumbo provincie Peru.

Chunnokort ban Peru.

Chupas plaptnen Peru.

Chuquiabo prouincie Peru.

35

340

439

394

179

$37 \mathrm{I}$

360.412

401

414.

Chuquimaio rieder enpeptovincie. 376

Chuquifaca in oe Charcas. $\quad 416$

Chuquinga in Peru. $\quad 4$ II

Cibo baben aen 'teplantot Breton. 53

Cibola peouincie ende fadt. $\quad 243.246$

Cigateo eplandt Lucajos. $\quad 32$

Ciguatlan riebier N. Galic. $\quad 2.27$

Cinalo pzobintie N. Galic. $\quad 227$

Cuito ballepin Peru. $\quad 386$

Real in Chiapa. $\quad 272$

delos Reyes Sta Martha. 330 de los Reyes Lima. $\quad 389$

de Lerma Tucuman. $\quad 447$

Cuidad $\{$ del Salvador Tucuman. 447 de Don Felippe Magallanic. 459.475

Realin la Plata.

(de S. Salvador Brafil.

Coca krupbt ín Peru.

Cochenilla boe die walt.

Coche eplanot bp Margarita. $\quad 601$

Cochabamba in Peru. $\quad 406$

Cocuy in Venezuela. $\quad 613$

Cofachiqui in Florid. $\quad 145$

Cogemyme in $\mathrm{R}$. das Amazonas. $\quad 56 \mathrm{I}$

Colima pzobincíe N. Hifp. 210

fabt ibidem.

Collao peobintie Peru.

Collas boldketen Peru.

Colliman gumme in Guaid

Collique Gallepe Peru. $\quad 574$

Collique ballepe Peru. $\quad 386$

Colymas nolck in N. Reyno. $\quad 337$

Comajaguain ide Honduras. $\quad 289$

Comagre eplanden. $\quad 316.318$

Comma bp de Marannan. $\quad 55^{\circ}$

Commenagod. 6 I9

Compottelain Xalifco. $\quad 225$

Conchos wakkeren N. Mexico. 259

Conchucos volckeren Peru. $\quad 397$

Confines fladt in Chile. $\quad 436$

Concepcion de la Vega in Hifp. II

Concepcion de Salaja Mechuoacan. 210

Hhh 4

Con- 
R E G I S T E R.

Concepcion de Veragua. ftadt in Chile.

Conciva eplanot Lucajos.

Cooshebery rieviet.

Copal berte N. Hifp.

Copallen pzobincie Peru.

Copavacana in Peru.

Copey in Peru.

Copiapo vallepe Chile.

Coquibocoa in Venezuelá.

Coquimbo ballep Chile. babenibidem.

Cordes hape Magallan.

Cordua taatot Tu cuman.

Coritini riebier Guaian.

Coro hooft-ltadt Venezuela.

Cofta Rica pzobinuie.

Cotabamba Peru.

Cotoche in Yucatan.

Cotuy llaut Hifp.

Cozcaquaulthli bogel N. Hifp.

Cozumel splanot bu Yucatan.

S, Cruz de la Sierra peouint. de Mopox Cartagena.

Cuba eplanotr.

Cubagua eplanot. $20.21, \& c$.

Cubias rapenin N. Reyno.

Cuenca ttadt Peru.

Culuacan probíncie.

Cumana probincie.

Cumbi laken Peru.

Cumbibilcas volck Peru.

Cupaiba boom Brafil.

Curacao eplanot.

Curateo eplanat Lucaios.

Curiapan punt Trinidad.

Curucaca dattgh Brafil.

Cufco booft-frater Peru.

Cuffe wine riebier Guaiana.

Cuyo poume. Chile.

D.

$\mathrm{D}$ A rien riebiet entae pzoluintie. Daule ríebier Peru.

Dawney rieuier Guaiana.

Demarari riebier Guaiana.

Deffeada eplanot Canibal.

Deffequebe rievier Guaiana.

Defuenturadas eplanden.

S. Doming o booft-ttadt Hifp.

Dominica eplanat Canibal.

Duoron eplandt N. Franc.

Durango münen N. Hifp.
299

430

32

564

173

376

415

$3^{82}$

428

620

429

$44^{8}$

464

446

577

612

297

401.406

217

II

206

217

422

325

600

335

374

226

619

362

394

508

618

32

594

506

403

576

439

313

373

586.587

577

36

577

$45^{\circ}$

$?$

36

56

231
E.

E. Catepec wintot-bergly Chiapa. 274 Elifabeths eplanaen N. Nederl. 102

Emeria peabincie Guaiana: $\quad 583$

Endehe lilluerminnen. $23 \mathrm{I}$

Eparagotes volcketen Guaiana. $\quad$ \$86

Epuremei bolckeren Guaiana. $\quad 986$

Erena ftadt Zacatecas.

Efquine boom Florid.

230

Effequebe riebier Guaiana.

162

Efteco in Tucuman.

577

Efurgny N. Franc. ' 66

Ethechemins toldk N. Franc. $\quad 77$

Eupari ballep $S^{\text {a }}$ Martha. $\quad 330$

Europa riebier Guaiana. $\quad 58.5$

S. Euftafio epland Canibal. $\quad 36$

Euvanirap boom N. Brafil. $\$ 41$

Ewaipanoma bolck londex bals.

\section{F.}

FArallones de Gaura Peru. $\quad 408$

F Santa Fe de Bogota N. Reyno. 336 de Antiochia Popaian. $\quad 344$ ftadt R. de la Plata. $\quad 486.494$ in De pzobincie Veragua. $\quad 299$

St Felippe ltadt Mechoacan. 209

Fernando Noronha equlanden. $\quad 535$

Ferrol baeben Peru. $\quad 407$

Flamencos togelg in Cuba. $\quad 21$

Florida eertte ontoeckingh. $\quad 137$

tweede ontaeckingly. $\quad 139$

Derde antoeckingh. $\quad 140$

bierde bu Soto.

bp or francoplen.

ghieitalte van 't lanot.

iteoen enoe fterckten.

Floripondio boom N. Hifp.

Formola haben Terreneuf.

$S^{\imath}$ Francifco del Quito Itadt. dela Vittoria Peru.

de Campeche.

142

153

162

165

172

49

366

405

215

Francifco de Vlloa uopagie, $\quad 234$

Vafques de Cornado. 243

Gualle California.

253

Fricos konüuen N. Reyno.

335

G.

CAchepe bauen N. Franc. Garafu bp Pernambuc.
60.65

523 
Gaura bauctim Pcru.

Gayra liebict Santa Martha. St German in Porto Rico.

Giboya Ilangdy Brail.

Goiana rietuicr Brafil.

Golfe S. Lunaire N. Franc. de Chaleuribid.

SDulce.

Golfo $\left\{\begin{array}{l}\text { de Honduras. } \\ \text { de Guanaios. } \\ \text { S. Miguel Panama. } \\ \text { de Paris ibid. } \\ \text { de los Coronados. } \\ \text { de Cariaco. }\end{array}\right.$

Gomeribo bp Wiapoco.

Gorgona eplandt Peru.

Gorrones bolckeren Peru.

Gow ateri cplanot Guaiana.

Goya ve boom N. Brafil.

Gracias a Dios laut Hondur.

Granada eplanot Canibal. thabt Nicaragua.

Gryalua ritbier N. Hifpan.

Guaba bzucht Peru.

Guacariga uogeltien.

Guadacheri in Peru.

Guadalaiara peobintic N. Galic. ende llabt albaer. de Buga ím Popajan.

Guadalupe eplanot Canibal.

Guadiana in N. Galicia.

Guaiaquil ftadt Peru.

Guaiabos boom inde eplanuen.

Guaiare rievier.

Guaiana probincie.

Guallarspa in Peru.

Guambacho vallepe Peru:

Guamachuco yzouincie Peru.

Guamanga ladat Peru.

Guamare jout-pannen N. Brafi

Guamo che veucht N. Galicia.

Guanabo eplanot bu Hifpan.

Guanaios eplanien.

Guanape ballep Peru. Jatuen ibid.

Guancas tuoldieren Peru.

Guanihani eplanut Lucaios.

Guanianes in Hifpaniola.

Guanima evlantot Lucaios.

Guanuco in Peru.

Guarabana boom.

Guaranies boick R. de la Plata.
R E G I S T E R.

389.408 Guaraz pzaluintie Peru.

33 I Guarco ballep Peru.

4 Guarmey ballsp Peru.

so5 Guafco ballep Chile.

53 I Guatao eplandt Lucaios.

Guatapori riebirt.

Guatemala probincie. De booft lladt.

291

ibid.

317

ibid.

443

603

566

356

349

568

$54 \mathrm{I}$

289

36

295

219

364

504

391

227

ibid.

354

37

$23 \mathrm{I}$

3,72

2

582

577

411

388

397

399.400

532

222

19

292

402

388

407

396

32

I6

33

398

314

491

H.

Higillo Pintado veucht.

Hifpaniola eplanot.

Hobo buom.

Hochelaga in Canada.

Holli gum N. Hifpan.

Honduras plobincie.

284

Guaxaca plouintie N. Hifpan. $\quad 197$

Guaxale in Florida. $\quad 146$

Guaxutla N.Hifpan. . $\quad 184$

Guayabos betutly. $\quad 364$

Guayaman eplantot Hondur. $\quad 292$

Guaylas in Peru. $\quad 396$

Guayra baben Venczuela. 609

tadut in la Plata. $\quad 493$

Guayangareo in Mechoacan. $\quad 209$

Guazacoalco in N. Hifpan. 201

Guirapanga bogel Brafil. . 5os

Guiraupiagara dang Brafil. ibid.

Gyromon plante N. Brafil. $\quad 543$

H Abafcon tuotel Virginia. $\quad$ I29

Hacari ballep Peru. 394.408

Hatibonico rievier Hifpaniola. 14

Hatorasko in Virginia. $\quad 133$

Hatuncolla in Peru. $\quad 412$

Hatuncannari in Peru. $\quad 369$

Havana ín Cuba. $\quad 24.25$

Hay oft Hauthi diet. . 504

Hayna ríeviex Hifpaniola. I3

Hernando Alarcon reque. $\quad 249$

Hetigh mastel Brafil. SIO

. Nederlandt. $\quad 104$

Horios Loomin Darien. $\quad 314$

Hormigas eplandekens. $\quad 3 \mathrm{I}$

Hubates volcli in N. Mexico. $\quad 265$

Hudfons vopagie. $\quad 100$

Hup eulanot N. Franc. , 56

Huitzpacotl krupot N. Hifpan. $\quad 198$

Hygney pzolíncie Hifpaniola. 7

I. Iaca-

\section{8} 7

33

.

4

6

3

5

43




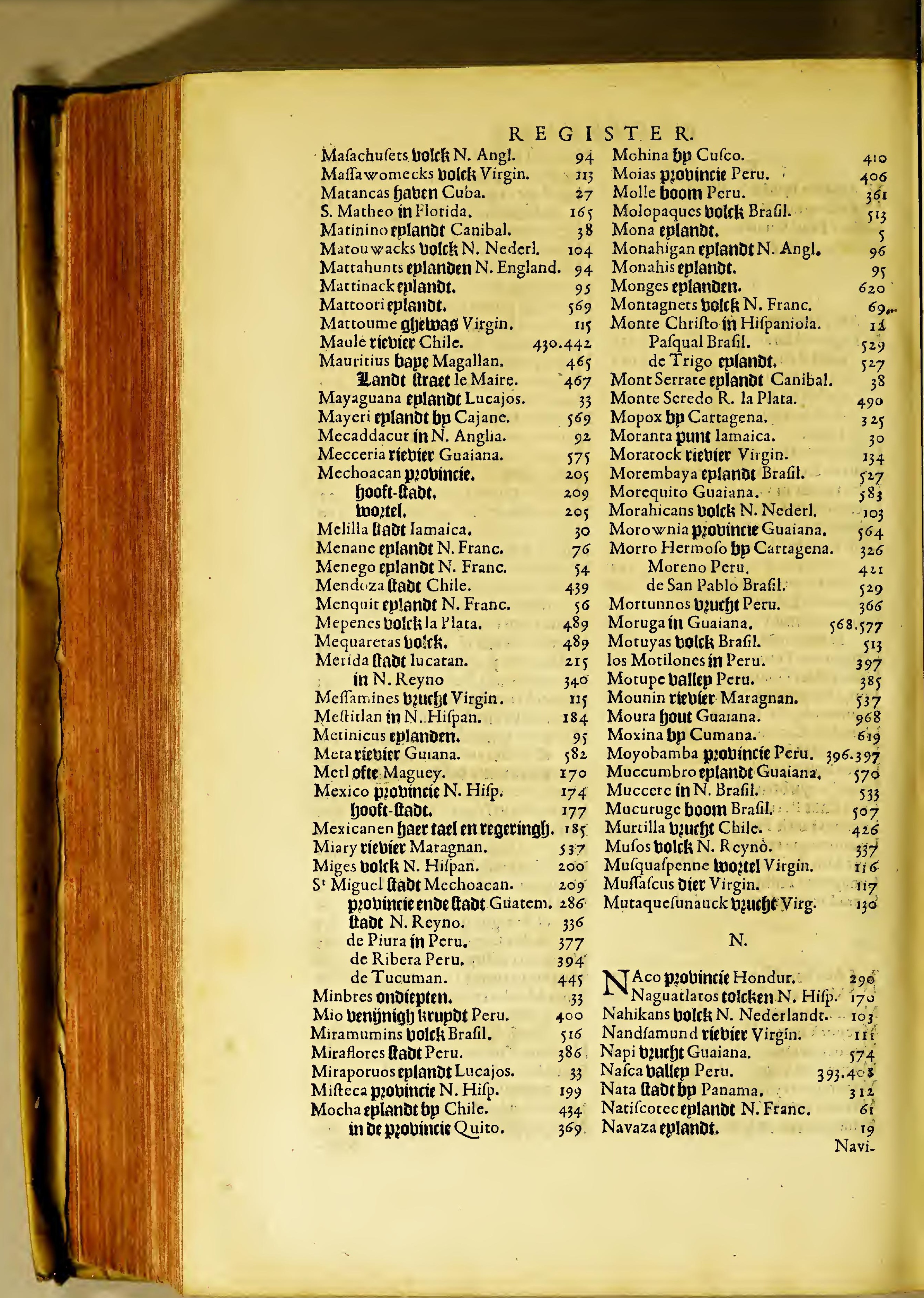




\section{$R$ E $G$ I S T E R.}

Navidad Gaben Mechoacan. Nawaas boldk N. Nederland. Nequen hrupdt.

Neveri riebrer Cumana.

Neuvo Reyno de Granada.

Nexapa ballep N. Hifp.

Nieves eplanot Canibales.

Nicuw $\left\{\begin{array}{l}\text { Engeland. } \\ \text { Pleynouth. } \\ \text { Nederland. }\end{array}\right.$

Nicaragua plobintie.

Nigua onghedierte.

riebier Hifpaniola.

Nicoya pzonintie.

Ninganis yaben Cab Breton.

Nizao riebier Hifpaniol. punt tan't eplandt.

Nombre de Dios Terr. Firm. vleck inde $Z$ acatecas.

Nombre de lefus Magallan.

Norembega in N. Franc.

Noftra Sennora de la Paz Peru.

Nova $\left\{\begin{array}{l}\text { de Carvalleda Venezuela } \\ \text { de la Vittoria Tabafco. } \\ \text { Gcotia. } \\ \text { Gizciaya. } \\ \text { Albion Californ. } \\ \text { Mexico. }\end{array}\right.$

o.

Bahava eplanot bp Cuba. Oca kolt uan Collao.

Ocali in Florida.

Ocanna in Santa Martha.

Ocaywita eplanot Guaiana.

Occam ríevier Virginia.

Ochile in Florida.

Ocoa baben Hifpaniola.

Oconna ballepe Peru.

Ocougtanamins beutht Virgin.

Okindgier boontjeng Virgin.

Olanohon in Honduras.

Olinda ltade Brafil.

Omapalcas riebier Peru.

Omafiyo in Collac.

Ombu Goom Brafi!

Ometepec rievier N. Hifp.

Oncaiare eplanot Guaiana.

Onda bímmenlanottebe bauen;

Ongol plapnen Chile.

Ontiveros in la Plata.
Opaffom Diec Virgin.

Openauck brotel Viroin $\quad$ II

Opon ghehergfte

.

Potar gyebergfte Peru.

Orellana fpn repfen.

333
406

$555.8 \mathrm{c}$. 5paegniatuarana. $\quad 577$ rieviercen (beren dact in vallende. $\quad 586$ gljeleglientferpt bo de ReDerlan= Ders betonden.

Oriftan fladt lamaica. $\quad 591$

Oropefa ltadt Peru. Affiento de Guancavelica 416

Ofachile in Florida. 402

\begin{tabular}{lr} 
Oforno ltaut in Chile. & 144 \\
\hline
\end{tabular}

Otabalo ím Peru. $\quad 366.368$

Otomies bolck N. Hifpan. $\quad 176$

Otzumba ín N. Hifp. $19 \mathrm{r}$

Onacoury boom N. Brafil. $\quad 54 \mathrm{I}$

Ovarerona boom N. Brafil. 540

\begin{tabular}{lr} 
Ovygoudy rieuier N. Franc. $\quad 540$ \\
\hline
\end{tabular}

Ozama riebier Hifpaniola. $\quad$ I2

P.

PAcas ghediette Brafil.

Pachacama ballepe Peri- 503

Pachami bolch N Nedera, $39 \mathrm{I}$

Pacos lobapen Peru.

Pacoury boum N. Brafi $\quad 363$

Pag oft Pague Dier. 542

Paicanos valck Pera. $\quad 503.547$

Paitaben Peru. 423

Palma in N. Reyno. $\quad 378$

Pamaunke rieluier Virgin. $\quad 340$

Pamplona ftadt N. Reyno. 112

Panama de peobincie. $\quad 34^{\circ}$

De ftadt. 302

303.304

Panches balck N. Reyno. $\quad 334.335$

Panuco peabintie N:Hifp. $\quad \begin{array}{r}332 \\ \hline\end{array}$ tadt.

Pao Amorello in Brafil.

Pao ríevier Guaiana.

Papamene rietuier.

Para in Guaiana.

Paracca jabuen Peru.

Paracoa aen Trinidad.

Paraguay rienier.

Paraiba Capitan. Brafil. riebier.

Parana rievier.

Parannamiri riebiex:

Parcos pallepgs Peru. rievier. 
R E GIS T E R.

Paria pz̧ouintie Peru.

4 is

391

$3^{8} 7$

577

Parime lack Guaiana.

Parinacocha Peru.

Paripamotu pzobincié.

Parmonga ballep Peru.

Paícanayo hallep Peru.

Paflaguates boldt N. Mexico.

Pafto peouíncie ende ftadt.

Pata rievier Guaiana.

Pata omeke riebiet Virgin.

Patiguataro op Cumana.

Paucura pzobintie Popaian.

Pauhatan rieviet Virgin. Honingly deg landtg.

$\mathrm{S}^{t}$ Paulo biect in Brafil.

Pawtuxunt vievier Virgin.

la Paz in Peru.

$S^{t}$ Pedroffadt Honduras.

Pedro Sarmiento bopagie.

Pehuame plante.

Pekey boom N. Brafil.

Pemtougouet rietuier N. Franc.

Penguin vogfelts.

Eplanot Terreneuf.

Pennobofc ot N. Anglia.

Pequatoos bolck N. Nederl.

Pequea boom Brafil.

Perico haven ban Panama.

Pernambuc Capitan. Brafil.

Peru beftyegutinghe in tghemepn. manieren van't bolck.

Dertueelimatye.

Petivares tuoltk Brafil.

Petockenock ín N. Nederl.

Picara piobincie Popaian.

Picoy in Peru.

Pilcomayo rievier:

Pillotois waet-leggfjer N. Franc.

Pincos pzouincie Peru.

Piquer rievier la Plata.

Pirito eplanden Cumana.

Pifca riebier ende bletk Peru.

Pifcobamba pzabinc. Peru.

Pita glyelïck kennep.

Piura vallep Peru.

Pizagua tievier Peru.

Plata fadt ín de Charcas.

Pockieró Dier Guaiana.

Poechos vallep Peru.

Pola culanot by Florida.

Popaian peovimcie.

394.411

607

388

371

258

353

582

113

608

348

111

120

SIS

113

414

290

450

205

543

76

459

S1

92.93

103

507

307

523

357

359

363

512

102

348

399

487

69

398

491

619

409

397

354

377

421

33
Popaian ftadt:

Pomatambo in Peru.

$34^{i}$

Pongo in Guaiana.

Popitango up Pernambuc.

Porcofiumer-münen Peru. $\quad 4: 624$

415

573

377

341

Pories bolck Brafil. 513

Port aux Anglois. 53

$$
\text { de Breft T. Franc. }
$$

$S^{t}$ Helaine.

de St Ieban.

du Rosignol.

all CMouton.

du cap Negré.

Royal.

Sante UMargarite.

au.x Mines.

Famin Magallan.

Defire.

Porto Seguro Capitan. Brafil. Caluo Brafil.

Poteingi ríevier N. Brafil.

Potofi ltadt entae mijnen.

Pozo peobintie Popaian.

Pueblo de los Angeles.

Pucara lercke plaetle Peru.

Puerto Rico eplandt.

tadt.

de Pinos.

de la Plata ftadt.

Hermofo Hifpaniol.

de Mofquitos.

Real Hifpaniola.

Frances ibid.

de Matancas.

del Principe Cuba.

de Cavallos Hondur.

Belo fadt Terr. Firm.

Veio fladt Peru.

Puerro de Sangalla Peru.

de Hacari Peru.

de S' Nicolas Peru.

de Ylo Peru.

de los Moxilones.

Bermeio Magallan.

Iulian Magallan.

de Biaca.

de la Candelaria.

de los Reýes.

de Patos.

de Leones.

de Biaca.

Pulches volckeren Chile.

Punta eplanat Poru. 


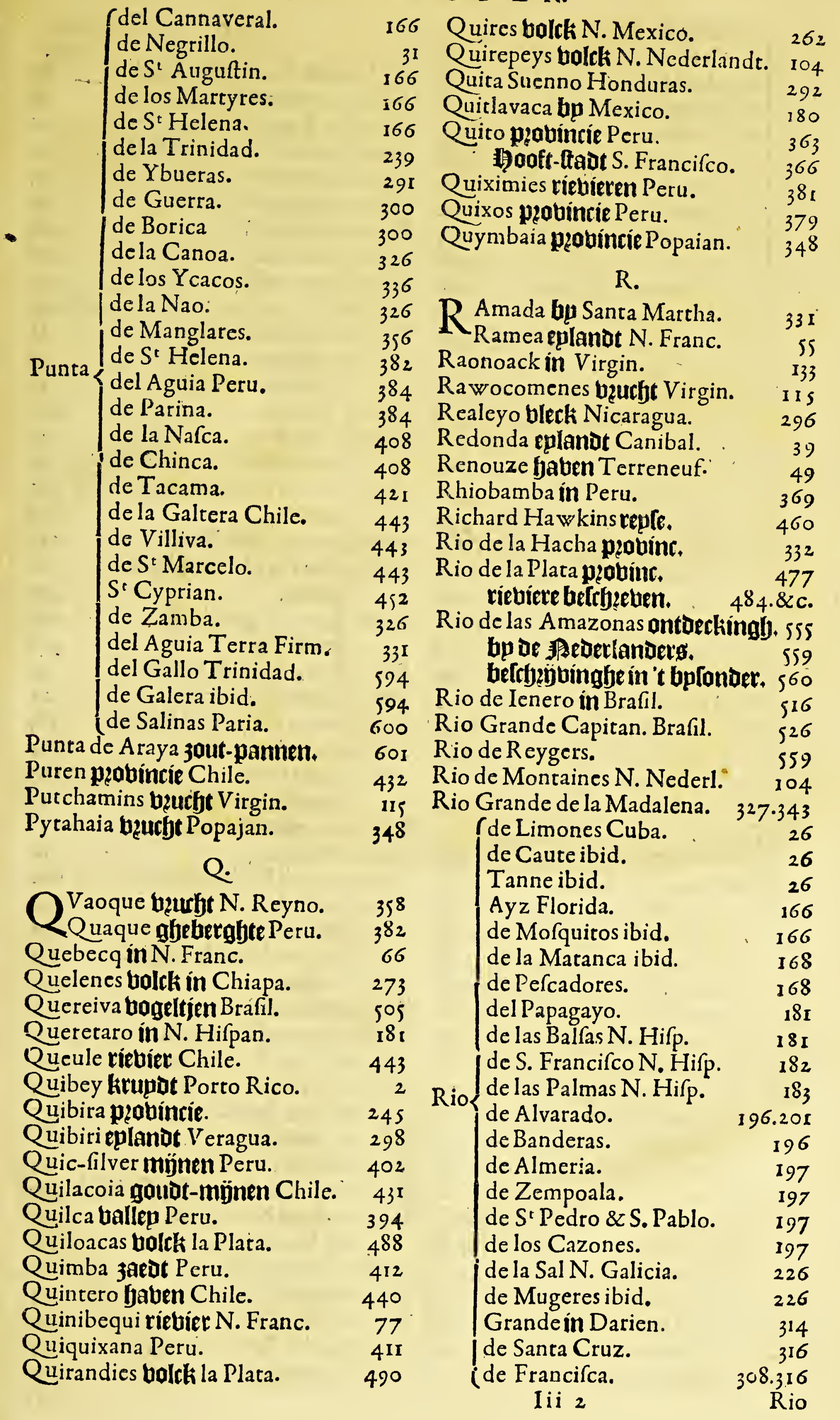




\section{R E G I S T E R.}

Cde Cruz N. Brafil.

de Camboftip ibid.

de Madalena.

de St Iago Peru.

de Oconna.

de Camana.

de Tolten Chile.

de Chabin.

Bermeio Tucuman.

el Salado.

de las Palmas, la Plata.

de los Beguaes.

Sant Francifco la Plata. 496.499

de Sant Illefonfo.

Santa Cruz.

de Santa Ana.

de Galegos.

Rior San Salvador.

de Lagoa.

grande la Plata.

de Martin Soufa.

de S. Pedro.

Vpaba.

dos Patos.

dos Reyes magos.

Tinhare.

Real Brafil.

Sant Miguel.

Dolce Brafil.

das Caravelas.

Grande Brafil.

Pariba.

des Contas.

Sant Francifco Brafil.

de Sanr Paulo.

de Bordones.

$\left\{\begin{array}{l}\text { St Marguarite N. Franc. } \\ \text { de Caen. } \\ \text { Sante Garie. } \\ \text { Sante Sufanne. } \\ \text { Sant Antoine. } \\ \text { Sant Iean Ouygoudy. } \\ \text { des Etechemins. } \\ \text { de May Florid. } \\ \text { Seine. } \\ \text { Somme. } \\ \text { Loire. } \\ \text { Charente. } \\ \text { de port Royal. }\end{array}\right.$

Roanoack Virgin.

Rocca eplanot bp Venezuela.

Roncador bp Iamaica.

Roucou vertue Maragnan.
533

533

343

38

394

ibid.

437

ibid.

444

445

488

488

496.499
477

$477 \cdot 482$

478

479.482

484

498

497

ibid.

ibid.

498

ibid.

528

529

530

ibid.

528

529

529.532

$53 \mathrm{I}$

529

530

554

619

62

60

67

67

73

75

75

153

ibid.

ibid.

ibid.

ibid.

IS3

134

618

31

539
S.

S Aaz ofte Safle ríevier Cuba. $\quad 26$

$S$ Saba exlandt Canibal.

Sacatan ttabt Chiapa. $\quad 274$

Sacque nummen er wodtel Virg. I30

Sagadahoc riebier N. Franc. $\quad 95$

Saquenay ríebier N. Franc. $\quad 63$

Saima peobincie.

Salamanca ttadt Yucatan.

Sallicoques bitch.

Salca in Tucuman.

Salualcon fiadt N. Hifp.

Samana eplandt Lucayos.

448.495

Golfo Hifpaniol.

II

33

18

Sandia in Peru.

406

Sangalla in Peru.

393

Sanhikans bolck N. Nederlandt. 105

San Salvador pyobintí Guatemal. 282 De ftadt.

285

San Salvador ftator Brafil.

522

Santa alias Parilla ltadt Peru. $\quad 387$

haben.

407

Santa Martha pequintif. $\quad 327$ jooft-lfadt. 328

Santa Cruz eplandt Canib. $\quad, 39$

Santi Spiritus tadt Cuba. $\quad 23$

Santi Stevan del puerto Panuco.' $\quad 183$

Sant lago de los Valles. $\quad \quad 183$

Santos latat Brafil. $\quad 514$

eplanut Canibal.

39

Saomoto eplandt Lucaios. $\quad 33$

Saona eplandt. 18

Sapanapoock R. Amazon. $\quad 56 I$

Sapenou ibid. $\quad 56 I$

Sarropein Florida. $\quad 157$

Safquefahanock bolck Virgin. $\quad{ }_{13}$

Saffafras fout.

Styaepen van Peru.

St Sebaftian in Cluiametla.

162

361.362

126

340

354

de la Plata Popaian.

515

Sebalds eplanden.

$48 \mathrm{r}$

Sebo dozp in Yucatan.

215

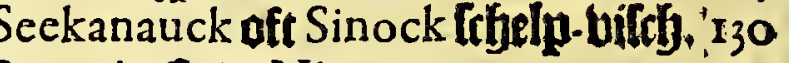

Segovia Atadt Nicaragua. 295

in Venezuela. 613

Segura ltadt Hifpaniol. $\quad 192$

Sequins holck N. Nederl. $\quad 103$

Serena thad Chile. $\quad 429$

Sergippo del Rey in Brafil. $\quad 525$

$\begin{array}{ll}\text { Sername rieluiet Guaiaṇa. } & 577 \\ & \text { Ser. }\end{array}$ 
Serrana eplandt.

scfambre N. Franc.

Sevilla ftadt lamaica. del Oro in de Q uixos.

Sewrano riebier Guaiana.

Siara in Brafil.

Siccanamos rietuír N. Nederl.

Siete Corrientes fladt la Plata.

- Sierras de Cobre Cuba.

Silck grag Virgin.

Sinamenari rictier Guaiana.

Sivvanois bolck N. Nederl.

Skallapa ftadt N. Hirp.

Sloep-baye N. Nederlandt.

Smiths eplanden.

Soconufco prabint.

Solana ballep Peru.

Sommer eplanotg Bermudes.

Sombrero eplanot Canibal.

Sorame riebier Guaiana.

Soras volcte Peru.

Soriquois bolcti N. Franc.

Sovvocatuck Virgin.

Spiritu Santo tadat Brafil.

Staten eplandt.

Strate van Le Maire.

Suchitepec p2obincie Guatemale. 275 $T$.

TAbago eplanot.

Tabafco prouincíe N. Hifp.

Taboga epland bp Panama.

Taboucouru ríeuier Maragnan.

Tacána peobincie Peru.

Tadouflac bauen N. Franc.

Tagare $z$ valck bp Cumana.

Taiahug rietuier Brafil.

Tairona glyeberghte.

Talavera ttadt Tucuman.

Talamameque $S^{\text {ta }}$ Martha.

Tamandua dier Brafil.

Tamaraca Brafil.

Tambopalla ballep Peru.

Tambos ban Peru.

Tamoyes bolck Brafil.

Tangara bogeltien Brafil.

Tampice ftadt Panuco.

Tanne rieviere Cuba.

Taperica eplandt Brafil.

Tapouytepere Maragnan.

Tappaans bolck N. Nederlandt.

Tapuca riebier.

Tapuyas bolck Brafil.
R E G I S T ER.

31 Tapyrete oft Tapyrofou dier. 502

$7^{\mathrm{I}}$ Taquari riebier. $49 \mathrm{I}$

30 Ta rapaca ballep enoeliaten Pert. 421

379 Tararequi splandt bu Panama. $\quad 318$

577 Tarama youintí Peru. - 399

532 Tarafcos voldi Mechoacan. 205

103 Taria ballep Tucuman. 447

489 Tarracoa peobincie Guaiana. $\quad 587$

19 Tafcaluza in Florida. $\quad 347$

I30 Tarou Armadillo. 503.547

$57^{6}$ Taximaroa in N. Hifpan. $\quad 208$

104 Tayacutigica berckeng. $\quad 503$

185 Taymoes uolck Brafil. SI4

I03 Teca zakdt in Chile. $\quad 426$

95 Tecomahaca ferte N. Hifpan. 174

275 Tecoantepec prabincie N. Hifp. 200

377 Tecunapa in N. Hifpan. 204

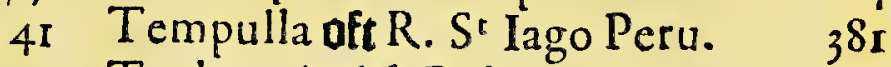

39 Tenbuys bolcli R. la Plata. $\quad 488$

577 Teneriffe ttadt Santa Martha. 330

4OI Tepeaca plobintie N. Hifpan. 192

69.73 Tepeaquilla bergh bp Mexico. I79

92 Terreneuf kplandt. $\quad 46$

si9 Tefcuco bp Mexico. 180

467 Teftiogs eplanden un Margar. 589.599

466 Texel eplandt N. Nederl. IO2

The comates betutht N. Hifpan. $\quad 223$

Thomebamba Peru. $\quad 370$

St Thomas de Caftilla Hondur. 290 lladt ap den Orenoque. $\quad 584$

Terra de Brea Trinidad. sos

Tiguez N. Galicia. - 248

Timana ltadt Popajan. $\quad 354$

406 Timbues uoldk la Plata. , $\quad 490$

62 Titicaca lackin Collao. $\quad 4 \mathrm{I2}$

605 Tiwitivas bolck Guaiana. $\quad 584$

499 Tlaquatzin dier N. Hifp. $\quad 272$

328 Tlafcala peobuincie N. Hifpan. 187

445 fedender fellue. 190

330 Tobo oft R. das Amazonas. 555

503.547 Tobofos valck N. Mexico. $\quad 259$

526 Tocayma ftaot N. Reyno. 336

394 Tocka wouge tucktel Virgin. $\quad$ Ir6

364 Tock wogh riebier Virgin. 114

514.528 Tocomans bolck Brafil. SI4

$\begin{array}{ll}\text { sos Toiuqua. } & 498\end{array}$

148 Tolten riebier Chile. 443

26 Tolu prabincie Cartagen: $\quad 325$

$\$ 23$ Tamahavi tminot Charcas. $\quad 417$

550.554 Tomonymenos volck Brafil. 512

ios Ton ongbedierte Brafil. 506. 548

499 Totonteac prabincie. : 248

519 Topia plabuncie. 232

$\mathrm{IiI}_{3}$ Topo- 


\section{$R$ E $G$ I S T E R.}

Toppohanoc riebiet Virgin.

Topinakes Brafil.

Topinambes bolck Brafil.

Torruga eplannt bu Hifpaniol. bp Florida.

bp De Margarita.

Totocke byutbt Amazonas.

Totoqueftal hogifel Chiapa.

Totora in'tlack Titicaca.

Toucan volek N.Brafil.

Tououpinambanty Brafil.

Toyma Lallepe bp Cufco.

Tragabigzanda booz-lanor.

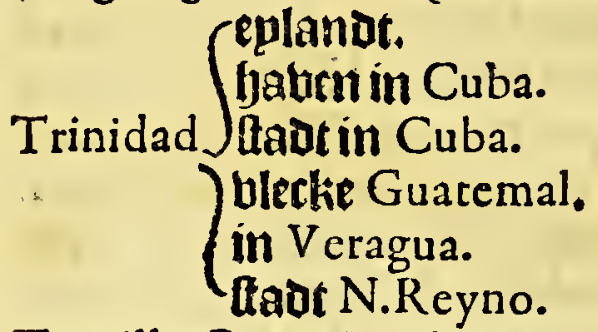

Truxillo ttadt Honduras.

taot Popayan.

tat Peru.

in Venezuela.

Tucan bogeltien Brafil.

Tucapel probincie Chile.

Tucaman pzouíntie.

Tucuyan peobintí.

Tucuio pgobincie Venezuela. tadt inde provincie.

Tumbez vallegu Peru. riebiete.

Tuna boom N. Hifpan.

Tunia pzovincie N: Reyno. De ftadt.

Tupinambas volck Brafil.

Tuqueme vallepe Peru.

Tutepeque pęabincie N.Hifpaniola.175

V.

VAldivia ftadt in Chile. tíebier.

Valencia nova Venezuela.

Vallodolid in Mechoacan.

in Yucatan.

in Honduras.

in Peru.

Valparayfo haven Chile.

Valuerde ttadt Peru.

Veja ende V ejo eplanden Lucayos.

Venczuela pzobincie.

Venta de Cruzes bu Panama.

Vera Cruz Itadr N. Hifp.

Veragua peobincie.
112

513

512.548

17

29.33

618

562

271

413

544

517

405

94

594

26

23

286

299

399

290

355

$3^{8} 7$

615

505 .

432

244

245

611

614

377

383

171

334

340

548

386

$43^{\circ}$

443

613

209

215

288

380

30.441

393

33

609

307

194

298
Verapaz peovintie.

Bertabe riebiet N.Nederl.

Vetchunquoys Dier Brafil.

Viachainde Charcas.

414

Villa $\left\{\begin{array}{l}\text { de las Palmas Tamalameque. } 330 \\ \text { del E }\end{array}\right.$ del Epiritu Santo N. Hifp. 201

Villacuri

vallep Peru.

393

Villarica ttadt Chile.

437 .

Vinaque rievier Peru.

400

St Vincente eplanut Canibal.

39

tadt ín Brafil.

Virgines eplanden Canib.

514

Virgin Gorda eplanot.

40

40

(berrbzeven ba Smith. $\quad 110$

Virginia vuturften ban 't landt. $\quad$ I 4 ghedierten. $\quad 117$ bolcks manieren: $\quad 118$

berbeguen bu Ralegh. $\quad 128$

Virribaracuxi in Florida. $\quad 143$

Vitangue in Florida. $\quad 149$

los Viticos Peru. $\quad 398$

Vittoria de Guamanga Peru. $\quad 399$

Vivor as eplandekeng.

Vnare ríbier Venezuela. $\quad 609$

Vnau monltreus diet. . $\quad 547$

Vnni butbt Chile. $\quad 426$

Vtpee bladeren Guaiana. $\quad 575$

Vraba Golfo. $\quad 313$

Vramarca pzouíncie Peru. $\quad 401$

Vrapo hout Guaiana. $\quad 568$

Vrira rievier Veragua. $\quad 299$

Vrchila eplanot. 618

Vtyla eplanat Hondur. $\quad 293$

Vruay rítvier la Plata. $\quad 488$

Vua.ere butfld N.Brafil. $\quad \$ 43$

Vyapari naem ban Den Orenoque. 578 ontoeckinge bp Ordas. $\quad 578$ bu Hieronymo Ortal. $\quad 579$ bpSedenno. $58 \mathrm{r}$ bp Ped. Hernando de Serpa. ibid. bp Iuan de Salinas. ibid. by Pedro de Orfua. ibid.

\section{W.}

W A carina rriltal-berghGuaiana. 58 Wainari riebier Guaiana. $\quad 566$

mal-rulten diet.

55

Walther Raleig tertte bopagic. $\quad 584$ Ielte bopagie. $\quad 586$

Wamenbec hoom N. Brafil. $\quad 542$

Waoranecks bolck N. Nederlandt. Ios Wapeigh 
Wapeigh terra figillat.

$$
R \text { E G I S T E R. }
$$

Wapenock natie N. Nederland ${ }^{2}$ I . Yarammacarou montreute phante.54

Waracayari riebier Gunianat. $\quad 103$ Yarepa tievier Nicarag. 296

Warana wancong bolcli N Neder. 587 Yarre tíebiet Hondur. 292

Wa febur bettue Virgin.

Waymores tolck Brafil.

Waytaquafes volck Brafil.

Wayana wafons volck Brafil.

I Wia rievier Guaiana.

Wiapoco rievier Guaiana.

Wickonzour eerten Virgin.

Wigafcan tuottel Virgin.

Wikiri uolck Cumana.

Winauk faffafras Virgin.

Winicapora ríetuier Guaiana.

Winipoco rietuiet Guaiana.

Wokokon equlanot Virgin.

$\mathrm{X}$.

X Aguas volckeretr.

boomenin Cuba.

$\mathrm{X}$ ahuali boom.

Xaianca ballepe Peru.

Xalapa N. Hifpan.

moztel Mechoacan.

Xalifco plobincie.

$X$ aquixaguana ballep Peru.

Xaragua pqubintie Hifpaniol.

Xarajes boltk la Plata.

$\begin{array}{lr}\text { Xauxa ballep Peru. } & 397.399 \\ \text { Xerez de la Frontera Guatemal, } 286\end{array}$

Yca ballepe Peru. 393

Ycayagua provimín Hifpanicla. 7

ibid. Yguarfongo probincie Peru. $\quad 506$

568 Ynagua eplandat Lucaios.

565 Ypiti rievier la Plata. $\quad 487$

129 Yroquois natie N. Franc. 69

316 Yfance in Popayan. 355

583 Ytapua lack. $\quad 494$

I3I Ytaten rievier Chile. $\quad 430.442$

587 Ytatin in la Plata. $\quad 424$

566 Yroco in N. Reyno. 340

133 Yucay balleq Peru. 405

Yucatan peouincie. 2 II

Yuina eplandt Lucaios. $\quad 34$

Yumbo gfielierafte Peru. $\quad 366$

580 Yumeto eplandt Lucayos. $\quad 34$

20 Yuna tiebier Hifpaniola. I3

338 Yzalcos pzobintie Guatemala. $\quad 28 \mathrm{t}$

385 Yzquepatli gfedierte N.Hifp. 206

196 Yztapalapa bu Mexico. 180

205

225

402 nova in Venezuela. in nova Galicia.

Xuala in Florida.

Xuta bogbel in Peru.

Y.

Yague thadt N. Reyno.

Yabaque eplanot.

Yaguana ftaot Hifpaniol.

in-bam.

Yaguna eplandt Lucaios.

Yalcones balck Popaian.

Yaqui rievier Hifpaniol.

Yaquimo peabincíe Hifpaniol.

habenín't telue eplandt.

\section{Z.}

A bana black belo bu oe Jindiané.8

Zacatecas pzovincie.

Zaccheo eplandt.

Zacatula Mechoaean. $\quad 208.210$

Zalango hatuen Peru. $\quad 382$

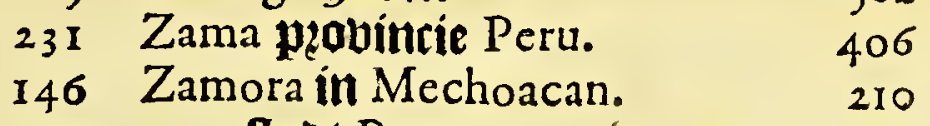

$371 \quad$ ftadt Peru. 375

Zana ballep Peru. $\quad 386$

Zapote boom. 28r

34I Zapotecas probincie N. Hifpan, 200

34 Zarza alias Loxa Peru. 374

1I Zarcaranna riebiet la Plata. 493

16 Zenu riebiet ende plobincie.

34 Zeybo ftadt Hifpaniola. II

354 Zoques volkt in Chiapa. $\quad 273$

12. Zuny płobincie N. Mexico. 2.64

7

IS

$\mathrm{F} I \mathrm{~N}$ I $S$, 


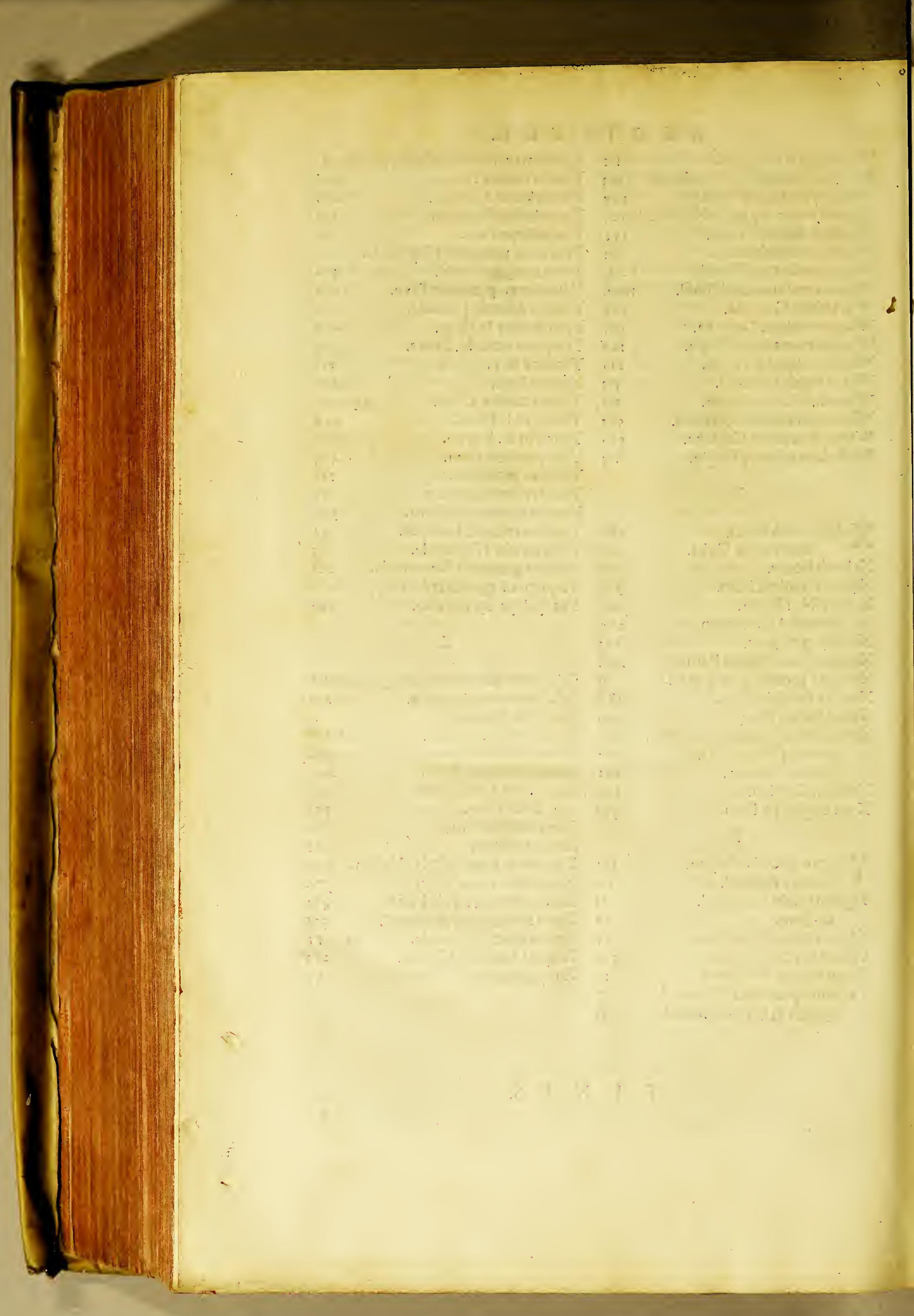




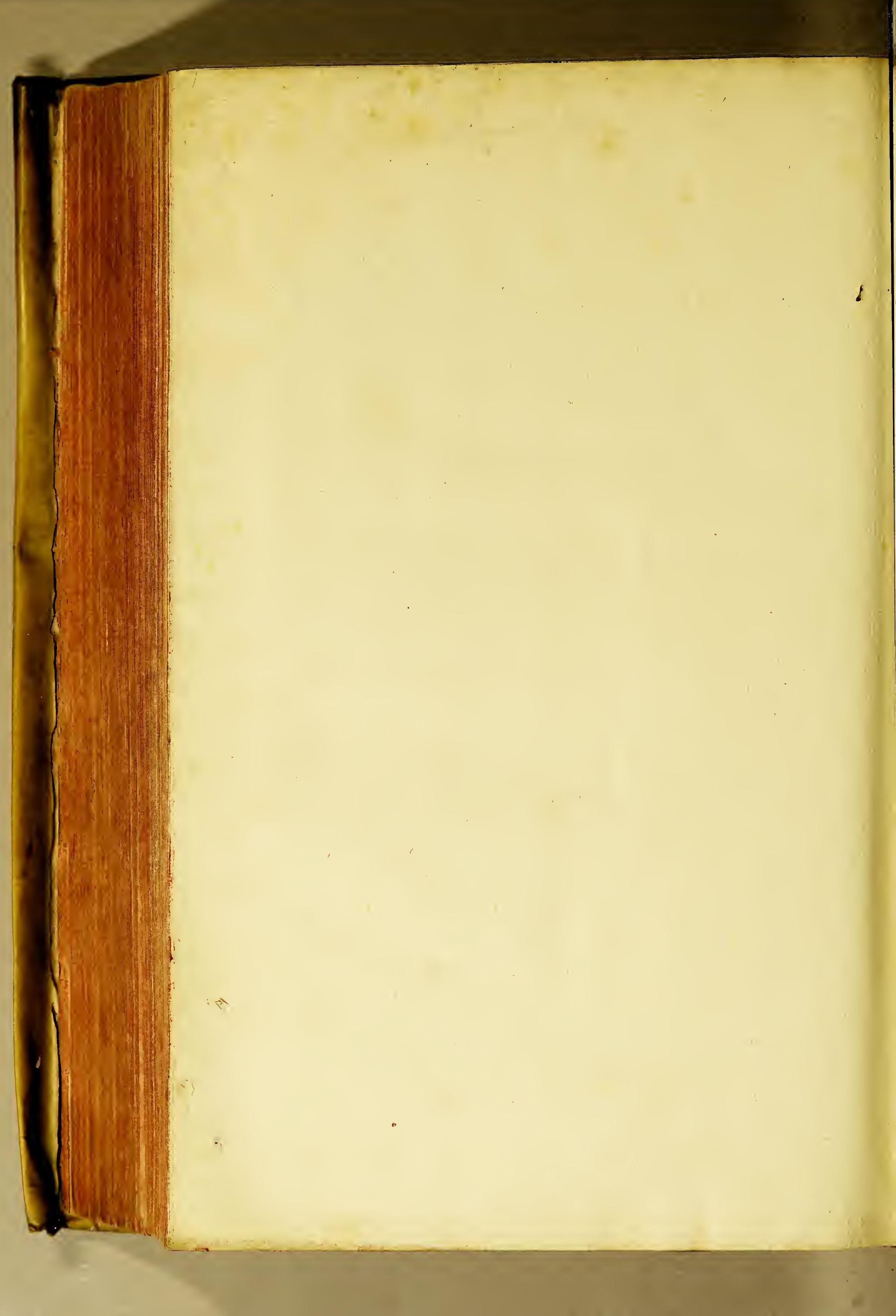


- 




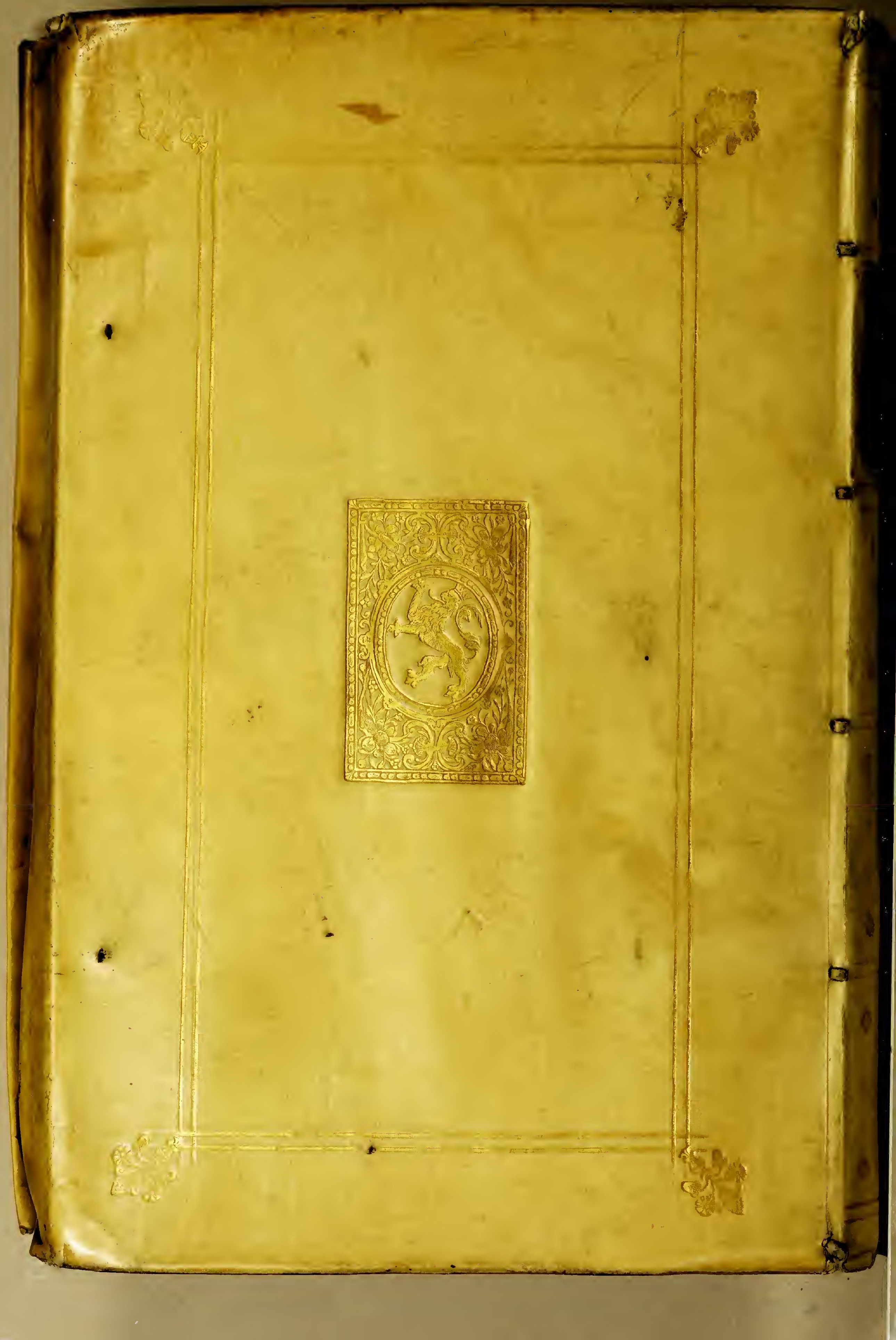

